Bibliothek der Brandenburgischen

und Preußischen Geschichte

Peter Bahl

\title{
Belastung und Bereicherung
}

Vertriebenenintegration in Brandenburg ab 1945 

Belastung und Bereicherung

ror 


\section{BIBLIOTHEK DER BRANDENBURGISCHEN UND PREUSSISCHEN GESCHICHTE}

Im Auftrag des Brandenburgischen Landeshauptarchivs

und der Historischen Kommission zu Berlin

herausgegeben von Mario Glauert und Michael Wildt

BAND 17 


\section{Peter Bahl}

\section{Belastung und Bereicherung}

Vertriebenenintegration in Brandenburg ab 1945 
Dieses Buch ist eine 0pen-Access-Publikation.

\section{(c) $(1) \Theta \Theta$}

Dieses Werk ist lizenziert unter einer Creative Commons Namensnennung Nicht kommerziell - Keine Bearbeitungen 4.0 International Lizenz.

https://creativecommons.org/licenses/by-nc-nd/4.0/deed.de

Bibliografische Information der Deutschen Nationalbibliothek:

Die Deutsche Nationalbibliothek verzeichnet diese Publikation in der Deutschen Nationalbibliografie; detaillierte bibliografische Daten sind im Internet über http://dnb.d-nb.de abrufbar.

Dieses Werk einschließlich aller seiner Teile ist urheberrechtlich geschützt. Jede Verwertung außerhalb der engen Grenzen des Urheberrechtes ist unzulässig und strafbar.

(c) 2020 BWV | BERLINER WISSENSCHAFTS-VERLAG GmbH, Behaimstr. 25, 10585 Berlin, E-Mail: bwv@bwv-verlag.de, Internet: http://www.bwv-verlag.de Umschlagabbildung:

Kombination von drei Ausschnitten aus dem Foto "Treck schlesischer Flüchtlinge bei Potsdam", Frühjahr 1945. Fotograf: Hilmar Pabel (Copyright: bpk/Hilmar Pabel).

Layout und Herstellung durch den Verlag Druck: Memminger MedienCentrum, Memmingen Gedruckt auf holzfreiem, chlor- und säurefreiem, alterungsbeständigem Papier. Printed in Germany.

ISBN Print 978-3-8305-5016-7

ISBN E-Book 978-3-8305-4186-8

https://doi.org/10.35998/9783830541868 


\section{Vorwort}

Die Eingliederung der Flüchtlinge und Vertriebenen im Nachkriegsdeutschland ist inzwischen seit längerem ein Thema der historischen Forschung, nach dem aber auch in der Öffentlichkeit immer öfter gefragt wird. Brandenburg spielt dabei meist eine Nebenrolle, obgleich es 1945/46 einer der entscheidenden Schauplätze war, seine Bevölkerung damals erheblich vergrößert und in ihrer Zusammensetzung stark verändert wurde - mit Auswirkungen bis heute.

Seit Jahren fehlte für diese umwälzenden und teilweise dramatischen Vorgänge in Brandenburg eine umfassende Überblicksdarstellung, in der Wissenschaft ebenso wie in der Gedenkkultur. Das Brandenburgische Landeshauptarchiv (BLHA) hatte deshalb schon vor Jahren als Basis weiterer Forschungen eine Quellenedition in sein Arbeitsprogramm aufgenommen, die daher im Konzept der Landesregierung für die Erinnerungskultur schon 2009 erwähnt wird. Zwei berufsbedingte Bearbeiterwechsel, ursprünglich Dr. Detlef Kotsch, dann Dr. Harald Engler, ab 2013 der Verf., haben die Vorarbeiten zur Quellenermittlung jedoch erheblich verzögert. Die 2013/14 von letzterem gänzlich neu erstellte Edition ist nun als unverzichtbare Ergänzung (Teil 3) in das hier vorgelegte Gesamtwerk integriert worden, nachdem sich 2015 die Möglichkeit ergeben hatte, den Bearbeiter durch eine Förderung der Beauftragten der Bundesregierung für Kultur und Medien (BKM) zusätzlich mit einer auswertenden monographischen Darstellung zu beauftragen. Die Ausschreibung verlangte eine vornehmlich auf die „Ereignisgeschichte“ der frühen Nachkriegsjahre konzentrierte Darstellung. ${ }^{1}$ Letzteres wird vor allem in der Ortsdokumentation (Teil 2) geboten, während die allgemeine Darstellung (Teil 1) die grundsätzlichen Entwicklungslinien bis zur Gegenwart zu verfolgen versucht. Doch auf diese inhaltlichen Fragen wird der Leser in der Einleitung noch ausführlicher eingestimmt. Hier dagegen ist vor allem der Ort des Dankes nach getaner Arbeit.

Für wichtige Hinweise und Gespräche zum Thema ist zahlreichen Personen zu danken. Sie sind ebenso wie die Institutionen, die logistische oder andere Unterstützung boten, am Ende des Buches aufgeführt. Es ist dem Verfasser jedoch ein Bedürfnis, an dieser Stelle jenen Menschen und Institutionen besonders Dank zu sagen, ohne deren Anregung und grundlegende Hilfe die Arbeit gar nicht bzw. nicht in dieser Form hätte geschrieben und abgeschlossen werden können. Die Initiative, zunächst zur Erarbeitung der Quellenedition im Auftrag des BLHA in Potsdam, ging von dessen Direktor, Prof. Dr. Klaus Neitmann, aus. Er hat den Abschluss des

1 „Akademisches Förderprogramm [2015-2017] für Universitäten und außeruniversitäre Forschungseinrichtungen: Umsiedlung, Flucht und Vertreibung der Deutschen aus dem östlichen Europa 1939-1948 und ihre Folgen: Ereignisgeschichtliche Studien“ (Ausschreibungstext): „Die Ausschreibung zielt auf die Förderung von Projekten, die sich mit konkreten Fragen zu dem historischen Geschehen befassen, um neben der unverzichtbaren Auseinandersetzung mit der,Geschichte zweiten Grades' (Pierre Nora) mehr Klarheit über die Fakten zu erhalten." Vgl. Akademische Förderprogramme zur Kultur und Geschichte der Deutschen im östlichen Europa. Hrsg.: Die Beauftragte der Bundesregierung für Kultur und Medien (BLM), Pressestelle, in Zsarb. mit: Bundesinstitut für Kultur und Geschichte der Deutschen im östlichen Europa (BKGE). Berlin 2016, S. 27. 
am Archiv angesiedelten und per Werkvertrag durchgeführten Editionsvorhabens selbst über die beiden Bearbeiterwechsel hinweg nie aus den Augen verloren. Ihm ist der Verf. für die stete, großzügig gewährte Unterstützung zu großem Dank verpflichtet.

Als sich durch die Ausschreibung der BKM 2015 die Möglichkeit zur Finanzierung einer Auswertung der gesammelten Quellen und damit einer wissenschaftlichen Darstellung ergab, brachte Prof. Neitmann dieses Vorhaben als Sektionsleiter Brandenburg der Historischen Kommission zu Berlin in deren Forschungsprogramm ein. Sehr zu danken ist der Behörde der BKM für die gewährte Förderung einer zweijährigen halben Projektstelle, die dazu 2015-2017 am Institut für Geschichtswissenschaften der Humboldt-Universität zu Berlin geschaffen werden konnte. ${ }^{2}$ Dies wäre ohne die Bereitschaft von Prof. Dr. Michael Wildt, das im Vorstand der Historischen Kommission zu Berlin gemeinsam geplante Projekt an seinen Lehrstuhl für „Deutsche Geschichte im 20. Jahrhundert mit einem Schwerpunkt in der Zeit des Nationalsozialismus" anzubinden, nicht möglich gewesen. Seine stets verlässliche Unterstützung bei der Absicherung der Rahmenbedingungen, aber nicht zuletzt seine immer offene Haltung sind mit nicht geringer Dankbarkeit ausdrücklich hervorzuheben. Den Kolleginnen und Kollegen im Vorstand der Historischen Kommission zu Berlin und deren Geschäftsführerin Ellen Franke sei zudem für stets kollegiales Wohlwollen gedankt.

Während bei der Quellenarbeit das BLHA die wichtigste Grundlage bildete und ihm und seinen Mitarbeiterinnen und Mitarbeitern insofern für ihre Hilfe besonders zu danken ist, war bei der intensiven Auswertung der Regionalliteratur die in Berlin ansässige Bibliothek der Landesgeschichtlichen Vereinigung für die Mark Brandenburg e. V. unverzichtbar. Nur die dem Verf. dort gebotenen Arbeitsmöglichkeiten haben ihn überhaupt in den Stand versetzt, in relativ begrenzter Zeit eine sehr große Zahl an Periodika und Monographien im Hinblick auf die Geschehnisse in den einzelnen Städten und Gemeinden auszuwerten, so dass er diesem ihm ohnehin nahen Verein einmal mehr Dank abstatten will. Ein Dank soll schließlich aber auch pauschal an jene Lokalhistoriker, Ortschronisten, Heimatforscher und für Geschichtspublikationen in den Landkreisen Verantwortlichen gehen, die sich trotz nach wie vor in Teilen der Öffentlichkeit verbreiteter Berührungsängste und Distanz nicht gescheut haben, Flucht und Vertreibung $\mathrm{zu}$ thematisieren, und dem Verf. damit ermöglichen, auch auf ihren vielen Schultern zu stehen.

Dass das Werk in der renommierten „Bibliothek der Brandenburgischen und Preußischen Geschichte“ erscheinen kann, wird der Rezeption nicht nur in der Wissenschaft, sondern auch im Land Brandenburg, mithin auch der Wahrnehmung durch viele im weitesten Sinne Betroffene gewiss förderlich sein. Für die Aufnahme ist den Herausgebern der Reihe herzlich zu danken.

Möge das Werk mit all seinen Thesen, Einsichten, den vielen kleinteiligen Fakten und sicherlich auch manchen Unvollkommenheiten insgesamt dazu beitragen, einer lange verzöger- 
ten Aufnahme des Themas in den Erinnerungshaushalt des Landes und seiner heutigen Menschen den Weg zu bereiten. Möge es neben und mit aller sachlichen Information auch die nötige Empathie erzeugen helfen, ohne die der Blick zurück - wenngleich ganz unbeabsichtigt - leicht unmenschlich wird. Niemand sollte darin freilich „Munition“ für aufgeregte Debatten zu finden versuchen, weder in der einen noch in der anderen Richtung.

All das Leid und Glück der Menschen, die ihm in den Quellen begegnet sind, haben den Verf. in den letzten Jahren daran gehindert, sich seiner eigenen Familie mehr als nur nebenbei zuzuwenden. Ihr sei das Buch daher in Liebe und Dankbarkeit gewidmet.

Berlin, im August 2019

Peter Bahl 



\section{Inhaltsübersicht}

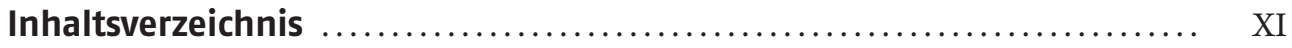

Teil 1: Darstellung.......................................... 1

Teil 2: Ortsdokumentation.

Historische Stätten der Vertriebenenintegration in Brandenburg ..... 515

Teil 3: Quellenedition .................................... 973

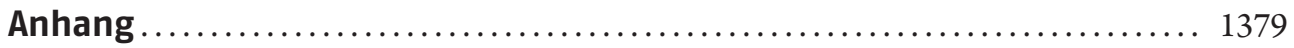

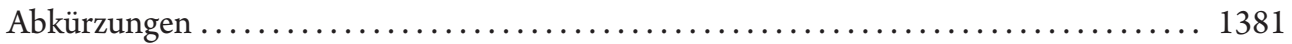

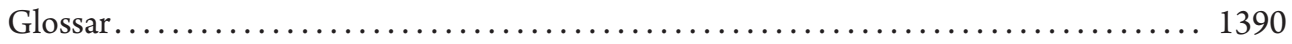

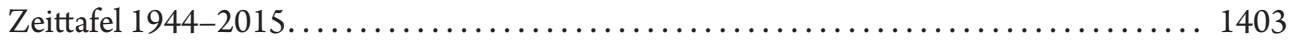

Quellen- und Literaturverzeichnis............................... 1419

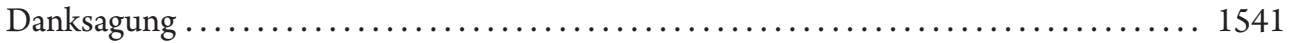

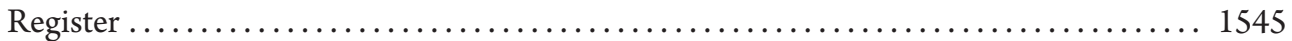





\section{Inhaltsverzeichnis}

Tabellenverzeichnis

XVII

\section{Teil 1: Darstellung}

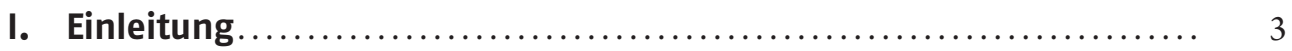

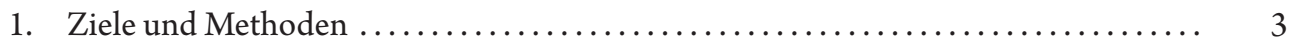

2. Forschungsstand und Stellenwert des Themas in der Erinnerungskultur.......... 9

Zeitgeschichte als historische Disziplin ........................... 9

Zeitgeschichtliche Erinnerungsarbeit - Initiativen der Landesregierung.......... 19

Landes- und Regionalgeschichte ............................... 23

Spezialdisziplinen und Nachbarwissenschaften....................... 29

Volkskunde/Ethnologie, Alltags- und Kulturgeschichte.................. 30

Zeitgeschichtliche Archäologie................................. 33

Kirchliche Zeit- und Bistumsgeschichte.......................... 35

Lokalgeschichte - Heimatforschung und Ortschronistik................. 39

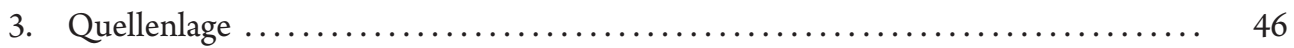

Quelleneditionen und zeitgenössische gedruckte Quellen................. 46

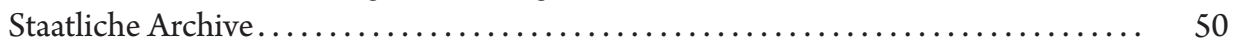

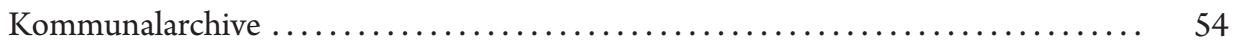

Kirchliche Archive ........................................ 56

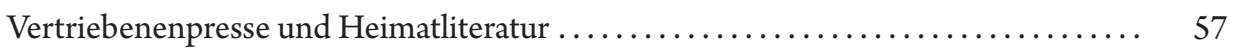

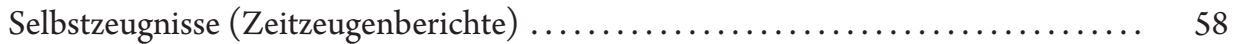

„Senioren“ als Zeitzeugen für Flucht und Vertreibung.................... 61

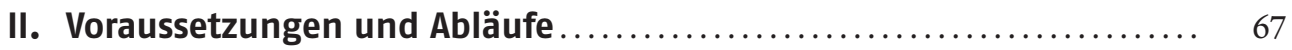

1. Flucht und Vertreibung ......................................... 67

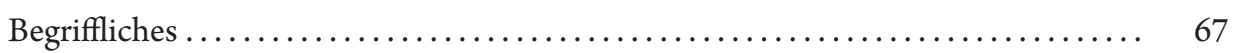

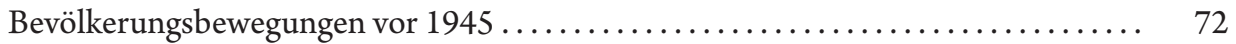

Zwangsevakuierung und Flucht von Januar 1945 bis Kriegsende.............. 78

Flucht Einheimischer westlich von Oder und Neiße $1945 \ldots \ldots \ldots \ldots \ldots \ldots \ldots . \ldots \ldots$

Flüchtlingsbetreuung im Krieg.................................. 119

„Wilde Vertreibungen" im Sommer 1945........................... 128 


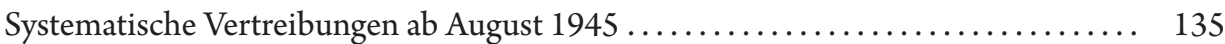

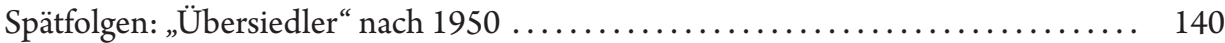

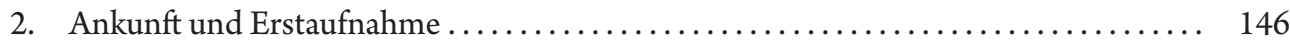

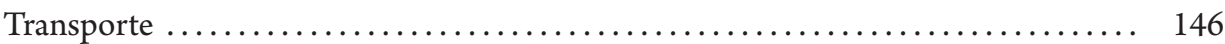

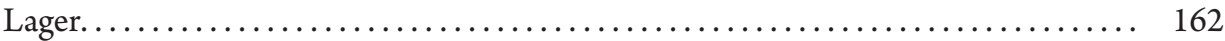

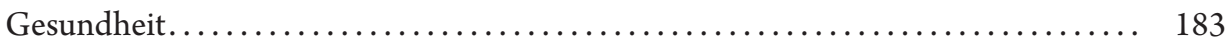

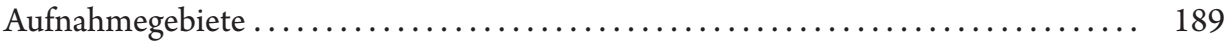

3. Herkunftsgebiete - landsmannschaftliche Differenzierung $\ldots \ldots \ldots \ldots \ldots \ldots \ldots .200$

Neumärker und Niederlausitzer................................ 203

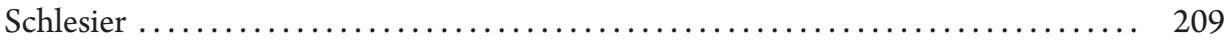

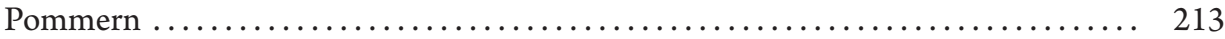

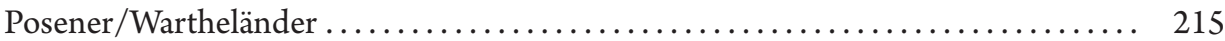

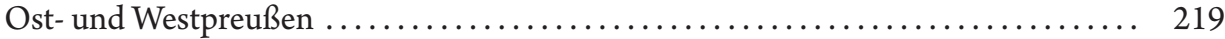

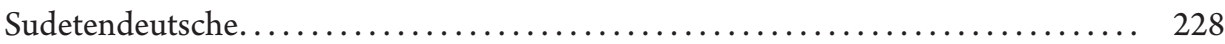

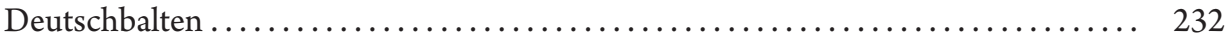

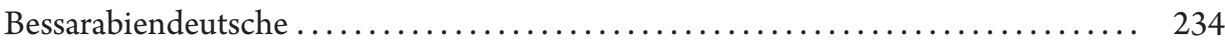

Dobrudschadeutsche........................................ 235

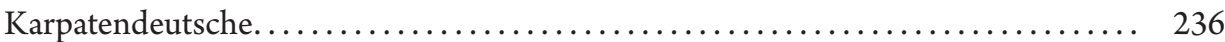

III. Materielle Aspekte - Fürsorge und Integration durch Assimilation ... 239

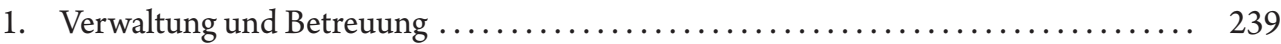

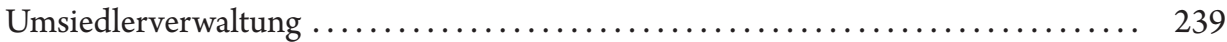

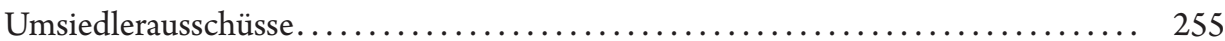

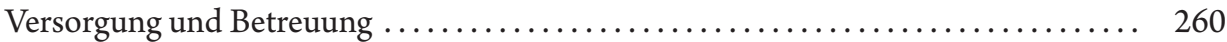

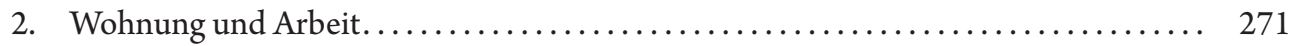

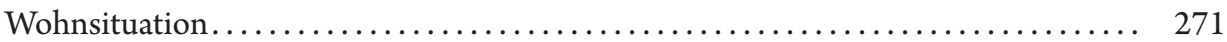

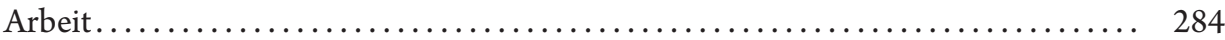

„Umsiedlergenossenschaften“................................... 299

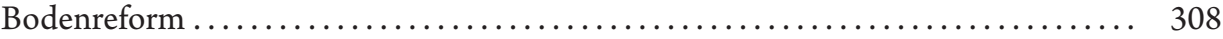

IV. Ideelle Aspekte - Integrationshemmendes und -förderndes........ 319

1. Die „Kalte Heimat" und das öffentliche „Tabu“ ........................ 319

Menschen unter Menschen ..................................... 319

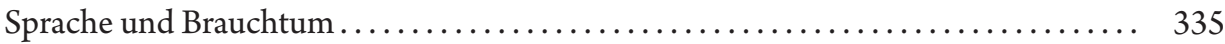

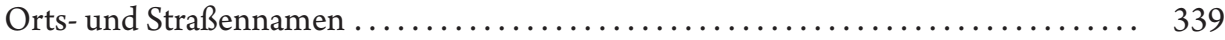

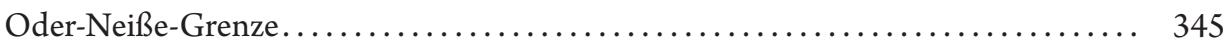

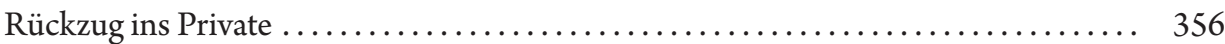


2. „Westkontakte“, illegale Selbstorganisation und Konspiration.............. 364

Teilnahme an Heimattreffen in West-Berlin . . . . . . . . . . . . . . . . . 367

Teilnahme an Heimattreffen in Westdeutschland .................... 377

Lektüre von Heimatzeitschriften und Heimatliteratur. . . . . . . . . . . . . . . . . 388

Vertriebenentreffen und korporative Tendenzen in Brandenburg ............. 405

„Der Tourismus in alte Heimaten blühte“ - Heimwehtourismus I . . . . . . . . . . . 417

Städtepartnerschaften als Patenschaftsersatz?................... 427

3. Die Kirchen und die Vertriebenen........................... 430

Evangelische Kirche..................................... 431

Berlin als Bezugspunkt evangelischer Brandenburger ................. 438

Katholische Kirche...................................... 442

V. Spätzeit - Entwicklungen nach $1989 \ldots \ldots \ldots \ldots \ldots \ldots \ldots \ldots \ldots \ldots . \ldots \ldots 3$

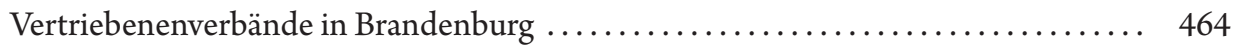

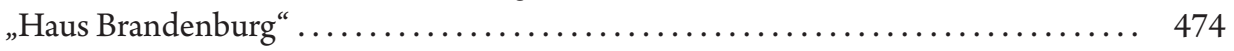

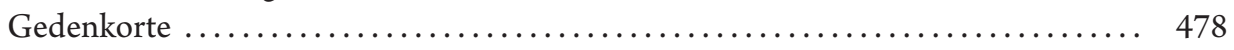

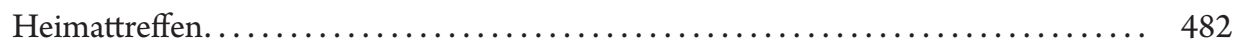

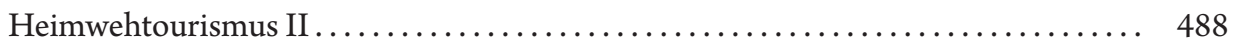

Städtepartnerschaften als Patenschaftsersatz $\ldots \ldots \ldots \ldots \ldots \ldots \ldots \ldots \ldots \ldots \ldots . \ldots \ldots 1$

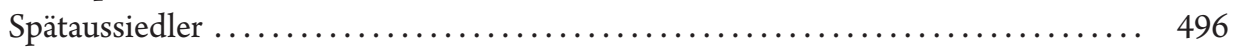

VI. Fazit - Vertriebene in der brandenburgischen Gesellschaft der Gegenwart ...................................... 503 
Teil 2: Ortsdokumentation.

Historische Stätten der Vertriebenenintegration in Brandenburg

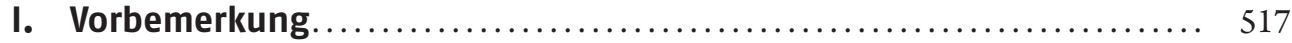

II. Gekürzt zitierte Literatur und Siglen........................ 520

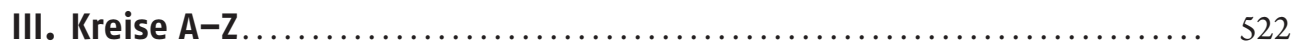

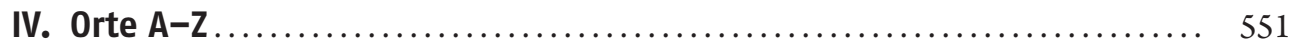

\section{Teil 3: Quellenedition}

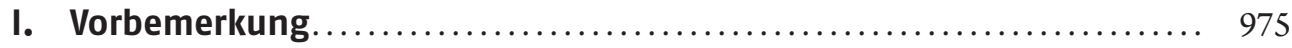

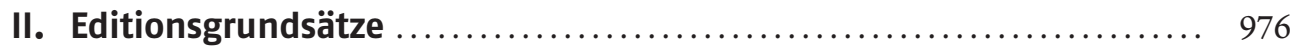

III. Übersicht über die edierten Quellentexte ..................... 977

IV. Quellentexte (1945-2018) ............................... 993

1. Ankunft und Erstaufnahme $(1945-1950) \ldots \ldots \ldots \ldots \ldots \ldots \ldots \ldots \ldots \ldots \ldots \ldots \ldots$

1.1 Flüchtlingsstrom und Vertriebenentransporte $(1945-1949) \ldots \ldots \ldots \ldots \ldots 993$

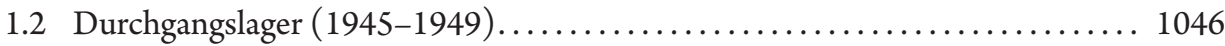

2. Versorgung, Eingliederung, Gleichstellung (1945-1951) .................. 1109

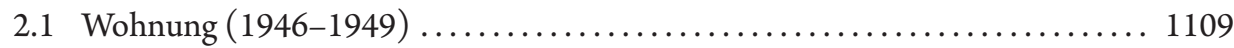

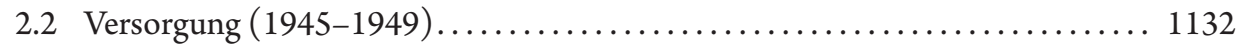

2.3 Eingliederungs- und Gleichstellungsbemühungen (1945-1949).......... 1151

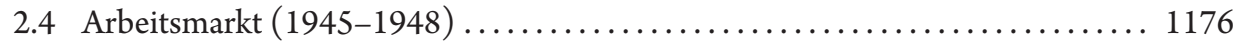

2.5 Bodenreform und Neubauernprogramm (1946-1951) ............... 1217

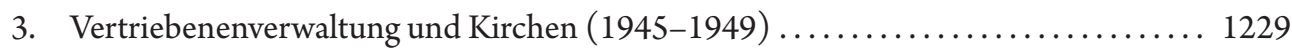

3.1 Provinzial-/Landesregierung, Kreise, Städte und Gemeinden (1946-1949) . . 1229

3.2 Suchdienst für vermißte Deutsche in der SBZ (1946-1949) .............. 1248

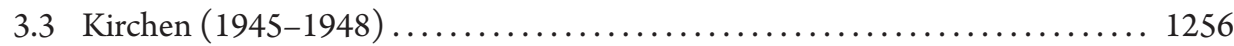

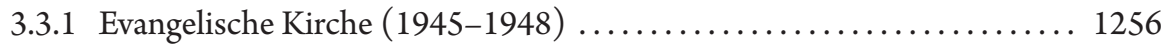

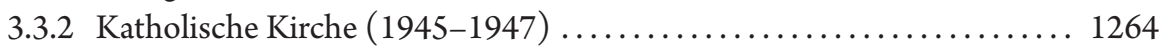


4. Überwachung der Bevölkerung durch Informanten und Volkspolizei (1946-1953) 1281

4.1 Allgemeine und politische Stimmungs- und Informationsberichte (1946-1950) 1281

4.2 Überwachung von Vertriebenentreffen und Kontakten zu westdeutschen Vertriebenenorganisationen $(1947-1953) \ldots \ldots \ldots \ldots \ldots 1338$

5. Aussiedlung Deutscher aus Polen $(1950-1965) \ldots \ldots \ldots \ldots \ldots \ldots \ldots \ldots \ldots \ldots \ldots \ldots \ldots$

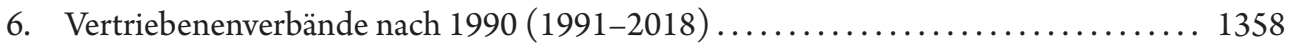

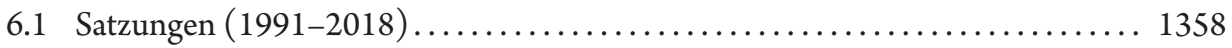

6.2 Protokolle, Berichte und Reden $(1992-2011) \ldots \ldots \ldots \ldots \ldots \ldots \ldots \ldots \ldots$

\section{Anhang}

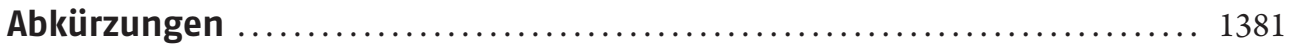

Glossar.................................................... 1390

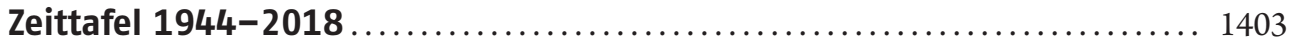

Quellen- und Literaturverzeichnis.............................. 1419

1. Archivalische Quellen ......................................... 1419

2. Gedruckte Quellen......................................... 1420

2.1 Quelleneditionen, archivische Findmittel und Beständeübersichten........ 1420

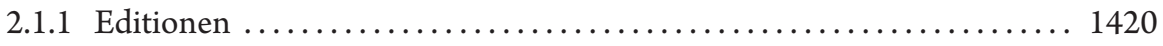

2.1.2 Findmittel und Beständeübersichten ..................... 1423

2.2 Druckschriften der Vertriebenenverbände ........................ 1424

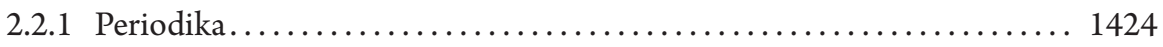

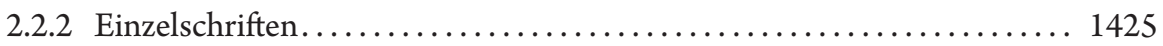

2.3 Sonstige zeitgenössische Druckschriften ..................... 1426

2.4 Erinnerungsberichte und sonstige Selbstzeugnisse.................. 1429

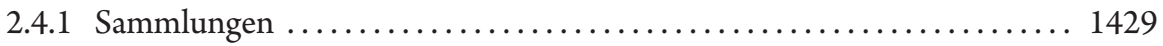

2.4.2 Einzelberichte von Flüchtlingen, Vertriebenen und Spätaussiedlern.... . 1434

2.4.3 Einzelberichte Einheimischer....................... 1472

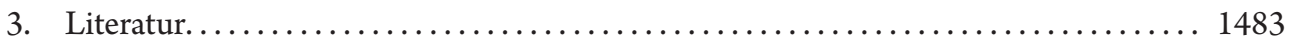

3.1 Nachschlagewerke................................... 1483

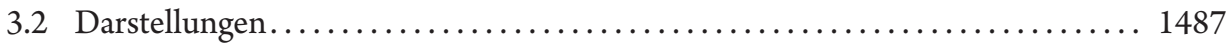




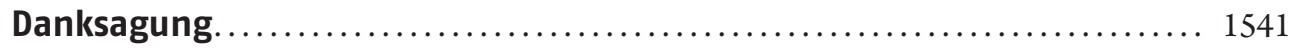

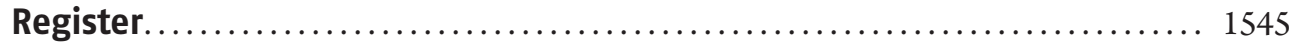

1. Geographisches Register A-Z (mit Ortsnamenkonkordanz) ............... 1545

2. Personenregister ............................................... 1609

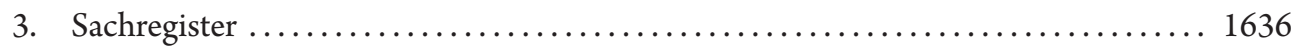




\section{Tabellenverzeichnis}

\section{Tabellen im Teil 1}

Tab. 1: Transporte in das „Umsiedlerlager“ Küchensee $1946-1949 \ldots \ldots \ldots \ldots \ldots \ldots \ldots$...... 150

Tab. 2: Verzeichnis der bis 31. Dezember 1945 erfassten „Umsiedlerlager“

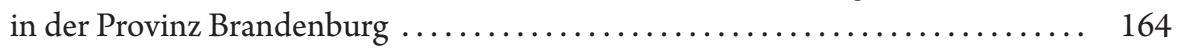

Tab. 3: Verzeichnis der „Umsiedlerlager“ in der Provinz Brandenburg, 30. April 1946 . 166

Tab. 4: Herkunftsgebiete der Vertriebenen in den brandenburgischen Kreisen, Okt. 1946 .

Tab. 5: Herkunftsregionen der Mitglieder des BdV-Kreisverbandes Potsdam 2003 . . . 201

Tab. 6: Aufenthaltsländer von Flüchtlingen aus dem Kreis Friedeberg/Nm., Dez. 1947

Tab. 7: Außerplanmäßig eingesetzte Flüchtlingsgeistliche im Bistum Berlin, 1946 _. . . 447

Tab. 8: Katholische Einwohner ausgewählter brandenburgischer Städte 1925 und 1946

Tab. 9: Brandenburgisch-polnische und -slowakische kommunale Partnerschaften (Auswahl)...

\section{Tabellen im Teil 3}

(22) Gemeindestatistik des Kreises Beeskow-Storkow über Vertriebenenzahl und Zerstörungsgrad. - Bernau, 26. Juli 1946

(23) Gemeindestatistik des Kreises Niederbarnim über Vertriebenenzahl und Zerstörungsgrad. - Bernau, 16. August 1946.

(24) Tabelle der „Herkunftsgebiete der Umsiedler“. - Potsdam, 31. Dezember 1947 



\section{Teil 1 Darstellung}





\section{Einleitung}

\section{Ziele und Methoden}

Dies ist keine Gesamtdarstellung der Geschichte Brandenburgs und seiner Orte und Menschen in den Jahren ab 1945. Es handelt sich vielmehr (nur) um eine Untersuchung zu einem Thema, das allerdings damals die einheimischen Brandenburger sehr beschäftigte, ja sie bisweilen - neben der ohnehin allgemeinen Ernährungsnot und dem Wieder-In-Gang-Bringen des Lebens allerorten beherrschte und oft auch überforderte. Für die in erster Linie Betroffenen, die Flüchtlinge und Vertriebenen selbst, war es ohnehin lebensbeherrschend, wenn nicht lebensbedrohlich. Viele Fragen aber, die die 1945 zum Zusammenleben gezwungene Bevölkerung - Einheimische wie Zugewanderte gleichermaßen - betrafen, müssen notgedrungen ausgespart werden, obgleich sie, will man sich ein vollständiges Bild der Zeit machen, teilweise unmittelbar daneben mitzudenken sind. Vieles betraf die alteingesessene Bevölkerung ebenfalls gravierend, auch wenn sie sich insgesamt in einer ungleich besseren Position befand als die Flüchtlinge und Vertriebenen. In mancher Hinsicht, etwa bei Epidemien, Hunger, Gewalt und dem Oderhochwasser (1947), saß man oft genug vorübergehend im selben Boot. Ein vollständiges Bild der Bevölkerung jener unruhigen frühen Nachkriegsjahre würde zudem nur dann entstehen, wenn man auch die vielen anderen Gruppen einbezöge, die damals in Brandenburg „unterwegs“ waren: die in ihre Heimatorte strebenden ehemaligen Zwangsarbeiter, die während des Bombenkrieges aus Nah und Fern innerhalb Deutschlands inklusive der nunmehrigen Vertreibungsgebiete Evakuierten, die laufend in großer Zahl aus West und Ost zurückkehrenden Kriegsgefangenen und - nicht zuletzt - jene KZ-Opfer, die in den Lagern im Land die nationalsozialistische Gewaltherrschaft gerade noch überlebt hatten.

Je länger der Verfasser sich mit seinem Gegenstand befasste, desto mehr reifte in ihm die Erkenntnis, dass eine dem Schicksal der Flüchtlinge und Vertriebenen in der Kriegs- und Nachkriegszeit Brandenburgs angemessene Darstellung im Grunde nur in einer umfassenden (Zeit-)Geschichte dieses Landes möglich wäre. Ohne den ständigen Blick auf das Ganze, dessen Teil und „Thema“ sie wurden, lässt sich die Situation der Flüchtlinge und Vertriebenen nicht wirklich gewichten. Zwar spiegelt sich z. B. in den eigenen Zeitzeugenberichten der Flüchtlinge und Vertriebenen immer wieder, dass sie vielfach ganz eigene, gruppenspezifische Erfahrungen gemacht haben, doch lässt sich, objektiv betrachtet, keiner ihrer Lebensbereiche angemessen beschreiben und verstehen, wenn er nicht in den Gesamtzusammenhang sowohl der vorausgehenden Geschehnisse als auch des nachkriegszeitlichen Lebens in Brandenburg und der SBZ/ DDR eingeordnet und zusammen mit dem der anderen Bevölkerungsgruppen, der einheimischen und der „unterwegs“ befindlichen, betrachtet wird. Eine zumindest stärkere Einbettung in die allgemeinen und die regionalen Rahmenbedingungen wäre insofern für das Verständnis wichtig, kann aber auch hier beim besten Willen nur ansatzweise geleistet werden.

Zum einen ist der zeitgeschichtliche Forschungsstand gerade für Brandenburg - trotz einzelner herausragender Arbeiten - noch zu rudimentär. Das betrifft die Nachkriegszeit ins- 
gesamt, ganz besonders aber die Vertriebenenthematik. Nur letztere sollte und konnte hier - in einem Rahmen, der dem Verfasser ohnehin auch formal enge Grenzen setzte - in Angriff genommen werden. Insofern sind viele Kapitel nicht viel mehr als erste Versuche, eine Bilanz des bisher Bekannten zu ziehen, dieses Wissen erstmals gebündelt und aufbereitet zu präsentieren. Das Hauptanliegen des Verfassers ist es folglich, dem Thema überhaupt im brandenburgischen Rahmen eine Ausgangsbasis für die künftige Forschung zu verschaffen und die Beschäftigung mit ihm - innerhalb, aber auch außerhalb der Wissenschaft - deutlich zu erleichtern. Vieles wird erst nach - für die Zukunft wünschenswerten, ja notwendigen - tiefergehenden Einzelforschungen, die nur von mehreren Personen parallel zu leisten sind, erschöpfend darstellbar sein. Vorerst geht es darum, den Nachholbedarf, den Brandenburg im Vergleich mit den anderen neuen Bundesländern ganz eindeutig aufzuweisen hat, mit einer Zwischenbilanz und einer Überblicksdarstellung, die zugleich eine Materialsammlung mitliefert, zu decken.

Der Verfasser (geb. 1963 Bielefeld), wissenschaftlich formal in der Frühen Neuzeit sozialisiert, versteht sich jedoch seit jeher als Landeshistoriker, der folglich Entwicklungen in bestimmten Räumen über längere Zeiträume bzw. über die gesamte Geschichte hinweg betrachtet. Ihm ist es daher ein zentrales Anliegen, die Geschehnisse von Flucht, Vertreibung und Integration nicht in erster Linie mit dem zumeist überregionalen Blick des Zeithistorikers zu betrachten, der seine Erkenntnisse an einem zusätzlichen, bislang weitgehend fehlenden Fallbeispiel weiter zu differenzieren sucht. Es geht ihm vielmehr darum, das Thema - zumindest auch - in die (brandenburgische) Landesgeschichte einzuführen, es in ihr zu verankern, da diese sonst unvollständig bleiben muss. Auch deshalb wird der Vor- und vor allem Nachgeschichte der Ereignisse der frühen Nachkriegsjahre größere Beachtung geschenkt, als dies in den meisten Arbeiten zur Vertreibung - wenn auch glücklicherweise inzwischen nicht mehr überall - geschieht. Landesgeschichte wird dabei als Oberbegriff verstanden, der Regional- und Ortsgeschichte einschließt. ${ }^{3}$ Auch bei letzteren liegen die Desiderate offen zu Tage und soll ihnen wenigstens eine neue Ausgangsbasis für viele künftig noch zu schreibende lokale Fallstudien geboten werden.

Ohne die in den letzten Jahren erschienenen - für den Verfasser als Grundlage und „Vorarbeiten" unverzichtbaren - Studien auf die SBZ/DDR spezialisierter Zeithistoriker wäre die Erarbeitung dieser Studie kaum möglich gewesen. Die inzwischen vielerorts geradezu boomende Erforschung der Vertriebeneneingliederung in der SBZ/DDR darf jedoch nicht begrenzt bleiben auf zwei gleichsam ihren jeweiligen Binnen-Diskurs führende Netze, das der Zeithistoriker und das der Vertriebenenverbände, die diese Forschungen ungeduldig verfolgen. Auch deshalb wurde großer Wert darauf gelegt, nicht nur eine Überblicksdarstellung zu liefern, die Festschrift auf 20 Jahre Die Mark Brandenburg. Hrsg. von Marcel Piethe. Berlin 2010, S. 132-138. - Ders.: Landesgeschichte in Berlin-Brandenburg heute. Institutionelle Anbindungen, Organisationsformen und Perspektiven. In: Landesgeschichtliche Vereinigung für die Mark Brandenburg. Mitteilungsblatt 110 (2009), S. 15-20. 
vom Berliner Schreibtisch aus - mal in diese, mal in jene Himmelsrichtung der „Provinz “ blickt, sondern ein im ganzen Land brauchbares und - auch für Schulen und Museen - hilfreiches Nachschlagewerk. Denn der Zweck eines Buches zu einem solchen, nach wie vor kontrovers diskutierten Thema kann nicht allein im wissenschaftsinternen Austausch liegen, er muss - wenigstens als Möglichkeit - auch der gegenwärtigen und zukünftigen Gesellschaft des Landes Brandenburg und der seiner Regionen und Kommunen dabei helfen, mit einem weiteren Teil ihrer Vergangenheit ins Reine zu kommen. Das erfordert letztlich z. B. auch, das Vertriebeneneingliederungsthema in die Erinnerungsarbeit und Gedenkkultur von Kommunen stärker zu integrieren und es in Dauerausstellungen von lokalen und regionalen Museen aufzunehmen. Dieses Ziel im Auge zu behalten hat 2009 z. B. auch die Landesgeschichtliche Vereinigung für die Mark Brandenburg e. V. angemahnt, als sie in ihrer Stellungnahme zum - unten noch näher behandelten - die zeitgeschichtliche Erinnerungskultur in Brandenburg kritisch beleuchtenden und ordnenden Papier des Ministeriums für Wissenschaft, Forschung und Kultur (MWFK) des Landes Brandenburg schrieb: „Uns erscheint es sehr wichtig, dass die Zeitgeschichte nicht allein in den - zweifellos zentralen - ihr in erster Linie dienenden und für ihre Aufarbeitung geschaffenen Institutionen betrieben und [S. 22] vermittelt wird. Vielmehr sollten dabei darüber hinaus stets auch jene Einrichtungen, die für die Bevölkerung wie für die Wissenschaft (Landes-) Geschichte insgesamt vermitteln, Beachtung finden. Es besteht sonst - sowohl in der ohnehin zur Spezialisierung neigenden Wissenschaft als auch im stark nach Interesse auswählenden Publikum - die Gefahr, dass gerade die Zeitgeschichte zwischen Preußen und Fontane, Schlössern und Feldsteinkirchen zu kurz kommt, wenn wir nicht dafür sorgen, dass sie bei der Formulierung und Formung von Aussagen, Publikationen und Veranstaltungen zur gesamten (Landes-) Geschichte allgemein stärker berücksichtigt wird.' (aus der E-Mail des Vorsitzenden an das MWFK vom 25. Februar 2009).“4

Der geographische und verwaltungsgeschichtliche Untersuchungsrahmen ist durch die Grenzen der Provinz Brandenburg im Jahr 1945 als Ausgangspunkt vorgegeben. Änderungen am territorialen Bestand, wie sie sich in der Folge ergeben haben, mussten weitgehend unberücksichtigt bleiben. ${ }^{5}$ Integration und Rolle der Flüchtlinge und Vertriebenen in Berlin wiederum bilden ein eigenes, vielschichtiges und den hier (vorgegebenen) Rahmen sprengendes Thema, das gesonderte Untersuchungen erforderte und hier - leider - weitgehend ausgespart werden muss. ${ }^{6}$ Einbezogen wird es nur, wenn unmittelbaren Berlin-Beziehungen zu den in

4 Hier zitiert nach: Hinweis der Schriftleitung zu: Petra Haustein: Geschichte vor Ort: Erinnerungskultur im Land Brandenburg für die Zeit von 1933 bis 1990 (Konzept der Landesregierung). In: Landesgeschichtliche Vereinigung für die Mark Brandenburg. Mitteilungsblatt 111 (2010), 21-22, hier S. $21 \mathrm{f}$.

5 Siehe aber die Hinweise im Vorspann zu Teil 2.

6 Siehe vorläufig den mehr auf Berlin als auf Brandenburg konzentrierten Überblick von Wolfgang Ribbe: Flüchtlinge - Vertriebene - Displaced Persons. Ihre Aufnahme, Weiterleitung bzw. Eingliederung in Berlin und Brandenburg bei Kriegsende 1945. In: Schaufenster der Systemkonkurrenz. Die Region Berlin-Brandenburg im Kalten Krieg. Michael Lemke (Hg.) (Zeithistorische Studien, Bd. 37). Köln u. a. 2006, S. 145162. - Ferner die Fallstudie auf Bezirksebene: Jürgen Hofmann: Heimatverlust und Neuanfang 1945/46. In: 
Brandenburg lebenden Vertriebenen nachgegangen wird, wie etwa dem Besuch von Treffen. Um ein umfassendes Verständnis der Geschehnisse im Gesamtraum zu gewinnen, wird man freilich Berlin immer einbeziehen und sich hüten müssen, die heute verbreitete, nur durch die heutigen Landesgrenzen und Organisationsformen der Forschung naheliegende Einteilung rückwärts - auf die Lebenswelt der Zeitgenossen der Nachkriegszeit - zu projizieren. Da der Forschungsstand für Berlin noch dünner ist als für Brandenburg, war die hier vollzogene Beschränkung auf Letzteres jedoch ohnehin zwingend.

Methodisch verfolgt die Arbeit im darstellenden Teil das Ziel, die Geschehnisse sowie die Erlebnisse und Empfindungen der Zeitgenossen nach Möglichkeit quellennah und multiperspektivisch zu betrachten. Das heißt, die dem Historiker - in ihrem zielorientierten Blick - allzu leicht indirekt die Feder führende zeitgenössische Verwaltung, deren Akten zweifellos eine unverzichtbare Grundlage bieten, wird durch eine große Zahl zeitgenössischer und nachträglicher Zeitzeugenberichte ergänzt. Diese können zwar ebenso wenig Realität objektiv abbilden, ihre möglichst häufige Einbeziehung hilft aber immerhin zu vermeiden, in eine einseitige Abhängigkeit von der Sicht der Behörden zu geraten - und umgekehrt. Ferner werden nach Möglichkeit die Zeitzeugenberichte von Flüchtlingen und Vertriebenen durch Aussagen aus entsprechenden zeitgenössischen oder nachträglichen Zeitzeugenberichten Einheimischer ergänzt, so dass immer wieder die Perspektiven der Aufnahmegesellschaft (Verwaltung und z.B. Quartiergeber, Nachbarn usw.) und der Hinzugekommenen wechseln. „Belastung“ und „Bereicherung“ werden also keineswegs nur als einseitige Wahrnehmungsbegriffe der Aufnahmegesellschaft betrachtet, sondern ebenso der „zur Unzeit“ eintreffenden Zuwanderer, die sich ihres Wertes in einer fremden, oft distanzierten Umwelt bisweilen erst wieder bewusst werden mussten, um ihr Bereicherungspotential ausschöpfen zu können.

Was den Quellenwert der Selbstzeugnisse angeht, so ist er bekanntlich durch die üblichen Faktoren bestimmt und eingeschränkt. Genannt seien beispielsweise nur die in der Person des jeweiligen Verfassers liegenden Voraussetzungen oder die Frage des zeitlichen Abstandes zum Geschehen bei Abfassung des Erinnerungstextes. Abgesehen von der - besonders bei gedruckten Selbstzeugnissen nicht immer vollständig möglichen - quellenkritischen Hinterfragung wurde jedoch stets versucht, die jeweiligen Aussagen durch Vergleich mit anderen Selbstzeugnissen und durch Konfrontation mit amtlichen Dokumenten und Literatur auf ihre Glaubwürdigkeit zu prüfen. Dabei treten zwar ebenso beliebte wie fragwürdige Flucht-Topoi zu Tage, wie der vom „letzten Zug“ oder „letzten Transport“, den viele genau zu kennen glaubten, aber ande-

Besiedlung, Bevölkerung, Migration. Hrsg.: Heimatverein Marzahn-Hellersdorf e. V. Red.: Christa Hübner u. a. (Beiträge zur Regionalgeschichte, 13). Berlin 2016, S. 89-101, 186-188. - Aus der Geschichte der Vertriebenen in Berlin. Hrsg.: Berliner Landesverband der Vertriebenen e. V. Berlin-Charlottenburg (1954). 35 S. [Nur Kurzdarstellungen der Landesverbände der einzelnen Landsmannschaften in West-Berlin]. - Wille I (wie Anm. 196), S. 125-127. - Akten der Zentralverwaltung für deutsche Umsiedler: BArch, DDO 2/37: Kontrollen, Berichte und Informationen über „Umsiedlerlager“ in Berlin, 1945-1949; BArch, DDO 2/28: Berichterstattung der Abteilungen Umsiedler der Landes- und Provinzialregierungen, hier Berlin, 1945-1948, enthält u. a.: Lagerordnung für Umsiedlerlager in Berlin, Magistratsvorlage über den Such- und Meldedienst. 
rerseits schärft sich der Blick des Lesers dieser Zeitzeugenberichte und lernt er spätestens nach dem hundertsten Text, die „Spreu vom Weizen“ zu trennen. Eine Darstellung, die auf solche Berichte Betroffener verzichten wollte, würde viele Bereiche des Alltagslebens und der mentalen Verarbeitung des Geschehenen kaum angemessen in den Blick nehmen können.

Der alle Quellentypen einbeziehenden Überblicks- bzw. Gesamtdarstellung (Teil 1) schließt sich ein konkreter Blick auf alle einzelnen Landkreise und vor allem sämtliche Städte sowie ausgewählte Gemeinden an (Teil 2), der vor allem zu Nachschlagezwecken dienen und letztlich Desiderate offen legen soll, aber auch Vergleiche ermöglicht. ${ }^{7}$ Das hier verwendete Prinzip, Zitate aus Quellen und Literatur gleichsam werkstattartig unverbunden wiederzugeben und dem Leser die Zusammenschau zu überlassen, wird wegen der Unmöglichkeit, hier und heute für jeden Ort eine schlüssige Entwicklungsgeschichte zu präsentieren, angewandt. Angesichts des für die einzelnen Kommunen noch überwiegend dürftigen Forschungsstandes soll vielmehr nicht durch vorschnelle Zusammenfassung ein abgerundetes Bild der Geschehnisse vorgegaukelt, sondern vielmehr der weiteren Lokalforschung eine ungewertete, sozusagen ungeschönte Basis und damit auch ein Anreiz geboten werden. Die Edition ausgewählter Quellentexte schließlich (Teil 3) bietet zum einen die Möglichkeit, das im Teil 1 oft notgedrungen verkürzend und verallgemeinernd Gesagte zumindest an Beispielen aus der großen Masse des überlieferten und auf Auswertung wartenden Verwaltungsschriftguts näher zu betrachten, zum anderen wird mit diesen amtlichen Dokumenten wiederum auch für die Arbeit von Schulen, Museen und besonders Studierenden eine Basis zur eigenen, „entdeckenden“ Beschäftigung mit der Thematik geschaffen. ${ }^{8}$ Der Nutzung als Nachschlagewerk und nicht zuletzt als Ausgangsbasis für kleinerräumige Fallstudien sollen ferner die im Anhang beigegebenen Informationen dienen. Neben einem die bisweilen sehr nahe beieinander liegenden, leicht irritierenden Begriffe erklärenden Glossar bietet vor allem das Verzeichnis der gedruckten Quellen mehr als nur Rechenschaft über das für Teil 1 und 2 Ausgewertete, sondern zugleich einen Katalog ausgewählter Selbstzeugnisse (Tagebücher, Erinnerungen u. ä.) sowohl von Vertriebenen als auch von Einheimischen, denen daher nach Möglichkeit jeweils Informationen zur Person des Verfassers und zum Inhalt bzw. Lebensweg beigefügt sind. Diese sind zudem in den Registern berücksichtigt, so dass der - im Buch nur teilweise geleisteten - weiteren sachthematisch oder geographisch orientierten Auswertung vielfältige Zugriffswege eröffnet werden.

Die Darstellungskapitel des Teils 1 sind entsprechend dem brandenburgischen Forschungsstand - anders als manche grundsätzlich vergleichbare Arbeit - weniger darauf gerichtet, alle für die SBZ/DDR bereits hinlänglich bekannten Abläufe und Verhaltensmuster nun nochmals am Beispiel Brandenburgs abzuspulen, als vielmehr die brandenburg-spezifischen Fragen und Desiderate oder zumindest noch zu selten behandelte Aspekte zu betonen. Dies hat auch Auswirkungen auf die unterschiedliche Länge der Kapitel. So werden in der ausführ- 
lichen Einleitung (Kapitel I) nicht nur der Forschungsstand im engeren Sinne - brandenburgspezifisch - analysiert und diskutiert, sondern auch die Frage der Einbeziehung des Themas in die Erinnerungskultur von der Landesregierung bis hin zur lokalen Seniorenarbeit. Das Kapitel II (Voraussetzungen und Abläufe) liefert neben den für das Verständnis der in den folgenden Kapiteln beleuchteten Fragen notwendigen Fakten erstmals den Versuch, Vertriebene nicht als scheinbar gleichförmige Gruppe zu sehen, sondern beispielsweise nach ihrer landsmannschaftlichen Herkunft und Prägung zu differenzieren. Die Kapitel III und IV schließlich sind den Kardinalfragen der Integration gewidmet. Materielle Aspekte wie die Versorgung mit Wohnraum und Arbeit werden hier bewusst von den immateriellen, ideellen getrennt behandelt, auch wenn es zwischen beiden gewiss Überschneidungen geben mag. Denn der ideelle Bereich, also all das, womit der einzelne Vertriebene in den privaten Raum und seine Erinnerungskultur in das „Familiengedächtnis“ verwiesen wurde, sind entscheidend für die Fragen nach den lange nachwirkenden Tabus, die heute immer mehr gestellt werden. Letztlich entscheidet sich nämlich anhand dieser - zugegeben groben - Einteilung für viele Betroffene die Frage nach dem Gelingen, dem Gelungensein von Integration. Ließen sich die materiellen Fragen früher oder später „klären“, kamen die „ideellen“ spätestens nach 1990 wieder an die Oberfläche und beschäftigen inzwischen selbst Nachgeborene in der dritten Generation. Dies leitet über zum letzten Kapitel (V), das darauf verweist, dass das Thema der Vertriebenenintegration nicht nur eines der (frühen) Nachkriegsjahre war, sondern viele Betroffene bis heute beschäftigt und nicht zuletzt im 1990 wieder errichteten Land Brandenburg seine Bedeutung für die Gesellschaft nicht verloren hat. Daher wurde der ursprünglich zeitlich begrenztere Zeitraum ${ }^{9}$ ganz bewusst - wenn auch weiterhin beginnend (erst) mit den Hauptströmen der Flüchtlinge im Jahr 1945 - ohne zeitlichen Abschluss gefasst.

Quellenzitate und Quellenbegriffe sind in den darstellenden Teilen 1 und 2 der Arbeit stets kursiv gesetzt. Im Teil 3 (Quellenedition) hingegen sind die - dort überwiegenden - Quellentexte normal gesetzt, Kursivierung dient dort abweichend (!) der Wiedergabe von Hervorhebungen in der Vorlage. ${ }^{10}$ Ein Schrägstrich / steht im normalen Textzitat für einen nicht wiedergegebenen Absatz, bei Inschriften jedoch für Zeilenumbruch, während dann // einen Absatz markiert. nen-in-brandenburg-nach-1945 [11.7.2017]: „Ziel des Projektes ist die Erarbeitung einer wissenschaftlichen monographischen Darstellung der Ereignisse, Abläufe und Schauplätze der Integration von Flüchtlingen und Vertriebenen in Brandenburg 1945-1952." 


\section{Forschungsstand und Stellenwert des Themas in der Erinnerungskultur}

\section{Zeitgeschichte als historische Disziplin}

„Das Schicksal von über 4,3 Millionen Vertriebenen oder 24,3\% der Gesamtbevölkerung der damaligen Sowjetischen Besatzungszone, die das schwere Los der Vertreibung traf, steht erst am Anfang seiner historischen Aufarbeitung." ${ }^{11}$ Dieser 1995 im Begleitband zu einer Berliner Ausstellung formulierte Satz gilt inzwischen zwar nicht mehr für die Gesamt-SBZ/DDR, seitdem grundlegende quellengestützte Untersuchungen, wie vor allem die von Heike Amos (geb. 1962 Berlin) ${ }^{12}$, Michael Schwartz (geb. 1963 Recklinghausen) ${ }^{13}$, Philipp Ther (geb. 1967 Mittelberg/Österreich) ${ }^{14}$ und schon zuvor die einschlägigen Aufsätze und Sammelbände sowie die Quellensammlung von Manfred Wille (geb. 1934 Magdeburg) ${ }^{15}$, vorgelegt werden konnten. ${ }^{16}$ Er gilt jedoch noch immer, blickt man auf die Situation in einzelnen Ländern, Regionen, Krei-

11 Wolfgang Meinicke: Die Aufnahme von Vertriebenen in der Sowjetischen Besatzungszone Deutschlands. In: „Wach auf, mein Herz, und denke“. Zur Geschichte der Beziehungen zwischen Schlesien und Berlin-Brandenburg von 1740 bis heute. Hrsg.: Gesellschaft für interregionalen Kulturaustausch e. V., Berlin, u. Verein Schlesisches Institut, Oppeln. Berlin/Opole 1995, S. 475-487, hier S. 475.

12 Heike Amos: Die Vertriebenenpolitik der SED 1949 bis 1990. München 2009. 296 S. (Schriftenreihe der Vierteljahrshefte für Zeitgeschichte, Sondernr.). - Dies.: Vertriebenenverbände im Fadenkreuz. Aktivitäten der DDR-Staatssicherheit 1949 bis 1989 . München 2011. VI, 321 S. (Schriftenreihe der Vierteljahrshefte für Zeitgeschichte, Sondernr.).

13 Habil.-Schr. Münster 2001: Michael Schwartz: Vertriebene und „Umsiedlerpolitik“. Integrationskonflikte in den deutschen Nachkriegs-Gesellschaften und die Assimilationsstrategien in der SBZ/DDR 1945-1961. München 2004. X, 1247 S. (Quellen und Darstellungen zur Zeitgeschichte, Bd. 61). - Für die zahlreichen einschlägigen Aufsätze von M. Schwartz siehe das Literaturverzeichnis.

14 Diss. FU Berlin 1997: Philipp Ther: Deutsche und polnische Vertriebene. Gesellschaft und Vertriebenenpolitik in der SBZ/DDR und in Polen 1945-1956. Göttingen 1998. 382 S. (Kritische Studien zur Geschichtswissenschaft, Bd. 127). - Ders.: Vertriebenenpolitik in der Sowjetischen Besatzungszone und der DDR 1945 bis 1953. In: Vertreibung, Neuanfang, Integration. Erfahrungen in Brandenburg. Christoph Kleßmann / Burghard Ciesla / Hans-Hermann Hertle (Hrsg.) (Protokolle). Potsdam 2001, S. 89-111. - Für die zahlreichen weiteren Aufsätze Thers siehe unten Anm. 49 sowie das Literaturverzeichnis.

15 Wille hat sich als Zeithistoriker seit den siebziger und verstärkt seit den achtziger Jahren an der Pädagogischen Hochschule Magdeburg mit den „Umsiedlern“ befasst und konnte dies mit mehreren Mitarbeiter und Schülern (siehe unten Anm. 17, 19, 20, 25) für einige Jahre zu einem Forschungsprojekt ausbauen, das über die Wende von 1989 hinaus betrieben wurde. Sein Verdienst liegt nicht zuletzt vor wie nach 1989/90 in der Anregung und Betreuung mehrerer Diplomarbeiten und Dissertationen zu Regional- bzw. Fallstudien. Für Willes zahlreiche eigene Aufsätze siehe das Literaturverzeichnis. Zu den Magdeburger Forschungen siehe den eigenen Rückblick in: Manfred Wille: Die „Umsiedler“-Problematik in der DDR-Geschichtsschreibung. In: Sie hatten alles verloren. Flüchtlinge und Vertriebene in der sowjetischen Besatzungszone Deutschlands. Hrsg. von Manfred Wille, Johannes Hoffmann u. Wolfgang Meinicke (Studien der Forschungsstelle Ostmitteleuropa an der Universität Dortmund, Bd. 13). Wiesbaden 1993, S. 159-177.

16 Im 2017 vorgelegten Konzept für die Dauerausstellung der Stiftung „Flucht, Vertreibung, Versöhnung“ in Berlin wird zwar überwiegend die bundesrepublikanische Situation beschreibend zugrundegelegt, aber an meh- 
sen, Städten oder Gemeinden. Vor allem gilt er nach wie vor für Brandenburg (und auch für Berlin). Für Brandenburg werden zwar mit der vorliegenden Arbeit ein zusammenfassender Überblick und eine Datensammlung geliefert, die den Forschungsstand bilanzieren, doch der Nachholbedarf ist so groß, dass dies eigentlich erst die Ausgangsbasis für weitere, tiefergehende Regional- und Fallstudien zu Städten, Gemeinden, Kreisen oder thematischen Teilaspekten sein kann. Diese Situation ergibt sich zwar zum einen aus der bekannten Tabuisierung des Themas in der gesamten DDR vor 1990, die Gründe sind aber - mit dem genaueren Blick auf Brandenburg - auch in Versäumnissen der Jahrzehnte nach 1990 zu suchen.

So ist Brandenburg das letzte der neuen Bundesländer, in dem nun eine Überblicksdarstellung vorgelegt wird, obgleich sich im Land seit langem universitäre und außeruniversitäre zeitgeschichtliche Forschungseinrichtungen befinden. Während in Westdeutschland bereits vor 1990 zahlreiche regionale und lokale Fallstudien erschienen sind und das Thema nach 1990 auch in Sachsen-Anhalt ${ }^{17}$, Sachsen $^{18}$, Mecklenburg-Vorpommern ${ }^{19}$ und Thüringen ${ }^{20}$, meist im

reren wichtigen Stellen werden auch die Unterschiede zur Lage der Vertriebenen in der DDR angesprochen (Stiftung Flucht, Vertreibung, Versöhnung. Konzept für die Dauerausstellung. Berlin 2017, S. 17, 42 f., 45).

Diss. Magdeburg 1997: Torsten Mehlhase: Flüchtlinge und Vertriebene nach dem Zweiten Weltkrieg in Sachsen-Anhalt. Ihre Aufnahme und Bestrebungen zur Eingliederung in die Gesellschaft. Münster 1999. 454 S. (Geschichte, Bd. 22). - Ders.: Die SED und die Vertriebenen. Versuche der politischen Einflußnahme und der „Umerziehung“ in den ersten Nachkriegsjahren in Sachsen-Anhalt. In: Sie hatten alles verloren (wie Anm. 15), S. 159-177.

18 Manfred Jahn: Auffang- und Quarantänelager 1945/46 in Sachsen - Zeitweilige Stationen vertriebener Sudetendeutscher nach ihrer Ankunft in der Sowjetischen Besatzungszone. In: Sächsiche Heimatblätter 39 (1993), S. 248-255. [Eine vergleichbare Arbeit (Oehlsen, Vertriebenenlager [wie Anm. 45]) erschien in Brandenburg erst 2006, in der die Erfassung und Lokalisierung möglichst aller Lager jedoch nicht Ziel war, was bei Jahn bereits versucht wurde]. - Irina Schwab: Flüchtlinge und Vertriebene in Leipzig 1945 bis zum Beginn der 50er Jahre. Leipzig 1999. 140 S. - Diss. Leipzig 2000: Notker Schrammek: Alltag und Selbstbild von Flüchtlingen und Vertriebenen in Sachsen 1945-1952. Frankfurt am Main u. a. 2004. 343 S. (Europäische Hochschulschriften, Reihe 3, Bd. 990). - Diss. Leipzig 2001: Irina Schwab: Flüchtlinge und Vertriebene in Sachsen 1945-1952. Die Rolle der Kreis- und Stadtverwaltungen bei Aufnahme und Integration. Frankfurt am Main u. a. 2002. 340 S. (Europäische Hochschulschriften, Reihe 3, Bd. 927); dies.: „Neue Heimat - neues Leben“? - Diss. Leipzig 2003: Christian Kurzweg: Die Vertriebenenpolitik der Liberal-Demokratischen Partei Deutschlands. Das Beispiel Sachsen 1945-1950. Hamburg 2004. 407 S. (Schriftenreihe Studien zur Zeitgeschichte, Bd. 41). - Diss. Leipzig 1999: Stefan Donth: Vertriebene und Flüchtlinge in Sachsen 1945 bis 1952. Die Politik der sowjetischen Militäradministration und der SED. Köln/Weimar/Wien 2000. XIV, 470 S. (Geschichte und Politik in Sachsen, Bd. 15). - Diss. Leipzig 2009: Ulrike Winterstein: Vertriebener Klerus in Sachsen 1945-1955. Paderborn u. a. 2010, 288 S. (Veröffentlichungen der Kommission für Zeitgeschichte, Reihe B: Forschungen, Bd. 118). - Diss. Leipzig 2012: Markus Wustmann: „Vertrieben, aber nicht aus der Kirche“? Vertreibung und kirchliche Vertriebenenintegration in SBZ und DDR am Beispiel der Evangelisch-Lutherischen Landeskirche Sachsens 1945 bis 1966. Leipzig 2013. 690 (Geschichte und Politik in Sachsen, Bd. 30). - Siehe auch: Manfred Jahn: Zur sächsischen Spezifik der Aufnahme von vertriebenen Deutschen 1945 bis 1949. Das Fallbeispiel Uranbergbau. In: Geglückte Integration? Spezifika und Vergleichbarkeiten der Vertriebenen-Eingliederung in der SBZ/DDR. Hrsg. von Dierk Hoffmann u. Michael Schwartz (Schriftenreihe der Vierteljahrshefte für Zeitgeschichte, Sondernr.). München 1999, S. 215-229. - Stefan Donth / Christian Kurzweg/Notker Schrammek/Irina Schwab: Aufnahme und Integration von Flüchtlingen und Vertriebenen in Sachsen von 
Rahmen von Dissertationen, untersucht worden ist, lässt sich weder in Brandenburg noch in Berlin, mithin an fünf Universitäten, die Vergabe eines solchen Themas oberhalb der Magisterbzw. Masterebene ermitteln. ${ }^{21}$ Nur als ein Aspekt neben anderen erscheint das Thema in der breiten Literatur zu Bodenreform und Neubauern. ${ }^{22}$ Auch die Fragen der (Spät-)Aussiedler-

1945 bis 1952 - Vorstellung eines Forschungsprojekts. In: Geglückte Integration? (wie vor), S. 347-364. Lars-Arne Dannenberg: Flucht und Vertreibung im Zittauer Zipfel 1945 bis 1950. In: Sächsische Heimatblätter 62 (2016), S. 155-162. - Für Sachsen liegt außerdem seit 2005 eine Quellenedition zum Thema vor (siehe Anm. 199).

19 Diss. Greifswald 2001: Martin Holz: Evakuierte, Flüchtlinge und Vertriebene auf der Insel Rügen 1943-1961. Köln 2003. XIII, 677 S. (Veröffentlichungen der Historischen Kommission für Pommern, Reihe V: Forschungen, Bd. 39). [Auch vergleichend zum Umland, z. B. Stralsund]. - Diss. Magdeburg 2006: Michael Richard Rusche: Die wirtschaftliche und soziale Eingliederung der Vertriebenen in Mecklenburg-Vorpommern, 1945 bis 1949. Magdeburg 2006. 274 Bl. [Masch.]. - Diss. Rostock 2009: Mirjam Seils: Die fremde Hälfte. Aufnahme und Integration der Flüchtlinge und Vertriebenen in Mecklenburg nach 1945. Schwerin 2012. 315 S. - Damian van Melis: „Angabe nicht möglich“ - Integration statt Entnazifizierung der Flüchtlinge in MecklenburgVorpommern. In: Geglückte Integration? (wie Anm. 18), S. 161-170.

20 Diss. Magdeburg 1989: Steffi Kaltenborn: Die Lösung des Umsiedlerproblems auf dem Territorium der Deutschen Demokratischen Republik, dargestellt am Beispiel des Landes Thüringen (1945-1948). Magdeburg 1989. [Die Verfn. hat auch nach 1989 in mehreren Aufsätzen weiter zum Thema in der SBZ/DDR und in Thüringen publiziert.] - Manfred Wille: Gehasst und umsorgt. Aufnahme und Eingliederung der Vertriebenen in Thüringen. Hrsg.: Bund der Vertriebenen, Landesverband Thüringen e. V. Stadtroda 2006. 174 S. (Edition Zeitgeschichte). - Uta Bretschneider: Neue Heimat Thüringen? Flüchtlinge und Vertriebene um 1945. Erfurt 2016. 93 S. (Hrsg.: Landeszentrale für politische Bildung Thüringen). - Diss. Jena 2014: Dies.: „Vom Ich zum Wir“? Flüchtlinge und Vertriebene als Neubauern in der LPG. Leipzig 2016. 576 S. (Schriften zur sächsischen Geschichte und Volkskunde, Bd. 53). [Am Beispiel zweier Dörfer in Sachsen und Thüringen].

21 Thers (insgesamt grundlegende) Berliner (FU-)Dissertation von 1997 (wie Anm. 14) ist international vergleichend für Deutschland (SBZ/DDR) und Polen angelegt und untersucht innerhalb Deutschlands u. a. als (brandenburgische) Fallbeispiele nur ausgewählte Kreise (Calau-Senftenberg, Cottbus und Lübben). An der Viadrina in Frankfurt (Oder) sind in den letzten Jahren zwei einschlägige Masterarbeiten entstanden. Siehe unten Anm. 129. - Eigenartig berührt auch, dass eine - schon 1993 verfasste - universitäte Hausarbeit zur Vertriebeneneingliederung am Beispiel der brandenburgischen Stadt Eberswalde nicht im Land, sondern an der TU Dresden entstand: Kathrin Schwarz: Die Eingliederung der Flüchtlinge und Vertriebenen in die Sowjetische Besatzungszone und die DDR. Lebensberichte - Am Beispiel der Stadt Eberswalde (Land Brandenburg). Schriftliche Hausarbeit TU Dresden, Inst. für Geschichte. Dresden 1993. 136 S. (unveröff. Typoskript, vorhanden im Kreisarchiv Barnim, Eberswalde) [Mit Interviewtexten und Quellenanhang]. Zehn Jahre später folgte, an der TU Berlin, die (erst 2015 publizierte) Arbeit von Wenzel (siehe unten Anm. 50).

22 Wolfgang Meinicke: Die Bodenreform und die Vertriebenen in der SBZ und in den Anfangsjahren der DDR. In: Sie hatten alles verloren (wie Anm. 15), S. 55-85. - Arnd Bauerkämper: Das Neubauernprogramm im Land Brandenburg. Voraussetzungen, Entwicklung und Auswirkungen 1947-1952. In: Jahrbuch für brandenburgische Landesgeschichte 45 (1994), S. 182-202. - „Junkerland in Bauernhand“? Durchführung, Auswirkungen und Stellenwert der Bodenreform in der Sowjetischen Besatzungszone. Hrsg. von Arnd Bauerkämper. Stuttgart 1996 (Historische Mitteilungen, Beiheft 20). - Arnd Bauerkämper: Flüchtlinge zwischen Ausschluß und Integration. Bodenreform und ländliche Gesellschaft in Brandenburg 1945-1948. In: 50 Jahre Flucht und Vertreibung. Gemeinsamkeiten und Unterschiede bei der Aufnahme und Integration der Vertriebenen in die Gesellschaften der Westzonen/Bundesrepublik und der SBZ/DDR. Hrsg. von Manfred Wille. Magdeburg 1997, S. 286-295. - Ders.: Die vorgetäuschte Integration. Die Auswirkungen der Bodenreform und 
Integration sind - mit vielen genuin brandenburgischen Fällen - an einer Universität außerhalb des Landes erforscht worden. ${ }^{23}$

Mit der partiellen Lockerung der „Zügel“ in der zweiten Hälfte der achtziger Jahre konnten die DDR-Historiker um Manfred Wille in Magdeburg (Pädagogische Hochschule) und Wolfgang Meinicke $^{24}$ in Ost-Berlin (Humboldt-Universität) zwar das „Umsiedler“-Thema, begrenzt auf die frühe, möglichst schnell abzuschließende Integrationsproblematik, intensiver untersuchen, doch blieben dabei nicht nur wesentliche Aspekte tabu, sondern ergab sich aus der überwiegend im akademischen Rahmen bleibenden Resonanz kein breiteres Hineinwirken in Gesellschaft und Öffentlichkeit, geschweige denn in die Lokalforschung. Gleichzeitig zeigten allerdings die literarischen Verarbeitungen des Themas durch einzelne Schriftsteller auch von einer anderen Seite her immer mehr die Notwendigkeit, sich dem „Tabu-Thema“ (Manfred Wille) zu stellen.

Die gleichwohl bis 1989 anhaltende weitgehende offizielle Ausblendung der Thematik aus öffentlichen ebenso wie aus wissenschaftlichen Bereichen bewirkte nach der Wende einen Nachholbedarf, dem mancherorts neue Rahmenbedingungen halfen, die versäumte „Aufarbeitung“ in Angriff zu nehmen. In vielen Köpfen jedoch wirkte und wirkt sie offenbar bis heute weiter nach und verhindert jedenfalls in Brandenburg eine ähnlich stark an Publikationen ablesbare Beschäftigung mit dem Thema, wie sie in den anderen neuen Bundesländern - in unterschiedlicher Intensität und Quantität, aber doch deutlich öfter und zahlreicher - durchaus feststellbar ist. Erschwerend für den brandenburgischen Fall kam freilich hinzu, dass von den an der Magdeburger Hochschule von Manfred Wille für alle fünf Länder der SBZ vergebenen Dissertationen als einzige die zu Brandenburg nicht abgeschlossen wurde. ${ }^{25}$ Der Berliner Be-

Flüchtlingssiedlung auf die berufliche Eingliederung von Vertriebenen in die Landwirtschaft in Deutschland 1945-1960. In: Geglückte Integration (wie Anm. 18), S. 193-214. - Ders.: Ländliche Gesellschaft in der kommunistischen Diktatur. Zwangsmodernisierung und Tradition in Brandenburg 1945-1963. Köln/Weimar/Wien 2002. 641 S. (Zeithistorische Studien, Bd. 21) [Habil.-Schr. FU Berlin 2001]. - Ders.: Gutachten für die Enquete-Kommission „Aufarbeitung der Geschichte und Bewältigung von Folgen der SED-Diktatur und des Übergangs in einen demokratischen Rechtsstaat im Land Brandenburg" des Landtages Brandenburg. Agrargeschichte des Landes Brandenburg vor 1989. Korrigierte Fassung: Ausgabe 01.11.2012 (PDF: www. landtag.brandenburg.de).

23 Claudia Schneider: Als Deutsche unter Deutschen? Übersiedlungen aus der Volksrepublik Polen in die DDR 1964-1987. Halle (Saale) 2015. Die Arbeit ist als Dissertation (2013) hervorgegangen aus einem DFG(Promotions-)Projekt „Umsiedlungen aus der VR Polen in die DDR in den 1960er Jahren“ am Lehrstuhl für Zeitgeschichte des Instituts für Geschichte der Martin-Luther-Universität Halle-Wittenberg. Siehe auch: Dies.: Als Deutsche unter Deutschen? „Übersiedler aus der VR Polen“ in der DDR ab 1964. In: Transit Transfer. Politik und Praxis der Einwanderung in die DDR 1945-1990. Kim Christian Priemel (Hrsg.). Berlin 2011, S. 51-74.

24 Wolfgang Meinicke: Zur Integration der Umsiedler in die Gesellschaft 1945-1952. In: Zeitschrift für Geschichtswissenschaft 10 (1988), S. 867-878. - Alexander von Plato / Wolfgang Meinicke: Alte Heimat - neue Zeit. Flüchtlinge, Umgesiedelte, Vertriebene in der Sowjetischen Besatzungszone und in der DDR. Berlin 1991.271 S.

25 Noch 1993 schrieb der Doktorvater, sie stehe „vor dem Abschluß“: Wille, Die „Umsiedler“-Problematik (wie Anm. 15), S. 8. 
fund ähnelt im Übrigen dem brandenburgischen, wobei in West-Berlin das Vertriebenenthema ohnehin schon zeitgenössisch - in Öffentlichkeit und Wissenschaft - bald und stark vom „Zonenflüchtlings“-Thema überlagert und in den Hintergrund gedrängt worden war. ${ }^{26}$

Die Situation der Flüchtlinge und Vertriebenen in der SBZ/DDR ist inzwischen vielfach analysiert und beschrieben worden, Forschungsstand und Literatur u. a. von Michael Schwartz ${ }^{27}$ treffend zusammengefasst. ${ }^{28}$ Für den speziellen Brandenburg-Fokus ist nach 1990 auf einzelne wissenschaftliche Aufsätze und einige wenige für einen breiteren Leserkreis konzipierte Buchveröffentlichungen hinzuweisen. Gleichsam von der frühen, in die letzten DDRJahre zurückreichenden Aktivität des Zeithistorikers Manfred Wille profitiert haben nicht nur Brandenburg, sondern im Grunde alle neuen Bundesländer, da sie nach und nach in ersten Darstellungen „abgearbeitet“ wurden. Nach wie vor wichtig sind die seinerzeit in Magdeburg entstandenen frühen Brandenburg-Aufsätze von Gerald Christopeit, der jedoch mittlerweile nicht mehr Brandenburg-spezifisch publiziert, ${ }^{29}$ sowie anderer Magdeburger Projektmitarbeiter $^{30}$ einschließlich des Leiters.

Einen gewissen Fortschritt bei der Berücksichtigung des Themas innerhalb des wissenschaftlichen wie des öffentlichen Diskurses brachten im Land Brandenburg um die Jahrtausendwende eine Fernsehdokumentation und einzelne öffentliche Tagungen, bei denen jeweils die Brandenburgische Landeszentrale für politische Bildung (Potsdam) unterstützend tätig

Günter Köhler: Notaufnahme. Evangelische Flüchtlingsseelsorge. Vierzig Jahre im Dienst für Umsiedler, Aussiedler und Übersiedler in Berlin. Berlin 1991. - Rajan Autze: Treibgut des Krieges. Flüchtlinge und Vertriebene in Berlin 1945. München 2001. - David Skrabania: Die Zentrale Aufnahmestelle für Aussiedler in Berlin-Marienfelde. 14. April 1953 bis 31. Juli 2010. Berlin 2011 (Blaue Reihe, Bd. 4). - Erst in jüngerer Zeit sind erstmals Arbeiten zu Vertriebenen in Berlin erschienen, die nicht die Flüchtlinge aus der SBZ/DDR in den Vordergrund stellen (siehe oben Anm. 6).

27 Schwartz, Vertriebene und „Umsiedlerpolitik“ (wie Anm. 13), S. 36-43.

28 Nach wie vor lesenswert ist auch die an versteckter Stelle erschienene, notgedrungen knappe, aber sehr treffende überregionale Analyse der Forschungssituation, ihrer Ergebnisse, aber auch Desiderate, die Harald Engler in einer Sammelrezension von sechs einschlägigen Büchern gelungen ist: Jahrbuch für die Geschichte Mittelund Ostdeutschlands 55 (2009 [2010]), S. 334-340.

29 Gerald Christopeit: Die Herkunft und Verteilung der Evakuierten, Flüchtlinge und Vertriebenen in der Provinz Mark Brandenburg und ihr Verhältnis zu der einheimischen Bevölkerung. In: Sie hatten alles verloren (wie Anm. 15), S. 86-109. - Ders.: Die Sudetendeutschen in der Provinz Mark Brandenburg 1945 bis 1948. In: Die Sudetendeutschen in der Sowjetischen Besatzungszone Deutschlands. Ankunft, Aufnahme und erste Integrationsversuche. Hrsg. von Manfred Wille (Magdeburger Forschungen, 10: Geschichte). Magdeburg 1993, S. 80-93. - Ders.: Die Vertriebenen im Gründungsjahr der DDR - Versuch einer Standortbestimmung anhand ihrer Lage im Land Brandenburg 1949. In: 50 Jahre Flucht und Vertreibung. Gemeinsamkeiten und Unterschiede bei der Aufnahme und Integration der Vertriebenen in die Gesellschaften der Westzonen/Bundesrepublik und der SBZ/DDR. Hrsg. von Manfred Wille. Magdeburg 1997, S. 256-270. - Ders.: Die deutschen Heimatvertriebenen von Weichsel und Warthe in der SBZ/DDR und die Entwicklung nach der Wende 1989/90. In: Jahrbuch Weichsel-Warthe 50 (2004), S. 120-144. - Siehe auch die volkskundlichen Arbeiten Christopeits in Anm. 115.

30 Petra Pape: Flüchtlinge und Vertriebene in der Provinz Brandenburg. In: Sie hatten alles verloren (wie Anm. 15), S. 110-132. 
wurde und den Druck der Referate ermöglichte. Der Ostdeutsche Rundfunk Brandenburg (ORB) strahlte im November 2000 eine dreiteilige Fernsehdokumentation „Zweite Heimat Brandenburg" aus, die vor allem Betroffene (Zeitzeugen) zu Wort kommen ließ, aber auch akribische Recherchen der Autoren im Brandenburgischen Landeshauptarchiv sowie in der zeitgenössischen Publizistik sowie in der wissenschaftlichen Literatur erkennen lässt. ${ }^{31}$ All dies ist dann in einen mit Endnoten versehenen, zudem mit gut gewählten Text- und Bilddokumenten illustrierten (und in einem im Land bekannten Verlag erschienenen) Begleitband eingegangen, der vielleicht mehr für das Thema bewirkt hat als mancher an entlegener Stelle gedruckte Beitrag eines Historikers. Immerhin wurden nicht nur Voraussetzungen und Abläufe, sondern auch weitergehende Integrationsfragen einbezogen. ${ }^{32}$ Eine „Film-Rezension“ teilte seinerzeit das Grundanliegen des Initiators, der das Fortwirken von Tabus in Form von Reserviertheit bei den einen und Hemmungen bei den anderen spürte, mit: „Der konzeptionelle Ansatz, vor allem ,den Betroffenen das Recht einzuräumen, über den Verlust ihrer Heimat zu trauern', ist dabei aus Sicht des verantwortlichen ORB-Redakteur Johannes Unger längst überfällig. Zehn Jahre nach der Wende hält er den Zeitpunkt für gekommen, mit der Thematik entspannter umzugehen [...]."33

Parallel zu den Fernsehsendungen veranstalteten das in Potsdam ansässige Zentrum für Zeithistorische Forschung (ZZF) und der ORB am 23. und 24. November 2000 in Potsdam eine wissenschaftliche Konferenz „Zweite Heimat Brandenburg: Vertreibung - Neuanfang - Integration“. Die Initiative dazu dürfte vom ORB ausgegangen sein. Neben Überblicksbeiträgen und solchen mit SBZ-Fokus wurde ausdrücklich Brandenburg in verschiedensten Facetten betrachtet, wenngleich der letztlich breite Adressatenkreis nur Kurzbeiträge, die „der besseren Lesbarkeit wegen teils in der Vortragsform belassen“ wurden, zuließ ${ }^{34}$ Allerdings handelt es sich ohnehin zumeist um Arbeiten der einschlägig tätigen Verfasser, die an anderer Stelle, in größeren, meist wiederum über Brandenburg hinausreichenden Zusammenhängen, ausführlicher publiziert haben. Die Herausgeber des zugehörigen, 2001 erschienen Tagungsbandes schlagen im Vorwort, was sonst seltener und in den eigentlichen Aufsätzen ohnehin kaum geschieht, chael Hartmann; Redaktion: Johannes Unger (geb. 1964 Braunschweig), ORB. Jürgen Ast/Kerstin Mauersberger: Zweite Heimat Brandenburg. Flucht, Vertreibung, Neuanfang. Berlin (be.bra) 2000. $144 \mathrm{~S}$.

33 Rezension von Rainer Braun in: Die Welt, 18.11.2000.

34 Vertreibung, Neuanfang, Integration. Erfahrungen in Brandenburg. Christoph Kleßmann / Burghard Ciesla / Hans-Hermann Hertle (Hrsg.) (Protokolle). Potsdam 2001, Zitat S. 9 (Vorwort). Enthaltene Beiträge mit Brandenburg-Schwerpunkt: Michael Schwartz: Brandenburg als Schmelztiegel? Vertriebenenproblem, „Umsiedlerpolitik“ und regionale Gesellschaftsentwicklung 1945-1953, S. 59-73. - Katarzyna Stokłossa: Integration durch Zwang 1948-1953. Die Oder-Neiße-Grenze und die mühsame Integration, S. 74-88. - Peter Hübner: Vertriebenenintegration durch industrielle Erwerbsarbeit in den fünfziger und sechziger Jahren am Beispiel des Landes Brandenburg, S. 112-122. - Arnd Bauerkämper: Scharfe Konflikte und „feine Unterschiede“. Vertriebene in der ländlichen Gesellschaft Brandenburgs von 1945 bis zu den frühen fünfziger Jahren, S. $123-150$. 
die Brücke zur eigenen Gegenwart, indem sie nicht nur auf „ethnische Säuberungen“ im Ausland hinweisen, sondern die anhaltende Relevanz des Themas im Land Brandenburg bis tief in die Familien hinein betonen: „Viele Flüchtlinge und Vertriebene zogen durch Brandenburg; mehr als 750000 Menschen suchten hier schließlich einen Neuanfang. In fast allen Brandenburger Familien finden sich dramatische und häufig traumatische Flüchtlings- und Vertreibungserfahrungen. Die schmerzhaften Erfahrungen an das damit verbundene Chaos und Leid, an den Verlust von Angehörigen, an den Neuanfang aus dem Nichts reichen bis in die Gegenwart [... "35 Weitere Aktivitäten des ZZF bzw. seiner Mitarbeiter zum Thema Flucht und Vertreibung sind bisher nicht bekannt geworden. ${ }^{36}$ Es ist kaum zu übersehen, dass das ZZF diesen Forschungsbereich dem Institut für Zeitgeschichte (Abt. Berlin) überlässt ${ }^{37}$, in dessen Reihen viele grundlegende Monographien hierzu erschienen sind. ${ }^{38}$ Soll man von Arbeitsteilung sprechen?

Ebenfalls 2000 widmeten sich, einer Anregung der Archivarin und Landeshistorikerin Lieselott Enders (1927-2009) folgend, die Brandenburgische Historische Kommission unter dem Vorsitz des Landeshauptarchiv-Direktors Klaus Neitmann (Potsdam) und der Uckermärkische Geschichtsverein zu Prenzlau e.V. unter dem Vorsitz des Prenzlauer Geschichtslehrers Jürgen Theil in Prenzlau dem Themenkomplex „Die Herkunft der Brandenburger“. Die sieben Referenten behandelten die unterschiedlichsten Zuwanderungsgruppen vom 12. bis 20. Jahrhundert, zwei davon die Zeit nach 1945, darunter Detlef Kotsch (geb. 1954 Frankfurt/Oder) „Vertriebene und Vertriebenenpolitik in Brandenburg nach dem Zweiten Weltkrieg “. ${ }^{99}$ Kotsch, der später auch an einer Quellenedition zur Eingliederung der Vertriebenen in Brandenburg arbeitete ${ }^{40}$, lieferte damit erstmals einen zwar knappen, aber alle wesentlichen Fragen anschneidenden und

Christoph Kleßmann / Burghard Ciesla / Hans-Hermann Hertle: Vorwort. In: Vertreibung, Neuanfang, Integration (wie Anm. 34), S. 7-9, hier S. 7.

36 Bei Tagungen wird mangels eigener Kräfte offenbar regelmäßig auf externe Kollegen zurückgegriffen, so auch bei der Veranstaltung „Mythos DDR ohne Vertriebene“ in Potsdam am 15. September 2011 (gemeinsam mit dem Deutschen Kulturforum östliches Europa) auf den wohl besten Kenner der Materie, Prof. Dr. Michael Schwartz vom Institut für Zeitgeschichte. Schon bei der Tagung „Schaufenster der Systemkonkurrenz. Die Region Berlin-Brandenburg im Kalten Krieg" behandelte das Flüchtlings- und Vertriebenenthema ebenfalls kein Mitarbeiter des ZZF, sondern der Berliner Landeshistoriker Prof. Dr. Wolfgang Ribbe (FU Berlin bzw. Historische Kommission zu Berlin) (vgl. Anm. 6). - 2016 erschien im Themenheft „Flucht“ (Heft 2/2016) der von der Leibniz-Gemeinschaft, der das ZZF angehört, herausgegebenen Zeitschrift „leibniz“ eine als Zeitstrahl geformte „Infografik“ „Europas Jahrhundert der Flucht“ (S. 56-57), in der es (S. 57) heißt: „1944-1949 13 Mio. Deutsche werden aus den ehemals besetzten [so!] Gebieten vertrieben." Die von Dr. Kathrin Kollmeier, Wiss. Mitarbeiterin am ZZF, konzipierte Grafik erhebe „keinen Anspruch auf Vollständigkeit“ (S. 57). zzf-potsdam.de/de/publikationen [16.6.2017].

38 ifz-muenchen.de/publikationen [16.6.2017].

39 Detlef Kotsch: Vertriebene und Vertriebenenpolitik in Brandenburg nach dem Zweiten Weltkrieg. In: Die Herkunft der Brandenburger. Sozial- und mentalitätsgeschichtliche Beiträge zur Bevölkerung Brandenburgs vom hohen Mittelalter bis zum 20. Jahrhundert. Hrsg. von Klaus Neitmann u. Jürgen Theil unter Mitw. von Olaf Gründel (Brandenburgische Historische Studien, Bd. 9; Arbeiten des Uckermärkischen Geschichtsvereins zu Prenzlau e. V., Bd. 4). Potsdam 2001, S. 127-137. 
auf eigenen Aktenstudien basierenden Überblick für Brandenburg, der noch heute überzeugen kann. Bemerkenswert ist - und darin unterscheidet er sich von sehr vielen anderen Arbeiten zum Thema - die gelungene Verbindung von seriöser wissenschaftlicher Methode einerseits und dennoch nicht ausgeblendeter Empathie für die Vertreibungsopfer andererseits; dabei benennt er durchaus Ursachen und Wirkungen und betont die Notwendigkeit einer Einordnung von Flucht und Vertreibung in den Gesamtzusammenhang der verbrecherischen NS-Politik. Wenige Historiker (und Heimatforscher) in Brandenburg haben es jedoch bislang vermocht, die Dimensionen von Flucht und Vertreibung wie auch die der anfänglichen Aufnahmeprobleme derart deutlich zu benennen: 1945 ,fiel nur wenige Wochen nach dem Kriegsende die für die meisten völlig unfaßbare Entscheidung, die deutsche Bevölkerung aus den von Deutschland nun abgetrennten Gebieten im Osten sowie aus anderen Teilen Mittelost- ${ }^{41}$, Ost- und Südosteuropas auszusiedeln. Diese zwangszweise Aussiedlung erfaßte am Ende mehr als 16 Millionen Menschen und erstreckte sich über einen Zeitraum von mehr als 5 Jahren. ${ }^{\text {442 }}$ Erkannt hatte Kotsch auch bereits, dass die wirkliche Dimension für die Zeitgenossen nicht in solchen statistischen Daten allein zu fassen ist, sondern letztlich unvorstellbar bleibt: „Völlig außerhalb jeder Vorstellungskraft bewegte sich mit 63,5 Prozent die Vertriebenenquote in der durch die Teilung arg mitgenommenen und benachteiligten ,Reststadt' Guben." ${ }^{3}$

2003 und 2006 hat dann die Brandenburgische Landeszentrale für politische Bildung nochmals mit zwei in ihren - weite Verbreitung garantierenden - Reihen erschienenen Broschüren auf das Thema aufmerksam gemacht, die zudem auch online abrufbar sind. Die Osteuropa-Historikerin und Polonistin Ruth Leiserowitz geb. Kibelka (geb. 1958 Prenzlau) hat sich darin 2003 mit einem auch im Fernsehen immer wieder behandelten Sonderthema befasst, den ostpreußischen „Wolfskindern“, von denen nicht wenige sogar erst nach 1949 nach Brandenburg kamen. ${ }^{44}$ Der Diplom-Archivar (FH) Sven Olaf Oehlsen (geb. 1971 Neuruppin) schließlich schrieb auf der Basis von Akten des BLHA und des Bundesarchivs eine knappe, aber instruktive, nach wie vor, allein schon wegen der enthaltenen 15 Tabellen, grundlegende Darstellung der zeitgenössisch offiziell „Umsiedlerlager“, anfangs aber noch „Flüchtlingslager“ ge-

41 Ein weit verbreiteter Lapsus: Gemeint ist Ostmitteleuropa bzw. das östliche Mitteleuropa.

42 Ebd., S. 128.

43 Ebd., S. 129.

44 Ruth Leiserowitz: Von Ostpreußen nach Kyritz. Wolfskinder auf dem Weg nach Brandenburg. Potsdam 2003. 108 S. - Ruth Leiserowitz hatte schon 1996, noch unter ihrem Geburtsnamen Kibelka, ein erstes Buch zum Thema „Wolfskinder“ veröffentlicht (Ruth Kibelka: Wolfskinder. Grenzgänger an der Memel. Berlin 1996. 4. Aufl. 2003. 5., erw. Aufl. 2010). - Siehe auch Ruth Kibelka: Die Deutsche Bevölkerung zwischen Anpassung und Ausweisung nördlich und südlich der Memel (1945-1948). Diss. Humboldt-Univ. zu Berlin. Berlin 1997. 321 Sp. - Ruth Kibelka: Ostpreußens Schicksalsjahre 1944-1948. Berlin 2000 (358 S.) Neuausg. 2016 (362 S.), darin S. 243-265 zur „Umsiedlung“ in die SBZ. - Christopher Spatz: Ostpreußische Wolfskinder. Erfahrungsräume und Identitäten in der deutschen Nachkriegsgesellschaft. Osnabrück 2016. 239 S. (Einzelveröffentlichungen des Deutschen Historischen Instituts Warschau, Bd. 35). [Diss. Humboldt-Univ. zu Berlin 2015]. - Ders.: Nur der Himmel blieb derselbe. Ostpreußens Hungerkinder erzählen vom Überleben. Hamburg 2016 (3. Aufl. 2018). 344 S. 
nannten Durchgangsstätten, die er Vertriebenenlager nennt. ${ }^{45}$ Er musste sich zwar bei der Untersuchung der Lagerthematik im engeren Sinne auf ein Beispiel (Fürstenwalde) beschränken, bleibt aber nicht bei der dortigen „Quarantäne“ stehen, sondern erweitert den Blick bereits auf die anschließenden Eingliederungs- sowie nachfolgende Abwanderungsprozesse im gesamten Land teilweise bis $1950^{46}$, anhand eines „Fallbeispiels“ einer einzelnen, aus Schlesien nach Karwesee (Kr. Osthavelland) gelangten Familie sogar bis in die Gegenwart. ${ }^{47}$

Noch viel zu tun bleibt, wie gesagt, in der Erforschung von Teilregionen oder einzelnen Kommunen Brandenburgs. Das gilt nicht nur für die lokale, meist von Laienforschern getragene Geschichtsarbeit ${ }^{48}$, sondern auch für Fallstudien der universitären Geschichtswissenschaft. Die einschlägigen vergleichenden Forschungen von Philipp Ther sind bisher im Grunde die einzigen geblieben, die einen brandenburgischen Landkreis zum Untersuchungsfeld genommen haben und darauf aufbauend zu allgemeineren Erkenntnissen gelangt sind. ${ }^{49}$ Aus einem „studentischen Forschungsprojekt zur Integration Heimatvertriebener in der SBZ/DDR“ an der TU Berlin (2002-2004) hervorgegangen ist die erst 2015 gedruckte verdienstvolle Lokalstudie des jetzt am von Wolfgang Benz geleiteten Institut für Vorurteils- und Konfliktforschung e. V. (Berlin) tätigen Historikers Mario Wenzel M.A. über die Aufnahme und Integration der Vertriebenen in Eber-

Sven Olaf Oehlsen: Vertriebenenlager in Brandenburg 1945-1953. Potsdam 2006. 136 S. (Brandenburgische Historische Hefte, 18) [auch online als PDF verfügbar]. Es handelt es sich um die (von Prof. Dr. Peter-Johannes Schuler angeregte) Diplomarbeit des Verf. an der FH Potsdam. Der inzwischen mit anderen Fragen befasste, seit 2012 als Archivar bei der Stiftung Preußische Schlösser und Gärten Berlin-Brandenburg in Potsdam tätige Oehlsen (www.oehlsen.info) publizierte noch zwei kleinere Arbeiten zum Thema: Sven Oehlsen: Flucht aus Schlesien. Auf eigene Faust zurück. In: Spiegel online, 10.11.2007 [16.6.2017]. [Weg einer schlesischen Vertriebenenfamilie nach Brandenburg (Großmutter der Ehefrau des Verf., aus Schmottseiffen, Kr. Löwenberg (freundliche Auskunft des Verf., 10.7.2018]. - Ders.: Deutsche Vertriebene in Brandenburg und Sachsen nach 1945. In: Preußen, Sachsen, Brandenburg. Nachbarschaften im Wandel. Hrsg. Brandenburgische Gesellschaft für Kultur und Geschichte gGmbH, Kulturland Brandenburg, Potsdam. Leipzig 2014, S. 38-45.

Oehlsen, Vertriebenenlager (wie Anm. 45), S. 101-122 (Tabellen 1-15): Vertriebenenlager in der Provinz Mark Brandenburg (Stichtag 1.1.1947) - Eingemeindungen in die (alle einzelnen!) Landkreise des Landes Brandenburg mit Stand 30.4.1947, Juni 1948, Febr. 1949 sowie nach den neuen Kreisgrenzen ab 1.7.1950 (Stand 30.9.1950) - Eingemeindungen und Berufsgliederungen 1948 und 1949 - Vertriebenen- und Heimkehrerunterstützung gemäß SMAD-Befehl 304 1948-49- Landverteilung nach Bodenreform 1948 und 1949 - An Neubauern verteiltes Vieh und landwirtschaftliche Gerätschaften 1948 und 1949 - Landaufgabe von Neubauern aus den Reihen der Vertriebenen 1948 und 1949 - Bauprogramm gemäß SMAD Befehl 209. Oehlsen: Vertriebenenlager (wie Anm. 45), S. 95-100. Zur selben Familie auch Oehlsen, Flucht aus Schlesien (wie Anm. 45).

48 Siehe dazu weiter unten.

49 Philipp Ther: Die Vertriebenenpolitik in der SBZ/DDR 1945-1953 am Beispiel des Kreises Calau-Senftenberg. In: Jahrbuch für brandenburgische Landesgeschichte 46 (1995), S. 159-168. - Ders.: Von Schlesien in die Lausitz. Ein Beispiel der Integration von Vertriebene in der DDR. In: „Wach auf, mein Herz, und denke“ (wie Anm. 11), S. 488-494 [Am Beispiel des Kreises Calau-Senftenberg]. - Ders.: Die Vertriebenenproblematik in Brandenburg und im Oppelner Schlesien 1945-1952. Ausgewählte Aspekte einer vergleichenden Landesgeschichte. In: Zeitschrift für Ostmitteleuropa-Forschung 46 (1997), S. 513-534. 
swalde 1945-1948..$^{50}$ Bereits aus der lokalen Forschungsebene stammt die - für Brandenburg ganz singuläre - kleine, aber sehr beachtenswerte Arbeit des Archivars und (seit 2008) Leiters des Kreisarchivs Dahme-Spreewald in Luckau Thomas Mietk (geb. 1984 Lübben), die die Situation der Flüchtlinge und Vertriebenen im Kreis Lübben in den Blick nimmt. ${ }^{51}$ Sie hebt sich durch ihre breite archivalische Quellenbasis von den meisten lokalen Arbeiten positiv ab, dürfte aber überwiegend auf einen Leserkreis in der Region beschränkt geblieben sein.

Mit den Lebensläufen der Arbeiter des Eisenhüttenstädter Kombinats hatte sich schon 1988/89 und nochmals 1990-1992 Dagmar Semmelmann (geb. 1943 Warnow/Wollin) in einem „Oral-History“-Projekt befasst. Da 31 Prozent der insgesamt 65 Personen umfassenden Untersuchungsgruppe Flüchtlinge bzw. Vertriebene waren, hat sie die Langzeitinterviews 1995/96 in Zusammenarbeit mit dem Institut für Zeitgeschichte gesondert auch unter dem Aspekt der Vertriebenen-Integration ausgewertet. ${ }^{52}$ Mit dieser Analyse retrospektiver Selbstzeugnisse in lebensgeschichtlicher Perspektive - der Grad der Integration wird über die Wende von 1989/90 hinaus hinterfragt - wurde ein Weg beschritten, der in der klassischen, überwiegend auf staatliche Akten bauenden Zeitgeschichtsforschung bislang eher unterrepräsentiert ist und überwiegend der Volkskunde/Ethnologie überlassen wird.

Es wären nun noch jene Veröffentlichungen zu nennen, die zwar das Jahr 1945 oder die Nachkriegszeit in Brandenburg behandeln, dabei aber Flüchtlingen und Vertriebenen keinerlei oder nur marginale Beachtung schenken, doch ist dies wohl ein unproduktives Unterfangen. ${ }^{53}$

50 Mario Wenzel: Die Aufnahme und Versorgung von Flüchtlingen und Vertriebenen in Eberswalde 1945-1948. In: Eberswalder Jahrbuch 2015, S. 136-145; auch online (ohne Abb., aber textgleich) unter dem Titel „Zur Aufnahme und Integration der Vertriebenen in Eberswalde 1945-1948“ im Internetportal: „Transodra online“ <www.transodra-online.net/de/node/1414>. Wenzel hat sich inzwischen auf die Geschichte des Nationalsozialismus, insbesondere der Judenverfolgung im besetzten Polen, spezialisiert und seither keine weiteren Arbeiten zum Vertriebenenthema mehr verfasst (Internetseite des Institut für Vorurteils- und Konfliktforschung e. V., Berlin, mit Schriftenverzeichnis: www.ivkf-berlin.de/seiten/wenzel.htm [4.1.2016]).

51 Thomas Mietk: Neuanfang im Kreis Lübben. Beitrag zur Flüchtlings- und Vertriebenenforschung am Ende des Zweiten Weltkrieges. Lübben 2010. 73 S. (Einzelveröffentlichung des Kreisarchivs Dahme-Spreewald, Bd. 1). Etwas eigenartig berührt der im Impressum (S. 73) aus formalrechtlichen Gründen beigefügte Satz „Diese Veröffentlichung stellt keine Meinungsäußerung des Landkreises Dahme-Spreewald dar." Dagmar Semmelmann: Zur Integration aus lebensgeschichtlicher Sicht. Eingliederungsverläufe von Flüchtlingen und Vertriebenen in der SBZ/DDR dargestellt am Sonderfall Eisenhüttenstadt. In: Geglückte Integration? (wie Anm. 18), S. 320-333. - Dies.: „Man war total entwurzelt und mußte erst wieder Wurzeln schlagen“. Zur Integration von Flüchtlingen und Vertriebenen in der SBZ/DDR aus lebensgeschichtlicher Sicht - dargestellt am Sonderfall Eisenhüttenstadt. Berlin 2005 (CD-Rom). - Siehe auch Dies.: November 1989: Krisenverarbeitung „an der Basis“ an einem biographischen Beispiel. In: Der lange Schatten. Widerspruchsvolle Erinnerungen an den Zweiten Weltkrieg und die Nachkriegszeit aus der Mitte Europas 1939-1989. Hrsg. von Karin Hartewig (Bios, 6, 1993, Sonderh.). Leverkusen 1993, S. 65-72.

53 Beispiel: Brandenburg. Neues altes Land. Geschichte und Gegenwart. Friedrich Beck u. a. (Hrsg.) (Brandenburgische Historische Studien, Bd. 15). Berlin 2010, S.96f. (Zweiter Weltkrieg ohne jede Erwähnung der Fluchtbewegungen), S. 100 (Flüchtlingsströme auf überfüllten Straßen, 1 Halbsatz und 1 Foto), 104 (Abtrennung der Neumark und Vertreibung der noch dort verbliebenen Deutschen, 1 Satz), 109 (Bodenreform, 1 Halbsatz). 
Viele Autoren sind sich offenkundig der Brisanz des Vertriebenenthemas für die Menschen und die Verwaltungen der Nachkriegsjahre auch heute noch nicht bewusst. Nur zu deutlich zeigt sich immer wieder - in übergreifenden wie in lokal begrenzten Darstellungen -, dass einige Verfasser für das Thema empfänglich sind ${ }^{54}$, andere es lieber umgehen.

\section{Zeitgeschichtliche Erinnerungsarbeit - Initiativen der Landesregierung}

Der seinerzeit zuständige Minister für Wissenschaft, Forschung und Kultur des Landes Brandenburg, Steffen Reiche (geb. 1960 Potsdam), hat sich in dem die Gedenkveranstaltungen im Land Brandenburg zum 50. Jahrestag der Befreiung 1995 dokumentierenden Band ${ }^{55}$ zu den damaligen Schwerpunktsetzungen der Landesregierung geäußert. Zur in ganz Deutschland vorausgehenden und begleitenden öffentlichen Debatte über den 8. Mai 1945 bezog er klar Stellung: „Die Vielzahl von geschichtsträchtigen Daten und ihre Würdigung barg meiner Ansicht nach auch problematische Elemente, da von einigen Versuche unternommen wurden, des Kriegsendes und der Befreiung in einem generalisierenden Kontext zu gedenken." Gemeint ist nicht nur die in den damaligen Diskussionen begegnende provokative Frage, ob man im Kriegsende „das Datum der Befreiung oder etwa“ den „Beginn neuen Unrechts“ sehen müsse, sondern auch die ebenso anzutreffende, meist im Verharmlosungsverdacht stehende Frage, ob man an diesem Tag nur allgemein an „alle Opfer des Weltkriegs“ erinnern solle oder ganz bewusst und konkret an die „Opfer des nationalsozialistischen Regimes und seiner kriegerischen Expansionen“. Das Land Brandenburg habe sich entschieden, „zum Jahrestag der Befreiung Gedenkveranstaltungen abzuhalten, in deren Mittelpunkt die Opfer des nationalsozialistischen Terrors stehen sollten" ${ }^{.6}$

Trotz der Knappheit des vorgegebenen Rahmens mit einem eigenen Abschnitt „Nachkriegszeit - Besatzungszeit": Gerd Heinrich: Land und Städte in Brandenbug und Berlin. II. Land und Städte in der Neuzeit bis zur Gegenwart. In: Städtebuch Brandenburg und Berlin. Hrsg. von Evamaria Engel u. a. (Deutsches Städtebuch. Neubearb., Bd. 2). Stuttgart u. a. 2000, S. XXXVI-L, darin S. XLVIII ein ganzer Absatz zur „Vertreibung von Teilen der Bevölkerung“. - Ders.: Geschichtliche Einführung. In: Berlin und Brandenburg. Mit Neumark und Grenzmark Posen-Westpreußen. Hrsg. von Gerd Heinrich. 3., überarb. u. erg. Aufl. (Handbuch der Historischen Stätten Deutschlands, Bd. 10). Stuttgart 1995, S. XV-CVI, zu Flucht und Vertreibung S. LXXXVIILXXXIX.

55 Erinnerung und Begegnung. Gedenken im Land Brandenburg zum 50. Jahrestag der Befreiung. Mit Beitr. von: Wolfgang Benz u.a. Hrsg. vom Ministerium für Wissenschaft, Forschung und Kultur des Landes Brandenburg. Projektleitung: Cordula Rinsche. Potsdam 1996, darin S. 184-197 ein chronologisches Verzeichnis der (auch lokalen) Veranstaltungen im Land vom 15. März 1995 bis 27. Januar 1996, darunter auch allgemeiner gehaltene Veranstaltungen, z. B. in Eisenhüttenstadt und Guben. - Siehe auch den von der Brandenburgischen Landeszentrale für politische Bildung publizierten Band: Der 8. Mai 1945 als historische Zäsur. Strukturen, Erfahrungen, Deutungen. Hrsg. von Arnd Bauerkämper, Christoph Kleßmann, Hans Misselwitz. Potsdam 1995 (Protokolle).

56 Steffen Reiche: Erinnerung und Begegnung in Brandenburg. Zur Philosophie und Zielsetzung der Gedenkveranstaltungen. In: Erinnerung und Begegnung (wie Anm. 55), S. 13-17, hier S. 13. - Zumindest mit deutlichen Worten erwähnt wird die Vertreibung in der Rede des damaligen Ministerpräsident Stolpe zum 8. Mai, wenn 
Ins Feld geführt wird als Begründung vor allem die Häufung von NS-Lagerstandorten im Land Brandenburg wie Sachsenhausen und Ravensbrück sowie in der Tat zahlloser Außen- und Nebenlager, so dass verständlicherweise die direkten Opfer des Nationalsozialismus in das Zentrum des Gedenkens gerückt wurden, zumal auch deren Erforschung - in den einzelnen Orten - noch längst nicht als fortgeschritten bezeichnet werden konnte. Die gleichsam indirekten Opfer, also auch die von Bombenkrieg, Flucht oder Vertreibung, wurden in das Gedenken nicht einbezogen. Dementsprechend fehlten Flucht und Vertreibung nahezu ganz in dem bereits 1995 vom Ministerium für Wissenschaft, Forschung und Kultur (MWFK) des Landes Brandenburg herausgegebenen und insofern offiziellen Gedenkband des Landes zum 50. Jahrestag der Befreiung. Die für den Band inhaltlich verantwortliche Historikerin Annette Leo (geb. 1948 Düsseldorf, ab 1952 aufgewachsen in der DDR) lässt lediglich zwei Seiten mit einem Textauszug aus dem Bericht eines Treckarztes stellvertretend für das vielschichtige Gesamtthema „Flucht und Vertreibung“ - unkommentiert - stehen und setzt vier Abbildungen hinzu, deren Inhalte nur unzureichend erläutert werden. ${ }^{57}$

Nachdem bereits ab der Jahrtausendwende in ganz Deutschland - in Wissenschaft und medialer Öffentlichkeit ${ }^{58}$ - das Thema Flucht und Vertreibung der Deutschen immer mehr diskutiert wurde und die Bundesregierung - auf der Basis des Koalitionsvertrages von 2005 - im Jahre 2008 die Errichtung einer „Stiftung Flucht, Vertreibung, Versöhnung“ auf den Weg gebracht hatte ${ }^{59}$, kam auch in Brandenburg etwas Bewegung in das Thema. So veröffentlichte das MWFK 2009 den Entwurf eines Konzepts der Landesregierung zur zeitgeschichtlichen Erinnerungskultur, in der die Gedenkkultur nun umfassend, für alle Opfergruppen des 20. Jahrhunderts, in den Blick genommen wurde. ${ }^{60}$ In der Geschichts- und Kulturarbeit tätige Institutionen und Personen sowie Vertreter von Opferverbänden (im weitesten Sinne) bat man um Stellungnahmen,

auch ohne Hinweis auf das Fluchtgeschehen der Monate vor dem 8. Mai 1945: „Danach [nach Kriegsende P. B.] war diese Region Ziel Hunderttausender von jenseits der Oder und Neiße. Bis Ende 1949 nahm das Land rund 700000 Flüchtlinge und Vertriebene auf. Fast ein Drittel der Bevölkerung Brandenburgs stammte aus dem deutschen Osten. Wohl keine Region Deutschlands war von den Ereignissen des Jahres 1945 stärker betroffen." (Manfred Stolpe: Der 8. Mai als Symbol deutscher Geschichte. In: Der 8. Mai 1945 als historische Zäsur [wie Anm. 55], S. 25-34, hier S. 26).

57 Geschichte wird Erinnerung. Zum 50. Jahrestag der Befreiung im Land Brandenburg. Berichte, Dokumente, Essays, Fotos. Hrsg. vom Ministerium für Wissenschaft, Forschung und Kultur des Landes Brandenburg u. der Brandenburgischen Landeszentrale für politische Bildung. Textausw. u. Red.: Annette Leo. Potsdam 1995, S. 140 f. Die knappen Bildunterschriften zu den auf den beiden anschließenden Seiten $142 \mathrm{f}$. abgedruckten vier Abbildungen zum Flüchtlingsthema sind so formuliert, dass sie teilweise desinformierend wirken.

58 Siehe als Beispiel für vieles andere: Spiegel special, Nr. 2/2002 „Die Flucht der Deutschen“, $130 \mathrm{~S}$.

59 Chronologie der Stiftungsgeschichte: www.sfvv.de/de/stiftung/chronologie [26.6.2017]. Weitere Hintergründe und Vorgeschichte in: Stefan Troebst: Bundesstiftung „Flucht, Vertreibung, Versöhnung“. In: Lexikon der Vertreibungen. Deportation, Zwangsaussiedlung und ethnische Säuberung im Europa des 20. Jahrhunderts. Detlef Brandes / Holm Sundhausen / Stefan Troebst (Hg.). Wien/Köln/Weimar 2010, S. 96-97.

60 Geschichte vor Ort: Erinnerungskultur im Land Brandenburg für die Zeit von 1933 bis 1990. Konzept der Landesregierung. Stand: 15. Januar 2009 (Entwurf). [Potsdam] (2009), hwww.mwfk.brandenburg.de/me dia/lbm1.a.1492.de/geschichtevorort.pdf [17.10.2016]. 
die anschließend als PDFs auf der Internetseite des Ministeriums veröffentlicht wurden. Ein Teil der in diesen enthaltenen Anregungen und Berichtigungen wurde in das Konzept eingearbeitet, konnten sie doch nach Darstellung der zuständigen Referentin „entscheidend zur Qualifizierung des Papiers beitragen“.61 Grundlegende Änderungswünsche zum Themenbereich Flucht und Vertreibung hatte nur der Landesverband Brandenburg des Bundes der Vertriebenen (BdV) in seiner Stellungnahme angemeldet, der auf „Lücken“ hinwies und dessen teils fundamentale, teils aber auch konkret-konstruktive Kritik in einigen kleineren Punkten berücksichtigt wurde. ${ }^{62}$ Anschließend wurde das überarbeitete Konzept von der Landesregierung beschlossen und vom Landtag Brandenburg - nach einer Parlamentsdebatte - als Drucksache veröffentlicht. ${ }^{63}$

Mit dem - von den MWFK-Referenten Dr. Ralf Kretschmann ${ }^{64}$ und Dr. Petra Haustein ${ }^{65}$ (geb. 1970) verfassten - Papier „will die Landesregierung, blinde Flecken“ im Zeitraum 1933 bis 1990 aufarbeiten und interessierte Bürgerinnen und Bürger sowie Mitarbeiterinnen und Mitarbeiter von Gedenkstätten, Archiven und Museen im Hinblick auf diese offenen Fragen anregen, sich zu engagieren und mit zu diskutieren.“66 Allerdings soll das Konzept nicht nur „eine erste Bilanz der Aufarbeitung der Zeitgeschichte im Land Brandenburg nach zwanzig Jahren deutscher Einheit“ sein, sondern zugleich „Prämissen im Umgang mit der deutschen Vergangenheit“ benennen und erläutern: „Die Landesregierung bekräftigt darin ihre Überzeugung, dass dem nationalsozialistischen Völkermord an den europäischen Juden, Sinti und Roma als bis dahin unvorstellbarem Zivilisationsbruch eine herausgehobene Bedeutung zukommt. Gleichzeitig betont sie, dass der verbrecherische Charakter des Stalinismus und das Unrecht der SED-Diktatur eindeutig benannt werden müssen." ${ }^{\text {"67 }}$

Flucht und Vertreibung werden in einem die öffentliche Bekanntmachung des Konzepts begleitenden zusammenfassenden Kurzbeitrag von Petra Haustein nicht erwähnt, sondern sind

Haustein, Geschichte vor Ort (wie Anm. 4), S. 21.

Schreiben des Landesvorsitzenden Harald Heerwagen vom 9.2.2009 (www.mwfk.brandenburg.de/media/ lbm1.a.1492.de/28stellungnahme.pdf).

Geschichte vor Ort: Erinnerungskultur im Land Brandenburg für die Zeit von 1933 bis 1990. Konzept der Landesregierung. Ausgegeben: 04.05.2009. [Potsdam] 2009 (Landtag Brandenburg, 4. Wahlperiode. Drucksache 4/7529), www.mwfk.brandenburg.de/media_fast/4055/Konzept_GeschichtevorOrt.pdf [17.10.2016].

Jurist (Diss. A. Univ. Leipzig 1990), 2019 Leiter des Referats 15 (Bau- und Liegenschaftsangelegenheiten, Koordinierung von EU-Strukturfonds) in der Zentralabt. des MWFK.

Politologin, Referentin im Referat 31 (Grundsatzangelegenheiten der Kultur) des MWFK, auch als „Gedenkstättenreferentin“ bezeichnet, seit 1995 hervorgetreten durch zahlreiche Publikationen zum Umgang der Gesellschaft mit ehemaligen Lagern der NS- und Nachkriegszeit und zur Gedenkstättenkultur, u. a.: Geschichte im Dissens. Die Auseinandersetzungen um die Gedenkstätte Sachsenhausen nach dem Ende der DDR. [Diss. FU Berlin 2005]. Leipzig 2006; Instrumentalisierung, Verdrängung, Aufarbeitung. Die sowjetischen Speziallager in der gesellschaftlichen Wahrnehmung 1945 bis heute. Hrsg. von Petra Haustein, Annette Kaminsky, Volkhard Knigge u. Bodo Ritscher. Göttingen 2006.

Zusammenfassende Formulierung nach einem Referat von Dr. Petra Haustein in der Konrad-Adenauer-Stiftung e. V. in Berlin am 21.4.2009 in dem Veranstaltungsbericht von Birgit Lißke: Vom Umgang mit der Vergangenheit. Historische Bildungsarbeit und Erinnerungskultur in Brandenburg, https://idw-online.de/de/ news313571 [16.6.2017].

Haustein, Geschichte vor Ort (wie Anm. 4), S. 21. 
nur summarisch mit zu denken in der Formulierung, das Papier beinhalte „den Zweiten Weltkrieg, die Nachkriegsordnung und den Neubeginn nach 1945“. Auch in dem Satz, der fünf Themen benennt, bei denen sich „Handlungsbedarf“ gezeigt habe, werden sie nicht genannt, hier heißt es u.a. nur „Zweiter Weltkrieg“ und „Alltagsgeschichte in der DDR“. Im Konzept selbst werden Flucht und Vertreibung zwar benannt, aber an etwas versteckter Stelle unter der Überschrift „Fürstenwalde“ ${ }^{68}$ Hier wird aber nicht, wie man erwarten könnte, zur spezifischen Nachkriegssituation an diesem Ort Stellung genommen, sondern ein allgemeiner, nicht Brandenburg-spezifischer Kurzüberblick (21 Zeilen) über das Vertreibungsthema eingefügt - mit einem Fußnotenverweis auf die weiterführende, als „ausführlich“ bezeichnete Broschüre von Oehlsen über die Vertriebenenlager in Brandenburg ${ }^{69}$. Es folgt ein 18-zeiliger Absatz zum in Fürstenwalde ansässigen „Haus Brandenburg“, dem, wenn auch wohl in Zusammenwirken mit Kooperationspartnern, letztlich die Behandlung und Darstellung des Vertreibungsthemas in Ausstellungen als einziger zuständiger Einrichtung im Land zugewiesen werden soll, obgleich das Haus eine klare Zuständigkeit lediglich für die Pflege der Geschichte und Kultur des ostbrandenburgischen Vertreibungsgebietes (Neumark und östliche Niederlausitz) besitzt und damit mehr als ausgelastet ist ${ }^{70}:$ „Zukünftige Ausstellungen sollten dabei auch einen Akzent auf die Integration der Menschen im Land Brandenburg setzen. Dabei kann auf die derzeit vom Brandenburgischen Landeshauptarchiv (BLHA) vorbereitete Quellenedition, Integration der Vertriebenen in Brandenburg in der frühen Nachkriegszeit ${ }^{71}$ zurückgegriffen werden." "W2 Weniger

Ebd., S. 75 f. Eine mehr beiläufige Erwähnung findet sich im sonst ganz dem Thema „Heimkehrer“ gewidmeten Abschnitt zu Frankfurt (Oder) (S. 74): „Hinzukamen aus den ehemaligen deutschen Ostgebieten vertriebene Deutsche, unter ihnen Frauen und Kinder. Teilweise waren die Menschen schwer krank und unfähig zum Weitertransport, sodass zahlreiche Notlazarette eingerichtet werden mussten." Außerdem finden Vertriebene beim Lager Jamlitz knappe Erwähnung (S. 39), mithin einem Ort, der - anders als etwa die Lager Küchensee, Rathenow-Magazininsel oder Rüdersdorf - für die Gruppe eine eher untergeordnete Rolle gespielt hat.

69 Oehlsen, Vertriebenenlager (wie Anm. 45). - Andreas Weigelt, dem diese Literaturbasis wohl auch etwas dünn erschien, verweist in seiner Stellungnahme zum Konzept-Entwurf (www.mwfk.brandenburg.de [17.10.2016]) immerhin auf eine bereits in Müllrose gezeigte Ausstellung und eine von Schülern zusammengestellte Broschüre: Flucht, Vertreibung, Neubeginn nach 1945. Schicksasle und Berichte aus dem Raum Lieberose. Mit Beitr. von: Karl Beerfelde u. a. Hrsg. von der Evang. Kirchengemeinde Lieberose und Land. Red.: Andreas Weigelt. Lieberose 2006.

70 Werner Vogel: Das Haus Brandenburg. Geschichte und Wirksamkeit. In: Landesherr, Adel und Städte in der mittelalterlichen und frühneuzeitlichen Neumark. Klaus Neitmann (Hrsg.) (Bibliothek der Brandenburgischen und Preußischen Geschichte, Bd. 14). Berlin 2015, S. 407-411. - Zur Neumark und Ostbrandenburg siehe den knappen Überblick: Beata Halicka / Matthias Diefenbach: Neumark/Ostbrandenburg/Ziemia Lubuska. In: Online-Lexikon zur Kultur und Geschichte der Deutschen im östlichen Europa, 2018. URL: ome-lexikon.uni-oldenburg.de/p38427 (Stand 23.01.2018).

71 Gemeint ist das zunächst von Dr. Detlef Kotsch, dann von Dr. Harald Engler im Auftrag des BLHA geplante Editionsvorhaben, in das der Verf. erst 2013 als Nachfolger Englers eingestiegen und das erst mit dem vorliegenden, um eine Darstellung erweiterten (aber auch im Quellenteil völlig neu konzipierten) Werk abgeschlossen worden ist.]

72 Ebd., S. 76. Im Entwurf (S. 60) hatte es noch knapper, aber weniger deutlich delegierend geheißen: „Zukünftige Ausstellungen können demnächst auf die derzeit vom Brandenburgischen Landeshauptarchiv (BLHA) vorbereitete Quellenedition ,Integration der Vertriebenen in Brandenburg in der frühen Nachkriegszeit' zurückgreifen." 
deutlich auf das Fürstenwalder Haus fokussiert ist die Formulierung im allgemeineren Abschnitt zu Desideraten: „Darüber hinaus gibt es einen dringenden Bedarf an einer auf der Grundlage des aktuellen Forschungsstands zu erarbeitenden ständigen Ausstellung zum Schicksal der deutschstämmigen ${ }^{73}$ Heimatvertriebenen. Hier ist zu diskutieren, von welcher Institution eine solche Einrichtung getragen werden könnte. In jedem Fall jedoch ist die Kooperation mit polnischen Partnerinstitutionen anzustreben. Hierbei kann an bereits bestehende Kontakte der Stiftung Brandenburg ${ }^{74}$ angeknüpft werden. ${ }^{\text {"75 }}$ Auch hier wird also zwar erstmals ausdrücklich das Desiderat einer Dauerausstellung formuliert, aber letztlich wohl doch wiederum der (vom Land rechtlich unabhängigen) Stiftung Brandenburg als Trägerin des Fürstenwalder Hauses, wenn auch indirekt, die Zuständigkeit zugewiesen. Demgegenüber hatte die Sozialforscherin und Geschäftsführerin der Bundesstiftung zur Aufarbeitung der SED-Diktatur Dr. Anna Kaminsky (geb. 1962 Gera) in ihrer Stellungnahme zum Entwurf des Konzepts bezüglich der „Frage nach dem Ort, an dem die Geschichte der Heimatvertriebenen aufgearbeitet und ausgestellt werden könnte“ behutsam kritisch angemerkt: „Käme hier nicht das Haus der Brandenburgischen Geschichte ${ }^{76}$ in Potsdam oder Eisenhüttenstadt $t^{77}$ in Frage? ${ }^{\text {"78 }}$

\section{Landes- und Regionalgeschichte}

„Forschungen zur Nachkriegszeit mit landes- bzw. regionalgeschichtlichen Bezügen fristen [...] immer noch ein eher stiefkindliches Dasein. Dies trifft generell auch für Brandenburg zu." ${ }^{\text {"79 }}$ So lautet die Bilanz eines aus dem Land stammenden Landeshistorikers. Die nach 1990 zunächst sehr geförderte, in den letzten Jahren aber kaum noch über (universitären) Einfluss, geschweige denn Ausbildungsstätten, verfügende landesgeschichtliche Forschung in Berlin und Brandenburg ${ }^{80}$ hat das Thema Flucht und Vertreibung in ihren Gesamtdarstellungen bislang - dem Stand der Forschung, aber auch dem der begrenzten öffentlichen Wahrnehmung entsprechend - nur ganz am Rande behandelt. In der bis heute maßgeblichen, 1995 erschienenen Gesamtdarstellung teilen sich zwei besonders als Berlin-Historiker ausgewiesene Autoren, beide - inzwischen emeritierte - Berliner Universitätsprofessoren, die Zeit vor und nach Kriegsende 1945. Laurenz

73 [Dieses Adjektiv fehte im Entwurf (S. 64).]

74 [Sie ist die Trägerin des oben genannten Hauses Brandenburg.]

75 Ebd., S. 79 (Abschnitt „2.6.1 Handlungsbedarf und Perspektiven für das Themenfeld, Erinnerung an die Nachkriegsordnung, den Neubeginn 1945 und den staatlichen Antifaschismus“").

76 [Gemeint ist das „Haus der Brandenburgisch-Preußischen Geschichte“ (HBPG).]

77 [Gemeint ist offenkundig das „Dokumentationszentrum Alltagskultur der DDR“.]

78 Stellungnahme auf www.mwfk.brandenburg.de [17.10.2016].

79 Matthias Helle: Nachkriegsjahre in der Provinz. Der brandenburgische Landkreis Zauch-Belzig 1945 bis 1952 (Studien zur brandenburgischen und vergleichenden Landesgeschichte, Bd. 4). Berlin 2011, S. 11.

80 Pessimistische Zwischenbilanz: Bahl, Landesgeschichte in Berlin-Brandenburg heute (wie Anm. 3). An dieser hat sich seither nicht viel geändert, da der seit Oktober 2019 im Aufbau befindlichen neuen Professur für „Brandenburg-preußische Geschichte“ am Historischen Institut der Universität Potsdam offenbar, soweit bislang erkennbar, historisch-landeskundliche Interdisziplinarität und epochenübergreifendes Konzept, über die Frühe Neuzeit hinaus, fehlen werden. 
Demps (geb. 1940 Berlin) konzentriert sich bei den letzten Jahren des Krieges fast ganz auf die militärischen Kriegshandlungen und den 20. Juli $1944 .{ }^{81}$ Er erwähnt zwar noch relativ ausführlich die Umquartierungen aus den „luftgefährdeten Gebieten“ (Berlin, Hamburg, Ruhrgebiet usw.) in die Provinz Brandenburg, lässt aber den gleichzeitigen riesigen Flüchtlingsstrom unerwähnt bzw. versteckt ihn geradezu in einem Zitat aus einer Weisung des Reichsinnenministers vom 12. Februar 1945, in der bezüglich der zu planenden (!) „Umquartierung Ost“ die „Evakuierung für die Mark“ angesprochen wird und dabei nur ganz nebenbei die „im Gau Brandenburg noch in Marsch befindlichen Trecks sowie teilweise sonstige Flüchtlinge aus dem Warthegau" Erwähnung finden, die „in den Gau Halle-Merseburg weitergeleitet“ werden sollten. ${ }^{82}$ Der un-, ja nunmehr desinformierte Leser kann daraus beim besten Willen nicht ersehen, was sich damals in Brandenburg bereits abspielte und wie viele dieser Menschen nicht weitergeleitet wurden. ${ }^{83}$ Der Autor, der die anschließenden sieben Nachkriegsjahre behandelt, Wolfgang Ribbe (geb. 1940 Berlin), bezieht dagegen, auf Akten gestützt, „Flüchtlinge/Vertriebene in Brandenburg und in der SBZ" (Tabellentitel) ein und beschreibt zu Beginn seines Beitrages sowohl deren Aufnahme 1945/46 als auch die ersten Eingliederungsbemühungen. ${ }^{84}$ In dem parallel erschienenen, für

81 Laurenz Demps: Die Provinz Brandenburg in der NS-Zeit (1933 bis 1945). In: Brandenburgische Geschichte. Hrsg. von Ingo Materna u. Wolfgang Ribbe. Berlin 1995, S. 619-676, zu den letzten Kriegsjahren S. 668-676, bes. S. 665 f. (S. 666 Tabelle der 1945 aus Gebieten westlich de Oder in die Provinz Brandenburg Evakuierten). - Noch stärker auf die rein militärischen Kriegshandlungen begrenzt ist die Darstellung in dem einzigen überhaupt die Zeit thematisierenden Beitrag zu einem für Brandenburg wichtigen zeitgeschichtlichen Sammelband: Richard Lakowski: Das Ende der Naziherrschaft in Brandenburg. Mit einer Dokumentation. In: Brandenburg in der NS-Zeit. Studien und Dokumente. Hrsg. von Dietrich Eichholtz unter Mitarb. von Almuth Püschel. Berlin 1993, S. 411-442. Ganz isoliert stehen am Ende des Dokumentenanhangs plötzlich (undatierte) Auszüge aus ,amtsärztlichen Berichten über die Zustände im Gesundheitswesen des Landes Brandenburg bei und unmittelbar nach Kriegsende“" (S. 440 f.). Hier wird - im letzten Satz des letzten Berichtes (S. 441) unkommentiert „das unkontrollierte Einströmen von Flüchtlingen aus dem Osten“ als gewichtige Ursache für die Ausbreitung von Seuchen benannt, ein damit an gleichsam versteckter Stelle angerissenes Problemfeld, mit dem der Leser aber allein gelassen wird.

82 Demps, Die Provinz Brandenburg in der NS-Zeit (wie Anm. 81), S. 666. - Auch für Berlin bleibt Demps - mit drei beiläufigen Zeilen zum Flüchtlingsthema vor Kriegsende 1945 - knapp. Siehe: Ders.: Berlin im Bombenkrieg. In: Berlin 1933-1945. Michael Wildt / Christoph Kreutzmüller (Hg.). Berlin 2013, S. 357-371, Kapitel „Die Versorgung der Berliner Bevölkerung nach den Luftangriffen“ (S. 368-370), hier S. 370: „In den letzten Kriegsmonaten wurden die Aufnahmegebiete [evakuierter Berliner - P. B.] im Osten des Reiches zu ,Entsendegauen', da deren Bewohner selbst zu Flüchtlingen vor der Roten Armee wurden. [...] Die Wege der flüchtenden Menschen überschnitten sich mit den aus dem Osten zurückflutenden Massen und den Flüchtlingstrecks. Transportzüge konnten nicht mehr eingesetzt werden."

83 Mit zweieinhalb Zeilen unter dem 11. Januar 1945 ebenfalls viel zu knapp, aber wesentlich informativer sind die Angaben von Ingo Materna (geb. 1932 Groß Lunow, Mecklenburg) in dem parallel erschienenen, für einen breiteren Leserkreis konzipierten Datenband: Ingo Materna: 1918 bis 1945. Brandenburg in der Weimarer Republik und während der NS-Herrschaft. In: Ders. / Wolfgang Ribbe: Geschichte in Daten. Brandenburg. München/Berlin 1995, S. 198-223, hier S. 222: „In die Mark Brandenburg sind 668000 Personen, umgesiedelt worden. Zu den Evakuierten kommen fortwährend Flüchtlinge aus den Ostprovinzen."

84 Wolfgang Ribbe: Das Land Brandenburg in der SBZ/DDR (1945 bis 1952). In: Brandenburgische Geschichte (wie Anm. 81), S. 677-726, hier S. 678-680 (S. 679 Tabelle „Flüchtlinge/Vertriebene in Brandenburg und in 
eine breitere Öffentlichkeit konzipierten Datenhandbuch existiert das Thema dagegen so gut wie gar nicht oder seine Kenntnis wird vorausgesetzt, obgleich viele andere, auch lokale und manche durchaus nebensächlichen Ereignisse mitgeteilt werden. Gleich zu Beginn des Nachkriegsabschnitts heißt es bei 1945: „Wegen der allgemeinen Wohnungsnot werden Flüchtlinge und heimkehrende Kriegsgefangene in Barackenlagern untergebracht, die während des Zweiten Weltkriegs für ausländische Zwangsarbeiter errichtet worden sind." ${ }^{\circ 5}$ Um welche Flüchtlinge aus welchen Gebieten es sich hier handelt, erfährt der Leser genauso wenig wie er irgendeine Information über die anschließenden Vertreibungen im Sommer und ab Herbst 1945 erhält. Drei Seiten weiter wird dann beim „Potsdamer Abkommen“ nur mitgeteilt, dass darin beschlossen worden sei, die deutsche Bevölkerung der Ostgebiete auszusiedeln, und dass diese anschließend bis auf wenige Reste vertrieben worden sei. Zwar heißt es dabei auch: „Brandenburg verliert damit mehr als ein Drittel seiner Fläche. " 86 Doch was die Vertreibung für das bei Deutschland verbleibende brandenburgische Gebiet bedeutete, bleibt ungesagt. Nur wer die der Zeittafel vorangestellte kurze Einleitung liest, erfährt - in einem einzelnen Satz und ohne jede konkretere zeitliche Angabe -, dass „durch und nach Brandenburg die meisten Flüchtlinge und Vertriebenen aus den östlichen Provinzen Preußens und mit ihnen auch viele heimkehrende Kriegsgefangene" gezogen sind. ${ }^{87}$ Knapper geht es nicht.

Demgegenüber gelingt dem sonst auf die Frühe Neuzeit konzentrierten - inzwischen ebenfalls emeritierten - Potsdamer Lehrstuhlinhaber für Brandenburg-Preußische Landesgeschichte (1992-2016), Peter-Michael Hahn (geb. 1951 Mönchengladbach), in seiner knappen (Gesamt-) „Geschichte Brandenburgs" trotz Beschränkung auf insgesamt 128 Seiten im Taschenbuchformat eine ebenso informative wie eindrückliche Schilderung der Thematik. Unter Verzicht auf abgedroschene und unspezifische Formulierungen schildert er die konkreten Auswirkungen auf die "Zusammensetzung der brandenburgischen Bevölkerung" als „tiefgreifende Neuformierung der Gesellschaft" und betont dabei, was oft übergangen wird, die „außergewöhnliche soziale Dramatik der Nachkriegszeit“ schließlich auch das „Umsiedler“-Erwähnungs-Tabu ab $1948 .{ }^{88}$

Erkennbar offen für das Thema ist auch der - inzwischen hauptberuflich nicht mehr in der Wissenschaft beschäftigte, aber weiter als Rezensent zeitgeschichtlicher Publikationen tätige - Autor, der die DDR-Zeit von 1952 bis 1990 im Rahmen der auf mehrere Bände angelegten Reihe „Brandenburgischen Geschichte in Einzeldarstellungen“ behandelt: Detlef Kotsch, der uns

der SBZ“ 1945/1946/1949), 714, 716. - Sehr knapp dagegen in der broschierten Stadt-Zeitgeschichte: Ders.: Berlin 1945-2000. Grundzüge der Stadtgeschichte. Berlin 2002, S. 19 (drei Sätze in sechseinhalb Zeilen beim Kriegsende: „Strom von Flüchtlingen“, „monatlich hunderttausende Vertriebene“, „Zuzugssperr“; dazu eine Fußnote als Quelle: 1946 gedruckter Bericht des Magistrats).

85 Rosemarie Baudisch: 1945 bis 1952. Brandenburg in der SBZ/DDR. In: Materna/Ribbe, Geschichte in Daten (wie Anm. 83), S. 224-246, hier S. 226.

86 Ebd., S. 229.

87 Ebd., S. 224.

88 Peter-Michael Hahn: Geschichte Brandenburgs. München 2009, S. 100 f., ferner zur Vertreibung „zwischen Arnswalde im Norden und Sorau im Süden" S. 102. 
bereits oben mit seinem beachtenswerten Beitrag zum Vertriebenen-Thema speziell begegnet ist, behandelt im u. a. den Nachbarn Brandenburgs gewidmeten Kapitel 10 allem voran das „deutsch-polnische Verhältnis in den östlichen Grenzgebieten“ und gelangt dabei zu einer - im Vergleich mit mancher anderen Publikation - bemerkenswert offenen Darstellung, in der er bis 1945 zurückblickend und bis 1990 weiterdenkend, schonungslos Ursachen und Folgen, auch für die Bewohner der Grenzregion, beschreibt und der weiteren Forschung auf beiden Seiten der Staatsgrenze damit bereits den Weg weist. ${ }^{89}$

Ähnlich interessiert wie Kotsch erscheint der - inzwischen im Berliner Schuldienst tätige - Autor einer in der damaligen Abteilung Historische Landeskunde des Friedrich-Meinecke-Instituts entstandenen Berliner FU-Dissertation von 2008 über den südwestbrandenburgischen Kreis Zauch-Belzig in der Nachkriegszeit, Matthias Helle (geb. 1969 Belzig), der im Kapitel „Soziale und demographische Verhältnisse“ einen sogar 16 Seiten starken Abschnitt „Heimatvertriebene“ bietet, für den er Akten des BLHA benutzt hat und daher für einen BeispielLandkreis nicht die üblichen Allgemeinplätze, sondern durchweg Konkretes und auch Neues bieten kann. ${ }^{90}$ Helle ist auch als Autor eines Überblicksbeitrages für die Zeit von 1945 bis 1952 in dem als Sammelband mehrerer Autoren in Vorbereitung befindlichen entsprechenden Band der „Brandenburgischen Geschichte in Einzeldarstellungen“ vorgesehen.

Die anerkannten Nachschlagewerke zur brandenburgischen Landes-, Regional- und Ortsgeschichte bieten beim Thema „Flüchtlinge und Vertriebene“ nur dürftige, meist schwer auffindbare Informationen. ${ }^{91}$ Im 2000 erschienenen Städtebuch werden „Umsiedlerlager“ nur in wenigen Artikeln - Forst (Lausitz), Fürstenwalde/Spree, Spremberg - summarisch und ohne genauere Lokalisierung genannt, obgleich vielen anderen, ebenfalls nur vorübergehenden Phänomenen Platz eingeräumt wird. ${ }^{92}$ Die anfangs zahlreichen „Umsiedlergenossenschaften“

Detlef Kotsch: Das Land Brandenburg zwischen Auflösung und Wiederbegründung. Politik, Wirtschaft und soziale Verhältnisse in den Bezirken Potsdam, Frankfurt (Oder) und Cottbus in der DDR (1952 bis 1990) (Bibliothek der Brandenburgischen und Preußischen Geschichte, Bd. 8; Brandenburgische Geschichte in Einzeldarstellungen, Bd. 8). Berlin 2001, S. 401-411. - Zur Oder-Neiße-Grenze jetzt auch die ebenso ungewöhnliche wie umfassende Studie von Wolfgang Blöß: Grenzen und Reformen in einer Umbruchgesellschaft. Vom Land Brandenburg zu den Bezirken 1945-1952 (Veröffentlichungen des Brandenburgischen Landeshauptarchivs, Bd. 66). Berlin 2014, darin S. 57-75 das Kapitel „Die Grenze gegen Polen“.

90 Helle, Nachkriegsjahre in der Provinz (wie Anm. 79), S. 292-308, ferner im Quellenanhang, S. 348 f., zwei Berichte zu „Umsiedlerlagern“. - Betreuer der Dissertation war der Landeshistoriker Gerd Heinrich (19312012), Zweitgutachter der Zeithistoriker Arnd Bauerkämper (geb. 1958 Detmold). Von dieser Arbeit gibt es auch eine ältere (Hochschulschriften-) Online-Version, der gegenüber aber nur noch die leicht überarbeitete gedruckte Version zitiert werden sollte.

91 Fehlanzeige auch in dem für einen breiteren Nutzerkreis gedachten Führer von Martin Kaule: Brandenburg 1933-1945. Der historische Reiseführer. Berlin 2012. 2., aktualis. Aufl. 2014. Hier kommen zwar Lagerstandorte wie Falkensee und Glöwen vor, aber ohne Berücksichtigung ihrer - unmittelbar aus den Geschehnissen der NS-Zeit folgenden - Zeit als Vertriebenen-/Heimkehrerlager.

92 Jeweils im Abschnitt 6a „Die städtische Bevölkerung und das Sozialgefüge“; „teilw. Unterbringung in Auffanglager u. Einsatz in Textilind.[ustrie]“ für den „Zustrom von Flüchtlingen u. Vertriebenen aus ehem. dt. O[st]-Gebieten“ erwähnt Uwe Meier im Art. Forst/Lausitz (Städtebuch Brandenburg und Berlin [wie Anm. 54], S. 158). Eva- 
werden nicht als solche erkennbar, da nur von „Genossenschaften“ gesprochen wird. Im Abschnitt „Die städtische Bevölkerung und das Sozialgefüge“ wird das Thema von den meisten Autoren kaum berücksichtigt, jedenfalls gehen sie - dies ist verbreitet - sehr unterschiedlich mit ihm um. ${ }^{93}$ Für Brandenburg an der Havel z. B. wird lediglich bei der „Zuwanderung“ von Katholiken ohne Zahlenangaben auch die „von Flüchtlingen und Vertriebenen 1945“ genannt; immerhin folgen dann noch Gesamtzahlen der ortsansässigen Katholiken, so dass die große Bedeutung dieses Zuzugs indirekt deutlich wird..$^{94}$ Ausgerechnet im Artikel „Guben“ wird ebenfalls vielen anderen Facetten der Bevölkerungsgeschichte Platz eingeräumt, z. B. der Beschäftigung „zahlr. poln. Gastarbeiter v. a. im Chemiefaserwerk" während der 1970er und 1980er Jahre" ${ }^{95}$ die gerade an diesem Ort so dramatischen und gravierenden (Bevölkerungs-)Veränderungen des Jahres 1945 aber - ganz anders als in der allgemeinen Einleitung ${ }^{96}$ - mit keinem Wort erwähnt; nur die lapidar gereihten Bevölkerungszahlen für beide Stadthälften lassen diese erkennen: 1945: östlich der Neiße ca. 37000, westlich 8000; 1946 westlich der Neiße 25 297, und auch noch 1964: 25 492. ${ }^{97}$ Im Artikel „Eisenhüttenstadt“ heißt es immerhin kurz: „Nach 2. WK Unterbringung von Flüchtlingen aus ehem. dt. Ostgebieten: am 5.9.1945 in F. [ürstenberg/Oder] (ohne Schönfließ) 128 Flüchtlinge, im Okt. 160.“98 Bei Baruth liest man sogar bezüglich der Bevölkerungszahl: „1945: 3000 Menschen, davon 1000 Evakuierte u. Flüchtlinge; 1946: 2232, davon ein Viertel Auswärtige “99 Solche Größenordnungen wären für die meisten Städte zu nennen, doch bleiben nicht nur die Ursachen meist unerwähnt, sondern in der Mehrzahl auch das bloße Phänomen. So stehen Städtebuch-Artikel, die von einem Flüchtlingszuzug sprechen, der die Bevölkerungszahl bisweilen vorübergehend fast verdoppelte ${ }^{100}$ - Beeskow, Dahme, Fehrbellin, Gransee, Havelberg, Peitz -, neben solchen, die das Thema, obwohl es in hohem Maße einschneidend war, wie eben in Guben, vollständig unerwähnt lassen. Die als geraffte Überblicksdarstellung

maria Engel und Katrin Sauerwein erwähnen für Frankfurt (Oder) das „Heimkehrerlager Gronenfelde als Durchgangs- bzw. Entlassungslager" (S. 167).

93 Durchweg ohne jeden Hinweis auf Flüchtlinge bleiben z. B. die Artikel von Rolf Barthel (geb. 1932 Frankenberg/Sachsen) und Lieselott Enders (geb. 1927 Elbing), stets erwähnt werden sie dagegen in den von Evamaria Engel (geb. 1934 Greifswald) verfassten.

94 Winfried Schich: Brandenburg an der Havel. In: Städtebuch Brandenburg und Berlin (wie Anm. 54), S. 4769, hier S. 55.

95 Harald Engler: Guben. In: Städtebuch Brandenburg und Berlin (wie Anm. 54), S. 225-234, hier S. 227.

96 Heinrich, Land und Städte in Brandenbug und Berlin. II (wie Anm. 54), S. XLVIII: „In der Neißestadt Guben wurde die gesamte Bevölkerung an einem Tage über den Fluß in die westliche Vorstadt getrieben."

97 Harald Engler: Guben. In: Städtebuch Brandenburg und Berlin (wie Anm. 54), S. 225-234, hier S. 227. Im Abschnitt 10b „Kriegsereignisse und Kriegsfolgen“ heißt es auch nur (1945): „Bev.[ölkerung] mußte G.[uben] räumen (7.2.)." Damit ist aber nur die Evakuierung vor der Front, wie sie in fast allen brandenburgischen Städten vorgenommen wurde, gemeint.

98 Klaus-Dieter Gansleweit: Eisenhüttenstadt. In. Städtebuch Brandenburg und Berlin (wie Anm. 54), S. 123133, hier S. 126.

99 Evamaria Engel: Baruth. In: Städtebuch Brandenburg und Berlin (wie Anm. 54), S. 22-26, hier S. 23.

100 Beiträge der Autoren H. Assing, W. Blaschke, E. Engel / K. Sauerwein, H. Engler (teilweise) und W. Schich. 
konzipierte geschichtliche Einleitung widmet dem Vertreibungsgeschehen immerhin mit acht Sätzen einen von sieben Absätzen zur „Nachkriegszeit - Besatzungzeit“ ${ }^{101}$

Sehr unterschiedlich ist die Berücksichtigung des Themas auch in den Stadtlexika einzelner Kommunen, die inzwischen für Brandenburg an der Havel, Potsdam und Prenzlau in umfangreicherer, für Bad Freienwalde und Guben in kleinerer Form vorliegen. Immerhin einen knappen Artikel „Vertriebene“ enthält das Stadtlexikon Prenzlau, das damit wenigstens deren Existenz nicht - wie es in vielen anderen, auch neueren lokalgeschichtlichen Arbeiten immer noch geschieht - aus der Stadtgeschichte ausblendet. ${ }^{102}$ Bei den sonstigen Einzelartikeln allerdings findet man kaum Erwähnungen. Nur das Gubener Lexikon enthält einen ausführlicheren Eintrag zu den für diese geteilte Stadt besonders einschneidenden „Vertreibungen vom 20. Juni 1945", dessen Autor es gelingt, in konzentrierter Form und doch außerordentlich faktenreich die Geschehnisse in dieser Grenzstadt und ihrem Umland mit der allgemeinen politischen Entwicklung zu verknüpfen und trotz der (für Guben entscheidenden) zeitlichen Fokussierung auf die „Wilden Vertreibungen“ vom Sommer 1945 auch deren Folgen für die beiden Stadthälften in den DDR-Jahren und schließlich bis zur Gegenwart anzusprechen. ${ }^{103}$

Auch wenn - neben dem Forschungsstand - nicht nur die Kenntnisse, sondern auch die Sozialisierung des jeweiligen Autors nach wie vor eine Rolle zu spielen scheinen ${ }^{104}$, wirkt der zunehmende zeitliche Abstand zum Geschehen des Jahres 1945 hier und da offenkundig entspannend und verwissenschaftlichend. So gibt es neuerdings auch erfreuliche Beispiele dafür, dass das Thema nicht mehr bewusst weggelassen oder aus Gedankenlosigkeit übergangen wird, sondern der Begriff „Flüchtlinge“, hier bezogen auf die des Jahres 1945, sogar in Sachregister jüngerer landeskundlicher Veröffentlichungen Eingang findet. ${ }^{105}$ An den großen - über die Vertriebenenzuwanderung hinausreichenden - bevölkerungsgeschichtlichen Desideraten, die der Landeshistoriker Gerd Heinrich (geb. 1931 Berlin, gest. 2012) 1990 in sehr gedrängter Form Flucht und Vertreibung nur am Rande mit nennend - aufzeigte, hat sich jedoch trotz der großen

101 Heinrich, Land und Städte in Brandenburg und Berlin. II (wie Anm. 54), S. XLVIII.

102 Prenzlauer Stadtlexikon und Geschichte in Daten. Hrsg.: Uckermärkischen Geschichtsvereins zu Prenzlau e. V. (Arbeiten des Uckermärkischen Geschichtsvereins zu Prenzlau e. V., Bd. 7). Prenzlau 2005, S. 197 f.

103 Gernod Arlt: Vertreibungen vom 20. Juni 1945. In: Heimatlexikon für Guben und Umgebung. Hrsg. vom Gubener Heimatkalender e. V. Gesamtleitung: Gernod Arlt (Koordinator) u. a. [Überarb. u. erw. Ausg.]. Guben 2002, S. 111-112.

104 Das betrifft sowohl Fälle starker Prägung durch die DDR-Geschichtspolitik, die noch heute oft zur Tabuisierung in Darstellungen beitragen, als auch das Phänomen, dass es sich bei den Autoren, die dem Thema mit besonderer Motivation näher treten, oft selbst um Nachfahren von Vertriebenen handelt.

105 Das Havelland um Rathenow und Premnitz. Eine landeskundliche Bestandaufnahme. Hrsg. von Sebastian Kinder u. Haik Thomas Porada im Auftr. des Leibniz-Inst. für Länderkunde u. der Sächs. Akad. der Wiss. zu Leipzig (Landschaften in Deutschland, Bd. 74). Köln u.a. 2017, S. 445-454 „Sachwortverzeichnis“ (bearb. von H. Th. Porada), hier S. 447 „Flüchtlinge, Heimatvertriebene“ (22 Seitenverweisungen), S. 448 „Heimatvertriebene. Siehe Flüchtlinge“. Die entsprechenden Textpassagen stammen von Sebastian Kinder (Überblickskapitel) und vor allem von Matthias Helle (Ortsartikel), der bereits in seiner Dissertation (wie Anm. 79) dem Thema breiteren Raum eingeräumt hatte. 
Möglichkeiten, die sich durch Öffnung von Grenzen, Archiven und geistigen Schranken seither bieten, kaum Grundsätzliches geändert. ${ }^{106}$

In den Regionalmuseen zeigt sich inzwischen hier und da allmählich, vor allem mit dem sich vollziehenden Generationswechsel, eine Öffnung auch für zeitgeschichtliche Themen. Dennoch bleibt noch viel zu tun, so dass die Zwischenbilanz der Vorsitzenden des Museumsverbandes Brandenburg noch 2017 kritisch ausfiel: „Das Feld der DDR-Geschichte wurde in vielen örtlichen Museen lange Zeit nicht beackert. So entstanden Brachflächen in der Museumslandschaft.، ${ }^{107}$ Immerhin nennt sie unter den Desideraten nun auch „Flucht und Vertreibung“, denn „auch die Geschichte der Migration“ gehöre in den Kontext der DDR-Industrieund Zeitgeschichte: „Man denke allein an die erheblichen Bevölkerungsverschiebungen in der Nachkriegszeit und frühen DDR, an Flucht und Vertreibung, an Enteignungen und Bodenreform, Flucht in den Westen, Abwanderung oder neue Zuwanderung im Zuge des Aufbaus neuer DDR-Industriestandorte, so zum Beispiel in Eisenhüttenstadt, Senftenberg oder Schwedt." Der Absatz mündet in den indirekten Appell, diese Themen endlich in Angriff zu nehmen: „Viele brandenburgische Orte bieten reichen Stoff zur Reflektion darüber. ${ }^{\text {“108 }}$

\section{Spezialdisziplinen und Nachbarwissenschaften}

Im Zusammenhang mit der Bodenreform sind teilweise einzelne Häusergruppen bzw. Teilsiedlungen entstanden, die innerhalb einer $\mathrm{H}$ is t or is chen $\mathrm{L}$ andeskunde insbesondere die Siedlungsforschung ${ }^{109}$, daneben auch die Volkskunde ${ }^{110}$ interessieren. De nkmalpflege sowie Bau- und Kunstgeschichte wenden sich inzwischen vermehrt auch der DDR-Zeit zu, wobei die „Ost-Moderne“ im Vordergrund des Interesses steht, aber neben „Kulturhäusern“ gelegentlich auch die im Zuge der Bodenreform entstandenen „Neubauernhäuser" in den Blick genommen werden. ${ }^{111}$ Die Medizingeschichte kann für Branden-

106 Gerd Heinrich: Landesgeschichtliche Arbeiten und Aufgaben in Berlin-Brandenburg. Rückblicke und Ausblicke. In: Jahrbuch für die Geschichte Mittel- und Ostdeutschlands 39 (1990), S. 1-42, S. 24-34: „Zukunftsaufgaben“, darin S. 32-34 „12. Bevölkerung“, hier S. 32: „Die Zu- und Abhänge [...] wurden schließlich durch Flucht, Vertreibung und Verdrängung erneut ausgelöst." Umfassender, nicht nur auf 1945 bezogen: „Trotz aller Umschichtungen und Abgänge blieb eine starke schicht bodenständiger ,Brandenburger' erhalten, und wurde durch Assimilierte aus der Neumark und aus Hinterpommern ergänzt".

107 Susanne Köstering: DDR-Geschichte in brandenburgischen Museen. Wo stehen wir, wo geht es hin? In: Museumsblätter. Mitteilungen des Museumsverbandes Brandenburg 31 (2017), S. 8-15, hier S. 9.

108 Ebd., S. 10.

109 Dorfentwicklung in Brandenburg. Hrsg.: Ministerium für Landwirtschaft, Umweltschutz und Raumordnung (MLUR) des Landes Brandenburg in Verb. mit Märkische Akademie ländlicher Raum e. V. Konzeption u. Gestaltung: Norbert Rauscher. Potsdam 2002, S. 16: „Bodenreformsiedlungen für Neubauern, Flüchtlinge und Vertriebene (Umsiedler) auf nach 1945 enteignetem Gutsland“.

110 Klaus Schreiner: Das Neubauerngehöft als museales Objekt im Agrarhistorischen Museum Alt Schwerin. In: Neubrandenburger Mosaik 1980, S. 33-42.

111 Ein Neusiedlerhaus in Caule bei Luckau ist (nach Sanierung) 2009 unter Denkmalschutz gestellt worden. Siehe dazu die ausführliche Baubeschreibung von Lothar Treder-Schmidt: Ein Neusiedlerhaus als Baudenk- 
burg inzwischen mit diversen Monographien zu einzelnen Krankenhäusern aufwarten, wobei auch die - z. T. schon zu DDR-Zeiten erschienenen - kleineren Aufsätze in der Regionalliteratur durchaus hilfreich sein können und nicht zuletzt die Erinnerungen einzelner Ärzte wichtige Quellenzeugnisse darstellen. ${ }^{112}$ Die Berücksichtigung der in den Kriegs- und Nachkriegsjahren einschneidenden Belastung der Häuser durch Flüchtlingsnot und Seuchen wird allerdings in den jeweiligen Arbeiten wiederum sehr unterschiedlich ausführlich berücksichtigt. Eher den bestehenden Forschungsbedarf der Bevölkerungsgeschichte bzw. Hist or ischen Demographie wie auch der Namenforschung als vorzeigbare Erkenntnisse offenbaren die lapidaren, von wenig Regionalkenntnis zeugenden Äußerungen des Onomastikers Jürgen Udolph (geb. 1943 Berlin-Pankow) zur „Zuwanderung durch Umsiedlung, Vertreibung und Flucht am Ende des 2. Weltkriegs", auf welch letztere er irrigerweise den größeren Teil slawischer Familiennamen im heutigen Brandenburg zurückführt. ${ }^{113}$

\section{Volkskunde/Ethnologie, Alltags- und Kulturgeschichte}

Zwar gab es in der Bundesrepublik schon frühzeitig eine Kommission für ostdeutsche (heute: deutsche und osteuropäische) Volkskunde in der Deutschen Gesellschaft für Volkskunde e.V. mit einem noch heute erscheinenden Jahrbuch ${ }^{114}$ und einer Schriftenreihe sowie vor allem das Institut für ostdeutsche Volkskunde (heute: Institut für Volkskunde der Deutschen des östlichen Europa) in Freiburg im Breisgau, die sich neben der volkskundlichen Erforschung der Ver-

mal? T. 1-2. In: Luckauer Heimatkalender 50 (2018), S. 48-54; 51 (2019), S. 25-29. - Bauliche Bestandsaufnahme für einen weiteren Beispielort: Klaus-Peter Mentzel: Die Neubauernsiedlungen in Falkensee. In: Heimatjahrbuch für Falkensee und Umgebung 2018 (2017), S. 28-33. - Siehe auch für das ehemals sachsenanhaltische, heute zu Brandenburg gehörige Freileben (zwischen Dahme und Herzberg/Elster) den Beitrag einer Denkmalpflegerin: Sybille Gramlich: Freileben. Das Neubauerndorf - Ein hoffnungsvoller Neubeginn. in: Brandenburgische Denkmalpflege 4 (1995), H. 1, S. 129-137.

112 Z.B. die Arbeiten des Cottbuser Klinkdirektors Obermedizinalrat Dr. Eberhard Hetzke (1931-2016), dessen Nachlass sich zudem im Stadtarchv Cottbus befindet; vgl. Nachruf von Klaus Lange in: Cottbuser Heimatkalender 2017, S. 122. - Siehe im Übrigen die Literaturangaben bei den jeweiligen Orten.

113 Jürgen Udolph: Schall und Rauch. Orts- und Familiennamen. In: Das Brandenbuch. Ein Land in Stichworten. Hrsg. von der Brandenburgischen Landeszentrale für politische Bildung. Potsdam 2015, S. 189-192, hier S. 191. Grotesk ist der auf die frühmittelalterliche slawische Zuwanderung bezogene Hinweis, es gebe auch „slawische Namen, die sehr viel früher in Brandenburg heimisch geworden sind“, während der hierfür viel wichtigere Zustrom aus den Ostprovinzen im 19. Jh. bzw. im Kaiserreich unerwähnt bleibt. Auf die alte slawische Bevölkerung Brandenburgs führt Udolph zudem Namen zurück, die zum größten Teil typisch pommersch und eben nicht brandenburgisch sind, folglich zum größeren Teil eher erst durch die Vertreibung von 1945 nach Brandenburg gelangt sein dürften. Viel häufiger als die von ihm angeführten (eher auf Arbeitsmigranten des 19. Jh. zurückgehenden) slawisch-oberschlesischen und polnischen Namen sind in Brandenburg z. B. die 1945 dorthin gelangten typisch (nieder)schlesischen Namen.

114 Ab 1955 „Jahrbuch für Volkskunde der Heimatvertriebenen“, ab 1963 fortgesetzt als „Jahrbuch für ostdeutsche Volkskunde“, seit 1995 "Jahrbuch für deutsche und osteuropäische Volkskunde“. 
treibungsgebiete auch intensiv mit Themen der Eingliederung von Flüchtlingen, Vertriebenen und (Spät-)Aussiedlern annahmen und bis heute annehmen. Einer Vielzahl von Untersuchungen zur Situation in den westlichen Bundesländern stehen jedoch bislang nur wenige zu der in SBZ/DDR und neuen Bundesländern gegenüber. ${ }^{115}$

Die seit 1995 als Wissenschaftliche Mitarbeiterin am Institut für Europäische Ethnologie der Humboldt-Universität zu Berlin lehrende habilitierte Volkskundlerin bzw. Ethnographin Leonore Scholze-Irrlitz (geb. 1963 Berlin), zugleich Leiterin der dort seit 1995 angebundenen Landesstelle für Berlin-Brandenburgische Volkskunde, hat sich, ausgehend von ihrer ehemaligen Museumsleitertätigkeit in Beeskow ${ }^{116}$, in den neunziger Jahren nebenbei auch mit der Lebenssituation von Flüchtlingen und Vertriebenen im brandenburgischen Landkreis BeeskowStorkow befasst und ist dabei insbesondere der Rolle der Frauen nachgegangen. Diese verdienstvollen Arbeiten sind jedoch für eine breitere Rezeption in der berlin-brandenburgischen Zeitgeschichtsforschung an relativ entlegener Stelle, teils weitab von Brandenburg ${ }^{117}$, teils mehr fachdisziplinintern erschienen ${ }^{118}$, das Thema gehört auch nicht mehr zu den aktuellen Forschungsgebieten der Verfasserin. Insofern ist es zu begrüßen, dass etwas später immerhin noch eine knappe Zusammenfassung in einem populären regionalen Periodikum am Ort bekannt gemacht wurde. ${ }^{119}$ Am Berliner Institut ist ferner 1995 eine von dem (selbst nicht mit dem Thema befassten) Kulturwissenschaftler und Volkskundler/Ethnologen Wolfgang Kaschuba (geb. 1950 Göppingen) betreute Diplomarbeit zu den Vertriebenen allgemein entstanden. ${ }^{120}$

115 Gerald Christopeit: Verschwiegene vier Millionen. Heimatvertriebene in der Sowjetischen Besatzungszone und der DDR. In: Jahrbuch für deutsche und osteuropäische Volkskunde 38 (1995), S. 222-251. - Ders.: Kerb und Klöppelspitzen im Kattenwinkel - Vertriebenensiedlungen in der SBZ/DDR? In: ebd. 40 (1997), S. 76-99. - Ders.: Die Glasmanufaktur Derenburg - von der sudetendeutschen Umsiedlergenossenschaft zur staatlichen Glasmanufaktur Harzkristall. In: ebd. 42 (1999), S. 118-145.

116 Vor Beginn ihrer Tätigkeit an der Humboldt-Universität war sie 1991 Leiterin des Museums für Natur- und Heimatgeschichte des Landkreises Beeskow und 1992-1995 Leiterin des Regionalmuseums „Burg Beeskow“.

117 Leonore Scholze-Irrlitz: Auf den Schultern der Frauen. Flucht und Vertreibung, Umsiedlung und Neuanfang im Landkreis Beeskow/Storkow (1945-1950). In: Flucht und Vertreibung 1945-1995. Hrsg. vom Haus der Heimat des Landes Baden-Württemberg. Filderstadt 1996, S. 35-47.

118 Leonore Scholze-Irrlitz: „Umsiedler“ im Landkreis Beeskow/Storkow. In: Alltagskultur im Umbruch. Festschrift für Wolfgang Jacobeit zu seinem 75. Geburtstag. Wolfgang Kaschuba/Thomas Scholze / Leonore Scholze-Irrlitz (Hg.). Weimar u. a. 1996, S. 135-149.

119 Leonore Scholze-Irrlitz: Die Bürde der Frauen. Erinnerungen an Vertreibung und Neuanfang (1945-1950). In: Kreiskalender Oder-Spree 2002, S. 16-18.

120 Reinhard Weigelt: Evakuierte - Umsiedler - Vertriebene. Umgesiedelte im Osten Deutschlands. [Eine Publikation ist offenbar nicht erfolgt.]. - 1999 wurde ferner eine von W. Kaschuba betreute Dissertation von Signe Roß über „Flucht und Vertreibung: Lebenswege und Formen in Mecklenburg-Vorpommern“ vergeben, die noch 2008 als „vergeben“ erwähnt wird, aber seither nicht abgeschlossen worden zu sein scheint (Deutsche Gesellschaft für Volkskunde, Datenbank Abschlussarbeiten, www.d-g-v.org [19.6.2017]). 
Die insbesondere in der Sorben-Forschung tätige Ethnographin Ines Keller ${ }^{121}$ (geb. 1964 Crostau) hat sich seit 2004, ausgehend von ihrem Interesse am sorbischen Siedlungsgebiet, auch mit Fragen der Integration von Flüchtlingen und Vertriebenen in der Lausitz (Nieder- und Oberlausitz) befasst. Grundlage des Interesses ist hier wohl letztlich die Frage der (positiven und negativen) Auswirkungen der Nachkriegszuwanderung auf die Assimilation der ansässigen sorbischen Minderheit. ${ }^{122}$ Ihre Quelle bilden Befragungen Betroffener, im Fokus stehen dabei neben allgemeinen Anpassungsmustern der Untersuchungsgruppe vor allem „Anpassungsstrategien der Kinder- und Jugendgeneration ".${ }^{123}$ Wie es scheint, werden diese für die Migrationsforschung und für die zeitgeschichtliche Vertriebenenforschung wichtigen Studien bislang jedoch eher in der sorabistischen und slawistischen Forschung rezipiert. ${ }^{124}$ Die Autorin hat aber immerhin ebenfalls dafür gesorgt, dass Kurzfassungen der Ergebnisse in der Niederlausitzer landes- und regionalgeschichtlichen Forschung ${ }^{125}$ und durchaus auch in der dortigen interessierten Öffentlichkeit ${ }^{126}$ bekannt wurden.

Eine stärkere interdisziplinäre Bündelung der Kompetenzen in der Erforschung der Eingliederung von Flüchtlingen und Vertriebenen steht - nicht nur in Berlin-Brandenburg - noch aus. Dass dies produktiv wirken kann, zeigen die Arbeiten mehrerer Wissenschaftlerinnen der Kulturwissenschaftlichen Fakultät der Europa-Universität Frankfurt (Oder) bzw. des wesentlich von der Posener Universität geführten Collegium Polonicum in Słubice, die sich seit Jahren mit der deutsch-polnischen Grenzregion an Oder und Neiße befassen und dabei auch der Lebenswelt der Bewohner nachgehen. Zwar stehen dabei die Situation der neuen (Nachkriegs-) Bevölkerung in den polnischen Westgebieten sowie weiträumige Vergleiche meist im Vordergrund des Interesses ${ }^{127}$, doch werden über vergleichende Studien immer wieder auch Fragen

121 1988-1991 Wissenschaftliche Mitarbeiterin der Abt. Volkskunde am Institut für sorbische Volksforschung Bautzen, seit 1992 desgleichen in der Abt. Empirische Kulturforschung/Volkskunde am Sorbischen Institut e. V. in Bautzen.

1221945 gab es unter den Sorben in der SBZ auf eine Verbindung mit der Tschechoslowakei zielende und von dort genährte Separationsbestrebungen. Siehe Blöß, Grenzen und Reformen (wie Anm. 89), S. 72 f.

123 Ines Keller: „Jetzt bin ich hier und das ist gut so“. Lebenswelten von Flüchtlingen und Vertriebenen in der Lausitz. Bautzen 2005. 196 S. (Lětopis 52, Sonderheft). - Dies.: Flüchtlinge und Vertriebene in der zweisprachigen (sorbischen) Lausitz. In: Volkskunde in Sachsen 23 (2011), S. 197-210.

124 Siehe die Zusammenstellung der Rezensionen zu Kellers Band von 2005: www.serbski-institut.de/de/KellerIch-bin-jetzt-hier/ [19.6.2017].

125 Ines Keller: Flüchtlinge und Vertriebene in der Lausitz. In: Niederlausitzer Studien 31 (2004), S. 88-91. [Kurzer Überblick über Befragungsergebnisse, Schwerpunkt jedoch Oberlausitz]. - Dies.: „Wenn man die Sprache braucht, dann lernt man sie auch. Bloß, wenn man sie nicht braucht, wird man sie auch nicht richtig lernen." Anpassungsstrategien von Flüchtlingen und Vertriebenen in der Niederlausitz. In: Niederlausitzer Studien 33 (2007), S. 138-144. [Befragung von Flüchtlingen und Vertriebenen, die einheimsche Partner sorbischer Herkunft geheiratet haben].

1262014 hielt sie z. B. im Lübbener Rathaus einen Vortrag „Heimat Niederlausitz. Flüchtlinge und Vertriebene im zweisprachigen Gebiet": www.luebben.de/de/Kultur/News/2-Heimat-Niederlausitz.html [19.6.2017].

127 Beata Halicka: Polens Wilder Westen. Erzwungene Migration und die kulturelle Aneignung des Oderraumes 1945-48. Padeborn 2013. 
von Flucht und Vertreibung der Deutschen einbezogen. ${ }^{128}$ Einzelstudien zur Eingliederung von Flüchtlingen und Vertriebenen in Brandenburg sind dort bisher aber wiederum nicht oberhalb der Ebene von Magister- und Masterarbeiten angesiedelt. ${ }^{129}$ Ein ähnlicher Befund ergibt sich aus der in Küstrin vom Museumsverband des Landes Brandenburg e. $V$. veranstalteten deutschpolnischen Tagung „Alte Heimat - neue Heimat. Deutsche und polnische Museen westlich und östlich der Oder nach dem Zweiten Weltkrieg“" (6. bis 8. Oktober 2016). Auch hier standen die polnische Hälfte der Oder-Grenzregion und der heutige Umgang mit deren deutscher Geschichte im Vordergrund. ${ }^{130}$

\section{Zeitgeschichtliche Archäologie}

Die Zeitgeschichtliche Archäologie hat sich in den letzten Jahren innerhalb einer relativ kurzen Zeit bereits etablieren können, ist aber mit der Bearbeitung der Hinterlassenschaften des NS-Lagersystems und des Krieges im engeren Sinne voll ausgelastet („Lagerarchäologie“). Eine in Brandenburg 2015 durchgeführte Tagung „Archäologie und Gedächtnis“ konnte immerhin

128 Dagmara Jajeśniak-Quast/Katarzyna Stokłossa: Geteilte Städte an Oder und Neiße. Frankfurt (Oder) Słubice, Guben - Gubin und Görlitz - Zgorzelec 1945-1995. Berlin 2000. - Beata Halicka: „Das Zäsurjahr 1945 an der Mittleren Oder in Erinnerung der Deutschen und der Polen“. In: Schwierige Nachbarn? 300 Jahre deutsch-polnische Nachbarschaft. Hrsg. im Auftr. des Landfrauenvereins „Mittleres Oderbruch“ e. V. Groß Neuendorf von Wolfgang Michalka u. Reinhard Schmook. Berlin 2007, S. 59-74. - Dies.: Deutsche und polnische Erinnerungen an erzwungene Migrationen als Gegenstand transnationaler Forschung, in: Jahrbuch des Wissenschaftlichen Zentrums der Polnischen Akademie der Wissenschaften 6 (2015), S. 221-232.

129 Wertvoll ist der aus einer an der Viadrina angefertigten (dem Verf. nicht zugänglich gewesenen) Masterarbeit über die „Umsiedlerintegration in Frankfurt (Oder) und Eisenhüttenstadt“ hervorgegangene, wenn auch begrifflich nicht immer unvoreingenommene („Umsiedler“, „BRD“) Aufsatz: Alexander Goller: Eine neue Heimat? Zur Aufnahme und Integration der Umsiedler im heutigen Eisenhüttenstadt. In: Transit - Transfer. Politik und Praxis der Einwanderung in die DDR 1945-1990. Kim Christian Priemel (Hrsg.) (Almanach des Instituts fürt Angewandte Geschichte). Berlin 2011, S. 25-50. [Der Autor (geb. 1983) hat sich anschließend anderen Feldern der Zeitgeschichte zugewandt und arbeitet inzwischen in Tübingen.] - Geographisch umfassender, aber auf die Quelle Zeitzeugeninterview (Aufruf u. a. in Brandenburger Rundschau 12 (2014) 8, S. 7) begrenzt ist die Nachweisführung der Tradierung von Vertriebenenschicksalen im Familiengedächtnis von DDR-Bürgern bis über die Wende hinaus: Lisa Haberkern: Heimatverlust im Familiengedächtnis. Eine OralHistory-Untersuchung unter Vertriebenenfamilien in Berlin und Brandenburg. Masterarbeit Europa-Universität Viadrina. Frankfurt (Oder) 2015. 80, IX, [100] S. [Die Autorin (geb. 1986) ist mittlerweile mit einem verwandten (Promotions-)Thema, konzentriert auf oberschlesische Familien in Polen und Deutschland, an die Schlesischen Universität Kattowitz gewechselt.]

130 Abdruck der Tagungsreferate (jeweils deutsch und polnisch) in: Museumsblätter. Mitteilungen des Museumsverbandes Brandenburg 30 (2017), darin ein (mit drei Endnoten versehener) knapper, aber informativer Überblick über das Vertreibungsgeschehen und die Ankunft der Flüchtlinge im Oderbruch aus der Feder des Volkskundlers und langjährigen Leiters des Oderlandmuseums Bad Freienwalde, Reinhard Schmook: Neue Heimat links der Oder - Vom Flüchtlingsalltag in den ersten Nachkriegsjahren, S. 26-33. Nur ganz am Rande erwähnt wird das Thema in dem Beitrag der Schwedter Museumsleiterin über das 2014 begründete deutschpolnische Netzwerk: Anke Grodon: Museumsnetzwerk Region Untere Oder - Der aktuelle Stand, S. 108-113, hier S. 110 der Hinweis auf ein „mit der Fakultät für Geschichte an der Universität Szczecin“ geplantes Projekt der 
resümieren, dass angesichts „von mehr als 100 Gästen aus sieben Nationen [...] die Zeit nun offenbar reif war", nachdem „eine Tagung zu diesem bisher als unbequem angesehen Thema noch vor zehn oder 15 Jahren als undenkbar galt“. ${ }^{131}$ Freilich schlösse „Krieg im weiteren Sinne“ die (Nach-) Kriegsfolgen ein, zu denen dann auch die Weiternutzung von Lagerstandorten gehörte, sei es als (Sowjetisches) Speziallager, als Vertriebenenlager oder etwa durch die Rote Armee. Bislang ist der Forschungszweig jedoch nahezu identisch mit dem Themenfeld NS-Lager und NSGedenkstätten und nicht nur in Brandenburg erkennbar eng verknüpft mit der gesellschaftlichen Aufarbeitung von NS-Unrecht (Zwangsarbeit, KZ-Außenlager). Flüchtlingslager treten daher nur dann überhaupt in seinen Blick, wenn sie als eine von mehreren vorübergehenden Nachnutzungen der untersuchten NS-Standorte mit zu erwähnen sind. ${ }^{132}$ Wird die Nachkriegszeit nicht nur am Rande einbezogen, so beschränkt sich auch hierbei das Interesse vorerst auf Stätten der Verfolgung (Speziallager). ${ }^{133}$

Auch wenn die Gruppe der Flüchtlinge und Vertriebenen im gesellschaftlichen und in dessen Folge im wissenschaftlichen Diskurs zwar immer mehr auch als Kriegsopfer und Erleidende gesehen wird, stehen verständlicherweise die unmittelbaren Opfer der NS-Gewaltherrschaft im Vordergrund, zumal selbst diese oft bis heute nicht angemessen gewürdigt worden sind. Die Verantwortung und zugleich die Chance, vergessene und fast verschwundene Stätten der frühen Vertriebenengeschichte hierbei in die Gesamtbemühungen der Bodendenkmalpflege zu integ-

Netzwerkplaner „Geschichte und Biografie“: „Ziel des Projektes ist das Festhalten von exemplarischen Biografien im Netzwerkraum. Die Interviwes geben einen Überblick über die verschiedenen Berufsgruppen, lassen Zeitzeugen, die Brüche wie die Vertreibung und Neuansiedlung 1945 erlebt haben, zu Wort kommen und stellen Persönlichkeiten des Netzwerkraumes vor."

131 Thomas Kersting, Franz Schopper u. Claudia Theune: Tagungsresümee: Sicht der Archäologischen Denkmalpflege. In: Archäologie und Gedächtnis. NS-Lagerstandorte. Erforschen - Bewahren - Vermitteln. Interdisziplinäre Konferenz im Archäologischen Landesmuseum Brandenburg an der Havel 17. bis 19. September 2015. Hrsg.: Thomas Kersting u. a. (Denkmalpflege in Berlin und Brandenburg, Arbeitsheft 4/2016). Petersberg 2016, S. 173-175, hier S. 173.

132 Bauliche Veränderungen für Flüchtlingsfamilien nach Kriegsende als Hilfe zur Datierung in einem ehem. NSArbeitserziehungslager: Axel Drieschner: Funktionen materieller Quellen für die zeithistorische Forschung. In: Archäologie und Gedächtnis (wie Anm. 131), S. 47-54, hier S. 51. - Bert Krüger / Barbara Schulz: Das Gelände des KZ-Außenlagers Falkensee bei Berlin - Gedenkstätte und zeithistorisch-archäologischer Lernort. In: Archäologie und Gedächtnis (wie vor), S. 155-171, hier S. 156f. (Kapitel „Nachnutzung“), 164 (Veränderungen der Innengestaltung von Baracken aus „der Nachnutzung als Flüchtlingslager“ als Terminus-ante-quemDatierungshilfe für NS-zeitliche Bemalung; Schornsteineinbau vor oder nach 1945).

133 „Betroffene von Konzentrations-, Kriegsgefangenen-, Zwangsarbeiter- oder sowjetischen Speziallagern etc.“: AnneKathrin Müller: Die Qual der Wahl? Zum Umgang mit Funden aus Grabungen an zeitgeschichtlichen Komplexen. In: Archäologie und Gedächtnis (wie Anm. 131), S. 75-85, hier S. 82. - Erst am Anfang steht die Archäologie historischer Stätten der deutschen Teilung (Grenzanlagen, Fluchttunnel), dürfte aber in Zukunft stärker in den Fokus geraten und dabei freilich die Orte der frühen Nachkriegszeit als Forschungsgegenstand wiederum überlagern. Siehe Anne-Kathrin Müller/Gerson H. Jeute: Von den Schwierigkeiten ein Ende zu finden ... Neuzeit, Zeitgeschichte und Gegenwart als Themen der Archäologie in Berlin und Brandenburg. In: Feuerstein und Fluchttunnel. Archäologie in Berlin und Brandenburg seit der Wende. Petersberg 2017, S. 243-258, hier S. 250. 
rieren, liegt aber an sich auf der Hand, zumal auch Flucht und Vertreibung, teils unmittelbar, teils mittelbar, Kriegsfolgen, also Teil des Gesamtthemas Nationalsozialismus und Zweiter Weltkrieg sind. Die für Archäologen ohnehin gewohnte häufige Schichtenüberlagerung - hier etwa, wenn Baracken erst von Häftlingen bzw. Zwangsarbeitern, dann von Flüchtlingen und Vertriebenen bewohnt wurden und beide Gruppen Spuren hinterlassen haben - erleichtert zwar sicherlich nicht die eindeutige Trennung und Deutung von Funden und Befunden, zwingt aber gerade deshalb die Ausgräber dazu, sich auch mit solchen „Nachnutzungen“ noch näher zu befassen. ${ }^{134} \mathrm{Ob}$ diese dann im Einzelfall auch einmal in den Fokus einer eigenen Untersuchung gerückt werden, hängt sicherlich auch von der - gewachsenen, aber immer noch nicht allgemeinen - Akzeptanz des Themas Vertreibung in der Geschichtswissenschaft ab, bleibt aber wohl vorerst auf Interesse und Motivation einzelner Forscher angewiesen. ${ }^{135}$ Die alleinige Konzentration auf die - überfällige - Sichtbarmachung der Überreste von Standorten und Schauplätzen der NS-Zwangssystems auch außerhalb der bereits seit langem bekannten und etablierten Gedenkstätten birgt jedoch letztlich die Gefahr, die Eigenbedeutung zeitlich anschließender Ereignisse zu marginalisieren oder gar die Umnutzung von NS-Lagern nach Kriegsende ausschließlich zu charakterisieren als eindimensionale Versuche einer Nachkriegsgesellschaft, NS-Bezüge unkenntlich zu machen. ${ }^{136}$

\section{Kirchliche Zeit- und Bistumsgeschichte}

Für Brandenburgs - trotz der inzwischen überwiegend nicht mehr kirchengebundenen Bevölkerung - konfessionelle Mehrheitskirche, die Evangelische Kirche in Berlin-Brandenburg (EKiBB), heute Evangelische Kirche Berlin-Brandenburg-schlesische Oberlausitz (EKBO), ist die Zuwanderung von Gläubigen wie auch von Flüchtlingspfarrern bislang kein Thema, das in offiziellen Veröffentlichungen oder in der wissenschaftlichen Kirchengeschichtsforschung eine Rolle spielte. ${ }^{137} \mathrm{Im}$ Rahmen einer 506-Seiten-Untersuchung über die evangelischen Pfar-

134 Auf die in der Zeitgeschichtlichen Archäologie größeren Nöte der „Fundauswahl“ und der Zuordnung einzelner Fundobjekte, d.h. die nicht immer mögliche „Fundkontextualisierung“, weist Anne-Kathrin Müller hin: Die Qual der Wahl? Zum Umgang mit Funden aus Grabungen an zeitgeschichtlichen Komplexen. In: Archäologie und Gedächtnis (wie Anm. 131), S. 75-85, bes. S. 76 f., 81. Auf die Gefahr, die in der subjektiven Bevorzugung bestimmter Relikte, die mit „boomenden“ Forschungsfeldern „korrespondieren“, liegt („erhalten bleibt nur, was meiner Geschichte nutzt") und die anderes unwiederbringlich zerstört, also nicht überliefert, verweist Jens-Christian Wagner: Mut zum Verlust - ein Plädoyer gegen den Fetisch der Relikte. In: Archäologie und Gedächtnis (wie vor), S. 169-171, hier S. 170.

135 Siehe für den Bereich der Hobbyforscher unten die Bemerkungen zu den Erkenntnissen von Kurt Neis bezüglich der Barackenstandorte und -bauformen in Fürstenberg (Havel).

136 Überzeichnet und den katastrophalen Nöten der Nachkriegszeit zu wenig Rechnung tragend erscheint z. B. die von Claudia Theune vorgenommene Gleichsetzung der Abtragung von Baracken mit der Beseitigung von NS-Symbolen: Claudia Theune: Zeitgeschichtliche Archäologie in ehemaligen Konzentrationslagern - Erinnerungsort, Denkmalpflege, Forschung. In: Archäologie und Gedächtnis (wie Anm. 131), S. 7-16, hier S. 15.

137 Zwar mit einem Abschitt „Ostbrandenburg“ über die Situation im heute polnischen Gebiet östlich von Oder und Neiße (S. 780-782), aber sonst nur mit einem einzigen, im Abschitt „Synoden“ versteckten Halbsatz zur auf der Synode in Berlin-Spandau 1946 beschlossenen „Förderung der Seelsorge der aus ihrer Heimat 
rer der Kirche Berlin-Brandenburg in den Jahren 1945 bis 1961 wird das Thema „Ostpfarrer“, d.h. aus den Ostgebieten stammende Flüchtlingspfarrer, zum Beispiel in ganzen fünf Zeilen abgehandelt. ${ }^{138}$ Auch das vom Wissenschaftlichen Beirat für Erinnerungskultur der EKBO 2014 verfasste „Konzept Erinnerungskultur und Gedenkstättenarbeit in der EKBO - Grundlagen und Handlungsstrukturen"139 setzt vornehmlich andere Schwerpunkte und delegiert die Vertreibungsfragen auf das ehemals zur Evangelischen Kirchenprovinz Schlesien gehörende und 2004 mit der Berlin-Brandenburgischen Kirche fusionierte (Rest-)Gebiet Görlitz, das nicht Teil der Provinz Brandenburg war und auch heute nicht zum Land Brandenburg, sondern zu Sachsen gehört: „Schwerpunkt der Erinnerungskultur im Gebiet Görlitz ist die Flüchtlings-, Umsiedelungs- und Migrationsproblematik verbunden mit dem schlesischen Erbe und der Geschichte der sorbischen und wendischen Minderheiten. Zudem existieren viele Kriegsgräber - auch aufkirchlichen Friedhöfen. "140 Dabei war die Zahl der aus den ehemaligen Ostgebieten nach Brandenburg gekommenen (evangelischen) Flüchtlinge keineswegs kleiner als in Sachsen.

Vertriebenen“ (S. 775), im Übrigen überwiegend auf die leitenden Ämter und Personen konzentriert: Gerd Heinrich: Alte Ordnungen und neue Anfechtungen. Die Kirche Berlin-Brandenburg im zerteilten Deutschland (1945 bis 1968). In: Tausend Jahre Kirche in Berlin-Brandenburg. Hrsg. von Gerd Heinrich. Berlin 1999, S. 763-842. - Fehlanzeige auch im sonst sehr verdienstvollen und auch zeitgeschichtlich an sich aktiven, von Jürgen Stenzel (ELAB) betreuten „Archivbericht der Evangelischen Kirche Berlin-Brandenburg-schlesiche Oberlausitz“. - Die überregionale Kirchengeschichtsforschung auch der Zeit nach 1990 ist überwiegend auf die Situation in Westdeutschland konzentriert: Christian-Erdmann Schott: Wandlungen in der Wahrnehmung. Die evangelische Kirche und ihre Vertriebenen. In: Vertriebene finden Heimat in der Kirche. Integrationsprozesse im geteilten Deutschland nach 1945. Hrsg. von Rainer Bendel (Forschungen und Quellen zur Kirchen- und Kulturgeschichte Ostdeutschlands, Bd. 38). Köln u. a. 2008, S. 147-162. - Als nicht existent erscheint das Thema aber auch bei Rudolf Mau: Der Protestantismus im Osten Deutschlands (1945-1990). Leipzig 2005 (Kirchengeschichte in Einzeldarstellungen, IV/3). Hier steht der einzige (Halb-)Satz „auch“ zu den „aus den Ostgebieten vertriebenen Deutschen“ in einem 12-Zeilen-Abschnitt „4. Kirchen als Anwalt der Menschen in der Nachkriegsnot" innerhalb einer beiläufigen Nennung eines auf "das deutsche Volk" insgesamt bezogenen, im März 1947 über die EKD an die Besatzungsmächte gerichteten Appells der Kirchlichen Ostkonferenz (S. 29). - Anders dagegen jetzt für Sachsen die umfangreiche Leipziger Dissertation (2012) von Markus Wustmann, „Vertrieben, aber nicht aus der Kirche?“ (wie Anm. 18).

138 Christian Halbrock: Evangelische Pfarrer der Kirche Berlin-Brandenburg 1945-1961. Amtsautonomie im vormundschaftlichen Staat? Berlin 2004, S. 64. - Ganz anders in der mecklenburgischen Nachbarkirche: Friedrich Wekel: Die Evangelisch-Lutherische Landeskirche Mecklenburgs und die ostdeutschen „Flüchtlingspastoren“ nach dem Zweiten Weltkrieg. In: Mecklenburgia sacra. Jahrbuch für Mecklenburgische Kirchengeschichte 17 (2015), S. 171-215. - Siehe auch allgemein zur integrationsfördernden Wirksamkeit von „Ostpfarrern“: Christian-Erdmann Schott: Die Rolle der Kirchen bei der Integration von Flüchtlingen und Vertriebenen nach dem II. Weltkrieg. In: Jahrbuch der Schlesischen Friedrich-Wilhelms-Universität zu Breslau 47/48 (2006/07 [2008]), S. 291-308, bes S. 298-302; Hellmut Eberlein: Zur Psychologie des Ostpfarrers. In: Jahrbuch für Schlesische Kirche und Kirchengeschichte, NF 32 (1953), S. 154-167, hier S. 162-165.

139 www.erinnerungskultur-ekbo.de/fileadmin/ekbo/mandant/erinnerungskultur-ekbo.de/PDF/Konzept_Er innerungskultur_und_Gedenkst\%C3\%A4ttenarbeit_EKBO.pdf [20.6.2017].

140 Ebd., S. 9. Konkreter genannt werden (S. 28) nur die in lokaler Trägerschaft einzelner Gemeinden befindlichen Objekte „Kirche in Lodenau und Martin-Luther-Gemeindehaus Hoyerswerda“, zu denen es heißt: „Beide Gebäude sind sogenannte Notkirchen des Architekten Bartning, die errichtet wurden, um den zusätzlichen Bedarf an 
Dieser Verweis auf die Geschichtsarbeit lokaler Kirchengemeinden kann in Berlin-Brandenburg zumindest ergänzt werden durch einen Hinweis auf die außergewöhnlichen Aktivitäten der Evangelischen Kirchengemeinde Lieberose (federführend: Dr. Andreas Weigelt ${ }^{141}$ ), die zwar im EKBO-Konzept ausführlich genannt wird („Zeitgeschichtliche Erinnerungsort JamlitzLieberose“ $)^{142}$, jedoch ohne Erwähnung der Tatsache, dass sich diese, hauptsächlich über ABM ermöglichte lokale Erinnerungsarbeit - sogar mit einer größeren Ausstellung am Ort und einer 2006 erschienenen Broschüre - auch auf Flucht und Vertreibung erstreckt. ${ }^{143}$

Ganz anders ist der Befund bei der Katholischen (Minderheits-)Kirche, wenngleich weniger für das (nördliche) Zentral-Gebiet des (Erz-)Bistums Berlin als für das (südliche) des (ehemals zur Breslauer Diözese gehörenden) Bistums Görlitz, das v. a. die gesamte Niederlausitz umfasst. Entsprechend der viel größeren Bedeutung, die die Vertriebenenzuwanderung für eine Diasporakirche hatte, ist die kirchliche Zeitgeschichtsforschung katholischer Provenienz, was das Gebiet der SBZ/DDR angeht, inzwischen weit fortgeschritten. ${ }^{144}$ So enthält der bislang wichtigste Sammelband zur katholisch-kirchlichen Integration in Gesamtdeutschland allein sechs Beiträge zur Situation in der SBZ/DDR ${ }^{145}$, darunter eine - mehr als die Hälfte des Bandes einnehmende - „Dokumentation“ (Quellenedition mit Einleitung) von Winfried Töpler, die zum größten Teil der Bewältigung „des schlesischen Flüchtlingsproblems im Gebiet des heutigen Bistums Görlitz" gewidmet ist. Mit dieser und den weiteren Arbeiten ${ }^{146}$ des zuständigen Görlitzer

gottesdienstlichen Räumen zu decken, der durch die Flüchtlinge und Vertriebenen nach dem Krieg im Görlitzer Kirchengebiet entstanden war. Träger: Ev. Kirchengemeinde Rothenburg und Johannes-Kirchengemeinde Hoyerswerda."

141 Geb. 1963, Historiker in Lieberose, erforscht seit Anfang der neunziger Jahre intensiv sowohl die NS-zeitliche Geschichte des KZ-Außenlagers Jamlitz als auch die der sowjetischen Speziallager Jamlitz und Ketschendorf und bemüht sich am Ort um angemessenes Gedenken (LR online, 7.1.2004); zahlreiche Publikationen zu beiden Bereichen, seit 2006 auch zu Vertriebenen im Raum Lieberose. Siehe auch Anm. 69.

142 Ebd., S. 26.

143 Flucht, Vertreibung, Neubeginn nach 1945. Schicksale und Berichte aus dem Raum Lieberose (wie Anm. 69). - Siehe auch Weigelts (mit EKBO-Briefkopf eingesandte) Stellungnahme zum Entwurf eines Konzepts der Landesregierung Brandenburg zur zeitgeschichtlichen Erinnerungskultur (wie Anm. 69).

144 Vertriebene finden Heimat in der Kirche (wie Anm. 137). - Aufnahme - Integration - Beheimatung. Flüchtlinge, Vertriebene und die „Ankunftsgesellschaft“. Hrsg. von Josef Pilvousek u. Elisabeth Preuß. Berlin/Münster 2009 (Studien zur kirchlichen Zeitgeschichte, Bd. 3). - Wichtig auch die Biographie des für die Niederlausitz zuständigen Görlitzer Residentialbischofs der Nachkriegsjahre: Konrad Hartelt: Ferdinand Piontek (1878-1963). Leben und Wirken eines schlesischen Priesters und Bischofs. Köln u. a. 2008 (Forschungen und Quellen zur Kirchen- und Kulturgeschichte Ostdeutschlands, Bd. 39).

145 U. a.: Josef Pilvousek / Elisabeth Preuß: Katholische Flüchtlinge und Vertriebene in der SBZ/DDR. Eine Bestandsaufnahme, S. 15-27. - Ulrike Winterstein: Der vertriebene Klerus in der SBZ/DDR. Zur Integration vertriebener Eliten im Bistum Meißen und im Diözesangebiet Görlitz-Cottbus, S. 131-143 (vgl. ihre Diss. in Anm. 18).

146 Winfried Töpler [Hrsg.]: Berichte der katholischen Geistlichkeit aus dem Jahr 1945. T. 1-2. In: Niederlausitzer Studien 32 (2005), S. 102-125; 33 (2007), S. 122-137. - Unsere Herzen bluten. Tagebücher und Aufzeichnungen aus der katholischen Gemeinde in Guben 1945/46. Im Auftr. der katholischen Gemeinde Guben und des Bistums Görlitz zsgest. u. bearb. von Winfried Töpler. Hrsg.: Bistum Görlitz. T. 1-2. Cottbus 2013. Zus. 793 S. 
Bistumsarchivars Winfried Töpler (geb. 1962 Guben) liegt inzwischen eine außergewöhnlich tiefgehende Dokumentenbasis vor, an der keine künftige Vertriebenenforschung in Brandenburg oder der Niederlausitz vorbeigehen kann. ${ }^{147}$ Eine separate Publikation auch der Görlitzer Quellensammlung hätte ihr allerdings gewiss noch mehr Aufmerksamkeit über den Kreis der wissenschaftlichen Benutzer von Sammelbänden hinaus, insbesondere in der Niederlausitz, verschaffen können.

Nicht unerwähnt bleiben sollen für den brandenburgischen Raum, zumindest den Berliner Sprengel, die von kirchlicher Seite herausgegebenen lokal- und regionalgeschichtlichen Arbeiten, die sich einzelner Kirchengemeinden annehmen. Auch hierbei ist das Phänomen unübersehbar, dass die katholischen Pfarreichroniken fast stets den Vertriebenen größere, gleichsam für sie selbstverständliche Beachtung schenken, während die evangelischen Gemeindegeschichten den Zuwachs an Mitgliedern kaum thematisieren (weil sie ihn für selbstverständlich halten?). Sehr instruktiv für den Überblick über die Bedeutung der jeweiligen Zuwanderung für den Auf- oder Ausbau katholischer Pfarreien sind vier von dem kirchengeschichtlich sehr aktiven Berliner Priester Matthias Brühe (geb. 1965) erarbeitete, 1998-2000 von der Pressestelle des Erzbistums Berlin herausgegebene Broschüren, in denen man meist sogleich die nötigen Fakten finden kann. ${ }^{148}$ Für Spezialfragen der karitativen Betreuung von Vertriebenen sehr hilfreich sind ferner die ausführlichen und faktenreichen Darstellungen, die Johannes Mertens (geb. 1952 Köln) über drei - selbst teilweise vertriebene - Schwesternkongregationen in deren Auftrag verfasst hat. ${ }^{149}$

147 Winfried Töpler: Der zehntausendfüßige Menschenwurm. Die Bewältigung der Kriegsfolgen und des schlesischen Flüchtlingsproblems im Gebiet des heutigen Bistums Görlitz. Texte aus dem Bistumsarchiv Görlitz. In: Vertriebene finden Heimat in der Kirche (wie Anm. 137), S. 291-635 (Einleitung S. 291-310).

148 (Im Wesentlichen eingearbeitet in die im vorliegenden Buch enthaltene Ortsdokumentation): Matthias Brühe: Katholische Kirche zwischen Uckermark und Oderland. Berlin 1998. - Ders.: Katholische Kirche zwischen Havel und Dahme. Berlin 1999. - Ders.: Katholische Kirche zwischen Prignitz und Havelland. Berlin 2000. - Ders.: Katholische Kirche in Vorpommern. Vollst. überarb. Neuaufl. Berlin 2000. - In die jüngere Gesamt-(Selbst-)Darstellung des Erzbistums sind diese Texte zwar großenteils und auch aktualisiert, in den hier interessierenden Einzelheiten aber oft nur gekürzt, eingeflossen: Harald Schwillus / Matthias Brühe: Erzbistum Berlin. Eine junge Diözese in langer Tradition. Kehl am Rhein 2009.

149 Johannes Mertens: Die Berliner Ordensprovinz der Grauen Schwestern von der heiligen Elisabeth 1859-1991. Hrsg. von der Berliner Ordensprovinz der Grauen Schwestern von der heiligen Elisabeth. Reinbek bei Hamburg 1992. - Ders.: Geschichte der Kongregation der Hedwigschwestern 1930-2000. Unveröff. Manuskript. Berlin 2004 [Für die gewährte Einsichtnahme danke ich dem Verf.]. - Ders.: Geschichte der Konregation der Marienschwestern von der Unbefleckten Empfängnis 1945-1999. Bd. 1-2. Berlin 2000. - Ders.: Geschichte der Konregation der Marienschwestern von der Unbefleckten Empfängnis in Berlin. In: Wichmann-Jahrbuch des Diözesangeschichtsvereins Berlin, N. F. 7 (2002/03 [2004]), S. 132-154 [auch zum Wirken in Brandenburg!]. 


\section{Lokalgeschichte - Heimatforschung und Ortschronistik}

Edgar Steiner (Havelberg) hat 1994 - aus der Sicht des lokalen Heimathistorikers - in Worte gefasst, was in Brandenburg und der gesamten DDR bis 1989 für alle galt, die nicht die offizielle Linie verinnerlicht hatten und sich mit dem Interesse am Thema Vertreibung oder gar dem eigenen oder familiären Betroffenenstatus in einer Art ,innerer Emigration“ befanden: „Die Geschichte und die Ereignisse des Jahres 1945 wurden in den Zeiten der DDR nicht selten verdrängt oder gar verfälscht. Das Thema, Flucht und Vertreibung' gehörte zu den Themenkomplexen, die für die Heimatforschung absolut tabu waren. Vieles wurde idealisiert. Erlebnisberichte passierten die Zensur und wurden entsprechend, frisiert', Archive blieben für den Heimatforscher geschlossen, und nur gelegentlich erfuhr der Interessierte etwas durch direkte Augenzeugen jener Tage und Wochen. Erst die politischen Ereignisse im Herbst 1989 machten es möglich, daß sich auch die Forschung in breiterem Maße mit allen zugänglichen Ergebnissen dem Flucht-, Vertreibungs- und Umsiedlerthema widmen konnte." 150

Die lokale brandenburgische Geschichtsliteratur, sei es von Ortschronisten und Heimatforschern oder Heimatvereinen direkt getragen, sei es in Verlagspublikationen, hat den Themenkomplex von Flucht und Vertreibung und erst recht den der Integration erst ansatzweise im Blick. Einzelne Arbeiten oder Abschnitte bilden zwar durchaus herausragende Vorreiter und Vorbilder, die sogar über das auf der gesamtbrandenburgischen Ebene Publizierte deutlich hinausgehen, oftmals aber handelt es sich nur um ein knappes Anreißen. Dabei ist der Erkenntnisprozess zuweilen doch schon sehr weit vorangeschritten, auch wenn die anschließend nötige Quellenforschung wohl zumeist noch nicht möglich war. Einige Beispiele können das Spektrum verdeutlichen. ${ }^{151}$

Bemerkenswert ist das für brandenburgische Verhältnisse ganz außergewöhnlich detaillierte und mit Empathie geschriebene Kapitel "Umsiedler und Vertriebene der beiden Weltkriege“ in Band 5 der „Letschiner Chronik“, das z. T. in die Vorgeschichte der Familien, etwa in Bessarabien, zurückgreift, sogar sämtliche Namen der betroffenen Familien mitteilt und einige von ihnen in aktuellen Fotos abbildet. ${ }^{152}$ Der schon vergleichsweise früh, 1995, erschienene, wesentlich von Mitarbeitern der „Heimatstube Letschin“ bearbeitete Band über das „Amt Letschin“

150 Edgar Steiner: Flüchtlinge und Vertriebene im Elb-Havel-Winkel. In: Kriegsende und Nachkriegszeit in Havelberg [II]. Hrsg.: Heimatverein Havelberg e. V. (Havelberger Regionalgeschichtliche Beiträge, Bd. 2). Havelberg 1994, S. 77-79, hier S. 77.

151 Die Lokalliteratur wird in den einzelnen Ortsartikeln nach Möglichkeit vollständig nachgewiesen. Nirgends in Brandenburg existiert aber bisher für eine Kommune eine wirklich umfassende, ausführlichere Darstellung des Themenkomplexes Vertriebene in Buchform. Vgl. dagegen für den ehemals schlesischen Bereich in Sachsen: Markus Lammert: Die Stadt der Vertriebenen. Görlitz 1945-1953. Görlitz 2012. 162 S. (Neues Lausitzisches Magazin, Beiheft 10). Eine solche Monographie bleibt z. B. mindestens für Guben, Cottbus und Frankfurt (Oder) ein dringendes Desiderat.

152 Sigrid Strenge / Marga van Tankeren: Letschiner Chronik. Bd. 1. Letschin 2001. Bd. 5. Letschin 2011, S. 186189. 
enthält zwar nur ein sehr kurzes Kapitel „Krieg“, das auf einer einzigen Seite in wenigen Absätzen vom Dreißigjährigen Krieg bis zum Zweiten Weltkrieg gelangt, das aber am Ende, auch wenn dazu keine weiteren Ausführungen im Buch folgen, doch einen deutlichen Akzent setzt: „Besonders aber nach dem Zweiten Weltkrieg fand durch Umsiedlung und Aussiedlung aus den polnischen und anderen Gebieten wiederum eine Wanderungsbewegung statt, die noch ungenügend erforscht ist. Wirtschaftliche, politische, soziale und kulturelle Einflüsse dürften hiermit verbunden sein. "153 Das Desiderat ist also erkannt und benannt. Wer nimmt sich seiner an?

In Frankfurt (Oder) brachte die CDU-Fraktion schon 1992 einen Antrag in der Stadtverordnetenversammlung ein, die Stadt möge den "Arbeitskreis der Historiker Frankfurts" dazu bewegen, „das Geschehen um die Heimkehr von Kriegsgefangenen und Vertriebenen zu erforschen“, um dabei „ein dem dramatischen Geschehen entsprechendes Gedenken zu erarbeiten“ und das „Interesse der Betroffenen im Bundesgebiet [...] durch entsprechende Öffentlichkeitsarbeit wieder aufzunehmen“. Als Begründung war formuliert worden: „Durch Geschichtsklitterung, Verschweigen und Verdrängen ist in der Zeit der kommunistischen Diktatur eine für ganz Deutschland bedeutende Funktion der Stadt Frankfurt (Oder) in Vergessenheit geraten. Von 1945 bis 1956 trafen Millionen Kriegsgefangene und Vertriebene in Frankfurt erstmals wieder auf deutschen Boden. Das Geschehen war in seiner Dramatik einmalig und muß in der Stadt und der Bundesrepublik wieder bekannt werden ... "154 Der Antrag wurde angenommen und der Beschluss am 4. März 1992 dem Historischen Verein zu Frankfurt (Oder) e.V. „zur Erstinformation“ zugeleitet. ${ }^{155}$ Der Verein hat sich daraufhin des Themas angenommen, eine „Arbeitsgruppe Gronenfelde“ ${ }^{\prime 156}$ gebildet und - mit finanzieller Unterstützung der Stadt Frankfurt - in einem mehrjährigen Forschungsprojekt auf der Grundlage intensiver Archivforschungen bis 1997 vor allem drei Studien von Wolfgang Buwert, Klaus Eichler und Helmut Hirthe in Aufsatzform erarbeitet, die als „erstes Ergebnis“ bei der Brandenburgischen Landeszentrale für politische Bildung zur Veröffentlichung eingereicht wurden und 1998 in deren Schriftenreihe erschienen sind. ${ }^{157}$ Der Vereinsvorsitzende Wolfgang Buwert, der sich schon seit 1985 im Sinne einer Enttabuisierung mit archivalischen Forschungen zum Kriegsende in Frankfurt befasst hatte ${ }^{158}$, schrieb im November 1997 in seiner Einleitung: „Diese Broschüre, eine Sonderausstellung des Frankfurter Museums VIADRINA mit Begleitband im Herbst 1998 und ein

153 Amt Letschin. Mitte des Oderbruchs. Text u. Ausw. der Fotos: E. Kühn u. a. Horb am Neckar 1995, S. 14.

154 Zitiert nach: Wolfgang Buwert: Einige einleitende Bemerkungen zum nachstehenden „Rückblick auf das Heimkehrerlager Gronenfelde bei Frankfurt/Oder“. In: Historischer Verein zu Frankfurt (Oder) e. V. Mitteilungen 1998, H. 2, S. 2-4, hier S. 2.

155 Ebd.

156 Beschluss der Mitglieder in der Vereinssitzung vom 24.3.1992 (Tätigkeitsbericht 1992 in: Historischer Verein zu Frankfurt (Oder) e. V. Mitteilungen 1993, H. 1, S. 2-4, hier S. 3).

157 Gefangene und Heimkehrer in Frankfurt (Oder) 1945-1950/56. Studien. Wolfgang Buwert (Hg.). Potsdam 1998 (Brandenburgische Historische Hefte, 9).

158 Wolfgang Buwert: Anmerkungen zum Stand der DDR-Geschichtswissenschaft und zur Befreiung und Zerstörung Frankfurts 1945. In: Historischer Verein zu Frankfurt (Oder) e. V. Mitteilungen 1991, H. 1, S. 11-24, bes. S. 15. - Ders.: Ergänzungen zur Richtigstellung der Geschichte der Festung Frankfurt. In: Historischer Verein zu Frankfurt (Oder) e. V. Mitteilungen 1991, H. 1, S. 25-28. 
,Mahnmal für den Frieden' 1999, errichtet vom Heimkehrerverband, sind Versuche, Frankfurts Stellung nunmehr in das der Stadt gebührende Licht der Geschichte zu rücken." An anderer Stelle, in den wesentlich weniger verbreiteten Vereinsmitteilungen, schrieb er Anfang 1999: „Die ursprünglich angedachte Quellenedition [...] konnte durch die Publikation der Brandenburgischen Landeszentrale für politische Bildung nicht realisiert werden. " ${ }^{159}$ Als Ersatz brachte der Historische Verein daher in seinen Mitteilungen die Edition eines vom letzten stellvertretenen Lagerleiter 1950 verfassten zusammenfassenden Berichts über die Entwicklung des Lagers Gronenfelde. ${ }^{160}$ Buwert schloss seine einleitenden Bemerkungen zur Edition mit Worten zurückhaltender Hoffnung: „Dem Leser obliegt es nun den Wert dieser Abhandlung zu prüfen. Vielleicht ergeben sich daraus auch weitere Anregungen, sich mit diesem Thema forschungsmäßig auseinanderzusetzen." ${ }^{161}$ Damit war die gestellte Aufgabe zunächst - beschränkt auf die Heimkehrer - abgearbeitet. Ungeschrieben geblieben ist dabei die Geschichte der ebenfalls durch Gronenfelde geschleusten Vertriebenen, von denen es in der Einleitung zur Broschüre der Landeszentrale immerhin - nach einem Hinweis auf die „in einer bisher unbekannten Größenordnung" in Frankfurt zum Abtransport in die Sowjetunion gesammelten ehemaligen Ostarbeiter und Kriegsgefangenen - heißt: „In noch größerer Zahl trafen in Frankfurt (Oder) Millionen Vertriebene und Umgesiedelte aus den deutschen Ostgebieten und Polen ein. "162 Auch in den während der neunziger Jahre parallel publizierten anderen - sehr verdienstvollen - Arbeiten Buwerts und weiterer Frankfurter Forscher, die sich dem Kriegsende am Ort widmen, spielen die Vertriebenen keine Rolle, behandelt werden lediglich die Flüchtlingstrecks vom Januar 1945. ${ }^{163}$ Gleichwohl sind alle diese Frankfurter lokalen Versuche einer Aufarbeitung lange vernachlässigter Themen, die bereits Akten und Zeitzeugenberichte gleichermaßen berücksichtigen, für sich genommen - gerade auch in ihrer Quellennähe - wertvolle Bausteine zu einer noch ausstehenden Untersuchung der Vertriebenen-Durchgangs- und End-Station Frankfurt (Oder).

Die Forschungssituation in den Städten unterscheidet sich von der auf dem Land kaum. ${ }^{164}$ Die nach 1990 fast überall von Heimatforschern bzw. Ortschronisten, allein oder im Team, mit

159 Buwert, Einige einleitende Bemerkungen (wie Anm. 154), S. 2.

160 (Rösch:) Rückblick auf das Heimkehrerlager Gronenfelde bei Frankfurt (Oder) vom 15.05.1950. In: Historischer Verein zu Frankfurt (Oder) e. V. Mitteilungen 1998, H. 2, S. 5-40. [Edition nach BArch, DO 2/47].

161 Buwert, Einige einleitende Bemerkungen (wie Anm. 154), S. 4.

162 Wolfgang Buwert: Einleitung. In: Gefangene und Heimkehrer in Frankfurt (Oder) (wie Anm. 157), S. 9-10, hier S. 9.

163 Wolfgang Buwert: Festung Frankfurt (Oder): eine Stadt am Kriegsende. In: Brandenburg im Jahr 1945. Studien. Hrsg. von Werner Stang unter Mitarb. von Kurt Arlt. Eine Publikation der Brandenburgischen Landeszentrale für politiche Bildung. Potsdam 1995, S. 38-83. [S. 46-51: Kapitel „Die Flüchtlinge kommen“]. - Brigitte Brisch / Wolfgang Buwert / Martin Schieck: Frankfurt (Oder) 1945. Ausgewählte Daten, Dokumente, Fotos und Erinnerungen. Frankfurt (Oder) [1995]. - Helmut Hirthe: Das Heimkehrerlager in Frankfurt-Gronenfelde. In: Wir waren damals 19. 50 Jahre 8. Mai in und um Frankfurt. Berichte, Dokumente, Recherchen, Tagebücher, Erinnerungen, Gespräche. Ein Lesebuch. Hrsg.: Jürgen Maerz. Frankfurt (Oder) 1995, S. 282-284.

164 Eine hervorragende Darstellung für den Raum Finsterwalde bietet: Manfred Woitzik: Was geschah vor 70 Jahren in Finsterwalde? In: Der Speicher 17 (2015), S. 104-122. 
oder ohne Unterstützung der Gemeinde, erstellten Dorfgeschichten enthalten viel wertvolles Material, manche nur am Ort überlieferten Fakten und Zeitzeugenberichte. Deutlich zu spüren ist freilich bei der Durchsicht, wie sehr es von der Fähigkeit und dem Willen des einzelnen Autors abhängt, ob das jahrzehntelange Tabu-Thema Flüchtlinge und Vertriebene nun unvoreingenommen und seiner jeweiligen lokalen Bedeutung entsprechend angemessen ausführlich dargestellt wird, oder ob es, kaum anders als vor 1989/90, marginalisiert und auf die Berücksichtigung von „Umsiedlern“ in der - ohnehin viele Darstellungen der Nachkriegsjahre vor wie nach 1989/90 dominierenden - Bodenreform beschränkt bleibt. Glücklicherweise bilden diejenigen Fälle, in denen man in einer Ortsgeschichte lediglich die allgemeinen Sachverhalte der Flucht und Vertreibung, wie sie sozusagen im Geschichtsbuch stehen, benennt und mit der eher lustlosen Formulierung, so sei es auch am betreffenden Ort gewesen, anreichert, die Ausnahme. In der Regel bemühen sich die Ortschronisten, konkrete lokale Zahlen ${ }^{165}$ und Unterbringungsstätten (seltener auch konkrete Personen- oder Familiennamen ${ }^{166}$ ) zu nennen, und beziehen oft Aussagen aus schriftlichen oder mündlichen Zeitzeugenberichten in ihre Darstellung ein. Die Bandbreite reicht dabei jedoch von nur sehr knappen Passagen bis zu ausführlichen Kapiteln. ${ }^{167}$ Das erschwert Vergleiche zwischen Gemeinden im Kreis ebenso wie landesweit.

Der Bredereicher Ortschronist Erich Köhler (1934-2016), selbst kein Vertriebener, sondern aus dem Erzgebirge nach Brandenburg zugewandert, hat sich 2002 in einem bemerkenswert sachlichen und doch einfühlsamen Beitrag über das Schicksal der 1945 nach Bredereiche in der Uckermark gekommenen Flüchtlinge und Vertriebenen aus Nahausen (Kr. Königsberg/ Neumark), von denen er einige interviewte, geäußert. Er spricht dabei auch den langfristigen Umgang mit dem Thema in der DDR und in der Gegenwart des heutigen Landes Brandenburg an und schließt sein letztes Kapitel „Nur Versöhnung hilft weiter“ mit den Worten: „Über die ver-

165 Oft werden die im Historischen Ortslexikon für Brandenburg (T. 1-11, Weimar 1962-1997) (im Folgenden zitiert HOL) mitgeteilten Angaben zur Verteilung von Bodenreformland wiedergegeben, auch dies genügt manchen Autoren, während andere es durch lokale Recherchen anreichern und bisweilen sogar korrigieren können (siehe Anm. 1369).

166 Hier spielt der Datenschutz nach wie vor eine Rolle. In der Regel werden die Angaben nur anonymisiert mitgeteilt, es sei denn Zeitzeugen berichteten selbst über ihren Werdegang, obgleich auch da die Namen bisweilen abgekürzt werden. Einige Autoren dagegen setzen sich darüber hinweg und nennen durchweg Namen, nicht nur bei Vertriebenen. Beispiele: Ingelore Kundoch / Dietrich Kundoch / Hans-Jürgen Nossack: Chronik Kiekebusch. Die Geschichte eines märkischen Dorfes. Hrsg.: Gemeinde Schönefeld. Schönefeld [2009], S. 46 (Familiennamen). - Bärbel Liehr: Zur Geschichte der Gemeinde Golzow 1933-2000. Chronik. Hrsg.: Chronistenvereinigung Potsdam-Mittelmark e.V.T. II. [Nuthetal] 2003, S. 32 f. (Personen-/Familiennamen). Lieselotte Marschner-Katzur: Aus der Geschichte der Gemeinde Neuendorf bei Brück. O. O. 2009, S. 88 (Namentliches „Verzeichnis der 18 Neuisiedler und Evakuierten vom 18. September 1946“ mit Herkunftsort).

167 Zwei Beispiele für die Bandbreite mögen hier genügen: Unvoreingenommen bis wohlwollend, sogar durch einen längeren Zeitzeugenbericht eines Flüchtingskindes noch besonders hervorgehoben, ist die Herangehensweise in Kiekebusch zu nennen: Kundoch/Kundoch/Nossack, Chronik Kiekebusch (wie Anm. 166), S. 44-51. Eher lieblos die sehr dürftige Darstellung in einem einzigen Absatz in: Groß Glienicke im Wandel der Zeit. Hrsg.: Groß Glienicker Kreis. Bearb: Otto Lehmberg, Karin Czech, Sigrid Dräger. 5., überarb. Ausg. Groß Glienicke 2001, S. 39. 
lorene Heimat durfte zur DDR-Zeit nicht gesprochen werden, und auch nach der Wende hat niemand mit den Betroffenen ernsthaft diskutiert. Da ist es an der Zeit, dieses Thema einmal aufzugreifen und an konkreten Beispielen zu zeigen, was 1945 geschah. ${ }^{168}$ Publiziert ist sein Beitrag freilich nicht in einem Periodikum der Aufnahmeregion, etwa dem im Kreis durchaus verbreiteten „Templiner Heimatkalender", sondern in einem wohl eher nur von Vertriebenen und deren Nachfahren gelesenen Medium, dem „Königsberger Kreiskalender“.

Fast schon skandalös könnte man die Darstellung in der Ortschronik von Jeserig (Fläming), einer Gemeinschaftsarbeit dreier Autoren, nennen. Die „Umsiedler (damals Flüchtlinge und heute Vertriebene genannt)", wie sich der aus Jeserig stammende Heimatforscher (und Bad Belziger Ehrenbürger) Gerhard Dorbritz (1926-2015) - scheinbar differenzierend und doch eher distanziert - ausdrückt, sind ihm in der von ihm mitverfassten, 150 Seiten umfassenden Jeseriger Chronik nur ganze acht Zeilen wert, obgleich gerade dieser Ort wie kaum ein anderer vom Flüchtlingszuzug geprägt war, gehörten dort doch bei Kriegsende - wie Dorbritz selbst mitteilt - 170 von 475 Einwohnern, mithin unvorstellbare 35,8 Prozent, zu dieser Bevölkerungsgruppe. ${ }^{169}$ Ein knapper Abschnitt zwischen ebenso knappen zu den „Kommunalwahlen am 15.9.1946“ und zur „Kartoffelkäferaktion“ muss genügen, um Nachgeborenen die Realität des Flüchtlingselends der Nachkriegsjahre nahezubringen. Dabei hätte Dorbritz als Zeitzeuge - er war ab 1. September 1945 Gemeindesekretär in Jeserig - wohl deutlich mehr dazu zu sagen gehabt. Zur Bodenreform schreibt er 29 Zeilen, obgleich gerade die Jeseriger Bauern, wie er klarstellt, „kaum Bodenreformland“ erhielten. ${ }^{170}$

In Darstellungen zur Geschichte einzelner Gebäude, vor allem Gaststätten und öffentlicher Einrichtungen (z.B. „Kulturhäuser“) und von ehemaligen militärischen Anlagen, die sich im Internet und in der lokalen Literatur finden, fehlt, auch in Zeittafeln, nahezu durchgehend die Erwähnung von Ereignissen, die mit der Erstverpflegung und Unterbringung von Flüchtlingen und Vertriebenen im Jahr 1945 oder noch danach in Zusammenhang stehen. Verantwortlich dafür ist aber nicht nur die jahrzehntelange Tabuisierung des Gesamtthemas, sondern auch die Tatsache, dass diese Nutzung von Liegenschaften oft wechselte und bisweilen nur Monate oder allenfalls ganz wenige Jahre dauerte, so dass sie leicht in Vergessenheit geraten konnte. Liest man heute die zeitgenössischen Berichte über die Zustände in solchen Auffangstellen, wird man allerdings zu dem Schluss kommen, dass auch für diese Geschehnisse und die sie erlebenden und erleidenden Menschen dringend eine Erinnerungskultur aufgebaut werden muss. Denn die Orte, an denen Flüchtlinge und Vertriebene ihre ersten Wochen und Monate in Brandenburg verbrachten - Restaurantsäle, Schulaulen, Bahnhofshallen u.a. - sind nicht nur beispielhafte

Erich Köhler: Das Flüchtlingselend neumärkischer Familien. In: Königsberger Kreiskalender 2002, S. 96-104, hier S. 104.

169 Gerhard Dorbritz: Erinnerungen an die Nachkriegszeit. In: Ders. / Helga Kästner / Ernst Neuendorf: Jeserig/ Fläming. Ein Dorf in der Brandtsheide. Beiträge zur Ortsgeschichte. Hrsg.: Gemeinde Wiesenburg, Ortsteile Jeserig. Red.: Helga Kästner. Wiesenburg 2003, S. 76-81, hier S. 77 f. Ebd., S. 76 f., Zitat S. 77. 
historische Stätten, die von einem gewaltigen Geschehen künden könnten, sondern sie sind fast immer auch Sterbeort unzähliger Betroffenen, vor allem alter Menschen, Frauen und Kinder. Ein Blick in die zeitgenössischen Sterberegister der Standesämter zeigt, wie die Verwaltung bemüht war, jedes Schicksal pflichtgemäß zu beurkunden, und wie sie sich doch oft genug damit überfordert sah und nur rudimentäre oder gar keine näheren Angaben zur Person eintragen konnte. ${ }^{171}$ Erst in wenigen Ausnahmefällen sind Massengräber der Jahre $1945 \mathrm{ff}$. überhaupt identifiziert oder gar markiert, geschweige denn mit Gedenksteinen versehen worden, obgleich es sie an sehr vielen Orten geben muss. Im Vordergrund standen dabei bisher Bestattungsorte von Soldaten, doch in vielen Fällen sind an gleicher Stelle auch Zivilisten beigesetzt worden. ${ }^{172}$ Auch diese Themen ruhen in der Ortsgeschichtsforschung noch weitgehend.

Gewisse Schübe mit einem nennenswerten Ertrag an Publikationen, bisweilen wohl auch überhaupt erstmals einen „Tabu-Bruch“ brachten in vielen Orten und Landkreisen die Aktivitäten zum Gedenken an das Kriegsende 1995 und erneut 2005, wobei - anders als in den oben genannten Gedenkbänden der Landesregierung - die Leiden der einheimischen Bevölkerung und dabei auch die der sich vorübergehend oder längerfristig am Ort aufhaltenden Flüchtlinge und Vertriebenen großen Raum einnehmen. Monographische Darstellungen oder zumindest Aufsätze, die ausschließlich dem Kriegsende gewidmet sind, erschienen und erscheinen seither allerorten in großer Zahl ${ }^{173}$, auch bei der ortsgeschichtlichen Literatur ist deutlich erkennbar, dass überwiegend erst ab 2000 die Wirkungen des Tabus nachließen. Publikationen ausschließlich zur (frühen) Nachkriegszeit in einzelnen Gemeinden oder Kreisen existieren allerdings, abgesehen von der oben schon genannten Dissertation über den Kreis Zauch-Belzig

171 Durchgesehen wurden die Register von Angermünde und Prenzlau. - In Beelitz bemühte sich der evangelische Pfarrer Dr. Runge 1945/46 in vielen Fällen um die Beurkundung der Sterbefälle in Massengräbern beigesetzter Soldaten und Zivilisten, unter denen auch Flüchtlinge gewesen sein dürften. Die Standesämter beurkundeten im Einzelfall auch den Tod „unbekannter“ Personen. Siehe dazu Herta Doil: Erinnerungen an Dr. Reinhard Runge. In: Um Beelitz harter Kampf. Beelitz 1999. S. 114-122, hier S. 123. - Für Rathenow hat der dortige Superintendent am 24. Mai 1945 in seinem Tagebuch notiert: „Bisher sind cirka 1400 Todesfälle seit dem Einbruch der Russen gemeldet. Standesamt und Friedhofsverwaltung können die Arbeit kaum bewältigen." (Georg Heimerdinger: Die ersten Tage des Friedens - das Tagebuch des Superintendenten Georg Heimerdinger. Rathenow o.J., S. 10).

172 Massengräber sind nicht nur im gleichsam spektakulären Einzelfall eingerichtet worden, sondern z. B. auch überall da, wo bei Kriegsende in großer Zahl Selbstmorde, Erschießungen und andere Exzesse stattfanden oder nach Kriegsende Opfer der Typhusepidemien neben Krankenstationen massenhaft ,anfielen“, außerdem da, wo in größerer Zahl (zunächst an Ort und Stelle des Todes notdürftig beerdigte, dann exhumierte) zivile wie militärische Opfer der letzten Kriegs- und ersten Friedenstage nachträglich beigesetzt wurden. Siehe vorläufig die Erwähnungen von Massengräbern in der Ortsdokumentation (Cottbus, Dabendorf, Dahme/Mark, Kolkwitz, Lobetal, Lübben, Zeuthen), ferner im Tagebuch des Rathenower Superintendenten Heimerdinger (wie Anm. 171), S. 12 f. - Vgl. auch die noch mit vielen Fragezeichen versehene Liste der Kriegsgräberstätten in Brandenburg in: Schicksal in Zahlen. Hrsg. vom Volksbund Deutsche Kriegsgräberfürsorge. 5. Aufl. Kassel 1997, S. 175 f. (Gemeinden, ,in denen mehr als 100 Kriegstote ruhen“).

173 Einzelne bibliographische Angaben siehe in der Ortsdokumentation. 
$(2008 / 11)^{174}$, bisher nur für Havelberg $(1992 / 94)^{175}$, Fürstenberg/Havel $(2004 / 11)^{176}$, Eichwalde $(2007)^{177}$, Lübben $(1997 / 2010)^{178}$, Fürstenberg/Oder (2011) und Guben (2011) $)^{179}$ sowie Rathenow und Umgebung (2014) ${ }^{180}$. Flüchtlingen und Vertriebenen allein gewidmet sind bisher nur kleinere Arbeiten oder Zeitschriftenbeiträge für Havelberg (1992) ${ }^{181}$, Wittenberge $(2001 / 15)^{182}$, Guben $(2000)^{183}$, Lübben $(2010)^{184}$, Eberswalde $(2015)^{185}$ sowie - jeweils Schülerarbeiten - für den Raum Lieberose $(2006)^{186}$ und den Raum Prenzlau (2008) ${ }^{187}$. Über-

174 Helle, Nachkriegsjahre in der Provinz (wie Anm. 79). 373 S.

175 Kriegsende und Nachkriegszeit in Havelberg [I]-[II]. Hrsg.: Heimatverein Havelberg e. V. Havelberg 19921994. 120; 90 S. (Havelberger Regionalgeschichtliche Beiträge, Bd. 1-2).

176 Kurt Neis: Fürstenberg/Havel. Eine Perle ohne Glanz? Erinnerungen und Betrachtungen aus der Zeit von 1946 bis zur Gegenwart 2011. Text- u. Bildbd. Privatdruck. 9., erg. Aufl. Fürstenberg/Havel 2011. 895 S. Wolfgang Stegemann: Die Nachkriegszeit 1945 bis 1948 in Zeitdokumenten. In: Ders. / Wolfgang Jacobeit: Fürstenberg/Havel, Ravensbrück. Beiträge zur Alltags- und Sozialgeschichte einer Region zwischen Brandenburg und Mecklenburg. Bd. 2. Teetz 2004, S. 223-257.

177 Wolfgang Müller: Nachkriegsjahre in Eichwalde. Zur Geschichte des Ortes von 1945 bis 1953. Eichwalde [2007]. 222 S. [S. 110 f. auch zu Heimkehrern].

178 Jörg Becken: Lübben nach dem Inferno. Die Jahre 1945-61. [Begleitband zur Ausstellung.] Hrsg.: Förderverein des Stadt- und Regionalmuseums Lübben (Spreewald) e. V. [Cottbus] 2010. 130 S. - Nur zum Jahr 1945: Rolf Ebert: Lübben und die Niederlausitz. Bd. 2: Lübben im April/Mai 1945. Lübben im Spreewald 1997.

179 Erich Opitz: Ereignisse der Nachkriegszeit in Fürstenberg (Oder) und Umgebung. In: Fürstenberger Blätter 1 (2011), S. 71-84. - Siehe auch die Quellenedition von Opitz (Anm. 209). - Guben 1945/1946. Berichte, Dokumente, Diskussionen. Hrsg. von Andreas Peter. Guben 1997. XII, 200 S.; 2., durchges. u. erw. Aufl. Guben 1997. XIII, 228 S. - Siehe auch die Gubener Quellenedition von Töpler (Anm. 146).

180 Die letzten Tage im Krieg und die ersten Wochen im Frieden in der Region um Rathenow. T. 1-3. Hrsg.: Rathenower Heimatbund e. V. [Red.:] Hans-Jürgen Wodtke u. a. 2. Aufl. (T. 1.: 4. Aufl.) Rathenow 2014-2018. [Ausgangspunkt waren die Beiträge der in Böhne bei Rathenow 2005 veranstalteten „2. Geschichtswerkstatt“; Wodtkes Mutter (geb. 1924) ist Flüchtling aus Ostpreußen.]

181 Steiner, Flüchtlinge und Vertriebene im Elb-Havel-Winkel (wie Anm. 150).

182 Günter Rodegast: „Umsiedler“ in Wittenberge. Eine Dokumentation. In: Prignitzer Heimat 29 (2001), S. 1417. - Ders.: 6000 Flüchtlinge in der Stadt. Die Gesundheitslage in Wittenberge 1945. In: Prignitzer Heimat 58 (2015), S. 54-55.

183 Zwei kurze Texte von jeweils 1 Seite Umfang in: Gubener Heimatkalender 44 (2000), S. 65 f.

184 Mietk, Neuanfang im Kreis Lübben (wie Anm. 51). 73 S.

185 Wenzel, Aufnahme und Versorgung von Flüchtlingen und Vertriebenen in Eberswalde (wie Anm. 50). - Siehe auch: Kathrin Schwarz, Eingliederung (wie Anm. 21); Ingrid Fischer: Zuwanderung nach dem Zweiten Weltkrieg. In: Fremde Heimat Eberswalde. Zuwanderungen in Vergangenheit und Gegenwart. Begleitheft zur Sonderausstellung im Rahmen des Kulturlandes Brandenburg 2003 Europa (Heimatkundliche Beiträge). Überarb. 2. Aufl. Eberswalde 2008 (1. Aufl. 2003), S. 33-43, darin S. 33-37: Kapitel „Flüchtlinge, Vertriebene und Umsiedler".

186 Flucht, Vertreibung, Neubeginn nach 1945. Schicksale und Berichte aus dem Raum Lieberose (wie Anm. 69). 187 Sarah Grandke: „Als die Füße nass und kalt waren, erkannte ich den Ernst der Lage.“ Flucht und Vertreibung 1944/45 und die schwierige Nachkriegszeit. Hrsg.: Uckermärkischer Geschichtsverein zu Prenzlau e.V. Prenzlau 2008. 64 S. (Schülerarbeiten zur Regionalgeschichte, H. 4) [2007 Landessiegerin im Geschichtswettbewerb des Bundespräsidenten "Jugendliche forschen vor Ort“ (S. 5)]. Grandke ist ein Beispiel für das Phänomen, dass Autoren, die sich dem Thema Flucht und Vertreibung widmen, häufig selbst einen familiären Bezug dazu haben. Lesenswert ist in diesem Zusammenhang auch ihr nachdenkliches Nachwort (S. 61-64), 
durchschnittlich umfangreiche Berücksichtigung in monographischen Ortschroniken u. ä. fand das Thema Flüchtlinge und Vertriebene bislang außer bei dem erwähnten Beispiel Letschin (Oderbruch) von 2011 auch in (Bad Belzig-)Ragösen 2002 (mit ausführlichen Abschnitten zu Aufnahme und Eingliederung) ${ }^{188}$ und Wilhelmshorst bei Potsdam 2007 (mit Abdruck von Zeitzeugenberichten) ${ }^{189}$.

Gerade die mit den örtlichen Gegebenheiten in Stadt und Dorf am besten vertrauten Heimatforscher und Ortschronisten sollten sich des Themas Flucht und Vertreibung noch viel stärker annehmen. So sind z.B. viele Fragen der genaueren Lokalisierung oder der Vor- und Nachnutzung von Flüchtlingslagern in der vorliegenden Arbeit nur teilweise zu klären gewesen und standen in der Überblicksdarstellung von Oehlsen ohnehin nicht im Fokus. ${ }^{190}$ Anders als für das bekannte Heimkehrerlager in Frankfurt-Gronenfelde ${ }^{191}$ besteht für die Standorte der eigentlichen Vertriebenenlager noch erheblicher Nachholbedarf in der Lokalgeschichtsforschung. Weitere Spezialliteratur zu einzelnen Orten, die nebenbei Flüchtlinge und Vertriebene erwähnt, ist in der Ortsdokumentation zusammengestellt.

\section{Quellenlage}

\section{Quelleneditionen und zeitgenössische gedruckte Quellen}

Die von der Bundesregierung initiierte und zwischen 1952 und 1962 erschienene, bis heute immer wieder nachgedruckte, auch als Taschenbuchausgabe verbreitete mehrbändige „Dokumentation der Vertreibung der Deutschen aus Ostmitteleuropa“192, kurz „Ost-Dokumentation“, genannt, ist die umfangreichste Sammlung von Selbstzeugnissen (Zeitzeugenberichten) Betroffener

in dem sie über ihren Großvater, einen Flüchtling aus Schlesien, spricht und ihre eigene Haltung zur Aktualität des Themas als Nachgeborene formuliert. - Siehe auch in derselben Reihe die Schülerarbeit über das Flüchtlingslager (Prenzlau-)Birkenhain (Anm. 190).

188 Ragösen. Beiträge zur Geschichte. T. 2: 1945 bis 1991. Autorenkollektiv: Helmut Bessel u. a. Hrsg.: Gemeinde Ragösen. Red.: Helga Kästner. Ragösen 2002, bes. S. 19f., 39, 41, 54 („Vom Schicksal der Flüchtlinge“).

189100 Jahre Wilhelmshorst 1907-2007. Eine Waldsiedlung vor den Toren der Hauptstadt. Hrsg. im Namen der Freunde und Förderer der Wilhelmshorster Ortsgeschichte e. V. von Rainer Paetau. Wilhelmshorst 2007, S. 338-350.

190 Ansätze bieten für einzelne wenige Lager: Anne Hacker: Birkenhain als Flüchtlingslager. Die Baracke als eine Zwischenstation zum neuen Leben in der „Zwangsheimat“ Deutschland. In: Birkenhain. Ein historischer Ort. Autoren: Judith Drescher u. a. Hrsg.: Uckermärkischer Geschichtsverein zu Prenzlau e. V. (Schülerarbeiten zur Regionalgeschichte, H. 3). Prenzlau 2007, S. 30-36.

191 Hirthe, Das Heimkehrerlager in Frankfurt-Gronenfelde (wie Anm. 163). - Hans-Georg Schneider: Zur Rolle und Bedeutung des Frankfurter Heimkehrerlagers Gronenfelde. In: Frankfurter Beiträge zur Geschichte 16 (1987), S. 5-9. - Joachim Schneider: Rückkehr nach Deutschland und doch nicht daheim. In: Historischer Verein zu Frankfurt (Oder) e. V. Mitteilungen 1993, H. 2, S. 2-3. - Karl-Konrad Tschäpe. Chronologie zu Deportation, Zwangsarbeit und Heimkehr in Frankfurt (Oder) 1938-1956 sowie zu deren Rezeprion bis 2018. In: Frankfurter Jahrbuch 2018, S. 86-179.

192 Dokumentation der Vertreibung der Deutschen aus Ost-Mitteleuropa. Hrsg. vom Bundesministerium für Ver- 
und muss trotz immer wieder vorgetragener konzeptioneller und politischer Kritikpunkte nach wie vor in die Behandlung des Themas einbezogen werden. ${ }^{193}$ Sie ist jedoch vornehmlich den unmittelbaren Vorgängen der Flucht und Vertreibung gewidmet, nur am Rande denen der hier interessierenden - Aufnahme, geschweige denn Eingliederung, die in vielen (oft ohnehin gekürzten) Berichten am Ende immerhin knappe Erwähnung findet, übrigens in nicht wenigen Fällen mit brandenburgischen Ziel- bzw. Ankunftsorten. ${ }^{194}$ Noch stärker auf die konkreten Vorgänge und Umstände bei Beginn der einzelnen Vertreibung konzentriert ist die neuere polnisch-deutsche Quellenedition, die anders als die „Ost-Dokumentation“ staatliche Akten aus polnischen Archiven präsentiert. ${ }^{195}$

Demgegenüber ist die von Manfred Wille in den Jahren 1996 bis 2003 herausgegebene dreibändige Edition - begrenzt auf die SBZ/DDR - ganz den Vorgängen vom Zeitpunkt des Flucht-Endes bzw. von der Ankunft am neuen, ersten oder künftigen Aufenthaltsort an gewidmet. ${ }^{196}$ Vergleichbares liegt bisher in diesem Umfang und dieser Tiefe für die westlichen Bundesländer nicht vor. Brandenburg wird von der Edition durchaus erfasst und ist mit diversen Dokumenten aus dem Brandenburgischen Landeshauptarchiv ${ }^{197}$ und dem Bundesarchiv vertreten, der Schwerpunkt liegt aber eher bei Mecklenburg und Thüringen sowie auch noch Sachsen-Anhalt und Sachsen, wohl weil für diese Länder in Willes Forschergruppe bereits fortgeschrittene oder fertiggestellte Monographien existierten. ${ }^{198}$ Während sodann schon seit 2005 sogar für ein einzelnes Land, Sachsen, eine nur diesem gewidmete Quellenedition vorliegt ${ }^{199}$, kann Brandenburg erst mit dem der vorliegenden Arbeit beigegebenen Teil 3 (Quellenedition) nachziehen, der jedoch, um allzu viele Doppelungen zu vermeiden, stärker auswählt; die

triebene. In Verb. mit Adolf Diestelkamp u. a. bearb. von Theodor Schieder. Bd. 1-5. Beih. 1-3. Reg. 19531963 (zitiert: Dokumentation der Vertreibung I-V).

193 Mathias Beer: „Dokumentation der Vertreibung der Deutschen aus Ostmitteleuropa“. In: Lexikon der Vertreibungen (wie Anm. 59), S. 215-218.

194 Hilfreich ist hierfür das 1963 erschienene Ortsregister (50 S. Kleindruck).

195 „Unsere Heimat ist uns ein fremdes Land geworden ..." Die Deutschen östlich von Oder und Neiße 19451950. Dokumente aus polnischen Archiven. Hrsg. von Włodzimierz Borodziej u. Hans Lemberg. Bd. 1-3. Marburg 2000-2004 (Quellen zur Geschichte und Landeskunde Ostmitteleuropas, 4/I-III).

196 Die Vertriebenen in der SBZ/DDR. Dokumente. Hrsg. u. eingel. von Manfred Wille unter Mitarb. von Steffi Kaltenborn (T. 1: Steffi Kaltenborn, Gerald Christopeit. Manfred Jahn). Wiesbaden 1996-2003 (Studien der Forschungsstelle Ostmitteleuropa an der Universität Dortmund, Bd. 19,1-3): [T.] 1. Ankunft und Aufnahme 1945. 1996. - [T.] 2. Massentransfer, Wohnen, Arbeit 1946-1949. 1999. - [T.] 3. Parteien, Organisationen, Institutionen und die „Umsiedler“ 1945-1953. 2003. [Im Folgenden zitiert Wille I-III]. Nicht übersehen werden sollten die kurzen, aber instruktiven Einleitungskapitel, die jedem einzelnen Abschnitt und Unterabschnitt der Edition beigefügt sind.

197 Die angegebenen Signaturen sind teilweise veraltet.

198 Siehe dazu oben im Kapitel I. 2 Forschungsstand.

199 „Umsiedler“ in Sachsen. Aufnahme und Integration von Flüchtlingen und Vertriebenen 1945-52. Eine Quellensammlung. [Bearb.:] Andreas Thüsing / Wolfgang Tischner. Unter Mitarb. von Notker Schrammek. Leipzig/Berlin 2005. 520 S. (EKF-Wissenschaft, Abt. Zeitgeschichte, Bd. 2). 
dreibändige Edition von Wille bleibt daneben weiter auch für Brandenburg grundlegend, nicht zuletzt durch Einbeziehung von die gesamte SBZ betreffenden Dokumenten.

Für die SBZ und damit auch für Brandenburg liegen jedoch noch einzelne andere thematisch allgemeiner gehaltene Quelleneditionen vor, die hier am Rande zu erwähnen sind, da sie immerhin die Rahmenbedingungen der Nachkriegszeit allgemein beleuchten und zudem in der Lokalgeschichtsforschung noch viel zu wenig rezipiert worden sind. Die von der Staatlichen Archivverwaltung der DDR noch 1989 herausgegebene, für Brandenburg von dem im Staatsarchiv Potsdam (jetzt wieder BLHA) tätigen Archivar Hans-Joachim Schreckenbach (geb. 1928 Dresden) betreute Sammlung der Berichte der Landes- und Provinzialverwaltungen aus den Jahren 1945 und $1946^{200}$ enthält sogar im „Sachweiser für die Dokumente“ etliche Fundstellen zum Begriff „Umsiedler“201, da u. a. - für Brandenburg - ein „Bericht der Provinzialverwaltung Mark Brandenburg über die Durchführung der Bodenreform "202 vom 20. März 1946 und ein „Tätigkeitsbericht des Amtes für Umsiedler der Provinzialverwaltung Mark Brandenburg

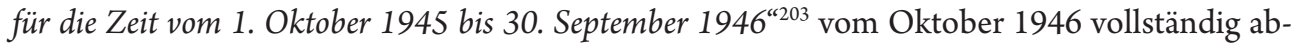
gedruckt werden. Letzterer ist in der wissenschaftlichen Literatur immer wieder auszugsweise zitiert und verwendet worden, bedarf aber dringend der Ergänzung durch Zeitzeugenberichte. 1994 erschien in der Veröffentlichungsreihe des BLHA eine umfangreiche Edition von Protokollen des „Landesblockausschusses der antifaschistisch-demokratischen Parteien Brandenburgs" für die Jahre 1945-1950. Unter den 34 wichtigsten behandelten Sachthemen findet sich immerhin die Bodenreform dreimal und die Oder-Neiße-Linie fünfmal ${ }^{204}$, doch kommt auch das Thema „Flüchtlinge“ gesondert vor, etwa wenn der zuständige Abteilungsleiter der Provinzialregierung Rederecht erhalten hatte. ${ }^{205}$

Weit über den kirchlichen oder gar den nur katholischen Bereich hinaus von Belang ist für das Thema die oben schon kurz angesprochene umfangreiche und sehr detailfreudige Quellenedition, die Winfried Töpler 2008 der Aufnahme der Flüchtlinge in der Niederlausitz gewidmet hat, die jedoch - nicht nur für nicht-katholische Lokalhistoriker in Brandenburg - an recht versteckter Stelle innerhalb eines Sammelbandes erschienen ist. ${ }^{206}$ Immerhin hatte Töpler, der ohnehin in der Niederlausitz vernetzt ist, schon 2005 in einem regionalgeschichtlichen PeSchreckenbach. Bearb.: Gottfried Börnert u. a. Berlin 1989. 484 S. (Publikationen der Staatlichen Archivverwaltung der DDR).

201 Ebd., S. 451.

202 Ebd., Dokument Nr. 35 (S. 202-214).

203 Ebd., Dokument Nr. 70 (S. 403-407).

204 Protokolle des Landesblockausschusses der antifaschistisch-demokratischen Parteien Brandenburgs 19451950. Eingel. u. bearb. von Fritz Reinert (Veröffentlichungen des Brandenburgischen Landeshauptarchivs, Bd. 30). Weimar 1994, S. LII f. - Ein Sachregister zu den über 400 Seiten umfassenden Protokolltexten fehlt. Ebd., S. 104f. (31.3.1947).

206 Töpler, Menschenwurm (wie Anm. 147). 
riodikum eine Teiledition vorgelegt. ${ }^{207}$ Er hat nun nicht geruht und der Forschung (wie auch der örtlichen Erinnerungsarbeit) mit der Edition von Zeitzeugenberichten der Jahre 1945/46 aus der katholischen Gemeinde Guben einen weiteren sehr umfangreichen Quellenfundus zur Verfügung gestellt, der die Situation in der - im Juni 1945 - vielleicht am stärksten von allen brandenburgischen Orten betroffenen Grenzstadt in eindringlichen Schilderungen vor Augen führt. ${ }^{208}$ Alle diese Dokumentensammlungen (katholisch-)kirchlicher Provenienz beleuchten freilich in erster Linie auch „nur“ die Not der Anfangszeit und spiegeln Eingliederungsbemühungen nur teilweise bzw. oft vorübergehend.

Umfangreichere lokale und kleinregionale Quellensammlungen für das Kriegsende und die unmittelbare erste Nachkriegszeit liegen in Brandenburg ebenfalls bislang nur für die Niederlausitz vor: für die Grenzstädte Fürstenberg/Oder-Eisenhüttenstadt ${ }^{209}$ und Guben ${ }^{210}$. Beide enthalten diverse für die Situation der Flüchtlinge und Vertriebenen aussagefähige Dokumente, die beispielhaft für andere stehen können. Die Eisenhüttenstädter Sammlung geht sogar bis in kleinste Vorfälle und Angelegenheiten einzelner - stets namentlich genannter - Personen. Wegen der geringen Auflage fast nur im Land rezipierbar sind die detailversessenenen Arbeiten von Stefan Lindemann (geb. 1973 Hennigsdorf) für Groß und Klein Behnitz (Westhavelland), in denen einzelne Quellen, z.B. zur Wohnraumbeschaffung und zur Bodenreform, erschlossen sowie in Regestenform mitgeteilt werden. ${ }^{211}$

Zeitgenössische und ausgewählte später gedruckte Statistiken bieten nur in einem sehr begrenzten Rahmen wichtige ergänzende Daten. Für Fragen der Langzeit-Eingliederung scheiden sie aus, da die gesonderte Erfassung der „Umsiedler“ in DDR-Statistiken ab 1950/51 un-

Töpler [Hrsg.], Berichte der katholischen Geistlichkeit aus dem Jahr 1945 (wie Anm. 146). Unsere Herzen bluten (wie Anm. 146).

„Die russische Kommandantur verlangt ..." Eine regionale Quellensammlung der ersten Nachkriegsjahre für Fürstenberg (Oder) und Umgebung 1945-1949. Hrsg.: Bürgervereinigung „Fürstenberg (Oder)“ e.V. Verantw.: Erich Opitz. Eisenhüttenstadt 2003. 192 S. Ein Teil dieser Quellen war bereits 1994 als Schülerarbeit am Gymnasium Neuzelle veröffentlicht worden: Chronik der ersten Jahre. Eine regionale Quellensammlung für Fürstenberg/Oder und Umgebung 1945-1949. Zsgest. von Bernd Bahro u. a. (Neuzelle 1994). 78 S.

(Mischung aus Darstellung und Quellenedition:) Guben 1945/1946 (wie Anm. 179).

Quellen zur Geschichte der Dörfer Groß und Klein Behnitz. Archivalische Quellen 1174/76-1989. Bearb. von Stefan Lindemann (Beiträge zur Geschichte der Dörfer Groß und Klein Behnitz (Havelland), Nr. 21). Potsdam 2006. CLXXXV, 1148 S. [S. LVI-LIX: Bodenreform]. - Erschließung der Einwohnermeldebücher Groß Behnitz (mit Ortsteil Quermathen) 1950-1983. Mit einer Liste der „Russland-Flüchtlinge“ 1945/46. Bearb. von Stefan Lindemann unter Mitarb. von Nele Möbius. Potsdam 2015. 221 S. [S. 197-198: Liste der Flüchtlinge aus Russland (und Litauen) 1945/46]. - Erschließung des Gesamtkirchenbuches Klein Behnitz. Taufen 1902-1949. Beerdigungen 1934-1975. Trauungen 1932-1976. Konfirmationen 1912-1927. Bearb. von Stefan Lindemann. Brandenburg/H.-Potsdam 2004. 160 S. - Stefan Lindemann: Erschließung der Kirchenbücher Groß und Klein Behnitz. Taufen Groß Behnitz 1937-1992. Taufen Klein Behnitz 1950-1992. Konfirmationen Groß und Klein Behnitz 1927-2010. Beerdigungen Groß Behnitz 1952-2011. Beerdigungen Groß Behnitz 1976-2015. (Privatdruck) Vitte (Hiddensee)/Potsdam 2016. - Ders.: Erschließung des Gesamtkirchenbuches Groß Behnitz (Teil 2). Taufen 1902-1936. Beerdigungen 1931-1951. Trauungen 19321959. Konfirmationen 1912-1926. (Privatdruck) Potsdam 2016. 
tersagt war und danach nur noch z. T. geheim erfolgte. ${ }^{212}$ Für die frühen Nachkriegsjahre liegen dagegen einzelne, teilweise brauchbare Daten aus der Bevölkerungszählung vom 29. Oktober $1946^{213}$ vor, die in manche lokale Darstellung und, meist nur knapp anreißend, bisweilen sogar etwas zu unkritisch, auch in die zeitgeschichtliche Literatur bereits Eingang gefunden haben, in landeskundlichen Nachschlagewerken aber nur selten zur Filterung der Gruppe der Flüchtlinge und Vertriebenen genutzt worden sind. ${ }^{214} 1946$ hat man nach dem Wohnort im „Normaljahr" 1939 gefragt. Für innerhalb des damaligen Deutschen Reiches liegende Gebiete sind die Zahlen in den publizierten Ergebnistabellen nach Provinzen gegliedert und somit für eine landsmannschaftliche Analyse recht differenziert aussagekräftig. Für die außerhalb des Reiches liegenden Wohnorte werden dagegen nur Staaten genannt, so dass zwar die drei baltischen als eine Gesamtgruppe für die Zeit vor der Eingliederung in die UdSSR noch gesondert erkennbar sind, aber beispielsweise keine Unterscheidung von Regionen innerhalb Polens (Posen/Westpreußen, Zentralpolen) möglich ist. ${ }^{215}$ Die Zahlen bleiben jedoch eine sehr wertvolle, singuläre Quelle, sofern man sich bewusst bleibt, dass auch nach dem Tag ihrer Erhebung (29. Oktober 1946) noch Transporte ins Land kamen und v. a. zahllose Wohnsitzwechsel und Abwanderungen erfolgten, sie also nur bedingt längerfristig bleibende Zustände spiegeln.

\section{Staatliche Archive}

Wesentliche Grundlage jeder Vertriebenenforschung sind neben Zeitzeugenberichten die staatlichen Akten, in Brandenburg - nach Auflösung der Mittelinstanzen - vornehmlich also die der Provinzial- bzw. Landesministerien, SBZ-weit die der Deutschen Zentralverwaltungen (Vorgänger der DDR-Ministerien), aber nicht minder die der Kreisebene (Landratsämter, Räte der Kreise), beide für Brandenburg im BLHA ${ }^{216}$, die oberste Ebene für die SBZ/DDR im Bundes$\operatorname{archiv}^{217}$ überliefert. Die Änderung der Ressortzuständigkeit während der frühen Jahre führt in

212 Amos, Die Vertriebenenpolitik der SED (wie Anm. 12), S. $22 \mathrm{f}$.

213 Endgültige Ergebnisse der Volks- und Berufszählung vom 29. Oktober 1946. Folge 1-8. In: Statistische Praxis 3 (1948), Beil. zu H. 5-12. - Siehe auch: Wolfgang Müller: Volkszählungen in Brandenburg nach dem Ende des 2. Weltkrieges. In: Heimatkalender Königs Wusterhausen und Dahmeland 2009, S. 130-132.

214 Siehe oben im Kapitel I. 2 zum Forschungsstand die Hinweise zum „Historischen Ortslexikon für Brandenburg“ (wie Anm. 165) und zum „Städtebuch Brandenburg und Berlin“ (wie Anm. 54), für die diese Quelle nur oberflächlich ausgeschöpft worden ist.

215 Siehe unten die danach für Brandenburg erstellte Tabelle 4.

216 Die Archivdatenbank ist online systematisch über die Tektonik recherchierbar (http://www.recherche. im.blha.de/archivplansuche.aspx), Digitalisate sind noch nicht verfügbar. - Überblick über Quellen für die Lokalforschung: Torsten Hartisch: Quellen des Brandenburgischen Landeshauptarchivs zur Ortsgeschichte in der Nachkriegszeit (http://blha.brandenburg.de/wp-content/uploads/2017/11/Hartisch_QuellenOrtsgeschichte-Nachkriegszeit.pdf [23.7.2018]). - Siehe ferner die beiden älteren Aufsätze zu Quellen zur Geschichte der Bodenreform in Anm. 1369.

217 www.bundesarchiv.de/recherche/index.html.de. 
Brandenburg dazu, dass der Arbeits- und Sozial- ${ }^{218}$ ebenso wie der Innenminister ${ }^{219}$ zeitweise vornehmlich von Belang waren. Wenig ergiebig sind dagegen die Überlieferungen des Ministerpräsidenten und des Finanzministers, während, wie zu erwarten, die der SED-Landesleitung oft die politisch wichtigsten Informationen enthalten ${ }^{220}$; gelegentlich lohnt noch ein Blick in die des Landtags ${ }^{221}$.

Die Überlieferung der einzelnen innerministeriellen Sachgebiete ist jedoch an vielen Stellen lückenhaft, während man an anderen, etwa in der Fülle der gesammelten - wertvollen - Berichte aus den Kreisen ${ }^{222}$, heute fast zu ertrinken droht. Statistische Daten finden sich in großer Zahl, auch die berufliche Eingliederung ist durch eine Vielzahl an Angaben aus Arbeitsämtern und anderen Verwaltungen gut dokumentiert. Schwierigkeiten bestehen in erster Linie bei den frühen Geschehnissen des Jahres 1945, da die zentralen, oberen Verwaltungen in der Provinz noch nicht mit entsprechenden Fachressorts arbeiteten, als die besonders dramatischen Ereignisse der sommerlichen „Wilden Vertreibungen“ zu schultern waren. Gleiches gilt für die noch kurz vor Kriegsende hereinströmenden Trecks und Transporte, die sich - wiederum von Zeitzeugenberichten abgesehen - fast nur noch durch lokale, kommunale Quellen rekonstruieren lassen. Erst ab Herbst, oftmals Oktober und stärker dann ab Dezember 1945 bieten die staatlichen Akten ausreichend Fakten, auch Transportlisten, die freilich nirgends komplett vorliegen, was folglich die Angabe konkreter Zahlen auch für diese Phase sehr erschwert.

Für die Gewichtung der brandenburgischen Geschehnisse innerhalb der SBZ bieten die Akten der Provinzial-/Landesministerien durchaus häufig eine Grundlage, indem mit Anlagen versehene Schreiben von der Deutschen Zentralverwaltung aus Berlin vielfach gleichlautend an alle fünf Landesverwaltungen gingen und daher auch Informationen über die vier anderen Länder Mecklenburg(-Vorpommern), Sachsen-Anhalt, Sachsen und Thüringen enthalten, die Vergleiche ermöglichen. ${ }^{223}$ Alles in allem zeigt der Blick in die - für den länderübergreifenden Blick noch aussagefähigeren - im Bundesarchiv überlieferten Akten der Zentralverwaltungen und Ministerien 224 - nicht nur der schon 1948 aufgelösten, für Umsiedler zuständigen Zentralverwaltung 225 - sowie nicht zuletzt in die der SED, des FDGB usw., dass grundlegende Entscheidungen auch in der Umsiedlerpolitik in Berlin, nicht in Potsdam getroffen wurden, dass

BLHA, Rep. 206 Ministerium für Wirtschaft und Arbeit; BLHA, Rep. 211 Ministerium für Gesundheitswesen.

219 BLHA, Rep. 203 Ministerium des Innern.

220 BLHA, Rep. 333 SED-Landesleitung Brandenburg.

221 BLHA, Rep. 201 Landtag, Nr. 181, 182, 185, 264, 331, 339, 403.

222 BLHA, Rep. 202 G Amt für Information. - Informations- und Stimmungsberichte finden sich aber auch in den Akten der Fachministerien.

223 Solche Dokumente für die Gesamtheit der SBZ-Länder sind überdies bereits in größerer Zahl verfügbar in der Edition von Wille (wie Anm. 196).

224 Siehe z. B. besonders: BArch, DO 1 Ministerium des Innern der DDR.

225 BArch, DO 2 Zentralverwaltung für deutsche Umsiedler. Laufzeit: 1945-1948 (1948-1954). Umfang: 3,5 1fm. Online-Findbuch, bearb. von Kerstin Risse, Koblenz April 2005 (mit Einleitung zur Behördengeschichte). 
für eine Betrachtung der Geschehnisse im einzelnen Land aber eine ausreichende Basis auch im betreffenden Landesarchiv vorliegt.

Eine wesentliche Ergänzung zur Ministerialüberlieferung bilden die Akten der Landratsämter bzw. Räte der Kreise. Sowohl die in mehreren Fällen bis 1945 reichenden Überlieferungen der alten Landratsämter liegen im BLHA ${ }^{226}$ als auch die der Nachkriegslandratsämter und frühen Räte der Kreise ${ }^{227}$, meist mit Laufzeiten bis 1953, erst die der Bezirkszeit nach 1952 dagegen finden sich in den Kreisarchiven ${ }^{228}$. „Von besonderer Aussagekraft sind dabei die Berichte der Landräte an die Provinzialverwaltung bzw. die Landesregierung. Sie setzen bereits im Sommer 1945 ein und dokumentieren in jeweils zehn bis zwölf vorgegebenen Punkten die Lage im Kreisgebiet von der Versorgung der Bevölkerung über die Eingliederung von Flüchtlingen, die

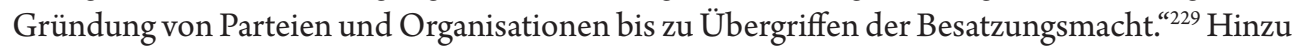
treten für eine nochmals basisnähere Ebene die Informantenberichte aus einzelnen Städten und Gemeinden, z. T. sogar aus Betrieben, die in den Landratsämtern nachgeordneten „Ämtern für Information" eingingen und aus denen Auszüge in die genannten Berichte an die Ministerien bzw. das (Landes-)Amt für Information gelangten. ${ }^{230}$ Bisweilen lässt sich an konkreten Beispielen zeigen, wie der ursprüngliche - nicht selten in mangelhaftem Deutsch abgefasste - lokale Informantenbericht im Landratsamt stark gekürzt und redigiert wird und sich in dieser Form dann in den Akten der Landesregierung wiederfindet. Zusammengenommen bilden die Überlieferungen der zentralen Verwaltungsebene (Ministerien) und der lokalen (Landratsämter) eine hervorragende Quellengrundlage, die überdies dadurch für die Forschung besonders gut auswertbar ist, dass sie geschlossen an einem Ort, im BLHA in Potsdam, zusammengeführt worden ist. ${ }^{231}$ Demgegenüber sind die Akten der nur in den Jahren 1945 bis 1947 bestehenden Zwischeninstanz, der Oberlandratsämter ${ }^{232}$, „lediglich bruchstückhaft“ überliefert. ${ }^{233}$

Die wohl schonungslosesten Berichte sind die von Ärzten (Lagerärzte, Leiter von Notkrankenhäusern, Hospitälern usw.) und medizinisch vorgebildeter Gesundheitsdezernenten. Sie liegen in großer Zahl in den verschiedensten Beständen vor und bilden oftmals - abgesehen von Berichten der betroffenen Flüchtlinge selbst - die frühesten Quellen für die Geschehnisse vor, während und unmittelbar nach der Flucht oder Vertreibung. Neben den im Quellenteil

Überblick: Kurzübersicht über die Archivbestände der Kreise, Städte und Gemeinden im Land Brandenburg. Hrsg. von Uwe Schaper (Quellen, Findbücher und Inventare des Brandenburgischen Landeshauptarchivs, Bd. 10). Frankfurt am Main 2001, S. 65-73.

227 Überblick: ebd., S. 74-79.

228 Überblick: ebd., S. 81-174.

229 Friedrich Beck: Quellen zur brandenburgischen Landesgeschichte. In: Brandenburgische Geschichte (wie Anm. 81), S. 801-824, hier S. 818.

230 Siehe die im Teil 3 (Quellenedition), Abschnitt 4.1, abgedruckten Beispiele.

231 Was sich für einen einzelnen Landkreis aus den Akten des Landratsamtes „herausholen“ lässt, zeigt die kleine Lübbener Arbeit von Mietk, Neuanfang im Kreis Lübben (wie Anm. 51).

232 BLHA, Rep. 230 (Laufzeit äußerstenfalls bis 1948).

233 Beck, Quellen (wie Anm. 229), S. 818. 
(Teil 3) abgedruckten Berichten von Lagerärzten, die über die Landesumsiedlerverwaltung in die Akten der Ministerien gelangt sind, eröffnet diese Quellengruppe auch für weiterführende Lokalforschungen noch ungenutzte Möglichkeiten, die die nicht wenigen kommunalen Archive in Brandenburg in großer Zahl bieten dürften.

Informationen über die Situation in den Lagern sowie allgemein über deren Verwaltung und Betrieb lassen sich zwar aus einer ganzen Reihe von Akten der Ministerien gewinnen, doch ist das Gros der in den Lagern selbst geführten Akten offenkundig vernichtet. Mit der Auflösung waren diese an das vorgesetzte Landessozial- bzw. Innenministerium abzugeben, Karteien sogar an die Zentralverwaltung für deutsche Umsiedler (ZVU) in Berlin bzw. den länderübergreifenden Suchdienst. ${ }^{234}$ Aus den Abgaben solchen Lager-Schriftgutes haben sich in den Ministerialüberlieferungen nur die aus dem „Umsiedlerlager“ Küchensee und aus dem „Heimkehrerlager“ Gronenfelde (Frankfurt/Oder) erhalten, die im BLHA wieder herausgelöst und gemäß ihrer ursprünglichen Provenienz als selbständige Bestände aufgestellt worden sind. ${ }^{235}$ Für die weitere Erforschung der Standorte und des Innenlebens der einzelnen Lager müsste folglich zusätzlich auch in lokalen Archiven noch nach „Ersatzquellen“ gesucht werden, die etwa Grundstücks-, Bau- oder Lieferfragen direkt oder indirekt ansprechen. ${ }^{236}$

Für die vorliegende Arbeit zwar nicht einbezogen, aber vor allem für jede über die ersten Nachkriegsjahre hinausgehende künftige Untersuchung erfolgversprechend und wichtig sind Recherchen in den - über die meist im Fokus der Öffentlichkeit stehenden Personendossiers hinaus - ebenfalls gut überlieferten Sachakten des Ministeriums für Staatssicherheit (MfS). ${ }^{237}$ Heike Amos, Michael Schwartz und auch Mirjam Seils haben bereits eindrucksvoll zeigen können, dass die Beobachtung der „Umsiedler“ als potentieller Unruhefaktor teilweise bis 1989 fortgeführt wurde und die MfS-Berichte im Grunde die einzigen staatlichen Akten sind, die nach der frühen Auflösung der gesonderten „Umsiedlerverwaltungen“ überhaupt noch Vertriebene als solche betreffen. ${ }^{238}$ Eine Vielzahl von Hinweisen z. B. auf „illegale“ Treffen und „WestKontakte" fand ihren Niederschlag in den MfS-Informantenberichten und dürfte bei systematischer Durchsicht auch für Brandenburg noch viele unerwartete Fakten unterhalb eines nur scheinbar hermetisch wirkenden Tabus zu Tage fördern.

Staatliche und kirchliche Überlieferungen, die in den Westzonen bzw. der alten Bundesrepublik im Zusammenhang mit der Vermisstensuche (Heimatortskarteien), der Prüfung

234 Sie könnten sich demnach heute, wenn überhaupt noch erhalten, beim Suchdienst des Deutschen Roten Kreuzes in München befinden, der nach dem 3. Oktober 1990 acht Millionen Karten des ehemaligen Suchdienstes des DRK in der DDR in seine Zentrale Namenskartei übernommen hat (BArch, Findbuch zum Bestand DO $105)$.

235 BLHA, Rep. 256 Heimkehrerlager Gronenfelde (1946-1950); BLHA, Rep. 256 Umsiedlerlager Küchensee (1945-1950).

236 Ansatzpunkte für viele Detailfragen bietet Oehlsen, Vertriebenenlager (wie Anm. 45).

237 Für Hinweise sei Frau Dr. Ines Oberling (Falkensee) gedankt.

238 Siehe dazu: Amos, Vertriebenenpolitik der SED (wie Anm. 12); Schwartz, Vertriebene und „Umsiedlerpolitik“" (wie Anm. 13); Seils (wie Anm. 19), S. 244-259. 
von Lastenausgleichsanträgen (Heimatauskunftsstellen u. a.), aber auch der Materialsammlung für die von der Bundesregierung in Auftrag gegebene „Ost-Dokumentation “239 in erheblichem Umfang entstanden, befinden sich heute größtenteils im Bundesarchiv-Lastenausgleichsarchiv in Bayreuth. Die enthaltenen Informationen betreffen jedoch keineswegs (nach 1945) nur in Westdeutschland lebende Personen, sondern sind auch für die in die SBZ/DDR gelangten Flüchtlinge und Vertriebenen von großem Interesse, obgleich diese nicht zu den Antragstellern oder Auskunftgebern gehörten. Dies kann hier freilich nur an einem - stichprobenartig erhobenen - Beispiel verdeutlicht werden, das zudem keinen unmittelbaren Brandenburg-Bezug aufweist. Es dürfte aber zeigen, dass bei einer gezielten Einzelrecherche, etwa zu neumärkischen Herkunftsorten, auch heutige brandenburgische Orte unmittelbar Betreffendes ebenso zu erwarten ist. So findet sich in der „Ost-Dokumentation“ für die Gemeinde Dürrkunzendorf (poln. Suszyna) im niederschlesischen Kreis Glatz eine der typischen ,Seelenlisten', die in die Westzonen gelangte frühere Bewohner für nahezu alle Vertreibungsorte zusammengestellt haben. Diese 1954 familienweise erstellte Liste der früheren Einwohner (Stand 1939 bzw. 1945) enthält für das eigentliche Dorf 259 Personen sowie 121 für den Ortsteil Finkenhübel und nennt jeweils, soweit möglich, ihren Verbleib, d.h. ob noch im Heimatort verstorben (mit Jahresangabe), gefallen, vermisst oder inzwischen anderswo wohnhaft. Im letzteren Fall ist der Ort (ohne genaue Anschrift) angegeben. ${ }^{240}$ Die Wohnorte nach 1945 (bzw. 1954) zeigen, dass hier offenkundig zwei Transport-Endpunkte für die 1946 vertriebene ${ }^{241}$ Dorfbevölkerung ausschlaggebend waren: Westfalen einerseits (122 Personen) und der Bezirk Magdeburg andererseits (56 Personen) überwiegen bei weitem. Hinzu kommen immerhin 70 weitere Personen mit sonstigen Wohnorten in der DDR (Sachsen, Sachsen-Anhalt und Thüringen), besonders Kreise Zeitz und Zerbst (beide im benachbarten Bezirk Halle) sowie Raum Leipzig, und 43 Personen in sonstigen westdeutschen Orten (meist Niedersachsen).

\section{Kommunalarchive}

Zwar liegt die schriftliche Überlieferung der Landratsämter und frühen Räte der Kreise im BLHA, doch bieten die in Brandenburg flächendeckend bestehenden Kreisarchive nicht nur die - für das Thema wohl weitgehend unergiebigen - Akten der Räte der Kreise ab 1952, sondern die besonders basisnahe Überlieferung zahlreicher kreisangehöriger Gemeinden, oft bis

239 Siehe dazu oben im Kapitel I. 3 den Abschnitt zu Quelleneditionen.

240 BArch-LAA, OSTDOK 3/713, B1.51-65. Angaben (Tabellenvordruck): „Name; Vorname; Geburtsjahr; Beruf oder Familienverhältnis; landwirt[schaftlicher] Grundbesitz (Gr[öße] in ha); nichtlandwirtsch. Grundbesitz/Hausbes[itz] usw.; heutige Anschrift / Postleitzahl, Ort, Post, Kreis; Vermerk über Tote, Vermißte, Verschleppte, Kriegsgefangene, Zivilinternierte / Datum, Ort und Ursache, Gewährsmann“.

241 „Die Ausweisungen unser[er] Dorfbewohner erfolgte[n] in vier Raten, u. zwar erste Rate am 11. März 1946 mit 34 Familien, zweite Rate am 24. März 1946 mit 4 Familien[,] dritte Rate am 16. Oktober 1946 mit 40 Familien[,] die achte Rate Anfang Dezember 1946 mit 5 Familien. [...]". Aussage (Fragebogenbericht) des Bruno Reimann sen., Schwarme über Verden (Aller), 1.10.1954 (BArch-LAA, OSTDOK 1/199, Bl. 75-78, hier Bl. 77). 
in die Kriegs- und Vorkriegszeit zurückreichend. ${ }^{242}$ Vielfach für das Thema noch ungehoben ist auch das Schriftgut derjenigen nicht kreisfreien Städte, die weiterhin eigene Stadtarchive unterhalten, aber bisher kaum über die Lokalforschung hinaus wahrgenommen werden. ${ }^{243}$ Die nach 2000 am jeweiligen Ort erschienene ortsgeschichtliche Literatur lässt dies bereits teils erkennen, teils erahnen.

Neuerdings bieten sich überdies mit den Standesamtsbüchern ganz neue Möglichkeiten, tief in die lokalen Geschehnisse und persönlichen Schicksale vorzudringen. Erst mit dem 2009 in Kraft getretenen Personenstandsrechtsreformgesetz, das die älteren Jahrgänge zu Archivgut erklärt, sind sie nach und nach für die Forschung wirklich nutzbar geworden. ${ }^{244}$ Damit sind zwar noch nicht die Geburts- (Schutzfrist: 110 Jahre) und die Heiratsregister (Schutzfrist: 80 Jahre), aber die hier besonders wichtigen Sterberegister (Schutzfrist: 30 Jahre) für die Kriegsund Nachkriegsjahre allgemein zugänglich. ${ }^{245}$ Insbesondere letztere sind eine (für die gesamte Zeitgeschichte) sehr gewichtige, noch längst nicht ausreichend ausgewertete und bisweilen wohl doch weiterhin unterschätzte, als bloß genealogisch relevant angesehene Quelle. ${ }^{246}$ Schon wegen der Dürftigkeit der zudem oft erst relativ spät einsetzenden schriftlichen Behördenüberlieferungen des Jahres 1945 kommt ihnen jedoch besondere Bedeutung zu. Denn die Standesämter waren durchgehend bemüht, selbst unter schwierigsten Bedingungen ihrem gesetzlichen Auftrag nachzukommen, und haben Sterbefälle notfalls auch nach einem Jahr noch eingetragen. Zudem sind in dieser Zeit (bzw. generell von 1937 bis 1958) auch die Todesursachen vermerkt worden, was den Wert für die zeitgeschichtliche Forschung (und manch andere Spezialdisziplin) noch wesentlich erhöht. Da die Bücher einiger ausgewählter brandenburgischen Städte und Gemeinden auch online benutzbar sind, konnten sie in die vorliegende Untersuchung teilweise einbezogen werden. ${ }^{247}$

242 Überblick: Kurzübersicht (wie Anm. 226), S. 81-174.

243 Für die kreisfreien Städte Brandenburg an der Havel, Cottbus, Frankfurt (Oder) und Potsdam siehe den Überblick in: Kurzübersicht (wie Anm. 226), S. 175-215.

244 Die Zweitbücher (Nebenregister) der NS-Zeit sind bereits in der DDR-Zeit zentralisiert worden und liegen heute in den zuständigen Staats-/Landesarchiven, für Brandenburg im BLHA. Siehe zur Quellengattung: Michael Scholz: Personenstandsunterlagen - eine neue Quellengruppe in den Archiven des Landes Brandenburg. In: Berichte und Forschungen aus dem Domstift Brandenburg 4 (2011), S. 171-181.

245 Sie liegen entweder im Stadt-/Gemeinde- oder im zuständigen Kreisarchiv, hier und da ist aber wohl die Abgabe aus dem Standesamt noch nicht erfolgt.

246 Für die Untersuchung der Geschehnisse bei und kurz nach Einmarsch der Roten Armee in Finsterwalde siehe die Auswertung der im Stadtarchiv liegenden Bücher in: Woitzik, Was geschah vor 70 Jahren in Finsterwalde? (wie Anm. 164), hier S. $117 \mathrm{f}$.

247 Die Bücher der Standesämter von Angermünde und Prenzlau sowie einzelner Gemeinden des heutigen Landkreises Teltow-Fläming sind von den zuständigen Stadt- und Kreisarchiven dem gewerblichen US-amerikanischen Dienstleister Ancestry (www.ancestry.de) für eine Digitalisierung und Indizierung im Internet zur Verfügung gestellt worden, die Einsichtnahme ist für den Benutzer kostenpflichtig, aber bequem. Nach „Redaktionsschluss" sind (am 17.1.2018) bereits weitere brandenburgische Standesamtsregister hinzugekommen, die hier nicht mehr ausgewertet werden konnten, aber für die Vertriebenenforschung künftig wertvolle 
Wichtige Quellen wären an sich auch die Einwohnermelderegister, ihre Auswertung ist jedoch aufgrund der Datenschutzbestimmungen kaum realisierbar. Wieweit die Register auch nur vorübergehend untergebrachte Flüchtlinge verlässlich und vollständig nachweisen, bleibt ohnehin fraglich, wie das Beispiel Rühstädt zeigt, wo, obwohl andere Quellen einen erheblichen „Strom“ aus den Ostgebieten belegen, 1945 „nur etwa dreißig Fremde“ im Meldebuch genannt werden, „und nur einer von ihnen stammte aus dem Osten“. 248

Um das Schriftgut der regionalen und lokalen Vertriebenenverbände haben sich öffentliche Archive bislang kaum gekümmert, obgleich inzwischen bereits eine große Zahl dieser in den frühen neunziger Jahren in Brandenburg flächendeckend gegründeten Vereine aufgelöst worden ist. Eine Ausnahme bildet das Stadtarchiv Prenzlau, das mit den Akten des Vereins Heimatvertriebene in der Uckermark e. V. (HVU) (2006-2008 Sitz Prenzlau) auch die Überlieferung von dessen Vorgänger, dem BdV-Kreisverband Prenzlau e. V., übernehmen konnte (Gesamtlaufzeit 1990-2008). Dieses Schriftgut enthält, wie die bei der Landesgeschäftsstelle in Potsdam zu den Kreisverbänden vorhandenen Akten zeigen, für die regionalen Aktivitäten sehr wertvolles Material, wie Mitgliederlisten (teilweise mit Geburts-/Herkunftsorten), Veranstaltungsprogramme und Berichte. Es sollte dringend auch in anderen Landkreisen gesichert werden.

\section{Kirchliche Archive}

Ebenso wie die Ärzte sind die Pfarrer beider Konfessionen Berichtende von besonderem Wert, da sie den örtlichen Geschehnissen ebenfalls sehr nahe waren und in der Seelsorge- und Fürsorgearbeit mit Aussagen Betroffener unmittelbar konfrontiert wurden. Berichte an ihre regionalen und zentralen Kirchenbehörden liegen in deren Überlieferung zahlreich vor, wie schon die für die Niederlausitz außerordentlich ergiebige Edition Töplers anhand der Aktenüberlieferung im Bistumsarchiv Görlitz gezeigt hat. ${ }^{249}$ Über die hier, in Darstellung und Quellenedition, in Teilen einbezogenen Akten des (evangelischen) Konsistoriums (Evangelisches Landeskirchliches Archiv in Berlin) und des (katholischen) Bischöflichen Ordinariats (Diözesanarchiv Berlin) hinaus sind für künftige Forschungen aber auch noch stärker die Archive kirchlicher und kirchennaher Fürsorgeeinrichtungen und -verbände zu berücksichtigen. ${ }^{250}$

Dass zudem auch in den lokalen kirchlichen Archiven - analog zu den nichtkirchlichen Gemeindearchiven - Quellen zum Flüchtlingsthema liegen, zeigen allein schon die wenigen publizierten Findbücher im Domstiftsarchiv Brandenburg deponierter evangelischer Pfarrarchive. ${ }^{251}$

Quellen darstellen: Sterberegister 1874-1971 aus dem Landkreis Ostprignitz-Ruppin (Kreisarchiv des Landkreis Ostprignitz-Ruppin, Neuruppin).

248 Transitzone Dorf. Ein Ort zwischen Bodenreform und Kollektivierung. Hrsg. von: Projektgruppe Umsiedlerin: Maria Hetzer [u. a.]. [Leipzig] 2015, S. 36.

249 Töpler, Menschenwurm (wie Anm. 147).

250 Z.B. das Archiv des Deutschen Caritasverbandes e. V. in Freiburg im Breisgau.

251 Stefan Lindemann: Findbuch zum Pfarrarchiv Legde. In: Mitteilungen des Vereins für Geschichte der Prignitz 6 (2006), S. 92-122, hier S. 93: Leg 2/17 (darin u. a. „kurzer Bericht des Legder Pfarrers Domke über die Pat- 
Noch ergiebiger dürften jedoch die katholischen Pfarrarchive sein, wie wiederum Arbeiten von Winfried Töpler zeigen. ${ }^{252}$ Noch kaum für die Thematik entdeckt sind die Kirchenbücher. ${ }^{253}$

\section{Vertriebenenpresse und Heimatliteratur}

Anders als $\mathrm{He}$ i m a tb ü ch er historisch ostdeutscher Landkreise, die inzwischen in mehreren Monographien analysiert worden sind ${ }^{254}$, und denen auch für die vorliegende Arbeit z. B. viele wertvolle Zeitzeugenberichte entnommen werden konnten, sind die Heimatzeit s ch r ift e n der deutschen Vertriebenen (zusammen mit Heimatzeitungen, -briefen usw. meist als „Vertriebenenpresse“ bezeichnet) bislang von der wissenschaftlichen Forschung kaum zur Kenntnis genommen worden, allenfalls einzelne enthaltene Artikel zu landeskundlichen oder biographischen Spezialfragen. Erst seit kurzem wird diese gedruckte Quelle auch systematisch und gattungsgeschichtlich etwas stärker in den Blick genommen, wie eine 2016 durchgeführte Freiburger Tagung zeigt, nach der bilanziert wurde: „Von der neueren Forschung wurde das Phänomen jedoch bislang eher stiefmütterlich behandelt. ${ }^{\text {“255 }}$ Für die brandenburgischen Ver-

ronats- und Flüchtlingsverhältnisse im Pfarrsprengel vom 28.12.1945“), S. 94: Leg 14726 (darin u. a.: „Listen der evang. ,Einheimischen' und Flüchtlinge von Abbendorf 1948“). - Ders.: Findbuch zum Pfarrarchiv Rühstädt. In: ebd. 7 (2007), S. 24-68, hier S. 42: Rü 159/164: „Inanspruchnahme von Rühstädter Kirchenacker für die Errichtung einer Neubauernstelle“, 1948; aussagefähig sein können auch Berichte, siehe z. B.S. 30: Rü 56/117 „Berichte über das kirchliche Leben im Pfarrsprengel“, u. a. 1946-1948, sowie die diversen Protokollbücher der Gemeindekirchenrates (ebd., S. 30).

252 Siehe für die kath. Gemeinde Guben: Unsere Herzen bluten (wie Anm. 146).

253 Ein gutes, wenn auch nur knappes Beispiel findet sich jedoch für Rühstädt (Kr. Westprignitz) in: Transitzone Dorf (wie Anm. 248), S. 76: „Aus den Rühstädter Kirchenbüchern lässt sich herauslesen, dass vor allem alleinstehende Frauen, die ihre Männer im Krieg verloren hatten, im [Feierabend-]Heim Unterkunft fanden." Ähnlich wie bei den inzwischen zugänglichen und z. T. sogar im Internet digital (gebührenpflichtig) einsehbaren Standesamtsregistern (siehe Anm. 247) können künftig (evangelische) Kirchenbücher (Sterberegister!) auch für die hier interessierenden Fragen in sehr viel größerem Umfang einbezogen werden, da sie nach und nach im Online-Kirchenbuchportal „Archion“ eingestellt werden, was bis zum „Redaktionsschluss“ der vorligegenden Arbeit noch nicht möglich bzw. nicht mehr zu leisten war. - Siehe auch unten im Kapitel IV. 3 den Abschnitt „Evangelische Kirche“ (mit Anm. 1893) sowie im Quellenteil Nr. 168.

254 Stellvertretend für die inzwischen angewachsene Literatur zu dieser Gattung: Ulrike Frede: „Unvergessene Heimat" Schlesien. Eine exemplarische Untersuchung des ostdeutschen Heimatbuches als Medium und Quelle spezifischer Erinnerungskultur. Marburg 2004 (Schriftenreihe der Kommission für deutsche und osteuropäische Volkskunde in der Deutschen Gesellschaft für Volkskunde e. V., Bd. 88). - Das Heimatbuch. Geschichte, Methodik, Wirkung. Matthias Beer (Hg.). Göttingen 2010. - Jutta Faehndrich: Erinnerungskultur und Umgang mit Vertreibung in Heimatbüchern deutschsprachiger Vertriebener. In: Zeitschrift für Ostmitteleuropa-Forschung 52 (2003), S. 191-229. - Dies.: Eine endliche Geschichte. Die Heimatbücher der deutschen Vertriebnenen. Köln u. a. 2011 (Visuelle Geschichtskultur, 5). - Dies.: Heimatbuch. In: OnlineLexikon zur Kultur und Geschichte im östlichen Europa, 2013. URL: ome-lexikon.uni-oldenburg.de/55232. html (Stand 26.9.2013).

255 Tagungsbericht: „Heimatbriefe“ der Deutschen in und aus dem östlichen Europa nach 1945. Perspektiven der Forschung und Erschließung, 26.10.2016-28.10.2016 Freiburg. In: H-Soz-Kult, 25 2.2017 [2.6.2017]. - Siehe jetzt den grundlegenden Tagungsband: Heimatzeitschriften. Funktionen, Netzwerke, Quellenwert. Tilman 
hältnisse sind ausgewählte Heimatbriefe bzw. Heimatzeitschriften in der vorliegenden Arbeit nun auswahlweise systematisch bzw. z. T. stichprobenartig ausgewertet worden. Dabei trat u. a. ein in der Zeitgeschichtsforschung durchaus geläufiger, aber anscheinend in breiteren Kreisen der neuen Bundesländern weitgehend in Vergessenheit geratener Aspekt zu Tage, dass nämlich nicht nur bis zum Mauerbau 1961, sondern zumindest Rentner auch noch danach in nicht wenigen Fällen Kontakt zu den in Westdeutschland ansässigen Herausgebern und Kreisgemeinschaften hielten und sogar Treffen dort oder in West-Berlin besucht haben. Eine sehr wichtige Quelle sind sodann die teils in den genannten Perdiodika abgedruckten, teils separat publizierten An s chriften listen, denn sie enthalten zwar nicht durchweg, aber in sehr vielen Fällen auch in der DDR und so auch in Brandenburg ansässige Personen.

\section{Selbstzeugnisse (Zeitzeugenberichte)}

Erinnerungsberichte von Flüchtlingen und Vertriebenen finden sich heutzutage in brandenburgischen Kreis- und Heimatkalendern sowie den sonstigen regionalen Periodika nicht mehr selten. Den Anfang machten im Land Brandenburg wohl 1994 die von der „Niederlausitzer Gesellschaft für Geschichte und Landeskunde“ herausgegebenen „Niederlausitzer Studien“ mit dem Bericht eines aus dem Ostteil des Kreises Guben stammenden Vertriebenen, der als postgeschichtlicher Autor der Lausitz zuvor bereits seit Jahren publiziert hatte, aber nun erstmals autobiographisch und zugleich regionalgeschichtlich hervortrat. ${ }^{256}$ Zeitlich früher liegen nur die einschlägigen Broschüren des im Nachbarland Sachsen-Anhalt ansässigen „Havelberger Heimatvereins e. V.“, die im Zusammenhang mit der Behandlung des Kriegsendes und der frühen Nachkriegsjahre schon 1992 und erneut 1994 mehrere Zeitzeugenberichte von Flüchtlingen und Vertriebenen brachten. ${ }^{257}$ Ansonsten finden sich in den ersten fünf Jahren nach der Wende solche - auf Brandenburg bezogenen - Berichte noch ausschließlich in der außerhalb Brandenburgs erschienenen Literatur von Vertriebenenverbänden. Mit dem Jahr 1995, in dem allerorten des fünfzigsten Jahrestages des Kriegsendes gedacht wurde, setzte dann aber ein re-

Kasten u. Elisabeth Fendl (Hg.) (Schriftenreihe des Instituts für Volkskunde der Deutschen des östlichen Europa, Bd. 18). Münster/New York 2017, darin wichtig neben mehreren Fallstudien v. a. die übergreifenden Beiträge: Tilman Kasten: Heimatzeitschriften im Kontext der „Vertriebenenpresse“. Zur Einführung in das Thema und den Tagungsband (S. 9-38; fordert u. a. terminologisch größere Genauigkeit in der Unterscheidung von Zeitung und Zeitschrift); Wolfgang Kessler: Die „ostdeutschen“ Heimatblätter in der Bundesrepublik Deutschland. Eine Annäherung (S. 39-75) [der einzige Tagungsbeitrag, der zumindest am Rande auch auf die Situation in DDR und neuen Bundesländern eingeht (S. 46, 52 f., 65, 68)]; Albert A. Feiber: Heimatbriefe als historische Quelle (S. 173-198). - Obgleich inzwischen durch manche Periodika und Standorte zu ergänzen, immer noch nützlich als Überblick, da nach den Herkunftsregionen gegliedert: Bestandsverzeichnis der deutschen Heimatvertriebenenpresse. Bearb. von Horst von Chmielewski u. Gert Hagelweide. Hrsg.: Stiftung Ostdeutscher Kulturrat OKR. München u. a. 1982.

256 Hans-Joachim Thiede: Schwere Tage im fünfundvierziger Jahr. Ein Tatsachenbericht. In: Niederlausitzer Studien 26 (1994), S. 89-95.

257 Kriegsende und Nachkriegszeit in Havelberg [I]-[II] (wie Anm. 175). 
gelrechter Boom ein, der wie eine Schleusenöffnung wirkte. Seither gibt es kaum noch ein regional- oder lokalgeschichtliches Publikationsorgan in Brandenburg, das nicht auch Flüchtlingen und Vertriebenen mehr oder weniger Platz für Erinnerungsberichte eingeräumt hätte, wobei darunter altersbedingt fast nur noch die Generation derjenigen vorkommt, die die Geschehnisse als Kinder oder Jugendliche erlebt haben. ${ }^{258}$ Ein in der Abfolge nahezu identischer Befund ergibt sich beim Blick auf die seit 1990 in Brandenburg und über Brandenburg publizierten Zeitzeugenberichte Einheimischer. ${ }^{259}$

Größere Sammlungen anzulegen bzw. zusammenzutragen hat bisher für Gesamt-Brandenburg (inklusive der heute polnischen Teile) nur das „Brandenburgische Literaturbüro“ unternommen, das mit seiner (auch um Briefe u. a. ergänzten) Tagebuchsammlung wichtige Arbeit in der Bewahrung gefährdeter privater Dokumente und in deren öffentlichen Bereitstellung geleistet hat und noch weiter leistet. Die Texte werden - nach dem Vorbild von Walter Kempowskis „Echolot“ - in der gedruckten ${ }^{260}$ und in der online zugänglichen Veröffentlichung ${ }^{261}$ „auseinandergenommen“ und die einzelnen Einträge (oder Briefe) jeweils den Tagesdaten zugeordnet, unter denen man somit ein ganzes Spektrum unterschiedlicher Perspektiven und Situationen geboten bekommt - ein für wissenschaftliche Zwecke nicht ganz unproblematisches Verfahren, das aber doch zu mancher ungeahnten Erkenntnis führen kann und vor allem über die Forschung hinaus in der Öffentlichkeit einen Weg geht, der Interesse hervorruft, mithin die gesellschaftliche „Aufarbeitung“ unterstützen kann.

$\mathrm{Zu}$ nennen sind als aktiv sammelnde Institutionen in Brandenburg ferner das Archiv der Stiftung Brandenburg in Fürstenwalde ${ }^{262}$ und das Archiv der Landesgeschichtlichen Vereinigung für die Mark Brandenburg e. V. in Berlin ${ }^{263}$. Alles andere sind im Grunde - überwiegend in den westlichen Bundesländern befindliche - Spezialsammlungen nur einzelner Aufnahmeorte oder Herkunftskreise, deren Museen, „Heimatstuben“ und „Heimatarchive“264 bereits

258 Siehe die Zusammenstellung ausgewählter Erinnerungsberichte und sonstiger Selbstzeugnisse im Quellenund Literaturverzeichnis, 2.4 .

259 Desgleichen.

260 „Die Russen sind da“. Kriegsalltag und Neubeginn 1945 in Tagebüchern aus Brandenburg. Peter Böthig u. Peter Walther (Hg). Mit einem Nachw. von Alexander Gauland. 1. Aufl. Berlin 2011.511 S. - 2., durchges. Aufl. 2011.511 S.

261 Zeitstimmen. Literatur und Alltag in Brandenburg. Projekt des Brandenburgischen Literaturbüros, www.zeit stimmen.de [25.5.2017].

262 Ausdrücklich zum Sammelgebiet gezählt werden: „Aufzeichnungen (Lebenserinnerungen, Erlebnisberichte, Tagebücher, Korrespondenzen)“ (www.stiftung-brandenburg.de/archiv.html [30.6.2017]).

263 Best. 4 A Manuskripte, darin u. a. Erlebnisberichte und Erinnerungen. Siehe: Das Archiv der Landesgeschichtlichen Vereinigung für die Mark Brandenburg und seine Bestände. Bearb. von Peter Bahl (Quellen, Findbücher und Inventare des Brandenburgischen Landeshauptarchivs, Bd. 24; zugl.: Schriften der Landesgeschichtlichen Vereinigung für die Mark Brandenburg, N. F., Bd. 3). Frankfurt am Main u. a. 2009, S. 102.

264 www.bkge.de/Heimatsammlungen/Verzeichnis/Herkunftsgebiete/Ostbrandenburg/Sorau.php [20.9.2016]. - Teilweise inzwischen veraltet die Bestandsaufnahme: Ostdeutsches Kulturgut in der Bundesrepublik Deutschland. Ein Handbuch der Sammlungen, Vereinigungen und Einrichtungen mit ihren Beständen. Bearb. 
viele Selbstzeugnisse besitzen dürften, die für die vorliegende Arbeit ebenso wenig in Gänze erfassbar waren wie Material familiengeschichtlicher Art, das ebenfalls zunehmend gesammelt wird $^{265}$. Neuerdings ist auch die in Berlin ansässige überregional tätige „Stiftung Flucht, Vertreibung, Versöhnung“ damit befasst, Zeitzeugeninterviews aktiv zu sammeln. ${ }^{266}$

Die Niederschrift von Erlebnissen hatte freilich bereits 1945 eingesetzt, vieles ist aber erst später aus mehr oder weniger entfernter zeitlicher Distanz zu Papier gebracht oder in Interviews mitgeteilt worden. Die Bandbreite der Geburtsjahrgänge der Verfasser ist daher inzwischen recht groß, nimmt man einerseits die in Archiven, Museen oder Privatbesitz befindlichen oder längst publizierten Selbstzeugnisse der frühen Jahre ebenso wie die neuerdings wieder verstärkt im Selbstverlag bzw. als „Book on demand“ herauskommende Erinnerungsliteratur zusammen. Es sollte dabei selbstverständlich sein, Entstehungszusammenhänge, -zeitpunkt und andere auf den Inhalt Einfluss nehmende Rahmenbedingungen, schließlich auch die Überlieferungsform kritisch zu gewichten. ${ }^{267}$ Einzelne Forscher haben überdies für ihren thematischen Fokus Volkskunde, Alltagsgeschichte usw. - Zeitzeugenbefragungen durchgeführt und mehr oder weniger große Teile der zugrunde liegenden Interviews in ihren Arbeiten mit veröffentlicht. ${ }^{268}$

Selbstzeugnisse, hier also Zeitzeugenberichte, sei es in schriftlicher Form vorgelegte, sei es mündlich vorgetragene, sind aber nicht nur wichtige Quellen für Historiker und historisch interessierte Nachgeborene, deren Abfassung ist vielmehr auch - für jedes dabei aktiv werdende Individuum - Teil des persönlichen Bewältigungs- und des gesellschaftlichen Integrationsprozesses, die der berichtende Zeitzeuge selbst in seinem Leben unfreiwillig durchläuft, mithin -

von Wolfgang Kessler. Hrsg.: Stiftung Ostdeutscher Kulturrat OKR. München u. a. 1989. - Kritische Analyse der Gattung aus Sicht einer Ethnologin/Volkskundlerin der Universität Kiel (Vortrag auf dem 19. Brandenburgischen Archivtag in Königs Wusterhausen 2016): Cornelia Eisler: (Ost)brandenburgische Sammlungen in Westdeutschland. Zum Phänomen der Heimatstuben und -archive von Flüchtlingen und Vertriebenen in der Bundesrepublik Deutschland. In: Brandenburgische Archive 34 (2017), S. 35-41; siehe auch Dies.: Verwaltete Erinnerung - symbolische Politik. Die Heimatsammlungen der deutschen Flüchtlinge, Vertriebenen und Aussiedler. München 2015 (Schriften des Bundesinstituts für Kultur und Geschichte der Deutschen im östlichen Europa, Bd. 57).

265 U.a. im in der Martin-Opitz-Bibliothek in Herne untergebrachten Archiv der Arbeitsgemeinschaft ostdeutscher Familienforscher e. V. (AGoFF) sowie in den Sammlungen der zahlreichen weiteren Vereine. Siehe die (z. T. durch die entsprechenden Internetseiten überholten) Angaben in: Wegweiser für genealogische und historische Forschungen in ehemals deutschen Siedlungsräumen im östlichen Europa. Bearb. von Andreas Rösler in Zsarb. mit der Arbeitsgemeinschaft ostdeutscher Familienforscher. 6. Aufl. Zittau 2009.

266 „Seit 2013 werden für das digitale Zeitzeugenarchiv audiovisuelle, lebensgeschichtliche Interviews durchgeführt. Bisher haben 38 Betroffene aus unterschiedlichen Regionen von ihren Erfahrungen mit Flucht und Vertreibung, Heimatverlust und Neubeginn berichtet. Auch die Auswirkungen auf nachfolgende Generationen werden über Interviews mit den Nachfahren von Vertriebenen berücksichtigt. Die Videos und Audiodokumente werden zukünftig im Dokumentationszentrum für die Öffentlichkeit zugänglich sein." (www.sfvv.de/ de/aktuelle-arbeit/zeitzeugenarbeit [30.6.2017]).

267 von Plato/Meinicke, Alte Heimat - neue Zeit (wie Anm. 24).

268 Siehe oben im Kapitel I. 2 Forschungsstand insbesondere die für Brandenburg wichtigen Arbeiten von Dagmar Semmelmann (Anm. 52), Leonore Scholze-Irrlitz (Anm. 117-119) und Ines Keller (Anm. 123 und 125). 
auch bei Vertriebenen in Brandenburg - Teil seines Lebens, seiner Biographie. Phasenweise, bisweilen auch erst spät, kommen die Erlebnisse und Erinnerungen in das Bewusstsein zurück. Sich selbst, u. U. durch ausführliche Niederschrift, über sie Rechenschaft zu geben, ist eine Form des Verarbeitens, was auch für die Nachgeborenen gelten kann, die ihren eigenen Umgang mit dem „Status“ eines Vertriebenennachfahren zu beschreiben suchen. Sie anderen mitzuteilen, mitteilen zu können, zu dürfen, bedeutet für manchen sogar erst dann - vergleichbar der viel diskutierten Rezeption von „DDR-Biographien“ im wiedervereinigten Deutschland - wirkliche Akzeptanz durch die Aufnahmegesellschaft. Der aus Köslin in Hinterpommern vertriebene, als Arzt in Frankfurt (Oder) wirkende Lothar Sonnemann (geb. 1936 Köslin) hat 2002 über sein eigenes Erzählen des Erlebten selbstkritisch formuliert: „Plötzlich wurde mir bewusst, wie ausschweifend ich über Ereignisse aus den Tagen des Krieges und der Zeit danach, wie ich als Kind sie erlebt, berichtet hatte. [...] Ich entschuldigte mich bei meinen Zuhörern, doch niemand nahm es übel. Sie waren alle jünger und hatten den Krieg so hautnah nicht erlebt. / Erlebnisse aus dem Krieg graben sich tief in die Erinnerung, bleiben lebendig und drängen immer wieder an die Oberfläche. Sie lassen sich nicht auslöschen, nicht bis zum Ende des Lebens." ${ }^{269}$

\section{"Senioren" als Zeitzeugen für Flucht und Vertreibung}

Gesonderter Erwähnung wert sind die in mehreren brandenburgischen Orten von Seniorenbeiräten nach 1995 organisierten Schreibwettbewerbe, in denen Zeitzeugen ihre Erinnerungen aufschreiben, die anschließend in Auswahl gedruckt werden. ${ }^{270}$ Diese Hefte bieten durchaus

269 Lothar Sonnemann: Bittere Medizin. Jacobsdorf 2002, S. 31. Die konkrete hier geschilderte Situation ist zwar fiktiv, beschreibt aber - in der Reflexion eines aufmerksamen Zeitzeugen - treffend das zweifellos verallgemeinerbare Phänomen.

270 Benutzt wurden Veröffentlichungen der Seniorenbeiräte Cottbus, Fredersdorf-Vogelsdorf, Neuenhagen, Potsdam (bis 201921 Hefte), Rüdersdorf, Storkow (Amt) und Strausberg sowie die vom Verein für Heimatgeschichte der Stadt Müncheberg e. V. herausgegebenen „Müncheberger Lebensläufe“ (bisher 5 Bände), ferner die von dem einfühlsamen Interviewer Siegfried Neubauer (geb. 1937 Berlin, bis 1945 aufgewachsen in Küstrin) geführten, sehr detaillierten „Gespräche mit ehemaligen Küstrinern“ (bisher 6 Bände) (siehe Quellenverzeichnis, 2.4.1). Nicht in allen Gemeinden sind aus solchen Aktivitäten Veröffentlichungen hervorgegangen. - Zu Potsdam siehe den Zwischenbericht: Christa Kikels / Karl Kreutz: 20 Jahre Arbeitsgruppe „Zeitzeugen“ beim Seniorenbeirat der Landeshauptstadt Potsdam. In: Aus unserem Leben. Lebenserinnerungen und Erzählungen wurden aufgeschrieben von Mitgliedern des Zirkels „Zeitzeugen“ beim Seniorenbeirat der Landeshauptstadt Potsdam. [18. Anthologie]. Hrsg.: Seniorenbeirat in der Landeshauptstadt Potsdam. Stadtverwaltung, Fachbereich 3 für Soziales, Jugend, Gesundheit, Ordnung u. Umweltschutz der Landeshauptstadt Potsdam (18. Heft). Potsdam 2016. S. 6-8 (S. 8: 2011 Ehrenamtspreis). - Auch in anderen (Neuen) Bundesländern sind vergleichbare Projekte durchgeführt worden. Siehe z.B. Heimat verlieren. Heimat finden. Geschichten von Krieg, Flucht und Vertreibung. Aus einer Erzählwerkstatt in der Bürgerwerkstatt Dresden. Hrsg. von Astrid von Friesen u. Wendelin Szalai. Dresden 2002. - Grundlegend und teilweise sehr informativ für Brandenburgs Kreise und kreisfreien Städte der, allerdings nur die frühen Entwicklungen erfassende Bericht: Seniorenbeiräte im Land Brandenburg. Erstellt durch den Seniorenrat des Landes Brandenburg e. V. in Zsarb. mit den Seniorenbeiräten der Landkreise und kreisfreien Städte. Hrsg.: Ministerium für Arbeit, Soziales, Gesundheit u. Frauen des Landes Brandenburg. Potsdam 1999: 15.6.1998 Bildung des Seniorenrates des Landes 
einen Querschnitt des Spektrums ganz unterschiedlicher Schicksale, wobei Vertriebene - dies ist ausdrücklich festzustellen - fast in jeder Ausgabe mit nicht wenigen Beispielen, mithin ihrem hohen Bevölkerungsanteil entsprechend, vertreten sind und keineswegs marginal eingeordnet werden. So sind die kurzen Erinnerungsbeiträge beispielsweise im zweiten derartigen Storkower Sammelband fünf Themenblöcken zugeordnet, von denen einer allein nur „Flucht und Vertreibung 1945“ gewidmet ist, wobei sich sogar auch in allen vier anderen Blöcken einzelne Erinnerungen von Flüchtlingen und Vertriebenen finden. Auffallend ist im Abschnitt zu Flucht und Vertreibung das deutliche Übergewicht weiblicher Autoren. ${ }^{271}$

Wie groß der Verbreitungsgrad dieser überwiegend nicht bzw. nur in Kommission im örtlichen Buchhandel erhältlichen Schriften ist, bleibt allerdings ungewiss; es ist wohl anzunehmen, dass sie in den meisten Fällen auch am jeweiligen Ort nicht breit rezipiert werden, sondern de facto mehr die Funktion einer „seniorengruppeninternen“ Dienstleistung für die (Mitteilungs- und Lese-)Bedürfnisse der älteren Generation erfüllen, auch wenn gelegentlich die Weitergabe von Erfahrungen an die jüngeren Generationen als (theoretisches) Ziel formuliert wird. Ausgangspunkt sind ohnehin oft Gesprächsrunden bzw. Interessengemeinschaften, in denen Senioren sich gegenseitig ihre Erlebnisse erzählen. ${ }^{272}$

Brandenburg e. V. (S. 9); Bildung der Seniorenbeiräte in den Landkreisen bis 1999 unterschiedlich, zu den einzelnen Seniorenbeiräten in den Landkreisen S. 11-42 und in den kreisfreien Städten S. 43-50; im Landkreis Märkisch-Oderland (S.22) z.B. 15 Seniorenbeiräte und 1 Kreisseniorenbeirat, insgesamt in Brandenburg Ende 199911 (Kreis-)Seniorenbeiräte in Landkreisen, 4 in kreisfreien Städten und 114 in kreisangehörigen Gemeinden. Auf Landesebene (nach Nov. 1996) zudem Bildung von acht „Arbeitsgruppen aus Mitgliedern des Landesseniorenbeirates unter Einbeziehung von Vorsitzenden örtlicher Seniorenbeiräte“, darunter als letzte auch eine „AG Kultur, Zeitzeugen, Seniorensport, Seniorenakademien“ (S. 51).

271 Storkower Zeitzeugen berichten. Erlebnisse, Erinnerungen, Erfahrungen, Erkenntnisse. [H.] 2. Hrsg. vom Seniorenbeirat des Amtes Storkow. Hrsg. vom Seniorenbeirat des Amtes Storkow. [Red.: Horst König]. Storkow 2001, S. 5-8 (Inhaltsverzeichnis): Themenblöcke: I. Kindheits- und Jugenderinnerungen [7 Beiträge von 2 Autoren und 1 Autorin], II. Krieg-Nachkrieg [12 Beiträge von 3 Autoren und 1 Autorin], III. Erzählberichte über Flucht und Vertreibung 1945 [5 Beiträge von 1 Autor und 4 Autorinnen], IV. DDR-Zeit [10 Beiträge 4 Autoren und 4 Autorinnen], V. Hier und heute [16 Beiträge von 4 Autoren und 5 Autorinnen].

272 Siehe z. B. Hildegard Wuntke: Lebensspuren neu und wieder entdeckt nach über 70 Jahren. In: Drei tolle Tage nach über 800 Jahren. Storkower Zeitzeugen berichten über die Feierlichkeiten zum 800. Jahrestag der Ersterwähnung unserer Stadt im Jahre 1209 und erzählen weitere Geschichten. Erlebnisse, Erinnerungen, Erfahrungen, Erkenntnisse. Hrsg. vom Storkower Ortsverband des Brand. Seniorenverbandes. Red.: Horst König, Reinhold Zielke. Storkow 2011, S. 104-114, hier S. 104: „In der Interessengemeinschaft Zeitzeugen arbeite ich seit etwa zehn Jahren mit, und das sehr gern. Ihre Mitglieder haben erkannt, dass es höchste Zeit, ist sich gegenseitig Lebensgeschichten zu erzählen und sie aufzuschreiben, um damit der Nachwelt etwas Bleibendes zu hinterlassen, das mahnt, erinnert und lehrt." - Siehe das auch „Erzähl-Café" des BdV-Regionalverbandes Jüterbog, 2007-2010 (Quellenteil, Nr. 259). - Ein „Dialog mit der jungen Generation“ wurde als Anspruch formuliert im Vorwort des (Sozial-)Ministers Alwin Ziel: Seniorenbeiräte im Land Brandenburg (wie Anm. 270), S. 5: „Sie sind auch Ausgangspunkt für zahlreiche ehrenamtliche Initiativen und Projekte, die letztlich allen Bürgerinnen und Bürgern zugute kommen. Positive Beispiele hierfür sind unter anderem die Zeitzeugenarbeit im Dialog mit der jungen Generation und die Pflege von Partnerschaften mit Seniorengruppen aus anderen Ländern, insbesondere unserem Nachbarland Polen." Auch für Cottbus mehr als Anspruch formuliert (ebd., S. 45): „Die Autoren 
Der stellvertretende Vorsitzende des Seniorenbeirats von Angermünde, Bernhard Stechow, hat im Jahr 2000 für das Beispiel seiner Stadt formuliert, was repräsentativ für die Beiräte im ganzen Land gelten kann: „Ohne den Sozialverbänden ins Handwerk [p]fuschen zu wollen, sieht der Beirat seine dritte Hauptaufgabe darin, den Senioren zu helfen, sich zurechtzufinden, sich nicht zu verkriechen und nicht $z u$ vereinsamen. Es handelt sich im wesentlichen um die Senioren der Geburtsjahrgänge 1920 bis 1940. Sie waren 1940 zwanzigjährig oder gerade erst geboren, 1945 waren sie 25 Jahre oder gerade erst 5 Jahre alt. Im Jahre 2000 erreichten sie ihr 80. bis 60. Lebensjahr. Ihre Lebensjahre waren gekennzeichnet durch Krieg, Not, Vertreibung, Entbehrung, Aufbau und Abwicklung. Hier wirkt eine Arbeitsgruppe ,Zeitzeugen' unter Leitung von Frau Wendt in Zusammenarbeit mit dem Stadtarchiv daran, daß das umfangreiche Wissen der heute noch lebenden Senioren aufgeschrieben, erhalten und der jüngeren Generation übermittelt wird. "273 Damit sind wesentliche Punkte benannt und die gleichsam nachgeholte Aufarbeitung des Vertreibungsgeschehens ausdrücklich mit erwähnt. Freilich ist das senioreninterne Festhalten von Zeitzeugenwissen, wenn auch unter Beteiligung des Stadtarchivs, erst der erste Schritt, Verbreitung dieses Wissens in der Gesellschaft und Weitergabe an die viel zitierte „jüngere Generation“ der zweite. ${ }^{274}$

Quellenkritisch ist neben den grundsätzlichen Problemen bei Selbstzeugnissen - die aber durch mannigfache Vorzüge im Vergleich mit staatlichen Akten ausgeglichen werden zu berücksichtigen, dass diese Berichte, da ihre Abfassung erst ab 1990 möglich wurde, fast ausschließlich die zweite Generation betreffen, d.h., von jenen stammen, die bei Flucht und Vertreibung 1945/46 noch im Kindes- oder höheren Jugendlichenalter standen. ${ }^{275}$ Zwar überliefern sie nicht selten auch Aussagen und Haltungen ihrer Eltern (bzw. oft nur der Mütter) und Großeltern, also der beiden „eigentlichen“ Vertriebenengruppen der ersten Generation,

wollen sich nicht nur an Gleichaltrige wenden, sie möchten auch den jüngeren Generationen Erlebnisse mitteilen, die nicht in Geschichtsbüchern zu finden sind.“ - Die gedruckten Zeitzeugen-Berichte der brandenburgischen Seniorenbeiräte sind jedoch leider in keiner dem Verf. bekannten brandenburgischen oder Berliner Bibliothek vollständig vorhanden.

273 Bernhard Stechow: Der Angermünder Seniorenbeirat. In: Angermünder Heimatkalender 2001, S. 191-193, hier S. 192. Siehe auch Margret Sperling: Zeitzeugenarbeit im Stadtarchiv Angermünde. In: Angermünder Heimatkalender 2001, S. 168-170.

274 Den spezifischen Erfahrungen und Verarbeitungsprozessen der zweiten Generation von Vertriebenen, die im Kindesalter ihre Heimat verlassen mussten, widmet sich Helga Hirsch: Schweres Gepäck. Flucht und Vertreibung als Lebensthema. Hamburg 2004. In Kurzform auch: Dies.: Flucht und Vertreibung. Kollektive Erinnerung im Wandel. In: Aus Politik und Zeitgeschichte (2003)40/41, S. 14-26, bes. S. 21-23. - Zu Kindheitstraumata aus der Zeit des Zweiten Weltkriegs siehe aus der inzwischen sehr breiten Literatur stellvertretend das für breitere Kreise geschriebene Buch einer 1947 geborenen Journalistin, die sich seit Mitte der neunziger Jahre mit dem Thema Kriegskinder beschäftigt (S. 13): Sabine Bode: Die vergessene Generation. Die Kriegskinder brechen ihr Schweigen. Stuttgart 2004. 33. Aufl. 2018.

275 Ein ganz ähnliches Bild der berichtenden Senioren-Geburtsjahrgänge wie das oben für Angermünde zitierte ergibt sich z.B. in Neuenhagen, wo in einem 2000 publizierten Sammelband 21 Zeitzeugen (12 Autorinnen und 9 Autoren) mit einem Durchschnittsalter von 74 Jahren begegnen: Lebenszeit VI. Neuenhagen 2000, S. 5 (Autorenliste mit Altersangaben). 
doch dies verständlicherweise durch ihre „Brille“, so dass sie sich nicht selten von der - meist doch härteren, DDR-kritischeren - Haltung und dem noch viel stärker heimatbezogenen Bewusstsein der 1945 bereits erwachsenen (Väter und) Mütter sowie der Großväter und -mütter unterscheiden. Deren Erinnerungsberichte finden sich eher in Heimatzeitschriften und Heimatbüchern vor 1990 gesammelt, stammen folglich dann zumeist nicht von in Brandenburg Gebliebenen, d.h. von Personen, die bereits 1945/46 nach Westdeutschland gelangt waren, oder von (brandenburgischen) „Republikflüchtlingen“, die „nur“ die späten vierziger oder noch die fünfziger Jahre in der SBZ/DDR verbracht hatten.

Mehr „seniorenintern“ zu verstehen ist jedenfalls das einem der wenigen gesamtbrandenburgisch ausgerichteten Hefte dieser Art 2003 vorangestellte Geleitwort des Ministers für Arbeit, Soziales, Gesundheit und Frauen des Landes Brandenburg, Günter Baaske (SPD) (geb. 1957 Belzig), da es lediglich die Anrede „Liebe Seniorinnen, liebe Senioren“ enthält ${ }^{276}$, obgleich im Text dann betont wird, die „jüngere Generation kann nur aus unseren Berichten erfahren, wie das damals war - in der DDR, mit all den heiteren und ernsten Tagen, die unser Leben damals ausmachten“.277 Stehen zwar in dieser Zielrichtung die „DDR-Biographien“ und ihr Wert im Bewusstseinshaushalt der Gegenwart im Mittelpunkt des Geleitwortes, so wird dabei den Vertriebenen, ohne diesen Begriff zu nennen, immerhin kein geringer Anteil beigemessen, wird ihr Schicksal doch schon im zweiten Absatz als erster Erlebnisbereich deutlich benannt, zumal der Titel „Zu Hause in Brandenburg" bereits die Verbindung von Einheimischen und Zugewanderten nahelegt: „Es war keine Kleinigkeit für die heute 70-, 80-Jährigen, die es mit den Kriegswirren und ihren Trecks aus dem Osten diesseits der Oder spülte, sich im Brandenburgischen einzurichten und ein neues Leben aufzubauen. Es war unsagbar schwer, dem zerstörten Land das Notwendige zum Leben abzutrotzen. Ebenso schwer war es, die Fragen von Schuld und Mitschuld, von Sühne und Vergebung für sich persönlich und gesellschaftlich zu klären. Das dauerte Jahre und Jahrzehnte. Manches ist bis heute ungeklärt und muss in der Annäherung der Völker Mittel- und Osteuropas in neuer Weise aufgearbeitet werden." 278

Festzuhalten bleibt, dass die lokalen Senioren-Zeitzeugen-Reihen trotz Geldmangels und nachlassender Manuskriptzufuhr aus den Reihen der immer älter werdenden Zeitzeugen zum Teil noch weiter erscheinen ${ }^{279}$, und dass sie neben mancher bloß „schönen Geschichte“

276 Günter Baaske: Geleitwort. In: Zeitzeugen berichten 2003. Zuhause in Brandenburg. Hrsg. vom Seniorenrat des Landes Brandenburg e. V. Ausw. u. Red.: Sieglinde Heppener u. Paul Lucht. Cottbus 2003, S. 9-12, hier S. 9. - „Diese Broschüre wurde durch die Brandenburgische Landeszentrale für politische Bildung gefördert“ (S. 2).

277 Ebd., S. 11. - Vgl. die Formulierung des Ministers Ziel 1999 (Anm. 272).

278 Ebd., S.9.

279 Z. B. hat sich die Storkower Gruppe 2015 aufgelöst (Mitteilung Horst König, Storkow, 6.7.2016). - In Neuenhagen wird die Arbeit und auch die Publikationsreihe noch immer weiter betrieben (Auskunft Marianne Wachtmann, Neuenhagen, 29.6.2016). Zu Neuenhagen siehe auch: Irina Voigt: 15. Ausgabe der Lesezeit. In: Märkische Onlinezeitung, 13.8.2015; Marianne Wachtmann: In eigener Sache - die Geschichte der Broschüre 
und Anekdote durchaus mehrere zeitgeschichtlich wertvolle, aussagekräftige Selbstzeugnisse enthalten, die das Spektrum der schriftlichen Quellen für die Nachkriegsjahre in Brandenburg wirklich bereichern. ${ }^{280}$

Bemerkenswert gerade für die grenzüberschreitende Aufarbeitung des Vertreibungsgeschehens ist in diesem Zusammenhang die von dem ehemaligen Gymnasialdirektor Günter Voigt (Neuenhagen) 1996 gegründete und, anfangs jährlich, mit wechselnden (Senioren-)Autorengruppen erstellte Neuenhagener Reihe „Lebenszeit" ${ }^{\text {281 }}$; hier hat man ortsansässige deutsche und bald auch aus der polnischen Partnerstadt Świebodzin (Schwiebus) ${ }^{282}$ kommende polnische Zeitzeugen berichten lassen. Unter letzteren finden sich dann entsprechend auch Erinnerungen aus Ostpolen Vertriebener, die in den neuen polnischen Westgebieten angesiedelt wurden. ${ }^{283}$

Leider sind jedoch nicht in allen Fällen aus solchen Aktivitäten gedruckte Sammelbände hervorgegangen, so dass die erwähnte und bezweckte Weitergabe an die jüngeren Generationen mancherorts erst noch nachzuholen wäre. In Angermünde beispielsweise sind die Aufzeichnungen nicht veröffentlicht, sondern im Stadtarchiv hinterlegt worden. ${ }^{284}$

Darüber hinaus gibt es mancherlei Initiativen von anderen Einrichtungen und auch Einzelpersonen, in deren Rahmen - anlässlich eines Jahrestages des Kriegsendes oder unabhängig davon - Zeitzeugeninterviews geführt worden sind. Auch die daraus entstandenen Publikationen haben nicht immer in ihrem Aussagewert angemessener Form Verbreitung gefunden, so dass ihre Wirksamkeit als Quelle weder für die lokale Öffentlichkeit noch für die überregionale

„Lebenszeit“ mit Geschichten aus Neuenhagen. In: Lebenszeit XVI. Neuenhagen bei Berlin [2018], S. 100104. - Nach wie vor aktiv ist (2019) auch der Zirkel bzw. die Arbeitsgruppe „Zeitzeugen“ beim Seniorenbeirat der Stadt Potsdam.

280 Alle dem Verf. zugänglich gewesenen Erinnerungsberichte sind im Quellenverzeichnis (B. 4) einzeln aufgeführt und mit knappen Angaben zur Person des Schreibers und zum Inhalt (u. a. einzelne Orte) versehen.

2811995 begründet, bis 2016 sind 15 Hefte erschienen. Zu Voigt siehe: Lebenszeit IX. Zu Hause in Neuenhagen. Hrsg.: Seniorenbeirat der Gemeinde Neuenhagen. Red.: Günter Voigt. Neuenhagen 2003, S. 114.

282 Teilnahme der Schwiebuser Seniorengruppe an der Neuenhagener Seniorenwoche ab 1999: Lebenszeit VII. Neuenhagen 2001, S. 67. Siehe auch die Einzelperspektive: Hans-Joachim Diehr: Begegnungen Swiebodzin Neuenhagen. In: ebd., S. 86-87.

283 Z. B.: Lebenszeit VII. Neuenhagen 2001, S. 98-100; Lebenszeit IX. Neuenhagen 2003, S. 45-62 (2. Kapitel „Von Freunden geschrieben“), bes. S. 51-55. Es finden sich dabei auch Erinnerungen einer in Lodz geborenen, heute in Zielona Góra (Grünberg in Schlesien) lebenden Polin an ihre Zwangsarbeit in Deutschland: Lebenszeit VIII. Neuenhagen 2002, S. 22-34. Bemerkenswert der einfühlsame Text eines Polen, der die Vertreibung der deutschen Bewohner von Polkwitz (Niederschlesien) miterlebt: Zbygniew Rajche: Erinnerungen an die Heimat. In: Lebenszeit VII. Neuenhagen 2001, S. 100-111, bes. S. 104-106. - Auch in anderen Orten bestehen Partnerschaften mit polnischen Seniorengruppen, siehe z. B. Renate Guhl: Storkower Senioren brachten sich aktiv ein. In: Drei tolle Tage nach über 800 Jahren (wie Anm. 272), S. 152-154, hier S. 154.

284 Für freundliche Hinweise und Auskünfte sei dem Leiter des Stadtarchivs, Herrn Steve Schmidt, gedankt. 
Wissenschaft sichergestellt ist. ${ }^{285}$ Auch dem Verfasser der vorliegenden Arbeit ist sicherlich die eine oder andere solcher Zusammenstellungen unbekannt geblieben.

285 Lebensgeschichten Neuruppiner Frauen. Aufgeschrieben von Heli Voss. Norderstedt [2006]. Die Herausgeberin dieses bemerkenswerten, bei „Books on Demand“ erschienenen Bandes, der doch viel eher von der Fontanestadt Neuruppin oder dem Landkreis Ostrignitz-Ruppin hätte verlegt und (auch in Schulen) vertrieben werden müssen, ist selbst 1938 in Ostpreußen geboren, lebte aber dann als Lehrerin in Westdeutschland, erwarb dort parallel einen Magisterabschluss in Sozialwissenschaft und hat erst nach 1990 mit ihrem Mann Neuruppin zum Altersruhesitz erkoren. Die von ihr zusammensgestellte Sammlung der Lebensberichte von fünf über achtzigjährigen Frauen basiert auf Tonbandaufnahmen, die sie bearbeitet und deren Druckfassung sie von den Zeitzeuginnen hat autorisieren lassen. Im Mittelpunkt steht jeweils das Erlebnis des Zweiten Weltkrieges, doch wird stets über das gesamte Leben berichtet. Drei einheimische Neuruppinerinnen stehen neben zwei am Ort lebenden Vertriebenen. 


\section{Voraussetzungen und Abläufe}

\section{Flucht und Vertreibung}

\section{Begriffliches}

Es hat sich eingebürgert, für die deutschen Heimatvertriebenen zwischen Flucht und Vertreibung zu unterscheiden bzw. den Gesamtvorgang ihres Heimatverlusts gleichsam entwicklungsgeschichtlich in einen ersten Zeitabschnitt, die Flucht (bis Kriegsende bzw. bis zum Eintreffen der Roten Armee), und einen zweiten für alle nachfolgenden Vorgänge - begrifflich - zu unterteilen. Diese - differenzierend gemeinte und doch nicht unproblematische - entsprechende Unterscheidung zwischen Flüchtlingen und Vertriebenen will quasi formal danach einteilen, ob die Betroffenen vor oder nach dem 8. Mai bzw. noch unter deutscher Regierung oder erst danach ihre Heimat verlassen haben. Die Bildung zweier solchen Großgruppen ist sehr verbreitet, entsprechend wird für die Gesamtgruppe gern das Begriffspaar „Flüchtlinge und Vertriebene“ verwendet. Einige Autoren, nicht nur in der Lokalliteratur, haben den DDR-Begriff „Umsiedler“ konserviert und schreiben dementsprechend dann auch „Flüchtlinge und Umsiedler“ ${ }^{286}$ Gleichwohl gelingt es Autoren selten, neben dieser relativ simplen begrifflichen Differenzierung auch eine getrennte Behandlung der Vorgänge vorzunehmen. In den meisten Arbeiten bilden die Begriffspaare „Flucht und Vertreibung" bzw. „Flüchtlinge und Vertriebene“ nichts anderes als einen zweiteiligen Sammelbegriff innerhalb einer gemeinsamen Abhandlung des Gesamtthemas. Davon ist auch die vorliegende Arbeit an den Stellen nicht frei, die den Gesamtvorgang behandeln.

$\mathrm{Zu}$ bedenken ist jedoch bei allen begrifflichen Differenzierungsversuchen, dass, anders als in den zeitgenössischen Quellen einschließlich Selbstzeugnissen, in der rückschauenden Betrachtung der Flüchtlingsbegriff für Betroffene an sich nur dann aufrecht erhalten werden kann, wenn der Betroffene nach Wegfall des Fluchtgrundes dauerhaft in seine Heimat zurückkehren konnte. ${ }^{287}$ Dies gilt aber nur für den größeren Teil der Bewohner brandenburgischer Städte und

286 „Flüchtlinge und später die Umsiedler“: Brigitte Meier: Fontanestadt Neuruppn. Karwe 2004, S. 237. „Unterbringung der Umsiedler und Flüchtlinge“: ebd., S. 238.

287 Selbst bei „organisierten“ Fluchtbewegungen bzw. Evakuierungen ist von Fall zu Fall zu differenzieren. Darauf hat Arno Herzig am Beispiel Breslaus immerhin - zugespitzt - hingewiesen, auch wenn seine Aussage im konkreten Fall recht weit geht: „Kaum als Flucht, eher als Vertreibung durch die nationalsozialistischen Behörden ist das Schicksal der 700000 zivilen Einwohner Breslaus zu werten, die im Januar 1945 die Stadt gleichsam über Nacht verlassen mussten, als diese zur Festung erklärt worden war. Der fanatische Gauleiter Karl Hanke hatte die Evakuierung seit dem Herbst 1944 hinausgezögert, dann aber im kalten Winter am 20. Januar für Frauen, Kinder und Alte das ,unverzügliche Verlassen der Stadt' angeordnet." (Arno Herzig: Flucht und Vertreibung aus Schlesien. In: Flucht und Vertreibung. Europa zwischen 1939 und 1948. Hamburg 2012, S. 118-149, hier S. 120). Diese Sicht gab es allerdings auch schon zeitgenössisch bei Betroffenen. Siehe die Tagebuchaufzeichnungen des Breslauer kath. Pfarrers Peikert, der im Räumungsbefehl des Gauleiters Hanke „ein Verbrechen am deutschen Volke“ sah, denn „es ist eine Hetze in den Tod“ (Paul Peikert: „Festung Breslau“ in 
Dörfer westlich von Oder und Neiße, die kurz vor dem Eintreffen der sowjetischen Truppen zu großen Teilen in Richtung Westen und Norden geflohen waren. Wer von östlich dieser neuen Grenzflüsse kam, konnte nach Kriegsende entweder - wie die meisten hier ansässigen, aber an einer der Fronten befindlichen Soldaten und die Kriegsgefangenen - nicht mehr in seine Heimat zurückkehren, oder dies gelang nur befristet bis zu einer endgültigen Vertreibung bzw. Aussiedlung. Auch die Flüchtlinge aus den deutschen Ostgebieten, die Anfang 1945 in Massen ihre Heimartorte verließen, wurden so - früher oder später - noch nachträglich oder gleichsam „automatisch“ zu Vertriebenen. Berichte von Zeitzeugen, die Anfang 1945 in brandenburgischen Städten oder Gemeinden westlich von Oder und Neiße lebten und kurz vor dem Einmarsch der Roten Armee evakuiert wurden oder, häufiger, auf Aufrufe hin nach Norden oder Nordwesten flüchteten, gibt es zahlreich. Ihre Verfasser benutzen ganz selbstverständlich die Begriffe Flüchtling als Selbst- und Fremdbezeichnung und vor allem auch Treck für ihre eigenes Umfeld und familiäres Erleben, was die Entwirrung der Geschehnisse im Einzelfall behindern kann und allzu schematische Einteilungen ohnehin erschwert. ${ }^{288}$

Beispiele für den Versuch der von der SED gesteuerten Verwaltung, den Flüchtlingsbegriff durch den - durch die Sowjetische Besatzungsmacht befohlenen - des Umsiedlers zu ersetzen, finden sich ab Ende 1945 zahlreich. ${ }^{289}$ „Insbesondere unter den Betroffenen selbst wurde dieser Sprachgebrauch aber nur bedingt nachvollzogen. ${ }^{\text {290 }}$ Denn ebenso oft enthalten nicht nur die Zeitzeugenberichte, sondern auch die behördlichen Akten noch jahrelang Belege dafür, dass es vielen Betroffenen und auch anderen schwer fiel, sich vom Flüchtlingsbegriff, der gleichsam wie selbstverständlich gebraucht und verstanden wurde, zu lösen. So verwandte das Standesamt Prenzlau bei Eintragungen im Sterberegister noch 1946 neben Umsiedler sehr oft auch die Begriffe Flüchtling und für Angaben zum letzten Wohn- bzw. Aufenthalts- und zum Sterbeort Flüchtlingslager, Flüchtlingsheim und Flüchtlingskrankenhaus. ${ }^{291}$ Das gleiche Bild bietet sich in

den Berichten eines Pfarrers. 22. Januar bis 6. Mai 1945. Hrsg. von Karol Jonca u. Alfred Konieczny. 3. Aufl. Berlin [Ost] 1970, S. 27).

288 Beispiele: Hans-Dieter Unger: Der Treck endete für zwei Familien in Dänemark. In: Eberswalde 1945. Eine Zusammenstellung von Ereignissen mit Dokumenten und Erinnerungen. Begleitheft zur Sonderausstellung im Stadt- und Kreismuseum. Eberswalde 1995, S. 30-35 [Eberswalde-Finower Familie, die am 19.4.1945 nach Fürstenberg/Havel flieht und von hier per Bahn nach Warnemünde fährt, von dort per Schiff (Flüchtlingstransporter „Theresa Rus“ nach Dänemark].

289 Grundlegend: Amos, Vertriebenenpolitik der SED (wie Anm. 12), S. 17-19; Michael Schwartz: „Vom Umsiedler zum Staatsbürger“. Totalitäres und Subversives in der Sprachpolitik der SBZ/DDR. In: Vertriebene in Deutschland. Interdisziplinäre Ergebnisse und Forschungsperspektiven. Dierk Hoffmann u.a. (Hg.). München 2000, S. 135-165. Siehe auch die Bemerkungen bei Schwartz, Vertriebene und „Umsiedlerpolitik“ (wie Anm. 13), S. 3-6. - Noch Anfang 1948 bemühte man sich um die „Abschaffung der Begriffe ,Umsiedler und Flüchtlinge“" (Rundschreiben des FDGB-Landesvorstandes Mecklenburg vom 27.1.1948: SAPMO-BArch, DY 34/27745, Bl. 103).

290 Stiftung Flucht, Vertreibung, Versöhnung (wie Anm. 16), S. 17.

291 Zwei Beispiele für viele („Flüchtling“): Stadtarchiv Prenzlau, Standesamt Prenzlau, Sterberegister Nr. 448/1946, 29.3.1946; Nr. 831/1946, 3.7.1946. 
den Sterberegistern des Standesamtes Angermünde, wo 1946 durchweg der (nicht seltene) Begriff Flüchtling verwendet wird. ${ }^{292}$ Wie schwer es war, alle beteiligten Stellen und Amtsträger terminologisch „auf Linie“ zu bringen, ließe sich an vielen Beispielen zeigen. In einem Redemanuskript der FDGB-„,Abt. Kriegsgefangene, Heimkehrer u. Umsiedler“ zur Ein-Jahres-Feier der ZVU, in dem der „Umsiedler"-Begriff zwar durchgehend verwendet wird, heißt es plötzlich, man wolle mit der ZVU „die Probleme, die uns durch die Vertreibung [!] weiter Kreise unseres Volkes aus ihrer Heimat gestellt sind, gemeinsam lösen“" 293

In einer offiziellen Entschließung des „Antifaschistisch-demokratischen Einheitsblocks für die Mark Brandenburg“ vom 30. Januar 1946 zur „Frühjahrsbestellung“, deren Text als Aufruf am 10. bzw. 13. Februar in den Zeitungen „Volkswille“ und „Der Märker“ erschien, wird der zu organisierende „Arbeitseinsatz der Landbevölkerung unter besonderer Berücksichtigung der Umsiedler und Flüchtlinge“ erwähnt. ${ }^{294}$ Doch dies ist kein versehentlicher terminologischer „Nachzügler“Einzelfall. Denn auch noch am 31. März 1947 wird das Thema Flüchtlinge im „Antifablock“ breit diskutiert, in den beiden diesbezüglichen Protokollabsätzen kommt der Begriff sieben Mal vor, teilweise im Wechsel mit dem hier seltener gebrauchten Umsiedler. ${ }^{295} \mathrm{Da}$ dabei auch die Situation der Evakuierten und Heimkehrer angesprochen wird, erscheint Umsiedler teilweise wie ein Oberbegriff, Flüchtlinge nur wie deren (größte) „Teilmenge“, doch wird in den zusammenfassenden Protokollformulierungen Flüchtlinge auch wiederum eindeutig synonym als Oberbegriff gebraucht, wohl weil der Flüchtlingsbegriff den meisten Zeitgenossen eben doch „in Fleisch und Blut" übergegangen war.

Der bewusste oder unbewusste Versuch, durch Differenzierung den „Flüchtlings“-Begriff zu „retten“ und zugleich den des „Umsiedlers“ aufzugreifen, zeigt sich beispielsweise noch 1947 mit der Gruppenbezeichnung der „Evakuierten, Flüchtlinge und Umsiedler“ im Evangelischen Konsistorium. ${ }^{296}$ Auch Anna Seghers hat 1950 bestätigt, dass die verordnete Terminologie sich zunächst nur schleppend durchsetzte. „Man nannte die Fremden auch immer weiter im Dorf, die Flüchtlinge' statt, die Umsiedler', wie sie in den Gesetzen hießen [...]." ${ }^{\text {"297 }}$ Dies galt wie selbstverständlich und bis tief in die Verwaltungen allemal in den vielen, der Zentrale fernen Gemeinden. ${ }^{298}$ Dass der Flüchtlingsbegriff sich im privaten Sprachgebrauch vieler DDR-Bürger durchgehend gehalten hatte, zeigt sich indirekt auch darin, dass Ursula Höntsch-Harendt ihren autobiographischen Roman 1985 nicht mehr, wie noch 1953 Anna Seghers ihre Novelle „Die

292 Stadtarchiv Angermünde, Standesamt Angermünde, Sterberegister 1946.

293 SAPMO-BArch, DY 34/27745, Bl. 10 (27.9.1946).

294 Protokolle des Landesblockausschusses (wie Anm. 204), S. 27.

295 Ebd., S. 104f.

296 ELAB, 29/367, unfol., 16.5.1947.

297 Anna Seghers: Die Umsiedlerin (1950). In: Dies.: Gesammelte Werke in Einzelausgaben. Bd. 10. Berlin/Weimar 1977, hier zit. nach DDR-Lesebuch. Von der SBZ zur DDR 1945-1949. Hrsg. von Ilse Spittmann, Gisela Helwig (Edition Deutschland Archiv). Köln 1989, S. 23-26, hier S. 23.

298 Beispielsweise in Hennickendorf (Kr. Niederbarnim) noch gegen Ende des Jahres 1945: Hennickendorf 1945 [Hennickendorf 2005], S. 20. 
Umsiedlerin“299, sondern „Wir Flüchtlingskinder“ nannte und nennen konnte. ${ }^{300}$ Dagegen blieben die früh einsetzenden Versuche der SED, auch den Umsiedler-Begriff zu tilgen, um den Abschluss der Integration auch begrifflich zu forcieren, ebenfalls ohne Breitenwirkung. Zunächst versuchte man, von ehemaligen Umsiedlern zu sprechen, wechselte dann aber offiziell zu Neubürgern, ohne dass diese politischen Vorgaben für die Verwaltung den allgemeinen Sprachgebrauch der Menschen beeinflussen konnten. ${ }^{301}$

Für die (Flüchtlinge und) Vertriebenen, die nach Brandenburg kamen, und für die Einheimischen, die mit ihnen konfrontiert wurden, gilt es, abgesehen von individuellen Einzelschicksalen, der Klarheit halber vornehmlich drei Bevölkerungsbewegungen zu unterscheiden, die daher im Folgenden getrennt behandelt werden:

1. die Flucht bis Kriegsende (meist im Januar/Februar, auch noch April 1945, seltener bereits Ende 1944),

2. die sogen. „Wilden Vertreibungen“ (im Juni/Juli 1945),

3. die (systematischen, „organisierten“) Vertreibungen nach dem Potsdamer Abkommen (meist ab Sept./Okt. 1945, zunächst bis 1946 anhaltend, Transporte teilweise noch bis 1950).

Verwaltung und Zeitzeugen berichten zeitgenössisch immer wieder vom (vorübergehenden) „Abflauen“ der Flüchtlings- bzw. Vertriebenenströme zwischen den drei Haupt-„Phasen“ bzw. auch innerhalb der ersten und zweiten. Gemeint sind damit meist zum einen die Monate März/ April und auch Mai 1945, zum anderen die Zeit zwischen Juni 1946 und Dezember 1948, in der „die Provinz Brandenburg nur noch eine vergleichsweise geringe Zahl Vertriebener“ aufnahm ${ }^{302}$. Spätere Transporte, die durchaus vorkamen, bilden dann ohnehin nur noch Einzelfälle.

In der Zeit nach dem Ende der Vertreibungen kommen als viertes, deutlich kleineres, aber vom Gesamtkomplex nicht zu trennendes Teilthema noch die „Aussiedler“ oder „Spätaussiedler" hinzu, zum einen noch in den unmittelbar folgenden Jahrzehnten ab 1950, zum anderen besonders nach 1990, die aber nur kursorisch behandelt werden können. Parallel zu den Ereignissen der letzten Kriegs- und der Nachkriegszeit lief sodann die Rückkehr von Kriegsgefangenen deutscher Staatsangehörigkeit (Heimkehrer, Kriegsheimkehrer), die jedoch als Sonderbereich hier weitgehend ausgespart werden muss.

Siehe Anm. 297 (Druck des 1950 bereits in der Tagespresse vorabgedruckten Textes in Buchform in: Dies.: Friedensgeschichten. Berlin 1953).

300 Ursula Höntsch-Harendt: Wir Flüchtlingskinder. Roman. Halle/Leipzig 1985.

301 Schwartz, „Vom Umsiedler zum Staatsbürger“ (wie Anm. 289).

302 Marcel Boldorf: Fürsorge im Umbruch. Die Provinz Brandenburg zwischen Weimarer Republik und DDRLänderreform. In: Fürsorge in Brandenburg. Entwicklungen - Kontinuitäten - Umbüche. Wolfgang Hofmann / Kristina Hübener / Paul Meusinger (Hg.) (Schriftenreihe zur Medizingeschichte, Bd. 15). Berlin 2007, S. 371-410, hier S. 403. 
Unter den 1945 aus den Ostgebieten des Deutschen Reiches Geflüchteten bzw. Vertriebenen befanden sich sodann nicht wenige Personen und Familien, die während der Kriegsjahre 1943 und 1944 aus westlicher gelegenen bombenkriegsgeschädigten bzw. -gefährdeten Städten evakuiert worden waren. ${ }^{303}$ Ihre Zahl lässt sich kaum eingrenzen, und sie lassen sich zumeist auch nicht leicht erkennen, zumal sie zunächst das Schicksal der in den Ostgebieten Alteingesessenen teilten. Westlich von Oder und Neiße bildeten diese Menschen freilich eine der vielen besonderen Gruppen, die die Verwaltung zunächst ebenso zu entlausen, zu verpflegen und registrieren hatte und die doch an ihre eigentlichen Wohnorte zurückzukehren trachteten. Krätzner schätzt die Einwohnerzahl von Königsberg/Neumark für Anfang 1945 grob auf 8000 und führt die Zunahme gegenüber der nachgewiesenen Einwohnerzahl von 6767 im Jahr 1939 auf die vielen Evakuierten zurück, die erst im Krieg in die Stadt gelangten. ${ }^{304}$ Ein ebenfalls neumärkisches Beispiel, jedoch vom Land, zeigt die Dimensionen dieser „Gruppe“ noch deutlicher, weil es konkrete Angaben bietet: In Zollen im Kreis Soldin sind in der Zeit vom Eintreffen der Roten Armee (30. Januar 1945) bis zur Abfahrt des letzten Sammeltransports (26. August $1945)$ „ums Leben gekommen“: 16 Einheimische, 6 Fremde aus dem Nachbardorf Wuthenow (vermutlich unter Wuthenow gemeldet gewesen) und „68 Fremde: Evakuierte aus dem Raum Aachen, Flüchtende, darunter 13 Ostpreußen“. ${ }^{305}$ Der Fall verweist zugleich darauf, dass sich unter den Vertriebenen aus einzelnen Ostprovinzen nicht nur Evakuierte aus bisweilen weit westlich liegenden Heimatstädten befanden, sondern auch Flüchtlinge aus - ganz entgegengesetzt - weit im Osten und z. T. sogar außerhalb der Reichsgrenzen liegenden Herkunftsorten. Letzteres betrifft nämlich zum Beispiel all jene, die bereits ab 1944 vor der bei ihnen angekommenen Front flohen, aber auch die schon zuvor offiziell „Umgesiedelten“, wie die Bessarabiendeutschen und die Galiziendeutschen (1939/40). Unter den aus dem „Warthegau“, aber auch aus benachbarten Gebieten Evakuierten bzw. Flüchtenden befanden sich sodann auch viele Deutschbalten, die schon 1939 ihre Heimat hatten verlassen müssen. ${ }^{306}$ Auf diese und andere „Vorläufer“ der Flüchtlinge und Vertriebenen wird daher im folgenden Abschnitt (nur) kurz eingegangen.

303 Beispiel: Deetz, Kr. Soldin (Heimatkreis Soldin/Neumark. Hrsg. vom Heimatkreis Soldin/Neumark. Soltau 1981, S. 574). Vgl. für Pommern als Evakuierungsgebiet, aber auch mit übertragbaren Angaben: Holz, Evakuierte, Flüchtlinge und Vertriebene auf der Insel Rügen (wie Anm. 19), S. 64 f.

304 Claus Krätzner: Das Schicksal der Bevölkerung der Kreisstadt Königsberg in der Neumark zum Ende des Zweiten Weltkrieges im Spiegel der Heimatkartei. Eine Untersuchung zu den Vertreibungsverlusten und zur Seßhaftwerdung der Heimatvertriebenen aus der Kreisstadt Königsberg/Neumark. (Privatdruck) Hilchenbach 1999, S. 45. Zu den Evakuierten zählt er noch die sonstigen kriegsbedingten Zuwanderungen hinzu, etwa Flugplatzpersonal.

305 Heimatkreis Soldin/Neumark (wie Anm. 303), S. 618 (Bericht von Horst Künkel aus Zollen, zusammengestellt 1952).

306 Beispiel: Eine Gruppe von etwa 20 bis 30 Deutschbalten kam im Sommer 1939 nach Schönow im Kreis Pyritz und wurde „bald in die Provinz Posen geschickt“. Heimatkreis Soldin/Neumark (wie Anm. 303), S. 573. 


\section{Bevölkerungsbewegungen vor 1945}

„Bevölkerungsbewegungen“, um diesen an sich sehr distanzierten, aber üblich gewordenen Begriff zu verwenden, hatte es bereits vor Kriegsende mehrfach gegeben, wobei hier eine Beschränkung auf Brandenburg vorzunehmen ist. ${ }^{307}$ Wenngleich „Durchschnittsdeutsche“ bei Deportationen der wegen ihrer jüdischen Herkunft Verfolgten sowie bei Zwangsumsiedlungen meist nur - wenig interessierte - Zaungäste blieben, führte der Bombenkrieg dann doch dazu, dass 1943/44 viele Großstädter, namentlich aus Berlin, aber auch aus Hamburg und aus dem Rheinland (Düsseldorf u.a.) aufs Land evakuiert und die dortigen Einheimischen aus ihrem Alltag gerissen wurden. Davon war auch Brandenburg besonders betroffen, so dass die Bevölkerung der Provinz beiderseits von Oder und Neiße nun auch in ihren eigenen Häusern und Wohnungen zu ersten direkten Kontakten mit eingewiesenen Fremden gezwungen war. Die freilich noch begrenzte Zahl und breite Streuung der aus den vom Luftkrieg bedrohten Städten Kommenden beunruhigten jedoch die zur Aufnahme Verpflichteten noch kaum. Auf den Gütern und bei Bauern waren im Krieg zudem vielerorts einzelne meist aus den östlichen besetzten Gebieten stammende „Ostarbeiter", besonders Polen, und französische und andere Kriegsgefangene untergebracht, die landwirtschaftliche Arbeiten zu verrichten hatten. Als dann ab Ende 1944, verstärkt ab Januar 1945 die deutschen Flüchtlinge und Vertriebenen in großer Zahl aus dem Osten kamen, trafen diese also in ihren Aufnahmeorten bereits oftmals auf eine Situation, die alles andere als „normal“ war. Eine damals junge Ostpreußin, die auf ihrer Flucht 1945 nach Wilhelmshorst bei Potsdam gelangt war, berichtete 2005: „Ich kann mich noch erinnern an eine größere Menschenmenge, von der es hieß, sie seien Russlanddeutsche, die auf Grund eines Abkommens zwischen dem Deutschen Reich und Stalins Sowjetunion ins Reichsgebiet übergesiedelt waren. Sie mussten sich Ende 1945 sammeln zum Rücktransport in die Sowjetunion." ${ }^{308}$ Liest man Zeitzeugenberichte einheimischer Brandenburger, so entsprechen diese jedoch meist dem, was man insgesamt für die Bevölkerung in der NS-Zeit diagnostiziert hat. Zwangsweise Bevölkerungsbewegungen und die Verdrängung oder gar Deportation einzelner Gruppen und Personen werden kaum thematisiert, das „Aufwachen“ aus dem persönlichen „Bewusstseins-Alltag“ wird selbst durch die massenhaften Flüchtlingstrecks ab Januar 1945 erst ansatzweise bewirkt. Wirklich in Frage gestellt wird vieles erst, als das eigene Leben auch in den Städten und Gemeinden westlich von Oder und Neiße in Frontnähe gerät, man fliehen muss und selbst - vorübergehend - Flüchtling wird oder regelrechte „Einquartierung“ erhält.

Die Parallelität von Bevölkerungsbewegungen und die der Hauptphase der Vertreibung der deutschen Bevölkerung vorausgehenden Umsiedlungen und Fluchtbewegungen sind lange

Siehe allgemein und international die weitgehend vollständigen Überblicksdarstellungen der einzelnen Vertreibungsphänomene in: Zwangsumsiedlung, Flucht und Vertreibung 1939-1959. Atlas zur Geschichte Ostmitteleuropas. Red.: Witold Sienkiewicz, Grzegorz Hryciuk. Warsazwa 2010. Lizenzausg. Bonn 2010. - Lexikon der Vertreibungen (wie Anm. 59).

308 Gretel Balschinat: Meine Nachkriegsjahre in Wilhelmshorst. In: 100 Jahre Wilhelmshorst (wie Anm. 189), S. 347-350, hier S. 349. 
Zeit bei der Betrachtung des Vertriebenenthemas in den Hintergrund gedrängt worden, ein Zusammenhang wurde auch und gerade von den Betroffenen selbst und den ihnen nahestehenden Autoren oft weder gesehen noch gesucht. ${ }^{309}$ Der einzelne, die Entwurzelung erlebende Mensch hatte - aus verständlichen Gründen - kein Bewusstsein für diese Geschichtsbetrachtung und auch gar kein Interesse daran, sein Leid womöglich relativiert zu sehen, relativierte aber damit bisweilen - unbewusst - die Leiden anderer. Die Gesamtheit der Geschehnisse, des „Gewaltexports“, zur Kenntnis zu nehmen gehört aber dazu, sucht man nach den Wurzeln jenes Tabu-Bruchs, bei dem Grenzverschiebungen mit „ethnischer Säuberung“ verbunden wurden.

Auch die Provinz Brandenburg, deren Kern und Vorgängerterritorium Mark Brandenburg eine über Jahrhunderte feste östliche Außengrenze besaß, hatte bereits eine lange (Vor-) Geschichte von Zuwanderung und Abwanderung, als nach 1918 Flüchtlinge bzw. Vertriebene aus den größtenteils an Polen abgetretenen Provinzen Posen und Westpreußen aufzunehmen und einzugliedern waren. ${ }^{310}$ Für sie hatte man in der Zeit der Weimarer Republik auch in mehreren brandenburgischen Städten besondere Siedlungen geschaffen und darin dann sogar Straßennamen vergeben, die auf die Herkunftsorte und -regionen der Zuwanderer Bezug nahmen. ${ }^{311}$ Beispiele sind etwa die bekannte „Ostmarksiedlung“ in Frankfurt (Oder) ${ }^{312}$, aber auch die 1923-1925 in Brandenburg an der Havel auf dem Görden erbaute Zollhaussiedlung „Memelland“313. Diese Bauten und ihre Bewohner gehörten bereits zum Land, als 1945 der viel größere Strom aus denselben und anderen benachbarten Provinzen einsetzte. Dass diese früheren „Ostflüchtlinge“, die gerade erst eine Generation zuvor im Land angekommen waren, für die Flüchtlinge und Vertriebenen nach 1945 landsmannschaftliche Bezugspunkte bilden konnten, ist eher fraglich, es sei denn, es bestanden, was durchaus vorkam, direkte verwandtschaftliche Beziehungen. Insgesamt waren die nach dem Ersten Weltkrieg Zugewanderten aber durch die Eingliederungsmaßnahmen der Weimarer Republik bereits Einheimische geworden und deren Situation mit der der Flüchtlinge nach dem Zweiten Weltkrieg wirtschaftlich und sozial nicht vergleichbar. ${ }^{314}$

Ein Gegenextrem bilden einige jüngere Arbeiten, deren Autoren der Behandlung von Flucht und Vertreibung des Jahres 1945/46 weit ausgreifende Kapitel voranstellen, in denen die nationalsozialistischen Vertreibungsverbrechen thematisiert werden, um die Kette von Ursachen und Folgen aufzuzeigen.

310 Die Herkunft der Brandenburger (wie Anm. 39).

311 Näheres dazu siehe unten im gesonderten Kapitel IV. 1 Orts- und Straßennamen.

312 Martin Kießling: Ostmarkbauten. Städtebau in einer Mittelstadt. Stuttgart 1925. - Eva-Maria Höper: Frankfurt an der Oder. Der Architekt Martin Kießling (1879-1944). Städtebau der zwanziger Jahre zwischen Traditionalismus und Reformbewegungen. In: Brandenburgische Denkmalpflege 3 (1994)2, S. 81-93. - Sybille Gramlich u. a.: Stadt Frankfurt (Oder) (Denkmale in Brandenburg, Bd. 3). Worms am Rhein 2002, S. 310312. - Horst Voigt: Die Ostmarkbauten in Frankfurt (Oder). In: Historischer Verein zu Frankfurt (Oder) e. V. Mitteilungen 2003, H. 2, S. 2-25.

313 Brandenburg an der Havel. Lexikon zur Stadtgeschichte. Berlin 2008, S. 132.

314 Insgesamt ist das Thema der Zuwanderung nach 1918 in Brandenburg noch kaum näher erforscht und wird in der Regional- und Lokalliteratur bislang meist allenfalls im Rahmen städtebaulicher Aussagen beiläufig angesprochen. Auch Selbstzeugnisse aus der Gruppe der Betroffenen sind nur selten zu finden. Ein Beispiel ist 
Auch wenn dies nicht die Mehrheit betraf, so ist es doch kein Einzelfall, dass manche Familien bereits eine oder mehrere „Wanderungen“ hinter sich hatten, als sie entweder nach 1918 oder nach 1945 zwangsweise ihre Heimat verlassen mussten. Die Familie Reinitz aus Neuenkirchen bei Osnabrück zog 1899 in die Provinz Posen und kam 1921, von dort ,ausgesiedelt", nach Letschin im Oderbruch. ${ }^{315}$ Als die Familie des neumärkischen Bauern Adolf Heintz im Januar 1945 wegen der herannahenden Front ihren Wohnort Groß Cammin (Kr. Landsberg/Warthe) fluchtartig verließ, traf dieses Schicksal dieselbe Generation, die hier erst 1920/21 eine Neusiedlerstelle übernommen hatte, wie sie nach dem Ersten Weltkrieg in vielen aufgesiedelten Gütern für Flüchtlinge aus den an Polen abgetretenen Teilen der Provinzen Posen und Westpreußen geschaffen worden waren. ${ }^{316}$ Das Beispiel des Adolf Heintz zeigt aber nun noch eine weitere Vorgeschichte, an die schließlich nach 1945 sogar dann doch angeknüpft werden konnte und die letztlich ein, wenn auch außergewöhnliches, Beispiel für das bekannte Phänomen ist, dass es Menschen, die bereits einmal eine „Fernwanderung“ hinter sich hatten, bisweilen leichter fiel, nochmals weiterzuwandern und nochmals ganz neu anzufangen. Denn dieser Bauer war erst 1912/13 mit seiner Familie aus der Pfalz nach Westpreußen gegangen, um dort eine der von der Ansiedlungskommission geschaffenen Siedlerstellen auf einem zuvor polnischen Gut östlich von Konitz zu übernehmen. Als die Großfamilie im Januar 1945 aus der Neumark nach Tietzow im Kreis Osthavelland gekommen war, blieben zwar Adolf Heintz und seine Enkeltochter, die sich am Ankunftsort dann verheiratete, hier wohnen und fanden eine neue - für den Großvater die vierte - „Heimat“. Die mittlere Generation, Adolfs Tochter, die in der Neumark die Ehe mit einem Groß Camminer Bauernsohn geschlossen hatte, verließ jedoch Tietzow und ging mit zwei Söhnen gen Westen, in den pfälzischen Heimatort des Vaters und Schwiegervaters und erwarb dort „ein kleines Anwesen mit Ackerland für Tabakanbau“.

Kaum noch bekannt ist selbst in den betreffenden Kommunen des heutigen Landes Brandenburg (und in den Berliner Bezirken), dass sie, wie in anderen preußischen Provinzen auch, im Ersten Weltkrieg vorübergehend Flüchtlinge aus dem 1914/15 russisch besetzten Teil Ostpreußens beherbergt hatten und beim Wiederaufbau Patenschaften für einzelne ostpreuBische Städte und Kreise übernahmen. ${ }^{317}$ Während sich in den Familien der von Flucht und

das der als Kind mit den Eltern 1919 aus dem Raum Hohensalza nach Neuenhagen bei Berlin gekommenen Elli Bandemer. Siehe: Renate Konhäusner: Nach Erzählungen Hochbetagter: Elli Bandemer: Der Zucker im Schnee. In: Lebenszeit. T. III. Zeitzeugen berichten. Hrsg. vom Landesseniorenbeirat Brandenburg u. dem Seniorenbeirat Neuenhagen. Neuenhagen [1998], S. 61-64.

315 Strenge/van Tankeren, Letschiner Chronik, Bd. 5 (wie Anm. 152), S. 182-184.

316 Das Heintz-Familienschickal nach: Johannes Müller: Geschichte von Dorf und Rittergut Gross-Kammin bis 1925. Privatdr. Heilbronn/Neckar 1997, S. 174f., Zitat S. 175.

317 Die Ostpreußenhilfe im Ersten Weltkrieg. Hrsg. vom Ostpreußischen Landesmuseum Lüneburg zur Ausstellung „Zum Besten der Ostpreußenhilfe“ (23.9.2006-28.1.2007). Husum 2006 (mit weiterer Literatur), S. 6, 26-29 (Berlin-Schöneberg/Domnau Kr. Bartenstein, Berlin-Wilmersdorf/Gerdauen, Berlin/Ortelsburg, [Berlin-]Charlottenburg/Soldau), 33 (Berlin/Gumbinnen), 44 (Kr. Teltow/Gerdauen), 68 f. Liste der Hilfsvereine, darin aus Brandenburg zusätzlich (S. 68): „Kriegshilfsverein Potsdam für Gr. Rominten und Dubeningken 
Vertreibung Betroffenen das Wissen von den Ereignissen und die seelischen Auswirkungen oft auch über die Generationswechsel hinweg erhalten, versiegt die Erinnerung der Aufnahmegemeinden an Zuwanderungsphänomene und -schicksale wohl zu allen Zeiten schneller.

Während des Zweiten Weltkrieges, aber auch schon in den Friedensjahren des „Dritten Reiches" waren dann weitere Bevölkerungsgruppen von außen in das damalige deutsche Reichsgebiet gelangt, die dem aufmerksamen Beobachter bereits anzeigen konnten, dass Europas in Jahrhunderten gewachsene Bevölkerungsstruktur in Bewegung, ins Rutschen geriet. Wenig bekannt ist, dass, zunächst nur kurzzeitig, einige Sudetendeutsche im September 1938, kurz vor dem „Münchener Abkommen“, aus der Tschechoslowakei flüchteten; ein „Transport sudetendeutscher Flüchtlinge“ kam z.B. 1938 in Soldin (Neumark) an und wurde vorübergehend im Flüchtlingslager Berlinchen (Kr. Soldin) in der dortigen Gauschule der „Deutschen Arbeitsfront " untergebracht und notdürftig versorgt. ${ }^{318}$ Schon damals wurden als Betreuung Krankenschwestern der „Nationalsozialistischen Volkswohlfahrt“ (NSV) eingesetzt, die dann ab Januar 1945 ein noch weit größeres Arbeitsfeld in der Flüchtlingsbetreuung erhalten sollten. Eine von ihnen, der die Leitung des Berlinchener Lagers anvertraut worden war, hat für zeitgenössische Propagandazwecke ${ }^{319}$ berichtet, dass die sudetendeutschen Flüchtlingsfrauen im September 1938 im Lager aufmerksam verfolgten, wie ihre Heimat an das nationalsozialistische Deutschland abgetreten wurde: „Der Abend am Rundfunk ist mir eine rechte Feierstunde. Gespannt verfolgen die Frauen die politischen Geschehnisse mit dem großen, gläubigen Vertrauen zum Führer. Dann werden Kampflieder gesungen, die sie begierig lernen wollen, und mit neuem Mut und großer Hoffnung gehen sie abends auseinander. Bei der Verkündung des Sieges weinen die Frauen vor Freude und sind voll Dank gegen den Führer. Das Deutschlandlied hat seinen eigenen Klang, gesungen von diesen Menschen, denen der Führer die Heimat Deutschland wiedergegeben hat. Da denken sie nicht an ihre Männer und Söhne, an ihr Hab und Gut, nur an Deutschland und an seinen größten Sohn und wissen, daß unser Deutschland größer, herrlicher und stolzer geworden ist. "320 Keine zehn Jahre später wendete sich das Blatt. Dieselben Frauen sollten zum Teil 1945 oder 1946 unter dramatischen und oft entwürdigenden Bedingungen ihre sudetendeutschen Heimatorte verlassen müssen und in einem verkleinerten Deutschland Aufnahme finden.

Deutschbalten, Deutsche aus Polen, Schwarzmeerdeutsche und andere zwischen 1939 und 1944 in das Reichsgebiet oder die besetzten Gebiete umgesiedelte „Volksdeutsche“ von außerhalb der Grenzen des Deutschen Reiches von 1937 kamen in größerer Zahl erst ab 1945 als

(Kreis Goldap)“, „Ostpreußenhilfe des Regierungsbezirks Potsdam (ohne Stadtkreise und Kr. Teltow) für Siedlungen im Kreis Gerdauen“, „Ostpreußenhilfe des Regierungsbezirks Frankfurt/Oder für Siedlungen im Kreis Gerdauen“.

318 NSV. hilft Sudetendeutschen. Schwester Lieselotte Richter, Karzig, erzählt. In: Heimatjahrbuch des Kreises Soldin Nm. 14 (1939), S. 83-84. [Gedruckt Ende 1938]. Zu den Flüchtlingswellen aus der Perspektive eines unmittelbaren reichsdeutschen (Aufnahme-)Nachbargebietes: Andreas Klose: Die Grafschaft Glatz in der Sudetenkrise. In: Schlesische Geschichtsblätter 45 (2018), S. 1-23, hier S. 12-19, 21-23.

319 „Verantwortlich für den Textteil“ des vom „Kreisausschuß des Kreises Soldin“ herausgegebenen Heimatjahrbuchs, in dem der Beitrag erschien, war laut Impressum die „Gaupropagandaleitung der NSDAP.“ (ebd., S. 2). Ebd., S. 84. 
Flüchtlinge und Vertriebene mit der Bevölkerung ihrer kriegszeitlichen Aufnahmegebiete nach Brandenburg, vor allem aus dem „Warthegau“. Es finden sich aber durchaus zuvor schon Hinweise auf eine Unterbringung in Gebieten auch westlich von Oder und Neiße. Am 13. Februar 1941 übersandte der Evangelische Oberkirchenrat (Berlin) dem Evangelischen Konsistorium der Mark Brandenburg „100 Stück des Sonderdrucks ,Heimkehr 1939. Aus der Geschichte unserer 1939 heimgekehrten Volks- und Glaubensgenossen" von Oberkonsistorialrat D. Dr. Schubert mit dem Ersuchen, jeder Superintendentur ein Stück zuzuleiten und den Rest in der Behörde zu verteilen" ${ }^{321}$ Der Kontakt mit Betroffenen dürfte also überall möglich gewesen sein, die Pfarrer sollten nicht unvorbereitet bleiben. In der betreffenden Konsistorialakte lässt sich der direkte Zusammenhang mit einer größeren Gruppe deutsch-polnischer „Umsiedler“ erkennen, die sich im Februar 1941 vorübergehend in mehreren Lagern in Cottbus und Umgebung befanden: deutsche Familien lutherischer Konfession aus Polen, die wegen ihrer teilweise mangelnden deutschen Sprachkenntnisse wohl zu den seit Generationen in kleineren Orten Zentralpolens ansässig gewesenen zählten. Schon eine Woche später überreicht Pfarrer Saretz aus Cottbus dem Konsistorium unter dem 21. Februar 1941 „ein Verzeichnis von 17 Rückwanderer-Konfirmanden aus den hiesigen Lagern, die von den Eltern zur Konfirmation angemeldet worden sind. ${ }^{322}$ Mit einer Ausnahme sind alle bereits schulentlassen und arbeiten in Fabriken und Geschäften. Für den Konfirmandenunterricht stehen deshalb nur der Sonnabend-Nachmittag und Sonntag zur Verfügung. / Keiner von ihnen beherrscht die deutsche Sprache soweit, dass er dem deutschen Unterricht folgen könnte. Deshalb hat in meiner Vertretung Pfarrer i. R. Kockott in Schmellwitz, der fünf Jahre Auslandspfarrer in Polen war und polnisch sprechen kann, den Unterricht seit Anfang Januar übernommen. Nach seiner Aussage bringen die Jugendlichen einige Kenntnis des polnischen luth. Katechismus mit und beteiligen sich aufmerksam und mit Erfolg am Unterricht. ${ }^{323}$

Die Eltern wünschen die Konfirmation jetzt hier, weil sie nicht wissen, wo sie im Laufe des Jahres hinkommen werden und ob sich dann noch eine Möglichkeit dazu bieten wird. Die meisten Jugendlichen sind aus dem Schmellwitzer Lager, das zu meinem Bezirk gehört. Einige kommen aus den Cottbuser Lagern ,Am Stern' und ,Neuholland'.

Es ist nun die Frage entstanden: Wer ist für die kirchliche Versorgung der Rückwanderer zuständig? Pfr. i. R. Kockott in Schmellwitz, der von der Geheimen Staatspolizei eine Verwarnung erhalten, weil er bei einer von den Rückwanderern erbetenen Abendmahlsfeier in der Kirche zu Schmellwitz teilweise die polnische Sprache gebraucht hat (manche ver- [B1. 5v] verstehen kein Wort deutsch!), be-

321 ELAB, 14/582 („Akten betr. Kirchliche Betreuung der Umsiedler“, Bd. 1, 14.2.1941 bis 14.5.1941, 14 Bl.), Bl. 3. Verf. D. Dr. phil. Ernst Schubert (1876-1943), ab 1928 Pfarrer in Berlin (zuvor in Rom), 1931 zugleich Konsistorialrat, 1938 Oberkonsistorialrat. Zu seiner „völkisch-nationale(n)“ Gesinnung siehe Britta Wellnitz: Deutsche evangelische Gemeinden im Ausland. Tübingen 2003, S. 8.

322 Ebd., Bl. 5. Das Verzeichnis liegt dem Schreiben nicht mehr bei.

323 Am linken Rand handschriftlich: „H[errn] K[onsistorial]R[at] Themel ergebenst: Können wir hierüber einmal sprechen? / Gruhl 25/II“. - Karl Kockott (geb. 1865 Horno bei Guben), evang. Pfarrer, zunächst in der Provinz Brandenburg, dann in Schlesien, emeritiert 1.11.1933 (Otto Fischer: Evangelisches Pfarrerbuch für die Mark Brandenburg. Berlin 1941, T. 2/1, S. 427). 
richtet, dass ihm von der Polizei gesagt wurde, für die Rückwanderer wären die Heerespfarrer zuständig. Der hiesige Wehrmachtspfarrer Kornrumpf ist seit Kriegsbeginn eingezogen, und der Standortpfarrer Schmidt ist mit Arbeit so überlastet, dass er sich um die Rückwanderer nicht kümmern kann.

Mir ist weder ein Verbot der polnischen Sprache im Gottesdienst noch die erwähnte Zuständigkeit bekannt. Um der Rückwanderer willen bin ich dankbar, dass Pfr. i. R. Kockott diesen seelsorgerlichen Dienst übernommen hat. Schon durch seine Kenntnis der polnischen Sprache ist dazu hier keiner geeigneter als er. Um sicher zu gehen, bitte ich um Anweisung, wie in dieser Sache verfahren werden soll.

In Aussicht genommen ist die Konfirmation der Rückwanderer mit den Gemeindekonfirmanden in einer gemeinsamen Feier am Sonntag, d. 23. März in der Kirche zu Schmellwitz, die Feier wird natürlich nur in deutscher Sprache gehalten werden. Um des nahen Termins willen bitte ich um baldigen Bescheid.“

Konsistorialrat Gruhl stimmte der gemeinsamen Feier intern zunächst grundsätzlich $\mathrm{zu}^{324}$, musste aber, vermutlich nach Rücksprache mit seinem Kollegen Themel ${ }^{325}$, bezüglich der Verwendung der polnischen Sprache zurückrudern, wie ein Vermerk zeigt: „Eilt./Notiz: Nach dem, was wir jüngst in der Nomadensache erlebt haben, können wir den Gebrauch der polnischen Sprache unter keinen Umständen dulden. (Trotz Art 7 21.24.)“. ${ }^{326}$ Dem Cottbuser Pfarrer antwortete er nun unter dem 27. Februar 1941, die Zuständigkeit der Heerespfarrer sei „uns nicht bekannt gegeben. Wir haben keine Bedenken dagegen, daß [dafür gestrichen: „können nur gutheißen, wenn"] die Rückwandererkinder in der Ortskirche von Schmellwitz eingesegnet werden. [Nachträglich eingefügt: „Ob das in einer besonderen Feier geschehen soll oder gemeinsam mit den Ortskindern, überlassen wir Ihrem pflichtmäßigen Ermessen."] Der Gebrauch der polnischen Sprache im Unterricht oder in öffentlichen Gottesdiensten und gemeinsamen Andachtsfeiern wird zu vermeiden sein. [Geändert aus ursprünglichem: Den ... können wir in keinem Fall gutheißen.] Erfahrungsgemäß gewinnen Fremdsprachige in deutscher Umgebung sehr schnell Kenntnis der deutschen Sprache, daß ein Unterricht in deutscher Sprache in einfacher Form möglich ist. Und wenn mit vollem Recht an eine Einsegnung in deutscher Sprache gedacht ist, so ist es nur folgerichtig, wenn auch der Unterricht so angelegt wird, daß ein verständnisvolles Miterleben der in deutscher Sprache gehaltenen Einsegnungsfeier ermöglicht wird. Die Anlage ist wieder beigefügt. ${ }^{\text {"327 }}$

Der Gebrauch des „Rückwanderer“-Begriffs sowohl durch den örtlichen Pfarrer als auch durch das Konsistorium war der Kirchenkanzlei der „Deutschen Evangelischen Kirche“ in BerlinCharlottenburg wohl auch sonst schon mehrfach bekannt geworden. Sie sah sich daher veran-

ELAB, 14/582, Bl. 5v Randvermerk Gruhls beim letzten Absatz bzgl. der gemeinsamen Feier am 23. März „Richtig! / Gr[uhl] 25/II“.

325 Siehe den in der vorigen Anm. genannten Randvermerk. - Themel ist in der Forschung mittlerweile als dem Nationalsozialismus dienstbarer Pfarrer bekannt. Siehe u. a. Manfred Gailus: Vom evangelischen Sozialpfarrer zum nationalsozialistischen Sippenforscher. Die merkwürdigen Lebensläufe des Berliner Theologen Karl Themel (1890-1973). In: Zeitschrift für Geschichtswissenschaft 49 (2001), S. 796-826.

326 ELAB, 14/582, Bl. 6.

327 Ebd. 
lasst, am 17. April 1941 „an die obersten Behörden der dt. ev. Landeskirchen und die Ev. Konsistorien des altpreuß. Aufsichtsbereichs“ zu schreiben und sie auf den „Führererlass“ vom 7. Oktober 1939 hinzuweisen: „Es hat sich als notwendig erwiesen, für die Volksgenossen, die aus ihrer seitherigen Heimat bezw. ihrem Aufenthaltsstaat in das Reichsgebiet im Rahmen einer Umsiedlungsaktion hereingeholt worden sind, eine einheitliche Bezeichnung festzulegen. Vielfach werden sie als Ein- oder Rückwanderer, Rückkehrer, auch als Rückgeführte usw. bezeichnet. Diese Bezeichnungen können indes zu Missverständnissen führen, da in einzelnen Geschäftsbereichen z. B. unter ,Ost-Rückwanderern' diejenigen Volksgenossen verstanden werden, die nach 1918 von den Polen verdrängt wurden und vom Reich aus ihre Rückkehr in die wiedergewonnenen Ostgebiete betreiben. Im Interesse einer klaren Unterscheidung empfiehlt es sich nicht, die vorerwähnten Begriffe auch für die aus dem Ausland im Rahmen einer Umsiedlungsaktion in das Reich aufgenommenen Volksgenossen zu verwenden. Der Reichsführer SS als Reichskommissar für die Festigung des deutschen Volkstums hat daher angeordnet, dass diese Volksgenossen künftig einheitlich als Um siedler zu bezeichnen sind. [...]." ${ }^{328}$ „Zur Erläuterung" wurden die entsprechenden Textpassagen des Erlasses hinzugefügt. Das Schreiben schließt mit dem Satz: „Wir bitten, auch dortseits künftig entsprechend zu verfahren. Von einer Veröffentlichung dieses Schreibens ist abzusehen. " 329 Das Konsistorium richtete sich danach, wie der Aktentitel ebenso zeigt wie alle folgenden enthaltenen Schreiben. So werden am 22. April „die aus Litauen umgesiedelten deutschen evangelischen Volksgenossen " 330 erwähnt und am 14. Mai 1941 die „Nachumsiedler aus Estland und Lettland“331.

Solche und ähnliche Fälle der Abweichung vom offiziell verordneten Sprachgebrauch begegnen ab Ende 1945 erneut. Auch dann versuchte eine andere Diktatur wieder, die Bezeichnungen für das Geschehen und für die von ihm Betroffenen festzulegen.

\section{Zwangsevakuierung und Flucht von Januar 1945 bis Kriegsende}

Das Fluchtgeschehen, die Trecks, die sich bereits im Januar und Februar 1945 auch nach und durch ganz Brandenburg quälten, können bei der Gesamtbetrachtung von Aufnahme und Integration der Vertriebenen nicht nur am Rand gestreift werden, wie dies, da kaum verlässliche amtliche Quellen vorliegen, allzu oft geschieht. ${ }^{332}$ Denn zum einen ist die Zahl der Menschen,

Ebd., Bl. 9.

Ebd.

330 Ebd., Bl. 12.

331 Ebd., Bl. 13-14.

332 Ganz knapp und oberflächlich behandelt z. B. in der ansonsten sehr verdienstvollen Arbeit von Seils, Die fremde Hälfte (wie Anm. 19). - Ähnlich unbefriedigend die wenigen Angaben in der ansonsten ebenfalls sehr verdienstvollen Arbeit von Matěj Spurný: Flucht und Vertreibung. Das Ende des Zweiten Weltkrieges in Niederschlesien, Sachsen und Nordböhmen. Dresden 2008, S. 149-153 (Kapitel „Die Ankunft der Flüchtlinge im nationalsozialistischen Sachsen“). - Kaum amtliche Quellen hierzu in: Wille I (wie Anm. 196), S. 8 ff. Ausführlicher und systematisch dagegen: Eva Hahn / Hans Henning Hahn: Die Vertreibung im deutschen Erinnern. Legenden, Mythos, Geschichte. Paderborn 2010, S. 260-282, 684f.; Holz, Evakuierte, Flüchtlinge und Vertriebene auf der Insel Rügen (wie Anm. 19), S. 71-90. 
die bereits vor dem Ende der Kampfhandlungen ins Land kamen, dafür zu groß; zum anderen wurden in dieser frühen Zeit Fakten geschaffen, was die regionale Verteilung betrifft, und leben, auch wenn nicht alle diese Flüchtlinge dauerhaft am Ort blieben, doch sehr viele bzw. deren Nachfahren noch heute in jenen ersten, noch deutlich vor Kriegsende erreichten Evakuierungsorten, z. B. in der Prignitz, im Ruppiner Raum oder in der Uckermark. Diese Geschehnisse, die Brandenburg westlich der Oder und Neiße spätestens ab Januar und zunächst bis Ende April/ Anfang Mai 1945 betrafen, sollen daher bewusst ausführlicher als die oft beschriebenen nachfolgenden behandelt und durch mehrere Zeitzeugenberichte vor Augen geführt werden.

In vielen Erinnerungsberichten Vertriebener, z. B. aus der Neumark ${ }^{333}$, ist ein mehrstufiger Verlauf des Heimatverlustes festgehalten. Zwar sind die konkreten Abläufe und Wege immer auch individuellen Rahmenbedingungen geschuldet und für den einzelnen Betroffenen auch gravierende Unterschiede nicht zu übersehen. Doch für einen erheblichen Teil der aus den Ostprovinzen Vertriebenen begann das Geschehen im Januar oder Februar 1945 mit der mehr oder weniger organisierten Flucht, den Flüchtlingstrecks, wie sie seit Jahresanfang weiter westlich fast überall ankommend bzw. durchziehend beobachtet werden konnten und in vielen Zeitzeugenberichten Einheimischer, aber mittlerweile auch in den meisten jüngeren Ortschroniken rückblickend erwähnt werden. Nicht wenige von diesen Flüchtlingen kehrten aber unmittelbar nach Ende der Kampfhandlungen gemeinsam oder - auf bisweilen abenteuerlichen Wegen individuell in ihre Heimatdörfer östlich von Oder und Neiße zurück, lebten dort unter schwierigen und bisweilen sehr schweren Bedingungen neben bereits frühzeitig zugewanderten Polen und mussten dann entweder im Hochsommer 1945 mit den sogen. „Wilden Vertreibungen“ oder ab Herbst in den auch 1946 noch weiterlaufenden offiziellen Ausweisungstransporten ihre Heimat erneut und nun endgültig verlassen, wobei die Endgültigkeit den meisten nicht sogleich bewusst wurde. ${ }^{334}$ Diese mindestens Zweistufigkeit, die im Übrigen aus Flüchtlingen dann auch Vertriebene machte, ist, so wenig sie verallgemeinert werden darf, ein Massenphänomen gewesen und hat viele Individualbiographien mit monatelangen, das ganze Leben prägenden Erlebnissen z. T. schrecklichster Art belastet.

In der von Einheimischen verfassten regionalgeschichtlichen Literatur ist dieses Phänomen des zweimaligen Alles-Aufgeben-Müssens innerhalb eines (1945) oder von zwei Jahren (1945/46) nur sehr selten bemerkt worden, da der Lebensweg der am jeweiligen Ort eintreffenden Menschen, eher distanziert als „Kommende“ und „Gehende“ erlebt, meist nicht über die Zeit ihrer Anwesenheit hinaus bekannt war und ist. Ohnehin wanderten ja nach Kriegsende,

333 Siehe die zahlreichen Einzelberichte in den Kreis-Heimatbüchern der ostbrandenburgischen Landkreise und in den Heimatzeitschriften der betreffenden Heimatkreisgemeinschaften, ferner z. B.: Dokumentation der Vertreibung I/1 (wie Anm. 192), S. 385-401.

334 Zahlreiche Beispiele für Rückkehr nach der Kapitulation oder schon nach dem „Überrolltwerden“ durch die Front u. a. für Schlesien in: Dokumentation der Vertreibung I/1 (wie Anm. 192), S. 405-466, zur Lage der Rückkehrer in Schlesien siehe u. a. die Berichte ebd., S. 467-494, insgesamt auch: „Unsere Heimat ist uns ein fremdes Land geworden ..." (wie Anm. 195). 
wie man immer wieder betonen muss, zahllose Menschen und Menschengruppen - befreite Häftlinge und Zwangsarbeiter, entlassene Kriegsgefangene, vorübergehend aus ihren Wohnorten westlich von Oder und Neiße Geflüchtete, Berliner und auch westdeutsche Bombenkriegsevakuierte usw. - in alle Himmelsrichtungen, um in ihre Heimat zurückzugelangen. Aus Finsterwalde ist eines der wenigen Gegenbeispiele zu nennen, wo es, auf das Tagebuch eines Einheimischen gestützt, heißt: „Anfang Mai setzte die Rückkehr der Flüchtlinge aus dem Osten in ihre Heimat ein. Sie wussten damals noch nicht, dass ihre Heimatgebiete auf Beschluss der Alliierten polnisches Staatsgebiet werden und - wenn sie die Heimat überhaupt erreichten aus dieser 1945 oder 1946 wieder ausgewiesen werden. Max Görner beobachtete den Rückzug der Flüchtlinge auf der B 96 von Betten aus: ,Seit heute [2.5.] setzt auch ein verstärktes Rückwandern der Flüchtlinge, die in Finsterwalde und Umgebung untergebracht sind, ein.' Sechs Tage später: ,Schon ganz früh [8.5.] kam ein langer Zug Flüchtlinge, ihre Habe auf Kinderwagen und Transportmitteln verstaut von Finsterwalde nach Osten." “335

Allzu sehr ist man in der Rückschau jedoch auf diejenigen Geschehnisse konzentriert, die im Fokus der Nachkriegsverwaltung standen und daher aktenkundig geworden sind. Diese begann aber oft erst im Juni/Juli 1945 und meist noch viel später zu arbeiten. Viele überlieferte Akten beginnen gar erst 1946, nur hier und da sind schon ab Herbst oder Winter 1945 einzelne Protokolle und Schreiben überliefert. Dagegen gibt es aus der privaten Überlieferung - sowohl auf Seiten der alteingesessenen Brandenburger Bevölkerung als auch auf Seiten der Flüchtlinge und Vertriebenen - kaum einen Erlebnisbericht des Jahres 1945, der nicht auch diese frühen, endlosen Pferde-und-Menschen-Knäuel auf ihrem Weg in oder nach Brandenburg und den Nachbarländern und auch weiter entfernten Zielorten erwähnte. „Brandenburg glich bei Kriegsende einem Durchgangsbahnhof von Ost nach West, und von West nach Ost“" 336 Die Vorgänge sollen daher hier aus beiden Perspektiven, der der Ankömmlinge und der der Einheimischen, mit Hilfe von jeweiligen Selbstzeugnissen näher betrachtet werden. Auch die - teilweise noch außerhalb Brandenburgs erlebten - Fluchterlebnisse werden dabei bewusst einbezogen, sind sie doch für die Psyche der in Brandenburg zu Integrierenden auf Jahre hinaus und bisweilen lebenslänglich prägend gewesen.

\section{Beispiele}

Mit dem Heranrücken der Front an die Ostgrenze des Reiches erfasste die Bewohner der Ostprovinzen, die sich bis dahin zumeist in relativer Sicherheit gewähnt hatten, Unruhe. Viele Entscheidungen wurden nun individuell getroffen, auch wenn die Mehrheit der einfachen Menschen sich oft erst in letzter Minute oder gar nicht mehr in Bewegung setzen konnte, da die

335 Woitzik, Was geschah vor 70 Jahren in Finsterwalde? (wie Anm. 164), S. 118 nach Tagebucheinträgen von Max Görner (Daten eingefügt von M.W., Kursivierung von P. B.).

336 Mario Wenzel: Die Aufnahme und Versorgung von Flüchtlingen und Vertriebenen in Eberswalde (wie Anm. 50), S. 136. 
Partei - verantwortlich für „Räumungsbefehle“ waren die NSDAP-Kreisleiter ${ }^{337}$ - bis zuletzt Trecks und Transporte verbot. ${ }^{338}$ Typisch für die fast überall ähnlichen Geschehnisse ist eine Äußerung, die Hans-Gotthard Merkel, Wehrbezirkskommandeur in Frankfurt (Oder), unter dem 13. Februar 1945 in seinen Tagebuchaufzeichnungen notiert hat: „Ein Gutsbesitzer, jenseits der Oder unweit von Frankfurt entfernt, erzählt, dass seine Angehörigen nicht abreisen durften, weil der Kreisleiter es verbot. Nachher war es zu spät, um noch wegzukommen. Er ist in grosser Sorge, bes. um 2 Töchter. Der Kreisleiter selbst sei rechtzeitig Tags zuvor abgefahren. “339 Wer über die Lage besser informiert und weitblickend - und mutig - genug war, konnte im Stillen rechtzeitig Vorbereitungen treffen, während viele von der Wucht der Ereignisse überrascht wurden, als es dafür zu spät war.

Die Tochter eines im ostpreußischen Königsberg dienstverpflichteten Schneiders - die Familie lebte nach dem Krieg in Wilhelmshorst bei Potsdam - berichtete 2005: „Die Entscheidung, vor der heranrückenden Front nach Wilhelmshorst zu flüchten, traf mein Vater bereits im Herbst 1944."340 Umgesetzt werden konnte sie zwar erst kurz vor Kriegsende und auch nicht von der ganzen Familie, doch zeigt gerade dieses Beispiel, wie individuell die Abläufe bei den vor Kriegsende Flüchtenden bisweilen waren: „So packten meine Eltern Kisten mit Kleidern, Federbetten und Lebensmitteln vom selbst geschlachteten Schwein und ließen sie zu unseren Verwandten nach Wilhelmshorst transportieren, mit denen alles brieflich abgesprochen worden war. So kam meine Mutter im April 1945 mit einem der letzten Flüchtlingsschiffe über Dänemark nach Wilhelmshorst zu unseren Verwandten [...]. Andere Verwandte aus Ostpreußen hatten dort schon vor uns Unterkunft gefunden. Da sich in Wilhelmshorst kein Flüchtlingslager befand, bat man vorher Verwandte um Aufnahme, Die Gemeinde regelte die Ausgabe von Lebensmittelkarten." ${ }^{441}$ Durchaus kein Einzelschicksal, sondern fast die Regel ist die vorübergehende Trennung der Familie. Während die Mutter mit einer Schwester aus Ostpreußen geflohen war und sie selbst Ende Juni 1945 aus der Neu-

337 Dokumentation der Vertreibung I/1 (wie Anm. 192), S. 31 E.

338 Selten finden sich brandenburgische Akten, die amtliche Vorkehrungen überhaupt erkennen lassen. Siehe: BLHA, Rep. 6 B Kreisverwaltung Züllichau-Schwiebus, Nr. 1: Vorbereitungen zur Verlegung der Kreisverwaltung Züllichau, 1944-1945; Nr. 2: Abwicklungsgeschäfte der Kreisverwaltung Züllichau in Neuruppin, 1944-1945 (enthält u. a.: Verzeichnis über den Verbleib der Beamten und Angestellten der Kreisverwaltung Züllichau-Schwiebus); Nr. 3: Verlegung der Kreisverwaltung Züllichau nach Guben, Calau und Neuruppin; Abwicklung der Geschäfte, 1945; Nr. 4: Auflösung der Kreiskommunalkasse Züllichau, 1945; Nr. 169: Umsiedlungsaktion im Kreise Züllichau-Schwiebus (enthält v.a.: Adressenlisten von Flüchtlingen [Heimatanschrift und aktueller Aufenthaltsort, überwiegend im Kreis Ruppin]), 1945. - BLHA, Rep. 6 B Kreisverwaltung Guben, Nr. 171: Abgabe der Kassenbücher und Kassenbestände der Gemeindekassen der Gemeinden Kuschern, Gubinchen und Klein Drenzig an das Landratsamt Guben wegen Räumung der Gemeinden im Kriegsgebiet, 1945.

339 Ralf-Rüdiger Targiel [Hrsg.]: Aufzeichnungen von Hans-Gotthard Merkel: Frankfurt im Februar/März 1945. In: Historischer Verein zu Frankfurt (Oder) e. V. Mitteilungen 1994, H. 2, S. 2-16, hier S. 6.

340 Balschinat, Meine Nachkriegsjahre in Wilhelmshorst (wie Anm. 308), S. 347.

341 Ebd. 
mark, wo sie wahrscheinlich dienstverpflichtet gewesen war, über Küstrin nach Wilhelmshorst gelangte, kam der Vater erst 1946 aus sowjetischer Kriegsgefangenschaft zu ihnen.

Beispiele dafür, dass man sich unmittelbar nach einem Eisenbahntransport oder Treck Ende Januar 1945 in Berlin oder an einem anderen Ankunftsort in der SBZ sogleich von der Evakuierungsgruppe trennte und bei Verwandten oder Freunden unterkam, gibt es sehr viele. Mancher hatte dafür bereits Monate zuvor Absprachen getroffen, andere standen ganz unverhofft bei einem mehr oder weniger nahen Verwandten oder Bekannten vor der Tür. So heißt es in den Erinnerungen einer damals jungen Landsbergerin, die am 30. Januar - Endziel war Ingolstadt, wo ihre Großmutter wohnte - mit dem Flüchtlingszug aus Landsberg/Warthe zunächst in Berlin eintraf: „Abends gegen 8 Uhr steigen wir am Bahnhof Zoo aus dem Zug und übernachten bei Bekannten. “342 Über eine andere Landsbergerin, die in den Morgenstunden des 30. Januar 1945 in einem Flüchtlingszug den Schlesischen Bahnhof in Berlin erreicht hatte, berichtet ihr Sohn: „Meine Mutter, sehr rührig, hatte eine Bahnverbindung nach Senftenberg/Lautawerk herausgefunden, und so erreichten wir am Abend des 30. Januars das kleine Siedlungshaus ihres Bruders in Lautawerk. Ich erinnere mich, wie meine Mutter mit kläglicher Stimme an der Haustür sagte: ,Herbert, wir sind es!' [...] In Lautawerk erlebten wir mehrere Bombenangriffe und als im April die letzte Offensive der Roten Armee begann, zogen wir mit dem Handwagen weiter in Richtung Westen. Weißenfels war unser Ziel. Dort wohnte mein Großvater. [...] Als mein Vater im November 1944 für kurze Zeit bei uns weilte, hatten wir diesen Ort als Ziel, zumindest aber für die Hinterlegung eine Nachricht festgelegt. ${ }^{\text {"343 }}$ Solche Beispiele finden sich in zahlreichen Berichten von Zeitzeugen, auch wenn nicht übersehen werden darf, dass die Mehrheit der Flüchtlinge über diesen „Luxus“ eines privaten Anlaufpunktes nicht verfügte und insbesondere diejenigen im Vorteil waren, die innerhalb der Provinz Brandenburg verbleiben konnten: die Neumärker und die von östlich der Neiße kommenden Niederlausitzer, beides Brandenburger.

Eine weitere „Teilmenge“ der Flüchtlinge, die meist unerwähnt bleibt, auch weil man kaum Quellen dazu findet, sind die nicht wenigen, gerade aus den westlich von Oder und Neiße gelegenen bombengefährdeten Städten Brandenburgs und aus Berlin in die Ostgebiete (Neumark, Niederschlesien, Ostpreußen) evakuierten Frauen mit kleinen Kindern. ${ }^{344}$ Eine 1905 geborene Potsdamerin mit drei Kindern, das jüngste gerade, im August 1943, geboren, erinnerte sich später: „Wir waren dann, als die Bombenangriffe zunahmen, evakuiert worden, d.h. ich mit den

342 Dorothea Albrecht: Die letzten 24 Stunden in der Heimat Landsberg. Aus dem handschriftlichen Bericht übertr. von Matthias Lehmann. In: Heimatblatt der ehemaligen Kirchengemeinden Landsberg/Warthe Stadt und Land 50 (2015), S. 13-17, hier S. 16.

343 Ernst-Günter Weber: Vor 70 Jahren - Flucht aus Landsberg. In: Heimatblatt der ehemaligen Kirchengemeinden Landsberg/Warthe Stadt und Land 50 (2015), S. 6-9, hier S. S. 7.

344 Auskünfte von damals im Kindesalter befindlichen Zeitzeugen: Dieter Hering (†) (Langenhagen) und Ilse Frfr. von Puttkamer geb. Schwabe (Mönchengladbach), beide mit ihren Müttern aus Berlin bzw. Potsdam evakuiert nach Amtshagen (Schirgupönen) im Kreis Gumbinnen (Ostpreußen); Manuela Schöps (Berlin), aus Berlin zu Verwandten nach Peiskersdorf bei Peterswaldau, Kr. Reichenbach im Eulengebirge (Niederschlesien) evakuiert. 
Kindern, und zwar nach Zantoch, einem Dorfbei Landsberg/a.d. Warthe. Und dort [hin] gingen meine Eltern mit. Da haben wir noch 1 1/2 Jahre in Ruhe verbringen können. [...] Ende [19]44 kamen wir nach Potsdam zurück und dann begann das Chaos. [14.4.1945 schwerer Bombenangriff auf Potsdam - P. B.] Vaters Herz machte nicht mehr mit. Er kam ins Krankenhaus, dann wieder nach Hause. 1950 starb er. “345 Andere Evakuierte kamen erst Anfang 1945 - als Flüchtlinge, die allen mitevakuierten Hausrat einbüßten.

Der größere Teil der Bewohner des Dorfes Zatten im Kreis Arnswalde, 195 Personen, ging kurz vor Ende Februar 1945 auf den etwa eine Woche vor Eindringen der Roten Armee erteilten Räumungsbefehl des NSDAP-Ortsgruppenleiters hin mit etwa 13 Treckwagen auf die Flucht. ${ }^{346}$ Die Restbevölkerung wurde am 2. Februar von der Wehrmacht mitgenommen. Der Treck war mit mehreren Zwischenstationen 15 Tage unterwegs, bis er die Oder überquerte und am 17. Februar im Kreis Greifswald seine Flucht vorläufig beendete. Ende April traf die Rote Armee auch hier ein. Am 6. Mai zogen die Zattener Flüchtlinge auf sowjetische Anordnung in ihre Heimat zurück, wo sie am 25. Mai ankamen. Am 9. Juli 1945 wurden sie durch die unmittelbar zuvor eingetroffene Polen von hier vertrieben. Eine bis 1974 geführte komplette Einwohnerliste mit Angaben zum Verbleib weist eine Verteilung sowohl auf Westdeutschland als auf die DDR nach. Die in die SBZ/DDR gelangten Zattener wohnten demnach mehrheitlich in Mecklenburg und Vorpommern, aber auch in Berlin (Ost und West) und in Brandenburg: zwei Familien im Kreis Angermünde, je eine in Wutzetz im Kreis Kyritz, Pätz im Kreis Königs Wusterhausen, Schildow bei Berlin, Eichwalde bei Berlin und Lübben sowie immerhin drei in Neu Zittau. ${ }^{347}$

Ein Beispiel für die unkoordinierten und immer wieder die Richtung ändernden Fluchtwege ist das der Einwohner des am Ostufer der Neiße, kurz vor deren Mündung, gelegenen Dorfes Kuschern (Kr. Guben). Als die Rote Armee am 2. Februar im Nachbardorf Schiedlo die Oder erreicht hatte, flohen viele von ihnen in Panik mit Pferde- und Kuhgespannen nach Süden in Richtung Guben und verharrten zunächst in zwei südlich Guben gelegenen Dörfern. Ein Teil von ihnen kehrte aufgrund neuer Gerüchte über Truppenbewegungen zurück bis nach Seitwann und wechselte am 20. Februar auf das Westufer der Neiße bei Breslack. Von hier setzten sie „später die Flucht nach Münchehofe (bei Märkisch Buchholz) fort, wo sie in der Schule ein Quartier fanden. [...] Als die Russen zur Großoffensive auf Berlin ansetzten, gerieten die Flüchtlinge in Münchehofe in den Kessel von Halbe und verloren ihr gesamtes Hab und Gut,

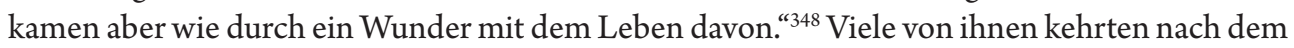
Schweigen der Waffen auf getrennten Wegen in ihr Heimatdort Kuschern zurück und versorgten ihre Wirtschaften. In der Nacht zum 20. Juni wurden sie alle von inzwischen eingetroffenen

345 Mitteilung Lieselotte Koppe geb. Große $(+)$, Potsdam, an den Verf.

346 Hermann Roeder / Hedwig Roeder: Unser Heimatdorf Zatten. Göttingen 1974, S. 4 f.

347 Ebd., S. 19-28.

348 Horst Wandke: Aufbruch ins Ungewisse. Wie die Kuscherner das Kriegsende erlebten. In: Heimatkalender Eisenhüttenstadt und Umgebung 23 (2005), S. 259-260. 
Polen aufgefordert, „,sich am nächsten Morgen zu sammeln. Später wurden sie zur Seitwanner Domäne geführt, wo man ihnen ihre Habseligkeiten abnahm, und in Buderose über die Neiße abgeschoben. Viele Kuscherner blieben in Guben und umliegenden Dörfern (Coschen, Breslack, Ratzdorf, Neuzelle u.a.) sowie in Fürstenberg, einige suchten in Westdeutschland eine neue Heimat. “349

Jürgen Noack hat sogar behauptet, sein unmittelbar an der Oder westlich Crossen gelegenes Heimatdorf Pollenzig (Kr. Crossen) habe sich nach Weihnachten 1944 „nach und nach“ geleert: „Viele Bewohner begaben sich mit Hand- und Leiterwagen oder Fuhrwerk auf die Flucht in Richtung Westen. Diese Flüchtlinge konnten wenigstens noch Wertgegenstände und Dokumente mitnehmen, was den später Vertriebenen nicht mehr möglich war. Der Winter 1944/45 war sehr streng und die Oder zugefroren, so dass viele über den Fluss gingen und große Umwege vermieden wurden. Die Brücken waren ja z. T. schon gesprengt oder von der Wehrmacht beschlagnahmt. Mitte Januar 1945 trafen meine Eltern nach beschwerlicher und abenteuerlicher Reise in Pollenzig ein. Sie kamen aus Cosel [Oberschlesien] und hatten dort ihr Schiff aufgeben müssen, weil der Ort schon unter Artilleriebeschuss der Russen stand. Zum Teil in offenen Güterwaggons waren sie bis Guben oder Wallwitz gefahren und dann zu Fuß über das Eis der Oder nach Pollenzig gelangt. Meine Freude war groß, dass ich sie endlich wiederhatte. Von meinen drei Brüdern wussten wir damals nichts. "350

Der damals zehnjährige Sohn des Bürgermeisters von Groß Gandern im Kreis Weststernberg berichtete 1997 über die Flucht mit dem letzten Zug (29. Januar 1945) vor Eintreffen der Roten Armee (31. Januar 1945): ${ }^{351}$ „[... ] Meine Mutter, Oma und wir vier Geschwister haben dann den letzten Zug in Richtung Reppen/Frankfurt (Oder) wahrgenommen. Es kostete uns viel Überwindung und Kraft, alles im Stich zu lassen. Wir waren alle kopflos. Aber meine Mutter und vor allem Oma haben sich rückblickend als wahre Heldinnen erwiesen. Wir befürchteten auch Fliegerangriffe auf unseren Zug. Am Fenster des Zuges hielt ich angespannt und ängstlich Ausschau nach Flugzeugen. Die späte Stunde und die Dunkelheit des Februar ${ }^{352}$ kamen uns zugute. Überall, in Hermania, Reppen und Kunersdorf, stiegen noch mehr zu. Selbst auf den Trittbrettern des Zuges standen die Leute und das bei Kältegraden. Nach vielen, angsterfüllten schrecklichen Stunden erreichten wir tief in der Nacht Frankfurt. Und wie nun weiter? Von Organisation keine Rede. Helfer auf dem Bahnsteig bemühten sich hektisch, den Leuten eine vorübergehende Unterkunft zu benennen. Aber Frankfurt war selbst voll von Militär und zuströmenden Menschen. Schon hier drifteten die Ganderner auseinander, eine Verwandtenanschrift im Auge, um ein erstes Ziel zu haben. Wir fuhren weiter in Richtung Berlin in die zerstörte Hauptstadt, die überquoll von Menschen und ein Bild des Chaos bot. Hier gab es ganz

Ebd., S. 260.

Jürgen Noack: Wie ich in Fürstenberg (Oder) eine neue Heimat fand. In: Heimatkalender Eisenhüttenstadt und Umgebung 23 (2005), S. 198-206. Der Vater stammte aus Pollenzig, die Mutter aus Brieg (Schlesien).

Heinz Schulze's Weg aus der Heimat. In: Heinz Materne / Hans Gerlach: Gross-Gandern und Klein-Gandern. Heimat im Sternberger Land. Wittingen/Bremen 1997, S. 88-89.

[Schulze spricht vom „letzten Zug“, der nach mehreren anderen, übereinstimmenden Informationen (ebd. S. 88 f.) aber bereits am 29. Januar gefahren war, so dass „Februar“ hier nur eine irrtümliche Angabe sein kann.] 
und gar keinen Platz für Flüchtlinge. Deshalb [S. 89] führte uns der Weg weiter nach Dannenberg/ Elbe [...].“

Die damals ebenfalls zehnjährige Renate Müllers geb. Materne aus demselben Ort berichtete über den Zug vom 29. Januar: „Morgens um sechs Uhr läuteten die Glocken. Wir begaben uns mit Kinderwagen, Schlitten und Rädern bepackt zum Bahnhof, wir, das waren Vater, Mutter, Bruder Reinhard und ich. Es war ein banges Warten auf dem Bahnhof, da der Zug auf sich warten ließ. [...] So gegen neun Uhr kam dann doch noch ein Zug mit zwei Personenwagen und Viehwagen in der Mitte. Die Lokomotive war beschossen worden; denn es kam Wasser aus dem Dampfkessel. Der Lokomotivführer war leichenblaß. Ich sehe ihn noch, wie er ein Stück Holz mit Lappen umwickelt in dieses Loch stopfte. Sehr viele Leute kehrten um und gingen wieder nach Hause. Wir stiegen ein. Ich kann mich erinnern, es war ein Viehwagen mit etwas Stroh darin. Der Zug fuhr dann endlich ab [...]. Schon hinterm Bahnhof und später im Wald konnten wir russische Panzer sehen. In Hermania sind wir beschossen worden. Aber nur die Personenwagen wurden getroffen. Die Russen waren wohl der Meinung, daß in Viehwagen keine Menschen transportiert werden. Wir erreichten Reppen. Der ganze Bahnhof war voller Flüchtlinge. Wir mußten noch den ganzen Tag in Reppen auf dem Bahnhof bleiben und hörten weiterhin Kanonendonner. Gerüchte gingen um, daß die Russen schon bis Kunersdorf vorgedungen wären und daß die Oderbrücke womöglich schon gesprengt sei. ${ }^{353}$ Am späten Abend wurde rangiert, und wir fuhren in Richtung Frankfurt (Oder). Als der Zug die Oderbrücke passierte, waren wir schon sehr erleichtert. Der Zug fuhr von Frankfurt sehr langsam und immer wieder haltend in Richtung Berlin weiter. Bei jedem Stopp gab es einen Ruck, und alles flog durcheinander. Irgendwo zwischen Frankfurt und Fürstenwalde hielt der Zug auffreier Strecke für längere Zeit. Jetzt sah man, daß der Zug übernormal lang war und von 5 Lokomotiven gezogen wurde. Meine Mutter und andere versuchten auf einem nahegelegenen Bauernhof etwas Trinkbares zu bekommen. Das hat auch geklappt, nur ich hatte unheimlich Angst, daß sich der Zug ohne meine Mutter wieder in Bewegung setzt. Ich erinnere mich noch, daß Herr Roy aus Klein-Gandern von Waggon zu Waggon ging und seine Familie suchte. Wir kamen spät in der Nacht in Berlin-Kleinmachnow an. In einer Schule wurden wir betreut, es gab eine Milchsuppe, die herrlich schmeckte, das erste Essen nach zwei Tagen. Gerade darauf erlebte ich den ersten Bombenangriff. Wir wurden in Kleinmachnow in einem Haus mit zwei Wohnungen untergebracht. Es war bitterkalt. Mein Vater versuchte erfolglos, [S. 90] die Heizung in Gang zu setzen. Wir bekamen dann ein Zimmer zugewiesen, ein Schlafzimmer mit hohen Nachtschränken. Der ältere Herr als Inhaber weinte und machte sich große Sorgen, daß das Zimmer ruiniert werden könnte. Bei Fliegeralarm gingen wir meistens in den Bunker der nahen Schule. [...] die näherrückende Front und die katastrophale Unterbringung hier im Berliner Raum drängten darauf, auf eigene Faust etwas zu tun. Auf Anfrage meiner Mutter antwortete meine Tante sofort, daß wir zu ihr nach Schleswig-Holstein kommen sollten. Das taten wir dann. [...].“

Andere versuchten mit Pferdewagen wegzukommen, was wegen der von den NSDAPOrtsgruppenleitern allenthalben ausgesprochenen Treck-Verbote bis zuletzt nur heimlich vor- 
bereitet werden konnte. „Bei etlichen Familien stand der vorbereitete Wagen auf dem Scheunenflur bereit, um nur noch die Pferde vorzuspannen und über die Oder abzufahren. Aufgeladen waren die meisten Lebensmittel aus Räucherkammer und Keller, Mehl, Kartoffeln, Betten, wichtige Kleidungsstücke und auch Körner, Rüben und Heu für die Pferde. Was war wichtig in solch panischer Situation? Darin waren alle überfordert. Aber es galt, die Nerven zu bewahren. Welcher Weg über die Oder war überhaupt noch offen? Reale Informationen gab es nicht. Die Russen waren schnell bis zur Frankfurter [S. 91] Dammvorstadt vorgestoßen. Ein Durchkommen schien hier gänzlich ausgeschlossen, erfolglose Versuche haben das belegt. Aus Aurith weiß man, daß Flüchtlinge und Aurither Einwohner über das Eis der Oder gefahren sind und Einbrüche nicht ausgeblieben sind. Bei Crossen, soviel war durchgesickert, wäre ein Herauskommen noch möglich. “354 Am 1. Februar 1945 gelang manchen Neumärkern so bei Crossen doch noch die Flucht über die Oder.

Bisweilen verschlimmerten Unglücke die ohnehin chaotische und höchst angespannte Lage. So fuhr am 30. Januar 1945 bei Wepritz (Neumark) ein Reichsbahnbetriebszug auf einen aus Landsberg/Warthe kommenden Flüchtlingszug auf, wodurch es viele Tote und Verletzte gab. Ein damals 14-Jähriger Flüchtling berichtet: „Wir Kinder wurden aber so gut abgeschirmt, dass wir erst viel später über den wahren Umfang des Unglücks unterrichtet wurden. Mir ist nur ein zum Teil noch brennender Personenzugwagen in Erinnerung, der bei unserer Weiterfahrt neben dem Bahndamm lag. ${ }^{\text {“355 }}$ Ein anderer Flüchtling vermisste seit diesem Tag seine Großmutter und vermutet sie unter den Opfern. ${ }^{356}$ Ein blutjunger Soldat, selbst Schlesier, erlebte im April 1945 den Kessel von Halbe, in dem sich nicht nur Militär befand: „Tausende von Flüchtlingen und Truppen aller Waffengattungen der Wehrmacht befanden sich in heilloser Flucht auf den Straßen und in den Wäldern. "357

Erste Evakuierungen bzw. Räumungen im Reichsgebiet wurden bereits bei Beginn der sowjetischen Sommeroffensive 1944 angeordnet. So verbrachte man vom 28. Juli bis 1. August Frauen und Kinder aus dem Ostteil des ostpreußischen Grenzkreises Treuburg (Oletzko) in den Westteil des Kreises und transportierte kinderreiche Familien per Bahn nach Rößel und sogar nach Thüringen und Sachsen. ${ }^{358}$ Auch Wirtschaftsunternehmen wird die Auslagerung wichtiger

354 Materne/Gerlach, Gross-Gandern und Klein-Gandern (wie Anm. 351), S. 90 f. - Einen ähnlichen Zwischenfall, den nächtlichen „Zusammenstoß mit abgestellten Wagen auf der Strecke“ gab es in der Nacht vom 12. zum 13.2.1945 zwischen Grünberg (Schlesien) und Crossen/Oder für den aus Christianstadt kommenden Flüchtlingszug: L. Schietke: Acht Jahre ist es her ... In: Das Heimatblatt für Sorau N./L.-Stadt und Land 1 (1953), Nr. 12, S. 8.

355 Udo Schlösser: Unsere Flucht aus Landsberg. In: Heimatblatt der ehemaligen Kirchengemeinden Landsberg/ Warthe Stadt und Land 49 (2014), S. 69-70, hier S. 70.

356 Werner Gabloffsky: Kinderjahre in Landsberg/Warthe. In: Heimatblatt der ehemaligen Kirchengemeinden Landsberg/Warthe Stadt und Land 50 (2015), S. 33-41, hier S. 41.

357 Günter Lange: Glück oder Schutzengel? In: Damals und heute. Storkower Zeitzeugen berichten. Hrsg. vom Seniorenbeirat des Amtes Storkow. Storkow 2003, S. 54-56, hier S. 55.

358 (Auch für das Folgende:) Walter Taubenthal: Die Räumung des Kreises Treuburg. In: Der Kreis Treuburg. Ein ostpreußisches Heimatbuch. Zsgest. im Auftr. der Kreisgemeinschaft Treuburg von Rudolf Grenz. Lübeck 1971, S. 422 f. 
Güter empfohlen. Noch sind viele solcher Maßnahmen aber sehr begrenzt, so wird dem Kreis Treuburg „der Landkreis Sensburg als Aufnahmekreis zugewiesen“, d. h. im „Ernstfall“ sollte die Restbevölkerung lediglich „provinzintern“ in den Nachbarkreis wechseln. Dies geschah dann tatsächlich mit Beginn der sowjetischen Herbstoffensive im Oktober 1944, als man vor Ort in eigener Verantwortung der Kreisbehörden die Räumung anordnete und dies dem Reichsverteidigungskommissar in Königsberg nur noch mitteilte. „Am 26. Oktober ist der Kreis vollständig geräumt. Die Behörden des Kreises befinden sich im Aufnahmekreis Sensburg.“ Im November erfolgen von hier aus weitere Transporte nach Sachsen. ${ }^{359}$ Als auch dieser Kreis im Januar 1945 von der Roten Armee überrannt wurde, war die Katastrophe eingetreten. Die Treuburger Räumung war zu spät erfolgt und bedeutete nur für etwa vierzig bis fünfzig Prozent der Bevölkerung Rettung. ${ }^{360}$ Es folgten ungeordnete Flucht-Trecks auf schneeverwehten Straßen zum Haff.

Der Ostpreuße Dieter Lyhs (geb. 1931), der später in Frankfurt (Oder) lebte, hat als Rentner die abenteuerliche Flucht seiner Familie im Februar 1945 beschrieben: „Nach drei Tagesmärschen erreichten wir Pillau. Das ganze Hafengelände war mit Flüchtlingen überfüllt. Zwei Riesendampfer lagen am Kai, vor jedem standen unüberschaubare Mengen an Flüchtlingen. Jeder hoffte irgendwie mitzukommen. Für mich sah das aussichtslos aus. Außerhalb des Bereichs der beiden Dampfer entdeckte ich zehn Minensuch- und Räumboote. Hier stellten wir uns in der Hoffnung an, von den Matrosen mitgenommen zu werden. Wir waren die ersten und warteten die ganze Nacht. Es hatte sich gelohnt. Am Morgen wurde eine Brücke zu einem Boot übergelegt und es wurde bekanntgemacht, dass jedes Schiff 50 Flüchtlinge aufnehmen wird. Wir sollten geordnet und ruhig die Boote betreten. Wir waren die ersten Flüchtlinge, die das Boot betraten. [...] Erst am nächsten Tag konnten wir auslaufen und kamen in der Nacht in Gotenhafen ${ }^{361}$ an. Im Hotel Berlin wurden wir in einen großen Saal einquartiert. Es war der 12. Februar. Im Saal gab es keinen Tisch und keinen Stuhl. An allen Wänden hatte man Strohschütten hergerichtet, mit Decken überzogen als Lager und eine Decke erhielten wir zum Zudecken. In dem warmen Haus wurden wir verpflegt und konnten uns wieder etwas erholen. Hier erlebte ich auch meinen 14. Geburtstag mit einer Rote-Kreuz-Suppe und trockenem Brot. Alle Männer wurden ob der Möglichkeit ihres Fronteinsatzes überprüft. Das galt auch für mich, aber meine 14 Jahre retteten mich davor. [...] Bei meinem Suchen nach einer Möglichkeit des Weiterkommens stellte ich fest, dass immer noch Züge in Richtung Stettin fuhren. Zwar nicht fahrplanmäßig, aber sie wurden zusammengestellt und fuhren ab, wenn sie voll waren. Und vor allem, wenn eine Lok vorhanden war. Trotz des heillosen Durcheinanders kam man ohne Fahrkarte nicht durch die Sperre. So kauften wir Fahrkarten und am 18. Februar, um 15.00 Uhr, verließen wir Gotenhafen in Richtung Stettin. Als wir am nächsten Mittag in Stolp eintrafen, hieß es, der Zug endet hier, alles aussteigen. [...] Jeder zivile Zugverkehr endete hier. ${ }^{\text {“362 }}$ Nach einem weiteren Zwischenhalt in Köslin kam die Familie zuletzt mit einem Militär-Lkw nach Stettin und von hier per Bahn nach Berlin. „Mit

359 Edgar Günther Lass: Flucht und Vertreibung. In: Der Kreis Treuburg (wie Anm. 358), S. 429-431, hier S. 430.

360 Ebd.

361 [1939-1945 (germanisierender) amtlicher deutscher Name für Gdingen (poln. Gdynia) bei Danzig.]

362 Dieter Lyhs: Flucht aus Ostpreußen (II). In: Damals und heute (wie Anm. 357), S. 40-44, hier S. 43. 
Mühe kamen wir in den Zug und standen am Abend des 22. Februar am Stadtrand von Berlin. Wir durften jedoch nicht hinein, weil die Stadt Tag und Nacht bombardiert wurde. Die ganze Nacht hatten wir die brennende Stadt vor Augen. Erst am nächsten Tag fuhr der Zug im Anhalter Bahnhof ein und wir gelangten mit dem Vorortzug nach Marzahn. Dort endete [...], bei der Schwester meiner Mutter, vorläufig unsere Odyssee." ${ }^{363}$

Auch die bei den Evakuierungen bzw. der Flucht Anfang 1945 neben den vielen auf die Straße verwiesenen Trecks eingesetzten Eisenbahnzüge bestanden teils, wenn vorhanden, noch aus Personenwagen, oft aber auch dann schon, wie später zumeist bei den Vertreibungen nach Kriegsende, trotz eisiger Winterkälte aus (offenen) Güterwaggons, was viele Flüchtlinge in ihren Erinnerungsberichten überliefert haben. ${ }^{364}$ Aber auch Personenzüge hatten nicht immer Toiletten: Eine 17-Jährige Niederlausitzerin aus Welzow, die sich 1944/45 in einem Arbeitsdienstlager bei Meseritz befand, wurde erst unmittelbar vor dem Einmarsch der Roten Armee mit ihren Altersgenossinnen vollkommen ungeordnet evakuiert: „Der Zug war überfüllt mit Flüchtlingen. Irgendwie schafften wir es kopfüber durch die Fenster in einen Wagen zu kommen. [...] scheinbar hatten die meisten aus unserem Lager den Zug erreicht, denn auf einem Bahnhof hörten wir die Durchsage, dass die Maiden aus dem Lager Paradies in Crossen an der Oder aussteigen und sich melden sollten. Für uns vier stand fest: Ohne uns! Wir blieben im Zug und wollten nach Haus. Die Fahrt war eine Odyssee. Der Zugfuhr Schrittempo auf irgendwelchen Nebenstrecken, hielt mehrmals stundenlang auf freier Strecke. Wir hatten nichts zu essen und zu trinken. Es gab keine einzige Toilette im Zug. Unsere Notdurft mussten wir während der Fahrt von den Trittbrettern herunter erledigen. In der zweiten Nacht während der endlosen Fahrt fuhr der Zug plötzlich schneller. Wir konnten Berliner S-Bahn[-]Stationen entziffern. Jetzt stand für uns fest, beim nächsten Halt auf freier Strecke steigen wir aus! Hinter Potsdam hielt der Zug wieder. Wir sprangen ab und versanken bis über die [S. 46] Knien [so!] im tiefen Schnee. Wir hatten uns total verschätzt. Nach langem strapaziösen Marsch erreichten wir im Morgengrauen den kaiserlichen Privatbahnhof hinter Potsdam [Wildpark]. Irgendwann fuhr der Zug nach Berlin und am nächsten Tag schaffte ich es bis Welzow. Meine Mutter erzählte mir, dass ich zu Hause die Küche betrat und bewusstlos umfiel. Einige Zeit war ich schwerkrank. Ich hatte keine Lebensmittelkarte, konnte mich nicht anmelden, denn ich war ja, fahnenflüchtig'. [...].“365

Ebd., S. 44.

Zwei Beispiele für viele: Arthur Weiß: Von Bessarabien nach Belzig. Meine Memoiren. Leipzig 2012, S. 113: „Dieser Transport fand nicht in Personenwagen sondern in Güterwagen statt.“ (14-tägiger Transport ab 20. Januar 1945 von Züllichau nach Dresden). - Gertraud Sewerin: Krankenschwester vom DRK. In: „... das Glockengeläut ist einzustellen“. Belzig 1995, S. 101-102, hier S. 101: „Ich erinnere mich an einen Flüchtlingszug, der als offener Güterzug bei 6 Grad Kälte aus Hohensalza hier ankam."

Eva-Maria Nutsch: Jahrgang 1927. In: Damals und heute (wie Anm. 357), S. 44-46, hier S. 45 f. 


\section{Zwischenhalte und Interimsquartiere}

Die schwierige, nicht immer von Hilfsbereitschaft geprägte Situation in den bloß interimistischen Nachtunterkünften ebenso wie in den Erstaufnahmeorten spiegelt sich in vielen Zeitzeugenberichten. Einige Beispiele, teils von Flüchtlingen, teils von Einheimischen, sollen dies aus den Perspektiven beider Gruppen verdeutlichen.

Der in Woltersdorf-Schönblick bei Berlin ansässige Künstler Fidus (Hugo Höppener) notiert am Sonntag, 28. Januar 1945 in sein Tagebuch: „vorm. kommt Forch ${ }^{366}$ mit Elfriede aus der Kirche und meldet neueste Ereignsse: „Man hatte im N. S. N. ${ }^{367}$ für viele Flüchtlinge vorgesorgt, als diese aber nach Westen weitergeleitet, abgesagt wurden, hätte man das Essbare selbst aufgegessen!"368 Am 17. März 1945 schreibt er, ein Bekannter habe sich darüber beklagt, „daß Forch als Flüchtlings-Betreuer ihm rücksichtslos unpassende, unreinliche Leute in seine Mietwohnung setzte.“369

Ein damals fünfzehnjähriger einheimischer Schüler erlebte das herannahende Kriegsende in seiner Heimatstadt Storkow: „Es muß Mitte oder Ende Januar 45 gewesen sein, als immer mehr Ostflüchtlinge in unserer Schule in der Storkower Altstadt einquartiert wurden. Zunächst nur in der Turnhalle, dann auch in Klassenräumen. Also war bis zum Endsieg kein Unterricht mehr. Ich mußte aber noch oft dorthin, denn ich war im Schulluftschutz." ${ }^{370}$ Auch in den Erinnerungsberichten alter einheimischer Dabendorfer (Kr. Teltow) spiegelt sich das Geschehen um ihre zeitweiligen oder dauerhaften neuen Nachbarn: „Vor den sowjetischen Soldaten trafen Flüchtlingstrecks aus dem Osten Deutschlands in Dabendorf ein. Sie wurden aus der Luft von einmotorigen sowjetischen Jagdflugzeugen angegriffen. An der Fernverkehrsstraße 96 lagen in den Straßengräben Verletzte, Tote, zertrümmerte Fuhrwerke und tote Pferde. In den letzten Kriegstagen war die Berliner Straße in Dabendorf vom Flüchtlingsstrom überfüllt. Die Flüchtlinge bemühten sich, in Richtung Westen voranzukommen. Im Bereich des heutigen Sportplatzes blieb ein Kleinkind zurück. Der kleine Junge wurde Peter L. genannt und von einem älteren Dabendorfer Ehepaar angenommen und großgezogen. “371

Ein 1945 noch minderjähriger Zeitzeuge hat Ankunft und Einweisung in einem nordwestbrandenburgischen Dorf, Glövzin (Kr. Westprignitz), erlebt: „Am Bahnhof in Premslin [Kr. Westprignitz] waren Flüchtlinge aus Bromberg eingetroffen. Sie sollten dort abgeholt werden. Ich war mit dem Schlitten dabei. Gepäck hatten sie nicht viel. Ich brachte eine Frau Schünemann mit ihrer kleinen Tochter ins Dorf. Sie wurden bei Bauer Willy Jahnke einquartiert. Das Zimmer befand sich unter dem Dach, auf dem Boden, mit Blick zur F5. [...] Der Strom der Militärfahrzeuge und

366 [Georg Walter Forch (1890-1971), NS-Amtswalter, Leiter des „Hauses der Heimat“ in Woltersdorf.]

367 [„Nationalsozialistisches Notopfer“.

368 Fidus - Hugo Höppener: Tagebuch Januar bis Juli 1945. Hrsg. von Rolf F. Lang. Berlin 1999, S. 12.

369 Ebd., S. 37.

370 Gerhard Rabaschus: 1945 - Schlimmes Ende, schwerer Anfang. In: Storkower Zeitzeugen berichten. [H. 1]. Hrsg. vom Seniorenbeirat des Amtes Storkow. Storkow 1999, S. 20-27, hier S. 20.

371 Detlef Polley: Schrecken, Not und Tod. Dabendorf am Ende des Zweiten Weltkriegs. In: Heimatjahrbuch für den Landkreis Teltow-Fläming 23 (2016), S. 113-119, hier S. 117. 
der Trecks mit pferdebespannten Fuhrwerken nahm immer mehr zu und riss dann gar nicht mehr $a b .{ }^{\text {"372 }}$

Fritz Reglin, der Krieg und Kriegsende als Kind in Fürstenwerder (Uckermark) erlebte, hat berichtet, wie im März 1945 Flüchtlinge hautnah in sein Leben traten: „Lange Trecks aus Pferdewagen, die durch Fürstenwerder zogen, wurden von uns Schulkindern bestaunt, nicht ahnend, dass wir auch bald mal so losziehen müssten. / Einige dieser ,Flüchtlinge' konnten nicht mehr weiter, sie waren bei Kälte und Schnee hunderte Kilometer von zu Hause unterwegs gewesen. Und so wurde auch bei uns im Haus eine Familie aus Ostpreußen einquartiert. Der alte Mann war schwer krank, ist dann auch bald verstorben und wurde hier auf dem Friedhof beerdigt. / Im Haus wohnte auch noch ein Ehepaar aus Posen (Poznan) und ein altes Ehepaar aus Berlin. Nebst meinen Großeltern, meiner Mutter und meiner Schwester waren auch noch zwei Soldaten einquartiert. So wohnten bei uns 13 Personen im Haus. / Wir wohnten nur in der Küche und im Schlafzimmer, abends wurde alles

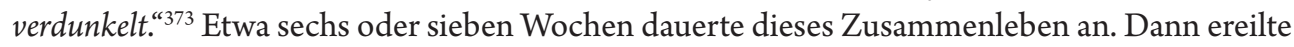
beide Gruppen, „Zugereiste“ wie Einheimische, ein gemeinsames Flüchtlingsschicksal: „In den letzten Tagen im April ging dann alles sehr hektisch. / Mein Großvater hatte unseren Handwagen mit den nötigsten Sachen für eine Flucht aus Fürstenwerder beladen. Gegen Abend des 26. April 1945 gingen wir dann alle zusammen, mit unseren Nachbarn Herrn Schmidt, dessen Frau und Tochter aus unserem Ort in Richtung Wrechen. Nur der alte Herr Braun aus Posen kam nicht mit. Er konnte mehrere Fremdsprachen und wollte sich als Pole ausgeben. Er hatte auch schon heimlich eine polnische Fahne vorbereitet. / Mit unserem Handwagen kamen wir aber nur bis zur Sandgrube an der Straße nach Wrechen. Hier war plötzlich die Straße mit flüchtenden deutschen Soldaten und Fahrzeugen verstopft, die alle zu den Amerikanern wollten. Wir blieben in der Sandgrube hinter einem Gebüsch bis zum nächsten Morgen. Da hörten wir dann von vorbeikommenden Soldaten und Flüchtlingen, dass die Russen schon in Kraatz wären. Wir sind dann ebenfalls mit dem Handwagen in Richtung Wrechen weiter- [S. 86] gezogen, aber hier mussten wir von der Straße in den Wald flüchten, weil Tiefflieger mit Maschinengewehren die Straße überflogen und schossen / Bis zum Dorf Lichtenberg mussten wir noch $2 \times$ von der Straße in den Wald wegen der Tiefflieger. [...] / Die Familie aus Ostpreußen und unser Nachbar mit Familie sind an der Straßengabelung dann auf einen Militär-Lkw aufgestiegen und in Richtung Bredenfelde mitgefahren. [...] Es war ein Chaos auf der Straße! Uns kamen Flüchtlinge entgegen und wir wollten dorthin, wo sie her kamen. Und so mussten wir dann eine Nacht in Lichtenberg verbringen, aber diesmal mit anderen Flüchtlingen in einem Bauernhaus im Keller." ${ }^{\text {"374 }}$

Insgesamt wohl zahlreicher sind Schilderungen dieser Geschehnisse in den Selbstzeugnissen der Flüchtlinge und Vertriebenen. Der Ostpreuße Alexander Fürst zu Dohna-Schlobitten (1899-1997), selbst Treckführer, hat die an den einzelnen Orten im Februar 1945 vorge-

372 Das Ende des Zweiten Weltkrieges im Mai 1945. Erinnerungen an die Prignitzdörfer Boberow und Glövzin. Hrsg.: Manfred Müller. Schwerin 2006, S. 113.

373 Fritz Reglin: Letzte Tage in Fürstenwerder, Flucht und Rettung unseres Hauses. In: Fürstenwerder Mosaik. T. 2. Fürstenwerder 2002, S. 84-89, hier S. 84.

374 Ebd., S. 85 f. 
fundene Situation in seinen Erinnerungen zusammengefasst: „Das Verhalten der Bevölkerung war sehr unterschiedlich. Die ,Standesgenossen' auf den Gütern halfen uns ausnahmslos, wo sie irgend konnten, anfänglich oft unter größten Entbehrungen, weil sie selbst kurz vor dem Aufbruch standen. In den Bauerndörfern empfing man uns unterschiedlich, persönlich verhandelte ich meist mit dem Bürgermeister oder Ortsgruppenleiter der Partei beziehungsweise ihren Stellvertretern. Sie hatten bis zur Elbe im allgemeinen keine generelle Flucht der Bevölkerung vorbereitet und überließen das jedem einzelnen, das heißt es geschah in der Regel nichts. Fast immer mußte man die Trecks in zwei bis drei verschiedenen Orten unterbringen, [...]. ${ }^{375}$ Der Weg des von Fürst Dohna geleiteten Trecks führte von Ostpreußen nach Pommern und kam schließlich über Mecklenburg nach Niedersachsen, durchquerte aber zuvor auch die uckermärkischen Landkreise Angermünde und Templin. ${ }^{376}$ Viele in Aussicht genommene Interimsquartiere fand er im Februar bereits überfüllt vor: „Wir machten bei Herrn von der Osten halt. Es war alles überfüllt mit Flüchtlingen [...]. Herr von der Osten empfahl uns, bei seinem Bruder in Blumberg die nächste Rast einzulegen. Es war ein kleineres Gut, so daß ein Teil in Radwitz untergebracht werden mußte. Aufgrund des Tauwetters war alles unglaublich schmutzig, aber wir hatten endlich wieder einmal Platz. [...] [S. 284] Einer von drei Flüchtlingspfarrern, die hier in der Gegend waren, hielt auf mein Bitte für uns einen Gottesdienst. Es war angebracht, über die Vergänglichkeit des Lebens nachzudenken. [...].“377 Auch am nächsten Zwischenhalt gab es schon andere „Untermieter“, da viele Dienststellen und Firmenverwaltungen aus Berlin an Auslagerungsorte in der Provinz Brandenburg ausgewichen waren. So kam der Treck nur mit Mühe und wegen der guten Beziehungen zum „Standesgenossen“ in Wilmersdorf (Kr. Angermünde) unter, da „Herr von Buch alles tadellos organisiert hatte, obwohl es an Platz mangelte, weil bei ihm die Japanische Botschaft aus Berlin einquartiert war. Der größte Teil der Leute bezog in der eigens für uns geheizten Kirche Quartier, die anderen kamen in dem geräumten Schafstall und im Gutshof unter. [...]."378 Am nächsten Halt, beim Vetter Joachim Graf Arnim auf dem geräumigen Gut Boitzenburg, gab es ebenfalls ausreichend Bleiben, aber auch hier war man keineswegs allein: „Es versteht sich von selbst, daß ich mit unserem Treck sehr herzlich begrüßt und aufgenommen wurde, obwohl schon alles mit Wehrmacht und Flüchtlingen überbelegt war. Um unsere Leute unterzubringen, hatte der große Wehrmachtsstab einen Teil des Schlosses geräumt; weiterer Platz war [S. 285] durch Übereinanderstellen der Möbel in wenige Zimmer geschaffen worden. Die Räume durften unsere Leute mit frischen Strohschütten belegen, nachdem der große Dreck halbwegs beseitigt worden war, den Bessarabier hier hinterlassen hatten. Nach einigem Ärger mit dem Schlobitter Treck ${ }^{379}$, der großzügig die besten Plätze für sich belegt hatte und nun zusammenrücken

375 Alexander Fürst zu Dohna-Schlobitten: Erinnerungen eines alten Ostpreußen. Berlin 1989, S. 260-291 (Kapitel „Der Treck“), hier S. 279.

376 Siehe die Karte „Der Weg des Trecks vom 22. Januar bis 20. März 1945“ in Dohna-Schlobitten, Erinnerungen (wie Anm. 375), S. 268 f.

377 Dohna-Schlobitten, Erinnerungen (wie Anm. 375), S. 283 f. - Blumberg bei Casekow (Kr. Randow), Radwitz meint Radewitz bei Penkun.

378 Ebd., S. 284.

379 [Es waren zwei Trecks gemeinsam unterwegs: aus Schlobitten und aus dem Nachbarort Prökelwitz.] 
mußte, ging alles glatt. Die Verpflegung erfolgte durch die NSV. Owi Arnim, die äußerst hilfsbereite Hausfrau, kochte für die Kleinkinder und Säuglinge - leider starb wieder eines. Tante Lenor besorgte einen Sarg und bemühte sich um ein richtiges Begräbnis durch einen Pfarrer.

Jetzt, unter, geregelteren Verhältnissen', konnten wir nicht mehr nur auf eigene Faust unsere Fahrwege und Unterkunftsplätze aussuchen, es gab ,Treckleitstellen'. Ich bestand darauf, in die Gegend von Verden an der Aller zu kommen. [...] Leider durften wir auf Anweisung des Ortsgruppenleiters nicht länger in Boitzenburg bleiben; weil andere Trecks nachrückten, wurde beschleunigte Weiterfahrt nach Dannenberg angeordnet, wo wir die Elbe überschreiten sollten. Der Aufbruch erfolgte am 21. Februar, wie üblich um 2.00 Uhr früh, [...]."380

Auch aus der umgekehrten Perspektive, der des Schlossherrn Graf Arnim, ist ein Bericht über das Geschehen dieser Wochen überliefert, der deutlich macht, was mit „andere(n) Trecks“ gemeint ist: „Es mögen wohl um die 30000 Flüchtlinge gewesen sein, die, bis zu unserem Fortgehen $^{381}$, durch Boitzenburg gezogen sind. Es konnte nur bewältigt werden dadurch, dass jeder Treck nur einmal übernachten durfte und am folgenden Morgen um 9 Uhr wieder weiter geleitet wurde. / Alle verfügbaren Räume und Stallungen im Ort, Hof und Schloss wurden belegt. Die Verpflegung konnte noch bestens durchgeführt werden, da große Hackfruchtmengen vorhanden waren und Wild zu diesem Zweck unbegrenzt geschossen werden durfte. Zwei Feldküchen zusätzlich zum großen Waschhauskessel wurden aufgestellt, und unter täglicher Hilfe der Frauen aus dem Dorf wurde alles bewältigt. Die Wagen, vorwiegend offene Leiterwagen, waren zum größten Teil durch die lange Treckzeit im kalten Winter in schlechtem Zustand. Das Bild wurde noch dadurch abgerundet, dass sich fast kein einziger Mann bei den Trecks befand, weil alle, völlig nutzlos als Volkssturmmänner zurückbehalten worden waren." ${ }^{382}$

Weiter südlich, in den Kreisen Lebus und Oberbarnim, irrten im Februar 1945 neumärkische Flüchtlingstrecks quartiersuchend umher. Die Gutsbesitzersfrau Anne von Klitzing (1883-1965) hat ihre Erlebnisse auf dem Treck von Charlottenhof (Kr. Landsberg/Warthe) nach Westen (30. Januar bis März 1945) beschrieben: „Auf der großen Provinzial-Chaussee trafen wir auf die nicht abreißenden Treckkolonnen, in die wir uns einreihen mußten, um nun Schritt für Schritt, zwei Reihen nebeneinander, gen Westen zu ziehen." 383 Anfang Februar: „Unterkommen war auf jeden Fall für uns nur auf großen Gütern zu finden, und selbst dann noch war die Sorge quälend, daß es dort nicht möglich sein würde. Wie dankbar waren wir daher, als wir gegen $1 / 24$ auf den Hof in Neu-Hardenberg einbogen, uns freundlichst bedeutet wurde, daß die Möglichkeit eines Unterkommens durchaus bestände [...] Es waren immer noch gegen 200 Menschen die untergebracht werden mußten

380 Dohna-Schlobitten, Erinnerungen (wie Anm. 375), S. $284 \mathrm{f}$.

381 [D.h. von Anfang Februar bis kurz vor Ende April 1945.]

382 Auszug aus dem unveröffentlichten Lebensbericht des letzten Besitzers von Schloss Boitzenburg Joachim Graf von Arnim-Boitzenburg (1898-1972), abgedruckt in: Hans-Joachim Stahl: Schloss Boitzenburg in den Jahren 1944/45 bis 1956. In: Beatrix Bluhm / Detlev von Heydebrand / Hans-Joachim Stahl: Schloss Boitzenburg in der Uckermark. Angermünde 2011, S. 86-138, hier S. 95.

383 Anne v. Klitzing: Die Flucht. In: Menschen und Schicksale. v. Klitzing'sche Häuser im 19. und 20. Jahrhundert (Die Familie von Klitzing, T. V). O. O. 1990, S. 196-204, hier S. 198. 
[...] Wir wären gerne einen Tag in Hardenberg geblieben, aber wir mußten militärischer Einquartierung weichen. Nach einem vergeblichen Versuch in Alt-Friedland [...] unterzukommen, ging es bei Dunkelwerden weiter nach Haselberg (ca. $40 \mathrm{~km}$ nordwestlich von Gorgast), wo wir uns dank eines militärischen Ferngesprächs ansagen konnten. Jedes Privattelefon war ja unterbunden. [...] Am 1. Februar hatte Tauwetter mit Regen eingesetzt, und innerhalb 48 Stunden war damit der hohe Schnee geschwunden. [14 Tage Aufenthalt in Haselberg] So weit wie möglich wurde der Treck verkleinert. Eine große Anzahl fuhr zu Verwandten nach Berlin und anderswohin, eine ebenso große Zahl übergaben wir in Freienwalde der NSV 384 [...] und hörten später, daß diese sie freundlichst untergebracht hat und für sie gut sorgte. [...].“385

Die Hintergründe dieser offenkundig für die Landsberger Kreisbevölkerung noch Ende Januar 1945 verfügten Einweisung in westliche, odernahe Landkreise erschließen sich in einem Rundschreiben vom 6. Februar 1945, in dem sich der bereits evakuierte Landrat des Kreises Landsberg/Warthe - „zur Zeit (2) Fürstenwalde/Spree“ -, laut Briefkopf „zugleich für den Oberbürgermeister der Stadt Landsberg/Warthe“, an die Landräte, Oberbürgermeister, Kreisleiter und Kreisamtsleiter der NSV mehrerer westlich der Oder gelegener brandenburgischen Kreise und kreisfreien Städte wendet. Er bittet, durch die Bürgermeister den Flüchtlingen aus Stadt und Kreis Landsberg bekanntzugeben, dass sie der eingerichteten Kreismeldestelle in Berlin ihren Aufenthaltsort mitzuteilen hätten: „Da die Bevölkerung von Landsberg Stadt und Land durch die Ereignisse des 30. Januar völlig zersprengt wurde, ist es erforderlich, daß alle Einwohner ihre Namen, Unterbringungsort und Anfragen über Familienangehörige an eine Zentralstelle richten. Es ist dies: [S. 39] Ministerialdirektor Lauenstein, (1) Berlin-Zehlendorf, Albertinenstraße 7. Hier befindet sich Kreisbaudirektor Sommer; die Beamten und Angestellten des Landrats und der Stadtverwaltung melden sich hier und nicht mehr bei der Regierung Frankfurt/Oder. "386 Der neuerliche Quartierwechsel einer Landkreisbehörde innerhalb weniger Tage, nun von Frankfurt (Oder) nach Berlin, sprach Bände: zwei Tage zuvor hatte in Frankfurt die systematische Evakuierung der Zivilbevölkerung begonnen, zwei Tage nach dem Schreiben wurde auch die Regierung Frankfurt, bei der man untergekommen war, verlegt. ${ }^{387}$ Die kritische Situation wird aber auch daran deutlich, dass zwar „Abdrucke für die kreisangehörigen Städte der Aufnahmekreise“ beigefügt seien, jedoch gebeten wird, „beschleunigt die Landgemeinden durch Rundschreiben von dort aus zu unterrichten“. Bei den angeschriebenen Stellen handelt es sich um die Verwaltungsleitungen derjenigen Städte und Kreise, die man von zentraler Stelle für die Evakuierung der Landsberger ausersehen hatte: „Die Gauamtsleitung der NSV hat als Aufnahmekreise für Stadt- und Landkreis Landsberg/Warthe die

384 [„Nationalsozialistische Volkswohlfahrt“.]

385 Ebd., S. 200.

386 Archiv der Stadt Ketzin; hier zitiert nach dem Abdruck in: Helmut Bergemann / Alfred Damaschke: Ketzin 1945. Die letzten Tage des Krieges - die ersten Tage des Friedens (Schriften des Heimatmuseums Ketzin, 4). Berlin 1996, S. 38 f. - Bei Ministerialdirektor (Dr. Johann Dietrich) Lauenstein handelt es sich um den Leiter der Reichsstelle für Landbeschaffung, der zugleich Leiter der Reichsumsiedlungsgesellschaft war. 
Kreise Oberbarnim, Niederbarnim. Osthavelland, Teltow bestimmt. Nach Möglichkeit sollen sich die Städte Eberswalde und Potsdam an der Aufnahme beteiligen." ${ }^{388}$ Dass die evakuierten Landkreisverwaltungen im Grunde bereits mit einer Steuerung der Abläufe überfordert waren, zeigt der letzte Satz des Schreibens, in dem der Landsberger Verantwortliche gewissermaßen Amtshilfe für seine kürzlich noch (südöstlichen) Nachbarkreise Schwerin/Warthe und Meseritz zu leisten versucht. „Der Landrat der Kreise Schwerin/Warthe und Meseritz bittet hierdurch, seine Kreisinsassen zu benachrichtigen, daß sie sich in das Aufnahmegebiet West- und Ostprignitz (Landratsämter in Perleberg und Kyritz) zu begeben haben. "389

Ein zweites Treckbeispiel aus dem Kreis Landsberg/Warthe mag zeigen, wieweit all diese hektischen Versuche, das Chaos noch zu steuern, überhaupt realisierbar waren. Der Führer eines Trecks aus Merzdorf nahe Landsberg/Warthe hat zeitgenössisch, wenige Wochen nach der Flucht, in einem ausführlichen Brief an einen als Soldat eingesetzten Verwandten über die Ereignisse Ende von Januar 1945 berichtet $^{390}$ und dabei viele Beobachtungen notiert, die das verzweifelte Hin und Her unterschiedlichster, sich gegenseitig behindernder Gruppen andeuten: „Nach Deiner Abfahrt zur Front wurden wir immer mehr von Flüchtlingen aus dem Wartheland überschwemmt. Täglich übernachteten in Merzdorf hunderte von Pferden und Menschen, ein unsagbares Elend offenbarte sich uns, das wir nach besten Kräften zu lindern versuchten. Das Packen machte gute Fortschritte; auch draußen wurde ein Wagen nach dem anderen fertig. Man hoffte jedoch von Tag zu Tag auf Besserung. Täglich fiel neuer Schnee und der unendliche Treck der Flüchtlinge wurde ständig größer und elender. Am Sonntag den 28.1. kamen die ersten aus Deutsch-Krone, gleichzeitig erhielt Friedeberg den Befehl zum Packen. Bei uns dagegen wurde die Parole ausgegeben: ,Die Kurmark bereitet nicht die Flucht vor, sondern die Verteidigung! Am Montag 29.1. beschlagnahmte die Wehrmacht in Landsberg die Fahrräder. Einige Tage vorher waren meine Schwiegereltern von Breslau überraschend gekommen, so daß ich auch mit ihrer Versorgung in Landsberg zu tun hatte. [...] [S. 222]

Dann fingen alle an, die Nerven zu verlieren, denn den ganzen Tag ging das Gespräch nur über das Thema: fliehen oder bleiben. Ilse war stets und ohne Schwanken entschlossen, dort zu bleiben: ich tion der Evakuierungen ist hier und da belegt, so z. B. für März 1945 in einem außerbrandenburgischen Fall. Zuständig für den weiteren Weg des bereits nach Eger (Sudetenland) gelangten Trecks aus Obernigk (Niederschlesien) war die „NSDAP-Gauleitung, Amt für Volkswohlfahrt Bayreuth-Wendelhöfen“, die einen Marschplan durch die „Treckstelle des Gaues Bayreuth bei der Kreisamtsleitung Eger“ ausstellen ließ, in dem Landshut (Bayern) als Bestimmungskreis angegeben war (Hellmut Seidel / Ekkehard Loch: Obernigk bei Breslau. Weiden 1996, S. 214).

389 Ebd., S. 39. Dass die Schweriner „im Kreis Kyritz in der Mark Brandenburg untergebracht werden“ sollten, bestätigen auch die Untersuchungen von Jacek Jeremicz: Der Verlust der Heimat der Deutschen am Beispiel des ehemaligen Kreises Schwerin/Warthe. In: Schwierige Nachbarn (wie Anm. 128), S. 107-134, hier S. S. 117.

390 Werner Schleusener: Der große Treck. In: Landsberg an der Warthe 1257 - 1945 - 1976. Stadt und Land im Umbruch der Zeiten. Hrsg. von Hans Beske u. Ernst Handke (Schriftenreihe der Bundesarbeitsgemeinschaft Landsberg (Warthe) Stadt und Land, Bd. 1). Bielefeld 1976 (3., unveränd. Aufl. 1995), S. 221-227, hier S. $221 \mathrm{f}$. 
zu fliehen; alle anderen hatten alle Stunde eine andere Meinung. [...]." Am 30. Januar 1945 setzte sich der Treck unter chaotischen Bedingungen in Bewegung. Da sowjetische Panzer bereits von Berlinchen aus auf Soldin vorstießen, verwarf man den Plan, die Brücke bei Schwedt zu wählen, und orientierte sich auf die Küstriner Oderbrücken. Der Treck setzte sich außer fünf deutschen Männern und mehreren ausländischen Kriegsgefangenen, die auf dem Gut gearbeitet hatten, vor allem aus rund 60 Frauen und Kindern zusammen. ${ }^{391}$ „Der hohe Schnee ließ weder Rad noch Motorrad durchkommen. Wie würde die Küstriner Chaussee nach Beginn der Räumung Landsbergs aussehen? [...] Um 10.30 Uhr fuhren acht Wagen [...] in Richtung Wepritz ab; die Berliner Chaussee war zwar voll von Fahrzeugen aller Art aus Richtung Landsberg, wir konnten uns aber in die Marschrichtung eingliedern. Nach einer halben Stunde hatten wir die erste Reifenpanne, die längeren Aufenthalt verursachte, [...]. Gegen 16 Uhr waren wir in Vietz, wo wir mindestens zwei Stunden futtern wollten, um dann im Nachtmarsch Küstrin zu erreichen. In Vietz waren schon viele Häuser leer, [...]; überall dasselbe Bild. [...] [S. 225] [...] Das Wetter war etwas milder geworden, der Schnee taute oben leicht und machte die Straßen noch viel glatter. Die Autos hatten größere Schwierigkeiten, als die ja scharf beschlagenen Pferde. Alles rutsche kreuz und quer durcheinander. An unsere Wagen hängten sich viele fremde Leute mit Handschlitten und Handwagen an; Fußgänger, auch Soldaten, setzten sich auf die Wagen, insgesamt sicher weit über 100 Menschen. In Küstrin verloren wir dann diese Mitläufer. [...] Auf den Küstriner Brücken ging es ziemlich ruhig zu, weil der Tamseler Berg alle aufgehalten hatte. Die Brücken waren zur Sprengung vorbereitet. Gegen fünf Uhr morgens hatten wir die letzte hinter uns und fuhren durch Küstrin-Kietz nach Manschnow. Die Straßenränder waren ohne Lücke von rastenden Trecks besetzt, denn jeder wollte hinter den Brücken erst einmal ausruhen. An Quartier war natürlich überhaupt nicht zu denken; damit wurde es immer schlimmer statt besser. In Gorgast ${ }^{392}$ machten wir Rast am Straßenrande, um wenigstens zu futtern und den Pferden Wasser $z u$ geben. In einer Gastwirtschaft hatte die NSV (Nationalsozialistische Volkswohlfahrt) eine Kaffeeküche eingerichtet, so bekamen die Leute, besonders die Kinder, wenigstens etwas Warmes. Dann machte ich mich mit Wagner und Brockmann auf die Suche nach einer Kochgelegenheit. Wagner fand einen Bauern, der uns seine Waschküche mit Kessel freigab. Schwieriger war es, Feuerung zu bekommen. Schließlich entdeckte ich eine Franzosenküche; der gefangene französische Koch gab mir eine Milchkanne Kaffee und vor allem einen großen Korb Kohlen. Zwei Stunden später gab es Graupen mit Speck, die erste richtige Mahlzeit nach 24 Stunden. Als besonders hilfreich erwiesen sich immer wieder die Kutscher, gefangene Russen. [...]

Gegen Mittag marschierten wir weiter. Ich hielt am alten Plan fest, nach Mecklenburg zu fahren; allerdings jetzt auf der anderen Oderseite. Die Straße war ständig verstopft und es ging nur langsam

391 Ebd., S. 224. Die weiteren Zitate ebd., S. 224-227.

392 [Fort Gorgast diente auch vielen anderen als Zwischenhalt. Überliefert ist z.B., dass eine zu Fuß aus Landsberg/W. kommende Flüchtlingsgruppe in den Kasematten, wohl denen der sog. Mittelkaserne, vorübergehend Unterschlupf fand und ihre Sachen trocknete, bevor sie mit ihren Handwagen nach Berlin weiterzog (Joachim Gasiecki: Kinderjahre in Landsberg/Warthe. In: Heimatblatt der ehemaligen Kirchengemeinden Landsberg/Warthe Stadt und Land, H. 50 (2015), S. 33-41; H. 52 (2016), S. 20-27, hier H. 52, S. 27).] 
vorwärts: Wehrmachtskraftwagen - sie fuhren ohne Ausnahme westwärts - beanspruchten die Hälfte der Straße. Gegen 16.30 Uhr gab es einen längeren Halt. Eine Kolonne von zwölf Berliner doppelstöckigen Autobussen kam im Gegenverkehr und wollte sich in Richtung Küstrin durchquälen [... ], [S. 226] [...] Verwundete abzuholen, dann zurück nach Berlin. [...] Die Autobusse kamen nicht mehr zu den Verwundeten, litten schon in Küstrin an Benzinmangel, blieben schließlich stehen, [...]. [S. 227] [...] Die nächste Nacht verbrachten wir in Friedrichsaue bei Zechlin [Zechin!] auf dem Gutshof. Am frühen Morgen bogen wir nach Seelow wieder zur Hauptstraße ab, die aber von Verkehrsgendarmen und Militärposten für die Wehrmacht gesperrt war; alle Flüchtlinge mußten nach Norden abbiegen, wir wollten aber nach Süden. So ging ich also mit Wagner und Marquardt auf Spähtrupp, um außerhalb der Verkehrsposten auf die Straße nach Müncheberg zu kommen. Wir bogen über einen Fußballplatz $a b,[\ldots]$. Am Freitag den 2. Februar marschierten wir von Müncheberg aus nördlich, um über Eberswalde Berlin zu umgehen. Die Straßen waren nicht ganz so überfüllt, wie an früheren Tagen, aber trotz des Tauwetters waren die Berge westlich Buckow in den Wäldern noch sehr glatt.

Am Sonnabend den 3. Februar hatten wir einen reibungslosen Marsch bis hinter Eberswalde. Ich fuhr mittags mit dem Rad voraus zum Krankenhaus, um wegen Lonni [schwerkranke Verwandte] anzufragen. Zu meiner Überraschung wurde mir sofort erklärt, daß ihre Aufnahme möglich sei. [...] Die nächste Nacht verbrachten wir in Golzow [Kr. Angermünde]. Es gab gute Quartiere, leckere Milchsuppe und Hafer für die Pferde. Wegen der glücklichen Umstände legten wir hier guten Gewissens einen Ruhetag ein, damit sich Menschen und Tiere etwas erholen konnten.

In der Nacht zum Sonntag, dem 4. Februar, hatten wir in Golzow zum ersten Mal seit Merzdorf ein Bett, ein richtiges Frühstück morgens am gedeckten Tisch." Über Neuruppin, Rathenow und Genthin fuhr der Treck dann weiter bis zu seinem Zielort Klein Wanzleben, wo der Treckführer in den Gutsbesitzern offenbar Verwandte oder Bekannte hatte. Er selbst fuhr über Berlin voraus, um den Treck anzukündigen. Da von Eberswalde aus kein Zug mehr nach Berlin ging, fuhr er per Rad nach Bernau, von dort mit der S-Bahn bis Potsdam, dann mit dem Zug über Brandenburg/Havel nach Magdeburg-Neustadt und von dort per Rad am 7. Februar nach Klein Wanzleben.

Eine Pastorenfrau aus Filehne (Posen), deren Treck im Januar/Februar 1945 in den Kreis Westprignitz dirigiert wurde, hat über die Umstände der „geplanten“ Verteilung berichtet. Nachdem sie zunächst noch vorübergehend in Radensleben im Kreis Ruppin untergekommen war, zeigten sich die Versuche der Verwaltung, des zugewiesenen Stromes durch dezentrale Unterbringung Herr zu werden: „Die nächsten Tage wurden wir alle ziemlich kreuz und quer geleitet. Das hatte wohl darin seinen Grund, daß man die Flüchtlingskolonnen möglichst gleichmäßig über das Land verteilen wollte, damit nicht nur Ortschaften an den Hauptstraßen die Last zu tragen hatten. Uns machte das nicht viel aus, da wir ja doch nicht länger als ein bis zwei Nächte an einem Ort bleiben durften, ehe wir in den Kreis kamen, der uns aufnehmen sollte. “393 


\section{Frauen und Kinder}

Viele Fluchtberichte stammen entweder von damals erwachsenen Frauen oder von Menschen, die damals noch Kinder waren. Frauen aller Altersgruppen und Kinder sind die hauptsächlichen Zeitzeugen, aber sie bilden auch, von inzwischen längst verstorbenen Großvätern abgesehen, die Mehrheit der Betroffenen, da Männer jüngeren und mittleren Alters sich überwiegend als Soldaten anderswo aufhielten. Die Geschichte der Frauen und auch die der Kinder auf der Flucht bzw. bei und nach der Vertreibung bilden eigene Themenkomplexe, die in gesonderten Darstellungen in den Mittelpunkt zu rücken wären. ${ }^{394}$ Hier müssen einige Streiflichter ausreichen: „Bei uns war ja auch kein Mann.“395 Diese einfache Aussage einer aus Bomst Stammenden, 1924 geborenen Vertriebenen, die 1945 nach Neuruppin gelangte, verweist auf die verantwortungsvolle, aber häufig schutzlose Situation, in die sich viele Frauen über Nacht gestellt sahen. Dieselbe Zeitzeugin schildert sodann, wie viele Frauen - „wir Frauen“ - mit ihrer Lage umgingen: „Der Zusammenhalt zwischen den Frauen auf der Flucht war ganz selbstverständlich. Wir haben uns gegenseitig geholfen."396 Doch ebenso häufig liest man von Gewalt gegen Frauen, derer sie sich auch vereint nicht erwehren konnten, von Verschleppung und Vergewaltigung. Nicht wenige Frauen sind noch von ihren Heimatorten aus, im Einzelfall oft willkürlich und ohne NS-Belastung, in sowjetische Arbeitslager verschleppt worden. Sie kamen, wenn sie die Strapazen überlebten, zum Teil erst Jahre später nach Deutschland zurück, auch sie dann de facto als Vertriebene. ${ }^{397}$

394 Vgl. die Bemerkungen und Quellenzitate im Kapitel IV. 1 „Menschen unter Menschen“, aber auch das Stichwort „Frauen“ im Sachregister! - Siehe ferner: Scholze-Irrlitz, Auf den Schultern der Frauen (wie Anm. 117). Scholze-Irrlitz, Die Bürde der Frauen (wie Anm. 119). - Marianne Weber: Frauen auf der Flucht. Aus dem Nachlaß von Max u. Marianne Weber hrsg. vom Marianne Weber Institut e. V. in Oerlinghausen. Bielefeld 2005. [Berichte über die Jahre 1944-1946]. - Notgedrungen nur an einzelnen Stellen kurz erwähnt wird die Gruppe der vertriebenen Frauen in der Überblicksdarstellung eines ohnehin großen Themas: Anna Kaminsky: Frauen in der DDR. Berlin 2016, S. 29 (bis Ende 1946 4,4 Mio. Vertriebene in der späteren DDR, davon 2,6 Mio. Frauen), 31 (Frauen allgemein: Tätigkeit in sozialen Bereichen wie schon zuvor im Krieg, u. a. Alten-, Flüchtlings- und Kinderbetreuung, Nähstuben, Enttrümmerung). - Siehe auch allgemein die zwar überwiegend auf westdeutsche (bayerische) Beispiele (Interviews) gestützte, aber auch solche aus der SBZ und sogar Brandenburg (Fluchtstationen) einbeziehende umfassende Studie von Margarete Dörr: Vertrieben, ausgebombt, auf sich gestellt. Frauen meistern Kriegs- und Nachkriegsjahre. Frankfurt/Main 1998, bes. S. 55-75: Kapitel „Zusammenleben mit Flüchtlingen“ (berücksichtigt beide Perspektiven, die der Einheimischen und die der Flüchtlinge). - Zu Kindern siehe Bode, Die vergessene Generation (wie Anm. 274).

395 Ruth Preuß: [Lebensgeschichte. Bearbeitung eines mündlichen Berichts von 2002 nach Tonbandaufzeichnung durch H. Voss]. In: Lebensgeschichten Neuruppiner Frauen (wie Anm. 285), S. 84-120, hier S. 109.

396 Ebd., S. 107.

397 Allgemein: Ute Schmidt: Flucht - Vertreibung - Deportation - Internierung. Erfahrungsberichte von Frauen in der Bundesrepublik und in der früheren DDR. Berlin 2007 (Arbeitspapiere des Forschungsverbundes SED-Staat, 37). - Spezieller: Freya Klier: Verschleppt ans Ende der Welt. Schicksale deutscher Frauen in sowjetischen Arbeitslagern. Frankfurt a. M. 1996. - Stefan Karner: Die vergessenen Zwangsarbeiter. In: Flucht und Vertreibung. Hamburg 2012, S. 210-219, 255-256. - Małgorzata Ruchniewicz: Deutsche und Polen aus den ehemaligen deutschen Ostgebieten: Deportation in die Sowjetunion. In: Lexikon der Vertreibungen (wie 
Besonders schlimm wirkte auf den Trecks ${ }^{398}$, aber auch in den ungeheizten Zügen die Winterkälte zu Jahresbeginn 1945, die vielen alten Menschen und Säuglingen das Leben kostete. Im Sommer wirkte die Hitze ähnlich verheerend. Ein im Juli 1945 mit einem Vertriebenentreck aus der Neumark, dann aus der Uckermark per Bahn nach Berlin gelangter ehemaliger Dorfbürgermeister hat viele tragische Erlebnisse beschrieben, die man in ähnlicher Form von allen - tage- oder gar wochenlangen - Trecks und Transporten kennt und in allen Erlebnisberichten wiederfinden kann. Überall waren Kinder und alte Menschen besonders betroffen: „Es war ein offener Güterwagen und jeder drängte, daß er noch mit hinein kam. Der Zug fuhr nach Berlin. Es waren viele junge Mütter mit Kleinst- und Kleinkindern. Da die Mütter keine Nahrung hatten, starben viele Kinder unterwegs. Es blieb nichts anderes übrig, da große Hitze war, ihren toten Liebling beim Halten des Zuges auf dem Gerstenfeldrand neben den Geleisen abzulegen. “399 Der Frankfurter Buchbindermeister Wilhelm Spenn (1874-1952) berichtet in seinem unmittelbar zeitgenössisch verfassten Tagebuch: „Noch vor Mitte Januar bewegten sich endlose Flüchtlingszüge aus Posen, Zielenzig und sonst aus dem Osten kommend, durch unsere Stadt. Da in dieser Zeit bittere Kälte herrschte, sind viele Erwachsene und Kinder unterwegs erfroren."

Eine in Kienitz an der Oder lebende Landwirtsfrau, deren Mann zu der Zeit noch als Soldat abwesend war, hat die „Stunde der Frauen“ (Christian Graf von Krockow) ${ }^{401}$ für Brandenburg angedeutet: „Mitte Januar 1945 zog ein stärkerer Flüchtlingsstrom vom Osten täglich durch unseren Ort und suchte am Abend Nachtquartier. Schließlich wurden die Schulen geschlossen, Strohlager in den Klassenräumen aufgeschüttet, um den Ermüdeten für die Nacht eine warme Bleibe zu bieten. Die Frauenschaft kochte an 3 Stellen in Waschkesseln einen warmen Eintopf. In einer Gastwirtschaft errichteten wir eine Krankenstube (für die Federbetten gestiftet wurden) mit ca. 6 Betten ... / Eine ostpreußische Flüchtlingsfrau wurde dort von ihrem 6. Kind entbunden, das sie stolz, Adolf' taufte, die aber nach knapp 8 Tagen mit dem Säugling weiterziehen mußte. Wir hatten damals eine vorzügliche Gemeindeschwester, - unser praktischer Arzt war eingezogen, der nächste in Golzow überlastet -, die unermüdlich und pausenlos sehr erfahren im Einsatz stand. Sie ist später nach eigener Flucht in einem Luftschutzkeller in Brandenburg von den Russen erschossen worden. Wir Frauen waren tagsüber voll im Einsatz und konnten nur abends unsere Vorbereitungen zu der eigenen Flucht, die uns trotz an-

Anm. 59), S. 163-165. - Siehe auch: www.vertriebene-frauen.de, ferner den Bericht eines Augenzeugen in Rostin (Neumark): Jörg Lüderitz: Heimat Brandenburg. Stationen meines Lebens. Berlin 2012, S. 15 (Verschleppung), 43 (Entlassung).

398 Aus der Fülle der oft bedrückenden Treckschilderungen: Clara von Arnim: Der grüne Baum des Lebens. Lebensstationen einer märkischen Gutsfrau in unserem Jahrhundert. In Zsarb. mit Peter-Anton von Arnim. 6. Aufl. Bern u. a. 1990, S. 305-311.

399 Fritz Löffler: [Erlebnisbericht, zusammengestellt 1980]. In: Heimatkreis Soldin/Neumark (wie Anm. 303), S. 573-579, hier S. 578.

400 [Wilhelm Spenn:] Stunde Null. Ein Tagebuch aus Frankfurt an der Oder. Hrsg.: Harro Hess. Bad Münstereifel 1995, S. 29.

401 Christian Graf von Krockow: Die Stunde der Frauen. Bericht aus Pommern 1944 bis 1947. Nach einer Erzählung von Libussa Fritz-Krockow. 11. Aufl. Stuttgart/München 2000. 
derslautenden Informationen bewußt wurde, treffen. Offiziell durfte man darüber gar nicht sprechen. Mit einem Treck kamen 2 elternlose Kinder aus dem Warthegau. Freunde hatten sie mitgenommen, da der Großvater des Fahrens unkundig, nicht zügig vorankam. Die Eltern mußten, da der Vater Ortsgruppenleiter und zur Zeit des Aufbruchs der Räumungsbefehl noch nicht ausgesprochen war, noch im Warthegau bleiben. Da sich in unserem Haus neben unserer eigenen Tochter noch 5 Kinder von 2 evakuierten Familien [Ausgebombte aus dem Raum Köln] tummelten, nahm ich sie bei uns auf. 2 Tage vor unserer eigenen Flucht konnte ich sie nach Telefonaten mit Verwandten ihrer glücklichen Mutter übergeben. / Schnee und Kälte hatten vermehrt eingesetzt. [...].“402

\section{Evakuierung des "Warthegaus"}

Die Flüchtlinge aus dem Reichsgau Wartheland, unter ihnen auch Umsiedler aus dem Baltikum, aus Bessarabien, Galizien und Wolhynien, gehören zu den in den Monaten vor Kriegsende Evakuierten und Flüchtenden, denen vielfach Aufnahmekreise in Brandenburg zugewiesen wurden. ${ }^{403}$ Ihre zeitweilige oder dauerhafte Präsenz im Land soll daher zuletzt beispielhaft in diesem Kapitel noch etwas näher beleuchtet werden. Als Anfang Januar 1945 die Rote Armee plötzlich die Frontlinie an der Weichsel durchbrach, setzten im angrenzenden „Reichsgau Wartheland" auf eine Anordnung des Reichsstatthalters vom 20. Januar hin - wie fast überall viel zu spät - fieberhafte Evakuierungsmaßnahmen ein. ${ }^{404}$ Die Organisation der Räumung wurde in die Hände der NSDAP-Kreisleiter und ihrer Organisationen gelegt ${ }^{405}$, „, was gravierende Auswirkun-

402 [Lotte Thieme in]: Hans und Lotte Thieme: Zechin und Friedrichsaue. Die Flucht aus der Heimat Ende Januar 1945. In: Ein leidgeprüftes Land. Bearb. von Fritz Knüppel. 2. Aufl. Barsinghausen 1990, S. 78-81, hier S. 79, Zusatz zur Herkunft der Ausgebombten nach ebd., S. 78.

403 Zu beachten ist, dass schon bei der „ersten“ Umsiedlung der Galizien- und Wolhyniendeutschen 1940 Brandenburg - wie andere deutsche Länder und Provinzen auch (Thüringen, Sachsen, Niedersachsen, Schlesien) mit Auffanglagern („Volksdeutsche Lager der NSDAP“; in der Ortsdokumentation als „Vorgeschichte“ erfasst: Bestensee, Brandmühle bei Vetschau, Cottbus, Finsterwalde, Forst, Glau, Guben, Kirchhain, Klein Köris, Lübben, Spremberg, Spremberg-Cantdorf, Templin; ferner mehrere in der Neumark und östlichen Niederlausitz sowie in Berlin: Köpenick, Lichterfelde-Süd) beteiligt war, dass diese Personengruppen aber noch während des Krieges zumeist im „Warthegau“ angesiedelt wurden, also damals jedenfalls mehrheitlich nicht in Brandenburg verblieben sind. In Gesamt-Brandenburg (in den damaligen Provinzgrenzen) befanden sich Ende Jan. 1940 in solchen Lagern 13222 ,volksdeutsche“ Umsiedler, das ist der nach dem des Sudetenlandes (29 153) höchste Anteil innerhalb des Deutschen Reiches (Schlesien an zweiter Stelle: 9225), die Zahlen verringerten sich aber noch im Laufe des Jahres 1940 rasch und deutlich (siehe dazu: Ortfried Kotzian: Die Umsiedler. Die Deutschen aus West-Wolhynien, Galizien, der Bukowina, Bessarabien, der Dobrudscha und in der Karpatenukraine. München 2005, S. 122-125). Siehe aber auch Ortsdokumentation Finsterwalde.

404 Die Räumung des „Reichsgaus Wartheland“ vom 16. bis 26. Januar 1945 im Spiegel amtlicher Berichte. Bearb. von Joachim Rogall. Sigmaringen 1993.

405 (Paul-Friedrich) Nebelung: Der Landkreis Eichenbrück (Wongrowitz) im Reichsgau Wartheland. in: Heimatbuch für den Kreis Eichenbrück-Wongrowitz. [Bd. 1]. Lüneburg [1967], S. 87-89, hier S. 89. [Nebelung war 1942-1945 Landrat des Kreises.] 
gen nicht zuletzt auf das Schicksal der Zivilbevölkerung zur Folge hatte" ${ }^{\text {“406 }}$. Weit vor Kriegsbeginn, seit der Wiederaufrüstung 1935/36 verschriftlichte theoretisch-bürokratische Planungen für die Räumung einzelner Teile des Reichsgebietes sowie für die Behandlung von „Flüchtlingsbewegungen aus benachbarten Ländern mit deutschstämmiger Grenzbevölkerung“ gab es zwar, doch erwiesen sie sich im sich 1945 ausbreitenden Chaos zum großen Teil als unbrauchbar, von den Ereignissen gleichsam überholt. ${ }^{407}$ So gelang es dem Landrat des Kreises Eichenbrück (Wongrowitz) „gemeinsam mit den örtlichen Behörden [...] die rund 12000 Deutschen des Kreises Eichenbrück geordnet in Marsch zu setzen“408 Allerdings hatte man kurz zuvor alle noch einigermaßen gesunden Männer zum Volkssturm eingezogen, „so daß viele Familien keine männliche Begleitung hatten“. Das führte dazu, dass vielfach die auf den Gütern und Höfen eingesetzten polnischen Zwangsarbeiter mitgenommen wurden, von denen einige sogar freiwillig mitgingen und manche später an den Aufnahmeorten in Deutschland blieben. ${ }^{409}$

Ein auf Februar 1945 datierter Evakuierungsplan für die Kreise des „Warthegaus“ und Teile der Neumark (Crossen, Züllichau-Schwiebus-Bomst) sowie Niederschlesiens (Fraustadt, Freystadt, Grünberg), der sich in den wohl kurz danach nach Neuruppin verlagerten Akten des Landratsamtes Züllichau-Schwiebus fand, sah für jeden zu evakuierenden Kreis einen Landkreis in der Provinz Brandenburg als Aufnahmegebiet vor. Die meisten Aufnahmekreise lagen westlich der Oder, einige aber auch zu diesem späten Zeitpunkt noch ganz oder teilweise rechts der Oder und Neiße (Königsberg/Nm., Landsberg/Warthe, Soldin, Guben, Sorau). ${ }^{410}$ Von den westlich der Oder gelegenen Landkreisen und kreisfreien Städten der Provinz Brandenburg fehlten zunächst nur die Kreise Lebus und Oberbarnim, wohl wegen ihrer zentralen Bedeutung als östliches Vorland von Berlin. Nachträglich sind dann aber doch mit Bleistift bei den für Ostund Westprignitz vorgesehenen Evakuierungskreisen in Klammern „Seelow“ und „Bad Freien-

406 Richard Lakowski: Planung und Realität des Kriegsendes. Fragen zum Thema Flucht und Vertreibung. In: Niederlage - Sieg - Neubeginn. Kriegsende 1945. Werner Künzel, Richard Lakowski (Hg) (Protokolle). Potsdam 2005, S. 58-78, hier S. 60.

407 Lakowski, Planung und Realität des Kriegsendes (wie Anm. 406), S. 60. Die Quellentexte der Jahre 1935/36 (und 1944) sind hier in einem Dokumentenanhang (S. 64-78) zusammengestellt, Quellenzitat S. 71. - Ein nach 1945 in Woltersdorf bei Berlin wohnhafter ehem. Mitarbeiter des Landratsamtes Soldin/Nm. berichtete, er habe dienstlich Evakuierungsplanungen für seinen Kreis aus den Jahren 1942/43 gesehen (Mitteilung Jörg Lüderitz, 10.8.2018).

408 Friedrich Schneider: Reppenstedt. In: Heimatbuch für den Kreis Eichenbrück-Wongrowitz. [Bd. 1]. Lüneburg [1967], S. 76-78, hier S. 76.

409 Dass auf den Gütern befindliche Zwangsarbeiter gemeinsam mit den deutschen Einwohnern flüchteten, wird in zahlreichen Erlebnisberichten deutscher Flüchtlinge erwähnt. Oft fungierten sie in den Trecks als Kutscher. Ein Beispiel für viele: Gertrud Nenast geb. Will: Die Flucht im Jahre 1945/46 aus dem Landkreis Eichenbrück aus der Sicht meiner Mutter. In: Heimatbuch für den Kreis Eichenbrück-Wongrowitz. Bd. 4. Wendisch Evern 1993, S. 116-141, hier S. 122: „Mutters Schwester [...], die einen Polen als Kutscher bei sich hatte“.

410 BLHA, Rep. 6 B Kreisverwaltung Züllichau-Schwiebus, Nr. 169, unfol. (vgl. den Abdruck in der Quellenedition, Nr. 2). - Ein ehem. Bewohner von Rostin (Kr. Soldin) hat z. B. berichtet, dass sein Heimatort Anfang 1945 „voll von Flüchtlingen aus dem Warthegau“ gewesen sei (Mitteilung Siegfried Müller, Berlin, 10.8.2018). 
walde“, also die beiden Kreissitz-Orte von Lebus und Oberbarnim, hinzugesetzt worden, wobei unklar bleibt, ob es sich um Alternativen bzw. Ergänzungen zu den Prignitz-Kreisen handeln sollte oder nur, wie man vermuten möchte, die Durchschleusungspunkte nach dort bezeichnet wurden.

\section{Evakuierung von Institutionen}

Noch kaum erforscht sind die offenkundig zahlreichen Evakuierungen von Behörden ${ }^{411}$, Banken, Sparkassen und Firmen, aber auch ganzen Alten- und Kinderheimen, Klöstern sowie Behinderteneinrichtungen, für die hier meist nur einige beiläufige Erwähnungen in Zeitzeugenberichten und - nicht systematisch berücksichtigte - nach 1945 in der Bundesrepublik erschienenen Darstellungen herangezogen werden konnten. ${ }^{412}$ Aus der Betrachtung des Evakuierungs-, Flucht- und Vertreibungsgeschehens wird schließlich meist ganz ausgeblendet, dass auch die „Todesmärsche“ und Transporte aus Konzentrationslagern oder - sofern man sie nicht an Ort und Stelle ermordete - die „Verlegung“ von Kriegsgefangenen und Zwangsarbeitern mit dem Herannahen der Front in Zusammenhang standen. ${ }^{413}$ Zwar gehört dieser Aspekt nicht zum Thema „Eingliederung“ in Brandenburg, doch wurden damals auch durch die mit Flüchtlingen angefüllten brandenburgischen Städte und Gemeinden KZ-Häftlinge aus den Ostgebieten geführt. Ein Niederlausitzer Lokalforscher hat das am Beispiel der Todesmärsche aus zwei Neben- bzw. Außenlagern des schlesischen KZ-Komplexes Groß Rosen, nämlich aus Schlesiersee I, Grünberg in Schlesien und Guben, näher untersucht und dabei detailliert zeigen können, dass die Häftlinge Ende Januar und Anfang Februar 1945 im Raum Cottbus, Vetschau, Lübben,

411 Beispiele für evakuierte Behörden (mit Ausweichstelle im Febr. 1945 laut BLHA, Rep. 6 B Züllichau-Schwiebus, Nr. 169, unfol.): „Kommandeur der Gendarmerie bei der Regierung Frankfurt (Oder)“ in Potsdam, Allee nach Sanssouci 6; Krankenhaus-Schule(?) Züllichau(?) in Meyenburg (Ostprignitz); Provinzialstraßenbauamt Crossen (Oder) in Luckau, Rathaus, II. Stock." - Siehe auch zum nach Neuruppin evakuierten Landratsamt des Kr. Züllichau-Schwiebus Anm. 451.

412 Mehrere evakuierte und teilweise auch vertriebene Altenheime, Kinderheime und sonstige soziale Einrichtungen meist kirchlicher Träger werden in der Ortsdokumentation aufgeführt (siehe auch Sachregister).

413 Durchzüge von scharf bewachten Kolonnen aus beiden Gruppen durch die Niederlausitz erfolgten seit Januar 1945 (Peter Hübner: „Durchhalten“ und „Durchkommen“. Niederlausitzer Industriearbeiter im Jahre 1945. In: Brandenburg im Jahr 1945 (wie Anm. 163), S. 136-166, hier S. 146). - Mehrheitlich ungeklärt ist das Schicksal (teilweise schwer) erkrankter Zwangsarbeiter („Ostarbeiter“), sehr wahrschinlich des Lagers Güldendorf bei Frankurt (Oder), und ihrer Kinder (187 Personen), die Anfang 1945 auf Befehl des Frankfurter Festungskommandanten in einem Lastkahn von Müllrose aus evakuiert wurden, der am 29.3. an der Langen Brücke in Potsdam festmachte. Der dortige Oberbürgermeister lehnte eine Aufnahme ab und verhängte eine Quarantäne. Am 20.4. heißt es (S. 31), „81 Tuberkulöse mit Arzt und Pflegepersonal“ seien ,in die Brandenburgische Pflegeanstalt Rotes Luch bei Dahmsdorf-Müncheberg aufgenommen“ worden. „Die übrigen rd. 140 [...] mit zugeteiltem Pflegepersonal (transportunfähige Leute, Mütter mit Säuglingen und Kindern)" konnten 1t. Schreiben des Landesmedizinalrats Dr. Baumann vom 20.4.1945 nicht untergebracht werden (Matthias Diefenbach / Michał Maćkowiak: Zwangsarbeit und Autobahn zwischen Frakfurt (Oder) und Poznań 19401945. Frankfurt (Oder)-Poznań 2017, S. 30 f., nach BLHA, Rep. 551 X, Nr. 1655). 
Lübbenau, Luckau vor allem durch zahlreiche Dörfer bis nach Jüterbog geführt wurden. ${ }^{414} \mathrm{Hier}$ verlud man die Häftlinge, vorwiegend Frauen und Mädchen jüdischer Abstammung, in Eisenbahnwaggons und transportierte sie dann in das KZ Bergen-Belsen weiter, womit sie sogleich wieder aus dem Brandenburger Blick gerieten. Ohnehin ist festzuhalten, dass die Todesmärsche „fast ausschließlich Nebenstraßen und unbefestigte Feldwege" benutzten, und auch die Wachmannschaften gingen zu Fuß. Nur ausnahmsweise ist im Lübbener Kreis die vorübergehende Nutzung der Spreewaldbahn überliefert. „Alles sollte möglichst ohne großes Aufsehen erfolgen, da man der verängstigten deutschen Bevölkerung nicht mehr traute. ${ }^{\text {"415 }} \mathrm{Da}$ aber doch Begegnungen mit Zeitzeugen überliefert sind, „unterwegs immer wieder Frauen zurückblieben und erschossen wurden “416 und sogar von wenigen Überlebenden, die sich verstecken konnten, berichtet wird ${ }^{417}$, bleiben noch Fragen offen.

Unklar ist, ob es sich bei der z. T. dramatischen, späten Evakuierung der gesamten Belegschaft des Reichsbahnausbesserungswerks (RAW) Osterode (Ostpreußen) in das RAW Wittenberge am 21. Januar 1945 „nur“ um eine Rettung der Menschen handelte, oder ob auch hier Verwaltungsakten mitgenommen wurden, wie das bei rechtzeitigen Auslagerungen von Behörden und Firmen geschah. ${ }^{418}$

414 Michael Bock: Die Todesmärsche jüdischer Frauen und Mädchen 1945 durch das Golßener Land. In: Luckauer Heimatkalender 50 (2018), S. 31-36. - Dazu passt auch die Beobachtung eines einheimischen Zeitzeugen aus Forst (Lausitz): „Im Januar [1945] kamen immer mehr Flüchtlinge aus Schlesien und dem sogenannten Warthegau durch Forst und wir hatten fast alle Tage Einquartierung. Einmal habe ich auch gesehen, wie ein großer Zug von KZ-Häftlingen durch Forst kam, Sie zogen aber nicht durch das Stadtzentrum, sondern am Stadtrand entlang. Vielen konnte man ansehen, dass sie erschöpft waren und ihnen das Laufen schwer fiel. Fast alle hatten nur Holzschuhe an. [...].“ (Wilhelm Hamann: Wie ich das Ende des II. Weltkrieges erlebte. In: Erlebte Geschichte. Aufgeschrieben aus persönlicher Sicht von Mitgliedern des Zirkels „Zeitzeugen“ beim Seniorenbeirat der Stadt Potsdam. [8. Anthologie]. Hrsg.: Seniorenbeirat in der Stadt Potsdam. Stadtverwaltung, Fachbereich 3 für Soziales, Jugend, Gesundheit, Ordnung u. Umweltschutz. Potsdam 2006, S. 13-22, hier S. 15).

415 Bock, Todesmärsche (wie Anm. 414), S. 32.

416 Ebd., S. 35.

417 Ebd., S. 32 f.

418 Mario Sembritzki: Flucht per Bahn aus Ostpreußen. Wie die Belegschaft des Reichsbahn-Ausbesserungswerkes Osterode mit vier Zügen nach Wittenberge kam. In: Brandenburger Rundschau 14 (2016) 8, S. 8-9 (Erstdruck in: Schweriner Volkszeitung, 10.2.2015). - Die Reichsbahndirektion Danzig sorgte zwischen 11.1. und 15.2.1945 für den Transport von „fast 3/4 Million Menschen“ nach Westen, obgleich „bei den nach Westen gelangten Eisenbahnern wenig Neigung (bestand), wieder in den Bezirk zurückzufahren“. Immer wieder kam es zu „Streckenverstopfungen“ auf der im Februar 1945 „einzige(n) zur Oder verbliebene(n) Strecke Stargard - Stettin. Siehe: Hans-Wolfgang Scharf: Eisenbahnen in Westpreußen. Rückzug, Räumung und Auflösung der Reichsbahndirektion Danzig. In: Westpreußen-Jahrbuch 37 (1987 [1986]), S. 83-95, hier S. 91. Die Eisenbahner der Reichsbahnausbesserungswerke Schneidemühl und Danzig trafen (mit ihren Familien sowie mit wichtigen Werkzeugen, Maschinen und Werkstoffen!) am 26. und 27.1.1945 in drei „Räumungszügen“ in Kirchmöser ein (Stefan Menzel/Walter Menzel/Jörg Schulze: Die Eisenbahn in Brandenburg an der Havel. Stendal 2017, S. 127). - Ein "Zug mit Eisenbahnern aus Christianstadt und Naumburg" lief am 13.2.1945 in Doberlug-Kirchhain ein, nahm dort durch Ankoppeln auch andere Flüchtlinge auf und wurde dann bis nach Franken weitergeleitet (Schietke, Acht Jahre ist es her ... [wie Anm. 354]). - Über diese sozu- 
Weiterhin - vorübergehend - arbeitsfähig gehalten wurden die Sparkassen. So verlegte man im Zuge der großen Evakuierungswelle Ende Januar und Anfang Februar 1945 „die östlichen Sparkassen der Provinz Brandenburg "419 in westlich gelegene Ausweichorte, d.h. es wurden Behelfsniederlassungen in den Räumen dortiger Sparkassen eingerichtet, in denen einzelne evakuierte Mitarbeiter die Geschäfte weiterzuführen hatten. ${ }^{420}$ So ist überliefert, dass Ende Januar die Crossener Sparkasse aus Crossen/Oder (Neumark) nach Nauen evakuiert wurde und man dort eine provisorische Niederlassung einrichtete, bei der geflüchtete Crossener - wie ein Zeitzeuge berichtet - tatsächlich Geld abgehoben haben. ${ }^{421}$ Aufnahmeort für mindestens zwei neumärkische Sparkassen war auch die Kreissparkasse Rathenow. Hier befanden sich im Februar 1945 der Sitz der evakuierten Stadtsparkasse Schwiebus ${ }^{422}$ und vom 2. Februar bis 26. April 1945 die Ausweichstelle der Stadtsparkasse zu Mohrin (Kr. Königsberg/Nm.) ${ }^{423}$. Solche kriegsbedingten Verlagerungen in Orte der späteren SBZ wurden freilich wohl meist schon mit Kriegsende obsolet, zumal wahrscheinlich auch von dort wiederum eine Flucht einsetzte, als die Rote Armee näher rückte. Die in der SBZ befindlichen Sparkassen wurden ohnehin von der

sagen reichsbahninternen Aktionen hinaus ist die zentrale Bedeutung der Eisenbahn (und von Brücken!) für die gesamten Evakuierungs-, Flucht- und Vertreibungsabläufe noch längst nicht aufgearbeitet. Hierzu müsste u. a. zunächst systematisch untersucht werden, welche Strecken zu welchem Zeitpunkt überhaupt (noch oder schon wieder) nutzbar waren. Zur Sprengung der Oderbrücken detailliert: Joachim Schneider: Die Oder während der Kriegshandlungen im Frühjahr 1945. In: Historischer Verein zu Frankfurt (Oder) e. V. Mitteilungen 2001, H. 2, S. 7-21, hier S. 9-17; ders.: Die Frankfurter Oderbrücken im Wandel der Zeit. In: ebd. 2002, H. 1, S. 7-21, hier S. 17. Zur Situation im Grenzraum an der Oder nach 1945 siehe auch die 2017 bei Paul Zalewski (geb. 1967 Białystok) an der Europa-Universität Viadrina Frankfurt (Oder) entstandene Masterarbeit (Studiengang „Schutz Europäischer Kulturgüter“) von Heike Eva Schlasse: Die Oderbrücke bei Neurüdnitz. Ein Denkmal der Verkehrsgeschichte und des Kalten Krieges. Petersberg 2019.

419 Formulierung des Betreffs in einem Schreiben der „Stadtsparkasse zu Mohrin / Postanschrift: Ausweichstelle bei der Kreissparkasse Rathenow in Rathenow" an den „Brandenburgischen Sparkassen- und Giroverband in Potsdam, Nauenerstr. 23“, Rathenow, 21.2.1945, abgedruckt in: Otto Bein: Stadtsparkasse zu Mohrin. In: Kreiskalender für den Heimatkreis Königsberg-Neumark 10 (1962), S. 75-86, hier S. 81-85, Zitat S. 81.

420 Bei einer systematischen Erforschung wäre folgende, hier nicht ausgewertete Akte durchzusehen: BLHA, Rep. 287 Brandenburgischer Sparkassenverband, Potsdam, Nr. 9: Übersichten über Ausweichstellen von Sparkassen aus ehemaligem deutschen Gebiet östlich von Oder und Neiße, 1945-1946. - In erster Linie auf die Situation deutscher Banken in den besetzten Gebieten blickend, aber auch die Evakuierung aus den deutschen Ostgebieten teilweise berücksichtigend: Ingo Loose: Kredite für NS-Verbrechen. Die deutschen Kreditinstitute in Polen und die Ausraubung der polnischen und jüdischen Bevölkerung 1939-1945 (Studien zur Zeitgeschichte, Bd. 75). München 2007, S. 433-443: „Die Evakuierung deutscher Kreditinstitute aus Polen und das Ende des Zweiten Weltkrieges 1944/1945“. Demnach berichtete die Dresdner Bank Kattowitz schon am 2.8.1944 an ihre Berliner Direktion, „dass es bei praktisch allen Niederlassungen im schlesischen Raum zu erhöhten Abhebungen, Übertragungen von Guthaben auf weiter westlich gelegene Filialen (Berlin, Dresden, Eisenach, Halle, Stuttgart) sowie zu Auflösungen von Depots gekommen sei, wobei Firmeninhaber neben den Geschäfts- zumeist auch die Privatkonten räumten“ (ebd., S. 442, nach Archiwum Państwowe w Katowicach [Staatsarchiv Kattowitz], Dresdner Bank Kattowitz, Nr. 145 b, Bl. 268 f.).

421 Helmut Pflaum: Meine Kindheit in Boberhöh. Eichwalde bei Berlin 2014, S. 15.

422 BLHA, Rep. 6 B Züllichau-Schwiebus, Nr. 169.

423 Bein, Stadtsparkasse zu Mohrin (wie Anm. 419), S. 81-86. 
SMAD frühzeitig, im April bzw. Juli 1945, aufgelöst, um einer neuen Struktur Platz zu machen, deren Einrichtungen „aber ausdrücklich nicht Rechtsnachfolgerinnen der geschlossenen Geldinstitute sein durften “ ${ }^{424}$ Immerhin wird aber in einer (im Westen herausgegebenen) Vertriebenenzeitung noch 1949 die Adresse des ehemaligen Leiters der Stadtsparkasse Oels (Schlesien) mit „Schwedt/Oder / Sparkasse“ angegeben. ${ }^{425}$ Offiziell war die Tätigkeit zwar unterbunden, die ehemaligen „Leiter taten trotzdem ihr Möglichstes, um zu raten und zu helfen“426, denn die Sorge um ihre Bankguthaben trieb viele Vertriebene nach wie vor um. Bis zum 31. Dezember 1950 konnten dann tatsächlich „Uraltguthaben“ angemeldet werden, da man sich in der SBZ zu einer „Umwertung“ entschlossen hatte ${ }^{427}$, die „mit 10:1 Ostmark in Form einer AltguthabenAblösungsanleihe“ erfolgte, sofern Kontenblätter existierten oder Sparbücher vorgelegt werden konnten. Kontoinhaber, die in der Bundesrepublik lebten, waren davon ausgeschlossen. ${ }^{428}$

Für den Mohriner Fall hat der letzte Leiter der Sparkasse noch unter dem 21. Februar 1945 dem Sparkassenverband in Potsdam einen ausführlichen Bericht erstattet, der hier ver-

424 Harald Engler: Von der Hauptsparkasse der Niederlausitz zur Sparkasse Dahme-Spreewald. Königs Wusterhausen/Potsdam-Bornim 2003, S. 48. - In Thüringen existierten noch im Nov. 1945 angeblich mehrere verlagerte schlesische Banken und Bankfilialen inklusive ihrer „Vertreter und derzeitigen Mitarbeiter“, die „ca. 200000 Firmen- und Privatkonten"verwalteten (Wille II [wie Anm. 196], S. 366 f., hier S. 367). - Für Brandenburg ist ebenfalls noch im Nov. 1945 - eine Ausweichstelle der Posener Filiale der Deutschen Bank in Potsdam belegt. Der Potsdamer Filial-Direktor hoffte (Tagebucheintrag vom 24.11.1945) „durch die Verwaltung der Fil[iale] Posen“ seiner eigenen Bankfiliale „noch ein gewißes Wohnrecht“ zu erhalten, „doch kann natürlich die Ausweisung jede Stunde erfolgen" (Friedrich Helms: Tagebuch. Wilhelmshorst 1945. Hrsg. von Tobias Wimbauer. HagenBerchum 2009, S. 182); die endgültge Liquidation erfolgte wenig später, am 29.11.1945 (ebd., S. 184). - Auch aus Mecklenburg(-Vorpommern) lässt sich in den Erinnerungen des letzten Flatower Sparkassendirektors ein Beispiel nachweisen: „Die Unterlagen der Kreissparkasse [Flatow], soweit diese für den Sparer und Kontoinhaber von Wert waren, gelangten [1945] bis Ueckermünde, so es noch einigermaßen klappte, was Zahlungen anbelangte. Ein Teil der Konten wurde noch bis zur Stadtsparkasse Greifswald verlagert, kam von dort aber später zurück nach Ueckermünde. Hier haben sie noch 1951 in der Kreissparkasse Pasewalk, Zweigstelle der Landesbank, gelegen." (Johannes Seele: Über 100 Jahre Kreissparkasse Flatow. In: Heimatbuch für den Kreis Flatow. (Gifhorn) 1971, S. 129-131, hier S. 131). - In Halle/Saale schließlich bestand von 1945 an noch bis 1948 eine Abwicklungsstelle der zuvor in Königsberg i. Pr. ansässig gewesenen Bank der Ostpreußischen Landschaft („Barol“) mit Horst Balau als Leiter, zuvor Mitglied des Hauptvorstandes (Robert Albinus: Lexikon der Stadt Königsberg Pr. und Umgebung. 2. Aufl. Leer 1988, S. 29).

425 Adressen aus der schlesischen Sparkassenorganisation. Gesammelt von Herrn Direktor Beck. 1. Adressen schlesischer Sparkassenleiter. In: Breslauer Nachrichten 1 (1949), Nr. 3-5, hier Nr. 3, o. S. (Sparkassenleiter K. Flöther). Der Sparkassendirektor der Kreissparkasse Freystadt (Schlesien), Walter Ring, wohnte 1949 in „Vetschau/Spreewald, Berlinerstr. 19“, der stellv. Leiter der Kreissparkasse Sagan, Kurt Seering, wohnte in „Finsterwalde N/L, Leipzigerstr. 11 (2)“, der stellv. Leiter der Stadtsparkasse Sprottau, Otto Weber, wohnte in „Cottbus, Burgstr. 30“ (ebd., Nr. 4, o. S.).

426 Friedrich Harder: Das Schicksal der schlesischen Sparkassen und Sparguthaben. In: Breslauer Nachrichten 1 (1949), Nr. 8, o. S.

427 hm.: Was wird aus unseren alten Sparkonten und Bankguthaben? Kleiner Lichtblick aus der Ostzone/Eine Ablösungsanleihe kommt. In: Breslauer Nachrichten 1 (1949), Nr. 14 (10. Sept.), o. S.

428 Wertpapiere - Uraltguthaben. Wichtig für Wertpapierbesitzer und Inhaber von Sparbüchern und Bankkonten aus dem Osten. In: Breslauer Nachrichten 1 (1949), Nr. 18 (20. Okt.), o. S. 
kürzt wiedergegeben wird: „Das Schreiben des Sparkassenverbandes vom 27. Januar 1945, in welchem unserer Kasse im Ernst- bezw. Räumungsfalle die Kreissparkasse Rathenow als Ausweichstelle zugewiesen wurde, ging bei uns am 29. Januar ein. Wir begannen daraufhin mit dem Packen und hatten am 30. Januar 1945 spät abends bis auf die für den laufenden Geschäftsverkehr benötigten Unterlagen alles gepackt. “429 Das Auftauchen sowjetischer Panzer verhinderte dann aber den Abtransport, so dass nur ein Bruchteil mitgenommen werden konnte. Zudem wurde der Berichterstatter auf seinem abenteuerlichen Fußmarsch „mit dem Geld und einigen persönlichen Habseligkeiten im Rucksack “430, den er am 1. Februar 1945 in Richtung Schwedt/Oder aufnahm und der ihn auf Umwegen von Angermünde per Bahn nach Eberswalde und schließlich nach Bad Freienwalde führte, am 5. Februar in Bralitz/Oder ${ }^{431}$ vom gleichfalls geflüchteten Landrat des Kreises Königsberg/Nm. kurzerhand mit der Wahrnehmung der Zahlmeistergeschäfte des Volkssturms betraut: „Seitdem versehe ich nun diesen Dienst. Wir befinden uns im Fronteinsatz am Brückenkopf Saldernbrücke ${ }^{432}$. / [S. 85] Um die Belange der Stadtsparkasse zu Mohrin wahrnehmen zu können, gab mir Landrat Reuscher zugleich als Führer des Volkssturmbataillons 16/123 einen Urlaub von acht Tagen. Ich befinde mich seit dem 12. Februar 1945 in Rathenow und habe Verbindung mit der Kreissparkasse Rathenow aufgenommen. Meine erste Buchhalterin, Frau Pitschel, ist bereits am 2. Februar in Rathenow eingetroffen. Sie hat die Hypothekendokumente gut hierher gebracht und bei der Kreissparkasse Rathenow in Verwahrung gegeben. Herr Kreissparkassendirektor Nennhaus und seine Mitarbeiter zeigen größtes Verständnis für unsere Lage und sind sehr entgegenkommend und hilfsbereit. Frau Pitschel wird unter Hinzuziehung unserer Angestellten Frau Zietz die Geschäfte der Sparkasse Mohrin in Rathenow weiterführen, soweit es ohne Karten und sonstigen Unterlagen möglich ist. Es können nur noch laufende Geschäfte, in der Hauptsache die Eingänge von der Girozentrale, auf prosivorische Konten etc. verbucht werden. [...] Sie wissen aus diesem Bericht nun, daß wir hier in Rathenow vor dem nichts stehen. Wenn das Rathaus in Mohrin, in welchem die Sparkasse untergebracht ist, nicht abgebrannt wird, werden wir bei unserer Rückkehr wohl auch noch etwas vorfinden, denn an vollgeschriebenen Seiten und Kontenkarten hat der Russe wohl kein Interesse. / Ich bitte Sie nun, alle Post nach Rathenow zu schicken. Wir werden hier alles auf provisorische Konten usw. buchen, um später auf den richtigen nachzubuchen. [...] Unsere Kasse muß jetzt eine zeitlang als Einmannstelle behandelt werden. Sollte auch ein Stempel oder Siegel fehlen, so bitte ich, auch hiervon Abstand zu nehmen, denn wir haben doch nichts bergen können. / In etwa zwei bis drei Wochen werde ich Landrat Reuscher wieder um einen kurzfristigen Urlaub bitten, um bei unserer Kasse in Rathenow nach dem Rechten zu sehen. / Den von mir aus Mohrin mitgenommenen Kassenbestand habe ich auf ein Konto zu Gunsten unserer Kasse bei der Kreissparkasse Rathenow eingezahlt." ${ }^{\text {"433 }}$

429 Bein, Stadtsparkasse zu Mohrin (wie Anm. 419), S. 82.

430 Ebd., S. 83.

431 [Nördlich von Bad Freienwalde an der Alten Oder, westlich Hohenwutzen.]

432 [Bei Hohenwutzen.]

433 Bein, Stadtsparkasse zu Mohrin (wie Anm. 419), S. 84 f. 
Der mit „Der Kassenleiter“ unterzeichnete Bericht zeigt deutlich die ganze Tragik des bis zuletzt auf das ordnungsgemäße Funktionieren bedachten Mannes, der - nach dem Abzug der Panzer - ganz selbstverständlich die Rückkehr in die alten Verhältnisse voraussetzt. Mit dem Abstand von etwa 17 Jahren hat er, nun in der Bundesrepublik lebend, den Bericht im Rahmen eines Heimatkalenderbeitrages über die „Stadtsparkasse zu Mohrin“ publiziert und hinzugesetzt: „Vom 9. bis 23. April 1945 war ich nochmals in Rathenow, wo Frau Pitschel arbeitete (Frau Zietz war nicht gekommen). Ich fand bei Frau Pitschel alles in besten Händen vor. Ein ganzer Teil Ersatzkonten waren angelegt worden. Mohriner Kunden, denen die Flucht gelungen war - die Kundschaft war in Mohrin von der Einrichrung der Ausweichstelle informiert worden -, fanden sich ein und konnten bedient werden. Aber auch in Rathenow wurde unserer Arbeit ein Ende gesetzt, [S. 86] auch hier marschierte die Rote Armee ein. Frau Pitschel schloß am 26. April 1946 die Ausweichstelle. Ob hier Unterlagen den Krieg überstanden haben, ist mir nicht bekannt, die Kreissparkasse Rathenow gibt auf meine Anfragen keine Antwort. / Obwohl mir keine Unterlagen zur Verfügung stehen, habe ich in den letzten Jahren aus meiner Erinnerung heraus doch vielen Sparern in ihrer Schadensermittlung helfen können. [...]." ${ }^{334}$ Ähnlich erfolglos verliefen die Auskunftsersuchen anderer in den Westzonen gelandeter Vertriebenen, die sich an Dienststellen in der SBZ wandten. So wurden Anfragen von Crossenern, die sich um Mitteilung bezüglich der schon ab 1942 an die Zentrale der 1945 liquidierten Niederlausitzer Bank AG in Cottbus gemeldeten Kontobewegungen der Zweigniederlassung Crossen bemüht hatten, von der Notenbank der DDR in Ost-Berlin „mit einem vervielfältigten Schreiben beantwortet, daß, Unterlagen der Niederlausitzer Bank bei einer amtlichen Stelle der DDR nicht vorhanden" seien."

\section{Trecks}

Die einzelnen Tagesstationen eines dagegen wohl typischen Treckwegs aus dem Kreis Kolmar in Posen nach Niedersachsen mögen hier als Beispiel für viele Schicksale aus der „normalen“ Bevölkerung stehen: 20.1. [Kr. Eichenbrück/Wongrowitz:] Hasenpoth, Schwertburg [Gollantsch], [Kr. Kolmar:] Margonin, 21.1. Kolmar, [Kr. Czarnikau:] Fitzerie, [...], 29.1. [Provinz Brandenburg (Neumark):] Königsberg/Nm., [ab hier Brandenburg westlich der Oder: Kr. Angermünde] Schwedt, 30.1. Angermünde, 31.1. Greiffenberg, 1.2. [Kr. Templin:] Götschendorf, Milmersdorf, Hassleben, 2.2. Boitzenburg, Funkenhagen, 3.2.-7.2. Mellenau, 7.2. Lychen, 8.2. [Mecklenburg:] Fürstenberg, [Kr. Ruppin:] Rheinsberg, 9.2. [Kr. Ostprignitz:] Zechlin, Schweinrich, Babitz, 10.2. Wittstock, Pritzwalk, [Kr. Westprignitz:] Gut Retzin, 11.2. Perleberg, Dergenthin, Nebelin, 12.2. Lanz, Lenzen, Mödlich, 13.2. [Mecklenburg:] Festung Dömitz, [Provinz Hannover:] Dannenberg Hitzacker [usw.]. ${ }^{436}$ Ein hierbei als Treckführer 
fungierender Zeitzeuge, der an sich möglichst nahe an seinem Heimatort hatte bleiben wollen, um nach Kriegsende zurückkehren zu können, hat später berichtet: „In Templin traf ich unseren Landrat Nebelung, der mir zu meinem Erstaunen den dienstlichen Befehl gab, mit allen Leuten nochmals weiterzutrecken, aus der Uckermark westwärts über die Elbe hinaus in das Lüneburgische. Sprachlos war ich und traute meinen Ohren nicht. [...] Am schwersten war es, die Bauern zu überreden, am nächsten Tag erneut zum Treck aufzubrechen. / Am 11.2. ging es durch Perleberg, eine nette, kleine Stadt, und hier erfuhren wir, daß wir nicht durch das überfüllte Wittenberge fahren sollten und nicht auf der dortigen Brücke die Elbe zu überqueren hatten, sondern wir sollten uns nordwärts halten und erst die Elbbrücke bei der Festung Dömitz benutzen. So kam es, daß wir parallel zur Elbe nordwärts fahrend noch zweimal in Dörfern übernachteten, in der Nacht zum 11.2. in Nebelin und die nächste Nacht in Mödlich. Diese sehr langgestreckten Elbdörfer waren sehr interessant, auch waren die Menschen recht nett zu uns. Wir fanden die Bauern seit Dergenthin und Lanz freundlicher und freigebiger als bisher. [...].“437

Wenn man sich vor Augen hält, dass wenig später, meist im April bzw. jeweils kurz vor dem Einrücken der Roten Armee, auch die Bevölkerung der westlich der Oder gelegenen brandenburgischen Kreise großenteils evakuiert wurde oder selbst (meist nach Mecklenburg) flüchtete, liegt es nahe anzunehmen, auch die aus den östlich der Oder dort ankommenden Trecks seien nicht hier geblieben. In der Tat gibt es viele Belege dafür, dass die „Trecks aus dem Osten" nach kurzen Versorgungsstopps in Brandenburg nach Westen weiterzogen. Es gibt aber deutliche Indizien und auch Belege dafür, dass ein nicht unwesentlicher Teil von ihnen in Brandenburg verblieben ist. Zum einen ist es nicht auszuschließen, dass sich einzelne Familien vom Treck trennten und aus individuellen Gründen an einem Zwischenhalt unterkamen oder von dort in eine andere Richtung weiterzogen. Das gilt besonders dann, wenn irgendwo in Brandenburg oder Berlin Verwandte als Anknüpfungspunkt lebten. Zum anderen lassen sich aber gerade für die aus dem „Wartheland“ und den im Evakuierungsplan genannten neumärkischen Nachbarkreisen stammenden Flüchtlinge mehrere gehäufte Ansiedlungen in Brandenburg ausmachen. Das Chaos der letzten Kriegsmonate führte offenkundig dazu, dass der Weg des einzelnen (Kreis-)Trecks individuell ablief. Im einen Fall verblieb er tatsächlich zu großen Teilen im behördlich bestimmten Aufnahmegebiet, im anderen zog er weiter nach Westen. Eine generelle Klärung aller Fälle ist nur durch Einzelrecherchen zu jedem Kreis möglich. Hier müssen Beispiele genügen, die beide Wege als Möglichkeiten aufzeigen.

Die bereits erwähnten Eichenbrücker (Wongrowitzer) Trecks waren laut Evakuierungsplan vom Februar für den Kreis Ruppin vorgesehen. In der Darstellung der später in West-

über einen Treck aus Salzdorf (Kr. Schubin/Altburgund) vom 21.1. bis 16.2.1945, der ebenfalls Neumark, Uckermark, Ruppiner Raum (mit fünftägigem Einquartierungs-Aufenthalt auf Bauernhöfen) und Prignitz durchlief, um in den Raum Celle zu gelangen: Lotte Martin / Margot Bitter: Unser Treck aus Salzdorf Stationen einer Flucht. In: Der Kreis Schubin. Geschichte, Erinnerungen, Skizzen. Hrsg. vom Heimatkreis Schubin - Altburgund e. V. Bergen 1990, S. 135. 
deutschland gegründeten „Eichenbrücker Vereinigung/Heimatkreisvereinigung Eichenbrück (Wongrowitz)" hat der ehemalige Eichenbrücker Landrat Nebelung jedoch für den Januar noch andere brandenburgische Kreise genannt, was einmal mehr die hektischen Änderungen zeigt, mit denen die Behörden bzw. Parteidienststellen auf die bisweilen täglich veränderte Situation zu reagieren versuchten. Nebelung berichtet 1967: „Es waren kaum Vorbereitungen getroffen. Die Anordnungen der Verlegung wurden im letzten Augenblick mündlich gegeben. Noch am 18. Januar abends wurde mir auffernmündliche Anfrage bei der Dienststelle des Reichsstatthalters in Posen die Auskunft erteilt, daß für das Gebiet Eichenbrück keine unmittelbare Kriegsgefahr bestände. Am 20. Januar vormittags wurde das Verwaltungsgut auf Ackerwagen verladen und mit dem Ziel Prenzlau in der Uckermnark befördert. Ein Teil der deutschen Menschen ${ }^{438}$ entkam den näherrückenden russischen Truppen mit der Eisenbahn. Die Kreisverwaltung mühte sich, diese Räumung in geordnete Bahnen zu lenken. Der Treckweg wurde empfohlen und beschildert, da die Hauptstraßen gemieden werden mußten, um militärische Bewegungen nicht zu behindern. ${ }^{439}$ Die Behörden der Durchzugsorte wurden verständigt. Während des Trecks wurde Templin als Aufnahmekreis benannt. Aber schon nach wenigen Tagen zeigte sich hier, daß auch dieses Gebiet die Menschenmassen mit ihren Pferden nicht mehr aufnehmen konnte. Ich empfahl nach Westen weiterzutrecken über die Elbe. Mit Hilfe des Regierungspräsidenten und der Parteiinstanzen in Lüneburg gelang es, die Bevölkerung des Kreises Eichenbrück im Kreis Lüneburg westlich der Elbe unterzubringen./Als Sitz der Verwaltung wurde Dahlenburg gewählt. Das evakuierte Verwaltungsgut war den Landratsämtern in Prenzlau und Templin übergeben worden." Damit ergibt sich ein Fluchtweg durch den Norden Brandenburgs, von einem Landkreis zum nächsten, und der Kreis Ruppin ordnet sich als dritter Versuch der Verwaltung, die Flüchtenden unterzubringen, nahtlos in diese Kette ein, auch wenn Nebelung ihn nicht erwähnt. Im Ruppinischen sesshaft gewordene Flüchtlinge aus dem „Warthegau“ lassen sich denn auch durchaus nachweisen. ${ }^{440}$

Während Landrat Nebelung als Treckorganisator einen größeren Überblick behielt und sich früh auf die Elbe orientierte, blieben die einfachen Menschen meist in Ungewissheit über die weitere Planung. Diese Perspektive spiegelt sich in dem Bericht von Friedrich Schneider aus Niehof (Kr. Eichenbrück): „In der Mark Brandenburg wurde es möglich, den vollkommen ermüdeten Pferden und vor allem alten Leuten und Kindern eine kleine Erholung zu gönnen; man nahm damals auch noch an, daß die Flucht beendet sein würde. Aber schon nach einigen Tagen war die Front so weit nachgerückt, daß der Marsch nach dem Westen fortgestezt werden mußte. Schon hier zeichnete sich ab, daß, wenn man nicht von den Russen überrollt werden

438 [Der Kreis war mehrheitlich von Polen bewohnt, nur etwa $22 \%$ Prozent der Einwohner waren Deutsche. Nebelung, Der Landkreis Eichenbrück (wie Anm. 405), S. 89.]

439 [Die bisweilen radikale und sogar mitunter brutale Verdrängung der Flüchtlingstrecks von Hauptstraßen durch zur Front eilende oder vor ihr fliehende Wehrmachtseinheiten wird in vielen Erlebnisberichten von Flüchtlingen erwähnt.]

440 Ein Beispiel ist deren Erwähnung in den Kindheitserinnerungen von Peter Glimm: Damals in Katerbow (Teil 1). In: Historischer Verein der Grafschaft Ruppin e. V. Mitteilungsblatt 16 (2006), S. 21-36, hier S. 22. Siehe auch Ortsdokumentation, Katerbow. 
wollte, unbedingt die Elbe erreicht werden mußte, um in einen Teil Deutschlands zu kommen, in dem die Engländer waren. Auch dies wurde geschafft. Am 17. Februar überschritten die inzwischen stark dezimierten örtlichen Trecks die Elbbrücke bei Lauenburg und waren somit dem Zugriff der Russen entkommen. Doch viele unserer Eichenbrücker Landsleute erreichten die Elbe nicht. Es hatten Wagen und Pferde und zum Teil auch Menschen die Strapazen nicht ausgehalten und waren zurückgeblieben. ${ }^{\text {“41 }}$ Der letzte Satz bezieht sich sicherlich vornehmlich auf Todesfälle, doch dürften auch einzelne geschwächte Flüchtlinge in Brandenburg verblieben sein. Das Gros wurde dann aber tatsächlich schon kurz hinter der Elbe heimisch, der Kreis Lüneburg übernahm sogar später die Patenschaft für den Kreis Eichenbrück/Wongrowitz.

Insgesamt wird gleichwohl in beiden Berichten der Eindruck erweckt, dass die Evakuierung doch zumindest in gewissen Bahnen geordnet und geleitet, vor allem aber in geschlossenen Ortstrecks ablief. Das kann aber nur für einen, wenn auch wohl den größeren Teil der Menschen gelten, wie ein Vergleich mit einem weiteren Fluchtbericht zeigt. So gab es Familien, die ebenfalls mit Pferd und Wagen, aber auf eigene Faust unterwegs waren, weil sie zum Beispiel den Anschluss an den Ortstreck verloren oder verpassten. Die aus dem Kreis Eichenbrück fliehende Familie Will hatte das Ziel vor Augen, „daß wir so schnell wie möglich in Schwedt über die Oder gelangen müssen “442 Sie wurde aber noch in der Neumark von der Roten Armee eingeholt, kehrte daher zurück und gelangte erst im Zuge der sogen. „Wilden Vertreibungen“ am 26. Juni 1945 (vorübergehend) in brandenburgisches Gebiet westlich der Oder, 1946 dann nach Westfalen. Der Sohn der Flüchtlingsfrau Will hat auf Unterschiede zwischen der Darstellung seiner Mutter und der des Landrats Nebelung hingewiesen: „Der Landrat schreibt, daß die Räumung in den Händen der Partei und ihrer Organisationen lag. Meine Mutter hat ihren Besitz aber nicht auf Anordnung der Partei geräumt, sondern ist aus eigener Initiative überstürzt aufgebrochen. Auch ist sie nicht mit einem Ortstreck geflüchtet und daher nicht die beschilderten Wege gefahrten. [...] Der Landrat nimmt an, daß die Flucht aller Bürger aus dem Landkreis Eichenbrück so planmäßig verlaufen ist wie seine. Daß das nicht der Fall ist, sieht man an dem Beispiel meiner Mutter. Meine Mutter weiß aber auch, daß viele andere Familien aus dem Kreis Eichenbrück einzeln geflüchtet sind und ein ähnliches Schicksal erlebt haben wie meine Mutter und ihre Angehörigen." ${ }^{443}$ Dabei darf allerdings nicht übersehen werden, dass die Kritik des Sohnes zwar auf reale Schicksale verweist, seine Mutter aber die Gründe für das ihre durchaus benennt: „Wir waren die zuletzt aufgebrochenen Flüchtlinge aus Liebenau." ${ }^{444}$

441 Schneider, Reppenstedt (wie Anm. 408), S. 76. Der Autor befand sich zwar nicht selbst in einem der Trecks, sondern kam erst im Herbst 1945 aus der Kriegsgefangenschaft direkt in den Aufnahmeort Reppenstedt bei Lüneburg (Britische Zone), wo er sogleich als Flüchtlingsbetreuer eingesetzt wurde. Schneider stützt sich aber für seinen Bericht auf die Erinnerungen der Treckteilnehmer, unter denen sich vermutlich auch seine eigene Familie befand.

442 Nenast, Die Flucht im Jahre 1945/46 aus dem Landkreis Eichenbrück (wie Anm. 409), S. 123.

443 Ebd., S. 140.

444 Ebd., S. 119. 
Während die Eichenbrück-Wongrowitzer offenbar mehrheitlich nach Niedersachsen gelangt sind, lässt sich für die aus dem Kreis Birnbaum Evakuierten ein Weiterwirken der Planung des letzten Kriegsjahres bis heute feststellen. Für die Bewohner des Kreises Birnbaum, der noch am 17. Januar - bereits zu spät - selbst zum Aufnahmekreis erklärt worden war (für den Kreis Koło/Warthbrücken) ${ }^{445}$, wurde nach der erwähnten Liste vom Februar 1945 der Kreis Westprignitz als Aufnahmegebiet bestimmt. ${ }^{446}$ Eine Häufung von Flüchtlingsfamilien aus dem Kreis Birnbaum lässt sich dort anhand der für Prignitzer nach 1990 organisierten regelmäßigen Fahrten in ihre Heimatorte noch heute ausmachen. ${ }^{477}$ Nimmt man den in der Liste nicht aufgeführten, aber vermutlich ähnlich gelagerten Evakuierungsfall Kreis Meseritz (Nachbarkreis von Birnbaum) hinzu, so fällt eine Häufung von dort Stammender ebenfalls in der Prignitz auf und zwar sowohl 1945 als auch noch heute. Am 31. Januar 1945 notierte der Pfarrer von Kuhsdorf (Kr. Ostprignitz): „Die ersten Flüchtlinge aus dem Osten - aus dem Kreise Meseritz-kommen mit der Bahn in Pritzwalk an. ${ }^{“ 48}$ In Perleberg (Kr. Westprignitz) wiederum werden seit 2001 regelmäßig (in ungeraden Jahren) „Heimatkreistreffen der Meseritzer und Birnbaumer" durchgeführt, veranstaltet vom Heimatkreis Meseritz e. V. und der 2001 in den Verein integrierten Heimatkreisgemeinschaft Birnbaum. ${ }^{449}$ Am Volkstrauertag finden an einem Gedenkstein in Plattenburg seit 1995 jährlich Kranzniederlegungen durch Mitglieder des Bundes der Vertriebenen Perleberg sowie der „Heimatfreunde des Heimatkreises Meseritz e. V.“ statt. Der 1995 vor der Burg aufgestellte Gedenkstein nimmt direkt Bezug auf eine der im Jahr 1945 „zentralen Sammelstellen des Kreises Westprignitz für Flüchtlinge und Vertriebene“450

Für den neumärkischen Kreis Züllichau-Schwiebus weist die Evakuierungsliste die drei uckermärkischen Kreise und den Kreis Ruppin aus. Außerdem lässt sich nachweisen, dass die Kreisverwaltung Züllichau Anfang 1945 nach Guben, Calau und Neuruppin evakuiert worden ist. ${ }^{451}$ Damit korrespondiert wiederum, dass eben in Neuruppin seit 1991 jährliche - anfangs mit weit über 1000 Teilnehmern - Treffen des „Heimatkreises Züllichau-Schwiebus“ veranstaltet

445 Karl A. Hielscher: Das Kriegsende 1944/45 für den Kreis Birnbaum. In: Birnbaum/Warthe. Hrsg. von Margarete Becker u. a. Hemmingen 1977, S. 9-18, hier S. 13.

446 BLHA, Rep. 6 B Kreisverwaltung Züllichau-Schwiebus, Nr. 169, unfol. - Ferner: Hielscher, Das Kriegsende 1944/45 für den Kreis Birnbaum (wie Anm. 445), S. 13.

447 Herybert Schulz: Die Prignitzer fuhren wieder in die Heimat. In: Heimatgruß. Zeitschrift für Mitglieder und Freunde des Heimatkreises Meseritz e. V. und der Heimatkreisgemeinschaft Birnbaum 218 (2016), S. 8-11.

448 Tagebuchaufzeichnungen von Pfarrer Herbert Salefsky, Jan. bis April 1945. In: Chronik der Pfarre zu Kuhsdorf. Transkribiert und vervielfältigt von Agnes u. Henning v. Kopp-Colomb. Haltern 2008, S. 128-131, hier S. 129.

449 Siehe die Einzelangaben und -belege in der Ortsdokumentation, Perleberg.

450 www.heimatkreis-meseritz.de [19.9.2016].

451 BLHA, Rep. 6 B Landratsamt Züllichau-Schwiebus, Nr. 3, unfol. - Die damals evakuierten Akten des Züllichauer Landratsamtes liegen im BLHA in Potsdam. So heißt es in dessen Beständeübersicht schon zu DDRZeiten 1967: „Registraturteile, die im Kriege von Züllichau nach Neuruppin verlagert worden waren, wurden im Brand. LHA 1950 archiviert und 1959 verzeichnet." (Übersicht über die Bestände des Brandenburgischen Landeshauptarchivs (Staatsarchiv Potsdam). T. 2. Weimar 1967, S. 515). Eventuelle andere Aktenauslagerun- 
werden, zu denen zwar auch Auswärtige aus dem gesamten Bundesgebiet anreisen, die aber einen nennenswerten Teilnehmerkreis aus der Region aufweisen. ${ }^{452}$ Ein drittes Beispiel ist der Evakuierungskreis Schroda, für den die Liste den Aufnahmekreis Jüterbog-Luckenwalde nennt. Auch hier ist zumindest überliefert, dass die Trecks aus dem Kreis Schroda tatsächlich dort angekommen sind und auf Quartiere verteilt wurden. In einem lokalgeschichtlichen Beitrag zum Kriegsende in Dahme (Mark), Kr. Jüterbog-Luckenwalde, heißt es nämlich: „Da war die deutschsprachige Bevölkerung eines ganzen Kreises in der Nähe von Posen, des Kreises Schroda. Die kam in endlosen Trecks, Pferdefuhrwerk für Pferdefuhrwerk. In Dahme wurde sie auf die einzelnen Ortschaften ,verteilt.“" ${ }^{\text {‘ }} 33$

Ein Gegenbeispiel zur Gültigkeit der Liste bildet offenbar der Kreis Leslau (Włocławek), für den sie den Aufnahmekreis Königsberg/Neumark ausweist, mithin ein Gebiet östlich der Oder, das schon bald selbst in die Frontlinie geriet und zu evakuieren war. So verwundert es nicht, wenn der Pfarrer von Kuhsdorf (Kr. Ostprignitz), der bereits am 1. Februar 1945 die „ersten Trecks aus dem Warthegau“ durch den Ort ziehen sah, für den 16. Februar 1945 notiert: „Die Kuhsdorfer Schule ist mit zwei Flüchtlingsfamilien aus dem Kreise Leslau belegt. "454 Und am 28. Februar schreibt er: „So fahren noch täglich d[ie] Trecks aus dem Osten. Sie werden nach Osthannover weitergeleitet." ${ }^{455}$

Die Beispiele zeigen, dass wohl eine erhebliche Zahl von Flüchtlingstrecks von den überforderten Aufnahmekreisen weitergeleitet wurde, dass aber eine offenkundig doch ebenfalls erhebliche Zahl von ihnen dort verblieben ist und in Quartiere in Stadt und Land eingewiesen werden konnte. Ihre Zahl dürfte nicht niedrig zu veranschlagen sein, selbst wenn sie sich durch spätere Abwanderung in den Westen verringerte. Diese Flüchtlinge im engeren Sinne wurden mehrheitlich in Privatquartieren untergebracht, hatten solche selbst als Ziel im Blick, wenn sie Verwandte oder Bekannte westlich der Oder benennen konnten, oder zogen noch weiter nach Westen, so dass sie zwar im Moment der Ankunft auf Straßen und Plätzen deutlich sichtbar waren, aber keine monatelang in Lagern konzentrierte Menschenmasse bildeten, wie diejenigen, die - wenige Monate später - erst nach Kriegsende eintrafen. Soweit diese Flüchtlinge bei Wohnungsinhabern zwangseinquartiert wurden, waren auch sie jedoch zunächst „ungebetene Gäste“ auf unbestimmte Zeit, die als fremde Sondergruppe zumeist mit gemischten Gefühlen empfangen wurden. Auch wenn sich ihre individuelle Wohnsituation nach und nach besserte, blieben sie Flüchtlinge bzw. Vertriebene und gehörten im Fokus von Verwaltung und einheimischer Bevölkerung seit Eintreffen der Vertriebenentransporte ab

gen aus östlich von Oder und Neiße gelegenen ehemals brandenburgischen Landratsämtern sind offenbar nicht in das BLHA gelangt.

452 Siehe die Einzelangaben und -belege in der Ortsdokumentation, Neuruppin.

453 Günter Wagenknecht: 20. April 1945: Für Dahme ist der Krieg zu Ende! In: Heimatjahrbuch für den Landkreis Teltow-Fläming 2 (1995), S. 21-28, hier S. 25.

454 Tagebuchaufzeichnungen von Pfarrer Herbert Salefsky (wie Anm. 448), S. 129.

455 Ebd., S. 130. 
Sommer 1945 genauso wie diese zur dann nicht mehr unterschiedenen Gesamtgruppe der „Flüchtlinge“ bzw. „Umsiedler“.

\section{Flucht Einheimischer westlich von Oder und Neiße 1945}

Eine im Kreis Lebus lebende Zeitzeugin hatte ähnliche, ja zunächst dieselben Erlebnisse und Gefühle wie die Flüchtlinge, die von östlich der Oder kamen: „Es ist mir ein unvergeßliches Bild, als wir bei strahlendem Sonnenschein auf der Höhe Seelow standen, und man unten in tiefer Winterlandschaft die Panzer auffahren sah - ein letzter Blick in die Heimat." ${ }^{\text {456 }}$ Zwangsevakuierung und Flucht vor dem Heranrücken der Front waren - anders als die Vertreibungen nach dem 8. Mai Teil des unmittelbaren Kriegsgeschehens. Sie erfolgten daher nicht nur östlich von Oder und Neiße, „nur“ dass die Bevölkerung nach Ende der Kampfhandlungen in ihre westlich dieser Linie gelegenen Wohnorte dauerhaft, östlich davon allenfalls vorübergehend zurückkehren konnte. Zunächst also wurden auch für die Bewohner etwa der uckermärkischen oder der Niederlausitzer Kreise Fluchtvorbereitungen, Evakuierungsbefehle und Trecks, die sie erst kurz zuvor als bloße Zaungäste erlebt hatten, zu ihrem eigenen Schicksal. Die überall ähnlichen Abläufe sind in der Zeitzeugenliteratur vielfach beschrieben. ${ }^{457}$ „Am 25. April 1945 waren die Prenzlauer

456 [Lotte Thieme in:] Thieme, Zechin und Friedrichsaue (wie Anm. 402), S. 80.

457 Wenige Beispiele für viele: Michael Sielmann [Hrsg.]: Flucht und Vertreibung: Tagebuch von Ina Maria Ohnesorge (verh. Sielmann) vom 19.04.1945 bis zum 16.07.1945. In: Mitteilungen des Uckermärkischen Geschichtsvereins zu Prenzlau 25 (2018), S. 128-141 [Flucht aus Prenzlau nach Lübeck]. - Annemarie Weyer: Meine Fluchterlebnisse als Kind während der letzten Tage des 2. Weltkrieges und danach. In: Heimatkalender Prenzlau 58 (2015), S. 120-123 [Flucht aus Prenzlau ab 21./22.4.1945 nach Westen über Gollmitz, Fürstenberg/Havel, Wesenberg bis kurz vor Parchim und zurück]. - Fritz Reglin: Letzte Tage in Fürstenwerder, Flucht und Rettung unseres Hauses. In: Fürstenwerder Mosaik. T. 2. Fürstenwerder 2002, S. 84-89. [Flucht 26.4.1945, Rückkehr 10.5.1945]. - Otto Karg: Was eine Großmutter ihrer Enkelin von der Flucht 1945 erzählt. In: Die Uckermark 1945. T. 2. 2. Aufl. Prenzlau 1995, S. 1-4 [27.4.1945 Flucht aus Parmen, Kr. Templin, nach Mecklenburg, nach Eintreffen der Roten Armee Rückkehr nach Parmen, S. 3: „Die Fahrt war aber noch schwieriger als die Flucht nach Westen."]. - Bernhard Herzog: Die misslungene Flucht Flieth - Schwerin. Erlebnisbericht aus den Jahren 1943-1945. In: Templiner Heimatkalender 2000 (1999), S. 113-118, bes. S. 114 f. [Bombenkriegsevakuierte Mutter mit Sohn aus Berlin, 1943-1945 bei befreundeter Familie in Flieth (Kr. Templin), Ende April 1945 Flucht nach Norden in Richtung Boitzenburg (mit polnischem Kutscher), Anf. Mai Rückkehr nach Flieth, Juni nach Berlin]. - Renate Fritsche: Meine Kriegszeit in Pritzwalk und Flucht 1945. In: Pritzwalker Heimatblätter 16 (2015), S.37-39 [„Am 30. April 1945 bestiegen wir dann den letzten LKW, der durch einen Einsatz von allen anderen Autos noch übrig geblieben war, und fuhren in Richtung Parchim gen Norden. (...) Meine Großeltern wollten nicht mitgehen, sie seien zu alt (...).“2.5.1945 Ankunft in Lübeck]. Probleme bei der Rückkehr nach Drögen bei Fürstenberg/Havel: Stegemann, Die Nachkriegszeit 1945 bis 1948 (wie Anm. 176), S. 235. - Kurt Seeger: Ein Freienwalder erinnert sich an die Jahre 1945/46. In: Bad Freienwalder Heimatkalender 56 (2012 [2011]), S. 66-71 [Jugenderinnerungen an die Flucht aus Freienwalde am 20.4.1945 nach Klütz in Mecklenburg, Unterkunft zusammen mit vielen anderen Flüchtlingen in Klassenzimmern auf Stroh, die Rückkehr Juli sowie das Leben in den ersten Monaten danach]. - Gerda Stellmacher: Erlebnisse im Kriegs- und Nachkriegsjahr 1945. In: Bad Freienwalder Heimatkalender 56 (2012 [2011]), S. 63-65. [Kindheitserinnerungen an die Flucht aus Freienwalde Mitte April 1945 nach Finow und weiter nach Altenhof/Joachimsthal, Rückkehr am 3. Mai, Leben in den ersten Monaten danach unter sow- 
aufgefordert worden, die Stadt strahlenförmig zu verlassen; es hatte eine Massenflucht nach Westen eingesetzt. “458 Eine einheimische Uckermärkerin, die selbst Ende April 1945 aus Kröchlendorf (Kr. Templin) nach Prenzlau durchkommen wollte, erlebte das Chaos in den Tagen des Einmarschs der Roten Armee in die Uckermark, währenddessen Zivilisten und deutsche Soldaten überall auf der Flucht waren: „In der Kleinen Heide trafen wir schon sehr viele Prenzlauer Flüchtlinge, die uns sagten, daß Prenzlau fast völlig vernichtet sei durch Bomben und Verteidigungsminen und daß noch große Brände wüteten. Es wäre also zwecklos gewesen, weiterzugehen, denn wir hätten doch in der Aufregung der ersten Tage nichts erreicht. Unterwegs kamen wir an verschiedenen Treckplätzen vorbei und konnten uns manches Brauchbare mitnehmen. Wir fanden z. B. im Laufe der nächsten Tage Zahnbürsten, fast neue sogar, Nagelbürsten, etwas Zwirn, eine Schuhbürste, etwas Wäschestoff etc. - alles brauchbar für jemand, der gar nichts hat. “459

Nicht selten vereinten sich im Chaos der Flucht vor der heranrückenden Front die Trecks der westlich und der östlich der Oder beheimateten Menschen, die nun vorübergehend das Flüchtlingsschicksal teilten. So wird aus Reitwein (Kr. Lebus) für den 3. Februar 1945, als die Kämpfe bereits benachbarte Dörfer und sogar Häuser im Ort erreicht, deutsche Soldaten diese aber vorübergehend ,freigekämpft“ hatten, berichtet: „Darauf hatten die Flüchtlingstrecks, von denen viele bereits mehrere Tage im Dorf weilten, Gelegenheit zum weiterziehen. Ihnen schlossen sich im Laufe des Vormittags schon die meisten Reitweiner Einwohner an, die sich aus dem Häuserkampf retten konnten." 460

In Neuenhagen nahe der östlichen Berliner Stadtgrenze notiert der Dorfschullehrer am 20. April 1945 um 14.30 Uhr in sein Tagebuch: „Nun ist es da, das Gefürchtete. Gestern stand die Front noch östlich von Müncheberg. Heute liegen Neuenhagen und Hoppegarten unter Beschuss. Von Zeit $z u$ Zeit heulen Granaten über uns weg und schlagen bald hier, bald ferner ein. Wir haben keinen Räumungsbefehl erhalten. Wir werden auch keinen bekommen, denn wo sollen wir hin? Gepackt ist alles, das Fahrrad voll beladen. Alle Ordnung im Haus ist aufgelöst, die Bewohner sitzen dauernd im Keller. Kein Strom, kein Wasser, kein Alarm. Ewiges Gedröhne und Gebrumme in der Luft, Bordwaffenbeschuss durch Tiefflieger - Luftkämpfe. Scharenweise kommen Flüchtlinge aus Straus- [S. 13] berg, Alt-

jetischer Besatzung, Typhusepidemie]. - Drei Zeitzeugenberichte Einheimischer in: Chronik der uckermärkischen Dörfer Jagow mit Karlstein und Lauenhof, Kutzerow mit Dolgen, Taschenberg mit Uhlendorf und Taschenberger Ausbau. Milow u. a. 2013, S. 96-99. - Hans-Eberhard Ernst: Das Ende des Krieges - Greiffenberg 1945. In: Angermnünder Heimatkalender 2020, S. 203-211 [Tagebuchaufzeichnungen eines am 26.4. evakuierten Schülers, 1.5.1945 in Schwerin].

458 Harald Engler: Das „sozialistische“ Prenzlau in der SBZ und der DDR (1945 bis 1990). In: Geschichte der Stadt Prenzlau. Im Auftr. der Stadt Prenzlau hrsg. von Klaus Neitmann u. Winfried Schich (Einzelveröffentlichungen der Brandenburgischen Historischen Kommission, Bd. 16). Horb am Neckar 2009, S. 274-339, hier S. 275 .

459 Bertha von Arnim-Kröchlendorff: Sommer 1945 in Kröchlendorff unter russischer Besatzung. Nach Notizen von Detlev v. Arnim-Kröchlendorff. In: Die Uckermark 1945. T. 2. 2. Aufl. Prenzlau 1995, S. 5-21, hier S. 7. [Der Bericht setzt am 274.1945 ein und reicht bis zum 4.8.1945.]

460 F. Kn.: Erlebnisse eines Oderbruchbauern von 1945-1957. Aufzeichnungen aus den Jahren 1958-59. In: Ein leidgeprüftes Land (wie Anm. 402), S. 53. 
landsberg und Umgebung und treten ihre Flucht nach Berlin oder sonst wohin unter Lebensgefahr an. Die Kühe vom Gutshof werden an unserem Haus vorbei in Richtung Berlin getrieben. Wir wollen nicht nach Berlin. Wir erwägen, uns nordwärts von Berlin nach Frohnau über Velten und Kremmen nach Ruppin durchzuschlagen. Aber wir fürchten, unterwegs vom Krieg eingeholt zu werden." ${ }^{461}$ Noch in der Nacht, um 0.30 Uhr, „wurde dann doch Räumgsbefehl gegeben“, und man floh nun doch nach Berlin hinein. Eine andere Neuenhagener Familie, Mutter und zwei Söhne, floh am 21. April zunächst ebenfalls in die östlichen Berliner Vororte, traf in Mahlsdorf aber Bekannte, die Verwandtschaft in Belzig besaßen, und schloss sich ihnen an: „Dadurch hatte unsere Flucht ein Ziel bekommen [...]. Doch bald traf auch in Belzig die Rote Armee ein. " ${ }^{662}$ Nach Ende der Kampfhandlungen kehrte man nach Neuenhagen zurück, bald kam auch der Familienvater aus der Gefangenschaft nach Hause. Die vorübergehenden Flüchtlinge und der Heimkehrer waren nun wieder in der Lage, anderen zu helfen: „Meine Eltern [S. 49] nahmen Umsiedler auf - 2 Erwachsene und 3 Kinder - die bei uns blieben, bis deren Vater eine Arbeit in Berlin fand, dann zog die ganze Familie dorthin." ${ }^{\text {"63 }}$

Ebenfalls am 20. April 1945 wurde die Evakuierung Hennickendorfs (Kr. Niederbarnim) befohlen: „Die meisten Hennickendorfer verließen unter Mitnahme von Habseligkeiten ihre Häuser, Wohnungen und Gehöfte. Zu Fuß, meist mit Handwagen, mit Fahrrädern, auch mit Pferdegespannen, vereinzelt mit Kraftfahrzeugen, flüchteten sie. Teilweise machten sich mehrere Familien gemeinsam auf den Weg. Auch die Feuerwehr verließ vollbesetzt den Ort. [...] Die Fluchtwege endeten teilweise schon nach wenigen Kilometern, aber auch erst nach mehreren Wochen. Ein recht großer Teil gelangte in die von westlichen Alliierten besetzten Gebiete - einige blieben sogar für immer dort. Andere gerieten in den Pulk zurückflutender Truppen und flüchtender Zivilpersonen, wurden von Fliegern angegriffen, gerieten unter Beschuss und wurden von der vorrückenden Front überrollt. Einige kamen dabei um. “464 Individuell verlief auch der weitere Weg. Viele kamen schon nach wenigen Tagen in ihre Heimatorte zurück, andere erst nach Wochen. In manchen Orten veränderte sich jedoch die Situation gravierend, wenn nämlich, wie in Frankfurt (Oder), die Mehrheit der Vorkriegsbevölkerung nicht mehr zurückkehrte. Eine Hennickendorfer Zeitzeugin hat über ihre „Evakuierung“ im April 1945 berichtet: „Schon in Woltersdorf wurden wur von einer Militärstreife angehalten und mein Vater [...] wurde in den Volkssturm eingegliedert. Unser Fluchtweg verlief über Niederlehme - Großbeeren - Potsdam Nauen - Kyritz - Pritzwalk - Parchim - Crivitz, nach Schwerin und dauerte mehrere Tage. Einmal erhielten wir Unterkunft bei einer Familie und durften in der, Guten Stube' auf dem Fußboden schlafen. Da wir vom Regen durchnässt waren, wurden unsere Sachen am warmen Ofen getrocknet. Kurz vor Schwerin verbrachten wir eine Nacht im Wald. Unzählige Menschen waren zu Fuß oder mit Pferd

461 (Paul Wolff:) Wir müssen Neuenhagen verlassen - die letzten Kriegstage 1945. [Hrsg.: Irmgard Meincke]. In: Lebenszeit XIII. Neuenhagener Geschichten. Neuenhagen o. J. [ca. 2010], S. 12-15, hier S. 12.

462 Wolfgang Hagemann: Meine Lehrzeit als „Umroller“ im Sommer 1945. In: Lebenszeit XIV. Neuenhagener Geschichten. Neuenhagen o. J. [ca. 2012], S. 45-49, hier S. 45.

463 Ebd., S. $48 \mathrm{f}$.

464 Hennickendorf 1945. [Hennickendorf 2005], S. 15. 
und Wagen auf der Flucht gen Westen. [...]."465 Erst am 12. Juli 1945 konnten sie mit Genehmigung der sowjetischen Besatzungsmacht aus Schwerin nach Hennickendorf zurückkehren. ${ }^{466}$

Kaum ein Dorf geschweige denn eine Stadt in Brandenburg sah somit 1945 nicht irgendeinen Treck durchziehen. Das Land wurde wochen- und monatelang vollständig überzogen von einem Strom flüchtender Menschen. Größere Treckverbände, aber auch kleinere und Einzelpersonen waren allerorten unterwegs, machten Station, zogen weiter. Die wenigen Autobahnen, aber auch Landstraßen wurden genutzt. Nicht nur das Kriegsgerät der Wehrmacht blieb am Straßenrand liegen, auch die Flüchtlinge hinterließen Spuren, bisweilen auch Gräber. Viele Orte, besonders in den am schlimmsten umkämpften Zonen, waren vorübergehend fast vollständig entleert. „In Spremberg wurden unmittelbar nach Beendigung der Kampfhandlungen 492 verbliebene Personen gezählt, über 13000 waren geflüchtet. Nur langsam kehrte die Bevölkerung wieder in ihre Heimatorte zurück. Bis zum 2. Mai 1945 hatten sich in der Kreisstadt erst wieder 3744 Personen eingefunden. “467

Die systematische (Zwangs-)Evakuierung der Zivilbevölkerung von Frankfurt (Oder) begann am 4. Februar, zunächst in den Vorstädten. ${ }^{468}$ In Schwedt/Oder erhielt die Bevölkerung am 25. März den Evakuierungsbefehl, bis auf die Arbeitsfähigen. Im Kreis Angermünde wurde die Bevölkerung ab 24. April 1945, also kurz vor dem Eintreffen der Roten Armee, die am 27. April die Kreisstadt erreichte, zwangsweise evakuiert: „Soweit die Menschen nicht schon vorher sich aus der Kampfzone entfernt hatten, wurden sie jetzt, wie in Stendell, mit Waffengewalt vertrieben. Deutsche Soldaten töteten das Vieh, damit nichts den Russen in die Hände fällt.“469 In den letzten Tagen, vom 25. bis 27. April, bot sich ein Bild, das sich kaum von dem in den Ostgebieten unterschied: „Die Städte und Dörfer des Kreises sind fast völlig entvölkert. Fast nur noch alte und gebrechliche Leute verstecken sich in den Kellern. “470 In der Stadt Angermünde wurden am 27. April mit denjenigen, die nicht geflohen waren, auch viele Flüchtlinge von der Front überrollt. Sie alle wurden bereits ab 29. April von den Eroberern als Arbeitskräfte eingesetzt, um „Panzersperren, Flakstellungen, Schützengräben und die Reste des Krieges auf den Angermünder Straßen zu beseitigen“.

Die Einwohner von Niederfinow (Kr. Angermünde) flüchteten, teilweise in Trecks, im April 1945 in die weitere Uckermark und nach Mecklenburg. ${ }^{472}$ Einige konnten erst im Juli 1945

465 Jutta Kalcher: Unsere Flucht im April 1945. In: Hennickendorf 1945. [Hennickendorf 2005], S. 27-28, hier S. 27.

466 Ebd., S. 28.

467 Günther Kaczmarek: Die Befreiung des Kreises Spremberg vom Hitlerfaschismus im April 1945. Spremberg 1980, S. 51.

468 Brisch/Buwert/Schieck, Frankfurt (Oder) 1945 (wie Anm. 163), S. 7.

469 Dietrich Kukla: Angermünde 1945. In: Angermünder Heimatkalender 1995, S. 38-49, hier S. 39.

470 Ebd.

471 Ebd.

472 Siegfried Schiefelbein: Niederfinow - Ein Ort mit schwebenden Schiffen. 1258 - 1267 - 2008. Niederfinow 2008, S. 107 (Abschnitt „Die große Flüchtlingswelle. Niederfinower Bürger“). 
zurückkehren. ${ }^{473}$ Andere berichteten: „Nach 14 Tagen durften wir in die Heimat zurückkehren. Einige Niederfinower kehrten nie mehr zurück, andere hatten auf der Flucht ihr gesamtes Hab und Gut verloren. “" ${ }^{474}$ Ein Einheimischer aus Fürstenwerder (Uckermark), dessen Familie am 26. April 1945 nach Mecklenburg floh und am 10. Mai zurückkehrte, hat berichtet: „Den Koffer mit Wäsche hat dann 1947 mein Vater mit dem Fahrrad aus der Nähe von Stavenhagen geholt. Er stand noch unberührt auf dem Boden des Wohnhauses eines Bauern, wo meine Tante ihn auf der ,Flucht stehen lassen musste, weil man ihr die Pferde ausgespannt hatte und sie nicht weiter konnte auf ihrer abenteuerlichen Fahrt. “475

Das Pflegepersonal der Landesanstalt Eberswalde musste auf Befehl des NSDAP-Kreisleiters am 21. April 1945 die Anstalt verlassen und floh „in mehreren kleineren und größeren Trecks nach Neuruppin“, wo man auf dem Gutshof der dortigen Landesanstalt unterkam. Die Flucht des Neuruppiner Personals wiederum setzte gerade „zu dem Zeitpunkt ein, als die Flüch- [S. 198] tenden aus Eberswalde eintrafen. ${ }^{476}$ Im Raum Strausberg war die Zivilbevölkerung „zum größten Teil kurz vor Beginn der Kampfhandlungen evakuiert worden. In den Städten waren höchstens einige Hundert Bewohner zurückgeblieben, in den Dörfern nur einzelne Personen oder gar niemand." 477

Aus Werben bei Cottbus, das am 22. April von der Roten Armee eingenommen wurde, berichtet ein damals 16-jähriger Landwirtssohn in seinen Erinnerungen: „Schon im Februar hatten die Werbener begonnen Vorbereitungen zu treffen für den Fall, daß Werben zum Frontgebiet würde. Manche Bauern, auch wir, versahen einen Kastenwagen mit einer Überdachung aus Planen, um erforderlichenfalls schnell aus dem Dorfflüchten zu können. Lebensmittel, insbesondere Schinken, Pökelfleisch, Getreide und vor allem auch Wertsachen wurden in Erdlöchern versteckt, um sie vor dem Zugriff der Russen zu retten. Mit der Frühjahrsbestellung haben sich die Bauern beeilt. Bei sehr günstigem Wetter wurde das Sommergetreide ausgesät und schon bis Mitte April war der größte Teil Kartoffeln ausgepflanzt." ${ }^{478}$

Die organisierte Flucht bzw. Evakuierung der Eisenbahnerfamilien aus Fürstenberg (Oder) am 5. Februar 1945 per Bahn nach Leipzig und die Rückkehr im Zug am 17. Oktober 1945 hat eine - damals fünfzigjährige - Betroffene, die Fürstenbergerin Martha Schulze, in ih-

473

474

475

Ebd., S. S. 111.

Ebd., S. 113 (eigener Bericht des damals 7-jährigen Verfassers Siegfried Schiefelbein, geb. 1938 in Niederfinow).

Fritz Reglin: Letzte Tage in Fürstenwerder, Flucht und Rettung unseres Hauses. In: Fürstenwerder Mosaik. T. 2. Fürstenwerder 2002, S. 84-89, hier S. 89.

Dietmar Schulze: Die Landesanstalt Neuruppin in der NS-Zeit (Schriftenreihe zur Medizin-Geschichte des Landes Brandenburg, Bd. 8). Berlin 2004, S. $197 \mathrm{f}$.

Rolf Barthel: Die Kampfhandlungen im April 1945. Die Befreiung der Orte des heutigen Kreisgebiets durch die Rote Armee. In: Heimatkalender für den Kreis Strausberg 3 (1990), S. 17-20, hier S. 20.

Erwin Gollasch: Das Ende des Zweiten Weltkrieges. Erlebnisbericht. In: Siegfried Ramoth: Das Gemüsedorf Werben im Wandel eines Jahrhunderts. Ein Lausitzer Heimatbuch. Bearb. u. hrsg. von Jürgen Heinrich. Cottbus 2001 (Cottbuser Bücher, Bd. 9). Cottbus 2001, S. 39-44, hier S. 42. 
rem Tagebuch festgehalten. Ende Januar und Anfang Februar war sie selbst noch als „Blockfrau“ zur Flüchtlingsbetreuung für die aus den Ostgebieten kommenden Trecks eingesetzt worden. Wenige Tage darauf wurde sie selbst Betroffene. Am 16. Februar schreibt sie, nun bereits in Gaschwitz bei Leipzig befindlich, in ihr Tagebuch: „Nun sind wir auch heimatlose Flüchtlinge geworden und mussten am 5.2. unser Städtchen Fürstenberg verlassen. Am Sonnabend, den 3.2. waren wir noch ganz ruhig." ${ }^{\text {"79 }}$

In den Erinnerungsberichten werden häufig die Begriffe „Flucht“, „Treck“ und „Flüchtlings$z u g^{\prime \prime}$ (für Eisenbahntransporte) verwendet, so dass nicht nur sachlich, sondern auch terminologisch kein Unterschied zur Flucht und Evakuierung aus den Gebieten östlich von Oder und Neiße erkennbar ist. Die Situation war aber in dieser Zeit zunächst tatsächlich für alle gleich, zumal selbst Flüchtlinge aus den Ostgebieten, besonders aus der Neumark, dann zunächst - bis zur endgültigen Vertreibung im Sommer oder ab Herbst 1945 - in ihre Heimatorte zurückkehrten. Erst mit der sich dann abzeichnenden Unmöglichkeit einer Rückkehr bzw. der endgültigen Vertreibung der einen trennten sich deren Biographien von denen der anderen, die westlich der beiden Flüsse beheimatet waren. Dieses vorübergehend gemeinsame Schicksal aller auf der Flucht vor der Front befindlichen Brandenburger erweitert mithin den Flucht- und den Flüchtlingsbegriff, so dass man bei der Lektüre der Berichte sehr genau unterscheiden muss. So machte es für die Bewohner der weiter westlich gelegenen Orte Brandenburgs in den ersten Monaten des Jahres 1945 keinen Unterschied, ob ein Treck von jenseits der Oder aus der Neumark oder z. B. aus dem diesseits gelegenen Kreis Lebus kam. Auch an diesen zeitweiligen Aufnahmeorten in West- und „Mittel“-Brandenburg entstanden damals Aufzeichnungen und später Berichte, die entsprechend begriffliche Unterscheidungen verständlicherweise nicht vornahmen. ${ }^{480}$

Dass die Flüchtlinge aus den Ostgebieten, die im Januar 1945 bereits hatten vor der Front fliehen müssen, für die Gefahr bisweilen notgedrungen sensibilisierter waren als die einheimische Bevölkerung in den Auffangorten, zeigen Äußerungen eines Flüchtlings, dessen Familie in einem kleinen mecklenburgischen Gutsdorf gelandet war. Als auch hier die Front Ende April nahte, wurde zwar durch den Gutsbesitzer die Flucht in den Wald organisiert, aber er betont doch, wie viel wertvolle Zeit verloren gegangen war, da „durch die Einheimischen das Vorrücken der Russen verdrängend ignoriert wurde“.481

Die erwähnten, von den NSDAP-Kreisleitern verhängten Treckverbote verhinderten freilich vielerorts bis zuletzt eine rechtzeitige Evakuierung vor der heranrückenden Front. Auch dies galt aber keineswegs nur für die östlich der Oder und Neiße gelegenen Kreise. Mehrere

479 [Martha Schulze:] „Hoffentlich überstehen wir diese böse Zeit.“ Das Fluchttagebuch der Martha Schulze. Hrsg.: Bürgervereinigung „Fürstenberg (Oder)“ e. V. Red.: Erich Opitz. Eisenhüttenstadt [2013], S. 9.

480 Siehe z. B. die zahlreichen Berichte westlich der Oder lebender Zeitzeugen über das Jahr 1945 in: Ein leidgeprüftes Land (wie Anm. 402), oder die Zeitzeugenberichte Einheimischer in: Um Beelitz harter Kampf. 1945. Hrsg.: Beelitzer Heimatverein. Beelitz 1999.

481 Otto Gedack: Erinnerungen am meinem ersten „1. Mai“. In: Damals und heute (wie Anm. 357), S. 57-58, hier S. 57. 
westlich der Oder ansässige Vertreter adliger Gutsbesitzerfamilien haben in ihren Erinnerungen die schwierige Situation geschildert, in der sie selbst an eigene, noch verbotene Treckvorbereitungen dachten und gleichzeitig mit der plötzlichen und nicht mehr endenden Unterbringung durchziehender Trecks aus dem Osten, denen sie einen ersten, vorübergehenden Ruhepunkt boten, konfrontiert wurden. Diese Geschehnisse sind aus allen Regionen berichtet worden, sie trafen offenkundig alle gleichermaßen. Für den Süden Brandenburgs kann Clara von Arnim auf Wiepersdorf (Kr. Jüterbog-Luckenwalde) als Zeitzeugin dienen: „Im Januar brach die Front im Osten völlig zusammen. Die Sowjetarmee überschritt die deutschen Grenzen. Man hörte die verlogenen Wehrmachtsberichte, versuchte, sich anhand der Landkarte einen Reim darauf zu machen, und schon kamen die Trecks. Der erste kam aus Westpreußen mit Bessarabiendeutschen, die zuvor schon einmal ihre Heimat hatten verlassen müssen. Sie erzählten uns von der furchtbaren Flucht durch Eis und Schnee. Menschen wie Pferde waren völlig erschöpft. Da alle verfügbaren Betten mit Evakuierten belegt waren, wurden für die neuankommenden Flüchtlinge Massenquartiere im alten Gutsbüro und in der Schule eingerichtet. Aber nach ein paar Tagen hatte sich alles eingespielt, und etwa hundert Menschen und dreißig Pferde wurden täglich reibungslos verpflegt und versorgt. In der Küche ging die Arbeit nun immer bis tief in die Nacht. Die Erwachsenen mußten mit Suppe, Kaffee und Brot, die Kinder mit Milch versorgt werden, darüber hinaus mußte man sich speziell um die Alten und Kranken kümmern.

Sehr unterschiedliche Menschen kamen mit den Trecks; ganz ärmliche Gestalten, dann wieder kräftige Bauern, dann ein ganzer Gutstreck. Manche aßen sehr viel, andere waren so erschöpft, daß sie kaum etwas zu essen vermochten. Daß ich noch helfen konnte, wo immer möglich, gab mir ein Gefühl der Befriedigung. Ich ahnte freilich, daß wir bald ebenso wie die anderen über die Landstraße ziehen würden, und sträubte mich innerlich gegen diesen Gedanken. Wohin sollte man gehen? Hatte es, da schon so viele Menschen in den Westen strömten, einen Sinn, wenn wir ihnen folgten? Wer würde uns dort aufnehmen?" ${ }^{\prime 482}$ Kurz vor dem Einmarsch der Roten Armee versiegte der Flüchtlingsstrom: „Der Durchzug von Trecks hatte aufgehört.“ Am 14. April verließ Clara von Arnim Wiepersdorf. ${ }^{483}$ Am Aufnahmeort, dem Gut Schönlage bei Wismar (Mecklenburg), herrschte zwar noch „idyllische Ruhe“ und ging im Haushalt noch alles „seinen gewohnten Gang“, doch waren auch hier bereits Flüchtlinge angekommen, die das Leben im Gutshaus veränderten. An sich wollte die Gutsbesitzerfamilie bereits Wertsachen in Sicherheit bringen: „Aber Dinge zu verstecken oder gar zu vergraben war schwierig, weil sich im Haus eine Anzahl von Flüchtlingen befand, die alles mißtrauisch beobachteten." 484

Im Norden Brandenburgs, in der südlichen Uckermark, sah es kaum anders aus. Die Frau des letzten Besitzers von Schloss Liebenberg (Kr. Templin), Marie Fürstin zu EulenburgHertefeld (1884-1960), die von Januar bis April 1945 viele Flüchtlingstrecks vorübergehend aufnahm, während sie selbst ebenfalls bereits eigene Treckvorbereitungen traf und im April ihr 
Gut so verlassen musste, hat die Geschehnisse in ihren „Aufzeichnungen für meine Kinder über die letzten Monate des Zweiten Weltkrieges“ geschildert: „Die Kreise östlich der Oder wurden evakuiert. Ein unbeschreiblicher Flüchtlingsstrom ergoß sich über unsere Gegend. Das Elend der jeden Abend gegen die Dämmerstunde bei uns einkehrenden Treckwagen mit frierenden, hungernden Menschen und erschöpften Pferden ist nicht zu beschreiben. In Waschkesseln wurde bei uns im Schloß und in [S. 176] der Wirtschaft Kartoffeleintopf gekocht. In den Parterreräumen, die Zentralheizung hatten, wurden Betten, Chaiselonguen, Einsätze, Matratzen aufgebaut, um die flüchtenden Gutsbesitzerfamilien und bessere Leute im Schloß unterzubringen. Die anderen fanden Aufnahme im Dorf und in Sammellagern, die in der Schule und dem Gasthaus hergerichtet waren. Was da nicht mehr Platz hatte, lagerte im warmen Kuh- und Schafstall. Eine Nacht hatten wir - außer den 200 ständigen Flüchtlingen 250 Passanten und über 100 Pferde auf dem Gut. Dann wurden die Chausseen, auf denen sich die Wagen gestaut hatten, leerer und boten nicht mehr dies herzzerreißende Bild des Jammers, obwohl die rote Flut sich langsam immer näher wälzte." ${ }^{485}$

\section{Flüchtlingsbetreuung im Krieg}

Die mit Pferdefuhrwerken auf zentralen Plätzen der weiter westlich gelegenen Städte ankommenden oder mit Zügen auf deren Bahnhöfen eintreffenden Flüchtlinge aus „dem Osten“, die Anfang 1945 vor der Front flohen, wurden an ihren ersten Aufnahmeorten vielen Einzelberichten zufolge in Sammelstellen wie Bahnhöfen und Schulen von DRK- und NSV-Schwestern erstbetreut. Aber auch HJ, BDM und Schulklassen ${ }^{486}$ wurden zur Flüchtlingsbetreuung auf Bahnhöfen und in Sammelstellen eingesetzt. Ein am Morgen des 30. Januar 1945 auf dem Schlesischen Bahnhof in Berlin eingetroffener Flüchtlingszug aus Landsberg/Warthe wurde nach der Erinnerung eines Fahrgasts in dieser Weise in Empfang genommen: „Von BDM-Mädchen und Rotkreuz-Schwestern bekamen wir ein warmes Getränk: Malzkaffee oder Tee und eine Schmalzstulle." ${ }^{487}$ Für Belzig lässt sich der Einsatz von höchstens 14-jährigen Mädchen („Jungmädel“) nachweisen, wie ein Beispiel aus der umgekehrten Perspektive zeigt: „Als Jungmädel war man stets ausgelastet. Singschar, Bastelnachmittag, Sammeln fürs Winterhilfswerk, Sportfeste und seit Anfang 1945 sogar Treckdienst. Wir kamen uns dabei sehr wichtig vor und nannten das ,Dienst' (ankommende Flüchtlingsgespanne empfangen und weiterleiten).“488 In Angermünde, wie die ganze Uckermark zeitweise besonders stark von Treckdurchzügen betroffen, war die Betreuung eine Herausforderung für beide Seiten: „In der grimmigen Kälte des Januar zog ein unaufhörlicher Zug flüch-

485 Marie Fürstin zu Eulenburg-Hertefeld: Aufzeichnungen für meine Kinder über die letzten Monate des Zweiten Weltkrieges. In: Wend Graf zu Eulenburg-Hertefeld: Ein Schloß in der Mark. Erinnerungen an Liebenberg. Hrsg. von Dirk Klose. Stuttgart 1990, S. 175-191, hier S. 175 f.

486 Z. B. Lehrkräfte und Schüler der Alten Städtischen Oberschule Frankfurt (Oder) am 29.1.1945 (Brisch/Buwert/Schieck, Frankfurt (Oder) 1945 [wie Anm. 163], S. 4).

487 Ernst-Günter Weber: Vor 70 Jahren - Flucht aus Landsberg. In: Heimatblatt der ehemaligen Kirchengemeinden Landsberg/Warthe Stadt und Land 50 (2015), S. 6-8, hier S. 7.

488 Gerda Liß: Jungmädelzeit. In: Um Beelitz harter Kampf (wie Anm. 480), S. 91. 
tender Deutscher aus den östlichen Provinzen über die Oder und über die vereisten Straßen unserer Stadt. [...] Der Stadt war es unmöglich, dieses Flüchtlingsstroms Herr zu werden. Es wurde versucht die Durchziehenden zu versorgen, aber bei diesen Menschenmassen, geschätzt täglich um vier- bis fünftausend, reichte die Fürsorge nicht. Die Kolonnen wurden in nordwestlicher Richtung nach Mecklenburg weitegeleitet." ${ }^{\text {"49 }}$

Eine offenbar zum Einsatz dienstverpflichtete Berlinerin (geb. 1920), hat 1982/83 ihre Tätigkeit als Betreuerin bei der Versorgung von Flüchtlingstrecks im Jahr 1945 geschildert ${ }^{490}$ : „Ich war in Frankfurt/Oder, das war ja schon ein bißchen Vorposten. Wir haben dann Transporte mit Lastwagen zusammengestellt, weil im Osten, gerade in diesem Frankfurter Gebiet, die Russen sehr schnell vorwärts gekommen sind und die Kinder wirklich in Gefahr waren. Das war wirklich ganz schrecklich. Die hatten ihre Kinder mit, aber kein Essen mehr. Da haben wir - das heißt eine Gruppe von zehn, zwölf Mädchen in meinem Alter - in Waschküchen große Kessel mit Suppe gekocht, Grießsuppe oder irgendwas. Die haben wir dann den Trecks entgegengebracht. Dann haben wir Stellen eingerichtet, wo die Kinder gewickelt werden konnten. Den ganzen Tag haben wir so Bettlaken zu Windeln gerissen. Irgendwie habe ich mich dabei infiziert und Diphterie und anschließend Scharlach gekriegt. Das war natürlich für solche Aktionen unmöglich. Ich bin dann auf sehr schrecklichen Wegen zurückgekommen, wir waren ziemlich weit vorn, weil die Trecks aus dem Osten ja immer empfangen werden mußten. $[\ldots]$..

Häufig wurden die noch am Ort befindlichen (nicht eingezogenen), meist also älteren Lehrer dazu beordert, Flüchtlinge zu registrieren. ${ }^{491}$ Für Perleberg liegt der Bericht des Ende Februar oder Anfang März 1945 in der Flüchtlingsbetreuung eingesetzten Lehrers Albert Hoppe (1894-1973) vor: „Der Flüchtlingsstrom wächst täglich, in unserer Stadt sind lange Wagenkolonnen. Der Schulhof gleicht nachts einer Wagenburg. [...] In den Schulräumen liegen Hunderte eng gedrängt auf Stroh. Alle werden verpflegt, registriert und weitergeleitet. Bei uns bleiben die Kreise Samter, Kolmar, Czarnikau, Stadt Meseritz, später auch Stadt Küstrin. Die Versprengten kommen ratlos auf unsere Suchstelle, hier befindet sich die Kartei für alle Durchreisenden. [...]."492 Anfang Mai trifft er in seiner unmittelbaren Wohnumgebung außer Neumärkern und Posenern bzw. Wartheländern auch auf einzelne Flüchtlinge aus Nieder- und Oberschlesien. ${ }^{493}$

„Fast in jedem Ort konnte man Pferdefutter und warmes Essen bei der NSV bekommen." So heißt es im Erlebnisbericht eines Bauern, der im Januar 1945 einen Treck aus dem Kreis Samter (Posen) durch die Neumark, bei Frankfurt über die Oder und nördlich an Berlin vorbei in die

489 Kukla, Angermünde 1945 (wie Anm. 469), S. 38.

490 Sibylle Meyer / Eva Schulze: Wie wir das alles geschafft haben. Alleinstehende Frauen berichten über ihr Leben nach 1945. Hrsg. vom Senator für Familie und Gesundheit in Berlin. München 1984, S. 39 (die Namen der Interviewten wurden von den Herausgeberinnen aus Datenschutzgründen geändert, daher hier weggelassen).

491 Teilweise sind sie es dann auch, die Todesfälle unter in Sammelunterkünften befindlichen Flüchtlingen beim Standesamt anzeigen (siehe z. B. Sterberegister des Standesämter Angermünde und Prenzlau).

492 Albert Hoppe: Perleberg 1945 - Tagebuchaufzeichnungen. In: Mitteilungen des Vereins für Geschichte der Prignitz 14 (2014), S. 63-132, hier S. 69.

493 Ebd., S. 89. 
Westprignitz führte. ${ }^{494}$ Allein schon aus der übereinstimmenden Erwähnung in zahllosen solcher Zeitzeugenberichte ist ersichtlich, dass die NSV - die „Nationalsozialistische Volkswohlfahrt “ - offiziell für die Flüchtlingsbetreuung zuständig war, auch wenn das Deutsche Rote Kreuz (DRK), die NS-Frauenschaft (NSF) und der BDM ebenfalls hierbei tätig wurden. Nach den Erinnerungen einer 1945 kurz vor Kriegsende bei der Flüchtlingsbetreuung in Belzig eingesetzten DRK-Krankenschwester war zwar „die Frauenschaft für die erste Verpflegung verantwortlich“495, und die tatsächliche Lage am einzelnen Ort mag mehr oder weniger improvisiert gesteuert worden sein. In der Mehrzahl der Berichte ist es jedoch die NSV, die die Vorbereitungen getroffen hatte und die dann die Erstbetreuung entweder selbst übernahm oder steuerte, also in diesen Fragen des praktischen Ablaufs gegenüber den örtlichen Stellen von DRK, BDM und NSF offenkundig weisungsbefugt war. Eine Kienitzer Treckführerin hatte sich daher Ende Januar 1945 „eine Bescheinigung von der NSV ausstellen lasen, daß ich einen Transport Mütter mit Kindern nach Mitteldeutschland führe“.496 In den Treckberichten gleichen sich die Aussagen: Nach dem Übergang über die Oder bei Penkun (in der ersten Februarhälfte 1945): „sahen wir neben der Straße zum ersten Mal eine Essenausgabe der NSV (Nationalsozialistische Volkswohlfahrt)“.497 In einem anderen Treckbericht heißt es für einen Zwischenhalt in Nauen, hier „wurde kurz Rast gemacht und wir erhielten Verpflegung durch die NSV“.498 Diese Beispiele aus der untersten Erlebnisebene der Betroffenen ließen sich mühelos vermehren. Stattdessen ist ein Blick in die planerischen Hintergründe auf der oberen Ebene zu werfen.

In einer Zusammenstellung der Arbeitsgebiete und Betreuungsgrundsätze der NSV vom 22. August 1944 werden als vierter von insgesamt sieben Tätigkeitsbereichen während des Krieges durchgeführte „zusätzlichen Aufgaben“ benannt: „IV. Die Kriegsaufgaben der NSV“. Darunter erscheint neben Kinderlandverschickung, Soldatenbetreuung u. a. als zweiter Punkt „Die Umquartierung": „Dabei hat die NSV die Aufgabe, den für die Umquartierung in Betracht kommenden Personenkreis zusammenzustellen, die Teilnehmer der Transporte zu betreuen und die Unterbringung der Umquartierten in den Aufnahmegauen durchzuführen." Ausdrücklich erwähnt werden hierbei eigene „Kriegs-Entbindungsheime“, „Kriegs-Mutter- und Kind-Heime“ sowie „Kriegs-Kinderheime“ für die Aufnahme werdender Mütter und Mütter mit Kleinkindern als „zur Verfügung“ ste-

Dokumentation der Vertreibung I/1 (wie Anm. 192), S. 381 (Niederschrift von Gerhard Jaeckel, 1951). Flüchtlinge aus dem Kr. Samter 1945, jedoch direkt nach Kriegsende, auch erwähnt in Rühstädt (Kr. Westprignitz); siehe: Transitzone Dorf (wie Anm. 248), S. 36.

495 Gertraud Sewerin: Krankenschwester vom DRK. In: „... das Glockengeläut ist einzustellen“. 1945 - das Jahr zwischen Krieg und Frieden. T. 1: Belzig und Umgebung. Belzig 1995, S. 101-102, hier S. 101.

496 [Lotte Thieme in]: Thieme, Zechin und Friedrichsaue (wie Anm. 402), S. 81. - Ähnlich im Tagebuch der am 19.2.1945 aus Küstrin geflüchteten Margarete Ammon, die unter dem 21.2.1945 aus dem ÜbernachtungsZwischenhalt Prenzlau berichtet: „Also ging ich zur N.S. V. [...] und bat um Genehmigung, nach Doberan weiterzufahren. Die bekam ich auch." (Das Tagebuch der Margarete Ammon (geb. 1909). Transkription von Siegfried Neubauer. In: Gespräche mit ehemaligen Küstrinern. Aufgez. u. bearb. von Siegfried Neubauer. Bd. 6. Frankfurt (Oder) 2017, S. 29-50, hier S. 37).

497 Dohna-Schlobitten, Erinnerungen (wie Anm. 375), S. 260-291 (Kapitel „Der Treck“), hier S. 283.

498 Ein leidgeprüftes Land (wie Anm. 402), S. 188. 
hend. ${ }^{499}$ Als zehnter und letzter Punkt werden ferner, ohne nähere Angaben, die „Sondereinsätze der NSV bei Umsiedlungen und Rückführungen“ genannt. ${ }^{500}$ Diese Sondereinsätze dürften ab spätestens Ende 1944 das Hauptarbeitsgebiet der NSV geworden sein, auch wenn sich dies in den in der bisherigen Literatur abgedruckten Quellen nur noch ansatzweise spiegelt, da letztere der archivalischen Überlieferungslage wegen überhaupt nur bis in den November 1944 reichen. ${ }^{501}$ Doch schon in den „NSV-Richtlinien für Umquartierungen“ vom 13. August 1943, zu einem Zeitpunkt also, als zwar schon in großer Zahl organisierte Bevölkerungsbewegungen stattfanden, aber noch nicht der riesige Strom der aus den Ostgebieten Flüchtenden eingesetzt hatte, heißt es bezeichnenderweise, dass die „Umquartierungsmaßnahmen“ für die NSV-Mitarbeiter "den Vorrang vor allen anderen Arbeiten zur Zeit haben“. ${ }^{02}$ Damit war zwar in erster Linie die „Umquartierung wegen Luftgefährdung und Bombenschäden“ gemeint, auf deren „Vorrang vor allen anderen Arbeiten" schon ein Rundschreiben des Oberbefehlsleiters der NSV vom 24. Juli 1943 hingewiesen hatte ${ }^{503}$, doch lassen sich die Vorkehrungen und Tätigkeitsbeschreibungen ohne weiteres auf die 1944/45 anstehenden Aufgaben übertragen, nur dass man in den chaotischen Verhältnissen ab Januar 1945 kaum noch Rücksicht auf die 1943 in einem Merkblatt geordneten Planungen nehmen konnte. Darin heißt es: „Personen, deren Aufenthalt im bisherigen Wohnort oder dessen Nähe nicht unbedingt notwendig ist und die wegen Fliegerschaden umquartiert werden müssen oder vorsorglich abzureisen beabsichtigen, werden durch die NSV in bestimmte Aufnahmegebiete des Reiches umquartiert. "504 Vollends obsolet und meist ganz unmöglich geworden waren 1945 Verfügungen, die man dabei noch 1943 wie selbstverständlich bezüglich der „Umquartierten“ getroffen hatte: „Sie erhalten durch die Gemeindebehörde ihres Wohnortes eine Abreisebescheinigung, wenn ihre Abreise aus öffentlichen Gründen notwendig oder wenigstens erwünscht ist, oder wenn die ihre noch vorhandene Wohnung oder Teile derselben für Unterbringungszwecke zur

Herwart Vorländer: Die NSV. Darstellung und Dokumentation einer nationalsozialistischen Organisation (Schriften des Bundesarchivs 35). Boppard am Rhein 1988, S. 520 (Nr. 296). Die Zusammenstellung ist vom Leiter der Partei-Kanzlei, Martin Bormann, unterzeichnet. - Siehe auch den ausführlichen zeitgenössischen Art. „Nationalsozialistische Volkswohlfahrt“ in: Meyers Lexikon. 8. Aufl. Bd. 8. Leipzig 1940, Sp. 154-157.

500 Ebd., S. 521.

501 Siehe das Kapitel „IV. Die NSV im Krieg“ bei Vorländer, S. 127 ff.

502 Ebd., S. 510 (Nr. 289, „Vertrauliche Information der Partei-Kanzlei“). - Siehe auch das Beispiel einer „um 1942“ in der NSV-Betreuung von „Flüchtlingen“ (aus Białystok) in Küstrin tätigen Frau (Johanna Kunstmann, geb. 1906, hauptberuflich 1938-1945 Stenotypistin im Wohlfahrtsamt der Stadt Küstrin) in: Gespräche mit ehemaligen Küstrinern. Aufgez. u. bearb. von Siegfried Neubauer. Bd. 4. Frankfurt (Oder) 2012, S. 54-56, hier auch die Erinnerung des Sohnes an die damit zusammenhängende eigene Einquartierung (S. 54): „Das ist von der NSV alles gesteuert worden. Die hatten jedenfalls Erhebungen angestellt, wo etwas [Wohnraum, P. B.] frei sein könnte. Zu der Zeit gab es noch keine Flüchtlingstrecks, wie Küstrin sie Ende 1944 erlebt hatte. Wir hatten damals eine Einquartierung in der Ostbahnstraße aus Riga bekommen. Das war ein hoher Angestellter, ein Finanzfachmann, der kam mit seinen zwei Kindern und seiner Frau zu uns. Wir hatten ihm dann bei uns ein Zimmer zur Verfügung gestellt, und an dem Tag, als wir Küstrin verlassen hatten, waren die schon wieder weg."

503 Ebd., S. 508 (Nr. 288).

504 Ebd., S. 506 (Nr. 286, „Merkblatt des Hauptamtes für Volkswohlfahrt zur Umquartierung im Bombenkrieg, 15. April 1943“). 
Verfügung stellen. Sie werden in planmäßigen Transporten durch die NSV in vorbereitete Quartiere gebracht. ${ }^{\text {"505 }}$ Allenfalls letzteres lässt sich begrenzt noch 1945 feststellen, wenngleich oftmals das schnelle Voranschreiten des Kriegsverlaufes zum Improvisieren und Umplanen zwang.

Die genannten Richtlinien von 1943 sind in den Einzelregelungen für die Betreuungsarbeit der NSV freilich durchaus auf die späteren Verhältnisse übertragbar, spiegeln sie doch im Kern genau jene Tätigkeiten und Vorgehensweisen, die aus zahllosen Zeitzeugenberichten von Flüchtlingen für die Zeit von Januar bis April/Mai 1945 überliefert sind, nur dass für die Merkblattverfasser wohl noch nicht die Dimensionen vorstellbar waren, unter denen manche bürokratische Feinheit schnell überholt war. Die Zuständigkeit erstreckte sich „vom Zeitpunkt der Erfassung der Betreuten bis zu deren Einweisung in die neuen Unterkünfte. ${ }^{506}$ Der „Betreuung der Transportzüge“ und der „Verpflegung an den vorgesehenen Verpflegungsstellen“ müsse ebenso Aufmerksamkeit zugewendet werden wie einer „verständnisvolle(n) Aufnahme“ an den Unterkunftsorten. „Auch hier kommt es entscheidend darauf an, daß die Betreuten von vornherein die Hilfsbereitschaft empfinden, die ihnen in der neuen Umgebung entgegengebracht wird./Für den Empfang auf den Bahnhöfen muß deshalb stets eine ausreichende Anzahl von Mitarbeitern bereit stehen." Während man 1943 zwar noch glaubte, der Berücksichtigung möglichst gleichartiger Lebensverhältnisse bei Betreuten und aufnehmenden Familien Beachtung schenken zu können, weisen andere Punkte schon auf die sich anbahnenden Entwicklungen hin. So sei „erforderlichenfalls eine Unterbringung der Betreuten am Unterkunftsort in Sammelquartieren vorzusehen", doch wird im Hochsommer 1943 nochmals eingeschränkt, es sei „besonders darauf zu achten, daß diese für eine zeitweilige Unterbringung der Betreuten geeignet sind." Dagegen heißt es dann in einem an die NSV-Gauämter der Aufnahme-Gaue gerichteten Fernschreiben des NSV-Oberbefehlsleiters Hilgenfeldt vom 27. November 1944: „Erfahrungen und Feststellungen der letzten Tage zwingen mich zu folgender Verfügung“. Schon zu diesem Zeitpunkt, d. h. mit dem Einbruch der Roten Armee in das Reichsgebiet, nämlich in Ostpreußen, galten viele der zuvor ausgearbeiteten Meldesysteme nicht mehr. Die Eindringlichkeit des Fernschreibens ist unmissverständlich, die Nervosität schon so groß, dass man ahnt, wie sich die Situation der Verwaltung in den folgenden Monaten, als alles bereits innerhalb kurzer Zeit drunter und drüber ging, zuspitzte: „Grundsätzlich können bei Aufnahme auch keine Atempausen eingelegt werden, weil es solche auch nicht an der Front und im Luftkrieg gibt." Außerdem wird verfügt, dass nunmehr, anders als noch im vorhergehenden Rundschreiben desselben Jahres, „die Hauptaufnahmegaue z. Zt. täglich fernschriftlich oder fernmündlich [...] über Stand der Umquartierung berichten " müssten.

Deutlich wird dabei zugleich, dass die Reichsleitung der NSV, also deren „Oberbefehlsleiter“, für die Festlegung der „Hauptaufnahmegaue“ zuständig war. Hilgenfeldt nennt dies „reichsmäßige Dispositonen“. Die reichsweite Regelung war schon deshalb für nötig erachtet worden, weil sich bereits einzelne Aufnahmeorte oder -gebiete teilweise oder ganz den ihnen auferlegten

Ebd.

506 Ebd., S. 510 (Nr. 289), auch für das Folgende. 
Verpflichtungen zu entziehen suchten. Es heißt daher unmissverständlich ${ }^{507}$ : „Die Entwicklung der Lage erfordert in erhöhtem Maße Räumungen und Umquartierungen. Auf diese Situation müssen sich die Aufnahmegaue voll und ganz einstellen. Aufnahmegaue müssen grundsätzlich alle an sie geleiteten Flüchtlingstransporte und auch Einzelflüchtlinge aus Regelzügen, notfalls auch über das bisher festgestezte Aufnahmesoll hinaus in jedem Fall aufnehmen und vorläufuig unterbringen. Jedes Abschieben von Transporten, sowie zielloses Weiterleiten anrollender Transporte untersage ich grundsätzlich. Alle Aufnahmegaue befinden sich in gleicher Lage und stehen vor gleichen Schwierigkeiten. Das Handeln der Aufnahmegaue muß berücksichtigen, daß es sich um Transporte mit geflüchteten Menschen und nicht um irgendwelche Materialien handelt." Behielt sich also die NSV-Leitung die Festlegung der Länder bzw. Großregionen (Gaue) als konkreten Aufnahmegebieten vor, so hatten diese offenbar die genauen Zielstationen, also Städte bzw. Orte bzw. Bahnhöfe, festzulegen. Hierfür sollten also offenkundig die Gauleitungen „im Entsendegau oder seiner unmittelbaren Nähe Leitstellen einrichten, die für alle abgehenden Sonderzüge vorher Zielstationen festlegen, ziellose Fahrten unter allen Umständen ausschalten und den Aufnahmegau nach Möglichkeit rechtzeitig von dem Eintreffen verständigen“. Für die zunächst noch „gau-internen“ Evakuierungen im „Warthegau“ (aus dem wenig später viele Menschen nach Brandenburg geleitet wurden) ist überliefert, dass die NSV im September 1944 Vorbereitungen traf, „um im Ernstfalle für die fliehende Bevölkerung zu sorgen. Zunächst geschah es in engem Kreise bis in die Ortsgruppen. Aber nach Wochen mußten auch die Vertrauensleute der einzelnen Orte herangezogen werden. Der Warthegau war in drei Zonen eingeteilt: A die östliche Zone mit Lodsch/Litzmannstadt etwa bis zur alten Grenze von 1914, B der mittlere Teil mit Posen und C der Westen [...]. Auf ein Stichwort sollten aus der Zone A zuerst die deutschen Frauen und Kinder fortgeschafft werden. Für die Bewohner jeden Kreises von dort war ein Aufnahmekreis vorgesehen. Dazu wurde festgestellt, wieviel Menschen in jedem Orte unterkommen konnten, ob und wo Volksküchen einzurichten waren und ebenso Krankenstuben, ob es eine Bäckerei gab und anderes mehr. ${ }^{\text {“508 }}$

Zur genaueren Planung „der Unterbringung, Verpflegung und Betreuung der zu erwartenden Flüchtlingsströme“ in Brandenburg „fand Mitte Januar 1945 im NSV-Gauamt in Frankfurt, Halbe Stadt 7, eine Tagung aller brandenburgischen NSV-Kreisamtsleiter statt." ${ }^{\text {"509 }}$ In Frankfurt (Oder) selbst begann dann der tatsächliche Einsatz der NSV am Sonntag, dem 21. Januar 1945. „Zur Unterstützung wurden das Deutsche Rote Kreuz, die NS-Frauenschaft, die $\mathrm{HJ}$, die Wehrmacht und der RAD herangezogen, zu denen noch zahlreiche freiwillige Helfer kamen. Die Mütterschule des Deutschen Frauenwerks richtete eine Krankenstelle im Kameradschaftsheim der Frankfurter Elektrizitätswerke in der Fischerstraße ein. Die Frankfurter Ärzte betreuten Sammelstellen. Ein Wehrmachtsverpflegungszug und der RAD mit seinen Küchenanlagen in der Gubener Straße 9 und im RAD-Lager Kliestow waren für das Kochen des warmen Essens verantwortlich. Für Schleimsuppen und Milch sorgte die NS-Frauenschaftsküche 
in der Junkerstraße.“510 Schulen wurden als Nachtquartier für Frauen, Kinder und alte Menschen "freigeräumt. ${ }^{511}$

In welchem Ausmaß diese Festlegungen der NSV wie auch der (NSDAP-),Aufnahmegaue" von der Wirklichkeit kurzfristig überholt wurden und wo und wie weit sie mit oder ohne Modifikationen wirklich in die Tat umgesetzt werden konnten, ist reichsweit noch nicht untersucht. Wegen der schwierigen Quellenlage ist das auch sicherlich nur teilweise zu leisten. ${ }^{512}$ Die Tatsache, dass die Evakuierungsmaßnahmen in den Händen der NSDAP bzw. der ihr nachgeordneten NSV und nicht in denen der (entmachteten) Gebietskörperschaften lagen, wird heute meist für die mangelnde Organisation verantwortlich gemacht. ${ }^{513}$ Für Brandenburg lassen sich immerhin sowohl „Aufnahme-Landkreise“ (!) nachweisen, die die in sie entsandten Transporte tatsächlich erhalten haben, als auch solche, die wohl nur vorübergehend in Aussicht genommen waren. ${ }^{514}$ Für die konkrete Betreuung am Ort lässt sich auch in Brandenburg die führende Rolle der NSV in zahllosen Fällen nachweisen. ${ }^{515}$ Daher dürfte die von Oliver Kersten vorgenommene Bewertung der „Rezeption“ in der Bevölkerung nicht fehl gehen. Denn er sieht zwar einerseits, wohl zu Recht, Macht und Einflussmöglichkeit der NSV-Leitung 1945 sehr eingeschränkt. „Dafür aber erwarb sich die NSV gerade bei der vielfältigen Betreuung der nicht abreißenden Zahl von Verwundetentransporten und der besonders aus dem Osten kommenden Flüchtlingsströme, bei der Bergung von Bombenopfern, der Verfolgung von Überlebenden und der Zuweisung von Notunterkünften hohes Ansehen in der notleidenden Bevölkerung. ${ }^{\text {“516 }}$ Auch Vorländer kommt zu einem ähnlichen Ergebnis: „Es war vor allem der selbstlose Einsatz vieler der über eine Million meist ehrenamtlichen Helfer von NSV und Rotem Kreuz, der den positiven Teil des Bildes der NS-Volkswohlfahrt in der Bevölkerung prägte. ${ }^{\text {“517 }}$ Eine Zeitzeugin hat es noch etwas zugespitzt und diese positive Sicht auf die NSV auf deren Funktionstüchtigkeit bezogen: „Die letzte Parteiorganisation, die noch gut funktionierte, war - vom Roten Kreuz einmal abgesehen - die N.S. V. [...] auf den Bahnhöfen ${ }^{518}$, die an die Kinder überall Milch verteilte. ${ }^{\text {"519 }}$ Auch andere Zeitzeugen haben denselben Eindruck überliefert, dass nämlich die NSV bis zum „Schluss“ im Einsatz war: Ein aus dem Kreis Obornik geflüchteter Pfarrer, der schließlich in den

510 Ebd.

511 Ebd., S. 48.

512 Keine Rolle spielt dieser Tätigkeitsbereich auch im darstellenden Teil (Kapitel 4. Totaler Krieg) der Monographie von Vorländer (wie Anm. 499), S. 164-175.

513 „Unsere Heimat ist uns ein fremdes Land geworden ...“ (wie Anm. 195), Bd. 3: Wojewodschaft Posen, Wojewodschaft Stettin (Hinterpommern) (Quellen zur Geschichte und Landeskunde Ostmitteleuropas, 4/III). Marburg 2004, S. 25 (hier für das Beispiel Lodz, 17./18.1.1945).

514 Siehe dazu die Hinweise zu einzelnen Kreisen im Teil 2.

515 Siehe den Zugang über das Sachregister.

516 Oliver Kersten: Die Nationalsozialistische Volkswohlfahrt insbesondere im Zweiten Weltkrieg. Magisterarbeit FU Berlin 1993, S. 90.

517 Vorländer (wie Anm. 499), S. 173.

518 Zum Bahnhofsdienst der NSV siehe auch Kersten (wie Anm. 516), S. 72 f.

519 Menschen und Schicksale (wie Anm. 383), S. 437. 
Kreis Ostprignitz gelangen wird, kommt Ende Januar 1945 als erster westlich der Oder gelegener Unterkunft in Küstrin-Kietz vorübergehend bei einem NSV-Leiter unter: „Er kommt erst spät abends aus seiner Arbeit für die Versorgung und Unterbringung der Flüchtlinge todmüde nach Hause [...]. Dieser NSV.-Leiter war der letzte Amtsträger, den ich in brauner Uniform sah. All die späteren westlich der Oder taten ihren Dienst in Zivil. "520

All diese Einsätze der NSV hatten freilich eine Vorgeschichte, denn bereits in der zweiten Hälfte der dreißiger Jahren war es ihr gelungen, in Konkurrenz mit kommunalen und konfessionellen Einrichtungen und Verbänden erheblichen Einfluss auf das lokale Fürsorgewesen zu gewinnen, bisweilen noch gesteigert durch Personalunionen bei Leitungsfunktionen in städtischen Wohlfahrtsämtern: „Gerade die Ämterhäufung ist ein Beleg für das wirkungsvolle Eindringen der Nationalsozialisten in das Netz kommunaler Wohlfahrtspflege. " 521

Nur mit dem in Teilen der Bevölkerung positiven Image der NSV ist es aber wohl zu erklären, dass es mehrere Fälle gibt, in denen nach Kriegsende die vielerorts in der Flüchtlingsbetreuung tätigen NSV-Schwestern ihre Arbeit offenbar zumindest in den ersten Tagen der sowjetischen Besatzungszeit noch fortsetzten, wie z.B. Clara von Arnim auf ihrer Flucht Anfang Mai (!) in Mecklenburg feststellen konnte: „Abends bekamen wir bei der ehemaligen [!] NSV, die erstaunlicherweise noch aktiv war, jeder einen Teller Suppe und würzten ihn mit dem wilden Schnittlauch, den wir auf der Wiese abgerupft hatten."522 Dass dies kein Einzelfall war und es angesichts des nicht nachlassenden Bedarfs wohl oft kaum eine Alternative zur Weiterbeschäftigung gab, ist für Brandenburg immerhin in Ragösen im Kreis Zauch-Belzig belegt. Laut Protokoll der ersten Sitzung des im Sommer 1945 aus je vier Vertretern von CDU, SPD, LDP und KPD gebildeten örtlichen Antifa-Ausschusses, der „für eine antifaschistische demokratische Ordnung im Dorf sorgen“ sollte, wurde „gestattet, dass die frühere NSV-Schwester Emma Perkuhn weiterhin ihren Dienst versieht“. Da allerdings Klage geführt wurde, „dass sie sich ihre Hausbesuche teuer bezahlen lässt (3,00 RM)“ wurde sogar vorgeschlagen, „sie fest anzustellen und ihr ein monatliches Gehalt zu zahlen“523 Sowohl in der letzten Kriegsphase 1944/45 als auch aus Murowana Goslin, Niederschrift von 1952), hier S. 371.

521 Boldorf, Fürsorge im Umbruch (wie Anm. 302), S. 396 f., Zitat S. 397.

522 Clara von Arnim, Der grüne Baum des Lebens (wie Anm. 398), S. 311.

523 Ragösen. Beiträge zur Geschichte, T. 2 (wie Anm. 188), S. 19 (Die hier wiedergegebenen Textpassagen geben den Inhalt des Protokolls wieder, sind aber nicht als Originalzitate daraus gekennzeichnet). Diese erste Ausschuss-Sitzung nebst Protokoll wird ebd., S. 18 f., fälschlich auf den 1. August 1946 datiert. Es muss sich jedoch zweifelsfrei bereits um einen Termin im Jahr 1945 (1. August 1945?) handeln, wie sich aus allen weiteren Schilderungen ergibt (u. a.: 2. Sitzung am 15.2.1946; anstelle von KPD bereits ab 22.5.1946 SED). - Nur am Rande sei darauf hingewiesen, dass der Familienname dieser Schwester unverkennbar ostpreußischen Ursprungs ist, auch wenn sie vermutlich nicht selbst zum Kreis der von ihr zu Betreuenden gehörte. - Zur nach und nach erfolgenden Übernahme der NSV-Einrichtungen und ihres Personals und der Integration in regionale Hilfsorganisationen siehe: Wolfgang Tischner: Katholische Kirche in der SBZ/DDR 1945-1951. Die Formierung einer Subgesellschaft im entstehenden sozialistischen Staat (Veröffentlichungen der Kommission für Zeitgeschichte, Reihe B: Forschungen, Bd. 90). Paderborn u. a. 2001, S. 421, 443 (Bahnhofsmission 
bei einem - bisher wohl eher nur vereinzelt nachweisbaren - befristeten Weiterwirken sahen sich die Helferinnen und Helfer oftmals extremen, bisweilen chaotischen bis katastrophalen Notsituationen gegenüber, die sofortiges Handeln ohne Ansehen der Person erforderten. Das dürfte es der NSV erschwert haben, in diesem Arbeitsfeld 1944/45 noch ebenso ideologisch zu agieren wie in der Vorkriegszeit, als sie sich noch „allein auf die ,erbgesunde, leistungstüchtige, deutsche Bevölkerung konzentrierte "und im Gegensatz zu den kirchlichen Fürsorgeverbänden „wenig Interesse für Kranke und Sieche“ entwickelt hatte. ${ }^{524}$

Viele Flüchtlinge haben sich allerdings von Anfang an auf eigene Faust geholfen und wann immer möglich bei Verwandten oder Bekannten Unterkunft gesucht und gefunden. Dafür gibt es zahlreiche Belege. Auch aus den Trecks scherten, wie mehrfach betont, immer wieder einzelne Flüchtlinge oder ganze Familien aus. So berichtet eine Treckführerin, die Ende Januar/ Anfang Februar 1945 mit vielen Müttern und Kindern aus dem Oderraum in Richtung Elbe unterwegs war: „Unser Ziel war Mitteldeutschland, genau Bernburg/Saale, wo meine Schwiegereltern wohnten. Für die 8-km-Strecke bis Seelow brauchten wir 12 Stunden, da immer wieder Halt geboten wurde durch die entgegenkommende Wehrmacht. / [...] [S. 81] In Treuenbrietzen hatte uns eine Mutter mit drei Kindern verlassen, die dort bei Bekannten eine Zuflucht hatte. Kurz vor unserem Ziel, das wir am 10.2.1945 erreichten, konnte ich meinen Schwiegervater verständigen: Bitte mache für die und die Personen noch Quartier. Es klappte alles nach preußischem Muster: Als wir ankamen, fand jeder eine Unterkunft, auch die Pferde und die Raupe hatten wieder einen Stall." 525

Nicht alle hatten freilich die Möglichkeit, schnell oder nach kurzer Zeit bei Verwandten oder Bekannten unterzukommen. Aber man rückte zusammen, wie das Beispiel eines Jugendlichen zeigt, der im Januar 1945 mit einem Zug aus dem Kreis Meseritz flüchtete ${ }^{526}$ : „Über Schwiebus, Sternberg, Reppen ging es dann bis Frankfurt/Oder. Ich war froh, daß der Zug wegen der schweren Luftangriffe nicht nach Berlin fuhr, sondern nach Eberswalde. Von dort aus kam ich in das nahegelegene Finowfurth [Finowfurt], wo wir in der Turnhalle untergebracht wurden. Wir schliefen auf Strohlagern." Der damals noch nicht Volljährige war auf sich gestellt, seine Familie hatte es, wie er erst nach Tagen brieflich erfuhr, nach Thüringen verschlagen. In Finowfurt fand er jedoch im Februar und März 1945 vorübergehend privaten Anschluss in einer Familie, die selbst Hilfe benötigte, so dass beiden Seiten in der Not geholfen war: „Ich trug immer noch die Uniform mit dem Ärmelstreifen Lehrerbildungsanstalt. Beim Betrachten des Ortes sprachen mich zwei Schüler an. Der jüngere war in der Schule schwach und brauchte Hilfe. Der ältere sagte, wir fragen mal unsere Mutter, ob sie mich aufnehmen würde. Sie hätten noch Platz für mich. Ihr Vater war Soldat und nicht zu Hause. Nach einer Weile kamen sie zur Turnhalle und sagten, ihre Mutter würde mich aufnehmen.

übernimmt „Aufgaben und Räumlichkeiten von den sich auflösenden NSV und DRK“, teilweise, so in Erfurt, offiziell beantragt).

524 Boldorf, Fürsorge im Umbruch (wie Anm. 302), S. 397.

525 Ebd., S. 80 f.

526 Fritz Schulz: Meine Flucht vor den Russen. In: Heimatgruß. Zeitschrift für Mitglieder und Freunde des Heimatkreises Meseritz e. V. und der Heimatkreisgemeinschaft Birnbaum 217 (2016), S. 34-35 
[...] [S. 35] Nun hatte ich wieder eine feste Adresse, schrieb an meine Tante Mathilde Hannemann, deren Adresse ich noch wußte, nach Erfurt, ob sie wüßte, wo meine Familie sich aufhielt. Die Post ging in den Februartagen 1945 nicht so schnell, aber nach einigen Tagen bekam ich eine Antwort. [...] Der Abschied bei der Familie Lieske, die mich als Flüchtling aufgenommen hatte, war auch nicht einfach, aber es mußte eben sein. [...].“

Das Zusammenrücken in der Not spiegelt sich auch in einem anderen Bericht, der als Beispiel dafür stehen mag, dass sich das ungleiche Verhältnis von Bedürftigkeit und Beschützung im Krieg zuweilen umkehren konnte. Eine junge Beelitzer Mutter, die bei Kriegsende 1945, damals 23 Jahre alt, mit ihrem zweieinhalbjährigen Sohn im Elternhaus wohnte, während ihr Mann sich noch in Kriegsgefangenschaft befand, hat später über das nahe Zusammenleben mit den Flüchtlingen berichtet. Im Haus waren eine Familie aus Ostpreußen und eine aus Posen einquartiert: „Beim Näherrücken der Front saßen wir alle bei uns im Luftschutzkeller. [...] Auf dem Kirchplatz war das NSV-Büro, wo unter anderem auch Alkohol für den Volkssturm gelagert war. Bei der Eroberung von Beelitz fiel er in die Hände der Rotarmisten und hinterließ natürlich böse Auswirkungen. [S. 83] Ich war verzweifelt und kopflos. Die Flüchtlingsfamilien nahmen sich meiner an und beschützten mich und meinen Sohn."

\section{„Wilde Vertreibungen" im Sommer 1945}

Für diejenigen, die beim Heranrücken der Front nicht geflüchtet waren, und die, die nach dem Ende der Kampfhandlungen in ihre östlich von Oder und Neiße gelegenen Heimatorte zurückkehrten, kam es bald zur Begegnung mit frühzeitig zuwandernden Polen, die noch vor den Entscheidungen der Siegermächte Fakten schaffen wollten und sollten. Diese Vorgänge können hier, mit dem vornehmlichen Blick auf die Geschehnisse westlich der neuen Grenze, ebenso wenig vertiefend behandelt werden wie die in zahlreichen Zeitzeugenberichten beschriebene, oft demütigende und auch lebensbedrohliche Lage, der sich Deutsche nach der Einrichtung polnischer bzw. tschechischer Verwaltungen schon bald und in vielen Fällen mindestens bis zur Vertreibung 1946/47 ausgesetzt sahen. ${ }^{528}$

527 Irmgard Hohenschild: Das Leben mit den Besatzern. In: Um Beelitz harter Kampf (wie Anm. 480), S. 84.

528 Siehe dazu, am schlesischen Beispiel, ausführlich: Andreas R. Hofmann: Die Nachkriegszeit in Schlesien. Gesellschafts- und Bevölkerungspolitik in den polnischen Siedlungsgebieten 1945-1948. Köln/Weimar/ Wien 2000. - Ferner: Sebastian Siebel-Achenbach: Niederschlesien 1942 bis 1949. Alliierte Diplomatie und Nachkriegswirklichkeit. Würzburg 2006, S. 147-189 (bis 1946). - Spurný, Flucht und Vertreibung (wie Anm. 332), S. 49-97 (Kapitel „Niederschlesien nach dem Kriegsende“). - Gregor Thum: Die fremde Stadt Breslau nach 1945. München 2006. - Quellen aus polnischen Archiven: „Unsere Heimat ist uns ein fremdes Land geworden ..." (wie Anm. 195). - Für die Situation in Ostbrandenburg siehe das Kapitel „Bevölkerung“ in: Richard Breyer: Ostbrandenburg unter polnischer Verwaltung. Frankfurt/Main-Berlin 1959, S. 14-37, und Magdalena Abraham-Diefenbach: Flucht, Vertreibung, Aussiedlung. Das östliche Brandenburg im Jahr 1945. In: Terra Transoderana. Zwischen Neumark und Ziemia Lubuska. Bernd Vogenbeck u. a. (Bearb.) (Almanach. Europäische Grenzregionen neu entdecken, Bd. 1). Berlin 2008, S. 39-47, hier S. 44 f. 
Ab 20. Juni 1945, in den sudetendeutschen (tschechischen) Gebieten schon ab 5. Juni ${ }^{529}$, kam es überall zu den sogen. „Wilden Vertreibungen“, d.h. nicht durch Beschlüsse der erst danach zu Verhandlungen zusammentretenden Alliierten abgesicherten Maßnahmen, die zudem durch die oft gewalttätigen und grausamen Begleitumstände ein besonders schreckliches Kapitel des Gesamtthemas bilden. ${ }^{530}$ Es muss hier genügen, die überall ähnlichen Abläufe, zu denen auch die oft sehr kurzfristige Bekanntgabe des Ausweisungsbefehls gehörte, an einzelnen Beispielen aufzuzeigen. Eine der dramatischsten „Wilden Vertreibungen“ ergab sich schon allein wegen der großen Zahl der zudem innerhalb kürzester Zeit mit dem Ausweisungsbefehl Konfrontierten, als am 20. Juni 1945 nahezu die komplette Bevölkerung der östlich der Neiße gelegenen (Haupt-) Teile der Stadt Guben durch den Fluss getrieben wurde und in den westlichen Vorstadtbereichen und dem Umland untergebracht werden musste. ${ }^{531}$ Eine Gubenerin hat später berichtet: „Das wenige, was wir mitnehmen konnten, wurde uns an der Grenze von den Polen weggenommen, sämtliche Papiere und Unterlagen schwammen die Neiße stromabwärts. Nachdem wir hier auf der anderen Seite Gubens nach tagelangem Hin und her ein Stübchen fanden, gingen die Sorgen um das Überleben und die Sorge um unsere Männer [Vater und Ehemann - P. B.] los, von denen wir keine Nachricht hatten." ${ }^{332}$

Auch ein aus Neudamm (Kr. Königsberg/Nm.) stammender Vertriebener, der - wie viele Neumärker - Anfang 1945 zunächst vor der Front geflohen (31. Januar 1945), dann aber wie viele Flüchtlinge - in den Heimatort zurückgekehrt war, hat die im Sommer einsetzende „Wilde Vertreibung“ erlebt und beschrieben. Seine knappe Beschreibung des als Kind Erlebten kann für das Schicksal vieler stehen, sie findet sich in ähnlicher Formulierung in den meisten Erinnerungsberichten: „Mai/Juni 1945. Wir hatten wieder versucht, aus dem wenigen noch vorgefundenen unser Leben neu zu gestalten. Auch Vater, der noch in den le[t]zten Januartagen 1945 zum Volkssturm nach Küstrin in die Stülpnagelkaserne eingezogen wurde, kam im Fußmarsch von Berlin über Schleichwege zurück. Wir versuchten, den Acker zu bestellen. Irgendwoher waren noch Saatkartoffeln aufgetrieben worden. Da geschah für uns das Unfaßbare: wir mußten unsere Heimat zum zweiten Mal verlassen, diesmal jedoch für immer. “533

Die besonders für die „Wilden Vertreibungen“ typische Willkür und Gewaltanwendung, meist durch polnische Miliz sowie die ebenfalls gängige vollständige Ausplünderung der zu-

529 Detlef Brandes: Wilde Vertreibung aus der Tschechoslowakei. In: Lexikon der Vertreibungen (wie Anm. 59), S. 728-730. - Ders.: Der Weg zur Vertreibung 1938-1945. München 2001, S. 377-385. - Fritz Peter Habel: Die Sudetendeutschen. 2., durchges. u. erw. Aufl. (Vertreibungsgebiete und vertriebene Deutsche. Studienbuchreihe der Stiftung Ostdeutscher Kulturrat, Bd. 1). München 1998, S. 96-101. - Spurný, Flucht und Vertreibung (wie Anm. 332), S. 99-121.

530 Krzysztof Ruchniewicz: Wilde Vertreibung aus Polen. In: Lexikon der Vertreibungen (wie Anm. 59), S. 725729. - Brandes, Der Weg zur Vertreibung (wie Anm. 529), S. 393-401.

531 Einzelheiten siehe in der Ortsdokumentation Guben.

532 Luzie Wittchen: Erinnerungen an die Heimat. In: Gubener Heimatbrief (1994)2, S. 59.

533 Kurt Krause: Erinnerungen an die Schreckenszeit vor 50 Jahren. In: Königsberger Kreiskalender 1996 (1995), S. 67-70, hier S. 69. 
nächst mit etwas Habe Aufgebrochenen noch kurz vor dem Grenzübertritt, oft durch Banden, beschreibt der Cottbuser Arzt Dr. Hammer, der am 21. April 1945 beim Einmarsch der Roten Armee zunächst gefangengenommen und in ein Lager nach Sagan (Schlesien) gebracht worden war und erst am 28. Juni 1945, nun als begleitender Treck-Arzt, nach Cottbus zurückkehren konnte: „Der Treck bestand aus schätzungsweise 1200 Personen. Die Zahl der mit Zugtieren bespannten mehr oder weniger großen Wagen mag gegen 30 betragen haben. Die Hauptmasse der aus der Heimat vertriebenen Unglücklichen mußte den Marsch nicht nur zu Fuß machen, sondern auch noch ihre gerettete Habe im Handwagen selbst schieben. [...] Der Zug hatte eine länge von zwei bis drei Kilometern und rückte in einem Tempo von $3 \mathrm{~km}$ pro Stunde auf der Chaussee nach Sorau vor. $[\ldots]$. ${ }^{534}$

In der Stadt Königsberg/Nm. begann die „Wilde Vertreibung“ am 23. Juni 1945. ${ }^{535}$ Die noch lebenden Bewohner von Burschen im südöstlichsten Zipfel des Kreis Oststernberg, von denen bei Eintreffen der Roten Armee am 30. Januar 1945 noch niemand geflohen war, wurden am 26. Juni 1945 durch bereits anwesende Polen ausgewiesen und mussten das Dorf innerhalb von vier Stunden räumen. Innerhalb von Tagen hatte man die $75 \mathrm{~km}$ bis zur Oder erreicht. „Nach Überschreitung der Oder löste sich die Dorfgemeinschaft auf und zerstob in alle Winde. Nur ganz allmählich konnten wieder Verbindungen aufgenommen werden und Schicksale geklärt werden. “536 Die am 26. Juni 1945 in Langenpfuhl im Kreis Oststernberg Ausgewiesenen kamen in einer etwa achttägigen Pferdewagenfahrt bis an die Oder. Eine von ihnen, eine 45-jährige Mutter dreier Kinder, erinnerte sich später: „Diesseits der Oder fiel der Treck auseinander. Wir wanderten bis Altlandsberg, wo wir am 6. Juli 1945 eintrafen. Meine Cousine [...] nahm uns in ihrem Haus auf, das schon überfüllt von Flüchtlingen war. Mein Mann [...] fand Arbeit auf der Domäne, die jetzt von der Besatzungsmacht bewirtschaftet wurde. Frau Skerl, die Lehrerkinder und Schwägerin Dore blieben 2 Tage in Altlandsberg, dann verließen sie uns, um in Berlin Unterkunft zu finden. Zuletzt arbeitete mein Mann in Berlin auf dem Bau. Er verunglückte an der Weberwiese bei der Arbeit am 30. Juni 1952 tödlich. Unsere Kinder waren da 19, 17 und 13 Jahre alt. Wir standen wieder vor dem Nichts!" 537

Die während der „Wilden Vertreibungen“ im Sommer 1945 Ausgewiesenen erlebten bisweilen regelrechte Odysseen. Eine damals Sechzehnjährige wurde am 24. Juni 1945 mit Mutter und Geschwistern aus der Neumark (Königswalde) vertrieben, wohin sie erst im Mai unter Strapazen aus ihrem Ausbildungsort Potsdam zurückgekehrt war. In Küstrin kamen sie zu Fuß an die Oder-Grenze: „Vor der provisorisch hergerichteten Oder-Brücke wurde unser Gepäck abge-

534 Dr. Hammer: Als Treck-Arzt von Sagan nach Cottbus. In: Geschichte wird Erinnerung (wie Anm. 57), S. 140141 [verfasst 1949].

535 Krätzner, Das Schicksal der Bevölkerung der Kreisstadt Königsberg in der Neumark (wie Anm. 304 ), S. 41.

536 Max Leibner: Mein Heimatdorf Burschen, Kreis Ost-Sternberg. In: Frankfurt (Oder)-Sternberger Kurier 4 (1955), Nr. 6, S. 11.

537 Barbara Kulla: Erinnerungen [ihrer Mutter Katharina Vollmer] an die Umsiedlung aus unserer Heimat. In: Lebenszeit [I.] Zeitzeugen berichten. Hrsg. vom Landesseniorenbeirat Brandenburg u. a. [Neuenhagen 1996], S. 46-47, hier S. 47. „Weberwiese“ meint den dortigen Wohnungsbau (Berlin-Friedrichshain). 
laden und wir wurden nun wie Freiwild über die Oder nach Deutschland entlassen. In Erinnerung [S. 43] habe ich die total zerstörte Stadt Küstrin behalten und die toten Menschen- und Tierleiber in der Oder. Es stank nach verwesten Leichen, und es durfte kein Wasser genommen werden. [...] Auf der anderen Seite der Oder erwartete uns niemand. Jeder musste entscheiden, was er nun begann. Wir versuchten, uns nach Potsdam zur Tante durchzuschlagen. Einen alten Handwagen hatten wir uns zusammen gebastelt, wo wir unser Gepäck aufluden. Nachts kamen sowjetische Soldaten und wollten Uhren und Schmuck, den wir aber nicht hatten. So nahmen sie auch die letzten Schuhe. Wir besaßen nur noch, was wir auf dem Leibe trugen. Ich erinnere mich an eine Gewitternacht, als unser großer Bruder ein großes Stück Blech organisiert hatte, dass wir zum Schutz vor dem Regen über uns legten. Nach Tagen kamen wir in Potsdam an. In der ersten Nacht schliefen wir mit 18 Personen auf dem Fußboden im einzigen Zimmer der ausgebombten Tante. Mutter ging am nächsten Tag zur Kommandantur, welche die Macht ausübte, um eine Wohnung für uns fünf zu bekommen. Ihr wurde mitgeteilt, dass es für uns in Potsdam keine Bleibe gebe und wir weiter nach Beelitz-Heilstätten ziehen müssen. Doch dort die selbe Reaktion, kein Platz für uns. Wir wurden zu Fuß weiter in den Kreis Beeskow geschickt. Hier dasselbe Bild. Wie die Zigeuner zogen wir, wie viele andere Vertriebene, weiter durch das Brandenburger Land in der Hoffnung, endlich unterzukommen. In Niederlehme, wohin man uns weiterschickte, kamen wir halbverhungert an. Unreife Äpfel hatten wir auf den Straßen aufgelesen und gegessen und uns von Dingen ernährt, die wir nachts auf den Feldern gestohlen hatten. In Niederlehme erhielten wir Quartier in einer Wohnung des Kalksandsteinwerkes. Für ein Jahr hausten wir hier ohne Arbeit und Geld. Kartoffelschalen gehörten zu unserer Nahrung, die wir uns erbettelten. Einmal erhielten wir braunen Zucker aus alten Beständen der Wehrmacht. Während dieses einen Jahres, das wir dort lebten, verhungerten in unseren Häusern 14 Menschen. [...] Da die Niederlehmer Fabrik wieder aufgebaut wurde, brauchte man nun die Wohnungen wieder für die Arbeiter, und für uns setzte sich die Vertreibung fort. Wir wurden nach Storkow in Marsch gesetzt. Dort wies man uns nach Groß Schauen zum Mittelbauern Graef ein. Der hatte selbst acht Kinder, [S. 44] und wir erhielten die Kutscherstube über dem Pferdestall als unser neues Quartier. Obwohl Mutter Graef selbst genug Esser zu versorgen hatte, erwies sie sich als Seele von Mensch und half uns, wo sie konnte. Ein Stück unbebautes Land konnten wir uns urbar machen und so begann die größte Not zu Ende zu gehen. Im Herbst 1946 ging ich nach Selchow zum Bauern Woike in Kost und Logis. Ich konnte dort in der Landwirtschaft arbeiten und bekam 20 Mark im Monat, zu essen und Milch sowie Brot für die Geschwister. Meine Familie musste zwei Jahre in der Kutscherstube ausharren, bis sie eine Wohnung in Groß-Schauen zugewiesen bekam. [...]." 538

Im Sommer 1945 führten die „Wilden Vertreibungen“ in den Aufnahmegebieten zu einer ähnlich dramatischen Situation, wie sie zwischen Januar und April für alle Teile Brandenburgs überliefert ist. Eine Zeitzeugin, die erlebt hatte, dass man in Berlin nicht bleiben durfte, musste mit ihrer Familie im Juli weiterziehen: „Die Dörfer von Berlin bis Neuruppin waren von Trecks und

538 Gertrud Friedrich: Vertreibung und Neubeginn. Erzählt von G. F. Aufgeschrieben von Horst König. In: Geschichten aus sieben Jahrzehnten. Storkower Zeitzeugen berichten. Hrsg. vom Seniorenbeirat der Stadt Storkow (Mark). Storkow 2005, S. 41-45, hier S. 42-44. 
Flüchtlingszügen überschwemmt. Wir waren ja die letzten. Wir fanden keine Aufnahme, kein Brot oder gekochtes Essen, wir haben gehungert. Nur abgekochtes Wasser tranken wir unterwegs. " 539

Die völlige Hilflosigkeit auch zu Empathie fähiger und bereiter Einheimischer in den Wochen und Monaten des größten Flüchtlingselends im Sommer 1945 hat der Domänenpächter des Amtes Friedrichsaue (Kr. Lebus), Curt Peters, im Juni 1946 in einem Brief an eine Bekannte beschrieben. Im Anschluss an die Erwähnung eigener Leiden seiner Familie sowie der Bewohner, von Plünderungen und Vergewaltigungen der ersten Zeit nach Kriegsende schreibt er über die eintreffenden Opfer der „Wilden Vertreibungen“: „Furchtbar war auch der Zug der östlich der Oder Vertriebenen, der mit vorgeschriebenen $10 \mathrm{~kg}$ bei uns durchzog. Alte Menschen, die an Krücken liefen, Kranke, denen wir nicht helfen konnten, die zu Hunderten in den Straßengräben lagen und aus deren Munde schon Maden - ja Maden - herauskrochen und kein Arzt, keine Medizin vorhanden um ihnen zu helfen. Mit dem auf der Dorfstraße gewählten provisorischen Bürgermeister habe ich beraten, auf welche Weise man diesen armen Menschen helfen könnte. Allein ich selbst habe an 86 Gräbern gesprochen, da kein Geistlicher zu Hand war und wir sie nicht wie Hunde verscharren wollten, aber natürlich ohne Sarg; sogar Papier fehlte, um die Leichen darin einzuwickeln. Nun kam der Typhus, die Leute starben wie die Fliegen, auch unser Oberinspektor und der Maschinenmeister. [...]." ${ }^{440}$ Einheimische wie Flüchtlinge und Vertriebene waren in dieser Hinsicht vorübergehend im selben Boot, Opfer der Ernährungs- und Hygiene-Notlage, die allerorten herrschte.

Aus einem im Juli 1945 aus der Uckermark nach Berlin fahrenden Transport mit vertriebenen Neumärkern hat ein Zeitzeuge berichtet: „Nach Tagen kamen wir in Berlin-Neukölln an. Der Zug hielt, aber keiner wußte, ob er aussteigen sollte oder nicht. Schließlich wurde doch ausgestiegen und die Sachen entladen. Als man noch damit beschäftigt war, fuhr der Zug los in Richtung Berlin-Oberscheineweide [-Oberschöneweide!]. Ich selbst und unser Dienstmädchen waren draußen, meine [S. 579] Frau, ihre Schwester mit den beiden Kindern und Frau Anna Meinert mit den beiden kleinen Jungens waren noch im Zug. Es war Pech. Mit sehr großer Mühe und unter ständiger Gefahr von vorbeifahrenden Zügen überrollt zu werden, kamen unsere Angehörigen wieder zurück, jedoch erst nach 2 Tagen. [...]. ${ }^{\text {"541 }}$ Die ersten Schritte in Berlin zeigen einmal mehr die Bedeutung individueller Hilfsmöglichkeiten, auf die nicht jeder zurückgreifen konnte: „Bin dann [...] durch das zerbombte Berlin bis nach Berlin-Gesundbrunnen gezogen, um Unterkunft bei meinem ältesten Bruder zu suchen. Leider standen wir vor einer Ruine. Zum Glück hatte mein Bruder seine neue Anschrift an die Restmauern angebracht, damit ich ihn finden konnte. Mit letzter Kraft haben wir es nach vielen Stunden geschafft. Als wir feststellen konnten, daß Berlin uns nicht aufnehmen konnte und wir auch nichts zu Essen bekamen, ging die Reise weiter. Vom Güterbahnhof Berlin-Lehrter Straße ging es dann los. Wir kamen bis nach Berlin-Spandau-West. Nach 24 Stunden sollte der Zug weiterrollen; da wurde bekannt, daß es in der Stadt warmes Essen für uns gibt. So sind wir also abwechselnd

541 Fritz Löffler: [Erlebnisbericht, zusammengestellt 1980]. In: Heimatkreis Soldin/Neumark (wie Anm. 303), S. 573-579, hier S. $578 \mathrm{f}$. 
dorthin marschiert, aber nur die Älteren, da sonst der Russe unsere paar Jüngeren einkassiert hätte. Es gab Kohl in Wasser, was trotzdem für uns ein fürstliches Essen war." Der Weitertransport endete schließlich in Tangermünde an der Elbe. ${ }^{542}$

Ein aus Hänchen im niederschlesischen Kreis Freystadt stammender Kleinbauernsohn, dessen Vater im März interniert und über den Sammelpunkt Grünberg in Schlesien in die Sowjetunion gebracht wurde, beschreibt die Vertreibung durch „polnische Zivilisten und sowjetische Soldaten“ im Juni $1945^{543}$ : „Schnell packten wir einen Wagen mit Betten und Essen voll, davon hatten wir ja genug. Keiner dachte an Dokumente. Ich spannte zwei Kühe ein und band zwei hinten am Wagen fest. Pferde besaßen wir ja als Kleinbauern nicht. Nach der Vertreibung von unseren Höfen kamen wir bis zum Ortsausgang Günt [h] ersdorf und warteten bis in die Nacht auf der Landstraße, bis alle Bürger aus den umliegenden Orten sich dem Treck angeschlossen hatten, der sich auf eine Länge von etwa zwei Kilometern hinzog. Unter dem Schutz sowjetischer Soldaten setzten wir uns in Richtung Westen in Bewegung. Vor Sommerfeldt [Sommerfeld] wurden wir von polnischen Bürgern überfallen, die uns zu plündern versuchten. Sowjetische Soldaten rissen die MP's hoch und riefen ,Halt! Stehenbleiben!' Die Polen blieben nicht stehen. Es fielen Schüsse und es gab Tote. Auf dem weiteren Treck über Grünberg nach Christianstadt ging es noch gut auf der Straße. [...] Unter dem Schutz der sowjetischen Soldaten gelangten wir dann am nächsten Tag bis an die Grenze nach Guben. [S. 30] Ich war inzwischen 15 Jahre alt geworden und durfte nicht mit in die Sowjetische Besatzungszone. Mit weiteren Jugendlichen wurde ich vorerst in einem Gebäude unmittelbar hinter der Neiße auf polnischem Gebiet untergebracht. Der große Treck war weitergezogen. Von polnischen Offizieren wurde uns mitgeteilt, daß wir in Polen bei Arbeiten gebraucht würden. Wir sollten vorerst die Pferde und Kühe des Trecks, die nicht mit über die Grenze durften, füttern und pflegen. Später sollten auch wir interniert und zur Wiedergutmachung eingesetzt werden. Nach dieser Ankündigung floh eine ganze Gruppe von uns nachts über die Neiße und fand wieder Anschluß an den Treck. Mit meiner Schulfreundin aus dem Heimatort war ich mit dabei. [...] Unserem Treck hatten sich auch einige Zwangsarbeiter angeschlossen. Ein Franzose und ein Ukrainer hatten so engen Kontakt zu den damals dagebliebenen und nun vertriebenen Deutschen, an deren Schicksal sie teilnehmen wollten. Der Ukrainer mit Tochter, der bei uns im Nachbarort bei einem Bauern untergebracht war, ist dann nicht eher in seine Heimat zurückgekehrt, bis der Rest unserer Familie in Pinnow am See, Kreis Guben, untergebracht waren. Solange ist er mit uns klauen gegangen, damit wir überleben konnten." ${ }^{444}$ Auch das weitere Schicksal des fünfzehnjährigen Vertriebenen war hart: „Im Februar 1947 verstarb meine Mutter im Alter von 50 Jahren im Krankenhaus Lieberose. Zu Herzmuskelschwäche und Wassersucht war eine doppelseitige Lungenentzündung hinzugekommen, die sie nicht lebend überstand." ${ }^{45}$ Sein älterer Bruder blieb als Soldat verschollen, sein Vater konnte zwar im Herbst 1946 aus der Gefangenschaft in der Sowjetunion zurückkehren, starb aber an den Folgen der Entbehrungen 1952 im Kreiskrankenhaus 
Guben. Er selbst war zunächst als Wald- und Landarbeiter tätig, wurde dann aber schließlich Offizier der NVA und arbeitete auch hauptamtlich in der SED. „Eine Hoffnung, in meine Heimat einmal wieder zurückkehren zu können, habe ich nicht gehabt. [...] In der späteren DDR fand ich meine neue Heimat."

Die Erinnerungsliteratur enthält aber auch zahllose Schilderungen jenes bereits oben angesprochenen oftmals mehrstufigen Vorgangs, der zum Massenschicksal wurde und in dem die „Wilden Vertreibungen“ gleichsam eine „Station“ bildeten. So berichtet der 1934 geborene, aus Schernewitz, einem Dorf im Ostteil des Landkreises Guben, stammende Bäckermeistersohn Siegfried Hamsch in geraffter Form über die wesentlichen Stationen von Flucht, Rückkehr und Vertreibung, wobei auch viele der geschilderten Begleiterscheinungen und familiären und sonstigen Rahmenbedingungen ebenfalls kein Einzelfall waren:

„Als die Front immer näher rückte, mussten wir am 14. Februar 1945 unser Heimatdorf und damit unser Anwesen verlassen. Eine Woche später waren dann die ersten Truppen der Roten Armee im Ort. Mit Handwagen und Koffern, nur das wichtigste Hab und Gut mitgenommen, ging es auf einen über mehrere Tage dauernden Treck nach Lindena bei Doberlugk-Kirchhain. Hier waren wir auf einem Bauerngehöft untergebracht und erlebten in der Nacht zum 23. April, meinem 11. Geburtstag, den Einmarsch der Roten Armee.

Gute zwei Wochen mussten wirt uns dort noch aufhalten. Nach Kriegsende am 8. Mai konnten wir wenige Tage später von Lindena wieder zu Fuß die lange Strecke zurück nach Schernewitz. Nach mehreren Tagen erreichten wir unser Heimatdorf. Mehrere Häuser waren zerstört. [...] Unser Haus [...] war zum Glück unversehrt.

Nur wenige Wochen wieder zu Hause, kam am 20. Juni 1945 um 4.30 Uhr die schicksalsschwere Nachricht, dass wir uns innerhalb einer Stunde auf der Dorfstraße zum Abmarsch einzufinden hatten. Es ging in Richtung Neiße, wo wir in der Nähe von Gubinchen durch den gerade Niedrigwasser führenden Fluss durchs Wasser ans andere Ufer mussten.

Wir wurden nach kurzem Aufenthalt in Kaltenborn nach Bahro beordert, wo wir, meine Mutter (Vater war im Krieg geblieben), meine jüngere Schwester und ich, sowie Oma und Opa und eine Tante, die jüngste Schwester meiner Mutter, bis August blieben. Da wir fast alle erkrankten und die Schwester meiner Mutter im Krankenhaus in Fürstenberg (Oder) an Typhus verstarb, holte uns die in Guben lebende älteste Schwester meiner Mutter, Tante Frieda, nach Guben in die Grünstraße 56, wo wir zu acht in einem Zimmer mit Küche etwa zwei Jahre lebten.

Mein Vater[,] von dem seit August 1944 kein Lebenszeichen mehr kam, ist nie aus dem Krieg zurückgekehrt. Mutter hatte mit uns zwei Kindern, meiner sieben Jahre jüngeren Schwester und mir, die schweren Jahre nach 1945 selbst zu tragen." ${ }^{457}$

Die ostbrandenburgische Bevölkerung, also die der Neumark und der östlich der Lausitzer Neiße gelegenen Teile der Niederlausitz, hatte - wie die der nördlich angrenzenden

Ebd.

547 Siegfried Hamsch: Erinnerungen und Ereignisse. Krieg - Vertreibung - Neuanfang. in: Jahrbuch für Gubener Geschichte 1 (2011/12), S. 190-208, hier S. 198 f. 
pommerschen und der südlich gelegenen niederschlesischen Landkreise und des sächsischen Reichenauer Zipfels ${ }^{548}$ - gewissermaßen teilweise das „Privileg“, auch nach 1945 westlich der neuen Grenze weiterhin zumindest noch in derselben Landschaft leben zu können, sofern es sie nicht im Chaos des Kriegsendes in weiter entfernte Regionen Deutschlands verschlagen oder die offiziellen Transporte sie nicht in fernere Gegenden zu gehen gezwungen hatten. Unmittelbar oder doch bald nach dem Schweigen der Waffen versuchten sehr viele aber, auf eigene Faust in den Heimatort zurückzugehen. Dies war für die meisten ein selbstverständlicher Gedanke, so irreal er heute erscheinen mag. Daher finden sich in den Erinnerungsberichten tage-, ja wochenlange Fußmärsche und auch „illegale“ Eisenbahnfahrten keineswegs nur bei jenen, die sozusagen nur den Fluss zu überqueren hatten, sondern auch bis tief nach Schlesien hinein und sogar nach Ostpreußen zog es Menschen, die Haus und Hof im Januar oder Februar hatten im Stich lassen müssen. Die meisten von ihnen sind - wie die Familie Hamsch - im Sommer 1945 bei den sogenannten „Wilden Vertreibungen“ wieder ausgewiesen worden. Gerade in dem der Oder und Neiße nahen Raum bewirkten die „Wilden Vertreibungen“ den größten „Schwund“ unter der deutschen Bevölkerung. ${ }^{549}$ Proteste wegen der Ausschreitungen, aber auch wegen der verheerenden Folgen für die wirtschaftliche Situation in den Vertreibungsgebieten führten im Juli 1945 zur „faktische(n) Einstellung unmittelbar vor der Konferenz von Potsdam“.550

\section{Systematische Vertreibungen ab August 1945}

Mit den Potsdamer Beschlüssen der Siegermächte war die Vertreibung als Ziel besiegelt. Ihre Ausführung sollte demnach zwar „in organisierter und humaner Weise“ erfolgen, doch die längst eingetretene Dynamik der Geschehnisse war nicht mehr aufzuhalten. Polnische und tschechische Behörden und lokale Machtinstanzen weiteten nun „die von ihnen seit Monaten praktizierte Vertreibung systematisch aus“; für Brandenburg bedeutete das einen nahtlosen Übergang von den im Juni und Juli aufzunehmenden Strömen der den „Wilden Vertreibungen“ ausgesetzten Bevölkerung aus den Oder und Neiße östlich benachbarten Kreisen zu den nun nicht mehr abreißenden Transporten aus nahezu allen, auch den entfernter liegenden Vertreibungsgebieten. ${ }^{551}$

Ein im Frühjahr 1945 noch in seinem neumärkischen Heimatort befindlicher, damals elfähriger Schwiebuser hat aus der Rückschau berichtet, dass nicht jeder Betroffene sogleich die Dimension der Geschehnisse erkannte: „Was damals die hohe Politik in Teheran, Jalta und später auch in Potsdam beschloß, war uns völlig unbekannt. Seit Monaten keine Zeitung und keine

548 Dannenberg, Flucht und Vertreibung im Zittauer Zipfel (wie Anm. 18).

549 Ruchniewicz bezeichnet das „Lebuser Land“ als das am stärksten betroffene Gebiet. Gemeint ist das Territorium der heutigen polnischen Woiwodschaft dieses Namens, das v. a. den größeren (mittleren und südlichen) Teil der ehemaligen Neumark und nordwestliche Teile Niederschlesiens um Grünberg und Freystadt einschließt. Ruchniewicz, Wilde Vertreibung aus Polen (wie Anm. 530), S. 728.

550 Ebd.

551 Wille I (wie Anm. 196), S. 121. 
Verbindung, nicht mal zum Nachbarorf. Daher hatten wir keine Ahnung, welchen Zweck das Auftreten der Zivilpolen verfolgte. Als später alle Deutschen in Gemeinschaftsarbeit die Felder bestellen mußten, sahen wir, daß die Polen das Kommando übernommen hatten. [...]." ${ }^{\text {"52 }}$ Doch auch die erst in Ansätzen arbeitsfähigen Behörden der Provinz Brandenburg waren vollkommen überfordert und wurden geradezu überrollt. „Seit August erlebten die östlichen und südöstlichen Regionen der SBZ einen Menschenzustrom von bisher nicht gekanntem Ausmaß. Vor allem die Städte an Oder und Neiße sowie an der deutsch-tschechischen Grenze wurden,Schauplatz einer grauenvollen Tragödie“." ${ }^{553}$ Die Mehrheit der Vertriebenen, die ihre Heimat nicht schon zuvor hatten verlassen müssen, wurde nun im Hochsommer, Herbst und Winter 1945 sowie fast das ganze Jahr 1946 hindurch systematisch erfasst und ausgewiesen. Der Gesamtvorgang erstreckte sich gleichwohl auch noch auf die Folgejahre 1947 und 1948. Danach kamen - 1949 und 1950 nur noch in besonderen Fällen weitere Transporte. Ab 1950 schloss sich - fast nahtlos - die Geschichte der (Spät-)Aussiedler an, die im Anschluss gesondert zu behandeln ist.

Über die Vorgänge bei den „organisierten“ Vertreibungen gibt es eine große Fülle an amtlichen und Zeitzeugenberichten. ${ }^{554}$ Dies kann und muss hier nicht ausführlich referiert werden. Wenige Äußerungen aus Zeitzeugenberichten mögen andeuten, was die Betroffenen an Erlebnissen nach Brandenburg „mitbrachten“. Schon vor der Ankunft in der SBZ hatten manche Vertriebenen bereits eine Odyssee hinter sich. Eine junge, 1929 geborene Ostpreußin wurde bereits im August 1944 mit einer kinderreichen Familie, bei der sie ihr „Pflichtjahr“ ableistete, nach Vorpommern evakuiert, erhielt aber im Januar 1945 eine Sondergenehmigung, zu ihrer Familie nach Ostpreußen zurückzukehren. „Nach siebenmaligem Umsteigen, Unterbrechung durch Fliegeralarm u. a. erreichte ich erschöpft, aber glücklich meine Angehörigen im Kreis Sensburg. Wenige Tage später mussten wir mit dem Flüchtlingstreck wieder aufbrechen, um nach 6 Wochen wieder in Pommern zu landen. “555 Dort erlebte sie das Kriegsende. „Hier lebten und arbeiteten wir unter polnischer Herrschaft noch 10 Monate lang.“ Im Januar 1946 folgte die Ausweisung. „Erst am 6. März 1946 fanden wir in Behrensdorf Siedlung [bei Beeskow] eine neue Heimat. "556

Eine junge Frau aus einem Dorf im neumärkischen Kreis Züllichau-Schwiebus, die, getrennt von ihren Eltern (und von fast allen Informationen), ab April 1945 mit zwei Schwestern fast sieben Monate in einem Lager in Posen hatte verbringen müssen, gelangte nach der Entlassung Ende Oktober zunächst in ihren Heimatort zurück. In ihren Erinnerungen an das Jahr 1945 hat sie den Tag beschrieben, an dem ihnen die Realität des bevorstehenden Heimatverzsgest. von Lothar Meißner. O. O. 1995, S. 66-72, hier S. 70.

554 Siehe u. a. Dokumentation der Vertreibung (wie Anm. 192) und „Unsere Heimat ist uns ein fremdes Land geworden ..." (wie Anm. 195).

555 Hildegard Rölke: Mein Pflichtjahr. In: Damals und heute (wie Anm. 357), S. 52-53, hier S. 53.

556 Hildegard Rölke: Wie ich das Jahr 1945 erlebte. In: Storkower Zeitzeugen berichten [H. 1] (wie Anm. 370), S. 27-30 (Zitate S. 35). 
lusts plötzlich vor Augen trat: „Zusammen mit einer polnisch sprechenden Frau verbrachten wir die letzte Nacht in Posen auf dem Bahnhof. Am Montag, dem 30. Oktober, bestiegen wir zusammen mit einer Frau aus Kutschlau ${ }^{557}$ den Personenzug in Richtung Frankfurt/O. und fuhren bis Schwiebus. Von hier aus gingen wir die rund $10 \mathrm{~km}$ bis nach Hause. Je näher wir unserem Heimatdorfe kamen, desto schneller wurden unsere Füße. Wir malten uns aus, wie alles wohl sein würd. Würden wir unsere Eltern noch antreffen? Nein! Wir hatten schon vorher gehört und auch unterwegs bemerkt, daß alle Deutschen vertrieben waren. Und dann standen wir endlich vor unserem Anwesen, auf dem wir geboren wurden. Doch wie groß war unsere Enttäuschung. Der elterliche Hof war von einer polnischen Familie besetzt. Es gab keine Verständigung, nur Tränen auf beiden Seiten. ${ }^{\text {"558 }}$ Es folgte die endgültige Ausweisung, der Weg führte dann über Schwiebus, Frankfurt (Oder) und Berlin zunächst nach Neuruppin: „Wir hatten gehört, daß im dortigen Arbeitsamt Listen ausliegen, aus denen zu ersehen war, wo Flüchtlinge aus unserem Kreis untergebracht waren. Wir stießen in den Listen auf die Namen Galke und Fischbach, Nachbarsfrauen aus unserem Heimatdorf, die jetzt im nahegelegenen Ort Dabergotz untergekommen waren. Sie standen im Briefwechsel mit unseren Eltern. Von ihnen erfuhren wir, daß die Eltern jetzt in Möllenbeck, in der Nähe von Neustrelitz wohnten. Nach einigen weiteren Tagen, am 9. November 1945, konnten wir dann endlich unsere Eltern, Schwester, Großmutter, Tante und Cousine Christa in die Arme schließen." 559

Die letzten noch in Landsberg/Warthe verliebenen Deutschen wurden erst am 10. September 1950 ausgewiesen. Man brachte sie zunächst in einem Personenzug über Posen in das Sammellager Breslau-Hundsfeld (poln. Psie Pole), von wo aus sie nach wenigen Tagen Lageraufenthalts zusammen mit dort für die Ausreise vorbereiteten Schlesiern nach Deutschland gefahren wurden. In Hundsfeld - so die Erinnerung eines Transportteilnehmers - „konnten wir einen anderen, langen Zug, bestehend aus Güterwagen für das Gepäck und vielen, mit Roten Kreuzen gekennzeichneten Schlafwagen besteigen und ab ging die Reise für viele Hunderte Menschen. Am späten Abend, im Dunkeln, überquerten wir die Neißebrücke, also die Grenze, bei Forst. Zwei Tage und zwei Nächte waren wir unterwegs, quer durch Deutschland. ${ }^{\text {“560 }}$ Der Zug fuhr über Leipzig und Plauen nach Oelsnitz im Vogtland, wo „der ganze Transport mitsamt unserem Gepäck auf der Burg hoch über der Stadt untergebracht" wurde. „Hier durchliefen wir das in Lagern übliche Programm: Entlausung, Körperpflege, ärztliche Kontrolle sowie Papiere, Papiere. Nach einigen Tagen wurden die Ersten entlassen und in Familiengruppen auf die Bahn in die neue Heimat gesetzt: Alle, die vorher schon Zuzugsgenehmigungen hatten, in die DDR oder in die Bundesrepublik, konnten fahren. Alle anderen bemühten sich um Zuzugsgenehmigungen zu Familienmitgliedern in der DDR oder der Bundesrepublik. Diese Gruppen

557 [Kr. Züllichau-Schwiebus.]

558 Marianne Modrau: Erlebnisse in Lanken. Zsgest. von Karl-Heinz Graff. In: Vor 50 Jahren. Als Flucht und Vertreibung im Kreis Züllichau-Schwiebus begannen. Auszüge aus Tagebüchern, Briefen und Aufzeichhungen. Im Auftr. des Heimatkreises zsgest. von Lothar Meißner. O. O. 1995, S. 27-32, hier S. 31.

559 Ebd., S. 32.

560 Werner Gabloffsky: Erinnerungen an Wanderjahre und Beruf. In: Heimatblatt der ehemaligen Kirchengemeinden Landsberg/Warthe Stadt und Land 52 (2016), S. 41-48, hier S. 42 (auch die folgenden Zitate). 
reisten wieder einige Tage später ab und so wurden auch die Landsberger in alle Winde zerstreut. Wir, wie wenige Andere, hatten keine Familienangehörigen, weder hier noch dort und sollten deshalb irgendwo in die DDR eingewiesen werden. Mein Vater sagte leise: ,Dann hätten wir gleich zu Hause bleiben können.' Er hatte wohl schon eine Ahnung davon, was in der DDR kommen würde. Jetzt waren wir schon 12 Tage dort und die Einweisung stand bevor. Schließlich kam ein Telegramm vom Ministerium für Flüchtlinge und Vertriebene aus Hannover und wir durften in die Bundesrepublik ausreisen. - Gott sei Dank." Hintergrund war, dass ein aus Küstrin vertriebener und in Niedersachsen gelandeter Onkel, der dort inzwischen politisch beim $\mathrm{BHE}^{561}$ aktiv war, sich für die Familie verwendet hatte.

Die zeitgenössische Provinzial- bzw. Landesverwaltung konnte 1945/46 die bisweilen täglich veränderte Situation kaum wirklich überblicken, war sie doch nicht nur oft kurzfristiger Befehlsempfänger der SMA, sondern wurde immer wieder auch von der tatsächlichen Abfolge der grenzüberschreitenden Züge überrascht. Am 5. September 1945 sah sie sich genötigt, die vielfach bereits mit den bis dahin erfolgten Zuweisungen überforderten brandenburgischen Landräte und Oberbürgermeister von einer erneuten Steigerung des Zustroms in Kenntnis zu setzen: „Lt. Befehl der Sowjetischen Militärischen Administration hat die Provinz Mark Brandenburg im September aus Polen, Ungarn, der Tschechoslowakei und anderen Balkanländern 700000 ausgewiesene Deutsche unterzubringen. Der Befehl muß unter allen Umständen durchgeführt werden. Der Landrat des Kreises wird persönlich haftbar gemacht für die ordnungsgemäßte Durchführung der Einweisung in die Kreise. ${ }^{\text {"562 }}$ Die dabei aufgestellten Pläne für die Unterbringungszahlen pro Kreis sind jedoch ebenso wie die vorgegebenen Transportwege aus den Auffanglagern in die Unterbringungskreise ${ }^{563}$ vielfach bloße Theorie geblieben, hilflose Versuche der Verwaltung, Ordnung in das - allein der schieren Zahlen wegen - kaum abwendbare Chaos zu bringen und den Befehlen, denen sie selbst ausgesetzt war, zu folgen. Am 2. Dezember 1945 erhielt die Berliner Zentralverwaltung für Deutsche Umsiedler einen Anruf aus Angermünde, von dem u.a. notiert wurde: „Es herrscht grosses Massensterben täglich. Zur Zeit des Anrufes wieder 20 Tote. Im Augenblick über 6000 Umsiedler in Angermünde. " 564

Nicht nur die verschiedensten örtlichen Unwägbarkeiten und mangelhaften Voraussetzungen in einem vom Krieg gezeichneten (Aufnahme-)Land verhinderten planmäßiges Vorgehen, sondern nicht zuletzt die Vertriebenen selbst wurden immer mehr zu einer kaum noch zu beherrschenden Bevölkerungsgruppe. Da sie „seit dem Beginn des qualvollen Weges meist schlechte Erfahrungen gemacht hatten“, suchten sie „ständig den geschlossenen Transporten zu entkommen". ${ }^{655}$ Auch auf deutscher, hier brandenburgischer, Seite kam es daher zu strengerem Vorgehen, das die Bereitschaft der Vertriebenen, sich „führen“ zu lassen, trotz aller Bedürftigkeit nicht unbedingt beförderte. Schon am 11. Oktober 1945 sah sich die Abteilung Polizei der

561 Block der Heimatvertriebenen und Entrechteten, politische Partei in den Westzonen und der Bundesrepublik.

562 Wille I (wie Anm. 196), S. 155 (nach BLHA, Rep. 250 Cottbus, Nr. 1303, Bl. 520).

563 Ebd., S. $156 \mathrm{f}$.

564 BArch, DO 2/38, Bl. 14. Siehe auch Teil 3 (Quellenedition), Nr. 15.

565 Christopeit, Herkunft und Verteilung (wie Anm. 29), S. 94. 
Provinzialverwaltung Brandenburg zu der Anordnung gezwungen, „daß jeder Transport durch Polizisten zu begleiten sei, damit die Transportangehörigen auf den Bahnhöfen nicht entweichen könnten" ${ }^{566}$ Erschwerend (und nur bisweilen erleichternd) kam für die einzelnen Aufnahmekreise hinzu, dass nicht immer sogleich Klarheit darüber herrschte, ob ein Transport - nach Quarantäneaufenthalt in einem Lager - komplett im Kreisgebiet anzusiedeln oder in einen anderen Kreis, ein anderes SBZ-Land oder gar eine andere Besatzungszone weiterzuleiten war. Auch die „bloßen“ Durchschleusungen erforderten großen Aufwand bei Quarantäne, Verpflegung, Unterbringung und Organisation der Transportkapazitäten. So stand man z. B. im Kreis Luckau Anfang Oktober 1945 vor der Aufgabe einer „Durchschleusung von 1 1/2 Millionen Umsiedlern aus Polen nach Mecklenburg“. 567 Der nächste Transport stand meist schon „vor der Tür“.

Über die Anzahl der in dieser Zeit der nahezu pausenlos eintreffenden Transporte nach Brandenburg gelangten Personen gibt es sehr unterschiedliche Angaben. ${ }^{58}$ Die Zahl der ins Land gekommenen und zumindest einige Jahre verbliebenen Vertriebenen ist erst recht kaum feststellbar, geschweige denn den einzelnen Phasen - Flucht vor Kriegsende, „Wilde Vertreibungen" oder Vertreibungen ab Sommer 1945 - zuzuordnen. Die stets schwankenden Zahlen, mit denen die Verwaltung im Herbst 1945 zu operieren versuchte - eine Volkszählung erfolgte erst ein Jahr später und wäre zuvor auch kaum möglich gewesen -, haben auch für die rückschauende Betrachtung den Nachteil, dass sie meist einen scheinbaren Ist-Zustand einschließlich der vor August 1945 gekommenen Personen meinen, die vielen im Januar/Februar 1945 nach Brandenburg Geflohenen aber oft gar nicht mehr enthalten. „Von Mai bis Oktober 1945 wurden in der Mark Brandenburg etwa 600000 Flüchtlinge und Vertriebene sowie 26000 Bombenevakuierte gezählt. “569 Bei der Volkszählung am 29. Oktober 1946 lebten im Land Brandenburg insgesamt 2527492 Menschen, von denen 709065 ihren Wohnsitz 1939 außerhalb des späteren Gebietes der SBZ gehabt hatten, d.h. hier einschließlich Evakuierter und anderer „Umsiedler“; davon hatten 522773 ihren Wohnsitz 1939 in den Vertreibungsgebieten. ${ }^{570}$ Daran, dass insgesamt eine sechsstellige Zahl von Personen nach Brandenburg gelangt ist, ist also kaum zu zweifeln ${ }^{571}$, auch wenn genauere Angaben allenfalls pro Kreis oder Gemeinde angegeben werden könnten. Die Dimensionen liegen damit aber offen, an ihnen änderte sich trotz der Abwanderung vieler in den Westen kaum noch etwas.

566 Ebd.

567 Maßnahmenplan des Kreises Luckau, 9.10.1945, abgedruckt in: Wille I (wie Anm. 196), S. 157-159 (nach BLHA, Rep. 250 Landratsamt Luckau, Nr. 292, Bl. 156), Zitat S. 157.

568 Manfred Wille: Heimatvertriebene in den ersten Nachkriegsjahren in der sowjetischen Besatzungszone Deutschlands - Anmerkungen zur Statistik. In: Ders. / Karlheinz Lau / Jörg Bernhard Bilke: Die Vertriebenen in Mitteldeutschland. Hrsg.: Bund der Vertriebenen (Deutschlandpolitische Schriftenreihe, 10). Bonn 1991, S. 1-8, hier S. 6.

569 Pape, Flüchtlinge und Vertriebene in der Provinz Brandenburg (wie Anm. 30), S. 110.

570 Endgültige Ergebnisse der Volks- und Berufszählung vom 29. Oktober 1946 (wie Anm. 213), hier H. 7, S. 1. Vgl. Tabelle 4.

571 Siehe zu den Gesamtzahlen oben im Kapitel II. 2 den Abschnitt „Aufnahmegebiete“. 


\section{Spätfolgen: „Übersiedler" nach 1950}

Das Thema „Aussiedler“ bzw. „Spätaussiedler“572 wurde und wird in der Öffentlichkeit zu Unrecht meist allein mit der alten Bundesrepublik in Verbindung gebracht. ${ }^{573}$ Auch in die DDR, wo man davon wenig und allenfalls von „Übersiedlern“ sprach, und in die brandenburgischen Bezirke sind jedoch, also schon vor 1990, nicht wenige Menschen - unter schwierigen Bedingungen - legal ausgereist. ${ }^{574}$ Nicht nur die Bundesrepublik, sondern auch die mit ihr auch auf diesem Feld geradezu die Konkurrenz suchende DDR „stellte sich dem Problem der durch Kriegsereignisse, Flucht und Vertreibung getrennten Familien. ${ }^{575}$ Diese waren keine Einzelfälle,

572 Die amtliche Bezeichnung in der Bundesrepublik lautete bis 1992 „Aussiedler“, erst danach wurde und wird zwischen bis 1992 zugezogenen Aussiedlern und ab 1993 zugezogenen Spätaussiedlern differenziert. Der inoffizielle Sprachgebrauch auch in der Öffentlichkeit bevorzugte aber schon vor 1993 den - einen Bezug zur „Vorgeschichte“ herstellenden - Begriff „Spätaussiedler“, auch ehemalige DDR-Bürger verwenden ihn zumindest heute in ihren rückblickenden Selbstzeugnissen.

573 Allein auf die Bundesrepublik fokussiert ist z. B. Jürgen Hensen: Zur Geschichte der Aussiedler- und Spätaussiedleraufnahme. In: Aussiedler- und Minderheitenpolitik in Deutschland. Bilanz und Perspektiven. Hrsg. von Christoph Bergner u. Matthias Weber (Schriften des Bundesinstituts für Kultur und Geschichte der Deutschen im östlichen Europa, Bd. 38). München 2009, S. 47-61. - Die Forschungsliteratur unterschiedlichster Fachdisziplinen ist in demselben Sanmelband, S. 263-287, zusammengestellt: Ulrich Reitemeier: Auswahlbibliographie: Aufnahme- und Integrationsprozess von Spätaussiedlern in Deutschland. - Vgl. auch Klaus J. Bade: Aussiedler - Rückwanderer über Generationen hinweg. In: Neue Heimat im Westen: Vertriebene, Flüchtlinge, Aussiedler. Münster 1990, S. 128-149. - Siehe auch das kurze, aber informative Kapitel „Rußlanddeutsche in der DDR“ in: Alfred Eisfeld: Die Rußlanddeutschen. Mit Beitr. von Detlev Brandes u. Wilhelm Kahle (Studienbuchreihe der Stiftung Ostdeutscher Kulturrat, Bd. 2). München 1992, S. $171 \mathrm{f}$.

574 Archivalische Quellen hierzu sind für das Land Brandenburg bereits zugänglich, sie konnten für die vorliegende Arbeit lediglich aus Zeitgründen nicht ausgewertet werden. - Beispiele: BLHA, Rep. 601 Rat des Bezirkes Cottbus, hier zahlreiche Akten zur Durchführung von Übersiedlungen (Ständige Einreisen) (1965-1979), Bearbeitung von Anträgen auf Ständige Einreisen (Übersiedlungen) (1947-1983), Zusammenarbeit mit den Räten der Kreise bei Familienzusammenführung (1952-1955), Nachweisbücher zu Einzelfällen (19641988) usw. - Kreisarchiv Dahme-Spreewald, A-1 Kreistag und Rat des Kreises Lübben, Nr. 690 (Arbeitsorganisation, Arbeitspläne sowie Zusammenarbeit mit ständigen Kommissionen, 1968-1972; enthält u. a.: Analyse Strafentlassene, kriminell gefährdete Bürger und Umsiedler aus Polen). - Kreisarchiv Potsdam-Mittelmark (Belzig), Bestand RdK Brb (Rat des Kreises Brandenburg, Abteilung Inneres/Genehmigungswesen), GW 1 (Übersiedlungen aus der Volksrepublik Polen, 1965-1973). - Ebd., Bestand RdK Pdm (Rat des Kreises Potsdam, Abteilung Inneres, Genehmigungswesen), 20.04/73 (Wohnsitzänderung aus dem Ausland in die DDR Familien Einzelpersonen überwiegend Bürger aus Polen, UdSSR, Tschechien, Ungarn, 1975-1988; enth. u. a. Listen über namentliche Aufstellung eingereister Bürger). - Siehe auch schon für die frühe Zeit: BLHA, Rep. 250 Landratsamt Templin, Nr. 27 (Schriftwechsel mit der Landesregierung Brandenburg und der Regierung der DDR, 1951-1952; enthält u. a.: Familienzusammenführung aus Polen). - Zur Überlieferung des DDRInnenministeriums im Bundesarchiv siehe unten Anm. 584.

575 Dazu ausführlich und mit Zahlen und weiterer Literatur sowie zur Politik der DDR gegenüber den betreffenden Staaten: Amos, Vertriebenenpolitik der SED (wie Anm. 12), S. 83-132 (Deutsche in Polen), S. 132-174 (Deutsche Minderheit in der Tschechoslowakischen (Sozialistischen) Republik), 174-185 (Deutsche in der Sowjetunion). 


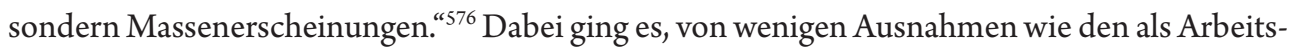
bzw. Fachkräfte zurückgehaltenen deutschen Bergleuten im Raum Waldenburg (Niederschlesien), vornehmlich um die 1945 in ihren Heimatorten verbliebenen bzw. dorthin zurückgekehrten, von Polen als „Autochthone“ eingestuften Oberschlesier, auch noch einige Masuren in Ostpreußen und nicht zuletzt um im sowjetischen Teil Ostpreußens und in Litauen aufgegriffene elternlose Kinder. ${ }^{577}$ Nach dem Ende der Vertreibungen bzw. Transporte von 1945/46, 1948 und 1950/51 kamen zwar auch aus der Tschechoslowakei immer wieder Deutsche in die Bundesrepublik und in die DDR, doch waren dies insgesamt deutlich weniger als aus Polen, da die Prager Regierung einen viel stärkeren Assimilierungskurs verfolgte. Der Anteil der aus der ČSSR in die DDR Kommenden gegenüber den nach Westdeutschland Strebenden war zudem ebenfalls noch einmal deutlich geringer als bei den aus Polen Ausreisenden: „1965 waren nur 313 Personen dauerhaft in die DDR gekommen, 1966 waren es sogar nur 199." ${ }^{\text {"578 }}$

$\mathrm{Da}$ es letztlich den Zufälligkeiten der Kriegsereignisse geschuldet war, wer von den „Übersiedlern“ nun Verwandte in Westdeutschland, wer in der DDR hatte, ergaben sich für die „Familienzusammenführung“ bisweilen schwierige Einzelverhandlungen mit den Betroffenen und ihren Angehörigen. Die DDR-Behörden waren dabei bestrebt, solche Personen, die in den Westen strebten („Westrepatrianten“), doch noch umzustimmen, und entwickelten im Einzelfall regelrechte Werbekampagnen. Für den Umgang mit einem angekündigten Sammeltransport aus Ostpreußen entschied die zuständige Abteilung Bevölkerungspolitik des Ministeriums des Innern der DDR „nach telefonischer Rücksprache mit dem Ministerium für Staatssicherheit“ am 11. Juni 1951: „Sämtliche Westrepatrianten sind erneut für ein Verbleiben in der DDR zu bearbeiten. Sollte trotz aller Bemühungen und auch bei Abgabe des Versprechens, die Angehörigen aus Westdeutschland nach hier zu übersiedeln, kein Erfolg zu erzielen sein, so können die Repatrianten einzeln bzw. in Familien zur Schleusung gebracht werden. Unter keinen Umständen darf jedoch ein Sammeltransport zusammengestellt werden." Doch selbst für dieses Verfahren gab es tunlichst zu beachtende Grenzen, wenn die Bemühungen nämlich bei den Betroffenen ins Gegenteil umzuschlagen drohten. Daher hatte dieselbe Abteilung schon unter dem 23. Mai 1951 bezüglich der Familienzusammenführung darauf hingewiesen, dass man diejenigen Deutschen aus den Sammeltransporten aus Königsberg, die Verwandte 1. oder 2. Grades in den Westzonen hätten (v. a. von ihren Ehemännern getrennte Frauen und von ihren Eltern getrennte Kinder) und daher nicht in der DDR bleiben, sondern sogleich zu diesen weiterreisen wollten („Westrepatrianten aus den Kaliningarder Transporten“), daran tunlichst nicht hindern sollte („Interzonenpass zum einmaligen Grenzübertritt"), da dies sonst zweifellos „den illegalen Grenzübertritt nach sich zie-

Ebd., S. 88 (hiernach auch das Folgende).

Claudia Schneider hat in den „überlieferten Antragskarten der Übersiedlungswilligen ab dem Jahr 1964“ festgestellt: „Anhand der Wohnorte kann eine deutliche Konzentration der Antragsteller in den damaligen Wojewodschaften Opole, Katowice und Olsztyn ausgemacht werden [...]." Schneider, Als Deutsche unter Deutschen? „Übersiedler aus der VR Polen“ (wie Anm. 23), hier S. 53 f.

Amos, Vertriebenenpolitik der SED (wie Anm. 12), S. 166. 
hen“ würde, „zumal diese Menschen über kein Grossgepäck verfügen“. Ferner heißt es abschließend: „Darüberhinaus dürfte sich die vorgesehene Massnahme politisch ungünstig auswirken, weil die illegal in Westdeutschland eintreffenden Repatrianten ihre Erlebnisse in der DDR und in der UdSSR über die Maßen aufbauschen und entstellen. Es ist damit zu rechnen, dass unsere politische Aufklärung während der Quarantänezeit ins Gegenteil umschlägt und diese Menschen bedingungslos der Westpropaganda ausliefert. - Die evtl. negativen Einstellungen der Repatrianten können u. E. durch ein Verbot der Ausreise nach Westdeutschland nicht verhindert werden, da der Postweg Jedermann offensteht. "579

Die gesamten fünfziger Jahre hindurch verhandelte die DDR mit der polnischen Regierung immer wieder über „Familienzusammenführung von Personen deutscher Nationalität“ (bis 1956) bzw. (später) über die „Übersiedlung von ehemaligen deutschen Staatsangehörigen in die DDR“. Die erste Übereinkunft zwischen der DDR und Polen „wurde im Januar 1950 in Ost-Berlin abgeschlossen“. Bis März 1951 verließen daraufhin „72621 Deutsche Polen, davon blieben 29941 in der DDR und 42680 reisten weiter nach Westdeutschland“. Während schon am 24. Januar 1952 ein weiteres gegenseitiges Abkommen über „Rückführungen“ unterzeichnet wurde und man sich sogar über Richtlinien für die „Zusammenführung“ mit „in der DDR wohnhaften Familienangehörigen“ verständigte, versuchte die polnische Regierung der damit wachsenden „Schleuse“ durch ebenfalls wachsenden Assimilierungsdruck auf die in ihrer Heimat verbliebenen Deutschen zu begegnen. ${ }^{50}$ Auch durch eine restriktive Bewilligungspolitik versuchte die polnische Regierung, die immer neuen Anforderungslisten ${ }^{581}$ der DDR einzudämmen. Die diplomatischen Kanäle wurden aber auch angesichts mancher Rückschläge und „Pausen“ weiter genutzt, wobei stets die Mehrheit der Aussiedler nach Westdeutschland strebte und kam, auch weil die polnischen Behörden - zum Ärger der SED - bei der Ausreise nach dort großzügiger verfuhren. ${ }^{582}$ Während zum Beispiel „von Januar bis September 1956 in die DDR nur 3000 Personen übersiedelten, gingen 8000 in die Bundesrepublik" ${ }^{583}$ Zwischen 1956 und 1958 kamen wiederum von etwa 250000 bis 290000 Deutschen nur 30000 bis 40000 in die DDR. ${ }^{584}$

BArch, DO 1/8408, unfol., gezeichnet „Büttner“ (Abteilungsleiter Kurt Büttner).

Amos, Vertriebenenpolitik der SED (wie Anm. 12), S. 89.

Anforderungslisten siehe u. a. BArch, DO 1/15827 (1942-1954), DO 1/15828 (1956).

Amos, Vertriebenenpolitik der SED (wie Anm. 12), S. 103 (mit Beispielen).

Ebd., S. 98.

Ebd., S. 112. - Aus dem Zeitraum 1950-1959 befinden sich im Bestand Ministerium des Innern der DDR im Bundesarchiv (BArch, DO1) u. a. in der Klassifikationsgruppe „Übersiedlungen aus und nach Polen“ 31 Aktenbände mit Transportlisten und Berichten über Transporte (DO 1/...): 8312-8317, 9166-9193, 1566515667, 15797, 15798 (Kindertransporte), ferner für die Jahre 1955-1978 26 Aktenbände „Zusammenarbeit mit den Räten der Bezirke. Mitteilungen, Einzelfälle“: 8326-8327, 9164, 9165, 14659-14663, 15864, 15865, 16654, 16655, 16666-16669, 16689, 16690, 16912, 16913, 16965, 16966-16968. Diverse weitere Akten reichen in dieser Klassifikationsgruppe bis 1988, Einzelfälle auch in: DO 1/15671 (1950-1951). - Entsprechende Akten zur Übersiedlung aus der UdSSR liegen hier für die Jahre 1950-1969 vor; siehe aber auch einzelne Akten in der Gruppe „Allgemeines“. - Ferner Polen und UdSSR (1950-1952) betreffend: DO 1/8192-8204 (Übersiedlungen aus Polen und der UdSSR. Anträge auf Familienzusammenführung, Heimkehrerunterstüt- 
Um 1960 erklärte man das Problem in Polen - nicht zum ersten Mal - vorschnell für gelöst. Doch die Ausreiseanträge wuchsen immer wieder nach, so dass auch in den sechziger Jahren Aussiedlungen erfolgten. Die Zahlenverhältnisse der Verteilung auf Bundesrepublik und DDR blieben, wenngleich auf einem niedrigeren Niveau, gleich: „1961 reisten nach ostdeutschen Angaben rund 1400 Deutsche aus Polen in die DDR ein, 1962 waren es zirka 1200 und 1963 1000. In die Bundesrepublik und nach West-Berlin siedelten 19618700 Deutsche über, 1962 waren es zirka 9200 Personen. ${ }^{\text {"855 }}$ Die DDR unterhielt sogar in Breslau und Danzig Konsulate, die in den sechziger Jahren ständig mit steigenden Ausreisenanträgen zu tun hatten. ${ }^{586}$ Die verschärften Diskriminierungen der deutschen Restbevölkerung in den polnischen Westgebieten einerseits, der Arbeitskräftebedarf der DDR und ihre Konkurrenzsituation zur Bundesrepublik andererseits führten 1964 zu einem erheblichen Aussiedlerschub. Allein das Breslauer DDR-Konsulat erteilte von Juni bis August 1964 ca. 11700 Einreisegenehmigungen, ${ }^{587}$ die jedoch nicht sämtlich umgesetzt werden konnten. Doch auch in den folgenden Jahren ließen weder der Druck der Ausreisewilligen noch die erteilten Einbürgerungsgenehmigungen in die DDR nach. Insgesamt wurden z. B. von Juli 1964 bis März 196516600 Einreisegenehmigungen erteilt - beantragt waren über $18400 .^{588}$

Die besondere Förderung der Wohnraumbereitstellung und schnellen Eingliederung in den Arbeitsprozess endete 1987. Insgesamt war auch bei den Aussiedlern („Übersiedlern“) die möglichst zügige und vollständige Assimilation beabsichtigt und zumindest nach außen hin auch erreicht. ${ }^{59}$ Strategien der „Übersiedler“, aber auch der Aufnahmekommunen lassen sich, wie die Forschungen von Claudia Schneider zeigen, auch für die brandenburgischen Bezirke recht gut nachvollziehen. So sah sich der Rat des Bezirkes Cottbus mit klaren Forderungen konfrontiert, die an die Situation bei heutigen Asylbewerbern erinnern: „Neubauwohnungen, Wohnungen am gleichen Ort, wo Verwandte oder Bekannte wohnen[,] und die Unterbringung nur in Städten “ ${ }^{590}$ Dahinter stand letztlich auch die „aus den städtischen Zentren Oberschlesiens“ mitgebrachte Furcht der Industriearbeiter vor sozialem Abstieg auf dem Land. „Dagegen waren Ermländer und Masuren, aber auch Menschen aus den landwirtschaftlich geprägten Regionen des Oppelner Schlesiens durchaus bereit, in Landgemeinden zu wohnen. " ${ }^{591}$

zung), DO 1/17274, DO 1/17275 (Aufnahmeheim Fürstenwalde. Kartei genehmigter Aufnahmen, 19591962); DO 1/17276-17279 (Kartei abgelehnter Aufnahmen, 1958-1962).

585 Amos, Vertriebenenpolitik der SED (wie Anm. 12), S. 126.

586 Ebd., S. 129 f. - Schneider, Als Deutsche unter Deutschen? „Übersiedler aus der VR Polen“ (wie Anm. 23), S. 57 (auf der Basis von Berichten der Konsulate).

587 Schneider, Als Deutsche unter Deutschen? „Übersiedler aus der VR Polen“ (wie Anm. 23), S. 60.

588 Ebd., S. 63. - Antragsformulare (Karteikarten DIN A 5 quer mit Passbild) sind in großer Zahl im Bestand MdI der DDR überliefert: BArch, DO 1/15498.

589 Ebd., S. 68: Bericht des Bezirkes Potsdam 1969, „daß die übergesiedelten Bürger eine gute Arbeitsmoral haben und gute Arbeitsleistungen vollbringen. Sie werden daher in den Kollektiven sehr geschätzt."

590 Ebd., S. 65.

591 Ebd., S. $66 f$. 
Die Zahl der Erinnerungen aus dem Kreis der in die DDR gelangten (Spät-)Aussiedler ist bislang deutlich kleiner als die der Flüchtlinge und Vertriebenen, die 1945 oder in der unmittelbaren Nachkriegszeit in die SBZ/DDR bzw. nach Brandenburg gekommen waren. Erst neuerdings ist nun aber auch aus dieser Betroffenengruppe die eine oder andere Stimme zu hören. ${ }^{592}$ So berichtet der 1974 als Spätaussiedlerkind mit Eltern und Geschwistern aus Bobrek in Oberschlesien in den deutschen Teil Gubens gelangte Rudolf Mierzwa über seine Erlebnisse, die alles andere als eine problemlose Integration zeigen. Denn zum einen erlebt er die offizielle Tabuisierung auch dieses Themas in der DDR, zum anderen erfährt er, ähnlich wie kurz nach 1945 und ähnlich wie Spätaussiedler, die nun zeitgleich nach Westdeutschland kommen, in seinem Umfeld blanke Ablehnung: „Aus Polen wurde schnell Polacke und dass wir Katholiken waren, setzte irgendwie immer noch einen drauf."

Auch bei den (Spät-)Aussiedlern spielt offenkundig die Grenznähe - neben anderen Faktoren wie dem Arbeitsplatzangebot in den großen Industriestandorten Eisenhüttenstadt und Schwedt/Oder - wiederum bzw. noch immer eine Rolle. So schreibt Mierzwa 2011: „Viele Oberschlesier leben im Grenzgebiet der ehemaligen DDR und jetzigen Bundesrepublik zu Polen. Früher ist mir das gar nicht so aufgefallen. Erst im jugendlichen oder fast erwachsenen Alter bekam ich einen Überblick und die Gewissheit, nicht allein in dieser Situation zu sein. An dieser späten Erkenntnis war nicht zuletzt der bedauernswert schlechte historische Rückblick auf die jüngste deutsche Geschichte in den Schulen der ehemaligen DDR schuld. Als Polacke verschrien, angemacht, verprügelt - das waren mitunter die ersten Eindrücke der Spätaussiedlerkinder aus Oberschlesien. / Es war sicherlich nicht immer leicht für mich, aber einer Abrechnung bedarf es hier nicht. Diese Zeilen sollen nur mal auf uns aufmerksam machen und auf die Probleme[,] die sich ergaben, hier und dort. Vielleicht regt es auch den einen oder anderen an, seine eigenen Erlebnisse aufzuschreiben, denn [S. 210] leider gibt es über dieses Thema kaum ein geschriebenes Wort in der mir bekannten Regionalliteratur." ${ }^{994}$

Mierzwa ist aber auch ein Beispiel dafür, dass Menschen, die durch ihr Schicksal einen Bezug zu den nun polnischen Gebieten besaßen oder sogar polnische Sprachkenntnisse mitgebracht hatten, spätestens nach 1990 eine Mittlerrolle zukommen konnte: „Unter uns drei Kindern hatte ich eigentlich das meiste Glück in dieser Situation. Mit 6 Jahren lernt man schnell und

592 Aufschlussreich ist auch die - eigene Erfahrungen und wissenschaftliche Reflexionen verbindende - Schilderung des 1939 geborenen, 1958 mit der Mutter aus Oppeln nach Weimar ausgesiedelten, später nach Ost-Berlin gelangten bekannten Professors für Polonistik an der Humboldt-Universität zu Berlin (ab 1988) Heinrich Olschowsky: Als Deutscher in Polen - als „Spätaussiedler“ in der DDR. In: „Wach auf, mein Herz, und denke“ (wie Anm. 11), S. 524-531. - 1974 aus Beuthen (Oberschlesien) nach Brandenburg gekommener Elektromeister (nach 1990 BdV-Kreisvorsitzender): Reinhold Bujok: Aus der Heimat in ein neues Zuhause. In: 100 Jahre Pfarrkirche Hl. Familie Rüdersdorf 1905 bis 2005. Hrsg. von der Kath. Kirchengemeinde H1. Familie in Rüdersdorf bei Berlin. Red.: Ariane Flemming u. a. Rüdersdorf bei Berlin 2005, S. 65-67. - Siehe auch die Zusammenstellung im Abschnitt „8. Aussiedlungserleben in Selbstzeugnissen“ in: Reitemeier: Auswahlbibliographie (wie Anm. 573), S. 287.

593 Rudolf Mierzwa: Als Spätaussiedler nach Guben. In: Jahrbuch für Gubener Geschichte 1 (2011/12), S. 209214, hier S. 213.

594 Ebd., S. 209 f. 
auch ohne Akzent eine Sprache, erst recht, wenn sie einem geläufig ist. In Bobrek wurde in der Familie ja auch deutsch gesprochen. So ergab es sich, dass ich deutsch akzentfrei (Hochdeutsch mit Gubener Einfluss), mit oberschlesischem Akzent (welchen viele mit polnischem verwechseln) [,] aber auch noch polnisch (sicher mit oberschlesischem Einfluss, aber nicht mit deutscher Herkunft erkennbar) [-] letzteres mehr oder weniger - beherrsche. Was, wie ich gern zugebe, gerade hier im Grenzgebiet sehr nützlich ist. ${ }^{\text {“595 }}$ Diesem Nutzen standen jedoch offenkundig jahrelang auch in formaler Hinsicht Zurücksetzungen gegenüber, die zu - absurd anmutenden - Mechanismen führten: „Die Millionen Versprengten, in den ehmals deutschen Gebieten Gebliebenen, waren kein Thema in Staatsbürgerkunde oder Geschichte, nicht in der DDR. So konnten wir nur Polen sein. Dass mein Vater erst als Deutscher akzeptiert wurde [,] als er sein arisches, ordentlich deutsches [,] mit Hakenkreuzen gestempeltes Abstammungsbuch seinen neuen, sozialistischen' Freunden präsentierte, ist uns heute nur noch ein müdes Lächeln wert." 596

Ein zweites brandenburgisches Beispiel für den typischen Verlauf des Integrationsprozesses bei (Spät-)Aussiedlern in der DDR ist der 1928 im oberschlesischen Beuthen geborene Reinhold Bujok. Der damals 17-Jährige Katholik war 1945 zunächst mit Mutter und Schwester in seinem Geburtsort verblieben und hatte dort in den fünfziger Jahren eine Familie gegründet, zu der 1962 drei Kinder gehörten ${ }^{597}$ : „Trotz meiner anfänglichen Schwierigkeiten mit der polnischen Sprache gelang es mir, den erlernten Beruf als Elektriker durch den Erwerb der Meisterprüfung zu ergänzen. Meine Frau war im Gesundheitswesen als Leiterin in der Röntgenabteilung tätig, so dass wir eigentlich ein zwar bescheidenes aber glükliches Leben in unserer alten Heimat führten." Als der seit 1944 als vermisst geltende Vater sich schließlich unverhofft aus Westdeutschland meldete, übersiedelten dessen Frau und Tochter zu ihm, dem Sohn mit Familie wurde die Ausreise jedoch er stellte 23 Ausreiseanträge - verwehrt. „Erst im Jahre 1970, als die DDR dringend Fachkräfte suchte, gelang es uns in die DDR auszureisen. So wurde Rüdersdorf unsere neue Heimat. Meine Frau fand entsprechend ihrer Qualifikation einen Arbeitsplatz in der Röntgenabteilung des Rüdersdorfer Krankenhauses und ich im Zementwerk." So reibungslos wie die Arbeitsplatzbeschaffung, die ohnehin Vorbedingung gewesen war, verlief der reale Integrationsprozess in den Berufsalltag freilich nicht: „Kollegen betrachteten mich als Ausländer, bedingt durch die [ober-] schlesische Mundart. Aber ich konnte dagegen halten, dass meine Kollegen nicht die Sütterlinschrift, die ich während meiner Schulzeit in Beuthen erlernte, lesen konnte (alte deutsche Schrift). Die Kollegen dachten, diese Schrift ist polnisch, ich sollte die Berichte in deutsch schreiben. Durch diese Hinweise hatte ich meine Ruhe." Doch die Eingliederung am Arbeitsplatz war eben nur die eine Hälfte des Prozesses: „Einige Jahre wohnten wir bis 1974 im Wohnlager des Zementwerkes. Es befand sich in Gebäuden des damaligen Krankenhauses bei Herzfelde. Das Einleben in die neue Umgebung fiel uns zwar nicht besonders schwer, aber auch unsere Kinder, die zwar polnisch sprechen konnten, aber nur deutsch sprachen, trafen nicht immer auf Wohlwollen unter Ihresgleichen. So wurden sie z. B. am Stienitzsee als Ausländer

Ebd.

596

Ebd., S. 214.

597 Das Folgende nach Bujok, Aus der Heimat in ein neues Zuhause (wie Anm. 592). 
beschimpft, weil sie mit Kindern, die nicht die deutsche Sprache beherrschten, polnisch sprachen. Sie wurden dafür sogar im Beisein westdeutscher Verwandter in Kleidung ins Wasser gestoßen." 598 Positive Integrationskraft erfuhr die Familie dagegen in ihrer katholischen Kirchengemeinde, wo sie, anfangs in Herzfelde, ab 1974 in Rüdersdorf „sehr freundlich aufgenommen“ wurde: „Da nun mal Vieles in den katholischen Kirchen, egal ob in Polen oder Deutschland identisch ist, war für uns die Kirche wie ein Stück aus unserer alten Heimat. Das hat uns sehr geholfen, sich hier in Rüdersdorf einzuleben.“ Resümierend schreibt der 77-Jährige 2005: „Meine Familie und ich haben uns in Rüdersdorf immer wohl gefühlt, wir haben uns hier eine neue Existenz, ein neues Zuhause aufgebaut, wir haben hier viele nette Menschen kennen gelernt. / Doch Beuthen, der Ort, in welchen [so!] ich meine Kindheit und Jugend verlebte, bleibt wohl meine eigentliche, mir unvergessene Heimat. "599 Diese im Altersrückblick der Nachwendezeit dann doch rundum positive, versöhnliche Gesamtbilanz spart freilich - vom letzten, knappen und doch vielschichtigen Satz abgesehen - die Frage der öffentlichen Tabuisierung bis 1989/90 aus.

\section{Ankunft und Erstaufnahme}

\section{Transporte}

Während die Evakuierungen und Fluchtbewegungen vor Kriegsende sich teilweise in Form von Eisenbahntransporten, vielfach aber Trecks unterschiedlicher Zusamensetzung - Pferdewagen, Handwagen, Fußgänger - abspielten, dominierten bei den „Wilden Vertreibungen“ die Fußmärsche. Im Folgenden werden vornehmlich die in den Vertreibungsgebieten von den neuen polnischen und tschechischen Behörden organisierten Bahntransporte behandelt. Die Quellenlage zu den nach dem Potsdamer Abkommen vom 2. August 1945 durchgeführten Vertreibungen ist dabei sehr unterschiedlich, Zugänglichkeit und Aufbereitung sehr konkreter Nachweise entwickeln sich inzwischen aber dynamisch. Im günstigsten Fall gibt es für die durchgeführten Eisenbahntransporte sowohl auf polnischer bzw. tschechischer oder russischer als auch auf deutscher Seite eine schriftliche Überlieferung in Form namentlicher Transportlisten. ${ }^{600}$ Diese wurden am Abfahrtort erstellt und in einem Exemplar zurückbehalten, in einem weiteren meist dem Transport mitgegeben, so dass sie nicht nur in polnische, tschechische und sowjetische bzw. russische Staatsarchive ${ }^{601}$, sondern auch in deutsche Archive gelangen konnten. Legt man hohe Maßstäbe

600 Liste aller feststellbaren Transporte aus der Tschechischen Republik, Österreich, Ungarn und der Slowakei: Wilhelm Jun: Die Flüchtlings-Transporte des Jahres 1946. Augsburg/Pohrlitz 2009.

601 Polen: Archiwum Państwowe w Szczecinie, Urząd Państwowy Repatriacyjny Powiatowy Oddział w Dębnie, Referat Przesiedleńcy, sygn. 7, 8 [Staatliches Archiv in Stettin, Staatliches Repatriierungsamt, Kreisabteilung in Neudamm, Umsiedlerreferat, Sign. 7, 8]: Listen von Deutschen, die ausgesiedelt werden (1947). Enthält: Vor- und Nachname, Beruf, Familienstand, Geburtsdatum, Wohnort (Online: http://www.szczecin.ap.gov. $\mathrm{pl} / \mathrm{iCmsModuleArchPublic/showDocuments/nrap/65/nrzesp/324/seria/2).} \mathrm{Solche} \mathrm{Unterlagen} \mathrm{gibt} \mathrm{es} \mathrm{von}$ 
vollständiger Überlieferung an, wird man freilich wohl eher in den polnischen, russischen und tschechischen Archiven geschlossene Konvolute finden als in den deutschen Staatsarchiven, da die Länderverwaltungen der SBZ/DDR nicht von allen „Umsiedlerlagern“, wo wieder neue Listen entstanden, Schriftgut übernommen bzw. archiviert haben und viele Listen in die kommunalen Registraturen gelangt sind. ${ }^{602}$

Diese für die Landes- und Ortsgeschichtsforschung zunächst schwierig erscheinende Ausgangsbasis kann aber verbessert werden, wenn man die zentralstaatlichen Überlieferungen hinzunimmt (Zentralverwaltung und Suchdienst), denn diese enthalten meist die originalen Transportlisten $^{603}$, die man allerdings teilweise nach 1990 an den Suchdienst des Deutschen Roten Kreuzes in München weitergereicht hat. ${ }^{604}$ Damit ist die Dokumentation der Transporte für die SBZ insgesamt wahrscheinlich sogar detaillierter und vollständiger als bei den anderen deutschen Aufnahmegebieten, wie jedenfalls die Stichprobenuntersuchung von Wilhelm Jun für das Jahr 1946 und beschränkt auf die Transporte aus Österreich, Ungarn und der Slowakei gezeigt hat. ${ }^{605}$ Auch für seine Recherchen war das verspätete Einsetzen der Tätigkeit der Flüchtlingsverwaltungen, die nicht sogleich am 1. Januar reagieren konnten, hinderlich. Umso mehr werden die Vorgänge des Jahres 1945 und erst recht die zwischen Januar und September 1945, als entweder die Behörden schon in kriegsbedingter Auflösung begriffen waren oder neue noch nicht exisitierten, immerhin für statistische Betrachtungen undeutlich bleiben.

Die unterschiedlich rigide Handhabung des Datenschutzes erleichtert allerdings nicht gerade die Recherechen in deutschen Archiven, während man in Polen mittlerweile bereits ausgewählte Digitalisate online gestellt hat. ${ }^{606}$ Letzteres gilt derzeit zumindest für das Staatsarchiv

allen Kreisen der Wojwodschaft Szczecin (freundlicher Hinweis Stefan Rückling, Berlin, 18.4.2017). - Russland: „Im Archiv der Verwaltung des Inneren Kaliningrad befinden sich, in alphabetischer Anordnung und nach Zügen gegliedert, die vollständigen Listen der Deutschen, die an den Übergabepunkten den Verwaltungsbehörden der Sowjetischen Besatzungszone bzw. der DDR übergeben worden sind. Darüber wurden Protokolle mit den entsprechenden Unterschriften angefertigt. Im gleichen Archiv liegt das ,Buch über die Ausgabe von Erlaubnisscheinen zur [S.399] Fahrt in die Sowjetische Okkupationszone Deutschlands für Deutsche im Jahre 1947“" Bernhard Fisch / Marina Klemeševa: Zum Schicksal der Deutschen in Königsberg 1945-1948 (im Spiegel bisher unbekannter Quellen). In: Zeitschrift für Ostmitteleuropa-Forschung 44 (1995), S. 391-400, hier S. 398 f.

602 Im BLHA liegen vereinzelt polnische Transportbegleitlisten vor (BLHA, Rep. 256 Küchensee).

603 Aus der Überlieferung der ZVU befinden sich im Bundesarchiv insbesondere für die (vom Quarantänelager Fürstenwalde in enger Abstimmung mit dem MfS) organisierten späten Transporte detailierte Listen: BArch, DO 1/8407, unfol., darin lange Listen der 1951 „Eingemeindeten“ und (in andere Besatzungszonen) „Weitergeleiteten“ mit Name, Vorname, Geburtsdatum, Eingemeindungsort, Arbeitsstelle, Verwandtschaftsgrad.

604 Jun, Die Flüchtlings-Transporte des Jahres 1946 (wie Anm. 600), S. 237.

605 Im Einzelnen ist aber mit größeren Abweichungen der Verfahrens- wie der Überlieferungswege zu rechnen. So sollen für die sudetendeutschen Transporte in die SBZ keine Listen mitgegeben, sondern erst am Ankunftsort (Bahnhof) erstellt worden sein (sudetendeutsche-familienforscher.de/transportlisten/ [31.3.2017]).

606 Bisher nicht in Tschechien, wo die Transportlisten zum größten Teil im Staatlichen Zentralarchiv Prag liegen, Kopien weitgehend auch im Sudetendeutschen Institut (SDI) in München, dort (offline) auch Excel-Tabellen der Listen einiger westböhmischer Abgangsbahnhöfe. Siehe dazu die jeweils aktualisierten Informationen der 
Stettin, das 2013 zunächst 19 solcher Transportlisten des Jahres 1947 digitalisiert und im Internet frei zugänglich gemacht hat. ${ }^{607}$ Diese enthalten über 28000 Namen aus Stadt und Kreis Stolp in Pommern vertriebener Personen („Repatriierte“), pro Transport rund 1500 . Deutsche Familiengeschichtsforscher haben diese Listen bis 2016 in einer Datenbank nach Namen recherchierbar gemacht. ${ }^{608}$ Enthalten sind in den Listen, bei denen es sich um Durchschläge maschinenschriftlich ausgefüllter Vordrucke ${ }^{609}$ handelt, Name ${ }^{610}$, Geburtsjahr und Geschlecht, oft eine Berufs- oder ähnliche Angabe. Herkunfts- oder Geburtsorte fehlen jedoch leider. Immerhin lassen sich der Auswertung folgende Grundlinien entnehmen. ${ }^{611}$

Jeder Transport erfolgte mit 50 Güterwagen à 30 Personen $^{612}$, gezogen von einer Dampflokomotive. Ein Personenwagen war für die polnische Begleitmannschaft reserviert, zwei Güterwagen enthielten Verpflegung für die meist zwei Tage lange, in Einzelfällen aber auch längere Fahrt, die zentral über Kohlfurt (poln. Węgliniec) bei Görlitz und Teuplitz, Kr. Sorau (polnisch Tuplice), erfolgte. Der letzte polnische Ort Teuplitz, ein Kreuzungspunkt zweier Bahnlinien, verweist bereits deutlich auf die Zielrichtung, den Grenzbahnhof Forst (Lausitz) bzw. die Bahnstrecke Forst-Cottbus ${ }^{613}$. Aus dem Kreis Stolp erfolgten durchschnittlich zwei Transporte pro Woche. Die online veröffentlichten Listen betreffen den Zeitraum vom 20. Juli (Nr. 29) bis 17. Oktober 1947 (Nr. 53). Sie bilden damit nur einen kleinen Teil des Gesamtgeschehens ab, können aber, auch wenn keineswegs alle Umstände verallgemeinerbar sind, als eingermaßen repräsentativ für diese "geordneten“ Vertreibungen gelten. Die Auswertungen haben ergeben, dass sich in den Stolper Transporten durchschnittlich „knapp $20 \%$ Männer (gezählt ab etwa 15 Jahren), fast $46 \%$ Frauen (ab etwa 15 Jahren) und ein Drittel Kinder bis 15 Jahre" befanden. Familien wurden zwar zusammengelassen, doch ist offenbar darauf geachtet worden, „Dorfgemeinschaften“ zu trennen und zu mischen. „Ein kleinerer Transport beförderte Kranke mit

Vereinigung Sudetendeutscher Familienforscher e.V. (VSFF) (sudetendeutsche-familienforscher.de/transportlisten/ [31.3.2017]). Das SDI bittet private Forscher, die im Besitz von Kopien sind, seit 2016 sogar per Inserat im Unterstützung bei der Sammlung: Siehe u. a. den Aufruf „Transportlisten der Vertreibung gesucht" in: Brandenburger Rundschau 14 (2016)9, S. 9.

607 www.szczecin.ap.gov.pl (31.3.2017).

608 Arbeitskreis Heimat- und Familienforschung im Stolper Heimatkreis e. V. (www.stolp.de/akff). Kurzhinweis in: Sedina-Archiv N. F. 62 (2016), S. 90.

609 Die vorgehefteten Seiten mit allgemeinen Angaben zum Transport enthalten vorgedruckte Texte in polnischer, russischer und englischer Sprache, die Eintragungen sind teilweise hand-, teilweise maschinenschiftlich. Die eigentlichen Listen sind in polnischer und deutscher Sprache vorgefertigt (teils gedruckt, teils maschinenenschriftlich) und in deutscher Sprache ausgefüllt.

610 Vom polnischen (oder auch kaschubischen?) weiblichen Begleitpersonal nach Gehör notiert.

611 Das Folgende nach Peter Siefert: Transportlisten von Vertriebenen 1947. In: www.stolp.de/akff (31.3.2017).

612 Ganz ähnliche Zahlen sind auch aus kirchlichen Kreisen überliefert, die mit der Betreuung an Haltepunkten betraut waren: "Jeder Transport bestand aus etwa 57 Güterwagen mit 1700 Ausgewiesenen, aus denn die Schwestern [Graue Schwestern von der Hl. Elisbeth - P. B.] täglich - im Winter bis zu 20 - Tote herausholten.“ (Thomas Mengel: Das Schicksal der schlesischen Frauenklöster während des Dritten Reiches und 1945/46. Köln/Wien 1986, S. 157).

613 Ehem. Strecke Cottbus-Sorau. 
einzelnen Begleitpersonen.“ Dass die Männer, wie schon bei den vorhergehenden Flucht- und Vertreibungswellen, in der Minderheit waren, erklärt sich leicht daraus, dass diese sich überwiegend noch in Kriegsgefangenschaft befanden oder gar gefallen waren. Jeweils ein Deutscher, darunter auch Frauen, wurde zum Waggonältesten (komendant wagonu) ernannt, ein Pole war Kommandant des gesamten Transports.

Viele Transportteilnehmer haben in ihren Erinnerungen berichtet, dass es eine „Fahrt ins Ungewisse ${ }^{\text {"614 }}$ war. Gleichlautend heißt es zumeist, dass keiner der Zuginsassen den Zielort kannte, nicht einmal, in welcher Besatzungszone dieser liegen würde. Weder bei der Abfahrt noch unterwegs wurden Informationen mitgeteilt. Mancher konnte die polnischen Bahnhofsnamen, an denen man vorbeikam, geographisch nicht einordnen, andere konnten nicht aus dem Wagen hinaussehen, so dass viele wechselnde Gerüchte die Runde machten. Auch nach der Überfahrt über die Grenze zur SBZ war oft noch nicht klar, welches Lager den Endpunkt bilden würde. Je nach Transport- und Lagerkapazität haben die deutschen und so auch die brandenburgischen Behörden improvisieren müssen, was für den Einzelnen bisweilen wie zielloses Umherfahren wirkten konnte. Ein im Januar 1946 aus Hinterpommern kommender Zeitzeuge hat berichtet: „Mal in Güterwagen, mal in Personenzügen fuhren wir durch das Land, und wir gewannen den Eindruck, dass niemand so recht wusste, wohin mit uns. Wir fuhren von Lager zu Lager, hausten bald hier und bald dort. Hunger und Kälte waren unsere treuen Begleiter." 615

Das mehrfache Hin-und-Her-Wandern bzw. -Geschickt-Werden zeigt sich am Beispiel einer jungen Frau, die Ende Januar 1945 nicht mit auf die Flucht aus ihrem neumärkischen Heimatdorf Groß Gandern im Kreis Weststernberg gegangen war. ${ }^{616}$ Im Februar wurde sie in östlicher Richtung ausgewiesen, kam von einem ins andere Dorf, um schließlich im Süden der Neumark, in Schwiebus, Ende März in ein Lager eingewiesen zu werden. Es folgte Anfang April die Deportation zum Arbeitseinsatz nach Russland (hinter Moskau). Durch schwere körperliche Arbeit gesundheitlich stark angeschlagen wurde sie im Dezember 1946 entlassen und kam am Heiligabend 1946 in Frankfurt (Oder) an. Von hier schickte man sie in ein Quarantänelager in Thüringen, aus dem sie schon im Januar $1947 \mathrm{zu}$ Verwandten nach Berlin entlassen wurde. Ihre Schwester holte sie von hier aber wiederum nach Hohenofen bei Neustadt (Dosse) - eine ebenso erstaunliche wie für jene Jahre dennoch keineswegs untypische Zick-Zack-Reise, durchlebt innerhalb von nur zwei Monaten.

Ein später nach Neuenhagen bei Berlin gelangter Vertriebener berichtet über seinen Weg: „Im Oktober 1947 wurden wir - meine verwitwete Mutter, meine 8-jährige Schwester und ich - als Deutsche aus Polen ausgewiesen. Über Kutno, Lodz und Breslau kamen wir mit der Eisenbahn in Güterwagen in Forst (Lausitz) über die Grenze nach der damaligen Sowjetischen Besatzungszone

614 Hildegard Rölke: Erinnerungen an den Aufenthalt im Flüchtlingslager Küchensee. In: Geschichten aus sieben Jahrzehnten (wie Anm. 538), S. 33-34, hier S. 33.

615 Sonnemann, Bittere Medizin (wie Anm. 269), S. 28.

616 Materne/Gerlach, Gross-Gandern und Klein-Gandern (wie Anm. 351), S. 97 (Tagebuchaufzeichnungen von Helga Müller geb. Paschke). 
Deutschlands. Im Quarantänelager Wernigerode sollten wir zwei Wochen bleiben; es wurden aber sechs Wochen daraus. "617 Viele, die zunächst in Brandenburg ankamen, blieben nicht. Sowohl individuelles Weiterwandern oder mehr oder weniger späteres Wegziehen als auch organisierte Durchschleusung ganzer Transporte, die nur ihre Quarantänewochen in einem brandenburgischen „Umsiedlerlager“ verbrachten, waren an der Tagesordnung.

Die unübersehbar große Zahl der gesamten von 1945 an bis 1950 durchgeführten Transporte lässt sich letztlich nur grob auf einen durchschnittlichen „Idealtyp“ reduzieren. Immer wieder gab es besondere Situationen und individuelle Maßnahmen, die es verhindern, von typischen Begleitumständen zu sprechen. Auch die oben für den Stolper Raum geschilderte Auswertung dürfte manchen Zeitzeugen aus einer anderen Provinz auf den Plan rufen, der es „ganz anders“ erlebt hat. Eine Ausnahme bilden ohnehin die sogen. „Antifa-Transporte“ sudetendeutscher Kommunisten und Sozialdemokraten aus der Tschechoslowakei, die daher unten noch gesondert beschrieben werden. Davon abgesehen ergaben sich aber auch immer wieder gesonderte Einzel-„Aktionen“ für „normale“ Vertriebene. So erfolgten vom 20. Februar bis Ende Dezember 1946 auf der Grundlage eines polnisch-britischen Abkommens in der sogen. Aktion „Swallow“ (Schwalbe) Aussiedlungen Deutscher aus den ehemaligen Ostgebieten, insbesondere aus Niederschlesien, ferner aus Danzig und „Westpommern“, in die Britische Zone. Sofern es sich nicht um Seetransporte handelte, führten die Wege mit Genehmigung der sowjetischen Besatzungsmacht durch die SBZ, im Norden über Stettin (Bahnhof Scheune) kommend, im Süden über den niederschlesischen Bahnknotenpunkt Kohlfurt. ${ }^{618}$

Die nachfolgende Tabelle bildet den Versuch, die in das „Umsiedlerlager“ Küchensee gelangten Vertriebenentransporte beispielhaft zu erfassen. Vollständigkeit ist auf der Basis des überlieferten Schriftgutes angestrebt worden, kann aber nicht garantiert werden.

\section{Tab. 1: Transporte in das „Umsiedlerlager" Küchensee 1946-1949}

In der Regel Ankunft und Ausladung auf Bahnhof Storkow, Lkw-Transport zum Lager; Aufenthalt im Lager meist 14 Tage (Quarantäne), dann Eingemeindung, teilweise Weitertransport per Bahn. Lager unbelegt: 1.1.-15.3.1948.

\begin{tabular}{|c|c|c|c|c|l|}
\hline $\begin{array}{c}\text { Transport- } \\
\text { Nr. }\end{array}$ & $\begin{array}{c}\text { Ankunfts- } \\
\text { tag }\end{array}$ & $\begin{array}{c}\text { Herkunft } \\
\text { (Abgangsort) }\end{array}$ & $\begin{array}{c}\text { Personen- } \\
\text { stärke }\end{array}$ & Bemerkungen & Quelle/Berichte \\
\hline 17159 & 07.02 .46 & $\begin{array}{l}\text { Berlin Schlesischer } \\
\text { Bahnhof }\end{array}$ & 1529 & & $\begin{array}{l}\text { Rep. 256 Küchensee, } \\
\text { Nr. 29 }\end{array}$ \\
\hline 4011 & 09.02 .46 & Pinnow & 1857 & & $\begin{array}{l}\text { Rep. 256 Küchensee, } \\
\text { Nr. 29 }\end{array}$ \\
\hline 17162 & 10.04 .46 & Völpke/Saale & 4177 & & $\begin{array}{l}\text { Rep. 250 Beeskow- } \\
\text { Storkow, Nr. 868 }\end{array}$ \\
\hline
\end{tabular}

617 Alfred Hirt: Mein Weg nach Neuenhagen. In: Lebenszeit IX. Zu Hause in Neuenhagen. Hrsg.: Seniorenbeirat der Gemeinde Neuenhagen. Neuenhagen 2003, S. 20-23, hier S. 20.

618 Krzysztof Ruchniewicz: Aktion „Swallow“. In: Lexikon der Vertreibungen (wie Anm. 59), S. 24-26. 


\begin{tabular}{|c|c|c|c|c|c|}
\hline $\begin{array}{c}\text { Transport- } \\
\text { Nr. }\end{array}$ & $\begin{array}{l}\text { Ankunfts- } \\
\text { tag }\end{array}$ & $\begin{array}{c}\text { Herkunft } \\
\text { (Abgangsort) }\end{array}$ & $\begin{array}{c}\text { Personen- } \\
\text { stärke }\end{array}$ & Bemerkungen & Quelle/Berichte \\
\hline 14871 & 02.05 .46 & \begin{tabular}{|l|} 
Berlin Schlesischer \\
Bahnhof
\end{tabular} & 992 & $\begin{array}{l}\text { "aus verschiedenen } \\
\text { Berliner Lagern } \\
\text { zusammengestellt" }\end{array}$ & $\begin{array}{l}\text { Rep. } 250 \text { Beeskow- } \\
\text { Storkow, Nr. } 868 \\
\text { und } 869\end{array}$ \\
\hline $\begin{array}{l}4390 / \\
118 \mathrm{P} .\end{array}$ & 05.07 .46 & \begin{tabular}{|l|} 
Warnsdorf/C.S.R. \\
(über Pirna)
\end{tabular} & 1200 & $\begin{array}{l}\text { "Transport mit } \\
\text { antifaschistischen } \\
\text { Umsiedlern aus der } \\
\text { C.S.R." }\end{array}$ & $\begin{array}{l}\text { Rep. } 256 \text { Küchensee, } \\
\text { Nr. 217; Rep. } 250 \\
\text { Beeskow-Storkow, } \\
\text { Nr. } 868 \text { und } 869\end{array}$ \\
\hline$[4550]$ & $\begin{array}{l}24.07 .46 \\
25.07 .46\end{array}$ & & 1217 & $\begin{array}{l}\text { "ein ganzes Altersheim } \\
\text { evakuiert"; Ankunft aus- } \\
\text { nahmsweise auf Bahn- } \\
\text { hof Beeskow }\end{array}$ & $\begin{array}{l}\text { Rep. } 256 \text { Küchensee, } \\
\text { Nr. 217; Rep. } 250 \\
\text { Beeskow-Storkow, } \\
\text { Nr. } 869\end{array}$ \\
\hline $4692 / 1511$ & 15.08 .46 & \begin{tabular}{|l|} 
Wildenschwert \\
a.d. Adler \\
(Übergangsstation \\
Prossen)
\end{tabular} & 1222 & $\begin{array}{l}\text { darunter „verschiede- } \\
\text { ne... Tschechen bezw. } \\
\text { Oesterreicher" }\end{array}$ & $\begin{array}{l}\text { Rep. } 256 \text { Küchensee, } \\
\text { Nr. 217; Rep. } 250 \\
\text { Beeskow-Storkow, } \\
\text { Nr. } 868\end{array}$ \\
\hline 4967 & $\begin{array}{l}13.09 .46 \\
14.09 .46\end{array}$ & $\begin{array}{l}\text { Kaaden } \\
\text { (über Pirna) }\end{array}$ & 1218 & $\begin{array}{l}\text { Ankunft } 22.15 \text { Uhr Bhf } \\
\text { Storkow }\end{array}$ & $\begin{array}{l}\text { Rep. } 256 \text { Küchensee, } \\
\text { Nr. 217; Rep. } 250 \\
\text { Beeskow-Storkow, } \\
\text { Nr. } 868 \text { und } 869\end{array}$ \\
\hline $\begin{array}{r}\text { UM } 381- \\
101\end{array}$ & 15.10 .46 & \begin{tabular}{|l} 
Namslau (zuletzt \\
aus dem Lager \\
Forst/Lausitz) \\
\end{tabular} & 1784 & & $\begin{array}{l}\text { Rep. } 250 \text { Beeskow- } \\
\text { Storkow, Nr. } 868 \\
\text { und } 869\end{array}$ \\
\hline \multirow[t]{2}{*}{$171 / 393$} & 01.01 .47 & $\begin{array}{l}\text { Schlawe/Pom. } \\
\text { (über Forst) }\end{array}$ & 1781 & $\begin{array}{l}\text { Ankunft } 18.10 \mathrm{Uhr} \text { Bhf } \\
\text { Storkow }\end{array}$ & $\begin{array}{l}\text { Rep. 256 Küchensee, } \\
\text { Nr. 217; Rep. } 250 \\
\text { Beeskow-Storkow, } \\
\text { Nr. } 869\end{array}$ \\
\hline & 05.04 .47 & Oderevakuierte & 128 & & $\begin{array}{l}\text { Rep. } 256 \text { Küchensee, } \\
\text { Nr. } 217\end{array}$ \\
\hline 19008 & 11.05 .47 & $\begin{array}{l}\text { Hasseloe bzw. } \\
\text { Kolding/ } \\
\text { Dänemark }\end{array}$ & 996 & & $\begin{array}{l}\text { Rep. } 256 \text { Küchensee, } \\
\text { Nr. 217; Rep. } 250 \\
\text { Beeskow-Storkow, } \\
\text { Nr. } 868\end{array}$ \\
\hline $\begin{array}{r}49 / 6981 / \\
4077\end{array}$ & 04.06 .47 & $\begin{array}{l}\text { Hirschberg/ } \\
\text { Schlesien }\end{array}$ & 1536 & $\begin{array}{l}\text { Ankunft nachts, Ausla- } \\
\text { den/Abtransport in das } \\
\text { Lager bis 5.6. vormittags } \\
9.00 \text { Uhr; Vertriebene } \\
\text { aus den Kreisen Hirsch- } \\
\text { berg, Löwenberg, Lan- } \\
\text { deshut, Waldenburg }\end{array}$ & $\begin{array}{l}\text { Rep. } 256 \text { Küchensee, } \\
\text { Nr. 217; Rep. } 250 \\
\text { Beeskow-Storkow, } \\
\text { Nr. } 868\end{array}$ \\
\hline 67 & 13.07.47 & Schlawe/Pommern & 1476 & & $\begin{array}{l}\text { Rep. } 256 \text { Küchensee, } \\
\text { Nr. 217; Rep. } 250 \\
\text { Beeskow-Storkow, } \\
\text { Nr. } 868\end{array}$ \\
\hline
\end{tabular}




\begin{tabular}{|c|c|c|c|c|c|}
\hline $\begin{array}{c}\text { Transport- } \\
\text { Nr. }\end{array}$ & $\begin{array}{c}\text { Ankunfts- } \\
\text { tag }\end{array}$ & $\begin{array}{c}\text { Herkunft } \\
\text { (Abgangsort) }\end{array}$ & $\begin{array}{l}\text { Personen- } \\
\text { stärke }\end{array}$ & Bemerkungen & Quelle/Berichte \\
\hline $90 / 7083$ & 06.08 .47 & Glatz & 1526 & & $\begin{array}{l}\text { Rep. } 250 \text { Beeskow- } \\
\text { Storkow, Nr. } 868 \text {, } \\
869\end{array}$ \\
\hline $122 / 7083$ & 04.09 .47 & Stettin & 1490 & $\begin{array}{l}\text { Ankunft Bhf Storkow } \\
12 \mathrm{Uhr}\end{array}$ & $\begin{array}{l}\text { Rep. } 256 \text { Küchensee, } \\
\text { Nr. 217; Rep. } 250 \\
\text { Beeskow-Storkow, } \\
\text { Nr. } 868,869\end{array}$ \\
\hline 97861 & 29.10 .47 & Kaliningrad & 1644 & & $\begin{array}{l}\text { Rep. } 250 \text { Beeskow- } \\
\text { Storkow, Nr. } 868\end{array}$ \\
\hline 2778 & 02.04 .48 & Kaliningrad & 1661 & Ankunft abends & $\begin{array}{l}\text { Rep. } 256 \text { Küchensee, } \\
\text { Nr. } 217\end{array}$ \\
\hline U 19-123 & 28.08 .48 & & & $\begin{array}{l}\text { Ankunft Bhf Storkow } \\
\text { gegen } 12 \mathrm{Uhr}\end{array}$ & $\begin{array}{l}\text { Rep. } 256 \text { Küchensee, } \\
\text { Nr. } 217\end{array}$ \\
\hline $\mathrm{U} 2148$ & 15.09 .48 & Insterburg & & $\begin{array}{l}\text { Aufenthalt im Lager bis } \\
29.9 .1948\end{array}$ & $\begin{array}{l}\text { Rep. } 256 \text { Küchensee, } \\
\text { Nr. } 217\end{array}$ \\
\hline U 19219 & 11.10 .48 & Kaliningrad & 2100 & $\begin{array}{l}\text { Aufenthalt im Lager bis } \\
24.10 .1948\end{array}$ & $\begin{array}{l}\text { Rep. } 256 \text { Küchensee, } \\
\text { Nr. } 217\end{array}$ \\
\hline U 35/7079 & 30.10 .48 & Lodz & 1610 & $\begin{array}{l}\text { Aufenthalt im Lager bis } \\
12.11 .1948\end{array}$ & $\begin{array}{l}\text { Rep. } 256 \text { Küchensee, } \\
\text { Nr. } 217\end{array}$ \\
\hline $\begin{array}{r}\text { UM Berlin } \\
696 / \mathrm{VII}\end{array}$ & 25.05 .49 & Potulice bei Lodz & 1502 & $\begin{array}{l}326 \text { Männer, } 933 \text { Frau- } \\
\text { en, } 243 \text { Kinder; 14-tägi- } \\
\text { ger Aufenthalt im Lager }\end{array}$ & $\begin{array}{l}\text { Rep. } 250 \text { Beeskow- } \\
\text { Storkow, Nr. 824, } \\
\text { unfol. }\end{array}$ \\
\hline
\end{tabular}

Dass die geordneten Eisenbahn-Transporte ab 1946 wohl überwiegend in Viehwagen erfolgten, ist vielfach belegt. ${ }^{619}$ Dabei handelte es sich teilweise um offene ${ }^{620}$, allenfalls mit Planen bedeck-

619 Beispiele: Pommern 1947: „ausschließlich Viehwaggons für die Deutschen“ (Krockow, Die Stunde der Frauen [wie Anm. 401], S. 234). - Marienwerder (Westpreußen) 1947: „Es klappte anscheinend nicht so mit den Transportmitteln, denn für 3000 Menschen mußten ja mehrere Viehwagenzüge zusammengestellt werden." (N. N.: Besatzungselend. In: Der Kreis Stuhm. Ein westpreußisches Heimatbuch. Hrsg. vom Kreisausschuß des Heimatkreises Stuhm. (Bad Pyrmont) 1975, S. 254-271, hier S. 269). - Wohlau (Schlesien) 26.10.1946: Viertägige „Fahrt im Viehwagen von Schlesien bis hierher", großer Transport aus dem Kreis Wohlau in ein Umsiedlerlager im Erzgebirge, „eingepfercht wie die Heringe, sehr schlecht verpflegt“ (Erlebnisse einer schlesischen Landfrau aus dem Kreis Wohlau (1944-1946). Hrsg. von Richard Hoppe. Wiesbaden 1978, S. 36 f.). - Greiffenberg in Pommern 11.3.1946: „Zu etwa 20 Personen kamen wir in einen Viehwagen ohne Sitzgelegenheit, dafür mußte uns unser Gepäck dienen. [...] Beim Rangieren und bei jedem Anfahren des Zuges polterten wir alle durcheinander, was besonders schlimm war, wenn man wirklich mal eingeschlafen war." (Käthe von Normann: Ein Tagebuch aus Pommern 1945-1946. 5. Aufl. München 1984, S. 171).

620 Sommer 1946: „Wir fuhren in offenen Güterwaggons [...].“ (Christa Stiemke: Lange verdrängt, aber unvergessen. Flucht - Vertreibung - neue Heimat. In: 100 Jahre Wilhelmshorst [wie Anm. 189], S. 338-344, hier S. 342). 
te Wagen ${ }^{621}$, meist kamen aber geschlossene Viehwagen zum Einsatz ${ }^{622}$. Am Güterbahnhof in Marienwerder (Westpreußen) ${ }^{623}$ standen 1947, nach dem Bericht einer aus dem Kreis Stuhm stammenden Frau „lange Züge mit Viehwagen bereit. 30 Menschen wurden abgezählt und in je einen Viehwagen verfrachtet. Es waren nicht einmal Strohschütten, geschweige denn Pritschen darin. [...] Die vielen Menschen wurden von keinem Arzt, keinem Roten Kreuz begleitet, ganz im Gegensatz zu späteren Transporten nach ca. zehn Jahren, als die Auswanderer sogar in Betten schlafen konnten. Der Zug hielt oft, nachts wurden wir auf tote Gleise abgestellt, dann lief alles hinaus, um seine menschlichen Bedürfnisse zu erledigen. Kamen wir einmal auf einem Bahnhof zum halten (wo, konnten wir wegen der polnischen Bezeichnungen nie feststellen), versuchten wir, Wasser zu bekommen, um uns doch etwas waschen zu können. Auch gab es einmal auf einem größeren Bahnhof für jeden einen Teller Suppe; sonst haben wir uns in den fünf Tagen, die wir unterwegs waren, immer kalt ernährt und waren mit unseren Lebensmitteln am dritten Tage fertig. Wir hatten alle großen Hunger, aber am schlimmsten waren doch die hygienischen Verhältnisse." Dass aber doch zumindest bei einigen Transporten ein Sanitätswagen " mitgeführt wurde, wird verschiedentlich überliefert. ${ }^{624}$ Obwohl die Entfernungen meist nicht allzu groß waren, brauchten die Transporte für die Fahrt durch die ehemaligen Ostgebiete meist Tage und bisweilen auch - anders als bei den oben geschilderten Stolper Beispielen - Wochen, da sie immer wieder Halte einlegen mussten, weil die Lok oder das Gleis anderweitig gebraucht wurde, und sie - was in den Erinnerungsberichten oft betont wird - sehr langsam fuhren. ${ }^{625}$

Eine schlesische Familie erlebte im November 1946 die Vertreibung ebenfalls in (geschlossenen) Viehwagen von Brieg aus. Der Bericht kann in vielen, auch von anderen immer wieder ähnlich berichteten Einzelheiten als repräsentativ gelten ${ }^{626}:$ „Nach einem einwöchigen Aufenthalt im Lager ${ }^{627}$ erfolgte die Verladung in den Transportzug. Dazu stand auf dem ein ganzes Stück

Bahnhof Kohlfurt (Eisenbahnknotenpunkt in Schlesien), 7.7.1945, kurz vor der Abfahrt: „ein endloser Güterzug, hochbepackt, die offenen Wagen mit Planen überdeckt. [...]. [S. 175] Da winken uns von einem der planenüberdeckten Wagen Kameraden aus den ersten Wandertagen $z u[\ldots]$ auch der Nebenwagen hat ein Planendach, wir beginnen hinaufzuklettern. [...] Auf dem Treppchen klammern sich noch Frauen an. Andere klettern auf das Dach [S. 177] des Nebenwagens und lagern sich dort. [...]." (Hugo Hartung: Schlesien 1944/45. Aufzeichnungen und Tagebücher. München 1956, S. 175-177).

622 Belegt u.a. für Kriegsgefangenentransport 1945 in die Sowjetunion und ebenso zurück 1949: Rudolf Ambrosch: Kriegsgefangenschaft. In: Storkower Zeitzeugen berichten [H. 1] (wie Anm. 370), S. 17-19, hier S. 17 u. 19.

623 N.N., Besatzungselend (wie Anm. 619), S. 270.

624 Toni Herms: Flucht aus der Heimat. Bericht aus Schöneiche Kreis Wohlau - Schlesien. Hrsg. von Richard Hoppe. Wiesbaden 1976, S. 8 (12.8.1946).

625 Beispiele: „zum Teil im Schneckentempo“ (Normann, Tagebuch aus Pommern 1945-1946 [wie Anm. 619], S. 171). - „Wir standen mehr als daß wir fuhren. Manchmal rollte der Zug wenige Minuten und stand dann wieder stundenlang herum. So dauerte die Fahrt durch Polen mehrere Tage, [...]. Aber schon bald ging die Fahrt in der gewohnt langsamen Weise weiter, und wie es uns schien, fuhren wir richtungslos hin und her." (Michael Wieck: Zeugnis vom Untergang Königsbergs. 7., veränd. Aufl. Heidelberg 2001, S. 340).

626 Eckhart Bürkner: Der Geruch der Erde. Eine Familie erinnert sich. Jena u. a. 2001, S. 135-138.

627 [Polnisches Sammellager in Schlesien.] 
vom Lager entfernten Verladebahnhof ein aus 53 Viehwaggons bestehender Güterzug bereit. Das Beladen begann früh und dauerte den ganzen Tag, denn jede Familie mußte mit ihrem Gepäck vorher in einen Kontrollraum. Hier wurde die letzte Möglichkeit zum Berauben der Flüchtlinge wahrgenommen, diesmal ganz offiziell durch die polnische Miliz. Die einzige Gerechtigkeit bestand hier darin, daß die Menschen in geordneter Reihenfolge abgefertigt wurden [...]. [S. 137] [...] Im Viehwaggon befanden sich unterhalb der Decke kleine Fenster, durch die wenig Licht drang. Die einzige Ausstattung im Innern bestand aus Stroh. Die Wagen wurden mit etwa dreißig Personen belegt einschließlich des Gepäcks und der Kinderwagen. Die Aufsicht hatte eine männliche Person. Nun saßen wir dort eine Woche lang eingepfercht, ohne daß der Zug angehalten hat oder der Waggon einmal geöffnet wurde. Die Notdurft ging über das Nachtgeschirr zur Fensterluke hinaus. Da die Fahrt kein Ende nahm und Stationen wegen der [S. 138] nicht vorhandenen Fenster nicht erkennbar waren, wußten wir nie, wo wir uns befanden. Dadurch kam die Furcht auf, daß wir nach dem Osten transportiert würden. Diese Angst war uns erst genommen, als der Zug anhielt. Wir waren in Forst angekommen.

Der Zug war auf einem Nebengleis abgestellt. Wir konnten aussteigen und das Notwendigste erledigen, waschen, die Kleinkinder baden. Warmes Essen wurde verteilt, es gab die erste Verpflegung in Deutschland für uns. Das Brot schmeckte trotz des Hungers nicht so recht, es war aus Soja oder Mais. Doch auch daran konnte man sich gewöhnen. [...]. Nach dieser notdürftigen Erstbetreuung ging die Fahrt weiter. Aber wohin? Niemand wußte es, niemandem wurde von offizieller Stelle irgendein Hinweis gegeben. Manch einer hatte die heimliche Hoffnung, daß es in westliche Richtung ginge. Der Zug fuhr aufgrund seiner Länge nicht gerade im Expreßtempo und wurde wahrscheinlich öfter umgeleitet, denn es dauerte lange, bevor wir in Wittenberge [Wittenberg!] ankamen. Hier erreichte uns das Gerücht, daß der Zug weiter westwärts fährt, doch er brachte uns über die nächste Station Jüterbog nach Treuenbrietzen."

Wenigen Betroffenen wird bewusst gewesen sein, dass die Zweckentfremdung der Viehwagen bereits im Krieg auch auf deutscher Seite praktiziert worden war - sehr selten findet man in den Erinnerungsberichten solche Assoziationen, wie sie dem - zuvor bereits durch die Hölle der Judenverfolgung - gegangenen Michael Wieck (geb. 1928 Königsberg i. Pr.) kamen, als er die Aussiedlung seiner bis 1948 im ostpreußischen Königsberg verbliebenen Familie in einem (geschlossenen) Wagen schilderte: „Die Güterwagen waren, wie man sie von den Gefangenentransporten her kannte. Stehen konnte man nur in der Mitte, da beide Seitenteile des Waggons auf halber Höhe abgeteilt waren, so daß die doppelte Anzahl Menschen Platz zum Liegen hatte. In der Mitte stand ein Kohlenofen, daneben lagen Briketts, Kohlen und etwas Holz. Wieder war da dieser Hobbock, ein stuhlhoher Blecheimer, wie ich ihn noch von Rothenstein ${ }^{628}$ in schlimmster Erinnerung hatte; die Nottoilette - für alle immer sichtbar - von Frauen und Männern gleichermaßen zu benutzen. Es war ein großer Transport mit sicherlich über tausend Menschen. Nachdem die gründlichen Kontrollen vorüber waren, wurden die Waggons nacheinander völlig wahllos mit Männern und Frauen gefüllt. Die Älteren legten sich auf den Boden, während wir Jüngeren auf die obere Etage kletterten. [...] 
Auch am Tage war es ziemlich dunkel, denn die schweren Waggontüren wurden von außen verriegelt. Die hoch angebrachten Entlüftungsklappen ließen nicht viel Licht herein und gaben nur wenigen die Möglichkeit hinauszuschauen."

Es wäre freilich zu einfach, sich die Bevölkerungsbewegungen von Juli/August 1945 bis 1950 als Einbahnstraßen vorzustellen. Schon mehrfach wurde auf die in ihre Heimatorte zurückkehrenden oder doch dies versuchenden ehemaligen Zwangsarbeiter und manche andere nach Deutschland Verschleppten hingewiesen, hinzu kamen nun nach Kriegsende umgekehrt zur Zwangsarbeit in die Sowjetunion abtransportierte Deutsche ${ }^{629}$. Die Hin- und Her-Bewegungen wurden nach Kriegsende aber vor allem auch noch durch die, mal einzeln, mal in Schüben, teilweise aber eben auch mit Eisenbahntransporten hinzukommenden „Heimkehrer“, also die aus der Kriegsgefangenschaft im Westen oder Osten entlassenen ehemaligen deutschen Soldaten, vermehrt. Überdies strebten, wie schon betont wurde, in großer Zahl ehemalige, in Deutschland als Kriegsgefangene festgehaltene Ausländer und auch nichtdeutsche KZ-Häftlinge in ihre Heimatländer, so dass in alle Himmelsrichtungen Menschen unterwegs waren, keineswegs nur von Ost nach West. Trotz aller Bemühungen der ohnehin vor wie nach dem Ende der Kampfhandlungen überforderten Verwaltungsstellen mehrten sich die Fälle individueller Bewegung, da sich nicht wenige Flüchtlinge von Transporten entfernten und auf eigene Faust ihr Ziel zu erreichen suchten. So entstand in der ersten Jahreshälfte 1945 ein kaum noch überschaubares Bild, in dem der Heimatvertriebene aus dem Osten wohl zu den am härtesten Getroffenen zählte, aber keineswegs der einzige Suchende und Bittsteller war.

Eine - notwendige, aber hier nicht zu leistende - Gesamtbetrachtung der Geschehnisse müsste auch diesen vielen, nicht nur deutschen Personen und Personengruppen Beachtung schenken. Doch auch unter den Deutschen, die bereits vor Kriegsende aus dem Osten in das Reichsgebiet verbracht worden waren, gab es sogar Gruppen, die nun zu einer Rückkehr gezwungen wurden, ein Schicksal, dass besonders - von der Sowjetunion als ihre Staatsbürger betrachtete - Russlanddeutsche traf. So bestand z. B. in Dessow (Kr. Ruppin) im Juli/August 1945 ein entsprechendes Lager, wie der damals örtlich zuständige evangelische Pfarrer überliefert hat: „Eine besondere seelsorgerische Arbeit fiel mir im August 1945 in Dessow zu. Die großen baulichen Anlagen des Gutes wurden von den Alliierten dazu bestimmt, den aus dem Osten während des Krieges nach Deutschland freiwillig oder gezwungen gekommenen Volksdeutschen als Sammellager für den Rücktransport nach Russland zu dienen. Eines Tages, Mitte Juli 1945, erschien im Pfarrhaus $z u$ Lögow bei mir die Frau eines Menno[n] itenpredigers in Russland und bat mich, doch ein schwer lungenkrankes Kind zu besuchen, das im Kartoffelbunker zu Dessow untergebracht war. [...] Es wurde den Volksdeutschen verboten, Dessow zu verlassen."630

Einen tiefen Einblick in die unübersichtliche menschliche „Gemengelage“, die sich in den nunmehrigen Grenzgebieten 1945 auf Bahnhöfen ergab, erlaubt auch die Schilderung einer im

630 Karl Schwachenwalde: Ein Pfarrerleben in der Mark. Falkensee 2013, S. 102. 
Oktober 1945 vorübergehend nach Schlesien zurückgekehrten Vertriebenen. Die 1945 zwanzigjährige Förstertochter aus Niederschlesien war, wie viele andere, im Mai über Böhmen vor der Roten Armee geflohen und befand sich im Herbst in Kolkwitz bei Cottbus, während ihre Familie noch im nun polnischen Heimatort verblieben war: „Schon fünf Monate waren vergangen, und ich wußte nichts von Zuhause und meinen Eltern. Nun plante ich illegal den Weg nach Polen (Schlesien). Erfahren hatte ich in Forst, daß russische Kohlenzüge nach Sagan fuhren und Deutsche sich über die Grenze schmuggelten. Ich wollte das auch versuchen, und es konnte mir niemand mehr ausreden. Ein Herr aus Kolkwitz wollte denselben Weg gehen, und ich fragte, ob ich mich ihm anschließen darf. Von Hähnchen ${ }^{631}$ lief ich früh bis Kolkwitz und dann weiter bis Forst. Wir mußten in einem Hotel nahe dem Bahnhof übernachten. Ich mußte mir das Zimmer mit drei fremden Männern teilen, die dieselbe Absicht hatten wie ich. Angezogen lag ich im Bett und konnte kaum schlafen. Einer von den dreien hatte einen Wecker, und da war ich froh. Es war noch finster, als wir zum Bahnhof gingen. Wir mußten uns verstecken, dann lief der Zug ein. Jeder war sich jetzt selbst überlassen. Einige buddelten sich in die Kohlen ein, ich schaffte es nicht. Dann fand ich ein Zugbegleiterhaus, wie sie an Güterzügen oft sind. Dort steckten schon zwei Soldaten drin. Wie ich später erfuhr, waren es Vater und Sohn, die sich zufällig im Gefangenenlager getroffen hatten. Sie wollten nach Oberschlesien. Nach zehn Minuten setzte sich der Zug in Bewegung, und wir waren im Moment froh, denn es ging über die Grenze. Kaum angefahren, hielt er [S. 45] schon wieder. Die Polen kontrollierten. Lautes Gespräch, und sie holten auch Leute heraus. Zu unserer Tür krochen sie auch hoch, doch wir hielten gemeinsam die Klinke fest und bis zu dem kleinen Fenster kamen sie wohl nicht hoch. Es trat Ruhe ein, und der Zug setzte sich wieder in Bewegung. Bei uns legte sich langsam die Angst. Der Zug fuhr dann bis Sagan durch, und dort sind wir alle ausgestiegen. Auf dem Bahnhof waren Massen von Menschen, Ostarbeiter aus allen Ländern, Soldaten und Flüchtlinge. Alle wollten irgendwohin. Wir standen einfach hilflos auf dem Bahnsteig. Der Herr von Kolkwitz fuhr mit dem nächsten Zug wieder nach Forst zurück. Er konnte es nervlich nicht verkraften, wie er es mir sagte. Ich überlegte auch, ob ich wieder zurückfahre. Dann traf ich zwei Soldaten, und mit ihnen ging ich zu einem Zug, der nach Breslau fahren sollte. Dort versuchten wir, irgendwo einen Platz zu finden. Es war unmöglich, die Menschen hätten uns ,Deutsche wieder heruntergestoßen. Zuletzt habe ich es auf dem Trittbrett der Lokomotive versucht. Als mich der Lokführer sah, mußte ich schnellstens weg, und der Zugfuhr ab. Die zwei Soldaten wollten den Weg zu Fuß antreten, und kurz entschlossen ging ich mit. [...]"632 Auf Umwegen kam sie dann tatsächlich bis zum Elternhaus: „Alle hatten mich für vermißt oder tot gehalten." ${ }^{33}$

631 [Hänchen, Nachbardorf von Kolkwitz südwestlich Cottbus.]

632 Wal[d]traut Winter: Der lange Weg zurück. In: Lebenszeit. T. V. Zeitzeugen berichten. Hrsg. vom Seniorenbeirat der Gemeinde Neuenhagen bei Berlin. Neuenhagen 1999, S. 44-48, hier S. $44 \mathrm{f}$. 


\section{"Antifa-Transporte"}

Eine Sondergruppe unter Transporten und den Transportierten bilden die sogen. „AntifaTransporte“.634 Spätestens im August 1945 hatte die Beneš-Dekrete die Sudetendeutschen staatenlos gemacht ${ }^{635}$ - mit einer kleinen Ausnahme: jenen „Antifaschisten, die eine aktive Anteilnahme an der Widerstandsbewegung" vorweisen konnten. ${ }^{636}$ Diese wurden jedoch ebenfalls vertrieben, auch wenn man ihre Aussiedlung in der SBZ/DDR als „freiwillig“ darstellte. „Auf der Grundlage eines Planes der SMAD, der sogenannten „Shukow-Aktion“637, begannen im November 1945 gezielte Transporte von rund 17000 kommunistischen Familien. Hinzu kamen 1800 Sozialdemokraten mit ihren Familien.“ Bis Ende 1946 sollen so nach Angaben der SED etwa „35000 bis 50000 sudetendeutsche Antifaschisten “ in die SBZ gekommen sein. ${ }^{638}$ Die Gesamtzahl der in die SBZ gelangten Sudetendeutschen lag 1945/46 bei 800000 (ungefähr 1,8 Millionen waren in die Westzonen gekommen und etwa 15000 waren bereits nach Österreich geflüchtet). ${ }^{639}$ Nach Brandenburg wurden bis Dezember 1946 in 16 geschlossenen Transporten 3968 „Antifa-Umsiedler“ in 1426 Familien geleitet. Sie kamen insbesondere aus den Gebieten um Gablonz, Trautenau, Böhmisch Leipa, Schluckenau, Nixdorf ${ }^{640}$, Friedland/Böhmen und Asch. ${ }^{641}$

In Vorbereitung eines solchen „Antifa-Transportes“ wandte sich die Informationskanzlei „Antifa“ Gablonz a. N. unter dem 6. Februar 1946 an die Ortsgruppe der KPČ in Ober Maxdorf (Nordböhmen) und übersandte ein „Verzeichnis jener Antifaschisten, welche zur politischen Arbeit nach Deutschland ausreisen“.642 Man bat die „Genossen“, den Ausreisenden „ein Zeugnis auszustellen, daß sie als gute Genossen und Antifaschisten und als ehemalige Nachbarn, nicht als Feinde des

Heike van Hoorn: Neue Heimat im Sozialismus. Die Umsiedlung und Integration sudetendeutscher AntifaUmsiedler in die SBZ/DDR. Essen 2004 (Diss. Münster 2002). - Jan Foitzik: Kadertransfer. Der organisierte Einsatz sudetendeutscher Kommunisten in der SBZ 1945/46. In: Vierteljahrshefte für Zeitgeschichte 31 (1983), S. 308-334. - Manfred Wille: Die „freiwillige Ausreise“ sudetendeutscher Antifaschisten in die Sowjetische Besatzungszone Deutschlands - erfüllte und enttäuschte Hoffnungen und Erwartungen. In: Die Sudetendeutschen in der Sowjetischen Besatzungszone Deutschlands (wie Anm. 29), S. 28-61. - Volker Zimmermann: Aktion „Ullmann“. In: Lexikon der Vertreibungen (wie Anm. 59), S. 26-27. - Adrian v. Arburg: Deutschsprachige Antifaschisten: Aussiedlung aus der Tschechoslowakei. In: Lexikon der Vertreibungen (wie Anm. 59), S. 209-211 - Dokumentation der Vertreibung IV/2, S. 518-549.

635 Detlef Brandes: Dekrete des tschechoslowakischen Präsidenten (Beneš-Dekrete") (Mai-Oktober 1945). In: Lexikon der Vertreibungen (wie Anm. 59), S. 112-114. - Spurný, Flucht und Vertreibung (wie Anm. 332), S. 122-133.

636 Amos, Vertriebenenpolitik der SED (wie Anm. 12), S. 133.

637 Benannt nach dem SMAD-Chef Georgi Konstantinowitsch Schukow (Shukov), da die SMAD während seiner Amtszeit die zugrundeliegende Vereinbarung zwischen den Kommunistischen Parteien der SBZ und der ČSR offiziell genehmigte.

638 Wille, Die „freiwillige Ausreise“ (wie Anm. 634), S. 134.

639 Ebd., S. 133.

640 Siehe im Kapitel III. 2 den Abschnitt „Umsiedlergenossenschaften“ sowie in der Ortsdokumentation die Angaben zu Leegebruch.

641 Christopeit, Die Sudetendeutschen in der Provinz Mark Brandenburg (wie Anm. 29), S. 82.

642 Abdruck einer aus dem Tschechischen übersetzten Abschrift bei Hans Schmutzer: ... auferstanden aus Ru- 
tschechoslowakischen Volkes die Republik verlassen, sondern deshalb, weil sie die tschechoslowakische Sprache ungenügend beherrschen und aus diesem Grunde in der CSR im politischen Leben keine richtige Fühlung nehmen können“. Aber auch noch weitere Formulierungen wurden den tschechischen Noch-Nachbarn in die Feder diktiert: „Wir bitten weiter anzuführen, daß die Ausreise dem Neuaufbau eines demokratischen Deutschlands dient, welches dann auch der beste Garant für die Freiheit und Demokratie der CSR wäre." Das kurze Schreiben endet mit dem Satz: „In Anbetracht der Dringlichkeit bitten wir Sie um baldige Erledigung dieses Antrages.“

„Für die SED hatten die sudetendeutschen Kommunisten strategische Bedeutung. Sie füllten ihren zentralen Parteiapparat mit ideologisch und politisch überprüften Funktionären auf und halfen mit, daß die SED in kurzer Zeit in eine sogenannte Partei neuen Typus, in eine leninistische Kaderpartei, umorganisiert wurde.“ „Der militärische und geheimdienstliche Apparat“ wurde für diejenigen, die nicht den Weg der Neubauern gingen, „zu ihren Haupteinsatzgebieten. ${ }^{“ 643}$ Die Teilnehmer der Antifa-Transporte erlangten aber kaum Führungspositionen im Apparat, nur einige wurden Botschafter in Warschau und Moskau. Während man aus ihren Reihen eher für Polizei und Eisenbahn Kräfte gewann, fanden lediglich fünf „Antifa-Umsiedler“ „Anstellung bei der brandenburgischen Provinzialverwaltung. Nur ein Sudetendeutscher bekleidete das Amt eines Landrates. Der einizige Sudetendeutsche aus der Provinz Brandenburg, der in der DDR einen hohen Posten übernahm, war der spätere Außenminister Oskar Fischer ${ }^{644}$. Er hatte seine Laufbahn als Kreisvorssitzender der Freien Deutschen Jugend in Spremberg begonnen. ${ }^{\text {“65 }}$ Die Mehrheit dürfte sich vielmehr nicht von den anderen sudetendeutschen und sonstigen Vertriebenen unterschieden und teils auf den Dörfern, teils in der Industrie Arbeit gesucht und gefunden haben. ${ }^{646}$ Wichtiger als die Nutzung als Reservoir für linientreuen Funktionärsnachschub dürfte denn auch ein anderer Aspekt gewesen sein, der die Gruppe propagandistisch nützlich werden ließ. Das lässt sich in Brandenburg sowohl in der überwiegend von „Antifa-Umsiedlern“ bewohnten Neugründung DorfZinna/Neuheim ${ }^{647}$ (bei Jüterbog) als auch in der entsprechenden Konzentration in Leegebruch bei Oranienburg erkennen. An beiden Orten gründeten die Vertriebenen sehr erfolgreiche „Umsiedlergenossenschaften“. Als Beweis gelungener Vertriebenenintegration in der SBZ/DDR verwies die SED daher auch öffentlich - z. B. in Wochenschauen - auf sie, was sie bei der Masse der als „unsichere Kan-

inen. Geschichte des Dorfes Dorf Zinna - Neuheim. Hrsg.: Dorfklub Neuheim und Betrieb VEB Gablona. [Neuheim 1966], S. $12 \mathrm{f}$.

643 Wille, Die „freiwillige Ausreise“ (wie Anm. 634), S. 134.

644 [Geb. 1923 Asch/Böhmen, gest. 2000 Berlin, gelernter Schneider, 1946 aus sowjetischer Kriegsgefangenschaft in die SBZ entlassen; 1950/51 MdL Brandenburg.]

645 Christopeit, Die Sudetendeutschen in der Provinz Mark Brandenburg (wie Anm. 29), S. 83.

$646 \mathrm{Zu}$ diesem Schluss kommt in ihrer Dissertaton auch Heike van Hoorn, Neue Heimat im Sozialismus (wie Anm. 634), die als erste der Integration speziell dieser Sondergruppe nachgeht und dabei nicht zuletzt brandenburgische Beispiele anführt. Umso bedauerlicher ist es, dass dieses Buch zwar in diversen Berliner, aber nur einer einzigen brandenburgischen Bibliothek nachgewiesen ist (lt. KVK 10.9.2018). 
tonisten“ eingeschätzten Vertriebenen tunlichst vermied. Die „Antifa-Umsiedler“ eigneten sich anfangs hervorragend, um sie - entgegen den Tatsachen - als ein für die Gesamtgruppe der Vertriebenen in der SBZ/DDR repräsentatives Beispiel auszugeben.

Dass diese angeblich „freiwilligen“ Aussiedler, die mit den „Antifa-Transporten“ in die DDR kamen, schon zu Beginn durchgehend besser behandelt worden wären als die „normalen“ Vertriebenen, ist offenkundig nicht der Fall. So heißt es in einem „Merkblatt für Transportführer" vom 7. Februar 1946, ausgegeben von der „Umsiedlerstelle der KPD Pirna“ u. a.: „Es kommt vor, daß bei dem Leerzug keine Personenwaggons beigestellt werden können und die Umsiedler in Güterwagen weiterbefördert werden müssen. In diesem Falle ist in den Güterwagen Sitzgelegenheit und ein kleiner Ofen sowie Heizmaterial zu geben. In erster Linie sind die Frauen und Kinder unterzubringen." ${ }^{648}$ Ein Teilnehmer eines solchen Transportes, der später in Berlin-Brandenburg journalistisch tätig war, hat überliefert, dass der Zug in seinem Fall (im Februar 1946) aus 22 Güterwaggons und nur 4 Personenwaggons bestand ${ }^{649}$.

\section{Berlin}

Nicht tiefergehend behandelt werden kann hier die allerdings für vertiefende Forschungen wichtige Situation in Berlin. ${ }^{650}$ Für auf den dortigen Bahnhöfen ankommende Transporte und Einzelpersonen richtete man zwar schon 1945 in allen Bezirken diverse Auffang- und Durchgangslager ein ${ }^{651}$, doch wurde der Mehrheit der zunächst hierher Gelangten keine Genehmigung zu einem längeren Aufenthalt in der Stadt erteilt. Der (offizielle) Zuzug von Flüchtlingen und Vertriebenen aus den Ostgebieten nach Berlin stand vielmehr spätestens ab 27. Juli 1945 unter Genehmigungsvorbehalt des Militärkommandanten. ${ }^{62}$ Schon am 24. Mai 1945 hieß es von Seiten des Bürgermeisters: „Der Zustrom der Bevölkerung nach Berlin müsse unbedingt abgestoppt werden. Alle aus Berlin Evakuierten sollen bleiben, wo sie sind, um die Schwierigkeiten hier nicht zu vergrößern.“653 Daher blieb die darnieder liegende ehemalige „Reichshaupt-

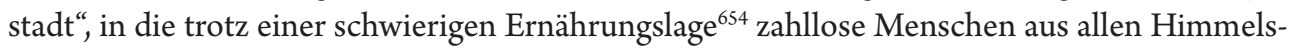

648 Abdruck einer Abschrift ebd., S. 10-12, Zitat S. 11.

649 Ebd., S. 15.

650 Siehe dazu Ribbe, Flüchtlinge - Vertriebene - Displaced Persons (wie Anm. 6).

651 Liste vom 30.4.1946 („Umsiedlerlager sämtlicher Verwaltungsbezirk““) als Anlage 1 in: DAB, I/9-15-1 Flüchtlingsseelsorge 1945-1951, unfol. - Zu den Lagern im Bezirk Lichtenberg siehe auch Hofmann, Heimatverlust und Neuanfang 1945/46 (wie Anm. 6), S. 91.

652 27.7.1945: „Mit Befehl Nr. 15 verbietet der Oberste Chef der Sowjetischen Militärverwaltung und Oberbefehlshaber der sowjetischen Besatzungstruppen in Deutschland die Einreise von ,Übersiedlern' aus den polnisch und sowjetisch verwalteten deutschen Ostgebieten nach Berlin ohne Erlaubnis des sowjetischen Stadtkommandanten“. Berlin. Kampf um Freiheit und Selbstverwaltung 1945-1946. Hrsg. im Auftr. des Senats von Berlin. 2., erg. u. erw. Aufl. (Schriftenreihe zur Berliner Zeitgeschichte, Bd. 1). Berlin 1961, S. 128 (Nr. 98 ).

653 Ebd., S. 66 (Nr. 82 d).

654 Ebd., S. 103 (Nr. 101 b), 3.7.1945: „Auf einer Sitzung der zuständigen Referenten der Bezirksämter beim Haupternährungsamt wird mitgeteilt, daß die in Verhandlungen mit sowjetischen Militärbehörden wieder- 
richtungen hinein (und andere hinaus) strebten, zumeist nur Zwischenstation ${ }^{655}$, Auffanglager existierten aber zunächst weiter. Bürgermeister Maron teilte am 4. Juli mit, „daß das Problem des Zustroms von Flüchtlingen und aus den Ostgebieten Ausgewiesener vor einigen Tagen Marschall Shukow vorgetragen worden sei. Der Marschall habe sofort den Befehl gegeben, den Flüchtlingsstrom vor den Toren Berlins abzufangen und nach Mecklenburg und dem Nordteil der Mark Brandenburg abzudrängen, um die Schwierigkeiten der Lebensmittelversorgung in

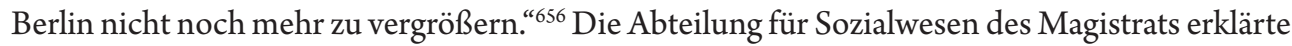
am 9. Juli, „daß in Berlin keine Unterkunfts-, Verpflegungs- oder Arbeitsmöglichkeit für ,Ausgewiesene aus den Ostbezirken' [!] besteht und darum jeder Zuzug zu unterbleiben hat. Auffanggebiete sind die Provinz Brandenburg und die Länder Sachsen und Mecklenburg." ${ }^{657}$

Doch selbst solche Versuche der Verwaltung, der ins Land und in die Hauptstadt drängenden Menschenmassen Herr zu werden, brachten allenfalls vorübergehend Teillösungen. Im Juli 1945 registrierte die Magistratsabteilung für Ausgewiesene und Heimkehrer „in den 48 Berliner Durchgangslagern 537000 Ausgewiesene“, die „in die Provinz Brandenburg sowie in die Länder Mecklenburg und Sachsen weitergeleitet" wurden. ${ }^{658}$ Bis November stieg die Zahl auf 1,3 Millionen. Schon Ende Juni war sich der Magistrat mit den Bezirksbürgermeistern darüber einig, „daß alle Bezirke und die gesamte Bevölkerung von Berlin gleichmäßig Opfer bringen müssen, um die Flüchtlinge und die durch den Flüchtlingsstrom besonders belasteten östlichen Stadtbezirke zu unterstützen“. Im Bezirk Lichtenberg waren von Mai bis Ende Juli 1945 in den eingerichteten Lagern rund 100000 Flüchtlinge zu betreuen und vorübergehend zu versorgen. Sie wurden anschließend „nach Wittstock (Dosse), ins Westhavelland und nach Mecklenburg weitergeleitet“ “659 Nicht nur die Ernährungslage und die Wohnsituation waren in Berlin angespannt, auch „die Verhütung der weiteren Einschleppung von Seuchen durch Flüchtlinge, die vielfach durch die Entbehrungen stark verwahrlost sind“660, war für den Groß-Berliner Magistrat ausschlaggebend für eine restriktive Haltung. Doch selbst der - offenbar nur zeitweise überhaupt praktisch umgesetzte bzw. umsetzbare - sowjetische Befehl und alle „Festlegungen“ des Magistrats fruchteten nicht im gewünschten Maße. Am 15. Juli 1945 war der Magistrat so ratlos, dass er nur noch an die Einsicht der Vertriebenen appellieren konnte. Er wandte sich

holt geäußerte Bitte um Zusatzkontingente für die Ernährung von Flüchtlingen, Kriegsgefangenen und für die Kranken- und Gaststättenverpflegung abgelehnt wurde. Der sowjetische Ernährungsoffizier für die Stadt Berlin, Oberst Kroll, habe erklärt, nicht in der Lage zu sein, zusätzliche Lebensmittel abzugeben. Flüchtlingen soll nicht mehr als eine Suppe und $100 \mathrm{Gramm}$ Brot als Verpflegung für einen Tag gegeben werden. Sie müßten innerhalb von 24 Stunden Berlin verlassen. [...].“

655 Ausnahmebeispiel: „383 Flüchtlinge, die in der Ernte als Arbeitskräfte gebraucht wurden und laut Bericht in Marzahn eine neue Heimstatt fanden“ (Hofmann, Heimatverlust und Neuanfang 1945/46 [wie Anm. 6], S. 93).

656 Berlin. Kampf um Freiheit und Selbstverwaltung 1945-1946 (wie Anm. 652), S. 105 (Nr. 16).

657 Ebd., S. 112 (Nr. 38).

658 Ebd., S. 132 (Nr. 115).

659 Hofmann, Heimatverlust und Neuanfang 1945/46 (wie Anm. 6), S. 91.

660 Berlin. Kampf um Freiheit und Selbstverwaltung 1945-1946 (wie Anm. 652), S. 96 (Nr. 101 b; 27.6.1945). 
nun „in einem Aufruf an die Flüchtlinge aus den Gebieten jenseits der Oder-Neiße-Linie, in dem er sie bittet [!], nicht in Berlin zu bleiben [!], weil hier die Möglichkeiten der Hilfe nur sehr begrenzt sind. Da keine Transportmittel vorhanden sind, werden die Ausgewiesenen aufgefordert, zu Fuß weiterzuziehen und im Ernteeinsatz zu helfen" ${ }^{661}$ Am 23. Juli heißt es in der Magistratssitzung: „Vor einigen Tagen sei ein Flüchtlingstransport in Berlin eingetroffen, der mit Lebensmitteln versorgt werden mußte. Aber keiner der leitenden Herren der Abteilung für Ernährung sei erreichbar gewesen, um die erforderlichen Maßnahmen zu veranlassen." ${ }^{662}$ Resignierend vertritt der Magistrat am 20. August „nach einer längeren Diskussion die Auffassung, daß sich das Flüchtlingsproblem im Grunde nur in einem großzügigen gesamtdeutschen Plan lösen lasse und beschließt deshalb als Notmaßnahme, Flüchtlinge und [heimgekehrte] Kriegsgefangene bis auf weiteres aus der Lebensmittellreserve der Abteilung für Ernährung auf der Basis der Lebensmittelkarte V zu versorgen“" ${ }^{663}$

Auch im Herbst 1945 ist die Lage eher noch weiter verschärft, die Kommandantur verweist am 11. September auf die „angesichts des ständigen Flüchtlingsstroms aus dem Osten“ weiter ansteigende Wohnungsnot. ${ }^{664}$ Die von den Kommandanten am 13. September verfügte Beschränkung des Lebensmittelkartenanspruchs auf Personen, „die sich am 30. September 1945 ständig in Berlin aufhalten“, bedeutete faktisch eine Zuwanderungssperre ab 1. Oktober. ${ }^{665}$ Bereits in der Magistratssitzung vom 12. November stellt Ernährungsstadtrat Klimpel (SPD) jedoch fest, dass trotz der Zuwanderungssperre „täglich tausende von Flüchtlingen nach Berlin“ strömten, die zumindest „im sowjetischen Sektor keine Lebensmittelkar- [S. 259] ten erhalten dürfen, so daß zweifellos große Härten entstehen. "666 Unter dem Eindruck der anschließenden „Schilderung des kaum vorstellbaren Flüchtlingselends durch Stadtrat Geschke (KPD)“ beschließt man auf dessen Antrag, ,einen Ausschuß für Umsiedler und Heimkehrer einzusetzen, dem Vertreter der Abteilungen für Sozialwesen, Ernährung, Arbeit, Bau- und Wohnungswesen sowie des Hauptgesundheitsamtes und des Beirates für kirchliche Angelegenheiten angehören sollen“ ${ }^{667}$ Am 16. November berichtet Geschke dann auch auf der Bezirksbürgermeisterkonferenz und „zeichnet ein Bild des unsagbaren Flüchtlingselends“, das „in ganz besonderem Maße einzelne Bezirke namentlich im Osten der Stadt vor fast unlösbare Aufgaben stellt“. Der Magistrat wolle das Problem „durch Aufrufe an die Bevölkerung zu umfassenden Hilfeleistungen, durch Beschlagnahmeaktionen von Textilien bei ehemaligen Nationalsozialisten, Errichtung weiterer Flüchtlingslager und behelfsmäßiger Altersheime sowie vordringlicher Verpflegungszuteilung so gut es geht steuern“. Auch hoffe man „auf weitgehende Unterstützung der Besat- 
zungsbehörden, die bereits selbst die bestehenden Zustände als untragbar bezeichnet haben“. Immer wieder behindern jedoch verschiedene „Vorfälle“ die Arbeit der Bezirksverwaltungen, da es z. B. „Unterschlagungen von Lebensmitteln durch Leiter von Flüchtlingslagern“ gibt und einem Bericht aus Reinickendorf zufolge - „fertiggestellte Flüchtlingslager [...] jeweils sofort von den Besatzungsbehören beschlagnahmt wurden, so daß kaum noch Unterkünfte für Flüchtlinge geschaffen werden können“. 668

Letztlich überrollen die von den Besatzungsmächten vorgegebenen Maßnahmen die Vorkehrungen der Verwaltung in Berlin genauso wie in der umliegenden Provinz Brandenburg immer wieder. So wird Berlin in dem am 20. November 1945 vom Allierten Kontrollrat vereinbarten - alle Besatzungszonen berücksichtigenden - „Umsiedlungsplan für die aus Österreich [Aufnahmegebiet: Französische Besatzungszone], der Tschechoslowakei [Aufnahmegebiet: Amerikanische Besatzungszone], Ungarn [Aufnahmegebiet: Französische Besatzungszone] und Polen [Aufnahmegebiet: Britische und Sowjetische Besatzungszone] ausgewiesenen Deutschen“ nicht ausgenommen, im Gegenteil sollte der Plan sogar „sinngemäß auf die vier Sektoren Berlins Anwendung finden“. ${ }^{669}$ Anfang 1946 versuchte der Magistrat dann auf die Frage, wer nach Berlin kommen sollte, Einfluss zu nehmen, um die lokalen Arbeitsmarktbedürfnisse besser berücksichtigen zu können. Sein Antrag, „die Übersiedlung von 5000 aus der Tschechoslowakei ausgewiesenen deutschen Bauhandwerkern nach Berlin zu genehmigen“, wurde von der Alliierten Kommandantur jedoch am 6. Februar abgelehnt. ${ }^{670}$ Berlin blieb mit dem vom Magistrat kaum zu beeinflussenden Zustrom auch weiter konfrontiert. Im März 1946 trafen nach „einem Bericht der Abteilung für Sozialwesen des Magistrats“ täglich (!) „durchschnittlich 1533 Umsiedler aus den sowjetisch und polnisch verwalteten deutschen Ostgebieten ein “6 ${ }^{671}$ Im April 1946 befanden sich „in den verschiedenen Berliner Lagern für Umsiedler“ nach einem Bericht des Stadtrats Geschke vom 11. April „gegenwärtig 20800 Vertriebene aus den polnisch verwalteten deutschen Ostgebieten“672 Von den „rund 105000 hilfsbedürftigen alten Menschen“, die damals insgesamt - Einheimische und Zugewanderte zusammengenommen! - in der Stadt lebten, waren nach Geschkes Bericht „bisher nur etwa 6000 in 27 Altersheimen untergebracht“ ${ }^{673}$

\section{Lager}

Während man bei der Erstaufnahme und Durchschleusung bis Kriegsende und noch im Sommer 1945 vielfach improvisierte, etwa Turnhallen und Schulgebäude genutzt wurden, war man mit dem Einsetzen der „organisierten“ Vertriebenentransporte, mit denen bald - oft mit nur 
sehr kurzfristiger Vorwarnung an die aufnehmenden brandenburgischen Landkreise - tausende Menschen an einem Tag eintrafen, gezwungen, Notunterkünfte einzurichten, in denen der Einzelne und seine Bedürfnisse in der Masse verschwanden. Erneut entstand so eine Lagerlandschaft im ganzen Land, und Nutzungskontinuitäten zur NS-Zeit waren nicht selten. Allerdings handelt es sich bei den für Flüchtlinge und Vertriebene genutzten Lagern aus der NS-Zeit nur in Ausnahmefällen um vorherige KZ-Außenlager, die Mehrheit bilden wohl die noch kurz zuvor in Tätigkeit gewesenen Zwangsarbeiter- und RAD-Lager sowie diverse Wehrmachtsanlagen.

Die Gesamtzahl der in Brandenburg eingerichteten Flüchtlings- bzw. „Umsiedlerlager“ lässt sich kaum feststellen. Zu stark war die Fluktuation, zu unscharf ist die „Übergangszone“, wollte man „Lager“ von „Sammelunterkünften“ trennen. Auch in der hier im Vordergrund stehenden Hauptphase des Betriebs von Vertriebenenlagern hat es laufend Schließungen, Neueinrichtungen und auch Wiedereröffnungen gegeben. Vor allem letztere verunklaren leicht das Bild, wenn man in den Akten und sogar in der Literatur von einer Schließung oder gar Auflösung liest, dann aber für später liegende Daten wieder eindeutige Nutzungsbelege (für neue, offenbar von den Behörden nicht erwartete Transporte) findet.

„Anfang November 1945 bestanden in der Sowjetischen Besatzungszone 588 solcher Lager mit einem Fassungsvermögen von 484000 Personen. Ende des Jahres gab es einen Höchststand von 640 Lagern, [S. 477] deren Zahl dann drastisch reduziert wurde und im Mai 1946 bei nur noch 183 mit einer Kapazität von über 215000 Personen lag."674 Ähnlich verlief die Entwicklung in Brandenburg. Auch hier existierten anfangs und mit der Zunahme der Transporte ab Oktober 1945 sowie Anfang 1946 ausgesprochen viele, heute kaum noch vollzählig ermittelbare oder gar genau lokalisierbare Lager bzw. als Lager bezeichnete lagerähnliche Unterbringungsorte ${ }^{675}$ In einer zum Jahreswechsel 1945/46 erstellten „Gesamtaufstellung der Lager mit Fassungsvermögen “676 werden für Brandenburg 83 Lager (wegen Doppelzählungen jedoch eigentlich nur 79) mit einer berechneten Gesamtkapazität von 123570 Personen genannt (Tabelle 2, siehe S. 164).

Im Februar 1946 heißt es in einem Bericht der zuständigen Leiterin des Umsiedleramtes der Provinzialverwaltung, Magda Sendhoff: „In der Provinz bestanden ausser den 5 Auffanglagern bis jetzt 91 Kreislager, die im Verlaufe der letzten Monate ausgebaut wurden. "677 Für den Zeitraum vom Kriegsende 1945 bis März 1946 nennt die Landesregierung in eimem rückblickenden Bericht von 1948 hingegen 84 Lager mit einer Kapazität von insgesamt 128000 Personen. ${ }^{678}$

Diese Zahlen erscheinen - trotz der Schwankungen - insgesamt realistisch, da sie offenkundig mehrere Lager pro Kreis einbeziehen. Alle späteren Zählungen in Akten der Landesregierung und der SED wie auch in der Literatur beziehen sich aber immer nur auf die großen, im

674 Meinicke, Die Aufnahme von Vertriebenen (wie Anm. 11), S. 476 f.

675 Grundlegend dazu, auch zum Innenleben (Verwaltungsstruktur) der Lager, Oehlsen, Vertriebenenlager (wie Anm. 45).

676 BArch, DO 2/45, Bl. 39 (masch.) mit Bleistiftzusatz: „Erfaßte Lager bis 31.12.1945“.

677 BLHA, Rep. 333 SED-Landesleitung Brandenburg, Nr. 574, Bl. 6 (vgl. Textabdruck im Quellenteil, Nr. 20).

678 BLHA, Rep. 203 MdI, Nr. 116, Bl. 3 (Siehe den Textabdruck im Quellenteil, Nr. 151). 
Tab. 2: Verzeichnis der bis 31. Dezember 1945 erfassten „Umsiedlerlager" in der Provinz Brandenburg ${ }^{679}$

\begin{tabular}{|c|c|}
\hline & [Bl. 40 (Bl. 1) \\
\hline Landkreis & Ort des Lagers/Fassungsvermögen \\
\hline Sorau & $\begin{array}{l}\text { Klein-Kölzig (120), Gross-Kölzig (60), Döbern: Hotel Fürstenau [Förstemann!] (120) } \\
\text { [Siehe auch unten Forst!] }\end{array}$ \\
\hline Lebus & Neu-Hardenberg (400) \\
\hline Oberbarnim & $\begin{array}{l}\text { Freienwalde (1300), Strausberg (2000), Wriezen: Motorsportschule (1 800), Wriezen } \\
(500) \text {, Bralitz (500) }\end{array}$ \\
\hline Angermünde & $\begin{array}{l}\text { Felchow (300), Altenhof: Jugendherberge (500), Britz: Privathäuser (1 000), Joachims- } \\
\text { thal (2 500), Pinnow (4000), Oderberg (2 000), Neu-Künkendorf: Gutsherrenhaus } \\
(200) \text {, Gramzow (2000), Angermünde: Kaisergarten (1 500) }\end{array}$ \\
\hline Templin & Engelsburg (1500), Lychen-Himmelpfort (2000) \\
\hline Prenzlau & Birkenhain (3000) \\
\hline Osthavelland & Henningsdorf [Hennigsdorf] (5200) \\
\hline Teltow & $\begin{array}{l}\text { Saalov [Saalow] (1 200), Dabendorf b. Zossen (500), Genshagen b. Zossen (500), Zerns- } \\
\text { dorf b. Königswusterhausen (800), Königswusterhausen (500), Arnsdorf [Ahrensdorf] } \\
(600) \text {, Körbeskrug [Körbiskrug] b. Bestensee (300) }\end{array}$ \\
\hline Beeskow-Storkow & Küchensee (1500) \\
\hline Niederbarnim & $\begin{array}{l}\text { Amalienfelde (100), Oranienburg (350), Erkner (150), Rüdersdorf (1000), Bernau } \\
(1000), \text { Gr[oß] Schönebeck (500) }\end{array}$ \\
\hline Zauch-Belzig & $\begin{array}{l}\text { Belzig: Borner Str. (2 000), Bergholzstr. (2000), Hospital (60), Schützenhaus (400), } \\
\text { Postbaracke (100); Treuenbrietzen: Koppwerke A (4000), Koppwerke B (4000); Belzig: } \\
\text { Lubnitzstr. (8.000); Caputh (-) }\end{array}$ \\
\hline Westhavelland & $\begin{array}{l}\text { Friesack (1 500), Wachow (200), Päverin [Päwesin] (300), Pritzerbe (300), Plaue (300), } \\
\text { Döberitz (200), Rathenow [Offensichtlich Doppelung zum Stadtkreis (s.u.)] (2000), } \\
\text { Buckow (500) }\end{array}$ \\
\hline West-Prignitz & Glöven [Glöwen] (4000), Bad Wilsnack (200) \\
\hline Lübben & Börn[i]chen (1 000), Kargau [Krugau] (2000), Lübben (1 500) \\
\hline & [Bl. $41(\mathrm{Bl} .2):]$ \\
\hline Jüterbog-Luckenwalde & $\begin{array}{l}\text { Dorf Zinna (1 000), Jüterbog-Fuchsberg (400), Luckenwalde Treuenbrietzen[er] Tor } \\
\text { (4000), Baruth (400) }\end{array}$ \\
\hline Luckau & Cahnsdorf (10000), Weissagk (2.000), Walddrehna (500) \\
\hline Calau & Senftenberg (350), Lübbenau (250) \\
\hline Spremberg & $\begin{array}{l}\text { Spremberg, Berliner Str. I (1 500), Welzow N. L. II (1 500), Paragma [Parma-] L[a]g[er] I } \\
(3000)\end{array}$ \\
\hline Stadtkreis & Ort des Lagers/Fassungsvermögen \\
\hline Potsdam & Potsdam, Zeppelinstr. 63 (360), Babelsberg (230) \\
\hline Forst & $\begin{array}{l}\text { Forst: Jahnschule (2000), Hotel Kaiserhof (500); Kl[ein] Kölzig: Schloss (120); Gr[oß] } \\
\text { Kölzig: Bruchmühle (60); Döbern: Hotel Förstemann (120) [Die drei letztgenannten } \\
\text { aber bereits oben beim Kr. Sorau aufgeführt!] }\end{array}$ \\
\hline Guben & Guben-Borsig-Werke (2000); Guben Liehrs-Hotel (300) \\
\hline Eberswalde & Eberswalde (2000), Breitscheidstr. (3 500) \\
\hline Brandenburg & Quenz (10000) \\
\hline Rathenow & $\begin{array}{l}\text { Rathenow-Magazinstr. [Magazininsel] (2000) [Offensichtlich Doppelung zur Angabe } \\
\text { beim Kr. Westhavelland] }\end{array}$ \\
\hline
\end{tabular}


Fokus der Landesregierung (und der Besatzungsmacht) befindlichen Lager, d.h. in der Regel auf die mindestens für 500, meist aber für 1000 und mehr (bis zu 3000) Personen ${ }^{680}$ ausgelegten „Kreisumsiedlerlager“, die als (Erst-)Aufnahme- bzw. Quarantänelager jeweils ganze Transporte aufzunehmen und theoretisch nur knapp befristet unterzubringen hatten, da oft bereits die nächsten Transporte angekündigt waren. Die für die in allen Landkreisen bestehenden „Kreisumsiedlerlager“ zuständigen Landratsämter (mit ihrem „Amt für Umsiedler“ oder „Kreisumsiedleramt") mussten daher - in enger Absprache mit der Umsiedlerabteilung der Landesregierung für „Eingemeindung“, d. h. Wohnungseinweisung im Kreis sorgen, was meist Verteilung auf die Dörfer bedeutete, oder nach Entlausung weiterleiten. Erschwert wird die rückschauende Lagerzählung schließlich noch dadurch, dass zeitgenössisch die „Heimkehrerlager“ bald mitgerechnet werden, bald gesondert erfasst sind, was sich aber letztlich daraus erklärt, dass es außer in Frankfurt (Gronenfelde) - entgegen mancherlei in den Quellen immer wieder anzutreffenden wechselnden Bezeichnungen - keine ausschließlichen „Heimkehrerlager“ gab, sondern nur solche, die entweder grundsätzlich für beide Gruppen, Vertriebene und heimkehrende Kriegsgefangene, genutzt wurden, oder in den Quellen zeitweise (!) nur als einer von beiden „Lagertypen“ bezeichnet werden.

Wenn auch mit all diesen Einschränkungen, lassen sich immerhin folgende Grundlinien bei den großen Lagern erkennen. 1946, wohl zu Jahresbeginn, exisitierten zunächst 33 „Umsiedlerlager“681 und 15 „Heimkehrerlager“682, an anderer Stelle werden für den Zeitraum April bis September 194629 (Kapazität: „45-48000“) und für das letzte Quartal 1946 noch 25 Lager (Kapazität: 44500 ) genannt. ${ }^{683}$ Schon ein „Verzeichnis der verbleibenden Umsiedlerlager in der Provinz Brandenburg“ vom 30. April 1946 enthält aber nur noch 20 „Umsiedlerlager“. Letzteres wird hier wiedergegeben, da bisher unpubliziert (Tabelle 3, siehe S. 166).

Die grundsätzliche Tendenz „nach unten“, also die Verringerung der Zahl der Lager zeigt sich schon an der für den Jahresanfang (1. Januar) 1947 überlieferten Zahl von nur noch 25 Vertriebenenlagern. ${ }^{64}$ Für das Jahr 1947 insgesamt gibt die Landesregierung an anderer Stelle noch 13 Lager mit einer Gesamtkapazität von 24500 Personen an, so dass spätestens hier deutlich wird, dass diese Statistiken sich bisweilen mehrmals im Jahr änderten, also sehr behutsam zu verwenden sind.$^{655}$ Noch stärker ist die Zahl nach einem weiteren Jahr reduziert. Denn aufgelöst

680 Tendenziell größer waren die Zahlen in den „Heimkehrerlagern“ für entlassene Kriegsgefangene, am höchsten wohl im Quenzlager in Brandenburg/H. mit 4000 im Jahr 1946 (Annette-Christine Kaminsky: „... es wird Zeit, daß wir nach Hause kommen ..."In: Frankfurter Jahrbuch 1996/97 (1997), S. 147-162, hier S. 160).

681 Abgedruckt in: Kaminsky, „... es wird Zeit, daß wir nach Hause kommen ..." (wie Anm. 680), S. 159: Tabelle 1: Umsiedlerlager 1946 mit Belegungsstärke (nach BLHA, Rep. 333, Nr. 576, Bl. 73).

682 Abgedruckt in: ebd., S. 160 (Quelle wie vor).

683 BLHA, Rep. 203 MdI, Nr. 116, Bl. 3 (Siehe den Textabdruck im Quellenteil, Nr. 62).

684 Abgedruckt in: Oehlsen, Vertriebenenlager (wie Anm. 45), S. 101 (BLHA, Rep. 203 MdI, Nr. 1074). Lt. BLHA, Rep. 203 MdI, Nr. 1166, Bl. 3 war diese Zahl (25) bereits im 4. Quartal 1946 erreicht (Kapazität: 44500).

685 BLHA, Rep. 203 MdI, Nr. 1166, Bl. 3 (Siehe den Textabdruck im Quellenteil, Nr. 62). 
Tab. 3: Verzeichnis der „Umsiedlerlager" in der Provinz Brandenburg, 30. April $1946^{686}$

\begin{tabular}{|c|c|}
\hline Bezirk [= Kreis] oder Stadt & Name des Lagers \\
\hline Bezirk Angermünde & Pinnow \\
\hline \multirow[t]{2}{*}{ Bezirk Guben-Stadt } & Lager Borsig Gasthaus Li $[\mathrm{eh}] \mathrm{r}$ \\
\hline & Försterei Brandenburg \\
\hline \multirow[t]{2}{*}{ Spremberg } & Firma Lager \\
\hline & Quenz Brandenburg \\
\hline Bezirk Sprenberg [Spremberg] & Welzow \\
\hline Kreis Luckau & Finsterwalde \\
\hline Bezirk Luckenwalde & Jüterbog \\
\hline Bezirk Beeskow & Küchensee \\
\hline Bezirk Teltow & Königswusterhausen \\
\hline Bezirk Niederbarnim & Bernau \\
\hline Bezirk Osthavelland & Falkensee \\
\hline Bezirk Oberbarnim & Wriezen \\
\hline Stadt Eberswalde & Stadt Eberswalde \\
\hline Bezirk Templin & Templin-Postheim \\
\hline Bezirk Prenzlau & Birkenhain \\
\hline Bezirk Westpriegnitz & Glöwen \\
\hline Bezirk Zauch-Belzig & Belzig, Bergholzerstr. \\
\hline " $\quad " \quad "$ & Treuenbrietzen \\
\hline Stadt Rathenow & Magazininsel \\
\hline
\end{tabular}

worden waren gemäß SMA-Befehl zum Jahresende 1947 Quenz, Engelsburg, Pinnow, Rüdersdorf, Finsterwalde und Saalow ${ }^{687}$, nach einer undatierten Liste von 1947, die SBZ-weit beabsichtigte Schließungen verzeichnet, „werden“ angeblich sogar 12 Lager "geschlossen “688 So heißt es in einer Aufstellung des brandenburgischen Innenministeriums vom Januar/Februar $1948^{689}$ :

686 Anlage 3 in: DAB, I/9-15-1 Flüchtlingsseelsorge 1945-1951, unfol., [30.4.1945]. - Typoskript, 1 Bl. - Undatierte dritte von vier Anlagen zum Schreiben des Generalvikars Dr. Maximilian Prange, [Berlin], 30. April 1946 (Tagebuch-Nr. 1213/46), an das Diaspora-Kommissariat der deutschen Bischöfe, Paderborn, mit dem er „die gewünschten Unterlagen zur Verteilung der Kollekte für die Ostflüchtlinge gemäß dem Beschluß der Konferenz der westlichen Bischöfe in Werl“ [übersendet] (Anlage 1-2: „Umsiedlerlager sämtlicher [Berliner] Verwaltungsbezirke“, [Anlage 3:] „Verzeichnis der verbleibenden Umsiedlerlager in der Provinz Brandenburg“, [Anlage 4]: „Verzeichnis der verbleibendern Umsiedlerlager in Vorpommern".

687 BLHA, Rep. 203 VP, Nr. 9, Bl. 43v.

688 SAPMO-BArch, DY 34/27745, B1. 91-92, Brandenburg B1. 92. Bl. 91 handschriftlicher Zusatz „Umsiedlungsheime [!] die geschlossen werden“. Die undatierte Liste ist in der Akte in der ersten Oktoberhälfte 1947 eingeordnet.

689 BLHA, Rep. 203 MdI, Nr. 1198, Bl. 28v. 
Umsiedler[-] bezw. Heimkehrerlager bestehen in Brandenburg nach Auflösung von 6 Lagern am 31.12.47 nur noch folgende 7 Lager:

1. Lager Gronenfelde in Frankfurt/Oder

2. Lager Glöwen/Kreis Westprignitz

3. Lager Forst-Jahnschule in Forst

4. Lager Fürstenwalde Kreis Lebus

5. Lager Küchensee Kreis Beeskow-Storkow

6. Lager Falkensee Kreis Osthavelland

7. Lager Selterhoff/Treuenbrietzen Kr. Z[auch]-Belz[ig]
Heimkehrerlager (Osten)

Heimkehrerlager (Westen)

Durchgangslager

Quarantänelager

Umsiedlerlager

Quarantänelager

Umsiedlerlager"

Auch die mehrfach einbezogene Statistik der Landesregierung von 1948 nennt für den Zeitraum von Januar bis Juni dieses Jahres sieben Lager, mit der Kapazität von 13900 Personen. ${ }^{690}$ Diese Zahl von unter 10 Lagern ist zwar für die späte Phase der Transporte zutreffend, doch finden sich in den zeitgenössischen Aufstellungen und Zählungen immer wieder Abweichungen. So heißt es zwar im Juli 1948: „Der Stand der Heimkehrer- und Umsiedlerlager ist noch derselbe wie am 1.1.48 und zwar: 1. Heimkehrerlager Gronenfelde /2. Heimkehrerlager Glöwen/3. Umsiedlerlager Küchensee /4. Umsiedlerlager Falkensee / 5. Umsiedlerlager Treuenbrietzen / 6. Durchgangslager Forst “ ${ }^{691}$ Doch offenkundig fehlt nun plötzlich das Lager Fürstenwalde, obgleich für dieses nachweislich noch aus dem Jahr 1950 Belegungszahlen (698 Personen am 14.12.1950) existieren ${ }^{692}$ und es sogar noch 1952 Transporte aufgenommen hat. ${ }^{693}$ Vollends verwirrend ist dann, dass in einer weiteren Liste des Innenministeriums vom Oktober/November 1948 im Land Brandenburg fünf Lager existiert haben sollen: „1. Frankfurt/Oder (Heimkehrerlager), 2. Selterhof/Treuenbrietzen (Heimkehrerlager), 3. Küchensee (Umsiedlerlager), 4. Fürstenwalde (Umsiedlerlager), 5. Forst, Jahnschule (Durchgangslager)“" ${ }^{694}$ D. h., Fürstenwalde ist nun plötzlich wieder dabei, dafür fehlen aber nun Falkensee und Glöwen, die offenbar inzwischen tatsächlich aufgelöst worden waren, was bei Falkensee wohl auch durch Hinweise auf Abbrucharbeiten belegt ist. ${ }^{695}$

Am 26. April 1949 existieren im Land Brandenburg ebenfalls noch fünf Lager, was die Glaubwürdigkeit der vorgenannten Liste zu vergrößern hilft: 1. [Frankfurt-] Gronenfelde (Heimkehrerlager), 2. [Treuenbrietzen-] Selterhof (Heimkehrerlager), 3. Küchensee (Umsiedlerlager), 4. Fürstenwalde (Heimkehrer- u. Umsiedlerlager), 5. Forst, Jahnschule (Durchgangslager). Selterhof sollte voraussichtlich „im Sommer 1949 aufgelöst werden“. Auch sonst ist nun alles auf weitestgehende Zentralisierung ausgerichtet: „Die Karteien oder Registrierlisten aller

690 BLHA, Rep. 203 MdI, Nr. 1166, Bl. 3 (Siehe den Textabdruck im Quellenteil, Nr. 62).

691 BLHA, Rep. 203 MdI, Nr. 1198, Bl. 43. Vgl. BLHA, Rep. 333, Nr. 575, Bl. 17: Verzeichnis der leitenden Angestellten in den Umsiedler- u. s. w. Lagern. Stand 1.1.1948 (Lager Falkensee, Forst, Gronenfelde, Fürstenwalde, Glöwen, Küchensee, Selterhof).

692 Oehlsen, Vertriebenenlager (wie Anm. 45), S. 55

693 BLHA, Rep. 203 MdI, Nr. 1193.

694 BLHA, Rep. 203 MdI, Nr. 1198, Bl. 46.

695 Siehe die Details in der Ortsdokumentation. 
seit meinem Dienstantritt (März 47) aufgelösten Lager befinden sich, mit Ausnahme der Papiere des Durchgangslagers Forst, beim Suchdienst in Berlin. [...]." ${ }^{696}$ Noch im Laufe des Jahres 1949 wurden Küchensee (Juni) und Treuenbrietzen-Selterhof, vermutlich auch das grenznahe ForstJahnschule aufgelöst. Zuletzt bestanden nur noch das Heimkehrerlager Gronenfelde, in dem in den fünfziger Jahren auch Dauer-Wohnungen für Vertriebene existierten, und Fürstenwalde, das zuletzt noch bis 1951/52 die späten (Kinder-)Transporte aus Ostpreußen aufzunehmen hatte.

Die Lokalisierung der Flüchtlings- bzw. „Umsiedlerlager“ ist noch nicht in allen Fällen mit genauer Adressenbezeichnung bzw. Grundstücks- oder Gebäude-Identifizierung gelungen. ${ }^{697}$ Hier ist die Lokalforschung aufgefordert, ihre Spezialkenntnis der örtlichen Gegebenheiten zu nutzen, um Lücken im Gesamtbild schließen zu können. Als Vorarbeiten und „Anknüpfungspunkte“ können dafür z. T. auch die Zusammenstellungen der in der NS-Zeit genutzten Lagerstandorte hilfreich sein, da die Mehrheit der nach Kriegsende genutzten Barackenlager auf die Nutzung bzw. Er-/Einrichtung zwischen 1933/39 und 1945 zurückging. ${ }^{698}$

\section{Lagerleben}

Ein kurzer Blick ist nun aber noch auf das Innenleben in den Lagern zu werfen. Oehlsen hat im Rahmen seiner Studie zu den Vertriebenenlagern in Brandenburg anhand des Fürstenwalder Beispiels die Situation in den Lagern etwas näher behandelt, Einzelfallstudien zu Lagern, die sowohl die bauliche als auch die organisatorische und vor allem die menschliche Seite beleuchten, fehlen aber bislang in Brandenburg. ${ }^{699}$ Handelte es sich nicht um größere Einzelgebäude wie

696 BLHA, Rep. 203 MdI, Nr. 1198, Bl. 66.

697 Nach Möglichkeit erfolgt diese in der Ortsdokumentation, die zugleich den Forschungsbedarf im Einzelfall offenlegt.

698 Sehr umfangreiche Listen, wenn auch weitestgehend ohne Angaben zur Nutzung nach 1945, in: Rainer Kubatzki: Zwangsarbeiter- und Kriegsgefangenenlager. Standorte und Topographie in Berlin und im brandenburgischen Umland 1939 bis 1945. Berlin 2001 (Berlin-Forschungen der Historischen Kommission zu Berlin, Bd. 1). - Hilfreich für die weitere Erforschung von Standortkontinuitäten könnten ferner die Listen der Jahre 1943/44 sein in: Helmut Bräutigam: Fremdarbeiter in Brandenburg in der NS-Zeit. Dokumentation zum ,Ausländereinsatz' im früheren Regierungsbezirk Potsdam 1939 bis 1945 (Interkulturelle Beiträge, 17). Potsdam 1996, S. 27-78.

699 Vgl. einstweilen - auch als Anregung für potentielle brandenburgische Autoren - aus dem unmittelbaren Grenzgebiet Sachsens zu Brandenburg die kleine, aber informative und quellengestützte Arbeit zum „Umsiedlerlager" Elsterhorst bei Hoyerswerda, die vorbildlich auch die Vorgeschichte als Kriegsgefangenenlager einbezieht: Karl-Heinz Hempel: Das Lager Elsterhorst. Erinnern - Gedenken - Mahnen. Hoyerswerda 2007. 70 S. (Neue Hoyerswerdaer Geschichtshefte, Nr. 10). - Sehr viel knapper, aber ebenfalls die Vorgeschichte (KZ-Außenlager) einbeziehend und auf Akten und Interviews gestützt eine Arbeit der Stellvertreterin des Landesbeauftragten für die Stasi-Untelagen in Mecklenburg-Vorpommern zu einem mecklenburgischen Flüchtlingslager der Jahre 1945-1947 (bei Ludwigslust): Anne Drescher: Das Lager Wöbbelin nach Kriegsende 1945 bis 1948. Hrsg.: Der Landesbeauftragte für Mecklenburg-Vorpommern für die Unterlagen des Staatssicherheitsdienstes der ehemaligen DDR. Schwerin 2008. 31 S. - Zeitzeugenbefragung und Abbildungen stärker einbeziehend die Arbeit zu einem weiteren mecklenburgischen Lager: Günter Koslowski: Aus dem 
Hotels, Gasthöfe mit Saal, Schulen o.ä. - auch solche Gebäude verbergen sich zumindest anfangs oft hinter der Bezeichnung „Flüchtlingslager“ -, so waren es ab Herbst 1945 zumeist die aus der Kriegs- oder unmittelbaren Vorkriegszeit stammenden Barackenlager der Wehrmacht, des RAD, von Rüstungsbetrieben (für Zwangsarbeiter) und diverser anderer Nutzer, die im gesamten Reichsgebiet in sehr großer Zahl errichtet worden waren. Beide Arten von „Lagergebäuden" sind heute nur noch schwer auszumachen, den einen sieht man ihre vorübergehende Zweckentfremdung ohnehin nicht an, die anderen verschwanden meist schon bald nach der Lagerschließung. Denn die Holzbaracken wurden, wie man vielfach feststellen und bisweilen sogar in den Akten der Umsiedlerverwaltung nachvollziehen kann, wenn man sie nicht am Ort umnutzte, komplett verkauft und umgesetzt oder als Baumaterial zerlegt. Der Ortschronist Manfred Kliche hat dies 2010 für das nach Kriegsende als Flüchtlingslager genutze ehemalige RAD-Lager Raddusch (Kr. Calau) sehr genau untersucht: „1946 wurde dann auf der Grundlage des ,Neusiedlerprogramms' damit begonnen, das Lager aufzulösen und einzelne Baracken zu verkaufen. Die Baracken wurden abgerissen und an anderen Standorten wieder aufgebaut. / So kaufte die Küchen- und Speisebaracke ein Tischler aus dem Kreis Lübben. Die Mannschaftsbaracken wurden nach Seese, Mlode und Pritzen verkauft und dort aufgebaut. Die Waschbaracke blieb stehen und wurde von einer Radduscher Familie gekauft. Sie steht heute noch an ihrer ursprünglichen Stelle. / Nur eine große Mannschaftsbaracke direkt an der Straße zur B 115 blieb für einige Radduscher und Flüchtlinge als Wohnraum erhalten. / Auch die Baracke für Fahrradwerkstatt und Heizmaterial sowie die Baracke zur Unterbringung der Fahrräder wurden abgerissen und in Groß Klessow beim Schnapshersteller Anton Hübel wieder aufgebaut. / Auch die beiden Baracken der Führungskräfte des ehemaligen Lagers wurden verkauft. Heute existieren noch drei Baracken vom einstigen Reichsarbeitsdienstlager in Raddusch."700

Im einzelnen gab es für die vorherrschenden Baracken mancherlei Typen-Varianten aus den Entwicklungsbüros v. a. des Oberkommandos des Heeres oder des Reichsluftfahrtministeriums, doch wurde im weiteren Verlauf des Krieges „die vom Reichsarbeitsdienst seit 1936 gewählte RAD-Baracke aus Kiefernholz mit Spanplatten bevorzugt und schließlich zum Haupttyp des Lagerbaues, der in verschiedenen zusammensetz- und kombinierbaren Ausführungen

Dunkel des Vergessens ... Schicksale, Berichte, Dokumente zum Quarantänelager Flessenow 1945-1947. In Zsarb. mit der Heimatstube Rubow u. d. Landeszentrale für Politische Bildung Mecklenburg-Vorpommern. Schwerin 1997. 106 S. - Ebenfalls für Brandenburg noch unerreicht ist die Ausführlichkeit (bis hin zu Listen und Statistiken der Transporte) der auch sonst wohl singulären Arbeit für das in der Britischen Zone gelegene Lager Mariental: Rolf Volkmann / Helga Volkmann: Das Flüchtlingslager Mariental (1945-1947) und die Vertriebenentransporte aus Schlesien (1946-1947). Ein Beitrag zur Nachkriegsgeschichte der Gemeinde Mariental und des Landkreises Helmstedt. Grasleben 1997. 239 S. - An versteckter Stelle findet sich immerhin eine aus der Erinnerung eines zehnjährigen Flüchtlingsjungen gezeichnete Grundriss-Skizze für das Barackenlager in Premnitz (Westhavelland) in: Wolfgang Bornstädt: Erinnerungen an die Flucht aus Woldenberg und den Neuanfang in Premnitz. In: Die letzten Tage im Krieg und die ersten Wochen im Frieden in der Region um Rathenow. T. 3. Hrsg.: Rathenower Heimatbund e. V. 2., unveränd. Aufl. Rathenow 2018, S. 14-54, hier S. 47.

700 Manfred Kliche: Das Reichsarbeitsdienstlager in Raddusch. In: Stog - Der Schober 2010 (2009), S. 79-82, hier S. 82 . 
geliefert wurde. Die Grundausstattung hatte eine Gebäudetiefe von 8,14 Meter, eine Tafelbreite von 1,10 und eine Seitenwandhöhe von 2,55 Meter. Die Mindestlänge betrug 3,30 Meter, die um dieses Maß verlängert werden konnte. "701 Je nach dem vom NS-System den Lagerinsassen zugebilligten „Wert“ wurden die konkrete Ausführung, die Ausstattung mit sanitären Anlagen und die Belegungszahlen variiert. ${ }^{702}$ Nach Kriegsende waren zwar diese menschenverachtenden Unterscheidungen weggefallen, doch regierte nun - im kriegszerstörten, von Hunger gegprägten Land - die blanke Not, so dass Flüchtlinge und Vertriebene überall untergebracht werden mussten, um nur wenigstens ein Dach über dem Kopf zu haben. Mancher kam daher vorübergehend in einer Baracke unter, die an sich als menschenunwürdig zu bezeichnen war. Das Leben in Baracken war jedoch grundsätzlich ein selbstverständlich gewordenes Schicksal in der Nachkriegsgesellschaft, die notorische Überbelegung und vor allem die notgedrungen betriebene Weiternutzung auch der nur minimal ausgestatteten Häftlingsbaracken führte jedoch auch zu teilweise hygienisch und psychologisch verheerenden Verhältnissen. 14 Tage Quarantäne $e^{703}$ waren die Regel, von der aber immer wieder auch, verkürzend oder verlängernd, abgewichen wurde. ${ }^{704}$ Für eines der vielen, über die Provinz verteilten kleineren, in den Akten der zentralen Verwaltungen meist gar nicht erwähnten Lager, das oben genannte in Raddusch, ist z. B. überliefert, dass es, was aber kein Einzelfall war, keine Wasserversorgung gab. „Das Wasser musste von den Flüchtlingen in Eimern vom Bahnwärterhäuschen geholt werden. / Die Toiletten reichten nicht aus, sodas viele Flüchtlinge ihre Notdurft auf dem Acker neben dem Lager verrichteten. / Viele Flüchtlinge wurden im Ort bei den Hausbesitzern einquartiert. Raddusch hatte in Spitzenzeiten über 600 Flüchtlinge unterzubringen. ${ }^{\text {“705 }}$

Wie beengt und vollkommen unzureichend die Flüchtlingsunterbringung in den Lagern zeitweise war, lässt sich z. B. auch daran erkennen, dass die noch bis Kriegsende teilweise vorhandene Unterteilung selbst von (Standard-)Häftlingsbaracken in Tagesraum und Schlafraum offenbar mit dem Einzug der Flüchtlinge aufgehoben werden musste, um überhaupt ausreichende Kapazitäten anbieten zu können. ${ }^{706}$ Berichte über Nachtlager auf dem Fußboden sind

701 Kubatzki, Zwangsarbeiter- und Kriegsgefangenenlager (wie Anm. 698), S. 20.

$702 \mathrm{Zu}$ Typen, Maßen und Funktionen der Gebäude sowie zu den „Inneneinrichtungen“ siehe u. a. ebd., S. $20 \mathrm{f}$.

703 Beispielbelege: Erlebnisse einer schlesischen Landfrau (wie Anm. 619), S. 37. Gleichlautend aber auch die offizielle Angabe im Abschnitt „Arbeits- und Sozialwesen“ des gedruckten Rechenschaftsberichts der Provinzialverwaltung für die Zeit vom 5.7.1945 bis 5.7.1946: „Es wurden Auffanglager vorgesehen, in denen eine 14tätige Quarantänezeit durchzumachen war" (Ein Jahr Bewährung der Mark Brandenburg. Rückblick und Rechenschaft. Hrsg. vom Präsidium der Provinzialverwaltung Mark Brandenburg. Potsdam 1946. ND 1989, S. 35-43, hier S. 42).

704 Lager Kirchmöser 1948: „nach Ablauf der dreiwöchigen Quarantänefrist“ (Wieck, Zeugnis vom Untergang Königsbergs [wie Anm. 625], S. 343.

705 Kliche, Reichsarbeitsdienstlager in Raddusch (wie Anm. 700), S. 82.

706 Bert Krüger/Barbara Schulz: Das Gelände des KZ-Außenlagers Falkensee bei Berlin - Gedenkstätte und zeithistorisch-archäologischer Lernort. In: Archäologie und Gedächtnis (wie Anm. 131). Petersberg 2016, S. 155-171, hier S. 164. Ob die im ehemaligen KZ-Außenlager Falkensee bei Berlin bei archäologischen Untersuchungen näher betrachteten Schornsteine ebenfalls erst eine Nachrkiegsveränderung (anstelle der kriegs- 
von Zeitzeugen ab 1945 überliefert: „Wir wurden [...] in einem Massenlager (in einem primitiven Fabrikgebäude) untergebracht, hunderte von Menschen in einer Halle, und nach den damals üblichen Hungersätzen ver- [S. 37] pflegt. ${ }^{\text {"707 }}$ Ein später in Brandenburg (Neuenhagen bei Berlin) lebender Vertriebener hat über seinen Aufenthalt im Quarantänelager Wernigerode berichtet: „Die Verpflegung war dürftig. Über den Zaun konnte man von Schwarzhändlern ein Brot für 50 RM bekommen. Nach zwei Wochen hatten wir zwei Tage freien Ausgang. Wir stromerten über Müllplätze und Felder, wobei wir nur noch Kartoffeln stoppelten. [...] Mit der Aushändigung eines Umsiedlerpasses wurde die Zeit im Quarantänelager beendet. Mit Umsiedlern aus Polen und Schlesien wurden wir zur Ansiedlung nach Sachsen-Anhalt gefahren. Hier wurden wir in einer Turnhalle des Dorfes Tschortau [Zschortau] zwischen Delitzsch und Leipzig untergebracht. Dort waren wir frei und suchten etwas zu essen. [...] [S. 21] [...]. Nach einer Woche wurden wir am 21.11.1947 mit einigen weiteren Familien per LKW nach Laußig [Lausick] an der Mulde, zwischen Eilenburg und Bad Düben, gebracht und dort angesiedelt. Zu dritt bekamen wir ein Zimmer mit Wasserhahn auf dem Flur und Toilette auf dem Hof. [...] Meine Mutter fand Arbeit auf dem Gut Hohenprießnitz, [...]. ${ }^{\text {"708 }}$

Auch aus Dabendorf (Kr. Teltow) ist überliefert, was durchaus verallgemeinert werden kann, auch wenn es in den amtlichen Berichten nicht vorkommt, dass nämlich die Lagerinsassen ihre Ernährung durch Streifzüge durch die Umgebung vervollständigen mussten, wie viele Zeitzeugen in ihren Erinnerungen berichten: „Den Flüchtlingen, die aus Niederschlesien, aus Grünberg (heute Zielona Góra), aus Küstrin und von jenseits der Oder kamen, wurden die leeren Wlassow-Baracken ${ }^{709}$ zur Verfügung gestellt. Die Vertriebenen hungerten und bettelten bei den Bauern im Ort um Nahrung. Viele starben in diesem Auffanglager an Unterernährung und Krankheiten. Eine vierköpfige Familie hatte Waldpilze gegessen und verstarb an einer Pilzvergiftung ${ }^{710}$ - vielleicht freiwillig. Alle Verstorbenen wurden in einem Massengrab im Dabendorfer Ausbau bestattet [...]. ${ }^{\text {“711 }}$ Im Umfeld des Lagers Kirchmöser bei Brandenburg/Havel sah es nicht anders aus. Ein selbst (aus dem Sudetenland) Vertriebener, der es bereits in ein Privatquartier geschafft hatte, beschreibt in seinem Tagebuch die Lage derer, die Ende 1946 noch im Lager leben mussten: „Wenn man sich das Gesamtbild der gegebenen Lage vor Augen hält, wenn man ersehen muß, unter welch düsteren Verhältnissen Umsiedler derzeit im Lager zu Kirchmöser

zeitlichen Beheizung der Häftlingsbaracken per Fernwärme von einem benachbarten Rüstungsbetrieb aus) oder Nachrüstungen noch vor Kriegsende darstellen, war zunächst noch ungeklärt (ebd.).

707 Beispielbelege: Erlebnisse einer schlesischen Landfrau (wie Anm. 619), S. 36 f.

708 Hirt, Mein Weg nach Neuenhagen (wie Anm. 617), S. 20-23, hier S. 20 f.

709 Im Zweiten Weltkrieg von der „Wlassow-Armee“, einem auf deutscher Seite kämpfenden russischen Freiwilligenverband, genutzt.

710 Auch andere Vertriebene und sicher nicht nur sie haben in der Hungerzeit manche ungenießbare Pilzsorte gegessen, wie eine Ostpreußien berichtet: „Pilze über Pilze! Alle Sorten, die auf dem trockenen märkischen Sandboden wuchsen, gab es in Hülle und Fülle. Sie waren unsere Lebensretter. Leider hatten wir doch einmal einen falschen Pilz erwischt und meine Eltern, ich und ein uns anvertrauter Spitz hatten eine Pilzvergiftung und es erging uns ziemlich schlecht." (Balschinat, Meine Nachkriegsjahre in Wilhelmshorst [wie Anm. 308], S. 348).

711 Detlef Polley: Schrecken, Not und Tod. Dabendorf am Ende des Zweiten Weltkriegs. In: Heimatjahrbuch für den Landkreis Teltow-Fläming 23 (2016), S. 113-119, hier S. 117. 
verbringen, besser: leben, deren Kinder von Haus zu Haus gehen und um ein Stückchen Brot betteln müssen, die kalte Mauern um sich haben, weder Kleidung, noch Federbetten, Wäsche und Geschirr mitnehmen durften, dann haben wir wirklich Grund dazu, Gott zu danken und sich mit dem bescheidenen Los zufrieden zu geben."

Ebenfalls nur angedeutet werden kann hier eine in den amtlichen Akten allenfalls indirekt erkennbar werdende frühzeitige Politisierung und propagandistische Vereinnahmung. Denn der Lageralltag enthielt nicht nur allgemeine, die Seele stärkende, vom Alltagselend kurzzeitig ablenkende Kulturprogramme ${ }^{713}$ und sachliche, die Eingliederung vorbereitende Informationsveranstaltungen über Rechte und Umgang mit Behörden, sondern wurde gezielt zur Beeinflussung im Sinne der SED genutzt. ${ }^{714}$ So berichtet die aus Westpreußen stammende Bäuerin Berta Penner, die erst am 24. Juni 1949 aus dem Lager Potulice in Polen entlassen wurde, aber schon im Oktober in die Westzonen übersiedelte: „Wir kamen ins Lager nach Fürstenwalde - Berlin. Dort mußten wir vierzehn Tage bleiben. Dreimal in der Woche mußten wir zur Kundgebung, es wurde uns gesagt, wir sollten nur nicht nach dem Westen, dort ist Hungersnot und keine Arbeit." ${ }^{\text {"15 }}$ Auch Werbungen für den Nachwuchs der verschiedenen Apparate, der Polizei, des Uranbergbaus usw. begannen frühzeitig im Quarantänelager. In einem Wochenschaubericht sah der aus dem „Umsiedlerlager“ Kirchmöser nach West-Berlin geflohene Michael Wieck, dessen Eltern im Lager verblieben waren, 1948 in einem Kino einen Bericht aus dem Lager: „Mit Staunen erkannte ich, daß man meine Eltern dazu benutzte, vorzutäuschen, daß auch alte Menschen aus Ostpreußen evakuiert werden. Aber meine Eltern waren die einzigen über Sechzigjährigen im Lager, und ich behaupte heute, daß es 1948 unter den fünfzehn bis zwanzig Prozent der Überlebenden [aus Königsberg - P. B.] kaum Kleinkinder und Menschen dieses Alters gegeben hat. Vater und Mutter waren eine Ausnahme. "“716

712 Tagebuch Emil Kämpf [Auszüge]. In: „Die Russen sind da“ (wie Anm. 260), S. 431-434, 436-437, hier S. 432 (Eintrag vom 31.12.1946).

713 BLHA, Rep. 256 Umsiedlerlager Küchensee, Nr. 166, unfol.: Programm eines gemeinsamen „Bunten Abends“ von Vertriebenen und Kriegsheimkehrern im Heimkehrer-Erholungsheim Küchensee, 1948 (Textabdruck im Quellenteil, Nr. 65). - Foto einer Theateraufführung im (sächsischen) Lager Elsterhorst bei Hoyerswerda: Hempel, Das Lager Elsterhorst (wie Anm. 699), S. 14.

714 BLHA, Rep. 333, Nr. 575, Bl. 18: Tabelle Veranstaltungen in den Lagern im Jahr 1947 (Glöwen, Selterhof, Quenz, Fürstenwalde, Engelsburg, Pinnow, Frankfurt/O., Forst, Finsterwalde, Küchensee, Falkensee, Rüdersdorf, Saalow). - BLHA, Rep. 250 Landratsamt Beeskow-Storkow, Nr. 869, unfol.: Tätigkeitsbericht der Abteilung Umsiedler und Heimkehrer im Amt für Arbeit und Sozialwesen des Kreises Beeskow-Storkow über die Betreuung eines Transportes aus Stettin im Umsiedlerlager Küchensee, Beeskow, 10. Oktober 1947 (Textabdruck im Quellenteil, Nr.61). - Beispiele für Veranstaltungsprogramme aus sächsischen Lagern bringt Spurný, Flucht und Vertreibung (wie Anm. 332), S. 177-179. - Siehe auch Spatz, Nur der Himmel blieb derselbe (wie Anm. 44), S. 150 f. (Proteste und provokatives Verhalten von Jugendlichen, Zwischenrufe während propagandistischer Rede eines Landrats im Lager Bischofswerda, 1951), 151 („Auch die erwachsenen Frauen zeigten sich mehrheitlich für die Bemühungen des Regimes unempfänglich. Sie verhielten sich allerdings nicht offen opponierend, sondern baten um Gottesdienste. In Wolfen und Fürstenwalde wurden diese von der Lagerleitung genehmigt, in Bischofswerda blieben sie verboten.").

715 Dokumentation der Vertreibung I/2 (wie Anm. 192), S. 476-481 (Erlebnisbericht, 1952), hier S. 481.

716 Wieck, Zeugnis vom Untergang Königsbergs (wie Anm. 625), S. 344. 
Ausgesprochen wenig ist bislang über das zahlreiche Personal der Lager - Leitung, Verwaltung, Santitätspersonal, Hifskräfte usw. - bekannt. Die Akten sowohl der Provinzial- bzw. Landesregierung als auch der ZVU bieten dazu vielfältige Angaben, die freilich hier weitgehend ausgespart werden mussten. Einzelne Daten und Fakten sind, ohne Anspruch auf Vollständigkeit, in die Ortsdokumentation aufgenommen worden, eine - wünschenswerte - generelle Darstellung zu diesem Personenkreis, zumindest den Leitern der Lager, war jedoch nicht zu leisten. ${ }^{717}$ Als auffällig darf immerhin bezeichnet werden, dass man offenbar formal auf SEDZugehörigkeit geachtet hat, dabei aber - auch im festangestellten Personal - „Umsiedler“, also letztlich Angehörige der Betroffenengruppe, gehäuft anzutreffen sind, zu denen dann noch die Baracken- und Stubenältesten als Betroffenenvertreter kommen. Im Lager Agneshof in Falkensee (Kr. Osthavelland) waren 1948 von 12 durch die ZVU (politisch) beurteilten Lager-Angestellten acht auch selbst „Umsiedler "7718, darunter sogar der Lagerleiter, Alfred David: „53 Jahre, Umsiedler aus Breslau, früherer Beruf Arbeiter", seit 1. April 1948 im Lager, vor 1933 SPD, jetzt SED, „Bruder Mitglied der NSDAP“. „Trotz größtem Eifer scheint David politisch und organisatorisch schwach. Z. B. hat er bei der ersten Zusammenberufung der Baracken- und Stubenältesten nicht das Hauptgewicht auf eine kurze Einführung in die politischen und wirtschaftlichen Verhältnisse der Ostzone gelegt, sondern sich darauf beschränkt, die Lagerordnung zu erläutern. Erfahrungsgemäß ist jedoch der erste Eindruck, den die Umsiedler in einem Lager erhalten, der entscheidende. [...]." ${ }^{\text {"719 }}$ Weniger Spielraum für „Linienuntreue“ dürfte sich jenen Lagerleitern geboten haben, deren Büro (manche wohnten gar im Lager) sich nicht zugleich im Lager, sondern im Landratsamt (Kreisumsiedleramt) befand. Jedenfalls scheint es sich bei den Lagerleitern um eine - politisch, biographisch und sozial - ausgesprochen heterogene Personengruppe gehandelt zu haben. Manche leisteten hervorragende organisatorische Arbeit, andere nutzten die nachkriegszeitlichen Möglichkeiten zur persönlichen Bereicherung und wurden abgesetzt oder setzen sich ab. Die Fluktuation in diesen Funktionen war nicht überall, aber doch häufig recht hoch.

Für das Innen- bzw. „Alltagsleben“ in den Lagern, für die Erlebnisse der Insassen bei der Aufnahme und ihr Überleben in den Baracken gibt es freilich weit weniger Zeitzeugenberichte

717 Siehe aber zum Spektrum der Tätigkeiten den Stellenplan des Kreisumsiedlerlagers Rüdersdorf (1946) im Quellenteil, Nr. 57. - Durch einen Zeitzeugen ist überliefert, dass im Flüchtlings-Barackenlager Premnitz auch noch nach Kriegsende 1945/46 eine für die Einhaltung von „Organisation und Disziplin“ verantwortliche „Barackenverantwortliche“ („Frau Gutsche“) vom Lagerleiter („Heimleiter“) eingesetzt wurde, die die nötige Erfahrung besaß, „da sie diese Aufgabe auch zu der Zeit übernommen hatte, als in diesem Heim noch die auswärtigen weiblichen Arbeitskräfte des in Premnitz ansässigen IG Farben Betriebes untergebracht waren " (Bornstädt, Erinnerungen an die Flucht [wie Anm. 699], S. 46).

718 BArch, DO 2/38, Bl. 85-87. Auch für das Lager in Raddusch (Kr. Calau) ist belegt, dass ein Flüchtling namens Roisch 1945 vom Bürgermeister als Lagerleiter eingesetzt wurde (Kliche, Reichsarbeitsdienstlager in Raddusch [wie Anm. 700], S. 82). Ebenso wird die Leiterin des Umsiedlerlagers in Forst (Lausitz), Hildegard Owczarek, 1946 als „ehem. Flüchtlingsfrau“ bezeichnet (BArch, DO 2/38, Bl. 102; vgl. Ortsdokumentation Forst/L.)

719 BArch, DO 2/38, B1. 85. 
als für die Erlebnisse der unmittelbaren Flucht und Vertreibung. ${ }^{720}$ Diverse amtliche Tätigkeitsberichte der Lagerleiter, bisweilen sogar tageweise geführt, Abschlussberichte von Lagerärzten und Berichte über (Kontroll-)Begehungen durch vorgesetzte Behörenvertreter sind zwar in den Akten der Landesregierung und der ZVU überliefert und werden als wertvolle Dokumente auch im Quellenteil (Teil 3) dieser Arbeit in Auswahl ediert, doch fehlt diesem Verwaltungsschriftgut naturgemäß der Fokus des Betroffenen, der prägende Erlebnisse und Hoffnungen in das Lagerleben mitnahm. Eine Auswahl von Stimmen aus dem Kreis jener Vertriebenen, die konkret fassbare brandenburgische Lager durchlaufen haben, soll daher hier abschließend die auch mentale (Innen-)Welt dieser Lager noch etwas genauer zu rekonstruieren helfen. Zumindest für sieben brandenburgische Lager ließen sich solche Teilberichte im Zusammenhang größerer Erinnerungsberichte ermitteln: Belzig (Roederhof), Falkensee, Kirchmöser (bei Brandenburg/ Havel), Küchensee (bei Storkow) Pinnow (bei Angermünde), Prenzlau und Rüdersdorf. Dabei kann der Reigen der Erlebnisberichte - leider nur ausnahmsweise - für Küchensee zusätzlich durch die Perspektive einer Flüchtlingsbetreuerin ergänzt werden, die aber nicht amtlich berichtet, sondern gleichfalls im Alter sich erinnert und das Gesehene aufgeschrieben hat.

\section{Belzig}

Eine Schlesierin, die als achtjähriges Kind vertrieben wurde, kam im Sommer 1946 mit Mutter und Geschwistern im Umsiedlerlager Roederhof bei Belzig unter, das bis vor kurzem noch KZ-Häftlinge beherbergt hatte. Sie erinnert sich: „Die Baracken quollen über vor Menschen. Alt und Jung, Männlein und Weiblein - allesamt hinein. Hier hatten wir aber wenigstens ein Dach über dem Kopf und konnten in richtigen Betten schlafen: einfache Pritschen mit Strohsäcken. [...] Alle Gespräche drehten sich nur um das Eine: Essen. Der ständige Hunger war in der Nachkriegszeit ein Existenzproblem, das mehr oder weniger alle betraf." ${ }^{“ 721}$

\section{Falkensee}

Ein Flüchtlingskind, Helga Naujoks aus Preußisch Eylau, kommt - ihrem späteren Erinnerungsbericht zufolge - Weihnachten 1947 als elternloses Kind - die Mutter ist nach Sibirien deportiert worden, der Vater im August 1945 verstorben, die Großeltern sind ebenfalls tot - Ende November 1947 aus Ostpreußen über Pommern nach Brandenburg, zunächst in das Lager Agneshof in Falkensee. Hier erlebt das Flüchtlingskind das Weihnachtsfest: „Wieder ein neues Lager, Falkensee bei Berlin, Umsiedlerlager Agneshof. Hier erlebe ich den Heiligen Abend 1947. Ein großer Saal mit einer glitzernden Tanne. An langen, festlich geschmückten Tafeln warten bunte Teller auf uns. Wir aber bleiben stumm am Eingang stehen. Es ist zu schön, wir sind wie verzaubert. Wir, das

720 Einen visuellen Einblick in das Lagerleben gewährt am Beispiel des Lagers Küchensee bei Storkow ein Wochenschaubericht von 1947 (siehe dazu unten Ortsdokumentation, Küchensee).

721 Stiemke, Lange verdrängt, aber unvergessen (wie Anm. 620), S. 343. 
sind entsetzlich magere Kinder mit Glatzen wegen der Läuse. Die Mädchen tragen alle die gleichen karierten Kleider. Viele von ihnen wurden vergewaltigt.

Hübsche Mädchen mit runden Gesichtern und schönen langen Haaren kommen uns holen, sie fassen uns an den Händen und führen uns zu unseren Plätzen. Die Mädchen und Jungen sind alle so freundlich, sie umarmen und streicheln uns immer wieder. Mir kommen sie vor wie Engel. Alle tragen blaue Hemden mit einer aufgehenden Sonne am Ärmel. Sie überreichen uns schön verpackte Geschenke. Ich bekomme ein Buch, für mich das beste Geschenk, sein Titel, Timur und sein Trupp'von Arkadi Gaidar. Darin steht eine Widmung: ,Für Dich! von der FDJ-Gruppe Falkensee.' Aber ich bin allein hier, wo sind meine Geschwister?"722

\section{Kirchmöser}

Der erst 1948 aus Königsberg in Ostpreußen ausgesiedelte, oben schon zweimal zitierte Michael Wieck (geb. 1928) schreibt in seinen Erinnerungen auch über die Tage der Ankunft in der Sowjetischen Besatzungszone, die er im Umsiedlerlager Kirchmöser ${ }^{723}$ bei Brandenburg an der Havel erlebte: „Was eine Demokratie ist, wußten die meisten nur vom Hörensagen, und die Erzählungen von der besseren Versorgungslage der Westzonen gaben in der Regel den Ausschlag. Aber in den Westen konnte nur, wer dort nachweislich Verwandte hatte. Das erfuhren wir dann alles in dem Quarantänelager Kirchmöser, welches endlich nach fünf-oder sechstägigem Herumreisen das Ziel war, an dem wir den Zug endgültig verlassen durften. [S. 341]

Die ersten Kontakte, Maßnahmen, Behandlungen, mit denen wir konfrontiert oder begrüßt wurden, waren eine gründliche Entlausung und eine noch gründlichere DDT-Bepuderung der aus den Entlausungsöfen zurückkommenden Kleider. Die Lagerbeamten, gereizt durch meine russischen Uniformstücke, schütteten eine halbe Büchse von dem später verbotenen Gift auf mich und meine Kleider, sichtlich angewidert davon, daß ein Deutscher an solchen Kleidungsstücken Gefallen finden konnteals hätte ich je eine Wahl gehabt. [...]

Man kann sich bestimmt vorstellen, was in mir und in den andren jungen Aussiedlern in dem Quarantänelager vorging, als eines Tages eine zukunfts- und berufsberatende Versammlung einberufen wurde. Schon fast mit Zwang wurden männliche Lagerinsassen in einen Raum beordert, dessen Ausgang von mehreren Beamten abgesperrt wurde. Wir hörten uns einen Propagandavortrag über das Leben in der russischen Besatzungszone an und bekamen bald zu verstehen, daß es sich hier um eine Anwerbekampagne für den Uranbergbau handelte. Nachdem man uns eine volle Stunde lang das Leben im Uranbergbau als das eigentliche Schlafraffenleben geschildert hatte, bei dem gute Bezah-

722 Helga Naujoks: „Dai kusotschka chleba!“ In: Hungern und hoffen. Jugend in Deutschland 1945-1950. 48 Geschichten und Berichte von Zeitzeugen. Hrsg. von Jürgen Kleindienst (Reihe Zeitgut, Bd. 10). Berlin 2000, S. $106 f$.

723 Kirchmöser am Westufer des Plauer Sees, obgleich dem Stadtgebiet von Brandenburg an der Havel unmittelbar gegenüber liegend, gehörte damals noch zum ehemals provinzsächsischen, nun sachsen-anhaltischen Kreis Jerichow II und wurde erst im folgenden Jahr 1949 an den brandenburgischen Kreis Westhavelland angegliedert und 1952 nach Brandenburg an der Havel eingemeindet. 
lung, Behausung und reichliche Verpflegung die einzigen für das Leben wichtigen Kriterien zu sein schienen - die Arbeit [S. 342] wurde nicht mit einem Satz erwähnt-, zogen sie fertige Listen hervor, auf denen unsere Namen bereits vorgedruckt standen, verteilten Kopierstifte und verlangten unsere Unterschriften. Als keiner bereit war zu unterschreiben, wollte man uns zwingen, noch einen weiteren Vortrag anzuhören. Gleichzeitig versperrte man die Ausgänge für diejenigen, die Anstalten machten, den Raum zu verlassen. Sofort hatten alle begriffen, was hier vorging, und in wenigen Augenblicken waren wir Königsberger Jungen eine Schar wütender, zu allem fähiger Individuen. Wir drohten den Beamten, die uns den Ausgang versperrten, so fürchterliche Prügel an, daß sie um ihr Leben bangen müßten, wenn sie uns nicht augenblicklich herausließen. Wir zögerten dabei nicht, sie mit festem Griff anzupacken. Mit unseren, nach all dem Überstandenen, voll Entschlossenheit funkelnden Augen zwangen wir sie zum widerstandslosen Nachgeben. Ungehindert verließen wir daraufhin den Raum. Es war der erste Schock im Lande unserer Hoffnungen: andere sollten folgen. $[\ldots] \cdot{ }^{\text {"724 }}$

Nach diesem Erlebnis wollte ich aus dem Lager fliehen, wozu ich bald Gelegenheit bekam.

\section{Küchensee}

Eine damals siebzehnjährige Ostpreußin kam mit einem Flüchtlingstransport im Februar 1946 nach Küchensee. Ihr (Güterwagen-)Transport war im Januar aus Schivelbein (Hinterpommern) kommend zunächst mehrere Tage lang in den Lagern Pinnow (Kr. Angermünde) und Angermünde untergebracht worden, dann aber nach Küchensee weitergeleitet worden: „Es wurde bekannt, dass das Flüchtlingslager Küchensee die letzte Station sei und wir dort zur Quarantäne hinsollten. Ich erinnere mich, dass wir bei Nacht durch das zerbombte, spärlich beleuchtete Berlin fuhren. Als es Tag wurde, hielt der Zug einige Kilometer vor Storkow. Mit dem Zug konnte es nicht weitergehen, da die Eisenbahnbrücke bei Philadelphia 1945 gesprengt worden war und noch in Trümmern lag. Unser Weg ging zu Fuß weiter, teilweise über gefrorene Äcker. Erschöpft und von Hunger geplagt bewegte sich ein langer Zug von Flüchtlingen durch Storkow, Richtung Küchensee. Es war der 9. Februar. Ich habe mir das Datum gemerkt, weil es mein 17. Geburtstag war, ein kalter regnerischer Tag. Durchnässt kamen wir in Küchensee an. Das Lager bestand aus mehreren Holzbaracken. Auf dem Fußboden war Stroh aufgeschüttet, welches uns als Nachtlager dienen sollte. Bei der Ankunft gab es Haferflockensuppe, daran kann ich mich noch heute erinnern. Die Haferflocken waren so stachlig, aber der Hunger war groß. Einige Kinder fielen ohne zu essen total erschöpft auf das Strohlager. Meine Schulfreundin war wegen der Strapazen der letzten [S. 34] Wochen unterwegs zusammengebrochen. Nur mit Hilfe ihrer Mutter konnte sie das Lager in Küchensee erreichen. In der Seeburg war ein provisorisches Krankenhaus eingerichtet, wo sie für einige Tage untergebracht wurde. In den einzelnen Räumen jeder Baracke waren die Menschen ziemlich beengt untergebracht. Ein kleiner eiserner Ofen spendete Tag und Nacht etwas Wärme. Toiletten gab es nicht. Draußen waren Gruben ausgehoben. Ich erinnere mich, dass man über einer Stange sitzen musste. Durch die schlechten hygienischen Ver- 
hältnisse, wir konnten wochenlang weder duschen noch baden, hatten sich bei vielen Flüchtlingen Kleiderläuse eingenistet. Um diese zu vernichten, wurden eines Tages alle Kleidungsstücke eingesammelt und auf Bügeln in einen großen, heißen Backofen gehängt. [...] Auch an einen Friedhof mit einem großen Holzkreuz erinnere ich mich, an Gräber von Soldaten und Flüchtlingen. Nach fast vier Wochen Aufenthalt im Lager Küchensee wurden wir mit Pferdewagen zunächst nach Wendisch Rietz zum damaligen, Ottos Hotel' gefahren. Einige Flüchtlinge fanden dort ihren provisorischen Wohnsitz, andere fanden in den umliegenden Dörfern ein Dach über dem Kopf. Unsere vierköpfige Familie bekam ein kleines Holzhäuschen mit zwei Räumen im Ortsteil Behren[s]dorf/Siedlung zugewiesen. Das Mittagessen, eine dünne Suppe, konnten wir uns täglich vom Hotel holen. Dort wurde für die Flüchtlinge gekocht. Trotzdem waren wir in dieser schlimmen Zeit froh, dass das Zigeunerleben ein Ende hatte und ich mit meiner Mutter und meinen beiden Geschwistern wieder als Familie leben durften. Eine allein stehende Frau aus unserem Dorf in Ostpreußen haben wir für einige Monate zu uns genommen. Wie glücklich war ich, als ich ab 1. Mai im Kinderheim in Behrensdorf eine Arbeit fand. Einige Monate später kam auch mein Vater aus dem Lazarett nach Hause. Langsam, aber optimistisch begannen wir in unserer neuen Heimat Brandenburg ein neues Leben aufzubauen. ${ }^{\text {"725 }}$

Eine damals sechzehnjährige Schlesierin kam mit ihrer Familie im Oktober 1946 mit einem Güterzug-Transport aus Schlesien zu einem vierzehntägigen Quarantäneaufenthalt in das Lager Küchensee ${ }^{726}$ : „Ein ganzer Güterzug mit jeweils 30 Personen in einem Güterwagen wurden gefüllt, und so fuhren wir mit vielen Halts und Rangierfahrten bei Forst über die neue, aber noch nicht bestätigte deutsch-polnische Grenze. Über Beeskow gelangten wir nach Storkow, wo wir auf freier Strecke nahe des Bahnübergangs an der Beeskower Chaussee entladen wurden. Über 500 Menschen, vorwiegend Frauen und Kinder [,] bewegten sich dann auf der Beeskower Chaussee Richtung Küchensee. Hier wurden wir in einem neu eingerichteten Flüchtlingslager untergebracht. [...] [S. 53] [...] Wir kamen mit den in unserem Waggon Mitfahrenden in einen großen Raum. Rings herum standen zweistöckige Holzbetten. Oben schliefen die jungen, unten die älteren Flüchtlinge. Für 14 Tage blieben wir hier und konnten uns von den Strapazen der Flucht erholen, wurden früh, mittags und abends aus der Baracke Nr. 1 verpflegt. Im Wechsel empfingen die Bewohner unseres Raumes das Essen und die Getränke. [...].“

Ein Sechsjähriger, der mit seiner Mutter und zwei Geschwistern Ende Mai aus Hirschberg in Schlesien vertrieben wurde, hat im Alter, 2008, über seine Ankunft berichtet: „Mehrere Tage und Nächte waren wir auf den Schienen unterwegs - bevor wir lt. Flüchtlings-Pass vom 4.6. bis 18.6.1947 Insassen im Lager des Ortes Küchensee waren. Nach meinen Erinnerungen waren wir im Lager in 3-Etagen-Kojen untergebracht. Wir wurden dort mit weißem Puder stark bestäubt bzw. bespritzt. Hannelore hat sich so gewehrt und geweint, dass die Ärztin ihr die Spritze in den Rücken gab. Hannelore wurde am 12. Juni im Lager 5 Jahre alt. Lt. Flüchtings-Pass bekamen wir für den 19. und

725 Hildegard Rölke: Erinnerungen an den Aufenthalt im Flüchtlingslager Küchensee. In: Geschichten aus sieben Jahrzehnten (wie Anm. 538), S. 33-34.

726 Ruth Below: Wie ich zu meiner neuen Heimat fand. Erzählt von G. F. Aufgeschrieben von Horst König. In: Geschichten aus sieben Jahrzehnten (wie Anm. 538), S. 52-53, hier S. 53. 
20. Juni Marschverpflegung und waren sodann wieder auf den Schienen unterwegs. Spät abends am 20. oder 21. Juni sind wir auf dem Bahnhofsgelände Eichwalde angkommen und wurden entladen. Viele Schwestern in Nonnenkleidung fragten nach Kranken und Verletzten."727

Eine junge Kindergärtnerin (geb. 1931), die später als Erzieherin in Fürstenwalde arbeitete, schildert in ihren Jugenderinnerungen einen Betreuungseinsatz im Umsiedlerlager Küchen$\operatorname{see}^{728}$ : „Mitte Februar 1949 wurde uns mitgeteilt, dass wir zur Betreuung von Kindern zu einem Einsatz nach Küchensee fahren würden. Am 21. Februar 1949 fuhr unsere Gruppe von Potsdam nach Storkow. Storkow, doch wo war Küchensee? Als wir auf dem Bahnhof in Storkow ausstiegen, klärte sich das schnell. Ein LKW stand vor dem Eingang und der brachte uns schnell nach Küchensee, einem damaligen Lager für Umsiedler und Heimkehrer. Das Lager lag mitten im Wald und war von einem Stacheldrahtzaun umgeben. Durch ein großes Tor, mit einem Schild ,Umsiedlerlager Küchensee' versehen, fuhren wir am Pförtnerhäuschen linkerhand vorbei zum Barackenkomplex mit 12 Holzbaracken. Wir hielten an der Baracke Nr. 10, über deren Eingangstür ein Schild mit dem Namen ,Waldfrieden' hing. Die Räume in dieser Baracke waren warm und in hellen Farben neu gestrichen. Es gab insgesamt vier Schlafräume für uns 40 Personen. Die Kindergärtnerin des Lagers und eine DRK-Schwester begrüßten uns. Nach kurzer Zeit des Einrichtens ging es in den Speisesaal. Er war neu eingerichtet, sehr groß und die Lagerleitung erwartete uns darin. Wir sangen das Lied ,Das neue Leben muss anders werden' und weihten damit diesen Saal ein. In einer anschließenden Arbeitsberatung mit einem Vertreter des Landesjugendamtes und dem pädagogischen Leiter für die Aktion wurde uns die Aufgabe erklärt: In Küchensee sollten Kinder zusammengefasst werden, die auf Grund einer Vereinbarung mit der britischen Besatzungsmacht in deren Zone überstellt werden sollten. Die Kinder waren Waisen und Halbwaisen, die ihre nächsten Angehörigen in der britischen Besatzungszone hatten. Sie hatten bis zu diesem Zeitpunkt in Heimen, bei Pflegeleltern oder entfernten Verwandten gelebt und sollten nun ausreisen. Es waren auch Kinder aus Polen dabei, die kaum deutsch sprachen und schwere Schickale mit sich trugen.

So begann am nächsten Tag unsere Arbeit in Gestalt der Vorbereitung in den Baracken, Decken verteilen, fegen und heizen. Leider waren die Barackenräume nicht sehr schön. Doppelstockbetten, in einigen sogar dreifach, Matratzen gab es wenige, blanke Bretter am Fußboden, einen Tisch und einen eiserner [so!] Ofen, der Tag und Nacht geheizt werden musste. Die Dusch- und Waschräume fanden wir damals ausreichend, doch Handtücher und Seife waren immer knapp. Am 22. Februar 1949 trafen täglich Transporte per LKW im Lager ein, mit denen die Kinder vom Bahnhof abgeholt wurden. Ganz schnell stieg die Zahl der zu betreuenden Kinder auf ca. 850. Dabei blieb es jedoch nicht, und für die jüngeren Kinder drohte sich die Qualität der Betreuung zu verschlechtern. Es wurde eine Gruppe für Ein- bis Zweijährige eingerichtet, um den Kleinen Ruhe und Beständigkeit zu sichern. Da weitere Kindergruppen im Lager eintrafen, wurde eine Trennung der Jungen und Mädchen über 14 Jahre vorgenommen. Sie lebten in eigener Verantwortung in getrennten Baracken. Kundoch / Hans-Jürgen Nossack: Chronik Kiekebusch. Die Geschichte eines märkischen Dorfes. Hrsg.: Gemeinde Schönefeld. Schönefeld [2009], S. 47-51, hier S. 48. 
Für uns junge Mädchen war die Arbeit schwer, doch verließ uns nie die Kraft und die Freude an der Arbeit mit den Kindern. Jede hatte eine Gruppe mit zwanzig Kindern, die ja beschäftigt werden mussten. Singen, erzählen, zuhören, trösten, [S. 74] stopfen und schlichten waren die Tätigkeiten des Tages. In drei Durchgängen nahmen wir die Mahlzeiten ein. Es gab einen täglichen Wechsel, denn der dritte Durchgang war der erstrebenswerteste, da gab es manchmal Nachschlag. Das Lager durfte weder von uns noch von den Kindern verlassen werden. Kaltes Wetter, Schnee und Eis herrschte an den ersten Tagen. Ich erinnere mich auch an Waschtröge voller Eis zwischen den Baracken. Für unsere Sicherheit gab es einen ständigen Wachdienst rund um das Lager durch junge Polizisten in dunkelblauen Uniformen, die uns mit viel Engagement und in netter Art unterstützten, sowohl bei den Nachtwachen als auch bei Problemen mit Jugendlichen. Unser Dienst ging von 07.00 bis 21.00 Uhr. Zwei Mädchen hatten Nachtwache: Sie gingen von Baracke zu Baracke, von Raum zu Raum, sie sahen nach dem Rechten, trösteten, topften die Bettnässer und heizten. Das Feuer durfte nicht ausgehen. Einmal, weil es sonst schnell kalt in den Räumen wurde und zum anderen waren Streichhölzer knapp. Die anderen Mädchen hatten am späten Abend Arbeitsbesprechung, die manchmal bis nach Mitternacht ging. Wir brauchten auch Zeit, um uns auszutauschen und Probleme zu verarbeiten. Für ca. 10 Tage war das Sammellager gedacht. Doch plötzlich erkrankten einige Kinder. Scharlach, Masern und Erkältungen häuften sich. Der schon angerollte Sonderzug fuhr wieder davon. So gab es neue, zum Teil schwere psychische Probleme bei den Kindern. Es wurde beschlossen, die Vorbereitung zur Abfahrt weiter zu betreiben und Veranstaltungen zu organisieren, um die Kinder abzulenken. Das Landesjugendamt und die Volkssolidarität sorgten für Kleidung und Schuhe, eine neue amtsärztliche Kommission aus Potsdam überprüfte alles und es gab ein dickes Lob für uns.

Am 14. März 1949 war es dann so weit. Ein ewig langer ehemaliger Lazarettzug rollte im Bahnhof Storkow ein. Jede, Erzieherin' bekam eine Gruppe Kinder mit vielen Listen der Namen und bestieg mit ihnen einen LKW. Doch der leitende Arzt schickte die Kinder nach eigenem Gutdünken in die bereitstehenden Waggons. Die Hälfte der Wagen war mit Betten ausgerüstet, in denen in erster Linie die Kleinen und Jüngeren untergebracht wurden. Die Großen und Jugendlichen bekamen alle Sitzplätze. Ein Krankenwaggon nahm die Erkrankten auf und wir wurden vom leitenden Arzt auf die Waggons aufgeteilt. Die Verpflegung erfolgte durch den Küchenwagen. Das Essen wurde in die Waggons geholt und Brote wurden von uns hergerichtet. Hygiene wurde klein geschrieben. Wenn der Zug hielt, rannten alle Betreuer mit einem vorgesehen Topf zur Lokomotive, um heißes Wasser zu empfangen, Neben dem Zug ging es schneller, aber wehe, wenn er langsam wieder anfuhr.

Am 16. März lief der Zug in Heiligenstadt ein. Langsam ging es weiter zur Grenzstation Arenshausen. Dort kamen ca. 500 Kinder auf bereitstehende LKW's und verließen die Ostzone in Richtung Britische Besatzungszone. Die restlichen Kinder blieben bis zum 18. März in Heiligenstadt, wozu noch ca. 250 Kinder aus einem Sammeltransport aus Thüringen kamen. [S. 75]

Unser Zugfuhr am 19. März wieder zurück nach Berlin. Mit uns Erzieherinnen fuhren 200 Kinder, die aus der Britischen Besatzungszone kamen und zu Verwandten in die Ostzone gebracht wurden.

Küchensee war beendet. Der verantwortliche Lagerleiter hieß Leo Kunz. Er kam aus Kyritz und hatte dort ein Kinderdorf gegründet. Später arbeitete er in Potsdam." 


\section{Pinnow}

Ein damals zehnjähriger Vertriebener aus Hinterpommern, der mit Mutter und Großeltern, nach vielen Monaten eines strapaziösen Überlebenskampfes mit zuletzt schlimmen Erlebnissen vor dem Grenzübertritt, in einem Transport im Januar 1946 nach Angermünde gekommen war, hat seine ersten Eindrücke nach der Ankunft und das darauf folgende mehrmonatige Lagerleben im „Umsiedlerlager“ Pinnow (Kr. Angermünde) später in seinen Erinnerungen beschrieben:

„In der kleinen Stadt Angermünde empfing man uns auf einem großen freien Platz, umgeben von Häusern, richtigen Häusern mit Türen und Fenstern, roten Dächern und Schornsteinen, aus denen dunkler Rauch kerzengerade in den Winterhimmel stieg. Ein nicht mehr gewohntes Bild. [...]

Auf einem erhöhten Podest stand ein Mann und hielt eine Rede, von der ich kein Wort verstand. Vielleicht sollte es ein Willkommensgruß in Deutschland sein. / Man steckte uns in eine eiskalte Turnhalle, bei deren Bau man nicht damit gerechnet hatte, dass sie einst einen ganzen Güterzug voller Menschen beherbergen müsste. Wir lagen so dicht beieinander, wie man in früheren Zeiten Sardinen in mit Öl gefüllten Büchsen gestopft hatte. Doch auf diese Weise wärmten wir uns gegenseitig. Zweimal am Tag gab es heißes Wasser und Brot, das schmeckte muffig und schimmlig. / Dann verbrachten wir einige Zeit in einem Lager in der Nähe des kleinen Ortes Pinnow im Land Brandenburg. Hier lebten wir in Baracken, in denen man sich fast schon wohlfühlen konnte. Die Räume waren reichlich mit Stroh ausgelegt, und es gab eiserne Öfen. Wir sammelten Holz im Wald und zerkleinerten Munitionskisten, die an einer in der Nähe vorbeiführenden Bahnstrecke herumlagen. [...] [S. 29] [...] Die Öfen verbreiteten Wärme, wie wir sie seit langem nicht mehr gespürt hatten. [...]

Mittags gab es Eintopf. Der Hauptbestandteil dieser Eintöpfe war Wasser, dazu ein gut Teil Kümmel, und wenn man aufmerksam suchte, fand man auch winzige Stückchen von Kartoffeln. Irgendwo musste man ein Kümmel-Lager gefunden haben. Nun verbrachte man diesen Kümmel in Mengen als Ersatz für anderes, was nicht aufzutreiben war. Alle nörgelten über den Zentimeter hohen Kümmelsatz am Ende jeder Mahlzeit. [...] Als Behälter zum Transport der mittäglichen Suppen dienten uns Gefäße, die man aus einem Lazarett oder Krankenhaus hervorgeholt hatte, denn es war offensichtlich, dass sie eigentlich zur Verabfolgung von Darmeinläufen gedacht waren. / In den Nähten meiner Hemden marschierten, diszipliniert in Reih und Glied, die Läuse auf und ab. Sie hatten längst das Ansehen von geduldeten Haustieren erworben. / Die fragwürdigen Wassersuppen führten $z u$ Bauchgrimmen und Durchfällen, und dann trieben wir uns ein um das andere mal auf den Aborten herum. Diese bestanden aus einer eilends ausgehobenen Grube, darum Bretter, durch Balkenwerk ein wenig erhöht. Auf diesen Brettern saßen wir dann wie die Hühner auf der Stange, ob Mann, ob Weib, ob Kind. Ein provisorisches Dach hatte man errichtet, doch Trennwände gab es nicht. [S. 30] Eines Tages endete das Lagerleben." 


\section{Prenzlau}

Ein damals achtzehnjähriger Vertriebener aus Grünberg in Schlesien, der mit seiner Mutter Ende September 1945 über kurze Zwischenstationen in Cottbus und Berlin zu einem Onkel in Fürstenwerder (Uckermark) als rettendem Anlaufpunkt unterwegs war, hat die Ankunft im Flüchtlingslager Prenzlau, Ende September oder Anfang Oktober, als letzte Übernachtungszwischenstation beschrieben: „Prenzlau! Hier mussten wir aussteigen, wenn wir nach Fürstenwerder wollten. / Nacht in Prenzlau. Auch hier Trümmer über Trümmer, Ruinen. Irgendjemand hatte uns den Weg zum Flüchtlingslager gewiesen. Es war weit. Wir schleppten uns mit letzter Kraft dorthin. Ein Barackenlager. Ein mürrischer Wächter führte uns. Wir froren. In der uns zugewiesenen Baracke brannte eine trübe Deckenlampe. Wir standen am Eingang und sahen einen endlos erscheinenden Raum. Hin und wieder gewahrten wir ein dunkles Bündel auf dem niedergelegenen Stroh; Menschen in Mänteln, einige in Decken eingewickelt. Landsererfahrung ${ }^{730}$ wurde in mir wach. Nicht ins Stroh legen! Gefahr, Wanzen oder[,] noch schlimmer, Läuse zu kriegen! Links stand eine Bank. Wir setzten uns und schliefen sofort ein. Nicht ins Stroh legen, war mein letzter Gedanke. / Als ich erwachte, lag ich im Stroh. Wie meine Mutter und ich nach Fürstenwerder [S. 96] kamen, weiß ich nicht mehr. Sicher $z u$ Fuß, vielleicht nahm uns auch mal ein Bauer mit seinem Fuhrwerk einige der ca. $25 \mathrm{~km} \mathrm{mit.}{ }^{731}$

\section{Rüdersdorf}

Eine mit einem Transport aus einem Sammellager in einer Kaserne in Marienwerder (Westpreußen) 1947 nach Berlin gelangte Vertriebene berichtete über Ankunft und Unterbringung im Umsiedlerlager Rüdersdorf ${ }^{732}$ : „An einem Sonntagmorgen näherten wir uns einer trostlos zerbombten Stadt: Berlin. Wir fuhren durch viele Stadtviertel, bevor wie endlich mittags in dem Ostberliner Lager Rüdersdorf ankamen. Je 20 Personen wurden immer in einen Raum eingewiesen, es war ein riesiges Lager. Hungrig wie die Wölfe hofften wir doch auf eine warme Mahlzeit, aber es wurde uns erklärt, am Sonntag arbeite das Personal nicht. So gingen wir auch an diesem langersehnten Tage hungrig zu Bett. Muttel war so schwach, daß sie in den folgenden Tagen nur auf der Pritsche liegen blieb, wie es viele alte Leute taten. Auch Winfried war sehr elend und bekam nach ärztlicher Untersuchung aller Kinder am nächsten Tage je einen Eßlöffel täglich voll Lebertran. Der Arzt hatte mir aber eingeschärft, nicht darüber zu sprechen. Es war so wenig vorhanden, daß nur die elendesten Kinder damit versorgt werden konnten.

Im Lager fing nun für uns Jüngere das ständige Anstehen nach Essen an. Einmal gab es Kaffee, dann wieder Brot, dann $50 \mathrm{~g}$ Zucker, dann einen Hering, kurz, das stundenlange Schlangestehen nach den kleinen Rationen erforderte so viel Kräfte, daß man es vermied, überhaupt noch einen unnötigen

730 [Ab April 1945 war er Flakhelfer gewesen und dann in amerikanische Gefangenschaft geraten. „Landser“ ist ein zeitgenössischer umgangssprachlicher Begriff füt den „einfachen“ Soldaten.]

731 Walter Wiede: Wieder ein neues Ziel - Fürstenwerder -. Umsiedler 1945 unterwegs. In: Fürstenwerder Mosaik. T. 2. Fürstenwerder 2002, S. 94-104, hier S. 95 f.

732 N. N., Besatzungselend (wie Anm. 619), S. 270 f. 
Weg zu machen. Mittags gabs einen halben Liter dünne Suppe; das ausgegebene wenige Brot am Morgen war auch für den Abend bestimmt. Fett sahen wir keins, und wir wurden immer schwächer. Das tägliche Aufwischen der Lagerstube war eine nicht zu beschreibende Kraftanstrengung.

Als gleich in den ersten Tagen die SED vor unserem Lager große Aufbauten mit roten Fahnen machte und wir dann aufgerufen wurden, uns zu wichtigen Bekanntmachungen einzufinden, hörten wir damals zum ersten Mal die uns später geläufigen Schmähreden gegen den Westen. Wir alle hatten ja bisher nur von Gerüchten gelebt, unsere Angehörigen im Westen mußten in Briefen mit politischen Äußerungen vorsichtig sein, so hatten wir keine Ahnung von dem erbitterten kalten Krieg, den die Siegermächte gegeneinander führten. An uns prallten aber alle Parolen ab. Wir hatten nur den einen Gedanken, so schnell wie möglich aus dem Lager herauszukommen. Doch 14 Tage mußten wir bleiben. Vom Lager aus durften wir Nachricht an unsere Angehörigen geben, daß wir glücklich aus ,Polen' heraus seien.

Lothar hatte mit Tante Margarete ausgemacht, daß wir bei ihr unsere erste Bleibe finden würden. Irmgard kam aus Frohnau herüber und brachte uns zwei Brötchen, eine große Kostbarkeit! Damals konnte man ja noch ungehindert von West-nach Ostberlin und umgekehrt. Nach 16 Tagen wurden wir entlassen. Ich versuchte noch, vom Küchenchef 3 Eßlöffel Grütze für ein Essen am nächsten Tag zu bekommen, aber alle meine Überredungskünste fielen auf unfruchtbaren Boden; dann könnten ja alle kommen, wurde mir gesagt.

Mit unseren Rucksäcken auf den Rücken, den Bettsäcken, die wir vor uns herkullerten (tragen konnte sie niemand mehr von uns dreien) standen wir auf einem der Bahnhöfe und warteten auf die S-Bahn, die uns nach Glienicke bringen sollte. Am Nachmittag erreichten wir unser Ziel."

Die Vertriebenenlager, anfangs noch meist „Flüchtlingslager“, offiziell bald „Umsiedlerlager“ genannt, spielten im Leben der Betroffenen, die sie durchlaufen haben, eine durchaus prägende Rolle. Zumindest die Mütter, Kinder und Alten hatten bis dahin Lager-,Leben“ nie aus der Nähe kennengelernt. Schon auf der Flucht und auf den Transporten sahen sie sich mit ihrem Schicksal nicht allein, doch erst in den Aufnahmelagern konstituierte sich gewissermaßen das Gruppenmerkmal, indem sie nun innerhalb der Aufnahmegebiete, wenn auch nur zeitweise, separiert und - in subjektiver Perspektive - deklassiert wurden. Die Unterkunft und Hilfe, die ihnen hier zuteil wurde, konnte sie kaum darüber hinwegtäuschen, dass sie nun zunächst wie auch immer ihre spezifische soziale und wirtschaftliche Situation zuvor ausgesehen haben mochte - am untersten Ende der sozialen Gesellschaftshierarchie angekommen waren, dass alles, was sie und ihre Familien in der Heimat an Besitz und Stellung aufgebaut und erlangt hatten, zunächst nicht mehr zählte. Der Lageraufenthalt, in der Folge in Gutshaus- und Privatquartieren oft nur bedingt gebessert, weil meist ebenfalls mit gravierenden Einschnitten in Privatsphäre und Gestaltungsmöglichkeiten verbunden, blieb für viele Flüchtlinge und Vertriebene eine einschneidende Erfahrung. Die (Orts-)Namen der Flüchtlingslager blieben daher im Bewusstsein der Betroffenen mit unguten Assoziationen verknüpft.

Liest man Erinnerungsberichte oder unterhält man sich mit Zeitzeugen, so begegnen Lagernamen wie „Magazininsel“ (Rathenow), „Quenz“ (Brandenburg/H.) oder „Rüdersdorf“ als feststehende Begriffe selbst dann noch, wenn die Betroffenen seit Jahrzehnten in ganz anderen 
Regionen Deutschlands lebten bzw. leben. Demgegenüber sind diese Vertriebenenlager am Ort und im Land Brandenburg fast vollständig in Vergessenheit geraten, die Erinnerungskultur hat sich gleichsam geteilt, das öffentliche Vergessen hat sie fast ganz in den Bereich der Familien oder der nach 1989 entstandenen Vertriebenenverbände verlagert. Das Gleiche galt lange Zeit trotz aller offiziellen antifaschistischen Gedenkkultur - partiell auch für die Erinnerung an die Geschehnisse in den Zwangsarbeiterlagern, erst recht lange Zeit an die in den sowjetischen Speziallagern. In diesen Bereichen immerhin hat sich mittlerweile eine auch lokale Gedenkkultur und eine wissenschaftliche Erforschung entwickeln können, deren Lückenschließung aber noch in vollem Gange ist. ${ }^{733}$ Auch wenn die Dimensionen und Kausalitäten von Gewalt und Tod hier ganz andere sind, könnte diese gelungene Integration der Geschehnisse und der Historischen Stätten in die Andenkenpflege von Kommunen und Land Vorbild sein auch für die vielfach noch ausstehende Aufnahme der Flüchtlingsschicksale und -lager in den Erinnerungshaushalt der jeweiligen lokalen oder regionalen Gesellschaft.

\section{Gesundheit}

Die gesundheitliche und hygienische Situation der Bevölkerung, aber auch ihre gesamte seelische Verfassung war während der ersten Nachkriegsjahre, auch außerhalb der Lager, bis zum äußersten angespannt, nicht selten geriet sie aus den Fugen. Zahlreiche Erinnerungsberichte von Zeitzeugen führen dies hautnah und eindringlich vor Augen, aber auch zeitgenössische Berichte von kompetenter ärztlicher Seite und spätere Memoiren von Medizinern zeigen, dass dies ein flächendeckendes Problem und kein sozial zu differenzierendes oder nur Flüchtlinge und Vertriebene betreffendes Phänomen darstellte. ${ }^{734}$ Diese waren jedoch durch die Entbehrungen und einschneidenden Erfahrungen der Flucht bzw. Vertreibung besonders geschwächt, so dass viele alte Menschen und Kleinkinder schon unterwegs oder bald nach der Ankunft starben. ${ }^{735}$

733 Jörg Morré: Speziallager des NKWD. Potsdam 1997. - Ders.: „Umschulungslager existieren nicht“. Zur Geschichte des sowjetischen Speziallagers Nr. 6 in Jamlitz 1945-1947. Potsdam 2001. - Instrumentalisierung, Verdrängung, Aufarbeitung (wie Anm. 65). - Totenbuch Sowjetisches Speziallager Nr. 6, Frankfurt/Oder 1945, Jamlitz 1945-1947. Im Auftr. der Evang. Kirchengemeinde Lieberose und Land hrsg. u. bearb. von Andreas Weigelt. 2. Aufl. Lieberose 2009. 155 S. - Siehe auch die tiefgehende, in ihren Kapiteln zum „Innenleben“" (Organisation, Struktur, Gebäude [mit Fotos], Häftlingsstruktur, Haftbedingungen, Lageralltag usw.) über das Beispiel hinaus wertvolle Untersuchung zu einem in der Neumark eingerichtenen Speziallager: Holm Kirsten: Das sowjetische Speziallager Nr. 4 Landsberg/Warthe. Hrsg. von der Stiftung Gedenkstätten Buchenwald und Mittelbau-Dora. Göttingen 2005 (S. 30 auch zu Durchgangslagern für deutsche Vertriebene).

734 Z.B. für Potsdam 1946/47 (Grippe, kalter Winter, teilzerstörte Wohnungen, Heizprobleme, Hunger, Gereiztheit, Missmut, Verarmung, Altersarmut): Heinz Goerke: Am Puls der Medizin. Hildesheim u. a. 1996, S. 124 f. - Für Brandenburg insgesamt: Ein Jahr Bewährung der Mark Brandenburg (wie Anm. 703), S. 43-49 (Abschnitt „Gesundheitswesen“).

735 Eine vorläufige Analyse russischer Quellen zu den Transporten aus Königsberg 1947/48 ergab: „Bei jedem Transport starben unterwegs pro Zug 3 bis 9 Menschen. Als Ursachen werden in den Protokollen genannt: An erster Stelle Unterernährung (Dystrophie), aber auch Altersschwäche, Ruhr (Dysenterie) und andere Krankheiten." Fisch/Klemeševa, Zum Schicksal der Deutschen in Königsberg (wie Anm. 601), S. 399. 
Die zudem allgemein katastrophalen medizinischen Verhältnisse ${ }^{736}$ - es fehlte überall an Medikamenten und Hilfsmitteln - trafen wiederum besonders Kinder und alte Menschen, nicht nur unter den Vertriebenen. ${ }^{737}$ „In den Berichten und nach Aussagen von Zeitzeugen gab es einen erheblichen Mangel an medizinischem Personal und die Ausstattung, die zum größen Teil aus Spenden und Sammlungen zusammengetragen wurde, war äußerst notdürftig. [...] Unterernährung, Mangel an Kleidung und Heizmaterial und vieles mehr trugen zu schlechten gesundheitlichen Auswirkungen bei und waren u. a. mit verantwortlich für die Ausbreitung von Seuchen (Ruhr, Typhus und Syphilis). Daher waren Schwerpunkte der Arbeit des Gesundheitswesens bis 1949 die Seuchenbekämpfung und Wiederherstellung der öffentlichen Hygiene.“738 Die Erinnerungen der Prenzlauer Ärztin Dr. Lena Ohnesorge (1898-1987) überliefern, wie man mit kriegsbedingt reduzierten Kräften von Januar bis April 1945 einem bis dahin nicht gekannten Ansturm ausgeliefert war: „Wirkliche Schwierigkeiten traten auf, als die Flüchtlingstrecks aus dem Osten ununterbrochen durch die Stadt rollten oder bei Einbruch der Dunkelheit anhielten, um warme Getränke und Reinigungsmögichkeiten zu suchen. Die NSV tat das Menschenmögliche. Sie sorgte für Quartiere, wenn es auch nur Strohlager in Schulen, Gaststätten oder anderswo wa- [S. 343] ren. Von Januar 1945 an habe ich pausenlos jede Nacht dort Nachtdienst gemacht, unterstützt von schnell ausgebildeten BDM-Mädchen. Das Elend war herzzerreißend: Wochenlang vernachlässigte akute Infektions- und Verschmutzungskrankheiten, übergroße Schwächezustände nach langen Fluchtwegen, schwerste Ernährungsstörungen, Sterbende und Tote. Diese wurden einfach in einem Sack oder Bettzeug an die Wagen gehängt. Viele Menschen kamen vollkommen erfroren an. Die Fußleiden waren bei der Kürze der Behandlungsmöglichkeit gar nicht zu heilen, und so ging es am nächsten Morgen in der Frühe nur verbunden weiter ins Ungewisse. / Das Kreiskrankenhaus war natürlich überfüllt. ${ }^{739}$

Einige Beispiele mögen für die Vielzahl ähnlicher Schicksale stehen, die in jenen Monaten und Jahren in Brandenburg endeten. Sie mögen zugleich vor Augen führen, wie groß die Zahl jener gewesen sein mag, für die eine „Flüchtlingsaufnahme“ oder gar „Vertriebenenintegration“ gar nicht erst begann, deren Hinterbliebene aber, wenn es solche überhaupt gab, eine zusätzliche seelische Belastung in ihre persönlichen „Integrationsgeschichten“ mitnahmen. Eine ostpreußische Familie, die im Januar 1945 nach Hinterpommern geflohen war und im September von dort vertrieben wurde, kam nun nach Eberswalde: „Nach einigen Tagen und Nächten langten wir ausgezehrt in Eberswalde an und erhielten bei Verwandten Unterkunft. Wir wurden polizeilich re-

736 Siehe z. B.: Potsdam und das Jahr 1945. Potsdam 1995, S. 20 f. - Rodegast, 6000 Flüchtlinge in der Stadt. Die Gesundheitslage in Wittenberge 1945 (wie Anm. 182).

737 Schilderungen finden sich in den Erinnerungen von Ärzte und Schwestern, z. B. in denen einer KrankenpflegeAuszubildenden im Städtischen Krankenhaus Cottbus 1947: Eva-Maria Nutsch: Krankenhausalltag kurz nach dem Ende des II. Weltkrieges. In: Damals und heute (wie Anm. 357), S. 46-47.

738 Anna-Maria Gaul: Zur Geschichte des Klinikums Frankfurt (Oder). In: Zeitreise durch die Geschichte des Klinikums Frankfurt (Oder). Hrsg. von Ulrich Knefelkamp. Berlin 2003, S. 11-27, hier S. 16.

739 Lena Ohnesorge: Erinnerungen an das Medizinalwesen in Prenzlau vor 1945. In: Prenzlau. Hauptstadt der Uckermark 1234-1984. Ein bürgerliches deutsches Lesebuch. Hrsg.: Heimatkreis Prenzlau. Barendorf 1984, S. 333-343, hier S. 342 f. 
gistriert und Vater bekam als Maurer sofort Arbeit und bescheidene Lebensmittelzuteilung. Er konnte aber nur drei Tage arbeiten, dann versagten seine Kräfte. Ich lag acht Wochen mit Typhus im Eberswalder Krankenhaus. Mein Vater mußte in dieser Zeit meine beiden Kinder versorgen. Gleich, als ich aus dem Krankenhaus kam, schloß mein Vater für immer die Augen. Seine Mission, die Kinder zu versorgen und zu retten, war erfüllt." ${ }^{\text {“740 }}$

Am 12. März 1945 um 22.30 Uhr starb im Waldhaus bei Gehren (Kr. Luckau) der „Flüchtling Wilhelm Genzius“. Eine Angestellte meldete den Todesfall beim zuständigen Standesamt in Riedebeck, im entsprechenden Eintrag im Sterberegister heißt es sowohl beim Geburtstag als auch beim Geburtsort und der Religion „nicht bekannt“, d. h. nicht einmal ein geschätztes Alter ist angegeben. Nur die Todesursache ist vermerkt: „Entkräftung“. Bemerkenswert ist das anstelle der Berufsbezeichnung gesetzte „Flüchtling “ ${ }^{\text {"71 }}$ Ob hier also Angehörige nicht sogleich zur Stelle waren oder ganz fehlten, muss offen bleiben. Am 8. April 1945 stirbt im Waldhaus um $22 \mathrm{Uhr}$ durch „Allgemeinen Marasmus“742 der „Flüchtling Ernst Budting“, dessen Tod eine im Waldhaus wohnhafte Hausgehilfin beim Standesamt anzeigt. Auch hier konnten außer dem Namen keinerlei Angaben zur Person eingetragen werden. ${ }^{73}$

1946 starben im Städtischen und im Kreiskrankenhaus Prenzlau ausweislich des standesamtlichen Sterberegisters zahlreiche Flüchtlinge, von denen die Mehrheit aus Pommern stammte, insbesondere aus dem Kreis Greifenhagen, daneben auch aus Schlesien, Posen, Polen (Lodz) und dem Baltikum. Neben Altersschwäche und Herzschwäche ist Anfang des Jahres als Todesursache häufig Bauchtyphus angegeben. ${ }^{744}$ Im Januar finden sich zudem im Krankenhaus Prenzlau mehrfach Sterbefälle von Flüchtlingen aus dem Flüchtlingslager Quenz bei Brandenburg an der Havel, z. B. der 1882 geborene Landwirt Adam Henschel, „wohnhaft in Leonow, Umsiedler aus dem Flüchtlingslager Quenz bei Brandenburg“, „Familienstand nicht bekannt“, der am 19. Januar 1946 im Kreiskrankenhaus Prenzlau an allgemeiner Entkräftung stirbt ${ }^{745}$, oder die 1885 in Lodz geborene Näherin Elmira Esslinger, „Wohnort unbekannt, Umsiedler aus dem Flüchtlingslager Quenz bei Brandenburg“, „Familienstand nicht bekannt“, die am 24. Januar 1946 im selben Krankenhaus ebenfalls an allgemeiner Entkräftung starb ${ }^{746}$. Auch drei weitere Sterbefälle im Kreiskrankenhaus Prenzlau Ende Januar 1946 - ein 53-jähriger Schlesier sowie eine 64-jährige, ein 66-jähriger und ein 62-jähriger Lodzer - sowie viele weitere im Februar, meist Deutsche

740 Eberswalde 1945. Dokumente und Erinnerungen. Ein Anhang der 2. Auflage des Begleitheftes zur 1995 im Eberswalder Museum gezeigten Sonderausstellung. (Eberswalde) o.J., S. 15.

741 Kreisarchiv Dahme-Spreewald, Standesamt Bornsdorf (Riedebeck in Bornsdorf), Sterberegister, Reg.Nr. 15/1945.

742 Protein- bzw. Energiemangel, meist durch Mangel- bzw. Unterernährung hervorgerufen.

743 Wie Anm. 741, Reg.-Nr. 20/1945.

744 Die standesamtlichen Sterberegister dieser Jahre, auch schon während des Krieges, enthalten ausnahmsweise, was zuvor und auch später nicht üblich war und ist, in einem Zusatz am unteren Seitenende auch die Todesursache. Siehe dazu auch oben den Abschnitt „Kommunalarchive“ des Kapitels I. 3.

745 Stadtarchiv Prenzlau, Standesamt Prenzlau, Sterberegister, Jg. 1946, Nr. 123.

746 Ebd., Jg. 1946, Nr. 126. 
aus dem Raum Lodz in Polen, tragen im Standesamtsregister ebenfalls den Vermerk „Umsiedler aus dem Lager Quenz bei Brandenburg“, die Todesursache ist den meisten Fällen „allgemeine Körperschwäche ${ }^{4747}$, auch Unterernährung ${ }^{748}$ und Hungerödeme ${ }^{749}$ kommen vor, einmal heißt es - bei einer aus Konstantinow (bei Lodz) gebürtigen 54-jährigen Näherin - bei der Todesursache: „Enteritis ${ }^{750}$, Unterernährung, schwerster Erschöpfungszustand“. ${ }^{751}$ Die „Umsiedler“ aus Quenz, die im Prenzlauer Kreiskrankenhaus sterben, finden sich dann erst am 29. März ${ }^{752}$ sowie am 1. und 2. April ${ }^{753}$, darunter ein 43-jähriger Schmied aus Ellgut-Turawa, dessen Todesursachen lauten: „Schwerer Erschöpungszustand. Hungeroedeme. Herzschwäche."

Auch aus dem Berliner Bereich, hier in kirchlichen (katholischen) Quellen für die „Seelsorge in Wuhlgarten“, ist für Oktober 1945 überliefert, dass die Erschöpfung und Entkräftung wiederum besonders der alten Flüchtlinge und Vertriebenen die Krankenhäuser überlastete und in vielen Fällen, wenn nicht schon zuvor auf dem Fluchtweg, mit dem baldigen Tod endete: „[...] Diese städtische Anstalt weist durchschnittlich ca 2000 meistens alte Leute auf, die gewöhnlich wegen Unheilbarkeit oder zu hohen Alters in andern Krankenhäusern keine Aufnahme finden und oft keine Angehörigen haben. Durch die vielen auf der Fahrt zusammengebrochenen schlesischen Flüchtlinge ist die Zahl der kath. Patienten verhältnismässig sehr hoch; desgleichen ist die Sterblichkeitsziffer und bedauerlicherweise auch die Zahl der unversehen sterbenden alten Leutchen, die aus einer gewissen Scheu den kath. Seelsorger nicht rufen oder deren Wunsch nicht weitergegeben wird, sehr beträchtlich. [...]"755

Im Hochsommer 1945 brach fast überall in Brandenburg, besonders stark wohl in den östlichen und südlichen Teilen, eine Typhusepidemie aus, die vollends eine medizinische Katastrophe herbeiführte, da sie - zusätzlich zu den geschilderten allgemeinen Rahmenbedingungen - gerade dann eintrat, als die große Welle der von den „Wilden Vertreibungen“ Betroffenen ins Land gekommen war. Die in diesen Monaten völliger Überlastung aller Beteiligten angelegten Massengräber sind heute vergessen, dürften aber an vielen Orten, nicht nur in der Nähe von Krankenhäusern und Lagern, existieren. ${ }^{756}$ Unter „Krankenhaus“ hat man sich damals nicht immer als solche errichtete Vorkriegsbauten vorzustellen, sondern, wenn diese durch den Krieg zerstört bzw. beschädigt oder von der Roten Armee beschlagnahmt waren ${ }^{757}$, oft genug

Ebd., Jg. 1946, Nr. 159, 160, 163, 165, 213, 234, 240, 246, 253, 268, 270, 278, 299, 475, 498, 499.

Ebd., Jg. 1946, Nr. 240, 246, 268.

Ebd., Jg. 1946, Nr. 253.

[Darmentzündung.]

Ebd., Jg. 1946, Nr. 268.

Ebd., Jg. 1946, Nr. 475.

Ebd., Jg. 1946, Nr. 498 und 499.

Ebd., Jg. 1946, Nr. 498.

DAB, I/5-12-Fedtke, unfol., Schreiben des Kath. Pfarramtes Berlin-Biesdorf-Nord, 18.10.1945, an das Bischöfliche Ordinariat in Berlin.

Siehe dazu oben Anm. 172.

So z.B. in Spremberg mehrmals: H. Wiesner: Die Entwicklung des Spremberger Krankenhauses seit 1945. In: Heimatkalender für den Kreis Spremberg 1959, S. 55-61, hier S. 56 f. - In Angermünde wurde das Kreis- 
nur - notdürftig hergerichtete - Baracken, aber auch Wohnhäuser, Turnhallen u. a. Immer wieder erwähnt wird in den Quellen auch der Mangel an Fachpersonal. Ein Beispiel mag Golzow (Oderbruch) bilden. Trotz des „aufopferungsvollen Einsatzes“ eines Tierarztes (!) und eines Apothekers „starb in den Monaten Juli und August 1945 fast täglich ein Mensch an Typhus. Bis zum Ende des Jahres 1945 gab es in Golzow 101 Todesfälle, darunter 15 Kinder. Von den Kleinkindern unter einem Jahr blieb keines am Leben. ${ }^{\text {"758 }}$ Eindringlich beschrieben sind die improvisierten Typhusimpfungen in dem Bericht einer damals Siebzehnjährigen, die hierbei 1945/46 als Krankenschwester in Welzow (Niederlausitz) eingesetzt war und doch gerade erst einen Rote-Kreuz-Kursus absolviert und in den Ferien in einem Lazarett geholfen hatte. ${ }^{759}$ Wegen der vielen Krankheitsfälle hatte man zum Beispiel in Rüdersdorf, wo ein großes „Umsiedlerlager“ bestand, Notkrankenhäuser eingerichtet. ${ }^{760}$ Überall wurden spätestens 1946 improvisierte Seuchenstationen eingerichtet, in Altlandsberg z. B. im Elektrizitätswerk. ${ }^{761}$

Unter den auftretenden Epidemien spielte der Typhus zeitweise die Hauptrolle. ${ }^{762}$ Der Arzt Dr. Manfred Schieche hat die Typhuserkrankungen des Jahres 1945 „wegen einer sehr günstigen Aktenlage“ für den sowjetischen Kommandanturbezirk Fürstenberg/Oder untersucht. ${ }^{763}$ Er stellt den Verlauf einer Welle von Juli bis November 1945 fest. „Am 24. Juli 1945 wurde in Fürstenberg/Oder der erste Typhusverdacht ausgesprochen." Im August häuften sich die Fälle. „Am 17. August verstarb der erste Typhuskranke. In der Woche vom 12. bis zum 18. August erkrankten in Fürstenberg/Oder 14 Personen an Typhus. “764 28 von 578 Erkrankten $(4,8 \%)$ verstarben. Nicht die Letalität, aber „die Anzahl der erkrankten Personen war in Fürstenberg/Oder und Umgebung 24mal höher als im Durchschnitt der übrigen SBZ“. Auch in Krayne westlich Guben kam es bereits im Juni 1945 aufgrund der katastrophalen Versorgungslage und der unvorstellbaren Entbehrungen „zu Unterernährung, Krankheiten und Todesfällen. Typhus und Ruhr wüteten grausam. Besonders betroffen waren Flüchtlinge

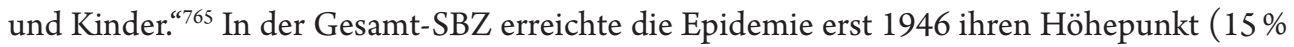
Letalität). ${ }^{766}$

krankenhaus von der Roten Armee 1945 beschlagnahmt und ausgeräumt: Kukla, Angermünde 1945 (wie Anm. 469), S. 42 f.

758700 Jahre Golzow 1308-2008. Golzow 2008, S. 17.

759 Eva-Maria Nutsch: Mein Jahr Null. In: Storkower Zeitzeugen berichten [H.] 2 (wie Anm. 271), S. 35.

760 Das berichtet der - wie sein 13-jähriger Bruder - selbst betroffene, damals 10-jährige Jörg Lüderitz, bei dem etwa zehn Tage nach der Ankunft des Trecks, mit der aus der Neumark gekommen war, Ende Juli 1945 Ruhrtypus ausbrach, der erst im September abklang: Lüderitz, Heimat Brandenburg (wie Anm. 397), S. 40 f.

761 Matthias Friske / Hartmut Niedrich: Altlandsberg. Neuenhagen 2000, S. 136.

762 Pflege eines typhuskranken Flüchtlingskindes: Lucie Hempel: Hilfe in großer Not. In: Kriegsende und Nachkriegszeit in Havelberg [II] (wie Anm. 175), S. 30-32.

763 Manfred Schieche: Typhusepidemie im Jahre 1945 in Fürstenberg/Oder und Umgebung. In: Heimatkalender Eisenhüttenstadt und Umgebung 15 (1997), S. 43-46, hier S. 43.

764 Ebd., S. 44.

765 Hartmut Schatte: Krayne. Teichperle der Niederlausitz. [Cottbus] 2005, S. 102.

766 Schieche, Typhusepidemie (wie Anm. 763), S. 46. 
In Frankfurt (Oder), das als neue Grenz- und Brückenstadt von durchziehenden Flüchtlingen sehr stark angefüllt war, wütete im Juli und August 1945 eine Typhusepidemie, die an manchen Tagen bis zu 180 Todesopfer forderte. ${ }^{767}$ Da auch noch die Ruhr auftrat und die schlechten Ernährungsverhältnisse ohnehin zu einem andauernd hohen Krankenstand geführt hatten, wurde noch 1945 die Einrichtung eines Seuchenkrankenhauses (Junkerstraße) nötig. ${ }^{768}$ In Frankfurt bestanden im August 1945 außer diesem noch zwei städtische Behelfskrankenhäuser, zwei Soldatenlazarette und ein Flüchtlingsbehelfskrankenhaus (in der Mittelschule Breite Straße $\left.{ }^{769}\right)$. Vier der Einrichtungen enthielten Entlausungsstationen, eine eine Unfallstation. ${ }^{770}$ Eine im Juni 1945 bei den „Wilden Vertreibungen“ aus der Neumark ausgewiesene Jugendliche hat ihren dortigen Aufenthalt im Alter rückblickend beschrieben ${ }^{771}$ : „Juli 1945, nun lag ich isoliert im Krankenbett des Notkrankenhauses in der Halben Stadt in Frankfurt (Oder). Ich war nach einigen Wochen Krankenhausaufenthalts endlich in der Lage, meine Gedanken etwas klarer schweifen $z u$ lassen. Der Arzt sagte: ,Mädchen, sie [Sie] haben Typhus. So etwas ist sehr ernst zu nehmen. Aber sie [Sie] können jetzt hoffen!' [...] Der Arzt meinte, die katastrophalen Bedingungen, denen wir im Osten, besonders während der Ausweisung, ausgesetzt waren, hätten nicht länger dauern dürfen, weil die gefährlichen, infektiösen Typhusbakterien leicht zur Epidemie führen, wenn der Köper durch Hunger geschwächt ist und der Erreger Nährboden findet. Und den hat er in den hinter uns liegenden schweren Wochen im Osten - verschmutztes Wasser, bedenkliche Lebensmittel sowie Schlamm und Ackererde - genügend gefunden. Schon in der letzten Zeit im Heimatort irrte ich total geschwächt und apathisch umher. Ärztliche Hilfe war unter den damaligen Umständen so gut wie ausgeschlossen. Ich war auf Selbsthilfe angewiesen und [S. 97] bereit, auch alte Hausmittel anzunehmen, wenn sie nur Linderung brachten und mich hoffen ließen. [...] Von Fieber geplagt, lag ich beim Zug aus der Heimat im Handwagen, den Mutter zog, ohne so recht wahrzunehmen, was um mich geschah, Mein Zustand war mehr als besorgniserregend. Rückblickend bin ich dankbar, daß es unter den Bedingungen von 1945 für mich ein Krankenhausbett in Frankfurt gab, wodurch ich trotz Medikamentenmangels die gewisse Ruhe, Hygiene und Pflege bekam, die mich allmählich wieder auf die Beine brachten. Ich war mit meinen 16 Jahren nochmal davongekommen. Meine Typhuserkrankung hat noch lange nachgewirkt."

„Lange Nachwirkungen“ dieser medizinischen Rahmenbedingungen der Geschehnisse von Flucht und Vertreibung gab es aber zuweilen auch indirekt. Nachdem ein sechsjähriges Mädchen in Prötzel bei Strausberg, von der Hungersnot geschwächt, im Sommer 1945 an Typhus gestorben war, entschied das sogar über den weiteren Lebensweg seiner Eltern. Denn die

767 Brisch/Buwert/Schieck, Frankfurt (Oder) 1945 (wie Anm. 163), S. 45, 49.

768 Ebd., S. 49 (in den Räumen des früheren Zollamtes, heutigen Museums, in der Junkerstraße, heutige CarlPhilipp-Emanuel-Bach-Straße).

769 Heute Rosa-Luxemburg-Straße.

770 Ebd., S. 48.

771 Ursula Klessen, in: Materne/Gerlach, Gross-Gandern und Klein-Gandern (wie Anm. 351), S. 96 f. 
Mutter wollte sich, wie eine Verwandte berichtet hat, nicht mehr vom Grab trennen, so dass der im Westen befindliche Vater entgegen seiner Planung in die SBZ übersiedeln musste. ${ }^{72}$

Unvorstellbares Elend entstand schon bei Fluchtbeginn und besonders unterwegs, wenn die Betroffenen sich selbst kaum oder gar nicht helfen konnten. So sank die Lebenserwartung etwa der Patienten von Einrichtungen für geistig Behinderte dramatisch. Unter den organisierten Transporten ab Herbst 1945 befanden sich durchaus immer wieder auch ganze Gruppen von Patienten. „So war die tschechische Heil- und Pflegeanstalt Wiesengrund bei Pilsen (Plzeň) Sammelstelle für (sudeten)deutsche Patienten. Ein Transport aus der Tschechoslowakei traf am

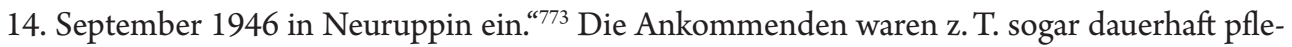
gebedürftig, wie das Beispiel eines bereits am 17. Juni 1939 in Wiesengrund aufgenommenen, damals 30-jährigen berufslosen, ledigen Mannes aus Brüx zeigt, der nun mit dem Transport nach Neuruppin gelangte; denn auf seinem Aufnahmenachweis wurde noch Jahre später, am 20. März 1957, vermerkt „Hilfsbedürftig“ ${ }^{774}$ Solch starker Patientenzuwachs war angesichts der katastrophalen Situation in den brandenburgischen Krankenhäusern zunächst nur schwer zu schultern. Entlastend wirkte immerhin, dass nach und nach die Ausweich- und Verbandskrankenhäuser im Berliner Umland und der weiteren Provinz aufgelöst bzw. nach Berlin zurückverlegt wurden.

\section{Aufnahmegebiete}

Auch wenn Zahlen Dimensionen anzeigen können, sagen sie wenig über die tatsächlichen Verhältnisse aus, wenn z. B. hohe Zahlen angekommener oder anwesender Flüchtlinge nicht durch die zur nachfolgenden Weiterwanderung ergänzt oder in Beziehung gesetzt werden können zur Zahl der Einheimischen, wenn konfessionelle Unterschiede nicht ablesbar sind, die Altersstruktur beider Bevölkerungsgruppen oder die Verteilung der Geschlechter. Einige Beobachtungen über brandenburg-spezifische Verteilungsvorgänge müssen hier gleichwohl genügen. ${ }^{775}$ Immerhin sei eingangs gesagt, dass in Brandenburg nach einer Aufstellung vom April 1946 von in der SBZ insgesamt lebenden 3250000 „Ostflüchtlinge(n)“ 450000 untergebracht waren, während der Spitzenreiter, das allerdings zuvor auch am dünnsten besiedelte Mecklenburg(-Vorpommern), 1100000 hatte, gefolgt von Brandenburgs Nachbar-Provinz Sachsen (zweifellos mit dem ehemaligen Land Anhalt) mit 800000 , dem kleineren Thüringen mit 700000 , in das vor allem 1945 viele Schlesier und Sudetendeutsche geleitet worden waren, und Sachsen mit

772 Albrecht, Die letzten 24 Stunden in der Heimat Landsberg (wie Anm. 342), S. 16.

773 Dietmar Schulze: Die Landesanstalt Neuruppin in der NS-Zeit (Schriftenreihe zur Medizin-Geschichte des Landes Brandenburg, Bd. 8). Berlin 2004, S. 208 (Angabe nach dem Aufnahme- und Entlassungsbuch der Landesanstalt Neuruppin, Bd. VI, 1940-1946, jetzt im Archiv der Ruppiner Kliniken GmbH).

774 Abbildung ebd., S. 207.

775 Siehe ansonsten die für Brandenburg kreisweise und nach Männern, Frauen und Kindern aufgeschlüsselten Eingemeindungsstatistiken für die einzelnen Jahre 1947, 1948, 1949 und 1950 in Oehlsen, Vertriebenenlager (wie Anm. 45), S. 102-105 (verkürzt, nur mit den Gesamtzahlen pro Kreis wiedergegeben auch im Dokumentationsteil der vorliegenden Arbeit). 
„nur“ $300000 .{ }^{776}$ Nach der Volkszählung vom 29. Oktober 1946 hatte Brandenburg 2527492 Einwohner, von denen 533964 am 1. September 1939 ihren Wohnsitz in den späteren Vertreibungebieten gehabt hatten. ${ }^{777}$ Ein Jahr später heißt es in einem Rundschreiben des FDGBLandesvorstandes Brandenburg vom 14. Oktober 1947: „Nach vorhandener Übersicht entfielen von den 15000000 umgesiedelten Deutschen 725000 auf das Land Brandenburg, sodass jeder 3. Brandenburger ein Umsiedler ist." ${ }^{\text {"778 }}$

Die Analyse der Folgen von Flucht und Vertreibung für die ehemaligen Bewohner von Ziebingen (Kr. Weststernberg) hat ein Ergebnis erbracht, das für viele Vertreibungsgebiete, zumal der Neumark, gelten kann, soweit sie am Evakuierungs- und Fluchtgeschehen vor Kriegsende Anteil hatten: „Für viele Landsleute sind die ersten Zufluchtsstätten die endgültige zweite Heimat geworden. Für manche waren sie aber nur vorläufig, denn vor allem in der damaligen sowjetischen Besatzungszone und in den ersten Jahrzehnten der DDR sind viele unter dem politischen Druck, dem sie sich ausgesetzt fühlten, ein zweites Mal geflohen." ${ }^{\text {"779 }}$ Ein im Herbst 1945 in Philadelphia (Kr. Beeskow-Storkow) kommissarisch als Gemeindesekretär fungierender Kriegsheimkehrer, der erst am 30. August selbst aus der Kriegsgefangenschaft zurückgekehrt war, sah die Menschen kommen und gehen: „Flüchtlinge kamen in das Dorf, blieben mehr oder weniger lange und zogen wieder weiter." ${ }^{\text {"780 }}$

$\mathrm{Zu}$ den Regionen mit einem besonders hohen Flüchtlingsanteil gehört die Prignitz - bereits seit Januar 1945. Auch in der katholischen Gemeindegeschichtsschreibung bildet sie eine der wesentlichen brandenburgischen Aufnahmelandschaften, deren Konfessionsstruktur sich änderte, „als katholische Heimatvertriebene in großer Zahl in die Prignitz kamen“781. In Wutike (Kr. Ostprignitz) beispielsweise stieg die Einwohnerzahl von 483 im Jahre 1939 auf 817 im Jahr 1946. ${ }^{782}$ Aber auch in anderen Regionen Brandenburgs, wo der Verlust an Einheimischen noch größer war, glichen die Vertriebenen ihn mindestens aus. In einigen stark zerstörten Orten (auch Städten), deren vor dem Einmarsch der Roten Armee geflohene Bevölkerung nur zum kleineren Teil zurückgekehrt war, wie in Müncheberg (Kr. Lebus) oder Frankfurt (Oder), bildeten die Vertriebenen sogar die quasi neue Bevölkerung. Nennenswert ist der Vertriebenenanteil auch in nahezu allen Teilen der Niederlausitz, keineswegs nur unter den dort trotz Vertreibung im „Heimatbistum“ verbliebenen schlesischen Katholiken.

Die Unterbringung auf dem Land wurde von der Verwaltung, aber auch von den Vertriebenen selbst bevorzugt, da die Städte großenteils stark zerstört waren, während der Wohnraum

776 DAB, I/9-15-1 Flüchtlingsseelsorge 1945-1951, unfol.

777 Endgültige Ergebnisse der Volks- und Berufszählung vom 29. Oktober 1946 (wie Anm. 213), hier H. 7, S. 1.

778 SAPMO-BArch, DY 34/27745, Bl. 99.

779 Manfred Schieche / Gerhard Jaeschke: Ziebingen. Ein Marktflecken im Sternberger Land. Eisenhüttenstadt u. a. 2001, S. 321.

780 Reinhard Kiesewetter: Unser Bürgermeister in Philadelphia. In: Storkower Zeitzeugen berichten [H. 1] (wie Anm. 370), S. 54-56, hier S. 54.

781 Schwillus/Brühe, Erzbistum Berlin (wie Anm. 148), S. 355.

782 HOL I (wie Anm. 165), S. 1019. 
in den meisten Dörfern relativ unbeschadet den Krieg überstanden hatte und die Gutshäuser nun noch hinzugenommen wurden. Auch die Ernährungsfrage war hier zumindest tendenziell leichter zu lösen. Es gibt daher kaum eine (brandenburgische) Landgemeinde, deren Einwohnerzahl sich 1945 nicht deutlich erhöht hätte. Allerdings sollte nicht übersehen werden, dass trotz allem auch in den meisten Städten ein Zuwachs durch Flüchtlinge - in absoluten Zahlen - feststellbar ist. So befanden sich ein Jahr nach Kriegesende, im Mai 1946, beispielsweise in Lübben neben 8644 „Ortsansässigen“ 1619 „Umsiedler“, in dem kleineren Lieberose gar neben 1666 „Ortsansässigen“ 761 „Umsiedler“ ${ }^{783}$ Nicht überall auf dem Land war der Zuzug bzw. die Zuweisung so dominant, dass er in die Hunderte ging, so dass die Hälfte oder bisweilen sogar die Mehrheit (!) der Dorfbewohner Flüchtlinge waren. Ein Anstieg mindestens im höheren zweistelligen, zumeist aber im dreistelligen und mancherorts im vierstelligen Bereich ist jedoch in nahezu sämtlichen Landgemeinden feststellbar. Das zeigt allein schon ein Blick in die entsprechende Rubrik des „Historischen Ortslexikons für Brandenburg“, in dessen Bänden man nur sehr wenige Gegenbeispiele findet. ${ }^{784}$ Ebenso lässt sich an den dort zusammengestellten Einwohnerzahlen bereits sehr schnell erkennen, dass die Zuwanderung der Flüchtlinge und Vertriebenen insgesamt langfristig eine Bevölkerungsvermehrung brachte, dass aber die hohen Zahlen der Anfangszeit 1945/46 sich bis zum Mauerbau 1961 wieder etwas reduzierten, in manchen Fällen wieder auf den vorherigen Stand, in den meisten aber doch auf einen höheren als 1939. Diese Abwanderung ist nicht auf die Gruppe der Flüchtlinge und Vertriebenen beschränkt, die Zwangskollektivierung trieb auch viele Altbauernfamilien in die Flucht. Hinzu kommt - wie überall - die Abwanderung in die in der DDR im Aufbau befindlichen städtischen Industriestandorte.

Der Landrat des Kreises Templin weist am 16. Juli 1945 in der Sitzung des Provinzialverbandes darauf hin, dass solche Unterschiede auch in seinem Bereich eine große Rolle spielten: „Die beiden Städte Templin und Lychen sind zu $50 \%$ niedergebrannt [...]. Dagegen der Bezirk Zehdenick, der auch noch zum Kreis Templin gehört, ist völlig unverseht geblieben."785

Der in Frankfurt (Oder)lebende Arzt Lothar Sonnemann hat beschrieben, wie wenig organisiert man gleichwohl in der chaotischen Anfangszeit bei der Verteilung von Vertriebenentransporten, hier 1946, vorging: „Weshalb bin ich nun heute ein Ossi und kein Wessi? /Viel später erfuhren wir es zufällg von Freunden aus der Heimat, die an dem gleichen Morgen wie wir Köslin verlassen hatten, aber in den Zug gestiegen waren, der dem unsrigen gegenüber stand. / Ebenso wie wir waren sie kreuz und quer durch Norddeutschland gefahren, und schließlich hatte ihre Reise in einer Stadt in Schlewsig-Holstein ihr Ende gefunden. / Nun nannten sie schon wieder Haus und Hof

783 Becken, Lübben nach dem Inferno (wie Anm. 178), S. 32.

784 HOL (wie Anm. 165), jeweils Punkt 10 Bevölkerungsziffern. Für die Niederlausitz fehlen im entsprechenden Werk (Historisches Ortslexikon für die Niederlausitz. Bearb. von Rudolf Lehmann. Bd. 1-2. Marburg 1979) vergleichbare Zahlen. Für Teile des Kreises Potsdam-Mittelmark siehe als Beispiel die entsprechenden Ausführungen, hier sogar z. T. mit den „Umsiedler“-Zahlen, in dem als ortsgeschichtliches Sammelwerk erschienenen Heft 3/4 (1993) von „Der Landkreis Potsdam“, bes. S. 32, 72, 85, 88, 119.

785 Rede des Landrats des Kreises Templin (16. Juli 1945). In: Die Uckermark 1945. T. 1. Prenzlau 1995, S. 110112, hier S. 112. 
ihr eigen. / Hätten wir an jenem kalten Januarmorgen des Jahres 1946 in dem rechts am Bahnsteig stehenden Zug eine freie Ecke gefunden, [S. 31] und wären wir dort eingestiegen, würde ich heute wohl inmitten des schönen Schleswig-Holstein leben und wäre ein Wessi. / Niemand hatte an jenem fernen Januarmorgen ahnen können, welche Bedeutung für ein Leben in Freiheit oder Unfreiheit es haben würde, ob man in den rechten oder linken der am Bahnsteig haltenden Güterzüge einstieg."

Doch schon die Planungen vom Jahresanfang 1945, z. B. der Bevölkerung des „Warthegaus" und Hinterpommerns pro Landkreis einen bestimmten, weiter westlich gelegenen Landkreis als Aufnahmekreis zuzuweisen, führten nur bedingt zum Ziel. Die Geschehnisse lassen sich in vielen Zeitzeugenberichten, $u$. a. von Treckführeren und ehemaligen Kommunalbeamten der Herkunftsgebiete, aber auch in Schilderungen einfacher Flüchtlinge ebenso wie von Einwohnern der Aufnahmegebiete finden. So berichtet der ehemalige Bürgermeister von Trebbin im Kreis Deutsch Krone (ehemals Westpreußen, ab 1938 Pommern) über den Weg des von ihm ab 27. Januar 1945 geführten Trecks, man habe Anfang Februar, auf der „Reichsautobahn (Bäderstraße)“ über Stettin kommend, „vor Prenzlau i.d. Uckermark die Autobahn verlassen“ müssen und sei „über Prenzlau, Woldegk, Neubrandenburg nach Altentreptow“ weitergezogen. „Hier wurde der Treck aufgelöst, da der Kreis Demmin Aufnahmekreis für Deutsch Krone war, und auf mehrere Orte verteilt. / [...] Ein Weitertrecken war von der [NSDAP-]Kreisleitung in Demmin verboten worden, [... . “787 Das Beispiel dieses Trecks einer Landgemeinde des Kreises Deutsch Krone kann bereits als Hinweis darauf dienen, dass die Evakuierungs- bzw. Fluchtwege aus diesem Raum vornehmlich in das Grenzgebiet von (Nord-)Brandenburg, (Ost-)Mecklenburg und Vorpommern führten. So überrascht es nicht, dass auch die in anderen Quellen ermittelten Deutsch Kroner, die nach Brandenburg gelangt waren, ausschließlich in der Uckermark begegnen. Im März 1945 findet sich der Tod eines Flüchtlings-Säuglings im Sterberegister des Standesamtes Prenzlau eingetragen. ${ }^{788} 1946-1948$ schließlich amtierte der aus Deutsch Krone stammende Anton Bigalke als Bürgermeister in Strasburg (Uckermark). Immerhin am Rande erwähnt sei, dass seit 2006 eine Städtepartnerschaft zwischen der zumindest nordbrandenburgischen (Prignitzer) Stadt Kyritz und dem nun polnischen Wałcz (Deutsch Krone) besteht.

Für den ehemals posenschen Kreis Samter („Warthegau“) bestand beispielsweise bereits im Januar die Festlegung des Kreises Westprignitz als Aufnahmekreis. ${ }^{789}$ Der als Treckführer fungierende Bauer Gerhard Jaeckel aus Kammthal (Grzebienisko) hat in seinem Erlebnisbericht festgehalten, dass am Tag des vom Landratsamt Samter an die Ortsvorsteher und Gutsverwaltungen übermittelten „Räumungsbefehls“ noch kein genaues Ziel genannt wurde, sondern nur der Auftrag, „über Neutomischel-Bentschen in Richtung Westen mit noch unbekanntem Ziel“

786 Sonnemann, Bittere Medizin (wie Anm. 269), S. $30 \mathrm{f}$.

787 Dokumentation der Vertreibung I/1 (wie Anm. 192), S. 189-192 (Nr. 46, Teilabdruck einer Niederschrift von 1950), hier S. 190.

788 Reg.-Nr. 217/1945.

789 Vgl. die Erwähnungen im Aufnahmekreis: Dokumentation der Vertreibung I/1 (wie Anm. 192), S. 381. Transitzone Dorf (wie Anm. 248), S. 36. 
abzufahren. ${ }^{790}$ Erst unterwegs, in Neu-Bentschen, wo Jaeckels Treck am 23. Januar eintraf, „waren überall Anschläge vorhanden, aus welchen die einzelnen Kreise ersehen konnten, in welchem Kreis für ihre Unterkunft gesorgt war. Der Kreis Samter sollte in der Westprignitz untergebracht werden." ${ }^{\text {"791 }}$ Auch der Bericht über das Ende des Trecks erweckt den Eindruck von Planung und Planbarkeit: „Über Neuruppin usw. kamen wir am 4. Februar in dem Kreis Westprignitz an, wo wir schon an der Kreisgrenze unser Quartier angewiesen erhielten." Doch verschweigt Jaeckel nicht, dass wegen der chaotischen Verhältnisse - Kriegseinwirkung (flüchtende Wehrmacht), Kälte und Schneetreiben, Sperrungen und Umleitungen, Vermischung mit anderen Trecks - viele Samterer Kreisbewohner und auch Familien voneinander getrennt, Trecks auseinandergerissen wurden und daher an unterschiedlichtsen Orten über die Oder gelangt sind. So wird es kaum allen gelungen sein, die Festlegungen der Zielkreise einzuhalten.

Diese teils ungeplanten äußeren Einflüsse führten ebenso zu einer Zerstreuung wie die häufig durch den schnellen Fortgang der Ereignisse immer wieder nötigen Änderungen offizieller Planungsvorgaben. So erhielt der ehemals posensche Kreis Wollstein („Warthegau“), ob-

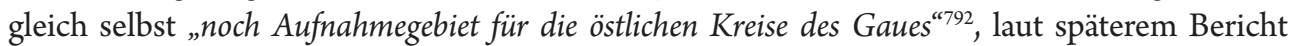
des Wollsteiner Landrates Rolf Schneider am 18. Januar zunächst einen Lebuser Zielort: „Als neue Befehlszentrale wurde Müncheberg bestimmt." 793 Nachdem „die Räumung am 20./21. Januar 1945 planmäßig durchgeführt werden“" konnte und die Trecks zu den Oderübergängen bei Neusalz (Schlesien), Crossen/Oder und Frankfurt (Oder) aufgebrochen waren, wurde am 24. Januar bekannt, „daß der Kreis Jüterbog-Luckenwalde für den Kreis Wollstein Aufnahmekreis sei. Von dem Wollsteiner Verwaltungsstab wurden die Herren Schnirpel, Schulz, Strunk und Tiemann den Trecks nachgesandt, die eine entsprechende Benachrichtigung vornahmen. Die Aufnahme und Unterbringung im Aufnahmekreis erfolgte dann durch den Meldekopf Wollstein in Baruth. Spätere Verlegung in den Kreis Nauen ${ }^{794}$ und Uelzen (Meldekopf Suhlendorf). “795 Teile der Bevölkerung wurden auch mit Eisenbahntransporten evakuiert, „ein kleiner Teil der Flüchtlinge, insbesondere Angehörige der Volksliste 3, [die] in den ersten Trecktagen Zweifel über die Zweckmäßigkeit eines Trecks bekamen, kehrten um und ließen sich von den Russen überrollen." ${ }^{\text {"796 }}$ Von diesen, später z. T. in Polen verbliebenen Kreisbewohnern abgesehen, kam zwar die übergroße Mehrheit, ca. 7500 Flüchtlinge, im Kreis Uelzen unter, ca. 200 aber auch im Kreis Osthavelland und ca. 300 im Kreis Jüterbog-Luckenwalde. ${ }^{797}$

Dokumentation der Vertreibung I/1 (wie Anm. 192), S. 379-381 (Nr. 100, Teilabdruck einer Niederschrift von 1951), hier S. 379.

Ebd., S. 380.

Dokumentation der Vertreibung I/1 (wie Anm. 192), S. 381-384 (Nr. 101, Teilabdruck einer Niederschrift von 1952), hier S. 382. Hier befanden sich z. B. auch schon zuvor umgesiedelte Deutschbalten, Bessarabiendeutsche, Bukowina- und Galiziendeutsche usw. sowie ca. 1800 „Bombenflüchtlinge aus dem Altreich“.

Ebd., S. 383.

[Gemeint ist der damalige Kreis Osthavelland mit der Kreishauptstadt Nauen.]

Dokumentation der Vertreibung I/1 (wie Anm. 192), S. 383.

Ebd., S. 384.

Ebd., S. 383. 
„Im April 1945 hielten sich in der Mark Brandenburg Hunderttausende Evakuierte und Flüchtlinge auf, überwiegend vor den Luftangriffen in das Umland geflüchtete Berliner, insbesondere aber Personen aus den Gebieten östlich der Oder, aus der Tschechoslowakei und aus westlichen Teilen Deutschlands." ${ }^{\text {"798 }}$ Nach Ende der Kampfhandlungen setzte allerorten eine Rückkehrbewegung ein, jeder wollte an seinen Wohn- bzw. Heimatort zurück. Zu diesem Menschenstrom, der in alle Himmelsrichtungen erfolgte, traten noch - wie man immer wieder betonen muss - die tausenden befreiten Zwangsarbeiter und ausländischen Kriegsgefangenen, die befreiten KZ-Häftlinge und bereits auf eigene Faust nach Hause strebende deutsche Soldaten, die der Kriegsgefangenschaft entgangen waren oder noch nicht von ihr erfasst waren. „Bis zum Juli 1945 kehrten 1125000 Menschen wieder in ihre alten Wohnorte zurück, davon etwa bis 400000 in östlicher Richtung. ${ }^{\text {"799 }}$ Die erst im (Wieder-)Aufbau befindlichen lokalen und provinzialen Verwaltungen „waren von der Eigendynamik dieser neuzeitlichen Völkerwanderung im Sommer 1945 überfordert “. 800 Versuche, die zahllosen individuellen Personenbewegungen zu steuern und sie als illegal zu klassifízieren, wurden allenthalben unternommen, konnten aber nur einen Teil der Menschen davon abhalten, ihr Ziel weiter zu verfolgen. Anfang Juni 1945 befahl beispielsweise „die Kreiskommandantur Teltow, daß alle, de ut s ch e n Flüchtlinge, die ihren Wohnort noch im Kreise Teltow haben und an ihren früheren Wohnort zurückkehren wollen', dafür einen schriftlichen Erlaubnisantrag an die Kreiskommandantur zu stellen hätten. Erst nach erfolgter Reisegenehmigung durch die Kreiskommandantur Teltow dürfe die ,Rückwanderung' erfolgen, hieß es. ${ }^{\text {“801 }}$ Reisen in andere Besatzungszonen, auch zwecks Wohnortwechsels, waren überdies bis 1947 „nur zu geschäftlichen Zwecken erlaubt und auf eine Dauer von 15 Tage beschränkt“. Auch noch nach einer Verfahrensänderung musste der Reisewillige nicht nur beim Bürgermeister einen Antrag stellen, wozu „ein Fragebogen (gehörte), der auf deutsch und Russisch auszufüllen war“. Nach Genehmigung durch die sowjetische Kreiskommandantur musste der Reiseanwärter seine Reisedokumente auch noch - mit drei Lichtbildern - bei der Bezirkskommandantur vorlegen, dasselbe war nach der Reise als Rückmeldung erforderlich, wobei der Ausweis wieder abzugeben war. ${ }^{802}$

Innerhalb Brandenburgs ergaben sich jedoch in den ersten Jahren aufgrund der reinen Ernährungs-, Unterbringungs- und Beschäftigungsnöte vielerlei geplante und ungeplante Wanderungsbewegungen. Wer nach Kriegsende zunächst in eines der „Umsiedlerlager“ geleitet worden war, kam durch die offizielle Einweisung in Wohnraum bisweilen in einem der zum betreffenden Landkreis gehörigen Orte unter, andere wurden nach ferneren Orten verlegt

798 Müller, Nachkriegsjahre in Eichwalde. (wie Anm. 177), S. 101.

799 Ebd., S. 101, Fn. 210.

800 Ebd., S. 102.

801 Ebd., S. 102 (Quellenzitat dort zitiert nach: Schulzendorfer Nachrichtenblatt, Nr. 35, 12. Juni 1945, Hervorhebung im Original).

802 Rolf Radochla: Vor 70 Jahren - Zonenreisebestimmungen im Kreisblatt. In: Kippensand. Heimatkalender für das Senftenberger Gebiet 5 (2017), S. 6. Der Beitrag betrifft das Calauer Kreisblatt, hier war die Bezirkskommandantur Cottbus zuständig. 
oder dann doch in andere Länder bzw. Zonen transportiert. Eine weit mehr von Zufällen und aktueller Frontlage abhängige Verteilung ergab sich für die noch vor Kriegsende Geflohenen und Evakuierten. Viele von ihnen fanden oder suchten sogar gezielt private Unterbringung bei Verwandten, Freunden und Bekannten, so dass diese Fluchtgruppe von Januar und Februar 1945 offenbar keine langen Lageraufenthalte zu absolvieren hatte. Die chaotischen Rahmenbedingungen in den letzten Kriegsmonaten, in denen sich viele Verwaltungsstrukturen auflösten, ermöglichten wohl auch manchem Flüchtling, sein Ziel stärker selbst zu bestimmen, jedenfalls aber nicht auf Einweisung warten zu müssen. Claus Krätzner, der sich mit dem neumärkischen Kreis Königsberg näher befasst hat, schließt aus der Wohnsitzverteilung seiner Untersuchungsgruppe, „daß die aus den weiter östlich gelegenen Kreisen Ostbrandenburgs kommenden Flüchtlinge und Vertriebenen nach den bereits zurückgelegten langen Wegen versuchten, bald hinter der Oder eine neue Bleibe zu finden, während die aus der odernahen Kreisstadt Königsberg noch eher bereit waren, weiter entfernt liegende Fluchtziele zu erreichen".803 Solchen an sich logisch erscheinenden Schlüssen gegenüber ist allerdings Vorsicht geboten. Aus dem Süden Brandenburgs, im durch die Neiße geteilten Landkreis Guben, ist bekannt, dass gerade hier viele Bewohner der neißenahen Dörfer (Ost) bewusst kurz hinter der Neiße in Dörfern (West) verblieben, um für den Fall der Änderung der Verhältnisse ihren Höfen nahe zu sein und diese schnell wieder in Besitz nehmen zu können. Auch aus dem Stadtgebiet Gubens ist bekannt, dass viele Bewohner der Osthälfte in die Westhälfte wechselten. Alle diese Flüchtlinge beendeten ihre Flucht also bereits nach kürzestem Weg.

In Krayne westlich Guben trafen bei den „Wilden Vertreibungen“ im Juni 1945 „,vor allem Flüchtlinge aus Drenzig, Döbern, Vettersfelde und Tschernitz ein, die auf die Gehöfte aufgeteilt wurden, insgesamt mehr als 30 Familien.“ Hier handelte es sich im wesentlichen um eine „Bevölkerungsverschiebung “ innerhalb des alten Gubener Landkreisgebietes, in dieser Grenzregion kein Einzelfall. Auch wenn diese Vertreibung mit dem Totalverlust an Hab und Gut verbunden war, spielte die Nähe zum Heimatdorf für viele Betroffene eine große Rolle in der seelischen Bewältigung ihres Schicksals. Einerseits führte sie die Tatsachen besonders schmerzlich vor Augen, zumal nicht wenige Vertriebene sich hier in eine Art Warteposition für den Fall der Gebietsrückgabe sahen; andererseits blieb ihre „Wohnsitzverlagerung“ landschaftlich und landsmannschaftlich, d.h. auch mundartlich und kulturell nicht mit einer Entwurzelung verbunden, wie sie viele andere erlebten, die es in eine konfessionell, wirtschaftlich, landschaftlich und klimatisch z. T. vollkommen konträre Neuheimat verschlug. Insofern bildet dieses Phänomen - gesteigert bei jenen, die ihre alten Höfe und Häuser am andern Oder- oder Neiße-Ufer weiterhin sehen konnten - innerhalb der Gesamtgruppe der aus dem Osten Vertriebenen einen Sonderfall, der eine Minderheit betrifft. Zu beobachten sind solche Fälle jedoch überall, wo der Fluss die neue Grenze bildete, in der (Neu-)Mark, der Niederlausitz und auch in Schlesien und Sachsen. ${ }^{804}$ 
Die Neumärker und Niederlausitzer, aber auch die aus dem angrenzenden Teil Niederschlesiens Gekommenen blieben zu einem erheblichen Teil in Grenznähe, manche Familien bis heute. Dies ist vielfach belegt, so zum Beispiel für viele Einwohner von Peetzig (Kr. Königsberg/Nm.), einem unmittelbar am Ostufer der Oder gelegenen Dorf. Ein von dort stammender Bauernsohn hat noch im Jahr 2000 überliefert, die im Mai 1945 noch einmal in ihr Heimatdorf zurückgekehrten, aber am 17. Juni endgültig vertriebenen Peetziger „klammerten sich auch jetzt noch an die Nähe zum Heimatdorf, immer in der Hoffnung, am Tage der Rückkehr als erste in Peetzig eintreffen zu können. So finden wir ihre Familiennamen bis heute hauptsächlich in den Dörfern zwischen Schwedt und Hohensaaten." ${ }^{\text {"05 }}$ Sie lebten also jahrzehntelang unmittelbar gegenüber von Peetzig auf dem westlichen Oderufer. Für das Beispiel der neumärkischen Gemeinde Ziebingen (Kr. Weststernberg) hat die Analyse einer Vielzahl von dort stammender Zeitzeugenberichte ergeben: „Der Gedanke der Heimkehr ließ [...] viele nicht los. Deshalb blieben wohl die meisten zumindest in den ersten Nachkriegsjahren, oft durch Verwandte oder Bekannte dazu ermuntert, in den angrenzenden westlich der Oder gelegenen Landstrichen. [... ] Schwerpunktmäßig harrte man so in den Regionen Frankfurt/Fürstenberg [Oder], Beeskow/ Storkow, Mittenwalde/Ragow und Drewitz/Potsdam aus. Viele allerdings, vor allem aus der nichtbäuerlichen Bevölkerung, zog es auch ganz weit westwärts. “806 Als weiteres Beispiel für die bisweilen sogar ganz unmittelbare Nachbarschaft von altem und neuem Heimatort mag die vertriebene Bevölkerung von Kuschern (Kr. Guben) genannt werden. Der Ort liegt direkt an der Neiße kurz vor ihrer Mündung in die Oder. Die Bewohner, teilweise schon zuvor vorübergehend geflüchtet, wurden am 20. Juni 1945 etwas weiter südlich, bei Guben, „in Buderose über die Neiße abgeschoben. Viele Kuscherner blieben in Guben und umliegenden Dörfern (Coschen, Breslack, Ratzdorf, Neuzelle u. a.) sowie in Fürstenberg, einige suchten in Westdeutschland eine neue Heimat. ${ }^{\text {"807 }}$

Ein Extrembeispiel ist aus dem Raum Bad Freienwalde (Oder) überliefert, das Erhard Bräsike aus der - mit Erzählungen seiner Eltern und Großeltern angereicherten - Kindheitserinnerung geschildert hat. ${ }^{808}$ Hier waren Familien aus dem am östlichen Oderufer gelegenen Niederwutzen bei der Flucht 1945 in den beiden unmittelbar gegenüber liegenden Gemeinden Hohenwutzen und Neuglietzen gelandet. Zehn Familien waren jedoch in Niederwutzen ver-

805 Karlheinz Gleß: Peetzig/Piasek - Erinnerungen an ein Dorf an der Oder. In: Vertreibung aus dem Osten. Hrsg. von Hans-Jürgen Bömelburg, Renate Stößinger, Robert Traba. Olsztyn 2000, S. 83-93, hier S. 91.

806 Schieche/Jaeschke, Ziebingen (wie Anm. 779), S. 320. - Siehe auch die deutlich erkennbare Häufung in den grenznahen Gebieten in der SBZ-Verteilungskarte für das 1946 (Peter-Heinz Seraphim: Die Heimatvertriebenen in der Sowjetzone. Berlin 1954, Karte 11).

807 Wandke, Aufbruch ins Ungewisse. (wie Anm. 348), S. 260. - Für den odernahen Raum Eisenhüttenstadt/ Frankfurt (Oder) hat man noch 1993 (!) diagnostiziert: „Vorbehalte und Erinnerungen an ihre Vertreibung 1945/46 aus polnischen Westgebieten bewegen verschiedene Deutsche in der hiesigen Grenzregion bis heute." Rolf Schade: Die Geschichte an der Oder befragt. In: Heimatkalender Eisenhüttenstadt und Umgebung 11 (1993), S. 55-58, hier S. 55.

808 Erhard Bräsike: Meine Kindheit in Niederwutzen. In: Viadrus 6 (2014), S. 67-72. 
blieben, darunter das Ehepaar Prawitz, nun durch die Oder von ihrer Tochter mit Mann und mehreren Kindern in Neuglietzen getrennt: „Unsere Familien wurden zum Kriegsende getrennt. Wir mussten zweimal auf die Flucht gehen. Nach der letzten Rückkehr blieben die meisten Familien auf dieser Seite der Oder. Unsere Familien fanden in Hohenwutzen und Neuglietzen eine Unterkunft. Aber immer in der Hoffnung: ,Wi koenen ja balle wedder na Hus'" "809 Ein 1941 geborener Enkel des Ehepaars Prawitz, eben jener Erhard Bräsike, wurde 1945/46 mehrmals über die Oder geschickt. „Mit Einverständnis von Polen und Russen bestand ein kleiner Fährverkehr zwischen Hohenwutzen und Niederwutzen, ca. einmal im Monat. [...] Bei den Eltern gab es wenig zu essen. Deshalb wurden wir Kinder monatlich zu den Großeltern ausgetauscht zum ,Durchfuttern'. [...] Von dieser Zeit sind über dreißig Briefe erhalten, die meine Großmutter aus Niederwutzen an meine Eltern in Hohenwutzen geschrieben hat. Teilweise auf Packpapier geschrieben, kamen die Briefe oft auf rätselhafte Weise zum Empfänger. Die Oma schreibt des öfteren von den ,Männern' oder von, unserem Überbringer ““ ${ }^{\prime 810}$ Dieser „Grenzverkehr“ wurde dann aber doch unterbunden: „[...], die Grenze wurde dichtgemacht und ich war bei den Großeltern in Polen." ${ }^{11}$ Als die Großmutter mit anderen Frauen auf dem Ostufer zur Arbeit - Säuberung von Soldatengräbern - eingesetzt war und den Enkel bei sich hatte, wurden die Arbeiten plötzlich „durch Rufe vom Hohenwutzener Ufer“ unterbrochen. „Meine Oma wußte sofort, wer auf der anderen Seite rief. - - - Es war mein Vater - - -. Meine Oma sagte mir ein paar Worte oder Sätze vor, die ich rufen sollte und mein Vater antwortete. So kam der erste bewußte Kontakt, über die Oder, zu meinem Vater zustande."

Im Winter kam es dann erneut zu einem direkten „Grenzverkehr“: „Der Winter 1946/47 brachte viel Schnee und Frost. Die Oder war fest zugefroren. ,Unsere Männer' gingen manchmal heimlich übers Eis nach Hohenwutzen. Nur nicht erwischen lassen. Die zugefrorene Oder wurde von beiden Seiten aufmerksam beobachtet. Dabei hatte der deutschen Bürgermeister Kontakt zu den Russen in Hohenwutzen. Bei dieser Gelegenheit wurde meine ,Umsiedlung' nach Hohenwutzen ausgehandelt. Alles natürlich streng geheim. Als Preis oder Bezahlung waren ein paar Flaschen Schnaps und Glasscheiben aus der Fabrik ausgemacht. Am 12. Januar 1947 war es dann so weit. Eingeweiht waren meine Großeltern, der Bürgermeister Franz Rex und ein Pole mit Namen Janek. Vom Bollwerk wurde ich abends illegal über die zugefrorene Oder zur Fährbuhne auf Hohenwutzener Seite geschmuggelt. Eine große Bettdecke und Sachen zum Anziehen wurden mit rüber gebracht. Ein Schlitten war auch dabei. Wer die zugefrorene Oder kennt, weiß, dass alles getragen werden musste. Ich weiß noch, ich musste meine Holzschuhe ausziehen, um nicht unnötige Geräusche zu machen. Somit bin ich auf Socken gelaufen. Alles ging gut." ${ }^{\text {“813 }}$ Der Bürgermeister und der Pole Janek wurden, nachdem das Verschwinden des Kindes bekannt geworden war, vorübergehend verhaftet und verhört. Die Ausweisung der Großeltern und der sonstigen deutschen Restbevölkerung von Niederwutzen

809 Ebd., S. 67.

810 Ebd.

811 Ebd.

812 Ebd., S. 71.

813 Ebd. 
erfolgte erst am 27. August 1947. ${ }^{114}$ Solche illegalen „Grenzgänge“, wie sie die aus Hohen- und Niederwutzen überlieferten Beispiele zeigen, waren ausgesprochen gefährlich, da sowjetische und polnische Soldaten von der Schusswaffe Gebrauch machten; sie werden in den Quellen auch kaum erwähnt und sind folglich schwer zu fassen, allenfalls in Erinnerungsberichten. Dass sie bei denjenigen Vertriebenen, die gleichsam nur das Flussufer gewechselt hatten, wohl doch mehrfach vorgekommen sind, legen Beobachtungen aus dem Nachbarland Sachsen nahe, wo sich im Sommer und Frühherbst 1945 aus mutigen Jugendlichen „regelrechte Gruppen herausgebildet“ hatten, „die sich in den Dörfern auskannten und meist in den Abend- und Nachtstunden loszogen", um bisweilen und nicht immer mit Erfolg sogar Nutztiere über die Neiße zu bringen. ${ }^{815}$ Offenkundig ging es nicht immer nur um die Beschaffung zurückgelassener Gegenstände, sondern es wurden sogar Tauschobjekte von West nach Ost mitgenommen, um im Gegenzug Lebensmittel zu erhalten. Im Zittauer Zipfel endeten diese waghalsigen Unternehmungen im Herbst 1945, als auf polnischen Gebiet die Wiederbesiedlung der Gehöfte zunahm.

Nur schwer fassbar sind nachbarschaftliche Netzwerke, die über Flucht und Vertreibung hinweg Bestand hatten, da die Mehrheit der Vertriebenen nicht in einem geschlossenen Ortsoder Familienverband angesiedelt wurde. Es gab aber - neben aller Fluktuation an den Zielorten, allem Weiterwandern - durchaus einige Fälle nennenswerter Gruppen von Familien, die aus demselben Heimatdorf gemeinsam geflohen oder vertrieben worden waren und auch im selben Aufnahmeort oder doch in benachbarten Orten landeten und bis heute blieben. Da sie in der SBZ und der DDR keine öffentlich sichtbare Organisationsform gründen durften, war die Kommunikation ganz auf den privaten Bereich beschränkt. Erst nach 1990 wurde an vielen Orten auch für den Außenstehenden sichtbar, welche Herkunftsregionen und -orte vornehmlich vertreten waren und sind.

Ein Beispiel ist das uckermärkische Dorf Bredereiche (Kr. Templin), heute Ortsteil von Fürstenberg/Havel. Bereits Anfang Februar 1945 wurde hier ein Teil des aus Nahausen im Kreis Königsberg/Neumark, kurz hinter Schwedt/Oder, eingetroffenen Trecks einquartiert. ${ }^{816}$ Obgleich viele dieser Flüchtlinge nach dem Ende der Kampfhandlungen in ihr nun bereits polnisches Heimatdorf zurückgingen, kamen nach der endgültigen Vertreibung im Juni 1945 einige erneut nach Bredereiche. „Viele der Nahausener sind später noch einmal geflüchtet, meist nach Westberlin, andere zogen dorthin, wo sie Arbeit fanden. Aber eine größere Gruppe blieb auch in Bredereiche." Das eigene aktive Integrationsbemühen der Betroffenen spiegelt sich in der bilanzierenden Formulierung eines ihrer Chronisten, der selbst nicht zu den Vertriebenen, sondern den Einheimischen ${ }^{817}$ zählte (2002): „Durch Fleiß und Tüchtigkeit haben sie die Verluste von

817 Nach 1945 zugewandert aus dem Erzgebirge (Sachsen) (Auskunft der Witwe des 2016 verstorbenen Erich

Köhler, Bredereiche, 27.1.2017).

Ebd., S. 72.

Dannenberg, Flucht und Vertreibung im Zittauer Zipfel (wie Anm. 18), S. 161.

Köhler, Das Flüchtlingselend neumärkischer Familien (wie Anm. 168), hiernach auch die folgenden Zitate (S. 103). 
Tab. 4: Herkunftsgebiete der Vertriebenen in den brandenburgischen Kreisen, 0kt. 1946

Quelle: Endgültige Ergebnisse der Volks- und Berufszählung vom 29. Oktober 1946. Folge 1-8. In: Statistische Praxis 3 (1948), Beil. zu H. 5-12, hier H. 7, S. 1-4: Folge 3: Die Wohnbevölkerung der sowjetischen Besatzungszone nach dem Wohnsitz bei Ausbruch des Krieges (1. September 1939), S. 1: Land Brandenburg.

Abkürzungen: Balt. = Estland, Lettland, Litauen einsch. Memelland. - Brand. $=$ Brandenburg östlich der Oder [und Neiße]. - Dzg. $=$ Freistaat $[$ Freie Stadt] Danzig. - Pol. $=$ Polen. - Pom. $=$ Pommern östlich der Oder. - Opr. $=$ Ostpreußen. - Rum. $=$ Rumänien. - Schl. $=$ Schlesien und Sachsen östlich der Oder und Neiße. - Sowj. $=$ Sowjetunion. Tsch. = Tschechoslowakei. - * Lagerinsassen: „Insassen von Umsiedler-, Kriegsgefangenen- usw. Durchgangslagern“.

\begin{tabular}{|c|c|c|c|c|c|c|c|c|c|c|}
\hline Kreis & Opr. & Pom. & Brand. & Schl. & Tsch. & Pol. & Dzg. & Rum. & Balt. & Sowj. \\
\hline Angermümde & 2435 & 7205 & 4367 & 2978 & 395 & 1348 & 387 & 314 & 204 & 79 \\
\hline Beesk.-Stork. & 1474 & 1490 & 8302 & 2265 & 1519 & 1152 & 309 & 57 & 104 & 54 \\
\hline Brandenburg & 1823 & 1329 & 1360 & 2549 & 318 & 633 & 199 & 37 & 223 & 42 \\
\hline Calau & 850 & 707 & 4694 & 14672 & 2943 & 2042 & 83 & 97 & 139 & 48 \\
\hline Cottbus-Stadt & 328 & 262 & 1902 & 4613 & 574 & 553 & 65 & 28 & 45 & 13 \\
\hline Cottbus-Land & 504 & 314 & 6252 & 9748 & 600 & 556 & 54 & 18 & 28 & 40 \\
\hline Eberswalde & 417 & 1083 & 520 & 394 & 101 & 230 & 203 & 3 & 43 & 28 \\
\hline Forst & 44 & 38 & 1301 & 500 & 76 & 93 & - & 1 & 9 & 4 \\
\hline Frankfurt & 397 & 389 & 3169 & 813 & 125 & 333 & 57 & 47 & 23 & 16 \\
\hline Guben-Stadt & 27 & 42 & 1254 & 463 & 29 & 60 & 18 & 3 & 13 & 2 \\
\hline Guben-Land & 92 & 212 & 9090 & 960 & 46 & 159 & 5 & 10 & 7 & 38 \\
\hline Lebus & 1717 & 2023 & 13617 & 3264 & 701 & 2375 & 251 & 658 & 135 & 191 \\
\hline Luckau & 1108 & 665 & 6068 & 11376 & 4073 & 1866 & 96 & 125 & 290 & 90 \\
\hline Luckenwalde & 1945 & 1890 & 2735 & 6606 & 2525 & 5698 & 208 & 1031 & 612 & 141 \\
\hline Lübben & 497 & 341 & 7373 & 4241 & 1458 & 504 & 42 & 22 & 85 & 8 \\
\hline Niederbarnim & 4088 & 4671 & 6203 & 3698 & 2858 & 2556 & 514 & 112 & 298 & 151 \\
\hline Oberbarnim & 2500 & 3510 & 10043 & 3313 & 274 & 2311 & 290 & 96 & 185 & 105 \\
\hline Osthavelland & 3515 & 3831 & 8524 & 4353 & 2628 & 2868 & 443 & 146 & 375 & 156 \\
\hline Ostprignitz & 3833 & 3664 & 9590 & 3225 & 1513 & 8036 & 535 & 1269 & 1227 & 204 \\
\hline Potsdam & 2391 & 2137 & 3573 & 2924 & 406 & 1430 & 360 & 127 & 501 & 96 \\
\hline Prenzlau & 2070 & 12019 & 1632 & 2504 & 220 & 2099 & 262 & 219 & 217 & 116 \\
\hline Rathenow & 351 & 451 & 289 & 498 & 136 & 435 & 99 & 49 & 438 & 31 \\
\hline Ruppin & 4694 & 5154 & 13553 & 4226 & 2511 & 3932 & 621 & 399 & 397 & 129 \\
\hline Spremberg & 247 & 142 & 1345 & 2921 & 447 & 401 & 35 & 17 & 42 & 11 \\
\hline Teltow & 3665 & 3324 & 5771 & 5021 & 2817 & 4465 & 318 & 541 & 292 & 284 \\
\hline Templin & 2960 & 4770 & 5026 & 2359 & 275 & 2551 & 864 & 196 & 215 & 105 \\
\hline Westhavelland & 1714 & 2148 & 2756 & 2137 & 3061 & 5874 & 476 & 1678 & 223 & 444 \\
\hline Westprignitz & 3067 & 3291 & 4274 & 3001 & 2770 & 7704 & 500 & 1010 & 401 & 118 \\
\hline Wittenberge & 2331 & 634 & 381 & 945 & 160 & 433 & 262 & 57 & 124 & 33 \\
\hline Zauch-Belzig & 2611 & 2611 & 5251 & 8083 & 3214 & 4906 & 308 & 1125 & 368 & 94 \\
\hline Summe & 53695 & 70347 & 150215 & 114650 & 38774 & 67603 & 7864 & 9492 & 7263 & 2871 \\
\hline Lagerinsassen* $^{*}$ & 546 & 193 & 159 & 6947 & 1427 & 571 & 80 & 1225 & 19 & 24 \\
\hline Summe & 54241 & 70540 & 150374 & 121597 & 40200 & 68174 & 7944 & 10717 & 7282 & 2895 \\
\hline
\end{tabular}


1945 aufgeholt, einige haben hier Partner für das Leben gefunden." Gelassenheit, aber auch Mitfühlen, spricht auch aus der vom selben Verfasser stammenden Beschreibung der Situation nach der Wende: „Alle zwei Jahre treffen sich die immer weniger werdenden Überlebenden in Schwedt zum Heimattreffen. Fast alle haben ,ihr Dorf' schon einmal besucht. Zwölf Nahausener leben heute noch in Bredereiche." ${ }^{\text {"818 }}$

\section{Herkunftsgebiete - landsmannschaftliche Differenzierung}

Heike Amos hat ein meist wenig beachtetes, aber doch wesentliches Element der assimilierenden Integration der Flüchtlinge und Vertriebenen in die SBZ-/DDR-Gesellschaft hervorgehoben: „Der repressiven SED-Vertriebenenpolitik war es [...] gelungen [...] die Vertriebenenidentität zu privatisieren, zu vereinzeln [S. 246] sowie die landsmannschaftliche Identität der Flüchtlinge und Vertriebenen zu unterdrücken. “819 Über „Flüchtlinge“ bzw. „Umsiedler“ konnte man unter bestimmten Umständen auch in den späteren DDR-Jahrzehnten rückblickend durchaus sprechen, vorausgesetzt man akzeptierte die offizielle Linie, dass deren Integration bereits seit 1950/52 abgeschlossen gewesen sei. Ganz undenkbar aber war die Thematisierung konkreter landsmannschaftlich definierter Flüchtlings- bzw. Vertriebenengruppen, sieht man von der - (partei-)politisch noch enger gefassten - Sondergruppe der mit den „Antifa-Transporten“ aus der Tschechoslowakei gekommenen Sudetendeutschen ab, die unter letzteren auch nur eine „Teilmenge“ bildeten.

Aus der gleichsam egalisierenden Gruppenbildung, die kaum noch Binnendifferenzierungen der Vertriebenen zuließ, aber ebenso dem Mangel entsprechender Quellen ergibt sich bis heute, dass auch in fast allen übergreifenden Darstellungen zu Vertriebenen in Brandenburg das landsmannschaftliche Element fehlt. Nur ganz selten wird konkret von Schlesiern oder Ostpreußen usw. gesprochen. Wenn sich in den lokalen Darstellungen solche Aufzählungen finden, stehen sie mehr stereotyp als Versuch einer begrifflichen Variante, ohne dass gesichert wäre, dass genau die genannten Herkunftsregionen am jeweiligen Ort wirklich repräsentiert waren. Im Folgenden soll daher ansatzweise versucht werden, die in Brandenburg untergekommenen Vertriebenen auch nach ihrer regionalen Herkunft zu betrachten. Denn dies geschieht bislang allenfalls - für Öffentlichkeit und Wissenschaft unsichtbar - landsmannschaftsintern, also ohne den gleichzeitigen Blick auf „das Ganze“, während die unspezifische begriffliche Bündelung, wie man sie in der DDR entwickelt hatte, seit 1990 sogar von der Strategie des BdV - „Einigkeit macht stark“ - befördert wird, der eine allzu deutlich sichtbare landsmannschaftliche Differenzierung unter seinen Mitgliedern eher als Schwächung seiner Position sehen muss.

Die Forschungen zu landsmannschaftlicher Verteilung in Brandenburg sind dadurch erheblich erschwert, dass es bis 1990 kaum Quellen dazu gibt, die theoretisch verwendbaren Anschriftenlisten der westdeutschen Vertriebenenverbände vor 1990 und Mitgliederverzeich- 
nisse örtlicher Verbände nach 1990 - schwer zugänglich sind. Erstere sind lückenhaft, letztere sind noch kaum zugänglich und enthalten ohnehin nur einen Teil der Vertriebenen. Hinzu kommt die große Fluktuation der SBZ-/DDR-Bevölkerung sowohl republik- und brandenburgintern als auch bezüglich der „Republikflucht“. Dennoch lassen sich gewisse Schwerpunkte aus Indizien und anderen Auffälligkeiten hochrechnen, zumal es neben der - bisweilen überbewerteten - Fluktuation auch erstaunliche Kontinuitäten gibt. So sind die noch vor Kriegsende mit den Trecks und Eisenbahntransporten geschaffenen Fakten, wie im Fluchtkapitel bereits gezeigt werden konnte, teilweise noch heute erkennbar, wenn etwa damalige EvakuierungsZielkreise auch nach 1990 weiterhin Schwerpunkte für Heimattreffen derselben Herkunftskreise bilden. Ähnliches lässt sich bei den späten Kindertransporten aus Ostpreußen sagen, die in den Nachkriegsjahren nach Brandenburg kamen. Insgesamt können hier gleichwohl nur einige Beobachtungen mitgeteilt werden, die über den bisherigen Kenntnisstand zwar bereits hinausgehen ${ }^{820}$, aber zugleich den noch bestehenden Bedarf weiterer Einzelforschung deutlich vor Augen führen.

Selbst mit allen vorgenannten Einschränkungen im Hinterkopf lohnt ein Blick in die Mitgliederliste des BdV-Kreisverbandes Potsdam ${ }^{821}$ mit Stand vom 19. Juni 2003. ${ }^{822}$ Denn sie enthält, was sonst meist fehlt, auch die Geburtsorte und, zusätzlich erleichternd, eine Zuordnung zu Herkunftsregionen, wobei sich der Ersteller der Liste nach der in den Vertriebenenverbänden üblichen Regionaleinteilung und den entsprechenden Bezeichnungen gerichtet hat, was der Einfachheit halber hier übernommen wird.

Tab. 5: Herkunftsregionen der Mitglieder des BdV-Kreisverbandes Potsdam 2003

\begin{tabular}{|l|c|}
\hline Schlesien & 108 \\
\hline Ost-Brandenburg & \multicolumn{1}{|c|}{92} \\
\hline Pommern & 53 \\
\hline Ostpreußen & 45 \\
\hline Weichsel-Warthe ${ }^{824}$ & 27 \\
\hline Sudetenland & 15 \\
\hline Westpreußen & 12 \\
\hline Bessarabien & 1 \\
\hline Bukowina & 1 \\
\hline
\end{tabular}

820 Christopeit, Herkunft und Verteilung (wie Anm. 29), S. 96.

821 Das Einzugsgebiet des inzwischen aufgelösten Verbandes waren die DDR-zeitlichen Kreis Potsdam-Stadt und Potsdam-Land, womit sich Überschneidungen zum Mitgliederbestand des Kreisverbandes Potsdam-Mittelmark (Sitz Brandenburg an der Havel) ergeben haben dürften.

822 Für die großzügig gewährte Einsicht ist Herrn Clemens von der Potsdamner Geschäftsstelle des BdV-Landesverbandes Brandenburg sehr zu danken.

823 Einschließlich von 6 Mitgliedern aus „Brandenburg“.

824 „Weichsel-Warthe“: 24, „Warthegau“ 2, „Schwarzhauland“ (ohne Zusatz) 1. 
Auch Ab- und Binnenwanderung vor dem Mauerbau sowie nach der Wende von 1989/90 können kaum etwas an den Größenverhältnissen in den „Spitzengruppen“ geändert haben. Dazu ist nicht nur deren Dominanz zu eindeutig. Vergleicht man nämlich diese Zahlen mit den Erkenntnissen aus allen anderen brandenburgischen Regionen, die - ohne dass dort eine ähnliche Quelle benutzt werden konnte - in den Dokumentationsteil der vorliegenden Arbeit eingeflossen sind, d.h. mit einer Vielzahl immerhin von Indizien, so darf man das statistische Bild mit einiger Vorsicht, aber doch guten Gewissens sogar als für Brandenburg weitgehend repräsentativ bezeichnen. In geradezu frappierender Weise weitgehend bestätigt wird dieses Bild nämlich auch bei einem Vergleich mit den Herkunftsangaben aus der Volkszählung von 1946 (Tabelle 4, siehe S. 199).

Zwar sind die Verhältnisse im einzelnen je nach Region zu differenzieren, doch lässt sich folgendes durchaus verallgemeinern und auch gut nachvollziehen. Die Spitzengruppe bilden sowohl in Tabelle 4 (1946) als auch in Tabelle 5 (2003) genau jene drei Landschaften, die dem Nachkriegsland Brandenburg unmittelbar benachbart liegen. ${ }^{825} \mathrm{Ihr}$ sehr hoher Anteil überrascht daher kaum. Geht man aus dem westlich Berlins gelegenen Kreis Potsdam weiter nach Osten, in die der (heutigen) Grenze zu Polen nahen Landkreise in der Uckermark (Angermünde), im Oderland, im Lebusischen, aber auch in den östlichsten Kreisen der verbliebenen Niederlausitz (Guben und Sorau/Forst), so rückt die Ostbrandenburg-Gruppe, die hier lange Zeit auf eine Rückkehrmöglichkeit hoffte und ihrer Heimat auch landschaftlich am nächsten blieb, sogar vor die der Schlesier. Im Südosten sind beide, Ostbrandenburger aus den Niederlausitz-Teilen östlich der Neiße und Niederschlesier, zahlreich. Im Süden Brandenburgs, den der Kreis Potsdam im Südwesten bereits tangiert, vor allem aber in der Niederlausitz, ist der Anteil der Schlesier jedenfalls ebenfalls dominant, außer im Kreis Lübben ist er hier sogar durchweg höher als der der Brandenburger. Im Norden und Nordwesten ist er zweifellos geringer, dort sind hingegen vor allem Pommern und, in kleineren Dimensionen, Ostpreußen kaum schwächer als im Kreis Potsdam vertreten, in der Westprignitz aber wesentlich stärker die Deutschen aus dem „Warthegau“ und Zentralpolen („Weichsel-Warthe“), die beide auch in der Ostprignitz gleichwohl 1946 sehr hohe Zahlen erreichen. Im Mittelfeld ergeben sich somit regional Differenzierungen. Die Sudetendeutschen sind, von wenigen Ausnahme-Landgemeinden abgesehen, nirgends in Brandenburg eine gewichtige Gruppe, aber sie waren und sind doch sehr wohl überall im Land anzutreffen. 1946 belegen sie mit gewissem Abstand „Platz 6“ - die kleinste noch fünfstellige Zahl nach den preußisch-deutschen Ostprovinzen und Polen, es folgen in sehr weitem Abstand nur noch die „Sonstigen“, die jeweils unter 10000 liegen. Ähnliches deutet ihre Zahl in der obigen Tabelle 5 an: eine eindeutig kleine Gruppe, aber doch keineswegs nur unter den „Sonstigen“ zu verorten. Schwieriger ist es mit den Westpreußen, da diese Bezeichnung spätestens seit der NS- 
Zeit vielfach in Konkurrenz stand zum (größeren, auch früher posensche Kreise umfassenden) Reichsgau Danzig-Westpreußen und zu Ostpreußen und Pommern, die beide nach 1918 auch westpreußische Kreise bzw. (Rest-)Kreise erhalten hatten. Mancherorts finden sich daher auch unter den Ostpreußen einige Westpreußen, zumal die 1918 abgetretenen östlichen Teile der Provinz (bis 1939) als „Regierungsbezirk Westpreußen“ an die Provinz Ostpreußen angeschlossen worden waren. Immerhin lebten 1946 im Land Brandenburg 7864 Danziger. Zählte man sie und ggf. einen Teil der in der Polen-Gruppe enthaltenen Westpreußen zu den Ostpreußen (53695) hinzu, so käme das „Preußenland“, also Ost- und Westpreußen mit Danzig insgesamt, sogar in die Nähe der Größenordnung der 1946 in Brandenburg lebenden Deutschen aus (Zentral-)Polen.

Der untere Rand der Tabelle schließlich ist ebenso wenig zu vernachlässigen, verweist er doch immerhin darauf, dass Vertriebene aus den dort genannten (und einigen weiteren) ferner liegenden Herkunftsregionen zwar auch in Brandenburg eindeutig in der Minderheit waren, aber eben hier und da durchaus anzutreffen sind, etwa mit den im Havelland konzentrierten Bessarabiendeutschen oder den Karpatendeutschen in und um Brück. Allerdings muss man bedenken, dass die Bessarabiendeutschen ebenso wie Deutschbalten oder Wolhynien-, Galizien und Bukowinadeutsche zumeist schon deutlich vor 1945 aus ihren Siedlungsgebieten „umgesiedelt" worden waren und daher in den Statistiken oft nur nach ihrem Wohnort Ende 1944 oder im Januar 1945 rubriziert wurden, der in vielen Fällen der „Warthegau“ war. Auch in der Bevölkerungszählung von 1946 ,verstecken“ sie sich wohl in verschiedenen Gruppen, nicht nur bei den 2871 aus der Sowjetunion und den fast 9500 aus Rumänien Stammenden.

\section{Neumärker und Niederlausitzer}

Den höchsten Anteil an den nach Brandenburg und Berlin gelangten Flüchtlingen und Vertriebenen stellten die aus dem östlichen Teil der Provinz Brandenburg Stammenden, also die mit den Alteingesessenen in den Aufnahmeorten sozusagen am nächsten „verwandten“ Neumärker und (Ost-)Niederlausitzer. Das lässt sich an vielen Stellen beobachten. Auf dieses Faktum hat bereits 1993 Gerald Christopeit hingewiesen und zugleich auf den Vergleich mit den anderen Ländern verwiesen: „in keinem Land der SBZ war die landsmannschaftliche Verwandtschaft der Vertriebenen mit der alteingesesenen Bevölkerung so groß wie in Brandenburg. ${ }^{\text {" } 26}$ In zwölf der 30 im Jahre 1946 bestehenden Stadt- und Landkreise Brandenburgs erreichten die insgesamt 150374 Ostbrandenburger Zahlen von über 5000 , die Schlesier nur in sechs, die Pommern und die „Polen-Deutschen“ in je drei Landkreisen. ${ }^{827}$ Spitzenwerte von über 13000 Ostbrandenbur-

826 Christopeit, Herkunft und Verteilung (wie Anm. 29), S. 97. Unergiebig, da kaum Brandenburg-spezifisch, der knappe Unterabschnitt „Die Ostbrandenburger in der Sowjetischen Besatzungszone“ (gemeint sind SBZ und DDR) in: Karlheinz Lau: Ostbrandenburg nach 1945. In: Eberhard Völker [Hrsg.]: Pommern und Ostbrandenburger (Vertreibungsgebiete und vertriebene Deutsche. Studienbuchreihe der Stiftung Ostdeutscher Kulturrat, Bd. 9). München 2000, S. 147-166, hier S. 156-162. 
gern zeigten sich in den Kreisen Lebus und Ruppin, von knapp über 10000 im Kreis Oberbarnim, von über 8000 in den Kreisen Ostprignitz, Osthavelland und Beeskow-Storkow. ${ }^{828}$ Auch unter den in Berlin (West) agierenden Vertriebenenverbänden, die Kontakt zu in Brandenburg bzw. in der SBZ/DDR Lebenden hielten, sind die entsprechenden ostbrandenburgischen Heimatkreisgemeinschaften in erster Linie zu nennen.

Für die Kreisstadt Kö n i g s b e r g / Neumark lässt sich die Verteilung der von dort Stammenden auf die einzelnen Bundesländer und die Länder der SBZ/DDR beispielhaft genauer nachvollziehen. Eine Analyse der - in Braunschweig ab den fünfziger Jahren geführten - Adresskartei des Königsberger Heimatkreisbetreuers und deren Vergleich mit den Daten des Statistischen Bundesamtes für das gesamte historische Ostbrandenburg hat gezeigt, dass sich die Schwerpunkte allerdings bis zum Mauerbau durchaus gravierend ändern konnten. ${ }^{829}$ Während die westdeutsche Statistik für das Jahr 1946 bei 71,1 \% der Ostbrandenburger den Wohnsitz in der SBZ angibt und das SBZ-Brandenburg dabei mit 46,6\% aller aus Ostbrandenburg Stammenden die mit erheblichem Abstand größte Gruppe aufgenommen hatte (Berlin insgesamt nur 4,8\%), ergab die Auswertung der Königsberger Heimatkartei für den Zeitraum der fünfziger und sechziger Jahre einen in Brandenburg wohnhaften Anteil an Stadt-Königsbergern von nur 16,1\% (SBZ insgesamt: $28,1 \%$, Berlin insgesamt: 10,5\%). Auch wenn im einen Fall das gesamte ostbrandenburgische Vertreibungsgebiet, im andern nur eine ausgewählte Stadt die Datenbasis bildet, sind die erheblichen Unterschiede nicht von der Hand zu weisen. Schon Claus Krätzner hat sie in seiner auf Königsberg/Nm. konzentrierten Studie nicht nur mit der Fluktuation innerhalb der Westzonen, sondern vor allem mit der bekanntlich unter den Vertriebenen besonders hohen Quote an „Republikflüchtlingen“ erklärt, die also zwischen 1945/46 und dem Mauerbau 1961 (mindestens) ein zweites Mal ihren Wohnort gewechselt haben, um aus der SBZ/DDR in die Westzonen abzuwandern. ${ }^{830}$ Für den von Krätzner in der Königsberger Kreiskartei ermittelten grob eingegrenzten Zeitraum („zwischen den fünfziger und sechziger Jahren“) ergaben sich die Wohnsitz-Spitzenwerte gezählter Personen (nicht Familien) aus der Stadt Königsberg in absoluten Zahlen wie folgt ${ }^{831}$ : Niedersachsen (811), Brandenburg (762), Nordrhein-Westfalen (723), Berlin (496), Schleswig-Holstein (467), Mecklenburg-Vorpommern (307), Hessen (211), Hamburg (186), Bayern (166), Baden-Württemberg (141), Rhein-

828 Siehe Tabelle 4. Vgl. auch Christopeit, Herkunft und Verteilung (wie Anm. 29), S. 96.

829 Krätzner, Das Schicksal der Bevölkerung der Kreisstadt Königsberg in der Neumark (wie Anm. 304). - Keine Aussagen zum Verbleib der Königsberger nach Flucht und Vertreibung enthält der auf die Frage nach kriegsbedingten Opfern (einschließlich unmittelbar auf der Flucht Umgekommenen) konzentrierte Beitrag desselben Verf.: Das Schicksal der Einwohner der Kreisstadt Königsberg/Neumark am Ende des Zweiten Weltkrieges. In: Königsberger Kreiskalender 2002, S. 75-83.

830 Krätzner, Das Schicksal der Bevölkerung der Kreisstadt Königsberg in der Neumark (wie Anm. 304 ), S. 51.

831 Ebd., S. 42, 52. 77 unleserliche, unbekannte und unidentifizierbare Wohnsitzangaben wären zwar zu den Zahlen zu addieren, dürften aber die grob erkennbaren Größenordnungen nicht wesentlich verändern. Die Ortsangaben wurden nach den Ländergrenzen West ab 1949 und Ost bis 1952 zugeordnet. Zu den methodischen Grundlagen der Auszählung siehe Krätzner (wie vor), S. 5f., 41-43. 
land-Pfalz (122), Sachsen-Anhalt (114), Thüringen (90), Bremen (64), Sachsen (56), Ausland (45), Saarland (14). Zählt man Brandenburg und Berlin zusammen, nimmt die Gesamtregion immer noch mit Abstand die Spitzenposition ein, doch leben nun über 60 \% der Königsberger in den Westzonen, rund $10 \%$ in Gesamtberlin und 28,1\% in der DDR. Innerhalb der DDR ist die Konzentration in den nördlichen Ländern deutlich erkennbar. Ebenfalls deutlich ablesbar ist auch an diesen Zahlen, dass Ostbrandenburger in erster Linie in das Land Brandenburg gelangt sind, denn ihr Anteil ist hier deutlich höher als in Mecklenburg-Vorpommern, dem SBZ/ DDR-Land mit der insgesamt höchsten Vertriebenenzahl.

Auch eine 1955 publizierte statistische Zusammenstellung der Wohnsitze der Vertriebenen aus dem neumärkischen Kreis O st sternberg ${ }^{832}$ weist Brandenburg mit dem mit Abstand höchsten Anteil (1903) aus, gefolgt von Niedersachsen (1051), West-Berlin (512), OstBerlin (458), Sachsen-Anhalt (408), Nordrhein-Westfalen (370), Mecklenburg-Vorpommern (264) und Schleswig-Holstein (168). Die Anteile aller anderen Länder liegen jeweils unter 100. Allerdings kommen 607 Personen mit nicht feststellbarer Anschrift hinzu und 1704 Verschollene sowie $1200 \mathrm{im}$ Zusammenhang mit Krieg und Flucht Verstorbene. Außerdem erfasst die für diese Statistik ausgewertete Heimatkreiskartei insgesamt nur 9258 „Landsleute“, während die Einwohnerzahl des Kreises vor 1945 mit 40938 angegeben wird. Zählt man West- und OstBerlin hinzu, ist der Schwerpunkt im Gesamtraum Berlin-Brandenburg trotz allem wiederum überdeutlich. Auch unter den Betroffenen war das zeitgenössisch bekannt, wie die Äußerung einer aus Zielenzig (Kr. Oststernberg) Vertriebenen von 1953 zeigt: „Die meisten Zielenziger wohnen in Berlin und Umgegend." ${ }^{833}$

In einer in der Bundesrepublik am 31. Dezember 1964 abgeschlossenen „Gesamterhebung zur Klärung des Schicksals der deutschen Bevölkerung in den Vertreibungsgebieten“"werden für den neumärkischen Kreis Soldin 11169 Personen (24,23 Prozent der Vorkriegsbevölkerung des Kreises) als in der DDR („in der SBZ und im Sowjetsektor von Berlin“) lebend genannt. ${ }^{834}$ 21976 Personen (47,67 Prozent) lebten „in der Bundesrepublik und Berlin (West)“. Der Rest (1,20 Prozent) lebte „im freien Ausland“ (322) oder noch „im alten Heimatkreis“ (231). Eine hundertprozentige namentliche Erfassung war 1964 allerdings nicht möglich, „weil ein Großteil der Bevölkerung in der damaligen SBZ und in Ost-Berlin [...] zurückblieb“ - „Eine Befragung dieses Personenkreises war leider nicht möglich. ${ }^{\text {"335 }}$ Unter den in der DDR lebenden Soldinern dürfte

832 G[eor]g Krause: Heimatkreiskartei Ost-Sternberg. In: Frankfurt (Oder)-Sternberger Kurier 4 (1955), Nr. 2, S. 9-10 hier S. 10 (Anhang „Verzeichnis der karteimäßig erfaßten Landsleute").

833 Vertreibung und Vertreibungsverbrechen 1945-1948. Bonn 1989, S. 244-245 (Dokument 22. Bericht von Florentine Gruhn), hier S. 245.

834 Heimatkreis Soldin/Neumark (wie Anm. 303), S. 629. Eine weitere Tabelle (S. 630 f.) schlüsselt die Zahlen nach sämtlichen einzelnen Städten und Gemeinde des Kreises auf. Demnach lebten 1964 beispielsweise 1187 Personen aus dem Soldiner Stadtgebiet in der DDR oder in Ost-Berlin gegenüber $2731 \mathrm{im}$ Westen (S. 631). Aus Berlinchen (S. 630) waren es 1551 (Bundesrepublik 3722), aus Lippehne (ebd.) 823 (Bundesrepublik 2200).

835 Ebd., S. 628. 
der größere Teil auf die brandenburgischen Bezirke oder Ost-Berlin entfallen. Rechnete man wiederum die in West-Berlin wohnenden hinzu, würde sich für die berlin-brandenburgische Gesamtregion sehr wahrscheinlich eine noch deutlich höhere Zahl ergeben.

Als Quelle für den Verbleib neumärkischer ${ }^{836}$ Flüchtlinge und Vertriebenen in den unmittelbaren Nachkriegsjahren kann beispielhaft schließlich noch die vom in Berlin ansässigen „Flüchtlingsausschuß Friedeberg/Nm., Altkarbe und Umgegend“ mit Stichdatum Dezember 1947 in zweiter Auflage herausgegebene gedruckte Anschriftenliste dienen. ${ }^{837}$ Die fünf AusschussMitglieder wohnten sämtlich in Berlin, vier von ihnen in den Westsektoren, einer, der vor 1945 beim Finanzamt Friedeberg/Nm. beschäftigt gewesene Hermann Oestreich (offenkundig der Schatzmeister $)^{838}$, in Berlin-Friedrichsfelde. Nach den Angaben im mit abgedruckten Jahresbericht (S. 4) fanden die zwischen August 1946 und August 1947 durchgeführten Veranstaltungen (Treffen) ausschließlich in den Westsektoren statt. ${ }^{839}$ Ganz ähnlich war die Situation beim „Driesener Flüchtlingsausschuß“ und beim „Woldenberger Flüchtlingsausschuß“, also Zusammenschlüssen von Flüchtlingen aus weiteren Städten des Kreises Fri ed e b e rg /Neumark. Auch hier wohnten alle Ausschuss-Mitglieder in den Berliner Westsektoren, die Treffen fanden bei den Driesenern ,jeden 2. Sonntag nach dem Monatsersten - für Potsdamer gut erreichbar - in Nikolassee, Restaurant ,Schloß Wannsee', Kronprinzessinnenweg [21]"statt, bei den Woldenbergern war der Treffpunkt das „Lokal Pfannenberg“ in Berlin-Neukölln, Richardstraße 35, also in unmittelbarer Nähe des „Ostsektors“ 840

Die dreispaltige Friedeberger Zusammenstellung von 1947 nennt nun in alphabetischer Reihenfolge die Namen der Flüchtlinge, teilweise mit Geburtsnamen und Beruf bzw. früherer Arbeitsstelle, z. B. Finanzamt Friedeberg, sowie vor allem „Heimatadresse“ und „Jetzige Anschrift". Letztere ist meist die genaue und vollständige Postanschrift, bisweilen aber auch nur der Ort. In nicht wenigen Fällen wohnen die Flüchtlinge offenkundig zur Untermiete, da die Namen der Vermieter bzw. Hauptwohnungsinhaber hinzugesetzt sind, z. B. „bei Bauer Zavckow“ in Schmolde im Kreis Ostprignitz ${ }^{841}$. Welche Wohnsituation sich hinter den unpersönlichen Adressen verbirgt, ist nicht festzustellen. Manche unscheinbare Anschrift mag ein Lager bezeichnen, ausdrücklich als Bestandteil der Anschrift genannt sind Lager, Baracke, Heim, Gasthof oder Krankenhaus nur in wenigen Fällen. Dörfer und Städte erscheinen bei den Unterbringungsorten gleichermaßen. Eine Auszählung nach Aufenthaltsländern ergibt folgendes Bild.

Der Kreis Friedeberg/Nm., altes neumärkisches Gebiet seit dem Mittelalter, gehörte bis 1938 zur Provinz Brandenburg, danach bis 1945 zur Provinz Pommern. Offenkundig betrachteten sich die Einwohner - nur neun Jahre nach dem Anschluss an Pommern - weiterhin als Neumärker, wie die Bezeichnung des Ausschusses und des Verzeichnisses zeigt.

837 Anschriften-Verzeichnis ehem. Einwohner von Friedeberg (Nm.), Alt-Karbe und Umgegend. (Berlin) 1947. $79 \mathrm{~S}$.

838 Zu Oestreich ebd., S. 1, 5, 48.

839 Ebd., S. 4.

840 Ebd., S. $18 \mathrm{f}$.

841 Ebd., S. 71. 
Tab. 6: Aufenthaltsländer von Flüchtlingen aus dem Kreis Friedeberg/Nm., Dez. 1947

\begin{tabular}{|l|c|}
\hline Berlin & 451 \\
\hline SBZ & 998 \\
\hline Westzonen & 501 \\
\hline Dänemark (Lager) & 3 \\
\hline UdSSR (Gefangenschaft) & 2 \\
\hline Summe & 1955 \\
\hline Berlin (Westsektoren) & 309 \\
\hline Berlin (Ostsektor) & 142 \\
\hline Brandenburg & 448 \\
\hline Mecklenburg-Vorpommern & 341 \\
\hline Sachsen-Anhalt & 149 \\
\hline Sachsen & 29 \\
\hline Thüringen & 31 \\
\hline
\end{tabular}

Demnach lebten Ende 1947 etwa ein Viertel dieser Personengruppe in den Westzonen (überwiegend in Schleswig-Holstein und Niedersachsen, aber vereinzelt auch in allen anderen Ländern) und etwa drei Viertel in der Sowjetischen Besatzungszone oder Berlin. In Brandenburg wohnten - auf das gesamte Land verteilt - ungefähr so viele Friedeberger wie in Gesamt-Berlin. Nur in Mecklenburg und Vorpommern ist noch ein immerhin vergleichbar großer Anteil untergekommen. Damit lebte dieser Personenkreis mehrheitlich in den unmittelbar an die Neumark angrenzenden Gebieten (einschließlich Berlin).

Dass aber trotz der bis zum Mauerbau erfolgenden Abwanderungen in den Westen auch nach 1961 die Neumärker in den brandenburgischen DDR-Bezirken noch immer sehr stark vertreten waren, lässt sich allein schon an vielen Indizien zeigen. Hier sei nur auf das Beispiel der Flüchtlinge und Vertriebenen aus Bärwalde/Nm. (Kr. Königsberg/Nm.) verwiesen. Deren Vertriebenenorganisation, der „Arbeitskreis Bärwalde Nm.“, saß zwar in Niedersachsen (Patenstadt: Braunschweig), aber allein schon dessen Jahresbericht 1968 zeigt, wo das Gros der Bärwalder lebte. Nach der darin mitgeteilten Liste der 1968 verstorbenen 32 ehemaligen Bärwal$\operatorname{der}^{842}$ hatten ihren letzten Wohnort 16, mithin die Hälfte und zugleich die größte Einzelgruppe in Brandenburg und Berlin ${ }^{843}$ (davon wiederum die Mehrheit - 12 - in Brandenburg ${ }^{844}$ ), nur

842 Arbeitskreis Bärwalde Nm Kreis Königsberg Nm. Jahresbericht [2] (1968 [1969]), o. S. (hektografiert maschinenschriftlich mit gedruckten Kopf, 6 S. DIN A 4, erstellt und versandt von Ulrich Grimm, Lüneburg).

843 Ob Ost- oder West-Berlin, ist nicht angegeben.

844 Je 1 (Ausnahme Neuruppin: 2) in: Bad Freienwalde, Blumberg bei Berlin, Falkenberg/Mark, Fürstenwalde/ Spree, Görn[e] bei Brandenburg/Havel, Groß Neuendorf/Oder, Küstrin-Kietz, Neuruppin, Potsdam, Schönwalde (Niederbarnim), Schulzendorf bei Wriezen. Angegeben sind Name, Vorname, Sterbedatum, letzter Wohnort und Alter. 
6 in Niedersachsen, 3 in Schleswig-Holstein, 3 in Baden-Württemberg und je 1 in Bremen und Hamburg sowie in der DDR noch je 1 in Mecklenburg-Vorpommern (Anklam) und Thüringen (Schleiz).

Mag der Schwerpunkt im Falle anderer Herkunftskreise aufgrund individueller Entwicklungen auch in anderen (Bundes-)Ländern liegen, so ist - gleichsam „innerbrandenburgisch“ betrachtet - der Anteil der in das Gebiet des heutigen Landes Brandenburg gekommenen Neumärker auch dann meist stärker der als aus anderen Vertreibungsregionen, von denen nur der „Warthegau“ und besonders (Nieder-)Schlesien ähnlich nennenswerte Zahlen in Brandenburg erreichten bzw. erreichen.

Ursächlich für den starken ostbrandenburgischen Anteil in der „Rest-Provinz“ sind zum einen die bereits erwähnten gezielten Evakuierungen im Januar 1945, wie etwa aus dem Kreis Crossen in den Raum Teltow und Osthavelland ${ }^{845}$ sowie aus dem Kreis Züllichau-Schwiebus in den Ruppiner und Ostprignitzer Raum ${ }^{846}$, zum anderen aber besonders das Bestreben der Vertriebenen vom Sommer und Herbst 1945, „für den Fall der Fälle“ in Grenznähe zu verbleiben, was zu einer Konzentration von Neumärkern in Uckermark, östlichem Barnim, Oderbruch, Lebus/Seelow und von Ost-Niederlausitzern in den westlich der Oder und Neiße liegenden Niederlausitzer Kreisen, besonders Guben und Cottbus, geführt hat. ${ }^{847}$ So sind z. B. $90 \%$ der Flüchtlinge aus Wartenberg und Hohenwartenberg (Kr. Königsberg/Nm.) im ihrer Heimat unmittelbar benachbarten Oderbruch und Barnim verblieben, nur $10 \%$ gingen - mit kurzer Zwischenstation in der Uckermark - in den Westen. ${ }^{848} \mathrm{Zu}$ berücksichtigen ist bei alledem aber, dass gerade bei den Neumärkern schon seit der Vorkriegszeit, oft seit dem Kaiserreich, auch verwandtschaftliche oder berufliche Kontakte und damit Anknüpungspunkte nach Berlin und Umgebung bestanden. Ebd.

847 Siehe im Einzelnen die Hinweise bei den Aufnahmeorten in der Ortsdokumentation. Als Beispiele für viele seien hier nur genannt die Apotheker Bernhard Thieme aus Königsberg/Nm. (in Falkenberg/Mark und Bad Freienwalde) und Ernst Versen aus Sorau (in Cottbus, mit Kreisapotheker-Zuständigkeit u. a. für Forst!); auch hierzu Näheres in der Ortsdokumentation, ausführlicher: Paul Biela: Schicksale deutscher Apotheker aus Ostbrandenburg am Ende des Zweiten Weltkrieges. Frankfurt (Oder) 2017, S. 18 f. bzw. S. 37, 44.

848 Freundliche Mitteilung Stefan Rückling (Berlin), der eine Dorfgeschichte Wartenbergs vorbereitet (Mail an den Verf. vom 30.1.2017). Siehe auch die angegebenen Sterbeorte nach 1945 (z. B. Pinnow, Kr. Angermünde, S. 176) in: Stefan Rückling: Familienbuch Wartenberg und Hohenwartenberg, Kreis Königsberg in der Neumark. Berlin 2018. - Auch die Ortschronistin von Liepe (Kr. Angermünde), Karin Többe-Wehberg, berichtete, dass es in ihrer odernahen uckermärkischen Heimatgemeinde Familien gab und gibt, die ihrem östlich der Oder liegenden Heimatort sehr nahe geblieben sind (freundliche Mitteilung vom 19.7.2018). 


\section{Schlesier}

Schlesier bilden mit den Ostbrandenburgern in vielen Regionen Brandenburgs die Mehrheit unter den Vertriebenen. ${ }^{849}$ Beide Gruppen waren in Brandenburg 1946 sogar die einzigen, die jeweils über 100000 Vertriebene stellten, die Schlesier $121597 .{ }^{850}$ In der Niederlausitz sind die Schlesier jedoch mit Abstand die größte Zuwanderergruppe. ${ }^{851}$ Wie bei anderen Gruppen waren für die starke Streuung und doch bisweilen ganz unterschiedliche Konzentration die nicht selten improvisierten und kurzfristig abgeänderten, mithin selten systematisch geplanten Verteilungen von Transporten verantwortlich. Bei den Schlesiern kommt jedoch, wie bei den Ostbrandenburgern, hinzu, dass sie in den Lausitzer Landkreisen und Städten (ebenso wie in Sachsen in denen der Oberlausitz) ihrer Heimat noch am nächsten bleiben konnten, was viele jahrelang zum dortigen Ausharren bewogen hat. ${ }^{852}$ Für die Niederlausitz ist ferner zu berücksichtigen, dass zumindest die Katholiken unter den Schlesiern hier in ihrem vertrauten Heimatbistum verbleiben konnten, denn - darauf wird unten noch näher eingegangen ${ }^{853}$ - das Erzbistum Breslau reichte ja bis tief in die Lausitz. Doch auch im Berliner Bistum hat dessen (schlesische) Patronin, die hl. Hedwig, vermutlich integrierend gewirkt. ${ }^{854}$

Schlesier - und das heißt in Brandenburg vor allem Niederschlesier, da ein nicht unerheblicher Teil der Oberschlesier zunächst oder sogar bis heute in ihren Wohngebieten verblieb - finden sich denn auch in fast allen brandenburgischen Landkreisen erwähnt, etwas seltener wohl nur im Westhavelland und im Oberbarnim, besonders stark im Kreis Zauch-Belzig,

849 Allgemein zu Schlesiern in SBZ/DDR siehe v. a.: Schlesier in der DDR. Berichte von Flüchtlingen, Vertriebenen und Umsiedlern. Michael Parak (Hrsg.). Eine Veröff. des Schlesischen Museums zu Görlitz. Görlitz 2009. - Nur sehr knapp dagegen das Unterkapitel „Die vertriebenen Schlesier in der Deutschen Demokratischen Republik“ in: Joachim Rogall: Krieg, Vertreibung und Neuanfang. Die Entwicklung Schlesiens und das Schicksal seiner Bewohner von 1939-1995. In: Joachim Bahlcke [Hrsg.]: Schlesien und die Schlesier (Vertreibungsgebiete und vertriebene Deutsche. Studienbuchreihe der Stiftung Ostdeutscher Kulturrat, Bd. 7). München 1996, S. 156-223, hier S. 180 f.

850 Darunter jedoch noch 6947 Lagerinsassen. Siehe Tabelle 4.

851 Ther, Von Schlesien in die Lausitz (wie Anm. 49), S. 488. - Siehe auch z. B. den Versuch einer Analyse der Wohnsitzverteilung der aus dem niederschlesischen Obernigk (Kr. Trebnitz) stammenden Vertriebenen, in dem für die neuen Bundesländer ausdrücklich auch Cottbus als ein Schwerpunkt neben Magdeburg, Gera, Halle/S. und Dessau genannt wird (Hellmut Seidel: Die Obernigker Heimatkartei (Stand 7/1995). In: Seidel/Loch, Obernigk [wie Anm. 388], S. 268-269, hier S. 269).

852 Eine Massierung von Vertriebenen an der Ostgrenze war noch 1950 festzustellen (Ther, Von Schlesien in die Lausitz [wie Anm. 49]), S. 494; siehe auch oben Anm. 806). Im Grunde würde aber man noch heute grundsätzlich Ähnliches feststellen.

853 Siehe unten im Kapitel IV. 3 den Abschnitt zur Katholischen Kirche.

854 „Viele [katholischen SBZ-]Flüchtlingsgemeinden nannten ihren Sakralraum in der neuen Heimat nach Hedwig, der Schutzpatronin Schlesiens." (Verena Schädler: Katholischer Sakralbau in der SBZ und in der DDR. Regensburg 2013, S. 76). So wurde z. B. in Bestensee (Kr. Teltow) die neue Kapelle bewusst unter Bezugnahme auf die „Vertriebenen aus Schlesien [...] der hl. Hedwig gewidmet“, was dem Bistum umso leichter fiel, als letztere für beide Seiten herausragende Bedeutung besaß (Brühe, Katholische Kirche zwischen Havel und Dahme [wie Anm. 148], S. 13). - Siehe auch Ortsdokumentation Neuzelle (u. a. Hedwigswallfahrt)! 
im Kreis Jüterbog-Luckenwalde und in nahezu allen niederlausitzischen Kreisen, aber durchaus auch in den mittleren Kreisen und Städten von Brandenburg/Havel über Potsdam bis in den Lebuser Raum. ${ }^{855}$ Nach der Volkszählung von 1946 waren - in dieser Reihenfolge - die auf über 8000 Schlesier kommenden Kreise Calau, Luckau, Cottbus-Land, Zauch-Belzig sowie die noch über 5000 kommenden Kreise Luckenwalde und Teltow die mit der höchsten Konzentration. ${ }^{856}$ Auffällig, aber eher untypisch ist der überdurchschnittliche Anteil von Oberschlesiern im ehemaligen Bergbauort (!) Rüdersdorf (Kr. Niederbarnim). Immerhin fünf der elf Autoren der 2002 erschienenen Festschrift des dortigen BdV-Kreisverbandes sind gebürtige Oberschlesier; die Herkunftsgebiete Ostpreußen, Westpreußen, Pommern und Ostbrandenburg sind hingegen nur mit je einem Autor vertreten, zwei Autoren sind Einheimische. Im Kreis Niederbarnim insgesamt standen die Schlesier nur an vierter Stelle nach Ostbrandenburgern, Pommern und Ostpreußen. Die geringste Zahl in einem Landkreis erreichten sie 1946 in Guben und Forst (Restkreis Sorau), wo man mit zusammengenommen über 10000 Ostbrandenburgern, die überwiegend aus der „Nachbarschaft“ gekommen sein dürften, ohnehin voll ausgelastet war.

Ähnlich vielfältig und bisweilen zufallsbedingt sind zwar grundsätzlich die schlesischen Herkunftskreise, die sich unter den nach Brandenburg Gekommenen finden. ${ }^{857}$ Überdurchschnittlich stark vertreten sind aber Flüchtlinge und Vertriebene aus den Brandenburg am nächsten benachbarten Kreisen Grünberg (poln. Zielona Góra) und Freystadt (poln. Kożuchów). Zusammen mit den in Brandenburg ebenfalls stark vertretenen Vertriebenen aus der östlichen Niederlausitz und der südlichen Neumark bilden diese Kreise letztlich genau jenes Gebiet, das heute in der neu geschaffenen polnischen Verwaltungsgliederung (und Geschichtskultur) des sogen. „Lebuser Landes“ (poln. Ziemia Lubuska) als Nachbar des Landes Brandenburg vereint ist. Hinweisen vor allem auf Stadt und Kreis Grünberg, aber ebenso auf Stadt und Kreis Freystadt kann man in den amtlichen brandenburgischen Quellen ebenso wie in den Zeitzeugenberichten, aber auch in Äußerungen und Berichten über heutige Vertriebenenfunktionäre immer wieder begegnen. Grünberger und Freystädter ${ }^{858}$ finden sich bis heute insbesondere im Raum Cottbus zuhauf, Freystädter auch im Raum Zauch-Belzig und in Brandenburg an der Havel. Im Raum Luckenwalde lassen sich sodann Vertriebene aus Stadt und Kreis Brieg (poln. Brzeg) -

855 Siehe auch die Erschließung der Vorkommen in der Ortsdokumenation über das Geographische Register.

856 Siehe Tabelle 4.

857 Mit einem Teil seiner Gemeinde (Kamöse, Kr. Neumarkt in Schlesien) wurde z.B. der katholische Pfarrer Max Kauschke in Guhlsdorf (Kr. Westprignitz) angesiedelt (siehe Ortsdokumentation). Zudem sind mehrere katholische Schwesternkonvente aus Nieder- und Oberschlesien ganz oder teilweise nach Brandenburg gelangt, z. B. Borromäerinnen (Plaue/Havel), Graue Schwestern (Altenhof am Werbellinsee), Hedwigschwestern (Bad Saarow und Wandlitzsee), Mägde Mariens (Wilhelmshorst). Im evangelischen Bereich sind z. B. zu nennen Diakonissen aus dem Diakonissenmutterhaus Grünberg in Niederschlesien und aus Miechowitz/ Mechtal in Oberschlesien (Heiligengrabe/Friedenshorst). Vgl. Ortsdokumentation. 
wiederum bis heute - in gewisser Häufung ausmachen ${ }^{859}$, solche aus Stadt und Kreis Nams$\mathrm{lau}^{860}$ (poln. Namysłów) im Raum Kyritz-Neustadt/Dosse-Neuruppin sowie um Rathenow. Insgesamt begegnet aber der Kreis Grünberg mit Abstand am häufigsten als Herkunftsgebiet, ${ }^{861}$ so dass es kaum verwundert, dass die Stadt Cottbus schon 1975 (!) ausgerechnet mit dem polnischen Zielona Góra (Grünberg in Schlesien) eine (bis heute bestehende) Städtepartnerschaft einging. ${ }^{862}$

Die Schlesier-Häufung ist letztlich auch dadurch zu erklären, dass aus - dem ohnehin bevölkerungsreichen - Schlesien in allen Phasen des Flucht- und Vertreibungsprozesses Transporte und Trecks nach Brandenburg geführt worden bzw. hier verblieben sind. Schon im Februar 1945 wurden die Kreise Niederbarnim und Osthavelland mit der Stadt Potsdam zum Aufnahmegebiet für die zu evakuierende Bevölkerung des Kreises Grünberg in Schlesien bestimmt; das Gleiche galt im Kreis Zauch-Belzig und in der Stadt Brandenburg/Havel für die Bevölkerung des Kreises Freystadt in Schlesien. ${ }^{863}$ Während der „Wilden Vertreibungen“ im Juni/Juli 1945 gelangten dann nochmals sehr viele Niederschlesier aus Glogau und erneut aus mehreren Orten des Kreises Grünberg (u. a. aus Deutsch Wartenberg), nach Brandenburg, insbesondere in den Raum Cottbus. ${ }^{864}$ Schließlich gilt das auch noch einmal für die Hauptphase der Vertreibungen nach der Potsdamer Konferenz, als „vor allem aus Schlesien ständig neue Flüchtlinge in den Kreis Lübben" kamen. ${ }^{865}$ Auch im östlichen Nachbarkreis Guben landeten nicht nur viele Neumärker und aus dem Ostteil des Gubener Kreises Stammende, sondern Vertriebene aus dem sozusagen - jenseits des Crossener Kreises - „übernächsten“ Nachbarkreis Grünberg in Schlesien: „Überall waren Schlesier“ - so empfand es z.B. ein aus dem unmittelbar

Siehe nähere Hinweise und Belege in der Ortsdokumentation. Zu beachten sind hierbei auch die schon 1973 angebahnten Partnerschaftskontakte zwischen Luckenwalde und dem polnischen Brzeg (Brieg).

860 In Kyritz bildete sich nach 1989 sogar eine regionale Gruppe der in der Bundesrepublik gegründeten „Namslauer Heimatfreunde e. V." - Siehe auch Ortsdokumentation bzw. Geographisches Register.

861 In Brück (Kr. Zauch-Belzig) befindet sich z. B. ein Gedenkstein für die im benachbarten Rottstock angesiedelten Vertriebenen aus Milzig (poln. Milsko), Kr. Grünberg (siehe Ortsdokumentation). - In Cottbus wurde 1945 ein komplettes Altersheim aus Grünberg aufgenommen (desgleichen; siehe auch Anm. 1865). - In Heiligengrabe (Kr. Ostprignitz) finden 1946 die oben (Anm. 857) erwähnten Diakonissen aus Grünberg Aufnahme (siehe Ortsdokumentation). - Die Konzentration im Süden Brandenburgs war auch den im Westen lebenden Grünbergern schon in den fünfziger Jahren bekannt. So heißt es im Stadt-Grünberger „Heimatbuch“: „Innerhalb des deutschen Gebietes haben sich Schwerpunkte gebildet, z. B. der Spreewald, Luckau, Peitz bei Cottbus, Berlin, Braunschweig, Hannover, Göttingen, Weidhausen bei Coburg, Stuttgart, München. Organisierte Grünberger Gruppen gibt es in Hannover, Berlin, Stuttgart, München und Frankfurt am Main, Coburg." (Ernst Clauss: Buch der Stadt Grünberg in Schlesien. Frankfurt am Main 1957 [2. Aufl. 1964], S. 105). Genannt wird ebd. auch der „Prediger Napparell in Weißag bei Luckau“ als eine der um die Sammlung der evangelischen Grünberger bemühten Personen.

862 www.cottbus.de/international/staedtepartnerschaften.html [31.8.2016]. Siehe auch unten im Kapitel IV. 2 den Abschnitt „Städtepartnerschaften als Patenschaftsersatz?“

863 BLHA, Rep. 6 B Kreisverwaltung Züllichau-Schwiebus, Nr. 169, unfol.

864 Töpler, Menschenwurm (wie Anm. 147), S. 364 mit diversen Beispielen (Bericht vom 23.7.1945).

865 Becken, Lübben nach dem Inferno (wie Anm. 178), S. 30. 
benachbarten Kreis Weststernberg kommender Neumärker, der nach Ziltendorf (Kr. Guben) eingewiesen wurde, wo um ihn herum fast ein ganzes - gemeinsam auf die Flucht gegangenes Dorf, Kreutz im Kreis Grünberg, begegnete. ${ }^{866}$ Letztlich setzte sich diese „Wanderung“ von (nun jedoch Ober-)Schlesiern nach Brandenburg auch noch in der der (Spät-)Aussiedler fort, und selbst bei diesen stößt man auf Konzentrationen im Grenzraum. ${ }^{867}$

Unter den Schlesiern in Brandenburg gab es anfangs Tendenzen zur Selbstorganisation bzw. zumindest Indizien für ein „Hochhalten“ des Schlesien-Begriffs, während die Neumärker mit ihrer ohnehin angestammten Zugehörigkeit zur Mark und Provinz Brandenburg kaum Voraussetzungen und Motivation für eine Gruppenidentität, allenfalls auf (Heimat-)Kreisebene, mitbrachten. In Jüterbog agierte 1948 ein nichtamtlicher „Schlesiersuchdienst“, der freilich bald verboten wurde. ${ }^{868}$ In Forst (Lausitz), wo zahllose Eisenbahntransporte aus dem nun polnischen Schlesien ankamen und die Stadt als ersten deutschen Aufnahmeort erlebten, wurde 1947 sogar eine - ebenfalls nicht genehmigte - „Interessengemeinschaft ausgesiedelter Schlesier in der russisch besetzten Zone Deutschlands“ gegründet mit einer sogen. „Landesleitung Brandenburg “, deren Initiator ein in Forst wohnhafter Oberschlesier war. ${ }^{869}$

„Schlesien“ blieb - wie „Ostpreußen“ - ein emotional besonders stark aufgeladener Landesname, ein Wort, dessen öffentliche Erwähnung für die von dort Stammenden immer mehr zum Problem wurde, das aber in vielen Köpfen gespeichert blieb und die Gemüter immer wieder beschäftigte. Noch 1960 fiel Vertretern des DDR-Innenministeriums negativ auf, dass das überwiegend aus Vertriebenen bestehende „Evangelische Frauenwerk des Kreises Prenzlau“ sich noch immer mit Themen wie "Schlesien einst und jetzt" beschäftigte. ${ }^{870}$ Wie bei den meisten Vertriebenengruppen in Brandenburg (und der gesamten DDR) entwickelte sich aber selbst aus dem Kreis der - an sich als besonders heimatbewussten geltenden - Schlesier nach 1989 neben den dominanten BdV-Strukturen keine landsmannschaftliche Landesgruppe. Während sich zumindest bei Ost- und Westpreußen und auch Sudetendeutschen zeitweise aus kleineren regionalen Gruppen Ansätze zu Landesgruppen entwickelten, galt und gilt für Schlesier gleichsam hilfsweise die Berliner Landesgruppe der Landsmannschaft Schlesien als ihr Vertreter in der Bundeslandsmannschaft. ${ }^{871}$ Das mag zum einen mit der - den Schlesiern wohl nicht ganz zu Unrecht nachgesagten - geringen „Kampfeslust“ und einer eher stark ausgebildeten Assimilationsfähigkeit zusammenhängen, zum anderen trafen die zahlreichen vertriebenen Schlesier in Berlin-Brandenburg aber auch auf einen Raum, der für sie spätestens seit 1740 und noch verstärkt im 19. Jahrhundert bereits ein fester Bezugspunkt geworden war, in den vor allem im

866 Aurith - Urad. Zwei Dörfer an der Oder - dwie wioski nad Odra. Text: Tina Veihelmann. Hrsg.: Deutsches Kulturforum östliches Europa. (Erstdr. 2006). 2., korr. Aufl. Potsdam 2009, S. 29-31, Zitat S. 34.

867 Siehe dazu unten im Kapitel V den Abschnitt „Spätaussiedler“.

868 BLHA, Rep. 203 MdI, Nr. 1197, Bl. 41. Siehe auch Ortsdokumentation.

869 Schwartz, Vertriebene und „Umsiedlerpolitik“ (wie Anm. 13), S. 508 (mit Quellenangaben und näheren Einzelheiten). Siehe aber auch Ortsdokumentation.

870 Schwartz, Vertriebene und „Umsiedlerpolitik“ (wie Anm. 13), S. 568 f.

871 BdV-Handbuch 1996, S. 166-168. 
Kaiserreich bereits tausende evangelische und katholische Landarbeiter aus Nieder- und aus Oberschlesien abgewandert waren. ${ }^{872}$ Auch wenn man diesen Gesichtspunkt gerade bei einem als sehr heimattreu geltenden Menschenschlag als Hilfe für eine Integration nicht überbewerten darf, so dürfte die Fremdheit und Andersartigkeit der neuen Umgebung zumindest von den aus den westlichen Teilen Niederschlesiens Gekommenen weniger stark empfunden worden sein als etwa von Ostpreußen oder Sudetendeutschen, zu schweigen von Bessarabiendeutschen.

\section{Pommern}

Flüchtlinge und Vertriebene aus Hinterpommern bildeten 1946, wenn auch mit deutlichem Abstand von Ostbrandenburgern und Schlesiern, die drittgrößte Gruppe Vertriebener in Brandenburg (70 540), noch deutlich vor den Ostpreußen. Vermutlich bereits als Ergebnis der Fluchtbewegung vom Januar 1945 waren sie 1946 in den nördlichen Teilen Brandenburgs (Ruppin, Niederbarnim, Uckermark, Prignitz) noch am ehesten anzutreffen. ${ }^{873}$ Aber auch in Potsdam lebten am 1. September 1945 immerhin 865 „Flüchtlinge und Umsiedler" aus Pommern, am 29. Oktober 1946 sogar 2391. In der Provinzhauptstadt war die Fluktuation in den folgenden Jahren allerdings besonders hoch.

Eine nähere Betrachtung von Einzelfällen hat zu berücksichtigen, dass die alten brandenburgischen (neumärkischen) Kreise Arnswalde und Friedeberg/Nm. im Zuge der Auflösung der Provinz Grenzmark Posen-Westpreußen 1938 an Pommern angegliedert wurden, so dass die von dort stammende Bevölkerung seither in manchen Darstellungen und Statistiken als brandenburgisch, in anderen als pommersch bezeichnet wird. Ähnliches gilt für diejenigen zuvor westpreußischen bzw. posenschen Kreise der Grenzmark, die ebenfalls erst 1938 pommersch wurden.

Die ungeordneten Fluchtbewegungen von Ende Januar und Februar 1945 führten einen Teil der hinterpommerschen Bevölkerung über die Oder nach Westen, überwiegend zunächst nach Vorpommern und Mecklenburg, teilweise jedoch auch in den angrenzenden Norden Brandenburgs (Uckermark). ${ }^{874}$ Der größere Teil dieser Flüchtlinge ging aber nach Ende der Kampf-

872 Siehe dazu: Wojciech Wrzesiński: Abwanderung aus Schlesien. In: „Wach auf, mein Herz, und denke“ (wie Anm. 11), S. 180-189. - Martin Düspohl: Arbeitsmigration nach Berlin im 19. Jahrhundert. Jeder zweite Berliner stammt aus Schlesien. In: ebd., S. 190-208. - Dietlinde Peters: Wie tausend andere auch. Drei schlesische Dienstmädchen in Berlin. In: ebd., S. 209-214. - Ulrike Treziak: Die vertriebenen Schlesier in West-Berlin. In: ebd., S. 495-502, bes. 497. - Siehe auch: Konrad Fuchs: Die wirtschaftlich-sozialen Verflechtungen zwischen Berlin und Schlesien. In: Jahrbuch der Schlesischen Friedrich-Wilhelms-Universität zu Breslau 29 (1988), S. 239-257. - Roswitha Schieb: Jeder zweite Berliner. Schlesische Spuren an der Spree. Potsdam 2012 (Potsdamer Bibliothek östliches Europa).

873 Tabelle 4. Siehe auch die Angaben in der Ortsdokumentation. Zur Flucht aus Pommern knapp: Hartmut Schiller / Jens Rüdiger: Flucht und Vertreibung der deutschen Bevölkerung aus Hinter- und Mittelpommern. In: Völker [Hrsg.], Pommern und Ostbrandenburger (wie Anm. 826), S. 122-126, hier S. 123 f.

874 Zahlreiche pommersche Flüchtlinge treffen bis Kriegsende u. a. in den drei uckermärkischen Kreisstädten Angermünde, Prenzlau und Templin, aber auch in der Prignitz und in Ruppin, ein (siehe die näheren Angaben und Belege in den Ort- und Kreissartikeln). 
handlungen zunächst in die Heimat zurück. „Nach Schätzungen sind im Mai und Juni 1945 etwa 180000 Personen über die Oder nach Mittel- und Hinterpommern zurückgekehrt. “875 Diese Menschen sind jedoch dann fast ausnahmslos bereits ab Juni 1945 und verstäkt im Oktober und November 1945 endgültig von dort vertrieben worden. Der Hauptteil der Herbsttransporte ging nun aber in die Britische Zone, also in den nordwestdeutschen Raum. ${ }^{876}$ Die bloße Ankunft eines solchen Transports aus Pommern in einem brandenburgischen Lager sagt daher noch nicht aus, dass die Eingliederung dann auch dort erfolgt sein muss. ${ }^{877}$ Viele der erst nach Kriegsende nach Brandenburg gelangten pommerschen Vertriebenen sind weitergeleitet worden oder selbst „weitergewandert“, so dass nur Einzelforschungen Klarheit schaffen können. Grundsätzlich sollte aber berücksichtigt werden, dass Brandenburg im Norden eine gemeinsame Grenze mit der alten Provinz Pommern hatte. So grenzten die Kreise Prenzlau und Angermünde unmittelbar an den pommerschen Kreis Greifenhagen, nicht weit östlich davon lag der Kreis Pyritz, aus dem mehrere Flüchtlinge 1945 nach Brandenburg gelangten und von wo z. B. der langjährige katholische Nachkriegspfarrer von Lindow (Mark), Carl Demmer, stammte. Die Tendenz vieler Vertriebener, sich, wenn möglich, in der Nähe ihrer Heimat anzusiedeln, dürfte so manche Familie über die Oder in die unmittelbar benachbarten Gebiete der östlichen Uckermark geführt haben. Nähere Untersuchungen würden auch die Umstände der Begründung einer Städtepartnerschaft zwischen Angermünde und Strzelce Krajeńskie (Friedeberg/ Nm.) (1972) und vor allem der zwischen Schwedt/Oder und dem nahen Gryfino (Greifenhagen in Pommern) (1994) verdienen.

Nach alledem ist es nicht verwunderlich, dass trotz aller erwähnten frühen Abwanderungen noch im Herbst 1946 laut Volkszählung in den drei uckermärkischen Landkreisen nicht nur eine hohe Konzentration von Pommern anzutreffen war, sondern diese in den Grenzkreisen Prenzlau (12019) und Angermünde (7205) mit sehr großem Abstand sogar die Spitzenposition unter den landsmannschaftichen Gruppen Vertriebener einnahmen. ${ }^{878}$ Diese Werte mögen später unterschritten worden sein, doch ist kaum zu bezweifeln, dass die Pommern, wie etwas weiter südlich die Ostbrandenburger und ganz im Süden (Sachsen) die Schlesier, in der Uckermark bis heute einen nennenswerten Teil der Bevölkerung bilden dürften. ${ }^{879}$

875 Schiller/Rüdiger, Flucht und Vertreibung der deutschen Bevölkerung aus Hinter- und Mittelpommern (wie Anm. 873), S. 124.

876 Ebd., S. $125 \mathrm{f}$.

877 Z.B. im Jan./Febr. 1946 Ankunft eines Transports aus Hinterpommern in Angermünde (Sonnemann, Bittere Medizin [wie Anm. 269], S. 28), am 1.1.1947 Ankunft eines Transports aus Schlawe/Pommern (1781 Personen) im Lager Küchensee, eines weiteren Transports mit 1476 Personen aus Schlawe ebenda am 1.7.1947 (BLHA, Rep. 256 Küchensee, Nr. 217; Rep. 250 Landratsamt Beeskow-Storkow, Nr. 868).

878 Siehe Tabelle 4.

879 Umso unverständlicher ist es, wenn die Darstellung der vertriebenen Pommern nach 1945 auf die Westzonen beschränkt bleibt, während den „Ostbrandenburgern“ in der SBZ im selben Band ein eigener Abschnitt gewidmet ist: Jens Rüdiger / Ilse Gudden-Lüddeke: Die Pommern in der Bundesrepublik Deutschland. In: Völker [Hrsg.], Pommern und Ostbrandenburger (wie Anm. 826), S. 126-132. 


\section{Posener/Wartheländer}

Auch der „Warthegau“ gehörte ab Januar 1945 zu den häufiger genannten Herkunftsregionen, wenn Flüchtlinge in Brandenburg eintrafen. „Täglich kamen die Kriegsflüchtlinge aus dem Warthegau" heißt es z.B. in einer Chronik der im Südwesten Brandenburgs gelegenen Kleinstadt Niemegk (Kr. Zauch-Belzig). Im (Groß-)Potsdamer Stadtgebiet zählte man am 1. September 1945 bereits „1 825 aus dem Warthegau und Polen“ stammende Flüchtlinge, die damit die am Ort zeitweise zweitgrößte landsmannschaftliche Vertriebenengruppe (nach den Ostbrandenburgern und nahe gefolgt von den Ostpreußen) bildeten. ${ }^{80}$ Auf diesen Zustrom von Flüchtlingstrecks aus dem „Warthegau“ ist oben bei der Behandlung der „Zwangsevakuierung und Flucht von Januar 1945 bis Kriegsende “881 bereits beispielhaft näher eingegangen worden, so dass hier nur noch wenige einordnende Bemerkungen folgen sollen.

Der Begriff „Warthegau“ entstand erst im Krieg, ist aber - wie viele Bezeichnungen dieser Jahre - vor allem unter Zeitzeugen bis heute sehr verbreitet und wird zumeist recht unreflektiert verwendet. Dabei handelt es sich im Grunde um eine nichtamtliche Kurzform für das Gebiet des „Reichsgaus Wartheland“, die nur beim davon zu unterscheidenden (NSDAP-),Gau Warthegau“ in den Jahren 1939-1940 kurzzeitig offiziell in Gebrauch war, denn auch dieser Partei-Gau wurde 1940 in „Gau Wartheland“ umbenannt. ${ }^{882}$ Der hier interessierende „Reichsgau Wartheland“ war ein nach der Besetzung Polens gebildetes, in das Deutsche Reich mit bestimmten Vorbehalten eingegliedertes Gebiet, das den größten Teil der ehemaligen Provinz Posen (ohne die Kreise Bromberg und Wirsitz, die Teil des „Reichsgaus Danzig-Westpreußen“ wurden, und ohne die grenzmärkischen Anteile) sowie die nicht im Generalgouvernement zusammengefassten oder an Ostpreußen und Oberschlesien angegliederten Teile Polens umfasste. Enthalten waren neben Posen auch die Städte Lodz und Kalisch, so dass sich im Grunde ein Gebiet ergab, dessen anteilig deutsche Bevölkerung vor 1939 durchweg als (Auslands-)Deutsche in Polen gelebt hatte. Gegliedert war der Reichsgau in die drei Regierungsbezirke Posen (der alte deutsche und preußisch-provinzzeitliche Name für Poznań) im Westen, Hohensalza (der germanisierende preußisch-deutsche Name für Inowrocław/Inowraclaw) im Nordosten und Litzmannstadt (der germanisierende, 1940 neugeschaffene Name für Lodz/Łódż) im Südosten. Auch einige weitere Städte- und Kreisnamen aus dem früheren „Russisch-Polen“, die in Quellen der Nachkriegszeit in Brandenburg begegnen, stammen aus der Zeit des Reichsgaus und sind als zuvor amtlich auch in der DDR-Zeit bzw. bis heute weiter in Dokumenten anzutreffen, z. B. Hermannsbad (poln.

880 Potsdam und das Jahr 1945. Hrsg.: Potsdam-Museum. Potsdam 1995, S. 23.

881 Siehe oben Kapitel II. 1.

882 Daniel J. Lemmen: Reichsgau Wartheland. In: Online-Lexikon zur Kultur und Geschichte der Deutschen im östlichen Europa, 2014, ome-lexikon.uni-oldenburg.de/p32578 (Stand 18.12.2014). Der Artikel enthält keinerlei Hinweise auf die Evakuierung oder den Verbleib der deutschen Bevölkerung, lediglich im Schlussabschnitt „4. Diskussion/Kontroversen“ heißt es, offenbar erklärend, kurz und knapp zur Forschungslage: „Eine Auseinandersetzung mit dem Thema Flucht und Vertreibung der Deutschen aus dem Warthegau findet kaum statt." 
Ciechocinek) oder Warthbrücken (poln. Koło), während Litzmannstadt als allzu offenkundig und auch außerhalb der Betroffenenkreise bekannt meist zu Lodz wurde.

Für den nicht zu gering anzusetzenden brandenburgischen Anteil an der ehemaligen deutschen Bevölkerungsgruppe Polens (in den Grenzen bis 1939) sind mehrere Bevölkerungsbewegungen als Ursache anzuführen. Den wohl wesentlichen Anteil machen - sehr wahrscheinlich trotz späterer $\mathrm{Ab}$-/Weiterwanderungen ${ }^{883}$ - die erwähnten frühen Trecks vom Jahresanfang 1945 aus, einen weiteren Anteil wohl auch die späten Transporte nach 1946, mit denen z. B. 1948 und 1949 Vertriebene aus dem Raum Lodz in das brandenburgische „Umsiedlerlager“ Küchensee kamen. ${ }^{884}$ Auch unter den (Spät-)Aussiedlern mag neben vielen Oberschlesiern und Ermländern noch mancher Deutsche aus Polen gekommen sein, der zu diesem Kreis zählte.

Die erstgenannte Gruppe ließe sich sogar noch etwas genauer verfolgen, würde man - in einer Fallstudie zu den nach Brandenburg gelangten Deutschen aus Polen und Posen - ihre Verteilung im Land untersuchen und dabei frühe Nachrichten über die Erstaufnahme mit späteren und heutigen Erwähnungen kombiniert betrachten. ${ }^{85}$ Hier muss es genügen, auf die Aufnahmekreise vom Februar 1945 hinzuweisen, die sich zumindest über einzelne Belege und Stichproben als wohl weitgehend tatsächlich umgesetzt - und nicht nur geplant und dann vom Kriegsverlauf überholt - erweisen. Grundlage ist der Evakuierungsplan für die Kreise des „Warthegaus“ sowie angrenzende Kreise der Neumark und Niederschlesiens vom Februar 1945. ${ }^{886}$ Er nennt (mit der einzigen Ausnahme des fehlenden Kreises Scharnikau/Czarnikau) für sämtliche 44 Stadt- und Landkreise des Reichsgaus Wartheland Aufnahmekreise in der westlich angrenzenden - Provinz Brandenburg. Von diesen lagen zwar, von den brandenburgischen Neiße-Grenzkreisen Guben und Sorau abgesehen, die für Leslau und Hermannsbad (Königsberg/Nm.), Waldrode und Kutno (Soldin), Warthbrücken und Gnesen (Landsberg/ Warthe) sowie Krotoschin und Rawitsch (Pyritz?) östlich der Oder und wurden damit schon nach kurzer Zeit obsolet, doch gehört nicht nur die Mehrheit der vorgesehenen Aufnahmekreise zum Gebiet des heutigen Landes Brandenburg, sondern es kommen im Evakuierungsplan zudem - ohne Ausnahme - alle damaligen brandenburgischen Landkreise, die heute zum Land gehören, vor. Folglich wird man, unter Berücksichtigung frontbedingter Umplanungen etwa im Oderraum um Bad Freienwalde und Lebus, sehr wahrscheinlich überall in Brandenburg „Warthegau“-Flüchtlinge finden können. Schwerpunkte bildeten zumindest 1946 (laut Volks-

883 So heißt es z.B. in einer Selbstdarstellung der aus dem Kreis Ostrowo stammenden Vertriebenen: „Die Einwohner unseres Heimatkreises sind über alle Länder der Bundesrepublik verteilt, ein großer Teil blieb in der DDR." (Otto Käding in: Heimatbuch für den Kreis Ostrowo/Provinz Posen mit angrenzenden Kreisen Kalisch und Kempen. Hrsg.: Heimatkreisgemeinschaft Ostrowo in der Landsmannschaft Weichsel-Warthe e.V. Zsgest. von Otto Käding. Kirchlengern 1983, S. 40).

884 Siehe oben im Kapitel II. 2, Abschnitt „Transporte“, die Tabelle 1 (Vertriebenentransporte nach Küchensee).

885 Aus der katholischen Gemeinde Golzow bei Seelow ist z. B. überliefert, dass „vor allem Flüchtlinge aus Schlesien, Ostpreußen und dem Warthegau [...] die neue Gemeinde" bildeten (Brühe, Katholische Kirche zwischen Uckermark und Oderland [wie Anm. 148], S. 45). 
zählung) die westlichen Grenzkreise Ost- und Westprignitz, Westhavelland, Zauch-Belzig und Luckau, allesamt Kreise, in denen diese Fakten schon im Januar/Februar 1945 geschaffen worden sein dürften. ${ }^{887}$

Neben den wenigen Belegen aus zeitgenössischen Akten gibt es weitere Indizien. So enthält der Plan für den „Warthegau“-Kreis Schroda den Aufnahmekreis Jüterbog-Luckenwalde. Hier lässt sich die tatsächliche Durchführung und Ankunft, worauf schon im Kapitel zur Flucht hingewiesen worden ist, am Zielort Dahme (Mark) durch Nachrichten von einheimischen Zeitzeugen und Ortschronisten belegen. ${ }^{88}$ Situationsbedingte Abweichungen vom Plan zeigen sich beispielsweise darin, dass die Bevölkerung des „Warthegau“-Kreises Wollstein eigentlich in den Kreis Osthavelland „wechseln“ sollte, aber dann doch ebenfalls in den Kreis JüterbogLuckenwalde geleitet wurde, wo die Organisation der „Aufnahme und Unterbringung im Aufnahmekreis [...] durch den Meldekopf Wollstein in Baruth" wahrgenommen wurde und überliefert ist, dass ca. 300 Flüchtlinge aus dem Kreis Wollstein im Kreis Jüterbog-Luckenwalde untergekommen seien. ${ }^{889}$ Erst etwas später kamen aber dann doch noch ca. 200 Flüchtlinge aus dem Kreis Wollstein im „Kreis Nauen“ (Osthavelland) unter. ${ }^{890}$

Aus dem Kreis Ostprignitz, der laut Plan die Bevölkerung der Kreise Mogilno und Obornik aufnehmen sollte, ist durch die Tagebuchnotiz eines Prignitzer Pfarrers überliefert, dass auch dies tatsächlich erfolgt ist. Am 5. Februar 1945 notiert Pfarrer Salefsky in Kuhsdorf: „Die Ostprignitz wird Aufnahmegebiet für die Kreise Mogilew [Mogilno] und Obornigk [Obornik]." ${ }^{\text {"891 }}$ Die Prignitz als ohnehin besonders stark mit Flüchtlingen, auch aus der Neumark und dem Netzekreis, konfrontierte Region erhielt auch in ihrer westlichen Hälfte Aufzunehmende aus dem „Warthegau“. Denn auch hier finden sich Entsprechungen zum Evakuierungsplan in anderen Nachrichten. Vorgesehen war die Westprignitz für die Bevölkerung der Kreise Birnbaum und Samter, und so überrascht es nicht mehr, wenn schon für etwa Ende Januar 1945 die Einrichtung einer Meldestelle für den Kreis Birnbaum in Dergenthin bei Wittenberge und einer weiteren durch Bürgermeister Thüte in Lanz bei Lenzen (Kr. Westprignitz) überliefert wird. ${ }^{892}$

Umplanungen erfolgten wohl auch bezüglich der in Aussicht genommenen Uckermarkkreise, denn für Hohensalza (Stadt und Land) waren im Plan Angermünde und Prenzlau vorgesehen, doch hat eine damals junge DRK-Helferin berichtet, dass wohl noch im April 1945 zumindest auch Belzig Zielort dortiger Flüchtlinge wurde: „Ich erinnere mich an einen Flücht-

887 Siehe Tabelle 4. Vgl. Christopeit, Herkunft und Verteilung (wie Anm. 29), S. 96.

888 Wagenknecht, 20. April 1945 (wie Anm. 453), S. 24 f. Siehe auch den Zeitzeugenbericht von Werner Pfeiffer in der Ortsdokumentation Dahme.

889 Dokumentation der Vertreibung I/1 (wie Anm. 192), S. 383. Siehe auch Ortsdokumentation Kr. JüterbogLuckenwalde und Baruth.

890 Dokumentation der Vertreibung I/1 (wie Anm. 192), S. 383.

891 Chronik der Pfarre zu Kuhsdorf (wie Anm. 448), S. 129. Siehe auch Ortsdokumentation Kuhsdorf.

892 Hielscher, Das Kriegsende 1944/45 für den Kreis Birnbaum (wie Anm. 445), S. 14. 
lingszug, der als offener Güterzug bei 6 Grad Kälte aus Hohensalza hier ankam." ${ }^{893}$ Andererseits lassen sich in den Sterberegistern des Standesamtes Prenzlau schon in den ersten Monaten des Jahres Flüchtlinge aus dem „Warthegau“ finden, so dass die Uckermark hierbei keineswegs ausgespart worden sein kann. Tiefergehende Einzeluntersuchungen würde freilich auch zu berücksichtigen haben, wie groß die Zahl der tatsächlich am Zielort ankommenden Trecks und Einzelpersonen im Vergleich zur ursprünglichen Bevölkerungszahl der jeweiligen Evakuierungskreise war. So ist z. B. für die Kreise Hohensalza und Leslau überliefert, dass es sich nur um ein Drittel gehandelt haben kann, da etwa zwei Drittel unterwegs den Tod fanden. ${ }^{894}$

Unter den aus dem „Warthegau“ nach Brandenburg Evakuierten bzw. Geflüchteten waren indes nicht nur Familien, die seit Generationen als Deutsche in Polen bzw. der Provinz Posen gelebt hatten oder während des Kaiserreiches dort angesiedelt worden waren, sondern auch solche, die erst kurz zuvor während der Kriegsjahre zum Zwecke der Germanisierung dieses alten polnischen Gebietes angesiedelt worden waren - aus ihren angestammten Siedlungsgebieten umgesiedelte Deutschbalten ${ }^{895}$, Bessarabiendeutsche ${ }^{896}$, Galizien- und Bukowinadeutsche ${ }^{897}$ so-

893 Gertraud Sewerin: Krankenschwester vom DRK. In: „... das Glockengeläut ist einzustellen“. Belzig 1995, S. 101-102, hier S. 101.

894 Kotzian, Die Umsiedler (wie Anm. 403), S. 103.

895 So finden sich z.B. im standesamtlichen Sterberegister für Prenzlau in den ersten Monaten des Jahres 1945 diverse Flüchtlinge aus dem „Warthegau“ mit baltischen Geburtsorten.

896 Ausdrücklich erwähnt wird sowohl die bessarabiendeutsche Herkunft als auch der Bezug zum (ab 1941) letzten Wohnsitz vor der Flucht im „Warthegau“ z. B. bei dem nach 1945 in Rathenow wirkenden Lehrer Theodor Muchin (siehe Ortsdokumentation Rathenow). - Brandenburgische (und unmittelbar benachbarte sachsen-anhaltische) Wohnorte (meist mit DDR-Postleitzahl) nach der Flucht 1945 (neben überwiegend westdeutschen, einigen US-amerikanischen und vereinzelten mecklenburg-vorpommerschen, sächsischen, thüringischen und weiteren sachsen-anhaltischen sowie mit nur allgemeiner Angabe „DDR“) werden für Bessarabiendeutsche z. B. auch erwähnt in der kompletten (vor 1989 gedruckten!) Bevölkerungserfassung eines bessarabiendeutschen Dorfes (insgesamt ca. 2000 Personen): Ernst Necker: Friedensfeld, Bessarabien. Familien- und Sippenregister. Stuttgart/Mühlacker 1984 (betrifft 1984 noch Lebende, sofern kein Todesdatum oder + vermerkt ist), S. 17 („Neu-Ruppin/DDR“, Witwe, gest. 1948), S. 23 („Glienecke/DDR“ [bei Ziesar]), S. 33 (2 × „Wusterwitz/ DDR 1806“, dabei Todesdatum 1954), S. 33 (gest. 1954 „Magdeburg DDR 3000“), S. 34 (2 × Magdeburg, dabei Todesdatum 1977), 49 (5 Personen: „Oschersleben/DDR“; ein Ehepaar, gest. 1955 „Wall/DDR 1951“ bzw. 1952 „Wustrau/DDR 1951“; „Brandenburg/DDR 1800“; „Kremmen/DDR 1423“), 66 (gest. 21.10.1945 „Teltow DDR 1530“), 71 (gets. 1953 „Neuholland/DDR 1401“), 78 (gest. 16.12.1945 „Luckenwalde DDR 1710“), 83 (gest. 1969 „Tremmen/DDR 1551“), 94 f. ( $2 \times$ gest. 1950 „Schulzendorf/DDR 1311“ [bei Bad Freienwalde]), 100 (gest. 1947 „Damerow/DDR“ [unklar welches], 103 („Pritzwalk/DDR 1920 “), 107 (gest. 1962 „Neuruppin/DDR 1950“), 126 („Hohenwalde/DDR 1201“ [Kr. Lebus]), 136 („Schwedt/DDR 1330“), 144 („Zernikow/DDR 2131“ [bei Prenzlau]; $2 \times$ „Hohenwalde/DDR 2091“ [bei Templin]), 164 (8 × „Hohenwalde/DDR 1201“ [Kr. Lebus], 167 u. 169 (4 × [darunter Todesfälle 1956 u. 1969] „Papenbruck/DDR 1931“ [Papenbruch bei Wittstock]), ferner Berlin S. 16, 38, 42-44, 55, 70, 73, 116, 125.

897 Ein Beispiel ist die 1940 aus der Bukowina nach Kalisch umgesiedelte Familie, die Anfang Januar 1945 zunächst nach Strasburg/Uckermark gelangte (im Plan war für Kalisch der Kreis Sorau vorgesehen) und im Februar bei Bekannten in Potsdam unterkam. Siehe die Schilderung von Edi Huber nach Tagebuchauszügen von Ada U. in einer Fortsetzungsserie in: Potsdamer Neueste Nachrichten, 28.1., 25.2., 1.4., 29.4., 23.9., 21.10., 23.12.1995. 
wie Dobrudschadeutsche ${ }^{898}$, die unten gesondert behandelt werden. In den Quellen und für die Zeitzeugen sind sie freilich bisweilen - ohne Differenzierung - unter den Flüchtlingen aus dem „Warthegau“ mit genannt, dann aber auch wieder als Sondergruppe und, wenn Einzelpersonen erwähnt werden, nach ihrer konkreten ursprünglichen Heimat bezeichnet. Diese Unterschiede erschweren nicht nur statistische Untersuchungen, doch ist zu bedenken, dass die nicht selten dramatischen Abläufe des Jahres 1945 ohnehin vielerorts dafür sorgten, dass Menschen aller nur denkbaren landsmannschaftlichen „Migrationshintergründe“ unterwegs waren und in den meisten Fällen eher „atomisiert“ denn als Gruppe wahrgenommen wurden. Nur an wenigen Stellen bestand überhaupt ein Interesse an der Erfassung der landsmannschaftlichen Eigenschaft - über die Angabe des Geburtsortes und -kreises hinaus - als für die Verwaltung interessantem Merkmal. Je mehr sich die neuen Verwaltungsstrukturen in der SBZ/DDR etablierten und je höher die jeweilige Ämterebene eingestuft war, desto mehr fragte man nur noch nach Staaten als Herkunftsgebieten, seltener nach Regionen, Provinzen oder gar Kreisen und Orten.

So lassen sich die aus dem Wartheland gekommenen Flüchtlinge und Vertriebenen in den publizierten Ergebnisdaten der Volkszählung von 1946 nicht als eigene Gruppe erkennen. ${ }^{899}$ Sie sind, zusammen mit den aus anderen Teilen Zentralpolens Gekommenen dem Stand von 1939 entsprechend als Deutsche aus (Vorkriegs-)Polen rubriziert, wobei man noch die Gruppe der Danziger hinzunehmen müsste, die allerdings im jeweiligen Aufnahmekreis kaum ins Gewicht fällt. Betrachtet man mit diesen Einschränkungen im Hinterkopf die 1939er „DeutschPolen“ von 1946, so stellten sie damals immerhin die viertgrößte landsmannschaftliche Gruppe in Brandenburg, mit den Danzigern zusammengenommen gar die drittgrößte. Bemerkenswert bleibt immerhin - und dies führt indirekt, aber dann doch auffällig zu den vorgenannten Schwerpunkten der evakuieriungsbedingten Ansiedlung von Wartheländern zurück -, dass die aus (Vorkriegs-)Polen stammenden Flüchtlinge und Vertriebenen 1946 in den Landkreisen Westprignitz und Westhavelland sogar mit sehr großem Abstand die Mehrheit bildeten, in der Ostprignitz immerhin noch - mit einer noch höheren Zahl als in den beiden anderen Kreisen an zweiter Stelle nach den Ostbrandenburgern und mit wiederum sehr großem Abstand vor allen anderen lagen.

\section{Ost- und Westpreußen}

Flüchtlinge aus Ostpreußen sind mit den Trecks vor Kriegsende - blickt man nur auf die SBZ/ DDR-Gebiete - zwar vornehmlich, geographisch naheliegend, im Norden, in Vorpommern und Mecklenburg, gelandet. ${ }^{900}$ Das zeigt nicht nur die Volkszählung von 1946, bei der sie hier

898 Im April 1946 wurden dobrudschadeutsche Flüchtlingsfamilien aus Rumänien, die seit 1940 im „Raum Posen/Warthegau" gelebt hatten, in Werder/Oderbruch angesiedelt (siehe Ortsdokumentation).

899 Siehe Tabelle 4.

900 Sie bildeten hier die zweitgrößte Gruppe nach den Pommern. Siehe die lose beiliegende Tabelle in Seils, Die fremde Hälfte (wie Anm. 19). 
mit Abstand am zahlreichsten vertreten waren und sogar auch, nach den (Hinter-)Pommern, die zweitgrößte landsmannschaftliche Gruppe bildeten. ${ }^{901}$ Es lässt sich vielmehr auch nach 1990 und bis heute schon allein daran ablesen, dass man größere ostpreußische Heimattreffen innerhalb der neuen Bundesländer weniger in Brandenburg, hingegen besonders in Anklam und Parchim findet. ${ }^{902}$ Gleichwohl lassen sich Ostpreußen in allen anderen SBZ/DDR-Ländern und so auch in Brandenburg nahezu überall, hier meist in den mittleren und auch noch den nördlichen Kreisen, antreffen, so dass ihr Anteil an den Vertriebenen in Brandenburg (bis heute) nicht unterschätzt werden darf. ${ }^{903}$

Die erste Welle der zwischen Oktober 1944 und Februar 1945 aus den nördlichen ehemaligen Ostprovinzen (Hinter-)Pommern, West- und Ostpreußen auch nach Brandenburg Evakuierten wurde nach Kriegsende, besonders 1947/48, aber noch bis 1951, durch Vertriebenen- bzw. Aussiedlungskontingente aus dem bis dahin weitgehend abgeriegelten nördlichen, nun sowjetischen Teil Ostpreußens (Kaliningrader Gebiet) und 1949 und 1951 aus den benachbarten litauischen Gebieten (Litauische SSR) stark erweitert. ${ }^{904}$ Mit den von dort in großer Zahl - über den Übernahmepunkt Pasewalk - auch nach Brandenburg geführten Eisenbahntransporten aus dem Sammelpunkt Königsberg (russ. Kaliningrad) ${ }^{905}$ kamen überdies neben Erwachsenen, die 1945 nicht mehr hatten fliehen können oder wollen, viele zunächst oder dauerhaft elternlose Kinder nach Brandenburg, auch ganze Kindertransporte, darunter die sogen. „Wolfskinder ${ }^{“ 906}$, die sich teilweise jahrelang umherstreifend oder bei litauischen Bauern durchgeschlagen hatten. ${ }^{907}$

901 Endgültige Ergebnisse der Volks- und Berufszählung vom 29. Oktober 1946 (wie Anm. 213), hier H. 7, S. 2.

902 Beispielbericht über ein Regionaltreffen am 27.4.1996: Gumbinner Heimattreffen in Parchim. In: Gumbinner Heimatbrief 89 (1996), S. 83.

903 Als Beispiele für Zeitzeugenberichte gebürtiger Ostpreußen siehe im Quellenverzeichnis die Selbstzeugnisse von Rudi Höpfner (Burg im Spreewald), Dieter Lyhs, Hildegard Rölke und Anneliese Thiel.

904 Leiserowitz, Von Ostpreußen nach Kyritz (wie Anm. 44), S. 29-33.

905 Wille II (wie Anm. 196), S. 116f. Alle fünf Länder der SBZ erhielten Kontingente dieser Transporte. Siehe auch: Fisch/Klemeševa, Zum Schicksal der Deutschen in Königsberg (wie Anm. 601), S. 398 f., S. 399 Tabelle 5 (Ablauf der Vertreibung): 1. Etappe April-Juni 1947 (3390 Personen), 2. Etappe 22.10.-30.11.1947 (30283 in 14 Zügen), 3. Etappe 16.3.-15.4.1948 (25 194 in 12 Zügen), 4. Etappe 21.8.-21.10.1948 (41 807 in 21 Zügen) (zusätzlich 8.10.1948 138 in 1 Zug), 5. Etappe Nov. 1949 (1402), 6. Etappe Mai 1951 (193).

906 Nach der 2014 neuformulierten Definition des in Berlin ansässigen, von Ruth Leiserowitz gegründeten „Wolfskinder-Geschichtsvereins e. V.“ ist der Begriff nur auf eine ganz konkrete Gruppe, nicht auf Flüchtlingsbzw. Kriegskinder allgemein, anzuwenden: „Bezeichnung für anhanglose deutsche Kinder und Jugendliche, die im Frühjahr 1947 dem drohenden Hungertod im nördlichen Ostpreußen zu entgehen versuchten, aus diesem Grund in Litauen in außerdeutsche Zusammenhänge gerieten und infolgedessen ihre Herkunft zeitweise oder mit Hilfe einer neuen Identität gar dauerhaft verschleiern mussten." (www.wolfskinder-geschichtsverein.de [21.8.2017]).

907 Auch noch nach 1990 sind einige (in den Nachkriegsjahren nach Litauen oder später in andere ehemalige Sowjetrepubliken gelangte) „Wolfskinder“ nach Brandenburg gekommen, so z. B. der 1942 in Königsberg i. Pr. geborene Hartmut Riemann, der von 1949 bis 1998 unter Verschleierung seiner deutschen Herkunft als Kazys Vaiciulis in Litauen und Kasachstan lebte, dann aber seinen deutschen Namen wieder annahnm und nach 
Viele ostpreußische Trecks sind schon ab spätestens Januar/Februar $1945^{908}$ durch brandenburgische Gebiete gezogen, die meisten wohl durch die Uckermark ${ }^{909}$, aber auch durch Barnim, Teltow, den Kreis Zauch-Belzig und das Havelland, und mancher wird schon damals an einem der Zwischenhalte bzw. Evakuierungsorte verblieben sein. ${ }^{910}$ Die Mehrheit der schließlich in Brandenburg ansässig gewordenen und teilweise noch heute dort lebenden Ostpreußen dürfte aber erst nach Kriegsende mit den erwähnten Eisenbahntransporten gekommen sein. Allein 1947 und 1948 gelangten von dort Transporte mit insgesamt über 10000 Menschen in das Lager Küchensee bei Storkow, kaum weniger dürften es bei den ebenfalls 1947 und 1948 nach Treuenbrietzen in das Lager Selterhof geleiteten gewesen sein. ${ }^{911}$ Als Zielpunkt für den 14. Transport aus dem nun sowjetischen Teil Ostpreußens wurde im Oktober 1947 zusätzlich das Lager Rüdersdorf vorgesehen. ${ }^{912}$ Aber auch anderswo werden Ostpreußen-Transporte immer wieder erwähnt, z. B. 1947 in der „Stadt Brandenburg/Quenzlager (Bhf.Altstadt)“913 und $1951 \mathrm{im}$ „Quarantänelager Fürstenwalde-Spree “914. So waren schon im Spätherbst 1945 per Bahn Vertriebenentransporte aus dem südlichen, nun polnischen Teil Ostpreußens in das Lager Luckenwal-

Schwedt/Oder übersiedelte. Siehe: Anette von Nayhauß: In: Hartmut Riemann. Mein Leben als Wolfskind. In: Berliner Morgenpost, 19.2.2011.

908 In Eberswalde offenbar schon 1944 (siehe Eberswalde 1945. Eberswalde 1995, S. 111; Fischer, Zuwanderung nach dem Zweiten Weltkrieg (wie Anm. 185), S. 34). Auch im Luise-Henriette-Stift in Lehnin werden schon 1944 „15 Flüchtlingskinder aus Ostpreußen“ aufgenommen (100 Jahre Diakonissenmutterhaus Luise-Henriette in Lehnin. Unna [2011], S. 140).

909 Im Sterberegister des Standesamtes Angermünde finden sich nicht nur über das ganze Jahr 1945 verteilt, sondern auch noch 1946 zahlreiche Flüchtlinge aus Ostpreußen. Siehe die Nachweise in der Ortsdokumentation.

910 Siehe die Erwähnungen von Trecks aus Ostpreußen in der Ortsdokumentation, u. a.: Angermünde, Bad Freienwalde, Beelitz, Bestensee (Kr. Teltow), Blankenfelde (Kr. Teltow), Brandenburg/Havel, Caputh (Kr. ZauchBelzig), Dallgow (Kr. Osthavelland), Liebenwalde, Potsdam, Prenzlau sowie Kreise Prenzlau und Templin. Die Ansiedlung von Vertriebenen aus Ostpreußen wird auch erwähnt für Felgentreu (Kr. Jüterbog-Luckenwalde), Fürstenwerder/Uckermark, Jahnberge (Kr. Westhavelland), Müncheberg, Neustadt/Dosse (Trakehner!), Schlepzig (Kr. Lübben), Seelow, Sperenberg.

911 BLHA, Rep. 256 Umsiedlerlager Küchensee, Nr. 166 und Nr. 217, jeweils unfol., und ebd., Nr. 166, unfol.: Berichte des Lagerleiters des „Umsiedlerlagers“ Küchensee über Ankunft und Aufnahme von Transporten aus Königsberg in Ostpreußen, Sept./Okt. 1948. - Wille II (wie Anm. 196), S. 117, 127, 136 f. - Bericht eines 1948 nach Küchensee gelangten Vertriebenen aus Ostpreußen: Vertreibung und Vertreibungsverbrechen 1945-1948. Bonn 1989, S. 244-245 (Dokument 8. Bauer Julius Jebram aus Scharnau, Kr. Neidenburg), hier S. 198-202, hier S. 202: Sept. 1948 Bahnhof Insterburg - Bahnhof Königsberg - 14 Tage Quarantänelager Küchensee. „Von hier kam ich nach Fredersdorf bei Berlin. In Küchensee habe ich durch einen Bekannten aus Wernigerode die Anschrift von meiner Familie erfahren und kann dann am 26. Oktober hier in Dahlenburg [Niedersachsen] an."

912 Wille II (wie Anm. 196), S. 117.

913 Ebd. (Zielpunkt für „normalen Transport“).

914 Quarantänebescheinigung dieses Lagers für Albert Pahm, geb. 1939 in Tilsit, „Quarantäne abgeleistet vom 13.5.51. bis 21.5.51./ Entlassen nach Kyritz" (Digitalisat: wolfskinder-geschichtsverein.de [7.8.2017]). Weiterleitung elternloser Kinder aus Fürstenwalde nach Kyritz im Mai 1951 auch erwähnt bei Sonya Winterberg: Wir sind die Wolfskinder. Verlassen in Ostpreußen. München/Zürich 2012, S. 180. 
de gekommen, in dem schlechte Bedingungen herrschten und sehr viele Menschen starben. ${ }^{915}$ An letztere, die besonders aus dem im Südwesten Ostpreußens gelegenen Kreis Mohrungen stammten, erinnert eine Gedenkstätte auf dem Waldfriedhof Luckenwalde, die Kriegsgräberanlage „Ehrenfeld Mohrungen"916, ein - mit der Nennung eines konkreten Vertreibungskreises seltener, in Brandenburg heute einmaliger Fall.

Nachweisbar sind vor Kriegsende nach Brandenburg gelangte ostpreußische Flüchtlinge ${ }^{917}$, die zumindest teilweise am Ort blieben, besonders in der Uckermark (Angermünde, Fürstenwerder, Schwedt/Oder ${ }^{918}$ ), aber auch in nahezu allen anderen nördlichen und mittleren Stadt- und Landkreisen, u. a. in Potsdam ${ }^{919}$, im Nieder- und Oberbarnim (Bad Freienwalde), im Kreis Lebus, in Prignitz und Ruppin sowie im Havelland, in Teltow, Zauch-Belzig und JüterbogLuckenwalde, weniger in der Niederlausitz, wo aber für einzelne Gemeinden dennoch Häufungen erwähnt werden..$^{920}$

Die Flüchtlinge aus dem ostpreußischen Ermland-Kreis Braunsberg, der als Beispiel dienen soll, befanden sich 1946 zwar mehrheitlich in den norddeutschen Ländern, vor allem in Schleswig-Holstein, viele aber auch in Niedersachsen, Mecklenburg und in Einzelfällen auch in anderen deutschen Ländern oder noch in dänischen Flüchtlingslagern. ${ }^{921}$ Es finden sich jedoch in dem im Herbst 1946 herausgegebenen Anschriftenverzeichnis auch acht Berliner und zwölf mit brandenburgischen Adressen: drei in Potsdam sowie je eine Person, meist Frauen, in Finsterwalde, Lehnitz/Nordbahn (Schwester im Kreiskrankenhaus), Lenzen (Untermiete), Lobetal (Hausmutter), Mellensee (Untermiete), Neuruppin (Untermiete), Teltow (Schwester), Treuenbrietzen (Landeskrankenhaus) und Zootzen im Kreis Ostprignitz. Dass nur eine einzige Person in der Niederlausitz nachgewiesen ist, verweist einmal mehr darauf, dass die Ostpreußen selbst innerhalb Brandenburgs eher in die mittleren Kreise und in den Norden gelangt waren.

Die Volkszählung von 1946 weist die Ostpreußen in Brandenburg insgesamt als fünftstärkste Gruppe aus (54241). ${ }^{922}$ Sie erreichte freilich - anders als Ostbrandenburger, Schlesier, Pommern und Deutsche aus (Vorkriegs-)Polen - in keinem brandenburgischen

915 Ilmar Degen: Flucht, Vertreibung und Deportation am Beispiel des Kreises Mohrungen/Ostpreußen. Wunstorf 2001.

916 Bericht mit Texten der Ansprachen und Grußworte von 2004 in: Mohrunger Heimatkreis-Nachrichten 104, 2004, S. 29-33. Siehe auch Ortsdokumentation.

917 Belege siehe in der Ortdokumentation.

918 Hier beruft der sowjetische Stadtkommandant im Mai 1945 sogar kurzzeitig einen Flüchtling aus Ostpreußen, den parteilosen Ackerbauern Kurt Wendt, zum Bürgermeister, der aber noch im Mai durch einen Einheimischen abgelöst wird (Wir wollten eigentlich nicht fliehen ... Schwedt im Frühjahr 1945. Hrsg.: Stadtmuseum Schwedt/Oder. Schwedt/Oder 2007, S. 83).

919 In Potsdam starb 1945 u. a. der ehem. evang. Pfarrer Dr. h.c. Eduard Korallus (1861-1945) aus Königsberg i. Pr., dort auch bekannt durch seine Arbeit im Verein für religiöse Kunst (Albinus, Lexikon Königsberg [wie Anm. 424], S. 180).

920 Schlepzig (Kr. Lübben).

921 Adressenliste der Braunsberger Gemeindeglieder. Stand: 25.11.1946. 13 S. u. 1 S. Nachtrag.

922 Siehe Tabelle 4. 
Stadt- oder Landkreis die Zahl 5 000. Die höchsten Konzentrationen finden sich 1946 in den Kreisen Ruppin (4694) und Niederbarnim (4088), wo sie sogar jeweils etwas zahlreicher waren als die fast überall stark vertretenen Schlesier, aber doch leicht hinter den Pommern rangierten. Nennenswert mit jeweils über 3000 Ostpreußen sind 1946 auch noch ihre Vorkommen in den Kreisen Ostprignitz, Osthavelland, Teltow und Westprignitz. Immerhin am Rande erwähnt sei, dass sie 1946 landesweit in einem einzigen (Stadt-)Kreis sogar die Mehrheit (unter den Flüchtlingen) bildeten: in Wittenberge, so dass der Wert für den Gesamtraum der Westprignitz zusammengenommen sogar auf dann doch bemerkenswerte 5398 stiege. Hier dürfte eine Rolle gespielt haben, dass von den oben bereits im Zusammenhang des Fluchtkapitels erwähnten rund 10000 Flüchtlingen, die Ende Januar 1945 per Bahn aus dem ostpreußischen Kreis Osterode (poln. Ostróda) nach Wittenberge evakuiert wurden, ein nennenswerter Teil am Ort verblieben ist. ${ }^{923}$

Wenngleich von den Transportinsassen nach einem Lageraufenthalt in Brandenburg viele in andere Länder überführt wurden oder zu anderswo lebenden Angehörigen wechselten, sind nicht wenige zweifellos im Land ansässig geworden. Auch evangelische und katholische Pfarrer aus Ostpreußen wurden in Brandenburg als Gemeindepfarrer eingesetzt. ${ }^{924}$ Ein deutliches Indiz für die Ansiedlung („Eingemeindung“) von Ostpreußen in und um Brandenburg an der Havel ist zum Beispiel, dass 1947 und 1948 größere Eisenbahntransporte mit Vertriebenen aus dem nun sowjetischen Teil Ostpreußens in das „Umsiedlerlager“ Brandenburg an der Havel geleitet wurden ${ }^{925}$ und dass in derselben Stadt, also wohl nicht zufällig, nach 1990 neben dem „üblichen“, landsmannschaftlich nicht näher definierten, Kreisverband des BdV auch eine „Kreisgruppe Ostpreußen/Westpreußen in Brandenburg an der Havel e. V." gegründet wurde. ${ }^{926}$ Auf deren Initiative entstand am Ort 2000 eine Ausstellung „Beziehungen der Begegnungsstätte mit dem russischen Oblast Königsberg/Kaliningrad“.927 Ähnlich darf man wohl die Tatsache deuten, dass die Kreisgemeinschaft Wehlau e.V. (Ostpreußen) mindestens in den Jahren 1998 und 1999 ihre Kreistreffen in Pritzwalk (Ostprignitz) durchgeführt hat. ${ }^{928}$ Eine Kreisgruppe Oranienburg e.V. der Landsmannschaft Ostpreußen bildete sich auch in Oranienburg (Niederbarnim), sie hatte allerdings schon 2016 nur noch 29 Mitglieder (2014: 59). ${ }^{929}$ Ferner gab es in Rathenow in den neunziger Jahren eine Kreisgruppe der Landsmannschaft Ostpreußen, die allerdings nur

923 Näheres (und Literatur) siehe in der Ortsdokumentation Wittenberge.

924 Siehe die Angaben im Pfarralmanach bzw. den Schematismen sowie unten das Kapitel IV. 3 zu den Kirchen.

925 Wille II (wie Anm. 196), S. 117, 136. - DAB, I/9-15-1 Flüchtlingsseelsorge 1945-1951, unfol., Jan. 1947: „Diesmal sind es meist Ostpreußen." - Siehe auch Ortsdokumentation Brandenburg an der Havel.

926 www.politische-bildung-brandenburg.de [2.6.2017]. Siehe auch Ortsdokumentation.

927 www.stadt-brandenburg.de [10.10.2016]); MAZ, 7.7.2005. Siehe auch Ortsdokumentation.

928 Wehlauer Heimatbrief 59 (1998), S. 5, 56-58; 60 (1999), S. 16 f., 44. - Beziehungen zum Heimatort Wehlau bestanden auch sonst in Brandenburg. So unterstützte die Landesgruppe Brandenburg der Landsmannscharft Ostpreußen um 2000 humanitäre Projekte in Königsberg (russ. Kaliningrad) und Wehlau (russ. Snamensk) (Bericht des Vorsitzenden H. Haut 2001; Mitteilung H.-J. Froese, Werder/H.).

929 Aileen Hohenstein, in: Märkische Onlinezeitung, 11.4.2016. 
kurze Zeit erwähnt wird und deren Vorsitz schon 1996 der Westpreuße (!) Herbert Kapahnke übernahm ${ }^{930}$, der dann bis zu seinem Tod 2015 mit einer an seinem Wohnort (Rathenow-) Semlin ansässigen Landesgruppe Brandenburg der Landsmannschaft Westpreußen e. V. erwähnt wird. ${ }^{931}$ Inzwischen besteht im Land Brandenburg keine eigenständige, auf Ostpreußen bezogene Kreisgruppe mehr, lediglich als Gruppe des BdV-Kreisverbandes arbeiten in Brandenburg an der Havel noch vertriebene Ostpreußen. ${ }^{932}$

Mancher BdV-Kreisverband hat inzwischen deutlichen Mitgliederschwund zu verzeichnen oder ist sogar schon aufgelöst worden. Selten und auffällig ist dagegen eine späte (ostpreuBische) Neugründung mit Sitz in Potsdam, wo sich am 1. September 1945 immerhin 1804 „Flüchtlinge und Umsiedler" aus Ostpreußen aufhielten ${ }^{933}$, 1948-1952 mit dem gebürtigen Allensteiner Hermann Gerigk (1924-1960) einer von ihnen sogar Bürgermeister war ${ }^{934}$ und auch nach 1990 ein Ostpreuße, Erwin Motzkus (1938-2010), Bürgermeister wurde. 2015 entstand hier eine Landesgruppe Ostpreußen der Landsmannschaft Ostpreußen neu, ${ }^{935}$ nachdem die 1993 gegründete Vorgängerin sich zuvor, begleitet von Vereinsquerelen, aufgelöst hatte. ${ }^{936}$

Eine Sondergruppe bilden schließlich die nicht wenigen, besonders in brandenburgische Kinderheime bzw. Waisenhäuser gelangten ostpreußischen Waisenkinder (teilweise auch „Wolfskinder“), die ab 1947 mit Bahntransporten aus Königsberg kamen. ${ }^{937}$ Letztere werden

930 Märkische Onlinezeitung (MOZ), 4.12.2015.

931 BdV-Handbuch 1996, S. 138, 168.

932 Auskünfte Hans-Jörg Froese (Werder/Havel), stellv. Vorsitzender der Landsmannschaft Ostpreußen e. V. und Vorsitzender der Landesgruppe Brandenburg der Landsmannschaft Ostpreußen e. V., 5.7.2017.

933 Potsdam und das Jahr 1945. Potsdam 1995, S. 23.

934 BLHA, Rep. 202 G Amt für Information, Nr. 162, Bl. 217. Er war eine schillernde Persönlichkeit, u. a. auch KGB-Informant (siehe Jürgen Köhler: Mein Vater war schlohweiß. Rekonstruktion eines politischen Mordes. In: Widerstand in Potsdam 1945-1989. Berlin 1999, S. 21-27, hier S. 22, 27).

935 lolgbrandenburg.wordpress.com/ [4.7.2017]. - Hans-Jörg Froese: Klares Bekenntnis zu Preußen, Ostpreußen und Brandenburg. Landesgruppe Brandenburg der Landsmannschaft Ostpreußen neu gegründet. In: Brandenburger Rundschau 14 (2016) 4, S. 11.

936 Auskünfte Hans-Jörg Froese (Werder/Havel), stellv. Vorsitzender der Landsmannschaft Ostpreußen e.V. (LMO) und seit 2015 Vorsitzender von deren neuer Landesgruppe Brandenburg, 5.7.2017. - Die aufgelöste frühere Landesgruppe Brandenburg der LMO mit Sitz in Potsdam (1993-2015) hatte am 16.1.1993 bzw. 7.6.1994 ihre Satzung angenommen und war am 7.12.1994 beim Amtsgericht Potsdam (VR 1328) eingetragen worden. Deren Vorsitzende waren: 1993-1995 Hartmut Borkmann (geb. 1934), Lehrer (Roskow bzw. Ziesar), 1995-1996 Albrecht Brommauer, Kalkulator in Rathenow, 1996-2008 Horst Haut (geb. 1932, gest. 2010, Meister für Maschinenbau in Oranienburg/Schmachtenhagen), 2008-2009 Eva Haut geb. Hainke (geb. 1935, Rentnerin in Oranienburg), 2009-2010 Wilhelm v. Gottberg (geb. 1940 Woopen, Kr. Bartenstein; Landwirt, Bürgermeister in Schnega, Kr. Lüchow-Dannenberg, 1992-2010 auch Bundesvorsitzender der Landsmannschaft Ostpreußen u. 1992-2012 Vizepräsident des BdV), 2010-2015 Elard v. Gottberg (geb. 1973 Bückeburg, Dipl.-Ing. agr. in Süsel, Kr. Eutin) (Mitteilungen Bundesgeschäftsstelle der Landsmannschaft Ostpreußen, Hamburg, und Akten der BdV-Landesgeschäftsstelle, Potsdam).

937 Leiserowitz, Von Ostpreußen nach Kyritz (wie Anm. 44), S. 102 f. - Ausführlich: Spatz, Nur der Himmel blieb derselbe (wie Anm. 44), bes. S. 117-140 („Eine Welt im Güterzug“), auch zum weiteren Schicksal in Heimen, bei Pflegefamilien usw. (S. 141 ff.). - Siehe auch Ortsdokumentation Crinitz (Kr. Luckau). - Dokumente zur 
in den zeitgenössischen Akten ausdrücklich als „Kindertransporte“, andere als „Normale Transporte“ bezeichnet. ${ }^{938}$ Zumindest 1947 diente für ihre Erstaufnahme („Durchschleusung“) vornehmlich das Lager Falkensee ${ }^{939}$, später (1949-1951) vor allem Fürstenwalde/Spree, „eines der drei großen Quarantänelager" für diese Transporte neben Wolfen bei Bitterfeld (Sachsen-Anhalt) und Bischofswerda (Sachsen $)^{940}$. Die weitere, teilweise jahrelange Unterbringung erfolgte in Kinderheimen in Altenhof am Werbellinsee, Bad Saarow, Pinnow bei Angermünde und ab 1951 im für diese Gruppe - auch als Bezugspunkt in der Erinnerung und bei Treffen bis heute wichtigsten Standort Kyritz. ${ }^{941}$ Im Wege der Familienzusammenführung gelang es in manchen Fällen noch nach Jahren, die Kinder wieder mit ihren Familien zu vereinigen, so dass eine nicht geringe, auch zonenübergreifende Fluktuation entstand. Viele von ihnen, vor allem die Vollwaisen, sind aber nachweislich in Brandenburg verblieben, andere sogar erst weit nach 1950 hierher gekommen ${ }^{942}$, so dass sich die Brandenburgische Landeszentrale für politische Bildung

„Aktion Kaliningrad“ bzw. Kindertransporten aus Ostpreußen: Wille II (wie Anm. 196), S. 110-138. - Definition des Begriffs „Wolfskinder“ siehe oben Anm. 906.

938 U. a. Wille II (wie Anm. 196), S. 117, Nr. 112 (23.10.1947).

939 BLHA, Rep. 203 MdI, Nr. 1198, Bl. 46. - Laut Wille II (wie Anm. 196), S. 117, als einziges brandenburgisches Auffanglager für Kindertransporte aus dem sowjetischen Teil Ostpreußens vorgesehen (Plan zur SBZAufschlüsselung vom 23.10.1947), was aber zweifellos später geändert wurde, da dann auch andere Lager, vornehmlich Fürstenwalde/Spree, erwähnt werden. Knappe Angaben zum Aufenthalt von (ostpreußischen) Kindern im Lager Agneshof in Falkensee (1945-1947) sowie (ab 1952) im Kreiskinderheim Falkensee-Finkenkrug siehe: Gudrun Kranert: 1945 - Ende des Zweiten Weltkrieges. Deutschland wird aufgeteilt - Flüchtlingsströme erreichen auch Falkensee. In: Heimatjahrbuch für Falkensee und Umgebung 2018 (2017), S. 6672, hier S. 67, 69, 71.

940 Das Ostpreußenblatt, 20.6.1951, zitiert nach Winterberg, Wir sind die Wolfskinder (wie Anm. 914), S. 179 f., hier S. 179. - BArch, DO 1/8408. - BLHA, Rep. 203 MdI, Nr. 1179-1181. - Auflösung des Lagers Bischofswerda (Putzkauer Str. 5) erst 1955 (BArch, DO 1/15801). - Ministerium für Volksbildung, HA Unterricht und Erziehung, Berlin, 16.4.1951 an MdI, Abt. Bevölkerungspolitik (Abt.-Leiterin Jacobs): „Für die Unterbringung des in Bischofswerda erwarteten Kindertransportes von 286 Kindern sind in den einzelnen Ländern der DDR nachstehende Heime in Aussicht genommen:/Mecklenburg: Kinderheim Alt Reese [Alt Rehse!] Brandenburg: Kinderheim Kyritz, Kinderheim Leuthen bei Cottbus/Sachsen/Anhalt: Kinderheim Wöbelsburg b. Hainrode / Kinderheim Bad Kösen/Sachsen: Kinderheim Erlbach/Vogtland/Thüringen: Kinderheim Ranis/Aufteilung der Kinder auf die Länder 55-60 je Land." (BArch, DO 1/8405, unfol.); in dieser Akte auch umfangreiche Listen (mit Zuverlässigkeits-„Charakteristiken“) der für die Abholung der Transporte aus „Tschernjachowskij“ (Tschernjachowsk, dt. Insterburg, Ostpreußen) zuständigen Personen; Leitung der Delegation 1951: Kurt Büttner (SED, VVN, DSF), MdI, Abt. Bevölkerungspolitik, geb. 1910; „Charakteristik: Leiter der Bevölkerungspolitik, seit 1946 verantwortlich für die Repatriierungsaktion der Umsiedler und Heimkehrer." - Zu den für Kindertransporte genutzten Lagern auch: Spatz, Nur der Himmel blieb derselbe (wie Anm. 44), bes. S. 138f., 166-186 (u. a. S. 169: „Meine Mutter hat uns, als wir in Fürstenwalde waren, ab sofort verboten, Litauisch zu sprechen. Aber das halbe Lager quatschte Litauisch und es ging immer wieder durch mit uns.").

941 Siehe die jeweiligen Abschnitte in der Ortsdokumentation.

942 Erst 1964 erhielt der im polnischen Teil Ostpreußens verbliebene Erwin Korsz eine Zuzugsgenehmigung nach Storkow: Erwin Korsz: Wie ich zum zweiten Mal Deutscher wurde. In: Geschichten aus sieben Jahrzehnten (wie Anm. 538), S. 29-32. 
2003 veranlasst sah, dem Thema eine eigene Publikation zu widmen. ${ }^{943}$ Dass das - in Fernsehdokumentationen immer wieder behandelte - Thema „Wolfskinder“ nicht nur, aber besonders auch zu Brandenburg gehört, weil es einen Teil seiner Bevölkerung bis heute direkt betrifft ${ }^{944}$ und „Kyritz“ in der Biographie vieler betroffener Menschen einer der wichtigsten Ortsnamen geworden ist, zeigte sich u. a. in einer Veranstaltung in Gransee, wo 2016 eine entsprechende Buchlesung Hörer nicht nur aus dem Ort selbst, sondern auch Fürstenberg/Havel, Dannenwalde und anderen Orten anzog. ${ }^{945}$ Diese Orte liegen - wie drei der oben genannten vier Standorte von („Wolfs-„,)Kinderheimen - sämtlich in nördlichen Landkreisen Brandenburgs.

Im von der Volkssolidarität getragenen Kyritzer Heim, damals noch als „Kinderdorf“ bezeichnet, verwandte man „ein pädagogisches Konzept, das für die damalige Zeit durchaus als fortschrittlich bezeichnet werden darf. Die einzelnen Wohngruppen sind in sogenannten Familien mit je zehn Kindern unterschiedlichen Alters organsiert. ${ }^{\text {“946 }}$ Allerdings wurde dieses System, das für den Zusammenhalt der unterschiedlich alten Geschwister zunächst sehr förderlich gewirkt hatte, schon 1951 aus ideologischen Gründen durch das der Kollektiverziehung in rein gleichaltrigen, nun größeren, ca. 20-köpfigen Gruppen ersetzt. ${ }^{947}$ Die „Kinderdörfer“ wurden $\mathrm{zu}$ „normalen“ Heimen. Dennoch blieb und bleibt das Kinderheim in Kyitz eine für die Waisenund „Wolfskinder“ entscheidend positive Lebensstation. Sowohl das einfühlsame Engagement der Leiter und Erzieher als auch das große, breitgefächerte Freizeitangebot - Sportgemeinschaften, Karneval, Mal- und Fotozirkel u.v.a. ${ }^{948}$ - sowie der überdurchschnittliche Aufwand für Betätigungsfelder in Landwirtschaft, Handwerk und vielen anderen Bereichen zwecks einer frühen Entwicklung von Verantwortungsgefühl werden in den Berichten der ehemaligen Heim-

943 Leiserowitz, Von Ostpreußen nach Kyritz (wie Anm. 44). Weder auf dem Titelblatt noch im Impressum oder im Nachwort (Vorwort fehlt), aber auf dem Umschlag wird die Landsmannschaft Ostpreußen e. V., Landesgruppe Brandenburg wie eine zweite, gleichberechtigte Mitherausgeberin genannt. - Siehe auch: Kibelka, Wolfskinder (wie Anm. 44) und die in Anm. 44 genannten weiteren Veröffentlichungen von Ruth Kibelka bzw. Leiserowitz. - Winterberg, Wir sind die Wolfskinder (wie Anm. 914). - wolfskinder-geschichtsverein. de. - Populäre Darstellung, nicht nur auf „Wolfskinder“ bezogen: Freya Klier: Wir letzten Kinder Ostpreußens. Zeugen einer vergessenen Generation. Freiburg u. a. 2014, bes. S. 236-275 (Kapitel „Die letzten Kinder Ostpreußens 1948“).

944 Immer öfter erscheinen Publikationen zum Thema, auch Zeitzeugenberichte, in den Medien ist es ebenfalls präsent. Winterberg, Wir sind die Wolfskinder (wie Anm. 914, S. 176), schrieb 2012: „Es bleibt meine Hoffnung, dass die Wolfskinder nicht länger als ,Täterkinder' gesehen, sondern in ihrem Leid als Opfer des Zweiten Weltkriegs ebenso wie des Kalten Kriegs anerkannt werden. Ihr Schicksal ist keineswegs zu Ende."

945 Bericht von Olaf Pasenau in: Brandenburger Rundschau 14 (2016) 5, S. 10-11, hier S. 10. Auch in Oranienburg, ebenfalls Landkreis Oberhavel (!), fand 2014 eine Zeitzeugengespräch statt, in dem „Wolfskinder“ zumindest ausdrücklich im Titel auch genannt und mitbehandelt wurden (www.politische-bildung-branden burg.de/node/10219 [5.6.2017]). Siehe ferner die häufigeren Berichte über Veranstaltungen zum Thema in: Brandenburger Rundschau, z.B. 12 (2014) 7, S. 8 f., 10.

946 Winterberg, Wir sind die Wolfskinder (wie Anm. 914), S. 181.

947 Leiserowitz, Von Ostpreußen nach Kyritz (wie Anm. 44), S. 37, 41 f. (Prinzip des sowjetischen Pädagogen Makarenko).

948 Winterberg, Wir sind die Wolfskinder (wie Anm. 914), S. 185. 
kinder immer wieder voller Dankbarkeit erwähnt. ${ }^{949}$ Viele „Wolfskinder“ kehrten und kehren bis heute auch als Erwachsene regelmäßig zu Besuchen dorthin zurück ${ }^{950}$, einige wurden zur DDR-Zeit hier sogar selbst Heimerzieherinnen. ${ }^{951}$ Eine Dokumentation in Kyritz und auch eine Gedenktafel am Gebäude - Zeitzeugen fordern dies seit längerem - sind wohl tatsächlich überfällig. Seit 2019 gibt es immerhin eine Informations-Stele.

Ein rückblickender Lebensbericht eines westpreußischen Flüchtlings, der als Kind im Kyritzer Heim Aufnahme fand, mag abschließend als Beispiel für die Schicksale der dort Untergebrachten stehen, die ja keineswegs sämtlich „Wolfskinder“, wohl aber Waisenkinder waren. Der 1942 geborene Richard Pekrul kam als Vollwaise mit den noch vor Kriegsende 1945 flüchtenden Großeltern nach Groß Pankow (Kr. Ostprignitz), wo man im Dachboden eines ehemaligen Wirtschaftsgebäudes eine notdürftige Unterkunft zugewiesen erhielt: „Mein Großvater ging bei den Bauern des Ortes arbeiten. Auch daran kann ich mich noch gut erinnern. Ich weiß, dass er für die Tagesarbeit manchmal mit einer Handvoll Kartoffeln nach Hause kam oder mit ein paar Scheiben trockenem Brot. 1947 starb dann meine Großmutter, ebenfalls [wie schon zuvor viele Flüchtlinge in einem Lager in Berlin - P. B.] an Typhus. Mein Großvater war damals mit uns Kindern hoffnungslos überfordert und so sind wir nach Bärensprung, Kreis Kyritz gekommen. Ab jetzt begann für uns eine neue Zeit. Wir hatten jetzt drei geregelte Ma[h]lzeiten, einen warmen Speiseraum, einmal in der Woche war Baden angesetzt und es gab auch eine Schule. Natürlich war im Heim alles sehr knapp. Damals war es so, dass die Bauern aus der Umgebung Sonntags im Heim eintrafen und sich dann Kinder aussuchen konnten, die sie dann bei sich aufnahmen und die in der Regel dann auch dort blieben. Ich war damals noch zu klein und mein Bruder wollte ohne mich nicht mit zum Bauern. Es kam immer wieder vor, dass dann Kinder von ihren neuen Pflegeeltern ausgerisen sind und dann ins Kinderheim zurück kamen. 1950 kamen wir dann in das Kinderdorf nach Kyritz, wo die Bedingungen für uns Kinder schon besser waren. Musik und Sport standen in der Freizeit ganz weit oben, ebenso gab es eine Volkstanzgruppe, einen Chor, einen Fanfarenzug, Modellbau, aber auch andere Möglichkeiten, um sich nach dem Unterricht zu beschäftigen. Aus heutiger Sicht weiß ich, wie wichtig es war, uns Kindern hier Einblick zu geben. Darüber hinaus gab es jedes Jahr ein Ferienlager, dann kamen die Jugendweihe-Stunden hinzu, um uns für das spätere Leben vorzubereiten. Ich besuchte die Grundschule, erlernte den Beruf eines Drehers im Motorradwerk Zschopau und arbeitete dann weitere 17 Jahre in diesem Beruf. Bemerkenswert fand ich auch, dass ehemalige Heimkinder den Beruf des Erziehers erlernten und diesen auch dann in ihrem alten Heim selbst ausübten. Im Nachhinein muss man sagen, dass Lehrer und Erzieher für die damaligen Verhältnisse sich zum Teil auch selbst aufgeopfert

949 Leiserowitz, Von Ostpreußen nach Kyritz (wie Anm. 44), S. 36-41.

950 Dagmar Möbius: Ehemalige Heimkinder treffen sich jährlich in der Ostprignitz. Kriegskinder und ihre Schicksale. (Erstdruck in: Der Märker, 8./9.5.2015). In: Brandenburger Rundschau 13 (2015) 5, S. 6-7. - Horst Schnick: Die Geschichten dürfen nicht verloren gehen, nichts darf verschwiegen werden! Wolfskinder trafen sich am 2. Mai in Bantikow. In: Brandenburger Rundschau 15 (2017) 5, S. 10.

951 Leiserowitz, Von Ostpreußen nach Kyritz (wie Anm. 44), S. 42. - Winterberg, Wir sind die Wolfskinder (wie Anm. 914), S. 183. 
haben, um uns Kindern eine sorglose Kindheit zu ermöglichen. Das gleiche traf auch für die anderen Mitarbeiter zu. Viele Kinder haben ihre Geburtsorte in den damaligen Ostgebieten später besucht. Es gibt heute noch einige unter uns, die in die Heimat regelmäßig fahren, um Hilfe zu leisten.

Nun treffen wir uns alle 2 Jahre in Bantikow bei Kyritz - und immer wieder bedanken wir uns bei unseren alten Erziehern und Lehrern (soweit sie noch am Leben sind) und drücken und herzen sie. Nie hatte ich das Empfinden, dass ich ungerecht behandelt oder dass jemand bevorzugt wurde. Das gleiche gilt auch für die Ausbilder, Lehrer und Erzieher im damaligen Motorradwerk Zschopau. Bis zum Jahre 2000 habe ich dann noch in einem Mutter-Kind[-]Kurheim gearbeitet. Jetzt sind meine Frau und ich Rentner. So oft es geht, fahren wir in meine ehemalige Heimat an die Weichsel. ${ }^{\text {"952 }}$

\section{Sudetendeutsche}

Sudetendeutsche ${ }^{953}$, deren Mehrheit - 1950 etwa 1 Million - in Bayern eine neue Heimat fand, sind zwar im Vergleich der neuen Bundesländer eher untypisch für Brandenburg, denn die meisten der in die SBZ gekommenen - 1950 lebten dort 612108 Sudetendeutsche - gelangten nach Sachsen-Anhalt (1950: 226042), gefolgt von Thüringen (146910) und Sachsen (110083). ${ }^{954}$ Die Bevölkerungszählung vom 29. Oktober 1946, also nach Eintreffen auch der „Antifa-Transporte“ und vor allem nach der erst unmittelbar zuvor, vom 10. bis 15. Oktober 1946, durchgeführten „Aktion 600 000“, in der „,insgesamt 586039 Deutsche aus der Tschechoslowakei in die SBZ gebracht“ worden waren, ergab für Brandenburg 40200 „Deutsche aus der Tschechoslowakei“, die Deutsche Zentralverwaltung für Umsiedler nannte wenige Wochen später, am 21. November 1946, immerhin 67330. ${ }^{955}$ Die relativ höchste Konzentration von Sudetendeutschen innerhalb Brandenburgs ergab sich nach der Volkszählung von 1946 mit jeweils über 3000 Personen in den Kreisen Luckau (4073), Zauch-Belzig (3214) und Westhavelland (3061).956

Die Gesamtzahl der nach Brandenburg gelangten Sudetendeutschen mag nicht nur gegenüber den in die anderen SBZ-Länder gelangten, sondern auch gegenüber nach Brandenburg

952 Richard Pekrul: Elternlos, aber Dank dem Schicksal gut betreut. Aus der Lebensgeschichte von Paul Pekrul. In: Brandenburger Rundschau 9 (2011) 8, S. 19.

953 Der Begriff „Sudetendeutsche“ ist in der Literatur, aber auch bei den Betroffenen selbst teilweise nicht unumstritten. Vieles spräche dafür, eher von „Deutschböhmen“ zu sprechen, wie dies mancher vor 1938 dort Geborene tut, doch ist der Begriff „Sudetendeutsche“ in den Quellen, in den meisten Publikationen und offenbar auch bei der Mehrheit der betroffenen Vertriebenen selbst, nicht nur bei der entsprechenden Landsmannschaft, durchweg in Gebrauch, weshalb er der Einfachheit halber auch hier verwendet wird.

954 Volker Zimmermann: Deutsche aus den böhmischen Ländern. In: Lexikon der Vertreibungen (wie Anm. 59), S. 133-136, hier S. 135. - Wenig ergiebig die knappen Bemerkungen im Unterkapitel „Die Sudetendeutschen in der SBZ/DDR“ in Habel, Die Sudetendeutschen (wie Anm. 529), S. 119-120.

955 Siehe Tabelle 4. - Vgl. Susann Bethke: Der Weg der Deutschen aus der Tschechoslowakei in die Sowjetische Besatzungszone Deutschlands (1945/46). In: Die Sudetendeutschen in der Sowjetischen Besatzungszone Deutschlands (wie Anm. 29), S. 5-27, hier S. 23. - Dokumentation der Vertreibung IV/2 (wie Anm. 192).

Siehe Tabelle 4. - Vgl. Christopeit, Herkunft und Verteilung (wie Anm. 29), S. 96. 
gekommenen Neumärkern oder Schlesiern klein sein, doch stößt man in allen Teilen des Landes immer wieder auf sie und findet auch ausdrückliche Erwähnungen ${ }^{957}$, was vermutlich mit ihrer - in den Augen der Einheimischen - partiellen Andersartigkeit zusammenhängt: mehrheitlich katholisch und mit ihrer österreich-ungarischen Vergangenheit zudem auch staatlich anders „sozialisiert“, hatten sie sich zuvor nur wenige Jahre ab 1938 im selben Staat befunden wie die „reichsdeutschen“ Brandenburger. Hinzu treten vielfach ganze Großfamilien und Gruppen prägende berufliche Gemeinsamkeiten, die neue, in Brandenburg bis dahin kaum heimische Gewerbezweige ins Land führten wie Schmuckwarenhersteller und Messerschmiede, die in Böhmen schon seit Generationen, also lange vor 1918, ganze Handwerks- und Industriezweige geprägt hatten. Auch von diesen Fachleuten kam die Mehrheit zwar nach Bayern und teilweise nach Thüringen, aber auch die weniger zahlreichen Neu-Brandenburger unter den Sudetendeutschen fielen schon durch ihre beruflichen Alleinstellungsmerkmale auf. Dass ein Teil von ihnen überdies zu der Sondergruppe der „Antifa-Umsiedler“958 gehörte, verstärkt dieses Bild insgesamt, sogar in der Perspektive der Umsiedler-Propaganda der SED. Gerald Christopeit, der als bislang einziger Historiker eine in Brandenburg lebende landsmannschaftlich definierte Vertriebenengruppe zum Thema eines Aufsatzes gemacht hat, geht sogar so weit, eine Sonderrolle festzuschreiben: „Die Sudetendeutschen stellten unter den Vertriebenen der Provinz Mark Brandenburg die einzige Gruppe dar, die in ihrer landsmannschaftlichen Eigenheit Spuren in der Mark, wie zum Beispiel geschlossene Vertriebenensiedlungen und die Einführung neuer Industrien hinterlassen hat. Dies stand eigentlich in krassem Gegensatz zu ihrer Anzahl ${ }^{\text {“959 Mit }}$ den „Industrien“ sind v. a. die geschlossenen Ansiedlungen von „Antifa-Transporten“, aus denen sich „Umsiedlergenossenschaften“ entwickelten, gemeint: die Glasfacharbeiter in Dorf Zinna/ Neuheim (Kr. Jüterbog-Luckenwalde) oder die Textilfacharbeiter in Neu Zittau (Kr. BeeskowStorkow) und die Messerschmiede in Leegebruch (Kr. Niederbarnim), die im Zusammenhang mit der wirtschaftlichen Vertriebenenintegration unten noch behandelt werden. ${ }^{960}$ Eine „Sonderrolle" ergab sich für Sudetendeutsche in der SBZ/DDR letztlich vor allem dadurch, dass die SED sie in ihrer „Umsiedler“-Propaganda gern als - vermeintlich auch auf die anderen Gruppen

957 Siehe die Erwähnungen in der Ortsdokumentation, ferner die Memoiren von Sudetendeutschen, die in der DDR gelebt hatten, im Quellenverzeichnis (2.4.2), beide erschlossen über das Geographische Register. Als Beispiel sei hier nur genannt, dass die langjährige Potsdamer Oberbürgermeisterin (1961-1984) Brunhilde Hanke geb. Anweiler (geb. 1930 Erfurt) mit einem 1945 vertriebenen Sudetendeutschen verheiratet war, dem bis 1986 an der Akademie für Gesellschaftswissenschaften beim ZK der SED (Berlin) und (durch Vermittlung von Lothar Bisky) 1987-1991 (zuletzt als Prorektor für Gesellschaftswissenschaften) an der Hochschule für Film und Fernsehen in Potsdam-Babelsberg tätigen Kulturwissenschaftler Prof. Dr. Helmut Hanke (geb. 1931 Herrnskretschen); sie sind die Eltern der ehemaligen Direktorin des Filmmuseums Potsdam Bärbel Dalichow geb. Hanke (geb. 1953 Potdam). Siehe Uwe-Karsten Heye / Bärbel Dalichow: „Wir wollten ein anderes Land“. Eine Familiengeschichte aus der DDR. München 2010 (S. 205-216 zum Vater, S. 206 auch kurz zu dessen NS-gläubiger Kindheit und Jugend im Sudetenland).

958 Siehe dazu oben im Kapitel II. 2 den Abschnitt „Transporte“.

959 Christopeit, Die Sudetendeutschen in der Provinz Mark Brandenburg (wie Anm. 29), S. 80.

960 Siehe oben im Kapitel III. 2 den Abschnitt „Umsiedlergenossenschaften“. 
übertragbares - Beispiel volkswirtschaftlich nützlicher, gewerbefleißiger und zugleich (partei-) politisch verlässlicher „Neubürger“ vorzeigte, deren Integration abgeschlossen sei. Dabei waren weder alle Sudetendeutschen - nämlich nur knapp 4000 - mit „Antifa-Transporten“ ins Land gekommene frühere tschechische KP-Mitglieder oder Sozialdemokraten ${ }^{961}$ noch betätigten sich alle in „Umsiedlergenossenschaften“, einem Modell wirtschaftlicher Verfasstheit, auf das die SED zudem schon nach einigen Jahren nicht mehr setzte. Anfangs noch in Firmen- bzw. Genossenschaftsnamen vorkommende Bezüge zum Herkunftsgebiet, wie bei der im Kreis Calau gegründeten Firma „Gebr. Reile, Sudetendeutsche Glasveredlung“, verschwanden meist noch früher, da sie für die SED untragbar waren. ${ }^{962}$

Ein Beispiel für auch nach der Vertreibung mit starkem Herkunftsbewusstsein ausgestattete Sudetendeutsche sind, auch unabhängig von „Antifa-Transporten“, die aus Gablonz (tschech. Jablonec nad Nisou) und Umgebung stammenden Vertriebenen, die in die SBZ/ DDR gelangt waren. ${ }^{963}$ Sie werden in den in den Westzonen kursierenden Heimatzeitschriften teilweise mit voller Anschrift genannt. ${ }^{964}$ So enthält der von 1949 bis 1959 in Bayreuth halbmonatlich erschienene „Gablonzer Heimat-Bote“ mit dem Untertitel „Organ des Heimatkreises Gablonz (Sudetenland)“ neben den allgemeinen Familienanzeigen („Aus unserer Familie“) und Suchmeldungen („Wo finde ich Isergebirgler?") ${ }^{965}$ noch mindestens bis 1953 sogar eine gesonderte Rubrik „Anschriften von Gablonzern in der Ostzone ${ }^{\text {“966 }}$, in der zwar thüringische und sachsen-anhaltische Adressen die Mehrheit bilden, aber auch brandenburgische vorkommen. ${ }^{967}$ In

961 Mit diesen Transporten sind bis Dezember 19463968 „Antifa-Umsiedler“ in 1426 Familien nach Brandenburg geleitet worden. Christopeit, Die Sudetendeutschen in der Provinz Mark Brandenburg (wie Anm. 29), S. 82 .

962 Rundscheiben des brandenburgischen Innenministeriums vom 8.2.1951 an die Kreise, mit dem die „Änderung von Namen der Umsiedlergenossenschaften und -betriebe, die an die alte Heimat erinnern", verfügt wurde. Teilabdruck einer Antwort (Negativbefind) aus Calau: Wille II (wie Anm. 196), S. 413 (nach BLHA, Rep. 250 Calau, Nr. 408).

963 Isergebirgler und ihre Schmuckindustrie im Thüringer Wald, Harz und Brandenburg. Hrsg.: Leutelt-Gesellschaft e.V. Schwäbisch Gmünd 2000. 160 S. (Jahresgabe für die Mitglieder der Leutelt-Gesellschaft, 2001; Gablonzer Bücher, 70).

964 Zu diesem Themenkomplex siehe unten im Kapitel IV. 2 den Abschnitt zur Lektüre von Heimatzeitschriften und Heimatliteratur.

965 Gablonzer Heimat-Bote 2 (1950) ff., passim (Familiennachrichten). U.a. in der Rubrik „Unsere Toten“ in 5 (1953), F. 1 (5.8.1953), S. 10, auch Personen in der „Sowjetzone“. Adressen in der SBZ/DDR lebender Gablonzer finden sich auch in der in Nürnberg erschienenen, für denselben Personenkreis gedachten „IsergebirgsRundschau. Gablonzer Heimatbote. Heimatkundliches Mitteilungsblatt für die Vertriebenen aus dem Isergebirge“ (geprüft wurde Jg. 4, 1950).

966 Gablonzer Heimat-Bote 4 (1952), F. 9, S. 4; 4 (1953), F. 19, S. 4.

967 Gablonzer Heimat-Bote 4 (1952), F. 9, S. 4: „Z[...], Walter, Michendorf-Markt Potsdam II, Rustenallee 3 (früher Angestellter des Stadtamtes Gablonz).“ Die unten behandelte fast rein sudetendeutsche Vertriebenensiedlung Neuheim bei Jüterbog spielte in der westdeutschen Gablonzer Vertriebenenpresse keine Rolle, auch finden sich keine dort wohnhaften Personen erwähnt. Das erklärt sich zweifellos aus dem besonderen Charakter der Siedlung, die aus einem der „Antifa-Transporte“ gebildet worden war und insofern als besonders SED-nahe gelten darf. 
der Rubrik „Unsere Toten“ wird 1953 neben anderen, in Sachsen-Anhalt und Sachsen Verstorbenen, sogar in einem siebenzeiligen Nachruf eines namentlich genannten „Lm.“ (Landsmanns) gedacht, der im Alter von 48 Jahren „an den Folgen einer Gasvergiftung, die er sich an seiner Arbeitsstätte in Stonsdorf ${ }^{668}, \mathrm{Kr}$. Teltow [Sowjetzone] zuzog, verschied“. ${ }^{\text {“99 }}$ Dass dieses „Outing“ nicht ganz risikolos war und zweifellos nicht durchgängig betrieben wurde, zeigt eine Notiz im „Gablonzer Heimat-Boten“ von 1953, betitelt „Herzliche Grüße aus der Ostzone“, in der die Redaktion einer zwar namentlich, aber ohne Anschrift genannten, 1874 geborenen ehemaligen Gablonzerin Platz einräumt und ihr Familienschicksal schildert. Sie sei „seit September 1945 in einem Bauerndorf vergraben" und "freut sich aufrichtig, wenn sie durch einen glücklichen Zufall einen, Gablonzer Heimat-Boten' in die Hand bekommt und dort bekannte Namen liest". Zum Schluss heißt es noch, die Redaktion gebe ihre Anschrift auf Wunsch gern bekannt, denn: „Bis jetzt hat sich Frau S[...] ,unsichtbar gemacht', würde sich jedoch freuen, von Gablonzer und Friedländer Bekannten etwas zu hören." 970

Insgesamt gab es, abgesehen von dem erwähnten Vorkommen einzelner Sudetendeutscher in nahezu allen Regionen und auch Städten sowie von den genannten Einzelfällen geschlossener „Gewerbe“-Ansiedlungen, Konzentrationen Sudetendeutscher nur in wenigen Kreisen. „Einer Erhebung der Provinzialverwaltung vom 1. November 1946 zufolge lebten die meisten Sudetendeutschen in den Kreisen Zauche-Belzig ${ }^{971}$, dort sind 3913 von ihnen eingemeindet worden, Westhavelland, dort lebten 3604 und Luckau ${ }^{972}$, wo 3026 Aufnahme fanden..$^{973}$ In den schwer zerstörten Ostkreisen der Provinz wie Prenzlau, Templin und Guben sind keine Sudetendeutschen verzeichnet. ${ }^{\text {“974 }}$ Vergleicht man diese Zahlen mit den in der Volkszählung vom 29. Oktober 1946 erhobenen, so ergibt sich zwar ein fast identisches Gesamtbild, doch sind die Werte im einzelnen keineswegs identisch, was abermals grundsätzlich auf Fluktuation, angesichts der fast identischen Datierung aber auch auf unterschiedliche statistische Rahmenbedingungen und Erhebungsgrundlagen verweist. Freilich war dort für den Wohnsitz am 1. September 1939 nicht nach dem „Sudetenland“, sondern nach der (da jedoch bereits „zerschlagenen“) Tschechoslowakei gefragt worden, aber die Betroffenen dürften gleichwohl fast sämtlich aus den Sudetengebieten stammen. Dennoch nennt die Volkszählung für den Kreis Luckau immerhin eine deutlich höhere Zahl (4073), für die Kreise Zauch-Belzig (3214) und

\footnotetext{
968 [Gemeint ist offenbar Stahnsdorf.]

969 Gablonzer Heimat-Bote 5 (1953), F. 1, S. 10 (eckige Klammern aus der Vorlage übernommen!).

970 Gablonzer Heimat-Bote 5 (1953), F. 4, S. 4 (Auslassung mit eckigen Klammern aus der Vorlage übernommen!).

971 [Muss heißen Zauch-Belzig.]

972 Besonders in Kirchhain (siehe Ortsdokumentation).

973 Siehe auch die Anordnung der Provinzialverwaltung vom 13.5.1946 zur Aufnahme von „50000 Umsiedlern aus der Tschechoslowakei" in die Auffanglager Jüterbog und Spremberg (Wille II [wie Anm. 196], S. 47 f., nach BLHA, Rep. 203 MdI, Nr. 1163, Bl. 381).

974 Christopeit, Die Sudetendeutschen in der Provinz Mark Brandenburg (wie Anm. 29), S. 80 (Angaben nach BLHA, Rep. 203 MdI, Nr. 1163).
} 
und Westhavelland (3061) dagegen erkennbar niedrigere, wenn auch in der Größenordnung ähnliche Zahlen. Die angebliche Fehlanzeige in den „Ostkreisen“ spiegelt sich ebenfalls nicht in der Volkszählung, wo zumindest in der Uckermark über 200, nur in Guben (Stadt und Land Zusammengenommen) unter 100 lebten.

Auch im Falle der Sudetendeutschen ist im Laufe der Jahre zweifellos eine starke Abwanderung nach dem Westen erfolgt ${ }^{975}$, doch zeigt die Tatsache, dass sich der Sitz der Landesgruppe Brandenburg der Sudetendeutschen Landsmannschaft 1996 im westhavelländischen Premnitz ${ }^{976}$, mithin in einem der vorgenannten Kreise ihrer höchsten Konzentration, befand, dass die Zahl der in Brandenburg gebliebenen keineswegs zu vernachlässigen ist.

\section{Deutschbalten}

Die Mehrheit der nach dem „Hitler-Stalin-Pakt“ von 1939 aus dem Baltikum in das Deutsche Reich umgesiedelten Deutschbalten ${ }^{977}$ wurde ab 1941 im „Warthegau“ und in DanzigWestpreußen untergebracht. ${ }^{978}$ Daraus ergibt sich, dass die meist schon im Januar 1945 nach Brandenburg gekommenen Angehörigen dieser Bevölkerungsgruppe statistisch nicht sichtbar sind, da sie in die größere Gruppe der Flüchtlinge aus dem „Warthegau“ eingereiht waren. ${ }^{979}$ Erkennbar wird das erst, wenn Daten zu einzelnen konkreten Personen vorliegen und einbezogen werden, was für die meisten Untersuchungen kaum machbar ist. ${ }^{980}$ Im Sterberegister des

975 Habel, Die Sudetendeutschen (wie Anm. 954), S. 120: „Während ihr Anteil an der Bevölkerung der damaligen SBZ etwa $5 \%$ ausmachte, betrug er unter den im Westen eintreffenden Flüchtlingen aus Mitteldeutschland rund 10\% (Ergebnis einer Zählung um 1960 im Durchgangslager Berlin).“

976 BdV-Handbuch 1996, S. 114, 168. - Schon 1945/46 werden in Premnitz Sudetendeutsche erwähnt. Christopeit, Die Sudetendeutschen in der Provinz Mark Brandenburg (wie Anm. 29), S. 81. - 2002 wird zwar der seit 1963 in Guben ansässige Dr. Herbert Fechtner als Landesobmann der Landesgrupope Brandenburg der Sudetendeutschen Landsmannschaft erwähnt (Mitteilung BdV-Landesgeschäftsstelle), doch wohnte auch er zuvor in Premnitz (LR online, 20.8.2007). Siehe zu der 1995 gegründeten Landesgruppe Brandenburg Ortsdokumentation/Potsdam.

977 Der Begriff Deutschbalten hat sich in der Literatur und auch als Selbstbezeichnung der Gruppe (auch DeutschBalten) gegenüber dem ebenfalls gängigen Begriff Baltendeutsche durchgesetzt und wird daher hier verwendet.

978 Jürgen von Hehn: Die Umsiedlung der baltischen Deutschen - das letzte Kapitel baltisch-deutscher Geschichte. Marburg/Lahn 1984 (Marburger Ostforschungen, Bd. 40). - Michael Garleff: Deutschbalten. In: Lexikon der Vertreibungen (wie Anm. 59), S. 126-128 (mit weiterer Literatur).

979 Dafür gibt es viele Beispiele, siehe den später als Lehrer und Redakteur in Göttingen lebenden Werner Pfeiffer (geb. 1929 Werro, Estland), der mit den Eltern 1941-1945 in Schroda (Wartheland) lebte, 1945 zur Zwangsarbeit nach Russland deportiert wurde und nach Entlassung und kurzem Aufenthalt in einem Flüchtlingslager in Berlin 1945 nach Dahme/Mark kam. Näheres in der Ortsdokumentation Dahme (mit Angaben zu seinen gedruckten Lebenserinnerungen). - In Altdöbern 1945-1947 als Arzt nachweisbar ist der aus Lodz nach dort gelangte, aber aus Riga stammende Gynäkologe Dr. Dr. Heinrich von Knorre (geb. 1897) (siehe Ortsdokumentation Altdöbern).

980 Siehe zeitgenössisch: Baltische Totenschau 1939-1947. Zsgest. u. hrsg. von Georg Adelheim. 1. Aufl. Göttingen 1947 (ersch. 1948). 477 S.; Nachtrag 1952, 183 S.; ferner, wesentlich erweitert und aktualisiert: Deutschbaltisches Gedenkbuch. Unsere Toten der Jahre 1939-1947. Bearb. von Karin von Borbély. Hrsg.: Deutsch- 
Standesamtes Prenzlau lässt sich beispielsweise erkennen, dass unter den von Januar bis März 1945 ankommenden Flüchtlingen auch viele im Baltikum gebürtig, aber vor Fluchtbeginn im „Warthegau“ wohnhaft waren. ${ }^{981}$ In lokalen Berichten und in Erinnerungen von Zeitzeugen werden für brandenburgische Städte gelegentlich Deutschbalten erwähnt, die bei Kriegsende mit ihren Russisch-Kenntnissen als Dolmetscher hilfreich waren. ${ }^{982}$ Insgesamt sind Deutschbalten in Brandenburg aber kaum ,auffällig“ geworden, beispielsweise auch nicht durch eine nach 1990 erfolgte Gründung einer entsprechenden Landesgruppe ihrer Landsmannschaft. ${ }^{983}$

Immerhin lebten - soweit erfassbar - in der gesamten DDR 1963 noch 10200 Deutschbalten (42 800 in Westdeutschland). ${ }^{984}$ Die Volkszählung von 1946 hatte für Brandenburg sogar 7263 Personen ergeben, die am 1. September 1939 in den Staaten Estland, Lettland oder Litauen lebten. Da hier noch nach dem Wohnort vor der während des Krieges erfolgten Umsiedlung gefragt worden war, bieten die ermittelten Zahlen als einzige greifbare Statistik für diese frühe Zeit einen gewissen Anhalt. Freilich dürfte die Abwanderung in die Westzonen und nach WestBerlin gerade unter den Deutschbalten besonders hoch gewesen sein, stammten doch viele von ihnen aus den alten Führungsschichten. Meist vergessen wird allerdings, dass es auch unter den Deutschbalten durchaus „einfachere“ Bevölkerungsschichten gab: Kraftfahrer, Nachtportier, Schornsteinfeger, Masseuse, Blumenbinderin, Verkäufer, diverse Handwerksgesellen u.a. ${ }^{985}$ Verglichen mit den zuvor behandelten landsmannschaftlichen Gruppen wären die - mit Abstand niedrigeren - Zahlen an sich hier kaum erwähnenswert. Der einzige Wert, der über 1000 Personen liegt, findet sich 1946 in der Ostprignitz, was kaum verwundert, ist dies doch der Landkreis mit dem damals mit Abstand höchsten Anteil Deutscher aus dem (Vorkriegs-)Polen, unter denen wiederum die aus dem „Warthegau“ geflüchteten zu suchen sind, mithin zahlreich gewesen sein dürften. Im südlichen Nachbarraum Westhavelland, in der damals kreisfreien Stadt Rathenow, befanden sich zumindest im Juni 1945 immerhin in so erheblicher Zahl Flüchtlinge auch aus Riga, dass es in der lokalgeschichtlichen Literatur ausdrücklich erwähnt wird. ${ }^{986}$

Baltische Genealogische Gesellschaft e.V. Darmstadt 1991. 517 S. (Versuch einer Gesamterfassung der im Zusammenhang mit Krieg, Umsiedlung, Flucht und Vertreibung verstorbenen Deutschbalten mit genauen Lebensdaten und Beruf, alphabetisch geordnet, darunter nicht wenige Sterbeorte in Brandenburg).

981 Stadtarchiv Prenzlau, Standesamt Prenzlau, Sterberegister 1945.

982 Ein Beispiel für viele: Gerhard Henniger: 700 Jahre Stadt Kremmen. Kremmen [1998], S. 49. Näheres siehe Ortsdokumentation Kremmen.

983 Die Betreuung übernahm die Berliner Landesgruppe der Deutsch-Baltischen Landsmannschaft e.V. (heute: Deutsch-Baltische Gesellschaft e.V.). (Bund der Vertriebenen, Vereinigte Landsmannschaften und Landesverbände. Handbuch. 3., überarb. Aufl. Bonn 1996, S. 167). Die heutige, weitgehend auf die alten Bundesländer konzentrierte (Sitz: Darmstadt; Patenland: Hessen) Deutsch-Baltische Gesellschaft e. V. hat keine Berliner Landesorganisation, wohl aber solche für Sachsen (Freital) und für Sachsen-Anhalt (Magdeburg) (www.deutschbalten.de [30.8.2017]).

984 Garleff, Deutschbalten (wie Anm. 978), S. 127.

985 Siehe die Berufsangaben in: Baltische Totenschau 1939-1947 (wie Anm. 980).

986 Rathenow. Chronik 1216-2007, S. 23 (vgl. Ortsdokumentation). 


\section{Bessarabiendeutsche}

Auch die Bessarabiendeutschen waren, wie die Deutschbalten, bereits im Zweiten Weltkrieg (1940/41) als Umsiedler in das Deutsche Reich gelangt und vornehmlich in „Warthegau“ und Danzig-Westpreußen angesiedelt worden. ${ }^{987}$ Insofern sind sie mit dem Blick auf die Situation in Brandenburg 1945 ebenfalls in erster Linie Flüchtlinge aus diesen Gebieten gewesen. Da sie sich in Brauchtum und Sprache stärker von den anderen Flüchtlingen unterschieden, wurden sie jedoch, als sie mit den dortigen einheimischen Deutschen 1945 flüchten mussten, auch an den neuen Aufnahmeorten als gesonderte Gruppe wahrgenommen und folglich oft gesondert erwähnt. Zwar ist auch von dieser Vertriebenengruppe die Mehrheit in die Westzonen gelangt (1964: 64383, mit West-Berlin) und veranstaltet bis heute Treffen vornehmlich im Raum Stuttgart, doch lebten 1964 in der DDR (einschließlich Ost-Berlin) noch 11920 „ehemalige Bessarabiendeutsche“, soweit solche Zahlen überhaupt zu ermitteln waren. ${ }^{988}$ Die meisten in der SBZ/DDR ansässig gewordenen Bessarabiendeutschen waren nach Mecklenburg gelangt, wo sie zum Teil in ganzen Dörfern zusammen blieben ${ }^{989}$, doch hat auch Brandenburg einen durchaus erwähnenswerten Anteil erhalten. Immerhin haben sich in brandenburgischen Orten Bessarabiendeutsche in der SBZ- und DDR-Zeit wiederholt, noch Jahre nach Kriegsende, im kirchlichen Rahmen getroffen. 1948 wurde in der Dorfkirche in Blumenthal (Kr. Ostprignitz) sogar der erste Glaubenstag für bessarabiendeutsche Flüchtinge in der SBZ gehalten, ein weiterer ist für 1968 in Letschin (Oderbruch) überliefert, veranstaltet durch den „Besuchsdienst im Evangelisch Kirchlichen Gnadauer Gemeinschaftswerk in der DDR“990

Als bessarabiendeutsches Ansiedlungsgebiet in Brandenburg hervorzuheben ist vor allem das nordwestliche Havelland ${ }^{991}$, besonders Schönholz ${ }^{992}$ (Kr. Westhavelland), wo eine größere Gruppe ansässig wurde und auch Bodenreformland sowie Neubauernhäuser erhielt, daneben, wohl in geringerer Zahl, auch der Raum Belzig ${ }^{993}$. Wenngleich in Mecklenburg eine deutlich

987 Grundlegend: Ute Schmidt: Die Deutschen aus Bessarabien. Eine Minderheit aus Südosteuropa (1814 bis heute). 3., unveränd. Aufl. Köln/Weimar/Wien 2006. - Hugo Schreiber: Umbrüche im Leben der Bessarabiendeutschen. In: Jahrbuch der Deutschen aus Bessarabien 56 (2005), S. 25-29.

988 Dirk Jachomowski: Deutsche aus Bessarabien. In: Lexikon der Vertreibungen (wie Anm. 59), S. 131-133, hier S. 133. - Kotzian, Die Umsiedler (wie Anm. 403), S. 241.

989 Ute Schmidt: „Drei- oder viermal im Leben neu anfangen zu müssen ...“- Beobachtungen zur ländlichen Vertriebenenintegration in mecklenburgischen „Bessarabier-Dörfern“. In: Geglückte Integration? (wie Anm. 18), S. 291-320. - Klaus Nitschke: Das Leben ging auch in Mecklenburg weiter. In: Jahrbuch der Deutschen aus Bessarabien 47 (1996), S. 75-78.

990 Herbert Keller / Arnulf Baumann: Bessarabischer Brüderbesuchsdienst in der DDR. In: Jahrbuch der Deutschen aus Bessarabien 59 (2008), S. 216-223, hier S. 217.

991 Dagmar Schubert: Schlange stehen in Havelland und der Lüneburger Heide. In: Mitteilungsblatt des Bessarabiendeutschen Vereins 70 (2015), H. 1, S. 20.

992 Siehe Näheres in der Ortsdokumentation.

993 Siehe die Erinnerungen eines nach Mörz bei Belzig gelangten Bessarabiendeutschen: Arthur Weiß: Von Bessarabien nach Belzig. Meine Memoiren. Leipzig 2012. - Ders.: Die letzten Kinder Bessarabiens. Neuanfang nach 
stärkere Konzentration feststellbar ist, so sind die in verschiedene Dörfer des Havellandes gelangten Bessarabiendeutschen dort doch - bis in die Esskultur hinein - ein noch heute sichtbares und immer wieder auch in der regionalen Presse thematisiertes Bevölkerungselement. Auch nach 1945 geborene Kinder und Enkel engagieren sich seit 1990 in einem Verein und in Treffen für den Zusammenhalt und die Bewahrung des mitgebrachten kulturellen Erbes ${ }^{994}$, z. B. am 13. Oktober 2013 in Stechow auf dem „5. Treffen des Regionalverbandes Havelland“ des Bessarabiendeutschen Vereins: „Rund 200 im Havelland lebende Bessarabiendeutsche waren in die Kulturscheune gekommen, um sich vor allem an ihre Heimat zu erinnern." Der persönlich aus Berlin angereiste moldavische Botschafter Aureliu Ciocoi brachte dabei mit seinem Grußwort ein gleichsam außenpolitisches Element in die brandenburgische „Provinz“: „Ein gutes Verhältnis zum Verein könne seinem Land helfen, der Europäischen Union näher zu kommen“.995

\section{Dobrudschadeutsche}

Wie die Bessarabiendeutschen gehören auch die Dobrudschadeutschen zu jenen Flüchtlingsgruppen, die 1945 bereits eine NS-zeitliche Umsiedlung in das Reichsgebiet hinter sich hatten und zumeist - für wenige Jahre - im „Warthegau“ angesiedelt worden waren, mithin $1945 \mathrm{zu}$ den vielen von dort kommenden Flüchtlingen zu zählen sind. ${ }^{996}$ Auch in ihrem Fall blieben besondere Gruppenmerkmale aber erkennbar, so dass sie an den Aufnahmegebieten dann doch eher als Dobrudschadeutsche denn als „Wartheländer“" auffielen und bezeichnet wurden. In der Volkszählung von 1946 sind sie freilich in der Gruppe der 1939 in Rumänien Lebenden verborgen (Brandenburg: 10717). ${ }^{997} 1964$ wohnten in der DDR 2318 Deutsche aus der Dobrudscha (Bundesrepublik: 8559). ${ }^{998}$ Für Brandenburg lassen sich Beispiele bisher nur in Schmergow (Kr. Zauch-Belzig) und Werder (Oderbruch) nachweisen. In Schmergow ermittelte das Volkspolizeikreisamt Potsdam nicht nur, dass dort drei im Januar 1953 „republikflüchtig“ gewordene „Kleinbauern“ zuvor „mit dem westdeutschen Umsiedlerverein ,Dobrucza-Deutsche“ in Verbindung standen“, sondern dass eine weitere Person, der örtliche Vorstand der NDPD, „der Verbindungsmann zu dieser Organisation war".999 In Werder (Oderbruch) wurden im April 1946 über 50 dobrudschadeutsche Flüchtlingsfamilien aus dem „Warthegau“ untergebracht, die hier anfangs in

Krieg, Flucht und Vertreibung in der DDR. Vier bewegende und tragische Geschwisterschicksale. Leipzig 2014.

994 Siehe z. B. die Ankündigung von Treffen der Bessarabiendeutschen in Stechow (bei Rathenow) und in Berlin in: Mitteilungsblatt des Bessarabiendeutschen Vereins 70 (2015), H. 11, S. 5.

995 Norbert Stein: Da staunte der Botschafter aus Moldavien! Regionaltreffen der Bessarabiendeutschen in Stechow. In: Brandenburger Rundschau 11 (2013) 10, S. 9.

996 Josef Sallanz: Dobrudscha. In: Online-Lexikon zur Kultur und Geschichte der Deutschen im östlichen Europa, 2012. URL: ome-lexikon.uni-oldenburg.de/54120.html (Stand 21.6.2012).

997 Siehe Tabelle 4.

998 Detef Brandes: Deutsche aus der Dobrudscha. In: Lexikon der Vertreibungen (wie Anm. 59), S. 138-139, hier S. 139. - Kotzian, Die Umsiedler (wie Anm. 403), S. 276.

999 BArch, DO 1/27887, Bl. 91. Vgl. vollständigen Textabdruck im Quellenteil, Nr. 241. 
katastrophalen Notunterkünften lebten, bis sie sich nach mehreren Jahren Wohnhäuser schaffen konnten. Der ausgeprägte Aufbauwille und Gemeinschaftsgeist der Siedler, gestärkt durch verwandtschaftliche Bande, erbrachte vorübergehend eine Art Musterbeispiel der Umsiedlereingliederung, das in zeitgenössischen Zeitungsberichten entsprechend präsentiert wurde. ${ }^{1000}$ Wie anderswo zerbrach die - auch landwirtschaftliche - „Erfolgsstory“ aber an der Zwangskollektivierung, die viele der Neusiedler in den Westen fliehen ließ und aus dem Oderbruchdorf bald einen „vergessenen Ort“ machte, der im Grunde erst ab 2006 durch Erinnerungsberichte und Presseartikel überhaupt wieder in das Bewusstsein der Brandenburger Öffentlichkeit gerückt wurde. ${ }^{1001}$

\section{Karpatendeutsche}

Anders als die bereits vor 1945 umgesiedelten Bessarabien- und die Dobrudschadeutschen kamen Karpatendeutsche erst nach Kriegsende als Vertriebene direkt aus ihren Heimatorten bzw. nahegelegenen Sammellagern ${ }^{1002}$ in der Oberzips (Slowakei) nach Deutschland und so teilweise nach Brandenburg, denn ihre Transporte wurden nicht nur in die Westzonen, sondern durchaus auch in die SBZ geleitet. Aus dem Lager Oberstuben (Nováky) kam z. B. die Mehrheit der Deutschen aus Münnichwies bei Deutsch-Proben 1946 nach Mecklenburg, nur - wie es in der eigenen Erinnerungsliteratur der Karpatendeutschen heißt - „kleinere Transporte hatten das Glück, was man damals so ,Glück' nannte, in die Länder der heutigen Bundesrepublik zu gelangen, und zwar hauptsächlich nach Bayern und Württemberg [...]. Seither sind viele Münnichwieser aus der Sowjetzone bzw. aus der späteren DDR in die Bundesrepublik geflüchtet, wo sich so mancher mit unermüdlichem Fleiß und in harter Arbeit inzwischen ein Eigenheim bauen konnte. “1003 Dass aber selbst diese Herkunftsgruppe sich innerhalb der SBZ/DDR nicht geographisch (auf Mecklenburg) begrenzen lässt, sondern auch Verbindungen nach Brandenburg entstanden, zeigen zumindest Einzelfälle. So schleppte ein als Fachschüler in Potsdam lernender Neunzehnjähriger eine karpatendeutsche Vertriebenen-Flugschrift ein, die er bei seinen Eltern in einem mecklenburgischen Dorf vorgefunden hatte. Eine Lehrerin fand sie während eines Stubendurchgangs am 22. April 1952 bei ihm. Im polizeilichen Verhör schwenkte der

1000 Anna Baudis: Werder - ein fast vergessenes Dörfchen im Oderbruch. In: Mitteilungsblatt des Bessarabiendeutschen Vereins 68 (2013), H. 4, S. 11-12.

1001 Vom Schwarzen Meer nach Werder. In: Märkische Oderzeitung [MOZ], 19.4.2006. - Siehe die näheren Angaben in der Ortsdokumentation.

1002 „Ende April 1946 wurde in der Kaserne in Poprad das Aussiedlungslager für Deutsche eingerichtet [...].“ (N. F.: Im Internierungslager Deutschendorf (Poprad) in der Zips. [Bericht des evang. Pfarrers]. In: Der Leidensweg der Karpatendeutschen 1944-1946. Eine Dokumentation. Hrsg. von der Arbeitsgemeinschaft der Karpatendeutschen aus der Slowakei. Red. von Adalbert Hudak. Stuttgart 1983, S. 82-85, hier S. 84). „Ende August 1946 ging der letzte Transport in die amerikanische Zone. [...] Danach wurde das Poprader Aussiedlungslager aufgelöst." (ebd., S. 85).

1003 E.B.: Schicksale der Deutschen in Münnichwiese bei Deutsch-Proben [Erstdruck in Karpatenjahrbuch 22, 1971, S. 111-113]. In: Der Leidensweg der Karpatendeutschen (wie Anm. 1002), S. 46-47, hier S. 47. 
junge Mann zwar auf die Parteilinie ein und meinte, seine Eltern würden „von irgend einer Stelle beeinflusst", doch die Broschüre, lag vor; vernichtet oder gar selbst der Polizei übergeben hatte er sie nicht. ${ }^{1004}$

Doch auch heute noch gibt es immerhin so viele und ihrer Herkunft bewusste Karpatendeutsche in Brandenburg, dass sie sogar Treffen veranstalten. Schwerpunkt ist der Raum südwestlich von Potsdam. ${ }^{1005}$ So trafen sich 2005 „in Brück 44 Karpatendeutsche mit Angehörigen. [...] Die Landsleute sind in Potsdam, Brück, Linthe, Neuseddin und Belzig angesiedelt." ${ }^{1006}$ In Brück wurde 1991 ein Landesverband Brandenburg der Karpatendeutschen Landsmannschaft Slowakei e. V. mit 80 Mitgliedern gegründet, der aber 2015 nur noch 30 Mitglieder hatte ${ }^{1007}$ und 2017 nur noch $17^{1008}$. Öffentliche Aufmerksamkeit erreichten sie mit den - letztlich 2015/16 bedingt erfolgreichen - Bemühungen um die Benennung einer Straße in Brück als „Oberzipser Straße" ${ }^{1009}$ sowie 2016 mit der Feier des „70. Jahrestages der Ankunft der Karpatendeutschen im Land Brandenburg", zu welcher "die Karpatendeutsche Landsmannschaft (KDLM) jetzt zu einem Erinnerungstreffen nach Brück eingeladen" hatte. „Dort waren 1946 zahlreiche Deutsche angekommen, die ihre Heimat in der heutigen Slowakei verlassen mussten. In der Brücker Lambertuskirche fand ein Festakt statt. Er begann mit dem Einzug der Teilnehmer, angeführt von Pfarrer Helmut Kautz. / Der Einladung waren viele ehemalige Zipser-Deutsche und auch deren Nachfahren aus Nah und Fern gefolgt, so dass die Kirche mit mehr als 100 Besuchern gut gefüllt war. Als Ehrengast nahm die Bundesvorsitzende der KDLM, Brunhilde Reitmeier-Zwick, an der Jubiläumsfeier teil. Der KDLMLandesvorsitzende, Michael Demko aus Brück, erwähnte den schwierigen, aber doch erfolgreichen Neuanfang der Zipser nach 1946 in der neuen Umgebung. / ,Nach Liedern, Glaubensbekenntnis und Evangelienlesung spielte eine Jugendband unsere Zipser Hymne und alle konnten mitsingen', berichtet Roland Hoffmann. Er ist ein Nachfahre der Fluchtgeneration und wurde 1947 als eines der ersten Kinder der Vertriebenen im Fläming geboren. Hoffmann pflegt die Verbindung in die alte Heimat seiner Eltern bis heute. [...]."

Wie bei den Bessarabiendeutschen in Rathenow und Umgebung bilden auch die Oberzipser Karpatendeutschen in Brück ein Beispiel dafür, dass nach der Vertreibung geborene Kinder und Enkel sich inzwischen der Geschichte ihrer Familie und der ihrer Herkunftsgruppe zuwenden, diese aktiv pflegen und damit auch öffentlich wahrgenommen werden. Der (nicht zu ihnen zählende) Brücker Pfarrer Helmut Kautz stellte ihnen z. B. am 15. April 2015 die evangelische Kirche für eine entsprechende Veranstaltung zur Verfügung, zu der er selbst einlud und so

1004 BArch, DO 1/27887, Bl. 77. Vgl. den vollständigen Text des Polizeiberichts im Quellenteil, Nr. 237.

1005 Hinzu kommen aber jene Deutsche aus der Karpatenukraine, die nach 1990 als Spätaussiedler nach Deutschland gelangten und deren Brandenburg-Anteil sich wohl in Eisenhüttenstadt konzentriert (Kotzian, Die Umsiedler (wie Anm. 403), S. 327).

1006 Die Karpatenblatt 14 (2005)4, S. 4.

1007 Die Karpatenpost 66 (2015)4, S. 4.

1008 Auskünfte Michael Demko, Brück.

1009 Siehe dazu unten im Kapitel V den Abschnitt „Städtepartnerschaften als Patenschaftsersatz“.

1010 MAZ online, 21.7.2016. 
eine Auseinandersetzung der örtlichen Bevölkerung mit dem Vertriebenenthema ermöglichte: Unter der Überschrift „Vertriebene und Flüchtlinge in Brück - ein Gemeindenachmittag mit Roland Hoffmann“ formulierte er eine „Herzliche Einladung zu Vortrag und Gespräch an Vertriebene, Zugezogene und Eingeborene!" und schrieb, den aktuellen Anlass aufgreifend, als Einladungstext: „In diesem Jahr kamen zum ersten Mal seit 1945/46 wieder Flüchtlinge nach Brück. Nun üben wir neu ein miteinander zu leben. Dabei kommen Erinnerungen und Fragen auf: Wie war das damals als die Flüchtlinge kamen? Wie ging das Leben weiter? Was ist vergleichbar mit heute und was ganz anders? / Beim Gemeindenachmittag am 22. April um 14.00 Uhr im Pfarrhaus Brück schaut Roland Hoffmann zurück und nach vorn. Seine Vorfahren lebten in der Hohen Tatra. Sie wurden vertrieben und kamen 1946 nach Brück. Sie kamen in ein kriegszerstörtes Land. Hielten sich nicht lange mit Trauer auf, packten an und bauten auf. / Herr Hoffmann wurde 1947 geboren. Sein Leben ist geprägt vom Schicksal seiner Eltern. Heute setzt er sich für die Erinnerung an die Vertriebenen und ihr Aufbauwerk in Brück ein. Desweiteren pflegt er den Kontakt in die ,Alte Heimat' und zu den heute dort Lebenden. / Beim Gemeindenachmittag soll nicht zuletzt mit Bildern zu einer Reise in die ehemalige Oberzips (Hohe Tatra) vom 12.-19. August 2015 eingeladen werden. [...] Gottes Segen wünscht Helmut Kautz (Pfarrer von Brück)." ${ }^{1011}$

1011 kirche-brueck.de/vertriebene-und-fluechtlinge-in-brueck-ein-gemeindenachmittag-mit-roland-hoffmann/ [2.6.2017]. 


\section{Materielle Aspekte - Fürsorge und Integration durch Assimilation}

\section{Verwaltung und Betreuung}

\section{Umsiedlerverwaltung}

Abgesehen von diversen anderen Ressorts (Wohnungsämter, Arbeitsämter usw.), mit denen Vertriebene ebenso wie die mit deren Eingliederung befassten Stellen im Einzelfall immer wieder zu kommunizieren hatten, existierte in den Jahren von 1945 bis 1950 im staatlichen und kommunalen Bereich eine differenzierte Struktur speziell für „Umsiedlerfragen“ zuständiger Fachbehörden bzw. Referenten. Deren Entwicklung, Benennung und vor allem Ressortzuordnung verlief - zentral, regional und lokal weitgehend parallel - von anfänglicher Sonderverwaltung oder an das jeweilige Arbeits- und Sozialwesen angelehnter bedingter Eigenständigkeit über eine Eingliederung in die Innenverwaltungen hin zur De-Facto- oder gar De-Jure-Auflösung. ${ }^{1012}$ Neben diesen zivilen deutschen Behörden und Behördenabteilungen ist - ebenfalls auf allen Ebenen von der SBZ über die Provinzen bzw. Länder bis zu Kreisen und Städten - die Rolle der SMA und der regionalen und lokalen sowjetischen Kommandanturen zu beachten, von denen nicht nur wesentliche Vorgaben oder zuweilen „beschleunigende“ Befehle kamen, sondern die auf SBZ- und Provinz-/Landesebene ebenfalls „Umsiedler“-Ressorts unterhielten. So wird auf der Zentralebene der SMAD beispielsweise beim Stellvertreter des Obersten Chefs für Fragen der Zivilverwaltung eine Abteilung für Umsiedlerfragen (Chef: Pereliwtschenko) erwähnt. ${ }^{1013}$ Ferner ist zu beachten, dass auch die Parteien - allen voran, aber nicht nur die KPD/ SED - Referenten für diesen Bereich besaßen ${ }^{1014}$ und auch im Provinziallandtag ein für Umsiedlerfragen zuständiger Ausschuss bestand ${ }^{1015}$.

Auf der Ebene der deutschen, länderübergreifenden SBZ-Verwaltungen arbeitete seit dem 15. September $1945^{1016}$ die auf Befehl der SMAD eingerichtete quasi-ministerielle „Zentralverwaltung für deutsche Umsiedler" (ZVU) (anfangs „Zentralverwaltung für deutsche Umsiedler im sowjetischen Okkupationsgebiet "1017 bzw. „Zentralverwaltung für Flüchtlingswesen und

1012 Michael Schwartz: Apparate und Kurswechsel.Zur institutionellen und personellen Dynamikvon „Umsiedler“Politik in der SBZ/DDR 1945-1953. In: Geglückte Integration? (wie Anm. 18), S. 105-135.

1013 Befehle der Sowjetischen Militäradministration des Landes Brandenburg 1945-1949. Frankfurt am Main 1997, S. 147.

1014 Siehe Schwartz, Vertriebene und „Umsiedlerpolitik“ (wie Anm. 13), S. 202.

1015 1946/47 „Ausschuß für Wiederaufbau, Gesundheit und Umsiedler“, Vorsitzender: Dr. Deeg (CDU) (Adreßbuch Groß-Potsdam 1947, T. 1, S. 15) (Dr. med. Arthur Deeg, geb. 1901 Schönwald, Oberfranken, Arzt in Greiffenberg, Kr. Angermünde, 1947 MdL [Handbuch des Landtages 1947 (wie Anm. 1064), S. 54, 107]).

1016 Gründung aufgrund eines SMAD-Befehls vom 14.9.1945

1017 Briefkopf 18.6.1946: „Zentralverwaltung für deutsche Umsiedler im sowjetischen Okkupationsgebiet, Berlin-Friedrichsfelde, Alt-Friedrichsfelde 1-2“, „Telegrammadresse: Umsiedlerzentrale Berlin“, Stempelaufdruck „Neue An- 
Heimkehrer" ${ }^{1018}$ ) mit Sitz in Berlin-Friedrichsfelde, Alt-Friedrichsfelde 1-2, bzw. (ab 1946) in Berlin-Mitte, Leipziger Str. 5-7, die den auf Landesebene eingerichteten und den dort zuständigen (Provinzial- bzw. Landes-)Ministerien untergeordneten (Landes-)Umsiedlerämtern ressortbezogene Weisungen erteilen konnte. ${ }^{1019} \mathrm{Ihr}$ Leiter (ab Oktober „Präsident“) war anfangs der - unmittelbar zuvor im Hauptamt für Sozialwesen der Stadt Berlin, Abteilung Ausgewiesene und Heimkehrer, tätig gewesene - aus Bayern stammende Altkommunist Joseph Schlaffer (1891-1964). ${ }^{1020}$ Nach seinem Ausscheiden am 15. Dezember 1945 folgte ihm der KPD-Mann Rudolf Engel (1903-1993), ein gebürtiger Berliner, der der ZVU, zunächst ihr Organisationsleiter, vom November 1946 bis April 1948 als Präsident vorstand. ${ }^{1021}$ Die ZVU wurde auf Beschluss der Kommission für Umsiedler und Heimkehrer vom 31. Mai 1948 und des Zentralsekretariats der SED vom 15. Juli 1948 als eigenständige Behörde aufgelöst ${ }^{1022}$, als Nachfolgerin arbeitete ab September 1948 die „Hauptabteilung Umsiedler und Heimkehrer in der Deutschen Verwaltung des Innern “1023 unter dem gebürtigen Breslauer Art(h)ur Vogt ${ }^{1024}$ (KPD/SED) mit Sitz im „Haus der Verwaltungen“ (dem späteren „Haus der Ministerien“, heute Detlev-Rohwedder-Haus/Bundesfinanzministerium) in Berlin-Mitte, Leipziger Straße 5-7. ${ }^{1025}$

Auf der brandenburgischen (Provinz-)Ebene wurde ein „Amt für deutsche Umsiedler“ ebenfalls erst im Herbst (27. September) 1945 eingerichtet. Zuvor hatte es allerdings seit Juli

schrift Haus der Zentralverwaltung, Berlin W 8, Leipziger Str. 5-7“ (BLHA, Rep. 601 VdN, Nr. 1562). - Dieselbe Behördenbezeichnung auch in: Branchen-Adressbuch Provinz Brandenburg mit Groß-Berlin. Ausgabe 1947. Berlin (1946), unpagin.: „Zentralverwaltung für deutsche Umsiedler im sowjetischen Okkupationsgebiet, Berlin W 8, Leipziger Str. 5-7“.

1018 SBZ-Handbuch. 2. Aufl. München 1993, S. 242 f.

1019 Manfred Wille: Die Zentralverwaltung für deutsche Umsiedler - Möglichkeiten und Grenzen ihres Wirkens (1945-1948). In: Sie hatten alles verloren (wie Anm. 15), S. 27-54. - Ein bemerkenswerter Hinweis auf die zumindest noch in der frühen Phase bestehende Doppelstellung der Provinzial-/Landesämter einerseits als Behörden der Provinzial-/Landesregierungen, die andererseits gleichwohl ressortbezogen auch als nachgeordnete Einrichtungen der entsprechenden ZVU gesehen wurden, ist der am 20.10.1945 in Potsdam verwendete Briefkopf „Provinzialverwaltung Mark Brandenburg, Unterabteilung der Zentralverwaltung für deutsche Umsiedler" mit Unterschrift von [Magda] Sendhoff (BLHA, Rep. 16 Nl Spiegelberg, Nr. 5, Bl. 1), gleichlautend u. a. auch schon in einem Schreiben vom 1.10.1945 (BArch, DO 2/39, Bl. 1).

1020 Wille I (wie Anm. 196), S. 231. - Wille, Zentralverwaltung (wie Anm. 1019), S. 29. - Kotsch, Vertriebene und Vertriebenenpolitik in Brandenburg (wie Anm. 39), S. 132. - SBZ-Handbuch (wie Anm. 1018), S. 1017 (mit offenbar falschem Datum 25.9.1945). - Kurt Schilde: Flucht über die Balkonmauer. Politische Biographie des Kommunisten Josef Schlaffer. In: Jahrbuch für historische Kommunismusforschung 2008, S. 310-318, bes. S. 316 .

1021 www.bundesstiftung-aufarbeitung.de/wer-war-wer-in-der-ddr [19.9.2017].

1022 Abwicklung „zum 30.6.1948“ laut Ther, Von Schlesien in die Lausitz (wie Anm. 49), S. 490.

1023 Oft auch nur als „Hauptabteilung Umsiedler“ (ohne den Heimkehrer-Zusatz) bezeichnet.

1024 Vogt gehörte jedoch nicht zu den Vertriebenen, er lebte schon lange vor 1945 nicht mehr in Schlesien (1914 Übersiedlung nach Leipzig) (www.bundesstiftung-aufarbeitung.de/wer-war-wer-in-der-ddr [19.9.2017]).

1025 SBZ-Handbuch (wie Anm. 1018), S. 217, 242 f. - Vor Vogt wirkten als Leiter noch, mit kurzen Amtszeiten, Michael Tschesno(-Hell) und Philipp Daub (beide KPD/SED). Vgl. Schwartz, Vertriebene und „Umsiedlerpolitik“ (wie Anm. 13), S. 202. 
1945 schon eine „Unterabteilung VII/2 Flüchtlingsfürsorge, Ausgewiesene und Heimkehrer" in der dem 3. Vizepräsidenten Fritz Rücker (1892-1974) (SPD/SED) zugeordneten Abteilung VII Arbeit und Sozialwesen gegeben, die bis zum 26. September arbeitete und insofern als unmittelbare Vorgängerin des Amtes anzusehen ist. ${ }^{1026}$ Leiter der Abteilung VII und in Personalunion auch der genannten Unterabteilung war seit Juli 1945 Dr. Gotthard Eberlein (18851970), ein im Vergleich mit den anderen Ressortvertretern dieser Jahre eher schon betagter, noch einmal für kurze Zeit eingesetzter Mann des Widerstandes gegen den Nationalsozialismus. ${ }^{1027}$ Der aus einer bekannten schlesischen evangelischen Pfarrerfamilie stammende, seit 1945 aber konfessionslose und seiner Herkunft und Familie weitgehend entfremdete Theologe und Pädagoge war in der Weimarer Republik als sozialistischer Pazifist hervorgetreten und bereits seit 1930 KPD-Mitglied. Das Kriegsende hatte er im Untergrund erlebt und war nach dem Einmarsch der Roten Armee im Mai 1945 sogleich kommissarischer Bürgermeister in seinem damaligen Aufenthaltsort Kolberg im Kreis Beeskow-Storkow geworden. Er trat dann aber nicht der KPD, sondern der SPD bei, der er, genauso wie seine Frau, die 1930 der KPD beigetretene Gesundheitsfürsorgerin Elsa Eberlein geb. Beyer (geb. 1910), schon vor 1930 viele Jahre angehört hatte. ${ }^{1028}$ Eberlein war in den ersten Monaten bis zur Ernennung seiner Stellvertreterin in der Abteilung VII, Magda Sendhoff (KPD), zur Leiterin des (der Abteilung untergeordneten) gesonderten „Amtes für deutsche Umsiedler“ (VII/2) ${ }^{1029}$ die für die Bewältigung der Flüchtlingsfrage wichtigste Person in der Provinzialverwaltung (Sept. 1945 eingestuft als Provinzialdirektor, 1946 Ministerialdirektor). ${ }^{1030}$ Seine Wortbeiträge in Sitzungen und Konferenzen zeugen von einem energischen Willen, die fast nicht zu bewältigenden Aufgaben zu meistern. Dabei scheute er das offene Wort nicht.

Auf der ersten zonalen Konferenz zum Flüchtlings- und Vertriebenenproblem am 3. September 1945 in Berlin berichtete Eberlein ebenso eindringlich wie dennoch resignierend über die unkontrolliert „umherwandernden Flüchtlinge“: „Man hätte einen Flüchtlingspaß einführen müssen. Die Flüchtlinge behaupten alle, keine Papiere zu haben. Der Flüchtlingspaß müßte folgende Angaben enthalten: Personalangaben, Ziel, Gesundheitszustand, um die Seuchengefahr zu vermeiden. Nur durch die Einführung dieses Passes kann vermieden werden, daß die Leute hin- und herziehen. Nach den Feststellungen der Landratsämter befinden sich 1,2 Millionen Flüchtlinge in den einzelnen Kreisen der Provinz Brandenburg. 800000 sind davon amtlich registriert, die anderen sind bei Bekannten untergeschlüpft. [...] Ein Vertreter der Landwirtschaftsabteilung ist sehr viel herumgekommen und hat beobachtet, daß an amtlicher Stelle $71 / 2$ Million Flüchtlinge durchgeschleust worden sind, die irgendwo geblieben sind. Er schätzt die Zahl der in Brandenburg befindlichen noch über 2

1026 Übersicht über die Bestände des Brandenburgischen Landeshauptarchivs. T. III/1. Berlin 2001, S. 351 ff., 369.

1027 Im Juli 1945 wohnte er offenbar noch zur Untermiete: „Jägerallee 7 bei Mog“ im Sept./Okt. 1946 hat er eine eigene Wohnung in Potsdam, Sonnenlandstraße 3 (BLHA, Rep. 203 MdI, PA 273).

1028 Personalakte: BLHA, Rep. 203 MdI, PA 273.

1029 BLHA, Rep. 203 MdI, Nr. 1166, Bl. 1.

1030 Siehe Wille I (wie Anm. 196), passim (S. 464). 
Millionen. Die russischen Besatzungsbehörden haben andere Zahlen von ihren Kreiskommandanten. Am Freitag wurde uns von der russischen Kommandantur mitgeteilt, daß aus der Tschechei nochmals 700000 Flüchtlinge kommen werden, die von der Provinz Brandenburg aufgenommen werden müssen. Der Präsident ${ }^{1031}$ hat festgelegt, jeder Kreis darf $60 \%$ aufnehmen, kein Kreis darf die Flüchtlinge weiter lassen. Jede Familie soll da bleiben, wo sie ist. Dieses [S. 212] weiterschicken von Kreis zu Kreis, von Provinz zu Provinz muß zu einem Chaos führen. [...]. “1032 Er schloss seinen kurzen zweiten Redebeitrag mit den Worten: „Wir müssen zu einer festeren Zahl kommen. Den Russen imponieren nur klare und konkrete Zahlen. "1033 Auch unter Sendhoffs Nachfolger blieb er dem Ressort noch bis zu seinem Rücktritt als Abteilungsleiter am 10. Oktober 1946 (mit Wirkung vom 31.10.) eng verbunden, auch wenn das de facto zunehmend wie eine selbständige Abteilung arbeitende Amt die tägliche Arbeit der „Umsiedlerverwaltung“ inzwischen wohl weitgehend allein wahrnahm.

Mit Magda (eigtl. Magdalene) S e ndh off geb. Müller, erst ab 1953 (nach Wiederverheiratung) Sendhoff-Trinkaus (1899-1963), einer gebürtigen Dortmunderin und ehemaligen Kontoristin, übernahm im September 1945 eine klassische Vertreterin der alten KPD der Weimarer Republik die Belange der brandenburgischen „Umsiedlerverwaltung“. Sie hatte vor 1933 ebenso in der KPD wie in der Roten Hilfe und der Internationalen Arbeiterhilfe gewirkt und Anfang der dreißiger Jahre in Moskau gearbeitet. Ihr erster Mann, der Schlosser und KPDFunktionär Heinrich Sendhoff (1900-1933), war 1933 im KZ Buchenwald ermordet worden, sie selbst hatte später im Zuchthaus gesessen. In einem 1962 abgefassten Lebenslauf schreibt sie: „(Nach der Kapitulation) war ich vom 1. Tage an mit tätig beim Aufbau des Bezirksamtes in [Berlin-] Weis[s]ensee und etwas später im Sekretariat der KPD beim Aufbau der Partei in Weissensee. Im Juni 1945 wurde ich vom Zentralkomitee [der KPD] eingesetzt in der Provinzialverwaltung Brandenburg in Potsdam als stellvertretende Leiterin der Abteilung Arbeit und Sozialfürsorge. "1034 Die offizielle Anstellung bei der Provinzialverwaltung Brandenburg erhielt sie den Akten zufolge am 18. Juli 1945, wohl als Stellvertreterin Eberleins, die aber bereits spätestens im August mit „Umsiedlerfragen" betraut wurde ${ }^{1035}$ und, ab 1. September 1945 Oberprovinzialrätin, im September Leiterin des neu gebildeten „Amtes für deutsche Umsiedler“, auch „Direktorium für Deutsche Umsiedler“. ${ }^{1036}$

1031 Der für die Abteilung VII Arbeit und Sozialwesen verantwortliche Fritz Rücker (SPD/SED), zugleich 3. VizePräsident der Provinzialverwaltung. Vgl. SBZ-Handbuch (wie Anm. 1018), S. 96.

1032 Wille I (wie Anm. 196), S. 210-216, Nr. 140 (BArch, DO 1, MdI, ZVU, Nr. 29, Bl. 2-6), hier S. 211 f.

1033 Ebd., S. 216.

1034 Lebenslauf (Typoskript) vom 8.2.1960 im Nachlass („Familienkonvolut Trinkaus-Sendhoff“) im Deutschen Historischen Museum (DHM) in Berlin, Sammlung Dokumente, DG 70/503, S. 2. - Sie wohnte aber weiterhin (z.B. 10.8.1945 und noch 1946) in Berlin-Weißensee, Berliner Allee 33, und wohl nur kurzzeitig während der Amtsübernahme in Potsdam im dortigen Hotel „Zum Schwan“ in der Waisenstraße 13 (bald darauf in Dortustraße umbenannt).

1035 Siehe den Hinweis auf eine Besprechung betr. Aufnahmestopps am 21.8.1945 in: BLHA, Rep. 250 Landratsamt Beeskow-Storkow, Nr. 824, unfol. (Textabdruck im Quellenteil, Nr. 5).

1036 Am 10.10.1945 ist ein Herr Schmid stellv. Leiter der „Unterabteilung für deutsche Umsiedler“ (Wille I [wie Anm. 196], S. 63, nr, 36 [BLHA, Rep. 202 A, Nr. 90, B1. 30]). 
Stolz blickt sie als Rentnerin 1962 auf ihre Parteiarbeit zurück: „Als ich im Juni 1945 nach Potsdam kam, wurde ich dort als Pol[itischer] Leiter der Betriebsgruppe der KPD in der Provinzialverwaltung gewählt. Seit der Vereinigung der KPD und SPD war ich dort Vorsitzende der Betriebsgruppe der SED. Bei meinem Weggang zählte die Betriebsgruppe über 600 Mitglieder. "1037

Schon seit 1945 (bis 1947) Mitglied im Frauen-Ausschuss Berlin, sah sie wohl ihre eigentliche Berufung in der Frauenarbeit. Nach etwas mehr als einem Dreivierteljahr dennoch sehr engagierter Arbeit in der „Umsiedlerverwaltung“ kündigte sie als (seit 12.3.1946) Ministerialrätin am 29. April mit Wirkung vom 31. Mai 1946 (bereits beurlaubt ab 1 . Mai) ${ }^{1038}$ ihre Stellung als stellvertretende Leiterin der Abteilung Arbeit und Sozialwesen ${ }^{1039}$ und wurde nun Leiterin des Zentralen Frauen-Ausschusses (und 1947 Mitbegründerin des DFD) sowie Leiterin der (Haupt-)Abteilung Frauen- und Jugend-Ausschüsse bei der Deutschen Zentralverwaltung für Volksbildung ${ }^{1040}$, später stellvertretende Leiterin der Hauptabteilung Amt für Information der DDR; 1946-1949 gehörte sie dem Präsidium des Zentralausschuses der Volkssolidarität an. ${ }^{1041}$

Auch Magda Sendhoff bemühte sich wie Eberlein nach Kräften und mit viel Engagement um die Bewältigung der Flüchtlingsnot. In einer ausführlichen Rede vor Mitgliedern der KPD und SPD in Potsdam im Februar 1946 beschrieb sie - ähnlich wie Eberlein in seinem erwähnten Redebeitrag im September des Vorjahres - schonungslos die Situation einschließlich der noch bevorstehenden Ereignisse ${ }^{1042}$ : „[... Im Moment sollen 1 1 1/2 Millionen Umsiedler, von Polen kommend, in die englische Zone transportiert werden. Die ersten organisierten Züge von Osten nach

1037 Lebenslauf 1962 (DHM, DG 70/503), S. 3. In dem Konvolut befinden sich ferner diverse Mitgliedskarten und -ausweise (teilweise mit Passbildern), aus denen sich ergibt: KPD seit 1927 (DG 70/475, 10.8.1945), FDGB seit 4.8.1945 (DG 70/477); SED (DG 70/474); VVN seit 28.1.1948 (DG 70/473.1; DG 707473.2); DSF seit Aug. 1949 (DG 70/486.1 und 70/486.2); Volkssolidarität seit 13.4.1958 (DG 70/481.1), „Freund der Volkssolidarität" bereits seit Aug. 1952 (DG 70/484.2).

1038 Personalakte (mit Porträtoto): BLHA, Rep. 203 MdI, PA 440; so auch im Lebenslauf 1962 (DHM, DG 70/503), S. 2 f.: „Ich arbeitete in dieser Abteilung bis zum 1. Mai 1946“. Dagegen heißt es im Jahresbericht des Umsiedleramtes im Dez. 1946, sie habe „bis zu ihrem Übertritt zur Zentralverwaltung für Arbeit und Sozialwesen in Berlin Ende März [!] die Geschäfte als Abteilungs-Direktorin wahrgenommen" (Wille I [wie Anm. 196], S. 102).

1039 Sie war also nicht nur $1945 \mathrm{im}$ Amt, wie es irrtümlich, wohl weil der Nachfolger Friedrichs unter ihr bereits 1945 wirkte, bei Schwartz, Vertriebene und „Umsiedlerpolitik“ (wie Anm. 13), S. 203, heißt.

1040 Lt. Personalakte. Dagegen heißt es im Lebenslauf 1962 (DHM, DG 70/503), S. 3: „Ich arbeitete in dieser Abteilung [Arbeit und Sozialwesen] bis zum 1. Mai 1946 und wurde dann vom Z. K. eingesetzt in Berlin in der Deutschen Verwaltung für Volksbildung als stellvertretende Leiterin der Abteilung „Kulturelle Aufklärung“.

1041 Lebenslauf (DHM, DG 70/503); Arbeitsbuch (DHM, DG 70/478), S. 8; SBZ-Handbuch (wie Anm. 1018), S. 1028. - 1949 wohnte sie in Kleinmachnow, 1952/57 in Wandlitzsee. Zuletzt war sie ab 1954 Leiterin der Leserbriefredaktion der „Wochenpost“, musste aber 1960 wegen eines Augenleidens in Rente gehen und übersiedelte im selben Jahr nach Leipzig, wo ihr zweiter Mann Hermann Trinkaus (geb. 1904), SED, FDGB, ursprünglich Techniker bzw. Konstruktionsingenieur, als Wissenschaftlicher Mitarbeiter am Georgi-DimitroffMuseum arbeitete. Eine Würdigung zu ihrem 50. Geburtstag erschien in: Neues Deutschland, 28.8.1949, ein Kurznachruf ebd., 30.11.1963.

1042 BLHA, Rep. 333 SED-Landesleitung Brandenburg, Nr. 574, Bl. 5-14. 
Westen sind Anfang voriger Woche gerollt. Es besteht jedoch die Gefahr, dass wegen zu wenig Aufnahmebereitschaft im Westen der Pole erneut wieder nach Brandenburg einschleusen wird und wir müssen dann den Aufgaben gewachsen sein. Die anderen Provinzen haben den Vorzug, dass sie nicht direkt der Einschleuspunkt sind und sie nutzen ihn so, dass sie sich nach Möglichkeit gegen die Aufnahme sperren. Die Provinz Brandenburg ist einfach gezwungen, weil die Menschen hereingepumpt werden, diese jetzt zu versorgen. Das ist besonders zu unterstreichen, weil unsere Provinz an sich am schlechtesten daran ist, einmal durch die Zerstörungen durch die Kriegsereignisse und weil sie auch ernährungsmässig am schlechtesten dasteht. Wenn man rechnet, dass die 1/4 Million Umsiedler, die nur durchgeschleust wurden, durchschnittlich mindestens 10 Tage in Brandenburg ernährt wurden, so kann man sich vorstellen, welche Lebensmittelmengen Brandenburg aufbringen musste. [...]. ${ }^{1043}$ Auch hier schenkte sie wie stets der Lage der Frauen besondere Beachtung: „Die letzten Transporte sahen [Bl. 8] z.B. folgendermassen aus: Ein Transport von 1100 Personen umfasste 50 alte Männer, ca. 450 Frauen, davon die Hälfte über 50 J., ca. 550 Kinder, von denen 80 Waisenkinder waren. Unter den Männern befanden sich 6, die fast erblindet [,] und 2, die ganz erblindet waren. So sieht also ein üblicher Umsiedlertransport aus. Trotz allem muss man immer wieder sehen, dass es sich um Menschen handelt, die ein Recht darauf haben, wieder irgendwo eine Heimat, ein Dach über dem Kopf zu finden. Man muss immer wieder davon ausgehen, dass man das Möglichste herausholen muss, um aus diesen Menschen Arbeitskräfte zu gewinnen. Es muss dafür gesorgt werden, dass bei der Ueberzahl der Frauen mit Kindern Kindergärten entstehen, um dadurch die Frauen zu entlasten und sie für die Arbeit freizumachen. Wir können diese Frauen mit Kindern nicht nur als Wohlfahrtsempfänger übernehmen. "1044 Auch die ihr besonders nahe Organisationsform baute sie in ihre Rede ein: „Die Frauenausschüsse haben bereits in den vergangenen Monaten vorbildliche Arbeit geleistet in der Betreuung der Umsiedler und werden auch in den kommenden Monaten das Gleiche leisten." 1045

Sendhoffs wie auch die oben zitierten Aussagen Eberleins zeigen, wie sehr das provinziale Umsiedleramt auf die Koordination der - von ihm grundsätzlich nicht zu beeinflussenden Transporte, die Verteilung auf die - nicht in gleichem Maße aufnahmefähigen - Kreise oder ihre Durchschleusung konzentriert war, solange die aus den Vertreibungsgebieten kommenden Wellen kaum abnahmen, so dass ein planendes, geschweige denn konzeptionelles Arbeiten kaum möglich war bzw. immer wieder von der Wirklichkeit eingeholt wurde. Schon Eberlein hatte zugeben müssen: „Die gesamten Maßnahmen innerhalb der Provinz Brandenburg mußten improvisiert werden. Die Einweisungen in die einzelnen Kreise waren vielfach abhängig von dem guten Willen des Kreiskommandanten. Manche Kommandanten sperrten einfach den Kreis. In BeeskowStorkow sagte der Kommandant eines Tages: Sämtliche Flüchtlinge, die angesiedelt sind und die Arbeit haben, haben binnen drei Tagen den Kreis zu verlassen. Durch diese nicht von zentraler Stelle [!] erteilten Anordnungen hat sich eine Art Mahlstrohm herausgebildet. Die Flüchtlinge bleiben hier 
und da, vermeiden eine amtliche Einweisung." ${ }^{1046}$ So ist es kaum verwunderlich, dass beide ersten Leiterpersönlichkeiten, Eberlein wie Sendhoff, kein ganzes Jahr aushielten.

Erst Sendhoffs Nachfolger Erich Friedrichs (geb. 1905) amtierte über einen - zumindest vergleichsweise - längeren Zeitraum, in dem zwar noch immer Transporte ins Land kamen, das von Eberlein vorhergesagte und auch tatsächlich längere Zeit herrschende „Chaos“ aber doch etwas besser planbaren Vorgängen wich. ${ }^{1047}$ So konnte er bereits im Herbst 1947, wenn auch etwas voreilig-zweckoptimistisch, „die Umsiedlung als beendet" bezeichnen und die „wesentliche verbleibende Aufgabe“ darin sehen, nunmehr „die Umsiedler zu verringern, d. h. ihnen die neue Heimat zu schaffen, so dass sie sich nicht mehr als Umsiedler fühlen ". ${ }^{1048}$ Auch Friedrichs mühte sich redlich, reiste durch das Land, sprach vor Vertriebenen in „Umsiedlerlagern“ und wurde nicht müde, auf Nöte und Notwendigkeiten hinzuweisen. Es war ihm immerhin vergönnt, die bisherige Unterabteilung, die wegen der besonders gravierenden Inhalte ihres Tuns schon länger zu unabhängigem Handeln tendiert hatte, am 1. Oktober 1946 „zur unabhängigen und selbständigen Abteilung für Umsiedler und Heimkehrer im Ministerium für Arbeit und Sozialwesen erhoben" zu sehen (nun Abt. VII/A) ${ }^{1049}$ Dennoch wusste er, dass dies letztlich in der täglichen Arbeit wenig bedeutete, beklagte daher noch im September 1947 auf einer Tagung der Kreisumsiedlerämter in Potsdam, „dass allgemein die Abteilung nicht die Anerkennung der anderen Dienststellen geniesst“ und führte dies darauf zurück, dass das „Umsiedlerproblem nicht ernst genug genommen wird“. Er werde alles daran setzen, „diese Anerkennung zu erringen“ ${ }^{1050}$ Der Erfolg war freilich zweifelhaft, denn die Probleme, die er ansprach, gab es auf SBZ-Ebene in der kaum bedeutenden ZVU ebenso wie auf Kreisebene. So brachten in der anschließenden Diskussion die anwesenden „Umsiedler“-Sachbearbeiterkollegen aus den Kreisen zum Ausdruck, „dass auch die Kreisumsiedlerämter gegenüber den Landräten auf zu wenig Verständnis stossen und mit grossen Schwierigkeiten zu kämpfen haben." Gerade die für die „Umsiedler“ zuständigen Verwaltungen waren genötigt, im Land und im Kreis präsent zu sein, die verschiedenen Lager zu besuchen, und konnten nicht nur vom Schreibtisch aus wirken, wenn sie erfolgreich sein wollten. Doch standen nicht einmal genügend Transportkapazitäten zur Verfügung, die die Landratsämter streng kontingentierten: „So ist es die Benzinfrage, die überall zu Ungunsten der Umsiedlerämter bearbeitet wird. Nur Luckenwalde kann von einer guten Zusammenarbeit berichten. ${ }^{1051}$ Auch 1948 änderte sich wenig. Friedrichs hatte längst bemerkt, dass eine bloß nominelle „Rangerhö-

1046 Wille I (wie Anm. 196), S. 211 (3.9.1945).

1047 Zu Friedrichs siehe besonders Schwartz, Vertriebene und „Umsiedlerpolitik“ (wie Anm. 13), passim (S. 1242).

1048 BLHA, Rep. 333 SED-Landesleitung Brandenburg, Nr. 574, B1. 199 (vgl. den vollständigen Textabdruck im Quellenteil, Nr. 150).

1049 BLHA, Rep. 203 MdI, Nr. 1166, Bl. 1. In einer Konferenz der Abt. VII mit dem Vizepräsidenten Rücker am 10.10.1946 wurde mitgeteilt: „Die Umsiedler-Abteilung wird von der Abt. VII losgelöst und selbständig. Der Suchdienst wird der Ums.[iedler-]Abt. angegliedert." (BLHA, Rep. 206, Nr. 2965, unfol.; siehe Quellenteil, Nr. 146).

1050 Tagungsbericht in: BLHA, Rep. 333 SED-Landesleitung Brandenburg, Nr. 574, Bl. 199 (vgl. vollständigen Textabdruck im Quellenteil, Nr. 150).

1051 Ebd. 
hung“ seiner Behörde nicht half. „Wichtig sei vielmehr deren faktische Selbständigkeit durch Ministerunterstellung“ ${ }^{1052}$ Doch die Zeichen standen im Gegenteil längst auf eine baldige Beendigung von Sonderverwaltungen, setzte die SED doch nun zunehmend darauf, den „Assimilationsprozess der Umsiedler“ (auch von einem „Verschmelzungsprozess“ wurde gesprochen) - auch begrifflich - zu forcieren, um das gefährliche Thema bald ganz von der Tagesordnung nehmen zu können. ${ }^{1053}$ Friedrichs kämpfte somit am Ende auf verlorenem Posten. Es ist nicht auszuschließen, dass man ihn trotz aller formalen Aufwertung weiterhin als bloßen „Sachbearbeiter“ betrachtete, dessen Ressort keine Zukunft hatte.

Der gebürtige Berlin-Schöneberger ${ }^{1054}$ Friedrichs, Handwerkerkind wie seine Vorgängerin, gehörte zudem nicht zu den bereits vor 1933 aktiven Kommunisten, die man sonst bei diffizileren Aufgaben bevorzugt einsetzte, sondern war vor 1945 parteilos gewesen und trat noch am 1. März 1946 der SPD bei. ${ }^{1055}$ Er hatte die Verwaltungsarbeit von der Pike auf gelernt, nach der Volksschule eine Lehre bei der Stadtverwaltung Strausberg absolviert, die Gemeindeverwaltungsschule des Deutschen Gemeindetages erfolgreich abgeschlossen und von 1927 bis 1940 bereits als Sachbearbeiter bei der Provinzialverwaltung der Provinz Brandenburg gearbeitet. ${ }^{1056}$ An Zugehörigkeiten zu Parteien oder Verbänden nannte er 1945 neben den üblichen, für die Entnazifizierung eher nebensächlichen NS-Organisationen DAF, NSV und Reichluftschutzbund nur den „Reichsbund der deutschen Beamten“. Als er im Juli 1945 aus britischer Kriegsgefangenschaft gekommen war (1940-1945 Soldat, zuletzt Obergefreiter), scheint er bald wieder alte Kontakte zur Provinzialverwaltung aufgenommen zu haben. Am 20. Oktober 1945 wurde er als Amtsrat und Referent für Umsiedlerfragen in der Abteilung VII (Arbeit und Sozialwesen) der Provinzialverwaltung Mark Brandenburg eingestellt. Bis März 1946 arbeitete er als Referent ${ }^{1057}$ und Stellvertreter der „Abteilungs-Direktorin“ im „Amt für deutsche Umsiedler“, nach Magda Sendhoffs Ausscheiden im März 1946 wurde er als ihr Nachfolger bis zum 30. Juni 1949 Leiter des Amtes. Ab 1. Oktober 1946 war er, zugleich eingestuft als Ministerialrat (zuletzt auch als Oberreferent bezeichnet) Leiter der verselbständigten Abteilung (VII/A) „Umsiedler“ (ab 11.1.1947: „und Heimkehrer“) im Ministerium für Arbeit und Sozialwesen der Landesregierung Brandenburg, inoffiziell gelegentlich auch weiter

1052 Schwartz, Vertriebene und „Umsiedlerpolitik“ (wie Anm. 13), S. 355.

1053 Ebd. - Die Begriffszitate u. a. im Beschluss des SED-Zentralsekretariats, hier zitiert nach BLHA, Rep. 333, Nr. 574, B1. 365.

1054 Nicht „gebürtigen Straußbergers“, wie es bei Schwartz, Vertriebene und „Umsiedlerpolitik“ (wie Anm. 13), S. 240, irrtümlich heißt.

1055 Personalakte: BLHA, Rep. 203 MdI, PA 276 (auch für das Folgende). Ferner: BLHA, Rep. 250 Landratsamt Beeskow-Storkow, Nr. 93, B1. 230; BLHA, Rep. 203 MdI, Nr. 517, Bl. 4, 39. - Friedrichs' Vater sei nomineller Pg. gewesen, heißt es in einer Beurteilung des Sohnes durch die Personalabteilung des Innenministeriums (BLHA, Rep. 203 MdI, PA 276, unfol.).

1056 Er wohnte bis 1933 in Potsdam, Am Plantagenhaus 3, 1945 in Berlin-Friedrichsfelde, dann von 1945 bis mindestens 1950 in Potsdam, Alte Zauche 67 (in unmittelbarer Nachbarschaft zum Dienstort).

1057 Am 10.8.1946 wird er in einem Schreiben des SED-Provinzialvorstandes als „Sachbearbeiter der Abt. Heimkehrer" bezeichnet (BLHA, Rep. 333 SED-Landesleitung Brandenburg, Nr. 574, Bl. 39). 
als „Amt für Umsiedler und Heimkehrer" oder „Amt für deutsche Umsiedler "1058 bezeichnet. Auch in Friedrichs' Fall wählte man also den Stellvertreter des Vorgängers, da die Einarbeitung in die „Umsiedlerfragen“ vermutlich diffiziler als in den „normalen“ Ressorts war. Anfang 1947 war die Stellvertreterstelle unter Friedrichs unbesetzt (erwähnt am 9.1.1947), vielleicht ein Anzeichen für die mittelfristig beabsichtigte Auflösung der Abteilung, ${ }^{1059}$ gegen die Friedrichs im Januar 1948 deutlich Stellung bezog ${ }^{1060}$.

Es überrascht nicht, wenn man - angesichts der geschilderten behördlichen und allgemeinpolitischen Rahmenbedingungen sowie des persönlichen beruflichen und parteipolitischen Hintergrundes - in einer im Februar 1949 verfassten Beurteilung durch die Personalabteilung des Innenministeriums - über Friedrichs fast nur Negatives bis hin zu - hier nicht wiedergegebenen - zutiefst ehrenrührigen Aussagen liest. ${ }^{1061}$ Der Text zählt, wie eine geforderte Begründung, um den unbequem gewordenen Kandidaten loszuwerden, eine Vielzahl angeblicher Verfehlungen und Schwächen auf. Wie zu erwarten spielt dabei auch seine Vorgeschichte eine Rolle. Friedrichs komme „politisch über das Niveau eines Verwaltungsangestellten[,] welcher der Weimarer Zeit und [der] des Naziregimes angehörte, nicht hinaus“. Der durch die Zwangsvereinigung zum SED-Mitglied gewordene SPD-Mann sei trotz „regelmäßigen Besuch[s] der Parteiveranstaltungen [...] politisch unklar, was seinen besonderen Ausdruck in der Grenzfrage Oder/ Neiße findet. In politischen Unterhaltungen sagte F., daß man den Siedlern den Glauben an eine evtl. Rückführung nicht nehmen soll, da man nicht weiß, ob die Zukunft nicht doch mal eine andere Entwicklung nimmt. Oder, vielleicht wird es mal anders." Zwar habe er sich in jüngerer Zeit „diesbezüglich revidiert. Jedoch wird eine innere Überzeugung bezweifelt. F. fehlt das Klassenbewußtsein und infolge dessen kann er keine positive politische Stellungnahme beziehen. Seine Referate sollen inhaltlich politisch negativ sein und sich mehr auf die rein menschliche Seite bezügl. Hilfe für die Umsiedler beziehen." Mit Wirkung vom 1. Juli 1949 versetzte man Friedrichs zur Obersten Bauleitung 209. ${ }^{1062}$ Nachfolger wurde sein bisheriger Stellvertreter Erich Kuhn (KPD/SED).

1058 Wille I (wie Anm. 196), S. 102 (Dez. 1946). Die Begriffe Amt und Abteilung werden in den ersten Jahren vielfach synonym verwendet, obwohl es sich anfangs allenfalls um eine Unterabteilung und ab 1946 eindeutig um eine Abteilung handelte. In einer Referentenbesprechung des Ministeriums für Arbeit und Sozialwesen am 27. Mai 1946 wurde sogar für die übergeordnete Abteilung „die Frage erörtert, ob es heißt: ,Amt für Arbeit und Sozialwesen' oder ,Abteilung für Arbeit und Sozialwesen “" obwohl an sich letzteres festgelegt war (BLHA, Rep. 206, Nr. 2965, unfol.). - Für 1949 ist eine andere Abteilungsnummer für die „Umsiedler“-Abteilung belegt. Neben der „Abteilung VII: Arbeit und Sozialfürsorge“ gab es die offenbar gleichgestellte „Abteilung XVIII: Umsiedler und Heimkehrer" (siehe: Dienststellen der Landesregierung Brandenburg in Potsdam. In: Wirtschafts-Wegweiser für Wittenberge und die Kreise West- und Ostprignitz, Potsdam (1949), S. VII).

1059 Dabei handelt es sich wohl um den von Schwartz, Vertriebene und „Umsiedlerpolitik“ (wie Anm. 13), S. 198, erwähnten „KPD-Funktionär“, den man Friedrichs anstelle eines zuvor tätig gewesenen „Fachbeamten der früheren Provinzialverwaltung “ als Stellvertreter beigegeben hatte.

1060 Bedenken gegen die Überführung in eine „Abteilung für Bevölkerungspolitik“: Wille III (wie Anm. 196), S. 308, Nr. 353 (BLHA, Rep. 333, Nr. 574, Bl. 89).

1061 BLHA, Rep. 203 MdI, PA 276, unfol. (vgl. Textabdruck im Quellenteil, Nr. 154).

10621950 (erwähnt 1.3.) war er bei der Landbau GmbH in Potsdam, Saarmunder Straße 1, tätig. 
Friedrichs war zwar SED-Mitglied und hat das auch in seiner behördlichen Tätigkeit trotz aller fachlichen und sozialen Bemühungen nicht verleugnet, indem er z.B. „die Aktivitäten anderer Parteien, insbesondere der CDU, in den Umsiedlerlagern nach Möglichkeit behinderte “1063. Die Entmachtung seiner Person und seiner Abteilung war jedoch Teil eines größeren (SBZ-),Projektes“, das die gesamte Zuständigkeit für die störenden „Umsiedlerfragen“ in die Innenressorts verlagern sollte. Dahinter stand letztlich die SMAD, die diese Entwicklung schon auf der höheren SBZ-Ebene 1948 mit der Auflösung der Zentralverwaltung für deutsche Umsiedler bzw. deren Überführung in die Deutsche Verwaltung des Innern angeordnet hatte. In Brandenburg übernahm kein geringerer als der Hardliner Bernhard Bechler (SED) (1911-2002), Innenminister von 1945 bis 1949, die entsprechende Umsetzung der Vorgaben. Noch bevor Friedrichs 1949 in die Marginalität versetzt wurde, musste sein ministerieller Chef Fritz Schwob (CDU), unter dem Friedrichs fast zwei Jahre (18.12.1946 bis 26.8.1948) gewirkt hatte, die Ressortzuständigkeit für „Umsiedler und Heimkehrer“ an Bechler abgeben. Der nicht zu den Vertriebenen zählende, aber aus Breslau gebürtige Katholik Schwob (1891-1956) passte nämlich noch viel weniger als Friedrichs in die sich - nach dem Willen der sowjetischen Besatzungsmacht und der SED - verändernde Landschaft. Der ehemalige preußische höhere Beamte, bis zu seiner 1934 aus politischen Gründen (Mitglied des Zentrums) erfolgten Versetzung in den Ruhestand zuletzt gar Mitglied des Preußischen Staatsrates und stellvertretender Reichskommissar für Optantenvermittlung (er war zuvor in der Provinz Grenzmark PosenWestpreußen tätig gewesen), war 1946 aus der Verwaltung im Kreis (Jüterbog-)Luckenwalde nach Potsdam gekommen und in der Landes-CDU rasch aufgestiegen. ${ }^{1064}$ Als Arbeits- und Sozialminister Brandenburgs hat er sich mit dem Vertriebenenproblem durchaus engagiert befasst und versuchte die Überführung der Zuständigkeit in das Innenressort - erfolglos - zu verhindern. ${ }^{1065} 1948$ verlor er sie an Bechler, dem am 14. September 1949 Bruno Lentzsch (19031972) (KPD/SED) folgte. Anfang 1950 erfolgte schließlich sogar eine von der SED gesteuerte politische Pressekampagne gegen Schwob, durch die er sich am 3. Februar 1950 zum Rücktritt gedrängt sah. ${ }^{1066}$

Bereits im März 1949 hörten die Mitglieder des Kreisumsiedlerausschusses Oberbarnim in einer Sitzung in Bad Freienwalde vom Sachbearbeiter der Kreisumsiedlerstelle Haack, dass nicht nur „die Auflösung aller Umsiedlerausschüsse bis Mitte April 1949 geplant ist und die Aufgaben der Umsiedlerausschüsse auf die Sozialkommissionen und Wohnungsausschüsse übergehen sollen“, sondern Haack berichtete außerdem von einer Tagung am 16. Februar 1949, auf der der Leiter der ZVU Vogt bekannt gegeben hatte, „dass das Umsiedlerproblem in der Ostzone in Zukunft nicht mehr ressortmässig, sondern von den gesamten Verwaltungsbehörden bearbeitet wer-

1063 Schwartz, Vertriebene und „Umsiedlerpolitik“ (wie Anm. 13), S. 224.

1064 Personalakte im BLHA, Rep. 203 MdI, PA 82. - Handbuch des Landtages des Landes Brandenburg. Potsdam 1947, S. 97 (mit Bild).

1065 Siehe dazu Schwartz, Vertriebene und „Umsiedlerpolitik“ (wie Anm. 13), S. 223-228.

1066 BLHA, Rep. 206 Ministerium für Wirtschaft und Arbeit, Nr. 3450 (Rücktritt, 1950). 
den soll und dadurch folglich die Umsiedlerämter in den Kreisen und Ländern in absehbarer Zeit in Fortfall kommen. “1067 Die Geschichte auch der brandenburgischen „Umsiedlerabteilung“ ist folglich seit der Überführung in das Innenministerium und vollends seit dem Ausscheiden ihres erfahrenen Leiters Erich Friedrichs kaum noch von Belang. Ab 1. Januar 1949 saß sie, bis 24. November 1950, als formal eigenständige (Unter-)Abteilung im Ministerium des Innern (MdI) beim Büro des Ministers. ${ }^{1068}$ Bereits unter Friedrichs' Nachfolger Kuhn erfolgte die endgültige Beerdigung mit der Beseitigung des „Umsiedler“-Begriffs im Behördennamen. Ab 25. November 1950 nannte man sie „Abteilung Bevölkerungspolitik“ (im Innenninisterium) und am 1. Januar 1951 wurde sie sie zu einem „Referat Bevölkerungspolitik“ in der „Hauptabteilung (HA) Staatliche Verwaltung " herabgestuft, das man im Juli 1952 auflöste. ${ }^{1069}$

Der letzte „Behörden“-Leiter, E r i ch Kuhn (1905-1974), Atheist und von Hause aus Tischlergeselle, war ein gebürtiger Ostpreuße aus Langendorf im Kreis Wehlau, aber schon 1937 nach Brandenburg gekommen. ${ }^{1070} \mathrm{Er}$ stammte aus der ostpreußischen KPD und war dort vor 1933 als „Arbeiterkorrespondent“ beim „Echo des Ostens“, einer kommunistischen Tageszeitung für Ostpreußen, für den politischen Teil verantwortlich gewesen. Ab 1933 in der Illegalität lebend, wurde er 1935 verhaftet und wegen „Vorbereitung zum Hochverrat“ vom Oberlandesgericht Königsberg zu zweieinhalb Jahren Zuchthaus verurteilt, die er in Wartenburg (Ostpreußen) und im KZ Sachsenhausen verbringen musste. Im Krieg im Bewährungsbataillon 999 eingesetzt, kam er 1946 aus jugoslawischer Gefangenschaft nach Berlin zurück und fand dort - am 20. Juni als „Opfer des Faschismus“ (OdF) anerkannt ${ }^{1071}$ - offenbar sogleich eine Anstellung bei der ZVU in der Leipziger Straße. ${ }^{1072}$ Im Juli 1946 ist sein Umzug nach Potsdam, in unmittelbare Nähe des provinzialen Umsiedleramtes, Drevesstraße 18/19 „bei Schwarz“ (hier noch 1952), belegt, 1947 wird er bereits als Referent bei der Abteilung Umsiedler und Heimkehrer der Landesregierung Brandenburg erwähnt, ${ }^{1073}$ stand aber, anders als Friedrichs, im Angestelltenverhältnis ${ }^{1074}$. Er blieb bis zur Auflösung des Referats, dessen letzter Leiter er war, im Amt. ${ }^{1075} 1953$ erfolgte seine Versetzung zum Rat des Bezirkes Frankfurt (Oder), wo er bis zum Eintritt in den Ruhestand tätig war (1.11.1961 Altersrentner) und bis zum Tod wohnte. ${ }^{1076}$

1067 BLHA, Rep. 333 SED-Landesleitung Brandenburg, Nr.574, Bl. 405 (vgl. Textabdruck im Quellenteil, Nr. 155).

1068 SBZ-Handbuch (wie Anm. 1018), S. 99.

1069 Übersicht über die Bestände des Brandenburgischen Landeshauptarchivs. T. III/1. Berlin 2001, S. 351 ff., 369.

1070 Eine behördliche Personalakte war nicht zu ermitteln. Das Folgende nach der VdN-Personalakte (mit Porträtfotos): BLHA, Rep. 601 VdN, Nr. 1562.

1071 Am 1.12.1946 auch als „Kämpfer“ (ebd.). - Siehe Quellenteil, Nr. 90 und 91.

1072 Wohnhaft im Juni 1946 in Berlin SO 36, Jugendheim Zeughofstraße.

1073 Zu Kuhns Tätigkeit siehe besonders Schwartz, Vertriebene und „Umsiedlerpolitik“ (wie Anm. 13), pas$\operatorname{sim}$ (S. 1244). - Kuhns Untervermieter in der Drevesstraße 18/19 war der Hilfsarbeiter Friedrich Schwarz (Adressbuch Groß-Potsdam 1949 [erschienen 1948], S. 541).

1074 Lt. Adressbuch Groß-Potsdam 1949 (erschienen 1948) war er „Angestellter“.

1075 Siehe u. a. BArch 1/8408, unfol. (1951).

1076 Er war verheiratet mit Herta geb. Manneck (geb. 1871). 
Über das Innenleben der Behörde ist bislang kaum etwas bekannt, obgleich die Leiter keineswegs „Ein-Mann-Unternehmen“ führten. Anfangs, 1945, saß sie mit anderen Teilen der Provinzialverwaltung noch im ehemaligen preußischen (Bezirks-)Regierungsgebäude (heute Stadthaus) in der Spandauer Straße 32/34 (Nauener Vorstadt), heute Friedrich-Ebert-Straße 79/81. ${ }^{1077} 1946$ findet man sie bereits auf dem Regierungsgelände an der Alten Zauche (Teltower Vorstadt), ${ }^{1078}$ Alte Zauche 67 blieb fortan die Adresse. Allerdings erfolgte am 13. August 1948 ein Umzug „in ein anderes Haus innerhalb des Regierungsgeländes Alte Zauche“. ${ }^{1079}$ „Alte Zauche" war damals der Name des Straßenabschnitts der heutigen Heinrich-Mann-Allee von der „Drevesstraße bis zur Stadtgrenze am Bahnhof Rehbrücke“1080. Es handelt sich bei diesen Bauten um die der ehemaligen Landesanstalt, die in den Nachkriegsjahren zunächst von mehreren Provinzial- bzw. Landesministerien, u. a. eben dem für Arbeit und Sozialwesen, genutzt wurden, während andere, wie das Innenministerium (1948: Haus 12), aber auch der Landtag, auf dem heute u. a. von der Staatskanzlei genutzten (ehemaligen Napola-)Areal im vorderen Bereich der Heinrich-Mann-Allee (heute deren Hausnummer 107, damals Saarmunder Straße 23) saßen. Neben den zur Alten Zauche 67 gehörigen Häusern 1 bis 11 gab es ein Haus Alte Zauche 67, in dem überwiegend Wohnungen bestanden und teilweise auch Landesbedienstete wohnten. ${ }^{1081}$

Die SMA hatte dem „Amt für Umsiedler“ im Herbst 1945 „eine Planstärke von 28 Angestellten genehmigt“. Dazu zählten neben der Leiterin bzw. dem Leiter nicht nur ein Stellvertreter und Schreibkräfte, sondern auch weitere Referenten. ${ }^{1082}$ So waren z. B. am 27. Mai 1946 bei

1077 Belegt u. a. 20.10.1945 (BLHA, Rep. 16 Nl Spiegelberg, Nr. 5, Bl. 1), 17.12.1945 (Briefkopf in: BLHA, Rep. 206, Nr. 3036, unfol.). Lt. SBZ-Handbuch (wie Anm. 1018) auch schon am 26.9.1945.

1078 Belegt u.a. 17.6.1946: (BLHA, Rep. 206, Nr, 2965, unfol.), 16.6.1948 (SBZ-Handbuch [wie Anm. 1018], S. 99).

1079 BLHA, Rep. 203 MdI, Nr. 1198, Bl.34v. - Die Haus-Angaben schwanken leicht: Am 17.6.1946 Haus I (BLHA, Rep. 206, Nr, 2965, unfol.), im Okt. 1948 Haus I b (BLHA, Rep. 203 MdI, Nr. 1198, Bl. 62). - Lt. Adreßbuch Groß-Potsdam 1949 (erschienen 1948) saß die Abt. VII des Arbeits- und Sozialministeriums im „Haus 1“.

1080 Klaus Arlt: Die Straßennamen der Stadt Potsdam. Geschichte und Bedeutung. 2., überarb. u. erw. Aufl. Potsdam 2010, S. 35. - Das gesamte Behördenareal gehört heute zur Hausnummer Heinrich-Mann-Allee 103.

1081 Lt. Adreßbuch Groß-Potsdam 1949, S. 492 u. a. Ministerialrat Erich Friedrichs und sein Vater, der Rentner Walter Friedrichs. - Ein Beispiel für wohl eher zufällige lokale Ortsbezüge ist, dass sich später (1991-1998) im Haus 16 ausgerechnet die Landesgeschäftsstelle des BdV befand (siehe Ortsdokumentation/Potsdam).

1082 Wille I (wie Anm. 196), S. 102 (BLHA, Rep. 203 MdI, Nr. 1074, Bl. 65). - Siehe auch „Stellenplan der Abt. Umsiedler und Heimkehrer" für die Jahre 1945 bis 1948 (quartalsweise nach Haushaltsplan, ohne Personennamen) in: BLHA, Rep. 203 MdI, Nr. 1166, Bl. 2. Darin werden als erste Stellenausstattung für das 4. Quartal 1945 nur genannt: 2 Regierungsräte, 5 Regierungsamtmänner, 3 Oberinspektoren, 4 Inspektoren, 3 Obersekretäre, 1 Regierungssekretär, 3 Kraftfahrer, 4 Assessoren. Seit dem 1. Quartal 1947 wird ein Ministerialrat aufgeführt. Im letzten Zeitraum, dem 4. Quartal 1948 gab es: 1 Ministerialrat (A 1a), 1 Oberregierungsrat (A 2b), 3 Regierungsräte (A 2c1), 2 Regierungsamtsräte (A 2d), 1 Regierungsamtsrat (A 3b), 7 Regierungsoberinspektoren (A 4b1), 5 Regierungsinspektoren (A 4c1), 2 Regierungsobersekretäre (A 5b), 2 Regierungssekretäre (A 7a), 2 Kraftfahrer „als Geh.E.“ (A 7a), keinen Kraftfahrer als Stundenlohnempfänger, 4 Regierungsassessoren (A 8a), 1 Amtsgehilfen (A 11), d. h. insgesamt 31 Planstellen nach dem Haushaltsplan. 
einer Referentenbesprechung im Ministerium für die „Umsiedler-Abteilung“ allein vier Fachreferenten anwesend: „Dr. Kunde ${ }^{1083}$ (Ref. Ges.[undheits-] Wesen), Friedrichs (Leitung), Timm (Ref. Wirtschaft und Versorgung), Lisch ${ }^{1084}$ (Ref. Organ[isation]), Flock ${ }^{1085}$ (Ref. Finanzen), Schöning ${ }^{1086}$ (Ref. Kriegsgefangene)“. ${ }^{1087}$ Diesem offenkundig zahlreichen und gewiss mehrfach wechselnden, gegen Ende aber zweifellos stark ausgedünnten Personalbestand im einzelnen nachzugehen, kann nur in gesonderten Untersuchungen geleistet werden. Hier soll nur noch ein Beispiel eines Mitarbeiters unterhalb der Leitungsebene, für den sich eine Personalakte erhalten hat, etwas näher vorgestellt werden.

Der gebürtige Berlin-Lankwitzer Walter Münchenhagen (geb. 1918), Sohn eines Malergesellen, hatte 1932-1935 eine Lehre als Handlungsgehilfe absolviert und in verschiedensten kleineren Stellungen gearbeitet. ${ }^{1088}$ Ab 1932 Mitglied des Deutschnationalen Handlungsgehilfenverbandes, kam er jedoch bald zur KPD, wurde Sekretär des Kommunistischen Jugendverbandes in Dresden und geriet als Soldat (Sanitätsunteroffizier) in Stalingrad 1943 in sowjetische Kriegsgefangenschaft. Nach Lageraufenthalten in Gorki und Moskau bis Juli 1946, während derer er die Antifaschule und Lehrgänge in Politökonomie, Philosophie sowie deutscher und russischer Geschichte besuchte, überdies schon ab 1943 Angehöriger des NKFD wurde, konnte er wohlvorbereitet in die SBZ zurückkehren und wurde noch im Juli SED-Mitglied. Am 27. Juli 1946 begann eine Laufbahn, die ihm auf den Leib geschnitten schien. Er wurde, wie er im Lebenslauf schreibt, „durch Vermittlung der Zentralverwaltung für deutsche Umsiedler der Prov[inzial]-Reg[ierung] zur pol[itischen] und kulturellen Betreuung der Heimkehrerlager eingesetzt", war bis zum 18. November kultureller Betreuer im Umsiedlerlager Treuenbrietzen/ Landesanstalt und wurde anschließend als Sachbearbeiter zum Heimkehrerlager Gronenfelde versetzt, am 1. Dezember aber gleichzeitig zur Landesregierung Brandenburg nach Potsdam abgeordnet und am 1. April 1947 als leitender Mitarbeiter zur Provinzialverwaltung Brandenburg, Abt. Umsiedler und Heimkehrer versetzt. ${ }^{1089}$ Hier war er laut Entlassungszeugnis von 1949,

1083 Dr. med. J. Kunde, 1948 Arzt, wohnhaft in Potsdam-Drewitz, Sternchaussee (Adressbuch Groß-Potsdam 1949, S. 237). Lt. Med. Diss. von 1939 (Univ. Berlin) Joachim Kunde. Sicher identisch mit dem 1955 als Schwiegersohn in der westdeutschen Todesanzeige für „Adolf Schauka, Bürgermeister a. D., früher Bischofstein, Ostpreußen" genannten Facharzt für Augenkrankheiten Dr. Joachim Kunde (Das Ostpreußenblatt 1955, Folge 7, T. 2, S. 8).

1084 Heinz Lisch, 1948 Regierungsamtmann, wohnhaft Am Brunnen 23 (Parallelstraße der Drevesstraße), also in unmittelbarer Nähe der Behörde (Adressbuch Groß-Potsdam 1949, S. 257).

1085 Hans Flock, 1948 Regierungsrat, wohnhaft Hans-Sachs-Straße 52 (Brandenburger Vorstadt) (Adressbuch Groß-Potsdam 1949, S. 106).

1086 Erich Schöning, 1948 Regierungsrat, wohnhaft Zeppelinstraße 107 (Brandenburger Vorstadt) (Adressbuch Groß-Potsdam 1949, S. 378).

1087 BLHA, Rep. 206 Ministerium für Wirtschaft und Arbeit, Nr. 2965, unfol.

1088 Personalakte (mit Porträtfoto): BLHA, Rep. 203 MdI, PA 486 (auch für das Folgende).

1089 Er wohnte 1947 in Potsdam, Unter den Eichen 27 d, 1948/49 ebd., Mauerstr. 8. Er war seit 1942 verheiratet mit Margarete geb. Raatz (geb. 1916), 1947 Angestellte der Bürgermeisterei Müllrose, Wirtschaftsamt, und (zumindest 1947) kinderlos. 
zunächst als Hauptsachbearbeiter, später Referent, mit den Arbeitsgebieten „Eingemeindung der Umsiedlertransporte, individuelle Arbeitsvermittlung der Umsiedler, Durchführung des Befehls Nr. 209 in bezug auf die Wohnraumfragen der Umsiedler usw.“ befasst, ferner „mit der Erledigung von Sonderaufträgen der Abteilung betraut". Eingruppiert war er ab 1. Juni 1947 als Regierungsoberinspektor, ab 1. Februar 1948 als Regierungsamtmann. Da ihm die sich anbahnende Entwicklung der Abteilung offenbar nicht verborgen blieb, kündigte er am 30. Juni zum 31. Juli 1948, um am 1. August eine neue Stelle anzutreten. Am 10. Juli nahm er die Kündigung zwar zurück, kündigte aber endgültig zum 31. Januar 1949. Von 1949 bis 1951 war er dann Leiter der Abteilung Staatliche Verwaltung im SED-Landesvorstand Brandenburg und 1950-1952 sogar Mitglied des Landtages Brandenburg (auch Ausschussvorsitzender), schließlich 1952-1954 2. Sekretär der SED-Bezirksleitung Cottbus, 1957-1960 1. Sekretär der SED-Stadtleitung Dresden, 1963 Sekretär der SED-Kreisleitung Dresden-Land und Leiter der Ideologischen Kommission der SED-Kreisleitung, 1965 stellvertretender Vorsitzender des Rates des Bezirkes Dresden sowie später Abteilungsleiter im Rat des Bezirkes. ${ }^{1090}$ Eine Bilderbuchkarriere, für die freilich weniger in der Potsdamer Episode als in Moskau der Grund gelegt wurde. Der Fall zeigt immerhin, dass der Personalbestand der brandenburgischen Umsiedlerverwaltung ein lohnendes Forschungsfeld bilden könnte. Dabei wäre dann allerdings auch den in den Kreisen, Amtsbezirken ${ }^{1091}$ und Gemeinden tätigen Amtsträgern noch mehr Beachtung zu schenken als dies hier, in einer zur Kürzung zwingenden Überblicksdarstellung, geschehen kann, zu schweigen vom Personal der „Umsiedlerlager“, den Lagerleitern und Lagerärzten etwa, deren „Vorleben“ ebenso im Dunkeln liegt wie ihr Verleib. ${ }^{1092}$ Insgesamt bildet die Gesamtheit aller mit dem „Umsiedlerproblem“, wenn auch nur für einige Jahre, befassten Personen aber - so viel ist sicher - eine kaum zu überblickende Zahl unterschiedlichster Biographien.

Hinzu kommt freilich der noch viel schwerer zu erforschende Bereich der Sowjetischen Militäradministration. Auch auf der Ebene der Provinz bzw. des Landes werden in den Jahren 1945-1949 mehrfach sowjetische Offiziere erwähnt, die nicht nur als für „Umsiedlerfragen“ zuständige ,Ansprechpartner' der deutschen Behörden fungierten, sondern v. a. als Befehlsgeber. Die offenkundig gleichzeitig mit der befohlenen Einrichtung einer zivilen deutschen „Umsiedlerverwaltung“ gegründete „Umsiedler-Abteilung“ bei der Kommandantur-Dienstverwaltung ${ }^{1093}$

1090 A. Herbst / W. Ranke / J. Winkler: So funktionierte die DDR. Bd. 3. Reinbek bei Hamburg 1994, S. 237 f. Protokolle des Landesblockausschusses (wie Anm. 204), S. 363, Fn. 3; SBZ-Handbuch (wie Anm. 1018), S. 984.

1091 Die Amtsbezirke 1946 als Verwaltungsinstanz zwischen Gemeinde und Landrat gebildet und zwar schon Ende März 1948 wieder aufgelöst. Zu ihren Aufgaben gehörten aber u. a. auch „Erfassung und Betreuung der Umsiedler" (Übersicht über die Bestände des Brandenburgischen Landeshauptarchivs. T. III/1. Berlin 2001, S. $261 \mathrm{f}$.).

1092 Stellenbesetzungsplan für das Lager Fürstenwalde abgedruckt bei Oehlsen, Vertriebenenlager (wie Anm. 45), S. 39).

1093 Chef der Abt. Kommandanturdienst und stellv. Chef der SMA-Verwaltung Brandenburg war 1945-1946 Generalmajor Alexandr Alexandrowitsch Fedotow (1887-1959), u.a. 12./18.10.1945 erwähnt (Wille I 
der SMA Provinz Mark Brandenburg ${ }^{1094}$ wurde ab Herbst 1945 geleitet von Major Iwanzow ${ }^{1095}$, dem in Major Malachow ein Stellvertreter und in Hauptmann Winogradsky ein Mitarbeiter zur Seite standen ${ }^{1096}$. Sie lässt sich zumindest noch 1947 und 1948 durch Erwähnung in Akten der Provinzialverwaltung nachweisen. ${ }^{1097} 1948$ fungierte als Leiter der Abteilung Innere Angelegenheiten in Major N. G. Kaplan (zusätzlich?) ein „Oberoffizier für Umsiedlung“.1098

Der deutschen ZVU nachgeordnet war schließlich als Sonderbereich der „Suchdienst für vermißte Deutsche in der Sowjetischen Besatzungszone Deutschlands" mit Sitz in Berlin-Mitte (W 8), Kanonierstraße 35, der auf der Grundlage des SMAD-Befehls Nr. 204 vom 19. Juli 1946 eingerichtet wurde und bis 1949 arbeitete. ${ }^{1099}$ Der Befehl enthielt zugleich ein Verbot der Betä-

[wie Anm. 196], S. 63f., 66), zuvor ab März 1945 Stadtkommandant in Stettin (SMAD-Handbuch. München 1009, S. 628). Nicht zu verwechseln (!) mit Generalleutnant Pjotr Wassiljewitsch Fedotow (Fedotoff) (1900-1963), 1946-1947 Chef der Ersten Hauptverwaltung (d.i. Auslandsaufklärung) des MGB der UdSSR und stellv. Minister für Staatssicherheit der UdSSR (Jan Foitzig / Nikita W. Petrow: Die sowjetischen Geheimdienste in der SBZ/DDR von 1945 bis 1953. Berlin u. a. 2009, S. 419). Nachfolger von Alexandr A. Fedotow war 1946 Generalmajor Wladimir Afanassjewitsch Tschistow (SMAD-Handbuch [wie vor], S. 532; vgl. unten Quellenteil, Nr. 113).

1094 Inventar der Offenen Befehle der Sowjetischen Militäradministration des Landes Brandenburg. Frankfurt am Main 2002, S. 37. - Zur SMA-Landesverwaltung Brandenburg (errichtet 9.7.1945) siehe: Jan Foitzik: Sowjetische Militäradministration in Deutschland (SMAD) 1945-1949. Struktur und Funktion. Berlin 1999, S. 452f. (Personalübersicht); SMAD-Handbuch (wie Anm. 1093), S. 527-534 (Organisation, Personal, archivalische Quellen). Der Sitz befand sich in Potsdam, Neue Königstraße 74(-77), nach der noch 1945 erfolgten und mit Umnumerierung verbundenen Straßenumbenennung: Berliner Str. 98(-101); die Straße hieß (ohne Hausnummernveränderung) 21.12.1949-15.11.1961 Stalinallee, seitdem wieder Berliner Straße (Arlt, Straßennamen [wie Anm. 1080], S. 18). Bei dem Gebäude handelt es sich um das der ehem. WasserstraBendirektion Kurmark, in der DDR-Zeit später Deutsches Zentralarchiv bzw. ab 1973 Zentrales Staatsarchiv der DDR (Hauptverwaltung und Historische Abt. I), heute Sitz verschiedener Behörden (Bundesanstalt für Immobilienaufgaben, Hauptzollamt Potsdam).

1095 U. a. am 8.10.1945 erwähnt (Wille I [wie Anm. 196], S. 50, 63, 303). Sonst bisher nicht zu ermitteln. Ob identisch mit dem sehr viel später erwähnten Oberst Wassili Wladimirowitsch Iwanow (geb. 1904), 1949 Chef der Politischen Abteilung und stellv. Chef für politische Fragen der SMA Brandenburg (SMAD-Handbuch [wie Anm. 1093], S. 532, 637)?

1096 Wille I (wie Anm. 196), S. 50 (bei Winogradsky mit Hinweis auf BLHA, Rep. 203 MdI, Nr. 1074, Bl. 91; Rep. 202 A Büro des Min.Präs., Befehlsschreiben der SMA Brandenburg, Nr. 90/91). Keiner dieser Offiziere wird erwähnt in: Foitzik, Sowjetische Militäradministration (wie Anm. 1094).

1097 BLHA, Rep. 203 MdI, Nr. 1108; lt. Rep. 203 MdI, Nr. 1166, Bl. 29 am 16.6.1948 Sitz Berliner Straße (d.h. im Haus Nr. 98-101; vgl. Anm. 1094).

1098 Erwähnt am 16.6.1948 in BLHA, Rep. 203 MdI, Nr. 1166, Bl. 29.

1099 Organigramm vom Juni/Juli 1949 (Bleistiftnotizen von Frau Orlowski): BLHA, Rep. 203 MdI, Nr. 1197, Bl. 8. - Leiter bzw. Präsident war 1946-1948 der gebürtige Münchener August Mayer (KPD/SED) (19981969) (erwähnt 8.5.1947 bis 18.11.1948 in: BLHA, Rep. 203 MdI, Nr. 1197, Bl. 32, 49; Nr. 1198, Bl. 2v); siehe: www.bundesstiftung-aufarbeitung.de/wer-war-wer-in-der-ddr [19.9.2017]). - Die Bekanntgabe der Einrichtung eines zentralen SBZ-Suchdienstes erfolgte offenbar nicht überall zeitnah; siehe z.B. das entsprechende Informationsschreiben des Bürgermeisters von Fürstenberg (Oder) an die Bürgermeister der in seinem Bezirk liegenden Landgemeinden vom 17.9.1946, abgedruckt in: „Die russische Kommandantur verlangt ..." [wie Anm. 209], S. 116). - Siehe auch die ausführliche Einleitung (mit weiterer Literatur) zum 
tigung aller bisherigen anderen Suchdienste, verfügte aber die Einrichtung von nachgeordneten und insofern wiederum weisungsgebundenen Provinzial- bzw. Landesbeauftragten. ${ }^{1100}$ Auch in diesem für die Flüchtlinge und Vertriebenen elementaren Bereich lag die Entscheidungsgewalt also nicht ausschließlich in Potsdam, sondern - abgesehen von der sowjetischen Ebene - im Zweifel stets in Berlin(-Ost). Der ebenfalls am 19. Juli 1946 eingerichteten brandenburgischen „Provinzial-“ bzw. „Landesbeauftragten des Suchdienst für vermißte Deutsche in der Sowjetischen Besatzungszone Deutschlands" mit Sitz bei der brandenburgischen „Umsiedlerabteilung“ in Potsdam $^{1101}$ waren die entsprechenden Beauftragten in den Städten und Kreisen nachgeordnet. ${ }^{1102}$

Die Leitung des brandenburgischen Suchdienstes ${ }^{1103}$ lag stets in der Hand von Frauen, anfangs kurze Zeit E. [Elli? ] ${ }^{1104}$ Schmidt (erwähnt 29.10. bis 6.11.1946) ${ }^{1105}$ und zuletzt, ebenfalls nur wenige Monate, [Auguste?] ${ }^{1106}$ Orlowski (ab 1.6.1949, noch erwähnt 22.8.1949) ${ }^{1107}$. Letztere bezeichnete sich selbst als „Umsiedlerin“. ${ }^{1108}$ Geprägt wurde die Arbeit jedoch vor allem durch die mehrjährige Amtszeit von Gertrud Friedrichs geb. Timm (SED) ${ }^{1109}$ (erwähnt ab 21.11.1946 ${ }^{1110}$, im Amt bis 31.5.1949). ${ }^{1111}$ Ihr Familienname war in der brandenburgischen „Umsiedlerverwaltung“ bereits allerorts geläufig, denn sie war mit dem kurz zuvor ins Amt gekommenen Leiter der Umsiedlerabteilung der Landesregierung, Erich Friedrichs, verheira-

Online-Findbuch des Bundesarchivs für den 11 lfm umfassenden Bestand DO 105 Suchdienst für vermisste Deutsche in der SBZ/in der DDR.

1100 Hektografierte Rundschreiben für die Beauftragten in den Ländern finden sich z. B. in den Akten der brandenburgischen Landesregierung: Nr. 1 (11.9.1948), Nr. 3 (18.11.1948), Nr. 4 (15.12.1948), Nr. 7 (10.3.1949) bis Nr. 11 (2.8.1949): BLHA, Rep. 203 MdI, Nr. 1197, Bl. 1-38. - Ebd., Bl. 49 Abschrift des Rundschreibens Nr. 7 (20.5.1947).

1101 Sitz Potsdam, Alte Zauche 67, Haus 2 (erw. 1947), später (1949) Haus 9 Zi 32 (im „Amt für Deutsche Umsiedler") (erwähnt 1946-1949); eine Provinzialannahmestelle (für Suchanträge) befand sich in der Hebbelstraße 6 (erwähnt 13.9.1946).

1102 BLHA, Rep. 203 MdI, Nr. 1196.

1103 Zur Tätigkeit siehe unten den Abschnitt „Versorgung und Betreuung“.

1104 Vermutlich ist sie identisch mit der in Berlin-Wedding geborenen KPD/SED-Funktionärin Elli Schmidt (1908-1980), die 1946 zwar überwiegend in Berlin, besonders in der Frauenpolitik, tätig war, aber auch in Potsdam bei Veranstaltungen nachweisbar ist (1948-1954 Vorsitzende des DFD; verheiratet mit dem durch die „Gruppe Ackermann“ bekannten KPD/SED-Funktionär Anton Ackermann). Siehe www.bundesstiftungaufarbeitung.de/wer-war-wer-in-der-ddr [19.9.2017]; Anna Kaminsky: Frauen in der DDR. Berlin 2016, S. 37 u. ö.

1105 BLHA, Rep. 203 MdI, Nr. 1196, Bl. 57-60, 63-74.

1106 Eine Auguste Orlowski wird ohne Berufsangabe mit Wohnsitz in der Brandenburger Vorstadt, „Goetheplatz 8 “ (1950 umbenannt in Schillerplatz), im Adressbuch Groß-Potsdam 1949 genannt (S. 306 und 581).

1107 BLHA, Rep. 203 MdI, Nr. 1195-1198, hier Nr. 1196, Bl. 43.

1108 BLHA, Rep. 203 MdI, Nr. 1198, Bl. 69r.

1109 Seit 1.1.1949 Mitglied der SED und des DFD, seit 6.10.1949 auch der DSF.

1110 BLHA, Rep. 203 MdI, Nr. 1196, Bl. 32. Allerdings nennt sie selbst an anderer Stelle als ihren Dienstantrittstermin März 1947 (BLHA, Rep. 203 MdI, Nr. 1198, Bl. 66r).

1111 BLHA, Rep. 203 MdI, Nr. 1195-1198. 
tet. ${ }^{112}$ Beide haben fast drei Jahre lang, bis 1949 parallel, um nicht zusagen gemeinsam, die Vertriebenenbelange in Brandenburg an maßgeblicher Stelle betreut.

\section{Umsiedlerausschüsse}

Die Verwaltung hatte, bis hin zu den örtlichen Verantwortlichen in den Landgemeinden, erhebliche Probleme, die durch immer neue Zuweisungen Vertriebener oftmals kritische Situation in den Griff zu bekommen. Anfragen wegen fehlender Kleidung, Nahrung oder nicht ausreichenden Wohnraums wurden an die staatlichen und kommunalen Stellen nahezu pausenlos herangetragen. Konflikte von Vertriebenen wie auch Behörden mit hilfsunwilligen Einheimischen waren an der Tagesordnung. In dieser Situation wurde versucht, durch die Bildung von „Umsiedlerausschüssen“ eine bessere Koordination des Verwaltungshandelns der beteiligten Stellen zu erreichen. ${ }^{1113}$ Das schon im Sommer 1945 geplante Gesamtsystem dieser Ausschüsse enthielt in jedem Land/Provinz theoretisch Gremien zur Unterstützung der Behörden aller drei Ebenen: Provinz/Land, Kreis und Gemeinden. Die Einrichtung eines zusätzlichen, länderübergreifenden Ausschusses für die SBZ scheiterte 1947 an dem Unwillen der SED, die bürgerlichen Parteien und die kirchlichen Hilfswerke stärker einzubeziehen. ${ }^{1114}$ Entsprechend sollten ein Provinzialumsiedlerausschuss ${ }^{115}$, in jedem Kreis ein Kreisumsiedlerausschuss und in jeder Gemeinde ein Ortsumsiedlerausschuss gebildet werden ${ }^{1116}$, wobei anfangs, bis in den Herbst 1945, häufig noch von Flüchtlingsausschüssen, nicht von Umsiedlerausschüssen gesprochen wurde. ${ }^{117}$ In Brandenburg forderte die Provinzialverwaltung schon am 25. August 1945 zur Einrichtung entsprechender Ausschüsse bei allen Landratsämtern auf. ${ }^{1118}$

Dem Interesse der Verwaltungen an einer verbesserten Effektivität ihrer Arbeit standen jedoch die verschiedensten Hindernisse im Wege, so dass das Ausschuss-Modell, dessen Umsetzung ohnehin bereits $1949 \mathrm{ihr}$ Ende fand, im Einzelfall nicht selten erst mit einer erheblichen

1112 BLHA, Rep. 203 MdI, PA 276 (Personalakte des Ehemannes).

1113 Grundlegend: Schwartz, Vertriebene und „Umsiedlerpolitik“ (wie Anm. 13), S. 572-611. - Michael Schwartz: Kontrollierte Partizipation. Die „Umsiedler-Ausschüsse“ der Sowjetischen Besatzungszone Deutschlands im Spannungsfeld von Sonderverwaltung, Parteipolitik und sozialen Interessen 1945-1949. In: Die Flüchtlingsfrage in der deutschen Nachkriegsgesellschaft. Sylvia Schraut, Thomas Grosser (Hg). Mannheim 1996, S. 161-191. - Quellen: Wille III (wie Anm. 196), S. 77-148.

1114 Wille III (wie Anm. 196), S. 86.

11151947 „Landesumsiedler- und Heimkehrerausschuss“ (Wille III [wie Anm. 196], S. 129).

1116 Ebd., S. 77.

1117 Z.B. am 1.9.1945 in einem Bericht des „Flüchtlingsausschusses“ beim Landratsamt des Kreises Beeskow-Storkow (BLHA, Rep. 250 Landratsamt Beeskow-Storkow, Nr. 867; vgl. Textabdruck im Quellenteil, Nr. 7). - Zu beachten ist, dass der Begriff „Flüchtlingsausschuß“ in den Westzonen und den Westsektoren Berlins gelegentlich auch später noch begegnet, als in der SBZ längst nur noch von Umsiedlerausschüssen gesprochen werden durfte. Im Westen allerdings bezog er sich auf ganz andere Körperschaften, nämlich eigene Interessenvertretungen der Flüchtlinge und Vertriebenen, wie beim „Flüchtlingsausschuß Friedeberg/Nm., Altkarbe und Umgegend".

1118 Wille III (wie Anm. 196), S. 90. 
Verzögerung überhaupt ins Leben treten konnte. Auch im SED-Landesvorstand Brandenburg war man sich dessen durchaus bewusst, wie eine Äußerung von 1947 zeigt: „Es war anfangs so, dass diese Ausschüsse immer nur auf dem Papier standen. " ${ }^{1119}$ In den zahlreichen Landgemeinden wurde die Einrichtung oftmals verschleppt, da die Bürgermeister und die hinter ihnen stehenden einheimischen Bauern wenig Neigung verspürten, Verteilungsmisstände in solchen Gremien offengelegt zu sehen. Aber auch auf Kreisebene musste die Provinzialverwaltung am 9. Oktober 1945 an ihre Aufforderung vom 25. August erinnern, indem sie auf die Dimension der zu regelnden Gesamtprobleme in einem sehr eindringlichen Appell an die Verantwortlichen hinwies: „Die Umsiedlerfrage, die sich als größte und schwer zu lösenste nach Kriegsbeendigung herausgestellt hat, ruft alle verfügbaren Kräfte auf den Plan, um zu helfen, wo nur zu helfen ist. Es müssen daher sofort [!] bei allen Landratsämtern, wie wir bereits in unserem Schreiben vom 25.8. d.J[ah]r[e]s forderten, Umsiedler-Ausschüsse gebildet werden. [... "1120.

Angesichts des auch 1946 unverminderten Zustroms von Vertriebenentransporten drohte die Lage in vielen Kreisen und Gemeinden zu einem Kollaps der Hilfskapazitäten zu führen. Der SED-Landesvorstand sah sich daher am 20. Juni 1946 genötigt, an die Kreisvorstände zu schreiben, um längst geregelt Erscheinendes endlich umzusetzen: „So wie bisher geht es auf keinen Fall weiter. Wir wissen, dass die meisten Kreisleitungen [...] nicht die nötige Sorgfalt den Heimkehrern und Umsiedlern haben angedeihen lassen, wie es unbedingt nötig gewesen wäre. Die Umsiedlerausschüsse bestehen in den [S. 103] meisten Fällen nur auf dem Papier, in verschiedenen Kreisen sind noch nicht einmal solche gebildet worden. Es gibt nur vereinzelte Umsiedlerausschüsse, die ihre Aufgaben politisch klar erkannt haben und die wirtschaftliche und politische Betreuung der Umsiedlerlager mit allem Ernst betrieben haben. Das Nichtfunktionieren der Umsiedler- und Heimkehrerausschüsse ist ein Mangel in unserer Partei." Diese Partei-(Selbst-)Kritik bezog auch die Frage des künftigen Wählerpotentials ein, das in den „Umsiedlern“ liege, „deren Stimmenzahl bei der kommenden Wahl nicht klein sein wird. Hier muss also eine Wandlung geschaffen werden. Jeder Kreisvorstand schafft sofort in seinem Kreis einen arbeitsfähigen Umsiedlerausschuss. Der Umsiedlerausschuss muss sich wie folgt zusammensetzen: aus Vertretern der antifaschistischen Parteien, der Gewerkschaft, dem Frauenausschuss, der Freien Deutschen Jugend und ein Vertreter des KreisSozialamtes. In Anbetracht der Wichtigkeit dieses Ausschusses wäre es zweckmäßig, wenn einer der beiden politischen Sekretäre unserer Partei die Verantwortung für die Durchführung der Aufgaben der Umsiedlerausschüsse übernehmen würde. [...]."1121

Zumindest bei der Zusammensetzung der Ortsumsiedlerausschüsse in den Gemeinden lässt sich die Mitgliedschaft von einem oder zwei bis drei „ortsansässigen Umsiedlern“ feststel-

1119 BLHA, Rep. 333 SED-Landesleitung Brandenburg, Nr. 574, Bl. 103 (vgl. Textabdruck im Quellenteil, Nr. 127).

1120 Wille III (wie Anm. 196), S. 90 (BLHA, Rep. 203 MdI, Nr. 1163, Bl. 37).

1121 Ebd., S. 102 f., Nr. 93 (BLHA, Rep. 333, Nr. 576, Bl. 20-21). 
len ${ }^{1122}$, auch wenn wohl „Antifa-Umsiedler“ nach Möglichkeit bevorzugt werden sollten. Damit ergab sich für die eigentlich Betroffenen immerhin eine Art lokaler Interessenvertretung, als die die Ausschüsse daher von ihrer Seite aus - im Gegensatz zu den Intentionen der Behörden und der SED - zunehmend gesehen wurden. Aber auch in ihrer inhaltlichen Arbeit blieben die Ortsumsiedlerausschüsse, sofern sie überhaupt ins Leben traten, hinter den von der SED und der Umsiedlerverwaltung beabsichtigten hohen Zielen der auch sozialen, kulturellen und atmosphärischen Integrationsförderung zurück. Während die ZVU den Ausschüssen „in den Kreisen und Gemeinden die Hauptlast des Vertriebenenproblems " übertragen wollte ${ }^{1123}$ und sie Anfang 1946 unmissverständlich aufforderte, ,für eine freundliche Aufnahme der Umsiedler und für ein gutes Einvernehmen zwischen der einheimischen Bevölkerung und den Umsiedlern Sorge zu tragen "1124, berichteten die örtlichen und Kreisverantwortlichen auch weiter immer wieder von kleinteiligen Streitigkeiten an der Basis, von deren Bewältigung die Ortsumsiedlerausschüsse schließlich als ihrem einzigen Betätigungsfeld gebunden wurden. Dabei konnten sie sich des Zuspruchs der notleidenden Vertriebenen, die praktische Hilfe und mindestens genauso dringend Ansprechpartner benötigten, durchaus erfreuen, wie z. B. der Tätigkeitsbericht des Umsiedlerausschusses Havelberg im Januar 1948 belegt: „Nach wie vor steht der Umsiedlerausschuss jeden Mittwochabend im Rathaus den Umsiedlern zur Verfügung, Diese Abende werden rege in Anspruch genommen." 1125 Mancher Vertriebene zog jedoch anschließend enttäuscht von dannen, da es kein Einzelfall war, dass die in den Ausschüssen zahlenmäßig dominierenden oder gar allein vertretenen Einheimischen nur darauf bedacht waren, ihre und ihrer Verwandten Besitzstände zu verteidigen. ${ }^{1126}$

Nachdem ab 1946 erneute Bemühungen dazu geführt hatten, dass immerhin in den Jahren 1947 und 1948 viele Ortsumsiedlerausschüsse gegründet waren und arbeiteten ${ }^{1127}$, versuchte die Verwaltung, namentlich die Zentralverwaltung in Berlin, diese zu instrumentalisieren, um von der verkündeten Aufgabe der gleichberechtigten Integration zu einer forcierten Assimilation überzugehen. Doch auch jetzt, als nochmals viele zusätzliche Transporte ins Land kamen, standen allem voran zunächst einmal wieder die elementarsten Bedürfnisse des Überlebens, des Übernachtens im Vordergrund, denen sich niemand entziehen konnte, der an der Basis im Einsatz war. Fragen der Wohnraumquadratmeter und der Herausgabe ungenutzten Mobiliars

1122 Ebd., S. 79. Es gab aber auch ganz anderes: In Werder bei Strausberg waren alle 7 Mitglieder des Umsiedlerausschusses „Umsiedler“ (BLHA, Rep. 333, Nr. 574, Bl. 370; siehe Textabdruck im Quellenteil, Nr. 84).

1123 Ebd.

1124 Ebd., S. 95 f., Nr. 84 (Aktennotiz, 21.1.1946; BArch, DO 2, Nr. 50, Bl. 6-8), hier S. 94.

1125 BLHA, Rep. 250 Landratsamt Westprignitz, Nr. 254, B1. 107.

1126 Wille III (wie Anm. 196), S. 79, auch zu Tendenzen Vertriebener, eigene Interessenvertretungen zu bilden (ein Beispiel vom Oktober 1945 aus dem Nachbarland Sachsen ebd. erwähnt in Fn. 284: Ein „Verband der Ostflüchtlinge und Evakuierten“ war hier im Begriff, sich „über die gesamte SBZ“ auszudehnen).

1127 Siehe die Beispiele für Berichte von Ortsumsiedlerausschüssen der Jahre 1947 und 1948 aus den Kreisen Beeskow-Storkow und Westprignitz im Quellenteil (Nr. 96-100, 101-104), sowie das Sitzungsprotokoll des Kreisumsiedlerausschusses des Kreises Oberbarnim (9.3.1949) ebd. (Nr. 155). Ferner die Sitzungsprotokolle des (Orts-)Umsiedlerausschusses Fürstenberg (Oder) in: „Die russische Kommandantur verlangt ..." (wie Anm. 209), S. 142 (27.2.1948), S. 154f. (12.7.1948), S. 163 (10.1.1949). 
standen auf der dörflichen und städtischen Tagesordnung, nicht dagegen nachhaltige Konzepte der Verschmelzung von Bevölkerungsgruppen. „Im Land Brandenburg beschränkte sich im Sommer 1947 die Tätigkeit der Gemeindeausschüsse darauf, im Auftrage der Bürgermeister und der Volkssolidarität Geschirr und Bekleidung auszugeben. "“128 So erhielten die Ausschüsse auch die Zuständigkeit für die Vorbereitung und Durchführung der in sogen. „Umsiedlerwochen" von der einheimischen Bevölkerung zu sammelnden Haushaltsgegenstände, die anschließend bedürftigen Vertriebenen zur Verfügung gestellt wurden. ${ }^{1129}$ Auch wenn selbst dabei oft ein nur mäßiger Erfolg erzielt wurde und der Ärger mit einheimischen Funktionsträgern nicht nachließ, bildeten die Ortsumsiedlerausschüsse letztlich doch die einzigen in der SBZ von den Betroffenen an der Basis wahrgenommenen Ansätze für eine staatliche Vertriebenenbetreuung. Je mehr sich jedoch in der Regierung und der SED die Tendenz bemerkbar machte, das „Umsiedlerproblem “ durch vollständige Assimilation bzw. Tabuisierung zu lösen, gerieten auch bei ihnen die Ausschüsse in die Kritik. Ihr Dasein endete ähnlich wie das Ressort einer gesonderten „Umsiedlerverwaltung“ schon nach wenigen Jahren. Am 26. August 1949 wies der brandenburgische Innenminister Bechler die Räte der Stadt- und Landkreise an, die Umsiedlerausschüsse „zu einer Abschluss-Sitzung zusammenzurufen “. ${ }^{1130}$ Etwa noch vorhandene "finanzielle Mittel, z.B. aus der Umsiedlerwoche oder sonstige Spenden“, waren „nach Prüfung und Verfügung des Rates der Kreise“ der Volkssolidarität Brandenburg zuzuführen. ${ }^{1131}$

Anders als die Ausschüsse auf Kreis- und Ortsebene, die zumindest häufig tagten und eine große Zahl von Beschwerden bearbeitet (und überliefert) haben, blieb der landesweit gedachte Ausschuss im engsten Fahrwasser der Verwaltung, bei der er ohnehin seinen „Briefkasten“ hatte. Auf Provinz- und Landesebene ist die Zusammensetzung des ersten „ProvinzialUmsiedler-und Heimkehrerausschusses" in einer Mitgliederliste für die Konstituierung im August 1946 überliefert. Brandenburg war mit diesem späten Datum (nach der Provinz Sachsen im Januar 1946 und Thüringen im Februar 1946) gleichwohl nicht das letzte Land, in dem er gebildet wurde. In Sachsen kam es erst im August 1947 dazu, in Mecklenburg(-Vorpommern) gar nicht. ${ }^{1132}$ In Brandenburg teilte der SED-Provinzialvorstand, Abteilung Arbeit und Sozialfürsorge (Frau [Gerda] Sucker), der Provinzialverwaltung, z.Hd. Herrn Friederichs, unter dem 14. August 1946 acht namentliche Vorschläge mit und forderte den Adressaten zur Einberufung der konstituierenden Sitzung auf. Zugleich wurde dieser gebeten, eine Vertreterin der unterzeichneten Abteilung, Frau [Else] Bauer oder Frau Sucker, an den Sitzungen beratend teilnehmen zu lassen. ${ }^{1133}$ Eine undatierte, offenbar von 1946 oder 1947 stammende Mitgliederliste des

1128 Wille III (wie Anm. 196), S. 85.

1129 Siehe dazu unten dem Abschnitt „Versorgung und Betreuung“.

1130 Wille III (wie Anm. 196), S. 147 f., Nr. 154 (BLHA, Rep. 203 MdI, Nr. 1163, Bl. 109), hier S. 147.

1131 Ebd.

1132 Ebd., S. 80 f.

1133 BLHA, Rep. 333 SED-Landesleitung Brandenburg, Nr. 574, Bl. 39-40 (Vorschlagsliste vom 10./14.8.1946); siehe Abdruck im Quellenteil, Nr. 145. Zu beiden Personen siehe ebd. 
Ausschusses ${ }^{1134}$ zeigt, dass alle „Vorschläge“ umgesetzt wurden, es fehlt nur der „Kollege Krüger, Betriebsrat $R A W^{*}$. Zusätzlich zu den von Gerda Sucker benannten Vertretern der Parteien sind die Behördenvertreter aus den in erster Linie in Frage kommenden Ressorts genannt:

„Vertreter der SED: Herbert Thiele [auch auf Vorschlagsliste]

Vertreter der LDP: Ferdinand Genske [auch auf Vorschlagsliste]

Vertreter der CDU: Frau Martha Scharf [auch auf Vorschlagsliste]

Vertreter des Frauenausschusses: Frau Emmi Plinz [auch auf Vorschlagsliste]

Vertreter des FDGB: Herr Eckart [auch auf Vorschlagsliste]

Vertreter der FDJ: Fritz Schiller [auch auf Vorschlagsliste]

Vertreter der Abt. VII Arbeit und Sozialwesen:

a) Landesarbeitsamt: Herr Walpuski, desgl. (Umschulung): Herr Gericke

b) Wohnungshygiene: Herr Brehmer

c) Arbeit und Löhne: Herr Menz [auch auf Vorschlagsliste]

Vertreter der Abt. II:

Planung und Wiederaufbau: Herr Dr. [Karl] Erbs

Industrie: Herr Hausdorf

Vertreter der Abt. VIII: Gesundheitswesen: Herr Dr. Günther

Informationsdienst: Herr Schackwitz

Vertreter der Abt. XI Handel und Versorgung: Herr Kahlert."

Im April 1947 erfolgte eine Neubildung des „Provinzial-Umsiedlerausschusses“ ${ }^{1135}$, der wahrscheinlich eine ebenfalls undatierte (1947/49?) Mitgliederliste des „Landesumsiedlerausschusses" zugewiesen werden kann $^{1136}$ :

„1.) Min.Dir. [Max] Fischer (Abt. Arbeit u. Sozialwesen),

2.) Min.Dir. Streit (Abt. Handel u. Versorgung),

3.) Min.Dir. Scholz (Abt. Wirtschaftsplanung),

4.) Min.Dir. [Karl] Erbs (Abt. Wiederaufbau),

5.) Min.Dir. Müller (Abt. Industrie),

6.) Min.Dir. Steimer (Abt. Polizei),

7.) Min.Rat Ramm (Abt. Verkehr),

8.) Min.Rat Dr. Winter (Abt. Gesundheitswesen?),

9.) Min.Dir. Hentschel (Abt. Allgem. Verwaltung),

10.) Min.Dir. Wegner (Abt. Landwirtschaft),

11.) [N.N.] (Landesforstamt). 
[Ferner:] SED (Wernsdorf), CDU (Frl. Dau), LDP (Herr Rosenow), FdJ (Potsdam, Berliner Str. 136), FdGB (Potsdam, Schopenhauerstr. 37, Fr. Przemski), VdGB (Potsdam, Mangerstr. 41), Handwerkskammer (Zimmermann), Ind.- u. Handelskammer (Saarmunderstr.), Inf. Dienst (Aulig, Seestr. 43), DFD (Seestr. 30), VVD (Lucher).“

Nach der Auflösung der ursprünglichen Umsiedlerausschuss-Strukturen gab es auf Landesebene zwar noch 1951 einen [Landtags-],Ausschuss für Sozial-, Gesundheitswesen und Umsiedler“, der nachweislich noch am 5. Januar und 18. Mai 1951 im Landtagsgebäude in Potsdam, Heinrich-Mann-Allee 107, tagte. ${ }^{137}$ In beiden Sitzungen erscheinen jedoch auf der Tagesordnung keine „Umsiedler“-Themen mehr. Vorsitzender war Fritz Wicke ${ }^{1138}$, stellvertretende Vorsitzende Margarete Schahn ${ }^{1139}$ und Schriftführer Helmut Altweck ${ }^{1140}$.

\section{Versorgung und Betreuung}

„Ich habe nicht mehr in Erinnerung, wovon wir überhaupt lebten, nur daß wir alle immer Hunger hatten. "1141

In der „Kalten Heimat“ bedeutete es nicht nur für viele Einheimische, die plötzlich neue Nachbarn oder gar Untermieter und Einquartierte bekommen hatten, einen Lernzprozess, sich auf deren mit ihren eigenen Nöten nicht vergleichbare Notsituation einzustellen. Auch die mit Einheimischen besetzten Behörden waren zumindest 1945 mit der Fülle an ungeplanten und unplanbaren Aufgaben überfordert. Die Provinzialregierung, die sich dann allmählich durch ihr Informantennetz ebenso wie über die Landratsämter laufend aus allen Kreisen berichten ließ, verfolgte die Entwicklungen aufmerksam und kritisch. Kurz vor dem ersten Friedensweihnachten fand am 21. Dezember 1945 in Potsdam eine Besprechung mit den Leitern der brandenburgischen Kreissozialämter statt, in der die Leiterin der Umsiedlerabteilung der Provinzialverwaltung, Magda Sendhoff, kein Blatt vor den Mund nahm. Wohlwissend, dass die Transporte und mit ihnen die Betreuungsarbeit noch längst nicht enden würden, sah sie mehr als ein halbes Jahr nach Kriegsende noch allerorten Nachholbedarf in der Bewusstseinsbildung, die ebenso wichtig war wie die Bereitstellung von materiellen Dingen. Den anwesenden Amtsleitern redete sie daher gleich zu Beginn ihres Referates über „Umsiedlerfragen“ ganz unbürokratisch und - nicht ohne eine gewisse Provokation - aufrüttelnd ins Gewissen: „Wir müssen uns immer wieder vor Augen halten, daß es sich bei der Betreuung der Ums [iedler] nicht um

1137 BLHA, Rep. 201 Landtag, Nr. 185 (II. Wahlperiode), Bl. 1-2. - Siehe auch Nr. 181-182 (I. Wahlperiode, 1947-1950).

1138 Am 5.1.1951 bestätigt, auch am 18.5. im Amt.

1139 Am 5.1. als solche bestätigt, am 18.5. fehlend. - Margarete Schahn (1903-1996), geb. in Forst (Lausitz), KPD/SED, 1950-1952 MdL Brandenburg, 1952-1953 Vorsitzende des Rates des Kr. Forst, 1953-1954 Bürgermeisterin und 1954 Oberbürgermeisterin von Cottbus.

1140 Am 5.1. bestätigt, am 18.5. vertreten durch Frieda Dictus.

1141 Eva Nolte: Wieder mit dem Handwagen unterwegs. In: Um Beelitz harter Kampf (wie Anm. 480), S. 77. 
Kartoffelsäcke[,] sondern um lebende Menschen handelt." ${ }^{1142}$ Sendhoff hatte längst erkannt, dass sich die Herausforderungen, denen sich die Behörden in nie gekanntem Umfang zu stellen hatten, nur mit einem gesamtgesellschaftlichen Umdenken meistern lassen würden. Ihre Sätze sind insofern programmatisch: „Diese Menschen haben genausoviel oder wenig Schuld an all ihrem Leid wie wir und das bedeutet, diesen Leuten zu helfen, nicht nur, daß sie etwas in den Magen bekommen, entlaust oder untersucht werden, sondern man muß diesen Menschen Lebensmut geben und wir wollen ihnen helfen und sind bereit, ihnen einen neuen Arbeitsplatz, Wohnung und Heimat $z u$ geben und am Wiederaufbau Deutschlands zu helfen. Die ganze Provinz muß noch stark auf das Neue vorbereitet werden." $" 1143$

Die kommunalen Verwaltungen, von ihrer Provinzialverwaltung ebenso wie diese von der Besatzungsmacht oftmals mit Unterbringung und Versorgung selbst großer Vertriebenenkontingente kurzfristig konfrontiert und mittelfristig allein gelassen, versuchten ohne Erfolg, Aufnahmestopps zu erwirken, und griffen dann in ihrer Not zu bisweilen drastischen Maßnahmen, um Unterbringung und Ernährung sicherzustellen. Dazu zählten nicht nur Zwangseinquartierungen, sondern auch rigorose direkte und indirekte Maßnahmen der Abweisung. ${ }^{1144}$ So hatte sich in Fürstenberg/Havel und Ravensbrück „die Personenzahl in den vier Wochen vom 12. Mai bis zum 10. Juni 1945 von 7648 auf 6716“ verringert. Dies wurde von der Stadtverwaltung auf die bewusst restriktive Ausgabe von Lebensmittelkarten zurückgeführt. Ihr Bericht vom 11. Juni 1945 verweist bei der Präsentation dieser Zahlen auf den Zusammenhang: Die Statistik zeige „eindeutig den Erfolg unserer Maßnahmen, daß gesunde Untätige und Flüchtlinge nicht mit Lebensmittel versorgt werden, was diese erwünschtermaßen zum schnellen Weiterzug aus Fürstenberg veranlaßte“. ${ }^{145}$ Wolfgang Stegemann hat allerdings vermutet, dass „dieses rigorose Vorgehen auch etwas mit der für den kleinen Ort proportional hohen Zahl der Besatzungstruppen zu tun hatte. Die Beschlagnahme ganzer Stadtteile und Häusergruppen durch die Rote Armee mag der Aufnahmekapazität weiterer Flüchtlinge enge Grenzen gesetzt haben. Die vorhandene Bevölkerung war ohnehin schon auf engstem Raum zusammengerückt.“1146

Solche vorübergehenden oder längerfristigen Absperrungen ganzer Straßen durch die Besatzungsmacht hat es in der Tat auch anderswo gegeben, sie stellten die Gemeinden über Nacht vor vollendete Tatsachen und nahmen ihnen dann zum ungünstigsten Zeitpunkt unverzichtbare räumliche Kapazitäten. ${ }^{1147}$ Gleiches ist bei der Beschlagnahme medizinischer Einrichtungen

1142 BLHA, Rep. 206 Ministerium für Wirtschaft und Arbeit, Nr, 2965, unfol. (vgl. Textabdruck im Quellenanhang, Abschnitt 2.3).

1143 Ebd.

1144 Siehe dazu auch oben im Kapitel II. 2, Abschnitt „Transporte“, die Bemerkungen zur Situation in Berlin.

1145 Stegemann, Die Nachkriegszeit 1945 bis 1948 (wie Anm. 176), S. 234.

1146 Ebd.

1147 Vgl. z.B. die Hinweise auf die Beschlagnahmung neu eingerichteter Flüchtlingslager in Berlin-Reinickendorf (oben im Kapitel II. 2, Abschnitt „Transporte“, Anm. 668). 
vorgekommen. ${ }^{1148}$ Ein ganzes Bündel widriger Umstände behinderte folglich nicht selten die zielgerichtete und erfolgreiche Versorgung und Betreuung der Vertriebenen. Funktionierte die Verwaltung, so konnte es dennoch an medizinischem Gerät und Medikamenten ebenso wie an Kleidung oder Schuhen mangeln. War der benötigte Wohnraum nicht oder nur in geringem Maße kriegszerstört und galt der betreffende Kreis daher als aufnahmefähig, so konnten kurzerhand vorgenommene Requirierungen durch die Besatzungsmacht die Unterbringung ebenso erschweren wie der Unwillen vieler Einheimischer, die falsche Angaben machten oder Anordnungen unterliefen. Da es an einer „Willkommenskultur“ auf Seiten derer fehlte, die selbst eben erst dem schlimmsten gekannten Krieg entronnen waren und vielleicht selbst auf die Rückkehr des Familienvaters aus der Gefangenschaft warteten oder Gefallene zu beklagen hatten, verzögerte sich vieles. Wirklich beschleunigend wirkte meist erst der Befehl eines sowjetischen (Orts-)Kommandanten. Die Umsiedlerabteilung der Provinzialregierung im fernen Potsdam verfügte über viel zu wenig Personal und hatte kaum Transportmittel, um überall im Land direkte Kontrollen ausführen zu können, und auch ein Landrat mit seinen Angestellten konnte nicht täglich die Arbeit eines Lagerleiters kontrollieren.

Nahezu überall war die Verwaltung daher darauf angewiesen, die Fürsorgearbeit kirchlicher und anderer nichtstaatlicher Einrichtungen zu dulden. Gerade die beiden großen Kirchen mit ihren sozialen Einrichtungen bis hin zur Basisarbeit eines motivierten, leistungs- und belastungsfähigen „Vor-Ort-Teams“ aus Pfarrer und Pfarrhelferinnen haben wesentlich zur Linderung der Not im Lande beigetragen. ${ }^{1149}$ Auch wenn die staatlichen Stellen, je mehr sie und dann auch die SED Tritt fassten, ab 1946 nach und nach bestrebt waren, die Zuständigkeiten in die eigenen Hände zu bekommen, ließen sie doch etwa im Bereich von Alten- und Kinderheimen die Kirchen noch länger gewähren als etwa bei politisch sensibleren Bereichen wie dem „Suchdienst“ oder allen Fragen der „Interessenvertretung “ ${ }^{1150}$, wo jede dezentrale oder gar private Organisationsform schon früher unterbunden wurde. Doch all dies war ein langwieriger Prozess, letztlich Teil des insgesamt in der SBZ ablaufenden Aufbaus eines zentralistischen, stalinistischen Systems. Manche Zentralisierung von Aufgaben war, wie in den Westzonen, zwingend, um überhaupt erfolgreich zu arbeiten. Die zunächst noch latenten, aber wachsenden Gegensätze zwischen SED einerseits und den sogen. bürgerlichen Parteien, den Kirchen und frei agierenden Unternehmern andererseits erschwerten die Integration der Vertriebenen aber schon bald.

1148 Siehe die Fälle von Beschlagnahmungen ganzer Krankenhausgebäude im Kapitel II. 2, Abschnitt „Gesundheit".

1149 Siehe unten das Kapitel IV. 3 „Die Kirche und die Vertriebenen“.

1150 Siehe unten im Kapitel IV. 2 den Abschnitt „Vertriebenentreffen und korporative Tendenzen in Brandenburg“. 


\section{Suchdienste}

Die anfänglich wichtige Rolle, die die Kirchen selbst bei der Einrichtung von Suchdiensten für vermisste Angehörige spielten, zeigt sich bis in die lokalen Pfarrämter, die von vielen als Anlaufstelle für Suchanzeigen verstanden und genutzt wurden. Die Pfarrämter wandten sich dann an die 1945 eingerichtete Zentrale Suchkartei in Leipzig. ${ }^{1151}$ In der katholischen Kirche musste man sich freilich ebenfalls mit der Frage einer Zersplitterung befassen und verfügte daher für den Bereich des (große Teile Brandenburgs umfassenden) Berliner Bistums Anfang 1946: „Der kirchliche Suchdienst, der den Flüchtlingen bei der Suche nach vermißten Angehörigen hilft, befindet sich nur in Berlin-Charlottenburg 9, Bayernallee 28, beim Deutschen Caritasverband." 1152 Der Oberlandrat in Eberswalde musste das dortige „Hilfswerk der evangelischen Kirche“ schon am 26. November 1946 darauf hinweisen, dass Sucharbeit nur vom zentralen staatlichen „Suchdienst für vermißte Deutsche in der SBZ“ in Berlin ausgeführt werde. ${ }^{1153}$ Denn inzwischen hatte man für die gesamte SBZ einen staatlichen Suchdienst eingerichtet, dem Landessuchdienste nachgeordnet waren. ${ }^{1154}$ Es dauerte jedoch noch geraume Zeit, bis man auch hier alle Fäden in der Hand hielt. So wurden zwar ab November 1946 Schritt für Schritt bekannt gewordene Aktivitäten „privater “ Suchdienste unterbunden und deren Unterlagen übernommen, doch finden sich in den entsprechenden Berichten, die aufgelöste Suchdienste auflisten, auch zahlreiche „Fälle“, die erst 1947 ihre Tätigkeit zwangsweise einstellten. ${ }^{155}$ Noch im Arbeitsbericht der „Landesbeauftragten für Brandenburg des Suchdienstes für vermißte Deutsche in der SBZ" vom 7. Oktober 1948 ${ }^{1156}$, also rund zwei Jahre nach dessen Gründung, heißt es im Punkt 7 „Tätigkeit anderer Suchdienste“: „Der CaritasVerband entfaltet immer noch eine rege Tätigkeit. Zu den $4 \mathrm{im}$ Land Brandenburg bekannt gewordenen Suchdiensten habe ich bereits berichtet, daß die Abschlußmeldung der Auflösung bis zum 31. ds. Mts. erfolgen wird. / Bei einem davon, dem Suchdienst in Katerbow [,] handelt es sich um eine unserer Annahmestellen. Der Herr Fritz Trispel hat sich Kopfbogen, Suchdienst Katerbow' angeschafft, im übrigen aber nach unseren Weisungen gehandelt. Gebühren hat er außer den Rm. 2 für die von ihm verauslagten Suchpostkarten keine kassiert." ${ }^{1157}$ An den Kirchen kam man kaum vorbei, wie das Beispiel des (katholischen) Caritas-Verbandes zeigt. Gerade das Katerbower Beispiel zeigt auch, wie weit der Potsdamer Arm (nur) reichte. Die Formulierungen deuten hier eher darauf hin, dass man einen funktionstüchtigen privaten Suchdienst dadurch in die Hand zu bekommen versuchte, dass man

1151 So belegt für Fürstenwerder (Uckermark): Ute Bleich: Kirchliches Leben zwischen 1930 und 1950. In: Fürstenwerder Mosaik. T. 2. Fürstenwerder 2002, S. 57-65, hier S. 62 f. (S. 62 Faksimile einer handschriftlichen Suchanzeige an das Pfarramt).

1152 Amtsblatt des Bischöflichen Ordinariats Berlin, 18. Jg., St. 2, 1.2.1946, S. 7.

1153 BLHA, Rep. 203 MdI, Nr. 1197, Bl. 41 (vgl. Textabdruck im Quellenteil, Nr. 161).

1154 Siehe oben im Kapitel III. 1 am Schluss des Abschnitts „Umsiedlerverwaltung“.

1155 BLHA, Rep. 203 MdI, Nr. 1197, Bl. 41-48 (vgl. den auf Brandenburg bezogenen Textauszug im Quellenteil, Nr. 161).

1156 BLHA, Rep. 203 MdI, Nr., 1198, Bl. 42-43 (vgl. Textabdruck im Quellenteil, Nr. 162).

1157 Ebd., Bl. 43. 
ihn kurzerhand zu einer „unserer Annahmestellen“ erklärte, die, wie es beschönigend heißt, „nach unseren Weisungen gehandelt" habe. Letztlich ist nur in einer - hier nicht zu leistenden - Einzelfallprüfung zu klären, welcher private Suchdienst gute, auch in dezentraler Form sinnvolle Arbeit leistete und welcher sich nur aus Gewinnstreben den Suchenden anbot, ohne ausreichende Leistungen bieten zu können, welcher gar aus den Reihen der Vertriebenen selbst gegründet und welcher von Einheimischen initiiert wurde. Auch in den Westzonen „wurden Ende 1946 alle privaten Suchdienste verboten“, da sich unter ihnen zu viele „Schwarze Schafe“ fanden, die die Notlage der Anfragenden ausnutzten und überzogene Honorare kassierten. ${ }^{1158}$ Alle diese Formen sind aber letztlich ein Beleg dafür, welch große Bedeutung das Thema der vermissten Angehörigen für die Menschen jener Jahre besaß. Auch Tageszeitungen und das Vorprogramm der Kinos nutzte man noch bis weit in die fünfziger Jahre, um Suchanzeigen zu verbreiten. Flucht und Vertreibung bzw. die Kriegsfolgen mit ihren zahllosen „Bevölkerungsverschiebungen“ insgesamt gehörten auf diese Weise noch jahrelang deutlich sichtbar zum Bewusstseinsalltag.

\section{Alltagssorgen}

Zum Alltag der hilfsbedürftigen Vertriebenen gehörte aber zu allererst ihre Versorgung in den Grundbedürfnissen: Lebensmittel, Kleidung und Unterkunft. Namentlich bei Kleidung und Schuhen lassen sich in zahllosen Zeitzeugenberichten Belege ebenso für Bedürftigkeit finden wie für die Hindernisse, die so einfache Dinge wie fehlendes Schuhwerk bei der Eingliederung in Arbeitswelt und Schulunterricht bedeuteten. Bereits wieder Arbeitende, aber sogar zu öffentlichen Arbeiten und solchen der Besatzungsmacht Verpflichtete hatten oftmals Schwierigkeiten, überhaupt den Fußmarsch zu ihrem Arbeitsplatz zu bewältigen. Doch auch sonst verhinderte der Schuhmangel nicht selten die reibungslose Umsetzung des allmählich wieder in Gang kommenden Alltagslebens. Neben den täglichen Ernährungssorgen und Krankheiten war der schlechte Zustand oder gar das Fehlen straßentauglicher Schuhe für viele Flüchtlinge ein tägliches Thema, das nicht nur gesundheitliche Risken barg, sondern erhebliche Einschränkungen bei der Nahrungsbeschaffung bedeutete. ${ }^{1159}$

Die 1945 gebildeten lokalen Verwaltungen hatten in den ersten Jahren ständig solche elementarsten Bedürfnisse zu regeln, wobei die Flüchtlinge nicht die einzigen Bedürftigen waren, aber doch diejenigen, denen zumeist keinerlei andere Hilfe als die öffentliche Fürsorge zur Verfügung stand. So stellte der „Antifa-Auschuss“ in Ragösen (Kr. Zauch-Belzig) in seiner zweiten Sitzung am 15. Februar 1946 fest: „Viele Flüchtlingskinder haben kein Schuhzeug mehr, um die Schule besuchen zu können. Es wird beschlossen, bei den Ortseinwohnern durch eine Entrümpelungs-

1158 Friederike Bauer: Jede Karte ein Schicksal. Suchdienste nach dem Zweiten Weltkrieg in Deutschland. In: Das Archiv. Magazin für Kommunikationsgeschichte (2016) 1 (Themenheft „Die Post nach 1945“), S. 28-35, hier S. 34 .

1159 Beispiel für die vielfachen Erwähnungen in Erinnerungen: Lothar Plath: Erinnerungen an das Kriegsende und die Nachkriegsjahre in Havelberg. In: Kriegsende und Nachkriegszeit in Havelberg [I] (wie Anm. 175), S. 37-84, hier S. 60-62 („Das leidige Schuhwerk“). 
aktion Schuhzeug zu erfassen." ${ }^{160}$ Ein im Sommer 1945 aus der Neumark Vertriebener hat seine ersten Schritte am Aufnahmeort Tangermünde beschrieben und dabei zugleich das für so viele Zeitgenossen damals drängende Problem benannt: „Am Deich der Elbe bin ich entlanggegangen und sah vor mir einen Schnürschuh liegen, den ich aufhob in der Hoffnung, dazu noch den zweiten $z u$ finden. Ich hatte Glück, ich fand noch einen, sie paßten zwar nicht zueinander, aber es waren ein rechter und linker Schuh. Wie glücklich war ich, daß ich endlich ein paar Schuhe an meinen Füßen hatte, denn bisher lief ich nur mit Korkeln, das sind Holzsohlen mit Lederriemen."1161 Auch in Berlin wird noch im Herbst 1946 über „Schuhmangel“ geklagt, so dass die Stadt „Bekleidung und Schuhwaren aus allen vier Besatzungszonen“ erhielt. Am 5. September wird berichtet, die „ersten Lieferungen seien bereits eingetroffen. Das Verteilungsamt habe bestimmt, daß zuerst die Flüchtlinge, die ohne jedes Schuhzeug nach Berlin kamen, dann die Opfer des Faschismus und die Heimkehrer aus der Gefangenschaft mit Schuhen beliefert werden. Doch würden die vorhandenen Mengen allein für den Bedarf dieser drei Gruppen kaum ausreichen. "1162

Auch andere grundlegendste Bedürfnisse gehörten als zeitraubende Sorgen zum Alltag. Wie wichtig für die Lösung - fern aller staatlichen Versorgungsmöglichkeiten - private Kontakte und Tauschhandel waren, zeigt eine typische Situationsschilderung, die von einer schlesischen Vertriebenen für das Jahr 1947 aus Welzow (Kr. Spremberg) überliefert ist: „Meine Mutter war mit uns fünf Kindern allein nach dem Krieg. Wir waren die Flüchtlinge aus Schlesien, die keiner wollte, die aber immer Hunger hatten! Unser Vater war nach dem Krieg in die französische Gefangenschaft gekommen, anschließend nicht zur Familie zurückgekehrt. Er schickte alle drei oder vier Monate ein kleines Päckchen von 300 Gramm, schwerer durfte die Sendung nicht sein. Den Inhalt der Päckchen (Nähseide, Garn, Feuersteine, Borte und Spitze usw.) konnten wir selbst selten gebrauchen, aber die Bauern haben uns diese Sachen gegen Naturalien eingetauscht." 1163 Tauschhandel gehörte als Grundelement zur Nachkriegszeit, doch die, die beim Tausch von Wertsachen gegen Lebensmittel nichts oder nur selten etwas anzubieten hatten, waren vor allem Vertriebene - „Wir Flüchtlinge hatten nichts zu bieten." 1164

Eine junge ostpreußische Vertriebene (geb. 1929) berichtet über die Ernährungslage ihrer gerade erst in Brandenburg angekommenen vierköpfigen vaterlosen Familie, die außer ihr aus ihrer Mutter und zwei jüngeren Geschwistern bestand und wie viele andere nach dem Aufenthalt im Quarantänelager in ein Dorf der Umgebung eingewiesen wurde ${ }^{1165}$ : „Es war Anfang April 1946.

1160 Ragösen. Beiträge zur Geschichte, T. 2 (wie Anm. 188), S. 19.

1161 Fritz Löffler: [Erlebnisbericht, zusammengestellt 1980]. In: Heimatkreis Soldin/Neumark (wie Anm. 303), S. 573-579, hier S. 579.

1162 Berlin. Kampf um Freiheit und Selbstverwaltung 1945-1946 (wie Anm. 652), S. 523 (Nr. 15 b).

1163 Margarete Richter: Der schöne Sirup. In: Lebenszeit. T. IV. Zeitzeugen berichten. Hrsg. vom Seniorenbeirat der Gemeinde Neuenhagen bei Berlin. Neuenhagen [1998], S. 9-13, hier S. 9.

1164 Heinz Parchert: Die Nacht der Erinnerungen. In: Die Uckermark 1945. T. 2. 2. Aufl. Prenzlau 1995, S. 33-39, hier S. 34.

1165 Hildegard Rölke: Ein Erlebnis aus dem Hungerjahr 1946. In: Storkower Zeitzeugen berichten [H. 1] (wie Anm. 370), S. 68-69, hier S. 68 f. 
nach der Flucht aus dem polnisch besetzten Gebiet und Aufenthalten in verschiedenen Flüchtlingslagern wurde uns in Wendisch-Rietz-Siedlung eine Unterkunft zugewiesen. Außer einem Rucksack und den Sachen, die wir am Leibe hatten, besaßen wir nichts. [...] Der Hunger war zu der Zeit groß. Mittags durften sich damals Flüchtlinge aus dem ehemaligen Ottos Hotel, später Hans-Loch-Heim, ein kärgliches Mittagessen holen. Dort wurde in einem großen Kessel täglich eine Suppe gekocht, die recht dünn war und auch unansehnlich aussah, da die Kartoffeln mit Schalen verarbeitet wurden. Die Brotrationen waren zu dieser Zeit sehr klein, so daß man ständig von Hunger geplagt war. Es gab für uns Flüchtlinge nur einen Ausweg: über die Dörfer zu ziehen und bei den Bauern um ein paar Kartoffeln zu betteln. Nur selten erbarmte sich jemand und gab uns ein paar Kartoffeln. Die Not war groß. Die Berliner kamen in Scharen und tauschten ihre Habseligkeiten wie Teppiche, Kleidung, Schmuck u. a. in Kartoffeln und Lebensmit[S. 69] tel um, denn jeder wollte überleben. Wir hatten nichts zu bieten und mußten meist leer ausgehen. Ein Fahrrad besaßen wir nicht, so hatten wir täglich viele Kilometer zu laufen. [...].“

\section{Volkssolidarität}

Neben die kirchlichen und staatlichen bzw. kommunalen Fürsorgestellen, die eine warme Mahlzeit oder Kleidung abgaben, trat in der SBZ eine weitere Hilfsquelle (nicht nur) für die Vertriebenen. ${ }^{1166}$ Über die Beteiligung der Ortsgruppen der „Märkischen Volkssolidarität“ (MVS) an der Heimkehrer-, Flüchtlings- und Vertriebenenfürsorge liegen für Brandenburg jedoch erst sehr wenige Erkenntnisse vor ${ }^{1167}$, obgleich Akten dazu in großer Zahl überliefert sind. ${ }^{1168}$ Ihre Wirksamkeit beginnt, anders als die kirchliche Fürsorge, erst frühestens gegen Ende 1945 (offizielle Gründung der Dachorganisation für die SBZ in Dresden am 17. Oktober 1945) $)^{1169}$, in Brandenburg sogar erst im Frühjahr 1946 (Aufruf zur Bildung von Komitees der MVS am 26. März 1946 in der Zeitung „Der Märker“ publiziert), wird dann aber in den Folgejahren zu einem wichtigen lokalen Bezugspunkt für Bedürftige. Eine zeitgenössische Beschreibung der Zuständigkeit lautet:

1166 Zur Frage der Relevanz für die Vertriebenenbetreuung siehe Wille III (wie Anm. 196), S. 80, 87.

1167 Lokale Literatur (außer der in den folgenden Fußnoten genannten): Georg Vogel: Die Volkssolidarität in Neuenhagen. In: Lebenszeit. T. III. Zeitzeugen berichten. Hrsg. vom Landesseniorenbeirat Brandenburg u. dem Seniorenbeirat Neuenhagen. Neuenhagen [1998], S. 117-120. - Renate Radoy: Umzug zum Jubiläum von Rüdersdorf. Volkssolidarität und BdV gestalteten zwei eindrucksvolle Bilder. In: Volkssolidarität im Barnim aktuell 2 (2010)4, S. 48-49.

1168 Siehe z.B. BLHA, Rep. 350 VdgB, Nr. 1569: Tätigkeit der Volkssolidarität und der Umsiedler- und Heimkehrerausschüsse im Land Brandenburg, 1946-1948; Nr. 1570: desgleichen, 1947-1950; Nr. 1571: desgleichen, 1948-1949; Nr. 1572: desgleichen, 1949-1950; Nr. 1573: desgleichen, 1951. - BLHA, Rep. 250 Landratsamt Cottbus, Nr. 1308: Bildung und Tätigkeit von Ortsausschüssen der Volkssolidarität, 1945-1950. - Z. T. finden sich in den Akten auch gedruckte Tätigkeitsberichte. - Siehe ferner die Erwähnungen im Quellenteil, erschlossen über das Sachregister.

1169 Gunnar Winkler: Zur Geschichte der Volkssolidarität 1945 bis 2010. Hrsg.: Volkssolidarität Bundesverband e. V. Berlin 2010, S. 6. - Winkler bietet ansonsten nur einen knappen Überblick, nennt aber weitere Literatur, siehe v. a.: Philipp Springer: Da konnt' ich mich dann so'n bißchen entfalten - Die Volkssolidarität in der SBZ/ DDR 1945-1969. Frankfurt am Main u. a. 1999 (Europäische Hochschulschriften, Reihe 3: Geschichte und ihre Hilfswissenschaften, Bd. 836). 
„Der Aufgaben- und Tätigkeitsbereich der Märkischen Volkssolidarität erstreckt sich über folgende Gebiete: Betreuung von Notleidenden, Bedürftigen, insbesondere alten Leuten, Heimkehrern, Flüchtlingen und Umsiedlern; Säuglingen und Kleinkindern in Heimen u. Krankenhäusern, tuberkulösen u. Waisenkindern, Kranken; Kinderverschickung, Schulspeisung, Speisung vorschulpflichtig. Kinder, Wohltätigkeitsveranstaltungren; Teilnahme am materiellen und kulturellen Umschulungs- und Aufbauprozeß der Stadt Potsdam “. ${ }^{170}$ Der letzte Punkt ist wohl dem Abdruck in einer speziell für das Potsdamer Publikum gedachten Druckschrift geschuldet, dürfte aber anderswo im Land anlaog gegolten haben. Die durchgesehenen Zeitzeugenberichte nennen als von der MVS zu unterstützende Bevölkerungsgruppen in erster Linie Kinder und ältere Menschen allgemein, die Akten zusätzlich auch Heimkehrer. ${ }^{1171}$ Dass unter den Betreuten besonders viele Flüchtlinge und Vertriebene waren, nicht zuletzt unter den (Waisen-)Kindern, liegt auf der Hand.

In (West-)Guben beispielsweise, einer besonders stark von Vertriebenen bevölkerten Stadt, wurde im Mai 1946 ein MVS-Komitee gegründet: „Unter der Losung ,Rettet das Kind! fanden zu bestimmten Höhepunkten Veranstaltungen statt, wurden Erholungsaufenthalte organisiert, wurde die Durchführung der Schulspeisung unterstützt und geholfen, das Kinderheim in Krayne zu errichten.“ Für die Rentner richtete man gemeinsam mit der Stadtverwaltung ,in den kalten Wintermonaten Wärmestuben ein (z.B. die Gaststätte an der Kugelbrücke), fanden für die Vertriebenen und Umsiedler Geld-, Textil- und Möbelsammlungen statt, erhielten Heimkehrer dringend benötigte Kleidung" ${ }^{1172}$

Die erste Vorsitzende der Volkssolidarität (VS) in Fürstenberg (Oder), Anna Körper (1900-1977), betreute in den ersten Nachkriegsjahren am Ort auch viele Vertriebene und deren Kinder. ${ }^{1173}$ „Sie sammelte und verteilte Kleidung, ließ Suppen kochen für die Bedürftigen

1170 Adressbuch Groß-Potsdam 1947. T. 1, S. 40. - Das Sekretariat des Provinzialausschusses der MVS befand sich 1946 in Potsdam, Friedrich-Ebert-Str. 38 (Ecke Behlertstr.), d. h. unmittelbar gegenüber dem Stadthaus. Geschäftsführerin war die Mitbegründerin und Landesvorsitzende der MVS, Gerda Sucker, die 1947 auch als Ausschuss-Vorsitzende genannt wird (BLHA, Rep. 333, Nr. 574, Bl. 22; vgl. Landbuch des Landtages 1957 [wie Anm. 1064], S. 99); nicht zu verwechseln mit dem Provinzialumsiedlerausschuß, dessen Mitglied Sucker ebenfalls war (siehe Quellenteil, Nr. 145). - 1948 ist im nunmehrigen Landesausschuß Brandenburg der MVS (Potsdam, Alleestr. 6a) Böhnke „Vorsitzender in Vertretung“ (Adreßbuch Groß-Potsdam 1949, S. 790).

1171 Ausnahmsweise für die frühen Nachkriegsjahre in Guben auch in neueren Selbstdarstellungen genannt: Werner Miksch: Bewegung und Begegnung bei der Volkssolidarität in Guben. In: Gubener Heimatbrief (2005)1, S. 38-46, hier S. 39: „Es ging damals vor allem um Einkleidungsprobleme der Heimkehrerbetreuung, um das Unterhalten von Wärmestuben, um die Pflege kranker Bürger, um das Einrichten von Volksküchen zur Versorgung Hilfsbedürftiger.“ - Ute Richter: 70 Jahre Volkssolidarität. In: Gubener Heimatkalender 59 (2015), S. 36-38, hier S. 37: „Hilfe für Kriegsheimkehrer“ bzw. „Auch den zurückkehrenden Kriegsgefangenen wurde jegliche Hilfe und Unterstützung gegeben.“

1172 Gisela Schulz: Aus dem Leben der Ortsgruppe 18 der Volkssolidarität in Guben. In: Gubener Heimatkalender 55 (2009), S. 77-80, hier S. 77. Siehe auch: 50 Jahre Volkssolidarität. In: Gubener Heimatkalender 40 (1996), S. 33-34.

1173 Gisela Pech: Entstehung und Entwicklung der Volkssolidarität in Fürstenberg und Eisenhüttenstadt. In: Heimatkalender Eisenhüttenstadt 18 (2000), S. 104-110 (insbes. nach Berichten ihrer Mutter Wranja Borsutzki, die die Aktivitäten als junge Frau miterlebt hatte). 
und richtete einen Kindergarten und eine Nähstube ein. Zuerst war ihre Küche ihr Büro und Treffpunkt für alle, später fand sie einen Raum in einer Baracke." Ein großer Teil der Arbeit bestand im Beschaffen brauchbarer Waren und Lebensmittel, an Heiligabend 1946 stellte der Gubener Landrat Fleisch aus Notschlachtungen zur Verfügung. ${ }^{1174}$ „Anna Körper sprach auch immer wieder Alteingesessene an, um Kleidung für die Vertriebenen zu sammeln. Sie ließ sie in der Nähstube ändern, heil machen, aus zwei eins machen, aus Armeedecken und der Bettwäsche aus Kasernen Kleidung nähen, so dass die Menschen etwas auf dem Leib hatten. 1948 wurde in Fürstenberg eine Tagesstätte für alte Menschen und Umsiedler eröffnet. "1175

Neben der Betreuung von Flüchtlingen und Vertriebenen im Rahmen der allgemeinen Fürsorge für Bedürftige gibt es aber auch noch andere Querverbindungen, die insgesamt freilich noch einer intensiveren Erforschung harren. So waren zum Beispiel unter den Mitgliedern der lokalen Umsiedlerausschüsse oft Angehörige der Volkssolidarität zu finden (analog war auf der Landesebene die MVS-Vorsitzende Gerda Sucker im Provinzial-/Landesumsiedlerausschuss tätig). Dass man von einer lokal ohnehin engen Verbindung ausgehen darf, zeigen sowohl Indizien der Zeit vor als auch der nach 1990. So trafen sich in Forst (Lausitz) am 1. Juni 1975 mehr als 50 Vertriebene aus Triebel (Kr. Sorau) in einem öffentlichen Lokal zu nichts anderem als einem Heimattreffen, das die „gelernten DDR-Bürger“ aber geschickt als „Ausflug der Volkssolidarität" tarnten. ${ }^{1176}$ Auch nach 1990 lassen sich lokale Verbindungen der Volkssolidarität zu Vertriebenen aufzeigen, die jedenfalls alles andere als Berührungsängste belegen. So heißt es in einem Zeitungsbericht über ein Heimattreffen des BdV-Gebietsverbandes Rathenow am Volkstrauertag 2015 im Lutherhaus in Rathenow, an dem der brandenburgische Kulturstaatssekretär Martin Gorholt (SPD) teilnahm: „Nach den Reden ging es zum gemütlichen Teil über. Der Chor der Volkssolidarität stimmte viele vertraute Lieder aus der alten Heimat an. Beim ,Pommernlied' und, Ännchen von Tharau' konnten die meisten noch auswendig mitsingen. Die Erinnerung an die alte Heimat hilft den Menschen auch 70 Jahre später immer noch dabei, den Schmerz der Vertreibung zu lindern. Egal, ob durch Gesang oder durch Gespräche mit Menschen, die das gleiche Schicksal haben. "1177 Vielfach dürften Personalunionen lokaler Ehrenamtler gerade nach 1990 vertrauensbildend gewirkt haben und noch weiter wirken. So zeichneten beim (dreißig „Bilder“ umfassenden) Festumzug zur 775-Jahr-Feier der Gemeinde Rüdersdorf am 4. Juli 2010 die Volkssolidarität und der örtliche Verband des BdV gemeinsam verantwortlich für die Bilder „Kriegsende in Rüdersdorf" und „Vom schweren Anfang nach dem Krieg “. ${ }^{1178}$ „Anwohner", „aber auch eine ganze VS-Familie" brachten sich in die Vorbereitungen ein. In der regionalen (Barnimer) VS-Zeitschrift heißt es dazu: „Unser Vorstandsmitglied Helga Just mit Tochter und Schwiegersohn, seine Schwestern nebst Familien und Freunden - insgesamt 10 Personen - waren dabei. Sie bildeten

1174 Ebd., S. 105.

1175 Ebd., S. 106.

1176 Amos, Vertriebenenpolitik der SED (wie Anm. 12), S. 224.

1177 Sandra Euent: Erinnerung an die Heimat. In: Märkische Onlinezeitung, 6.11.2015 (MAZ).

1178 Näheres siehe in der Ortsdokumentation/Rüdersdorf. 
zusammen mit anderen die Darsteller der Gruppe der Heimkehrer und Flüchtlinge. Sie waren in entsprechender Kleidung, mit Handwagen, Gepäck und typischen Utensilien ausgerüstet, die Trümmerfrauen mit Kopftuch und Hammer."1179

\section{Kinder}

„Flüchtlingskinder" hatten in den Nachkriegsjahren besonders zu leiden - ihre Geschichte wäre noch zu schreiben. ${ }^{1180}$ Die oft auf sich gestellten, mittellosen Mütter waren mit ihrer Ernährung und sonstigen Versorgung überfordert, hinzu kam die wachsende Zahl von Waisenkindern, die auf der Flucht von ihren Eltern getrennt worden waren, deren Mütter an Entkräftung verstarben, deren Väter sich noch in Kriegsgefangenschaft befanden oder die bereits mit Transporten aus komplett evakuierten Kinderheimen ankamen. Am 15. Februar 1946 entschied der AntifaAusschuss Ragösen (Kr. Zauch-Belzig) in seiner zweiten Sitzung, die Speisung der Flüchtlingskinder auf alle Schulkinder auszudehnen." ${ }^{1181}$ Doch auch in der dritten Sitzung, ebenfalls im Februar, waren die „Flüchtlingskinder“ wiederum Thema: „Ein dringender Notschrei ist die Frage der unterernährten Flüchtlingskinder.“ Die Landwirte wurden daher öffentlich dazu aufgerufen, „durch zusätzliche Abgabe von Kartoffeln, Mehl usw. Abhilfe zu schaf- [S. 20] fen. Es kann festgestellt werden, dass bereits 18 Stellen zur Verfügung stehen, wo Kinder einen freien Mittagstisch erhalten. Auch im Pfarrhaus gab es einen freien Mittagstisch für Flüchtlingskinder. Frau Potratz und Frau Adler kochten." ${ }^{1182}$

Die Fürsorge für Bedürftige - unter ihnen besonders zahlreich die Vertriebenen - und für besonders Bedürftige - Alte, Schwache, Kranke und die oft mangelernährten Kleininder - war eine alltägliche Herausforderung für die Aufnahmegesellschaft wie für die Vertriebenenfamilien selbst. Sie war insofern eine täglich von vielen Helfern und Hilfsbedürftigen geschulterte, für das Über-, aber auch das Zusammenleben notwendige Aufgabe, für die sich in Zeitzeugenberichten Vertriebener und Einheimischer manch eindringliche, mal anrührende, mal auch schockierende, Beschreibung finden lässt. Eine Darstellung der Sozial- und Alltagsgeschichte brandenburgischer Stadt- und Dorfgesellschaften in den Jahren nach 1945 würde diesen Vorgängen und Verhältnissen angemessenen Raum geben müssen und könnte - anders als eine nur auf das Verwaltungshandeln konzentrierte Arbeit - lehrreich sein.

1179 Radoy, Umzug zum Jubiläum von Rüdersdorf (wie Anm. 1167), S. 48.

1180 Siehe hier nur die kurzen Bemerkungen (und Literaturhinweise) zu Waisen- und „Wolfskindern“ oben im Kapitel II. 3, Abschnitt „Ostpreußen“. Vgl. außerdem die Angaben zu Kinderheimen und Waisenhäusern in der Ortsdokumentation sowie die entsprechenden Verweisungen im Sachregister, schließlich allgemein: Bode, Die vergessene Generation (wie Anm. 274).

1181 Ragösen. Beiträge zur Geschichte, T. 2 (wie Anm. 188), S. 19.

1182 Ebd., S. 19 f. (Zitate wohl nur teilweise Originalzitate aus dem Sitzungsprotokoll, mit paraphrasierenden Formulierungen des „Autorenkollektivs“ vermischt). 


\section{"Umsiedlerwochen"}

Gegenüber der täglichen Arbeit von lokalen Behörden, Kirchen und sozialen Einrichtungen waren die sogen. „Umsiedlerwochen “ - mit dem Blick auf das ganze große Thema der Eingliederung der Flüchtlinge und Vertriebenen - propagandistisch verwertbare Vorzeigeprojekte, für die „Zuwendungsempfänger“ aber eher „Events“ von nur von begrenztem praktischen Nutzen. Beispiele finden sich schon 1947 vielerorts. ${ }^{1183}$ In der gesamten SBZ führte man dann erneut vom 22. bis 29. Februar 1948 eine Sammelaktion zugunsten der „Umsiedler“ durch, in der die einheimische Bevölkerung in öffentlichen Veranstaltungen für das Integrationsproblem sensibilisiert werden, vor allem aber Einheimische Sachspenden (Kleidung, Hausrat usw.) leisten sollten und geleistet haben. ${ }^{1184}$ Die gezielte Planung und verpflichtende Durchführung in allen Ländern und allen Gemeinden hat dazu geführt, dass auch in der staatlichen Aktenüberlieferung eine Fülle an „Papier“ zur „Umsiedlerwoche“ überliefert ist. Für die formalen Vorgänge kann hier auf die im Quellenteil (Teil 3) edierten Berichte verwiesen werden. ${ }^{1185}$ Aufschlussreich sind darin freilich weniger die Erfolgsmeldungen als kritische Äußerungen in nachfolgenden, auswertenden Diskussionen.

Der Vorsitzende des Ortsumsiedlerausschusses in Wolfshagen (Kr. Westprignitz) berichtete seinem Landrat über die Ergebnisse einer schon 1947 durchgeführten „Umsiedlerwoche“: „Trotz der vielen Hinweise auf den Ernst der Sache sind die Spenden ausgeblieben. Die SED in den Ortsteilen Wolfshagen und Hellburg hat versagt. " ${ }^{1186}$ Der in Potsdam ansässige „Umsiedler" Zindler, selbst SED-Mitglied, hat auf einer SED-Konferenz über „Umsiedlerfragen“ im Februar 1949 das ausgesprochen, was viele Zeitzeugen in ähnlichen Worten überliefert haben: „Die Umsiedlerwoche in Potsdam hat sich als Entrümplungswoche gezeigt." ${ }^{1187}$ D. h., die „neue Heimat" habe sich wieder einmal von ihrer „kalten“ Seite gezeigt, indem sie nur das abgab, was sie ohnehin entbehren konnte und wollte. Das aber rührte an ein grundsätzliches Dilemma, in der SBZ eine fortschrittlichere, erfolgreichere Form der Vertriebenenintegration vorweisen zu wollen als in den Westzonen. ${ }^{1188}$ Ein anderer Genosse, das Mitglied des SED-Landesvorstandes Hoffmann, beeilte sich deshalb, den Kritiker sogleich in die betreffende Ecke zu stellen: „Bei dem Gen[ossen]

1183 Allgemein zur Planung: Wille III (wie Anm. 196), S. 261-263.

1184 Grundlegend: Schwartz, Kontrollierte Partizipation (wie Anm. 1113).

1185 Siehe im Quellenteil (Nr. 92-95) die Berichte für Jüterbog, Luckenwalde und Deibow (Kr. Westprignitz).

1186 BLHA, Rep. 250 Landratsamt Westprignitz, Nr. 256, Bl. 65 (vgl. Textabdruck im Quellenteil, Nr. 96).

1187 BLHA, Rep. 333 SED-Landesleitung Brandenburg, Nr.574, Bl. 389 (vgl. Textabdruck im Quellenteil, Nr. 118).

1188 Vgl. u. a. die gedruckt vervielfältigten Schulungsschriften: Das Leben der Umsiedler in der Ostzone und in den westlichen Zonen Deutschlands. Rededisposition. Hrsg. vom Landesvorstand der SED Brandenburg, Abt. Arbeit und Sozialfürsorge. (Potsdam 1947). 10 S. - Können die Umsiedler in unserem Lande eine neue Heimat finden? Rededisposition. Hrsg. vom Landesvorstand der SED Brandenburg, Abt. Arbeit und Sozialfürsorge. (Potsdam 1947). 10 S. (Exemplare u. a. in: BLHA, Rep. 33, Nr. 524, Bl. 424 bzw. 425). - Siehe allgemein: Michael Schwartz: Verteilungskonflikte unter Werktätigen müssen unter allen Umständen vermieden werden.“ Lastenausgleichs-Diskussionen und Soforthilfe-Politik in der SBZ/DDR. In: Rechnung für Hitlers Krieg. 
Zindler hat man den Eindruck wirklich, er sei ein Schumachermann. ${ }^{1189}$ Er schiebt das Umsiedlerproblem auf andere Leute. Die Selbstkritik fehlt. Wir müssen zu allen Aufgaben klar und kritisch Stellung nehmen und somit unsere Arbeit verbessern." 1190

\section{Wohnung und Arbeit}

\section{Wohnsituation}

Die Unterbringung der alles bis dahin Gekannte übersteigenden Zahl von Flüchtlingen und Vertriebenen war wohl das größte Problem, vor das die Verwaltung und mit ihr die einheimische Gesellschaft sich gestellt sahen. Systematische Untersuchungen liegen bislang nicht vor ${ }^{1191}$, in bereits durch Editionen zugänglichen Quellen werden viele Einzelfälle der Nachkriegsjahre, die über Beschwerden in die Akten gelangt sind, sichtbar. ${ }^{1192}$ Langzeitentwicklungen der sich verändernden Wohnsituation von Vertriebenen sind dagegen meist nur deren eigenen Erinnerungsberichten zu entnehmen. Auch das Thema Wohnung lässt sich aber kaum auf einen einfachen Nenner bringen, zu groß sind die Unterschiede. Außerordentlich hoch war - das zeigt sich bei der Lektüre einer Vielzahl an Zeitzeugenberichten - vor wie nach Kriegsende die Zahl derjenigen, die auf eigene Faust Unterkunft bei Verwandten oder Bekannten fanden. Für die Verwaltung verringerte sich zwar dadurch die Zahl der in den - selten ausreichenden und angemessenen - Sammelunterkünften Unterzubringenden, doch erschwert das Phänomen auch die Erforschung. Immer wieder versuchten die Behörden das individuelle „Wandern“ zu unterbinden, erlaubten das dauerhafte Verlassen eines Lagers nur, wenn eine Wohnraumzuweisung erfolgt war, doch individuelle Sorgen und Nöte waren oftmals stärker.

Weitere Unterschiede, die das Bild selbst innerhalb Brandenburgs stark differenzieren und gegenüber vorschnellen Zusammenfassungen Vorsicht gebieten, kommen hinzu. Die regionale und lokale Situation hing wesentlich vom Grad der Kriegszerstörung des vorhandenen Wohnraums, aber auch von der vorherigen Bevölkerungsdichte und nicht selten von Bedarf und Bedürfnissen der Roten Armee bzw. der Besatzungsmacht ab, die, wie bereits gezeigt, gelegent-

Aspekte und Probleme des Lastenausgleichs. Paul Erker (Hg.) (Pforzheimer Gespräche 3). Heidelberg u. a. 2004, S. 217-233.

1189 Gemeint ist Kurt Schumacher (1895-1952), SPD-Vorsitzender in den Westzonen, einer der schärfsten Gegner der Vereinigung mit der KPD. Hoffmann nahm unmittelbar auf eine Äußerung Zindlers bezug, der auch gesagt hatte: „Man muss annehmen, dass ich ein Schumachermann bin, aber nein, ich bin und bleibe Sozialist. Wir als Umsiedler haben am meisten geopfert im Krieg." (BLHA, Rep. 333, Nr. 574, B1. 389).

1190 BLHA, Rep. 333 SED-Landesleitung Brandenburg, Nr. 574, B1. 390.

1191 Vgl. aber für Brandenburgs nördliches Nachbarland: Michael Rusche: Die Eingliederung der Vertriebenen in Mecklenburg-Vorpommern, dargestellt unter besonderer Berücksichtigung der Wohnraumproblematik. In: Sie hatten alles verloren (wie Anm. 15), S. 133-147. - Für Brandenburg siehe (mit Abb.): Ast/Mauersberger (wie Anm. 32), S. 62-67.

1192 Wille II (wie Anm. 196), S. 157 ff. - Siehe auch - für die Jahre 1946-1949 - den Quellenteil der vorliegenden Arbeit, Abschnitt 2.1 (S. 1109-1131). 
lich zur Räumung und Sperrung ganzer Straßenzüge führen konnten. Zu unterscheiden sind ferner, zumindest für die Anfangssituation der Betroffenen, die unterschiedlichen Verhältnisse in den drei Phasen vor Kriegsende, als ein noch immer funktionsfähiger Repressionsapparat vieles mit Androhung schärfster Gewalt durchzusetzen im Stande war, sodann im Sommer, als noch kaum Vorbereitungen hatten getroffen werden können, und schließlich ab Herbst, als die neuen Verwaltungen - nun unter Befehlsgewalt der sowjetischen Besatzungsmacht - arbeitsfähig waren und eine Vielzahl an Lagern einrichteten bzw. als solche bestimmten.

Verteilung und Unterbringung in dem Niederlausitzer Dorf Werben (Kr. Cottbus) sind rückblickend in einer ortsgeschichtlichen Darstellung beschrieben worden. Darin deuten sich einige Grundlinien an, zumindest wohl für die Lage im Sommer und Herbst 1945: „Die Heimatvertriebenen, die in dieser Region blieben, kamen meist aus dem östlichen Teil der Lausitz mit den Kreisen Sorau, Sommerfeld und Teilen des Kreises Guben, aus dem Kreis Crossen oder aus Niederschlesien. / Von den Kreisbehörden wurden die Flüchtlingsfamilien auf die einzelnen Gemeinden aufgeteilt, viele suchten sich aber aus eigener Initiative eine Bleibe. Auch die Gemeinde Werben nahm zunächst an die 700 Flüchtinge auf. Eine größere Anzahl wurde im ehemaligen Barackenlager des RAD (Reichsarbeitsdienst), im Gemeindehaus der Kirche sowie im [Guts-] Haus von Schönfeldt untergebracht. / Auch Heinrich Schulz, der spätere Kreisvorsitzende des Bundes der Vertriebenen, war mit den Großeltern und der Mutter aus Grünberg vertrieben worden. Er erinnert sich: ,Wir lebten dort in diesem Lager, wie die Menschen überall, unter ärmlichsten Verhältnissen. Der Hunger war unser ständiger Begleiter.' In Folge der Entbehrungen starben Dutzende von ihnen, geschwächt, krank, vom Typhus dahingerafft. Auch der Großvater von Heinrich Schulz war darunter." ${ }^{\text {"193 }}$

Diese Verhältnisse ähneln dem, was in sehr vielen Berichten und Selbstzeugnissen für die Jahre 1945/46 und z. T. noch später beschrieben wird. Für die zahlreichen bereits vor Kriegsende ins Land gekommenen Flüchtlinge war das Lagerleben jedoch weniger typisch, sieht man von der Erstaufnahme in Turnhallen und Schulen, wie sie im Januar und Februar 1945 die Regel war, einmal ab. Einige Beispiele aus Zeitzeugenberichten sollen auch die Verhältnisse, auf die diese „ersten Gruppe“ vielerorts traf, verdeutlichen helfen.

Eine Einheimische aus Pritzwalk hat nach ihren zeitgenössischen Tagebuchaufzeichnungen später berichtet: „Viele Flüchtlinge waren bereits aus dem Osten hierher gekommen. Darunter die jüngste Schwester meiner Mutter mit drei Kindern aus Sorau, die sich nun auch hier im Hause aufhielten."1194 Das Zusammenrücken - teilweise, wenn auch nicht immer, erleichtert, wenn es sich um Verwandte handelte - war man häufig schon zuvor gewohnt, da Evakuierte aus den bombenkriegsgefährdeten Städten aufs Land kamen und in den Städten selbst spätestens ab 1944 die Zahl der obdachlos gewordenen Einheimischen zunahm. „Exemplarisch für diese Zeit war [in Fürstenberg/Havel] das ehemalige Hotel Wegert, das bis unter das Dach mit Flücht-

1193 Ramoth, Gemüsedorf Werben (wie Anm. 478), S. 45 f.

1194 Ilse Hüning: Erlebnisbericht vom Kriegsende im April und Mai 1945. In: Pritzwalker Heimatblätter 16 (2015), S. 11-14, hier S. 11. 
lingen und obdachlos gewordenen Fürstenbergern angefüllt war. Aus den Fenstern ragten die qualmenden Blechrohre von Kanonenöfen und Kochherden. "1195 Eine später in Storkow (Mark) lebende Flüchtlingsfrau aus Lodz kam im Januar 1945 über Posen nach Berlin zu ihren Schwiegereltern, dann nach Etzin bei Ketzin (Kr. Osthavelland) zur nach dort evakuierten Mutter und Schwester und erlebte hier das Kriegsende. ${ }^{1196}$ Ein Flüchtling aus Ostpreußen, der gleichfalls später in Storkow lebte, flüchtete im Januar 1945 aus Pillau nach Stettin und konnte im Februar von dort noch per Bahn nach Berlin fahren, um bei Verwandten in Berlin-Marzahn unterzukommen. ${ }^{1197}$ Ein junger Neumärker schließlich flüchtete mit seiner Mutter am 1. Februar 1945 aus Reppen per Bahn nach Frankfurt (Oder) und weiter nach Berlin, wo er am 2. Februar ankam und zunächst bei Bekannten privat Aufnahnme fand, bis man - als inzwischen bombengeschädigte Flüchtlinge - in eine verlassene Wohnung eingewiesen wurde und schließlich noch am 21. März 1945 in ein Zimmer in Falkensee-Finkenkrug umziehen konnte, ein bewusst erstrebter Zielort, da in Falkensee viele Reppener untergekommen waren. ${ }^{1198}$

Als im April und vor allem nach dem Schweigen der Waffen im Juni 1945 erneut eine „Treckwelle“ ins Land floss, war die Situation jeweils am schlimmsten. In der Endphase des Krieges gerieten die Flüchtlinge sogar westlich der rettenden Oder in unmittelbare Kriegshandlungen und kamen teilweise in Orte, deren Bevölkerung selbst auf der Flucht war. Als diese nach Wochen oder Monaten zurückkehrte, reichte der noch bewohnbare Raum weder für die einen noch für die anderen. Auch im Juni und noch weiter im Juli 1945 fanden die Vertriebenen oft genug kriegszerstörte oder noch nach dem 8. Mai angezündete Häuser vor. In Templin gab es durch die starken Kriegszerstörungen „Von den früheren 2393 Wohnungen nur noch 1743 für jetzt 11500 Einwohner.“1199 „Verstärkt wurde die so entstandene Wohnungsnot noch durch die zugewiesenen Flüchtlinge sowie die aus dem Westen wieder zurückkehrenden Familien. So kam es vor, dass von der Flucht zurückkehrende Wohnungsinhaber schon von Flüchtlingen oder Ausgebombten belegte Wohnungen vorfanden. Jede Person hatte nur Anspruch auf $8 \mathrm{~m}^{2}$ Wohnraum, sodass mehrere Familien sich eine Wohnung teilten. Wegen Widerstandes bei der Wohnraumbeschlagnahme für Wohnungssuchende kam es zu Bestrafungen, sogar Gefängnis bis zu einem Jahr wurde

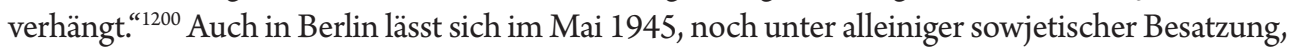
Ähnliches beobachten. Zunächst erfolgte zwar auch schon Unterbringung in notdürftigen Barackenlagern, dann aber oft genug die „Beschlagnahmung von Zimmern in Privathäusern“ ${ }^{1201}$

1195 Stegemann, Die Nachkriegszeit 1945 bis 1948 (wie Anm. 176), S. 234.

1196 Erika Keller: Erlebnisse aus dem zweiten Weltkrieg. In: Storkower Zeitzeugen berichten [H.] 2 (wie Anm. 271), S. 46-49.

1197 Dieter Lyhs: Flucht aus Ostpreußen (II). In: Damals und heute (wie Anm. 357), S. 40-44.

1198 Hans-Ulrich Rhinow: 1945: Ein dankbarer Rückblick auf meine kriegsbedingten Fluchtwege von Reppen nach Falkensee. In: Heimatjahrbuch für Falkensee und Umgebung 2015 (2014), S. 51-54.

1199 Bärbel Makowitz / Eitel Knitter / Martin Kunze: Templin. 2. Aufl. Strasburg (Um.)/Berlin 2013, S. 232.

1200 Ebd., S. 235.

1201 Mai 1945, noch unter sowjetischer Besatzung, in Berlin-Kladow (Bez. Spandau): Renate Wenzel: Kladow und seine Flüchtlinge. In: 750 Jahre Kladow 1267-2017. Berlin 2017, S. 107-123, hier S. 109-111. 
Als die „Wilden Vertreibungen“ im Juni 1945 die selbst darniederliegende Provinz Brandenburg im schlimmsten Moment mit einer unübersehbaren Welle zutiefst hilfsbedürftiger, weil meist vollständig ausgeraubter Menschen konfrontieren, ist bisweilen jeder sich selbst der Nächste. Eine zwei Tage zuvor aus Christianstadt am Bober (östliche Niederlausitz) vertriebene Mutter mit vier Kindern kommt am 26. Juni 1945 mit einem Treck in Forst (Lausitz) an. „Wir wurden in einer der großen Fabrikhallen untergebracht. Die Mutter begab sich auf Wohnungssuche. Überall wurden ihr Absagen zuteil." Auf dem Landratsamt erreicht sie es schließlich mit viel Geschick und Glück - der Landrat entpuppte sich als ehemaliger Bürgermeister ihrer Heimatstadt und gar als dortiger Nachfolger ihres Vaters vor 1933 -, einem für den nächsten Vormittag geplanten Lkw-Transport nach Luckau, der von dort Gemüse holen soll, zugewiesen $\mathrm{zu}$ werden. Insgesamt 13 Vertriebenenfamilien werden mitgenommen. In Luckau meldet sich der Fahrer - mitten in der Nacht - bei der sowjetischen Kommandantur. Ein Soldat führt die Leute in eine Vorstadtstraße und requiriert kurzerhand bei Einheimischen Wohnraum: „Der Soldat marschierte ab. Wildfremde Menschen wurden so in der Gartenstraße Nr. 26 zu mitternächtlicher Stunde der mütterlichen Obhut von Frau Jahn und ihrem halbwüchsigen Sohn Kutti überlassen. Nachdem diese schlichte Bauersfrau von unserem Schicksal erfahren hatte, stellte sie ohne viel Worte köstlich duftendes Bauernbrot, Schmalz und Gersten-Kaffee auf den Tisch. Während wir unseren Heißhunger stillten, räumte Mutter Jahn mit tatkräftiger Hilfe des Sohnes in ihrer guten Stube Tisch und Stühle zur Seite und schüttete viel Stroh auf die Dielen. Dreizehn Christianstädter Frauen, Männer und Kinder betteten nebeneinander dankbar ihre müden Häupter auf das Stroh in dieser uns noch so fremden Stadt. " ${ }^{1202}$ Der nächste Schritt bei der Lösung des Wohnungsproblems war zumindest in diesem Fall den Vertriebenen selbst überlassen. Der Mutter des Zeitzeugen ,fiel ein, dass von unserem Nachbarn an der Sorauer Straße in Christianstadt, dem Mühlenbesitzer Rudolf Marschner, in diesem Städtchen eine Verwandte wohnen sollte. Es gelang ihr tatsächlich, diese aufzuspüren, Diese Dame vermittelte uns die leer stehende Wohnung in der Bahnhofstraße 6. In die erste Etage zogen ein: Gastwirt Paul Heinrich und Frau Meta, Ofensetzer Silz und Frau und unsere Mammi, Frau Schwerin[,] mit vier Kindern nebst Oma Borchert. Der Gatterführer Hermann Marschner und Frau erhielten ein Zimmer in der Langen Straße, darunter war einige Zeit die Tauschzentrale untergebracht. " ${ }^{1203}$

Der Fall zeigt, dass diejenigen Vertriebenen, die aus den Grenzkreisen östlich von Oder und Neiße stammten und in einem Kreis derselben Provinz Brandenburg westlich der Grenze unterkamen, im Vorteil sein konnten. Gegenüber der großen Masse, die, wie etwa Ostpreußen, Oberschlesier oder gar Deutsche aus Zentralpolen, weite Distanzen zu überwinden hatten und auch landsmannschaftlich Fremde wurden, kamen sie wohl in einer "fremden Stadt", aber doch noch in derselben bzw. einer ganz ähnlich strukturierten Landschaft unter. Besonders deutlich ist das bei denjenigen, die sogar im selben Landkreis verbleiben konnten: Königsberg/Neumark, Guben, Sorau. Die Wahrscheinlichkeit, dann als „Nahwanderer“ sogar bereits bestehen-

1202 Helmut Rieger: Licht und Brot in Luckau. In: Luckauer Heimatkalender 32 (2000), S. 18-21, hier S. 20.

1203 Ebd., S. 21. 
de Vorkriegsverbindungen nutzen zu können, war innerhalb des noch vor kurzem zusammengehörigen brandenburgischen Verwaltungsgebietes immerhin etwas größer, wenn auch gewiss keineswegs ein Mehrheitsphänomen - die Mehrheit der Flüchtlinge und Vertriebenen war auf Hilfe der sich gerade erst mühsam organisierenden Behörden angewiesen.

Eine Neumärkerin aus Groß Gandern (Kr. Weststernberg), die im Rahmen der „Wilden Vertreibungen“ am 23. Juni 1945 ausgewiesen wurde, berichtet über ihre Aufnahme in der SBZ: ${ }^{1204}$ „Am Morgen des zweiten Tages weiter auf der Reichsstraße Crossen Frankfurt. Wegen unbeschreiblicher Fülle von Menschen der Züge aus den Oderdörfern ging es nur langsam voran. Immer wieder die Aufstauungen und das Verweilenmüssen auf den letzten $\mathrm{km}$ bis Frankfurt. Eine weitere Nacht bei Muttergrün lag in der Luft. Wir passierten die Frankfurter Oderbrücke. Nun hätte ein erlösendes Gefühl aufkommen müssen. Aber dem war nicht so. Große Ratlosigkeit, schlimmes Durcheinander bei der Menschenfülle. Wer sagt uns, wo und wie es zunächst weitergeht? Die Ordner am Wege wußten es mit Sicherheit selbst nicht, waren aber sichtlich bemüht, kein Verweilen der Menschenmassen zu haben und uns südwärts in Richtung Beeskow-Storkow zu schleusen. Unsere Lage war zu diesem Zeitpunkt noch undurchschaubar und alles andere als mutmachend. Nach den ersten Erkenntnissen im verbliebenen Deutschland war schnell Ernüchterung geworden, jetzt selbst zusehen zu müssen, wie man weiterkommt. So war in der Tat eine Verwandten- oder Freundesadresse die Möglichkeit, eine erste Zuflucht zu finden. Für diejenigen war es andererseits der Anfang einer zermürbenden Odyssee, mit öffentlichen Verkehrsmitteln zu der Zeit noch nicht rechnen zu können und nie zu wissen, wie man am Ziel empfangen wird. So war der Leidensweg noch lange nicht zu Ende. Einige Groß-Ganderner fragten vor Beeskow in Müllrose und Ragow von sich aus nach einer Bleibemöglichkeit. Und richtig, der Bürgermeister von Ragow, Paul Graske, meinte, daß es in der Gemeinde jetzt zur Erntezeit genug Arbeit gäbe und er auch zahlenmäßige Aufnahmeverpflichtung bekommen habe. Aber über Näheres würde das Landratsamt Beeskow befinden. [...] Durch eigenes Bemühen beim Landratsamt gab es für 8 Ganderner Familien tatsächlich eine Zuweisung für die Gemeinde Ragow. Andere kamen nach Kohl[s]dorf, Tauche, Stremmen, Buckow sowie nach Reichenwalde bei Storkow. Etliche von ihnen wurden durch Erwerb einer Siedlung und Hausbau mit Nebengebäuden bodenständig. Doch für die meisten und im allgemeinen gab es nur Übergangsbleibe und Zwischenstationen unterschiedlicher Art, um eines Tages weit verstreut - im Osten oder Westen - doch noch Fuß zu fassen."

Andere erlebten anderes. Eine aus Hinterpommern vertriebene Mutter mit zwei Kindern, die ebenfalls den individuellen Weg zu Verwandten in die Uckermark wählen konnte, hatte einen fünftägigen Fußmarsch von Stettin nach Prenzlau hinter sich: „Mitte Juli 1945 kamen wir in Fürstenwerder bei unseren Verwandten an. Der Bruder meiner Mutter war Bäckermeister Karl Ihlenfeldt. Wir wurden aufgenommen, obwohl die Wohnverhältnisse in dem Haus nicht gerade üppig waren." ${ }^{1205}$ Der Bericht eines Schlesiers wiederum zeigt die andere Seite, wie sehr es nämlich für

1204 Erinnerungsbericht einer Frau aus Groß Gandern (Kr. Weststernberg) in: Materne/Gerlach, Gross-Gandern und Klein-Gandern (wie Anm. 351), S. 96.

1205 Herbert Kernchen: Jugenderinnerungen an Fürstenwerder. In: Fürstenwerder Mosaik. T. 2. Fürstenwerder 2002, S. 122-131, hier S. 123. 
die, die keine „Verbindungen“ hatten, darauf ankam, sich selbst durchzusetzen, durchzukämpfen: „In Luckau empfing man uns natürlich nicht mit offenen Armen, sondern wollte uns aus der Stadt heraushaben. Mit viel Anstrengung und nach langen Auseinandersetzungen gelang es aber meinem Vater, uns Vier dort am 7. Juli [1945] unterzubringen." ${ }^{1206}$ Dies war freilich ein dornenreicher Weg, bei dem viele Schwache - kranke und alte Menschen - auf der Strecke blieben, so dass überall da, wo Flüchtlinge und Vertriebene sich zeitweise aufhielten, auch endgültige Wohnungen - Gräber - entstanden.

Die Wohnungsfrage war nicht nur, wie es oft hervorgehoben und wie sie gern reduzierend thematisiert wird, eine des Zusammenrückens, woraus dann Kontakte und Konflikte mit Einheimischen entstanden, sondern fast immer auch eine bürokratische. In Ragösen (Kr. ZauchBelzig) musste sich der örtliche „Antifa-Ausschuss“ schon in seiner ersten Sitzung im Sommer 1945 damit befassen, dass „wegen nicht gezahlter Mieten“ Zahlungsbefehle an die Mieter eines großen Hauses am Bahnhof ergangen waren. Bei den Mietern handelte es sich jedoch durchweg um „Vertriebene, die über keinerlei Gelder verfügen“. Der Ausschuss schickte die Zahlungsbefehle daher an das Amtsgericht zurück und beschloss, „bedürftigen Flüchtlingen einen kleinen Unterhalt aus Haushaltsmitteln zu zahlen“"1207

Die Verhältnisse der sogen. organisierten Vertreibungen ab Herbst 1945 brachten nur scheinbar Planbarkeit für die deutschen Verwaltungen. Aus den mindestens vierzehntägigen Quarantäneaufenthalten in den überall in Brandenburg in kurzer Zeit aus dem Boden gestampften Lagern wird nicht selten ein längerer Aufenthalt, wenn der Transport nicht gar in ein anderes Land weiter-- bisweilen auch hin- und her- - geleitet werden muss. Nur idealtypisch ist der Fall, dass nach den 14 Tagen eine Wohnungseinweisung, „Eingemeindung“ erfolgen kann, vielfach dauert es deutlich länger, wenn nicht ein angekündigter nächster Transport schnelle „Durchschleusung“ erzwingt. Ein im Januar aus Hinterpommern Geflüchteter, der zunächst im Lager Angermünde landete, wurde in das benachbarte Lager Pinnow (Kr. Angermünde) weitergeschickt und erlebte schließlich - nach nochmaliger Verlegung - in einem ganz anderen Landkreis (Beeskow-Storkow) die Lagerentlassung: „Eines Tages endete das Lagerleben. / Es war an einem sonnigen ersten Mai, als wir in einer kleinen märkischen Stadt eine bescheidene Dachwohnung bezogen. Einige gebrauchte Sachen, die zuletzt im Lager verteilt worden waren, luden wir auf einen Handwagen, den uns eine Arbeiterin dort geliehen hatte. Als wir den Wagen mit seinen Rädern aus von Eisen reifen gehaltenen Holzspeichen mit lautem Geklapper und Gepolter über das Kopfsteinpflaster der Hauptstraße vom Lager zur Wohnung zogen, hörten wir aus einiger Entfernung hell und kraftvoll schmetternde Marschmusik. [...] Es war der erste Mai des Jahres 1946 in Storkow in der Mark. $[\ldots]$..."1208

1206 Winfried Krakau: Flucht aus Schlesien. Mein langer Weg von Glogau nach Wilhelmshorst. In: 100 Jahre Wilhelmshorst (wie Anm. 189), S. 345-346, hier, S. 346.

1207 Ragösen. Beiträge zur Geschichte, T. 2 (wie Anm. 188), S. 19 (Zitate hiernach, nicht wörtlich dem Protokoll entnommen). Zur richtigen Datierung der Ausschuss-Sitzung siehe oben Anm. 523.

1208 Sonnemann, Bittere Medizin (wie Anm. 269), S. 30. 
Oft genug muss bei der Verteilung der bisweilen sehr kurzfristig angekündigten Transporte improvisiert werden, so dass auch „umgekehrt“ verfahren wird: Nicht wenige Zeitzeugenberichte schildern, dass ein Vertriebenentransport schon am (städtischen) Bahnhof auf die umliegenden Dörfer verteilt wurde, zwangsweise unterkunftgebende Bauern zur Abholung bereit standen oder schlicht ein Fußweg begann. Zuweilen war die Quarantänezeit dann schon zuvor in Forst (Lausitz) oder in einem sächsischen Lager wie Pirna erfolgt. Doch auch der im Gegensatz dazu so komfortabel und beneidenswert erscheinende direkte Weg zu Verwandten führte keineswegs immer zu beiderseitiger Wiedersehensfreude: Unangemeldet kommen Vertriebene aus Schlesien, eine Mutter mit Sohn, im Herbst 1945 zu einem Verwandten, Bruder des Ehemannes und Vaters, in die Uckermark. In der Erinnerung des damals achtzehnjährigen Sohnes lief die erste Begegnung so ab: „Wir machen uns bemerkbar. Der Onkel und seine Frau kommen fast gleichzeitig. Sie erkennen uns nicht. Wir müssen uns vorstellen. Staunen und beklommene Stimmung. Wir reagieren feinfühlig aus der Defensive./Aber: Kommt herein, setzt euch, erzählt. Und wir erzählen wieder, wie schon bei Tante Martha [kurzer Besuch in Berlin ohne Zuzugsgenehmigung P. B.]. Sie verstehen. Doch der Onkel fragt trotzdem, wann wir wieder weiter wollen. Verständlich! Wir bleiben einige Tage." Die Suche nach einer ersehnten anderen Unterkunft im Ort liegt nahe und hat irgendwann auch Erfolg: „Meine Mutter hat inzwischen Bekannte meines Vaters, aus seiner Lehrzeit als Dachdecker, aufgesucht. Sie bewohnen ein kleines Haus in der Nähe [...]. Diese Familie nimmt uns freundlich auf. Wir können unbegrenzt bleiben. Eine kleine Dachkammer mit zwei Betten, einem Schrank, einem Tisch mit zwei Stühlen wird für die nächste Zeit unser Zuhause. Es geht auf die Mitte Oktober $1945 z u$."1209

Ein anderer Fall beleuchtet wiederum bekannte Facetten wie die bürokratische, verweist aber zugleich auf die kaum statistisch zu spezifizierende Gruppe derjenigen, für die Brandenburg nur eine mehr oder weniger lange Zwischenstation blieb. Eine am 10. September 1945 aus Schwiebus ausgewiesene Mutter mit elfährigem Sohn kam nach zehntätiger Güterzugfahrt in Neuruppin an. Der Sohn hat später Erinnerungen an die erste Zeit der Unterkunftssuche niedergeschrieben. Eine in ihrem Transport befindliche Nachbarfamilie fand in Treskow bei Neuruppin Unterkunft. „Wir trafen eine Frau Gebauer aus Schwiebus. Bei dieser Familie, der Mann war Briefträger, durften wir auf dem Fußboden übernachten, um nicht auf der Straße bleiben zu müssen. Am nächsten Tag ging es wieder auf Wohnungssuche. Dreimal liefen wir zu Fuß von Neuruppin bis Bechlin ca. $5 \mathrm{~km}$, um Formalitäten zu erledigen. Einmal fehlte die Zuzugsgenehmigung, dann die Einweisung usw. Beim dritten Mal sagte uns ein Gemeindeangestellter (Berliner), daß uns eine Frau Arndt aufnehmen würde. Diese Wohnung war nicht vom Wohnungsamt beschlag- [S. 72] nahmt. Daher konnten wir sie ohne jede Formalitäten erhalten. Frau Arndt wohnte in Neuruppin bei ihren Eltern, da ihr Mann gefallen war. Ihre Bechliner Wohnung stand leer. Wir durften einziehen. Ihre Möbel durften wir alle benutzen. Nach unseren vorherigen Verhältnissen konnten wir jetzt wieder menschlich leben, obgleich wir sehr ausgehungert waren und die Verpflegung ausgesprochen schlecht 
war. Zu einer Mahlzeit aß ich mal 35 Pellkartoffeln, zur anderen 10 Stullen. Tagtäglich gingen wir Kartoffelnstoppeln. Am 1. Oktober begann die Schule." Doch die Familie hatte in ihrer Heimat bei Kriegsende Gewalttaten der Roten Armee gegenüber Zivilisten erlebt - „Wir glaubten, das Weltende sei da“ - und blieb davon geprägt: „Wir sahen bald ein, daß unser Bleiben in Bechlin nicht von Dauer sein konnte. Der bloße Anblick eines Russen, Neuruppin ist Garnisionsstadt [so!], jagte uns kalte Schauer über den Rücken. Eine Karte ging nach dem Westen zu unseren Verwandten [...]. Wir sollten kommen, lautete die Antwort. Endlich Anfang Dezember waren alle Formalitäten erledigt. Eines Morgens zogen wir mit unserer geringen Habe wieder los. / Groß war die Freude, als wir dort ankamen. Hier fühlten wir uns endlich geborgen und konnten ein neues Leben beginnen und wieder ohne Schrecken in die Zukunft schauen, wenn es uns zu Anfang auch noch recht sauer wurde." ${ }^{210}$

Manche Landkreis- und Gemeindeverwaltung versuchte, sich gegen eine erneute Zuweisung zu wehren, verwies auf Überbelegung oder zu starke Kriegszerstörung. Im Kreis BeeskowStorkow schrieb der Bürgermeister des Amtsbezirks Pfaffendorf, in dem 171 Flüchtlinge aufgenommen worden waren, am 24. August 1945 an sein Landratsamt: „Mit der Aufnahme weiterer Flüchtlinge kann ich mich auf keinen Fall einverstanden erklären." Zur Begründung führt er nicht nur das Fehlen weiterer „Unterbringungsmöglichkeiten“ an, sondern verweist darauf, dass die Kreisbehörde ohnehin von irrigen Vorannahmen ausgehe, wenn sie sich auf die Einwohnerzahl von 1938 stütze, in der noch die nun nicht mehr zugehörige Gemeinde Kunersdorf enthalten gewesen sei. ${ }^{1211}$ Selten halfen solche Schreiben, da die Provinzialverwaltung zumindest in den Zeiten des stärksten Zustroms ihrerseits Befehlsempfänger war. Wie zu anderen Zeiten und unter anderen Rahmenbedingungen auch, versuchte man die Ernährungsgrundlagen in den weniger zerstörten ländlichen Gebieten zu berücksichtigen, besonders beeinträchtigte Städte zu entlasten, doch finden sich genügend Beispiele dafür, dass solche Ansätze oft genug von den Ereignissen überrollt wurden. Stadt und Land sind durchaus beide einem starken Flüchtlingszustrom ausgesetzt gewesen. Zu Hilfe kam den Städten die - aber ebenfalls keineswegs durchgängige - Bevorzugung der vermeintlich besser gestellten Landgemeinden durch viele Vertriebene, die selbst vom Land kamen: „Das Ziel der Stadtverwaltung [in Fürstenberg/Havel], den unerwünschten Zuzug von Flüchtlingen und Vertriebenen rigoros einzudämmen, fand seine Entsprechung in dem Bestreben vieler Heimatsuchender, die ,nahrungsarme‘ Kleinstadt zu meiden und ein Unterkommen auf dem Lande zu finden. "1212 So lag der Anteil der Vertriebenen unter den Schülern in der Stadt Fürstenberg/Havel 1947 bei rund einem Drittel, in den umliegenden Dörfern dagegen stellten sie in den meisten Fällen die Mehrheit, bisweilen gar über 80 Prozent. $^{1213}$

1211 Wille II (wie Anm. 196), S. 171, Nr. 163 (nach BLHA, Rep. 255 Kreis Beeskow-Storkow, Amtsbezirk GroßRietz, Nr. 15).

1212 Stegemann, Die Nachkriegszeit 1945 bis 1948 (wie Anm. 176), S. 236.

1213 Ebd. - Zahlenverhältnisse, bei denen die Flüchtlinge ein Drittel bis die Hälfte ausmachten, lassen sich auch anderswo vielfach finden. Weiter östlich, in Passow (Kr. Angermünde), wo in der Dorfschule bereits am 1.5.1944 


\section{Baracken}

Schließlich ist noch ein etwas näherer Blick auf zwei - neben den individuellen privaten Notunterkünften in Hinterzimmern, Dachkammern u. ä. - häufige und für einen Großteil der Vertriebenen in Brandenburg wichtige, letztlich typische Lebens- und Wohnstationen zu werfen: Barackenlager und Gutshäuser. Mit Barackenlagern sind hier vor allem Anlagen gemeint, deren Funktion als offizielle „Umsiedlerlager“ abgeschlossen war, die aber in sozusagen „offener“ Form weiterhin zu Wohnzwecken dienten oder für andere Unterkünfte als hölzerner „Steinbruch“ herhalten mussten. Denn auch zugewiesenen Notunterkünften fehlten oft Fenster, Türen und Möbel, so dass Selbsthilfe nötig wurde und an der Tagesordnung war. Das ehemalige Reichsarbeitsdienstlager am Wirchensee bei Fürstenberg (Oder) wurde beispielsweise „regelrecht geplündert. Die Einwohner der umliegenden Dörfer, besonders die Vertriebenen in Henzendorf, Groß Muckrow und Kieselwitz, holten sich Barackenteile, Tische, Stühle, Bänke und andere brauchbare Gegenstände. "1214 Dass Baracken zudem nicht selten noch in den fünfziger Jahren von Flüchtlingsfamilien bewohnt waren ${ }^{1215}$, zeigen Beispiele in vielen Orten, im Westen wie im Osten Deutschlands. Solche Holzbaracken, die auf Betonstreifenfundamenten ruhten und deshalb keinen direkten Bodenkontakt hatten, haben verständlicherweise nur selten die Zeiten überlebt, sind aber z. B. in Brück bis heute erhalten geblieben, weil den Flüchtlingen eine Nutzung im Rahmen eines staatlichen Antennenmessplatzes folgte. ${ }^{1216}$

Der Schiffersohn Jürgen Noack (geb. 1937) aus Pollenzig (Kr. Crossen), dessen Familie am 20. Juni 1945 vertrieben wurde und auf weiten Umwegen über Lübben und Lychen schließlich nach Fürstenberg (Oder) kam, hat später berichtet ${ }^{1217}$, dass der hier wieder als Schiffer tätige Vater und eine weitere Familie [ca. 1947/48] „die Genehmigung erhielten, sich in den Wachbaracken des Stalag III B eine Wohnung zu nehmen und auszubauen. Fenster, Türen, Licht, Wasser und Ofenheizung mussten hergerichtet werden. Jede Familie bekam in der ersten Baracke, in

85 einheimischen 28 evakuierte Schüler gegenüberstanden, gab es am 1.10.1945 neben 92 Passower Kindern bereits 67 Flüchtlingskinder und am 1.10.1946 standen 95 einheimischen 74 Flüchtlingskinder gegenüber (Frieda Braunschweig: Aufbau der Schule in Passow nach 1945. in: Angermünder Heimatkalender 2020, S. 212-217, hier S. 213).

1214 Erich Opitz: Zur Geschichte des Arbeitsdienstes in unserer Heimat. In: Heimatkalender Eisenhüttenstadt und Umgebung 21 (2003), S. 71-76, hier S. 76 (1t. Fn. 13 aufgrund einer Schilderung eines Herrn Materne aus Henzendorf von 2002, der „als Kind mit seinem Vater eine Fuhre voll holte“).

1215 Auch für Potsdam ist dies belegt, wo vor 1945 eine zeitweise für Obdachlose genutzte Anlage in der Pappelallee noch Jahre nach Kriegsende von Flüchtlingen bewohnt war (freundliche Mitteilung Hartmut Knitter, ehemals Abt.-Leiter im Potsdam-Museum).

1216 Beispiel Brück: Karl-Heinz Schmidt: Der Antennenmessplatz Brück. In: Das Archiv. Magazin für Kommunikationsgeschichte (2016) 4, S. 68-71, hier S. 68 (mit Abb. des Zustandes 2016). Nach dem Verkauf der Anlage durch die Telekom 2009 folgte eine Nutzung als Reiterhof. Gegen Pläne zum Abriss der (inzwischen unter Denkmalschutz stehenden) Türme setzte sich bisher ein Verein „Brücker Turm e.V.“ erfolgreich zur Wehr (ebd., S. 71). Ob damit auch die Baracken mit ihrer älteren Geschichte gesichert sind, bleibt fraglich.

1217 Jürgen Noack: Wie ich in Fürstenberg (Oder) eine neue Heimat fand. In: Heimatkalender Eisenhüttenstadt und Umgebung 23 (2005), S. 198-206. Der Vater stammte aus Pollenzig, die Mutter aus Brieg (Schlesien). 
der sich jetzt die Hundepension befindet, zwei Räume zugewiesen. Die Ausstattung war primitiv und wir schliefen auf Strohsäcken. Wasser musste leider noch von einer zentralen Stelle geholt werden." Das Provisorium verfestigte sich: „Etwa ein Jahr später wurden die Baracken von der Stadt offiziell zum Bewohnen freigegeben und ausgebaut. Nach und nach sind sechs bis sieben Baracken belegt worden, pro Familie zwei Räume. Das Stalag III B wurde nun in ,Stadtrandsiedlung' umbenannt. Unsere Baracke erhielt die Nr. 4, die noch in meinem Arbeitsbuch vom Lehrbeginn 1953 steht. Nun herrschte hier bald ein reges Leben. Bekanntschaften wurden geschlossen und wir Kinder freundeten uns ebenfalls an. Für Kinder war die Gegend ein richtiger Abenteuerspielplatz. Es waren ja noch die Ruinen des ehemaligen Gefangenenlagers vorhanden, in deren Schächten und unterirdischen Gängen wir herumkletterten. Dabei fanden wir verrostete Handfeuerwaffen, Bajonette und Gasmasken." 1218 Da der Vater als Schiffer wieder "gutes Geld“ bekam und die Mutter, „die mit einigen Frauen aus der Siedlung im Getreidespeicher arbeitete", hinzuverdiente, gehörten bald Fahrrad, Radio und anderes zum Lebensstandard. In Westdeutschland sowie im überseeischen Ausland lebende Verwandte schickten zur Unterstützung Pakete. ${ }^{1219}$ „1952 wurde ich eingesegnet und es gab eine bescheidene Familienfeier. Meine Kusine buk sogar eine Cremetorte." 1952/53 wurde die Siedlung wegen der Planungen für das EKO-Stahlwerk und ein Zementwerk zwar aufgelöst. „Wir blieben aber noch. [...] 1955 bekamen meine Eltern eine Wohnung in der Glashüttenstraße 9 zugewiesen, auf die wir uns natürlich sehr freuten, war es da doch viel bequemer." Jürgen Noack selbst absolvierte eine Schifferlehre, begann 1956 noch eine Qualifizierung zum Lehrausbilder in der Binnenschiffahrt und heiratete 1958 eine Vertriebene, „ein Flüchtlingskind aus Guben“, mit der er nach der Geburt zweier Kinder 1961 „in eine schöne Wohnung in der Arbeiterwohnungsbaugenossenschaft (AWG) in Fürstenberg (Oder) “ zog. ${ }^{1220}$ Rückblickend schreibt er, er habe in Fürstenberg ,eine neue Heimat" gefunden. ${ }^{1221}$

Ähnliche Transformationen von Lagern der NS-Zeit hat es auch anderswo gegeben. ${ }^{1222}$ Nicht selten wurde aus einem solchen Standort zunächst ein Vertriebenenlager und nach ein paar Jahren eine offene „Siedlung“. Mancher Lagerinsasse des Vertriebenenlagers blieb sogar in der Baracke, Um- und Ausbauten kamen ebenso vor wie „Dauer-Provisorien“. ${ }^{1223}$

Kurt Neis hat sich mit den verschiedenen Barackentypen, die in der Kriegs- und Nachkriegszeit für Wohn- bzw. Unterbringungszwecke - innerhalb, aber auch außerhalb von Lagern - genutzt wurden, am Beispiel von Fürstenberg/Havel eingehend beschäftigt. ${ }^{1224}$ Seine

1218 Ebd., S. 203.

1219 Ebd., S. 204.

1220 Ebd., S. 205.

1221 Ebd., S. 198, 206.

1222 Siehe z.B. das „Borsiglager“ in Guben, das 1947 in „Waldsiedlung“ umbenannt wurde und dessen Baracken später als Altersheim bzw. Kindergarten dienten.

12231947 beabsichtigt ein Vertriebener in Angermünde die Gründung eines Kleinindustriebetriebes. „Eröffnet wird der Betrieb in den ehemaligen Räumen des Umsiedlerlagers Angermünde“. Wille II (wie Anm. 196), S. 363, Nr. 376 (BLHA, Rep. 250 Angermünde, Nr. 518, Bl. 50).

1224 Neis, Fürstenberg/Havel (wie Anm. 176), bes. S. 493-495, 497, 499-503. 
detaillierten Beschreibungen erhellen sowohl bautechnische Einzelheiten als auch den Alltag der Nutzer. In ihrem Informationsgehalt - und in ihrem tiefgehenden Interesse am Thema ${ }^{1225}$ stehen sie allerdings bislang für das Land Brandenburg vollkommen allein. Während sich die „Zeitgeschichtliche Archäologie“ als neuer Zweig des Faches noch allein auf die Zeit von 1933 bis 1945 konzentriert, dokumentiert Neis bauarchäologisch ausdrücklich auch die Relikte der Nachkriegszeit im (freilich auch vor 1945, als Ravensbrücker KZ-Außenlager, genutzten) Lager Dahmshöhe ${ }^{1226}$ sowie im Stadtgebiet von Fürstenberg/Havel ${ }^{1227}$. Dabei kann er zum einen die nur rudimentären, aber bei genauerem Hinsehen noch heute erkennbaren Spuren einzelner Barackenstandorte zeigen, zum anderen belegen, dass manches „Behelfsheim“ und manche „Baracke“ nicht nur für mehrere Jahre, sondern zuweilen sogar noch Jahrzehnte später bewohnt war. $^{1228}$

Eines der während des Zweiten Weltkrieges zur „vorläufigen Unterbringung von so genannten ,Ausgebombten“ aus den deutschen Großstädten“ im südlichen Teil der Bornmühlensiedlung in Fürstenberg/Havel errichteten „Behelfsheime“ fand Neis noch 2004 nicht nur, wenngleich inzwischen auf ein Mauerfundament gestellt und auch sonst etwas verändert, grundsätzlich „in seiner ursprünglichen Gestalt erhalten“vor, sondern konnte auch feststellen, dass es „bis vor wenigen Jahren noch bewohnt“ war. ${ }^{1229}$ Es handelt sich bei diesem Typus, der meist zur Unterbringung einzelner Familien von mindestens vier Personen diente, um Bauten „aus Holz-Fertigteilen, die zu einer Fläche von $5 \mathrm{~m}$ Breite und $4 \mathrm{~m}$ Raumtiefe mit Pultdach, Holzfußboden, Trennwänden, Eingangstür und mehreren Fenstern montiert, ähnlich den Baracken, ohne festes Fundament, überall leicht und schnell aufzustellen waren“. Zur Beheizung „wurden gemauerte Feuerstellen errichtet oder transportable Öfen aufgestellt. “" ${ }^{1230}$ Beispielhaft, aber eben bislang kaum verbreitet, ist es nun auch, wie Neis den sichtbaren Spuren bis zur Gegenwart nachgeht und schließlich für einen Denkmalschutz plädiert ${ }^{1231}$, der nicht zwischen Kriegs- und Nachkriegsnutzung trennt: „Im Komplex der Bornmühlensiedlung umbauten in den Folgejahren einige Eigentümer ihre Behelfsheime mit massivem Mauerwerk und erweiter-

1225 Kurt Neis, geb. 1936 in Aussig/Elbe, ist selbst (als Kind aus dem Sudetenland) Vertriebener, der 1946 mit einem Eisenbahntransport nach Neustrelitz kam und nach 14-tägiger Quarantäne von dort nach Fürstenberg/ Havel (Barackenlager „Faserstoff-Baracken“) weitergeleitet wurde (lt. Kurzbiographie auf dem Buchumschlag und eigener Auskunft vom 25.1.2017).

1226 Neis, Fürstenberg/Havel (wie Anm. 176), S. 508 f., 511

1227 Ebd., S. 63.

1228 Ebd., S. 63. Behelfsheim Eckermannstraße 5 in der Bornmühlensiedlung in Fürstenberg/Havel.

1229 Ebd., S. 63, mit Außenansicht (Foto 2004). Bauveränderung: „auf ein Mauerfundament gestellt und der im Original überstehende vordere Meter der Überdachung nachträglich umbaut“. Foto des ursprünglichen $\mathrm{Zu}$ standes eines Behelfsheims ebd. S. 492 (private Aufnahme der Bewohnerfamilie, 1945).

1230 Ebd., S. 63. Siehe zu diesem „Behelfsheim“-Typus des Deutschen Wohnungs-Hilfswerks (DWH) auch: Frank Stier: Kriegsauftrag 160. Behelfsheimbau im Ghetto Litzmannstadt (Łódź) und im KZ-Außenlager Königs Wusterhausen durch das Deutsche Wohnungshilfswerk (Einzelveröffentlichung der Brandenburgischen Historischen Kommission, Bd. 1). Berlin 1999, S. 8, 12 f., 32 (jeweils mit Abb.).

1231 Bisher erfolglos, wie er dem Verf. am 25.1.2017 mitteilte. 
ten darüber hinaus die Wohnflächen durch entsprechende Anbauten. Damit sind ihre ursprünglichen Baukörper heute nicht mehr erkennbar und die jetzt an diesen Standorten sichtbaren Gebäude gingen aus dieser Metamorphose hervor. Sie befinden sich im Umfeld des letzten noch stehenden Original-Behelfsheimes, das man erhalten sollte, da es ein in der Stadt Fürstenberg und ihrer weiteren Umgebung einmaliges, noch vorhandenes Bauwerk ist, das an eine historisch erst vor kurzem zu Ende gegangene Etappe leidvollen Geschehens der deutschen Geschichte erinnert und sehr anschaulich verdeutlicht, wie Menschen damals in dieser Situation leben und wohnen mußten." ${ }^{232}$

\section{Gutshäuser}

Belege für die Nutzung von Guts- bzw. Herrenhäuern als Wohnraum für Flüchtlinge und Vertriebene schließlich finden sich in der Regional- und Lokalgeschichtsliteratur und in Studien zu brandenburgischen Schlössern und Gärten sehr zahlreich. ${ }^{1233}$ Zuvor hatten die meisten Eigentümer, soweit nach Kriegsende noch anwesend, aufgrund „einer Verfügung der SMAD vom 1. Oktober 1945“ ihre Häuser verlassen müssen. ${ }^{1234}$ An sich war die Raumstruktur der Gutshäuser für diese neue Nutzung völlig ungeeignet ${ }^{1235}$, zu schweigen - umgekehrt - von den Auswirkungen auf wertvolle Ausstattungsstücke, doch die Not der Zeit fragte danach nicht, und in den politischen Vorstellungen der KPD/SED existierte diese Welt ohnehin nicht mehr. ${ }^{1236} \mathrm{Nach}$ den eingehenden Untersuchungen von Bernd Maether dienten sogar die meisten brandenburgischen Schlösser und Herrenhäuser in den ersten Nachkriegsjahren als „Wohnungen für Umsiedler" ${ }^{1237}$ In den Verhandlungen zwischen verschiedenen beteiligten Verwaltungsstellen um den von der SED favorisierten Abriss oder die meist lokal oder regional gewünschte weitere Nutzung diente dies bisweilen als Hemmnis für einen Abriss. So wurden die neuen Bewohner

1232 Neis, Fürstenberg/Havel (wie Anm. 176), S. 64.

1233 Beispiele: Das Havelland um Rathenow und Premnitz (wie Anm. 105), passim. - Müncheberger Lebensläufe. Zsgest. u. zumeist aufgeschrieben von Andreas Gehrke u. Frank Geißler. T. 2. Müncheberg 2008, S. 52 („ungefähr 40 Flüchtlingsfamilien“ im „Schloss Trebnitz“ bis 1950).

1234 Peter Goralczyk: Das Schicksal von Schlössern, Herrenhäusern und Burgen in der DDR-Zeit. In: Schlösser, Herrenhäuser, Burgen und Gärten in Brandenburg und Berlin. Sibylle Badstübner-Gröger (Hg.). Berlin 2002, 51-67, hier S. 51.

1235 Der Umsiedlerausschuss der Gemeinde Lübbinchen (Kr. Guben) berichtet am 20. Juni 1947: „[...] die sogenannten Schloßbewohner leben viel unruhiger, es ähnelt einer Mietskaserne, meist haben sie nur eine Stube mit Kammer ohne Ofen nur mit einer kleinen Kochmaschine, die sie sich allmählich besorgt haben, weil dieses Haus ja mit Zentralheizung ausgestattet war. Genau so ist es mit den Vieh- und Kleinviehställen, alles gemeinschaftlich im großen Stall, einer beklaut den anderen [...]." Wille II (wie Anm. 196), S. 343 f., Nr. 351 (Schreiben an die Umsiedlerabteilung des Landratsamtes; BLHA, Rep. 250 Landratsamt Guben-Frankfurt/O., Nr. 283), hier S. 343.

1236 Goralczyk, Das Schicksal von Schlössern (wie Anm. 1234), S. $51 \mathrm{f}$.

1237 Maether bereitet eine umfassende quellengestützte Studie zum Nachkriegsschicksal der brandenburgischen Herrenhäuser vor, in der auch die Wohnnutzung für Flüchtlinge und Vertriebene ausführlicher behandelt werden wird (Mitteilung an den Verf.). Siehe vorläufig die kleinere Arbeit: Bernd Maether: Brandenburgs Schlösser und Herrenhäuser 1945-1952. Potsdam 1999 (Brandenburgische Historische Hefte, 12). 
teils instrumentalisiert, teils ignoriert. In einem (Kommissions-),Bericht über die Durchführung der Anordnung bezüglich des Abrisses der Schlösser und Gutshäuser im Lande Brandenburg" vom 1. April 1948 wird zum Beispiel nur für 21 Häuser eine vorgesehene oder schon zugeteilte Weiterverwendung als Unterkunft für „Umsiedler“ angegeben, während man aus ideologischen Gründen 643 von 779 Herrenhäusern abreißen wollte. ${ }^{1238}$

Von den rund 60 Herrenhäusern der Kreise Ost- und Westhavelland wurden in den ersten Nachkriegsjahren mindestens 24 mit Flüchtlingen belegt. ${ }^{1239}$ Im Herrenhaus Görne brachte man Flüchtlinge aus dem Schwarzmeerraum unter. ${ }^{1240}$ Das Möthlower Gutshaus nahm 13 oder 14 Flüchtlingsfamilien auf ${ }^{1241}$, das Briesener $12^{1242}$. Im geplünderten und enteigneten Herrenhaus Rhinow hatte die noch geduldete Hauseigentümerin, Frau von der Hagen, „acht Flüchtlingsfamilien aufzunehmen, die in den Schlaf- und Wohnzimmern auf beiden Etagen sowie im ,Salon' untergebracht waren. Die einquartierten Familien mußten der Frau von der Hagen eine Miete für die Unterkunft und auch für das von ihnen genutzte Mobiliar zahlen. "1243 Umnutzung oder Abriss der Gebäude beendeten diese Unterbringungen bisweilen nach wenigen Jahren, zumal Baumaterial und Inventar vielfach ausdrücklich für die Er- und Einrichtung von Neubauerngehöften dienen sollten. ${ }^{1244}$ Die nicht abgerissenen oder dem Verfall preisgegebenen oder für andere als Wohnzwecke dienenden Herrenhäuser wurden in das ländliche Kontingent „normalen"Wohnraums integriert und durch Einziehen von Zwischenwänden in Einzelwohnungen aufgeteilt. Auch äußere bauliche Veränderungen und Teilabrisse veränderten das Aussehen und ließen diese Gebäude manchmal gar als „normale “Wohnhäuser erscheinen. ${ }^{1245}$ Im Herrenhaus Friesack II richtete die Volkssolidarität anfangs „für Umsiedler und Kriegsheimkehrer eine Ausgabestelle für Kleidung und Lebensmittel ein" " ${ }^{1246}$

Ähnliche Verhältnisse herrschten auch in den anderen Landkreisen der an ehemaligen Rittergütern reichen Provinz Brandenburg, zumal, wie angedeutet, sehr viele Flüchtlinge und Vertriebenen nicht in den - viel stärker kriegszerstörten - Städten, sondern auf dem Land untergebracht wurden und oft selbst dorthin strebten. Für die Gutsdörfer im Raum Fürstenberg/

1238 Ebd., S. 25, Dokumentenanhang S. 82. - Siehe auch: Gerd Heinrich: Preußische Herrensitze in Brandenburg. Brandenburgs alte Familien in den Stürmen des 20. Jahrhunderts. Traditionen, Vertreibung und Aufbau. In: Deutsches Adelsblatt 44 (2005), S. 89-96, hier S. 91-94 (Kapitel III. Vertreibung 1945-1950), bes. S. 93.

1239 Almut Andreae / Udo Geiseler (Hg.): Die Herrenhäuser des Havellandes. Eine Dokumentation ihrer Geschichte bis in die Gegenwart. Berlin 2001, S. 25, 76, 83, 91, 96, 100, 123, 131, 142, 146, 178, 189, 201, 209, 212, 218, 233, 253 f., 270, 284, 288, 291, 295, 299, 303.

1240 Ebd., S. 131.

1241 Ebd., S. 209.

1242 Ebd., S. 83.

1243 Ebd., S. $253 \mathrm{f}$.

1244 Maether, Brandenburgs Schlösser und Herrenhäuser (wie Anm. 1237), S. 12 f., 18, 20, 23, 25, 32, 34, 58 f.

1245 Die Auflösung des Gutscharakters bis zur Unkenntlichkeit war - neben der Schaffung geeigneten Wohnraums aus ideologischen Gründen ausdrückliches Ziel von Umbaumaßnahmen, die mit der historischen Kontinuität bewusst brachen. Siehe dazu Maether, Brandenburgs Schlösser und Herrenhäuser (wie Anm. 1237), S. 24.

1246 Andreae/Geiseler, Die Herrenhäuser des Havellandes (wie Anm. 1239), S. 126. 
Havel verweist Wolfgang Stegemann dabei zugleich auf das erwähnte Problem der „DauerProvisorien“: „Die Gutshäuser dienten einem Teil der Flüchtlinge und Vertriebenen für längere Zeit als neues Zuhause. ${ }^{\text {1247 }}$ Auch im (gut untersuchten) Havelland gab es Fälle, in denen die einquartierten Familien Wohnrecht behielten. So lebten im Untersuchungsjahr 2001 - 55 Jahre nach Kriegsende - im ehemaligen Herrenhaus Ohnewitz (Westhavelland) und dem angrenzenden Wirtschaftsgebäude noch immer die Nachkommen der einst hier einquartierten Flüchtlinge. ${ }^{1248}$

\section{Arbeit}

Die Integration der Flüchtlinge und Vertriebene in den Arbeitsprozess, in die erst allmählich wieder in Gang kommende Wirtschaft erfolgte nach Kriegsende oft schleppend. ${ }^{1249}$ Einheimische und Flüchtlinge fanden sich bei den von den lokalen sowjetischen Kommandanturen befohlenen Arbeitseinsätzen hingegen schon sehr bald im selben Boot wieder: Aufräumarbeiten, Trümmerbeseitigung, Brückenbau, Minenräumung (an Oder und Neiße), aber auch Transporte aller Art. ${ }^{1250}$ In Fürstenberg/Havel zeigen die Tagesberichte des Arbeitsamtes, dass von Anfang Mai 1945 „bis in die erste Juniwoche seit der Besatzung oftmals über 1200 Personen täglich einsatzverpflichtet waren und meist über 12 Arbeitsstunden - ohne Wegzeit! - befehlsgemäß insbesondere am Bahnhof und dem KZ-Lager leisteten. Durch diese ungewohnten Schwerarbeiten hauptsächlich am Bahnhof (Bleiplatten verladen) sind viele Unglücksfälle (Hand-, Fuß-, Beinverletzungen) und Unterleibserkrankungen eingetreten, so daß die Zahl der einsatzfähigen Personen tagtäglich durch von Ärzten bescheinigte Krankmeldungen beunruhigend abnahm. "1251 Eine „Liste der Minen- und Sprengstofftoten“ aus dem Raum Guben verzeichnet für die Jahre 1945 bis 1950 (mit Schwerpunkt 1945) neben Kindern, die beim Spielen zu Opfern wurden, viele Erwachsene. Mancher von ihnen war mehr oder weniger freiwilliger „Minensucher“ gewesen, die meisten aber wohl eher Unfall- bzw. Kriegsfolgenopfer. ${ }^{1252}$ Die Angaben zu den Geburtsorten bieten aber zugleich eine Art Querschnitt durch die damalige Bevölkerung dieses nun zum Grenzgebiet gewordenen Landstrichs. Neben vielen Gubenern, unter denen auch solche aus dem Ostteil gewesen sein dürften, finden sich nicht nur zahlreiche weitere Niederlausitzer von dies- und jenseits der Neiße, sondern auch Männer und Frauen aus der Neumark (Kreise Crossen und Weststernberg), aus Schlesien (Kreise Freystadt, Glatz und Sagan), der Provinz Posen (Kreise Lissa und Samter), aus (Mittel-)Polen (Zduńska Wola) und dem Sudetenland (Asch, Aussig).

1247 Stegemann, Die Nachkriegszeit 1945 bis 1948 (wie Anm. 176), S. 236.

1248 Andreae/Geiseler, Die Herrenhäuser des Havellandes (wie Anm. 1239), S. 218.

1249 Quellen zur Eingliederung in den Arbeitsprozess, auch in Brandenburg, bietet Wille II (wie Anm. 196), S. 362-489.

1250 Fürstenberg/Havel: Stegemann, Die Nachkriegszeit 1945 bis 1948 (wie Anm. 176), S. 237 f.

1251 Ebd., S. 237 (Zitat aus zusammenfassendem Bericht der Stadtverwaltung vom 11. Juni 1945).

1252 Erich Opitz: Tragische Folgen eines Weltkrieges. In: Jahrbuch für Gubener Geschichte 2012/13 (2013), S. 133-171, hier S. 145-155. 
Vielfach beschrieben ist die Situation der Vertriebenen, die auf dem Land bei einheimischen Bauern untergekommen waren und ihr Wohnrecht mit Land- oder Hausarbeit bezahlten. Auch der Schriftsteller Günter de Bruyn (geb. 1926 Berlin, gest. 2020) hat das Neben- und Miteinander von Einheimischen und Flüchtlingen in den Jahren 1946 bis 1949 als Neulehrer in dem westhavelländischen Bauerndorf Garlitz erlebt: „Obwohl viele Männer gefallen oder gefangen waren, manche Wirtschaften also von Frauen und Greisen geleitet wurden, gab es Arbeitskräfte genug; denn die Vertriebenen, Flüchtlinge genannt, meist Frauen und Kinder, die aus Schlesien und Ostpreußen, aus der Neumark, dem Wartheland und aus Bessarabien gekommen waren, bezahlten das Dach über dem Kopf mit Arbeitsleistung und wurden vorwiegend mit Naturalien entlohnt."1253

Eine damals etwa zehnjährige einheimische Dorfbewohnerin in Glashütte bei Baruth erinnerte sich 2015: „Die im Ort untergekommenen Flüchtlingsfamilien arbeiteten ebenfalls bei den Bauern, um nicht hungern zu müssen. Beim Dreschen lernte ich Edith kennen, die mit ihren Eltern aus Pommern geflohen war. Die Familie hatte zwar im ehemaligen Haus des nach 1945 enteigneten Großbauern eine Bleibe gefunden, doch mangelte es ihr an fast allem. Ediths Mutter musste täglich dafür sorgen, dass ihre sechs Kinder einigermaßen satt wurden. " ${ }^{254}$

Eine damals sechzehnjährige Schlesierin berichtete später über die nach vierzehntägigem Quarantäneaufenthalt im Lager Küchensee erfolgte „Eingemeindung“ im Kreisgebiet BeeskowStorkow ${ }^{1255}$ : „Mit meinen Eltern und meiner Schwester wurden wir nach Kehrigk transportiert und bei der Familie Pasan in einem Zimmer untergebracht. Wir hatten einen Kohleofen im Zimmer, einen Tisch und vier Stühle. Auf Stroh fanden wir unser Nachtlager. Wasser holten wir von einer Pumpe im Dorf, das Plumsklo auf dem Bauernhof durften wir benutzen. Mein Vater bekam bald Arbeit in der Försterei. ${ }^{1256}$ Mit einer Axt hatte er gefällte Bäume zu entästen. Er nahm mich oft mit zur Arbeit. Ich hatte Äste zu Haufen zusammenzutragen. So lebten wir die ersten Jahre dahin und hielten uns über Wasser. Sommers über halfen wir den ansässigen Bauern bei der Feldarbeit, und im Winter gingen wir wieder in den Wald."

Ein Flüchtlingskind aus Ostpreußen hat im Alter in Kindheitserinnerungen über den sozialen Abstieg berichtet. Während sie, eine neunköpfige Bauernfamilie, „in unserer Heimat Ostpreußen Vieh besessen hatten“, mussten sie sich nun mit der Wohnung „in einem Backhaus, das uns ein Burger ${ }^{1257}$ Bauer auf seinem Grundstück vermietet hatte“, zufrieden geben. ${ }^{1258}$ Doch Stück für Stück arbeitete man sich hoch, wenngleich die Formulierung den bescheidenen Grad der Verbesserungen andeutet: „Allmählich ging es uns wirtschaftlich wieder ein klein wenig besser.“ Typisch für die Erinnerungen von Flüchtlingskindern, die es meist viel leichter hatten, mit den

1253 Günter de Bruyn: Zwischenbilanz. Eine Jugend in Berlin. 3. Aufl. Frankfurt am Main 1992, S. 333.

1254 Sieglinde Schulze: Not macht erfinderisch. Kindheitserinnerungen aus der Nachkriegszeit. In: Heimatjahrbuch für den Landkreis Teltow-Fläming 23 (2016), S. 120-124, hier S. 121.

1255 Below, Wie ich zu meiner neuen Heimat fand (wie Anm. 726), S. 53.

1256 Er war vor 1945 Schmied.

1257 [Burg im Spreewald (Kr. Cottbus).]

1258 Rudi Höpfner: Erinnerungen eines Flüchtlingskindes an Burg. In: Stog - Der Schober 2005 (2004), S. 91-94, hier S. $91 \mathrm{f}$. 
Umstellungen zurecht zu kommen, als ihre Eltern, sind auch diese Sätze, die derselbe Ostpreuße und Neu-Burger über die Eingliederung geschrieben hat: „Nach einem Jahr hatten wir uns in Burg eingelebt. Meine Mutter war wegen ihres Fleißes bei den Bauern bekannt und als Arbeitshilfe gern gesehen. Wenn ein Bauer kam, um sie für einen Arbeitstag vorzubestellen, wurden wir Kinder gleich mit einbezogen. Natürlich hatten wir nicht immer Lust auf Feldarbeit. Da aber stets eine gute Mahlzeit in Aussicht gestellt war, und wir das Ansehen unserer Mutter in Bedacht hatten, gingen wir doch aufs Feld." 1259

Auch eine in Wilhelmshorst bei Potsdam gelandete Ostpreußin (geb. ca. 1926) zeigt in ihren Erinnerungen den positiven Lebensmut und Aufbauwillen, der viele jüngere Vertriebene beseelte und ihre Integration erleichterte, sofern Arbeit und Wohnung gesichert waren und der Hunger nicht mehr regierte: „Im September 1945 bekamen Mutter und ich bei Erna Kröhl im Grünen Weg 29 Arbeit und Wohnung. Meine Mutter sollte Frau Kröhls 90-jährige Tante und ihre 85-jährige Mutter betreuen. Dabei half ich natürlich. Wir hatten es wunderbar getroffen, es blieb mit Frau Kröhl eine Freundschaft auf Lebenszeit. “1260 „Meine Mutter hatte zu diesem Zeitpunkt [Herbst 1945] eine Nebenbeschäftigung. Sie wusch mit anderen Frauen zusammen Wäsche für das russische Militär. [...] Im Spätsommer 1945 eröffnete Herr Dietz [...] in einer Baracke eine Werkstatt zur Herstellung von Regenmänteln. Eigentlich war er Schirmfabrikant und hatte eine Filiale in Königsberg ${ }^{1261}$ gehabt, aber es fehlten zu den geretteten Stoffen leider die Gestelle. Er stellte ungefähr ein Dutzend Frauen ein, hauptsächlich Schneiderinnen. Meine Königsberger Tante und ich wurden auch eingestellt, obwohl ich keine Schneiderin war. Wie glücklich waren wir, etwas verdienen zu können, denn alle ReichsmarkKonten waren zu dieser Zeit gesperrt. "1262

In den vielen kleineren Städten war die Situation anfangs nicht grundsätzlich anders. Ein erheblicher Prozentsatz der hier untergekommenen Vertriebenen bestand aus Frauen mit Kindern $^{1263}$, die zur Untermiete wohnten, auf ihren in Gefangenschaft befindlichen Mann warteten oder Witwe waren. Um den Lebensunterhalt zu bestreiten, übernahmen sie Hilfstätigkeiten. Andere junge Frauen kamen aus mehr oder weniger weit entfernten Dörfern, um in der Stadt ihr Heil zu suchen oder für die daheim auf dem Land Befindlichen ein Zubrot zu erlangen. Eine im Sommer 1945 als 24-Jährige in ein Dorf bei Neuruppin gelangte Vertriebene, die im Krieg bereits als Erntekindergartenleiterin gearbeitet hatte, schreibt im Alter rückblickend: „Im Oktober 1947 bin ich auf Wanderschaft gegangen und habe mir Arbeit gesucht. Die Russen wollten,

Ebd., S. 91.

Balschinat, Meine Nachkriegsjahre in Wilhelmshorst (wie Anm. 308), S. 348.

[Königsberg i. Pr. (Ostpreußen). Er hatte dort nicht nur „eine Filiale“, sondern die als Kommanditgesellschaft verfasste Firma besaß ein Hauptgeschäft und zwei Filialen: Vgl. Einwohnerbuch Königsberg (Pr) 89 (1941), T. I, S. 48: „Dietz \& Co., K.-G., Verkaufsgeschäfte: Kantstraße 8, Französische Straße 12-13“), T. II, S. 79 (Französische Straße 12.13: „Schirmfabrik Dietz \& Co., K.-G. (p[arterre])“, S. 151 (Kantstraße 8: „Dietz \& Co. - Schirme- u. Lederwarengeschäft", die Firma hier zugleich Hauseigentümer), S. 184 (Lindenstraße 16.17 und 18-20 [Hauptsitz], hier jeweils Hauseigentümer: „Dietz \& Co., K.-G., Schirmfabrik“.]

Ebd.

Dies betont auch Oehlsen, Deutsche Vertriebene in Brandenburg und Sachsen (wie Anm. 45). 
dass die Mädchen zur MUNA ${ }^{1264}$ nach Wulkow gehen. Als ich das hörte, [S. 113] war für mich der Riemen runter, und ich bin gleich nach Neuruppin gegangen. Als ich hörte, hier ist ein Kinderheim, bin ich sofort hingegangen. [...] Da bin ich dann sieben Jahre gewesen, von 1947 bis 1954. [...]."1265

Eine andere, ebenfalls junge Vertriebene (geb. 1929), später Kindergartenleiterin, hat die materielle, familiäre und seelische Lage, in der sich die meisten Leidensgenossen bei Kriegsende befanden, ebenso knapp wie treffend skizziert: „Nach der Flucht aus meinem Heimatland Ostpreußen, einer beschwerlichen Reise mit Treck und Güterzug, verbunden mit trostlosen Aufenthalten in vielen Flüchtlingslagern, fand ich im März 1946 mit meiner Mutter und den Geschwistern eine erste Bleibe in Behrensdorf/Siedlung [bei Beeskow]. Mein Vater war Soldat und wir wußten zu diesem Zeitpunkt nicht, ob er den Krieg überlebt hat. Der Hunger war groß und außer den Sachen, die wir am Leib hatten, besaßen wir nichts. Wie glücklich war ich, als ich einige Wochen später im dortigen Kinderheim eine Arbeit fand. Ich wurde, obwohl erst siebzehnjährig, als Betreuerin für 25 Kinder von 0-14 Jahren eingesetzt. Drei Säuglinge sowie Findelkinder gehörten zu meiner Gruppe, die irgendwo elternlos aufgegriffen worden waren. Der Lohn war ein Taschengeld, aber er ermöglichte für meine Familie den Hunger etwas einzuschränken."1266

Selbständig gewesene Gewerbetreibende hatten es besonders schwer, da ihnen zwar ihr Know-how nicht abhanden gekommen war, aber - außer bei dem einen oder anderen Neumärker - meist sämtliche Geschäftsbeziehungen, oft auch die Papiere und, was bisweilen noch schwerer wog, ein Kundenumfeld, das ihren guten Ruf bezeugen konnte. Ein einst selbständiger Schneidermeister, der in Köslin in Hinterpommern ein angesehener „Meister seines Handwerks“ gewesen war und dort „Festanzüge und Gehröcke für die Honoratioren der Stadt und kostbare Abendgarderoben für die Damen" gefertigt hatte, musste sich an seinem neuen Wohnort Storkow (Mark) mit weniger begnügen, auch wenn er mit seinem Chef offensichtlich gut auskam, wie sein Enkel später berichtet hat: „Mein Großvater fand Arbeit bei einem Schneidermeister, dessen Werkstatt sich ganz in der Nähe unserer Dachwohnung befand. Es entstand zwischen meinem Großvater und dem, der nun sein Meister war, bald eine von Freundschaft und Vertrauen geprägte Arbeitsatmosphäre. " 1267 Doch der Großvater war längst im Rentenalter und hatte nur wegen der Nachkriegsnotlage der ernährerlosen Familie seiner Tochter wieder zu arbeiten angefangen. „Im Spätherbst des folgenden Jahres starb der Großvater. Meine Mutter, die einiges von ihrem Vater gelernt hatte, fand eine Anstellung bei einem Schneider in einem Winkel des Storkower Marktes gegenüber dem Rathaus. Er war schon weit in die Jahre gekommen [...].“

Überall angesehene und ohnehin dringend benötigte Berufe boten den Betroffenen dagegen - außer politischen - kaum Hindernisse für ein Anknüpfen an ihre Vorkriegsverhältnisse. Der Arzt Dr. Franz Freund beispielsweise „war zusammen mit Frau und Sohn 1945 aus Schlesien

1264 [Munitionsanstalt.]

1265 Ruth Preuß, [Lebensgeschichte] (wie Anm. 395), S. 112 f.

1266 Hildegard Rölke: Der erste Kindergarten. In: Storkower Zeitzeugen berichten [H. 1] (wie Anm. 271), S. 6466, hier S. 64.

1267 Sonnemann, Bittere Medizin (wie Anm. 269), S. 32 (hier auch das folgende Zitat). 
nach Altlandsberg gekommen." Sein jüngerer (einheimischer) Strausberger Kreisarztkollege Dr. Horst Rocholl hat später treffend formuliert, welche Bedeutung der Beruf für die Integration in der neuen Heimat hatte: „Er [Dr. Freund] gehörte zu denen, die nur für die Dauer der Flucht Flüchtlinge blieben. In Altlandsberg angekommen, fand er reichlich Arbeit und gewann sehr schnell wieder den Ruf, den er in seiner früheren Heimat gehabt hatte, den eines guten, menschenfreundlichen Arztes." 1268

\section{Unternehmerische Aktivität}

Aber sogar ganz außergewöhnliche Integrationsformen für Unternehmer hat es zunächst gegeben, bis die Wirtschaftspolitik der SED deren Eigenständigkeit immer mehr untergrub. Noch in den ersten Nachkriegsjahren gründeten nicht wenige vertriebene Geschäfts- und Firmeninhaber an ihren neuen Wohnorten neue Industrie- oder Handelsbetriebe, in denen sie ihre Branchentätigkeit fortzusetzen gedachten. ${ }^{269}$ Der Vorkriegs-Inhaber der Landmaschinenfabrik „Schütz \& Bethke“ aus Lippehne (Kr. Soldin/Neumark) erwarb im Mai 1946 in Frankfurt (Oder) ein 55000 qm großes Gelände hinter dem Schlachthof. Die „Märkische Volksstimme“ berichtete darüber am 10. Januar 1947: „Mit Unterstützung offizieller Stellen konnte die Firma Schütz \& Bethke in Schlosserei, Dreherei und Formerei Arbeiten wieder aufnehmen. Im Frühjahr 1947 kommen Schmiede und Gießerei dazu. Das Konstruktionsbüro arbeitet Pläne für die weitere Produktion aus. Anfangs werden vor allem Ersatzteile für Pflüge hergestellt und Reparaturen an beschädigten Landmaschinen vorgenommen. Es ist die Herstellung von Schwingplügen geplant. Ein Gemeinschaftsraum wird eingerichtet, eine Werkskantine sorgt für warmes Essen zum Preis von 40 Pf. Ein Heim für elternlose 14-17jährige Lehrlinge soll entstehen. "1270 Im Jahr 1950 hatte die Firma bereits ca. 110 Mitarbeiter. Neben dem Inhaber Waldemar Hollert, der hier eine schon in Lippehne zur Belegschaft gehörende Mitarbeiterin heiratete, stammten in den verschiedensten Abteilungen mehrere der neuen aus dem Kreis der alten Lippehner Betriebsangehörigen, unter ihnen ein Ingenieur, ein Schlossermeister und ein Werkzeugmachermeister, ein Schmied, ein Tischler und drei Former sowie vier Frauen. Die nicht zuletzt im Export starke, erfolgreich arbeitende Firma befand sich noch 1964 zumindest zur Hälfte in privater Hand, ging aber 1971 den Weg so vieler Unternehmen und wurde ein VEB. ${ }^{1271}$ Nach der Reprivatisierung bzw. Umwandlungser-

1268 Horst Rocholl: Zwei Schildkröten (Andenken an Dr. Freund). In: Lebenszeit. T. III. Zeitzeugen berichten. Hrsg. vom Landesseniorenbeirat Brandenburg u. dem Seniorenbeirat Neuenhagen. Neuenhagen [1998], S. 86-87, hier S. 86. - Es dürfte sich um den vor 1945 in Jannowitz (Riesengebirge) tätigen Arzt Franz Freund handeln (Reichs-Medizinal-Kalender 58, 1937, T. 2, S. 259).

1269 Siehe die 1947 aufgestellte umfangreiche Liste der „durch Umsiedler“ gegründeten Betriebe: BLHA, Rep. 333 SED-Landesleitung Brandenburg, Nr. 574, Bl. 225r-238v (Teilabdruck im Quellenteil, Nr. 131).

1270 Zeitungsbericht der Märkischen Volksstimme vom 10.1.1947, hier nach: Paul Hakus: Die Geschichte der Firma Schütz \& Bethke, gegr. 1857, in Lippehne, Kreis Soldin/Nemark. II. Teil: Frankfurt (Oder) 1946/47 bis 1971. In: Heimatblatt des Kreises Soldin/Neumark 63 (2011), Nr. 211, S. 10-11, hier S. 10.

1271 Ebd., S. 11. 
klärung vom 30. August 1990 übernahm der letzte Betriebsleiter, ein Enkel Waldemar Hollerts, der 1941 noch in Lippehne geborene Ingenieur Peter Bokelmann, 1991 die Firma als persönlich haftender Gesellschafter (Schütz und Bethke KG) und führte sie bis zu seinem Tod 2000. Mit der Löschung der Kommanditistin, seiner als Ärztin in Frankfurt (Oder) tätigen Schwester Dr. Christa Blunck geb. Bokelmann wurde die Gesellschaft Ende 2005, da Erben fehlten, aufgelöst. ${ }^{1272}$ Trotz des späten Endes ist diese Firmen- und Familiengeschichte ein - sehr ungewöhnliches - Beispiel für die Zähigkeit, mit der eine vertriebene Familie und ihre Nachkommen am neuen Standort, mithin in unmittelbarer Nähe zur Neumark, unter schwierigen Bedingungen und in engem Zusammenhalten ${ }^{1273}$ Kontinuität wahren konnte.

In Falkensee eröffnete der aus Sommerfeld/NL (Kr. Crossen) geflüchtete Bäckermeister und Schokoladenfabrikant Julius Lohan schon kurz nach Kriegsende eine neue Schokoladenfabrik „und erreichte wieder eine Beschäftigtenzahl bis zu 40 Betriebsangehörigen“. Er starb allerdings schon 1946, seine Witwe, Pauline geb. Drabach, 1952. Der Sohn, Kaufmann Erich Lohan, der 1946 und 1950 in Berlin-Spandau weitere verwandte Firmen gegründet hatte (später in Berlin-Charlottenburg, Salzufer 20), konnte den Falkenseer Standort nur noch wenige Jahre halten und verließ ihn $1951 .^{1274}$

Auch aus der Prignitz ist ein solcher Versuch, nach 1945 Kontinuität in der Firmengeschichte zu wahren, überliefert. Anfang des 20. Jahrhunderts hatte der Schäfermeister Paul Schulz in Politzig (Kr. Meseritz) in der Provinz Posen begonnen, sich in Dränagearbeiten zu versuchen, und gründete schließlich kurz vor dem Ersten Weltkrieg am Ort ein Tiefbauunternehmen. In den zwanziger Jahren saß die Firma, nun „Schulz \& Schöler“ in Meseritz und arbeitete mit 30 bis 40 Arbeitskräften u. a. an der laufenden Instandhaltung der Obra, der Eisenbahnstrecken der Bahnmeisterei Meseritz, der Meseritzer Kanalisation sowie im Straßenbau. 1938 übergab der Gründer das Unternehmen an seine beiden Söhne. „Auch während des Krieges lief der Betrieb weiter. Bis dann durch Flucht und Vertreibung im Januar bzw. Juni 1945 schlagartig Feierabend geboten wurde.“ Pauls Enkel Herybert Schulz schrieb 2011 über den „Neubeginn westlich der Oder“: „Nachdem sich unsere Familie nach dem Krieg in Neu Krüssow in der Prignitz etabliert hatte, waren wir bei Frau Reibe in Brot und Lohn. Frau Reibe hatte eine Landwirtschaft von 45 ha. Arbeit war also ausreichend vorhanden. / Allmählich ordneten sich die Verhältnisse und mein Vater sowie Onkel Georg wollten sich wieder selbständig machen. Onkel Georg mit seiner Familie wohnte $7 \mathrm{~km}$ entfernt von uns in Bölzke und war auch in der Landwirtschaft tätig. / Ende Mai 1947 wurde der Antrag gestellt und so konnten wir am 1. Juli 1947 als Tiefbauunternehmen Friedrich

1272 Ebd., S. 12 (nach dem Eintrag im Handelsregister).

1273 Den engen Zusammenhalt der Familien Hollert und Bokelmann hebt ein ehem. Mitarbeiter als Zeitzeuge (ebd., S. 11) hervor.

1274 Max Platzke: Geschichte einer ostdeutschen Kleinstadt kommunalpolitisch betrachtet. Berlin-Charlottenburg 1956, S. 50. - Adreßbuch der Stadt Sommerfeld (Niederlausitz) 1940, S. 34 (Pförtener Str. 17). - GVBl. Brandenburg 1947, S. 224 (Eintragung in das Handelsregister beim Amtsgericht Falkensee, 19.5.1947: Inhaber: Witwe Pauline L., Prokuristen: Erich L. und Ehefrau Gertrud geb. Pfütze, alle wohnhaft Falkensee). - Amtsblatt für Berlin 1959, Bd. 9, S. 894 (Vergleichsverfahren aufgehoben). 
und Georg Schulz Neu Krüssow die Arbeit beginnen. Unsere Hauptauftraggeber waren die Wiesenbauämter, später die Wasserwirtschaftsdirektionen und Kommunen. Ab 1.10.1947 war ich dann als Lehrling, Vorarbeiter und später als Hilfsschachtarbeiter tätig. Onkel Georg schied 1954 krankheitsbedingt aus. / Auf Anweisung von Partei und Regierung der DDR wurde der Familienbetrieb Schulz bei voller Auftragslage am 1.10.1958 zm VEB (K) Tiefbau Pritzwalk umfunktioniert. Mit uns gingen noch zwei weitere Firmen diesen Weg./Mein Vater fand Anstellung als Technischer Leiter und ich als Bauleiter. An der Bauschule Blankenburg/Harz habe ich die Meisterschule absolviert. Bis zum Rentenalter meines Vaters war ich dann noch im Tiefbau Pritzwalk tätig. / Mein neuer Brötchengeber wurde dann die Wasserwirtschaftsdirektion Magdeburg. Hier habe ich mich dann nach 7 Jahren zum Dipl.[-]Ing. qualifiziert. Im Bereich der Mittleren Elbe, Sude-Elde, war ich bis 1993 als Inspektor der Staatlichen Gewässeraufsicht tätig. Nach der Auflösung der WWD Potsdam wurde ich vom Landkreis Prignitz übernommen und konnte dort sogar noch $1 / 2$ Jahr über mein Rentenalter hinaus in der unteren Wasserbehörde arbeiten. / In den genau 49 Jahren meiner Tätigkeit hier in der Prignitz führte ich meinen Traumberuf mit Hingabe aus. Während unserer Zusammenkünfte innerhalb der Familie kamen wir aber immer wieder auf die Obra zu sprechen. ${ }^{1275}$

\section{Deklassierung oder Aufstieg?}

Letztlich kann mit diesen wenigen Integrationsbeispielen, die etwas holzschnittartig Fälle von Aufstieg bzw. Bewahrenkönnen des alten Status einerseits und sozialer Deklassierung andererseits aufzeigen, das Spektrum nur grob umrissen werden. Zudem sind im Grunde nur lückenlos bis zum Lebensende überlieferte Biographien wirklich aussagekräftig, um sich ein Urteil bilden zu können. Wertvoll sind dafür zumindest die lebensgeschichtlichen Interviews, die von Seiten der Volkskunde und Alltagsgeschichte geführt worden sind. ${ }^{1276}$ Das im Folgenden anhand ihrer eigenen Aussagen geschilderte Beispiel einer Vertriebenen, die schwere körperliche und seelische Belastungen in ihr Erwachsenenleben mitbrachte, mag immerhin aufzeigen, dass Arbeit und Wohnung nicht immer ausreichten, um sich als Staatsbürger wieder wertgeschätzt zu fühlen. Eine junge Neumärkerin aus dem Kreis Reppen, Erika Breske geb. Roy (geb. 1924), die im Februar 1945 durch sowjetische Soldaten ihre Mutter verlor, wurde kurz darauf mit anderen

1275 Herybert Schulz: Die Obra - ein Nebenfluß der Warthe. Gründung des Tiefbauunternehmens Schulz. Neubeginn westlich der Oder. In: Heimatgruß. Zeitschrift für Mitglieder und Freunde des Heimatkreises Meseritz e. V. und der Heimatkreisgemeinschaft Birnbaum 196 (2011), S. 28-29, Zitate S. 29. - Ein ähnliches Beispiel der „Transformation“ einer von einem Vertriebenen in der neuen Heimat wiedereröffneten Firma bildet das Küstriner Bauunternehmen Christian Zölker, das nach der Flucht in Frankfurt (Oder) ansässig wurde, sich dort u.a. 1947 im Brückenbau betätigte und in mindestens einem (belegten) Fall sogar einen ehemaligen Küstriner Beschäftgten nach dessen Rückkehr aus Gefangenschaft wieder einstellte. Dessen 1947 zeitweise ebenfalls in der Firma tätiger Neffe, Horst Burghause (geb. 1928), erinnerte sich im Alter: „Später wurde dann aus dieser Firma die Frankfurter Bauunion" [VEB Bauunion Frankfurt (Oder)] (Gespräche mit ehemaligen Küstrinern. Aufgez. u. bearb. von Siegfried Neubauer. Bd. 3. Petershausen 2005, S. 29-60, hier S. 49). Zur Firma siehe auch (nicht eingesehen): BLHA, Rep. 280 IHK, Nr. 377 (Laufzeit 1948-1950).

1276 Siehe besonders die Arbeiten von Dagmar Semmelmann (wie Anm. 52). 
Frauen und Mädchen in das Lager Schwiebus gebracht und von dort per Viehwaggon in ein Arbeitslager im Norden der Sowjetunion transportiert, wo sie, wie viele andere, Schwerstarbeit leisten musste. Nach Typhuserkrankung und diagnostizierter Herzmuskelschädigung wurde sie im Dezember 1945 nach Deutschland entlassen ${ }^{1277}$ : „An einen Güterzug wurden nun drei Viehwaggons mit Schwerkranken angekoppelt und nach Deutschland transportiert, wieder ohne Decke, aber mit Blechnapf und Holzlöffel versehen! Auf dem Bahnhof in Reppen bekamen wir dann wirklich mit, daß wir uns in Polen und nicht mehr in Deutschland befanden. In Frankfurt wurden wir ausgeladen und unter militärischer Bewachung in Kasernen untergebracht. Am nächsten Tag ging es zum Güterbahnhof und wieder in Viehwaggons Richtung Berlin. Gesagt wurde uns nie etwas. Aber es sickerte durch, daß wir in ein Lager nach Brandenburg gebracht werden sollten. Der Gedanke daran war schrecklich! Nein, nie wieder ein russisches Lager. Im Dezember 1945 verließen zwei Mädchen und ich im völlig zerstörten Berlin unsere Waggons, um uns auf eigene Faust auf die Suche nach unseren Angehörigen zu machen. Der einzige Anhaltspunkt war Richtung Storkow. Ohne einen Pfennig Geld in der Tasche machten wir uns auf den Weg und landeten schließlich nach einer beschwerlichen Wegstrecke bei der Familie Hauke ${ }^{1278}$ in Tauche ${ }^{1279}$. Ihnen konnten wir eine erfreuliche Nachricht überbringen: Tochter Hilde sei gesund und arbeite im Lazarett, aus dem wir kamen. Bei Haukes erfuhr ich, daß mein Schwester im Krankenhaus in Beeskow gewesen sei, aber ob sie noch lebe, wußten sie nicht. Das waren wieder bange Stunden. Ein Pferdewagen nahm uns mit nach Beeskow. Froh war ich, daß meine Schwester lebte, aber traurig, daß sie Beeskow bereits verlassen hatte. Erst im Februar 1946 sah ich sie in Nörten-Hardenberg ${ }^{1280}$ wieder. Kurz danach hatte sich mein Vater aus englischer Gefangenschaft nach Beeskow begeben, weil er mich dort vermutete. Schweren Herzens fuhr ich also von Nörten-Hardenberg wieder nach Beeskow zurück; in meiner Anmeldebescheinigung des Einwohnermeldeamtes vom 18.12.45 stand [S. 148] der Vermerk ,... aus russischer Kriegsgefangenschaft.' Im September 1946 war ich dann gesundheitlich soweit, daß ich eine Anstellung als Kindergärtnerin im damaligen Schulkindergarten in Beeskow antreten konnte." Die im sowjetischen Arbeitslagerlazarett zeitweise mit dem Tode ringende junge Frau hatte psychisch Kraft und Lebenswillen geschöpft auch aus dem einen Gedanken „Ich wollte meinen Vater und meine Schwester wiedersehen. “ Folgen und Spätfolgen blieben - neben aller allmählichen Integration in das neue Arbeits- und Familienleben in der DDR - gleichwohl zurück. Rückblickend hat sie nach 1990 dazu geschrieben: „Durch

1277 Erika Breske: Schlimme Erinnerungen an 1945. In: Materne/Gerlach, Gross-Gandern und Klein-Gandern (wie Anm. 351), S. 146-148, die folgenden Zitate S. 147 f. - Das Lager Schwiebus (poln. Świebodzin) war ein sowjet. Speziallager (Ende Sept. 1945 verlegt nach Mühlberg/Elbe). Siehe den ausführlichen Bericht des Lagerarztes (ebenfalls ab Febr. 1945, zuvor Arzt in Berlinchen/Nm.) S[iegfried] von Sivers: Das Gefangenenlager in Schwiebus. In: Ostbrandenburg-Neumark 4 (1953), Nr. 8, S. 6-7; Nr. 9, S. 5-7; Nr. 12, S. 6; Nr. 13, S. 6-7; Nr. 14, S. 8-9; Forts.: Unsere Märkische Heimat 4 (1953), Nr. 19, S. 8-9; Nr. 20, S. 4-5; Nr. 21, S. 4-5; Nr. 22, S. 4-5; Nr. 23, S. 8-9; Nr. 24, S. 6-7; 5 (1954), Nr. 1/2, S. 4-7; Nr. 3, S. 4-5; Nr. 4, S. 6-8; Nr. 6, S. 4-5; Nr. 8, S. 4-5; Nr. 9, S. 5.

1278 [Aus demselben Heimatdorf stammend.]

1279 [Bei Beeskow.]

1280 [Bei Göttingen (Britische Zone).] 
die Verschleppung und deren Folgen war ich gesundheitlich ziemlich angeschlagen. Immer wieder mußte ich meine Berufstätigkeit unterbrechen und die Versorgung der Familie meinem Mann allein überlassen. Zu DDR-Zeiten waren Verschleppung von Zivilpersonen in die Sowjet-Union und ähnliche Dinge Tabuthemen. Nach der Wende stellte ich einen Antrag auf Kriegsopferversorgung für die erlittenen gesundheitlichen und seelischen Schäden. Weitgefehlt! Zweimal bekam ich einen abschlägigen Bescheid. Angeblich bestünde kein Zusammenhang zwischen meinen schweren Erkrankungen in der Sowjet-Union unter primitivsten Bedingungen und meinen jetzigen gesundheitlichen Beschwerden. [...] Diesbezüglich bin ich traurig und enttäuscht. Ich fühle mich in keiner Weise rehabilitiert, habe aber bis jetzt überlebt. [...]." Erika Breske steht für jene vertriebenen Frauen und Männer, deren Schicksal nicht nur durch Heimatverlust und Flucht- bzw. Vertreibungsgeschehen geprägt ist, sondern auch durch Deportation und Lageraufenthalt. ${ }^{1281}$

Die Vertriebenen waren freilich keineswegs in Gänze oder gar auf Dauer zu versorgende Sozialfälle. So sehr sie für die Kommunen zunächst die „belastende“ Zahl der Hungrigen und notgedrungen Unzufriedenen vergrößerten, so groß war schließlich doch das „bereichernde “Werktätigenpotential, das sich dem neuen Staatswesen in Fülle bot. Nicht nur durch den Krieg gerissene Lücken in der einheimischen Bevölkerung ließen sich so - aus volkswirtschaftlicher Sicht - schließen, sondern gerade ein im Aufbau befindliches System, das auf Polizei und dann auch Militär, auf neue Verwaltungs- und Schulstrukturen und nicht zuletzt auf neue, große Industrien setzte, um sein Modell einer sozialistischen Gesellschaft aufzubauen, benötigte in großer Zahl Menschen, die bereit waren, sich von ihm führen zu lassen. So sehr die SED auf der einen Seite gerade in den Vertriebenen ein fortdauernd zu beobachtendes, politisch „unzuverlässiges“ Unruhepotential sah, so sehr lag auf der anderen Seite gerade in der Atomisierung, in der Trennung einer so großen Menschenmenge von ihren bisherigen heimatlichen, großfamiliären, konfessionellen, sozialen und wirtschaftlichen Lebensstrukturen auch ein - durch Wohltaten zu gewinnendes - großes Potential für einen Neuanfang. Wer alles verloren hatte, nichts besaß, dem bot - gerade bei den jüngeren, Orientierung suchenden Vertriebenen - die Versorgung mit einer neuen, festen Struktur Halt und gab seinem Leben auch wieder Sinn. Zwar darf man die besonders unter den Vertriebenen überdurchschnittlich hohe Zahl von „Republikflüchtlingen“, die gerade nicht mit den neuen politischen Verhältnissen einverstanden waren, nicht vergessen, doch ist ebenso offenkundig, dass wie in der Bundesrepublik auch - das Potential aufbau- und aufstiegswilliger Vertriebenen der mittleren und jüngeren Jahrgänge für Staat und Wirtschaft von elementarer Bedeutung war. In der DDR - das zeigen viele Erinnerungen Vertriebener, die dort blieben - war es zumindest für die, die keinen bürgerlichen „Ballast“ mit sich schleppten oder als Neubauern dann in die Kollektivierung gedrängt wurden, möglich, eine Heimat zu finden, die Arbeit, Brot und auch Halt gab, wenn man sich auf die politische Linie einließ oder wenigstens mit ihr zu arrangieren wusste.

Ein 1945 im Zuge der „Wilden Vertreibungen“ aus Schlesien Vertriebener (geb. ca. 1929), der über Forst (Lausitz) vorübergehend nach Luckau gelangte, 1952 aber (mit seinen Eltern 
und seiner Freundin und späteren Frau) einen festen Lebensmittelpunkt in Wilhelmshorst bei Potsdam fand, hat seine Aufnahme in der DDR, seine Integration - wie viele andere - mit dem verbreiteten Begriff der „neuen Heimat“ bezeichnet und letztlich positiv bewertet: „Luckau wurde dadurch für uns eine Zwischenheimat von fünf Jahren. Hier machte ich mein Abitur und verlebte die ersten Nachkriegsjahre. [...] Hier in Wilhelmshorst leben wir nun seit über 50 Jahren und haben für uns und unsere Kinder eine neue Heimat gefunden [... . " ${ }^{1282}$ In seinem Fall heilte die Zeit nicht nur die eine große Wunde des Heimatverlusts, sondern selbst den „Karriereknick“, den ihm die SED in jungen Jahren beschert hatte. 1950-1952 hatte er an der damaligen Brandenburgischen Landeshochschule in Potsdam (der späteren Pädagogischen Hochschule und heutigen Universität) Psychologie zu studieren begonnen, wurde aber - Näheres erfährt man nicht - „aus politischen Gründen relegiert“. Lapidar schreibt er dann: „Im brandenburgischen Vermessungsdienst in Potsdam fand ich schließlich Arbeit als Zeichner. "1283 Rückzug ins Private?

\section{Staatsorgane und Industriebetriebe}

Ein 1926 geborener Kriegsheimkehrer, der 1949 aus sowjetischer Gefangenschaft zurückkehrte und später Offizier der Volkspolizei wurde, hat seinen Weg als Heimatloser etwas näher beschrieben: „Als ich mich noch in russischer Gefangenschaft befand, wurden meine Eltern 1946 als Deutsche aus dem Sudetenland ausgesiedelt. In einem Brief, den ich 1949 im Lager erhielt, erfuhr ich, daß sie in Lubart [Lubast!], Kreis Wittenberg, ihr neues Zuhause gefunden hatten. Darum führte mich mein Weg aus der Gefangenschaft am 1. April 1949 über Frankfurt/Oder, Berlin-Anhalterbahnhof in Richtung Wittenberg. [...]. “1284 Die Eltern lebten außerhalb des Ortes in einem Häuschen tief im Wald. „Als ich das Haus betrat, fand ich mein neues jämmerliches Zuhause. Aber das spielte jetzt keine Rolle. Nach fünf Jahren Trennung und Warten und einem spärlichen Weg hatten wir uns wiedergefunden. Nun gingen die normalen amtlichen Regelungen vonstatten und die Suche nach Arbeit begann. Bei einem Friseurmeister konnte ich am Wochenende ein paar Mark verdienen, aber es reichte nicht zum Leben. Auf dem Arbeitsamt konnte man mir nur eine Arbeit nachweisen: Erzbergbau in Johanngeorgenstadt. Ich sagte zu. [...]. [S. 37] [...] Als im im Herbst 1949 wieder einmal bei meinen Eltern weilte, wurde ich angesprochen, ob ich mich nicht zur Volkspolizei melden wollte. Es war eine schwere Entscheidung, nach zwei Jahren Arbeitsdienst und vier Jahren Gefangenschaft wieder eine Uniform anzuziehen. Aber da die Zustände im Erzbergbau katastrophal waren und für mich fast unerträglich wurden, ging ich diesen weg. Ich meldete mich freiwillig und kam zur HVA ${ }^{1285}$, dem Vorläufer der kasernierten Volkspolizei, zu der ich am 10.12.1949 nach Brandenburg/Havel, Dienststelle Hohenstücken eingezogen wurde.“

1282 Krakau, Flucht aus Schlesien (wie Anm. 1206), S. 346.

1283 Ebd.

1284 Rudi Ambrosch: Aus der Gefangenschaft in ein unbekanntes Land. In: Storkower Zeitzeugen berichten [H. 1] (wie Anm. 271), S. 37-38.

1285 [Hauptverwaltung Ausbildung (im Ministerium des Innern der DDR).] 
Die Werbung für die Polizei, den Uranbergbau und manches andere Feld begann, wie oben gezeigt, oft schon in den Vertriebenen- und Heimkehrerlagern, erfolgte aber auch sonst allerorten. ${ }^{1286}$ Dass z.B. sudetendeutsche Kommunisten willkommenes Personal für die Geheimpolizei boten, ist an anderer Stelle bereits erwähnt worden. ${ }^{1287}$ Letztlich war aber der Vertriebenenhintergrund, der Orientierungs- und Haltsuche mit sich bringen konnte, weniger entscheidend als die im Aufbau befindliche, für alle, auch Einheimische, gleiche Struktur einer egalisierten Gesellschaft ohne „ablenkende“ Milieus wie bürgerliche Vereine, Kirchen oder gar die Definition über landsmannschaftliche Elemente. In einer Massengesellschaft und z. B. in einem großen „Staatsorgan“ war der Sachse, der Brandenburger oder der Mecklenburger nicht anders gestellt als der Schlesier, der Ostpreuße oder Sudetendeutsche, wenn letztere sich nicht über ihre Herkunft und Heimat, sondern über die dienstliche Zugehörigkeit definierten, mithin sich auf dem Wege einer Assimilation integrierten und ihren „Vertriebenenhintergrund“ allenfalls noch zu Hause, in der Familie thematisierten und pflegten. So wird man in der DDR - bis in die höchsten Funktionen hinein - kaum einen Bereich finden, in dem nicht auch Vertriebene „untergekommen“ sind. Auch unter den Generälen der NVA finden sich später neben den mehrheitlich vertretenen Sachsen und Mecklenburgern, wenn auch ohne den hier in erster Linie interessierenden Brandenburg-Bezug, einzelne Vertriebene aus den ehemaligen deutschen Ostgebieten (Neumark, Ostpreußen, Schlesien) ${ }^{1288}$ und dem Sudetenland ${ }^{1289}$, unter letzteren ein ehemaliger Funktionär der Kommunistischen Partei der ČSR ${ }^{1290}$.

1286 Ein aus der Neumark stammender Vertriebener z. B. berichtet: „Vom Arbeitsamt wurde uns dringend angeraten, als einzige Möglichkeit, zum Uranerzabbau zur DASG [SDAG] Wismut Aue zu gehen. Nein, das wollten wir nicht, $z u$ viele schlechte Nachrichten über die Verhältnisse bei dieser Deutsch-Sowjetischen [Sowjetisch-Deutschen] Aktiengesellschaft waren im Umlauf. Seit längerer Zeit wurde aber auch für die ,Deutsche Volkspolizei' geworben. Viele mir bekannte Jugendliche waren dort hingegangen [...]. In der FDJ wurde dafür geworben, Offiziere und Parteigenossen der SED schilderten das Leben bei der Volkspolizei in den schönsten Farben. / Kurzer Entschluß von uns drei Arbeitslosen, wir gehen zur Polizei. Fragebogen ausfüllen, Bewerbung schreiben und zwischen Weihnachten und Neujahr 1950 war der Einberufungsbefehl da. / Zunächst ging es nach Brandenburg/Havel, Objekt Hohenstücken. " [...].“ (Karl-Heinz Preuß: Die Gedanken sind frei. Lebensgeschichte eines Vertriebenen. Privatdruck o. O. [ca. 2009], S. 109). - Siehe auch Quellenteil, Nr. 66 (Lager Küchensee, Tagesbericht vom 2.9.1948). - Anfangs gab es für den (Wismut-)Uranerzbergbau sogar Zwangsrekrutierungen, besonders von Flüchtlingen und Vertriebenen sowie entlassenen Kriegsgefangenen (siehe z. B. Holz, Evakuierte, Flüchtlinge und Vertriebene auf der Insel Rügen [wie Anm. 19], S. 527). - Zu Vertriebenen im Uranbergbau in Sachsen siehe Jahn, Zur sächsischen Spezifik der Aufnahme von Vertriebenen Deutschen 1945 bis 1949. Das Fallbeispiel Uranbergbau (wie Anm. 18).

1287 Siehe oben im Kapitel II. 2 den Abschnitt zu den Transporten.

1288 Klaus Froh / Rüdiger Wenzke: Die Generale und Admirale der NVA. Ein biographisches Handbuch. Hrsg. vom Militärgeschichtlichen Forschungsamt. 2., durchges. Aufl. Berlin 2000, S. 124 (Erwin Kohlmay, geb. 1930 Rehdorf/Neumark); S. 125 (Raimund Kokott, geb. 1930 Geses [Geseß!], Kr. Neisse; „1945 bis 1948 ,Umsiedlung“ in d. SBZ“), S. 180 (Horst Skerra, geb. 1930 „Kulsen (Polen)“ [Kr. Goldap, Ostpreußen], „1945 bis 1948 Traktorist, UdSSR, ,Umsiedlung“ in d. SBZ“), S. 209 (Manfred Zeh, geb. 1933 Heidewilxen, Kr. Trebnitz, „1945 bis 1946 ,Umsiedlung“ in d. SBZ“).

1289 Ebd., S. 110 f. Walter Herkner, geb. 1928 Alt-Habendorf, Kr. Reichenberg (ČSR), „1945 bis 1948 ,Umsiedlung' in d. SBZ" (S. 111).

1290 Ebd., S. 117 (Fritz Johne aus Ketten, Kr. Reichenberg), „1946/47 ,Umsiedlung“ in d. SBZ“. 
Die neu gegründeten industriellen Großbetriebe, die die DDR besonders in Grenznähe errichtete - Schwedt ${ }^{1291}$, Eisenhüttenstadt ${ }^{1292}$, Guben ${ }^{1293}$-, wurden republikweit Anziehungspunkte für Arbeitskräfte. Nicht immer wird in den dazu erschienenen Darstellungen darauf hingewiesen, dass dieses Phänomen auch erhebliche Bedeutung für die Eingliederung der Vertriebenen besaß. ${ }^{1294}$ Aber die egalisierende, assimilierende Wirkung der Aufnahme in die zahlreiche Belegschaft eines solchen Großbetriebs ließ eben auch hier den zugewanderten Sachsen oder Mecklenburger genauso in der „Masse“ „aufgehen“ wie den Vertriebenen. Insofern sind auch diese Unternehmen nicht in erster Linie ein Sammelpunkt für das durch Flucht und Vertreibung zur Verfügung stehende Arbeitskräftereservoir, aber sie bilden doch - wie Volkspolizei und NVA - ein Element, das zumindest indirekt und wirtschaftlich-finanziell mit zu einer oberflächlichen - Lösung der „Umsiedlerfrage“ beitrug.

Nicht zu unterschätzen ist in diesem Zusammenhang auch die gleichsam - oberflächlich „befriedende“ Wirkung dieser - damals als auf Dauer sicher anzunehmenden - Arbeitsplatzgeber auf das von SED (und MfS) noch Jahre nach Kriegsende beobachtete Potential besonders kritischer Bewohner der Grenzregionen, die zum Teil noch immer auf Rückkehr in ihre Heimat hofften, zum Teil die Oder-Neiße-Grenze ablehnten und zuweilen auch offen kritisierten. So hatte das Chemiefaserwerk in der durch die Abtrennung von der Altstadt stark geschwächten Reststadt Guben einen großen Einzugsbereich, weit über die zahlreichen in der Stadt selbst neu angesiedelten Mitarbeiter hinaus: „Ein Großbetrieb mit fast 8000 Beschäftigten, von denen Frauen und Mädchen mit 5000 den größten Anteil stellten, war entstanden. Zwischen Forst, Cottbus, Peitz, Eisenhüt- [S. 106] tenstadt, den umliegenden Gemeinden, Polen und Guben herrschte reger Berufsverkehr. Mit Bahn und Bus, dem eigenen PKW, dem Rad und zu Fuß waren die Leute unterwegs. Jeder Schichtwechsel glich einer Völkerwanderung. " ${ }^{1295}$ Da die SED aus der fortdauernden Beobachtung Vertriebener durch das MfS wusste, dass die Oder-NeißeGrenze keineswegs von allen als unverrückbare „Friedensgrenze“ angesehen wurde und ein erheblicher Teil von ihnen in den Grenzgebieten gerade auch der brandenburgischen Bezirke Frankfurt (Oder) und Cottbus wohnte, wird man in der gezielten Ansiedlung Arbeit gebender grenznaher Industrie-Großbetriebe in Schwedt, Eisenhüttenstadt und Guben - neben diversen anderen, wohl primären Gründen ${ }^{1296}$ - zumindest auch die Ruhigstellung dieses potentiellen

1291 Ab 1960 Erdölverarbeitungswerk Schwedt, ab 1970 Petrolchemisches Kombinat.

1292 Ab 1951 Eisenhüttenkombinat Ost (EKO).

1293 Ab 1964 Chemiefaserwerk Wilhelm-Pieck-Stadt Guben.

1294 Siehe aber jetzt Goller, Eine neue Heimat? (wie Anm. 129); ferner: Dierk Hoffmann: Vertriebenenintegration durch Arbeitsmarktlenkung? Zur Beschäftigungspolitik der SBZ/DDR (1945-1950). In: Geglückte Integration? (wie Anm. 18), S. 173-192.

1295 Rita Kirsch: Wie ein Großbetrieb das Leben in Guben veränderte. In: Gubener Heimatkalender 44 (2000), S. 104-108, hier S. $105 \mathrm{f}$.

1296 Zur Diskussion um die Mehrschichtgkeit der Gründe für die Standortwahl siehe u. a. Goller, Eine neue Heimat? (wie Anm. 129), S. 29f. - Siehe auch: Gerhard Buschmann: Vor 50 Jahren: Grundsteinlegung zum „Chemiefaserkombinat Guben“. In: Gubneer Heimatkalender 54 (2010), S. 61. 
Unruheherds durch Versorgung mit Arbeit und Bindung an Wohnraum, wenn nicht gar die Zerschlagung von Vertriebenenmilieus, die sich aber letztlich dann auch „automatisch“ ergab, sehen können. ${ }^{1297}$

Hinzu kommt, dass die SED nicht nur auf dem Land, sondern auch in den Städten eine massive Modernisierung der Arbeitswelt nach Stalins Vorbild anstrebte. Da diese parallel zum Aufbau einer „sozialistischen Gesellschaft“ verlief, ließen sich politisch schwer zu beherrschende Gruppen wie jene, die noch immer von Rückkehr in ihre Heimat träumten, viel leichter dadurch für das neue System gewinnen, dass man sie und ihre Herkunftsbindungen in den großen Industriebetrieben mit ihren anonymisierten Belegschaften oder in den staatlichen Organen wie Polizei und anderen aufgehen ließ. Anders als in den ländlichen und auch den kleinstädtischen Milieus, wo Einheimische und Zugewanderte noch jahrelang erkennbar blieben, waren in der Fabrik oder bei der Polizei alle gleich. Das trug, neben der Bevorzugung bei der Vergabe von (Neubau-)Wohnraum, ganz wesentlich zur Steigerung der Attraktivität dieser (sozialistischen) Arbeits- und Lebensbereiche bei und zog gerade die entwurzelten jüngeren Vertriebenen besonders an. Sozialismus und Modernisierung gingen hier Hand in Hand, der Einzelne profitierte vordergründig, aber er musste dafür langfristig betrachtet auch Opfer bringen, nicht zuletzt das der Lösung von fast allen alten Bindungen.

\section{Neulehrer}

Ein ebenfalls häufig mit „Umsiedlern“ und nachkriegszeitlichem „Neuaufbau“ in der SBZ in Verbindung gebrachtes Tätigkeitsfeld sind die Schulen. Der Typus des „Neulehrers“ findet sich nicht selten in der Biographie junger Vertriebener, doch sollte man auch hier berücksichtigen, dass es sich um keine „Arbeitsbeschaffungsmaßnahme“ für „Entwurzelte“ handelte, sondern um ein Modell, das generell mit nicht durch den NS-Lehrerbund vorbelasteten Kräften die neue (sozialistische) Einheitsschule aufbauen helfen sollte. ${ }^{1298}$ Daher kam auch hier grundsätz-

1297 Nur am Rande sei hier darauf hingewiesen, dass die DDR-Führung auch in anderen Bereichen darauf achtete, dass die Vertriebenen in der Bevölkerung der östlichen Grenzregionen möglichst nicht zu einem Unruheherd wurden: „Zehn Projekte neuer katholischer Sakralbauten, also ein ziemlich großer Anteil an der Gesamtmenge, entstanden verhältnismäßig dicht an der Grenze zu den Nachbarstaaten Polen und ČSSR. Einige von diesen waren bereits seit den 1950er Jahren beabsichtigt, wurden jedoch wegen der politischen Brisanz lange verzögert und erst zu dieser Zeit [in den 1960er Jahren] genehmigt." (Schädler, Katholischer Sakralbau [wie Anm. 854], S. 83).

1298 Siehe besonders die Arbeiten der Literaturhistorikerin Petra Gruner (geb. 1958), v. a.: „... Steineklopfen wär’ auch möglich gewesen“. Der Neubeginn in der Erfahrung von Neulehrern. In: Der 8. Mai 1945 als historische Zäsur (wie Anm. 55), S. 128-151 [bringt auch Beispiele Vertriebener: S. 137-139 Joachim Helm, Schlesier, später bis 1988 Lehrer an einer POS; S. 141 f. Elisabeth Nowak, aus Böhmen; basierend auf Interviews, „im Rahmen des vom Ministerium für Bildung, Jugend und Sport des Landes Brandenburg geförderten Projekts ,Biographien, Karrieremuster und Bedeutung der Neulehrer für die Sozialgeschichte der Erziehung der DDR‘ geführt“ (gemeinsam mit Horst Messmer, Univ. Marburg)]. - Dies.: Die Neulehrer: Schlüsselsymbol der DDR-Gesellschaft. In: Aus Politik und Zeitgeschichte (1999)38, S. 25-31 (ohne Thematisierung der TeilRekrutierungsgruppe Vertriebene). - Dies.: Die Neulehrer - ein Schlüsselsymbol der DDR-Gesellschaft. Bio- 
lich der Einheimische genauso als Kandidat in Frage, und so findet man in Brandenburg unter den „Neulehrern“ nicht wenige arbeitslose einheimische frühere Landarbeiter neben - zahlreichen - Vertriebenen: „1500 nicht belastete Umsiedlerlehrer und 2000 Neulehrer, die notdürftig geschult wurden, traten an die Stelle der entlassenen." 1299

Die Attraktivität solcher Angebote des neuen Staates zeigt sich auch im Fall eines achtzehnjährigen Vertriebenen, der, am 1. September 1945 nach Kriegsverletzung schwerstbeschädigt aus dem Gefangenenlagerlazarett Küchensee (bei Storkow) entlassen, zunächst einen zweijährigen Arbeitsvertrag als Zivilbeschäftigter bei verschiedenen sowjetischen Kommandanturen erhielt: „So zog ich durch das Land und versuchte meine Angehörigen zu finden. Ich hatte Glück. Bei Drehna sprach ich zufällig eine Schlesierin an, die aus meinem Heimatort war. Sie wusste, dass meine Mutter im Nachbarort leben würde. ${ }^{1300}$ Dort also war endlich wieder ein Halt gefunden. Er wurde dann - Neulehrer.

Der erste Neulehrerkursus in der Provinz Brandenburg begann bereits am 8. Oktober 1945 immerhin in Wittenberge, mithin in der besonders stark von Vertriebenen bevölkerten Prignitz. ${ }^{1301}$ Eine 1928 geborene Teilnehmerin eines im Schloss Dallmin (Westprignitz) 1947/48 durchgeführten Neulehrer-Lehrgangs, selbst nicht vertrieben, berichtet: „In Dallmin war ich mit 100 jungen Leuten für elf Monate in einem Schloss zu Hause. Wir hatten alle das gleiche Ziel - wir wollten Lehrer werden in einem neuen Staat, von dem wir noch nicht viel wussten, der uns aber diese Chance bot. ${ }^{\text {"1302 }}$ Die Teilnehmer boten bezüglich Herkunft und Bildungsniveau „das

graphische Konstruktionen von Lehrern zwischen Erfahrungen und gesellschaftlichen Erwartungen. Weinheim 2000 (Bibliothek für Bildungsforschung, Bd. 18). - Allgemein, ohne die Vertriebenenproblematik zu streifen: Kathy Otto: Zur Entnazifizierung des Lehrpersonals und zur Ausbildung von Neulehreren in den Jahren 1945/1946 in Potsdam. In: Beiträge zur Geschichte des Potsdamer Schulwesens. Vorbem.: (Wolfgang) Rocksch (Potsdamer Forschungen der Pädagogischen Hochschule „Karl Liebknecht“ Potsdam, Erziehungswiss. Reihe, H. 86). Potsdam 1990, S. 112-135, bes. S. 119-135.

1299 Karl Steinhoff: Das Land Brandenburg in den ersten Nachkriegsjahren. In: Märkische Heimat 3 (1959), S. 138-145, hier S. 143. - Als konkrete Beispiele siehe z. B. die Erinnerungen einer 1945 aus Crossen/Oder vertriebenen Berlinerin, die 1966 den Titel „Verdienter Lehrer des Volkes“ erhielt: Hildegard Wuntke: Von einer, die auszog, das Lehren zu lernen - Erinnerungen einer Studienrätin aus den Jahren 1939 bis 1966. In: Gelebte Geschichte. Storkower Zeitzeugen berichten aus 8 Jahrzehnten. Erlebnisse, Erinnerungen, Erfahrungen, Erkenntnisse. Hrsg. vom Seniorenbeirat der Stadt Storkow (Mark). Storkow 2007, S. 133-141. [1950 Neulehrerausbildung in Dallmin (Kr. Westprignitz)]. - Für Brandenburg auch aufschlussreich die Erinnerungen eines Einheimischen: Werner Kieckbusch: Schulen und Schüler ohne Lehrer - Was tun? Erinnerungen an die Neulehrerausbildung an den Schulen im Altkreis Templin zwischen 1945 und 1952. In: Mitteilungen des Uckermärkischen Geschichtsvereins zu Prenzlau 22 (2015), S. 215-243. - Nur knapp am Ende des Buches streift der vertriebene Schlesier Hans Zeidler (geb. 1920) seinen Neulehrer-Einsatz in Schöneiche: Als Ostpreußen verloren ging. Berlin 1998, S. $61 \mathrm{f}$.

1300 Günter Lange: Glück oder Schutzengel? In: Damals und heute (wie Anm. 357), S. 54-56, hier S. 56.

1301 Heinz Muchow: Wittenberge 1945. Eine Chronologie. Wittenberge 1991, S. 54.

1302 Gertrud Schönig: So fing es an. In: Spuren aus ihrem Leben. Senioren erinnern sich. Hrsg.: Seniorenbeirat in der Stadt Potsdam. Potsdam 2003, S. 47-54, hier S. 47. 
Bild einer bunt zusammengewürfelten Truppe“. ${ }^{1303}$ Der Unterricht erfolgte gemeinsam für „vierzig Kursanten zwischen 18 und 30 Jahren [...]. Es waren überwiegend ehemalige Flüchtlinge, Ausgebombte, Soldaten und Kriegsgefangene, die sich ernsthaft und hartnäckig für ihren zukünftigen Beruf vorbereiten wollten." 1304

Ein bei Kriegsende in sowjetische Gefangenschaft geratener Apothekersohn aus Schlesien hat im Alter sein Vertriebenenschicksal beschrieben. ${ }^{1305}$ Anfang 1946 aus der Gefangenschaft entlassen und - ohne Kenntnis des Aufenthaltsortes seiner Familie - ganz auf sich gestellt, kam er über Schwedt (Oder) und Berlin, mit der Bahn, nach Frankfurt (Oder). Anders als mancher andere hatte er keine weiteren nahen oder entfernten Verwandten, bei denen er vorübergehend hätte unterkommen können: Die gesamte Großfamilie hatte bis 1945 durchweg innerhalb der schlesischen Provinzgrenzen gelebt: „Ein Umstand, der sich 1945 in der Zeit von Flucht und Vertreibung aus Schlesien negativ bemerkbar machte, denn wir hatten ,im Reich' keinerlei Verwandte noch nähere Bekannte, denen man einen Flüchtling zumuten konnte." ${ }^{1306}$ In Frankfurt (Oder) war $\mathrm{ihm}$ „,von der Verwaltung eine Unterkunft in einem der halbzerstörten Kasernengebäude zugewiesen worden und ich hatte Arbeit in einer Stadtkolonne gefunden “. ${ }^{1307}$ Der dreiundzwanzigjährige Sohn aus politisch konservativem Elternhaus strebte aber nach einer Berufsausbildung „und so erschien mir die Ausschreibung eines zweisemestrigen Ausbildungskursus für Neulehrer in Frankfurt a.d. Oder als ein Strohhalm, nach dem ich griff. [...] Von jedem Teilnehmer des Neulehrer-Lehrgangs wurde die Mitgliedschaft in einer demokratischen Partei erwartet, ganz offen bevorzugt natürlich der SED. Am 21./22. April 1946 erfolgte die Vereinigung und an jeden von uns wurden schon am nächsten [S. 53] Tag Aufnahmeanträge für die SED verteilt. SPD- und KPD-Mitglieder wurden automatisch in die SED überführt. Ich zögerte lange, fand aber ganz zufällig Kontakt zur Liberal-Demokratischen Partei Deutschlands (LDP). [...] Meine Heimatlosigkeit blieb trotz aller Not des Tages eine bleibende Belastung, die ich zwar mit manchem Teilnehmer des Neulehrer-Lehrgangs teilen konnte, wenngleich ich der einzige Schlesier war. Die anderen waren in der Neumark, in Pommern und der ehemaligen Provinz Posen beheimatet. ${ }^{\text {"1308 }}$ Im Sommer 1946 erfuhr er, dass Mutter und Schwester im Erzgebirge gelandet waren, er besuchte sie, trat aber im September als Schulamtsbewerber in Frankfurt in den Schuldienst ein und bekam eine Lehrerstelle an der Martin-Luther-Schule in der Leipziger Straße zugewiesen. Auch in der Schule wurde er mit Vertriebenen konfrontiert: „Mit Beginn des Schuljahres 1947/48 erfolgte meine Versetzung an die August-Bebel-Schule in der gleichnamigen Straße, zu deren Bezirk die Dörfer Rosengarten und Kliestow gehörten, durch die nun auch ländliches Milieu in den Schulalltag getragen wurde. Da es sich in beiden Fällen um Gutsdörfer handelte, hatte sich durch die so genannte Bodenreform - Junkerland in Bauernhand' - bereits der

1305 Ekkehard Lindner: Neulehrer in Frankfurt an der Oder. In: Schlesier in der DDR (wie Anm. 849), S. 48-61.

1306 Ebd., S. 49.

1307 Ebd., S. 52

1308 Ebd., S. 52 f. 
Klassenkampf ausgetobt und durch Enteignung des Großgrundbesitzes und Aufsiedlung des Bodens in viel zu kleine Parzellen, die hier an der Odergrenze hauptsächlich an flüchtige und vertriebene Bauern aus den ehemaligen deutschen Ostgebieten verteilt wurden. Diese wohnten zusammengepfercht im Gutshaus in Kliestow, während im Schloss Rosengarten über 100 elternlose Kinder fast jedes Alters eine Heimat gefunden hatten. Das Vertriebenenschicksal war also auch in der Schule hautnah zu spüren und wirkte bis in den Unterricht hinein, wenn es auch offiziell geleugnet werden musste." ${ }^{1309}$ Seine Integration in den Alltag war in den fünfziger Jahren vordergründig sozial und wirtschaftlich gelungen, politisch-ideologisch nicht. Der inzwischen verheiratete und aus der LDP Ausgetretene war zwar nach dem 17. Juni 1953 zu einem von zwei stellvertretenden Schulleitern berufen worden, doch seine regimekritische Haltung fiel immer wieder auf und führte 1958 zur Kündigung in dieser Position, wobei es hieß, seine Weiterbeschäftigung als Lehrer bliebe davon unberührt. Bald darauf floh er nach West-Berlin und wurde nach Westdeutschland ausgeflogen, wo er als Realschullehrer arbeiten konnte und später zum Volkshochschulleiter aufstieg - einer von sehr vielen Vertriebenen, die die DDR bis zum Mauerbau nicht aus wirtschaftlichen, sondern politisch-weltanschaulichen Gründen verließen.

\section{"Umsiedlergenossenschaften"}

Nicht nur in Brandenburg, auch anderswo in der SBZ ${ }^{1310}$ gab es in den frühen Nachkriegsjahren ein Element der Integration Vertriebener, das zugleich eine wirtschaftliche Bereicherung der heimischen Volkswirtschaft zu werden schien. ${ }^{1311}$ Wie in anderen Lebensbereichen - auf dem Land bei eigenständig wirtschaftenden Neubauern, die dann in die LPG gedrängt wurden führte die Änderung der Wirtschaftspolitik ab Anfang der fünfziger Jahre jedoch dazu, dass das Modell der Umsiedlergenossenschaft schließlich staatlich dirigierten Großbetrieben weichen musste, auch wenn sich an manchen Stellen die betreffenden Betriebe in stark veränderter Form noch bis 1990 halten konnten. ${ }^{1312}$ Welches Potential hier anfangs freigesetzt wurde, lässt sich an

1309 Ebd., S. 54.

1310 Steffi Kaltenborn: Der Versuch einer Wiederbelebung des Gablonzer Kunsthandwerks im Land Thüringen Utopie oder reale Möglichkeit? In: Wirtschaftliche Folgelasten des Krieges in der SBZ/DDR. Hrsg. von Christoph Buchheim. Baden-Baden 1995, S. 383-402. - Christopeit, Die Glasmanufaktur Derenburg (wie Anm. 115).

1311 Steffi Kaltenborn: Herausbildung und Entwicklung der Umsiedlergenossenschaften in der Sowjetischen Besatzungszone Deutschlands nach dem zweiten Weltkrieg. In: Sie hatten alles verloren (wie Anm. 15), S. 178192. - Gisela Conrad: Können Produktionsgemeinschaften einen Beitrag zur wirtschaftlichen Entwicklung de Umsiedler leisten? Eine Untersuchung am Beispiel des Landes Brandenburg. Diss. FU Berlin 1950 [Masch]. Schwartz, Vertriebene und „Umsiedlerpolitik“ (wie Anm. 13), S. 572-611.

1312 Vier Jahrzehnte Gablona Schmuckwaren Neuheim. Ein Entwicklungsweg von der Glas- und Bijouteriegenossenschaft zum Leitbetrieb der Erzeugnisgruppe „Modeschmuck“ in der Deutschen Demokratischen Republik. In: Heimatkalender des Kreises Jüterbog 1986, S. 21-25. - Ines Oberling: Falkenseer Wirtschaftsgeschichte (3): Von der Zigarettenfabrik Leon Mardirossian zum VEB Gablona Falkensee. In: Heimatjahrbuch für Falkensee und Umgebung 2009, S. 42-48. - Siehe auch unten das Beispiel der Messerschmiede in Leegebruch. 
den Listen ablesen, die eine Vielzahl solcher - heute überwiegend längst vergessenen - Genossenschaften enthalten. ${ }^{1313}$ Im März 1947 existierten nach einem Bericht der Abteilung Arbeit und Sozialfürsorge des SED-Landesvorstandes Brandenburg bereits 16, und 17 weitere befanden sich in Planung. ${ }^{1314}$ Noch wesentlich größer war die Zahl der sonstigen von „Umsiedlern“ gegründeten Handels- und Industriebetriebe. ${ }^{1315}$

Die Wertschätzung, deren sich die Umsiedlergenossenschaften anfangs erfreuen durften, zeigte sich vor allem, wenn man sie propagandistisch als Modell erfolgreicher Integration vorweisen konnte. Als die ZVU am 28. September $1946 \mathrm{ihr}$ einjähriges Bestehen in einer - vom Streichquartett der Berliner Staatsoper mit Musik von Beethoven und Tschaikowsky umrahmten - "Jahresfeier“ im Festsaal des „Hauses der Verwaltungen“ in Berlin-Mitte beging, sprachen nach Präsident Engel und Vizepräsident Tschesno auch „Vertreter der Umsiedler“. „Im Vorraum des Festsaales“ wurde eine „Ausstellung von Schaubildern und Erzeugnissen von Umsiedlergenossenschaften " gezeigt. ${ }^{1316}$ Die positive Bewertung und anfängliche Förderung zeigt u. a. auch ein mit dem Vermerk „Eilt sehr!" versehenes Schreiben der Umsiedlerabteilung des brandenburgischen Arbeits- und Sozialministeriums vom 8. April 1948 an die Umsiedlerabteilung des Rates des durch die Gründung mehrerer Umsiedlergenossenschaften aufgefallenen Kreises BeeskowStorkow, in dem es heißt: „Im Lande Brandenburg haben sich erfreulicherweise eine größere Anzahl Genossenschaften und Betriebe aus Umsiedlerkreisen gebildet, an deren Fortbestand und Erweiterung nicht nur die SMA stärkstens interessiert ist, sondern ihre Existenz beweist auch, daß seitens der Kreise an der Schaffung von Arbeits- und Produktionsmöglichkeiten z. T. mit gutem Erfolg gearbeitet wurde. " ${ }^{1317}$ Schon unter dem 24. Mai 1948 schreibt jedoch dieselbe Behörde an denselben Empfänger: „Die Firmierung ,Umsiedlergenossenschaft Neuzittau' halten wir nicht für zweckmässig. Bekanntlich soll die Verschmelzung der Umsiedler mit den Alteingesessenen gefördert werden und die Bezeichnung,Umsiedler' schließlich aus dem Wortschatz verschwinden. Aus diesem Grunde bitten wir darauf hinzuwirken, daß die Genossenschaft wie folgt eingetragen wird: Genossenschaft zur Erzeugung von Industrie- $u$. Wirtschaftsartikeln, Neuzittau. "1318

Auch in Jüterbog, wo sich Sudetendeutsche zu einer „Produktiv- und Handelsgenossenschaft der Kunstblumen- und -früchteindustrie“ zusammengeschlossen hatten, zeigen sich 1948 trotz der - wie anderswo auch - ausgesprochen erfolgreichen, sogar auf Expansion zielenden Arbeit dieser Betriebe - Hürden, die bereits andeuteten, dass man in der SED auf andere Formen setzte. So heißt es in einem für den Abdruck in einer Zeitung verfassten Bericht von Erwin Schleusener: „65 Mitarbeiter zählt dieser Genossenschaftsbetrieb und ist damit einer der grössten in Jüterbog. 87 \%

1313 Beispiele: Bericht der Abt. Arbeit und Sozialfürsorge des Landesvorstandes Brandenburg der SED vom 15.3.1947 im Quellenteil, Nr. 127. - Wille II (wie Anm. 196), S. 398 f.

1314 BLHA, Rep. 333 SED-Landesleitung Brandenburg, Nr. 574, Bl. 105-106 (Liste) (Textabdruck im Quellenteil, Nr. 128).

1315 Ebd., Bl. 225-238 (kreisweise Listen) (auszugsweiser Textabdruck im Quellenteil, Nr. 131).

1316 SAPMO-BArch, DY 34/27745, Bl. 7 (gedruckte Einladungskarte).

1317 BLHA, Rep. 250 Landratsamt Beeskow-Storkow, Nr. 881, unfol. (vgl. Textabdruck im Quellenteil, Nr. 132).

1318 Ebd., unfol. (vgl. Textabdruck im Quellenteil, Nr. 133). 
davon sind Frauen, von denen über die Hälfte als Heimarbeiterinnen beschäftigt werden. Der Betrieb könnte bei einer entsprechenden Unterstützung durch die Stadtverwaltung, vor allem durch Lösung der Raumfrage, in kürzester Zeit auf 200 Betriebsangehörige erweitert werden. Leider - so betonen die Genossenschaftsmitglieder - haben die Stadtväter von Jüterbog die Bedeutung dieser Industrie, im einzelnen für die Zukunft der Stadt und im besonderen für den deutschen Export, noch nicht erkannt."1319

Die Umsiedlergenossenschaften waren meist von erfahrenen sudetendeutschen Fachkräften, hochspezialisierten Handwerkern in der Tschechoslowakei bzw. in Österreich-Ungarn seit dem 19. Jahrhundert boomender Industriezweige gegründet und hatten damit ganz neue Branchen nach Brandenburg gebracht, z. B. in die Kreise Beeskow-Storkow (u.a. Neu Zittau), Jüterbog-Luckenwalde (Dorf Zinna, Jüterbog u.a.), Niederbarnim (Grünheide), Ost- und Westhavelland (u.a. Rhinow), aber auch in die Niederlausitz. ${ }^{1320}$ Auch hier entwickelten sie sich trotz vielerlei Schwierigkeiten bei der Raum- und Materialbeschaffung mit hochmotivierten (Mit-)Arbeitern dynamisch. In Dorf Zinna (ab 1951 Neuheim) bei Jüterbog z. B. wurden anfangs sogar „viele Wohnungen als Werkstätten für die ,sich rasch entwickelnde(n) Industrie, mitgenutzt. Nach dem Bau der Fabrik wurden diese wieder zu Wohnungen. "1321 Besonders bekannt und auch im Export weltweit erfolgreich wurden die Messerschmiede in Leegebruch bei Oranienburg (Sudetendeutsche aus Nixdorf), sehr bekannt waren schließlich die Schmuckund Glaswarenhersteller in Dorf Zinna/Neuheim, deren Firmenname noch jahrzehntelang, zwar für SED-Augen etwas „bereinigt“, aber doch weiter unverkennbar auf ihren Herkunftsort Gablonz/Neiße hinwies (VEB „Gablona“ Bijouterie- und glasverarbeitende Industrie). ${ }^{1322}$ Die betreffende Umsiedlergenossenschaft war freilich schon 1952 beseitigt, der Betrieb fertigte jedoch weiter. Im Genossenschaftsregister heißt es dazu, die Firma sei laut Eintragung vom 11. Oktober 1952 erloschen („von Amts wegen zu löschen“) und: „Der VEB [Gablona Neuheim] ist als völlig neues Werk anzusehen." 1323

Die Gründung und auch die Lebensumstände der sudetendeutschen Genossenschaftsgründer in Dorf Zinna/Neuheim und als zweites Beispiel die der sudetendeutschen Messerschmiede in Leegebruch sollen nun noch etwas näher beschrieben werden. Beide sind von „Antifa-Umsiedlern“ gegründet worden und mussten in der „Umsiedler-Integrations-Propaganda“ der SED in zeitgenössischen Medien immer wieder als Musterbeispiele gelungener Eingliede-

1319 BLHA, Rep. 250 Landratsamt Luckenwalde, Nr. 105, Bl. 171-172, hier Bl. 171 (vgl. Textabdruck im Quellenteil, Nr. 134). - Die grundsätzliche Eignung mehrerer brandenburgischer Umsiedlergenossenschaften für den Export wird auch von der Landesregierung zunächst betont, vgl. Wille II (wie Anm. 196), S. 398 (Liste mit dem einleitenden Vermerk „Für den Export eignen sich insbesondere die folgenden Betriebe“, wohl Anf. 1948).

1320 Oehlsen, Vertriebenenlager (wie Anm. 45), S. 90. - Siehe auch die 1947 von der Zentralverwaltung für Umsiedler als Orientierungspapier erarbeitete Aufstellung der für die Ansiedlung in der SBZ in Betracht kommenden Spezialgewerbe und -industrien des Sudetengebietes (Textabdruck: Wille II [wie Anm. 196], S. 370 f., Nr. 384).

1321 Schmutzer, ... auferstanden aus Ruinen (wie Anm. 642), S. 28.

1322 Ebd., S. 62 ff. (Mitgliederverzeichnis der Genossenschaft: S. 64-66).

1323 Genossenschaftsregister-Akte des Amtsgerichts Jüterbog: BLHA, Rep. 260 AG Jüterbog, Nr. 30, Bl. 39. 
rung herhalten. ${ }^{1324} \mathrm{Ne}$ uhe i m bei Jüterbog galt geradezu als „ein Muster-Neusiedlerdorf“, indem man die „Neuheimer“ dem ob seines schweren Schicksals deprimierten Vertriebenen als Vorbild präsentierte: „Um so höher sind der Lebensmut und der Aufbauwille jener Glasarbeiter aus dem Iser-Gebirge einzuschätzen, die entsprechend der Beschlüsse von Jalta aus ihrer He imat, der heutigen CSSR, umgesiedelt und in Neuheim unter den sich entwickelnden Bedingungen unseres Arbeiter-und-Bauern-Staates ein neues Dorf aufzubauen, sich selber einen neuen optimistischen Lebensinhalt gaben und für unsere Republik einen völlig neuen Produktionszweig aufbauten. "1325 Stolz hebt der selbst zu der Gablonzer Gruppe zählende Chronist des Ortes, Hans Schmutzer, hervor, dass „wir einen völlig neuen Industriezweig - die Schmuckindustrie - errichteten“" ${ }^{1326}$

Dabei stellte die Vertriebenensiedlung Dorf Zinna/Neuheim wirklich einen Sonderfall dar. ${ }^{1327}$ Denn hier traf eine fast geschlossene Gruppe gleicher Herkunft auf ein wegen seiner Auflassung im Krieg vollständig leeres Dorf, eine Situation mit der kaum einer der vielen tausend anderen Vertriebenen je konfrontiert war. ${ }^{1328}$ Für 1946 werden drei sudetendeutsche Transporte nach Dorf Zinna erwähnt. ${ }^{1329}$ Der erste „Antifa-Transport“ führte im Februar 194690 Familien mit 286 Personen, der zweite, am 19. Februar 1946 von Gablonz nach Schönebeck geleitet, brachte drei weitere Familien und der dritte „Antifa-Transport“ am 23. Juni, von Ilmenau kommend, elf weitere Familien, die sich von diesem lösten und am 1. Juli 1946 ebenfalls in Dorf Zinna ankamen. ${ }^{1330}$ Drei Bauern aus „Schlesien, Warthegau und Pommern“ kamen noch hinzu. ${ }^{1331}$ Weiterer sudetendeutscher „Nachschub“ kam nochmals $1947 .{ }^{1332}$

1324 Die Leegebrucher z. B. in dem DEFA-Dokumentarfilm „Der Augenzeuge 1947/38“ von 1947.

1325 Schmutzer, ... auferstanden aus Ruinen (wie Anm. 642), S. 3. (Der Verf. gehörte selbst zu den „Umgesiedelten“ - das geht aus seinen Formulierungen u. a. auf S. 3 und 6 hervor - und berichtete ab 1947 als „Volkskorrespondent" über den Ort.)

1326 Ebd., S. 8.

1327 Grundlegend: van Hoorn, Neue Heimat im Sozialismus (wie Anm. 634), S. 242 ff. - Siehe auch: Heike van Hoorn: Die Schaffung einer politischen Lebenswelt. Das Antifa-Umsiedlerdorf Zinna/Neuheim in Brandenburg. In: Politik vor Ort. Sinngebung in ländlichen und kleinstädtischen Lebenswelten (Jahrbuch für Geschichte des ländlichen Raumes, 4). Innsbruck u. a. 2007, S. 149-159.

1328 Beschreibung der Ausgangssituation mit Gebäuden und Baracken: Schmutzer, ... auferstanden aus Ruinen (wie Anm. 642), S. 5 f. Die Angabe für 1937 „aufgegeben und niedergerissen“ (HOL X, S. 377) erscheint insofern übertrieben, als die Wohngebäude, wenn auch entleert, durchaus noch 1946 bestanden. - Vergleichbar mit Neuheim wäre allenfalls die auf brach liegendem ehemaligem (vorpommerschem) Gutsland 1948 neu angelegte und 1949 offiziell gegründete Siedlung Neurochlitz bei Gartz/Oder, für die größtenteils Vertriebene, die zunächst in Rochlitz (Sachsen) untergekommen waren, daneben auch Ausgebombte und Rochlitzer Alteinwohner angeworben wurden. Der Ort gehörte jedoch bis 1950 zum Land Mecklenburg und kam erst 1950 zum brandenburgischen Kreis Angermünde (seit 2002 Ortsteil von Mescherin); siehe dazu: Ortsdokumentation Neurochlitz sowie Berkenkamp: Entstehung und Entwicklung der Gemeinde Neurochlitz. In: Heimatkalender des Kreises Angermünde 1959, S. 107-108.

1329 Schmutzer, ... auferstanden aus Ruinen (wie Anm. 642), S. 15 und 19.

1330 Ebd., S. 27. Namenlisten der Haushaltungsvorstände ebd., S. 27 f.

1331 Ebd., S. 28.

1332 Ebd., S. 25. 
Einer der Siedler, der erwähnte Hans Schmutzer, hat über Entstehung und Entwicklung der Neusiedlung mehrfach als „Volkskorrespondent“ in der Presse berichtet und daraus, angereichert mit vielen weiteren Fakten und sogar Dokumenten, eine Chronik zusammengestellt, die der „Dorfklub Neuheim“ und der am Ort ansässige „Betrieb VEB Gablona“ anlässlich des zwanzigjährigen Jubiläums der Neubesiedlung 1966 gemeinsam als gedrucktes Buch herausgaben. Dieses 101 Seiten umfassende kleinformatige Werk ist eine zwar insgesamt durch die offizielle SED-Sicht gefärbte, dennoch bemerkenswert offenherzige und detaillierte Schilderung, die nur an wenigen Stellen beschönigt. Die schonungslose Darstellung aller denkbaren Unzulänglichkeiten und Schwierigkeiten bis hin zu Beeinträchtigungen durch die benachbarte Rote Armee und nicht zuletzt die realistische Schilderung der Vertreibung, die Nennung der sudetendeutschen Heimatorte sowie die Erwähnung auch Schlesiens und anderer ostdeutscher Herkunftsgebiete der neuen Bewohner verleihen dem Buch den Status einer einzigartigen Quelle sowohl direkt zu den Fakten der Dorfentwicklung als auch indirekt zum Umgang mit dem Vertreibungsthema. Schmutzer nennt in seiner Chronik in Listen der Neubauern und Kleinsiedler sogar die deutschsprachigen Namen der Geburtsorte. ${ }^{1333}$ Zeitgenössisch dürfte dem Buch allerdings keine weite Verbreitung beschieden gewesen sein, vermutlich war die Auflage gering und der Verbreitungsgrad vor allem auf die Betroffenen beschränkt, d. h. die Bewohner und die Betriebsangehörigen. Ob das Buch womöglich sogar wegen seiner Offenheit „aus dem Verkehr“ gezogen wurde, wäre noch zu klären; es ist heute ausgesprochen, ja auffällig selten zu finden. ${ }^{1334}$

Schmutzer schreibt: „Dorf Zinna wurde von uns im Februar des Jahres 1946 neu besiedelt. Die neue Bevölkerung stammte vorwiegend aus dem nordböhmischen Industriegebiet - Gablonzund seiner Umgebung. Diese neuen Bewohner von Dorf Zinna waren hauptsächlich Glas- und Bijouteriearbeiter." 1335 Bei der Wiederbesiedlung bestand das Dorf aus 72 Häusern, 1960 waren es $86 .{ }^{1336}$ Eindringlich schildet Schmutzer schon die unzureichenden Vorbereitungen. ${ }^{1337}$ Drei Tage nach der Ankunft „waren bereits 4-6 Familie aus der Kaserne weggelaufen und hatten sich ohne Einweisung in dem bereits bekannten Ort einquartiert “. ${ }^{1338}$ Da sich für Neuheim in der Um-

1334 Eine am 27.5.2016 durchgeführte Recherche im Karlsruher Virtuellen Bibliothekskatalog (KVK), der auch den regionalen Katalogverbund Kooperativer Bibliotheksverbund Berlin-Brandenburg (KOBV) einschließt, ergab nur einen einzigen Nachweis für ein Exemplar des Buches in deutschen (und ausländischen) Bibliotheken (Bibliothek der Landesgeschichtlichen Vereinigung für die Mark Brandenburg e. V., Berlin, Sign. E 3809; lt. Mitteilung der Bibliothek durch Kauf erst 2001 erworben. Eine erneute Recherche am 22.7.2018 ergab ein weiteres Exemplar im Bundesarchiv (offenbar Altbestand). Trotz der Seltenheit ist es in jüngerer Zeit mehrfach rezipiert worden. Vgl. van Hoorn, Neue Heimat im Sozialismus (wie Anm. 634), S. 242-252, 361; Peter Pragal: Von Gablonz nach Neuheim. Wie Sudetendeutsche, Antifa-Umsiedler' in Brandenburg ihre industrielle Tradition fortsetzten. www.kulturforum.info/de/startseite-de/1019554-themen/6992-von-gablonz-nachneuheim [27.5.2016].

1335 Schmutzer, ... auferstanden aus Ruinen (wie Anm. 642), S. 8.

1336 Ebd., S. 54.

1337 Ebd., S. $15 \mathrm{f}$.

1338 Ebd., S. 17. 
gebung bald der Begriff „Das Rote Dorf Zinna“ verbreitete, hatten es die bei den Bauern der umliegenden Dörfer um Nahrung oder Geräte für die Frühjahrsbestellung bittenden Neusiedler immer schwerer, oftmals wurden ihnen die Höfe versperrt. „Nur wenige Bauern gewährten den Umsiedlern Hilfe, um die vollkommen verunkrauteten Felder für die Frühjahrsbestellung vorzubereiten. Der Schwarzhandel blühte und unmögliche Preise wurden für Lebensmittel verlangt."1339

Ungeschminkt beschreibt Schmutzer in der Rückschau auch die Wohnsituation: „Es gab Ungeziefer und die Wohnverhältnisse waren insgesamt wenig hygienisch, und der Hunger, der sich immer stärker einstellte, erhöhte die erbärmlichen Verhältnisse der Menschen. "1340 Hinzu kam, dass mehrere Gebäude sowie die im Ort vorhandenen ehemaligen RAD-Baracken teilweise noch von der Roten Armee genutzt wurden, mit der man daher in unmittelbarer Nachbarschaft lebte und sozusagen um die Ressourcen kämpfte. Sogar eines der Steinhäuser wurde „nach zweijähriger Benutzung als Wohnung [...] von der Roten Armee beschlagnahmt" und erst 1958 wieder freigegeben. ${ }^{1341}$ Schmutzer bringt in seiner Chronik an vielen Stellen Hinweise auf diese störende Nachbarschaft unter. ${ }^{1342}$ Im nahen Wald fanden Truppenübungen statt, die die Bauern daran hinderten, die ihnen zugeteilten Waldstücke zu erreichen. Schmutzer bringt es dennoch fertig, die „Störer“ umgekehrt in den Bauern zu sehen: „Deshalb wurde es schwerer für die Bauern, in ihren zugeteilten Wald zu fahren, da sie oft störend wirkten bei den Übungen der Sowjetarmee, die den Wald für Übungszwecke benutzte. Wegen dieses Umstandes fanden viele Versammlungen statt und wurde auch der Beschluß gefaßt, den Wald in staatliche Verwaltung zu geben."

Euphorie spricht aus den Worten des im Grundstein des 1953 neuerbauten Wohnblocks deponierten Schriftstücks, das mit dem Satz endet: „Wir danken den wahren Vertretern des Volkes mit dem Versprechen, die Industrie so aufzubauen, daß das Dorf zur Stadt wird." ${ }^{3344}$ Die sozialistische Einstellung der Bewohner Neuheims wird in Berichten gern hervorgehoben, auch die hohen Ergebnisse für die SED bei Wahlen. ${ }^{1345}$ Die vom Ortsschronisten Schmutzer, 1946 selbst

1342 Ebd.: Ein größeres Gebäude wurde von der sowjetischen Armee 1948 zur Bäckerei umgebaut, 1950 aber für den Gablona-Betrieb freigegeben (S. 54). Eine der für die Bodenreform vorgesehenen Siedlerstellen blieb unbesetzt und wurde „etwas später von der Roten Armee für eine Auto-Fahrschule benützt“ (S. 87). Die Gemeindeverwaltung bemühte sich schon sehr früh um eine katasteramtliche Abgrenzung zum sowjetisch genutzten Schießplatz, bekam aber vom Jüterboger Kreiskommandanten nur eine lapidare Antwort (S. 86). Schmutzer hält (ebd.) sogar fest, dass die sowjetische Besatzungsmacht in den benachbarten Kasernen in Jüterbog II und Forst Zinna Türen und Fenster ausbaute, in Forst Zinna auch mit dem Abbau der Dachstühle begann, was als Demontage zwecks Entmilitarisierung erklärt wird (nach angeblicher Änderung der Planung wieder instandgesetzt).

1343 Ebd., S. 99.

1344 Ebd., S. 57.

1345 Ebd., S. 18, 20-22. Siehe auch die Erfolgsmeldung im Pressetext vom 6.8.1949: „Das Dorf Zinna ist reines Neubauerndorf und hat in dem Wettbewerb der Dörfer des Kreises Luckenwalde in der Pflichtablieferung den Sieg davon getragen." BLHA, Rep. 250 Landratsamt Luckenwalde, Nr. 108, Bl. 431 (Textabdruck im Quellenteil, Nr. 141). 
Gründungsmitglied der lokalen KPD-Parteileitung, mitgeteilten statistischen Daten zeigen aber auch, dass die hier durch die gezielte Lenkung und Ansiedlung der entsprechenden Transporte dominierenden Antifaschisten nicht durchweg und von vornherein vollständig auf KPD-/SEDLinie gewesen sein können. 1946 gehörten 180 Erwachsene der im Ort politisch führenden KPD-Ortsgruppe an, 1947 waren es 50 Prozent der örtlichen Wahlberechtigten. ${ }^{1346}$ Interessant sind in diesem Zusammenhang auch Schmutzers bevölkerungsstatistische Mitteilungen. Vom 16. März 1946 bis zum 30. März 1960 sind in den ortsansässigen Familien 100 Kinder geboren worden. „Das geburtenreichste Jahr war 1960 mit 14 Kindern.“ Schmutzer hebt dann hervor, das "fortschrittliche Leben mit fortschrittlichem Gedankengut bewegte die Menschen, von der kirchlichen Taufe Abstand zu nehmen und sich der sozialistischen Namensgebung anzuschließen." Dass aber die erste „sozialistischen Namensgebung“ erst am 28. Mai 1961, im Kulturraum des VEB Gablona, stattfand, bedeutet offenbar, dass 15 Jahre lang noch durchweg getauft worden war. In den ersten Jahren hatten allerdings die Begräbnisse einen betont profanen Charakter. So wurde bei der ersten Beerdigung am 16. April 1946 anstelle eines Kreuzes „die Rote Fahne vorangetragen “ und „die Grabrede hielt ein Arbeiter. Ein Pfarrer war in den ersten Jahren nicht bei Begräbnissen. Erst bei später hinzugekommenen, christlich stark eingebundenen Einwohnern war ein Pfarrer bei Beerdigungen anwesend."1347 1953 gab es in Neuheim nur „5 oder 6 Familien, welche der evangelischen, [und] ebenso viele [, die] der katholischen Kirche angehörten". ${ }^{1348}$

Auch sonst gab es zwar Erfolgsmeldungen aus der Arbeit der Gablona, doch das Zusammenleben der Menschen hinkte dem offenbar hinterher. Die Festschrift zum zwanzigjährigen Bestehen benennt zwar aus allen Lebensbereichen Positives - den ersten Fernseher 1955, das erste Auto 1958 u. a. -, beschönigt aber keineswegs die Misserfolge. Schmutzers detaillierte Schilderungen machen vor kaum einer Alltagsrealität halt. Rückschläge bei der Befahrbarkeit der Straßen scheut er sich beispielsweise nicht, auf „Militärische Kettenfahrzeuge“, womit keine anderen als die um Jüterbog sehr präsenten sowjetischen gemeint sein können, und starken Autoverkehr zurückzuführen. „Risse und Löcher“ in der „neuerbauten Betonstraß“" mussten „mit Bitum ausgegossen und repariert werden " ${ }^{1349}$ Auch war zunächst ein Jugendheim geplant, für das Jugendliche bereits alte Ziegel putzten, doch wurde das Projekt dann nicht realisiert. Schmutzer schreibt dazu: „Dafür gab es eine Reihe subjektiver Gründe. Die verantwortlichen Jugendfreunde nahmen in Potsdam und Berlin eine neue Tätigkeit auf, baufreudige Bauern und Bürger des Ortes nahmen sich zur Instandsetzung ihrer Wohnungen und Wirtschaftsgebäude die sauber aufgeschichteten Ziegelsteine. ${ }^{1350}$ Vieles andere ging nur schleppend voran, die Verhältnisse waren keineswegs die eines „sozialistischen Musterdorfs“, als welches man es allerdings, trotz der gezielten Ansiedlung von „Antifa-Umsiedlern“, wohl auch nie geplant hatte. Erst Ende 1954 gab es den

1346 Schmutzer, ... auferstanden aus Ruinen (wie Anm. 642), S. 30.

1347 Ebd., S. 29.

1348 Ebd., S. 61.

1349 Ebd., S. 52 f.

1350 Ebd., S. 34. 
ersten Briefkasten im Dorf. ${ }^{1351}$ Als es mit der sachgerechten Bedienung des 1958 im Klubhaus aufgestellten Fernsehers nicht klappte und immer wieder Reparaturen nötig wurden, stellte ihn die Gablona-Betriebsleitung in einen internen Speiseraum. „Dort war er gänzlich unbeaufsichtigt und [so kam es, dass] Jugendliche diese Möglichkeit wahrnahmen, Hetzsendungen aus dem westlichen Sender zu sehen. "1352 Bei der 1948 im Ort installierten Lautsprecheranlage, die "für alle Informationen an die Bevölkerung eingesetzt" wurde, wurde schon „nach einigen Monaten“ einer von zwei Lautsprechern gestohlen. „Ungefähr 3 Jahre später existierte die Anlage nicht mehr." 1353

Die Landflucht konnte auch in Neuheim nicht aufgehalten werden: „Im Sommer 1962 übersiedelten die ersten Familien aus dem Dorf in die neuen Wohnungen in das sozialistische Stadtviertel Jüterbog. " ${ }^{3354}$ Aber auch sonst machten die DDR-typischen Entwicklungen vor Neuheim nicht halt. Bis zum Mauerbau verließen selbst einen mit „Antifaschisten“ neu besiedelten Ort wie Neuheim über 50 Personen, um in den Westen zu gehen, erste Abwanderungen gab es sogar schon nach dem 17. Juni 1953. ${ }^{1355}$

Vierzig Jahre nach der Ankunft des ersten „Antifa-Transports“ in Dorf Zinna/Neuheim erschien in dem von der Abteilung Kultur des Rates des Kreises Jüterbog herausgegebenen Heimatkalender für den Kreis Jüterbog 1986 ein Beitrag von „L. Fischer, Parteiveteran“ mit dem Titel „Neuheim - Eine Heimatstadt des Friedens“. ${ }^{1356}$ Der Verfasser, Lothar Fischer (geb. 1905), war der am 12. Februar 1946 in Gablonz (Jablonec n. N.) ernannte Leiter des „erste(n) Transport(s) deutscher antifaschistischer Umsiedler aus der $\check{C} S R^{“ 1357}$, der in Neuheim erster Parteisekretär der neugegründeten KPD-Ortsgruppe wurde. Sein dreieinhalbseitiger Kalenderbeitrag ist eine Mischung aus eigenem Erinnerungsbericht und parteipropagandistischer Jubiläumsschrift, die letztlich eine reine, unkritische Erfolgsgeschichte präsentiert.

1355 Ebd., S. 20, heißt es: „Bis zum Bau des antifaschistischen Schutzwalles in Berlin, am 13. August 1961, verließen 54 Personen unseren Ort.“ S. 29 schreibt Schmutzer jedoch: „Bis Ende 1960 verzogen 164 Personen. 58 [!] Erwachsene wurden republikflüchtig mit 10 Kindern und 14 Personen siedelten nach Westdeutschland über." Ausdrücklich vermerkt ist „(republikflüchtig)“ in Klammern beim namentlich genannten Förster Porzig (S. 48). Siehe auch den Hinweis zur „Republikflucht des Unternehmers Fritz Lindner in Luckenwalde“, dessen Betrieb 1953 in Treuhandverwaltung von der Gablona übernommen wurde (S. 73). Ferner die detaillierte Liste „Aus dem Dorf verzogene Personen/Von 1946-1960“ (S. 78-81), in der sich als Zielort mehrmals „Berlin“ und „unbek.[annt] verz.[ogen]“ finden, daneben auch nur „-- -“ und dreimal „C.S.R.“, also Rückkehr.

1356 L(othar)Fischer: Neuheim - eine Heimatstadt des Friedens. In: Heimatkalender des Kreises Jüterbog 1986, S. $17-21$.

1357 Ebd., S. 17. - Ebd., S. 19 Abb. der deutschsprachigen „Bescheinigung“ der „Informationskanzlei ,Antifa“ Jablonec n.N.“ über die Ernennung Fischers zum „Transportführer“, Jablonec n. N., 12.2.1946 (nur obere Hälfte des Blatts mit Kopf und wesentlicher Textpassaage) mit tschechischsprachigem Stempel „Informační kancelár ANTIFA v Jablonci $n$. N.“ 
Ein zweites Beispiel der Ansiedlung von Sudetendeutschen, die mit einem „Antifa-Transport" nach Brandenburg gekommen waren, findet sich in L e e g e b r u ch bei Oranienburg. Die dort im Zuge des Aufbaus der Rüstungsindustrie (Heinkel-Werke) im benachbarten Oranienburg ab 1936 neu angelegte große Werkssiedlung stand nach Kriegsende zum Teil leer, da viele der erst wenige Jahre zuvor eingezogenen Arbeiter aus allen Teilen Deutschlands mangels neuer Beschäftigungsperspektiven in ihre Herkunftsorte zurückgekehrt waren, soweit diese nicht in den nun polnischen bzw. sowjetischen (Ost-)Gebieten lagen. ${ }^{1358}$

Im April 1946 kamen über Bad Schandau, wo ein einwöchiger Zwischenaufenthalt stattfand, zwei weitere „Antifa-Transporte“ nach Deutschland. Die Verteilung in Sachsen (Vogtland) und Brandenburg (Osthavelland, Niederbarnim) erfolgte teilweise nach Arbeitsmarktgesichtspunkten. „Wer etwas von der Textilindustrie verstand, kam nach Werdau oder Bernau und wer Kenntnisse der Messerindustrie hatte, schließlich nach Leegebruch. ${ }^{\text {1359 }}$ Bei letzteren handelte es sich um Fachkräfte aus einer der Hochburgen der Stahlwaren- und Messerfabrikation des ehemaligen Österreich-Ungarn im nordböhmischen Nixdorf (Mikulášovice), gelegen im „Schluckenauer Zipfel“ zwischen Dresden und Zittau. Die „Nixdorfer Messerfachleute wurden über ganz Deutschland verstreut", ein Teil von ihnen konnte den alten Industriezweig in der neuen Heimat fortzusetzen. Dies war aber offenbar gar nicht geplant, ergab sich jedoch schließlich als Möglichkeit daraus, dass den „Antifa-Transporten“, anders als den anderen Vertriebenen, die Mitnahme von zusätzlichem Gepäck gestattet wurde. „Zum einen brachte Wenzel Pelinka aus seiner kleinen Schlosserei in der sudetendeutschen Heimat eine Drehbank, einen Schleifstein, eine Bohrmaschine sowie Kleinwerkzeuge mit. Dies war der Grundstock für die Grün- [S. 86] dung einer Produktionsstätte, die auf dem zur Verfügung gestellten Gelände am Ortseingang von Leegebruch entstand. ${ }^{“ 1360}$ Bereits am 1 . August 1946 gründeten 16 Vertriebene eine „Umsiedlergenossenschaft“, die „Genossenschaft der Messerschmiede Leegebruch (GML)“.1361 Die Anfänge waren bescheiden, aber von hoher Motivation der „Genossen“ befördert und von Land und Kreis unterstützt, wobei auch aus den nicht demontierten Teile der Heinkel-Werke Maschinenteile und Werkzeuge weiterverwendet werden konnten. Die weitere Geschichte der „GML“ ist eine durchaus internationale Erfolgsstory, die bis in die Wendezeit reicht, auch wenn die SED die Genossenschaft 1955 zur Verstaatlichung zwang und den gewählten Geschäftsführer Josef Kittel, der bis 1945 im KZ Dachau gesessen und dann die Transporte mit organisiert hatte, gegen den Protest der Genossenschaftsmitglieder absetzte. ${ }^{1362}$

1358 Auch aus Ostpreußen und Oberschlesien waren Arbeiter angeworben worden.

1359 Alfred Funke: Die Messerschmiede - das märkische Klein-Solingen. In: Leegebruch. Hrsg.: Arbeitsgruppe Heimatgeschichte im Kulturverein Leegebruch. 2. Aufl. Leegebruch [2003], S. 85-92, hier S. 85.

1360 Ebd., S. 85 f.

1361 Wenzel Pelinka, Max Hering, Josef Höhne, Franz Scholz, Johann Scheffler, Josef Pelinka, Marta Kumpf, Rosa Ehrlich, Josef Münzberg, Alfred Funke sen., Josef Hensel, Karl Ulrich, Anton Lißner, Josef Kittel sen. und Josef Kittel jun. (ebd., S. 86).

1362 Zur weiteren Firmenentwicklung bis zum traurigen Ende und zur (weitgehend von dem Sohn eines Genossenschaftsgründungsmitglieds verfassten) Literatur siehe den Ortsartikel Leegebruch. 
Dass die „Antifa-Transporte“ eine kleine, nicht repräsentative Sondergruppe der Vertriebenen bilden, deren Insassen wegen ihrer KPD-Zugehörigkeit oder doch -Nähe für die SED gewissermaßen hoffähig waren, zeigt sich u. a. auch an anderen Unterschieden zur Mehrheit der Vertriebenen. Denn für diese bildeten Glaube und Kirche zumeist einen großen Halt. Gerade die überwiegend katholischen Vertriebenen aus dem Sudetenland verstärkten auch in Brandenburg manche Diasporagemeinde, doch gilt dies eben nicht für die Orte, in die „Antifa-Transporte“ kamen. So bilanziert ein Mitglied des katholischen Leegebrucher Pfarrgemeinderates in der Gemeindechronik: „Die Heimatvertriebenen aus dem böhmischen Nixdorf, die in den Gründerjahren der DDR maßgeblichen Einfluss auf die Geschicke des Ortes nahmen, ließen sich dagegen nur schwer in das Gemeindeleben integieren. Nur ein Bruchteil von ihnen beteiligte sich wirklich an den Gottesdiensten und Veranstaltungen“. ${ }^{1363}$

\section{Bodenreform}

Die Bodenreform in der SBZ wurde mit der Verkündung des Beschlusses in einer Rede Wilhelm Piecks auf der Kreisbauernkonferenz des Kreis Ostprignitz am 2. September 1945 in Kyritz eingeleitet. ${ }^{1364}$ Sie gehört zwar zu den immer wieder gefeierten und vor wie nach 1990 thematisierten Mythen der DDR-Geschichtsschreibung, bildet aber - in der Gesamtbilanz - weniger eine Wohltat des Staates für die besitzlosen Flüchtlinge und Vertriebenen als eine der wichtigsten Maßnahmen zur dauerhaften Entmachtung der alten „ostelbischen“ Eliten und zur Schaffung einer homogenen sozialistischen Massengesellschaft. ${ }^{1365}$ Dabei ist nicht zu übersehen, dass diejenigen Vertriebenen, die bei der Landvergabe überhaupt berücksichtigt wurden - keineswegs deren Mehrheit - zunächst einen auch psychologisch positiven „Schub“ erhielten und empfanden, der sie aus der in den Lagern herrschenden Lethargie und aus den Abhängigkeitsverhältnissen zur Untermiete wohnender, auf Hilfstätigkeiten Angewiesener herauszuführen schien. Eine nähere Betrachtung der Ausgangsbedingungen ebenso wie der Nachhaltigkeit - das „Elend der Durchführung “1366 - zeigt jedoch, dass die Bedeutung der Bodenreform für die Integration und „Zufriedenstellung“ der Vertriebenen - entgegen aller fortdauernden Wirkung der Propaganda bestenfalls im Falle einer Minderheit als gelungen und segensreich angesehen werden kann. ${ }^{1367}$

1363 Gisbert Augsten: Die katholische Kirche St. Petrus zu Leegebruch. Ein historischer Abriss und eine Würdigung aus Anlass des 50. Jahrestages der Kirchweihe (Leegebrucher historische Blätter, H. 2). Leegebruch 2000, S. 46.

1364 Siehe Ortsdokumentation Kyritz.

1365 Grundlegend: „Junkerland in Bauernhand“? Hrsg. von Arnd Bauerkämper (wie Anm. 22). - Bauerkämper, Ländliche Gesellschaft (wie Anm. 22). - Arnd Bauerkämper: Die Bodenreform in der Provinz Mark Brandenburg. Wandel und Beharrung in der Agrarwirtschaft und ländlichen Gesellschaft 1945. In: Brandenburg im Jahr 1945 (wie Anm. 163), S. 265-296. - Ferner: Meinicke, Die Bodenreform und die Vertriebenen (wie Anm. 22).

1366 Transitzone Dorf (wie Anm. 248), S. 88.

1367 Eine Zusammenstellung aufschlussreicher Quellen bietet Wille II (wie Anm. 196), S. 327-362 (auch Beispiele und Statistiken für Brandenburg). 
In vielen Fällen waren die „Umsiedler“, wie sie zumeist in den Bodenreformstatistiken und -akten ${ }^{1368}$ heißen, unter den bei der Landvergabe berücksichtigten Personen in der Minderheit. ${ }^{1369}$ Im September 1946 waren in Brandenburg von 64135 Neubauernstellen nur 22870 $(37,7 \%)$ an „Umsiedler“ vergeben worden, in Quadratmetern gerechnet hatten sie von den 398367 ha bis dahin insgesamt verteilter Fläche immerhin 173522 (43,6\%) erhalten. ${ }^{1370}$ Vertriebene, die erst später nach Brandenburg kamen, gingen ohnehin leer aus. Aber auch in den Gemeindebodenkommissionen wurden sie nicht etwa als eine besonders vordringlich zu versorgende Zielgruppe behandelt. So waren von 690 gewählten Mitgliedern der Kommission für den Kreis Ostprignitz 376 Landarbeiter, 115 Kleinpächter und Bauern, 107 „Umsiedler“ und 92 „andere“ 1371 Die Gruppenbezeichnung als „Umsiedler“ kennzeichnet indirekt alle anderen als Einheimische bzw. Nicht-Vertriebene. Zusammengenommen machten letztere also in diesem Kreis, in dem 1945 besonders viele Flüchtlinge und Vertriebene aus der Neumark und aus dem „Warthegau“ lebten, 583 gegenüber nur 102 Vertriebenen aus. Die politische Verteilung in der Kommission sah wie folgt aus: 357 Parteilose, 192 Kommunisten, 126 Sozialdemokraten und 15 Mitglieder der anderen Blockparteien. Die Vertriebenen dürften zu diesem frühen Zeitpunkt noch überwiegend unter den Parteilosen zu finden gewesen sein.

Nachdem die Kommission die wesentlichen Arbeiten durchgeführt hatte, ergab eine vorläufige Bilanz der Bodenreform im Kreis Ostprignitz, dass 57 420,65 ha an 7895 Bodenempfänger verteilt worden waren, „und zwar an 800 Kleinbauern, an 3785 Landlose, Landarbeiter und kleine Pächter, sowie an 3310 „Umsiedler“. Die Kleinbauern erhielten insgesamt 6 855,61 ha, die Landlosten, Landarbeiter und kleinen Pächter 24273,54 ha, die „Umsiedler“ 20 491,50

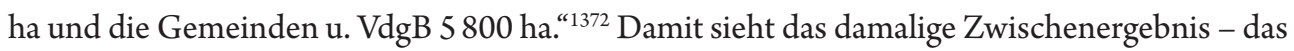

1368 Vgl. Quellenteil, Abschnitt 2.5 (S. 1217-1229).

1369 Siehe die (leider nicht in allen Bänden mit Gruppenbezeichnungen versehenen) Angaben im „Historischen Ortslexikon für Brandenburg“ (HOL) (wie Anm. 165), jeweils Punkt 6, im vorliegenden Buch teilweise berücksichtigt in der Ortsdokumentation (Teil 2). - Dass gegenüber den Angaben zur Bodenreform im HOL Vorsicht geboten ist, zeigt z.B. auch der Fall Jeserig/Fläming, in dem von einem Heimatforscher am Ort nachgewiesen wurde, dass der Bearbeiter des HOL oder bereits der der von ihm benutzten Unterlagen Zuständigkeiten der Jeseriger Bodenreformkommission für den Nachbarort Setzsteig falsch interpretiert hatte (Dorbritz, Erinnerungen an die Nachkriegszeit [wie Anm. 169], S. 77). - Siehe allgemein auch die trotz gewisser entstehungszeitlich bedingter Abstriche hilfreichen Beiträge: Fritz Reinert: Methodische Hinwesie zur Quellenauswertung von Archivalien über die Geschichte der demokratischen Bodenreform. In: Beiträge zur Geschichte der demokratischen Bodenreform im Land Brandenburg. Hrsg. vom Staatsarchiv Potsdam u. der SED-Bezirksleitung Potsdam, Kommission zur Erforschung der Geschichte der örtlichen Arbeiterbewegung. Potsdam 1966, S. 23-44; Hans-Joachim Schreckenbach: Archivalische Quellen zur Geschichte der demokratischen Bodenreform im Staatsarchiv Potsdam. In: ebd., S. 45-61.

1370 SAPMO-BArch, DY 34/27745, Bl. 26 (Tätigkeitsbericht der ZVU).

1371 Dorte Schmeissner: Kyritz, die Stadt der Bodenreform. T. II. In: Jahrbuch Ostprignitz-Ruppin 17 (2008), S. 77-92, hier S. 82.

1372 Ebd., S. 91. Genaue Zahlen für 12 Gemeinden des Kreises in: Andreas Noetzel: Bemerkungen zur demokratischen Bodenreform am Beispiel der Region Kyritz. In: Jahrbuch Ostprignitz-Ruppin 25 (2016), S. 217-237, Tabelle S. 231. 
noch nichts über eine in vielen Fällen später folgende Aufgabe der Siedlerstelle oder gar die zahlreichen Abwanderungen aussagt - wesentlich vertriebenenfreundlicher aus als die anfangs genannten Zahlen, umso mehr, als der Prozentsatz der berücksichtigten „Umsiedler“ ihrem Anteil (3 424) an der Zahl der Antragsteller im Kreis recht nahe kam, auch wenn die Angehörigen der anderen Gruppen von einheimischen Einzelpersonen letztlich sogar mehr Berücksichtigte (4585) als Antragsteller (4243) aufwiesen. ${ }^{1373}$ Doch auch jetzt waren die „Umsiedler“ unter den Begünstigten weder in der Mehrheit noch stellten sie die größte Gruppe. Dieses in der Tendenz durchaus für das gesamte Land repräsentative Ergebnis bleibt vor allem immer dann zu berücksichtigen, wenn in der zeitgenössischen, aber auch in der späteren und noch in der heutigen ortsgeschichtlichen Literatur der Bodenreform das Image eines „ostdeutschen Lastenausgleichs" für die Vertriebenen insgesamt zu geben versucht wurde und wird.

Nahezu überall bietet sich beim näheren Blick hinter die Kulissen der Bodenreform ein geradezu trostloses Bild, was den damaligen brandenburgischen CDU-Politiker Peter Bloch in der Rückschau zu der Formulierung „zuwenig zum Leben und zuviel zum Sterben“1374 veranlasste. Viele Neubauern erhielten zwar Landzuteilungen, aber weder Gebäude noch Geräte. Kaum ein Fall, in dem es nicht hieße: „bei Übergabe fehlte jegliches Inventar, Maschinen, Düngemittel und Vieh" ${ }^{1375}$ oder „es ist weder Vieh, Geräte gegeben worden"1376. Für eine Existenzneugründung mindestens ebenso wenig hilfreich war aber das fast überall festzustellende Fehlen von Wohnraum für die bei der Landzuteilung Berücksichtigten. Wer als Einheimischer solchen besaß „aufgestockte Altbauern“1377 - und nun seine Bewirtschaftungsfläche abrunden konnte, hatte damit keine Probleme. Für die mittellosen, auf Notquartiere angewiesenen Vertriebenen hieß das, dass nur durch Eigeninitiative von ihrem propagandistisch-euphemistisch beschriebenen neuen Status aus überhaupt eine lebensfähige, lebenserhaltende Wirtschaft zu entwickeln war. Manche Familie hat erst nach Jahren ein zugehöriges Wohnhaus selbst bauen können, andere hatten inzwischen längst aufgegeben. ${ }^{1378}$

Nachkriegszeitliche Improvisation und verzweifelte Notmaßnahmen spiegeln sich in einem Bericht aus der Waltersdorfer Gemeinderatssitzung vom 12. Januar 1946: „Das Barackenlager der Heinkel-Werke für Fremdarbeiter und Gefangene ist von der Bodenreform beschlagnahmt worden, um den Neubauern Gelegenheit zur Besorgung von Steinen aus den Bunkern zu geben." ${ }^{3379}$

1373 Dorte Schmeissner: Kyritz, die Stadt der Bodenreform. T. I. In: Jahrbuch Ostprignitz-Ruppin 15 (2006), S. 77-87, hier S. 87.

1374 Peter Bloch: Zwischen Hoffnung und Resignation. Köln 1986, S. 143.

1375 Schmeissner, Kyritz, die Stadt der Bodenreform, T. I (wie Anm. 1373), S. 85.

1376 Wille II (wie Anm. 196), S. 343, Nr. 350 (Schreiben eines „Umsiedler-Neubauern“ in Alt Zeschdorf, Kr. Lebus, an den FDGB, 25.5.1946).

1377 Noetzel, Bemerkungen zur demokratischen Bodenreform (wie Anm. 1372), S. 231.

1378 In Falkensee bei Berlin z. B. zog sich die Errichtung von Neubauernhäusern z. T. jahrelang hin, teilweise bis 1952. Siehe Mentzel, Neubauernsiedlungen (wie Anm. 111), S. 31 f. Der ganz auf die Bauten konzentrierte Beitrag sagt allerdings nichts über die Berücksichtigung von Flüchtlingen und Vertriebenen.

1379 Erich Sychold: Chronik Waltersdorf. Waltersdorf (2001), S. 71. [Waltersdorf, Kr. Teltow.] 
Dieser Weg wurde einige Monate später nach einem Runderlass der Provinzialverwaltung vom 6. April 1946 auch sonst beschritten. Demnach sollten „alle verfügbaren oder verfügbar werdenden Baracken oder Barackenteile, die aus Mitteln des Reiches, des Landes ${ }^{1380}$ oder der Provinz errichtet worden sind, [...] soweit sie nicht für vordringliche Zwecke der Verwaltung benötigt werden ${ }^{1381}$, in erster Linie zur Schaffung von Notunterkünften für Neusiedler zur Verfügung gestellt" werden. ${ }^{1382}$ Hinzu kam noch, dass die - selbst nicht immer von Not verschonte, aber oft wenig altruistische - einheimische Nachbarschaft mit Widerstand reagierte. So heißt es in einem Bericht über eine wiederum Waltersdorfer öffentliche Versammlung vom 3. März 1946: „Im Zusammenhang mit der Bodenreform war die Frage der Lösung des Wohnungsproblems für die Neubauern außerordentlich schwierig, [S. 72] zumal von verschiedenen Volksgenossen wenig Verständnis dafür aufgebracht wurde, daß den Neusiedlern nach ihrer Verpflichtung zur Sicherstellung der Volksernährung auch der notwendige Wohn-, Stall- und Scheunenraum zur Verfügung gestellt werden muß. Wenn die Gemeindeverwaltung aus diesen Gründen gezwungen war, verschiedentlich Wohnungstausch anzuordnen und dabei einige Einwohner etwas härter angefaßt wurden, so haben diese Leute das ihrem eigenen Verhalten zuzuschreiben." 1383

Das im Herbst 1947 begonnene größere, SBZ-weite (Neubauern-)Bauprogramm sollte die schwierige Lage vieler Neubauern verbessern ${ }^{1384}$, ging aber letztlich gerade für die Vertriebenen insgesamt eher in die entgegengesetzte Richtung, da man mit Abrissen von Gutsgebäuden den Mangel an Baumaterial zu beheben suchte, ein Weg, den privat längst viele Einheimische wie Zugewanderte gingen, wo immer ein Gebäude ruinös oder herrenlos war. ${ }^{1385}$ Die Herren-

1380 [Gemeint ist das erst 1947 offiziell aufgelöste Land Preußen.]

1381 [Gemeint sind offenbar v. a. die Baracken in den zahlreichen „Umsiedlerlagern“.]

1382 Wille II (wie Anm. 196), S. 344 f., Nr. 352, hier S. 344. Auch die einzelnen Bestimmungen zeigten mehr die Legalisierung eines längst praktizierten Verfahrens als vorausschauende Planung: „Die Abgabe der Baracken an Neusiedler kann kostenlos erfolgen." (S. 345)

1383 Ebd., S. 71 f.

1384 Meinicke, Die Bodenreform und die Vertriebenen (wie Anm. 22), S. 71-77. - Bauerkämper, Das Neubauernprogramm im Land Brandenburg (wie Anm. 22).

1385 Die Hauptabteilung Bodenordnung der für die SBZ zuständigen Deutschen Verwaltung für Land- und Forstwirtschaft war in einer Ausarbeitung über „Die soziale Lage der Neubauern“ am 7.8.1947 zu dem Ergebnis gekommen, dass zwar die „Aufteilung des Grund und Bodens [...] im allgemein als abgeschlossen zu betrachten“ sei: „Die Landempfänger sind Eigentümer dieses Landes geworden, sie bewirtschaften es selber und sind als Eigentümer rechtlich gesichert durch die Eintragung ins Grundbuch. Dagegen fehlt es den Neubauern an fast allen Betriebsmitteln, wie Wohn- und Wirtschaftsgebäuden, bäuerlichem Inventar und Mobiliar, Spann- und Nutzvieh. [...]." (Wille II [wie Anm. 196], S. 352 f., Nr. 361 [BArch, DK 1, Nr. 8899, Bl. 1-3], hier S. 351). Als Lösung des Problems müssen die Gutsgebäude herhalten, mit deren Beseitigung zugleich, wie mit der Bodenreform insgesamt, auch die letzten alten Strukturen beseitigt werden könnten: „Wenn wir heute auf das Land kommen, so sehen wir wohl auf den Feldern eine bäuerliche Arbeits- und Wirtschaftsweise, aber in den Dörfern ist trotz Bodenreform der Gutshof noch immer erhalten geblieben. Es ist noch nicht anstelle des Gutshofes das Bauerndorf getreten. Solange diese ehemaligen Gutsgebäude nicht abgebrochen und aus ihrem Material Neubauernhöfe aufgebaut worden sind, ist das Gesicht der Bodenreform noch nicht hergestellt, und die enteigneten Junker und Kriegsverbrecher glauben noch immer, eines Tages wiederkehren, um in alter Weise mit der Wirtschaft beginnen zu können. Eine unserer vor- 
bzw. Gutshäuser aber dienten gerade vielen anderen Flüchtlingen und Vertriebenen nach wie vor als Wohnraum. ${ }^{1386}$ Ihre Zahl zu verringern, nützte an der einen, musste die Probleme an anderer Stelle aber verschlimmern. Die Wohnraumprobleme der Flüchtlinge und Vertriebenen waren so an manchen Orten noch Jahre nach Kriegsende spürbar. ${ }^{1387}$ Letztlich kam nur eine Minderheit in den Genuss von eigens errichteten (Fachwerk-)Neubauten (Siedlerhäuser, z. T. Typenhäuser ${ }^{1388}$ ). Solche entstanden als „Neubauernhöfe, die als Einzelgehöfte in die Dörfer eingefügt, in Gruppen am Rande bestehender Orte oder als sogenannte Ausbauten auf der Gemeindeflur angelegt wurden. ${ }^{1389}$ Beispiele sind in verschiedenen Regionen Brandenburgs noch erhalten und teilweise unter Denkmalschutz gestellt worden. In Schönholz (Kr. Westhavelland) hat sich ein Wohnstallhaus erhalten, das um 1947 „teilweise aus Abbruchmaterial eines ehemaligen Vorwerkes zum Gut Hohennauen“ für Vertriebene aus Bessarabien errichtet worden ist. ${ }^{1390}$ Ein Beispiel für ein ganzes, 1945/46 angelegtes und 1947/49 planmäßig ausgebautes Neubauerndorf, auch als „Musterdorf“ und als „sozialistisches Dorf“ bezeichnet, findet sich im damals grenznahen sachsen-anhaltischen Freileben (heute Ldkr. Elbe-Elster, Brandenburg). ${ }^{1391}$ In Neupetershain (Kr. Calau) erhielten die aus Niederschlesien Vertriebenen in der Bodenreform schon 1946 „weitestgehend standardisierte Neubauernhäuser. ${ }^{1392}$ Mensch und Vieh unter einem Dach, getrennt durch eine Futterküche."1393

Als eines der größten Probleme bei der Umsetzung der Bodenreform erwiesen sich - für die Vertriebenen - die gut funktionierenden Strukturen der einheimischen Familien. Denn

dringlichsten Aufgaben wird es also sein müssen, diese ehemaligen Gutsgebäude unter grösster Schonung des Materials abzutragen und aus dem so gewonnenen Material unter Zuhilfenahme von neuem Baumaterial sowie Lehm und Holz aus dem Neubauernwald Hofstellen für die Neubauern zu errichten. Wäre so statt vieler Worte und Pläne, durch die kein Neubauer auch nur einen Schuppen gebaut erhält, bereits in den zwei hinter uns liegenden Jahren verfahren worden, so ständen heute Neubauerngehöfte dort, wo jetzt noch nicht einmal ein Bebauungsplan vorliegt." (ebd., S. 352). - Beispiel aus dem Kr. Niederbarnim: Michael Braun: Erste Nachkriegsjahre in Hönow. In: Jahrbuch Märkisch-Oderland 25 (2018), S. 46-48 (Abriss des Herrenhauses, Fotos: Bau von Neubauernhäusern).

1386 Siehe dazu oben den Abschnitt „Wohnsituation“ im selben Kapitel.

1387 Noetzel, Bemerkungen zur demokratischen Bodenreform (wie Anm. 1372), hier S. 227 f.

1388 Neubauernsiedlung und Wiederaufbau des Landes. Merkblätter für die Gesamt- und Einzelplanung von Neubauernsiedlungen und Handwerkerstellen. Autorengruppe unter Karl Erbs. Hrsg. vom Referat für ländliches Bauwesen in Verb. mit dem Amt für Planung und Wiederaufbau der Landesverwaltung Brandenburg. Textteil u. 81 Plantafeln mit Musterzeichnungen. Berlin 1947.

1389 Gramlich, Freileben (wie Anm. 111), S. 129. - Siehe zu Neubauernsiedlungen grundsätzlich auch Wolfgang Blöß: Kommunale Strukturen im Spannungsfeld gesellschaftlicher Umwälzungen. Die Grenzen von Gemeinden und Kreisen in Brandenburg 1945-1952. Berlin 2018, S. 130-138, 166-169.

1390 www.fotografie-architektur.de/dorfentwicklung_in_brandenburg_1.html [9.6.2017].

1391 Gramlich, Freileben (wie Anm. 111), S. 129 („Mustersiedlung Waidmannsruh“), 137 Fn. 26 („Das erste sozialistische Dorf des Kreises Herzberg“, Titel einer Publikation von 1979).

1392 [Der Standard ließ sich aber nicht überall einhalten. Siehe das Beispiel für Stroh- statt Ziegeldach in Kienitz (Kr. Lebus), überdies erst Anfang Okt. 1949 im Bau befindlich: Wille II (wie Anm. 196), S. 353 f., Nr. 364 (BLHA, Rep. 206, Nr. 2691).]

1393 Horst Kittan: Die Russen kommen. Cottbus 2011, S. 243. 
in den örtlichen Vergabekommissionen wussten vielfach die Bürgermeister ihre Verwandten zu berücksichtigen bzw. zu bevorzugen, so dass die wirklich Bedürftigen nicht selten an der Realität der kleinen, lokalen Verhältnisse scheiterten. ${ }^{1394}$ Aufgrund von Äußerungen in ihrer eigenen (Vertriebenen-)Familie schreibt Sarah Grandke, die sich mit der Vertriebeneneingliederung im Raum Prenzlau befasst hat: „Allerdings berichteten einige (ehemalige) Vertriebene, dass sie zwar Agrarflächen erhielten, diese aber in einem schlechteren Zustand waren als die der ansässigen Kleinbauern. " ${ }^{1395}$ Dieser Eindruck wird kaum nur subjektiv gewesen sein, denn das Phänomen - Teil des vielschichtigen „Kalte-Heimat-Problems“ - war nur zu verbreitet. Doch es ging auch noch anders: „In einigen Dörfern waren die Umsiedler von der Verteilung der Bodenreformflächen ausgeschlossen worden mit dem Argument, sie würden doch bald wieder nach Hause zurückgelangen. Die angesetzten Umsiedler wiederum ließen es an Engagement fehlen. Sie waren kaum in der Lage, sich und ihre Familien zu ernähren; noch weniger konnten sie zur Verbesserung der Ernährungslage im Lande beitragen. Ihnen wurde verbreitete Interesselosigkeit bescheinigt. Die völlig unzureichene Unterbringung von Mensch und Tier verschärfte die Lage und bestärkte das Bestreben, in die alte Heimat zurückzukehren. "1396

Weiterhin ist - in der Frage des persönlichen Engagements - auch noch zu berücksichtigen, dass es sich bei den mit Siedlerland versehenen Personen keineswegs immer um erfahrende Landwirte handelte, die in ihrer Heimat Haus und Hof besessen hatten, sondern nicht selten um bestenfalls aus der Landarbeit auf Gütern, oft aber auch aus Städten kommende, mithin um Menschen, die als für ihre neuen Aufgaben „ungelernt" bezeichnet werden müssen, zumindest aber als mit den Anforderungen überfordert. So heißt es in einem Bericht des Informationsdienstes des Kreises Angermünde vom 15. April 1950 über die „Lage der Umsiedler im Kreise Angermünde“, wo am 1. Januar 1950 immerhin 32 Prozent der Einwohner „Umsiedler“ waren und von diesen fast drei Viertel auf dem Land lebten: „Die besondere Schwierigkeit liegt hinsichtlich der Umsiedlerfrage in der geringen Industrialisierung des Kreises, die bei einem nicht unwesentlichen Teil eine berufsfremde [!] Beschäftigung notwendig mache. / Einen gewissen Ausgleich schuf die Bodenreform, wo aus der gesamt zu versiedelnden Fläche von 78160 ha rund 17000 ha, also ca. $22 \%$, an 1680 Umsiedler mit ca. 6600 Familienangehörigen, insgesamt 8280 Umsiedler, das sind ca. $25 \%$ der Gesamtumsiedler, versiedelt wurden. ${ }^{\prime 1397}$ D. h., nur eine Minderheit der im Kreis insgesamt lebenden 28015 Vertriebenen kam überhaupt in den Genuss von Bodenreformland, und von diesen waren viele ohne landwirtschaftliche Kenntnisse, kamen aus anderen Berufen und gar aus Städten. ${ }^{1398}$

$1394 \mathrm{Zu}$ Benachteiligung Vertriebener siehe u.a. Meinicke, Die Aufnahme von Vertriebenen (wie Anm. 11), S. 481 f.; Bauerkämper, Flüchtlinge zwischen Ausschluß und Integration (wie Anm. 22); Boris Spix: Die Bodenreform in Brandenburg 1945-47. Münster 1997, S. 90. - Zum Losverfahren: Otto Gedack: Wie ich die Bodenreform erlebte. In: Damals und heute (wie Anm. 357), S. 58-60.

1395 Grandke, „Als die Füße nass und kalt waren, erkannte ich den Ernst der Lage.“ (wie Anm. 187), S. 48.

1396 Blöß, Grenzen und Reformen (wie Anm. 89), S. 66.

1397 BLHA, Rep. 202 G Amt für Information, Nr. 170, Bl. 27r (vgl. Textabdruck im Quellenteil, Nr. 214).

1398 Die bestenfalls starke Mischung der Herkunftsregionen zeigt sich z. B. in Wilhelmshayn bei Fürstenwerder (Kr. Prenzlau), hier sogar einschließlich eines aus Berlin gekommenen Ehepaars: Hans-Christoph Hey- 
Aber ebenso konnten sich noch aus ganz anderen Umständen - auch im größerräumigen Vergleich - Benachteiligungen ergeben. So fehlen Bodenreformzuteilungen an Vertriebene nicht nur, wenn andere Personen bzw. Gruppen bevorzugt wurden, sondern auch da, wo gar kein aufteilbares Gutsland zur Verfügung stand und doch Interessenten lebten: „In Ragösen [Kr. Zauch-Belzig] gab es kein Gut und auch keine anderen Flächen, die aufgeteilt werden konnten. Da aber Ragösen auch etwas abbekommen sollte, wurden 24 ha Acker, 30 ha Wiese und 271 ha Wald, die dem Fiskus gehörten, an die bisherigen Pächter und an Kleinlandwirte aufgeteilt." ${ }^{\text {"1399 }}$ Ähnliches zeigt der Vergleich des Bauerndorfes Abbendorf mit dem benachbarten Gutsdorf Rühstädt (beide Kr. Westprignitz). ${ }^{1400}$

All diese nicht unwesentlichen Probleme sind als Startbedingungen vielerorts zu bedenken, will man Schlüsse ziehen, ohne die konkrete Situation untersucht zu haben. ${ }^{1401}$ Doch gerade in der Landwirtschaft erfahrenere und womöglich zuvor mit einem größeren Hof ausgestattet gewesene Vertriebene spürten zudem bald, dass sie für eine langfristige Aufbauplanung auf „eigener Scholle“ in der SED gar keinen verlässlichen Partner besaßen. Ein in den dreißiger Jahren noch in Bessarabien geborener Bauernsohn, der - nach Umsiedlung in den „Warthegau“, wo die Eltern 1940 bis 1945 ebenfalls einen Hof bewirtschafteten, - im Februar 1945 als Flüchtling nach Mörz bei Belzig gekommen war, erlebte hier zunächst die Bodenreform, aber dann auch die Zwangskollektivierung: „Die Enteignung von Gutsbesitzern und Großbauern setzte ein, sodass wir als Geschwister in der Landwirtschaft keine Zukunft mehr sahen. Das führte mich dazu, einen Handwerksberuf zu ergreifen, was meine Geschwister etwas später auch taten. Unsere Mutter, eine stolze Bauernfrau auf eigener Scholle, blieb für viele Jahre Magd auf dem fremden Hof.

mann / Bodo Desjardins / Detlef Graf von Schwerin: 200 Jahre Wilhelmshayn. Wilhelmshayn 2016, S. 38-65 (mit Namen und weiteren Angaben zu allen Erstsiedlern der Bodenreformsiedlung!).

1399 Ragösen. Beiträge zur Geschichte, T. 2 (wie Anm. 188), S. 20, vgl. auch ebd., S. 108.

1400 Transitzone Dorf (wie Anm. 248).

1401 Nach 1990 ist in der Lokalforschung erst eine Handvoll brauchbarer kleinerer Arbeiten zur Bodenreform in einzelnen brandenburgischen Gemeinden und Kreisen erschienen. Siehe z. B.: Hermann Berlin: Wie sich die Landwirtschaft in Hammelspring nach 1945 entwickelt hat. In: Templiner Heimatkalender 2016 (2015), S. 66-70. [Auch zu „Umsiedlern“ als Empfängern von Bodenreformland]. - Winfried Dartsch: Junkerland in Bauernhand. Zur demokratischen Bodenreform 1945/46 in Groß Breesen. In: Gubener Heimatkalender 29 (1985), S. 44-49. - Günter Fromm: Bodenreform 1945/46 in Ziltendorf - Ortsteile Thälmannsiedlung und Aurith. In: Heimatkalender Eisenhüttenstadt und Umgebung 15 (1997), S. 80-86. - Lutz Kühne: Die Bodenreform im Kreis Beeskow-Storkow. In: Kreiskalender Oder-Spree 2006, S. 22-26. - Noetzel, Bemerkungen zur demokratischen Bodenreform (wie Anm. 1372) [Region Kyritz]. - Schmeissner, Kyritz, die Stadt der Bodenreform, T. I (wie Anm. 1373) und T. II (wie Anm. 1371). - Michael Braun: Die nicht ganz erste LPG in der DDR. In: Jahrbuch Märkisch-Oderland 27 (2020 [2019]), S. 39-45 [Worin, Kr. Lebus; S. 39 und $44 \mathrm{f}$. auch zum ersten Vorsitzenden (1952-1975) der Woriner LPG „Thomas Müntzer“ Bernhard Grünert (1906-1997), Gutsarbeitersohn und gelernter Maurer, Vertriebener aus Schlesien, vor 1945 dort Bau-Gelegenheitsarbeiter und KPD-Funktionär, 1946 Neubauer in Worin, 1950-1952 Landtagsabgeordneter (SED) in Brandenburg]. - Siehe aber auch die ältere Arbeit von Gisela Wirth: Zum 30. Jahrestag der Durchführung der demokratischen Bodenreform in Letschin. In: Heimatkalender für die Gemeine Letschin 1 (1975/76), S. 21-27. 
Irgendwann wurde die Landarbeit für Mutter zu schwer und sie nahm eine Arbeit im Altersheim als Stationshilfe an. "1402

Selbst in Dorf Zinna/Neuheim, dem von größtenteils sudetendeutschen „Antifa-Umsiedlern“ begründeten Kandidaten für den Status eines sozialistischen „Musterdorfs“, ist die Bilanz eher ernüchternd. Die für die Flächenaufteilung gegründete Bodenkommission setzte sich in Dorf Zinna zwar sogar ausschließlich aus - am Ort in der großen Mehrheit vertretenen - Vertriebenen zusammen. Doch führten die beschriebenen Rahmenbedingungen auch hier zu einem bestenfalls vorübergehenden Erfolgsmodell. Nach den von dem zeitgenössischen Neuheimer Chronisten Hans Schmutzer 1966 publizierten Listen (Stand 1.3.1946) gab es in Neuheim 20 Neubauern (VdgB-Mitglieder) mit je 11,5 ha und 40 Kleinsiedler mit je 0,25 ha. ${ }^{1403}$ Elf Neubauern waren Landwirte und einer Schweizer, zwei Glasspinner, zwei sonstige Handwerker, zwei Arbeiter, einer Eisenbahner und einer Gastwirt. Unter den Kleinsiedlern waren nur drei Landwirte, sonst überwiegend Handwerker, Glas- und andere Arbeiter, drei von diesen waren Frauen, eine weitere Frau arbeitete als Hausfrau. Sämtliche Neubauern und Kleinsiedler waren SED-Mitglieder. Während die Kleinsiedler ausweislich ihrer Geburtsorte und des Zusatzes „CSR“ ausschließlich aus dem Sudetenland stammten, waren es bei den Neubauern nur die Hälfte (10), bei den anderen zehn Neubauern steht statt „CSR“ „Deutsch“. Letztere stammten teils aus anderen Vertreibungsgebieten (Oberschlesien), teils aus anderen Ländern der SBZ, in drei Fällen auch aus Nachbardörfern. Das Durchschnittsalter der aus dem Sudetenland vertriebenen Neubauern lag bei 43 Jahren, das der aus anderen Gegenden stammenden bei $51 .{ }^{1404}$ Bei den Kleinsiedlern lag der Altersdurchschnitt 1946 bei 45 Jahren.

Schmutzer selbst liefert im Text zum Teil davon abweichende Angaben, wobei allerdings bei den Listen ein genaues Stichdatum vermerkt ist, während die Beschreibung allgemeiner gehalten bleibt: „Von den Neubauern waren nur 4 wirkliche Bauern. Alle anderen kamen aus der Industrie. Von den 19 Neubauern kamen 11 aus der CSR und 8 aus Schlesien, dem Warthegau und Ostpreußen. Je ein Gespann mit 2 Pferden hatten nur die Bauern Johann Jesse, Heinrich Lindner, Siegfried Hirte. [Alle drei gehörten nicht zu den sudetendeutschen Vertriebenen, laut Neubauernliste ${ }^{1405}$ waren zwei Landwirte, einer Gastwirt! - P. B.] Alle anderen hatten zum Anfang weder Gespanne, noch irgendwelche Vieh oder Geräte. Für diese war es besonders schwer mit dem Beginn der Landwirtschaft. “ ${ }^{1406}$ Ende März 1946 vermittelte das Landratsamt dem Dorf 10 Pferde, „wovon kurz darauf 4 Pferde wieder gestohlen wurden“ 1407 "Bei den Kleinsiedlerstellen gab es später auch

1402 Weiß, Die letzten Kinder Bessarabiens (wie Anm. 993), S. 14.

1403 Ebd., S. 84-86.

1404 Der in der Liste unter „Deutsch“ eingeordnete Oberschlesier Josef Urbansky gehörte mit etwas über 34 Jahren zu den Jüngsten. Die Schwankungen sind bei dieser „Deutsch“-Gruppe größer, die Geburtsjahre liegen zwischen 1888 und 1921, bei den Sudetendeutschen dagegen zwischen 1896 und 1908, sechs von ihnen sind 1903, 1904 oder 1905 geboren.

1405 Schmutzer, ... auferstanden aus Ruinen (wie Anm. 642), S. 84f., Nr. 11, 12, und 18.

1406 Ebd., S. 88.

1407 Ebd. 
Ärger. Ein Teil der Besitzer ließ das Land brach liegen, oder verpachtete es an einen Bauern. "1408 Auch bezüglich der Kollektivierung ist Schmutzers Bilanz für Neuheim wenig propagandatauglich: „Die noch außenstehenden Bauern konnten sich nicht entschließen den entscheidenden Schritt zur sozialistischen Arbeit in der Landwirtschaft zu tun. Ein jeder von ihnen fand eine andere Ausrede." ${ }^{1409}$

Aber auch die Langzeitbilanz eines anderen Chronisten zeigt 1984 - hier für den Raum Paulinenaue bei Neuruppin - kaum andere Entwicklungen: „Die Neubauernstellen in Bärhorst und Eichberge haben sich nur 10 bis 20 Jahre gehalten. In den ersten Nachkriegsjahren gaben sie den Umsiedlern eine neue Existenz in der Landwirtschaft, und die Bewirtschaftung des Bodens war gewährleistet. Mit der Zeit erwiesen sich jedoch die Arbeits- und Lebensbedingungen, einsam und weit draußen im Luch, als sehr nachteilig. Hinzu kam, daß die 1960 beginnende mechanisierte Großraumwirtschaft eine effektivere landwirtschaftliche Produktion mit zunehmend höherer Arbeitsproduktivität ermöglichte. Die Siedler sind nach und nach wieder weggezogen, zumeist in die Zentralgemeinde Paulinenaue. Mitte der 50er Jahre hatte Eichberge 47 Einwohner, heute wohnen dort nur noch 2 Familien mit 7 Personen auf dem Gehöft Seehawer. Bärhorst hatte 43 Einwohner, heute wohnt dort keiner mehr, und die 8 Neubauernhäuser sind wieder abgerissen worden. " ${ }^{1410}$

So bleibt bei aller teilweisen oder befristeten Besserung der Lage eines Teils der Vertriebenen in der SBZ und auch in Brandenburg ein letztlich sehr zwiespältiger Eindruck, den selbst die Verantwortlichen keineswegs immer zerstreuten: „Die Durchführung der Bodenreform war in erster Linie eine wichtige politische Maßnahme" schreibt in der Rückschau Bernhard Bechler, der damals den Vorsitz der zuständigen Provinzialkommission innehatte. Erst in zweiter Linie sei sie „weiterhin eine wirtschaftliche“ gewesen und „schließlich“ eine „soziale Maßnahme, die Tausenden von Umsiedlern wieder Grund und Boden und damit eine neue Heimat gab; ganz im Gegensatz zu Westdeutschland, wo zwar Entschädigungen gezahlt, aber die Umsiedler aus politischen Gründen nicht seßhaft gemacht wurden. "1411 Man kann getrost davon ausgehen, dass diese einseitige agitatorische Interpretation noch heute in vielen Köpfen das Bild von der Bodenreform prägt und diese vielen Zeitgenossen irrigerweise als beabsichtigte und auch umgesetzte Lösung der Flüchtlingsfrage gilt. Dabei zeigt schon Bechlers Gewichtung des primär politischen (und allgemein wirtschaftlichen) Charakters an, dass dies allenfalls eines von mehreren Zielen darstellte und vielmehr die Schaffung einer egalisierten sozialistischen Gesellschaft bezweckt wurde. ${ }^{1412}$

Mehrere Faktoren verhinderten überdies, wie zusammenfassend noch einmal festzuhalten ist, dass die Bodenreform für die Vertriebenen in Brandenburg das werden konnte, was

1408 Ebd.

1409 Ebd., S. 97.

1410 Günther Wacker: Paulinenaue. Eine Ortschronik aus dem Havelland. Digitalisierte Version der ersten Ausgabe von 1984 (http://archiv.paulinenaue.info/allgemeines/chroniken/wacker.pdf [7.1.2017), S. 18.

1411 Bernhard Bechler: Erinnerungen an die Bodenreform. In: Märkische Heimat. Beiträge zur Heimatgeschichte des Bezirkes Potsdam 4 (1985), S. 12-23.

1412 Siehe dazu auch: Bauerkämper, Die vorgetäuschte Integration (wie Anm. 22). 
sie vielen Darstellungen zufolge zu sein schien. Schon die geringe Zahl der in den Genuss von Bodenreformland kommenden Flüchtlinge und Vertriebenen war entscheidend. Die an vielen Orten feststellbare Bevorzugung der Altbauern bzw. Einheimischen schließlich vertiefte bei den Zugezogenen sogar noch den Eindruck, nicht willkommen zu sein. Die vollkommen unzureichende Ausstattung mit notwendigem Geräten, Maschinen, Vieh und nicht zuletzt Gebäuden ließ viele bald scheitern. Hierin bot die Mark Brandenburg, anders als etwa Thüringen, wo der durchschnittliche Viehbesitz generell besser aussah, „ein trauriges Bild“" ${ }^{1413}$ Vor allem aber die nur wenige Jahre wirksame Versorgung mit eigenem, eigenverantwortlich und ohne $\mathrm{Ab}$ lieferungssoll bewirtschaftetem Land tat ein Übriges, da die nach wenigen Jahren einsetzende Zwangskollektivierung die meisten Bauern, nun alte wie neue, zur Aufgabe ihrer Wirtschaften trieb, viele von ihnen sogar zum Verlassen der DDR. ${ }^{1414}$ Resigniert berichtet der Umsiedlerausschuss der Gemeinde Lübbinchen 1947 an die Umsiedlerabteilung des Gubener Landratsamtes: „Es ist ein Bruchteil[,] die lebensfähig sind, vielleicht 8-10[,] die anderen gehen früher oder später ein." ${ }^{1415}$ Der Anteil der Vertriebenen nicht nur unter den LPG-Unwilligen, sondern auch unter den „Republikflüchtigen“ ist, darauf wurde schon mehrfach hingewiesen, nicht gering gewesen und hat neben anderen Ursachen diejenige, dass - aus einem gleichsam traditionellen Bauernmilieu kommende - landwirtschaftliche Eigenverantwortung unerwünscht war und - wie bei den Einheimischen - der Kollektivierung zu weichen hatte.

1413 Pape, Flüchtlinge und Vertriebene in der Provinz Brandenburg (wie Anm. 30), S. 119.

1414 Siehe dazu die detaillierten monatlichen Tabellen zur „Landaufgabe von Neubauern aus den Reihen der Vertriebenen“ für 1948 und 1949, jeweils aufgeschlüsselt nach 14 „Gründe(n) der Aufgabe“, in: Oehlsen, Vertriebenenlager (wie Anm. 45), S. 118-121.

1415 Wille II (wie Anm. 196), S. 343 f., Nr. 351 (BLHA, Rep. 250 Guben-Frankfurt/O., Nr. 283), hier S. 343. 



\section{Ideelle Aspekte - Integrationshemmendes und -förderndes}

\section{Die „Kalte Heimat" und das öffentliche „Tabu"}

\section{Menschen unter Menschen}

Der Körper lebte mit seinen Bedürfnissen längst in einer neuen Heimat, die Seele war nicht so leicht zu integrieren. Mit großem zeitlichen Abstand, aber unverändertem Sich-HineinfühlenKönnen in die Kindheitserlebnisse schreibt eine nach Brandenburg vertriebene Schlesierin über ihre Gefühle in den Nachkriegsjahren: „das Heimweh war auch noch sehr groß. Und viele klammerten sich lange an die Hoffnung, eines Tages doch wieder nach Hause fahren zu können. Ich erinnere mich, dass unsere Mutter immer weinen musste, wenn von irgendwoher Musik erklang. Musik im Allgemeinen, aber heimische Schlesische im Besonderen. Leider hatten wir lange Zeit kein eigenes Radio."1416

Die mit dem Wort von der „Kalten Heimat“ (Andreas Kossert) umschriebene Erfahrung des Nicht-Willkommenseins traf die Flüchtlinge häufig schon vor Kriegsende, wo ohnehin alle Einheimischen selbst unter ständigem Druck standen und nun argwöhnisch die Neuankömmlinge betrachteten, denen oft nur durch die Macht der Behörden und der Partei zu einer Unterkunft verholfen werden konnte. Die Zeitzeugenberichte der Flüchtlinge zeigen aber auch, dass es nicht wenige positive Gegenbeispiele bereitweilig gewährter Hilfe gegeben hat. Nicht anders war es nach Kriegsende, nur dass jetzt in der SBZ eine bewusste Politik darauf abzielte, die bald beschönigend zu „Umsiedlern“ erklärten Vertriebenen so schnell wie möglich unsichtbar zu machen.

Will man eine Bilanz der Integration ziehen, so wächst die Bedeutung dieses „ideellen Moments" umso mehr, je länger man sich mit der Materie befasst. Denn unleugbar ist - in Ost genauso wie in West - bei der Eingliederung der Flüchtlinge und Vertriebenen in ein wieder funktionierendes Leben im Frieden einerseits viel geleistet worden, konnten Millionen Menschen Arbeit und Wohnung verschafft werden. Andererseits hätte angesichts der auch seelischen Tragödie des Heimatverlusts eine ideelle Hilfestellung dringend notgetan, kam aber selbst von den Kirchen nur teilweise. Stattdessen wurde der nicht nur materielle Verlust früh durch vielfache Ablehnung an den Aufnahmeorten und scheinbar auf Dauer durch den Zwang zur Selbstverleugnung noch verstärkt. Wie die Betroffenen damit umgegangen sind, ist - wie die Menschen an sich - unterschiedlich. Die Bandbreite reicht von Abwanderung in den Westen über das Abtauchen ins Private, was die Thematisierung der Heimat angeht, bis zu einem Sich-Lossagen von Herkunft und vollständigem Sich-Einlassen auf das Neue, das Arbeit und Brot gab. Für alle aber waren die gleichsam seelischen Rahmenbedingungen, diese Vorausset- 
zungen für die genannten Reaktionsmuster, gleichermaßen vorgegeben. Daher sollen sie hier etwas näher behandelt werden, als dies gemeinhin geschieht.

Zunächst ist es wichtig, sich darüber bewusst zu werden, dass die damaligen Flüchtlinge und Vertriebenen - wie heutige - teilweise schlimmste auch seelische Wunden bereits mitbrachten, zunächst aus Kriegshandlungen, dann aus nachkriegszeitlichen Erfahrungen mit Stigmatisierung und Gewalt. Die oftmals schlimmen Erlebnisse während der letzten Kriegswochen, die Entbehrungen und Todesfälle im engsten Familienkreis auf der Flucht - junge Mütter müssen ihr totes Baby, Familien den eben erst verstorbenen Großvater am Straßenand unbeerdigt liegen lassen und weiterziehen -, Gewalt und Tod bei und nach dem Einmarsch der Roten Armee sowie die einschneidenden Demütigungen, denen sich die zunächst noch in den Heimatorten Verbliebenen in den ersten Besatzungsmonaten bis zur und während der Ausweisung ausgesetzt sahen, all dies dürfte tiefe Einschnitte im seelischen Haushalt hinterlassen haben. Die Bewältigung war kurz- und mittelfristig oft nur durch Verdrängung im Überlebensalltag möglich. Langfristig blieben Narben, und das Bedürfnis nach Erzählung und Erinnerung, nach Wiedersehen und Erinnern konnte sich bei vielen letztlich erst nach 1990 wirklich Bahn brechen - meist nur die jüngeren Vertriebenen erlebten dies noch. ${ }^{1417}$

Was diese Menschen, meist Frauen, Kinder und Alte, während der Flucht oder Vertreibung erlebt und erlitten hatten, ist vielfach überliefert und beschrieben worden. Es muss daher hier, bei einer Darstellung vornehmlich der Aufnahme und Integration in der neuen Heimat, nicht ausführlich einbezogen werden, muss aber als eine wesentliche Voraussetzung und individuelle Ausgangssituation doch immer mitbedacht werden. Denn die aufzunehmenden und zu integrierenden Menschen brachten fast alle ähnliche Zivilisationsbruchs-Erlebnisse in das zivile Leben mit, die ihre Psyche zutiefst geprägt hatten und den Neuanfang, je nach persönlicher Verarbeitungskraft, entweder verzögerten und damit erschwerten oder auch erleichterten, wenn man alles, auch die Erinnerung, zunächst hinter sich ließ und im tiefsten Inneren verkapselte.

Stellvertretend für die innere Verfassung der Ankommenden mag hier stehen, was eine damals 21-jährige Frau im Alter rückblickend erzählt hat. Sie hatte 1945 in Bomst erlebt, wie Frauen aus dem benachbarten Züllichau aus Angst vor weiterer Vergewaltigung „ins Wasser gegangen sind“. „Diese Erlebnisse haben uns sprachlos gemacht. Ich bin nach Neuruppin gekommen und konnte nicht mehr lachen und weinen. Bei uns war alles weg, wir hatten keine Menstruation mehr. ${ }^{1418}$ Es war seelischer Stillstand. Man konnte es einfach nicht mehr verkraften. "1419 Ähnliche Wirkung

1417 Eindrucksvoll ist der Umgang mit ihren frühkindlichen Traumata, den die erst 1942 geborene Schriftstellerin Sigrid Grabner (Potsdam) in ihren Erinnerungen (Jahrgang ,42. Leipzig 2003, Neduruck Kisslegg 2011) schildert. Siehe allgemein zu Traumata von Kriegskindern Bode, Die vergessene Generation (wie Anm. 274), zu Flüchtlingskindern u. a.S. 111 ff. (allgemein), 251-253 (Fallbeispiel eines später in der DDR lebenden Mädchens).

1418 Die umgekehrte Reaktion ihres geschwächten Körpers erlebt eine 34-jährige Flüchtlingsfrau, die während des Fluchttrecks mit irregulären Blutungen zu kämpfen hat: Gisela Reimnitz: Jahre der Herausforderung. Lebenserinnerungen einer Gutsfrau. 2. Aufl. Paderborn 1992, S. 19 f.

1419 Ruth Preuß, [Lebensgeschichte] (wie Anm. 395), S. 98. 
hatten viele andere Erlebnisse, die nicht nur Frauen betrafen, sondern ganze Familien, die plötzlich mit dem Tod oder der Verschleppung eines nahen Angehörigen konfrontiert wurden oder einfach der alltäglichen Gegenwart von Tod und Hunger ausgeliefert waren. „Man kann die Empfindugen überhaupt nicht darstellen, die man im Moment hatte, wir waren seelisch kaputt." 1420

Hinzu kam vor allem bei denjenigen, die ab Sommer 1945 vertrieben wurden und bis dahin in einer monatelangen Rechtlosigkeit gelebt hatten, das nahezu völlige Abgeschnittensein von Informationen über die Weltlage. Die 1945 aus Bomst vertriebene Ruth Preuß (Neuruppin) steht mit ihrer Beschreibung nicht allein, wenn sie sagt: „April, Mai 1945 - ob damals Kriegsschluss war, das wussten wir alles nicht. Wir hatten ja keine Erfahrung mit politischen Dingen. Wer hat uns gesagt, dass Kriegsschluss ist? Niemand. Wir haben nicht gewusst, dass im Mai etwas gefallen war. Wir hatten keine Radios. Wer sollte uns das sagen? Die Russen und die Polen sind mit uns umgegangen, aber wir wussten nichts von Politik. / In der Stadt waren wir teilweise sehr isoliert, zur Arbeit eingesetzt. Wenn man Deutsche sah, hat man sich gefreut." ${ }^{\text {1421 }}$ Dieser Extremsituation, der sich die nicht rechtzeitig Geflüchteten zwischen Kriegsende und Ausweisung ausgesetzt sahen, standen die Erlebnisse der noch während des Krieges Geflohenen und Evakuierten nicht immer nach, gerieten diese doch oft genug in verheerend chaotische Szenen im Kampfgebiet oder wurde selbst Opfer z. B. von Luftangriffen.

\section{Nächstenliebe unter Belastung}

Die Erfahrungen in den Aufnahmeorten schwankten nun dessen ungeachtet zwischen hilfsbereiter Freundlichkeit und kalter Ablehnung. Der Schriftsteller Hugo Hartung (1902-1972), der von 1947 bis 1950 in Potsdam lebte ${ }^{1422}$, schildert - autobiographisch - die ersten Gefühle und Eindrücke des am 8. Juli 1945 unter den Alteingesessenen im Spreetal, dem Beginn des Spreewaldes, in der Oberlausitz, angekommenen Vertriebenen, der eben noch, in der ersten Jahreshälfte, unter katastrophalen Lebensbedingungen in der Festung Breslau eingeschlossen gewesen war. Dabei begegnen ihm, wie wohl allen Schicksalsgenossen, beide - zeitlosen - Formen der „Begrüßungskultur“, die willkommen heißende, gastfreundliche wie die abweisende: „[...] die Bürgermeisterfamilie besteht aus gastlichen Menschen. Zunächst werden wir auf einige Bauernhöfe verteilt, und schlafen sollen wir gemeinsam in einem Nachbarhaus, in dem sich das Amtszimmer der Gemeinde befindet. Ich darf gleich hierbleiben, in der wunderschönen, mich geradezu märchenhaft anmutenden Wohnung. Wie Hans im Glück komme ich mir vor. Man bringt mir warmes Wasser. Ich wasche und rasiere mich mit Lust. Man bringt mir Hausschuhe, kühlende Salbe und reine Mullbinden

1420 Ebd., S. 100.

1421 Ebd., S. 103.

1422 Günter Wirth: Der andere Geist von Potsdam. Zur Kulturgeschichte einer Stadt 1918-1989. Frankfurt am Main 2000, S. 170, zu Hartungs Nachdenken über „Heimat“ S. 179. - Siehe auch Monika Melchert: Der Zeitgeschichtsroman nach 1945 am Beispiel von Werner Wilk und Hugo Hartung. In: „Hoffnung und Erinnerung“. Potsdamer Literatur 1945 bis 1950. Hrsg. von Mathias Iven. Milow/Berlin 1998, S. 178-187, hier S. $184-187$. 
für meine zerschundenen Füße. Wie ein Fürst schreite ich in den weichen Pantoffeln über den Hof. Die Kühe im Stall werden gemolken. Kinder in Sonntagskleidern sitzen auf einer Bank vorm Stall und warten mit ihren Krügen auf die frische, warme Milch. In einem Bauerngärtchen blühen leuchtende Sommerblumen - gepflegt und geharkt ist der Kiesweg, der hineinführt. Daß es das alles noch gibt! So nahe dem toten schlesischen Land an der Neiße... [...] [S. 189] In einem großen Dorf gehen Schorsch und Hans auskundschaften, ob es irgendwo zum zweiten Frühstück einen Morgenkaffee gibt, aber die Bauern hier sind verschlossener, abweisender als drüben in Schlesien. Dabei kennen sie noch keine Not. Oder sind sie so abweisend, weil sie noch keine Not kennen?"1423

In Werben im Spreewald, einer jener Gemeinden mit besonders hohem Flüchtlingsanteil, gibt es einen angestammten Gemeindefriedhof und einen in den Nachkriegsjahren aus Kapazitätsnöten unmittelbar neben dem großen Flüchtlingslager angelegten „Waldfriedhof“, auf dem eine nach 1990 angelegte Gedenkstätte an die Flüchtingstoten erinnert. Der 1992 als Ortsfremder ins Amt gekommene Werbener evangelische Gemeindepfarrer, also auch Gemeindeseelsorger, hat noch in seinem Beitrag zur 2001 erschienenen Ortschronik schonungslos seine Eindrücke formuliert, mit denen er als Nachgeborener - noch Jahrzehnte nach Kriegsende - in seiner Gemeinde konfrontiert wurde: „In Werben sind noch heute bei den ,Flüchtlingen' tiefe seelische Verletzungen vorhanden, weil ihre Angehörigen nicht auf dem Dorffriedhof beigesetzt wurden. Alle Sachzwänge, welche die Einrichtung dieses Friedhofes rechtferigen, werden davon hinterfragt, daß nur Flüchtlinge dort ihre Angehörigen begraben mußten." ${ }^{1424}$

Aus Potsdam ist in Tagebuchnotizen überliefert, dass das Stadtgespräch im Mai 1945 für Plünderungen in einem Lebensmittellager - zu Unrecht allein - die Flüchtlinge verantwortlich machte: „Nun wird gesagt, daß sich an derartigen Vorgängen weniger die alte Potsdamer Bevölkerung beteiligt habe, die sich vorwiegend aus dem Mittelstand zusammensetzt, sondern daß die vielen Flüchtlinge, die aus Schlesien, Oberschlesien und aus dem Wartheland mit ehemaligen Weißrussen und Schwarzmeerdeutschen hergekommen sind, die Ausschreitungen vorgenommen hätten. "1425

Schon beim Bombenangriff im April war man zur Nachbarschaft gezwungen: „Die Hausbewohner hatten mit den einquartierten Flüchtlingsfamilien in den beiden Luftschutzkellern die gewohnten Plätze eingenommen. " ${ }^{1426}$ Aber auch auf dem Land treten allzumenschliche, rein sachlich motivierte Verhaltensweisen zutage: Im hohen Alter erinnert sich eine Schlesiern an ihre Erlebnisse 1945, damals junge Mutter: „So kamen wir bis in den Spreewald. Zuerst haben wir in den Wäldern rumgelegen. Dann kamen wir in Lübben in eine leergeräumte Wagenhalle. Nach und nach

1423 Hartung, Schlesien 1944/45 (wie Anm. 621), S. 188 f.

1424 Bernd Puhlmann: Die Kirche zu Werben. In: Ramoth, Gemüsedorf Werben (wie Anm. 478), S. 90-96, hier S. 95 .

1425 Hermann Kasack: Dreizehn Wochen. Tage- und Nachtblätter. Aufzeichnungen aus dem Jahre 1945 über das Kriegsende in Potsdam. Hrsg. von Wolfgang Kasack. Mit einem Geleitw. von Walter Kempowski. Nachw. u. Erl. von Günter Wirth. Berlin 1996, S. 22.

1426 Ebd., S. 39. 
wurden die Leute auf die Dörfer verteilt. [...] Die Bauern wollten uns Flüchtlinge nicht, besonders nicht die mit Kindern, weil die vielleicht $z$ u viel gegesen haben." ${ }^{1427}$

Die „negative Begrüßungskultur“ in der Anfangszeit ist aus vielen Zeitzeugenberichten überliefert, aber selbst Thema von Verwaltungsakten geworden, wenn Einheimische von den Behörden dazu gezwungen werden mussten, sich auf ihre neuen Mitbewohner einzustellen. ${ }^{1428}$ Eine Hausbesitzerin in Eichwalde (Kr. Teltow), „obwohl rechtzeitig über die erwartete Ankunft der Umsiedler informiert, hatte absichtlich das Haus verlassen, weil sie glaubte, damit eine $\mathrm{Zu}$ weisung vermeiden zu können." Der nun vor verschlossener Tür stehenden niederschlesischen Flüchtlingsfrau (mit vier Kindern), die im Juni 1947 mit „Marschverpflegung für 2 Tage“ aus dem Lager Küchensee nach Eichwalde eingewiesen wurde, habe - nach dem Erinnerungsbericht ihrer Tochter - erst ein Beauftragter der Gemeindeverwaltung zu ihrem Recht verholfen. „Nach kurzer schikanöser Wohnzeit“ wechselte sie jedoch zu einer anderen Familie, „von der sie sehr gut aufgenommen wurden “. Die Tochter äußerte sich im Alter rückschauend insgesamt positiv über die Betreuung durch die Gemeindeverwaltung. „In der Schule wäre niemals zu spüren gewesen [...], dass es eine Kluft zwischen Umsiedlern und Einheimischen gegeben habe. "1429

Ein Gegenbeispiel - insgesamt große Anteilnahme der neuen Nachbarschaft - liefert der Neumärker Jörg Lüderitz (geb. 1935), der allerdings von Anfang an - mit Großmutter und Bruder - einen Sonderweg gegangen war, indem sie kurz vor Berlin den Treck verlassen hatten, um privat bei Verwandten in Rüdersdorf unterzukommen. ${ }^{1430}$ Auch die Anlehnung an diese Verwandten half bei der positiven Wahrnehmung durch die Nachbarn. Fälle von Mitmenschlichkeit gab es überall, auch wenn sie im Gesamtbild der Zeit nicht die Mehrheit zu bilden scheinen. Eine 15-Jährige, die mit ihrer Familie im Juli 1945 aus Brätz (Kr. Meseritz) vertrieben worden war, berichtet über die Versorgung auf dem Weg über deutsche Dörfer. Im August 1945 kamen sie für 14 Tage im Oderbruch unter: „In Neutrebbin bekamen wir ein Zimmer. Wir schliefen im Stroh. [...] Im Fleischerladen gab es eines Tages Pferdefleisch. Ich stellte mich an, um 1/4 Pfund Gehacktes für die Familie zu bekommen. Ehe ich an der Reihe war, fiel ich um. Eine Frau sagte: ,Gebt dem Mädel auch meine Ration, die hat es nötiger." "1431

Kinder, die Flucht und Vertreibung überstanden, hatten es ohnehin - trotz anfangs bisweilen mehrjähriger materieller Not und Deklassierung - tendenziell leichter. „In der neuen Heimat gelang es den Kindern und Jugendlichen oft schnell neue Freunde zu finden. Die meisten älteren Flüchtlinge hingegen konnten nur sehr schwer Bekanntschaften schließen, denn die

1427 Grete Tamaschke: Auf der Flucht von Schlesien in den Spreewald und dann nach Fredersdorf. In: Zeitzeugen berichten [2]. Erinnerungen, Erfahrungen, Erlebnisse, Erkenntnisse. Hrsg. von der Gemeinde u. dem Seniorenbeirat Fredersdorf-Vogelsdorf. Fredersdorf-Vogelsdorf 2001, S. 25-31, hier S. 28.

1428 Siehe z.B. die im Quellenteil (Abschnitt 2.1, S. 1109-1131) edierten Dokumente.

1429 Müller, Nachkriegsjahre in Eichwalde (wie Anm. 177), S. 108 f.

1430 Lüderitz, Heimat Brandenburg (wie Anm. 397), S. 42.

1431 Lieselotte Becker: Flucht und Vertreibung aus Strese. In: Heimatgruß. Zeitschrift für Mitglieder und Freunde des Heimatkreises Meseritz e. V. und der Heimatkreisgemeinschaft Birnbaum 215 (2015), S. 32-35, hier S. 34. 
ansässige Bevölkerung sah die neuen Nachbarn meist als ,Eindringlinge und Fremde an. ${ }^{1432}$ So gibt es zumindest unterschiedliche Stimmungsberichte aus Schulklassen: Mal heben die Zeitzeugen die Schwierigkeiten der nur schleppend voranschreitenden Integration durch Gleichbehandlung hervor, mal erzählen sie von fröhlichem Miteinander. Es war oft aber schlicht eine Frage der Perspketive: Betroffene sahen eher als die Kinder der Einheimischen die Mängel. Ein damals etwa zehnjähriger Einheimischer, später CDU-Mitglied, erlebte in Madlow nahe Cottbus, als für ihn am 1. Oktober 1945 die Schule wieder los ging, nach seinem - in der Rückschau berichteten - Eindruck eine scheinbare Symbiose: „Viele ,Flüchtlingskinder' (aus Schlesien vor allem) saßen zwischen den ,Einheimischen'. Unterschiede gab es bei den Kindern nicht." Da seine eigenen Großeltern Vertriebene waren, stand er dem Flüchtlingsschicksal, wenn auch selbst nicht direkt betroffen, nicht ganz fern. ${ }^{1433}$

Kinder litten einerseits besonders unter Ernährungsnotständen, hatten es andererseits leichter, im Alltag kleine Freuden zu finden. Die als Kind aus Jauer in Schlesien vertriebene Christa Stiemke (geb. 1938) kam nach Wilhelmshorst bei Potsdam. Sie hatte in ihrer Heimat fast zwei Schuljahre durch Unterrichtsausfall verloren: „Wir Kinder gewöhnten uns in der Wilhelmshorster Schule gut ein und waren bald im Schulgeschehen voll integriert." "1434

Der 1936 geborene Siegfried Schulze aus dem neumärkischen Pinnow (Kr. Weststernberg), der mit seiner Familie 1945 „als Umsiedlerkind nach Hermsdorf“ bei Beeskow gekommen war, schildert in seinen Erinnerungen an die folgenden Jahre eine ungetrübte Karriere „Vom Umsiedlerjungen zum Diplomingenieur“. Nach Abschluss der achten Schulklasse absolvierte er eine Landmaschinen- und Traktorenschlosserlehre und wurde durch Kontakt zum Betriebsdirektor der örtlichen Maschinenausleihstation dazu angeregt, „sich immer weitere Bildung anzueignen“. Die Förderung durch den Chef führte schließlich auch zur Vermittlung einer Wohnung. Mit 41 Jahren, 1977, „zog ich dann in ein Eigenheim ein.“ Schulze blieb bis ins Alter im selben Landkreis, in den ihn das Schicksal 1945 geführt hatte. Auch wenn seine knappen, etwas den „Erfolgsbilanztexten“ der Zeit vor 1990 ähnelnden Seniorenerinnerungen von 2009 mehr an äußerlichen Stationen des Lebensweges orientiert sind und das Innenleben ausblenden, liefert er offenkundig ein Beispiel gelungener sozialer und wirtschaftlicher Integration der zweiten Generation und eines vom System ermöglichten sozialen Aufstiegs. Sein Beispiel verweist aber einmal mehr auf ein in der heutigen Sicht auf das Vertriebenenthema leicht und oft übersehenes Problem, dass nämlich die (inzwischen längst verstorbenen) 1945 bereits erwachsenen oder gar älteren Vertriebenen es vielfach sehr viel schwerer hatten, sich auf Neues einzulassen, und dass heutige Diskussionen mit Zeitzeugen in den neuen Bundesländern weitgehend von den damals im Kindesalter Befindlichen bestimmt werden.

1432 Grandke, „Als die Füße nass und kalt waren, erkannte ich den Ernst der Lage.“ (wie Anm. 187), S. 63.

1433 Ulrich Winz: Mein Jahr 1945. In: Cottbuser Heimatkalender 1991, S. 60-66, Zitat S. 66.

1434 Stiemke, Lange verdrängt, aber unvergessen (wie Anm. 620), S. 343. 


\section{Das Tabu}

Als gewissermaßen dauerhaft „Kalte Heimat“ empfanden - zahllosen Berichten zufolge - viele, wenn nicht die meisten Vertriebenen das verordnete Tabu, sich jahrzehntelang allenfalls als „Umsiedler“ bezeichnen zu dürfen, aber kaum öffentlich an die eigene Heimat erinnern oder sie auch nur im nicht nur engsten privat-familiären Rahmen erwähnen zu dürfen. ${ }^{1435}$ Der Polonist Heinrich Olschowsky, selbst als Spätaussiedler in der DDR lebend, zog nach 1990 eine bittere Bilanz: „Allen schmerzlichen Streitfragen wich man mit der Floskel vom proletarischen Internationalismus aus. Die bloße Erwähnung der ehemaligen deutschen Ostgebiete als eines Verlustes stand unter Revisionismusverdacht, wurde als Hetze gegen den Frieden kriminalisiert. "1436 Wie weit dieses Ausblenden ging, zeigt nicht zuletzt der Umgang mit dem für den „Bevölkerungstransfer“ grundlegenden „Potsdamer Abkommen“ der Siegermächte des Zweiten Weltkriegs, das in der DDR immer wieder als „Grundgesetz“ der Nachkriegsfriedensordnung gefeiert wurde. Zum vierzigsten Jahrestag erschien im für Leser im Bezirk Potsdam gedachten Kulturbund-Jahresheft „Märkische Heimat“ ein kurzer Beitrag der Leiterin der „Historischen Gedenkstätte Cecilienhof", also des ehemaligen Tagungsortes im Potsdamer Neuen Garten, Rosemare Heise. ${ }^{1437}$ Der im Abkommen festgelegte Bevölkerungstransfer wird darin nicht erwähnt, es bleibt bei allgemeinen Formulierungen wie der, die Siegermächte hätten die Verpflichtung übernommen, „das Leben des deutschen Volkes auf der Grundlage einer antifaschistisch-demokratischen Ordnung neu zu gestalten". 1438

Der als Kind aus dem Sudetenland vertriebene DDR-Geschichtsdidaktiker Friedrich Hora (Falkensee/Potsdam) wendet sich in seiner von SED-Apologie nicht ganz freien Autobiographie gegen die Behauptung, „das Thema Zwangsaussiedlung sei zu DDR-Zeiten ein Tabuthema gewesen" und meint, Berechtigung habe der Begriff Tabu aber „durchaus dann, wenn man feststellt, daß Ungesetzlichkeiten und Verbrechen bei den, wilden Vertreibungen' offiziell nicht diskutiert wurden “ ${ }^{1439}$ Zumindest für sich persönlich nimmt er in Anspruch, „daß ich sowohl als Geschichtslehrer in meinen Klassen als auch in Lehrveranstaltungen vor Studenten über meine/unsere Erlebnisse 1945 stets in aller Offenheit und ohne taktische Aussparungen gesprochen habe, wenn auch immer in der aufklärerischen Absicht, durch offenes und ungeschminktes Benennen dessen, was war, Völkerverständnis und Ausgleich (heute pflegt man das Schlußstrich zu nennen) zu befördern, wenn auch mit der Intention, zu einem vernünftigen Geschichtsbild zu verhelfen." Das einzige Beispiel, dass er als Beleg bringt, stammt jedoch erst aus der nicht mit den ersten Jahrzehnten vergleichbaren Spät-

1435 Karlheinz Lau: Ostdeutschland und die Vertriebenen im öffentlichen Bewußtsein und im Geschichtsbild der DDR bis 1989. In: Wille/Lau/Bilke, Die Vertriebenen in Mitteldeutschland (wie Anm. 568), u.a.S. 11 f. zu Schulbüchern für den Geschichstunterricht).

1436 Olschowsky, Als Deutscher in Polen - als „Spätaussiedler“ in der DDR (wie Anm. 592), S. 530.

1437 Rosemarie Heise: 40 Jahre Potsdamer Abkommen. In: Märkische Heimat 4 (1985), S. 4-13 (Nachdruck aus Archivmitteilungen 4/1985).

1438 Ebd., S. 12.

1439 Friedrich Hora: Eine politische Biographie. T. 1 [1935-1961]. (Privatdr.) o. O. 2012, S. 78-81, hier S. 79 
zeit der DDR: Am „Tag der Befreiung“ 1985 hielt er in der Ernst-Thälmann-Oberschule in Falkensee die Festrede, in der er die Doppelgesichtigkeit des Kriegsendes als Befreiung ansprach, das sich für ihn persönlich zugleich „mit dem Verlust meiner alten Heimat“ verbinde: „Das hat mich schon beeindruckt, mit insgesamt $30 \mathrm{~kg}$ Gepäck für die ganze Familie innerhalb einer Stunde die Wohnung verlassen zu müssen. Die Zeit werde ich nicht vergessen und - das klingt zuerst seltsam - ich will und darf diese Zeit nicht vergessen!"1440

Der letztlich von ihm zwischen den Zeilen zugegebenen Existenz des Tabus in der Öffentlichkeit, allemal aber in den Köpfen entsprach keineswegs immer ein solches im kleineren Kreis, auch wenn der Grat zwischen gerade noch Toleriertem und strafbarer Handlung schmal war. So berichtet Hora aus seiner Potsdamer Studentenzeit während der fünfziger Jahre, „daß wir, charakteristisch für unsere ketzerischen Blödeleien, in unserer 161. Kampfgruppenbereitschaft der Pädagogischen Hochschule Potsdam, die Bildung einer sudetendeutschen Landsmannschaft erörterten" ${ }^{1441}$ Das war zwar lediglich jugendlich-übermütiger Spaß und bloß theoretische Provokation, zeigt aber die alltägliche Präsenz des Herkunftskriteriums, wie es nicht selten schon an der Sprache oder bisweilen dem Familiennamen für jedermann ablesbar war und sich damit nie ganz auf den privaten Raum begrenzen ließ. Horas Vater, ein noch im österreichisch-ungarischen Böhmen ausgebildeter Gymnasiallehrer alter Schule, fiel als Lehrer im Vogtland schon mit seiner ,für vogtländische Ohren ungewohnten Aussprache" als vertriebener Sudetendeutscher auf. ${ }^{1442}$

Von der SED wurde Integration - anders als von den Menschen - nur als eine formalrechtliche Frage sowie eine von Wohnung und Arbeit gesehen, so dass man das Thema Anfang der fünfziger Jahre für beendet erklärte. Politisch galt ihr die Integration allerdings - in der geheimen Beobachtung der Betroffenen durch das Ministerium für Staatssicherheit - auch weiterhin als Desiderat, solange z. B. nicht alle Vertriebenen die Oder-Neiße-Grenze anerkannten und in ihren Kreisen Ruhe einkehrte, d.h. die zunächst überall und immer wieder aufflackernde Rückkehrforderung nicht mehr artikuliert wurde.

\section{Grabsteine}

Der Umgang Betroffener mit dieser Situation in den fünfziger bis achtziger Jahren ist erst ansatzweise beleuchtet. Es ist jedoch erstaunlich, welche Bandbreite an Formen des Herkunftsbezugs man in der DDR auch nach Jahren und Jahrzehnten noch antreffen konnte (und in den neuen Bundesländern bis heute antreffen kann). Wenig beachtet, wohl auch, weil in der heutigen Rückschau kaum für möglich gehalten, ist z. B. eine Form der Selbstbezeichnung nach der Herkunft aus einem Vertreibungsgebiet oder -ort, die sich auf Grabsteinen findet. Die Angabe des Geburtsortes, ggf. mit Zusatz der Provinz oder der Region, lässt sich auf älteren Grabsteinen des 19. und 20. Jahrhunderts gar nicht selten finden. Auf Dorffriedhöfen kleinerer Gemein-

1440 Ebd., S. 80 f., Festreden-Zitat S. 81.

1441 Ebd., S. 87.

1442 Ebd., S. 135. 
den bleibt dies zumeist auf Auswärtige bzw. von außen Zugezogene beschränkt. Ist ein solcher Fried- bzw. Kirchhof für mehrere benachbarte (eingepfarrte) Orte zuständig, stehen (unterschiedliche) Geburts- oder Wohnorte freilich auch öfters bei Einheimischen. In Großstädten ist die Variationsbreite der Inschriftenformen gewiss etwas größer.

Der Verfasser hat in den letzten Jahren in Grabsteininschriften auf Friedhöfen auch in den neuen Bundesländern immer wieder ausdrückliche Hinweise auf die Herkunft aus den Vertreibungsgebieten gefunden, gewiss nicht so häufig wie in manchen westdeutschen Gebieten ${ }^{1443}$, aber auch keineswegs nur in seltenen Ausnahmefällen. Zuletzt hat die stichprobenartige (Zufalls-)Begehung von diversen Friedhöfen in kleineren mecklenburgischen und vorpommerschen Gemeinden in fast allen Fällen solche Hinweise erbracht, zumeist aus den Jahren vor 1960, oft aber auch noch aus den sechziger, siebziger und achtziger Jahren (und auch nach 1990 bis in die jüngste Zeit). ${ }^{1444}$ Bedenkt man, wie viele Steine aus dieser Zeit mittlerweile ohnehin abgeräumt sind, so dürfte die ursprüngliche Zahl deutlich größer sein. So ist es gar nicht so wenig, wenn man - wie der Verfasser in den betreffenden Gemeinden - noch 2017/18 mal nur einen oder zwei, dann aber auch bis zu sechs Steine auf einem einzigen kleinen Dorffriedhof, hier Ahrenshoop, entdeckt. Vielfach handelt es sich um Inschriften, bei denen - wie in Familienanzeigen - der Geburtsort mit einer zusätzlichen Lagebezeichnung versehen ist, die bei kleineren, wenig bekannten Orten allein die Zuordnung erschließt. Sollte in der - nicht jedem geläufigen - Abkürzung, die bei solchen Lagebezeichnungen angetroffen wurde, mancherorts der Schlüssel zur Unbedenklichkeit gelegen haben ${ }^{1445}$ So findet sich allein in Ahrenshoop eine ganze Gruppe von Grabsteinen aus dem Sudetenland stammender Personen mit dem geradezu verschlüsselnd abgekürzten Zusatz Sdtld. beim Geburtsort und in Zingst - auf einem einzelnen, ganz am Friedhofsrand liegenden Stein - die Lagebezeichnung Riesengebirge in der üblichen, aber eben auch sehr knappen Form Rsgb. Andererseits finden sich auf Rügen immer wieder die unabgekürzten Inschriften Sudetenland (häufig) und Ostpreußen (gelegentlich). Zudem kann man neben „unauffälligen“ Dorfnamen durchaus auch Städtenamen finden, wie Bad Polzin (Hinterpommern), Breslau, Danzig oder Stettin. Dagegen wird der auf dem Berliner Sophien-

1443 Beispielsammlungen nach Friedhofsbegehungen des Verf.: Peter Bahl: Gräber Ostdeutscher im Fichtelgebirge (Franken). In: Ostdeutsche Familienkunde 54 (2006), S. 443-445. - Ders.: Gräber Ostdeutscher in Norden (Ostfriesland). In: Ostdeutsche Familienkunde 56 (2008), S. 275-281. - Gräber Ostdeutscher auf dem Hauptfriedhof Herne. Gesammelt von Peter Bahl. In: Archiv ostdeutscher Familienforscher 19 (2011), S. 247-248.

1444 Begehungen durch den Verf. im Juli 2017 und August 2018. Für Hinweise danke ich Frau Arne Liedtke (Sellin/Rügen).

1445 Andreas Kossert, der solche Grabinschriften jüngst als Indiz der „Sehnsucht“ nach den „Heimatorte(n) der Verstorbenen“ bezeichnete, nennt dagegen für Brandenburg (auf „den Friedhöfen dieses Landes“) ausdrücklich, aber ohne Quellen- bzw. Ortsangabe prominente Städtenamen: „Landsberg, Schwerin an der Warthe, Königsberg, Reichenberg, Breslau“ (Andreas Kossert: Jeder vierte Brandenburger: Vertriebene und Flüchtlinge nach 1945. Eine Spurensuche. In: wir erben. europa in Brandenburg, brandenburg in europa. Hrsg.: Brandenburgische Gesellschaft für Kultur und Geschichte gGmbH, Kulturland Brandenburg, Potsdam. Leipzig 2018, S. 139-143, hier S. 141). 
kirchhof II (Bergstraße) noch heute anzutreffende, 1977 oder 1986 beschriftete Grabstein mit einem Hinweis auf den Geburtsort Schönbrunn/Landskron nur demjenigen etwas gesagt haben bzw. sagen, der weiß, dass es sich bei Landskron (tschech. Lanškroun) um eine Stadt im ehemals sudetendeutschen bzw. mährisch-deutschen Siedlungsgebiet „Schönhengstgau“ handelt. ${ }^{1446}$

Eine systematische Begehung ausgewählter Friedhöfe auch im heutigen Land Brandenburg konnte dagegen vom Verfasser nicht geleistet werden. Doch wird das für diese aus dem nördlichen Nachbarland - mit gewisser Vorsicht - hochzurechnende gleiche Bild durch andere Beobachter bestätigt. Im Rahmen eines größeren genealogischen Erfassungsprojektes werden im Land Brandenburg seit einigen Jahren systematisch die Grabsteine einzelner Friedhöfe vollständig durchfotografiert, um die Daten in einer Datenbank zu erfassen. ${ }^{1447}$ Der dabei bislang besonders in den (heutigen) Landkreisen Potsdam-Mittelmark, Prignitz und TeltowFläming - Gebieten mit einem hohen Vertriebenenanteil - aktive Genealoge Gerd Schwarzlose (Stahnsdorf) beantwortete die Frage des Verfassers, ob ihm dabei Bezüge zu Heimatorten Vertriebener begegnet seien, ebenso spontan wie eindeutig: „Solche Grabsteine sind mir immer wieder begegnet. “1448 Dabei konnte er aus seinem laufend wachsenden Fotobestand bereits Beispiele sowohl aus der frühesten als auch aus der „Spätzeit“ präsentieren. Drei Fälle mögen hier stellvertretend stehen.

In Wiepersdorf (Kr. Jüterbog-Luckenwalde, heute Landkreis Teltow-Fläming) fand sich der aufrecht stehende, offenkundig 1960 gleichmäßig beschriftete Grabstein des Apothekers Fritz Melcher (1877-1960) und seiner Frau Wanda Melcher geb. Lück (1889-1946). ${ }^{1449}$ Beim Ehemann steht unter dem Geburtsdatum „i.[n] Breslau“, bei der Ehefrau „i.[n] Chropaczow“.

1446 „Fachlehrer Erich Koblischke/Schönbrunn/Landskron/[folgen Lebensdaten, gest. 1977, darunter Ehefrau, gest. 1986]“" (Begehung durch den Verf. am 27.8.2017).

1447 Die bereits sehr umfangreiche „Datenbank zur Erfassung von Grabsteininschriften auf Berliner und Brandenburger Friedhöfen“, die die Brandenburgische Genealogische Gesellschaft „Roter Adler“ e. V. online anbietet (226008 Grabsteine auf 1996 Friedhöfen), enthält allerdings keine solchen zusätzlichen Angaben, sondern jeweils nur Name, Vorname und Sterbedatum: www.bggroteradler.de [16.8.2017]. Siehe aber jetzt - in einer entsprechenden Projektskizze - immerhin den Hinweis auf die Veränderungen in der Bevölkerungsstruktur der Prignitz, „welche noch einmal nach 1945 mit Tausenden von Flüchtlingen aus dem Osten zu verzeichnen waren ": Gerd Schwarzlose / Maik Senninger: Friedhöfe im Land Brandenburg. Die Prignitz. In: Brandenburgische Genealogische Nachrichten 12 (2017), S. 85-88, hier S. 86. - Grundsätzlich auswertbar, wenn auch nicht elektronisch recherchierbar, sind dagegen alle in Inschriften enthaltenen Angaben in der Grabstein-Datenbank des Vereins für Computergenealogie e. V., da sie vollständige Fotos der Grabsteine in großer Zahl - auch für viele brandenburgische Friedhöfe! - enthält: grabsteine.genealogy.net [16.8.2017]. - Siehe als für eine brandenburgische Landgemeinde bisher wohl singulären Fall die teilweise bebilderte kleine Dokumentation des Friedhofs in Pießig (Kr. Luckau): Monika Neumann / Martin Ziegler: Flucht, Vertreibung und Neuanfang in der neuen Heimat nach 1945 am Beispiel Pießigs. In: Sonnewalder Heimatblätter 19 (2019), S. 93-110, hier S. 107 f. (Bild 8: Grabsteininschrift „aus Lindewiese O/Schl.“ [Kr. Neisse, Oberschlesien]).

1448 E-Mail an den Verf., 21.9.2017. Für bereitwillig gegebene Auskünfte und übersandte Grabfotos sei Herrn Schwarzlose herzlich gedankt.

1449 Foto von Gerd Schwarzlose aufgenommen am 6.5.2016. - Fritz Melcher (aus Beuthen/OS) wohnte 1949 in Jüterbog. Vgl. Verzeichnis der schlesischen Apotheker und Berufsangehörigen. Zsgest. von Charlotte Groß. 2. 
Beide Geburtsorte verweisen auf Schlesier. Breslau dürfte auch in der DDR kaum eines Zusatzes bedurft haben. Bei dem weniger bekannten Chropaczow ${ }^{1450}$ handelt es sich um eine ehemalige Landgemeinde bei Schwientochlowitz im Kreis Beuthen in (Ost-)Oberschlesien, die 1922-1939 zu Polen gehörte und von 1909-1922 sowie 1939-1945 den germanisierenden Namen „Schlesiergrube“ trug. In Feldheim (Kr. Wittenberg, ab 1950 Kr. Luckenwalde), heute einem Ortsteil von Treuenbrietzen, heißt es auf dem aufrecht stehenden, dem Aussehen nach zu schließen zeitgenössischen Grabstein für Selma Wehner geb. Scholz (1888-1955) sogar ausdrücklich „aus Matzdorf in Schlesien“. ${ }^{1451}$ In Potsdam-Drewitz schließlich lautet die Inschrift auf einem ebenfalls aufrecht stehenden, deutlich moderner gestalteten Stein „Anna Ost / 1898 Primkenau/ 1988 - Babelsberg “. ${ }^{1452}$ Primkenau war bis 1945 eine Kleinstadt im niederschlesischen Kreis Sprottau.

Auch die Autoren eines neueren, 2001 erschienenen Erinnerungsbuches über Ziebingen (Kr. Weststernberg) haben ganz Ähnliches festgestellt und - im Gegensatz zu den meisten vergleichbaren Chroniken, die das gar nicht thematisieren - auch festgehalten. Dies ist - mit dem Blick auf das breite Spektrum ortsgeschichtlicher Literatur - ausgesprochen bemerkenswert und soll daher hier ausführlicher zitiert werden: „Aus der Demütigung, alles verloren zu haben und jetzt ein heimatloser Habenichts zu sein, entwickelte sich aber auch ein neues Selbstbewusstsein. Man bekannte sich zu seiner Heimat ausdrücklich und ließ dies auch über den Tod hinaus dokumentieren. [...] So findet man vor allem auf brandenburgischen Friedhöfen Hinweise darauf, dass hier Menschen in für sie fremd gebliebener Erde ruhen und auf ihren Grabsteinen, wie sonst nicht üblich, der Herkunftsort mitgeteilt wird. [...] So war und ist auch heute noch auf so manchem Grabstein zu lesen, dass die verstorbene Person aus Ziebingen stammte. Diese Gesten sind vor allem deshalb so bemerkenswert, weil alte deutsche Ortsbezeichnungen nach 1945 in Mitteldeutschland ${ }^{1453}$ für Orte östlich der Oder und Neiße bei den Verwaltungen verpönt waren. [... . “1454 Auch hier dürfte es sich also um die mehr oder weniger dezente Form, d. h. nur um den - nicht jedem Betrachter geläufigen - Ortsnamen ohne etwa den Zusatz „Neumark“ handeln. ${ }^{1455}$ Allerdings war auch eine solche Nennung in einem grenznahen Ort wohl

Aug. Werl 1949, S. 4 (Tod der Ehefrau), 20; eine Tätigkeit in Jüterboger Apotheken nach dem Krieg ist nicht nachweisbar (freundlicher Hinweis Jochen Schröder, Stuttgart.)

1450 Polnisch Chropaczów, seit 1951 Stadtteil von Schwientochlowitz (poln. Świętochłowice).

1451 Foto von Gerd Schwarzlose aufgenommen am 20.6.2015. Gemeint ist sicherlich Matzdorf im Kreis Löwenberg (Niederschlesien), nicht das gleichnamige Dorf im Kreis Kreuzburg (Oberschlesien).

1452 Foto von Gerd Schwarzlose aufgenommen am 4.4.2013.

1453 [Hier wird der in der alten Bundesrepublik in den 1950er Jahren für die SBZ-/DDR-Länder eingeführte Sammelbegriff verwendet (im Gegensatz zu „Ostdeutschland“ für die ehem. deutschen Ostgebiete).]

1454 Schieche/Jaeschke, Ziebingen (wie Anm. 779), S. 320.

1455 Immerhin wird der Landkreis (Crossen/Oder) genannt in einer auf 1952 datierten Grabsteininschrift in Straupitz im Spreewald für die aus „Preichow Kr. Krossen“ 1945 vertriebene ehemalige Hebamme Wilhelmine Hahn. Siehe Abbildung des Grabsteins: Helmut Klinke: Der Südkreis schätzte „Hebamms Mutter“. In: Wanderungen durch Südostbrandenburg an und jenseits der Oder-Neiße-Grenze 1996/97 (1996), S. 181-182, hier S. 182. 
schon ein deutlicheres Statement. In jedem Fall wurde mit dem Herkunftsbezug der Unterschied zur einheimischen Bevölkerung hervorgehoben und auf einem für diese sichtbaren und wichtigen Bereich - durchaus selbstbewusst - betont.

Ein letztes Beispiel, wiederum aus einer an Flüchtlingen und Vertriebenen reichen Region, führt noch einmal in die ganz frühe Phase der Nachkriegszeit. Der aus Bromberg stammende Hartwig Spitzer (geb. 1929) übersiedelte 1997 aus seiner langjährigen neuen Heimat Hessen nach Potsdam. Bei Fahrten durch Brandenburg machte er auch in Neuruppin Station: „Dort fand ich das Grab meiner Großmutter Gesell, überrascht, dass es noch nicht aufgelassen worden war. /,Paula Gesell, geb. Sauter/*3.4.1876 in Liliendorf Kr. Strelno/+10.5.1948 in Neuruppin' stand auf dem schlichten Grabstein." 1456 Sie war 1945 „mit Tochter und Schwiegersohn Dr. Storch nach Neuruppin“" geflohen, „wo sie nicht mehr lange lebte [...]. ,Das Grab haben wir übersehen", sagte der Gärtner [...]."1457

\section{Bereicherung}

Eine „Integrationsbilanz"1458 wird neben der Beobachtung des sich vom Neben- zum Miteinander entwickelnden Alltagslebens Assimilierter auch auf gleichsam umgekehrte Formen zu achten haben, in denen der Zuwanderer nach einiger Zeit nicht nur geachtet, sondern geradezu als Bereicherung gesehen wurde, durch den der für ihn neue Heimatort - auch in der Sicht der Einheimischen - einen „Mehrwert“ erhalten hatte. So ist es ist kein Einzelfall in Integrationsprozessen, wenn ein Zugewanderter sich besonders stark mit seiner neuen Heimat identifiziert. Bisweilen sind die vorausgegangenen Verlusterfahrungen so groß, dass dieses vollkommene Sich-Einlassen auf das Neue der einzige Weg zum Überleben ist. Dass dies den Angehörigen der jüngeren Generation leichter fiel als jenen, die bereits in ihrer Heimat alle wichtigen Entscheidungen ihrer Biographie getroffen hatten, ist allgemein bekannt und wurde auch hier bereits mehrfach betont.

Dafür lassen sich auch in Brandenburg Beispiele finden, sowohl unter den vielen, die nach 1945 aus Sachsen dorthin kamen, als auch unter den Vertriebenen. Die bei Kriegsende erst neunzehnjährige deutsche Buchhaltertochter Ruth Fleischmann (geb. 1926) aus Lodz, die es nach Rathenow verschlug, wurde beispielsweise Lehrerin und engagierte sich in ihrem späteren (ab 1956) westhavelländischen Wirkungsort Rhinow so stark als Ortschronistin, dass man sie anlässich ihres achtzigsten Geburtstags 2006 zur Ehrenbürgerin ernannte. Dabei war sie zu Anfang keineswegs aus ihrem Flüchtlingsschicksal herausgelöst. Ihr Vater war bereits 1946 verstorben, ihre Familie bestand in den Rathenower Nachkriegsjahren aus der Mutter und einer Tante. Als junger Dorfschullehrerin in Spaatz (Westhavelland) stand ihr das „Thema“ auch außerhalb der Familie täglich vor Augen, da sie sich anfangs allein um 120 Schüler kümmern

1456 Hartwig Spitzer: Potsdamer Jahre. Erlebnisse und Gedanken. Potsdam 2016, S. 131.

1457 Ebd., S. 132.

1458 Siehe dazu auch: Ther, Von Schlesien in die Lausitz (wie Anm. 49), S. 494. 
musste, darunter viele Flüchtlinge, die Ähnliches erlebt hatten, wie sie selbst. „Die ersten Jahre waren sehr hart", hat sie im hohen Alter bekannt, sowohl die allgemeinen Lebensumstände als auch die schulische Situation. In Gesprächen, die man mit ihr anlässlich ihres 90. Geburtstages führte, zeigte sich ein Mensch, der in seiner neuen Heimat - wenn auch selbst unverheiratet und kinderlos geblieben - gesellschaftlich subjektiv wie objektiv vollständig integriert scheint und von einem großen Freundeskreis umgeben ist. Doch während sie von ihrer Lodzer Kindheit als einer glücklichen Zeit erzählt, blieb die schmerzvolle Erinnerung an die Vertreibung, wie eine Journalistin feststellte: „Ihre Heimatstadt Lodz besuchte Ruth Fleischmann nach dem Krieg nur ein einziges Mal, für weitere Besuche waren die Erinnerungen zu schmerzlich. Stattdessen reiste sie durch Europa. ,Norwegen hat mir besonders gut gefallen', schwärmt die Jubilarin. Auch die Normandie, Italien, Spanien und Moskau hat sie gesehen." ${ }^{1459}$

Die Vertriebenen waren keineswegs immer und überall eine sozial im Abstieg begriffene Randgruppe, dazu war auch die Ausgangsposition der Einheimischen bei Kriegsende oft genug viel zu schwierig. Da die Neuankömmlinge in die nicht selten monostrukturell geprägten brandenburgischen Kleinstädte und Dörfer häufig berufliche Differenzierungen mitbrachten und, wenn die Ernährung endlich ausreichte, auch eine besondere Motivation zum Neuanfang, bereicherten sie zum Teil nicht nur ihre neuen Heimatorte, sondern erleichterten damit selbst ihre eigene Integration. Das betraf keineswegs nur lebenswichtige Bereiche der Basisversorgung, wie das Beispiel des Niederlausitzer Wintersportzentrums Gehren bei Luckau zeigt. Reinhard Knuth, der 1945 als Flüchtlingskind dorthin kam, überliefert in seinen Erinnerungen Eindrücke, die in den meisten anderen Berichten ganz vom täglichen, nackten Überlebenskampf überlagert werden: „Als ich 1945 als Flüchtling aus dem Raum östlich der Oder nach Gehren kam, erlebte ich meinen ersten Winter in der Niederlausitz 1945/46: Die Gehrener Berge in weißer Pracht und Schulkinder, die jeden Nachmittag dort begeistert den Wintersport betrieben [...]. Rodeln und Skilauf war Massensport ohne sportliche Einrichtungen. [...] Ich Fremder war sofort für den Wintersport begeistert - aber jeder Flüchtling war total besitzlos. ${ }^{\text {“1460 }}$ Knuth erlebte am Ort in der Nachkriegszeit nun „eine große Bewegung zum Aufbau des Volkssports. In Gehren waren es zwei Flüchtlinge: der Tischlermeister Georg Behrend und der Schuhmachermeister Emil Körner und in Waltersdorf der Melkermeister Fritz Blaschke - das waren die ersten aktiven Organisatoren. "1461

Welche förderlichen Langzeitwirkungen sich bisweilen ergeben, zeigt ein Beispiel der Nachwendezeit. Eine aus Bomst (Grenzmark Posen-Westpreußen, zuletzt ab 1938 Provinz Brandenburg) nach Neuruppin gelangte Vertriebene (die bereits erwähnte Ruth Preuß, geb. 1924) wurde 2002 durch eine aus dem Westen Deutschlands nach 1990 zugezogene Sozialwissenschaftlerin zu ihrem Lebensweg interviewt. Dabei ergab sich, dass die Vertriebene der Neubürgerin ideelle Integrationshilfe leisten konnte, obgleich diese selbst am Ort noch immer

1459 Christin Schmidt: Rhinows Ehrenbürgerin wird 90. In: Märkische Allgemeine Zeitung, 10.9.2016.

1460 Reinhard Knuth: Erinnerungen an das Wintersportzentrum Gehren. In: Luckauer Heimatkalender 48 (2016), S. 43-47, hier S. 43.

1461 Ebd., S. 44. 
als nicht verwurzelt galt: „Sie hat mir geholfen, als Neue in dieser Stadt anzukommen. Etwa 20 Jahre lang hat sie in ihrer Geburts- und Heimatstadt Bomst/Ostbrandenburg gelebt. In Neuruppin lebt sie nun über 50 Jahre und ist immer die Heimatvertriebene geblieben. " 1462 Solche Beobachtungen und auch Selbstbeschreibungen Vertriebener sind kein Einzelfall, die Zeitzeugenliteratur ist voll davon. Das belegt einmal mehr, wie sehr Vertriebenenintegration kein nur ökonomisches Thema war und ist, sondern wie stark psychische und mentale Bereiche dabei beteiligt sind, sowohl beim zu Integrierenden als auch bei der einheimischen Aufnahme-Gesellschaft.

Vieles folgte und folgt genuin menschlichen Verhaltensmustern. Man rückte zusammen, half einander, ging aber eigene Wege, sobald eine Besserung der wirtschaftlichen Lage eintrat. Das scheint oft genug in Erinnerungsberichten durch, wie etwa in diesen Worten einer 1946 (als Kind) aus Schlesien Vertriebenen: „Nach anfänglichen Schwierigkeiten der Eingewöhnung in Wilhelmshorst besserte sich unsere Alltagssituation. Anfangs hielten die Flüchtlingsfamilien untereinander guten Kontakt. Gemeinsames Leid verbindet [...]." ${ }^{1463}$ Dieses anfängliche Zusammenhalten der Leidensgenossen aus einem gleichen Ort oder Kreis war bisweilen eine wesentliche Hilfe, auch für die Informationsweitergabe. So erlebte eine Bomsterin (wiederum Ruth Preuß) im Juli 1945 die Ankunft in der als erste Durchgangsstation und Verteilungsort fungierenden Kreisstadt nicht nur als fremd: „In Neuruppin waren ja schon viele Bomster angekommen, und der Buschfunk ging. " 1464

Letztlich waren beide Seiten, Einheimische wie Vertriebene, wenn sie nicht in den Westen abwanderten, gezwungen, sich zu arrangieren. Aus Dallgow bei Nauen wird berichtet: „Fast in jedes Haus im Ort wurden durch die Gemeindeverwaltung Flüchtlinge eingewiesen. Wo durch den Krieg schmerzliche Lücken gerissen waren, füllten nun die Flüchtlinge die Reihen. Die alteingesessenen Dallgower beobachteten zurück- [S. 108] haltend und kritisch das Treiben der ,Neu Dallgower', die sich in der neuen Heimat beweisen und behaupten wollten. / Die Jugend der Zugezogenen fügte sich bald in das Dorfleben ein, In der wiedereröffneten Dorfgaststätte Rietdorf tanzten sie gemeinsam mit den Dallgowern zur Musik von Grammophon und lernten sich kennen. [...].“1465

Der Strausberger Kreisarzt Horst Rocholl (1908-2004) hat, wenn auch anhand eines wohl eher außergewöhnlichen Beispiels, mit feinem Gespür das schwierige Thema des dabei nötigen Aufeinanderzugehens von Einheimischen und Vertriebenen in einem Dorf seines $\mathrm{Zu}$ ständigkeitsbereichs beschrieben und gezeigt, welche Rolle einerseits die spezifischen sozialen und wirtschaftlichen Rahmenbedingungen in der Gesellschaft eines Aufnahmeortes spielten, und wie viel andererseits ein vertriebener Neuankömmling auch ohne materielle Güter bereichernd einbringen konnte: „Kurz vor Ende des II. Weltkrieges mußte Frieda Kretschmer mit ihren Eltern und ihren vier Jungen aus Bergsdorf [wohl Berndorf] bei Liegnitz, einer größeren Ortschaft,

1462 Lebensgeschichten Neuruppiner Frauen (wie Anm. 285), S. 85.

1463 Stiemke, Lange verdrängt, aber unvergessen (wie Anm. 620), S. 344.

1464 Ruth Preuß, [Lebensgeschichte] (wie Anm. 395), S. 108.

1465 Ursula Kluchert: Dallgow. Dallgow-Döberitz 2009, S. 107 f. 
in der ihr Mann eine Bäckerei hatte, vor der herannahenden Front flüchten, kehrte dann wieder zurück, mußte aber später ihr Heimatdorf verlassen. Sie und ihre Angehörigen fanden Unterkunft und gute Hilfsbereitschaft in Buchholz bei Altlandsberg. Sie gab dafür, was sie zu geben vermochte, faßte unermüdlich zu und brachte in das Leben des Dorfes ein, was sie an Wissen, Können und Mütterlichkeit besaß. Ich war aufgrund dessen, was ich über Frieda Kretschmer wußte, in der Gefahr, um ihr Wirken in Buchholz eine Legende zu weben, die Legende von einem Dorf, das nichts zu sagen hatte, und von einer Frau, die es zum Leben erweckte. Ich hätte damit nichts Gutes bewirkt. Buchholz hatte sich seit der Aufsiedlung des Gutes in den ersten Jahren nach dem Weltkrieg 1914/18 zu einem Bauerndorf mit gutem Gemeinschaftssinn entwickelt. So nahmen die Buchholzer zum Unterschied von manchem anderen Dorf die 1945/46 zu ihnen gekommenen Flüchtlinge und Umsiedler freundlich auf, und das, was Frieda Kretschmer an Erfahrungen aus dem geselligen Leben von Bergsdorf mitbrachte, fiel deshalb nicht auf Sandboden, sondern in fruchtbare Schwarzerde." ${ }^{1466}$ Die parteilose Frieda Kretschmer übernahm 1950 die Leitung der örtlichen DFD-Gruppe und hat viele Frauen und Kinder sozial zu unterstützen geholfen. Die Buchholzer verliehen ihr gleichsam als Ehrentitel die - unverkennbar schlesischer Mundart entnommene - Bezeichnung „Muttel“. ${ }^{1467}$

\section{Zurücksetzungen}

Allgemein menschliche Verhaltensweisen, die sich häufig auf „Fremde“ richten, ohne dass die Vertriebenen besonders und mehr als andere davon betroffen wären, sind freilich nicht zu unterschätzen. Ein aus dem Sudetenland Vertriebener, der sich auf das neue politische System in der SBZ und DDR einließ, beobachtete (im Vogtland) gleichwohl die Reserviertheit der alteingesessenen Milieus: „den Ruch des Zugelaufenseins bekam man nur schwer los“ “ ${ }^{1468}$ Damit ist auch auf einen weiteren Punkt hingewiesen, der zu Differenzierung zwingt. Es ist der Unterschied zwischen verordnetem Verhalten einerseits und der gesellschaftlichen Realität im gegenseitigen Miteinander andererseits. Während bei letzterem vieles - negativ, aber ebenso positiv - nach wie vor möglich war und Spielräume auch geschickt genutzt wurden, trifft man da, wo die offizielle Parteilinie hochgehalten und durchgesetzt wurde, immer wieder auf Benachteiligungen und Deklassierungen, die dann auch neue seelische Verwundungen hervorriefen.

Ein schon oben als Beispiel herangezogener, aus Schlesien stammender Neulehrer (geb. 1922) hatte sich in Frankfurt (Oder) bis zum stellvertretenden Schulleiter hochgearbeitet, doch war seine SED-kritische Haltung nicht verborgen geblieben. Beides, Herkunft und Haltung, bildeten eine problematische Mischung. Dass zwischen vordergründiger Integration und voller Gleichberechtigung noch ein Unterschied bestehen könnte, wurde ihm daher während der

1466 Horst Rocholl: Frieda Kretschmer (die Muttel von Buchholz). In: Lebenszeit. T. III. Zeitzeugen berichten. Hrsg. vom Landesseniorenbeirat Brandenburg u. dem Seniorenbeirat Neuenhagen. Neuenhagen [1998], S. 88-90, hier S. 88.

1467 Ebd., S. 89.

1468 Hora, Eine politische Biographie, T. 1 (wie Anm. 1439), S. 135. 
fünfziger Jahre anhand eines konkreten Anlasses sehr deutlich, der ihn vor allem seinen Sonderstatus als „Umsiedler“ mehr als zehn Jahre nach Kriegsende noch spüren ließ: „Denn als es um einen Gegenbesuch bei den polnischen Schulpartnern in Neusalz a. O./Nowa Sól ging, die sich bei ihrem Besuch in Frankfurt a.d. Oder zum Entsetzen aller SED-Funktionäre als, Schule aus Neusalz' vorgestellt hatten, wurde mir doch bedeutet, dass man befürchte, meine Teilnahme als Schlesier könne Unfrieden stiften. Dass ich nicht in die entstehenden ,Kampfgruppen der Arbeiterklasse‘ berufen wurde, wunderte mich bei meinem fehlenden proletarischen Hintergrund nun wirklich gar nicht, erfreute mich eher, machte aber deutlich, dass meine Kompetenzen zwar für die gegenwärtige antifaschistischdemokratische Entwicklungsstufe der DDR nützlich waren, der Aufbau des Sozialismus mir aber alle leitenden Funktionen verschließen würde. "1469

Ein Potsdamer Lehramtsstudent, der seine sudetendeutsche Heimat 1945 als Zehnjähriger hatte verlassen müssen, erlebte, obgleich linientreues SED-Mitglied, Ähnliches: „Seit Mitte der 50er Jahre hatten die Beziehungen der Pädagogischen Hochschule Potsdam zu ausländischen Partnereinrichtungen begonnen, unter anderem zur Prager Karlsuniversität, und im Jahre 1957 sollte auch eine Delegation von Angehörigen des Historischen Institutes die CSR besuchen. Ich rechnete erfreut mit meiner Teilnahme. Außerdem wäre es meine erste Auslandsreise gewesen; denn damals war Westdeutschland noch nicht ausdrücklich zum Ausland erklärt worden. Aus meiner Teilnahme wurde nichts, erst 1964 sollte ich CSR-Boden betreten und meine alte Heimat wiedersehen. Warum nicht? Gehörte ich nicht zur [S. 365] Leistungsspitze, war ich nicht gar der Agitation im Westen für würdig befunden worden? Ein besonders linientreuer Genosse und Kommilitone (der wurde später ein ,Reisekader') erläuterte mir ernsthaft, ich sei doch ehemaliger Sudetendeutscher und meine Teilnahme könne, was heißt könne, würde bestimmt die tschechischen Gastgeber stören. Ob damit seine eigene Teilnahme begründet und ermöglicht werden sollte, weiß ich nicht, aber meine Enttäuschung kann ich noch heute fühlen. Und erst recht heute schüttle ich den Kopf über diese dumme Begründung, vor allem aber darüber, daß sie mir zuguterletzt sogar einleuchtete." 1470

Letztlich ließ sich die Seele auch dann vorübergehend zufrieden stellen, wenn man sich ideell ganz auf das Neue einließ, der Herkunft entsagte. Wenn dann gelegentlich - im SED-Sinne - der Erfolg der „Umsiedler-Integration“ in SBZ/DDR öffentlich hervorgehoben und einzelnen Mißständen in der Bundesrepublik propagandistisch gegenübergestellt wurde, wie etwa in populären Spiel- und Fernsehfilmen ${ }^{1471}$, dann war es oft ein Leichtes, die Gemüter zu beruhigen. Die Entwurzelung und darauf folgende Orientierungslosigkeit vieler Jugendlichen und jungen Erwachsenen beförderte dies bisweilen sogar noch, machte die verschiedensten Organisationen attraktiv für die Betroffenen und verschaffte ihnen Zulauf, da sie dem einzelnen Vertriebenen ein soziales Umfeld und Orientierung verschafften oder zu verschaffen versprachen. So versuchte die FDJ weitgehend den Freizeitbereich der Jugend abzudecken. Da es nach dem Krieg

1469 Lindner, Neulehrer in Frankfurt an der Oder (wie Anm. 1305), S. 56.

1470 Hora, Eine politische Biographie, T. 1 (wie Anm. 1439), S. 364 f.

1471 Siehe jetzt: Alina Laura Tiews: Fluchtpunkt Film. Integration von Flüchtlingen und Vertriebenen durch den deutschen Nachkriegfilm 1945-1990. Berlin 2017. 
kaum andere Angebote gab, hatte sie vielfach Erfolg. ${ }^{1472}$ In Fürstenberg (Oder) bemühte sich um „Flüchtlinge und Zuwanderer, die sich in der Stadt niedergelassen hatten“, beispielsweise anfangs aber auch der von 1945 bis 1955 amtierende Pastor der freikirchlichen „Adventgemeinde“ (Siebenten-Tages-Adventisten) Hans-Heinrich Oesterreich. ${ }^{1473}$ Stärker wirkten auf Dauer auf diesem „Feld“ jedoch die staatsnahen Organisationen. Da sie den Einzelnen atomisierten, ihn Teil einer neuen großen Massenbewegung zu machen versuchten, in der Vergangenes nicht mehr zählte, wirkten sie de facto integrationsfördernd, wenn auch unter erzwungener Verleugnung der landsmannschaftlichen Identitäten. Selbst die - ohnehin nur oberflächliche - Prüfung auf eine ehemalige NSDAP-Zugehörigkeit im Falle der Vertriebenen war in diesem dynamischen und machtvoll gesteuerten Prozess kein Hindernis. ${ }^{1474}$

\section{Sprache und Brauchtum}

Von volkskundlicher Seite sind in den letzten Jahren beachtliche Feldforschungen betrieben worden, Interviews minutiös mundartgerecht aufgezeichnet und Forschungsergebnisse publiziert worden, die die Vertriebenenintegration auch in Brandenburg betreffen. ${ }^{1475}$ Leider fehlt es noch an einer Synthese, die diese Fragen in den Gesamtzusammenhang stellt. Immerhin sei auf die Bedeutung auch dieser gleichsam ideellen Aspekte kurz hingewiesen.

Ihre Mundart bzw. Aussprache verloren die jüngeren Vertriebenen im Zuge der Assimilierung nach und nach um so schneller, je mehr sie von landsmannschaftlich-nachbarschaftlichen Zusammenhängen getrennt wurden, die allenfalls bei Treffen kurzzeitig wieder auflebten. Dörfer wie Neuheim (Dorf Zinna) bei Jüterbog, in denen man nahezu unter sich war, bildeten seltene Ausnahmen. In dieser fast vollständig von sudetendeutschen „Antifa-Umsiedlern“ gegründeten Gemeinde stellte der (selbst zur Einwohnerschaft zählende) Chronist Hans Schmutzer schon 1966 fest: „An Bräuchen und Sitten aus der alten Heimat hat sich nichts erhalten. Nur ei-

1472 Kernchen, Jugenderinnerungen an Fürstenwerder (wie Anm. 1205), S. $128 \mathrm{f}$.

1473 Daniel Heinz: Eine protestantische Freikirche stellt sich vor: die Adventgemeinde in Eisenhüttenstadt. In: Heimatkalender Eisenhüttenstadt und Umgebung 23 (2005), S. 166-168, hier S. 168.

1474 van Melis, „Angabe nicht möglich“ (wie Anm. 19). - Zu Beginn finden sich noch Hinweise auf gezielte Prüfung, so in einer Anordnung vom 9.10.1945 im Kreis Luckau, wonach von der „politischen Prüfungsstelle im Lager Cahnsdorf“ ein „Politischer Vermerk im Umsiedlerpaß“ eingetragen werden sollte. Aufgaben der Prüfungsstelle waren zuvor: „Einwandfreie politische Durchleuchtung, eidesstattl. Erklärung, Hinzuziehung von Vertrauensleuten aus den Umsiedlern. Bei Feststellung von aktiven Nazis, Unterbringung in ein gesondertes Lager mit der gesamten Familie.“ (Wille I [wie Anm. 196], S. 157). Gesonderte Lager bei den „Umsiedlerlagern“ sind aber wohl nicht eingerichtet, sondern die schwerer belasteten Personen vermutlich direkt in die sowjetischen Speziallager überführt worden. (Zum „Umsiedlerpaß“ und den Schwierigkeiten seiner - offenkundig nicht durchgehenden - Einführung 1945/46 siehe Wille I [wie Anm. 196], S. 266, 284-289.) Siehe allgemein: Manfred Wille: Entnazifizierung in der Sowjetischen Besatzungszone Deutschlands 1945-48. Magdeburg 1993; ferner für Brandenburgs westliches Nachbarland ders.: Die Entnazifizierung in Sachsen-Anhalt. in: Magdeburger Blätter 1982, S. 15-27, bes. S. 19 f. (Verzögerungen, 1946), 23 (schleppende Bearbeitung, Dez. 1947).

1475 Siehe dazu oben das Einleitungskapitel I. 2 zum Forschungsstand und insbesondere die dort genannten, für Brandenburg wichtigen Arbeiten von Keller (Anm. 123 und 125) und Scholze-Irrlitz (Anm. 117-119). 
nige Jahre sah man das Eierabholen der Kinder zum Gründonnerstag von den Verwandten. Lediglich die Sprache aus dem Iser-Gebirge blieb Gewohnheit der älteren Bewohner." ${ }^{1476}$ Zerstreuung in alle Winde war die Regel, meist blieben als nachbarschaftliche Gruppen nur einzelne Familien in erreichbarer Nähe. Die Jüngeren passten sich ohnehin nicht selten - bewusst oder unbewusst leichter und schneller an, die Älteren hielten - bewusst oder unbewusst - an ihrer Gewohnheit fest. Die Vielzahl an Mundarten, die sich zumal in den Städten West- wie Ostdeutschlands nach 1945 ergab, dürfte ein eigenartiges Gemisch gebildet haben, das sich jeder Integration, auch der geplanten Assimilierung wie ein Naturelement widersetzte. Die gesamte DDR-Zeit hindurch (und gelegentlich noch heute) gab es in allen beruflichen Bereichen Menschen, die ihre landsmannschaftliche Herkunft ob ihrer Aussprache nicht verleugnen konnten, selbst wenn sie es gewollt hätten. Freilich gab es Unterschiede: Das harte ostpreußische Idiom blieb gewiss bis zuletzt erkennbar, während Niederschlesier in der Oberlausitz weniger und Neumärker in Brandenburg meist gar nicht weiter auffielen. ${ }^{1477}$

Ein Neumärker aus dem Kreis Weststernberg hat diese Entwicklungen anhand der vertriebenen Bewohner seines Heimatdorfes Groß Gandern beobachtet und nach 1990 beschrieben: „Das Einleben in der neuen Umgebung war nicht immer eine materiell-wirtschaftliche Frage, sondern auch eine sprachliche. Und deshalb versuchte so mancher, sprachlich schnell integriert zu werden. Das war schon sehr schwer und gelang den Älteren überhaupt nicht. Jetzt [nach 1990] bei den Heimattreffen und sonstigen Gesprächen fällt auf, daß die in und um Berlin lebenden Landsleute ihre alte Sprechweise fast gänzlich beibehalten haben, was leicht zu erklären ist. Dagegen haben sich die im nordwestdeutschen und süddeutschen Raum sprachlich mehr oder weniger angepaßt, ja sogar den Akzent ihrer neuen Heimat übernommen." 1478

Auch die in der Rückschau häufig unbedacht egalisierende Zusammenfassung der - sehr heterogenen - Bevölkerungs-Großgruppe der Flüchtlinge und Vertriebenen trägt dazu bei, ein wenig differenziertes Bild der Vorgänge von Integration und Assimilation zu erzeugen. Lassen sich die mundartlichen Eigenständigkeiten der aus den Ostprovinzen Stammenden noch relativ leicht an die der in der SBZ bereits Lebenden „andocken“, zumal der Großraum Berlin schon seit dem 19. Jahrhundert erheblich Zuwanderung von dort erhalten hatte, so kommen nun auch kaum gekannte Gruppen „Auslandsdeutscher“ ins Land, deren Sprache und ungewohntes Auf-

1476 Schmutzer, ... auferstanden aus Ruinen (wie Anm. 642), S. 17.

1477 Ein etwas anders gelagertes Beispiel betont der aus Bromberg gebürtige Hartwig Spitzer: „Eine der großen Gemeinsamkeiten war die gleiche Sprache. In Bromberg, in dem ich aufgewachsen bin, sprach die deutsche Bevölkerung hochdeutsch, das beste Deutsch, wie meine Mutter meinte. Dialekte kamen nicht vor. [...]." Während er in seinen zunächst westdeutschen Wohnorten gerade mit seinem Hochdeutsch auffiel, erleichterte ihm dieses nach der Wende das „Ankommen“ in Potsdam, wo er auf eine ohnehin stark gemischte Bevölkerung traf: „Kommt man nach Köln, Mainz oder München, so fällt der stadttypische Tonfall, der Singsang, auf. Mit reinem Hochdeutsch fällt man dort als Fremder [S. 30] auf. In Potsdam war das nicht so. [...]." (Spitzer, Potsdamer Jahre [wie Anm. 1456], S. 29f.).

1478 Materne/Gerlach, Gross-Gandern und Klein-Gandern (wie Anm. 351), S. 83. 
treten für die Einheimischen besonders fremd waren und die gängigen Muster an Reserviertheit erzeugen mussten.

Ein selbst mit der Mutter aus Stettin nach Havelberg geflüchteter Fünfähriger erlebt noch vor Kriegsende 1945 die Ankunft von Flüchtlingszügen auf dem Bahnhof und sieht Menschen, die er so aus seiner Heimat nicht kannte, vermutlich aus dem „Warthegau“ evakuierte Bessarabiendeutsche: „Ein Zug voller Menschen, vorwiegend Frauen und Kinder. ,Flüchtlinge heißt es, die in Havelberg und den umliegenden Dörfern untergebracht werden mußten. Mir fiel die ungewohnte Kleidung vieler Frauen auf. Sie trugen dunkle Kopftücher und lange dunkle Röcke. Noch Monate später erkannte ich Flüchtlinge in Havelberg an ihrer Kleidung. " ${ }^{1479}$ Auch der damalige Neulehrer Günter de Bruyn empfand offenkundig das Fremde an der Mutter eines Schülers, die ihn aufsuchte und, wie er sich in seinen Jugenderinnerungen ausdrückt, „in dem schwerverständlichen Idiom der Bessarabiendeutschen“ sprach, „das sich anhörte, als wollte ein Russe Schwäbisch sprechen“; auch der Sohn wirkte anders als die Kinder der Einheimischen: „ein pfiffger Zwölfjähriger, der hervorragend rechnen, aber nicht schreiben konnte, weil er seine Schuljahre vorwiegend auf Trecks zwischen dem Schwarzen Meer und der Weichsel verbracht hatte [...]".1480

Eine Angehörige der 1946 in Werder (Oderbruch) als geschlossene Gruppe angesiedelten Dobrudscha-Deutschen schrieb im Alter rückblickend über die schwierigen Anfänge, sich auf dem zugeteilten Land und den nahezu vollständig kriegszerstörten Höfen eine neue Lebensgrundlage aufzubauen, und ging dabei auch auf andere als die in Berichten zumeist in den Vordergrund gestellten materiellen Bedürfnisse ein: „Vieles geschah in verwandtschaftlicher Gemeinschaftsarbeit. In Werder wurden wir heimisch und fanden Geborgenheit. Hier sprach man die vertrauten Mundarten, sang die alten Lieder und kochte die besonderen Speisen. Doch trotz des großen Fleißes und der sichtbaren Erfolge als Bauern und in anderen Berufen waren wir viele Jahre Ausgegrenzte durch unsere Herkunft und Andersartigkeit in Sprache, Frisur und Kleidung. Erst im Laufe der Jahre akzeptierte man unsere Leistungen in der Schule und im Beruf."1481

Solche Erfahrungen und Gefühle der Fremdheit gab es folglich auf beiden Seiten, der der Einheimischen wie der der Hinzukommenden. Erst in Verbindung mit der jeweiligen sozialen und wirtschaftlichen Situation des Betreffenden ergaben sich daraus Konflikte, bei denen die Flüchtlinge und Vertriebenen oft auf Jahre hinaus die Schwächeren blieben. Zumindest Jüngere hat das bisweilen dazu geführt, sich um des Erfolgs willen ganz von ihrer Herkunft loszusagen, oder zumindest motiviert, weniger auffallen zu wollen und sich so leichter zu integrieren bzw. zu assimilieren. Die unübersehbar große Zahl der „Neubürger“, der neuen Nachbarn, zwang aber hier und da auch die Einheimischen dazu, sich auf die neue Mischgesellschaft einzustellen. Letztlich entschied sich in der einzelnen Familie, wie die Integration verlief, ob als assimilatorische „Einbahnstraße“ oder als Fusion, bei der etwas Neues entstand. So dürften gerade die

1479 Plath, Erinnerungen an das Kriegsende und die Nachkriegsjahre in Havelberg (wie Anm. 1179), hier S. 39.

1480 Günter de Bruyn, Zwischenbilanz (wie Anm. 1253), S. 337.

1481 Anna Baudis: Werder wurde Heimstatt für Flüchtinge. In: Märkische Oderzeitung, 5.5.2016. 
vielen „Mischehen“ zwischen Einheimischen und Vertriebenen ${ }^{1482}$ je nach Persönlichkeit des einzelnen Ehepartners darüber entschieden haben, ob „in den eigenen vier Wänden“ die als gewohntes Rezept mitgebrachten „Königsberger Klopse“ weiter so hießen, in „Kochklopse“ umgetauft wurden oder durch anderes ganz vom Speisenplan verdrängt wurden. ${ }^{1483}$

Generationenübergreifende (nach 1990 geführte) Interviews mit Vertriebenenfamilien, die in der DDR gelebt hatten, zeigen freilich im privaten, familiären Rahmen kaum andere Abläufe als in den westdeutschen Aufnahmegebieten, wenn es um Speisen geht. Spätestens beim Eingehen einer Ehe mit einem oder einer Einheimischen stellt sich die Frage, ob die Essgewohnheiten der einen oder der anderen Familie sich durchsetzen, ob sie zueinander in Konkurrenz treten, das Hinzukommende irgendwann verschwindet oder gar als Bereicherung in den Speisenplan integriert wird. In den von Lisa Haberkern geführten Interviews zeigt sich sogar, wie Elemente der heimatlichen (Vertriebenen-)Küche symbolhaft auf (positive) Eigenschaften und Werte einer verlorenen Regionalkultur und des Wesens ihrer Menschen insgesamt übertragen werden. So ist für den Enkel eines 1931 in Niederschlesien geborenen, 1945 Vertriebenen, der dann in Luckenwalde lebte, „Schlesien mit der Vergangenheit des Großvaters verbunden, hat aber keine klare Form. Schlesisch ist eine positive, wertsteigernde Eigenschaft. Beispielsweise ,sieht [die Suppe] schon recht gut nach Schlesien aus' und der schlesische Mohnkuchen ,[d]en konnte nur die Muddl [H. F.s Mutter] [...] backen', war an Weihnachten besonders wichtig. H. F. [der vertriebene Großvater selbst - P. B.] dehnt den Begriff noch weiter aus und erhebt die schlesische Herkunft zu einem Teil des Ursprungs des harmonischen Familienlebens. Zu den positiven Eigenschaften, die den Schlesiern zugeordnet werden, zählen des Weiteren Fleiß, Ordnungsliebe und Ehrgeiz. " ${ }^{1484}$ Auch ein weiteres Beispiel aus Haberkerns Interviews verweist auf Speisen und Rezepte, die als Unterscheidungsmerkmale zwischen Vertriebenen und Einheimischen empfunden und auch benannt werden: „Dem schlesischen Mohnkuchen aus Familie F. kann der ,Karpfen in Biersoße` in Familie M. zur Seite gestellt werden: Grundsätzlich machen T.M., E.M. 1 und 2 wenige Unterschiede in ihrem Familienleben im Gegensatz zu dem anderer Familien aus, die darauf zurückzuführen sind, dass F. M. vertrieben wurde. Jedoch nennen sowohl T.M. als auch E. M. 1, nach Familientraditionen und -bräuchen gefragt, die sich von denen der alteingesessenen Bevölkerung unterscheiden, den ,Karpfen in Biersoße. Hierbei handelt es

1482 Hartmut Schatte hat am Beispiel eines bei Guben gelegenen Dorfes das Gelingen von Integration an 21 Familiengründungen von Flüchtlingen festgemacht, die in den Nachkriegsjahren Ehen mit Einheimischen eingingen. Diese Form der Integration bzw. Assimilation gab es deutschlandweit, allerdings ist darauf hinzuweisen, dass sie im Raum Guben dadurch besonders erleichtert wurde, dass die Vertriebenen fast alle aus dem Ostteil desselben Kreises stammten, also beide Gruppen, die nun aufeinander stießen, im Grunde identische Sozialisation und Kultur mitbrachten. Siehe: Hartmut Schatte: Groß Drewitz. Geschichte und Geschichten eines Dorfes in der Niederlausitz. Cottbus/Guben 1999, S. 331 (mit Namensnennungen).

1483 Matthias Biskupek: Was heißt eigentlich „DDR“? Böhmische Dörfer in Deutsch \& Geschichte. Berlin 2003, S. 154. - Vgl. auch Barbara Pischel: Gestaltung und Wandlung von Bräuchen am Beispiel Heimatvertriebener in Berlin. In: Jahrbuch für Volkskunde der Heimatvertriebenen 3 (1958), S. 123-150.

1484 Haberkern, Heimatverlust im Familiengedächtnis (wie Anm. 129), S. 64. H. F. = Heinz Fröhlich. 
sich um ein Rezept, das im Oderbruch von den Familien gekocht wird, deren Wurzeln in den odernahen Vertreibungsgebieten, wie es Weststernberg war, liegen." ${ }^{1485}$

\section{Orts- und Straßennamen}

Ein öffentlich sichtbares Bekenntnis zur Erinnerung an die Herkunftsgebiete der Vertriebenen waren und sind Straßennamen. ${ }^{1486}$ „Der wesentliche Unterschied zwischen der DDR und der Bundesrepublik Deutschland bestand hinsichtlich der Straßennamenpolitik darin, dass in der DDR manche Bezeichnungen mit ,östlichem' Bezug verschwanden, während in der Bundesrepublik bewusst solche Straßennamen neu benutzt wurden. “1487 Während in den Westzonen in den Aufbaujahren Straßengruppen in Neubaugebieten, aber auch einzelne mitunter durchaus zentrale Straßen und Plätze in vielen Städten die Namen von Orten, Landschaften, Provinzen oder Gewässern der ehemaligen Ostgebiete des Deutschen Reiches, aber auch solcher aus „Mitteldeutschland“ (SBZ/DDR), erhielten und meist bis zur Gegenwart behalten haben, fehlen solche Benennungen in der DDR, da sie das Verhältnis zum sozialistischen „Bruderland“ Polen beeinträchtigt hätten. Schon bald nach Gründung der Republik ging man hier vielmehr daran, diejenigen Straßennamen, die bereits vor 1945 vorhanden waren, auf ihre politische Tragbarkeit hin zu prüfen. Denn bereits nach dem Ersten Weltkrieg und besonders nach 1933 hatte es Benennungswellen gegeben, aus denen noch vielfach Straßennamen existierten, die an die abgetrennten Gebiete der Provinzen Posen und Westpreußen, aber auch an andere historisch ostdeutsche Städte und Provinzen erinnerten. ${ }^{1488}$ Darunter sind insbesondere solche in Vertriebenensiedlungen, die während der Weimarer Republik vom „Ostbund“ (Gemeinnützige Siedlungsgesellschaft Deutscher Ostbund $\mathrm{mbH}$, Berlin) und anderen Trägern errichtetet worden waren.

Beispielesind dieBrombergerund diePosenerStraßein derWriezener „Ostbundsiedlung“ ${ }^{1489}$ Dieselben beiden Straßennamen existierten bis Anfang der fünfziger Jahre in Bad Freienwalde;

1485 Ebd. H.M. = Helga Moeck, Sieversdorf (geb. 1934 Schmagorei, Kr. Weststernberg), im Spätsommer 1945 vertrieben); T.M. = Heike Hoffmann (Tochter der Vorgenannten); E. M. 1 und 2 = Maria und Lisa Hoffmann (Enkeltöchter der vertriebenen Helga Moeck).

1486 Vgl. Tobias Weger: Straßennamen. In: Die Erinnerung an Flucht und Vertreibung. Ein Handbuch der Medien und Praktiken. Stephan Scholz / Maren Röger / Bill Niven (Hg.). Paderborn 2015, S. 409-419 (mit weiterführender Lit.).

1487 Ebd., S. 413. Siehe für die westdeutsche Situation z. B.: Hans Vastag: Stuttgart - neues Zuhause für deutsche Heimatvertriebenen und Spätaussiedler. Straßen, Plätze, Verbände, Einrichtungen benannt nach Ortschaften, Personen, Landschaften der Herkunftsgebiete. Eine Dokumentation. Nach einer Idee von Albert Reich. Hrsg.: Bund der Vertriebenen (BdV) - Vereinigte Landsmannschaften, Landesverband Baden-Württemberg u. Kreisverband Stuttgart. Stuttgart 2012. - Listen von nach schlesischen Orten oder Persönlichkeiten benannten Berliner Straßennamen bietet Schieb, Jeder zweite Berliner (wie Anm. 872), S. 346-348.

1488 Siehe dazu knapp ebd., S. 410 f., mit Verweis auf entsprechende Empfehlungen (1922) und Richtlinien (1925) des deutschen Städtetages.

1489 Freundlicher Hinweis Dr. Reinhard Schmook (Bad Freienwalde), 22.2.2016. 
hier benannte man die Bromberger Straße dann in Beethovenstraße und die Posener Straße in Ernst-Thälmann-Straße (seit 1991 Waldstraße) um. ${ }^{1490}$ In Strausberg erfolgten die entsprechenden Umbenennungen am 14. Juli 1950: Bromberger Straße in Gorkistraße ${ }^{1491}$, Kleine Bromberger Straße in Uhlandstraße ${ }^{1492}$, Danziger Straße in Goethestraße, Dirschauer Straße in Bruno-BürgelStraße, Gnesener Straße in Tolstoistraße, Graudenzer Straße in Heinestraße (später HeinrichHeine-Straße), Lissaer Straße in Lessingstraße, Thorner Straße in Schillerstraße, Tilsiter Straße in Freiligrathstraße. ${ }^{1493}$ In Luckenwalde gab es 1950 das gleiche Prozedere, ebenso in Fürstenwalde/Spree, wo z. B. aus der Bromberger Straße die Wladimir-Komarow-Straße wurde. ${ }^{1444}$ Die üblichen „grenzlanddeutschen“ Straßennamen, in diesem Fall erst seit 1939 existierend, mussten harmlosen Baum-Namen weichen: Die Danziger Straße wurde zum Eschenweg, die Graudenzer zum Buchenweg, die Masurenstraße zur Akazienallee, die Memeler Straße zur Birkenstraße, die Posener zur Eichenstraße und selbst die nun gar nicht mehr mit diesen vergleichbare Flensburger Straße wurde dabei kurzerhand zur Ahornallee. ${ }^{1495}$

Im deutschen Teil Gubens, wo die unmittelbare Grenznähe zu Polen Anlass zu verstärkter Wachsamkeit gegenüber Angriffspunkten für den Nachbarn bot, wo andererseits besonders viele Flüchtlinge als „Unruhepotential“ lebten, beschloss die Stadtverordnetenversammlung am 8. Juli 1951 die Umbenennung der Schlesischen Straße in Gartenstraße, der Breslauer Straße in Blumenweg sowie der Danziger Straße in Elsterweg. ${ }^{1496} \mathrm{Im}$ benachbarten Fürstenberg/Oder erhielt die Stadtverwaltung bereits am 3. Mai 1948 von der am Ort ansässigen Geschäftsstelle der „Brandenburgischen Schiffahrts- u. Umschlags-Gesellschaft vormals Schlesische Dampfer Compagnie-Berliner Lloyd Aktien-Gesellschaft" eine Mitteilung über die Zusammenlegung der "Schlesischen Dampfer Compagnie-Berliner Lloyd AG Fürstenberg/Oder und Berlin“ mit der „Neuen Norddeutschen und Vereinigten Elbeschiffahrt AG, Berlin“ unter dem neuen Namen „Brandenburgische Schiffahrts- . Umschlags-Gesellschaft", d.h. die zeitbedingte Fusion wurde zugleich genutzt, um den Schlesien-Bezug im Namen zu beseitigen. ${ }^{1497}$

In der besonders exponierten Grenzstadt Frankfurt (Oder) erfolgten die Umbenennungen teils schon 1948, teils erst $1953 .{ }^{1498}$ Hier handelte es sich in erster Linie wiederum um

1490 Ullrich Künkel: Bad Freienwalder Lexikon. 1. Ausg. [Rinteln] 1994, S. 43 f.

1491 Der in West-Ost-Richtung verlaufende Teil später in Uhlandstraße umbenannt.

1492 Später der Gorkistraße zugeordnet.

1493 Claus Béringuier: Sammlung zur Geschichte und Herkunft Strausberger Namen (Akanthus-Mitteilungen, H. 21). Strausberg 2008, S. 18.

1494 Siehe im einzelnen die Angaben unten in der Ortsdokumentation.

1495 Dietrich Maetz: Chronik der Stadt Luckenwalde. Luckenwalde 2016, S. 337-346.

1496 Der Kreis Guben im Jahre 1951. Zsgest. von W. Dartsch. In: Gubener Heimatkalender 35 (1991); S. 79-82, hier S. 81.

1497 Abdruck des Schreibens in: „Die russische Kommandantur verlangt ...” (wie Anm. 209), S. 150.

1498 Das Folgende nach: http://www.museum-viadrina.de/Strassenlexikon_Frankfurt/konkordanz.htm (Stand: 29.2.2016). Die auf den ostpreußischen Ort, aber vor allem auf die dortigen Schlachten bezogene Tannenbergstraße (seit 1938) wurde 1948 in Beethovenstraße, die Gnesener Straße (seit 1927), ebenfalls 1948, in GerhartHauptmann-Straße umbenannt. Der Königsberger Platz (seit 1933) erhielt 1953 den Namen Wismarer Platz. 
ein aus der Zeit der Weimarer Republik stammendes Konglomerat, das sich in der bekannten „Ostmark“-Siedlung in Paulinenhof (heute „Paulinenhofsiedlung“) befand und an die nach dem Ersten Weltkrieg verlorenen Gebiete erinnern sollte. Diese Siedlung war in den Jahren 1922 bis 1925 für die rund 600 Angehörigen der - aus den Restbezirken der ehemaligen Eisenbahnverwaltungen Posen und Bromberg - entstandenen Reichsbahndirektion Osten geschaffen worden. Hierfür hatte die Stadt Frankfurt gemeinsam mit der Reichsbahnverwaltung eine

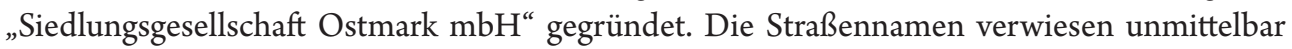
auf die Herkunft der Bewohner, seit der Umbenennung ist daraus, den Namen nach, überwiegend ein „Musikerviertel“ geworden, womit auf das „Musikheim“ Bezug genommen wurde: Bromberger Ring (Franz-Liszt-Ring), Danziger Straße (Albert-Fellert-Straße), Dirschauer Straße (Georg-Friedrich-Händel-Straße), Graudenzer Weg (Harfenweg), Culmer/Kulmer Straße (Albert-Lortzing-Straße), Ostmarkstraße (Hermann-Boian-Straße), Posener Ring (Peter-Tschaikowsky-Ring), Thorner Grund (Joseph-Haydn-Straße). Die qualitätvollen Bauten dieser von Martin Kießling (1879-1944) entworfenen Gartenstadt-Siedlung stehen heute unter Denkmalschutz. ${ }^{1499} \mathrm{Zu}$ einer konsequenten denkmalpflegerischen Wiederherstellung des Gesamtensembles könnte man nun theoretisch auch Straßennamen zählen. Doch sind die Musikernamen inzwischen ebenfalls Teil der Geschichte, der „Außenhaut“ der Anlage. Es gibt jedoch in Frankfurt auch Straßennamen, die anfangs noch geduldet wurden. So ist der Name der im „Hansaviertel“, einem Wohngebiet mit vorwiegend nach Hansestädten (darunter auch Bremen und Hamburg) benannten Straßen, gelegenen Stettiner Straße erst 1953 in Rostocker Straße geändert worden. Den Namen der (seit 1927) auf eine Stadt im Süden der Neumark bezogenen Züllichauer Straße hat man sogar erst 1965 in Finkenheerder Straße umbenannt.

Die Landeshauptstadt Potsdam hatte solche Straßennamen nicht zu bieten, hier herrschte die Erinnerung an das Haus Hohenzollern vor, Kaiser Wilhelm wich nach dem Krieg Hegel. ${ }^{1500}$

Die in den meisten Fällen nahe beieinander liegenden Umbenennungsdaten verweisen bereits darauf: Im zentralistischen SED-Staat waren dies keine Einzelfallentscheidungen um das richtige Gedenken ringender Kommunen, sondern die örtliche Ausführung von Vorgaben aus der Berliner Zentrale. Das Ministerium des Innern (MdI) der DDR hatte in einer Verordnung vom 30. März 1950 die Umbenennung „nicht mehr tragbarer Benennungen von Straßen, Wegen und Plätzen" verfügt; diese hatte bis zum 31. Juli 1950 zu erfolgen. ${ }^{1501}$ Die Mehrheit der noch nicht umbenannten Straßen verlor ihre Namen in diesem Zusammenhang, Beispiele wür-

1499 Gramlich u. a., Stadt Frankfurt (Oder) (wie Anm. 312), S. 310-312.

1500 Arlt, Die Straßennamen der Stadt Potsdam (wie Anm. 1080).

1501 GBl. der DDR Nr. 39, 5.4.1950, S. 296 (Verordnung zur Beseitigung nicht mehr tragbarer Benennungen von Straßen, Wegen und Plätzen vom 30. März 1950). Vgl. dazu den Runderlass des brandenburgischen Innenministeriums Nr. 11/50 vom 24. April 1950. Weitere Verordnungen, in denen die Benennung nach Persönlichkeiten geregelt wurde, waren vorausgegangen bzw. folgten. Siehe dazu: Wolfgang Blöß: Umbruch und Namen. Ortsnamenpolitik in Brandenburg 1945-1952. In: Jahrbuch für die Geschichte Mittel- und Ostdeutschlands 55 (2009 [2010]), S. 177 f. 
den sich bei systematischer Recherche wohl noch an vielen anderen Orten finden lassen. ${ }^{1502}$ Dahinter standen konkrete außenpolitische Rücksichten, denn die DDR wollte bzw. musste im Juni „unbelastet“ in die Warschauer Gespräche gehen, die dann am 6. Juli 1950 im Görlitzer Abkommen mit der Volksrepublik Polen zur Anerkennung der Oder-Neiße-Grenze führten. Ein Teil der durchaus in Frage kommenden Namen konnte sich gleichwohl noch mehrere Jahre halten und belegt, dass trotz allem keine lückenlose Erfassung des Lebens gelang. ${ }^{1503}$

In Ost-Berlin gab es in dieser frühen Zeit eine analoge Umbenennungswelle, die aber, wohl wegen des anfangs noch stärker respektierten Viermächtestatus, nicht vollständig zeitgleich ablief. Interessant ist, dass sich hier sogar mancher Name, obgleich der Magistrat zumindest später zweifellos hätte handeln können, bis zum Ende der DDR (und bis heute) halten konnte. Zwar sind größere, in der Stadtmitte belegene Namen wie Danziger Straße und Elbinger Straße (beide im Bezirk Prenzlauer Berg) schon früh, sogar noch vor der MdI-Verfügung, nämlich am 27. Februar 1950, in Dimitroffstraße $\mathrm{e}^{1504}$ und die Memeler Straße am 22. März 1950 im Bezirk Friedrichshain in Marchlewskistraße $\mathrm{e}^{1505}$ umbenannt worden, doch ist man in Ost-Berlin insgesamt nicht ganz so rigide vorgegangen. Während man die Landsberger Allee und den Landsberger Platz am 22. April 1950, also fristgerecht, in Leninallee und Leninplatz umbenannte ${ }^{1506}$, wurde die Deutsch-Kroner Straße im selben Bezirk erst am 4. September 1951 (in Fritz-RiedelStraße) umbenannt, die Breslauer Straße und die Königsberger Straße in Friedrichshain behielten ihre Namen gar bis $1964 .{ }^{1507}$ Erst zum zwanzigsten Jubiläum der DDR-Staatsgründung wur-

1502 Siehe u. a. für Blankenfelde (Kr. Teltow) die, wenn auch nur allgemein gehaltenen, Angaben bei: Günter Meier: Die Straßennamen von Blankenfelde 1918 bis 2002. Ein Spiegel der politischen Machtstrukturen in Deutschland. In: Heimatjahrbuch für den Landkreis Teltow-Fläming 9 (2002), S. 47-53, hier S. 52: „Namen von $[\ldots]$ ehemals deutschen Städten und Grenzgebieten gestrichen“).

1503 Dennoch erscheint Wegers, aus einer Arbeit von Christian Lotz (2010) übernommene Aussage, es seien insgesamt ,aber auch im Osten Deutschlands relativ viele Straßennamen mit östlichem Inhalt belassen worden“ (Weger, Straßennamen [wie Anm. 1486], S. 412), außer für das Stadtgebiet von Ost-Berlin stark übertrieben.

1504 Berlin. Ringen um Einheit und Wiederaufbau 1948-1951. Hrsg. im Auftr. des Senats von Berlin (Schriftenreihe zur Berliner Zeitgeschichte, Bd. 3). Berlin 1962, S. 595. - Abweichendes Umbenennungsdatum 1. Januar 1950 laut: Lexikon Alle Berliner Straßen und Plätze. Von der Gründung bis zur Gegenwart. Hrsg. von HansJürgen Mende. Bd. 1-4. Berlin 1998, Bd. 1, S. 398, 483 (so auch: www.berlingeschichte.de/strassen).

1505 Berlin. Ringen um Einheit und Wiederaufbau 1948-1951 (wie Anm. 1504), S. 617. - Abweichendes Umbenennungsdatum 16. März 1950 lt.: Lexikon Alle Berliner Straßen und Plätze (wie Anm. 1504), Bd. 3, S. 103, 148 (so auch: www.berlingeschichte.de/strassen).

1506 Berlin. Ringen um Einheit und Wiederaufbau 1948-1951 (wie Anm. 1504), S. 645.

1507 Lexikon Alle Berliner Straßen und Plätze (wie Anm. 1504), Bd. 1, S. 311, 412; Bd. 2, S. 504. - Als Reaktion auf die am 20.3.1964 erfolgte Tilgung des Namens Breslauer Straße benannte man in West-Berlin am 1.10.1964 den Lauterplatz in Friedenau (im Bezirk Schöneberg, dem Patenbezirk der Schlesier Berlins) in Breslauer Platz um. Die Umbenennung der Königsberger Straße in Ost-Berlin erfolgte am 20.4.1964, und bereits am 1.12.1964 erhielt in West-Berlin die Giesensdorfer Straße in Lichterfelde (Bezirk Steglitz, Patenbezirk der Ostpreußen Berlins) den Namen Königsberger Straße (Kauperts Straßenführer durch Berlin, https://berlin.kauperts.de/ Strassen). 
de die Tilsiter Straße am 7. November 1969 in Richard-Sorge-Straße umbenannt. ${ }^{1508}$ Auch bei deutlich sichtbaren Bahnhofsnamen ließ man sich Zeit. Erst am 1. Dezember 1950, also über ein Jahr nach Gründung der DDR und fast fünf Monate nach Abschluss des Görlitzer Vertrages, folgten die Bahnhofsumbenennungen: Aus dem Schlesischen Bahnhof (Bezirk Friedrichshain) wurde der Ostbahnhof (1987-1998 Hauptbahnhof), aus dem Stettiner Bahnhof (Bezirk Mitte) der Nordbahnhof, analog verfuhr man mit den Namen der benachbarten S-Bahnhöfe. ${ }^{1509}$

Unbeschadet überstanden hat die gesamte DDR-Zeit eine Gruppe ostpreußischer Landschaftsnamen, die jedoch möglicherweise nur wenigen bekannt waren und daher - zudem in „Nischen“ am Stadtrand gelegen - nicht auffielen. Es handelt sich dabei um die in Berlin-Buch (Bezirk Pankow) an der Zepernicker Straße, unmittelbar vor der Stadtgrenze zu Brandenburg, 1927 entstandene Einfamilienhaussiedlung aus Nadrauer, Schalauer und Sudauer Straße. ${ }^{1510}$ Ähnlich gelagert ist wohl der Fall der - abseits größerer Aufmerksamkeit gelegenen - Siedlung in Berlin-Friedrichshagen (Westend-Siedlung) mit teilweise in den Jahren 1929 bis 1931 vergebenen Straßennamen, die sich auf ost- und westpreußische Städte beziehen: Gilgenburger Pfad und Straße, Jastrower Weg (bis 1935 Jastrower Straße), Liebstadter Gang, Löbauer Weg, Marienwerder Weg. ${ }^{1511}$ Ebenfalls über die gesamte DDR-Zeit und bis heute erhalten geblieben ist der 1876 eingeführte Name der Küstriner Straße in Fürstenwalde/Spree. Vermutlich blieb der Name bestehen, weil sich in dieser Straße vor wie nach 1945 die Gaststätte „Küstriner Wappen“ befand (und befindet), die nicht zuletzt in der Geschichte der lokalen Arbeiterbewegung eine Rolle gespielt hatte, so dass über den Umweg dieser Gaststätten-Bezugnahme der Name weiterhin toleriert werden konnte. ${ }^{1512}$

Ein außergewöhnlicher Fall der Andenkenpflege an die ostdeutsche Heimat wurde in den frühen Nachkriegsjahren in Frankfurt (Oder) geschaffen und zumindest vorübergehend geduldet. Die Stadtverwaltung benannte die Straße, in der sich die aus der neumärkischen Kleinstadt Lippehne (Kreis Soldin) stammende Landmaschinenfabrik Schütz \& Bethke nach der Flucht

1508 Weger, Straßennamen (wie Anm. 1486), S. 412.

1509 Berlin. Ringen um Einheit und Wiederaufbau 1948-1951 (wie Anm. 1504), S. 836.

1510 Lexikon Alle Berliner Straßen und Plätze (wie Anm. 1504), Bd. 3, S. 205, 548; Bd. 4, S. 166.

1511 Ebd., Bd. 2, S. 93, 363; Bd. 3, S. 25, 48, 113. Ähnlich uninformativ, nämlich ohne jede Hintergrundinformation, und sogar ahnungslos die Angaben in: Rolf u. Inge Kießhauer: Friedrichshagener Straße, Wege und Plätze. Geschichte und Gegenwart. H. 2.: Zwischen Spree und Eisenbahn. Berlin-Friedrichshagen 1993, S. 32 f., 3537, 41 f.; S. 42 heißt es in völliger Verkennung der sogar auf S. 35 formulierten Zusammenhänge (,insgesamt nach west- bzw. ostpreußischen Orten benannt“): „Namengeber war vermutlich die Stadt Löbau in Sachsen“, richtig dagegen in: Lexikon Alle Berliner Straßen und Plätze (wie Anm. 1504), Bd. 3, S. 48: „Löbau, westpreuBische Kreisstadt“. Vor 1990 könnte der Irrtum (?) allerdings sogar hilfreich gewesen sein.

1512 Freundlicher Hinweis des früheren Fürstenwalder Museumsleiters Florian Wilke vom 21.6.2018. - Die Gaststätte in der Küstriner Straße 9 war von dem um 1880/90 nach Fürstenwalde zugezogenen Küstriner Albert Schön (1851-1928) begründet und zur „Erinnerung an seine Geburtsstadt und in Anlehnung an den Straßennamen" so benannt worden (Gespräche mit ehemaligen Küstrinern. Aufgez. u. bearb. von Siegfried Neubauer. Bd. 7. Frankfurt (Oder) 2018, S. 37 f., Zitat S. 37). 
1946 ansässig gemacht hatte, vermutlich auf Antrag der Firma, in Lippehner Straße um. ${ }^{1513}$ Die Bezugnahme auf den Herkunftsort war offensichtlich. Noch im November 1947 vermerkte die Industrie- und Handelskammer Mark Brandenburg in einer „Aufstellung von Industriebetrieben, die durch Umsiedler errichtet wurden", beim Stadtkreis Frankfurt unter der Firma Schütz \& Bethke: „Frankfurt/O./Lippehner-Str./früh[er] Lippehne/NM.“1514 Nicht unter den Augen der Öffentlichkeit, sondern innerhalb der Firmengebäude gab es hier 1946 sogar eine weitere Erinnerungsstätte: Im Gemeinschaftsraum hatten selbst zu den Vertriebenen zählende ehemalige Lippehner und nun Frankfurter Betriebangehörige der Firma ein Wandbild geschaffen, das die Lippehner Fabrikanlage zeigte, darunter war auf einem schwungvollen Spruchband in großer Schrift zu lesen „Schütz u. Bethke/Werk Lippehne / 1857-1945““ ${ }^{1515}$ Anlässlich des fünfjährigen Bestehens der Firma in Frankfurt (Oder) hieß es in der „Märkischen Volksstimme“ am 8. August 1951: „Seit 1857 bestand diese Firma in Lippehne."1516

Die Beseitigung der oftmals wenige Jahre oder Jahrzehnte zuvor erst eingeführten Straßennamen, die auf 1918 vom Deutschen Reich abgetrennte Gebiete verweisen sollten, lässt sich mit dem weiten zeitlichen Abstand des heutigen Betrachters leicht marginalisieren oder als durchaus notwendigen Akt der Beseitigung letztlich propagandistisch zu verstehender Namen sehen. Außerdem war ja die beabsichtigte Funktion dieser Straßennamen, den Gedanken an eine Revision (Ost-)Grenze von 1918 wachzuhalten, durch die neue, nun wesentlich weiter westlich gezogene Oder-Neiße-Grenze von 1945 schon allein sachlich gleichsam erledigt. Versetzt man sich aber in die Gemüter der Flüchtlinge und Vertriebenen der Jahre 1945-1950, so kann die flächendeckende Beseitigung dieser letztlich wenigen noch verbliebenen und öffentlich sichtbaren Namen wohl nur als weiterer Akt einer „Kalten Heimat“ gesehen werden, der bei jenen Menschen, die teilweise aus genau diesen Städten kamen, den Eindruck verfestigt haben wird, nicht willkommen zu sein bzw. ihre Identität fortan verleugnen zu müssen.

Dennoch sollte man berücksichtigen, dass dieser öffentlich sichtbare Gebrauch von Namen, der bald mit einem Tabu belegt wurde, nie eine vollständige Entsprechung im persönlichen Umgang und Alltag fand und die Gewöhnung der Bevölkerung an die offizielle Sprachregelung eine lange Zeit benötigte. Zwar lernten die Beflisseneren bald die polnischen Ortsnamen, obgleich sie sich mit deren korrekter Aussprache meist schwer taten und tun. Doch für viele DDR-Bürger bis tief in die Reihen der SED-Genossen hinein blieben noch auf Jahre hinaus

1513 Zeitungsbericht der „Märkischen Volksstimme“ vom 10.1.1947, hier nach: Hakus, Die Geschichte der Firma Schütz \& Bethke, (wie Anm. 1270), hier S. 10. - Offiziell jedoch 1952/53 umbenannt in Am Schlachthof. Nähere Angaben siehe Ortsdokumentation Frankfurt (Oder) / Straßenumbenennungen. - Im Branchen-Fernsprechbuch für die Bezirke Cottbus, Frankfurt (Oder), Potsdam 1961, S. 100, ist die Firma Schütz \& Bethke KG mit einer Anzeige vertreten, in der bereits „Am Schlachthof 1-10“ als Sitz genannt wird (In der 1. Ausg. 1951 ist die Firma nicht erwähnt).

1514 BLHA, Rep. 333 SED-Landesleitung Brandenburg, Nr. 574, Bl. 226r. Die Liste wurde am 8.11.1947 der SEDKreisleitung in Potsdam übersandt (ebd., Bl. 224a).

1515 Abb. ebd., S. 10.

1516 Ebd. 
die deutschen Ortsnamen gleichsam selbstverständlicher Teil ihres Wortschatzes. So hat Heike Amos bei ihren Quellenrecherchen, zumindest für die fünfziger Jahre, feststellen können: „In offiziellen Dokumenten und Verlautbarungen hielt sich die DDR strikt und überkorrekt an die nun polnischen Namen für die ehemals deutschen Ostgebiete. [...] In den internen Dokumenten des SED-Apparates allerdings scheuten sich die Funktionäre nicht vor dem Gebrauch der alten deutschen Städtenamen wie Stettin, Breslau oder Danzig.“1517

In den Altbundesländern war es nach 1990 längst kein Thema mehr, bei neuen Straßennamen auf historisch ostdeutsche Herkunftsorte Vertriebener Bezug zu nehmen. Eher gerieten solche Benennungen aus der Nachkriegszeit nun ebenso wie die Patenschaften in die Diskussion. Umso überraschender ist es, dass die Stadtverordneten in Premnitz (Westhavelland) - nach drei Jahre währenden kontroversen Debatten - 2013 einstimmig für die Benennung eines bis dahin namenlosen Platzes nach einer neumärkischen Kleinstadt, aus der eine nennenswerte Zahl von Flüchtlingen Anfang 1945 nach Premnitz gelangt war, votierten. Der Vorschlag war 2007 aus dem Kreis dieser Betroffenen gekommen, andere an den einsetzenden Diskussionen Beteiligte hatten dann zunächst eine Umbenennung der Leninstraße in Woldenberger Stra$\beta e$ vorgeschlagen, was aber, nicht zuletzt von Anwohnern, abgelehnt wurde. Seit 2013 gibt es nun - mit unmittelbarem Bezug zu einem Teil der Premnitzer Bevölkerung - einen Woldenberger Platz, an dessen Straßenschild sogar eine Erläuterungstafel das Vertreibungsgeschehen allgemein thematisiert und schließlich darauf hinweist, dass es sich um ein bis heute in der Welt vorkommendes Unrecht handle. ${ }^{1518}$

\section{Oder-Neiße-Grenze}

Die neu geschaffene Oder-Neiße-Grenzlinie, die auf keine Staatsgrenze älterer Zeit bezug nahm ${ }^{1519}$, war zwar 1945 eine materielle Realität geworden, wurde aber im Gedanken- und Gefühlshaushalt der Vertriebenen zu einem geradezu symbolhaft aufgeladenen Begriff, in dem sich

1517 Amos, Vertriebenenpolitik der SED (wie Anm. 12), S. 101.

1518 Einzelheiten und Belege siehe unten in der Ortsdokumentation Premnitz sowie im Quellenteil die Einweihungsrede (Nr. 261). - Einem ganz anderen, rein städtepartnerschaftlichen Entstehungszusammenhang, ohne Bezugnahme auf Flucht und Vertreibung, entstammt die 2018 erfolgte Benennung der „Opolestraße“ in Potsdam-Bornstedt nach der oberschlesischen Stadt Oppeln (poln. Opole), seit 1973 Partnerstadt von Potsdam (siehe Ortsdokumentation Potsdam/Städtepartnerschaften).

1519 Blöß, Grenzen und Reformen (wie Anm. 89), S. 61. Zudem ist an die Teilung ganzer Städte, aber, was weniger bekannt ist, auch von Landgemeinden (z. B. Aurith) zu erinnern. Ferner sind - gleichsam umgekehrt - „20 einst neumärkische Orte im Niederoderbruch und der westliche Teil der geteilten Stadt Küstrin bei Brandenburg"verblieben, da die Alte und nicht die für die Grenzziehung entscheidende Neue Oder die alte Grenze zur Neumark bildete (Reinhard Schmook: Eine neue Grenze im Osten. In: Grenzgänge. Brandenburgs Grenzen und Nachbarn in Geschichte und Gegenwart. Bad Freienwalde (Oder)/Prenzlau 2014, S. 92-94, hier S. 93). Gelegentlich „vergaß“ man anfangs (1945/46) die Bewohner solcher „Rest-Gemeinden“, die ihren Bezug zu einem Kreis östlich der Oder/Neiße verloren hatten: „Zeitzeugen berichten, dass es passierte, dass die Einwohner der beiden Orte [Küstrin-Kietz und Bleyen, Kr. Königsberg/Nm.] bei der Zuteilung [von Lebensmit- 
für sie die Grundfrage ihres Daseins bündelte. ${ }^{1520}$ Für die Mehrheit der Vertriebenen war die Grenz- und damit Gebietsfrage - in völliger Verkennung der Realitäten - zumindest in den (ersten) Nachkriegsjahren noch offen. Befördert wurde diese Haltung durch immer wieder neue Hoffnung schürende öffentliche Äußerungen von SED- und erst recht anderen Partei-Funktionären bis 1947/48 vielfach und selbst $1949^{1521}$, so dass sogar in der Verwaltung eine Atmosphäre der „Unsicherheit und Widersprüchlichkeit“ entstand ${ }^{1522}$. „In den unteren Verwaltungen wurde [1946 - P.B.] eine klare Haltung gegenüber der Ostgrenze nach Möglichkleit vermieden. Es überwogen Unsicherheit und offene Ablehnung. Fragen aus der Bevölkerung wurden hinhaltend beantwortet. “1523 Noch im „Mai 1949 erklärten Mitglieder des K[reis]V[erbandes] Oberbarnim der SED auf einer erweiterten KV-Sitzung, daß sie sich nicht in der Lage sähen, in

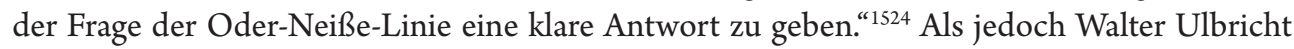
Ende 1948 „die bereits 1945 von W. Gomulka ${ }^{1525}$ eingeführte Bezeichnung ,Friedensgrenze auch als prägenden Begriff in die politische Terminologie der SED und SBZ einführte “1526 und in der DDR ab 1949 die „Friedensgrenze“ zu einem Teil der Staatsräson wurde, fühlten sich viele Vertriebene, die ohnehin Gewalt zur Beseitigung der „Friedensgrenze“ mehrheitlich ab-

telkarten] einfach vergessen wurden [... .“ (Andy Steinhauf: Die wirschaftliche Entwicklung in Küstrin-Kietz von 1945 bis 1995. Ein Report. Frankfurt (Oder) 2018, S. 49). - Einzelne nun innerhalb der (Rest-)Provinz Brandenburg durchgeführte Änderungen kommunaler Verwaltungsgrenzen, die die „herrenlos“ gewordenen, z. T. unbesiedelten Flächen östlich der Oder und Neiße gelegener Gemeinden betrafen, wurden erst im Jahr des Abschlusses des Görlitzer Grenzvertrages (1950) vorgenommen. Siehe dazu im einzelnen die Ortsdokumentation sowie allgemein Blöß, Grenzen und Reformen (wie Anm. 89), S. 74, und konkret Wolfgang Blöß: Brandenburgische Kreise und Gemeinden 1945-1952. Grenzänderungen, Eingemeindungen und Ausgemeindungen. Potsdam 2010; ders., Kommunale Strukturen im Spannungsfeld gesellschaftlicher Umwälzungen (wie Anm. 1389). - Entsprechend verfuhr auch die Volksrepublik Polen, die erst im Juni 1950 die Wojewodschaftsgrenzen in ihren Westgebieten neu ordnete (Blöß, Grenzen und Reformen [wie Anm. 89], S. 74).

1520 Zwar gibt es aus der alten Bundesrepublik eine Fülle an staatsrechtlicher und politischer Literatur (darunter viele Broschüren) zur „Oder-Neiße-Frage“ und zur entsprechenden Grenzlinie, diese ist für die spezifischen brandenburgischen Verhältnisse und für die reale Situation der Bewohner im Grenzraum jedoch unergiebig. Grundlegend ist vielmehr: Blöß, Grenzen und Reformen (wie Anm. 89), S. 57-75: Kapitel II. 1. „Die Grenze gegen Polen“. - Siehe ferner Amos, Vertriebenenpolitik der SED (wie Anm. 12), S. 25 ff. - Jajeśniak-Quast/ Stokłossa, Geteilte Städte (wie Anm. 128), S. 63-109: Die Geschichte der Grenze 1945 bis 1995. - Ther, Von Schlesien in die Lausitz (wie Anm. 49), S. 494. - Wichtig auch die Dokumente zur kritischen Diskussion und z. T. Vorkommnissen offener Ablehnung: Wille III (wie Anm. 196), S. 337-405. Allgemein siehe: Burkhard Olschowsky: Oder-Neiße-Grenze. In: Online-Lexikon zur Kultur und Geschichte der Deutschen im östlichen Europa, 2018. URL: ome-lexikon.uni-oldenburg.de/p32798 (Stand 16.05.2018).

1521 Blöß, Grenzen und Reformen (wie Anm. 89), S. 62-65, 70 f.

1522 Ebd., S. 61. - Siehe auch Karl-Heinz Gräfe: Kernprobleme ostdeutsch-polnischer Beziehungen 1945 bis 1949. In: Sächsische Heimatblätter 39 (1993), S. 260-261.

1523 Blöß, Grenzen und Reformen (wie Anm. 89), S. 71 mit diversen Belegen aus BLHA, Rep. 202A, Rep. 203 MdI, Rep. 250 Landratsamt Guben, Rep. 333 und der „Märkischen Volksstimme“ (Fn. 156).

1524 Ebd., S. 70.

1525 [Władysław Gomułka (1905-1982), Generalsekretär der Polnischen Vereinigten Arbeiterpartei, stellv. polnischer Ministerpräsident und Minister für die „Wiedergewonnenen Gebiete“.]

1526 Blöß, Grenzen und Reformen (wie Anm. 89), S. 64. 
lehnten, mit ihren Sorgen und Gefühlen - ähnlich wie beim vorgeschriebenen Gebrauch des beschönigenden Begriffs „Umsiedler“ - aus dem öffentlichen Leben verdrängt. Ein Mitarbeiter des VEB Gubener Schuhfabrik äußerte sich auf einer Betriebswahlversammlung am 28. September 1950 dazu: „Es ist verboten, von der Oder-Neisse-Linie zu sprechen und wer darüber spricht, ist ein Kriegshetzer. Im Radio der Ostsender spielt man das schöne Lied ,In einem kühlen Grunde. ${ }^{1527}$ Auf der einen Seite verbietet man von der Heimat zu reden, auf der anderen erinnert man mit diesen Liedern immer wieder daran. " 1528 Der Umgang mit der Grenze und mit dem Begriff wurde für die Vertriebenen zu einem „Integrationshindernis“"1529, weshalb dieser zentrale Aspekt des Themas hier vor allem als ideeller behandelt wird.

Zumindest am Rande muss bei der Frage nach der symbolhaften Aufladung der Flussnamen für Bewusstsein und Integrationsfähigkeit des einzelnen Vertriebenen auch mitbedacht werden, dass die beiden Grenzflüsse Oder und Neiße für viele mit zutiefst einschneidenden, bisweilen traumatischen Erlebnissen bei Flucht oder Vertreibung verbunden gewesen sind. Eine 15-Jährige Vertriebene aus dem Kreis Meseritz zum Beispiel, die Ende Juli 1945 mit Mutter, Großmutter, einer älteren Schwester und zwei jüngeren Brüdern südlich Küstrin an die Oder gelangt war, berichtet: „Meiner Schwester ging es auch nicht gut. Sie war verzweifelt. Ich zog sie mit Gewalt vom Brückengeländer herunter. Sie wollte in die Oder springen. So haben wir gemeinsam die Oder überquert. ${ }^{\text {1530 }}$ Die in Frankfurt (Oder) aufgewachsene Marianne Bandt (geb. 1928) schreibt in ihren Jugenderinnerungen, die viele Orte dies- und jenseits der Oder als ehemals ungetrennten Lebensraum bis hin nach Göritz und Reitwein nennen: „Es wäre undenkbar gewesen, dass die Oder einmal die Stadt teilen würde. Das Kriegsende brachte an beide Oderufer ungeheuer viel Leid. Menschen wurden vertrieben. Doch viele [S. 17] blieben an den westlichen Ufern, weil sie glaubten, wieder zurück zu können. Andere Vertriebene landeten östlich der Oder an der jetzigen Grenze Polens. Oft standen wir später an der Oder und schauten auf das Land, das wir liebten und unendlich viele Jahr nicht betreten durften. Heute haben wir polnische Freunde dort und wir erzählen uns gegenseitig unsere Geschichten. Ein weiter Weg war das." ${ }^{1531}$

Der Gedanke an eine Rückkehr beschäftigte gerade die in Brandenburg gelandeten Vertriebenen, nicht nur die z.T. bewusst in Grenznähe verbleibenden, teilweise noch jahrelang, manche aus der ältesten Generation wohl auch bis zum Lebensende. Auf Versammlungen und in verschiedensten Äußerungen Vertriebener war die Ostgrenze neben der Wohnungsfrage in

1527 [Gedicht des schlesischen Dichters Joseph von Eichendorff (1788-1857), auch in vertonter Fassung vor und nach 1945 sehr verbreitet und bekannt. Der Bereich des Rundfunks (wie auch des Films) als integrationsfördernder oder -hemmender Faktor kann hier nicht vertieft werden. Siehe aber die Bemerkungen im folgenden 2. Kapitel am Schluss des Abschnitts „Teilnahme an Heimattreffen in West-Berlin“ sowie vor allem die verschiedenen Erwähnungen des Rundfunks im Quellenteil, erschlossen über das Sachregister.]

1528 BLHA, Rep. 202 G Amt für Information, Nr. 170, Bl. 385v (vgl. Textabdruck im Quellenteil, Nr. 221).

1529 Goller, Eine neue Heimat? (wie Anm. 129), S. 29.

1530 Becker, Flucht und Vertreibung aus (wie Anm. 1431), S. 34.

1531 Marianne Bandt: Meine Stadt gestern und heute. In: Zeitzeugen berichten 2003. Zuhause in Brandenburg (wie Anm. 276), S. 13-17, hier S. $16 \mathrm{f}$. 
den Jahren 1945 bis 1950 die alles andere marginalisierende Frage. Insofern bildete die OderNeiße-Grenze ein gewichtiges Thema, das immer wieder für Unsicherheit und Unzufriedenheit sorgte. Zusätzlich zu den damals weite Kreise ziehenden Äußerungen Wilhelm Piecks, der im Gegensatz zum längst (seit 1945) entschiedenen Walter Ulbricht ${ }^{1532}$ (und zum brandenburgischen Innenninister Bernhard Bechler ${ }^{1533}$ ) 1946 auf mehreren Kundgebungen in Guben Hoffnungen auf eine Revision der Ostgrenze durch einen Friedensvertrag ausdrücklich ansprach und nährte ${ }^{1534}$, kursierten gerade in den Grenzorten ${ }^{1535}$, etwa in Forst, in den ersten Nachkriegsjahren immer wieder die absurdesten Gerüchte über eine angeblich bevorstehende Veränderung der Verhältnisse. ${ }^{1536}$ Aufmerksam und jeweils voller größter Hoffnungen auf eine Lösung der Frage der deutschen Ostgebiete in ihrem Sinne verfolgten die Vertriebenen auch jedes damals angekündigte internationale Zusammentreffen, so auch die in vielen Informationsberichten erwähnte Londoner Konferenz des Rates der Außenminister der Siegermächte (25.11. bis 15.12.1947). ${ }^{1537}$ Selbst eine Gubener SED-Genossin äußerte sich Anfang Dezember 1947 durchaus als Betroffene: „Die Belegschaft unserer Fa. der Berlin-Gubener-Hutfabrik verfolgt aufmerksam den Verlauf der Londoner Konferenz. Unser Hauptaugenmerk ist auf eine baldige Regelung der Ost- und Westgrenze gerichtet und insbesondere auf die endgültige Festlegung der Ostgrenze."1538 Aus Fürstenberg/Oder, wo sehr viele Vertriebene lebten, berichtet ein Gubener Informant nach Ende der Konferenz: „Das Scheitern der Londoner Konferenz hat unter der Bevölkerung wie eine Bombe eingeschlagen. Ein grosser Teil hatte geglaubt, dass es in letzter Minute noch zur Einigung kommen und endlich die Zonengrenzen fallen würden." ${ }^{539}$

Über Piecks in der Literatur und von Zeitzeugen oft erwähnte Gubener Rede berichtete das „Neue Deutschland“ in seiner Ausgabe vom 7. Mai 1946 (und sprach darin insbesondere die „Berliner und Berlinerinnen“ als Leser an). Einleitend wird auf die Vorkriegsbeziehungen der Berliner nach Guben hingewiesen und sodann die Situation der geteilten Neiße-Stadt beschrieben: „Der Krieg schlug auch dieser Stadt schwerste Wunden. Durch die mitten hindurch fließende Neiße ist Guben heute in zwei Teile getrennt. Der kleine westliche Teil steht unter deutscher Selbstver-

1532 „Ulbricht hatte bereits auf der 1. Funktionärskonferenz der KPD Groß-Berlins am 25. Juni 1945 erklärt, die Gebiete östlich von Oder und Neiße seien für immer verspielt [...].“ (Blöß, Grenzen und Reformen [wie Anm. 89], S. 62).

1533 „Er bezeichnete schon auf der Konferenz der Landräte und Oberbürgermeister am 16./17. Juli 1945 die OderNeiße-Linie als Ostgrenze." (Blöß, Grenzen und Reformen [wie Anm. 89], S. 71).

$1534 \mathrm{Zu}$ Zeitpunkt und Örtlichkeit der verschiedenen in der Literatur kursierenden Angaben über Redeauftritte siehe die Ortsdokumentation Guben.

1535 Ulrich Stephan: Guben und die Oder-Neiße-Grenze. In: Gubener Heimatkalender 39 (1995), S. 40-47. Katarzyna Stokłossa: Die Oder-Neiße-Grenze im Bewußtsein der Bewohner von Guben und Gubin (19451972). In: Grenzen im Ostblock und ihre Überwindung. Helga Schultz (Hg.). Berlin 2001, S. 113-134.

1536 Blöß, Grenzen und Reformen (wie Anm. 89), S. 66-68.

1537 Siehe Quellenteil die Berichte vom Nov./Dez. 1947 (Nr. 193-198) sowie vom 24.2.1948 (Nr. 200).

1538 BLHA, Rep. 250 Landratsamt Guben/Frankfurt(Oder), Nr. 83, Bl. 212 (vgl. Textabdruck im Quellenteil, Nr. 195).

1539 Ebd., Bl. 230 (vgl. Textabdruck im Quellenteil, Nr. 200). 
waltung und sowjetischer Besatzung, der östliche untersteht polnischer Verwaltung. Dieser Umstand hat zur Folge, daß in dem unter deutscher Verwaltung befindlichen Stadtteil an Stelle der früheren 6000 Einwohner heute 26000 Menschen Unterkunft finden mußten. Doch wie Berlin strebt auch Guben zu neuem Leben und geht mit allen Kräften an den Wiederaufbau [...]." Der „bekanntlich“ aus Guben gebürtige Wilhelm Pieck habe es sich als Vorsitzender der SED „nicht nehmen lassen, einer Einladung der Stadt [...] Folge zu leisten“, er erhielt auf einer Kundgebung am 5. Mai 1946 den Ehrenbürgerbrief. „Im Verlauf der Kundgebung ergriff Genosse Wilhelm Pieck das Wort zu bedeutsamen Ausführungen [...]“: „Von der Ausrottung des Militarismus und der Reaktion, vom Aufbau der Demokratie, von der gesamten Entwicklung in Deutschland werde es abhängen, in welchem Umfang bei der Festlegung der Friedensbedingungen die Lebensinteressen des deutschen Volkes Berücksichtigung finden werden, auch hinsichtlich der Grenzfrage: So können auch die Werktätigen Gubens, wenn sie im Geiste striktester Demokratie mit aller Kraft am Aufbau arbeiten, die Hoffnung haben, daß eines Tages auch jenseits der Neiße liegende Teil der Stadt Guben wieder unter deutsche Verwaltung gestellt wird [...].“1540

Für die SED und die Behörden blieb ein nur schwer beherrschbares Unruhepotential bestehen. Auch in späteren Jahren und noch Jahrzehnten gehörte aber der „politisch korrekte“ Umgang mit der „Friedensgrenze“ („Hetze gegen die Oder-Neiße-Grenze“) weiterhin zu den vornehmlichen Beobachtungsfeldern, dann nicht mehr öffentlich, aber in den Beobachtungen des MfS. ${ }^{1541}$ Die besondere Nervosität der SED bei diesem Punkt ergab sich aber auch aus den erwähnten Unsicherheiten in den eigenen Reihen und nicht minder denen der anderen Parteien. Von der Grenze betroffene „Umsiedler“ gab es inzwischen ohnehin in allen Teilen der Bevölkerung, auch in der SED. Rückblickend wird in der DDR-zeitlichen Historiographie jedoch „der Anschein erweckt, die SED habe von Beginn an die neue Grenzlinie akzeptiert". In Wahrheit währte es „geraume Zeit, bis sich diese Sicht in der gesamten SED-Führung und noch länger, bis sie sich in den Leitungen der anderen Parteien durchgesetzt hatte. ${ }^{1542}$ Der brandenburgische CDU-Politiker Peter Bloch (1900-1984), spätestens seit seiner Flucht von Kleinmachnow nach West-Berlin im März 1950 für die SED eine „Unperson“, erwähnt in seinen Erinnerungen, wohl für das Jahr 1949, einen Auftritt vor Vertriebenen: „ich bin auf einer Umsiedlerversammlung gegen die Anerkennung der Oder-Neiße-Grenze aufgetreten" ${ }^{1543}$

Einige Beispiele mögen aufzeigen, welche Rolle die Oder-Neiße-Grenze auch in vielen anderen, kleineren örtlichen Versammlungen und Bevölkerungsgruppen noch mindestens bis 1950, d. h. bis zum Görlitzer Grenz-Abkommen mit Polen, spielte. Im April 1950 kam man im

1540 „Guben empfängt Wilhelm Pieck.“ Zitiert nach dem auszugsweisen Abdruck in: Gubener Heimatkalender 44 (2000), S. 67 (mit Foto der Rednertribüne der Kundgebung auf dem Reipoplatz am 1.[!]5.1946).

1541 Siehe dazu unten im Kapitel IV. 2 den Abschnitt zu Vertriebenentreffen in Brandenburg (mit Literaturhinweisen).

1542 Blöß, Grenzen und Reformen (wie Anm. 89), S. 65.

1543 Bloch, Zwischen Hoffnung und Resignation (wie Anm. 1374), S. 143. - Bloch war auch Mitglied des Landtagspräsidiums (3. Schriftführer); vgl. Handbuch des Landtages 1947 (wie Anm. 1064), S. 54, 61 mit Bild, 121. 
„Informationsdienst des Rates des Kreises Angermünde“ bei der Analyse der Mitgliederzahlen der politischen Parteien zu dem Schluss, dass dafür auch der Frage, wie sich die jeweilige Partei zur Oder-Neiße-Grenze äußere, besondere Bedeutung zukomme ${ }^{1544}$ : „[...] Bei der Gegenüberstellung der Zahlen der Demokratischen Bauernpartei [im Kreis über 50\% „Umsiedler“-Anteil P.B.] dürfte das Resultat hauptsächlich durch die überwiegende Mehrzahl der Umsiedler auf dem Lande kommen, aber auch auf der weniger brüsken Betonung der Unabänderlichkeit der Oder/ Neisse-Linie. Ganz klar ersichtlich ist dieser Prozentsatz bei der CDU, die diese Frage bisher grundsätzlich vermieden [hat] entscheiden[d] zu erörtern, und bei der N.D.P., wo der im Vordergrund stehende Nationalgedanke verquickt wird mit der Hoffnung der Herstellung der alten ,Nationalen Grenzen. Die S.E.D., als die Partei, die die Oder/Neisse-Linie entscheidend als Friedensgrenze betont, hat einen Umsiedleranteil von nur ca. 11 \%. [...]. Die Meinung breiterer Bevölkerungsschichten und hier auch vornehmlich Umsiedler in ihrer besonderen Empfindlichkeit durch die verlorene Heimat betrachten die SED durchaus als Russenpartei.“ Auch bei den Mitgliederzahlen der „Gesellschaft für deutsch-sowjetische Freundschaft" im Kreis spielte der Verlust der Ostgebiete eine wichtige Rolle: „Da die Oder/Neisse-Linie als Friedensgrenze aktiv nur durch die Einheitspartei deklariert wird, legt man diese Feststellung auch der sowjetischen Besatzungsmacht von Seiten der Umsiedler zur Last. Und so ergeben die Zahlen der Ges[ellschaft] f[ür] deutsch-sowj[etische] Freundschaft bei 3586 Mitgliedern nur einen Umsiedleranteil von 275 Mitgliedern, d. s. ca. $8 \%$. [...] so hat z. B. das Britzer Eisenwerk bei 150 Umsiedlern nur 18 Personen = ca. 11,6\%. Im Schotterwerk Althüttendorf [ist] bei 42 Umsiedler [n] keiner in der Ges. f. dtsch.-sowj. Freundschaft. In der Eisengiesserei, Jonny Scheer von 8 Umsiedlern 2-25\%. Bei der UTVG Schwedt von 19 Umsiedlern 1 in der Gesellschaft." ${ }^{1545}$ Resigniert muss der Informationsamtsleiter feststellen, dass selbst weniger SED-kritische Bürger beim Thema Oder-Neiße-Grenze nicht ohne weiteres „auf Linie“ zu bringen sind: „Die Einschränkung und der leise Hoffnungsschimmer, selbst positiver Kräfte geht deutlich aus dem Bericht unseres Mitarbeiters Schöps, aus der Gemeinde Gramzow, hervor: [...] Die Befragten bejahen die Nationale Front und arbeiten auch mit, sie betrachten die Oder/Neisse-Linie als Friedensgrenze, wünschen aber, dass bei den späteren Friedensverhandlungen diese Grenzen noch einmal überprüft werden, denn sie haben alles in Schlesien bezw. Ostpreussen verloren. Da sie aber in Frieden mit allen Völkern leben wollen, erkennen sie die Oder/Neisse-Linie als Grenze an."1546

Wenn auch regelrechte Gewaltbereitschaft, wie die aus dem ganzen Land überlieferten Informantenberichte zeigen, die Ausnahme blieb und Äußerungen, man würde zur Grenzrevision einen neuen Krieg in Kauf nehmen - „Lieber Krieg und wieder in die alte Heimat!“1547 -, nur

1544 BLHA, Rep. 202 G Amt für Information, Nr. 170, Bl. 27-31, hier Bl. 29r (vgl. Textabdruck im Quellenteil, Nr. 214).

1545 Ebd., Bl. 29v.

1546 Ebd., Bl. 30v.

1547 Äußerung mehrerer Mitarbeiter des KWU (Kommunalen Wirtschaftsunternehmens) Hochbau Guben auf einer Belegschaftsversammlung im Juli 1950, zitiert nach Blöß, Grenzen und Reformen (wie Anm. 89), S. 69. 
selten zu finden sind ${ }^{1548}$, so war die Ablehnung der Gebiets- und Grenzregelung doch vielfach unmissverständlich, der Görlitzer Vertrag stieß „auf starken Widerstand in der Bevölkerung."1549 Dies musste auch ein Informant des Landratsamtes Angermünde erfahren, der am 14. Juli 1950, also kurz nach Abschluss des für die Vertriebenen besonders einschneidenden Grenzvertrages (4. Juli), gemeinsam mit dem FDGB-Kreissekretär an „einer Betriebsversammlung der Oberförsterei Joachimsthal teil[nahm], die von ca. 300 bis 350 Menschen besucht war", vor allem Waldarbeiter und -arbeiterinnen ${ }^{1550}$ : „Bereits die Ausführungen im Hauptreferat des Kol[legen]. Genz, hinsichtlich der Oder/Neisselinie führten zu zahlreichen gegnerischen Stellungnahmen. Etwa in der Form, dass man solange die Grenze nicht beseitigt sei, von einer freundschaftlichen Beziehung nicht sprechen könne, da z.Zt. dort drüben Disteln wüchsen und eine Stimme aus dem Hintergrund deutete den Begriff,Waffengewalt' an. / Zu einer ernsten Situation entwickelte sich der Abstimmungsversuch nach dem Arbeitsbericht des Forstamtsleiters Dr. Schöbitz, über eine Resolution wo der Forstamtsbezirk Joachimsthal mit einem polnischen Förstereibetrieb in Verbindung treten soll. Bei dem ersten Abstimmungsversuch erhoben sich nur ca. 6 bis 8 Hände von der gesamten Belegschaft, sonst eisiges Schweigen. Als Herr Dr. Schöbitz einige Personen befragte warum sie sich denn zu dieser so wichtigen Frage so ablehnend verhielten, erhielt er keine Antwort, aber ca. 30 bis 40 Personen verliessen nach und nach den Saal, um wahrscheinlich einer weiteren Abstimmung zu entgehen." In dieser kritischen Situation, in der den Funktionären der Führungsanspruch zu entgleiten droht, wenden sie noch einmal all ihre Erfahrung im Umgang mit Menschen an und können so die Form wahren, sind sich aber der bloß äußerlichen, trügerischen Einigkeit voll bewusst: „Da unter diesem Gesichtspunkt die Frage stand, wer die Oberhand behält, nahm der Kreissekretär des FDGB, Kol. Genz, [B1.59v] der Vorsitzende der Betriebsgruppe des Kreisforstamtes und wir noch einmal zu diesem Problem Stellung, mit dem Resultat, dass beim dritten Anlauf knapp $2 / 3$ der Hände zur Abstimmung in die Höhe schlichen und sich zur, Gegenprobe' niemand meldete. Somit war eine formale Einstimmigkeit erreicht. Der Inhalt dieser Abstimmung muss aber als glatte Niederlage angesehen werden. "1551

Ebenfalls eine gute Woche nach dem Abschluss des Grenzvertrages mit Polen heißt es unter dem 14. Juli 1950 in Angermünde: „Wie uns vom Inf[ormations-] Dienst Frankfurt/Oder mitgeteilt wird, steht noch der grössere Teil der Bevölkerung auf dem Standpunkt, dass die Oder-Neisse-Grenze keine gerechte Grenze sei. Immer wieder taucht die Frage auf: ,Kommen wir wieder zurück in unsere Heimat.' Einen Schwerpunkt in der Oder-Neisse-Frage bilden die Eisenbahner, die nach Polen fahren und die immer wieder zum Ausdruck bringen, daß in Polen viele Gebiete brach liegen würden." ${ }^{1552}$ Aber nicht nur in den Grenzregionen, auch andernorts, selbst in der Landeshauptstadt Potsdam, konnten die Informanten noch Monate nach dem Abschluss des Grenzvertrages mit Polen, im September 1950 keine „Besserung“ feststellen: „Besonders schwierig und wenig er-

1548 Beispielebelege siehe ebd., S. 69, Fn. 152.

1549 Ther, Von Schlesien in die Lausitz (wie Anm. 49), S. 494.

1550 [Handschriftlich korrigiert aus:] „nahm ich“.

1551 BLHA, Rep. 202 G Amt für Information, Nr. 170, B1. 59r-59v (vgl. Textabdruck im Quellenteil, Nr. 215).

1552 Ebd., Bl. 91 (vgl. Textabdruck im Quellenteil, Nr. 218). 
folgreich ist die Diskussion um die Oder-Neiße-Linie als Friedensgrenze. Im großen gesehen denkt die Bevölkerung jedoch nicht daran, die Oder-Neiße-Linie zu einer Frage des Krieges zu machen. Sie ist jedoch vielfach der Meinung, daß auf dem Wege von Verhandlungen eine Änderung geschaffen werden könnte. Aus Umsiedlerkreisen hört man immer wieder: ,Auf allen Vieren würde ich rüberkrauchen' oder ,Bei der jetzigen Freundschaft mit Polen müßte es doch möglich sein, daß die Deutschen unter polnischer Regierung wieder in ihre Heimat zurück können'“1553

Wieweit die Ostgrenze und die Ostgebiete in Forderungen am 17. Juni 1953 eine (Neben-)Rolle spielten, ist in der Literatur bislang nicht systematisch untersucht. Festzustellen ist aber, dass es in den für diese Fragen stets besonders ,anfälligen“ Grenzkreisen und -städten entsprechende Einzelfälle gegeben hat, dass dies andererseits keineswegs überall da, wo man es erwarten könnte, vorkam. Der diesbezügliche Forschungsbedarf zeigt sich, wenn man sieht, dass in dem DDR-weiten Überblick über die Geschehnisse um den 17. Juni von Wolfgang Ribbe für Eisenhüttenstadt oder für den Bezirk Cottbus keine Forderungen zur Revision der Oder-Neiße-Grenze genannt werden, ${ }^{1554}$ obwohl „Forderungen nach Rückgabe der bis 1945 deutschen Gebiete“ am 17. Juni 1953 in jedem Fall während einer Demonstration in Fürstenberg (Eisenhüttenstadt) laut wurden und mehrfach belegt sind. ${ }^{1555}$ In Frankfurt (Oder) tat sich hingegen wohl ohnehin wenig, wie auch ein Zeitzeuge bestätigt hat. ${ }^{1556}$ Dennoch bleiben Zweifel, inwieweit die einen wie die anderen Aussagen zutreffen. Denn auch für Guben, dessen Situation im Jahr 1953 unten noch behandelt wird, sind sogar in Zeitungen entsprechende Protestaktionen erwähnt, die die Literatur jedoch nicht anspricht, möglicherweise, weil die Frage der Formulierung des Protestes in anderen Quellen uneindeutig oder ungenau überliefert ist.

Im „Sorauer Heimatblatt“, der (in Hamm/Westfalen verlegten) Monatszeitung für die Vertriebenen aus „Stadt und Land“, d. h. aus dem ehemaligen Kreis Sorau, erschien in der MärzNummer 1954 ein in (West-)Berlin abgefasster Beitrag ${ }^{1557}$, der recht konkrete Nachrichten aus offiziellen DDR-Quellen wiedergibt: „Durch die sowjetzonale Presse wird nunmehr bestätigt, daß während der Berliner Außenministerkonferenz in verschiedenen Städten und Ortschaften an der Oder und Neiße seitens der Arbeiterschaft in öffentlichen Diskussionen die Rückgabe der deutschen Ostgebiete gefordert worden ist. Es kam insbesondere in Fürstenberg an der Oder zu heftigen Auseinandersetzungen zwischen der Arbeiterschaft des Eisenhüttenkombinats Ost und SED-Funktionären. Hier

1553 BLHA, Rep. 202 G Amt für Information, Nr. 162, Bl. 132 (vgl. Textabdruck im Quellenteil, Nr. 220).

1554 Wolfgang Ribbe: Der Juni-Aufstand 1953 in den Regionen der DDR. Ein Forschungs- und Literaturbericht. In: Jahrbuch für die Geschichte Mittel- und Ostdeutschlands 51 (2005 [2006]), S. 147-226 (mit Bibliographie), zu Brandenburg S. 165-172, Eisenhüttenstadt S. 170, Bezirk Cottbus S. $171 \mathrm{f}$. - Ebenso Fehlanzeige in: Kotsch, Das Land Brandenburg (wie Anm. 89), S. 359-366 (Kapitel 8 „Der 17. Juni 1953 in den brandenburgischen Bezirken“); „Freiheit wollen wir!“ - Der 17. Juni 1953 im Land Brandenburg. Ausstellungskatalog. Hg.: Gabriele Schnell. Berlin 2003.

1555 Hübner, Vertriebenenintegration durch industrielle Erwerbsarbeit (wie Anm. 34), S. 117.

1556 Lindner, Neulehrer in Frankfurt an der Oder (wie Anm. 1305), S. 55.

1557 [Ohne Verf.: Nach den Protestaktionen gegen die Oder-Neiße-,Grenze“: SED fordert „unerbittliches Vorgehen" gegen Heimatvertriebene. In: Sorauer Heimatblatt 3 (1954), Nr. 1, S. 2. 
hatten - trotz Anwesenheit zahlreicher Volkspolizsten im Versammlungsraum - Sprechgruppen die Revision der Oder-Neiße-Linie gefordert. In den Städten Frankfurt, Guben und Görlitz kam es ebenfalls zu Protestaktionen. Es wurden nachts die, Friedensgrenze' verherrlichende Propagandaplakate entfernt oder unleserlich gemacht. Wie nun bekannt wird, fanden auch auf den von der SED veranstalteten Versammlungen in den Bezirken Dresden, Schwerin und Cottbus Protestaktionen der Bevölkerung statt. Die SED-Presse berichtet darüber, es hätten dort, Klassengegener antisowjetische Hetze betrieben und chauvinistische Forderungen gegen die Oder-Neiße-Friedensgrenze gestellt'. Besonders in den ,Grenzbezirken' an der Oder sei, die unerhörte faschistische Behauptung erhoben worden, die Friedensgrenze sei ungerecht'. Dabei hätten sich insbesonderre die ,Umsiedler' - so werden in der SED-Propaganda die Heimatvertriebenen genannt - hervorgetan. Nunmehr sind die SED-Organe ,zum verschärften Kampf gegen den Klassengegner und seine Agenten' aufgerufen worden. Die ,staatlichen Sicherheitsorgane und die demokratische Justiz' müßten nunmehr, unerbittlich scharf' gegen derartige Elemente vorgehen, heißt es in einer Rundverfügung der SED-Bezirksleitung von Frankfurt an der Oder." Die Verlässlichkeit dieser Zitate vorausgesetzt, dürfte der Beitrag mehr als deutlich aufzeigen, welcher Forschungsbedarf zum einen in der regionalen und lokalen Geschichte des 17. Juni noch besteht, zum anderen erinnert er einmal mehr daran, wie falsch es ist, die Geschichte der Vertriebeneneingliederung in der DDR als ein bloßes Thema der ersten Nachkriegsjahre, in denen es eine „Umsiedlerverwaltung“ gab, aus der folglich entsprechende Akten vorliegen, zu sehen.

Andreas Peter, ein guter Kenner der Gubener Verhältnisse, hat die Frage untersucht, weshalb - nach seinen Recherchen - am 17. Juni 1953 in der Stadt Guben keine nennenswerten Protestaktionen nachweisbar sind. Er macht dafür „einen Bruch in den traditionellen Strukturen und Bindungen der Arbeiterschaft" verantwortlich, den die Teilung der Stadt und die komplette Vertreibung der Bevölkerung aus dem größeren Ostteil bewirkt habe. „Die 45000 vertriebenen Gubener seien damit „praktisch in alle Winde zerstreut “ worden. ${ }^{1558}$ Vor allem aber sieht er acht Jahre nach Kriegsende, Vertreibung und Beginn der Teilung bereits eine Situation, in der sich viele im Kreis mit der LPG-Gründung angefreundet hätten und somit „vielen Menschen sicherlich mehr daran lag, ihre wenn auch sehr bescheidenen Lebensverhältnisse zu erhalten, als sich in ein gefährliches Unternehmen mit ungewissem Ausgang zu stürzen“. Noch wichtiger für das geringe Potential an „Widerstand“ scheint jedoch, was Peter aufgrund der Analyse von Verhaftungen und Republikfluchten im Kreis Guben feststellt: „Jene, die vielleicht zu Aktionen gegen die Staatsmacht bereit gewesen wären, befanden sich bereits seit der ersten Hälfte des Jahres 1953 hinter Gittern oder hatten die Stadt und den Kreis Guben in Richtung Bundesrepublik verlassen. ${ }^{\text {"1559 }}$ Vor allem letzteres ließe sich zweifellos unter den Vertriebenen besonders häufig feststellen. Die große Masse von ihnen war notgedrungen dabei, die zwangsweise Tabuisierung ihres Schicksals hinzunehmen oder gar zu verinnerlichen, viele fanden in den ökonomischen

1558 Andreas Peter: Der Juni-Aufstand im Bezirk Cottbus. In: Deutschland-Archiv 27 (1994), S. 585-594, hier S. 592 .

1559 Ebd., S. 593. 
und sonstigen beruflichen Feldern, die das neue Staatswesen anbot, die Befriedigung ihrer Grundbedürfnisse, viele ließen sich aber auch, teils voller Hoffnung, teils opportunistisch, auf einen Neuanfang, auf die neue politische Linie ein. „Hardliner“ hatte der Polizeiapparat nach wenigen Jahren mundtot gemacht oder sie waren eben in den Westen gegangen.

Entgegen dem Bild, das die SED offiziell von ihrer Bevölkerung zeichnete, gab es aber auch nach dem 17. Juni immer wieder kleinere Vorfälle, die man freilich nur noch durch intensive Recherchen in MfS- und Polizeiakten sowie auf der Basis lokaler Überlieferungen überhaupt wird ermitteln und rekonstruieren können. Ein einziges Beispiel mag dies andeuten. In der Gaststätte Balzke in Eisenhüttenstadt-Fürstenberg (Oder) verkehrten nach Feststellung der „Revierkriminalstelle Stalinstadt" des Volkspolizeikreisamtes (VPKA) Fürstenberg/Oder 1954 „Personen, die sich gegen unsere Gesetze vergingen und somit bestraft werden mussten “ ${ }^{1560}$ Von einer angetrunkenen Gruppe von sechs bis acht Männern soll in einem Nebenraum der Gaststätte gesungen worden sein: „Um den Feldern klingt es rum, / klingt es rum, / Pieck ist dumm“. Auf der Polizeidienststelle behauptete einer der Männer dagegen, es sei „In den Keller ist es dumpf, Pieck ist Trumpf" gesungen worden. Derselbe oder ein anderer Mann trat in der Gaststätte am 7. Juli 1954 einem als SED-Mitglied erkennbaren Arbeiter gegenüber aggressiv und handgreiflich auf, beschimpfte ihn und drohte ihm: „Solche Kerle habe ich schon verschiedentlich fertiggemacht." Dabei fiel nach Aussage des berichtenden Volkspolizeimeisters auch der Satz: „Wilhelm Pieck hat seine Heimat, sowie Schlesien an Polen verschachert." Der „Täter“, ein in „Stalinstadt" wohnhafter regelmäßiger Besucher der Gaststätte, „wurde festgenommen und der Staatssicherheit übergeben“, nachdem er in der Vernehmung die Äußerungen zugegeben hatte. Die Gaststätte bezeichnet der Berichterstatter als „eine verrufene, wo nur derartige Elemente verkehrten“. Nach seinen Ermittlungen bevorzugten die Männer dieses Lokal, „obwohl die HO.-Gaststätte nur einige hundert Meter entfernt ist. [...] Es besteht der Verdacht, dass sie nur deshalb die Gaststätte Balzke aufsuchen, weil sie dort ungehindert ihre provokatorischen Lieder singen könne. Es wird daher vorgeschlagen, dem Gastwirt die Konzession zu entziehen, da wir es hier bei uns in Stalinstadt nicht zulassen können, dass sich derartige Vorkommnisse wiederholen." Die Gaststätte wurde tatsächlich geschlossen und im „September 1954 als HO-Gaststätte ,Oberschleuse` im HO-Gaststättenverband StalinstadtFürstenberg wiedereröffnet“" ${ }^{1561}$

Während und weil für das Gros der Vertriebenen die Oder-Neiße-Grenze ein negativ konnotierter, zumindest aber ein mit Wehmut besetzter Begriff blieb, zelebrierte man in der SBZ schon 1947 und in der DDR endgültig seit dem Grenzvertrag mit Polen, insbesondere in den Grenzstädten und grenznahen Orten, die neue offizielle, positive Belegung des Begriffs als „Friedensgrenze“. Man verwendete ihn möglichst oft und übertrug zudem den Namen an mehreren Stellen symbolisch auf Objekte. So gab man z. B. einem Kino in Guben 1956 den Na-

1560 Erich Opitz: Anfang und Ende einer Schiffergaststätte an der Oberschleuse. In: Heimatkalender Eisenhüttenstadt und Umgebung 15 (1997), S. 35-40, Zitate, auch die folgenden, S. 38 f.

1561 Ebd., S. 40. 
men Filmtheater „Friedensgrenze“1562 und die Gaststätte „Goldene Löwe“ in Fürstenberg (Oder) wurde 1953 in „Hotel zur Friedensgrenze“ umbenannt ${ }^{1563}$. Landwirtschaftliche Produktionsgenossenschaften (LPG) mit dem Namen „Friedensgrenze“ gab es ab 1953 in Groß Gastrose bei Guben ${ }^{1564}$ und auch (ab 1958?) in Kliestow bei Frankfurt (Oder) ${ }^{1565}$; in Frankfurt gründete man zudem 1960 eine Arbeiterwohnungsbaugenossenschaft „Friedensgrenze“1566. Diese Namen sind nach der Wende bald verschwunden.

Geblieben ist die „Friedensglocke“ in Frankfurt (Oder), die 1953 ebenfalls zur Erinnerung an die Unterzeichnung des Oder-Neiße-Grenzvertrages eingeweiht worden war, inzwischen aber mehr mit dem „Weltfriedenstag“ verbunden wird, an dem sie ertönt. ${ }^{1567}$ Die - ähnlich wie im Verhältnis zum sowjetischen „Bruderland“ - verordneten Begegnungen („Freundschaftstreffen") mit Polen, etwa auf der Brücke in Guben oder gemeinsame Sportveranstaltungen in Gubin (z. B. ein Fußballspiel am 22. Juli 1959) ${ }^{1568}$, blieben in ihrer Wirkung auf die Bewältigung der Grundprobleme im deutsch-polnischen Verhältnis weitgehend folgenlos. In den fünfziger Jahren ließ der Kreis Eisenhüttenstadt z. B. an der „Friedensgrenze“ jährlich vor dem 1. Mai „Friedensfeuer" ausrichten. Der in Aurith an der Oder ansässige Heinz Thurian, Flüchtling aus Schlesien, erinnert sich: „Da haben wir immer auf der Fährbuhne einen großen Haufen aus Holz und Sperrmüll und was man so rumstehen hatte gemacht. Alles ruff. Und dann angezündet. Dann saßen wir da so und haben Stuss erzählt, das war immer schön. Und die Polen haben auf der anderen Seite das Gleiche gemacht. Wir haben auch gewunken. Wann das war? Ich glaube, so sechziger Jahre müsste das gewesen sein. Jetzt fällt mir ein, was das war. Das hieß ,Friedensfeuer'. Ich weiß gar nicht, wann das wieder aufgehört hat. Aber irgendwann muss es wieder aufgehört haben. "1569

Persönliche Begegnungen, wie sie in den Kapiteln zum „Heimwehtourismus“ beschrieben werden, haben auf Dauer mehr bewirkt als die inszenierten Gruppentreffen, konnten aber erst nach 1989 einen spürbaren Wandel auf beiden Seiten einleiten. „Die neue Nachbarschaft zwischen den Brandenburgern und den [S. 93] polnischen Bewohnern der einstigen Neumark gestaltete sich lange Zeit schwierig. Zu tief saßen die Vorbehalte bei den Polen gegen die Deutschen und das Trauma der verlorenen Heimat bei den Deutschen. Es sollte lange dauern, bis der Prozess der Verständigung und Versöhnung in Gang kam. ${ }^{1570}$

1562 Filmtheater „Friedensgrenze“ in der Karl-Marx-Straße. In: Der Märkische Bote, 7.11.2009. - Ganzseitige Innenansicht des Foyers als Kalenderblatt für den Monat August in: Gubener Heimatkalender 7 (1962).

1563 Klaus-Dieter Gansleweit/Erich Opitz: Fürstenberg (Oder) im Wandel der Zeiten. T. 3. In: Fürstenberger Blätter 2 (2017), S. 6-24, hier S. 20: Zustimmung der Stadtverordnetenversammlung zu einem Antrag der HOGaststätten am 13.5.1953.

1564 Schiller: Das Entstehen und die Entwicklung der LPG „Friedensgrenze“ Groß-Gastrose. In: Gubener Heimatkalender für das Jahr 1959, S. 54-55, hier S. 54.

1565 Siehe dazu unten Ortsdokumentation, Kliestow.

1566 Siehe Dokumentation, Frankfurt (Oder).

1567 Desgleichen.

1568 Hartmut Schatte: Kowalski trifft Schmidt ... In: Gubener Heimatkalender 50 (2006), S. 90-93, hier S. 90 f.

1569 Aurith - Urad (wie Anm. 866), S. 45.

1570 Schmook, Eine neue Grenze im Osten (wie Anm. 1519), S. 93 f. 


\section{Rückzug ins Private}

Zwar hatte die „Umsiedler“-Verwaltung in der SBZ schon früh erkannt, dass für eine Integration der Vertriebenen entscheidend war, dass die Betroffenen einerseits nicht allzulange mit einem Sonderstatus versehen wurden, der sie gleichsam stigmatisierte, andererseits eine vollständige Tabuisierung von Unterscheidungsmerkmalen ebenfalls Gefahren für den jungen Staat barg, indem sie Abwendung und Abwanderung nahelegte. In Büchern, Zeitschriften und Filmen hat es daher in der SBZ und auch in der DDR „Umsiedler“-Thematisierungen immer wieder gegeben, bei denen aber stets die - als Erfolgsgeschichte erzählte - Integration im Vordergrund stand, nicht deren Vorgeschichte. ${ }^{1571}$ Angesichts der - nach Piecks Abrücken von seinen frühen Reden - unmissverständlichen Position der SED und der der sowjetischen Besatzungsmacht zur Frage der Ostgrenze sowie der Ostgebiete konnte jedes direkte oder indirekte Bekenntnis zu deren deutscher Geschichte dagegen - für den neuen Staat und Nachbarn Polens - grundgefährlich sein. So war es den Flüchtlingen und Vertriebenen in Brandenburg und der gesamten SBZ/DDR bis 1990 verwehrt, öffentlich an ihre Heimat zu erinnern. Gedenkstätten sind daher in Brandenburg in Form von Gedenksteinen und Gedenkkreuzen erst in den Jahren ab 1993 entstanden. ${ }^{1572}$ Undenkbar waren zum Beispiel öffentlich sichtbare Wandbilder, die an die Heimatstädte erinnerten, wie dies etwa in West-Berlin zu finden war. ${ }^{1573}$

1571 Zur „Umsiedler“-Thematik in DEFA-Spielfilmen, soweit mit Brandenburg-Bezug, siehe unten die Angaben in der Ortsdokumentation unter Potsdam und Kr. Westprignitz („Freies Land“, 1946), Wusterhausen/Dosse und Zehdenick („Die Brücke“, 1949), für Wochenschauen ebd. unter Lager Küchensee und Leegebruch (beide 1947).

1572 Teilweise wird damit an bestimmte Personengruppen erinnert, bisweilen handelt es auch aber auch um Gedenksteine für alle Opfer von Krieg und Gewaltherrschaft, in deren Inschrift die Vertriebenen bzw. der Begriff Vertreibung neben anderen in einer Aufzählung benannt ist. Vgl. Mahn- und Gedenkstätten der deutschen Heimatvertriebenen. Hrsg.: Bund der Vertriebenen - Vereinigte Landsmannschaften und Landesverbände. Bearb.: Heinrich Kucharczyk. Bonn 2008, S. 175-179 (Brandenburg): 1993 Hohenwutzen (Gedenkstein / ehem. Kreis Königsberg/Neumark), 1995 Neustadt/Dosse (Gedenkkreuz/Opfer der Vertreibung), 1995 Plattenburg, Prignitz (Gedenkstein / Flucht und Vertreibung), 1995 Neißebrücke von Groß Särchen, später transferiert nach Jerischke (Gedenkstein mit Hinweis auf „Aussöhnung im Heute“), 2002 Brandenburg/Havel (Gedenkstein / „Den Opfern von Weltkrieg, Flucht, Vertreibung und Deportation zum Gedenken"), 2003 Neuer Friedhof Fürstenwalde (Gedenkkreuz/Russlanddeutsche), 2004 Waldfriedhof Luckenwalde (Ehrenfeld für „Heimatvertriebene aus dem Kreis Mohrungen in Ostpreußen und anderen Heimatgebieten im Osten, die von 1945 bis 1947 im Luckenwalder Umfeld durch Krieg und Flucht ihr Leben verloren"). In Potsdam wurde am 15.11.2003 neben dem Alten Rathaus auf Initiative des Landesverbandes Brandenburg des Bundes der Vertriebenen ein Gedenkstein eingeweiht, der - mit einem Zitat von Albert Schweitzer - jegliche Vertreibung brandmarkt (Potsdamer Jahreschronik 2003 in: www.geschichtsverein-potsdam.de). Die bisher gedruckten oder im Internet veröffentlichten Listen von Gedenksteinen in Brandenburg sind sämtlich unvollständig. Siehe die Angaben in der Ortsdokumentation, auch diese vermutlich nicht ganz vollständig.

1573 In einer in den fünfziger Jahren erbauten Mehrfamlienhaussiedlung in Berlin-Britz zeigten die zum Quarzweg hin ausgerichteten Hausfassaden bis zur 2014 vorgenommenen Übermalung Wandbilder mit großformatigen Städtenamen und -wappen, u. a. von Breslau, Königsberg und Stettin. Beispiel-Abb. (Stettin) in: Bodo Mane- 
Die wirkliche innere Verfassung der Vertriebenen, ihr seelisches Befinden, dessen Wandel durch Integration ebenso wie bleibende Narben - über all diese wichtigen Momente der persönlichen Bewältigung des Flucht- bzw. Vertreibungsschicksals schweigt verständlicherweise das Gros der amtlichen Quellen. Meist sind dafür nicht einmal die Selbstzeugnisse - Erinnerungsberichte, Briefe, Memoiren - ausreichend aussagekräftig. Vieles ist wohl allenfalls einem Arzt oder Pfarrer anvertraut worden und bleibt so der Überlieferung entzogen. Oral-HistoryInterviews sind meist erst nach vielen Jahrzehnten geführt worden, wenn sich nach den politischen auch die gesellschaftlichen und die mentalen Rahmenbedingungen soweit entspannt hatten, dass alte Menschen Dinge an- und aussprechen konnten, die mitzuteilen sie sich in jüngeren Jahren nie getraut hätten. Für Brandenburg ist das bisher nur sporadisch in Angriff genommen worden ${ }^{1574}$, war auch für die vorliegende Arbeit nicht zu leisten und dürfte in einigen Jahren ohnehin unmöglich geworden sein.

In den Erinnerungen von Ärzten scheinen aber immerhin gelegentlich - anonymisiert Fälle durch, die erahnen lassen, welch schwieriges Langzeitunternehmen es oftmals für den einzelnen vertriebenen Menschen war, das Erlebte angesichts und trotz öffentlicher Tabuisierung zu verarbeiten und gleichzeitig als Staatsbürger und Werktätiger zu funktionieren, mithin im Integration (er)fordernden Alltag äußerlich anzukommen und innerlich dabei nicht in eine Isolation zu geraten. Einzelne Beispiele finden sich in der erst 2014 publizierten Sammlung von Patienten-Psychogrammen, die Karl-Ludwig von Klitzing (geb. 1942) mit der Schilderung seiner eigenen Entwicklung vom jungen Hochschulabsolventen zum erfahrenen Arzt eindrucksvoll verknüpft hat. ${ }^{1575}$ Fast über sein ganzes Medizinerleben hat er in der Grenzstadt Frankfurt

gold: Alt-Buckower Heimat-Chronik. T. 88. In: Buckower und Großziethener Prismagazin 2019, März/April, S. 17-19, hier S. 17.

1574 Keller, „Jetzt bin ich hier und das ist gut so“ (wie Anm. 123), S. 87-187 „Biographische Porträts“ (Interviewtexte). - Haberkern, Heimatverlust im Familiengedächtnis (wie Anm. 129). - Mehrere Arbeiten von Dagmar Semmelmann (siehe Anm. 52). Siehe aber auch oben im Einleitungskapitel I. 3 den Abschnitt zu „Senioren“ als Zeitzeugen.

1575 Karl-Ludwig von Klitzing: Atemlos. Erlebnisse eines Brandenburger Mediziners. Berlin 2014. Klitzing hat offenkundig zeitgenössisch Aufzeichnungen über ihn besonders interessierende Fälle vorgenommen, ohne die die detaillierte Schilderung nach Jahrzehnten nicht denkbar wäre. Ob die von ihm gesetzten Anführungszeichen bei Aussagen von Patienten formal berechtigt sind, ist zwar nicht mit Sicherheit zu sagen, es darf aber davon ausgegangen werden, dass er die ihn besonders beeindruckenden Aussagen sich unmittelbar anschließend notiert hatte und insofern dem Wortlaut noch sehr nahe war. Eine überdies lektorierende Glättung für die Publikation ist gleichwohl anzunehmen. Wir geben die Passagen hier in Anführungszeichen wieder, setzen sie aber bewusst nicht kursiv. - Das Schicksal eines Kriegsheimkehrers schildert er im Kapitel „Das Kriegsopfer“ (S. 119-125). Auch hier öffnet er beim Patienten die entscheidende Schleuse: „Der Lauf der Geschichte verlangte nun von dem Mann schier Unmögliches: Er sollte seine Erlebnisse wahrheitsgetreu kundtun. Dabei hatte er doch das durchgemachte Martyrium tief im Innern für immer verschlossen und versteckt gehalten. Ganz behutsam gingen wir gemeinsam vor. Und wir kamen voran. Zum einen reizte ihn meine Neugier, andererseits befreite ihn das Gespräch. Zum Schluss schmunzelte er über sich selbst. Er hatte zu seiner eigenen Verwunderung mehrere kleine Details aus seinem Gedächtnis zurückgeholt. Später würde er sie aufschreiben." (S. 123). 
(Oder) gearbeitet. In den ersten Jahren seiner Ausbildung, d.h. in den späten sechziger und frühen siebziger Jahren, war er Stationsarzt auf einer inneren Frauenstation: „Besonders gern erinnere ich mich an eine Frau mittleren Alters. ${ }^{\text {"1576 }}$ Sie war wegen Magenblutens eingeliefert worden, ein Magengeschwür konnte diagnostiziert werden. „Ich spürte in der Patientin einen großen seelischen Druck. "1577 Die ersten Versuche, etwas über ihren Geburtsort und frühen Werdegang zu erfragen, erbrachten bei der Patientin nur Schweigen und dann sogar wachsende Nervosität und Unruhe. Erst nach Anwendung manches psychologischen Tricks und Herstellung einer Vertrauensatmosphäre im Stationszimmer konnte er der Patientin ihre Lebensgeschichte entlocken. „Geboren bin ich in Schlesien auf einem Bauernhof. [...] Ich war sechzehn, als die Flucht begann." Sie schildert dann all die für so viele Leidensgenoss(inn)en typischen Fluchterlebnisse, wohl auf Januar/Februar 1945 zu datieren und in einem schlesischen Dorf, wo sie kurzzeitig in einer Scheune untergekommen waren, zu verorten: das Überrolltwerden des Fluchttrecks durch die Rote Armee, den Tod von Vater und Schwester, die Vergewaltigung durch sowjetische Soldaten, schließlich das weitere - nichttypische - Schicksal: „Nach einer ganzen Weile kamen Leute aus einem Nachbarhof. Sie nahmen mich mit. Ich war die einzige Überlebende unserer Familie. Viele Tage blieb ich bei fremden Leuten, dann setzten sie mich in einen Zug. Irgendwo in der Lausitz ging es nicht mehr weiter. Ich war schwanger. Eine alte Frau hat es mir in irgendeinem Stall weggemacht. Leute, die dort einquartiert waren, haben neugierig zugesehen. Es war die Hölle. Am nächsten Tag kam wieder ein Zug. Ich fuhr weiter. Tage später bin ich hier in Frankfurt (Oder) gelandet. Die Schwester meiner Mutter lebte in der Stadt. In den Ferien war ich manchmal bei ihr gewesen. Das Haus der Tante stand nicht mehr. Ich suchte zwischen den Ruinen nach Spuren - wie andere auch. Ein älteres Ehepaar sprach mich an. Sie waren die Nachbarn der Tante. Bei ihnen fand ich eine Bleibe. Endlich." ${ }^{578}$ [...] „Ich bekam Papiere, Essenmarken. Ich sorgte für die beiden Alten und die sorgten für mich. Man teilte mich zu Aufräumarbeiten ein. Mehrere Jahre war ich Trümmerfrau, [S. 20] arbeiten hatte ich ja zu Hause gelernt. Und Männer gab es doch keine. Es hieß dann später, wir könnten einen Beruf erlernen, wir hätten uns das verdient. Ich bin im Büro in der Verwaltung untergekommen. Von da an ging es aufwärts. Vor einigen Jahren sind meine Pflegeeltern gestorben, Ich bin nun allein. "1579 Die Patientin wurde operiert und konnte geheilt entlassen werden. Klitzing suggeriert dem Leser in seinem gut geschriebenen Buch, die Frau sei durch die ausführlichen Gespräche und die damit einhergehende Selbstreflexion auch seelisch geheilt worden. Ob das der Fall war, kann hier offen bleiben. Immerhin hat er sie zum Lachen bringen können, sie habe gesagt: „Ich habe doch schon Jahre lang nicht mehr gelacht, überhaupt nicht mehr."1580 Vielleicht kamen andere Gespräche noch hinzu, über deren Inhalt wir nicht informiert sind, so berich-

1576 Klitzing, Atemlos (wie Anm. 1575), S. 12-23 (Kapitel „Das Magengeschwür“), hier S. 13.

1577 Ebd., S. 15.

1578 Ebd., S. 19.

1579 Ebd., S. 19 f.

1580 Ebd., S. 22. 
tete ihm die Stationsschwester: „Der katholische Priester sei bei ihr [der Patientin] gewesen. Das war damals recht außergewöhnlich. "1581

Aber auch Menschen, die nicht derart einschneidende traumatische Erlebnisse von Tod und Gewalt am eigenen Leib oder in der engsten Familie erlebt hatten, empfanden den Verlust als Bürde. Die Aufgabe von Haus und Hof, aber auch der angestammten Heimat haben viele trotz aller Alltagsintegration - innerlich weiter mit sich „herumgetragen“. Vor allem Angehörige der älteren Generation kamen davon meist nicht mehr los. So schreibt der selbst nicht betroffene Cottbuser Enkel von Sorauer Vertriebenen, die es im Juni 1945 bei den „Wilden Vertreibungen“ getroffen hatte: „Das haben die Großeltern nicht verwinden können."1582 Jüngere hatten, wie man nicht oft genug betonen kann, oft die größere Chance zu einem zweiten (Neu-)Anfang. Der erst 1942 im niederschlesischen Lauban geborene DEFA-Regisseur und spätere DDR-Bürgerrechtler Konrad Weiß, war in seinem Genthiner DDR-Zuhause zwar von Kindesbeinen an mit dem Thema konfrontiert, zumal sein Vater im Frühjahr 1945 , an den Folgen der Flucht gestorben“ war: „Diese Flucht, der Schmerz meiner Mutter über den Verlust des Mannes und den Verlust der Heimat haben meine Kindheit geprägt." Doch konnte er in Lauban keine „Heimat für mich“ mehr sehen. „Meine Geburtsstadt ist für mich eine fremde Stadt, ich habe keine lebendigen Erinnerungen, kein vertrautes Gefühl. Daß es nun eine polnische Stadt ist, bereitet mir keinen Schmerz." So weit konnte die eigentliche Erlebnisgeneration zumeist naturgemäß nicht gehen: „Für meine Mutter war das natürlich ganz anders. Sie hat bis zu ihrem Tod unter dem Verlust der Heimat gelitten: Lauban blieb bis zuletzt ihre Heimatstadt. Aber so groß auch ihr Schmerz war, sie wußte, daß ihr Verlust die Folge des verlorenen Krieges war, des verbrecherischen Krieges, den die Deutschen begonnen und mit schrecklicher Grausamkeit geführt hatten. Ich habe von meiner Mutter nie ein Wort des Hasses auf die Polen, die nun in Lauban lebten, gehört. Sie war nicht frei von Vorurteilen gegenüber den Polen, nein, das nicht, Vorurteile hatte diese Generation wohl zu tief verinnerlicht. Aber sie wollte, daß jene, die heute in Schlesien leben, dort ihre Heimat haben und sich dieser Heimat sicher sind. / Diese einfache Frau, meine Mutter, hatte die Größe, das Unrecht, das ihr angetan worden war, anzunehmen als Sühne für die Verbrechen, die im Namen des deutschen Volkes begangen worden waren. Sie lebte eine schlichte [katholische] Frömmigkeit, in der die Erfahrung von Schuld und Vergebung, von Reue und Buße durch die Versöhnung erst möglich war." 1583

$1581 \quad$ Ebd., S. 21.

1582 Winz, Mein Jahr 1945 (wie Anm. 1433), S. 65. - Ähnliche Äußerungen, die den Unterschied zwischen der Sichtweise 1945 Erwachsener und damals noch im Kindes- oder Jugendlichenalter Befindlicher verdeutlichen, finden sich in den Erinnerungen Vertriebener häufig. So heißt es im Bericht über das 2017 geführte Interview mit einem in der Ostprignitz lebenden, 1929 geborenen Vertriebenen aus dem Kreis Meseritz: „Während seine Eltern in Blumenthal immer von der alten Heimat erzählten, sieht Gerhard Pöhlchen dies mit gemischten Gefühlen." (Christamaria Ruch: Gerhard Pöhlchen ist fest verwurzelt. In: Märkische Allgemeine, Ostprignitz-Ruppin, 6.11.2017).

1583 Konrad Weiß: Die SED-Propaganda wirkt noch nach. Deutsch-polnische Erfahrungen: Die persönlichen Kontakte haben Brücken gebaut. In: Frankfurter Allgemeine Zeitung, Nr. 161, 13.7.1996, Beilage „Ereignisse 
Wieweit der Einzelne das Erlebte durch - bisweilen vollständige - Verdrängung verarbeitete, blieb naturgemäß auch eine individuelle Frage. Das Leben im Hier und Jetzt, die Ausrichtung auf die Zukunft, aber auch auf das Naheliegende, Reale und Mögliche dürfte für viele jüngere Vertriebene ebenso automatisch bestimmend geworden und gewesen sein wie für die Einheimischen, denen sich bei Kriegsende ebenfalls Überlebensfragen stellten. So darf man die sicherlich nicht geringe Zahl derjenigen Vertriebenen nicht unterschätzen, für die die Vergangenheit „abgehakt“ war. Da es darüber keine statistischen Untersuchungen gibt, bleibt letztlich nur festzustellen, dass die in den Selbstzeugnisse Vertriebener, die hier im Buch an verschiedensten Stellen als Quelle herangezogen werden, beschriebenen oder doch erkennbar werdenden Verlusterfahrungen und seelischen Nöte zwar nicht generell verallgemeinert werden können; sehr viele Verhaltsmuster und Verarbeitungstechniken, zahllose überall ähnlich anzutreffende Beschreibungen und Formulierungen lassen aber doch den Schluss zu, dass es sich um Mehrheitsphänomene handelt. Dazu gehört auch, dass der verordnete Zwang, sich öffentlich als „Umsiedler“ bezeichnen lassen zu müssen, viele Betroffene gekränkt hat, weil sie das Erlittene damit nicht angemessen definiert sahen. So sehr vielen von ihnen der oft gehörte „Umsiedler“-Begriff dennoch in Fleisch und Blut übergegangen war und damit auch etwas von seinem euphemistischen Beigeschmack verloren haben mochte, fiel er nicht wenigen doch nach 1990 wieder „auf die Füße“, als sie von „ethnischen Säuberungen“, mithin neuen Vertreibungen in Europa und der Welt Kenntnis erhielten, diese gar im Fernsehen fast hautnah sahen. Eine 1945 als Kind aus Hinterpommern vertriebene Potsdamerin (geb. 1933) äußerte dem Verfasser gegenüber 2015, gerade durch das jahrzehntelange Verdrängenmüssen und die Vorgabe, sich als „bloße Umsiedler" sehen zu sollen, komme nun im Alter alles „wieder hoch“.1584

Wer die nach 1989 und bis heute noch immer weiter in großer Zahl publizierten, wenn auch keineswegs leicht erreichbaren oder gar immer äußerlich erkennbaren Erinnerungsberichte Vertriebener liest, findet naturgemäß viele Facetten des Umgangs mit dem Geschehenen. Auch wenn zudem schon die Tatsache der Mitteilung und gar der Publikation nur einen Einblick in das Denken einer "Teilmenge“ der Betroffenen bietet, so ist häufig genug erkennbar, dass die Erzählenden oder Schreibenden nicht nur Chronisten oder interviewtaugliche Zeitzeugen sind, sondern beim Mitteilen auch selbst verarbeiten. Das Verarbeiten ist für den Einzelnen ein innerer Prozess, wie er sich letztlich für jeden Menschen lebenslang ergibt. Für die DDR-Zeit aber kommt hinzu, dass die kommunikative Verarbeitung, das Gespräch über das Geschehene außerhalb der eigenen vier Wände für den Einzelnen nicht ratsam war und dass folglich auch prominente Vorbilder, in denen man sich wiederfinden konnte, fehlten. Das führte - neben der erwähnten Verdrängung - zu einer Beschränkung auf die Weitergabe im Familienkreis. Das (private) „Familiengedächtnis“, das (auch) in einheimischen Familien stets zur Weitergabe von

und Gestalten“ o. S. - Weiß engagierte sich u. a. auch in der deutsch-polnischen Aussöhnung und erhielt 2012 den Verdienstorden der Republik Polen. 
Herkunftswissen dient, wurde für die Vertriebenen in der DDR zum einzigen möglichen Ort der Andenkenpflege.

Ein aus der südlichen Neumark stammender Vertriebener, der zur DDR-Zeit (seit der Flucht Anfang 1945) in Dreetz bei Neuruppin lebte und durch eine Kriegsverletzung erblindet war, hat die gerettete Dorfchronik seines im ehemaligen Kreis Züllichau-Schwiebus gelegenen Heimatortes Rietschütz in den siebziger Jahren gemeinsam mit einem aus demselben Dorf stammenden Freund auf Tonband aufgenommen. Seine Tochter hat den Text später (2000) veröffentlicht. Im 1999 datierten Vorwort schreibt sie: „An die vielen Nachmittage Anfang der siebziger Jahre, ich war damals vier oder fünf Jahre alt, kann ich mich entfernt erinnern. Sie sind für mich meist langweilig und still abgelaufen, da mein Kindergequassel auf der Aufnahme gestört hätte. Außerdem war es wohl eine glückliche Fügung, daß mein Geist noch so klein war und ich kein Interesse an den für mich damals langweiligen Geschichten von Onkel Hoffmann [dem Verf. der Chronik - P. B.] hatte, denn das Verfassen einer Chronik über ein Ostmarkdorf ${ }^{1585}$ war zu DDRZeiten eine heikle und gefährliche Angelegenheit, über die niemand etwas ausplaudern durfte. Nur wenige sehr gute Rietscher [verkürzt für Rietschützer - P. B.] Freunde wußten davon, und sie beflügelte wohl [S. 6] der Gedanke, sich ihre Heimat, die sie unter schrecklichen Umständen verlassen mußten, wieder etwas näher zu bringen, als eventuelle persönlich-politische Probleme zu bekommen. Eine Verbreitung der Aufnahmen wäre in dieser Zeit aber undenkbar gewesen. / Mit den Jahren wurde die Tonqualität der Aufzeichnungen immer schlechter und so entschloß sich meine Mutter (aus Jehser, einem Rietschützer Nachbardorf, stammend) Ende der achtziger Jahre die Chronik auf einer ,ERIKA'-Schreibmachine zu Papier zu bringen. Zu dieser Zeit hatte ich gerade die Pubertät überstanden, und meine Interessen galten am wenigsten den Schriftstücken über Geschichten, von vor dem Krieg'. Einige kannte ich zwar aus immer wiederkehrenden Erzählungen der Eltern und fand sie mehr oder weniger beeindruckend. / Nach der Wende hatte die Geheimhaltung der Existenz der Rietschützer Dorfchronik ein Ende und so gibt es in fast jedem Haushalt der Rietscher das kopierte ,ERIKASchreibmaschinenmanuskript'. / Und dieses fiel mir vor Monaten durch meinem Mutter in die Hände. Mir kam der Gedanke, es für die Nachkommen der Rietschützer und die an diesem Thema interessierten Leser zu veröffentlichen. / Man kann es an einem Abend komplett durchlesen und wird nicht dümmer. Mich begeisterte die mit Präzision aber auch mit Witz und Charme verfaßte Erzählung des Baumeisters ,Onkel' Ernst Hoffmann und des Stellmachers ,Vater' Gerhard Tschirpig [...]."1586 Die Herausgeberin hat in den Text der Chronik an einigen Stellen Zitate und Hinweise auf außerhalb des Chroniktextes stehende Mitteilungen eingebaut, die dem Tonband zu entnehmen waren. Sie überliefern den Wortlaut einzelner Äußerungen der damals Handelnden und zeigen

1585 Der in der Weimarer Republik und NS-Zeit häufiger anzutreffende Begriff Ostmark meint ein geographisches Gebilde aus Provinz Grenzmark Posen-Westpreußen, Neumark und weiteren östlichen Teilen der Provinz Brandenburg westlich von Oder und Neiße.

1586 Jutta Noll-Haiduga (geb. Tschirpig): Vorwort. In: Ernst Hoffmann / Gerhard Tschirpig: Dorfchronik Rietschütz. Eine kleine Lektüre für Rietscher Enkel, Urenkel und deren Nachkommen. Überarb. u. hrsg. von Jutta Noll-Haiduga. Berlin 2000, S. 5 f. 
deutlich, dass sich der „verschworene“ Kreis, eigentlich ja nur zwei Personen, doch immer wieder um Verwandte, Freunde und Bekannte erweiterte, die denselben Rietschützer Flucht- und Vertreibungshintergrund mitbrachten: „Vom Tonband hört man meinen Vater, Gerhard Tschirpig, nun sagen: Heute ist der 22. Januar 1972. Es regnet schon den ganzen Tag, der Frühling ist zu Ende und wir hoffen, daß sich das Wetter bessert. Wir sind wieder zur weiteren Arbeit versamnmelt. Unser Freund Alfred Schulz gibt eine wahre Begebenheit [aus Rietschütz] zur Chronik: [...]." ${ }^{1587}$ Selbst Besucher aus Westdeutschland, die aus Rietschütz stammten, wurden in das Tun einbezogen: „Mein Vater spricht: ,Dreetz, den 27.07.1972. Wir haben heute Besuch. Anwesend sind Trautchen Schulz und Adelheit Wöhlke, geb. Kalliske, Tochter von Bernhard Kalliske [aus Rietschüt]. Sie beehrte uns heute Abend und wir wollen sie in unserer Dorfchronik verewigen. [,] Adelheids Stimme klingt fröhlich: ,Ich bin 44 Jahre, habe 3 Kinder und wohne mit meiner Familie in der Lüneburger Gegend. [,] Trautchen Schulz, Schwiegertochter, von Alfred Schulz, grüßt auch alle mit ihrer Stimme: ,Ich bin 39 Jahre alt, habe 2 Kinder und wohne mit meinem Mann Alfons hier ins [so!] Dreetz. Die Männer sind zur Zeit am schönen Dreetzer See. “"1588 Beigefügt sind dem Büchlein dann noch drei Fotos vom Heimattreffen des Kreises Züllichau-Schwiebus 1999 in Gildenhall bei Neuruppin, die u. a. einen speziellen Tisch mit Personen aus Rietschütz (Ortsschild) zeigen. Die Kontakte hatten also über alle die Jahrzehnte Bestand.

Lisa Haberkern hat die Entwicklung des Familiengedächtnisses in (interviewten) Vertriebenenfamilien aus den neuen Bundesländern, die die DDR-Zeit erlebt hatten, untersucht und Unterschiede in der Sicht- und Herangehensweise der Generationen festgestellt ${ }^{1589}$ : „H.F. [Angehöriger der Erlebnisgeneration ${ }^{1590}$ - P. B.] spricht von verlorenen Dingen und meint damit Geldwerte wie den zurückgelassenen Besitz und ein Erbe, das ihm durch die Vertreibung und deren Folgen vorenthalten geblieben sei. T.F. [Tochter des Vertriebenen, nach 1945 geboren - P. B.] spricht von Verlust und geht hierbei auf Dinge mit sentimentalem Wert ein, wie Fotoalben, anhand derer man Familiengeschichte vermittelt bekomme und vermittele. Für den E. F. liegt der Wert nicht in Dingen. Er versteht die Erinnerungen an die Vergangenheit als Wert, den es zu erhalten gelte. Diese Umdeutung von Wert nimmt vorweg, dass der Verlust der Vergangenheit zugeordnet und als abgeschlossen betrachtet wird. Hieran ist zu erkennen, dass sich in Bezug auf die Erinnerungen an Verlust innerhalb des Familiengedächtnisses eine stufenweise Entwicklung vollzieht: Von Erinnerungen an materielle Dinge über Erinnerungen an ideelle Werte entwickelt sie sich über drei Generationen hin zu der Wertschätzung ideeller Werte." ${ }^{1591}$ Zwar handelt es sich bei diesem Beispiel um eine teilweise im BdV aktive, darin also für die

1587 Hoffmann/Tschirpig, Dorfchronik Rietschütz (wie Anm. 1586), S. 57.

1588 Ebd., S. 58.

1589 Haberkern, Heimatverlust im Familiengedächtnis (wie Anm. 129), Anhang (Gedankenprotokolle und Transkripte).

1590 Ebd., S. 53. H. F. = Heinz Fröhlich (geb. 1931 Grünberg in Schlesien), Luckenwalde, Vorsitzender des dortigen BdV-Ortsverbandes.

1591 Ebd., S. 66. 
Mehrheit der Vertriebenen nicht repräsentative Familie, doch lassen sich, von Haberkern auch in anderen Beispielfamilien angetroffene, Muster feststellen, die letztlich nicht auf Vertriebene begrenzt werden können, aber doch zeigen, wie der private Verarbeitungs- und Integrationsprozess verlaufen konnte und kann. War die materielle „Lebensfähigkeit“ erreicht, gefestigt, jahrelang bewährt, wenn auch unter Verlust früheren Eigentums, dann konnte auch der Beschäftigung mit den ideellen Erinnerungswerten Zeit und Raum gegeben werden, wobei der Anstoß dazu und die Wertschätzung oft von den nach 1945 Geborenen ausging bzw. ausgeht, für die sich die Frage der materiellen Integration nie stellte.

Einen Ausgleich für die Unmöglichkeit, öffentlich über sein Schicksal zu sprechen, einen gewissen Ersatz für die fehlende Heimatliteratur und auch ein Ventil für die Sehnsucht nach der Heimat bildeten in der Spätzeit der DDR neu entstehende romanhafte Darstellungen, die daher große Beachtung fanden, zumal ihre Inhalte oft - offenkundig - nur zum Teil fiktiv waren. ${ }^{1592}$ Ursula Höntsch-Harendts (1934-2000) „Wir Flüchtlingskinder“ beispielsweise, erschienen 1985 im Mitteldeutschen Verlag in Halle an der Saale und Leipzig, konnte man getrost als autobiographisches Erinnerungsbuch lesen, auch wenn einzelne Dialoge nicht wortwörtlich schriftlicher oder mündlicher Überlieferung, sondern dem Kopf einer (Historikerin und) Schriftstellerin entstammten, die aber eben selbst Flüchtlingskind war. „Was Ursula Höntsch 1985 ihre Romanfiguren aussprechen ließ, stand in keinem DDR-Geschichtsbuch. Ihr Buch enthielt mehr historische Fakten und Wahrheiten als in der wissenschaftlichen und historischen Literatur nachzu-

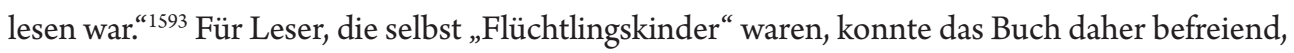
anerkennend und insofern spät auch integrationsfördernd wirken. Für die Autorin selbst hat es jedoch den eigenen Prozess der Verarbeitung ihres Schicksals möglicherweise nicht dauerhaft befördern können. Dies jedenfalls ist der Eindruck, den ihre - selbst ebenfalls vertriebene und mit der Bewältigung des eigenen Weges ringende - Schriftstellerkollegin Sigrid Grabner (geb. 1942) im Anschluss an die Schilderung einer eigenen, noch vorwendezeitlichen Heimatreise in das ehemalige Sudetenland wiedergibt: „Böhmen, das wurde mir auf dieser Reise bewusst, blieb eine

1592 Siehe aus der inzwischen zahlreichen Literatur zum Thema: Jörg Bernhard Bilke: Unerwünschte Erinnerungen. Flucht und Vertreibung in der DDR-Literatur. In: Wille/Lau/Bilke, Die Vertriebenen in Mitteldeutschland (wie Anm. 568), zu Reaktionen in Leserbriefen von DDR-Bürgern (auf den 1986 erschienenen Roman „Der Puppenkönig und ich“ des aus Schlesien stammenden Schriftstellers Armin Müller), S. 22 f. - Andreas Kossert: Kalte Heimat. 4. Aufl. München 2009, S. 290-300: Kapitel „Vertriebene in der Literatur der DDR“. Elke Mehnert: Vertriebene versus Umsiedler - der ostdeutsche Blick auf ein Kapitel Nachkriegsgeschichte. In: Landschaften der Erinnerung. Flucht und Vertreibung aus deutscher, polnischer und tschechischer Sicht. Elke Mehnert (Hrsg.) (Studien zur Reiseliteratur- und Imagologieforschung, Bd. 5). Frankfurt am Main u. a. 2001, S. 133-157, bes. S. 144-153. - Michael Schwartz: Tabu und Erinnerung. Zur Vertriebenen-Problematik in Politik und literarischer Öffentlichkeit der DDR. In: Zeitschrift für Geschichtswissenschaft 51 (2003), S. 85-101. - Günter Wirth: Heimat in dreifach gebrochener Perspektive: Böhmen - DDR - Deutschland. Zur Rolle der Vertriebenen in der DDR-Literatur am Beispiel von Hanns Cibulka. In: Böhmen. Vielfalt und Einheit einer literarischen Provinz. Hrsg. von Frank-Lothar Kroll (Literarische Landschaften, Bd. 2). Berlin 2000, S. 151-165.

1593 Amos, Vertriebenenpolitik der SED (wie Anm. 12), S. 246. 
offene Wunde, an die zu rühren ich mir verbot, weil ich an der Heilung verzweifelte. Ungleich meiner Lektorin und Freundin Ursula, ein Flüchtlingskind aus Schlesien und acht Jahre älter als ich, weigerte ich mich, die Verletzungen zu thematisieren. In den Achtzigerjahren sollte Ursula ihre Erlebnise in dem DDR-Bessteller ,Wir Flüchtlingskinder' beschreiben. Linderung brachte ihr das aber auch nicht." ${ }^{1594}$

\section{2. "Westkontakte", illegale Selbstorganisation und Konspiration}

Die offizielle, legale Organisation von Vertriebenen war - in den Westzonen - ab spätestens 1948 ein Massenphänomen von Nord bis Süd mit zahllosen lokalen Orts- und Kreisgruppen, bei denen entweder - nach dem landsmannschaftlichen Prinzip - die Herkunftsregion ausschlaggebend war oder, wie bis heute beim BdV, der Wohnort als neue Heimat. Es liegt nahe, dass zumindest die landsmannschaftlich orientierten Verantwortlichen auch die in der SBZ/ DDR Wohnenden einbeziehen wollten, ebenso wie von diesen sehr viele mit gespanntem Interesse auf die sich bildenden Verbände oder auch nur einen einzelnen Pfarrer als Ansprechpartner blickten. Als Bindeglieder dienten die Korrespondenz, persönliche Besuche, kleinere und auch größere Treffen und schließlich gedruckte Informationen, vor allem in Form der Heimatzeitschriften. Kontakte mit all diesen Bereichen sind für die Situation der Flüchtlinge und Vertriebenen in der SBZ/DDR, wo Selbstorganisation untersagt war, von Bedeutung, will man neben Arbeitsplatz, Kleidung und Wohnraum auch die seelische Befindlichkeit in den Blick bekommen. Untersucht sind diese Aspekte gleichwohl noch kaum, obwohl sie durchaus erkannt und versuchsweise zusammenfassend beschrieben worden sind. ${ }^{1595}$

Welcher Prozentsatz der in Brandenburg bzw. in der SBZ/DDR Lebenden von Vertriebenenverbänden organisierte Heimattreffen in West-Berlin oder Westdeutschland besucht hat, ist kaum feststellbar. ${ }^{1596}$ Aus Sicht der Veranstalter und auch im unmittelbaren Erlebnis später berichtender Teilnehmer waren die Zusammenkünfte aber offenkundig jahrelang, auch von aus der DDR besuchsweise Anreisenden, gut besucht und fanden ohnedies in großer Zahl statt. ${ }^{1597}$ Dass sie gleichwohl nie die Gesamtheit oder auch nur die Mehrheit der Vertriebenen erreicht

1594 Grabner, Jahrgang ,42 (wie Anm. 1417), S. 331.

1595 Siehe vor allem die überregionalen Arbeiten: Kossert, Kalte Heimat (wie Anm. 1592); Amos, Vertriebenenpolitik der SED (wie Anm. 12); Schwartz, Vertriebene und „Umsiedlerpolitik“ (wie Anm. 13); ferner am Beispiel Mecklenburg(-Vorpommern)s: Seils, Die fremde Hälfte (wie Anm. 19), S. 244-262.

1596 Teilnehmerlisten können sich durchaus im Schriftgut der örtlichen landsmannschaftlichen Verbände (Heimatkreise, Heimatkreisgemeinschaften) vielfach erhalten haben, das teilweise bereits in öffentlich zugängliche Sammlungen (Stadtarchive von Patenstädten, Bibliotheken) gelangt ist (z. B. Martin-Opitz-Bibliothek Herne, Bibliothek der Stiftung Brandenburg im Haus Brandenburg in Fürstenwalde), ihre Erschließung und Auswertung ist aber nur bei spezialisierter Einzelforschung zu leisten. Nur wenige Beispiele, die aber das Quellenpotential belegen, konnten vom Verf. ausgewertet werden (siehe unten Kap. IV 2 / Teilnahme an Heimattreffen in Westdeutschland).

1597 Dies der Eindruck nach der Lektüre zahlreicher Berichte in der Vertriebenenpresse sowie in Zeitzeugenberichten (Leserbriefe, Erinnerungen u. a.). 
haben können, dürfte außer Frage stehen. Wie in den Westzonen teilten sich die nur theoretisch als „Gruppe“ fassbaren Vertriebenen auch in der SBZ/DDR schon bald nach dem ersten Fußfassen in solche, die ihre Herkunft schneller abstreiften, und andere, die sich weiterhin, wenngleich eher ideell, über diese zu definieren suchten. Wie in den Westzonen war es also letztlich eine - wenn auch in der SBZ/DDR deutlich erschwerte - Entscheidung des Einzelnen, ob er sich - unabhängig von der offiziellen politischen Linie - innerlich weiterhin als Vertriebener verstand, Treffen, sofern möglich, besuchte, zu den entsprechenden Verbänden in Berlin oder anderswo Kontakt hielt und deren Publikationsorgan, wenn überhaupt möglich, las.

Neben der von manchen wahrgenommenen Möglichkeit, Treffen im Westen als Rentner auch noch nach dem Mauerbau zu besuchen, und dem für die DDR-Öffentlichkeit unsichtbaren Gespräch im engeren Familienkreis hat es auch über 1961 hinweg fortbestehende Netzwerke gegeben, die einen größeren Personenkreis als nur den der Verwandten betrafen. Ein Beispiel ist der weiterbestehende Kontakt der nach Westdeutschland (Niedersachsen) geflüchteten ehemaligen Gutsbesitzerfamilie Rittwagen/Berndt aus dem neumärkischen Kemnath (Kr. Oststernberg), die brieflich mit mehreren in der DDR (Falkensee, Jüterbog, Werder bei Jüterbog) lebenden ehemaligen Kemnathern in Verbindung stand. Ausweislich der publizierten Briefe aus den Jahren 1962 bis 1988 wirkte das alte patriarchalische Verhältnis der Gutsbesitzer und ihrer Kinder zu den einst in ihren Diensten stehenden „Leuten“ in West und Ost weiter. ${ }^{1598}$ Aus dem Westen kamen Pakete, aus dem Osten Dankesbriefe. Die Anrede für die ehemalige Gutsbesitzerin und ihre Tochter ist stets „liebe gute Frau ..." Beide Seiten berichteten über sich, ihre Familien sowie über nicht wenige Dritte und hielten so die gedankliche Verbindung eines größeren Kreises immer weiter aufrecht. ${ }^{1599}$ So schrieb eine DDR-Bürgerin 1962 aus Werder: „Ach ich denke doch so oft an alle Lieben, habe auch an jungen Herrn Rittwagen seinen Geburtstag gedacht. ${ }^{1600}$ Letzterer war der Sohn des letzten Gutsbesitzers. Weiterhin werden Grüße an im Westen lebende Kemnather aufgetragen, und auch die treue Dienstbarkeit wäre jederzeit wieder aktivierbar, wenn es die Grenze nicht gäbe: „Liebe Frau Berndt, es ist doch zu schade, das wir so weit von einander sein, wenn ich in Ihrer Nähe wär würde ich Ihnen so viel in ihrem Garten helfen. Ich

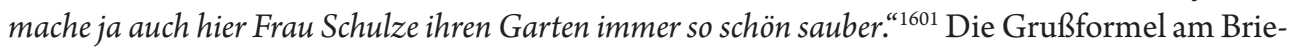
fende zeigt das neumärkische Kemnather Netzwerk in Brandenburg besonders deutlich: „Auch von die anderen Kemnather die noch hier wohnen / Herzliche Grüße“. ${ }^{162}$ Ganz ähnlich sind die Fomulierungen im Brief einer in Falkensee lebenden Kemnatherin 1962: „Denke so oft an alle Menschen von denen man jetzt getrennt leben muß. Träume oft von ihnen, Frau Rittwagen und Frau Berndt, immer thun wir zusammen wirtschaften. Das macht mein schlechter Schlaf. Nun nochmals

1598 Friedel Remenyi: Geschichte eines Gutes in der Neumark. Kassel 2007, S. 61: „Dorthin [Werder bei Jüterbog - P. B.] hatten sich unsere Leute mit dem zweiten Gummiwagen durchgeschlagen“.

1599 Ebd., S. 98-113. Die Orthographie der Briefe wurde beibehalten.

1600 Ebd., S. 98-100 (Brief Berta Wenzel, Werder, 23.11.1962), hier S. 99.

1601 Ebd.

1602 Ebd., S. 100. 
vielen Dank ihr lieben alle dort. " ${ }^{1603}$ Wie zu erwarten ist es aber in erster Linie eine Verbindung der (1945 erwachsenen) Erlebnisgeneration. Schon 1972 schreibt eine weitere Kemnatherin: „[...] ich bin von die Heimat nur noch allein in der Werderschen Gemeinde hier die sind schon Alle wo anders hingezogen und manche sind auch schon tot. ${ }^{\text {"1604 }}$ Aus Jüterbog dankt eine nun schon sehr kränkelnde Kemnatherin 1983 für „Ihr liebes gutes Paket und liebe Karte“: „Es ist doch so sehr Heimatlich, wenn man so eine sehr große Freude bekommt." 1605

Private deutsch-deutsche Briefwechsel aus den Zeiten der Teilung sind erst in geringer Zahl publiziert oder gar ausgewertet worden. Ohnehin ist ihre Zugänglichkeit für die Forschung noch kaum gewährleistet, wenn nicht Familienmitglieder selbst sie edieren. Für die dabei interessierende Gruppe der Vertriebenen in Ost und West gilt das noch viel stärker, bilden sie doch nur eine „Teilmenge“ der vom Mauerbau Betroffenen. Wie intensiv bisweilen auch nach 1961 Verbindungen zwischen Verwandten oder Bekannten gleicher landsmannschaftlicher Herkunft gepflegt worden sind, wird in den verschiedensten im vorliegenden Buch untersuchten Bereichen deutlich. Es ist kaum zu bezweifeln, darin auch einen gewichtigen „Faktor dissidenter Kommunikation“ zu sehen, der die in der DDR lebenden Vertriebenen mit dort offiziell unerwünschten Sichtweisen immer wieder in Kontakt brachte und hielt. ${ }^{1606}$ Wie tief die reale ebenso wie die in die Köpfe dringende mentale Mauer aber auch solche zuvor ungeteilten Familienbande unterbrechen und z.B. Geschwisterbeziehungen spalten konnte, ist aus vielen Schilderungen allgemein bekannt und kein Thema nur der Vertriebenen. So spielt z. B. die gemeinsame schlesische Herkunft in dem von Hildegard Baumgart auszugsweise publizierten Briefwechsel der Jahre 1965 bis 1967 - offenkundig nicht nur der (Selbst-)Zensur wegen - gar keine Rolle mehr, vielmehr wird die tiefe Kluft deutlich, die durch die Ideologisierung der in Bitterfeld, Dittersdorf und Potsdam Lebenden, die den DDR-Sozialismus überzeugt und stereotyp argumentierend verteidigen, entstanden ist, während der „Westverwandte“ in seinen Briefen „Politik und Meinung der CDU“ vertritt, so dass zumindest brieflich keine Einigung möglich war. ${ }^{1607}$ Auch wenn es sich hier um einen erst 1965 wieder aufgenommenen, also kaum repräsentativen Kontakt zwischen einem im Westen lebenden jüngeren Schlesier des Geburtsjahrgangs 1929 mit seinem älteren Onkel und dessen Tochter handelt, bei dem die Entfremdung schon allein durch die offenbar zwanzigjährige Unterbrechung entstanden war, kann der Briefwechsel beispielhaft zeigen, wie die spezifischen Sorgen und Nöte der Vertriebenen vom Ost-West-Konflikt, der bis tief in die Familien hineinwirkte, überlagert werden und als „Thema“ in den Hintergrund rücken konnten: auch dies eine Form der "gelungenen“ bzw. de facto entstandenen Integration.

1603 Ebd., S. 100-101 (Brief Frau Busse, Falkensee, 6.12.1962), hier S. 101.

1604 Ebd., S. 103 (Brief Frieda Domke, 1972).

1605 Ebd., S. 104 (Brief Frau Domke, Jüterbog, 28.12.1983).

1606 Schwartz, Vertriebene und „Umsiedlerpolitik“ (wie Anm. 13), S. 523.

1607 Nur die Briefe der einen Seite, der in der DDR Lebenden, sind publiziert, lassen aber auf Äußerungen des im Westen lebenden Briefpartners indirekt schließen. Siehe: Briefe aus einem anderen Land. Briefe aus der DDR. Hrsg. von Hildegard Baumgart. 2. Aufl. Hamburg 1971, S. 229-240 (Abschnitt „Bekehrte Bürger“). 


\section{Teilnahme an Heimattreffen in West-Berlin}

In einem zeitgenössischen Bericht über ein neumärkisches Heimattreffen in West-Berlin 1953 wird eindringlich hervorgehoben: „die Not und das Elend der Heimatvertriebenen [...], die nirgends sichtbarer sind als bei den Heimattreffen in Berlin, bei denen die wenigen Westberliner Landsleute mit ihren Mitgliedsbeiträgen die doppelt und dreifach so große Zahl der Landsleute aus der Ostzone und dem Ostsektor mit durchhalten helfen. Wer einmal bei einem Treffen von der Bühne herab einen vollen Saal mit leeren Tischen, auf denen kaum eine Tasse Kaffee oder ein Glas Bier stehen, gesehen hat, und wem bekannt ist, daß sich die armen, aber so treuen Landsleute aus der Ostzone ihren dünnen Kaffee in der Thermosflasche mitbringen müssen, weil sie den fünfmal teureren Kaffee in Westberlin nicht bezahlen können, der kann erst den tiefsten Sinn der Worte verstehen: Wie ein Schrei muß es durch ganz Deutschland klingen: [,] Gebt uns unsere Heimat wieder[,] alle andere Nichtigkeiten interessieren uns nicht! " 1608

Die Bedeutung West-Berlins für die Menschen in Brandenburg und in der gesamten SBZ/ DDR wird oft zu wenig berücksichtigt, obwohl der Zugang bekanntlich erst 1961 vollständig unterbunden wurde. Selten sind in nach 1990 erschienenen Chroniken brandenburgischer Gemeinden Sätze zu lesen wie in der für Ragösen (Zauch-Belzig) in der Zeit von 1945 bis 1991 (2002): „Will man das Leben der Dorfbewohner nach dem Krieg beschreiben, so dürfen die Westberlinfahrten vieler Bürger nicht vergessen werden. Man handelte auf dem Schwarzmarkt, brachte Waren zu Bekannten, tauschte ein, was es zu Hause nicht gab, z. B. Bindegarn. In Westberlin gab es zu DDR-Zeiten Westgeld. Fast täglich machten sich [Menschen], meist Frauen, auf den Weg, die unter ihren Mänteln landwirtschaftliche Produkte aus eigener Produktion versteckt hatten, um ungehindert an den Grenzkontrollen vorbeizukommen. Manche versuchten sogar Heidekrautsträuße, Feldblumensträuße oder klein gehacktes Brennholz in Berlin an den Mann zu bringen. / Produkte wie Butter, Schlackwurst, Eier usw. wurden verkauft. Der Kurs schwankte zwischen 1:4 und 1:6 = West - Ost. Oft wurden dafür wertvolle Waren eingekauft, die dann wiederum an den Kontrollstellen (Griebnitzsee) vorbeigeschmuggelt werden mussten. Auch in der Bahn gab es Razzien. Manchmal führte die VP (Volkspolizei) Kontrollen am Aussteigebahnhof in Baitz durch. Die Waren wurden beschlagnahmt.“1609

Dieser rege Austausch mit West-Berlin betraf aber nicht nur den Warenhandel, sondern muss viel stärker, als dies bislang geschehen ist, auch als Möglichkeit für Flüchtlinge und Vertriebene gesehen werden, mit Vertriebenenverbänden in direkten Kontakt zu treten und vor allem - für die Betroffenen meist viel wichtiger als politische Bekundungen - an den von diesen veranstalteten kleineren und größeren „Heimattreffen“ - ohne Übernachtung - teilzunehmen. Zudem zeigte sich in den fünfziger Jahren auch das Land Berlin ebenso offen für die Vertriebe-

1608 Bericht des Berliner Ortsbetreuers der Heimatvertriebenen aus Drossen in der Landsmannschaft Ostbrandenburg-Neumark e. V., Heinrich Prenzel (1905-1985), über das „Heimattreffen des Kreises West-Sternberg in Braunschweig“ (am 5. Juli 1953), in: Frankfurt (Oder)-Sternberger Kurier 2 (1953), Nr. 12, S. [13]. 
nenbetreuung wie viele westdeutsche Bundesländer und Kommunen. So übernahmen WestBerliner Bezirke Patenschaften über einzelne Vertreibungsgebiete, darunter Schöneberg für Schlesien, Charlottenburg für Pommern, Kreuzberg für Ostbrandenburg und das Sudetenland, Wilmersdorf für Westpreußen und Steglitz für Ostpreußen. Auch Schulen wurden in diese Patenschaften einbezogen und erhielten entsprechende Ländernamen. ${ }^{1610}$ Die nach und nach aus informellen Anfängen - zu einer festen, organisierten Struktur herangewachsenen Vertriebenenverbände waren Neugründungen Betroffener. ${ }^{1611}$ Wieweit sich bereits vor 1945 in Berlin ansässige Landsleute hierbei durch Hilfestellung betätigten, ist nur im Einzelfall zu klären. Auch wenn aus der Vorkriegszeit stammende Vereine offiziell zunächst noch nicht wieder zugelassen wurden, existierten doch oft noch die personellen Strukturen. So hatte sich in der Vorkriegsbevölkerung der Reichshauptstadt eine Vielzahl auch an Heimatvereinen gegründet, die das Heimatgefühl Zugewanderter bewahren wollten. ${ }^{1612}$ Dass solche Vereine bis 1945 außerhalb Berlins auch in brandenburgischen Städten bestanden, sei nur am Rande bemerkt. ${ }^{1613}$ Auf ihre

1610 Westberlins Patenschaften für Ostdeutschland. In: Landsmannschaft Schlesien Nieder- und Oberschlesien. Rundbrief der Bundesgeschäftsstelle, Nr. 7, 10.4.1956, S. 3.

1611 Siehe: Aus der Geschichte der Vertriebenen in Berlin (wie Anm. 6).

1612 Im Berliner Adreßbuch 1943, T. 3, S. 89, finden sich in der Rubrik „Landsmannschaftliche Vereine " folgende auf die Ostprovinzen sowie einzelne dortige Kreise oder Städte bezogenen Vereine: Bromberger Heimatbund; Bund deutscher Osten, Gauverband Berlin e. V. Landsmannschaft heimattreuer Ostrower e. V.; Bund heimattreuer Ost- und Westpreußen E. V.; Bund heimattreuer Schlesier e. V.; Danziger Bundesgruppe Berlin; Filehner Landsmannschaft; Heimatverein Drossen; Landsmannschaft Czarnikau; Landsmannschaft der Bentschener; Landsmannschaft der Lissaer; Landsmannschaft der Wollsteiner (Rehbrücke bei Potsdam); Landsmannschaft Ostmark e. V.; Memelland-Bundesgruppe im B. D. O. [Bund deutscher Osten]; Pommernbund zur Förderung heimatlicher Kunst und Art (gegr. 1914); Schlesier-RGB[Riesengebirgs]-Zweigverein Rübezahl Berlin; Verein der Driesener zu Berlin; Verein der Heimatfreunde Krs. Greifenhagen i. Pom.; Verein der Landsleute der Grafschaft Glatz zu Berlin; Verein der Neustettiner; Verein der Schweriner a. W.; Verein heimattreuer Schmiegler. - Dies dürften längst nicht alle vor 1945 existierenden Zusammenschlüsse sein, wie etwa das im Archiv der Landesgeschichtlichen Vereingung für die Mark Brandenburg (Best. C 1, unverz.) als Einblattdruck überlieferte, undatierte „Heimatlied des Vereins heimattreuer Soldiner in Berlin“, verfasst von Rudolf Gottschalk, zeigt. - Von einem (offenbar 1887 gegründeten) Klub der in Berlin wohnhaften Friedeberger (Friedeberg/Nm.) heißt es im 1974 erschienenen Heimatbuch des Kreises Friedeberg/ Nm., dass er „bis in die Gegenwart treu zusammengehalten hat“ (Erinnerungen an Stadt + Land Friedeberg Nm. Hrsg. von E(rhard) Schendel u. Hans Schauer. Berlin 1974, S. 350). Insofern mögen manche dieser Zusammenschlüsse auch später noch, jedoch unterhalb öffentlicher Wahrnehmung, bestanden haben. Im Taschenbuch des Berliner Lebens, hrsg. von Walter Habel, Berlin-Grunewald 1957, finden sich in der umfangreichen Liste der „Vereinigungen allgemeiner Art“ (S. 347-373) neben den zahlreichen nach 1945 gegründeten, dem Berliner Landesverband der Vertriebenen e. V. angeschlossenen 14 Landsmannschaften u. ä. nur noch der o. g. Bund heimattreuer Ost-und Westpreußen e. V. (S. 353) sowie der diesem angeschlossene Memellandbund im Bund heimattreuer Ost- und Westpreußen e.V. (S. 364). Zur Anknüpfung an noch bestehende ältere Schlesier-Gruppen in Berlin siehe auch Treziak, Die vertriebenen Schlesier in West-Berlin (wie Anm. 872), S. 497.

1613 In Potsdam existierten 1936 vier solche Vereine: Ortsgruppe Potsdam des Bundes heimattreuer Posener im Bund deutscher Osten (Ortsgruppenleiter: H. Schieferdecker, Lehrer, Margaretenstr. 14); Bundesgruppe Potsdam des Bundes heimattreuer Schlesier (Vereinigte Oberschlesier und Schlesier) (Bundesgruppenleiter: Fritz Dorn, kfm. Angest., Lennéstr. 48); Bundesgruppe „Heimattreue Westpreußen Potsdam“ (Bundesgruppenleiter: Stadtinspektor J. Steingräber, Drevesstr. 45); Ortsgruppe Potsdam-Nowawes des Sudetendeutschen Heimatbun- 
Beteiligung an der Flüchtlingsbetreuung im Berlin der Jahre ab 1945 wird für die Neumark z. B. im Soldiner Heimatbuch ausdrücklich hingewiesen: „Seit 1923 hatten sich die Lippehner, seit 1929 die Soldiner, Berlinchener und die Bernsteiner zusammengeschlossen um die Heimatliebe $z u$ pflegen und in der Großstadt Kraft daraus zu schöpfen. Sie stellten ihre Heimatliebe unter Beweis und halfen den flüchtenden Landsleuten, wo und wie sie nur konnten, obwohl Berlin in Trümmern lag und jeder dort in Not lebte. Genannt werden oft die Landsleute aus dem Kreis Soldin stammend: Emil Höhne, Wolff und Fritz Gottschalk; sie setzten sich bereits 1945 in mühevoller, selbstloser Arbeit ein. / 1947 konnten sie zum ersten Male Zusammenkünfte der Soldiner in Berlin mit Geflüchteten organisieren, wenn es auch noch verboten war. / Die Kirche kam zu Hilfe [...] Die Kirche setzte eine Betreuungsstelle für Flüchtlinge ein. Gustav Frick organisierte ein Treffen am 21. September 1947 im ,Alten Eierhaus! zu Berlin[-]Treptow, bei dem sich viele Kreis-Soldiner um ihren verehrten ehemaligen Superintendenten des Soldiner Kirchenkreises, Max Wallis, scharten. Gottesdienste waren erlaubt, sonst aber keinerlei Zusammenkünfte. ${ }^{\text {1614 }}$ Das Beispiel zeigt, wie schnell die Netzwerke sich entwickelten und trotz aller Schwierigkeiten funktionierten.

SBZ-/DDR-Bürger, die West-Berlin besuchten, fanden dort mithin mannigfache Anknüpfungspünkte. Hauptziel für sie waren aber die von Vertriebenenverbänden organisierten Treffen, von denen viele - von den ganz großen, überregionalen in der „Waldbühne“ einmal abgesehen - im Evangelischen Johannesstift in Spandau, aber die kleineren auch auf eine Vielzahl von Sälen in Gaststätten und anderen Einrichtungen verteilt stattfanden. ${ }^{1615}$ Wie in den Westzonen, aber im Grunde auch in der SBZ, war es die Kirche, in deren Obhut sich die ersten Treffen ermöglichen ließen. Die kirchlichen Vertriebenentreffen entsprachen aber offenkundig auch einem breiten Bedürfnis und stießen jedenfalls in den noch stärker von Not regierten Anfangsjahren auf nachhaltiges Interesse. Für das Beispiel der Vertriebenen aus Landsberg an der Warthe wird dies in einem Bericht von Else Schmaeling sehr deutlich. Nach überschwenglichen Berichten vom Mai und Juni 1948 über Treffen in den Westzonen schreibt sie im 7. Monatsbericht vom Juli 1948 über den am 6. Juni 1948 ab $9 \mathrm{Uhr}^{1616}$ im Spandauer Johannesstift durchgeführten 4. Kirchentag ${ }^{1617}$ :

des e. V. (Ortsgruppenführer: Josef Weiß, Maschinenmeister, Große Fischerstr. 10 I). (Adreßbuch der Städte Potsdam, Nowawes und Werder 1936/37, T. 1, S. 32 f.).

1614 Heimatkreis Soldin/Neumark (wie Anm. 303), S. 649 (Kapitel „Die Heimatkreisgemeinschaft“ ohne Verfasserangabe).

1615 Die sehr zahlreichen Treffen beispielsweise aller neumärkischen bzw. ostbrandenburgischen Heimatkreise in Berlin lassen sich durch die laufenden Ankündigungen bzw. Einladungen und Berichte im Mitteilungsblatt der „Landsmannschaft Ostbrandenburg-Neumark im Berliner Landesverband der Heimatvertriebenen“ anscheinend relativ lückenlos nachvollziehen; siehe: Ostbrandenburg-Neumark (ab 1953, Nr. 19: Unsere Märkische Heimat) 1 (1950) ff. - Vgl. Schwartz, Vertriebene und „Umsiedlerpolitik“ (wie Anm. 13), S. 524.

1616 Lt. der Programmankündigung im 4. Monatsbericht, April 1948, S. 1: „Ab 9 Uhr: Sammlung der Teilnehmer im großen Festsaal/Um 11 Uhr: Gottesdienst in der Stiftskirche/Um 15 Uhr: Bericht der Flüchtlingsbetreuerin Else Schmaeling über die Kirchentage im Westen und Verlesung von Vermißten/17.30 Uhr: Kirchlicher Ausklang in der Stiftskirche / Kaffeeausgabe ab 13 Uhr - Becher mitbringen".

1617 Ehemalige Kirchengemeinden von Landsberg, Warthe, Stadt und Land, 7. Monatsbericht, Juli 1948, S. 2 f. 
„Das Gotteshaus im Johannesstift reichte für die vielen Landsberger aus Stadt und Land, die herbeigeströmt waren, nicht aus, trotzdem auch die Altarstufen und sogar die Kanzeltreppe besetzt und alle Gänge überfüllt waren. So mußte ich schnell noch einen zweiten Gottesdienst im großen Festsaal vorbereiten. Nachdem Herr Superintendent [Gerhard] Rothkegel [geb. 1886 Berlin] (früher Vietz) [1932-1945 Pfarrer in Vietz], jetzt in Vetschau bei Cottbus, Schloßstr. 16, in der Kirche das Grußwort gesprochen hatte, kam er herüber in den großen Festsaal und hielt dort den zweiten Gottesdienst ab, an dem noch viele hundert Landsberger teilnahmen, die in die übervolle Kirche nicht mehr hineinkamen.

Wir sangen in beiden Gottesdiensten die gleichen Kirchenlieder, die wir im Westen gesungen hatten. Eine große Heimatgemeinde, verbunden über Zeit und Raum. Andachtsvoll, tief ergriffen und bewegt beim Gedenken an unsere lieben Toten saßen die Landsberger aus Stadt und Land zu Füßen ihrer Heimatpfarrer. Pfarrer [Joachim] Meuß [Rathenow, geb. 1901 Berlin-Charlottenburg] (früher Gralow [bei Landsberg/W.]) hielt die Schluß-Liturgie. Eva Koch verschönte die Gottesdienste durch ihren Gesang. Auch Pfarrer [Leo] Grunau [geb. 1894 Elbing, 1934-1945 Pfarrer an der Marienkirche Landsberg/W.] und Pfarrer [Johannes] Wandam [Trebatsch, geb. 1874 Zägensdorf bei Arnswalde, ab 1914 Pfarrer in Kernein bei Landsberg/W.] nahmen an unserem Kirchentag teil und überall sah man Gruppen stehen, die ihre Pfarrer sprechen wollten. Drei bis viertausend Landsberger aus dem Stadt-und Landkreis sollen es schätzungsweise gewesen sein, die sich zu diesem Kirchentag am 6. Juni zusammengefunden hatten, um die Heimatpfarrer sprechen zu hören und sich wiederzusehen. Schon früh um acht [S. 3] Uhr waren die Straßenbahnen nach Spandau überfüllt, an jeder Haltestelle sah man bekannte Gesichter. - Wie schön war es doch und - - - den allerschönsten Sonnenschein ließ uns der Herrgott kosten'. - Am Nachmittag habe ich vom "Westen erzählt und alle lieben Grüße unserer Landsleute bestellt. - Superintendent Rothkegel sammelte zum ersten Mal auch seine Vietzer um sich und Pfarrer Meuß war mit seinen Gralowern, Zantochern und Jahnsfeldern im Wichernsaal zusammen. - Wieder und immer wieder finden sich erst auf unseren Kirchentagen Verwandte und Freunde. Wir haben viele Vermißte aufgerufen und auch manchen Hinweis bekommen. Wer war nicht tief erschüttert, als zwei alte Männer sich weinend um den Hals fielen, die nicht mehr geglaubt hatten, sich in diesem Leben noch einmal wiederzusehen. Man kann nicht alles schildern, was man erlebte; solche einen Tag muß man mitgemacht haben, um die große Freude zu fühlen und zu verstehen. Wieviel unsere Kirchentage allen geben, sehen wir an den dankbaren Briefen, die wie immer wieder erhalten.

Pfarrer Meuß hielt die Schlußandacht in der Stiftskirche am späten Nachmittag. Still wurde es dann wieder unter den Bäumen des Johannesstifts. Wir gehen wohl stets mit schwerem Herzen wieder auseinander, jedoch gestärkt durch Gotteswort und getröstet in dem Gedanken, daß wir uns - trotz allem - doch immer wieder zusammenfinden und unlösbar zusammenhalten wollen. [...].“

West-Berlin bildete offenkundig den Dreh- und Angelpunkt für die in der SBZ wohnhaften vertriebenen Landsberger. Es gibt in den Monatsberichten direkte und indirekte Belege dafür, dass die "Landsberger Kirchentage“ in Spandau von vielen in der SBZ Lebenden besucht worden sind (und dass die Monatsberichte gelesen worden sind). So wird aus einem Brief der 
Apothekerassistentin Eveline Bundschuh (Halle/Saale) zitiert: „[... In Berlin hat es mir großartig auf dem Kirchentag gefallen. Ich hatte sogar noch das Glück, in die Kirche hineinzukommen [...]. ${ }^{“ 618}$ Dann wird ihr noch der Wunsch erfüllt, ihre Verlobung mit Stud. rer. pol. Werner Krüger-Dümchen (Forst/Lausitz) bekanntzugeben, und auch die Anschriften ihrer in Bayern lebenden Schwestern werden mitgeteilt. Das starke Bemühen, diesen zonenübergreifenden $\mathrm{Zu}$ sammenhalt zu leben und zu dokumentieren, spiegelt sich in den Monatsberichten deutlich. Wieweit es für die Vertriebenenkreise als repräsentativ angesehen kann, ist freilich unsicher. Ein Kreis, der die bevölkerungsreichste neumärkische Stadt einschloss, hatte zweifellos auch in der Vertriebenen-Diaspora mehr Potential als manche andere, überwiegend ländlich geprägte Region. Die zitierte Eveline Bundschuh meldete sich wenig später nochmals zu Wort, nun aus Büschdorf bei Halle: „Ich komme beruflich viel mit Flüchtlingen anderer Städte, Länder und Provinzen zusammen. Bisher ist mir aber noch niemand begegnet, der sich rühmen könnte, eine solche Gemeinde, wie wir Landsberger aufzuweisen [...]".1619

Die Abteilung Polizei des MdI der Landesregierung Brandenburg teilte der Deutschen Verwaltung des Innern in der SBZ unter dem Betreff „Umsiedler-Organisation“ unter dem 27. April 1949 mit: „Durch Rückfrage bei den [brandenburgischen] Kreispolizeiämtern auf dem Gebiete der Umsiedler ist von fast allen Kreisen, Fehlanzeige' gemeldet worden, was jedoch nicht ganz den Tatsachen entspricht. / Durch persönliche Beobachtung ist festgestellt worden, dass unter den Decknamen von ,Heimattreffen'Veranstaltungen im Westen Berlins durchgeführt werden. / Das Kreispolizeiamt Bernau meldet dazu konkrete Fälle, in denen an Umsiedler die Aufforderung ergangen ist, an Veranstaltungen in Berlin am Bahnhof Zoo sowie in Berlin-Spandau, teilzunehmen. Es ist festgestellt worden, dass ein kleiner Teil der Umsiedler an den Veranstaltungen teilnimmt, der grössere Teil verhält sich passiv. / Mittelsmänner oder Gewährsleute konnten bisher nicht festgestellt werden. / Es ist den Kreispolizeichefs aufgetragen, diesem Bezug grösste Aufmerksamkeit zu widmen und allmonatlich Meldung zu erstatten. "1620 Auch sonst weist die Landespolizeibehörde Brandenburg (Sitz Potsdam) 1949 und 1950 immer wieder auf die Existenz sowie geplante oder durchgeführte Treffen von „Umsiedlerorganisationen“ in Berlin hin. ${ }^{1621}$ So wird mit Schreiben vom 10. August 1950 unter dem Betreff „Umsiedlerorganisation (Angerburger)“ ein - sogar in Ost-Berlin - für

1618 Ebd., S. 4.

1619 Ebd.

1620 BArch, DO 1/27886, Bl. 10.

1621 BArch, DO 1/27886, B1. 76. - Aber auch der Umsiedlerverwaltung der brandenburgischen Landesregierung entging die rege Teilnahme brandenburgischer „Umsiedler“ an „Treffen im Johannis-Stift in Spandau“, nicht. Beobachtungen in Werder bei Strausberg zufolge stammten sie 1948 „zum grosen Teil aus der Landsberger und Schweriner Gegend“. Besonders die Frauen würden teilnehmen, unter ihnen „selbst die Frau des Ortsgruppenvorsitzenden der SED und Neusiedlers Topp “. Den Kopf der Verbindungen sah man allerdings in dem Vorsitzenden der CDU-Ortsgruppe Werder, der selbst „Umsiedler und Neubauer“ war (BLHA, Rep. 333, Nr. 574, Bl. 371; vgl. den vollständigen Text des Berichts vom 13.12.1948 im Quellenteil, Nr. 84). Demnach handelte es sich keinewegs immer nur um einen kleinen „Teil der Umsiedler“. 
den 28. Mai 1950 geplantes „Heimattreffen in Berlin, Friedrichstadtpalast (Demokr[atischer] Sektor)“ gemeldet. „Der Leiter dieses Treffens ist der Pfarrer aus dem Kreis Angerburg." 1622

Beispiele aus dem Süden des ostbrandenburgischen Vertreibungsgebietes mögen das Geschilderte auf eine noch etwas breitere Basis stellen. So hatten sich an der Weihnachtsfeier der „Sorauer Heimatfreunde zu Berlin“ im Jahr 1952 „unter dem brennenden Christbaum fast 400 Landsleute aus Berlin und der sowjetischen Besatzungszone zu einer schönen Feierstunde vereint " ${ }^{1623}$ Während die persönliche Besuchsmöglichkeit zwischen Westdeutschland und der DDR kaum noch möglich war ${ }^{1624}$, bot West-Berlin weiterhin ein offenkundig von vielen genutztes Feld der Begegnung. So wird auch 1953 in einer Vertriebenenzeitschrift berichtet: Zum „traditionellen Pfingstschießen der ,Sorauer Heimatfreunde zu Berlin'trafen sich am Pfingstsonntag im Spandauer Schützenhaus rund 200 Sorauer Heimatfreunde“. Der Vorsitzende, Karl Karge, dankte in seiner Begrüßungsansprache all denen, „die weder Mühe noch Kosten gescheut haben, den weiten Weg nach Berlin zu unternehmen [...] Trotz aller Schikane der sowjetzonalen Behörden waren sie von weit her gekommen, jung und alt." 1625 Im Heimatblatt wurde unter den drei besten Schützen sogar der (Familien-)Name eines „aus der Sowjetzone“ Stammenden, wenn auch ohne genauere Wohnortangabe, genannt. Zugleich wurden unter der Überschrift „Wir sehen uns wieder!“ die nächsten Trefftermine angekündigt, darunter ein „Sommertreffen“ am 16. August mit „Vogelschießen und Tanz im Schützenhaus Spandau“: „Eintritt 1,20 DM. Für Landsleute aus der Ostzone und dem Ostsektor 1,20 Mark Ost. ${ }^{\text {1626 }} 150$ der 350 Teilnehmer des Sommertreffens kamen nach Angaben des Veranstalters wiederum aus der DDR, „um in der großen Heimatfamilie wieder einmal ein paar recht frohe Stunden zu verleben" ${ }^{1627}$

Auch die Sternberger handhabten es nicht anders. Am 11. September 1955 ab 11 Uhr wurde in Hamburg ein „Heimatkreistreffen der Kreise Ost- und West-Sternberg“ durchgeführt. Ab 15.30 Uhr trafen sich in einem anderen Lokal in Hamburg die „Heimatvertriebenen aus Frankfurt

$1622 \mathrm{Ob}$ das Treffen, wie zu vermuten, tatsächlich stattgefunden hat, konnte in der Akte nicht ermittelt werden. Am 22. August 1950 meldet dieselbe Behörde unter dem Betreff „Kreisgemeinschaft Angerburg“ auch Aktivitäten derselben in Neuruppin, wo Familien überwacht wurden und der Heimatbrief und andere Druckerzeugnisse der Kreisgemeinschaft durch das VPKA Ruppin beschlagnahmt worden waren, die in der Anlage übersandt werden.

1623 Das Heimatblatt für Sorau N./L.-Stadt und Land 2 (1953), Nr. 1, S. 2.

1624 Trotz Telegramm keine Einreiseerlaubnis. Auch Todesfall kein „triftiger Grund“. In: Das Heimatblatt für Sorau N./L.-Stadt und Land 2 (1953), Nr. 3, S. 14.

1625 [Bericht:] Pfingstschießen in Spandau. In: Das Heimatblatt für Sorau N./L.-Stadt und Land 2 (1953), Nr. 4, S. 10 .

1626 Das Heimatblatt für Sorau N./L.-Stadt und Land 2 (1953), Nr. 4, S. 10. - Gemeint ist vermutlich der 1911-12 erbaute, im Krieg unzerstört gebliebene "Schützenhof" in Spandau-Hakenfelde (Niederneuendorfer Allee 12), denn das große ältere „Schützenhaus“ (Neuendorfer Str.) von 1877 war im Krieg zerstört worden (650 Jahre Schützengilde zu Spandau (Korp. 1334). Ausstellungskatalog. Berlin 1985, S. 10, 12).

1627 [Bericht:] Königsschießen Berlin-Spandau. In: Das Heimatblatt für Sorau N./L.-Stadt und Land 2 (1953), Nr. 7, S. 8. 
(Oder)““ ${ }^{1628}$ Am selben Tag hatte der (West-)Berliner Ortsbetreuer für die aus „Stadt Sternberg und Umgegend (Neumark)" Stammenden, Franz Witzke, um 15 Uhr zu einem Treffen in Berlin eingeladen. ${ }^{1629}$ Dieser Einladung nach Berlin "waren wieder viele Landsleute aus Ost und West gefolgt, so daß das Treffen sehr gut besucht war [...]. Um 15 Uhr begrüßte der Ortsbetreuer, Landsmann Franz Witzke, die erschienenen Landsleute, die, wie schon erwähnt, nicht allein aus Ost- und West-Berlin, sondern zum Teil auch aus der Mittelzone und Westdeutschland gekommen waren. Er hob hervor, daß die Landsleute keine Unkosten und Mühen gescheut haben, um an dem Treffen teilzunehmen, weil ja der Zweck des Treffens sei, mit den Landsleuten das Andenken an die Heimat zu pflegen und einen Zusammenhalt der Landsleute herbeizuführen. Viele der erschienenen Landsleute nahmen zum ersten Male an einem Treffen teil, die nach 1945 stattgefunden haben, und waren erstaunt über die große Zahl der von ihnen angetroffenen Landsleute. So kam es, daß zwischen den zum ersten Male Erschienenen herzliche Umarmungen erfolgten und auch viele Tränen aus Freude über das Wiedersehen flossen. So wurde das Treffen wieder ein wirklich gemütliches Beisammensein. Nach dem gemeinsamen Gesang, Heimat deine Sterne' spielte die den Landsleuten bekannte und beliebte Kapelle Fritz Daubitz aus Sternberg zum Tanz, und es gab auch mehrere Soloeinlagen des Kapellmeisters. Der Landsmann R. T. brachte ein von ihm selbst verfaßtes Heimatgedicht zum Vortrag, das viel Anerkennung und großen Beifall fand“. Der Dichter dürfte aus der DDR angereist gewesen sein, denn ansonsten war es in den Berichten damals, lange vor dem Datenschutzzeitalter, gänzlich unüblich, Personen nur mit Initialen zu bezeichnen. Auch sonst war man in diesem Fall aber vorsichtig: $\mathrm{Zu}$ dem Treffen war im vorhinein keine Einladung im Heimatblatt abgedruckt worden. Der Berichterstatter weist im nachhinein ausdrücklich darauf hin, der Ortsbetreuer sei bereit, Postkarten mit Gruppenbild des Treffens „den interessierten Landsleuten in Westdeutschland zuzusenden“. Die in Berlin Wohnenden erreichte man wohl auch über persönliche Kontakte, die in der DDR aber blieben damit doch ausdrücklich unerwähnt.

Bis zum Mauerbau bildeten die verschiedenen Heimattreffen, die in West-Berlin im kleineren oder größeren Rahmen, teils jährlich, teils deutlich öfter, stattfanden, mithin nachweislich Bezugspunkte auch für viele der über das gesamte Gebiet der SBZ/DDR verteilten Vertriebenen. Das lässt sich aus einer Vielzahl solcher Einzelberichte ablesen, sowohl solchen der Veranstalter als auch solchen von SED- und VP-Informanten. ${ }^{1630}$ Die West-Berliner Vertriebenen-Treffen der Jahre 1945 bis 1961 bilden also einen Teilaspekt des Umgangs der Betroffenen mit dem eigenen Schicksal. Auch wenn sie keine „Vollversammlungen“ einer Gruppe darstellten, können sie als ein Ventil verstanden werden, das den in Brandenburg und der SBZ/DDR Lebenden eine Möglichkeit eröffnete, ihre Identität für die Dauer eines knappen Tages nicht zu verleugnen. Vielleicht ist es neben der Tatsache, dass die Mehrheit der Teilnehmer Rentner

1628 Einladung mit Programm in: Frankfurt (Oder)-Sternberger Kurier 4 (1955), Nr. 9, S. 16.

1629 - fre -: Heimattreffen Stadt Sternberg und Umgegend (Neumark). In: Heimatblatt für deutsche Volksgemeinschaft. Frankfurt (Oder)-Sternberger Kurier 4 (1955), Nr. 12, S. 13.

1630 Siehe Quellenteil 4.2 (S. 1338-1355). Weitere Quellen dürften Berichte von Informanten des MfS sein, die für vertiefende und weiterführende Recherchen bei der BStU zu suchen wären. 
waren, diese Ventil-Wirkung gewesen, die die SED die Treffen zwar argwöhnisch beobachten und auch heftig kritisieren und die Teilnahme häufig, aber zunächst noch nicht konsequent verhindern ließ. ${ }^{1631}$ Aus einem Schreiben des Ministeriums für Staatssicherheit vom 9. Juni 1951 bezüglich eines „Treffen(s) sämtlicher Landsmannschaften der Umsiedler“ am 5. August 1951 in der West-Berliner „Waldbühne“ geht hervor, dass man in der frühen Zeit noch vornehmlich darauf setzte, Spitzel (GM/Geheime Mitarbeiter, später IM/Inoffizielle Mitarbeiter genannt) zu entsenden, „um zu erfahren inwieweit sich die Landsmannschaften gegen die DDR u. Volksdemokratien feindlich stellen. / Über die Entsendung von GMs aus Umsiedlerkreisen zu dem Treffen in der Waldbühne ist uns zu berichten." 1632 Auch 1960 setzte man in der Vorbereitung auf den für den 4. September in der „Waldbühne“ geplanten „Tag der Heimat“ weiterhin auf die Entsendung von IM, plante nun aber auch minutiös, weitere „IM so einzusetzen, daß sie Personen, welche die Absicht haben am Treffen teilzunehmen, aufklären und selbst mit dazu beitragen, diese Personen von der Teilnahme an diesem Treffen in Westberlin abzuhalten. "1633 Doch dieses indirekte Vorgehen war nur ein Teil des Ganzen, heißt es doch im selben Schreiben des MfS vom 12. August 1960 zugleich: „Die Hauptabteilung I sowie die Abteilungen VII und XIII des MfS haben in Absprachen mit der Deutschen Grenzpolizei, Deutschen Volkspolizei, TRAPO ${ }^{1634}$ und AZKW ${ }^{1635}$ festzulegen, daß in der Zeit vom 3. bis 5.9.1960 verstärkte Zugkontrollen durchzuführen sind. Solche Personen, die beabsichtigen, am Treffen teilzunehmen, sind in ihre Heimatorte zurückzuschicken, namentlich zu erfassen und der entsprechenden Bezirksverwaltung mitzuteilen. Die Bezirksverwaltungen haben in Verbindung mit der VP diese Personen zu überprüfen. Nach dem Aufklärungsergebnis ist zu entscheiden, ob operative Bearbeitung oder entsprechende Aussprachen in Absprache mit der Partei durchzuführen sind./Diese Maßnahmen sind so durchzuführen, daß keine Unruhe unter der Bevölkerung entsteht. " ${ }^{1636}$ Gerade letzteres dürfte in der Zeit bis zum Mauerbau, in der ohnehin viele Vertriebene zu „Republikflüchtlingen“ wurden, ein nicht unwesentlicher Gesichtspunkt gewesen sein, wusste man doch, wie groß die Zahl der „Umsiedler“ in der DDR war.

Zumindest in der frühen Zeit scheint es zudem aber für VP und MfS auch noch schwierig gewesen zu sein, rechtzeitig über alle geplanten Treffen informiert zu sein. Die Landespolizeibehörde Brandenburg konnte dem MdI in Berlin sogar erst rückwirkend unter dem 27.

1631 Hinweise auf zu den betreffenden Terminen gezielt und verstärkt durchgeführte Personalausweis- und Grenzkontrollen sowie Be- und Verhinderung von größeren Personen-Transportmöglichkeiten u. a. lassen sich im Schriftwechsel der Polizeibehörden mehrfach nachweisen, regelrechte Grenzsperrungen hat es aber nicht gegeben. Vgl. BArch, DO 1/28887, Bl. 84-87 (Landsberger Treffen in West-Berlin 28.12.1952), Bl. 88 (Treffen im Hallenser Zoo am 12.10.1952).

1632 Lau, Ostbrandenburg nach 1945 (wie Anm. 826), S, 157: Schreiben der MfS-Abt. V vom 9.6.1951 an die Verwaltung Groß-Berlin des MfS.

1633 Ebd., S. 158 (Schreiben des MfS/Stellvertreter des Ministers vom 12.8.1960 an den Leiter der Verwaltung Groß-Berlin).

1634 [Transportpolizei].

1635 [Amt für Zoll und Kontrolle des Warenverkehrs].

1636 Ebd., S. 159 (desgleichen). 
November 1950 über ein für den 12. November in Ost-Berlin (!) (Oberschöneweide) angekündigtes kirchliches „Umsiedlertreffen“ berichten, von dem man durch - im Kreis Westhavelland aufgetauchte - Einladungen erst nach einer dortigen Meldung vom 16. November erfahren hatte: „Das VPKA Westhavelland bekam erst 2 Tage danach Kenntnis[,] sodaß von dort respektive der LBdVP keine weiteren Maßnahmen entwickelt werden konnten. "1637 Auch aus dem Jahr 1952 finden sich Belege dafür, dass Informationen mühsam gesammelt werden mussten und dass trotz allem keineswegs nur einzelne DDR-Bürger zu Heimattreffen nach West-Berlin fuhren. So berichtete ein VP-Meister, er habe am 21. April 1952 „im Triebwagen der Kleinbahn Fürstenwalde-Seelow“ folgende Feststellung gemacht: „Im Wagen war zwischen einigen Fahrgästen ein Gespräch im Gange[,] aus welchem hervorging, dass sie am Sonnabend, den 19.4.1952 und Sonntag, den 20.4.1952 an einem Treffen ehemaliger Umsiedler teilgenommen hatten. Dieses Treffen fand in Berlin-Zehlendorf (amerikanischer Sektor) statt. [...] Als sie bemerkten, dass ein VP.-Angehöriger im Wagen sass, brachen sie das Gepräch ab. / Bei den Leuten handelt es sich um umgefähr 10 Personen, die teils in Dolgelin und teils in Arensdorf wohnhaft sind. ${ }^{1638}$ An dem Treffen sollen insgesamt 300 Personen teilgenommen haben." 1639

Der Mauerbau 1961 beendete diese direkten Begegnungen in West-Berlin nicht vollständig. Vertriebene, die das Rentenalter erreicht hatten, konnten ab 1964 unter bestimmten Bedingungen wieder teilnehmen. Im Jahresbericht des „Arbeitskreises Bärwalde Nm.“ für 1975, also bereits weit nach dem Mauerbau, heißt es beispielsweise: „Am 11. Mai 75 hatten wir unser Jahrestreffen in Berlin-Lankwitz ${ }^{1640}$. Noch nie zuvor war der Besuch aus der Zone so gross. Es war wirklich eine runde Sache, wie jemand feststellte. [...] Am 31. Mai konnten wir zu Hause bei Bechlys unseren Bärwalder Bus aus Ost-Berlin begrüssen. Viele Bärwalder waren per Pkw aus Sachsen, Brandenburg, Mecklenburg und Ost-Berlin angereist. [...] Regelmässig traf sich unser Bärwalder Kaffeekränzchen drüben. Sie sind uns in vielen Dingen eine grosse Hilfe. Unser Gruss verbindet sich mit Grüssen an alle Bärwalder drüben im anderen Teil unseres Vaterlandes. [...]." ${ }^{1641}$ Auch in der Programmvorschau für 1976 ist wiederum das traditionelle Treffen in Berlin-Lankwitz (23. Mai) erwähnt: „Beson-

1637 BArch DO 1/27886, Bl. 159. Vgl. den vollständigen Abdruck im Quellenteil, Nr. 231. - LBdVP = Landesbehörde der VP.

1638 Kreis Lebus.

1639 BArch DO 1/27887, Bl. 75 (vgl. den vollständigen Abdruck im Quellenteil, Nr. 236).

1640 Bis 1984 fanden die Bärwalder Jahrestreffen in „Pichler's Viktoriagarten“ in Berlin-Lankwitz, Leonorenstraße 18-20 Ecke Siemensstraße, statt, 1985 wechselte man aus Kostengründen in das Restaurant „Elefant“ in Berlin-Steglitz, Steglitzer Damm 29, 1987 in das Deutschlandhaus in Berlin-Kreuzberg, Stresemannstr. 90 (hier noch 1989). „Pichler's Viktoriagarten“ war ein beliebter, 1884 gegründeter Hotelbetrieb, den auch andere Heimatkreisgemeinschaften, z.B. die für Bad Schönfließ/Neumark, gern und oft als Veranstaltungsort nutzten (1994 geschlossen und abgerissen, Grundstück 1995 mit Wohnblock neu bebaut); Abbildung der Außenansicht in: Jahresbericht Arbeitskreis Bärwalde Nm. 1972, S. 8. - Zur Bildung einer hier tagenden Ortsgruppe der Schönfließer 1947/49 siehe Erinnerungsschrift an die Stadt Bad Schönfließ/Nm aus Anlaß ihres 675jährigen Bestehens 23. Juni 1956. Zsgest. von Benno Riech. Überreicht von Paul Lehmann. (Berlin) 1956, S. 11.

1641 Arbeitskreises Bärwalde Nm. Kreis Königsberg Nm. Jahresbericht 9 (1975), S. 2. 
ders freuen wir uns über den angekündigten Besuch unserer Landsleute aus der Zone."1642 Daneben organisierten die Bärwalder auch Klassentreffen und zwar sogar in Ost-Berlin am Vortag der allgemeinen Lankwitzer Zusammenkunft: „Treffen im Mai 1976 in Berlin. Am 22.5. hatten wir ein Klassen- bzw. Jahrgangstreffen in Ost-Berlin. Es war Klasse. Dank an unseren Jahrgangsbetreuer Gerhard Malten, Dank an die Helfer von drüben. Unser Treffen am 23.5. in Berlin-Lankwitz war gut besucht. Besuch aus dem Westen und zahlreiche Teilnehmer von drüben."

Diese Treffen nach dem Mauerbau setzten sich bis 1989/90 fort, wenn auch nun nur noch mit reiseberechtigten Rentnern. Ein Boom, der den Nachholbedarf zeigt, folgte nach 1990, denn nicht jeder hatte die Teilnahme zuvor gewagt oder in die Tat umsetzen können.

Den Grad der Politisierung der vielen mittleren und kleineren Heimattreffen einzelner Kreise oder Gemeinden wird man - über stereotype Begrüßungsansprachen hinaus - nicht überschätzen dürfen. Für die meisten Teilnehmer stand - vielen Zeitzeugenaussagen zufolge die Begegnung mit bzw. die Suche nach aus der Jugend vertrauten Menschen im Vordergrund: „Die Treffen waren eine Mischung von Kundgebung und Familientreffen. Der Einsatz von Blaskapellen, Chören und Trachtengruppen kam den emotionalen Bedürfnissen der Teilnehmer entgegen. Das zeigte sich auch in einer beeindruckenden Zahl von Landsleuten, die zu solchen Begegnungen erschienen. "1643 Der Rückblick in die erlebte Vergangenheit stand für den Durchschnitt der Besucher im Vordergrund gegenüber der Situation oder gar den (Gruppen-)Rechten in der eigenen Gegenwart und Zukunft: „Bei den landsmannschaftlichen Treffen tauschten die Teilnehmer Informationen über die Heimat, über gemeinsame Bekannte aus und reichten Bilder aus vergangenen Zeiten herum. "1644 Diese Einschätzung eines nachgeborenen Autors wird sogar durch zeitgenössische VP-Informantenberichte bestätigt, die zwar bezüglich der Inhalte von offiziellen Grußworten, Ansprachen und schriftlichen Verlautbarungen stets die „Hetze gegen die Oder-Neiße-Grenze" vorfanden ${ }^{1645}$, bei der Masse der Teilnehmer aber - beinahe überrascht - eine zumeist ganz unpolitische Haltung beschreiben. So heißt es in einem Bericht der brandenburgischen VP über ein am 29. Oktober 1950 in der Hasenheide im West-Berliner Bezirk Kreuzberg durchgeführtes Crossener Treffen, das ca. 450 Personen besuchten: „Es handelte sich meistens um Menschen, die bäuerlicher Arbeit nachgehen und zu ca. $90 \%$ [!] in der DDR

1642 Ebd., S. 3.

1643 Peter Senftleben: „Steige hoch, du roter Adler ..." Ein Versuch der Annäherung an die Landsmannschaft Berlin-Mark Brandenburg. In: Der Speicher 17 (2015), S. 141-145, hier S. 143.

1644 Ebd., S. 144. - Ähnlich die Erinnerung einer in Erkner ansäässig gewordenen Küstrinerin (geb. 1932): „Immer wieder kamen wehmütige Gedanken an die alte Heimat hoch. Küstiner-Treffen in Berlin-Lichterfelde, wo jedes Mal viele ehemalige Freunde, Bekannte und Schulkameradinnen zusammenkamen und Erinnerungen austauschten, halfen nach und nach den Trennungsschmerz zu vergessen. Es wurde viel von vergangenen Zeiten geredet. Fragen wiederholten sich: ,Wie geht's euch jetzt, wo seid ihr untergekommen?' Adressen wurden notiert und in den ersten Nachkriegsjahren viel miteinander korrespondiert. Aber nach und nach stellte sich das Vergessen ein. Man lebte sich in die neue Heimat ein und hatte den Alltag zu bewältigen." (Annelise Zippan: „Das Hochhaus am Kohlenweg“. Erinnerungen einer Küstriner Familie. In: Gespräche mit ehemaligen Küstrinern. Aufgez. u. bearb. von Siegfried Neubauer. Bd. 2. Petershausen 2004, S. 223-235, hier S. 235).

1645 BArch, DO 1/27886, Bl. 91 (1950). - BArch, DO 1/27887, Bl. 37 (1951). 
wohnen. Ca. $60 \%$ der Teilnehmer waren Frauen. Die überwiegende Anzahl waren über 40 Jahre alt, nur sehr wenige Jugendliche waren vertreten. / Der Leiter der Veranstaltung behandelte vor allen Dingen die Aufwertung der Uraltkonten. Es war auffällig, daß politische Dinge überhaupt nicht erwähnt wurden. [...] Die Besucher benutzten die Gelegenheit des Wiedersehens, um ihre persönlichen Erlebnisse auszutauschen und beachteten die Worte des Referenten fast gar nicht." ${ }^{1646}$

Noch gar nicht untersucht ist die Bedeutung der Rundfunksender im West-Berlin für Vertriebene in der SBZ/DDR. Dass sie eine ähnliche Rolle gespielt haben dürften wie Publikationen und Treffen, gerade die Information über letztere aber oft erst ermöglicht haben werden, dürfte außer Frage stehen. In den zahlreichen vom Verfasser durchgesehenen Selbstzeugnissen Vertriebener werden sie jedoch nicht erwähnt. Dass die Sender aber für Flüchtlinge und Vertriebene durchaus Angebote bereit hielten, mag ein Beispiel von 1956 verdeutlichen. Der Sender Freies Berlin (SFB) hatte am 7. Februar u. a. im Programm „Aus der alten Heimat. Volkslieder“, am 18. Februar um 15.30 Uhr „Alte und neue Heimat. Sendung für Heimatvertriebene und Flüchtlinge“. 1647

\section{Teilnahme an Heimattreffen in Westdeutschland}

Dass es zumindest bis zum Mauerbau auch für in der DDR lebende Vertriebene keineswegs ungewöhnlich war, Westreisen zu Verwandten zu unternehmen, ist allein schon an den zahllosen Berichten, aber auch Informationen, Hinweisen und Ratschlägen zu erkennen, die in der vielfältigen Vertriebenenpresse abgedruckt sind. ${ }^{1648}$ So berichtet die Landsmannschaft Schlesien in ihrem Rundbrief in den fünfziger Jahren wiederholt über konkrete Möglichkeiten der finanziellen Unterstützung, „Reisekostenvergütung für Besucher aus der sowjetischen Besatzungszo$n e^{\text {“ durch „das Sozialamt des Besuchtortes" }}$ "1649 oder „Fahrpreisermäßigung beim Oster-Interzonenverkehr“, die „bei geschlossener Lösung von Hin- und Rückfahrscheinen“ 25 Prozent ausmache ${ }^{1650}$. Zum Jahresende 1956 schließlich teilte man unter der Überschrift „Erleicherungen für ,Zonen'Besucher" mit, dass die Bundesregierung "für Reisende aus der Sowjetzone, die in der Bundesrepublik Verwandtenbesuche usw. abstatten, einige Hilfsmaßnahmen beschlossen " habe. So erhalte jeder „Besucher aus der Sowjetzone [...] aus einem Sonderfonds zehn DM für erste notwendige Ausgaben" und übernehme die Aufenthaltsgemeinde „im Falle der Erkrankung die Kosten der Medikamente und des Krankenhausaufenthaltes". ${ }^{1651}$ Zusammen genommen mit den Fahrkostenerstattungen, zunächst immerhin für die Strecke westlich der Grenze, konnten die Maßnahmen sicherlich zumindest finanzielle Unwägbarkeiten aus dem Weg räumen. Eine außergewöhnliche Form der

1646 BArch DO 1/27886, Bl. 140 (vgl. den vollständigen Abdruck im Quellenteil, Nr. 229).

1647 Landsmannschaft Schlesien Nieder- und Oberschlesien. Rundbrief der Bundesgeschäftsstelle, Nr. 2, 25.1.1956, S. 6.

1648 Schwartz, Vertriebene und „Umsiedlerpolitik“ (wie Anm. 13), S. 523 f.

1649 Ebd., Nr. 3, 10.2.1956, S. 4.

1650 Ebd., Nr. 6, 25.3.1956, S. 6.

1651 Ebd., Nr. 23, 10.12.1956, S. 3. 
Unterstützung seiner „Landsleute aus Mitteldeutschland“ schuf der in Niedersachsen ansässige Verein „Deutsch Kroner Heimathaus e. V.“, der 1974/75 in Bad Essen (Patenstadt von Deutsch Krone) und 1976/78 in Bad Rothenfelde mit Spendengeldern eigene Tagungszentren mit Appartements als Neubauten errichtete. Einen Teil der Appartements, fünf in Bad Essen und drei in Bad Rothenfelde, behielt der Verein für sich: „Damit haben wir die Möglichkeit geschaffen, diese Räume verbilligt bzw. unentgeltlich (Landsleute aus Mitteldeutschland, Deutsch Krone) zur Verfügung zu stellen." 1652

Umgekehrt wird in solchen Organen vor bestimmten Maßnahmen der DDR-Regierung gewarnt, beispielsweise 1956: „Selbst mit Telegrammen, so heißt es, versuchten die sowjetzonalen Behörden zur Zeit, Flüchtlinge wieder in sowjetzonales Gebiet zu locken und dort festzunehmen. Man scheue dabei nicht davor zurück, den Flüchtlingen Todes- oder Krankheitsfälle Angehöriger vorzugaukeln“. ${ }^{1653}$ Das führt zwar in die gesamtdeutsche Thematik der „Republikflucht“ allgemein, doch verließen bekanntlich „überproportional viele Vertriebene die sowjetische Besatzungszone und später die DDR"1654 und sah sich die Landsmannschaft Schlesien daher nicht ohne Grund zu einer solchen Mitteilung an ihren Adressatenkreis veranlasst. Wie aufmerksam die DDR-Behörden auch außerhalb ihres „Zuständigkeitsgebietes“ veranstaltete Heimattreffen im Blick behielten, zeigt beispielsweise ein Fernschreiben der Hauptverwaltung Deutsche Volkspolizei (VP), Hauptabteilung Paß- und Meldewesen, Berlin, vom 26. Juni 1953 an alle Bezirksverwaltungen der Deutschen Volkspolizei (BDVP) und das Präsidium der VP Berlin betreffend ein geplantes Heimattreffen im württembergischen Böblingen: „Wie bekannt wird, findet am 4. und 5.7.1953 in Boeblingen (Westdeutschland) ein sogenanntes Heimattreffen der Heimatvertriebenen statt. / Es besteht der Verdacht, daß Bürger der DDR zu diesem Zwecke Interzonenpässe nach Westdeutschand beantragen. / Die BDVP werden angewiesen:/1. nach Boeblingen und Umgebung keine I-Pässe auszustellen, /2. Personen[,] die aus diesem Grunde I-Pässe beantragen[,] umgehend der Hauptverwaltung PM zu melden. "1655

Studiert man die zahllosen Ankündigungen und Berichte zu Heimattreffen in den Zeitschriften und Zeitungen der Vertriebenengemeinschaften, so wird aber deutlich, dass die in Westdeutschland durchgeführten Zusammenkünfte, wenn auch in begrenzter Zahl, von DDRBürgern trotz aller Hindernisse durchaus besucht wurden. Das wird in den Berichten der Veranstalter immer wieder hervorgehoben, auch wenn diese Treffen in erster Linie auf die im Westen Deutschlands wohnenden Vertriebenen zugeschnitten waren, während man die (West-)Berliner Treffen ausdrücklich auch als Ziel und Sammelpunkte für die in der SBZ/DDR lebenden

1652 Deutsch Kroner Heimatkreis 1949-1980. In: Deutsch Krone. Stadt und Kreis. Hrsg. von Karl Ruprecht im Auftr. des Vereins Deutsch Kroner Heimathaus e. V. Bad Essen 1981, S. 341-348, hier S. 346. Gemeint sind 14-Tage-Aufenthalte (ebd., S. 348).

1653 Ebd., Nr. 5, 10.3.1956, S. 6.

1654 Stiftung Flucht, Vertreibung, Versöhnung (wie Anm. 16), S. 43.

1655 BArch, DO 1/27887, Bl. 107. 
verstand: „Mit unserem Flug von Berlin nach dem Westen (anders konnten wir uns gar nicht nach Braunschweig wagen) $[\ldots] .{ }^{\text {1656 }}$

Belege für die Teilnahme von DDR-Bürgern an Vertriebenentreffen in der Bundesrepublik lassen sich - vor und auch noch nach dem Mauerbau - überall finden. Im Folgenden soll dies an Beispielen neumärkischer bzw. ostbrandenburgischer Treffen aufgezeigt werden. Dass es aber durchaus kein nur „inner-märkisches“ Phänomen und ebenso anzutreffen sein dürfte, würde man die Berichte auch nicht-neumärkischer Landsmannschaften und Heimatkreisgemeinschaften systematisch daraufhin durchsehen ${ }^{1657}$, mag vorab ein schlesisches Beispiel pars pro toto andeuten. Schon ab 1947 trafen sich Vertriebene aus Stadt und Kreis Neisse (Oberschlesien) jährlich in den Westzonen, anfangs vor allem in Bayern (Schwabach), später regelmäßig in Niedersachsen (Hildesheim). Daneben entwickelten sich wie bei allen anderen Herkunftsregionen regelmäßige Treffen in kleinerem Rahmen für Vertriebene aus einzelnen Gemeinden. Zumindest zu den großen (Bundes-)Treffen des in Hildesheim ansässigen „Neisser Kultur- und Heimatbundes e. V.“ „,fanden sich“ - gemeint sind offenbar die Jahre von 1948 bis 1961 - „immer wieder Besucher aus der Sowjetzone bzw. der DDR ein, die aber möglichst im Hintergreund bleiben wollten; sie hätten, wären sie ordentliche Mitglieder geworden, wahrscheinlich im anderen Teil Deutschlands mit Strafmaßnahmen rechnen müssen“.1658

Auf dem von „an die 600“ Teilnehmern besuchten „Frühjahrstreffen des Sternberger Landes“ im Gewerkschaftshaus in Frankfurt am Main am 6. Mai 1962 begrüßte der Heimatkreisbetreuer Ost-Sternberg, Georg Krause, nach den namentlich genannten Ehrengästen en bloc gesondert auch „unsere Landsleute aus Berlin und, falls anwesend, ich weiß es nicht, aus der Zone“ ${ }^{1659}$ Anschließend begrüßte der Bundessprecher der Landsmannschaft Berlin-Mark Brandenburg, Dr. Heinz Kiekebusch (1908-1971) (Kiel), „in seiner ruhigen und zuversichtlichen Art“ und betonte ebenfalls besonders den Zusammenhalt mit den in der DDR Lebenden, man den-

1656 Aus einem Aufruf des Berliner Ortsbetreuers der Heimatvertriebenen aus Drossen in der Landsmannschaft Ostbrandenburg-Neumark e.V., Heinrich Prenzel, am Schluss eines Berichts über das „Heimattreffen des Kreises West-Sternberg in Braunschweig" (am 5. Juli 1953), in: Frankfurt (Oder)-Sternberger Kurier 2 (1953), Nr. 12, S. [13].

1657 Hinzu kommt noch das - hier nur am Rande zu erwähnende - Phänomen, dass für die Städte und Kreise sowie ehemaligen Länder der DDR („Mitteldeutschlands“) in der Bundesrepublik ebenfalls „Exil-Verbände“ (sowie Patenschaften) bestanden, die gleichfalls Treffen veranstalteten, Publikationen herausgaben und insofern im Fokus manches DDR-Bürgers standen. Auch „Rundbriefe“ gab es - wie für die Vertreibungsgebiete für die aus den „mitteldeutschen“ Ländern in den Westen Geflohenen, z. B. für den brandenburgischen Kreis Luckau, für den es heißt: „An einem Landestreffen in München im August 1959 nahmen u. a. zu Gast weilende Besucher aus Finsterwalde teil, [...]." (Senftleben, „Steige hoch, du roter Adler ...“ [wie Anm. 1643], S. 143).

1658 Franz-Christian Jarczyk: Zur Geschichte des Neisser Kultur- und Heimatbundes e. V. Hildesheim. In: Oberschlesisches Jahrbuch 23/24 (2007/08 [2009]), S. 135-150, hier S. 136. Bereits seit 1946 hatte der in der SBZ (später in Fulda) wirkende ehemalige Neisser Kaplan Herbert Schlensog einen (Neisser) Suchdienst für die SBZ eingerichtet, neben dem andere in den Westzonen bestanden.

1659 A[rthur] Ohm: Das Frühjahrstreffen des Sternberger Landes in Frankfurt am Main. In: Heimatblatt für deutsche Volksgemeinschaft. Frankfurt (Oder)-Sternberger Kurier 11 (1962), Nr. 5, S. 10-11, hier S. 10. 
ke "heute an die 17 Millionen unserer Landsleute in der Zone und in Ostberlin, ebenso aber auch an die 2,2 Millionen in Westberlin." Dieses erste Treffen nach dem Mauerbau war stark von der „Spaltung“ bzw. „Teilung der Nation“ geprägt, die Teilnahme von DDR-Bürgern war, wenn überhaupt, nur noch in kleinerem Rahmen möglich, so dass Kiekebusch ausdrücklich an das vorherige erinnerte, um dann die Rolle der Landsmannschaft als legitimen Vertreter auch der in der DDR lebenden Vertriebenen zu postulieren: „12000 Landsleute aus der Zone nahmen noch im vorigen Jahr an unserem Großtreffen in Berlin teil. Unsere Landsmannschaft ist der Repräsentant der Landsleute in der Zone." 1660

Da Rentner ab 1964 auf Einladung auch zu Verwandten in die Bundesrepublik reisen durften ${ }^{1661}$, beschränkten sich die persönlichen Begegnungen keineswegs auf die Insel WestBerlin, wie wiederum das Bärwalder Beispiel zeigen mag: „Höhepunkt des Jahres [1976] war jedoch unser Gelsenkirchen-Treffen am 9. und 10. Oktober im Hans-Sachs-Haus. Die ersten Teilnehmer waren am 8. da, die letzten Bärwalder fuhren am 11. wieder ab. Wir konnten Besuch aus Berlin, aus Mitteldeutschland und sogar aus den USA begrüssen. Am Gelingen dieser Tage haben viele aktiv mitgearbeitet. Allen sei herzlich gedankt. ${ }^{\text {“1662 }}$ Diese lapidaren Sätze lassen kaum erkennen, welche Hürden im Einzelfall zu nehmen waren, denn es war für die DDR-Bürger nicht mit dem Kauf einer Fahrkarte getan. Neben der Überwindung bürokratischer Hindernisse waren bisweilen verschlungene Pfade zu gehen, um eine private Einladung, einen Verwandtschaftsstatus zu konstruieren. Man ahnt, was alles hinter dem Satz „Am Gelingen dieser Tage haben viele aktiv mitgearbeitet" gestanden haben mag: simple organisatorische Selbstverständlichkeiten ebenso wie konspirative Aktivitäten.

Es ist inzwischen bekannt, dass das Ministerium für Staatssicherheit zumindest über die größeren in Westdeutschland und West-Berlin agierenden Vertriebenenverbände, die Landsmannschaften, gut informiert war. ${ }^{1663}$ Neben den gedruckt zugänglichen Informationen nutzte es hierfür auch Informanten aus dem Kreis der Vertriebenen selbst. So entsandte das MfS

1660 Ebd. - Heinz Kiekebusch war ein Sohn des bekannten Berliner Prähistorikers Albert Kiekebusch (18701935).

1661 Beschluss des Ministerrates der DDR vom 10.9.1964 (Peter Borowsky: Deutschland 1963-1969. Hannover 1983, S. 186). - In der Vorankündigung des vierten „Neusalzer Treffens“ in der Patenstadt Offenbach 1965 (zugleich Feier des zehnjährigen Bestehens der Patenschaft) heißt es bezüglich der „Teilnahme von Besuchern aus der SBZ [!] “ in den Neusalzer Nachrichten, Nr. 41, 1965, S. 53: „Verwandte und Bekannte von Neusalzern, die in der sowjetischen Besatzungszone leben und während des Treffens sich in der Bundesrepublik aufhalten, werden gebeten, die Teilnahme dieser Neusalzer am Treffen umgehend dem Hauptamt der Stadt Offenbach am Main, Kaiserstraße 18, mitzuteilen, das dann über Vergünstigungen für die Teilnehmer aus der SBZ einzeln Auskunft erteilen wird."

1662 Arbeitskreises Bärwalde Nm. Kreis Königsberg Nm. Jahresbericht 10 (1976), S. 8.

1663 Beispielbelege sind zusammengestellt in: Amos, Vertriebenenpolitik der SED (wie Anm. 12), S. 195. Siehe ferner: Amos, Vertriebenenverbände (wie Anm. 12). Auch Michael Schwartz hat in seinen jüngeren Publikationen zunehmend BStU-Quellen einbezogen und auch das eine oder andere Beispiel einer MfS-Überwachung in Brandenburg ermittelt. Eine systematische Auswertung der MfS-Akten zu Vertriebenen in Brandenburg bleibt aber vorerst Desiderat. 
„Inoffizielle Mitarbeiter“ (IM) im Rentenalter zu den größeren Heimattreffen des BdV in der Bundesrepublik und in West-Berlin („Tag der Heimat“1664 u. ä.). Sie „sollten über die allgemeine Stimmungslage auf den Veranstaltungen berichten, die Namen von DDR-Rentnern, die an diesen Vertriebenentreffen teilnahmen, in Erfahrung bringen, und möglicherweise auch anderweitige Kontakte knüpfen“ ${ }^{1665}$ Heike Amos hat auf der Grundlage von Berichten und Dossiers der MfS-Bezirksverwaltungen Rostock und Neubrandenburg - letztere betraf im Süden auch brandenburgische Gebiete um Prenzlau - wahrscheinlich gemacht, dass zumindest bei den großen Landsmannschaftstreffen „zirka 30 bis 40 MfS-,IMs“ im Rentenalter anwesend waren“. Ihren Recherchen zufolge hatte in der Regel ,jede MfS-Bezirksverwaltung“ in den sechziger Jahren „nicht mehr als zwei bis vier ,Rentner-IM", die selbst Vertriebene waren“1666

Insgesamt ist auch in den gedruckten, also grundsätzlich für jedermann zugänglichen Heimatzeitschriften deutlich zu spüren, dass die im Westen lebenden Redakteure vorsichtig waren und wussten, wie weit sie mit Informationsverbreitung über DDR-Bürger gehen konnten. Vieles, was jeder wusste, blieb unausgesprochen und ist daher heute bisweilen schwerer fassbar. Wenn nötig wurden Berichte, besonders Leserbriefe oder andere Zuschriften, die sich bei den Heimatkreisbetreuern als willkommener Manuskriptfundus stapelten, im Druck anonymisiert. ${ }^{1667}$ Das gilt beispielsweise für die 1986 in der Heimatzeitschrift der Vertriebenen aus Schwerin (Warthe) abgedruckten „Betrachtungen zu den traditionellen Bundestreffen unseres Heimatkreises in Paderborn aus der Sicht eines DDR-Bürgers“ ${ }^{1668}$ Der nicht genannte Verfasser stand offensichtlich bereits im Rentenalter. Seine Aussagen sind ein bemerkenswertes Zeugnis der grenzüberschreitenden Verbindungen unter den Vertriebenen in der Zeit des „Kalten Krieges“. Sie sollen daher hier, auch wenn sie sicherlich nicht als für die Mehrheit der Vertriebenen repräsentativ stehen können, ausführlicher zitiert werden, zumal die Teilnahme für den

$1664 \mathrm{Zu}$ diesen Großveranstaltungen siehe: Matthias Stickler: „Ostdeutsch heißt Gesamtdeutsch“. Organisation, Selbstverständnis und heimatpolitische Zielsetzungen der deutschen Vertriebenenverbände 1949-1972 (Forschungen und Quellen zur Zeitgeschichte, Bd. 46). Düsseldorf 2004, S. 155-172.

1665 Ebd., S. 196.

1666 Ebd.

1667 Solche Zuschriften dürften sich mit voller Absenderangabe, auch von Brandenburgern, zahlreich im Schriftgut vieler Vertriebenengemeinschaften finden. Eine Auswertung wäre gewiss lohnend, war für die vorliegende Untersuchung, die sich auf gedruckt zugängliche Quellen der Heimatkreisgemeinschaften beschränken muss, leider nicht zu leisten. Dass zumindest einige der „Heimatkreisarchive“ (und „Heimatstuben“) jedoch keineswegs „nur“ der (meist im Vordergrund stehenden) Sammlung der aus der Heimat geretteten Originaldokumente Beachtung schenken, sondern auch das aus ihrer eigenen (nach 1945 und oft noch bis zur Gegenwart reichenden) Tätigkeit erwachsende Schriftgut bewahren, zeigt das Beispiel des im Eigentum der „Kreisgemeinschaft Gumbinnen e. V." befindlichen, seit 2007 als Depositum im Stadtarchiv Bielefeld (Patenstadt für den Kreis Gumbinnen, Ostpreußen) untergebrachten „Kreisarchivs Gumbinnen“; siehe die Verzeichnung in der Archivdatenbank www.archive.nrw.de (u. a. der Teilbestand A 08 Schriftleitung „Gumbinner Heimatbrief“ mit 71 Nummern); zur vom Verf. 1989 entwickelten archivischen Konzeption und Tektonik: Peter Bahl: Das Kreisarchiv Gumbinnen. In: Gumbinner Heimatbrief 72 (1989), S. 39-41.

1668 Unser Heimatkreis Schwerin (Warthe) 50 (1986), S. 7-8. 
Verfasser offensichtlich kein einmaliges Ereignis war und er zu einer vergleichenden Langzeitbetrachtung daher durchaus in der Lage war. Da ein erheblicher Teil der Schweriner 1945 nach Brandenburg, insbesondere in die Prignitz, gelangt ist, ist der hier in erster Linie interessierende Brandenburg-Bezug mindestens indirekt gegeben, auch wenn der anonym gebliebene Verfasser selbst vielleicht anderswo in der DDR lebte.

„Seit dem Jahre 1978 ist es mir und meiner Frau vergönnt, an den Bundestreffen des Heimatkreises Schwerin (Warthe) teilzunehmen ${ }^{1669}$, und jedes Treffen ist immer wieder ein tief beeindruckendes Erlebnis für uns, die wir nach dem Ende des verheerenden 2. Weltkrieges in der DDR unsere 2. Heimat gefunden haben.

Dieses umso mehr, als es hier keine gelenkten Verbindungen der hier in der DDR ansässig gewordenen Landsleute miteinander gibt. Einige hier inzwischen doch entstandenen Verbindungen sind in erster Linie jedoch nur möglich geworden durch die in jeder Weise vorbildlich und mit großer Hingabe organisierten Bundestreffen unseres Heimatkreises, für die zu allererst der langjährige verdienstvolle 1. Vorsitzende, Herr Erich Klemt ${ }^{1670}$, verantwortlich zeichnet, wofür ihm auch von unserer Seite nicht genug gedankt werden kann, zumal durch seine Initiative wir DDR-Bürger in diesem Rahmen stets mit einer materiellen Unterstützung erfreut werden." Der Verfasser der Betrachtungen bringt sodann seinen Dank an Klemt und dessen „von allen Landsleuten geschätzte(n) Gattin“ noch etwas ausführlicher zum Ausdruck. Er betont die jedesmalige Vorfreude auf das Wiedersehen mit alten und neuen Bekanntschaften und betont, dass nicht jeder in der DDR in der Lage ist, die Heimatzeitschrift zu verfolgen: „Und wie hart empfindet man dann aber, wenn man erfährt oder gar selbst feststellt - denn die Mitteilungen des Heimatkreises (Heimatrundbriefe) dürfen uns nicht zugeschickt werden - wie sich die Reihen der Landsleute von einem Treffen zum anderen doch gelichtet haben. Bei der letzten Begegnung in Paderborn waren wir noch froh und munter mit ihm oder ihr zusammen und in der Zwischenzeit hat ihr Schicksal für uns sich still erfüllt. Aber ist nicht der Großteil unserer Landsleute, die ständige Teilnehmer der Bundestreffen sind, schon in dem Alter, daß jederzeit damit gerechnet werden muß, den letzten Weg gehen zu müssen?

Ich möchte nun aber nicht sentimental werden sondern besser den Blick wieder voraus werfen und mich schon jetzt auf das frohe Wiedersehen beim nächsten Bundestreffen mit alten und neuen Freunden sowie Bekannten aus der Heimat freuen, wo es ganz gewiß wieder gilt, alte Bekanntschaften aufzufrischen oder neue zu schließen." Man merkt den Betrachtungen an mehreren Stellen an, dass sich hier jemand bewusst als Sprachrohr vieler versteht, der selbst dann, wenn er ausdrücklich eigenes Erleben berichtet, die Verallgemeinerung mitzutransportieren versucht.

„Von mir persönlich möchte ich noch mit Freuden berichten, daß ich auf diesem Treffen auch Landsleute wieder getroffen habe, die meine Frau und mich vor lauter Freude des Wiedersehens auch

1669 Er dürfte also in diesem Jahr das Rentenalter erreicht haben, mithin 1913 geboren sein.

1670 Erich Klemt (1909-1989), von 1947 (offiziell ab 1952) bis 1955 und erneut von 1969 bis 1988 Heimatkreisbetreuer für den Heimatkreis Schwerin (Warthe). Siehe über ihn u. a. Otto Schulz: Landsmann Erich Klemt 70 Jahre alt. In: Unser Heimatkreis Schwerin (Warthe) 28 (1979), S. 12 (mit Bild); ferner Unser Heimatkreis Schwerin (Warthe) 132 (2014), S. 18; Liste der Heimatkreisbetreuer/Vorsitzenden: ebd. 108 (2006), S. 21. 
noch zu sich nach Hause eingeladen haben, wovon wir auch mit Begeisterung Gebrauch gemacht haben. Besonders beeindruckend hierbei ist für uns DDR-Bürger immer wieder die große Herzlichkeit, die über all diesen persönlichen Besuchen steht, wozu in erster Linie die jährlichen Besuche zu meinen beiden Jugendfreundinnen und zu den Angehörigen meines besten, leider zu frü[h]zeitig gefallenen, Jugendfreundes und Nachbarn gehören. Es ist daher nur allzuverständlich, daß wir uns auf diese Besuche schon das ganze Jahr vorher freuen. Bei all diesen Besuchen wird dann immer nur in gemeinsamen Erinnerungen geschwelgt und die gemeinsam erlebte Vergangenheit ist dann wieder hellwach. Von diesen aufgefrischten Erinnerungen zehren wir dann wieder das ganze Jahr bis hin zum nächsten Wiedersehen."

Die Betrachtungen werden dann nochmals ins Allgemeine gehoben, indem die Ausstellung des Heimatkreises auf der Wewelsburg ${ }^{1671}$ bei Paderborn als anschaulich, lebensnah und wirkungsvoll empfohlen wird, und münden schließlich in ein Plädoyer zur Pflege des Heimatgedankens, in das ein - angesichts des sonst durchgehend unpolitischen Tenors - dann doch überraschender Hinweis auf die Staatsgrenzen in Mitteleuropa eingebaut wird: „Diese Ausstellung kann aus meiner Sicht als das markanteste Herzstück im Rahmen der Pflege des Heimatgedankens an- [S. 8] gesehen werden, und es muß Anliegen aller Landsleute sein und bleiben, nicht nachzulassen, diese Verbundenheit mit der Heimat weiter zu pflegen, wozu ein Besuch diese Ausstellung immer wieder Veranlassung geben sollte, auch wenn es unserer Generation nicht mehr vergönnt sein wird, eine Änderung der Grenzen zu unser aller Gunsten zu erleben, worüber hier in der DDR leider in keiner Weise ein [e] Diskussion möglich ist."

Die Betrachtungen schließen mit einem Bekenntnis, wiederum im Namen der vertriebenen Schweriner in der DDR: „Für die Zukunft möchte ich allen Teilnehmern künftiger Bundestreffen von Herzen beste Gesundheit und weitere beeindruckende Erlebnisse wünschen in dem Sinne, den Gedanken an die Heimat in jeder Weise wachzuhalten, wozu wir Schweriner Landsleute, die jetzt in der DDR beheimatet sind, jederzeit auch einen bescheidenen Beitrag leisten wollen." Der Schlußsatz lässt vermuten, dass die Redaktion ihn so bekommen und abgedruckt hat, weil es sich beim Verfasser tatsächlich um jemanden handelte, der als vertraulicher Ansprechpartner mit Überblick über Adressen fungierte. Das MfS wird darüber gleichwohl im Bilde gewesen sein. ${ }^{1672}$ Nicht alle in Westdeutschland ansässigen Vertriebenenverbände haben freilich die Aufnahme

1671 Die 1984 eröffnete und „in erster Linie den beiden ehemaligen Kreisen Meseritz und Schwerin/Warthe gewidmet(e)“ Abteilung „Deutsche im östlichen Mitteleuropa - Kultur, Vertreibung, Integration“ im Kreismusem Wewelsburg behandelt im vierten von fünf Räumen auch „Flucht und Vertreibung“, jedoch ausschließlich auf die in die Westzonen gelangten Personen bezogen, obwohl nachweislich zahlreiche Schweriner in der DDR lebten. Siehe dazu: Wulff-Eberhard Brebeck / Andreas Ruppert: Deutsche im östlichen Mitteleuropa. Kultur, Vertreibung, Integration. Meseritz/Miedzyrzecz - Paderborn - Schwerin/Warthe/Skwierzyna. Einführung in die Ausstellung im Kreismuseum Wewelsburg (Schriftenreihe des Kreismuseums Wewelsburg, Bd. 2). Paderborn 1987, S. 133-153 (Zitat aus beiliegendem separaten Faltblatt zur Ausstellungsabteilung, S. 1).

1672 Die Nutzung der in der Vertriebenenpresse enthaltenen Informationen konnte u. a. auch über deren Bestand in der gesamtdeutsch sammelnden Deutschen Bücherei in Leipzig geschehen, die allerdings nur einen Teil zu beschaffen in der Lage war. Siehe dazu weiter unten. 
von DDR-Bürgern in Anschriftenverzeichnisse über die Jahrzehnte beibehalten. So ist die 1979 vom Heimatkreis Schwerin (Warthe) in Hattingen (Nordrhein-Westfalen) herausgegebene Liste ausdrücklich auf die „in der Bundesrepublik Deutschland, Westberlin und im westlichen Ausland“ wohnhaften „Landsleute“ beschränkt worden. ${ }^{1673}$

Ein Beispiel für die Vertriebenen aus dem Kreis Königsberg/Neumark bietet wiederum der Arbeitsbericht des Arbeitskreises Bärwalde Nm., in dessen Ausgabe für das Jahr 1968 sich folgende Hinweise auf DDR-Bürger finden ${ }^{1674}$ : Am 19. Mai 1968 „treffen sich 130 Bärwalder in Berlin. Besuch aus dem Bundesgebiet und aus der Zone. Dias-Vortrag. Tellersammlung durch Ldsm. [Landsmann] Wilhelm Schönfeld.“ Am 16. Juli 1968 „Selliner Treffen in Bergkirchen. Grosse Beteiligung aus Bundesgebiet, Berlin und aus der Zone. Bärwalder Teilnahme." Am 8. September 1968 Kreistreffen in Hamburg: „Bärwalde, Sellin, Gossow, Klossow, Bellin mit Besuch aus der Zone." Am 28./29. September 1968 „Bärwalder Erntedanktreffen in Gelsenkirchen. Beisammensein mit Dias und Tonbändern am Sonnabend. Teilnehmer am Sonntag aus Bundesgebiet, Berlin und der Zone. Dias-Vortrag." Auch diese Aufstellung belegt, dass DDR-Bürger im Rentenalter auf westdeutschen Vertriebenentreffen immer wieder präsent waren.

Die zitierten Berichte der Vertriebenenfunktionäre in ihren Organen bleiben notgedrungen summarisch, erst nach der Wende konnte man es sich erlauben, namentliche Teilnehmerlisten abzudrucken. Zur Klärung der tatsächlichen Frequenz müssten folglich Akten der veranstaltenden Verbände mit Teilnehmerlisten eingesehen werden, was systematischen Einzelforschungen vorbehalten bleiben muss. Als Stichproben konnten aber immerhin fünf Gästebücher von Heimattreffen durchgesehen werden. ${ }^{1675}$ Es handelt sich zum einen um ein Anwesenheitsbuch der zweijährlichen Treffen der „Gemeinschaft der ehemaligen Aufbau-/Heimschüler von Drossen“ (Drossen, Kr. Weststernberg; poln. Ośno Lubuskie) für die Jahre 1974 bis $2013^{1676}$, sodann um ein Gästebuch der Heimattreffen des „Heimatbundes Kreis Soldin/Neumark im Patenkreis Soltau“ (Soldin/Neumark; poln. Myślibórz) für die Jahre 1954 bis $1957^{1677}$, drittens um das Gästebuch des des „Soldiner Heimatabends Stadt und Land Hannover“ von 1955 bis $1967^{1678}$, viertens das Gästebuch der Heimatstube des Heimatkreises Soldin in Soltau (Niedersachsen) aus den Jahren 1966 bis $2006^{1679}$ sowie fünftens um das Gästebuch der Bundestreffen

1673 Anschriften der Landsleute des Heimatkreises Schwerin (Warthe) in der Bundesrepublik Deutschland, Westberlin und im westlichen Ausland. Zsgest. vom Heimatkreisbetreuer des Kreises Schwerin (Warthe) Erich Klemt u. Käte Bornmann. Stand April 1979. Hattingen 1979.

1674 Arbeitskreis Bärwalde Nm. Kreis Königsberg Nm. Jahresbericht [2] (1968), S. [3].

1675 Archiv der Stiftung Brandenburg, Fürstenwalde/Spree (Haus Brandenburg). Dessen seinerzeitiger rühriger Bibliothekarin, Frau Maria Petzoldt, sei für freundliche Hinweise und die gewährte Einsichtnahme herzlich gedankt.

1676 Stiftung Brandenburg, Archiv, AX0648 (unfol.), ab 1984 mit eingeklebten Fotos (meist Gruppenbilder).

1677 Stiftung Brandenburg, Archiv, AJ 06/66, Nr. 130 (unfol.). Hinten im Buch „Kartei von Soldin“ (Adressenliste, ohne DDR-Bürger).

1678 Stiftung Brandenburg, Archiv, AJ 06/66, Nr. 465 (unfol.).

1679 Stiftung Brandenburg, Archiv, AJ 06/66, Nr. 546. 
der Kreis-Soldiner für die Jahre 1979 bis $2000^{1680}$. Um es vorweg zu nehmen: Grundsätzlich finden sich in allen fünf Beispielen auch Besucher aus der DDR.

Bei dem Drossener Beispiel handelt es sich nicht um den klassischen Typus der allgemeinen Heimattreffen, sondern um den besonderen Fall von (meist dreitägigen) Ehemaligen- bzw. Schulklassentreffen Vertriebener. Dies mag den stärkeren Zusammenhalt als bei einer Dorfbevölkerung erklären. Bemerkenswert ist gleichwohl schon die Tatsache, dass das Gästebuch, das seinen ersten Einsatz 1974 beim 8. Treffen in Hann. Münden (Niedersachsen) fand, ein Geschenk einer in der DDR lebenden Mitschülerin ist, die ausweislich der Teilnehmerliste (Unterschriftenliste) selbst anwesend war und also das Buch mitgebracht hat. Es enthält vorn auf dem Vorsatz ihre Widmung: „Daß oft aufrichtige/und liebenswerte Menschen/Eure Gäste sein mögen / wünscht Euch / Eure Elfi Kardach / Sömmerda, 1.6.74“. Elfi Kardach geb. Bornmann und ihr Mann Walter Kardach nahmen auch an den folgenden, regelmäßig alle zwei Jahre in Hann. München durchgeführten Treffen bis 1984 teil, fehlten nur 1988. 1982 ist ihre Anschrift, „DDR 5020 Erfurt“, sogar mit Straße und Hausnummer vermerkt. Im Mai 1990 aber ist Elfi Kardach wieder dabei, nun mit Sohn, 1992 findet sich sogar die ganze, nun vierköpfige Familie. Auch andere Teilnehmer aus der DDR bleiben der Sache über Wende und Wiedervereinigung hinaus treu, unter ihnen auch Brandenburger: Gertrud Schubert geb. Görlitz aus „7303 Kolkwitz/Cottbus DDR" ist von 1978 bis 1995 ohne Ausnahme stets in den Listen zu finden, ebenso Käte Zuch aus Röbel (Mecklenburg) von 1978 bis 1990, manchmal fehlen die Unterschriften, dann ist die Teilnahme vom westdeutschen Buchführer nachgetragen, 1976 mit dem Zusatz „Teilnehmer aus Mitteldeutschland“, 1978 „Teilnehmer aus ,DDR“. 1978 sind von insgesamt 65 Teilnehmern vier aus der DDR, 1980 von 52 mindestens vier, 1982 von 54 nachweislich vier. 1978 erhielten die aus der DDR angereisten Teilnehmer „pro Pers. 50,- Taschengeld + freie Pension." Beim ersten Treffen nach der Wende, im Mai 1990, heißt es im Gästebuch: „Eine besondere Freude ist die zahlreiche Teilnahme der Kameradinnen u. Kameraden aus der DDR. Das nächste Mal wird es hoffentlich keine „BRD“ u. „DDR" mehr geben!" 1993 findet das Treffen erstmals im Heimatort Drossen mit „Empfang durch die polnische Schule in unsererm ehemaligen ,Kasten" "und "Gottesdienst in der Jakobi-Kirche mit Pfarrer Jan Loziol u. H. J. Brühe" statt. Es folgen dann noch weiter, ab 1995 im Bonifatiushaus in Fulda, zweijährige bzw. ab 2005 jährliche Treffen, bis man sich 2012 entschloss, das Treffen zum letzten zu erklären, da altersbedingt nur noch fünf Einzelpersonen und vier Ehepaare „als letztes Aufgebot“ erschienen waren. Der „Obmann“, der mit einer Drossener Fabrikantentochter verheiratete Berliner Studiendirektor Hartwig Frhr. von Coburg (1926-2018), notiert 2012: „Unser Treffen war wieder mit der Erwartung auf ein Wiedersehen und dem Austausch unserer gegenseitigen Lebensumstände verbunden. Die Zahl der Freunde war wieder geringer geworden, aber die Freundschaft und die persönlichen Kontakte waren erhalten geblieben." 1995 bezeichnete der Buchführende die vier (von 76) Teilnehmer aus den neuen Bundesländern ohne Umschweife als „Ostdeutsche“. Eine von ihnen schrieb 2005 in ihren Dan-

1680 Stiftung Brandenburg, Archiv, Aj 2011/13. 
kesworten „Durch die Einheit kamen die ,Ostler' dazu“, wobei ihr offenbar gar nicht bewusst war, dass ein Teil von ihnen schon über dreißig Jahre früher teilnahm. Am Ende war sogar ein „Ostdeutscher“, Dr. Helmut Munkow (Eichwalde) derjenige, der das Archiv der Gemeinschaft - sieben Ordner, eine Kartei und das Gästebuch - verwaltete und 2014 dem „Haus Brandenburg“ in Fürstenwalde übergab.

Von den vier den Kreis Soldin betreffenden Gästebüchern nennt das älteste für die Gesamtkreistreffen beim ersten Treffen 1954 in Heidelberg einen Teilnehmer aus Berlin-Weißensee und eine Teilnehmerin aus Nauen, 1957, wiederum in Heidelberg, einen, bei dem es heißt „früher Lippehne, jetzt Buckow/Ostzone“. Doch selbst das nur für den „Soldiner Heimatabend Stadt und Land Hannover" geführte Gästebuch, in dem bis auf zwei Ausnahmen nur Namen und Datum ohne Wohnort notiert sind, nennt nicht nur sogleich zu Beginn 1955 einen Teilnehmer mit Namen „(als Gast aus Dresden)“1681, sondern es heißt in einem, maschinenschriftlichen (eingeklebten) Vorwort, das auf die gästebuchlosen ersten Jahre von 1949 bis 1954 zurückblickt: „Die in Stadt und Land Hannover nach 1945 ansässig gewordenen Heimatvertriebenen aus dem Kreis Soldin in der Neumark trafen sich zum ersten Male am Dienstag, dem 8. November 1949 in Hannover, Restaurant Horrido, Bahnhofstraße 4, zu einer Wiedersehensfeier. Seitdem hat diese Gruppe der in treuer Heimatverbundenheit lebenden Landsleute sich an jedem ersten Dienstag eines Monats hier ein Stelldichein gegeben, bei dem es manchmal in später Stunde recht fröhlich zuging. Viele unserer guten Frende, die jetzt in Berlin, in der russisch besetzten Zone und in dem Gebiet der Bundesrepublik wohnen, waren in den vergangenen 5 Jahren bei der einen oder anderen Zusammenkunft anwesend. Und einige dieser Getreuen deckt bereits der grüne Rasen. Ihnen bewahren wir ein bleibendes Angedenken. /Von nun an soll dieses Büchlein von den Teilnehmern am Soldiner Heimatabend berichten."

Das Gästebuch der Heimatstube des Heimatkreises Soldin in Soltau verzeichnet schon beim Bundestreffen 1968 eine Teilnehmerin „aus Soldin, jetzt Arnstadt/Thür.“, 1969 eine Besucherin aus „Leegebruch b/Velten“, offensichtlich eingetragen von einer in Cloppenburg ansässigen Verwandten, wahrscheinlich ihrer Tochter, 1977 einen Besucher aus „Zehdenick (Havel)“, 1981 eine Besucherin aus „Rehberg Krs. Strasburg DDR“ und am 8. Juni 1990 eine Besucherin aus „DDR Nauen“.

Zuletzt ist noch ein Blick auf das bei den Bundestreffen der Vertriebenen aus dem neumärkischen Kreis Soldin geführte Gästebuch zu werfen. Darin werden auch Abwesende, die grüßen lassen, erwähnt. Auf dem Bundestreffen 1979 in Schneverdingen lassen 23 Personen Grüße ausrichten, darunter drei namentlich genannte aus der DDR, 1981 sendet nur eine DDR-Bürgerin „Heimatgrüße“, 1982 sind es in Munster dann aber sogar sechs DDR-Bürger, die grüßen lassen, und 13 Teilnehmer, die persönlich anwesend sind, meist mit dem - selbst notierten - Zusatz „DDR“, in einem Fall „Ostzone“. Allein zehn der Anwesenden DDR-Bürger sind mit dem Heimatort Karzig vermerkt, in einem Fall ist dabei der (brandenburgische) Wohnort

1681 Die andere Ausnahme ist, ebenfalls 1955, ein weiblicher Teilnehmer gleichen Familiennamens „(als Gast aus Berlin)“. 
„(Staffelde)“ hinzugesetzt. Auch in den folgenden Jahren bis 1990 geht es ähnlich weiter, 1996 kommen einzelne Teilnehmer aus Prerow/Ostsee, Markranstädt und Gommern. Auch die vom Heimatkreis Soldin/Neumark publizierten Berichte über Treffen aus der Zeit der deutschen Teilung verweisen immer wieder auf die Teilnahme der „Schwestern und Brüder“, wie etwa zum 1. Bundestreffen 1960 in Soltau ${ }^{1682}$ : „Mit Musik begrüßt wird der Bus aus Berlin voller KreisSoldiner, die eine weite Reise mit unangenehmen Grenzkontrollen inmitten Deutschlands auf sich genommen haben. Besonders herzlich werden die Landsleute aus der ,Zone' (DDR später) aufgenommen und etwas unterstützt, denn sie mußten ja 4 Ostmark aufbringen, um einen Kaffee für 1,-DM zu bekommen; sie müssen viel erzählen. " ${ }^{1683}$ Kaum anders klingt es auch noch nach dem Mauerbau, hier zum Bundestreffen 1970 in Schneverdingen: „Die [West-]Berliner sorgen wieder für einen fröhlichen Empfang, und die Landsleute aus der Zone werden besonders gastlich aufgenommen, sie müssen viel erzählen vom Leben drüben hinterm Stacheldraht." 1684

Zusammenfassend lässt sich demnach hochrechnen, dass die Teilnahme - und zusätzlich das Mitverfolgen und Grüßen aus der Ferne - für DDR-Bürger zwar kein Massenphänomen sein konnte, aber auch keineswegs erst eine Neuentdeckung der Nachwendezeit, wie man häufig hören und lesen kann. Es blieb, wenn auch durch die Tabus erheblich erschwert und auf Rentner beschränkt, - wie in Westdeutschland - die persönliche Entscheidung jedes Einzelnen, ob er Kontakt hielt oder nicht. So findet sich in Selbstzeugnissen aus der Nachwendezeit nicht selten auch völlige Ablehnung der „Revanchistentreffen“, die man nie besucht habe. Doch es gibt - selten - auch retrospektive Selbstzeugnisse, die die Teilnahme oder Nichtteilnahme an solchen Treffen kritisch reflektierend behandeln.

Ein ehemaliger DDR-Bürger, der aus einem neumärkischen Dorf im Kreis Landsberg/ Warthe stammende Dr. Walter Kracht (geb. 1930), hat nach 1990 in der von ihm verfassten Chronik seines Heimatdorfes, wohl auf die Zeit vor 1961 bezogen, eindrücklich beschrieben, „wie stark die gegenseitige Verbundenheit noch immer ausgeprägt war“, obwohl die vertriebenen ehemaligen Nachbarn über die gesamte DDR und auch die Westzonen verstreut lebten. ${ }^{1685}$ Bemerkenswert ist Krachts Schilderung des in der „Diaspora“ weiterwirkenden Stennewitzer „DorfNetzwerks“, das als eine Form des Umgehens mit dem Vertriebenen-Schicksal erscheint. Dabei wurde zwar der Kontakt zu den organisierten Kreistreffen eher gemieden und dennoch für einen Personenkreis gemeinsamer Herkunft - über den eigenen Verwandtenkreis hinaus (!) -, zumindest bei aus Dörfern, also kleineren ehemaligen Nachbarschafts- und Großverwandtschaftsgrup-

1682 Der Landkreis Soltau (Niedersachsen) hatte kurz zuvor, am 11. April 1960, durch „einstimmigen Beschluß des Kreistages" die Patenschaft für den Kreis Soldin übernommen (Heimatkreis Soldin/Neumark [wie Anm. 303], S. 663). Die auf den 13. August 1960, also den Tag des Bundestreffens, ausgestellte Patenschaftsurkunde wurde „zu Beginn des ersten Bundeshaupttreffens“ überreicht (ebd., S. 664).

1683 Heimatkreis Soldin/Neumark (wie Anm. 303), S. 665.

1684 Ebd., S. 671.

1685 Walter Kracht: Stennewitz. Ein brandenburgisches Dorf in der Neumark wurde zum polnischen Stanowice. Berlin 2003. Für den Zeitpunkt der „Teilung Deutschlands“ schätzt Kracht, dass von den 1945 aus seinem Heimatdorf Stennewitz Vertriebenen „etwa 48 in Ostdeutschland und 55 in Westdeutschland“ wohnten. 
pen, stammenden Vertriebenen, weiter reale Handlungen ausgelöst: „Es gab mehrere Beispiele für eine gegenseitige Hilfe, die zeigten, dass ein enges Gefühl der gegenseitigen Verbundenheit erhalten geblieben war und man sich wie in einer Familie, füreinander verantwortlich fühlte." ${ }^{1686}$

Unter den in die DDR gelangten Stennewitzern gab es eine auch weiterhin nachbarschaftliche Konzentration in Wulkow bei Neuruppin und in Thüringen (je zwei Familien), im Westen lebten zwei Familien einander benachbart im Rheinland. In mehreren Fällen wurden über Ländergrenzen hinweg Wohnung und Arbeit privat vermittelt, in Thüringen lebende Stennewitzer halfen Stennewitzern, die sich an anderem Ort in Thüringen oder gar in Mecklenburg befanden: „Als Viergotts erfuhren, dass bei uns [in Thüringen] sogar Kartoffeln knapp waren, kamen plötzlich mit der Post mehrere Pakete mit Kartoffeln aus dem nördlichen Brandenburg." ${ }^{1687}$ Solche (leider undatierten) Hilfsmaßnahmen gab es aber wohl nur in den ersten Jahren. „Mit zunehmendem zeitlichen Abstand lockerten sich diese Verbindungen, da jeder um die eigene Existenz zu kämpfen hatte."

Demgegenüber scheinen die Stennewitzer von den größeren (West-)Treffen enttäuscht gewesen $\mathrm{zu}$ sein oder sich davon weniger versprochen zu haben. „Eine Teilnahme an einem [Kreis-] Treffen der Landsberger in Westberlin, vor 1961, war wenig hilfreich, da wir niemand kannten und keinen Kontakt fanden. Ähnliche Erfahrungen machten wir auch, als wir nach der Wiedervereinigung an Landsberger Treffen in [Berlin-] Tegel teilnahmen, Wir schlussfolgerten daraus, dass nur Treffen mit uns bekannten Dorfbewohnern sinnvoll seien. Die Idee eines Treffens der Stennewitzer bewegte uns schon immer. Im Osten Deutschlands hatten aber nur wenige ein Telefon, so dass selbst das Recherchieren schwierig war. Zudem war zur Zeit der DDR die Veranstaltung von Heimattreffen unerwünscht, nahezu verboten. Man meinte, dass derartige Treffen nur einen revanchistischen Charakter haben könnten. Nach dem Bau der Mauer wäre die Teilnahme ohnehin nur auf die in Ostdeutschland lebenden begrenzt gewesen. Mit Interesse hörten wir, dass sich auch in der Bundesrepublik niemand dazu aufraffte, ein Treffen der Stennewitzer zu veranstalten. "Kracht hat dann 1994 in Petzow bei Potsdam selbst ein erstes Treffen mit knapp 100 Teilnehmern organisiert und in der Folge im zweijährigen Turnus weitere durchgeführt. Resümierend schreibt er 2003 zum ersten NachWende-Treffen: „Die in der DDR verbreitete öffentliche Meinung, dass Heimattreffen zwangsläufig einen revanchistschen Charakter haben müssen, wurde völlig ad absurdum geführt." ${ }^{688}$

\section{Lektüre von Heimatzeitschriften und Heimatliteratur}

In den in Westdeutschland herausgegebenen Heimatblättern der Vertriebenenverbände finden sich oft Aufrufe, man möge die Landsleute in der DDR entsprechend informieren, was nur heißen konnte, sichere, unverfängliche Kanäle zu nutzen. Doch die in der DDR Lebenden werden gelegentlich auch in den Heimatblättern direkt angesprochen. Jeder wusste, dass deren 
Bezug nicht gestattet war ${ }^{1689}$, um Verbreitung in der DDR über private Kontakte hat man sich dennoch - offensichtlich mit Erfolg - immer wieder bemüht. DDR-Bürger werden in nicht wenigen Ausgaben der Heimatvertriebenenpresse namentlich genannt. Die beliebte Rubrik der „Familienanzeigen“ bzw. „Familiennachrichten“ brachte fast stets auch Todesfälle aus der DDR mit vollem Namen, oft sogar mit Traueradresse. Auch bei Geburtstags- und Hochzeitsjubläen sowie Vermählungsanzeigen erscheinen DDR-Bürger und durchaus nicht immer nur Rentner, zudem oft durchgehend bis zum Mauerfall 1989. ${ }^{1690}$ Der Schwerpunkt lag jedoch sicherlich bei Rentnern und Todesfällen, also jenen Bereichen, die für die Staatsorgane der DDR weitgehend „uninteressant“ waren. Doch finden sich auch Hinweise auf jüngere Personen und ganze Familien. Dass all dies eine Gratwanderung war und blieb, wird wohl den meisten bewusst gewesen sein, auch wenn unterschiedlich freimütig damit umgegangen wurde. Eine in den Westen gelangte Neumärkerin äußerte sich schon 1953 viel vorsichtiger, als mancher Herausgeber eines Heimatbriefes: „Ich kann auch keine Anschrift angeben, weil ein Briefwechsel mit Zonenangehörigen in dieser Art gefährlich ist." ${ }^{691}$

Wie genau sich die DDR-Staatsorgane mit den in der Vertriebenenpresse gleichwohl in nicht geringer Zahl publizierten personenbezogenen Daten befassten, zeigt ein Fernschreiben

1689 Zwei Beispiele für Verfolgung durch die Staatssicherheit wegen des als strafbar eingestuften Bezugs von Heimatbriefen in Mecklenburg(-Vorpommern) bringt Seils, Die fremde Hälfte (wie Anm. 19), S. 253 f. Eine 80 Jahre alte Flüchtlingsfrau aus Greifenberg/Pommern, die 1951 in einem Barackenlager auf Usedom lebte, bezog regelmäßig den „Greifenberger Heimatbrief" und gab ihn auch an andere weiter. Sie wurde verhaftet und verhört, dann zwar entlassen, wohl weil sie ziemlich altersschwach wirkte und es nach „Einschätzung des zuständigen MfS-Offiziers tatsächlich aus Unwissenheit und politischer Indifferentheit sowie aus dem Drang nach Heimat und der Suche nach Gedankenaustausch mit anderen Greifenbergern" getan habe, sie wurde weiter überwacht, es ließen sich aber keine Zusendungen mehr feststellen, worauf man die Ermittlungen einstellte (S. 253). - Eine in Boizenburg/Elbe wohnhafte Rentnerin aus Schlesien wurde 1953 wegen Einfuhr der „Brieger Heimatbriefe“ [gemeint sind die „Briegischen Briefe“] (die Paketsendungen ihrer in Nürnberg lebenden Schwester beigelegen hatten) verhaftet und, da sie sich schuldig bekannte, „1954 wegen Boykott- und Kriegshetze nach Artikel 6 der Verfassung der DDR und der Kontrollratsdirektive 38, Abschnitt II, Art. III A III vor dem Bezirksgericht Schwerin angeklagt“, das sie unter „Anrechung ihrer Untersuchungshaft [...] zu einem Jahr Gefängnis“verurteilte (S. 253 f., Zitat S. 254).

1690 Gut sichtbar oben auf der letzten (=Außen-)Seite einer Dezember-Ausgabe übereinander: 1. Vermählungsanzeige eines Brautpaars, datiert „in Lebusa, den 1. August 1953 / Kr. Herzberg a.d. Elster (Sachsen-Anhalt) / früher Guschau, Kreis Sorau“ in: Sorauer Heimatblatt 2 (1953), Nr. 10, S. 20; 2. Danksagung für „die vielen Glückwünsche zu unserer goldenen Hochzeit“ („Statt Karten!") eines Ehepaars in „Langengrassau Nr. 1 über Luckau (früher Guschau)“ ebd. Zu dieser Goldenen Hochzeit findet sich in derselben Ausgabe auch noch ein 15-zeiliger Bericht in der redaktionellen (3-Spalten-)Rubrik „Aus den Heimatgemeinschaften/Wir gratulieren herzlich:“ Hier sind die im 77. und 76. Lebensjahr stehenden Eheleute sogar im Bild zu sehen (ebd., S. 13). Die Rubrik (S. 12-13) enthält ferner noch diverse weitere, v. a. in Cottbus lebende Geburtstagsjubilare im Rentenalter, jedoch auch eine noch berufstätige Frau mit voller Anschrift: „Postassistentin Luise Grunert hatte am 1. Januar 1953 ihr 40jähriges Dienstjubiläum. Die Jubilarin, die viele Jahre beim Postamt Teuplitz beschäftigt war, arbeitet noch heute in ihrem Beruf in Forst. Sie wohnt in Forst, Karlstraße 27." (ebd., S. 13).

1691 Vertreibung und Vertreibungsverbrechen 1945-1948. Bonn 1989, S. 244-245 (Dokument 22. Bericht von Florentine Gruhn), hier S. 245. 
des Volkspolizeiamtes (VPKA) Gransee vom 13. Oktober 1954 an die Bezirksbehörde der Deutschen Volkspolizei, Abt. Paß- und Meldewesen, in Potsdam betreffend „Das Ostpreussenblatt vom 21.8.54 und 4.9.1954“. Über diese beiden Ausgaben des überregionalen Organs der Landsmannschaft Ostpreußen heißt es: „In den angeführten Zeitungen sind unter Todesanzeigen als Hinterbliebene folgende Personen erwähnt, die in der DDR wohnen: [... (folgt Liste von 16 Personen)]./Als verstorben wird angezeigt: [... (1 Person)] / Unter den Vermählungsanzeigen sind als Eltern angegeben: [... (1 Eintrag)] / Zum Geburtstag wird gratuliert: [... (5 Personen)] / Bei den angeführten Personen, wo nur sowjetische Besatzungszone angeführt ist, fehlt jede nähere Anschrift./Artikel, welche unsere DDR betreffen, sind wie folgt: [... (folgen Bl. 112-113 Teilabschriften)].“1692

Breiten Raum nimmt in der Vertriebenenpresse neben Personalia aber auch die Hilfstätigkeit der im Westen ansässigen Vertriebenenverbände für in der DDR lebende Landsleute ein. Die „Heimatkreisbetreuung Sorau N.-L." rief 1953 ein „Sorauer Hilfswerk“ ins Leben und bat hierfür unter den Lesern des Heimatblattes um Spenden. ${ }^{1693}$ Der „Festausschuß der Sorauer Heimattreffen" hatte überdies im Februar 1953 beschlossen, Überschüsse, die nicht zur Vorbereitung der - jährlich im westfälischen Hamm, der Patenstadt - durchgeführten Kreistreffen benötigt würden, ebenfalls dem Hilfswerk zufließen zu lassen. Angesichts der "große(n) Notlage noch vieler unserer Landsleute, besonders in der russischen Besatzungszone“, sollte es „durch PäckchenVersendung bitterste Not von Sorauer Landsleuten so gut wie möglich lindern" helfen. Den Festausschuss hatten „viele sorgenvolle Briefe [...] vor allem aus Mitteldeutschland“ erreicht, „aus denen die Not, die besondere Not unserer lieben Landsleute dort spricht", so dass man möglichst schnelle und laufende Hilfe für nötig erachtete, wie es im Spendenaufruf heißt. Es wurde um Bekanntgabe der Namen und Adressen hilfsbedürftiger Vertriebener gebeten, über die Päckchenvergabe sollten „nach kurzer Prüfung“ die Hilfswerk-Kommission des Festausschusses und die Heimatkreisbetreuung entscheiden. Mit der Versendung der Hilfswerkpakete wurde der in Siegburg (Rheinland) ansässige Paul Schildt betraut, „der durch seine weihnachtliche Liebesgabenaktion schon viel Freude in Mitteldeutschland schuf" und der "uns beste Gewähr für richtige Beachtung aller Versendungsvorschriften, für korrekte Durchführung des Auftrages und beste Auswahl hochwertiger Lebensmittel“ gab. „Es ist zunächst daran gedacht, die außerordentliche Not von alten Leuten und kinderreichen Familien in der Ostzone und evtl. auch noch im Kreisgebiet Sorau mit Lebensmittelpaketen (im Werte von zirka DM 8,- bis DM 10,-) zu lindern." In der nächsten Nummer des monatlich erscheinenden Heimatblattes hieß es bereits, die „Briefe und Karten mit den Anschriften von besonders notleidenden Sorauer Landsleuten in der Sowjetzone häufen sich schon beim Vorsitzenden des Festausschusses, und all diese Zeilen sagen uns von großer, großer Not, von bittersten Schicksalen, 
wirklichem Elend und kümmerlichsten Verhältnissen". ${ }^{1694}$ An Spenden waren allerdings erst DM 33,50 eingegangen, so dass der Aufruf bekräftigt wurde. Die meisten Spenden wurden bereits regelmäßig für die Finanzierung des Heimatblattes erbeten und flossen, wie die Spendenlisten zeigen, laufend in großer Zahl, so dass ein neuer, zusätzlicher Aufruf es nun zunächst schwer hatte. Schon die nächste Heimatblatt-Nummer enthielt dann allerdings eine namentliche Spenderliste des Hilfswerks und nannte einen Kontostand von DM 88,50. ${ }^{1695}$ In der übernächsten, im Juli 1953 herausgegebenen Nummer „drängt es heute die Hilfswerk-Kommission, Euch allen kurz zu berichten“; es folgen „Auszüge aus den Briefen und Karten, die uns voller Dankbarkeit aus Ostberlin und der Sowjetzone - teils auf Umwegen - erreichten" ${ }^{1696} \mathrm{Im}$ Oktober 1953 werden dann Spendernamen bekanntgegeben mit genauer Höhe des jeweiligen Geldbetrages und Datum des Eingangs. Dabei heißt es unter „Ausgaben“ für Mai bis Juni 1953 „Paketsendungen des ,Sorauer Hilfswerkes' an besonders hilfsbedürftige Landsleute in der Sowjetzone“: „80,-DM“. ${ }^{\prime 697}$ Ferner wird unter „Neue Ausgaben“ aufgeführt: „16.-20.8.1953: Verschiedene Zuwendungen in die Sowjetzone (für Säuglingssachen usw.) ... 30,-DM“ und unter dem „25.9.1953: 35 Paketsendungen in die Sowjetzone ... 350,- DM““1698 In der November-Nummer wird über den Rückgang der Spenden geklagt werden und zur Ermunterung der Gemüter vier längere Zitate aus Dankeskarten und -briefen abgedruckt. ${ }^{1699}$ Das erste Beispiel beginnt mit den Worten: „Heute früh kam ein Päckchen an mich von unbekannter Hand, worüber ich sehr erstaunt, aber hocherfreut war. Es tut so wohl, wenn man merkt, daß man hier in der Ostzone nicht ganz vergessen ist. Recht herzlichen Dank allen Spendern für die herrlichen, nahrhaften Lebensmittel, die mir gerade jetzt sehr erwünscht sind, da ich durch eine längere Krankheit sehr heruntergekommen bin. Erst vor 4 Wochen bin ich aus dem Krankenhaus als gebessert entlassen worden [...]. "1700 Während solche Abdrucke natürlich ohne Absendernamen erfolgten, finden sich aber durchaus auch einfache Grüße mit vollem Namen und Wohnortangabe, etwa 1953 in der Nummer 6 unter der gesonderten Überschrift „Gruß aus der Oszone“ nur von einer Person, nämlich „Anna Schiemenz geborene Harterl, früher Triebel, Sorauer Straße 40, jetzt Nachterstedt über Aschersleben“1701. Sie schreibt: „Liebe Triebeler! Auch ich habe vom Sorauer Heimattreffen in Hamm gehört und grüße Euch alle recht herzlich. Ich bedauere außerordentlich, an dem Treffen nicht teilnehmen zu können. Ich würde trotz meiner 70 Jahre gern

1694 Hier spricht das „Sorauer Hilfswerk“. In: Das Heimatblatt für Sorau N./L.-Stadt und Land 2 (1953), Nr. 2, S. 4-5, hier S. 4.

1695 Hier spricht das „Sorauer Hilfswerk“. In: Das Heimatblatt für Sorau N./L.-Stadt und Land 2 (1953), Nr. 3, S. 10.

1696 Hilfswerk lindert Not! In: Das Heimatblatt für Sorau N./L.-Stadt und Land 2 (1953), Nr. 5, S. 6.

1697 Hier spricht das „Sorauer Hilfswerk“. In: Das Heimatblatt für Sorau N./L.-Stadt und Land 2 (1953), Nr. 8, S. 10.

1698 Ebd.

1699 Es ist nicht auszuschließen, dass sich diese wertvolle Korrespondenz-Quelle in der in das Stadtarchiv Forst (Lausitz) gelangten „Sorauer Sammlung“ erhalten hat.

1700 Hier spricht das „Sorauer Hilfswerk“. In: Das Heimatblatt für Sorau N./L.-Stadt und Land 2 (1953), Nr. 9, S. 9.

1701 [Sachsen-Anhalt.] 
kommen, wenn wir nicht durch die Zonengrenze daran gehindert wären. / Ich wünsche Euch allen ein gesundes Wiedersehen!" 1702

Dass die Heimatzeitschriften als zonenübergreifendes Bindeglied fungierten und als Informationsbörse funktionieren konnten, zeigt sich im Sorauer Fall auch an der Berichterstattung über in der DDR Lebende oder von dort in den Westen Gegangene. So heißt es im August 1953: „Am 26. April d. J. traf Herr Karl Lande aus unserer lieben Heimatstadt Sorau in der Sowjetzone ein. Er wurde am 22. Februar 1878 in Pommern geboren und 1922 aus der Provinz Posen nach Sorau evakuiert, wo er bis 1945 an der Gasanstalt tätig war. Wie viele Hausfrauen erinnern sich gewiß gerne des stets freundlichen, hilfsbereiten Mannes, der ihre Gasherde in Ordnung brachte! 1945 blieb die Gasanstalt außer Betrieb, und Herr Lande wurde an das Wasserwerk verpflichtet, das er bis zu seinem Weggang leitete. Über Grünberg und Stettin traf er in Fürstenwalde ein, wo ihn seine Tochter abholte und zu sich nahm, um dem geliebten Vater nach acht schweren Jahren einen sorgenlosen, schönen Lebensabend zu bereiten. Leider starb Frau Lande am 15. Juni 1950 am Herzschlag. ${ }^{1703}$ Der andere Fall, bei dem vertriebene Sorauer die DDR verlasen hatten, wurde ebenfalls bisweilen mitgeteilt, hier im November 1953: „Wie uns berichtet wurde, sind zwei Gassener Familien aus der Sowjetzone in Westdeutschland eingetroffen. Landsmann Karl Müller mit Ehefrau, früher Gassen, Sommerfelder Straße, wohnt vorübergehend im Talbothaus in Aachen. Landsmann Bruno Donat, Ingenieur, und seine Ehefrau Liesel geb. Hientzsch, früher Gassen, Markt, haben im Flüchtlingslager von Plettenberg Aufnahme gefunden. " 1704 Auch in ganz andere Texte immer wieder eingestreute kleine Textblöcke mit dem Aufruf „Vergiss nicht die Ostzone! ${ }^{“ 1705}$ sollten die Spendenbereitschaft ebenso wie das Zusammengehörigkeitsgefühl wachhalten.

Dass die Sorauer kein Sonderfall waren, mag noch ein zweites Beispiel verdeutlichen. Der im November 1948 im Westen gegründete „Arbeitskreis Crossen“, die Kreisgemeinschaft der aus der Neumark vertriebenen Crossener, veröffentlichte in seinem Organ „Crossener Heimatgrüße“ im Juni 1949 einen Spendenaufruf „Zur Fortführung unserer Heimatarbeit, die täglich an Umfang wächst, zur Herausgabe weiterer ,Heimatgrüße' und zur Ermöglichung ihrer Versendung an die Landsleute in der Ostzone sind ständig Geldmittel notwendig." ${ }^{1706}$ In der folgenden Ausgabe heißt es dann: „Aus der Ostzone sind dem Arbeitskreis als Unkostenbeiträge bisher insgesamt rund 130 Ostmark zugegangen. Das sind knapp 25 Westmark, die noch längst nicht einmal reichen, um, die für die Ostzone aufzuwendenden Portokosten zu decken. Das wollen unsere Landsleute im Osten, deren schwere Lage wir kennen, bedenken, wenn nicht alle Ersuchen um Zusendung der, Heimatgrüße' er-

1702 Das Heimatblatt für Sorau N./L.-Stadt und Land 2 (1953), Nr. 6, S. 15.

1703 Aus der Heimat eingetroffen. In: Das Heimatblatt für Sorau N./L.-Stadt und Land 2 (1953), Nr. 6, S. 7.

1704 Als Sowjetzonenflüchtling eingetroffen. In: Das Heimatblatt für Sorau N./L.-Stadt und Land 2 (1953), Nr. 9, S. 5 .

1705 In: Das Heimatblatt für Sorau N./L.-Stadt und Land 2 (1953), Nr. 10, S. 5 (Text in Versalien).

1706 Crossener Heimatgrüße. Rundschreiben des „Arbeitskreises Crossen“ an alle heimatvertriebenen früheren Einwohner des Kreises Crossen/Oder. Für den Inhalt verantwortlich: Karl Wein, Itzehoe, Brunnenstraße 39. Ausg. Ende Juni 1949, unpagin. 2. Bl., S. [1]. 
füllt werden können. Die Empfänger aber bitten wir, die Blätter im Bekanntenkreise weitergeben zu wollen, damit recht viele Heimatgefährten sie lesen können." 1707

Liest man die - meist einen ehemaligen Landkreis umgreifenden - Heimatbriefe, -zeitschriften und Jahresberichte, die in Westdeutschland oder West-Berlin herausgegeben wurden, so fällt immer wieder die fast durchweg große Zahl, nicht selten mit voller Anschrift erwähnter SBZ/DDR-Bürger auf. Die im Westen ansässigen Heimatkreisbetreuer setzten alle Hebel in Bewegung, gleichsam auch an die letzte noch fehlende Nachkriegsanschrift zu gelangen, was ihnen freilich mit unterschiedlichem Erfolg gelang und zuletzt, in der Spätzeit und gegen Ende der DDR, z. T. wohl sogar aufgegeben worden war. Ein sehr umfangreicher Briefwechsel mit in der SBZ/DDR lebenden Vertriebenen wurde von ihnen geführt. Zahlreich sind die Zitate daraus, die, oft mit Absenderangabe, aber oft auch anonymisiert, in der Vertriebenenpresse abgedruckt wurden. Unter den mit Angabe des letzten Wohnsitzes versehenen Todesmeldungen finden sich in neumärkischen Heimatbriefen bisweilen sogar mehr Personen aus SBZ/DDR als aus dem Westen. ${ }^{1708}$ Aber auch die weniger ungefährlichen „Familiennachrichten “ über Lebende sind zahlreich und zwar auch noch nach 1961. So wird im in einfacher Qualität gedruckten DIN-A-4-Jahresbericht des „Arbeitskreises Bärwalde Nm.“, der im niedersächsischen Lüneburg erstellt wurde, über die (1967 begründete) „Geburtstagspäckchenaktion 1971" berichtet: „Allen Geburtstagskindern in der Zone und in Ost-Berlin geht vom 70. Lebensjahr an zu jedem Geburtstag ein kleines Päckchen im Werte von 10,- DM zu. Ihre Spenden, liebe Bärwalder, ermöglichen diesen Gruss der alten Heimatgemeinde. Viel Freude bringen wir damit in ihrem Namen, das zeigen die Dankesbriefe und die Grüsse, die dabei an alle Bärwalder bestellt werden. - Erneut konnten wir die Aktion steigern, denn 115 Geburtstagspäckchen wurden von fleissigen Händen 1971 verschickt. ${ }^{\text {1709 }}$ Es wird dann den sechs Helfern namentlich gedankt, allesamt Frauen, zwei in Wolfsburg, vier in [West-] Berlin wohnhaft. Bewusst liefen solche Aktionen über private Einzelpersonen als Versender. Schon die Tatsache, dass in Dankesbriefen Grüße „an alle Bärwalder“ bestellt werden, dürfte aber zeigen, dass es für die Staatssicherheit genügend Informationen gab, die nur zusammengetragen werden mussten, wollte man über die Aktivitäten im Bilde sein.

Die Möglichkeit zur Lektüre der Heimatbriefe ergab sich für Volkspolizei und MfS zum einen bei Beschlagnahmungen ${ }^{1710}$, zum anderen konnte man sie notfalls im Deutschlandhaus

1707 Crossener Heimatgrüße, Ausg. Ende Sept. 1949, unpagin., 2. Bl., S. [2].

1708 Arbeitskreis Bärwalde Nm. Kreis Königsberg Nm. Jahresbericht 7 (1973), S. 3 f.: 49 Tote aus Bärwalde und Nachbardörfern stammend, davon 9 in West-Berlin und 20 in der DDR, hiervon 15 in Brandenburg und 2 in Ost-Berlin.

1709 Arbeitskreis Bärwalde Nm. Kreis Königsberg Nm. Jahresbericht 5 (1971), S. 7.

1710 Volkspolizei beschlagnahmt Heimatbriefe und zitiert in Berichten daraus: Schwartz, Vertriebene und „Umsiedlerpolitik“ (wie Anm. 13), S. 528. - Mehrere Beispiele für durch die Post oder bei Vertriebenen beschlagnahmte (und oft im Original in der Akte enthaltene) Druckschriften von Vertriebenenverbänden, darunter auch in geringer Auflage erschienene, in den Akten des MdI, Haupverwaltung Deutsche Volkspolizei: BArch, DO DO 1/27886 (Vereinigungen, 1947-1950). Hier Fehlendes und Weiteres dürfte sich in MfS-Sachakten befinden. 
in Berlin (West) einsehen, wenn keine passenden Informanten in den Westzonen zur Verfügung standen. Die Deutsche Bücherei in Leipzig bemühte sich, auch die Vertriebenenpresse zu sammeln, wenngleich sie am Ort nicht für jedermann benutzbar gewesen ist. Ihre direkten Bestellungen oder Bitten um laufende Zusendung wurden von den im Westen ansässigen Verlagen allerdings keineswegs immer positiv beantwortet, wusste man doch, dass hier auch eine Informationsquelle für die Staatssicherheit beschafft werden sollte und man damit die Situation der in der DDR ansässigen Vertriebenen nicht erleichterte. Überliefert ist das nach Leipzig gesandte Antwortschreiben des Herausgebers eines schlesischen Heimatblattes, in dem es u.a. heißt: „Ihren Wunsch kann ich nicht erfüllen. Solange es unseren Heimatfreunden in der Mittelzone nicht gestattet ist, unsere Drucksachen zu lesen und ungestraft zu empfangen, habe ich keine Veranlassung, Sie mit Material zu versehen, welches sie letzten Endes gegen unsere Autoren auswerten, die es sich gestatten, auch einige Zeilen für unsere Heimatfreunde [in der DDR] zu schreiben. Es geht auch nicht an, daß Emp- [S. 8] fänger unserer Post als ,Spitzel für den Westen' bezeichnet und bestraft werden. Unter diesen Bedingungen muß ich es ablehnen, Sie zu unterstützen." ${ }^{1711}$ Die „Auswertung“ führte, wie schon die MdI-Akten zeigen, tatsächlich dazu, dass identifizierte Kontaktpersonen in der DDR „überprüft“ wurden. Teilweise finden sich in den Akten dann „Charakteristiken“ dieser zu überwachenden Personen. ${ }^{1712}$

Unter dem 14. September 1950 meldet die Landespolizeibehörde Brandenburg (Sitz Potsdam) der VP-Hauptverwaltung des MdI (Sitz Berlin-Niederschönhausen) die Beschlagnahmung eines Exemplars des gedruckten „Schönfließer Heimatbriefs" durch das VPKA Ruppin, das als Anlage ${ }^{1713}$ mitgesandt wird, und schreibt als „Einschätzung“ dazu: „Wir erkennen hieraus eine systematisch und bewußt betriebene Abkapselung von der Wirklichkeit und eine immer wieder neu getriebene Hetze gegen die Oder-Neiße[-] Grenze. ${ }^{\text {1714 }}$ Die Volkspolizei-Hauptabteilung Verwaltungspolizei wendet sich daraufhin am 27. September an das Präsidium der VP und berichtet, aus dem Heimatbrief gehe hervor, dass die herausgebende, in der „Westzone“ ansässige „Umsiedlerorganisation“ ein Postscheckkonto in „Berlin NW“ unterhalte, „auf welches Spenden in Ostmark eingezahlt werden. Dieses Konto ist zu sperren und die Höhe des Betrages festzustellen." ${ }^{" 1715}$ Am selben Tag geht von der Hauptabteilung Verwaltungspolizei ein Schreiben an die Landesbehörde der VP Brandenburg heraus, in dem die Anschriften zweier im Land Brandenburg ansässigen Personen - zwei Herren in Angermünde und Zepernick -, die aus dem „Schönfließer Heimatbrief“ ersichtlich seien, mitgeteilt werden. „Die obigen Personen sind zu überprüfen und

1711 -ht-: Vorbildliche Antwort an ein Sowjet-Institut. In: Landsmannschaft Schlesien Nieder- und Oberschlesien. Rundbrief der Bundesgeschäftsstelle, Nr. 12, 25.6.1956, S.S. 7 f.

1712 Siehe z.B. die „Charakteristik“ des aus Ostpreußen stammenden, 1950 in einer Angerburger Anschriftenliste entdeckten Arztes Dr. Max Rosenfeld (Groß Pankow) im Quellenteil, Nr. 230.

1713 BArch, DO 1/27886, B1. 90: Schönfließer Heimatbrief. Rundbrief an alle Freunde und Bekannte aus Bad Schönfließ und Umgebung, Nr. 2, Berlin, im August 1950. Verantwortlich: Johannes Götze, Berlin-Steglitz. (4 ungez. S.)

1714 BArch, DO 1/27886, B1. 91.

1715 BArch, DO 1/27886, B1. 92. 
eine weitere Tätigkeit mit dieser westlichen Umsiedlerorganisation ist zu untersagen. "1716 Bezüglich des Postscheckkontos geht in Berlin-Niederschönhausen am 15. Dezember ein Schreiben des Präsidenten der VP in Berlin, „Abt. V3/1 (Druck)“, vom 8. Dezember ein, in dem es heißt, laut „Kontoauszugsdoppel des Postscheckamtes zeigte das Konto nur eine geringe Bewegung“. Namen und Anschriften der vier "für die Zeit vom 6.5.-19.10.50 aufgeführten Einzahler" mit „Wohnsitz im Gebiet der DDR“ werden gleichzeitig mitgeteilt. ${ }^{1717}$ In einem VP-Vermerk vom selben Tag heißt es: „Als Kontoinhaber wurde Johannes Götze, Berlin-Steglitz, Wilseder Str. 4 (amerikan. Sektor) festgestellt. ${ }^{1718} \mathrm{Da}$ die Gelder aus einer strafbaren Handlung stammen, wurde das Konto auf Grund eines von hier aus beantragten richterlichen Beschlusses v. 1.11 .50 gesperrt". Zuletzt wies das Konto „ein Guthaben von DM 59,70 auf. Der Vorgang ist der Staatsanwaltschaft zur Einleitung eines Strafverfahrens wegen Verstoßes gegen den Befehl Nr. 105 der SMAD, sowie gegen das Sammelgesetz zuzuleiten. [...]."1719

Konnten die Staatsorgane eines Heimatbriefes oder einer Anschriftenliste habhaft werden, so werteten sie diese sogleich aus. Am 27. September 1950 teilt die Hauptabteilung Verwaltungspolizei im MdI der Landesbehörde der VP Brandenburg zuständigkeitshalber 17 Namen (ausschließlich Familiennamen mit den Anfangsbuchstaben A und B) in Brandenburg ansässiger Personen mit deren genauen Anschriften mit, die aus dem „Aussiger Bote und 14. Gemeindebrief der Kath. Gemeinde Aussig“ hervorgingen, „die einer Überprüfung zu unterziehen sind und denen jede weitere Verbindung mit dieser Umsiedlerorganisation zu untersagen ist" ${ }^{1720}$ Solche Verfahrensweisen zeigen sich immerhin in den frühen Jahren bis 1950 in den MdI/VP-Akten an enthaltenen Exemplaren und der zugehörigen Behördenkorrespondenz. ${ }^{1721}$ Man gewinnt freilich den Eindruck, dass es sich (noch?) nicht um eine systematische, auf Vollständigkeit zie-

1716 BArch, DO 1/27886, Bl. 93.

1717 BArch, DO 1/27886, Bl. 95.

1718 [Johannes Götze (geb. ca. 1890, gest. 1953) war vor 1945 Gastwirt in Bad Schönfließ/Nm. (BahnhofsSchankwirtschaft; vgl. Erinnerungsschrift an die Stadt Bad Schönfließ/Nm [wie Anm. 1640], S. 19). Ab 1948 wirkte er in und von West-Berlin aus als Ortsbetreuer für die Vertriebenen aus Bad Schönfließ und war auch Mitbegründer und Pressewart der in Berlin ansässigen Landsmannschaft Ostbrandenburg-Neumark, deren Mitteilungsblatt „Ostbrandenburg-Neumark“ (nach seinem Tod umbenannt in „Unsere Märkische Heimat“), das „ihm zum Lebensinhalt der letzten Jahre geworden“ war, er initiiert und bis zuletzt redigiert hat. Vgl. die Nachrufe u. Todesanzeigen in: Ostbrandenburg-Neumark 4 (1953), Nr. 18, S. 3 (mit Bild; hier Zitat), S. 15 f.]

1719 BArch, DO 1/27886, Bl. 96.

1720 BArch, DO 1/27886, Bl. 111. Wohnorte: Fehrbellin (2), Luckau, Pirow b. Perleberg, Glövzin Post Karstädt, Blüthen b. Karstädt, Kirchhain (2), Wittenberge/Elbe (2), Freienwalde, Schmachtenhagen üb. Oranienburg, Groß-Linde Post Perleberg, Brandenburg/Havel, Betzin üb. Nauen, Perleberg, Karstädt/Westprignitz. - Listen mit weiteren Personen gingen am selben Tag zuständigkeitshalber an die Landespolizeibehörden Mecklenburg (22 Personen, Bl. 110), Sachsen-Anhalt (41 Personen, Bl. 112-113), Sachsen (25 Personen, Bl. 113) und Thüringen (23 Personen, Bl. 115) sowie an das Präsidium der VP Berlin (2 Personen in Berlin-Hohenschönhausen und Woltersdorf bei Erkner, Bl. 114).

1721 Beispiel: umfangreiches hektografiertes Anschriftenverzeichnis der vertriebenen Friedländer (Stadt und Bezirk Friedland im Isergebirge) von April/Mai 1949, 24 S. (BArch, DO 1/27887, Bl. 114-125, dazu Nachträge bis Bl. 138). 
lende Beschaffung handelte. Die „Materialbasis“ war - auf die Gesamtheit erscheinender Heimatbriefe u. ä. bezogen - noch dünn und die „Beschaffungswege“ zu individuell. Gelegentliche Hinweise in den VP-Schreiben, das MfS habe die weitere Bearbeitung übernommen, sowie das Fehlen zunächst übersandter Anlagen weisen wohl darauf hin, dass sich in - hier nicht benutzten - MfS-Akten wesentlich mehr dazu finden lassen dürfte.

Das Katz-und-Maus-Spiel in der innerdeutschen Kommunikation konnte partiell unterlaufen werden, wenn man sich auf - zwar nicht poststempel-, aber absenderlose - Postkartengrüße anstelle von Päckchen beschränkte. ${ }^{1722}$ So heißt es im Bärwalder Jahresbericht für 1977: „Die Bärwalder Geburtstagskartenaktion wurde seit 1962 von Wolfgang Amtsberg durchgeführt. Rund 3000 Ansichtskarten sind den Geburtstagskindern in Ost und West zugegangen." ${ }^{1723}$ Ein offizieller Postversand der Heimabriefe in die DDR war dagegen schon früh unterbunden worden, so dass diese, wenn überhaupt, nur auf Umwegen und durch riskante persönliche Mitnahme ihre Empfänger erreichten. Im Bärwalder Jahresbericht für 1986 heißt es denn auch: „Auch in diesem Jahr gehen unsere Jahresberichte an unsere Bärwalder Familien, immer noch müssen wir unsere Landsleute in der DDR davon ausschließen. "1724 Aus einer schlesischen Vertriebenenzeitschrift von 1957 ist überliefert, dass sich die in der DDR Lebenden „über Nachrichtenmangel beklagen“, die im Westen lebenden Leser sollten deshalb Seiten ausschneiden und [mit privatem Absender] „im Briefumschlag versenden“. ${ }^{1725}$

Unter dem 16. August 1950 meldet die „Landesbehörde der Volkspolizei Land Brandenburg, Abteilung VA, Referat 3 Ko.", aus Potsdam der Hauptabteilung Verwaltungspolizei der Hauptverwaltung der DVP in Berlin-Niederschönhausen, dass nach Ermittlungen des VPKA Brandenburg/Havel von „einem Superintendenten [Heinrich] Gawel“ [aus Schlesien stammend] in Essen "laufend Rundbriefe an einen Herrn Gustav Knauerhase“ in Döbeln in Sachsen gesandt würden. „Dieser hat dann die Aufgabe, diese Steinauer Rundbriefe in der DDR zu verbreiten. / Geldspenden, die die Herausgabe des Rundbriefes möglich machen, sollen an die Schwester des Superintendenten, Martha Gawel / L übben/Spreew [ald], Luckauerstrasse 2/gesandt werden. ${ }^{" 1726} \mathrm{Ab}-$

1722 „Postkarten ohne Absender und Unterschrift“ bewährten sich ab Herbst 1961 „vielfach“ auch allgemein im Kontakt zwischen West-Berlinern und DDR-Bürgern, wie ein berlin-brandenburgisches Beispiel zeigt: Peter P. Rohrlach: Die Landesgeschichtliche Vereinigung für die Mark Brandenburg. Eine persönliche Erinnerung aus den Jahren 1946-1996. In: Die Landesgeschichtliche Vereinigung für die Mark Brandenburg in Vergangenheit und Gegenwart. Aus Anlass ihres 125jährigen Bestehens bearb. u. hrsg. von Peter Bahl. Berlin 2009, S. 73-95, hier S. 87.

1723 Arbeitskreis Bärwalde Nm. Kreis Königsberg Nm. Jahresbericht 11 (1977), S. 4.

1724 Ebd. 20 (1986), S. [7].

1725 Hellmut Seidel: Die Obernigker Gemeindebriefe. In: Seidel/Loch, Obernigk (wie Anm. 388), S. 263-267, hier S. 265 (Beilage „Obernigker Gemeindebrief“ zur Wochenzeitung „Der Schlesier“). - Auch für den seit 1949 erscheinenden Heimatbrief („Heimatgruß $\left.\beta^{\prime \prime}\right)$ der aus Stadt und Kreis Meseritz Vertriebenen ist überliefert, dass er noch nach 1961 von der Patenstadt Husum aus ,auch auf vielfach verschlungenen Wegen Verbindung nach ,drüben' hält" (Stadt und Kreis Meseritz. [Bd. 1]. O. O. [1972], S. 343).

1726 BArch, DO 1/27886 (Umsiedlerorganisationen), Bl. 100. - Es handelt sich um Steinau/Oder (Niederschlesien). 
schriftlich werden einzelne Textauszüge aus den Rundbriefen „zur Kenntnisnahme und eigenen Auswertung“ mitgeteilt. Informiert habe man auch die sächsische Landespolizeibehörde. „Das VPKA Lübben wurde angewiesen, vertrauliche Ermittlungen über Martha Gawel zu führen."

Ein mögliches Verfahren, in gewisser Anzahl bereits in die DDR transportierte Druckschriften im Land zu verteilen, war also die Verwendung eines geeigneten, unverfänglichen Absenders, was freilich voraussetzte, dass zusätzliche Mitwisser ins Spiel kamen. Privatleute dürften aber für den Versand in größerer Stückzahl kaum in Frage gekommen sein. Die Landespolizeibehörde Brandenburg meldete der Hauptverwaltung der DVP, Hauptabteilung Verwaltungspolizei am 13. Dezember 1950 unter dem Betreff „Heimatkalender für Schlesier“ folgendes verblüffende Vorkommnis: „Durch Ermittlungen wurde festgestellt, daß die schlesischen Umsiedlerorganisationen im verstärkten Maße Bestellscheine für obigen Kalender versenden. Der Versand vollzieht sich in Briefumschlägen[,] welche den Absender tragen/Volk und Wissen-Verlag, Berlin/ Leipzig, Leipzig S 3/Die Bestellscheine tragen folgende Anschrift/Kirchliche Hilfsstelle, München 15, Schubert-Strasse 2“ ${ }^{1727}$ Um diesen Aktivitäten eines in der DDR ansässigen und zwecks Verschleierung als Absender gewählten, thematisch aber gar nicht involvierten (!) Verlages genauer nachgehen zu können, bat die Hauptabteilung die Brandenburger Kollegen unter dem 30. Januar 1951 „um Übersendung eines der sichergestellten Briefumschläge“. ${ }^{1728}$ Dem konnte man in Potsdam jedoch nicht entsprechen, da, wie man unter dem 6. Februar nach Berlin antwortete, „dasselbe von Seiten des Ministeriums für Staatssicherheit zwecks weiterer Bearbeitung, eingezogen wurde ${ }^{1729}$ Ähnliches hatten die Landespolizeibehörde Brandenburg am 18. Juli 1951 zu berichten, als sie die sehr knappe Meldung bezüglich eines „Umsiedlertreffens“ mit dem Satz schloss: „Das Ministerium f. Staatssicherheit in Neuruppin hat sich vorbehalten, diesen Vorgang selbst weiter zu bearbeiten." 1730

Es ist in diesem Zusammenhang auch zu berücksichtigen, dass es vielerlei Grauzonen gab, in denen bisweilen weder die Staatsorgane noch die Vertriebenenverbände ganz sicher sein konnten und wussten, woran sie waren. Vertriebene gab es in allen Bereichen, auch (und durch die verstärkte Werbung gerade) bei denen, die für Überwachung und Abwehr der Bestrebungen zuständig waren. Zumindest bei den unteren VP-Dienstgraden mag hin und wieder jemand schwankend geworden sein. Beide „Richtungen“ kamen vor: Vertriebene bespitzelten ihresgleichen, umgekehrt interessierten sich gelegentlich Angehörige der Staatsorgane für die Sache der Vertriebenen auch privat, wenn sie selbst Betroffene waren. So nutzte z. B. ein selbst aus Ostpreußen stammender VP-Angehöriger 1950 die dienstliche Befragung eines durch Kontakte zur „Kreisgemeinschaft Angerburg“ Aufgefallenen in Berlin-Adlershof für private Zwecke. Da der Verdächtige Verbindung zu einer ostpreußischen Vermisstensuchstelle in Bayern hatte, 
hat er ihn auch „nach seinem Onkel gefragt [,] der früher in Gumbinnen wohnte“ "1731 Als geschickter Informant baute er also seine Herkunft ein, um einerseits zu dem zu Befragenden ein Vertrauensverhältnis aufzubauen, andererseits profitierte er wohl auch privat. In Havelberg erfuhr 1951 ein VP-Wachtmeister durch seine eigene, aus Landsberg/Warthe stammende Mutter von einem geplanten Vertriebenentreffen und meldete dies seinem zuständigen VPKA Westprignitz. ${ }^{1732}$

Weitere Indizien liefert auch ein anderes Vorkommnis, dass zwar weder aus Brandenburg stammt noch tief genug durchleuchtet werden kann, dass aber immerhin die Schwierigkeiten der Überwacher ebenso wie die Möglichkeiten der Überwachten recht eindringlich aufzeigen kann. So schrieb die VP-Hauptverwaltung im MdI unter dem 9. November 1950 an das Präsidium der VP Berlin, durch Ermittlungen der thüringischen VP sei festgestellt worden, dass eine der in einer beschlagnahmten gedruckten „Liste der Angerburger" enthaltenen Personen, Walter K., geboren 1920, „Angehöriger der Volkspolizei ist und bei seinen Eltern in Berlin NO [...] wohnt. Es wurde festgestellt, daß er Verbindungen mit einer gewissen Frau Sobol, Großenstein, Kreis Gera, welche laufend Umsiedlerkreise aus Angerburg um sich versammelt, aufrecht erhält. So wurde u.a. festgestellt, daß K. am 9.9.1950 mit einem PKw der VP (grauer Opel) in Großenstein war und sich bei der Sobol aufgehalten hat. " ${ }^{1733}$ Die Landesbehörde der VP Thüringen berichtet daraufhin unter dem 1. November 1950 - auf etwas mehr als fünf eng beschriebenen Seiten - detailliert und mit acht Anlagen über Aktivitäten der „Angerburger“"1734, der Präsident der VP in Berlin stellt dann unter dem 20. November 1950 richtig, dass K. „nicht Angehöriger der Berliner VP, sondern der HV Ausbildung " sei. ${ }^{1735}$ Das Präsidium der VP in Berlin schreibt ferner unter dem 5. Dezember 1950 betreffend „Umsiedlerorganisation (Kreisgemeinschaft Angerburg)“, die ihm übermittelten Anschriften seien „eingehend überprüft“ worden. „Den in Frage kommenden Personen wurde eröffnet, dass sie jede Verbindung mit dieser westlichen Umsiedlerorganisation zu unterlassen haben. In Fällen wo ihnen Druckstücke zugesandt werden sollten, die von dieser Umsiedlerorganisation stammen, sind diese an die zuständige Verwaltungsdienststelle der Volkspolizei abzuliefern." ${ }^{1736}$ Sind nun womöglich - illegal - die aus dem Westen stammenden Vertriebenendruckschriften mit einem Pkw der Volkspolizei transportiert worden, um sie zu verteilen, dann aber - dienstlich - ebenso ein beschlagnahmtes Belegstück?

Offenherzige Mitteilungen über DDR-Bürger finden sich in den Heimatbriefen ebenso wie anonymisierte, bei denen ausdrücklich hinzugesetzt wird, man könne aus verständlichen Gründen die Namen nicht nennen. ${ }^{1737}$ Leichter fiel sicherlich der Abdruck einer Mitteilung zu einem betagteren Rentner, während in voller beruflicher Verantwortung stehende Vertriebene

1731 BArch, DO 1/27886, Bl. 88. Vgl. den vollständigen Abdruck des Berichts ebd.

1732 BArch, DO 1/27887, Bl. 37. Vgl. den vollständigen Abdruck des Berichts im Quellenteil (Nr. 233).

1733 BArch, DO 1/27886, B1. 82.

1734 BArch, DO 1/27886, Bl. 83-85 (Anlagen fehlen).

1735 BArch, DO 1/27886, Bl. 86.

1736 BArch, DO 1/27886, Bl. 88.

1737 Arbeitskreis Bärwalde Nm. Kreis Königsberg Nm. Jahresbericht 11 (1977), S. [8]: „Viele Grüsse durften wir bestellen, aus Platzmangel fast nur die aus Mitteldeutschland." 
seltener ausführlich genannt sind. Im erwähnten Bärwalder Jahresbericht für 1971 findet sich ein zwölfzeiliger Glückwunsch zum 96. Geburtstag des „älteste(n) Bärwalder Einwohner(s) Emil Palm“, dessen Porträtfoto dabei sogar abgebildet wird. ${ }^{1738}$ Es heißt aber nicht nur sehr konkret, er „lebt heute in X 1542 Falkensee, Ruppiner Str. 20.32, Pflegeheim“. Vielmehr wird auch ganz offenherzig mitgeteilt: „Oft hat er uns geschrieben und immer Grüsse an alle Bärwalder bestellt. [...] Ihm und seiner Frau alles, alles Gute.“ Doch man geht noch weiter: „Emil Palm freut sich über Bärwalder Post. Wollen wir ihm nicht mal alle schreiben?" Auch sonst gab man sich selbstbewusst, heißt es doch 1978 im Zusammenhang mit der Päckchenaktion des Jahres für in der DDR lebende Jubilare über 70: „Die von keinem Deutschen gewollte Elbe-Grenze ist für unsere Bärwalder Heimatgemeinde nicht vorhanden. " 1739

Dieses Bärwalder Beispiel ist durchaus repräsentativ für die neumärkischen Heimatbriefe, wenngleich die Nennung von Ross und Reiter in einigen von ihnen nach 1961 zurückhaltender geschah. Deutlich wird aber, dass diese Druckerzeugnisse bis 1961 ihren Weg zu den Adressaten in der SBZ/DDR vielfach gefunden haben und dort tatsächlich gelesen wurden. Unter den wesentlich erschwerten Bedingungen nach 1961 ist dies zwar zurückgegangen, aber keineswegs beendet worden. Die Zusammengehörigkeit wurde demonstrativ gelebt. Selbst Besuche in der alten Heimat unternahm man sogar bisweilen gemeinsam und bildete dann Gruppenfotos im Jahresbericht ab. ${ }^{170}$

Im Sternberger Heimatbrief enthält die „Familienchronik“ genannte Gratulationsrubrik beispielsweise 1962 Lebensjubiläen ab dem 50. Geburtstag mit voller Anschrift. In der DDR Lebende finden sich darin - mit voller Postanschrift - erst vom 71. Geburtstag an (Finkenheerd bei Frankfurt/Oder, Lehnin, Neustadt/Dosse). ${ }^{1741}$ In der nächsten Nummer finden sie sich erst zum 87. Geburtstag und nun nur mit Ort, ohne Straße und Hausnummer (Bad Berka/ Thüringen, Lebus bei Frankfurt/Oder) ${ }^{1742}$, in einer späteren Nummer aber doch wieder mit voller Anschrift und schon ab dem 63. Geburtstag, hier mit einem aus Sonnenburg/Nm. Stammenden, der nun in Tangermünde lebt, die älteren Geburtstagskinder (77 bis 87 Jahre alt) leben in Lindau (Anhalt), Lübben (Spreewald), Naumburg (Saale) und Rüthnick, „Kr. Ruppin (Mark)“; ${ }^{1743}$ einem aus Reppen (Neumark) stammenden Ehepaar wird zur diamantenen Hochzeit gratuliert, ,jetzt Babelsberg bei Potsdam, In der Aue 41“.

1738 Ebd., S. 7. Dies ist kein Einzelfall. Siehe Nachruf (mit Bild) auf den Lehrer Helmut Krüger in Neutrebbin/ Oderbruch in: Jahresbericht 9 (1975), S. 8.

1739 Arbeitskreis Bärwalde Nm. Kreis Königsberg Nm. Jahresbericht 11 (1977), S. 6.

1740 Ebd., S. 8: „Viele Selliner und zahlreiche Bärwalder waren vom 9. bis 13.6.1977 in der Heimat. [...] Der Sonnabend - 11.6.77 - sah eine grosses Wiedersehen mit Bärwaldern aus Sachsen, Thüringen, Mecklenburg, Brandenburg und Ost-Berlin in unserem alten Städtchen." Dazu wird ein Gruppenfoto vor der Kirche in Landsberg/Warthe abgedruckt und die Namen der sechs Abgebildeten aufgeführt.

1741 Heimatblatt für deutsche Volksgemeinschaft. Frankfurt (Oder)-Sternberger Kurier 11 (1962), Nr. 5, S. 10-11, hier S. 14-16, hier S. 14.

1742 Ebd. 11 (1962), Nr. 6, S. 14.

1743 Ebd. 11 (1962), Nr. 10, S. 13-14, hier S. 13 f. 
Zwar finden sich unter solchen Gratulationen und noch häufiger unter Totenlisten viele DDR-Bürger, selten sind aber die Fälle, in denen sich regelrechte (Todes-)Anzeigen auf sie beziehen, wobei unklar bleiben muss, ob die wenigen Beispiele von den in der DDR lebenden Hinterbliebenen selbst oder von im Westen wohnenden Verwandten für sie eingesandt und bezahlt worden sind. In jedem Fall ist es aber eine Tatsache, dass, wenn auch nur gelegentlich, doch auch DDR-Bürger mit solchen Anzeigen in den im Westen herausgegebenen Heimatzeitschriften erscheinen. Ein Beispiel ist die $7 \times 9 \mathrm{~cm}$ große Todesanzeige für eine „im gesegneten Alter von 80 Jahren“ verstorbene Urgroßmutter „aus Göritz (Oder)“, die im odernahen Finkenheerd bei Frankfurt (Oder) gelebt hatte und am 5. Oktober 1962 verstorben war. Drei männliche Namensträger „nebst Angehörigen“ unterzeichnen als Hinterbliebene „im Namen aller Angehörigen“, es müssen Söhne und/oder Enkel sein. Die Traueranschrift ist „Richard-Sonnenburg-Straße 4“ in Finkenheerd, die Beerdigung hat bereits, auf dem Friedhof Brieskow/Finkenheerd, stattgefunden. ${ }^{1744}$ Die geographische Nähe zum Herkunftsort Göritz unmittelbar hinter der Oder ist auffällig groß, sie zeigt einmal mehr die Tendenz nicht weniger Vertriebener, ihrer Heimat, wenn es solche Möglichkeiten gab, nahe zu bleiben.

Die nicht nachlassende Thematisierung des Vertriebenenstatus bekam vielfach einen zusätzlichen deutschlandpolitischen Zusammenhang. Zwar trat sie nicht hinter diesen zurück, unterschied sich aber in den zahlreichen Aufrufen, die Landsleute in der DDR nicht zu vergessen, kaum von allgemeinen Verlautbarungen der Bundesregierung und westdeutscher Parteien und Verbände, die die deutsche Teilung ganz ohne einen Zusammenhang mit dem Vertriebenenthema betrafen. So appelliert der Heimatkreisbetreuer für den Kreis Weststernberg, Werner Oskar Simon, 1954 in einem Bericht über ein Treffen in Herford, an die in Westdeutschland lebenden Leser des „Frankfurt (Oder)-Sternberg-Kuriers“: „Die Verbindung mit [...] unseren Landsleuten in Berlin und in der Sowjetzone muß von jede m Landsmann gepflegt werden. "1745 Nach dem Mauerbau finden sich dann in manchen Heimatbriefen verstärkt eingestreute Grafiken, die mit eingängigen Worten und Symbolen mahnen sollten, die Unterstützung der in der DDR Lebenden nicht zu vergessen. ${ }^{1746}$ Nicht übersehen werden darf dabei aber, dass die geschwisterliche deutsch-deutsche Päckchen-Unterstützung zwar kein bloßes Vertriebenenthema war, in deren Familien und Netzwerken aber immer zugleich die gemeinsame Herkunft als Merkmal im Bewusstsein hielt. Einige Beispiele aus Berichten des „Heimatkreises Bärwalde/Neumark“ mögen verdeutlichen, dass dies alles bis zur Maueröffnung anhielt, also nicht mit fortschreitender Integration „einschlief“: 1978: „157 Päckchen verschickten wir 1978 an Geburtstagskinder in der Zone vom 70. Geburtstag an. Insgesamt packten die Helfer [wohl gemeint: seit 1967] 1617 Päckchen. Und 23 959,04 DM insgesamt spendeten Bärwalder für diese Aktion.“1747 1981: „Auch 1981 haben

1745 Frankfurt (Oder)-Sternberger Kurier 3 (1954), Nr. 7, S. 10.

1746 Beispiele in: Heimatblatt für deutsche Volksgemeinschaft. Frankfurt (Oder)-Sternberger Kurier 11 (1962), Nr. 2, S. 13 („Dein Päckchen nach drüben“), Nr. 4, S. 15 („Denk an dein Osterei nach drüben!“).

1747 Arbeitskreis Bärwalde Nm. Kreis Königsberg Nm. Jahresbericht 12 (1978), S. 4. 
wir die Kaffeesendungen für unser Kaffeekränzchen drüben fortgesetzt. Das soll auch 1982 geschehen. Wenn sich Bärwalder dort treffen, soll wenigstens eine gute Tasse Kaffee dabei sein. Lotti und Herbert Bartky sei für diese Arbeit gedankt." ${ }^{1748}$ Schließlich noch 1986: Die „Aufgliederung der Einnahme und Ausgaben 1986“ des Arbeitskreises Bärwalde Nm. enthält unter den Ausgaben von insgesamt 4827,56 DM als höchste Ausgabenposition den Päckchenversand - „128 Stück einschl. Sonderporto für Polen u. Gratulationen " - mit 3089,00 DM, hier sind die in der DDR Lebenden mit eingeschlossen. Ausdrücklich für Unterstützung von DDR-Bürgern dienten die beiden Positionen „Zuschuß für Ostbesucher zum Treffen in Berlin u. Gelsenkirchen" mit 240,00 DM und „Kaffee-Sendung für Kränzchen in Ost[-]Berlin u. Treffen bei Frau Löschmann u. Päckchen-Porto“ mit 111,38 DM. “1749 Die Päckchenaktion für Bärwalder Vertriebene in der DDR wurde zum größeren Teil von in West-Berlin lebenden Bärwaldern getragen, die Finanzierung des aufzubauenden Heimatarchivs übernahmen dagegen überwiegend im Bundesgebiet wohnende. ${ }^{1750}$

Es finden sich seit 1990 - in West- und Ostdeutschland - viele Stimmen, die den Eindruck vermitteln, als hätten die Publikationen der Vertriebenenverbände für DDR-Bürger gänzlich außerhalb ihres Gesichts- und Interessenkreises gelegen. Zwei nach 1990 aufgezeichnete Aussagen ehemaliger DDR-Bürger mögen abschließend verdeutlichen, dass dies zumindest nicht generell gegolten haben kann. Der Schwiegersohn eines aus Landsberg/Warthe stammenden Bauern, der mit ihm in der DDR-Zeit nordöstlich von Berlin lebte, berichtet: „Um an landsmannschaftlichen Treffen teil zu nehmen, fehlte nicht der Wille, aber die Zeit, es wurde ja ganz selten mal eine kleine Reise unternommen. Dafür wurden diesbezügliche Nachrichten regelrecht aufgesogen. Ein Artikel über das Landsberg-Heimattreffen vom 7./8.10.1972 der Landsmannschaft Berlin-Mark Brandenburg in Herford wurde als kleines Heiligtum sorgfältig im Schreibtisch dort verwahrt, wo auch die Unterlagen aus der alten Heimat lagerten. " ${ }^{1751}$ Der Gubener Historiker Andreas Peter (geb. 1963 Guben), dessen Mutter aus dem Ostteil des Kreises Guben stammt, schrieb 2002 über die Kenntnisse, die er als DDR-Bürger von den Aktivitäten des „zuständigen“ Vertriebenenverbandes hatte: „Meine erste Bekanntschaft mit dem, Gubener Heimatbund' geht auf den Sommer 1988 zurück. Damals besuchte ich meinen Onkel in Schenkendöbern, und bei dieser Gelegenheit bekam ich von Siegfried Bähr zwei Hefte für einige Tage zum Lesen. Sie trugen den Titel ,Aus unserer Heimat'. Damals verschlang ich als junger Geschichtsstudent diese Lektüre, zumal sie mir mit einer gewissen Heimlichkeit anvertraut wurde, kamen diese Hefte doch, von drüben'. Von dem Herausgeber der Hefte, dem ,Gubener Heimatbund', hatte ich indes auch lange Zeit danach keinerlei Vorstellung./Nun, das ist schon länger als ein Dutzend Jahre her, und inzwischen wandelte sich mein anfängliches Interesse zu aufrichtigem Respekt für die Arbeit dieses Vereins, der im Mai 2002

1748 Ebd. 15 (1981), S. [6]. Vgl. auch ähnlich 16 (1982), S. [7].

1749 Ebd. 20 (1986), S. [7].

1750 Im Januar [1968] geht die Päckchenaktion, da der bisherige Betreuer sie krankheitshalber nicht mehr schultern kann, „auf einen Helferkreis in Berlin über“. Arbeitskreis Bärwalde Nm. Kreis Königsberg Nm. Jahresbericht [2] (1968), S. [6].

1751 Mitteilungen von Detlev Stark, Hoya/Weser, an den Verf., 3.12.2016. 
sein 50jähriges Jubiläum begeht."1752 Auch diese Indizien sprechen wiederum wohl doch deutlich dafür, das Thema Flucht und Vertreibung nicht als ein solches der frühen Nachkriegsjahre abzuhandeln, sondern als eines, dessen Auswirkungen mit den Lebenswegen der Betroffenen mindestens bis zu ihrem Tod bzw. bis zur Gegenwart reicht.

Nur am Rande kann hier in aller Kürze darauf hingewiesen werden, dass die weitere Publikationstätigkeit der Heimatkreisgemeinschaften sowie anderer Einrichtungen und Verlage auch Monographien aufweist, allen voran die verbreiteten „Heimatbücher“ als bestandsaufnehmende Kreisbeschreibungen und Vermächtnisse. Für diese wie auch für die Periodika und nicht zuletzt für ungedruckte Sammlungen in den zahlreichen Heimatstuben und Heimatarchiven wurden Zeitzeugenberichte gesammelt, wie dies auch das Bundesarchiv tat. Nicht zu übersehen ist, dass unter den Autoren und Einsendern auch DDR-Bürger waren, wenngleich sie nicht immer öffentlich namentlich genannt werden konnten. Ein auf den 18. Dezember 1950 datierter Augenzeugenbericht über die Ereignisse am Kriegsende 1945 in Tankow im Kreis Friedeberg/ Neumark ist von damals in der DDR lebenden Tankower Vertriebenen verfasst worden und im Bundesarchiv/Lastenausgleichsarchiv überliefert. Er ist nicht der einzige Bericht, dessen in der DDR lebende Verfasser „aus Angst vor Repressalien ihre Identität verbargen “. ${ }^{1753}$ Auch der 1975 im Heimatbuch für den westpreußischen Kreis Stuhm abgedruckte Bericht „Besatzungselend“ über Erlebnisse des Jahres 1945 ist - als einziger im Buch - ohne Verfasserangabe geblieben, da die Autorin offenkundig in Ost-Berlin oder noch an dem berlinnahen Ort lebte, an den sie auf der Flucht 1945 gelangt war, im brandenburgischen Glienicke/Nordbahn, also damals im DDR-Bezirk Potsdam. ${ }^{1754}$

Weder im Buchhandel noch in den Beständen der öffentlichen Bibliotheken in der DDR gab es frei zugängliche Literatur zu den Vertreibungsgebieten, die deren deutsche Vergangenheit behandelte. „In der Deutschen Bücherei Leipzig sind beispielsweise die vor 1990 in der Bundesrepublik Deutschland erschienenen Heimatbücher der Vertriebenen mit ,Giftschrank'Etikett versehen (rotes Dreieck oder doppelt rotes Dreieck mit der Spitze nach oben weisend), d.h. sie wurden nur Benutzern ausgehändigt, die ein ,berechtigtes wissenschaftliches Interesse

1752 Andreas Peter: 50 Jahre Gubener Heimatbund. In: Gubener Heimatkalender 46 (2002), S. 31. Peter wurde später (2014/15) Vorsitzender des Gubener Heimatbundes und 2014-2016 seiner Regionalgruppe Guben (siehe Ortsdokumentation Guben).

1753 Edward Rymar: Tankow/Danków im Wandel der Geschichte. Strzelce Krajeńskie 2009, S. 84. - Beispiele für in Heimatzeitschriften ohne Verfasserangabe abgedruckte Berichte von DDR-Bürgern über Reisen in ihre Heimatorte (Stettin 1965, Bublitz in Pommern 1967, Danzig 1968, Stadt und Kreis Jauer in Schlesien 1968/71, Nipter im Kr. Meseritz 1974) nachgewiesen bei Kessler, Die „ostdeutschen“ Heimatblätter (wie Anm. 255), S. 65 f., Fn. 29.

1754 N. N., Besatzungselend (wie Anm. 619), bes. S. 270 f. - Ähnliches berichtet 2010 eine (aus Brieg stammende, damals in Dresden lebende) ehemalige DDR-Bürgerin, die 1968 für ein von der „Bundesvereinigung der Brieger" herausgegebenes Bildbändchen „Brieg - Einst und Jetzt“ aktuelle Fotos in dem nun polnischen Brzeg fertigte und über ihren westdeutschen Bruder zur Verfügung stellte. „Natürlich durfte ihr Name als Fotografin nicht bekannt werden." Dorothea Tscheschner: Die Brieger in SBZ und DDR und die Goslarer Patenschaft. In: Briegische Briefe 31 (2009)6, S. 35-38; 32 (2010)1, S. 19-22, 32 (2010)2, 25-28, hier S. 21. 
nachweisen konnten. ${ }^{1755}$ In den Westzonen hingegen entstand schon bald ein breites Spektrum an öffentlich sichtbarer „Heimatliteratur“: Orts- und Kreischroniken („Heimatbücher “1756), Gedicht-, Lieder- und Sagensammlungen u. a., die von den Landsmannschaften und Heimatkreisgemeinschaften, aber auch von mehreren spezialisierten Verlagen herausgebracht wurden. Stadt- und Kreisbibliotheken sowie Buchhandlungen richteten besondere Sachgruppen und Regale für die Landeskunde der historisch ostdeutschen Gebiete ein, die erst nach 1990 allmählich aufgelöst wurden. ${ }^{1757}$ Dies alles fehlte in SBZ/DDR und so auch in Brandenburg vollständig, die Einfuhr solcher Literatur war untersagt und wurde vom DDR-Zoll bzw. der Post unterbunden. ${ }^{1758}$ Es wäre interessant zu erforschen, welche Druckschriften dennoch „illegal“ ihren Weg in die DDR fanden. Antiquarisches fand ebenfalls Abnehmer oder wurde gar nicht erst aus der Hand gegeben. So hat der Verfasser in den letzten Jahrzehnten in vielen Bücherregalen ehemaliger DDR-Bürger auch vor 1945 erschienene Werke über Städte und Landschaften der ehemaligen Ostgebiete gesehen, aus denen - jenseits des offiziellen Tabus und der Propaganda - Wissen bezogen werden konnte.

Zusammenfassend ist hier festzuhalten: In SBZ und DDR wurden private Organisationsformen von Flüchtlingen und Vertriebenen nicht geduldet. ${ }^{1759}$ Die in West-Berlin und den Westzonen in großer Zahl entstehenden Zusammenschlüsse sammelten jedoch auch Daten und Anschriften ihrer in der SBZ/DDR wohnenden Landsleute und publizierten diese von Anfang an (sogar teilweise noch nach dem Mauerbau und bisweilen durchgehend bis 1989/90 ${ }^{1760}$ ) in ihren

1755 Faehndrich, Erinnerungskultur (wie Anm. 254), S. 197, Anm. 14.

$1756 \mathrm{Zu}$ dieser Literaturgattung siehe die in Anm. 254 genannte neuere Literatur. - (Ältere) Bibliographie: Wolfgang Kessler: Ost- und südostdeutsche Heimatbücher und Ortsmonographien nach 1945. Eine Bibliographie zur historischen Landeskunde der Vertreibungsgebiete. Hrsg. von der Stiftung Ostdeutscher Kulturrat. München/New York 1979.

1757 Im Regierungsbezirk Münster/Westfalen beispielsweise wurden 1952 durch Förderung des Landesvertriebenenamtes Nordrhein-Westfalen „rund 100 öffentliche Büchereien der Gemeinden und Kirchen mit Bücherspenden ostdeutscher Literatur bedacht“ (Bücher für die Ostvertriebenen. In: Das Heimatblatt für Sorau N./L.-Stadt und Land 1 (1952), Nr. 1, S. 11).

1758 Beispiel für die enge Zusammenarbeit von Post und Polizei: Im Oktober 1950 übersendet die Landespolizeibehörde Brandenburg der Hauptverwaltung der DVP im MdI, Hauptabteilung Verwaltungspolizei, drei beschlagnahmte Exemplare der Zeitschrift „Königsteiner Rufe“. Die Zeitschrift „wurde durch die Post der Abt. VA, Ref. 3 zugeleitet.“ (BArch, DO 1/27886, Bl. 139). - (Die katholischen „Königsteiner Rufe. Monatsschrift für Heimatvertriebene und Förderer der Königsteiner Anstalten" erschienen in Königstein/Ts. von 1949 bis 1997.)

1759 Ausführlich dazu: Amos, Vertriebenenpolitik der SED (wie Anm. 12), S. 22-27.

1760 Bis 1990 und insofern ohne Unterbrechung von den ersten Nachkriegsjahren an bis heute finden sich Adressen in SBZ/DDR bzw. neuen Bundesländern in den „Briegischen Briefen“ (freundlicher Hinweis Andreas Rösler, Forschungsgruppe Brieg der Arbeitsgemeinschaft ostdeutscher Familienforscher e. V., Berlin, 2.4.2016). Ebenfalls durchgehend von 1964 bis 1986 mit vollem Namen und voller Anschrift im in loser Folge in und von der Patenstadt Goslar, „Betreuungsstelle Brieg“, herausgegebenen „Brieger Anschriften-Verzeichnis. Stadt und Landkreis Brieg“, Jg. 1 (1962) - 17 (1986). - Die zu DDR-Zeiten zunächst in Dresden, dann in (Ost-) Berlin lebende Architektin Dorothea Tscheschner (geb. 1928 Brieg), nach 1990 stellv. Vorsitzende der Bundesvereinigung der Brieger, schrieb rückschauend 2010 über die in der DDR lebenden vertriebenen Brieger (Tscheschner, Die Brieger in SBZ und DDR [wie Anm. 1754]): „Dank dieser zahlreichen persönlichen Ver- 
Heimatbriefen, Vertriebenenzeitschriften und Anschriftenlisten, die ihren Weg im Einzelfall - illegal - auch nach Brandenburg gefunden haben dürften. Der Abdruck der Adressen geschah allerdings auf der Grundlage verschiedenster Informationen, musste also keineswegs vom Betroffenen selbst mitgeteilt worden sein. ${ }^{1761}$ Diese Listen und auch Familienanzeigen sind eine ungehobene Quelle für in die SBZ/DDR gelangte Personen, da das dortige Vereinigungsverbot die Erstellung und Überlieferung solcher Listen verhinderte und im Land Brandenburg daher kaum Nachweise existieren, die über statistische Daten hinausgehen. Von in der DDR Lebenden aufgegebene Familienanzeigen sind zudem ein deutliches Indiz für das Unterlaufen der Verbote und Tabus. Auch wenn regelrechte Todesanzeigen mit Orts- oder gar Adressangabe in der DDR gegenüber denen in der Bundesrepublik Verstorbener in deutlich geringerer Zahl begegnen, sind es doch durchaus keine ganz seltenen Ausnahmen. Drei Jahre nach dem Mauerbau findet sich im „Ostpreußenblatt" die Todesanzeige eines in der Niederlausitz Verstorbenen. Aufgegeben worden ist die Anzeige wahrscheinlich von einer in Irrel (Kr. Bitburg), mithin in der Bundesrepublik, wohnenden, namentlich nicht genannten Angehörigen. Die in der DDR lebende Witwe wird aber namentlich und mit Wohnort ebenso aufgeführt wie drei weitere dortige Wohnorte Hinterbliebener: „Unser lieber Vater und Großvater / Stellmacher / Karl Spitz / *am 25.11.1897 + 15.5.1963 / aus Gr.-Hubnicken, Kreis Samland/wurde nach langer Krankheit in die Ewigkeit abberufen. / Um ein stilles Gebet bittet/im Namen von Mutter, Geschwistern/und allen Angehörigen/Frau Edith Britzen, geb. Spitz / Crinitz/N.-Laus., Irrel, Herzberg/Elster, Döbern und Tröbitz." ${ }^{1762}$

Die Heimatvertriebenenpresse ist überdies eine bislang kaum berücksichtigte Quelle für die nicht geringe Rolle, die (West-)Berlin gleichsam als Ersatz-Treffpunkt für viele Vertriebene

bindungen wurden die Herausgabe der ,Briegischen Briefe; die Bildung der ,Bundesvereinigung der Brieger und natürlich die Gründung der Patenschaft Goslar-Brieg 1950 in weiten Kreisen der SBZ/DDR-Brieger sehr schnell bekannt. So gingen die in die ,Zone' gelangten Exemplare der ,Brieger Zeitung' von Hand zu Hand, die Anschriftenverzeichnisse halfen vielen, ihre Angehörigen zu finden und die ersten Brieger Treffen in Goslar wurden mit großem Interesse verfolgt, zumal es manchem trotz Währungsreform durch Spenden oder auf Kosten Verwandter gelang, mit großer Freude daran teilzunehmen und nach Rückkehr darüber zu berichten.“ (S. 38). „Goslar und die Briegischen Briefe wurden so zum wichtigsten, wenn auch illegalen Bezugspunkt der Ostdeutschen zu ihrer verlorenen Heimat." (S. 20).

1761 Ein Beispiel für offenbar von den Betroffenen selbst eingesandte Meldungen mit Adressenangabe ist die Rubrik „Grüße“ im Heimatgruß-Rundbrief Arnswalde, Nr. 32, 1952, in der unter 22 Personen bzw. Ehepaaren 9 mit Namen und vollständigen Wohnanschriften (inkl. Hausnummer) in der DDR genannt sind (bei 2 weiteren ist kein Ort genannt). Von diesen lebten 6 in Mecklenburg (Malchow und Waren/Müritz) und je 1 in Brandenburg (Premnitz), Sachsen-Anhalt (Weißenfels) und Thüringen (Erfurt). - Die polizeiliche Überprüfung von Personen, deren Anschriften man 1950 im „Angerburger Heimatbrief“ fand, „ergab, dass 5 Personen von dem Bestehen der Kreisgemeinschaft Angerburg keine Kenntnis hatten. Weiteren 5 Personen wurden hin und wieder Werbeschreiben zugesandt, die sie unbeachtet liessen. Ausserdem sind 6 von den aufgeführten Personen nach Ausserhalb verzogen." (BArch, DO 1/27886, Bl. 88; vgl. den vollständigen Abdruck im Quellenteil, Nr. 226). Dieses gemischte Bild dürfte durchaus zutreffend spiegeln, dass Anschriften grundsätzlich auch ohne Wissen der Betroffenen aufgenommen wurden, andererseits kann die Leugnung von Kontakten im Einzelfall immer auch reine Schutzbehauptung der Betroffenen gewesen sein.

1762 Das Ostpreußenblatt, Jg. 14, Folge 24, 5.6.1963, S. 20. 
aus Brandenburg und der gesamten SBZ/DDR zum Teil sogar noch bis zum Mauerbau 1961 gespielt hat. Die in Berlin und Brandenburg besonders zahlreich untergekommenen Neumärker spielten dabei eine besondere Rolle, während diejenigen, deren Mehrheit in andere und nicht zuletzt westdeutsche Gebiete gelangt waren - z. B. Ostpreußen oder Sudetendeutsche -, dabei weniger in Erscheinung traten.

\section{Vertriebenentreffen und korporative Tendenzen in Brandenburg}

Während die oben kurz skizzierten, in den Westsektoren Berlins durchgeführten Vertriebenentreffen zwar bislang unerforscht sind, aber viele von ihnen durch die zeitgenössischen Einladungen und gedruckten Kurzberichte einigermaßen rekonstruierbar wären, lassen sich Treffen innerhalb der SBZ/DDR ungleich schwerer greifen. Sie haben zwar - als Vertriebenentreffen gekennzeichnet - nie bzw. allenfalls in den ersten Jahren im öffentlichen Rahmen stattgefunden, es hat sie aber - in einem sehr beschränkten Rahmen privat und vor allem in kirchlichen Zusammenhängen sowie in indirekter Form - durchaus gegeben. Korporative Tendenzen, d. h. unabhängige Zusammenschlüsse oder Interessenvertretungen zu gründen, hat es ebenfalls, auch in Brandenburg gegeben, wenngleich diese für die SED noch viel weniger akzeptable Betätigungsform bei der Republikgründung 1949 bereits unterbunden war. ${ }^{1763}$ Die Forschungen zu beiden Bereichen stehen für Brandenburg noch fast ganz am Anfang, so dass beiläufig gefundene Einzelbelege hier genügen müssen, um das Thema zu skizzieren. ${ }^{1764}$

In Cottbus wird 1947 ein „Verband der Ostumsiedler“ erwähnt, dessen Vorsitzender jedoch - offenkundig sogleich nach Bekanntwerden - vom Oberbürgermeister schriftlich auf die Ungesetzlichkeit seines Tuns hingewiesen wird. Mit Schreibem vom 19. April 1947 wird ihm jede derartige Betätigung verboten und der bereits gebildete, aus vier Herren und zwei Damen bestehende Vorstand aufgelöst. „Außerdem fordere ich Sie auf, bis zum 22. April 1947, 12 Uhr

1763 Die verschiedentlich entstandenen „Interessengemeinschaften für Umsiedler“ wurden „als so gefährlich angesehen, daß sie mit Runderlaß vom 14. Juni 1948 verboten wurden“ (Blöß, Grenzen und Reformen [wie Anm. 89], S. 66). - Aus Thüringen ist durch einen VP-Ermittlungsbericht die Gründungsversammlung eines „Neubürgervereins Apolda“ am 18.9.1949 im dortigen Promenadengarten überliefert (BArch, DO 1/27886, Bl. 14). Lt. VP-Bericht über die 2. Mitgliederversammlung am 16.10.1949 zeige sich, dass es sich um Schlesier handelt, die „die Oder-Neiße-Linie nicht als Friedensgrenze anerkennen“ (ebd., Bl. 13). Auch sonst gab es in Thüringen rege korporative Vertriebenen-Aktivitäten. Beim Volkspolizei-Kreisamt Mühlhausen sprach ein Daniel Pitschmann (Mühlhausen) vor, der um Genehmigung bat, dass im Briefverkehr untereinander ein Wappen verwendet werde, das auf dem alten Stadtwappen der Stadt Grünberg in Schlesien basierte (Meldung vom 27.10.1949; ebd., Bl. 15, Wappen-Abb. [Schwarz-Weiß-Reprofoto]: Bl. 16).

1764 Siehe, mit dem Blick auf die gesamte SBZ/DDR, die Auswertungen von BStU-Akten in den drei Standardwerken von Amos und Schwartz: Amos, Vertriebenenpolitik der SED (wie Anm. 12). - Amos, Vertriebenenverbände (wie Anm. 12). - Schwartz, Vertriebene und „Umsiedlerpolitik“ (wie Anm. 13), S. 477 ff., S. 499 (Finsterwalde), S. 504f. (Cottbus), S. 507f. und 513f. (Forst/Lausitz). - Wie ergiebig die Akten zumal der MfS-Bezirksverwaltungen sein können, zeigt für Mecklenburg(-Vorpommern) (einschließlich 1952-1990 zu den Bezirken Schwerin und Neubrandenburg zählender brandenburgischen Kreise!) Seils, Die fremde Hälfte (wie Anm. 19), S. 244-259 („Vertriebene im Visier des MfS“), S. 259-268 („Vertriebene im Dienst des MfS“). 
mittags, bei der Kriminalpolizei in Cottbus, Zimmer 16, alle in Ihrem oder im Besitz von anderen Mitgliedern befindlichen Unterlagen, wie Mitgliederlisten, Geldmittel, Karteikarten, Protokolle, Korrespondenz, kurz das gesamte Material abzuliefern. Gleichzeitig fordere ich Sie auf, etwaige inzwischen ins Leben gerufene Zweigstellen des ,Verbandes' von der Einstellung der Tätigkeit und Auflösung zu benachrichtitgen, wobei Sie die volle Verantwortung für eine evtl. Weiterarbeit solcher Zweigstellen tragen. [...]. ${ }^{\text {1765 }} 1948$ wird in Forst (Lausitz) kurzzeitig eine von einem Oberschlesier aber schon im Herbst 1947 gegründete nichtstaatliche „Interessengemeinschaft ausgesiedeleter Schlesier in der russisch besetzten Zone Deutschlands" erwähnt. ${ }^{1766}$ Während der Rat des Kreises Lebus die Mitglieder der von der „Interessensgemeinschaft“ angeschriebenen Ortsumsiedlerausschüsse unter dem 12. Mai 1948 noch in rein bürokratischer Form vor jedem Kontakt warnte, als handelte es sich um eine bloß unabgesprochene Privatinitiative ${ }^{1767}$, ließ die sowjetische Kreiskommandantur den Initiator im Mai kurzerhand verhaften, womit sie sogar der brandenburgischen Geheimpolizei noch zuvor kam. ${ }^{1768}$

Da Zusammenschlüsse Vertriebener und als Heimatvertriebenentreffen deklarierte entsprechende Zusammenkünfte in der SBZ unerwünscht und ab 1949 auch amtlich nicht mehr erlaubt waren ${ }^{1769}$, verlagerte sich die Netzwerkarbeit einerseits in den kirchlichen und in den privaten Bereich, andererseits auf die in West-Berlin agierenden Kreisgemeinschaften und Betreuer. Anfang 1950 wies das DDR-Innenministerium die Landesministerien an, „alle Volksgruppentreffen [!] der früheren [!] Schlesier, Ostpreußen und Pommern zu unterbinden und zu verbieten, da diese Zusammenkünfte dazu beitragen, die Sicherheit und Ordnung sowie die freundschaftlichen Beziehungen zu den jetzt in Schlesien, Ostpreußen und Pommern bestimmenden Ländern zu gefährden'. Alle solchen „Volksgruppentreffen“ und landsmannschaftlichen Zusammenkünfte wurden als ,westlich inspirierte Versuche zur Stiftung von Unruhe und Unzufriedenheit bezeichnet "1770 oder auf „faschistische Umtriebe“ zurückgeführt. Letzteres zeigt z.B. der Bericht eines SEDMitglieds über den Verlauf einer „Umsiedlerversammlung“ am 28. Oktober 1947 in Rathenow, in dem es u. a. heißt: „Es handelt sich um wurzellose und politisch charakterlose Menschen, von denen anzunehmen ist, daß sie zu einem hohen Prozentsatz früher dem Nationalsozialismus angehört haben. ${ }^{\text {1771 }}$ Kriminalisiert wurde folglich schon das Singen von landsmannschaftlich geprägten Heimatliedern, das nach wie vor anzutreffen war, aber auch alle anderen öffentlichen Bekun-

1765 Wille III (wie Anm. 196), S. 361, Nr. 389 (Stadtarchiv Cottbus, Sozial- und Gesundheitswesen, Sozialamt, Nr. 489).

1766 Schwartz, Vertriebene und „Umsiedlerpolitik“ (wie Anm. 13), S. 507.

1767 Wille III (wie Anm. 196), S. 143, Nr. 145 (nach BLHA, Rep. 250 Lebus, Nr. 356).

1768 Schwartz, Vertriebene und „Umsiedlerpolitik“ (wie Anm. 13), S. 507.

1769 Siehe u. a.: BArch, DO 1/27887, Bl. 47 (Schreiben des MdI, HVDVP, Berlin, 8.8.1951, auf eine Anfrage der Landesbehörde der VP Sachsen): „[...] wird mitgeteilt, daß grundsätzlich in allen Ländern der DDR die Veranstaltungen und Zusammenkünfte der ehemaligen Umsiedler in Zusammenarbeit mit den zuständigen Dienststellen des Ministeriums für Staatssicherheit unterbunden werden".

$1770 \mathrm{P}$ [eter] H[einz] Seraphim: Die Heimatvertriebenen in der Sowjetischen Besatzungszone. Bonn 1955, S. 29.

1771 Wille III (wie Anm. 196), S. 352 f., Nr. 393 (BLHA, Rep. 333, Nr. 575, Bl. 255). 
dungen, Selbstorganisationstendenzen und „Westkontakte“. Dennoch staffindende Treffen gehörten bis 1989 zu den Beobachtungs- und Verhinderungsobjekten des Staatssicherheitsdienstes.

Neben „verdächtigen“ Einzelpersonen gerieten besonders alle Arten von „,Konzentrationen von Umsiedlern', das heißt Orte, in denen mehrere Vertriebene einer Herkunftsregion wieder zusammen lebten“, in den Blick des MfS. ${ }^{1772}$ Ein wohl auf Mitte der sechziger Jahre zu datierender Fragenkatalog der Bezirksverwaltung Neubrandenburg ${ }^{1773}$ für die nachgeordneten Kreisdienststellen enthält zwölf Punkte, mit denen die Überwachungstätigkeit des „Sachgebietes ,Umsiedler" auf eine neue Grundlage gestellt werden sollte. ${ }^{1774}$ Schwerpunkte waren „Aufklärung der Konzentrationen, operative Bearbeitung von Umsiedlern, die illegale Gruppenbildung oder Hetze gegen die Oder-Neiße-Grenze betrieben, sowie Aufdecken von Empfängern von Heimatzeitschriften und Inhabern von Westkontakten“" ${ }^{1775}$ Der Weg zur Informationsbeschaffung sollte auch über aus dem Vertriebenenmilieu - mit den gängigen Methoden - anzuwerbende Inoffizielle Mitarbeiter (IM) beschritten werden. Mirjam Seils kommt in ihrer Untersuchung zu Mecklenburg-Vorpommern für die fünfziger Jahre, in denen das MfS auch insgesamt noch „Personalmangel“ hatte, zu dem Schluss: „Da die Umsiedler meistens unter sich blieben, wurden sie vorwiegend von den eigenen Landsleuten verraten. ${ }^{\text {"1776 }}$ Auch das MfS bot gerade den entwurzelten Vertriebenen überdies - wie der gesamte Staatsdienst der DDR - außerordentliche Aufstiegsperspektiven. ${ }^{1777}$ Seils geht auf der Grundlage ihrer Beobachtungen von einem im MfS ähnlich leicht überdurchschnittlichen Prozentsatz der Vertriebenen wie im gesamten Staatsapparat aus. ${ }^{1778}$

Eine systematische Recherche nach formlosen, inoffiziellen Treffen in SBZ und DDR ist bisher nicht geleistet worden und kann auch hier - für Brandenburg - nicht geboten werden. Einzelne Beobachtungen und Funde müssen vorerst genügen, eine gesonderte Untersuchung wäre wünschenswert. Michael Schwartz hat für die Lausitz bereits auf Methoden hingewiesen, die Vertriebene anwandten, um die Verbote zu unterlaufen. ${ }^{1779}$ In Sachsen war der Leipziger Zoo vor allem während der Messe ein beliebter Ort, gemeinsame Café- und Restaurantbesuche über den Verwandtschaftskreis hinaus hat es ebenfalls gegeben. ${ }^{1780}$ In Sachsen-Anhalt war

1772 Seils, Die fremde Hälfte (wie Anm. 19), S. 249.

1773 Der Süden des Bezirks umfasste auch brandenburgische Gebiete um Prenzlau.

1774 „Auftrag für alle IM bei der Überwachung der Umsiedler“. BStU, BV Neubrandenburg, Abt. XX, Nr. 263, Bl. 44. Text abgedruckt bei Seils, Die fremde Hälfte (wie Anm. 19), S. 260.

1775 Seils, Die fremde Hälfte (wie Anm. 19), S. 259.

1776 Ebd.

1777 Ebd., S. 268.

1778 Ebd.

1779 Schwartz, Vertriebene und „Umsiedlerpolitik“ (wie Anm. 13), S. 508.

1780 In einem VP-Bericht heißt es: „Am 6.8.50 („Tag der Heimat“) versammelten sich im Leipziger Zoo ca. 500 ehem. Umsiedler aus der CSR, die aus den Kreisgebieten Leipzig, Dresden, Halle und Thüringen zusammengekommen waren." (BArch, DO 1/27886, Bl. 87). Vgl. Schwartz, Vertriebene und „Umsiedlerpolitik“ (wie Anm. 13), S. 535 f. - In einer „Übersicht“ des MfS über die „Schwerpunkte“ der „feindlichen Tätigkeit der revanchistischen 
es anlaog der Hallenser Zoo. ${ }^{1781}$ Viele selbst zu den Vertriebenen zählende evangelische Gemeindepfarrer gehörten zu den besonders Aktiven. Sie versuchten, teils von den Westzonen oder von West-Berlin aus, teils aber durchaus auch von Wohnorten in der SBZ/DDR aus, ihre ehemaligen Gemeindemitglieder zusammenzuhalten, und organisierten speziell für diese gedachte Gottesdienste, zu denen sie per Rundbrief einluden. Derartige Aktivitäten lassen sich für die vierziger Jahren noch relativ zahlreich und durchaus auch öffentlich nachweisen, in den folgenden Jahrzehnten aber war Konspiration angesagt. Auch für ein in der frühen Zeit in Gotha (Thüringen) durchgeführtes kleineres Soldiner Heimattreffen ist jedoch schon auf die Gefährdung der Organisatoren hingewiesen worden: „Den Mut dazu hatten die Landsleute Paul Kohl, der Fotograf aus Soldin, und Kurt Nitsch, die es Pfingsten 1948 organisiert hatten. "1782 Ein im Soldiner Heimatbuch abgedrucktes Gruppenfoto zeigt 40 Teilnehmer aller Altersjahrgänge. ${ }^{1783}$

Der in seinem früheren Wirkungsort ehemals sehr angesehene frühere Kantor und Leiter der Volksschule von Königsbach (poln. Bukowiec) bei Lodz (Polen bzw. Wartheland), Karl Meier, der nach 1945 als Schulleiter in Vahldorf bei Magdeburg amtierte, lebte im Ruhestand, also wohl ab 1951, in Lebus (Oder), wo er sich noch bis zu seinem Tod 1966 als Organist der evangelischen Kirche betätigte. „Von Lebus aus besuchte er des öfteren die ehemaligen Königsbacher, die sich in Großgörschen bei Leipzig angesiedelt hatten, und hatte brieflichen und persönlichen Kontakt zu seinen ehemaligen Schülern in der Bundesrepublik Deutschland."1784 Der kirchentreue, glaubensstarke und dem NS-Regime kritisch gegenüberstehende Christ, der vor 1939 in Königsbach allgemein als „Vater des Dorfes“ geschätzt wurde, galt also auch nach 1945 wieder als eine den Zusammenhalt mindestens noch in den fünfziger Jahren fortführende Bezugsperson. In diesem Fall wurden Treffen deutlich erleichtert, denn das „Gros der Königs-

Landsmannschaften“ heißt es (Datum? Offenbar 1950er Jahre): „Als zahlenmäßig größte Zusammenkünfte sind die jährlich jeweils am 1. Sonntag nach Pfingsten stattfindenden Treffen ehem. Umsiedler aus der ČSSR im Leipziger Zoo anzusehen. Der Teilnehmerkreis umfaßt immer mehrere hundert Personen aus verschiedenen Bezirken der DDR. Die revanchistischen Ziele der Landsmannschaften werden hier in individuellen Gesprächen diskutiert. Es ist bekannt, daß dieses Treffen jedes Jahr ohne vorherige Einladung stattfindet. Verbindungen nach Westdeutschland oder Westberlin wurden ebenfalls noch nicht festgestellt. (Operative Bearbeitung erfolgt.)" (zitiert nach Habel, Die Sudetendeutschen [wie Anm. 954], S. 120).

1781 BArch, DO 1/27887, Bl. 88: Fernschreiben der HVDVP, Berlin, 10.10.1952, an die Chefs aller Bezirksbehörden der VP (außer der direkt informierten in Halle) und Präsidium der VP Berlin, dass am 12.10.1952 "erneut ein Umsiedlertreffen im Zoo Halle stattfindet", weshalb um Einleitung verschiedener Maßnahmen gebeten wird, u. a. Verhinderung von Personentransporten und Sonderzügen u. ä. am genannten Termin in Rücksprache mit ATG und den Dienststellen der Reichsbahn, Überwachung von 17 konkret mit Kennzeichen genannten $\mathrm{Kfz}$, die „bei dem vergangenen Umsiedlertreffen festgestellt“ worden waren, sowie v. a. Ermittlung der Organisatoren.

1782 Heimatkreis Soldin/Neumark (wie Anm. 303), S. 651.

1783 Ebd., „1. Heimattreffen in Gotha (SBZ)“.

1784 Leopold Schenzel: Königsbach. Das Schicksal einer ostdeutschen Schwabensiedlung. In: Otto Heike: 150 Jahre Schwabensiedlungen in Polen 1795-1945. Leverkusen 1979, S. 217-293, hier S. 261. Siehe über ihn auch ebd., S. 264. 
bacher Schwaben kam nach der Vertreibung in das historisch bedeutsame Gutsdorf Großgörschen bei Leipzig. Hier und in drei weiteren [unmittelbar benachbarten] Gemeinden Kleingörschen, Rahner [Rahna] und Kaja fanden die Nachfahren der Kolonisten aus Süddeutschland eine neue Heimat. Nur wenige sind dank verwandtschaftlicher Beziehungen Ende der vierziger Jahre in die Bundesrepublik gekommen." ${ }^{1785}$

Für die Flüchtlinge und Vertriebenen aus dem neumärkischen Ziebingen (Kr. Weststernberg) wurde ihr letzter (evangelischer) Pfarrer Herbert Rettig (1906-1961), seit 1947 Pfarrer an der Gethsemanekirche in Berlin-Prenzlauer Berg, der entscheidende Bezugspunkt. Mit vervielfältigten Gemeindebriefen - an „Meine lieben Gemeindeglieder aus Ziebingen, Balkow und Grimnitz!"1786 - hielt er (bis mindestens 1948) über alle Zonengrenzen hinweg seine Ziebinger „Schäfchen“ zusammen, persönliche Kontakte und Besuchsreisen zu ihnen setzte er bis in sein Sterbejahr 1961 fort. In seinem Gemeindebrief vom Januar 1948 wird beispielsweise nicht nur ein erneutes Treffen angekündigt, sondern auch der rege briefliche Austausch deutlich: „So Gott will, wollen wir uns auch im neuen Jahr 1948 wieder zu einem Gottesdienst und Beisammensein treffen. Es wird nach Ostern voraussichtlich in Beeskow und Frankfurt/O. stattfinden, Einladungen werden rechtzeitig ergehen." Bei dieser Gelegenheit fügt Rettig eine Liste der bis dahin durchgeführten Treffen der vertriebenen Ziebinger an, die auch deutlich zeigt, wo die Mehrheit von ihnen zumindest damals wohnte:

„Am 26. Oktober 1946 in Frankfurt/O. mit 200 Besuchern, am 13. April 1947 in Frankfurt/O. mit 400 Besuchern,

am 31. August 1947 in Beeskow mit 464 Besuchern, am 26. Oktober 1947 in Frankfurt/O. mit 350 Besuchern.

Außerdem fanden in kleinerem Kreise drei Zusammenkünfte in Berlin statt." ${ }^{1787}$

Die großen Teilnehmerzahlen der Beeskower und Frankfurter Treffen lassen vermuten, dass diese in Kirchen stattgefunden haben. Rettig führte ein Tagebuch, in dem sich aber auch die vielen kleineren Kontakte spiegeln. Auszüge werden hier angesichts der Seltenheit solcher Quellen wiedergegeben:

1785 Ebd., S. 247. Schenzel bemerkt ferner: „die meisten [haben] ihre schwäbische Mundart auch nach 1945 nicht verlernt, wie sch bei einem Besuch in Großgörschen feststellen ließ“ (ebd., S. 276). Zur weiteren Entwicklung (Zwangskollektivierung usw.) ebd., S. $287 \mathrm{f}$.

1786 Schieche/Jaeschke, Ziebingen (wie Anm. 779), S. 321. Diese Ortsgeschichte enthält ein bemerkenswertes Kapitel „Ziebinger in der Fremde“ (S. 320-323), dessen Niveau weit über dem vieler Heimatchroniken liegt. Siehe auch das sehr informative vorausgehende Kapitel „Ziebingen und Ziebinger 1945/46“ (S. 298-319). Ein anderes Beispiel eines vom (1948 in der SBZ lebenden) ehemaligen Pfarrer seiner niederschlesischen Vertriebenengemeinde (aus dem Kr. Guhrau) verfassten hektografierten Rundbriefs als Faksimile vollständig abgebildet in: Kessler, Die „ostdeutschen“ Heimatblätter (wie Anm. 255), S. 52 f. (H. Schmidt, Bautzen).

1787 Ebd., S. 323. 
„23.-25.10.1948:

5. Treffen der Ziebinger in Frankfurt.

Spaziergang durch die Riehtst [raße] bis an die Trümmer der Oderbrücke. Drüben die heimatlichen herbstlichen Wälder. ${ }^{1788}$... Am Montag in Unterlindow ${ }^{1789}$ richtige Ziebinger Beerdigung, den alten Schneidermeister Kanisch.

\subsubsection{8:}

Am 2. Advent hatten wir ein Ziebinger Treffen bei uns, an dem 50 teilnahmen. Zum ersten Mal hatte ich auch Flüchtlinge aus meiner eigenen Gemeinde [Gethsemanegemeinde Berlin] eingeladen, sechs waren gekommen.

\section{Mai 1949:}

Am 24.4.49 hatten wir im Johannisstift in Spandau einen Sternberger ${ }^{1790}$ Kirchentag, an dem 300 bis 400 Besucher teilnahmen. Ich hielt die Predigt in der Stiftskirche über 1. Mose 26,1-5: ,Sei ein Fremdling und ich will mit dir sein und will dich segnen" [...] Ich denke, im nächsten Jahr wird diese Arbeit ganz zur Ruhe kommen.

Am 16./17. Juni 1951 war ich in Frankfurt zur Trauung von Lina Drescher.

Am 21.12.1951 habe ich eine Trauung in Stremmen bei Beeskow beim ehemaligen Konfirmanden Hubrich aus Ziebingen.

Dezember 1955:

Die letzte Woche brachte Hanna [Rettig] und mir eine Fahrt nach Müllrose zur Goldenen Hochzeit von Raasches (Schuhmachermeister). Es war schön, mit so vielen alten Ziebingern zusammnen $z$ u sein $[\ldots]$. ${ }^{1791}$

Donnerstag, den 23.2.1961 beerdigte ich eine alte Sandowerin ${ }^{1792}$ und traf dabei eine ganze Reihe alter Gemeindemitglieder aus Ziebingen. Es bleibt doch immer wieder beschwingend und beglückend, wie eng man sich mit ihnen verbunden weiß. Und nun ist es immer ein Kreis alter und schon sehr alter Menschen, den man trifft."1793

1788 [Unmittelbar östlich der Frankfurter Stadtgrenze lag der Kreis Weststernberg, zu dem das etwas weiter südlich in Odernähe gelegene Ziebingen gehörte.]

1789 [Unterlindow (Kr. Lebus) südlich Frankfurt/O. in Odernähe.]

1790 [Das Sternberger Land bestand aus den Kreisen West- und Oststernberg.]

1791 [Gruppenbild der Hochzeitsgesellschaft (31 Personen mit Namen) [hier jedoch auf 1956 datiert] in: Gerhard Jaeschke / Manfred Schieche: Ziebingen im Sternberger Land. Ein Ort und seine Menschen. Berlin/Eisenhüttenstadt 2002, S. 176.]

1792 [Sandow (Kr. Weststernberg) nahe Ziebingen (poln. Sądów).]

1793 Schieche/Jaeschke, Ziebingen (wie Anm. 779), S. 323. Einfügungen in eckigen Klammern bereits in Vorlage, Auslassungen und Fußnoten von P.B. - Eine Fortsetzung fanden die Ziebinger Heimattreffen noch zu späten DDR-Zeiten auf Initiative einiger im Raum Frankfurt (Oder) lebenden Ziebinger der Geburtsjahrgänge 1922/23, die sich per „Buschfunk“ zu Treffen in Privaträumen und dann bis 1989, teilweise als „Klassentreffen" getarnt, in einer Gaststätte in Müllrose trafen, was in größerem Rahmen auch nach 1989 fortgesetzt wer- 
Die, wenn auch keineswegs uneingeschränkte oder gar ungefährliche, gesamtdeutsche Bewegungsfreiheit ermöglichte zunächst noch zonenübergreifende Aktivitäten, die später auf Briefverkehr reduziert werden mussten. Aus dem September 1947 ist ein weiteres frühes Beispiel eines Großtreffens in der SBZ überliefert, das zwar in Sachsen-Anhalt stattfand, an dem aber zweifellos zahlreiche in Brandenburg und Berlin lebende Vertriebene teilgenommen haben dürften. Es handelt sich um ein als „Landsberger Kirchentag“ bezeichnetes Treffen, das die kirchlichen Landsberger Heimatkreisbetreuer, „Flüchtlingsfürsorgepfarrer“ Georg Wegner ${ }^{1794}$ (geb. 1892) (Berlin-Reinickendorf-Ost) und die „Flüchtlingsfürsorgerin“ Else Schmaeling ${ }^{1795}$ († 1956) (Berlin-Charlottenburg), unterstützt von in Magdeburg ansässig gewordenen Mitgliedern der ehemaligen Landsberger Fabrikbesitzerfamilie Bahr, organisierten. Nicht wenige Landsberger, wenn auch insgesamt über ganz Deutschland verstreut ${ }^{1796}$, lebten in Berlin und Brandenburg, die Betreuer saßen ebenfalls in Berlin (West). Dementsprechend fanden ab Herbst $1946^{1797}$ regelmäßig Treffen („Kirchentage“) in Berlin, in der Tegeler „Kirche am See“, besonders aber im Evangelischen Johannesstift in Spandau, statt, kleinere Treffen aber auch in Niedersachsen, Schleswig-Holstein, Hamburg u. a. Die im Charlottenburger „Cecilienhaus“ (Berliner Straße 137) ansässige Else Schmaeling fuhr 1947 ständig in alle Besatzungszonen, um ehemalige Stadtund-Kreis-Landsberger persönlich aufzusuchen. ${ }^{1798}$ Über das Magdeburger Treffen berichtet sie in ihrem als hektografierter Rundbrief versandten „10. Monatsbericht“ vom September 1947: „[...] Etwa 300 Landsberger (Stadt u. Land) waren nach Magdeburg gekommen und wir fanden im ,Alten Dessauer' zur Mittagszeit schon viel liebe alte Bekannte vor. Überall große Wiedersehensfreude! Um 3 Uhr begann der Gottesdienst. Vollbesetzt der Saal! Sind wir Landsberger auch räumlich getrennt, so stehen wir doch vereint unter Gottes Wort. Unser lieber treuer Pfarrer Wegner spricht in warmen, zu Herzen gehenden Worten zu seiner alten Heimatgemeinde. [...]."1799 Das Treffen war demnach ein kirchliches, fand aber nicht in kirchlichen Räumen statt.

Nicht über alle Landsberger Treffen liegen Berichte oder auch nur Erwähnungen geschweige denn Einladungen in den Monatsberichten vor. ${ }^{1800}$ Dass aber in der SBZ und auch in Brandenburg „Landsberger Kirchentage“ stattgefunden haben, belegt eine beiläufige Bemerkung

den konnte. Vgl. Wie die Treffen der Ziebinger wuchsen. Beginn mit DDR-Buschfunk - 96 wieder mit Fahrt in die Heimat. In: Crossener Heimatgrüße 47 (1995), Nr. 6, S. 19 (siehe auch Ortsdokumentaton Müllrose).

1794 Siehe zu ihm Anm. 2371.

1795 Nachrufe in: Heimatblatt der ehemaligen Kirchengemeinden Landsberg/Warthe, Stadt und Land 8 (1956), Nr. 9/10, o. S. und Sondernr. vom 26. Sept.

1796 Die im Mai 1947 ausgewiesenen Landsberger waren zunächst in das Auffang- bzw. Umsiedlerlager Bitterfeld gekommen (Ehemalige Kirchengemeinden von Landsberg, Warthe, Stadt und Land, 7. Monatsbericht, Mai 1947, S. 2; 10. Monatsbericht, Sept. 1947, S. 5 ).

1797 Ehemalige Kirchengemeinden von Landsberg, Warthe, Stadt und Land. 2. Monatsbericht, Sept. 1948, S. 1.

1798 Ebd., Monatsberichte 1947, passim, u. a. 10. Monatsbericht, Sept. 1947, S. 1: „Im Juli war ich in Eisenach. Am 10. August fuhr ich im Interzonenzug nach Hannover, ruhte bei Frau Stahlberg aus und fuhr dann gen Bayern. [...]."

1799 Ehemalige Kirchengemeinden von Landsberg, Warthe, Stadt und Land. 10. Monatsbericht, Sept. 1947, S. 1.

1800 Siehe aber den Polizeibericht über ein Landsberger Treffen in einer Ausflugsgaststätte bei Havelberg am 20.5.1951 mit 22 Teilnehmern (Quellenteil, Nr. 233). 
der „Flüchtlingsfürsorgerin“ Else Schmaeling vom Januar 1948: „Wir wurden nun schon oft gebeten, auch Kirchentage außerhalb von Berlin abzuhalten und geschah dies 1947 bereits in Eisenach, Bad Tölz (Bayern), Magdeburg und Zaatzke (Ostprignitz).“"1801 Emil Wartenberg berichtet in derselben Nummer der Monatsberichte „Vom Gemeindetag in Bernburg“ (Anhalt): „Angehörige der ehemaligen Kirchengemeinde in Landsberg/W. hatten sich am Sonntag, dem 28.12.47, nachmittags 3 Uhr, im Alten Ratskeller in Bernburg a.d. Saale zusammengefunden. Viele Liebe alte Weihnachtserinnerungen wurden aufgefrischt. Frau Zimmer, LaW. [Landsberg/Warthe], Küstrinerstr. 8, brachte ihren Sohn, den Heimkehrer Gerhard Zimmer, mit, welcher am 17.12.47 in Bernburg, aus Frankfurt/ Oder kommend, eingetroffen war. Noch größer wurde die Freude, als sich im Laufe der Unterhaltung herausstellte, daß der Heimkehrer aus einem Lager kam, in welchem auch der Ehemann von Frau Charlotte Stiller ist. Wenn sich beide auch nicht kannten und auch nicht gesprochen hatte, so wußte er doch [...] von seinem Gesundheitszustand zu berichten. [...] Wie so oft, brachte eben auch diese Begegnung Freud und Leid. Am 18. Januar möchten wir wieder einen Heimkehrer begrüßen; ob uns das gelingen wird?" ${ }^{1802}$ Beide Anliegen der Besucher solcher Treffen spiegeln sich in diesem Bericht: zum einen die Gelegenheit, sich durch gemeinsames Erinnern seelisch zu stärken, zum anderen aber auch die Nutzung als „Informationsbörse“, wozu noch die als „Kontaktbörse“ hinzuzunehmen wäre.

Mit „indirekter Form“ ist gemeint, dass es Treffen gegeben hat, deren äußerer Rahmen anders definiert war, die aber de facto auch Vertriebenentreffen waren oder sogar bewusst einen Deckmantel, wie „Klassentreffen“ o. ä., suchten. Ingeborg Kiene, eine Vertriebene aus Altcüstrinchen (Kr. Königsberg/Nm.), hat dies nach 1990 der Presse berichtet: „Weil in der DDR Heimattreffen nicht gerne gesehen waren, deklarierten es die Ehemaligen als „Dorffest“. ,Alle wussten Bescheid', freut sich Ingeborg Kiene noch heute über den Coup. 1989, kurz bevor die Grenzen fielen, trafen sie sich in Braunschweig. Doch schon seit 1990 ist Altglietzen der Ort des Wiedersehens." ${ }^{1803}$

Als die evangelische Kirche im niederlausitzischen Lübben 1950 eine neue Glocke erhielt, gab die Feier der Weihe indirekt Anlass zu einem Vertriebenentreffen. Denn es handelte sich um eine ehemals in der Stadtpfarrkirche von Sommerfeld (Niederlausitz), nun Lubsko (Polen), hängende Glocke, die zu den vielen während des Krieges abgenommenen und dann doch nicht mehr eingeschmolzenen gehörte. Man fand sie nach dem Krieg auf einem Schrottplatz in Oranienburg. Offenkundig funktionierte die Informationsverbreitung unter den in der DDR lebenden Sommerfeldern bestens und auch rechtzeitig: „Zum Einweihungsgottesdienst waren ohne besondere Einladung mehrere hundert Landsleute teilweise von weither zusammengeströmt." ${ }^{1804}$

1802 Ebd., 1. Monatsbericht, Jan. 1948, S. 5.

1803 Märkische Onlinezeitung, 11.7.2011 [20.9.2016]. - Siehe auch die „Klassentreffen“ der neumärkischen Ziebinger vor 1990 in Müllrose (Anm. 1793).

1804 Herbert Renke: Der Heimat Glocke klingt nun wieder. In: Crossener Heimatgrüße, Nr. 11, 1950, unpagin. (S. $[7])$. 
Die in Westdeutschland erscheinenden „Crossener Heimatgrüße“, die sich auch der vertriebenen Sommerfelder annahmen ${ }^{1805}$, berichteten 1950: „In Lübben/Spreewald wurde am Himmelfahrtstag eine aus Sommerfeld stammende Glocke, die vor der Vernichtung bewahrt geblieben und der dortigen Kirche zugeteilt worden ist, feierlich geweiht. Ueber 200 Landsleute kamen zum Teil von weither herbeigeeilt, um an dem Festgottesdienst teilzunehmen, nachmittags versammelte man sich in zwei Gaststätten, um noch ein wenig in zwanglosem Geplauder heimatliche Erinnerungen zu pflegen." ${ }^{1806}$ Lübben war aber auch Schauplatz noch anderer Vertriebenentreffen. In der Niederlausitz lebende Schlesier aus Grünberg trafen sich hier ebenfalls 1950. Auf Einladung ihres ehemaligen evangelischen Pfarrers Dr. Friedrich Böhm (1882-1963) - nun Superintendent in Strausberg - kamen ca. 1000 Personen zu einem Gottesdienst und anschließendem geselligen Beisammensein. Für 1951 war eine Wiederholung geplant, die wohl auch durchgeführt worden ist. Bei deren Vorbereitung zeigte sich ein funktionierendes Grünberger „Netzwerk“, indem der Pächter des für das Beisammensein nach dem Kirchgang vorgesehen Lokals „ebenfalls gebürtiger Grünberger" war. ${ }^{1807}$

In den in Lüdersen bei Hannover erschienenen „Briegischen Briefen“, einem Heimatblatt für die aus dem niederschlesischen Kreis Brieg (poln. Brzeg) Vertriebenen, der im ersten Jahrgang 1947 immer wieder mit Papierknappheit zu kämpfen hatte, finden sich in der AugustNummer 1947 in der Rubrik „Brieger regen sich“ Kurzmeldungen über zahlreiche namentlich genannte Brieger, die sich in den Westzonen, aber auch mehrere in Sachsen-Anhalt und einzelne in Sachsen, Thüringen und Brandenburg etabliert hatten, z. B.: „Frau Melanie Kusch hat in einer größeren märkischen Stadt ein Massageinstitut eröffnet. ${ }^{1808}$ Immerhin für andere Länder der SBZ werden in den „Briegischen Briefen“ 1947 überdies auch Personen genannt, die nicht nur zur großen Zahl der allerorts in Deutschland untergekommenen Heimatvertriebenen zählten, sondern die sich aktiv an den Bemühungen um Zusammenhalt und Information beteiligten, indem sie Karteien oder Anschriftenlisten führten. ${ }^{1809}$ In diesen frühen Jahren gab es sogar unter den (namentlich und mit Anschrift genannten) Autoren noch solche, die in der SBZ wohnten, wie der in Spremberg ansässig gewordene ehemalige Brieger Studienrat und Lokalhistoriker Dr. Eberhard Richtsteig (1892-1962), der in den Jahren 1947 und 1948 zahlreiche historische Beiträge für die „Briegischen Briefe“ lieferte, ${ }^{1810}$ aus denen auch hervorgeht, dass er brieflich mit dem

1805 Sommerfeld (poln. Lubsko), obgleich zur Niederlausitz gezählt, gehörte bis 1945 zum Kreis Crossen.

1806 Sommerfelder Glocke in Lübben. In: Crossener Heimatgrüße, Nr. 10, 1950, unpagin. (S. [6]).

1807 BArch, DO 1/27887, Bl. 41. Siehe den vollständigen Bericht im Quellenteil, Nr. 234.

1808 Briegische Briefe 1 (1947), Nr. 15/16, 1./15.8.1947, S. 180.

1809 Ebd., Nr. 8, 15.4.1947, S. 60. Von den vier in dieser Ausgabe genannten Ansprechpartnern wohnten zwei in der SBZ: „Brieger Anschriften. Fast alle Anschriften der Mangschützer besitzt Frau A. Thomas, (19) Jessnitz (Anhalt), Langestr. 58./Schlesische Anschriftenverzeichnisse. Ein Grottkauer Anschriftenverzeichnis besitzt Herr A. Kolbe, Lugau im Erzgebirge."

1810 Zur Frühgeschichte von Brieg. In: Briegische Briefe 1 (1947), 9-12, 25-27. - Ring und Rathaus zu Brieg. In: ebd., S. 29-31. - Friedrich von Logau und die Gegenwart. In: ebd., S. 43-44. - Johannes Heermann zum Gedächtnis! In: ebd., S. 70-72. - Johann Christian Günther und Brieg. In: ebd., S. 151-152. - Wer kann helfen? 
Bibliotheksrat Dr. Robert Samulski (1908-1990) in Münster/Westf. in regem wissenschaftlichen Austausch stand.

Die August-Ausgabe des Jahres 1947 enthält ferner Kurzberichte über durchgeführte „Weitere Brieger Treffen“ ${ }^{1811}$ Hier stehen an der Spitze zunächst die etwas ausführlicheren Meldungen zu Treffen in den Westzonen (Bayreuth, Oldenburg, Springe/Deister und Bad Pyrmont), es folgen dann aber auch etwas knappere zu kleineren Treffen in der SBZ: Thüringen (Suhl und Jena), Sachsen-Anhalt (Halle/Saale und Bernburg), Brandenburg (Luckenwalde) und zuletzt noch einmal weiter westlich Niederbayern. Während in Bayreuth 300 Teilnehmer gezählt wurden und in Oldenburg noch 150, waren es in Springe nur 11, in Bad Pyrmont „mehrere" und in den Ländern der SBZ ebenfalls nur wenige: Immerhin hält man überregional, und das heißt über die Zonengrenzen hinweg, Verbindung: „Ein kleines Brieger Treffen fand am 14.6. in Suhl statt, von dem aus herzliche Heimatgrüße an die Brieger im Hannoverland gesandt wurden, die von Pyrmont aus herzlichst erwidert wurden. - In Jena kommen die Brieger im kleinen Kreise drei oder vier Familien - zu einem Plauderstündchen oder Skat zusammen." Für Sachsen-Anhalt heißt es: „In Halle treffen sich die Brieger regelmäßig. ${ }^{1812}$ Freilich hapert es dort an vielem. Es ist kein richtiger Zusammenhang. Man sitzt in einem schöngelegenen Gartenrestaurant an der Saale inmitten anderer Kaffeegäste und besucht sich von Tisch zu Tisch. Wer schüchtern ist, zum ersten mal erscheint, hundert fremde Gesichter sieht und nicht weiß, wohin er sich wenden soll, geht freilich abends betrübt von dannen." Im anhaltischen Bernburg ,fanden sich die Brieger am Sonntag, 13. Juli, im ,Paradies' zusammen. Sie wollen in Zukunft regelmäßig an jedem 1. Sonntag im Monat zusammenkommen. [....$^{\text {“1813 }}$ Der einzige brandenburgische Ort, der genannt wird, steht in einem gemeinsamen Absatz mit dem niederbayerischen Ergoldsbach, wo etwa 130 Vertriebene aus Schönfeld (Kr. Brieg) untergebracht sind, womit Luckenwalde nicht „konkurrieren“ konnte, doch: „Auch in Luckenwalde vereinigten sich die Brieger am 13.7. zu einem Treffen, zu dem zwar nur 5 Landsleute erschienen waren, das aber doch gemütlich verlief. ${ }^{“ 1814}$ Dass dies kein einmaliges Treffen blieb, zeigen spätere Meldungen des Schriftleiters, der im April 1948, vermutlich aufgrund einer Postkartennachricht, wie selbstverständlich schreibt: „Von einem kleinen Treffen in Luckenwalde, das im Januar stattfand, sandten uns sieben Brieger treue Heimatgrüße. " 1815

[Bestandsaufnahme der verfügbaren Quellen und Literatur zur Brieger Geschichtsforschung]. In: ebd., S. 8889. - Heinrich Schoenborn und die Brieger Heimatgeschichte. In: ebd. 2 (1948), Nr. 1/3, S. 7-10. - Goethe am Mittagstische eines Briegers. In: ebd., Nr. 15/16, S. 7-9. - Herzog Georg II. von Brieg. In: ebd., Nr. 17/18, S. 5-10.

1811 Briegische Briefe 1 (1947), Nr. 15/16, 1./15.8.1947, S. 174-176.

1812 Dies wurde auch zuvor schon, im Februar 1947, gemeldet: „So finden z. B. in Halle jeweils an einem bestimmten Tage nach dem Monatsersten regelmäßige Zusammenkünfte von Flüchtlingen aus Stadt und Kreis Brieg statt, wie ein Teilnehmer, der greise, weit über 80 Jahre alte Kantor Gruß berichtet." (Briegische Briefe 1 (1947), Nr. 4, 15.2.1947, S. 14-16, hier S. 15; vgl. auch die ähnlich lautende Meldung S. 17).

1813 Ebd., S. 175. Monatliche Treffen in Bernburg auch schon gemeldet in: Briegische Briefe 1 (1947), S. 74: „Das Maitreffen ist bereits das 14. Treffen."

1814 Luckenwalde: Briegische Briefe 1 (1947), Nr. 15/16, 1./15.8.1947, S. 176.

1815 Ebd. 2 (1948), Nr. 7/8, S. 12. 
Treffen hat es also letztlich überall gegeben, auch wenn es sich in der SBZ eher um kleinere und nichtöffentliche handelte, deren Zahl bald abnahm oder die sich ganz in den privaten oder kirchlichen Sektor bzw. in unangreifbare Formen des Unkonkreten zurückziehen mussten, auch schob man ganz andere, unverfängliche Anlässe vor. ${ }^{1816}$ Die vergleichweise geringe Zahl für Brandenburg erklärt sich im vorliegenden Fall zum einen daraus, dass „die große Flüchtlingswoge aus Brieg" im Januar 1945 überwiegend in andere Teile Deutschlands gelangt war, mehrheitlich ohnehin weiter nach Westen mit Schwerpunkt in Bayern und Niedersachsen, auf dem Gebiet der späteren SBZ in größerer Zahl nur nach Sachsen-Anhalt (Halle/Saale), Sachsen und Thüringen, besonders aber nach Mecklenburg (Wismar und Umgebung). ${ }^{1817}$ Zum anderen war mancher Ort in der allerersten Zeit der noch während des Krieges erfolgten Fluchtbewegung nur Zwischenstation auf dem Weg nach Westen. So entstand z.B. die stärkere Konzentration von Briegern in und um Bayreuth noch während des Jahres 1945 und noch vor Kriegsende durch Verlagerung aus der ersten Interimsunterkunft in Weißwasser in der Oberlausitz, wohin im Januar 1945 zunächst „alle Brieger Lazarette“ mitsamt den „Brieger Ärzte(n), die zum Dienst in den Lazaretten einberufen worden waren“, gebracht worden waren. Auch die Familien der Ärzte sowie „viele weitere Brieger Familien, aus denen Angehörige als Pflege- und sonstiges Personal in den Lazaretten beschädftigt waren“, hatten „mit den Lazaretten und deren Hilfszügen nach Weißwasser bzw. Bayreuth mitgenommen werden" können. ${ }^{1818}$ Für die nach Brandenburg gelangten Brieger darf aber, wie für alle Vertriebenen in der SBZ/DDR, wiederum die Bedeutung Berlins als Bezugspunkt nicht unterschätzt werden. Dort „tagten“ bereits am 8. Dezember 1946 auf Einladung des Lehrers Hannes Hüttemann „die Brieger Groß-Berlins“ ${ }^{1819}$ Die Klage des Schriftleiters der „Briegischen Briefe“, Walter Schulz (Lüdersen), es würden zu wenig Berichte über solche Treffen eingesandt ${ }^{1820}$, zeigt deutlich, dass auch die zeitgenössischen Heimatzeitschriften die Gesamtheit der Aktivitäten nur teilweise abbilden. ${ }^{1821}$

1816 Der rückblickende Sammelbericht von W(alter) S(chulz) „Ein Sommer der Brieger Treffen“ in Briegische Briefe 1 (1947), Nr. 24, 8.12.1947, S. 22-23, nennt ausschließlich Treffen in den Westzonen: Bad Pyrmont, Goslar, Hannover, Hamburg, Fuhlen/Weser (Jugendtreffen), Bielefeld, Münster/Westf. (Ankündigung), Detmold, Straubing, Passau, Stuttgart, Bayreuth.

1817 Paul Heilmann: Brieger in der Fremde. In: Briegische Briefe 1 (1947), Nr. 4, 15.2.1947, S. 14-16, hier S. 15 f.

1818 Ebd., S. 15.

1819 Ebd., S. 17.

1820 „Schweigsames Berlin“. In: Briegische Briefe 1 (1947), S. 74: „In Berlin besteht eine große Brieger Kolonie. In Hannes Hüttmann hat sie einen rührigen und lebendigen -, ja wie sagt man: Vorsitzenden, Präsidenten, Betreuer? Sagen wir: Kopf! Und ab und an hört man, daß die Berliner zusammenkommen, daß es 160 Leutel gewesen seien usw. Aber auf den Gedanken, den B. B. einmal einen Bericht über so ein Treffen zu übersenden, kommt in ganz Groß-Berlin niemand. [...] Die Hallenser haben über ihre Treffen auch noch nicht berichtet. Warum eigentlich nicht? [...] Solche Nachrichten sind interessant, feuern die Säumigen und Lauen an und binden uns immer mehr zusammen. [...]."

1821 Beiläufig wurden immer wieder Treffen in knapper Form gemeldet, wenn sie dem Schriftleiter im nachhinein zur Kenntnis gelangt waren, so z. B. in Briegische Briefe 1 (1947), S. 195: „Am 30. Juli trafen sich in Görlitz einige Brieger mit anderen schlesischen Landsleuten in einem Görlitzer Hotel.“ 
Sieht man dann noch die Rubriken „Todesfälle“ und „Suchanzeigen“ durch, so finden sich neben den mehrheitlich in den Westzonen lebenden durchaus immer wieder auch in Sachsen, Sachsen-Anhalt, Thüringen, Mecklenburg-Vorpommern und - mit voller Postanschrift - in mehreren Orten Brandenburgs, insbesondere der Niederlausitz, ansässig gewordene Brieger. ${ }^{1822}$ Ganz selbstverständlich war es offenbar für sie, sich an den in der Britischen Zone (Günther Schippke, Hannover) ansässigen „Suchdienst“ der „Briegischen Briefe“ zu wenden, der dann Suchanzeigen abdruckte wie beispielsweise in der Nr. 13a vom 1. Juli 1947 aus dem brandenburgischen Glöwen (Kr. Westprignitz), wo ein großes „Umsiedlerlager“ bestand: „Flakhelfer Dieter Gerlach wurde im Februar 1945 von der Heimatflak Breslau zum RAD nach Dux gezogen. Die Abt. wurde dann nach Jüterborg [richtig: Jüterbog] verlegt. Wer von den Brieger Jungen hat ihn gesehen, wer war mit ihm zusammen? Gebt Nachricht an seine Mutter Helene Gerlach (2) Glöwen, Bahnhofstr. 4, Westprignitz/Brandenburg “' ${ }^{1823}$

Dr. Curt Schelenz ${ }^{1824}$, der die Heimatkreisvereinigung Züllichau-Schwiebus kurz nach dem Krieg aufgebaut hatte, äußerte sich in einem Rückblick 1970 zur Frage der „Vertriebenenarbeit“ in den SBZ-Jahren: „Damals war es unmöglich, Berührung aufzunehmen mit den Landsleuten, die jenseits der Elbe geblieben waren. Wir wußten von den politischen Schwierigkeiten, die einer Vertriebenenarbeit dort entgegenstanden. Private Briefe brachten aber doch Nachrichten von dem Verbleib einzelner Landsleute und bereicherten daher für spätere Nachfragen unsere Kartei. Ein gegenseitiges Besuchen mußte unterbleiben, da meistens die Geldmittel fehlten. So unterblieb von vornherein ein planmäßiges Zusammenarbeiten mit unseren Landsleuten in der späteren DDR. Dankbar hörten wir aber, daß kirchliche Arbeit eine Betreuung unserer Landsleute in der SBZ sichergestellt hatte. Solche Kirchentage unter der Leitung von Superintendent Günther Leppin dienten dem Zusammenhalt mit der Betreuerarbeit in der Bundesrepublik. ${ }^{\text {"1825 }}$ Es ist bezeichnend für die engen Gren-

1822 Beispiele für Brandenburg (ohne Berlin) in Briegische Briefe 1 (1947): Angermünde (S. 250, 260), Belzig, TBC-Krankenhaus (S. 254), Blorsdorf [wohl Blasdorf] über Lieberose, Kr. Lübben (S. 230), Cottbus (S. 119: „im Lager Cottbus starb im September 1945 Frau Geier"), Drös[s]ig bei Finsterwalde (S. 80, 124, 254), Ferchesar [bei] Rathenow, Kr. Westhavelland (S. 229), Friedrichshain, Kr. Spremberg (S. 47), Fürstenwalde/ Spree, Heimkehrerlager (S. 183), Glöwen, Kr. Westprignitz (S. 124), Kirchhain NL. (S. 228), Klettwitz/N.-L. (S. 220), Forsthaus Labolz [Lubolz?] bei Königs Wusterhausen (S. 198), Lindthal bei Finsterwalde (S. 119), Luckau N/L. (S. 232), Luckenwalde (S. 80, 188, 198, 211, 230, 251), Neu-Petershain N.L. (S. 231), Plaue/ Havel (S. 211), Potsdam (S. 252, 260), Schipkau, Kr. Calau (S. 63), Schmellwitz bei Cottbus (S. 183, 192, 230, 241), Seelübbe Post Bietikow, Kr. Prenzlau (S. 253), Spremberg (S. 36, 119, 200, 234, 239), Techow, Kr. Ostprignitz, Gasthaus Abel (S. 79), Zepernick bei Berlin (S. 260), Zinnitz N/L. (S. 261).

1823 Briegische Briefe 1 (1947), S. 124.

1824 Arzt aus Trebschen, lud 1947 zum ersten Heimattreffen nach Hannover ein (über 300 Teilnehmer). „1958 übernahm Otto Schettler aus Schwiebus die Betreuung des Heimatkreises“, 1959-1963 Charlotte Michaelis, 1963-2005 Ruth Schulz, 2005-2015 Siegfried Reimann, dann Martin Reim (Heimatbrief des Heimatkreises Züllichau-Schwiebus 49, 2016, S. 17 f.).

1825 Curt Schelenz: Heimatkreis Züllichau-Schwiebus. 25 Jahre Heimatkreisbetreuung. In: Kreis ZüllichauSchwiebus. Hrsg. im Auftr. der Heimatkreisvereinigung von Curt Schelenz. Frankfurt am Main 1970, 2. Aufl. 1975, S. 196-201, hier S. 198. 
zen solcher Aktivitäten in der SBZ, dass gerade Leppin, der sich also doch sichtbar exponiert hatte, schon 1948 in den Westen fliehen musste.

\section{"Der Tourismus in alte Heimaten blühte"1826 - Heimwehtourismus I}

In mehreren kleinen Gedichten hat eine damals knapp 17-Jährige, in der SBZ lebende Vertriebene aus dem Raum Lodz 1946 ihr Heimweh ausgedrückt. Im Alter schrieb sie dazu: „Damals habe ich nicht geglaubt, meine Heimatstadt noch einmal wiederzusehen. Und beinahe wäre es auch so gekommen." In einem der Gedichte heißt es u. a.: „[...]/Meine Heimat hab' ich verloren, / durch den bösen bittren Krieg / und vor Sehnsucht nach der Heimat / wein' ich manchmal bitterlich. / Denn so gut wie in der Heimat/ist es nirgends auf der Welt, / wenn es einem auch woanders / manchmal noch so gut gefällt. / O, du heißgeliebte Heimat, / nie wird' ich dich wiedersehen, / wo es war einst doch so herrlich / und so wunder-wunderschön." 1827

Reisen in die Heimartorte waren für Vertriebene im ersten Vierteljahrhundert nach Kriegsende noch kaum möglich. Doch die in Westdeutschland Lebenden hatten manche Informationsmöglichkeit und lasen in der Vertriebenenpresse, aber auch in Zeitungen und Illustrierten vielerlei Nachrichten über die Nachkriegsentwicklung ihrer Herkunftsorte. Solche Informationen wurden direkt, aber mehr noch indirekt auch in die DDR getragen. Das zeigt u.a. der oben zitierte Briefwechsel, den Neumärker aus Kemnath über die Mauer hinweg pflegten. 1962 heißt es in einem Brief von Ost nach West: „[...] wer wird in der lieben Heimat die Gräber von unseren Lieben schmücken, aber wir sagen immer beide mit Frau Kuhlmey: Da wird wohl alles eingefallen sein. Einmal möchten wir unsere Heimat noch mal wiedersehen. Meine liebe Schwägerin, die früher in Tirschtiegel gewohnt hat, wohnt jetzt doch in Grassel, Kreis Gifhorn, die schreibt mir auch so liebe Briefe, neulich schreibt sie mir, das die schöne Kirche in Tirschtiegel auch abgerissen ist, wo wir alle darin getauft und konfirmiert sind, auch Herr Rittwagen, das hat mir einen ordentlichen Stich gegeben, als ich das gelesen habe." ${ }^{1828}$

In den siebziger Jahren wurden Reisen in die Heimatorte für viele möglich, ab 1972 in die nun in Polen liegenden, bereits ab 1967 in die in der ČSSR liegenden. ${ }^{1829}$ Eine in Westdeutsch-

1826 Christa Wolf: Kindheitsmuster. Berlin und Weimar 1976, S. 10. - Wenn auch nicht für die spezielle Situation der DDR-Bürger, so doch allgemein für das Thema hilfreich: Sarah Scholl-Schneider: „Besucht die alte Heimat, ein schönes Land und liebe Menschen erwarten Euch!“ Zum Potenzial von Heimatperiodika als Quelle zur Erforschung von Heimatreisen. In: Heimatzeitschriften (wie Anm. 255), S. 237-255 (mit weiterer Literatur).

1827 Edith Kunert: Besuch in der alten Heimat. In: Lebenszeit. T. III. Zeitzeugen berichten. Hrsg. vom Landesseniorenbeirat Brandenburg u. dem Seniorenbeirat Neuenhagen. Neuenhagen [1998], S. 58-60, hier S. 58.

1828 Remenyi, Geschichte eines Gutes in der Neumark (wie Anm. 1598), S. 99. „Herr Rittwagen“ ist der Sohn des Kemnather Gutsbesitzers.

1829 Uta Bretschneider: Ostpreußen als Randnotiz? Selbst- und Fremdbilder von „Umsiedlern“ in der DDR. In: Jahrbuch des Bundesinstitutts für Kultur und Geschichte der Deutschen im östlichen Europa 24 (2016), S. 193-214, hier S. 211. - Bereits 1966 und 1967 reiste der bekannte, ab 1949 in Märkisch Buchholz und OstBerlin lebende DDR-Schriftsteller Franz Fühmann (1922-1984) in seine böhmische Riesengebirgsheimat - 
land lebende Vertriebene aus der Provinz Posen schildert ihren Grenzübertritt bei Frankfurt (Oder) 1978: „Der Kontrollpunkt liegt sehr hübsch auf dem östl. Oderufer mit Blick auf den Fluß und die Stadt. Zu unserem Erstaunen wartet eine lange Schlange von Fahrzeugen vor der Schranke, die Straße von Berlin nach Frankfurt schien leer zu sein. Es sind alles westl. Wagen z. T. mit Wohnwagen, die warten müssen. Autos der DDR oder SU kommen schnell durch die Kontrolle. [...]."1830

Eine Reise in den Geburts- bzw. Heimatort in den Vertreibungsgebieten war jedoch vor 1990 nicht selbstverständlich. Aber es war auch kein Einzelfall und keineswegs etwa ein bloß westdeutsches Phänomen. Ebenso wenig lässt es sich etwa auf dem SED-Regime ferner stehende Menschen beschränken. Für DDR-Bürger „mit Vertreibungshintergrund“ kam bis 1990 freilich nur ein verdecktes Vorgehen in Frage. Reisen in die sozialistischen Bruderländer wurden nach und nach fester Bestandteil des Sommer- und Winter-Tourismus und dienten offiziell auch der Verständigung. Wenn sich der am Wege liegende Heimatort dabei „mitnehmen“ ließ oder gar, ohne dass das auffiel, Hauptziel sein konnte, wurden die Möglichkeiten genutzt.

In den meisten Selbstzeugnissen Vertriebener, die in der DDR lebten, wird deutlich, dass sie - ob sie nun der SED und dem neuen System näher oder ferner standen, ob sie sich in der neuen Umgebung gut oder weniger gut eingelebt hatten - den Gedanken an ihren Heimatort nie ganz verdrängten oder verdrängen konnten. ${ }^{1831}$ Auch die in Landsberg an der Warthe geborene, von 1962 bis 1976 in Kleinmachnow, dann in Berlin (Ost) lebende Schriftstellerin Christa Wolf (1929-2011) reiste mit ihrer nach dem Krieg in der DDR gegründeten Familie 1971 in ihre Heimatstadt. Fünf Jahre später erschien eine literarische, aber autobiographisch zu verste-

mit (im Werk nachweisbaren) „emotionalen Wirkungen des Besuchs im alten Rochlitz“ [Rochlitz an der Iser, tschech. Rokytnice nad Jizerou]; siehe dazu ausführlich Hans Richter: Franz Fühmann. Ein (un)verlorener Sohn Böhmens. In: Böhmen. Vielfalt und Einheit einer literarischen Provinz. Hrsg. von Frank-Lothar Kroll (Literarische Landschaften, Bd. 2). Berlin 2000, S. 127-150, hier S. 141.

1830 Elke Wöstenberg (geb. Streckenbach): Reise nach Ostrowo und Kalisch vom 8.7.-16.7.1978. In: Heimatbuch für den Kreis Ostrowo/Provinz Posen mit angrenzenden Kreisen Kalisch und Kempen. Hrsg.: Heimatkreisgemeinschaft Ostrowo in der Landsmannschaft Weichsel-Warthe e. V. Zsgest. von Otto Käding. Kirchlengern 1983, S. 64-71, hier S. 64.

1831 Siehe oben im Kapitel IV. 1, Abschnitt „Menschen unter Menschen“ (Anm. 1441) die Äußerungen des SEDMitglied Friedrich Hora, der schon 1964, nicht einmal 30 Jahre alt, in seine sudetendeutsche Heimat fuhr. Ferner die Äußerung eines 1929 geborenen, aus Haaso im Ostteil des Kreises Guben stammenden (bis 1990) DDR-Bürgers 2001: „Trotz der für mich befriedigenden Arbeit und der Erfolge in meiner neuen Heimat konnte ich all' die Jahre unser Haaso nicht vergessen. Zu gern wollte ich sehen, wie es jetzt dort wohl aussehen mag. Wohnen Leute in unserem Haus? Wie sehen die Felder dort aus? / Da kam es mir gerade recht, als unser jetziger Nachbar Emil Jagode, der aus Merzwiese/Wezicska [Wężyska - P. B.] aus dem Kreis Krossen stammte, mich eines Tages [1964] fragte, ob ich nicht mit ihm und seinem Neffen in die alte Heimat fahren würde. (Ich besaß damals einen alten 311 Wartburg). Freudig stimmte ich zu. [...]." (Horst Göhler: Erinnerungen an unsere Vertreibung 1945. In: Gubener Heimatbrief (2001)2, S. 66-72, hier S. 70). - Siehe auch das Kapitel „Fahrt in die Heimat“ in den Erinnerungen des vertriebenen Neumärkers Karl-Heinz Preuß, Die Gedanken sind frei (wie Anm. 1286), S. 225-236, hier S. 225: „Nun war es endlich so weit.“ Er nimmt sogar in der Ablage der Autotür „eine Landkarte aus deutscher Zeit" mit, die aber von den Grenzpolizisten der DDR in Pomellen beschlagnahmt wird. 
hende Verarbeitung in ihrem bekannten Roman „Kindheitsmuster“ ${ }^{1832}$ Das sogleich in Ost wie West viel gelesene Buch behandelt nicht nur die Kindheit im Geburtsort und die Flucht 1945, sondern reflektiert auch die nach Jahrzehnten unternommene Wiederbegegnungsreise. ${ }^{1833}$ „Der Tourismus in alte Heimaten blühte" heißt es darin schon für den Sommer 1971, also die Zeit noch vor dem visafreien Reiseverkehr; und die Autorin notiert außerdem, dass „der nichtssagende Vermerk ,Stadtbesichtigung', in die zweifach auszufertigenden Antragsformulare unter der Rubrik ,Begründung' eingetragen, anstandslos durchging. Zutreffende Angaben wie ,Arbeitsreise' oder ,Gedächtnisüberprüfung' hätten Befremden erregt. (Besichtigung der sogenannten Vaterstadt!)“.1834

Zur Wiederbegegnung mit dem Heimatort konnten Urlaubsreisen ins polnisch-schlesische oder tschechoslowakische Riesengebirge ebenso dienen wie Dienstreisen, bei denen bisweilen Umwege gefahren wurden, um die Stätten der Jugend, das Elternhaus und anderes wiederzusehen. Die meisten Betroffenen, die über keine solchen Gelegenheiten verfügten, ließen freilich aus dem Gedanken erst nach 1989 Realität werden, insbesondere mit den dann bald boomenden organisierten Seniorengruppenreisen. Aber auch die Erleichterungen des Grenzübertritts nach Polen, die die vertragliche Regelung zwischen der DDR und der Volksrepublik ab 1972 brachte, wurde bis zur Schließung der Grenze im Oktober 1980 bereits von sehr vielen DDR-Bürgern genutzt.

Das Verkehrsabkommen von 1971 zwischen der DDR und Polen enthielt eine Regelung für den visafreien Reiseverkehr, die zum 1. Januar 1972 in Kraft trat und die Bürger beider Staaten berechtigte, allein mit dem Personalausweis die Grenze zu passieren. „In den folgenden acht Jahren entwickelte sich ein reger Grenzverkehr in beide Richtungen, der das gegenseitige Kennenlernen förderte. “1835 Der verstärkte Einkaufstourismus polnischer Besucher führte zwar zu Ressentiments in der warenknappen $\mathrm{DDR}^{1836}$, aber die Möglichkeit, selbst nach Polen reisen zu können, wurde nicht nur positiv aufgenommen, sondern von vielen dazu genutzt, „das Land jenseits der Oder zu erkunden. Ihnen begegneten die polnischen Bewohner meist mit herzlicher Gastfreundschaft, aber auch mit alten Ängsten.“ Denn viele DDR-Bürger, die nun in die Neumark, nach Schlesien und in die anderen ehemaligen Ostgebiete reisten, waren nicht Durchschnittstouristen, sondern suchten gezielt ihre alten Geburts- und Heimatorte auf, standen plötzlich unangemeldet vor ihren Geburts- oder ehemaligen Wohnhäusern und kamen mit den neuen Bewohnern doch oft schnell in Kontakt. „Vom 1. Januar 1972 an strömten [in

1832 Christa Wolf, Kindheitsmuster (wie Anm. 1826).

1833 Kerstin Hinrichsen: Reine Reise nach L. In: Terra Transoderana. zwischen Neumark und Ziemia Lubuska. Bernd Vogenbeck u. a. (Bearb.). Berlin 2008, S. 237-239. Der Roman wurde noch vor der Wende auch ins Polnische übersetzt und erschien 1981 unter dem Titel „Wzorce dzieciństwa“ in Polen.

1834 Christa Wolf, Kindheitsmuster (wie Anm. 1826), S. 10.

1835 Reinhard Schmook: Schwierige Nachbarn im Osten. In: Grenzgänge. Brandenburgs Grenzen und Nachbarn in Geschichte und Gegenwart. Bad Freienwalde (Oder)/Prenzlau 2014, S. 96-97, hier S. 97.

1836 „Guben als Grenzstadt war vom Besucherstrom besonders betroffen, was die Versorgungslage noch verschärfte." Rita Kirsch: Wie ein Großbetrieb das Leben in Guben veränderte. In: Gubener Heimatkalender 44 (2000), S. 104-108, hier S. 107. 
Frankfurt (Oder)] täglich Tausende DDR-Bürger über die Brücke [nach Słubice, also in den ehem. Ostteil (Dammvorstadt) und von dort aus weiter], um das unbekannte Nachbarland zu entdecken, oft auch, um ihre 1945 verlassenen Häuser und Wohnungen zum ersten Mal seit Kriegsende in Augenschein zu nehmen. Dieser historische Augenblick war für viele der in der DDR lebenden Flüchtlinge und Vertriebenen ein befreiender Moment - nun konnten sie nach Jahren des Schweigens und der Tabuisierung ohne Einladung und Visum an den Ort ihrer Kindheit fahren und an den noch vorhandenen Gräbern ihrer Verwandten Blumen niederlegen." ${ }^{1837}$

Der Gubener Stadthistoriker Gerhard Gunia (1933-2017), ein bereits als Kind vor 1939 nach Guben (Westteil) gekommener Ostpreuße aus Königsberg, hat die Bedeutung der Grenzöffnung von 1972 für die 1945 aus dem Ost- in den Westteil der Stadt Vertriebenen im Jahre 2000 betont: „Es wird den heutigen - vor allem jungen - Menschen kaum verständlich sein, was der Besuch im einstigen Ostteil der Stadt vielen Gubenern damals bedeutete: Erinnerungen an Kindheit und Jugend, Begegnungen mit Vertrautem und Verlorenem in der früheren Perle der Niederlausitz ließen den Schmerz der Teilung und des Verlustes deutlich werden. Und die Fragen nach Schuld und Sühne im deutschen Volk sind bis heute nicht verstummt. ${ }^{\text {"1838 }}$ Diese ungewöhnlich deutlichen, freilich „nur“ in einem lokalen Heimatkalender abgedruckten Worte verweisen auch darauf, dass das Vertreibungsthema für die in den grenznahen Gebieten wohnenden Betroffenen meist viel präsenter geblieben ist als bei denen, die in ganz neuer Umgebung gelandet waren. Die unmittelbare geographische Nähe, noch gesteigert durch die ständige Anschauung in den geteilten Städten und Gemeinden (Aurith, Forst/Lausitz, Frankfurt/Oder, Guben, Küstrin), verhinderte jene Distanz zum Thema, die sich überall sonst früher oder später eingestellt hat.

Im Oktober 1980 fand die Reise-Freizügigkeit „ein jähes Ende“, weil die SED den Einfluss der neu entstandenen polnischen Gewerkschaft Solidarność fürchtete. Als Mitte 1989 schließlich die Republikflucht aus der DDR über Polen zunahm, wurde die Grenze - bis sich die Welt noch im selben Jahr grundlegend änderte - ganz geschlossen.

Je tiefer man in der Zeitzeugenliteratur oder in Gesprächen mit Betroffenen bohrt, desto mehr Beispiele treten aber auch zu Tage, in denen Vertriebene, die in der DDR lebten, schon deutlich früher, also vor 1972, Wege gefunden hatten, die Stätten ihrer Kindheit in Polen aufzusuchen. Es mögen - auf die Zahl der Vertriebenen in der DDR insgesamt bezogen - wenige gewesen sein, als bloße Ausnahmen lassen sie sich dennoch kaum abtun, dazu sind entsprechende Hinweise von Zeitzeugen doch zu häufig. ${ }^{1839}$ Aufschlussreich für das Verhältnis zwischen der

1837 Felix Ackermann: Die Stadtbrücke Frankfurt (Oder) - Słubice (1952-2002). In: Frankfurt an der Oder 1253-2003. Hrsg. von Ulrich Knefelkamp u. Siegfried Griesa. Berlin 2003, S. 311-320, hier S. 317.

1838 Gerhard Gunia: Gedanken zur Grenzöffnung 1972. In: Gubener Heimatkalender 44 (2000), S. 103.

1839 Ast/Mauersberger (wie Anm. 32), S. 33 (Aussage eines in der Prignitz ansässig gewordenen Vertriebenen): „Sobald es möglich war, 1967, fuhr die gesamte Familie mit meinem ersten PKW nach Hause" [Neudamm/Neumark], dazu ebd. Abb. „Besuch in der alten Heimat [...] Ende der sechziger Jahre in Neudamm“. - Siehe auch die Beispiele aus den Jahren 1965-1971 in Anm. 1753. - Jörg Lüderitz (Frankfurt/O./Łagów) berichtete in einer Vortragsdiskussion in Berlin-Lichterfelde am 10.8.2018, entscheidende Voraussetzung sei die Vorlage einer Einladung aus Polen gewesen, mit der er zu seinem zuständigen Volkspolizeikreisamt gegangen sei. Dessen 
Sicht des nachgeborenen Außenstehenden und der des erlebenden Betroffenen ist, dass man als Historiker üblicherweise in diesen Fällen die frühe Datierung mit einem „schon“ versieht, Vertriebene selbst aber trotz allem - rückschauend - oft mit einem „erst“. ${ }^{1840}$ Oft mussten solche „frühen“ Fahrten noch unter riskanten Umständen durchgeführt werden, doch zeigen sie, wie sehr das Problem die Menschen innerlich seit dem Tag, an dem sie ihren Heimatort verlassen hatten, umtrieb. So hat der aus dem Westteil Gubens stammende, seit 1948 in Potsdam lebende Geobotaniker und Landeskundler Heinz-Dieter Krausch (geb. 1928 Guben) berichtet, dass er schon 1963 in den polnischen Ostteil Gubens reiste, um nach dem Haus seiner Großeltern zu sehen, das er einst hatte erben sollen. Er nutzte dafür die Teilnahme an einer wissenschaftlichen Tagung in Warschau, für die ihm ein in ganz Polen gültiger Pass ausgestellt worden war, fuhr mit der Bahn von Warszawa nach Gubin, fotografierte ausgiebig und stand auch am damals noch erhaltenen großelterlichen Grab auf dem Ostfriedhof, während man von Wilhelm-Pieck-Stadt Guben aus - ebenso wie in Frankfurt (Oder) - erst 1972 direkt in den Ostteil gehen durfte. ${ }^{1841}$ Ein Neumärker aus Woldenberg, der die Flucht im Januar 1945 als Achtjähriger erlebt hatte und mit Mutter und Brüdern nach Premnitz evakuiert worden war, wo er auch heute noch lebt, hat 2017 ganz lapidar erklärt: „Im Jahr 1967 habe ich das erste Mal meinen Geburtsort wieder besucht. Seite den 1990er Jahren jedes Jahr."1842

Ein 1928 geborener Schlesier aus dem Kreis Grünberg, der in den Raum Cottbus gelangt war und dort blieb, berichtete nach der Wende: „1964 haben wir unseren Trabant bekommen und 1965 sind wir das erste Mal gefahren. Damals mussten wir noch über Frankfurt fahren und die Einreise nach Polen musste genehmigt werden. Dann sind wir, meine Frau [eine Einheimische - P. B.] und ich, gefahren. Mein Schwiegervater und mein Vater - das war später. Es war schwierig, ich glaube, man musste eine Einladung von polnischer Seite haben. Und das musste sich erst irgendwie ergeben. Ich muss sagen, zunächst einmal gab es eine Enttäuschung bei meiner Frau, weil ich ihr das viel schöner geschildert hatte. [...] Und jetzt muss man dazu sagen, als wir durch das Dorf fuhren, trauten wir uns noch gar nicht rein. Meinem Vater ist es sehr schwer gefallen. Das muss ich auch sagen. Für meine Eltern war das ganz anders als für mich als junger Mensch. Das erste Mal haben wir uns nur bis ans

Beamte hätten die Genehimigung dann ohne Frage nach dem Reiseanlass erteilt, wobei sein im Pass vermerkter neumärkischer Geburtsort ohnehin keine Verheimlichung zugelassen hätte.

1840 Beispiele: [„erst 1964“ (Friedrich Hora, geb. 1935, aus dem Sudetenland):] Hora, Eine politische Biographie, T. 1 (wie Anm. 1439), S. 364. - [„erst 1966“ (Hubert Grajewski, geb. 1937, aus Guben-Ost):] Katarzyna Korsan: Beiderseits der Oder. In: Grenzerfahrungen. Hrsg. von Alicja Wancerz-Gluza. Hamburg 2003, S. 345356, hier S. 352 (bezogen auf Reise nach Polen mit Aufenthalt in Schlesien; S. 353 erster Besuch in Gubin 1967).

1841 Interview mit dem Verf., 8.3.2017. Ähnliches, wenn auch ohne eigenen oder familiären Vertreibungshintergrund, erreichte auch der Ost-Berliner Bibliothekar Dr. Peter P. Rohrlach (geb. 1933 Berlin), der durch geschickte Nutzung beruflicher und persönlicher Beziehungen schon ab 1964 mehrfach nach Liegnitz (Legnica) reisen konnte, um im dortigen polnischen Staatsarchiv - nach vorheriger persönlicher Anmeldung und Vorsprache bei der Staatlichen Archivverwaltung in Warschau - für private Forschungsthemen zu recherchieren (Mitteilung vom 8.3.2017).

1842 Aussage von Wolfgang Bornstädt, zitiert in: Brandenburger Rundschau 15 (2017) 8, S. 11. 
Hoftor getraut. Man hat uns gar nicht reingelassen. Die waren auch vertrieben worden. Sie wollten keinen Kontakt und wir hätten uns sowieso nicht verständigen können. Meine Frau kam auch nicht mit dem Polnischen klar, obwohl sie wendisch kann. [...] Wir hatten im Großen und Ganzen auch noch nichts anderes erwartet. Wir wollten erst einmal sehen, wie es dort aussieht. [...] Heute gibt es zwischen Drehnow [bei Cottbus] und Ochla ${ }^{1843}$ eine Partnerschaft und wir kommen im Jahr ein paar Mal zusammen. [...] Wir fahren noch mit einer anderen Familie unabhängig privat dorthin. Wir fahren durch das Dorf, sehen uns alles an, damit wir es nicht ganz vergessen. "1844

Der bereits an anderer Stelle zitierte vertriebene Niederlausitzer Siegfried Hamsch (geb. 1934) lebte von 1945 bis 1974 ebenfalls in Guben, danach in Ost-Berlin. Er war anfangs Bäckergeselle und dann seit Mitte der fünfziger Jahre an beiden Orten jahrzehntelang hauptamtlicher Kulturbundsekretär. Bis zur Übersiedlung nach Berlin konnte er den Bezug zur unmittelbar benachbart sichtbaren Heimat kaum verdrängen. Von 1951 bis 1954 arbeitete er „in der HOKonditorei an der Neißebrücke. Da die Herstellungsräume im Keller des Gebäudes der ehemaligen Konditorei Schönberger lagen, war von den Kellerfenstern zur Neißeseite der Blick auf den Fluss mit seinen zu dieser Zeit und entsprechend des Wasserstandes vorhandenen Sandbänken gegeben.

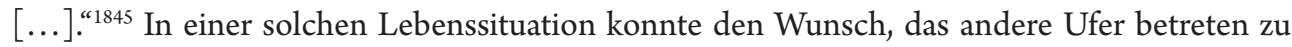
können, nicht in Vergessenheit geraten. „Jahrzehntelang waren diese Gebiete für uns nicht erreichbar. Erst von 1971 [S. 199] bis 1981 wurde die Grenze nach Polen seitens der DDR geöffnet, danach aber wieder geschlossen. Hier nutzten wir einmal diese Gelegenheit noch gemeinsam mit meiner Mutter, die 1994 verstarb, unseren ehemaligen Heimatort aufzusuchen. Dabei stellten wir fest, dass unser Haus bewohnt und im Laden ein Lebensmittelgeschäft geführt wird. Hier kauften wir auch einiges zum Verzehr und konnten uns, zwar mehr mit Zeichensprache, mit dem Ladeninhaber einigermaßen verständlich machen. Seit den 1990er Jahren ist der Zugang zum ehemaligen Heimatdorf leichter. So besuchten wir den Ort inzwischen mehrmals und bemerkten dabei, dass der Ladenbeitzer mehrmals wechselte und das Haus an der Fassade auch mehrere Verschönerungen erfahren hat. [...]." ${ }^{1846}$ Diese fast lapidar zu nennende, nüchterne Schilderung, hinter der doch die Emotionen zu ahnen sind, zeigt die Kontinuität, mit der der Gedanke an die Heimat in der Familie während der so unterschiedlichen Rahmenbedingungen der fünfziger und siebziger Jahre und bis über die Wendezeit 1989/90 hinweg nie ganz verloren ging, sondern sogar - trotz der offiziellen, öffentlichen Tabuisierung und Verdrängung - bei jeder passenden Gelegenheit „parat“ war.

1843 Deutscher Name: Ochelhermsdorf (Kr. Grünberg in Schlesien).

1844 Keller, „Jetzt bin ich hier und das ist gut so“ (wie Anm. 123), S. 174-180 (Interview mit Herrn GG), hier S. 179. Ähnlich auch in weiteren dort abgedruckten Interviews mit in die Niederlausitz gelangten Vertriebenen: Frau C (geb. ca. 1936 im Kr. Löwenberg in Schlesien): „Unser Vater war das erste Mal nach vielen [!] Jahren mit meinem Mann vielleicht 1964 dort. Ich war 1963 das erste Mal wieder in Schlesien." (S. 122). - Herr EE aus dem Kr. Grünberg: „Zu DDR-Zeiten war ich schon ein paar Mal drüben. Einmal waren wir als Touristen in Grünberg. Wir haben unser Zuhause gesehen, aber wir können doch den Polen nichts sagen. Die wollen doch genauso leben wie wir." (S. 173)

1845 Hamsch, Erinnerungen und Ereignisse (wie Anm. 547), S. 201.

1846 Ebd., S. 199 f. 
Der neumärkische Bauernsohn Karlheinz Gleß aus Peetzig/Oder (poln. Piasek) im Kreis Königsberg/Nm. war als Kind 1945 mit seiner Familie - wie viele Nachbarn aus dem Dorf - in der unmittelbar benachbarten Uckermark ansässig geworden. Nach 1990 hat er im Zusammenhang mit der Niederschrift seiner Jugenderinnerungen auch dem späteren „Heimwehtourismus" vor und nach 1989/90 mehrere Absätze gewidmet. Seine Formulierungen verdeutlichen indirekt, wie sehr das Thema der Herkunft - aus einem fast in Sichtweite gelegenen, aber schwer zugänglichen Ort - über all die Jahrzehnte Gesprächsgegenstand in der Gesamtfamilie geblieben sein muss. Er verweist auf die unterschiedlichen Erfahrungshorizonte der drei Generationen, die nach 1945 die (Vertriebenen-)Familien bildeten und bilanziert dies für das Jahr der ersten Reise in den Heimatort 1968:

„In diesem Vierteljahrhundert reifte eine neue Menschengeneration heran; in gleicher Zeit alterte eine andere, die soeben noch in Blüte stand. Für die einen ist es eine sehr lange Zeit, für die anderen nur eine kurze Spanne. Solches mag die unterschiedlichen Eindrücke während unserer Besuchsreise nach Piasek im Jahre 1968 bestimmt haben. Denn drei Generationen ehemaliger Peetziger reisten hin; die jüngste war allerdings schon in einer anderen Heimat geboren worden und dort aufgewachsen.

Die Mutter beurteilte kritisch, wie ihr Lebenswerk - Haus, Hof und Garten - genutzt, instandgehalten und gepflegt wurde; sie war zufrieden! Für meinen Bruder und mich schien das Dorf geschrumpft zu sein; in der Erinnerung dehnte sich alles viel räumlicher aus. Unsere Kinder aber sahen in den dortigen Mädchen und Jungen nur Gleichaltrige wie auch anderswo, und trotz unterschiedlicher Sprache entstanden keine Verständigungsprobleme. In wenigen Stunden verband uns mit unseren polnischen Gastgebern ein so herzliches Verhältnis, daß beim Abschied so manche Träne rollte. "1847 Ein weiterer Besuch im Jahr 1993 endete dagegen „mit einer herben Enttäuschung. Dort, wo wir im Jahre 1968 blühende Gärten angetroffen hatten, wuchs mannshohes Unkraut." ${ }^{1848}$

Der mit seiner Frau im Sommer 1945 aus Landsberg/Warthe vertriebene Schmied Helmut Hartwig (1901-1976) lebte nach dem Krieg als Schmiedemeister in Hirschfelde bei Werneuchen. Sein Schwiegersohn hat über ihn berichtet: „Mein Schwiegervater war kein Mann, der viele Worte machte. Seine ablehnende Haltung zur Oder-Neiße-Grenze stand fest und war im Ort allgemein bekannt. Da sein Bruder Hans eine andere Position bezog, sprachen die beiden kaum noch miteinander. Die spätere innere Aussöhnung geschah ebenfalls ohne große Worte [...]. " ${ }^{1849}$ Helmut Hartwig widerstand zwar den Werbungen, in die SED einzutreten, verweigerte sich aber nicht der Arbeit in gesellschaftlichen Funktionen: „Noch vor der Gebietsreform 1952 erfolgte“, nominiert von der VdgB, „Helmuts Wahl in den Gemeinderat, in dem er viele Jahre als Abgeordneter, Vorsitzender des Gemeinderats, Leiter des Bauausschusses bzw. Standesbeamter tätig war." Doch die Distanz zum DDR-Sozialismus, der ihn mit seinem kleinen Ackerstück aus der Bodenreform

1847 Gleß, Peetzig/Piasek (wie Anm. 805), S. 93.

1848 Ebd.

1849 Mitteilungen von Detlev Stark, Hoya/Weser, an den Verf., 3.12.2016 (hiernach auch die folgenden Zitate). 
in die LPG gezwungen hatte, war nicht gewichen. Am Ende stand kein Bürgermeister und kein Vertreter des Gemeinderates an seinem Grab. „Der Pfarrer war es, der seine langjährige Arbeit für den Ort ausführlich würdigte."

Das Unterkommen als Schmied in Hirschfelde (Kr. Oberbarnim) war für Helmut Hartwig, obwohl in beengten Wohnverhältnissen und mit „Plumpsklo“ auf dem Hof, nach den Strapazen des Fluchtweges „mit dem Karren über eine Behelfsbrücke, die bei Küstrin über die Oder führte“, der nun hier endete, der Punkt, an dem er bleiben wollte: „wenigstens ein Dach über'n Kopf, Schluss mit dem Kampieren auf der Landstraße, mit Bettelei und dem ganzen Elend. Helmut, dem war das alles recht, denn bis zur Oder und nach Landsberg war es von hier nicht weit, er konnte sich nicht vorstellen, dass es kein Zurück geben sollte. Der zweirädrige Karren wurde konserviert und bekam einen sicheren, trockenen Platz auf dem Hof." In der Wohnung hing an der Wand der Spruch: „Durst ist schlimmer als Heimweh.“ Immer wieder konnte der Schwiegersohn beobachten: „Das Leben ging weiter, und Landsberg war noch nicht vergessen. "Das zeigte sich bei den verschiedensten Gelegenheiten und an Nebensächlichkeiten: „Landsberg war immer wieder Gegenstand von Unterhaltungen, das ging soweit, dass bei Fahrten mit dem Zug von Werftpfuhl nach Berlin geäußert wurde, ,dann wollen wir mal wieder in den Vorort von Landsberg (Berlin) fahren'. In Gedanken gingen Ida und Helmut des öfteren die Straßen von Landsberg ab und waren enttäuscht[,] wenn die Tochter Christa sich an keine Einzelheiten erinnerte. Auch wenn die Schwestern von Ida in Hirschfelde zu Besuch waren, wiederholt auch nach 1961, war ein Thema aufjeden Fall Landsberg."

Schließlich bot sich in den siebziger Jahren die Möglichkeit, legal nach Polen zu fahren. Der Schwiegersohn berichtet über die $1975 \mathrm{zu}$ viert unternommene Reise in die Heimatstadt seiner Frau: „Die Initiative zur Fahrt nach Landsberg ging von mir aus. Lange war es nicht möglich einfach dort visafrei hin zu fahren, dann fehlte auch der fahrbare Untersatz. Ich war auch neugierig auf die Stadt [,] über die ich so viel im Hause meines Schwiegervaters gehört hatte und in der meine Frau geboren worden war. Außerdem wünschte ich mir[,] das[s] vor allem mein Schwiegervater endlich einen Strich unter diesem Lebensabschnitt zieht." Mit Frau, Tochter und Schwiegersohn machte sich Helmut Hartwig voller Erwartungen auf den Weg: „Es gab noch keinen Grenzübergang in Küstrin, deshalb über Frankfurt, immer an der Oder und später der Warthe entlang mit erstem Halt in Wieprzyce (Wepritz), einem Vorort von Gorzow [Gorzów Wlkp., dt. Landsberg/Warthe]. Auf dem Friedhof fanden wir nur noch wenige deutsche Grabsteine, in Gorzow suchten und fanden wir die ehemalige Schönhoffstraße, ihr Name war jetzt Ulica Wojska Polskiego, also die Straße der polnischen Armee. Über eine Brücke führte uns der Weg zur Sankt Marienkirche, nun wieder katholisch. Wir bummelten durch die Geschäfte, kauften ein paar Andenken und kamen mit einem Polen ins Gespräch, der uns in seine Wohnung zum Kaffee einlud. Die Stadt machte auf uns einen guten Eindruck, sie hatte sich weiter entwickelt und man spürte, dass sich die Menschen, die hier lebten, wohl fühlen, / Zurück in Hirschfelde zog Helmut den alten zweirädrigen Karren aus der Remise und zerlegte ihn zu Brennholz ... / Ein Jahr später [...] ist er verstorben." In einem Nachsatz heißt es: „Noch mal zu meinem Schwiegervater, die Zertrümmerung des zweirädrigen Karrens war für ihn der Abschied von einer Rückreise, er war endlich in der neuen Heimat angekommen!" 
Eine aus dem niederlausitzischen Dorf Saude im Ostteil des Kreises Guben stammende Flüchtlingsfamilie, die in ihrer Heimat eine kleine Landwirtschaft besessen hatte, kam nach Kriegsende 1946 als Neusiedler in Aurith (Kr. Guben), unmittelbar an der Oder(-Grenze) unter. Der bei der Flucht dreizehnjährige Sohn Heinz Thurian hat 2006 über Reisen, die man seit der Visaregelung mit Polen 1972 in den Herkunftsort unternahm, erzählt. Man packte „etwas Reiseproviant in ein Auto und machte sich auf den Weg nach Polen." Dabei war einerseits der Drang, den Heimatort endlich einmal wiederzusehen, offenkundig sehr groß, er hatte sich seit immerhin 27 Jahren angestaut. Doch andererseits war der Gedanke an dauerhafte Rückkehr, der viele (vor allem ältere) Vertriebene zunächst - in der SBZ/DDR ebenso wie Westdeutschland - noch jahrelang nicht losließ, inzwischen verschwunden. Eine Sudetendeutsche (geb. 1932), die 1946 über Mecklenburg nach Sachsen gekommen war, erklärte 2012 rückblickend die allmähliche Distanzierung: „Ich meine, man konnte dann rein und hat das nochmal gesehen, aber wie gesagt, grade [...] meine Schwester und a' [auch] die Großeltern, also wo sie wussten, es gibt kein Zurück, war [S. 212] für die das abgeschlossen. Sie wollten das dann nich' sehen, nochmal das

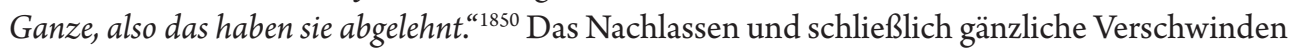
dieser zunächst sehr präsenten Rückkehrvorstellungen scheint sich in Ost wie West spätestens in den siebziger Jahren vollzogen zu haben. Diese Ost-West-Parallelität trotz unterschiedlicher Rahmenbedingungen dürfte nicht nur mit dem immer geringer werdenden Realitätsbezug solcher Hoffnungen zusammenhängen, sondern mit der vorangeschrittenen Integration in den Lebensrhythmus der neuen Heimat. ${ }^{1851}$ Thurian schreibt:

„Wenn es jetzt hieße, wir könnten wieder zurück nach Saude, ich wollte nicht wieder hin. Mir hat es in Aurith immer gefallen, und wir haben heute einen größeren Hof als wir ihn in Saude hatten. Das habe ich den Polen auch gleich gesagt, als wir das erste Mal drüben waren. / Unser Haus stand noch. Drinnen lebten offenbar ältere Leute, aber wir wollten nicht einfach klingeln, denn wir hätten uns nicht verständigen können. Und wenn $\mathrm{Du}$ nichts verstehst, bringt es ja nichts. Erst mussten wir also jemanden finden, der übersetzen konnte. Im Haus nebenan wohnte eine Frau, die konnte Polnisch und Deutsch, die fragten wir, ob sie uns helfen könnte. Sie sagte ja. Na und dann ging das. / [S. 47] Die Leute in unserem Dorf haben uns überall rumgeführt, vom Boden bis zum Keller. Es waren nette Leute. Hatten alles gut in Schuss gehalten, sogar ein Bad mit Kacheln und Warmwasser aus der Wand hatten sie eingebaut. Als wir früher da wohnten, hatten wir ja nur ein Plumpsklo übern Hof gehabt." Mancher wollte den Ort seiner Kindheit nur einmal wiedersehen und war dann mit allem im Reinen. Viele aber kamen immer wieder, knüpften sogar Kontakte, so auch Thurian: „Und dann fuhren wir wieder und wieder hin, und jedes Mal haben wir etwas mitgebracht, denn die hatten ja Knappheit, und bei uns ging es schon viel besser zu dieser Zeit. Wir dachten: Jetzt müssen wir die Gelegenheit nutzen, bestimmt ist bald wieder Schluss mit der Visafreiheit. Und so war es ja dann auch, dann sind wir erst nach der Wende wieder nach Polen gefahren! [...]." ${ }^{1852}$

1850 Bretschneider, Ostpreußen als Randnotiz? (wie Anm. 1829), S. $211 \mathrm{f}$.

1851 Siehe dazu auch Faehndrich, Erinnerungskultur (wie Anm. 254), S. 221.

1852 Aurith - Urad (wie Anm. 821), S. 46 f. 
Ähnliches wie bei den nun polnischen Westgebieten ließe sich für die Randbereiche der Tschechoslowakei zeigen. Denn auch in die ehemaligen sudetendeutschen Gebiete boomte bereits Mitte der sechziger Jahre der „Heimwehtourismus“ auch bei DDR-Bürgern, wobei sich wie in Polen - nicht immer und überall nur die oben geschilderen herzlichen Kontakte ergaben, sondern bisweilen auch die Schattenseiten des Nationalitäten-Verhältnisses zeigten. So stellte die Prager DDR-Botschaft damals im überheblichen Verhalten keine Unterschiede zwischen west- und ostdeutschen Touristen fest. ${ }^{1853}$

Die Tatsache, dass ab 1972 ,jährlich Hunderttausende DDR-Bürger, darunter auch sehr viele Vertriebene und ihre Familien, vor allem die angrenzenden polnischen Westgebiete" besuchten, war dem Ministerium für Staatssicherheit durchaus bekannt, ein Grund zum Alarmschlagen war ihm dies aber nicht. ${ }^{1854}$ So heißt es in einem MfS-Bericht vom 14. August 1971 ( „Einschätzung des Reise- und Touristenverkehrs zur VKP und sich ergebende politisch-operative Probleme“) nur lapidar, dass die Reisenden dabei ihre „ehemaligen Wohnstätten besuchten " und dabei auch „Bekanntschaften schlossen bzw. erneuerten“ ${ }^{1855}$ Auch die in den Grenzstädten beobachteten Vorgänge wurden nicht als Gefahr für die DDR „eingeschätzt“, da man sie als Ausnahmefälle und auf ältere Bürger beschränkt sah. So heißt es in einer vom NDPD-Kreisvorstand Guben formulierten „Information über Meinungen und Reaktionen von Parteifreunden zum Besucherverkehr aus der VR Polen und der ČSSR“ vom 7. Januar 1972 sehr distanziert-unaufgeregt, dass „bestimmte ideologische Probleme seitens der Parteifreunde und anderer Bürger älteren Jahrgangs zu erwarten sind, die einst im heutigen Gubin ihren Wohnsitz hatten" ${ }^{1856}$

Das Thema privater Reisen nach Polen vor 1990 bzw. 1980 und bisweilen gar vor 1972 ist allerdings in den größeren Zusammenhang von Reisefreiheit, Freizeitverhalten und Tourismusgeschichte zu stellen. ${ }^{1857}$ Der „Heimwehtourismus“ ist dabei nur ein Aspekt innerhalb des größeren Themas der - nicht auf die Gruppe der Vertriebenen beschränkten - Entwicklung neuer Beziehungen zwischen Deutschen und Polen bzw. DDR-Deutschen und den Bewohnern der anderen „Ostblock“-Staaten. ${ }^{1858}$ Einen Sonderbereich bildet schließlich das Thema der Besuchsreisen von DDR-Bürgern zu in den Vertreibungsgebieten, vor allem in Oberschlesien, verbliebenen Familienangehörigen. In den fünfziger Jahren, auch noch nach 1955, hatten DDR-Bürger vielfach Schwierigkeiten, Reisen zu ihren Verwandten in Polen von der polnischen Botschaft in OstBerlin genehmigt zu bekommen. Besuchsanträge wurden häufig verschleppt oder abgelehnt. ${ }^{1859}$

1853 Amos, Vertriebenenpolitik der SED (wie Anm. 12), S. 165.

1854 Ebd., S. 131.

1855 Ebd., S. 132 (nach: BStU, MfS HA VI 14850, Bl. 4-196).

1856 Ebd., S. 132 (nach: SAPMO-BA DY 16/79).

1857 Auf den staatlich organisierten Urlaub innerhalb der DDR-Grenzen beschränkt: Christopher Görlich: Urlaub vom Staat. Tourismus in der DDR. Köln/Weimar/Wien 2012.

1858 Siehe u. a.: Mateusz J. Hartwich: Reisen von DDR-Bürgern ins Riesengebirge in den 50er und 60er Jahren. In: Schlesier in der DDR (wie Anm. 849), S. 119-133.

1859 Amos, Vertriebenenpolitik der SED (wie Anm. 12), S. 104 (mit Beispiel aus Magdeburg, 1956). 
Vielfach mündeten die fortbestehenden verwandtschaftlichen Kontakte in Ausreiseanträge der in Polen Lebenden.

\section{Städtepartnerschaften als Patenschaftsersatz?}

In der Bundesrepubik entwickelte sich ab 1950 nach und nach ein breites Spektrum institutioneller Patenschaften. ${ }^{1860}$ Neben den öffentlich sichtbaren gebietskörperschaftlichen Patenschaften für ganze Provinzen und Landsmannschaften (Bundesländer) sowie vor allem für Kommunen (Kreise und Städte) gab es noch mancherlei weniger bekannte Beispiele, besonders im schulischen Bereich, aber auch bei Vereinen. Westdeutsche Schulen übernahmen die Patenschaft für einzelne Schulen der Vertreibungsgebiete und waren mehr oder weniger bemüht, die Tradition weiterzuführen, wie etwa im Falle der Christophorusschulen des christlichen Jugenddorfwerkes in Oberurff/Hessen, die in einer Feierstunde 1964 die Traditionspflege für das berühmte (neumärkische) Züllichauer Pädagogium übernahmen, „der Göttinger Geschichtsverein [übernahm] die Patenschaft über den ehemaligen Verein für Geschichte der Neumark“ (Sitz bis 1945: Landsberg/Warthe). ${ }^{1861}$ Die Ehemaligen-Vereinigungen der Schulen aus den Ostgebieten gaben überdies Mitgliederzeitschriften heraus. ${ }^{1862}$ All dies fehlte in der DDR, da es verboten und der Kontakt zu den westdeutschen Einrichtungen dieser Art unerwünscht war. Auch dies hat zur nahezu gänzlichen Abschneidung von Traditionen und Bezugsrahmen geführt, die den einzelnen Vertriebenen zunächst umgaben.

Betrachtet man nun die während der DDR-Jahrzehnte gepflegten Kontakte oder gar offiziell eingegangenen Partnerschaften zwischen brandenburgischen Städten einerseits und pol-

1860 Siehe für Ostbrandenburg: Werner Bader: Patenschaften über Brandenburger Heimatvertriebene und politische Flüchtlinge aus Brandenburg. Eine Dokumentation des Kulturförderverein Mark-Brandenburg. Görne [2007]. - In West-Berlin übernahmen in den fünfziger Jahren einzelne Verwaltungsbezirke Patenschaften für ostdeutsche Landsmannschaften bzw. deren Berliner Landesgruppen: Charlottenburg (Pommern; 2006 beendet), Kreuzberg (Ostbrandenburg und Sudetenland; gekündigt), Schöneberg (Schlesien; noch bestehend), Steglitz (Ostpreußen; noch bestehend), Tiergarten (Oberschleisen; bereits vor Jahrzehnten beendet), Wilmersdorf (Westpreußen; 2006 beendet).

1861 Patenschaft über das Züllichauer Pädagogium: Günther Leppin: Evangelisches Kirchentum im Kreis Züllichau-Schwiebus. In: Kreis Züllichau-Schwiebus. Hrsg. im Auftr. der Heimatkreisvereinigung von Curt Schelenz. Frankfurt am Main 1970, 2. Aufl. 1975, S. 48-52, hier S. 50; Curt Schelenz: Die Steinbartsche Stiftung in Züllichau. Pädagogium und Alumnat. In: ebd., S. 59-62, hier S. 61. - Patenschaft über den Verein für Geschichte der Neumark: Otto Kaplick: Geschichte der Neumark. in: Landsberg an der Warthe 1257 1945 - 1978. Aus Kultur und Geschichte im Spiegel der Jahrhunderte. Hrsg. von Hans Beske u. Ernst Handke (Schriftenreihe der Bundesarbeitsgemeinschaft Landsberg (Warthe) Stadt und Land, Bd. 2). Bielefeld 1978, S. 170-173, hier S. 173.

1862 Beispiele: „Vereinigung der Ehemaligen des Pädagogiums und Waisenhauses bei Züllichau e. V.“, „Vereinigung ehem. Marienstifter e.V.“ (Stettin; Patenschule: Katharineum Lübeck), „Matthesianer-Verband“ (St. Matthias-Gymnasium Breslau; Patenschule ab 1954: Gymnasium Paulinum Münster/Westf.). Siehe auch: Pommersche Schulvereinigungen. Zsgest. von Gottfried Loeck. In: Die pommerschen Heimatkreise 1945-1995. Hrsg. vom Pommerschen Kreis- und Städtetag. Zsgest. von Hans-Günter Cnotka. Lübeck 1998, S. 368-371. 
nischen andererseits ${ }^{1863}$, so ergeben sich manche Indizien dafür, dass dies auf deutscher Seite keineswegs immer zufällig auf einen Partner fiel, der ohne jede Beziehung zum Gegenüber gewesen wäre. Wohl hat es solche Fälle gegeben, in denen sich DDR-Kommunen bei ihren Oberen um Partnerschaftsanbahnungen bemühten und dann mehr oder weniger zufällig eine z. B. tschechische Stadt vorgeschlagen erhielten, doch ist nicht zu übersehen, dass die Fälle „mit Vorgeschichte" wohl auch keine ganz zu vernachlässigenden Ausnahmen bilden.

So ging die Bezirkshauptstadt Cottbus schon 1975 eine Städtepartnerschaft mit dem polnischen Zielona Góra (Grünberg in Schlesien) ein. ${ }^{1864}$ Damit begegneten sich nicht nur zwei geographisch benachbarte Gebiete, der Lausitzer DDR-Bezirk und die immerhin grenznahe polnische Woiwodschaft Zielona Góra, sondern zugleich das aktuelle mit dem ehemaligen Wohngebiet vieler Vertriebenen. Denn nicht nur lebte in der Lausitz ein großer Teil der heimatvertriebenen (Nieder-)Schlesier, sondern gerade in der Stadt Cottbus waren 1945 Transporte aus Grünberg angekommen, darunter fast ein komplettes Grünberger Altenheim, ${ }^{1865}$ und Vertriebene aus dem „Raum um Grünberg“ finden sich auch sonst in der weiteren Umgebung, z. B. in Neupetershain (Kr. Calau). ${ }^{1866}$

Auf den bereits zuvor, am 6. Juni 1973, zwischen den Stadträten von Potsdam und Oppeln abgeschlossenen Städte-Freundschaftsvertrag folgte ein breites Spektrum organisierter offizieller Begegnungen zwischen polnischen Einrichtungen und Gruppen aus der polnischen Woiwodschaft Opole (Oppeln) in Oberschlesien einerseits und solchen im DDR-Bezirk Potsdam andererseits. Zu nennen sind neben wirtschaftlichen Kontakten auf Kombinatsebene ein Erfahrungsaustausch landwirtschaftlich-technischer Institute und von Spezialisten im Bauwesen, ferner Jugendaustausch, Freilicht- und andere Ausstellungen, Publikationstausch der

1863 Siehe u. a. Aleksandra Trzcielińska-Polus: Beziehungen zwischen dem Oppelner Schlesien und dem Bezirk Potsdam bis 1989. In: „Wach auf, mein Herz, und denke“ (wie Anm. 11), S. 532-542. - Bisher ermittelte Kontakte vor 1990 (genauere Daten und Nachweise siehe in der Ortsdokumentation): Angermünde (1972 Strzelce Krajeńskie-Friedeberg/Nm.), Belzig (nach 1973 Głogówek-Oberglogau), Bernau (1979 Skwierzyna-Schwerin/Warthe), Brandenburg an der Havel (nach 1973 Kędzierzyn-Koźle-Kandrzin-Cosel), Cottbus (1975 Zielona Góra-Grünberg), Frankfurt (Oder) (1975 Gorzów Wlkp.-Landsberg/W. und Słubice-Dammvorstadt; Bezirk Frankfurt (1959 Woiwodschaft Zielona Góra-Grünberg), Eisenhüttenstadt (1972 Głogów-Glogau), Hennigsdorf (Kralupy nad Vltavou-Kralup an der Moldau), Jüterbog (nach 1973 Głubczyce-Leobschütz), Lübbenau (1981 Nowogród Bobrzański-Naumburg am Bober), Luckenwalde (nach 1973 Brzeg-Brieg), Neuruppin (nach 1973 Namysłów-Namslau), Oranienburg (nach 1973 Prudnik-Neustadt, Oberschlesien und 1974 Mělník-Melnik), Potsdam (1973 Opole-Oppeln), Pritzwalk (nach 1973 Kietrz-Katscher), Rathenow (nach 1973 Kluczbork-Kreuzburg), Strausberg (1978 Dębno-Neudamm), Templin (1977 Polczin Zdrój-Bad Polzin), Wittstock (nach 1973 Krapkowice-Krappitz), Zernitz (Kr. Ostprignitz) (nach 1973 Baborów-Bauerwitz), Zossen (nach 1973 Nysa-Neisse). - Zum Fortbestehen nach 1990 siehe die einzelnen Artikel in der Ortsdokumentation (Teil 2) sowie unten die Tabelle 9 im Kapitel V.

1864 https://www.cottbus.de/international/staedtepartnerschaften.html [31.8.2016].

1865 Wo verblieb das Altenheim? In: Grünberger Rundbrief 8 (1949), o. S.

1866 Horst Kittan: Die Russen kommen. Cottbus 2011, S. 243. - Siehe auch oben im Kapitel II. 3 den Abschnitt zur Verteilung der Neumärker und Niederlausitzer. 
Leitbibliotheken und anderes mehr. ${ }^{1867}$ Zehn Städte und eine Landgemeinde aus dem Bezirk Potsdam nahmen in der Folge Kontakte mit Partnerstädten bzw. -gemeinden in der Oppelner Woiwodschaft auf; hierbei kann es sich aber - anders als bei der nach 1990 mehrfach bekräftigten Partnerschaft Potsdam-Oppeln - nur um kurzzeitige, wohl doch mehr verordnete als gelebte Kontakte handeln, denn es finden sich weder Hinweise auf eine Fortsetzung nach 1990 noch sonst Erwähnungen in der DDR-zeitlichen deutschen Literatur. ${ }^{1868} \mathrm{Ob}$ der immerhin beachtliche Anteil schlesischer Flüchtlinge, der sich am 1. September 1945 in Potsdam aufhielt ${ }^{1869}$, für die spätere Partnerschaftsanbahnung eine Rolle gespielt hat, ist vorläufig ungeklärt.

Mit Händen zu greifen, obgleich bisher nicht konkreter erforscht, sind die Voraussetzungen im Falle der nach 1973 aufgenommenen, wenn auch nicht in eine formalisierte Partnerschaft überführten Kontakte zwischen Luckenwalde und Brzeg, Polen (Brieg, Schlesien). ${ }^{1870}$ Denn nach Luckenwalde waren überdurchschnittlich viele Vertriebene aus Stadt und Kreis Brieg gelangt, die hier schon im Juli 1947 ein zwar nur sehr kleines, aber doch aktenkundiges Heimattreffen von Vertriebenen aus dem Kreis Brieg (Schlesien) mit 5 Teilnehmern durchführten $^{1871}$, dem im Januar 1948 ein weiteres mit 7 Teilnehmern folgte ${ }^{1872}$. Es gibt noch mancherlei Brieger Indizien in Luckenwalde, wo z. B. am 5. August 1947 der ehemalige Brieger Ehrenbürger, Stadtälteste und ehemalige Stadtrat Bäckermeister Paul Mende im Bürgerhospital verstarb $^{1873}$, so dass lokale Recherchen erwünscht wären.

Zumindest „verdächtig“ ist es schließlich auch, dass nach 1973 die Stadt Neuruppin unformalisierte Kontakte mit Namysłów, Polen (Namslau, Schlesien) aufbaute ${ }^{1874}$. Denn hier ist zwar bislang noch kein unmittelbar am Ort ansässig gewordener Namslauer nachgewiesen, aber im nicht allzuweit entfernten Neustadt/Dosse, immerhin ebenfalls altes Ruppiner Kreisgebiet, treffen sich die in diesem Raum und im nahen Kyritz gelandeten Namslauer noch heute (seit 2012 jährlich). ${ }^{1875}$

Ohne diese hier überdies nur angerissenen Indizienfälle überbewerten zu wollen, könnte eine nähere Untersuchung womöglich ein lohnendes Forschungsfeld eröffnen. Zu fragen ist, ob und ggf. wie DDR-Bürger mit Vertreibungshintergrund im Rahmen von Städtepartnerschaften

Ausführlicher dazu und mit weiteren Beispielen: Trzcielińska-Polus, Beziehungen (wie Anm. 1863), S. 535541.

1868 Bislang einziger ermittelter Beleg bei Trzcielińska-Polus, Beziehungen (wie Anm. 1863), S. 537 f., nennt ohne Beleg (vermutlich auf der Grundlage von polnischen Oppelner Quellen) Kontakte zwischen den Städten Belzig/Obeglogau, Brandenburg an der Havel/Kandrzin-Cosel, Jüterbog/Leobschütz, Luckenwalde/Brieg, Neuruppin/Namslau, Oranienburg/Neustadt/OS, Pritzwalk/Katscher, Rathenow/Kreuzburg/OS, Wittstock/Krappitz sowie die Gemeinden Zernitz/Bauerwitz. Weitere Angaben siehe Anm. 1863.

1869 Potsdam und das Jahr 1945. Potsdam 2005, S. 23.

1870 Trzcielińska-Polus, Beziehungen (wie Anm. 1863), S. 538.

1871 Briegische Briefe 1 (1947), S. 176.

1872 Ebd. 2 (1948), Nr. 7/8, S. 12.

1873 GenWiki/Brieg [6.7.2017].

1874 Trzcielińska-Polus, Beziehungen (wie Anm. 1863), S. 538.

1875 Siehe die näheren Angaben in den Ortsdokumentationen, auch unter Rathenow. 
eine Strategie entwickelt haben, das sie persönlich betreffende Tabu der öffentlich sichtbaren Beschäftigung mit der Heimat zu umgehen.

\section{Die Kirchen und die Vertriebenen}

Auffällig ist, dass in Gemeindechroniken katholischer Pfarreien fast stets dem Flüchtlings- und Vertriebenenzuzug Platz eingeräumt wird, in den Pendants evangelischer Kirchengemeinden eher selten und wenn, dann meist nur sehr beiläufig. ${ }^{1876}$ Die unterschiedliche Bedeutung des Gläubigenzuwachses für die beiden Kirchen liegt aber auf der Hand und dürfte dies erklären: Für die katholischen Diasporagemeinden in Berlin und Brandenburg bedeutete der Zuwachs durch die Vertriebenen zumeist eine sehr starke und in vielfacher Hinsicht spürbare Bereicherung des Gemeindelebens. Vielerorts wurde überhaupt erstmals - seit der Reformation - wieder eine nennenswerte Zahl von Gläubigen erreicht oder doch diese so deutlich verstärkt, dass Pfarrer und Gläubige sich nun in ihrem bis dahin eher schwierigen Minderheitenstatus ermutigt fühlen konnten und die mentalen Folgen ihres Diasporadaseins deutlich abgemildert wurden.

Demgegenüber änderte die Vergrößerung der Zahl der Gemeindemitglieder durch den Zuzug von Flüchtlingen und Vertriebenen in der Evangelischen Kirche in Berlin-Brandenburg aber, obgleich sie oft viel stärker war als bei den Katholiken, nichts am ohnehin starken Übergewicht der Protestanten in den Stadt- und Landgemeinden und somit auch nicht an ihrem Selbstgefühl. Denn diese hatten - seit der Reformation und trotz der auch im 19. und 20. Jahrhundert schon starken Bevölkerungszuwächse aus den preußischen Ostprovinzen - stets die Mehrheit gebildet, eine Situation, die erst durch den Wandel zu einer nicht mehr christlichkirchlichen Mehrheitsgesellschaft im Laufe der DDR-Zeit und vollends nach 1990 in Frage gestellt wurde. Diese Mehrheitsposition erleichterte zum einen die Integration der vielen evangelischen Flüchtlinge und Vertriebenen, besonders aus der Neumark, aus Niederschlesien, (Hinter-)Pommern und aus Gebieten der ehemaligen Provinz Posen, gehörten sie doch wie die Brandenburger „Einheimischen“ zur selben Kirche der Altpreußischen Union.

Die konfessionelle Mehrheitsposition der evangelischen Kirche hat zum anderen aber in der Folge offenbar auch dazu geführt, dass die Gemeinden in der Vertriebenenzuwanderung kein besonders erinnernswertes Ereignis sahen und sehen, das sich von anderen Phasen ihrer Geschichte unterschieden hätte. Ganz lapidar und fast buchhalterisch klingt z. B. die Formulierung in der 1998 erschienenen Chronik der Potsdamer Erlöserkirchengemeinde für das Jahr 1945: „Änderung der Zusammensetzung der Erlösergemeinde durch den Flüchtlingsstrom aus den Gebieten jenseits der Oder und Neiße und dem Sudetenland. Die Heimatvertriebenen werden in die Gemeinde integriert. ${ }^{\text {1877 }}$ Obgleich die Formulierung die große Dimension des Zuzugs und des-

1876 Auch dieser Quellen- und Literaturlage wegen wird „Katholiken“ in der Ortsdokumentation (Teil 2) als eigener Punkt ausgewiesen.

1877 Rudolf Knaack: 100 Jahre Erlöserkirche in Daten. Ausgewählt von R. K. In: Die Erlöserkirche in Potsdam 1898-1998. Festschrift zur 100-Jahr-Feier am 4. Mai 1998. Hrsg. vom Gemeindekirchenrat der Erlöserkir- 
sen Folgen für die Einheimischen an sich andeutet, schließt der knappe zweite Satz das Thema als scheinbar schnell gelöst ab. Zwar folgt, ebenfalls für 1945, noch ein Satz über die „Aufstellung eines ,Barmherzigen Brotkorbs' und Sammlung anderer Nahrungsmittel zur Linderung der Not der Flüchtlinge, [S. 50] entlassenen Kriegsgefangenen und Verwundeten" und eine - nicht auf Flüchtlinge beschränkte - Formulierung über die „Starke Zunahme der kirchlichen Beerdigungen, so daß die Pfarrer ,kaum vom Friedhof ' kommen "1878, doch erwähnt die Zeittafel ab Mitte 1945 nirgends irgendwelche Folgen der „Änderung der Zusammensetzung der Erlösergemeinde“, das Thema ist hier offenbar abgeschlossen, noch bevor der SED-Staat es Anfang der fünfziger Jahre generell für gelöst erklärt. Die Verhältnisse sind ebenso wie die konfessionelle Erinnerungskultur mithin wohl doch als so verschieden anzusehen, dass eine getrennte Behandlung erforderlich scheint.

\section{Evangelische Kirche}

Nach den ersten ungeordneten Wochen und Monaten nahm sich die Brandenburgische Landeskirche ab Herbst 1945 gezielter der Flüchtlingsbetreuung an, zum einen auf die neuen Gemeindeglieder allgemein gerichtet, zum anderen auf die besondere Gruppe vertriebener Pfarrer. Bischof Dibelius, dem die Gefahr bewusst war, die von einer abgesondert lebenden Gruppe ausging, setzte sich in Rundbriefen und Predigten immer wieder mit besonderem Nachdruck dafür ein, die „Ostflüchtlinge“ einzubeziehen, und nutzte sogar ihm persönlich zur Verfügung stehende Fonds für wirtschaftliche Eingliederungshilfen. Die tägliche Hauptarbeit lag aber bei den Gemeinden, die anfangs sogar als Suchdienstanlaufstellen fungierten ${ }^{1879}$, und vor allem bei den verschiedenen Hilfswerken. Der Bischof ließ den berlin-brandenburgischen Pfarrern unter dem 22. April 1947 durch (den aus Posen geflüchteten) Richard Kammel (1882-1957) („Der Evangelische Bischof von Berlin / Kirchendienst Ost “1880) mitteilen, er werde am Sonntag, 1. Juni, vormittags $10.30 \mathrm{Uhr}$, „im Gottesdienst in der Marienkirche sich besonders an die Ostflüchtlinge wenden, ihnen ein Wort des Trostes zu ihrer schwierigen Lage und einen Willkommensgruß unserer Kirche namens der Kirchenleitung sagen. Alle erreichbaren Ostflüchtlinge sind zu diesem Gottesdienst herzlich eingeladen. Ich wäre Ihnen sehr dankbar, wenn Sie freundlichst dieses durch Abkündigung in den Gottesdiensten Ihrer Gemeinde bekanntgäben und auch sonstige sich bietende Gelegenheiten zur Einladung für diesen Gottesdienst benutzten." ${ }^{1881}$

Bewusst setzte man in der Flüchtlingsbetreuung vertriebene Pfarrer ein, um auf die Sorgen und Nöte angemessen einfühlsam und damit produktiv-integrierend reagieren zu können. Dibelius hat das Problem in einem seiner Rundbriefe an die Pfarrer seiner Landeskirche 1948

chengemeinde Potsdam. Red.: Martin Kwaschik, Rudolf Knaack, Ewald Gerth. Potsdam 1998, S. 25-69, hier S. 49.

1878 Ebd., S. 49 f.

1879 Belegt z. B. für Fürstenwerder (Uckermark); siehe oben im Kapitel IV. 2 den Abschnitt „Vertriebenentreffen und korporative Tendenzen in Brandenburg" bzw. Bleich, Kirchliches Leben (wie Anm. 1151), S. 62 f.

1880 Sitz: Berlin-Dahlem, Reichensteiner Weg 24.

1881 ELAB, 29/367, unfol. (22.4.1947). 
ganz offen angesprochen: „Dabei lehrt die Erfahrung immer wieder, daß die Flüchtlinge leichter auf einen Pfarrer hören, der selbst aus dem Osten vertrieben wurde, als auf den eingesessenen, dem gegenüber sie allzu leicht das Vorurteil haben, daß er sie nicht recht verstehen könne. "1882 Um so mehr galt es, diese Geistlichen überhaupt in den Stand zu setzen, ihren erschwerten Aufgaben nachzukommen. Wie sehr sie dabei buchstäblich mit „Nichts“ anfangen mussten, offenbart ein vom Bischof unter dem 11. Juli 1946 versandter „Aufruf zur amtsbrüderlichen Hilfe für Flüchtlingspfarrer" ${ }^{\text {"1883, }}$ in dem es heißt: „Es ist eine nicht unbeträchtliche Zahl von Pfarrern und Hilfsgeistlichen, die für Gottesdienste und Amtshandlungen weder einen Talar noch überhaupt ein schwarzes Kleidungsstück besitzen. Teils handelt es sich um Flüchtlinge, teils um Ausgebombte oder Heimkehrer aus der Kriegsgefangenschaft. Alle Versuche, eine Spinnstoffwarenzuteilung von dem Landeswirtschaftsamt Berlin oder der Mark Brandenburg zur Anfertigung neuer Talare zu erhalten, sind bisher gescheitert. In einigen Fällen hat das Hilfswerk eintreten können. Aber der Mangel ist zu groß. Darum rufe ich die Pfarrer, Ruheständler und Pfarrwitwen zur Hilfe auf. Hier muß die Liebe brennend und das Wort Johannes des Täufers wegweisend werden: ,Wer zwei Röcke hat, der gebe dem, der keinen hat' (Luk. 3,11). Es gibt noch Pfarrer, die zwei Talare haben. Es sind noch Lutherröcke, Gehröcke, schwarze oder gestreifte Hosen in manchem Schrank, die nur noch selten oder vielleicht nie mehr angezogen werden. Und gerade weil es sich um Stücke handelt, die sonst für Kleiderspenden nicht geeignet sind, ist selbst in der Gemeinde die letzte Möglichkeit noch nicht erschöpft. [...] Ich bitte, soweit nicht direkt von Bruder zu Bruder geholfen werden kann, Talare usw. an den, Barmherzigen Kleiderschrank' von Pfarrer Dr. Wenzel ${ }^{1884}$, Berlin-Nikolassee, Teutonenstr. 22 zu senden oder dort anzumelden. [...].“

In der Evangelischen Kirche in Berlin-Brandenburg fanden auch wegen des geschilderten Bedarfs an unmittelbarem seelsorgerlichem Kontakt zu den neuen Gemeindemitgliedern zahlreiche Vertriebene neue Funktionen. Dabei kam es bisweilen keineswegs nur zu Assimilationen, sondern sogar zur Veränderung bestehender Verhältnisse in den Aufnahmeorten. So hatten die im Januar 1945 aus der Posener Diakonissenanstalt geflohenen Diakonissen „zunächst keinen festen Sitz; die Schwestern arbeiteten verstreut in Ost und West. ${ }^{1885}$ Am 8.1.1947 kam es zu einer gemeinsamen Sitzung von Vertretern der Posener Diakonissenanstalt und der Samariteranstalten in Ketschendorf (Fürstenwalde/Spree). Man faßte den Beschluß einer Vereinigung beider Anstalten (in Kraft getreten mit dem 1.2.1947)." Damit war zwar äußerlich die Herkunft aus den Vertreibungsgebieten nicht mehr sichtbar und die Eingliederung gewissermaßen durch Assimilation erfolgt, tatsächlich erhielten aber - blickt man hinter diese äußerlichen Formen der Integration - Vertriebene keineswegs nur untergeordneten Stellen. Oberin der fusionierten Anstalt wurde nämlich die aus dem Sudetenland stammende ehemalige (seit 1940) Posener

1882 ELAB, 1/2453, unfol. (14.2.1948).

1883 ELAB, 29/367, unfol. (11.7.1946).

1884 Kirchenrat Pastor D. Dr. Theodor Wenzel (geb. 1895 Grünberg in Schlesien, gest. 1954), Geschäftsführender Direktor des Gesamtverbandes der Berliner Inneren Missionen.

1885 Angaben zur Posener Diakonissenanstalt und der Fortsetzung in Ketschendorf nach ELAB, 1/2453, Dokumentation, S. 38 . 
Oberin Emma Lichtenberg (1894-1974), und auch noch deren Nachfolgerin ab 1968 war bis 1979 wiederum eine Vertriebene, die aus Thorn stammende ehemalige Posener Diakonisse Hildegard Scharlowski (geb. 1910). Auch das Diakonissenhaus „Lutherstift“ in Frankfurt (Oder) wurde von 1946 an bis in die sechziger Jahre von Vertriebenen geleitet: 1946-1948 von dem aus Pleschen (Posen) gekommenen Pfarrer Joachim Scholz (geb. 1902), 1948-1952 vom ehemaligen (letzten) Posener Stadtsuperintendenten Johannes Steffani (1889-1976) und ab 1952 viele Jahre von dem aus Reichthal stammenden Pfarrer Dietrich Hemmerling (geb. 1917). ${ }^{1886}$ Ebenso lassen sich unter den nicht-theologischen Mitarbeitern der Berlin-Brandenburger Kirche Vertriebene durchaus in Leitungspositionen finden. So war der ehemalige Arzt am Diakonissenhaus in Posen Dr. Gustav Schülke (1907-1966) von 1945 bis Anfang 1959 Chefarzt des Luise-Henrietten-Stiftes in Lehnin/Mark. ${ }^{1887}$

Auf die Tatsache, dass sich für beide Seiten, die „einheimische“ Landeskirche wie die Gruppe der „Flüchtlingspfarrer“, in der durch den Krieg entstandenen Situation der Kirchengemeinden gemeinsame Interessen entwickelten, ist andernorts bereits hingewiesen worden. „Vor allem dem Zustrom von ,Ostpfarrern' aus den verlorenen deutschen Gebieten jenseits von Oder und Neiße und dem Einsatz von Nicht-Volltheologen war es nach 1945 zu verdanken, daß in der Evangelischen Kirche Berlin-Brandenburg die Kriegsverluste bis 1952 größtenteils überwunden werden konnten. So stammten nach einer Aufstellung von 1948 von den 1197 BerlinBrandenburger Pfarrern insgesamt 149 aus den ehemaligen Ostgebieten. “1888 Dass die Vertriebeneneigenschaft der Betreffenden dabei keineswegs kaschiert wurde, zeigen die - zweifellos auch für das SED-Regime zugänglichen - gedruckten und vervielfältigten Verzeichnisse, die bereits früh im Umlauf waren, mehrfach aktualisiert wurden und diversen (kirchlichen) Stellen als Informationsquelle dienten. Detaillierte Anschriftenlisten der (geflohenen bzw. vertriebenen) „evangelischen Pfarrer, Ruheständler und Hinterbliebenen “ hatte der „Kirchendienst Ost" 1947 bereits in zweiter Ausgabe zusammengestellt. Sie enthalten, gegliedert nach den Herkunftsregionen, Amtsbezeichnung, Name, Vorname, früheren Wohnort und aktuellen Wohnort. ${ }^{1889}$ Hierin finden sich neben zahlreichen in Berlin gelandeten auch viele in Brandenburg Wirkende und zwar auch sie mit Angabe der Adresse.

Die angestrebte Integration als wirkliche Gleichbehandlung hatte im Alltag dennoch immer wieder unerwartete, auch formale Hürden zu überwinden. So versandte das Evangelische Konsistorium der Mark Brandenburg unter dem 10. August 1946 aus Berlin-Dahlem, Rudeloffweg 27, an die „Herren Superintendenten unseres Aufsichtsbereichs“ die Abschrift eines Rundschreibens der Kanzlei der Evangelischen Kirche in Deutschland, Schwäbisch Gmünd, vom 29. Mai 1946 an die Landeskirchenregierungen zur Kenntnis und Beachtung bezüglich

1886 Ebd.

1887 Ebd.

1888 Halbrock, Evangelische Pfarrer (wie Anm. 138), S. 64.

1889 Auszüge (Teillisten für Baltikum, Westpreußen, „Wartheland (Ost) (Lodz)“, „Wartheland (West) (Posen)“): ELAB, 1/2453 (unfol.). 
„Vertretung der Ostflüchtlinge im Kirchenvorstand““ ${ }^{1890}$ Da das Wahlrecht und die Wählbarkeit zu den kirchlichen Gemeindekörperschaften „von einer bestimmten Dauer der Zugehörigkeit zu der betreffenden Kirchengemeinde abhängig gemacht" wurden, blieben „die Ostflüchtlinge für die Amtsdauer der in diesen Monaten gewählten Kirchengemeinden unvertreten“. „Wo die Frist für die Erlangung des Wahlrechtes oder der Wählbarkeit ein Jahr überschreitet, ist zu erwägen, ob man nicht den Ostflüchtlingen, die in ihrer Heimat Ämter in kirchlichen Körperschaften hatten, durch eine gesetzliche Ausnahmebestimmung die Wählbarkeit früher zuerkennen sollte. Dies gilt insbesondere für diejenigen Gebiete der EKD, deren kirchliche Verhältnisse von denen der Heimatgemeinden der dort vorwiegend untergebrachten Ostflüchtlinge nicht gar zu verschieden sind. Wenn eine solche Regelung nicht getroffen werden kann, müßte aus dem Kreis der Ostflüchtlinge nach möglichst umfassender Fühlungsnahme mit diesen und mit dem zu ihrer Betreuung bestellten Pfarrer, ein Vertrauensmann berufen werden, der regelmäßig zu den Sitzungen der Gemeindevertretung zugezogen wird und in ihr die Anliegen der Flüchtlinge vertritt. Aus diesen Vertrauensmännern in den kirchlichen Gemeindekörperschaften könnte ein kleinerer Ausschuß gebildet werden, der die gleichen Aufgaben für den Kirchenkreis übernimmt. Die Berufung der Vertrauensmänner und die Bildung der Ausschüsse müßte den Kirchengemeinden und Kirchenkreisen zur Pflicht gemacht werden. (...)."Wieweit diese an einem gesamtdeutsch agierenden Schreibtisch verfasste „Anregung“ im (brandenburgischen) Einzelfall tatsächliche Probleme benannte und ob sie Folgen hatte, erscheint allerdings, solange keine breite Analyse aufgrund lokaler Quellen vorliegt, fraglich. Das dem Superintendenten des Kirchenkreises Kölln-Land I zugestellte Exemplar trägt dessen - in Berlin geschriebene, aber auf Brandenburg bezogene - handschriftliche Notiz „Kommt kaum für unsere Landgemeinden in Frage. / D.“1891

Auch mit dem - klassisch bürokratisch motivierten - Vorstoß der Kirchenleitung vom 16. Mai 1947, gesonderte „Flüchtlingskarteien“ und sogar eigens „Flüchtlingsbücher“, wenn auch nicht anstelle der Eintragungen gottesdienstlicher Handlungen in den normalen Kirchenbüchern, sondern zusätzlich, aber ausführlicher als dort zu führen ${ }^{1892}$, scheint man die zeitlichen Möglichkeiten und die Belastungsfähigkeit der Gemeindepfarrer und -küster grundlegend falsch eingeschätzt zu haben. Jedenfalls haben sich auffällig wenige solcher Bücher erhalten und dürften sich folglich kaum alle Gemeinden veranlasst gesehen haben, dem Auftrag nachzukommen. ${ }^{1893}$

1890 ELAB, 29/367, unfol. (hiernach auch die folgenden Zitate).

1891 Ebd.

1892 ELAB, 29/367, unfol. (16.5.1947).

1893 Siehe dazu Quellenteil, Nr. 168. - Im ELAB ließ sich als Beispiel für ein noch vorhandenes „Flüchtlingsbuch“ nur das für Zeuthen (Zeitraum 1947-1951) ermitteln (ELAB, Best. 2 17 08/1 Kirchengemeinde ZeuthenMiersdorf, Nr. 70 (Original, unverfilmt; lt. Findbuch, S. 13, „mit Erklärungen der Unterzeichneten zu ihrer Taufe in ihren Herkunftsorten“); vgl. auch ELAB-Kirchenbuchkatalog, S. 494. - Einen kirchlichen Weg, den Nöten der Flüchtlinge, die ihre Papiere eingebüßt hatten, abzuhelfen, zeigt das für Lanz (Kr. Westprignitz) nach 1945 angelegte „Ersatzkirchenbuch für verlorene Taufscheine von Flüchtlingen aus den Ostgebieten“ mit dokumentierten Taufen aus dem Zeitraum 1925-1945 (Verfilmung: ELAB, Nr. 24136) (freundliche Hinweise Bert Buchholz/ELAB). 
Eine Möglichkeit, das Flüchtlingsthema in den brandenburgischen Gemeinden weiter offen zu benennen, bestand für das in Berlin ansässige Konsistorium in den Vorgaben für landeskirchenweite Kollekten. So enthält der Ende November an die Superintendenturen verteilte „Kollektenplan des Konsistoriums der Evangelischen Kirche der Mark Brandenburg für 1947" unter den 62 Kollekten (an jedem Sonntag sowie an Feiertagen) mehrere, die teilweise indirekt darauf Bezug nahmen. ${ }^{1894}$ Dabei erscheint zwar die Zahl gering, doch dürfte die offenkundig bewusste Wahl der Termine - mehrere hohe Feiertage - einen um so größeren Kreis von Spendern erreicht haben:

26.01. (3. n. Epiphanias): Für das Kirchliche Hilfswerk v. Berlin u. Brandenburg

06.04. (1. Ostertag): Für Flüchtlingsseelsorge (Hilfswerk der E. K. i.D., Zentralbüro Ost)

29.06. (4. n. Trinitatis): Für die Arbeit an anhanglosen Kindern aus dem Osten (Hilfswerk)

19.11. (Bußtag) Für evangelische Bahnhofsmission u. Flüchtlingsfürsorge (Hilfswerk)

24.12. (Weihnachten) Für heimatlose Heimkehrer (Hilfswerk)

Eine im gesamtdeutschen Rahmen federführende Rolle übernahmen kirchliche Betreuungsdienste speziell für die neumärkischen bzw. ostbrandenburgischen Vertriebenen, von denen nicht wenige in die deutsch gebliebenen Teile Brandenburgs gelangt waren. ${ }^{1895}$ Die Mehrheit dieser Aktivitäten konnte nur von West-Berlin aus betrieben werden, doch reichten diese nicht nur in den brandenburgischen Bereich hinein, sondern gab es auch in Brandenburg selbst zumindest in der frühen Zeit einzelne dabei aktiv werdende Funktionsträger. Zu nennen ist hier der Wittstocker Superintendent Günther Leppin, der in der zweiten Hälfte der vierziger Jahre „Flüchtlingsbeauftragter im Hilfswerk der EKD“ für Brandenburg war und zuvor als (letzter) Superintendent in Züllichau gewirkt hatte. ${ }^{1896}$ Er wurde, wie er selbst es beschreibt, erst „Ende 1952 durch die Kirchenleitung Berlin-Brandenburg wegen unmittelbarer Gefährdung aus dem kommunistischen Machtbereich herausgenommen und in die BRD freigegeben“. Für die Zeit bis dahin spricht er in einem späteren Bericht 1971, nun als Superintendent i. R. von Detmold aus, von „der Arbeit unseres Hilfskomitees“ als „des einzigen innerhalb der DDR ansässigen und arbeitenden“ ${ }^{1897}$ Der

1894 ELAB, 29/367 (Akte des Kirchenkreises Kölln-Land I betr. „Konsistorium“), 1946-1947, unfol. (Eingang 29.11.1946 bei Superintendentur Kölln-Land I).

1895 Arbeitsberichte des Kirchlichen Betreuungsdienstes für die ehemaligen Ostbrandenburgischen Kirchengemeinden Kirchenkreise Landsberg/W., Arnswalde/Neumark u. Friedeberg-Woldenberg Nm. für die Jahre 1970 bis 1973 (1974 nur noch für Arnswalde) in: ELAB, 1/2453 (unfol.). Allgemein zur Arbeit (ohne besondere Bezugnahme auf die Situation in SBZ/DDR): Erhard Schendel: Der kirchliche Betreuungsdienst. In: Erinnerungen an Stadt + Land Friedeberg Nm. Hrsg. von E(rhard) Schendel u. Hans Schauer. Berlin 1974, S. 381-385. - Siehe auch oben im Kapitel II.3 den Abschnitt „Neumärker und Niederlausitzer“.

1896 Handbuch der Deutschen Evangelischen Kirchen 1918 bis 1949. Organe - Ämter - Verbände - Personen. Bd. 1: Überregionale Einrichtungen. Bearb. von Heinz Boberach, Carsten Nikolaisen u. Ruth Pabst (Arbeiten zur Kirchlichen Zeitgeschichte, Reihe A: Quellen, Bd. 18). Göttingen 2010, S. 277.

1897 Tätigkeitsbericht (für 1970) des Hilfskomitees für die (ehem.) ostbrandenburgischen Kirchengemeinden (östlich der Oder), Vorsitzender und Geschäftsführer: Günther Leppin, Sup. i. R., Detmold-Hiddessen, 6.4.1971 (ELAB 1/2453, unfol.). 
Kontakt zu den Neumärkern in der DDR scheint freilich dann weitgehend abgerissen zu sein. Der Radius der Tätigkeit auch des Nachfolgers, Superintendent a.D. Erhard Schendel, Berlin (West) ${ }^{1898}$, von 1971 bis 1973 als „Flüchtlingsbeauftragter der Evangelischen Kirche Berlin-Brandenburg (Hilfskomitee der ehem. ost-brandenburgischen Kirchengemeinden östlich der Oder)“1899, verkleinerte sich stark.

Leppin hat die Bemühungen der (evangelischen) Kirche um die Vertriebenen, hier am Beispiel seines ehemaligen Züllichauer Kirchenkreises, 1970 beschrieben und dabei bereits indirekt aufgezeigt, dass die ersten Nachkriegsjahre dafür wohl noch Raum ließen, die Rahmenbedingungen in späteren Jahren aber kaum noch solche Möglichkeiten boten: „Das Wort Gottes gab vielen Kraft und Trost, wenn wir in den bitterschweren Jahren unmittelbar nach der Vertreibung zu unseren Heimatgottesdiensten zusammenkamen, in Erfurt und Kottbus, in Leipzig und Neuruppin, in Torgau und anderswo, ganz besonders in Berlin, wohin die Menschen von weit her, aus Thüringen und Mecklenburg, unter oft schwierigsten Verkehrsbedingungen und unter dem Mißtrauen der Machthaber anreisten. [...] In der sowjetischen Besatzungszone hatte einzig und allein die Kirche die Möglichkeit, Menschen aus den verlorenen Gebieten zu sammeln und zu betreuen. Sie mußte sich streng im gottesdienstlich-kultischen Rahmen halten und war in ihrer Arbeit auf kircheneigene Versammlungsstätten beschränkt. Neben die dortigen Heimatgottesdienste traten seelsorgliche Rundbriefe, deren erster schon zu Weihnachten 1945 hinausging. Sie haben nicht nur Menschen, die in alle Winde zerstreut waren, durch einen umfassenden Suchdienst wieder zusammengeführt und Licht in manches dunkle Schicksal gebracht. Vielmehr haben sie manch einem geholfen, durch eine weitverzweigte Einzel-Briefseelsorge unterstützt, geduldig und tapfer Schweres und Schwerstes zu tragen." ${ }^{1900}$

Welche bisweilen existentielle Bedeutung für viele Vertriebene (beider Konfessionen) die Kirche und der Pfarrer als Bezugspunkt und gleichsam seelischer Ansprechpartner zumindest in den ersten Jahren der Suche nach Halt und Orientierung besaßen, zeigen viele Selbstzeugnisse sowohl aus dem Kreis einfacher Gemeindemitglieder als auch von Pfarrern. „Die treuesten Gottesdienstbesucher waren die Flüchtlinge aus dem deutschen Osten" schreibt der selbst - aus Niederschlesien - vertriebene evangelische Pfarrer Willi Hanke (1910-1988), der zunächst nach Sachsen und dann nach Thüringen geflüchtet war und ab 1949 in Werder/Havel, ab 1954 in Potsdam-Bornstedt amtierte. ${ }^{1901}$ Er sieht in der - oben bereits angesprochenen - Zugehörig-

1898 Sitz 1971-1973: Berlin 33 (Grunewald), Auguste-Viktoria-Str. 20.

1899 ELAB, 1/2453, unfol. (23.11.1971); auch Beauftragter der Kirchenleitung [der Ev. Kirche in Berlin-Brandenburg] für die ehem. Ost-Brandenburgischen Kirchengemeinden, Sup. Erhard Schendel (ELAB, 1/2453, unfol., 10.1.1971).

1900 Günther Leppin: Evangelisches Kirchentum im Kreis Züllichau-Schwiebus. In: Kreis Züllichau-Schwiebus. Hrsg. im Auftr. der Heimatkreisvereinigung von Curt Schelenz. Frankfurt am Main 1970, 2. Aufl. 1975, S. 4852, hier S. 52.

1901 Ab 1964 auch Superintendent des Kirchenkreises Falkensee. Willi Hanke / Peter Bahl: Ahnen und Seitenverwandte der Geschwister Hanke (Schlesien und Ostpreußen). In: Archiv ostdeutscher Familienforscher, Bd. 15, 2003, S. 505-508, hier S. 506. - Hanke war sogar Treckführer gewesen, und einige Pfarrer, die nach Kriegsende den Kontakt zu ihren ehemaligen Gemeindemitgliedern hielten, hatten sich bereits im Sommer 
keit zur selben Kirche der Altpreußischen Union eine wesentliche Hilfe bei der Eingliederung der evangelischen Christen aus den Ostprovinzen, die nach Brandenburg gelangt waren: „Wenn schon alles fremd war; in der Kirche mit ihrer Liturgie war man zu Hause. Und vom Pfarrer, auch wenn er kein Flüchtling war, konnte man erwarten, daß er vermittelte, wenn man als lästig empfungen wurde." 1902 Dies hat er offenkundig auch selbst so praktiziert. Die gravierenden Probleme von Aufnahmne und Eingliederung, wie sie sich besonders in den ersten Monaten und Jahren stellten, benennt er deutlich, bemüht sich aber auch um Gerechtigkeit gegenüber den Einheimischen, deren oft ablehnende Haltung er sogar am eigenen Leib (als Treckführer) erlebt hatte: „Die Flüchtlinge oder , die Vertriebenen', wie man sie nannte, waren ein großes Problem. Ein Kleineres, solange man hoffen durfte, daß sie in Kürze wieder in ihre Heimat zurückkehren würden; ein Größeres, ja sehr Großes, als sie auf Dauer untergebracht werden mußten. Man muß das von beiden Seiten besehen. Wer schränkt sich auf der einen Seite gern ein, wenn man schon eingeschränkt ist. Wer gibt gern etwas ab, wenn man durch den Krieg schon ausgepowert ist. Aber die andere Seite, die der Flüchtlinge, die der Chronist am eigenen Leibe erlebt hat. Wir haben einmal nach dreiwöchigem Treck [im Februar 1945 in Sachsen, P. B.] endlich eine Gemeinde genannt bekommen, die solange noch Krieg ist, uns aufnehmen soll. Bürgermeister und Parteigrößen erklären, daß das Dorf schon von anderen Trecks belegt sei. ${ }^{1903}$ Er hat später auch berichtet, daß „ich, als sich herumgesprochen hatte, dass ich $z u$,diesen' gehörte, sehr bald darauf angesprochen wurde." 1904

Die Kirche war für den einzelnen Gläubigen aber nicht nur ein Hilfselement in der Notsituation, sondern wurde auch zum Integrationsfeld. In der Perspektive einer damals Jugendlichen, 1945 aus dem neumärkischen Crossen/Oder Geflüchteten und in Reichenwalde (Kr. Beeskow-Storkow) Gelandeten, entschied sich die Kardinalfrage der Gleichberechtigung mit Einheimischen nicht zuletzt auch im kirchlichen Rahmen: „1947 sollte ich in der Reichenwalder Kirche konfirmiert werden. Tradition war es, dass die Konfirmanden mit [S. 108] Pferdewagen von Wendisch Rietz nach Reichenwalde gefahren wurden. Also wurden die Wagen geputzt und geschmückt. Ich armes Vertriebenenkind hatte auch einen Wagen abbekommen, ganz für mich, wie die anderen auch. Doch was für ein Schreck in der Morgenstunde! Als wir uns zur Kirche fahren wollten, hieß es: Kein Pferdegespann, der russische Kommandant hatte angewiesen, es wird Holz gefahren. Wir waren in dieser Zeit so viel gelaufen, also liefen wir wieder, diesmal zur Kirche. ${ }^{1905}$ Für Ragösen

1945 unter polnisch-sowjetischer Besatzung als hilfreiche Anker für die noch in ihren Heimatdörfern Verbliebenen bzw. vorübergehend dorthin Zurückgekehrten betätigt. Siehe z. B. Hans-Otto Furian: Vom Kirchenkampf zum Christuskampf. Kirchliches Leben in der östlichen Neumark 1933 bis 1945 (Zur Geschichte des Kirchenkampfes 3/1). Hrsg. im Auftr. der Kirchenleitung der Evang. Kirche Berlin-Brandenburg-schlesische Oberlausitz von Erich Schuppan. Berlin 2005. Furian behandelt (S. 277-292) auch das Schicksal und das Wirken einzelner Pfarrer in den bereits besetzten Orten der Neumark bis zur Vertreibung 1945.

1902 Willi Hanke: „Bornstedt nahe bey Sanssouci“. Geschichte der Evangelischen Kirchengemeinde PotsdamBornstedt. Potsdam 2006, S. 262.

1903 Ebd.

1904 Ebd., S. 263.

1905 Wuntke, Lebensspuren neu und wieder entdeckt nach über 70 Jahren (wie Anm. 272), S. 107 f. 
(Kr. Zauch-Belzig) ist überliefert, dass die Kirche nach wie vor eine für die gesamte (politische) Landgemeinde wichtige Rolle spielte: „Allmählich kehrten viele Männer aus der Gefangenschaft zurück. Wenn am Nachmittag um 15 Uhr die Glocken läuteten, wusste man, dass wieder ein Heimkehrer angekommen war. 1951 läuteten sie das letzte Mal, dann nämlich kamen die letzten nach Haus. [...] Alle anderen blieben vermisst.“1906

\section{Berlin als Bezugspunkt evangelischer Brandenburger}

(West-)Berlin war stets ein fester Bezugspunkt für die in der Provinz bzw. dem Land Brandenburg lebenden Flüchtlinge und Vertriebenen. Hier befanden sich ohnehin vor wie nach 1945 zahlreiche evangelische kirchliche Hilfsstellen. ${ }^{1907}$ Neben dem auch nach Kriegsende weiter arbeitenden Hilfswerk für Berlin-Brandenburg des durch seine Arbeit für verfolgte Christen jüdischer Abstammung bekannten Propstes Heinrich Grüber (1891-1975) ${ }^{1908}$ ist vor allem das in Berlin ansässige, überregional arbeitende Hilfskomitee „Kirchendienst Ost“ unter seinem noch 1945 von Bischof Dibelius eingesetzten, selbst aus Posen stammenden Leiter Lic. Dr. Richard Kammel (1882-1957) ${ }^{1909}$ zu nennen. ${ }^{1910}$ Es belegt wie viele andere Strukturen in der - kirchlichen wie nichtkirchlichen - Vertriebenenbetreuung die große Rolle, die selbst Betroffene, also Vertriebene, in solchen Funktionen spielten, denn auch die meisten von Kammels Mitarbeitern gehörten früher zur Posener Kirche. ${ }^{1911}$ Der „Kirchendienst Ost“, der „die gesamte Betreuung der Umsiedler in unserer Kirchenprovinz "1912 zusammenfassen sollte, hatte dabei eine doppelte Aufgabe: „1. die aus dem Osten stammenden kirchlichen Amtsträger und ihre Angehörigen zu beraten und zu betreuen; 2. den evangelischen Restgemeinden und Gemeindegliedern im polnischen bzw. polnisch verwalteten Gebiet kirchliche Fürsorge zuzuwenden. “1913 Zu nennen sind ferner der „Evangelische Flüchtlingsseelsorger in West-Berlin“ Dr. Walter Taube (1889-1962), vor 1945 Pfarrer in Danzig ${ }^{1914}$, und der „Berliner Konvent der Hilfskomitees der zerstreuten evangelischen Ostkirchen“ in Berlin-Nikolassee, Teutonenstraße 9, unter seinem Vorsitzenden Kirchenrat Walter Schian

1906 Ragösen. Beiträge zur Geschichte, T. 2 (wie Anm. 188), S. 26.

1907 Dokumentation in ELAB, 1/2453.

1908 Handbuch der Deutschen Evangelischen Kirchen 1918 bis 1949 (wie Anm. 1896), S. 274: Hilfswerke/BerlinBrandenburg: Bevollmächtigter: Heinrich Grüber, Propst, Berlin, ab 1945; Hauptgeschäftsführer: Rohde, 1946 bis 1948; Arnold Krüger, ab 1948.

1909 ELAB, 1/2453, unfol.; Kirchliches Jahrbuch 81 (1954), S. 198.

1910 Kammel war bis 1952 im Amt, ihm folgte Harald Kruska (1908-1999). 1970 wurde der Kirchendienst formal aufgelöst bzw. als „Büro Kruska“ weitergeführt. Zur Tätigkeit siehe die Rückblicke des Leiters: [Harald] Kruska: Zehn Jahre Kirchendienst Ost. In: Kirchliches Jahrbuch für die Evangelische Kirche in Deutschland 81 (1954), S. 198-228. - Harald Kruska: Der Kirchendienst Ost in Berlin. In: Die Unverlierbarkeit evangelischen Kirchentums aus dem Osten. Hrsg. von Carl Brummack. Ulm/Donau 1964, S. 97-106.

1911 ELAB, 1/2453, Dokumentation, S. 54.

1912 ELAB, 1/2453, unfol. (Rundbrief des Bischofs Dibelius vom 14.2.1948).

1913 Kruska, Zehn Jahre Kirchendienst Ost (wie Anm. 1910), S. 199 f.

1914 ELAB, 1/2453, Dokumentation, S. 31. 
(1905-1993), der, wiederum selbst (aus Schlesien) vertrieben, nach Kriegsende, ab 1. Oktober 1945, bis zu seinem Wechsel nach West-Berlin als Superintendent in Belzig, also in Brandenburg, gewirkt hatte. ${ }^{1915}$ Hinzu trat das sehr aktive Gustav-Adolf-Werk der evangelischen Kirche für Berlin und Brandenburg mit seinem Hauptvorstand in Berlin.

Die „Betreuungsarbeit“ musste sich notgedrungen oft auf geistig-seelische Kontaktpflege konzentrieren, war aber schon damit gut ausgelastet, wie die Bemerkungen von Else Schmaeling im Monatsbericht für „Ehemalige Kirchengemeinden von Landsberg, Warthe, Stadt und Land“ vom Januar 1948 zeigen: „Nun sind schon seit dem Beginn unserer Arbeit [1946] $]^{1916}$ über 8000 Briefe, Karten und Telegramme bei uns eingegangen, die von viel Leid und Sorgen erzählen und viele Wünsche bergen. ${ }^{1917}$ Wir mühen uns zu helfen, soweit es in unseren Kräften steht. Leider sind ja die Grenzen eng gesteckt. Ich kann z. B. nach außerhalb von Berlin keine Bekleidung besorgen. Bitte geht zu eurem Pfarrer, der vielleicht die Möglichkeit hat, durch das große evangelische Hilfswerk und die innere Mission etwas für Euch zu beschaffen. Auch in Berlin muß sich jeder an den Pfarrer seiner Gemeinde und die Bezirksstelle der inneren Mission wenden. Wenn es möglich ist, helfen wir mit. $[\ldots]$. ${ }^{1918}$

Nicht zuletzt im unmittelbaren Umland Berlins Wohnende nahmen, solange der Weg ihnen nicht versperrt wurde, immer wieder an kirchlichen oder nichtkirchlichen Treffen und Versammlungen in West-, aber auch Ost-Berlin teil. Diverse Gemeindesäle und Kirchen boten hierfür eine Heimstatt, evangelische und katholische Pfarrer von Berliner Gemeinden führten gesonderte „Heimatgottesdienste “1919 für Vertriebene bzw. speziell für die aus bestimmten Landoder Kirchenkreisen der Vertreibungsgebiete Stammenden durch. Besonders häufig fanden solche Veranstaltungen - Kirchentage, Abendmahlsfeiern, Gottesdienste und Führungen - im Evangelischen Johannesstift in Berlin-Spandau statt, aber durchaus auch in vielen Berliner Einzelgemeinden, für die neben allgemeinen Gottesdiensten Adventsfeiern, Jugendtreffen und Totengedenkfeiern belegt sind. ${ }^{1920}$

Im November 1947 wurde an die vertriebenen Landsberger, über deren Adressen die kirchlichen Flüchtlingsbetreuer in West-Berlin verfügten, ein hektografierter Weihnachtsrund-

1915 ELAB, 1/2453, unfol. (15.4.1970).

1916 Der Betreuungsdienst für die evangelischen Vertriebenene aus Stadt und Kreis Landsberg wurde 1946 in Berlin von den Geschwistern Else und Paul Schmaeling gegründet (so lt. Hans Beske: Die Landsberger nach 1945. In: Landsberg an der Warthe 1257 - 1945 - 1976 [wie Anm. 390], S. 251-265, hier S. 252), schon 1945 aber von Pfarrer Georg Wegner und Else Schmaeling (beide zunächst federführend) gemeinsam mit Paul Schmaeling begonnen (Heimatblatt der ehemaligen Kirchengemeinden Landsberg/Warthe, Stadt und Land 8 (1956), Sondernr. vom 26. Sept.; 18 (1966), Nr. 7/8, S. 2).

1917 Zahllose Auszüge aus solchen Einsendungen werden in den Monatsberichten der Jahre 1947/48 zitiert oder zusammenfassend mitgeteilt.

1918 Ehemalige Kirchengemeinden von Landsberg, Warthe, Stadt und Land. 1. Monatsbericht, Jan. 1948, S. 3.

1919 Der Begriff u. a. in ELAB, 1/2453, Dokumentation, S. 36.

1920 Veranstaltungslisten mit genauen Tagesdaten und Orten z.B. für Vertriebene aus neumärkischen evangelischen Kirchenkreisen im Jahr 1947 in: ELAB, 1/2453, Dokumentation, S. 16-18. - Siehe auch oben im Kapitel IV. 2 den Abschnitt zum Besuch von Heimatteffen in West-Berlin. 
brief verschickt, den sechs - aus Stadt und Kreis Landsberg/Warthe stammende - Pfarrer in je eigenen kurzen Abschnitten für ihre ehemaligen Gemeindemitglieder unterzeichnet hatten. ${ }^{1921}$ Außer dem in West-Berlin ansässigen Flüchtlingsfürsorgepfarrer Georg Wegner (1892-1954) unterzeichneten zwei Pfarrer ohne Angabe ihres aktuellen Wohnortes, einer schrieb aus Hamm in Westfalen (gerichtet an „Liebe katholische Gemeindemitglieder von Landsberg-Brückenvorstadt!") und immerhin zwei aus Brandenburg: Joachim Meuß (geb. 1901) („Rathenow, Forststr. 39“), der sich an „Meine lieben Gralower, Jahnsfelder und Zantocher!“ wandte und „Pfarrer i.R. Wandam und Frau“ aus „Trebatsch (Krs. Beeskow-Storkow)“, der „An meine alten lieben Gemeindeglieder von Kernein, Seidlitz, Bürgerwiesen und auch vom Pfarrsprengel Dechsel und Altensorge" schrieb. ${ }^{1922}$ Am Ende der Rückseite des DIN-A-4-Blattes steht die Ankündigung einer Adventsfeier im Gemeindehaus der Luisen-Gemeinde in Berlin-Charlottenburg mit Hinweis auf die Fahrgelegenheit auch aus Spandau, also vermutlich auf Havelländer zielend. Das einfache Programm bestand aus Ansprache (Pfarrer Wegner), Weihnachtsliedern (Eva Koch) und „Kinderchor und Krippenspiel“.

Dass solche Treffen den SBZ-/DDR-Behörden nicht verborgen blieben, sogar Informanten daran teilnahmen und ebenfalls von auswärts anreisten, zeigt (als eines von vielen) ein Beispiel aus dem Jahr 1950. ${ }^{1923}$ Der selbst aus Trebschen (Kr. Züllichau-Schwiebus) vertriebene Pfarrer Hans Richter (geb. 1906) von der evangelischen Marienkirchengemeinde Frankfurt (Oder) hielt am 23. April in der evangelischen Kirche in Berlin-Nikolassee eine „Ansprache“ für Vertriebene aus seinem früheren Wirkungsort, die sich anschließend im gegenüber liegenden Gasthof zu einem „gemütliche(n) Beisammensein“ trafen. Ein Informant aus Frankfurt (Oder) besuchte das Treffen, da zwei in Frankfurt lebende Familien daran teilnahmen. Er stellte fest, dass zu der „Versammlung der Bewohner des Ortes Trebschen - ehemals Odergebiet, jetzt polnisch [-] in Nikolassee“ Teilnehmer „aus den verschiedensten Orten [...] auch aus dem Westsektor Berlin“ kamen. Als „Grund der Teilnahme“ ergab seine Befragung „das Wiedersehen mit den ehemaligen Dorfbewohnern des jetzt polnischen Gebietes“. Wie er darüber hinaus ermitteln konnte, hatten „bisher drei Zusammenkünfte der ehemaligen Trebschener Einwohner in Nikolassee stattgefunden“, die „immer mit einem Gottesdienst vormittags um $10.00 \mathrm{Uhr}^{\text {“ }}$ begannen. ${ }^{1924}$ In Frankfurt (Oder)

1921 Ehemalige Kirchengemeinden von Landsberg, Warthe, Stadt und Land, 12. Monatsbericht, Nov. 1947, S. 1 f.

1922 Für solche Grüße in Brandenburg lebender Pfarrer an ihre ehemaligen Gemeindemitglieder aus dem Vertreibungsgebiet ließen sich weitere Beispiele anführen, etwa die Ostergrüße von Pfarrer Ulrich Damerow, „Spremberg, Niederlausitz (Stadtkirche) - Postfach 33“, der im 3. Monatsbericht vom März 1948 tröstende Worte schreibt und darunter setzt: „Es grüßt ein dankbarer Sohn Landsbergs alle bekannten, vor allem die alten Gemeindeglieder von Alexandersdorf, Johanneswunsch, Morrn und Pollychen." Damerow (geb. 1903 Sorno, Kr. Calau) war 1932-1937 evang. Pfarrer in Alexandersdorf (Kr. Landsberg/W.) und 1937-1945 in Boyadel (Kr. Grünberg in Schlesien), ab 1947 Pfarrer u. Seelsorger am Städt. Krankenhaus in Spremberg (Pfarralmanach 1950, S. 263).

1923 Siehe ferner die Informanten- und Polizeiberichte im Quellenteil, Abschnitt 4.2 (Nr. 224, 225, 228, 230, 231, 234, 235, 238).

1924 BLHA, Rep. 202 G Amt für Information, Nr. 170, Bl. 586. Siehe den vollständigen Abdruck im Quellenteil, Nr. 228. 
wäre das nicht oder nur im Geheimen möglich gewesen, doch immerhin wagte es Pfarrer Richter, einen hektografierten „Trebschener Gemeindebrief“ im Umfang einer einseitig maschinenschriftlich eng beschriebenen DIN-A-4-Seite zu zeichnen mit „Euer Pastor/Frankfurt-Oder, im März 1950“. ${ }^{1925}$ Der Text enthält in der ersten Hälfte auf Joh. 14,1, „Euer Herz erschrecke nicht, glaubet an Gott und glaubet an mich", aufbauende Worte geistlicher Betreuung, in der zweiten einen kurzen Bericht über Besuche bei Trebschenern, Suchmeldungen und eine Spendenbitte „zu den Unkosten des Rundbriefs“, wobei „im Westen“ ansässige Trebschener sie an den in Hamburg lebenden Bruder des Pfarrers schicken könnten.

Solche Zusammenkünfte lassen sich aber, wenngleich in deutlich geringerer Zahl, auch für (berlin-fernere) brandenburgische Orte nachweisen. ${ }^{1926}$ So wurden am 12. Oktober 1947 in Gusow bei Seelow zwei Kirchentage für Vertriebene aus dem neumärkischen Kirchenkreis Arnswalde durchgeführt. Pfarrer Kurt Rausendorff (geb. 1900 Marienburg, 1928-1945 Pfarrer in Gleißen) hielt hier am 20. Juli und am 26. September 1947 Gottesdienste speziell für die aus Gleißen im Kreis Oststernberg stammenden evangelischen Kirchenmitglieder und am 26. Oktober desgleichen für die aus Königswalde im selben Kreis. Auch Pfarrer Merting hielt am 31. August 1947 in Ketschendorf bei Fürstenwalde/Spree einen gesonderten Gottesdienst für die Vertriebenen aus seiner ehemaligen Gemeinde Fahlenwerder im Kreis Soldin/Neumark. ${ }^{1927}$ Schwerpunkt musste jedoch West-Berlin bleiben, da die Behörden in Brandenburg solche Treffen zu verhindern suchten. ${ }^{1928}$ Bis zum Mauerbau 1961 wurden dazu „die Brüder und Schwestern aus der DDR und Ost-Berlin" geladen, wie es etwa für die ab 1946 in West-Berlin unter der verantwortlichen Leitung des aus Thorn gebürtigen ehemaligen Posener Pfarrers Harald Kruska (1908-1999) durchgeführten Posener „Heimatgottesdienste“ überliefert ist. ${ }^{1929}$ Gehalten wurden diese anfangs drei- bis viermal, später zweimal pro Jahr durchgeführten Gottesdienste „meist von Posenern, aber auch von Westpreußen, Balten, Deutschen aus Mittelpolen usw. “1930 Die Teilnehmer stammten nicht nur aus der ehemaligen Provinz Posen, sondern aus dem „Einzugsgebiet“ der „Landsmannschaft Weichsel-Warthe“, d. h. auch aus Mittelpolen, Galizien ${ }^{1931}$ und Wolhynien.

1925 Ein Exemplar befindet sich als Anlage zum o.g. Informantenbericht in den Akten des Amtes für Information der brandenburgischen Landesregierung (BLHA, Rep. 202 G, Nr. 170, Bl. 587).

1926 Siehe dazu ausführlicher oben im Kapitel IV. 2 den Abschnitt „Vertriebenentreffen und korporative Tendenzen in Brandenburg".

1927 ELAB, 1/2453, Dokumentation, S. 16-18 (alle vorgenannten Beispiele). - August Merting (in der Dokumentation fälschlich „Märting“ geschrieben), geb. 1909 Welzow (Niederlausitz) war ab 1937 Pfarrer in Fahlenwerder gewesen (Fischer, Pfarrerbuch [wie Anm. 323], T. 2/2, S. 548).

1928 Siehe ausführlicher oben im Kapitel IV. 2 den Abschnitt „Teilnahme an Heimattreffen in Berlin“.

1929 ELAB, 1/2453, Dokumentation, S. 36. - Zu Kruska siehe auch Anm. 1910.

1930 Ebd.

1931 Galiziendeutsche in Brandenburg sind ein kaum erforschtes Thema. Kotzian schließt aus dem Vergleich der geplanten Aufnahmekreise (für Deutsche aus dem „Warthegau“, unter denen meist auch Galiziendeutsche waren) mit Nachrichten über spätere Wohnorte auf eine innerbrandenburgische Konzentration in den Kreisen Ostprignitz, Osthavelland und Zauch-Belzig: Kotzian, Die Umsiedler (wie Anm. 403), S. 103. 


\section{Katholische Kirche}

Die Zahl der Katholiken verdoppelte sich in der gesamten SBZ bis 1946 im Vergleich zum Vorkriegszustand, „so dass nun etwa $12 \%$ der Bevölkerung in diesen protestantisch geprägten Gegenden der katholischen Kirche angehörten“. 1932 Überall in der SBZ vermehrte sich die Zahl der Katholiken ab 1945 gewaltig, außer im thüringischen Eichsfeld veränderte sie deren Stellung fast überall. Im Bereich des späteren Bistums Görlitz stieg die Zahl der Katholiken von 53433 im Jahr 1939 auf 695000 im Jahr 1949. ${ }^{1933}$ Der hohe Anteil katholischer Christen besonders unter den oberschlesischen und den sudetendeutschen Vertriebenen veränderte die Verhältnisse in den Aufnahmeorten und -gemeinden bisweilen stark. Wolfgang Knauft weist auf die tiefgreifende Änderung der „Konfessionsstruktur in der SBZ“ hin, als von ca. 12 Millionen Vertriebenen rund zwei Millionen in deren Gebiet kamen, konzentriert sich aber auf die außerberlinischen Diözesen. ${ }^{1934}$ Dabei bildeten die Vertriebenen gerade im Berliner Bistum nach 1945 einen erheblichen Teil der Katholiken. ${ }^{1935}$ Im Land Brandenburg lebten 1949 sogar - nach einer Statistik des Caritasverbandes für Berlin E. V. - mehr vertriebene (174923) als einheimische (162 708) Katholiken. ${ }^{1936}$ Die Region Berlin-Brandenburg war und ist zwar katholisches Diasporagebiet, doch hatte sie den nicht wenigen schlesischen Vertriebenen zumindest insofern eine ideelle Heimat anzubieten, als schon vor dem Krieg enge Bindungen zum Breslauer Oberhirten bestanden hatten. Hinzu kamen in Brandenburg auch, in geringerer Zahl, Katholiken aus dem Ermland ${ }^{1937}$ und anderen Gebieten.

Die Erzdiözese Berlin mit dem größeren Teil Brandenburgs war aus dem Anfang des 19. Jahrhunderts gebildeten Delegaturbezirk des Fürstbistums Breslau entstanden, ihre Kathedralkirche war und ist der schlesischen Landespatronin, der hl. Hedwig, geweiht. ${ }^{1938}$ Der Süden Brandenburgs, der Raum Beeskow-Storkow, Teile der Kreise Jüterbog-Luckenwalde und Teltow, insbesondere aber die Niederlausitz mit Cottbus und bis an die Neiße bei Fürstenberg/ Oder (Eisenhüttenstadt), Neuzelle und Guben sowie, immerhin bis 1972, ein kleiner historisch

1932 Schwillus/Brühe, Erzbistum Berlin (wie Anm. 148), S. 124.

1933 Ebd., S. 195.

1934 Wolfgang Knauft: Katholische Kirche in der DDR. Gemeinden in der Bewährung 1945-1980. Mainz 1980, S. 14-16, Zitat S. 14.

1935 Harald Schwillus: Geschichte des Erzbistums Berlin. In: Schwillus/Brühe, Erzbistum Berlin (wie Anm. 148), S. 10-193, hier S. 128.

1936 DAB, I/9-15-1 Flüchtlingsseelsorge 1945-1951, unfol., 14.9.1949.

1937 Etwa ein Drittel der ermländischen Vorkriegsbevölkerung (rd. 90000) soll in der SBZ, die Mehreit (rd. $160000)$ in den Westzonen gelandet sein. Weitgehend auf die Entwicklung in den Westzonen konzentriert, aber in der Beschreibung ermländischer Glaubensspezifika auch für SBZ/DDR wichtig: Karolina Lang: Identität, Heimat und Vernetzung unter dem Schirm Gottes. Die ermländische Glaubensgemeinschaft im Nachkriegsdeutschland. In: Vertriebene finden Heimat in der Kirche (wie Anm. 137), S. 163-173, zur „russischen Zone“ bzw. „Ostzone“ knapp S. $165 \mathrm{f}$.

1938 Einen Überblick über die Berliner (Erz-)Bistumsgeschichte vermittelt: Der Glaube lebt. 50 Jahre Bistum Berlin 1930-1980. Hrsg. vom Bischöflichen Ordinariat Berlin. Leipzig 1980. 
neumärkischer Gebietsteil an der Oder (um Golzow), waren 1945 sogar unmittelbar Teil des Erzbistums Breslau. ${ }^{1939}$ Dieser Bereich büßte freilich bald zumindest seine offizielle Bindung an Breslau ein. Es handelte sich dabei kirchenrechtlich lediglich um ein durch die neue Grenzziehung an Oder und Neiße entstandenes Gebilde, das nie selbständig gewesen war. Der sozusagen deutsch gebliebene Rest der Breslauer Erzdiözese erhielt erst nach 1945 in Görlitz (ehemals Provinz Schlesien, nun Land Sachsen) hilfsweise ein neues Verwaltungszentrum und wurde von 1946 bis 1972 als „Erzbischöfliches Amt Görlitz“ bezeichnet, ab 1972 als „Katholische Administratur Görlitz" und ist erst seit 1994 wieder ein (dem Erzbistum Berlin als Suffraganbistum zugeordnetes) eigenes Bistum Görlitz. ${ }^{1940}$ Beide getrennten Bistumsgebiete, das Berliner im Norden (wo es bis nach Vorpommern reicht) und in den mittleren Gebieten, das Görlitzer im Süden, haben für Brandenburg wesentliche Bedeutung, die Diözesangrenze ist freilich immer zu bedenken, nicht zuletzt bei der Lektüre von Quellen und Literatur.

Die Niederlausitz, die einen erheblichen schlesischen und damit z. T. katholischen Zuzug von Vertriebenen aufzunehmen hatte ${ }^{1941}$, besaß eine auch geographische Einheit mit ihrem bischöflichen Verwaltungssitz Görlitz. Bei den deutsch gebliebenen Teilen des Breslauer Bistumsgebietes im Oderbruch hingegen handelte es sich um ein seit der Grenzziehung ähnlich „in der Luft" hängendes Gebilde wie bei der staatlichen Verwaltungsgliederung. Während man die Orte der „weltlichen“ Restkreise, vor allem die der zum größeren Teil östlich der Grenze liegenden Kreise Königsberg/Nm. und Sorau, 1946 den westlich benachbarten Landkreisen zuwies $^{1942}$, behielt die katholische Verwaltungsstruktur im Oderbruch bis 1972 ihre Situation als Görlitzer Exklave am Rand des Berliner Bistumsgebietes, da ihre „Landverbindung“ zum Rest der Breslauer Erzdiözese östlich der Oder lag. Es handelt sich um die zwischen „Alter Oder“ und dem nunmehrigen Grenzfluss Oder gelegenen Orte des Archipresbyterats Landsberg an

1939 Handbuch für das katholische Schlesien. Hrsg. von Johannes Kaps. München 1951, nach S. 233: „Übersichtskarte des Görlitzer Anteils der Erzdiözese Breslau“. - Johannes Kaps: Die katholische Kirchenverwaltung in Ostdeutschland vor und nach 1945. In: Jahrbuch der Schlesischen Friedrich-Wilhelms-Universität zu Breslau 11 (1957), S. 7-39, hier S. 13.

1940 Wolfgang Müller: Der deutsche Restteil des Erzbistums Breslau die Diözese Görlitz. In: Erbe und Auftrag der schlesischen Kirche/Dziedzictwo i posłannictwo śląskiego Kościoła. 1000. Jahre Bistum Breslau/1000 lat diecezji wrocławskiej. Hrsg. von Winfried König. Dülmen 2001, S. 310-337. - Mathias Homagk: Der Neubeginn - Vom „Restteil“ des Erzbistums Breslau zum Bistum Görlitz. In: „Ich gehe mit dem Gedanken um, in Kirchhain einen Betsaal zu bauen ..." Festschrift anlässlich des 100-jährigen Kirchweihjubiläums der katholischen Kirche in Kirchhain. Hrsg. von dems. u. Kathleen Hirschnitz in Zsarb. mit der kath. Pfarrgemeinde Doberlug-Kirchhain. Halle/Saale 2008, S. 27-35. - Winfried Töpler: Die Neustrukturierung der katholischen Kirche im Bereich der Niederlausitz nach 1815 - Vom Bistum Meißen über das Bistum und Erzbistum Breslau zum Bistum Görlitz. in: Niederlausitzer Studien 42 (2016), S. 49-72 (S. 66: Karte „Katholische Gemeinden des Erzbistums Breslau im Regierungsbezirk Frankfurt/Oder“).

1941 Zur Bedeutung der Schlesier für das katholische Leben in der DDR siehe: Josef Pilvousek / Elisabeth Preuß: Katholische Flüchtlinge und Vertriebene in der SBZ/DDR. Eine Bestandsaufnahme. In: Vertriebene finden Heimat in der Kirche (wie Anm. 137), S. 15-27. - Franz Georg Friemel: Schlesische (und andere) Katholiken in der DDR. In: Erbe und Auftrage der schlesischen Kirche (wie Anm. 1940), S. 300-309.

1942 Dazu detailliert: Blöß, Brandenburgische Kreise und Gemeinden (wie Anm. 1519). 
der Warthe (Pfarrei Küstrin/Seelow, dann Golzow). ${ }^{1943}$ Erst mit der Neuordnung der Bistümer 1994 (!) wurde das Gebiet der Berliner Diözese zugewiesen. Die (wenigen) Katholiken, die hier lebten, behielten insofern mit ihrem Görlitzer Oberhirten jahrzehntelang einen direkten Kontinuitätsbezug zu Breslau, denn der Görlitzer Residentialbischof Ferdinand Piontek (1878-1963) war bis 1946 in der Breslauer Bistumsverwaltung tätig gewesen, und auch seine Nachfolger als Administratoren und Bischöfe sind bis 2006 stets vertriebene Schlesier gewesen. Dieser formale, aber damit auch eine Traditionslinie bildende Schlesien-Bezug sollte in seiner ideellen (und damit indirekt auch politischen) Bedeutung für die in Brandenburgs Süden lebenden, meist selbst vertriebenen Katholiken nicht unterschätzt werden. Der nach 1945 in München wirkende, ebenfalls aus der Breslauer Diözesanverwaltung kommende Erzbischöfliche Konsistorialrat Dr. Johannes Kaps (1906-1959) gab seiner Bestandsaufnahme der Breslauer Erzdiözese, die all die genannten brandenburgischen Regionen und Orte natürlich mit erfasst, den Titel „Handbuch für das katholische Schlesien“. ${ }^{1944}$ Dieses Nachschlagewerk ist zwar im Westen, in München, erschienen, wird aber auch im Görlitzer Klerus, mithin in der DDR, verbreitet und genutzt worden sein, sollte es doch nach den Worten seines Herausgebers nicht nur dazu dienen, Wissen "für die Nachwelt zu bewahren“, sondern „darüber hinaus ein geistiges Band sein, das die schlesischen Priester und Gläubigen in der Zerstreuung verbindet und in dem so zahlreichen schlesischen Priesternachwuchs die Verpflichtung gegenüber dem Vatererbe wachhält“ ${ }^{1945}$

Für die „Flüchtlingsgeistlichen“ insgesamt gab es ab 1947 die alle Diözesen (und Orden) erfassenden sogen. „Ostpriesterverzeichnisse“, vom Priesterreferat in Königstein im Taunus herausgegebene detaillierte gedruckte Anschriftenlisten, auch als „Königsteiner Schematismus“ bezeichnet. ${ }^{1946}$ Sie enthalten durchgängig, noch nach dem Mauerbau (bis 1988), alle, also auch die in der SBZ bzw. dann der DDR lebenden, vertriebenen Priester mit vollem Namen, also auch Vornamen, Geburts- und Weihedatum, früherem Wirkungsort sowie Heimatdiözese, insbesondere aber die postalisch genaue Anschrift und die Aufnahmediözese. Die in Brandenburg gelandeten Priester sind dabei zwar verständlicherweise nicht übermäßig zahlreich, doch sie sind enthalten und waren so für jedermann, der ein solches Verzeichnis in Händen hielt, leicht

1943 Handbuch für das katholische Schlesien (wie Anm. 1939), nach S. 233: „Übersichtskarte des Erzbistums Breslau. Stand von 1945“. - Liste der zur Pfarrei gehörenden Ortschaften: Orts- und Personenverzeichnis des Erzbischöflichen Amtes Görlitz. Hrsg. vom Erzbischöflichen Amt Görlitz. 2. Ausg. Stand vom 1. April 1954, S. 36 .

1944 Handbuch für das katholische Schlesien (wie Anm. 1939) (Kommisionsverlag „Christ Unterwegs").

1945 Ebd., S. 5 (Vorwort).

1946 Verzeichnis der heimatvertriebenen Priester aus dem Osten [Ausg. 2-3: soweit sie in den vier Zonen Deutschlands leben]. Hrsg. vom Priesterreferat [Ausg. 8: Hrsg.: Albertus-Magnus-Kolleg]. Königstein im Taunus. [1.] 1947, 2. 1949, 3. 1951, 4. 1954. - Fortsetzung u. d. T. Verzeichnis der deutschen vertriebenen Priester aus dem Osten. 5. 1960, 6. 1969. - Forsetzung u. d. T. Ostpriesterverzeichnis (Königsteiner Schematismus). 7. 1978, 8.1988. - Die Ausgaben 1 bis 6 enthalten darüber hinaus diverse statistische Zusammenstellungen des Personenkreises mit entsprechenden Auswertungen. 
identifizierbar. Nicht angegeben ist allerdings ihre jeweilige aktuelle Funktion; dafür mussten und müssen die Schematismen der Bistümer Berlin bzw. Görlitz herangezogen werden.

Erhebliche Teile des vertriebenen Klerus der Breslauer Erzdiözese fanden in dem überwiegend lausitzischen Restterritorium ihrer Heimatdiözse neue Wirkungsstätten ${ }^{1947}$, auch wenn einige von ihnen später in den Westen gingen ${ }^{1948}$. Die Eingliederung der vertriebenen katholischen Priester - kirchenintern hier wie auch in der Berliner Diözese missverständlich als „Flüchtlingspriester“ oder „Flüchtlingsgeistliche“ bezeichnet ${ }^{1949}$, inoffiziell und weniger sachlich auch als „Rucksackpriester“ ${ }^{1950}$ - wurde durch kirchenrechtliche Hürden erschwert. Nach dem katholischen Kirchenrecht (Codex Juris Canonici) ist jeder katholische Geistliche zwingend einem Diözesanverband zugehörig, „vagabundierende“ werden nicht geduldet. Mit der sogenannten Inkardination (in einen Diözesanverband), gleichzeitig mit der Tonsur, entsteht ein Verhältnis von Treue und andererseits Fürsorge, das den Geistlichen an einen Bischof bindet, ohne dessen Zustimmung der Wechsel in einen anderen Diözesanverband nicht gestattet ist; zudem hat der betreffende Kandidat, will er in seinem neuen Wohnort eine Pfarrstelle erlangen, ausreichende urkundliche Nachweise über sein bisheriges Leben vorzulegen. ${ }^{1951}$ Es liegt auf der Hand, dass nicht nur letzteres für Flüchtlinge und Vertriebene schwierig sein konnte. Vielmehr bestand, solange die politischen Veränderungen in den Vertreibungsgebieten kirchlicherseits nicht anerkannt wurden, auch aus übergeordneten Erwägungen ein Interesse daran, die Bindung der vertriebenen Geistlichen an ihre „Heimatbistümer“ nicht aufzugeben. Aus kirchenrechtlichen und realpolitischen Gründen erscheinen daher die vertriebenen Priester in den Schematismen ihrer „Aufnahmediözesen“ jeweils im Anhang in der Rubrik „Priester auswärtiger Bistümer“ ${ }^{1952}$ Sofern nicht im Einzelfall die Exkardination aus der „Vertreibungsdiözese“ und die Inkardination in eine neue Diözese bereits gelang, konnten diese Personen zumeist keine vollen Pfarrstellen

1947 Winterstein, Der vertriebene Klerus in der SBZ/DDR (wie Anm. 145), bes. S. 137.

1948 Svenja Hecklau: Aufbau der Seelsorge im Gebiet Görlitz 1945-1972. In: Vertriebene finden Heimat in der Kirche (wie Anm. 137), S. 79-93, hier S. $81 \mathrm{f}$.

1949 Amtsblatt des Bischöflichen Ordinariats Berlin 18 (1946), S. 7 (Nr. 23), 26 (Nr. 88). Siehe auch Amtsblatt ebd. 19 (1947), St. 3, 1.3.1947, S. 10: „Nr. 29. Flüchtlingsgeistliche innerhalb der Diözese Berlin / Beim Bischöflichen Ordinariat Berlin haben sich bisher folgende Flüchtlingspriester gemeldet, die z.Zt. innerhalb der Diözese Anstellung gefunden bzw. Wohnung genommen haben: [...]" [folgt Liste von nach ihren Heimatdiözesen geordneten 67 Personen mit Anschriften, darunter 32 in Berlin, 26 in Brandenburg, 9 in Pommern].

1950 Gerold Schneider: Seelsorge für Heimatvertriebene in der ehemaligen DDR. In: Kirche und Heimat. Die katholische Vertriebenen- und Aussiedlerseelsorge in Deutschland (Arbeitshilfen, 146). Bonn 1999, S. 26-33, hier S. 30.

1951 Nikolaus Hilling: Das Personenrecht des Codex Juris Canonici. Paderborn 1924, S. 95-97 (Kapitel „Der Diözesanverband der Kleriker").

1952 Schematismus des Bistums Berlin (zit. Schematismus) für das Jahr 1947, S. 148-156. Zwar stammen von den hier aufgeführten Priestern 21 aus mittel- und westdeutschen Diözesen (Fulda, Meißen, Münster, Regensburg) sowie dem westlichen Ausland (Holland, Italien) und Übersee (Brasilien), in der Mehrheit (44) aber handelt es sich um Priester der ostdeutschen Bistümer, vornehmlich Breslau, ferner Culm, Danzig, Ermland, Leitmeritz, Prag und Schneidemühl. Die Rubrik, die es auch vor 1945 bereits gab, erscheint letztmalig im Schematismus für das Bistum Berlin 22 (1968), S. 174-179, nicht mehr in der folgenden Ausgabe 23 (1970). 
erlangen, sondern mussten sich mit Administrationen und Kaplaneien begnügen. Das konnte hier und da - wie in nichtkirchlichen Berufsbereichen auch - zu einem „Einsatz" unterhalb der bereits in der Heimat erreichten Hierarchiestufe führen, also letztlich befristet oder gar dauerhaft sozialen Abstieg bedeuten, wie er bei den einfachen Gläubigen freilich oft genug gang und gäbe war. Neben Vertretungen in denjenigen Pfarrstellen, die durch die Kriegsereignisse personell Vakanzen aufwiesen, wurden „Flüchtlingspriester aus anderen Diözesen“ oftmals in der Flüchtlingsseelsorge eingesetzt, auch dies aber eine eher interimistische Notmaßnahme - für die Betreuten ebenso wie für die Geistlichen.

Die überdies dem einzelnen vertriebenen Priester im Alltag begegnenden Schwierigkeiten lassen sich erahnen, wenn man liest, dass sie „sich in Besoldungsangelegenheiten für sich und evtl. eingesetzte Laienkräfte an ihren zuständigen Pfarrer" zu wenden hatten. ${ }^{1953}$ Die Akten sind voll davon, dass die katholischen Pfarrer in jenen Jahren um Unterstützung, Einsetzung von Hilfsgeistlichen, Transportmittel u. a. bitten, um ihre Aufgaben überhaupt angemessen erfüllen zu können. ${ }^{1954}$ Dass sie in der schwierigen Situation der Nachkriegsjahre für ihre eigentliche Arbeit am neuen Wirkungsort oft genug nicht einmal auf die nötigen Gegenstände zurückgreifen konnten, zeigen auch Spendenaufrufe, mit denen das Bischöfliche Ordinariat Berlin ihnen zumindest indirekt zu helfen versuchte. So heißt es im Berliner Bistums-Amtsblatt: „Für die Flüchtlingspriester werden dringend Breviere, theol. Literatur, Ascetica, Seelsorgsbücher, Gebetbücher, Biblische Geschichten, Katechismen u. dergl., sowie Missalien, Paramente, Kultgeräte usw. benötigt. Spenden sind zu senden an den Katholischen Flüchtlingsdienst, Berlin-Wilmersdorf, Pfalzburger Str. 18, oder an das Salvatorkolleg, Berlin O 34, Warschauer Str. 57, vorn III. "1955 Fast zeitgleich findet sich auch im für die Gläubigen des Bistums herausgegebenen „Petrusblatt“ ein entsprechender Hinweis auf die „Büchersammlung“: „Viele Priester und Seelsorgshelferinnen, die in der Flüchtlingsseelsorge in den Diasporagebieten eingesetzt sind, haben bei ihrer Flucht aus den Ostgebieten nicht ein einziges Buch mitnehmen können. Mehrere Priester haben nicht einmal ein Brevier. Für die Erteilung des Religionsunterrichtes an Flüchtlingskinder steht manchmal nicht ein Katechismus oder eine Biblische Geschichte zur Verfügung. Priester und Seelsorgshelferinnen möchten manchen Flüchtlingen in ihrer seelischen Not und Vereinsamung ein religiöses Buch zu lesen geben. Der ,Flüchtlingsdienst' beim Karitasverband bittet darum alle Katholiken herzlich um Spendung von Büchern. Erwünscht sind: [...] / Die Bücher werden angenommen: / Kath. Flüchtlingsdienst, Berlin W 15, Pfalzburger Straße 18. / Salvator-Kolleg, Berlin O 34, Warschauer Str. 57, vorn III. “1956

Einige brandenburgische Beispiele dafür, dass Priester in Positionen „unterkamen“, die nicht ihrem Vorkriegsstatus als Gemeindepfarrer entsprachen, könnten ebenso für andere, über ganz Deutschland verstreute Fälle stehen: Der frühere Pfarrer von Jordan (Kr. Züllichau-Schwiebus, Neumark), Johannes Arnold (geb. 1885), starb 1947 als Hausgeistlicher im Marienstift

1953 Amtsblatt des Bischöflichen Ordinariats Berlin, 18. Jg., Stück 2, 1. Februar 1946, S. 7 (Nr. 23).

1954 Siehe u. a. Töpler, Menschenwurm (wie Anm. 147), passim.

1955 Amtsblatt des Bischöflichen Ordinariats Berlin, 18. Jg., Stück 2, 1. Februar 1946, S. 7 (Nr. 23 ).

1956 Petrusblatt 2 (1946), Nr. 1, S. 7. 
Frankfurt (Oder), der frühere Pfarrer von Sagan (Schlesien), Ehrenerzpriester Georg Lompa (geb. 1879), starb 1949 als ,heimatvertr[iebener] Hausgeistl[icher] im Caritasheim zu Alt-Döbern, Kr. Calau“ " [gemeint sein dürfte das Caritasheim in Döbern, Kr. Sorau/Spremberg!]; Der Geistliche Rat Dr. Konrad Metzger (geb. 1883) aus Breslau-Ohlewiesen wirkte noch kurze Zeit als Hausgeistlicher im Carolusheim in Neuzelle, verstarb aber schon 1947 im St. Hedwigskrankenhaus in Berlin; der frühere Pfarrer von Dittersbach (Kr. Sagan), Henrich Wilkens (geb. 1881), starb 1948 als „heimatvertr[iebener] Hausgeistlicher im St. Annaheim in Berlin-Schöneberg“ ${ }^{1957}$

Teilweise vor 1945 bereits als (Gemeinde-)Pfarrer, Propst oder Konsistorialrat wirkende Geistliche finden sich auch in der auf den 22. August 1946 datierten, von Generalvikar Dr. [Maximilian] $\operatorname{Pr}\left[\right.$ ange ${ }^{1958}$ unterzeichneten Berliner „Aufstellung der Flüchtlingsgeistlichen, die in unserem Bistum ausserplanmäßig in Brandenburg bezw. Pommern eingesetzt sind" ${ }^{1959}$.

Tab. 7: Außerplanmäßig eingesetzte Flüchtlingsgeistliche im Bistum Berlin, 1946

\begin{tabular}{lll}
\hline Propst Düllick, Franz & Bernau b/Berlin, & Börnickerstr. 12 \\
Propst Bönigk, Hubert & Treuenbrietzen, & Großstr. 10 \\
Pf[arre]r. Pienski, Johannes & Wiesenburg & Görzker Str. 8 \\
Kons.Rat Dr. Maier, Johs. & Neuzittau b/Berlin & Berlinerstr. 29 \\
Kapl[an]. Klein, Georg & Dahme/Mark & Dresdener Str. 7 \\
Pfr. Westphal, Hans & Nauen Kr. Osthavelland & Gartenstr. 71 \\
Pfr. Abendroth, Herbert & Rheinsberg/Mark & Strelitzerstr./Villa Irene \\
Lokalpr. Hawlitzky, Karl & Bad Wilsnack, & Ziegelberg 8 \\
Pfr. Krause, Albrecht & Zossen/Mark & Bahnhofstr. 35 \\
P[ater]. Klaar SVD & Poststr. 19 \\
Pfr. Morzynski, Albert & Jarmen Kr.Demmin, & Feldstr. 25 \\
Kpl. Ungar, Erwin & Altentreptow Kr.Demmin & Leipziger Str. 39 \\
\hline
\end{tabular}

Eine später in der deutsch-polnischen Versöhnungsarbeit besonders engagierte Persönlichkeit ist der katholische Flüchtlingspfarrer in Pritzwalk Kurt Reuter (1908-1965) gewesen, der vor 1945 in Swinemünde tätig war ${ }^{1961}$ und nun, wie viele andere auch, „in der Luft“ hing. 1959 wies das Bi-

1957 Vom Sterben schlesischer Priester 1945/56. Ein Ausschnitt aus der schlesischen Passion. München 1950, S. 111 (Arnold), 119 (Lompa, Metzger), 126 (Wilkens).

1958 Geb. 23.8.1893 Berlin, Monsignore, Päpstlicher Hausprälat, Konsistorialrat, Vorsitzender des Diözesanvorstandes des Bonifatiusvereins (Schematismus 1947, S. 15).

1959 DAB, I/9-15-1 Flüchtlingsseelsorge 1945-1951, unfol., 22.8.1946.

1960 [Societas Verbi Divini (Gesellschaft des Göttlichen Worts), Orden der Steyler Missionare.]

1961 Ab 1940 Kaplan und Landjahrseelsorger in Swinemünde, ab 1941 Pfarradministrator ebd., ab 1944 Titulierter Pfarrer ebd. (Schematismus des Bistums Berlin 1960, S. 139). - Zu Reuters späterer deutsch-polnischer Verständigungsarbeit siehe: Robert Żurek: Kurt Reuter. Ein vergessener Vorreiter der deutsch-polnischen Versöhnung. In: Wichmann-Jahrbuch 50/51 (2010/11 [2011]), S. 132-143. 
schöfliche Ordinariat den damals 51-Jährigen auf die Pfarrvakanz in Eberswalde hin und forderte ihn zur Bewerbung auf. ${ }^{1962}$ Ende 1959 schreibt er dem Generalvikar: „Bezüglich Eberswalde ein kurzes Wort: Ich habe nicht die Absicht mich zu bewerben, da ich als Utraquist mich freihalten möchte für die Ostgebiete unserer Diözese, aus denen ich 1946 ausgesiedelt wurde. In jüngster Vergangenheit wurde doch wiederholt davon gesprochen, daß die UdSSR bereit wäre zu einem Sonderfriedensvertrag mit der DDR und Rückgabe einiger unter poln. Verwaltung stehender Gebiete an die DDR. Darunter wären gewiß Gebiete unserer Diözese, in die ich sofort bereit wäre zu gehen." ${ }^{1963}$ Mit dieser Sicht befand sich Reuter zwar mit offiziellen Verlautbarungen der katholischen Kirche, wie sie zumindest im Westen Deutschlands zu finden waren, immerhin insofern in Einklang, als man grundsätzlich, auch „wenn der Heimatgedanke schwächer geworden ist, [...] eine letzte Verantwortung für den Osten im Priesternachwuchs zu erhalten" gedachte, doch ging man Ende der fünfziger Jahre längst von einem Zustand aus, dessen Beendigung nicht absehbar sei. ${ }^{1964}$ Immerhin hielt man daran fest, dass die Inkarnierung künftiger Priester, „Flüchtlings-Studenten“, in eine ihrem Wohn- bzw. Wirkungsort entsprechende Diözese an die beiden Bedingungen geknüpft blieb, dass zum einen der inkarnierende Bischof einer Rückkehr in die Herkunftsdiözese zustimmt, „sobald die Rückkehr dieser Kleriker in ihre Herkunftsdiözese möglich ist und der Ordinarius der Herkunftsdiözeen sie anfordert", zum anderen „die Kleriker selber sich bereit erklären zu solcher Rückkehr ${ }^{\text {“ }} .{ }^{1965}$ Doch auch dies waren kirchenrechtliche Formalia, während Reuters fast euphorische Reaktion auf vorübergehende weltpolitische Tauwetteranzeichen eher realitätsblind anmutet. Aus Berlin dürfte man ihm daher nun nochmals um so deutlicher zu verstehen gegeben haben, dass er trotz langfristiger Hoffnungen kurzfristig in Eberswalde nicht nur eine Stellenbesetzung in Aussicht habe, sondern dort gebraucht werde und sich daher umgehend bewerben möge. Schon rund zwei Wochen nach Eingang des zitierten Briefes im Bischöflichen Orinariat teilte ihm dieses nämlich unter dem 13. Januar 1960 mit, „dass $S$ [eine] E[minenz] der Hochwürdigste Herr Kardinal [Erzbischof Julius Döpfner] Ihnen die vakante Pfarrei St. Peter und Paul, Eberswalde, auf Ihre Bewerbung [!] verliehen hat". ${ }^{1966}$ Spätestens 1960 war Reuter mithin auch formal integriert. Da er sich zum Zeitpunkt der Vertreibung zwar in Hinterpommern, damit aber auf Berliner Bistumsgebiet befand und ohnehin ursprünglich aus Berlin stammte, fiel in seinem Fall auch das Problem der Inkarnation bzw. des meist lange aufgescho-

1962 DA, I/3a-3 (Protokollbuch des Bischöflichen Ordinariats), S. 170 (Sitzung 22.12.1959: „Pfr. Reuter soll aufgefordert werden, sich um Pfarrei Eberswalde zu bewerben."

1963 DAB I/5-12-Reuter, Kurt, unfol. (Pritzwalk, 22.12.1959; Eingangsstempel 28.12.1959).

1964 Siehe z.B. die Formulierungen in der Einführung zum (gesamtdeutschen) „Ostpriesterverzeichnis“, in dem auch Kurt Reuter verzeichnet ist und die sich fast durchgängig, so in der Ausgabe von 1954, aber auch noch der von 1988, finden. „Die Vertreibung ist ein Unrecht, das nach Wiedergutmachung verlangt. Da man aber nicht absehen kann, wann die Rückkehr in die alte Heimat erfolgen [...] kann [...]." (4. Verzeichnis der deutschen vertriebenen Priester aus dem Osten. Königstein/Ts. 1954, S. 11*; Ostpriesterverzeichnis (8. Königsteiner Schematismus). Königstein/Ts. 1988, S. 13*).

1965 Die Zitate aus einem päpstlichen Dekret vom 5.2.1955, hier nach 5. Verzeichnis der deutschen vertriebenen Priester aus dem Osten. Königstein/Ts. 1960, S. 25* (Zur Weihe der Ost-Theologen).

1966 DAB I/5-12-Reuter, Kurt, unfol. (Berlin-Charlottenburg, 13.1.1960). Vgl. Protokoll der Ordinariats-Sitzung vom 16.1.1960 (DAB, I/3a-3, S. 172, 2. unfol. Beilage). 
benen Wechsels der formalen Diözesanzuordnung weg. Der ab 1960 neben ihm in Eberswalde amtierende Kaplan hingegen kam beispielsweise aus Danzig und blieb für das Berliner Ordinariat daher kirchenrechtlich Angehöriger der erwähnten „Randgruppe“, der sogen. „Priester anderer Bistümer" 1967

Reuter scheint im Übrigen - ausweislich der Schematismen - auf der lokalen Pfarreiebene des Bistums Berlin der einzige katholische Pfarrer gewesen zu sein, der formal als für eine Flüchtlingsgemeinde zuständiger „Flüchtlingspfarrer“ berufen worden ist und nicht nur, was in anderen Fällen vorkam, wegen seiner eigenen Flüchtlingseigenschaft als solcher bezeichnet wurde. ${ }^{1968}$ Sieben wegen ihres eigenen (!) Flüchtlingsschicksals als „Flüchtlingsgeistliche“ bezeichnete Pfarrer sind z. B. aufgelistet in einem Pensionsangelegenheiten ansprechenden Schreiben des (selbst betroffenen und mit genannten) Caritasreferenten Ludwig Polzin (1892-1964) vom 10. Januar 1952 an das Ordinariat betreffend solche, „die zwar in der Diözese Berlin sich aufhalten, aber nicht für die Diözese Dienst tun " ${ }^{1969}$, darunter sechs in Berlin wohnhafte, einer in Schöneiche bei Berlin (Franz Friedrich). Auch in nichtkirchlichen Bereichen gab es offenkundig die Tendenz, Personen, die selbst Flüchtling waren und interimistisch Funktionen übernahmen, mit entsprechenden Bezeichnungen zu versehen, wie das Beispiel einer „Flüchtlingslehrerin“ zeigt, die im havelländischen Knoblauch den zum Volkssturm eingesetzten hauptamtlichen Lehrer entlastete und in der zeitgenössischen Schulchronik 1945 so bezeichnet wird. ${ }^{1970}$

Die vielfältigen Evakuierungen innerhalb des Reiches hatten bereits im Laufe des Krieges dazu geführt, dass immer mehr neu errichtete Seelsorgestellen entstanden, die z. T. mit den ebenfalls evakuierten Priestern besetzt wurden. „Als dann ab dem Winter 1944 immer mehr katholische Flüchtlinge aus Ostpreußen und Schlesien eintrafen, bewährten sich diese als Provisorium gedachten Strukturen. Mit ihrer Hilfe war man in der Lage, die steigende Zahl katholischer Menschen in ihrer neuen Heimat zu integrieren. "1971 Allerdings muss man dieser Formulierung aus einer offiziellen Darstellung des Erzbistums Berlin (2009) hinzufügen, dass auch die katholischen Gemeinden wie alle anderen und wie die „Profanbehörden“ in Stadt und Land von der Wucht des Bevölkerungsstroms der Jahre 1945/46 und der in kurzer Zeit großen Zahl hereinströmender Flüchtlinge und Vertriebenen zunächst überfordert waren. Auch in den Folgejahren nach 1946 mussten immer wieder neue Gemeinden gegründet oder aus bestehenden herausgelöst werden, um der Situation Herr zu werden. Die Gesamtbilanz, die Harald Schwillus in seiner Darstellung der Bistumsgeschichte gezogen hat, ist gleichwohl - gerade in ihrem Vergleich mit der Situation bei der Evangelischen Kirche in Berlin-Brandenburg - richtig: „Die Integration der Flüchtlinge gelang relativ gut, da die Gruppe der Hinzukommenden etwa ge-

1967 Schematismus für das Bistum Berlin 1960, S. 70, 162.

1968 Durchgesehen wurde im Schematismus neben dem Sachregister der Nachkriegsbände für die Jahrgänge 1947 und 1960 auch die Rubrik „Priester des Bistums und ihre bisherigen Anstellungen“.

1969 Überliefert in seiner eigenen Personalakte, DAB, I/5-12-Polzin, Ludwig, unfol.

1970 Textabdruck in: Bergemann/Damaschke, Ketzin 1945 (wie Anm. 386), S. 48.

1971 Schwillus/Brühe, Erzbistum Berlin (wie Anm. 148), S. 124. 
nauso groß war wie die Gruppe der einheimischen Katholiken und Katholikinnen. Darüber hinaus brachten sie aus den deutschen Ostgebieten i.d.R. ihre ebenfalls vertriebenen Pfarrer und Kapläne mit. Anders als in protestantischen Gemeinden entstanden daher in den sich vergrößernden katholischen Gemeinden kaum Spannungen." ${ }^{1972}$

Wie in der evangelischen Kirche bildete die katholische aber nicht nur durch ihre Pfarrseelsorge ein wesentliches Element in der Flüchtlingsbetreuung und -integration, sondern auch durch eine Vielzahl - auch überkonfessionell tätiger - karitativer Einrichtungen, die teils von Berlin aus, teils direkt in einzelnen Orten der Provinz Brandenburg agierten. Dabei handelte es sich bisweilen um einzelne Gruppen geflüchteter Schwestern, vielfach aber sogar um selbst aus den Vertreibungsgebieten „transferierte“ komplette Konvente und Heime, die in ihrer neuen Heimat selbständig weiterwirken oder sich an dort vorhandene Einrichtungen anlehnen konnten. ${ }^{1973}$

Ein Beispiel sind die „Marienschwestern“ (Marienschwestern von der Unbefleckten Empfängnis). Sitz ihrer Generalleitung war bis 1945 Breslau, nach der Vertreibung befand er sich in West-Berlin, im Hospital Maria Trost in Berlin-Lankwitz, ${ }^{1974}$ anfangs bis 1948 im St. AntoniusKrankenhaus in Berlin-Friedrichshagen ${ }^{1975}$. Als Kurator wirkte 1949-1976 der vormalige Breslauer Kirchenrechtler Dr. Alois Wuttke (1899-1985), der bis zum Mauerbau auch für den Ostteil der Brandenburgischen Provinz zuständig war ${ }^{1976}$, ab 1963 hier der Berliner Weihbischof Heinrich Theissing (1917-1988) ${ }^{1977}$. Durch den Zuzug vertriebener Marienschwestern „entstanden in den Jahren 1945 bis 1948 sieben neue Filialen. Das Provinzhaus blieb in Ost-Berlin am Michaelkirchplatz. ${ }^{1978}$ Die sieben neuen Filialen (Niederlassungen) befanden sich in BerlinFrohnau (1948-1952), Berlin-Lankwitz/Gallwitzallee (seit 1948) und ebenda/Kaulbachsatraße (1945-1952), Berlin-Prenzlauer Berg/Bötzowstraße (1945-1948), in Erkner ${ }^{1979}$ (1947-1952), Schöneiche ${ }^{1980}$ (1947-1990) und im sachsen-anhaltischen Zeitz (1946-1995). ${ }^{1981}$

Ebd.

1973 Siehe dazu z.B. die umfassenden Bestandsaufnahmen von Johannes Mertens (wie Anm. 149) sowie die entsprechenden Angaben in der Ortsdokumentation (Teil 2), bes.: Altenhof (Werbellinsee): St. Maria-ElisabethHeim (1947-1949 von aus Schlesien vertriebenen Grauen Schwestern geführt). - Bad Saarow-Pieskow, Caritas-Kinderheim St. Antonius (Hedwigschwestern aus Breslau und Glogau). - Belzig: Station der Grauen Schwestern für ambulante Pflege (aus Schlesien). - Biesenthal: Katholisches Kinderheim St. Joseph (19471954 geleitet von Hedwigschwestern aus Peterswaldau und Niedersteine in Schlesien). - Blankenfelde: Haus St. Marien der Grauen Schwestern („aus den Ostgebieten evakuiert“). - Döbern, Caritasheim (Hedwigschwestern aus Glogau). - Zur eigenen Flucht und Vertreibung der schlesischen Konvente, aber auch zu ihrem Einsatz in der Flüchtlingsbetreuung siehe die ebenfalls umfassende Bestandsaufnahme: Mengel, Das Schicksal der schlesischen Frauenklöster (wie Anm. 612).

1974 Mertens, Marienschwestern (wie Anm. 149), Bd. 1, S. 51, 659.

1975 Ebd., Bd. 1, S. 49.

1976 Ebd., Bd. 2, S. 659.

1977 Ebd., Bd. 2, S. 660.

1978 Ebd., Bd. 1, S. 57.

1979 Ebd., Bd. 2, S. 495 f.

1980 Ebd., Bd. 2, S. 506-510.

1981 Ebd., Bd. 2, S. $394 \mathrm{ff}$. 
Neben der allgemeinen Fürsorge für Bedürftige widmeten sich solche Schwesternkonvente besonders der Arbeit in den Flüchtlingslagern, z. B. „Graue Schwestern“ aus Breslau in dem zeitweise sehr großen Lager Cahnsdorf bei Luckau ${ }^{1982}$, und der für Waisenkinder, z. B. „Hedwigschwestern" aus Breslau im Caritasheim in Bad Saarow, das als gemeinsame Auffangstation für Schwestern und Kinder aus Schlesien, später auch für ostpreußische Waisenkinder, diente. ${ }^{1983}$ Teilweise betreuten also Flüchtlinge und Vertriebene ihresgleichen. Das Bad Saarower Heim ist zugleich ein Beispiel dafür, dass die in der Anfangsnot als unverzichtbar akzeptierte kirchliche karitative Flüchtlingsarbeit von der SED nach und nach zunehmend kritisch betrachtet wurde. So kam es hier im Mai 1953 sogar zu einer örtlichen Hetzkampagne der FDJ und vorübergehender Beschlagnahme durch die Behörden. ${ }^{1984}$ Die durch die gesamten DDR-Jahrzehnte hindurch weiter aktive Caritas, die auch im Berliner Bistum mit einer eigenen Struktur agierte ${ }^{1985}$, bildete gerade im Süden Brandenburgs einen für die schlesischen katholischen Flüchtlinge und Vertriebenen besonderen Bezug zu ihrer Heimat, handelte es sich doch bei der 1945 hierher verlagerten Caritas-Geschäftsstelle in Cottbus ebenfalls um eine selbst vertriebene Einrichtung, die nun im deutschen Restgebiet weiterwirkende Caritas-Geschäftsstelle des Erzbistums Breslau, deren Leiter, Caritasdirektor Prälat Johannes Zinke (1903-1968), bereits seit 1938 in Breslau diese Funktion ausgeübt hatte. ${ }^{1986}$ Auch als er 1946 nach Berlin wechselte, blieb die Leitung der Cottbuser Geschäftstelle in der Hand selbst vertriebener Schlesier und er selbst „bis zu seinem Tod eine der bestimmenden Persönlichkeiten der katholischen Kirche in der DDR“, der „fast täglich die Mauer von Westberlin aus relativ ungehindert durchqueren konnte“.1987

1982 Töpler, Menschenwurm (wie Anm. 147), S. 463. - Siehe auch Ortsdokumentation Cahnsdorf.

1983 Details und Nachweise siehe in der Ortsdokumentation.

1984 Brühe, Katholische Kirche zwischen Uckermark und Oderland (wie Anm. 148), S. 14. - Ausführlicher: Mertens, Hedwigschwestern (wie Anm. 149), S. 471.

1985 Kirchlicher Suchdienst, „der den Flüchtlingen bei der Suche nach vermißten Angehörigen hilft": Berlin-Charlottenburg 9, Bayernallee 28 beim Deutschen Caritasverband (Petrusblatt 8, 1946, Nr. 8, S. 7). - Katholischer Flüchtlingsdienst, Berlin W 15, Pfalzburger Straße 18 (Petrusblatt 2 (1946), Nr. 1, S. 7). Leiter: Ludwig Polzin, Pfarrer, Geistl. Rat, Caritasreferent, geb. 19.8.1892 Breitenstein Kr. Deutsch Krone, wohnt Berlin-Friedenau, Büro: Berlin-Wilmersdorf, Pfalzburger Str. 18 (Schematismus 1947, S. 156); wohnt Berlin-Friedenau, Büro: Berlin-Charlottenburg, Bayernallee 28 (Schematismus 1949, S. 149; 1951, S. 148). - Diözesan-Beauftragter für Flüchtlingsseelsorge und -fürsorge: Georg Meißner, Pfarrer, geb. 14.12.1907 Posen, wohnt 1949/51 Berlin SW 29, Büro: Berlin W 15, Düsseldorfer Str. 13 (Caritasverband) (Schematismus 1949, S. 149; 1951, S. 148; 1953 nicht mehr genannt, Meißner nun - S. 11 - Leiter des Referats für Seelsorge im Bischöflichen Ordinariat). Zum organisatorischen Neuaufbau der Caritas-Strukturen in der SBZ siehe Tischner, Katholische Kirche in der SBZ/DDR (wie Anm. 523), S. 386 ff., zu ihren Schwierigkeiten mit der neuen Staatsmacht S. 442-448 („Die Bahnhofsmission als Beispiel kommunistischer Vereinnahmungspolitik“).

1986 Töpler, Menschenwurm (wie Anm. 147), S. 355 f. - Weitere Details und Nachweise siehe in der Ortsdokumentation Cottbus.

1987 Heinz Dietrich Thiel: Johannes Zinke (1903-1968). In: 75 Jahre Bistum Berlin. 20 Persönlichkeiten. Hrsg. von Michael Höhle (Wichmann-Jahrbuch des Diözesangeschichtsvereins Berlin, N. F. 8, 2004/05). Heiligenstadt 2005, S. 177-185, hier S. 177. 
In der Berliner Bistumszeitung wird - dies sei immerhin am Rande noch erwähnt - als Ansprechpartner ferner ausdrücklich aufgeführt: „Beauftragter für deutsche katholische Flüchtlinge, Bischof Kaller, Frankfurt-Main, Stresemannallee 36“" ${ }^{1988}$ Der selbst heimatlos gewordene Ermländer Bischof Maximilian Kaller (1880-1947) wurde am 24. Juni 1946 von Papst Pius XII. zum „Sonderbeauftragten des Heiligen Vaters für die heimatvertriebenen Deutschen“ ernannt. ${ }^{1989} \mathrm{Er}$ agierte zwar vornehmlich in den Westzonen ${ }^{1990}$, verschaffte aber den Vertriebenen zumindest als Gesamtgruppe für kurze Zeit Gehör in den Medien, u. a. durch Rundfunkbeiträge bis hin zu „Radio Vatikan“, und führte sie auch bei mehreren Besuchen, Treffen und Wallfahrten in großer Zahl zusammen. Seine aufopferungsvolle Betreuungs- und „Lobby“-Arbeit fand jedoch schon am 7. Juli 1947 durch seinen unerwartet frühen Tod ein baldiges Ende.

Ähnlich wie die evangelische Kirche und ihre Hilfswerke boten auch die katholischen Diözesen den Flüchtlingen Ansprechpartner für verschiedenste Anliegen und Suchdienste, bis die SED letztere zugunsten des staatlichen Suchdienstes verbot. In Inseraten im Berliner „Petrusblatt" teilen Vertriebene, z. B. aus Schlesien und der Neumark, ihre neue Anschrift mit. Typisch sind Suchanzeigen (Inserate) wie die von „Frau Schreiber und Töchter, jetzt Lindow/Mark“, die nach Bekannten aus Landsberg (Warthe) und Betsche Kr. Meseritz suchen. ${ }^{1991} 1946$ findet sich sogar ein sechszeiliges Inserat eines in Zossen gelandeten Galiziendeutschen: „Umsiedler aus der Bukowina!/Anton Horn aus Czernowitz bitte alle Verwandten und Bekannten um bald[ige]. Nachricht, wo sie sich befinden. [...]".1992

Noch im Februar 1946 hieß es im Berliner Bistumsamtsblatt mit offenkundig indirektem Hinweis auf das Agieren verschiedener dezentral agierender Stellen: „Der kirchliche Suchdienst, der den Flüchtlingen bei der Suche nach vermißten Angehörigen hilft, befindet sich nur in Berlin-Charlottenburg 9, Bayernallee 28, beim Deutschen Caritasverband.“1993 Ebenfalls ähnlich wie bei der evangelischen Kirche bildete zumindest für die in Brandenburg lebenden Katholiken des Bistums Berlin West-Berlin einen wesentlichen Bezugspunkt, auf den sie in den verschiedensten Angelegenheiten gleichsam automatisch verwiesen wurden, wie nicht nur die Charlottenburger Adresse des Caritasverbandes zeigt, sondern z. B. auch der in derselben Ausgabe des Bistumsamtsblatts mitgeteilte Zehlendorf-Hinweis: „An Personen im polnisch besetzten Gebiet kann man Nachricht gelangen lassen in Form einer einfachen Postkarte (25 Worte in Druckschrift!) über das Rote Kreuz in Berlin-Zehlendorf, Berliner Str. 11. Gebühr für Porto 3,- RM.“"1994

1988 Petrusblatt 2 (1946), Nr. 43, S. 6.

1989 Aus der inzwischen großen Zahl an Publikationen über Kaller sei hier nur auf die der Berliner Situation näherstehende Arbeit verwiesen: Hans Jürgen Brandt: Maximilian Kaller (1880-1947). In: 75 Jahre Bistum Berlin (wie Anm. 1987), S. 75-86, hier S. 84 f.

1990 Petrusblatt 2 (1946), Nr. 43, S. 6.

1991 Petrusblatt 2 (1946), Nr. 19, S. 8.

1992 Petrusblatt 2 (1946), Nr. 31, S. 8.

1993 Amtsblatt des Bischöflichen Ordinariats Berlin 18. Jg., St. 2, 1.2.1946, S. 7. - Siehe auch ebd., 20. Jg., 1948, St. 5, 1.5.1948, S. 20, Nr. 67, den Hinweis auf die „Heimatkarteien der Caritas für Flüchtlinge“.

1994 Ebd. 
Aber nicht nur die spezielle Flüchtlingsbetreuung der Caritas und anderer Einrichtungen, sondern auch der „normale“ Gottesdienst in den brandenburgischen Gemeinden erhielt aus Berlin immer wieder „Anregungen“, die die Bedeutung der Unterstützung und Eingliederung der Flüchtlinge in das Bewusstsein der einheimischen Gläubigen (und Geistlichen) trug. Dazu dienten beispielweise verbindliche bischöfliche Kollektenpläne. So findet sich schon 1945 in der zweiten überhaupt erschienenen Nummer des „Petrusblattes“ eine „Kollekte für Flüchtlinge und Rückwanderer aus den Ostgebieten “ in allen katholischen Gottesdiensten im Bistum Berlin auf Weisung des Bischöflichen Ordinariats erwähnt. ${ }^{1995}$ Auch der Kollektenplan für 1947 enthielt z. B. eine spezielle Kollekte für Flüchtlinge am Karfreitag, Karsamstag und Ostermontag sowie am 19. Oktober ${ }^{1996}$, und waren die darin gesammelten Gelder „zu 100 Prz. [Prozent] des Ertrages [...] [an die Bistumskasse] abzuliefern“ "1997 Auch der Kollektenplan für 1950 wies, als im brandenburgischen Bistumsgebiet staatlicherseits längst der „Umsiedler“-Begriff vorgegeben und sogar dieser zunehmend vermieden wurde, noch immer eine „Kollekte für Flüchtlinge und Heimkehrer" am Karfreitag, Karsamstag und Ostermontag aus. ${ }^{1998}$

Wenngleich also die Flüchtlingsarbeit der katholischen Kirche und überhaupt der Kirchen in der SBZ/DDR kaum SED-konform genannt werden kann, hat sie doch zur Integration der Flüchtlinge und Vertriebenen wesentlich beigetragen. Dabei ist die Arbeit des einzelnen lokalen Seelsorgers oft entscheidend gewesen, Bischof und Ordinariat versuchten aber durch Anordnungen, „Hirtenbriefe “1999 und eine vielfältige konfessionelle Publizistik unterstützend zu wirken und auch dem einzelnen Vertriebenen die Notwendigkeit, an der eigenen Eingliederung selbst mitzuwirken, vor Augen zu führen. Ein Beispiel ist das „Gebetbüchlein für katholische Flüchtlinge“ mit dem Haupttitel „Heimat in Gott", das 1946 im Auftrag des Berliner Bischofs gedruckt und verteilt wurde. ${ }^{2000}$ Darin heißt es u. a.: „Ein wichtiges Gebot für Flüchtlinge: Du sollst Dich als Flüchtling bald in Deine neue Pfarrfamilie einordnen, in die Dich Gott auf Deinem Leidensweg geführt hat. Wenn es auch nicht Deine Heimatkirche ist - er ist derselbe göttliche Freund im Tabernakel. Melde deswegen Dich und Deine Kinder möglichst bald persönlich oder schriftlich beim nächsten katholischen Pfarrer an und beteilige Dich am religiösen Leben der Pfarrfamilie. Denke aber immer daran, wie groß der Priestermangel ist! Nicht in jedem Orte kann ein katholischer Priester sein. Bringe deswegen auch das Opfer einer Wegstunde bis zur nächsten katholischen Gottesdienststation."2001

1995 Petrusblatt 1 (1945), Nr. 2 (26.12.1945), S. 8.

1996 Amtsblatt des Bischöflichen Ordinariats Berlin, 19. Jg., St. 4, 1.4.1947, S. 15 (Nr. 43).

1997 Ebd., S. 16.

1998 Amtsblatt des Bischöflichen Ordinariats Berlin 21 (1949), S. 46 f., hier S. 47.

1999 Petrusblatt 2 (1946), Nr. 48, S. 7; Nr. 49, S. 4.

2000 Heimat in Gott. Gebetbüchlein für katholische Flüchtlinge. Hrsg. im Auftr. Sr. Eminenz des Bischofs von Berlin Konrad Kardinal von Preysing. (Berlin) 1946. 48 S. „Imprimatur/Berolini, die 25 Maii 1946. / Prange, Vic. gen." [Generalvikar (Vicarius generalis) Dr. Maximilian Prange].

2001 Ebd., Umschlagseite 4 (Sperrung im Original). 
Die in diesen Worten auch durchscheinende Hoffnung auf ein verstärktes katholisches Leben war nicht unbegründet. Schon allein ein Vergleich der Vorkriegs- mit den Nachkriegszahlen der in brandenburgischen Städten ansässigen Katholiken zeigt indirekt deutlich die eingangs bereits für die SBZ/DDR insgesamt angesprochene - große Bedeutung der Flüchtlinge und Vertriebenen für die Veränderung der Konfessionsstruktur. Die Situaton auf dem Land ist in den Quellen schwerer zu überblicken. Eine Stärkung der katholischen Gemeinden hat es auch dort gegeben, eine grundlegende Veränderung der konfessionellen Strukturen blieb hier aber die Ausnahme. In den Industriestädten, nicht nur in der Niederlausitz, war die Zahl der Katholiken - für Diasporaverhältnisse - auch vor 1945 schon relativ hoch. In Fürstenberg (Oder), heute Teil von Eisenhüttenstadt, zählte die Gemeinde 1929 einschließlich 14 eingepfarrter Orte immerhin schon 778 Mitglieder. Nach Kriegsende nahm sie viele Vertriebene auf und erreichte damit trotz der kriegsbedingten Abgänge schon 1949 die Zahl von 1000 Gemeindemitgliedern, so dass ein größerer Kirchenraum nötig wurde. In den Jahren 1951 bis 1953 passte man daher das vorhandene Gebäude durch Um- und Anbauten den neuen Verhältnissen, die sich aus der Zuwanderung ergaben, an. ${ }^{2002}$

Tab. 8: Katholische Einwohner ausgewählter brandenburgischer Städte 1925 und $1946^{2003}$ Abweichende Vorkriegszahlen: ${ }^{*} 1928,{ }^{* *} 1930,{ }^{* * *} 1939$.

\section{Ost- und Westprignitz, Ruppin}

\begin{tabular}{|l|r|r|}
\hline \multicolumn{1}{|c|}{ Stadt } & $\mathbf{1 9 2 5}$ & $\mathbf{1 9 4 6}$ \\
\hline Freyenstein** & 19 & 148 \\
\hline Gransee & 187 & 544 \\
\hline Havelberg & 122 & 542 \\
\hline Kyritz & 167 & 726 \\
\hline Lenzen & 33 & 119 \\
\hline Meyenburg & 47 & 332 \\
\hline Neuruppin & 54 & 237 \\
\hline Neustadt (Dosse) & 138 & 297 \\
\hline Perleberg & 356 & 1002 \\
\hline Pritzwalk & 327 & 606 \\
\hline Putlitz & 51 & 120 \\
\hline Rheinsberg & 61 & 208 \\
\hline Wittenberge & 983 & 2487 \\
\hline Wittstock & 210 & 839 \\
\hline Wusterhausen/Dosse & 57 & 333 \\
\hline
\end{tabular}

2002 Winfried Pohl: Aus der Geschichte der katholischen Gemeinde [Fürstenberg/Eisenhüttenstadt]. In: Heimatkalender Eisenhüttenstadt und Umgebung 23 (2005), S. 164-165, hier S. 165.

2003 Quelle: Städtebuch Brandenburg und Berlin (wie Anm. 54). Die Zahlen der Jahre 1925 und 1946 beruhen auf den Volkszählungen. Weggelassen wurden nur die Städte, für die keine Vergleiche möglich sind, da Vor- oder Nachkriegszahlen im Städtebuch fehlen. 
Uckermark (Angermünde, Prenzlau, Templin)

\begin{tabular}{|l|r|c|}
\hline \multicolumn{1}{|c|}{ Stadt } & $\mathbf{1 9 2 5}$ & $\mathbf{1 9 4 6}$ \\
\hline Greiffenberg & 23 & 110 \\
\hline Joachimsthal & 47 & 241 \\
\hline Lychen & 122 & 193 \\
\hline Oderberg & 40 & 213 \\
\hline Prenzlau & 930 & 1176 \\
\hline Schwedt/Oder & 423 & 257 \\
\hline Templin & 198 & 666 \\
\hline Vierraden & 5 & 17 \\
\hline Zehdenick & 989 & 1449 \\
\hline
\end{tabular}

Lebus, Frankfurt (Oder), Beeskow-Storkow

\begin{tabular}{|l|r|c|}
\hline \multicolumn{1}{|c|}{ Stadt } & $\mathbf{1 9 2 5}$ & $\mathbf{1 9 4 6}$ \\
\hline Beeskow & 155 & 525 \\
\hline Buckow $^{2004}$ & 65 & 381 \\
\hline Frankfurt (Oder) & 4964 & 3874 \\
\hline Fürstenwalde/Spree & 1340 & 1532 \\
\hline Lebus & 0 & 40 \\
\hline Müllrose & 91 & 372 \\
\hline Müncheberg & 229 & 272 \\
\hline Seelow** & 91 & 145 \\
\hline Storkow & 88 & 323 \\
\hline
\end{tabular}

\section{Nieder- und Oberbarnim}

\begin{tabular}{|l|r|r|}
\hline \multicolumn{1}{|c|}{ Stadt } & $\mathbf{1 9 2 5}$ & $\mathbf{1 9 4 6}$ \\
\hline Altlandsberg** & 146 & 512 \\
\hline Bad Freienwalde & 432 & $\mathbf{6 9 7}$ \\
\hline Bernau & 551 & 2066 \\
\hline Eberswalde & 1430 & 464 \\
\hline Erkner & 302 & 299 \\
\hline Liebenwalde & 67 & 1868 \\
\hline Oranienburg & 811 & 772 \\
\hline Strausberg & 422 & 285 \\
\hline Werneuchen & 89 & 237 \\
\hline Wriezen & 229 & 162 \\
\hline
\end{tabular}

20041955 bereits 750 katholische Einwohner, was die Autorinnen mit dem Zusatz „(Umsiedler!)“ kurz, aber eindeutig erklären (Städtebuch Brandenburg und Berlin [wie Anm. 54], S. 77). 
Teltow

\begin{tabular}{|l|r|r|}
\hline \multicolumn{1}{|c|}{ Stadt } & $\mathbf{1 9 2 5}$ & $\mathbf{1 9 4 6}$ \\
\hline Königs Wusterhausen & 327 & 520 \\
\hline Mittenwalde & 105 & 282 \\
\hline Teltow & 475 & 1434 \\
\hline Teupitz & 83 & 136 \\
\hline Trebbin & 109 & 347 \\
\hline Zossen & 234 & 512 \\
\hline
\end{tabular}

Ost- und Westhavelland, Potsdam, Rathenow, Ziesar

\begin{tabular}{|l|r|r|}
\hline \multicolumn{1}{|c|}{ Stadt } & $\mathbf{1 9 2 5}$ & $\mathbf{1 9 4 6}$ \\
\hline Brandenburg an der Havel $^{\prime}$ & 3927 & $\mathbf{7 4 2 0}$ \\
\hline Brandenburg-Plaue* $^{*}$ & 159 & 648 \\
\hline Falkensee & 442 & 2614 \\
\hline Fehrbellin* & 183 & 657 \\
\hline Friesack & 137 & 627 \\
\hline Hennigsdorf & 1620 & 3450 \\
\hline Ketzin & 267 & 712 \\
\hline Kremmen & 108 & 298 \\
\hline Nauen & 781 & 1592 \\
\hline Potsdam (gerundete Zahlen) & 4600 & 9800 \\
\hline Premnitz & 131 & 1614 \\
\hline Pritzerbe & 28 & 277 \\
\hline Rathenow & 1001 & 1910 \\
\hline Rhinow & 27 & 268 \\
\hline Velten & 521 & 1118 \\
\hline Ziesar** & 50 & 505 \\
\hline
\end{tabular}

Zauch-Belzig, Jüterbog-Luckenwalde

\begin{tabular}{|l|r|c|}
\hline \multicolumn{1}{|c|}{ Stadt } & $\mathbf{1 9 2 5}$ & $\mathbf{1 9 4 6}$ \\
\hline Baruth & 30 & 134 \\
\hline Belzig & 104 & 703 \\
\hline Brück & 15 & 237 \\
\hline Dahme & 100 & 569 \\
\hline Jüterbog & 286 & 1678 \\
\hline Luckenwalde & 1102 & 2767 \\
\hline Niemegk & 17 & 269 \\
\hline Treuenbrietzen & 138 & 853 \\
\hline Werder (Havel) & 289 & 845 \\
\hline
\end{tabular}


Niederlausitz

\begin{tabular}{|l|r|r|}
\hline \multicolumn{1}{|c|}{ Stadt } & $\mathbf{1 9 2 5}$ & $\mathbf{1 9 4 6}$ \\
\hline Calau & 121 & 477 \\
\hline Cottbus & 2656 & 4858 \\
\hline Doberlug-Kirchhain & 49 & 202 \\
\hline Döbern & 619 & 532 \\
\hline Eisenhüttenstadt (Fürstenberg/Oder) & 712 & 477 \\
\hline Finsterwalde & 540 & 2826 \\
\hline Forst (Lausitz) & 2243 & 1673 \\
\hline Golßen & 31 & 203 \\
\hline Guben & 1789 & 1015 \\
\hline Luckau & 113 & 466 \\
\hline Lübben & 333 & 730 \\
\hline Lübbenau & 85 & 438 \\
\hline Peitz & 69 & 639 \\
\hline Senftenberg & 2710 & 3104 \\
\hline Sonnewalde & 26 & 133 \\
\hline Spremberg & 720 & 1414 \\
\hline Vetschau & 148 & 302 \\
\hline Welzow & 839 & 895 \\
\hline
\end{tabular}

Die Tabelle weist nur in wenigen Fällen einen Rückgang der Katholikenzahl aus, der dann aber durchweg mit einem kriegsbedingten dramatischen Rückgang der Gesamtbevölkerungszahl einherging. In der überwiegenden Zahl der Städte hingegen ist der Zuwachs an katholischen Kirchenmitgliedern gravierend. Dass dies zum größten Teil, wenn nicht gar fast ausschließlich auf den Zuzug der Flüchtlinge und Vertriebenen zurückzuführen ist, liegt auf der Hand. ${ }^{2005}$ Die Vergleichszahlen der Protestanten sind hier entbehrlich, diese blieben ja ohnehin vor wie nach 1945 in der überwiegenden Mehrheit, in Fürstenwalde/Spree etwa gab es - ein durchaus repräsentatives Beispiel - 193987 Prozent evangelische und nur 7 Prozent katholische Kirchenmitglieder. ${ }^{2006}$ Auch die evangelischen Kirchengemeinden erhielten zwar - darauf wurde bereits hingewiesen - durch den Zuzug von Flüchtlingen und Vertriebenen erheblichen Zuwachs, doch änderte dies ihre dominante Mehrheitssituation nicht merklich. Dagegen bedeutete der Zuzug

2005 Zumindest einer der Autoren des Städtebuches Brandenburg und Berlin (wie Anm. 54), Winfried Schich, führt die Zunahme katholischer Einwohner in den von ihm verfassten Artikeln auch jeweils ausdrücklich darauf zurück: Brandenburg an der Havel (S. 55: „von Flüchtlingen und Vertriebenen“), Fehrbellin (S. 147: „Flüchtlinge und Vertriebene nach 1945“), Friesack (S. 190: „durch westf. Siedler 1932/33 u. Flüchtlinge 1945“), Pritzerbe (S. 427: „durch Umsiedler u. Flüchtlinge“), Rhinow (S. 450: „durch Flüchtlinge u. Vertriebene"), Ziesar (S. 571: „durch Flüchtlinge“).

2006 Städtebuch Brandenburg und Berlin (wie Anm. 54), S. 201. 
für die katholischen (Diaspora-)Pfarrgemeinden im Land eine vollkommene Veränderung ihrer Basis. Dabei kamen nun sowohl die neuen Gemeindemitglieder als auch die „Flüchtlingspfarrer" oft aus denselben Gebieten, die schon im späten 19. Jahrhundert die typischen Herkunftsregionen gebildet hatten: Ober- und - in etwas geringerem Maße - auch Niederschlesien und Westpreußen sowie das Ermland, ganz neu war nur die „Zuwanderung“ aus dem Sudetenland. Allesamt aber kamen sie gleichwohl in seit Jahrhunderten überwiegend protestantisch geprägte Milieus. Zumeist waren überhaupt erst durch den Zuzug von Arbeitskräften im 19. Jahrhundert während der Industrialisierung und des Kaiserreiches wieder katholische Pfarreien gegründet worden und Gemeinden entstanden. Diese erhielten nun oftmals einen so starken Zuwachs, dass sich - trotz aller Alltagssorgen und Mängel, die zunächst das Leben in der Nachkriegszeit bestimmten - für das Erzbistum Berlin und im Süden (Niederlausitz) das Bistum Görlitz, aus der Sicht der bereits angesessenen Katholiken, in der Gesamtbilanz eine deutliche Bereicherung und Stärkung des katholischen Gemeindelebens ergab.

So kann man zwar keineswegs für jeden Ort, aber doch in manchen Fällen den - sehr zugespitzt formulierten - Befund von Christoph Kösters gerade im kirchlich-konfessionellen Rahmen gelten lassen: „Unter dem Druck der Flüchtlingswelle zerbrachen die überkommenen demographischen Strukturen. Das galt insbesondere für die Verhältnise auf dem Lande und die Konfessionszugehörigkeit. “2007 Wünschenswerte Fallstudien zu einzelnen Kommunen würden freilich auch den Prozentsatz der in der Arbeiterschaft schon zu Beginn der DDR-Säkularisationsepoche nicht ganz geringen Anteil Konfessionsloser noch näher zu beleuchten haben. Neben der im Laufe der Jahrzehnte fortschreitenden Entchristlichung des Landes ist schließlich auch die Abwanderung in den Westen als Faktor zu berücksichtigen. So war zwar allein im Bistum Berlin die Zahl der Katholiken in Stadt und Land (einschließlich Berlins) von 1945 bis 1948 um 25,6 Prozent (Höchtstand 1948: 695000) angewachsen, und entsprechend war für eine geistliche Betreuung zu sorgen, so dass die Zahl der Pfarreien im selben Zeitraum von 187 auf 235 erhöht wurde, die der weiteren Gottesdienststellen gar von 25 auf 78. ${ }^{2008}$ Bis 1954 nahm die Zahl der Katholiken im Berliner Bistum jedoch durch Fortzug von 53000 Gläubigen (13 Prozent) wieder stark ab, nicht wenige von ihnen werden in die Westzonen geflohen sein.

Für die Diaspora-Katholiken in Brandenburg und nicht zuletzt für ihre Geistlichen bedeuteten die Vertriebenen aber nicht nur eine deutliche Vergrößerung ihrer Gemeinden. Viel-

2007 Christoph Kösters: Katholiken in der Minderheit. Befunde, Thesen und Fragen zu einer sozial- und mentalitätsgeschichtlichen Erforschung ders Diasporakatholizismus in Mitteldeutschland und der DDR (1830/401961). In: Wichmann-Jahrbuch des Diözesangeschichtsvereins Berlin, N. F. 4 (1996/97 [1997]), S. 169-204, hier S. 194.

2008 Felix Escher: Die katholische Kirche im 19. und 20. Jahrhundert. In: Tausend Jahre Kirche in Berin-Brandenburg. Hrsg. von Gerd Heinrich. Berlin 1999, S. 647-702, hier S. 680. - Die Urkunden über die Errichtung von Pfarreien und Kuratien sowie über Umpfarrungen sind (nach dem jeweiligen Abdruck im Amtsblatt des Bischöflichen Ordinariats Berlin) zusammenegestellt in: Urkunden-Sammlung zur Geschichte des Erzbistums Berlin von 1600 bis 1994. Hrsg. vom Bistumsarchiv Berlin. Verantw.: Heribert Rosal. Bd. 1-3. Berlin 1994, hier Bd. 3: 1946-1994. (Bd. 2 und 3 enthalten keine Urkunden aus dem Jahr 1945.) 
fach brachten sie auch einen gleichsam spirituellen „Schub“, da viele der aus den Ostgebieten, zumal den ländlichen Regionen Kommenden in ihrer Heimat noch eine tiefere Religiosität gepflegt hatten als die seit längerem der „Verweltlichung“ ausgesetzten Katholiken des Großraums Berlin, wo zudem immer mehr konfessoionelle „Mischehen“ entstanden waren. So vermerkte der auch für Mildenberg (Kr. Templin) zuständige Zehdenicker Pfarrer Joseph Eismann über die nach 1945 hinzugekommenen Flüchtlinge und Vertriebenen: „Die Zugezogenen bildeten bald den lebendigeren Teil der Gemeinde, so in Zehdenick und Mildenberg. "2009 Eine geradezu ungewohnte Ergriffenheit von Gottesdienstbesuchern hatte der Pfarrer Kockott schon 1941 in Schmellwitz bei Cottbus bei „deutschen Rückwanderern aus Polen“ festgestellt. ${ }^{2010}$

Dass die neu hinzugekommenen Gemeindemitglieder ihre auch landsmannschaftliche Identität mitunter sogar selbstbewusst in die Gemeinschaft einbrachten, zeigt ein - freilich wohl seltenes - Beispiel aus der Niederlausitz. In Kirchhain (Kr. Luckau) präsentierten sich seit der Zeit des ab 1949 (bis 1963) amtierenden, selbst aus Schlesien stammenden Pfarrers Stephan Wagner (1910-1963) die Einheimischen ebenso wie die drei größeren landsmannschaftlichen (katholischen) Vertriebenengruppen als gleichberechtigte Teile des Ganzen: „Als ein jährlicher Höhepunkt des Gemeindelebens ist seit dieser Zeit das Fronleichnamsfest anzusehen. Die damals individuell gestalteten und geschmückten Altäre aller zur Gemeinde gehörenden Landsmannschaften sind hierbei besonders hervorzuheben. ${ }^{2011}$ Die Altäre wurden von Angehörigen der betreffenden Gruppen selbst gestaltet: „Alt-Kirchhainer, Schlesier, Sudetendeutsche, Ermländer. ${ }^{2012}$

Der Verfasser der zum hundertjährigen Bestehen 1977 erstellten Chronik der Katholischen Pfarrkirche in Eberswalde, der damalige Pfarrer, schildert bei der Behandlung der Nachkriegszeit zunächst die dramatischen Rahmenbedingungen bei Kriegsende - Seuchen, Hunger, Gewalt - und formuliert dann ganz ungeschminkt: „So sah die Stunde des Anfangs nach dem Kriege aus. Hauptaufgabe war, den vielen Vertriebenen Heimat zu schaffen. Das schien unlösbar, denn die Vertriebenen waren zahlenmäßig mehr als die vorhandene Gemeinde. Heimat in aller Not war die Kirche, der gemeinsame Glaube, der Tabernakel." Es ist kein Einzelfall, wenn der Verfasser der Chronik dann einen Eindruck widergibt, den auch katholische Pfarrer, die selbst Zeitgenossen des Jahres 1945 waren, formuliert haben: „Es klingt wie ein Widerspruch, wenn gerade aus den Notjahren des Anfangs erzählt wird von einer Fröhlichkeit und Geselligkeit, wie sie uns heute fremd sind. Hat uns der Wohlstand satt und müde gemacht? Mehr als dreißig Jahre sind seitdem vergangen, fast ein Drittel des Zeitraums, den wir heute überblicken bei der Hundertjahrfeier. Aber dieses Jahr 1945

200975 Jahre Katholische Kirche Heilig Kreuz in Mildenberg. 1937-2012. Templin (2012), S. 25.

2010 Bericht vom 10.3.1941 in: ELAB, Best. 14 Evang. Konsistorium der Mark Brandenburg, Nr. 582, Bl. 7-8.

2011 Mathias Homagk: 100 Jahre Gemeindegeschichte. In: „Ich gehe mit dem Gedanken um, in Kirchhain einen Betsaal zu bauen ..." Hrsg. von dems. u. Kathleen Hirschnitz. Halle/Saale 2008, S. 44-49, hier S. 50.

2012 Ebd., S. 58, Anm. 28. 
war ein so tiefer Einschnitt in unser Denken, daß wir alle das Empfinden haben: Geschichte - das ist alles das vor 45; seitdem ist für uns Gegenwart. [...]."2013

Doch dies sind sozusagen innerkatholische Nuancen, die in den Nachkriegsjahren wohl vorkamen, aber von vielen, weit existentielleren und profaneren Problemen überdeckt wurden. Viel gravierender als die Begegnung mit „neuer“ Frömmigkeit war das Aufeinanderprallen der unterschiedlichen Konfessionen, das von den Behörden bei der Leitung der Flüchtlingsströme in West wie Ost nur selten bewusst vermieden wurde. Da man vielmehr bei der Verteilung der Vertriebenen weder auf ihre Konfession noch auf die der Einheimischen Rücksicht nahm, kam es an vielen Orten zur Begegnung geschlossen protestantischer Milieus mit vertriebenen Katholiken, die eine Diasporagemeinde begründeten oder verstärkten. Die Folge waren jedoch offenkundig weniger Konflikte als eine Phase geradezu ökumenischen Charakters. Denn in den frühen Nachkriegsnotjahren halfen die Geistlichen beider Konfessionen einander, evangelische Dorfkirchen wurden sehr oft vorübergehend für katholische Gottesdienste zur Verfügung gestellt. Im benachbarten Bistum Dresden/Meißen z. B. gewährten allein 200 evangelische Kirchen den katholischen Vertriebenengemeinden für einen oft nur symbolischen Mietbeitrag bis „hoch in die fünfziger Jahre hinein“ Gastrecht, andere trafen sich in Wohnräumen und Gasthaussälen. ${ }^{2014}$ Überall da, wo plötzlich in größerer Zahl katholische Gläubige lebten, ohne dass schon eine Pfarrei geschweige denn ein ausreichender Kirchenbau in erreichbarer Nähe bestanden hätte, war die Hilfe der evangelischen Kirchengemeinden im Grunde unerlässlich. In der gesamten SBZ/DDR wurden durch Katholiken „1949 knapp 3000 protestantische Kirchen benutzt",2015 ein Phänomen zeitweiliger interkonfessioneller, brüderlicher Hilfe, das auch aus zahlreichen brandenburgischen Gemeinden überliefert ist. ${ }^{2016}$

So berichtet der katholische Pfarrer in Wittstock/Dosse, Karl Hullin, unter dem 15. März 1946 an das Bischöfliche Ordinariat Berlin, auf dessen Fragebogen zur Flüchtlingsseelsorge antwortend: „[...] Gottesdienste habe ich bereits gehalten in Ganz in der ev. Kirche, notwendig wäre dieser noch in Fretzdorf, Grabow, Freyenstein. [Bl. 2] Gottesdienst könnte in den ev. Kirchen der Orte gehalten werden. Die Pastoren haben mir bisher ihre Kirchen ohne Schwierigkeiten zur Verfügung gestellt." ${ }^{2017}$

Dass dieses - sehr häufig praktizierte - Verfahren des Zusammenrückens der beiden Konfessionen gelegentlich auch in umgekehrter Richtung funktionieren konnte, belegt eine Schilderung für Erkner: „Die bittere Zeit verband nicht nur die katholischen Christen untereinander, sondern auch die beiden Kirchengemeinden von Erkner. Man kooperierte in ökumenischer

2013 N[orbert] I[llmann]: 100 Jahre Katholische Pfarrkirche „St. Peter und Paul“ in Eberswalde. (Eberswalde) [1977], S. 27.

2014 Schneider, Seelsorge für Heimatvertriebene in der ehemaligen DDR (wie Anm. 1950), S. 30.

2015 Kösters, Katholiken in der Minderheit (wie Anm. 2007), S. 196.

2016 Siehe z. B. Töpler, Menschenwurm (wie Anm. 147), passim. Auch in vielen Zeitzeugenberichten Geistlicher und auch anderer Personen wird dies für brandenburgische Gemeinden angesprochen.

2017 DAB, I/9-15-1 Flüchtlingsseelsorge 1945-1951, unfol., 15.3.1946, Bl. $1 \mathrm{f}$. 
Verbundenheit sehr eng. In der Not ging man weit über die offiziell zulässigen Grenzen beider Konfessionen hinaus. So fanden im katholischen Pfarrsaal auch evangelische Gottesdienste sowie eine Konfirmation statt. Da die evangelische Gemeinde ohne Pfarrer war [...], hielt von Kiedrowski ${ }^{2018}$ als katholischer Priester selbst eigene Gottesdienste für die evangelischen Mitchristen. Ebenso führte er bei Bedarf evangelische Beisetzungen durch. Bis zur Wiederbesetzung der evangelischen Pfarrstelle wurde er so praktisch zum Pfarrer beider Konfessionen." ${ }^{2019}$ Zumindest vorübergehend kam es auch vor, dass eine evangelisch geprägte Heimatzeitschrift wie die Monatblätter für die Vertriebenen aus Stadt und Kreis Landsberg/Warthe - offenbar ganz selbstverständlich - z. B. auch einen Weihnachtsgruß des (aus Landsberg vertriebenen und nun in Storkow tätigen) katholischen Pfarrers Dubjansky [richtig: Dubianski] ${ }^{2020}$ und die Ankündigung eines katholischen Gemeindetreffens in Schöneweide [Kr. Teltow? abdruckten. $^{2021}$

Dass man allerorten, auch in kirchlichen Fragen zum Improvisieren gezwungen war, konnte auch der damalige Neulehrer Günter de Bruyn (geb. 1926) im Havelland beobachten, wo ein aus Oberschlesien stammender Priester, also ein „Flüchtlingspfarrer“, an dem ihm die „polnisch gefärbte Artikulation des Deutschen“ auffiel, vor einer Trauung die Beichte abnahm: „[...] die Sakristei hinter dem Chorraum, die den Beichtstuhl ersetzen mußte, verschloß keine Tür, sondern ein rotes Tuch. Um aus der protestantischen Helligkeit ein katholisches Dämmern zu machen, waren die Sakristeifenster mit Decken verhängt worden, doch drang die Sonne des heißen Augusttages durch viele Spalten herein. “2022 Die in erster Linie konfessionell bedingte Fremdheit empfand damals auch der selbst katholische, aber seit langem kirchenferne de Bruyn „in der reformatorisch-nüchternen Kirche, wo ein gemalter Luther streng auf die katholische Betriebsamkeit blickte und das nicht verständliche, aber doch vernehmbare Beichtgeflüster zu mißbilligen schien. “2023 Der Priester hatte den Lehrer, um „den staunenden Protestanten auch katholische Pracht bieten [S. 355] zu können“, veranlasst, „eine Meßdienerschar, Musikanten und einen Chor zu bezahlen, und, da Sündenlasten das Sakrament der Ehe unwirksam machten, mich dringend gemahnt, auch zur Beichte zu gehen."2024 De Bruyn schildert, nicht ohne Ironie, die dörfliche Situation, wie sie sich durch Zuwanderung nun immer öfter ergab: „Die katholische Trauung, die der evangelische Dorfpastor nicht ohne Grund als Kindertrauung diffamierte, fand am Sonntag nach der Messe statt; davor wurde die Beichte gehört. Da ich bei allen drei Anlässen zugegen sein mußte, die nichtkatholische Braut nur bei zweien, war die Organisation schwierig und mein Anteil daran peinlich, weil ich den Weg zweimal machen, die Strecke

2018 [Johannes von Kiedrowski, 1931-1950 kath. Pfarrer in Erkner.]

2019 Reinhard und Cornelia Peschke: „Ein Haus voll Glorie ...“ 75 Jahre katholische Kirche Erkner. Erkner 2007, S. 19.

2020 Monatsberichte der ehemaligen Kirchengemeinden von Landsberg (Warthe) Stadt und Land 1948, H. 11/12, S. 2 f.

2021 Ebd. 1948, H. 9, S. 4. - Mit Schöneweide ist wohl das im Kr. Teltow (ab 1952 zum Kr. Luckenwalde) gemeint (oder doch Berlin-Nieder-/Oberschöneweide?).

2022 Günter de Bruyn, Zwischenbilanz (wie Anm. 1253), S. 357.

2023 Ebd.

2024 Ebd., S. 355 f. 
zwischen Hochzeitshaus und Kirche also viermal zurücklegen mußte, an Hunderten von Schau- und Spottlustigen vorbei. Das halbe Havelland war auf den Beinen. Neben den katholischen Flüchtlingen, die der Messe wegen gekommen waren, hatten sich auch viele Neugierige eingefunden; denn seit der Reformation hatte das Dorf keine katholische Hochzeit erlebt." ${ }^{2025}$

Der unerwartet große Zustrom katholischer Vertriebenen auch in bis dahin nahezu rein evangelische Orte zwang zu Notbehelfen. Außer der Mitnutzuung evangelischer Gotteshäuser wurden auch Baracken, Garagen und andere nichtkirchliche Bauten als Provisorien verwendet, aus denen sich bisweilen - nach Umbau und Erweiterung - feste Kapellen und Kirchengebäude entwickelten. In Lenzen (Elbe) etwa, wo 1947 vertriebene sudetendeutsche Katholiken erwähnt werden, fand 1946 die erste hl. Messe zunächst im Schützenhaus statt. „Später konnte man die Sakristei der evangelischen Katharinenkirche nutzen. Schließlich gelang es, den Sitzungssaal der Stadtsparkasse in der Hamburger Str. 23 zu mieten und ihn als Gottesdienstraum herzurichten. Am 8.9.1947 wurde er eingeweiht [... ${ }^{“ 2026}$ Aber auch unter freiem Himmel wurden Gottesdienste veranstaltet. In Orte, in denen anfangs noch die entsprechenden Pfarrstrukturen fehlten, wurden Flüchtlingsgeistliche entsandt. Eine Sonderform bildeten überdies die „Kapellenwagen“2027 des 1952 von dem ab 1947 in der Diaspora-Betreuung der katholischen Vertriebenen in den Westzonen Deutschlands tätigen niederländischen Ordenspriester Werenfried van Straaten (1913-2003) gegründeten Hilfswerks „Kirche in Not“, die in den fünfziger Jahren auch in der DDR eingesetzt wurden. ${ }^{2028}$

Ebd., S. 355.

2026 Brühe, Katholische Kirche zwischen Prignitz und Havelland (wie Anm. 148), S. 27.

2027 Sattelschlepper von 14 Metern Länge, in der Mitte ein zur Seite ausklappbarer Altar.

2028 Der angeblich „letzte existierende ,Kapellenwagen“ des Paters Werenfried van Straten“ wurde 2015 auf dem Flugplatz Werneuchen (Brandenburg) als künftiges Berliner Ausstellungsexponat an die Stiftung „Flucht, Vertreibung, Versöhnung“ übergeben. Kurzbericht mit Bild in: Brandenburger Rundschau 13 (2015) 6, S. 9. 


\title{
V. Spätzeit - Entwicklungen nach 1989
}

\author{
"Ich habe gar nicht gewusst, wie viele Vertriebene hier waren." \\ Ruth Preuß (Neuruppin), $2002^{2029}$
}

Mit Wende und Wiedervereinigung wurden nicht nur freie Meinungsäußerung und Freizügigkeit beim Reisen möglich. Auch juristisch eröffneten sich plötzlich Möglichkeiten, die man wohl aus dem Westfernsehen und von Westverwandten kannte, die aber kein Teil des eigenen Lebens mehr hatten sein können. Nun entstanden bei vielen von jenen, für die plötzlich das Bundesvertriebenengesetz galt, Hoffnungen und Wünsche, ja Forderungen nach Entschädigung oder doch wenigstens nach einem gewissen „Lastenausgleich“.

Die Bundesregierung bereitete auf Drängen des Bundes der Vertriebenen (BdV) eine einmalige Zahlung für alle in der DDR wohnhaft gewesenen Vertriebenen vor, die letztlich Symbolcharakter hatte, aber weder darin zu unterschätzen ist noch in ihrer Bedeutung für finanziell schlecht gestellte Bürger. „Entschädigung“ und „Wiedergutmachung“ in symbolischer, finanzieller Form wurde plötzlich zu einem die Betroffenen elektrisierenden Thema. Liest man die Publikationsorgane der sich Anfang der neunziger Jahre auch in Brandenburg ganz neu bildenden Vertriebenenverbände, so nimmt dies vorübergehend einen nenneswerten Raum ein. Es wurden Hinweise auf zuständige Ämter gegeben, notwendige Voraussetzungen wie die Beschaffung von Nachweisen erläutert und vieles mehr, aber auch weitergehende Forderungen erhoben. ${ }^{2030}$ Die Politik spürte den Handlungsbedarf auch auf Landesebene. So nutzte der brandenburgische Ministerpräsident Manfred Stolpe sein persönliches Grußwort auf der Versammlung Vertriebener aus dem Kreis Züllichau-Schwiebus in Gildenhall bei Neuruppin 1994 auch dazu, die Bestrebungen seiner eigenen Landesregierung hervorzuheben, auf Bundesebene eine Entschädigung von $4000 \mathrm{DM}$ zu beschließen für „die Landsleute, die von östlich der Oder und Neiße kommen und hier geblieben sind“. Dies sei nun dringend. „Ganz abgesehen davon, daß ich jeden Morgen zwischen halb sechs und sechs Uhr von meinem 93jährigen Vater Druck bekomme. Er sagt, ,Wann kommt denn das nun endlich? Was macht ihr da eigentlich solange?" "2031

Diese Vorgänge unterscheiden sich letztlich aber nicht von denen in den anderen neuen Bundesländern $^{2032}$, auch wenn mancher Brandenburger sich in der dem Gesetz vorausgehenden „Lobbyarbeit“ besonders betätigt hat, wie der Rüdersdorfer Reinhold Bujok, der 1992 in Bonn dem Petitionsausschuss des Bundestages eine „Protestresolution und Listen mit 700 Unter-

2029 Ruth Preuß, [Lebensgeschichte] (wie Anm. 395), S. 117.

2030 Beispiel: Landsmannschaft Berlin-Mark Brandenburg: [15] Fragen und Antworten zum Vertriebenenzuwendungsgesetz. In: Oststernberger Heimatbrief (1995)1, S. 4-5 (Nachdruck aus: Märkischer Informationsdienst 10/1994).

2031 Bericht über das Treffen, verfasst von Lothar Meißner, mit Redetext in: Märkischer Informationsdienst 1994, Nr. 6/7, S. 1-3, hier S. 2. - Stolpe und sein Vater sind selbst Vertriebene (siehe unten Anm. 2169).

2032 Siehe den kurzen Überblick in: Amos, Vertriebenenpolitik der SED (wie Anm. 12), S. 250-252. 
schriften“ übergab. ${ }^{2033}$ In seinem Rückblick auf die Rüdersdorfer Verbandsarbeit schreibt Bujok 2002: „Nach meinen Kenntnissen waren wir zumindest im Land Brandenburg die einzigen, die so etwas unternommen haben. 1993 haben sich etwa 30 Mitglieder unserer BdV-Geschäftsstelle, gemeinsam mit mehreren Tausend BdV-Mitgliedern der neuen Bundesländer an einer Protestaktion in Bonn beteiligt. ${ }^{2034}$ Am 27. September 1994 kam dann das entsprechende Bundesgesetz, das „Entschädigungs- und Ausgleichsleistungsgesetz“ (EALG), das einen die Vertriebenen, die bis zuletzt in der DDR gelebt hatten, betreffenden Teil enthält, das „Gesetz über eine einmalige Zuwendung an die im Beitrittsgebiet lebenden Vertriebenen“ (Art. 9 Vertriebenenzuwendungsgesetz $\left(\right.$ VertrZuwG)). ${ }^{2035}$

\section{Vertriebenenverbände in Brandenburg}

Neu war 1990 auch der Wegfall des jahrzehntelang geltenden Vereinigungsverbotes, so dass sich in den neuen Bundesländern nun erstmals ein legales Netz korporativer Strukturen unter Vertriebenen entwickeln konnte. Hierfür boten sich die in den Altbundesländern existierenden Organisationsformen an, so dass sich örtliche Initiativen in Brandenburg mit „Aufbauhilfe“ aus dem Westen begegneten. Soweit Äußerungen dabei aktiver Vereinsgründer vorliegen, war es im Einzelfall durchaus unterschiedlich, von wo die Initiative ausging. Teils bemühten sich die in den westlichen Bundesländern und im nahen (West-)Berlin ansässigen Vertriebenenverbände gezielt um Kontaktpersonen am Ort, teils gingen solche aber auch frühzeitig von sich aus auf erstere zu.

„So gründeten sich in Brandenburg 1990 die ersten Kreis-, Regional- und Ortsverbände des Bundes der Vertriebenen. Anfang 1991 konstituierte sich der Landesverband Brandenburg mit 29 Kreis- und Regionalverbänden sowie landsmannschaftlichen Gruppen. Unterstützt wurde der Landesverband durch den Landesverband Berlin (West), der auf jahrzehntelange

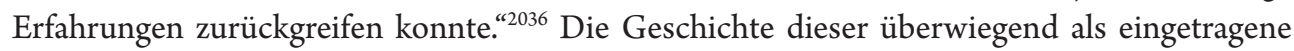
Vereine verfassten und zumeist als gemeinnützig anerkannten Vertriebenenverbände ${ }^{2037}$ ist über seltene und knappe Selbstdarstellungen hinaus - noch zu schreiben, sie kann auch hier nur in groben Ansätzen skizziert werden. Wie stets im Vereinswesen hat es auch mancherlei Auseinandersetzungen auf Grund finanzieller oder sachlicher Interessensgegensätze und vor allem durch persönliche Unverträglichkeiten gegeben, bis hin zu vor Gericht endenden Streitigkeiten zwischen dem Landesverband und einzelnen Mitgliedsverbänden, doch sind dies wohl

2033 Reinhold Bujok: 10 Jahre BdV-Arbeit in Rüdersdorf und Umgebung. In: 10 Jahre Bund der Vertriebenen in Rüdersdorf und Umgebung. Rüdersdorf 2002, S. 9-19, hier S. 11.

2034 Ebd.

2035 BGBl. I S. 2624; 1995 I S. 110.

2036 Oehlsen, Deutsche Vertriebene in Brandenburg und Sachsen (wie Anm. 45), S. 45 (auf der Grundlage von Informationen des BdV-Landesverbandes).

2037 Die steuerliche Freistellung erfolgte bzw. erfolgt laut den Freistellungsbescheiden der Finanzämter für die BdV-Kreisverbände fast stets für die „Förderung der Hilfe für Vertriebene“ (Akten der Landesgeschäftsstelle). 
Ausnahmen. Erschwerend für eine Darstellung ist die vielfach heterogene Gliederung in hier und da geographisch sich überschneidende Kreis-, Regional-, Gebiets- und Ortsverbände des Bundes der Vertriebenen (BdV), der überdies - seiner Doppelstruktur entsprechend - auch die erwähnten landsmannschaftlichen Kreisgruppen, z. B. der Ostpreußen oder Sudetendeutschen usw., einschloss bzw. einschließt, die daher sowohl als seine Gliederungen als auch zugleich als Teile der jeweiligen Landsmannschaft erscheinen (siehe zu allen diesen Verbänden die Angaben in der Ortsdokumentation beim jeweiligen Sitzort).

Schon vor 1990 hatten sich vor allem die auf einzelne Kreise und Städte der Vertreibungsgebiete bezogenen (in der Bundesrepublik ansässigen) Heimatkreisgemeinschaften immer bemüht, Adressen auch in der DDR Lebender zu sammeln und Kontakt zu halten. ${ }^{2038}$ Darauf konnte man aufbauen, auch wenn 1989/90 vielfach doch bei Null angefangen werden musste, da manche Adressen veraltet und Verbindungen abgerissen waren. ${ }^{2039}$ Im einzelnen dürfte es von den individuellen, bisweilen zufälligen Entwicklungen, Aktivitäten und „West-Kontakten“ am Ort bestimmt worden sein, wer sich welcher Organisationsform bediente bzw. welchem Verein anschloss. War es im einen Ort eher der BdV, dem sich eine Gruppe als neuer Ortsverband anschloss, so suchte anderswo ein - dann oft eher informeller - Zusammenschluss Anlehnung an einen der jeweiligen Landsmannschaft nahestehenden Heimatkreis. Letzteres gilt z. B. für die Kyritzer Gruppe der bereits als eingetragener Verein in Euskirchen (Nordrhein-Westfalen) existierenden (schlesischen) „Namslauer Heimatfreunde e. V.“ Ersteres gilt z. B. für die Neugründungen von BdV-Ortsverbänden in Brandenburg an der Havel, Rathenow oder Rüdersdorf. ${ }^{2040}$ Insgesamt ist aber das flächendeckende, alle 1990 bestehenden Kreise - und nach 1993 alle neuen Großkreise - abdeckende Netz der BdV-Kreisverbände das in Brandenburg und generell in den neuen Bundesländern vorherrschende Modell, so dass man durchaus von einer Dominanz des BdV sprechen kann. ${ }^{2041}$ „1993 waren 17800 Brandenburger im Landesverband organi-

2038 Siehe dazu oben das Kapitel IV. 2.

2039 Der Vorsitzende der Heimatkreisvereinigung Züllichau-Schwiebus, Siegfried Reimann (1929-2015), äußerte sich bei dem traditionellen Heimattreffen im Land Brandenburg 2011 gegenüber der Presse, er sei „davon überzeugt, dass gerade in Brandenburg noch mehr frühere Züllichauer und Schwiebuser leben, die noch nie auf einem Heimattreffen gewesen sind oder überhaupt davon wissen, dass es solche Treffen gibt. Das östlichste der vier Treffen in Deutschland, das alljährlich im Seehotel Gildenhall in Neuruppin stattfindet, ist jedenfalls mit rund 500 Teilnehmern immer am besten besucht." (Von Züllichau nach Sulechów. In: Märkische Onlinezeitung, 7.6.2011 [20.9.2016]).

2040 Die Anfänge in Rüdersdorf einschließlich des vorausgehenden Einblicknehmens in die Organisationsstruktur eines westdeutschen BdV-Ortsverbandes schildert der Rüdersdorfer BdV-Gründer und -Vorsitzende Reinhold Bujok: 10 Jahre BdV-Arbeit in Rüdersdorf und Umgebung (wie Anm. 2033), S. 9-12.

2041 Siehe die genaueren Angaben in der Ortsdokumentation unter dem jeweiligen Sitzort. - Im ersten Organisationshandbuch nach der deutschen Wiedervereinigung (Bund der Vertriebenen. Handbuch. 2. Aufl. 1993) heißt es (S. 274): „Bisher wurden 26 BdV-Kreisverbände und eine landsmannschaftliche Landesgruppe gegründet.“ Angaben zu den einzelnen Kreisverbänden enthielt diese erste Ausgabe nach 1989 jedoch noch nicht, und bis zur nächsten Ausgabe (1996) waren bereits die durch die Kreisreform bedingten Änderungen (meist, wenn auch keineswegs immer, Zusammenschlüsse nach „Großkreisen“) vollzogen. 
siert." Durch das erwähnte, 1994 in Kraft getretene Vertriebenenzuwendungsgesetz stiegen „die Mitgliederzahlen auf 35 000“, sanken „aber nach der Zahlung der Zuwendungen wieder ab“2042

Die in den alten Bundesländern ansässigen Heimatkreisgemeinschaften erhielten nun ständig neue Adressen und vergrößerten damit zwar den Kreis der Verteiler ihrer „Heimatbriefe“, aus dem sie zumeist ihren Spenderkreis generieren, als Organisationsform und Interessenvertreteung der Vertriebenen an ihrem Wohnort kamen sie jedoch nicht in Frage. Neben den Vereinsneugründungen entwickelte sich aber vor allem eine große Zahl von Heimattreffen auch in Brandenburg, die wiederum für beide Trägerorganisationsformen Betätigungsfelder eröffnete. Auch sie entstanden daher teils aus örtlicher Initiative, teils wurden sie von den aus den alten Bundesländern agierenden Vereins- und Verbandsfunktionären angeregt. Manches entwickelte sich dabei sogleich Anfang der neunziger Jahre, anderes entstand erst nach der Jahrtausendwende.

Vielfach sahen sich die neuen oder neu hinzutretenden Vertriebenenverbände in Brandenburg Anfeindungen ausgesetzt, wobei die kleineren, an (Heimat-)Kreisen und -Gemeinden orientierten wohl nach und nach leichter Vertrauen bei den Kommunen aufbauen konnten, da sie weniger politisiert als der bundesweite Dachverband „Bund der Vertriebenen“ und die (Bundes-)Landsmannschaften auftraten bzw. nicht als (politische) Interessenvertretung wahrgenommen wurden. Welche kleinteiligen Schwierigkeiten sich aber noch Anfang der neunziger Jahre zum Beispiel auch dem in Hannover ansässigen „Heimatkreis Königsberg/Neumark e. V.“ auf kommunaler Ebene in den Weg stellten, bis 1993 auf dem deutsch gebliebenen Restkreisgebiet nach bürokratischen Umwegen und Verzögerungen ein Gedenkstein für den alten Landkreis Königsberg/Nm. aufgestellt werden konnte, hat der damalige Heimatkreisvorsitzende HansGottfried Bluhm (1924-2010) fünf Jahre später - nun bereits mit größere Gelassenheit erzeugendem Abstand - beschrieben. ${ }^{2043}$ Gerade die Grenz- und grenznahen Städte sind es jedoch, in denen sich nach 1990 einerseits ein besonderes Verhältnis zu den ortsansässigen Vertriebenen und ihren Vertretungen, andererseits intensive Kontakte zu den polnischen Nachbarkommunen entwickelten. So konnte der „Heimatkreis Königsberg/Neumark e. V.“ sein in Westdeutschland aufgebautes Archiv mit Unterstützung des dortigen Bürgermeisters nach Bad Freienwalde (Oder) und damit in unmittelbare Nähe zum ehemaligen Heimat-Kreisgebiet überführen. ${ }^{2044}$

Ein Sonderfall ist der „Gubener Heimatbund“, der - aufbauend auf Vorläufern von 1948 in der Bundesrepublik seit 1952 öffentlich agierte und mit seinen regelmäßigen Publikationen ebenso wie mit mehreren über Westdeutschland verteilten Regionalgruppen zu den stärksten

2042 Oehlsen, Deutsche Vertriebene in Brandenburg und Sachsen (wie Anm. 45), S. 45 (nach Informationen des BdV-Landesverbandes).

2043 Hans-Gottfried Bluhm: Fünf Jahre Gedenkstein für den Heimatkreis Königsberg/Neumark. Eine Posse gerät zum würdigen Denkmal. In: Königsberger Kreiskalender 1998 (1997), S. 155-160. - Christian Ritter: HansGottfried Bluhm (1924-2010). In: Landesgeschichtliche Vereinigung für die Mark Brandenburg. Mitteilungsblatt 114 (2013), S. 55-56.

2044 „Stiftung Heimatkreisarchiv Königsberg/Neumark e.V.“ Näheres und Literatur siehe Ortsdokumentation Bad Freienwalde. 
ostbrandenburgischen Kreis-Heimatverbänden gezählt haben dürfte. ${ }^{2045}$ Der Sonderfall besteht darin, dass sich zumindest in dem westlich der Neiße liegenden Teil der Stadt Guben auch in Deutschland weiterhin ein - nach 1989 auch für in Westdeutschland Lebende wieder vollständig erreichbares - „Stück Heimat“ fand und findet, während die meisten anderen Vertriebenengemeinschaften gleichsam im Exil verbleiben mussten. So konnte sich der „Gubener Heimatbund" nach 1990 allmählich von einem Exil-Verband zu einem wieder bedingt in der Heimat ansässigen entwickeln. Zwar hat auch er seit mehreren Jahren mit Mitgliederschwund und die von ihm in Guben eröffnete Heimatstube mit schwächeren Besucherzahlen zu kämpfen, doch ist dies kein nur auf die Vertriebenenarbeit begrenztes kulturelles Gegenwartsphänomen. Insgesamt hat es der „Gubener Heimatbund“ vielmehr vermocht, sich in der deutschen (Rest-)Stadt Guben fest zu verankern, indem die Ehrenämter nicht nur der schon 1991 am Ort eingerichteten Regionalgruppe, sondern ab 1996 auch die des überregionalen Bundes nach und nach ganz in die Hände von in Guben und Umgebung Ansässigen gelangten: Lebten die Vorsitzenden der Jahre bis 2006 in den Alt-Bundesländern, so wohnten bzw. wohnen die seitdem Amtierenden ausschließlich in Guben. Der erste, der in Guben lebte, Lutz Materne (1940-2011), war schon zehn Jahre zuvor als stellvertretender Vorsitzender in den Vorstand gewählt worden und zudem bereits seit Anfang 1992 Mitglied des Heimatbundes und seiner Gubener Regionalgruppe. Schritt für Schritt wurden die Aktivitäten an die Neiße verlagert, 1995 die bis dahin in Hannover untergebrachte Heimatstube mit Archiv, 1995 führte man auch das jährliche Bundestreffen erstmals in Guben durch. Weitere Stufen und Schritte der Verzahnung waren sicherlich die Verleihung der Gubener Ehrenbürgerwürde an den bis zum Tod in Nordrhein-Westfalen ansässigen Heimatbundvorsitzenden Prof. Dr. Otto Hockwin (1925-2002) und vor allem 2011 die Übernahme von Herausgeberschaft und Redaktion des - am Ort seit DDR-Zeiten, bereits seit 1956, als jährliches Periodikum eingeführten - „Gubener Heimatkalenders“ durch den Heimatbund $^{2046}$. Vergleichbar ist wohl - bedingt - allenfalls noch Forst, wo man schon 1991 den in Lübeck ansässigen Heimatkreisbetreuer der Landsmannschaft Berlin-Mark Brandenburg für Forst Gerhard Krumm (1909-2003) zum Ehrenbürger machte, der vor 1990 zahlreiche Forster Heimattreffen in Westdeutschland organisiert hatte. ${ }^{2047}$ Doch ist in Forst eher auf die Bemühungen um die Andenkenpflege für die Vertriebenen aus dem benachbarten, nun polnischen Sorau zu verweisen. ${ }^{2048}$ Die Beispiele verdeutlichen einmal mehr, dass die Situation in den grenznahen Regionen und Städten nicht mit der im Land sonst vergleichbar ist. Auch die „Einheimischen“ in Guben, Forst oder Schwedt/Oder sind entweder selbst oft Vertriebene bzw. Vertriebenen-

2045 Festschrift zum 50jährigen Jubiläum des Gubener Heimatbundes e. V. 1952-2002. Hrsg.: Gubener Heimatbund e. V. Verantw. Red.: Lutz Materne. Guben 2002. - Lutz Materne: 60 Jahre Gubener Heimatbund. In: Gubener Heimatkalender 56 (2012), S. 26-31.

2046 Gubener Heimatbrief 1/2012, S. 6, $12 \mathrm{f}$.

2047 Märkischer Informationsdienst 1991, Nr. 2/3, S. 4.

2048 Siehe Ortsdokumentation Forst (Lausitz). 
nachfahren, oder die unmittelbare geographische Nähe zu den Vertreibungsgebieten hat die sonst überall eingetretene Distanz zum Thema verhindert.

Der Hauptkritikpunkt, dem sich einige der Verbände, vornehmlich der BdV, immer wieder aussetzen, sind Eigentumsansprüche und Rückgabeforderungen. Betrachtet man daraufhin die regionalen Verbände in Brandenburg, so treten freilich Unterschiede zu Tage, die das Bild deutlich differenzieren. Während sich in den neunziger Jahren, wo manchem vieles nicht unmöglich schien, die BdV-Kreisverbände zu einem erheblichen Teil auch als Interessenverbände verstanden, die für ihre Mitglieder Rechte (in erster Linie aber innenpolitisch) zu erkämpfen suchten, ist dies zwar bis heute grundsätzlich auch noch Teil der Arbeit, tritt aber doch mit dem Auslaufen der Entschädigungsanträge ${ }^{2049}$ allmählich in den Hintergrund gegenüber den heute allenthalben in den Selbstdarstellungen im Internet formulierten Bereichen der historisch-kulturellen Andenkenpflege ${ }^{2050}$, der Erinnerungsarbeit und der völkerverbindenden freundschaftlichen Partnerschaftspflege mit der heutigen Verwaltung und Bevölkerung der Herkunftsorte. In den (brandenburgischen) Kreisverbänden des BdV zeigen sich allerdings ab und zu noch unterschiedliche Töne, was auf die persönliche Einstellung der jeweiligen Amtsträger zurückzuführen sein mag. Während sich mancherorts nicht zuletzt aus Vertriebenenfamilien Stammende der aktuellen Flüchtlingsbetreuung zuwenden, wird andernorts noch immer über Eigentumsfragen diskutiert ${ }^{2051}$. Daraus ergibt sich in einigen Kreisverbänden und vor allem im Landesverband neben dem besonderen Betonen der „völkerrechtswidrigen und menschenverachtenden Vertreibungen der Menschen aus ihrer angestammten Heimat ${ }^{\text {2052 }}$ nach wie vor gelegentlich auch die Forderung nach Entschädigungen und - ausweislich der Texte in seinem Organ „Brandenburger Rundschau" seit 2017 hier und da eine wohl (seit dem Austritt der ehemaligen BdV-Präsidentin Erika Steinbach [geb. 1943 Rahmel, Westpreußen] aus der CDU) stärker werdende politische

2049 Eines der letzten Themen auf diesem Feld ist die „Entschädigung ziviler deutscher Zwangsarbeiter“. V. a. in Polen waren nach Kriegsende nicht wenige der nicht geflüchteten Deutschen in Arbeitslager verbracht worden, die zudem eine hohe Sterberate aufwiesen. 2017 war dies in der vom BdV-Landesverband Brandenburg herausgegebenen „Brandenburger Rundschau“ immer wieder Thema, da die Antragsfrist beim Bundesverwaltungsamt am 31.12.2017 endete. Siehe z.B. die entsprechenden Informationen, aber auch weitere redaktionelle Texte zum „Opfergedenken“ in: Brandenburger Rundschau 15 (2017) 8, S. 9. Die BdV-Landesgeschäftsstelle hat mehrere Betroffene 2017 bei der Abfassung der Anträge beraten und teilweise entsprechende Schriftsätze für die mit Nachweisen verständlicherweise meist Überforderten verfasst (Mitteilung Eberhard Clemens, 2.8.2018).

2050 Beispiel BdV-Kreisverband Kyritz laut einem eigenen Text: „Dabei soll die Pflege unseres Kulturerbes gemeinsam mit Freunden aus unserer ehemaligen Heimat im Vordergrund stehen." Unmittelbar anschließend steht freillich der sehr interpretationsfähig gehaltene Satz: „Von den gewählten Politikern wollen wir Stellungnahmen über uns gemeinsam interessierende Fragen abverlangen." (MAZ, 6.10.2004). - Siehe auch Quellenteil, Nr. 257-259 (Veranstaltungsplanungen und Tätigkeitsbericht ausgewählter BdV-Kreis-/Regionalverbände).

2051 Simone Wendler: Forderungen mit Sprengkraft. In: Lausitzer Rundschau, 3.9.2004 (Diskussionen im BdVKreisverband Cottbus über Forderungen der „Preußischen Treuhand“ nach Rückgabe „im Osten von den Vertreiberstaaten völkerrechtswidrig konfiszierten Eigentums").

2052 Brandenburger Rundschau 10 (2012) 3, S. 17 (BdV-Kreisverband Oberhavel). 
Parteinahme für die „Alternative für Deutschland“ (AfD), die einigen Verfassern offenbar als „letzte Hoffnung“ der organisierten Vertriebenen erscheint. Im Jahres- und Tagesalltag überwiegt jedoch die soziale Betreuungstätigkeit und die Erinnerungsarbeit am Wohnort. So heißt es 2013 über den BdV-Gebietsverband Rathenow in einem (typischen) Bericht über seine im Lutherhaus durchgeführte Jahreshauptversammlung, für ihn habe „insbesondere die Betreuung seiner vielen älteren Mitglieder an Bedeutung gewonnen." Nicht ohne Stolz wird unmittelbar anschließend auf die Anerkennung in der Öffentlichkeit hingewiesen: „Die dazu aufgebauten ehrenamtlichen Strukturen und das Engagement für Spätaussiedler lobte in einem Grußwort Kreisdezernent Henning Kellner, der als Vertreter des Landrates Gast der Versammlung war." ${ }^{2053}$ Die Betreuung und Hilfestellung für einzugliedernde Spätaussiedler wird heute auch in der Politik z. T. als letztes noch akzeptiertes Argument gesehen, weshalb die darin vielfach sehr rührigen Vertriebenenverbände noch eine Existenz- und folglich Förderberechtigung hätten. ${ }^{2054}$ Da aber auch die Aktualität dieses Themas zurückgeht, wird in absehbarer Zeit wohl nur noch die Erinnerungsarbeit - ohne die dann nicht mehr lebenden Zeitzeugen - als Arbeitsfeld im engeren Sinn verbleiben, wie es bei den gesamtdeutsch agierenden Heimatkreisvereinigungen schon jetzt der Fall ist. Allerdings hat sich die Aussiedler-Beratungstätigkeit des BdV inzwischen zu einer allgemeinen, durchaus frequentierten Migrationsberatung entwickelt, die wiederum höchst aktuell ist und insofern eine Zukunft haben könnte.

Insgesamt lässt sich feststellen, dass die nach dem Mitgliederschwund noch verbliebenen brandenburgischen Kreis- und Ortsverbände an ihren Sitzorten gesellschaftlich und politisch öffentlich grundsätzlich akzeptiert wurden und werden, auch wenn dies, wie bei anderen (Wähler-)Gruppen auch, bisweilen wohl mehr formal und oberflächlich gelten mag. Acht brandenburgische Stadt-, Gemeinde- und Amtsverwaltungen haben sich sogar inzwischen entschlossen, „mit 5 Cent pro Einwohner“ Pate der 2000 vom BdV gegründeten Stiftung „Zentrum gegen Vertreibungen" (Sitz: Wiesbaden, Organisationsbüro: Bonn) - nicht zu verwechseln mit der 2008 gegründeten, von der Stiftung Deutsches Historisches Museum getragenen (Bundes-)Stiftung „Flucht, Vertreibung, Versöhnung“ (Sitz: Berlin) - zu werden. ${ }^{2055}$ BdV-Kreisgruppen erscheinen mit ihren Geschäftsstellen inzwischen in amtlichen Wegweisern und Verzeichnissen, und die

2053 Zahlreiche Veranstaltungen dokumentieren engagiertes Verbandsleben. Gebietsverband Rathenow zog Bilanz seiner Arbeit. In: Brandenburger Rundschau 10 (2012), 6, S. 5.

2054 Joachim Kliemann: Zur gegenwärtigen Situation der Spätaussiedler im Land Brandenburg. Bericht des Spätaussiedlerbeauftragten. In: BdV-Notizen 1 (2003) 1, S.3-4. - Dr.-Ing. Joachim Kliemann, Potsdam (geb. 1944, Sohn von Vertriebenen) war 1996-2002 Mitarbeiter der Geschäftsstelle des BdV-Landesverbandes, hier auch Sachbearbeiter für Aussiedlerberatung u. -betreuung und 2000-2007 zugleich (ehrenamtlicher) BdV-Landesaussiedlerbeauftragter. Letzteres Amt hatten zuvor inne: bis 1997 Cornelia Friedrich (geb. 1953), Berlin, 1997-2000 Renate Schulze, Brandenburg/Havel. Seit dem (von der Bundesregierung gewünschten) Wechsel von einer vorwiegend auf russlanddeutsche Spätaussiedler ausgerichteten Beratung zu einer allgemeinen Migrationsberatung 2005 wird die unmittelbare Beratungstätigkeit durch beim BdV beschäftigte ausgebildete Kräfte wahrgenommen (Stand 2018).

2055 Brandenburgische Patengemeinden der Stiftung „Zentrum gegen Vertreibungen“: Bestensee (Gemeindeverwaltung), Eberswalde (Stadt), Leegebruch (Gemeinde), Letschin (Amt), Oranienburg (Stadtverwaltung) 
Landräte und Bürgermeister lassen es sich genauso wenig wie 1994 der Ministerpräsident nehmen, Grußworte auf deren Treffen zu halten. Verständlicherweise sehen die Betroffenen, die zumeist den größten Teil ihres Lebens bereits hinter sich haben, darin mehr Lippenbekenntnisse ohne (finanzielle) Konsequenzen.

Auch die Berichte in der Regional- und Lokalpresse sind überwiegend eher wohlwollend formuliert, Fundamentalkritik kommt zumeist nur noch von der extremen Linken des politischen Spektrums, außerhalb der in Parlamenten vertretenen Parteien. ${ }^{2056}$ Das einzige Thema, das wohl alle in den BdV-Kreisverbänden organisierten Vertriebenen nach wie vor beherrscht und in dem sie sich weder auf Kreis- noch gar auf Landesebene wirklich akzeptiert sehen, ist die Rolle des Themas Flucht und Vertreibung in der allgemeinen Erinnerungs- und Gedenkkultur von Politik, Staat und Gesellschaft, Schulen und Presse, wobei in den beiden letztgenannten Bereichen manche Veränderung zu sehen ist. Immer wieder wird aber auf Versäumnisse und mangelnde Wahrnehmung hingewiesen. Von 1994 bis 2000 wurden daher in Falkenrehde und Brandenburg an der Havel ${ }^{2057}$ neun „Brandenburger Vertriebenenseminare“ als „Beiträge zur Aufarbeitung von Vertreibungsverbrechen " veranstaltet. ${ }^{2058}$ Auch in der vorliegenden Arbeit sind zwar einzelne Bereiche der offiziellen Erinnerungsarbeit des Landes im betreffenden Einleitungskapitel kritisch beleuchtet worden, doch konnten dabei auch die, bis in Schulen hinein, nicht wenigen Belege für eine zunehmende Beschäftigung mit dem Thema in den einzelnen Gemeinden und Kreisen benannt werden. Letzteres wird von den Vertriebenenverbänden insgesamt wohl noch zu wenig gesehen, der einzelne Mensch freilich wird mit dem Blick auf sein eigenes hohes Alter ungeduldig geworden sein.

Eine große Rolle im Verhältnis zwischen den Vertriebenenverbänden und der Landesregierung spielt die von ersteren immer wieder beklagte, wohl als Indifferenz wahrgenommene Zurückhaltung der letzteren bezüglich einer stärkeren Unterstützung jenseits von Grußworten. So sei Brandenburg das einzige Bundesland, das sich nicht zu einer institutionellen Förderung der Verbände entschließen könne. ${ }^{2059}$ Erst 2002 gelang es dem BdV-Landesverband, den damaligen Innenminiter Jörg Schönbohm (1937-2019) (CDU) zu einer jährlichen Zuwendung von 50000 Euro zu bewegen, die aber schon sehr bald auf 20000 und schließlich auf 16000 Euro

sowie die drei zum Amt Wusterwitz gehörenden Gemeinden Bensdorf, Rosenau und Wusterwitz (www.z-g-v. $\mathrm{de} / \mathrm{zgv} /$ patenlaender-und-patengemeinden/ [23.6.2017]).

2056 Siehe dazu unten die Hinweise auf Aktivitäten der Potsdamer „Kampagne gegen Wehrpflicht, Zwangsdienste und Militär“ und der Potsdamer „Antifa-Gruppe“ im Kapitel V, Abschnitt „Gedenkorte“, bes. Anm. 2096.

2057 Das achte Seminar 2001 ausnahmsweise, als „Deutsch-polnisch-russische Begegnung“ im „Kaschubischen Zentrum für Europa“ im Schloss Krockow/Krokowa bei Danzig.

2058 Menschenrechte sind unteilbar. Die Brandenburger Vertriebenenseminare 1994-2000 als Beiträge zur Aufarbeitung von Vertreibungsverbrechen. Hrsg.: Landsmannschaft Ostpreußen, Landesgruppe Brandenburg e. V. und Bund der Vertriebenen-Landesverband Brandenburg e. V. Ziesar 2000.

2059 Dieser Tenor findet sich immer wieder in den entsprechenden Verbandszeitschriften, etwa in der vom BdVLandesverband Brandenburg herausgegebenen „Brandenburger Rundschau“, ist aber auch aus dem Umkreis des ebenfalls nur projektbezogen, nicht institutionell geförderten „Hauses Brandenburg“ in Fürstenwalde und anderswo vielfach zu hören. 
(zuzüglich Eigenmittel des BdV) gesenkt wurde. Dabei handelt es sich zwar - wie auch beim „Haus Brandenburg“ - um keine institutionelle, sondern eine projektbezogene Förderung, mit der aber ein Teil der Geschäftsstellenarbeit aufrecht erhalten werden kann. Auch ein (verbandsinternes) gedrucktes Mitteilungsblatt des BdV-Landesverbandes Brandenburg erscheint erst seit 1999. ${ }^{2060}$ Die drei vom BdV-Landesverband betriebenen Migrationsberatungsstellen in Eberswalde, Berlin-Marzahn und Potsdam werden dagegen durch Mittelzuwendungen des Bundesamtes (!) für Migration und Flüchtlinge (BAMF) nebst Eigenmitteln des BdV finanziert. $^{2061}$

Während die BdV-Kreisverbände Sammelbecken für Vertriebene aus den unterschiedlichsten landsmannschaftlichen Herkunftsgebieten - von Ostpreußen bis in die Sudetengebiete - bilden, haben sich die nicht wenigen im Land Brandenburg lebenden neumärkischen Vertriebenen oftmals auch den betreffenden, vor 1989 in der Bundesrepublik gegründeten und (juristisch) meist weiterhin dort ansässigen Heimatgemeinschaften zugewandt. Unter diesen „Ostbrandenburgern“ im Land Brandenburg, die während der DDR-Zeit keine Möglichkeit zur öffentlichen Betätigung in diesen Bereichen hatten, fand sich nach 1990 mancher motiviert, nun aktiv mitzuarbeiten. So sind unter den Redakteuren ostbrandenburgischer Kreis-Heimatbriefe nach 1990 und teilweise bis heute verstärkt in Brandenburg Lebende. ${ }^{2062}$ Das Potential zu aktivem Mittun bereiter Personen, das den bis 1990 in den alten Bundesländern vielfach an ihre Grenzen geratenen Vereinen, Verbänden und auch Verlagen mit Wende und Wiedervereinigung zuwuchs, sicherte einigen Zeitschriften die Fortsetzung bis über die Jahrtausendwende, zumal auch die Leserschaft nun wieder größer war. ${ }^{2063}$ Inzwischen sind aber schon mehrere dieser ostbrandenburgischen Periodika eingestellt worden, bei weiteren ist dies wohl absehbar,

2060 Anfangs: Brandenburg[-]Nachrichten. Informationsblatt des Bundes der Vertriebenen Landesverband Brandenburg e. V. Nachgewiesen: 1. Ausg. 1999, 4. Quartal, bis 5. Ausg. 2000, 4. Quartal. - Fortsetzung: BdV[-]Notizen. Informationsblatt. Jg. 1, Ausgabe März 2003 (16 S.). Siehe darin, S. 2 f. das Geleitwort von Manfred Walther (Vorsitzender) und Reiner Nowak (1939-2014; geb. Görkau/Sudetenland; stellv. Vorsitzender) „BdV Notizen - unsere Stimme in Brandenburg". Ferner in 1 (2003)6, S. 5 f.: N[ery] Arias Porras: Ein Jahr BdV-Notizen! Eine kritische Bilanz zur Arbeit eines Jahres. Brief der Redaktion an Leser und Schreiber. Die Redaktion lag und liegt in den Händen der BdV-Landesgeschäftsstelle (2002/03 redaktionelle Mitarbeit: Dr. Nery Arias Porras als ABM-Kraft; Redaktion: seit April 2000 [seit 2009 im Impressum genannt]: Eberhard Clemens [geb. 1942 Berlin-Buch]), Geschäftsstellenmitarbeiter (de facto -leiter). Bis zum 7. Jg. (2009) erschien das Blatt zweimonatlich, seitdem erscheint es monatlich (die Jahrgänge 2007/08 sind jedoch nicht erschienen). Der Titel wechselte schon 2004 mit der etwas breiteren Streuung zu „Brandenburger Rundschau“.

2061 Auskünfte der Geschäftsstelle des BdV-Landesverbandes Brandenburg in Potsdam (Eberhard Clemens), 19.7.2017.

2062 Redakteur des Heimatbriefs Weststernberg war z. B. ab 1995 der Journalist Karl-Heinz Schneider, Bernau (geb. 1936 Frankfurt/O., aufgewachsen in Pulverkrug, Kr. Weststernberg). Siehe ders.: Heimatbrief Weststernberg - eine Zeitung auf Spurensuche (Vortrag auf der Konferenz „Was ist Heimat?“ im Collegium Polonicum, 18./19.11.2006). In: Transodra online (www.transodra-online.net/de/node/1391 [30.7.2018]).

2063 [Ohne Verf.:] Welche Aufgaben hat unsere Landsmannschaft und mit ihr die Heimatkreise heute? In: Brandenburgkurier 19 (2005), Nr. 1, S. 2-3, hier S. 2. 
nur wenige haben dem durch Gründung von Stiftungen institutionell oder durch Heranziehung jüngerer Redakteure auch personell zumindest vorübergehend vorbauen können.

In den ostbrandenburgischen Heimatkreisvereinen scheinen sich aber allmählich auch die Leitung und weitere Funktionen in mehreren Fällen nach Brandenburg verlagert zu haben. Nicht nur die große Zahl der hier Lebenden Neumärker und vertriebener (Ost-)Niederlausitzer war bzw. ist dafür ausschlaggebend, sondern auch die Tatsache, dass die betreffenden Heimatkreise im „Haus Brandenburg“ in Fürstenwalde bei Berlin ein geeignetes Zentrum für Zusammenkünfte bekommen hatten. Im Falle des „Heimatkreises Oststernberg e. V.“ beispielswiese lässt sich der Wechsel von in den alten Bundesländern wohnhaften Vorsitzenden (ab 1951: Bad Bramstedt, Sontra-Wichmannshausen, Celle, West-Berlin; ab 1990: Hürth, Gelsenkirchen, Hürth) auf 2001 datieren. Danach saßen die Vorsitzenden in Burg im Spreewald (Ulrich Wilhelm, 2001-2009) und Chorin in der Uckermark (Hans-Dieter Winkler, 2009-2010), zuletzt bis zur Vereinsauflösung 2015 nochmals in Berlin. ${ }^{2064}$

Vielfältig sind die Formen der Beteiligung organisierter, aber auch anderer Vertriebener an deutsch-polnischen Projekten, die den heute ostbrandenburgischen Grenzraum betreffen. In vielen Gedenkstunden, sonstigen Veranstaltungen und Schülerprojekten ${ }^{2065}$ sowie in Denkmalrestaurierungen ${ }^{2066}$ in den Vertreibungsgebieten agieren Vertriebene oder deren Verbände (Heimatkreise) meist in enger Kooperation mit den dortigen Verwaltungen (z. B. Landsberg/ Warthe-Gorzów Wlkp., Sonnenburg-Słońsk u.a.), zuweilen unterstützt von Kommunen im Land Brandenburg. Der inzwischen durch Rückgang der Mitgliederzahlen in Auflösung befindliche BdV-Kreisverband Kyritz e.V. beispielsweise unternahm, wie alle diese regionalen Vereinigungen, zahlreiche Reisen in die Heimatgebiete seiner Mitglieder, widmete sich dabei aber auch „den Kontakten zu den jetzt dort wohnenden Menschen“, etwa durch „Unterstützung der dortigen Altenheime mit Wäschespenden “ ${ }^{2067}$ Mehrere Heimatkreisbetreuer wurden Ehrenbürger ihrer nun polnischen Heimatstädte.

2065 Siehe u. a. die Berichte (z. T. mit Ansprachen deutscher Teilnehmer) in: Brandenburgkurier 28 (2014) 1, S. 3 f. („Tage des Gedenkens und der Versöhnung“ in Landsberg/Warthe-Gorzów Wlkp.), S. 4f. (Gedenken in Sonnenburg-Słońsk an Massaker an Häftlingen des KZ Sonnenburg).

2066 Reinhard Schmook: Erfahrungen beim Wiederaufbau der Marienkriche in Chojna - Königsberg/Neumark ein deutsch-polnisches Stiftungsprojekt. In: Schwierige Nachbarn? (wie Anm. 128), S. 135-141, hier S. 136: 1994 Gründung der polnischen-deutschen „Stiftung Marienkirche in Königsberg/NM-Chojna“ (Fundacja Kościół Mariacki w Chojnie-Königsberg/Neumark; Sitz: Chojna) zum Wiederaufbau der Stadtkirche in Königsberg/Nm. (Chojna) auf Initiative eines bereits 1989 von einigen ehemaligen Königsbergern in Hannover gegründeten Fördervereins. Zu den Mitglidern der Stiftung gehört auch die Stadt Bad Freienwalde (ebd., S. 137). - Projekt „Sanierung des Turmes der Stadtkirche in der Eurostadt Gubin-Guben - Workshop für Kultur, Kunst und Wissenschaft“ (,auf die Initiative der Niederlausitzer Bürger zurückzuführen“): Anna Dziadek / Günter Quiel: Anno 2014. In: Gubener Heimatkalendert 59 (2015), S. 119-125, hier S. 119.

2067 Horst Schnick: Informationen und Überzeugungsarbeit aus „erster Hand“. Kreisverband Kyritz begrüßte Gast aus Berlin. In: Brandenburger Rundschau 10 (2012) 3, S. 15. 
Insgesamt gewinnt man von den brandenburgischen BdV-Verbänden heute - bei einer vorurteilsfreien Betrachtung - den Eindruck auf Versöhnung und Begegnung mit den neuen Bewohnern ihrer Herkuftsgebiete gerichteter Zusammenschlüsse ${ }^{2068}$ in die deutsche Gegenwartsgesellschaft integrierter Staatsbürger, die freilich zunehmend damit hadern, dass erlittenes Unrecht öffentlich nicht angemessen dargestellt und benannt werde ${ }^{2069}$. Dabei betrachtet man die „Charta der deutschen Heimatvertriebenen“ von 1950 in nahezu allen Vertriebenenverbänden Brandenburgs als Leitbild. Sie wird als Grundsatzpapier vielfach in Versammlungen benannt ${ }^{2070}$ und bestätigt und findet sich auch in den Satzungen vieler Vereine verankert ${ }^{2071}$. Teilweise bildet das Datum ihrer Unterzeichnung, der 5. August, auch den Anlass für Gedenkfeiern und Kranzniederlegungen, beispielsweise 2014 durch den BdV-Kreisverband Kyritz in Neustadt/ Dosse. $^{2072}$

2068 Siehe z.B. die Formulierung im Titel des Heimatblattes des „Bundes der Vertriebenen - Kreisverband PotsdamMittelmark mit den Kreisgruppen Ostpreußen/Westpreußen“, der den Zusatz enthält „Begegnungsstätte und Museum für Ostdeutsche Geschichte und Kultur-Brücke zu den östlichen Nachbarn“ (Ausgabe 2017). Siehe auch: Ingrid Schellhaas: Die Entwicklung der Beziehungen zwischen den früheren und jetzigen Bewohnern im jenseits von Oder und Neiße liegenden Teil der ehemaligen Provinz Brandenburg. In: Brandenburgkurier 23 (2009), Nr. 1, S. 7.

2069 Entsprechend findet sich auf dem Titelblatt des in der vorigen Anm. genannten BdV-Heftes unten links sozusagen zusätzlich der Satz von Simon Wiesenthal „Es gibt keine Freiheit ohne Gerechtigkeit und keine Gerechtigkleit ohne Wahrheit".

2070 Z.B. heißt es im Bericht über die in am 3.3.2012 Oranienburg durchgeführte Mitgliederversammlung des BdV-Kreisverbandes Oberhavel: „In einer regen Diskussion über die weitere Arbeit wurden folgende Zielstellungen für die Arbeit des Kreisverbandes beschlossen: Leitlinie unseres Handelns war, ist und bleibt die Charta der Heimatvertriebenen von 1950. Nichts, aber auch gar nichts, haben wir mit der braunen Ideologie und ihren Vertretern gemeinsam. Von der braunen Ideologie grenzen wir uns ganz klar und eindeutig ab. [...]." (Brandenburger Rundschau 10 (2012) 3, S. 17). - Selbst in Todesanzeigen wird sie bisweilen erwähnt, hier für den 2013 verstorbenen Helmut Lipske: „Als Vorsitzender des Kreisverbandes Oberspreewald-Lausitz des BdV seit Juni 1995 stand er mit seinen Mitgliedern fest auf den Grundsätzen der Charta der Vertriebenen" (Brandenburger Rundschau 11 (2013) 8, S. 6). - Der Text der Charta findet sich vielfach, auch als Einzelblatt, gedruckt (online zugänglich u. a.: www.bund-der-vertriebenen.de/charta-der-deutschen-heimatvertriebenen/charta-in-deutsch.html [21.8.2018]). Siehe allgemein und zur kontroversen Bewertung: Matthias Stickler: Charta der deutschen Heimatvertriebenen. In: Online-Lexikon zur Kultur und Geschichte der Deutschen im östlichen Europa, 2012. URL: ome-lexikon.uni-oldenburg.de/54028.html (Stand 02.06.2015).

2071 Siehe die betreffenden Auszüge aus Satzungen im Quellenteil (Nr. 245-254) sowie das Interview mit einer BdV-Kreisverbandsvorsitzenden (Nr. 260). - Für die gewährte Einsicht in die Satzungen der BdV-Kreisverbände ist Herrn Clemens von der BdV-Landesgeschäftsstelle in Potsdam zu danken.

2072 Horst Schnick: 64 Jahre Charta der deutschen Heimatvertriebenen. Gedenkfeier und Kranzniederlegung des BdV Kyritz. In: Brandenburger Rundschau 12 (2014) 9, S. 5. 


\section{"Haus Brandenburg"}

Nach einer längeren Vorgeschichte und Standortsuche $e^{2073}$ ab 1990 verlagerte die bis dahin in ihrem Patenland Baden-Württemberg ${ }^{2074}$ ansässige Landsmannschaft Berlin-Mark Brandenburg ${ }^{2075}$ ihre auf das brandenburgische Vertreibungsgebiet (Neumark und östliche Niederlausitz) konzentrierte Bibliothek ${ }^{2076}$ in das Land Brandenburg, wo seit 1999 das neu (als Fertighaus) erbaute „Haus Brandenburg“ in Fürstenwalde/Spree für die Unterbringung von Bibliothek und Archiv sowie für Ausstellungen, Vorträge, Treffen und Sitzungen vielfältig genutzt wird. ${ }^{2077} 2002$ übereignete die Landsmannschaft das Haus an die von ihr 1974 in Baden-Württemberg gegründete Stiftung Brandenburg, die seitdem das Haus betreibt. ${ }^{2078}$

Das „Haus Brandenburg“, das in seiner Position im Fokus der Landesregierung schon kurz behandelt worden ist und an dessen Einweihung auch der brandenburgische Ministerpräsident Manfred Stolpe teilnahm, verweist einmal mehr auf einen besonderen Aspekt des Vertreibungsthemas im heutigen Brandenburg, in dem sich das Land zumindest von Sachsen-Anhalt und Thüringen sowie Berlin und ohnehin sämtlichen Alt-Bundesländern unterscheidet. Brandenburg hat nicht nur, wie alle anderen deutschen Länder, Vertriebene aufgenommen, sondern ist

2073 Zunächst war an Frankfurt (Oder)-Rosengarten gedacht. „Die Stadtverwaltung Frankfurt/Oder wollte das ehemals im Besitz der Familie Schulz-Rosengarten befindliche Gutshaus an die Landsmannschaft Berlin-Mark Brandenburg verkaufen. Sie veranschlagte einen Wert von 860000 DM, bei Reparaturkosten von 1400000 DM. Mit Widerständen im Stadtparlament sei jedoch zu rechnen, erklärte der Oberbürgermeister." Nach Verkauf des Gutshauses an einen Privatmann, „wohl dem ehemaligen Besitzer Schulz“, der unter bestimmten Bedingungen das Haus der Landsmannschaft schenken wollte, kam mit diesem jedoch (1997) keine Einigung zustande, auch überschritten die absehbaren Instandsetzungskosten die finanziellen Möglichkeiten der Landsmannschaft. (Darstellung nach Werner Vogel: Die Stiftung Brandenburg. Geschichte, Aufgaben, Wirksamkeit. In: Historiker und Archivar im Dienste Preußens. Festschrift für Jürgen Kloosterhuis. Hrsg. von Hans-Christof Kraus u. Frank-Lothar Kroll. Berlin 2015, S. 245-262, hier S. 252.) Bei der Suche nach einem Grundstück für ein - nun in Aussicht genommenes - Fertighaus kam man auf den heutigen Standort in Fürstenwalde, Parkallee 14, „dessen Erwerb nach intensiven Verhandlungen mit [S. 253] der Stadtverwaltung und den städtischen Abgeordneten, die davon überzeugt werden mussten, dass die Stiftung Brandenburg kein revanchistisches Unternehmen ist, letztlich gelang." (ebd., S. 252 f.).

2074 Die Patenschaft bestand seit 11.5.1965 (Beschluss des Ministerrates). Bader, Patenschaften über Brandenburger Heimatvertriebene (wie Anm. 1860), S. 5.

20752015 umbenannt in Landsmannschaft Ostbrandenburg/Neumark (Brandenburger Rundschau 13 (2015) 6, S. 12).

2076 In der Stuttgarter Zeit hatte der Bibliothekar der Stiftung, Dipl.-Bibl. Ch. Assenbaum, einen gedruckten Katalog bearbeitet: Bibliothek der Stiftung Brandenburg Stuttgart. Bestandskatalog 1991. Bearb. von Christian Assenbaum. Stuttgart 1991. Assenbaum wurde wegen der finanziellen Belastung durch den Neubau noch vor dem Umzug gekündigt.

2077 Vogel, Haus Brandenburg (wie Anm. 70). - 2017 wurden Verhandlungen mit der Stadt Frankfurt (Oder) über eine Verlagerung nach dort geführt.

2078 Vogel, Stiftung Brandenburg (wie Anm. 2073). - Dietrich Handt: Stiftung Brandenburg. In: Brandenburgkurier 20 (2006), Nr. 2, S. 2-6. - Schenkungsvertrag vom 19.2.2002 (Vogel, Haus Brandenburg [wie Anm. 70], S. 408). Übergabe der Trägerschaft bereits durch Beschluss der "Brandenburgischen Landesversammlung“ 24.3.2001 (Vogel, Stiftung Brandenburg [wie vor], S. 254). 
selbst, wie Mecklenburg-Vorpommern und mit dem Reichenauer Gebiet auch Sachsen, gewissermaßen Vertreibungsopfer durch Gebietsverluste, indem etwa ein Drittel der Vorkriegsfläche der Provinz Brandenburg heute zu Polen gehört. Der Pflege von Kultur und Geschichte dieses brandenburgischen Vertreibungsgebietes ist das „Haus Brandenburg“ gewidmet. Für das Land Brandenburg, seine Regierung, seine Menschen und seine historisch arbeitenden Institutionen sind folglich beim Thema Flucht und Vertreibung stets zwei Bereiche zu bedenken: zum einen das Schicksal der ins Land, nach Brandenburg gekommenen Flüchtlinge und Vertriebenen, zum anderen aber auch die Beschäftigung mit der Pflege des Andenkens an das historische Ostbrandenburg (östlich von Oder und Neiße), zu unterscheiden vom heutigen Ostbrandenburg (etwa zwischen Berlin und der polnischen Grenze). ${ }^{2079}$ Während der erstgenannte Themenbereich hier im Mittelpunkt steht und immerhin auf eine Vielzahl von Entwicklungen und Aktivitäten seit 1990 verwiesen werden konnte, stellen sich bei der Frage nach Brandenburgs Umgang mit seinen eigenen „historischen Ostgebieten“ weitere Fragen, die über den hier interessierenden Radius hinausgehen. Es scheint aber, dass man zum einen die Chance zur Verknüpfung beider Bereiche in der Erinnerungarbeit bislang kaum nutzt, zum anderen die Pflege der Kultur des historischen Ostbrandenburg, wie sie im $\$ 96$ Bundesvertriebenengesetz für alle Vertreibungsgebiete formuliert ist, überwiegend von den Betroffenen selbst betrieben wird. Weder hat sich das Land Brandenburg bisher zu einer - nicht nur kulturell-publizistische und bibliothekarische, sondern wissenschaftliche Arbeit im „Haus Brandenburg“ ermöglichenden - institutionellen Förderung der Stiftung entschließen können, noch hat der Bund die Lücke geschlossen, die dadurch entstanden ist, dass für das nie selbständig gewesene Teilterritorium Neumark/Ostbrandenburg - anders als für Pommern, West- und Ostpreußen oder Schlesien - kein Landesmuseum existiert.

Bis zur Wende hatte das Bundesland Baden-Württemberg als Patenland für Ostbrandenburg die Landsmannschaft Berlin-Mark Brandenburg ,jährlich mit einem Betrag von rund 100000 DM gefördert, der im Landeshaushalt eingestellt war. Die Verwendung des Geldes musste auch nach den Landesrichtlinien abgerechnet werden. "2080 Der langjährige (1985-1999) Bundessprecher (Vorsitzende) der Landsmannschaft, der aus der Niederlausitz gebürtige (nicht zum Kreis der aus den Ostgebieten Vertriebenen zählende) Journalist Werner Bader (1922-2014), hat 2007 rückblickend das Schicksal dieser Patenbeziehung geschildert: „Diese Patenschaftsmittel für die Landsmannschaft Berlin-Mark Brandenburg wurden nach der Wende in wenigen Jahren bis auf 20000 DM gesenkt, mit der Begründung, nun hätten die Brandenburger ja mit ihrem Bundesland Brandenburg den größten Teil ihrer Heimat wieder, und das Land Brandenburg müsse die Förderung der Landsmannschaft übernehmen. Die Patenschaft wurde aufgelöst. “2081 Bader konnte dann zwar in Verhandlungen noch erreichen, dass der jährliche Betrag von 20000 DM, den man ,für Verwaltungsaufgaben und für die soziale und kulturelle Arbeit" verwendete, noch bis 2006 weiter

2079 Reinhard Schmook: Wo liegt „Ostbrandenburg“? Zur Geographie und Geschichte der historischen Region. In: Königsberger Kreiskalender 71 (2016), S. 32-39.

2080 Bader, Patenschaften über Brandenburger Heimatvertriebene (wie Anm. 1860), S. 2.

2081 Ebd. 
gezahlt wurde. Dann aber endete die Beziehung der vertriebenen (Ost-)Brandenburger in den deutschen Südwesten endgültig. „Mit Genehmigung der jeweiligen Innenministerien“ verlegte „die Stiftung Brandenburg im Dezember 2007 ihren Sitz vom Land Baden-Württemberg in das Land Brandenburg “2082 Auch der im Kreis Spremberg geborene Bader siedelte sich nun in Brandenburg (Görne, Havelland) an, wandte sich aber dann anderen, gesamtbrandenburgischen Feldern der Kultur- und Literaturgeschichte zu. ${ }^{2083}$ Die erwartete Übernahme bzw. Weiterführung der Patenschaft durch das Mutterland Brandenburg trat nicht ein, wie der Kurator des „Hauses Brandenburg“, Werner Vogel, 2015 resigniert feststellte: „Das Land Baden-Württemberg zog sich Ende 2006 aus der institutionellen Förderung der Stiftung Brandenburg zurück und gab zugleich seinen Sitz im Stiftungsrat auf. Es gelang freilich trotz intensiver Bemühungen nicht, die Regierung des Landes Brandenburg zur Nachfolge und Übernahme eines Sitzes im Stiftungsrat zu bewegen, obwohl die gesetzliche Auflage des Bundes bei der Gründung der Stiftungen 1974 dies verlangte." 2084

Im März 2008 dankte Vogel als Stiftungskurator im landsmannschaftlichen Mitteilungsblatt dem bisherigen Patenland und wies einer Fortsetzung in Brandenburg diplomatisch den Weg: „Dem Land Baden-Württemberg gebührt zum Abschied unser herzlicher Dank für die jahrzehntelang großzügig gewährte finanzielle Unterstützung und für die engagierte Mitarbeit im Stiftungsrat. Unsere Hoffnung, daß das Land Brandenburg in gleichem Maße die Nachfolge antreten wird, hat insoweit einen guten Anfang genommen, als uns im vorigen Jahr ein ansehnlicher Beitrag zu den Personalkosten und für die wissenschaftliche Erschließungsarbeit der Bestände des Hauses Brandenburg gewährt wurde. Sehr erfreulich entwickelte sich dabei die Zusammenarbeit mit dem Ministerium für Wissenschaft, Forschung und Kultur. “2085 Vogels unermüdliche Verhandlungen konnten zwar an der Grundentscheidung der Landesregierung nichts ändern, schufen aber Vertrauen und führten zu einer langsamen Annäherung, die die Zahlung von Projektzuschüssen ermöglichte. So heißt es 2010 im landsmannschaftlichen Mitteilungsorgan: „Nach vielen Mühen und zahlreichen Gesprächen konnten erfreuliche Kontakte zur Brandenburgischen Landesregierung hergestellt werden, die u. a. ihren Ausdruck fanden in einem immerhin hilfreichen jährlichen Zuschußzu den Personalkosten des Hauses sowie zu einer zweijährigen Maßnahme zur elektronischen Erfassung der inzwischen im Haus Brandenburg befindlichen Heimatstuben." 2086

2082 Der Kurator: Stiftung Brandenburg in Fürstenwalde (Spree). In: Brandenburgkurier 22 (2008), Nr. 1, S. 1.

20832003 Gründung eines „Kulturfördervereins Mark Brandenburg“, 2009 Aufstellung einer Fontane-Büste ebd., Einrichtung einer Bibliothek (und Lese-Café) in Görne (inzwischen aufgelöst), 2010 Planung einer „Dichterstraße“ im Land Brandenburg, allesamt jedoch Episoden, die vielleicht der Eitelkeit ihres Stifters dienen mochten, aber ohne jede „Nachhaltigkeit“ geblieben und längst wieder von der Bildfläche verschwunden sind. Siehe gleichwohl die positive Würdigung von Peter Dietze: Abschied von Werner Bader. In: Rathenower Heimatkalender 59 (2015 [2014]), S. 65-67.

2084 Vogel, Stiftung Brandenburg (wie Anm. 2073), S. 255; zur Frage des vom Land zu übernehmenden bzw. diesem einzuräumenden Sitzes im Stitungsrat S. 248 f., siehe auch Text der Stiftungssatzung von 1974 ebd., S. 260 ( $\$ 6$ Abs. 3 b).

2085 Ebd.

2086 [Ohne Verf.: Neuer Kurator der Stiftung Brandenburg. In: Brandenburgkurier 24 (2010), Nr. 1, S. 1. - Siehe auch: Werner Vogel: Rückblick auf das Jahr 2008 und Vorschau für 2009. In: Brandenburgkurier 23 (2009), 
Auch Vogels Nachfolger als Kurator, Hans-Christian Petzoldt, konnte in der Bilanz seiner kurzen Amtszeit 2010/11 nur auf kleine Fortschritte verweisen: „Erstmals ist es gelungen, von Seiten der Bundesregierung Geldmittel für zwei Projekte der Stiftung zu erhalten. In den Bewilligungsschreiben wird ausdrücklich anerkannt, dass die Region Brandenburgs östlich von Oder und Neiße Vertreibungsgebiet und somit förderfähig nach $\$ 96$ des Bundesvertriebenengesetzes ist. Wir müssen diese Bescheide als Erfolge werten, auch wenn das eigentliche Ziel, die sogenannte institutionelle Förderung, (noch) nicht durchsetzbar war. Mit diesen Geldmitteln sind zwei wesentliche Wirkungen des Hauses Brandenburg gestärkt worden. Zum einen wurde mit der deutsch-polnischen Fotoausstellung ,Landschaft ohne Grenzen - zwei Länder - eine Landschaft' die Zusammenarbeit und Verständigung mit den jetzt polnischen Bewohnern verbessert und gepflegt. Zum anderen wurde das Projekt ,Digitalisierung und Online-Stellung von Sammlungen der Stiftung Brandenburg' bearbeitet und ist seit kurzem jedermann zugänglich. Die Neumark, das historische Ostbrandenburg, wird präsentiert und erreicht nun eine große Öffentlichkeit über das Internet. Das historische Ostbrandenburg wird überliefert und der Nachwelt nahegebracht!"2087

Petzoldts verhaltener Optimismus verweist auf das große Potential, das in den immer umfangreicher werdenden Sammlungen des Hauses, aber auch im zunehmenden Interesse von Teilen der brandenburgischen Öffentlichkeit sowie polnischer Wissenschaftler liegt. Ohne eine dauerhafte Anbindung an eine wissenschaftliche Einrichtung oder die Schaffung eigener wissenschaftlicher Arbeitsmöglichkeiten im Haus wird es freilich auf Dauer brach liegen, jedenfalls nicht die Funktion ausüben können, die ihm 2009 im Konzeptpapier zur zeitgeschichtlichen Erinnerungskultur im Land Brandenburg zugewiesen worden ist. ${ }^{2088}$ Zur Zeit der Abfassung dieser Zeilen, 2017, prüfte die Stiftung Möglichkeiten einer Übersiedlung des mit seinen laufend wachsenden Sammlungen aus allen „Nähten“ platzenden Hauses nach Frankfurt (Oder). Damit würde zwar der logistische Vorteil zentraler Lage am Stadtrand Berlins, der immer auch ein Angebot an die dort lebenden Forscher war und ist, aufgegeben. Doch die stärkere Vernetzung mit der Europa-Universität Viadrina in Frankfurt (Oder) und die unmittelbare Nachbarschaft zu jenem Raum, um den es geht, dürfte der Sache am Ende doch den notwendigen größeren Schub bringen, ohne den wohl - auf längere Sicht - Stillstand einträte.

Nr. 1, S. 1-2, hier S. 2. - [Ders.: 10 Jahre Haus Brandenburg in Fürstenwalde (Spree). In: Brandenburgkurier 23 (2009), Nr. 1, S. 1-2, hier S. 2. - Peter Bahl: Werner Vogel (1930-2016). In: Jahrbuch für brandenburgische Landesgeschichte 68 (2017), S. 317-320, hier S. 319.

2087 Hans-Christian Petzoldt: Zentrum für Kulturgut der Ostbrandenburger stärken und ausbauen. Rückblick des Kurators der Stiftung Brandenburg auf seine zu Ende gehende Amtszeit 2010-2011. In: Brandenburgkurier 25 (2011), Nr. 4, S. 2.

2088 Geschichte vor Ort (wie Anm. 59). Siehe dazu oben im Einleitungskapitel I.2 den Abschnitt ,Zeitgeschichtliche Erinnerungsarbeit - Initiativen der Landesregierung“. 


\section{Gedenkorte}

Mit Wende und Wiedervereinigung wurde es auch in den neuen Bundesländern möglich, Flucht und Vertreibung öffentlich zu gedenken. Während im Westen Deutschlands, besonders in den fünfziger und nochmals in den achtziger Jahren, bereits eine große Zahl an Denkmälern geschaffen worden war (2010 wurden dort 1287 gezählt), erlebte zwar der Osten in den neunziger Jahren ebenfalls eine Hochphase der Denkmalserrichtung, doch sind bis 2010 insgesamt nur 59 Fälle bekannt geworden, die meisten (46\%) in Thüringen, während alle anderen neuen Bundesländer deutlich geringere Zahlen von Vertriebenendenkmälern (zwischen 10 und 17\%) aufweisen. ${ }^{2089}$ Dabei ist allerdings berücksichtigen, dass die gedruckten und online gestellten Listen hierzu wohl selten, für Brandenburg bislang durchweg nicht vollständig sind ${ }^{2090}$ Mancher kleine Gedenkstein eines örtlichen Verbandes in einer Landgemeinde oder Kleinstadt wird kaum überregional wahrgenommen, was freilich auch vor Vandalismus schützen kann, also bisweilen gezielte Informationsbegrenzung auf den Kreis der Teilnehmer an lokalen Gedenkfeiern bedeuten mag. Hinzu kommt, dass inzwischen mehrere Heimatgemeinschaften eines einzelnen Ortes oder Kreises der Vertreibungsgebiete nicht nur an bestimmten Plätzen im heutigen Deutschland, z.B. auf Friedhöfen, Denkmäler errichtet haben, sondern nicht selten auch - im Zusammenwirken mit den polnischen Bürgermeistern - in ihren Herkunftsorten. ${ }^{2091}$ Auffällig ist die in den neuen Bundesländern dominierende Rolle des BdV (bzw. seiner Kreisverbände) als Initiator in „66 \% aller Denkmalsetzungen“, während im Westen nur $17 \%$ auf ihn zurückgeführt werden können. ${ }^{2092}$ Zumindest in Brandenburg erklärt sich das mit seiner oben

2089 Hans Hesse: Denkmäler und Gedenkstätten der deutschen Vertriebenen. In: Lexikon der Vertreibungen (wie Anm. 59), S. 114-117, hier S. 115. Siehe auch: Stephan Scholz: Vertriebenendenkmäler - Topographie einer deutschen Erinnerungslandschaft. Paderborn 2015; ders.: Denkmäler. In: Die Erinnerung an Flucht und Vertreibung (wie Anm. 1486), S. 75-88; ders.: Vertriebenendenkmäler. In: Online-Lexikon zur Kultur und Geschichte der Deutschen im östlichen Europa, 2014, ome-lexikon.uni-oldenburg.de/62398.html (Stand 24.8.2015).

2090 Mahn- und Gedenkstätten der deutschen Heimatvertriebenen. Hrsg.: Bund der Vertriebenen - Vereinigte Landsmannschaften und Landesverbände. Bearb.: Heinrich Kucharczyk. Bonn 2008. - Mahn- und Gedenkstätten Brandenburg. Hrsg.: BdV (www.bund-der-vertriebenen.de [20.9.2016]). - Unvollständig auch: Wikipedia/Liste der Vertriebenendenkmale in Brandenburg [19.7.2017].

2091 Z.B. auf dem Ostfriedhof in Gubin (Lutz Materne: Weihe eines Gedenksteines auf dem früheren Ostfriedhof. In: Gubener Heimatbrief 1/2004, S. 25-27) und in vielen weiteren Stadt- und Landgemeinden der Neumark und der östlichen Niederlausitz. Eine vom BdV-Landesverband Brandenburg in Kooperation mit Werner Bader zusammengestellte „Übersicht der Gedenksteine und Gedenktafeln in deutsch und polnisch“ für den Bereich der ehemals brandenburgischen Kreise in Polen enthält bis einschließlich 200046 Nummern (thematisch weit gefasst, einschließlich auf einzelne Persönlichkeiten bezogener Gedenktafeln, aber mehrheitlich allgemeiner Gedenksteine/-tafeln „für die [deutschen] Verstorbenen“). Nr. 1 ist „vor 1992“ datiert, die weiteren Aufstellungsjahre sind (in Klammern die Anzahl): 1992 (1), 1993 (9), 1994 (3), 1995 (14), 1996 (2), 1997 (3), 1998 (3), 1999 (4), 2000 (6) (Liste zur Verfügung gestellt von der BdV-Landesgeschäftsstelle in Potsdam, 18.7.2017).

2092 Ebd., S. 117. 
bereits angesprochenen Dominanz als meist sozusagen einziger offizieller Vertriebenenvertretung, während die Landsmannschaften und ihre Landesverbände ebenso wie die auf einzelne Herkunftskreise bezogenen Heimatkreisgemeinschaften stärker vom Wohnort der Mitglieder unabhängig arbeiten. Außerdem gibt es kaum noch größere öffentlich bekannte bzw. sichtbare landsmannschaftliche Konzentrationen in einzelnen Orten oder Kreisen Brandenburgs. Am einzelnen Wohnort, im einzelnen Landkreis ist man ohnehin - mit dem starken altersbedingten Rückgang der Interessentenzahlen - pragmatisch und agiert bisweilen in Personalunion zwischen BdV-Kreisverband und Kreisverband einer Landsmannschaft. ${ }^{2093}$

Die Initiative zur Aufstellung und die Antragstellung für Genehmigungen übernahmen meist einzelne besonders engagierte Personen aus dem Kreis der am Ort lebenden Vertriebenen, die sich zuweilen über mehrere Jahre um eine schrittweise lokalpolitische Akzeptanz in Parteien und Verwaltungen bemüht hatten. Ihre Berichte sind voll von Erlebnissen mit Reserviertheit oder gar offener Ablehung auf Seiten der lokalen Öffentlichkeit und der Verwaltung, wobei am Ende meist doch sogar eine nennenswerte Zahl von Vertretern des öffentlichen Lebens an den Einweihungsfeierlichkeiten teilnahm. In Rüdersdorf beispielsweise, wo der BdVKreisvorsitzende Reinhold Bujok (1928-2015), ein aus Beuthen gebürtiger Oberschlesier, seit 1998 um die Aufstellungsgenehmigung bemüht war, waren anfangs 20 von 22 Abgeordneten der Gemeinde gegen die vorgeschlagene Form, stimmten aber 1999 doch mehrheitlich dafür, als man sich auf die Reduzierung auf einen Inschriftentext ohne die gewünschten alten ostdeutschen Provinzialwappen geeinigt hatte. ${ }^{2094} 2000$ schließlich nahmen der Bürgermeister und Bujok gemeinsam die Enthüllung vor, unter den über 200 Teilnehmern waren Vertreter der Landkreisverwaltung, die Amtsdirektorin, mehrere Bürgermeister benachbarter Landgemeinden, Vertreter der CDU und der PDS u. v. a. „Unter dem Klang der Kirchenglocken weihten und segneten der Pfarrer der katholischen Kirche Herr J. Reetz und der Pfarrer der evangelischen Kirche Herr Ch. Langhammer den Gedenkstein ein." Da zudem auch der Rüdersdorfer Schützenverein, die Rüdersdorfer Bergmannskapelle, der Fürstenwalder BdV-Chor für eine musikalische Umrahmung sorgten und nicht zuletzt auch „Delegationen von Rußlanddeutschen und von der deutschen Minderheit aus Polen“ anwesend waren, gestaltete sich die feierliche Zeremonie zu einem keineswegs nur vertriebeneninternen Ereignis.

Während diese Formen der örtlichen und kleinregionalen Symbiose, mindestens aber Duldung wohl die Regel bilden, stand der - mehrfach beschmierte - Gedenkstein in der Landeshauptstadt Potsdam dagegen von Anfang an im auch überregionalen Rampenlicht. ${ }^{2095}$ So konnte seine Einweihung an prominenter Stelle direkt neben dem Alten Rathaus am 15. No-

2093 Siehe die jeweiligen Angaben in der Ortsdokumentation.

2094 Das Folgende nach: Gustav Niedzballa: Ein Stein des Gedenkens und der Versöhnung und nicht ein Stein des Anstoßes. In: 10 Jahre Bund der Vertriebenen in Rüdersdorf und Umgebung. Rüdersdorf 2002, S. 23-26, Zitate S. 25.

2095 E[berhard] C[lemens]: Gedenkstein für die Opfer von Flucht und Vertreibung am Alten Markt in Potsdam erneut beschmiert. In: Brandenburger Rundschau 3 (2005) 2, S. 24-25. 
vember 2003 nur unter starkem Gegenwind anwesender Kritiker durchgeführt werden. Während der bekannte SPD-Politiker und ehemalige DDR-Bürgerrechtler Markus Meckel (geb. 1952 Müncheberg) vor etwa 150 Anwesenden als offizieller Festredner (anstelle des eigentlich vorgesehenen Ministerpräsidenten Platzeck) sprach, protestierten die Potsdamer „Kampagne gegen Wehrpflicht, Zwangsdienste und Militär“ und die Potsdamer „Antifa-Gruppe “ lautstark und entrollten auch im vorausgehenden ökumenischen Gottesdienst in der benachbarten Nikolaikirche (Predigt: Stadtpfarrer Martin Vogel) Transparente vor dem Altar, bis der Organist sie zum Verlassen des Kirchenraumes aufforderte. ${ }^{2096}$

Allgemeine Gedenksteine oder -kreuze für die Flüchtlinge und Vertriebenen insgesamt sind in fast allen heutigen brandenburgischen Landkreisen vom jeweiligen regionalen BdV-Verband initiiert und teilweise von ihm selbst, teilweise von den Kommunen aufgestellt worden. Es handelt sich meist um Granitsteine mit Inschrifttafeln, gelegentlich aber auch um künstlerisch gestaltete Sonderformen sowie Stein- oder Holzkreuze. ${ }^{2097}$ Außer in Potsdam (Alter Markt) befinden sich die in Städten aufgestellten Gedenksteine meist eher in Randlage oder auf Friedhöfen. In den größeren Städten sind Gedenksteine außerhalb von Friedhöfen erst nach 2000 aufgestellt worden: 2002 in Brandenburg an der Havel (Marienberg), 2003 in Eberswalde (ehemaliges LAGA-Gelände), Potsdam und Rathenow (Fontanepark), 2015 in Oranienburg und Prenzlau. Cottbus und Frankfurt (Oder) sind bislang offenbar ohne derartige Gedenkorte geblieben, für Cottbus kann aber auf die benachbarten Friedhöfe in Kolkwitz und Werben verwiesen werden. Im kleinen Plattenburg bei Bad Wilsnack (Prignitz) erfolgte eine Aufstellung schon 1995. Auf Friedhöfen wurden Gedenksteine oder -kreuze ebenfalls schon in den neunziger Jahren eingeweiht, ihre Zahl ist deutlich größer: 1994/98 Waldfriedhof Werben/Spreewald (SpreeNeiße), 1996/2004 Waldfriedhof Luckenwalde (Kriegsgräberstätte „Ehrenfeld Mohrungen“), 1998 Neustadt/Dosse (Ostprignitz-Ruppin), 1999 Cahnsdorf (Dahme-Spreewald), 2000 Kalkberger Friedhof Rüdersdorf (Märkisch-Oderland), 2002 Neuer Friedhof Fürstenwalde/ Spree (Gedenkkreuz für die Russlanddeutschen), 2004 vor dem Friedhof Seelow (MärkischOderland), 2006 Waldfriedhof Spremberg (1945/46 aus Flüchtlingszügen und Vertriebenentransporten 1945/46 tot geborgene Kinder), 2011 Kolkwitz bei Cottbus (Spree-Neiße), ferner (Datum unbekannt) Lübben (Dahme-Spreewald) und Neuruppin (Ostprginitz-Ruppin). Ein

2096 Kurt Baller / Siegfried Lück: Gedenktafeln, -steine und Stelen in Potsdam. Barleben 2016, S. 244f.; BdVLandesgeschäftsstelle Potsdam, Ordner Projekt Gedenkstein; Auskunft des Teilnehmers Eberhard Clemens (Potsdam), 18.7.2017 und 31.7.2018. Sehr scharfe Kritik übte auch der an den Protesten beteiligte, in der o. g. „Kampagne“ aktive Potsdamer Stadtverordnete Lutz Boede (Fraktion „Die Andere“) (Potsdamer Neueste Nachrichten, 29.12.2003). - Der Gedenkstein wurde in der Folge 2003-2005 jährlich einmal nachts von Unbekannten beschmiert: 29./30.11.2003 mit schwarzer Farbe „Deutsche Täter sind keine Opfer“, 21./22.4.2004 „mit weißer Farbe Steinvorderfront mit Tafel flächendeckend übergossen“, 26./27.2.2005 „mit blauer Farbe ,Nazis raus" (BdV-Landesgeschäftsstelle Potsdam, Ordner Projekt Gedenkstein). - Bei der Einweihung 2003 sprach der Potsdamer Oberbürgermeister Jann Jakobs ein Grußwort (MAZ, Potsdamer Stadtkurier, 17.11.2003, S. 15).

2097 Siehe außer den folgenden Aufzählungen die genaueren Angaben in der Ortsdokumentation. 
Sonderfall individueller Initiative ist der vom Gründer des Brandenburg-Preußen-Museums in Wustrau (Ostprignitz-Ruppin), Ehrhardt Böddecker (1925-2016), auf dessen Außenbereich 2000 aufgestellte Gedenkstein. ${ }^{2098}$ Darüber hinaus existieren kombinierte Gedenkorte für verschiedene Opfergruppen der NS-Zeit und/oder des Zweiten Weltkrieges, die zum Teil Flüchtlinge ausdrücklich einbeziehen, in den Kirchen in Brüssow (Uckermark) und Fürstenwalde/ Spree (Märkisch-Oderland) (seit 2003), auf dem Friedhof in Reitwein (Märkisch-Oderland) 2006 sowie in Form der Gedächtniskirche in Rosow (Uckermark) seit 2007.

Von auf einzelne Heimatorte bezogenen Verbänden initiierte Gedenksteine sind schwerer zu ermitteln, da sie oft nur in deren Publikationen und nicht immer im Internet erwähnt werden. Bekannt geworden sind Beispiele der Vertriebenen aus und in Guben (Waldfriedhof, 1995), derjenigen aus Milzig (Kr. Grünberg in Schlesien; poln. Milsko) in Brück (PotsdamMittelmark), aus Braschen (Kr. Crossen) in Jamlitz (Friedhof) sowie der neumärkischen KreisKönigsberger in Hohenwutzen (Märkisch-Oderland, 1993) und in Güstebieser Loose (Märkisch-Oderland, 2003), schließlich der Sorauer in Jerischke-Pusack (Spree-Neiße). In wenigen Fällen wurden bzw. werden auch Heimatstuben und Begegnungsstätten als Gedenkorte bezeichnet, so die erst 2014 in Guben eingerichtete „Kreis Crossen a. O. Gedenk- und Heimatstube“.

Die zumeist enge Verknüpfung mit den Initiatoren, sei es am Ort sitzenden BdV-Verbänden, sei es regelmäßig an den Ort reisenden Heimatorts- und Kreisgemeinschaften, verweist auf die wohl überall anzutreffende Form der Vertriebenengedenkkultur. Am Volkstrauertag, am (Welt-)Flüchtlingstag, aber auch zu anderen Terminen kommen Gruppen zu Feierstunden mit Ansprachen oder sonst individuell zu stillem Gedenken an den Gedenkorten zusammen. Berichte hierüber finden sich regelmäßig in den Verbandszeitschriften, gelegentlich auch in der lokalen und regionalen Presse. Stellvertretend für die Nutzung der Gedenksteine als gleichsam gruppeninterne und doch öffentlich sichtbare Erinnerungsorte für die organisierten Vertriebenen mag ein von einem Vertriebenen ${ }^{2099}$ selbst in die Regionalpresse lancierter Bericht über eine BdV-Gedenkfeier zum Volkstrauertag 2009 in Rathenow stehen. Unter der Überschrift „Erinnerung und Mahnung zugleich“ heißt es darin:

„Wie alljährlich hatte der Bund der Vertriebenen, Gebietsverband Rathenow, zum Volkstrauertag am Sonntag, dem 15. November, um $10 \mathrm{Uhr}$ am Gedenkstein Forststraße/Fontaneplatz eingeladen. / Zu dieser öffentlichen Gedenkfeier erschienen zahlreiche Heimatvertriebenen und weitere Interessenten insbesondere auch der Bürgermeister Ronald Seeger. Die musikalische Umrahmung erfolgte durch eine Bläsergruppe der Musikschule Rathenow mit mehreren Liedern.

In seiner kurzen Ansprache ging der Vorsitzende Herbert Kapahnke auf die Bedeutung des Volkstrauertages ein. Er erinnerte dann nicht nur an die vielen Tote der beiden Weltkriege einschließlich der zahlreichen Opfer von Flucht und Vertreibung, sondern auch an die Opfer der vielen anderen Kriege und Bürgerkriege auf unserer Erde in der Vergangenheit bis in die Gegenwart. Auch die vielen

2098 Näheres dazu siehe in der Ortsdokumentation Wustrau im Teil 2.

2099 Herbert Kapahnke (1939-2015), Vorsitzender des BdV-Gebietsverbandes Rathenow. 
anderen Opfer bei den Juden und durch den Terrorismus wurden genannt. / Besonders an die jüngere Generation geht der Appell, die schrecklichen Ereignisse der Vergangenheit nicht zu vergessen und eine Wiederholung solcher Ereignisse zu verhindern. / Danach erfolgte eine Rezitation von Ursula Brommauer, daran anschließend wurde die Totenehrung von Hans-Joachim König vorgetragen. Als Vertreter der Heimatvertriebenen legte Alfred Hinz am Gedenkstein ein Blumengebinde nieder. Weitere Teilnehmer hinterlegten ebenfalls am Gedenkstein Blumen als Erinnerung und Mahnung. ${ }^{\text {"100 }}$

\section{Heimattreffen}

Die Bürgermeister der Städte und Gemeinden stellten sich nach anfänglich wohl überwiegender Zurückhaltung dann doch bald darauf ein, dass in ihren Kommunen nicht nur aus dem Westen kommende Vertriebenenfunktionäre, sondern zahlreiche längst ansässige Nachbarn (und Wähler) an den Heimattreffen teilnahmen, die die gesamte DDR-Zeit über nicht öffentlich über ihre landsmannschaftliche Herkunft hatten sprechen dürfen und nun endlich ein unterdrücktes Bedürfnis stillen konnten. Die langsam wachsende Empathie für die persönlichen und familiären Schicksale und Biographien und die Abstinenz doch vieler älterer Betroffenen gegenüber einseitiger Politisierung ermöglichte es, aus dem privaten in den öffentlichen Bereich zu gehen und große Treffen in vielen kleineren und größeren brandenburgischen Gemeinden durchzuführen, über die zumeist wohlwollende Berichte in der Lokalpresse erschienen. Vielfach gab und gibt es daher seitdem und bis heute auch Grußworte der Stadtoberhäupter der Tagungsorte und inzwischen auch offizielle Gast-Grußredner aus den nun polnischen (Heimat-)Gemeinden. Insgesamt spielte und spielt sich dieses Geschehen aber auf einer eher lokalen oder bestenfalls regionalen Ebene ab. Großtreffen von Landsmannschaften fanden und finden dagegen eher in anderen Bundesländern einschließlich Berlins statt. Nur der BdV-Landesverband hat sich von 1998 bis 2013 mit den durchnumerierten „Ostdeutschen Kulturtagen“ an Großveranstaltungen herangewagt, die anfangs über 1000 , zuletzt aber nur noch rund 300 Teilnehmer hatten und auch finanziell nicht mehr zu stemmen waren. ${ }^{2101}$

Der „Landesvater“, Ministerpräsident Manfred Stolpe, ließ es sich gleichwohl nicht nehmen, gelegentlich an größeren Regionaltreffen teilzunehmen. Bei dem der Züllichau-Schwiebuser in Gildenhall bei Neuruppin 1994 sagte er in seiner oben schon kurz erwähnten langen Begrüßungsansprache vor den rund 2500 anwesenden neumärkischen Vertriebenen u. a.: „Liebe Landsleute, Sie hier, die Sie in der Neumark gelebt haben, Sie haben 1945 die Heimat verlas-

2100 MAZ, Ausgabe „Westhavelländer“, 18.11.2009.

21011 (1998) Potsdam (Alter Markt), 2 (1999) Paaren im Glien, 3 (2000) Luckenwalde, 4 (2001) Neustadt/ Dosse, 5 (2002) Cottbus, 6 (2003) Brandenburg an der Havel, 7 (2004) Erkner, 8 (2005) Hohen Neuendorf, 9 (2006) Strausberg, 10 (2007) Fürstenwalde/Spree, 11 (2008) Rathenow, 12 (2009) Eberswalde, 13 (2010) Erkner, 14 (2011) Erkner, 15 (2013) Oranienburg (Akten hierzu in der BdV-Landesgeschäftsstelle). Für Auskünfte ist Herrn Eberhard Clemens vom BdV-Landesverband Brandenburg zu danken. - Zum Programm siehe beispielsweise den bebilderten Bericht von Eberhard Clemens: 15. Ostdeutscher Kulturtag des Landesverbandes in der Stadt Oranienburg. In: Brandenburger Rundschau 11 (2013) 10, S. 1-4. 
sen müssen. Aber die Tatsache, daß Sie hier stehen, zeigt, daß Sie diese Heimat aus dem Herzen nie verlieren, genauso wie ich mein Stettin ein Leben lang im Herzen tragen werde." ${ }^{2102}$ Hauptsächlich behandelte er zwar den wirtschaftlichen Wiederaufbau des Landes Brandenburg und den partnerschaftlichen Kontakt mit den polnischen Nachbarn, ermunterte aber auch die anwesenden Vertriebenen zur Versöhnung mit den heutigen Bewohnern ihrer Heimatorte, nicht ohne auf ihre gerade hierbei bereits durchaus erkennbaren Leistungen hinzuweisen: „Ich bin bei meinen politischen Gesprächen mit Wojwoden, aber auch mit der Warschauer Regierung, auf die Spuren Ihrer positiven Arbeit gestoßen.“2103

Vertriebenentreffen wie das genannte Neuruppiner, das inzwischen von den ZüllichauSchwiebusern regelmäßig durchgeführt wird, wurden und werden seit 1990 in den neuen Bundesländern vielerorts, meist als Heimattreffen bezeichnet, veranstaltet. Damit wurde ein insgesamt im Osten des heutigen Deutschland - wie die große Beteiligung zeigt - starker Nachholbedarf gedeckt. Die Wahl der Veranstaltungsorte berücksichtigt zum einen Verkehrsanbindungen und die Kapazitäten der anzumietenden Räume (v.a. Hotels, Gasthöfe, Tagungszentren). Sie nimmt aber auch Bezug auf die besondere lokale oder regionale Konzentration der Vertriebenen aus bestimmten Regionen oder gar ehemaligen Landkreisen der Vertreibungsgebiete. Dabei bilden die konkreten Veranstaltungsorte nicht immer solche Konzentrationen im unmittelbaren lokalen Umfeld ab, zumal geschäftstüchtige Gastronomen und Tagungshausleiter gezielt für ihre Lokale warben und werben. ${ }^{2104}$ Dennoch können diese Veranstaltungsorte deutliche Indizien für die Schwerpunkte sogar der ursprünglichen Nachkriegsansiedlung sein. Oft wohnen die Organisatoren, insbesondere der kleineren, auf nur ein einzelnes Herkunftsdorf bezogenen Treffen am Treffort oder in dessen Nähe. Freilich sind unter den zu den meist jährlichen Treffen Anreisenden auch viele, die über das gesamte Bundesgebiet verteilt wohnen. Für diesen Gesichtspunkt vernachlässigen kann man zumeist die nur wegen der Verkehrsanbindung in Berlin oder dessen unmittelbarer Umgebung (Paaren im Glien, Petzow u. a.) durchgeführten Zusammenkünfte. Konzentrationen im unmittelbaren Grenzgebiet zu Polen - z. B. in Altglietzen (bei Bad Freienwalde) und Forst (Lausitz) - erklären sich dagegen zum einen aus der - oft genutzten - Möglichkeit, im Anschluss an ein Treffen auch gemeinsam mit einem Reisebus nach Polen in den Heimatort zu fahren, zum anderen spiegeln sie aber noch nach 1990 und sogar noch heute die Ansiedlung vieler Neumärker und (Nieder-)Schlesier in den Grenzkreisen, wo sie in den ersten Jahren nach 1945 bewusst verblieben waren oder wohin sie bald danach bewusst übersiedelten und wo sie oft noch lange auf eine Rückkehrmöglichkeit hofften. Der vor und nach 1989 als katholischer Pfarrer in Cottbus wirkende Gerold Schneider (19272011), selbst aus Niederschlesien (Freystadt) stammend, hat nicht nur überliefert, wie stark katholische (Nieder-)Schlesier in seiner Region vertreten waren und sind, sondern hat auch

2102 Redetext: Märkischer Informationsdienst 1994, Nr. 6/7, S. 1-3, hier S. 2. - Bericht über das Treffen, verfasst von Lothar Meißner, ebd., S. 3-5.

2103 Ebd., S. 3.

2104 Siehe die entsprechenden Beiträge und Anzeigen im „Märkischen Informationsdienst“. 
eindringlich vor Augen geführt, wie sehr diese Menschen zu DDR-Zeiten in einer Art ,inneren Emigration“ lebten, weil sie sich nicht nur öffentlich nicht zu ihrer Heimat bekennen durften. Selbst in der Beichte oder im sonstigen Gespräch mit dem Seelsorger mögen sie die Ohren der ominpräsenten Staatssicherheit gefürchtet haben. Schneider, der ab 1969 in Cottbus tätig war, schreibt rückblickend 1999: „Viele, die aus unseren Gemeinden abwanderten, verabschiedeten sich vorher von ihrem Pfarrer. Häufig hörte ich von ihnen die Begründung, daß sie ihre Kinder dem starken sozialistischen Einfluß der Schule entziehen wollten; andere sagten, daß sie eine Rückkehr in die Heimat nicht mehr erhofften und sich nun in Freiheit ein neues Leben aufbauen wollten. [...]/Bei vielen Priestern blieb über Jahrzehnte das Bewußtsein lebendig, daß viele Vertriebene besonderer seelsorglicher Aufmerksamkeit bedürfen. Doch als dann im Jahre 1989 die Mauer fiel und bald die ersten Heimattreffen im Cottbuser Raum stattfanden, gab es ein großes Erstaunen, wieviele aus verschiedenen niederschlesischen Orten zurückgeblieben waren und sich nun endlich zusammenfinden konnten. [...] / Für mich war das nicht nur ein frohes, sondern auch ein bedenkenswertes Ereignis. Denn - wie gesagt - war ich achtzehn Jahre Pfarrer in Cottbus, wohl [S. 33] wissend, daß ein großer Anteil der Gemeinde aus Vertriebenen bestand; doch ihre wirkliche Zahl und das immer noch starke Bedürfnis sich zu versammeln, hatte ich um Größenordnungen unterschätzt." 2105

Weniger bekannt ist, dass aber auch aus grenzferneren Ansiedlungsorten nach 1990 keineswegs zufällig - Trefforte wurden. Insbesondere in der Prignitz und im Ruppiner Land handelt es sich dabei sogar um Evakuierungsregionen aus den ersten Monaten des Jahres 1945, mithin noch vor Kriegsende. ${ }^{2106}$ Wohl bewusst symbolisch gewählt sind dabei bisweilen sogar die konkreten Gebäude. So wählte die „Kreisgemeinschaft Wehlau e.V.“ (Ostpreußen) für ihr Kreistreffen $1998^{2107}$ mit dem Hotel „Pritzwalker Hof“ in Pritzwalk genau jenes Gebäude, in dem 1945/46 (damals noch „Gaststätte Sengbusch“) ein Flüchtlingslager bestand. ${ }^{2108}$ Auch die jährlich am Volkstrauertag durch Mitglieder des „BdV Perleberg“ sowie des „Heimatkreises Meseritz e. V." vorgenommenen Kranzniederlegungen am Gedenkstein für Flucht und Vertreibung vor der Plattenburg stellen einen solchen direkten Bezug her, bestand doch 1945 in der - direkt

2105 Schneider, Seelsorge für Heimatvertriebene in der ehemaligen DDR (wie Anm. 1950), S.32f. - Gerold Schneider wurde 1953 in Neuzelle zum Priester geweiht und war 1954-1969 zunächst im Bistum Meißen tätig, dann im Bistum Görlitz: 1969-1987 Pfarrer in Cottbus, 1988-1998 Kuratialpfarrer in Altdöbern und zugleich Dekan des Dekanats Senftenberg, 1975-1994 (1.) Vorsitzender des Diözesancaritasrats der Diözese Görlitz. Beigesetzt wurde er auf dem Südfriedhof in Cottbus (Nachrufe auf: www.dicvgoerlitz.caritas.de und www.bistum-dresden-meissen.de [16.7.2018]). Siehe auch seine persönlichen Erinnerungen an Kriegsende, Flucht, sowjetische Lagerhaft und Vertreibung 1946: Gerold Schneider: Vergangenheit, die nicht vergehen will. Irrwege deutsch-polnischer Nachbarschaft. Leipzig 1998, 4. Aufl. [2001]; Berlin 2017 (E-Book).

2106 „Nach der Wiedervereinigung war es auch unseren Landsleuten aus der ehemaligen ,DDR' möglich sich der Heimatkreisgemeinschaft anzuschließen. So konnten wir auf unseren Treffen ab dem Jahr 1990 viele Landsleute aus den neuen Bundesländern, insbesondere aus der Prignitz, wieder persönlich begrüßen. Pritzwalk war den Mogilnoern als Fluchtziel vorgegeben." (http://www.heimatkreis-mogilno.de/html/body_wir.html [20.9.2016]).

2107 Wehlauer Heimatbrief 59 (1998), S. 5, 56-58.

2108 Pritzwalker Heimatblätter 16 (2015), S. 23 mit Abb., 25 f. 
hinter dem Gedenkstein befindlichen - Burg Plattenburg ebenfalls ein Flüchtlingslager. ${ }^{2109} \mathrm{Al}-$ lerdings sind solche frühen, bisweilen nur Wochen oder wenige Monate bestehenden Nachkriegsnutzungen von Gebäuden wohl nicht immer in dauernder Erinnerung geblieben. In Guben, wo das Gedenken an die dramatische Vertreibung vom 20. Juni 1945 einerseits durchaus noch heute sehr präsent ist, findet sich andererseits in den Berichten über Heimattreffen im „Volkshaus“ kein Hinweis darauf, dass dieses 1945 als früheres „Hotel zum Kronprinzen“ zu den ersten Flüchtlingslagern gehörte. ${ }^{2110}$

„Der ,Heimatkreis Meseritz e. V., der nach der Wende um eine große Zahl von „Heimatfreunden" aus den neuen Bundesländern, mit Schwerpunkt in der Prignitz, erweitert wurde, hatte seine zunächst alle zwei Jahre stattfindenden, Großen Heimatkreistreffen ' im Schützenhof, heute ,Hansesaal', in Paderborn abgehalten. Seit 2001 gibt es jedes Jahr ein Heimatkreistreffen, in den geraden Jahren wie von Anbeginn an als ,Großes Heimatkreistreffen' in Paderborn, in den ungeraden Jahren als ,Kleines Heimatkreistreffen im ,Neuen Hennings Hof " in Perleberg/Westprignitz. 2001 und 2003 versammelten sich 800 „Heimatfreunde“ in Perleberg. Das Datum für die Treffen ist in der Regel das zweite Mai-Wochenende. Neben den zentralen Treffen in Paderborn und Perleberg finden Treffen der Heimatfreunde aus den Kleinstädten und Dörfern der alten Heimat mehr oder weniger regelmäßig an vielen Orten der Bundesrepublik statt. Die in Berlin und Umgebung lebenden „Heimatfreunde“ treffen sich mehrfach im Jahr, wie zum Erntedankfest und zur Weihnachtsfeier, was vornehmlich auf die Aktivität des 2010 verstorbenen Kurt Schiller (aus Tirschtiegel) zurückzuführen war; ihm folgte Ottargo Nickel (†2011). Heute werden die „Berliner Meseritzer“ zusammengehalten von Hans-Jürgen Balz, dem Schwiegersohn von Kurt Schiller. ${ }^{2111}$

Die ostpreußischen Wehlauer entschlossen sich 1999 zu einer Verkürzung auf ein eintägiges Treffen am 30. Mai, weil, wie der in Schleswig-Holstein wohnhafte Organisator Joachim Rudat feststellte, „wir die Erfahrung machen mußten, daß unsere Landsleute aus Berlin, MecklenburgVorpommern und Brandenburg morgens sehr zeitig anreisen, um dann abends wieder nach Hause zu fahren. Eintägig aber auch, um zu verhindern, daß sich Landsleute auf diesem Treffen verpassen, wie es anläßlich des letzten Treffens in Pritzwalk häufig geschehen ist. "2112

Über die - auch im Dokumentationsteil der vorliegenden Arteit nur unvollständig geleistete - bloße Erfassung solcher und ähnlicher Treffen hinaus ist nach Inhalten, Frequenz und Rezeption zu fragen. Programm, Ablauf und Teilnehmerfrequenz sind in den Berichten, die die Veranstalter in den jeweiligen Heimatbriefen publiziert haben und weiterhin, wie auch inzwischen oftmals auf ihren Internetseiten, publizieren, gut nachvollziehbar. Standardmäßig gehören dazu neben den Formalia wie einleitenden Ansprachen und Totenehrung sowie Gruß-

2109 www.heimatkreis-meseritz.de [19.9.2016]; Mahn- und Gedenkstätten Brandenburg (wie Anm. 2090), mit Abb.

2110 Siehe v. a. den Gubener Heimatbrief.

2111 www.heimatkreis-meseritz.de

2112 Kreistreffen in Pritzwalk 1999. In: Wehlauer Heimatbrief 60 (1999), S. 16-17. 
worten der Bürgermeister als Hauptinhalt die persönlichen Gespräche beim Essen bzw. Kaffee und Kuchen, die meist Jugenderinnerungen auffrischen, aber auch dem gegenseitigen Mitteilen des eigenen Werdeganges seit dem letzten Treffen und dem Austausch von Neuigkeiten über Bekannte und Verwandte dienen. Manche Treffen enthalten noch Gottesdienste, viele auch gemeinsames Gedenken an einem geeigneten Ort (Gedenkstein, Denkmal, Friedhof), was, etwa am 20. Juni, Hauptanlass sein kann, und die meisten eine anschließende Besichtigung von Sehenswürdigeiten des Treffortes oder eine Busfahrt nach Potsdam, Berlin und vor allem nach Polen in den Heimatort. Wie schon vor 1990 in Westdeutschland und West-Berlin beschränken sich politische Stellungnahmen eher auf die größeren Treffen an größeren Orten (mit über 200 Teilnehmern), während die - kaum vollständig feststellbare - Masse der immer noch zahlreichen Treffen in Kleinstädten und vor allem auch in stadtnahen Landgemeinden oft nur unter 100, inzwischen gar unter 20 Teilnehmer in Gasthöfen zusammenführt. ${ }^{2113}$

Die 1945 nach Neuruppin gelangte und dort bis ins Alter verbliebene Bomsterin ${ }^{2114}$ Ruth Preuß (1924-2010) hat in ihren Erinnerungen über die Situation berichtet, wie sie sich 1990 für viele Brandenburger stellte. Man hatte jahrzehntelang zwar Herkunft und Heimat nicht vergessen, war aber damit im DDR-Alltag nie mehr konfrontiert worden. Vielfach ist zwar der Umwelt, den einheimischen Nachbarn, den Berufskollegen, durchaus bekannt gewesen, dass man zu den „Umsiedlern“ zählte, aber jeder war doch mit der Bewältigung des Alltags ausgelastet. Nicht alle Vertriebenen verspürten nun nach 1990 im Innersten den Drang, etwas nachzuholen, aufzuarbeiten, auszusprechen, aber sehr viele, auch „staatsnah“ gewesene Bürger besannen sich als Rentner im wiedervereinigten Deutschland nun doch auf etwas, das sie meist tief geprägt hatte, die Bindung an einen inzwischen polnischen, russischen oder tschechischen Heimatort. Aus Brandenburg gibt es dafür zahlreiche Belege. Für den einen kam die Anregung dazu gleichsam aus dem Westen herüber, für den anderen ergab sie sich auch ohne solche „Aufbauhilfe“. Ruth Preuß, inzwischen im Ruhestand lebende ehemalige Kindergartenleiterin, hat ihre Gedanken dazu 2002 in Tonbandaufzeichnungen eines Zeitzeugenbefragungsprojektes formuliert:

„Nach der Wende wurde hier im Stadtgarten [in Neuruppin] eine Rede gehalten für die Vertriebenen. Es hieß, wer mitmachen möchte, soll sich melden oder eintragen. Ich habe gar nicht gewusst, wie viele Vertriebene hier waren. Wir durften doch nie darüber reden. Wir durften nicht sagen, wir sind vertrieben. Wir durften nur sagen, wir sind umgesiedelt worden. Wir [S. 118] haben doch nicht alles der Wahrheit entsprechend sagen dürfen. Und die, die wir nicht Parteigenossen waren, wir mussten uns noch mehr vorsehen, obwohl wir doch die freie Meinungsäußerung in uns hatten. / Da ist erst das wach geworden in uns, wo unsere Heimat ist. / Ich habe dann einen Artikel in die Zeitung gesetzt, wer nach Hause fahren will. Ich habe das organisiert, und wir sind mit zwei Bussen nach Hause ge-

2113 Eine Auswahl an Treffen mit Teilnehmerzahlen ist in der Ortsdokumentation unter dem jeweiligen Treffort angegeben.

2114 Die Stadt Bomst war bis 1918 eine Kreisstadt der Provinz Posen, gehörte dann mit einem Rest des auf Polen und Deutschland aufgeteilten Kreises Bomst zur Provinz Grenzmark Posen-Westpreußen und kam bei deren Auflösung 1938 zum Kreis Züllichau-Schwiebus in der Provinz Brandenburg. 
fahren, nach Landsberg, nach Züllichau, Schwiebus, und wo sie alle herkamen. / Ich habe die Arbeit mit dem Vertriebenen-Verband jetzt 12 Jahre lang gemacht, aber es geht nun nicht mehr. Ich habe es gerne gemacht, die Fahrten und die Feiern. / Ich wollte auch immer, dass der Bund der Vertriebenen Versöhnung stiften soll zwischen den Polen und den Deutschen, es sind doch immer Menschen, die Krieg machen und Frieden. Was ich tue und getan habe mit den Vertriebenen, will ich nicht für mich, sondern will es für die nächste Generation. Das sind die Menschen, die weiterleben und die es weiterbringen sollen. / [...]."2115

Mag Ruth Preuß als aktive „Vertriebenenfunktionärin“ noch ein Sonderfall sein, wie es ihn aber landauf, landab gab und derzeit noch gibt, so finden sich auch nicht wenige Äußerungen aus dem Kreis der mehr passiven Teilnehmer an solchen Zusammenkünften in Brandenburg. Eine in Storkow lebende Ostpreußin (geb. 1927) hat über das 2002 im Land Brandenburg durchgeführte dritte Treffen der Vertriebenen aus ihrem Heimatdorf berichtet:

„Nachdem die vorangegangenen Treffen im Erzgebirge und in Oberhof stattfanden, lag in diesem Jahr der Treffpunkt fast vor der Haustür, nämlich im Waldhotel in Berlin-Wandlitz [richtig: Wandlitz bei Berlin]. Auch für dieses Jahr hatten sich 80 Teilnehmer aus meinem Heimatdorf und einigen Nachbardörfern angemeldet. [...] Im Waldhotel in Wandlitz waren bei meiner Ankunft schon fast alle versammelt, die Wiedersehensfreude mit meinen Bergauern ${ }^{2116}$ war groß. Für mich ist es wie ein Klassentreffen, da bis auf wenige Ausnahmen alle meine Mitschüler meines Jahrganges dabei sind. Wir ,Bergenauer' und die Teilnehmer der anderen Dörfer setzten sich Tischweise [so!] zusammen, denn wie immer gab es viel zu erzählen. [...] Der offizielle Teil unseres Treffens bestand aus einer kurzen Begrüßungsrede. Sie hatte vom Inhalt nichts mit den Landsmannschaftstreffen mit großen Reden zu tun, wie wir sie von früher aus dem Fernsehen kannten. Wir freuten uns einfach über unser Wiedersehen. Nach einem tollen warm-kalten Büffet saßen wir draußen in großer Runde bei Bier und Wein zusammen. [...].“2117 Am nächsten und übernächsten Tag folgten Besichtigungsausflüge nach Berlin und Potsdam.

Von der Vertreibungsthematik nicht zu trennen, aber in den größeren Zusammenhang der deutsch-polnischen Verständigung gehörig sind die Begegnungen, die vor und verstärkt nach 1990 in den geteilten oder ohne Teilung grenznahen Orten stattfinden. In der geteilten Neiße-Stadt Guben trafen sich die deutschen und polnischen Bürger beider Stadthälften erstmals 1997 auf der bis dahin weitgehend unzugänglichen, zu Polen gehörigen Neißeinsel. ${ }^{2118}$ Auch weiter nördlich, bei Bad Freienwalde (Oder), gab es ähnlich symbolhafte Begegnungen. Die „traditionelle Handelsroute“ über die 1904 erbaute Saldernbrücke bei Hohenwutzen, die seit 1930 auch dem Eisenbahnverkehr diente, war seit der kurz vor Kriegsende von der Wehr-

2115 Ruth Preuß, [Lebensgeschichte] (wie Anm. 395), S. 117 f.

2116 [Bergau, Kr. Königsberg i. Pr.]

2117 Hildegard Rölke: Mein 3. Heimattreffen. In: Damals und heute (wie Anm. 357), S. 145-146, hier S. 145.

2118 Jana Wilke [lebt in Guben]: Kleine Insel in der Lausitzer Neiße. In: Jahrbuch für Gubener Geschichte 1 $(2011 / 12)$, S. 27-48, hier S. 28. 
macht vorgenommenen Teilsprengung unterbrochen. ${ }^{2119}$ In den fünfziger Jahren beseitigten die DDR-Behörden die baulichen Reste und ließen bis 1957 eine neue, nun auf den Straßenverkehr beschränkte Brücke errichten. Sie blieb jedoch „der Öffentlichkeit für Jahrzehnte verschlossen. Diesseits unterbanden Grenztruppen und Volkspolizei ihr unerlaubtes Betreten, jenseits polnische Sicherheitskräfte von einem Beobachtungsturm aus. So war es bis auf sehr geringe Ausnahmen“, etwa für Militär oder Feuerwehr. ${ }^{2120}$ Nach 1990 dauerte es noch einige Jahre, in denen die Statik geprüft und eine Teilinstandsetzung vorgenommen wurde, bis die Brücke am 1. März 1993 als Grenzübergang für Autos und Fußgänger eröffnet werden konnte. Der (Er-) Öffnungstag wurde zum deutsch-polnischen Ereignis: „Tausende von Menschen wanderten von Hohenwutzen nach Polen. Es schien, als sollte nachgeholt werden, was man seit 1945 nicht mehr durfte." ${ }^{2121}$

\section{Heimwehtourismus II}

Für viele Vertriebene, DDR-Bürger ebenso wie in Westdeutschland lebende, blieb ein Wiedersehen mit den Stätten der Kindheit bis 1990 trotz mancher Möglichkeiten ein - mehr oder weniger verdrängter - bloßer Gedanke. Die neuen Möglichkeiten nach der Wende, nochmals verstärkt durch den Wegfall der Grenzkontrollen zu Polen 2007, und die allerorten begegnenden Anregungen durch Medien, Publikationen und werbende Reiseveranstalter änderten das, und mancher bedurfte solch eines Anschubs gar nicht. Wie die Betroffenen damit umgingen, blieb ohnehin individuell. Regelmäßige Besuche, aus denen sich gar eine aktive Beteiligung an der Entwicklung der deutsch-polnischen Beziehungen an der „Basis“ entwickelte, wurden ein durchaus häufiges Phänomen, betrafen und betreffen aber nicht die Mehrheit. Seniorenreisegruppen, mittlerweile vorwiegend nur noch aus jenen zusammengesetzt, die 1945 Kinder waren, gibt es, wenn auch in abnehmender Zahl, nach wie vor. ${ }^{2122}$ Nicht gering ist aber auch die Zahl derjenigen, die nur ein einziges Mal ihre Heimat wiedersehen wollten, und es nach der Umsetzung des Gedankens dabei beließen, sei es, dass die Wiederbegegnung mit der eigenen Vergangenheit zu schmerzlich war, sei es, dass sie spürten, dass die eingetretene - innere wie äußere - Distanz zum Heimatort das Interesse an solchen Fahrten minimierte. Es gab und gibt schließlich aber auch Menschen, die niemand motivieren konnte oder kann, eine solche

2119 Wilfried Schöning: Die Brücke über die Oder bei Hohenwutzen. In: Königsberger Kreiskalender 1996 (1995), S. 148-153, hier S. 148.

2120 Ebd., S. 151.

2121 Ebd.

2122 In den Heimatzeitschriften, -briefen und Mitteilungsblättern der jeweiligen kleinerräumigen Vertriebenenverbände nehmen die (bebilderten) Berichte von solchen Fahrten meist großen Raum ein. Zwei Beispiele (aus BdV-Kreisverbänden) für viele: Martha-Maria Schulz: Es zog uns wieder in die Heimat. Tagesausflug nach Grünberg und Crossen des Kreisverbandes Eberswalde. In: Brandenburger Rundschau 11 (2013) 8, S. 9. Irene Schulze: Unvergessene Heimat - die Neumark. Stationen einer Reise des Kreisverbandes Potsdam-Mittelmark. In: ebd., S. 11-12. 
Fahrt auf sich zu nehmen. Sie geben als Grund zumeist an, dass sie ihre Heimat in der Form in Erinnerung behalten möchten, wie sie sie - in unzerstörtem Zustand - gekannt hatten. Drei Beispiele von Aussagen in Brandenburg lebender Vertriebener mögen die unterschiedliche Herangehensweise noch etwas näher beleuchten.

Nicht untypisch für viele Zeitzeugenberichte ist die - ganz unaufgeregte - Formulierung der Witwe eines aus Frauenburg (poln. Frombork) in Ostpreußen stammenden Rüdersdorfers: „Als nun 1989 die Wende kam und man nun auch dort hinfahren konnte, machten wir uns privat mit einigen Freunden auf den Weg in seine alte Heimat. [...] Mein Mann fand auch gleich das Haus, in dem er geboren wurde und auch bis zur Flucht lebte. [...] Aber die jetzt dort heimischen Leute merkten, wie wir dort etwas ratlos standen, denn die polnische Sprache beherrschten wir ja nicht. Ein Herr ging plötzlich los und kam mit einem anderen Herrn zurück, der deutsch sprechen konnte. Im Dom hatte er damals als 15jähriger noch deutsche Bibeln gefunden und die Domherren sagten: ,Kannst du nehmen'. Nun hatte er heimlich die deutsche Schrift gelernt und auch gelernt deutsch zu sprechen. Er lud uns in seine Wohnung ein, in der er geboren wurde und in der er noch immer mit seiner Frau lebt. Er [...] war ca. Ende 40. Wir erlebten eine große Überraschung, gewissermaßen ein Zufall im Leben, denn in dieser Wohnung hatte mein Mann seine Kindheit verlebt. Es wurde viel erzählt und es entstand eine Freundschaft, die es heute immer noch gibt. [...]."2123

Eine als Jugendliche aus Zentralpolen Vertriebene, die dann in der DDR bis zur Rente als Verwaltungsangestellte beim VEB Deutrans tätig war, kam 1996 auf einer Seniorenreise der Caritas erstmals wieder in ihren Geburtsort: „Bisher gab es immer wieder andere Gründe, die einen Besuch verhinderten. Nun aber stand fest, von Pila ${ }^{2124}$ aus besuchte ich meine Geburts- und Heimatstadt Alexandrow Krs. Lodz (Polen), und mein Wunsch ging in Erfüllung. [...] [S. 60] [...] Ich habe mich gefreut, die alte Heimat noch einmal wiedergesehen zu haben und trotz der vielen Enttäuschungen hat dieser Besuch mich sehr berührt und einen tiefen Eindruck hinterlassen. Das Heimweh ist vergangen, aber meine Gedanken werden noch sehr oft in die Heimat wandern, wo ich so schöne, unbeschwerte Jahre verleben durfte. Heute bin ich alt und - die Zeit heilt doch die meisten Wunden." ${ }^{2125}$

Den Wunsch, die Heimat zumindest besuchsweise einmal wiederzusehen, hatte auch eine in Storkow lebende Ostpreußin nie vergessen, konnte ihn aber auch erst nach 1990 in die Tat umsetzen: „Es war immer mein Wunsch, meine ehemalige Heimat, Ostpreußen, einmal wiederzusehen. 1992 sollte dieser Wunsch in Erfüllung gehen. Meine Schulfreundin und ihr Mann, beide wohnen jetzt in Sachsen, waren bereit, mich mit ihrem PKW mitzunehmen. Wir freuten uns beide sehr auf das Wiedersehen mit unserer ehemaligen Heimat, die ich schon 1944 als Vierzehnjährige verlassen

2123 Helga Siedler: Menschliche Schicksale und die Zufälle des Lebens. Ein Besuch in der Heimat ließ Freundschaften entstehen. In: Brandenburger Rundschau 11 (2013) 11, S. 18.

2124 [Piła (Schneidemühl).]

2125 Kunert, Besuch in der alten Heimat (wie Anm. 1827), S. 58 und 60. - Kein Heimweh, aber „Heimatgefühle" noch 2017 auch bei einem 1945 in die Ostprignitz gelangten Vertriebenen aus dem Kreis Meseritz (geb. 1929): „Hier empfinde ich keine Sehnsucht nach Schierzig, aber wenn ich einmal im Jahr dort bin, entstehen Heimatgefühle." (Ruch, Gerhard Pöhlchen ist fest verwurzelt [wie Anm. 1582]). 
mußte. [...]."2126 Es kommt dann sogar zu einem ungeplanten Kaffeetrinken im Wohnzimmer ihres Elternhauses. „Wir lernten fleißige und vor allem sehr gastfreundliche Menschen kennen, zu denen wir noch heute Kontakte haben. Bei der Rückreise hatte ich das Gefühl, ich habe meine ostpreuBische Heimat neu erlebt, und es wird bestimmt nicht das letzte Mal gewesen sein." ${ }^{2127}$

Der als Kind aus Neudamm (Neumark) (polnisch: Dębno) vertriebene Kurt Krause (Ketzin) gehörte ebenfalls zu jenen, die sich erst nach $1990 \mathrm{zu}$ einer Wiederbegegnung entschlossen: „Sommer 1993. Ich hatte nach all den Jahren doch den drängenden Wunsch, noch einmal das, was ich als Kind verlassen hatte, wiederzusehen. Auch meine Frau hatte schon länger den Wunsch geäußert, einmal meine Heimat zu sehen." Er hatte dann allerdings, wohl weil er 1945 noch zu klein gewesen war, Schwierigkeiten, sich zu orientieren: „nur noch wenig stimmte mit meiner Erinnerung überein. So standen wir dann gedankenverloren auf dem Marktplatz vor unserer Kirche. Diese und auch beide Pfarrhäuser standen so, wie ich sie noch in Erinnerung hatte. Darüberhinaus erinnerte ich mich nur noch wenig an das einmal Verlassene. Mit wehmütigen Gefühlen mußte ich erkennen, wie sicherlich viele vor mir, daß selbst eine Erinnerung an unsere Toten nicht mehr möglich ist. Unser gepflegter Waldfriedhof mit seiner ihn überragenden Kapelle war ein Park geworden. Wenigstens kein Unland, unter dem unsere Toten ruhen."

Liest man die mit großem zeitlichen Abstand zum Jahr 1945 und erst nach dem Ende der DDR geschriebenen Erinnerungen Vertriebener, so hat die Mehrheit von ihnen ihren persönlichen Frieden mit dem „Bevölkerungsaustausch“ gemacht, selbst diejenigen, die keine persönliche - meist sehr gastfreundliche - Begegnung mit den neuen Bewohnern ihrer Häuser erlebt haben. So endet auch Krause seinen kurzen Erinnerungs- und Reisebericht versöhnlich: „Damit schloß sich ein Kreis, den meine Gedanken durchwandert hatten, nach fast 50 Jahren Trennung von der alten Heimat. Mögen die Menschen, die nun in Debno [Dębno - P. B.] wohnen und geboren werden, ebenso glücklich sein, wie wir es in Neudamm waren. “2128 Dass das Thema mit einem solchen, gleichsam humanen „Schlußstrich“ des von Vertreibung direkt Betroffenen, in seiner neuen Heimat Integrierten endgültig abgeschlossen wäre, ist gleichwohl nicht festzustellen. Denn mittlerweile liest oder sieht man immer öfter Berichte Nachgeborener, die dem bestenfalls aus Erzählungen Gekannten selbst nachgehen, die Wohnorte ihrer Großeltern und Vorfahren aufsuchen, ja die jeweiligen „Geschichten“ erforschen und bisweilen gar in engerem oder weiterem

2126 Hildegard Rölke: Eine Reise in die Vergangenheit. In: Storkower Zeitzeugen berichten [H. 1] (wie Anm. 370), S. 106-108, hier S. 106.

2127 Ebd., S. 108.

2128 Krause, Erinnerungen an die Schreckenszeit vor 50 Jahren (wie Anm. 533), S. 70. - Freundschaftliche Kontakte zu den polnischen Bewohnern des ehemaligen Elternhauses (siehe jeweils die kurzen Inhaltsangaben im Quellenverzeichnis, Abschnitt 2.4.2): Horst Göhler: Erinnerungen an unsere Vertreibung 1945. In: Gubener Heimatbrief (2001)2, S. 66-72; Marta Regieli / Leander Schurig: Endgültige Abreise ins Ungewisse. Über Flucht und Vertreibung und das Finden einer neuen Heimat. In: Stog - Der Schober 2018 (2017), S. 35-41 (hier sogar noch in der beiderseitigen (Ur-)Enkel-Generation und bis hin zu einem gemeinsam verfassten Heimatkalender-Beitrag). 
Rahmen darstellen. Wie in anderen Bereichen der Zeitgeschichte ist es nicht selten (erst) die Enkelgeneration, die die das Tabu bricht, Fragen stellt.

\section{Städtepartnerschaften als Patenschaftsersatz}

In den neuen Bundesländern bestanden, anders als in Westdeutschland, keine Patenschaften für historisch ostdeutsche Städte und sind auch nach 1990 nicht mehr neu übernommen wurden. Dass jedoch bei der Anbahnung und Pflege von (Städte-)Partnerschaften mit (polnischen) Städten in den Vertreibungsgebieten, wie schon oben für die Zeit vor 1990 gezeigt $^{2129}$, auch nach 1989/90 - nun verstärkt und auch öffentlich konkret benannt - bisweilen durchaus ein konkreterer Bezug zu von dort Vertriebenen bestand oder besteht, lässt sich an mehreren Beispielen zeigen.

Zwar schlief nach 1989/90, wohl auch schon zuvor, manches der in der DDR-Zeit „verordneten" brüderlichen Freundschaftstreffen ein, doch wurden im Zuge der durch die Grenzöffnung entstandenen Möglichkeiten neuer Nachbarschaft auch viele solcher Beziehungen bestätigt, andere traten neu hinzu, wobei es nun sogar Fälle gibt, in denen einzelne Vertriebene dabei eine Rolle spielten, welche konkreten Orte miteinander eine Partnerschaft eingingen bzw. intensiver pflegten. Damit soll keinesfalls gesagt werden, dass dies die Regel war, denn es gab durchaus auch mehr zufällige Verfahren der Partnerschafts-„Anbahnung“. Ein Beispiel, wo der Bezug jedoch „mit Händen zu greifen“ ist, bildet Dr.-Ing. Helmut Munkow, geboren 1930 in Herzogswalde im Kreis Oststernberg (Neumark), von dem es in der 2007 erschienenen Darstellung der Nachkriegszeit in Eichwalde heißt: „seit vielen Jahren schon Eichwalder, unterstützt nach Kräften die [seit 1995 bestehende] Städtepartnerschaft zwischen Eichwalde und dem polnischen Ort Osno [Ośno Lubuskie - P. B.], früher Drossen, Kreis Weststernberg. Hier war er als Kind zur Schule gegangen. “2130 Mit solchen persönlichen Beziehungen Vertriebener, die aus der Partnerstadt ihrer neuen Heimatgemeinde stammen, gewannen manche deutschpolnischen Städte- und Gemeindepartnerschaften - ganz anders etwa als die mit Städten in Übersee - einen besonderen Charakter, der nicht nur das auf die Motivation Betroffener gebaute Versöhnungselement an der Basis enthält, sondern - zumindest für einzelne - indirekt doch eine Art Patenstadt kreierte, ohne diesem Modell formal und offiziell zu entsprechen.

Kaum zu übersehen ist wohl der Zusammenhang auch bei Neuruppin und dem polnischen Babimost (dt. Bomst), die seit 2005 eine Städtepartnerschaft verbindet. Denn seit 1991 finden die jährlichen Treffen des „Heimatkreises Züllichau-Schwiebus“ nicht zufällig in Neuruppin statt, hatte sich doch schon im Januar 1945 hier und im Umland eine besondere Konzentration von Flüchtlingen aus diesem ostbrandenburgischen Kreis entwickelt, die in den Treffen trotz mancher Abwanderung - indirekt noch heute erkennbar ist. Das ehemals posensche bzw.

2129 Siehe oben im Kapitel IV. 2 den Abschnitt „Städtepartnerschaften als Patenschaftsersatz?“

2130 Müller, Nachkriegsjahre in Eichwalde (wie Anm. 177), S. 108. - Siehe auch oben die Hinweise auf Munkows Aktivität bei Drossener (Schul-)Heimattreffen im Kapitel IV.2, Abschnitt „Teilnahme an Heimattreffen in Westdeutschland“. 
grenzmärkische Bomst wiederum gehörte von 1938 bis 1945 zu eben diesem brandenburgischen Kreis Züllichau-Schwiebus. Der Zusammenhang bestätigt sich bei näherer Recherche. Denn eine aus Bomst stammende Vertriebene, Ruth Preuß (1924-2010), die schon oben als Organisatorin von Vertriebenentreffen in Neuruppin erwähnt wurde, ist die Initiatorin gewesen. So hieß es 2005 in der Presse über sie: „Ruth Preuß wurde 1924 in Bomst geboren und lebt seit fünf Jahrzehnten in Neuruppin. Seit der Wende hat sie sich mit all ihrer Kraft der Verständigung mit Polen gewidmet. In unermüdlicher Arbeit und mit ,Zähigkeit' erreichte sie die Freundschaft zwischen Neuruppin und ihrer Heimatstadt Bomst/Babimost, die nun in einer offiziellen Partnerschaft ihre Krönung fand. Hierfür und für ihren Einsatz für ,ihre' Züllichau-Schwiebusser Landsleute in Brandenburg erhielt Frau Preuß die Ehrenmedaille der Stadt Neuruppin." ${ }^{2131}$ Eine systematische Untersuchung zu den vor und nach 1990 in Brandenburg (bzw. in den gesamten neuen Bundesländern) begründeten Städte- sowie Gemeinde- und Amts-Partnerschaften dürfte noch weitere Beispiele zu Tage fördern, in denen Vertriebene in der Vorbereitung eine Rolle gespielt haben und gewissermaßen Patenschaftselemente durchscheinen. ${ }^{2132}$

Das zweite Partnerschaftsmodell, bei dem die Vertreibungsgebiete eine Rolle spielen, sind die inzwischen nicht wenigen gelebten Partnerschaften oder doch regelmäßigen Begegnungen zwischen unmittelbar oder nahe an der deutsch-polnischen Grenze liegenden Nachbarorten, bei denen, wie vor allem in Guben ${ }^{2133}$, aber auch in kleineren Orten wie Aurith ${ }^{2134}$ und anderswo, das Vertreibungsthema viel präsenter geblieben ist und immer mit zur Sprache kommt, da die auf deutscher Seite Wohnenden nicht selten aus der „anderen Hälfte“, der nunmehrigen Partnergemeinde, stammen. Da die Stadt Schwedt/Oder seit 1994 mit sogar vier ehemals neumärkischen und pommerschen, teilweise nahe benachbarten Städten Partnerschaftsverträge geschlossen hat, dürfte auch hier kaum „nur“ die neue Nachbarschaft eine Rolle gespielt haben, zumal bekannt ist, dass viele Neumärker und aus den westlichen Kreisen Hinterpommerns stammende Vertriebene 1945 in Grenznähe, also auch in den Schwedt umgebenden Gebieten der Uckermark, verblieben sind.

Aber auch ganz weite geographische Distanzen - z. B. von Brandenburg bis in die slowakischen Karpaten - werden nun, von Menschen, die in der DDR gelebt hatten und jetzt all diese Möglichkeiten nutzen konnten, nicht nur überwunden, sondern gezielt von Betroffenen, die dort ihre Heimat hatten, genutzt. So heißt es in der „Karpatenpost“ 2015: „Roland Hoff-

2131 Aus dem Heimatkreis Züllichau-Schwiebus. in: Brandenburgkurier 19 (2005)4, S. 7 (nach Presseberichten der Märkischen Allgemeinen und im Ruppiner Anzeiger vom 4.10.2005).

2132 Alle ermittelten ehemaligen oder noch bestehenden Partnerschaften sind in der Ortsdokumentation in jeweils eigenen Abschnitten aufgeführt. Ganz eindeutig ist die Initiative Vertriebener als Anlass für eine (2000 vertragliche vereinbnarte) Partnerschaft mit ihrem Heimatort Ochelhermsdorf bei Grünberg in Schlesien (poln. Ochla) in Drehnow bei Cottbus (siehe Ortsddokumentation Drehnow).

2133 Der Partnerschaftsvertrag mit Gubin (Polen) wurde am 19. Januar 1991 geschlossen (Jajeśniak-Quast/ Stokłossa, Geteilte Städte an Oder und Neiße [wie Anm. 128], S. 102). - Siehe aber auch die in der Ortsdokumentation angegebenen Hinweise auf Begegnungen und die dort genannte zahlreiche Literatur.

2134 Aurith - Urad (wie Anm. 821). 
mann (Jahrgang 1947) wuchs dagegen in eine Zeit hinein, in der das Thema Vertreibung weitgehend ausgeblendet war. Erst eine Reise mit seinem Vater in die alte Heimat, nach Zipser Bela, machte ihn neugierig. So neugierig, dass er Jahrzehnte später maßgeblich dazu beitrug, dass im Jahre 2010 eine Partnerschaft zwischen seiner Heimat, der Stadt Brück im Fläming, und der Heimat seiner Eltern, dem Oberzipser Städtchen Zipser Bela/Spišská Bela, zustande kam. "2135 Hinzu traten dann weitere Elemente, die man aus Patenschaften kennt, die aber genauso zu Partnerstädten gehören. Schon 1998 hatte ein anderer in Brück lebender Kapatendeutscher den Vorschlag gemacht, eine Straße in einem Brücker Neubaugebiet nach seiner Heimatregion, der Oberzips, zu benennen. Nach einigen Jahren bürokratischer Verzögerungen durch die Gemeinde, aber ebenso hartnäckigen Nachhakens des Vorschlagenden kam es 2015/16 zur Benennung einer kurzen Querstraße der Gartenstraße (mit zwei Hausnummern) als „Oberzipser Straße“ nach der Region, aus der viele der vertriebenen Karpatendeutschen 1946 nach Brück gekommen waren. ${ }^{2136}$ Gleichzeitig wurde eine andere Straße nach der slowakischen Partnerstadt Spišská Belá (Zipser Bela) benannt. ${ }^{2137}$

Während in der Bundesrepublik schon vor 1989 die Patenschaften vielerorts in die kontroverse Gesamtdiskussion und manche nachfolgend in eine Krise gerieten, die in einigen Fällen zur Aufkündigung seitens der Patenschaftsträger führte - und mancher Gesprächspartner den Unterschied zwischen einer Paten- und Partnerstadt auch gar nicht mehr (er)kannte -, näherten sich nach 1990 in West- wie Ostdeutschland Patenschafts- und Partnerschaftsgedanke weiter an, so dass inzwischen vielerorts Städtepartnerschaften mit Kommunen in den polnischen Westgebieten neben der deutsch-polnischen Begegnung zugleich eine wohlwollende Einbeziehung der jeweiligen Vertriebenen ermöglichen. Letztere gehören sogar oft zu den besonderen Motoren der Pflege auch von Partnerschaften, im „Idealfall“ zwischen Wohnort und Heimatort wie beim geschilderten Beispiel Eichwalde/Drossen. Mit dem absehbaren Auslaufen weiterer (in westdeutschen Kommunen noch bestehender) Patenschaften, vor allem aber mit der - durch Mitgliederschwund bedingten - zunehmenden Auflösung von Heimatkreisvereinen fällt die institutionalisierte und damit ehemals auch finanzielle Basis immer öfter fort. Partnerschaften, mancherorts bereits von einem kommunalen Partnerschaftsbeauftragten gebündelt betreut, treten als Modell der Beziehungspflege immer mehr in den Vordergrund, auch in der Perspektive der Vertriebenen. Entsprechend formulierte die in Fürstenwalde/Spree ansässige Landsmannschaft Ostbrandenburg/Neumark e.V. 2016: „Da die Partnerschaften durch einen Vertrag zwischen zwei Kommunen besiegelt sind, freuen sich die Heimatkreise daß die so entstandenen Verbindungen weiter bestehen, auch wenn die Heimatkreise nicht mehr mitwirken."2138

2135 Werner Laser: Späte Aufarbeitung der eigenen Geschichte. Die Flucht aus der Slowakei war für die Karpatendeutschen im Hohen Fläming lange ein Tabuthema. In: Die Karpatenpost 66 (2015), Folge 4, S. 4.

2136 Märkische Onlinezeitung, 5.7.2016; Abb. des Straßenschildes in: Die Karpatenpost 68, 2017, Folge 3, S. 3.

2137 Auskünfte Michael Demko, Brück.

2138 [Ohne Verf.:] Städtepartnerschaften zwischen deutschen und bis 1945 deutschen, jetzt polnischen Städten in Ostbrandenburg. In: Brandenburgkurier 30 (2016), Nr. 1, S. 1. 
Ähnliche Sichtweisen, die auf Partnerschaft mit den heutigen polnischen Kommunen setzen, finden sich in den Vertriebenenzeitschriften inzwischen zahlreich. So heißt es in einem Bericht über einen am 21. Januar 2016 im „Haus Brandenburg“ in Fürstenwalde/Spree gehaltenen Vortrag „Von Züllichau nach Sulechów - Überliefertes, Gemeinsamkeiten und zukünftig Verbindendes ... “ im Schlussabschnitt unter der Überschrift „Das zukünftig Verbindende“: „Aus dem Überlieferten und dem Gemeinsamen führt ein Weg zum Verbindenden, so die These des Vortrags. Das kann zum Beispiel in Form von institutionellen Verbindungen geschehen, wie etwa mit der seit 2014 bestehenden Städtepartnerschaft zwischen Sulechów und Fürstenwalde. Eine solche Partnerschaft will kontinuierlich mit Leben gefüllt werden. Insbesondere ist aber auch ein Grenzen überschreitendes zivilgesellschaftliches Engagement gefragt, um zukünftig Verbindendes zu schaffen, eine gemeinsame deutsch-polnische Zukunft gerade im regionalen Kontext zu verankern und um der europäischen Idee Inhalt zu geben. Deshalb besteht weiterhin eine besondere Verantwortung zur Pflege der Erinnerung, die es folgenden Generationen erlaubt, das Gemeinsame und Verbindende zu finden und $z u$ erhalten. "2139 Hier ist also gewissermaßen (längst) umgesattelt worden auf das als zeitgemäß betrachtete Modell der (Städte-)Partnerschaft, aber es wird zugleich betont, dass die „Pflege der Erinnerung“ in die neue Form integriert werden müsse.

Tab. 9: Brandenburgisch-polnische und -slowakische kommunale Partnerschaften (Auswahl) Grenzgebiete zu Polen: (L) = Lebus, (NL) = Niederlausitz, $(\mathrm{OB})=$ Oberbarnim, $(\mathrm{UM})=$ Uckermark. Nähere Angaben (und Quellen) zu den einzelnen Partnerschaften siehe im Teil 2 (Ortsdokumentation).

\begin{tabular}{|c|c|c|c|}
\hline Jahr & Ort & Partnerstadt/-gemeinde & Bemerkungen \\
\hline & & $\begin{array}{l}\text { a) Ostbranden burg } \\
\text { (mit den ehem. grenzmärkischen Kreisen) }\end{array}$ & \\
\hline 1972 & Angermünde (UM) & Friedeberg/Nm. - Strzelce Krajeńskie & 1990 bestätigt \\
\hline 1975 & Frankfurt (Oder) & Landsberg/Warthe - Gorzów Wlkp. & besteht weiter \\
\hline 1975 & Frankfurt (Oder) & Dammvorstadt - Słubice & besteht weiter \\
\hline 1978 & Strausberg (OB) & Neudamm, Kr. Königsberg/Nm. - Dębno & 1992 erneuert \\
\hline 1979 & Bernau (OB) & Schwerin/Warthe - Skwierzyna & 1996 erneuert \\
\hline nach 1990 & Wriezen/Oder (OB) & Bärwalde/Nm. - Mieszkowice & \\
\hline 1991 & Guben (NL) & Guben - Gubin & \\
\hline 1992 & Fürstenwalde/Spree (L) & Arnswalde - Choszczno & \\
\hline 1994 & Peitz (NL) & Küstrin, Kr. Königsberg/Nm. - Kostrzyn & \\
\hline 1994 & Schwedt/Oder (UM) & Königsberg/Nm. - Chojna & \\
\hline 1995 & Eichwalde & Drossen, Kr. Weststernberg - Ośno Lubuskie & \\
\hline 1998 & Buckow (L) & Lagow, Kr. Oststernberg - Łagów & 2003 und 2013 verlängert \\
\hline 1998 & Müncheberg (L) & Vietz, Kr. Landsberg/W. - Witnica & \\
\hline
\end{tabular}

2139 [Ohne Verf.:] Vortrag: Von Züllichau nach Sulechów - Überliefertes, Gemeinsamkeiten und zukünftig Verbindendes ... von Horst Krüger. In: Brandenburgkurier 30 (2016), Nr. 1, S. 3-4, hier S. 4. 


\begin{tabular}{|c|c|c|c|}
\hline Jahr & Ort & Partnerstadt/-gemeinde & Bemerkungen \\
\hline 1998 & Seelow (L) & Küstrin, Kr. Königsberg/Nm. - Kostrzyn & \\
\hline 2000 & Forst (Lausitz) (NL) & Sommerfeld/NL, Kr. Crossen - Lubsko & \\
\hline 2000 & Forst (Lausitz) (NL) & Pförten, Kr. Sorau - Brody & \\
\hline 2000 & Peitz (Amt) (NL) & Neu Bentschen, Kr. Meseritz - Zbąszynek & \\
\hline 2000 & Schwedt/Oder (UM) & Mohrin, Kr. Königsberg/Nm. - Moryn & \\
\hline 2001 & Lindow-Banzendorf & Petersdorf, Kr. Oststernberg - Jemiołów & \\
\hline 2001 & Eberswalde (OB) & Landsberg/Warthe - Gorzów Wlkp. & \\
\hline 2001 & Bad Freienwalde (OB) & Meseritz - Międzyrzecz & \\
\hline 2002 & Altlandsberg & Kriescht, Kr. Oststernberg - Krzeszyce & \\
\hline 2002 & Beeskow & Zielenzig, Kr. Oststernberg - Sulęcin & \\
\hline 2005 & Frankfurt (Oder) & Kreis Słubice & \\
\hline 2005 & Friedland (NL) & Zielenzig, Kr. Oststernberg - Sulęcin & \\
\hline 2005 & Neuenhagen & Schwiebus - Świebodzin & \\
\hline 2005 & Neuruppin & Bomst, Kr. Züllichau-Schwiebus - Babimost & \\
\hline 2007 & $\begin{array}{l}\text { Joachimsthal (Amt) } \\
\text { (UM) }\end{array}$ & Mohrin, Kr. Königsberg/Nm.- Moryn & \\
\hline 2010 & Prenzlau (UM) & Berlinchen, Kr. Soldin - Barlinek & \\
\hline 2014 & Fürstenwalde/Spree (L) & $\begin{array}{l}\text { Züllichau, Kr. Züllichau-Schwiebus - Su- } \\
\text { lechów }\end{array}$ & \\
\hline 2014 & Fürstenwalde/Spree (L) & Zantoch, Kr. Landsberg/W. - Santok & \\
\hline \multirow[t]{2}{*}{2014} & Wusterhausen/Dosse & Prittisch, Kr. Schwerin/W. - Przytoczna & Absichtserklärung \\
\hline & & $\begin{array}{l}\text { b) Pom mern } \\
\text { (mit den ehem. grenzmärkischen Kreisen) }\end{array}$ & \\
\hline 1977 & Templin (UM) & Bad Polzin - Polczin Zdrój & 1997 erneuert \\
\hline 1991 & Rathenow & Flatow - Złotów & \\
\hline 1994 & Brüssow (UM) & Rewahl, Kr. Greifenberg - Rewal & \\
\hline 1994 & Schwedt/Oder (UM) & Greifenhagen - Gryfino & \\
\hline 1995 & Wildau & Rewahl, Kr. Greifenberg - Rewal & \\
\hline 1996 & Joachimsthal (UM) & Gülzow, Kr. Cammin - Golczewo & \\
\hline 1996 & Werneuchen (OB) & Berg-Dievenow, Kr. Cammin - Dziwnów & \\
\hline 1998 & Werneuchen (OB) & Henkenhagen, Kr. Kolberg - Ustronie Morskie & \\
\hline 1999 & Welzow (NL) & Massow, Kr. Naugard - Maszewo & \\
\hline 2004 & Schwedt/Oder (UM) & Köslin - Koszalin & \\
\hline 2004 & Strasburg (UM) & Dramburg - Drawsko Pomorskie & \\
\hline 2006 & Kyritz & Deutsch Krone - Wałcz & \\
\hline
\end{tabular}




\begin{tabular}{|c|c|c|c|}
\hline Jahr & Ort & Partnerstadt/-gemeinde & Bemerkungen \\
\hline & & c) Schlesien & \\
\hline 1959 & Bezirk Frankfurt (Oder) & Woiwodschaft Zielona Góra (Grünberg) & (Bezirk!) \\
\hline 1972 & Eisenhüttenstadt (NL) & Glogau - Głogów & besteht weiter \\
\hline 1973 & Potsdam & Oppeln (Oberschlesien) - Opole & 1995 und 2003 bekräftigt \\
\hline 1975 & Cottbus (NL) & Grünberg in Schlesien - Zielona Góra & besteht weiter \\
\hline 1981 & Lübbenau (NL) & Naumburg/Bober - Nowogród Bobrzański & 2001 erneuert \\
\hline 1991 & Luckau (NL) & Schlawa (Schlesiersee) - Ślawa & \\
\hline 1992 & Senftenberg (NL) & Neusalz/Oder - Nowa Sól & \\
\hline 1999 & Spremberg (NL) & Sprottau - Szprotawa & \\
\hline 2000 & Drebkau (NL) & $\begin{array}{l}\text { Rothenburg/Oder, Kr. Grünberg - } \\
\text { Czerwieńsk }\end{array}$ & \\
\hline 2000 & Drehnow (NL) & Ochelmersdorf, Kr. Grünberg - Ochla & \\
\hline 2005 & Lübbenau (NL) & Schweidnitz - Świdnica & \\
\hline \multirow[t]{2}{*}{2006} & Teltow & Sagan - Żagań & \\
\hline & & d) Provinz Posen/Wartheland & \\
\hline 1993 & Lübben (NL) & Wollstein - Wolsztyn & \\
\hline 1998 & Seelow $(\mathrm{L})$ & Birnbaum - Międzychód & \\
\hline 1999 & $\begin{array}{l}\text { Biesenthal-Barnim } \\
\text { (Amt) }\end{array}$ & Neutomischel - Nowy Tomyśl & \\
\hline 2000 & Lübbenau (NL) & Pinne, Kr. Samter - Pniewe & \\
\hline 2002 & Bestensee & Priment, Kr. Bomst - Przemęt & \\
\hline 2004 & Storkow & Opalenitza, Kr. Grätz - Opalenica & \\
\hline \multirow[t]{2}{*}{2012} & Hennigsdorf & Schroda - Środa Wlkp. & \\
\hline & & e) Westpreußen & \\
\hline \multirow[t]{2}{*}{1998} & Friesack & Parchau, Kr. Karthaus- Parchowo & \\
\hline & & f) Zips (Slowakei) & \\
\hline 2007 & Brück (Amt) & Zipser Bela - Spiŝská Belá & \\
\hline
\end{tabular}

\section{Spätaussiedler}

Auch nach 1990 blieb das oben bereits für die DDR-Zeit behandelte Thema der Neueingliederung von Menschen deutscher Abstammung ${ }^{2140}$ aktuell. Die „zahlenmäßig stärkste Gruppe“ stellen seit 1990 „Personen aus der ehemaligen Sowjetunion“: „Inzwischen kommen Spätaus-

2140 Aktuelle juristische Definition des Spätaussiedler-Status: Allgemeine Verwaltungsvorschrift zum Bundesvertriebenengesetz (BVFG-VwV) vom 1. Januar 2016 (GMBl 2016 Nr. 6, S. 118). 
siedler mit ihren Angehörigen fast ausschließlich von dort.“2141 Durch das am 1. Januar 1993 in Kraft getretene bundesdeutsche Kriegsfolgenbereinigungsgesetz ( $\mathrm{KfbG}$ ) wurde der Status „Spätaussiedler“ erstmals definiert und nun „im Wesentlichen auf deutsche Volkszugehörige aus den Republiken der ehem. Sowjetunion eingeschränkt“2142 Teilweise sind auch hierzu bereits Akten in (brandenburgische) Archive gelangt. ${ }^{2143}$ Dagegen ist die Literatur (zu Brandenburg) verständlicherweise noch spärlich. ${ }^{2144}$ Brandenburg bekam „nach dem im Vertriebenengesetz festgelegten Schlüssel 3,5 Prozent der Aussiedler. ${ }^{2145}$ Das sind etwa 3500 im Jahr. Jedes Land entscheidet für sich, wer als Spätaussiedler anerkannt und damit eingebürgert wird.“2146 Die Zahl der in Brandenburg aufgenommenen Aussiedler stieg zunächst kontinuierlich von 1438 im Jahr 1991 auf 5020 im Jahr 1993 an, sank dann 1992 auf 2 826, um 1996 ihren Höchststand mit 6269 zu erreichen und seitdem allmählich zurückzugehen (1998 aber noch 3761). ${ }^{2147}$ Die Erklärung für den Boom des Jahres 1996 findet sich im Bericht des zuständigen Ministeriums: „Erst nach Inkrafttreten des Wohnortzuweisungsgesetzes ${ }^{2148} 1996$ konnte die Quote annähernd erfüllt werden, da vorher viele Aussiedler in andere Bundesländer weiterzogen. Ursache der Weiterwanderung waren fehlende Arbeitsplätze und Wohnungsangebote sowie familiäre Gründe. [...] Dieses Wohnortzuweisungsgesetz bedingt den zahlenmäßigen Anstieg der in Brandenburg

2141 Migrationsbericht des Bundesamtes für Migration und Flüchtlinge im Auftrag der Bundesregierung. Migrationsbericht 2011. Hrsg.: Bundesministerium des Innern. Berlin 2013, S. 51.

2142 Mathias Beer: Bundesvertriebenengesetz (BVFG). In: Lexikon der Vertreibungen. Wien/Köln/Weimar 2010, S. 97-100, hier S. 99.

2143 Beispiele: Kreisarchiv Potsdam-Mittelmark, FB 1 Amt Brück, Gv 491 (Verteilung von Spätaussiedlern und ausländischen Flüchtlingen im Amt Brück, 1992-2001). - BLHA (Weiteres in der Archivdatenbank): BLHA, Rep. 601 Bezirksverwaltungsbehörde Frankfurt (Oder), Nr. 26449 (Aussiedler und Asylbewerber, 1990); Nr. 26486 (Vorbereitungen zur Aufnahme von ausländischen Aussiedlern und Asylbewerbern, 1990-1991). BLHA, 2200 Landesrechnungshof Brandenburg, Nr. 220 (Prüfung der ordnungsgemäßen Anforderung und Verwendung der Zuwendungen des Landes Brandenburg für die Errichtung und erstmalige Einrichtung des „Übergangswohnheimes für Ausländer/Aussiedler in Lübben“, 1993-1995). - Noch nicht für die Benutzung zugänglich ist der Bestand BLHA, Rep. 1610 Landesamt für Soziales und Versorgung Cottbus (7 lfm, 19922006).

2144 Mit volkskundlichem Blick auf mitgebrachte russlanddeutsche Festtagsbräuche der erst nach 1991 Ausgesiedelten: Katalin Wargenau: Feste feiern - Traditionen bei den Aussiedlerfamilien in Wiesenau, Ortsteil KunitzLoose. In: Heimatkalender Eisenhüttenstadt und Umgebung 12 (1994), S. 91-92.

2145 Zum insgesamt geringen Prozentsatz der in die neuen Bundesländer gelangten, mehrheitlich in den Altbundesländern lebenden (Spät-)Aussiedler siehe: Susanne Worbs u. a.: (Spät-)Aussiedler in Deutschland. Eine Analyse aktueller Daten und Forschungsergebnisse. Forschungsbericht 20. Hrsg.: Bundesamt für Migration und Flüchtlinge. Nürnberg 2013, S. 98-104.

2146 Frank Pergande: Leben in Deutschland lernen. Aussiedler in fremder Umgebung. In: Frankfurter Allgemeine Zeitung, 29.4.2006.

2147 Diagramm „Aussiedleraufnahme im Land Brandenburg 1991 bis 1998“ in: Sozialberichterstattung. Sozialpolitik im Überblick. Hrsg.: Ministerium für Arbeit, Soziales, Gesundheit und Frauen des Landes Brandenburg, Öffentlichkeitsarbeit. Potsdam 1991, S. 54.

2148 Es bestimmt, dass in den ersten vier Jahren des Aufenthalts Sozialhilfe nur an dem Ort gezahlt wird, dem der Aussiedler zugewiesen wurde. Sozialberichterstattung (wie Anm. 2147), S. 55. 
aufgenommenen und auch verbliebenen Spätaussiedler seit 1996 trotz bundesweit um 50 \% zurückgegangener Aufnahmezahlen." 2149

Auch aus dem Kreis der erst nach 1990 zugewanderten Spätaussiedler sind inzwischen Äußerungen Betroffener publiziert worden. ${ }^{2150}$ Ein Russlanddeutscher aus dem Wolgagebiet (geb. 1928), der 1941 nach Kasachstan deportiert wurde, lebte dort, anfangs als Heimkind und bald russifiziert, bis in die neunziger Jahre. Als er nach 36 Jahren unverhofft seine in Deutschland lebende Schwester wiedersah, war es für ihn „ein Tag, der mein ganzes Leben auf den Kopf gestellt hat. [...] Ich wusste jetzt aber gar nicht mehr, wer ich bin: Ein Russe oder ein Deutscher." Er entschied sich für letzteres und übersiedelte mit seiner Familie nach Deutschland: „Uns hat das Land Brandenburg aufgenommen. Hier in der Stadt Senftenberg, am Senftenberger See, habe ich mein neues Zuhause, meine neue - alte - Heimat gefunden."2151 Eine 1950 geborene Russlanddeutsche, die 2000 aus Kasachstan nach Finsterwalde kam, stellte dort fest: „Langsam nahmen wir es wahr, dass wir unser früheres Leben zurückgelassen hatten und in Deutschland, der Heimat unserer Familie angekommen waren." 2152

Zuständig für die Eingliederung dieser Zuwanderer war ab 1991 die dem Innenministerium nachgeordnete Landesoberbehörde „Landesstelle für Aussiedler des Landes Brandenburg“ in Peitz ${ }^{2153}$, die alle zugewiesenen Aussiedler zu durchlaufen hatten und von wo sie „auf die Kreise und kreisfreien Städte verteilt" wurden ${ }^{2154}$. In jedem Kreis bestanden Aussiedlerheime für die vorübergehende Unterbringung bis zur Einweisung in eigene Wohnungen. Die Landesstelle war anfangs noch zusätzlich stark ausgelastet mit der Auszahlung von Entschädigungen an die bereits vor 1990 in der DDR lebenden Vertriebenen ${ }^{2155}$, die sich nun auf die Regelung berufen konnten. Nach 1993 kümmerte sie sich aber überwiegend um die meist aus Russland und Kasachstan kommenden Spätaussiedler. ${ }^{2156}$ Sie übernahm das Brandenburger Kontingent aus

2149 Ebd., S. 55.

2150 Z.B. knapp in: Ida Kretzschmar: Auf der Suche nach Heimat. In: Lausitzer Rundschau, 11.2.2011.

2151 Reinhardt Baumann: Was ist Heimat? In: Zeitzeugen berichten 2003. Zuhause in Brandenburg (wie Anm. 276), S. 18-19, hier S. 19.

2152 Vilma Kühl: Eine Familiengeschichte Wolgadeutscher. In: Heimatkalender Bad Liebenwerda 56 (2004/05), S. 77-87, hier S. 85 .

$2153 \mathrm{Zu}$ unterscheiden von der (dem Innenministerium nachgeordneten) 1991 gegründeten „Zentralen Aufnahmestelle für Asylbewerber“ bzw. „Zentralen Ausländerbehörde“ in Eisenhüttenstadt, Poststraße 72, die lediglich in den 1990er Jahren vorübergehend aushilfsweise Personal nach Peitz abordnete, um den dortigen Antragsboom Vertriebener bewältigen zu helfen (Mitteilung des Leiters Frank Nürnberger, Eisenhüttenstadt, 7.6.2017)

2154 Sozialberichterstattung (wie Anm. 2147), S. 55.

2155 Kotsch, Vertriebene und Vertriebenenpolitik in Brandenburg (wie Anm. 39), S. 137. - Behörden rechnen mit 250000 Anträgen auf Entschädigungen: 30 Millionen für Vertriebene. In: Berliner Zeitung, 9.12.1994.

2156 Außerdem war die Landesstelle zuständig für die Eingliederung jüdischer Zuwanderer aus den GUS-Staaten (Ausländeraufnahmeheim Blumberg) und ehemaliger Vertragsarbeiter. Für wertvolle Auskünfte zur Behördengeschichte danke ich Frau Dr. Ilona Schulz (Spremberg), die 1991-2005 für Öffentlichkeitsarbeit zuständig war und eine (unveröffentlichte) Chronik führte. Siehe auch Kliemann, Zur gegenwärtigen Situation der Spätaussiedler im Land Brandenburg (wie Anm. 254). 
dem (seit 2002 allein) für die Erstaufnahme zuständigen, dem Bundesverwaltungsamt nachgeordneten „Grenzdurchgangslager Friedland“ bei Göttingen (Niedersachsen). In Peitz wurde die Sozialarbeit von mit der Behörde kooperierenden freien Trägern, u. a. der Caritas, der Evangelischen Flüchtlingshilfe und dem Diakonischen Werk, durchgeführt. ${ }^{2157}$ Der Unterricht für die schulpflichtigen Kinder der Spätaussiedler-Familien fand in einem 1991 neu gegründeten Gymnasium in Peitz statt. ${ }^{2158}$ Aus der Perspektive einer aus Kasachstan über Osnabrück und Bramsche nach Peitz gekommenen und schließlich in Finsterwalde ansässig gewordenen Russlanddeutschen stellte sich dies wie folgt dar: „In Peitz waren wir ungefähr drei Wochen. Mit der Antragsbearbeitung, zahlreichen wichtigen Treffen, Vorlesungen, Sprachkursen für Anfänger und Kinderbetreuung für Bedürftige war die Zeit ausgefüllt. Das dritte und letzte Heim war in Pahlsdorf [bei Sonnewalde]. Dort führte man das Aufnahmeverfahren zu Ende, und wir bekamen Wohnungen! / Seit dem 1. Juli 2000 wohnen wir in Finsterwalde [...]. / Und immer waren wir für jede Hilfe sehr dankbar. [...]. / Bei dem Ausfüllen von Fragebögen halfen und helfen uns stets Mitarbeiter des Roten Kreuzes, Caritas, Kirche, Diakonie, Arbeitsamt, Juristen, Ärzte [...], Sozialamt [...]. Ab September 2000 hatten meine ältere Tochter Silvia und ich sechs Monate einen Sprachkurs in Deutsch, den wir mit Erfolg beendeten. [...].“2159

Zum 1. Januar 1997 wurde die Landesstelle zwar formal aufgelöst ${ }^{2160}$, wechselte de facto aber als nunmehriges „Landesvertriebenen- und Aussiedleramt“ in das Ressort des dem Ministerium für Arbeit und Sozialwesen nachgeordneten Landesamtes für Soziales und Versorgung (Cottbus) ${ }^{2161}$, arbeitete aber ansonsten unverändert in Peitz weiter, bis es mit dem starken Rückgang von Aussiedlern Ende 2005 als Abteilung 6 in das Landesamt für Soziales und Verwaltung, nummehr in Cottbus, übernommen wurde. ${ }^{2162}$ Diese Abteilung ist inzwischen ebenfalls aufgelöst worden, das Landesamt ist aber weiterhin u. a. auch für Spätausiedler zuständig. ${ }^{2163}$

2157 Zur Zusammenarbeit der Evang. Flüchtlingsseelsorge mit der lokalen evang. Kirchengemeinde Peitz („Peitzer Modell“) siehe: Köhler, Notaufnahme (wie Anm. 26), S. 413-430. - Auch in vielen anderen brandenburgischen Städten befanden oder befinden sich kirchliche (evang. gemeindliche oder kath. Caritas-)Beratungsstellen für (insbesondere russlanddeutsche) Aussiedler.

2158 Auskünfte Dr. Ilona Schulz (Spremberg), 7.6.2017.

2159 Kühl, Eine Familiengeschichte Wolgadeutscher (wie Anm. 2152), S. 85.

2160 Auflösungsverordnung (GVBl. II/96, [Nr. 41], S. 864).

2161 Landesaufnahmegesetz („Gesetz über die Aufnahme von Flüchtlingen, spätausgesiedelten und weiteren aus dem Ausland zugewanderten Personen im Land Brandenburg sowie zur Durchführung des Asylbewerberleistungsgesetz") vom 17. Dezember 1996 (GVBl. I S. 358, 360).

2162 Für hilfreiche Auskünfte danke ich Frau Dr. Ilona Schulz (Spremberg), 7.6.2017; Angaben zur Behördengeschichte: Archivdatenbank des BLHA, hier Rep. 1610 Landesamt für Soziales und Versorgung Cottbus. Über die Zeittafel zur Behördengeschichte hinaus unergiebig ist die offizielle Broschüre des Amtes: Jubiläum. 20 Jahre Landesamt für Soziales und Versorgung. Aufbrüche, Kontinuitäten, Perspektiven. Hrsg.: Landesamt für Soziales und Versorgung. Red.: Kristina Hübener, Petra Schmoger. Cottbus 2011.50 S.

2163 Wie der aktuellen Internetseite, s. v. „Zuwanderung“, zu entnehmen ist: „Die Aufnahme und Verteilung von Spätaussiedlern, jüdischen Zuwanderern und besonders schutzbedürftigen Personen sind Kernstücke unserer Arbeit. / Unsere Aufgaben sind: [...] Aufnahme und Verteilung der Spätausiedler und ihrer Familienmitglieder auf Grundlage des $\$ 8$ Bundesvertriebenengesetz (BVFG) sowie des Landesaufnahmegesetztes (LAufnG)/[...]/Erteilung einer 
Die Landesstelle ist wegen der großen Zahl von Menschen, für die sie eine - gleichsam symbolisch - entscheidende Stätte in ihrem Leben wurde, auch in der Presse immer wieder gewürdigt worden. So schrieb der Berliner „Tagesspiegel“ anlässlich ihrer Auflösung 2005: „In dem schlichten Plattenbau in der Nähe der Fischteiche von Peitz sammelten in den vergangenen 15 Jahren Zehntausende Einwanderer aus Osteuropa ihre ersten Eindrücke von Deutschland und Brandenburg. Hier lernten sie den Umgang mit Formularen, die Eröffnung eines Bankkontos oder die Beantragung von Rente und Kindergeld. Zwei Wochen lebten die Spätaussiedler und jüdischen Zuwanderer aus der früheren Sowjetunion, aus Polen, Rumänien, Ungarn und dem Kosovo in der Juri-GagarinStraße, ehe sie auf einzelne Orte überall in Brandenburg verteilt wurden. / Am Jahresende ist damit Schluss, die ,Landesaufnahmeeinrichtung' in Peitz schließt ihre Türen. Es gibt einfach immer weniger Antragsteller. Die Aufgaben übernimmt die Bundeszentrale im niedersächsischen Friedland. Alle in Peitz beschäftigten 13 Mitarbeiter erhalten nach Auskunft der Staatskanzlei eine Beschäftigung im Landesamt für Soziales und Versorgung im nahen Cottbus. Noch Anfang August war eine Ärztin aus der Ukraine als 55 000. Aussiedlerin in Brandenburg begrüßt worden. [...]“2164

Den zwanzigsten Jahrestag der Eröffnung der Landesstelle in Peitz (11. Februar 1991) nahm am 11. Februar 2011 die „Lausitzer Rundschau“ zum Anlass, an die Arbeit der Behörde zu erinnern ${ }^{2165}$ : „Heute vor 20 Jahren öffnete die Landesaufnahmestelle für Aussiedler in Peitz (SpreeNeiße) ihre Türen. Insgesamt hat das Land Brandenburg seither fast 56300 Menschen deutscher Abstammung und ihre Angehörigen aufgenommen. Sie kamen mit großen Hoffnungen vor allem aus der ehemaligen Sowjetunion, aber auch aus Ungarn, Polen und Rumänien. [...] Rainer Zwiers, von 1991 bis 2003 Leiter der Landesaufnahmestelle für Aussiedler in Peitz, hat sie alle kommen und gehen gesehen, die meisten aber längst aus den Augen verloren. ,Es waren Menschen mit den unterschiedlichsten Einzelschicksalen. Aber alle hatten riesige Erwartungen, wollten unbedingt einen Neuanfang', erinnert sich der heutige Abteilungsdirektor des Landesvertriebenen- und Aussiedleramtes/Förderaufgaben im Landesamt für Soziales und Versorgung und setzt hinzu: ,Ende der 90er-Jahre änderte sich das etwas. Meist waren es Nachkömmlinge, die nun eintrafen. Sie waren weniger mit der deutschen Sprache und Kultur vertraut und hatten es schwerer, sich auf die neue Situation einzustellen." "Der Beitrag schildert darüber hinaus, in Auszügen aus Interviews mit Spätaussiedlern, Fälle gelungener und weniger gelunger Integration. Er endet mit dem Beispiel einer in den neunziger Jahren nach Brandenburg gekommenen Russlanddeutschen: „Als sie 2006 bei einem Besuch in Kasachstan gefragt wurde, ob sie sich in Deutschland zu Hause fühle, hatte sie nach kurzem Überlegen geantwortet: ,Ja, jetzt schon.' Andere sind noch auf dem mühsamen Weg dahin. Wer nicht zurück will, hat keine Wahl. Sergej Fischer bringt es auf den Punkt: ,Wir müssen uns selbst integrieren." “

Zweitschrift von Vertriebenenausweisen und Spätausiedlerbescheinigungen gem. $\$ 15$ Bundesvertriebenengesetz $(B V F G)$ “ (www.lasv.brandenburg.de [7.6.2017]).

2164 Claus-Dieter Steyer: Land schließt Aufnahmeheim für Aussiedler. In: Der Tagesspiegel, 17.11.2005.

2165 Ida Kretzschmar: Auf der Suche nach Heimat. Am 11. Februar vor 20 Jahren kamen die ersten Aussiedler mit großen Hoffnungen in Peitz an. In: Lausitzer Rundschau, 11.2.2011. 
Dies sind nur einige wenige Schlaglichter auf einen ohnehin am Rande des hier behandelten Hauptthemas stehenden Aspekt der - auch Brandenburg betreffenden - Bevölkerungsbewegungen des 20. Jahrhunderts. Systematische Recherchen zu Spätaussiedlern in Brandenburg stehen noch aus. Eine Zwischenbilanz, die der Landesjugendring Brandenburg und das Landesjugendamt des Landes Brandenburg 2003 zogen, zeigt deutlich eine Reihe von Schwierigkeiten auf, die sich der Erfassung und Erforschung dieses Gegenwartsphänomens für den auf Quellen angewiesenen Historiker stellen und auch in Zukunft stellen werden, die begrenzte Wahrnehmbarkeit einerseits und andererseits die kaum ausreichende Erfassbarkeit: „Im Land Brandenburg leben rund 48800 Ausländer (Stand Ende 2001), das entspricht einem Anteil von rund 1,9\% an der gesamten Bevölkerung. Dies ist deutlich weniger als der Bundesdurchschnitt, der bei $9 \%$ Ausländern an der Gesamtbevölkerung liegt. Noch geringer ist die Zahl deutschstämmiger Einwanderer. Schätzungsweise kommen jährlich rund 4000 Spätaussiedler nach Brandenburg, von denen ein Großteil allerdings nach Berlin oder in die alten Bundesländer umzieht. Zur Zeit geht das Sozialministerium von insgesamt rund 20000 Spätaussiedlern in Brandenburg aus. Wegen ihres Rechtsanspruches auf Einbürgerung in Deutschland werden sie statistisch nicht gesondert erhoben." ${ }^{2166}$

Immerhin bemerkenswert ist, dass die Lokalgeschichtsforschung auch dieses Thema mittlerweile nicht mehr unerwähnt lässt, auch wenn das erst für wenige Orte, wie etwa Eberswalde ${ }^{2167}$, gilt. So verweisen die Autorinnen des 2011 erschienenen Bandes der „Letschiner Chronik“ darauf, dass „Nachfahren von Russlanddeutschen als Spätaussiedler auch in die neuen Bundesländer“ kamen und zunächst „meist in Sammelunterkünften untergebracht“ wurden. „Von 2000 bis 2001 kamen insgesamt 24 Spätaussiedler nach Letschin und von 2001 bis 2004 waren alle wieder weggezogen." Trotz dieser Fluktuation stellen die Autorinnen zumindest für ihre Gesamtregion fest: „Heute leben ca. 1000 Spätaussiedler/Russlanddeutsche im Kreis Märkisch-Oderland.“2168

2166 Jugendarbeit in Brandenburg. Hrsg.: Landesjugendring Brandenburg e. V. und Landesjugendamt des Landes Brandenburg. Red.: Gerhard Mittelstädt, Bernd Mones. Potsdam/Bernau [2003], S. 12.

2167 Marieta Böttger / Mohamed Hamdali: Neue Heimat Eberswalde nach der politischen Wende 1990. Zuwanderung in den Barnim - Chancen und Probleme. In: Fremde Heimat Eberswalde (wie Anm. 185), S. 51-60, darin S. 53-60 Kapitel „Russlanddeutsche - Aussiedler/innen“. - Vgl. für Berlin-Marzahn-Hellersdorf: Alexander Reiser: Russlanddeutsche. Angekommen zu Hause in der Fremde. In: Besiedlung, Bevölkerung, Migration (wie Anm. 6), S. 142-166.

2168 Strenge/van Tankeren, Letschiner Chronik, Bd. 5 (wie Anm. 152), S. 189 (hier auch die folgenden Zitate). 



\section{Fazit - Vertriebene in der brandenburgischen Gesellschaft der Gegenwart}

Flüchtlinge und Vertriebene sind im öffentlichen Leben des 1990 wiederbegründeten Landes Brandenburg in hohe Ämter gelangt. Nicht nur der aus der pommerschen Hauptstadt Stettin (poln. Szczecin) stammende Ministerpräsident Manfred Stolpe ${ }^{2169}$ (1936-2019), sondern auch die beiden ersten Landtagspräsidenten Herbert Knoblich ${ }^{2170}$ (geb. 1939) aus dem niederschlesischen Alt Jauer (poln. Stary Jawor), Kreis Jauer, und Gunter Fritsch ${ }^{2171}$ (geb. 1942) aus dem neumärkischen Landsberg an der Warthe (poln. Gorzów Wlkp.) zählen zu ihnen. Auch unter den sonstigen Abgeordneten des ersten Landtages der Jahre 1990-1994 finden sich viele mit Geburtsorten in den Vertreibungsgebieten: mehr als ein Drittel der vor 1945 geborenen Landtagsmitglieder, darunter der allerdings nach der Flucht aus Hinterpommern zunächst in Schleswig-Holstein aufgewachsene Vizepräsident Lothar Bisky (1941-2013) und der aus dem Sudetenland stammende erste Alterspräsident Gustav Just (1921-2011). ${ }^{2172}$ Der Initiator (1990)

2169 Ungewohnt offener Bericht über seine Herkunft und den Weg seiner Familie 1945: Manfred Stolpe: Von Pommern nach Potsdam. Ein Leben im Gespräch. Das Interview mit Christoph Singelnstein und Jost-Arend Bösenberg. Berlin 2016, S. 11-16. Siehe aber auch schon die Formulierungen in seinem „Grußwort zum 80. Geburtstag von Propst Dr. Hans-Otto Furian“ vom 30.4.2011 (Text auf seiner eigenen Internetseite: manfredstolpe.de [22.7.2018]): „Beide haben wir Kriegsende und Vertreibung voll miterlebt und beide lieben wir Brandenburg. Die geografischen Wurzeln sind nahe beieinander in der Neumark von Ihrem Kürtow/Arnswalde - Nörenberg - Dramburg zu meinem Schievelbein [richtig: Schivelbein]. Alles Neumark, alles unter Hitler Pommern zugeschlagen. Aber Brandenburg im Herzen - bis heute!" Siehe auch BBL, S. 383 f.

2170 Herkunft und Flüchtlingsstatus u. a. erwähnt in: BBL, S. 228; Lausitzer Rundschau, 15.2.2015.

2171 „Die Flucht vor der Roten Armee 1945 endete für Gunter Fritsch und seine Familie in Tabarz/Thür. Wald. Erst 1947 kehrte sie wieder nach Brandenburg zurück und siedelte sich in Tempelberg (damals Landkreis Lebus) bei Fürstenwalde/Spree an. [...] 1957 zog die Familie nach Müncheberg um." (Wikipedia [4.7.2017]). - Am 23. November 2011 hielt Fritsch anlässlich der Präsentation der Ausstellung „Landsberg - Gorzow“ zu den Wissenschaftstagen der Fachhochschule Lausitz in Cottbus ein Grußwort (www.landtag.brandenburg.de/de/ meldungenterminhinweise [4.7.2017]).

2172 Von insgesamt 88 Abgeordneten waren 43 vor 1945 (1921-1943) geboren. Von diesen hatten 16 (37,2 Prozent) einen Geburtsort in diesen Gebieten angegeben: Niederschlesien (7), Oberschlesien (1), Neumark (1: Joachim Franck aus Küstrin), Hinterpommern (2: Lothar Bisky und Manfred Stolpe), Ostpreußen (2), Westpreußen (1: Alwin Ziel [als Flüchtling mit vier Jahren zunächst nach Mecklenburg gelangt]), Sudetenland (2, darunter Gustav Just) (Quelle: Kurzbiographien der Abgeordneten in: Landtag Brandenburg. 1. Wahlperiode 1990-1994. Volkshandbuch. Stand: Januar 1991. Rheinbreitbach 1991, S. 21-50). Selbst wenn einzelne von ihnen ihren Geburtsort bereits vor Kriegsende bzw. nicht durch Flucht oder Vertreibung verlassen haben sollten - was eher nicht anzunehmen ist, da die meisten erst im Krieg geboren sind -, bliebe höchstwahrscheinlich die Größenordnung ähnlich, ein persönlicher Bezug zu den Gebieten wäre dennoch gegeben; hinzu kämen ohnehin ggf. noch nach 1945 in SBZ/DDR geborene Kinder von Vertriebenen. Betont werden muss freilich, dass nur ein Teil der Betroffenen die Nachkriegsjahre in Brandenburg verlebt hat und erst später zugezogen ist. - Zum Vergleich die Zahlen für den ersten Landtag 1947: 32 von 102 Abgeordneten (31,4 Prozent) hatten Geburtsorte in den Vertreibungsgebieten: Niederschlesien (9), Oberschlesien (4), Ostbrandenburg (5), Provinz Posen (5), Ostpreußen (4), Pommern (3), Westpreußen (2) (Quelle: Handbuch des Landtages 1947 [wie Anm. 1064]). - Klaus-Dieter Arlt (geb. 1942 Breslau, aufgewachsen in Neuenhagen), war 1990 1. Stell- 
und künstlerische Leiter (bis 2014) der Kammeroper Schloss Rheinsberg, der Komponist Prof. Siegfried Matthus, geboren 1934 in Malenuppen (Kr. Darkehmen, Ostpreußen), ist ein ebenfalls „Flüchtlingskind“ und wuchs als Neubauernsohn in Läsikow (Kr. Ruppin) auf. ${ }^{2173}$ Der Generaldirektor der Stiftung Preußische Schlösser und Gärten Berlin-Brandenburg in Potsdam, der Kunsthistoriker Prof. Dr. Hans-Joachim Giersberg (1938-2014), war gebürtiger Liegnitzer (poln. Legnica): „Die Familie, Flüchtlinge aus Schlesien, war 1950 an die Havel gekommen.“2174 Auch Giersbergs Frau und Schwiegereltern waren Vertriebene, jedoch aus Ostpreußen. ${ }^{2175}$ Diese Aufzählung ließe sich auch in anderen Bereichen der Gesellschaft und in der zweiten und dritten Reihe mit nicht wenigen Beispielen fortführen. ${ }^{2176}$ Die Landes-, dann Bezirks- und seit 1990 wieder Landeshauptstadt Potsdam war dabei geradezu ein Schmelztiegel der aus allen Himmelsrichtungen Zuwandernden ${ }^{2177}$, erst recht nachdem ihre alten Führungsschichten weit-

vertreter der Regierungsbevollmächtigten für den Bezirk Frankfurt (Oder) und 1990-1992 MdL (CDU) (H.J. Onnen: Profile aus Potsdam, Bd. 2, S. 15). - Zu Lothar Bisky (geb. 1941 Zollbrück, Kr. Rummelsburg, gest. 2013) siehe seine Erinnerungen: So viele Träume. Mein Leben. Berlin 2005, bes. S. 13-36 (1945 Flucht mit Mutter u. Bruder, dann zunächst Rückkehr, 1947 Vertreibung über Stettin nach Schleswig-Holstein, wuchs in Brekendorf bei Eckernförde auf, wo er die „Kalte Heimat“ und eine „unsichtbare Grenze“ zwischen „uns und den Einheimischen" erlebte [S. 26f.], Oberschulbesuch in Rendsburg, 1959 Übersiedlung in die DDR); HansJoachim Onnen: Profile aus Potsdam und dem Landkreis Potsdam-Mittelmark. Bd. 1. Potsdam 1998, S. 41. Zu Gustav Ju st (geb. 1921 Reinowitz bei Gablonz, gest. 2011 Prenden) siehe seine Erinnerungen: Deutsch, Jahrgang 1921. Ein Lebensbericht. Potsdam 2001.

2173 Frank Schneider: Siegfried Matthus. In: Ders.: Momentaufnahme. Notate zu Musikern in der DDR (Reihe Kunstwissenschaften). Leipzig 1969, S. 123-142. Die Familie flüchtete am 22. Oktober 1944 in den Westen und kam dann von dort Brandenburg, der Sohn besuchte bis zum Abitur die Oberschule in Rheinsberg. 1997 Kulturpreisträger der Landsmannschaft Ostpreußen für Musik (www.ostpreussen.de [22.8.2017]). Matthus wohnt in Stolzenhagen-Wandlitz und Berlin (Wikipedia).

2174 Thorsten Metzner: Trauer um Potsdamer Ehrenbürger. Potsdams gutes Gewissen. In: Potsdamer Neueste Nachrichten, 1.5.2014 [Nachruf]; BBL, S. 142 f. - Die Familie war 1946 zunächst in den Kreis Niesky vertrieben worden und kam dann nach Kyritz, wo der Vater, Hans Herbert G. (1908-1970), Straßenbauamtsleiter wurde, von dort nach Potsdam, wo er die gleiche Funktion innehatte. Hans-Joachim Giersberg besuchte seinen Heimatort vor 1989 gelegentlich einer Dienstreise (freundliche Mitteilung von Frau Dr. Bettina Giersberg, Näfels/Schweiz, 17.7.2017).

2175 Mitteilung Dr. B. Giersberg (wie vor). Giersbergs Schwiegervater war der bekannte, aus Masuren gebürtige Potsdamer Gynäkologe und Klinikdirektor Dr. Ruthardt Horn.

2176 Wenige Beispiele für viele: Dr. Reinhard E. Fischer (geb. 1937 Nimptsch, Schlesien), brandenburgischer Namenforscher. - Hans-Otto Fu rian (geb. 1931 Arnswalde, Neumark), ev. Pfarrer u. Superintendent, 19881990 Propst der Evangelischen Kirche in Berlin-Brandenburg (Bereich Ost) und 1991-1996 Propst der wiedervereinigten Evangelischen Kirche von Berlin-Brandenburg (wikipedia). - Gisela Heller geb. Hielscher (geb. 1929 Breslau), Schriftstellerin in Kleinmachnow. - Hans-Joachim Thie de (geb. 1933 Niemaschkleba, Kr. Guben [Ostteil]), Niederlausitzer Postgeschichtsforscher (Thiede, Schwere Tage im fünfundvierziger Jahr [wie Anm. 256]; Nachruf von Hans Kober. In: Niederlausitzer Studien 36 (2010), S. 184-186).

2177 Beispiele für Flüchtlinge und Vertriebene in Potsdam sind, auch schon vor 1990, neben dem genannten „Sanssouci-Chef“ Giersberg: Dr. sc. Kurt Ad a my (geb. 1932 Altwasser, Kr. Sorau), Historiker, Dozent an der Pädagogischen Hochschule bzw. Universität Potsdam („Die Familie flüchtete Ende 1944 vor der herannahenden sowjet. Armee aus dem Warthegau, wohin sein Vater zuvor dienstlich versetzt worden war." Mitteilung Prof. Dr. Frank Göse, Potsdam, 12.7.2017). - Dr. Helmut Domke (geb. 1943 Schönau, Kr. Schlochau, Pfar- 
gehend in den Westen gegangen und eine beachtliche Zahl personalbedürftiger Einrichtungen neu errichtet worden war. ${ }^{2178}$

Mehr als ein halbes Jahrhundert, bald ein Dreivierteljahrhundert nach den Geschehnissen von Flucht und Vertreibung sind diese Beispiele allerdings nicht mehr Gradmesser für Erfolg und Karriere von Vertriebenen, sondern zeigen letztlich, dass dies gar kein Thema mehr ist.

rersohn), Physiker, Schulbesuch bis zum Abitur (1960) in Bad Wilsnack, 1966-1990 wissenschaftlicher Mitarbeiter am Astrophysikalischen Observatorium in Potsdam, 1990 DDR-Staatssekretär, 1990-1994 Bevollmächtiger des brand. Ministerpräs. für Abzug der sowjet. Streiftkräfte/Konversion, 2004-2017 Vors. (dann Ehrenvors.) der Stiftung West-Östliche Begegnungen (Onnen [wie Anm. 2172], Bd. 1, S. 69; Der Ministerrat der DDR 1990, S. 27; www.stiftung-woeb.de/ [6.8.2018]). - Dorothee Geßner geb. Hanke (geb. 1939 Brauchitschdorf, Kr. Lüben, Schlesien), Bibliothekarin und Landesbibliographin in Potsdam, Tochter des oben erwähnten Bornstedter Pfarrers Willi Hanke (eigene Auskünfte). - Sigrid Grabner geb. Hauf (geb. 1942 Tetschen-Bodenbach, Sudetenland), Schriftstellerin in Potsdam (Grabner, Jahrgang ,42 [wie Anm. 1417]; BBL, S. 148f.). - Horst Gramlich: „In Antonufka in der Ukraine am 31.3.1938 geboren, verschlugen ihn die Kriegswirren in die Prignitz. Seit 1951 in Potsdam lebend, verbrachte er hier den Rest seiner Schulzeit und durchlief eine Lehre als Bankkaufmann." Später Dipl.-Finanzwirt, wiss. Mitarbeiter an der Akademie für Staats- u. Rechtswissenschaften in Potsdam-Babelsberg, 1990-1998 Oberbürgermeister (SPD) (Onnen [wie Anm. 2172], Bd. 1, S. 109). - Dr. Manfred Horlitz (geb. 1930 Neusalz/Oder, Schlesien, gest. 2014), 1987-1995 Leiter des Theodor-Fontane-Archivs in Potsdam, 1945 Flucht mit der Mutter nach Thüringen, ab 1953 in Brandenburg (Auskünfte der Witwe, Doris Horlitz, Potsdam, 29.8.2017). - Dr. Otfried Keiler (geb. 1931 Breslau, gest. 2016), Literaturwissenschaftler, Dozent an der PH Potsdam, 1980-1987 Leiter des Theodor-Fontane-Archivs, 1987-1990 Cheflektor im Verlag der Nation in Ost-Berlin; 1945 Flucht über Böhmen nach Thüringen (Nachruf von Peter Schaefer in: Fontane-Blätter 102, 2016, S. 174-177; ergänzende Informationen von Doris Horlitz, Potsdam, 29.8.2017). - Hartmut Knitter (geb. 1934 Soldin/Neumark), Historiker und Abteilungsleiter im Potsdam-Museum (eigene Auskünfte). - Prof. Dr. Rolf Mitzner (geb. 1931 Riga), nach dem Abitur (1949) Studium an der Brand. Landeshochschule (spätere PH, heutige Univ.) in Potsdam, dort 1967 Prof. für Physikalische Chemie, 1990 Rektor, 1991 auch Gründungsrektor der Univ., 1993 Rektor (Onnen [wie Anm. 2172], Bd. 1, S. 227: „verschlug es den 8jährigen durch die Umsiedlung nach Deutschland“). - Erwin Motzkus (geb. 1938 Ostpreußen, gest. 2010), Ingenieur, 1990-1994 Bürgermeister der Stadt Potsdam (CDU), Mitglied des BdV-Kreisverbandes Potsdam (Brandenburger Rundschau 8 (2010) 8, S. 12; Potsdamer Neueste Nachrichten, 7.9.2010). - Dr. sc. Reinhard Nis sel (geb. 1944 Wehlau/ Ostpreußen), Jurist, 1990 Prorektor der Hochschule für Recht u. Verwaltung Potsdam (Der Ministerat der DDR 1990, S. 62). - Horst Prietz (geb. 1938 Bärfelde/Nm.), Kartograph beim Kartographischen Dienst ab 1961, 1990 Stadtverordneter, Vors. des Kulturausschuss, später CDU (Onnen [wie Anm. 2172], Bd. 1, S. 261: 1945 Flucht. „So wurde Potsdam, anfangs nur Zufluchtsort, langsam zur zweiten Heimat.“).

2178 Auf eine für ihn überraschende Aufgeschlossenheit für Gespräche über die Vertriebenintegration in Ost und West traf der 1997 aus den Altbundesländern nach Potsdam zuziehende Bromberger Vertriebene Hartwig Spitzer: „Bei dem Kennenlernen war das erste Thema das Ergehen nach dem Kriegsende 1945. Unweigerlich. Das überraschte uns zunächst, denn im Westen war dieses Thema abgearbeitet und hatte kein Gewicht mehr. Es war immer unbeliebt gewesen weil es die Frage barg, ob den Flüchtlingen seinerzeit ausreichend geholfen worden war. Außerdem wusste man in Württemberg oder Hessen nur ungenau über den Deutschen Osten Bescheid./ [...] Das war nun in Potsdam anders. Ich brauchte Westpreußen nicht zu erklären. Auch Bromberg war eine Selbstverständlichkeit, während diese Stadt im Westen nur mühsam bekannt zu machen war. [...]. Gemeinsamkeiten ergaben sich mit den Potsdamern, die aus Schlesien oder [S. 27] Hinterpommern gekommen waren. Abweichend waren zwischen uns allerdings die Meinungen über die Zahl der Vertriebenen. Die Potsdamer meinten fest, dass die DDR die meisten von ihnen aufgenommen hatte. [...]." (Spitzer, Potsdamer Jahre [wie Anm. 1456], S. 26f.). 
Denn die Genannten haben zwar ihre Herkunft während ihrer Jahre in öffentlichen Ämtern von Zeit zu Zeit - der eine mehr, der andere weniger - durchaus erwähnt, so dass die brandenburgische Öffentlichkeit der Nachwendezeit darüber im Bilde war. Diese „Vertriebenen-Merkmale“ werden aber heute nur noch als Teile individueller Biographien wahrgenommen wie jedes andere Merkmal auch, etwa konfessionelle Bindung, sexuelle Orientierung oder der Beruf, so dass daraus in der Betrachtung zwar ein Gruppenmerkmal gebildet werden könnte, aber keine als solche wahrgenommene Gruppe mehr konstituiert wird. Bei den drei genannten Politikern, die für viele andere - nicht im Rampenlicht der Öffentlichkeit stehende - Vertriebene in Brandenburg stehen können, handelt es sich ohnehin um Menschen, die 1945 noch Kinder, also leichter integrierbar waren als ihre Eltern und Großeltern. Alle drei sind mittlerweile aus ihrer aktiven Laufbahn in den Ruhestand übergetreten.

Die Integration der noch in den Vertreibungsgebieten Geborenen in die brandenburgische Nachkriegsgesellschaft ist heute als abgeschlossen anzusehen. Denn allein der zeitliche Abstand hat nahezu alle praktischen Probleme und Fragen gleichsam (auf-)gelöst. Zum anderen hat sich die „Aufnahmegesellschaft“ selbst - durch viele Faktoren struktureller Veränderung, darunter auch durch den Zuzug der Vertriebenen - so stark weiterentwickelt, dass andere Fragen im Vordergrund stehen und Vertriebene bzw. Vertriebenennachfahren selbst in die Rolle von Einheimischen gelangt sind, die neue Zuwandernde erleben. Die weitere Entwicklung im Gebiet des heutigen Brandenburg nach 1945/49 und nach 1990 hat zudem eine Bevölkerung und eine Gesellschaft geformt, die insgesamt sehr stark durch $\mathrm{Zu}$ - und Abwanderung geprägt ist, so dass viele verschiedene Biographien, Herkünfte und Schicksale nebeneinander gestellt worden sind, Menschen in Nachbarschaft und bisweilen auch in neuer Verwandtschaft zusammen leben, die recht unterschiedliche „Vorgeschichten“ in sich tragen. Die schematische Einteilung in Eingesessene und Vertriebene konnte zunächst ab 1945 gelten und mag hier und da in manchem dörflichen Milieu auch Brandenburgs noch heute von älteren Bewohnern verinnerlicht, empfunden und geäußert werden. So sagte eine vermutlich ältere einheimische Besucherin der Weihnachtsfeier im „Dorfkrug“ des Biesenthaler Ortsteils Danewitz 2010 (!), als sie die Teilnehmer gegenüber der Presse beschrieb, noch immer in Gruppen einteilend: „In Danewitz gibt es drei Arten Einwohner: Die schon immer da waren, die Umsiedler, die 1945 dazukamen und die Neuen. “2179 Insofern mögen sich in kleineren Orten noch Bewusstseinskontinuitäten offenbaren, doch ist die Zusammensetzung der brandenburgischen Bevölkerung, auch auf dem ohnehin ausblutenden Land, durch die mannigfaltigen Veränderungen in der DDR-Zeit und nun nochmals die der Wende-Jahre sowie weiterhin die Landflucht bis heute so stark verändert, dass neben den Vertriebenen längst die großen Gruppen der aus anderen Teilen der DDR vorzugsweise, aber keineswegs nur aus Sachsen - Zugezogenen das Bild differenzieren, wenn nicht dominieren. Der Zuzug aus den westlichen Bundesländern seit 1990 hat die Zusammensetzung - keineswegs nur, aber vor allem in den Städten - weiter entwickelt, so dass sich längst 
die nächste und übernächste „Gruppen“-Integration vollzogen hat bzw. vollzieht. Während man hier und da zwischen „Alt-Einheimischen“ und den im Laufe der DDR-Zeit Zugewanderten noch unterscheiden kann und sich das Zusammenwachsen mit den nach 1990 Zugezogenen bzw. laufend weiter Hinzukommenden bis hin zu - gar nicht seltenen - Eheschließungen oder Partnerschaften im vollen Gang befindet, ist das ältere Thema „Vertriebene“ im öffentlichen Diskurs schon wegen dieser Überlagerungen und des zeitlichen Abstandes im Grunde nicht mehr an wesentlicher Stelle vertreten. ${ }^{2180}$ Da die letzte Generation derjenigen, die noch mit wachen eigenen Augen ihre Herkunftsorte jenseits von Oder und Neiße gesehen hatten, mehr und mehr verstummt, verändert sich auch der gesellschaftliche Zugang zum Thema. Die Welle der von Betroffenen verfassten Zeitzeugnisse ist zwar noch nicht ganz abgeebbt, aber auch sie wird merklich schwächer, je mehr Zeitzeugen, inzwischen meist weit über 80 Jahre alt, abtreten.

Die Beschäftigung mit den Vertreibungsgebieten ist in Brandenburg im Großen und Ganzen kein breitere Kreise interessierendes Thema, weder für die Gesellschaft noch für die Wissenschaft, die Kunst oder die Politik. Impulse sind aber immer wieder von - meist polnischen - Wissenschaftlerinnen an der Europa-Universität Viadrina ausgegangen. ${ }^{2181}$ In der lokalen und regionalen Ortschronistik und Heimatgeschichte, wie sie sich in den Landkreisen vollzieht und in „Heimatkalendern“ spiegelt, ist ein Interesse brandenburgischer Akteure feststellbar, die unmittelbar als Nachbarn an Oder und Neiße arbeiten. So befassen sich die in Bad Freienwalde (Oder) erscheinenden Periodika, das „Jahrbuch Märkisch Oderland“ und der „Viadrus“, gelegentlich auch mit Fragen der östlichen Nachbarregion bis hin zur Aufarbeitung des Geschehens der Flucht- und Vertreibungsjahre. Gleiches gilt für Guben ${ }^{2182}$ sowie Fürstenberg (Oder) und Umgebung. Ist solchen heimatgeschichtlichen Aktivitäten noch eine gewisse - aufgeschlossene, positive - lokale und regionale Resonanz sicher, so spielt sich die Tätigkeit der wenigen noch verbliebenen, nach 1990 zunächst überall im Land gegründeten Vertriebenenverbände überwiegend abseits öffentlicher Wahrnehmung ab, zumal auch Anlässe wie neue Gedenksteineinweihungen inzwischen kaum noch vorkommen. Auch wenn die Presse, z. B. im Raum Cottbus, öfters über kleinere Zusammenkünfte berichtet, ist absehbar, dass schon in einigen Jahren nur noch ganz wenige BdV-Kreisverbände lebensfähig sein werden. In öffentlichen Vortrags- und Diskussionsveranstaltungen, Lesungen und kleineren Ausstellungen einzelner regionaler Bildungsträger ist in den letzten Jahren den Geschehnissen der Nachkriegszeit aber immerhin mehrfach nachgegangen worden, mit einer Ausstellung widmete sich nun auch das HBPG in Potsdam 2018/19 dem Vertreibungsgeschehen in den Grenzgebieten. ${ }^{2183}$

2180 Auf die wenigen Aktivitäten und Publikationen mit einem Radius und Echo im gesamten Land ist in der Einleitung hingewiesen worden.

2181 Siehe Anm. $127 \mathrm{f}$.

2182 Bemerkenswert ist der 44. Jahrgang (2000) des Gubener Heimatkalenders, in dem die Stadtgeschichte des 20. Jahrhunderts in verschiedensten Facetten dargestellt wird und Flucht, Vertreibung und Teilung der Stadt mehrfach zur Sprache kommen.

2183 Zu regionalen Aktivitäten siehe z. B. den Bericht über eine Veranstaltung im Rahmen der „Trebnitzer Schlossgespräche" mit dem Zeithistoriker Michael Schwartz (Berlin) und dem Dokumentarfilmer Thomas Grimm 
Wieweit die gegenwärtige brandenburgische Gesellschaft sich mit dem Thema „Vertriebene" heute und in Zukunft - neu, rückschauend, erinnernd - auseinandersetzt, bleibt zu beobachten. Wie in Deutschland insgesamt, wird dieses Thema auch in Brandenburg lokal und regional, auch in der Presse, von einzelnen Jüngeren, Nachgeborenen mehr und mehr behandelt, nicht nur wegen des anlassgebenden neuen Flüchtlingsstroms. Die in der Skizzierung des Forschungsstandes genannten kleineren lokalen Arbeiten aus Nord und Süd, West und Ost des heutigen Landes zeigen deutlich, dass auch diese „Vorgeschichte“ der heutigen brandenburgischen Gesellschaft eigentlich noch ihrer Aufarbeitung harrt, dass aber immerhin nicht mehr ganz so wenige Zeitgenossen bereits erkannt haben, dass sie vonnöten ist, um einen angemessenen Umgang mit allen Brüchen, die Brandenburgs Geschichte aufweist, zu erreichen.

Die bisher erkennbaren Bemühungen um eine umfassendere regionale Erinnerungsarbeit zeigen überall, dass die Aufarbeitung auch dieses Teils der Zeitgeschichte, wie sie etwa von Lehrerinnen und Lehrern in Schülerprojekten betrieben wird, keine neuen Gräben aufreißt, keine Täter-Opfer-Diskussionen vom Zaun brechen muss oder gar das Gedenken an die im deutschen Namen begangenen nationalsozialistischen Verbrechen behindert. Die vielfach zu beobachtende Unvoreingenommenheit junger Menschen eröffnet die Möglichkeit, dem Vergessen in jeder Hinsicht - und nicht „germanozentrisch“ - entgegen zu arbeiten; die freilich ebenso zu beobachtende und nicht immer von ersterer zu trennende Unwissenheit nicht nur der jüngsten Generationen in Bezug auf die - allgemeine wie regionale - Geschichte sollte allerdings dazu ermahnen, in der Arbeit des Gedenkens nicht nachzulassen.

Welche Rolle der Themenkomplex „Flucht und Vertreibung“ im „normalen“ Unterricht an (brandenburgischen) Schulen spielt, sei dahin gestellt, da auch der Geschichtsunterricht insgesamt immer mehr in existentielle Bedrängnis gerät. Gegenwartsbezüge (Migration) bieten jedenfalls ebenso Ansatzpunkte wie die jährliche öffentliche Bezugnahme auf den 8. Mai 1945

in der „Begegnungsstätte Schloss Trebnitz“ (bei Müncheberg): Ulf Grieger: Zweiter Schock bei der Ankunft. Behandlung der Vertriebenen im Nachkriegsdeutschland noch immer Tabu-Thema in den Dörfern. In: MOZ. de, 14.5.2013. - Siehe ferner die Hinweise auf Veranstaltungen und Ausstellungen in der Ortsdokumentation, z. B. Gransee, Kyritz, Oranienburg. - Zur Ausstellung im HBPG siehe Ortsdokumentation Potsdam im Teil 2 sowie den kurzen Vorab-Beitrag der Kuratoren: Thomas Wernicke/Julia Bork: Beiderseits der Oder. Geschichtsraum/Grenzraum/Begegnungsraum.7. September 2018 bis 20. Januar 2019. In: MuseumsJournal Berlin \& Potsdam (2018) 3, S. 78-79, hier bislang in Brandenburg ganz ungewohnte Formulierungen wie (S. 78): „Infolge der nationalsozialistischen Besatzungspolitik und des Zweiten Weltkriegs sowie der alliierten Nachkriegsordnung vollzog sich in dieser Region die Tragödie der größten europäischen Zwangsumsiedlung des 20. Jahrhunderts. Noch heute haben beinahe ein Drittel der in der deutschen Oderregion lebenden Menschen Vorfahren, die von jenseits der Oder geflohen sind, vertrieben oder ausgesiedelt wurden. Ähnlich auf polnischer Seite: Hierhin kamen heimatlos Gewordene aus den ehemaligen polnischen Ostgebieten, Umsiedler aus Zentralpolen, ehemalige Zwangsarbeiter, die auf den einst deutschen Bauernhöfen geblieben waren, und ab 1947 die in der Aktion ,Weichsel“ aus dem Südosten Polens zwangsausgesiedelten Ukrainer." (S. 79:) „Ob dies- oder jenseits der Oder - die Erfahrungen von Flucht, Vertreibung und Umsiedlung und das staatlich verordnete Schweigen darüber blieben über viele Jahrzehnte und oft bis in die nachfolgenden Generationen hinein traumatische Erinnerungen." 
oder der „Geschichtswettbewerb des Bundespräsidenten“2184. Angeregt durch den Brandenburgischen Museumsverband wurde anlässlich des siebzigsten Jahrestages des Kriegsendes 2015 das Projekt „Spurensicherung 1945“ an die Schulen herangetragen. ${ }^{2185}$ „Dieser Aufruf stieß bei der Arbeitsgemeinschaft Geschichte der Grund- und Oberschule Massen/Niederlausitz auf offene Ohren. ${ }^{\text {"2186 }}$ Auf der Basis von Zeitzeugeninterviews wurde eine Facebook-Seite entwickelt, die über die „Spurensicherung“ der von ihrem Lehrer und zwei Historikerinnen begleiteten Schüler berichtet. Die Aufnahmen der Interviews sind darüber hinaus im Sänger- und Kaufmannsmuseum Finsterwalde für die Forschung gesichert worden. Öffentlich sichtbare Nachhaltigkeit bleibt jedoch auch bei solchen Projekten oftmals bloße Idee.

Da das Vertreibungsgeschehen in den letzten Jahren ohnehin in der deutschen Öffentlichkeit, in den Medien und Büchern, häufiger thematisiert wird, wurde es auch in dem Finsterwalder Schülerprojekt nicht mehr ausgespart, sondern sogar stark gewichtet. So enthielt der Fragenkatalog auch die - in einem lokalen Milieu vor einer Generation noch tabuisiert gewesene - Frage „Wie wurde man als junges Flüchtlingsmädchen aus dem Sudentenland [so!] von den Bettener Bauern behandelt, und wie fühlt sich richtiger Hunger an?" ${ }^{2187}$ Wie präsent die Herkunft aus den Vertreibungsgebieten, wenn auch nicht in der lokalen Öffentlichkeit, so doch im privaten, familiären Raum noch heute, sieben Jahrzehnte nach Kriegsende, sein kann, erfuhr die recherchierende Schülergruppe, als sie auf ein Erinnerungsobjekt stieß, „das in die begleitende Ausstellung des Brandenburgischen Museumsverbunds [Museumsverbands!] im Potsdam Museum aufgenommen wurde. ${ }^{2188}$ Die rund 80 Zentimeter hohe Madonnenfigur ist eine Leihgabe der Zeitzeugin Anni Jagieniak, die mit der Figur Erinnerungen an die Bewahrung ihres katholischen Glaubens

2184 Schon 2002 gab es hier Beiträge zum Thema „Füchtlinge und Vertriebene“. Siehe Spuren suchen 17 (2003) über die Ergebnisse des Wettbewerbs („Weggehen - Ankommen. Migration in der Geschichte“). 2013 und 2015 finden sich auch bemerkenswerte Beiträge hochmotivierter Gymnasiasten aus dem Land Brandenburg, die z. T. Zeitzeugen befragten, Archive besuchten und bisweilen sogar ein Beispiel aus der eigenen Familie untersuchten: 2013 beim Wettbewerb „Vertraute Fremde. Nachbarn in der Geschichte“: Jakob Putz: Wie aus Fremden Nachbarn wurden. Nachbarschaften zwischen Vertriebenen und Uckermärkern nach dem Zweiten Weltkrieg (Christa-und-Peter-Scherpf-Gymnasium Prenzlau, Klasse 9, Tutor: Jürgen Theil; siehe. www. uckermaerkischer-geschichtsverein.de/online-lesesaal); Anna Kathrin Gudat/Laura Kerstin Schmidt: Das nachbarschaftliche Zusammenleben während Flucht, Vertreibung und Integration am Beispiel von Heimatvertriebenen in der Stadt Brandenburg an der Havel (Bertolt-Brecht-Gymnasium Brandenburg an der Havel, Klasse 11, Tutorin: Gesine Scholz); 2015 beim Wettbewerb „Anders sein. Außenseiter in der Geschchte“: Krystian Burchart: Das gerollte „R“ (2015, Oberstufenzentrum I Cottbus, Klasse 11, Tutor: Bernhard Neidnicht). - Siehe dazu im einzelnen: www.koerber-stiftung.de/geschichtswettbewerb/ [10.7.2018].

2185 Roman Guski / Claudia Schlaier: Projekt „Spurensicherung 1945“. Ansatz, Arbeitsschritte, Ausstellung. In: Museumsblätter. Mitteilungen des Museumsverbandes Brandenburg 27 (2015), S. 28-35.

2186 Babette Weber / Christian Rasemann: Spuren sichern - Geschichte erfahren. Massener Oberschüler befragen Zeitzeugen zum Weltkriegsende und zeigen die Ergebnise in einer Facebook-Chronik. In: Der Speicher 17 (1995), S. 138-140, hier S. 138.

2187 Ebd., S. 140.

2188 Zur Ausstellung siehe Guski/Schlaier, Projekt „Spurensicherung 1945“ (wie Anm. 2185) sowie den Katalog: Projekt Spurensicherung 1945. Ein Katalog zur Ausstellung des Brandenburgischen Museumsverbandes im 
im nationalsozialistischen [!] Sudentenland [so!], an Vertreibung und Flucht und an die Diaspora in der DDR verbindet. Dass sie die in ihrer Familie hoch verehrte Madonna für die Ausstellung zur Verfügung stellte, war für die Schüler ein großer Vertrauensbeweis. "2189

Ähnlich wie der Blick einer Gesellschaft auf sich und ihre Teile in der Gegenwart noch immer Aufgaben in der Überwindung von Benachteiligungen ausmachen wird, lassen sich beim Rückblick auf die Lebenswege der handelnden und der erleidenden Brandenburger des 20. Jahrhunderts nach wie vor Opfer finden, deren Schicksal vergessen ist. Insofern bleibt auch in Brandenburg der Enkelgeneration - der Enkel der Vertriebenen, aber ebenso der der Einheimischen - die Aufgabe gestellt, das nachzuholen, was zwischen 1945 und 1990 versäumt worden ist bzw. unmöglich war, nämlich an die Stelle einer Integration durch Assimilation und öffentlichen „Gedächtnisverlust“ zumindest nachträglich in der Geschichtsschreibung eine Würdigung - gleichsam eine posthume „Willkommenskultur“ - zu schaffen für die Betroffenen mit all ihrem Leid und mit ihrem - nicht geringen - Anteil am Wiederaufbau des gesamten Lebens in Brandenburg nach 1945.

Die Aktualität des Flüchtlingsthemas scheint bisher - außerhalb eines engeren Interessentenkreises von wenigen Zeithistorikern - noch nicht zu häufigeren Nachfragen nach der Situation der Jahre ab 1945 zu führen oder gar die gesellschaftliche Empathie auch für damalige Vertreibungsopfer zu verstärken. Dabei liegen manche Parallelen - trotz der gravierenden Unterschiede ${ }^{2190}$ - auf der Hand. Der Vergleich hat freilich seine Tücken und nützt wegen der politisierten und vielerorts weltanschaulich stark aufgeladenen Diskussion letztlich weder der „Aufarbeitung“ des Nachkriegsgeschehens noch der „Bewältigung“ moderner „Flüchtlingskrisen“. So vermied ihn 2017 auch der Pressesprecher des Landkreises Märkisch-Oderland in seinem Appell, aufeinander zuzugehen, und konzentrierte sich ganz auf Gegenwart und Zukunft. Seine nüchterne Lagebeschreibung erinnert - in den reinen Fakten und Zahlen - dennoch sehr an die Geschehnisse, um die es im vorliegenden Buch geht und die sich ganz ähnlich auch in damaligen Berichten formuliert finden: „Galt es beispielsweise noch nach der ersten Prognose für das Jahr

Potsdam Museum, 7. August bis 4. Oktober 2015. Hrsg.: Museumsverband des Landes Brandenburg e.V. Potsdam 2015.

2189 Ebd.

2190 Auf die enge kulturelle Verwandtschaft der meisten Vertriebenen mit den Einheimischen verweist z. B. - entgegen der von letzteren $1945 \mathrm{ff}$. oft subjektiv empfundenen und behaupteten, de facto jedoch kaum gegebenen Fremdheit - Spiegel-Schmidt, zwar bezogen auf die Integrationsfragen in der Bundesrepublik, die sich in der SBZ/DDR aber genauso stellten: „Ebenso darf man sich nicht bestimmen lassen von der Wunschvorstellung, es existiere eine kulturelle Kluft, die in Wirklichkeit nicht vorhanden ist. Die Vertriebenen kamen nicht in eine andere Kultur, wenn sie aus dem Osten in den Westen kamen. Trotz aller landsmannschaftlichen Besonderheiten war es die gleiche, gemeinsame, gesamtdeutsche Kultur, zu der sie schon gehörten." (Zusammenfassung des Vortrags von Prodekan Friedrich Spiegel-Schmidt, München, über die „Bedingungen und Voraussetzungen für die Erstellung der Dokumentation der kirchlichen Aufnahme der Heimatvertriebenen " in der Niederschrift über die Sitzung der Beauftragten für die Dokumentation am 26.11.1971 in Hannover, S. 3, in: ELAB, 1/2453, unfol.). Anders jetzt Kossert, der meint, „die Unterschiede konnten kaum größer sein“ (Kossert, Jeder vierte Brandenburger [wie Anm. 1445], S. 140). 
2015, insgesamt 680 Asylsuchende im Landkreis aufzunehmen, so hat sich diese Zahl schrittweise auf über 1800 Menschen erhöht, sodass zum Jahresende in den Gemeinschaftsunterkünften und Wohnverbünden in Märkisch-Oderland 2178 Menschen untergebracht waren. Gab es Ende des Jahres 2014 noch sechs Unterkünfte für Geflüchtete im Landkreis, so hat sich die Anzahl Ende 2015 bereits auf 18, darunter auch zwei Notunterkünfte in Turnhallen, erhöht. Zusätzlich zu den erwachsenen Flüchtlingen kam zum Jahresende noch die Gruppe der minderjährigen unbegleiteten Flüchtlinge hinzu, die in Zuständigkeit des Jugendamtes untergebracht und betreut wurden und werden." ${ }^{2191}$ Schon 2005 war Ähnliches zu hören, als der amtierende Landrat desselben Landkreises in seinem Grußwort zur Eröffnung der - in Seelow vom lokalen Publikum mit größtem Interesse verfolgten - gemeinsamen Konferenz des Landkreises und der Brandenburgischen Landeszentrale für politische Bildung zum Kriegsende 1945 sagte: „Bis Ende 1946 nahm das Land Brandenburg mehr als 616000 Menschen auf, die hier Zuflucht suchten. Die Zahlen allein sind in ihrem Ausmaß kaum fassbar. Es ist der Blick auf die einzelnen Schicksale, der einen sprachlos zurück lässt." ${ }^{2192}$

Überblicksdarstellungen der Zuwanderungsgruppen, wie sie in der brandenburgischen Landeshauptstadt Potsdam für die Zeit vom Großen Kurfürsten bis zur Gegenwart - zumeist auf Veranlassung des „Magistrats der Landeshauptstadt“ - seit 1990 immer wieder erscheinen, sparen die Vertriebenen der Jahre 1945 ff. stets aus. ${ }^{2193}$ Dabei zielen diese Broschüren, die sich vornehmlich mit seit dem 17. Jahrhundert aus dem Ausland zugewanderten Bevölkerungsgruppen befassen, durchaus auf eine breitere Öffentlichkeit. Obgleich darin nun in jüngster Zeit (2016) der Fokus nicht mehr nur auf den europäischen ausländischen Immigrantengruppen der Frühen Neuzeit (Niederländer, Hugenotten, österreichische Juden, katholische Lütticher Gewehrarbeiter, Schweizer) und des 19. Jahrhunderts (Russische Sänger in der Kolonie Alexandrowka) liegt, sondern allgemeiner die „Rolle der Zugewanderten für die Entwicklung Potsdams“ - teilweise sogar über die Stadt hinaus in ganz Brandenburg - bis zur Gegenwart behandelt und selbst bloßen Episoden wie der Tätigkeit polnischer Restauratoren (1976-1980) ein eigener Abschnitt gewidmet wird, fehlen die Flüchtlinge und Vertriebenen der Zeit ab 1945, aber auch die für die Stadtgesellschaft bis heute sehr wichtige und starke DDR-zeitliche Zuwanderung aus Sachsen und anderen deutschen Nachbarländern. ${ }^{2194}$

2191 Thomas Berendt: Asylsuchende im Landkreis Märkisch-Oderland. In: Jahrbuch Märkisch-Oderland 24 (2017), S. 44.

2192 Michael Bonin: Grußwort des amtierenden Landrates des Kreises Märkisch-Oderland. In: Niederlage - Sieg Neubeginn. Kriegsende 1945. Werner Künzel, Richard Lakowski (Hg) (Protokolle). Potsdam 2005, S. 8-9, hier S. 8 .

2193 Von der Stadtverwaltung zuletzt: Internationale Impulse für Potsdam. Zur Rolle der Zugewanderten für die Entwicklung Potsdams. Hrsg.: Landeshauptstadt Potsdam, Der Oberbürgermeister. Verantw.: Büro für Chancengleichheit und Vielfalt, Magdalena Grasnick. Autoren: Ulrich Schmelz, Ursula Langer, Karl-Enst Plagemann, Hans-Martin Randacek, Birgit Zimmermann. 4., aktualis. u. erw. Aufl. Potsdam 2016. 100 S.

2194 Das einleitende Überblickskapitel von Ulrich Schmelz „Von Einwanderern zu Einheimischen. Brandenburg als Schmelztiegel der Völker Europas“ bleibt trotz des deutlich erweiterten Inhalts der Broschüre auch in der 4. Auflage (wie Anm. 2193) auf das 17./18. Jahrhundert beschränkt. In eigenen Kapiteln behandelt werden für das 20. Jahrhundert: Ausländische Arbeiter beim Bau des Teltow-Kanals 1901/06 (S. 34f.), Zwangsarbeiter 
Ganz anders ist man bereits 2003 in Eberswalde mit dem Thema umgegangen. Das dortige Stadtmuseum „hat sich in Kooperation mit lokalen Partnern in einer Veranstaltungsreihe dem Thema der Zuwanderungen gewidmet. Höhepunkt war die Ausstellung ,Fremde Heimat Eberswalde? - Zuwanderungen in Vergangenheit und Gegenwart, ein Projekt des Kulturlandes Brandenburg ${ }^{2195}$ im Europa-Jahr. ${ }^{\text {“2196 }}$ Zur Ausstellung erschien ein Begleitheft, das 2008 nochmals, in überarbeiteter und aktualisierter Auflage, herausgegeben wurde und das - bis zur Gegenwart - keine Zuwanderergruppe ausspart. Bereits im Vorwort heißt es u.a.: „Als Folge des Zweiten Weltkrieges veränderte sich die Bevölkerungsstruktur. Durch Flucht, Vertreibung und Umsiedlung kamen Menschen aus den östlichen Gebieten hierher und fast 50 Jahre lang lebten russische Soldaten und Zivilangehörige in Eberswalde. ${ }^{\text {"2197 }}$ Den entsprechenden Abschnitt über beide Teilthemen hatte die damalige Museumsleiterin Ingrid Fischer (geb. 1941 Troppau [tschech. Opava]) übernommen. ${ }^{2198}$ Ähnliches war 2005 auch schon im Nachbarland Berlin möglich, wo sich eine Ausstellung des Museums Neukölln (7. Mai 2005 bis 2. April 2006) mit dem Titel „Tiefe Spuren, Kriegsflüchtlinge 1945-2005“ ebenso wie das knapp gehaltene begleitende Katalogheft neun Flüchtlingsgruppen annahm und von Afghanen bis zu Vietnamesen reicht, ohne dabei im Alphabet zwischen Kurden und Palästinensern pars pro toto die „Ostpreußen“ auszusparen. Alle beispielhaften Darstellungen basierten auf Interviews mit in Neukölln lebenden Betroffenen, im ostpreußischen Fall mit dem ehemaligen Pfarrer der Brüdergemeine Albert Schönleber. ${ }^{2199}$

1933/45 (S. 36f.), Exil-Chilenen 1973/74-1987 (S. 38), „Vietnamesische Arbeitskräfte in Betrieben Brandenburgs“ ab 1980 (S. 39), polnische Denkmalrestauratoren 1976-1980 (S. 40 f.), „Neues jüdisches Leben in Potsdam seit Anfang der 1990er Jahre“ (S. 42 f.), „Muslimische Gemeinden in der Stadt" (S. 44f.). - Der gleiche Befund auch in der mit Unterstützung der Stadt und des Potsdam Museums publizierten Ausstellungsbegleitbroschüre: Ankommen in Potsdam. Integration als Teil der Stadtgeschichte. Hrsg.: ArchitraV e. V. c/o Thomas Sander. Potsdam 2018 (mit Vorwort der Geschäftsführerin der Brandenburgischen Gesellschaft für Kultur und Geschichte GmbH, Kulturland Brandenburg, Brigitte Faber-Schmidt [S. 2], da es sich um ein „Projekt im Rahmen des Themenjahres Kulturland Brandenburg 2018 , wir erben. Europa in Brandenburg Brandenburg in Europa " handelt.): Hier werden acht Zuwanderergruppen behandelt, sechs davon bilden die sattsam bekannten Gruppen des 17./18. Jh., eine weitere die gleichfalls oft thematisierte der russischen Sänger (Anfang 19. Jh.); für die Zeit danach und das gesamte 20. Jh. stehen allein die „Russen in Potsdam zwischen 1945 und heute" (S. 72-81, Verf.: Hannes Wittenberg).

2195 [Gemeint ist der Projektträger „Kulturland Brandenburg e. V.“]

2196 Ingrid Fischer / Mohamed Hamdali / Marieta Böttger: Vorwort zur 1. Auflage. In: Fremde Heimat Eberswalde (wie Anm. 185), S. 7.

2197 Ebd. (1. Aufl. 200359 S., 2. Aufl. 200863 S.).

2198 Fischer, Zuwanderung nach dem Zweiten Weltkrieg (wie Anm. 185), S. 33-37: Kapitel „Flüchtlinge, Vertriebene und Umsiedler". - Ingrid Fischer lebte nach 1945 zunächst in Thüringen, ab 1960 in Brandenburg (eigene Auskunft, 20.8.2018).

2199 Tiefe Spuren. Kriegsflüchtlinge 1945-2005. Begleitband zur Ausstellung. Udo Gößwald (Hg.). Im Auftr. des Bezirksamts Neukölln von Berlin, Abt. Bildung, Schule u. Kultur, Kulturamt/Museum Neukölln. Berlin 2005, allgemein S. 34f. („Verlorene Heimat - Ostpreußen“), zum Zeitzeugen S. 36f. („Flucht über das Eis - Albert Schönleber“; Interview: Christa Jančik). 
Ein allmählicher Wandel zeichnet sich aber inzwischen doch auch an manchen anderen, keineswegs mehr peripheren Stellen ab, so dass die Ausblendung des Themas künftig wohl nicht mehr weiter fortwirken wird. So enthält das Begleitbuch zur „Ersten Brandenburgischen Landesausstellung“ 2014 einen siebenseitigen Beitrag des durch seine Publikation über die „Vertriebenenlager in Brandenburg" bekannt gewordenen Archivars Sven Olav Oehlsen, der die bislang beste, freilich auch einzige Kurzfassung des Gesamtthemas - mit Brandenburg-Fokus darstellt. ${ }^{2200}$ Das programmatische Auftaktbuch des Landes Brandenburg zum Kulturland-Themenjahr 2018 - „Brandenburg in Europa - Europa in Brandenburg. Europäisches Kulturerbe im Land Brandenburg" - schließlich enthält wie selbstverständlich unter rund 25 kurzen Text- und Bildbeiträgen auch einen Textbeitrag des überregional für das Thema ausgewiesenen und durch seine weit verbreiteten Bücher bekannten Historikers Andreas Kossert (geb. 1970): „Jeder vierte Brandenburger: Vertriebene und Flüchtlinge nach 1945“ “2201 Zwar zeigt sich bei näherem Hinsehen - anders als bei Oehlsen - nur wenig Brandenburg-Spezifisches, doch allein die Einbeziehung des Themas in diesen ein breites Spektrum anreißenden Band und die Titelformulierung sind abermals ein untrügliches Zeichen einer Normalisierung, einer Entspannung im Umgang mit einem alten Tabu.

Die Gesellschaft scheint sich also trotz weiterhin kontroverser Diskussionen über einzelne Aspekte in der grundsätzlichen Empathie auf eine Neubewertung zu verständigen. Hier und da wird dieser Prozess noch seine Zeit benötigen. Einzelne Autoren waren damit auch vor wenigen Jahren ihrer Zeit noch weit voraus, wie abschließend an einem aus dem kirchlichen Bereich stammenden Beispiel gezeigt werden soll. In einem 1991 von der Evangelischen Kirche in Berlin-Brandenburg initiierten, vom Eberswalder Generalsuperintendenten Leopold Esselbach (geb. 1931) herausgegebenen und in der Evangelischen Verlagsanstalt erschienenen Sammelwerk, mit dem die Vielfalt evangelisch-kirchlichen Lebens im Land dargestellt werden sollte, ist die Zuwanderergruppe der Flüchtlinge und Vertriebenen sogar - im letzten (sechzehnzeiligen) Absatz eines Beitrages über "Einwanderungen in der Mark durch die Jahrhunderte“ - so ungewohnt einfühlsam benannt und trotz der Kürze so treffend beschrieben, dass der kleine Text hier vollständig wiedergegeben werden soll, könnte er doch so mancher Verlautbarung nichtkirchlicher Stellen im Land zum Vorbild dienen. Nachdem der Verfasser, der Fürstenwalder Superintendent Günter Kuhn ${ }^{202}$ (1928-2018), auf eine Vielzahl von Bevölkerungsgruppen,

2200 Oehlsen, Deutsche Vertriebene in Brandenburg und Sachsen (wie Anm. 45). Etwas gewagt erscheinen lediglich zwei Formulierungen, zum einen zu den „organisierten Vertreibungen“ 1945, bei denen die Betroffenen „zwar ohne persönliche Sachen die Grenze“ überschritten hätten, „meist aber körperlich verhältnismäßig unversehrt“ geblieben seien (S. 40). Dem stehen jedenfalls zahlreiche Arztberichte entgegen. Zum anderen resümiert Oehlsen im Schlußsatz (S. 45) vielleicht doch noch etwas zu optimistisch: „So ist die Vertreibung der deutschen Bevölkerung aus Ost- und Südosteuropa heute ein fester Bestandteil der Erinnerungskultur in Brandenburg und Sachsen."

2201 Kossert, Jeder vierte Brandenburger (wie Anm. 1445).

2202 Kuhn, geb. in Wernigerode, wohnte während der Kriegsjahre selbst im Sudetenland. Nach 1990 hat er sich in mehreren Publikationen u. a. mit der Geschichte der Jüdischen Gemeinde Fürstenwalde befasst. 
die im Laufe der Geschichte nach Brandenburg gekommen sind, und unmittelbar zuvor auf das in Garnisonorten im 18. Jahrhundert, namentlich bei den „Langen Kerls“ in Potsdam, entstandene „Bevölkerungsgemisch“ jeweils kurz eingegangen ist, sagt er abschließend:

„Aber all diese Bevölkerungsbewegungen sind nur ein Bruchteil des Zustromes, des Durcheinanderwirbelns von Alteingesessenen und Neubürgern, der sich infolge des zweiten Weltkrieges ergab. In Dörfern des Kreises Eisenhüttenstadt betrug der Anteil der Hinzugekommenen 50 \% der Einwohner. Im Kreis Seelow und im Oderbruch noch mehr. Unzählige flüchteten, andere wurden auf Befehl deutscher Dienststellen aus den zum Kampfgebiet erklärten Orten getrieben, und beide Gruppen kamen als bedauernswerter Treck oder in überfüllten Zügen und zu Fuß in die noch ruhigeren märkischen Gebiete. Nach dem Kriegsende setzte zusätzlich die Aussiedlung der Menschen ein, die in den jetzt sowjetischen und polnischen Gebieten lebten. ${ }^{2203}$ Kamen mehrere Familien aus dem gleichen Ort, der gleichen Gegend in ein märkisches Dorf, dann markierten sie sich lange Zeit als eine eigene Gruppe, die auch kirchlich auffiel. Einzelne ,Flüchtlinge‘ oder ,Neusiedler' hatten es da oft schwerer. Weithin empfing das kirchliche Leben wichtige Verstärkung durch diese neuen Mitbürger. Je weiter die Assimilierung voranschreitet, um so mehr werden sie ,Märker. Und das heißt, sie sind mitzuzählen zu diesem ,mixtum compositum ' - zusammengemischt durch den Lauf der Geschichte."2204

2203 Hinweis P.B.: Hier fehlen die (auch in Brandenburg zahlreichen) aus der Tschechoslowakischen Republik vertriebenen Sudetendeutschen.

2204 Günter Kuhn: Die Märker - ein mixtum compositum. Einwanderungen in der Mark durch die Jahrhunderte. In: Kirche auf märkischem Sand. Bilder aus der Evangelischen Kirche in Berlin-Brandenburg. Hrsg.: Leopold Esselbach. Berlin 1991, S. 22-29, hier S. 29. 


\section{Teil 2 Ortsdokumentation}

Historische Stätten der

Vertriebenenintegration in Brandenburg 



\section{Vorbemerkung}

Berücksichtigt sind grundsätzlich nur Orte auf dem Gebiet der Provinz Mark Brandenburg in den Grenzen von 1945, um den Blick auf die zeitgenössische Situation im vornehmlichen Untersuchungszeitraum nicht zu verunklaren. Erst 1990 zum Land Brandenburg (bzw. 1952 zum Bezirk Cottbus) gekommene Städte und Gemeinden, die 1945 zu Sachsen-Anhalt (ehem. Provinz Sachsen) oder Sachsen (ehem. Provinz Schlesien) gehörten, wie z.B. Mühlberg oder Schlieben, bleiben deshalb ausgespart. Ausnahmsweise aufgenommen sind jedoch Orte, die zwar bis 1945 nicht zu Brandenburg zählten, aber noch in den frühen Nachkriegsjahren ihre Landeszugehörigkeit wechselten: Fürstenberg/Havel, Kirchmöser, Rathenow-West (Magazininsel), Ziesar, ferner die 1945 polnisch gewordenen (Küstrin-)Altdrewitz und Küstrin-Neustadt wegen der hier vorübergehend bestehenden und dann in Wriezen fortgeführten wichtigen brandenburgischen Durchgangslager (vgl. dazu Quellenteil, Nr. 20, Bl. 5).

Aufgenommen sind alle Stadtgemeinden, von den Landgemeinden und Wohnplätzen nur diejenigen, für die - nach dem gegenwärtigen Forschungsstand - eine überproportional große Zuwanderung oder besondere mit dem Thema Flucht und Vertreibung in Verbindung stehende Geschehnisse (auch nach 1990) fassbar sind, ferner alle Orte, denen 1950 westlich der Oder/ Neiße gelegene Flächen von nun polnisch gewordenen Gemeinden zugewiesen worden sind; die zahllosen Heimattreffen nach 1990 konnten ohnehin nur in Auswahl berücksichtigt werden. Die getroffene Auswahl der Landgemeinden darf insofern nicht missinterpretiert werden. Auch an anderen Orten bzw. sogar wohl in nahezu allen Gemeinden Brandenburgs sind nach 1945 Flüchtlinge und Vertriebene aufgenommen worden. Vieles ist jedoch noch unpubliziert, unentdeckt oder sogar selbst am Ort vergessen. Die Auswahl der Landgemeinden ist - dies sei ausdrücklich betont - nicht als repräsentativ zu betrachten, sondern dem Forschungsstand geschuldet. Auch die erwähnten Lager - der Begriff „Umsiedlerlager“ wird hier, auch ohne Kennzeichnung, als Quellenbegriff verwendet - bilden nur die „Spitze des Eisberges“, nämlich die in den Akten der Provinzial-/Landesverwaltung oder bereits in der Literatur erwähnten, meist etwas größeren Flüchtlings- und Vertriebenenlager, während viele interimistisch bestehende kleinere hier fehlen und überhaupt nur noch in geduldiger Lokalforschung zu ermitteln sein werden.

Aus den Angaben zu einzelnen Kreisen und Orten könnte man in den meisten Fällen mühelos eine ausformulierte, leicht lesbare Kurzdarstellung der lokalen „Geschichte von Aufnahme und Eingliederung der Flüchtlinge und Vertriebenen“ formen. Dies wurde jedoch bewusst unterlassen, um nicht den Eindruck eines durchgehend lückenlosen lokalen Forschungsstandes zu erwecken. Vielmehr soll dieser faktenorientierte handbuchartige Dokumentationsteil zum einen über die lokalen Ereignisse und Entwicklungen nach Möglichkeit informieren, zum anderen aber immer auch den sehr unterschiedlichen und oftmals erst recht dürftigen Kenntnisstand vor Augen führen. Jede zusammenführend ausformulierte Darstellung wäre zudem bereits Interpretation, daher wird das Datenmaterial hier unverbunden als Quellen- oder Literaturzitat ohne Wertung (lediglich mit Kennzeichnung etwaiger erkennbarer Fehler und Irrtümer) 
präsentiert, was mitunter auch die eine oder andere noch vom SED-Geschichtsbild geprägte Formulierung - als Zitat - einschließt. Bewusst wird vieles ausführlicher zitiert, um die - den Forschungs- und auch den allgemeinen Kenntnisstand spiegelnde - Berücksichtigung des Themas in der landes-, regional-, orts- bzw. heimatgeschichtlichen Literatur zu zeigen. Der lokalen Forschung in den Kreisen, Städten und Gemeinden soll damit eine möglichst sichere (und ungeschönte) Ausgangsbasis geliefert werden. Zugleich soll sie Anreize erhalten, Lücken zu schließen, Unklarheiten, etwa bei nebeneinander gestellten sich widersprechenden Angaben, nachzugehen und Desiderate zum Gegenstand ihrer eigenen Forschung zu machen. Die überregionale Vertreibungsforschung erhält darüber hinaus die Möglichkeit, ihre Untersuchung an kleineren Räumen unterhalb der Landesebene und zwischen diesen vergleichend vorzunehmen. Der Gesellschaft des heutigen Landes Brandenburg bzw. seiner Kommunen schießlich bietet dieser Versuch eines „Handbuchs“ Historischer Stätten der Vertriebeneneingliederung die Möglichkeit, sich - auf dem derzeitigen Kenntnisstand - schnell und gezielt über ihren je eigenen Anteil an dem Geschehen zu informieren und bewusst zu werden.

BevöLKeRUnGSzahlen: Bei den Landkreisen bezieht sich die Zahl für das Jahr 1939 auf die Wohnbevölkerung am 17. Mai 1939. Bei Städten und Gemeinden werden nach Möglichkeit zwei oder drei Zählungen der Zeit vor 1945 mitgeteilt, um die Situation im Aufnahmeort vor dem Zuzug von Flüchtlingen und Vertriebenen aufzuzeigen; ferner werden von den Nachkriegszählungen mindestens noch die der Jahre 1950 und 1964 mitgeteilt, um ggf. auch die einer oft zunächst erhöhten Zahl in den ersten Nachkriegsjahren später folgende Abwanderung (meist durch „Republikflucht“, aber auch Umzug in DDR-Industriestandorte) zumindest indirekt zu spiegeln.

Strassenumbenennungen: Aufgenommen sind hier Straßen- und Platzbenennungen nach Orten, Landschaften oder Regionen/Ländern sowie Flüssen der Vertreibungsgebiete im weitesten Sinne. Im wesentlichen handelt es sich dabei um die um 1950 oder schon zuvor, seltener danach (und nur sehr selten gar nicht) getilgten Namen, ferner um Rückbenennungen nach 1990. Nur in ganz wenigen Fällen finden sich nach 1990 Neubenennungen ohne früheren Bezug ( $\rightarrow$ Brück, $\rightarrow$ Premnitz).

STÄDTEPARTNERSCHAFTEN stehen zwar nicht in direktem Zusammenhang mit der Tatsache, dass die Kommune lange zuvor Flüchtlinge aufgenommen hatte. (Städte-, Amts- und Gemeinde-)Partnerschaften mit Städten und Gemeinden in den ehemaligen Vertreibungsgebieten sowie überhaupt im östlichen Mitteleuropa werden hier jedoch vermerkt, um den Gesamtrahmen der Beziehungen der betroffenen Kommunen zu diesem Raum, vorzugsweise den ehemaligen Ostgebieten, aber auch darüber hinausgehend, aufzuzeigen. Ob im Einzel- bzw. Ausnahmefall ein Bezug zu in der Kommune ansässigen Vertriebenen und deren Nachfahren vorliegt oder ganz ausgeschlossen werden kann, muss hier offen bleiben. Immerhin ist dies in Schwedt (Königsberg/Nm.) und Seelow (Küstrin), wo unmittelbare Nachbarschaft besteht, zu vermuten. Für ältere Menschen (Seniorenvereine), aber auch Schüler (Jugendaustausch) bedeuten die Städtepartnerschaften zumeist die Möglichkeit, an einer Reise in die polnische 
oder tschechische Stadt teilzunehmen, was gerade bei den schon vor 1990 vereinbarten Partnerschaften ggf. auch Vertriebenen bisweilen erstmals die Möglichkeit bot, überhaupt diese Gebiete aufzusuchen (siehe dazu ausführlicher oben die beiden Kapitel zu Städtepartnerschaften als „Patenschatzsersatz“ vor bzw. nach 1989/90).

VerTRIEBENENVERBÄNDE NACH 1990: Hier wurde versucht, alle am jeweiligen Sitzort nachweisbaren Verbände und Vereine zu ermitteln. Insbesondere für die frühen 1990er Jahre ist dies jedoch erheblich erschwert, da die betreffenden Organsationen inzwischen meist umbenannt, vielfach aber auch bereits aufgelöst und viele Vorstandsmitglider der „ersten Stunde“ als Ansprechpartner nicht mehr erreichbar oder verstorben sind. Zudem ist die Aktenüberlieferung in der BdV-Landesgeschäftsstelle für die Zeit vor 2000 trotz einzelner Rekonstruktionsversuche sehr lückenhaft. Hier muss also vieles an Ergänzung, Konkretisierung und wohl auch Berichtigung Lokalforschern überlassen werden, die die letzten Zeitzeugen befragen und regionale Zeitungen auswerten sollten. Die meist überalterten Verbände sind ohne Hilfe von außen kaum noch in der Lage, ihre eigene Geschichte aufzuarbeiten und zu schreiben. Selbst für die Sicherung des Schriftgutes (Protokolle, Tätigkeits-, Veranstaltungs- und Reiseberichte, Korrespondenz, Mitglieder- und Anwesenheitslisten, Fotos sowie Film- und Tondokumente von Veranstaltungen!) wird bei der Vereinsauflösung wohl nur in seltenen Fällen Sorge getragen.

Archivalische Quellen: Für die aufgenommenen Kreise, Städte und Gemeinden konnte im Projektzeitrahmen verständlicherweise nicht jede Akte nach jedem lokalen Detail durchgesehen werden. Wer der Situation und Vorgängen in einzelnen Kommunen genauer nachgehen will, sollte daher sowohl die angegebenen Archivalien nochmals einsehen als auch weitere aus denselben und anderen Archivbeständen der vornehmlich benutzten staatlichen Archive (BArch und BLHA) hinzuziehen (Online-Archivdatenbanken!). Im Vorspann zu den Kreisen und zu den Orten sind zudem jeweils Quellen aufgeführt, die grundsätzlich herangezogen werden sollten, da sie zumeist alle Kreise betreffen. Quellen aus Kreis- und Stadtarchiven konnten bis auf wenige Ausnahmen nicht eingesehen und auch nicht systematisch erfasst werden, so dass diese Archivaliengruppe bei künftigen Forschungen zusätzlich zu beachten bleibt! Weitere Hinweise siehe oben im Einleitungskapitel 3 (Quellenlage).

Gedruckte Quellen und Literatur: Diese werden jeweils am Ende eines Kreisoder Ortsartikels mit den wesentlichen bibliographischen Angaben aufgeführt, im Text nur verkürzt. Die vollständigen bibliographischen Angaben sind dagegen nur im (Gesamt-)Literaturverzeichnis zu finden. Im Vorspann zu den Kreisen und zu den Orten sind zudem jeweils einige wenige gedruckte Quellen aufgeführt, die grundsätzlich herangezogen werden sollten, da sie alle Kreise bzw. ggf. auch die meisten Gemeinden betreffen. Eine Auswahl besonders häufig zitierter Veröffentlichungen wird nur mit Kurztitel oder Sigel zitiert, die im Folgenden aufgelöst sind.

Zitate aus zeitgenössischen Quellen sowie aus Zeitzeugenberichten sind kursiv gesetzt. 


\section{Gekürzt zitierte Literatur und Siglen}

AGV = Amtliches Gemeindeverzeichnis für das Deutsche Reich auf Grund der Volkszählung 1939.

Hrsg. vom Statistischen Reichsamt. 2. Aufl. Berlin 1941 (Statistik des Deutschen Reiches, Bd. 550).

Andreae $/$ Geiseler $=$ Almut Andreae $/$ Udo Geiseler (Hg.): Die Herrenhäuser des Havellandes. Eine

Dokumentation ihrer Geschichte bis in die Gegenwart. Berlin 2001.

Ast/Mauersberger = Jürgen Ast / Kerstin Mauersberger: Zweite Heimat Brandenburg. Flucht, Vertreibung, Neuanfang. Berlin 2000.

BArch $=$ Bundesarchiv.

BLHA = Brandenburgisches Landeshauptarchiv.

Blöß, Kreise und Gemeinden = Wolfgang Blöß: Brandenburgische Kreise und Gemeinden 1945-1952. Grenzänderungen, Eingemeindungen und Ausgemeindungen. Potsdam 2010 (Veröffentlichungen der Landesfachstelle Archive und öffentliche Bibliotheken im Brandenburgischen Landeshauptarchiv, Bd. 6).

Borodziej/Lemberg = „Unsere Heimat ist uns ein fremdes Land geworden ...“ Die Deutschen östlich von Oder und Neiße 1945-1950. Dokumente aus polnischen Archiven. Hrsg. von Włodzimierz Borodziej u. Hans Lemberg. Bd. 1-3. Marburg 2000-2004 (Quellen zur Geschichte und Landeskunde Ostmitteleuropas, 4).

$\mathrm{BR}=$ Brandenburger Rundschau .

Brandenburgische Gemeinden 1945 = Brandenburgische Gemeinden kurz nach dem Kriegsende von 1945. Aus eigenen Berichten der Gemeinden niedergeschrieben Ende 1945. Potsdam 2013.

Christopeit $=$ Christopeit, Gerald: Die Sudetendeutschen in der Provinz Mark Brandenburg 1945 bis 1948. In: Die Sudetendeutschen in der Sowjetischen Besatzungszone Deutschlands. Manfred Wille (Hrsg.). Magdeburg 1993, S. 80-93.

Dokumentation der Vertreibung = Dokumentation der Vertreibung der Deutschen aus Ost-Mitteleuropa. Hrsg. vom Bundesministerium für Vertriebene. In Verb. mit Adolf Diestelkamp u. a. bearb. von Theodor Schieder. Bd. 1-5. Beih. 1-3. Reg. 1953-1963.

Gedenkstätten NS II = Gedenkstätten für die Opfer des Nationalsozialismus. Eine Dokumentation. Bd. II: Bundesländer Berlin, Brandenburg, Mecklenburg-Vorpommern, Sachsen-Anhalt, Sachsen, Thüringen. Autorinnen: Stefanie Endlich (Berlin, Brandenburg) u. a. Bonn 2000.

Grandke $=$ Grandke, Sarah: „Als die Füße nass und kalt waren, erkannte ich den Ernst der Lage.“ Flucht und Vertreibung 1944/45 und die schwierige Nachkriegszeit. Prenzlau 2008. [Bevölkerungszahlen nach BLHA, Rep. 203 MdI, Nr. 1147].

HGV EE $=$ Historisches Gemeindeverzeichnis des Landes Brandenburg 1875 bis 2005. Landkreis ElbeElster. Potsdam 2006 (Beiträge zur Statistik, 19.4).

HGV LDS $=$ Historisches Gemeindeverzeichnis des Landes Brandenburg 1875 bis 2005. Landkreis Dahme-Spreewald. Potsdam 2006 (Beiträge zur Statistik, 19.3).

HGV OSL $=$ Historisches Gemeindeverzeichnis des Landes Brandenburg 1875 bis 2005. Landkreis Märkisch-Oderland. Potsdam 2006 (Beiträge zur Statistik, 19.6).

HGV OSL $=$ Historisches Gemeindeverzeichnis des Landes Brandenburg 1875 bis 2005. Landkreis Oberspreewald-Lausitz. Potsdam 2006 (Beiträge zur Statistik, 19.8).

HGV SN = Historisches Gemeindeverzeichnis des Landes Brandenburg 1875 bis 2005. Landkreis Spree-Neiße. Potsdam 2006 (Beiträge zur Statistik, 19.13).

HOL I-XI = Historisches Ortslexikon für Brandenburg. Teil 1-11. Weimar 1962-1997.

HOL NL I-II = Historisches Ortslexikon für die Niederlausitz. Bearb. von Rudolf Lehmann. Bd. 1-2. Marburg 1979. 
Jun = Wilhelm Jun: Die Flüchtlings-Transporte des Jahres 1946. Augsburg/Pohrlitz 2009.

Kaminsky = Annette-Christine Kaminsky: „... es wird Zeit, daß wir nach Hause kommen ... “ In: Frankfurter Jahrbuch 1996/97 (1997), S. 147-162 (S. 159 Liste der Umsiedlerlager mit Belegungsstärken).

Kotsch $=$ Detlef Kotsch: Vertriebene und Vertriebenenpolitik in Brandenburg nach dem Zweiten Weltkrieg. In: Die Herkunft der Brandenburger. Sozial- und mentalitätsgeschichtliche Beiträge zur Bevölkerung Brandenburgs vom hohen Mittelalter bis zum 20. Jahrhundert. Hrsg. von Klaus Neitmann u. Jürgen Theil unter Mitw. von Olaf Gründel (Brandenburgische Historische Studien, Bd. 9; Arbeiten des Uckermärkischen Geschichtsvereins zu Prenzlau e. V., Bd. 4). Potsdam 2001, S. 127-137.

Krätzner $=$ Claus Krätzner: Das Schicksal der Bevölkerung der Kreisstadt Königsberg in der Neumark zum Ende des Zweiten Weltkrieges im Spiegel der Heimatkartei. Hilchenbach 1999.

Kriegstagebuch des OKW 4,2 = Kriegstagebuch des Oberkommandos der Wehrmacht (Wehrmachtführungsstab) 1940-1945. geführt von Helmuth Greiner u. Percy Ernst Schramm. Im Auftr. d. Arbeitskreises für Wehrforschung hrsg. von Percy Ernst Schramm. Bd. IV: 1. Januar 1944-22. Mai 1945. Eingel. u. erl. von Percy Ernst Schramm. 2. halbbd. Frankfurt am Main 1961.

Mietk = Thomas Mietk: Neuanfang im Kreis Lübben. Beitrag zur Flüchtlings- und Vertriebenenforschung am Ende des Zweiten Weltkrieges. Lübben 2010 (Einzelveröffentlichung des Kreisarchivs Dahme-Spreewald, Bd. 1).

Oehlsen $=$ Sven Olaf Oehlsen: Vertriebenenlager in Brandenburg 1945-1953. Potsdam 2006.

Ostpriesterverzeichnis $=$ Verzeichnis der heimatvertriebenen Priester aus dem Osten

Schematismus Berlin ... = Schematismus des Bistums Berlin für das Jahr ...

Schematismus Görlitz 1954 = Orts- und Personenverzeichnis des Erzbischöflichen Amtes Görlitz. Hrsg. vom Erzbischöflichen Amt Görlitz. 2. Ausg. Stand vom 1. April 1954.

Schematismus Görlitz 1961 = Orts- und Personenverzeichnis des Erzbischöflichen Amtes Görlitz. Hrsg. vom Erzbischöflichen Amt Görlitz. 4. Ausg. Stand vom 1. Januar 1961.

Schwillus/Brühe = Harald Schwillus / Matthias Brühe: Erzbistum Berlin. Eine junge Diözese in langer Tradition. Kehl am Rhein 2009.

Städtebuch $=$ Städtebuch Brandenburg und Berlin. Hrsg. von Evamaria Engel u. a. Stuttgart u. a. 2000.

Töpler, Menschenwurm = Winfried Töpler: Der zehntausendfüßige Menschenwurm. Die Bewältigung der Kriegsfolgen und des schlesischen Flüchtlingsproblems im Gebiet des heutigen Bistums Görlitz. Texte aus dem Bistumsarchiv Görlitz. In: Vertriebene finden Heimat in der Kirche. Integrationsprozesse im geteilten Deutschland nach 1945. Hrsg. von Rainer Bendel (Forschungen und Quellen zur Kirchen- und Kulturgeschichte Ostdeutschlands, Bd. 38). Köln u. a. 2008, S. 291-635.

Trzcielińska-Polus $=$ Aleksandra Trzcielińska-Polus: Beziehungen zwischen dem Oppelner Schlesien und dem Bezirk Potsdam bis 1989. In: „Wach auf, mein Herz, und denke“. Berlin/Opole 1995, S. 532-542.

Volkszählung 1946 = Endgültige Ergebnisse der Volks- und Berufszählung vom 29. Oktober 1946. Folge 3. In: Statistische Praxis 3 (1948), Beil. zu H. 7, S. 1-4, hier S. 1. [Vgl. Tabelle 4.]

Wille I, II, III = Die Vertriebenen in der SBZ/DDR. Dokumente. Hrsg. u. eingel. von Manfred Wille. [T.] 1-3. Wiesbaden 1996-2003 (Studien der Forschungsstelle Ostmitteleuropa an der Universität Dortmund, Bd. 19,1-3). 


\section{Kreise $\mathrm{A}-\mathrm{Z}$}

Archivalische Quellen: BArch, DO 2 ZVU, Nr. 38, 2/39, 2/45 (Lager, 1945-1949), 2/50 (Kreise), 2/60, Bl. 56 f.-v („Umsiedler“-Betriebe in 18 Orten, wohl 1946/47). - BLHA, Rep. 202 E Statistisches Landesamt, Nr. 1921 (Sonderfragebogen zur statistischen Erfassung und Seßhaftmachung der Flüchtlinge in den Landkreisen der Provinz Mark Brandenburg, 1945: Nr. 19 A bis N; Nr. 20 O bis P; Nr. 21 R bis Z); Nr. 42-43 (Bevölkerungsstatistik mit Angaben über Gesamtbevölkerung, Bevölkerungsentwicklung, Zahl der Umsiedler, der Arbeitenden und Arbeitslosen in den Stadt- und Landkreisen, 1946-1948); Nr. 45 (Statistische Angaben über den Stand der Umsiedler in den Stadt- und Landkreisen, 1946-1948). - BLHA, Rep. 202 G Amt für Information, Nr. 91 bis 181 (Berichte der Informationsdienste der Kreise und Stimmen aus der Bevölkerung zu politischen, ökonomischen, kulturellen Fragen und Maßnahmen der Regierung, 1945-1952; enthält u. a.: Lage der Umsiedler [jeweils eine oder mehrere Akten pro Kreis]). - Rep. 203 MdI, Nr. 1116 (Statistische Erhebung über Gesamtbevölkerung und Umsiedler im Land Brandenburg: Umsiedler- und Heimkehrerstatistiken, 1948; enthält: Erfassung der Umsiedler in den einzelnen Kreisen der SBZ zum 1. Dez. 1945 sowie statistische Berichte der einzelnen Gemeinden); Nr. 1117 (desgleichen, 1946-1947); Nr. 1118 (desgleichen, 1948); Nr. 1119 (Umsiedler- und Heimkehrerstatistiken, 1945-1946; enthält: Oberlandratsämter); Nr. 1156 (Umsiedler- und Heimkehrerstatistiken, 1949-1950; enthält: Umsiedler und Umsiedlertransporte, dabei u. a.: Aufnahmesoll der Kreise ab 1. Jan. 1949; Ermittlungen zur Wohnraumfrage; Angaben über Umsiedler in den einzelnen Kreisen); Nr. 1167 (Umsiedlerbetreuung, 1947-1948; enthält u. a.: Berichte der Kreisgesundheitsämter über die gesundheitliche Betreuung der Umsiedler); Nr. 1168 (Meldungen der Kreise über einmalige Umsiedlerunterstützung gemäß Rundverfügung Nr. 39/VIII vom 10. April 1947 nach SMAD-Befehl Nr. 304; Mai, Juni 1947).

Gedruckte Quellen und Literatur: Blöß, Kreise und Gemeinden. - Blöß, Wolfgang: Kommunale Strukturen im Spannungsfeld gesellschaftlicher Umwälzungen. Die Grenzen von Gemeinden und Kreisen in Brandenburg 19451952. Berlin 2018. - Branchen-Adressbuch Provinz Brandenburg mit Groß-Berlin. Ausgabe 1947. Berlin (1946), T. 2 (S. 1-235): „Alphabetisches Verzeichnis von sämtlichen Industriefirmen, Handels- und Gewerbetreibenden, behördlichen Einrichtungen der Provinz Brandenburg“ [nach Orten!], T. 3 (S. I-X, 1-547): „Branchenteil nebst alphabetischem Branchen-Verzeichnis“ [nach Branchen!]. - Branchen-Fernsprechbuch. Handels-, Gewerbe- und Berufsverzeichnis für den Bezirk der Oberpostdirektion Potsdam. Stand: 1. März 1951. 1. Ausg. Berlin 1951. [Enthält auch „Behördenteil“ (S. 171-194)]. - Branchen-Fernsprechbuch für die Bezirke Cottbus, Frankfurt (Oder), Potsdam 1961. Stand: Mai 1961. - Oehlsen, S. 102-105 (statistische Tabellen der „Eingemeindungen in die [Stadt- und] Landkreise des Landes Brandenburg" für die Stichdaten 30.4.1947, Juni 1948, Febr. 1949 und 30.9.1950, jeweils [außer 1950] auch differenziert nach Männern, Frauen und Kindern). - Töpler, Menschenwurm. - Volkszählung 1946. Wille I, S. 156f.; II, S. 194, 222 u. ö.

\section{Kreis Angermünde}

EREIGNISSE BIS KRIEGSENDE: „Zum Ende des 2. Weltkrieges 1939-1945 zogen seit Dezember 1944 Menschen auf dem Treck, die vor dem Krieg flüchteten, durch unseren Kreis. [...] Einschließlich der durchziehenden Flüchtlinge starben an Krankheiten und insbesondere an Unterernährung insgesamt 1919 Erwachsene und Kinder." (Kukla, Kreis Angermünde, S. 13). - Febr. 1945: Der Kreis Angermünde wird zum Aufnahmegebiet für die zu evakuierende Bevölkerung des Kreises Züllichau-Schwiebus mit Bomst (gemeinsam mit den Kreisen $\rightarrow$ Prenzlau, $\rightarrow$ Ruppin und $\rightarrow$ Templin) und des Kreises Hohensalza-Stadt (Wartheland) bestimmt (BLHA, Rep. 6 B Kreisverwaltung Züllichau-Schwiebus, Nr. 169, unfol.). - 23.2.1945: „Aus den Oderranddörfern Criewen, Zützen und Meyenburg wurden Frauen und Kinder schon vor einigen Tagen abtransportiert, bis auf die arbeitenden männlichen Bewohner." (Wir wollten eigentlich nicht 
fliehen ..., S. 13). - „Ein großer Teil der Bevölkerung des Kreises war während der von Februar bis April 1945 an der Oder stattfindenden Kämpfe ebenfalls auf die Flucht gegangen bzw. evakuiert worden." (Kukla, Kreis Angermünde, S. 13). - 24.4.1945 Beginn der Evakuierungsmaßnahmen für das Kreisgebiet (Kukla, Angermünde 1945, S. 39).

EREIGNISSE NACH KRIEGSENDE: „Nach den Kämpfen waren nach einer Zählung Anfang Juni 1945 im Kreis eine Einwohnerzahl von 31 880[,] davon 2977 Flüchtlinge, registriert. / Durch die Vertreibung der deutschen Bevölkerung aus den Ostgebieten war dann im Januar 1946 die Bevölkerung auf 67642 Einwohner, davon 22253 Flüchtlinge, angestiegen. Ein weit[er] es Ansteigen war im September 1946 auf 73528 Einwohner, davon 27152 Flüchtlinge zu verzeichnen. / Die Unterbringung und Verpflegung dieser Flüchtlinge, die im Kreis ansässig wurden und der in der Zeit von Januar bis September 1946 durch die Lager Angermünde und Pinnow gehenden 23723 Flüchtlinge, stellte die Verwaltung vor hohe Anforderungen. / Unser Kreis hatte in seiner vorwiegend landwirtschaftlichen Struktur für die Versorgung der Bevölkerung eine besondere Bedeutung. / Trotz des Einsatzes aller verfügbaren Kräfte gelang es 1945/46 nichtl alle Nutzungsflächen zu bestellen. / Eine entscheidende Veränderung der Sozialstruktur unseres Agrarkreises trat mit der im September 1945 beschlossenen Bodenreform ein. Bis zum 1. September 1946 wurden im Kreis Angermünde 51 076,13 ha an Boden und Wald an 1976 Landarbeiter und landlose Bauern, an 1531 Umsiedler und weitere verteilt." (Kukla, Kreis Angermünde, S. 13). - 1945: „Typhus- und Diphterie-Epidemien raffen viele Menschen dahin, allein in Angermünde starben zeitweise täglich bis zu 25 Personen." (www.angermuende. de). - 5.9.1945 Verfügung der Provinzialregierung über eine Verpflichtung zur Unterbringung von 40000 weiteren Flüchtlingen im Kreis Angermünde auf Befehl der Besatzungsmacht (Ast/ Mauersberger, S. 43). - 1.9.1945 508 Typhus- u. 189 Verdachtsfälle, 27.9.1945630 Typhusfälle, 10.10.1945 750 Typhus- u. 32 Verdachtsfälle im Kreis (Wille I, S. 420). - 18.10.1945 (Bericht der Zentralverwaltung für das Gesundheitswesen): „Vier Auffanglager im Kreis Angermünde sind in Vorbreitung. [...] Im Kreis sind über 1000 Typhusfälle. Desinfektionsittel sind nicht vorhanden. Die Flüchtlinge sind stark demoralisiert. [...].“ (Wille I, S. 419). - 12.12.1945: „Neben den täglichen Erfordernissen der Unterbringung und Verpflegung der Einwohnerschaft haben die Aemter die Riesenaufgabe der Flüchtlingsbetreuung zu erledigen. Dem Kreise sind 40000 Flüchtlinge zur Ansiedlung zugewiesen worden. Weitere 120000 Flüchtlinge wrden durch Angermünde nach anderen Gegenden hindurchgeschleust. Diese Arbeit ist in vollem Fluss." (Brandenburgische Gemeinden 1945, S. 4).

EREIGNISSE NACH 1990: 1995 Unterbringung eines Teilkontingents der 186 dem Ldkr. Uckermark zugewiesenen Aussiedler in Flemsdorf als einer von drei Gemeinden (Theil, S. 17).

Bevölkerungszahlen: Wohnbevölkerung 1939: 67877 (AGV, S. 10). - 1946: 76022, davon aus Ostpreußen: 2435, Hinterpommern 7205, Ostbrandenburg 4367, Schlesien 2978, Tschechoslowakei 395, Polen 1348, Danzig 387, Rumänien 314, Baltikum 204, Sowjetunion 79 (Volkszählung 1946). - Ende 1945: „Dem Kreis sind 40000 Flüchtlinge zur Ansiedlung zu- 
gewiesen worden. Weitere 120000 Flüchtlinge werden durch Angermünde nach anderen Gegenden hindurchgeschleust. Diese Arbeit ist in vollem Fluß." (Dahl, S. 156). - Eingemeindung von Vertriebenen: 30.4.1947: 24854 (Oehlsen, S. 102), Juni 1948: 26555 (ebd., S. 103), Febr. 1949: 26947 (ebd., S. 104), 30.9.1950 („nach den neuen Kreisgrenzen ab 1.7.1950“): 22354 (ebd., S. 105). - 31.12.1948: Gesamtbevölkerung: 81 584, davon „Umsiedler und Evakuierte“: 27898 (Grandke, S. 46).

ORTE: $\rightarrow$ Altenhof am Werbellinsee, $\rightarrow$ Angermünde, $\rightarrow$ Britz, $\rightarrow$ Criewen, $\rightarrow$ Felchow, $\rightarrow$ Gramzow, $\rightarrow$ Greiffenberg, $\rightarrow$ Joachimsthal, $\rightarrow$ Neu Künkendorf, $\rightarrow$ Niederfinow, $\rightarrow$ Oderberg/Mark, $\rightarrow$ Pinnow, $\rightarrow$ Rosow, $\rightarrow$ Schwedt/Oder, $\rightarrow$ Seehausen, $\rightarrow$ Stützkow, $\rightarrow$ Vierraden, $\rightarrow$ Zützen.

LAGER: $\rightarrow$ Altenhof am Werbellinsee, $\rightarrow$ Angermünde, $\rightarrow$ Britz, $\rightarrow$ Felchow, $\rightarrow$ Gramzow, $\rightarrow$ Joachimsthal, $\rightarrow$ Neu Künkendorf, $\rightarrow$ Oderberg/Mark, $\rightarrow$ Pinnow, $\rightarrow$ Schwedt/Oder.

Archivalische Quellen: BLHA, Rep. 203 MdI, Nr. 1126 (Umsiedler- und Heimkehrerstatistiken, 1945-1946; enthält: Erfassung der Umsiedler in den einzelnen Kreisen der SBZ zum 1. Dez. 1945 sowie statistische Berichte der einzelnen Gemeinden, hier Kreis Angermünde). - BLHA, Rep. 250 Landratsamt Angermünde. - Siehe auch Quellenteil, Nr. 214, 215, 218.

Gedruckte Quellen und Literatur: HOL VIII. - Ammon, Margarete: Tagebuch. In: Gespräche mit ehemaligen Küstrinern. Bd. 6. Frankfurt (Oder) 2017, S. 29-50 (S. 44 f.). - Braunschweig, Frieda: Aufbau der Schule in Passow nach 1945. in: Angermünder Heimatkalender 2020, S. 212-217. - Dahl, Erich: Der Stadtkreis Angermünde nach dem Zusammenbruch des „Tausendjährigen Reiches“. In: Heimatkalender für den Kreis Angermünde 1960, S. 155-156 [Niederschrift Ende 1945]. - Discher, Holm: Karl Voigt und Ernst Lösche - Ein Porträt der ersten Angermünder Landräte der Nachkriegszeit. In: Angermünder Heimatkalender 2016 (2015), S. 192-201. - Kukla, Dietrich: Angermünde 1945. In: ebd. 1995, S. 38-49. - Kukla, D[ietrich]: Kreis Angermünde 1817-1993. In: ebd. 1994, S. 9-16. - Theil, Jürgen: Prenzlauer Stadtlexikon und Geschichte in Daten. Prenzlau 2005. - Wille I, S. 418-420, 456; II, S. 180, 191, 239 (Lage der Vertriebenen in Lüdersdorf, 1948), 363, 397 (Seidenraupenzucht); III, S. 111 (Tätigkeitsbericht des Kreisumsiedlerausschusses für Dez. 1946), 174, 396 (Oder-Neiße-Grenze, 1951). - Wir wollten eigentlich nicht fliehen ... Schwedt im Frühjahr 1945. Hrsg.: Stadtmuseum Schwedt/Oder. Schwedt/Oder 2007. - http://www.angermuende. $\mathrm{de} / \mathrm{cms} /$ upload/Stadtarchiv/Ausstellungen/Tafel11.pdf (16.8.2016).

\section{Kreis Beeskow-Storkow}

EREIGNISSE BIS KRIEGSENDE: 23.1.1945: „alle Bürgermeister des Kreises Beeskow-Storkow erhalten die Mitteilung des Landrates, dass der Schulbetrieb eingestellt ist und die Schulräume als Massenquartier für Flüchtlinge vorzubereiten sind.“ (Kurt Zahn in: Tschechne, S. 85). - Febr. 1945: Der Kreis „Beeskow“[-Storkow] wird (gemeinsam mit dem Kreis Guben) zum Aufnahmegebiet für die zu evakuierende Bevölkerung der Kreises Wielun (Wartheland) bestimmt (BLHA, Rep.6 B Kreisverwaltung Züllichau-Schwiebus, Nr. 169, unfol.).

EReignisse NACH KRIEgSEnde: 5.9.1945 Verfügung der Provinzialregierung über eine Verpflichtung zur Unterbringung von 20000 weiteren Flüchtlingen im Kreis Beeskow-Storkow auf Befehl der Besatzungsmacht (Ast/Mauersberger, S. 43). - Der Kreis ist noch in den 1950er 
Jahren eines der Schwerpunktwohngebiete Vertriebener aus Ziebingen (Kr. Weststernberg) (Schieche/Jaeschke, S. 320).

Bevölkerungszahlen: Wohnbevölkerung 1939: 62983 (AGV, S. 10). - 1946: 73 521, davon aus Ostpreußen: 1474, Hinterpommern 1490, Ostbrandenburg 8302, Schlesien 2265, Tschechoslowakei 1519, Polen 1 152, Danzig 309, Rumänien 57, Baltikum 104, Sowjetunion 54 (Volkszählung 1946). - 1947: 75584 Stammeinwohner, ca. 23000 Vertriebene (Müller, S. 397). - Eingemeindung von Vertriebenen: 30.4.1947: 24138 (Oehlsen, S. 102), Juni 1948: 24371 (ebd., S. 103), Febr. 1949: 24413 (ebd., S. 104), 30.9 .1950 („nach den neuen Kreisgrenzen ab 1.7.1950“): - (ebd., S. 105). - 31.12.1948: Gesamtbevölkerung: 76318, davon „Umsiedler und Evakuierte“: 23214 (Grandke, S. 46).

Orte: $\rightarrow$ Bad Saarow(-Pieskow), $\rightarrow$ Beeskow, $\rightarrow$ Gosen, $\rightarrow$ Herzberg, $\rightarrow$ Küchensee, $\rightarrow$ Märkisch Buchholz, $\rightarrow$ Neu Zittau, $\rightarrow$ Reichenwalde, $\rightarrow$ Storkow, $\rightarrow$ Storkow-Hirschluch.

LAGER: $\rightarrow$ Bad Saarow, $\rightarrow$ Küchensee (Kreisumsiedlerlager).

Archivalische Quellen: BLHA, Rep. 202 E Statistisches Landesamt, Nr. 17: Statistische Aufstellung zur Bevölkerungsaufnahme (einschließlich Flüchtlinge und zurückgekehrte Kriegsgefangene) Kreise Beeskow-Storkow, Niederbarnim, Osthavelland, Teltow, 1945-1946. - BLHA, Rep. 203 MdI, Nr. 1127 (Umsiedler- und Heimkehrerstatistiken, 1945-1946; enthält: Erfassung der Umsiedler in den einzelnen Kreisen der SBZ zum 1. Dez. 1945 sowie statistische Berichte der einzelnen Gemeinden, hier Kreis Beeskow-Storkow). - BLHA, Rep. 250 Landratsamt Beeskow-Storkow.

Gedruckte Quellen und Literatur: HOL IX. - Kühne, Lutz: Die Bodenreform im Kreis Beeskow-Storkow. In: Kreiskalender Oder-Spree 2006, S. 22-26. - Pfeiler, Jürgen: „Der Krieg war plötzlich da.“ Alltag westlich Oder, Spree und Dahme zwischen Neujahr und Himmelfahrt. Eine Chronik. In: Brandenburg im Jahr 1945. Studien. Hrsg. von Werner Stang. Potsdam 1995, S. 84-105. - Schieche, Manfred/Jaeschke, Gerhard: Ziebingen. Eisenhüttenstadt u. a. 2001. - Scholze-Irrlitz, Leonore: Auf den Schultern der Frauen. Flucht und Vertreibung, Umsiedlung und Neuanfang im Landkreis Beeskow/Storkow (1945-1950). In: Flucht und Vertreibung 1945-1995. Hrsg. vom Haus der Heimat des Landes Baden-Württemberg. Filderstadt 1996, S. 35-47. - Dies.: „Umsiedler“ im Landkreis Beeskow-Storkow. In: Alltagskultur im Umbruch. Wolfgang Kaschuba u. a. (Hg.). Weimar u. a. 1996, S. 135-149. - Dies.: Die Bürde der Frauen. Erinnerungen an Vertreibung und Neuanfang im Landkreis Beeskow/Storkow 1945-50. In: Kreiskalender Oder-Spree 2002, S. 16-19. - Wille I, S. 55, 211; II, S. 172 (Amtsbezirk Wendisch-Rietz, 1945), 241 f., 247, 306f., 308, 400 f. („Umsiedlerbetriebe“, 1948); III, S. 265 („Umsiedlerwoche“ in Lebbin, 1947).

\section{Kreis Calau}

(1950 in Kr. Senftenberg umbenannt)

EReignisse BIS KRIEgSEnde: Febr. 1945: Der Kreis Calau wird zum Aufnahmegebiet für die zu evakuierende Bevölkerung des Kreises Wreschen (Wartheland) bestimmt (BLHA, Rep. 6 B Kreisverwaltung Züllichau-Schwiebus, Nr. 169, unfol.). - Jan./Febr. 1945: „In dieser Zeit ist die 169 nicht nur mit Kohle- und Wehrmachtsautos belegt. Schier endlose Flüchtlingstrecks mit Pferdewagen, zunächst aus Ostpreußen, dann aus Schlesien und der Ostmark, wälzen sich Richtung Senftenberg." (Kittan, S. 112). 
EReignisse NACH KRIEgSende: 5.9.1945 Verfügung der Provinzialregierung über eine Verpflichtung zur Unterbringung von 32000 weiteren Flüchtlingen im Kreis Calau auf Befehl der Besatzungsmacht (Ast/Mauersberger, S. 43). - 14.2.1946 (Bericht): „Der Kreis Calau hat, ebenso wie $[\rightarrow]$ Luckau, ebenso eine große Zahl Evakuierter wie $[\rightarrow]$ Cottbus $[\ldots]$.." (Töpler, Menschenwurm, S. 501).

BevöLkerungszahlen: Wohnbevölkerung 1939: 111902 (AGV, S. 11). - 1946: 130548 , davon aus Ostpreußen: 850, Hinterpommern 707, Ostbrandenburg 4694, Schlesien 14672, Tschechoslowakei 2943, Polen 2042, Danzig 83, Rumänien 97, Baltikum 139, Sowjetunion 48 (Volkszählung 1946). - Eingemeindung von Vertriebenen: 30.4.1947: 33381 (Oehlsen, S. 102), Juni 1948: 35167 (ebd., S. 103), Febr. 1949: 35274 (ebd., S. 104), 30.9.1950 („nach den neuen Kreisgrenzen ab 1.7.1950“): - (ebd., S. 105). - 31.12.1948: Gesamtbevölkerung: 136 196, davon „Umsiedler und Evakuierte“: 35037 (Grandke, S. 46).

OrTE: $\rightarrow$ Altdöbern, $\rightarrow$ Calau, $\rightarrow$ Drebkau, $\rightarrow$ Großräschen, $\rightarrow$ Lauta, $\rightarrow$ Lübbenau, $\rightarrow$ Neupetershain, $\rightarrow$ Schwarzheide, $\rightarrow$ Senftenberg, $\rightarrow$ Sorno, $\rightarrow$ Vetschau.

LAGER: $\rightarrow$ Lübbenau, $\rightarrow$ Senftenberg, $\rightarrow$ Vetschau.

Archivalische Quellen: BLHA, Rep. 203 MdI, Nr. 1128 (Umsiedler- und Heimkehrerstatistiken, 1945-1946; enthält: Erfassung der Umsiedler in den einzelnen Kreisen der SBZ zum 1. Dez. 1945 sowie statistische Berichte der einzelnen Gemeinden, hier Kreis Calau). - BLHA, Rep. 250 Landratsamt Calau/Senftenberg.

Gedruckte Quellen und Literatur: HOL NL I. - Kittan, Horst: Die Russen kommen. Cottbus 2011. - Ther, Philipp: Die Vertriebenenpolitik in der SBZ/DDR 1945-1953 am Beispiel des Kreises Calau-Senftenberg. In: Jahrbuch für brandenburgische Landesgeschichte 46 (1995), S. 159-168. - Ders.: Von Schlesien in die Lausitz. Ein Beispiel der Integration von Vertriebenen in der DDR. In: „Wach auf, mein Herz, und denke“. Berlin/Opole 1995, S. 488-494 [am Beispiel des Kreises Calau-Senftenberg]. - Töpler, Menschenwurm, S. 301, 451. - Wille I, S. 37, 66; II, S. 413; III, S. 385.

\section{Kreis Cottbus}

EREIGNisSe bis Kriegsende: Ende Jan./Anf. Febr. 1945 Räumung der Dörfer des Kr. Freystadt in Schlesien; die Trecks „endeten zumeist in Sachsen im Raum um Oschatz, in der Gegend um Cottbus und auch schon bald in den Ortschaften dicht hinter der Neiße" (Der Kreis Freystadt, S. 239). - Febr. 1945: Der Kreis Cottbus wird zum Aufnahmegebiet für die zu evakuierende Bevölkerung der Kreise Lask [Łask] und Litzmannstadt-Stadt [Lodz] (Wartheland) bestimmt (BLHA, Rep. 6 B Kreisverwaltung Züllichau-Schwiebus, Nr. 169, unfol.).

EREIGNISSE NACH KRIEGSENDE: 9.7.1945 (Bericht des Landrates, Zusammenfassung): „In einer Woche sind 150000 Flüchtlinge durch den Kreis gekommen. Die Flüchtlinge kommen aus dem Sudetengebiet, mit Zug bis Cottbus. [...] Cottbuser Gebiet, das bereits 18000 Flüchtlinge für die Landwirtschaft aufgenommen hat und Mehr-Leistungen nicht tragen kann." (Wille I, S. 37). - 23.8.1945 Zurückweisung eines Vertriebenentrecks (270 Personen) wegen Überfül- 
lung des Stadt- u. Landkreises Cottbus und Seuchengefahr (Faksimile des Schreibens des Landrates in: Ast/Mauersberger, S. 39). - In der Verfügung der Provinzialregierung vom 5.9.1945 über eine Verpflichtung zur Unterbringung weiterer Flüchtlinge auf Befehl der Besatzungsmacht wird der Kreis Cottbus als einer von drei (sämtlich niederlausitzischen) Kreisen wegen Überbelastung freigestellt (Ast/Mauersberger, S. 43 f.). - Entsprechend heißt es in einem Bericht über eine Arbeitstagung beim Oberlandrat in $\rightarrow$ Cottbus am 24.10.1945 über den Ldkr. Cottbus: „Braucht keine Auffang- und Sammellager herzurichten. Ein Reservelager kann CottbusLand nicht schaffen. Es erhält den Auftrag in Frauendorf ein Lager für arbeitsunfähige Umsiedler einzurichten. Das Schloss Branitz wird als Kinderheim vorgesehen. Die Bezirksverwaltung [Bezirks des Oberlandrats, P. B.] wird dieserhalb mit der [sowjetischen, P. B.] Bezirkskommandantur verhandeln." (Töpler, Menschenwurm, S. 450). - 14.2.1946 (Bericht): „Der Kreis [ $\rightarrow$ ] Calau hat, ebenso wie $[\rightarrow]$ Luckau, ebenso eine große Zahl Evakuierter wie Cottbus [...].“ (ebd., S. 501).

BEVÖLKERUNGSZAHLEN: Wohnbevölkerung 1939: 61423 (AGV, S. 11). - 1946: 76343, davon aus Ostpreußen: 504, Hinterpommern 262, Ostbrandenburg 6252, Schlesien 9748, Tschechoslowakei 600, Polen 556, Danzig 54, Rumänien 18, Baltikum 28, Sowjetunion 40 (Volkszählung 1946). - Eingemeindung von Vertriebenen: 30.4.1947: 21212 (Oehlsen, S. 102), Juni 1948: 21359 (ebd., S. 103), Febr. 1949: 20979 (ebd., S. 104), 30.9 .1950 („nach den neuen Kreisgrenzen ab 1.7.1950“): 57259 (ebd., S. 105).- 31.12.1948: Gesamtbevölkerung: 77739, davon „Umsiedler und Evakuierte“: 21596 (Grandke, S. 46).

Katholiken: Zahlreiche katholische Flüchtlinge aus Schlesien (u. a. aus Deutsch Wartenberg und Umgebung, Friedersdorf, Kr. Grünberg, und Glogau) kommen 1945 im Kreis Cottbus unter (Töpler, Menschenwurm, S. 364).

OrTE: $\rightarrow$ Cottbus, $\rightarrow$ Drachhausen, $\rightarrow$ Drehnow, $\rightarrow$ Jocksdorf, $\rightarrow$ Kiekebusch, $\rightarrow$ Kolkwitz, $\rightarrow$ Leuthen, $\rightarrow$ Peitz, $\rightarrow$ Schmellwitz, $\rightarrow$ Weissagk, $\rightarrow$ Werben (Spreewald).

LAGER: $\rightarrow$ Cottbus, $\rightarrow$ Werben (Spreewald).

Archivalische Quellen: BLHA, Rep. 203 MdI, Nr. 1129 (Umsiedler- und Heimkehrerstatistiken, 1945-1946; enthält: Erfassung der Umsiedler in den einzelnen Kreisen der SBZ zum 1. Dez. 1945 sowie statistische Berichte der einzelnen Gemeinden, hier Kreis Cottbus). - BLHA, Rep. 205 A Ministerium für Volksbildung, Nr. 447 (Schulverhältnisse im Kreis Cottbus, 1950-1952; enthält u. a.: Hilfe für Umsiedlerkinder). - BLHA, Rep. 250 Landratsamt Cottbus.

Gedruckte Quellen und Literatur: HOL NL II. - Ast, Jürgen / Mauersberger, Kerstin: Zweite Heimat Brandenburg. Flucht, Vertreibung, Neuanfang. Berlin 2000. - Der Kreis Freystadt. Scheinfeld 1969. - Töpler, Menschenwurm, S. 363-365. - Wille I, S. 37, 41 f., 55, 64, 457. 


\section{Kreis Guben}

EREIGNISSE BIS KRIEgSENDE: Febr. 1945: Der (noch ungeteilte) Kreis Guben wird (gemeinsam mit dem Kreis Beeskow) zum Aufnahmegebiet für die zu evakuierende Bevölkerung der Kreises Wielun (Wartheland) bestimmt (BLHA, Rep. 6 B Kreisverwaltung Züllichau-Schwiebus, Nr. 169, unfol.).

EREIGNisSe NACH KRIEgSEnde: 6.6.1945 Landrat an alle Bürgermeister des Kreises: „Solange die Polenfrage nicht gelöst ist, sind eine Anzahl Flüchtlinge nicht in der Lage, [nach Osten - P.B.] über die Neiße zu kommen. Sie müssen westlich der Neiße im Landkreis Guben untergebracht werden. Die Gemeinden, soweit sie in unmittelbarer Nähe der Stadt Guben liegen, sind mit Flüchtlingen überfüllt. Es muß deshalb darauf gesehen werden, daß diese Flüchtlinge in andere abgelegene Gemeinden verteilt und untergebracht werden. Die Flüchtlinge sind zur Arbeit heranzuziehen, soweit sie dazu in der Lage sind, und auch mit entsprechenden Lebensmitteln zu versorgen. Es darf auf keinen Fall vorkommen, daß Flüchtlinge ohne Arbeit und ohne Lebensmittelversorgung gelassen werden." (Die russische Kommandantur verlangt ..., S. 15). - Juni 1945 Festlegung der Neiße-Grenze und somit Teilung des Stadt- und des Landkreises (Sebastian, S. 38 f.), die Hälfte des Kreisgebietes fällt an Polen (Heimatlexikon, S. 68). - 5.7.1945: Anweisung des Bürgermeisters von Fürstenberg/Oder an die Ortsältesten, „die in Ihrem Dorfe zur Zeit eine größere Einwohnerzahl als vor dem Kriege“ haben, aufgenommene Flüchtlinge „auf Anordnung der Kommandantur schnellstens wieder auszubürgern“ („Die russische Kommandantur verlangt ...,, S. 26). - 24.7.1945 Rundschreiben des Landrates des Kr. Guben an die Bürgermeister): „Flü chtl inge, welche nicht aus dem Kreise Guben stammen, müssen den Kreis verlassen, wenn sie nicht unbedingt zur Einbringung der Ernte benötigt werden. Die aus dem Kreise Guben stammenden Flüchtlinge sind in Wohnungen unterzubringen, Sie sind genau so zu verpflegen und zur Arbeit heranzuziehen wie die eingesessenen Dorfbewohner. Hierauf möchte ich nochmals besonders hinweisen.“ („Die russische Kommandantur verlangt ...", S. 39). - Tätigkeitsbericht der Stadtverwaltung Guben vom 3.8.1945 für Juli (Stadtarchiv Guben I/1214): „Eine große Sorge verursachte die Unterbringung der Deutschen aus dem östlich der Neiße gelegenen Stadt- und Landkreis Guben. Die Unterbringung war sehr schwierig, weil der Westteil des Land- und Stadtkreises schon von anderen Flüchtlingen überfüllt war." (Sebastian, S. 39). „Das Territorium des damaligen Landkreises Guben lag östlich und westlich der Neiße mit 106 Gemeinden, 51 befanden sich im westlichen Teil. Der Stadtkreis nahm eine Fläche von ca. 3000 ha östlich der Neiße und ca. 972 ha im westlichen Teil ein. Die wichtigsten staatlichen und Verwaltungsdienststellen, Sozial- und Gesundheitseinrichtungen, sowie ca $79 \%$ des Wohnraumes lagen im östlichen Teil der Stadt. Im westlichen [...] befand sich nur ca. $21 \%$ des Wohnraumes, davon waren 300 Wohnungen total vernichtet." (ebd., S. 40). - In der Verfügung der Provinzialregierung vom 5.9.1945 über eine Verpflichtung zur Unterbringung weiterer Flüchtlinge auf Befehl der Besatzungsmacht wird der Kreis Guben als einer von drei (sämtlich niederlausitzischen) Kreisen wegen Überbelastung freigestellt (Ast/Mauersberger, S. 43 f.). - Bei der Bodenreform im Ldkr. Guben 4998 ha an 776 „Umsiedler“verteilt (Heimat- 
lexikon, S. 29). - 4.11.1949: „Im Telegramm der Kreisdelegiertenkonferenz der SED an die Leitung der PVAP in Gubin wird die Oder-Neiße-Grenze als verbindende Friedensgrenze charakterisiert." (Der Kreis Guben im Gründungsjahr, S. 27). - 6.6.1950 (DDR-Regierungsbeschluss) Auflösung des Landkreises Guben und Bestimmung des Landkreises Frankfurt (Oder) zum Nachfolgekreis. „Die Gubener Gemeinden wurden auf die Landkreise Cottbus und Frankfurt (Oder) aufgeteilt.“ (Blöß, Kreise und Gemeinden, S. 48). - 30.6.1950 „Auflösung des Landkreises Guben“ (Guben zu Zeiten der DDR, S. 72).

Bevölkerungszahlen: Wohnbevölkerung des Gesamtkreises (!) 1939: 45646 (AGV, S. 11). - 1946: 35 192, davon aus Ostpreußen: 92, Hinterpommern 212, Ostbrandenburg 9090 , Schlesien 960, Tschechoslowakei 46, Polen 159, Danzig 5, Rumänien 10, Baltikum 7, Sowjetunion 38 (Volkszählung 1946). - Eingemeindung von Vertriebenen im Westteil: 30.4.1947: 12766 (Oehlsen, S. 102), Juni 1948: 14257 (ebd., S. 103), Febr. 1949: 14598 (ebd., S. 104), 30.9.1950 („nach den neuen Kreisgrenzen ab 1.7.1950“): - (ebd., S. 105). - 31.12.1948: Gesamtbevölkerung: 39677, davon „Umsiedler und Evakuierte“: 14664 (Grandke, S. 46).

ORTE: $\rightarrow$ Aurith, $\rightarrow$ Bärenklau, $\rightarrow$ Coschen, $\rightarrow$ Fürstenberg/Oder, $\rightarrow$ Grießen, $\rightarrow$ Groß Breesen, $\rightarrow$ Groß Drewitz, $\rightarrow$ Groß Gastrose, $\rightarrow$ Guben, $\rightarrow$ Jamlitz, $\rightarrow$ Kerkwitz, $\rightarrow$ Krayne, $\rightarrow$ Neuzelle, $\rightarrow$ Wiesenau, $\rightarrow$ Ziltendorf.

LAGER: $\rightarrow$ Bärenklau, $\rightarrow$ Fürstenberg/Oder, $\rightarrow$ Grießen, $\rightarrow$ Guben, $\rightarrow$ Jamlitz (bei Lieberose).

Archivalische Quellen: BLHA, Rep. 203 MdI, Nr. 1131 (Umsiedler- und Heimkehrerstatistiken, 1945-1946; enthält: Erfassung der Umsiedler in den einzelnen Kreisen der SBZ zum 1. Dez. 1945 sowie statistische Berichte der einzelnen Gemeinden, hier Kreis Guben). - BLHA, Rep. 250 Landratsamt Guben/Frankfurt (Oder). - Siehe auch Quellenteil, Nr. 179-181, 183-185, 188-202, 204, 205, 221, 222.

Gedruckte Quellen und Literatur: HOL NL II. - Blöß, Wolfgang: Grenzen und Reformen in einer Umbruchgesellschaft. Berlin 2014. - Ders.: Kommunale Strukturen im Spannungsfeld gesellschaftlicher Umwälzungen. Die Grenzen von Gemeinden und Kreisen in Brandenburg 1945-1952. Berlin 2018. - Guben zu Zeiten der DDR. In: Gubener Heimatkalender 44 (2000), S. 72-77, hier S. 72 [Auflösung]. - Gubener Heimatbrief. Hrsg.: Gubener Heimatbund e. V. 1985-2017. - Heimatlexikon für Guben und Umgebung. Guben [2002]. - Jachnick, Erwin: Flucht und Vertreibung aus Ossig. In: Gubener Heimatbrief (1995)1, S. 60-73. - Der Kreis Guben im Gründungsjahr der DDR 1949. Zsgest.: W. Dartsch. In: Gubener Heimatkalender 33 (1989), S. 21-28 [Meldungen aus der „Märkischen Volksstimme“]. - Lengauer, Hans Georg: Soldatengräber an der Neißefront. In: Gubener Heimatbrief (2017)1, S. 56-61. Peter, Andreas: Der Juni-Aufstand im Bezirk Cottbus. In: Deutschland Archiv 27 (1994), S. 585-594 [v. a. am Beispiel des Kr. Guben]. - „Die russische Kommandantur verlangt ...“ Eine regionale Quellensammlung der ersten Nachkriegsjahre für Fürstenberg (Oder) und Umgebung 1945-1949. Eisenhüttenstadt 2003. - Sebastian, Günter: Guben im Jahre 1945. In: Gubener Heimatkalender 17 (1972), S. 35-48. - Töpler, Menschenwurm, S. 450. - Wandke, Horst: Aufbruch ins Ungewisse. Wie die Kuscherner das Kriegsende erlebten. In: Heimatkalender Eisenhüttenstadt und Umgebung 23 (2005), S. 259-260. - Wieviel Einwohner hat der Kreis Guben? In: Gubener Heimatkalender 11 (1966), S. 126. - Wille I, S. 38, 43, 412 f., 458; II, S. 305 f., 310, 343 f. (Lübbinchen), 397; III, S. 127 und 132 f. (Ortsumsiedlerausschüsse, 1947), 182, 195, 267 f. („Umsiedlerwoche“, 1947), 356 (Stimmung unter den Vertriebenen, bes. in Horno, 1948). 


\section{Kreis Jüterbog-Luckenwalde}

\section{(12.3.1946 in Kreis Luckenwalde umbenannt)}

EREIGNISSE BIS KRIEgSEnde: Jan./Febr. 1945: Der Kreis Jüterbog-Luckenwalde wird zum Aufnahmegebiet für die zu evakuierende Bevölkerung der Kreise Schroda, Schrimm und Kosten (Wartheland) bestimmt (Febr. lt.: BLHA, Rep. 6 B Kreisverwaltung Züllichau-Schwiebus, Nr. 169, unfol.; 24. Jan. lt. Dokumentation der Vertreibung I/1, S. 383). - „Am 24. Januar wurde bekannt, daß der Kreis Jüterbog-Luckenwalde für den Kreis Wollstein Aufnahmekreis sei. [...] Die Aufnahme und Unterbringung im Aufnahmekreis erfolgte dann durch den Meldekopf Wollstein in $[\rightarrow]$ Baruth. Ca. 300 Flüchtlinge aus dem Kr. Wollstein kommen daraufhin im Kr. JüterbogLuckenwalde unter (Dokumentation der Vertreibung I/1, S. 383).

EReIgnisse NACH KRIEgSEnde: 5.9.1945 Verfügung der Provinzialregierung über eine Verpflichtung zur Unterbringung von 40000 weiteren Flüchtlingen im Kreis Jüterbog-Luckenwalde auf Befehl der Besatzungsmacht (Ast/Mauersberger, S. 43). - Okt. 1945 Aufnahme von 5000 „Personen Deutsche, jugoslawischer Untertanenschaft" aus ihrem Durchgangsaufenthaltsort $\rightarrow$ Forst (Lausitz) (Wille I 63f.). - 24.10.1945 Bericht eines Vertreters des Landratsamtes (auf Arbeitsagung beim Oberlandrat in $\rightarrow$ Cottbus): „Luckenwalde [gemeint ist wohl der Kreis, P. B.] habe 1000 sogenannte Volksdeutsche von einer russischen Umsiedlerstelle übernehmen müssen [wahrscheinlich Transport aus Ostpreußen, P. B.], 5000 Umsiedler seien von $[\rightarrow]$ Forst unterwegs. Der Kreiskommandeur lasse aus der Tschechoslowakei kommende Umsiedler nicht in den Bezirk, mache überhaupt grosse Schwierigkeiten (Verpflegung). Ganz allgemein hätten die Jugoslaven aus Forst zuviel Gepäck, 5 Erwachsene brauchten einen Waggon allein. Oblt. [Oberleutnant] Kuzenko, dem das vorgetragen wird, hält sich in dieser Angelegenheit nicht für zuständig. / Es stellt sich heraus, dass die Jugoslaven anscheinend überhaupt fehlgeleitet sind und unmittelbar nach Stralsund gefahren werden sollten." (Töpler, Menschenwurm, S. 451). - Nach Kriegsende amtiert in Welsickendorf als evang. Pfarrer 13 Jahre lang der 1945 aus Gottschimmerbruch (Kr. Friedeberg/ Nm.) vertriebene Theodor Risch (Risch, S. 276).

BevöLKerungszahlen: Wohnbevölkerung 1939: 91323 (AGV, S. 10). - 1946: 101 037, davon aus Ostpreußen: 1945, Hinterpommern 1890, Ostbrandenburg 2735, Schlesien 6606, Tschechoslowakei 2525, Polen 5698, Danzig 208, Rumänien 1031, Baltikum 612, Sowjetunion 141 (Volkszählung 1946). - 24.10.1947: 73000 alteingesessene Einwohner und „über 30000 Umsiedler“ (Maetz, S. 222). - 16.1.1948: 104331 Einwohner, „davon 30594 Umsiedler“ (ebd., S. 223). - Eingemeindung von Vertriebenen: 30.4.1947: 29022 (Oehlsen, S. 102), Juni 1948: 30194 (ebd., S. 103), Febr. 1949: 30296 (ebd., S. 104), 30.9 .1950 („nach den neuen Kreisgrenzen ab 1.7.1950“): 27159 (ebd., S. 105). - 31.12.1948: Gesamtbevölkerung: 104903, davon „Umsiedler und Evakuierte“: 32865 (Grandke, S. 46).

OrTE: $\rightarrow$ Baruth, $\rightarrow$ Dahme, $\rightarrow$ Felgentreu, $\rightarrow$ Frankenfelde, $\rightarrow$ Jüterbog, $\rightarrow$ Luckenwalde, $\rightarrow$ Neuheim (Dorf Zinna). 
LAGER: $\rightarrow$ Baruth, $\rightarrow$ Jüterbog (Kreisumsiedlerlager Kaserne), $\rightarrow$ Luckenwalde, $\rightarrow$ Neuheim (Dorf Zinna).

Archivalische Quellen: BLHA, Rep. 203 MdI, Nr. 1132 (Umsiedler- und Heimkehrerstatistiken, 1945-1946; enthält: Erfassung der Umsiedler in den einzelnen Kreisen der SBZ zum 1. Dez. 1945 sowie statistische Berichte der einzelnen Gemeinden, hier Kreis Luckenwalde). - BLHA, Rep. 250 Landratsamt Luckenwalde. - Siehe auch Quellenteil, Nr. 186, 187, 203, 206-208.

Gedruckte Quellen und Literatur: HOL X. - Dokumentation der Vertreibung I/1, S. 383. - Maetz, Dietrich: Chronik der Stadt Luckenwalde. Luckenwalde 2016. - Risch, Theodor: Als Pfarrer im Netzebruch 1912-45. In: Erinnerungen an Stadt + Land Friedeberg Nm. Hrsg. von E(rhard) Schendel u. Hans Schauer. Berlin 1974, S. 263-277. Wille I, S. 64, 66; III, S. 90 (Umsiedlerausschüsse).

\section{(Rest-)Kreis Königsberg/Neumark}

EReignisse NACH Kriegsende: Der Kreis fiel 1945 größtenteils an Polen. Ein kleinerer, als Kreis nicht lebensfähiger Teil (818665 ha), das Gebiet zwischen Alter und Neuer Oder, also westlich des aktuellen Oderlaufs, verblieb bei Deutschland und wurde, zunächst von der Provinzialverwaltung als „Restkreis Königsberg“ bezeichnet, am 15.3.1946 (Beschluss vom 25.1.1946) den benachbarten Landkreisen zugewiesen: überwiegend dem Kreis $\rightarrow$ Oberbarnim (19 Orte, 6 Ortsteile, 3 einwohnerlose Flächen von rechts der Oder gelegenen Gemeinden), kleinere Teile kamen an den Kreis Lebus (1 Gemeinde, 1 Ortsteil [Küstrin-Kietz], 2 einwohnerlose Wiesenflächen von rechts der Oder gelegenen Gemeinden) bzw. an den Kreis Angermünde (nur einwohnerloses Wiesenland von rechts der Oder gelegenen Gemeinden) (Blöß, Kreise und Gemeinden, S. 11, 41 f.).

BevölKerungszahlen: [1946:] 6949 Kreisinsassen und 3095 Flüchtlinge (Blöß, Kreise und Gemeinden, S. 41).

OrTE: $\rightarrow$ Altglietzen, $\rightarrow$ Bralitz, $\rightarrow$ Güstebieser Loose, $\rightarrow$ Hohenwutzen, $\rightarrow$ Küstrin-Kietz, $\rightarrow$ Neuküstrinchen, $\rightarrow$ Neulietzegöricke, $\rightarrow$ Neuranft, $\rightarrow$ Neurüdnitz, $\rightarrow$ Zäckericker Loose, $\rightarrow$ Zelliner Loose.

LAGER: $\rightarrow$ Bralitz. - (DurChGangs-)LAGER (im Ostteil!): $\rightarrow$ Küstrin.

Archivalische Quellen: Stiftung Heimatkreisarchiv Königsberg/Neumark, Bad Freienwalde.

GedRUCKTE QUELlen und Literatur: Blöß, Wolfgang: Grenzen und Reformen in einer Umbruchgesellschaft. Berlin 2014. - Ders.: Kommunale Strukturen im Spannungsfeld gesellschaftlicher Umwälzungen. Die Grenzen von Gemeinden und Kreisen in Brandenburg 1945-1952. Berlin 2018. - Kreis Königsberg/Neumark. Hrsg. vom Heimatkreis Königsberg/Neumark e. V. Berlin/Bonn 2006. 


\section{Kreis Lebus}

EREIGNISSE BIS KRIEGSENDE: 31.1. bzw. 1.2.1945 „durch das Eis begünstigt“, Überschreiten der Oder durch die Rote Armee an mehreren Stellen nördlich von Küstrin, v. a. bei Genschmar, Kienitz und Groß Neuendorf (Ein leidgeprüftes Land, S. 23). - 2.2.1945 Überschreiten der (zugefrorenen) Oder zwischen Göritz (Kr. Weststernberg) und Reitwein (Kr. Lebus) durch die Rote Armee, in der Folge werden das Oderbruch und der Raum Lebus bald zum schwerstens in Mitleidenschaft gezogenen Kampfgebiet (ebd., S. 19 ff.). - „Die Zivilbevölkerung verließ die Altstadt von $[\rightarrow]$ Küstrin über die freigekämpfte Verbindungslinie Bleyen - Genschmar.“ (Ebd., S. 23). - [Aus dem Bericht des Hanns Baron Freytag von Loringhoven, 1945 Adjutant des Volkssturmbataillons 7/1078 Franken in Lebus:] „Am 2. Februar hieß es, das Oderufer zu besetzen, denn von Reitwein klang Gefechtslärm herüber. Dort war russischen Kräften der Oderübergang gelungen [S. 28] und wir mußten hier in Lebus ebenfalls mit Übersetzversuchen rechnen. [...] Die Kompanien verteidigten Lebus und den Abschnitt bis Frankfurt soweit es ihnen mit ihren schwachen Kräften möglich war. Dabei ist vor allem zu erwähnen, daß es unter der Leitung des Bataillonsführers Rieger und dem tapferen Einsatz von Fährleuten gelang, Soldaten und Flüchtlinge vom östlichen Oderufer zu retten, bevor die Russen das gesamte Ufer besezten." (ebd., S. 27 f.).

EREIGNisSE NACH KRIEgSENDE: Eine am 12.2.1945 aus $\rightarrow$ Lebus zu ihrem aus $\rightarrow$ Frankfurt (Oder) nach $\rightarrow$ Potsdam evakuierten Bruder geflohene Lebuser Hausbesitzerin berichtet in Briefen an ihre Angehörigen: „Am 30.6.45 trat ich dann in Begleitung von Bruder und Schwägerin die Rückreise nach Lebus an, teils mit der Bahn über Berlin, teils zu Fuß bis Müncheberg. Von dort aus kamen uns lange Elendszüge vertriebener Deutscher aus den Dörfern jenseits der Oder entgegen. Über $[\rightarrow]$ Seelow und Schönfliess gelang es uns dann endlich Lebus zu erreichen, wo wir [S. 30] so um den 4.7.45 wieder eintrafen. [...]." (Ein leidgeprüftes Land, S. 29f.). - 5.9.1945 Verfügung der Provinzialregierung über eine Verpflichtung zur Unterbringung von 20000 weiteren Flüchtlingen im Kreis Lebus auf Befehl der Besatzungsmacht (Ast/Mauersberger, S. 43). - 1946 Der DEFASpielfilm „Freies Land“ (Regie: Milo Harbich) behandelt das Flüchtlingsschicksal am Beispiel eines Dorfes in der $\rightarrow$ Westprignitz u. thematisiert daneben auch die Lage im „Notstandsgebiet Lebus" am Beispiel von $\rightarrow$ Sachsendorf, Premiere 19.10.1946 in $\rightarrow$ Potsdam (wikipedia, www. defa-stiftung.de/milo-harbich [10.7.2018]).

BevölkerungsZahlen: Wohnbevölkerung 1939: 107403 (AGV, S. 11). - 1946: 98 469, davon aus Ostpreußen: 1717, Hinterpommern 2023, Ostbrandenburg 13617, Schlesien 3264, Tschechoslowakei 701, Polen 2375, Danzig 251, Rumänien 658, Baltikum 135, Sowjetunion 191 (Volkszählung 1946). - Eingemeindung von Vertriebenen: 30.4.1947: 26767 (Oehlsen, S. 102), Juni 1948: 30917 (ebd., S. 103), Febr. 1949: 32120 (ebd., S. 104), 30.9.1950 („nach den neuen Kreisgrenzen ab 1.7.1950“): - (ebd., S. 105). - 31.12.1948: Gesamtbevölkerung: 111357, davon „Umsiedler und Evakuierte“: 31952 (Grandke, S. 46). 
OrTE: $\rightarrow$ Alttucheband, $\rightarrow$ Alt Zeschdorf, $\rightarrow$ Brieskow(-Finkenheerd), $\rightarrow$ Buckow, $\rightarrow$ Fürstenwalde/Spree, $\rightarrow$ (Fürstenwalde-)Ketschendorf, $\rightarrow$ Genschmar, $\rightarrow$ Golzow (Oderbruch), $\rightarrow$ Gorgast, $\rightarrow$ Gusow, $\rightarrow$ Hathenow, $\rightarrow$ Kienitz, $\rightarrow$ Klessin, $\rightarrow$ Kliestow, $\rightarrow$ Küstrin-Kietz, $\rightarrow$ Lebus, $\rightarrow$ Letschin, $\rightarrow$ Müllrose, $\rightarrow$ Müncheberg, $\rightarrow$ Neuhardenberg, $\rightarrow$ Podelzig, $\rightarrow$ Reitwein, $\rightarrow$ Sachsendorf, $\rightarrow$ Seelow, $\rightarrow$ Sophienthal, $\rightarrow$ Waldsieversdorf, $\rightarrow$ Weißenspring, $\rightarrow$ Werder (Oderbruch).

LAGER: $\rightarrow$ Fürstenwalde/Spree (Kreisumsiedlerlager).

Archivalische Quellen: BArch, DO 1 Ministerium des Innern der DDR, 27887, B1. 75, 87 (Teilnahme von Kreisbewohnern an Vertriebenentreffen in West-Berlin, 1951-1952). - BArch, DO 2 ZVU, Nr. 39, Bl. 8-9 (Umsiedlerlager, 1945). - BLHA, Rep. 203 MdI, Nr. 1133 (Umsiedler- und Heimkehrerstatistiken, 1945-1946; enthält: Erfassung der Umsiedler in den einzelnen Kreisen der SBZ zum 1. Dez. 1945 sowie statistische Berichte der einzelnen Gemeinden, hier Kreis Lebus). - BLHA, Rep. 250 Landratsamt Lebus/Seelow. - Siehe auch Quellenteil, Nr. 239.

Gedruckte Quellen und Literatur: HOL VII. - Blöß, Wolfgang: Grenzen und Reformen in einer Umbruchgesellschaft. Berlin 2014. - Braun, Michael: Die nicht ganz erste LPG in der DDR. In: Jahrbuch Märkisch-Oderland 2020 (2019), S. 39-45 [Worin]. - Kirchen im Oderbruch und ihre Schicksale seit dem Frühjahr 1945. Hrsg. von Hans-Georg Rieger u. Günter-Alexander von Wittich im Namen des Heimatkreises Lebus. Berlin 1992. - Ein leidgeprüftes Land. Der brandenburgische Kreis Lebus in den Wirren der Jahre 1945-1952. Ereignisse und Erlebnisberichte ehemaliger Kreisbewohner. Bearb. von Fritz Knüppel. 2., durchges. Aufl. Barsinghausen 1990. - Schneider, Joachim: Die Kämpfe um Lebus im Frühjahr 1945. In: ebd. 2007, H. 1, S. 27-48. - Töpler, Menschenwurm. - Wille I, S. 55, 64, 245, 258; III, S. 131 f. (Auszug aus Protokoll des Kreisumsiedlerausschusses, 1947), 143, 443.

\section{Kreis Luckau}

EREIGNISSE BIS KRIEgSENDE: Febr. 1945: Der Kreis Luckau wird zum Aufnahmegebiet für die zu evakuierende Bevölkerung der Kreise Gostin (Gostyn) und Lissa (Wartheland) bestimmt (BLHA, Rep. 6 B Kreisverwaltung Züllichau-Schwiebus, Nr. 169, unfol.).

EREIGNisSe NACH KRIEgSENde: 5.9.1945 Verfügung der Provinzialregierung über eine Verpflichtung zur Unterbringung von 35000 weiteren Flüchtlingen im Kreis Luckau auf Befehl der Besatzungsmacht (Ast/Mauersberger, S. 43). - 9.10.1945 Maßnahmenplan des Kr. Luckau zur Bewältigung der geplanten „Umsiedleraktion“, d. h. Zuweisung von 33000 Flüchtlingen (Druck: Wille I, S. 157-159). - 16.11.1945 (Zeitungsbericht): „Der Kreis Luckau hat bereits 26000 Umsiedler aus den Ostgebieten aufgenommen und wird in nächster Zeit weitere 33000 Umsiedler unterbringen, Damit wächst die Bevölkerung um $75 \%$ an. Weitere 120000 Umsiedler werden durch den Kreis geschleust, um im Mecklenburgischen Raum eine neue Heimat zu finden. Der Kreisausschuß füt Umsiedlerfragen errichtete in $[\rightarrow]$ Cahnsdorf, $2 \mathrm{~km}$ von $[\rightarrow]$ Luckau, ein Auffanglager [...]." (Berliner Zeitung, 16.11.1945, zitiert nach: Töpler, Menschenwurm, S. 462). - 14.2.1946 (Bericht): „Der Kreis $[\rightarrow]$ Calau hat, ebenso wie Luckau, ebenso eine große Zahl Evakuierter wie $[\rightarrow]$ Cottbus [...].“ (Töpler, Menschenwurm, S. 501). - Auf Neubauernhöfen siedelten ab 1947 „ehemalige Landarbeiter und heimatvertriebene Flüchtlinge [...], in unserer Region [Kr. Luckau] waren das vor allem Schlesier“, u. a. in Caule (Treder-Schmidt, S. 48). 
BevöLkerungszahlen: Wohnbevölkerung 1939: 80496 (AGV, S. 11). - 1946: 101333, davon aus Ostpreußen: 1 108, Hinterpommern 665, Ostbrandenburg 6068, Schlesien 11376, Tschechoslowakei 4073, Polen 1866, Danzig 96, Rumänien 125, Baltikum 290, Sowjetunion 90 (Volkszählung 1946). - Eingemeindung von Vertriebenen: 30.4.1947: 32250 (Oehlsen, S. 102), Juni 1948: 33232 (ebd., S. 103), Febr. 1949: 33938 (ebd., S. 104), 30.9 .1950 („nach den neuen Kreisgrenzen ab 1.7.1950“): 30038 (ebd., S. 105). - Am 1.11.1946 sind im Kreis 3026 Sudetendeutsche eingemeindet (Kreis mit dritthöchster Konzentration nach $\rightarrow$ ZauchBelzig und $\rightarrow$ Westhavelland) (Christopeit, S. 80). - 31.12.1948: Gesamtbevölkerung: 104378, davon „Umsiedler und Evakuierte“: 34089 (Grandke, S. 46).

ORTE: $\rightarrow$ Cahnsdorf, $\rightarrow$ Crinitz, $\rightarrow$ Doberlug, $\rightarrow$ Finsterwalde, $\rightarrow$ Golßen, $\rightarrow$ Kirchhain, $\rightarrow$ Luckau, $\rightarrow$ Schönwalde, $\rightarrow$ Sonnewalde, $\rightarrow$ Tröbitz, $\rightarrow$ Walddrehna, $\rightarrow$ Waldsieversdorf, $\rightarrow$ Weißack.

LAGER: $\rightarrow$ Cahnsdorf, $\rightarrow$ Finsterwalde, $\rightarrow$ Kirchhain, $\rightarrow$ Schönwalde, $\rightarrow$ Walddrehna.

Archivalische Quellen: BArch, DO 2 ZVU, Nr. 50, Bl. 226-230 (1947). - BLHA, Rep. 6 B Luckau, Nr. 378 (Namenslisten der in den Gemeinden des Kreises untergebrachten Flüchtlinge aus den deutschen Ostgebieten und den östlichen Kreisen der Provinz Brandenburg, insbesondere aus Kreis und Stadt Guben, Jan./Febr. bis April 1945, Gemeinden A bis K), Nr. 379 (desgleichen, Gemeinden L bis Z). - BLHA, Rep. 203 MdI, Nr. 1134 (Umsiedler- und Heimkehrerstatistiken, 1945-1946; enthält: Erfassung der Umsiedler in den einzelnen Kreisen der SBZ zum 1. Dez. 1945 sowie statistische Berichte der einzelnen Gemeinden, hier Kreis Luckau). - BLHA, Rep. 250 Landratsamt Luckau.

Gedruckte Quellen und Literatur: HOL NL I. - Christopeit. - Neumann, Monika / Ziegler, Martin: Flucht, Vertreibung und Neuanfang in der neuen Heimat nach 1945 am Beispiel Pießigs. In: Sonnewalder Heimatblätter 19 (2019), S. 93-110. Töpler, Menschenwurm, S. 451. - Treder-Schmidt, Lothar: Ein Neusiedlerhaus als Baudenkmal? In: Luckauer Heimatkalender 50 (2018), S. 48-54 [Caule bei Luckau]. - Wille I, S. 37, 55, 66, 157-159; III, S. 447 (Schilda bei Kirchhain, 1951).

\section{Kreis Lübben}

EREIGNisSe BIS KRIEgSENDE: Febr. 1945: Der Kreis Lübben wird zum Aufnahmegebiet für die zu evakuierende Bevölkerung des Kreises Litzmannstadt-Land [Lodz] (Wartheland) bestimmt (BLHA, Rep. 6 B Kreisverwaltung Züllichau-Schwiebus, Nr. 169, unfol.). - „Zu Beginn des Jahres 1945 zogen Tausende vor dem Krieg Fliehende durch den Landkreis Lübben, hinzu kamen immer mehr Vertriebene. [...] Dabei gehörte der Landkreis Lübben zu jenen im Land Brandenburg, die am dichtesten mit Flüchtlingen belegt waren. [...]. (Becken, S. 28).

EREIGNisse NACH KRIEgSEnde: „Der Kreissozialamtsleiter Thümmel beklagte im Frühsommer 1945 das immer größer werdende Elend der oft mittellosen Flüchtlinge, die ziellos unherrirten und durch die Verwaltungen im Land hin- und hergeschoben würden. Die Kreise wurden angewiesen, Unterbringungsmöglichkeiten und Sammellalger einzurichten. Die Baracken des ehemaligen Reichsarbeitsdienstes im Kreis Lübben in $[\rightarrow]$ Kuschkow, $[\rightarrow]$ Lübben und 
$[\rightarrow]$ Wußwerk, $[\rightarrow]$ Schönwalde und $[\rightarrow]$ Schlepzig wurden hergerichtet. In $[\rightarrow]$ Börnichen, der Lübbener Jägerkaserne und vor allem in $[\rightarrow]$ Krugau konnten Tausende vorerst bleiben. $[\ldots][$ S. 29] [...] Die elternlosen Kinder des Kreises wurden nach $[\rightarrow]$ Leibchel in das von der Roten Armee beschlagnahmte Gutshaus gebracht. [... . [S. 30] Nachdem die Alliierten auf der Potsdamer Konferenz 1945 die Überführung der umzusiedelnden Deutschen [...] beschlossen hatten, kamen vor allem aus Schlesien ständig neue Flüchtlinge in den Kreis Lübben." (Becken, S. 28-30). - 5.9.1945 Verfügung der Provinzialregierung über eine Verpflichtung zur Unterbringung von 30000 weiteren Flüchtlingen im Kreis Lübben auf Befehl der Besatzungsmacht (Ast/Mauersberger, S. 43). „Im März 1946 wohnten im Kreis Lübben 29526 Kreiseingesessene und 14306 Flüchtlinge. Da die Stadt Lübben mit ihren 10000 Einwohnern stark zerstört war, befanden sich diese Flüchtlinge meist auf dem Land, so dass die Dörfer im Durchschnitt zu $70 \%$ der Bevölkerung mit Flüchtlingen belegt waren. / Einige Dörfer hatten sogar 100 bis $200 \%$ an Flüchtlingen aufgenommen. [...]. (Becken, S. 30). - 1.5.1946: „Der Kreis ist mit $48 \%$ Umsiedlern belegt!“ (Statistik des Kreiseinwohnermeldeamtes, in: ebd., S. 33). - „Kleine Abteilungen [der Vertriebenen aus Hennersdorf, Kr. Ohlau, Schlesien] wohnen in Mecklenburg, im Spreewald und einzelne auch in Bayern." (Brzoska, S. 461).

BevöLKeRUnGSZAHLEN: Wohnbevölkerung 1939: 33397 (AGV, S. 11). - 1946: 43986, davon aus Ostpreußen: 497, Hinterpommern 341, Ostbrandenburg 7373, Schlesien 4241, Tschechoslowakei 1458, Polen 504, Danzig 42, Rumänien 22, Baltikum 85, Sowjetunion 8 (Volkszählung 1946). - 1.5.1946 Flüchtlingsbelegung: $14306=48 \%$ (Ortsansässige: 29604$)$ (Becken, S. 33). - Eingemeindung von Vertriebenen: 30.4.1947: 17798 (Oehlsen, S. 102), Juni 1948: 16696 (ebd., S. 103), Febr. 1949: 16961 (ebd., S. 104), 30.9 .1950 („nach den neuen Kreisgrenzen ab 1.7.1950“): 23754 (ebd., S. 105). - 31.12.1948: Gesamtbevölkerung: 43744, davon „Umsiedler und Evakuierte“: 16626 (Grandke, S. 46). - Weitere detaillierte Angaben zur „Bevölkerungsentwicklung im Kreis Lübben Mai 1945 - September 1950“ siehe Mietk, S. 60-62 (nach Quellen im BLHA).

OrTE: $\rightarrow$ Börnichen, $\rightarrow$ Friedland, $\rightarrow$ Jamlitz, $\rightarrow$ Krugau, $\rightarrow$ Kuschkow, $\rightarrow$ Leibchel, $\rightarrow$ Lieberose, $\rightarrow$ Lübben, $\rightarrow$ Radensdorf (Lausitz), $\rightarrow$ Schlepzig, $\rightarrow$ Schönwalde, $\rightarrow$ Straupitz, $\rightarrow$ Wußwerk.

LAGER: $\rightarrow$ Börnichen, $\rightarrow$ Jamlitz, $\rightarrow$ Krugau, $\rightarrow$ Kuschkow, $\rightarrow$ Leibchel, $\rightarrow$ Lübben, $\rightarrow$ Schlepzig, $\rightarrow$ Wußwerk.

Archivalische Quellen: BLHA, Rep. 203 MdI, Nr. 1135 (Umsiedler- und Heimkehrerstatistiken, 1945-1946; enthält: Erfassung der Umsiedler in den einzelnen Kreisen der SBZ zum 1. Dez. 1945 sowie statistische Berichte der einzelnen Gemeinden, hier Kreis Lübben). - BLHA, Rep. 250 Landratsamt Lübben.

Gedruckte Quellen und Literatur: HOL NL I. - Becken, Jörg: Lübben nach dem Inferno. Die Jahre $1945-61$. [Cottbus] 2010 (S. 32 f.: „Uebersicht der Flüchtlingsbelegung der Gemeinden des Kreises Lübben [in absoluten Zahlen und] in Prozentsätzen. Stand vom 1. Mai 1946", erstellt vom Kreiseinwohnermeldeamt). - Brzoska, Alfred: Ein Pfarrer schildert das furchtbare Martyrium seiner Gemeinde. In: Schlesien. Die letzten Tage im Kampf um Deutschlands 
reichste Provinz. Velen [1985], S. 456-461. - Mietk, Thomas: Neuanfang im Kreis Lübben. Beitrag zur Flüchtlingsund Vertriebenenforschung am Ende des Zweiten Weltkrieges. Lübben 2010. - Töpler, Menschenwurm, S. 451. Wille I, S. 37, 55, 66, 459; III, S. 354.

\section{Kreis Niederbarnim}

EREIGNisSe BIS KRIEGSENDE: Febr. 1945: Der Kreis Niederbarnim wird zum Aufnahmegebiet für die zu evakuierende Bevölkerung des Kreises Grünberg in Schlesien (gemeinsam mit dem Kreis $\rightarrow$ Osthavelland und der Stadt $\rightarrow$ Potsdam) bestimmt (BLHA, Rep. 6 B Kreisverwaltung Züllichau-Schwiebus, Nr. 169, unfol.).

EREIGNisSe NACH KRIEgSEnde: 5.9.1945 Verfügung der Provinzialregierung über eine Verpflichtung zur Unterbringung von 35000 weiteren Flüchtlingen im Kreis Niederbarnim auf Befehl der Besatzungsmacht (Ast/Mauersberger, S. 43). - Juli 1946 „Der erste Transport von Antifaschisten aus der Tschechoslowakei hat die Zeit der Quarantäne im Umsiedlerlager in $[\rightarrow]$ Bernau beendet. In einer Zusammenkunft im Umsiedlerlager zwischen dem Sprecher der Umsiedler und dem Landrat des Kreises Niederbarnim wurde die Verteilung der Transportteilnehmer auf mehrere Orte unseres Kreises vorgenommen." (Kurznachricht in: Märkische Volksstimme, Nr. 68, 11.7.1946).

BevöLkerungszahlen: Wohnbevölkerung 1939: 233992 (AGV, S. 10). - 1946: 222992, davon aus Ostpreußen: 4088, Hinterpommern 4671, Ostbrandenburg 6203, Schlesien 3698 , Tschechoslowakei 2858, Polen 2 556, Danzig 514, Rumänien 112, Baltikum 298, Sowjetunion 151 (Volkszählung 1946). - Eingemeindung von Vertriebenen: 30.4.1947: 29659 (Oehlsen, S. 102), Juni 1948: 39377 (ebd., S. 103), Febr. 1949: 42051 (ebd., S. 104), 30.9.1950 („nach den neuen Kreisgrenzen ab 1.7.1950“): 29888 (ebd., S. 105). - 31.12.1948: „Umsiedler und Evakuierte“: 41358 (Grandke, S. 46).

OrTE: $\rightarrow$ Alt Buchhorst, $\rightarrow$ Altlandsberg, $\rightarrow$ Basdorf, $\rightarrow$ Bernau, $\rightarrow$ Birkenwerder, $\rightarrow$ Erkner, $\rightarrow$ Freienhagen, $\rightarrow$ Groß Schönebeck, $\rightarrow$ Grünheide, $\rightarrow$ Hohen Neuendorf, $\rightarrow$ Liebenwalde, $\rightarrow$ Mönchwinkel, $\rightarrow$ Neuenhagen, $\rightarrow$ Neu Lindenberg, $\rightarrow$ Oranienburg, $\rightarrow$ Rüdersdorf, $\rightarrow$ Schmachtenhagen, $\rightarrow$ Schöneiche, $\rightarrow$ Schwanebeck-Gehrenberge, $\rightarrow$ Wandlitz, $\rightarrow$ Wandlitzsee.

LAGER: $\rightarrow$ Bernau, $\rightarrow$ Erkner, $\rightarrow$ Groß Schönebeck, $\rightarrow$ Oranienburg, $\rightarrow$ Rüdersdorf (Kreisumsiedlerlager).

Archivalische Quellen: BLHA, Rep. 202 E Statistisches Landesamt, Nr. 17: Statistische Aufstellung zur Bevölkerungsaufnahme (einschließlich Flüchtlinge und zurückgekehrte Kriegsgefangene) Kreise Beeskow-Storkow, Niederbarnim, Osthavelland, Teltow, 1945-1946. - BLHA, Rep. 250 Landratsamt Niederbarnim.

Gedruckte Quellen und Literatur: HOL VI. - Braun, Michael: Erste Nachkriegsjahre in Hönow. In: Jahrbuch Märkisch-Oderland 25 (2018), S. 46-48. - Oehlsen, S. 90. - Wirtschafts-Wegweiser für den Kreis Niederbarnim. Branchen-Adreßbuch. Potsdam (1949). 


\section{Kreis Oberbarnim}

EReignisse bis KriegSende: „Am 16. April 1945 überschritt die 1. Polnische Armee die Oder zwischen $\rightarrow$ Wriezen und Bad $\rightarrow$ Freienwalde." (Schonert, S. 69).

EReignisSe NACH KriegSEnde: 5.9.1945 Verfügung der Provinzialregierung über eine Verpflichtung zur Unterbringung von 45000 weiteren Flüchtlingen im Kreis Oberbarnim auf Befehl der Besatzungsmacht (Ast/Mauersberger, S. 43).

BevÖLKeRUngszahlen: Wohnbevölkerung 1939: 92395 (AGV, S. 10). - 1946: 100 838, davon aus Ostpreußen: 2500, Hinterpommern 3510, Ostbrandenburg 10043, Schlesien 3313, Tschechoslowakei 274, Polen 2311, Danzig 290, Rumänien 96, Baltikum 185, Sowjetunion 105 (Volkszählung 1946). - Eingemeindung von Vertriebenen: 30.4.1947: 26765 (Oehlsen, S. 102), Juni 1948: 28505 (ebd., S. 103), Febr. 1949: 29402 (ebd., S. 104), 30.9.1950 („nach den neuen Kreisgrenzen ab 1.7.1950“): 28244 (ebd., S. 105). - 31.12.1948: Gesamtbevölkerung: 109969, davon „Umsiedler und Evakuierte“: 25139 (Grandke, S. 46).

Orte: $\rightarrow$ Altglietzen, $\rightarrow$ Bad Freienwalde, $\rightarrow$ Biesenthal, $\rightarrow$ Bralitz, $\rightarrow$ Britz, $\rightarrow$ Falkenberg/Mark, $\rightarrow$ Finow, $\rightarrow$ Güstebieser Loose, $\rightarrow$ Hohenwutzen, $\rightarrow$ Lobetal, $\rightarrow$ Neuküstrinchen, $\rightarrow$ Neulietzegöricke, $\rightarrow$ Neuranft, $\rightarrow$ Neurüdnitz, $\rightarrow$ Niederfinow, $\rightarrow$ Oderberg/Mark, $\rightarrow$ Strausberg, $\rightarrow$ Werneuchen, $\rightarrow$ Wriezen/Oder, $\rightarrow$ Zäckericker Loose, $\rightarrow$ Zelliner Loose.

LAGER: $\rightarrow$ Bad Freienwalde, $\rightarrow$ Eberswalde, $\rightarrow$ Finow (Heimkehrerlager), $\rightarrow$ Lobetal, $\rightarrow$ Strausberg, $\rightarrow$ Wriezen/Oder (Kreisumsiedlerlager).

Archivalische Quellen: BArch, DO 2 ZVU, Nr. 39, Bl. 13-15 (Umsiedlerlager, 1945). - BLHA, Rep. 203 MdI, Nr. 1136 (Umsiedler- und Heimkehrerstatistiken, 1945-1946; enthält: Erfassung der Umsiedler in den einzelnen Kreisen der SBZ zum 1. Dez. 1945 sowie statistische Berichte der einzelnen Gemeinden, hier Kreis Oberbarnim). BLHA, Rep. 250 Landratsamt Oberbarnim.

Gedruckte Quellen und Literatur: HOL VI. - Oehlsen, S. 89. - Schonert, Udo: Gedenken an 70 Jahre Kriegsende im nördlichen Oderbruch. In: Bad Freienwalder Heimatkalender 59 (2015 [2014]), S. 69-75. - Wille II, S. 364 f. („Umsiedlerbetriebe“ im Kreis, Auszug aus Liste von 1946; Familiennamen nur mit Initialen wiedergegeben).

\section{Kreis 0sthavelland}

EReignisse Bis KRIEgSende: Febr. 1945: Der Kreis Osthavelland wird zum Aufnahmegebiet für die zu evakuierende Bevölkerung des Kreises Crossen/Oder (gemeinsam mit dem Kreis $\rightarrow$ Teltow), des Kreises Grünberg in Schlesien (gemeinsam mit dem Kreis Niederbarnim und der Stadt $\rightarrow$ Potsdam) und des Kreises Wollstein (Wartheland) bestimmt (BLHA, Rep. 6 B Kreisverwaltung Züllichau-Schwiebus, Nr. 169, unfol.; vgl. aber für Wollstein: Dokumentation der Vertreibung I/1, S. 383, wonach am 24.1.1945 der Kreis $\rightarrow$ Jüterbog-Luckenwalde als Aufnahmekreis vorgesehen war und erst später Verlegungen in die Kreise „Nauen und Uelzen“ erfolgten; ca. 200 Flüchtlinge aus dem Kr. Wollstein kommen daraufhin im „Kreis Nauen“ [Ost- 
havelland] unter (Dokumentation der Vertreibung I/1, S. 383). - 9.2.1945 Befehl des NSDAPKreisleiters des Kr. Teltow zur Aufnahme (Einquartierung) der evakuierten Bewohner des Kr. Crossen (Neumark) in den Kr. Teltow u. Osthavelland (Adamy/Hübener, S. 172).

EREIGNisSe NACH KRIEgSEnde: 5.9.1945 Verfügung der Provinzialregierung über eine Verpflichtung zur Unterbringung von 50000 weiteren Flüchtlingen im Kreis Osthavelland auf Befehl der Besatzungsmacht (Ast/Mauersberger, S. 43).

BevöLkerungszahlen: Wohnbevölkerung 1939: 132294 (AGV, S. 10). - 1946: 143292 , davon aus Ostpreußen: 3515 , Hinterpommern 3 831, Ostbrandenburg 8524, Schlesien 4353, Tschechoslowakei 2628, Polen 2 868, Danzig 443, Rumänien 146, Baltikum 375, Sowjetunion 156 (Volkszählung 1946). - Eingemeindung von Vertriebenen: 30.4.1947: 37075 (Oehlsen, S. 102), Juni 1948: 43537 (ebd., S. 103), Febr. 1949: 44727 (ebd., S. 104), 30.9.1950 („nach den neuen Kreisgrenzen ab 1.7.1950“): 40832 (ebd., S. 105). - 31.12.1948: Gesamtbevölkerung: 150958, davon „Umsiedler und Evakuierte“: 44433 (Grandke, S. 46).

ORTE: $\rightarrow$ Bötzow, $\rightarrow$ Brieselang, $\rightarrow$ Dallgow, $\rightarrow$ Döberitz, $\rightarrow$ Falkensee, $\rightarrow$ Fehrbellin, $\rightarrow$ Hennigsdorf, $\rightarrow$ Kartzow, $\rightarrow$ Ketzin/Havel, $\rightarrow$ Kremmen, $\rightarrow$ Leegebruch, $\rightarrow$ Marquardt, $\rightarrow$ Nauen, $\rightarrow$ Paaren im Glien, $\rightarrow$ Paretz, $\rightarrow$ Potsdam-Neu Fahrland, $\rightarrow$ Schönwalde, $\rightarrow$ Velten, $\rightarrow$ Wustermark.

LAGER: $\rightarrow$ Döberitz, $\rightarrow$ Falkensee (Kreisumsiedlerlager), $\rightarrow$ Hennigsdorf.

Archivalische Quellen: BLHA, Rep. 202 E Statistisches Landesamt, Nr. 17: Statistische Aufstellung zur Bevölkerungsaufnahme (einschließlich Flüchtlinge und zurückgekehrte Kriegsgefangene) Kreise Beeskow-Storkow, Niederbarnim, Osthavelland, Teltow, 1945-1946. - BLHA, Rep. 250 Landratsamt Osthavelland.

Gedruckte Quellen und Literatur: HOL III. - Adamy, Kurt / Hübener, Kristina: Königs Wusterhausen in der Zeit der Weimarer Republik und des Nationalsozialismus (1918-1945). In: Königs Wusterhausen. Hrsg. von Kurt Adamy, Kristina Hübener, Marko Leps. Berlin 1998, S. 123-174. - Andreae/Geiseler. - Dokumentation der Vertreibung I/1, S. 383. - Oehlsen, S. 89. - Wille II, S. 333 (Vergabe von Bodenreformland an Vertriebene). - WirtschaftsWegweiser für den Kreis Osthavelland. Branchen-Adressbuch. Potsdam [1947].

\section{Kreis 0stprignitz}

Ereignisse bis Kriegsende: Jan. 1945 Ziel eines Trecks aus dem Kr. Obornik (Posen) (Dokumentation der Vertreibung I/1, S. 370f.). - Ende Jan. 1945 wird der Kreis „Kyritz“ als Unterbringungskreis für die Bevölkereung des Kreises Schwerin/W. vorgesehen (Hielscher, S. 20). - Febr. 1945: Der Kreis Ostprignitz wird zum Aufnahmegebiet für die zu evakuierende Bevölkerung der Kreise Mogilno und Obornik (Wartheland) bestimmt, wohl über den Durchschleusungspunkt Seelow (BLHA, Rep. 6 B Kreisverwaltung Züllichau-Schwiebus, Nr. 169, unfol.). - 5.2.1945 (Tagebuchnotiz Pfarrer Salefsky, [ $\rightarrow$ ] Kuhsdorf): „Die Ostprignitz wird Aufnahmegebiet für die Kreise Mogilew [muss heißen: Mogilno] und Obornigk [Obornik]." (Chronik 
Kuhsdorf, S. 129). - Die Flüchtlinge aus Stadt u. Kreis Meseritz kamen „vornehmlich in die Gegend um Kyritz/Perleberg“ (Stadt und Kreis Meseritz. [Bd. 1], S. 341).

EREIGNISSE NACH KRIEgSENDE: 5.9.1945 Verfügung der Provinzialregierung über eine Verpflichtung zur Unterbringung von 40000 weiteren Flüchtlingen im Kreis Ostprignitz auf Befehl der Besatzungsmacht (Ast/Mauersberger, S. 43).

BevöLKeRUnGSZAHLEN: Wohnbevölkerung 1939: 71381 (AGV, S. 10). - 1946: 98 673, davon aus Ostpreußen: 3 833, Hinterpommern 3664 , Ostbrandenburg 9590, Schlesien 3225 , Tschechoslowakei 1513, Polen 8036, Danzig 535, Rumänien 1269, Baltikum 1227, Sowjetunion 204 (Volkszählung 1946). - Eingemeindung von Vertriebenen: 30.4.1947: 42743 (Oehlsen, S. 102), Juni 1948: 43869 (ebd., S. 103), Febr. 1949: 44081 (ebd., S. 104), 30.9.1950 („nach den neuen Kreisgrenzen ab 1.7.1950“): 38850 (ebd., S. 105). - 31.12.1948: Gesamtbevölkerung: 102 633, davon „Umsiedler und Evakuierte“: 43864 (Grandke, S. 46).

OrTE: $\rightarrow$ Blumenthal, $\rightarrow$ Buchholz, $\rightarrow$ Freyenstein, $\rightarrow$ Heiligengrabe, $\rightarrow$ Kuhbier, $\rightarrow$ Kuhsdorf, $\rightarrow$ Kyritz, $\rightarrow$ Lindenberg, $\rightarrow$ Meyenburg, $\rightarrow$ Pritzwalk, $\rightarrow$ Wittstock, $\rightarrow$ Wutike, $\rightarrow$ Zaatzke, $\rightarrow$ Zernitz.

LAGER: $\rightarrow$ Kyritz, $\rightarrow$ Pritzwalk.

Archivalische Quellen: BLHA, Rep. 203 MdI, Nr. 1137 (Umsiedler- und Heimkehrerstatistiken, 1945-1946; enthält: Erfassung der Umsiedler in den einzelnen Kreisen der SBZ zum 1. Dez. 1945 sowie statistische Berichte der einzelnen Gemeinden, hier Kreis Ostprignitz); Nr. 1138 (desgleichen, Zusammenfassung). - BLHA, Rep. 250 Landratsamt Ostprignitz.

Gedruckte Quellen und Literatur: HOL I. - Chronik der Pfarre zu Kuhsdorf. Transkribiert u. vervielfältigt von Agnes u. Henning v. Kopp-Colomb. Haltern 2008. - Dokumentation der Vertreibung I/1, S. 371. - Hielscher, Alexander Karl: Das Kriegsende 1945 im Westen des Warthelandes und im Osten der Kurmark. Typoskript. [Bielefeld 1986] (Archiv der Landesgeschichtlichen Vereinigung für die Mark Brandenburg, Berlin). - Noetzel, Andreas: Bemerkungen zur demokratischen Bodenreform am Beispiel der Region Kyritz. In: Jahrbuch Ostprignitz-Ruppin 25 (2016), S. 217-237. - Schmeissner, Dorte: Kyritz, die Stadt der Bodenreform. T. I. In: ebd. 15 (2006), S. 77-87 [auch zum Kreis]. - Dies.: Dass. T. II. In: ebd. 17 (2008), S. 77-92 [auch zu einzelnen (heute nach Kyritz eingemeindeten) Dörfern: Berlitt, Gantikow, Ganz, Mechow]. - Spix, Boris: Die Bodenreform in Brandenburg 1945-47. Konstruktion einer Gesellschaft am Beispiel der Kreise West- und Ostprignitz. Münster 1997. - Stadt und Kreis Meseritz. [Bd. 1]. O. O. [1972]. - Stephan, Herbert: Die demokratische Bodenreform - erster Schritt auf dem Wege zur endgültigen Befreiung der Bauern (dargestellt am Beispiel des Landkreises Ostprignitz im ehemaligen Land Brandenburg). Kyritz 1965. - Wille III, S. 435 f. (Situationsbericht des Kreissozialamtes, 1950), 454 (Berlinchen, 1952). - WirtschaftsWegweiser für Wittenberge und die Kreise West- und Ostprignitz. Branchen-Adreßbuch. Potsdam (1949).

\section{Kreis Prenzlau}

EReignisse bis KriegSende: Ende Jan./Anf. Febr. 1945: „Durch die Uckermark und die Stadt Prenzlau ziehen in ständig zunehmendem Strom Flüchtlingstrecks aus Ost-, Westpreußen und Pommern.“ (Chronik, S. 473). - Anf. Febr. 1945: „Die große Chaussee [ $\rightarrow$ ] Prenzlau - $[\rightarrow]$ Boit- 
zenburg - $[\rightarrow]$ Lychen nach Westen war als Treckstrecke bestimmt. Auf dieser kamen nun seit Anfang Februar 1945 Tag für Tag, ununterbrochen, die zum Teil elendsten Trecks aus Ostpreußen, Pommern und der Neumark." (Bericht von Joachim Graf von Arnim-Boitzenburg, abgedruckt in: Stahl, S. 94). - Febr. 1945: Der Kreis Prenzlau wird zum Aufnahmegebiet für die zu evakuierende Bevölkerung des Kreises Züllichau-Schwiebus mit Bomst (gemeinsam mit den Kreisen $\rightarrow$ Angermünde, $\rightarrow$ Ruppin und $\rightarrow$ Templin) und des Kreises Hohensalza-Land (Wartheland) bestimmt (BLHA, Rep. 6 B Kreisverwaltung Züllichau-Schwiebus, Nr. 169, unfol.). - Febr. 1945 Todesfälle von in Landgemeinden des Kreises untergebrachten Flüchtlingen im Kreiskrankenhaus Prenzlau (u. a. 19.2. [aus Greifenhagen], „aufhaltsam zuletzt in Trebenow Kr. Prenzlau als Flüchtling“) (Stadtarchiv Prenzlau, Standesamt Prenzlau, Sterberegister 1945, Nr. 215). - 26.4.1945: „Zahlreiche Trecks verlassen die Dörfer zwischen Randow und Ucker in zunehmendem Umfang." (Chronik, S. 477).

EReignisse NACH KRIEgSende: „Aus einem Befehl der SMA Brandenburg (Generalmajor Scharow) geht [S. 199] hervor, dass die Vertriebenen aus Polen (Raum Stettin) im nordöstlichen Teil der Provinz Brandenburg, also in der nördlichen Uckermark, ,auszusiedeln' waren." (Theil, S. 198 f.). 5.9.1945 Verfügung der Provinzialregierung über eine Verpflichtung zur Unterbringung von 30000 weiteren Flüchtlingen im Kreis Prenzlau auf Befehl der Besatzungsmacht (Ast/Mauersberger, S. 43). - „Immerhin fiel Vertretern des DDR-Innenministeriums noch 1960 negativ auf, dass das überwiegend aus Vertriebenen bestehende Evangelische Frauenwerk des Kreises Prenzlau sich noch immer mit Themen wie ,Schlesien einst und jetzt ' oder ,Die Zukunft gehört uns' beschäftigte.“ (Schwartz, Vertriebene, S. 568 f.; vgl. Engler, S. 275 f.).

EREIGNISSE NACH 1990: 1995 Unterbringung eines Teilkontingents der 186 dem Ldkr. Uckermark zugewiesenen Aussiedler in Wittstock [Kr. Prenzlau] als einer von drei Gemeinden (Theil, S. 17).

BevöLkerungszahlen: Wohnbevölkerung 1939: 67167 (AGV, S. 10). - Am 26.10.1945 befinden sich laut „Märkischer Volksstimme“ im Kreis (!) Prenzlau 72000 Einwohner, darunter etwa 25000 „Umsiedler“ (Engler, S. 304). - 1946: 73490 Einwohner, davon aus Ostpreußen: 2070, Hinterpommern 12019, Ostbrandenburg 1632, Schlesien 2504, Tschechoslowakei 220, Polen 2099, Danzig 262, Rumänien 219, Baltikum 217, Sowjetunion 116 (Volkszählung 1946). - 1947: 77 650, davon 27691 Vertriebene (Theil, S. 199; Bevölkerungsstatistik des Amtes für deutsche Umsiedler für die brandenburgischen Kreise v. 5. Juli 1947 in: BLHA, Rep. 203 MdI, Nr. 1172, Bl. 202.) - Eingemeindung von Vertriebenen: 30.4.1947: 25361 (Oehlsen, S. 102), Juni 1948: 30260 (ebd., S. 103), Febr. 1949: 30550 (ebd., S. 104), 30.9 .1950 („nach den neuen Kreisgrenzen ab 1.7.1950“): 28546 (ebd., S. 105). - 31.12.1948: Gesamtbevölkerung: 80 147, davon „Umsiedler und Evakuierte“: 30607 (Grandke, S. 46).

OrTE: $\rightarrow$ Brüssow, $\rightarrow$ Fürstenwerder, $\rightarrow$ Prenzlau, $\rightarrow$ Prenzlau-Birkenhain, $\rightarrow$ Prenzlau-Bündigershof, $\rightarrow$ Rittgarten, $\rightarrow$ Strasburg (Uckermark). 
LAGER: $\rightarrow$ Prenzlau, $\rightarrow$ Prenzlau-Birkenhain (Kreisumsiedlerlager), $\rightarrow$ Prenzlau-Bündigershof, $\rightarrow$ Strasburg (Uckermark).

Archivalische Quellen: BLHA, Rep. 203 MdI, Nr. 1139 (Umsiedler- und Heimkehrerstatistiken, 1945-1946; enthält: Erfassung der Umsiedler in den einzelnen Kreisen der SBZ zum 1. Dez. 1945 sowie statistische Berichte der einzelnen Gemeinden, hier Kreis Prenzlau). - BLHA, Rep. 250 Landratsamt Prenzlau.

Gedruckte Quellen und Literatur: HOL VIII. - Chronik der Stadt Prenzlau in Auszügen: 1945-1984. In: Prenzlau. Barendorf 1984, S. 473-500. - Chronik der uckermärkischen Dörfer Jagow mit Karlstein und Lauenhof, Kutzerow mit Dolgen, Taschenberg mit Uhlendorf und Taschenberger Ausbau. Milow u. a. 2013. - Oehlsen, S. 90. Putz, Jakob: Wie aus Fremden Nachbarn wurden. Nachbarschaften zwischen Vertriebenen und Uckermärkern nach dem zweiten Weltkrieg. Wettbewerbsbeitrag (am Christa-und-Peter-Scherpf-Gymnasium Prenzlau) zum Thema: Vertraute Fremde - Nachbarn in der Geschichte. Prenzlau 2013 (www.uckermaerkischer-geschichtsverein.de/onlinelesesaal) [Zeitzeugenbefragung]. - Stahl, Hans-Joachim: Schloss Boitzenburg in den Jahren 1944/45 bis 1956. In: Beatrix Bluhm / Detlev von Heydebrand / Hans-Joachim Stahl: Schloss Boitzenburg in der Uckermark. Angermünde 2011, S. 86-138. - Theil, Jürgen: Prenzlauer Stadtlexikon uind Geschichte in Daten. Prenzlau 2005. - Die Uckermark 1945. T. 1. Prenzlau 1995, S. 110, 112-115. - Wille II, S. 397 (Seidenbau und Angorazucht, 1947); III, S. 106 (Umsiedlerausschüsse, 1946).

\section{Kreis Ruppin}

EReignisSe bis KrIEgSEnde: Febr. 1945: Der Kreis Ruppin wird zum Aufnahmegebiet für die zu evakuierende Bevölkerung des Kreises Züllichau-Schwiebus (mit Bomst) (gemeinsam mit den Kreisen $\rightarrow$ Angermünde, $\rightarrow$ Prenzlau und $\rightarrow$ Templin) und der Wartheland-Kreise Altburgund [Schubin] und Eichenbrück [Wongrowitz] bestimmt (BLHA, Rep. 6 B Kreisverwaltung Züllichau-Schwiebus, Nr. 169, unfol.).

EReignisse nach KriegSende: „Die meisten Personen kamen im Landkreis Ruppin unter, wo der Anteil der Vertriebenen knapp 40 Prozent ausmachte.“ (Kotsch, S. 129). - Auch nach Kriegsende werden (im Juli u. Okt.) 1945 mehrere Vertriebenentransporte bzw. Trecks aus dem Kreis Züllichau-Schwiebus (mit Bomst) nach $\rightarrow$ Neuruppin geleitet, von wo die Unterbringung meist in benachbarten Dörfern, u. a. in Bechlin, Dabergotz u. Treskow, erfolgte (Vor 50 Jahren, S. 25, 32, 71 f.). - 5.9.1945 Verfügung der Provinzialregierung über eine Verpflichtung zur Unterbringung von 30000 weiteren Flüchtlingen im Kreis Ruppin auf Befehl der Besatzungsmacht (Ast/Mauersberger, S. 43). - 10.11.1945 (Landrat): Friedensbevölkerung 85012, registrierte Umsiedler 31.10.1945: 52 173. „Wie festgestellt worden ist, muß der Kreis Ruppin von allen Kreisen der Provinz als am stärksten belegt angesehen werden." (Wille I, S. 371).

BevöLKerungszahlen: Wohnbevölkerung 1939: 92376 (AGV, S. 10). - 6.9.1945: 75000 Flüchtlinge sind im Kreis untergebracht (Wille II, S. 172). - 31.10.1945: 52173 registrierte „Umsiedler“ (Wille I, S. 371). - 1946: 124836, davon aus Ostpreußen: 4694, Hinterpommern 5154, Ostbrandenburg 13 553, Schlesien 4226, Tschechoslowakei 2 511, Polen 3932, Danzig 621, Rumänien 399, Baltikum 397, Sowjetunion 129 (Volkszählung 1946). - 1949: 125825 Einwohner (davon 50680 „Umsiedler") (Meier, S. 239). - Eingemeindung von Vertriebenen: 
30.4.1947: 49309 (Oehlsen, S. 102), Juni 1948: 50399 (ebd., S. 103), Febr. 1949: 52301 (ebd., S. 104), 30.9 .1950 („nach den neuen Kreisgrenzen ab 1.7.1950“): 43250 (ebd., S. 105).31.12.1948: Gesamtbevölkerung: 125 145, davon „Umsiedler und Evakuierte“: 50458 (Grandke, S. 46).

OrTE: $\rightarrow$ Gransee, $\rightarrow$ Grüneberg, $\rightarrow$ Katerbow, $\rightarrow$ Lindow, $\rightarrow$ Neuruppin, $\rightarrow$ Neustadt (Dosse), $\rightarrow$ Radensleben, $\rightarrow$ Rheinsberg, $\rightarrow$ Sieversdorf, $\rightarrow$ Wusterhausen/Dosse, $\rightarrow$ Wustrau.

LAGER: $\rightarrow$ Grüneberg, $\rightarrow$ Neuruppin, $\rightarrow$ Rheinsberg, $\rightarrow$ Wustrau.

Archivalische Quellen: BLHA, Rep. 6 B Züllichau-Schwiebus, Nr. 169: Umsiedlungsaktion im Kreise ZüllichauSchwiebus, 1945; enthält v. a.: Adressenlisten von Flüchtlingen (Heimatanschrift und aktueller Aufenthaltsort, überwiegend im Kreis Ruppin). - BLHA, Rep. 203 MdI, Nr. 1140 (Umsiedler- und Heimkehrerstatistiken, 1945-1946; enthält: Erfassung der Umsiedler in den einzelnen Kreisen der SBZ zum 1. Dez. 1945 sowie statistische Berichte der einzelnen Gemeinden, hier Kreis Ruppin). - BLHA, Rep. 250 Landratsamt Ruppin.

Gedruckte Quellen und Literatur: HOL II. - Meier, Brigitte: Fontanestadt Neuruppin. Karwe 2004. - Vor 50 Jahren. Als Flucht und Vertreibung im Kreis Züllichau-Schwiebus begannen. O. O. 1995. - Wille I, S. 371 f.; II, S. 172 f., 203 f., 205; III, S. 105 f., 108 f. (Umsiedlerausschüsse, 1946), 128 f. (desgl., 1947), 167, 169, 359.

\section{(Rest-)Kreis Sorau}

(1945/46 auch „Restkreis Sorau-Forst" und „Landkreis Forst“)

EReignisse bis Kriegsende: Febr. 1945: Der (noch ungeteilte) Kreis Sorau (Niederlausitz) wird zum Aufnahmegebiet für die zu evakuierende Bevölkerung der Kreise Jarotschin, Kalisch (Wartheland) und Fraustadt in Schlesien bestimmt (BLHA, Rep. 6 B Kreisverwaltung Züllichau-Schwiebus, Nr. 169, unfol.).

Ereignisse nach Kriegsende: Der Kreis fiel 1945 größtenteils an Polen. Ein kleinerer, als Kreis nicht lebensfähiger Teil (25000 ha), das Gebiet links der Neiße, verblieb bei Deutschland und wurde, zunächst von der Provinzialverwaltung als „Restkreis Sorau“, „Restkreis SorauForst“ und auch als „Landkreis Forst“ bezeichnet, am 15.3.1946 (Beschluss vom 25.1.1946) den benachbarten Landkreisen zugewiesen: überwiegend dem Landkreis $\rightarrow$ Cottbus (16 Gemeinden), kleinere Teile kamen an den Kreis Spremberg (13 Gemeinden) bzw. an den Stadtkreis Forst (2 Gemeinden und 2 einwohnerlose Flächen von an den Landkreis Cottbus gefallenen Gemeinden) (Blöß, Kreise und Gemeinden, S. 12, 42).

BevöLkerungszahlen: Wohnbevölkerung des Gesamtkreises (!) 1939: 86683 (AGV, S. 11). -[1946:] 14000 (Blöß, Kreise und Gemeinden, S. 42). - Eingemeindung von Vertriebenen: 30.4.1947 (Ldkr. Forst): 1464 (Oehlsen, S. 102).

ORTE: $\rightarrow$ Döbern, $\rightarrow$ Groß Kölzig, $\rightarrow$ Jerischke-Pusack, $\rightarrow$ Jocksdorf, $\rightarrow$ Klein Kölzig, $\rightarrow$ Kromlau, $\rightarrow$ Noßdorf, $\rightarrow$ Simmersdorf, $\rightarrow$ Weissagk. 
LAGER: $\rightarrow$ Döbern, $\rightarrow$ Groß Kölzig, $\rightarrow$ Jocksdorf, $\rightarrow$ Klein Kölzig, $\rightarrow$ Kromlau, $\rightarrow$ Simmersdorf, $\rightarrow$ Weissagk.

Archivalische Quellen: BLHA, Rep. 203 MdI, Nr. 1130 (Umsiedler- und Heimkehrerstatistiken, 1945-1946; enthält: Erfassung der Umsiedler in den einzelnen Kreisen der SBZ zum 1. Dez. 1945 sowie statistische Berichte der einzelnen Gemeinden, hier Kreis Forst).

GedRUCKTE QUeLLEn UNd LiterATUR: HOL NL II. - Blöß, Wolfgang: Grenzen und Reformen in einer Umbruchgesellschaft. Berlin 2014. - Ders.: Kommunale Strukturen im Spannungsfeld gesellschaftlicher Umwälzungen. Die Grenzen von Gemeinden und Kreisen in Brandenburg 1945-1952. Berlin 2018. - Sorauer Heimatblatt 1 (1952/53) 50 (2001). - Töpler, Menschenwurm, S. 300 f., 450. - Wille I, S. 64.

\section{Kreis Spremberg}

EREIGNISSE BIS KRIEGSENDE: Febr. 1945: Der Kreis Spremberg wird zum Aufnahmegebiet für die zu evakuierende Bevölkerung der Kreise Kempen und Ostrowo (Wartheland) bestimmt (BLHA, Rep. 6 B Kreisverwaltung Züllichau-Schwiebus, Nr. 169, unfol.).

EREIGNISSE NACH KRIEgSENDE: In der Verfügung der Provinzialregierung vom 5.9.1945 über eine Verpflichtung zur Unterbringung weiterer Flüchtlinge im Kreis Spremberg auf Befehl der Besatzungsmacht wird der Kreis als einer von drei (sämtlich niederlausitzischen) Kreisen wegen Überbelastung freigestellt (Ast/Mauersberger, S. 43).

BeVÖLKeRUnGSZAHLEN: Wohnbevölkerung 1939: 45020 (AGV, S. 11). - 1946: 49422, davon aus Ostpreußen: 247, Hinterpommern 142, Ostbrandenburg 1345, Schlesien 2921, Tschechoslowakei 447, Polen 401, Danzig 35, Rumänien 17, Baltikum 42, Sowjetunion 11 (Volkszählung 1946). - Eingemeindung von Vertriebenen: 30.4.1947: 10525 (Oehlsen, S. 102), Juni 1948: 10302 (ebd., S. 103), Febr. 1949: 10311 (ebd., S. 104), 30.9 .1950 („nach den neuen Kreisgrenzen ab 1.7.1950“): 9280 (ebd., S. 105). - 31.12.1948: Gesamtbevölkerung: 53 519, davon „Umsiedler und Evakuierte“: 10302 (Grandke, S. 46).

OrTE: $\rightarrow$ Döbern, $\rightarrow$ Groß Kölzig, $\rightarrow$ Jerischke-Pusack, $\rightarrow$ Jocksdorf, $\rightarrow$ Klein Kölzig, $\rightarrow$ Kromlau, $\rightarrow$ Spremberg, $\rightarrow$ Spremberg-Cantdorf, $\rightarrow$ Spremberg-Trattendorf, $\rightarrow$ Welzow, $\rightarrow$ Weskow.

LAGER: $\rightarrow$ Klein Kölzig, $\rightarrow$ Kromlau, $\rightarrow$ Spremberg, $\rightarrow$ Spremberg-Cantdorf, $\rightarrow$ SprembergTrattendorf, $\rightarrow$ Welzow (Kreisumsiedlerlager Flugplatz), $\rightarrow$ Weskow.

Archivalische Quellen: BLHA, Rep. 203 MdI, Nr. 1141 (Umsiedler- und Heimkehrerstatistiken, 1945-1946; enthält: Erfassung der Umsiedler in den einzelnen Kreisen der SBZ zum 1. Dez. 1945 sowie statistische Berichte der einzelnen Gemeinden, hier Kreis Spremberg). - BLHA, Rep. 250 Landratsamt Spremberg.

Gedruckte Quellen und Literatur: HOL NL II. - Kaczmarek, Günther: Die Befreiung des Kreises Spremberg vom Hitlerfaschismus im April 1945. Spremberg 1980. - Töpler, Menschenwurm, S. 451. 


\section{Kreis Teltow}

EREIGNISSE VOR 1939: Im Ersten Weltkrieg wird nach den Zerstörungen in ostpreußischen Städten der „Kriegshilfsverein im Kreise Teltow für ländliche Ortschaften im Kreis Gerdauen“ gegründet (Die Ostpreußenhilfe, S. 44, 68).

Ereignisse Bis Kriegsende: Febr. 1945: Der Kreis Teltow wird zum Aufnahmegebiet für die zu evakuierende Bevölkerung des Kreises Crossen/Oder (gemeinsam mit dem Kreis Osthavelland) bestimmt (BLHA, Rep. 6 B Kreisverwaltung Züllichau-Schwiebus, Nr. 169, unfol.). 9.2.1945 Befehl des NSDAP-Kreisleiters des Kr. Teltow zur Aufnahme (Einquartierung) der evakuierten Bewohner des Kr. Crossen (Neumark) in den Kr. Teltow u. Osthavelland; ferner Plan zur Aufnahme der Trecks aus den Kr. Kosten u. Lissa (Wartheland) im Kr. Teltow (Adamy/Hübener, S. 172).

EReignisse NACH KRIEgSende: 5.9.1945 Verfügung der Provinzialregierung über eine Verpflichtung zur Unterbringung von 35000 weiteren Flüchtlingen im Kreis Teltow auf Befehl der Besatzungsmacht (Ast/Mauersberger, S. 43).

BevöLKerungszahlen: Wohnbevölkerung 1939: 176943 (AGV, S. 10). - 1946: 175 551, davon aus Ostpreußen: 3665 , Hinterpommern 3324, Ostbrandenburg 5771, Schlesien 5021 , Tschechoslowakei 2817, Polen 4465, Danzig 318, Rumänien 541, Baltikum 292, Sowjetunion 284 (Volkszählung 1946). - Eingemeindung von Vertriebenen: 30.4.1947: 38872 (Oehlsen, S. 102), Juni 1948: 47447 (ebd., S. 103), Febr. 1949: 46558 (ebd., S. 104), 30.9 .1950 („nach den neuen Kreisgrenzen ab 1.7.1950“): 41756 (ebd., S. 105). - 31.12.1948: Gesamtbevölkerung: 188 432, davon „Umsiedler und Evakuierte“: 47 ?89 (Grandke, S. 46).

OrTE: $\rightarrow$ Ahrensdorf, $\rightarrow$ Alexanderhof, $\rightarrow$ Bestensee, $\rightarrow$ Blankenfelde, $\rightarrow$ Dabendorf, $\rightarrow$ Diedersdorf, $\rightarrow$ Eichwalde, $\rightarrow$ Genshagen, $\rightarrow$ Halbe, $\rightarrow$ Klein Köris, $\rightarrow$ Kleinmachnow, $\rightarrow$ Königs Wusterhausen, $\rightarrow$ Körbiskrug, $\rightarrow$ Ludwigsfelde, $\rightarrow$ Mahlow, $\rightarrow$ Mittenwalde, $\rightarrow$ Rangsdorf, $\rightarrow$ Saalow, $\rightarrow$ Selchow, $\rightarrow$ Sperenberg, $\rightarrow$ Stahnsdorf, $\rightarrow$ Teltow, $\rightarrow$ Telz, $\rightarrow$ Teupitz, $\rightarrow$ Trebbin, $\rightarrow$ Waltersdorf, $\rightarrow$ Wildau, $\rightarrow$ Wünsdorf, $\rightarrow$ Zernsdorf, $\rightarrow$ Zeuthen, $\rightarrow$ Zossen.

LAGER: $\rightarrow$ Blankenfelde, $\rightarrow$ Dabendorf, $\rightarrow$ Genshagen, $\rightarrow$ Königs Wusterhause (u. a. Kreisumsiedlerlager), $\rightarrow$ Körbiskrug, $\rightarrow$ Saalow (Kreisumsiedlerlager), $\rightarrow$ Teltow, $\rightarrow$ Zernsdorf.

Archivalische Quellen: BLHA, Rep. 202 E Statistisches Landesamt, Nr. 17: Statistische Aufstellung zur Bevölkerungsaufnahme (einschließlich Flüchtlinge und zurückgekehrte Kriegsgefangene) Kreise Beeskow-Storkow, Niederbarnim, Osthavelland, Teltow, 1945-1946. - BLHA, Rep. 203 MdI, Nr. 1142 (Umsiedler- und Heimkehrerstatistiken, 1945-1946; enthält: Erfassung der Umsiedler in den einzelnen Kreisen der SBZ zum 1. Dez. 1945 sowie statistische Berichte der einzelnen Gemeinden, hier Kreis Teltow). - BLHA, Rep. 250 Landratsamt Teltow.

Gedruckte Quellen und Literatur: HOL IV. - Adamy, Kurt / Hübener, Kristina: Königs Wusterhausen in der Zeit der Weimarer Republik und des Nationalsozialismus (1918-1945). In: Königs Wusterhausen. Hrsg. von Kurt Adamy u.a. Berlin 1998, S. 123-174. - Müller, Wolfgang: Nachkriegsjahre in Eichwalde. Eichwalde [2007] [bes. S. 101-111 Kap. 2.2. „Fremde Heimat“]. - 1945. Das Jahr in der Region Dahme-Spreewald. Dokumentation zur 
Geschichte. T. 2. Zeuthen 2010, S. 220-229 (Zeitzeugenberichte und Quellen zum Thema „Flüchtlinge/Vertriebene - Kriegsgefangene"). - Oehlsen, S. 90. - Onnen, Hans-Joachim: Profile aus Potsdam und dem Landkreis PotsdamMittelmark. Bd. 1-3. Potsdam 1998-2000. - Die Ostpreußenhilfe im Ersten Weltkrieg. Husum 2006.

\section{Kreis Templin}

EReignisse bis Kriegsende: Jan. 1945 Gerswalde (Kr. Templin) wird dem Treck aus Peetzig (Kr. Königsberg/Nm.) als Zielort genannt (Gleß, S. 87). - Gegen Ende Jan. 1945 wird während des (wohl bereits im überlasteten $\mathrm{Kr}$. $\rightarrow$ Prenzlau befindlichen) Trecks für die evakuierten Einwohner des Kreises Eichenbrück/Wongrowitz (Wartheland) der Kreis Templin „als Aufnahmekreis benannt. Aber schon nach wenigen Tagen zeigte sich hier, daß auch dieses Gebiet die Menschenmassen mit ihren Pferden nicht mehr aufnehmen konnte." (Nebelung, S. 89): - Anf. Febr. 1945: „Die große Chaussee $[\rightarrow]$ Prenzlau $-[\rightarrow]$ Boitzenburg $-[\rightarrow]$ Lychen nach Westen war als Treckstrecke bestimmt. Auf dieser kamen nun seit Anfang Februar 1945 Tag für Tag, ununterbrochen, die zum Teil elendsten Trecks aus Ostpreußen, Pommern und der Neumark." (Bericht von Joachim Graf von Arnim-Boitzenburg, abgedruckt in: Stahl, S. 94). - Febr. 1945: Der Kreis Templin wird zum Aufnahmegebiet für die zu evakuierende Bevölkerung des Kreises Züllichau-Schwiebus (mit Bomst) (gemeinsam mit den Kreisen Angermünde, Prenzlau und Ruppin) und des Wartheland-Kreises Dietfurt [Znin] bestimmt (BLHA, Rep. 6 B Kreisverwaltung ZüllichauSchwiebus, Nr. 169, unfol.). - Anfang Februar 1945 auch „für die Aufnahme der Flüchtlinge aus dem Kreis Königsberg [in der Neumark] vorgesehen“ (Köhler, S. 100).

EReignisSe NACH KRIEgSEnde: 16.7.1945 (Rede des Landrats in der ersten Sitzung des Provinzialverbandes): „Die Städte Lychen und Templin sind ungefähr zu $50 \%$ vollständig niedergebrannt, so daß wir dort wenigstens nicht im Moment, aber in den nächsten Tagen und Wochen, Wohnungsschwierigkeiten zu verzeichnen haben werden, da ein großer Teil der geflüchteten Einwohner zurückkommt und Wohnungen sucht. Die Wohnungen sind zum größten Teil besetzt und zwar durch die Flüchtlinge aus dem Osten. Eines möchte ich gleich vorausschicken, daß sich bei uns die Flüchtlinge so ansammeln, weil der Landrat von Prenzlau diese nicht aufnimmt [,] und an die Schwierigkeit darin, daß zum Teil die Lebensmittelversorgung sehr schlecht ist. [...] Die sich [so!] bei uns befindlichen Flüchtlinge sind bereits zum größten Teil auf dem platten Land untergekommen. Wir können diese Leute natürlich nur in großen Gütern unterbringen. [...]." (Die Uckermark 1945, S. 110). 5.9.1945 Verfügung der Provinzialregierung über eine Verpflichtung zur Unterbringung von 50000 weiteren Flüchtlingen im Kreis Templin auf Befehl der Besatzungsmacht (Ast/Mauersberger, S. 43).

EREIGNISSE NACH 1990: 1995 Unterbringung eines Teilkontingents der 186 dem Ldkr. Uckermark zugewiesenen Aussiedler in Röddelin als einer von drei Gemeinden (Theil, S. 17).

Bevölkerungszahlen: Wohnbevölkerung 1939: 59052 (AGV, S. 10). - 1946: 72 094, davon aus Ostpreußen: 2960, Hinterpommern 4770, Ostbrandenburg 5026, Schlesien 2359, 
Tschechoslowakei 275, Polen 2 551, Danzig 864, Rumänien 196, Baltikum 215, Sowjetunion 105 (Volkszählung 1946). - Eingemeindung von Vertriebenen: 30.4.1947: 24705 (Oehlsen, S. 102), Juni 1948: 25467 (ebd., S. 103), Febr. 1949: 25646 (ebd., S. 104), 30.9.1950 („nach den neuen Kreisgrenzen ab 1.7.1950“): 22999 (ebd., S. 105). - 31.12.1948: Gesamtbevölkerung: 76548, davon „Umsiedler und Evakuierte“: 25921 (Grandke, S. 46).

ORTE: $\rightarrow$ Altthymen-Dahmshöhe, $\rightarrow$ Beenz, $\rightarrow$ Boitzenburg, $\rightarrow$ Bredereiche, $\rightarrow$ Engelsburg bei Milmersdorf, $\rightarrow$ Himmelpfort, $\rightarrow$ Lychen, $\rightarrow$ Mildenberg, $\rightarrow$ Ravensbrück, $\rightarrow$ Templin, $\rightarrow$ Zehdenick.

LAGER: $\rightarrow$ Altthymen-Dahmshöhe, $\rightarrow$ Engelsburg, $\rightarrow$ Fürstenberg/Havel, $\rightarrow$ Himmelpfort, $\rightarrow$ Lychen, $\rightarrow$ Templin (Postheim) (Kreisumsiedlerlager), $\rightarrow$ Zehdenick.

Archivalische Quellen: BArch, DO 2 ZVU, Nr. 50, Bl. 223 (Umsiedler-Ausschüsse, 1947). - BLHA, Rep. 203 MdI, Nr. 1143 (Umsiedler- und Heimkehrerstatistiken, 1945-1946; enthält: Erfassung der Umsiedler in den einzelnen Kreisen der SBZ zum 1. Dez. 1945 sowie statistische Berichte der einzelnen Gemeinden, hier Kreis Templin). BLHA, Rep. 250 Landratsamt Templin.

Gedruckte Quellen und Literatur: HOL VIII. - Berlin, Hermann: Meine Erlebnisse in Hammelspring im Jahre 1945. In: Templiner Heimatkalender 2014 (2013), S. 104-108. - Gleß, Karlheinz: Peetzig/Piasek - Erinnerungen an ein Dorf an der Oder. In: Vertreibung aus dem Osten. Hrsg. von Hans-Jürgen Bömelburg, Renate Stößinger, Robert Traba. Olsztyn 2000, S. 83-93. - Köhler, Erich: Das Flüchtlingselend neumärkischer Familien. In: Königsberger Kreiskalender 2002, S. 96-104. - Nebelung, (Paul-Friedrich): Der Landkreis Eichenbrück (Wongrowitz) im Reichsgau Wartheland. in: Heimatbuch für den Kreis Eichenbrück-Wongrowitz. [Bd. 1]. Lüneburg [1967], S. 87-89. - Oehlsen, S. 89. - Stahl, Hans-Joachim: Schloss Boitzenburg in den Jahren 1944/45 bis 1956. In: Beatrix Bluhm / Detlev von Heydebrand / Hans-Joachim Stahl: Schloss Boitzenburg in der Uckermark. Angermünde 2011, S. 86-138. - Theil, Jürgen: Prenzlauer Stadtlexikon uind Geschichte in Daten. Prenzlau 2005. - Die Uckermark 1945. T. 1. Prenzlau 1995. - Wille III, S. 198 f.

\section{Kreis Westhavelland}

EReignisse bis Kriegsende: [Erinnerungen eines Einwohners von Posedin, Kr. Lebus; um den 20.1.1945:] „Bei ca. 20 Grad Kälte ziehen Treckwagen von Küstrin kommend in Richtung $[\rightarrow]$ Wriezen. Nach dem Westhavelland sollen sie. Wo das liegt wissen sie nicht, nur immer weiter in Richtung Westen, der Russe war ihnen auf den Fersen. Schon über $750 \mathrm{~km}$ sind sie gezogen, alte Frauen und kleine Kinder sind unterwegs gestorben, sagen sie. Sie liegen irgendwo längs des großen Treckweges an den Straßen begraben. Immer weiter heißt es, die Pferde können kaum noch, die Stollen sind abgelaufen. Der Dorfschmied tut sein möglichstes [...]." (Ein leidgeprüftes Land, S. 140). - Febr. 1945: Der Kreis Westhavelland wird zum Aufnahmegebiet für die zu evakuierende Bevölkerung der Kreise Konin, Lentschütz und Turek (Wartheland) bestimmt (BLHA, Rep. 6 B Kreisverwaltung Züllichau-Schwiebus, Nr. 169, unfol.).

EREIGNISSE NACH KRIEGSENDE: „In den letzten Kriegswochen waren Tausende Flüchtlinge aus den östlichen Reichsteilen auch in das Havelland eingeströmt. Ihnen folgten nach dem 
Kriegsende Vertriebene aus den ehemaligen deutschen Ostgebieten. Die Einwohnerzahl fast aller Dörfer [...] nahm in diesen Monaten um das Zwei- bis Dreifache der Vorkriegsbevölkerung zu. Die Flüchtlinge sahen sich prekären Lebensbedingungen ausgesetzt. Oft wurden sie notweise in den nun leer stehenden Herrenhäusern untergebracht. Ohne Wohnung, Arbeit und die lebensnotwendigen Dinge waren sie aber ohne eine wirkliche Perspektive." (Das Havelland um Rathenow und Premnitz, S. 93). - 5.9.1945 Verfügung der Provinzialregierung über eine Verpflichtung zur Unterbringung von 50000 weiteren Flüchtlingen im Kreis Westhavelland auf Befehl der Besatzungsmacht (Ast/Mauersberger, S. 43). - 1946 (Bericht des Kreisarbeitsamtes): „Bei den Antifa-Familien, welche wir aus der Tschechei zugewiesen erhielten, machte uns der grosse Wohnraumanspruch dieser Familien viele Schwierigkeiten, da jede Familie eine komplette Wohnung verlangte. Diese Durchführung gelang uns nur in wenigen Fällen." (BLHA, Rep. 206, Nr. 2997).

BevöLKeRUngSZAHLEN: Wohnbevölkerung 1939: 46914 (AGV, S. 10). - 1946: 64717, davon aus Ostpreußen: 1714, Hinterpommern 2 148, Ostbrandenburg 2756, Schlesien 2 137, Tschechoslowakei 3061, Polen 5874, Danzig 476, Rumänien 1678, Baltikum 223, Sowjetunion 444 (Volkszählung 1946). - Eingemeindung von Vertriebenen: 30.4.1947: 25664 (Oehlsen, S. 102), Juni 1948: 28480 (ebd., S. 103), Febr. 1949: 29039 (ebd., S. 104), 30.9.1950 („nach den neuen Kreisgrenzen ab 1.7.1950“): 28057 (ebd., S. 105). - Am 1.11.1946 sind im Kreis 3604 Sudetendeutsche eingemeindet (Kreis mit zweithöchster Konzentration nach $\rightarrow$ ZauchBelzig und vor $\rightarrow$ Luckau) (Christopeit, S. 80). - 31.12.1948: Gesamtbevölkerung: 68 964, davon „Umsiedler und Evakuierte“: 27759 (Grandke, S. 46).

ORTE: $\rightarrow$ Bergerdamm, $\rightarrow$ Brädikow, $\rightarrow$ Buckow, $\rightarrow$ Döberitz, $\rightarrow$ Friesack, $\rightarrow$ Garlitz, $\rightarrow$ Görne, $\rightarrow$ Groß Behnitz, $\rightarrow$ Haage, $\rightarrow$ Jahnberge, $\rightarrow$ Nennhausen, $\rightarrow$ Päwesin, $\rightarrow$ Paulinenaue, $\rightarrow$ (Brandenburg-)Plaue/Havel, $\rightarrow$ Premnitz, $\rightarrow$ Pritzerbe, $\rightarrow$ Rathenow, $\rightarrow$ Rhinow, $\rightarrow$ Schönholz, $\rightarrow$ Senzke, $\rightarrow$ Stechow, $\rightarrow$ Wachow.

LAGER: $\rightarrow$ Bergerdamm, $\rightarrow$ Buckow, $\rightarrow$ Friesack, $\rightarrow$ Kirchmöser, $\rightarrow$ Päwesin, $\rightarrow$ Plaue/Havel, $\rightarrow$ Premnitz, $\rightarrow$ Pritzerbe, $\rightarrow$ Rathenow (Magazininsel) (Kreisumsiedlerlager), $\rightarrow$ Wachow.

Archivalische Quellen: BLHA, Rep. 203 MdI, Nr. 1144 (Umsiedler- und Heimkehrerstatistiken, 1945-1946; enthält: Erfassung der Umsiedler in den einzelnen Kreisen der SBZ zum 1. Dez. 1945 sowie statistische Berichte der einzelnen Gemeinden, hier Kreis Westhavelland). - BLHA, Rep. 250 Landratsamt Westhavelland.

Gedruckte Quellen und Literatur: HOL III. - Andreae/Geiseler. - Christopeit. - Die letzten Tage im Krieg und die ersten Wochen im Frieden in der Region um Rathenow. T. 1-3. Hrsg.: Rathenower Heimatbund e. V. [Red.:] Hans-Jürgen Wodtke u. a. 2. Aufl. (T. 1.: 4. Aufl.) Rathenow 2014-2018. - Das Havelland um Rathenow und Premnitz. Köln u. a. 2017. - Ein leidgeprüftes Land. Bearb. von Fritz Knüppel. 2. Aufl. Barsinghausen 1990. - Oehlsen, S. 89 f. - Wille III, S. 212 f. 


\section{Kreis Westprignitz}

EReIGNisSe BIS KRIEgSEnde: Jan./Febr. 1945: Der Kreis Westprignitz wird zum Aufnahmegebiet für die zu evakuierende Bevölkerung der Kreise Kolmar, Samter und Birnbaum (Wartheland) bestimmt, wohl über den Durchschleusungspunkt Bad Freienwalde (Febr.: BLHA, Rep. 6 B Kreisverwaltung Züllichau-Schwiebus, Nr. 169, unfol.; für Kr. Samter auch schon am 23. Jan. bekannt: Dokumentation der Vertreibung I/1, S. 380; Kr. Birnbaum: Hielscher, S. 13). - Ca. Ende Jan. 1945 Einrichtung einer Meldestelle für den Kr. Birnbaum in Dergenthin bei Wittenberge und einer weiteren durch Bürgermeister Thüte in Lanz (Hielscher, S. 14). - 4.2.1945 Ankunft eines Trecks aus Filehne an der Westprignitzer Kreisgrenze (Dokumentation der Vertreibung I/1, S. 381). - Febr. 1945 Transport aus Hirschberg im Riesengebirge, darunter mindestens eine Familie in Mellen einquartiert (Kegler, S. 91): „In Mellen und Umgebung gab es viele Flüchtlinge aus dem Osten." (ebd., S. 93). - Die Flüchtlinge aus Stadt u. Kreis Meseritz kamen „vornehmlich in die Gegend um Kyritz/Perleberg“" (Stadt und Kreis Meseritz. [Bd. 1], S. 341).

EREIGNISSE NACH KRIEgSENDE: Direkt nach Kriegsende Einrichtung einer Flüchtlingsstelle in $\rightarrow$ Bad Wilsnack zur namentlichen Erfassung und Verteilung auf die Dörfer (Transitzone Dorf, S. 36). - Anf. Aug. 1945 (Bericht des Landrats): „Der Flüchtlingsstrom hält noch ununterbrochen an. Täglich ist im Kreise mit 200 neu hinzukommenden Flüchtlingen zu rechnen. Demgegenüber ist ein nennenswerter Abgang z. Zt. noch nicht zu verzeichnen." (BLHA, Rep. 250 Westprignitz, Nr. 24/9, Bl. 2, zitiert nach Transitzone Dorf, S. 36). - 5.9.1945 Verfügung der Provinzialregierung über eine Verpflichtung zur Unterbringung von 50000 weiteren Flüchtlingen im Kreis Westprignitz auf Befehl der Besatzungsmacht (Ast/Mauersberger, S. 43), 20.9.1945 entsprechende Information des Landrates an die Bürgermeister (Wille I, S. 332). - 1946 Der DEFA-Spielfilm „Freies Land“ (Regie: Milo Harbich; Drehbuch: Kurt Hahne, Milo Harbich; Produzent: Kurt Hahne) behandelt das Flüchtlingsschicksal am Beispiel eines Dorfes in der Westprignitz (Darsteller sind neben professionellen Schauspielern Laiendarsteller mit Flüchtlingsschicksal und einheimische Bauern), Premiere 19.10.1946 in $\rightarrow$ Potsdam (wikipedia, www.defa-stiftung.de/miloharbich [10.7.2018]).

EREIGNisSe NACH 1990: Regelmäßige Busfahrten von in der Prignitz ansässigen Vertriebenen unter der Reiseleitung des aus Meseritz stammenden Herybert Schulz in ihre Heimatorte in den ehem. Kreisen Meseritz und Birnbaum, 2016 bereits zum siebzehnten Mal (Heimatgruß 218,2016, S. 8 ).

BevöLkerungszahlen: Wohnbevölkerung 1939: 65407 (AGV, S. 10; Wille I, S. 101: 63400). - 2.8.1945: ca. 56000 Ortsansässige, 47000 Flüchtlinge (Wille I, S. 101). - 1946: 88487 , davon aus Ostpreußen: 3067, Hinterpommern 3291, Ostbrandenburg 4274, Schlesien 3 001, Tschechoslowakei 2770, Polen 7704, Danzig 500, Rumänien 1 010, Baltikum 401, Sowjetunion 118 (Volkszählung 1946). - Eingemeindung von Vertriebenen: 30.4.1947: 36467 (Oehlsen, S. 102), Juni 1948: 33854 (ebd., S. 103), Febr. 1949: 33283 (ebd., S. 104), 30.9.1950 
(„nach den neuen Kreisgrenzen ab 1.7.1950“): 35894 (ebd., S. 105). - 31.12.1948: Gesamtbevölkerung: 91 374, davon „Umsiedler und Evakuierte“: 29060 (Grandke, S. 46).

Orte: $\rightarrow$ Bad Wilsnack, $\rightarrow$ Glöwen, $\rightarrow$ Groß Breese, $\rightarrow$ Guhlsdorf, $\rightarrow$ Havelberg, $\rightarrow$ Klein Warnow, $\rightarrow$ Lenzen (Elbe), $\rightarrow$ Perleberg, $\rightarrow$ Plattenburg, $\rightarrow$ Putlitz, $\rightarrow$ Roddahn, $\rightarrow$ Rühstädt, $\rightarrow$ Sagast, $\rightarrow$ Stavenow.

LAGER: $\rightarrow$ Bad Wilsnack, $\rightarrow$ Glöwen (Kreisumsiedlerlager und Heimkehrerlager); siehe auch $\rightarrow$ Wittenberge (Stadtkr.).

Archivalische QUellen: BLHA, Rep. 203 MdI, Nr. 1145 (Umsiedler- und Heimkehrerstatistiken, 1945-1946; enthält: Erfassung der Umsiedler in den einzelnen Kreisen der SBZ zum 1. Dez. 1945 sowie statistische Berichte der einzelnen Gemeinden, hier Kreis Westprignitz); Nr. 1157 (Statistische Meldungen der Gemeinden im Kreis Westprignitz über das Flüchtlingswesen, Okt.-Nov. 1945). - BLHA, Rep. 250 Landratsamt Westprignitz.

Gedruckte Quellen und Literatur: HOL I. - Dokumentation der Vertreibung I/1, S. 371-381. - Das Ende des Zweiten Weltkrieges im Mai 1945. Erinnerungen an die Prignitzdörfer Boberow und Glövzin. Hrsg.: Manfred Müller. Schwerin 2006. - Hielscher, Karl A.: Das Kriegsende 1944/45 für den Kreis Birnbaum. In: Birnbaum/Warthe. Hrsg. von Margarete Becker u. a. Hemmingen 1977, S. 9-18. - Hoheisel, Wilhelm: Aus dem Treckbericht der Elsenauer. In: Heimatbuch für den Kreis Eichenbrück-Wongrowitz. Bd. 2. Wendisch Evern 1978, S. 121-129. - Kegler, Hartmut: Kriegsende und Nachkriegszeit in der westlichen Prignitz. In: Kriegsende und Nachkriegszeit in Havelberg [I]. Havelberg 1992, S. 91-93 [Erinnerungen eines in Mellen untergekommenen Flüchtlingskindes aus Schlesien]. Kriegsende und Nachkriegszeit in Havelberg [I]. Havelberg 1992. - Kriegsende und Nachkriegszeit in Havelberg [II]. Havelberg 1994. - Pöhlchen, Gerhard: Wir erkunden die Schierziger Heimat. In: ebd., S. 12 [Reisebericht, Ergänzung zum nachstehenden Hauptbericht]. - Schulz, Herybert: Die Prignitzer fuhren wieder in die Heimat. In: Heimatgruß. Zeitschrift für Mitglieder und Freunde des Heimatkreises Meseritz e. V. und der Heimatkreisgemeinschaft Birnbaum 218 (2016), S. 8-11 [Reisebericht]. - Spix, Boris: Die Bodenreform in Brandenburg 1945-47. Konstruktion einer Gesellschaft am Beispiel der Kreise West- und Ostprignitz. Münster 1997. - Stadt und Kreis Meseritz. [Bd. 1]. O. O. [1972]. - Transitzone Dorf. Ein Ort zwischen Bodenreform und Kollektivierung. Hrsg. von: Projektgruppe Umsiedlerin: Maria Hetzer [u.a.]. O. O. 2015. - Wille I, S. 101 f., 155, 332; II, S. 243 (Groß Gottschow), 309; III, S. 185, $397 \mathrm{f}$. - Wirtschafts-Wegweiser für Wittenberge und die Kreise West- und Ostprignitz. Branchen-Adreßbuch. Potsdam (1949).

\section{Kreis Zauch-Belzig}

EREIGNISSE BIS KRIEGSENDE: „19. Januar 1945, die ersten Flüchtlingswagen kamen von Beelitz in Richtung Brück-Belzig durch unser Dorf [Reesdorf]. [...] bald hatten wir zu Hause auch eine Familie aus dem Warthegau zu wohnen [...]." (Um Beelitz harter Kampf, S. 107). - Febr. 1945: Der „Kreis Belzig“ wird zum Aufnahmegebiet für die zu evakuierende Bevölkerung der Kreis Posen (Land) und Grätz, der Kreis Zauch-Belzig und die Stadt Brandenburg/Havel für die des Kreises Freystadt in Schlesien bestimmt (BLHA, Rep. 6 B Kreisverwaltung Züllichau-Schwiebus, Nr. 169, unfol.). - „Um den 10. bis 23. April [ziehen] kilometerlange Flüchtlingstrecks durch und nach Rieben" (Um Beelitz harter Kampf, S. 39).

EREIGNISSE NACH KRIEGSENDE: 5.9.1945 Verfügung der Provinzialregierung über eine Verpflichtung zur Unterbringung von 50000 weiteren Flüchtlingen im Kreis Zauch-Belzig auf Be- 
fehl der Besatzungsmacht (Ast/Mauersberger, S. 43). - Okt. 1945 Aufnahme von 4270 „Personen Deutsche, jugoslawischer Untertanenschaft" aus ihrem Durchgangsaufenthaltsort $\rightarrow$ Forst (Lausitz) (Wille I, S. 63 f.).

BevöLkerungszahlen: Wohnbevölkerung 1939: 109700 (AGV, S. 10). - 1946: 134652, davon aus Ostpreußen: 2611, Hinterpommern 2611, Ostbrandenburg 5251, Schlesien 8083 , Tschechoslowakei 3214, Polen 4906, Danzig 308, Rumänien 1 125, Baltikum 368, Sowjetunion 94 (Volkszählung 1946). - Eingemeindung von Vertriebenen: 30.4.1947: 41246 (Oehlsen, S. 102), Juni 1948: 42624 (ebd., S. 103), Febr. 1949: 42759 (ebd., S. 104), 30.9.1950 („nach den neuen Kreisgrenzen ab 1.7.1950“): 35984 (ebd., S. 105). - Am 1.11.1946 sind im Kreis 3913 Sudetendeutsche eingemeindet (Kreis mit höchster Konzentration vor $\rightarrow$ Westhavelland und $\rightarrow$ Luckau) (Christopeit, S. 80). - 31.12.1948: Gesamtbevölkerung: 139286, davon „Umsiedler und Evakuierte“: 41921 (Grandke, S. 46).

OrTE: $\rightarrow$ Beelitz, $\rightarrow$ (Bad) Belzig, $\rightarrow$ Borkheide, $\rightarrow$ Brück, $\rightarrow$ Cammer, $\rightarrow$ Caputh, $\rightarrow$ Ferch, $\rightarrow$ Jeserig, $\rightarrow$ Jeserig/Fläming, $\rightarrow$ Jeserigerhütten, $\rightarrow$ Lehnin, $\rightarrow$ Michendorf, $\rightarrow$ Mörz, $\rightarrow$ Neuseddin, $\rightarrow$ Niemegk, $\rightarrow$ Ragösen, $\rightarrow$ Reppinchen, $\rightarrow$ Schenkenberg, $\rightarrow$ Treuenbrietzen, $\rightarrow$ Werder (Havel), $\rightarrow$ Wiesenburg/Mark, $\rightarrow$ Wilhelmshorst.

LAGER: $\rightarrow$ Belzig (einschl. Klinkengrund), $\rightarrow$ Treuenbrietzen (Kreisumsiedlerlager Landesanstalt und Selterhof).

Archivalische Quellen: BLHA, Rep. 203 MdI, Nr. 1146 (Umsiedler- und Heimkehrerstatistiken, 1945-1946; enthält: Erfassung der Umsiedler in den einzelnen Kreisen der SBZ zum 1. Dez. 1945 sowie statistische Berichte der einzelnen Gemeinden, hier Kreis Zauch-Belzig). - BLHA, Rep. 250 Landratsamt Zauch-Belzig.

Gedruckte Quellen und Literatur: HOL V. - Adressbuch Groß-Potsdam 1949 (enthält auch Caputh, Ferch, Michendorf, Werder/H., Wilhelmshorst). - Christopeit. - „... das Glockengeläut ist einzustellen“. 1945 - das Jahr zwischen Krieg und Frieden. T. 1: Belzig und Umgebung. Belzig 1995. - Helle, Matthias: Nachkriegsjahre in der Provinz. Der brandenburgische Landkreis Zauch-Belzig 1945 bis 1952. Berlin 2011. - Oehlsen, S. 89. - Onnen, HansJoachim: Profile aus Potsdam und dem Landkreis Potsdam-Mittelmark. Bd. 1-3. Potsdam 1998-2000. - ... schwere Kämpfe in und um Treuenbrietzen (OKW-Bericht). 1945. Das Jahr zwischen Krieg und Frieden. Treuenbrietzen und Umgebung. Treuenbrietzen 1995 [enthält u.a. Berichte zu einzelnen Dörfern]. - Um Beelitz harter Kampf. 1945. Das Jahr zwischen Krieg und Frieden. Beelitz und Umgebung. Hrsg.: Beelitzer Heimatverein. Red.: Hannelore Bothe / Fritz Klewitz. Beelitz 1999. - Wille I, S. 64; II, S. 186, 188, 190; III, S. 414 (Reetz, 1949). 


\section{Orte $\mathbf{A}-\mathbf{Z}$}

Archivalische Quellen: BLHA, Rep. 202 E Statistisches Landesamt, Nr. 18 (Sonderfragebogen zur statistischen Erfassung und Seßhaftmachung der Flüchtlinge in den Stadtkreisen der Provinz Mark Brandenburg, 1945-1946); Nr. 23-25 (Bevölkerungsstatistik (Fragebogen) der Stadtkreise der Provinz Mark Brandenburg, 1945; enthält u. a.: Umsiedler, Flüchtlinge: Nr. 23: A bis L, Nr. 24: N bis R, Nr. 25: S bis Z); Nr. 42-43 (Bevölkerungsstatistik mit Angaben über Gesamtbevölkerung, Bevölkerungsentwicklung, Zahl der Umsiedler, der Arbeitenden und Arbeitslosen in den Stadt- und Landkreisen, 1946-1948); Nr. 45 (Statistische Angaben über den Stand der Umsiedler in den Stadtund Landkreisen, 1946-1948). - Rep. 203 MdI, Nr. 1116 (Statistische Erhebung über Gesamtbevölkerung und Umsiedler im Land Brandenburg: Umsiedler- und Heimkehrerstatistiken, 1948; enthält: Erfassung der Umsiedler in den einzelnen Kreisen der SBZ zum 1. Dez. 1945 sowie statistische Berichte der einzelnen Gemeinden); Nr. 1117 (desgleichen, 1946-1947); Nr. 1118 (desgleichen, 1948); Nr. 1164 (Verteilung der Umsiedler auf einzelne Gemeinden. Stand: Dez. 1947).

Gedruckte Quellen und Literatur: Blöß, Kreise und Gemeinden. - Blöß, Wolfgang: Kommunale Strukturen im Spannungsfeld gesellschaftlicher Umwälzungen. Die Grenzen von Gemeinden und Kreisen in Brandenburg 19451952. Berlin 2018. - Branchen-Adressbuch Provinz Brandenburg mit Groß-Berlin. Ausgabe 1947. Berlin (1946), T. 2 (S. 1-235): „Alphabetisches Verzeichnis von sämtlichen Industriefirmen, Handels- und Gewerbetreibenden, behördlichen Einrichtungen der Provinz Brandenburg“ [nach Orten!], T. 3 (S. I-X, 1-547): „Branchenteil nebst alphabetischem Branchen-Verzeichnis“ [nach Branchen!]. - Töpler, Menschenwurm.

\section{Ahrensdorf}

Landgemeinde (seit 2001 Ortsteil der Stadt $\rightarrow$ Ludwigsfelde), bis 1952 Kr. Teltow, 1952-1990 Kr. Zossen (Bez. Potsdam), 1990-1993 Ldkr. Zossen, 1993 Ldkr. Teltow-Fläming

BeVÖLKERUNGSZAHLEN: 1925: 488, 1939: 481, 1946: 545, 1964: 385 (HOL IV, S. 5). - „Durch den Zuzug von Flüchtlingen bis Kriegsende und von Zwangsumsiedlern aus dem Osten nach Kriegsende erhöht sich die Einwohnerzahl des Ortes auf 545 (1939: 490)." (Wietstruk, S. 111).

UMSIEDlerlager: Kapazität am 31.12.1945 (Lager „Arnsdorf“ im Kr. Teltow): 600 (BArch, DO $2 / 45, \mathrm{Bl} .40)$.

Literatur: Siegfried Wietstruk: 750 Jahre Ahrensdorf (Kreis Zossen). Ahrensdorf 1992.

\section{Alexanderhof}

Teil der Landgemeinde Alexanderdorf (seit 1974 Kummersdorf-Alexanderdorf, dieses seit 2002 Ortsteil von Am Mellensee), bis 1952 Kr. Teltow, 1952-1990 Kr. Zossen (Bez. Potsdam), 1990-1993 Ldkr. Zossen, 1993 Ldkr. Teltow-Fläming

EREIGNISSE NACH KRIEGSENDE: 1946 (Bericht der Kreisverwaltung über „Umsiedlergenossneschaft“): „Im Kreis Teltow, Gemeinde Alexanderhof ist eine Weberei im Entstehen." (BLHA, Rep. 203 MdI, Nr. 1074, zitiert nach: Oehlsen, S. 90). 
BEVÖLKERUNGSZAHLEN (Alexanderdorf): 1925: 105, 1939: 154, 1946: 223, 1964: 206 (HOL IV, S. 5).

\section{Alt Buchhorst}

Landgemeinde (seit 2001 Ortsteil von $\rightarrow$ Grünheide/Mark), bis 1952 Kr. Niederbarnim, 1952-1990 Kr. Fürstenwalde (Bez. Frankfurt/Oder), 1990-1993 Ldkr. Fürstenwalde, 1993 Ldkr. Oder-Spree

Katholiken (Christian-Schreiber-Haus [Jugendhaus des Bistums Berlin] mit Marienkapelle, Feldweg 10): „In der Kriegszeit waren nur wenige Jugendliche hier, nach 1945 waren zahlreiche Flüchtlinge seelsorglich zu betreuen, doch schon 1946 wurde das Haus wiedereröffnet. / Da für Jugendliche aus dem Ost-Teil des Bistums die Teilnahme an den großen Jugendveranstaltungen in West-Berlin immer schwieriger wurde, wurde 1954 die erste Wallfahrt mit Ost-Berliner Jugendlichen nach „AB“ gehalten, seit 1963 gab es dann die Jugendwallfahrten für den Ost-Teil des Bistums. Doch nicht nur Jugendliche nutzten das Haus für Kurse des Bischöflichen Jugendamtes, Dekanatswochen und -wochenenden. Seit 1966 gibt es die jährliche Familienwallfahrt, seit Mitte der 1980er Jahre die Schwesternwallfahrt und seit 1984 die Seniorenwallfahrt. 1990 geht aus den Jugendwallfahrten der Bistumsjugendtag hervor. / Unter Rektor Wolfram Lewicki wurde 1957 hinter den Häusern eine Wallfahrtskapelle - eigentlich nur ein überdachtes Altarpodest - eingeweiht." (Schwillus/Brühe, S. 321).

\section{Altdöbern}

Landgemeinde, bis 1952 Kr. Calau (ab 1950 Kr. Senftenberg), 1952-1990 Kr. Calau (Bez. Cottbus), 1990-1993 Ldkr. Calau, 1993 Ldkr. Oberspreewald-Lausitz

EReignisse BIS KriegSEnde: 19.4.1945 Einmarsch der Roten Armee (Natusch, S. 172 f.).

EREIGNisSe NACH KRIEgSENDE: Juni 1945: „nach dem Ende eines Lazaretts für deutsche Soldaten richtet der vor geraumer Zeit aus Riga zugezogene [!] Arzt Dr. phil. Dr. med. Heinrich von Knorre im ehemaligen Krankenhaus-Komplex an der Jauerschen Straße ein Seuchenbehelfskrankenhaus ein." (Natusch, S. 174); der parteilose Knorre gehörte der Ende Sept. 1945 gebildeten Gemeindeverwaltung als für das Gesundheitswesen Verantwortlicher an (ebd., S. 175) [Heinrich v. K. (1897-1978) war „Facharzt f. Gynäkologie in Riga, [ab 1939] Litzmannstadt (Lodz) u. [ab 1945] Altdöbern N.L." (Deutschbaltisches Biographisches Lexikon 1710-1960. Köln/Wien 1970, S. 393), kam also sicherlich nicht direkt aus Riga nach Altdöbern, sondern aus Lodz]. - 14.10.1945: „Der Altdöberner Bodenkommission gehören zur Zeit 3 Kleinbauern, 2 Landarbeiter, 1 Umsiedler und 1 Angestellter an.“ (ebd.). - 18.10.1945: Vollständige Räumung des Schülerheims, „weil der gesamte frühere Krankenhaus-Komplex als Seuchenbehelfskrankenhaus (Typhus und Ruhr) gebraucht wird.“ (ebd., S. 176). - [25.3.] 
1946 „wird das Schloß auf 20 Jahre durch den katholischen Caritas-Verband zum Zwecke der Einrichtung und des Betriebes eines Alten- und Kinderheimes gepachtet" (tatsächlich bis 1974 dafür genutzt). „In der Schloßhalle wird ein Gottesdienstraum für den schnell steigenden Anteil römisch-katholischer Mitbürger an der Wohnbevölkerung entstehen.“ (ebd., S. 178); Betreiber: „Arme Schulschwestern“ (Töpler, Menschenwurm, S. 529; genaues Datum ebd. S. 307 Fn. 74), 1949 erwähnt als Caritasheim „Maria Rast“ (ebd., S. 624). - 20.3.1947: „Das Seuchen-Behelfskrankenhaus wird in ein Mütter- und Säuglingsheim mit Entbindungsabteilung umgewandetlt. [... Leitender Arzt ist Dr. Dr. Heinrich von Knorre." (Natusch, S. 178). Knorres Sohn (Prof. Dr. med. habil.) Georg Heinrich von Knorre (geb. 1936 Riga) wuchs in Altdöbern auf (Abitur an der Oberschule ebd.) und war später Facharzt für Kardiologie an der Klinik für Innere Medizin der Universität Rostock (1968 Stationsarzt, 1973 Oberarzt, 1983 stellv. Abteilungsleiter, 1999 kommissarischer Abteilungsleiter, 2000 stellv. Abteilungsleiter, 2001 emeritiert; 1984 Hochschuldozent, 1992 Prof.) (historischesarchiv.dgk.org; http://cpr.uni-rostock.de/resolve/ id/cpr_person_00001196); der jüngere Sohn Dr. Dietrich von Knorre (geb. 1938 Riga), ebenfalls aufgewachsen in Altdöbern, war später ein bekannter thüringischer Zoologe (Ornithologe) in Jena, der aber in seinen frühen Jahren u. a. auch zur Vogelwelt des Spreewalds publizierte (Bössneck/Köhler, S. 49 f.; Heyer/Peter). - Juli 1947 „und weiter“: „Hier treffen in mehreren Gruppen Umsiedler aus Schlesien und anderen Ostgebieten ein. Ihre Unterbringung ist sehr schwierig. Die Einwohnerzahl steigt deutlich an." (Natusch, S. 179).

EREIGNISSE NACH 1949: 20.3.1987 Verleihung des Namens „Heinrich von Knorre“ (s. o.) an das Kreiskrankenhaus anlässlich des 40-jährigen Bestehens der Frauenklinik, 1992 geschlossen (LR online, 6.8.2015).

Bevölkerungszahlen: 1925: 2103, 1939: 2236 (HOL NL I, S. 264); 29.10.1946: 2762 (HGV OSL, S. 15); 1948: 3091 (Natusch, S. 179); 1950: 3115 (HGV OSL, S. 15).

Katholiken: In Altdöbern lebte 1949 der bis 1945 in Hainspach, Diözese Leitmeritz (Sudetenland), wirkende Pfarrer Erzdechant Wenzel Frind (geb. 1868) (Ostpriesterverzeichnis 2, 1949, S. 25).

Gedruckte Quellen und Literatur Bössneck, Ulrich / Köhler, Günter: Der Dietrich von Knorre - der Malakologe, Musologe und Naturschützer sowie einer der letzten klassischen Zoologen Deutschlands wurd 80 Jahre alt. In: Mitteilungen der Deutschen Malakolozoologischen Gesellschaft 100 (2019), S. 49-62. - Heyer, Jürgen / Peter, HansUlrich: Dr. Dietrich von Knorre zum 60. Geburtstag. In: Anzeiger des Vereins Thüringer Ornithologen 3 (1999), S. 263. - Natusch, Kurt: Altdöbern in der Niederlausitz. Altdöbern 1994. - Töpler, Menschenwurm. 


\section{Altenhof am Werbelinsee (bei Joachimsthal), Schorfheide}

Landgemeinde, bis 1952 Kr. Angermünde, 1952-1990 Kr. Eberswalde (Bez. Frankfurt/Oder), 1990-1993 Ldkr. Eberswalde, 1993 Ldkr. Uckermark

UmSiedlerlager Altenhof: Kapazität am 31.12.1945 (Lager „Altenhof-Jugendherberge“): 500 (BArch, DO 2/45, Bl. 40). - Kapazität am 1.1.1946: 600 (BLHA, Rep. 203 MdI, Nr. 1163, Bl. 50). - 1946 Belegungsstärke („Angermünde/Altenberg“ [so!]): 1000 (Kaminsky, S. 159).

KINDERHEIM: 1949 befinden sich hier ostpreußische Waisenkinder („Wolfskinder“) (Leiserowitz, S. 102 f.). - 30.1.1949 Tod des in „Altenhof, Kinderheim“ wohnhaften, 1941 in Königsberg in Ostpreußen geborenen Kindes Kurt Lesch im Kreiskrankenhaus $\rightarrow$ Angermünde, Todesursache: „Tuberkulose Hirnhautentzündung“ (Stadtarchiv Angermünde, Standesamt Angermünde, Sterberegister, Nr. 44/1949), offensichtlich ein Waisenkind (genaues Geburtsdatum und Namen der Eltern konnten nicht angegeben werden). - „Eine Zeit lang wurden Vorschulkinder [...] in Altenhof untergebracht. 1949 eröffnete man an diesem Ort die Pionierrepublik und die dortigen Heiminsassen kamen nach $\rightarrow$ Bad Saarow.“ (Leiserowitz, S. 37). - 1951-1953 Errichtung der „Pionierrepublik Wilhem Pieck“ im Wald nördlich Altenhof (HOL VIII, S. 14), eingeweiht 1951 (Kaule/Wolle, S. 24). [Identisch mit dem von den Grauen Schwestern von der hl. Elisabeth ebd. 1947-1949 betriebenen Kinderheim? (Brühe, S. 23, 56)]. - „Pionierrepublik“ heute Europäische Jugenderholungs- und -begegnungsstätte Werbelinsee „EJB Werbellinsee GmbH“, Joachimsthaler Str. 20 (Kaule/Wolle, S. 24; www.ejb-werbellinsee.de).

St. Maria-Elisabeth-Heim (Caritas-Altersheim), Kurze Str., am Werbellinsee, 1947-1949 von den Grauen Schwestern geführt: Sept. 1947 Pachtung eines Hauses durch den Berliner Caritasverband und Übergabe an die Grauen Schwestern; 1.10.1947 Gründung eines Altenheims für Graue Schwestern durch deren Berliner Provinzhaus, „das auch andere alte Leute aufnahm. Die Schwestern arbeiteten nebenbei in der ambulanten Krankenpflege. 1947: 25 Schwestern, Mai 1948: 35 Schwestern u. 16 alte Leute. „Die Schwestern kamen aus Schlesien; die meisten von ihnen waren nicht mehr arbeitsfähig." (Mertens, S. 473 f.). Sommer 1948 zeitweiliger Auszug auf Wunsch der sowjet. Besatzung, die eigene Schulkinder im Haus unterbringen wollte. 1948 Haus durch die Landesregierung unter Verwaltung eines Treuhänders gestellt, ab Jan. 1949 zunehmende Gerüchtekampagne einer geplanten Überführung in „Volkseigentum“. Die Oberin bemühte sich mit Unterstützung des Angermünders Bürgermeisters und Sozialamtes, jedoch erfolglos, um ein anderes geeignetes Haus. 1.4.1949 Übersiedlung von sechs alten Schwestern in das Haus Afra nach Ützdorf, 6 Schwestern und einige alte Heimbewohnerinnen gingen nach Berlin. 11.10.1949 Auflösung des Heims und Übergabe an den Bürgermeister von Altenhof. Konventsoberin: Canisia Kaulich (1.10.1947-11.10.1949) (ebd., S. 473-476). - 1949 war hier der aus Hohenstein (Kr. Osterode) im Ermland vertriebene Pfarrer Paulinus Pienski (geb. 1886 Krojanke, Kr. Flatow) tätig, zuvor in $\rightarrow$ Wiesenburg/Mark (Schematismus Berlin 1949, S. 63, 94, 144; Ostpriesterverzeichnis 2, 1949, S. 64). 
Archivalische Quellen: Kreisarchiv Barnim, K.I.Altenh 2088 (Umsiedlerlager: Meldungen der entlassenen Kriegsgefangenen, Rückkehrer, Umsiedler, Flüchtlinge und zugezogenen Personen, 1945-1950). - Siehe auch Quellenteil, Nr. 214.

Literatur: Altenhof, Schorfheide. (Eberswalde) 1956, S. 4f. - Brühe, Matthias: Katholische Kirche zwischen Uckermark und Oderland. Berlin 1998. - Kaule, Martin / Wolle, Stefan: 100 Orte der DDR-Geschichte. Berlin 2018, S. 24f. - Leiserowitz, Ruth: Von Ostpreußen nach Kyritz. Potsdam 2003. - Mertens, Johannes: Die Berliner Ordensprovinz der Grauen Schwestern von der heiligen Elisabeth 1859-1991. Reinbek bei Hamburg 1992, S. 473-476.

\section{Altglietzen}

Landgemeinde (seit 2003 Stadtteil von $\rightarrow$ Bad Freienwalde/Oder), bis 15.3.1946 (Rest-)Kr. Königsberg/Nm., 1946-1952 Kr. Oberbarnim, 1952-1990 Kr. Bad Freienwalde (Bez. Frankfurt/Oder), 1990-1993 Ldkr. Bad Freienwalde, 1993 Ldkr. Märkisch-Oderland

EREIGNISSE NACH 1990: Seit 1990 Heimattreffen vertriebener ehemaliger Bewohner des auf dem gegenüber liegenden Oderufer gelegenen Alt-Küstrinchen (Stary Kostrzynek, Polen), ehem. Kr. Königsberg/Nm., im Gasthaus „Zum Oderblick“, am 9.7.2011 gemeinsam mit den aus dem benachbarten, ebenfalls auf dem nun polnischen Oderufer gelegenen Niederwutzen (Osinów-Dolny), ehem. Kr. Königsberg/Nm., seit 1987 organisiert von Ingeborg Kiene (Hannover): „Beim ersten Mal im damaligen Kulturhaus von Neuküstrinchen kamen noch 89 Bürger, jetzt waren es um die 50. Wir wissen nie wie viele kommen', sagt Ingeborg Kiene. Weil in der DDR Heimattreffen nicht gerne gesehen waren, deklarierten es die Ehemaligen als Dorffest. ,Alle wussten Bescheid', freut sich Ingeborg Kiene noch heute über den Coup. 1989, kurz bevor die Grenzen fielen, trafen sie sich in Braunschweig. Doch schon seit 1990 ist Altglietzen der Ort des Wiedersehens. Von dort lässt sich ein Ausflug in die alte Heimat schnell organisieren. Die Alt-Küstrinchener sind verstreut über ganz Deutschland, sehr viele leben jedoch im Oderbruch." (Märkische Onlinezeitung, 11.7.2011 [20.9.2016]). - Nach 1990 fanden hier bis 2010 etwa 15 "Zehdener Heimattreffen“ vertriebener ehemaliger Bewohner der benachbarten, auf dem östlichen Oderufer gelegenen neumärkischen Kleinstadt Zehden/Oder (Cedynia, Polen), ehem. Kr. Königsberg/Nm., im Vereinsraum des Gasthauses „Zum Oderblick“ statt, anfangs mit über 60 Teilnehmern aus dem gesamten Bundesgebiet, 2010 letztmalig mit „rund drei Dutzend“ Teilnehmern: „Die Teilnehmer verabredeten, dass das diesjährige [2010] die letzte der fest organisierten Zusammenkünfte sein solle. Künftig wollen sich nur noch einige Zehdener zwanglos treffen." (Märkische Onlinezeitung, 1.6.2010).

BEVÖLKERUNGSZAHLEN: 1925: 685, 1939: 738, 29.10.1946: 674, 1950: 725, 1964: 653 (HGV MOL, S. 18f.). 


\section{Altlandsberg}

Stadtgemeinde, bis 1952 Kr. Niederbarnim, 1952-1990 Kr. Strausberg (Bez. Frankfurt/Oder), 1990-1993 Ldkr. Strausberg, 1993 Ldkr. Märkisch-Oderland

EREIGNisse BIS Kriegsende: „Am 20.4.1945 verließen die meisten Bewohner die Stadt.“ (Friske/Niedrich, S. 133). - 21. April Einmarsch der Roten Armee (ebd.).

EREIGNisSe NACH KRIEgSENDE: „Die Unterbringung von Flüchtlingen und Rückkehrern“ zählt zu den „vordringlischsten Aufgaben“ der Stadtverwaltung (Friske/Niedrich, S. 136f.). „Altlandsberg war Flüchtlings-Leitstelle, von Juli bis November [1945] mit einem Durchsatz von 5000 Personen, und hatte selbst nacheinander bis zu 1600 Flüchtlinge aufzunehmen und zu versorgen. Daraus resultierte u. a. ein Befehl der Kommandantur an die Bäcker, durch Zusätze (auch Kartoffeln) aus $20 \mathrm{~kg}$ Mehl mindestens $30 \mathrm{~kg}$ Brot zu backen. Ab Anfang 1946 kümmerte sich ein Frauenausschuss um elternlose Kinder sowie um Schulspeisung, Kleidung und Hygiene aller bedürftigen Kinder." (ebd., S. 137). - 1945/46 in der Bodenreform 500 ha (von 1185 ha) an 67 „Umsiedler“ bzw. Flüchtlingsfamilien vergeben (HOL VI, S. 310; Friske/ Niedrich, S. 141-143). - Aug. 1946 „Der Frauenausschuß Altlandsberg hatte für seine monatliche Frauentagung diesmal zu einer Feierstunde nach Altlandsberg-Süd eingeladen. Den unserer Gemeinde zugewiesenen acht Umsiedlerfamilien wurde seitens der Leiterin des Frauenausschusses, Frau Dähne, und dem Bürgermeister der Stadt an bescheidener Kaffeetafel ein Willkommen geboten. [...] Man nahm miteinander Kontakt auf und die Ankündigung eines 70jährigen Genossen aus Friedland, daß auch die Umsiedler nicht zurückstehen werden, wenn es gilt, unsere heimkehrenden Kriegsgefangenen mit der nötigsten Kleidung zu versehen, fand begeisterten Beifall." (Kurznachricht in: Märkische Volksstimme, Nr. 93, 8.8.1946). - Aug. 1946 „Der Kreis Niederbarnim will versuchen, für 3500 zurückkehrende Kriegsgefangene Zivilkleidung zu beschaffen. [...]." (Kurznachricht in: ebd.). „1948 wurde das Krankenhaus durch Kreistagsbeschluss, gegen den Willen der Stadt, in eine regionale Typhus-Klinik umgewandelt." (Friske/Niedrich, S. 136).

BEVÖLKERUNGSZAHLEN: 1925: 2 872, 1939: 5 135, 1946: 5 606, 1964: 3312 (Städtebuch, S. 2).

Katholiken: 1930: 146, 1946: 512, 1985: ca. 50 (Städtebuch, S. 2). - 1945: „Gemeinde zählt jetzt 900 Seelen durch Zuwanderung von Flüchtlingen. [...] 19461000 Seelen. [...] 1948800 Seelen (Abwanderung nach dem Westen)“ (Chronik, S. 8). - Auf die gesamte Pfarrei bezogen: „Nach dem II. Weltkrieg stieg die Zahl der Katholiken auf über 1000 an.“ (Brühe, S. 119; textähnlich Schwillus/Brühe, S. 307), 1948 seelsorgerlich selbständig Kuratie (ebd.). „Durch die starken Flüchtlingsströme gleich nach dem 2. Weltkrieg, vor allem in den Jahren 1945 und 1946, wuchs die Zahl der Katholiken in Altlandsberg auf 1000 Gläubige an. Die Kapelle in der Berliner Allee 23 musste vergrössert werden, in dem eine weitere Trennwand entfernt wurde und der rechts daneben befindliche nicht mehr genutzte Pferdestall zur Sakristei umgebaut wurde. Die Zahl der sonntäglichen und feiertäglichen Gottesdienste musste von zwei auf drei erhöht werden.“ (Ruhl, S. 11). - „Die Altlandsberger Katholiken feierten 1946- 
1983 ihre Fronleichnamsprozessionen in den Obstplantagen der Familie Piontek." (Schwillus/Brühe, S. 307).

Städtepartnerschaften: Aug. 2002 Gemeinde [!] Krzeszyce, Polen (Kriescht, ehem. Kr. Oststernberg, Provinz Brandenburg).

GEDRUCKTE QUelLen UND LiteratUR: Brühe, Matthias: Katholische Kirche zwischen Uckermark und Oderland. Berlin 1998, S. 119. - Friske, Matthias / Niedrich, Hartmut: Altlandsberg. Neuenhagen 2000. - Chronik der katholischen Kirchengemeinde St. Maria von Lourdes, Altlandsberg. Altlandsberg 2012. - Dokumentation der Vertreibung I/1, S. 381. - Ruhl, Johannes: Katholisches Leben in der Stadt Altlandsberg seit 1230. (Altlandsberg) 2008. - Schwillus/Brühe, S. 307.

\section{Altthymen-Dahmshöhe}

Dahmshöhe Gut/Wohnplatz (seit 1971 Ortsteil) von Altthymen (seit 2003 Ortsteil von $\rightarrow$ Fürstenberg/Havel), bis 1952 Kr. Templin, 1952-1990 Kr. Gransee (Bez. Potsdam), 19901993 Ldkr. Gransee (Land Brandenburg), 1993 Ldkr. Oberhavel

LAGER DAнmsнöнe (Barackenlager auf dem ehem. Gut Dahmshöhe mit zahlreichen Baracken des bis Anf. 1945 hier befindlichen Außenlagers des KZ $\rightarrow$ Ravensbrück sowie der ehem. Reitschule der Waffen-SS): „Im ehemaligen Barackenlager der SS in Dahmshöhe hatten sich bis Ende 1945 Soldaten der Roten Armee einquartiert. Als sie es räumten, diente zunächst eine der Baracken als Quarantänestation für typhus- und diphteriekranke Menschen. Im Laufe des Jahres 1946 füllten dann Heimatvertriebene aus dem Osten das Gutshaus und das Barackenlager." (Stegemann, Nachkriegszeit, S. 233). - Im Sept. 1945 ist der Landrat von Stargard (Mecklenburg) „mit der Einrichtung eines Durchgangslagers für Flüchtlinge beauftragt“ und hat „dafür ein im Bezirk der sowjetischen Kommandantur Fürstenberg, aber im brandenburgischen Dahms- [S. 166] dorf (OT von Altthymen, Kr. Templin) liegendes Lager ausersehen“ und beantragt daher eine Grenzbereinigung zwischen Mecklenburg und Brandenburg (Blöß, Kreise und Gemeinden, S. 165f.). - „Das Gelände des KZ-Außenlagers, der Lehrschwadron des Gutes Dahmshöhe mit allen Gebäuden und Baracken, wurde nach der Befreiung 1945 durch die Rote Armee besetzt. Ab 1946 diente es als ,Umsiedlerlager'. Die Baracken wurden ab Mitte der 1960er Jahre demontiert und teilweise anderweitig verwendet. Heute erinnert nichts in dem inzwischen bewachsenen Waldstück an die Häftlinge und die Ausbildungsabteilung der SS." (Schwarz, S. 539). Nach Kriegsende vorübergehend noch Unterkunft für die ehem. Häftlinge. - [Lager] „ab Ende 1945/Anfang 1946 zum Zweck der Unterbringung von Flüchtlingen und Heimatvertriebenen genutzt. [...] Im Lager Dahmshöhe waren nur Vertriebene aus dem Sudetenland untergebracht. Es kann geschätzt werden, daß die Belegungsstärke mehr als achthundert Personen betrug. [S. 506] Dahmshöhe war damit das größte Lager rings um Fürstenberg, das auch noch bis weit in die 1960er Jahre hinein von einigen damaligen Heimatvertriebenen bewohnt wurde. [...] Es gab eine zentrale Lagerleitung, die aus 3 Personen bestand - Herr Kante, Herr Wulff und Herr Effenberger [...]. Diese Lagerleitung bestand aber 
nicht aus Mitgliedern der Heimatvertriebenen, sondern kam aus Neustrelitz - da Fürstenberg damals zum Kreis Neustrelitz gehörte - und war von zentraler Stelle für diese Aufgabe eingesetzt worden. [...] Allerdings gab es im Laufe der Zeit doch recht bedenkliche Unregelmäßigkeiten seitens [S. 507] dieser Lagerleitung, sodaß dann zusätzlich als Vertreter der Bewohner aus dem Lager die Herren Krolopp und Rittau mit beratender Stimme hinzukamen. [...]. Die Unterbringung in den ersten jahren war äußerst beengt. [...] In vielen Baracken wohnten so je Baracke bis 150 Personen! [...] Diese Baracken hatten eine Dimension von etwa $30 \mathrm{~m}$ bis $40 \mathrm{~m}$ Länge und $12 \mathrm{~m}$ Breite. Sie wiesen in der Längsachse einen Mittelgang als Flur auf, von dem aus die einzelnen Räume zu erreichen waren. / Das gesamte Lager Dahmshöhe wies ursprünglich 42 Baracken auf, von denen jedoch nach 1945 nur 10 Baracken für Wohnzwecke genutzt wurden, da die anderen ursprünglich unterschiedlichen Lagerzwecken dienten, aber auch spezielle Werkstätten, darunter solche für Kfz-Reparaturen, beherbergten. Für Wohnzwecke waren sie nicht geeignet. / [...] Jede Familie baute sich aus alten Teilen einiger abrißreifer ehemaliger Lagerbaracken die noch in einer großen Anzahl auf dem Gelände des Wohnlagers standen und nun nicht mehr benötigt wurden, einen Schuppen, um Brennstoffe und sonstige Gegenstände darin zu lagern. [S. 508] [...] Die Heimatvertriebenen des Wohnlagers gehörten überwiegend der katholischen Kirche an. [...] Und so wurde der Speisesaal jeweils sonntags und an besonderen kirchlichen Feiertagen als Kirchenraum genutzt und darin der Gottesdienst gehalten. Die Betreuung erfolgte durch das katholische Pfarramt Fürstenberg. / Interessant ist auch die als Theater bezeichnete große Baracke, die einen Zuschauerraum und eine Bühne mit Orchestergraben aufwies. / Diese Baracke diente auch als Kino. In ihr fanden Filmvorführungen, aber auch andere kulturelle Veranstaltungen ín der Zeit des Wohnlagers ab 1946 statt." (Neis, S. 505-511, mit mehreren historischen Fotos sowie solchen vom überwucherten Zustand 2005; S. 511 Lagerplan des Zustandes von 1946).

KATHOLIKEN: [Zum Seelsorgebezirk $\rightarrow$ Fürstenberg/Havel] „gehörten auch die Flüchtlingsbaracken in Dahmshöhe, wo 1965 eine kleine Filialkapelle geweiht werden konnte. [...]." (Stegemann, Fürstenberg/Havel, Ravensbrück, Bd. 1, S. 77).

LiterAtUR: Blöß, Wolfgang: Grenzen und Reformen in einer Umbruchgesellschaft. Berlin 2014, S. 165 f. - Neis, Kurt: Fürstenberg/Havel. Privatdruck. 9., erg. Aufl. Fürstenberg/Havrel 2011. - Schwarz, Erika: Dahmshöhe. In: Der Ort des Terrors. Hrsg. von Wolfgang Benz u. Barbara Distel. Bd. 4. München 2006, S. 538-539. - Stegemann, Wolfgang: Fürstenberg/Havel, Ravensbrück. Bd. 1. Teetz (1999). - Ders.: Die Nachkriegszeit 1945 bis 1948 in Zeitdokumenten. In: Ders. / Wolfgang Jacobeit: Fürstenberg/Havel, Ravensbrück. Bd. 2. Teetz 2004, S. 223-257.

\section{Alttucheband}

Landgemeinde, bis 1950 Kr. Lebus, 1950-1990 Kr. Seelow (ab 1952 Bez. Frankfurt/Oder), 1990-1993 Ldkr. Seelow, 1993 Ldkr. Märkisch-Oderland

EREIGNisse NACH KRIEgSEnde: „Nach dem Krieg hat die [evang.] Gemeinde Alttucheband mit Karl Liesert, einem Flüchtingspastor aus Schlesien, in dem wiederaufgebauten Pfarrhaus 
einen Kirchsaal eingerichtet.“ (Kirchen im Oderbruch, S. 72). - 1946 in der Bodenreform 87,7 ha von 652,2 ha an 39 Umsiedler vergeben (HOL VII, S. 430).

BevölKeRUnGSZAHLEN: 1925: 778, 1939: 744, 1946: 640, 1964: 851 (HOL VII, S. 431).

Katholiken (bis 1994 Erzbistum Breslau/Erzbischöfliches Amt Görlitz, dann Erzbistum Berlin): 1954 (mit Ortsteil Hackenow): 200 (Schematismus Görlitz 1954, S. 36).

LiterATUR: Kirchen im Oderbruch und ihre Schicksale seit dem Frühjahr 1945. Berlin 1992, S. 71-74.

\section{Alt Zeschdorf}

Landgemeinde (seit 1997 Ortsteil von Zeschdorf), bis 1950 Kr. Lebus, 1950-1990 Kr. Seelow (ab 1952 Bez. Frankfurt/Oder), 1990-1993 Ldkr. Seelow, 1993 Ldkr. Märkisch-Oderland

EREIGNISSE: „Auf dem Friedhof von Altzeschdorf fanden deutsche Soldaten und Flüchtlinge ihre letzte Ruhestätte." (Kirchen im Oderbruch, S. 49). - 1946 in der Bodenreform 2 ha von 1482,5 ha an 62 Umsiedler vergeben (HOL VII, S. 474), darunter „Antifa-Umsiedler“ aus Schlesien (Wille II, S. 334.

BevÖLKeRUngSZAhLEN: 1925: 192, 1939: 488, 1946: 684, 1964: 784 (HOL VII, S. 474).

GedRUCKTE QUELLEN UND Literatur: Kirchen im Oderbruch und ihre Schicksale seit dem Frühjahr 1945. Berlin 1992, S. 49. - Wille II, S. 334, 343.

\section{Amalienfelde $\rightarrow$ Kremmen (Umsiedlerlager)}

\section{Angermünde}

Stadtgemeinde (bis 1993 Kreissitz), bis 1952 Kr. Angermünde, 1952-1990 Kr. Angermünde (Bez. Frankfurt/Oder), 1990-1993 Ldkr. Angermünde, 1993 Ldkr. Uckermark

EREIGNISSE BIS KRIEGSENDE: Jan. 1945 Durchzug von Flüchtlingsströmen, „geschätzt täglich um vier- bis fünftausend“, die nur notdürftig versorgt werden können und nach Mecklenburg weitergeleitet werden (Kukla, Angermünde 1945, S. 38). - Jan. 1945 (Bericht der Stadtverwaltung vom Nov. oder Dez. 1945): „In der grimmigen Kälte des Januar zog ein $30 \mathrm{~km}$ langer Zug flüchtiger Landleute durch die vereisten Strassen. Auf der rasch zusammengeraffen Habe in offenen Leiterwagen saßen die flüchtigen Scharen mit erfrorenen Gliedern. Die abgetriebenen Pferde ruckten meterweis ihre schwere Last hinter sich her, bis eines oder das andere zusmmenbrach und gleich seinem Herrn am Strassenrand verendete." (Brandenburgische Gemeinden 1945, S. 3). - Im Jan. und Febr. 1945 finden sich im Sterberegister des Standesamtes Angermünde Flüchtlinge aus den Ostgebieten, insbesondere aus Westpreußen, ab Februar auch auch aus Ostpreußen, 
Oberschlesien, Posen und der Neumark, die meist im Kreiskrankenhaus sterben, teilweise aber noch zuvor auf der Bahnfahrt („zur Zeit auf Rückführungsfahrt“) von Christburg (Kr. Stuhm) nach Angermünde an Kreislaufschwäche und Erschöpfung sowie Kälteeinwirkung (so am 23. und 26.1.1945, Nr. 60/1945, 62/1945, 90/1945) oder auf dem Bahnhof Angermünde (so am 30.1.1945, Nr. 64/1945 u. a.). - 1.2.1945 Selbstmord eines aus dem Kr. Züllichau-Schwiebus gebürtigen Postassistenten „in Angermünde im Flüchtlingszug 6978“ (ebd., Nr. 81/1945) und Tod einer unbekannten Frau, „etwa 78 Jahre alt“ („Kreislaufschwäche, wahrscheinlich Erschöpfungszustand“) im „Flüchtlingszug Königsberg-Angermünde“ (ebd., Nr. 89/1945). - 10.2.1945 Tod eines Kindes im „Flüchtlingszug Stargard-Angermünde“ (ebd., Nr. 99/1945). - 24.2.1945 Tod eines Postschaffners im „Lazarettzug von Danzig nach Angermünde“ (ebd., Nr. 121/1945). 27.4.1945 Kampflose Einnahme der Stadt durch die Rote Armee (Kukla, Angermünde 1945, S. 39).

EREIGNisSe NACH KriegSende: Ende Mai 1945 Kreiskrankenhaus (rd. 200 Betten) von Roter Armee beschlagnahmt und ausgeräumt, provisorisches Ersatz-Krankenhaus mit 80 Betten in Schulgebäude eingerichtet, leidet aber unter Arznei- und Lebensmittelmangel (Kukla, Angermünde 1945, S. 42 f.). Ab Juni 1945 Sterbefälle von Flüchtlingen aus den Ostgebieten, bes. aus der Neumark (v. a. Kr. Königsberg/Nm.) und Pommern, im behelfsmäßigen „Kreiskrankenhaus (Oberschule)“ und im Städtischen Altersheim (Jägerstraße 1a) (ebd.). - 22.6.1945 (Tagebuch einer Flüchtlingsfrau aus Küstrin): „Überall russische Propaganda. Stalin in Überlebensgröße, Lenin u.a. [...].“ (Ammon, S. 44). - „Im Juli 1945 passierten ca. 30000 Flüchtlinge die Stadt, die zumeist aus der Neumark kamen. Die Unterbringung der Flüchtlinge hat umfangreiche Maßnahmen erfordert. Es mußten 4 Unterkünfte geschaffen werden, in denen zum Teil auch Verpflegung (Mittag und Abendessn) zur Abgabe gelangt. In den letzten 4 Tagen sind durchschnittlich 770 Flüchtlinge aufgenommen und zum größen Teil verpflegt worden." (Bürgermeister-Bericht vom 1.8.1945 nach Kukla, Angermünde 1945, S. 45). - „Im Monat Juli 1945 erhielten Flüchtlinge in Angermünde Unterkunft und Verpflegung: Mittagessen 14742. Unterkunft und Abendessen 13900 Zusammen 28642 Personen" (desgleichen vom 10.8.1945 nach Kukla, Angermünde 1945, S. 45). - 12.7., 25.8. und 18.11.1945 3 Todesfälle von Flüchtlingen/Vertriebenen aus Königsberg/Nm. in Angermünde (Krätzner, S. 23, 25, nach Angaben in der „Heimatkartei“). - 13.7.1945: „Auf dem Bahnhof 100 te von Menschen mit allen möglichen Fahrzeugen, und keiner weiß recht, wohin. Einige liegen schon 48 Stunden hier. [...] Um 11 Uhr fährt ein Zug durch, überfüllt. [...] Überall wird wieder auf 2 oder 3 Steinen Feuer gemacht und gekocht." (Tagebuch Prochnow [Treckführer aus Woldenberg/Nm.)], S. 294). - 14.7.1945 Tod eines aus Werblitz (Kr. Soldin/Neumark) gekommener Maurers, „wohnhaft in Werblitz, zur Zeit Bahnhof Angermünde“ an Erschöpfung (Sterberegister des Standesamtes Angermünde, Nr. 400/1945). - 19.7.1945 Tod eines 22-jährigen Bessarabiendeutschen im Kreiskrankenhaus (ebd., Nr.455). - 22.7.1945 Tod eines Säuglings aus Soldin auf dem Bahnhof Angermünde (ebd., Nr. 476). - Sommer 1945 wird erwähnt, dass der Angermünde evang. Propst Borrmann, „ein geborener Ostpreuße“, „sein Pfarrhaus $z$ u einer Herberge der vertriebenen Ostpfarrer gemacht hatte" (Dokumentation der Vertreibung 
I/2, S. 654). - „Im August sind an vier Tagen durchschnittlich 770 Flüchtlinge aufgenommen worden. Untergebracht sind sie unter anderem in der ,Herberge zur Heimat', im ,Schwarzen Adler', im ,Goldenen Lamm' und in der Berufsschule Jägerstraße." (Angermünde nach 1945: Der Neuanfang, www.angermuende.de/cms/upload/Stadtarchiv/Ausstellungen/Tafel11.pdf [16.8.2016], nach: Stadtarchiv Angermünde, Akte 2748, Verwaltungsberichte der Stadtverwaltung). - 10.9.1945 (Bürgermeister-Bericht): „Um die aus dem Osten eintreffenden Transporte verwundeter und kranker ehemaliger deutscher Soldaten unterbringen zu können, ist die Gehegemühle als Unterkunft eingerichtet worden." (Kukla, Angermünde 1945, S. 46). - 18.10.1945 (Bericht der Zentralverwaltung für das Gesundheitswesen): „Sehr viele Flüchtlinge sind in der Stadt und Umgebung untergebracht. Ein Flüchtlingsheim für 1000 Mann ist vorhanden, eine Seuchenstation im Gymnasium vorbereitet. Als Arzt für die Flüchtlinge ist ein Kollege eingesetzt, zwei Entlausungs-Stationen mit Heißluft sind vorhanden. [...] starke Typhusverbreitung [...]. (Wille I, S. 419). - „Im November 1945 wurden 6251 Einwohner registriert. Typhus- und Diphterie-Epidemien raffen viele Menschen dahin, allein in Angermünde starben zeitweise täglich bis zu 25 Personen.“ (Angermünde nach 1945: Der Neuanfang, www.angermuende.de/cms/upload/Stadtarchiv/ Ausstel lungen/Tafel11.pdf [16.8.2016]). - 17.11.1945 860 Umsiedler („in der Umgebung von Schwedt a. Oder durchgesickert") in Angermünde gesammelt und nach Schwerin weitergeleitet (Wille I, S. 375). - 2.12.1945 (telefonische Meldung aus Angermünde an ZVU), „dass festgesetzte Flüchtlingsströme durchschnittlich 1500 pro Tag aus Scheune b. Stettin von den Polen nach Angermünde gesandt werden. Diese Menschen kommen in einem unglaublichen Zustand an. Vollkommen verdreckt, verlaust, zerschlagen, vollkommen ausgeplündert, der grösste Teil ohne Handgepäck und ohne Verpflegung, halb verhungert in Angermünde an. [...] Es bestehen keine Unterbringungsmöglichkeiten mehr in Angermünde, da alle zur Verfügung stehenden Räume, wie Schulen, Gastwirtschaften und sonstige Gebäude überbelegt sind. Verpflegungsschwierigkeiten bestehen, [...]. Für Angermünde besteht dadurch grösste Seuchengefahr. Eine Abänderung dieser Zustände war bisher nicht möglich, auch nicht durch Eingreifen des russ. Kommandanten. Es herrscht grosses Massensterben täglich. Zur Zeit des Anrufes wieder 20 Tote. Im Augenblick über 6000 Umsiedler in Angermünde." (BArch, DO 2/38, Bl. 14; vgl. unten Quellenteil, Nr. 15; auszugsweise nach anderer Akte: Wille I, S. 319). - 12.12.1945: ca. 10000 Einwohner. „An die 4000 Fremde haben sich neu angesiedelt" (Brandenburgische Gemeinden 1945, S. 4). - Zahlreiche Flüchtlinge, vorwiegend aus Ostpreußen, daneben aus Westpreußen und Danzig sowie aus Hinterpommern und anderen Regionen stammend, versterben 1946 in Angermünde im Kreiskrankenhaus, im Umsiedlerlager „Kaisergarten" (erwähnt 1./2.1.1946, Stadtarchiv Angermünde, Standesamt Angermünde, Sterberegister, Nr. 7/1946, 9/1946 usw.) und im (damit identischen?) Flüchtlingslager (erwähnt 1./2.1.1946, Nr. 3/1946, 13/1946 usw.) sowie in den Notunterkünften Gymnasium (erwähnt 1./3.1.1946, Nr.8/1946, 10/1946 usw.), Knabenschule (erwähnt 5.1., Nr. 24/1946 usw.), Schützenhaus (erwähnt 10.1., Nr. 62/1946) und Waisenhaus (erwähnt 12.1., Nr. 67/1946), aber auch zuvor an Erschöpfung oder Herzschwäche auf dem Bahnhof (5./9.1., Nr. 101, 102) noch im Zug (3.1., Nr. 71/1946) oder im Wartesaal (17.1., Nr. 91/1946). - 26.1.1946 Bericht 
der ZVU (Born) über Kontrollfahrt nach Angermünde vom 26.1.1946 (Auszug): „In Angermünde fanden wir ca. 1000 Umsiedler, alle aus Danzig über Scheune kommend, neuangekommen vor. Die Umsiedler mussten ca. 2 Std. auf der Strasse herumliegen, da der Tanzssal und die Kegelbahn von den am Tage zuvor Angekommenen freigemacht werden musste. Die am Tage zuvor Angekommenen wurden in provisorisch hergerichteten Ställen in der gleichen Strasse untergebracht. Räume, die vollkommen unzureichend waren, sodass wir die Umsiedler im wahrsten Sinne des Wortes hineinpferchen mussten. Die neuangekommenen elternlosen Kinder sonderte ich sofort ab und brachte sie in das Lokal ,Schwarzer Adler. / Der Umsiedlerleiter [...] sowie der Lagerleiter, waren nicht in der Lage Herr über die 1000 neuangekommenen Umsiedler zu werden. Erst durch unser Eingreifen wurde hier Ordnung geschaffen. da die Angestellten des Umsiedleramtes schon am Nachmittag um 2 Uhr Feierabend machten, konnte keine Verpflegung für die durchgefrorenen, verhungerten und seit dem 22.1.46 auf der Bahn liegenden Umsiedler ausgegeben werden. Ich ging daraufhin zum Bürgermeister der Stadt und bat diesen, mit mir ins Lager zu kommen, um sich die katastrophale Lage anzusehen, was dieser wegen angeblicher Arbeitsüberlastung ablehnte. Auch der Landrat war aus dienstlichen Gründen ortsabwesend." (BArch, DO 2/38, Bl. 11). - Jan./Febr. 1946 Vertriebenentransport aus Hinterpommern wird auf „großem freien Platz“ begrüßt (Sonnemann, S. 28). - In der Bodenreform 321 ha (von 796 ha) an 29 Umsiedler vergeben (HOL VIII, S. 24). - 1954 Verleihung der Ehrenbürgerschaft an den seit 1950 in Bad Doberan (Mecklenburg) lebenden, in Briesenbrow (seit 2003 Ortsteil von Angermünde) geborenen, 1945 aus Neuenkirchen bei Stettin (Wohnsitz ab 1940) vertriebenen und im Juli 1945 zunächst nach Ueckermünde gelangten, 1946-1950 in Schwerin ansässigen Schriftsteller Ehm Welk (1884-1966) (www.museumangermünde.de [9.9.2018]).

BevöLKerungszAhlen: 1925: 8666, 1939: 9476, 1946: 10318, 1964: 12308 (Städtebuch, S. 5). - 25.9.1945: 8382 (Kukla, Angermünde 1945, S. 46). - Ende 1945: „An die 4000 Fremde haben sich neu angesiedelt und der wirtschaftliche Aufbau schreitet vorwärts. Etwa die gleiche Anzahl der früheren Einwohner ist noch flüchtig oder verdorben, gestorben." (Dahl, S. 156).

Katholiken: 1925: 375 (Städtebuch, S. 6). - 14.7.1945 (Fluchttagebuch einer kath. Schlesierin): „In Angermünde schien es zuerst sehr schlecht [S. 20] mit Quartier zu werden. Ich ging dann fragen ins kath. Pfarrhaus u. hörte zu meiner großen Freude, daß der Pfarrer Ritter aus Liegnitz war. Er nahm uns demzufolge herzlich auf $u$. wir mußten viel von Liegnitz erzählen." (MOB, AGoFFArchiv, B 42-00016, S. 19f.).

Herberge zur Heimat: 19./20./21./22./24./25./27./29./31.7. und 1./2./3./4./5./8./ 9.8.1945 Todesfälle von meist älteren Flüchtlingen aus Neumark, Pommern und OstpreuBen in der „Herberge zur Heimat“, Todesursache meist Darmkatarrh und Herzschwäche, auch Entkräftung (Jg. 1945, Nr. 447, 452, 453, 457, 461, 466, 467, 474, 477, 478, 486, 500, 501, $509,521,532,542,553,554,555,567,568,569,586,587,593,594)$, ferner ebd. 22.7.1945 Tod eines 2-jährigen Waisenkindes aus Hinterpommern an „Ernährungsstörung“ (Nr. 471) 
und Selbstmord eines Rentner-Ehepaares (er aus Schneidemühl gebürtig) durch Erhängen (Nr. 472/473).

FlüChtlings-/UmSiedlerlager Kaisergarten: Ehem. Hotel „Kaisergarten“ (Schwedter Straße/Straße der Freundschaft, am Schwedter Tor; bis 1945 große, beliebte Gaststätte mit Gartenlokal und diversen Anbauten, seit 1912 auch mit Lichtspieltheater „Union-Lichtspiele“). 29.6.1945 erster Todesfall eines in „Kaisergarten Gaststätten“ wohnhaften (neumärkischen) Flüchtlings (Reg.-Nr. 343), 4.7.1945 Tod einer unbekannten männlichen Person („Wohnort unbekannt") in „Kaisergarten Gaststätten“ (Reg.-Nr. 352), weitere Todesfälle, meist Neumärker und Pommern, ebd. 18./20.7., 3./7.8.1945 (Jg. 1945, Nr. 449, 460, 575, 581). - Ende Dez. 1945 (Bericht der ZVU): „Der Zustand des Lagers selbst (Kaisergarten und Schützenhaus) läßt sehr zu wünschen übrig, da die Umsiedler infolge Fehlens von Blockleitern und Polizeikräften sehr undiszipliniert sind. [...]." Bisheriger Wirtschafts- und Lagerverwalter Herr Przylucki am 31.12.1945 ausgeschieden. Neu: Lagerleiter: Herr Hoffmann [... . „Am 30.12.45 befanden sich 703 Umsiedler im Lager. Der tägliche Zugang schwankte in den letzten Tagen zwischen 200-400 Personen. [...] Die Weiterleitung der in den Lagern Angermünde und Schwedt befindlichen restlichen Umsiedler wird Anfang Januar 1946 vor sich gehen." (BArch, DO 2/38, B1. 1). - Kapazität am 31.12.1945 (Lager „Angermünde-Kaisergarten“): 1500 (BArch, DO 2/45, Bl. 40). - Kapazität am 1.1.1946: 1500 (BLHA, Rep. 203 MdI, Nr. 1163, Bl. 50). - 1946 Belegungsstärke: 1500 (Kaminsky, S. 159). Lagerarzt im Jan. 1946 Dr. Bahr (er zeigt in der Regel die Sterbefälle des Lagers beim Standesamt an). - 26.1.1946 Kontrolle des Lagers durch ZVU (Born) ergibt „katastrophale Lage“ infolge Überlastung durch laufend neu ankommende Transporte, aber auch Missmanagement (Bericht: BArch, DO 2/38, Bl. 11, s. o.). - 24.8.1946 Umsiedlerlager Angermünde Stadt (zur Unterscheidung von $\rightarrow$ Pinnow, Kr. Angermünde], Kapazität: 1000 (SAPMO-BArch, DY 34/27880, Bl. 291). - 1.1.1947 Lager, Kapazität: 800 (Oehlsen, S. 101). - 30.1.1946 (Bericht der Zentralverwaltung für Umsiedler): „[... L Lager in Angermünde, für das uns Potsdam eine mögliche Aufnahmefähigkeit von 1500 Personen nannte. Wir haben festgestellt, dass dieses Lager unter den heutigen Verhältnissen nicht einmal in der Lage wäre, auch nur 200 Personen menschenwürdig zu beherbergen. Die Verhältnisse dort waren in jeder Beziehung katastrophal (...) Potsdam ist zu wiederholten Malen auf diese Mängel hingewiesen worden, ohne dass Abhilfe geschaffen wurde. [...].“ (Kotsch, S. 132). - 24.4.1947: 1t. Monatbericht der Umsiedlerabt. des Landratsamtes steht die Eröffnung eines von einem Vertriebenen gegründeten Kleinindustriebetriebs für „Kinderspielpuppen [...], Geschenkartikel und Spielwaren aller Art“ bevor. „Beschäftigt werden in diesem Betrieb bei Eröffnung nur Umsiedler und Schwerkriegsbeschädigte. Eröffnet wird der Betrieb in den ehemaligen [!] Räumen des Umsiedlerlagers Angermünde, mit einer Belegschaftsstärke von 100 Personen wird gerechnet." (Wille II, S. 376). - 1947 Schließung bevorstehend (SAPMO-BArch, DY 34/27745, Bl. 92). - Entwicklung nach Schließung des Lagers: Zunächst „Volkshaus“, darin bis 1948 auch die Büroräume des FDGB-Kreisvorstandes, 1952 die Gesamtanlage der FDJ zur Nutzung als „Haus der Jugend“ übergeben“, Rechtsträger ist nun der Rat der Stadt, ab 1963 der Rat des Kreises, zugleich Umbenennung in „Kreiskulturhaus“, 1965 Restaurierung, 1970 
Rückgabe an den Rat der Stadt, anschließend Renovierung und Umgestaltung der Innenräume (Kukla, Unser Kreiskulturhaus, S. 43).

StÄDtepartnerschaften: 1972 Strzelce Krajeńskie, Polen (Friedeberg/Nm., ehem. Kreisstadt in der Provinz Brandenburg, 1938-1945 Provinz Pommern), 1990 bestätigt (http:// www.angermuende.de [31.8.2016]). - [1945 flüchtete der zuvor in Friedeberg/Nm. tätige Gymnasialprofessor Dr. Paul Müller (1878-1957) nach Angermünde, wo er (bis zu seinem Tod) erster Museumspfleger wurde (heimatverein-ang.de [30.10.2018]); Weiß, S. 115.]

VERTRIEBENENVERBÄNDE NACH 1990: BdV-Kreisverband Angermünde/Schwedt, erwähnt 1994; Vorsitzender bis 1994: Siegfried Gabriel (gest. 7.8.1994), dann 1994 zunächst als amtierender Vorsitzender Ernst Eschler, Passow, durch Bildung des Großkreises Uckermark aber im BdVKreisverband Uckermark ( $\rightarrow$ Prenzlau) aufgegangen (Akten der BdV-Landesgeschäftsstelle),

Archivalische Quellen: BArch, DO 2 ZVU, Nr. 38, Bl. 1-30 (Lager, Ende Dez. 1945-30.3.1946). - BArch, DO 2/39, Bl. 44, 52, 59 (Lager, 1945). - BLHA, Rep. 250 Landratsamt Angermünde, Nr. 520 (Gehaltslisten des Lagers Angermünde, 1946). - Martin-Opitz-Bibliothek (MOB) Herne, AGoFF-Archiv, B 42-00016 (Fluchttagebuch). Stadtarchiv Angermünde, Standesamtsregister 1945-1946 (ancestry.de).

Gedruckte Quellen: Ammon, Margarete: Tagebuch. In: Gespräche mit ehemaligen Küstrinern. Bd. 6. Frankfurt (Oder) 2017, S. 29-50. - Brandenburgische Gemeinden 1945, S. 3-5. - Dahl, Erich: Der Stadtkreis Angermünde nach dem Zusammenbruch des „Tausendjährigen Reiches“. In: Heimatkalender für den Kreis Angermünde 1960, S. 155-156 [Niederschrift Ende 1945]. - Dokumentation der Vertreibung I/2, S. 654, 747, 752. - Sonnemann, Lothar: Bittere Medizin. Jacobsdorf 2002. - Tagebuch Ernst Prochnow [Auszüge]. In: „Die Russen sind da“. Peter Böthig u. Peter Walther (Hg). Berlin 2011, S. 294. - Wille I, S. 319, 419f., 456; II, S. 191, 363.

LiterAtUR: Baas, Friedrich-Karl: Angermünde und sein Krankenhaus im Herbst 1945 aus der Sicht eines Durchreisenden. In: Angermünder Heimatkalender 2016 (2015), S. 179-189. - Discher, Holm: Karl Voigt und Ernst Lösche Ein Porträt der ersten Angermünder Landräte der Nachkriegszeit. In: Angermünder Heimatkalender 2016 (2015), S. 192-201. - Krätzner, S. 23, 25. - Kukla, [Dietrich]: Unser Kreiskulturhaus. In: Heimatkalender Kreis Angermünde 1988, S. 40-43. - Kukla, Dietrich: Angermünde 1945. In: Angermünder Heimatkalender 1995, S. $38-49$ [Betr. Zeitraum Febr. bis Dez. 1945, nach Erlebnisberichten von Zeitzeugen und den Berichten der Stadtverwaltung an die sowjetische Kommandantur vom 29.5. bis 27.12.1945]. - Otto, Gerhard: Deutsch-polnische Kontakte und Beziehungen entlang der Oder. In: Königsberger Kreiskalender 1996 (1995), S. 41-44 [Der aus Niederkränig (Kr. Königsberg/ Nm.) stammende Verf. lebte nach 1945 in Angermünde]. - Sperling, Margret: Zeitzeugenarbeit im Stadtarchiv Angermünde. In: Angermünder Heimatkalender 2001, S. 168-170. - Stechow, Bernhard: Der Angermünder Seniorenbeirat. In: ebd. 2001, S. 191-193. - Tuchscherer, Steffen: Vom Hitlerjungen zum FDJ-Funktionär. Geschichte der Nachkriegsjugend in Angermünde. In: Angermünder Heimatkalender 2016 (2015), S. 203-111. - Weiß, W[alter]: Prof. Dr. Paul Müller. In: Heimatkalender für den Kreis Angermünde 1960, S. 114-117.

\section{Aurith}

Landgemeinde-Teil (seit 1945 zwischen Deutschland und Polen geteilt, seit 1950 Ortsteil von $\rightarrow$ Ziltendorf), bis 1946 (Rest-)Kr. Weststernberg, 1946-1952 Kr. Guben, 1952-1990 Kr. Fürstenberg/Oder bzw. (ab 1961) Kr. Eisenhüttenstadt-Land (Bez. Frankfurt/Oder), 19901993 Ldkr. Eisenhüttenstadt, 1993 Ldkr. Oder-Spree 
EREIGNISSE NACH KRIEGSENDE: [Erinnerung des vertriebenen Schlesiers Karl Starkbauer, Aurith:] „Wir kamen aus Kreu[t]z im Kreis Grünberg, wir nannten es das ,schlesische Himmelreich'. Das ganze Dorf war gemeinsam auf die Flucht gegangen. Man hatte uns im benachbarten $[\rightarrow]$ Ziltendorf einquartiert, weil Aurith ja kaputt war. / Im Herbst' 45 haben wir zum ersten Mal unser neues Land gesehen. Es stand beinhoch voller Disteln und zwischen dem Gestrüpp lagen tote Soldaten. Die Schützengräben hatten sie schon zugeschüttet, aber die Jungs hatten sie liegen gelassen. / [S. 30] Später, als wir unsere Felder bestellten, gerieten sie uns unter den Pflug, denn im hohen Unkraut sahen wir sie nicht. Wir gruben dann mit der Schippe ein Loch und beerdigten sie, damit sie nicht noch einmal in die Maschine kamen. Hier liegen zig Soldaten, keiner weiß, wer sie sind und keiner hat sie gezählt. / Im März' 46 wurde in Aurith das Land zugeteilt und wir zimmerten uns eine Hütte aus Brettern. Den Schornstein bauten wir aus Granathülsen, die draußen herumlagen. Als es kälter wurde, froren wir, da mauerten wir noch eine Schicht Schutt um das Holz und wickelten Quecken drumherum, zum Dämmen. /Vier jahre lang haben wir in der Erdhütte gewohnt. Im Winter'46/47 sanken die Temperaturen auf 25 Grad unter Null. Da froren wir wie die Hunde, doch in diesem Winter damals war die Kälte unser Glück. Denn die Oder hatte so hoch Wasser, das es bis zur Deichkrone stand. Man hätte sich auf den Deich legen und abtrinken können. [...]/ [S. 31] [...] Mit dem Neubauernprogramm haben wir angefangen unser eigenes Haus zu bauen. Wir waren heilfroh - endlich ein richtiges Dach über dem Kopf! Wie wir so bauten, hörten wir immer wieder, wie es drüben am anderen [polnischen] Ufer krachte und polterte. Da kollerten Steine und fielen Häuser in sich zusammen - die rissen da große, gute Häuser ab. Man sagte, dass sie die Steine direkt nach Warschau gefahren haben. Mit der Bahn. Und mit dem Schiff. Zum Wiederaufbau, denn unsere hatten Warschau ja kaputtgemacht." (Aurith - Urad, S. 29-31). - Ein Flüchtling aus dem unmittelbar gegenüber gelegenen Hauptteil von Aurith, den er am 1.2.1945 hatte verlassen müssen, kam drei Jahre später in den westlichen Teil: „Ein bisschen fremd fühlte sich Wilhelm Genz, als er 1948 nach Aurith kam. Überall waren Schlesier. Nur er kam aus Aurith - Genz stammte vom anderen Oderufer." (Ebd., S. 34). - 3.10.1950 Zuweisung von westlich der Oder gelegenen Flächen der nun polnischen Gemeinde Aurith/Urad (ehem. Kr. Weststernberg) an die Gemeinde $\rightarrow$ Ziltendorf (Blöß, Kreise und Gemeinden, S. 31), nun deren Ortsteil Aurith.

EREIGNISSE NACH 1990: 1.5.2004 Einrichtung eines vorübergehenden Fährverkehrs zwischen dem deutschen Aurith und dem polnischen Urad am Tag des polnischen EU-Beitritts, Begegnungen der Bewohner und Durchführung eines dem gegenseitigen Kennenlernen dienenden Kunstprojekts „Wandzeitung/Gazeta ścienna“ (Rada, S. 116).

Literatur: Aurith - Urad. Zwei Dörfer an der Oder - dwie wioski nad Odra. 2., korr. Aufl. Potsdam 2009. - Fromm, Günter: Bodenreform 1945/46 in Ziltendorf - Ortsteile Thälmannsiedlung und Aurith. In: Heimatkalender Eisenhüttenstadt und Umgebung 15 (1997), S. 80-86. - Rada, Uwe: Labor. Der Grenzraum als Chance. In: Das Brandenbuch. Potsdam 2015, S. 115-118. 


\section{Bad Belzig $\rightarrow$ Belzig}

\section{Bad Freienwalde}

Stadtgemeinde (bis 1993 Kreissitz), bis 1952 Kr. Oberbarnim, 1952-1990 Kr. Bad Freienwalde (Bez. Frankfurt/Oder), 1990-1993 Ldkr. Bad Freienwalde, 1993 Ldkr. Märkisch-Oderland

EReignisse bis Kriegsende: Febr. 1945: Bad Freienwalde wird als Zwischenstation (wohl Durchschleusungspunkt) für die in den Kreis Westprignitz zu evakuierende Bevölkerung der Kreise Samter und Birnbaum (Wartheland) bestimmt (BLHA, Rep. 6 B Kreisverwaltung Züllichau-Schwiebus, Nr. 169, unfol.). - „Auf höhere Anordnung begann am 8. Februar die Evakuierung einer 15-km-Zone westlich der Oder, in der auch Bad Freienwalde lag. Sonderzüge schafften zunächst Frauen und Kinder aus der Stadt [...]. Der Flüchtlingsanteil unter der städtischen Bevölkerung wuchs ständig an. Allerdings zogen die vor der heranrückenden Front fliehenden Menschen aus dem Osten zumeist gleich weiter gen Westen. Als Ende März die Festung Küstrin gefallen war, wurde die endgültige Räumung der 15-km-Zone westlich der Oder befohlen." (Schmook, 700 Jahre, S. 86, ebd. auch Abb. des Räumungsbefehls [Aushangs] vom 26.3.1945). - April 1945 unmittelbar im Kampfgebiet gelegen. 20.4.1945 morgens Abzug der deutschen Truppen in Richtung Eberswalde. „Zwischen das zurückgehende Militär mischten sich Flüchtlingstrecks, die in gleicher Richtung auf der Flucht waren.“ Im Tagesverlauf Einmarsch der Roten Armee (ebd., S. 87 f., Zitat, S. 88).

EReignisse NACH KrIEgSEnde: Seit 1945 in unmittelbarer Grenzlage an der Oder. - „In Bad Freienwalde grassierte der Typhus und wochenlang kamen Tausende von Heimatvertriebenen aus der Neumark [in] die Stadt, die man notdürftig versorgte, bevor sie weiterzogen. Viele von ihnen starben an Entkräftung und Krankheiten und wurden ohne Sarg in dem Teil des Friedhofes beerdigt, der dem Parkplatz gegenüberliegt. Nach und nach kamen auch die Einwohner zurück.“ (Schmook, 700 Jahre, S. 89). - „Nach dem Kriegsende 1945 gab es wieder große Veränderungen. [...] [In der Oberschule] waren viele Flüchtlinge aus Schlesien, Ostpreußen und Pommern hinzugekommen." (Stellmacher, Kindheit, S. 77). - April bis Sept. 194515 nachgewiesene Todesfälle von Flüchtlingen/Vertriebenen aus Königsberg/Nm. in Bad Freienwalde: April (o.D., „an den Folgen und Leiden der Flucht“), Juli (2 Fälle, o. D.), 20.7., 25.7. („in einer Flüchtlingsbaracke"), Aug. (o.D. [oder Aug. 1946]), 6.8. (2 Fälle, davon einer „im Flüchtlingslager"), 25.8. ( „an Mißhandlungen in Bad Freienwalde verstorben“), 8.9. („im Flüchtlingslager“), 9.9., 17.9. („im Flüchtlingslager“), 21.9. („im Flüchtlingslager“) und 2 Fälle 1945 o.D. (Krätzner, S. 21, 23-27, nach Angaben in der „Heimatkartei“). - „Die Kriegsfolgen machten die Einrichtung einer Station für Typhuskranke notwendig. Diese gab es dann im Gebäude der heutigen Stadtverwaltung." (Wolff, S. 111). - 18.1.1946: „kein einziges Fieberthermometer im Infektionskrankenhaus, keine Entlausungsstation, kein Feuerungsmaterial" (Wille I, S. 423). - 1946: in der Bodenreform 99 ha (von 345 ha) an 18 Umsiedler vergeben (HOL VI, S. 160). - Der aus Ostpreußen vertriebene 
Fritz Zastrow erwirbt nach 1945 eine Hälfte des Hauses Gesundbrunnenstraße 1, in der er „für die Dauer von vier bis fünf Jahren eine Hotel-Pension betrieb, bevor er in den Westen ging " (R. Schmook in MOZ, 30.1.2014). - 25.3. bis April 1947 Überschwemmung aller unteren Stadtviertel einschl. des Bahnhofs beim Oderhochwasser (Schmook, 700 Jahre, S. 90 f.). - 1952 Gründung des „VEB (Z) Wasserwirtschaft Oder-Neiße“ anstelle des aufgelösten „Deichverbands Oderbruch“ (Seidel, S. 82), später VEB Gewässerunterhaltung und Meliorationsbau in Bad Freienwalde. - 1960-1963 leitet der aus Königsberg/Nm. vertriebene, zunächst 1945-1960 in $\rightarrow$ Falkenberg/Mark tätige Apotheker Bernhard Thieme (1896-1979) die Staatliche „Alte Apotheke“ (Biela, S. 29).

EREIGNISSE NACH 1990: „1991/92 diente das Haus [ehemaliges Krankenhausgebäude, Berliner Straße/Ecke August-Heese-Straße] vor allem Rußlandumsiedlern als erste Unterkunft; 1993/94 leerstehend.“ (Künkel, S. 78). - 1993 Treffen des Heimatkreises Königsberg/Nm. (Märkischer Informationsdienst 1993, Nr. 7/8, S. 7 f.), verbunden mit Gedenksteineinweihung im benachbarten $\rightarrow$ Hohenwutzen.

Bevölkerungszahlen: 1925: 10727, 1939: 12 376, 1946: $10667,1964: 11816$ (Städtebuch, S. 11). - 12.4.1946: 10250, davon „etwa 1500 Flüchtlinge“ (Bericht der Stadtverwaltung, zit. nach Schmook, 700 Jahre, S. 89).

KATHOLIKEN: 1925: 432, 1946: 697 (Städtebuch, S. 11).

Umsiedlerlager Bad Freienwalde (Auffanglager), Bromberger Straße (heute Beethovenstraße), massiv gebaute Barackensiedlung im Bereich des heutigen Schwimmbad-Standortes, nach 1918 für Flüchtlinge aus den Provinzen Posen und Westpreußen genutzt (Auskunft Schmook): Aug./Sept. 19454 Todesfälle von Flüchtlingen aus Königsberg/Nm. im „Flüchtlingslager Bad Freienwalde“ (Krätzner, S. 21, 23 f., 27; vgl. oben). - 13.10.1945 „Durchgangslager Bad Freienwalde (Oder)“: Lagerleiter: Otto Lade. Kapazität: 2650 Personen; Unterbringungsmöglichkeiten: a) 2 Baracken auf dem Gelände der Schamottefabrik 150 Pers[onen]/b) 2 massive Gebäude Oberkietzmühle 300 Pers. /c) 2 Baracken auf dem Tennisplatz (Brunnenhotel) 150 Pers. /d) 1 Landhaus (Brunnenhotel) 300 Pers./d) 1 Landbundhaus 200 Pers./f) ehemaliges Kreis-Altersheim Wilhelmstraße 50 Pers. /g) Landwirtschaftsschule Wilhelmstraße 1200 Pers. /h) Benekendorf'sche Ziegelei Eberswalder Straße 600 Pers. /i) 3 Baracken beim Städtischen Krankenhaus Berliner Straße 100 Pers./j) Seifert'sche Werkhallen Neukietz 400 Pers." (BArch, DO 2/39, B1. 13); noch im selben Bericht: „Nachtrag: / Inzwischen wird bekannt, daß die für Freienwalde (Oder) gemeldeten Unterbringungshäuser/Landhaus (Brunnenhotel) für 300 Pers./Seifert'sche Werkhalle Neukietz für 200 Pers. / von den Russen beschlagnahmt und belegt worden sind." (ebd., B1. 15). - Dez. 1945 findet im Lager eine Seuchen- u. Hygiene-Inspektion durch die Hauptabt. Sanitätswesen der Deutschen Zentralverwaltung für Gesundheit statt (Wille I, S. 423). - Kapazität am 31.12.1945: 1300 (BArch, DO 2/45, Bl. 40). - Kapazität am 1.1.1946: 1300 (BLHA, Rep. 203 MdI, Nr. 1163, Bl. 50). - 18.1.1946 (in Freienwalde u. Wriezen): „Hygienische Ver- 
hältnisse gänzlich unzulänglich [...]. Einfache Strohschütten, keine Decken, keine Bettwäsche, keine Waschschüsseln, keine Seife. Ernährung ebenfalls unzureichend, Abortanlagen unzulänglich [...]." (Wille I, S. 423). - 1946 Belegungsstärke: 800 (Kaminsky, S. 159). - In den frühen Nachkriegsjahren gehört zu den in Bad Freienwalde tätigen Ärzten „z. B. Herr Dr. Blieske, der als Flüchtling aus Schlesien hierher in das Lager für Vertriebene kam und dort die Patienten versorgte. Er richtete dann später in unserer Stadt eine Praxis ein." (Wolff, S. 111) [Gottfried Blieske war 1937 Arzt in Jordansmühl, Kr. Reichenbach (Eulengebirge) (Reichs-Medizinal-Kalender 35 (1937), T. II, S. 253)]. - Baracken 1950/60er Jahre abgerissen (Auskunft Schmook).

Rettungshaus Coethenerheim (heute Waldhaus der Stephanus-Stiftung), Frankfurter Straße 73/74: Die hier untergebrachte Knabenerziehungsanstalt war 1942 nach $\rightarrow$ Brüssow (Uckermark) verlegt worden und gleichzeitig das Brüssower Kinderheim für nervenkranke Kleinkinder in das Freienwalder Coethenerheim, dem man hier eine Abteilung für Säuglinge angegliederte. „Nach Kriegsende änderte sich die Aufgabenstellung für das Heim erneut. Zu den 70 behinderten Kindern kamen im Hause unzählige elternlose Flüchtlingskinder unter. Beinahe täglich wurden Findelkinder ins Haus getragen oder einfach vor die Tür gelegt. Nun mussten jeden Tag 100 bis 150 Kinder zusätzlich versorgt werden [...]. Jeweils drei Kinder mussten sich ein Bett teilen. 20 Mitarbeiter mühten sich, die [S. 96] Eltern von 170 bis 230 Kindern zu ersetzen. In jenen Jahren versah die damalige Leiterin Gabriele Kirchner voller Zuversicht ihren Dienst. [...]. Die folgenden Jahre waren durch ständige Überbelegung geprägt, Alles war nur unzureichend vorhanden. Schulfähige und geistig behinderte Kinder lebten zusammen. [...] Im Laufe der Jahre wuchs das Coethenerheim hinüber in das ,Spezialkinderheim Waldhaus', das einige Zeit unter der Verantwortung des evangelischen Jugend- und Fürsorgewerkes stand. Der Betreuungsschwerpunkt verlagerte sich auf mehrfach schwerst behinderte Kinder." (Schmook, Waldhaus, S. 95 f.). - „Nach 1945 wurden verwaiste und verlorengegangene Kinder von Flüchtlingen aus den Ostgebieten aufgenommen, oftmals vor die Tür gelegte Findelkinder. Das Heim war meist völlig überbelegt mit tageweise 220 Kindern bei 20 Mitarbeitern und einer Kapazität von 70 Kindern. In den 50er und 60er Jahren war die Tendenz rückläufig. Von 1962-1974 stand das Heim unter staatlicher Leitung. 1974 übernahm die Stephanus-Stiftung die Trägerschaft." (Künkel, S. 108).

Strassenumbenennungen: Anfang der fünfziger Jahre [vmtl. 1950] Bromberger Straße in Beethovenstraße und Posener Straße in Ernst-Thälmann-Straße (seit 1991 Waldstraße) (Künkel, S. $43 \mathrm{f}$.).

Städtepartnerschaften: 4.5.2001 Międzyrzecz, Polen (Meseritz, ehem. Provinz Posen, 1938-1945 Provinz Brandenburg).

Vertriebenenverbände NaCh 1990: BdV-Kreisverband Eberswalde, Freienwalde, Bernau e. $V$. (Sitz $\rightarrow$ Eberswalde). 
Stiftung Heimatkreisarchiv Königsberg/Neumark (im Oderlandmuseum, Uchtenhagenstraße 2): Die bis dahin in Braunschweig, der Patenstadt des ehem. Kreises Königsberg/ Nm., untergebrachten Sammlungen (Archivalien u. Bücher) wurden 2003 nach Bad Freienwalde überführt und im Okt. 2003 die vom Innenministerium des Landes Brandenburg genehmigte Stiftung gegründet. „Schon im Sommer 2002 bemühte sich der Bürgermeister der Stadt Bad Freien- [S. 19] walde, Ralf Lehmann, um den Verbleib des Archivs in der Stadt. So beschloß dann die Stadtverordnetenversammlung am 12. Februar 2003 einstimmig, das Archiv im Oderlandmuseum unterzubringen. Die vorgesehenen Räume wurden im Sommer 2004 frei, und nach Überführung des Bildarchivs wurde am 10. September 2004 in einer Festveranstaltung die offizielle Eröffnung von der Stiftung bekannt gegegeben." (Bluhm, S. 18 f.). - Nach Trägerwechsel des Oderlandmuseums auf die Albert-Heyde-Stiftung 2017 Auszug des Heimatkreisarchivs an anderen Standort in der Stadt (Ritter).

Archivalische Quellen und Auskünfte: BArch, DO 2 ZVU, Nr. 39, Bl. 4, 11, 13, 15, 56-57 (Umsiedlerlager, 1945). - Auskünfte Christian Ritter (Berlin), Vorsitzender des „Heimatkreises Königsberg/Neumark e. V., 25.1.2017; Dr. Reinhard Schmook, Direktor des Oderlandmuseums Bad Freienwalde, 15.10.2016.

Gedruckte Quellen: Stellmacher, Gerda: Erlebnisse im Kriegs- und Nachkriegsjahr 1945. In: Bad Freienwalder Heimatkalender 56 (2012 [2011]), S. 63-65. - Dies.: Kindheit von 1932 bis 1945 in Bad Freienwalde. In: Bad Freienwalder Heimatkalender 58 (2014 [2013]), S. 72-80. - Wille I, S. 157, 260, 265, 305, 413, 423, 428, 431.

Literatur: Biela, Paul: Schicksale deutscher Apotheker aus Ostbrandenburg am Ende des Zweiten Weltkrieges. Frankfurt (Oder) 2017. - Bluhm, Hans-Gottfried: Heimatkreisarchiv jetzt im Oderlandmuseum Bad Freienwalde. In: Königsberger Kreiskalender 2005, S. 18-20. - Duncklau, Heinz: Bad Freienwalde in den 50er Jahren. In: Viadrus 6 (2014), S. 118-120 [Verf. geb. in Küstrin]. - Heimatkreisarchiv/Königsberg/Nm. In: http://stiftungsarchive. de/archive/1400 [26.1.2017]. - Krätzner. - Künkel, Ullrich: Bad Freienwalder Lexikon. 1. Ausg. [Rinteln] 1994. Schmook, Reinhard: 150 Jahre Waldhaus in Bad Freienwalde. In: Bad Freienwalder Heimatkalender 51 (2007), S. 93-98. - Ders.: 700 Jahre Bad Freienwalde (Oder). Horb 2016. - Seidel: Der volkseigene Betrieb Wasserwirtschaft Oder-Neiße. In: Heimatkalender für den Kreis Bad Freienwalde 1 (1957), 79-82. - Wolff, Gerhard: Vom Hospital zum modernen Krankenhaus. In: Bad Freienwalder Heimatkalender 40 (1996), S. 109-112.

\section{Bad Saarow (-Pieskow)}

Landgemeinde, bis 1950 Kr. Beeskow-Storkow, 1950-1952 Kr. Fürstenwalde (Bezirk Frankfurt/Oder), 19590-1993 Fürstenwalde, Ldkr. 1993 Ldkr. Oder-Spree

EREIGNISSE BIS KRIEgSENDE: 26.1.1945: „Meldung des Bürgermeisters von Bad Saarow an den Landrat über ,Zahlen der aufgenommenen Flüchtlinge und Umquartierten aus feindbedrohtem Gebiet': ,1. Reichsdeutsche aus dem Grenzgebiet innerhalb des Reiches: 294 Personen, 2. Volkdeutsche a) aus dem Grenzgebiet innerhalb des Reiches: 13 Personen; 3. Fremdvölkische: 4 Esten, 3 Franzosen und evtl. andere." (Pfeiler, S. 88).

EREIGNiSSE NACH KRIEgSENDE: 1946 in der Bodenreform 16 ha (von 403 ha) im Ortsteil Silberberg an 16 Umsiedler vergeben (HOL IX, S. 225). 
Bevölkerungszahlen: 1925: 1249, 1939: 2467 (davon 2176 ständige Bevölkerung, 291 Militär bzw. Arbeitsdienst), 1946: 2697, 1964: 3330 (HOL IX, S. 226).

Katholiken: „Seit 1952 ist die Gemeinde seelsorglich selbständige Kuratie, zu dieser Zeit wurden fast 1000 Katholiken gezählt." (Brühe, S. 14). - Siehe auch unten Caritas-Kinderheim St. Antonius.

UMSIEDleRlager: Dez. 1945 Dauerlager für 3000 Personen und Quarantänelager für 2000 Personen in Saarow (ehem. Wehrmachtsbaracken) sowie weiteres Quarantänelager für 1600 Personen in Pieskow werden zur Aufnahme hergerichtet, „was in ca. 4 Wochen beendet sein wird“ (Bericht vom 11.12.1945, BLHA, Rep. 250 Beeskow-Storkow, Nr. 867, unfol.).

Caritas-Kinderheim St. Antonius (Kronprinzendamm [ca. 1947/48 umbenannt in KarlMarx-Damm] 59/61): 1923 gegründet, 1940 von NS-Organisationen beschlagnahmt, bei Kriegsende Wehrmachtslazarett, 1945 von der Roten Armee besetzt, Dez. 1945 wieder in den Besitz der Caritas gelangt (Kienitz, S. 121 f.). 1942-1956 wirkt hier als kath. Pfarrer Bernhard Michaltsek (Kapelle St. Antonius), der die kath. Hedwigschwestern bittet, die Leitung des Hauses zu übernehmen (28.1.1945 drei Schwestern eingetroffen; am „3. September verließ auch die Generaloberin Breslau und kam nach einem dreiwöchigen Lagerleben in Bad Saarow an " [Mengel, S. 164]). Nach 1945 Kinderheim mit Kindergarten und Krankenpflege (sowie Gästehaus der Hedwigschwestern), 1.5.1946 offiziell eröffnet (Mertens, S. 470); 1947: 5 Mitglieder, 1947: 17 Mitglieder, Träger: Hedwigschwestern (Mutterhaus Breslau bzw. dann Berlin-Nikolassee) (Schematismus Berlin 1947, S. 69, 102; 1949, S. 65, 95). - „Das Caritasheim diente als Auffangstation für Schwestern und Kinder, die aus Schlesien vertrieben waren. Am 30. März 1946 kam Mater Immaculata Biernoth mit einer weiteren Schwester und einigen Kindern aus Briesnitz (Brzeżnica) nach Bad Saarow und übernahm das Amt der Hausoberin [bis Aug. 1952]. Aus Glogau (Głogów) kam im Mai 1946 eine Gruppe von Schwestern und Kindern, die zwischenzeitlich in $[\rightarrow]$ Wandlitzsee gewesen war. Am 15. Dezember 1946 traf eine weitere Gruppe von 25 Kindern aus Briesnitz in Bad Saarow ein. [... .." (Mertens, S. 470; vgl. Mengel, S. 166, 171); in Briesnitz (Kr. Frankenstein, Niederschlesien) befanden sich seit Sommer 1944 auch zahlreiche aus Breslau evakuierte Kinder, seit Jan. 1945 weitere aus Breslau u. aus Peterswaldau (Mertens, S. 83). - „Nach umfangreichen Aufräumungsarbeiten wurden im April 1946 die ersten Flüchtlingskinder aus Ostpreußen und Schlesien aufgenommen. Sie halfen im Hausgarten, um Gemüse für die Zusatzversorgung zu produzieren." (Kienitz, S. 122). - [Ende 1946 betreuten die Schwestern] „im Caritasheim 125 Kinder und zwölf Erwachsene. Der Konvent umfaßte fünfzehn Schwestern. Neben dem Caritasheim arbeiteten sie in der ambulanten Krankenpflege sowie in der Altenpflege und spielten die Orgel in der Kirche““ (Mertens, S. 470). - „1949 lebten im Caritas-Kinderheim 180 Kinder und zehn alte Leute. Eigentümer und Täger des Haues war weiterhin der Caritasverband Berlin. Sechzehn Schwestern gehörten zum Konvent.“ (ebd., S. 471). - „Die Schwestern nahmen elternlose Flüchtlingskinder auf, die zumeist aus Ostpreußen kamen, sowie alte Leute." (Mertens, S. 470). - 1949 wurden ostpreußische Waisenkinder 
(„Wolfskinder“) im Vorschulalter aus dem Kinderheim $\rightarrow$ Altenhof hierher verlegt (Leiserowitz, S. 37, 103). - „Am 13.5.1953 wird es [das Caritasheim] nach einer örtlichen Hetzkampagne [der FDJ] durch DDR-Behörden beschlagnahmt (wobei auch ein gewisser Erich Honecker beteiligt ist), am 22.6. aber wieder zurückgegeben. [...] Weil die Zahl der zugewiesenen Kinder immer weiter zurückging, wird das Kinderheim 1989 aufgelöst und in die Einrichtung in $[\rightarrow]$ Schwedt überführt. Hedwigsschwestern arbeiten noch bis 1994 in Bad Saarow." (Brühe, S. 14; ausführlicher dazu: Mertens, S. 471; weitgehend unkritisch und teilweise mit irrtümlicher Jahreszahl 1957 statt 1953: Kienitz, S. 122). - „Auf Grund der Teilung Deutschlands wurde die Niederlassung in Bad Saarow Mutterhaussekretariat [der Hedwigschwestern] und fungierte als dem Mutterhaus in West-Berlin untergeordnete Verwaltungsstelle für die Niederlassungen in der DDR." (Mertens, S. 471). - Nach 1990 noch bis Aug./Sept. 2016 Heimbildungsstätte der Caritas, anschließend Umbau zur Caritas-Gemeinschaftsunterkunft (mit Bildungsangeboten) für Flüchtlinge (Pressemitteilung des Caritasverbandes für das Erzbistum Berlin e.V., 4.5.2016, http://www.amt-scharmuetzelsee.de/pdf/Caritas\%20Verband\%20Information.pdf $[30.8 .2016])$.

Literatur: Brühe, Matthias: Katholische Kirche zwischen Uckermark und Oderland. Berlin 1998, S. 14. - Kienitz, Reinhard: Traumgehäuse. 4. Aufl. Bad Saarow 2014. - Leiserowitz, Ruth: Von Ostpreußen nach Kyritz. Potsdam 2003. - Mertens, Johannes: Geschichte der Kongregation der Hedwigschwestern 1930-2000. Manuskript. Berlin 2004, S. 83-85 (Briesnitz), 470-473 (Bad Saarow). - Pfeiler, Jürgen: „Der Krieg war plötzlich da.“ Alltag westlich Oder, Spree und Dahme zwischen Neujahr und Himmelfahrt. Eine Chronik. In: Brandenburg im Jahr 1945. Studien. Hrsg. von Werner Stang. Potsdam 1995, S. 84-105. - Schwillus/Brühe, S. 320-321.

\section{Bad Wilsnack}

Stadtgemeinde, bis 1952 Kr. Westprignitz, 1952-1990 Kr. Perleberg (Bezirk Schwerin), 1990_ 1993 Ldkr. Perleberg (Land Brandenburg), 1993 Ldkr. Prignitz

EReignisse NACH KRIEgSende: [„Direkt nach Kriegsende“ 1945:] „In [...] Bad Wilsnack wurde [...] eine Flüchtlingsstelle eingerichtet, in der Ankömmlinge namentlich erfasst und auf die Dörfer verteilt wurden." (Transitzone Dorf, S. 36).

Bevölkerungszahlen: 1925: 2226, 1939: 2300, 1946: 3661, 1964: 2696 (Städtebuch, S. 19).

Katholiken: 1925: 41 (Städtebuch, S. 19). 1953 (Kuratie!): 1100 (Brühe, S. 10); „erst seit 1946 wurde wieder regelmäßig in Bad Wilsnack die Eucharistie gefeiert, als sich infolge der Vertreibungen Katholiken in größerer Anzahl in der Umgebung ansiedelten.“ (Brühe, S. 10). „Die große Zahl der Flüchtlinge in Bad Wilsnack und den umliegenden Dörfern machten die Anstellung eines eigenen Geistlichen für Bad Wilsnack notwendig. / Am 1. Februar [1946] wurde der Kaplan Karl Hawlitzky - Flüchtlingspriester aus der Prälatur Schneidemühl - mit der Seelsorge in Bad Wilsnack beauftragt [bis 1952 im Amt (Brühe, S. 10)]. Der Gottesdienst wurde zunächst 
in der evangelischen Kirche gehalten [...].“ (Bolwin, S. 193). - 22.8.1946 „Lokalpr. Hawlitzky, Karl, Bad Wilsnack, Ziegelberg 8“ erwähnt in einer Aufstellung der außerplanmäßig eingesetzten „Flüchtlingsgeistlichen“ (DAB, I/9-15-1 Flüchtlingsseelsorge 1945-1951, unfol.). Hawlitzky (geb. 1908 Berlin) war bis 1945 Pfarrer in Kleistdorf (Ortsname bis 1937: Neukramzig), Kr. Bomst (Ostpriesterverzeichnis 2, 1949, S. 33; Schematismus Berlin 1949, S. 141). - Am 8.12.1946 wurde auf dem Grundstück Am Ziegelberg 8 eine aus einem Schafstall umgebaute Kapelle eingeweiht." (Brühe, S. 10; lt. Bolwin Kapellenweihe am 8.9.1946). - 1.9.1947 Seelsorgestelle Bad Wilsnack zu einer selbständigen Kuratie erhoben (Bolwin, S. 196). - 1996 Kapelle aufgegeben (Brühe, S. 10).

UMSIEDLERLAGER BAD WilsNACK: 1945 (15.9.1945 bereits existent) wurde ein Auffanglager „für 500 Personen“ eingerichtet (Wenzel, S. 138). - Kapazität am 31.12.1945: 200 (BArch, DO 2/45, B1. 40). Kapazität am 1.1.1946: 200 (BLHA, Rep. 203 MdI, Nr. 1163, Bl. 50).

Literatur: [Bolwin, Jacob:] Chronik der Missionspfarrei Wittenberge. Wittenberge [2006]. - Brühe, Matthias: Katholische Kirche zwischen Prignitz und Havelland. Berlin 2000, S. 10. - Schwillus/Brühe, S. 355. - Transitzone Dorf. Ein Ort zwischen Bodenreform und Kollektivierung. Hrsg. von: Projektgruppe Umsiedlerin: Maria Hetzer [u.a.]. O. O. 2015. - Wenzel, Mario: Die Aufnahme und Versorgung von Flüchtlingen und Vertriebenen in Eberswalde 1945-1948. In: Eberswalder Jahrbuch 2015, S. 136-145, hier S. 138.

\section{Bärenklau}

Landgemeinde, bis 1952 Kr. Guben, 1952-1990 Kr. Guben (Bez. Cottbus), 1990-1993 Ldkr. Guben, 1993 Ldkr. Spree-Neiße

UMSIEDLERLAGER: 24.10.1945 (Bericht auf Arbeitstagung beim Oberlandrat in Cottbus): „Landkreis Guben richtet in Bärenklau ein Umsiedlerlager für 150 Personen und in der Gauschule Griesen [ $\rightarrow$ Grießen] eins für Arbeitsunfähige - 30 Personen - ein." (Töpler, Menschenwurm, S. 450). - Im „Verzeichnis der errichteten und vorgesehenen Umsiedlerlager im Verwaltungsbezirk Cottbus“ vom 15.12.1945 mit „Personenzahl“ 150 genannt (ebd., S. 472). - Wohl nicht identisch mit dem 1945 enteigneten und dann bis 1950 als Arbeitererholungsheim genutzten ehem. Herrenhaus des Rittergutes der Gubener Tuchfabrikantenfamilie Lehmann (1956-1990 „Genesungsheim [für Geschwulstkranke] Georgi Dimitroff") (Chronik Bärenklau/www.schen kendoebern.de [19.9.2016]; Der Märkische Bote, 6.11.2015).

BevöLKerungSzahlen: 1925: 328, 1939: 346 (HOL NL II, S. 174); 1946: 549, 1950: 562, 1964: 485 (HGV SN, S. 27). - 1.1.1965: 485 (Wieviel Einwohner hat der Kreis Guben?, S. 126).

Gedruckte Quellen und Literatur: Töpler, Menschenwurm, S. 450, 472. - Wieviel Einwohner hat der Kreis Guben? In: Gubener Heimatkalender 11 (1966), S. 126. - Wille II, S. 306. 


\section{Baruth}

Stadtgemeinde, bis 1946 Kr. Jüterbog-Luckenwalde, 1946-1952 Kr. Luckenwalde, 1952-1990 Kr. Zossen (Bez. Potsdam), 1990-1993 Ldkr. Zossen, 1993 Ldkr. Teltow-Fläming

EREIGNISSE BIS KRIEGSENDE: (Nach 24.) Jan. 1945 Koordinierung der Unterbringung der aus dem Kreis Wollstein (Posen) kommenden, für den Kreis Jüterbog-Luckenwalde vorgesehenen Flüchtlinge durch den „Meldekopf Wollstein in Baruth“, also eine Vorausabteilung der Kreisverwaltung Wollstein (Dokumentation der Vertreibung I/1, S. 383). - Die hart umkämpfte Stadt wurde zu 80 Prozent zerstört [...].“ (Schulze, S. 60).

EREIGNISSE NACH KRIEGSENDE: 4.7.1945 Foto (vorgedruckter) „Quartierschein [des Bürgermeisters der Stadt Baruth] für eine Nacht in ,Italiener-Baracke' bei Carl Müller, Golßener Straße 39, an 5 Personen" (Abb.: Meinicke, S. 476). - In der Bodenreform 13 ha (von 466 ha) an 5 Umsiedler vergeben (HOL X, S. 29).

Bevölkerungszahlen: „1925: 2010, 1939: 2 143, Frühjahr 1945: 3000 Menschen, davon 1000 Evakuierte u. Flüchtlinge; 1946: 2232, davon ein Viertel Auswärtige; 1964: 1912“ (Städtebuch, S. 23).

Katholiken (Erzbistum Breslau/Erzbischöfliches Amt Görlitz): 1925: 30, 1946: 134 (Städtebuch, S. 24). - Bericht des Pfarrers Alfred Brucks, Luckau, vom 19.8.1945: „Die evangelischen Gemeinden in $[\rightarrow]$ Golßen und Baruth stellten ihre Kirchen zur Abhaltung des katholischen Gottesdienstes bereitwillig zur Verfügung." (Töpler, Menschenwurm, S. 380).

UMSIEDLERLAGER: Kapazität am 31.12.1945: 400 (BArch, DO 2/45, Bl. 41). - Kapazität am 1.1.1946: 400 (BLHA, Rep. 203 MdI, Nr. 1163, Bl. 51).

Gedruckte Quellen und Literatur: Dokumentation der Vertreibung I/1, S. 383. - Meinicke, Wolfgang: Die Aufnahme von Vertriebenen in der Sowjetischen Besatzungszone Deutschlands. In: „Wach auf, mein Herz, und denke“. Berlin/Opole 1995, S. 475-487. - Schulze, Sieglinde: Als Baruth wieder mal in Schutt und Asche lag. In: Heimatjahrbuch für den Landkreis Teltow-Fläming 9 (2002), S. 60-64. - Töpler, Menschenwurm.

\section{Basdorf}

Landgemeinde (seit 2003 Ortsteil von $\rightarrow$ Wandlitz), bis $1952 \mathrm{Kr}$. Niederbarnim, 1952-1990 Kr. Bernau (Bez. Frankfurt/Oder), 1990-1993 Ldkr. Bernau, 1993 Ldkr. Barnim

BevöLKERUNGSZAHLEN: 1925: 657, 1939: 1408, 1946: 2 708, 1964: 2723 (HOL VI, S. 18).

Katholiken: 1.10.1948 Anstellung des dem Erzbistum Prag angehörenden und bis 1945 in Peterswaldau, Kr. Reichenbach (Schlesien) wirkenden Pfarrers Theodor Schramm (geb. 1894 Glatz) als Lokalkaplan in der Lokalie Basdorf, Waldsiedlung 22 (Schematismus Berlin 1949, S. 45, 146; Ostpriesterverzeichnis 2, 1949, S. 77). 


\section{Beelitz}

Stadtgemeinde, bis 1946 Kr. Zauch-Belzig, 1952-1990 Kr. Potsdam (Land) (Bezirk Potsdam), 1990-1993 Ldkr. Potsdam, 1993 Ldkr. Potsdam-Mittelmark

EREIGNISSE BIS KRIEgSENDE: „Schon 1944 wurde die Schule geräumt und Doppelstockbetten (Holzpritschen) aufgestellt, denn es zogen viele Trecks durch Beelitz mit vielen Kranken. Meine Schwester Gertrud Winter und ich versorgten die Kranken. [...] Abends suchten meine Schwester und ich gegenseitig die Kleidung nach Läusen ab, die die Flüchtlinge oftmals mitbrachten. Da sie viele Kleidungsstücke übereinander trugen, nisteten sich schnell Läuse ein.“ (Tyrolt, S. 32). - „Ende 1944 kamen viele Flüchtlinge nach Beelitz. In unser Haus wurden drei Erwachsene und zwei Kinder eingewiesen. Es waren Flüchtlinge aus der Ukraine, Schwarzmeerdeutsche, die dort schon lange gelebt hatten. Fast gleichzeitig nahmen wir noch eine Frau mit sechs Kindern und einem Baby auf, die auch aus den Ostgebieten stammten. Da die Frau und das Baby in ein Krankenhaus kamen, hatten wir nun sechs Kinder zu betreuen. Große Probleme brachten uns die mehrmaligen nächtlichen Fliegeralarme, denn bis wir die recht lebhaften Kinder alle angezogen hatten, waren die Flugzeuge meist schon über Beelitz." (Wardin, S. 22). - „Als sich im Winter 1944/45 die Sowjetarmee den deutschen Grenzen näherte, flohen die Menschen aus ihrer Heimat. Große Trecks zogen in Richtung Westen und kamen auch nach Beelitz. Ich sehe noch heute die Planwagen, von Pferden gezogen, auf dem Kirchplatz und den Straßen der Altstadt stehen, beladen mit Menschen, Frauen, [S. 20] Kindern, sogar auch Tieren und ihrer letzten geretteten Habe. Sie hatten Schreckliches erlebt und eine strapaziöse Fahrt bei Eis und Schnee hinter sich. Sie wurden erstmals provisorisch in den Häusern untergebracht. Auch bei uns zog eine Frau mit zwei Kindern ein, die aber noch vor Kriegsende nach Westen weiterzog." (Nolte, S. 29f.). - 1945: Auf dem Kirchplatz war das NSV-Büro [...]." (Um Beelitz harter Kampf, S. 83). - „Kurz vor Eintreffen der sowjetischen Truppen hatten sich alle Verwandten und Bekannten meiner Familie im Hause meiner Großeltern in Beelitz in der Bekkerstraße einquartiert. Das waren Verwandte, die in Berlin ausgebombt waren, und entfernte Verwandte, die aus Posen geflüchtet waren, sowie unsere Nachbarn aus der Trebbiner Straße." (Wernitz, S. 33). - [Wohl Ende April/Anf. Mai 1945:] Massengräber für z.T. unidentifizierte Soldaten und Zivilisten erwähnt, teilweise auch Umbettungen aus Beelitz-Heilstätten (ebd., S. 35, 114-122). - 23.4.1945 Einmarsch der Roten Armee (Um Beelitz harter Kampf, S. 25, 27, 32 f., 83).

EREIGNISSE NACH KRIEgSENDE: [April/Mai 1945:] Anwesenheit einquartierter Schwarzmeerdeutscher noch nach dem Einmarsch der Roten Armee nachgewiesen (Um Beelitz harter Kampf, S. 32). - [Erinnerungsbericht einer Beelitzerin, April/Mai 1945:] „Mit im Hause wohnten [...] zwei Flüchtlingsfamilien, eine aus Ostpreußen und eine aus Posen. [...]." (ebd., S. 83). 29.5.1945 Ersuchen des Landrates d. Kr. Guben an den Bürgermeister von Schenkendöbern, einem Treck mit „Flüchtlingen aus Be[e]litz“ (105 Personen u. 16 Pferde) „vorübergehend Unterkunft zu gewähren" (Wille I, S. 38). - 26.7.1946 Ankunft eines Transports mit 780 Vertriebenen aus Friedland in Böhmen (Jun, S. 247). 
Bevölkerungszahlen: 1925: 5 167, 1939: 5432, 1946: 5895, 1964: 5070 (Städtebuch, S. 27).

Katholiken: 1885: 26, (Gemeinde seit 1937), 1997: rund 400 (Städtebuch, S. 27). - Die 1937 im Pfarrverband mit $\rightarrow$ Werder (Havel) gegründete Lokalie „Beelitz selbst wurde zum 1.7.1946 mit etwa 160 Katholiken, darunter zahlreiche Flüchtlinge und Vertriebene, vermögensrechtlich selbständige Kuratie. Bereits am 16.12.1945 war eine an das Pfarrhaus angebaute ehemalige Baracke als neue Kapelle eingeweiht worden. Eva-Maria Klemp [1914-2000], eine zur Gemeinde gehörende Heimatvertriebene, schuf sechs Fenster zu Bibelstellen, in denen der Hl. Geist erwähnt wird, ebenso Fenster mit Darstellungen Mariens und des Erzengels Michael." (Brühe, S. 11; weitgehend textgleich, aber gekürzt: Schwillus/Brühe, S. 332). Standort der Kapelle: Karl-Liebknecht-Str. 10 (ebd.), 2007 verkauft und 2014 abgerissen (www.erzbistum berlin.de [5.3.2017]). - „Eine besondere Prägung erhielt die Notkirche durch einen Zyklus von Fensterbildern zum Heiligen Geist. Die damals in Seddin lebende Malerin Eva-Maria Klemp schuf in den Jahren 1947/48 acht Bilder mit biblischen Motiven, teilweise aber auch demonstrativ katholischem Symbolgehalt. So wird neben Fensterbildern zur Schöpfung, zur Verkündigung und Taufe Jesu sowie zur Kreuzigung auch der Petersdom nebst Petrusstatue unter der Taube des Heiligen Geistes dargestellt. Über die Auswahl der Motive ist nichts überliefert. / Ob hier Pfarrer Foerster mitwirkte oder der akademische Lehrer der Künstlerin, der ,schlesische Madonnenmaler' Paul Plontke, ist nicht dokumentiert. Da das Abiturzeugnis die Malerin als evangelisch ausweist und über eine etwaige Konversion keine Informationen vorliegen, sind solche Einflüsse aber naheliegend. / Neben den Glasbildern, deren Rahmenbemalung teilweise verloren ist, entstand an der Außenwand auch ein Fresko mit der Pietà, das in den folgenden Jahren nicht nur dem Gedenken der Kriegstoten sondern auch als Fronleichnamsaltar diente. Weitere religiöse Arbeiten der Künstlerin sind nicht bekannt. Seit mindestens 1940 war sie an Ausstellungen des Vereins der Berliner Künstlerinnen beteiligt, zunächst mit Blumenmotiven, später mit abstrakten Gemälden. Nach dem Krieg studierte sie an der Hochschule für Bildende Künste [Berlin]. Von 1955 bis 1958 war sie Vorsitzende des Vereins der Berliner Künstlerinnen. / Der Heilig Geist-Zyklus ist nur noch bis Ende Mai zu den Vorabendmessen zu sehen. Als Folge der Finanzkrise des Bistums wurde das Grundstück vor zehn Jahren verkauft, die Kapelle wird im Juni abgerissen. Damit verliert das Erzbistum eine der letzten Notkapellen und die Beelitzer Gemeinde ihre eigene geistliche Heimat. Den etwa 600 Katholiken im Umfeld steht dann die Pfarrkirche in $[\rightarrow]$ Michendorf zur Verfügung. Die Bilder sollen gesichert werden.“ (Marin). - 2015 Bestands- und Zustandserfassung des Freskos „Pietà mit Johannes dem Evangelisten“ durch Restauratoren/Studierende der Fachhochschule Potsdam, Studienrichtung Konservierung und Restaurierung - Wandmalerei, Abnahme des Wandbildes jedoch gescheitert, in situ verblieben und eingemauert (www.fh-potsdam.de [5.3.2017]).

Archivalische Quellen: Kreisarchiv Potsdam-Mittelmark, 42.011/3 (Befehle des Militärkommandanten des Bezirkes Beelitz, 1945-1946, darin u. a.: Befehl Nr. 466: Verbot der Aufnahme von Umsiedlern aus Polen und der ČSR); 42.021/2 (Bereitstellung von Öfen und Schränken für Umsiedler, 1947-1950). 
Gedruckte Quellen: Wille I, S. 38. - Erinnerungsberichte: Hohenschild, Irmgard: Das Leben mit den Besatzern. In: Um Beelitz harter Kampf. 1945. Beelitz 1999, S. 83-85. [Erlebt Flüchtlingsfamilien im Haus]. - Manthey, Gerda: Endstation des Flüchtlingstrecks: Beelitz. In: ebd., S. 91-92. [Flüchtlingstreck aus dem Oderbruch ab Febr. 1945; erste Unterbringung im Turnsaal in Beelitz-Heilstätten, dann im Kindergarten in der Nürnbergstraße in Beelitz]. - Nolte, Eva: Das also war der Krieg! In: ebd., S. 29-31. - Tyrolt, Margarete: Kreidezeichen an der Tür. In: ebd., S. 31-32 [1944/45 in der Flüchtlingsbetreuung eingesetzt]. - Wernitz, Wolfgang: Eine tragische Zeit für meine Familie. In: ebd., S. 32-35 [Familie nimmt 1945 entfernte Verwandte aus Posen auf].

Literatur: Brühe, Matthias: Katholische Kirche zwischen Havel und Dahme. Berlin 1999, S. 11. - Marin, Thomas: Was wird aus den Bildern? Beim Abriss von Heilig Geist in Beelitz soll die Kunst erhalten bleiben. In: Katholische Sonntagszeitung, 20.3.2014 (auch auf: www.erzbistumberlin.de [5.3.2017]). - Schädler, Verena: Katholischer Sakralbau in der SBZ und in der DDR. Regensburg 2013. - Schwillus/Brühe, S. 332. - Um Beelitz harter Kampf. 1945. Das Jahr zwischen Krieg und Frieden. Beelitz und Umgebung. Hrsg.: Beelitzer Heimatverein. Beelitz 1999.

\section{Beenz}

Landgemeinde (seit 31.12.2001 Ortsteil von $\rightarrow$ Lychen), bis 1952 Kr. Templin, 1952-1990 Kr. Templin (Bez. Neubrandenburg), 1990-1993 Ldkr. Templin (Land Brandenburg), 1993 Ldkr. Uckermark

EREIGNISSE BIS KRIEgSENDE: „Um den“ 6.2.1945 Aufteilung eines in $\rightarrow$ Templin eingetroffenen Flüchtlingstrecks aus Nahausen (Kr. Königsberg/Nm.) auf die im Kr. Templin gelegenen Dörfer Beenz u. $\rightarrow$ Bredereiche (Köhler, S. 100).

EREIGNISSE NACH KRIEGSENDE: In der Bodenreform 97 ha von 221 ha an 7 „Umsiedler“ vergeben (HOL VIII, S. 61).

BeVÖLKERUNGSZAHLEN: 1925: 237, 1939: 190, 1946: 308, 1964: 229 (HOL VIII, S. 61).

Literatur: Köhler, Erich: Das Flüchtlingselend neumärkischer Familien. In: Königsberger Kreiskalender 2002, S. 96-104.

\section{Beeskow}

Stadtgemeinde (Kreissitz), bis 1950 Kr. Beeskow-Storkow, 1950-1952 Kr. Fürstenwalde, 1952-1990 Kr. Beeskow (Bez. Frankfurt/Oder), 1990-1993 Ldkr. Beeskow, 1993 Ldkr. OderSpree

EREIGNisSe BIS Kriegsende: 24.4.1945 [Beeskow und westliches Umland]: „Alle Straßen voll von Flüchtlingen." (Tagebucheintrag des Leitenden Arztes des Krankenhauses Beeskow Dr. Erich Marsch, zit. nach Berg, S. 13).

EREIGNISSE NACH KRIEGSENDE: 1.12.1945 Ausstellung eines deutsch- und russischsprachigen Ausweises für die im Febr. 1945 aus Liegnitz evakuierte und im Juni 1945 zunächst nach Berlin gelangte, nun in „Beeskow, Krankenhaus“ wohnhafte „Rote-Kreuz-Schwester Rosemarie Sommer“ 
durch den Bürgermeister von Beeskow (Abb.: Meinicke, S. 481; dazu Interviewauszug ebd., S. 480). - 31.8.1947 Treffen von Vertriebenen aus Ziebingen (Kr. Weststernberg) mit 464 Besuchern (Schieche/Jaeschke, S. 323). - In der Region Beeskow leben noch in den 1950er Jahren besonders viele Vertriebene aus Ziebingen (Kr. Weststernberg) (ebd., S. 320). - 4.9.1994 „Abschied und Ankunft": Lesung aus einem deutschen und einem polnischen autobiographischen Werk zu Flucht und Vertreibung (Ursula Höntsch aus Berlin und Joanna Konopińska aus Breslau) im Regionalmuseum Burg Beeskow, veranstaltet von der Deutsch-Polnischen Gesellschaft Brandenburg e. V. in Kooperation mit der Gesellschaft für interregionalen Kulturaustausch e. V., Berlin, mit Unterstützung der Brandenburgischen Landeszentrale für politische Bildung (www. dpg-brandenburg.de [4.6.2018]).

Bevölkerungszahlen: „1925: 5454, 1939: 5997 einschl. 141 vom Militär bzw. Arbeitsdienst, 1946: 7814 (trotz Kriegsopfer u. Sterbefällen wegen Zuzug von ca. 2000 Umsiedlern), 1964: 7412 “ (Städtebuch, S. 32).

Katholiken (Erzbistum Breslau/Erzbischöfliches Amt Görlitz): 1925: 155, 1946: 525 (Städtebuch, S. 32).

Heimkehrerlager „Krankenhaus Beeskow“: 1946 Belegungsstärke: 500 (Kaminsky, S. 160).

Städtepartnerschaften: 2002 Sulęcin, Polen (Zielenzig, ehem. Kr. Oststernberg, Provinz Brandenburg).

Archivalische Quellen: BLHA, Rep. 250 Beeskow-Storkow, Nr. 918 („Verzeichnis der Umsiedler in der Stadt Beeskow, Stand: 12. Dez. 1947“); Nr. 1635 („Anträge auf Siedlungsentzug des Neusiedlers Herbert Christopei in Beeskow, 1947-1950).

Gedruckte Quellen und Literatur: Berg, Horst: Vom Nikolaus-Hospital zum Kreiskrankenhaus. Beeskow 2002 [ohne Erwähnung des Lagers]. - Meinicke, Wolfgang: Die Aufnahme von Vertriebenen in der Sowjetischen Besatzungszone Deutschlands. In: „Wach auf, mein Herz, und denke“. Berlin/Opole 1995, S. 475-487. - Pfeiler, Jürgen: „Der Krieg war plötzlich da." Alltag westlich Oder, Spree und Dahme zwischen Neujahr und Himmelfahrt. Eine Chronik. In: Brandenburg im Jahr 1945. Studien. Hrsg. von Werner Stang. Potsdam 1995, S. 84-105. - Schieche, Manfred / Jaeschke, Gerhard: Ziebingen. Eisenhüttenstadt u. a. 2001. - Töpler, Menschenwurm.

\section{Belzig (seit 2010 Bad Belzig)}

Stadtgemeinde (Kreissitz), bis 1952 Kr. Zauch-Belzig, 1952-1990 Kr. Belzig (Bez. Potsdam), 1990-1993 Ldkr. Belzig, 1993 Ldkr. Potsdam-Mittelmark

EREIGNISSE BIS KRIEGSENDE: 19.1.1945 Eintreffen eines Eisenbahn-Flüchtlingstransports aus dem Sammellager Züllichau (Flüchtlinge aus dem „Warthegau“) bzw. der Zwischenstation Dresden, Erstaufnahme im Kinosaal der Gaststätte „Zur Grünen Tanne“, anschließend Einquartierung bei Bauern in den umliegenden Dörfern (Weiß, Von Bessarabien nach Belzig, S. 114). - 
[Erinnerungen einer jungen DRK-Helferin, wohl April 1945: ],Ich erinnere mich an einen Flüchtlingszug, der als offener Güterzug bei 6 Grad Kälte aus Hohensalza hier ankam. Zu der Zeit hatten wir schon die Tieffliegerangriffe. Wir versorgten die Kinder und die Kranken. Sie lagen auf Stroh, oft nur dürftig bekleidet. Schon vor der Ankunft wurde Wohnraum bei verschiedenen Familien beschafft, dort wurden sie dann eingewiesen. Ein Zug kam aus Züllichau bei Schwiebus. Nach der Ankunft gingen sie zuerst zu Thieles. Dort war die Frauenschaft für die erste Verpflegung verantwortlich. Einige Kinder hatten nicht einmal Schuhe an. Ich erinnere mich auch an Schwarzmeerfamilien aus Polen. Sie sprachen süddeutschen Dialekt. Ich glaube, sie zogen dann nach Klepzig weiter. Ein Kind hatte stark erfrorene Füße, es mußte sofort in ein Krankenhaus. Die Mutter bangte um das Kind und wollte es nicht hergeben. Ich konnte die Frau gut verstehen. Auf dem Marktplatz standen öfter Flüchtlingstrecks mit Pferdewagen. [...] [Auch Verwundetentransporte] [S. 102] [...] Es kamen auch Tote an. In den Lazaretten verstarben noch viele. Anfangs standen die Kreuze auf dem Friedhof, später war alles eingeebnet. Auch unbekannte Soldaten wurden dort beerdigt. Dort, wo heute die Urnen sind." (Sewerin, Krankenschwester, S. 101 f.). - 3.5.1945 Einmarsch der Roten Armee (Dorbritz, Der 3. Mai 1945, S. 103).

EREIGNISSE NACH KRIEGSENDE: 1945: „Durch die vielen Flüchtlinge war unser Haus, wie wohl jedes Haus in der Stadt, voll belegt. 16 Kinder von 1-16 Jahren waren wir vorübergehend im Haus, in drei Wohnungen." Hollmann, S. 118). - Ca. Mai 1945: „Vor dem Wirtschaftsamt (neben dem Fotogeschäft am Markt) standen Belziger und Flüchtlinge oft Schlange bis zum Café." (Sewerin, Die armen Kerle, S. 112). - 18.12.1945 (Bericht der städtischen Organisationsabteilung): „Eine schwere Aufgabe hatte und hat Belzig als Sammel- und Durchschleusungspunkt für die Umsiedler $z$ u erfüllen. Hier hat Herr Pfarrer Tschetschog durch seinen ständigen Einsatz für das bittere Los der Heimatlosen sich besondere Verdienste erworben. In den ersten Sommermonaten, als es noch keine Anweisungen, keine Provinzialverwaltung gab, hatte Belzig als erste Stadt des Kreises für diese Vertriebenen Unterkunft und Verpflegung zu schaffen gewußt. Bis zu 1800 Essen wurden oft an einem Tage ausgegeben. Später wurden an einem Tage 4500 Flüchtlinge, die in zwei Eisenbahnzügen mit einem Vielfachen an Gepäck hier eintrafen, durch unsere Lager geschleust. Die An- und Abfahrt gestaltete sich für bisherige Begriffe zu einem Triumph der Organisation. Hunderte von Fahrzeugen kreuzten in ununterbrochener Folge den $3 \mathrm{~km}$ langen Weg von der Station zu den Aufnahmepunkten." (Brandenburgische Gemeinden 1945, S. 11). - „Aufruf im März 1946: Wir haben Heimkehrer, Kranke aus Lagern und viele Flüchtlinge, die ohne Heimat und ohne Angehörige sind. Habt ein Herz auch für diese Einsamen, gebt von ganzem Herzen, die Ihr ein Stück Land Euer eigen nennt, und der Himmel wird es Euch doppelt lohnen." (Chronik der Stadt Belzig, S. 79). - 28.10.1947 „Tag der Heimat“ („Heimabend für die Belziger Umsiedler und Einheimischen“) im Rahmen der „Umsiedlerwoche“, veranstaltet vom Ortsumsiedlerausschuss im Saal des „Hauses der Kultur“. „Die verschiedensten Dialekte konnte man vernehmen: schlesisch, ostpreussisch und sudetendeutsch“ (Wille III, S. 264, Informationsbericht). - 1948 Erwähnung der von sudetendeutschen Vertriebenen gegründeten „Produktionsgenossenschaft Holzwarenerzeugnisse Belzig“" (Christopeit, S. 86). 
EREIGNISSE NACH 1990: 13.6.2013 Heimattreffen ehemaliger Bewohner von Lauterbach (Schönhengstgau/Böhmen) im Hotel/Restaurant „Springbach-Mühle“, Mühlenweg 2 (Mitteilung vom 13.3.2013 nach Schönhengster Heimatzeitung im Schönhengst-Forum http://www. schönhengstforum.de [20.9.2016]).

Bevölkerungszahlen: 1925: 3622 (1 447 Männer, 2175 Frauen), 1939: 5664 (2 639 Männer, 3025 F.), 1946: 8125 (3 167 M., 4958 F.), 1960: 6852 (3023 M., 3829 F.) (Städtebuch, S. 37). - 1925: 104, 1946: 703 kath. Einwohner (ebd., S. 37 f.).

Katholiken: 1925: 104, 1946: 703 (Städtebuch, S. 37f.). 1933-1965 Pfarrer Erich Tschetschog war „maßgeblich an der kampflosen Übergabe Belzigs beteiligt und wurde später zum Ehrenbürger der Stadt ernannt." Seit 1934 seelsorglich selbständige Kuratie, zugeordnet waren ihr u. a. auch $\rightarrow$ Treuenbrietzen und $\rightarrow$ Brück (Schwillus/Brühe, S. 201).

UMSIEDLERLAGER [welches der folgenden?]: 1946 Heimkehrerlager, Belegungsstärke: 2000 bis 3000 (Kaminsky, S. 160). - 30.4.1946 als eines der verbleibenden Umsiedlerlager genannt (DAB, I/9-15-1 Flüchtlingsseelsorge 1945-1951, unfol., [30.6.1946], [Anlage 3]). - 16.5. bis 6.7.1946 2636 Kriegsgefangene (Heimkehrerlager) (Oehlsen, S. 35). - Sept. 1946: Foto (Gruppenbild mit 32 Personen vor Baracke): „Wölfelsgrunder Vertriebene, Umsiedlerlager Belzig im September 1946“ (Chronik zu Wölfelsgrund, S. 546). - 24.7.1946 Ankunft eines Transports mit 1225 Vertriebenen aus Friedland in Böhmen (Jun, S. 247). - 17.11.1946 Ankunft eines Transports mit 270 Vertriebenen aus Trebnitz (Jun, S. 247 [hier der Bahnstation Trebnitz bei Lobositz in Böhmen zugeordnet; vgl. aber die Schilderung des am 16.11.1946 aus Oels in Schlesien abgehenden, vmtl. um den 22.11.1946 „im Lager Belzig/Mark“ endenden ersten von drei Transporten für die Bevölkerung von Trebnitz in Schlesien (!) von G. Kienast in: Bülow, S. 50 f., Zitat S. 51). - 1.1.1947 Lager, Kapazität: 2500 (Oehlsen, S. 101).

UMSIEDLERLAGER Bergholzer STRASSe (Quarantänelager; ehemaliges Barackenlager der OKW-Außenstelle): Als erstes Auffang- u. Quarantänelager im Kr. Zauch-Belzig ab 20.10.1945 innerhalb weniger Tage hergerichtet (Helle, S. 296). - Okt. 19455 Todesfälle (siehe unten beim Gertraudenfriedhof). - Erstbelegung: 23.10. bis Nov. 1945 großer Transport aus Durchgangslager Forst (Lausitz) mit Vertriebenen aus Jugoslawien (zusammen mit Lager Borner Str. 4523 Personen im Lager) (ebd., S. 296, 349f.). - Kapazität Mitte Nov. 1945: 2500 (ebd., S. 296). - Kapazität am 31.12.1945: 2000 (BArch, DO 2/45, Bl. 40). - Kapazität am 1.1.1946: 1000 (BLHA, Rep. 203 MdI, Nr. 1163, Bl. 49). - 1946 bald aufgelöst (Helle, S. 297).

UMSIEDlerlager Borner Strasse (Quarantänelager; auf dem Areal der früheren „Reichsschule Technische Nothilfe“): Als zweites Auffang- u. Quarantänelager im Kr. Zauch-Belzig fast zeitgleich mit dem Lager Bergholzer Straße eingerichtet, erwähnt 1.11.1945 (Helle, S. 296). Erstbelegung: 26.10. bis 13.11.1945 großer Transport aus Durchgangslager Forst (Lausitz) mit Vertriebenen aus Jugoslawien (zusammen mit Lager Bergholzer Str. 4523 Personen) im Lager, 12.11.1945 Revolte (ebd., S. 349f.). - Kapazität Mitte Nov. 1945: 2500 (ebd., S. 296). - Kapa- 
zität am 31.12.1945: 2000 (BArch, DO 2/45, Bl. 40). - Kapazität am 1.1.1946: 1200 (BLHA, Rep. 203 MdI, Nr. 1163, Bl. 50). - 1946 bald aufgelöst (Helle, S. 297).

(KREIS-)UMSIEDLERLAGER LÜBNITZER STRASSE (Quarantänelager; ehemaliges [ab 1943/44] KZ-Außen-, [ab 1942/43] Zwangsarbeiter- u. Kriegsgefangenen-Areal beim RoEDERHOF, zuvor Buschland): Kapazität Mitte Nov. 1945: 3000 (Helle, S. 296 mit Hinweis auf irrige Angabe einer Kapazität von 8000 Personen in BLHA, Rep. 250 Zauch-Belzig, Nr. 615, Bl. 218); vgl. BArch, DO 2/45, Bl. 40: Kapazität am 31.12.1945 (Lager „Lubnitzstr.“: 8000 . - Kapazität am 1.1.1946: 1800 (BLHA, Rep. 203 MdI, Nr. 1163, Bl. 49). - 14.2.1946 Kreis- und Quarantänelager, Kapazität: 1800 (Oehlsen, S. 28). - 2.4.1946 Einweisung einer in Beelitz-Heilstätten untergebrachten Familie zu einem 14-tägigen Quarantäneaufenthalt in das Lager („Quarantänestation Kreis Zauch-Belzig“) durch die Stadtverwaltung Beelitz, laut Zeitzeugenbericht „mehrere dunkelgrüne Holzbaracken, zu einem $U$ angeordnet, eine große Freifläche in der Mitte bildend, [...] mit einem hohen Maschendrahtzaun umgrenzt. [...] Das Quarantänelager war nur zum Teil belegt. Alle Räume waren für vier bis sechs Personen nit Doppelstockbetten ausgerüstet." (Kästner/Grüneberg, S. 21). - 24.8.1946 Umsiedlerlager Lübnitzer Str., Kapazität: 2000 (SAPMO-BArch, DY 34/27880, Bl. 291). - 11.9.1946 „Umsiedlungslager Belzig“, „Lübnitzer Str.“ erwähnt (Abbildung einer „Kontrollkarte für Reihenuntersuchungen/für Impfungen“ für eine 32 Jahre alte Frau aus Breslau in: ebd., S. 21). - 13.9.1946 „Umsiedlerlager Belzig“, „Lübnitzer Straße“ erwähnt (Abbildung eines „Quarantänescheins“ für eine am 31.8. aufgenommene und am 13.9. entlassene 32 Jahre alte Frau aus Bad Charlottenbrunn in Schlesien in: ebd., S. 20). - Spätestens Jan. 1947 aufgelöst (Helle, S. 297; vgl. aber: SAPMO-BArch, DY 34/27745, Bl. 92, demnach Schließung eventuell erst im Okt. 1947 bevorstehend). - 1952: „52 Familien wohnen seit Kriegsende im Barackenlager. Im März 1952 leben noch 35 dort, in den letzten Jahren konnten 15 Familien feste Wohnquartiere erhalten. Im laufenden Jahre können 4 weitere Familien in die Stadt umziehen. 1952 wurden 20 Neubau-Wohnungen bei der Landesregierung beantragt, [...]." (Chronik der Stadt Belzig. Kriegstagebuch April 1945, S. 122). - 25.3.1952: „Es besteht weiterhin in Belzig Wohnungsnot, noch besteht ein Barackenlager mit unzureichenden menschenunwürdigen Wohnverhältnissen. 20 Familien wurden schon umquartiert, weitere 47 Familien wohnen noch im Lübnitzer Lager." (Chronik der Stadt Belzig. Kriegstagebuch April 1945, S. 122). - „Die volkseigenen Holzbauten des Lagers Roederhof bestehen 12 bis 14 Jahre, sie stehen auf Holzpfählen, die inzwischen morsch sind. Sie müssten abgerissen und massiv aufgebaut werden. Mittel und Material sind nicht vorhanden. [...]. / Anfangs waren 52 Familien dort untergebracht, 15 wohnen nun in der Stadt, vier weitere Unterkünfte in der Stadt sind vorgesehen. [...].“ (ebd., S. 123). - „Die Baracken im Lager Roederhof wurden noch bis in die 60er Jahre bewohnt.“ (Rousseau, S. 21, zwei Fotos). - „So systematisch der Aufbau des [Zwangsarbeiter-] Lagers erfolgte, so unsystematisch geschah der Abbruch der Baracken nach dem Krieg. Zuerst wurde mit dem Raubbau des KZ Lagers begonnen. Raubbau deswegen, weil sich die ,Bauherrn' aus Belzig und Umgebung nicht nur für die Barackenteile und ihren Inhalt, sondern auch für die Wasser- und Abwasserflussleitungen interessierten. / Ein nicht geringer Teil des Zwangsarbeiter- und Kriegsgefangenenlagers war noch funktionsfähig. 
Hier wohnten noch bis 1960/61 Umsiedler. Die PGH Holz hatte in der ehemaligen Speise- und Küchenbaracke ihre Produktonsstätte bis zum Umzug in die Bahnhofstraße. Die untere Baracke hat sich die Familie Ernst Maddey als Wohnung ausgebaut, das einzige Erinnerungsstück.“ (Dorbritz, Schicksale, S. 118).

FLÜCHTLINGSLAGER/UMSIEDLERLAGER KLINKENGRUND (bis 1945 Barackenlager der Wehrmacht bzw. Wehrmachtsstreifen-Lehrabteilung): Einrichtung zw. Mitte Nov. 1945 u. 1.1.1946 (Helle, S. 296 f.). - Kapazität am 1.1.1946: 1500 (BLHA, Rep. 203 MdI, Nr. 1163, Bl. 49). 24.8.1946 Umsiedlerlager Klinkengrund, Kapazität: 500 (SAPMO-BArch, DY 34/27880, Bl. 291). - 1.1.1947 Lager, Kapazität: 1.100 (Oehlsen, S. 101). - „Neun aus Schlesien vertriebene Graue Schwestern kamen am 9. Oktober 1946 in das Quarantänelager Klinkengrund in Belzig [...], das zu dieser Zeit gerade in ein Altenheim umgewandelt wurde. Die Schwestern übernahmen die Betreuung der Flüchtlinge und die Krankenpflege. Da ihre Zahl nicht ausreichte, wurden auch weltliche Krankenschwestern eingesetzt. Nach kurzer Zeit kehrten einige Graue Schwestern nach Berlin-Tempelhof zurück; in Belzig blieben vier Schwestern. Am 31. Oktober 1946 wurde hier eine neue Filiale [der Grauen Schwestern] gegründet. / Am 1. Februar 1947 eröffnete man in dem Belziger Lager offiziell ein ,Provinzial-Altersheim', in dem fünf Schwestern 223 alte Leute betreuten. Die Baracken des Lagers waren allerdings in so schlechtem Zustand, daß es hereinregnete. Weil die Schäden wegen des Mangels an Material nicht behoben werden konnten, löste man das Heim am 20. Februar 1947 bereits wieder auf und verlegte die alten Leute nach und nach in andere Heime.“ (Mertens, S. 466). - 1947 Schließung des Lagers bevorstehend (SAPMO-BArch, DY 34/27745, B1. 92).

UMSIEdlerlager Hospital: Kapazität am 31.12.1945: 500 (BArch, DO 2/45, Bl. 40).

UMSIEdLerlager Schützenhaus: Kapazität am 31.12.1945: 400 (BArch, DO 2/45, B1. 40). - Kapazität am 1.1.1946: 400 (BLHA, Rep. 203 MdI, Nr. 1163, B1. 49). - Spätestens Jan. 1947 aufgelöst (Helle, S. 297).

UMSiedlerlager Postbaracke: Kapazität am 31.12.1945: 500 (BArch, DO 2/45, Bl. 40).

Station der Grauen Schwestern für ambulante Pflege (Straße der Einheit 114), 1946-1963: Auf Wunsch der kath. Pfarrgemeinde und mit Unterstützung des kath. Pfarrers Erich Tschetschog zogen die aus Schlesien vertriebenen, seit 1946 im Flüchtlingslager Klinkengrund (siehe oben) tätigen und auch dort wohnhaften Schwestern am 26.3.1948 aus ihrer Barackenunterkunft in eine Zweizimmerwohnung. „Seit November 1948 lebten hier vier Schwestern. Sie betreuten weiterhin Flüchtlinge, übten ambulante Krankenpflege aus, halfen in der Seelsorge und erteilten Religionsunterricht." (Mertens, S. 466). 1.10.1963 geschlossen (ebd., S. 467). - Konventsoberinnen: Aloysiana Sebastian (bis etwa Okt. 1946), Chrysanta Machrowiak (15.11.1946-1952), Ceslawa Reimann (11.8.1952-29.10.1958), Honorata Schulze (ab 29.10.1958) (ebd., S. 465). 
Gertraudenfriedhof, Straße der Einheit 72: „Beerdigungen im Jahr 1945 [auf dem (kirchlichen evangelischen) Gertraudenfriedhof], die im Kirchenbuch eingetragen sind“ / Im Januar 1945 fanden 26 Beerdigungen statt. [...] Bei sieben weiteren Verstorbenen [S. 80] wurde ,Flüchtling' eingetragen: ein Mann mit 4 Kindern aus Wriezen, eine 93-jährige, ein vier Monate altes Kind ist auf dem Transport von Posen erfroren. Josef, 56 Jahre, aus Leutschütz [Lentschütz], Paul, 69 Jahre, aus Posen und Emma, 82 Jahre, aus dem Wartheland. / Im Februar wurden 23 Beerdigungen eingetragen: 12 Flüchtlinge verstarben. [...]. / Im März sterben 24 Personen, 11 Flüchtlinge und Evakuierte aus Alt-Obra, Litzmannstadt, Weidenfeld (früher Leutschen [Lentschen]), $[\rightarrow]$ Küstrin, Neuzauche, $[\rightarrow]$ Lebus, $[\rightarrow]$ Schlepzig, $[\rightarrow]$ Frankfurt/Oder, Küstrin, Albrechtsdorf bei Sorau. [...]. Amtsrichter Erich Kubi aus Pernau in Estland war zur Zeit als Dolmetscher bei der Lufthansa tätig. Er starb mit 44 Jahren an Tuberkulose, [...]. [S. 82] [...] / Im Oktober[:] [...] Im Flüchtlingslager an der Bergholzer Chaussee starben fünf Flüchtlinge, Altersschwäche und Schlaganfall wird als Todesursache angegeben. Es war auch Quarantänelager.“ (Chronik der Stadt Belzig. Kriegstagebuch April 1945, S. 79-82).

StÄDtepartnerschaften: Nach 1973 Kontakte mit Głogówek, Polen (Oberglogau, Oberschlesien) (Trzcielińska-Polus, S. 537).

ArChivalische Quellen: BLHA, Rep. 250 Zauch-Belzig, Nr. 616 „Berichte über das Umsiedlerlager in Belzig“, 1950-1951). - BLHA, Rep. 333 SED-Landesleitung Brandenburg, Nr. 577 („Heimkehrerlager“, 1946-1949; enthält u. a.: Belzig). - Kreisarchiv Potsdam-Mittelmark, Nachlass Gerhard Dorbritz, GD-34 (darin u. a.: Bericht zum Umsiedlerwesen, zum Lager Selterhof Treuenbrietzen und zum Lager Belzig in der Lübnitzer Straße).

GedRuckte Quellen (zeitgenössische Berichte und Erinnerungsberichte): Brandenburgische Gemeinden 1945, S. 9-11 (auch abgedruckt in: „... das Glockengeläut ist einzustellen“. Belzig 1995, S. 127). - Hollmann, Henriette: Ich war zwar erst sechs Jahre alt. In: „... das Glockengeläut ist einzustellen“. Belzig 1995, S. 117-118. - Rousseau, Jean: Erinnerungen an die Zeit im Konzentrationslager Roederhof. In: ebd., S. 20-21. - Sewerin, Gertraud: Krankenschwester vom DRK. In: ebd., S. 101-102 [Flüchtlings- und Verwundetenbetreuung in Belzig 1945, noch während des Krieges]. - Dies.: Die armen Kerle mußten ja irgendwie versorgt werden. In: ebd., S. 112-114 [Kranken- u. Verwundetenbetreuung]. - Töpler, Menschenwurm. - Weiß, Arthur: Von Bessarabien nach Belzig. Meine Memoiren. Leipzig 2012. - Ders.: Die letzten Kinder Bessarabiens. Neuanfang nach Krieg, Flucht und Vertreibung in der DDR. Vier bewegende und tragische Geschwisterschicksale. Leipzig 2014. - Wille I, S. 261.

Literatur: Brühe, Matthias: Katholische Kirche zwischen Havel und Dahme. Berlin 1999, S. 12. - Bülow, Ursula Maria von: Flucht und Vertreibung aus dem schlesischen Kreis Oels. Würzburg 1996. - Die Chronik zu Wölfelsgrund, Kreis Habelschwerdt, Grafschaft Glatz in Schlesien. [Wenden 2005]. - Christopeit. - Chronik der Stadt Belzig 1934 bis 1945. Hrsg. von Helga u. Günter Kästner. [Berlin] 2016. - Chronik der Stadt Belzig. Kriegstagebuch April 1945. Munitionsfabrik Roederhof. Zsgest. von Helga u. Günter Kästner. Berlin 2016. - „... das Glockengeläut ist einzustellen“. 1945 - das Jahr zwischen Krieg und Frieden. T. 1: Belzig und Umgebung. Belzig 1995. - Dorbritz, Gerhard: Der 3. Mai 1945 - die kampflose Übergabe. In: „... das Glockengeläut ist einzustellen“. Belzig 1995, S. 102-104. - Ders.: Schicksale. Dokumentation über das Zwangsarbeiterlager Roederhof in Belzig. Belzig 2001. - Ders.: (Außenlager) Belzig. In: Der Ort des Terrors. Hrsg. von Wolfgang Benz u. Barbara Distel. Bd. 3. München 2006, S. 78-80 (ohne Erwähnung der Nachkriegsnutzung für Flüchtlinge). - Helle, Matthias: Nachkriegsjahre in der Provinz. Berlin 2011, S. 296f., 349f. - Kästner, Helga / Grünberg, Willi: 8000 Menschen nach Kriegsende in Belziger Quarantänelager. Maßnahmen zur Unterbringung und Versorgung in Bad Belzig, In: Bad Belzig Journal 7 (2017)1, S. 20-21 (mit Abb. zweier Baracken). - Mertens, Johannes: Die Berliner Ordensprovinz der Grauen Schwestern von der heiligen Elisabeth 1859-1991. Reinbek bei Hamburg 1992, S. 465-467. - Nitschke, Johannes: 150 Jahre Pfarrkirche „Heilige 
Dreifaltigkeit“" Brandenburg an der Havel. Brandenburg an der Havel [2001], S.31. - Schwillus/Brühe, S. 201. Trzcielińska-Polus.

\section{Bergerdamm}

Landgemeinde (seit 2003 Ortsteil von $\rightarrow$ Nauen), bis $1952 \mathrm{Kr}$. Westhavelland, 1952-1990 Kr. Nauen (Bez. Potsdam), 1990-1993 Ldkr. Nauen, 1993 Ldkr. Havelland

FLÜCHTLINGSLAGER/UMSIEDLERLAGER: „Bergerdamm-Lager ist im ersten Weltkrieg als Kriegsgefangenenlager gegründet worden und wurde nach dem zweiten Weltkrieg mit Umsiedlern bevölkert.“ (http://www.funkstadt-nauen.de [15.6.2017]). - In der Bodenreform 6 „Umsiedler" berücksichtigt (HOL III, S. 19).

BevÖLKeRUnGSZAHLEN: 1925: 253, 1939: 179, 1946: 216, 1964: 767 (HOL III, S. 19).

LiterATUR: Blöß, Wolfgang: Kommunale Strukturen im Spannungsfeld gesellschaftlicher Umwälzungen. Berlin 2018, S. 270-272.

\section{Bernau}

Stadtgemeinde (1945-1993 Kreissitz), bis 1952 Kr. Niederbarnim, 1952-1990 Kr. Bernau (Bez. Frankfurt/Oder), 1990-1993 Ldkr. Bernau, 1993 Ldkr. Barnim

EREIGNISSE BIS KRIEGSENDE: 1938 wurden auf dem Marktplatz im Rahmen der Hussitenfestspiele „Fahnen von Abordnungen der sudetendeutschen Henlein-Faschisten“ geweiht (Bülow, S. 278). - Der am 13.12.1944 aus Schwiebus (Neumark) als „Umsiedler“ (Bülow) nach Bernau gekommene Franz Engler übt in Bernau bis 1957 sein Gewerbe als Pantoffel- u. Filzschuhmacher aus (Bülow, S. 96). - 20./21.4.1945 Einmarsch der Roten Armee (Bülow 1, S. 6).

EREIGNisSe NACH KriegSende: „Im April und Mai [1945] starben 77 Flüchtlinge und durch Bernau Ziehende“ (Bülow, S. 303). - Mitte Juni 1945 Ruhrepidemie (Bülow 1, S. 6). - 1945 „umfangreicher Zuzug“ durch „Umsiedler aus den Gebieten östlich der Oder und aus dem Sudetenland“, dennoch bis 1946 Bevölkerungsrückgang infolge hoher Sterblichkeit durch Krankheiten (Bülow, S. 265). - 1945/46 in der Bodenreform 38 ha (von 408 ha) an 6 Umsiedler vergeben (HOL VI, S. 34), unter den 165 Bewerbern waren 31 Flüchtlinge (Bülow 1, S. 11). - April 1946: Vertriebene aus einem „Antifa-Transport“ aus dem ehem. Sudetenland werden teilweise nach Bernau geleitet: „Wer etwas von der Textilindustrie verstand, kam nach Werdau [Vogtland] oder Bernau [...].“ (Funke, S. 85). - 31.5.1946 Begrüßung eines „Antifa-Transports“ aus der Tschechoslowakei durch den Landrat des Kr. Niederbarnim (Christopeit, S. 83). - Herbst 1946 Beschwerde seit dem 10.7.1946 in Bernau gemeldeter, zuvor fünf Wochen im Quarantänelager $\rightarrow$ Hennigsdorf untergebrachter sudetendeutscher „Antifa-Umsiedler“ an die Provinzialverwaltung über die Vorenthaltung des Wahlrechts (Christopeit, S. 83). - 1946-1948 Spendensammlungen der 
Volkssolidarität „für die Unterstützung der Heimkehrer und Umsiedler, für die Kinderverschickung und Altenbetreuung“ (Bülow, S. 313). - „In einzelnen Gewerken war durch den Zuzug von Umsiedlern ein Überangebot entstanden, das in den Folgejahren auf ein Normalmaß zurückging." (Bülow, S. 103). - 1979-1990 war der 1944 aus seinem Geburtsort Breslau nach Arneburg/Elbe evakuierte Joachim Klein (geb. 1935) Bürgermeister der Stadt Bernau (Bülow, S. 248 f.).

BevöLKerungSzAHLEN: 1925: 9962, 1939: 15311, 1946: 12 984, 1964: 11893 (Städtebuch, S. 41). - 16.8.1946: 12414 Stammbevölkerung, $1116+155$ „Tsch[echen]“ (BLHA, Rep. 230 Bernau, Nr. 20, Bl. 3).

Katholiken: 1925: 551, 1946: 1162 (Städtebuch, S. 42). - 22.8.1946 „Propst Düllick, Franz, Bernau b/Berlin, Börnickerstr. 12" erwähnt in einer Aufstellung der außerplanmäßig eingesetzten „Flüchtlingsgeistlichen“ (DAB, I/9-15-1 Flüchtlingsseelsorge 1945-1951, unfol.), ab 1.7.1947 Kuratus in $\rightarrow$ Schwanebeck (Kr. Niederbarnim), wohnt Zepernick, Siedlung Gehrenberge, Kolpingstr. 16 (seine Bistumszugehörigkeit als „Priester auswärtiger Bistümer“ weiterhin: Schneidemühl) (Schematismus Berlin 1949, S. 61, 140; vgl. $\rightarrow$ Bernau). - Kaplan der Bernauer Herz-Jesu-Pfarrei war ab 15.9.1947 der Schlesier Siegfried Zimmer (geb. 1914 Rudelsdorf, Kr. Groß Wartenberg), der als „Priester auswärtiger Bistümer“ auch 1949 noch dem Bistum Breslau zugeordnet war (ebd., S. 61, 147).

FlüChtLINGS-/(KREIS-)UMSIEDleRlager (zuvor 1943-1945 Kasernen der SS-Lehr- und Versorgungsabteilung für Brieftauben [„Taubenstation“]), Sachtelebenstraße (während DDRZeit: Straße der Befreiung): 1945 „vorübergehend Auffanglager für Flüchtlinge“ (Bülow, S. 110, 264). - Kapazität am 31.12.1945: 1000 (BArch, DO 2/45, Bl. 40). - Kapazität am 1.1.1946: 1000 (BLHA, Rep. 203 MdI, Nr. 1163, Bl. 49). - 14.2.1946 Kreis- und Quarantänelager, Kapazität: 1000 (Oehlsen, S. 28). - 1946 Belegungsstärke: 1000 (Kaminsky, S. 159). - Die Zahlen zur Lagerkapazität sind offenbar in der Realität nicht erreicht worden, meist wohl nur etwa 500 Personen (Eccarius). - 30.4.1946 als eines der verbleibenden Umsiedlerlager genannt (DAB, I/9-15-1 Flüchtlingsseelsorge 1945-1951, unfol., [30.6.1946], [Anlage 3]). - Juli 1946 „Der erste Transport von Antifaschisten aus der Tschechoslowakei hat die Zeit der Quarantäne im Umsiedlerlager in Bernau beendet. In einer Zusammenkunft im Umsiedlerlager zwischen dem Sprecher der Umsiedler und dem Landrat des Kreises Niederbarnim wurde die Verteilung der Transportteilnehmer auf mehrere Orte unseres Kreises vorgenommen." (Kurznachricht in: Märkische Volksstimme, Nr. 68, 11.7.1946). - 24.8.1946 Umsiedlerlager, Kapazität: 800 (SAPMO-BArch, DY 34/27880, Bl. 291). - 19.9.1946: Razzia des Arbeitsamtes (mit Kreispolizei) am Bahnhof Bernau: „In 151 Fällen, in denen die Arbeitspapiere nicht in Ordnung waren bzw. eine Urlaubsbescheinigung nicht vorlag, erfolgte die Einweisung zu Aufräumungsarbeiten in dem früheren Flüchtlingslager, der ,Taubenstation" “ (Kurznachricht in: Märkische Volksstimme, Nr. 133, 24.9.1946). - Die Gebäude wurden anschließend (bis 1993) von der Sowjet. Armee als Kasernen genutzt, nach 1994 Konversion, Umbau zu behindertengerechten Wohnungen (Eccarius; Bülow, S. 110). - In Bernau befand sich 1945 außerdem ein Repatriierungslager (Eccarius). 
FlüChtlingsdurchgangslager Elysium (ehem. Restaurant „Elysium“ am Steintor, Berliner Straße 1: [Vor 2.8.] 1946 von der Stadtverwaltung, die laut Grundbuch Vorkaufsrecht hatte, käuflich erworben. „In den ersten Jahren nach dem 2. Weltkrieg wurde die Einrichtung für verschiedene Zwecke genutzt, z. B. Durchgangslage für Flüchtlinge“, da mit großem Saal ausgestattet. Ostern 1950 Wiedereröffnung als (1951-1990 HO-)Gaststätte, 1979/80 Umbau u. Neubau des Saales, 1995/97 erneuter Umbau u. Teilabriss (Bülow, S. 127-129, Zitat S. 128), heute ebd. wieder Gaststätte „Elysium“.

Strassenumbenennungen: Im seit 1932 besiedelten Ortsteil Friedenstal wurden zahlreiche Straßen nach deutschen Flüssen benannt, 1974 traten russische und 1995 weitere deutsche hinzu. Unter den 1932 benannten finden sich auch Neiße-, Oder- und Weichselstraße (Bülow, S. 187).

Städtepartnerschaften: 1979 Skwierzyna, Polen (Schwerin/Warthe, ehem. Provinz Posen, 1938-1945 Provinz Brandenburg), 1996 erneuert.

VertriebenenVERBÄNDE NACH 1990: (1) BdV-Kreisverband Eberswalde, Freienwalde, Bernau e.V. (Sitz $\rightarrow$ Eberswalde), gegründet 1991 (Märkischer Informationsdienst 8/1994, S. 14). (2) 1995-2007 lag die Schriftleitung des vom Heimatkreis Weststernberg e. V. (Sitz: Marl) herausgegebenen "Heimatbriefs Weststernberg“ in den Händen von Karl-Heinz Schneider (geb. 1936), Bernau.

Archivalische und sonstige ungedruckte Quellen: BArch, DO 2/39, Bl. 88 (Lager, Dez. 1945). - BLHA, Rep. 250 Niederbarnim, Nr. 1334 („Ermittlungen gegen Großhändler Günter Brammer, Bernau, wegen unzulässiger Preisgestaltung bei Möbeln für Zwecke der Umsiedler“, 1948). - Auskünfte Bernd Eccarius (Archiv/Museum Bernau), 13.9.2016.

Gedruckte Quellen und Literatur: Bülow, Karl: Chronik der Stadt Bernau 1945-2000. T. 1. Bernau 2000. Ders.: Chronik der Stadt Bernau 1945-2000. Überarb. Fass. [in 1 Bd.]. Bernau 2007 (CD). - Christopeit. - Dokumentation der Vertreibung I/2, S. 714. - Funke, Alfred: Die Messerschmiede - das märkische Klein-Solingen. In: Leegebruch. Hrsg.: Arbeitsgruppe Heimatgeschichte im Kulturverein Leegebruch. 2. Aufl. Leegebruch [2003], S. 85-92, hier S. 85. - Schwillus/Brühe, S. $298 \mathrm{f}$.

\section{Bestensee}

Landgemeinde, bis 1952 Kr. Teltow, 1952-1990 Kr. Königs Wusterhausen (Bez. Potsdam), 1990-1993 Ldkr. Königs Wusterhausen, 1993 Ldkr. Dahme-Spreewald

EReignisse bis KriegSende: Anf. Jan. 1940 besteht in Bestensee ein Auffanglager für 250 umgesiedelte Wolhynien- und Galiziendeutsche (Müller, S. 122). - „Im Januar und Februar 1945 zogen die ersten ,Flüchtlings-Wagenzüge - von Osten kommend - durch Bestensee." (Schäffer, S. 122). - [Anf. bis April 1945:] „Flüchtlinge, die Wochen und Tage zuvor aus dem Osten kommend durch Bestensee zogen oder hier eine Bleibe suchten, kündigten an, dass der Tag nicht mehr fern sei, an dem auch Bestensee von Truppen der Roten Armee besetzt werden 
sollte،“ (Bestensee, S. 213). - [April 1945:] „Das NS-Müttererholungsheim am Seechen bekam den Status als Lazarett der Wehrmacht. Viele Hausbesitzer bekamen nun geflohene Menschen aus den ostdeutschen Gebieten, ... als Zwangsmieter zugewiesen. [...].“ (ebd., S. 213 f.; fast textgleich: Schäffer, S. 122f.). - 26.4.1945 Einmarsch der Roten Armee (Bestensee, S. 214f.; Schäffer, S. 125).

EReIGnisse NACH KRIEgSEnde: [Mai 1945]: „Flüchtlinge strömten von Ostpreußen, Schlesien, Pommern, dem Sudetenland, aus dem zerbombten Berlin und aus dem Bereich des Kampfgebietes Halbe-Märkisch Buchholz-Baruth nach und durch Bestensee. Sehr viele suchten hier eine Bleibe." (Bestensee, S. 216). - Mehrere Kolonnen Kriegsgefangener kampieren auf dem Marienhofer Berg (ebd., S. 216f.) - „Unser Ort von Flüchtlingen überschwemmt, die Tanzsäle, Schulen, Kirche belegt mit Verwundeten; dies war die Situation im Mai 1945“ (Wahlaufruf der SED Bestensee 1946, zit. nach Bestensee, S. 217). - Mai 1945 Einwohnerzahl gegenüber 1939 mehr als verdoppelt. „Im Vorwerk Marienhof, in den Gaststätten Rodominsky und Zur Linde, wo zum Teil noch Verwundete lagen[,] und in sehr vielen Bestenseer Wohnhäusern wurden Flüchtlinge untergebracht. Jedes Wochenendhaus, jede Gartenlaube war übervoll mit Menschen belegt. [...].“ (Bestensee, S. 217). - 1945 Bodenreform (HOL IV, S. 17: Umsiedler nicht gesondert erwähnt). - 11.9.1946 Wahlaufruf der SED: „Die Nähstube [des Frauenausschusses] bewährte sich besonders und es konnten Bedürftige, insonderheit Flüchtlinge, mit schützender Kleidung versorgt werden." (Bestensee, S. 222).

EREIGNisSe NACH 1990: Durch Beschluss der Gemeindeverwaltung ist Bestensee eine der Patengemeinden der Stiftung „Zentrum gegen Vertreibungen“ (http://www.z-g-v.de/ [23.6.2017]).

BeVÖLKERUNGSZAHLEN: 1939: 2 802, 1946: 3378, 1964: 3349 (HOL IV, S. 18).

Katholiken: „Als die Pfarrei nach dem Krieg auf über 3000 Katholiken anwuchs, erwarb ein Gemeindemitglied die massive Baracke einer früheren Kammfabrik und stellte sie für den Gottesdienst in Bestensee zur Verfügung. Am 29.1.1950 benedizierte Domkapitular Georg Puchowski die neue Kapelle auf dem Grundstück zwischen Freiligrath- und Mozartstraße. [...].“ [Freiligrathstr. 11]. (Brühe, S. 13; textähnlich, aber verkürzt: Schwillus/Brühe, S. 329). „Wegen der Vertriebenen aus Schlesien war die Kapelle seit ihrer Benediktion der hl. Hedwig gewidmet [...].“ (Brühe, S. 13; textidentisch: Schwillus/Brühe, S. 329).

Luisenheim, „Evangelisches Wohn- und Altersheim Bestensee“ (Landheim der Berliner Stadtmission für Frauen), „auf einem seitens der Berliner Stadtmission von der Berliner LuisenstadtKirchgemeinde gepachteten Gelände“ am See: [Ca. 1951:] „Unter den hier beheimateten Frauen - etwa 25 können Aufnahme finden - sind Flüchtlinge und überwiegend Berlinerinnen, die ihr Heim während des Luftkrieges verloren." (Fünfundsiebzig Jahre Berliner Stadtmission, S. 119; Gebäude-Abb. S. 120). 
Gemeindepartnerschaft: 2002 Przemęt, Polen (Priment, ehem. Kr. Bomst, Provinz Posen/ Wartheland) (przemet.pl [25.8.2018]).

Literatur: Bestensee. Die Chronik eines märkischen Ortes. Bestensee 2006. - Brühe, Matthias: Katholische Kirche zwischen Havel und Dahme. Berlin 1999, S. 13. - Fünfundsiebzig Jahre Berliner Stadtmission. Berlin 1952. - Müller, Erich: Transporte, Lager, Ansiedlung im Warthegau: Das Schicksal der galizien- und wolhyniendeutschen Umsiedler nach ihrem Grenzübertritt 1939/40. In: Zeitweiser der Galiziendeutschen 43 (2005), S. 104-157. - Schäffer, Harry: Bestensee im Winter und Frühjahr 1945 und das Ende der nationalsozialistischen Herrschaft. In: Heimatkalender Königs Wusterhausen und Dahmeland 2014, S. 122-125. - Schwillus/Brühe, S. 329.

\section{Biesenthal}

Stadtgemeinde, bis 1950 Kr. Oberbarnim, 1950-1952 Kr. Niederbarnim, 1952-1990 Kr. Bernau (Bez. Frankfurt/Oder), 1990-1993 Ldkr. Bernau, 1993 Ldkr. Barnim

EREIGNISSE BIS KRIEGSENDE: Ab Jan./Febr. 1945 Unterbringung von 2000 Flüchtlingen (400 bis 800 waren angekündigt), je zur Hälfte in Bahnhof (nach anderen Orten weitergeleitet) u. ab April Schule (in Biesenthal verblieben), z. T. kath. Konfession (Auskünfte Poppe, 30.8.2016, nach Augenzeugenberichten u. Tagebuch Stephan). - Schule ab April „Frontlazarett der Wehrmacht und Flüchtlingsunterkunft“ (Poppe, Neuanfang, T. 3, S. 17). - 20.4.1945: Zwangsevakuierung der Stadt; Zugunglück am Bahnhof Biesenthal: Ein aus Richtung Bernau kommender, nach Tieffliegerangriff unbesetzter Tankzug fährt auf einen mit Flüchtlingen besetzten Personenzug ungeklärter Herkunft, den auch Biesenthaler Einwohner zur Evakuierung nutzen wollten, auf; zahlreiche Verletzte, laut Standesamt 16 Tote (vollständige Zahl der Toten u. Namen unbekannt); 22.4.1945 kampfloser Einmarsch polnischer Truppen und der Roten Armee, dabei Beschießung des Zuges; Verbleib der Leichen aus dem Zug ungeklärt, vielleicht auf dem benachbarten Friedhof Melchow, wo 20 unidentifizierte Opfer der letzten Kriegstage liegen (Mitteilung Poppe, 4.10.2016, nach Zeitzeugenberichten; Ausstellungs-Zeittafel des Heimatvereins Biesenthal e. V., Taf. 4.1).

EReignisse NACH KRIEgSEnde: 194522 Todesfälle durch Typhus (Poppe, Die Biesenthaler Kriegstoten). - 15.9.1945 Einrichtung der „Umsiedlerfürsorge“ der Stadt Biesenthal (laut Rechenschaftsbericht im Amtsarchiv Biesenthal, Mitteilung Poppe, 4.10.2016). - „Für die fast 600 Umsiedler, Flüchtlinge und Vetrriebene, die in Biesenthal untergekommen waren, bestand bei der Stadtverwaltung eine Abteilung Umsiedlerfürsorge. [...] In der Aktion ,Rettet das Kind! wurde eine besondere Sammlung von der Bezirksbürgermeisterei [...] veranstaltet und Sachen an Flüchtlinge in den zugehörigen Dörfern verteilt. [...].“ (Poppe, Neuanfang, T. 4, S. 16). 1945/46: in der Bodenreform 64 ha (von 171 ha) an 17 Umsiedler vergeben (HOL VI, S. 46; Poppe, Neuanfang, T. 5, S. 16); laut Rechenschaftsbericht der Umsiedlerfürsorge haben in Biesenthal „29 Umsiedler Land (Neubauernstellen) erhalten“ (Amtsarchiv Biesenthal, Mitteilung Poppe, 4.10.2016). - Jan. 1946 aus nach Thüringen durchfahrendem Vertriebenentransportzug aus Danzig u. Hinterpommern „in Biesenthal angeblich 20 Tote entnommen“ (Wille I, S. 325). - 
Am 7.6.1948 bestehen in Biesenthal neun von Vertriebenen (überwiegend 1946, in je einem Fall im Dez. 1945 und im Jan. 1948) eingerichtete Handwerksbetriebe (Wille II, S. 365 f.: Liste mit Angabe des Gewerbes, der Adresse u. des Inhaber-Vornamens, Familienname abgekürzt).

BevöLkerungszahlen: 1925: 3250, 1939: 4236, 1946: 4212, 1964: 4632 (Städtebuch, S, 45). - 1.5.1945: 2251 (539 Männer, 1209 Frauen, 503 Kinder). „Das war rund die Hälfte der gemeldeten Einwohner. Erst bis Jahresende 1945 normalisierte sich die Einwohnerzahl wieder: 1283 Geflüchtete kamen zurück, 169 Soldaten kehrten heim, 327 Neusiedler und Flüchtlinge von jenseits der Oder kamen dazu." (Poppe, Neuanfang, T. 2, S. 16). - Rechenschaftsbericht der Umsiedlerfürsorge [undatiert, wohl 1946]: „Biesenthal hat z. Zt. ca. 550 bis 600 Umsiedler aufgenommen." (Amtsarchiv Biesenthal, Mitteilung Poppe, 4.10.2016).

Katholiken: 1946: 374 (Städtebuch, S. 45). - „Bald nach Kriegsende kamen große Flüchtlingsströme auch in das weite Gebiet der Pfarrgemeinde Biesenthal. Da unter den Flüchtlingen auch viele Katholiken waren, wuchs die Zahl der Gemeindmitglieder enorm an. Auf den vielen Dörfern, auf denen früher kaum ein Katholik gewohnt hatte, entstanden kleine Kirchengemeinden. So richtete Pfarrer Josef Brzycki in Grüntal und in Hoffnungstal Gottesdienststationen ein, auf die er regelmäßig mit dem Fahrrad rausfuhr, um mit diesen Sontags- und Feiertagsgottesdienste zu feiern." (Ruhl, S. 127).

Katholisches Kinderheim St. Joseph (Bahnhofstraße 49), 1947-1954 geleitet von Hedwigschwestern: 1947 von der Caritas den aus ihren schlesischen Niederlassungen Peterswaldau (Pieszyce), Kr. Reichenbach, am 23.11.1946 u. Niedersteine (Ścinawka Dolna), Kr. Neurode, am 22.11.1946 vertriebenen $u$. mit den dort untergebrachten Kindern zunächst in ein Durchgangslager nach Leipzig (Peterswaldau) bzw. nach Berlin (Niedersteine) transportierten Hedwigschwestern zur Verfügung gestellt: „Die [Peterswaldauer] Kinder wurden den Schwestern trotz heftigen Widerstandes weggenommen und von den Behörden in Familienpflegestellen untergebracht. Die Schwestern kamen nach Berlin-Schöneberg. Nachdem die Caritas ihnen ein Haus in Biesenthal zur Verfügung gestellt hatte, gelang es ihnen, die Kinder wieder zurückzubekommen.“ (Mertens, S. 114; vgl. Mengel, S. 169). - „Die ersten Schwestern bezogen das neue Kinderheim St. Josef [...] am 3. Februar 1947. Mitte Februar erhielten weitere Schwestern die Zuzugsgenehmigung, so daß der Konvent auf sechs Schwestern wuchs. Das Haus war vollständig leer, und es herrschte bittere Kälte. Die nötigsten Möbel und Lebensmittel erhielten die Schwestern von den Nachbarn. Am 9. März 1947 trafen die Kinder aus Niedersteine (Ścinawka Dolna) mit zwei weiteren Hedwigschwestern in einem Omnibus ein. Die Kinder kampierten anfangs in Strohsäcken auf der Erde. Durch Wohltäter kamen bald Bettstellen und anderes Notwendige. Die Federbetten hatten die Schwestern bei der Vertreibung mitnehmen können, so daß die Kinder bald gut untergebracht waren. Am 1. Juni 1947 weihte der Gemeindepfarrer eine Hauskapelle im Kinderheim ein. / Die Zahl der Kinder stieg beständig. Anfangs waren nur 27 Kinder aus Niedersteine im Heim. Allmählich gelang es den Schwestern jedoch, auch die Kinder aus Peterswaldau, die in Pflegestellen untergebracht waren, wieder zurückzubekommen. 
Ende 1947 waren bereits über sechzig Kinder in Biesenthal, darunter auch zahlreiche aus Berlin. [...].“ (Mertens, S. 488). - „1949 betreuten neun Schwestern die Kinder im Heim und gingen der ambulanten Krankenpflege nach. Die Kinder besuchten die Ortsschule. Das Gebäude des Kinderheimes war von der Kongregation gemietet. [...] Weil das Haus auf Dauer nicht für die Unterbringung von Kindern geeignet war, wurde das Kinderheim am 1. Juli 1954 mit dem Ende des Schuljahrs aufgelöst. Der Konvent verkleinerte sich auf drei Schwestern, die zunächst noch in dem bisherigen Haus blieben, bis es einen neuen Bewohner fand. Im April 1955 bezogen sie eine kleine Dreizimmerwohnung in der Thälmannstraße 16. Von hier aus setzten sie die ambulante Krankenpflege, die Arbeit in der Sakristei und den Seelsorgedienst fort." (ebd.). Zuletzt nur noch zwei Schwestern, ab Nov. 1959 in der Thälmannstraße 41 (ebd., S. 488 f.). „Als den beiden Schwestern auch diese Wohnung gekündigt wurde, verließen sie Biesenthal am 1. Juli 1960, und die Niederlassung wurde aufgelöst." (ebd., S. 489). - 1949 Kinderheim der Hedwigsschwestern mit 8 Mitgliedern (Schematismus Berlin 1949, S, 95). - Zuletzt lebten ca. 50 bis 54 Kinder im Heim. „Von den Kindern des Katholischen Kinderheims sind 11 in Biesenthal verblieben und [haben] hier eine Familie gegründet, die Nachkommen von ihnen leben noch heute in Biesenthal." (Brief Poppe, 4.10.2016). - Abb. des Hauses: Ruhl, S. 17 f. - Das Kinderheim St. Joseph ist nicht identisch mit dem „Haus Sonnenblick“ in der Bahnhofstr. 42.

StÄdtepartnerschaft (des Amtes Biesenthal-Barnim): 13.12.1999 Nowy Tomyśl, Polen (Neutomischel, ehem. Kreisstadt in der Provinz Posen) (http://www.amt-biesenthal-barnim. de/amt9.htm [30.9.2016]).

Quellen: Auskünfte Gertrud Poppe (Ortschronistin), Biesenthal, 30.8. und 11.10.2016 und Brief vom 4.10.2016. Page, Regina: Der Albtraum meiner Kindheit und Jugend. Zwangseinweisung in deutsche Erziehungsheime. Leipzig 2009 (Kap. „Der Heimaufenthalt. Von 1952-1954 im Kinderheim Biesenthal“). - Schematismus Berlin 1949, S. 62, 95. - Stephan, Klara: „Kriegstagebuch“ 1939-1945 (Manuskript im Besitz des Heimatvereins Biesenthal e. V.). - Wille II, S. 365 f. (Liste der von Vertriebenen in Biesenthal eingerichteten Handwerksbetriebe, 1948; Familiennamen nur mit Initialen wiedergegeben).

Literatur: Brühe, Matthias: Katholische Kirche zwischen Uckermark und Oderland. Berlin 1998, 17. - Mengel, Thomas: Das Schicksal der schlesischen Frauenklöster während des Dritten Reiches und 1945/46. Köln/Wien 1986. - Mertens, Johannes: Geschichte der Kongregation der Hedwigschwestern 1930-2000. Manuskript. Berlin 2004, S. 114-115 (Peterswaldau), 132133 (Niedersteine), 488-489 (Biesenthal). - Poppe, Gertrud: Die Biesenthaler Kriegstoten. In: Biesenthaler Anzeiger 5 (1995)6, S. 20. - Dies.: Der Neuanfang 1945/46. T. 2: Arbeit war für alle mehr als genug. In: ebd. 5 (1995)8, S. 15-16; T. 3: Die Schule beginnt wieder. In ebd., S. 17-20; T. 4: Die Kindertagesstätten entstehen neu. In: ebd. 5 (1995)9, S. 14-16; T. 5: Die Land- und Forstwirtschaft nach dem Kriege. Bodenreform und Umsiedlerfürsorge. In: ebd. 5 (1995)9, S. 16-17. - Ruhl, Johannes: St. Marien Biesenthal 1909-1999. [Biesenthal] 1999. - 700 Jahre Stadtrecht Biesenthal. Die Entwicklung unserer Stadt von der Frühgeschichte bis in unsere Zeit in 8 Themen [Zeittafel in 10 Ausstellungstafeln] (www.heimatverein-biesenthal.de [11.10.2016]). 


\section{Birkenwerder}

Landgemeinde, bis 1952 Kr. Niederbarnim, 1952-1990 Kr. Oranienburg (Bez. Potsdam), 1990-1993 Ldkr. Oranienburg, 1993 Ldkr. Oberhavel

BEVÖLKERUNGSZAHLEN: 1925: 3 640, 1939: 6648, 1946: 7 023, 1964: 6976 (HOL VI, S. 51).

Katholiken: 1945-1946 wirkt als Kaplan in Birkenwerder der der dem Erzbistum Breslau angehörige, bis 1945 in Küstrin wirkende Kaplan Alfons Kuschbert (geb. 1911 Neisse) (Ostpriesterverzeichnis 2, 1949, S. 50), ab 1946 in $\rightarrow$ Lübben (Schematismus Görlitz, S. 68). - 1949 lebt in Birkenwerder, Summter Str. 36, der dem Erzbistum Breslau angehörige, vor 1945 in Giesmannsdorf im Kr. Jauer (Schlesien) wirkende Pfarrer Alfons Raschke (geb. 1888 Breslau) (Ostpriesterverzeichnis 2, 1949, S. 67; Schematismus Berlin 1949, S. 145).

Ada-von-Manteuffel-Stift (1949-1989 „WALdhaus“), Am Wacholderbusch 1-3: 1930/31 eingerichtet auf Beschluss des Kurländischen Landtags als Witwenstift für deutschbaltische (kurländische) adlige Witwen aus den Mitteln des der Kurländischen Ritterschaft u. a. dazu testamentarisch vermachten Vermögens der Ada Baronin von Manteuffel (1849-1914). „Das Haus nahm [1945] immer mehr den Charakter eines Flüchtlingsheims für evakuierte baltische Landsleute der Frauen an. Als im April 1945 die Rote Armee in Birkenwerder einrückte, wurde das Haus verwüstet." Die Witwen mussten das Stiftsgebäude verlassen, vegetierten in einem Keller und konnten nach einer Woche in das innen komplett zerstörte Haus zurückkehren. „,Durch mangelhafte Ernährung konnten die geschwächten Körper nicht mehr den Krankheiten wie Ruhr, Hungertyphus, Wassersucht und Rose Widerstand leisten. Eine nach der anderen entschlief und wurde auf dem Birkenwerder Friedhof beerdigt" [...]. Nur fünf Damen überlebten diese Zeit. Die älteste starb 1971 im Alter von 99 Jahren. / Zu DDR-Zeiten wurde das ,Waldhaus', wie es hieß, als Schwesternwohnheim der Klinik genutzt. Nach der Wende wurde das Haus in Erbpacht vergeben." Eigentümer sind die Vereinigten Kurländischen Stiftungen (VKS) der Baltischen Ritterschaften (Sitz München). Auf dem Waldfriedhof befanden sich die Gräber von 21 adligen Witwen, „die nach dem Zweiten Weltkrieg in Birkenwerder verstorben sind“ (2013 nicht mehr vorhanden) (OGA, 27.3.2013). - „Von 1949 bis 1989 verpachtete Walter Baron Koskull, als Bevollmächtigter Geschäftsführer, das Haus mit Grundstück. In diesem Zeitraum war das Haus ein Schwesternwohnheim. Nach Kündigung des Pachtvertrages wurde ein Investor gesucht und es entstanden Eigentumswohnungen in diesem Haus." (www.birken werder.de). - Der Geschäftsführer der VKS, Andreas Baron von Mirbach, bemühte sich 2013 um die Errichtung eines Gedenksteins für die Witwen auf dem Waldfriedhof anlässlich des 100-jährigen Bestehens der Stiftung 2014 (OGA, 11.4.2013). Am 23.6.2013 beriet der Ortsentwicklungsausschuss darüber (www.birkenwerder.de) und sprach sich nach kontroverser Diskussion gegen die Aufstellung aus (Mitteilung Mirbach).

QUellen und Literatur: Baltische Totenschau 1939-1947. Zsgest. u. hrsg. von Georg Adelheim. Göttingen 1947 (1948) (Todesfälle im Manteuffelstift). - Deutsch-baltisches Gedenkbuch. Bearb. von Karin von Borbély. Darm- 
stadt 1991. - Gerüchte ranken um einen Gedenkstein, der nicht da ist. In: Oranienburger Generalanzeiger (OGA), 27.3.2013. - Alte baltische Witwen starben an Schwäche. In: Oranienburger Generalanzeiger (OGA), 11.4.2013. Schwillus/Brühe, S. 300. - www.birkenwerder.de/uploads/tx_3bdocs/2013-03-26_Unterlagen_Oeffentlichkeit_In ternet.pdf [3.10.2017]. - Mitteilung Andreas Baron von Mirbach/VKS, Hersbruck, 5.10.2017).

\section{Blankenfelde}

Landgemeinde (seit 2003 Ortsteil von Blankenfelde-Mahlow, vgl. $\rightarrow$ Mahlow), bis 1952 Kr. Teltow, 1952-1990 Kr. Zossen (Bez. Potsdam), 1990-1993 Ldkr. Zossen, 1993 Ldkr. TeltowFläming

EREIGNisSE BIS KRIEgSENDE: 1945: „Über die Blankenfelder Straßen zogen gegen Kriegsende immer häufiger lange Flüchtlingskolonnen." (Peters, S. 41). - März bis Anf. Mai 1945 Tod zahlreicher Flüchtlinge, darunter solche aus Schlesien und (Mittel-)Polen (Sterberegister Standesamt Blankenfelde). - 22.4.1945 Einmarsch der Roten Armee (ebd., S. 42). - 25.4.1945 „Selbstmord durch Vergiften“ eines 20-jährigen Drehers, „zur Zeit wohnhaft in Blankenfelde“, „Ortsansässig: nein“, „letzter Wohnort laut polizeilicher Meldung: Kotzenau/Kr. Lüben Schles[ien]“ (Sterberegister Standesamt Blankenfelde, Nr. 77/1946).

EREIGNisSe NACH KRIEgSEnde: [1945/46:] „Die Lebensmittelsituation blieb [...] unverändert schwierig, zumal Blankenfelde in dieser Zeit wegen der großen Zahl von Flüchtlingen etwa 9000 Einwohner hatte. (Viele fanden in den Wohnungen geflüchteter Nazis Unterkunft.)“ (Peters, S. 47). - Juni 1945 bis 1946 Tod zahlreicher Flüchtlinge aus der Neumark, aus Ostpreußen, Pommern, Schlesien und vereinzelt Baltikum, Bessarabien, „Warthegau“, Sudetenland und (Mittel-)Polen in Blankenfelde, oft an allgemeiner oder Herz-/Kreislaufschwäche, Kreislaufstörungen, teilweise an Unternernährung (Sterberegister Standesamt Blankenfelde), u.a. 16.12.1945 Tod einer 83-jährigen Frau aus Bessarabien (ausgewiesen durch „Umsiedlerausweis“; ebd., Nr. 355/1945), 13.2.1946 Tod eines 69-jährigen, nicht ortsansässisgen Pensionärs aus Ostpreußen an „Entkräftung, Herzmuskelschwäche, Unternernährung, Lungenentzündung“ (ebd., Nr. 69/1946). - Ab 14.9.1945 Bodenreform (ebd., S. 49f.). - Ende Juli 1948 im Verzeichnis (von der Landesregierung) verbotener Suchdienste erwähnt: Pfitzner, Blankenfelde Post Mahlow üb. Berlin, Steigerwaldweg 15 (BLHA, Rep. 203 MdI, Nr. 1197, Bl. 41).

BevölKerungSzAHLEN: 1925: 742, 1939: 6228, 1946: 6667, 1963: 6811 (HOL IV, S. 25).

DurChgangslager: 18.7.1945 Tod eines am 21. Jan. 1945 in Grünberg in Schlesien geborenen Kindes, „wohnhaft in Grünberg/Schlesien, Breslauer Straße 17 A, zur Zeit mit den Eltern in Blankenfelde auf der Durchreise [...] in Blankenfelde Kreis Teltow im Durchgangslager“ „an „Ernährungsstörungen" (Sterberegister Standesamt Blankenfelde, Nr. 190/1945).

Haus St. Marien der Grauen Schwestern (Station für ambulante Krankenpflege, Hilfe in der kath. Seelsorge und die Betreuung der kath. Kirche) (Am Bruch 17), 1947-1991: Eingerichtet 
auf Wunsch des (aus dem Bistum Münster/Westf. stammenden) kath. Blankenfelder Pfarrers Bernhard Kuckelmann (geb. 1899 Warendorf/Westf. [Schematismus Berlin 1949, S. 143]). „Am 29. Juli 1947 schickte das Provinzhaus in [Berlin-]Tempelhof vier Schwestern in seine Gemeinde, die aus den Ostgebieten evakuiert worden waren. Die Pfarrei stellte ihnen ein Einfamilienhaus [...] zur Verfügung und bezahlte die Miete." 2.11.1947 Einweihung. Eigentümer des Hauses war eine 1946 in den Westen gegangene Frau aus Blankenfelde, die dem Pfarrer die Nutzung gegen Mietzahlung gestattet hatte; später an die Kommunale Wohnungsverwaltung in der DDR übergegangen. (Mertens, S. 469). - 1951: 4 Schwestern, auch Hauskrankenpflege in benachbarten Orten, ab 1957 mit Moped. 1969: 3 Schwestern (ebd., S. 470). - „1972 feierte die Filiale ihr 25jähriges Bestehen unter großer Beteiligung der Gemeinde. Die Bürgermeisterin, die Vertreter der Nationalen Front und der CDU dankten in ihren Festansprachen für die gute Zusammenarbeit. [...].“ (ebd., S. 471). - 10.9.1991 Schließung (ebd., S. 472). - Konventsoberinnen: Aurelia Schneider (29.7.1947-17.1.1950), Eduarda Lingk (17.1.1950-30.6.1953) (die weiteren bis 1991 bei Mertens, S. 468, genannt).

Strassenumbenennungen: Am 3.7.1945 noch nachgewiesen: Memelländer Straße (Sterberegister Standesamt Blankenfelde, Nr. 173/1945). - Nach 1945 [1950?]: „Ohne Ausnahme wurde das Straßenviertel mit den Namen von Kolonien und ehemals deutschen Städten und Grenzgebieten gestrichen. Hier wurden die Namen meist deutscher bildender Künstler eingesetzt [...]." (Meier, S. 52).

Archivalische Quellen: Gemeindearchiv Blankenfelde-Mahlow, Sterberegister des Standesamtes Blankenfelde 1945-1946 (www.ancestry.de).

Literatur: Brühe, Matthias: Katholische Kirche zwischen Havel und Dahme. Berlin 1999, S. 14. - Meier, Günter: Die Straßennamen von Blankenfelde 1918 bis 2002. In: Heimatjahrbuch für den Landkreis Teltow-Fläming 9 (2002), S. 47-53. - Mertens, Johannes: Die Berliner Ordensprovinz der Grauen Schwestern von der heiligen Elisabeth 18591991. Reinbek bei Hamburg 1992, S. 468-472. - Peters, Jan: 600 Jahre Blankenfelde Kr. Zossen. Blankenfelde, Kr. Zossen 1975.

\section{Blumenthal}

Landgemeinde (seit 2003 Ortsteil von $\rightarrow$ Heiligengrabe), bis 1952 Kr. Ostprignitz, 1952-1990 Kr. Pritzwalk (Bez. Potsdam), 1990-1993 Ldkr. Pritzwalk, 1993 Ldkr. Ostprignitz-Ruppin

EREIGNISSE NACH KRIEGSENDE: 17.4.1948: Missionsinspektor Martin Urban (Heiligengrabe) hält in der Dorfkirche den ersten Glaubenstag für bessarabiendeutsche Flüchtinge in der SBZ (Keller/Baumann, S. 217).

Bevölkerungszahlen: 1925: 395, 1939: 435, 1946: 814, 1964: 1283 (HOL I, S. 68).

Gedruckte Quellen und Literatur: Keller, Herbert / Baumann, Arnulf: Bessarabischer Brüderbesuchsdienst in der DDR. In: Jahrbuch der Deutschen aus Bessarabien 59 (2008), S. 216-223. - Pöhlchen, Gerhard: Wir erkunden die Schierziger Heimat. In: Heimatgruß. Zeitschrift für Mitglieder und Freunde des Heimatkreises Meseritz e. V. und 
der Heimatkreisgemeinschaft Birnbaum 218 (2016), S. 12 [Reisebericht des 1945 aus Schierzig (Kr. Meseritz) nach Blumenthal Vertriebenen]. - Ruch, Christamaria: Gerhard Pöhlchen ist fest verwurzelt. In: Märkische Allgemeine, Ostprignitz-Ruppin, 6.11.2017 [Lebensweg des vorgenannten Autors (geb. 1929): 27.1.1945 Flucht nach Dahlhausen (Kr. Ostprignitz), nach 1.5.1945 Rückkehr in den Heimatort, 26.6.1945 Vertreibung mit den Eltern, 1947 Zimmergesellenpüfung in $\rightarrow$ Pritzwalk, später Bauingenieur in Potsdam, wo er seine 1945 aus Schlesien nach $\rightarrow$ Trebbin vertriebene Frau Brigitte kennenlernt, später Lehrerin in Blumenthal].

\section{Börnichen}

Oberförsterei/Wohnplatz (heute Teil von Lübben/Spreewald), bis 1952 Kr. Lübben, 19521990 Kr. Lübben (Bez. Cottbus), 1990-1993 Ldkr. Lübben, 1993 Ldkr. Dahme-Spreewald

UMSIEDLERLAGER KINDERHEIM: Im „Verzeichnis der errichteten und vorgesehenen Umsiedlerlager im Verwaltungsbezirk Cottbus" vom 15.12.1945 zusammen mit dem Umsiedlerlager $\rightarrow$ Schlepzig mit „Personenzahl“ 500-800 genannt (Töpler, Menschenwurm, S. 472). - Kapazität am 31.12.1945: 1000 (BArch, DO 2/45, Bl. 40). Kapazität am 1.1.1946: 800 (BLHA, Rep. 203 MdI, Nr. 1163, Bl. 51); „Lager Börnichen“ nach anderen Angaben „für 1000 Personen ausgelegt“ (Mietk, S. 18). - Ungeklärt ist, ob das „Waldlager Börnichen“ mit dem späteren Lehrlingswohnheim identisch ist; vgl. aber auch (1945) „Waldlager Schlepzig-Börnichen“ $(\rightarrow$ Schlepzig).

GedRUCKTe Quellen und Literatur: Becken, Jörg: Lübben nach dem Inferno. [Cottbus] 2010, S. 28. - Liebert, Bodo: Lübben - der Wiederaufbau ab 1945. In: Lübbener Heimatkalender 2019 (2018), S. 28-53, hier S. 33-35. Töpler, Menschenwurm, S. 472.

\section{Bötzow}

Landgemeinde (seit 2001 Orteteil von Oberkrämer), bis 1952 Kr. Osthavelland, 1952-1990 Kr. Oranienburg (Bezirk Potsdam), 1990-1993 Ldkr. Oranienburg, 1993 Ldkr. Oberhavel

EREIGNISSE BIS KRIEGSENDE: 22.4.1945 Einmarsch der Roten Armee (polnische KavallerieTruppen) (Heimatbuch, S. 167).

EREIGNISSE NACH KRIEgSENDE: 6.9.1945 Bodenreform in Bötzow (Heimatbuch, S. 167). [1945/46?]: „Typhus- und Kinderlähmungsepidemie in Bötzow: [...] Zuerst trat der Typhus im Ort in Erscheinung. Die 4 Ärzte, die es durch die Flucht nach Bötzow verschlagen hatte, behandelten die Krankheitsfälle. Das Barackenlager auf der Fuchsfarm wurde als Hilfskrankenhaus hergerichtet und alle akuten Fälle dort isoliert. Gleichzeitig setzet eine allgemeine Impfaktion ein [...]. Ein großer Teil unserer Bevölkerung steckte sich an und musste ins Hilfskrankenhaus in die Friedhofsstraße. Es gab auch mehrere Tote. Die Impfaktion wurde in Abständen wiederholt. Dadurch gingen die neuen Krankheitsfälle merklich zurück und hörten dann ganz auf. Besonders aber waren davon die Flüchtlinge betroffen, die ohne sonstige Unterstützung nur von ihrer kargen Ration leben mussten. [...].“ (ebd., S. 95). 
BevöLKeRUngSzAHLEN: 1925: 911, 1939: 2 700, 1946: 2 808, 1964: 2303 (HOL III, S. 28).

Katholiken: „Ab 1946 einigten sich die beiden Konfessionen darüber, dass für die Bötzower Katholiken auch die evangelische Nikolaikirche für Gottesdienste zur Verfügung steht, die dann bis 2003 hier stattfanden." (Heimatbuch, S. 118).

LiteratUR: Heimatbuch Cotzebant/Bötzow. Bötzow 2005.

\section{Boitzenburg}

Landgemeinde, bis 1952 Kr. Templin, 1952-1990 Kr. Templin (Bez. Neubrandenburg), 19901993 Ldkr. Templin, 1993 Ldk. Uckermark

EReIgnisSe BIS Kriegsende: Febr. bis April 1945: Durchschleusung (Verpflegung und z.T. einmalige Übernachtung) von Trecks mit rund 30000 Flüchtlingen aus den Ostgebieten (Stahl, S. 95). - „Im Jahre 1987 wurde hinter dem Kriegerdenkmal ein Fußweg mit Treppen gebaut. Bei den recht flachen Ausschachtungsarbeiten für die Treppen, am unmittelbaren Rand zur Straße, wurden zwei Kinderskelette geborgen. Die Polizei wurde benachrichtigt. Das gerichtsmedizinische Gutachten, über das die Gemeindeverwaltung informiert wurde, ergab, dass es sich um Skelette aus der Zeit von 1945 handelte. Es ist sicher anzunehmen, dass zwei tote Kinder aus einem Treck am Straßenrand notdürftig begraben worden waren." (ebd., S. 95). 27.4.1945 Einmarsch der Roten Armee (ebd., S. 98).

EREIGNISSE NACH KRIEGSENDE: „Als erste Aufgabe des Bürgermeisters galt es, die vielen heimat- und wohnungslosen Menschen unterzubringen. Dazu musste das leer stehende Schloss Boitzenburg genutzt werden. Die Einwohnerzahl Boitzenburgs war 1944/45 sprunghaft um rund $30 \%$ angestiegen. / Es wird eingeschätzt, dass in den Monaten Mai/Juni 1945 etwa 10 bis 20 Flüchtlinge durch die Gemeindeverwaltung in das Schloss eingewiesen wurden. Andere fanden im Dorf Quartier. Die Anzahl der Flüchtlinge stieg jedoch im Laufe des Jahres 1945 rasant an. Die Fluktuation der Menschen, die dann im Schloss lebten, war außerordentlich hoch. Dafür gab es vielfältige Ursachen: Familienzusammenführungen, Tod und Krankheit, Repressalien durch die Besatzung sowie wirtschaftliche Not mögen einige Gründe für den ständigen Wechsel in der Belegung des Schlosses gewesen sein. Ende 1945 waren im Schloss etwa 250 Personen untergebracht. / Die Lebensverhältnisse der Flüchtlinge waren katastrophal. In den großen Räumen versuchten sie mit gespannten Leinen und daran befestigten Decken oder Planen Winkel mit etwas Intimität zu schaffen. Man unterhielt offene Feuerstellen für die Bereitung der spärlichen Mahlzeiten. Geräusche waren ständig gegenwärtig. / Diese Umstände hatten Auswirkungen auf den baulichen Zustand, aber vor allem auf das bewegliche Inventar des Schlosses. [S. 103] [...] zwischen den Schlossbewohnern und der ortsansässigen Bevölkerung entwickelte sich auch ein reger Tauschhandel von Nahrungsmitteln und Gebrauchsgegenständen [...]. [S. 104] [...] Von Juni 1945 bis September 1946 war im 
Altschloss das [Gemeinde-]Hilfskrankenhaus mit Typhuspatienten untergebracht.“ (Ebd., S. 102-104). - Wegen des Mangels an medizinischem Fachpersonal traten „5 erfahrene Diakonissen des Danziger Diakonissen-Mutterhauses“, das inzwischen seinen Sitz in Genthin hatte, „ihren Dienst in Boitzenburg an“ (ebd., S. 107). - „Die ärztliche Betreuung sicherte zunächst Frau Dr. Josephine Russe, die auch noch im Ort Boitzenburg eine Praxis (heute Goethestraße 6) unterhielt. Sie [...] war selber Flüchtling. [...] / Trotz aller Bemühungen starben in Folge ihrer Erkrankungen 1945/46, vor allem an Typhus, im Hilfskrankenhaus 51 Personen, davon sind 29 auf dem Friedhof Boitzenburg beigesetzt. Wiederum hat Hermann Schöttler die Toten beerdigt. / [S. 111] Er führte ein Buch, in dem die Anzahl und Grablage aufgeschrieben war, es ist leider verschollen. / Auf dem Friedhof erinnert nichts mehr an diese Kriegsopfer.“ (ebd., S. 110 f.). - 1946/47: „Ende September konnte das Hilfskrankenhaus geschlosen werden. / Eine große Anzahl der unmittelbaren Kriegs- bzw. Frontflüchtlinge ist in nahe gelegene Heimatorte zurückgekehrt, in den umliegenden Dörfern sesshaft geworden oder ist in andere Besatzungszonen übergesiedelt. / Dafür nahm die Anzahl der Heimatvertriebenen zu, diese Zahl erreichte aber nicht den Umfang, wie die der Flüchtlinge 1944/45. Im Zeitraum 1946/47 lebten durchschnittlich 70 bis 80 Menschen zumeist im Altschloss, häufig große Familien.“ (Ebd., S. 112). - 1946 Einrichtung eines „Musterheims für elternlose Kinder sowie eines Altenheims“ im Schloss (ebd., S. 113). - „Konrad Drescher, ein Heimatvertriebener, der mit seiner Familie, seit dem 1.12.1946, im Schloss eine Bleibe gefunden hatte, schloss mit dem Direktor der SVK einen Pachtvertrag über die Nutzung der Grünflächen im Schlosspark ab. Er war ein kluger Mann, der Neubauer wurde und dessen Adresse nun ,Schloss Boitzenburg ' lautete. Bereits früher in Schlesien in der Landwirtschaft tätig gewesen, baute er an einer neuen Existenz. [...].“ (Ebd., S. 114). - In der Bodenreform 200 ha von 7125 ha an 23 „Umsiedler“ vergeben (HOL VIII, S. 113).

BevölkerungszAHLEN: 1925: 933, 1939: 783, 1946: 1094, 1964: 1016 (HOL VIII, S. 113).

Literatur: Stahl, Hans-Joachim: Schloss Boitzenburg in den Jahren 1944/45 bis 1956. In: Beatrix Bluhm / Detlev von Heydebrand / Hans-Joachim Stahl: Schloss Boitzenburg in der Uckermark. Angermünde 2011, S. 86-138.

\section{Borkheide}

Landgemeinde, bis 1952 im Kr. Zauch-Belzig, 1952-1990 Kr. Belzig (Bez. Potsdam), 19901993 Ldkr. Belzig, 1993 Ldkr. Potsdam-Mittelmark

BevölkeRUngszahlen: 1925: 156, 1939: 828, 1946: 1 520, 1964: 1232 (Städtebuch, S. 43).

Katholiken: „1938 der neuen Gemeinde $[\rightarrow]$ Beelitz zugeteilt. Nach dem II. Weltkrieg wude Konsistorialrat Pfr. Artur Heinke aus dem Erzbistum Prag ab dem 14.11.1946 mit der Wahrnehmung der Seelsorge beauftragt. Zeitweilig war die Seelsorgestelle, offenbar wegen der besseren Verkehrsverhältnisse, Belzig zugeordnet. Nach dem Tod Pfr. Heinkes ging sie zm 1.9.1959 in der Gemeinde $[\rightarrow]$ Brück auf.“ (Brühe, S. 45). Heinke (geb. 1883 Breslau, gest. 1959 Berlin) 
wirkte bis 1945 als Pfarrer in Ebersdorf, Kr. Habelschwerdt (Grafschaft Glatz) (Anschriftenverzeichnis des Klerus der Grafschaft Glatz 1945-1950, S. 4; Ostpriesterverzeichnis 2, 1949, S. 34; Schematismus Berlin 1949, S. 141) und war zugleich Glatzer Diözesankonservator (www.her der-institut.de [17.1.2017]). „Nach seiner Vertreibung 1946 lebte er in dürftigsten Verhältnissen in der kleinen Diasporagemeinde Borkheide in den großen Kiefernwäldern bei Berlin. Er [...] wurde auf dem Berliner St. Hedwigs-Friedhof beerdigt.“ (Sie gehören zu uns, S. 47-49 mit Bild, hier S. 49).

Archivalische Quellen: Kreisarchiv Potsdam-Mittelmark, Gemeinde Borkheide, K 14 (Unterbringung der Evakuierten und Flüchtlinge, 1944-1945).

LiteratuR: Brühe, Matthias: Katholische Kirche zwischen Havel und Dahme. Berlin 1999, S. 45. - Sie gehören zu uns. Von Glatzer Heimatpriestern. Hrsg. von Großdechant Leo Christoph. Reinbek b. Hamburg 1969.

\section{Bornstedt $\rightarrow$ Potsdam-Bornstedt}

\section{Borsiglager $\rightarrow$ Guben}

\section{Brädikow}

Landgemeinde, bis 1952 Kr. Westhavelland, 1952-1990 Kr. Nauen (Bez. Potsdam), 1990-1993 Ldkr. Nauen, 1993 Ldkr. Havelland

EREIGNISSE NACH KRIEGSENDE: „Nach Kriegsende strömten zahlreiche Heimatvertriebene und Flüchtlinge in das Dorf. Mit rund 450 Flüchtlingen von jenseites der Oder hatte sich Ende der 1940er Jahre die Einwohnerzahl nahezu verdoppelt." (Das Havelland um Rathenow und Premnitz, S. 222). - In der Bodenreform 44 neue Eigentümer berücksichtigt, davon 20 Umsiedler (HOL III, S. 35). - 1955 „Gründung einer LPG Typ III ,Professor Mitscherlich“ “ für Pflanzenproduktion (Das Havelland um Rathenow und Premnitz, S. 222), benannt nach dem 1949-1956 als Institutsdirektor in $\rightarrow$ Paulinennaue wirkenden Pflanzenbau-Wissenschaftler Eilhard Alfred Mitscherlich (aus Königsberg in Preußen).

BevölKerungszahlen: 1925: 330, 1939: 536, 1946: 897, 1964: 437 (HOL III, S. 35). - Febr. 1948: 975, davon „407 Flüchtlinge von jenseits d[er] Oder, 530 Reichsdeutsche, 38 Volksdeutsche aus Polen" (Amtsbereich Friesack, S. 121).

LiteratUR: Amtsbereich Friesack. Horb am Neckar 1996, S. 116-126 (Kap. 2.7 Haage). - Das Havelland um Rathenow und Premnitz. Köln u. a. 2017. 


\section{Bralitz}

Landgemeinde (seit 26.10.2003 Ortsteil von $\rightarrow$ Bad Freienwalde), bis 15.3.1946 (Rest-)Kr. Königsberg/Nm., 1946-1952 Kr. Oberbarnim, 1952-1990 Kr. Bad Freienwalde (Bez. Frankfurt/Oder), 1990-1993 Ldkr. Bad Freienwalde, 1993 Ldkr. Märkisch-Oderland

BevölkeRUngSzAHLEN: 1925: 330, 1939: 536, 1946: 897, 1964: 437 (HOL III, S. 35).

UMSIEDLERLAGer: 23.10.1945 Teillager Bralitz (Oder) erwähnt (3 Baracken, Kapazität: 500 Personen); Lagerleiter: Erwin Papst (BArch, DO 2/39, Bl. 12). - Kapazität am 31.12.1945: 1300 (BArch, DO 2/45, Bl. 40).

ARChivalische Quellen: BArch, DO 2/39, Bl. 4, 13 (Lager, 1945).

\section{Brandenburg an der Havel}

Seit 1881 kreisfrei (eigener Stadtkr.) (1952-1990 im Bez. Potsdam)

EREIGNISSE VOR 1933: 1923-1925 Zollhaussiedlung „Memelland“ auf dem Görden erbaut (Brandenburg an der Havel. Lexikon zur Stadtgeschichte, S. 132).

EREIGNisSE BIS KRIEgSENDE: „In den ersten Wochen des Jahres 1945 lernten die Brandenburger ein neues, bislang nur seltenes gehörtes Geräusch kennen. Fortwährendes Pferdegetrappel hallte durch die Brandenburger Hauptstraßen. Eine nicht enden wollende Wagenkolonne mit Familien aus den östlichen Provinzen des Reiches [...] zogen Tag und Nacht durch die Stadt. Viele der [S. 67] völlig erschöpften Menschen legten einen Halt ein und wurden, soweit es die angespannte Lage zuließ, versorgt. Man hörte ihre Herkunftsorte: Gumbinnen, Schneidemühl, Allenstein, Ben $[\mathrm{t}]$ schen, Turek, Litzmannstadt. Sie kamen aus Ostpreußen, Westpreußen und aus Schlesien. Der, [Brandenburger] Anzeiger' nannte sie ,Rückgeführte. [...].“ (Kusior, S. 66 f.; S. 66 auch Foto „Flüchtlingstreck aus Ostpreußen im Februar 1945“]. - Anfang 1945 befindet sich in der Landesanstalt Görden u. a. die aus $\rightarrow$ Guben evakuierte Landesgehörlosenschule der Provinz Brandenburg (Rose, Anstaltspsychiatrie, S. 30, Fn. 2). - Febr. 1945: Brandenburg wird (gemeinsam mit dem Kreis Zauch-Belzig) zum Aufnahmegebiet für die zu evakuierende Bevölkerung des Kreises Freystadt in Schlesien bestimmt (BLHA, Rep. 6 B Kreisverwaltung Züllichau-Schwiebus, Nr. 169, unfol.). - „Pioniere eines Panzerzuges errichteten am 22. April 1945 auf der Brandenburgischen Städtebahn sowie zwischen den Bahnhöfen Brandenburg Neustadt und Brandenburg Rb eine provisorische Fahrstraße zur schnellen Evakuierung der Brandenburger Lazarette. Zwischenzeitlich war der Flüchtlingsstrom in die Stadt so stark angeschwollen, daß die Evakuierungszüge in Richtung $[\rightarrow]$ Neustadt (Dosse) überfüllt waren. Am 24. April 1945 erreichten die Kämpfe um Brandenburg ihren Höhepunkt. Die Rote Armee rückte von $[\rightarrow]$ Nauen und $[\rightarrow]$ Lehnin kommend über Schmerzke auf die Stadt vor und verwickelte die Verbände der Wehrmacht und der SS in schwere Kämpfe. Aus diesem Grund schickte die DRB [Deutsche Reichsbahn] ohne 
Rückmeldung mehrere Züge in Richtung Brandenburg Altstadt. Erst gegen 18 Uhr konnte der letzte Zug nach $[\rightarrow]$ Rathenow abfahren. [...] Besetzung der Brandenburger Altstadt am 1. und 2. Mai 1945“ (Menzel/Menzel/Schulze, S. 23). - 24.4.1945 „Tausende Brandenburger, Flüchtlinge, ausländische Zwangsarbeiter und entlassene verwundete deutsche Soldaten verließen die Stadt in Richtung, Plaue, Fohrde und Wilhelmsdorf.“ (Brekow, S. 45). - „Die Brücke nach dem Stahl- und Walzwerk führte über den Silokanal. [...] Die Brücke hat als einzige der BStB [Brandenburgischen Städtebahn] das Kriegsende 1945 unbeschädigt überstanden. Eine Sprengladung war bereits angebracht, doch wollte man die Strecke nach Rathenow noch für Flüchtlingszüge nutzen. Als die Rote Armee bereits vor der südwestlichen Stadtgrenze von Brandenburg stand, verhinderten mutige Eisenbahner die Zerstörung des Bauwerkes.“ (Menzel/Menzel/Schulze, S. 77). - 26.4.1945: „Sowjetpanzer drangen in Brandenburg ein.“ (Kriegstagebuch des OKW 4,2, S. 1267). - 30.4.1945 Einmarsch der Roten Armee (ebd., S. 45 f.).

EREIGNISSE NACH KRIEgSENDE: 17.8.1945 Todesfall einer 18-jährigen Flüchtlingsfrau aus Königsberg/Nm. in Brandenburg-Görden (Krätzner, S. 25, nach Angaben in der „Heimatkartei $\left.{ }^{\prime}\right)$ - 14.12.1945 erste Sitzung des antifaschistisch-demokratischen Blocks beschließt: „1. Durchführung einer Sammelaktion von Kleidern, Decken und Hausgeräten für die Umsiedler, für heimkehrende Soldaten und für die Not leidenden Kinder. 2. Einrichtung einer Auskunftsstelle für Umsiedler und die zurückkehrenden Soldaten. 3. Schaffung von Wärmehallen mit Ausgabe von heißem Kaffee.“ (Heß, Brandenburg 1945, S. 69). - „In Flüchtlingslagern, im Quenzlager und in der ehemaligen Opel-Siedlung Hohenstücken kümmerten sich engagierte Frauen wie Martha Piter und Mia Herm um die Versorgung der Heimatlosen und ihrer Kinder. Bis Dezember war die Zahl der Flüchtlinge oder Vertriebenen in diesen Behelfsquartieren auf annähernd 1000 angewachsen." (Kusior, S. 79). - „Die Gefahr einer massenhaften Ausbreitung von Typhus und Fleckfieber erhöhte sich durch die Einrichtung eines Lagers für entlassene Kriegsgefangene und Vertriebene im ehemaligen Fremdarbeiterlager am Quenz. Viele dieser Menschen waren an Typhus oder Fleckfieber erkrankt. Das Behelfsinfektionskrankenhaus am Altstädtischen Markt genügte nicht den einfachsten hygienischen Ansprüchen. Ende 1945 gab es täglich 10 bis 12 Todesfälle allein durch Fleckfieber.“ (Heß/Richter, S. 214). - „Ende 1945 starben täglich etwa 10 Menschen, vor allem an Hungertyphus.“ (Kusior, S. 79). - [1945?]: Die Kath. Kirchengemeinde richtet eine Nähstube im Pfarrhaus ein, „die dringend benötigte Sachen für Heimkehrer herstellte. [...] Für das [Quenz-]Lager organisierte man BrotschnittenSammlungen." (Escher, S. 296). - Anf. Juli 194680 Personen aus dem Umsiedlerlager $\rightarrow$ Potsdam nach Brandenburg/Havel überführt (Potsdam und das Jahr 1945, S. 23). - Ende Juli 1948 im Verzeichnis (von der Landesregierung) verbotener Suchdienste erwähnt: Wietzke, Schreibbüro, Auskunftei, Brandenburg/Havel, Gotthardwinkel 1 („lt. Abr.Ber. Potsdam v. 7.11.47 aufgelöst u. Material [an staatl. Suchdienst] ausgelief[ert]“) (BLHA, Rep. 203 MdI, Nr. 1197, Bl. 41). 18.8.1963: „Die traditionelle Wallfahrt nach Werder, die vor allem auf die Initiative von Herrn Dolata zurückgeht. Es ist vor allem ein schlesisches Heimattreffen mit schlesischen Liedern und schlesischer Frömmigkeit.“ (http://www.hl-dreifaltigkeit.de/chronik). 
EREIGNISSE NACH 1990: 1990 Einrichtung einer Heimatstube des BdV (s. u.). - 2002 Einweihung eines Gedenksteins (s.u.). - 20.9.2003 „6. Ostdeutscher Kulturtag“ des BdV-Landesverbandes Brandenburg im Speisesaal der Zahnradgetriebefabrik GmbH Friedrichshafen (Akten der BdV-Landesgeschäftsstelle). - 23.8.2003 bis 31.3.2004 (Sonder-)Ausstellung „Fremde Heimat Brandenburg. Vertreibung und Zuwanderung von und nach Brandenburg - durch die Geschichte bis zur Gegenwart. Eine Ausstellung des Kulturland Brandenburg e. V. in Zusammenarbeit mit der Stadtverwaltung Brandenburg - Museen und Gedenkstätten" in der Ritterstraße 96. [Ankündigungstext:] „In dieser Sonderausstellung widmet sich das Museum in einem weit gespannten geschichtlichen Bogen dem Thema Vertreibung und Zuwanderung von und nach Brandenburg. Dabei soll die Einwanderungswelle der Hugenotten ebenso dargestellt werden wie die Zuwanderungsbewegung aus den Ostgebieten und Polen im Zuge der Industrialisierung; die Vertreibung und Tötung der Juden nach 1933, die Vertreibung der Deutschen aus den Ostgebieten nach 1945 bis hin zur Migration der Russland-Deutschen in der Gegenwart. Die Ausstellung wird in enger Kooperation mit dem Bund der Vertriebenen und einer Gruppe von Schülern erarbeitet." (http://www.kulturforum.info [19.4.2017]). - 10.10.2015 Rede des Kulturstaatssekretärs Martin Gorholt auf dem „Tag der Heimat“ des BdV-Kreisverbandes im Gemeindesaal der Kath. Gemeinde „Heilige Dreifaltigkeit“, Neustädtische Heidestraße 25 (www.mwfk.brandenburg.de [2.6.2017]).

Bevölkerungszahlen (ohne Plaue, 1925 ohne Dom): „1925: 59898, 1939: 79052, 1944: einschl. Zwangsarbeiter u. Kriegsgefangene ca. 115000, 1946: 70632, 1964: 89754“ (Städtebuch, S. 54). - Juli 1946: 5607 „Umsiedler“ (BLHA, Rep. 203 MdI, Nr. 1074, Bl. 52; Abb.: Mietk, S. 66). - 29.10.1946: 70632 Einwohner, davon aus Ostpreußen: 1823, Hinterpommern 1329, Ostbrandenburg 1360, Schlesien 2549 , Tschechoslowakei 318, Polen 633, Danzig 199, Rumänien 37, Baltikum 223, Sowjetunion 42 (Volkszählung 1946). - „Durch den Zuzug von Flüchtlingen und Vertriebenen erhöhte sich die Einwohnerzahl der Stadt bis März 1948 um 6976." (stg-brandenburg.de/gedenken [11.7.2017]). - 31.12.1948: Gesamtbevölkerung: 72 557, davon „Umsiedler und Evakuierte“: 7815 (Grandke, S. 46). - Eingemeindung von Vertriebenen: 30.4.1947: 6478 (Oehlsen, S. 102), Juni 1948: 7714 (ebd., S. 103), Febr. 1949: 7842 (ebd., S. 104), 30.9.1950 („nach den neuen Kreisgrenzen ab 1.7.1950“): 7466 (ebd., S. 105).

Katholiken: 1925: 3927, 1946: 7420 (Städtebuch, S. 55); 1938: 5300 (Schwillus/Brühe, S. 302). - Da unter den „Flüchtlingen und Heimatvertriebenen“ im Quenz-Lager, aber „auch in der Stadt und in den umliegenden Dörfern“ viele „katholisch waren, vergrößerten sich die Gemeinde Hl. Dreifaltigkeit und die Gemeinden der Vorstadtsiedlungen Görden und Quenz erheblich. Auch auf dem Land nahm der Anteil der katholischen Bevölkerung zu. So wurden an vielen Orten wieder katholische Gottesdienste und Religionsunterricht eingeführt. Unermüdlich waren die persönlichen Einsätze Pfarrer [Albrecht] Jochmanns und seiner bewährten Helferinnen. Neben der pastoralen Betreuung waren vor allem menschliche Zuwendung und soziale Unterstützung gefragt. Anfang Januar 1946 konnte eine Nähstube eingerichtet werden. Sechs Frauen aus der Gemeinde bemühten sich, Bedürftige mit Wäsche und Oberbekleidung zu ver- 
sorgen. / 1947 erhielt die Gemeinde die Bauerlaubnis für den Wiederaufbau ihrer Pfarrkirche. Baumaterial und zusätzliche Arbeitskräfte wurden nicht bewilligt. [...].“ (Nitschke, S. 15). Brandenburg-Görden: Gottesdienst in der evang. Notkapelle seit 1942. „Als es 1947 gelang, in der Mendelssohnstr. 3 ein Haus mit Grundstück zu erwerben, richtete man in zwei Zimmern der Erdgeschosswohnung eine Notkapelle ein. Die Seelsorge übernahm Pfarrer Anton Scholz. Durch den Zuzug von Heimatvertriebenen aus dem Osten des ehemaligen Deutschen Reiches nach 1945 war die Gemeinde Görden auf 1800 Mitglieder angewachsen. So konnte am Sonntag nur ein geringer Teil am Gottesdienst teilnehmen, auch wenn der Geistliche drei Sonntagsgottesdienste hielt. Daher fuhren viele zur Kirche in die Stadt." Unter dem Nachfolger Kuratus Karl Rudolph Metzen daher 1951-1952 Bau einer eigenen Kirche (Nitschke, S. 33). „Für die durch Umsiedler stark vergrößerte Gemeinde wurde 1952 die St. Elisabethkirche auf dem Görden geweiht u. 1956 ebenfalls zu einer Kuratie erhoben." (Escher, (Art.) Katholische Kirche, S. 202). - In Brandenburg-Quenz bereits 1934 Kapelle (St. Bernhard) eingeweiht, 1940 selbständige Kuratie (Nitschke, S. 32 f.).

St. Marienkrankenhaus, Bergstr. 1/3: 1949 wohnten im St. Marienkrankenhaus zwei kath. Geistliche aus dem Erzbistum Breslau, der aus Neisse vertriebene Geistliche Rat Max Herden (geb. 1870 Glumpenau, Kr. Neisse) (Schematismus Berlin 1949, S. 142; Ostpriesterverzeichnis 2, 1949, S. 35) und der aus Hindenburg (Oberschlesien) vertriebene Studienrat Prof. i. R. Dr. Bruno Seidel (geb. 1876 Neisse) (Schematismus Berlin 1949, S. 146; Ostpriesterverzeichnis 2, 1949, S. 79).

UMSIEDleRlager/Heimkehrerlager „Quenz-Lager“ (auf dem Quenz), Bahnhof Altstadt: Quenz bis Kriegsende eines von mehreren großen Barackenlagern für Zwangsarbeiter (Heß, Republik und NS-Diktatur, S. 78). - Nach Kriegsende: „1945 Sammellager für dt. Kriegsgefangene (ca. 30000 ) am Quenzsee, Flüchtlings- u. Heimkehrerlager“ (Städtebuch, S. 62). - 18.9.1945 bereits existent „für 5-8000 Personen“ (Wenzel, S. 138). - Kapazität am 31.12.1945: 10000 (BArch, DO 2/45, Bl.41). - „Auf der stadtzugewandten Seite des Quenzsees, wo jetzt das Fußballstadion liegt, befand sich ein großes Quarantänelager, durch welches 1946 und 1947 etwa 35000 Kriegsgefangene oder entlassene Kriegsheimkehrer und 12000 Umsiedler geschleust wurden. Zahlreiche deutsche Kriegsgefangene wurden von dort für einige Jahre als Arbeitskräfte in die Sowjetunion gebracht." (Kusior, S. 83). - Kapazität am 1.1.1946: 4000 (BLHA, Rep. 203 MdI, Nr. 1163, Bl. 49). - 14.2.1946 Heimkehrerlager „Quenz“, Kapazität: 4000 (Oehlsen, S. 28). - 1946 Heimkehrerlager („Quenzlager“), Belegungsstärke: 4000 (Kaminsky, S. 160). - 30.4.1946 als eines der verbleibenden Umsiedlerlager genannt (DAB, I/9-15-1 Flüchtlingsseelsorge 1945-1951, unfol., [30.6.1946], [Anlage 3]). 1.5. bis 3.8.1946 32240 Kriegsgefangene (Heimkehrerlager) (Oehlsen, S. 35). - 24.8.1946 Heimkehrerlager, Kapazität: 6000 (SAPMO-BArch, DY 34/27880, Bl. 291). - [1946:] Im Verzeichnis (von der Landesregierung) verbotener Suchdienste von Ende Juli 1948 erwähnt: Umsiedlerlager „Quenz", Brandenburg/Havel („lt. Schr[eiben] Quenz v. 28.11.46 aufgelöst") (BLHA, 
Rep. 203 MdI, Nr. 1197, Bl. 41). - 1.1.1947 Kapazität: 4000 (Oehlsen, S. 101). - Jan. 1947 Bericht über die katholische Flüchtlingsseelsorge im Quenz-Lager in Brandenburg an der Havel (DAB, I/9-15-1 Flüchtlingsseelsorge 1945-1951, unfol., [Jan. 1947]). - 9.6.1947 Quarantänelager, Kapazität: 4000, Belegung: 1741, Quarantäne beendet am 13.6. (SAPMO-BArch, DY 34/27880, Bl. 239). - Juni 1947 Ankunft eines Vertriebenentransports aus Görlitz (Oehlsen, Flucht). - 23.10.1947 „Stadt Brandenburg/Quenzlager (Bhf. Altstadt)“ als Zielpunkt für den 10. Transport aus dem sowjet. Teil Ostpreußens vorgesehen (Wille II, S. 117). - 25.11.1947 in Befehl der SMA Brandenburg in Liste „der [zum 30.12.1947] zu schließenden Lager“ aufgeführt (BLHA, Rep. 203 VP, Nr. 9, Bl. 43v), anschließende Nutzung als Wohnraum für Vertriebene vorgesehen (Oehlsen, S. 32). - „Es [das Lager - P. B.] war vom 15. Oktober 1945 bis 31. Dezember 1947 von Vertriebenen und Flüchtlingen bewohnt. 388 Menschen, die in diesem Lager an den Folgen der Flucht starben, fanden in der Nähe des Rosenhains ihre letzte Ruhestätte." (stg-brandenburg.de/gedenken [11.7.2017]). - 1948 Heimkehrerlager, Belegungsstärke: 4000 (Kaminsky, S. 160). - Ende Nov. 1948 erneuter Transport aus dem sowjet. besetzten Teil Ostpreußens (I. Aktion) (2021 Personen) (Wille II, S. 136).

StÄdtepartnerschaften: Nach 1973 Kontakte mit Kędzierzyn-Koźle, Polen (KandrzinCosel, Oberschlesien) (Trzcielińska-Polus, S. 537).

VERTRIEBENENVERBÄNDE NACH 1990: (1) BdV-Kreisverband Brandenburg-Stadt, gegründet 1990 (Auskunft der Landsmannschaft Ostpreußen, Hamburg), BdV-Kreisverband Brandenburg/Havel 22.10.1991 eingetragen beim Kreisgericht Brandenburg (VR 317) (Akten der BdVLandesgeschäftsstelle), 1996 erwähnt mit Sitz Starweg 26 (BdV-Handbuch 1996, S. 168); 31. 122005 hatten die sogen. Mitglieder-Stützpunkte folgende Mitgliederzahlen: Brandenburg an der Havel 63, Lehnin 28, Golzow 29, Damsdorf 24, Groß Kreutz 35, Plötzin 21. 2018 Kreisverband noch existent, aber zuletzt nicht mehr mit Landesverband verbunden. Vorsitzende: 1993/94 Hans Pinzer, Brandenburg/H. (geb. 1930); 1997-2003 Siegfried Kaatz, Damsdorf (geb. 1932; aus Seidlitz bei Landsberg/Warthe), 1999 auch Aussiedlerbetreuer des Kreisverbandes); seit 2003 (noch 2018) Kurt Brodöhl, Groß Kreutz (geb. 1941; aus Pabianice bei Lask; siehe auch BR 8 (2010)11, S. 8) (Akten der BdV-Landesgeschäftsstelle). - (2) Ab 1997/98 BdV-Kreisverband Potsdam-Mittelmark mit der Kreisgruppe Ostpreußen/Westpreußen in Brandenburg an der Havel e. V., Sitz Brandenburg an der Havel, Pauliner Straße 11 (www.politischebildung-brandenburg.de [2.6.2017]; Amtsgericht Brandenburg, VR 741), ab Juni 2017 in kleinerem Rahmen im „Haus der Begegnung“, Jacobstr. 12 (BR 15 (2017) 5, S. 11); gibt jährlich erscheinendes, vervielfältigtes „Heimatblatt“ heraus; Vorsitzende: 1997-2008 Hartmut Borkmann, Ziesar (geb. 1934 Danzig, gest. 2008; Herbst 1945 mit Mutter u. Bruder vertrieben, Lager in Küstrin-Kietz, dann über Berlin nach Neustadt/D. gelangt, später Lehrer in Roskow bis 1996/97) (BR 8 (2010)4, S. 19; Nachruf von Jürgen Lauterbach in MAZ, 31.1.2008), seit 2008 Jürgen Rasztuttis, Angestellter in Brandenburg/H. (geb. 1944) (Akten der BdV-Landesgeschäftsstelle). 
Heimatstube des BdV(-Kreisverbandes), zuletzt Museum und Begegnungsstätte „Ostdeutsche Geschichte und Kultur - Brücke zu den östlichen Nachbarvölkern“ mit Ausstellung „Beziehungen der Begegnungsstätte mit dem russischen Oblast Königsberg/Kaliningrad“" [www.stadt-bran denburg.de, 10.10.2016]); Fundus ab 1992 aufgebaut, 1999 als Heimatsube eingerichtet in der Kurstr. 13, 2010 (nach Kündigung des Mietverhältnisses infolge Verkaufs des Gebäudes) Umzug in Pauliner Straße 11 (Eingang über Neustädtische Heidestraße 38 (3 Räume im Parterre + Keller inkl. Museum), 31.5.2017 nach sieben Jahren an diesem Standort aus Personalmangel geschlossen (BR 15 (2017) 5, S. 11, mit Bild); Umzug der BdV-Geschäftsstelle in Jacobstr. 12 (Haus der Begegnung), hier jedoch nur noch Büro u. Seniorenberatung, Museum nicht mehr wiedereröffnet (Mitteilung der BdV-Landesgeschäftsstelle). - Darstellung 2012 (Pauliner Str. 11): „Die Heimatstube in Brandenburg/Havel wurde 1990 [wohl irrig, sondern 1992, s. o.] gegründet. Ein Viertel der Stadtbevölkerung hat Vorfahren in Pommern, Ostpreußen beziehungsweise Schlesien oder sind Sudetendeutsche und Donauschwaben. Diese Regionen und ihre Bevölkerung werden anhand von Karten, Fotografien, Fahnen und Wappen in der Heimatstube vorgestellt ebenso wie die Ereignisse der Flucht und Vertreibung. Didaktische Tafeln zur Geschichte und Bevölkerungsstatistiken ergänzen das Bildmaterial. In Vitrinen sind alte Dokumente und Erinnerungsstücke mit ihren oft sehr persönlichen Objektgeschichten präsentiert. Fotoberichte und Informationsmaterial bieten Einblicke in die Arbeit des Bundes der Vertriebenen." (Ostdeutsche Heimatsammlungen (überregional), www.bkge.de, Stand 20.3.2012 [10.10.2016]). - Siehe auch Kurzvorstellung von Marianne Rasztuttis mit Fotos: BR 11 (2013)2, S. 6-7.

GeDENKStÄTTE beim Ehrenmal am Marienberg (Willi-Sänger-Straße): 17.11 .2002 eingeweihter Gedenkstein mit Inschrift „Den Opfern von Weltkrieg, Flucht, Vertreibung und Deportation zum Gedenken / Bund der Vertriebenen Stadt Brandenburg an der Havel" (Mahn- und Gedenkstätten Brandenburg, mit Abb.), aufgestellt von der Stadt Brandenburg auf Anregung des BdV (stg-brandenburg.de/gedenken [11.7.2017]).

Archivalische Quellen: BArch, DO 2 ZVU, Nr.39, Bl. 60-62 (Quenzlager, Dez. 1945). - BArch, DO 2/50, Bl. 451-452 (Quenz-Lager). - BLHA, Rep. 202 A, Nr. 454 (1947-1950, enth. u. a. „Nutzung des Umsiedlerlagers Brandenburg-Quenz"). - Stadtarchiv Brandenburg an der Havel: Rat der Stadt Brandenburg, Gesundheits- und Sozialwesen, u. a.: Umsiedler- und Quarantänelager Quenz, 1945-1948.

Gedruckte Quellen: Töpler, Menschenwurm. - Wirtschafts-Wegweiser für Brandenburg (Havel) mit Plaue und Kirchmöser. Branchen-Adressbuch. Potsdam [1948?].

Literatur: HOL III, S. 306 (Art. Quenzsiedlung, ohne Erwähnung des Lagers). - Bode, Sabine: Die vergessene Generation. 33. Aufl. Stuttgart 2018, S. 119f. (zitiert Beitrag von Erich Kästner über einen in Brandenburg haltenden Vertriebenentransportzug aus „Die Neue Zeitung“, 1947). - Brekow, Frank: Die Kampfhandlungen um Brandenburg an der Havel im April und Mai 1945. In: Jahresbericht Historischer Verein Brandenburg (Havel) e. V. 20 (2010/11 [2011]), S. 41-52. - Chronik Katholische Pfarrgemeinde Heilige Dreifaltigkeit Brandenburg a. d. Havel 1903-2000 (http://www.hl-dreifaltigkeit.de/chronik/[20.9.2016]). - Escher, Felix: Die katholische Kirche. In: Stahl und Brennabor. Hrsg. von Gerd Heinrich u. a. Potsdam 1998, S. 285-300. - Ders.: (Art.) Katholische Kirche. In: Brandenburg an der Havel. Lexikon zur Stadtgeschichte. Berlin 2008, S. 201-202. - Heß, Klaus / Richter, Anke: Die Stadt Brandenburg im Jahre 1945. In: Brandenburg im Jahr 1945. Hrsg. von Werner Stang. Potsdam 1995, S. 195-222. - Heß, 
Klaus: Republik und NS-Diktatur: Die Stadtverwaltung und der Stadtkreis in der Phase des Ausbaus der Stadt zum zweitgrößten Industrieort der Provinz Mark Brandenburg (1918-1945). In: Stahl und Brennabor. Hrsg. von Gerd Heinrich u. a. Potsdam 1998, S. 59-80. - Ders.: Besatzungszeit und SED-Herrschaft (1945-1989). In: ebd., S. 149169. - Ders.: Die Stadt Brandenburg nach Kriegsende im Jahr 1945. In: Jahresbericht Historischer Verein Brandenburg (Havel) e. V. 20 (2010/11 [2011]), S. 53-72. - Krätzner, S. 25. - Kusior, Wolfgang: Die Stadt Brandenburg im Jahrhundertrückblick. Berlin 2000. - Lexikon Brandenburg, S. 204 [nur Quenz-Lager bis 1945; Flüchtlings- bzw. Umsiedler-/Heimkehrerlager nicht erwähnt]. - Mahn- und Gedenkstätten Brandenburg. Hrsg.: BdV (http://www. bund-der-vertriebenen.de [20.9.2016]). - Menzel, Stefan / Menzel, Walter / Schulze, Jörg: Die Eisenbahn in Brandenburg an der Havel. Stendal 2017. - Nitschke, Johannes: 150 Jahre Pfarrkirche „Heilige Dreifaltigkeit“ Brandenburg an der Havel. Brandenburg an der Havel [2001]. - Oehlsen, Sven: Flucht aus Schlesien. Auf eigene Faust zurück. In: Spiegel online, 10.11.2007 [16.6.2017]. - Rose, Wolfgang: Anstaltspsychiatrie in der DDR. Berlin 2005, S. 29ff. Schwillus/Brühe, S. 302-304. - Seniorenbeiräte im Land Brandenburg. Potsdam 1999, S. 43 f. - Städtebuch, S. 62 (Lager nach 1945 erwähnt). - Trzcielińska-Polus. - Wenzel, Mario: Die Aufnahme und Versorgung von Flüchtlingen und Vertriebenen in Eberswalde 1945-1948. In: Eberswalder Jahrbuch 2015, S. 136-145, hier S. 138. - Wille I, S. 310, 428, 430, 445; III, S. 93 (Umsiedlerausschuss, 1945).

\section{Brandenburg-Kirchmöser $\rightarrow$ Kirchmöser}

\section{Brandenburg-Plaue $\rightarrow$ Plaue/Havel}

\section{Bredereiche}

Landgemeinde (seit 2003 Ortsteil von $\rightarrow$ Fürstenberg/Havel), bis 1952 Kr. Templin, 19521990 Kr. Gransee (Bez. Potsdam), 1990-1993 Ldkr. Gransee, 1993 Ldkr. Oberhavel

EReignisSE BIS KRIEgSENDE: „Um den“ 6.2.1945 Aufteilung eines in $\rightarrow$ Templin eingetroffenen Flüchtlingstrecks aus Nahausen (Kr. Königsberg/Nm.) auf die im Kr. Templin gelegenen Dörfer $\rightarrow$ Beenz u. Bredereiche (Köhler, S. 100).

EREIGNISSE NACH KRIEgSENDE: Die im Febr. 1945 nach Bredereiche gekommenen Flüchtlinge aus Nahausen kehrten teilweise nach Ende der Kampfhandlungen wieder in ihren Heimatort zurück und wurden am 22.6.1945 von dort endgültig vertrieben. „Einige kamen [nun] auch wieder nach Bredereiche zurück.“ (Köhler, S. 102). - „Viele der Nahausener sind später noch einmal geflüchtet, meist nach Westberlin, andere zogen dorthin, wo sie Arbeit fanden. Aber eine größere Gruppe blieb auch in Bredereiche. [...] Zwölf leben heute [2002] noch in Bredereiche““ (ebd., S. 103). - „Ohne hier auf Einzelschicksale einzugehen, wissen wir doch von einer größeren Zahl von Flüchtlingen aus dem Dorf Nahausen in der Nähe von Schwedt, jedoch jenseits der Oder. [...] Sollte einmal die Chronik von Bredereiche geschrieben werden, müßte sie unbedingt ein Kapitel ,Nahausen' enthalten.“ (ebd., S. 96).

EREIGNISSE NACH KRIEGSENDE: In der Bodenreform 38 ha von 180 ha an 2 „Umsiedler“vergeben (HOL VIII, S. 120). 
BEVÖLKERUNGSZAHLEN: 1925: 1501, 1939: 1492, 1946: 1765, 1964: 1218 (HOL VIII, S. 121). - „Im April/Mai 1945 hatte Bredereiche [...] etwa 2200 Einwohner. Zu den 1700 Bredereichern waren über 500 Flüchtlinge gekommen [...].“ (Köhler, S. 96).

Literatur: Köhler, Erich: Das Flüchtlingselend neumärkischer Familien. In: Königsberger Kreiskalender 2002, S. 96-104. [Verf. lebt in Bredereiche].

\section{Brieselang}

Landgemeinde, bis 1952 Kr. Osthavelland, 1952-1990 Kr. Nauen (Bez. Potsdam), 1990-1993 Ldkr. Nauen, 1993 Ldkr. Potsdam-Mittelmark

EREIGNisSe BIS KRIEgSEnde: 24.4.1945 Einmarsch der Roten Armee (Festschrift, S. 31).

EREIGNISSE NACH KRIEGSENDE: 1945 (Bericht der Gemeindeverwaltung vom 19.11.1945 über den „Wiederaufbau von Brieselang“:) Das Schulgebäude dient „nur zum geringsten Teil seiner Aufgabe“: „Neben der Unterbringung der Gemeindekasse und des Wirtschaftsamtes wurden Räume für Quartiere von Flüchtlingen und sogar zur Aufbewahrung von Munition benutzt." (Brandenburgische Gemeinden 1945, S. 17). - In der Bodenreform 15 „Umsiedler“ berücksichtigt (HOL III, S. 49).

BEvöLKERUNGSZAHLEN: 1925: 1 833, 1939: 3 846, 1946: 4977, 1964: 4863 (HOL III, S. 50). Archivalische Quellen: Siehe Quellenteil, Nr. 224.

Gedruckte Quellen und Literatur: Brandenburgische Gemeinden 1945, S. 15-18. - Festschrift 75 Jahre Brieselang. Falkensee 2000] (darin S. 26-30 Kapitel „Nachkrieg und Neubeginn“, S. 28 f. Abschnitt „Flüchtlinge und Umsiedler - die Heimatvertriebenen des 2. Weltkrieges“). - Wille I, S. 321.

\section{Brieskow (-Finkenheerd)}

Landgemeinde (bis 1949 Brieskow [mit Wohnplatz Finkenheerd], seit 1.1.1949 Brieskow-Finkenheerd), bis 1950 Kr. Lebus, 1950-1952 Kr. Frankfurt (Oder), 1952-1990 Kr. Fürstenberg/ Oder bzw. (ab 1961) Kr. Eisenhüttenstadt-Land (Bez. Frankfurt/Oder), 1990-1993 Ldkr. Eisenhüttenstadt, 1993 Ldkr. Oder-Spree

EREIGNISSE NACH KRIEgSENDE: 3.10.1950 Zuweisung von westlich der Oder gelegenen Flächen [10,7 ha (HOL VII, S. 40)] der nun polnischen Gemeinde Kunitz/Kunice (anteilig; vgl. $\rightarrow$ Frankfurt/Oder und $\rightarrow$ Wiesenau) (ehem. Kr. Weststernberg) an die Gemeinde BrieskowFinkenheerd (Blöß, Kreise und Gemeinden, S. 31).

BeVÖLKeRUNGSZAHLEN: 1925: 1442, 1939: 2 942, 1946: 3 022, 1964: 3592 (HOL VII, S. 42). Literatur: Schwillus/Brühe, S. 317. 


\section{Britz}

Landgemeinde, bis $1950 \mathrm{Kr}$. Angermünde, 1.7.1950-1952 Kr. Oberbarnim, 1952-1990 Kr. Eberswalde (Bez. Frankfurt/Oder), 1990-1993 Ldkr. Eberswalde, 1993 Ldkr. Uckermark

BevölkeRUngSzAHLEN: 1925: 1795, 1939: 2290, 1946: 2345, 1964: 2445 (HOL VIII, S. 133).

UMSIEDLERLAGER: Kapazität am 31.12.1945 (Lager „Britz - Privathäuser“): 300 (BArch, DO 2/45, Bl. 40). - Kapazität am 1.1.1946: 1000 (BLHA, Rep. 203 MdI, Nr. 1163, Bl. 50).

\section{Brück}

Stadtgemeinde, bis 1952 Kr. Zauch-Belzig, 1952-1990 Kr. Belzig (Bez. Potsdam), 1990-1993 Ldkr. Belzig, 1993 Ldkr. Potsdam-Mittelmark

EREIGNISSE NACH KRIEGSENDE: 1946 Ansiedlung von vertriebenen (überwiegend evangelischen) Karpatendeutschen, überwiegend Oberzipsern, in Brück und Umgebung (besonders in Freienthal, Linthe [hier die meisten], Neuendorf bei Brück, Rietz, Rottstock, Schlalach und Treuenbrietzen) (Auskünfte M. Demko): „Am 29. Juni 1946 kamen die vertriebenen Karpatendeutschen (Zipser) in dem bis Kriegsende als Munitionsfabrik dienenden Lager Selterhof bei $[\rightarrow]$ Treuenbrietzen an [...] und waren dort 14 Tage in Quarantäne. Damit ging die mehretappige seit Dezember 1944 währende Flucht infolge des Partisanenaufstands und der Vertreibung nach Rückkehr aus den Evakuierungsgebieten (Sudetenland) in die Heimat nach dem Kriegsende zu Ende. [...] Sie haben Spuren hinterlassen in Brück und der Umgebung. ,Sie sind heimisch geworden. Das merkt man, wenn Michael Demko, er gehört noch zur Erlebensgeneration, und Roland Hoffmann, hier geboren, an der Kreuzung Gartenstraße/Oberzipserstraße [Oberzipser Straße, P.B.] in Brück stehen', so Pfarrer Helmut Kautz. In der Gartenstraße haben viele ,Zipser' gebaut. Die Oberzipserstraße ist nach der Gegend benannt, aus der viele der Vertriebenen kamen. (Juliane Keiner in: Märkische Onlinezeitung, 5.7.2016; vgl. auch MAZ online, 21.7.2016).

EREIGNISSE NACH 1990: 1991 Gründung eines Landesverbandes Brandenburg der „Karpatendeutschen Landsmannschaft“ in Brück mit 80 Mitgliedern, 2015 noch 30 Mitglieder (Die Karpatenpost, 66 (2015) 4, S. 4). - „Zu Jahresbginn 2005 trafen sich in Brück 44 Karpatendeutsche mit Angehörigen. [...] Die Landsleute sind in Potsdam, Brück, Linthe, Neuseddin und Belzig angesiedelt." (Karpatenblatt 14 (2005)4, S. 4). - 10.7.2016: Gedenkfeier in der Kirche: „Anlässlich des 70. Jahrestages der Ankunft der Karpatendeutschen im Land Brandenburg hatte die Karpatendeutsche Landsmannschaft (KDLM) jetzt zu einem Erinnerungstreffen nach Brück eingeladen. Dort waren 1946 zahlreiche Deutsche angekommen, die ihre Heimat in der heutigen Slowakei verlassen mussten. In der Brücker Lambertuskirche fand ein Festakt statt. Er begann mit dem Einzug der Teilnehmer, angeführt von Pfarrer Helmut Kautz. / Der Einladung waren viele ehemalige Zipser- 
Deutsche und auch deren Nachfahren aus Nah und Fern gefolgt, so dass die Kirche mit mehr als 100 Besuchern gut gefüllt war. Als Ehrengast nahm die Bundesvorsitzende der KDLM, Brunhilde Reitmeier-Zwick, an der Jubiläumsfeier teil. Der KDLM-Landesvorsitzende, Michael Demko aus Brück, erwähnte den schwierigen, aber doch erfolgreichen Neuanfang der Zipser nach 1946 in der neuen Umgebung. /,Nach Liedern, Glaubensbekenntnis und Evangelienlesung spielte eine Jugendband unsere Zipser Hymne und alle konnten mitsingen', berichtet Roland Hoffmann. Er ist ein Nachfahre der Fluchtgeneration und wurde 1947 als eines der ersten Kinder der Vertriebenen im Fläming geboren. Hoffmann pflegt die Verbindung in die alte Heimat seiner Eltern bis heute. ,Als besondere Bereicherung empfanden die Gäste den Beitrag von Julius Reich aus Sachsen-Anhalt, der über seine eigenen Erlebnisse zur Kinderlandverschickung sprach', erzählt der Brücker./Brunhilde Reitmeier-Zwick, die bereits zum vierten Mal nach Brück gereist war, würdigte das Engagement aller Karpatendeutschen. Willi Eschholz, ein Ur-Brücker Bürger, der die Ankunft der Vertriebenen hautnah miterlebte und später selbst die Heimat der Zipser erkundete, richtete Grußworte an alle Gäste." (MAZ online, 21.7.2016).

BevöLKerungSzAHLEN: 1925: 1542, 1939: 1746, 1946: 2583, 1964: 3202 (Städtebuch, S. 70).

Katholiken: 1925: 15, 1946: 237 (Städtebuch, S. 71). - „Schon am 26.12.1933 hielt der neue $[\rightarrow]$ Belziger Seelsorger Erich Tschetschog die erste hl. Messe in einem Privathaus in Brück. 1946 schuf er eine ständige Seelsorgestelle, in der zunächst für einige Monate P. Alfons Engler MSF ( $\rightarrow$ Lehnin) wirkte, gefolgt von Pfr. Kurt Sauer (1947-55) aus dem Erzbistum Breslau. Zum 1.9.1955 wurde mit dem Amtsantritt von Hans Joachim Rupprecht (1955-60) eine Lokalie mit dem Namen „Zu den hl. Engeln“ gegründet und genau ein Jahr später im Pfarrhaus in der Straße des Friedens eine kleine Werktagskapelle eingeweiht. Sämtliche Sonntagsgottesdienste wurden aber in evangelischen Kirchen gehalten." 1965 Lokalie aufgelöst (Muttergemeinde Belzig), Kapelle noch bis 1986 genutzt. (Brühe, S. 45). - Kurt Sauer (geb. 1881 Berlin) wirkte vor 1945 in Arnsdorf, Kr. Schweidnitz (Schlesien) (Ostpriesterverzeichnis 2, 1949, S. 72; Handbuch des Erzbistums Breslau für das Jahr 1934, S. 100; Schematismus Berlin 1949, S. 145).

Baracken auf Dem Antennenmessplatz: „Von 1945 bis 1955 dienten die Baracken als Wohnraum für Flüchtlinge und Vertriebene.“ (Hanusch, S. 50). - „Bis heute stehen auf dem Antennenmessplatz Brück Reste von Gebäuden aus der Zeit vor 1945, unter anderem der sogenannte Bunker und Holzbaracken, in denen nach dem Krieg Umsiedler untergebracht waren. [...] Hier lebten bis in die 1950er Jahre Flüchtlingsfamilien aus den ehemaligen deutschen Ostgebieten. Diese Baracken ruhten auf Betonstreifenfundamenten und hatten deshalb keinen direkten Bodenkontakt. So zu bauen war [Mitte der 1930er Jahre - P. B.] wohlüberlegt, denn das Wasser stand früher circa 10 bis 15 Zentimeter über dem Gelände. Der Zugang zum Gebäude erfolgte über hochgelegte Holzstege." (Schmidt, S. 68). - Hier lebten bereits 1945 eingetroffene Flüchtlinge aus dem „Warthegau“, später aber auch einzelne Karpatendeutsche (Auskünfte M. Demko). 
Strassenumbenennungen: 1998 Vorschlag von Michael Demko (s. o.) zu einer Umbenennung der Gartenstraße im Neubaugebiet wird zurückgestellt. - 19.4.2012 Einwohnerfragestunde in der Sitzung der Stadtverordnentenversammlung (SVV) in der Gaststätte „Schützenhaus“: „Herr [Roland] Hoffmann [Sohn einer Zipser Vertriebenenfamilie, P. B.] mahnt an, dass bei der Vergabe von Straßennamen, z.B. im WG [Wohngebiet, P.B.] Gänsematen die Namen ,Zipser' oder ,Oberzipser' nicht berücksichtigt wurden und bittet um eine Beschlussvorlage bis zur nächsten SVV." (ris.amt-brueck.de [2.6.2017], Sitzungsprotokoll, S. 5). - 2015/16 kurze Querstraße der Gartenstraße mit 2 Hausnummern wird Oberzipser Straße benannt nach der Region, aus der viele der Vertriebenen Karpatendeutschen 1946 nach Brück kamen (Märkische Onlinezeitung, 5.7.2016; Abb. des Straßenschildes in: Die Karpatenpost 68, 2017, Folge 3, S. 3), gleichzeitig wurde eine andere Straße nach der slowakischen Partnerstadt Spišská Belá benannt (Auskünfte M. Demko).

StÄDtepartnerschaft (Amt Brück): 2007 Spišská Belá (Zipser Bela), Slowakei. „Die beiden Brücker Bürger [Albin Meschar und Roland Hoffmann (geb. 1947)] haben ihre Wurzeln in der am Fuße der Hohen Tatra gelegenen Region Zips und sind die Initiatoren der Städtepartnerschaft. In Brück leben heute zahlreiche zipser-deutsche Familien, die aus der Region stammen und in Folge des Zweiten Weltkrieges ihre Heimat verlassen mussten. [... F Für den mittlerweile 79 Jahre alten Albin Meschar war es nun die 115. Fahrt in seine frühere Heimat. Dort ist er bereits Ehrenbürger. Nun wurde ihm erneut ein[e] besondere Ehre zuteil, als Bürgermeister Stefan Bielak ihm ein geschnitztes Holzbild mit dem Motiv des Stadtzentrums von Spišská Bela überreichte. Damit würdigten die Slowaken Meschars Verdienste um die Städtepartnerschaft.“ (Thomas Wachs in: MAZ, 9.10.2015).

VERTRIEBENENVERBÄNDE NACH 1990: 1991 Gründung eines Landesverbandes Brandenburg der Karpatendeutschen Landsmannschaft Slowakei e. V. mit 80 Mitgliedern, 2015 noch 30 Mitglieder (Die Karpatenpost 66 (2015) 4, S. 4), 2017 noch 17 Mitglieder, jährlich 2 Treffen in der Gaststätte Borgmann's (Auskünfte M. Demko). - 1991-1995 Vorsitzender: Hans Neupauer (geb. 1926, Lehrer). - Vorstand (Stand 2017): Vorsitzender: Michael Demko (Brück) [geb. 1932, Lehrer] seit 1995; Stellvertreterin: Gertrud Turek (Brück); Kassier: Anna Gericke (Brück) (www.karpatendeutsche.de [2.6.2017]). - Sitz 1996: Straße der Einheit 52 (Michael Demko) (BdV-Handbuch 1996, S. 167).

Gedenkstein der u. a. in $\rightarrow$ Rottstock angesiedelten Vertriebenen aus Milzig (poln. Milsko), Kr. Grünberg in Schlesien, an der Heinrich-Heine-Straße (Auskünfte M. Demko).

Archivalische Quellen: Kreisarchiv Potsdam-Mittelmark, FB 1 Amt Brück, Gv 491 (Verteilung von Spätaussiedlern und ausländischen Flüchtlingen im Amt Brück, 1992-2001).

Sonstige Quellen und Literatur: Brühe, Matthias: Katholische Kirche zwischen Havel und Dahme. Berlin 1999, S. 45. - Hanusch, Karin: Die Türme von Brück. In: Zwischen Havel und Fläming 2018 (2017), S. 48-51. - Die Karpatenpost. - Schmidt, Karl-Heinz: Der Antennenmessplatz Brück. In: Das Archiv 2016, H. 4, S. 68-71. - Aus- 
künfte Michael Demko, Vorsitzender des Landesverbandes Brandenburg der Karpatendeutschen Landsmannschaft, Brück, 2.6.2017.

\section{Brüssow}

Stadtgemeinde, bis 1952 im Kr. Prenzlau, 1952-1990 Kr. Pasewalk (Bez. Neubrandenburg), 1990-1992 Ldkr. Pasewalk (Land Mecklenburg-Vorpommern) 1.8.1992 Ldkr. Prenzlau (Land Brandenburg), 1993 Ldkr. Uckermark

EREIGNISSE NACH KRIEgSENDE: 1945 (Bericht der Stadtverwaltung vom Dez. 1945, verfasst von Ewald Genz): 19331700 Einwohner, bis 1939 kaum wesentlich erhöht. „Erst durch die Umquartierten und Flüchtlinge stieg sie auf rund 2500 im Dezember 1945." (Brandenburgische Gemeinden 1945, S. 22). „Wie schon aus den Einwohnerzahlen hervorgeht, nahm die Stadt insgesamt etwas mehr als 800 Flüchtinge auf. Viele von ihnen wurden arbeitstechnisch in der Landwirtschaft untergebracht, ein geringerer Teil besteht aus den überall gern gesehehen Handwerkern; aber auch solche Personen, vor allem Mütter mit kleinen Kindern und alte Leute, die nicht unbedingt und nicht dauernd in den Arbeitsprozess eingereiht werden können, nahm die Stadtverwaltung aus sozialem Gewisen heraus auf. Andere Flüchtlingszüge wurden durchgeschleust und in den Dörfern der Umgegend untergebracht. Die Ernährungsfrage konnte befriedigend gelöst werden." (ebd., S. 17). „Der Gesundheitszustand der Brüssower Bevölkerung ist wohl nicht besser und nicht schlechter als im Durchschnitt der deutschen Kleinstädte. Für die Seuchenbekämpfung beschlagnahmte die Rote Armee das Heim des ,Kirchlichen Erziehungsverbandes der Mark Brandenburg'. Noch im Oktober 1945 beherbergte dieses Behelfskrankenhaus 110 Typhuskranke. Mit dem Kälteeinbruch ging die Seuche so erfreulich zurück, dass das Haus Mitte Dezember nur noch mit 50 Kranken belegt war." (ebd., S. 23).

BeVÖLKeRUNGSZAHLEN: 1925: 1502, 1939: 2085, 1946: 2431, 1964: 2214 (Städtebuch, S. 73; HOL VIII, S. 152).

STADTKIRCHE: 2015 Einweihung einer neuen, baumförmigen Holz-Gedächtnistafel für die Toten des Zweiten Weltkrieges im Erdgeschoss des Turmes, insbesondere für die (namentlich genannten) gefallenen Soldaten (für die aber bereits ältere Gefallenenkreuze existieren). „Am wurzellosen Stamm des Baumes wird auf drei Schildchen allgemein dreier Opfergruppen gedacht: ,Zum Gedenken / an die Opfer von / Euthanasie und Gewalt', ,Flucht und Vertreibung sowie ,Hunger und Krankheiten.“' (Müller-Pfeifruck, S. 261).

Gemeindepartnerschaft: 16.12.1994 Rewal, Polen (Rewahl, ehem. Kr. Greifenberg, Pommern) (www.rewal.pl [25.8.2018]).

Gedruckte Quellen und Literatur: Brandenburgische Gemeinden 1945, S. 21-23. - Müller-Pfeifruck, Sylvia: Die Kreuze für die Gefallenen des Zweiten Weltkriegs in der Stadtkirche Brüssow - Ein Forschungsbeitrag zu den Kriegergedächtnismalen in den evangelischen Kirchen des Landes Brandenburg. In: Jahrbuch für Berlin-Brandenburgische Kirchengeschichte 70 (2015), 236-261. 


\section{Buchholz}

Landgemeinde (seit 31.12.2002 Ortsteil von Pritzwalk), bis 1952 Kr. Ostprignitz, 1952-1990 Kr. Pritzwalk (Bez. Potsdam), 1990-1993 Ldkr. Pritzwalk, 1993 Ldkr. Prignitz

EREIGNISSE BEI KRIEGSENDE: [Aus den Erinnerungen einer Buchholzerin:] „Viele Flüchtlinge waren am 2. Mai 1945 mit uns im Schulhaus, alle warteten auf die Russen. Der Unterricht war bereits am 28. April 1945 eingestellt worden. Alle Klassenzimmer wurden mit Stroh ausgelegt, auf dem die Flüchtlinge schliefen. [...] Danach kamen auch sowjetische Soldaten in unser Haus [...]. Am Tisch saßen auch Flüchtlinge aus Wolhynien, die sich mit den russischen Soldaten verständigen konnten. [...] [Am 3. Mai] mussten jetzt alle sofort das Haus verlassen, wir sollten in die Bauarbeiterhütten am Ortseingang hinein. [...] Dann ging es weiter zum Bauernhof an der Mühle und zwar in die dortige Scheune hinein. Hier befanden sich schon viele Flüchtlinge. [...]. [S. 16] [...] Wir kehrten im Laufe des 4. Mai wieder zur Mühle zurück, danach ging es in ein kleines Haus hinter dem Friedhof. Wir haben dort mit anderen Flüchtlingen mindestens eine Woche gelebt. Die Männer schliefen in Ställen, die Frauen und Kinder in zwei kleinen Zimmern, einige auch im Keller [...].“ (Schladitz, S. 15 f.).

Gedruckte Quellen und Literatur: Schladitz, Johanna [geb. Breuel]: Der Einmarsch der Roten Armee am 2. Mai 1945 in Buchholz: „Kein Mensch war zu sehen, niemand war auf der Straße. [Aufzeichnung nach Interview]. In: Pritzwalker Heimatblätter 16 (2015), S. 15-16.

\section{Buckow (Märkische Schweiz)}

Stadtgemeinde, bis 1950 Kr. Lebus, 1950-1952 Kr. Seelow, 1952-1990 Kr. Strausberg (Bez. Frankfurt/Oder), 1990-1993 Ldkr. Strausberg, 1993 Ldkr. Märkisch-Oderland

Ereignisse bis Kriegsende: 19.4.1945 Einmarsch der Roten Armee (Krügel, S. 67).

EREIGNisSE NACH KRIEgSENDE: „Beide Orte [Buckow und Müncheberg, P.B.] lagen 1945 auf der Marschroute der Roten Armee nach Berlin. Nach der Evakuierung waren nicht nur die katholischen Gotteshäuser verwüstet, auch ein Großteil der Einwohner kehrte nicht mehr zurück und die Gemeinden bildeten sich nun aus Flüchtlingen und Heimatvertriebenen weitgehend neu." (Schwillus/Brühe, S. 306).

EREIGNISSE NACH 1990: 12.4.2015 19. Treffen der im östlichen Teil Brandenburgs wohnhaften Heimatvertriebenen aus der Grafschaft Glatz: „Es kamen 40 Personen von Cottbus bis Bernau, von Königs Wusterhausen bis Frankfurt/Oder, aus Berlin und dem Umland. Sie feierten zunächst mit Großdechant Franz Jung [kath. Visitator für Priester und Gläubige aus der Grafschaft Glatz] in der Heilig-Geist-Kapelle in Buckow einen Gottesdienst, der mit Musik aus der Schubert-Messe umrahmt wurde. [...]. Anschließend ging es nach $[\rightarrow]$ Waldsieversdorf zum Mittagessen im CVJMHaus. Danach konnten alle bei eine DVD-Vorführung noch einmal die Jubiläumsfeier des Großdechanten miterleben. Auch der gemütliche Teil mit Vorträgen auf ,Pauersch' kam nicht zu kurz [...]. 
Nach der gemeinsamen Kaffeetafel traten alle wieder den Heimweg an." (Rundbrief des Großdechanten, H. 3/2015, S. 20 f.); 20. Treffen 2016 ebd. (www.grafschaft-glatz.de [20.9.2016]).

BevöLKerungszahlen: 1925: 2314, 1939: 2210, 1946: 2344, 1964: 2536 (Städtebuch, S. 76). - „Durch den Zuzug von Flüchtlingen und Umsiedlern aus den besetzten Ostgebieten erhöhte sich die Zahl der Einwohner von 2300 auf rund 3 000.“ (Krügel, S. 67).

Katholiken: 1925: 65, 1946: 381, „1955: 750 kath. (Umsiedler!)“ (Städtebuch, S. 27). „Nach dem Zusammenbruch [1945] wurde der Gottesdienst in verschiedenen Privathäusern abgehalten, zuletzt im Hause Klinger, Königstr. 5/6. Pfarrer [Franz] Jantes [seit 1934 im Amt] starb im Jahre 1947. Durch den Zuzug zahlreicher katholischer Umsiedler aus den besetzten Ostgebieten vergrößerte sich die Gemeinde, so, daß an den Erwerb eines eigenen Grundstücks gedacht werden konnte. 1951 wurde das Haus Lindenstraße 55 angekauft und als Kapelle und Pfarrhaus umgebaut.“ (Krügel, S. 73). - „Nach der Räumung Buckows [1945] kehrte ein Großteil der Einwohner nicht mehr zurück. Die vor allem durch sudetendeutsche Flüchtlinge quasi neuentstandene [kath. Kirchen-]Gemeinde sammelt sich zunächst im Haus einer Drogerie, K[a]pl[an] Fritz Palm (1948-53) kann dann ein ehemaliges Fabrikgebäude erwerben. [...].“ (Brühe, S. 19). - 1994 Namengebung „St. Hedwig“ für die neue, mit Müncheberg fusionierte Pfarrgemeinde (Schwillus/Brühe, S. 306).

Gemeindepartnerschaft: 1998 Partnerschaftsvertrag mit Łagów, Polen (Lagow, ehem. Kr. Oststernberg, Provinz Brandenburg) geschlossen [Beide Städte waren inder Fremdenverkehrswerbung schon vor 1945 miteinander verglichen worden (freundlicher Hinweis Jörg Lüderitz, Frankfurt (Oder)/Łagów, 10.8.2018)]. „2003 wurde er verlängert auf 10 Jahre und 2013 wurde er nach Neugestaltung auf 15 Jahre verlängert." Erste, inoffizielle Kontakte gab es bereits Mitte der 1980er Jahre (Auskunft der Partnerschaftsbeauftragten der Stadt Buckow, Melitta Schubert und Maxi Pincus-Pamperin, 22.6.2018). In Buckow lebten zudem noch nach 1990 zwei (inzwischen verstorbene) ehemalige Lagower: Friedhelm Gossert und Günther Schäpe (Auskunft Melitta Schubert, 18.6.2018).

Literatur: Brühe, Matthias: Katholische Kirche zwischen Uckermark und Oderland. Berlin 1998, S. 19. - Heinze: 19. Treffen der Grafschafter in Buckow-Waldsieversdorf. In: Rundbrief des Großdechanten, H. 3/2015, S. 20-21. Krügel, Max: Buckow im Landes Lebus. Berlin 1957. - Schwillus/Brühe, S. 306.

\section{Buckow}

Landgemeinde (seit 31.12.2002 Ortsteil von $\rightarrow$ Nennhausen), bis $1952 \mathrm{Kr}$. Westhavelland, 1952-1990 Kr. Rathenow (Bez. Potsdam), 1990-1993 Ldkr. Rathenow, 1993 Ldkr. Havelland BevölkeRUngSZAHLEN: 1925: 205, 1939: 175, 1946: 261, 1964: 154 (HOL III, S. 57).

UMSIEDLERLAGER: Kapazität am 31.12.1945: 500 (BArch, DO 2/45, Bl. 40). 


\section{Cahnsdorf}

Landgemeinde, bis 1952 Kr. Luckau, 1952-1990 Kr. Luckau (Bez. Cottbus), 1990-1993 Ldkr. Luckau, 1993 Ldkr. Dahme-Spreewald

BevöLKERUNGSZAHLEN: 1925: 337, 1939: 351, 29.10.1946: 556, 1950: 530, 1964: 410 (HGV LDS, S. 22 f.).

FLÜCHTLINGSLAGER/AUfFANGLAGER: Sept. 1945 als Auffanglager eingerichtet für vorübergehende Unterbringung von (angeblich 5000, auch 8000 [Wenzel, S. 138], auch 10000 Personen [Wille I, S. 245, 333] Flüchtlingen aus Schlesien vor der Einweisung in andere Kreise Brandenburgs bzw. Weiterleitung nach Mecklenburg. - 5.9.1945 Befehl der Provinzialregierung an Landrat Holland in $\rightarrow$ Luckau zur ordnungsgemäßen Durchführung der Einweisung in die Kreise noch vor dem Winter, daraufhin am 14.9.1945 im Landratsamt Beschluss zur vollständigen Räumung des Bauerndorfes Cahnsdorf (ca. 800 altangesessene Einwohner, 1945 aber wohl nur 300 anwesend) und Umsetzung am selben Tag, zunächst Einweisung von 300 ersten Flüchtlingen, im Oktober und vor allem im November 1945 folgte der eigentliche Flüchtlingsstrom (über Bahnhof Luckau ankommend), am 31.10 .1945 bereits 7533 amtlich registrierte Flüchtlinge. - 9.10.1945 Anordnung: „Sofortige Einrichtung der bereits angeordneten politischen Prüfstelle im Lager Cahnsdorf [...]“ (Wille I, S. 157). - 24.10.1945 „Kahnsdorf ist von der zivilen Bevölkerung geräumt und der gesamte Ort als Umsiedlerlager bestimmt, die eingesessene Bevölkerung auf die Nachbardörfer verteilt worden und bestellt von dort ihre Landwirtschaft." (Bericht des Landratsamtes, in: Töpler, Menschenwurm, S. 451). - 29.10.1945 (Bericht des Oberlandratsamtes Cottbus): „Quarantänelager Cahnsdorf, gegenwärtig mit 5000 Mann belegt, [...] die festen Gebäude mit dieser Zahl restlos gefüllt [...] Verpflegung [...] ohnehin mangelhaft" (Wille I, S. 335). - 16.11.1945 Zeitungsbericht „Umsiedler-Auffanglager in Cahnsdorf“: „, ... ] Der Kreisausschuß für Umsiedlerfragen errichtete in Cahnsdorf, $2 \mathrm{~km}$ von Luckau, ein Auffanglager, in dem die Umsiedler im allgemeinen fünf Tage verbleiben. Hier ist neben ihrer namentlichen und politischen Erfassung vor allem für ärztliche Betreuung gesorgt. [...] Reparaturbedürftiges Schuhwerk wird in einer Werkstatt im Lager überholt. Zur Unterbringung kranker, nicht transportfähiger Umsiedler ist ein Ausweichlager eingerichtet. [...]." (Berliner Zeitung, 16.11.1945, zitiert nach Töpler, Menschenwurm, S. 462). - 23.11.1945 Transport von Cahnsdorf nach Mecklenburg (2000 Personen mit 2 Schwestern in 57 Wagen, davon 41 ab Cahnsdorf besetzt; ärztliche Betreuung: Dr. Walter, Cahnsdorf) (Wille I, S. 319). - Okt./Nov. 1945: „78 Personen [starben] im Lager Cahnsdorf bei Luckau, wo auch wir von Mitte Oktober 1945 bis Anfang November 1945 einen Zwischenaufenthalt einzulegen hatten." (Horst Höricke, in: BR 10 (2012) 2, S. 11). - Schließung des Lagers zu Weihnachten 1945; Schlussbilanz: 163 Personen zwischen 16.9. und 1.12.1945 im Lager verstorben, 39 im Krankenhaus Luckau, 185 haben sich durch Flucht der Quarantäne entzogen; in der Sanitätsstation des Lagers (v. a. zur Entlausung und Eindämmung der Typhusgefahr) standen 2980 Personen in ambulanter Behandlung; Höchstbesetzung im Lager: 4000. - Kapazität bis 31.12.1945: 10000 (BArch, DO 2/45, Bl. 41). - Seit 1999 Gedenkstein auf dem Friedhof mit 
Inschrift „Hier fanden in der Zeit vom Sept. bis Dez. 1945163 schlesische Flüchtlinge ihre letzte Ruhestätte“.

Kath. LAgerseelsorge: Lagerseelsorger (Anton Erzepky) für das im Bereich der Pfarrei Luckau gelegene Lager 1945 offenbar frühzeitig eingesetzt (lt. Bericht vom 15.12.1945 in „den letzten Monaten ab Juli 1945“ [also frühestens im September, P. B.]; „Seelenzahl je nach Besetzung bis 1200 Seelen“) (Töpler, Menschenwurm, S. $471 \mathrm{f}$.).

Flüchtlingsbetreuung im Lager durch Graue Schwestern: „Das erste Lager, in dem Graue Schwestern die Pflege übernahmen [...]. Hier arbeiteten sechs Schwestern, unter ihnen die spätere Provinzialoberin Schwester Blandina Schubert. Die Schwestern wohnten in zwei kleinen Zimmern, die vom Berliner Provinzhaus notdürftig eingerichtet wurden. In dem Lager lebten etwa 5000 Flüchtlinge, von denen viele Typhus und Ruhr hatten. / Die Schwestern arbeiteten hier vom 12. November bis zum 14. Dezember 1945, als das Lager nach $[\rightarrow]$ Finsterwalde $[\ldots]$ verlegt wurde. Die Schwestern verteilten sich auf die neu entstehenden Niederlassungen in Finsterwalde und $[\rightarrow$ ] Luckau. [...].“ (Mertens, S. 478). - 20.11.1945 (Bericht über Besuch im Lager): „Die 6 Schwestern aus Breslau leben primitiv in apostolischer Einfachheit." (Töpler, Menschenwurm, S. 463).

ArChivalische Quellen: BArch, DO 2739, Bl. 85-86 (Lager, Dez. 1945). - BLHA, Rep. 250 Landratsamt Luckau, Nr. 296 („Sanitäre Betreuung und Überprüfung der Umsiedlerlager Cahnsdorf und Finsterwalde“, 1945-1946).

Gedruckte Quellen: Minia, [Günther]: Lager Cahnsdorf (Niederlausitz). Abschließender Bericht über das Auffanglager Cahnsdorf durch den Bevöllmächtigten für die Flüchtlingsfürsorge der deutschen Ev. Kirche der Niederlausitz, Superintendent Lic. Minia (Luckau). In: 700 Jahre Cahnsdorf 1297-1997. Cahnsdorf 1997, S. 15-17. - Töpler, Menschenwurm, S. 451, 462 f., 466-468, 471 f., 500. - Wille I, S. 158 f., 245, 319, 333, 335, 445.

LiteratUR: BR 10 (2012) 2, S. 11. - Mertens, Johannes: Die Berliner Ordensprovinz der Grauen Schwestern von der heiligen Elisabeth 1859-1991. Reinbek bei Hamburg 1992, S. 477 f. - Regina Scheer: Der Umgang mit den Denkmälern. [Potsdam] 2003, S. 147. - Wagner, Hans: 100 Jahre Krankenhaus Luckau (1903-2003). In: Luckauer Heimatkalender 36 (2004), S. 24-36, hier S. 28. - Wenzel, Mario: Die Aufnahme und Versorgung von Flüchtlingen und Vertriebenen in Eberswalde 1945-1948. In: Eberswalder Jahrbuch 2015, S. 136-145, hier S. 138 (irrtümlich „Krahnsdorf“).

\section{Calau}

Stadtgemeinde (bis 1947 und 1952-1993 Kreissitz), bis 1952 Kr. Calau (1950 umbenannt in Kr. Senftenberg), 1952-1990 Kr. Calau (Bez. Cottbus), 1990-1993 Ldkr. Calau, 1993 Ldkr. Oberspreewald-Lausitz

EREIGNisse BIS KRIEgSENDE: 1945 Kreisverwaltung Züllichau nach $\rightarrow$ Guben, Calau und $\rightarrow$ Neuruppin evakuiert (BLHA, Rep. 6 B Züllichau-Schwiebus, Nr. 3). - Am 12.2.1945 berichtet der kath. Pfarrer: „[...] 2 Nächte war die Kirche auf Bitten der Behörden mit Flüchtlingen der großen Trecks belegt. [...] In der Stadtpfarrkirche sind immer noch Flüchtlinge. Die Flüchtlinge stammen aus den Kreisen Krotoschin und Rawitsch. Es sind Schwarzmeerdeutsche. Vor Beginn des Rußlandfeldzuges nach Bessarabien/Rumänien zusammengezogen, von dort nach dem Warthegau 
gebracht. Und jetzt hier in der Diaspora. Soweit sie katholisch sind, - und das scheinen sie in der größern Mehrheit zu sein - sind sie sehr treu im Glauben. Die religiöse Ausbildung mancher Dörfer ist vorbildlich. Zum größten Teil waren sie hier zur hl. Beichte u. hl. Kommunion. Die Kirche gefüllt, die Ministranten müssen bei der Predigt auf den Altarstufen sitzen. Und das bei den vielen hl. Messen. Für die Leute hier ein ungewohntes Bild. Taufen und Begräbisse am laufenden Band [...]." (Töpler, Menschenwurm, S. 316). - 19.4.1945 Einmarsch der Roten Armee (ebd., S. 330). - 20.4.1945: „Sowjets [...] in Calau eingedrungen.“ (Kriegstagebuch des OKW 4,2, S. 1257). - Die Stadt gilt bei Kriegsende als schwer zerstört (ebd., S. 295).

Bevölkerungszahlen: 1925: 3678, 1939: 4459, 1946: 5372, 1964: 6733 (Städtebuch, S. $80 \mathrm{f}$.).

Katholiken (Erzbistum Breslau/Erzbischöfliches Amt Görlitz): 1925: 121, 1946: 477 (ebd., S. 81). - Kuratial-Pfarrer war ab 1944 der (zuvor in Ostpreußen amtierende) Studienrat Dr. theol. Franz Budek (geb. 1905 Gleiwitz), 1949 wurde er Dekanatserzpriester (Ostpriesterverzeichnis 2, 1949, S. 18; Schematismus Görlitz 1954, S. 58; 1961, S. 75). Am 12.2.1945 berichtet er: „Jeden Tag sind 5 heilige Messen. [...].“ (Töpler, Menschenwurm, S. 316). - 1945/46 war der ehem. Breslauer Univ.-Prof. Dr. theol. Felix Haase $(\rightarrow$ Kirchhain) zur Aushilfe in Calau und $\rightarrow$ Vetschau eingesetzt (ebd., S. 641).

VertriebenENVERBÄNDE NACH 1990: BdV-Kreisverband Calau, 18.10.1994 erwähnt mit Herrn Gäbler als Vorsitzendem (Akten der BdV-Landesgeschäftsstelle), siehe $\rightarrow$ Lübben.

Archivalische Quellen: BLHA, Rep. 6 B Züllichau-Schwiebus, Nr. 3 (Verlegung der Kreisverwaltung Züllichau nach Guben, Calau und Neuruppin; Abwicklung der Geschäfte, 1945).

Gedruckte Quellen und Literatur: Kriegstagebuch des OKW 4,2, S. 1257. - Ther, Philipp: Die Vertriebenenpolitik in der SBZ/DDR 1945-1953 am Beispiel des Kreises Calau-Senftenberg. In: Jahrbuch für brandenburgische Landesgeschichte 46 (1995), S. 159-168. - Töpler, Menschenwurm, S. 316 f. (Bericht über die Lage in Calau, Febr. 1945), 329-332 (Bericht über Kriegsende in Calau) u. ö. (siehe S. 662).

\section{Cammer}

Landgemeinde (seoit 2002 Gemeineteil von Planebruch), bis 1952 Kr. Zauch-Belzig, 19521990 Kr. Potsdam-Land (Bez. Potsdam), 1990-1993 Ldkr. Potsdam, 1993 Ldkr. Potsdam-Mittelmark

EREIGNisSe NACH KRIEgSEnde: Bei der Bodenreform Umsiedler nicht gesondert erwähnt (HOL V, S. 71).

BeVÖLKERUNGSZAHLEN: 1925: 814, 1939: 876, 1946: 971, 1964: 690 (HOL V, S. 72).

Katholiken: 14.11.1946: Pfarrer Rudolf Firlej als Vertriebener aus dem Erzbistum Prag mit der Seelsorge in Cammer und Golzow beauftragt, die damals beide zur Pfarrei $\rightarrow$ Brandenburg/ 
Havel gehörten, 1951 jedoch zu $\rightarrow$ Belzig. „Seit 1953 war kein Seelsorger mehr am Ort.“ (Brühe, S. 46; Schematismus Berlin 1949, S. 141). Firlej (geb. 1903 Worbis) war bis 1945 Pfarrer in Oberlangenau, Kr. Habelschwerdt (Grafschaft Glatz, Schlesien) (Anschriftenverzeichnis des Klerus der Grafschaft Glatz 1945-1950, S. 3; Ostpriesterverzeichnis 2, 1949, S. 22; Schematismus Berlin 1949, S. 141).

Literatur: Brühe, Matthias: Katholische Kirche zwischen Havel und Dahme. Berlin 1999, S. 46.

\section{Cantdorf $\rightarrow$ Spremberg-Cantdorf}

\section{Caputh}

Landgemeinde, bis 1952 Kr. Zauch-Belzig, 1952-1990 Kr. Potsdam-Land (Bez. Potsdam), 1990-1993 Ldkr. Potsdam, 1993 Ldkr. Potsdam-Mittelmark

EREIGNISSE BIS KRIEGSENDE: Jan. 1945: „In dieser Zeit kamen auch die ersten Trecks mit Flüchtlingen aus Ostpreußen, die meist mit Pferdewagen unterwegs gewesen sind. Sie kamen auch zu uns und wollten Brot oder etwas zum Essen kaufen. Wir konnten ihnen aber kein Brot geben, da wir selbst die Brotscheiben abzählen und einteilen mussten. [...] Jedenfalls konnten auch die Bäckereien den Flüchtlingen nichts geben, da das Mehl gerade zum Backen für das Brot der Caputher reichte. Und da die Menschen in den Trecks auf der Flucht waren, hatten sie auch keine Lebensmittelmarken. Sie waren ja nirgends angemeldet. Das einzige, was wir ihnen geben konnten, waren Äpfel und Möhren. Dankbar waren sie auch für eine Tasse warmen Malzkaffee oder Kräutertee. Es war ein Elend! Manche Menschen sind bereits vier oder sechs Wochen unterwegs gewesen. Als wir dies sahen, beschlossen wir, niemals zu fliehen und auf die Landstraße zu gehen, solange wir hier noch ein Dach über dem Kopf hatten. [...]. [S. 52] [...] [April 1945:] Jetzt hielt der Flüchtlingsstrom Tag und Nacht an. Aber sie kamen nur noch vereinzelt mit Pferdewagen, Fahrrad, Handwagen, Kinderwagen oder gelaufen. Alle hatten Angst vor der immer näher rückenden Front. Wo wollten denn die Menschen alle hin? Trotzdem packten auch wir einen alten Kinderwagen mit dem Nötigsten zusammen. [...] [14.4.1945 (Bombenangriff auf Potsdam):] Zwei Bomben gingen auch in Caputh nieder, eine in der Waldstraße und eine in der Siedlung. In der Waldstraße gabe es 6 Tote, darunter zwei Flüchtlinge aus dem Sudetenland, die dort Unterkunft gefunden hatten." (Erinnerungen von Inge Dallorso als Mädchen, aufgezeichnet 1985; in: Gedenken in Caputh, S. 51 f.). - 26.4.1945 Einmarsch der Roten Armee (Gedenken in Caputh, S. 63).

EReignisse NACH KRIEgSEnde: Sommer 1945: „Auf dem Gebiet der Fürsorge spielt das Flüchtlingsproblem die Hauptrolle. Vorläufig wurde unser Ort als Sperrgebiet erklärt, da er durch Besatzungsgtruppen der Roten Armee überaus stark belegt ist. Für später ist die Unterbringung von 1000 Flüchtlingen vorgesehen." (Zeitgenössischer Bericht von Richard Probst: Caputh zum Kriegsende; in: Gedenken in Caputh, S. 61). - In der Bodenreform 2,7 ha von 373,38 ha an 6 „Umsiedler" vergeben (HOL V, S. 74). 
BeVÖLKERUNGSZAHLEN: 1925: 3069, 1939: 3608, 1946: 3973 , 1964: 3640 (HOL V, S. 74).

UMSIEDLERLAGER: In Liste der brandenburgischen Lager für den 31.12.1945 mit aufgeführt, aber ohne Kapazität (anstelle einer Zahl steht hier „-“), eventuell also vorbereitet, aber noch nicht einsatzbereit (BArch, DO 2/45, B1. 40).

Gedruckte Quellen und Literatur: Adreßbuch Groß-Potsdam 1949, S. 845-857 (Gemeinde Caputh). - Dallorso, Inge: Das Ende des Faschismus und die Befreiung von Caputh. In: Wald-, Blütendorf und Strandbad Caputh. Heimatgeschichtliche Beiträge. Potsdam (1986), S. 11-14 [Gekürzte Version, vgl. unten die Originalfassung]. - Gedenken in Caputh. Den Opfern von Krieg und Gewalt. Ausgew. u. bearb. von Klaus Hugler. Caputh 2005 (darin u. a.: Inge Dallorso: Befreiung Capuths vom Faschismus [Erinnerungen, aufgezeichnet 1985], S. 50-57; Richard Probst: Caputh zum Kriegsende [zeitgenössischer Bericht, auf Aufforderung des Bürgermeisters verfasst im Sommer 1945], S. 57-61).

\section{Coschen}

Landgemeinde, bis 1952 Kr. Guben, 1952-1990 Kr. Fürstenberg/Oder bzw. (ab 1961) Kr. Eisenhüttenstadt (Bez. Frankfurt/Oder), 1990-1993 Ldkr. Eisenhüttenstadt, 1993 Ldkr. OderSpree

EREIGNISSE NACH KRIEGSENDE: 3.10.1950 Zuweisung von westlich der Neiße gelegenen Flächen der nun polnischen Gemeinde Buderose/Budoradz (ehem. Kr. Guben) an die unmittelbar an der Neiße gelegene Gemeinde Coschen (Blöß, Kreise und Gemeinden, S. 31).

\section{Cottbus}

Stadtgemeinde, kreisfreie Stadt seit 1886, 1.7.1950-1954 Ldkr. Cottbus, seit 1954 Stadtkr. (1952-1990 Bezirksstadt im gleichnamigen Bez.)

EReignisse bis Kriegsende: Anf. Jan. 1940 besteht in Cottbus ein Auffanglager für 300 umgesiedelte Wolhynien- und Galiziendeutsche (Müller, S. 124). - „Seit dem Oktober 1944 gehörten Flüchtlinge zum Erscheinungsbild auf dem Cottbuser Bahnhof. Es waren überwiegend nach 1939 in das sogenannte Generalgouvernement umgesiedelte und nochmals 1941/42 dem Ruf Hitlers gefolgte Familien, sich in den ,eroberten und besetzten Ostgebieten' niederzulassen. [...] Rechtzeitig und ordnungsgemäß von den deutschen Militärkommandanturen abgewickelt, trafen die Heimkehrer mit weniger Habe, verstaut in mitfahrenden Güterwagen, in Deutschland ein. Nun sah man sie in der Cottbuser Bahnhofshalle sitzen, von Neugierigen umringt. Mit mehrfach übereinandergezogenen Kleidungsstücken, ein Wolltuch um den Kopf geschlungen und darüber noch einen Hut, sowie die Kleinkinder ,eingemummelt', so harrten sie apathisch der kommenden Dinge. Um die ,Ostlandbauern' kümmerten sich besorgt die Bahnhofswache und das Rote Kreuz, unterstützt von der NS-Frauenschaft und des BDM. / Ihr Schicksal wurde Herumtstehenden erst deutlich, wenn die [S. 20] gereichte Suppe, das ein- 
zig Warme seit Stunden Bahnfahrt, aus Waschschüsseln gemeinsam mit den Kindern gelöffelt werden musste. Trotzdem gab es für diese Flüchtenden gegenüber den Nachfolgenden einen Lichtblick: Sie wurden überwiegend auf brandenburgischen Gütern untergebracht. Mit dem Einsetzen der Weichsel-Oder-Operation im Zuge der Winteroffensive der Roten Armee am 12./14. Januar 1945, die an Wucht und Tempo alle Erwartungen übertraf, trat auch für Cottbus eine neue Situation ein. Die Anzahl eintreffender ,Flüchtender vor den Russen` erhöhte sich beträchtlich, besonders solcher, die sich, wild auf den Weg' gemacht hatten. Jedem aus $[\rightarrow] \mathrm{Gu}-$ ben, $[\rightarrow]$ Forst und $[\rightarrow]$ Spremberg eintreffenden Zug entstiegen Flüchtlinge. Auch sie wurden noch durch den Bahnhofsdienst versorgt, um dann zu Verwandten und Bekannten weiterzufahren. Dann jedoch trafen die ein, die als deutsche Zivilbevölkerung im Sog der zurückweichenden deutschen Panzer- und Grenadier-Divisionen flüchteten. Seitdem nahm der Flüchtlingsstrom Ausmaße an, die von der Cottbuser Stadtverwaltung nicht mehr beherrscht wurden. Mit dem 20. Januar 1945 traf der erste, fast 60 Pferdefuhrwerke umfassende Flüchtlingstreck mit der transportfähigen [S. 21] Habe, über die Forster Chaussee kommend, in Cottbus ein. ,Zwei Tage standen die Wagen auf dem Berliner Platz. Ich half, einige Pferde neu zu beschlagen', so ein Brunschwiger Hufschmied, während die Frauen und ihre Kinder sich bei Altmann versorgten. Beim Kriegsschadensamt hatte man 420 Menschen notiert, die am 22. Januar nach $[\rightarrow]$ Vetschau weiterzogen. Das Thermometer zeigte $-22^{\circ}$ Celsius. Aus allen Himmelsrichtungen trafen die Trecks ein. Sogar über Ströbitz in die Berliner Straße führte ein Weg. $[\rightarrow]$ Lübbenau glaubte wegen Überfüllung, solche Flüchtlingszüge nach Cottbus ,umleiten' zu können. ,Wir kochten Tee und schleppten den Bottich von der Wohnung in der Schillerstraße zur Berliner Straße, um das Elend der Menschen wenigstens etwas zu lindern', so die Aussage einer Zeitzeugin. Doch es sollte noch schlimmer kommen. [...] [Mit den durch den Vormarsch der Roten Armee nach Schlesien veranlassten Fluchtbewegungen nach dem 20. Jan. 1945] wurde die ,Stadt Cottbus ... eine Schleuse des großen Einfalltores aus dem Osten, und unbeschreibliches Elend wälzte sich von Tag zu Tag durch die Straßen', so hieß es im Bericht des Sozialamts vom 28. August 1945. Täglich fuhren mehrere Eisenbahnzüge, zum Teil offene Wagen, in den Bahnhof ein. Die Erforenen und an Entkräftung Verstorbenen wurden auf dem Südfriedhof zur letzten Ruhe gebettet. Manches Kind erblickte unter diesen Umständen das Licht der Welt. Auch Kleinkinder gingen auf dem überfüllten Bahnsteig, trotz der Ausrufe über die Bahnhofslautsprecher, verloren. / ,Wir spielten mit ihnen oder lasen Märchen jeden Nachmittag vor, um den heimat- und nun auch mutterlosen Kindern das schwere Los zu erleichtern', so erinnerte sich eine Cott- [S. 22] buserin an ihren Einsatz als Schülerin im Sozialamt Thiemstraße. [... D Die Cottbuser Stadtverwaltung musste im Neuen Rathaus am Neumarkt zusammenrücken und die Verwaltung von Litzmannstadt (Lódz) und des $[\rightarrow]$ Frankfurter Regierungspräsidenten aufnehmen. Die Beamten richteten sich ein, als ob ihr Wirkungsfeld in Kürze wieder befreit würde. So gab es die ,Annahmestelle von Entschädigungsforderungen wegen Haushaltsverlust bei Feindannäherung. / In den Turnhallen der Schulen, die mit Doppelstockbetten ausgestattet oder nur mit Strohballen ausgelegt waren, fanden viele eine erste Ruhepause. ,Jungmädchen;, abkommandiert von ihren Führerinnen, betreuten die 
heimatlosgewordenen, bis sie in Ungewissheit weiterzogen. Die Plätze wurden für die Nachfolgenden benötigt. [...].“ (Petzold, Als für Cottbus der 2. Weltkrieg endete, S. 19-22; Kursivierungen von P. B.). - „Noch am 12.2. fuhr ein Amtswalter der damaligen NSV (Volkswohlfahrt), Crossen a/O., nach Cottbus, um über die Möglichkeiten des Abtransportes der Sommerfelder [Sommerfeld/NL, Kr. Crossen) Kinder zu verhandeln [...].“ (Platzke, S. 98). - 15.2.1945 schwerer Luftangriff auf den Bahnhof Cottbus, große Opferzahl (etwa 2000[?]), darunter viele nicht registrierte Flüchtlinge (Menschen und Schicksale, S. 464; Töpler, Menschenwurm, S. 325). - 22.4.1945 Einmarsch der Roten Armee (Töpler, Menschenwurm, S. 326). - Die Stadt gilt bei Kriegsende als schwer zerstört (ebd., S. 295). - „Die Polizei [von Sommerfeld/ $\mathrm{NL}, \mathrm{Kr}$. Crossen] hatte in Cottbus Unterkunft gefunden, ebenso viele Sommerfelder, die möglichst nahe der Heimat auf den Tag der Rückkehr warten wollten." (Platzke, S. 102).

EREIGNISSE 1945 NACH KRIEGSENDE: 11.6.1945 (Tagebucheintrag eines Cottbusers): 11-köpfige Vertriebenenfamilie aus dem Sudetenland, zu Fuß eingetroffen, wird für eine Übernachtung privat aufgenommen (Tagebuch Kretschmer). - [Ab] Juni 1945 (Bericht einer am 23.6. aus Sorau Vertriebenen): „[...] täglich kamen mindestens drei Monate lang 2000 Vertriebene durch Cottbus, und hier fing sich alles an zu stauen. / Wer kein bestimmtes Ziel hatte, blieb hier in der stillen Hoffnung, bald wieder zurück in die Heimat zu können. Geld hatten die wenigstens von uns, Arbeit gab es auch keine, so zog man auf die Dörfer, bettelte um ein paar Kartoffeln, Gurken oder Mohrrüben. Cottbus wurde eine Stadt des Grauens, eine Stadt des Sterbens. Auch ich mußte mit ansehen, wie drei sehr gute Bekannte von mir vor meinen Augen verhungerten. [...]." (Dokumentation der Vertreibung I/2, S. 689). - Lt. Bericht des kath. Pfarrers Budek (Calau) vom 20.7.1945 ist Cottbus „die Stell“, die von Trecks „am meisten überlaufen wird“ (Töpler, Menschenwum, 356). Bis 11.7.1945 passieren Cottbus 180000 Flüchtlinge (überwiegend auf der Durchreise), bis 26.12.1945 (Hetzke, Wiederaufbau, S. 35) „waren es 1,3 Millionen und bis Juli 1946 1,5 Millionen Menschen, die sich durch die Straßen der zerstörten Stadt schleppten. Alle wollten essen, viele nur eine Unterkunft für die Nacht. Vor allem alte Menschen konnten vor Erschöpfung oft nicht mehr weiter. Die endlosen Flüchtlingstrecks, die schlechten sanitär-hygienischen Verhältnisse, die Unterbringung in primitiven Massenquartieren und der zunehmende Hunger verursachten epidemische Erkrankungen und Seuchen." (Hetzke, Kampf, S. 71). - 4.7.1945 (Tagebucheintrag eines Cottbusers): „Auf dem Rückweg Hindenburgplatz Elendswagen mit Flüchtlingen aus Glogau getroffen, die ich in die OT [Organisation Todt]-Baracken wies. Im Hause seit $h 14$ [Uhr] 14 Torgauer Flüchtlinge, die nach Luckau sollen. Das Flüchtlingselend in der Stadt immer noch unsagbar, stumpft mich schon ab u. macht direkt apathisch. Bald 6 Monate geht das jetzt!! Jetzt verursachen Polen $u$. Tschechen das meiste davon. Wallstraße noch nicht freigegeben. Russen sah man heute weniger im Stadtbild." (Tagebuch Kretschmer). - 9.7.1945 (Bericht des Landratsamtes): „Viele [Flüchtlinge] sterben auf dem Bahnhof, Frauen und Kinder, so daß die Sanitäter mit dem Abtransport nicht nachkommen." (Wille I, S. 37). - 20.7. oder 20.8.1945 Bericht des kath. Pfarrers Broß: „Anfang Juli täglich bis 20000 Flüchtlinge durch Cottbus“ (Töpler, Menschenwum, S. 358). - 2.8.1945 (Erinnerungsbericht einer im Juli aus Wohlau Vertriebenen): „In Cottbus 
zehn Stunden Warten. Auf dem zerstörten Bahnhof lagen die Menschen auf den Bahnsteigen herum und kochten auf den toten Gleisen ihr Essen ab. Nirgends kümmerte sich einer um den andern. Wer sich nicht mehr selber helfen konnte, war eben verloren. " (Dokumentation der Vertreibung I/2, S. 698). - 23.8.1945 Zurückweisung eines Vertriebenentrecks (270 Personen) wegen Überfüllung des Stadt- u. Landkreises Cottbus und Seuchengefahr (Faksimile des Schreibens des Landrates in: Ast/Mauersberger, S. 39). - Im Sept. 1945 halten sich vorübergehend fast 12000 Flüchtlinge in der Stadt auf (Chronik, S. 69). - Sept. 1945 Höhepunkt einer Typhus- u. Paratyphusepidemie im Raum Cottbus (Hetzke, Kampf, S. 72), im Herbst 1945 dadurch mehr als 200 Tote (Chronik, S. 70). - Am Jahresende 1945 gibt es vier Flüchtlingslager in der Stadt mit etwa 1200 Insassen (Chronik, S. 70).

EREIGNISSE 1946-1952: Sommer 1946 (Kurzaufenthalt eines Vertriebenentransports aus Schlesien auf dem Bahnhof, Zeitzeugenbericht): „Unser nächster Halt fand schon in Cottbus statt. Dort gab es eine katholische Bahnhofsmission, eine kleine Baracke, die provisorisch auf einem der Bahnsteige stand, denn das Bahnhofsgebäude lag durch einen Bombenangriff in Trümmern. Pfarrer Bruno Broß von der Marienkirche in Cottbus hatte diese lobenswerte Einrichtung im zähen Kampf mit den Behörden gegründet und mit seinen ehrenamtlichen Helfern zehntausenden von Vertriebenen und Heimkehrern erste Hilfe zuteil werden lassen. [...] Leider existierte die Bahnhofsmission nur bis zum Beginn der fünfziger Jahre; kurz nach Gründung der DDR wurde sie von den SED-Behörden zwangsweise geschlossen. / Doch unser Transportzug hielt nicht an den Bahnsteigen, sondern weit davon entfernt auf dem ausgedehnten Güterbahnhof. Wir hatten dort lange mit uns zu tun, nämlich eine Zapfstelle für Trinkwasser zu suchen, Kochmöglichkeiten zu improvisieren, Brennholz zusammenlesen, und vor allem den Älteren zu helfen, aus den Waggons auszusteigen. An einem Bahnhsteig fällt das ja nicht schwer, aber wenn man vom hohen Trittbrett auf den tiefliegenden Bahnkörper springen muß, braucht man wenigstens einen Rest jugendlicher Beweglichkeit. / So fanden einige von uns erst nach Stunden die Baracke der Bahnhofsmission, deren Helfer uns wegen der weiten Entfernung auch nicht entdeckt hatten. Kurz darauf fuhr der Zug weiter. Wir konnten nicht einmal unsere Kranken ausladen, [...]. Die Helfer der Cottbuser Bahnhofsmission wollten sich jedenfalls für die ärztliche Versorgung unserer Kranken einsetzen. Es ging nicht mehr; wir konnten sie nicht mehr ausladen, denn der lange Transportzug setzte sich ohne jede Rücksicht in Bewegung." (Schneider, Vergangenheit, 1. Aufl., S. 81 f.). - Sept. 1946 Rede Wilhelm Piecks auf einer Kundgebung in Cottbus, in der er für eine Revision der Ostgrenze auf einer kommenden Friedenskonferenz eintritt (Blöß, Grenzen und Reformen, S. 62); Herbst 1946 Wahlkampf-Flugblatt der SED Cottbus mit der Formulierung „Die SED ist für eine Revision der Ostgrenze [...].“ (ebd., S. 64). - 15.3.1947 Erwähnung einer „Umsiedlergenossenschaft“ (Heimarbeit) „Metallgiesserei Genossenschaft, Cottbus - Josef Berger" mit 4 Arbeitern (BLHA, Rep. 333, Nr. 574, B1. 105). - 1947 Gründung eines unabhängigen „Verbandes der Ostumsiedler“ (BArch, DO 2/50, Bl. 494-499), Meldung an Provinzialregierung, 16.7.1947, „dass eine Umsiedlerorganisation in Cottbus gegründet worden ist“; 1. Vorsitzender: Hans Hermann, Cottbus; Stellvertr.: Kurt Schröder, Ströbitz; Schriftführer: Otto Kochner, Cottbus; Stellvertr.: Christa Pallesche, Cottbus; Kassierer: Waldemar Assmann, 
Ströbitz; Stellv.: Gertrud Palleschke, Cottbus (ebd., Bl. 496, Statut: Bl. 472-476), kurz danach wieder aufgelöst (ebd., Bl. 497). - Ende Juli 1948 im Verzeichnis (von der Landesregierung) verbotener Suchdienste erwähnt: Oberlandrat Bezirksverwaltung Cottbus, Referat für Arbeit u. Sozialwesen, Cottbus, Karl-Liebknecht-Str. („Material am 7.11.46 [vom staatl. Suchdienst] übernommen") (BLHA, Rep. 203 MdI, Nr. 1197, Bl. 41). - 1951 Übernahme der Leitung der verstaatlichten Löwen-Apotheke durch den 1945 aus Sorau geflüchteten Apotheker Ernst Versen (1902-1970), auch Kreisapotheker für das Gebiet Cottbus/Forst/Guben bzw. ab 1952 für den Stadtkr. Cottbus, zuvor ab 1946 bereits Mitarbeiter der Adler-Apotheke in Cottbus, bis 1945 Apothekenpächter in Sorau (Biela, S. 37, 44). - 6.7.1952 Kirchliches Triebeler Vertriebenentreffen als Gottesdienst in der Lutherkirche, geleitet von dem ehem. Triebeler Oberpfarrer Hans Klahre (1878-1957), Pfarrer in $\rightarrow$ Luckau (BArch, DO 1727887, Bl. 80-81, vgl. Bericht im Quellenteil, Nr. 238).

EREIGNISSE NACH 1990: 7./8.5.1994 „Költscher Heimattreffen“: „Fast 50 Jahre nach ihrer Vertreibung aus dem kleinen niederschlesischen Schiffer-und Bauerndörfchen Költsch a. Oder trafen sich über 100 Heimatfreunde aus dem gesamten Bundesgebiet zum erstenmal in Cottbus" (Neusalzer Nachrichten, Nr. 178, 1994, S. 408); 2. Treffen 3./4.6.1996 im Hotel Branitz (ebd., Nr. 188, 1997, S. 355-357). - 23.9.2000 Heimattreffen der vertriebenen ehem. Bewohner von Amtitz (Kr. Guben) in der Bahnhofsgaststätte „Gleis 13“ mit 28 Teilnehmern (Bericht von Joachim Faßke [Cottbus] mit Teilnehmerliste [ohne Wohnortangabe]: Gubener Heimatbrief 1/2001, S. 72-73). - 13.7.2002 „5. Ostdeutscher Kulturtag“ des BdV-Landesverbandes Brandenburg in der Messehalle 2 („Congress, Messe \& Touristik Zentrum“) (Akten der BdV-Landesgeschäftsstelle). - 25.5.2003 7. Hermswalder Heimattreffen in der Gaststätte „Mannes Inn“ in der Cottbuser Heidesiedlung für ehem. Einwohner von Hermswalde bei Sommerfeld/Lubsko (Kr. Crossen) und Nachbargemeinden; angemeldet hatten sich 50 Teilnehmer (Lausitzer Rundschau, 22.5.2003).

BevölKerungSZAHLEN: 1925: 50 600, 1939: 55 509, 1946: 49131 („Im April 1945 befanden sich nur etwa 6000-8000 Menschen in C.“), 1964: 73358 (Städtebuch, S. 86). - Juli 1945 „absoluter Tiefstand“ (Krestin, S. 48, mit falscher Zahl). - Juli 1946: 13947 „Umsiedler“ (BLHA, Rep. 203 MdI, Nr. 1074, Bl. 52; Abb.: Mietk, S. 66). - 29.10.1946: 49131 Einwohner, davon aus Ostpreußen: 328, Hinterpommern 314, Ostbrandenburg 1902, Schlesien 4613, Tschechoslowakei 574, Polen 553, Danzig 65, Rumänien 28, Baltikum 45, Sowjetunion 13 (Volkszählung 1946). - 31.12.1948: Gesamtbevölkerung: 51547, davon „Umsiedler und Evakuierte“: 14250 (Grandke, S. 46). - Eingemeindung von Vertriebenen: 30.4.1947: 17742 (Oehlsen, S. 102), Juni 1948: 18771 (ebd., S. 103), Febr. 1949: 19248 (ebd., S. 104).

Katholiken (Erzbistum Breslau/Erzbischöfliches Amt Görlitz): 1925: 2656, 1946: 4858 (ebd., S. 87). - „Im Cottbuser Pfarrhaus St. Marien [Lausitzer Str. (1948 umbenannt in Wilhelm-Külz-Str.) 59; P. B.] kampierten im Sommer 1945 monatelang einhundert und mehr Personen, erschöpfte Frauen, Kinder und alte Leute, die jedoch ständig wechselten. Flure, Treppen- 
haus, Pfarrbüro, die große Wohnung des Pfarrers, alles war dicht mit Menschen belegt. Bruno Broß hieß der Pfarrer, und Franz Scholz, der letzte Pfarrer von Görlitz-Ost, [...] war damals Caritasdirektor. Was diese Männer und ihre Mitarbeiter damals Tag und Nacht leisteten, auf welche Weise sie in dieser extremen Hungerregion Nahrungsmittel, Decken und andere lebensnotwendige Dinge heranschafften, trotz allem aber die seelsorgliche Betreuung dieser unglücklichen Menschen wahrnahmen, erschien mir später ganz unbegreiflich.“ (Schneider, Seelsorge, S. 29). - Die in Cottbus ansässigen „Armen Dienstmägde Jesu Christi“, die Anfang April nach Bockwitz geflohen waren, kehrten am 12. Mai nach Cottbus zurück. „Vom dortigen Pfarrhaus aus versuchten sie, die immer stärker werdende Flüchtlingsnot zu lindern. Erst im November 1945 konnten sie wieder in das eigene Haus ziehen. [...] Diese Niederlassung war die einizge der drei Niederlassungen der Kongregation im Erzbistum Breslau, die über die Kriegszeit hinaus, ja bis in die fünfziger Jahre hinein, erhalten blieb. [...].“ (Mengel, S. 136). - 20.7. oder 20.8.1945 Bericht des kath. Pfarrers Broß: „Schwestern noch im Pfarrhaus untergebracht. Dazu Pfarrer [Bruno] Horzin-Züllichau [geb. 1875 (Ostpriesterverzeichnis 2, 1949, S. 38)], Pfarrer [Felix] Bannert-Brunzelwaldau [richtig: Barnert!], [Julius] Görlich-Liebenzig, Pater [Hellmuth] Hertzsch-Glogau. Pfarrer und Kuratus vollbeschäftigt, viel Aussengottesdienste für Flüchtlinge. [...] Gemeindekaritas im Pfarrhaus und in hilfsbereiten Familien bis zum Äussersten angespannt. [...] Kirchliche Arbeit durch die vielen Flüchtlinge sehr rege. Große Kinder-und Alterssterblichkeit. Kaplan [Heinrich] Theissing Glogau zur Flüchtlingsseelsorge eingesetzt. Gottesdienst zur Zeit an 14 Orten im Kreis." (Töpler, Menschenwum, 358). - 1949 lebten der aus dem Erzbistum Breslau stammende Kaplan Rudolf Bernhardt (1917-1989) (Ostpriesterverzeichnis 2, 1949, S. 14) und der vor 1945 in Krehlau im Kr. Wohlau (Schlesien) wirkende Kaplan Bernhard Geilich (geb. 1914) in Cottbus (ebd., S. 27). - 1962 Errichtung eines kath. Katechetinnenseminars nach dem Modell des Görlitzer Katechetenseminars, 1966 beide zusammengelegt und 1969 aufgelöst (Cwiertina, S. 68-75; Homagk, S. 28f.). - 1969-1987 war der in Freystadt in Schlesien geborene, 1946 mit einem Vertriebenentransport zunächst über Cottbus zunächst in den Westen gelangte Gerold Schneider (1927-2011) kath. Pfarrer in Cottbus; Grab auf dem Südfriedhof (Schneider, Seelsorge, S. 32; Nachruf von Michael Bautz: www.bistum-dresden-meissen.de [6.9.2017]).

CARItAs-GeschäFtsstelle (des Erzbistums Breslau bzw. Erzbischöflichen Amtes Görlitz): 1945 Caritas-Geschäftsstelle der Erzdiözese Breslau (Caritas-Direktor Zinke) aus Breslau nach Cottbus verlagert (Töpler, Menschenwurm, S. 355 f.) bzw. Herbst 1945 Gründung einer „Außenstelle des [Caritas-] Diözesanverbandes Breslau für das Gebiet der russischen Zone" in Cottbus und Ernennung des $\rightarrow$ Calauer Pfarrers Dr. Franz Budek (1905-1974) zum (nebenamtlichen) geschäftsführenden Vorsitzenden bzw. „Caritasreferent in der sowjetischen Okkupationszone im Gebiet westlich der Oder und Neiße beim Diözesanverband Breslau/Zweigstelle Cottbus" (Hartelt, S. 256). - Ende Juli 1948 im Verzeichnis (von der Landesregierung) verbotener Suchdienste erwähnt: „Caritas-Suchdienst der Diözese Breslau/Zweigstelle Cottbus, Cottbus, Lausitzer Str. 59“ (BLHA, Rep. 203 MdI, Nr. 1197, Bl. 41). - Amtsräume des Diözesan-Caritasverbandes Görlitz-Cottbus 1954/61 im Caritashaus, Cottbus, Wilhelm-Külz-Str. [Straßenname bis 1948: 
Lausitzer Str.] 57/58, erworben 1945/46 (Schematismus Görlitz 1954, S. 6; 1961, S. 10, 12). Diözesan-Caritasdirektoren: 1938-1946 Johannes Zinke (1903-1968), bis 1945 in Breslau amtierend (wird 1946 Leiter der Hauptvertretung des Deutschen Caritasverbandes in Berlin und Flüchtlingsseelsorger); 20.11.1946-1949 Dr. Franz Scholz (1909-1998), zuvor KuratialPfarrer in Görlitz-Ost); Nov. 1949-1953 Pfarrer Heribert Titze (1907-1971), anschließend Pfarrer in $\rightarrow$ Senftenberg); 1953-1960 Dr. Robert Mommert (1910-1993); Dez. 1960-1964 Hans-Werner Cebulla (1921-1987) (ebd., S. 256f.).

Caritasheim St. Johannes (St. Johannes-Heim), Wilhelm-Külz-Str. [Straßenname bis 1948: Lausitzer Str.] 57 (im Caritashaus): 1948-1962 von den Grauen Schwestern von der hl. Elisabeth geführt (Mertens, S. 483-486; Schematismus Görlitz 1954, S. 8; 1958, S. 7; 1961, S. 11 f.).

Baнnhof: Der Cottbuser Bahnhof (Gebäude, Bahnsteige und Gleisanlagen) war 1945 Schauplatz dramatischster Vorgänge, da sich hier Trecks und Transporte stauten. Bereits beim Bombenangriff am 15.2.1945 starben hier sehr viele Menschen, darunter besonders (nicht registrierte) Flüchtlinge, von Juni bis August 1945 lagerten hier tausende Vertriebene, von denen viele an Ort und Stelle an Entkräftung verstarben oder verhungerten (Näheres siehe oben bei Ereignisse).

FlüChtlingslager „Johannes“: Lt. Bericht des kath. Pfarrers Broß vom 18.7.1945 „Pfarrhaus [Lausitzer Str. 59; P. B.] u. Schwesternhaus mit seit 6 Wochen 3000 Schlafgästen" (Töpler, Menschenwurm, S. 356).

FlÜCHTLINGSLAGER „Elias“ (in Fabrikgebäuden der Firma „Elias“): „Anfang Juni 1945 zu einem Auffanglager für 3000 Flüchtlinge hergerichtet“ (Töpler, Menschenwurm, S. 356, nach Geschichte der Stadt Cottbus, S. 179).

FlüChtlingslager (Notaltersheime) ab Juni 1945: „Das Altersheim [aus Grünberg in Schlesien, P. B.] wurde, soweit die Insassen nicht bettlägerig waren, am 24. oder 26.6 .45 von den Polen per Bahn abgeschoben, nachdem die Schwestern einen Tag zuvor mit einem Treck auf den Weg geschickt worden waren. Die Alten müssen anscheinend zunächst nach $[\rightarrow]$ Guben gelangt sein, und ein Teil ist dann nach Cottbus befördert worden. Im Laufe des Jahres ist dann wohl der größte Teil der Altersheiminsassen verstorben und auf dem Südfriedhof in Massengräbern beigesetzt. Auskunft könnte evtl. die Verwaltung des Südfriedhofes Cottbus, Dresdener Str. 81, geben oder der Rat der Stadt Cottbus-Sozialamt-Möbel und Bekleidungslager in Cottbus, Mauerstr. 35. / Auch meine Mutter, Frau verw. Sophie Brüggemann, Blücherstr. 23, ist zusammen mit Schwester Adelheid Häusler aus dem Feierabendhaus Bethesda [in Grünberg, P.B.] nach Cottbus gelangt. Sie waren in den sogenannten O. T. Baracken untergebracht. Meine Mutter ist dort am 2.10.45 verstorben, Schwester Adelheid Häusler Mitte September 1945. / Anlässlich meines Besuches in Cottbus im Sommer 1948 wurde mir bei den dortigen Verwaltungsstellen erzählt, daß die s. Zt. von den Polen aus allen möglichen Städten ausgewiesenen Altersheiminsassen in großer Zahl nach Cottbus kamen, sodaß dort drei große Lager zur Aufnahme hergerichtet werden mußten. Infolge der überstandenen Aufregungen und Strapazen 
seien dann die alten Menschen in mehr oder weniger kurzer Zeit verstorben." (Bericht von Elly Prietz geb. Brüggemann, Bad Pyrmont, abgedruckt in: Grünberger Rundbrief 8, 1949, o. S.). - 20.7. oder 20.8.1945 Bericht des kath. Pfarrers Broß: „Zwei große Notaltersheime in Cottbus, Anfang Juli täglich bis 20000 Flüchtlinge durch Cottbus“ (Töpler, Menschenwum, 358).

Flüchtlings-/Umsiedlerlager AB Herbst 1945: 24.10.1945: Kreis Cottbus-Stadt hält „als Dauerlager für alte, sieche Leute die Läger Spreestrasse mit 300, Annabergstr. mit 500 und Wernerstr. mit 200 Belegestärke vor." (Töpler, Menschenwurm, S. 451). - Am Jahresende 1945 gibt es vier Flüchtlingslager in der Stadt mit etwa 1200 Insassen (Chronik, S. 70). - 1946 Belegungsstärke des Umsiedlerlagers Cottbus: 1200 (Kaminsky, S. 159). - „Vom katastrophalen Gesundheitszustand besonders älterer Flüchtlinge im Lager Cottbus wird [im Obernigker Gemeindebrief, Nr. 5, Weihnachten 1946] berichtet, 500 Todesfälle von Juli bis Oktober [1946]." (Seidel/Loch, S. 264).

Bezirksheim Cottbus: 1965 erwähnt als Durchgangsstation für Übersiedler aus Polen (BArch, DO 1/15659).

StÄDtepartnerschaften: 1975 Zielona Góra, Polen (Grünberg in Schlesien) (www.cott bus.de/international/staedtepartnerschaften.html [31.8.2016]). - U.a. „Deutsch-Polnische Seniorenarbeit“: „Seit Jahren werden sich ständig vertiefende Kontakte zur Universität des dritten Lebensalters in Zielona Gorá [so!] gepflegt. [...]. Höhepunkt war 1998 die Erarbeitung einer Broschüre über Lebenserinnerungen deutscher und polnischer Senioren. Es war ein langer Weg, Autoren für dieses Vorhaben zu finden und schließlich die Übersetzungen so vorzunehmen, dass die Fülle der Empfindungen der Autoren sich widerspiegelten. / Die Erzählungen entstanden aus der Reflexion über sich selbst, dem eigenen Schicksal, das oft in die turbulente und schmerzliche Geschichte eingeflochten war. Die Autoren wollen sich nicht nur an Gleichaltrige wenden, sie möchten auch den jüngeren Generationen Erlebnisse mitteilen, die nicht in Geschichtsbüchern zu finden sind." (Seniorenbeiräte im Land Brandenburg, S. 45).

VertriebenEN-Organisationsformen NACH 1945: „Verband der Ostumsiedler“: 19.4.1947 Schreiben des Oberbürgermeisters der Stadt Cottbus an den Vorsitzenden des in der Stadt gegründeten Verbandes betreffend dessen sofortige Auflösung (Wille III, Nr. 389, S. 351). - Siehe auch oben Caritas.

Vertriebenenverbände NACH 1990: BdV-Kreisverband Cottbus Stadt und Land (LR, 8.8.2008), gegründet 25.1.1991 (Märkischer Informationsdienst 8/1994, S. 14: BR 8 (2010)3, S. 17), 1996 erwähnt mit Sitz Dammzollstr. 27 in $\rightarrow$ Peitz (BdV-Handbuch 1996, S. 168), Büro nach Umzug ab 2005: Straße der Jugend 33, Cottbus (Spremberger Vorstadt) (LR, 30.11.2005). - Mitgliederzahlen: Mitte 1990er Jahre: etwa 800 (LR, 17.3.2009), 2004: etwa 400 (LR, 3.9.2004), 2009: etwa 240 (LR, 17.3.2009), Febr. 2010: 297 (Akten der BdV-Landesgeschäftsstelle). „Der Verband ist ein Auslaufmodell, in einigen Jahren ist hier Schluss“ (Vorsitzender W. Tschöcke in LR, 17.3.2009); 28.2.2015 aufgelöst (Akten der BdV-Landesgeschäftsstel- 
le). - Vorsitzende: 1992-2006 Heinrich Schulz, Peitz, Mitbegründer (geb. 1934 in Glauchow, Kr. Züllichau-Schwiebus, gest. 2009) (LR, 3.9.2004, 3.8.2006; BR 7 (2009)5, S. 21; 8 (2010)3, S. 17), 2006-2015 Werner Tschöcke (geb. 1937 Niederbielau, Kr. Görlitz), zuvor stellv. Vorsitzender (LR, 3.9.2004, 3.8.2006, 17.3.2009). - „Die meisten der organisierten Vertriebenen in Cottbus und Umgebung stammen aus dem heutigen Grenzgebiet. ,Die Leute ließen sich hier im Osten Brandenburgs nieder, weil sie schnell zurück wollten. [W. Tschöcke].“ (LR, 17.3.2009).

Wissenschaftliche Vereine: 2001-2007 befand sich die Forschungsgruppe Groß-Strehlitz der (in Herne ansässigen, 1927 in Breslau begründeten) Arbeitsgemeinschaft ostdeutscher Familienforscher e. V. (AGoFF) in Cottbus; Leiterin: Barbara Rommel geb. Scholtyssek, Cottbus (geb. 1945 Stilow/Vorpommern, gest. 2007 Cottbus) (Kühn).

Gedenkstein: Der gelegentlich im Zusammenhang mit Cottbus genannte Gedenkstein für 1945 verstorbene Flüchtlinge befindet sich auf dem $\rightarrow$ Kolkwitzer Friedhof bei Cottbus.

SüDFRIEDHOF: 1945 Bestattungsort (Massengräber) für Flüchtlinge (Petzold, Als für Cottbus der 2. Weltkreg endete, S. 21; siehe auch oben $\rightarrow$ Flüchtlingslager (Notaltersheime) ab Juni 1945.

Landesamt für Soziales und Versorgung, Zittauer Straße 19, später Lipezker Straße 45, (Haus 6): seit 1997 auch zuständig für Erstaufnahme von Spätaussiedlern im Land Brandenburg, bis 2005 aber noch durch nachgeordnete Einrichtung in $\rightarrow$ Peitz (Nachfolgebehörde der am 1.1.1997 aufgelösten Landesstelle für Aussiedler) wahrgenommen, erst seit 2006 direkt durch das Amt in Cottbus, bis 2013 durch dessen dann aufgelöste Abt. 6 „Landesvertriebenen- und Aussiedleramt/Förderaufgaben" (Jubiläum, S. 20, 22 f.; Mitteilung Dr. Ilona Schulz, 7.6.2017; Landesaufnahmegesetz; www.lasv.brandenburg.de [7.6.2017]; LR, 15.9.2006), Abteilungsleiter ab 2006 Hannelore Mudra, zuletzt bis 2013 Rainer Zwiers (Auskunft Landesamt, 15.6.2017); seit 2013 bezüglich Vertriebener nur noch Ansprechpartner für Ausstellung von Ausweis-Zweitschriften: „Für in Brandenburg erteilte Vertriebenen- bzw. Flüchtlingsausweise oder Bescheinigungen nach $\int 15$ BVFG werden bei Verlust durch das Landesamt für Soziales und Versorgung auf Antrag Zweitschriften erteilt., aber weiterhin zuständig für Spätaussiedler: „Die Aufnahme und Verteilung von Spätaussiedlern, jüdischen Zuwanderern und besonders schutzbedürftigen Personen sind Kernstücke unserer Arbeit." (www.lasv.brandenburg.de [15.6.2017]).

Archivalische Quellen: BArch, DO 1 Ministerium des Innern der DDR, 27887, Bl. 80-81 (Triebeler Vertriebenentreffen in Cottbus, 1952). - BArch, DO 1 Ministerium des Innern der DDR, Nr. 15659 (Übersiedlung aus Polen, 1965). - Stadtarchiv Cottbus.

Gedruckte und Online-Quellen: Dokumentation der Vertreibung I/1, S. 142 E, 455, 485; I/2, S. 52, 635, 688 f., 839; IV/2, S. 140. - Ehrich, Brigitte: [Lebenslauf]. In: Müncheberger Lebensläufe. T. 3. Müncheberg 2012, S. 9-18 [S. 11 Bombenangriff 13.2.1945]. - Dr. Hammer: Als Treck-Arzt von Sagan nach Cottbus. In: Geschichte wird Erinnerung. Potsdam 1995, S. 140-141 [Treck Vertriebener aus dem Kr. Fraustadt, 28.6.1945; Bericht verfasst 1949]. - Kasprzik, Horst: Wie ich den Bombenangriff auf Cottbus erlebte. In: Zeitgebunden. Brücken zur Vergangenheit. Hrsg. vom Seniorenbeirat der Stadt Cottbus. Cottbus 2010, S. 18-21. - Pflaum, Herbert: Meine Kindheit in 
Boberhöh. Flucht und Vertreibung im Jahr 1945. [Privatdruck]. Eichwalde bei Berlin 2014, S. 13f., 26. - Schneider, Gerold: Vergangenheit, die nicht vergehen will. Leipzig 1998 u. ö. - Tagebuch des Cottbusers N. N. Kretschmer aus dem Stadtmuseum Cottbus, www.zeitstimmen.de [25.5.2017]. - Töpler, Menschenwurm, S. 325-329 (Bericht über Kriegsereignisse April/Mai 1945), 355-358, 364f. (nach Cottbus geflüchtete kath. Priester aus Schlesien), 475-477 u. ö. (siehe S. 662). - Wille I, S. 34 f., 457; II, S. 263 f.; III, S. 204 (Ortsumsiedlerausschuss, 1947), 349, 351 („Verband der Ostumsiedler“, 1947), 393, 422 f. (schulische Förderung der „Umsiedlerkinder“, 1950).

Literatur: Ast/Mauersberger, S. 38. - Biela, Paul: Schicksale deutscher Apotheker aus Ostbrandenburg am Ende des Zweiten Weltkrieges. Frankfurt (Oder) 2017. - Blöß, Wolfgang: Grenzen und Reformen in einer Umbruchgesellschaft. Berlin 2014. - Blöß, Kreise und Gemeinden, S. 13. - (Clauß, Ernst:) Wo verblieb das Altersheim? In: Grünberger Rundbrief 8 (1949); o. S. - Chronik zur Geschichte der Stadt Cottbus. Nordhorn 2003. - Cwiertnia, Beate: Das Katechetensemninar in Görlitz und das Katechetinnenseminar in Cottbus. In: Vertriebene finden Heimat in der Kirche. Hrsg. von Rainer Bendel. Köln u. a. 2008, S. 57-77. - Hartelt, Konrad: Ferdinand Piontek (1878-1963). Köln u. a. 2008. - Hetzke, Eberhard: Der Wiederaufbau des Städtischen Krankenhauses Cottbus nach seiner Zerstörung am 15. Februar 1945 in den Jahren 1945-1949. In: Geschichte und Gegenwart des Bezirkes Cottbus 16 (1982), S. 3145. - Ders.: Hilfsaktion „Rettet die Kinder“ in Cottbus im Jahre 1945. In: Geschichte und Gegenwart des Bezirkes Cottbus 19 (1985), S. 56-66. - Ders.: Die epidemiologiche Lage nach dem zweiten Weltkrieg im Raum Cottbus, unter besonderer Berücksichtigung der Typhus- und Paratyphusepidmie des Jahres 1945. In: Geschichte und Gegenwart des Bezirkes Cottbus 23 (1989), S. 44-49. - Ders.: Der Kampf der Ärzte nach dem Inferno. In: Cottbuser Heimatkalender 1990, S. 71-74. - Homagk, Mathias: Der Neubeginn - Vom „Restteil“ des Erzbistums Breslau zum Bistum Görlitz. In: „Ich gehe mit dem Gedanken um, in Kirchhain einen Betsaal zu bauen ..."Halle/Saale 2008, S. 2735. - Jubiläum. 20 Jahre Landesamt für Soziales und Versorgung. Cottbus 2011. - Krestin, Steffen: Cottbus - eine Stadt verändert ihr Gesicht. In: Preußen, Sachsen, Brandenburg. Nachbarschaften im Wandel. Leipzig 2014, S. 46-55 [Entwicklung ab 1945]. - Kühn, Detlef: Barbara Rommel +. In: Arbeitsbericht der Arbeitsgemeinschaft ostdeutscher Familienforscher e. V., Bd. 12, 2007, H. 2, S. 3. - Mengel, Thomas: Das Schicksal der schlesischen Frauenklöster während des Dritten Reiches und 1945/46. Köln/Wien 1986. - Menschen und Schicksale. v. Klitzing'sche Häuser im 19. und 20. Jahrhundert. (Kassel) 1990 (S. 464-466 Trecktagebuch). - Mertens, Johannes: Die Berliner Ordensprovinz der Grauen Schwestern von der heiligen Elisabeth 1859-1991. Reinbek bei Hamburg 1992, S. 483-486. - Müller, Erich: Transporte, Lager, Ansiedlung im Warthegau: Das Schicksal der galizien- und wolhyniendeutschen Umsiedler nach ihrem Grenzübertritt 1939/40. In: Zeitweiser der Galiziendeutschen 43 (2005), S. 104-157. - Petzold, Heinz: Cottbus zwischen Januar und Mai 1945. In: Brandenburg im Jahr 1945. Studien. Hrsg. von Werner Stang. Potsdam 1995, S. 106-135. - Ders.: Als für Cottbus der 2. Weltkrieg endete. Zum Geschehen vor 60 Jahren. Cottbus 2005. Platzke, Max: Geschichte einer ostdeutschen Kleinstadt kommunalpolitisch betrachtet. Berlin-Charlottenburg 1956. - Schneider, Gerold: Seelsorge für Heimatvertriebene in der ehemaligen DDR. In: Kirche und Heimat. Bonn 1999, S. 26-33. - Seidel, Hellmut / Loch, Ekkehard: Obernigk bei Breslau. Weiden 1996. - Seniorenbeiräte im Land Brandenburg. Potsdam 1999, S. 45 f. - Walther, Karl Klaus: Die Bergung von Kulturgut in Cottbus im Jahre 1945. In: Mitteldeutsches Jahrbuch für Kultur und Geschichte 16 (2009), S. 165-171.

\section{Cottbus-Schmellwitz $\rightarrow$ Schmellwitz}

\section{Criewen}

Landgemeinde (seit 1.8.2001 Ortsteil von $\rightarrow$ Schwedt/Oder), bis 1952 Kr. Angermünde, 1952-1990 Kr. Angermünde (Bez. Frankfurt/Oder), 1952-1990 Kr. Angermünde, 1993 Ldkr. Uckermark 
EREIGNISSE NACH KRIEGSENDE: 3.10.1950 Zuweisung von westlich der Oder gelegenen einwohnerlosen Flächen der nun polnischen Gemeinden Peetzig/Oder (Piasek) und Raduhn (Raduń) (ehem. Kr. Königsberg/Nm.) an die Gemeinde Criewen sowie weiterer Teile der Gemeinde Peetzig/Oder an die Gemeinde $\rightarrow$ Stützkow (Blöß, Kreise und Gemeinden, S. 31).

BEVÖLKERUNGSZAHLEN: 1925: 463, 1939: 430, 1946: 610, 1964: 596 (HOL VIII, S. 184).

\section{Crinitz}

Landgemeinde, bis 1952 Kr. Luckau, 1952-1990 Kr. Finsterwalde (Bez. Cottbus), 1990-1993 Ldkr. Finsterwalde, 1993 Ldkr. Elbe-Elster

BevÖLKeRUngszahlen: 1925: 1 134, 1939: 1482, 29.10.1946: 2049, 1950: 2 142, 1964 : 2008 (HGV EE, S. 10 f.).

Katholiken (Erzbistum Breslau/Erzbischöfliches Amt Görlitz): „Als sich nach Ende des Zweiten Weltkrieges Ströme von Flüchtlingen und Heimatvertriebenen über das Land ergossen, fanden viele von ihnen ein neues Zuhause in der Region um $[\rightarrow]$ Finsterwalde. Nach einem Aufenthalt in einem Quarantäne-Lager in dieser Stadt, wurden die größtenteils aus Schlesien und dem Sudetenland stammenden Vertriebenen auf die umliegenden Ortschaften verteilt. Auch Franz Bernert, seit 1932 Pfarrer in Kamnitz-Grenztal [richtig: Kamitz] bei Neisse, hatte seine schlesische Heimat verlassen müssen und war am 27. März 1946 mit seiner Schwester Agnes und seiner Nichte Hedwig Kaps nach Crinitz gekommen [...]. / Bereits vier Tage später, am 31. März, feierte Pfarrer Bernert die erste Heilige Messe in Crinitz in der Friedhofskapelle, damals wie heute in kommunalem Besitz, in der auch evangelische Gottesdienste abgehalten wurden. Bald konnten auch in einigen evangelischen Kirchen in der Umgebung heilige Messen gefeiert werden. [...] viele Gemeindemitglieder halfen mit, so bei der Gestaltung der Gottesdienste oder durch Übernahme notwendiger handwerklicher Arbeiten auf dem Grundstück. / Es entfaltete sich ein reges katholisches Leben. Das Brauchtum wurde gepflegt, und mit Maiandachten, Rosenkranzandachten, dem Kreuzweg oder der Palmsonntags- und Fronleichnamsprozession zum Ausdruck gebracht. [...]. / Nach dem Tod von Pfarrer Bernert wurde die Kuratie aufgelöst und die Seelsorge von der Mutterpfarrei Finsterwalde übernommen. [...] (Rudolf Keßler: Letzte heilige Messe in Crinitz. In: Tage des Herrn, 30.7.2015).“ - Der in Bärdorf [Kr. Münsterberg bzw. Frankenstein in Schlesien] geborene Franz Bernert (1886-1965) war bis 1945 Pfarrer in Grenztal [bis 1936 Kamitz!] bei Patschkau (Kr. Neisse, Schlesien) (Ostpriesterverzeichnis 2, 1949, S. 14; Schematismus Görlitz 1961, S. 73). - 2015 Aufhebung der Filiale Crinitz in der Pfarrei Finsterwalde (Tage des Herrn, 30.7.2015).

Pflegeheim (Behindertenwohnstätte), Im Park 1-2: „Die beiden Villen haben schon viel gesehen, einst dienten sie Fabrikanten- und Arztfamilien als Wohnhaus, waren Kinder- und Pflegeheim. ,Zu DDR-Zeiten wurde es ein Heim für Behinderte und Umsiedler, aber vor allem für 
Leute, die sonst niemand haben wollte: Verwirrte, psychisch Kranke, Alkoholiker, Behinderte', erzählt die ehemalige Heimleiterin Rosemarie Klausch [...]." (Yvonne Kommolk, in: LR, 28.5.2014). - 2014 20-jähriges Bestehen als Behindertenwohnstätte Crinitz unter der Regie des Vereins Lebenshilfe Finsterwalde e. V.“ (ebd.). - 2016 Abriss von Haus 1 zugunsten eines Parkplatzes (lebenshilfe-finsterwalde.de/wiki/Wohnstätte_Crinitz [5.6.2017]). - 2017 Haus 2 weiterhin als Behindertenwohnstätte genutzt (http://www.lkee-barrierefrei.de [5.6.2017]).

Robert-Hofmann-STRASSE: „[...] Wer war eigentlich Robert Hofmann? Nur wenige Crinitzer kennen diesen Mann. Horst Hofmann, der Bürgermeister, kennt ihn. Es ist sein Opa. / Soviel weiß man im Dorf: ,Robert Hofmann hat viel für Crinitz getan.' Nur wenige Ältere, die einst als Flüchtlinge aus dem Osten kamen und nach 1945 die Einwohnerzahl auf 2300 hochschnellen ließen, werden diesen Mann nicht vergessen., Wir waren 14 Kinder, sind aus Ostpreußen in Crinitz gelandet, hatten Hunger und brauchten eine Bleibes, erinnert sich Grete Hill. Und da fällt immer wieder der Name Robert Hofmann. ,Er hat organisiert, dass die Flüchtlinge zu essen und ein Dach über dem Kopf hatten', weiß der Enkel Horst Hofmann zu berichten. So habe der Opa Milch und Mehl von den Bauern aus den Nachbardörfern Tugam, Stiebsdorf und Wanninchen besorgt. Zu Weihnachten sind die Flüchtlingskinder mit Päckchen überrascht worden. / Die Hofmanns waren als Kommunisten im Dorf bekannt." (Dieter Babbe, in: LR, 13.2.2010, Kursivierung P. B.).

\section{Dabendorf}

Landgemeinde (ab 1974 Ortsteil und seit 2003 Gemeindeteil von $\rightarrow$ Zossen), bis 1952 Kr. Teltow, 1952-1990 Kr. Zossen (Bez. Potsdam), 1990-1993 Ldkr. Zossen, seit 1993 Ldkr. TeltowFläming

EREIGNISSE BIS KRIEGSENDE: Febr. 1945 Flüchtlingstransport aus Schwiebus mit Feuerwehrfahrzeugen nach $\rightarrow$ Niemegk und Dabendorf überführt (BLHA). - „Im Frühjahr 1945 befanden sich in Dabendorf unzählige ausländische Zivilisten (,Fremdarbeiter'), Kriegsgefangene unterschiedlicher Nationalitäten, ausgebombte Berliner und Flüchtlinge aus den bereits eroberten deutschen Ostgebieten." (Nagel, S. 57).

BeVÖLKeRUnGSZAHLEN: 1925: 1049, 1939: 1791, 1946: 2284, 1964: 1844 (HOL IV, S. 43 ).

UMSIEDLERLAGER: Kapazität am 31.12.1945: 500 (BArch, DO 2/45, Bl. 40).

Archivalische Quellen: BLHA, Rep. 6 B Züllichau-Schwiebus, Nr. 169 (Umsiedlungsaktion im Kreise ZüllichauSchwiebus, 1945; enthält u. a.: Namentliche Liste des aus Schwiebus mit Feuerwehrfahrzeugen nach Niemegk und Dabendorf (Kr. Zauch-Belzig) überführten Flüchtlingstransports, Febr. 1945).

Literatur: Nagel, Günter: Kriegsgefangenenlager in Dabendorf. In: Heimatjahrbuch für den Landkreis Teltow-Fläming 26 (2019), S. 43-48. - Polley, Detlef: Schrecken, Not und Tod. Dabendorf am Ende des Zweiten Weltkriegs. In: Heimatjahrbuch für den Landkreis Teltow-Fläming 23 (2016), S. 113-119. 


\section{Dahme/Mark}

Stadtgemeinde, bis 1946 Kr. Jüterbog-Luckenwalde, 1946-1952 Kr. Luckenwalde, 1952-1990 Kr. Luckau (Bez. Cottbus), 1990-1993 Ldkr. Luckau, 1993 Ldkr. Teltow-Fläming

EREIGNISSE BIS KRIEGSENDE: „Schon in den letzten Kriegsmonaten war Dahme zum Ziel- und Sammelpunkt für die Flüchtlinge aus Schroda bestimmt worden. So traf ich manche alte Bekannte wieder, die ich schon aus der Schule oder aus der Hitler-Jugend kannte." (Pfeiffer, S. 7). - April 1945: „Die Mauern unserer kleinen Stadt Dahme, in Friedenszeiten mit reichlich 5000 Einwohnern, beherbergten jetzt täglich etwa 8000 bis 10000 Menschen. Da war- [S. 25] ren zunächst einmal die Ausgebombten und Evakuierten, meist aus Berlin. Da war die deutschsprachige Bevölkerung eines ganzen Kreises in der Nähe von Posen, des Kreises Schroda. Die kam in endlosen Trecks, Pferdefuhrwerk für Pferdefuhrwerk. In Dahme wurde sie auf die einzelnen Ortschaften ,verteilt'. Dann kamen zahllose andere Flüchtlingstrecks hinzu, alles Menschen, die in Kälte und Wintersturm Hunderte von Kilometern zurückgelegt hatten, erforene Angehörige am Straßenrand zurücklassen mußten, die keine Aufnahme fanden und weiterzogen, ohne Ziel, nur immer auf der Flucht vor der Front. Doch diese kam immer näher. Für die Weiterziehenden hatte man in der Fleischerei Fink (heute Bauer) [Hauptstraße 15; P. B.] eine Versorgungsstelle eingerichtet. Kurze Pause, etwas Warmes in den Magen, dann ging es weiter. Feldgendarmerie kontrollierte die Wagen. Unter den Flüchtenden hätten sich ja auch Soldaten verbergen können, die dem sinnlosen Kampf entgehen wollten. Gleichgültig ließen die Menschen diese Kontrollen über sich ergehen. Die wievielte war es schon auf ihrer langen Fahrt? / Im Schützenhaus [Am Schützenhaus 1; P. B.] hatte man Massenquartiere eingerichtet für etwa 1000 Personen. Das waren wohl nur Frauen, Kinder und Greise. Daß die Sanitäreinrichtungen dem niemals standhalten konnten, was machte das schon? Ändern konnte das doch keiner. Den davon Betroffenen war das letztlich auch gleichgültig. Sie waren von dem langen Marsch und dem Elend, das sie unterwegs sahen und selbst erleben mußten, so apathisch, daß sie mit einem Dach über dem Kopf und einem warmen Raum zufrieden waren. Schließlich ging es ja ihren Leidensgefährten, die da weiterziehen mußten, noch schlechter." (Wagenknecht, S. 23, 25) - 20.4.1945 Einmarsch der Roten Armee (ebd., S. 27 f.).

EREIGNISSE NACH KRIEGSENDE: 15.3.1947 Erwähnung einer „Umsiedlergenossenschaft“ (Heimarbeit) „Schneidwarengenossenschaft“ mit 12 Arbeitern (BLHA, Rep. 333, Nr. 574, B1. 105). - 29.3.1947 Erwähnung einer „Umsiedlergenossenschaft für Herstellung und Vertrieb von Stahlwaren und medizinischen Instrumenten e. G. m.H." (Wille II, S. 404). - Erwähnung der von sudetendeutschen Vertriebenen gegründeten „Produktionsgenossenschaft für endlosgewebte Treibriemen und Schnelltriebbänder Dahme“ (Christopeit, S. 86). - Der später als Lehrer und Redakteur in Göttingen lebende Werner Pfeiffer (geb. 1929 Werro, Estland) lebte mit den Eltern 1941-1945 in Schroda (Wartheland) und wurde 1945 zur Zwangsarbeit nach Russland deportiert. Nach Entlassung und kurzem Aufenthalt in einem Flüchtlingslager in Berlin 1945 lebte er in Dahme, hier am 25.4.1947 wegen „Verbreitung antisowjetischer Propaganda“ (Mit- 
wisserschaft bei einer Flugblattverteilung) als Schüler mit seinem Klassenkameradem Helmut Schiff erneut verhaftet, in $\rightarrow$ Cottbus durch sowjet. Militärtribunal zu 10 Jahren „Arbeits-Erziehungslager" verurteilt; 16.1.1954 aus Waldheim entlassen, Flucht in den Westen, veröffentlicht später seine Erinnerungen an das Jahr 1945 „Mit 15 in die Hölle. Ein Tatsachenbericht“, Bonn 1994, sowie an die zweite Haftzeit „Abgeholt. Chronik einer geraubten Jugend“, Gütersloh 2000 (Gotzmann/Hörner, S. 1019).

BevöLKerungszahlen: 1925: 5229, 1939: 5 149, „Frühjahr 1945 8-10000 Menschen, darunter ausgebombte u. evakuierte Berliner, Flüchtlinge aus dem Osten“; 1946: 6391, 1964: 5395 (Städtebuch, S. 96).

Katholiken: 1925: 100, 1946: 569 (Städtebuch, S. 97). - Seit 1932 Kapelle (Muttergemeinde $\rightarrow$ Jüterbog). „Nach 1945 wohnten kurzzeitig 2000 Katholiken in ihrem Einzugsbereich. So wurde 1952 eine Kuratie gegründt, die 1954 auch vermögensrechtlich selbständig wurde. [...] Von 1945-82 war ein eigener Seelsorger am Ort. Die Gemeinde zählte zuletzt [1994] etwa 200 Katholiken und kam am 10.11.1994 bei der Neuordnung der Bistumsgrenzen zum Bistum Görlitz." (Brühe, S. 47). - 22.8.1946: Der 1919 in Danzig-Langfuhr geborene „Kapl. Klein, Georg, Dahme/Mark, Dresdener Str. 7“ erwähnt in einer Aufstellung der außerplanmäßig eingesetzten „Flüchtlingsgeistlichen“ (DAB, I/9-15-1 Flüchtlingsseelsorge 1945-1951, unfol.), ab 1.10.1948 Kaplan in Berlin-Weißensee, als „Priester auswärtiger Bistümer“ weiterhin dem Bistum Danzig zugeordnet (Schematismus Berlin 1949, S. 60, 142). - Ab 1.10.1948 war der bis 1945 in Brätz (Kr. Meseritz) wirkende Vikar bzw. Kaplan Bruno Stolpmann (geb. 1913 Groß Jenznick, Kr. Schlochau, gest. 1973 Schöneiche bei Berlin) Lokalkaplan der St.-Antonius-Kapelle (Lokalie, Dresdener Straße 7, Kapelle Schellstraße), als „Priester auswärtiger Bistümer“ Schneidemühl zugeordnet (ebd., S. 71, 146; Ostpriesterverzeichnis 2, 1949, S. 83).

VeRTRIEBENENVERBÄNDE NACH 1990: Kreisgruppe der Ostpreußen im BdV, betreut von Fritz Gorny, jährlich drei Veranstaltungen (erwähnt im Bericht des Landesvorsitzenden der Landsmannschaft Ostpreußen für die Jahre 2003-2005), 200530 Mitglieder, davon 28 älter als 70 Jahre (Auskunft der Landsmannschaft Ostpreußen, Hamburg).

Gedenktafel auf dem StÄDt. Friedhof: „Auf Initiative des örtlichen Heimatvereins steht nun [seit 23.8.2018] dort eine Gedenktafel, die darüber informiert, welch traurige Geschichte der Platz hat.“ (Schulze, S. 26). „In einem Massengrab sind hier zivile Opfer bestattet, die in den letzten Kriegstagen ihr Leben ließen. Es waren Flüchtlinge und Vertriebene, die an Entkräftung starben, Zwangsarbeiter, denen eine Rückkehr in die Heimat nicht vergönnt war, und auch Einwohner, die aus Furcht vor der herannahenden Front ihrem Leben ein Ende setzten, sagt Museumsleiter Tilo Wolf. Manche seien namentlich bekannt, andere nicht. Für alle steht auf der Tafel das Brecht-Zitat: ,Der Mensch ist erst wirklich tot, wenn niemand mehr an ihn denkt." (Berg). Archivalische Quellen: BArch, DO 2 ZVU, Nr. 50, Bl. 223 (ZVU-Dienstreise, 2.7.1947). 
Gedruckte Quellen: Wille II, S. 404. - Erinnerungsberichte: Pfeiffer, Werner: Abgeholt. Gütersloh 2000. Pflaum, Herbert: Meine Kindheit in Boberhöh. Flucht und Vertreibung im Jahr 1945. [Privatdruck]. Eichwalde bei Berlin 2014, S. 42-47.

Literatur: Berg, Carmen: Nach mehr als 70 Jahren. Tote erhalten ihre Würde zurück. In Dahme erinnert jetzt eine Tafel an einem Massengrab an zivile Opfer der letzten Kriegstage. In: LR online, 23.8.2018. - Brühe, Matthias: Katholische Kirche zwischen Havel und Dahme. Berlin 1999, S. 47. - Christopeit. - Gottzmann, Carola L. / Hörner, Petra: Lexikon der deutschsprachigen Literatur des Baltikums und St. Petersburgs. Bd. 1. Berlin/New York 2007, S. 1019 (Art. Pfeiffer, Werner). - Schulze, H(enrik): Kriegsgräberstätte in Dahme/M. In: Barbara-Meldung 37 (2018), S. 2627. - Wagenknecht, Günter: 20. April 1945: Für Dahme ist der Krieg zu Ende! In: Heimatjahrbuch für den Landkreis Teltow-Fläming 2 (1995), S. 21-28.

\section{Dahmshöhe $\rightarrow$ Altthymen-Dahmshöhe}

\section{Dallgow}

Landgemeinde (heute Dallgow-Döberitz), bis 1952 Kr. Osthavelland, 1952-1990 Kr. Nauen (Bez. Potsdam), 1990-1993 Ldkr. Nauen, 1993 Ldkr. Havelland

EREIGNISSE BIS KRIEgSENDE: [1944:] „Mit dem Rückzug im Osten kam der Treck der fliehenden ostpreußischen Bevölkerung. Es waren die Frauen, die ohne die Hilfe ihrer Männer in Schnee und Eis die Heimat verließen. In Dallgow machten Flüchtlinge aus Bessarabien und Ostpreußen Halt und fanden Aufnahme bei den Bauern[,] bis sie ihre Flucht Richtung Westen am nächsten Tag fortsetzten. / Die Front kam immer näher. Anfang 1945 trafen die ersten Flüchtlinge aus Westpreußen ein und fanden Unterkunft im Dorf." (Kluchert, S. 98). - 24.3.1945 Einmarsch der Roten Armee (ebd., S. 98 f.).

EREIGNISSE NACH KRIEGSENDE: „Am 3. Mai 1945 gaben Flüchtlinge im Dallgower Pfarrhaus ein kleines Mädchen ab, noch nicht ein Jahr alt.“ [Wird als Findelkind aufgenommen und großgezogen (...) ]. (ebd., S. 101). - „Fast in jedes Haus im Ort wurden durch die Gemeindeverwaltung Flüchtlinge eingewiesen. Wo durch den Krieg schmerzliche Lücken gerissen waren, füllten nun die Flüchtlinge die Reihen. Die alteingesessenen Dallgower beobachteten zurück- [S. 108] haltend und kritisch das Treiben der ,Neu Dallgower, die sich in der neuen Heimat beweisen und behaupten wollten. / Die Jugend der Zugezogenen fügte sich bald in das Dorfleben ein, In der wiedereröffneten Dorfgaststätte Rietdorf tanzten sie gemeinsam mit den Dallgowern zur Musik von Grammophon und lernten sich kennen. [...].“ (S. 107f.). - 1945 Bodenreform [...] (S. 110-112), dabei 4 Umsiedler berücksichigt (HOL III, S. 66).

EREIGNISSE NACH 1990: 20.5.1995 „4. Heimattreffen der ehemals deutschen Bewohner des Ortes ,Ziegelscheune und Umgebung' (ehemals Provinz Posen) im Landhaus Dallgow. An dem Treffen nahmen wiederum mehr als 100 Landsleute teil." (Bericht von Wilfried Redlich in: Heimatgruß Meseritz 134, 1995, S. 23). 
BevöLKERUNGSZAHLEN: 1925: 1289, 1939: 3220, 1946: 3 405, 1964: 3753 (HOL II, S. 67). Literatur: Kluchert, Ursula: Dallgow. Dallgow-Döberitz 2009.

\section{Diedersdorf}

Landgemeinde (seit 31.12.2001 Ortsteil von Großbeeren), bis $1952 \mathrm{Kr}$. Teltow, 1952-1990 Kr. Zossen (Bez. Potsdam), 1990-1993 Ldkr. Zossen, 1993 Ldkr. Teltow-Fläming

EReignisse bis Kriegsende: 7.4.1945 Tod eines Kindes bessarabiendeutscher Eltern in Diedersdorf (Sterberegister Standesamt Blankenfelde, Nr. 42/1945).

EREIGNISSE NACH KRIEgSEnde: 31.3.1946 Tod eines bei einem Diedersdorfer Bauern untergekommenen knapp 57-jährigen Landwirts, gebürtig aus „Kulm in Bessarabien“ („Ortsansässig: nein / Flüchtling“) an Herzschwäche (Sterberegister Standesamt Blankenfelde, Nr. 90/1946).

BevölkerungSZAhlen: 1925: 560, 1939: 575, 1946: 618, 1964: 475 (HOL IV, S. 50).

Quellen: Gemeindearchiv Blankenfelde-Mahlow, Sterberegister des Standesamtes Blankenfelde 1945-1946.

\section{Doberlug}

Stadtgemeinde (22.5.1950 Zusammenschluss mit $\rightarrow$ Kirchhain zu Doberlug-Kirchhain), bis 1952 Kr. Luckau, 1952-1990 Kr. Finsterwalde (Bez. Cottbus), 1990-1993 Ldkr. Finsterwalde, 1993 Ldkr. Elbe-Elster

EREIGNISSE BIS KRIEGSENDE: „22.4.1945 Einmarsch der Roten Armee“ (Doberlug-Kirchhain, S. 9).

EREIGNisSe NACH KRIEgSENDE: 1945 „starker Zustrom von Flüchtlingen“, führte zu großen Wohnungs- und Versorgungsproblemen.“ (Doberlug-Kirchhain, S. 9). - Ende 1945 (Bericht der Stadtverwaltung vom Nov. oder Dez. 1945): „Die 600 Flüchtlinge und Umsiedler sind sehr wohnlich untergebracht." (Brandenburgische Gemeinden 1945, S. 35).

BevölKerungszahlen: 1900: 1446, 1939: 2 360, 1946: 2909 (Städtebuch, S. 102). - Doberlug-Kirchhain: 1955: 9789, 1964: 9100 (ebd.).

Katholiken (Erzbistum Breslau/Erzbischöfliches Amt Görlitz): 1925: 49, 1946: 202 (Städtebuch, S. 102).

Gedruckte Quellen und Literatur: Brandenburgische Gemeinden 1945, S. 35-36. - Doberlug-Kirchhain. Bilder erzählen. Horb am Neckar 1994. - Wille I, S. 187 f. 


\section{Döberitz}

Landgemeinde (heute Ortsteil von $\rightarrow$ Dallgow-Döberitz), bis 1952 Kr. Osthavelland, 19521990 Kr. Nauen (Bez. Potsdam), 1990-1993 Ldkr. Nauen, 1993 Ldkr. Havelland

UMSIEDLERLAGER: „Ab 1944 bis Kriegsende existierten in Dallgow-Döberitz Außenstellen des KZ Sachsenhausen für Männer und des KZ Uckermark [ $\rightarrow$ Ravensbrück] für Mädchen und junge Frauen sowie ein Zwangsarbeiterlager, in dem sowjetische Zwangsarbeiter interniert waren. / In den zum Truppenübungsplatz gehörenden Gebäuden und Anlagen (sogenanntes Barackenlager) wurden nach dem Zweiten Weltkrieg Flüchtlinge untergebracht. / 1947 übernahm die Rote Armee das Lager und stationierte dort bis zu 20000 Soldaten. Mit dem Abzug der russischen Truppen 1992 endete die militärische Nutzung. Sämtliche Gebäude für die Unterbringung der Mannschaften wurden abgerissen. Das Gelände des ehemaligen Lagers ist das heutige Neubaugebiet Neu-Döberitz, wobei der alte Baumbestand und der Lagergrundriss weitgehend erhalten blieben." (Wikipedia/Döberitz [30.7.2018]). - [Die folgende Angabe bezieht sich möglicherweise auf Döberitz, Kr. Westhavelland!]: Kapazität am 1.1.1946: 150 (BLHA, Rep. 203 MdI, Nr. 1163, Bl. 50).]

Bevölkerungszahlen: 1925: 63, 1939: 3209 , 1946: - (HOL III, S. 76).

\section{Döberitz}

Landgemeinde (heute Ortsteil von $\rightarrow$ Premnitz), bis 1952 Kr. Westhavelland, 1952-1990 Kr. Rathenow (Bez. Potsdam), 1990-1993 Ldkr. Rathenow, 1993 Ldkr. Havelland

EREIGNISSE NACH KRIEGSENDE: Herrenhaus vor der Bodenreform zeitweise „als Wohnheim für Flüchtlinge und Neubauern" genutzt, dann abgebrochen (Andreae/Geiseler, S. 106).

UMSIEDLERLAGER: Kapazität [Lager Döberitz, Kr. Westhavelland!] am 31.12.1945: 200 (BArch, DO 2/45, Bl. 40). - [Die folgende Angabe bezieht sich möglicherweise auf Döberitz, Kr. Osthavelland!]: Kapazität am 1.1.1946: 150 (BLHA, Rep. 203 MdI, Nr. 1163, Bl. 50).

BevölKerungszahlen: 1925: 625, 1939: 1012, 1946: 1 107, 1964: 1089 (HOL III, S. 74).

\section{Döbern}

Landgemeinde (1969 Stadtrecht), bis 1945 Kr. Sorau, 1945-1946 (Rest-)Kr. Sorau bzw. Kr. Forst, 1.4.1946-1952 Kr. Spremberg, 1952-1990 Kr. Forst (Bez. Cottbus), 1990-1993 Ldkr. Forst, 1993 Ldkr. Spree-Neiße

Bevölkerungszahlen: 1925: 3541, 1939: 4012, 1946: 3738, 1964: 4404 (Städtebuch, S. 107). 
Katholiken (Erzbistum Breslau/Erzbischöfliches Amt Görlitz): 1925: 619, 1946: 532 (Städtebuch, S. 107). - 20.7. oder 20.8.1945 (Bericht Pfarrer Broß, Cottbus): „Döbern: Pfarrer krank, Kaplan Rosalski O/S zur Vertretung da. Kirche halb zerstört, Schwesternhaus in Arbeit." (Töpler, Menschenwurm, S. 359). - 23.7.1945 (Bericht über kath. Pfarreien): „Döbern war Zufluchtsort für die Pfarrer von Forst, Muskau, die ihre Gemeinden verlassen mussten[n]. [...]." (Töpler, Menschenwurm, S. 364).

UMSIEDLERLAGER JAHNSCHULE: Im „Verzeichnis der errichteten und vorgesehenen Umsiedlerlager im Verwaltungsbezirk Cottbus" vom 15.12.1945 ohne „Personenzahl“ genannt (Töpler, Menschenwurm, S. 472), für entsprechende Bereitstellung vorgesehen auch schon lt. Bericht vom 24.10.1945 (ebd., S. 450).

UMSiedlerlager Hotel Förstemann: Kapazität am 31.12.1945: 120 (BArch, DO 2/45, Bl. 40 [hier irrtümlich als Lager „Hotel Fürstenau“ bezeichnet], Bl. 41 [hier richtig als Lager „Hotel Förstemann").

CARITASheim, Friedrichshainer Str. 19: 1926 gegründet, Leitung den Hedwigschwestern übertragen, verwaltet von deren Mutterhaus Breslau, bis „die Generaloberin Breslau 1946 verließ und nach Deutschland [siehe $\rightarrow$ Bad Saarow] ging“, später zur Deutschen Provinz der Kongregation gehörig. „In der DDR konnte sich das Caritasheim trotz zahlreicher Schwierigkeiten behaupten, wurde aber vom Krankenhaus zum Altenpflegeheim herabgestuft." Die Hedwigschwestern widmeten sich auch der ambulanten Krankenpflege und unterhielten einen Kindergarten (Mertens, S. 500). „Nach dem Zweiten Weltkrieg setzten neun Schwestern die Arbeit im Caritasheim mit fünfzig Betten fort. Die Niederlassung umfaßte die Arbeitsgebiete Krankenhaus, Altenheim, ambulante Krankenpflege und Kindergarten.“ Aug. 1949 zunächst Anerkennung als Krankenhaus behördlich entzogen, nach Protesten aus Gemeinde u. Betrieben 14.1.1949 Anerkennung als Behelfskrankenhaus (ebd., S. 501). - „Im Januar 1945 mußten [Hedwig-]Schwestern und Kinder aus dem St. Klemens-Hofbauer-Stift in Glogau (Głogów) vor der heranrückenden Front flüchten. Sie gingen zunächst nach Döbern und von dort weiter nach $[\rightarrow]$ Wandlitzsee in Brandenburg." (ebd., S. 535). - „Beim Herannahen der Front flüchteten die [Hedwig-]Schwestern [aus Quilitz, Kr. Glogau] nach Döbern. Dort haben sie den Russeneinfall miterlebt. Anschließend kehrten sie in ihre Niederlassung zurück, bis sie den Ausreisebefehl erhielten. Nach drei Wochen Lageraufenthalt kamen sie nach Berlin-Schöneberg. Ein Teil der Schwestern war in Quilitz geblieben." (Mengel, S. 169). - 23.7.1945 (Bericht über kath. Pfarreien): „Die Hedwigsschwestern haben wieder ihr Haus, nachdem sie ein paar Tage schwer zu leiden hatten." (Töpler, Menschenwurm, S. 364). - Ein sonstiger unmittelbarer Bezug zum Vertreibungsgeschehen ist zwar nicht erkennbar, da das Haus 1945 bereits als Niederlassung der Hedwigschwestern bestand, doch ist davon auszugehen, dass unter den Patienten zahlreiche Flüchtlinge und Vertriebenen waren, da Döbern nahe bei dem für Transporte wichtigen Grenzübergangsort Forst (Lausitz) und auch nahe der sächsischen Grenze liegt. - 1949 wohnt im Caritasheim der aus Branitz, Kr. Leobschütz (Oberschlesien) vertriebene Kaplan Bernhard Krummschmidt (geb. 1892) (Ostpriesterverzeichnis 2, 1949, S. 48). 
GeDRUCKTe QuelLen und Literatur: Mengel, Thomas: Das Schicksal der schlesischen Frauenklöster während des Dritten Reiches und 1945/46. Köln/Wien 1986. - Mertens, Johannes: Geschichte der Kongregation der Hedwigschwestern 1930-2000. Manuskript. Berlin 2004, S. 500-503 (Döbern), 535 (Wandlitzsee). - Töpler, Menschenwurm, S. 300 f., 319 f., 338 f., 364, 450, 472 u. ö. (siehe S. 662).

\section{Dorf Zinna (Kr. Jüterbog-Luckenwalde) $\rightarrow$ Neuheim}

\section{Drachhausen}

Landgemeinde, bis 1952 Kr. Cottbus, 1952-1990 Kr. Cottbus (Bez. Cottbus), 1990-1993 Ldkr. Cottbus, 1993 Ldkr. Spree-Neiße

EReignisse NACH KriegSende: „Nach dem Krieg wurden Menschen jenseits der Oder und Neiße aus ihrer Heimat vertrieben und auch bei uns, nur deutsch sprechend, in die schon bescheidenen Wohnverhältnisse eingepfercht. Um nicht gastunfreundlich zu sein, mußte deutsch gesprochen werden." (Das kulturelle Leben der Drachhausener Jugend und die sorbischen/ wendischen Traditionen, http://www.peitz.de [1.7.2017]).

EREIGNISSE NACH 1990: Ab 1996 Heimattreffen der vertriebenen ehem. Bewohner von Sachsdorf (poln. Chęciny) und Laaso (poln. Łazy) (beide Kr. Guben) in Drachhausen (Gubener Heimatbrief 1/1997, S. 78; 1/1998, S. 84).

BevölKerungszahlen: 1925: 1231, 1939: 1161 (HOL NL II, S. 27); 29.10.1946: 1480 , 31.8.1950: 1414, 1964: 1168 (HGV SN, S. 11).

\section{Drebkau}

Stadtgemeinde, bis 1952 Kr. Calau (ab 1950 Kr. Senftenberg), 1952-1990 Kr. Cottbus-Land (Bez. Cottbus), 1990-1993 Ldkr. Cottbus, 1993 Ldkr. Spree-Neiße

EREIGNISSE BIS KRIEgSENDE: [(April) 1945:] „Flüchtlingstrecks durchzogen unser kleines Städtchen und verstärkten unsere Zukunftsängste." (Wilke, S. 47). - 18.4.1945 Kämpfe im Drebkauer Raum „in eine entscheidende Phase eingetreten“ (ebd., S. 47).

BevölkerungSZAhlen: 1925: 2 127, 1939: 2 185, 1946: 2518, 1964: 2541 (Städtebuch, S. 110).

Katholiken (Erzbistum Breslau/Erzbischöfliches Amt Görlitz): 1925: 121 (Städtebuch, S. 111).

StÄdtepartnerschaften: 23.9.2000 Czerwieńsk, Polen (ehem. Rothenburg an der Oder, Kr. Grünberg, Schlesien). Außerdem bestehen zwischen acht (von zehn) heutigen Ortsteilen der Stadt Drebkau u. allen acht Ortsteilen der Partnerstadt Czerwieńsk Partnerschaften: Ca- 
sel - Będów (Bindow, Kr. Crossen), Greifenhain - Nietków (Polnisch Nettkow, Kr. Grünberg), Jehserig - Leśniów Wielki (Groß Lessen, Kr. Grünberg), Kausche - Laski (Läsgen, Kr. Grünberg), $\rightarrow$ Leuthen - Nietkowice (Deutsch Nettkow, Kr. Crossen, Schorbus - Płoty (Plothow, Kr. Grünberg), Siewisch - Wysokie (Woitscheke [1936-1945 Schäferberg], Kr. Grünberg) (www.drebkau.de [24.8.2018]). „Die Zeit des Oder-Hochwassers 1997 in Polen war die Geburtsstunde der Partnerschaft der Stadt Drebkau mit Czerwieńsk. Das damalige Amt Drebkau (Niederlausitz) und insbesondere sein damaliger Amtsdirektor, Werner Roß, leistete, in dieser für Czerwieńsk schwierigen Zeit, Nachbarschaftshilfe. / Mit der Unterzeichnung des Partnerschaftsvertrages am 23.09.2000 wurde diese Partnerschaft von beiden Seiten amtlich bestätigt." (www.drebkau.de [24.8.2018]).

Gedruckte Quellen: Töpler, Menschenwurm. - Wilke, Dorothea: Der Krieg ist aus. In: Zeitgebunden. Brücken zur Vergangenheit. Hrsg. vom Seniorenbeirat der Stadt Cottbus. Cottbus 2010, S. 47-51.

\section{Drehnow}

Landgemeinde, bis 1952 Kr. Cottbus, 1952-1990 Kr. Cottbus (Bez. Cottbus), 1990-1993 Ldkr. Cottbus, 1993 Ldkr. Spree-Neiße

BeVÖLKeRUNGSzAHLEN: 1925: 686, 939: 722 (HOL NL II, S. 28); 1925: 691, 1939: 722, 1946: 888, 1950: 839, 1964: 712 (HGV SN, S. 10 f.).

Gemeindepartnerschaften: 15.2.2000 Ochla, Polen (ehem. Ochelhermsdorf, Kr. Grünberg in Schlesien): „Zustande kam diese Partnerschaft durch die Bemühungen der 1995 gegründeten ,Ochelhermsdorfer Gruppe. Ochelhermsdorf ist der frühere deutsche Name des Dorfes Ochla, das heute zur Gemeinde Zielona Góra (Grünberg) gehört. Nach dem Krieg fanden viele Ochelhermsdorfer in Drehnow ein neues Zuhause. Die Gruppe arbeitet seit ihrem Bestehen eng mit den Gemeindevertretern und Einwohnern von Ochla zusammen und pflegt beispielhaft das deutsche Denkmal auf dem dortigen Friedhof. [...] / Engagement seit fünf Jahren: Die Ochelhermsdorfer Gruppe / Im April 1995 hat sich die Ochelhermsdorfer Gruppe gebildet. Seither haben die ehemaligen deutschen Einwohner Ochlas einen ,Freundschaftsvertrag ohne Paragraphen mit Leben erfüllt', wie der ehemalige Drehnower Bürgermeister Fritz Kschammer deren Engagement auf einer Pressekonferenz im Vorfeld des Partnerschaftsschlusses würdigte. Aus dem herzlichen Verhältnis zu den Ochlaer Bürgern ging die offizielle Gemeindepartnerschaft hervor. Mit ihr soll der Kontakt über die Zeitläufe fortbestehen, denn, irgendwann wird es den letzten Ochelhermsdorfer geben; so Kschammer. Heute leben noch neun Ochelhermsdorfer in Drehnow, 67 im Amt Peitz. Ein großer Teil landete nach dem Krieg in Mecklenburg, viele wohnen in den alten Bundesländern, einige in Übersee. / In den 70er-Jahren schwächten sich die Kontakte nach Ochla wegen der Unruhen in Polen zwar ab, aber ganz abgerissen sind sie nie. 1994 rief eine Rentnerin aus $[\rightarrow$ ] Lübben in einem Brief, der im Schneeballsystem bundesweit verbreitet wurde, zu einem Treffen auf, das 1995 mit 170 Besuchern stattfand. Seit 
Beginn ihren [so!] Bestehens hat die Gruppe mit den Gemeindevertretern und Bürgern Ochlas zusammengearbeitet. Die bisherigen Begegnungen verliefen in freundschaftlicher und aufgeschlossener Atmosphäre. Alljährliche Höhepunkte sind die Pflanz- und Pflegeaktionen am Denkmal in Ochla, das 1996 auf dem Friedhof aus alten deutschen Grabsteinen errichtet und vom $[\rightarrow]$ Peitzer Pfarrer Kurt Malk eingeweiht wurde, und die Heimatfeste." (http://www. peitz.de [23.8.2018]).

\section{Eberswalde}

Stadtgemeinde (Kreissitz), 1911-1950 eigener Stadtkr. (vorher Kr. Oberbarnim), 1950-1952 Kr. Oberbarnim, 1952-1990 Kr. Eberswalde (Bez. Frankfurt/Oder), 1990-1993 Ldkr. Eberswalde, 1993 Ldkr. Barnim

EREIGNISSE BIS KRIEgSENDE: „Die ersten Flüchtlinge aus Ostpreußen und Schlesien trafen schon 1944 in Eberswalde ein. Sie wurden im $[\rightarrow]$ Evangelischen Gemeindehaus in der Eisenbahnstraße, von der Nationalsozialistischen [Volks-]Wohlfahrt (NSV) und dem Bund Deutscher Mädchen [Mädel] (BDM) auf dem Bahnhof sowie in weiteren Notunterkünften betreut, bevor sie weiter gegen Westen zogen." (Fischer, S. 34). - April 1945 Evakuierung der Bevölkerung (Eberswalde 1945, S. 30, 36f.), Eberswalde zur Festung erklärt (Nerlich, S. 211). 23./24.4.1945 (nachts) Sprengung aller Zugangsbrücken zur Stadt (Nerlich, S. 211).24.4.1945 Einmarsch der Roten Armee (ebd., S. 46, 50-54, 57; Fischer, S. 34; Nerlich, S. 211); Finow: 25.4.1945 (Eberswalde 1945, S. 65). - Nacht 25./26.4.1945 starke Zerstörungen (35\% der Innenstadt) bei deutschem Luftangriff (Eberswalde 1945, S. 55-62; Fischer, S. 34; Nerlich, S. 211).

EReignisse NACH KRIEgSENDE: „Schon seit Anfang 1945 nahm die Sterblichkeit zu. Das ist im Laufe der Zeit noch schlimmer geworden, seit dem Frühsommer breiteten sich Ruhr, Typhus, TBC und Geschlechtskrankheiten aus. Ich habe irgendwann mal Zahlen aufgeschrieben. So hatte ich im Jahr 1945 in dieser Stadt 1532 Beerdigungen gehalten, einmnal an einem Tag 24, einmal in einer Woche 84. [...]." (Bericht Pfarrer Erich Schuppan [1995], in: Eberswalde 1945, S. 114). - 1945: „Der Typhus ist dort durch die Flüchtlinge verschleppt.“ 25.6. bis 15.10.19452821 Typhus-Fälle in Eberswalde (Wille I, S. $418 \mathrm{f}$.). - „Die Flüchtlingsströme erreichten nach dem 8. Mai weitere Höhepunkte." (Bericht Schuppan, in: Eberswalde 1945, S. 115). - „Die Flüchtlingsströme konzentrierten sich auf die noch erhalten gebliebenen Säle der Restaurants am Weidendamm („Neumanns Festsäle“) und „Harmonie“ [siehe unten - P. B.] in der Weinbergstraße (heute „Haus Schwärzetal“). Dort herrschte ein unbeschreibliches Chaos vor allem aufgrund des Ausfalls der Wasser- und Abwasserversorgung. Ruhr, Typhus, Ratten und Läuse begannen sich auszubreiten." (Fischer, S. 34). - 22.6.1945 (Tagebuch einer durchziehenden Flüchtlingsfrau): „Eberswalde ist ganz zerschossen." (Ammon, S. 45). - 13.7.1945 Bericht des Dezernenten für Gesundheitswesen, Dr. Seele, in der Bezirksbürgermeister-Sitzung (Protokoll): „Herr Dr. Seele 
enthüllt ein trauriges und erschütterndes Bild über die Notlage in der Behandlung der Krankheitsfälle und über das Flüchtlingselend. Herr Dr. Seele berichtet von steigenden Typhusfällen. [...] [S. 102] [...] / Da alle Krankenhäuser stark belegt sind, müssen die Kranken, sobald es irgend angängig ist, wieder entlassen werden. / Ein schwieriges Kapitel bietet nach wie vor die Lebensmittelfrage, besonders für die Auswärtigen. Zuschüsse seitens der angrenzenden Kreise sind trotz Zusage bisher nicht geleistet worden. / Erschütternd ist das Flüchtlingselend, das zudem eine fast unerträgliche Belastung für die beteiligten Ärzte, Schwestern u.s.w. darstellt. Die Flüchtlinge werden in der Harmonie, Neumanns Festsäle, in der Oberrealschule und im Turnsaal Karlstraße untergebracht. Der Eberswalder Hof in der Jüdenstraße mußte als Flüchtlingsquartier geschlossen weredne, weil festgestellt wurde, daß die Flüchtlinge sich dort 4, 5 Tage und länger aufhielten und sich jeglicher Kontrolle entzogen. / Die Zahl der in Notquartieren untergebrachten Flüchtlinge stieg ständig und betrug in der letzten Nacht 500 Personen. Die Aufenthaltsdauer ist auf 24 Stunden, in Ausnahmefällen höchstens 48 Stunden, begrenzt. / Beim Eintreffen der Flüchtlinge erfolgt zunächst eine gründliche ärztliche Untersuchung und alle Kranken, besonders Infektionskranke werden sofort ausgesondert. Die Zubereitung der Verpflegung und Verteilung der Lebensmittel erfolgt durch das Gemeindehaus unter Leitung von Herrn Pastor Schuppan. Allerdings kann nicht für alle Flüchtlinge Beköstigung gegeben werden. [...] / Bedauerlicher Weise läßt auch die Haltung der Flüchtlinge häufig zu wünschen übrig. Sie kochen auf den Plätzen um die Quartiere herum und verwenden als Brennholz hierzu alles, was ihnen irgendwie in die Hand kommt. Außerdem herrscht große Unsauberkeit in den Quartieren, wodurch wiederum Seuchenherde entstehen. [S. 103] [...] Zur Unterstützung von Herrn Dr. Seele, der diese Aufgabe nicht mehr allein bewältigen kann, übernimmt Herr Dr. [Heinrich] Ehlers die ärztliche Fürsorge der Flüchtlinge. / Herr Dr. Seele beklagte noch die immer wieder vorkommende Beraubung, Bedrohung und Vergewaltigung der Flüchtlinge durch russische Soldaten. [...]. / Es kommt dann der hiesige Bahnhofsvorstand, Herr Vorwerg, zu Worte, um über die Flüchtlingsnot auf dem Bahnhof zu berichten. Da nicht alle Flüchtlinge in den städtischen Notquartieren untergebracht werden können, viele Flüchtlinge sich auch gar nicht dorthin wenden, hat die Reichsbahn erhebliche Schwierigkeiten und Sorgen durch diese Flüchtlinge, die auf dem Bahnhof und Bahnhofsvorplätzen herum liegen und sich dort oft tagelang aufhalten. / Unter diesen Flüchtlingen befinden sich viele Kranke, insbesondere Darmkranke, die keiner ärztlichen Betreuung unterstehen und eine große Gefahr für die Allgemeinheit bilden. Da die Bedürfnisanstalten unter diesen Verhältnissen nicht ausreichren, ist der ganze Bahnhofsvorplatz verschmutzt und bildet einen weiteren Seuchenherd./Die vorgesehen Züge verkehren nicht regelmäßig, beziehungsweise sind überhaupt noch nicht gefahren, wodurch die Stauung der Flüchtlinge immer mehr zunimmt. Auch am Bahnhof wird abgekocht und Brennholz gestohlen. Da hierzu in großem Umfange auch die den Bahnhof und das Bahnhofsgelände einsäumenden Zäune abgerissen worden sind, ist eine Kontrolle des Bahnhofsgeländes nicht mehr möglich./[...]/Eine nicht unerhebliche Schwierigkeit bietet auch die täglich unter den Flüchtlingen vorkommenden Todes- und Krankheitsfälle. / Die Aussprache ergab leider keine befriediegende Lösung darüber, wo und wie diese am Bahnhof lagernden Flüchtlinge noch unterzubringen sind." (Eberswalde 1945, S. 101103; leicht gekürzt auch in: Wenzel, S. 141). - 15.7.1945 (Treck aus Woldenberg/Nm.): „In 
Eberswalde ist wenigstens etwas für Flüchtlinge gesorgt. Gemeinschaftsquartiere, ärztliche Betreuung, Rote-Kreuz-Schwestern, aber keine Verpflegung!" (Tagebuch Prochnow, S. 296). - Sommer 1945 Einrichtung einer Bahnhofsmission durch Pfarrer Schuppan („mit Hilfe vieler Frauen und Män$\left.n e r^{\prime \prime}\right)$ für Empfang und Erstverpflegung der Flüchtlinge (ebd., S. 142). - 26.7. und 1.8.1945 zwei Todesfälle von Flüchtlingen aus Königsberg/Nm. in Eberswalde (Krätzner, S. 25 f., nach Angaben in der „Heimatkartei“). - 23.12.1945: Zugunglück am Bahnhof Eberswalde: Ein aus Danzig kommender, mit seit Dez. 1944 auf der Flucht befindlichen Flüchtlingen besetzter Zug fährt auf einen stehenden Güterzug auf; 14 Tote, 15 Schwer- u. 25 Leichtverletzte (Mitteilung Gertrud Poppe, Biesenthal, nach Auskunft des Kreisarchivs Barnim).

EREIGNISSE NACH 1990: Durch Beschluss der Stadtverwaltung ist Eberswalde eine der Patengemeinden der Stiftung „Zentrum gegen Vertreibungen“ (http://www.z-g-v.de/ [23.6.2017]). 2004 Sonderausstellung „Fremde Heimat Eberswalde“ im „Museum in der Adler-Apotheke“ der Stadt Eberswalde. „Die Ausstellung im Dachgeschoss des Museums wollte nicht nur die historischen Zuwanderungsbewegungen darstellen, sondern hatte darüber hinaus das Ziel, zur Auseinandersetzung mit der gegenwärtigen gesellschaftlichen Situation aufzurufen. / Die Ausstellung und eine Reihe von Begleitveranstaltungen wurden in Kooperation mit mehreren Partnern wie z. B. der Koordinierungsstelle für Toleranz und gegen Fremdenfeindlichkeit in Eberswalde, der Ausländerbeauftragten des Landkreises Barnim, der Selbsthilfegruppe „Kontakt“ im $\mathrm{BdV}$ realisiert. Die Vernissage war sehr gut besucht. Positiv zu verzeichnen ist dabei vor allem das große Interesse der jugendlichen Zielgruppe. Die Ausstellung eignete sich insbesondere für Unterrichtszwecke und wurde von vielen Eberswalder Schulklassen besucht. / Fördersumme $8000,00 €$ (Bericht der Landesregierung über Projekte und Initiativen der kulturellen Bildung, Landtag Brandenburg, 4. Wahlperiode, Drucksache 4/7599 [2009], S. 40; siehe auch Abb. der Stelltafeln und Exponate [Handwagen und Koffer] in: Fischer, S. 36). - 26.9.2009 „12. Ostdeutscher Kulturtag“ des BdV-Landesverbandes Brandenburg in der Stadthalle „Hufeisenfabrik“ im „Familiengarten“ (Akten der BdV-Landesgeschäftsstelle).

BeVÖLKERUNGSZAHLEN: 1925: 5317, 1939: 10481, 1946: 9616, 1964: 9980 (Städtebuch, S. 116). - „Ende April 1945 lebten in Eberswalde etwa 9000 Menschen, am 2. Mai wurden bereits 17500 Einwohner gezählt und Ende Juni habe die Einwohnerzahl mehr als 21000 betragen." (Wenzel, S. 144 nach der unveröff. „Geschichte des VEB Kranbau Eberswalde. Chronik T. 1“, 1958, im Kreisarchiv Barnim, Eberswalde); detailliertere „augenblickliche Kopfzahlstärke“ nach Stadtbezirken für den 2.5.1945 in Bericht über Bezirksbürgermeister-Sitzung, demnach Gesamtzahl „15800 + 10\% / Es wurden demnach rund 17500 Einwohner angenommen“, doch wurde betont, „daß sich die Kopfzahl dauernd verstärken wird durch Rückkehr von Flüchtlingen“ (Eberswalde 1945, S. 74). - Juli 1946: 2751 „Umsiedler“ (BLHA, Rep. 203 MdI, Nr. 1074, Bl. 52; Abb.: Mietk, S. 66). - 29.10.1946: 30186 Einwohner, davon aus Ostpreußen: 417, Hinterpommern 1083 , Ostbrandenburg 520, Schlesien 394, Tschechoslowakei 101, Polen 230, Danzig 203, Rumänien 3, Baltikum 43, Sowjetunion 28 (Volkszählung 1946). - Okt. 1946: „Im Stadtkreis Eberswalde be- 
finden sich gegenwärtig 3380 Umsiedler" (Märkische Volksstimme, 28.10.1946; Faksimile: Wenzel, S. 145). - 31.12.1948: Gesamtbevölkerung: 32 730, davon „Umsiedler und Evakuierte“: 3667 (Grandke, S. 46). - Eingemeindung von Vertriebenen: 30.4.1947: 3516 (Oehlsen, S. 102), Juni 1948: 3691 (ebd., S. 103), Febr. 1949: 3762 (ebd., S. 104).

Katholiken: 1925: 1430, 1946: 2066 ( $\rightarrow$ Finow: 529) (Städtebuch, S. 117). - „Nach dem II. Weltkrieg kommen wie überall die Vertriebenen, die Gemeinde wächst kurzzeitig auf $4000 \mathrm{Ka}-$ tholiken.“ (Brühe, S. 21; siehe auch Schwillus/Brühe, S. 310). - [nach 1945:] „Hauptaufgabe war, den vielen Vertriebenen Heimat zu schaffen. Das schien unlösbar, denn die Vertriebenen waren zahlenmäßig mehr als die vorhandene Gemeinde. Heimat in aller Not war die Kirche, der gemeinsame Glaube, der Tabernakel. [...].“ (Illmann, 1977, S. 27). - 1960-1965 amtiert hier (zuvor in $\rightarrow$ Meyenburg) der 1946 aus Swinemünde vertriebene Pfarrer Kurt Reuter (19081965; begraben in Eberswalde), der in der deutsch-polnischen Versöhnungsarbeit aktiv tätig ist und polnische Priester in Polen unterstützt (Żurek). - In der 1872 gegründeten „Herz-JesuAnstalt", einer Pflegeeinrichtung der Grauen Schwestern, kümmerten sich nach Kriegsende die verbliebenen „fünf bis sechs Schwestern“ neben der ambulanten Krankenpflege auch „um Flüchtlinge und Heimkehrer, halfen in der Seelsorge und übernahmen Küsterdienste" (Mertens, S. 443; vgl. Wühle, S. 163: „Sechs Schwestern“).

Auffangstelle Restaurant „Harmonie“, Weinbergstraße 6a: Jan. 1945 Einrichtung eines Feldlazaretts (wie schon 1870 und 1916) (Wikipedia, „Haus Schwärzetal“, 4.1.2017). - Juli 1945 als Auffang- und Übernachtungsstelle eingerichtet. Der Dezernent für das Gesundheitswesen „Dr. Seele berichtete, dass bereits in der Nacht vom 5. zum 6. Juli [1945] in der ,Harmonie' ca. 60 Personen untergebracht worden seien. Der Saal der ,Harmonie“ habe etwa 100 Personen, der Nebenraum noch einmal 40 Personen Platz geboten. Die Flüchtlinge sollten zuerst zur „Harmonie' geschickt und von dort aus durch eine Helferin in die Hindenburg-Oberrealschule weitergeleitet werden. Die Verpflegung erfolgte im evangelischen Gemeindehaus. Die Unterkunft sollte nur für eine Nacht gewährt werden, jedoch könnten Kranke für eine längere Zeit beherbergt werden.“ (Wenzel, S. 140). „Das war damals der einzige große Saal, der noch einigermaßen brauchbar war. [...] Aber da gab's 'n Drama, weil nämlich für die vielen Flüchtlinge, die in dem riesigen Saal schliefen und in den ganzen Nebenräumen: auf der Bühne, neben der Bühne, in der Garderobe, oben in den Räumen und überall, die hygienischen Verhältnisse nicht in Ordnung waren. Denn die paar Toiletten, die vorhanden waren, reichten nicht aus" (ebd., nach Zeitzeugeninterview bei Schwarz, S. 71 f.). - 15.7.1945 (Treck aus Woldenberg/Nm.): „Wir kommen in die ,Harmonie', ein Vergnügungslokal, und sichern uns im großen Saal ein paar harte Pritschen, aber besser wie verlaustes Stroh. An einhundert Wagen mit Genossen sind schon im Garten. Aus einer Bombenruine in der Nachbarschaft wird Holz [S. 297] besorgt und ein großer Topf Kaffee gebrüht." (Tagebuch Prochnow, S. 296f.). - 16.7.1945: „Bahnhof. Auf dem Vorplatz sind 100te Wagen und 2000 Menschen. An einigen Stellen wird abgekocht. Ein Bild des Jammers. Dazwischen suchen die Russen immer wieder Männer raus zum Arbeiten. Etwa 13 Uhr kommt ein Personenzug. Nur 
Leute ohne Wagen dürfen mit, und einige 100 finden noch auf den Wagendächern platz." (ebd., S. 297). - Okt. 1945 „Fassungsvermögen: 500 [...], Heizung: teils vorhand., Kochmöglichkeit: nein“ (ebd., S. 143). - „Die Räume der ,Harmonie“ wurden bis spätestens Frühjahr 1946 zur Unterbringung von Vertriebenen genutzt“, anschließend Nutzung als „Volkshaus“ vorgesehen (ebd., S. 144). - 1948 Beginn von Sanierungsarbeiten, 1950 Wiedereröffnung als „Volkshaus“, 1957 „Klubhaus der Jugend“, 1964 „Kreiskulturhaus“, 1984 „Kulturhaus Schwärzetal“, seit 1995 Kulturhaus „Haus Schwärzetal“ (Wikipedia, 4.1.2017).

Evangelisches Gemeindehaus, Eisenbahnstraße 84 (Verpflegungsstation für Flüchtlinge): Bis wenige Tage vor dem 20.4.1945 Einquartierung eines Berliner Altersheims seit Ende 1943/ Anf. 1944, großer und kleiner Saal „völlig überbelegt mit Betten“ (Bericht Pfarrer Erich Schuppan [1995], in: Eberswalde 1945, S. 111). - Ab Juli 1945 im Gemeindehaus Erstverpflegung der Flüchtlinge: „Der Zubereitung der Verpflegung und Verteilung der Lebensmittel hatte sich das Gemeindehaus unter Leitung von Herrn Pastor Schuppan angenommen." (Wenzel, S. 141). „Nach Aussage des Pfarrers Schuppan, waren alle Räume, der Hof, die Treppen gefüllt mit Flüchtlingen.“ (ebd., S. 140, nach Schwarz, Anh., S. 17). - Bericht Pfarrer Schuppan (1995): „Seit 1944 kamen die Flüchtlinge dazu, aus Ostpreußen, aus Pommern, aus Schlesien. Ende Januar 1945 war ja die Oder von sowjetischen Truppen überquert, so daß die Zahl der Flüchtlinge erheblich zunahm. Sie kamen aus der Richtung Stettiner Straße oder von Sommerfelde [Sommerfeld] her und gingen immer auf die Eisenbahnstraße, also auf das Gemeindehaus zu. Die Eisenbahnstraße war zuweilen so dicht, daß man kaum durchkam. Die Flüchtlinge standen dann vor unserer Tür. Wir hatten in unserer Wohnung Dienstzimmer und unser Schlafzimmer. Alles andere war mit Flüchtlingen belegt, die aber alle mit dem Gedanken kamen: ,Also weiter! Weiter!'. Natürlich gab es mit ihnen auch zahlreiche intensive Gespräche, die Leute kamen ja mit wenig Habe, manche hatten unterwegs schon alles verloren. [...] [S. 114] Eindrucksvoll war für mich auch, wenn durch die Eisenbahnstraße herrenlose Herden zogen, weil eben alles in Richtung Westen zog. Da gab es niemanden, der sich ihrer annahm und so drängten diese Tiere weiter. [...]. [S. 115] [...] Das Gemeindehaus selbst war völlig verstopft, alle Räume waren belegt, die Treppen und der Hof waren belegt. Es war schrecklich, das Schrecklichste vom Schrecklichen, wenn ich morgens, fast täglich in einer gewissen Zeit, Menschen abschneiden mußte, weil sie sich in der Nacht das Leben genommen hatten. / Was ich auch nicht vergesse, und was mir heute noch sehr nahegeht. Wir mußten abends das Tor zum Hof des Gemeindehauses abschließen, weil es nicht anders ging, es war ja nicht mehr möglich, Leute unterzubringen. [...]. Im Sommer habe ich einen Suchdienst in der Stadt eingerichtet und konnte extra jemanden dafür einstellen. [...]." (Eberswalde 1945, S. 111, 114f.). Ende Juli 1948 im Verzeichnis (von der Landesregierung) verbotener Suchdienste erwähnt: Hilfswerk der evangelischen Kirche, Eberswalde, Eisenbahnstr. 84, „lt. Schr[ei]b[en]. Oberlandrat, Bez. Verw. Eberswalde, v. 26.11.46 darauf hingew [iesen]., dass Sucharbeit nur von uns [staatl. Suchdienst] ausgeführt wird“ (BLHA, Rep. 203 MdI, Nr. 1197, Bl. 41).

(Kreis-)UMSIEDlERlager, Kaiser-Friedrich-Str. 81 (Rudolf-Breitscheid-Straße), ehem. Reichsfeuerwehrschule: Okt. 1945 Bestimmung der Baracken in der Kaiser-Friedrich-Straße 
(Fassungsvermögen: 2000 Personen) als Quarantänelager für den Stadtkreis Eberswalde durch den Ortsumsiedlerausschuss, Einrichtung von Küche, Wirtschaftsräumen und Wohnung des Lagerleiters sowie Räumen für die ärztliche Betreuung und Pflegepersonal im zugehörigen Wohnhaus der ehem. Reichsfeuerwehrschule (Wenzel, S. 142 f.; Fischer, S. 35). „An den vorhandenen Baracken fehlten zunächst Fenster, Türen und Schlösser, Lichtanlagen sowie neue Kochgelegenheiten mussten beschafft und aufgestellt werden. Die notwendigen Einrichtungsgegenstände sollten aus den öffentlichen städtischen Gebäuden (Bürgerschule III, Luftschutzkeller Rathaus, Gymnasium und Pestalozzi-Waisenhaus) besorgt werden. Für die medizinische Betreuung standen zwei Entlausungsanlagen im Krankenhaus Kurmark, eine im städtischen Krankenhaus und eine in der Oderberger Straße zur Verfügung. In seiner Arbeit wurde Dr. Seele [Gesundheitsdezernent] von drei Sanitätern und dreizehn Rote-Kreuz-Helferinnen unterstützt.“ (ebd., S. 143). - 18.10.1945 Bericht der Zentralverwaltung für das Gesundheitswesen über eine Inspektion: „Es wird ein Sammellager gebaut für 2000 Personen, dasselbe soll bis zum 25.10.45 fertig sein. Es ist berechnet für 14 Tage Aufenthalt, also eine Art,Quarantäne'; ein Lattenzaun ist darum herum. Das Lager ist heizbar, die Frage der Kohlen steht günstig. Für [S. 419] die Unterbringung von 2000 Flüchtlingen erscheint nach einer Besichtigung das Lager als geeignet. Es sind 4 intakte Entwesungsapparate vorhanden, nur fehlt für diese Apparate reines Benzol. Außerdem ist ein Heißluftentwesungsofen da. Eine Waschküche wird eingerichtet als Baderaum und ein zweiter Heißluftofen außerdem. Bakteriologische Untersuchungen werden nach Berlin geschickt werden. Entlausungspuder wäre erwünscht. [...].“ (Wille I, S. 418 f.). - Dez. 1945 erneute Seuchen- u. Hygiene-Inspektion der Hauptabt. Sanitätswesen der Zentralverwaltung für Gesundheit im Lager (Wille I, S. 423). - Kapazität am 31.12.1945 (Lager „Breitscheidstr.“): 3500 (BArch, DO 2/45, Bl. 41). - Kapazität am 1.1.1946: 1500 (BLHA, Rep. 203 MdI, Nr. 1163, Bl. 49). - 1946 Heimkehrerlager, Belegungsstärke: 2000 (Kaminsky, S. 160). - 14.2.1946 Kreis- und Quarantänelager, Kapazität: 2000 (Oehlsen, S. 28). - 30.4.1946 als eines der verbleibenden Umsiedlerlager genannt (DAB, I/9-15-1 Flüchtlingsseelsorge 1945-1951, unfol., [30.6.1946], [Anlage 3]). - 24.7.1946 in Liste der Lager für „Ostheimkehrer“ genannt (Lager „Rud.Breitscheidstr.“) mit Kapazität 1000 (BArch, DO 2/45, Bl. 76). - 24.8.1946 Umsiedlerlager Breidscheidstr., Kapazität: 1200 (SAPMO-BArch, DY 34/27880, Bl. 291). - 1.1.1947 Kapazität: 1200 (Oehlsen, S. 101). - 1947 Schließung bevorstehend (SAPMO-BArch, DY 34/27745, Bl.92). - SchlieBung 31.1.1947, Abwicklung der Geschäfte bis 28.2.1947, Weiterverwendung „zur Schaffung zusätzlichen Wohnraums sowie von Werkstätten für ,Umsiedler“", Inventar sollte „bevorzugt für den Bedarf der verbleibenden Lager in der Provinz Brandenburg sowie der im Stadtkreis Eberswalde eingewiesenen [S. 144],Umsiedler'Verwendung finden“' 8.2.1947 Transport umfangreicher Sanitätsmittel nach Potsdam, April oder Mai 1947 Abgabe von Medikamenten, Arznei- und Verbandsmitteln an das Umsiedlerlager $\rightarrow$ Saalow (Wenzel, S. 143 f.).

UMSIEDlerlager EberSwalde: Kapazität am 31.12.1945: 2000 (BArch, DO 2/45, Bl. 41) [Dieses Lager „Eberswalde“ hier für den Stadtkreis an erster Stelle von zwei Lagern, vor dem o. g. Lager „Breitscheidstr.“, aufgeführt (ob identisch mit dem Lager auf dem Ardelt-Gelände?)]. 
FlÜCHTLINGSLAger auf dem Werksgelände der Firma Kranbau Eberswalde (Ardelt-Werke): [1945] (Bericht Pfarrer Erich Schuppan, 1995): „[...] die eindrucksvollsten Gottesdienste [...]. Die habe ich im Kranbau gehalten. Dort waren große Flüchtlingslager eingerichtet. Vieles war ja kaputt, aber in einigen Hallen waren die Menschen und warteten auf die Worte, die sie trösteten." (Eberswalde 1945, S. 115). - November 1946 (Bericht des Antifaschistischen Frauenausschusses an den Oberbürgermeister Dr. Göhre): ,In dem Lager befinden sich 99 Männer und 34 Familien mit 29, zum Teil schulpflichtigen Kindern. Die Leute kommen als Flüchtlinge von der Gegend Stettin her. I In dem Lager herrschen furchtbare hygienische Zustände... Alles starrt vor Schmutz und zum Teil auch vor Ungeziefer... Die Kinder des Lagers gehen in die Westendschule und es besteht die Gefahr, dass die Krankheiten und Läuse sich evtl. auf die anderen Schulkinder übertragen." (Fischer, S. 34).

Märkische Gehörlosenschule: Die am 20.1.1945 durch Zugtransport nach $\rightarrow$ Pritzwalk (Ankunft: 21.1.) evakuierte Gehörlosenschule Posen (Kinder u. 11 Begleitpersonen) wurde im Februar 1946 von der Provinzialverwaltung Brandenburg übernommen, mangels Weiterbildungsmöglichkeiten in Pritzwalk aber im Aug. 1946 als nunmehrige „Märkische Gehörlosenschu$l e$ “ in das Schloss $\rightarrow$ Marquardt bei Potsdam und wegen der dortigen katastrophalen Raumsituation 1947 nach Eberswalde verlegt. „Am 21.4.1947 kommen die Kinder nach Eberswalde. Es sind zunächst 150, später 190 Schüler. Das ist die Gründung der Landesgehörlosenschule Eberswalde. [...].“ (Pelzer/Pelzer, S. 14).

Strassenumbenennungen: 23.5.1950 Stettiner Straße (und Breite Straße) in Straße der Jugend (Klitzke, S. 6), nach 1990 Breite Straße.

Vertriebenen- Und AUSSIEDleRverbände NACH 1990: 19.2.1991 (12.10.1995 Vereinsregistereintragung) BdV-Kreisverband Eberswalde, Bad Freienwalde, Bernau e.V. (Sitz Eberswalde, Geschäftsstelle in Finowfurt; 1996-2010 Sitz Eberswalde, Karl-Marx-Platz 8 erwähnt (BdV-Handbuch 1996, S. 168; Akten der BdV-Landesgeschäftsstelle), anfangs „mehr als 1000 Mitglieder“ (MOZ/Barnim-Echo, 9.4.2014, S. 16), 1.4.1995 bei Mitgliederversammlung im Kurhaus Bad $\rightarrow$ Freienwalde, Gesundbrunnenstr. 12, 195 Mitglieder anwesend, 31.12.2010 54 Mitglieder (Akten wie vor); 2014 Auflösungsbeschluss, zuletzt knapp 100 Mitglieder (1991 über 1000) (MOZ/Barnim-Echo, 9.4.2016, S. 16; Märkische Onlinezeitung, 9.4.2014). - Vorsitzende: 1994-1995 Peter Krebs, Metallurge in Eberswalde, 1.4.1995-2014 Martha-Maria Schulz, Finowfurt (geb. 1930 Thränsdorf, Pommern) (BR 8 (2010)7, S. 17; Akten wie vor; Foto in MOZ/Barnim-Echo, 9.4.2016, S. 16). - Der BdV-Kreisverband war Träger einer auch nach seiner Auflösung weitergeführten (Märkische Onlinezeitung, 9.4.2014) und inzwischen selbständigen Migrationsberatungsstelle (auch „Migrationsfachdienst“) im Bürgerzentrum in Eberswalde, Schorfheidestraße 13, deren Leiterin, der 1994 nach Eberswalde gekommenen russlanddeutschen Spätaussiedlerin (aus Karasu/Kasachstan) Irina Holzmann geb. Gerter (geb. 1972) [siehe über sie ihre Selbstdarstellung in Böttger/Hamdali, S. 56], 2009 der Integrationspreis des Landes Brandenburg verliehen wurde (Märkische Oderzeitung, 17.7.2009): „2001 
wurde in Eberswalde die Selbsthilfegruppe (SHG), Kontakt' im Bund der Vertriebenen (BdV) gegründet. Der inzwischen selbstständige Verein ,KONTAKT Eberswalde` e. V. ist eine von den Aussiedler/innen organisierte Einrichtung zur Selbst- und gegenseitigen Hilfe. Sein wichtigstes Ziel ist die Unterstützung der Integration der Spätaussiedler/innen und ihrer Familien." (Böttger/Hamdali, S. 54; vgl. Ordner „Kontakt“ in der BdV-Landesgeschäftsstelle). - 2003 war die vom BdV getragene Selbsthilfegruppe KONTAKT Eberswalde e. V. Kooperationspartner des Stadtmuseums bei der Ausstellung „Fremde Heimat Eberswalde“ (siehe oben). - 2003 Aufstellung eines Gedenksteins (siehe unten) auf Initiative des BdV-Kreisverbandes (Fischer, S. 33).

StÄDtepartnerschaften: 19.6.2001 Gorzów Wlkp., Polen (Landsberg an der Warthe, ehem. neumärkischer Stadtkr. in der Provinz Brandenburg) (www.moz.de, 12.4.2018 [20.8.2018]).

Gedenkstein auf dem Gelände der Landesgartenschau (Findling mit Metallbuchstaben). Inschrift: „Zum Gedenken / Den Opfern der Kriege / aus Flucht, Vertreibung / und Internierung / Den Lebenden zur Mahnung", aufgestellt 24.5.2003 auf Initiative des BdV-Kreisverbands (Fischer, S. 33 mit Abb.).

Archivalische Quellen: BArch, DO 2 ZVU, Nr. 39, Bl. 11, 42 (Lager, 1945). - BLHA, Rep. 203 MdI, Nr. 1120 (Umsiedler- und Heimkehrerstatistiken, 1945-1946; enthält: Erfassung der Umsiedler in den einzelnen Kreisen der SBZ zum 1. Dez. 1945 sowie statistische Berichte der einzelnen Gemeinden, hier Stadtkreis Eberswalde).

Gedruckte Quellen: Ammon, Margarete: Tagebuch. In: Gespräche mit ehemaligen Küstrinern. Bd. 6. Frankfurt (Oder) 2017, S. 29-50. - Dokumentation der Vertreibung I/1, S. 359. - Eberswalde 1945. Eine Zusammenstellung von Ereignissen mit Dokumenten und Erinnerungen. Begleitheft zur Sonderausstellung im Stadt- und Kreismuseum. Eberswalde 1995, bes. S. 101-103, 111-115. - Eberswalde 1945. Dokumente und Erinnerungen. Ein Anhang der 2. Auflage des Begleitheftes zur 1995 im Eberswalder Museum gezeigten Sonderausstellung. (Eberswalde) o. J., S. 14-15: Erlebnisbericht Hilda Langhans (Flucht aus Ostpreußen, Sept. 1945 Ankunft in Eberswalde). - Tagebuch Ernst Prochnow [Auszüge]. In: „Die Russen sind da“. Kriegsalltag und Neubeginn 1945 in Tagebüchern aus Brandenburg. Peter Böthig u. Peter Walther (Hg). Berlin 2011, S. 296 f. - Töpler, Menschenwurm, S. 531. - Wille I, S. 418 f., $423,428,430$.

Literatur: Böttger, Marieta / Hamdali, Mohamed: Neue Heimat Eberswalde nach der politischen Wende 1990. In: Fremde Heimat Eberswalde. Überarb. 2. Aufl. Eberswalde 2008, S. 51-60. - Brühe, Matthias: Katholische Kirche zwischen Uckermark und Oderland. Berlin 1998, S. 20-21. - Fischer, Ingrid: Zuwanderung nach dem Zweiten Weltkrieg. In: Fremde Heimat Eberswalde. Zuwanderungen in Vergangenheit und Gegenwart. Begleitheft zur Sonderausstellung im Rahmen des Kulturlandes Brandenburg 2003 Europa. Überarb. 2. Aufl. Eberswalde 2008 (1. Aufl. 2003), S. 33-43, darin S. 33-37: Kapitel „Flüchtlinge, Vertriebene und Umsiedler“. - I[1lmann], N[orbert]: 100 Jahre Katholische Pfarrkirche „St. Peter und Paul“ in Eberswalde. (Eberswalde) [1977]. - Klitzke, B[irgit]: Die Friedensbrücke - eine wechselhafte Geschichte. In: report e 18 (2011) 2, S. 6. - Krätzner, S. 25f. - Mertens, Johannes: Die Berliner Ordensprovinz der Grauen Schwestern von der heiligen Elisabeth 1859-1991. Reinbek bei Hamburg 1992, S. 439-443 (Herz-Jesu-Anstalt). - Nerlich, Bruno P.: Die Hilfe der sowjetischen Kommandantur beim wirtschaftlichen Wiederaufbau der Stadt Eberswalde (1945-1949). In: Befreiung und Neubeginn. Berlin 1968, S. 210220. - Oehlsen, S. 89. - Pelzer, Rotraut / Pelzer, Susanne: Das Gehörlosenschulwesen der Provinz Brandenburg. In: Pritzwalker Heimatblätter 2 (1989), S. 12-14. - Rose, Wolfgang: Anstaltspsychiatrie in der DDR. Berlin 2005, S. 29 ff. - Schwarz, Kathrin: Die Eingliederung der Flüchtlinge und Vertriebenen in die Sowjetische Besatzungszone und die DDR. Lebensberichte - Am Beispiel der Stadt Eberswalde (Land Brandenburg). Schriftl. Hausarbeit Inst. für Geschichte TU Dresden 1993 (vorh. im Kreisarchiv Barnim). - Schwillus/Brühe, S. 310-312. - Wegemund, An- 
dreas: Eisenbahnknoten Eberswalde. Berlin 2012. - Wenzel, Mario: Die Aufnahme und Versorgung von Flüchtlingen und Vertriebenen in Eberswalde 1945-1948. In: Eberswalder Jahrbuch 2015, S. 136-145 (textgleich, aber ohne Abb. u. d. T.: Zur Aufnahme und Integration der Vertriebenen in Eberswakde 1945-1948. In: Transodra online, www. transodra-online.net/de/node/1414). - Wühle, Eberhard: Die Grauen Schwestern in Eberswalde - eine Chronik. In: Eberswalder Jahrbuch 2012, S. 158-163. - Żurek, Robert: Kurt Reuter. Ein vergessener Vorreiter der deutschpolnischen Versöhnung. In: Wichmann-Jahrbuch, N. F. 11 (2010/11 [2011]), S. 132-143.

\section{Eichwalde}

Landgemeinde, bis 1952 Kr. Teltow, 1952-1990 Kr. Königs Wusterhausen (Bez. Potsdam), 1990-1993 Ldkr. Königs Wusterhausen, 1993 Ldkr. Dahme-Spreewald

EREIGNisSe Bis Kriegsende: 23.4.1945 Einmarsch der Roten Armee (Müller, S. 101).

EREIGNISSE NACH KRIEGSENDE: „Der Ort hatte im Hinblick auf die kaum von Kriegsschäden betroffene Wohnsubstanz recht gute Unterbringungsmöglichkeiten. Bisher [bis zum Sommer 1945, P.B.] waren hauptsächlich alle Schulräume, Baracken und sonstigen Räumlichkeiten als Notquartiere erfasst und dicht belegt.“ (Müller, S. 102). - „Am 19.6.1947 wurde die Feuerwehr durch die Gemeindeverwaltung Eichwalde zum Abtransport von 225 eingetroffenen Flüchtlingen eingesetzt. Der gegen 22.30 Uhr auf dem Eichwalder Güterbahnhof eingetroffene Flüchtlingszug wurde mit Unterstützung der Feuerwehrmänner [...] entladen und die Personen mittels LKW [...] zu ihrer Unterkunft befördert" (Eintrag vom 5.7.1947 im Dienstbuch der Feuerwehr, zitiert nach Müller, S. 106). - 20./21.6.1947 (Erinnerungsbericht eines als Kind vertriebenen Schlesiers, unmittelbar aus Lager $\rightarrow$ Küchensee kommend): „Spät abends am 20. oder 21. Juni sind wir auf dem Bahnhofsgelände angekommen und wurden entladen. Viele Schwestern in Nonnenkleidung fragten nach Kranken und Verletzten. [...] Hannelore und Muttel sind sofort ins Krankenhaus Eichwalde gekommen, das lediglich aus Baracken bestand. [...] Danach wurde uns ein leeres Zimmer mit Blick auf die Bahnschienen zugewiesen in einem 1-Familien-Haus in der Straße an der Bahn auf der Schulzendorfer Seite. Leider waren die Fenster mit Pappe vernagelt, aber zum Glück war es Sommer und warm. / Wir hatten nun das leere Zimme und Kochbenutzung bei dem Vermieter. [...]." (Hübner, S. 48). - „Am 2.9.1947 kamen wieder Umsiedler nach Eichwalde, für die fast in jedem Haus Platz geschaffen wurde. Noch mehr Ofenrohre aus den Fenstern zieren die Fassaden." (Tagebuch Gerda Dolke, Triftstraße, zitiert nach Müller, S. 107). - „Bei den zugewiesenen Umsiedlern handelte es sich meist um Landarbeiter und Bauern, denen aber andernorts Arbeitsstellen vermittelt werdne konnten. Einige beantragten bald eine Neusiedlerstelle, andere wurden durch Anforderung der sowjetischen Besatzungsmacht bei Demontagearbeiten in $[\rightarrow]$ Wildau oder Schönefeld beschäftigt.“ (Müller, S. 107). - Der Bevölkerungsrückgang gegenüber der Vorkriegszeit erlaubte die Zuweisung weiterer Vertriebenen: „Am 25 Oktober 1948 trafen auf Veranlassung der Abteilung Umsiedler des Rates des Kreises Teltow weitere 30 Personen in Eichwalde ,zur Eingemeindung' ein. Unter diesen Umsiedlern, die wieder aus dem Lager $[\rightarrow]$ Küchensee kamen und neun separate Haushaltungen bildeten, befand sich nur eine erwachsene männliche Person 
im Alter von 65 Jahren. Noch am 6. Juni 1949 erfolgte auf Anordnung der Landesregierung, Abt. Umsiedler und Heimkehrer, die Einbürgerung von weiteren 26 Personen, unter denen sich ebenfalls kein erwachsener Mann befand, sondern nur Frauen und Kinder bzw. Jugendliche. Die nach dem 1. April 1949 aus Polen eingetroffenen Umsiedler erhielten jetzt außer den im Quarantänelager pro Person ausgezahlten 50 DM eine einmalige Unterstützung in Form eines Warengutscheins.“ (Müller, S. 110). - „Es leben heute [2007, P. B.] noch manche Bürger im Ort, die als Umsiedler direkt oder auf Umwegen zu Eichwaldern geworden waren. Einige von ihnen wohnen seit dieser Zeit ununterbrochen hier." (ebd., S. 108, mit namentlichen Beispielen für Vertriebene aus Pommern, Ostpreußen, dem „Warthegau“, Niederschlesien [u. a. eine Familie 1947 aus dem Lager $\rightarrow$ Küchensee nach Eichwalde eingewiesen] und der Neumark, die teilweise auf dem Umweg über andere deutsche Länder nach Brandenburg gelangt waren).

BeVÖLKerungszahlen: 1925: 3334, 1939: 6318, 1946: 5 847, 1964: 6346 (HOL IV, S. 59). Aug. 1945: „etwa 8000 , darunter 1270 Flüchtlinge und Evakuierte gemeldet“ (Müller, S. 103), Dez. 1945: ca. 6000 (ebd., S. 104f.), Mai 1945: 6000 (ebd., S. 106), 1948: 6524, davon 1162 Umsiedler oder Neubürger (ebd., S. 109 f.). - „Besonders die Zugänge der Monate Juni mit 205, Juli mit 72 und September mit 270 Personen im Sommer 1947 trugen dazu bei, dass Eichwalde vom 1. Oktober 1946 bis September 1947 insgesamt 1015 Umsiedler zur Einbürgerung aufgenommen hatte." (ebd., S. 106).

Katholiken: 1935: etwa 2 000. Gemeinde 1948 zur Pfarrei erhoben (Brühe, S. 21; Schwillus/ Brühe, S. 313). - „In der katholischen St. Antonius-Gemeinde lebt die Erinnerung an Schwester Elisabeth (Kühnel), die sich seit November 1947 als Umsiedlerin aufopferungsvoll um die Betreuung der aus ihrer Heimat vertriebenen Menschen kümmerte. Sie half den katholischen Gläubigen, wenigstens durch Kirche und Gottesdienst ein Stück Heimatgefühl wieder zu finden." (Müller, S. 109).

Partnerschaft: 6.5.1995 Partnerschaftsvertrag mit der Stadt Ośno Lubuskie, Polen (Drossen, ehem. Kr. Weststernberg, Provinz Brandenburg) (Crossener Heimatgrüße 47, 1995, Nr. 3, S. 8), Partnerschaft „nach Kräften“ unterstützt von dem in Eichwalde lebenden, in Drossen zur Schule gegangenen vertriebenen Neumärker Helmut Munkow (geb. 1930) (Müller, S. 108).

Gedruckte Quellen und Literatur: Brühe, Matthias: Katholische Kirche zwischen Havel und Dahme. Berlin 1999, S. 21. - Müller, Wolfgang: Nachkriegsjahre in Eichwalde. Eichwalde [2007], bes. S. 101-111 (ausführliches Kapitel 2.2. „Fremde Heimat“). - Hübner, Hans: Meine Kindheit und der schwere Anfang in Kiekebusch. In: Ingelore Kundoch / Dietrich Kundoch / Hans-Jürgen Nossack: Chronik Kiekebusch. Schönefeld [2009], S. 47-51, hier S. 48 f. [Wohnungseinweisung in Eichwalde 1947 (Vertriebenenfamilie aus Kr. Hirschberg/Schlesien, unmittelbar aus Lager Küchensee kommend)]. 


\section{Eisenhüttenstadt $\rightarrow$ Fürstenberg (Oder)}

\section{Engelsburg bei Milmersdorf}

Wohnplatz, bis 1952 Kr. Templin, 1952-1990 Kr. Templin (Bez. Neubrandenburg), 19901993 Ldkr. Templin (Land Brandenburg), 1993 Ldk. Uckermark

UMSiedlerlager, dann Heimkehrerlager: 1937 Gelände im Templiner Wohnplatz Engelsburg von der Deutschen Reichspost erworben, die hier Gebäude errichtet, bis 1945 funktechnische Einrichtung der Wehrmacht, bei Kriegsende Leerstand (Seybold, S. 50). - Nov. 1945 Einrichtung als Flüchtlingslager (Leiter: Herr Stabingis, Bürokraft: Frau Marschall), als solches genutzt bis Aug. 1946 (Seybold, S. 51). - Kapazität am 31.12.1945: 1500 (BArch, DO 2/45, Bl. 40). - Kapazität am 1.1.1946: 1500 (BLHA, Rep. 203 MdI, Nr. 1163, Bl. 51). - 24.7.1946 in Liste der Lager für „Ostheimkehrer" genannt mit Kapazität 1000 und Bestimmung ,f[ür] Leichtkranke „(BArch, DO 2/45, B1. 76). - 24.8.1946 Heimkehrerlager, Kapazität: 1000 (SAPMOBArch, DY 34/27880, Bl. 291). - Ab 31.8.1946 Heimkehrerlager, zeitweise Unterbringung von 1800 ehemaligen Kriegsgefangenen aus Russland (Seybold, S. 51). - 1946 Heimkehrerlager, Belegungsstärke: 1000 (Kaminsky, S. 160). - 9.6.1947 Heimkehrerlager, Kapazität: 1000, Belegung: 6 (SAPMO-BArch, DY 34/27880, Bl. 239). - 25.11.1947 in Befehl der SMA Brandenburg in Liste „der [zum 30.12.1947] zu schließenden Lager“ aufgeführt (BLHA, Rep. 302, VP, Nr. 9, Bl. 43v), anschließende Nutzung als Kinderheim vorgesehen (Oehlsen, S. 32). - Ende 1947 Auflösung des Heimkehrerlagers (Seybold, S. 51). - [Wohl Ende 1947] Verlegung des Heims aus dem Postheim in $\rightarrow$ Templin nach Engelsburg (Makowitz/Knitter/Kuntze, S. 229) und 2.1.1948 „Eröffnung des Altenfeierabendheimes des Landes Brandenburg“ (Leiter: Herr Brandt), später Feierabend- und Pflegeheim, ab 1981 Pflegeheim („Pflegeheim Engelsburg“), 1992 Übernahme der Trägerschaft durch die St. Elisabeth-Stiftung Berlin (Seybold, S. 51 f.), heute Kinderheim der Stephanus-Stiftung (Engelsburg 1, Milmersdorf) (www.stephanus.org/ standorte/stephanus-stiftung-engelsburg/ [18.8.2016]).

LiterATUR: HOL VIII, S. 235 (ohne Erwähnung des Lagers). - Makowitz, Bärbel / Knitter, Eitel / Kunze, Martin: Templin. 2. Aufl. Strasburg (Um.)/Berlin 2013, S. 226, 229. - Seybold, Wolff-Hasso: Die „Engelsburg“ und ihre Entwicklung. In: Templiner Heimatkalender 1999 (1998), S. 50-52 (mit Abb.).

\section{Erkner}

Landgemeinde (1998 Stadtrecht), bis 1946 Kr. Niederbarnim, 1.7.1950-1990 Kr. Fürstenwalde (Bez. Frankfurt/Oder), 1990-1993 Ldkr. Fürstenwalde, 1993 Ldkr. Oder-Spree

EREIGNISSE BIS KRIEgSENDE: [Fluchtbericht einer Küstrinerin:] „Als sich die Familie am 5. Februar 1945 beim Gemeindeamt in Erkner meldete, war es kein sehr freundlicher Empfang. Die Bombardierung des Ortes ein Jahr zuvor hatte einschneidende Spuren an Wohnraum und Versorgung 
hinterlassen. Flüchtlinge wurden also nur ungern aufgenommen. [...]. Sie wurden behandelt, als hätten sie aus reinem Vergnügen diese Strapazen auf sich genommen." (Gespräche, S. 230). - 21.4.1945 Einmarsch der Roten Armee (ebd., S. 230 f.).

EREIGNISSE NACH 1990: 18.9.2004 „7. Ostdeutscher Kulturtag“ des BdV-Landesverbandes Brandenburg in der Stadthalle (Akten der BdV-Landesgeschäftsstelle). - 18.9.2010 „13. Ostdeutscher Kulturtag“ in der Stadthalle (ebd.). - 1.10.2011 „14. Ostdeutscher Kulturtag“ in der Stadthalle (ebd.); parallel dazu (Wander-)Ausstellung „Meine Ostpreußen“, anschließend 2012 in $\rightarrow$ Gransee u. zuvor 2010 in $\rightarrow$ Zehdenick gezeigt (konzipiert u. gestaltet von Angelika u. Olaf Pasenau, Gransee).

BeVÖLKerungsZAHLEN: 1925: 5703, 1939: 8234, 1946: 6459, 1964: 8334 (Städtebuch, S. 138).

Katholiken: 1925: 302, 1946: 464 (Städtebuch, S. 138).

UMSIEDLERLAGER: Kapazität am 31.12.1945: 150 (BArch, DO 2/45, Bl. 40).

Gedruckte Quellen und Literatur: Gespräche mit ehemaligen Küstrinern über Küstrin, Vertreibung und Neuanfang in Küstrin-Kietz und anderswo. Aufgez. u. bearb. von Siegfried Neubauer. Bd. 2. Petershausen 2004, S. 230235. - Peschke, Reinhard und Cornelia: „Ein Haus voll Glorie ...“75 Jahre katholische Kirche Erkner. Erkner 2007. Schwillus/Brühe, S. 314.

\section{Falkenberg/Mark}

Landgemeinde, bis 1952 Kr. Oberbarnim, 1952-1990 Kr. Bad Freienwalde (Bez. Frankfurt/ Oder), 1990-1993 Ldkr. Bad Freienwalde, 1993 Ldkr. Märkisch-Oderland

EReIGNISSE NACH KRIEgSEnde: 27.8.1945 Todesfall eines 12-jährigen Flüchtlingsjungen aus Königsberg/Nm. im Kinderheim Falkenberg, dessen Mutter am 25.7. in einer Flüchtlingsbaracke in $\rightarrow$ Bad Freienwalde und dessen vermutlicher Großvater am 26.7.1945 in $\rightarrow$ Eberswalde verstorben war (Krätzner, S. 26, nach Angaben in der „Heimatkartei“). - Ende 1945 (Bericht der Gemeindeverwaltung vom Nov. oder Dez. 1945, unterzeichnet von Ritter): „Die Flüchtlingsfürsorge hat uns sehr große Schwierigkeiten bereitet, da alle Wohnungen zerstört, Türen und Fenster zerbrochen und kaum Wohnmöglichkeit für die Bevölkerung zu beschaffen, was [so!] aber mit gutem Willen der Gesamtbevölkerung und reger Beteiligung unseres Bürgermeisters konnten viele Schäden behoben werden, sodaß wir jetzt schon 598 Flüchtlinge unterbringen konnten." (Brandenburgische Gemeinden 1945, S. 40). - 15.11.1945 Pachtung der Falken-Apotheke durch den aus Königsberg/Nm. vertriebenen Apotheker Bernhard Thieme (1896-1979), der die Apotheke nach der Verstaatlichung 1952 noch bis 1960 weiter leitet und anschließend bis 1963 die Leitung der Staatlichen „Alten Apotheke“ in Bad Freienwalde übernimmt (Biela, S. 18f.). - Am 12.6.1946 bestehen im Ort acht von Vertriebenen eingerichtete „Umsiedlerbetriebe“, darunter sieben Handwerksbetriebe mit je bis zu drei Beschäftigten und eine Gärtnerei mit 120 Beschäftigten, davon 80 „Umsiedler“ (Wille II, S. 365). 
Gedruckte Quellen und Literatur: Biela, Paul: Schicksale deutscher Apotheker aus Ostbrandenburg am Ende des Zweiten Weltkrieges. Frankfurt (Oder) 2017. - Brandenburgische Gemeinden 1945, S. 39-41. - Krätzner, S. 26. - Wille II, S. 364.

\section{Falkensee}

Landgemeinde (7.10.1961 Stadtrecht), bis 1952 Kr. Osthavelland, 1952-1990 Kr. Nauen (Bez. Potsdam), 1990-1993 Ldkr. Nauen, 1993 Ldkr. Havelland

EREIGNISSE BIS KRIEGSENDE: 3.2.1945 (Tagebucheintrag der Falkenseerin Hedwig Schob:) „3. Febr. Frl. Kowalewski hat Flüchtlinge: Frl. Westphal mit Lehrmädchen (Irmgard) aus Krossen an der Oder. In Falkensee kam wieder ein Transport an, zu uns noch keiner. [...].“ („Die Russen sind da“, S. 38). - 5.2.1945 (wie vor): „5. Febr. Abends kommen Flüchtlinge, älteres Ehepaar Herr und Frau Nickel aus Neuli?schaften [?] $10 \mathrm{~km}$ östlich von Frankfurt/Oder. Landarbeiter 14 Morgen, erscheinen ruhig, höflich, räumen Westzimmer, Vati hilft mit: Bett + Schrank aus Ostzimmer, Schreibtisch und Truhen ins Ostzimmer. Siegfried ist dauernd bei Nickels, Alarm 3.40-4.25, fünf Menschen mehr im Keller“ (ebd., S. 39). - 1943-1945 war der Bürgermeister [Hugo Porsack] von Sommerfeld/NL (Kr. Crossen) „nur von Freitag bis Montag jeder Woche am Ort, an den übrigen Tagen war er in Falkensee/Osthavelland kommissarisch tätig." (Platzke, S. 98; vgl. S. 102). Am 13.2.1945 war er „auf dringendes Anraten seiner älteren Mitarbeiter nicht wieder nach Falkensee gefahren“ (ebd., S. 99). Er ordnete am Abend „die Beladung des städtischen Pferdegespanns an, auf dem die Kassenbücher, Personalakten etc. verstaut wurden. Den Gespannführer begleiteten die [drei] städtischen Beamten [...]. Sie verließen die Stadt [...] mit dem Ziel Falkensee." (ebd., S. 100). Noch beim Einmarsch der Roten Armee im April befand er sich mit einem „Stab Sommerfelder Beamten“ in Falkensee. (ebd., S. 102). - 27.2.1945 (wie vor): „7000 Flüchtlinge kamen nach Falkensee, Lebensmittel vorübergehend knapp. Ration für 8 Wochen muß jetzt für 9 Wochen reichen. Der böse Angriff am 3. Februar auf Berlin galt den Flüchtlingen, ebenso 2. Angriff aufDresden, wo alle Schönheiten vernichtet wurden." (ebd., S. 45). - 26.4.1945 Einmarsch der Roten Armee (Krüger/ Schulz, S. 156; Kerl, S. 53).

EREIGNISSE NACH KrIEgSENDE: „Die Stadt ist überfüllt mit ausgebombten Berlinern, Flüchtlingen aus den Ostgebieten und umherrirrenden Menschen, die ihre Angehörigen im nahen Berlin suchen. In den Häusern Falkensees müssen die Familien zudammenrücken. Selbst die Baracken der ehemaligen Zwangsarbeitslager werden als sogenannte Behelfsheime sofort mit Flüchtlingen und ersten Gewerken belegt, was bei der Firma Siemens Unmut erregt, da sie sich weiterhin als rechtmäßiger Besitzer bzw. Pächter fühlt. Doch die Stadt beruft sich auf den Befehl Nr. 124 des Marschalls der Sowjetunion G. Shukow, der alle Lager der Firma Siemens beschlagnahmte. [...].“ (Dittmer, S. 172). - „Nach dem 2. Weltkrieg eröffnete [der zuvor in Sommerfeld/NL, Kr. Crossen, ansässige Bäckermeister Julius] Lohan den Betrieb [eine nach 1918 in Sommerfeld gegründete Schokoladenfabrik] in Falkensee/Osthavelland und erreichte wieder eine Beschäftigtenzahl bis zu 40 Betriebsangehörigen. Dieser Pionier starb 1946, seine 
Lebensgefährtin 1952. Inzwischen hatte sein Sohn, der den Betrieb leitete, 1946 und 1950 auch in [Berlin-]Spandau berufsverwandte Gesellschaften gegründet und verließ Falkensee. [...].“ (Platzke, S. 50). - „Nachdem schon während des Krieges zahlreiche Flüchtlinge eingetroffen waren, kamen jetzt die Vertriebenen in Gruppen zu etwa 350 Personen ab Februar 1946 in Falkensee an. Sie wurden in den Baracken des ehemaligen KZ und im Arbeitslager „Agneshof ' untergebracht. Falkensee war von der Landesregierung als Zwischenstation für 50000 Vertriebene vorgesehen, von denen etwa 10000 in Falkensee verbleiben sollten. / Den Vertriebenen ein neues Zuhause zu geben war schwierig und verlief nicht reibungslos. Am 18. September 1948 erließ der Bürgermeister deshalb einen Aufruf an die Falkenseer Bevölkerung. Darin wurde beklagt, dass ein Teil der Haus- und Wohnungsbesitzer den Vertriebenen ,jedes Menschlichkeitsgefühl vermissen lassen. [...].“ (Wagner, S. 145). - 1948 Erwähnung der von sudetendeutschen Vertriebenen gegründeten „Textilgenossenschaft Falkensee“ (Christopeit, S. 86).

EREIGNISSE NACH 1990: 7.5.2006 Heimattreffen von 58 Vertriebenen aus dem Kreis Meseritz (aus den Heimatorten im Kirchenkreis Kupferhammer sowie aus Neutomischel, Bentschen, Strese und, „wieder am stärksten vertreten“, Ziegelscheune) im Hotel Seeblick (Bericht von Wilfried Redlich mit Bild in: Heimatgruß Meseritz 177, 2006, S. 11). - Seit 2000 lebt in Falkensee der zuvor in Potsdam ansässige, als Kind zunächst aus Neisse, dann aus der Tschechoslowakei vertriebene und dann in der Altmark (Beetzendorf) aufgewachsene DEFA-Kinderfilmregisseur Hans Kratzert (geb. 1940 Heerwegen [bis 1937 Polkwitz], Kr. Glogau) (www.defa-stiftung.de/ kratzert-hans, wikipedia, [10.7.2018]).

BevöLKeRUnGSZAhlen: 1925: 8 180, 1939: 24824, 1946: 28275, 1964: 29919 (Städtebuch, S. 144). - Mai 1945 rund 33000 Einwohner, darunter etwa 6000 Ortsfremde (Wagner, S. 140). - 1946: 4049 Konfessionslose (Städtebuch, S. 144).

Katholiken: 1925: 442, 1946: 2614 (Städtebuch, S. 144).

(Kreis-)Umsiedlerlager (auch: Quarantäne-Lager) Agneshof, An der Spandauer Chaussee, $3 \mathrm{~km}$ vom Bahnhof Agneshof (auch Quarantänelager für Kriegsgefangene): Bis Kriegsende Außenlager des KZ Sachsenhausen, bezeichnet als Lager Falkenhöh, FalkenseeAgneshof, aber auch Berlin-Albrechtshof (Woinar, S. 170-173; Kranert, S. 66), sofortige Räumung am 26.4.1945 durch die Rote Armee veranlasst (Krüger/Schulz, S. 156). - „Ab Sommer 1945 wurden die Gebäude des ehemaligen KZ-Außenlagers Falkensee für mehrere Jahre als ,Quarantänelager Agneshof ‘ zur Unterbringung von Vertriebenen und Flüchtlingen aus den ehemaligen deutschen Gebieten östlich von Oder und Neiße sowie als Sammellager für entlassene bzw. heimgekehrte deutsche Kriegsgefangene genutzt (ebd.; vgl. auch Woinar, S. 172). „Am 9. Juli 1945 begann die Registrierung der Umsiedler, Heimehrer und Flüchtlinge. / Im August 1945 wurde eine Baracke des ehemaligen KZ Falkenhöh umgebaut. Die Umsiedler konnten dort für eine Nacht bleiben. Später wurde das Lager erweitert. In die Steinbaracken wurden Öfen eingebaut und es mußte Strom gelegt werden. / Zum technischen Personal gehörten außer dem Lagerleiter und 
dem Stellvertreter noch 4 Frauen im Büro, 46 Wachposten und 4-6 Arbeiter. Von 1945-1947 war Herr Richter Lagerleiter, dann kam Herr David und danach Herr Zahn. Zum medizinischen Dienst zählten der Arzt Dr. Roderburg, 2-3 Krankenschwestern, 1 Krankenpfleger, eine Frau in der Desinfektion und zeitweise auch ein Apotheker." (Kranert, S. 66). - 1945/46 Wiederaufbau des ehem. KZ-Lagers als Flüchtlingslager (BLHA, Rep. 250 Osthavelland, Nr. 817). - Kapazität des Lagers für Umsiedler am 1.1.1946: 1500 (BLHA, Rep. 203 MdI, Nr. 1163, Bl. 49). - 14.2.1946 Kreis- und Quarantänelager, Kapazität: 1500 (Oehlsen, S. 28). - 1946 Heimkehrerlager, Belegungsstärke: 1500, weiteres Heimkehrerlager (?): 1000 (Kaminsky, S. 160). - 30.4.1946 als eines der verbleibenden Umsiedlerlager genannt (DAB, I/9-15-1 Flüchtlingsseelsorge 19451951, unfol., [30.6.1946], [Anlage 3]). - 19.7. bis 7.9.1946 1060 Kriegsgefangene (Heimkehrerlager) (Oehlsen, S. 35). - 24.7.1946 in Liste der Lager für „Ostheimkehrer“ genannt mit Kapazität 1600 und „Bestimmungsstation“ Berlin („f. Berliner“) (BArch, DO 2/45, Bl. 76). 24.8.1946 Heimkehrerlager, Kapazität: 1600 (SAPMO-BArch, DY 34/27880, Bl. 291).10.11.1946 Umsiedler- und Quarantänelager für Heimkehrer. Steinbaracken. Kapazität 1946: 600 (BLHA, Rep. 230 Bernau, Nr. 287). - Lagerpersonal 15.11.1946: Lagerleiter: Paul Richter, geb. 15.5.1916; Wirtschaftsleiter: Alfred David, geb. 26.1. 1895; Lagerarzt: Dr. Hans Roderburg, geb. 13.3. 1888 (1.11.1946: Dr. Helmuth Ahrens, geb. 11.1.1900) (BLHA, Rep. 230 Bernau, Nr. 287, Bl. 52-57, 70-78, 85-86). - 1.1.1947 Lager, Kapazität: 1600 (Oehlsen, S. 101). - 9.6.1947 Heimkehrerlager, Kapazität: 1600, Belegung: 26 (SAPMO-BArch, DY 34/27880, Bl. 239). - Durch dieses Lager wurden die Kindertransporte aus Ostpreußen geschleust (BLHA, Rep. 203 MdI, Nr. 1198, Bl. 46) [23. Okt. 1947 Falkensee als (einziges brandenburgisches) Auffanglager für Kindertransporte aus dem sowjet. Teil Ostpreußens vorgesehen laut Wille II, S. 117; Aufnahme von Kindertransporten 1945-1947 nachgewiesen (Kranert, S. 67) ]; 1948 Einrichtung eines Kinderheims in Falkensee zurückgestellt, 1951 Kinderheim der SED, Finkenkrug, Donaustraße 15, nach $\rightarrow$ Brandenburg verlegt, für 1952 Übernahme des von der Landjugend-GmbH Charlottenburg verwalteten Landjugendheims Finkenkrug als Kinderheim geplant [Kranert, S. 67]). - 25.11.1947 „Aufnahmefähigkeit von 1600 Mann, Quarantänelager für Kriegsgefangene“ (BLHA, Rep. 302, VP, Nr. 9, Bl. 43). - 31.12.1947, Jan./Febr. 1948 Quarantänelager Falkensee eines von 7 verbleibenden Lagern in Brandenburg (BLHA, Rep. 203 MdI, Nr. 1198, Bl. 28v). - Lagerpersonal am 1.1.1948: Lagerleiter: David; Wirtschaftsleiter: Försterling; Lagerarzt: Dr. Roderburg (BLHA, Rep. 333, Nr. 575, Bl. 27 [Liste der leitenden Angestellten]). - Jan. 1948 (Anf./Ende) laut Lagerbestandsmeldung vom 10.2.1948 im Lager 211 / 58 Insassen (BLHA, Rep. 203 MdI, Nr. 1115, Bl. 7). - 20.9.1948 Kontrolle des Lagers durch ZVU (Bericht vom 21.9.1948: BArch, DO 2/38, Bl. 81-88, darin Liste des Lagerpersonals, z. T. mit Beurteilungen): Lagerleiter: „David, Alfred, 53 Jahre, Umsiedler aus Breslau, früherer Beruf Arbeiter", seit 1.4.1948 im Lager, vor 1933 SPD, jetzt SED (B1. 85). Lagerarzt: Dr. Roderburg, Hans, 60 Jahre, „Umsiedler“, im Lager seit 1947, 1933-45 NSDAP und SA. „Bemerkung: Nach den vorliegenden Personalakten ist durch einen Beschluß des Ausschusses zur Durchführung des Gesetzes 24 die Weiterbeschäftigung von Dr. R. als Lagerarzt im 
Lager Falkensee untersagt und seine Entlassung gefordert worden. Das Kreisgesundheitsamt hat ihn jedoch nachfolgend als Lagerarzt in Falkensee dienstverpflichtet bei täglicher Kündigung und Herabsetzung seines Gehalts auf RM 500,- monatlich. Irgendein Hinweis, daß dies im Einverständnis mit dem vorgenannten Ausschuß geschehen ist, liegt nicht vor." (ebd.). - Okt./Nov. 1948 aufgelöst (BLHA, Rep. 203 MdI, Nr. 1198, Bl. 46), anschließend „Abbruch aller aufgehenden Bauten bis auf das noch heute erhaltene Unterkunftsgebäude und ein Gebäude, das unter anderem eine Transformatorenanlage aufnahm. In dem vormaligen Unterkunftsgebäude ließ die Gemeindeverwaltung Falkensee aus dem Trümmerschutt neue Steine herstellen, die man für den Wiederaufbau zerstörter [S. 157] Häuser benötigte. Das nahegelegene Demag-Werk war schon bis 1950 demontiert worden. [...].“ (Krüger/Schulz, S. 156 f.). - Ab 1960er Jahre genutzt vom VEB (K) Betonwarenfabrik ,Havelland‘ 1546 Staaken als Garagen und Sozialgebäude. 1993 wurde das inzwischen verwahrloste Gelände der Stadt Falkensee übertragen, 1995 zu einem öfftentlichen Geschichtspark umgestaltet, „in dem die baulichen Zeugnisse des ehemaligen KZ-Außenlagers freigelegt und teilweise mit Erläuterungstafeln versehen wurden“" (Woinar, S. 173; ausführlicher dazu: Krüger/Schulz, S. 157 ff.; siehe auch Kaule, S. 16).

Archivalische Quellen: BArch, DO 2 ZVU, Nr. 38, Bl. 31-90 (Lager Falkensee/Agneshof, 23.1.1946-16.10.1948, u. a. Bl. 85 Liste des Lagerpersonals, 21.9.1948); Bl. 291-293 (Lager Agneshof/Falkensee, 31.7.-3.8.1946). - BLHA, Rep. 250 Osthavelland, Nr. 817 (Wiederaufbau des ehemaligen KZ-Lagers in Falkensee zwecks Verwendung als Flüchtlingslager, 1945-1946; enthält auch: „Arbeitsverpflichtungen und Bestrafungen wegen Arbeitsverweigerungen beim Aufbau des Flüchtlingslagers"); Nr. 853 (Berichte über Besichtigungen der Umsiedlerlager Falkensee und Hennigsdorf, 1946). - BLHA, Rep. 333 SED-Landesleitung Brandenburg, Nr. 577 (Heimkehrerlager, 1946-1949; enthält u. a.: Agneshof).

Literatur: Christopeit. - Chronik Falkensee 1945-1961. Falkensee (1983). - Dittmer, Gisela: Auf der Suche nach dem Verlorenen. Nach dem Krieg wird alles anders. In: 750 Jahre Seegefeld. Christliches Leben im Wind der Zeiten. Festschrift der Evang. Gemeinde Falkensee-Seegefeld zur 750-Jahr-Feier im Jahr 2015. Hrsg.: Gisela Dittmer. Falkensee 2015, S. 171-182. - Kaule, Martin: Brandenburg 1933-1945. Berlin 2012. - Kerl, Brigitte: das Kriegsende 1945 in Falkensee. In: Heimatjahrbuch für Falkensee und Umgebung 2020 (2019), S. 51-54. - Kranert, Gudrun: 1945 - Ende des Zweiten Weltkrieges. Deutschland wird aufgeteilt - Flüchtlingsströme erreichen auch Falkensee. In: Heimatjahrbuch für Falkensee und Umgebung 2018 (2017), S. 66-72. - Krüger, Bert / Schulz, Barbara: Das Gelände des KZ-Außenlagers Falkensee bei Berlin - Gedenkstätte und zeithistoisch-archäologischer Lernort. In: Archäologie und Gedächtnis. Hrsg. Thomas Kersting u. a. Petersberg 2016, S. 155-171. - Mentzel, Klaus-Peter: Die Neubauernsiedlungen in Falkensee. In: Heimatjahrbuch für Falkensee und Umgebung 2018 (2017), S. 28-33. - Ders.: Neubauernsiedlungen in Falkensee - Fortsetzung. In: ebd. 2020 (2019), S. 88-90. - Oberling, Ines: Falkenseer Wirtschaftsgeschichte (3): Von der Zigarettenfabrik Leon Mardirossian zum VEB Gablona Falkensee. In: Heimatjahrbuch für Falkensee und Umgebung 2009, S. 42-48. - Platzke, Max: Geschichte einer ostdeutschen Kleinstadt kommunalpolitisch betrachtet. Berlin-Charlottenburg 1956. - Schwillus/Brühe, S. 315. - Wagner, Richard: Illustrierte Geschichte von Falkensee. Falkensee 2003. - Woinar, Klaus: (Außenlager) Falkensee. In: Der Ort des Terrors. Hrsg. von Wolfgang Benz u. Barbara Distel. Bd. 3. München 2006, S. 585-587. 


\section{Fehrbellin}

Stadtgemeinde, bis 1952 Kr. Osthavelland, 1952-1990 Kr. Neuruppin (Bez. Potsdam), 19901993 Ldkr. Neuruppin, 1993 Ldkr. Ostprignitz-Ruppin

EREIGNISSE NACH KRIEGSENDE: Bei der Bodenreform 28 neue Eigentümer berücksichtigt, davon 7 „Umsiedler“ (HOL III, S. 100). - 1947-1951 amtierte in Fehrbellin der aus Kürtow (Kr. Arnswalde) vertriebene Pfarrer Hans-Georg Furian (1903-1968) als evang. Superintendent, anschließend ab 1951 in $\rightarrow$ Nauen (Pfarralmanach 1953, S. 156).

Bevölkerungszahlen: 1925: 1618, 1939: 2223, 1946: 3875, 1964: 2984 (Städtebuch, S. 147).

Katholiken: 1928: 182, 1946: 657; „Zunahme der kath. Einwohner durch Flüchtlinge und Vertriebene nach 1945“ (Städtebuch, S. 147). - „Über 50 Jahre wirkte Alois Jammer (1906/7-58) als Pfarrer. Seine erste Kaplansstelle hatte er in Schlesien. Unter den Heimatvertriebenen, die die Zahl der Katholiken von 350 im Jahre 1939 auf 1800 im Jahre 1953 ansteigen ließ[en], konnte er dann sogar Mitglieder aus seiner früheren Gemeinde begrüßen." (Schwillus/Brühe, S. 335).

Literatur: Schwillus/Brühe, S. 335.

\section{Felchow}

Landgemeinde (seit 31.12.2001 Ortsteil von Schöneberg), bis 1952 Kr. Angermünde, 19521990 Kr. Angermünde (Bez. Frankfurt/Oder), 1990-1993 Ldkr. Angermünde, 1993 Ldkr. Uckermark

BEVÖLKERUNGSZAHLEN: 1925: 505, 1939: 337, 1946: 418, 1964: 425 (HOL VIII, S. 254).

UMSIEDLERLAGER: Kapazität am 31.12.1945: 300 (BArch, DO 2/45, Bl. 40).

\section{Felgentreu}

Landgemeinde (seit 1993 Ortsteil von Nuthe-Urstromtal), bis 1946 Kr. Jüterbog-Luckenwalde, 1946-1952 Kr. Luckenwalde, 1952-1990 Kr. Luckenwalde (Bez. Potsdam), 1990-1993 Ldkr. Luckenwalde, 1993 Ldkr. Teltow-Fläming

EREIGNISSE BIS KRIEgSENDE: Von der Wehrmacht (zusammen mit Mehlsdorf und Zinna) als Übungsgelände genutzt, Bevölkerung daher zuvor 1936/37 umgesiedelt (Gedenkstätten NS II, S. 265), anschließend „Umsiedler angesetzt“ (HOL X, S. 130). - „In Felgentreu hatten die Nationalsozialisten die Ländereien von 52 Bauernfamilien aufgekauft. Hier wurde ein Außenkommando des Zuchthauses Luckau [...] mit etwa 50 bis 60 Häftlingen eingerichtet." (Gedenkstätten NS II, S. 265). - 24.4.1945 Einmarsch der Roten Armee (Halter, S. 122). 
EREIGNisSe NACH KRIEgSENDE: „Auch in Felgentreu ließen sich Umsiedler nieder, vermutlich aus Ostpreußen.“ (Gedenkstätten NS II, S. 265). - Nach Kriegsende wurde das Dorf wieder besiedelt, überwiegend durch „Umsiedler aus dem Osten.“ (Bauer, S. 75). - „[...] Lange Zeit war jedes Leben in diesem Dorf erloschen. Als nach dem Zusammenbruch den vielen Umsiedlern eine neue Heimat geschaffen werden mußte, zog neues Leben in Felgentreu ein. Von den früheren Bewohnern kehrten nur wenige zurück, so daß heute in Felgentreu fast ausschließlich Umsiedler wohnen. [...]." (ADN-Bildtext zu den Pressefotos „Felgentreu, Blick auf ein Neubauernhaus“, „Felgentreu, Blumenkohlernte“ und „Felgentreu, Blick in ein Gewächshaus“, 6.7.1950, Aufn.: Klein; Bundesarchiv, Bild 183-S97321 bzw. Bild 183-S97324 bzw. Bild 183-S97325). - Ansiedlung von 800 Flüchtlingen. „Es waren Deutsche aus Bessarabien am Schwarzen Meer, aus der Bukowina in Rumänien, aus den Karpaten, aus Wolhynien, aus Polen - aus sieben Ländern, so hieß es, und manche alten Bauern konnten slawische Sprachen. Aber niemand hatte ein Pferd retten können." (Halter, S. 122).

BeVÖLKeRUngSZAHLEN: 1925: 379, 1946: 181, 1964: 560 (HOL X, S. 130).

Archivalische Quellen: BArch, Fotoserie Felgentreu der Allgemeinen deutschen Nachrichtenagentur - Zentralbild, 6.7.1950.

Literatur: Bauer, Herbert: Stalag III A. [Luckenwalde] [1996]. - Halter, Hans: Aktion Rote Faust (Felgentreu - ein „sozialistisches“ Flüchtlingsdorf). In: Die Flucht der Deutschen. Spiegel special 2/2002, S. 122-123.

\section{Ferch}

Landgemeinde, bis 1952 Kr. Zauch-Belzig, 1952-1990 Kr. Potsdam-Land (Bez. Potsdam), 1990-1993 Ldkr. Potsdam, 1993 Ldkr. Potsdam-Mittelmark

EReignisse NACH KRIEgSEnde: „Nach dem Ende des Krieges kamen über 400 Umsiedler nach Ferch, wodurch die Zahl der Einwohner des Ortes sich auf über 1200 erhöhte. Später verringerte sich diese Zahl wieder etwas, so daß heute ihn Ferch etwa 950 Menschen leben." (Protze/Schenk, S. 32).

BEVÖLKERUNGSZAHLEN: 1925: 351, 1939: 896, 1946: 1 116, 1964: 964 (HOL V, S. 109).

Gedruckte Quellen und Literatur: Adreßbuch Groß-Potsdam 1949, S. 858-861 (Gemeinde Ferch). - Protze, Ingrid / Schenk, Holger: Ferch, Mittelbusch, Kammerode und Kemmnitzer Heide. In: Der Landkreis Potsdam 3/4 (1993), S. 31-33.

\section{Finow}

Stadtgemeinde (seit 1935; seit 1970 Stadtteil von Eberswalde [1970-1993 Eberswalde-Finow]), bis 1952 Kr. Oberbarnim, 1952-1990 Kr. Eberswalde (Bez. Frankfurt/Oder), 19901993 Ldkr. Eberswalde, 1993 Ldkr. Barnim

EREIGNisSE BIS KRIEgSENDE: 25.4.1945 Einmarsch der Roten Armee (ebd., S. 65). 
EREIGNISSE NACH KRIEGSENDE: 5.11.1950 feierliche Glockenweihe der evang. Friedenskirche Finow mit zwei neu erworbenen Glocken, von denen eine aus Billendorf (Kr. Sorau) stammt, die von dort 1942 zur Einschmelzung auf den Hamburger „Glockenfriedhof “ überführt worden war (Appel, S. 58-60).

BevölkerungszAHLEN: 1925: 5317, 1939: 10481, 1946: 9616, 1964: 9980 (HOL VI, S. 145).

Katholiken: 1946: 529 (Städtebuch, S. 117). - Pfarrer war 1949 der bis 1945 in Stettin amtierende Johannes Flatau (geb. 1907) (Ostpriesterverzeichnis 2, 1949, S. 24).

LAGER: Heimkehrerlager „Waldlager“ (BLHA, Rep. 333, Nr. 577).

Archivalische Quellen: BArch, DO 2 ZVU, Nr. 39, Bl. 88 (Lager, Dez. 1945). - BLHA, Rep. 333 SED-Landesleitung Brandenburg, Nr. 577 („Heimkehrerlager“, 1946-1949; enthält u. a.: Finow-Waldlager). - Kreisarchiv Barnim, B.II.Finow (Stadt Finow), Nr. 15541 (Übersicht der Flüchtlinge aus dem Lager $[\rightarrow]$ Pinnow, 1945, 3 Bl.).

Literatur: Appel, Heidemarie u. Martin: Geschichte der Glocken der evangelischen Friedenskirche zu Finow. in: Eberswalder Jahrbuch 2016, S. 58-61.

\section{Finsterwalde}

Stadtgemeinde (1952-1993 Kreissitz), bis 1952 Kr. Luckau, 1952-1990 Kr. Finsterwalde (Bez. Cottbus), 1990-1993 Ldkr. Finsterwalde, 1993 Ldkr. Elbe-Elster

EREIGNisSe BIS KRIEgSENDE: Anf. Jan. 1940 besteht in Finsterwalde ein Auffanglager für 250 umgesiedelte Wolhynien- und Galiziendeutsche (Müller, S. 124). - Der „bekannte Lemberger Zahnarzt Willy Schweitzer“, der bereits 1940 als galiziendeutscher Umsiedler vorübergehend im Auffangslager Finsterwalde untergebracht war, flüchtete Anf. 1945 aus Litzmannstadt (Lodz) vor der Roten Armee zu Bekannten aus dieser Zeit nach Finsterwalde, „gründete dann in Finsterwalde eine gutgehende Zahnarztpraxis und verblieb dort bis zu seinem Ableben im Januar 1976“ (ebd., S. 124). - 29.1.1945 wird das Reserve-Lazarett Meseritz nach Finsterwalde evakuiert. „Dort nahm das Lazarett seine Tätigkeit wieder auf, bis es im April 1945 nach $[\rightarrow]$ Zossen ausweichen mußte" (Hielscher, Bl. 16). - 21.4.1945 Einmarsch der Roten Armee (Woitzik, S. 110; vgl. Töpler, Menschenwurm, S. 332). - Die Stadt gilt bei Kriegsende als relativ unbeschadet geblieben (Töpler, Menschenwurm, S. 295).

EREIGNISSE NACH KRIEGSENDE: „Über das ganze Jahr 1945 hin gab es Beerdigungen in erschreckender Zahl. Vaters [Superintendent Richard Spree] Kalender verzeichnete allein 423, ohne die vorgenannte Massenbeerdigung [nach ca. 80 Selbsmorden].“ (Woitzik, S. 117). - „1945 und 1946 starben in Finsterwalde sehr viele Babys (insgesamt 118). Sie starben hauptsächlich an Verdauungsstörungen." (Interview mit Ilse Block geb. Eknigk, zit. Woitzig, S. 117). - 29.4.1946: Alwin Schulz, Finsterwalde, Goethestraße 11, wendet sich wegen seines Vorhabens der Gründung einer „Arbeitsgemeinschaft deutscher Flüchtlinge“ an die Zentralverwaltung für deutsche Umsiedler 
in Berlin (Ost), die das Vorhaben in ihrer Antwort vom 14.5.1946 fallen zu lassen bittet (BArch, DO 1, Nr. 10/50, Bl. 423).

EREIGNISSE NACH 1990: 26.6.2004 „Familienfest mit Rußlanddeutschen in der Diakonie Finsterwalde“, dabei „Aussiedlerchor Edelweiß“ mitwirkend (Kühl, S. 86/Foto). - 2015 Aufstellung von Gedenksteinen am Lagereingang (s.u.).

BeVÖLKerungSzAHLEN: 1925: 15774, 1939: 19726, 1946: 20766, 1964: 22338 (Städtebuch, S. 151).

Katholiken (Erzbistum Breslau/Erzbischöfliches Amt Görlitz): 1925: 540, 1946: 2826 (Städtebuch, S. 151). - 1945: „Kuratus [Heinrich] Niedenzu [Pförten, Kr. Sorau] verliess bei der Räumung durch die Wehrmacht die Gemeinde [Pförten] und zog über Kottbus [ $\rightarrow$ Cottbus] nach Finsterwalde, wo er einige Wochen Aushilfe leistete. Von dort nach Erfurt, wo er Diasporahilfe leistete." (Töpler, Menschenwurm, S. 364). - Kaplan in Finsterwalde war 1945-1948 der bis 1945 in Brunzelwaldau (Kr. Freystadt in Schlesien) amtierende Felix Barnert (1883-1961), anschließend Kuratus in $\rightarrow$ Sonnewalde (Ostpriesterverzeichnis 2, 1949, S. 12; Töpler, Menschenwurm, S. 637).

(KREIS-)UMSIEDLERLAGER (Lager Wiesenhain), am Weg nach Siebenbrunnen/Ecke Lindenallee: 1943-1945 Zwangsarbeitslager („Fremarbeiterlager“), vorwiegend für polnische Zwangsarbeiter des Rüstungsbetriebs FIMAG, aber auch Franzosen u. Letten (LR online, 8.9.2007; Oette, S. 94-96, S. 94 Lageplan, S. 95 f. genaue Beschreibung der Anlage). - „Ende April 1945 war das Wiesenlager leer." (Oette, S. 96). - „Etwa ab Mai 1945 wurden im Wiesenlager deutsche Flüchtlinge untergebracht, bis sie teilweise andere Quartiere erhielten." (ebd., S. 97). - 14.9.1945 Befehl der Besatzungsmacht, das bisher „von Rückwanderern (Repatrianten)“ besetzte Lager Finsterwalde, das hierfür zum 10.9.1945 freigemacht werde, sofort „zur Aufnahme der Umsiedler vorzubereiten“ als „1 Lager für 10000 Menschen“ (Wille I, S. 64 f., in Liste von 9 in der Provinz Sachsen/Anhalt gelegenen Lagern genannt). - Ab 15.12.1945 belegt durch Anwesenheit der Grauen Schwestern im Lager (s. u.). - Kapazität am 1.1.1946: 2200 (BLHA, Rep. 203 MdI, Nr. 1163, Bl. 49). - 14.2.1946 Kreis- und Quarantänelager, Kapazität: 2200 (Oehlsen, S. 28). 14.2.1946 (Bericht): „Finsterwalde hat zwei Lager in Betrieb und einige im Aufbau [...]." (Töpler, Menschenwurm, S. 501). - 1946 Belegungsstärke: 2200 (Kaminsky, S. 159). - 30.4.1946 als eines der verbleibenden Umsiedlerlager genannt (DAB, I/9-15-1 Flüchtlingsseelsorge 19451951, unfol., [30.6.1946], [Anlage 3]) - 24.8.1946 Umsiedlerlager, Kapazität: 1500 (SAPMOBArch, DY 34/27880, Bl. 291). - „1946 im Sommer und im Frühherbst war das Lager erste Unterkunft für deutsche Heimatvertriebene. Danach diente das Gelände als Quarantänelager für Kriegsheimkehrer, die, um den Entlassungsschein und Lebensmittelkarten zu erhalten, sich hier der Prozedur der Entlausung und ärztlichen Untersuchungen unterziehen mussten." (Oette, S. 97). - 1.1.1947 Lager, Kapazität: 2400 (Oehlsen, S. 101). - 9.6.1947 Quarantänelager, Kapazität: 1500, Belegung: 7 (SAPMO-BArch, DY 34/27880, Bl. 239). - 25.11.1947 in Be- 
fehl der SMA Brandenburg in Liste „der [zum 30.12.1947] zu schließenden Lager“ aufgeführt (BLHA, Rep. 203 VP, Nr. 9, Bl. 43v), anschließende Nutzung als Wohnraum für Vertriebene vorgesehen (Oehlsen, S. 32). - „Ab 1947 (bis 1960) wurde das Lager Wiesenhain als TBCHeilstätte genutzt. Das verstärkte Auftreten dieser Krankheit war eine der vielen Folgen der Not der Kriegs- und Nachkriegsjahre. Zeitweise hielten sich hier über 100 Kranke mit offener Tbc auf, die so wegen der großen Ansteckungsgefahr von anderen Patienten des städtischen Krankenhauses und von der sonstigen Bevölkerung isoliert werden sollten. Die ärztliche Betreuung erfolgte durch den Lungenfacharzt Dr. Gattig und seine Krankenschwestern. Fast wäre diese Nutzung nicht möglich gewesen, denn der Befehl Nr. 71 der SMAD verlangte 1948 den Abriss der Baracken, um sie teilweise, u. a. in das Oderbruch, umzusetzen. Die Finsterwalder Stadtverwaltung erhob dagegen am 25.11.1948 bei der Landesregierung Einspruch und bat mit schließlichem Erfolg - um Übereignung an die Stadt Finsterwalde. / Ab 1961/62 wurde das Gelände umgestaltet, und erste Kleingärten entstanden. [...] Auf dem ehemaligen Küchenareal [...] ist inzwischen eine private Firma sesshaft. [...] / Einzelne Bereiche des Terrains Wiesenlager erfuhren jedoch auch andere Nutzungen, so unterhielt hier bis etwa 1991 der einstige VEB FIMAG ein Ersatzteillager, und die Stasi richtete in der ehemaligen Baracke 7 einen konspirativen Treff ein. [...].“ (Oette, S. 97). - „Aus eigenem Erleben als Kind berichtete Heinz Oette von Plünderungen des Lagers am Kriegsende durch Bürger der Stadt und zeichnete ein Bild der Nutzung in den folgenden Jahren zunächst als Durchgangslager für Flüchtlinge, 1946 als Aufnahmelager für die Vertriebenenwelle. Daran erinnert sich Alfred Burghardt noch deutlich. ,Wir sind mit dem Pferdefuhrunternehmen Thielow dort hingefahren worden, blieben zwei Wochen, bevor wir dann nach Crinitz kamen.' / Kriegsheimkehrer mussten ab 1947 das Wiesenlager als Quarantänelager durchlaufen, bevor sie Genehmigungen für Lebensmittelkarten bekamen, habe ihm Walter Starig aus eigenem Erleben im Gespräch bestätigt, erzählte Oette. [...] Wenige der festen Gebäude existieren bis heute und werden genutzt." (LR online, 8.9.2007 [Vortragsbericht]). - GedenKsteIn, seit 21.9.2015 am Ort des ehemaligen Lagereingangs, privat initiiert von Peter Schmidt (geb. 1943 Finsterwalde als Peter Pavlik), dessen tschechische Mutter 1943 Zwangsarbeiterin im Lager war (www.wege-gegen-das-vergessen.info [7.8.2018]): „Im Jahr 2011 holte er aus der mährischen Heimat seiner Mutter einen Baum, einen Speierling, und pflanzte ihn als ,Freiheitsbaum. Die Gedenksteine, von Vattenfall bereitgestellte Findlinge aus dem Tagebau $[\rightarrow]$ Welzow-Süd, die von der Pankau Naturstein GmbH bestens bearbeitet und und aufgestellt wurden, erinnern konkret an das Zwangsarbeiterlager der Nazis und das integrierte ,Kinderheim', in dem viele Kinder von Zwangsarbeiterinnen elendiglich starben. Die Gedenksteine stehen dort, wo sich der Eingang zum Lager befand und jetzt die Gartenanlage ,Am Wiesenhain' Erholung verspricht. Erinnert werden soll auch daran, dass das Lager bis 1954 als Auffang- und Quarantänelager und als Tbc-Station gedient hat. Allein 1946/47 seien über 10000 Menschen, Heimkehrer, Vertriebene und Flüchtlinge durchgeschleust worden. Hier schließt sich für Peter Schmidt der Bogen im Angesicht gegenwärtiger Flüchtlingsströme in Europa siebzig Jahre nach Ende des Zweiten Weltkrieges.“ Inschriften: 1. großer, aufrecht ste- 
hender Findling: „Erinnern/Zwangslager / Wiesenhain / 1943-1945 / 1945-1954 / Gedenken“; daneben kleinerer Findling: „Kinderlager / 1943-1945“ (LR online, 22.9.2015 mit Foto).

Station für ambulante Krankenpflege der Grauen Schwestern, ab 1946: Die zuvor in der Flüchtlingsbetreuung im Lager $\rightarrow$ Cahnsdorf tätigen Schwestern arbeiteten vom 15.12.1945 bis 1.12.1946 im Lager Finsterwalde. „Anfang 1946 mußten sie sich eine eigene Unterkunft außerhalb des Lagers in Finsterwalde suchen. Hier wurde am 6. Januar 1946 eine Niederlassung errichtet. Die Schwestern wohnten in der Uhlandstraße bei Frau Smolka" (Mertens, S. 478), mussten jedoch auf Wunsch des Bürgermeisters ausziehen und fanden erst am 1.6.1947 eine eigene Wohnung in der Wilhelm-Liebknecht-Straße 21, ab 15.8.1950 in größerer Dreizimmerwohnung in der Wilhelm-Liebknecht-Straße 5 (4 Schwestern, ambulante Pflege und Hilfe in der Seelsorge). Die Niederlassung gehörte zunächst zur Mutterhausprovinz, ab 22.7.1948 der Berliner Provinz unterstellt und, nach dem Mauerbau, am 2.10.1962 der Dresdener Ordensprovinz zugeteilt (ebd., S. 477-479). - Konventsoberinnen: Blandina Schubert (ab 1946, Richardis Heide (18.6.1947-1952), Chrysanta Machrowiak (25.11.1952-30.10.1958), Ceslawa Reimann (30.10.195-1.10.1959), Reinharda Kwaschny (ab 1.10.1959) (ebd., S. 477f.).

STÄDTEPARTNERSCHAFTEN: 10.9.1994 (Absichtserklärung) Dzierzgoń (Christburg, ehem. Westpreußen), 2006 noch erwähnt, nach 2010 nicht mehr erwähnt (Mitt. Stadtverwaltung Finsterwalde/Frau Freund, 31.8.2016).

VeRTRIEBENENVERBÄNDE NACH 1990: 21.3.1992 Vorbereitende „Versammlung der Heimatvertriebenen des Kreises Finsterwalde in der Gaststätte Lindenhof" mit ca. 400 Teilnehmern beschließt, Kreisverband zu gründen (Protokoll in den Akten der BdV-Landesgeschäftsstelle). - BdV-Kreisverband Finsterwalde, 8.4.1993, Ansprechpartner (erwähnt 1.7.1993): Hubert Arlt, Gruhno, erwähnt (Akten wie vor); 18.10.1994 bereits aufgegangen im (hier nicht behandelten) Kreisverband Elbe-Elster (Finsterwalde/Elsterwerda/Liebenwerda/Mühlberg/Herzberg) (Akten wie vor).

Archivalische Quellen: BArch, DO 1, Nr. 10/50, Bl. 423. - BLHA, Rep. 250 Landratsamt Luckau, Nr. 296 („Sanitäre Betreuung und Überprüfung der Umsiedlerlager Cahnsdorf und Finsterwalde“, 1945-1946); Nr. 298 („Umsiedlerlager Finsterwalde, Lager Wiesenhain“, 1946, 1947; enthält u. a.: Sterbeurkunden); Nr. 299 („Stellenpläne, Personalsachen und Abwicklungsangelegenheiten bei der Auflösung des Umsiedlerlagers Finsterwalde 1948“, 1946-1949).

Gedruckte Quellen und Literatur: Hielscher, Alexander Karl: Das Kriegsende 1945 im Westen des Warthelandes und im Osten der Kurmark. Typoskript. [Bielefeld 1986] (Archiv der Landesgeschichtlichen Vereinigung für die Mark Brandenburg, Berlin). - Kühl, Vilma: Eine Familiengeschichte Wolgadeutscher. In: Heimatkalender Bad Liebenwerda 56 (2004/05), S. 77-87. - Mertens, Johannes: Die Berliner Ordensprovinz der Grauen Schwestern von der heiligen Elisabeth 1859-1991. Reinbek bei Hamburg 1992, S. 477-479. - Müller, Erich: Transporte, Lager, Ansiedlung im Warthegau: Das Schicksal der galizien- und wolhyniendeutschen Umsiedler nach ihrem Grenzübertritt 1939/40. In: Zeitweiser der Galiziendeutschen 43 (2005), S. 104-157. - Oette, Heinz: Fremdarbeiterlager Wiesenhain. In: Der Speicher 12 (2009), S. 94-98. - Sieberhagen, Maik: Etwas zum Lager Wiesenhagen. In: Finsterwalder Heimatkalender 52 (2013 [2012]), S. 69-71 [Aufenthalt eines aus Breitenau stammenden Verwandten des Verf. als Kriegsheimkehrer im Lager, 24.5. bis 9.6.1946, aus Kriegsgefangenschaft in Frankreich über das Auffanglager Siebenborn bei Eisenach kommend, nennt Verpflegungsmengen für die Tage 7. bis 9.6.1946]. - Töpler, Menschenwurm, 
S. 332 f. (Bericht über Kriegsende in Finsterwalde), 501 u. ö. (siehe S. 663). - Wille I, S. 34, 64f. - Woitzik, Manfred: Was geschah vor 70 Jahren in Finsterwalde? In: Der Speicher 17 (2015), S. 104-122.

\section{Forst (Lausitz)}

Stadtgemeinde, 1897-1950 kreisfrei, 1.7.1950-1952 Ldkr. Cottbus, 1952-1990 kreisfrei (1952-1990 im Bez. Cottbus), 1990-1993 Ldkr. Forst (Kreissitz), 1993 Ldkr. Spree-Neiße (Kreissitz). - Die ehem. Stadtteile Forst-Berge (poln. Zasieki) und Forst-Scheuno (poln. Brożek) auf dem Ostufer der Neiße gehören seit 1945 zu Polen.

EREIGNisSe BIS KRIEgSEnde: Anf. Jan. 1940 besteht in Forst ein Auffanglager für 150 umgesiedelte Wolhynien- und Galiziendeutsche (Müller, S. 124). - Febr. 1945 finden die Schwestern der Kongregation der „Armen Dienstmägde Jesu Christi“ aus der Niederlassung Pförten (Kr. Sorau) nach dortigem Räumungsbefehl vom 13.2.1945 in der Niederlassung Forst Aufnahme, vier Pförtner Schwestern müssen aber noch im Febr. von hier weiter nach Erfurt flüchten (Mengel, S. 136). - Am 13.2.1945 „sammelte sich in [Sommerfeld/NL (Kr. Crossen)] ein größerer Treck [... von etwa] 1000 Personen mit Handwagen und Schubkarren [...]. Die Mehrzahl der Flüchtlinge ist in jener Nacht noch bis Forst gewandert, wo man sie in Sälen unterbrachte, denn Lagerstätten waren nicht vorbereitet.“ (Platzke, S. 100). - „Am 21. Februar 1945 forderte der Oberbürgermeister von Forst die Bevölkerung auf, die Stadt zu verlassen.“ (ebd.). - 16.4.1945: [Sowjet.] „Großangriff im Raum von Muskau - Forst.“ (Kriegstagebuch des OKW 4,2, S. 1244). - 17.4.1945: „Im Raum von Forst 1000 Luftwaffen-Einsätze und Angriffe auf 2 Brücken. Jedoch wurden die eigenen Linien im wesentlichen gehalten." (ebd., S. 1246). - 18.4.1945: „Bei Forst kam der Gegner vor. Um Forst selbst wird gekämpft." (ebd., S. 1249). - 19.4.1945: „Forst ging ganz verloren.“ (ebd., S. 1251). - „Am 19.4.1945 überqueren starke sowjetische Truppen bei Forst die Neiße." (Mewes, S. 31). - Im Zweiten Weltkrieg 85 \% der Bausubstanz zerstört (Städtebuch, S. 158).

EREIGNISSE NACH KRIEGSENDE BIS 1948: Ab 1945 wichtiger Grenzübergang für Vertriebenentransporte aus Polen (Schlesien). „Der Flüchtlingsstrom aus dem Osten überschwemmt Forst wie eine mächtige Flutwelle. Hinzu kommt eine katastrophale Ernährungslage" (Rieger, S. 18). 26.6.1945 Ankunft eines Trecks aus Christianstadt am Bober (Neumark), vorübergehende Unterbringung „in einer der großen Fabrikhallen“ (ebd.). - 8.10.1945 (SMA Brandenburg an Präsident der Provinzialverwaltung): ,in der Stadt Forst befinden sich 9270 Personen Deutsche, jugoslawischer Untertanenschaft. Diese Umsiedler haben keine Arbeit und ständigen Wohnort" (Wille I, S. 63), 15. bis 25.10.1945 soll deren Weiterleitung in die Kr. Luckenwalde (5000) u. ZauchBelzig (4270) erfolgen (ebd., S. 63 f.). - 21.10.1945 (Bericht der ZVU vom 25.10.1945): „Am letzten Samstag (21.10.45) sollen etwa 4000 Personen in Forst eingetroffen sein, wovon sie 2000 nach Cottbus abgeschoben haben sollen. Die übrigen sind in anderen Richtungen weitergezogen." (BArch, DO 2/38, Bl. 95). - 3.12.1945: „In Forst sind gestern 6000 Umsiedler eingetroffen. Weitere Tausende werden erwartet. Von einem Stop an der Grenze ist anscheinend nichts bekannt." (BArch, 
DO 2/39, Bl. 53). - Ab Juli 1946 werden die Transporte aus Stettin in die SBZ über Posen und Zielona Góra/Grünberg in Schlesien nach Forst geleitet (Borodzej/Lemberg, Bd. 3, S. 492). „Bis Oktober 1947 sind etwa 800 000“Vertriebene über das Durchgangslager Teuplitz (Kr. Sorau) und den Grenzübergang Forst geschleust worden (Mengel, S. 157). - Herbst 1947 Bildung einer nicht genehmigten „Interessengemeinschaft ausgesiedelter Schlesier in der russisch besetzten Zone Deutschlands“ in Forst mit „Landesleitung Brandenburg“, initiiert von einem aus Oberschlesien stammenden, in Forst wohnhaften Diplomkaufmann und Versicherungsagenten (geb. ca. 1903, LDP-Mitglied), die von ihrem Forster Büro aus im Frühjahr (wohl Mai) 1948 „etwa 500 Postkarten [...] an sämtliche Umsiedlerausschüsse des Landes Brandenburg [...]" verschickt mit der Bitte, „uns eine Persönlichkeit aus den Umsiedlerkreisen namhaft zu machen, die bereit ist, für uns als Vertrauensperson in ihrer Gemeinde tätig zu sein", worauf 176 Orts-Umsiedlerausschüsse antworten; Mai 1948 Durchsuchung des Büros und vorübergehende Verhaftung des Initiators, der sich nach Entlassung angeblich in den Kr. Teltow absetzt (Schwartz, S. 508 mit Quellenangaben und näheren Einzelheiten, vgl. auch S. 463 f.); 12.5.1948 Warnung des Rates des Kr. Lebus an die Mitglieder der Ortsumsiedlerausschüsse, sich an der Interessengemeinschaft zu beteiligen (Wille III, S. 143, Nr. 145 nach BLHA, Rep. 250 Lebus, Nr. 356). - 1948 werden die Transporte aus dem Sammelpunkt Stargard Szczeciński/Stargard in Pommern in die SBZ über Tuplice/Teuplitz [Kr. Sorau] nach Forst geleitet (Borodziej/Lemberg, Bd. 3, S. 570).

EREIGNISSE 1949-1990: „Ende 1949 waberte des Gerücht durch die Stadt, das ehemals deutsche Gebiet sei Polen nur für fünf Jahre überlassen worden; eine baldige Revision stehe deshalb an" (Blöß, Grenzen und Reformen, S. 67). - 1.6.1975 Heimattreffen von mehr als 50 Vertriebenen aus Triebel (Kr. Sorau) in einem öffentlichen Lokal, als „Ausflug der Volkssolidarität“ getarnt (Amos, S. 224).

EREIGNISSE NACH 1990: 1990 erstes gesamtdeutsches Forster Heimatreffen in Forst (LR, 26.10.2009). - Seit 1990 regelmäßige Heimattreffen der vertriebenen ehem. Bewohner der Kleinstadt Gassen (Kr. Sorau) (poln. Jasień), bis 2002 (organisiert von Helmut Schüttke) im „Gasthaus Sacro“ in Forst, ab 2003 in $\rightarrow$ Simmersdorf (LR, 29.8.2003). - „Seit 1992 gibt es Kontakte des Museumsvereins Forst zum Sorauer Heimatkreis." (Lausitzer Rundschau, 14.5.2005). - 1993 Amtsniederlegung des Vorsitzenden des Landesverbandes Brandenburg der Landsmannschaft Berlin-Mark Brandenburg, Ullrich Kohlstock (Forst/L.) (Märkischer Informationsdienst 1993, Nr.7/8, S.18).- 16.12.2002 Eröffnung der deutsch-polnischen Grenzbrücke Forst-Zasieki nach 13-monatiger Bauzeit (www.forst-lausitz.de [2.6.2017]; BdV-Notizen 1 (2003)1, S. 7). - 2004 (nach Vorgesprächen seit 1994) Übergabe der Sorauer Heimatsammlung von Günther Krause (Dortmund), ehem. Herausgeber des „Sorauer Heimatblatts“, an die Stadt Forst (s.u.). - Seit 2006 jährliche „Heimattreffen des ehem. Sorauer Landes“ im Landgasthof „Gasthaus Sacro“ (Forster Straße 75), zuvor in $\rightarrow$ Kolkwitz (Newsletter Sorauer Land, Nr. 1/Senioren-Union der CDU Cottbus, Sept. 2015; Sorauer Sommerfelder Hefte, 16, 2016, Nr. 2, S. 3); 10./11.9.2016 25. Heimattreffen (65 Teilnehmer) mit Übernahme der 
Patenschaft für ein Rosenbeet im Ostdeutschen Rosengarten durch die Sorauer Heimatfreunde am 10.9., am 11.9. Fahrt nach Sorau/Żary (Lausitzer Rundschau, 29.8.2016; Sorauer Sommerfelder Hefte, 16, 2016, Nr. 2, S. 4 mit Abb.). - 2008 15. (und aus Altersgründen letztes) Pförtener Heimattreffen im „Gasthaus Sacro“ mit 70 Teilnehmern (Lausitzer Rundschau, 12.6.2008; erstes Treffen 1993 in $\rightarrow$ Kolkwitz). - 17.10.2015 (jährliches) Heimattreffen des Glogauer Heimatbundes, Bezirksgruppe Lausitz/Forst, in der Gaststätte Rennbahn (Lausitzer Rundschau, 13.10.2015).

BevölKerungszAhlen: 1925: 37 693, 1939: 44763, 1946: 29 829, 1964: 29860 (Städtebuch, S. 158). - Juli 1946: 1627 „Umsiedler“ (BLHA, Rep. 203 MdI, Nr. 1074, Bl. 52; Abb.: Mietk, S. 66). - 29.10.1946: 29829 Einwohner, davon aus Ostpreußen: 44, Hinterpommern 38, Ostbrandenburg 1301, Schlesien 500, Tschechoslowakei 76, Polen 93, Danzig-, Rumänien 1, Baltikum 9, Sowjetunion 4 (Volkszählung 1946). - 31.12.1948: Gesamtbevölkerung: 31 842, davon „Umsiedler und Evakuierte“: 9476 (Grandke, S. 46). - Eingemeindung von Vertriebenen: Juni 1948: 1735 (ebd., S. 103), Febr. 1949: 9528 (ebd., S. 104).

Katholiken (Erzbistum Breslau/Erzbischöfliches Amt Görlitz): 1925: 2243, 1930: 2 195, 1946: 1673 (Städtebuch, S. 158).

UMSIEDlERLAGER KaISERHOF („Hotel Kaiserhof“): Kapazität am 31.12.1945 (Lager „Hotel Kaiserhof"): 500 (BArch, DO 2/45, Bl. 41). - Kapazität am 1.1.1946: 500 (BLHA, Rep. 203 MdI, Nr. 1163, Bl. 49). - 14.2.1946 Auffanglager „Kaiserhof“, Kapazität: 500 (Oehlsen, S. 28). 1946 Belegungsstärke („Forst“): 500 (Kaminsky, S. 159). - 20.5.1946: Aufnahmfähigkeit: 500 (für Quarantäne nur 300). Lagerleiter: Hildegard Owczarek, wohnt Forst (Lausitz) Kaiserhof (BArch, DO 2/38, Bl. 98) [wahrscheinlich identisch mit der späteren Lehrerin Hildegard Owczarek geb. N.N. (später in 2. Ehe verh. Goerz) in Forst (geb. 1914, gest. 1993; freundlicher Hinweis Frank Owczarek, Forst, 31.7.2018)]. - 4.7.1946 (Reisebericht der ZVU): „Das Lager ist vom Hotel Kaiserhof seit Anfang Juni in die Jahn-Schule, Jahnstr. verlegt worden." (BArch, DO 2/38, Bl. 101-104, hier Bl. 101). - „Nach Kriegsende diente das Hotel ca. ein halbes Jahr als Lazarett und es waren auch kurzzeitig die Russen drin. Gleich danach ging es mit dem Betrieb wieder weiter als ,Hotel Dahms.“' (Mitteilung Frank Brekow, Forst, 22.7.2018).

UmSiedlerlager Jahnschule (Durchgangslager), Jahnstraße 3, am Südrand des Stadions (bis Kriegsende Nutzung als Reservelazarett, Schulbetrieb Dez. 1944 eingestellt, Gebäude bei Kriegsende nur leicht bechädigt; seit 1991 „Friedrich-Ludwig-Jahn-Gymnasium Forst“): 24.10.1945 noch von der sowjet. Besattungsmacht besetzt, aber als Auffanglager für Flüchtlinge vorgesehen: „Die Bezirksverwaltung wird über den Bezirkskommandanten die Freimachung der Jahnschule durch die Besatzung zu erreichen suchen [...]." (Töpler, Menschenwurm, S. 450). Im „Verzeichnis der errichteten und vorgesehenen Umsiedlerlager im Verwaltungsbezirk Cottbus“ vom 15.12.1945 ohne „Personenzahl“ genannt (Töpler, Menschenwurm, S. 472; Zuordnung $\mathrm{zu} \rightarrow$ Döbern hier offenbar irrtümlich). - 17.12.1945 als eines von drei Auffanglagern erwähnt 
(BLHA, Rep. 206, Nr. 2965, unfol.). - Kapazität am 31.12.1945 (Lager „Forst-Jahnschule“): 2000 (BArch, DO 2/45, Bl. 41). - 4.7.1946 (lt. Reisebericht der ZVU): Lagerleiterin: „Frau Owczarek (ehem. Flüchtlingsfrau)“. Aufnahmefähigkeit: 3000. Sanitäre Betreuung: Frl. Dr. Zimmermann, „die auch dort wohnt" (BArch, DO 2/38, Bl. 102). - 24.8.1946 Umsiedlerlager Jahnschule, Kapazität: 1 500-2 500 (SAPMO-BArch, DY 34/27880, Bl. 291). - 1.1.1947 Kapazität: 2500 (Oehlsen, S. 101). - 9.6.1947 Durchgangslager, Kapazität: 2 500, Belegung: 81, TyphusFälle: 2 (SAPMO-BArch, DY 34/27880, Bl. 239). - 25.11.1947 „Aufnahmefähigkeit von 2500 Mann, Annahmestelle für Umsiedler" (BLHA, Rep. 302, VP, Nr. 9, Bl. 43). - 31.12.1947, Jan./ Febr. 1948 Durchgangslager Forst-Jahnschule eines von 7 verbleibenden Lagern in Brandenburg (BLHA, Rep. 203 MdI, Nr. 1198, Bl. 28v). - Jan. 1948 (Anf./Ende) laut Lagerbestandsmeldung vom 10.2.1948 im Lager 6/ 1 Insassen (BLHA, Rep. 203 MdI, Nr. 1115, Bl. 7). Okt./Nov. 1948 Durchgangslager, untergebracht in der Jahnschule Forst, eines von 5 Lagern in Brandenburg (BLHA, Rep. 203 MdI, Nr. 1198, Bl. 46; siehe auch Wille II, S. 135, Nr. 136). 26.4.1949 desgleichen (BLHA, Rep. 203 MdI, Nr. 1198, Bl. 66). - Lagerpersonal am 1.1.1948: Lagerleiter: Gahrau; Wirtschaftsleiter: Wendt; Lagerarzt: ... [?] (BLHA, Rep. 333, Nr. 575, B1. 27 [Liste der leitenden Angestellten]). - 26.4.1949 „Forst, Jahnschule (Durchgangslager)“ noch in Lagerliste genannt (BLHA, Rep. 203 MdI, Nr. 1198, Bl. 66).

StÄdtepartnerschaften: 2000 Lubsko, Polen (Sommerfeld/NL, ehem. Kr. Crossen, Provinz Brandenburg) und Brody, Polen (Pförten, ehem. Kr. Sorau, Provinz Brandenburg).

VERTRIEBENENVERBÄNDE NACH 1990: (1) BdV-Kreisverband Forst/Nl., gegründet 1991 (Märkischer Informationsdienst 8/1994, S. 14), 18.10.1994 erwähnt mit Liselotte Schefter als Vorsitzender (Akten der BdV-Landesgeschäftsstelle, ebd. keine weiteren Unterlagen). - (2) Landsmannschaft Berlin-Mark Brandenburg, Kreisgruppe Forst/Nl., 1996 erwähnt mit Sitz in Forst, Gymnasialstr. 17, wo sich auch eine mobile Ausstellung (kleine Wand) „Landsmannschaft Berlin-Mark Brandenburg" befindet (BdV-Handbuch 1996, S. 45). 4.3.1991 wird der (in Lübeck ansässige) Heimatkreisbetreuer der Landsmannschaft Berlin-Mark Brandenburg für Forst Gerhard Krumm (1909-2003) Ehrenbürger von Forst (Märkischer Informationsdienst 1991, Nr. 2/3, S. 4), er hatte vor 1990 zahlreiche Forster Heimattreffen in Westdeutschland organisiert, beigesetzt 13.2.2004 auf dem Forster Friedhof (LR, 26.10.2009).

SAMmLung Sorau (Sorauer Heimatarchiv) im Stadtarchiv Forst (Lausitz): „Das Sorauer Heimatarchiv wurde initiiert und betreut von Günther Krause aus Dortmund. Das Archiv war von 1961 bis 1990 in der Sorauer Heimatstube in Hamm/Westfalen ausgestellt. Im Jahr 2004 übergab Günther Krause die Sammlung zur Bewahrung an die Stadt Forst in der Niederlausitz. Dort betreute das Stadtarchiv in Zusammenarbeit mit dem Brandenburgischen Textilmuseum Forst die Bestände, die im Jahr 2005 im Rahmen einer Sonderausstellung der Öffentlichkeit präsentiert wurden. Für einige Zeit war die Sammlung im Depot des Textilmuseums untergebracht. Im November 2009 erfolgte der Umzug in das Magazin des Stadtarchivs im Forster Rathaus, wo die Bestände nun in der Obhut der Mitarbeiter des Stadtarchivs für Recherchen zugäng- 
lich sind. Teile der Sammlung sollen zukünftig im Zuge der Umgestaltung der Forster Kultureinrichtungen in einer ständigen Ausstellung präsentiert werden. / Die regionalgeschichtliche Sammlung für den früheren Landkreis Sorau enthält vor allem Schriftgut, Bücher zur Regionalgeschichte, Ortschroniken, Archivalien, Zeitungsausschnitte sowie historische Karten und Pläne. Zu ihren Beständen gehören aber auch archäologische Funde (Urnen), Sorauer Textilien und Porzellan der Firma Carstens aus den Jahren vor 1945." (www.bkge.de/Heimatsammlun gen). - Das Stadtarchiv Forst bemüht sich um die Weiterführung der Sammlungstätigkeit zum Kreis Sorau (vgl. Aufruf, Dokumente, Fotos u. a. einzusenden. in: Sorauer Sommerfelder Hefte 16, 2016, Nr. 2, S. 249).

ARchivalische QUeLlen: BArch, DO 2 ZVU, Nr. 38, enthält u. a.: zahlreiche und z.T. sehr ausführliche Berichte zum Lager Forst (Kaiserhof u. Jahnschule) durch örtliche Lagerleiter und Bereisung durch ZVU, 8.9.1945 bis 28.6.1949 (Bl. 91-178); „Bericht über die Lage in Forst", 25.10.1945 (Bl. 95-97); Wirtschaftsberichte des Lagers Forst (Kaiserhof) für 1. u. 2. Hälfte Mai 1946 (Bl. 98-99); ausführlicher Reisebericht der ZVU über die Lage in Forst, 4.7.1946 (Bl. 101-104); ausführlicher Bericht der Stadtverwaltung über Kontrolle des Umsiedlerlagers Jahnschule (Abschrift), 20.8.1946 (Bl. 106r-107v). - BArch, DO 2/39, Bl. 32-33, 59 (Lager, 1945). - BLHA, Rep. 256 Umsiedlerlager Küchensee, Nr. 242 (Transport Nr. 381 aus Forst/L., 6.10.1946). - Stadtarchiv Forst (Lausitz).

GedRuckte QUellen: Dokumentation der Vertreibung I/1, S. 431; I/2, S. 224, 243, 347 f., 549, 635, 774, 838. Forster Wochenblatt. Die Heimatzeitung für Forst und Umgebung 1 (1990) ff. - 25. Sorauer Heimattreffen. In: Sorauer Sommerfelder Hefte 16 (2016), Nr. 2, S. 3-4. - Kriegstagebuch des OKW 4,2, S. 1122, 1125, 1128, 1132, 1147, 1244, 1246, 1249, 1251. - Töpler, Menschenwurm, S. 450 u. ö. (siehe S. 663). - Wille I, S. 63 f. (Nr. 35-37), 245, 260 f., 311 f.; II, S. 74 f., 77 f., 80, 83 f., 135; III, S. 143, 394.

Literatur: Amos, Heike: Die Vertriebenenpolitik der SED 1949 bis 1990. München 2009, S. 224. - Blöß, Wolfgang: Grenzen und Reformen in einer Umbruchgesellschaft. Berlin 2014. - Borodziej/Lemberg, Bd. 3. - Mewes, Fritz: 8. Mai - 60. Gedenktag zum Ende des 2. Weltkrieges. In: Rathenower Heimatkalender 49 (2005 [2004]), S. 31-34. Müller, Erich: Transporte, Lager, Ansiedlung im Warthegau: Das Schicksal der galizien- und wolhyniendeutschen Umsiedler nach ihrem Grenzübertritt 1939/40. In: Zeitweiser der Galiziendeutschen 43 (2005), S. 104-157. - Platzke, Max: Geschichte einer ostdeutschen Kleinstadt kommunalpolitisch betrachtet. Berlin-Charlottenburg 1956. Rieger, Helmut: Licht und Brot in Luckau. In: Luckauer Heimatkalender 32 (2000), S. 18-21 [Zwischenaufenthalt von Christianstädter Familien 26./27. Juni 1945]. - Schwartz, Michael: Vertriebene und „Umsiedlerpolitik“. München 2004, S. 463 f., 507-509. - Waack, Christoph: Stadträume und Staatsgrenzen. Geteilte Grenzstädte des mittleren und östlichen Europa im Kontext lokaler Alltagswelten, nationaler Politik und supranationaler Anforderungen. Leipzig 2000, S. 56-61. -www.bkge.de/Heimatsammlungen/Verzeichnis/Herkunftsgebiete/Ostbrandenburg/Sorau.php [20.9.2016].

\section{Forst-Noßdorf}

1940 nach $\rightarrow$ Forst (Lausitz) eingemeindet (zuvor Landgemeinde im Kr. Sorau)

EReignisse NACH KRIEgSEnde: 1949 „Umsiedlerball“, organisiert von Käthe Herkner und Erika Dziumbla für vertriebene ehem. Bewohner der nun polnischen Kleinstadt Gassen (Kr. Sorau) [poln. Jasień]. „Damals hatten sich Hunderte der ehemals knapp 4000 Einwohner von Gassen in Noßdorf getroffen." Das Treffen „durfte keine Neuauflage erfahren“. Seit 1990 treffen sich die ehem. Gassener in $\rightarrow$ Simmersdorf (Lausitzer Rundschau, 19.8.2005). 


\section{Frankenfelde}

Landgemeinde (seit 5.12.1993 Ortsteil von $\rightarrow$ Luckenwalde), bis $1946 \mathrm{Kr}$. Jüterbog-Luckenwalde, 1946-1952 Kr. Luckenwalde, 1952-1990 Kr. Luckenwalde (Bez. Potsdam), 1990-1993 Ldkr. Luckenwalde, 1993 Ldkr. Teltow-Fläming

EREIGNISSE NACH KRIEgSENDE: 1945 „Umsiedlerfamilien aus allen Teilen Europas zogen täglich durch unser Dorf. Manche machten Halt. Viele zogen weiter. Die Bauernhäuser waren zum Teil bis unters Dach belegt, selbst auf den Stallböden oder Kellerböden wurde gehaust. Die Einwohnerzahl war demzufolge 1946 auf 559 angestiegen." (http://www.unser-frankenfelde. de/Chronikseite.htm [6.1.2017]). - In der Bodenreform 13,7 ha von 289 ha an 4 Umsiedler vergeben (HOL X, S. 138).

Bevölkerungszahlen: 1925: 488, 1939: 396, 1946: 559, 1964: 420 (HOL X, S. 139).

\section{Frankfurt (0der)}

Stadtgemeinde, bis 1950 Stadtkr., 1.7.1950-1952 Ldkr. Frankfurt (Oder), ab 1952 Stadtkr. (1952-1990 Bezirksstadt im gleichnamigen Bez.)

EREIGNISSE vor 1933: Nach 1918 Zuzug von Flüchtlingen aus Posen und Westpreußen („Ostmark“- bzw. Paulinenhofsiedlung).

Literatur zu Den Siedlungsbauten: Gramlich, Sybille, u. a.: Stadt Frankfurt (Oder) (Denkmale in Brandenburg, Bd. 3). Worms am Rhein 2002, S. 310-312. - Höper, Eva-Maria: Frankfurt an der Oder. Der Architekt Martin Kießling (1879-1944). Städtebau der zwanziger Jahre zwischen Traditionalismus und Reformbewegungen. In: Brandenburgische Denkmalpflege 3 (1994)2, S. 81-93. - Kießling, Martin: Ostmarkbauten. Städtebau in einer Mittelstadt. Stuttgart 1925. - Voigt, Horst: Die Ostmarkbauten in Frankfurt (Oder). In: Historischer Verein zu Frankfurt (Oder) e. V. Mitteilungen 2003, H. 2, S. 2-25.

EREIGNISSE BIS KRIEGSENDE 1945: 1945: Mitte Jan. Tagung aller brandenburgischen [mit der Unterbringung, Verpflegung und Betreuung der Flüchtlingsströme beauftragten] NSV-Kreisamtsleiter im NSV-Gauamt in Frankfurt (Oder), Halbe Stadt 7 (Buwert, S. 47). - 19.1. Sprengung der Eisenbahnbrücke durch Wehrmachttruppen (Brisch/Buwert/Schieck, S. 7). - 20.1. Eintreffen des Gauleiters und Reichsstatthalters Arthur Greiser aus Posen in Frankfurt (Oder) (Buwert, S. 50; Brisch/Buwert/Schieck, S. 4; Tschäpe, S. 109). - 21.1. Eintreffen der ersten Flüchtlingswelle aus Ost- und Westpreußen, dem Wartheland und der Neumark in Frankfurt (Oder) per Bahn und mit motorisierten Fahrzeugen (Buwert, S. 49); Frankfurt (Oder) wird Durchgangsstadt für die Ostflüchtlinge (Brisch/Buwert/Schieck, S. 4). „An den Wagenschildern konnte man Fuhrwerke aus Ost- und Westpreußen, dem Wartheland und Ostbrandenburg erkennen ... z B. erinnere ich mich an mehrere städtische Verkehrsbusse aus Lodz (damals Litzmannstadt), die durch ihre merkwürdige Karosserie und die Linienschilder auffielen." (Erinnerung des damaligen Frankfurter Schülers Dietrich Ehrhardt, 1992, zit. in Buwert, S. 49). - 21.1.1945: 
„Unter den Strömen von Flüchtlingen, die sich über die Oder retten, erreichte zuletzt am 21. Januar 1945 ein Treck aus dem Posener Land Frankfurt. Flüchtlinge zu Fuß, mit Pferdewagen oder auf Eisenbahnzügen ergossen sich in die bis dahin offene Stadt." (Słubice, S. 108). - Ab 21.1.1945 erreichten über die Stadtbrücke (Steinbrücke) „viele Flüchtlinge, insbesondere aus dem Warthegau, das rettende Westufer der Oder" (Schneider, Frankfurter Oderbrücken, S. 9). - 22.1. Nachsprengung der Eisenbahnbrücke (Brisch/Buwert/Schieck, S. 7); HJ und BDM organisieren einen Bahnhofsdienst für die ankommenden Flüchtlinge (Brisch/Buwert/Schieck, S. 4). - 25.1. Eröffnung der Zentralstelle für vermisste Flüchtlinge in Frankfurt (Oder), Halbe Stadt 7 (Brisch/Buwert/Schieck, S. 4). - 26.1. Frankfurt (Oder) zur Festung erklärt (Buwert, S. 49; Brisch/Buwert/Schieck, S. 4). - 29.1. Lehrkräfte und Schüler der Alten Städtischen Oberschule werden zur Flüchtlingsbetreuung und für Kurierdienste eingesetzt (Brisch/Buwert/Schieck, S. 4). - Ende Januar 1945 Eintreffen der zweiten Flüchtlingswelle (Trecks mit Pferdegespannen und Fußgängern) (Buwert, S. 51). - 31.1. Rote Armee überschreitet die Oder bei Frankfurt und bildet Brückenkopf. - 3.2. Sprengung des Fliegerhorsts im benachbarten Kunersdorf, Kr. Weststernberg (Wir waren damals 19, S. 132) - - 4.2. Beginn der systematischen Zwangsevakuierung der Frankfurter Zivilbevölkerung (Brisch/Buwert/ Schieck, S. 7); Zwangsräumung der Dammvorstadt sowie von Beresinchen (Wir waren damals 19, S. 131). „Eine förmliche Evakuierung der umliegenden Dörfer erging nicht; hier setzte beim Herannahen der Roten Armee eine verzweifelte Fluchtbewegung ein." (Stubice, S. 108). - 5.2. Räumung der Gubener Vorstadt (Wir waren damals 19, S. 131). - 8.2. Geheime Verlegung der Regierung Frankfurt nach Westen auf Anordnung Himmlers; nur ein höherer Beamter soll in der Stadt verbleiben; der städtische Omnibusverkehr wird ausschließlich für den Transport der Flüchtlinge eingesetzt (Brisch/Buwert/Schieck, S. 7). - 13.2.1945 Einstellung des Straßenbahnbetriebs einschließlich der Verbindung in die Dammvorstadt (Słubice, S. 115). - Nächte zum 22. und zum 23.2.1945 Sprengung der Eisenbahnbrücke (Nachsprengung auf der Westseite in der Nacht zum 5.4.) (Schneider, Oder, S. 12; ders, Frankfurter Oderbrücken, S. 17). 24.2. Befehl des NSDAP-Kreisleiters zur Zwangsevakuierung der Lebuser und der Gubener Vorstadt (Wir waren damals 19, S. 133). - 20.3. Auflösung der Wehrbezirkskommandantur Frankfurt und Verlegung nach Fürstenwalde (Brisch/Buwert/Schieck, S. 12). - 18.4. (abends) Beginn der Räumung des Brückenkopfes Dammvorstadt (Brisch/Buwert/Schieck, S. 14). 19.4. (morgens 5.29 Uhr) Sprengung der steinernen Oderbrücke (Stadtbrücke) durch die abziehende Wehrmacht (Brisch/Buwert/Schieck, S. 14, 16; Schneider, Oder, S. 13; ders., Frankfurter Oderbrücken, S. 9 f.; Słubice, S. 108). - 21.4. Aufhebung des Festungsstatus (Brisch/ Buwert/Schieck, S. 14). - 22.4. (abends) Rückzug der Wehrmachts- und Volkssturmverbände aus Frankfurt (Brisch/Buwert/Schieck, S. 14). - 23.4. (frühe Morgenstunden) Einmarsch der sowjet. Truppen nach dreimonatiger Belagerung (Brisch/Buwert/Schieck, S. 14; Wir waren damals 19, S. 136; Słubice, S. 109). - 23.4. Einzug der bereits in Zielenzig gebildeten sowjet. Kommandantur für Frankfurt in die Stadt (Brisch/Buwert/Schieck, S. 14). - Stadt zu 65 \% zerstört (Jentsch, S. 442). 
EREIGNISSE NACH KRIEGSENDE: 4.5.1945 Fertigstellung einer provisorischen Oderbrücke (Behelfsbrücke, hölzerne Pontonbrücke auf gerammten Pfählen) nördlich der zerstörten Steinbrücke (von Lebuser Mauerstraße zum Standort des Denkmals für Prinz Leopold von Braunschweig), für Pferdefuhrwerke und leichte Kraftfahrzeuge passierbar, genutzt nachweislich im Mai 1945 von Rückkehrern zur Dammvorstadt und am 17. Juni 1945 von Vertriebenen, abgebrochen erst nach Mai 1953, nachdem Stadtbrücke wieder nutzbar (detailliert: Reiß, Oderübergänge; Schneider, Frankfurter Oderbrücken, S. 10 f.; ferner: Słubice, S. 109). - Ab Sommer 1945 (geteilte) Grenzstadt, jahrelang wichtige Durchgangsstation für Millionen Heimkehrer, Flüchtlinge und Vertriebene. „Umsiedler-, Heimkehrer- u. Kriegsgefangenenströme unbekannten Ausmaßes über F.[rankfurt (Oder)] Richtung W[esten]“ (Städtebuch, S. 167). Ansiedlung zahlreicher Vertriebener in der weitgehend evakuierten bzw. verlassenen Stadt. - 1945 (Erinnerungsbericht des ab Ende Juni 1945 in der Stadt befindlichen KPD-Organisationsleiters): „Zehntausende von Flüchtlingen durchzogen täglich die zertrümmerte Stadt von Ost nach West. An der Oder staute sich alles. Sie wollten Obdach, Nahrung und Hilfe für Kranke und Erschöpfte. Im Weiterziehen hinterließen sie uns in den Ruinen Leichen, Kranke und elternlose Kinder. Es gab nur einige behelfsmäßige Hospitäler, wo kranke und operierte Menschen auf Strohsäcken, ohne Bettwäsche auf dem Fußboden liegen mußten. Mangel an Ärzten, Pflegepersonal und Medikamenten machte jede Hilfeleistung fast zur Unmöglichkeit. Die Seuchengefahr steigerte sich täglich. Es gab weder Milch noch andere Stärkungsmittel. Es gab nicht einmal Brot. Als es uns gelungen war, etwas Getreide aus den umliegenden Landkreisen zu requirieren, fehlte es an Transportmitteln. Als wir dann etwas Getreide herangeschafft hatte [n], konnte es in den zerstörten Mühlen nicht zu Mehl verarbeitet werden. Das große Entgegenkommen des sowjetischen Stadtkommandanten ermöglichte es, in der großen Mühle in $[\rightarrow]$ Müllrose zu mahlen. Die noch brauchbaren Bäckereien waren bereit zu backen, jedoch fehlte es an Brennmaterial. Tüchtige Bürger und besonders junge Genossen bargen Holz aus den Ruinen. [...].“ (Jentsch, S. 443). - 27.6.1945: „Flüchtlinge aus Drossen, die aus Frankfurt mit dem Zug gekommen sind, hat der Russe mit dem Wagons [so!] auf dem Bahnhof [Pillgram bei Frankfurt (Oder)] stehen lassen. Die Lokomotive abgehängt und die Flüchtlinge dem Schicksal überlassen. Jetzt warten sie vergeblich, bis der nächste Zug kommen soll, der sie mitnehmen soll, aber nun halten die Züge nicht mehr in Pillgram." (Tagebuch Willy Lorenz, S. 275). - Ende Juni 1945 (Erinnerungsbericht einer aus Birkholz, Kr. Züllichau-Schwiebus, Vertriebenen): „Hunderttausende von Flüchtlingen waren angekommen, und immer neue Trecks überfluteten die Straßen. Die Stadt war diesem Zustrom gegenüber hilflos, es gab keine Quartiere und kein Brot für diese hilflosen Menschen, die nun obdachlos auf den Straßen blieben. Als wir ankamen, standen viele beladene Karren und Kisten an der Oderbrücke. Wir hörten, daß kurz vor unserer Ankunft dort ca. 70 Familien eines Trecks ihrem Leben ein Ende gemacht hatten, indem sie sich in die Oder stürzten, denn diese Bauern konnten den Verlust ihrer Höfe nicht fassen und begingen aus Verzweiflung Selbstmord. Vier Nächte lagen wir in den Tunnels des Hauptbahnhofes, [...]. Wir warteten darauf, in einen der überfüllten Kohlenwagen der Züge nach Berlin einsteigen zu können. Sie wurden aber von Tausenden gestürmt und es war mir unmöglich, da heraufzusteigen." / [...]. „(Dokumentation der Vertreibung I/2, S. 687).- 
7.7.1945 (Tagebucheintrag einer von der Roten Armee dienstverpflichteten deutschen Schwesternhelferin): „Die Deutschen auf der polnischen Oderseite sind alle über die Oder abgeschoben worden. Tagelang ziehen endlose Kolonnen an unseren Fenstern vorbei. Männer, Frauen und Kinder, mit Handwagen und Paketen, ein furchtbares Bild. Am Anfang haben wir ihnen ein bisschen Obst [S. 87] gegeben, aber das ist uns schnell streng verboten worden, und vor unseren Fenstern läuft deshalb dauernd eine Wache herum." (Ruf, S. 86f.).- 15.7.1945 verstärktes Eintreffen durchziehender Flüchtingsströme aus dem Osten in Frankfurt (Oder) (Brisch/Buwert/Schieck, S. 45). - [Juli] 1945: „Frankfurt/Oder war von Vertriebenen und Flüchtlingen überfüllt. Sie erhielten keine Nahrung und wurden von der Verwaltung aufgefordert, weiterzuziehen. Alte und Gebrechliche, die nicht mehr gehen konnten, wurden mit Wagen bis zur Stadtgrenze transportiert. Von dort transportierten sie andere, angrenzende Gemeinden weiter. I In den folgenden Monaten starben dort sehr viele Menschen an Hunger, Seuchen und Entkräftung. Es sollen bis September 1945 allein in Frankfurt über 14000 gewesen sein." (Typoskript Post, S. 4). - Juli/Aug. 1945 Typhusepidemie (z. T. täglich bis 180 Tote) (Städtebuch (S. 167). - [1945:] „In Frankfurt starben viele Menschen an Typhus, die dann in Massengräbern bestattet wurden. Es fehlte noch in vielen Familien an Nahrung. Besonders die alten Leute und die kleinen Kinder überlebten diese Entbehrungen nicht. Mein Bruder, mein Vater und ich hatten an den Beinen offene Stellen bekommen. Es klebte immer an den Strümpfen und blutete. Pflaster gab es nicht und es gab kaum Ärzte und so sind wir durch Zufall auf einen sowjetischen Arzt gfestoßen, der uns Salbe gegeben hat und unsere Wunden versorgte." (Ehrich, S. 12). - 1945 (Bericht der Stadtverwaltung vom Dez. 1945): „Den Flüchtlingen und den hier zur Entlassung kommenden Kriegsgefangenen galt unsere besondere Fürsorge. Den ungezählten Tausenden, die Frankfurt als Einfallstor in die neue Heimat benutzten, konnten im Anfang täglich nicht nur Quartier, sondern auch zwei warme Mahlzeiten verabfolgt werden. Letzteres konnte leider nur bis Mitte September aufrecht erhalten bleiben, weil einfach die Vorräte verbraucht und Ersatz nicht herangeschafft werden konnte. Was aber bis heute nicht vesagte, war unser Rat und unsere Hilfe, den Ärmsten den Weg in ihre neue Heimat, wenn auch nur mit ein paar lieben Worten zu ebnen. / Der Stadt Frankfurt stehen als Grenzstadt ungeheure Aufgaben bevor. Die an der Spitze stehenden Männer, von einem unbändigen Willen beseelt, werden die Geschicke meistern und der Stadt wieder zu ihrem alten guten Ruf verhelfen, den sie einst genoss: Handelsstadt und Umschlagplatz für den Verkehr mit unserm östlichen Nachbarn, der über kurz oder lang wieder kommen muss." (Brandenburgische Gemeinden 1945, S. 45).3.11.1945 Internierung der am 29.1.1945 aus Saabor (Kr. Grünberg in Schlesien) zunächst über Berlin nach Roßla (Südharz) geflüchteten Witwe des letzten Deutschen Kaisers, Hermine Prinzessin Reuß ä.L. (1887-1947), auf Anordung der sowjet. Besatzungsmacht, zunächst ,in einem von russischen Soldaten belegten Haus in der Goepelstraße“, nach zwei Tagen aber in der leerstehenden Villa Blumenstraße 4 (Paulinenhof) bis zu ihrem Tod ebd. am 7.8.1947, Überführung der Leiche nach Potsdam-Sanssouci [Antikentempel] (Toom/Klein, S. 93-101, Zitat S. 93; Eichler, Die wichtigsten Ereignisse; ausführlicher: Ludwig, S. 35-84). - 13.1.1947 polnisches Memorandum an den sowjet. Außenminister Molotow mit der Forderung nach einer Grenzkorrektur an der Oder einschl. der gesamten Stadt Frankfurt (Blöß, Grenzen und Refor- 
men, S. 60 f.). - März 1947 Fertigstellung der wiederhergestellten Eisenbahnbrücke in Stahlkonstruktion (Schneider, Oder, S. 12). - Mai 1947 Transport mit 200 aus Ostpreußen zunächst nach Russland verbrachter Frauen und Mädchen trifft in Frankfurt ein (Dokumentation der Vertreibung I/2, S. 34). - 1947/48 größere Treffen von Vertriebenen aus Ziebingen (Kr. Weststernberg): 26.10 .1947 (200 Besucher), 13.4.1947 (400 Besucher), 26.10.1947 (350 Bewohner), 23. bis 25.10.1948 (Schieche/Jaeschke, S. 323). - 3.10.1950 Zuweisung von westlich der Oder gelegenen Flächen der nun polnischen Gemeinden Kunitz/Kunice (anteilig; vgl. $\rightarrow$ Brieskow-Finkenheerd und $\rightarrow$ Wiesenau) und Schwetig/Świecko (ehem. Kr. Weststernberg) an die Stadt Frankfurt (Oder) (Blöß, Kreise und Gemeinden, S. 31). - 27.1.1951 Unterzeichnung des Protokolls über die vollzogene Markierung der Oder-Neiße-Grenze im Haus der DSF durch die Außenminister der VR Polen und der DDR im gefolge des 1950 vereinbarten Görlitzer Abkommens (Gedenktafel Halbe Stadt 23) (Historischer Führer, S. 279). - 1952 Wiederaufbau der (seit 1945 provisorischen) Oder-Straßenbrücke (Stadtbrücke), nun „Brücke der Freundschaft“ benannt, bis 1.1.1972 jedoch nur mit Genehmigung passierbar, dann bis 30.10.1980 für den pass- u. visafreien Grenzverkehr nach Polen freigegeben (Danyel/Kaule/Zündorf, S. 51; Schneider, Oder, S. 13; ders.; Frankfurter Oderbrücken, S. 12-16 [ausführlich]; wikipedia „Stadtbrücke Frankfurt (Oder)“ [14.9.2018]).

EREIGNISSE NACH 1989: 1990 Fortsetzung der zuvor in $\rightarrow$ Müllrose durchgeführten Heimattreffen von ehem. Bewohnern von Ziebingen (Kr. Weststernberg), aus Platzgründen bald verlegt nach $\rightarrow$ Weißenspring (Crossener Heimatgrüße 47, 1995, Nr. 6, S. 19). - 8.4.1991 Freigabe der Oderbrücke (Stadtbrücke) für den visafreien Grenzverkehr nach Polen (wikipedia „Stadtbrücke Frankfurt (Oder)“ [14.9.2018]; Schneider, Frankfurter Oderbrücken, S. 16). - 3.9.1994 „Abschied und Ankunft": Lesung aus einem deutschen und einem polnischen autobiographischen Werk zu Flucht und Vertreibung (Ursula Höntsch aus Berlin und Joanna Konopińska aus Breslau) im Deutsch-Polnischen Literaturbüro Oderregion im Haus der Künste, Lindenstr. 7, veranstaltet von der Deutsch-Polnischen Gesellschaft Brandenburg e. V. in Kooperation mit der Gesellschaft für interregionalen Kulturaustausch e. V., Berlin, mit Unterstützung der Brandenburgischen Landeszentrale für politische Bildung (www.dpg-brandenburg.de [4.6.2018]).18.12.1995 feierliche Übergabe und 4.12.1997 Einweihung (durch Bundeskanzler Helmut Kohl und den poln. Ministerpräsidenten Jerzy Buzek) der neuen Autobahnbrücke (Schneider, Frankfurter Oderbrücken, S. 19f.). - 30.6.2003 Tagung an der Europa-Universität Viadrina „Erinnerung und Aufklärung. Das Erbe der Vertreibung im heutigen Europa“, veranstaltet von der Viadrina, dem Deutschen Polen-Institut und dem Geisteswissenschaftlichen Zentrum für Geschichte und Kultur Ostmitteleuropas (Leipzig) in Zusammenarbeit mit der Konrad-Adenauer-Stiftung und der Friedrich-Ebert-Stiftung (BdV-Notizen 1 (2003)3, S. 3-4). - Martin Patzelt (CDU) (geb. 1947 Frankfurt/O., kath., Sozialpädagoge) war 1994-2000 Beigeordneter der Stadt Frankfurt u. 2000-2006 Oberbürgermeister ebd.; er bezeichnete sich 2003 als „Kind einer Flüchtlingsfamilie (meine Mutter wurde mit sechs Geschwistern gewalttätig vertrieben)" (Akten der BdV-Landesgeschäftsstelle), seit 2013 Mitglied des Bundestages (Direktkandidat im Wahl- 
kreis Frankfurt (Oder) - Oder-Spree), verteidigte sein Mandat 2017 gegen Alexander Gauland (wikipedia [1.8.2018]). „Im August 2014 rief er in einem offenen Brief Mitbürger dazu auf, sie mögen darüber nachdenken, in ihren privaten Häusern und Wohnungen Flüchtlinge aufzunehmen, und zwar insbesondere Mütter und Kleinkinder. Er bezeichnete die Bedingungen in Massenquartieren als prekär und besonders für Kinder schwer erträglich. In der Presse wurde in diesem Zusammenhang hervorgehoben, dass einige Bundesländer (etwa NRW) eine Unterbringung von Flüchtlingen in Privatwohnungen nicht gestatten oder nur in Ausnahmefällen erlauben. Anschließend nahm Patzelt zwei Männer aus Eritrea bei sich zu Hause auf." (ebd.).

Bevölkerungszahlen: 1925: 71 139, 1939: 83 573, Mai 1945: 11 576, 1946: 51 577, 1964: 57975 (Städtebuch, S. 167); „nachdem Frankfurt seit 27.1.1945 zur Festung erklärt, Evakuierung der Bevölkerung, Apr. 1945 etwa 5000-6000 Menschen in der Stadt [...]; nach 1945 starke Wandlungen in Zuammensetzung der Bevölkerung: Rückkehr von nur etwa $20 \%$ der früheren Einwohner, Abtretung der östlich der Oder gelegenen Teile der Stadt an Polen, Umsiedler-, Heimkehrer- u. Kriegsgefangenenströme unbekannten Ausmaßes über Frankfurt Richtung Westen (Heimkehrerlager Gronenfelde als Durchgangs- bzw. Entlassungslager 1946-50; 1,1 Mio. Heimkehrer über dieses Lagern nach Deutschland)“ (ebd.). - Juli 1946: 4530 „Umsiedler“ (BLHA, Rep. 203 MdI, Nr. 1074, Bl. 52; Abb.: Mietk, S. 66). - 29.10.1946: 51577 Einwohner, davon aus Ostpreußen: 397, Hinterpommern 389, Ostbrandenburg 3 169, Schlesien 813, Tschechoslowakei 125, Polen 333, Danzig 57, Rumänien 47, Baltikum 23, Sowjetunion 16 (Volkszählung 1946). - 31.12.1948: Gesamtbevölkerung: 53926, davon „Umsiedler und Evakuierte“: 13465 (Grandke, S. 46). - Eingemeindung von Vertriebenen: 30.4.1947: 13015 (Oehlsen, S. 102), Juni 1948: 13032 (ebd., S. 103), Febr. 1949: 13138 (ebd., S. 104), 30.9.1950 (Ldkr. Frankfurt [!], „,nach den neuen Kreisgrenzen ab 1.7.1950“): 25060 (ebd., S. 105).

Katholiken: 1925: 4964, 1946: 3874 (Städtebuch, S. 168). - „Mit den vielen Heimatvertriebenen aus den Gebieten jenseits der Oder kamen auch Flüchtlingsgeistliche nach Frankfurt und fanden Aufnahme im Pfarrhaus. An drei von ihnen erinnere ich mich noch sehr genau, vor allem wohl auch dehalb, weil sie längere Zeit in Frankfurt blieben: P far rer [Johannes] A rnold aus Jordan bei Schwiebus [geb. 1885, gest. 18.6.1947 Frankfurt (Oder)], Propst Hubert Bönigk aus Meseritz, späterer Pfarrer der Gemeinde Heilige Familie in Berlin-Prenzlauer Berg, Ka plan Erwin Ungar aus Mährisch-Ostrau, der für mehrere Jahre als Kaplan in Frankfurt blieb. Diese drei Seelsorger sind mir in Erinnerung geblieben. Es waren sicher noch [S. 167] weitere, die mir aber nicht bekannt sind und die offenbar bald weitergezogen sind. / [...].“ (Roske, S. 166f.). - 22.8.1946 „Kpl. Ungar, Erwin, Frankfurt/Oder, Leipziger Str. 39“ erwähnt in einer Aufstellung der außerplanmäßig eingesetzten „Flüchtlingsgeistlichen“ (DAB, I/9-15-1 Flüchtlingsseelsorge 1945-1951, unfol.). Der der Erzdiözese Prag angehörende, bis 1945 in Kladno (Böhmen) wirkende Erwin Ungar (geb. 1915 Mährisch-Ostrau-Witkowitz) war am 1.7.1946 ebd. bei Hl. Kreuz als Kaplan angestellt worden (Schematismus Berlin 1949, S. 64; Ostpriesterverzeichnis 2, 1949, S. 87); siehe auch $\rightarrow$ Frankfurt (Oder), wo Ungar ab 1955 wirkte. 
Kath. Marienstift (Kinderheim, Niederlassung der Grauen Schwestern): „Im Zweiten Weltkrieg wurde das Marienstift [Marienstr. 3] völlig zerstört. In einem neuen Gebäude führten die Grauen Schwestern nach dem Krieg ihre Arbeit weiter und eröffneten zusätzlich ein Altenheim. 1958 wurde die Niederlassung aufgegeben, da die Behörden der DDR ihr die Arbeit unmöglich machten." (Mertens, S. 431). Als der Krieg vorbei war, kehrten die evakuierten Schwestern mit den Kindern aus Wulfersdorf [bei Kyritz] nach Frankfurt zurück und bezogen am 13. Juni 1934 das Evangelische Fürsorgeheim in der Luisenstraße 22. [... . Durch den Flüchtlingsstrom nahm die Zahl der Kinder ständig zu. Sie befanden sich in sehr schlechtem Zustand. Die meisten Kinder hatten Krätze und Kleiderläuse, waren nur unzureichend bekleidet und sehr schmutzig. [...] Insgesamt nahmen die Schwestern im Laufe des Jahres 1945 unter diesen schwierigen Bedingungen 360 Kinder auf. / [...] [S. 435] [...] Als der Strom der Flüchtlinge 1945 über Frankfurt kam, starben viele alte und kranke Menschen auf der Straße. Die Stadtverwaltung bat die Schwestern, nach Möglichkeit die alten Leute in ihr Haus aufzunehmen. Im Juli waren schon vierzig Personen im Fürsorgeheim. Insgesamt wurden in diesem Jahr siebzig alte und kranke Flüchtlinge aufgenom- [S. 436] men, von denen die meisten nach kurzer Zeit starben. Die Schwestern setzten die aus dieser Notlage entstandene Altenbetreuung auch in den folgenden Jahren fort. / [...] Die Schwestern mieteten 1946 die Häuser am Stiftsplatz 5 und 5a. Sie mußten erst instand gesetzt werden, was wegen des Mangels an Material nur langsam geschah. Am 1. Oktober 1947 zogen die Schwestern in das neue Marienstift um. [...]. [S. 437] [...] Die Landesregierung in Potsdam erteilte dem Marienstift am 29. August 1949 die Erlaubnis, als Dauerkinderheim 120 Kinder im Alter von zwei bis vierzehn Jahren aufzunehmen. Es waren jedoch mehr Kinder im Heim. / [...]." (ebd., S. 435-437). - „Auch die Kinder des Kinderheimes ,St. Marienstift' [...] kamen wieder zurück, und ihre Zahl wurde immer größer. Viele Flüchtlingswaisen [...] fanden im Marienstift Aufnahme. Ihre genaue Zahl weiß ich nicht. Ich kann sie nur aus den übervollen für die, Stiftskinder' eigens eingerichteten Bankreihen in der Kirche ungefähr nachvollziehen - schätzungsweise 80 bis 100 Mädchen und Jungen waren es sicher. Die Stadt Frankfurt stellte dem, Marienstift' zunächst ein frei stehendes Haus der Evangelischen Kirche zur Verfügung, bis dann eine andere Ersatzlösung für das zerstörte Marienstift in unmittelbarer Nähe der Pfarrei gefunden wurde.“ (Roske, S. 166). - „Der erste Nachkriegs-Oberbürgermeister, Dr. Ernst Ruge, sorgte persönlich dafür, das[s] die Insassen des zerstörten Marienstiftes zusammen mit weiteren Kindern und Schwestern eines evakuierten Kinderheimes aus Königsberg (Ostpreußen) hier [Luisenstr. 22] unterkamen." (Klemm, S. 22). „1947 wird am Stiftsplatz ein neues Marienstift [anstelle des im Krieg zerstörten] errichtet, in dem zeitweilig über 120 Kinder untergebracht sind. Da die DDR-Behörden die Arbeit jedoch unmöglich machten, wurde die Niederlassung 1958 aufgegeben." (Schwillus/Brühe, S. 316). „Am 30. September 1958 übernahm die Stadt die Räumlichkeiten vom Marienstift und nannte es in ,Städtisches Pflegeheim' um. Am Abend verließen die letzten Grauen Schwestern Frankfurt (Oder) für immer in Richtung Berlin. [...] / Die Stadt führte das Pflegeheim solange weiter, bis ein neues städtisches Heim fertiggestellt wurde. Der Abbruch der beiden alten Häuser Stiftsplatz 5 und 5a erfolgte vermutlich spätestens im Frühjahr 1977." (Klemm, S. 23). 
Diakonissenhaus Lutherstift: Von 1946 bis in die sechziger Jahre von Vertriebenen geleitet: 1946-1948 Pfarrer Joachim Scholz (geb. 1902, vor 1945 evang. Pfarrer in Pleschen/Posen), 1948-1952 Johannes Steffani (geb. 1889 Posen, gest. 1976 Lüneburg, 1941-1945 letzter evang. Stadtsuperintendent in Posen, im Sommer 1945 von Bischof Dibelius nach Frankfurt entstandt, 1952 wegen schwerer Erkrankung in den Ruhestand getreten, bereits seit Jan. 1945 u. ab 1952 von Berlin aus Leiter der Ausweichstelle des Konsistoriums der Posener Evangelischen Kirche in Berlin-Charlottenburg, Jebensstr. 3 [Evang. Oberkirchenrat], später Vorstandsmitglied des Hilfskomitees der Glieder der Posener Evangelischen Kirche), ab 1952 viele Jahre Pfarrer Dietrich Hemmerling (geb. 1917, vor 1945 evang. Pfarrer in Reichtal/Posen) (ELAB, 1/2453, Dokumentation, S. 37-39; zu Steffani auch Schammert, S. 178).

SäUglingSheim UND Kinderheim IM Lutherstift, Heinrich-Hildebrand-Straße 22: „Ein wichtiger sozialer Arbeitsbereich für die Diakonissen des Lutherstiftes, nach dem Krieg, waren die Säuglinge und Kleinkinder, die in den Ruinen der Häuser hinter Trümmern lagen, oder verlassen in Zügen und auf dem Bahnsteig standen. Diese Kinder wurden im Lutherstift abgegeben, meist ohne Anhaltspunkt für Personalien. Da es seit 1921 eine Säuglingspflegeschule im Lutherstift gab, war dort für diese Kinder ausgebildetes Personal vorhanden. Auf diese Weise entstand im Lutherstift ein Säuglingsheim, das 194980 Kinder unter drei Jahren hatte. In einem Gebäude in Birnbaumsmühle 42 waren Kinder von drei bis vierzehn Jahren untergebracht. Um die ärztliche Betreuung dieser Waisenkinder kümmerte sich Frau Dr. [Ursula] Sellschop[p] [1915-1998]“ (Dittmer, Klinik für Kinder- und Jugendheilkunde, S. 48), eine Gynäkologin, die im Mai 1946 aus der Berliner Charité nach Frankfurt (Oder) gekommen war [1997 Ehrenbürgerin] (ebd., S. 53). - Oberin im Diakonissenmutterhaus und der Krankenanstalt Lutherstift war später viele Jahre die aus Sternberg (Neumark) stammende, in der DDR-Zeit über die Bezirksstadt hinaus in hohem Ansehen stehende Johanna Keller geb. Karge (gest. 1988 Frankfurt/O., 74 Jahre alt), die 1945 den ersten Kindergarten in der Tunnelstraße eröffnet hatte (Nachruf von Hans Boese in: Oststernberger Heimatbrief 1/1989, S. 53, mit Bild). - Heute: „Evangelisches Krankenhaus Lutherstift, Standort Frankfurt (Oder)“, Einrichtung der Lutherstift gGmbH, Schwerpunkt Geriatrie (www.diakonissenhaus.de [11.7.2017]).

Heimkehrerkrankenhaus („Heimkehrerlazaretr“) Horn-Kaserne, Nuhnenstraße 40 (jetzt Polizeipräsidium Ost), „hinter den Steinhäusern in einem Barackenlager in der Südostecke des Kasernengeländes, vom Verkehrskreisel aus gesehen Südausfahrt, rechte Seite“ (Eichler, Zum ersten Kommandanten, S. 24): „Am 3. Oktober 1947 wurde das Heimkehrerlazarett am Westkreuz in der Fürstenwalder Poststraße eröffnet. Im Vorderhaus waren die Chirurgie und die Innere Abteilung untergebracht. Ein Extragebäude im Hof war die Infektionsabteilung. [... ] Im weiteren Verlauf der Zeit verlor das Heimkehrerlazarett an Notwendigkeit. Ab Frühsommer 1948 wurden Vorbereitungen getroffen, dort eine Poliklinik einzurichten. [...].“ (Dittmer, Kurzer Überblick, S. 33). - „Eine vom Museum Viadrina gestaltete Ausstellung [„Willkommen in der Heimat" $]$ und das vom Heimkehrerverband gestiftete Mahnmal für den Frieden sollen 
an die Rückkehr von fast zwei Millionen deutschen Kriegsgefangenen und Zivilinternierten über Frankfurt (Oder) erinnern.“ (http://www.museum-viadrina.de [4.1.2017]). - „Am 22. November 1998 wurde auf Initiative des Verbandes der Heimkehrer ein Mahnmal für diejenigen eingeweiht, die über Frankfurt (Oder) nach Deutschland zurückgekehrt sind. Das privat finanzierte Mahnmal wurde von Christian Roehl gestaltet. Es handelt sich um einen Findling aus dem Tagebau Cottbus und um eine Edelstahlstele. / Die Inschrift der Stele lautet: ,Unser / Mahnmal / für den / Frieden // Heimkehrerlager / Frankfurt/Oder / Gronenfelde - / Hornkaserne / 1945-1950//Wir Heimkehrer/mahnen!/Völker/entsagt dem Hass - /versöhnt Euch!/Dient dem Frieden in Freiheit - / Baut Brücken zueinander!' Auf der Rückseite ist zu lesen: ,1998/Errichtet vom/Verband der Heimkehrer, / Kriegsgefangenen/und Vermisstenangehörigen / Deutschlands e.V.//Auf Initiative/des VDH-Landesverbandes / Brandenburg." (Orte des Erinnerns, S. 188). - Siehe auch Gefangene und Heimkehrer, passim (zum Friedhof S. 42); Eichler, Zum ersten Kommandanten; ders., Zur Studie; Tschäpe, passim.

DAmmvorstadt (poln. Słubice), östlich der Oder: 21.1.1945 „Innerhalb weniger Stunden trafen massiv Flüchtlinge aus dem Raum Posen in der Stadt ein“ (Reiß, Das Ende, S. 26). 4.2.1945 Zwangsräumung (ebd., S. 25, 27; Wir waren damals 19, S. 131). „Am 4. Februar 1945 erging um acht Uhr morgens der Aufruf, die Dammvorstadt bis neun Uhr zu räumen.“ (Słubice, S. 108). - 18./19.4.1945 militärische Räumung (Reiß, Das Ende, S. 29) . - 19.4.1945 Einmarsch der Roten Armee nach der Brückensprengung durch die Wehrmacht (ebd.).4.5.1945 beginnende Rückkehr von Frankfurtern in ihre Wohnungen in der Dammvorstadt über die am selben Tag errichtete provisorische Holzbrücke (Brisch/Buwert/Schieck, S. 39). „Bis Ende Mai waren es rund 3000 Personen." (Crossener Heimatgrüße 47 (1995) 4, S. 49). 15.5.1945 polnische Beschriftung der Straßen (Brisch/Buwert/Schieck, S. 39). - 17.5.1945 Einrichtung des sowjet. Speziallagers Nr. 6 In Wohnbauten an der ehem. Wachsbleiche, 11./12.9.1945 Verlegung nach $\rightarrow$ Jamlitz bei Lieberose, teilweise Weiternutzung als Repatriierungslager des NKWD wohl bis 1951 (Słubice, S. 117-119). - 25.5.1945 Übergabe der Dammvorstadt an die polnische Verwaltung (Brisch/Buwert/Schieck, S. 39) . - 27.5.1945 Beginn der Ausweisung der deutschen Bevölkerung; Ende Mai Einrichtung eines Internierungslagers (Brisch/Buwert/Schieck, S. 39). - „Anf. Juni 1945 lebten einem polnischen Bericht zufolge 8000 Deutsche und nur 80 Polen im Bereich Słubice (es bleibt unklar, welcher Bereich gemeint ist). Zum 15./16. Juni ordnete der polnische Verwalter die Ausweisung aller Deutschen an." (Brandenburgkurier 24, 2010, Nr. 2, S. 6). - 25.6.1945 Ausweisung der deutschen Restbevölkerung (Brisch/Buwert/Schieck, S. 42). - 1945 (Bericht der deutschen Frankfurter Stadtverwaltung von Dez. 1945): „Hier muss gleich bemerkt werden, daß die Dammvorstadt, rechts der Oder gelegen, heute polnisches Gebiet ist. Der Umsicht der Stadtverwaltung und der Einsicht der russischen Kommandanten ist es zu danken, daß die Bewohner dieses Stadtteils in elf eingemeindeten Orten [westlich der Oder] sofort untergebracht werden konnten." (Brandenburgische Gemeinden 1945, S. 45). - „Eine gewisse Zahl anerkannter Deutscher blieb zu Arbeitseinsätzen in Słubice und eine sehr kleine Anzahl, Autochtoner' siedelte sich hier dauerhaft an. Diese 
Personengruppe umfaßte Ermländer, Kaschuben oder Masuren. Die in Słubice verbliebenen Personen waren vielfach deutsche Ehepartner von ethnischen Polen oder vereinzelt ethnische Polen." (Słubice, S. 111).

FriedensGlocke, Oderpromnade: Erste „Friedensglocke“ der DDR. Stiftung der CDU anlässlich ihres VI. Parteitages in Berlin; 27.1.1953 feierliche Übergabe an die Stadt auf einer Großkundgebung (am Vorabend des Parteitages) zur Erinnerung an die Unterzeichnung des Oder-Neiße-Grenzvertrages zwischen DDR und VR Polen (1950). Auf der Glocke Emblem der CDU und Inschrift „Friede und Freundschaft mit allen Völkern“. Glockenstuhl „gemauerter, verputzter Turm mit flachem Zeltdach, auf allen vier Seiten durch hohe Rundbögen geöffnet, um die Glocke zu zeigen“" (Gramlich, S. 247); ursprünglich (1952) war hölzerne Ausführung geplant. - Standort: Auf seit der Enttrümmerung unbebautem Gelände am Holzmarkt nahe der Oder, vom Rathaus aus über die Stadtbrache zu sehen. 2002 Beschluss zur Versetzung an das südliche Ende des Holzmarktes. 2011 Errichtung eines neuen Glockenturms an neuem Standort an der Oderpromenade (Edelstahlrahmen) und Restaurierung der Glocke, Anbringung einer Steinplatte mit Widmung aus dem Innern des alten Glockenhauses neben der neuen Aufhängung, 30.8.2011 Einweihung. - Traditionell wird die Glocke am 1. September zum „Weltfriedenstag“ geläutet.

Literatur zUR Friedensglocke: Architekturführer DDR. Bezirk Frankfurt (Oder). Berlin 1987, S. 22. - Gramlich, Sybille, u. a.: Stadt Frankfurt (Oder) (Denkmaltopographie Bundesrepublik Deutschland. Denkmale in Brandenburg, Bd. 3). Worms am Rhein 2002, S. 247. - Klemm, Bernhard: Frankfurter Denkmalgeschichte. In: Historischer Verein zu Frankfurt (Oder). Mitteilungen 1997, H. 1, S. 8-21, hier S. 19. - Wikipedia [17.8.2016].

Arbeiterwohnungsbaugenossenschaft (AWG) „Friedensgrenze“ (1960-1990): Gründung 1960 durch Verschmelzung der 1954 bzw. 1957 gegründeten Arbeiterwohnungsbaugenossenschaften „Einheit und Frieden“ und „Solidarität“, 1975 Zusammenschluss mit drei Gemeinnützigen Wohnungsbaugenossenschaften unter dem gemeinsamen Namen AWG „Friedensgrenze“, 27.9.1990 Umgründung in die „Wohnungsbaugenossenschaft Frankfurt (Oder) eG - WohnBau Frankfurt“ auf Beschluss der Vertreterversammlung, 6.12.1990 Eintragung in das Genossenschaftsregister unter Nummer 46. - Die AWG „Friedensgrenze“ besaß in verschiedenen Stadtteilen zahlreiche Wohnungen, im neuen (Plattenbau-)Stadtteil Neuberesinchen übernahm sie bis 1989 rund 4700 Wohnungen (http://www.wohnbau-frankfurt.de/ wbf/unternehmen/geschichte/ [17.8.2016]).

Strassenumbenennungen: 29.8.1946 Benennung der in Ost-West-Richtung verlaufenden, bislang unbezeichneten Straße hinter dem Schlachthof in Lippehner Straße [Sitz einer aus Lippehne evakuierten Firma] (Beschluss der 2. Öffentlichen Sitzung des Rates der Stadt; Mitt. des Stadtarchivs Frankfurt/R.-R. Targiel vom 22.8.2016; fehlt in Hausdorf/Noack, S. 161). 16.9.1948 Danziger Straße (seit 1923, Siedlung Paulinenhof) in Albert-Fellert-Straße, Gnesener Straße (seit 1927) in Gerhart-Hauptmann-Straße, Ostmarkstraße [fälschlich „Ostmark-Straße“] (seit 1923, Siedlung Paulinenhof) in Hermann-Boian-Straße, Tannenbergstraße (seit 1938) in 
Beethovenstraße (www.museum-viadrina.de/Straßenlexikon [30.8.2016]). - 11.10.1952 Lippehner Straße in Am Schlachthof (Beschluss der Stadtverordnetenversammlung [Stadtarchiv Frankfurt, Best. II, Nr. 913, Bl. 14], amtlich geworden durch Bekanntmachung in „Neuer Tag“ vom 30.3.1953; Mitt. Stadtarchivs Frankfurt/R.-R. Targiel vom 23.8.2016), jedoch von dort ansässigen Betrieben noch 1987 als „Lippehner Str.“ bezeichnet (Aktennotiz des Planungsamtes 1987 lt. Mitteilung des Stadtarchivs wie vor). - 1953 Königsberger Platz (seit 1933) in Wismarer Platz, Stettiner Straße (seit 1932) in Rostocker Straße sowie in der Siedlung Paulinenhof: Bromberger Ring (seit 1923) in Franz-Liszt-Ring, Dirschauer Straße (seit 1923) in Georg-FriedrichHändel-Straße, Graudenzer Weg (seit 1923) in Harfenweg, Culmer/Kulmer Straße (seit 1922) in Albert-Lortzing-Straße, Posener Ring (seit 1923) in Peter-Tschaikowsky-Ring, Thorner Grund (seit 1923) in Joseph-Haydn-Straße (ebd.). - 1959 (nicht 1965!) Küstriner Straße [ab 1938; 1846-1938 Cüstriner Straße] in Herbert-Jensch-Straße, Sorauer Straße [1879-1927 Tunnelstraße] in Tunnelstraße und Züllichauer Straße [bis 1927 Am Beresinchen] in Finkenheerder Straße (Beschluss der Stadtverordnetenversammlung Nr. 79 vom 29.9.1959, Sitzung Nr. 15/1959; Mitt. des Stadtarchivs Frankfurt/R.-R. Targiel vom 23.8.2016; www.museum-viadrina.de/Stra ßenlexikon [30.8.2016, hier Züllichauer Str. mit falschem Umbenennungsjahr 1965 (ebenso in Hausdorf/Noack, S. 47)]). - 1996 Posener Hof (Sackgasse beim Bahnhofsplatz, früher Zufuhr-, Ladestraße; Benennung analog zur volkstümlichen Bezeichnung Posener Hof für den Bereich der Gleisanlagen des Reinigungshofes für Reisezüge, ehemals zur „Märkisch-Posener Eisenbahn" gehörig; Hausdorf/Noack, S. 120). - 2001 Küstriner Berg (in Frankfurt-Güldendorf, Anrainer nur: zwei Kleingarten- u. eine Kompostieranlage) (ebd., S. 92).

StÄDtepartnerschaften: 1975 Gorzów Wlkp., Polen (Landsberg an der Warthe) und Słubice, Polen (ehem. Dammvorstadt von Frankfurt/Oder); 2005 Kr. Słubice, Polen (Gemeinden Słubice, Cybinka-Ziebingen, Rzepin-Reppen, Ośno Lubuskie-Drossen, Górzyca-Göritz/Oder) (www.frankfurt-oder.de [23.8.2018]). - BEZIRKSPARTNERSCHAFT: 1959 Partnerschaftsabkommen des Bezirks Frankfurt (Oder) mit der polnischen Woiwodschaft Zielona Góra (Grünberg in Schlesien).

VeRTRIEBENENVERBÄNDE NACH 1990: BdV-Kreisverband Frankfurt (Oder), gegründet 1991 (Märkischer Informationsdienst 8/1994, S. 14), 1996 Sitz Heinrich-Hildebrand-Str. 16 a (BdVHandbuch 1996, S. 168). - 3.7.2001 (mit Satzung vom 13.3.2001) beim Amtsgericht Frankfurt (Oder) (VR 768) eingetragen; 10.10.2010 Mitgliederversammlung im Haus der Begegnung, Klabundstr. 10 (18 Teilnehmer), 30.1.2008 25 Mitglieder, zum 31.12.2008 aufgelöst (Akten der BdV-Landesgeschäftsstelle). - Vorsitzende: 1992 Schicht, 1995/97 Dieter Kuschinske, Frankfurt (Oder) (geb. 1946), erwähnt als Ansprechpartner (wohl Vorsitzender), 2000-2008 Walter Kraus, Frankfurt (Oder) (geb. 1938; zugleich Vorsitzender des Landesschiedsgerichts des BdV Brandenburg) (Akten wie vor).

Institut für ANGEWAndte Geschichte - Gesellschaft und Wissenschaft im Dialog e. V., Frankfurt (Oder), Große Scharrnstr. 59: 2001 auf Initiative von deutschen und polnischen 
Studenten der Europa-Universität Viadrina gegründeter ehrenamtlich tätiger Verein: „Es ging um die Erforschung und Herausbildung einer regionalen Identität in der Ziemia Lubuska, jenem polnischen Teil des Lebuser Landes, das einst als Neumark zu Brandenburg gehört hatte. Darüber hinaus boten sie ,Heimatreisen' an, auf denen polnischsprachige Studierende aus Deutschland und Polen deutsche Heimwehtouristen auf ihren Fahrten nach Schlesien oder nach Danzig begleiteten.“ (Rada, S. 117). - „Zweck des Vereins ist die Förderung von Wissenschaft und Forschung sowie deren Verbindung mit bürgerschaftlichem Engagement zugunsten einer internationalen Gesinnung, der Toleranz auf allen Gebieten der Kultur und des Völkerverständigungsgedankens.“ „Der Satzungszweck wird insbesondere verwirklicht durch die Durchführung wissenschaftlicher und kultureller Veranstaltungen und Forschungsvorhaben, beispielsweise internationalen Kulturprojekten, historischen Seminaren, offentlichen Diskussionen, Exkursionen mit Geschichtsbezug und vergleichbaren Formaten der historisch-politischen Bildung. Dabei sollen transnationale Begegnungen sowie ein Austausch auf europaischer Ebene stattfinden. Speziell die theoretische und praktische, grenzüberschreitende Auseinandersetzung mit der Geschichte und Gegenwart europäischer Grenzen und Regionen wie der Oderregion ist ein Anliegen des Vereins." (Satzung, in: www. instytut.net [27.6.2017]).

Archivalische Quellen: BArch, DO 1 Ministerium des Innern der DDR, Nr. 14660 (Übersiedlung aus Polen, 1965). - BLHA, Rep. 203 MdI, Nr. 1121 (Umsiedler- und Heimkehrerstatistiken, 1945-1946; enthält: Erfassung der Umsiedler in den einzelnen Kreisen der SBZ zum 1. Dez. 1945 sowie statistische Berichte der einzelnen Gemeinden, hier Stadtkreis Frankfurt/O.). - Stadtarchiv Frankfurt (Oder). - Archiv der Landesgeschichtlichen Vereinigung für die Mark Brandenburg e. V., Berlin, Best. C 4A, Nr. 147 (Georg Post: Unser Neuanfang nach der Vertreibung in Pillgram bei Frankfurt/Oder. Typoskript, 20 S. (Fotokopie aus dem Kreisarchiv Gumbinnen; anonymisierter Teildruck in Wille I, S. 26-29)].

GedRUCKTE Quellen: Brandenburgische Gemeinden 1945, S. 45-48. - Brisch, Brigitt / Buwert, Wolfgang / Schieck, Martin: Frankfurt (Oder) 1945. Ausgewählte Daten, Dokumente, Fotos und Erinnerungen. Frankfurt (Oder) [1995]. - Dokumentation der Vertreibung I/1, S. 29 E, 142 E, 358, 381, 383, 393, 839; I/2, S. 5, 8, 18, 21, 27, 29, 33 f., 41, 46 f., 51, 80, 85, 88, 103 f., 481, 678, 682, $686 \mathrm{f}$. (Trecks an der Oderbrücke, Situation in der überfüllten Stadt, Juni 1945), 713 f.; III, S. 80 E, 239, 249, 260, 267, 270, 281; V, S. 96 E, 312f., 318, 332, 337. - Ehrich, Brigitte: [Lebenslauf]. In: Müncheberger Lebensläufe. T. 3. Müncheberg 2012, S. 9-18. [Lebte (mit Unterbrechungen) ca. 1932-1951 in Frankfurt]. - Emmrich, Eva: Mein viertes Schuljahr. In: Zeitzeugen aus Strausberg berichten. Hrsg. vom Seniorenbeirat der Stadt Strausberg. Strausberg (1999), S. 14-16 [Kriegsende 1945]. - [Hasse, Felix:] ... und an der anderen Seite das Ausland zu wissen. Aus der Chronik der katholischen Pfarrei. In: Wir waren damals 19. Frankfurt (Oder) 1995, S. 152-158. - Jentsch, Willy: Im antifaschistischen Kampf gestärkt - für den Aufbau einer neuen Ordnung in Frankfurt/Oder. In: Wissenschaftliche Zeitschrift der Pädagogischen Hochschule Potsdam, Math.-Naturw. Reihe 10 (1966), S. 441-445. - [Pündik]: Die politisch-ökonomischen Verhältnisse zum Zeitpunkt der Organisation und des Aufbaus der Militärkommandantur. Dokumentation über die Tätigkeit der sowjetischen Militärkommandantur Frankfurt (Oder) vom 20. Februar 1945 bis 1. Januar 1949 (Major Pündik). In: Wir waren damals 19. Frankfurt (Oder) 1995, S. 187-209. - Ruf, Johanna: Eine Backpfeife für den kleinen Goebbels. Berlin 2017 [Schwesterneinsatz in Kleist-Kaserne u. Speziallager Dammvorstadt Mai bis Juli 1945]. - Schönke, [Günther]: Die Frankfurter Schicksalstage (Vorfrühling 1945). In: Wir waren damals 19. Frankfurt (Oder) 1995, S. 130-139. - Stage, Hannelore: Mit Sandalen fing alles an [Erinnerungen an den Tag der Befreiung]. In: Geschichten. Aus Nah und Fern. Zeitzeugen aus Strausberg erzählen. Hrsg.: Seniorenbeirat der Stadt Strausberg. Strausberg 2006, S. 12-14. - Tagebuch Willy Lorenz [Auszüge]. In: „Die Russen sind da“. Peter Böthig u. Peter Walther (Hg). Berlin 2011. - Töpler, Menschenwurm. Wille I, S. 245, 458; II, S. 105; III, S. 428 f. (schulische Förderung der „Umsiedlerkinder", 1950). - Wir waren damals 
19. 50 Jahre 8. Mai in und um Frankfurt. Berichte, Dokumente, Recherchen, Tagebücher, Erinnerungen, Gespräche. Ein Lesebuch. Hrsg.: Jürgen Maerz. Frankfurt (Oder) 1995.

Literatur: Ackermann, Felix: Die Stadtbrücke Frankfurt (Oder) - Słubice (1952-2002). In: Frankfurt an der Oder 1253-2003. Hrsg. von Ulrich Knefelkamp u. Siegfried Griesa. Berlin 2003, S. 311-320. - Ast/Mauersberger, S. 125. - Borodziej/Lemberg, Bd. 3. - Blöß, Wolfgang: Grenzen und Reformen in einer Umbruchgesellschaft. Berlin 2014, S. 60 f. - Blöß, Kreise und Gemeinden, S. 14. - Buwert, Wolfgang: Festung Frankfurt (Oder): eine Stadt am Kriegsende. In: Brandenburg im Jahr 1945. Hrsg. von Werner Stang. Potsdam 1995, S. 38-83. [S. 46-51: Kapitel „Die Flüchtlinge kommen“]. - Crossener Heimatgrüße 47 (1995)4, S. 1-2, 4 [Kriegsende u. Vertreibung in der Dammvorstadt]. - Danyel, Jürgen / Kaule, Martin / Zündorf, Irmgard: Brandenburg 1945-1990. Berlin 2018, S. 51 f. („Brücke der Freundschaft/Stadtbrücke“). - Dittmer, Katja: Klinik für Frauenheilkunde und Geburtshilfe. In: Zeitreise durch die Geschichte des Klinikums Frankfurt (Oder). Hrsg. von Ulrich Knefelkamp. Berlin 2003, S. 53-56. Dies.: Klinik für Kinder- und Jugendheilkunde. In: Zeitreise durch die Geschichte des Klinikums Frankfurt (Oder) (wie vor), S. 48-52. - Dies.: Kurzer Überblick über die Lazarette und Krankenhäuser unmittelbar nach dem Zweiten Weltkrieg. In: Zeitreise durch die Geschichte des Klinikums Frankfurt (Oder) (wie vor), S. 31-32. - Eichler, Klaus: Zum ersten Kommandanten Sano des Entlassungslagers in der Horn-Kaserne Frankfurt (Oder) für kriegsgefangene deutsche Soldaten aus der Sowjetunion - Rudolf Voigt. In: Historischer Verein zu Frankfurt (Oder) e. V. Mitteilungen 2001, H. 1, S. 24-37. - Ders.: Zu der Serie „Von der Festung zur Lazarettstadt - Frankfurt (Oder) 1945 bis 1949 “. In: ebd. 2005, H. 2, S. 25-32. -Ders.: Zur Studie „Unbekannte Grablagen verstorbener deutscher Kriegsgefangener in Frankfurt (Oder) aus der Zeit von 1945/50" vom 15.04.2005. In: ebd., 2007, H. 1, S. 7-16. - Ders.: Die wichtigsten Ereignisse für die Kaiserin-Witwe Hermine von Preußen in Frankfurt (Oder). In: ebd. 2008, H. 2, S. 31-32. Ders.: Zum Kreisverband der Heimkehrer, Kriegsgefangenen und Vermißtenangehörigen e. V. Frankfurt (Oder) mit seiner Auflösung zum 31.12.2009. In: ebd. 2010, H. 1, S. 26-29 [gegr. 4.9.1991]. - Frankfurt an der Oder - Stadt der Heimkehrer. In: Geteilte Städte - Amputiertes Land. Celle [1959], S. 24-29. - Gefangene und Heimkehrer in Frankfurt (Oder) 1945-1950/56. Studien. Wolfgang Buwert (Hg.): Potsdam 1998 (Brandenburgische Historische Hefte, 9). - Hausdorf, Walter / Noack, Siegrid: Frankfurt (Oder). Straßen, Wege, Plätze in ihrer historischen Entwicklung. In: Frankfurter Jahrbuch 2002, S. 3-166. - Heimkehrer-Friedhöfe gezielt beseitigt. In: Wanderungen durch Südostbrandenburg an und jenseits der Oder-Neiße-Grenze 1996/97 (1996), S. 64-65. - Historischer Führer. Stätten und Denkmale der Geschichte in den Bezirken Potsdam, Frankfurt (Oder). Leipzig u. a. 1987. - Jajeśniak-Quast, Dagmara / Stokłossa, Katarzyna: Geteilte Städte an Oder und Neiße. Frankfurt (Oder) - Słubice, Guben - Gubin und Görlitz - Zgorzelec 1945-1995. Berlin 2000. - Kaminsky, Annette-Christine: „... es wird Zeit, daß wir nach Hause kommen ..." In: Frankfurter Jahrbuch 1996/97/1997), S. 147-162. - Klemm, Bernhard: Das Marienstift - aus der Geschichte einer katholischen Erziehungs- und Fürsorgeanstalt. In: Historischer Verein zu Frankfurt (Oder) e. V. Mitteilungen 2017, H. 2, S. 17-23. - Ludwig, Bernhard: Hermine von Preußen. In: Frankfurter Jahrbuch 2018, S. 6-85. Mertens, Johannes: Die Berliner Ordensprovinz der Grauen Schwestern von der heiligen Elisabeth 1859-1991. Reinbek bei Hamburg 1992, S. 431-438 (Marienstift). - Nechamkis, Wlodzimierz: Die Grenze. In: Wir waren damals 19. Frankfurt (Oder) 1995, S. 395-399. - Orte des Erinnerns. Hrsg. von Anna Kaminsky. 3., überarb. u. erw. Aufl. Berlin 1996, S. 188 (Mahnmal an der ehemaligen Hornkaserne). - Rada, Uwe: Labor. Der Grenzraum als Chance. In: Das Brandenbuch. Potsdam 2015, S. 115-118. - Reiß, Eckard: Das Ende der Frankfurter Dammvorstadt und das Entstehen von Slubice. In: Historischer Verein zu Frankfurt (Oder) e. V. Mitteilungen 2003, H. 2, S. 26-40. - Ders.: Die Oderübergänge der Roten Armee als Ersatz für die im April 1945 gesprengte Oderbrücke. in: ebd. 2014, H. 2, S. 19-23. - Röhr, Rita: Polen in Frankfurt (Oder) zur Zeit der DDR. In: Frankfurt an der Oder 1253-2003. Hrsg. von Ulrich Knefelkamp u. Siegfried Griesa. Berlin 2003, S. 249-262. - Roske, Peter: Die Katholische Kirchengemeinde Heilig Kreuz in Frankfurt (Oder) 1945. In: Wichmann-Jahrbuch des Diözesangeschichtsvereins Berlin, N. F. 14 (2016/17 [2017]), S. 162-168. - Schade, Rolf: Die Geschichte an der Oder befragt. In: Heimatkalender Eisenhüttenstadt und Umgebung 11 (1993), S. 55-58. - Schammert, Günther: (Art.) Steffani, Johannes. In: Beiträge zu einem Biographischen Lexikon der Deutschen aus dem Raum der Provinz Posen. Herne 2003, S. 178-179. - Schieche, Manfred / Jaeschke, Gerhard: Ziebingen. Eisenhüttenstadt u. a. 2001. - Schneider, Joachim: Die Oder während der Kriegshandlungen im Frühjahr 1945. In: Historischer Verein zu Frankfurt (Oder) e. V. Mitteilungen 2001, H. 2, 
S. 7-21. - Ders.: Die Frankfurter Oderbrücken im Wandel der Zeit. In: ebd. 2002, H. 1, S. 7-21. - Seniorenbeiräte im Land Brandenburg. Potsdam 1999, S. 47 f. - Ders.: Der Aufmarsch der Roten Armee vor der Frankfurter Dammvorstadt im Februar 1945. In: ebd. 2002, H. 2, S. 2-20. - Słubice. Historia, topografia, rozwój/Geschichte, Topografie, Entwicklung. Stubice 2003. - Sorotkin, Elke: Die soziale Situation in Frankfurt (Oder) 1945-1949. (Dipl.-Arb. Humboldt-Univ. zu Berlin). Frankfurt (Oder) 1991 [Nicht eingesehen]. - Straßenlexikon Frankfurt, www.museumviadrina.de/Strassenlexikon_Frankfurt/konkordanz.htm [29.2.2016]). - Schwillus/Brühe, S. 316-317. - Stribrny, Wolfgang / Zäpke, Fritz: Frankfurt/Oder. Porträt einer Brückenstadt. Berlin/Bonn 1990, S. 90-108. - Thiel, HansJürgen: Die Bedeutung der Stadt Frankfurt (Oder) als „Tor der Freundschaft“ und als Verkehrsknotenpunkt zur Sowjetunion. In: Frankfurter Beiträge zur Geschichte 16 (1987), S. 16-19. - Toom, Friedhild den / Klein, Sven Michael: Hermine - die zweite Gemahlin von Wilhelm II. Greiz 2007. - Tschäpe, Karl-Konrad. Chronologie zu Deportation, Zwangsarbeit und Heimkehr in Frankfurt (Oder) 1938-1956 sowie zu deren Rezeprion bis 2018. In: Frankfurter Jahrbuch 2018, S. 86-179. - Vsevolodov, Vladimir: Über die Repatriierung der deutschen Kriegsgefangenen und das Lager 69 in Frankfurt (Oder) - Ein Blick aus Moskau. In: Historischer Verein zu Frankfurt (Oder) e. V. Mitteilungen 2010, H. 2, S. 2-22. - Ders.: „Russische Tage“ in Frankfurt an der Oder (1945-1949): Alltag im Spiegel von Dokumenten aus russischen Archiven. In: ebd. 2018, H. 2, S. 2-22 (vgl. Anmerkungen dazu von Wolfgang Buwert ebd., S. 23-26). - Waack, Christoph: Stadträume und Staatsgrenzen. Geteilte Grenzstädte des mittleren und östlichen Europa im Kontext lokaler Alltagswelten, nationaler Politik und supranationaler Anforderungen. Leipzig 2000, S. 56-61.

\section{Frankfurt/0der-Gronenfelde}

Heimkehrerlager Gronenfelde (Durchgangs- und Entlassungslager), $1 \mathrm{~km}$ westlich des Haltepunktes Gronenfelde/Klingetal: „Am 27. Juli 1946 wurde das im Stadtgebiet Frankfurt (Oder) gelegene Heimkehrerlager eröffnet. Es befand sich auf dem Gelände eines ehemaligen Kriegsgefangenenlagers und diente als Durchgangslager für Heimkehrer (95\%) und Zivilinternierte (5\%). Neben den Wohnbaracken für bis zu 3000 Heimkehrer verfügte es auch über eine Krankenbaracke, Sanitär- und Desinfektionsgebäude, Werkstätten, Verwaltungsgebäude, Küche und Lagerbibliothek. Im Lager waren 73 Angestellte, darunter ein Arzt, drei Schwestern und zwei Sanitäter beschäftigt. Zum 15. August 1950 wurde das Lager aufgelöst. - Bestandsgeschichte: Die überlieferten Akten des Heimkehrerlagers Gronenfelde befanden sich ursprünglich im Stadtarchiv Frankfurt (Oder) und wurden dort auch verzeichnet. Einzelne Bände über die Zusammensetzung von Flüchtlingstransporten wurden nach Auflösung des Lagers an den ,Suchdienst für vermisste Deutsche' in Berlin abgegeben. Das Stadtarchiv Frankfurt (Oder) übergab den Bestand und die dazugehörige Findkartei 1987 dem BLHA.“ (BLHA, Rep. 256 Heimkehrerlager Gronenfelde, Findbuch-Einleitung von Torsten Hartisch). - 16.6.1945 bis 4.4.1946 38500 und 29.4. bis 26.7.1946 778 Kriegsgefangene (Heimkehrerlager, offenbar Vorgänger) (Oehlsen, S. 35). - 2.9.1945 erste Bestattung auf dem Friedhof für Heimkehrer auf den Kiesbergen südlich des Hauptfriedhofes; bis zum 23.10.1946 werden dort 3736 Heimkehrer bestattet (Brisch/Buwert/Schieck, S. 51). - 1946-1950 1,1 Mio. Heimkehrer über dieses Lager nach Deutschland entlassen (Städtebuch, S. 167). - 24.8.1946 Heimkehrerlager, Kapazität: 3000 (SAPMO-BArch, DY 34/27880, Bl. 291). - 25.9.1946 Kundgebung im Lager „anlässlich der Begrüssung des 120000. Kriegsgefangenen" (SAPMO-BArch, DY 34/27781, B1. 179). - 1946 Heimkehrerlager, Belegungsstärke: 3 000, weiteres Heimkehrerlager in Frankfurt (?): 1000 (Ka- 
minsky, S. 160). - 1.1.1947 Lager, Kapazität: 3500 (Oehlsen, S. 101). - 9.6.1947 Durchgangslager, Kapazität: 3000, Belegung: 66 (SAPMO-BArch, DY 34/27880, Bl. 239) - 25.11.1947 „Aufnahmefähigkeit von 3000 Mann - Annahmestelle für Kriegsgefangene“ (BLHA, Rep. 302, VP, Nr. 9, Bl. 43). - 31.12.1947, Jan./Febr. 1948 Heimkehrerlager für entlassene Kriegsgefangene aus dem Osten, eines von 7 verbleibenden Lagern in Brandenburg (BLHA, Rep. 203 MdI, Nr. 1198, Bl. 28v). - Jan. 1948 (Anf./Ende) laut Lagerbestandsmeldung vom 10.2.1948 im Lager 167 / 106 Insassen (BLHA, Rep. 203 MdI, Nr. 1115, Bl. 7). - Okt./Nov. 1948 Heimkehrerlager (BLHA, Rep. 203 MdI, Nr. 1198, Bl. 46). - Okt./Nov. 1948 Heimkehrerlager Frankfurt/ Oder eines von 5 Lagern in Brandenburg (BLHA, Rep. 203 MdI, Nr. 1198, B1. 46). - 26.4.1949 Heimkehrerlager Gronenfelde eines von 5 Lagern in Brandenburg (BLHA, Rep. 203 MdI, Nr. 1198, Bl. 66). - Lagerpersonal am 1.1.1948: Lagerleiter: Vogel; stellv. Lagerleiter: Rösch [noch 1950]; Wirtschaftsleiter: Höpner; Lagerarzt: Dr. Gehring (BLHA, Rep. 256 Heimkehrerlager Gronenfelde; BLHA, Rep. 333, Nr. 575, Bl. 27 [Liste der leitenden Angestellten]). - Noch im Febr. 1950 auch für Vertriebenentransporte aus Polen genutzt (BLHA, Rep. 333, Nr. 574, Bl. 422). - „Als keine Heimkehrer mehr kamen, wurde das Lager desinfiziert und entlaust. Dort erlebten Hunderte von Frankfurter Kindern fröhliche Sommerferien. [...].“ (Stage, S. 14).

Mahnmal (eingeweiht 1998): siehe $\rightarrow$ Frankfurt (Oder), Heimkehrerkrankenhaus Hornkaserne (Orte des Erinnerns, S. 188).

Archivalische Quellen: BArch, DO 2 ZVU, Nr. 39, Bl. 32-33, 56-57 (Lager, 1945). - BArch, DO 2/77 (Rückkehr entlassener Kriegsgefangener. Bd. 1, 1946-1949; enthält u. a.: Pressekonferenzen im Heimkehrlager Gronenfelde bei Frankfurt/Oder). - 2/105 (Heimkehrerlager Gronenfelde bei Frankfurt/Oder, 1945-1946, enthält u. a.: Besichtigungen, Kontrollen, Berichte und Personalfragen). - BArch, DY 34/27989 (Berichte über das Heimkehrerlager Gronenfelde, 1946-1948); DY 27/880 (Betreuung von Heimkehrern und Umsiedlern und Versorgung von Heimkehrerlagern, Bd. 1: 1946-1950; enthält u. a.: Versorgung im Heimkehrerlager Gronenfelde). - BLHA, Rep. 203 MdI, Nr. 1180 (Umsiedlertransporte aus Polen und der Sowjetunion, 1949; enthält u. a.: Transporte über Gronenfelde); Nr. 1181 (desgleichen, März - Dez. 1950; enthält u. a.: Transporte über Gronenfelde). - BLHA, Rep. 256 Heimkehrerlager Gronenfelde (0,9 lfm, 1946-1950, Finanz- und Personalverwaltung; Heimkehrerangelegenheiten). - BLHA, Rep. 256 Umsiedlerlager Küchensee, Nr. 59 („Eingemeindungen und Weiterleitung von Umsiedlern“, 1948; enthält: auch: „Einweisungen von Heimkehrern nach Gronenfelde“). - BLHA, Rep. 333 SED-Landesleitung Brandenburg, Nr. 577 („Heimkehrerlager“, 1946-1949; enthält u. a.: Frankfurt/Oder); Nr. 578 („Heimkehrerlager“, 1946-1949; enthält u. a.: Gronenfelde).

Gedruckte Quellen und Literatur: HOL VII, S. 151 f. (ohne Erwähnung des Lagers). - Brisch, Brigitte / Buwert, Wolfgang / Schieck, Martin: Frankfurt (Oder) 1945. Ausgewählte Daten, Dokumente, Fotos und Erinnerungen. Frankfurt (Oder) [1995]. - Dokumentation der Vertreibung I/2, S. 103. - Gefangene und Heimkehrer in Frankfurt (Oder) 1945-1950/56. Studien. Wolfgang Buwert (Hg.). Potsdam 1998. - Dittmer, Katja: Kurzer Überblick über die Lazarette und Krankenhäuser unmittelbar nach dem Zweiten Weltkrieg. In: Zeitreise durch die Geschichte des Klinikums Frankfurt (Oder). Hrsg. von Ulrich Knefelkamp. Berlin 2003, S. 31-32. - Geschichte vor Ort: Erinnerungskultur im Land Brandenburg für die Zeit von 1933 bis 1990. Konzept der Landesregierung. [Potsdam] 2009, S. 74 (www.mwfk.brandenburg.de [17.10.2016]). - Hartisch, Torsten: BLHA, Rep. 256 Heimkehrerlager Gronenfelde. Findbuch-Einleitung. - Hirthe, Helmut: Das Heimkehrerlager in Frankfurt-Gronenfelde. In: Wir waren damals 19. 50 Jahre 8. Mai in und um Frankfurt. Hrsg.: Jürgen Maerz. Frankfurt (Oder) 1995, S. 282-284. - Orte des Erinnerns. Hrsg. von Anna Kaminsky. 3., überarb. u. erw. Aufl. Berlin 1996, S. 188 (Mahnmal an der ehemaligen Hornkaserne, auch für Lager Gronenfelde). - Pfeiffer, Günter Wilhelm: Von Stoberau, meinem Heimatort, in die Fremde. Erin- 
nerungen. In: BR 13 (2015) 2, S. 16-17. - (Rösch:) Rückblick auf das Heimkehrerlager Gronenfelde bei Frankfurt (Oder) vom 15.05.1950. In: Historischer Verein zu Frankfurt (Oder) e. V. Mitteilungen 1998, H. 2, S. 5-40 [Bericht des stellv. Lagerleiters, Edition nach BArch, DO 2/47). - Scheer, Regina: Der Umgang mit den Denkmälern. Eine Recherche in Brandenburg. [Potsdam] 2003, S. 145 f. - Schneider, Hans-Georg: Zur Rolle und Bedeutung des Frankfurter Heimkehrerlagers Gronenfelde. In: Frankfurter Beiträge zur Geschichte 16 (1987), S. 5-9. - Städtebuch Brandenburg und Berlin. Stuttgart u. a. 2000, S. 167. - Stage, Hannelore: Mit Sandalen fing alles an (Erinnerungen an den Tag der Befreiung). In: Geschichten. Aus Nah und Fern. Zeitzeugen aus Strausberg erzählen. Hrsg.: Seniorenbeirat der Stadt Strausberg. Strausberg 2006, S. 12-14. - Tschäpe, Karl-Konrad. Chronologie zu Deportation, Zwangsarbeit und Heimkehr in Frankfurt (Oder) 1938-1956 sowie zu deren Rezeprion bis 2018. In: Frankfurter Jahrbuch 2018, S. 86-179. - Übersicht über die Bestände des Brandenburgischen Landeshauptarchivs. T. III/ 1. Berlin 2001, S. 83. Wille I, S. 245.

Haltepunkt Gronenfelde, heute Klingetal (nicht mit dem gleichnamigen Heimkehrerlager Gronenfelde zu verwechseln!): Endhaltepunkt der Transportzüge. In der Nähe wurden 1993 Skelette gefunden, die wohl überwiegend von Heimkehrern stammen (1945/46).

LITERATUR: Schneider, Joachim: Rückkehr nach Deutschland und doch nicht daheim. In: Historischer Verein zu Frankfurt (Oder) e. V. Mitteilungen 1993, H. 2, S. 2-3. - Tschäpe (s. o.), S. 93 (Abb. 47).

\section{Frankfurt/0der-Kliestow $\rightarrow$ Kliestow}

\section{Freienhagen}

Landgemeinde (heute Ortsteil von $\rightarrow$ Liebenwalde), bis $1952 \mathrm{Kr}$. Niederbarnim, 1952-1990 Kr. Oranienburg (Bez. Potsdam), 1990-1993 Ldkr. Oranienburg 1993 Ldkr. Oberhavel

Bevölkerungszahlen: 1925: 290, 1939: 473, 1946: 540, 1964: 427 (HOL VI, S. 156). „Durch Flüchtlinge und Umsiedler stieg die Einwohnerzahl 1946 bis auf 540 an." (Lehmann, S. 19).

LITERATUR: Lehmann, Jörg: Die Stadt Liebenwalde. Karwe 2004.

\section{Freienwalde (Kr. Oberbarnim) $\rightarrow$ Bad Freienwalde}

\section{Freyenstein}

Stadtgemeinde, bis 1952 Kr. Ostprignitz, 1952-1990 Kr. Wittstock (Bez. Potsdam), 1990-1993 Ldkr. Wittstock, 1993 Ldkr. Ostprignitz-Ruppin

EReignisse bis KriegSEnde: 3.5.1945 Einmarsch der Roten Armee (Techen, S. 1 f.).

EREIGNISSE NACH KRIEGSENDE: 1945 (Erinnerungen einer schlesischen Flüchtlingsfrau, 1945 18 Jahre alt:) „Am 18. Juli trafen wir in Berlin ein. Wir suchten Arbeit auf dem Land und zu Essen, 
um zu Überleben. Zum Ernteeinsatz in $[\rightarrow]$ Kyritz hatten wir uns angemeldet. Am 24. Juli wurden wir mit einem Lastauto durch das zerstörte Berlin zum Schlesischen Bahnhof gefahren. Nach einer Nacht im Waggon auf dem Bahnhof sind wir in Freyenstein angekommen. Am folgenden Tag konnten wir eine warme Mahlzeit (Erbsensuppe) in der Fleischerei Wetzel zu uns nehmen. Die erste warme Mahlzeit nach langer Zeit! Auf dem Marktplatz wurden wir den Bauern zugeteilt. Die Predigerstraße wurde unser vorläufiges Zuhause. Meine Eltern und meine Schwester Hanna, 10 Jahre, kamen zu Willi Alpermann. Ich wurde Herbert Koop zugeteilt, der eine kleine Landwirtschaft hatte. [...] Ich erzählte viel von meiner Heimat [...]. [S. 4] [...] Unsere Verwandten waren in weiter Ferne. Trotzdem haben wir immer wieder gefragt: ,Wann geht es wieder nach Hause?'Im ersten Jahr bin ich in Freyenstein nicht weggegangen, nur jeden Abend zu meinen Eltern. Dort haben wir mit unserem Nachbarn und dessen Tochter eine Bekanntschaft aufbauen können. Alltag und Sorgen waren kurz vergessen. Nach und nach haben meine Eltern aus einer alten Rumpelkammer eine kleine Wohnung geschaffen. Ja, unsere Schuhe gingen auch mal kaputt. Aber es war schwierig, sie wieder heil zu kriegen. Denn wir hatten keine Lebensmittel, um damit bezahlen zu können. Schuhmacher Reißdorf, auch ein Flüchtling, hat sie wieder heil gemacht. Einem armen Flüchtling und einem damaligen Kutscher brauchte man ja nicht die Hand reichen zur Begrüßung. Das konnte auch mein Vater, Fritz Kirsch, ehemaliger Fleischermeister und Gasthausbesitzer in Wabnitz, Kreis Oels in Schlesien so erleben." (Kanzler, S. 3 f.).

BevöLkerungszahlen: 1925: 1577, 1939: 1593, 1946: 2 119, 1964: 1694 (Städtebuch, S. 183).

Katholiken: 1930: 19, 1946: 148 (Städtebuch, S. 183).

Gedruckte Quellen und Literatur: Kanzler, Magda, geb. Kirsch: Es war einmal ... wir waren Flüchtlinge in Freyenstein. In: Wir in Freyenstein 68 (2015), S. 3-4. - Techen, Thomas: Freyenstein im Mai 1945. In: ebd., S. 1-3.

\section{Friedland}

Stadtgemeinde, bis 1952 Kr. Lübben, 1952-1990 Kr. Beeskow (Bez. Frankfurt/Oder), 19901993 Ldkr. Beeskow, 1993 Ldkr. Oder-Spree

BeVÖLKERUNGSZAHLEN: 1925: 912, 1939: 862, 1946: 1260, 1964: 952 (Städtebuch, S. 186).

Katholiken (Erzbistum Breslau/Erzbischöfliches Amt Görlitz): 1946: 78 (Städtebuch, S. 186).

StÄdtepartnerschaften: Mai 2005 Sulęcin, Polen (Zielenzig, ehem. Kr. Oststernberg, Provinz Brandenburg) (Oststernberg Heimatbrief 2/2015, S. 23 f.). 


\section{Friesack}

Stadtgemeinde, bis 1952 Kr. Westhavelland, 1952-1990 Kr. Nauen (Bez. Potsdam), 1990-1993 Ldkr. Nauen, 1993 Ldkr. Havelland

EREIGNisSE NACH KrIEgSENDE: [Herrenhaus Friesack I]: „1945 wurden Umsiedler in dem Gebäude einquartiert.“ (1956 abgerissen) (Andreae/Geiseler, S. 123). - [Herrenhaus Friesack II]: „Nach 1945 war in dem Gebäude zeitweise ein Kindergarten untergebracht, außerdem richtete die Volkssolidarität dort für Umsiedler und Kriegsheimkehrer eine Ausgabestelle für Kleidung und Lebensmittel ein.“ (1948 abgebrannt, später abgetragen) (ebd., S. 126). - 1945 (Bericht der Stadtverwaltung vom Nov. oder Dez. 1945): „Die Stadt zählte vor dem Einsetzen des Flüchtlingstroms 2500 Einwohner, heute sind es 3400. [...] Der Flüchtlingsfürsorge ist die Arbeit vom Ratsmann Ernst Lutter gewidmet, die auch durch die eigens hierfür angestellte Schwester Toni in Verbindung mit dem prakt. Arzt [Otto] Collin sachgemäß geleitet wird." (Brandenburgische Gemeinden 1945, S. 52).

Bevölkerungszahlen: 1925: 2923, 1939: 2952, 1946: 3551, 1964: 3271 (Städtebuch, S. 189).

Katholiken: 1925: 137, 1946: 627. „Zunahme der kath. Einwohner durch westf. Siedler 1932/33 u. Flüchtlinge 1945“ (Städtebuch, S. 190). - „1932 zogen [... 20 katholische Bauernfamilien aus Westfalen zu, die bis heute den Stamm der Gemeinde bilden. Nach dem II. Weltkrieg stieg auch hier durch Heimatvertriebenen die Zahl der Gläubigen, fast 1500 waren es 1953.“ (Brühe, S. 17; textähnlich: Schwillus/Brühe, S. 334).

UMSIEDLERLAGER: Kapazität am 31.12.1945: 1500 (BArch, DO 2/45, Bl. 40). - Kapazität am 1.1.1946: 400 (BLHA, Rep. 203 MdI, Nr. 1163, Bl. 50). - 1946 Belegungsstärke: 400 (Kaminsky, S. 159).

Gemeindepartnerschaft: 1998 Gemeinde [!] Parchowo (Parchau, ehem. Kr. Karthaus, Westpreußen) (Friesacker Quitzow-Kurier, Nr. 3, 2002).

Gedruckte Quellen und Literatur: Andreae/Geiseler, S. 123, 126. - Brandenburgische Gemeinden 1945, S. 51-53. - Brühe, Matthias: Katholische Kirche zwischen Prignitz und Havelland. Berlin 2000, S. 17. - Schwillus/ Brühe, S. 334.

\section{Fürstenberg/Havel}

Stadtgemeinde, bis 1950 im Land Mecklenburg: 1934-1946 Kr. Stargard (Sitz: Neustrelitz), 1946-1950 Kr. Neustrelitz; 1.7.1950-1952 Kr. Templin (Land Brandenburg), 1952-1990 Kr. Gransee (Bez. Potsdam), 1990-1993 Ldkr. Gransee (Land Brandenburg), 1993 Ldkr. Oberhavel EREIGNISSE BIS KRIEGSENDE: 30.4.1945 Einmarsch der Roten Armee (Stegemann, Nachkriegszeit, S. 151, 223; lt. Neis, S. 72: 29.4.). 
EREIGNisSe NACH KRIEgSEnde: [1945/46:] „Mangelnde Hygiene, katastrophale Wohnverhältnisse und Unterernährung trugen in der Folgezeit zu einer epidemischen Ausbreitung der Tbc bei. [...]." (Stegemann, Nachkriegszeit, S. 233). - „Für elternlose Kinder wurde in der Steinförder Straße ein provisorisches Heim eingerichtet, in dem auch Kinder betreut wurden, deren Mütter tagsüber an verschiedenen Stellen zur Arbeit eingesetzt waren. Später erhielt dieses Waisenkinderheim seinen Platz in der ehemaligen Villa Behrns in der Havelstraße. [...] / Exemplarisch für diese Zeit war das ehemalige Hotel Wegert, das bis unter das Dach mit Flüchtlingen und obdachlos gewordenen Fürstenbergern angefüllt war. Aus den Fenstern ragten die qualmenden Blechrohre von Kanonenöfen und Kochherden.“ (ebd., S. 234).

BEVÖLKERUNGSZAHLEN: 1925: 3293, 1939: 5089, 1946: 6601, 1964: 6095 (Städtebuch, S. 194). - „In Fürstenberg waren [im September 1947] von den 1143 Schülern 403 Jungen und 363 Mädchen Einheimische und 209 Jungen und 168 Mädchen Umsiedler, also ein Verhältnis von ungefähr zwei Dritteln zu einem Drittel. In den [umliegenden] Dörfern sah der Umsiedleranteil an Schülern folgendermaßen aus: Steinförde 83\%, Gramzow 36\%, Dannenwalde 54\%, Tornow $87 \%$, Barsdorf $30 \%$ und Blumenow $70 \%$. Dieser hohe Anteil ergab sich insbesondere aus den Maßnahmen der Bodenreform auf den (bis auf Steinförde) enteigneten Rittergütern. In Barsdorf stand der Aufbau eines ausschließlich aus Umsiedlern bestehenden Ortsteils Qualzow noch bevor. Die Gutshäuser dienten einem Teil der Flüchtlinge und Vertriebenen für längere Zeit als neues Zuhause." (Stegemann, Nachkriegszeit, S. 236).

Katholiken (1930 Bistum Osnabrück, 1946 Bischöfliches Amt Schwerin, 1994 Erzbistum Hamburg): 1946: 1068 (Städtebuch, S. 194). - „Nach dem II. Weltkrieg wurden hier bald etwa 2000 Katholiken gezählt, so dass zum 1.7.1948 eine Lokalie gegründet wurde und mit Josef Hille (1949-54) ein eigener Geistlicher kam.“ (Brühe, S. 18; nahezu textidentisch: Schwillus/ Brühe, S. 318). - „Nach dem Ende des Zweiten Weltkrieges hatte die bisher sehr kleine [katholische] Gemeinde durch Umsiedler und Vertriebene aus dem Osten einen erheblichen Zuwachs zu verzeichnen, der dazu führte, daß Fürstenberg 1948 ein eigener Seelsorgebezirk wurde. Zu ihm gehörten auch die Flüchtlingsbaracken in [ $\rightarrow$ Altthymen- $]$ Dahmshöhe, wo 1965 eine kleine Filialkapelle geweiht werden konnte. [...].“ (Stegemann, Fürstenberg/Havel, Ravensbrück, Bd. 1, S. 77).

Flüchtlingslager (BARAckenlager) Berliner Strasse 76/77 (heute Standort der „Drei-Seen-Grundschule“): Drei Baracken (Baracke 1 zwischen Haus-Nr. 74/75 und 78/79, Baracken 2 und 3 hinter Haus-Nr. 74/75, gegenüber der Einmündung der Goethestraße). „Im Zuge der in den Jahren 1945/46 allgemein erforderlichen Notaufnahme von Flüchtlingen und Vertriebenen mußten auch diese Baracken dafür bereitgetellt werden. In ihnen wurden vor allem Heimatvertriebene aus dem Sudetenland für die nächsten Jahre untergebracht. / Der eigentliche und ursprüngliche Verwendungszweck während des Zweiten Weltkrieges war die Unterbringung von Gefangenen. Diese Baracken waren damals aus diesem Anlaß bereits in den 1930er Jahren aufgebaut worden. / Die Baracke 1 war die größte ihrer Art mit einem Mit- 
telgang, von dem aus die einzelnen Wohnräume betreten werden konnten. Sie war auch die bis 1948 am längsten bewohnte Baracken-Unterkunft auf diesem Komplex. Die anderen beiden Baracken waren schon [S. 491] etwas früher von ihren Bewohnern geräumt. Sie wurden nachmalig allerdings noch in den 1950er Jahren für Lager- und andere Zwecke genutzt. / Die Baracke 2 fungierte ab etwa 1954 für mehrere Jahre hindurch als Stützpunkt für den Reitsport der GST [...]. / Die Baracke 3 wurde durch die 1953 gegründete Landwirtschaftliche Produktionsgenossenschaft ,Solidarität', Fürstenberg, für die Lagerung von Futtermitteln herangezogen. [... / In der Baracke 1 war ab ungefähr 1950 bis gegen Ende der 1960er Jahre seitens des Forstwirtschaftsbetriebes Fürstenberg ein Produktionsbetrieb zur Fertigung von Zäunen und Zaunpfählen untergebracht. / Ab etwa 1955 fanden auf dem Areal dieses Standortes bis zum Bau der Gesamtschule - heute Grundschule - jeweils Rummel und Zirkus bei Gastspielen in Fürstenberg ein vorübegehendes Domizil. / Im Zuge der Entscheidung zum Bau der Gesamtschule auf diesem Gelände, der heutigen „Drei-Seen-Grundschule“, wurden diese drei Baracken in der zweiten Hälfte der 1960der Jahre abgebrochen und verschwanden damit aus dem Stadtbild.“ (Neis, S. 490 f.; S. 490 auch Lageplan, Stand um 1950, und Foto von Baracke 1, 1948). - „Vor dem Gebäude der heutigen Schule am Berliner Ring wurden Baracken für Flüchtlinge und Vertriebene aufgebaut, die mit großer Wahrscheinlichkeit auch aus dem ehemaligen $\mathrm{KZ}[\rightarrow] \mathrm{Ra}-$ vensbrück stammten. Neben ihnen wurden damals die inzwischen prächtigen Lärchen angepflanzt, die heute den Standort markieren. Ein kleiner Findling mit kurzem Text an dieser Stelle könnte dem Vergessen ortsgeschichtlicher Begebenheiten nach Ende des 2. Weltkrieges durchaus entgegenwirken und zum Nachdenken anregen." (Stegemann, Nachkriegszeit, S. 236).

Lager „FASerstoff-Baracken“, Zehdenicker Straße 34-36 (heute Standort von drei zu Beginn der 1980er Jahre errichteten Wohnblöcken): Bis Ende April 1945 KriegsgefangenenBarackenlager für russische Zwangsarbeiter der Faserstoff-Fabrik, dann von der Roten Armee in Beschlag genommen. „Die Besatzer benötigten nun ihrerseits selbst deutsche Arbeitskräfte für die Reparatur von Lastkraftwagen und auch Panzern in dem ehemaligen Faserstoffwerk. Dazu wurden unter anderem auch aus dem damaligen Sportlager Neustrelitz, das 1946 hauptsächlich als Aufnahmelager für Heimatvertriebene aus dem Sudetenland diente, Arbeitskräfte geholt. Sie wurden hier in den Baracken des ehemaligen Kriegsgefangenenlagers, die offiziell und damit auch postalisch als Wohnanschrift mit ,Faserstoff-Baracken Nr. 1 bis $13^{\prime}$ bezeichnet wurden, untergebracht. / Diese Baracken befanden sich nun aber nicht mehr in einem soliden Zustand, sondern im Laufe des Jahres 1945 bis Mitte 1946 waren bereits mehrere Baracken in Auflösung begriffen. Man hatte vereinzelt schon damit begonnen, Zwischenwände der aus Fertigteilen hergestellten Baracken in ihrem Inneren zu demontieren, um sie an anderer Stelle für andere Zwecke zu verwenden. / Und so war bereits Mitte 1946 nicht mehr die ganze zahlenmäßige Abfolge der ursprünglichen 12 Baracken für Wohnzwecke nutzbar, denn die Baracken 7 und 8 waren zu diesem Zeitpunkt schon zum Teil ihrer Innenausstattung und der Zwischenwände beraubt. / Wir kamen Mitte August 1946 in diese Baracken und erhielten eine sehr dürftige Unterkunft in der Baracke 12. Das war ein großer Raum von etwa $6 \times 8 m$ für 6 Personen. [Folgt ausführliche 
Beschreibung der Baracke, der Latrinenanlage und anderer Lagerbereiche]." (Neis, S. 493). „Aus dem Gesamtkomplex der Faserstoff-Baracken wurde die Baracke 1 - zm 1947/48 - als erste offiziell demontiert und am Standort Kreuzdamm, mit einer etwas veränderten Anordnung der Fenster und der Eingangstür wieder aufgebaut. Sie beherbergte dann ab diesem Zeitpunkt anschließend - als eine Zwischenlösung - für rund 10 Jahre unter eingeschränkten Bedingungen einen städtischen Kindergarten. / Ab 1958 diente sie der Konsumgenossenschaft Fürstenberg als Sitz ihrer Verwaltung, in der diese dann bis 1967 verblieb. Die Odyssee dieser Baracke war damit aber noch nicht beendet, denn sie mußte dann für den Neubau eines 32-WEBlocks - dem heutigen Kreuzdamm Nr. 2-5 Platz machen. Ihre Demonatge und Umsetzung erfolgte 1968 für [S. 496] die Konsumgenossenschaft nunmehr am Peetscher Weg 1, allerdings in einer größeren und veränderten Dimension von $25 \mathrm{~m}$ mal $8 \mathrm{~m}$. In ihr war dann der Verwaltungssitz der Konsumgenossenschaft noch bis Mitte 1992 in Fürstenberg präsent. [...] / 1994 wurde sie endgültig abgerisen [...]. / Durch weitere Bauten ist die vorhandene freie Fläche inzwischen für Gewerbe- und Wohnzwecke sinnvoll aufgesiedelt worden. Damit ist auch das letzte Zeugnis der ehemaligen Faserstoff-Baracken endgültig verschwunden. [...]. / [S. 497] Es gibt leider aus der damaligen Zeit nur sehr wenige und nicht besonders aussagefähige Fotodokumente von den Baracken an ihrem eigentlichen Standort im ehemaligen Kriegsgefangenenlager und späteren Wohnlager im Zustand von 1945 bis 1949. [...].“ (Neis, S. 495-497; S. 495: Lageplan, Zustand 1946; S. 496, 499, 503: Fotos).

Siehe auch Flüchtlingslager DahmshöHe in $\rightarrow$ Altthymen-Dahmshöhe.

Gedruckte Quellen und Literatur: Blöß, Kreise und Gemeinden, S. 16, 26, 125 f. - Blöß, Wolfgang: Grenzen und Reformen in einer Umbruchgesellschaft. Berlin 2014, S. 165 f. - Brandenburgische Gemeinden 1945, S. 51-53. Matthias Brühe: Katholische Kirche zwischen Prignitz und Havelland. Berlin 2000, S. 18. - Neis, Kurt: Fürstenberg/ Havel. Privatdruck. 9., erg. Aufl. Fürstenberg/Havrel 2011, S. 63 f. (Behelfsheime), 484-487 (Wohnungsnot und Wohnungsamt), S. 488-511 (Barackenstandorte). - Schwillus/Brühe, S. 318. - Stegemann, Wolfgang: Fürstenberg/Havel, Ravensbrück. Bd. 1. Teetz (1999). - Ders.: Die Nachkriegszeit 1945 bis 1948 in Zeitdokumenten. In: Ders. / Wolfgang Jacobeit: Fürstenberg/Havel, Ravensbrück. Bd. 2. Teetz 2004, S. 223-257. - Töpler, Menschenwurm, S. 466.

\section{Fürstenberg/0der (und Eisenhüttenstadt)}

Stadtgemeinde (ab 13.11.1961 Teil von Eisenhüttenstadt), bis 1950 Kr. Guben, 1.7.1950-1952 Ldkr. Frankfurt (Oder), 1952-1961 Kr. Fürstenberg/Oder, 1961-1993 Teil der kreisfreien Stadt (Stadtkr.) Eisenhüttenstadt (Eisenhüttenstadt zuvor 1953-1961 Stalinstadt) (bis 1990 Bez. Frankfurt/Oder), seit 1993 Teil der amtsfreien Stadt Eisenhüttenstadt im Ldkr. OderSpree

EReignisse BIS Kriegsende: „1944 Ausbreitung einer Typhusepidemie“ (Städtebuch, S. 126). - 4.2.1945 Sprengung der großen Oderbrücke bei Fürstenberg durch einen Wehrmachtspionier (Westteil dabei total zerstört, bis heute nicht wieder aufgebaut) (Schneider, 
Oder, S. 12). - [1945:] „Fürstenberg war für drei Monate Frontstadt und danach Grenzstadt.“ (Schieche, Krankenanstalten, S. 71). - 24.4.1945 Einmarsch der Roten Armee (Ludwig, S. 18).

EREIGNISSE NACH KRIEGSENDE: „1945 Bauchtyphusepidemie nach Kriegsende mit 26 Todesopfern in Fürstenberg/Oder" (Städtebuch, S. 126). - Am 5.9.1945 halten sich in Fürstenberg/Oder (ohne Schönfließ) 128 Flüchtlinge aus den ehem. Ostgebieten auf, im Okt. 160 (Städtebuch, S. 126; vgl. die namentliche Liste vom 5.9.1945, abgedruckt in: „Die russische Kommandantur verlangt ..., S. 54-57). - In der Bodenreform werden 234 „Umsiedler“ berücksichtigt (Käthner, S. 18). - 12.10.1946: Schreiben des Bürgermeisters von Fürstenberg/O. an den Landrat in Guben wegen „Bereitstellung von zusätzlichen Nahrungsmitteln für die Speisewirtschaften“: „Sie müssen sich vor Augen halten, daß noch ständig von Polen Flüchtlinge herüberkommen, denen wie ein warmes Mittagessen geben müssen. [...].“ („Die russische Kommandantur verlangt ..., S. 123). - 27.2.1948 „Neukonstituierung des Umsiedler-Ausschusses“ im Café Krüger (Protokoll: ebd., S. 142). - 3.5.1948 Mitteilung der „Brandenburgischen Schiffahrtsu. Umschlags-Gesellschaft" an die Stadtverwaltung Fürstenberg/O. über die Zusammenlegung der „Schlesischen Dampfer Compagnie-Berliner Lloyd AG Fürstenberg/Oder und Berlin" und der „Neuen Norddeutschen und Vereinigten Elbeschiffahrt AG, Berlin“ unter dem vorgenannten neuen Namen (ebd., S. 150). - 10.1.1949 Umsiedler-Ausschuss befasst sich u. a. mit der Wohnungsraumbeschaffung für "heimatlose Binnenschiffer mit Familien und schulpflichtigen Kindern" (Sitzungsprotokoll in: ebd., S. 163). - 1950 Errichtung des Eisenhüttenkombinats Ost (EKO) und der dazugehörigen Wohnstadt auf Beschluss des 3. Parteitages der SED (die Wohnstadt verwaltungsmäßig zunächst Fürstenberg angegliedert, 1953 aus der Altstadt herausgelöst u. zu einem selbständigen Stadtkr. Stalinstadt erklärt). - 1950-1954 besuchte der spätere Philosoph, Sozialökologe u. (Grünen-)Politiker Rudolf Bahro (geb. 1935 Bad Flinsberg, Schlesien, gest. 1997 Berlin; 1945 Flucht) die Oberschule in Fürstenberg (Vater, aus Gefangenschaft zurückgekehrt, inzwischen Landwirt in Rießen, Kr. Guben), anschließend Studium an der Humboldt-Univ. zu Berlin (A. Fromm, S. 76-79). - 15.5.1953 Umbenennung dert Gaststätte „Goldener Löwe“ in „Hotel zur Friedensgrenze“ (Gansleweit/Opitz, S. 20). - 17.6.1953 „Forderungen nach Rückgabe der bis 1945 deutschen Gebiete" werden während einer Demonstration in Fürstenberg laut (Hübner, Vertriebenenintegration, S. 117). - [Eisenhüttenkombinat:] „Über 30 Prozent der hier Anfang der fünfziger Jahre Beschäftigten waren ,Umsiedler “ (Ast/Mauersberger, S. 131). „Der Bedarf an gesundheitlicher Vorsorge schnellte wiederum in die Höhe, als nach Kriegsende Ströme von Flüchtlingen und Vertriebenen mit ihren Familien hier strandeten. Viele verharrten an dieser sensiblen grenze. Ihre Integration war einer der gewichtigsten Gründe, in dieser bislang ausschließlich agrarisch geprägten Region einen Stahlstandort zu errichten. [...].“ (Eisenhüttenstädter Lesebuch. Profile 2002, S. 140).

EREIGNISSE NACH 1990: „Ein Großteil der Mitglieder der Bürgervereinigung [Bürgervereinigung „Fürstenberg (Oder)“ e.V.] setzt sich aus gebürtigen Fürstenbergern und aus Vertriebenen, deren Heimat einmal östlich der Oder lag, zusammen. Mit der Aufnahme von Polen in 
die Europäische Union kam Interesse auf, historische Orte der deutschen Geschichte diesseits und jenseits der Oder aufzusuchen. Vielfach kam es dabei auch zu Erinnerungen und Gesprächen über die Kindheit und Jugendzeit in der früheren Heimat. Heimatgeschichtliche Bus- und Schiffsfahrten führt der Verein seit 1997 durch: [...] [Folgt Liste der Fahrtziele in Polen 19972017]." (Kahlisch, S. 158).

BeVÖLKeRUnGSZAHLen: Fürstenberg: 1925: 7294, 1939: 6808, 1946: 7691 (davon 5259 in Fürstenberg), 1950: 10 095, 1960: 6749 (Städtebuch, S. 126). - 11.9.1945: 124 „Flüchtlinge in Fürstenberg (Oder)“ („Die russische Kommandantur verlangt ..., S. 58, hier auch Differenzierung nach Altersgruppen). - 1948: 9 100, davon ca. 3000 „Umsiedler“; Anfang 1949 „mit $36 \%$ Umsiedler [so!] belegt [...], [...] die umliegenden Ortschaften mit 10\%" (Goller, S. 28). - Stalinstadt: 1955: 15 517, 1960: 24372; Eisenhüttenstadt: 1961: 32 970, 1971: 45410 (Städtebuch, S. 126).

Katholiken (Erzbistum Breslau/Erzbischöfliches Amt Görlitz): 1925: 712, 1946: 477 (Städtebuch, S. 126). - Pfarrer war 1949 der bis 1945 in Rinnersdorf u. Leimnitz, Kr. ZüllichauSchwiebus (Neumark), amtierende Joseph Birnbach (1886-1970) (Ostpriesterverzeichnis 2, 1949, S. 15; Töpler, Menschenwurm, S. 638).

UMSIEDLERLAGER: 1946 eines von zwei Auffanglagern, in denen die Entlausung vorgenommen wird (erwähnt 17.6.1946) (BLHA, Rep. 206, Nr. 2965, unfol.).

StÄdtepartnerschaften: Seit 1972 Głogów, Polen (Glogau, Schlesien) (www.eisenhuet tenstadt.de [31.5.2017]; Neuer Glogauer Anzeiger, Nr. 9, 2012). „Beide Städte sind seit 1972 städtepartnerschaftlich eng verbunden. Aus politischer und wirtschaftlicher Verantwortung unserer Kommunen, zur Mit- und Neugestaltung des Europahauses, sind in den letzten Jahren vielfältige wirtschaftliche Kontakte geknüpft worden. Auftritte von Gesangs- und Tanzgruppen zu den kulturellen Höhepunkten in beiden Städten sind schon zu einer guten Tradition geworden. Jugendbegegnungen in Workshops, bei Schulprojekten und Jugendcamps tragen zu einem besseren Verständnis, einem offenen und toleranten Umgang miteinander bei." (Offizielle Seite der Stadtverwaltung Eisenhüttenstadt zu Partnerstädten, www.eisenhuettenstadt.de [31.5.2017]).

VerTRIEBENENVERBÄNDE NACH 1990: (1) BdV-Kreisverband Eisenhüttenstadt, 30.5.1991 gegründet (Gründungsversammlung in der Alten Försterei in $\rightarrow$ Wiesenau, wählt Heinz Blüml zum Vorsitzenden), 22, 4, 1993 Vereinsregistereintragung, ab 8.1.1992 Geschäftsstelle ErichWeinert-Allee 3. „Allein 6000 Eisenhüttenstädter Bürger haben den Antrag gestellt, die ihnen laut Gesetz [BVFG] zustehenden 4000 DM zu erhalten." (Mitteilung Stadtarchiv Eisenhüttenstadt 8.8.2018 nach MOZ, 5.6.1996, hiernach auch Zitat); 1996 erwähnt mit Sitz Straße der Republik 17 (BdV-Handbuch 1996, S. 168), zugleich Privatanschrift des Vorsitzenden O. Bierfreund (Geschäftsstelle zuvor: Erich-Weinert-Allee 3 [hier jetzt Dokumentationszentrum Alltagskultur der DDR]); der offenbar identische BdV-Ortsverband Eisenhüttenstadt wurde im Febr. 1998 aufgelöst (17.12.1997 außerordentliche Mitgliederversammlung zwecks Auflösung im „Fürs- 
tenberger Gesellschaftshaus“), letzter Vorsitzender ab 1995: Otto Bierfreund (geb. 1920 Mietzelfelde, Kr. Soldin, gest. 2017, Schmied, später Dipl.-Ing., 1950/51 noch BGL-Vorsitzender im Walzwerk Kirchmöser, ab 1956 in Eisenhüttenstadt, hier auch Gewerkschaftsfunktionär; Todesanzeige in: Der Oderlandspiegel 24, 2018, Nr. 3, S. 8), der aber in nachfolgendem Verband (2) weiter aktiv blieb. [Otto Bierfreund:] „Ich bin jetzt Vorsitzender vom Bund der Vertriebenen hier in Eisenhüttenstadt, werde also zu den Revanchisten gezählt." (Eisenhüttenstädter Lesebuch, Bd. 2, S. 57). - (2) Landsmannschaft Berlin-Mark Brandenburg, Landesverband Berlin-Brandenburg, Ortsverband Eisenhüttenstadt (gegr. 1991), Vorsitzender: Otto Bierfreund, erwähnt noch 2001 (Akten der BdV-Landesgeschäftsstelle).

Evangelisch-Freikirchliche Gemeinde Eisenhüttenstadt (Baptisten), Gemeindesaal Bahnhofstraße 12: „In den Gemeinderäumen treffen sich am Sonntagnachmittag auch russischsprachige Aussiedler zum Gottesdienst." (www.baptisten-bb.de/eisenhuettenstadt.htm [5.6.2017]).

UnGEDRUCKTE QUeLLEN: Auskünfte Erich Opitz (Bürgervereinigung „Fürstenberg (Oder)“ e.V.) und Stadtarchiv Eisenhüttenstadt (zu Otto Bierfreund), 7. und 10.8.2018.

GedRUCKTE QUELLEN: Eisenhüttenstädter Lesebuch. Bd. 1-2. Hrsg. von Dagmar Semmelmann u. a. Berlin 20002004 [Gesprächsprotokolle]. - Noack, Jürgen: Wie ich in Fürstenberg (Oder) eine neue Heimat fand. In: Heimatkalender Eisenhüttenstadt und Umgebung 23 (2005), S. 198-206. - „Die russische Kommandantur verlangt ...” Eine regionale Quellensammlung der ersten Nachkriegsjahre für Fürstenberg (Oder) und Umgebung 1945-1949. Eisenhüttenstadt 2003 (u. a. S. 54-57: Namentliche Aufstellung der in Fürstenberg/Oder untergebrachten Flüchtlinge, 5.9.1945). - Töpler, Menschenwurm. - Warmbold, Alfred: Flucht, Heimkehr und Vertreibung 1945 (Teil 1). In: Zeitschrift für Ostdeutsche Familiengeschichte 66 (2018), S. 321-334, hier S. 325. - Wille II, S. 310.

LiterATUR: Ast/Mauersberger, S. 129-131. - Blöß, Wolfgang: Grenzen und Reformen in einer Umbruchgesellschaft. Berlin 2014. - Blöß, Kreise und Gemeinden, S. 13. - Czerny, Jochen: Der Aufbau des Eisenhüttenkombinates Ost 1950/51. Phil. Diss. A. Jena 1970 [Verf. geb. 1934 Berlin, lebte zwei Jahre in Stalinstadt; nicht eingesehen]. - Ders.: Die Herausbildung sozialistischer Kollektive und Arbeiterpersönlichkeiten beim Aufbau des Eisenhüttenkombinats Ost (EKO). In: Jahrbuch für Geschichte 17 (1977), S. 419-563. - Eisenhüttenstädter Lesebuch. Profile 2002. Hrsg. u. verf. von Gudrun Prengel. Berlin 2002 [Hrsg. geb. 1942 Schweidnitz/Schlesien, Soziologin in Berlin]. - Fromm, Alexander: Die Jugend des Rudolf Bahro. In: Heimatkalender Eisenhüttenstadt und Umgebung 18 (2000), S. $76-$ 81. - Fromm, Günter: Nieder mit der Regierung! Der 17. Juni in Stalinstadt und Fürstenberg/Oder. In: Eisenhüttenstadt: „Erste sozialistische Stadt Deutschlands“. Hrsg.: Arbeitsgruppe Stadtgeschichte. Berlin 1999, S. 138-148. Gansleweit, Klaus-Dieter / Opitz, Erich: Fürstenberg (Oder) im Wandel der Zeiten. T. 3. In: Fürstenberger Blätter 2 (2017), S. 6-24. - Goller, Alexander: Eine neue Heimat? Zur Aufnahme und Integration der Umsiedler im heutigen Eisenhüttenstadt. In: Transit - Transfer. Politik und Praxis der Einwanderung in die DDR 1945-1990. Kim Christian Priemel (Hrsg.). Berlin 2011, S. 25-50. - Hecklau, Svenja: Aufbau der Seelsorge im Gebiet Görlitz 1945-1972. In: Vertriebene finden Heimat in der Kirche. Hrsg. von Rainer Bendel. Köln u. a. 2008, S. 79-93, hier S. 89 f. - Hübner, Peter: „Durchhalten“ und „Durchkommen“. Niederlausitzer Industriearbeiter im Jahre 1945. In: Brandenburg im Jahr 1945. Hrsg. von Werner Stang. Potsdam 1995, S. 136-166. - Ders.: Vertriebenenintegration durch industrielle Erwerbsarbeit in den fünfziger und sechziger Jahren am Beispiel des Landes Brandenburg. In: Vertreibung, Neuanfang, Integration. Erfahrungen in Brandenburg. Christoph Kleßmann / Burghard Ciesla / Hans-Hermann Hertle (Hrsg.). Potsdam 2001, S. 112-122. - Käthner, Klaus: Fritz Schulz - der erste Bürgermeister, als Friede ward an der Oder. In: Heimatkalender für den Stadt- und Landkreis Eisenhüttenstadt 1983, S. 16-18. - Kahlisch, Bertram: 25 Jahre Vereinsarbeit für die Heimatstadt Fürstenberg (Oder). In: Fürstenberger Blätter 2 (2017), S. 148-165. - Opitz, Erich: 
Anfang und Ende einer Schiffergaststätte an der Oberschleuse. In: Heimatkalender Eisenhüttenstadt und Umgebung 15 (1997), S. 35-40. - Ders.: Ereignisse der Nachkriegszeit in Fürstenberg (Oder) und Umgebung. In: Fürstenberger Blätter 1 (2011), S. 71-84. [Minen- und Munitionstote, Wohnungsnot (dabei auch starker Zuzug von Flüchtlingen u. Vertriebenen), Nachkriegsverbrechen; S. 74-76: Liste der vom 15. Mai 1945 bis Februar 1957 durch Minen- oder Munitionsexplosionen zu Tode Gekommenen]. - Pech, Gisela: Entstehung und Entwicklung der Volkssolidarität in Fürstenberg und Eisenhüttenstadt. In: Heimatkalender Eisenhüttenstadt 18 (2000), S. 104-110. - Schade, Rolf: Die Geschichte an der Oder befragt. In: ebd. 11 (1993), S. 55-58. Schieche, Manfred: Typhusepidemie im Jahre 1945 in Fürstenberg/Oder und Umgebung. In: Heimatkalender Eisenhüttenstadt und Umgebung 15 (1997), S. 43-46. Ders.: Die Krankenanstalten der Stadt Fürstenberg (Oder). In: ebd. 16 (1998), S. 66-72. - Schneider, Joachim: Die Oder während der Kriegshandlungen im Frühjahr 1945. In: Historischer Verein zu Frankfurt (Oder) e. V. Mitteilungen 2001, H. 2, S. 7-21. - Semmelmann, Dagmar: Zur Integration aus lebensgeschichtlicher Sicht. Eingliederungsverläufe von Flüchtlingen und Vertriebenen in der SBZ/DDR dargestellt am Sonderfall Eisenhüttenstadt. In: Geglückte Integration? Hrsg. von Dierk Hoffmann u. Michael Schwartz. München 1999, S. 320-333. - Dies.: „Man war total entwurzelt und mußte erst wieder Wurzeln schlagen“. Zur Integration von Flüchtlingen und Vertriebenen in der SBZ/ DDR aus lebensgeschichtlicher Sicht - dargestellt am Sonderfall Eisenhüttenstadt. Berlin 2005 (CD-Rom). - Dies.: Der 17. Juni 1953 in Stalinstadt/Fürstenberg in der Erinnerung von Bauarbeitern aus Eisenhüttenstadt. Zur Wahrnehmungs- und Verarbeitungsweise der Junierhebung durch Beschäftigte der Region. München 2008.

\section{Fürstenwalde/Spree}

Stadtgemeinde, bis 1950 Kr. Lebus, 1.7.1950-1990 Kr. Fürstenwalde (nach Zusammenschluss mit Ketschendorf [Fürstenwalde-Süd] Kreisstadt) (Bez. Frankfurt/Oder), 1990-1993 Ldkr. Fürstenwalde, 1993 Ldkr. Oder-Spree

EREIGNISSE BIS KRIEGSENDE: 1.2.1945 „Aufruf an die Fürstenwalder Bevölkerung zur Aufnahme von Flüchtlingen aus dem Warthegau“" (70 Jahre Kriegsende, o. S.). - Ende Febr. 1945 (Bericht des Fürstenwalder Forstverwalters Otto Lehmann): „Verwandte aus Ostpreußen kommen. Die Glücklichen konnten noch mit dem letzten Zug über Pommern aus Ostpreußen ausreisen." (Ein leidgeprüftes Land, S. 255). - [April 1945]: „Die große Mehrheit der fast 28000 Einwohner und Flüchtlinge mußte [...] flüchtend die Stadt verlassen.“ (Schultz, S. 2); „viele(n) Flüchtlinge aus den ehemaligen deutschen Ostgebieten“ (Bietz, S. 17). - 15.4.1945 (Eindrücke bei einem Stadtspaziergang): „Immer mehr Flüchtlinge zogen durch Fürstenwalde oder blieben hier, die schlimme Nachrichten mitbrachten." (Ein leidgeprüftes Land, S. 252). - 21.4.1945 (Bericht des Fürstenwalder Forstverwalters Otto Lehmann): „Unser Gehöft wird Feldlazarett. Im geräumigen Forsthaus werden Krankenstuben eingerichtet. Uns und den im Forsthaus befindlichen Flüchtlingen bleibt aber noch genügend Raum." (Ein leidgeprüftes Land, S. 256). - 22.4.1945 Einmarsch der Roten Armee (Bietz, S. 16; Schultz, S. 2; 70 Jahre Kriegsende, o. S.).

EREIGNISSE NACH KRIEGSENDE: 24.4.1945 Einrichtung eines Notkrankenhauses in der Lessingschule (spärter Oberschule IV, heute Rahn-Schule) (70 Jahre Kriegsende, o. S.). - „Im Frühsommer 1945 waren 20000 Bürger nach Fürstenwalde zurückgekehrt. Es waren kaum Lebensmittel und nur wenig Wohnraum vorhanden.“ (Schultz, S. 3). - „Im Sommer 1945 zählt man monatl. etwa 400-500 Tote durch verschiedene Krankheiten. [...] Ab August werden wö- 
chentlich über 50 Typhuserkrankungen erfaßt, im Sept./Okt. 45 kommt die Hungerepidemie dazu.“ (70 Jahre Kriegsende, o. S.). - „Wegen der vielen Umsiedlerkinder errichtete man [...] für einige Jahre in Molkenberg unter Fürstenwalder Leitung eine einklassigte Schule im ehemaligen Schloss." (Fremde in Fürstenwalde, S. 33).

EREIGNISSE NACH 1990: 1992 Gründung eines BdV-Kreisverbandes Fürstenwalde (s. u.). - 1994 Namengebung „Haus Posen“ der Samariteranstalten (s.u.). - 1999 Einweihung des „Hauses Brandenburg" (s.u.). - 2001 Anbringung einer Gedenktafel für die Diakonissen des Posener Mutterhauses am Haus Posen der Samariteranstalten (s. u.). - 2002 Einweihung eines Gedenkkreuzes für die Russlanddeutschen auf dem Neuen Friedhof (s. u.). - 22.9.2007 „10. Ostdeutscher Kulturtag" des BdV-Landesverbandes Brandenburg in der Pneumant-Sporthalle (Akten der BdV-Landesgeschäftsstelle).

BevölKerungszahlen: 1925: 23 278, 1939: 29472, Mai 1945: knapp 2000 [!], 1946: 21782 , 1964: 30458 (Städtebuch, S. 200). - 26.4.1945 (Arbeitsbeginn des Einwohnermeldeamtes): „In der Stadt sind etwa 8000 [!] Einwohner“ (70 Jahre Kriegsende, o. S.). - „Mai 1945 waren etwa 18000 Einwohner wieder in der Stadt“ (ebd.). - „Herkunft von Schülern mit Migrationshintergrund von 1938-1950 an der Volksschule III[:] Neumark 116 [=] 46,6\% / Schlesien 47 [=] 18,9\% / Ostpreußen 28 [=] 11,2\% / Pommern 25 [=] 10\%/Westpreußen/Posen 20 [=] $8 \%$ / Polen $7[=]$ 2,8\%/ Andere $6[=] 2,4 \%$ " (Fremde in Fürstenwalde, S. 34).

Katholiken: 1925: 1340, 1946: 1532 (Städtebuch, S. 201).

[KREIS-]UMSIEDLERLAGER: Ehemaliges Barackenlager für Zwangsarbeiter („Fremdarbeiter“) der Pintsch-Werke („Pintsch-Baracken“) an der Trebuser Straße, auf Beschluss des Umsiedleramtes Brandenburg vom 13.5.1946 zum Umsiedlerlager umfunktioniert (zuvor [Mai?] 1945 bereits als eines von mehreren Behelfskrankenhäusern hergerichtet [70 Jahre Kriegsende, o.S.]), vorgesehen zur Aufnahme ehem. Kriegsgefangener („Heimkehrer“), 19.6.1946 Meldung: $80 \%$ aufnahmebereit, 27.6.1946 bezugsfertig für 2000 Personen, ausbaufähig für ca. 4000 Personen (Oehlsen, S. 36). - 1946 Heimkehrerlager, Belegungsstärke: 2000 bis 3000 , weiteres Heimkehrerlager (?): 2000 (Kaminsky, S. 160). - 25.6.1946 Erstbelegung: 830 Personen (Oehlsen, S. 55). - 24.7.1946 in Liste der Lager für „Ostheimkehrer“ als „Waldlager Pintsch" genannt mit Kapazität 3000 und Bestimmung ,f[ür $]$ Leichtkranke u. Erholungsbedürftige" (BArch, DO 2/45, Bl. 76). - 24.8.1946 Heimkehrerlager, Kapazität: 2000 (SAPMO-BArch, DY 34/27880, Bl. 291). - 1946 Belegungsstärke: ohne Angabe (Kaminsky, S. 159). - 1.1.1947 Lager, Kapazität: 2200 (Oehlsen, S. 101). - Bis Mai 1947 insgesamt 2560 Umsiedler „in Lagern" in Fürstenwalde untergebracht (Städtebuch, S. 200). - 9.6.1947 Heimkehrerlager, Kapazität: 2000, Belegung: 42 (SAPMO-BArch, DY 34/27880, Bl. 239). - 10.10.1947 Lagerleiter: Kriegel, Wirtschaftsleiterin: Holz (SAPMO-BArch, DY 34/27781, B1. 9). - 25.11.1947 „Aufnahmefähigkeit von 2000 Mann Quarantänelager für Umsiedler" (BLHA, Rep. 302, VP, Nr. 9, B1. 43). - 31.12.1947, Jan./Febr. 1948 Quarantänelager, eines von 7 verbleibenden Lagern in 
Brandenburg (BLHA, Rep. 203 MdI, Nr. 1198, Bl. 28v). - Jan. 1948 (Anf./Ende) laut Lagerbestandsmeldung vom 10.2.1948 im Lager 280 / 227 Insassen (BLHA, Rep. 203 MdI, Nr. 1115, Bl. 7). - Bis Febr. 1948 insgesamt 2797 Umsiedler „in Lagern“ in Fürstenwalde untergebracht (Städtebuch, S. 200). - Okt./Nov. 1948 Umsiedlerlager Fürstenwalde eines von 5 Lagern in Brandenburg (BLHA, Rep. 203 MdI, Nr. 1198, Bl. 46). - 1949-1950/51 Aufnahme von „Umsiedlertransporten" aus Polen und der Sowjetunion (BLHA, Rep. 203 MdI, Nr. 1179-1181). 26.4.1949 Heimkehrer- u. Umsiedlerlager Fürstenwalde eines von 5 Lagern in Brandenburg (BLHA, Rep. 203 MdI, Nr. 1198, Bl. 66). - Lagerpersonal am 1.1.1948: Lagerleiter: Dr. Kriegel; Wirtschaftsleiter: Waldoch; Lagerarzt: „ständiger Lagerarzt z.Zt. noch nicht vorhanden. (Vertretung durch einen Stadtarzt)“ (BLHA, Rep. 333, Nr. 575, B1. 27 [Liste der leitenden Angestellten]). - 1949-1951 Lager Fürstenwalde/Spree, „eines der drei großen Quarantänelager“ neben Wolfen bei Bitterfeld (Sachsen-Anhalt) und Bischofswerda (Sachsen) für die (Kinder-) Transporte aus Ostpreußen und Litauen (Winterberg, S. 179). - März 1950 Stempel „Heimkehrerlager Fürstenwalde/Spree" in Gebrauch (BArch, DO 1/8207, unfol.). - 14.12.1950 letzte Zahl über Belegung: 698 Personen (Oehlsen, S. 55). - Im März 1951 befinden sich deutsche „Repatrianten aus Swinoujsce“ (Swinemünde) im Lager (SAPMO-BArch, DY 34/27737, Bl. 43; vgl. BArch, DO 1/15804). - 1951 Lagerleiter (seit 1.5.1946): Fritz Piepenburg (geb. 1922), SED, DSF; Kassenleiter (seit 1.5.1949): Heinz Thiel (geb. 1930), SED; DSF, FDGB (BArch, DO 1/8405, unfol.). - Lager nimmt auch 1952 noch Transporte auf (BLHA, Rep. 203 MdI, Nr. 1193). - 1954-1961 erwähnt als Aufnahmeneim für Personen aus Kaliningrad (u.a. BArch, DO 1/8405, DO 1/8406, DO 1/13543, DO 1/13695 [hierin monatliche altersmäßige Aufnahmestatistiken für „Personen aus der UdSSR“ von Juli 1958 bis Dez. 1961]). Lagerleiter des „Aufnahmeheims“ (auch „Unterkunftsstelle“) 1954-1945: Herr Kratschke (BArch, DO 1/8406, unfol.).

Archivalische Quellen zum Lager: BArch, DO 1 Ministerium des Innern der DDR, Nr. 8205 bis 8408, 13695 (Quarantänelager für Transporte aus Kaliningrad, 1950-1961). - BArch, DO 1/17274, DO 1/17275 (Aufnahmeheim Fürstenwalde. Kartei genehmigter Aufnahmen, 1959-1962). - BArch, DO 1/13543 (enthält u.a. Meldungen des Aufnahmeheims Fürstenwalde, 1960-1962). - BArch, DO 1/8408 (Übersiedlungen aus der UdSSR, hier: Normative, Statistiken, Berichte, Transportlisten, Bd. 1: 1950-1955, enthält u. a.: Transporte aus Kaliningrad; Berichte der Quarantänelager Bischofswerda, Wolfen, Fürstenwalde/Spree; Einzelreisende); DO 1/8408 (desgl., Bd. 5: 19541956, enthält v. a.: Statistiken zu Personen, die das Aufnahmeheim Fürstenwalde/Spree passierten; Transportlisten Einzelreisende); DO 1/13695 (desgl., Bd. 10: 1957-1962; enthält v. a.: Statistiken zu Personen, die das Aufnahmeheim Fürstenwalde/Spree passierten; Transportlisten zu Einzelreisenden). - BArch, DO 1/16616 (Unterbringung von obdachlosen und sozialgefährdeten Personen im Lager Fürstenwalde, 1951-1953). - BArch, DO 1/13520, 13521, 14532-14534 (Zusammenarbeit [des MdI] mit dem Aufnahmeheim Fürstenwalde/Spree [5 Bände], bes. Transporte aus UdSSR und Polen, auch Weiterleitung in die Bezirke u. a., 1956-1962). - BArch, DO 2/39. - SAPMO-BArch, DY 34/27880 (Betreuung von Heimkehrern und Umsiedlern und Versorgung von Heimkehrerlagern, Bd. 1: 1946-1950; enthält u. a.: Versorgung im Heimkehrerlager Fürstenwalde); DY 34/27881 (desgleichen, Bd. 2, 1947-1950). - BLHA, Rep. 203 MdI, Nr. 1180 (Umsiedlertransporte aus Polen und der Sowjetunion, 1949; enthält u. a.: Transporte über Fürstenwalde); Nr. 1181 (desgleichen, März - Dez. 1950; enthält u.a.: Transporte über Fürstenwalde); Nr. 1179 (desgleichen, Aug. 1950 - Jan. 1951; enthält u. a.: Statistische Meldungen des Quarantänelagers Fürstenwalde); Nr. 1192 (Angelegenheiten des Quarantänelagers Fürstenwalde/Spree, 1950-1952; enthält u. a.: Versorgungsfragen; Weiterleitung der Umsiedler; vorübergehende Nutzung des Lagers für asoziale und obdachlose 
Personen aus Berlin); Nr. 1193 (desgleichen, 1952; enthält u. a.: Berichte über Umsiedlertransporte mit Namensangaben; Aufstellung über Lagerbelegung, Zugänge und ehemalige Internierte; Berichte über die kulturelle und politische Bedeutung). - BLHA, Rep. 256 Heimkehrerlager Gronenfelde, Nr. 37 („Schriftwechsel mit der Zentralverwaltung für deutsche Umsiedler sowie Verfügungen und Bekanntmachungen der Lagerleitung und anderer Dienststellen“, Jan. 1947 - Sept. 1949; enthält u. a.: Überweisungen von Heimkehrern zur Weiterleitung aus dem Heimkehrerlager Fürstenwalde/Spree). - BLHA, Rep. 333 SED-Landesleitung Brandenburg, Nr. 577 („Heimkehrerlager“, 1946-1949; enthält u. a.: Fürstenwalde).

Gedruckte Literatur und Literatur zum Lager: Dokumentation der Vertreibung I/2, S. 481 (1949), 544 (1950). - Oehlsen, Sven Olaf: Vertriebenenlager in Brandenburg 1945-1953. Potsdam 2006, S. 36-55 (Kapitel 5 „Das Vertriebenenlager Fürstenwalde“, S. 37 Abb. 9 Lageplan; S. 39 Stellenbesetzungsplan; S. 55: Tabelle der Belegung 25.6.1946 bis 14.12.1950). - Spatz, Christopher: Nur der Himmel blieb derselbe. Ostpreußens Hungerkinder erzählen vom Überleben. Hamburg 2016. - Städtebuch Brandenburg und Berlin. Stuttgart u. a. 2000, S. 200. - Winterberg, Sonya: Wir sind die Wolfskinder. München/Zürich 2012, S. 179 f.

Strassenumbenennungen: (1) 12.11.1876 Zweite Straße umbenannt in Küstriner Straße, nach 1945 und bis heute nicht verändert, vermutlich wegen der stadtbekannten, auch in der Geschichte der lokalen Arbeiterbewegung traditionsreichen Gaststätte „Küstriner Wappen“ (Küstriner Straße 9) (Mitteilung Florian Wilke, Fürstenwalde, 21.6.2018; Gespräche mit ehemaligen Küstrinern. Bd. 7. Frankfurt (Oder) 2018, S. 37-39 mit Abb.). - (2) 1925-1928 (und 1932/34) Siedlungsneubau auf dem ehemaligen Flugplatzgelände im Nordosten der Stadt, hier 2.4.1927 Neubenennungen, nach 1945 folgende umbenannt (in Klammern die vorherigen Straßennamen bis 1927 und die späteren bzw. aktuellen nach 1945; Eigentümer lt. Adressbuch Privatpersonen, wenn nichts anderes angegeben): Bentschener Straße (ab 1926 als Straße ohne Bezeichnung [Bauträger lt. Adressbuch 1929: GEWOBA - Gemeinnützige Wohnungsbau- und Eigenheim-Genossenschaft eGmbH]; seit 30.11.1951 Verdistraße), Bromberger Straße (ab 1925 als Straße C; ab 30.11.1951 Händelstraße, seit 30.6.1977 Wladimir-M.-Komarow-Straße), Dirschauer Straße (ab 1926 als Straße J; seit 30.11.1951 Tschaikowskistraße), Gnesener Straße (ab 1926 als Straße H; seit 30.11.1951 Mozartstraße), Graudenzer Straße (ab 1926 als Ringstraße; seit 30.11.1951 Beethovenstraße), Kattowitzer Straße (ab 1922 als Straße Q [Eigentümer lt. Adressbuch 1929: Stadt Fürstenwalde]; seit 30.11.1951 Chopinstraße; „mit Errichtung des Neubauviertels Ende der 1970er Jahre Wegfall der Straße durch Überbauung"), Konitzer Straße (ab 1926 als Straße K; seit 30.11.1951 Käthe-Kollwitz-Straße), Lissaer Straße (ab 1926 als Straße 20; seit 30.11.1951 Richard-Strauss-Straße), Posener Straße (ab 1815 bestehend, ab um 1922 Straße A; ab 13.6.1946 August-Bebel-Straße, seit 29.11.1951 [wegen Doppelung im 1950 eingemeindeten Ort Ketschendorf] Johann-Sebastian-Bach-Straße), Soldauer Straße (ab 1926 als Straße P [Eigentümer lt. Adressbuch 1929: „Städtische Kleinsiedlung"]; seit 30.11.1951 RichardWagner-Straße), Tarnowitzer Straße (ab 1922 als Straße E [Eigentümer 1t. Adressbuch 1929: Stadt Fürstenwalde]; ab 30.11.1951 Franz-Liszt-Straße, seit 30.6.1977 Georgi-DobrowolskiStraße), Thorner Straße (ab 1926 als Straße F, seit 30.11.1951 Haydnstraße) (Mitteilung Guido Strohfeldt, Museum Fürstenwalde, 22.6.2018). - 19.5.1932 Benennung der neu angelegten Kulmer Straße (seit 30.11.1951 Brahmsstraße; „mit Errichtung des Neubauviertels Ende der 1970er Jahre Wegfall der Straße durch Überbauung“); 13.3.1934 Neubenennungen 1933 neu 
angelegter Straßen: Hohensalzaer Straße (seit 30.11.1951 Borodinstraße); Rawitscher Straße („bis heute Straße ohne Wohnadresse und deshalb nie umbenannt“) (Quelle: wie vor).

Städtepartnerschaften: (1) 1992 Choszczno, Polen (Arnswalde, ehem. Kreisstadt in der Provinz Brandenburg, 1938-1945 Provinz Pommern). - (2) 2014 Sulechów, Polen (Züllichau). - (3) Freundschaftsabkommen mit der Gemeinde Santok, Polen (Zantoch, ehem. Kr. Landsberg/Warthe, Provinz Brandenburg).

VeRTRIEBENENVERBÄNDE NACH 1990: (1) BdV-Kreisverband Fürstenwalde (ab 1993 BdV-Kreisverband Oder-Spree) e. V., gegründet 1992 durch Hans Apelt, Reinhold Bujok (s. u.), Max Grünwald, Gerda Kubiak und Hermann Schmück (s.u.), 24.8.1993 Satzung errichtet, 19.1.1995 eingetragen beim Amtsgericht Fürstenwalde (VR 496) (Akten der BdV-Landesgeschäftsstelle). Geschäftsstelle und Begegnungsstätte für Senioren: Ernst-Thälmann-Straße $114 \mathrm{~d}$ (noch 2018 erwähnt); Aktivitäten u.a.: Reisen und Tagesfahrten in die alte Heimat, langjährige Kontakte zur deutschen Minderheit in Arnswalde/Choszczno, länderübergreifende Arbeit mit Kindern und Jugendlichen, regelmäßige Kultur-, Sozial- und Informationsveranstaltungen, Auftritte des vereinseigenen Chores der „Fröhlichen Sänger“. 19.10.2012 Festveranstaltung zum 20-jährigen Bestehen des Kreisverbandes im „Fürstenwalder Hof“ (http://www.blickpunkt-brandenburg. de [10.10.2016]); „relativ große Streuung der Mitglieder weit von Fürstenwalde“ (10 Jahre Bund der Vertriebenen, S. 13); Sitz 1996: Trebuser Str. 60 (BdV-Handbuch 1996, S. 168). Der Verband gibt (wohl seit 1996) gemeinsam mit dem $\rightarrow$ Rüdersdorfer Verband ein Informationsblatt heraus: „Feelinchen. Informationsblatt des Bundes der Vertriebenen Oder-Spree e. V. und Amt Rüdersdorf und Umgebung e.V." (anfangs zwei-, später dreimonatlich; 2018 (Jan./Febr./ März) erschien Nr. 125; siehe auch Keller). - Mitgliederzahlen: 20.7.2010: 182, 1.1.2011: 188, 19.12.2011: 185, 11.12.2012: 188, 31.12.2013: 184, 26.9.2016: 166 (Akten der BdV-Landesgeschäftsstelle). - Vorsitzende: 1992-2000 Hermann Schmück (geb. 1920 Reetz), Rentner in Fürstenwalde (1. stellv. Vorsitzender 1992 Reinhold Bujok, $\rightarrow$ Rüdersdorf), 2000-2014 Reinhard Wenzel (geb. 1948 Biegen [bei Briesen/Mark, Kr. Lebus]), ebd., später Jacobsdorf OT Petersdorf (BR 10 (2012)9, S. 7; Feelinchen 122, 2017, S. 49; Akten wie vor), 2014-2016 Hermann Schmück (auch Ehrenvorsitzender), 2016-2018 Reinhard Wenzel, ab 18.4.2018 Wolfgang Löchelt (geb. ca. 1953, Familie aus Neudorf/Schlesien). - (2) Ab 2008 zusätzlich $B d V$-Arbeitsgemeinschaft „Grenzüberschreitende Arbeit" der Region Oder-Spree e. V. (Vorsitzender: Hermann Schmück [wie oben]). „Im Bund der Vertriebenen im Landkreis Oder-Spree hat sich die bisherige Arbeitsgruppe ,Grenzüberschreitende Zusammenarbeit' selbstständig gemacht: 37 Mitglieder haben unter dem Vorsitzenden Hermann Schmück einen eigenen Verein gegründet. [...] / Schmück hat ein Positionspapier verfasst, mit sechs Punkten zu Vertriebenen-Fragen. So lehnt der Verein die Bestrebungen der Preußischen Treuhand ab, die Besitzansprüche in Polen verfolgt. Schmück geht es um eine europäische Verständigung, er will ausdrücklich auch die Vertreibung von Polen im Zweiten Weltkrieg thematisieren." (MOZ.de, 28.6.2008). 2013 in BdV-Landesverband aufgenommen, pflegt bereits Kontakte mit dem polnischen Verein 
„Kinder des Krieges“ und will „zielgerichtet die weitere Zusammenarbeit mit dem Verein und anderen Organisationen ausbauen“, dabei neue Mitglieder gewinnen und sich auch für „Nichtvertriebene aller Altersgruppen" öffnen (Akten wie vor, aber nur bis 2008). - (3) Bauernverband der Vertriebenen e. V., Landesobmann für Brandenburg, erwähnt 1996: Hermann Schmück, KarlLiebknecht-Str. 10, Fürstenwalde (BdV-Handbuch 1996, S. 221), Nachfolger: Manfred John, Elsterwerda (geb. 1938) (Auskunft BdV-Landesgeschäftsstelle/Clemens, 7.7.2017).

Gedruckte Quellen und Literatur zum BdV: Feelinchen 1996 ff. - Keller, Elfriede: 100-mal Feelinchen. Zur 100. Ausgabe des Informationsblattes ded Kreisverbandes Oder-Spree. In: BR 11 (2013) 9, S. 9. - Reichhaltiges und erfolgreiches Vereinsleben. Kreisverband Oder-Spree feierte 20jähriges Bestehen. In: BR 11 (2013)1, S. 6. - 10 Jahre Bund der Vertriebenen in Rüdersdorf und Umgebung. Rüdersdorf 2002, S. 13. - 20 Jahre Bund der Vertriebenen Kreisverband OderSpree e. V. Hrsg.: Bund der Vertriebenen Kreisverband Oder-Spree e. V. Fürstenwalde (2012). 20 S.

Neuer Friedhof (Friedhofstraße): (1) Steinernes Gedenkkreuz für die Russlanddeutschen. „Im Jahr 2003 lebten in Fürstenwalde etwa 1000 Russlanddeutsche. Auf ihre Initiative und mit der Hilfe von Spenden konnte am 28. Augut 2003 auf dem Neuen Friedhof ein Gedenkkreuz zur Erinnerung an die in der Sowjetunion verfolgten Russlanddeutschen errichtet werden. Die Inschrift des Kreuzes lautet: ,Dem Andenken der / Russlanddeutschen / von denen über eine / Million in der Sowjetunion / unter dem Stalin-Regime / in Lagern vernichtet/wurden. Fürstenwalde, den 28.8.2003؛ (Orte des Erinnerns, S. 194). Darüber steht der Text des „Vater Unser“. Die Einweihung erfolgte mit einem ökumenischen Gottesdienst (Mahn- und Gedenkstätten Brandenburg, mit Abb.). - (2) Gedenkstein des BdV-Kreisverbandes Oder-Spree (rechts hinter der Feierhalle), Enthüllung Juni 2007: zwei stehende spitzwinklige Dreiecke, in der Mitte Aussparung in Kreuzform, Inschrift „Zum Gedenken an die Opfer von Gewalt, Flucht und Vertreibung / und allen zur Mahnung / Bund der Vertriebenen Kreisverband Oder-Spree“ (BR 11 (2013)1, S. 7 mit Foto; Angaben von Martina Rohde 2008 auf http://www.denkmalprojekt.org [16.6.2018]).

Quellen und Literatur zum Gedenkkreuz: Mahn- und Gedenkstätten Brandenburg. Hrsg.: BdV (http://www. bund-der-vertriebenen.de [20.9.2016]). - Orte des Erinnerns. Hrsg. von Anna Kaminsky. 3., überarb. u. erw. Aufl. Berlin 1996, S. $193 \mathrm{f}$.

„Haus Brandenburg“, Parkallee 14: Dokumentations- und Kulturzentrum/Begegnungsstätte mit Bibliothek (zuvor in Stuttgart untergebracht; Leiterin der Bibliothek bis 2017: Dipl.Bibliothekarin Maria Petzoldt), Archiv und Ausstellung für die Pflege des Andenkens an die Geschichte und Kultur der Deutschen im historischen Ostbrandenburg (Neumark und östliche Niederlausitz). Auf Initiative ihres Bundessprechers Werner Bader von der Landsmannschaft Berlin-Mark Brandenburg mit Spendenmitteln errichtet und am 12.4.1999 im Beisein des Ministerpräsidenten Stolpe eingeweiht (Baubeginn: Dez. 1998), 1.4.2002 Übertragung an die (1974 in Baden-Württemberg gegründete) Stiftung Brandenburg (Sitz seit Ende 2007/Anf. 2008 in Fürstenwalde, zuvor in Stuttgart). Als Veranstaltungsort für Gremiensitzungen, Versammlungen und Tagungen bis heute häufig von Landsmannschaft und verschiedenen neumärkischen Heimatkreisen genutzt. Kuratoren: bis 2006 Dietrich Handt (Herford), 2006-2009 Prof. Dr. Werner Vogel (Berlin), 2009-2011 Prof. Dr. Hans-Christian Petzoldt (Fürstenwal- 
de), 2012-2019 Karl-Christoph v. Stünzner-Karbe (Waldsieversdorf), dann erneut Petzoldt. 28.10.2002 Gründung des „Haus Brandenburg - Freundeskreis e.V.“ (Brandenburgkurier 26 (2012), Nr. 3, S. 4). - „Märkisches Gesprächsforum“ als Veranstaltungsreihe im Haus; Moderation: Karlheinz Lau (Berlin), ab 2015 Gerhard Weiduschat (Berlin) (Brandenburgkurier 29 (2015), Nr. 1, S. 3). - 2013 Zulegung der „Stiftung Landsberg/Warthe“ (Herford) zur „Stiftung Brandenburg" in Fürstenwalde (Spree)" (Brandenburgkurier 27, 2013, Nr. 2, S. 1) und Umzug des Archivs in das „Haus Brandenburg“ (ebd., 27, 2013, Nr. 3, S. 2-4). - 2016 Verleihung des „Brandenburgischen Archivpreises 2016“ des Landesverbandes Brandenburg des Verbandes deutscher Archivarinnen und Archivare e. V. an die Stiftung Brandenburg (ebd., 30, 2016, Nr. 2, S. 1). - Ab 2017 Vorplanung eines Umzugs nach $\rightarrow$ Frankfurt (Oder).

Literatur zum „Haus BrandenburG“: Brandenburgkurier 19 (2005) ff. [Darin Tätigkeitsbericht der Stiftung Brandenburg und des Hauses Brandenburg]. - Geschichte vor Ort: Erinnerungskultur im Land Brandenburg für die Zeit von 1933 bis 1990. Konzept der Landesregierung. [Potsdam] 2009, S. 75-76 (www.mwfk.brandenburg.de [17.10.2016]). - Petzoldt, Maria: Die Bibliothek im Haus Brandenburg - Was bietet sie, was leistet sie ... In: Königsberger Kreiskalender 2003, S. 94-96. - Schellhaas, Ingrid: Kultur- und Begegnungsstätte - Haus Brandenburg Fürstenwalde. In: Kreiskalender Oder-Spree 2002, S. 44-45. - Vogel, Werner: Das Haus Brandenburg. Geschichte und Wirksamkeit. In: Landesherr, Adel und Städte in der mittelalterlichen und frühneuzeitlichen Neumark. Klaus Neitmann (Hrsg.). Berlin 2015, S. 407-411. - Ders.: Die Stiftung Brandenburg. Geschichte, Aufgaben, Wirksamkeit. In: Historiker und Archivar im Dienste Preußens. Festschrift für Jürgen Kloosterhuis. Hrsg. von Hans-Christof Kraus u. Frank-Lothar Kroll. Berlin 2015, S. 245-262 (zum Haus Brandnburg S. 252-258).

Gedruckte Quellen und Literatur zu Flüchtlingen und Vertriebenen in Fürstenwalde allgemein: Bietz, Gerd-Dieter: Der Weg der Befreier Fürstenwaldes. In: Heimatkalender Kreis Fürstenwalde 1990, S. 16-18. Dokumentation der Vertreibung I/2, S. 670. - Fremde in Fürstenwalde. Fakten, Fragen, Fragmente. Hrsg. von der Kulturfabrik Fürstenwalde gGmbH. Fürstenwalde [2007]. - Ein leidgeprüftes Land. Bearb. von Fritz Knüppel. 2. Aufl. Barsinghausen 1990. - Schultz, Rudolf: Vor 45 Jahren befreiten sowjetische Truppen unsere Stadt. In: Heimatkalender Kreis Fürstenwalde 1990, S. 2-3. - Schwillus/Brühe, S. 320-321 - 70 Jahre Kriegsende in Fürstenwalde. [Ausstellungstexte]. [Hrsg.:] Museum Fürstenwalde. Fürstenwalde [2015]. - Weiß, Waltraud: Ein Teller Wassersuppe. Auszüge aus einem Fürstenwalder Tagebuch der Nachkriegszeit. In: Fürstenwalder Lesebuch. Berlin 1997, S. $100-102$.

\section{Fürstenwalde-Ketschendorf}

Ketschendorf (Spree) bis 1950 Landgemeinde im Kr. Lebus, 1950 eingemeindet nach $\rightarrow$ Fürstenwalde, seitdem Teil von Fürstenwalde-Süd

Sowjetisches Speziallager Nr.5 (1945-1947): Flüchtlinge und Vertriebene sind als Gruppe nicht unter den Häftlingen auszumachen, in Einzelfällen aber angesichts der Vielzahl inhaftierter Zivilisten zu vermuten. Die am 3. Mai 2003 in der Martin-Luther-Kirche in $\rightarrow$ Fürstenwalde eingeweihte hölzerne Gedenktafel für die Opfer des Speziallagers nimmt in ihrem Inschriftentext auf alle Opfergruppen der beiden Weltkriege, der NS-Diktatur ab 1933 und der Nachkriegszeit bis 1947 Bezug, darunter ausdrücklich auch allgemein auf Vertriebene („vertrieben/heimatlos verloren") (Orte des Erinnerns, S. 192). 
Posener Diakonissen-Mutterhaus der Samariteranstalten Fürstenwalde/Spree (Ketschendorf/Spree, August-Bebelstraße 1-4 und Langenwahler Straße 70): 7.2.1947: „Das Posener und das Fürstenwalder Mutterhaus werden, gemäß Beschluss beider Vorstände vom 11 . Dezember 1946, zum ,Posener Diakonissen-Mutterhaus der Samariteranstalten Fürstenwalde/ Spree' vereinigt." (120 Jahre Samariteranstalten, S. 30). Oberin wird am 1.2.1947 die 1945 aus Posen geflohene Oberin der dortigen Evangelischen Diakonissenanstalt, deren Schwestern in Fürstenwalde eine neue Wirkungsstätte finden. „Die letzte Oberin [1940 bis Jan. 1945] Emma Lichtenberg [1894-1974] versieht ihr Amt auch in der Verbannung weiter." (Gotthold Rhode: Geschichts der Stadt Posen. Neuendettelsau 1953, S. 233; siehe auch Kronika miasta Poznania. Tom 1. Poznań 2011, S. 123, 131; Daten ergänzt nach ELAB, 1/2453, Dokumentation, S. 38). Frühjahr 1947: „Nach und nach ziehen die Posener Schwestern in den Samariteranstalten ein. Sie übernehmen zunächst die Arbeit in Küche und Waschküche, dann auch die auf den Kinderstationen, später auch in Neuendorf [bei Fürstenwalde]. Sie sind überwiegend ausgebildete Krankenschwestern und stellen sich nun auf ihr neues Arbeitsgebiet ein.“ (120 Jahre Samariteranstalten, S. 30) - „Das wichtigste Ereignis der Nachkriegszeit für die Samariteranstalten und zugleich unmittelbar auf Ergebnisse des Kriegss zurückzuführen war jedoch die Aufnahme des Posener Diakonissenmutterhauses in Fürstenwalde. [...] [S. 110] [...] Es war eine doppelte Aufgabe: Die Samariteranstalten boten der vertriebenen Schwesterngemeinschaft ein Obdach und diese öffnete sich den verbliebenen Diakonissen des Fürstenwalder Mutterhauses. Die neue Bezeichnung der Einrichtung lautete ,Posener Diakonissenmutterhaus der Samariteranstalten Fürstenwalde/Spree, den Hausvorstand bildeten Oberin Lichtenberg und Pfarrer [Karl Friedrich] Hoffmann [geb. 1890, bis 1945 Pfarrer in Schwiebus, P. B.]. / Die feierliche Vereinigung der beiden Mutterhäuser in einem Gottesdienst fand am 25. Juni 1947 im Festsaal der Samariterkirche statt. Nachdem die [S. 111] Schwestern zunächst nur in kleiner Zahl nach Fürstenwalde gekommen waren, stand mit der endgültigen Rückgabe des Lutherhauses im Juli 1947 genug Platz zur Verfügung, um eine größere Gruppe von Feierabendschwestern in das neue Stammhaus zu holen. [...] Die ürigen verteilten sich, der Tradition des Posener Mutterhauses entsprechend, auf zahlreiche Außenstationen, wobei allein 45 im Kreiskrankenhaus Salzwedel arbeiteten. [...].“ (Rose, S. 109-111). - 26.6.1947 Festgottesdienst zur Fusion des Posener mit dem Fürstenwalder Diakonissen-Mutterhaus. Zur Unterstützung kommt „eine große Kleiderstoff-Spende von Schweizer Mutterhäusern, da alles Schwesterngepäck, wie auch alle Papiere in Posen geblieben sind. Die Zahl der Schwestern reichte für den Dienst in den Anstalten nicht, aus dem Krankenhaus in Hellesen [Haus Hellesen bei Lüdenscheid, Westfalen], das die Posenerinnen übernommen hatten, mussten weitere Schwestern gerufen werden. Sie entschlossen sich schweren Herzens, nach Fürstenwalde zu kommen.“ (ebd., S. 30). - Pfingsten 1950: „Die Mutterhäuser in Rotenburg/Wümme und Tannenhof [Remscheid] übernehmen die Patenschaft für das Posener Mutterhaus. Im Laufe der kommenden Jahre schicken sie viele Spenden und Geschenke.“ (ebd., S. 32). - 7.2.1956: „Jubiläumsfest zum 90. Geburtstag des Posener Mutterhauses. Gottesdienst mit Abendmahlsfeier, Lichtbildervortrag über die Geschichte und klei- 
ne Ausstellung im Wohnzimmer der Diakonissen.“ (ebd., S. 34). - „Auch in diesem Jahrzehnt [1958-1968] bilden die Diakonissen der 1866 in Posen gegründeten Schwesternschaft in Fürstenwalde die tragende Säule der Mitarbeiterschaft in den Häusern der Alten und Behinderten." (Schreiter 1992, S. 44). - Im Frühjahr 1968 wird Hildegard Scharlowski (geb. 1910, aus Thorn, vor 1945 Diakonisse in Posen) Oberin der Samariteranstalten (ELAB, 1/2453, Dokumentation, S. 38) . - 1991 „Posener Diakonissen-Mutterhaus“ als eine der Einrichtungen der Samariteranstalten Fürstenwalde erwähnt (Schreiter 1992, S. 344). - Ein neuer Wohnbereich erhält 1994 zu Ehren der Posener Dakonissen den Namen „Haus Posen“ (120 Jahre Samariteranstalten, S. 46). - 9.6.2001 Anbringung einer Gedenktafel für die Diakonissen des Posener Mutterhauses am „Haus Posen“ der Samariteranstalten in Fürstenwalde-Ketschendorf (ebd., S. 48); Text: „Haus Posen/Diakonissen des Posener/Mutterhauses/übernehmen 1947 den Dienst/in den Samariteranstalten“ (notiert 30.5.2019). - 2007 Tod der letzten Posener Diakonisse (ebd., S. 50).

ARchivalische QuelLen: BLHA, Rep. 256 Umsiedlerlager Küchensee, Nr. 92 („Gewährung von Umsiedlerbeihilfe“, Juli - Sept. 1948; enthält nur: Familie Vier in Ketschendorf); Nr. 329 („Eingemeindungen von Umsiedlern im Amtsbezirk Neu-Zittau und Ketschendorf“; enthält: „Umsiedlerlisten“, Juli 1946). - ELAB, 1/2453, Dokumentation, S. 38 .

Gedruckte Quellen und Literatur: Handbuch der deutschen evangelischen Kirchen 1918 bis 1949. Bd. 1. Göttingen 2010, S. 358 (Kaiserswerther Verband deutscher Diakonissen-Mutterhäuser). - 120 Jahre Samariteranstalten 1892-2012. Fürstenwalde 2012 (Unterwegs dokumentiert, 2/2012). - Orte des Erinnerns. Hrsg. von Anna Kaminsky. 3., überarb. u. erw. Aufl. Berlin 1996, S. 192 (Gedenktafel für die Opfer des Speziallagers Nr. 5). - Rose, Wolfgang: Die Samariteranstalten in der SBZ und DDR (1945-1990). In: Die Samariteranstalten Fürstenwalde. Eine diakonische Stiftung zwischen Kaiserreich und Bundesrepublik. Jens C. Franze / Paul-Gerhardt Voget (Hrsg.). Berlin 2013, S. 105-140. - Schreiter, Jürgen: 100 Jahre Samariteranstalten Fürstenwalde. In: Heimatkalender Landkreis Fürstenwalde 1992, S. 41-44. - Ders.: Einer Kultur der Barmherzigkeit Raum schaffen. In: Kreiskalender Oder-Spree 2002, S. 31-35. - Andreas Weigelt: Totenbuch Sowjetisches Speziallager Nr. 5 Ketschendorf 1945-1947. Hrsg. von der Initiativgruppe Internierungslager Ketschendorf/Speziallager Nr. 5 e. V. Berlin 2014.

\section{Fürstenwerder/Uckermark}

Landgemeinde, bis 1952 Kr. Prenzlau, 1952-1990 Kr. Prenzlau (Bez. Neubrandenburg), 19901993 Ldkr. Prenzlau (Land Brandenburg), 1993 Ldkr. Uckermark

EReIgnisse: „Ab Januar 1945 kamen Flüchtlinge durch den Ort. Im März traf ein Treck aus Westpreußen ein. Von diesen Flüchtlingen starben [vom 1. bis 23. März] 3 alte Menschen und 1 Kind. Sie erhielten noch ein richtiges Begräbnis; ihre Daten erscheinen im [kirchlichen] Sterberegister (Bleich, Kriegsopfer, S. 72; Daten mit Namen ebd. S. 79). - 1945: „Als Folgeerscheinung des Krieges, der vielen Flüchtlinge und der schlechten Versorgung, schnellte die Krankenzahl schlagartig in die Höhe.“ (Neels, S. 90). - Aug. 1945 Einrichtung eines „Notkrankenhauses" (Arztpraxis und Krankenzimmer) im leerstehenden evang. Pfarrhaus (bis Anf. 1949) und dann auch im (Ende 1946 aus hygienischen Gründen gesperrten) Betsaal (Bleich, Krankenversorgung, S. 90 f.). - 1945: „Auch zahlreiche Flüchtlinge hatte es nach hier verschlagen.“ 
(Wiede, S. 96). - 1945 (Bericht der Gemeindeverwaltung vom Nov. oder Dez. 1945): „[...] Der entstandene Wohnraummangel belastet dauernd die Einwohnerschaft, die eng zusammen rücken muss, um neben den Abgebrannten auch noch die Flücht- [S. 58] linge unterzubringen. Für diese sind teils Privat- teils Massenquartiere eingerichtet. Die Versorgung aller dieser Menschen inmitten einer landwirtschaftlichen Umgebung ist erschwert durch die hohe Sollablieferung an Agrarprodukten. [...]." (Brandenburgische Gemeinden 1945, S. 57 f.). - In Fürstenwerder und Umgebung wurden insbesondere Flüchtlinge bzw. Vertriebene „aus Jugoslawien und Ostpreußen“ untergebracht (Schulz). - In der Bodenreform 346 ha von 1682 ha an 27 „Umsiedler" vergeben (HOL VOIII, S. 291). - „An Tuberkulose starb ein Flüchtling 1947, ein anderer im Winter 1950.“ (Bleich, Kriegsopfer, S. 75).

Bevölkerungszahlen: 1925: 1134, 1939: 1394, 1946: 1828, 1964: 1214 (HOL VIII, S. 291). - 1945 (Bericht der Gemeindeverwaltung vom Nov. oder Dez. 1945): Einwohnerzahl: „Vor 80 Jahren noch 1700 zählend, war diese Zahl 1933 auf 1342 gesunken, und wenn sie sich heute auf 1440 beläuft, so ist diese scheinbare Zunahme durch die ausserordentliche Aufnahme zahlreicher Flüchtlinge zu erklären. [...].“ (Brandenburgische Gemeinden 1945, S. 57).

UMSIEDleRlager: Kapazität am 1.1.1946: 400 (BLHA, Rep. 203 MdI, Nr. 1163, Bl. 50). 1946 Belegungsstärke: 400 (Kaminsky, S. 159).

Gedruckte Quellen und Auskünfte: Brandenburgische Gemeinden 1945, S. 57-58. - Kernchen, Herbert: Jugenderinnerungen an Fürstenwerder. In: Fürstenwerder Mosaik. T. 2. Fürstenwerder 2002, S. 122-131 [Vertriebener aus Hinterpommern]. - Reglin, Fritz: Letzte Tage in Fürstenwerder, Flucht und Rettung unseres Hauses. In: ebd., S. 84-89. - Wiede, Walter: Wieder ein neues Ziel - Fürstenwerder -. Umsiedler 1945 unterwegs. In: ebd., S. 94-104 [Vertriebener aus Grünberg/Schlesien]. - Auskünfte Karl Wilhelm Schulz (Berlin), 6.10.2016.

Literatur: Bleich, Ute: Kirchliches Leben zwischen 1930 und 1950. In: Fürstenwerder Mosaik. T. 2. Fürstenwerder 2002, S. 57-65. - Dies.: Kriegsopfer in Fürstenwerder. In: ebd., S. 72-81. - Neels, Hildegard u. Wolfgang: Krankenversorgung in Fürstenwerder von 1945-1949. In: ebd., S. 90-93.

\section{Garlitz}

Landgemeinde, bis 1952 Kr. Westhavelland, 1952-1990 Kr. Rathenow (Bez. Potsdam), 19901993 Ldkr. Rathenow, 1993 Ldkr. Havelland

EREIGNISSE AB 1945: „Wie auch in den umliegenden Dörfern des Havellandes wurden 1945 viele Flüchtlinge aus den ehemaligen deutschen Ostgebieten in Garlitz untergebracht. Im Zuge der Bodenreform wurden 397 ha Land neu verteilt. Am östlichen Rand wurden für einige der Neubauern so genannte Neubauernhöfe errichtet." (Das Havelland um Rathenow und Premnitz, S. 354); in der Bodenreform wurden unter 60 Landempfängern 5 „Umsiedler“ berücksichtigt (HOL III, S. 124). - Der Schriftsteller Günter de Bruyn (geb. 1926 Berlin), der 19461949 als Neulehrer in Garlitz wirkte, hat das Neben- und Miteinander von Einheimischen und Flüchtlingen erlebt: „Obwohl viele Männer gefallen oder gefangen waren, manche Wirtschaften also 
von Frauen und Greisen geleitet wurden, gab es Arbeitskräfte genug; denn die Vertriebenen, Flüchtlinge genannt, meist Frauen und Kinder, die aus Schlesien und Ostpreußen, aus der Neumark, dem Wartheland und aus Bessarabien gekommen waren, bezahlten das Dach über dem Kopf mit Arbeitsleistung und wurden vorwiegend mit Naturalien entlohnt." (de Bruyn, S. 333); er schildert auch ein Erlebnis mit einem bessarabiendeutschen Schüler und dessen Mutter (ebd., S. 337).

Bevölkerungszahlen: 1925: 603, 1939: 586, 1946: 810, 1964: 541 (HOL III, S. 124).

GedRuckte QuelLen und Literatur: Bruyn, Günter de: Zwischenbilanz. 3. Aufl. Frankfurt am Main 1992. - Das Havelland um Rathenow und Premnitz. Köln u. a. 2017.

\section{Genschmar}

Landgemeinde, bis 1950 Kr. Lebus, 1950-1990 Kr. Seelow (ab 1952 Bez. Frankfurt/Oder), 1990-1993 Ldkr. Seelow, 1993 Ldkr. Märkisch-Oderland

EREIGNISSE NACH KRIEGSENDE: 3.10.1950 Zuweisung von westlich der Oder gelegenen Flächen der nun polnischen Gemeinden Darrmietzel/Dargomyśl, Fürstenfelde/Boleszkowice, Kalenzig/Kaleńsko, Neumühl/Namyślin, Schaumburg/Szumiłowo, Zicher/Cychry und Zorndorf/Sarbinowo (alle ehem. Kr. Königsberg/Nm.) an die Gemeinde Genschmar (Blöß, Kreise und Gemeinden, S. 31 f.).

BevöLKerungszAHLEN: 1925: 736, 1939: 663, 1946: 527, 1964: 612 (HOL VII, S. 135).

Katholiken (bis 1994 Erzbistum Breslau/Erzbischöfliches Amt Görlitz, dann Erzbistum Berlin): 1954: 7 (Schematismus Görlitz 1954, S. 36).

\section{Genshagen}

Landgemeinde (seit 1997 Ortsteil von $\rightarrow$ Ludwigsfelde), bis $1952 \mathrm{Kr}$. Teltow, 1952-1990 Kr. Zossen (Bez. Potsdam), 1990-1993 Ldkr. Zossen, 1993 Ldkr. Teltow-Fläming

BevölkerungSZAhlen: 1925: 459, 1939: 556, 1946: 463, 1964: 530 (HOL IV, S. 75).

UMSIEDLERLAGER: 23.10.1945 ehem. englisches Gefangenenlager und RAD-Lager erwähnt (BArch, DO 2/39, Bl. 16-18). - Kapazität am 31.12.1945: 500 (BArch, DO 2/45, Bl. 40). Kapazität am 1.1.1946: 1500 (BLHA, Rep. 203 MdI, Nr. 1163, Bl. 50). - Belegungstärke 1946: 1000 (Kaminsky, S. 159).

Archivalische Quellen: BArch, DO 2 ZVU, Nr. 39, Bl. 16-18 (Lager, 1945). 


\section{Glau}

Landgemeinde (seit 1998 Ortsteil von $\rightarrow$ Trebbin), bis 1946 Kr. Jüterbog-Luckenwalde, 19461950 Kr. Luckenwalde, 1950-1952 Kr. Teltow, 1952-1990 Kr. Luckenwalde (Bez. Potsdam), 1990-1993 Ldkr. Luckenwalde, 1993 Ldkr. Teltow-Fläming

EReignisse bis KriegSende: Anf. Jan. 1940 besteht in Glau ein Auffanglager für 500 umgesiedelte Wolhynien- und Galiziendeutsche (Müller, S. 122).

BevÖLKeRUnGSZAHLEN: 1925: 204, 1939: 572, 1946: 389, 1964: 250 (HOL X, S. 154).

Literatur: Müller, Erich: Transporte, Lager, Ansiedlung im Warthegau: Das Schicksal der galizien- und wolhyniendeutschen Umsiedler nach ihrem Grenzübertritt 1939/40. In: Zeitweiser der Galiziendeutschen 43 (2005), S. $104-157$.

\section{Glöwen}

Landgemeinde (seit 31.12.2001 Ortsteil der Gemeinde $\rightarrow$ Plattenburg), bis 1952 Kr. Westprignitz, 1952-1990 Kr. Perleberg (Bez. Schwerin), 1990-1993 Ldkr. Perleberg (Land Brandenburg), 1993 Ldkr. Prignitz

EREIGNISSE BIS KRIEGSENDE: 1944/45 besteht hier im Zusammenhang eines seit 1939 aufgebauten größeren Militärareals ein Außenlager des KZ Sachsenhausen (Lager Glöwen der Dynamit Actien-Gesellschaft) (Irmer, S. 169, 172). - 2.5.1945 Einmarsch der Roten Armee (Kriegsende und Nachkriegszeit in Havelberg [II], S. 33).

BevöLKERUNGSZAHLEN: 1925: 972, 1939: 1 198, 1946: 1684, 1964: 1603 (HOL I, S. 262).

(Kreis-)UMSIEDlerlager (insbes. Quarantänelager für heimkehrende Kriegsgefangene; zuvor Wehrmachtslager): Kapazität am 31.12.1945: 4000 (BArch, DO 2/45, Bl. 40). - 1946: Quarantänelager, vorwiegend Heimkehrerlager (BLHA, Rep. 250 Westprignitz, Nr. 261, unfol. [Statistik]). - 1946 Heimkehrerlager, Belegungsstärke: 2000 (Kaminsky, S. 160). - Kapazität am 1.1.1946: 2000 (BLHA, Rep. 203 MdI, Nr. 1163, Bl. 49). - 14.2.1946 Kreis- und Quarantänelager, Kapazität: 2000 (Oehlsen, S. 28). - 31.3. bis 29.9.1946 11432 Kriegsgefangene (Heimkehrerlager) (Oehlsen, S. 35). - 30.4.1946 als eines der verbleibenden Umsiedlerlager genannt (DAB, I/9-15-1 Flüchtlingsseelsorge 1945-1951, unfol., [30.6.1946], [Anlage 3]). - 24.8.1946 Heimkehrerlager, Kapazität: 2000 (SAPMO-BArch, DY 34/27880, Bl. 291). - 1.1.1947 Kapazität: 2000 (Oehlsen, S. 101). - 9.6.1947 Heimkehrerlager, Kapazität: 2000, Belegung: 979, Quarantäne beendet am 14.6. (SAPMO-BArch, DY 34/27880, Bl. 239). - 17.7.1947 „Kreisumsiedlerlager Glöwen“ (DHM). - 25.11.1947 „Aufnahmefähigkeit von 1800 Mann, Quarantänelager für Kriegsgefangene“ (BLHA, Rep. 302, VP, Nr. 9, Bl. 43). 31.12.1947, Jan./Febr. 1948 Heimkehrerlager für entlassene Kriegsgefangene aus dem Westen, eines von 7 verbleibenden Lagern in Brandenburg (BLHA, Rep. 203 MdI, Nr. 1198, Bl. 28v). Jan. 1948 (Anf./Ende) laut Lagerbestandsmeldung vom 10.2.1948 im Lager 559 / 1708 Insas- 
sen (BLHA, Rep. 203 MdI, Nr. 1115, Bl. 7). - Lagerpersonal 1946: Lagerleiter: Gustav Dobler, Wirtschaftsleiter: Ernst Schmahel, Lagerarzt: Dr. Schulze (BLHA, Rep. 250 Westprignitz, Nr. 261, unfol. [Statistik]). - Lagerpersonal am 1.1.1948: Lagerleiter: Keil; Wirtschaftsleiter: Zachow; Lagerarzt: Dr. Seidler (BLHA, Rep. 333, Nr. 575, Bl. 27 ([Liste der leitenden Angestellten]). - 31.5.1948 Stempel „Kreisumsiedlerlager Glöwen“ verwendet (BArch, DO 2/38, Bl. 281v). - Okt./Nov. 1948 nicht mehr aufgeführt in einer Liste der im Land Brandenburg existierenden 5 Lager (BLHA, Rep. 203 MdI, Nr. 1198, Bl. 46).

Weitere ARChivalische QUellen: BArch, DO 2 ZVU, Nr. 38, Bl. 178-283 (Lager Glöwen, 13.6.194631.5.1948). - BArch, DY 34/27881 (Betreuung von Heimkehrern und Umsiedlern und Versorgung von Heimkehrerlagern, Bd. 2: 1947-1950; enthält u. a.: Versorgung im Heimkehrerlager Glöwen). - BLHA, Rep. 204 A, Nr. 1951a: „Heimkehrerlager (ehem. Wehrmachtslager) Glöwen, Kr. Westprignitz“, 1947-1950. - BLHA, Rep. 250 Angermünde, Nr. 521 (Wirtschaftsberichte des Lagers Glöwen, 1947). - Rep. 250 Westprignitz, Nr. 250 („Umsiedlerbetreuung im Kreis“, 1945-1948; enthält u. a.: Tätigkeitsberichte des Lagers Glöwen). - BLHA, Rep. 250 Westprignitz, Nr. 258 bis 272 (Lager Glöwen, 1945-1948, v. a.: Personalia der Beschäftigten, Tätigkeitsberichte, Zu- und Abgangs- bzw. Transportmeldungen, Wirtschaftsführung, Haus- und Lagerordnung, Wochenpläne zur kulturellen Betreuung und politischen Schulung, Stimmungsberichte, Unterschlagungen und Diebstähle). - BLHA, Rep. 333 SED-Landesleitung Brandenburg, Nr. 575; Nr. 577 („Heimkehrerlager“, 1946-1949; enthält u. a.: Glöwen). - DHM, Inv.-Nr. Do 2 2000/2068 (Quarantäneschein für einen Berliner, 17.7.1947)

LiterATUR: HOL I, S. 260-263 (Art. Glöwen, ohne Erwähnung des Lagers). - Irmer, Thomas: Zwangsarbeit im „Beutelager“ - das KZ-Außenlager Glöwen. In: Havelberg - kleine Stadt mit großer Vergangenheit. Halle 1998, S. 169-180 [Nur zur Nutzung bis Kriegsende]. - Kriegsende und Nachkriegszeit in Havelberg [II]. Havelberg 1994.

\section{Görne}

Landgemeinde (seit 31.12.2002 Ortteil von Kleßen-Görne), bis $1952 \mathrm{Kr}$. Westhavelland, 1952-1990 Kr. Rathenow (Bez. Potsdam), 1990-1993 Ldkr. Rathenow, 1993 Ldkr. Havelland

EREIGNisse NACH Kriegsende: Im Nov. 1945 waren im Obergeschoss des Herrenhauses wurden „deutsche Flüchtlinge aus dem Schwarzmeerraum untergebracht“ (Andreae/Geiseler, S. 131).

BevöLKerungszahlen: 1925: 350, 1939: 373, 1946: 599, 1964: 326 (HOL III, S. 134).

\section{Golßen}

Stadtgemeinde, bis 1952 Kr. Luckau, 1952-1990 Kr. Luckau (Bez. Cottbus), 1990-1993 Ldkr. Luckau, 1993 Ldkr. Dahme-Spreewald

EREIGNISSE: „Ein leidvolles Schicksal hatten auch die Flüchtlinge und Heimatvertriebenen hinter sich, die die Stadt während und nach dem Krieg bevölkerten und überfüllten. Einige von ihnen sind seßhaft geworden. Dazu trug die Verteilung von 574 ha Ackerland an Bauern und Neusiedler in Golßen bei." (Rose/Bock, S. 18). 
BevölKerungszahlen: 1925: 1762, 1933: 1709, 1939: 1874, 1946: 2327, 1964: 2195 (Städtebuch, S. 210).

Katholiken (Erzbistum Breslau/Erzbischöfliches Amt Görlitz): 1925: 31, 1946: 203 (Städtebuch, S. 210). - Ab Juli 1945 wirkt der aus Schollendorf (Kr. Groß Wartenberg, Schlesien) vertriebene Erzpriester Anton Kopka (geb. 1884 Schmograu [Kr. Namslau/Schlesien], gest. 1959) als Pfarrer (ab 1946 Kuratus, ab 1957 Kuratial-Pfarrer) in Golßen (und Umgebung), wohnt 1949 Stadtwall 12 (Töpler, Menschenwurm, S. 375, 644; Ostpriesterverzeichnis 2, 1949, S. 46; Schematismus Görlitz 1954, S. 56; 1961, S. 112). Er berichtet am 10.8.1945 aus Golßen u. a.: „[...] Gott hat mir zu einer neu[en] Stelle hier in G[olßen]. verholfen und so wohne ich nun sch[on seit] 2 Wochen und betreue seelsorglich die hiesigen [Katho]liken und die der Umgegend. [...] Hier in der evangel. Kirche wird sonntags nachm. 5 Uhr (Russ. Zeit) die hl. Messe mit Predigt gehalten. [...] Hoffentlich reiche ich mit dem deutschen Gelde, das ich mir aus der Tschechei gerettet habe, bis Amfang Winter aus. [...].“ (Töpler, Menschenwurm, S. 375). „Herr Erzpriester Kopka aus Schollendorf Kr. Trachenberg [Schlesien] konnte bei seinem Durchzug durch $[\rightarrow]$ Luckau sich in Golßen niederlassen (Golßen, Stadtwall 12 bei Fam. Klaßen), wo er die Seelsorge über Golßen und die umliegenden Ortschaften übernehmen konnte, mit Genehmigung des Hochw. Erzb. Commissarius von Finsterwalde." (ebd., S. 380). Kopka starb 1959 in Storkow-Hubertushöhe als dortiger Hausgeistlicher (Schematismus Görlitz 1961, S. 112). - Bericht des Pfarrers Alfred Brucks, Luckau, vom 19.8.1945: „Die evangelischen Gemeinden in Golßen und $[\rightarrow]$ Baruth stellten ihre Kirchen zur Abhaltung des katholischen Gottesdienstes bereitwillig zur Verfügung." (Töpler, Menschenwurm, S. 380).

Gasthof „Goldener AdleR“ (Hauptstr. 26): „Noch im selben Jahr 1945 übernahm die aus Grünberg in Schlesien geflüchtete Hotelierfamilie Witt das verwüstete Grundstück. Senior Hans Witt kam zwar mit langjähriger Berufserfahrung nach Golßen; so kurz nach Kriegsende stand er hier aber vor ungewohnten Problemen. Wie dessen Tochter, Frau Herzog, berichtete, beschaffte Witt u. a. Tische und Stühle und sorgte für Lieferanten. Das Wichtigste für den nun ausschließlichen Gaststättenbetrieb war eine Schankgenehmigung von der Besatzungsmacht. Die erhielt Witt. Nach zwei bis drei Jahren folgte jedoch ein ,Rausschmiss', so Frau Herzog. Inzwischen hatte sich der FDGB (Freier Deutscher Gewerkschaftsbund) auch in Golßen etabliert und suchte Büro- und Versammlungsräume. Kurzerhand wurde das ehemalige Netzker'sche Grundstück dem FDGB übergeben und Witts vor vollendete Tatsachen gestellt. Aus dem Gasthaus ,Goldener Adler' wurde so die Gaststätte ,Gewerkschaftshaus. / Im Obergeschoss hatten sich inzwischen Flüchtlingsfamilien notdürftig eingerichtet. [...]. (Rose 2017, S. 66).

Literatur: Rose, Lars / Bock, Michael: Golßen in historischen Ansichten. Horb am Neckar 2001. - Rose, Lars: Ein Golßener Haus mit viel Geschichte(n). In: Luckauer Heimatkalender 49 (2017), S. 62-66. - Töpler, Menschenwurm, S. 375,380 u. ö. 


\section{Golzow (0derbruch)}

Landgemeinde (Kreissitz), 1945-1950 Kr. Lebus, 1950-1952 Kr. Seelow, 1952-1990 Kr. Seelow (Bez. Frankfurt/Oder), 1990-1993 Ldkr. Seelow, 1993 Ldkr. Märkisch-Oderland

EREIGNISSE VOR 1933: 1920/22 Bau einer Kriegerheimstättensiedlung mit 25 Doppelhäusern (49 Wohneinheiten) am Bahnhof, in der ausschließlich Ortsfremde einziehen. „Viele kamen aus den Gebieten jenseits der Oder [... “": Neumark, Posen, Westpreußen (700 Jahre Golzow, S. 62).

EREIGNISSE BIS KRIEGSENDE: [1945:] „Die Zivilbevölkerung verließ die Altstadt von Küstrin über die freigekämpfte Verbindungslinie Bleyen - Genschmar. / Am 22.3. früh griffen russische Verbände nach stärkstem Artilleriefeuer und Schlachtfliegereinsatz mit etwa 100 Panzern den Zugangsschlauch nach Küstrin von beiden Seiten an und durchbrachen ihn bei Golzow. Der Gegenangriff der 25. Pz. Gren. Div. blieb beim Bahnhof Golzow liegen. [... ." (Ein leidgeprüftes Land, S. 23). - 14.4.1945 (nachmittags) Einmarsch der Roten Armee in das fast vollständig zerstörte Dorf (700 Jahre Golzow, S. 61).

EReignisse NACH KRIEgSende: [Sommer 1945:] [Aus dem Bericht des Golzower Bauern Erich Schütz:] „Weizengarben, deren Ertrag ich auf 10 Ztr. schätzte, waren im Viehstall untergebracht, und als Wintervorrat gedacht. Im Sommer kamen viele Flüchtlinge aus Ostpreußen und schnitten Ähren ab, zerkleinerten die Körner mit Steinen. Das Schrot wurde mit Wasser in Blechbüchsen gekocht. Das war die Tagesration der Armen! Wir gaben auch von unserem Brot ab. Wir waren alle erkrankt, lagen bis Weihnachten. Da machten sich die Flüchtlinge über den Weizen im Stall her. Nichts war mehr da als ich aufstehen konnte. / Die fett- wie eiweißarme Ernährung führte zum Hungertyphus. Geschwüre kamen hinzu. Arzt wie Apotheker gab es nicht mehr im Ort. So war die Todesrate groß. Unser alter Tierarzt hatte sich wieder eingefunden. [...].“ (Ein leidgeprüftes Land, S. 73). - 1961-2007 DEFA-Langzeitdokumentation „Die Kinder von Golzow“ verfolgt in mehreren Filmen das Leben von Menschen aus dem Ort. - 1963 wird der im Sept. 1945 aus Oberschlesien vertriebene und zunächst nach Westfalen gelangte, dann aber, da ein Onkel in Golzow lebte, hierher übergesiedelte Heinz Riedel (geb. 1929 Kirchberg) Bürgermeister (700 Jahre Golzow, S. 31).

EREIGNISSE NACH 1990: 2015: Zu Vorbehalten in Golzow gegenüber der Unterbringung von Flüchtlingsfamilien im Dorf sagte Bürgermeister Frank Schütz rückblickend 2017: „So manche Gerüchte und Vorbehalte machten in der 800-Seelengemeinde die Runde. Aber da hat wohl geholfen, dass in Golzow viele Umsiedler leben, die 1945 hierher kamen. Die wissen, wie es ist, vor einem Krieg zu fliehen und mit nichts dazustehen. Als dann die neuen Flüchtlinge kamen, haben die Leute Möbel und Hausrat gespendet und manchen guten Rat dazugegeben." (Schindler, S. 52). - Febr. 2015 Diskussion in der Gemeindevetretung: „Von den Einwohnern, die Rederecht erhalten hatten, erinnerte der ehemalige Bürgermeister Christian Dorn an die Zeit, als er vor 70 Jahren Flüchtlingskind war. Als Siebenjähriger hatte er die Flucht aus Neudamm, heute Debno, erlebt. ,Ich 
weiß, wie dankbar wir waren, als Flüchtlinge und Vertriebene aufgenommen zu werden. Wenn hier zwei Familien einziehen, dann finde ich das gut. Natürlich müssen sie betreut werden. Aber wenn Kinder dabei sind, gibt es kein Problem. Kinder kommen immer zuerst miteinander aus. Das ging uns damals nicht anders." (Ulf Grieger: Aussprache zu Flüchtlingen begonnen. In: MOZ, 25.2.2015).

Bevölkerungszahlen: 1925: 1968, 1939: 1620, 1946: 1217, 1964: 1286 (HOL VII, S. 148). - 20.5.1945 (nach Rückkehr des Bauerntrecks der einheimischen Bevölkerung): 150. „Durch weitere heimkehrende Golzower und die Unterbringung von Menschen, die [...] aus den deutschen Gebieten östlich von Oder und Neiße zwangsausgesiedelt wurden, entwickelte sich die Einwohnerzahl in den folgenden Monaten wie folgt": 1.6.1945: 273, 1.7.1945: 557, 1.8.1945: 716, 1.9.1945: 840, 1.10.1945: 856, 1.11.1945: 867, 1.12.1945: 879, 1.1.1946: 906 (700 Jahre Golzow, S. 17).

Katholiken (bis 1994 Erzbistum Breslau/Erzbischöfliches Amt Görlitz, dann Erzbistum Berlin): 1954: 114 (Schematismus Görlitz 1954, S. 36). - „Als Pfarrer Alois Pech in den letzten Kriegstagen das zur Festung erklärte Küstrin verlassen mußte, sammelte er seine wenigen Gläubigen zunächst in der Kreisstadt $[\rightarrow]$ Seelow. Schließlich konnte er 1946 in der Nähe des Bahnhofs Golzow ein Grundstück erwerben. Der Name ,Kath. Pfarrei Küstrin - Sitz Golzow‘ war den damaligen politisch Verantwortlichen zu revanchistsch, so daß 1949 die Pfarrei Christus König, Golzow, entstand.“ Nach der Oderbruch-Flutkatastrophe (1947) 1949 Errichtung einer Baracke für Kirche und Pfarrwohnung [Tuchebander Chaussee], 1952 massives Pfarrhaus. „Als letzter von Görlitz eingesetzter Pfarrer wirkte Rudolf Struzina von 1968-89 im Oderbruch. Seitdem wird die Gemeinde von $[\rightarrow]$ Frankfurt/Oder aus beteut. Das frühere Pfarrhaus dient seit 1990 zahlreichen Gruppen und Kreisen aus der Umgebung als Quartier." (Brühe, S. 30; textähnlich, teilweise aber gekürzt: Schwillus/Brühe, S. 317; siehe auch: 700 Jahre Golzow, S. 58). - 2003 Fusion der Gemeinde mit der Pfarrei Frankfurt (Oder) (Schwillus/Brühe, S. 317).

Gedruckte Quellen und Literatur: Brühe, Matthias: Katholische Kirche zwischen Uckermark und Oderland. Berlin 1998, S. 30. - Dokumentation der Vertreibung I/2, S. 681. - Schindler, Christine: Eine neue Heimat im Dorf. In: Dorf und Familie. Bauernzeitung 2017, 13. Woche, S. 52-53. - Schwillus/Brühe, S. 317. - Ein leidgeprüftes Land. Bearb. von Fritz Knüppel. 2. Aufl. Barsinghausen 1990. - 700 Jahre Golzow 1308-2008. Golzow 2008.

\section{Gorgast}

Landgemeinde (seit 31.12.1997 Ortsteil der Gemeinde Küstriner Vorland, mit $\rightarrow$ Küstrin Kietz und Manschnow), 1945-1950 Kr. Lebus, 1950-1952 Kr. Seelow, 1952-1990 Kr. Seelow (Bez. Frankfurt/Oder), 1990-1993 Ldkr. Seelow, 1993 Ldkr. Märkisch-Oderland

EReignisse NACH KriegSende: 1945 (?): Fotos (aufgenommen von Gerhard Gronefeld; Fotoarchiv DHM Berlin) „Winterfest gemachtes Notquartier in Gorgast/Oderbruch“ und 
„Flüchtlinge in Gorgast/Oderbruch“ (Abb.: Meinicke, S. 478f.); Fotos provisorischer Notunterkünfte, u. a. in einem Stall (Ast/Mauersberger, S. 62 f., 93).

BevölKerungszahlen: 1925: 1218, 1939: 1267, 1946: 1183, 1964: 1264 (HOL VII, S. 151).

Katholiken (bis 1994 Erzbistum Breslau/Erzbischöfliches Amt Görlitz, dann Erzbistum Berlin): 1954: 54 (Schematismus Görlitz 1954, S. 36).

GeDRUCKte Quellen: Dawidowski, Rudolf: Die Flucht der Familie Dawidowski nach Gorgast. In: 1945. Als Küstrin in Trümmer sank. Zsgest. u. bearb. von Fritz Kohlase. Überarb., erw. u. ill. 2. Aufl. Sehnde 2006, S. 379-380. - Völker, Elisabeth: Wie Gorgast für mich unvergeßlich wurde. In: Ebd., S. 381-387.

LiteratuR: Ast/Mauersberger, S. 62 f., 93 (Fotos von Notunterkünften für Vertriebene; Aufnahmen: Gerhard Gronefeld; DHM Berlin). - Meinicke, Wolfgang: Die Aufnahme von Vertriebenen in der Sowjetischen Besatzungszone Deutschlands. In: „Wach auf, mein Herz, und denke“. Berlin/Opole 1995, S. 475-487 (desgleichen).

\section{Gosen}

Landgemeinde (seit 2003 Ortsteil von Gosen-Neu Zittau durch Fusion mit $\rightarrow$ Neu Zittau), bis 1950 Kr. Beeskow-Storkow, 1950-1993 Ldkr. Fürstenwalde (ab 1952 Bez. Frankfurt/Oder), 1990-1993 Ldkr. Fürstenwalde, 1993 Ldkr. Oder-Spree

EREIGNISSE NACH KRIEGSENDE: 1946 Versuch zur Gründung einer „Umsiedlergenossenschaft“ zur Herstellung von Glaswaren (BLHA, Rep. 203 MdI, Nr. 1074, zit. nach Oehlsen, S. 84).

BeVÖLKerungszahlen: 1925: 950, 1939: 1000, 1946: 1059, 1964: 852 (HOL IX, S. 99). 26.7.1946: 711 „Stammeinwohner“, 183 „Umsiedler) (BLHA, Rep. 250 Beeskow-Storkow, Nr. 905, Bl. 7).

Archivalische Quellen: BLHA, Rep. 250 Beeskow-Storkow, Nr. 905 („Erhebungen über Stammeinwohner und Umsiedler in den Gemeinden Görsdorf bei Storkow, Görzig, Gosen, Groß-Eichholz und Groß-Rietz“, 1945-1948).

\section{Gramzow}

Landgemeinde, bis 1952 Kr. Angermünde, 1952-1990 Kr. Prenzlau (Bez. Neubrandenburg), 1990-1993 Ldkr. Prenzlau (Land Brandenburg), 1993 Ldkr. Uckermark

EREIGNisSe NACH KRIEgSEnde: 12.7.1934 Durchzug eines Trecks aus Woldenberg/Nm., einzelne Personen verbleiben in Gramzow (Tagebuch Prochnow, S. 292).

BeVÖLKERUNGSZAHLEN: 1925: 1738, 1939: 1778, 1946: 2152, 1964: 1850 (HOL VIII, S. 349).

Katholiken: „Katholisches Leben entwickelte sich [in nachreformatorischer Zeit] in größerem Ausmaß erst wieder, als sich nach dem II. Weltkrieg Flüchtlinge, vor allem aus dem Kreis 
Fraustadt/Schlesien, in der Umgebung Gramzows niederließen. Am 26.6.1946 wude vom zuständigen Prenzlauer Pfarrer in der alten Schule die erste Messe [„für die zahlreichen Heimatvertriebenen“" (Schwillus/Brühe, S. 345)] gefeiert. 1953 konnte in der Nähe des Bahnhofs die Maria-Frieden-Kirche in Eigenleistung der Gläubigen erbaut werden. [...]. Unter Pf[a]r[rer] Peter Beier (1960-66) wurde auf dem weitläufigen Grundstück eine Baracke als Pfarrhaus errichtet, staatlicher Widerstand verhinderte einen festen Bau. [... 1972 wurde dem Gramzower Pfarrer nach der Neuregelung der Bistumsgrenze zu Polen die Seelsorgestelle in Penkun mitübertragen. Deren Gebiet hatte bis dahin kirchenrechtlich noch zur Propsteigemeinde Stettin gehört und wurde seit 1959 von einem Prenzlauer Kaplan betreut. [...]. 1975 (Gramzow und Penkun): 1100 Katholiken. 1989 (nach Rückgang der Zahl der Katholiken) Pfarramt und Kapelle in Penkun aufgelöst. 1996 Gemeinde Gramzow wieder von Mutterpfarrei Penkun [richtig: Prenzlau] mitbetreut. 1998 in Gramzow etwa 600 Katholiken (Brühe, S. 31, 40; vgl. Schwillus/Brühe, S. 345).

UMSIEDLERLAGER: 22.10.1945 erwähnt (BArch, DO 2/39, Bl. 10). - Kapazität am 31.12.1945: 2000 (BArch, DO 2/45, Bl.40). - Kapazität am 1.1.1946: 1000 (BLHA, Rep. 203 MdI, Nr. 1163, Bl. 50).

ARchivalische Quellen: BArch, DO 2 ZVU, Nr.39, Bl. 10 (Umsiedlerlager, 1945). - Siehe auch Quellenteil, Nr. 214.

Gedruckte Quellen: Brandenburgische Gemeinden 1945, S. 3. - Dokumentation der Vertreibung I/1, S. 377. Tagebuch Ernst Prochnow [Auszüge]. In: „Die Russen sind da“. Peter Böthig u. Peter Walther (Hg). Berlin 2011, S. 292.

Literatur: Brühe, Matthias: Katholische Kirche zwischen Uckermark und Oderland. Berlin 1998, S. 31, 40.Schwillus/Brühe, S. 345 .

\section{Gransee}

Stadtgemeinde, bis 1952 Kr. Ruppin, 1952-1990 Kr. Gransee (Bez. Potsdam), 1990-1993 Ldkr. Gransee, 1993 Ldkr. Oberhavel

EREIGNISSE NACH KRIEGSENDE: 6.9.1945 (Bericht des Landrats): „1 500 Flüchtlinge [wohnen] in einem offenen Trockenschuppen einer Ziegelei in Gransee. Ob es gelingen wird, für diese Flüchtlinge noch bis zum Beginn der Kälte heizbare Räume zu schaffen ist sehr zweifelhaft und erfüllt mich mit großer Sorge." (Wille II, S. 173).

EREIGNISSE NACH 1990: Ab 2009 wurden von dem 1998 aus Litauen nach Ludwigsburg bei Stuttgart u. 2008 von dort nach Gransee gezogenen Ehepaar Angelika u. Olaf Pasenau mehrere Ausstellungen (über Vertreibung, „Wolfskinder“, Ostpreußen, Litauen u. a.) konzipiert, selbst gestaltet u. in Gransee u. anderen Orten gezeigt (A. Pasenau geb. 1945 in Litauen, Tochter einer Litauerin u. eines Deutschen, 1991-1994 Mitbegründerin u. stellv. Vorsitzende des litauischen Vereins „Edelweiß" (ab 1993 „Edelweiß-Wolfskinder“) [Interessenvereinigung der in Litauen leben- 
den „Wolfskinder“] in Memel/Klaipèda; O. Pasenau geb. 1934 Allenstein, lebte 1945-1947 in Königsberg in Ostpreußen, ab 1947 als „Wolfskind“ in Litauen, ab 1991 Vorsitzender des Vereins „Edelweiß") (Auskünfte A. Pasenau, 7.8.2018), u. a.: 2010-2012 Wanderausstellung „Meine Ostpreußen" in $\rightarrow$ Oranienburg (2010), $\rightarrow$ Zehdenick (2010), $\rightarrow$ Erkner (2011, beim Ostdeutschen Kulturtag des BdV) u. Gransee (ab 19.2.2012, s. u.). - Nov. 2011 Gastausstellung des Ostpreußischen Landesmuseums Lüneburg „Die große Flucht und Vertreibung 1944/45 in grafischen Bildzeugnissen“ im Heimatmuseum Gransee. - Ab 19.2.2012 Ausstellung „Meine Ostpreußen“ (u. a. auch zu Flucht, Vertreibung u. Versöhnung) im Heimatmuseum (Hospitalkapelle) (Konzeption: O.u.A. Pasenau), eröffnet in Anwesenheit des Kulturattachés der litauischen Botschaft (BR 10 (2012) 3, S. 15). - 2013 dritte von A. und O. Pasenau gestaltete [„Wolfskinder“-]Ausstellung („Litauen in Gransee“) im Heimatmuseum (ebd. 11 (2013) 9, S. 10). - 2016 „Wolfskinder“-Ausstellung „Die letzten Zeugen“ im Heimatmuseum (Konzeption: O. u. A. Pasenau). - 2016 Buchlesung zum Thema „Wolfskinder“ in Ostpreußen und Litauen durch Schüler der 9. Klasse des StrittmatterGymnasiums Gransee unter der Leitung der Lehrerin Kathrin Bartel und des Schulleiters Dr. Uwe Zietmann im Heimatmuseum (Hospitalkapelle). „Mehr als 50 jüngere und ältere Besucher aus Gransee, $[\rightarrow$ ] Fürstenberg[/Havel], Dannenwalde und anderen Orten hatten sich in der Hospitalkapelle Gransee versammelt." (Bericht von Olaf Pasenau in: BR 14, 2016, Nr. 5, S. 10-11, hier S. 10).

Bevölkerungszahlen: „Nach 1945 Zunahme der Bevölkerung um die Hälfte duch starke Zuwanderung von Flüchtlingen u. Umsiedlern“ (Städtebuch, S. 214), nach den Gesamteinwohnerzahlen Zunahme jedoch etwas geringer: 1925: 4044, 1939: 4521, 1946: 6092, 1964: 5276 (ebd.).

Katholiken: 1925: 187, 1946: 544 (Städtebuch, S. 214); 1953 (Gemeinde): etwa 1700 (Brühe, S. 19; Schwillus/Brühe, S. 318). - 15.1.1948 Anstellung des bis 1945 in Cammin (Pommern) amtierenden Pfarrers Paul Bartsch (geb. 1901 Borek) als Pfarrer der Kuratie Mariä Himmelfahrt, Grünstr. 2 (Ostpriesterverzeichnis 2, 1949, S. 12; Schematismus Berlin 1949, S. 67). - „In diesem vor dem Einstrom der Flüchtlinge fast rein evangelischen Gebiet bestand nach dem Krieg eine katholische Diasporagemeinde, die 42 Dörfer in einem an die 1000 qkm großen Pfarrbezirk umfaßte. 1400 Katholiken, davon 80 \% Flüchtlinge, lebten dort. Der Pfarrer wollte seine Gemeindekinder nun wenigstens einmal im Jahr [S. 81] zu einem eigenen Gottesdienst versammeln und rief zu einer ,Wallfahrt' in die Pfarrkirche Gransee, eine Mariä-Himmelfahrt-Kirche, auf. Er fand bei den Heimatvertriebenen ein sehr positives Echo; sie faßten diesen teilweise kilometerweiten Weg zum gemeinsamen Pfarrgottesdienst durchaus als Pilgergang und als Ersatz für ihre altgewohnten heimatlichen Wallfahrten auf; auch aus Berlin waren heimatvertriebene Pilger gekommen. Im Pfarrbüro wurde ein behelfsmäßiger Devotionalienladen errichtet, in dem man Andachtsgegenstände erwerben konnte. Der Bericht über diese Wallfahrt schließt mit der Feststellung: Alles in allem: unser Bistum / Berlin / hat einem neuen Wallfahrtsort, so ganz der alten Tradition getreu ... Keiner vergißt mehr das Wort, dem sie / die Pilger / gefolgt waren: Jeder einmal im Jahr zu unserer lieben Frau, der Himmelskönigin, nach 
Gransee, in die Pfarrkirche, in der Wallfahrtswoche vom 15. bis 22. August ' [...]. Dieser Versuch, eine neue Tradition zu begründen, ist allerdings fehlgeschlagen." (Schroubek, S. 80 f.; Einfügungen in / / von Schroubek, der von ihm zitierte Bericht aus: Christ Unterwegs 4, 1950, H. 11 (Nov.), S. 20 f., dort wiederum nach einem Bericht im „Petrusblatt“ wiedergegeben).

StÄDTEPARTNERSCHAFTEN: Kolin (Tschechien), 1.6.1997 Vereinbarung über die Bekräftigung der bereits seit drei Jahrzehnten bestehenden Städtepartnerschaft der Städte Gransee u. Kolin; ferner existiert in Gransee seit der DDR-Zeit eine Koliner Straße (Auskunft der Amtsverwaltung Gransee, Kathrin Reiffler, lt. der Urkunde, 3.8.2018). - Daneben besteht seit 5.12.1996 eine Partnerschaft des Amtes Gransee und Gemeinden mit der Gemeinde Siemiatyce-Land in Polen (vgl. Partnerschaft mit zw. den Städten Siemiatyce u. $\rightarrow$ Zehdenick), begründet im Zusammenhang mit der Vereinbarung einer Partnerschaft zwischen dem Landkr. Oberhavel und der poln. Woiwodschaft Podlachien/Podlasie (Quelle wie vor).

ORGANiSATIONEN NACH 1990: 2015 Initiative „Kriegskinder“ Gransee, gegründet von Angelika u. Olaf Pasenau (s. o.) u. weiteren Mitstreitern in Gransee u. Berlin (Sprecher: Henryk Wichmann, $\rightarrow$ Lychen, geb. $1977 \rightarrow$ Templin, CDU-MdL Brandenburg), befasst sich insbesondere mit den „Wolfskindern“ u. ihrer Anerkennung als Kriegsopfer, u. a. maßgeblich beteiligt an der 2018 im Landtag in $\rightarrow$ Potsdam gezeigten „Wolfskinder“-Ausstellung (BR 16 (2018) 8, S. 4).

GedRuckte Quellen und Literatur: Brühe, Matthias: Katholische Kirche zwischen Prignitz und Havelland. Berlin 2000, S. 19. - Dokumentation der Vertreibung I/1, S. 359. - Schroubek, Georg R.: Wallfahrt und Heimatverlust. Marburg 1968. - Schwillus/Brühe, S. 318. - Wille I, S. 372; II, S. 173.

\section{Greiffenberg}

Stadtgemeinde, bis 1952 Kr. Angermünde, 1952-1990 Kr. Angermünde (Bez. Frankfurt/ Oder), 1990-1993 Ldkr. Angermünde, 1993 Ldkr. Uckermark

EREIGNISSE BIS KRIEGSENDE: 25.4.1945 (bis 26.4. morgens 2.30 Uhr) Räumungsbefehl für Zivilpersonen (Ernst, S. 205).

EREIGNISSE NACH KRIEGSENDE: 22.6.1945 Einweisung von Vertriebenen in den Amtsbezirk Greiffenberg: ein Landwirt aus Wolhynien, eine dreiköpfige Familie aus dem Kr. Gumbinnen in Ostpreußen (Wille II, S. 168).

Bevölkerungszahlen: 1925: 1200, 1939: 1213, 1946: 1626, 1964: 1262 (Städtebuch, S. 219).

KATHOLIKEN: 1925: 23, 1946: 110 (Städtebuch, S. 219).

Gedruckte Quellen und Literatur: Ernst, Hans-Eberhard: Das Ende des Krieges - Greiffenberg 1945. In: Angermnünder Heimatkalender 2020, S. 203-211 [Mit später überarbeiteten Tagebuchaufzeichnungen des 1945 13-jährigen Schülers Arnold Sepanski (1932-2017)]. 


\section{Grießen}

Landgemeinde (seit 2003 Ortsteil der Gemeinde Jänschwalde), bis 1952 Kr. Guben, 1952 1990 Kr. Guben (Bez. Cottbus), 1990-1993 Ldkr. Guben, 1993 Ldkr. Spree-Neiße

EREIGNISSE NACH KRIEGSENDE: 3.10.1950 Zuweisung von westlich der Neiße gelegenen einwohnerlosen Flächen der nun polnischen Gemeinde Pohsen/Późna (ehem. Kr. Guben) an die Gemeinde Grießen sowie weiterer Teile an die Gemeinde $\rightarrow$ Groß Gastrose (Blöß, Kreise und Gemeinden, S. 31). - 1.11.1950 „Kinderheim Grießen wird in der Villa eines $[\rightarrow]$ Forster Tuchfabrikanten eröffnet" (Guben zu Zeiten der DDR, S. 72).

UMSIEDleRlager Gauschule (für Arbeitsunfähige): 24.10.1945 [Bericht auf Arbeitstagung bei Oberlandrat in Cottbus:] „Landkreis Guben richtet in $[\rightarrow]$ Bärenklau ein Umsiedlerlager für 150 Personen und in der Gauschule Griesen [so!] eins für Arbeitsunfähige - 30 Personen - ein." (Töpler, Menschenwurm, S. 450). - Im „Verzeichnis der errichteten und vorgesehenen Umsiedlerlager im Verwaltungsbezirk Cottbus“ vom 15.12.1945 mit „Personenzahl“ 30 genannt (Töpler, Menschenwurm, S. 472) [Grießen lag an der (inzwischen stillgelegten) Bahnstrecke Forst-Guben].

BeVÖLKerungszahlen: 1925: 290, 1939: 297 (HOL NL II, S. 198); 1946: 394, 1950: 359, 1964: 384 (HGV SN, S. 19).

Gedruckte Quellen und Literatur: Guben zu Zeiten der DDR. In: Gubener Heimatkalender 44 (2000). S. $72-$ 77. - Töpler, Menschenwurm, S. 450, 472.

\section{Gronenfelde $\rightarrow$ Frankfurt/Oder-Gronenfelde}

\section{Groß Behnitz}

Landgemeinde, bis 1952 Kr. Westhavelland, 1952-1990 Kr. Nauen (Bez. Potsdam), 1990-1993 Ldkr. Nauen, 1993 Ldkr. Havelland

EReIgnisse NACH KriegSende: 21.11.1950: Die Neusiedlerin E. Höhne in Quermathen bei Groß Behnitz beschwert sich erfolglos über die Verkleinerung der ihr 1946 zugewiesenen Neubauernstelle: „Es ist so schwer für uns Flüchtlinge aus dem Osten, wenn so ungerecht gehandelt wird." (Archivalische Quellen, S. 272).

Gedruckte Quellen: Erschließung der Einwohnermeldebücher Groß Behnitz (mit Ortsteil Quermathen) 19501983. Mit einer Liste der „Russland-Flüchtlinge“ 1945/46. Bearb. von Stefan Lindemann unter Mitarb. von Nele Möbius. Potsdam 2015. 221 S. [S. 197-198: Liste der Flüchtlinge aus Russland (und Litauen) 1945/46]. - Lindemann, Stefan: Erschließung der Kirchenbücher Groß und Klein Behnitz. Taufen Groß Behnitz 1937-1992. Taufen Klein Behnitz 1950-1992. Konfirmationen Groß und Klein Behnitz 1927-2010. Beerdigungen Groß Behnitz 1952-2011. Beerdigungen Groß Behnitz 1976-2015. (Privatdruck) Vitte (Hiddensee)/Potsdam 2016. - Ders.: Erschließung des Gesamtkirchenbuches Groß Behnitz (Teil 2). Taufen 1902-1936. Beerdigungen 1931-1951. Trauungen 1932-1959. 
Konfirmationen 1912-1926. (Privatdruck) Potsdam 2016. - Quellen zur Geschichte der Dörfer Groß und Klein Behnitz. Archivalische Quellen 1174/76-1989. Bearb. von Stefan Lindemann. Potsdam 2006 (Beiträge zur Geschichte der Dörfer Groß und Klein Behnitz (Havelland), Nr. 21).

\section{Groß Breese}

Landgemeinde, bis 1952 Kr. Westprignitz, 1952-1990 Kr. Perleberg (Bez. Schwerin), 19901993 Ldkr. Perleberg, 1993 Ldkr. Prignitz

BevölKerungSZAhlen: 1925: 218, 1939: 241, 1946: 389, 1964: 299 (HOL I, S. 92).

Archivalische Quellen: Kreisarchiv Prignitz, Rat der Gemeinde Groß Breese, G 00295 (Wahlen, 1945-1949; enthält u. a.: Volks- und Berufszählung und Flüchtlingsliste).

\section{Groß Breesen}

Landgemeinde (seit 1.7.1950 Ortsteil von $\rightarrow$ Guben), bis 1952 Kr. Guben, 1952-1990 Kr. Guben (Bez. Cottbus), 1990-1993 Ldkr. Guben, 1993 Ldkr. Spree-Neiße

EReignisse bis Kriegsende: Ab Jan. 1945 Aufnahme von Flüchtlingen aus dem Ostteil des Kr. Guben (der Ort liegt unmittelbar an der Neiße nördlich Guben).

EREIGNISSE NACH KRIEGSENDE: 6.9.1945 Vergabe von 600 ha Bodenreformland an Landarme, Landlose, Umsiedler und Neubauern (Sebastian, S. 45), davon 339,33 ha an „Umsiedler u. russ. Kommandantur“ (Dartsch, S. 46); „115 Antragsteller, davon 39 Heimatvertriebene“ (Heimatlexikon, S. 80 f.). - 19.12.1945 „Das Schloß beherbergte schon sechzehn Umsiedlerfamilien; auch die Frau des ehemaligen Besitzers wohnte noch dort. [...].“ (Dartsch, S. 48). - 7.9.1949: „Der Groß Breesener Gemeinderat beschloß, der Straße durch die neue Siedlung den Namen ,Straße der Bodenreform' zu geben." (Der Kreis Guben im Gründungsjahr, S. 26).

EREIGNISSE NACH 1990: 23.6.1996 Heimattreffen der ehem. Bewohner des Kirchspiels Stargardt (Kr. Guben) in Groß Breesen in der Dorfkirche (Gedenkgottesdienst) bzw. in der Landgaststätte Waldow „mit großer Beteiligung“ (Bericht von G. Stengler: Gubener Heimatbrief 1/1997, S. 83 f.). - 20.6.2013 20. Treffen (wie vor) mit 30 Teilnehmern ebd. (Bericht von Christa Sturm in: Gubener Heimatbrief (2013)2, S. 27: „Treffen der Heimatfreunde des Kirchspiels Stargard $[t]$ mit den Orten Schernewitz, Beesgen, Plesse am 20. Juni, dem Tag der Vertreibung aus diesen Orten").

Bevölkerungszahlen: 1933: 1206, 1939: 1240, 1946: 1681 (HGV SN, S. 18 f.; Heimatlexikon, S. 80).

GedRUCKTE QUelLen und LiteratuR: Dartsch, Winfried: Junkerland in Bauernhand. Zur demokratischen Bodenreform 1945/46 in Groß Breesen. In: Gubener Heimatkalender 29 (1985), S. 44-49. - Guben zu Zeiten der DDR. In: Gubener Heimatkalender 44 (2000), S. 72-77, hier S. 72 [Eingemeindung]. - Heimatlexikon für Guben und 
Umgebung. Guben [2002]. - Der Kreis Guben im Gründungsjahr der DDR 1949. Zsgest.: W. Dartsch. In: Gubener Heimatkalender 33 (1989), S. 21-28 [Meldungen aus der „Märkischen Volksstimme“]. - Lehmann, Günter: Flüchtlinge und Soldaten 1945 in Groß-Breesen, Kr. Guben. In: Brandenburgische Genealogische Nachrichten 6 (2011), S. 14-21. [Chronologische Liste der im Ort Verstorbenen bzw. Beigesetzten, Jan. bis April 1945 (aus KB), überwiegend aus dem Ostteil des Kreises Guben und aus dem Ort selbst stammend]. - Sebastian, Günter: Guben im Jahre 1945. In: Gubener Heimatkalender 17 (1972), S. 35-48.

\section{Groß Drewitz}

Landgemeinde (1999-2003 Ortsteil von Lutzketal, seit 2003 von Schenkendöbern), bis 1952 Kr. Guben, 1952-1990 Kr. Guben (Bez. Cottbus), 1990-1993 Ldkr. Guben, 1993 Ldkr. SpreeNeiße

BeVÖLKERUNGSZAHLEN: 1925: 376, 1939: 303 (HOL NL II, S. 189); 29.10.1946: 469, 1950: 475, 1964: 409 (HGV SN, S. 27). - 1.1.1965: 409 (Wieviel Einwohner hat der Kreis Guben?, S. 126).

Gedruckte Quellen und Literatur: Schatte, Hartmut: Groß Drewitz. Geschichte und Geschichten eines Dorfes in der Niederlausitz. Cottbus/Guben 1999. - Ders.: Der Schmerz ist gewichen, die Erinnerung bleibt. In: Gubener Heimatkalender 59 (2015), S. 82-87, hier S. 83 [betr. den ersten „Grünen“ im Gubener Land Willi Jagott aus Wallwitz, Kr. Guben (Ostteil)]. - Töpler, Menschenwurm, S. 472. - Wieviel Einwohner hat der Kreis Guben? In: Gubener Heimatkalender 11 (1966), S. 126.

\section{Groß Gastrose}

Landgemeinde (1998 Zusammenschluss mit $\rightarrow$ Kerkwitz zu Gastrose-Kerkwitz, seit 2003 Ortsteil von Schenkendöbern), bis 1952 Kr. Guben, 1952-1990 Kr. Guben (Bez. Cottbus), 1990-1993 Ldkr. Guben, 1993 Ldkr. Spree-Neiße

EREIGNISSE NACH KRIEGSENDE: 3.10.1950 Zuweisung der westlich der Neiße gelegenen einwohnerlosen Flächen der nun polnischen Gemeinden Markersdorf/Markosice und (teilweise, vgl. $\rightarrow$ Grießen) Pohsen/Późna (ehem. Kr. Guben) an die Gemeinde Groß Gastrose (Blöß, Kreise und Gemeinden, S. 31). - 1953 Gründung der LPG „Friedensgrenze“ [der Ort liegt unmittelbar an der Neiße südlich Guben] (Schiller).

BevöLKerungszahlen: 1925: 420, 1939: 509 (HOL NL II, S. 193); 29.10.1946: 528, 1950: 659, 1964: 668 (HGV SN, S. 27).

Literatur: Schiller: Das Entstehen und die Entwicklung der LPG „Friedensgrenze“ Groß-Gastrose. In: Gubener Heimatkalender für das Jahr 1959, S. 54-55. 


\section{Groß Kölzig}

Landgemeinde (Seit 31.12.2001 Ortsteil von Neiße-Malxetal), bis 1945 Kr. Sorau, 1945-1946 (Rest-)Kr. Sorau bzw. Kr. Forst, 1.4.1946-1952 Kr. Spremberg, 1952-1990 Kr. Forst (Bez. Cottbus), 1990-1993 Ldkr. Forst, 1993 Ldkr. Spree-Neiße

BevölKerungszahlen: 1925: 1628, 1939: 1721 (HOL NL II, S. 356); 29.10.1946: 1727, 1950: 1832 , 1964: 1575 (HGV SN, S. 23).

UMSIEDLERLAGER (Bruchmühle): Im „Verzeichnis der errichteten und vorgesehenen Umsiedlerlager im Verwaltungsbezirk Cottbus“ vom 15.12.1945 ohne „Personenzahl“ genannt (Töpler, Menschenwurm, S. 472), für entsprechende Bereitstellung vorgesehen auch schon lt. Bericht vom 24.10.1945 (ebd., S. 450). - Kapazität am 31.12.1945 (Lager „Gr. Kölzig-Bruchmühl““): 60 (BArch, DO 2/45, Bl. 40, 41).

Gedruckte Quellen und Literatur: Töpler, Menschenwurm, S. 450, 472. - Wille I, S. 193-199.

\section{Großräschen}

Landgemeinde (1965 Stadtrecht), bis 1952 Kr. Calau (ab 1950 Kr. Senftenberg), 1952-1990 Kr. Senftenberg (Bez. Cottbus), 1990-1993 Ldkr. Senftenberg, 1993 Ldkr. OberspreewaldLausitz

EREIGNISSE BIS KRIEGSENDE: Die Gemeinde gilt bei Kriegsende als relativ unbeschadet geblieben (Töpler, Menschenwurm, S. 295).

BevöLKERUNGSZAHLEN: 1925: 6779, 1939: 7268, 1946: 11 895, 1964: 12609 (Städtebuch, S. 222).

Katholiken (Erzbistum Breslau/Erzbischöfliches Amt Görlitz): 1946: 2357 (Städtebuch, S. 223).

Gedruckte Quellen und Literatur: Töpler, Menschenwurm.

\section{Groß Schacksdorf-Simmersdorf (Kr. Sorau) $\rightarrow$ Simmersdorf}

\section{Groß Schönebeck}

Landgemeinde, bis 1952 Kr. Niederbarnim, 1952-1990 Kr. Bernau (Bez. Frankfurt/Oder), 1990-1993 Ldkr. Bernau, 1993 Ldkr. Barnim

BevölKeRUngszAHLEN: 1925: 1757, 1939: 2 184, 1946: 2697, 1964: 2326 (HOL VI, S. 488). 
UMSIEDLERLAGER: Kapazität am 31.12.1945: 500 (BArch, DO 2/45, Bl. 40). - Kapazität am 1.1.1946: 500 (BLHA, Rep. 203 MdI, Nr. 1163, Bl. 50).

Archivalische Quellen: BLHA, Rep. 250 Niederbarnim, Nr. 1101 (Kreisumsiedlerlager Rüdersdorf, 1946-1948; enthält auch: Gehaltszahlungsforderungen des Leiters des ehemaligen Umsiedlerlagers Groß Schönebeck).

\section{Grüneberg}

Landgemeinde (seit 31.12.1997 Ortsteil von Löwenberger Land), bis 1952 Kr. Ruppin, 1952 1990 Kr. Gransee (Bez. Potsdam), 1990-1993 Ldkr. Gransee, 1993 Ldkr. Oberhavel

EREIGNisSe BIS KrIEgSENDE: 1943-1945 bestand hier ein Außenlager des KZ $\rightarrow$ Ravensbrück.

UMSIEDLERLAGER: Kapazität am 1.1.1946: 500 („Grünberg“) (BLHA, Rep. 203 MdI, Nr. 1163, Bl. 50).

\section{Grünheide (Mark)}

Landgemeinde, bis 1950 Kr. Niederbarnim, 1.7.1950-1990 Kr. Fürstenwalde (ab 1952 Bez. Frankfurt/Oder), 1990-1993 Ldkr. Fürstenwalde, 1993 Ldkr. Oder-Spree

EREIGNISSE NACH KRIEgSENDE: 1946 (Bericht der Kreisverwaltung über „Umsiedlergenossenschaft“): „Im Kreis Niederbarnim, Grünheide ist eine Produktionsgenosseschaft gegründet, die Spitzen klöppeln wird." (BLHA, Rep. 203 MdI, Nr. 1074, zitiert nach: Oehlsen, S. 90). 15.3.1947 Erwähnung zweier „Umsiedlergenossenschaften“ (Heimarbeit) „für Spitzenklöppel Genossenschaft m.b.H. [...] (Herr Singer) [/] Belegschaft 22 Arbeiter und weitere Heimarb [eiter]" und „Möbel- und Erzeugungs-Genossenschaft [...] [/] Belegschaft 16 Arbeiter" (BLHA, Rep. 333, Nr. 574, Bl. 105). - 1948 Erwähnung der von sudetendeutschen Vertriebenen gegründeten „Spitzenklöppeleigenossenschaft Grünheide“ (Christopeit, S. 86). - [1948?] „bat der Bürgermeister persönlich um Zuweisung von Umsiedlerfamilien. Im Interesse seines Ortes wünscht er den Zuzug von Familien, damit die notwendigen Wiederaufbauarbeiten durchgeführt werden können" (BLHA, Rep. 203 MdI, Nr. 1074, zitiert nach: Oehlsen, S. 75).

Archivalische Quellen: BLHA, Rep. 203 MdI, Nr. 1074; Rep. 333 SED-Landesleitung Brandenburg, Nr. 574, B1. 105 .

LITERATUR: Christopeit. - Oehlsen, S. 75, 84, 90. 


\section{Guben}

Stadtgemeinde (seit Juni 1945 an der Neiße geteilt in deutschen [Guben] und polnischen Teil [Gubin]), 1884-1950 Stadtkr., 1.7.1950-1952 Ldkr. Cottbus, 1952-1990 Kr. Guben (Bez. Cottbus), 1990-1993 Ldkr. Guben, 1993 Ldkr. Spree-Neiße

EREIGNISSE VOR 1945: Anf. Jan. 1940 besteht in Guben ein Auffanglager für 400 umgesiedelte Wolhynien- und Galiziendeutsche (Müller, S. 124).

EReignisse 1945 bis KriegSende: Jan. 1945: „Zu dieser Zeit erreichten Tausende von Flüchtlingen, viele auf Pferdewagen, die Grenze der Stadt. [...] Jetzt sah man die Ankommenden auf der Schützenhausinsel rasten, bei offenem Lagerfeuer, harrend einer ungewissen Zukunft. Schulen, Turnhallen und Kinos wurden geräumt, um Menschen und auch Militär unterzubringen.“ (Gunia, „Bis fünf Minuten nach zwölf ...., S. 36). - Anf. 1945 Kreisverwaltung Züllichau nach Guben, $\rightarrow$ Calau und $\rightarrow$ Neuruppin evakuiert (BLHA, Rep. 6 B Züllichau-Schwiebus, Nr. 3). 6.2.1945 Räumungsbefehl für die Stadtbevölkerung, nur teilweise befolgt (Grünitz, S. 17). 14.2.1945 „Letzter Evakuierungszug verläßt Guben“ (Guben unter dem Nationalsozialismus, S. 45). - 18.2.1945 „Einstellung des Bahnhofbetriebs“ (ebd.). - 18.2. bis 12.3.1945 Kämpfe in Raum Guben (Kriegstagebuch des OKW 4,2, S. 1105-1116). - 22.2.1945: „In Guben drang der Feind ein." (ebd., S. 1116). - 12.3.1945: „Der Nordrand von Guben ist wieder in eigener Hand." (ebd., S. 1167). - 19.4.1945 Zerstörung aller Brücken durch die Wehrmacht (Heimatlexikon, S. 46; vgl. Gunia, Neissestadt, S. 64; Guben 1945/1946, S. 79; Kabisch). - Am 20.4.1945 wird „der östliche Stadtteil von deutschen Truppen geräumt“" (Gunia, S. 64). - 24.4.1945 Einmarsch der Roten Armee in die zur „Festung“ erklärte Stadt (Gunia, Neissestadt, S. 64; Heimatlexikon, S. 46; Augustyniak, Ende, S. 51; Sebastian I, S. 35). - Altstadt (östlich der Neiße) zu 88 \% zerstört (Heimatlexikon, S. 46). „Auf der Westseite der Neiße betrug der Zerstörungsgrad etwa $20 \%[\ldots]$ “.. (Augustyniak, Ende, S. 51).

EReignisse 1945 NACH Kriegsende: Ab April 1945 „kehrten die evakuierten und geflüchteten Gubener nach und nach in ihre Heimatstadt zurück“ (Augustyniak/Möhring, S. 10). „Schon Ende April kehrten frühere Einwohner der Stadt zurück. Keine Brücke war mehr vorhanden. Unterhalb der Eisenbahnbrücke am ,Dietrich' war durch russische Truppen eine Behelfsbrücke gebaut worden, über die nur eine Rückkehr in den östlichen Stadtteil möglich war. [...] Der Verkehr mit dem westlichen Stadtteil geschah dann später auch an der ehemaligen Achenbachbrücke." (Bericht des Sparkassendirektors Paul Drose, zitiert in Gunia, Neissestadt, S. 64). - „Nach Kriegsende wurde an gleicher Stelle [der der zerstörten Achenbachbrücke - P. B.] aus Bohlen und Brettern ein Notübergang über die Neiße geschaffen, über den die von der Evakuierung zurückkehrenden Ost-Gubener in ihre Wohnungen gelangen konnten." (Winkler, S. 36). - 27.4.1945 Bau einer „Behelfsbrücke an der gesprengten Eisenbahnbrücke bei Grunewald über die Neiße“ (Sebastian I, S. 35). - Ab 13.5.1945 Passieren der Neiße durch die neue Grenzfestsetzung verboten (Augustyniak/Möhring, S. 13). - 13.5.1945 Neueinrichtung eines Städt. Krankenhauses in ei- 
ner Villa in der Uferstr. 9 (da altes Städt. Krankenhaus östlich der Neiße u. zerstört) (ebd., S. 36; Abb. S. 41). - 16.5.1945 Eröffnung eines Ambulatoriums in der Bahnhofstr. 37 (ebd., S. 36). 29.5.1945 Eröffnung einer Isolierstation des Städt. Krankenhauses in „Liehr's Hotel“ [1930: „Liehrs Bahnhofs-Hotel“], Berliner Str. 3A (spätere Bahnhofstr.) (ebd., S. 36; Adressbuch Guben 1930). - Juni 1945 auf Beschluß der Alliierten Teilung der Stadt in östlich der Neiße gelegenen (Gubin) u. westlichen Teil als Grenzstadt; deutsche Bevölkerung aus östlich der Neiße gelegener Altstadt vertrieben“ (Städtebuch, S. 231). - 12.6.1945 Flüchtlinge aus Crossen/Oder werden am Neißeübergang gehindert (Wille I, S. 43). - 13.6.1945 Bekanntmachung: „Der Kommandant der Stadt Guben gibt bekannt, daß durch die Grenzfestsetzung ab 13.6.1945 das Passieren der Neiße verboten ist" (ebd., S. 37). - 20./21.6.1945 Vertreibung der deutschen Bevölkerung aus dem östlichen Teil der Stadt Guben (heute Gubin) durch polnisches Militär (Heimatlexikon, S. 46, 111); „Hauptübergang in Guben war ein Notsteg unweit der zerstörten Achenbachbrücke Alte Poststr., darüberhinaus Flucht durch mehrere Furten (u. a. bei $[\rightarrow]$ Groß Gastrose)“ (ebd., S. 111; vgl. Brüllke, S. 73: „wir zogen über eine Behelfsbrücke [...] Vorher mussten alle Vertriebenen über den großen Hof einer Villa, wo sie von den Polen intensiv durchsucht wurden."; vgl. Fuhrmann, S. 26: „wir [...] zogen über eine notdürftig hergestellte Holzbrücke“; lt. Winkler, S. 36: „über die im Wasser liegenden Reste der Achenbachbrücke“); „dadurch Überbelegung des Wohnraums im westl. Teil der Stadt - Notunterkünfte (Unterbringung in 7 Lagern: Pestalozzischule, ,Feldschlößchen', Borsiglager, Wilkestift, Liehr's Hotel, Kindergärten Cockerillstr. u. Alte Poststr.)“ (ebd., S. 46). „Von den 841 Bewohnern dieser Lager waren 803 aus Guben.“ (Augustyniak/ Möhring, S. 13); „Zusammenstellung von Sammeltransporten von aus den Regionen Crossen, Sommerfeld, Grünberg und dem ,Warthegau' vertriebenen Deutschen“ (ebd., S. 111) „zur Verteilung in weitere Gebiete der SBZ“ (ebd., S. 46); Tätigkeitsbericht vom 3.8.1945 für Juli (Stadtarchiv Guben I/1214): ,Eine große Sorge verursachte die Unterbringung der Deutschen aus dem östlich der Neiße gelegenen Stadt- und Landkreis Guben. Die Unterbringung war sehr schwierig, weil der Westteil des Land- und Stadtkreises schon von anderen Flüchtlingen überfüllt war." (Sebastian I, S. 39). „Vor Kriegsende hatte die Stadt Guben 47000 Einwohner, davon im Westteil nur ca. 9000. Es galt nun, 13500 Einwohner aus dem Ostteil im westlichen zusätzlich unterzubringen. Durch die Beauftragten des Wohnungsamtes wurden 8151 Zimmer mit $143017 \mathrm{~m}^{2}$ erfaßt und bis zum 17. September 1945 davon 6793 Zimmer neu verteilt.“ (ebd., S. 40). - „Zwischen 22. Juni u. 31.12.1945 1475 Sterbefälle - Stadt auf Grund der Vertreibungen überfüllt, Zunahme der Seuchengefahr; Typhus- (Obersprucke) u. Quarantänebaracken (Borsiglager)“ (Heimatlexikon, S. 67). - Juni 1945 Einrichtung eines Behelfskrankenhauses mit 14 Betten im Stadtteil Sprucke (Sebastian I, S. 41). - Zw. 22.6. u. 31.12.1945 1475 Sterbefälle, davon 144 unter $1 \mathrm{Jahr}$ alt, 219 an Unterernährung, 176 an Ruhr, 130 an Typhus (ebd., S. 48). - 28.6.1945 Einrichtung einer Betreuungsstelle für Flüchtlinge als Abteilung „Flüchtlingswesen“ der Stadtverwaltung (Guben 1945/1946, S. 72). - 28.12.1945 (Bericht des Volksbildungsamtes, unterzeichnet vom Referenten für Presse und Rundfunk Jänsch): „Die Stadt Guben, die ehemals ca. 45000 Einwohner hatte, zeigt heute dem Besucher nur noch die Zahl von ungefähr 27000 Personen. / Ein unablässi- 
ger Flüchtlingsstrom flutet über die Neisse herüber und bedrückt das schon frisch fröhliche Gesicht der Strassen." (Brandenburgische Gemeinden 1945, S. 57 f.).

EREIGNISSE 1946-1948: 1.5.1946 Kundgebung auf dem „Reipoplatz“ [Reichsbahn- und PostSportplatz, heute Lok-Sportplatz, Gasstraße] mit dem SED-Vorsitzenden Wilhelm Pieck (Foto der Rednertribüne in: Gubener Heimatkalender 44, 2000, S. 67). - 5.5.1946 (vormittags) Rede Piecks im Volkshaus [ehem. Hotel „Zum Kronprinz“, Berliner Straße 6]: er sei „fest überzeugt [S. 46], daß wir später einmal wieder unsere gesamte Stadt in der Verwaltung haben werden" (Stephan, S. 44, 46, nach Mitschrift im Stadtarchiv Guben). - 5.5.1946 (früher Nachmittag) Rede Piecks auf dem „Reipoplatz“ vor 10000 Gubenern; Verleihung des Ehrenbürgerrechts an Pieck (Sebastian II, S. 33; Stephan, S. 44), u. a. mit der Aussage, „daß die Ostgrenze Deutschlands bei der ersten Friedenskonferenz festgesetzt werden soll" (Stephan, S. 46 nach Mitschrift der Rede im Stadtarchiv Guben) und der (anschließend sinngemäß verbreiteten) Aussage „So können auch die Werktätigen Gubens, wenn sie im Geiste striktester Demokratie mit aller Kraft am Aufbau arbeiten, die Hoffnung haben, daß eines Tages auch jenseits der Neiße liegende Teil der Stadt Guben wieder unter deutsche Verwaltung gestellt wird" (indirekte Wiedergabe der Ausführungen Piecks in: Neues Deutschland, 7.5.1946, hier zitiert nach dem auszugsweisen Abdruck in: Gubener Heimatkalender 44, 2000, S. 67). - 13.9.1946 „Großkundgebung mit Wilhelm Pieck im damaligen Volkspark (Reipoplatz)“ (ebd., S. 38) „mit umstrittenen Äußerungen zur Oder-NeißeGrenze“ (Heimatlexikon, S. 47). - 1947 Rede Piecks auf einer Versammlung in Guben, in der er geäußert haben soll, „,bei der nächsten Baumblüte würden wir alle [die Gubener] wieder in den Gubener Bergen spazieren gehen können“ (Krausch, S. 55). - 19.7.1947: „Die auf polnischer Seite liegende Kläranlage (Schießstände) wurde durch polnische und deutsche Facharbeiter zum Nutzen der Bürger von Guben und Gubin in Gang gebracht" (Sebastian III, S. 23). - 1. (oder 9.) 5.1948 Rede Piecks auf dem „Reipoplatz“ in Guben, in der er eine Revision der OderNeiße-Grenze als friedensgefährdende Forderung der „Kriegstreiber“ im Westen bezeichnet (Krausch, S. 55; Jajeśniak-Quast/Stokłossa, S. 44 mit Foto, datiert auf 1.5.).

EREIGNISSE 1949-1989: 1949 „Heimkehrertreffen“ (BLHA, Rep. 250 Guben, Nr. 284).1.9.1949: erste Freundschaftskundgebung der FDJ mit der Jugend in Gubin an der „OderNeiße-Friedensgrenze“ (Möhring, Weltfriedenstag, S. 28; vgl. auch Möhring, Ein früher Versuch). - 4.11.1949: „Im Telegramm der Kreisdelegiertenkonferenz der SED an die Leitung der PVAP in Gubin wird die Oder-Neiße-Grenze als verbindende Friedensgrenze charakterisiert." (Der Kreis Guben im Gründungsjahr, S. 27). - 24.5.1950: „Auf einer Massenkundgebung auf dem Dreieck kennzeichnete Dieter Müller, 2. Sekretär der Kreisleitung der SED, das kursierende Gerücht, daß ganz Guben polnisch werden soll, als einen untauglichen imperialistischen Versuch, die deutsch-polnische Freundschaft zu torpedieren." (Der Kreis Guben im Jahre 1950, S. 31). - 10.9.1950 deutsch-polnisches Grenzlandtreffen (BLHA, Rep. 202 G, Nr. 170, B1. 578). - 3.10.1950 Zuweisung der westlich der Neiße gelegenen einwohnerlosen Flächen der nun polnischen Gemeinde Gubinchen/Gubinek (ehem. Kr. Guben) an die Stadt Guben (Blöß, 
Kreise und Gemeinden, S. 31). - 13.12.1950 Gründungsversammlung einer Ortsgruppe der „Deutsch-Polnischen Gesellschaft für Frieden und gute Nachbarschaft“ im Haus der Gesellschaft für Deutsch-Sowjetische Freundschaft (alle Anwesenden mit einer Ausnahme „Umsiedler“; erste Eintritte bereits zuvor am 22.7.1950 aus dem Kreis der „Kollegen“ des VEB Gubener Eisenwerke; 19.12.1950: ca. 60 Mitglieder; I. Vorsitzender: Karl Puhlmann [SED], Schulleiter, gebürtiger Gubener) (BLHA, Rep. 202 G, Nr. 170, Bl. 578). - 8.3.1956 Eröffnung des (1954 begonnenen Neubaus des) Filmtheaters „Friedensgrenze“ (Karl-Marx-Str. 56) (1990 Umbenennung in „Filmtheater Guben“, 2000 Schließung) (Der Märkische Bote, 7.11.2009; Guben zu Zeiten der DDR, S. 72). - 1957 Brücke über die Neiße errichtet, weitgehend nur für polnische Arbeitskräfte nutzbar (Ansorge, S. 36). - 3.1.1961 Umbenennung der deutschen Reststadt Guben in „Wilhelm-Pieck-Stadt Guben“ nach dem $1876 \mathrm{im}$ Ostteil geborenen (nicht vertriebenen, sondern bereits vor 1900 von dort verzogenen) ersten Staatspräsidenten der DDR, Festveranstaltung im Filmtheater „Friedensgrenze“ (Machnik, S. 30, 32); „ursprünglich war nur die Bezeichnung Wilhelm-Pieck-Stadt vorgesehen; auf Einwände der Wirtschaft wurde die alte Ortsbezeichnung Guben erhalten" (Guben zu Zeiten der DDR, S. 74); Straßenbenennung am Geburtshaus in Gubin in „ulica Wilhelm Pieck“ (Schmichen, S. 32). - 1964 Inbetriebnahme des Chemiefaserwerks (größer Betrieb Gubens nach 1945; Grundsteinlegeung 7.5.1960 auf dem Gelände des ehem. Rheinmetall-Borsig-Werks) (Heimatlexikon, S. 33 f.; Schulz, S. 38; Guben zu Zeiten der DDR, S. 74). - „Am 15.3.1966 überschritt die erste Gruppe von hundert polnischen Frauen und Mädchen die ,Brücke der Freundschaft' an der Oder-Neiße-Friedensgrenze, um eine neue Tätigkeit im Chemiefaserwerk in der befreundeten DDR aufzunehmen. Inzwischen [1977] ist die Zahl der polnischen Arbeiterinnen allein in diesem Werk auf über tausend angewachsen, das ist ein Sechstel aller Beschäftigten. Sie kamen entsprechend einer Vereinbarung der beiden benachbarten Staaten [...]. [S. 26] [1977] treffen [...], bei jedem Schichtwechsel, sieben Busse mit Arbeiterinnen aus Guben [poln. Gubin], Lubsko [dt. Sommerfeld/NL], Krosno [dt. Crossen/Oder], Jasien [dt. Gassen] ein" (Die Zusammenarbeit ..., S. 25 f.). - 15.5.1969 Vereidigung von 300 Soldaten der NVA im Chemiefaserkombinat (Kleine Chronik ... 1969, S. 40). - 19.7.1969 Eröffnung der Tage des polnischen Films in Anwesenheit von polnischen Filmschauspielern (ebd.). - 22.7.1969 „Freundschaftskundgebung mit Feuerwerk an der Neißebrücke anläßlich des 25. Jahrestages der Wiedergeburt Polens“ (ebd.). - 1.1.1972 Eröffnung des Grenzübergangs Neißebrücke für den visafreien Grenzverkehr (1981 wieder geschlossen) (Heimatlexikon, S. 49; Ansorge, S. 36). - Jan. 1976 Errichtung eines Wilhelm-Pieck-Denkmals (anlässlich des 100. Geburtstags; Standort: Klaus-Hermann-Straße), 2014 saniert (Danyel/Kaule/Zündorf, S. 78 f.).

EREIGNISSE SEIT 1989: 1989 Friedenstreffen deutscher und polnischer Gubener auf der NeiBebrücke (Gubener Heimatbrief 1/1993, S. 61). - 1990 Rückbenennung der Stadt in „Guben" (Gubener Heimatbrief 1/1993, S. 1). - Seit 1990 allmähliche Kooperation zwischen der polnischen und der deutschen Stadtverwaltung (gemeinsame Kläranlage in Gubin seit 1998, berufliche Förderung von Jugendlichen) (Städtebuch, S. 231; Heimatlexikon, S. 52; diverse Presseberichte im Gubener Heimatbrief nachgedruckt). - 2.3.1991 Lkw-Blockade des 
Grenzübergangs in Guben (Jajeśniak-Quast/Stokłossa, S. 104 mit Foto). - 26.12.1992 Friedenstreffen deutscher und polnischer Gubener auf der Neißebrücke (LR, 28.12.1992; Gubener Heimatbrief 1/1993, S. 60 f. mit Abb.). - 26.12.1994 „Über 500 Gubener und Gubiner finden sich zum traditionellen Treffen auf der Neißebrücke ein" (Guben nach der Wiedervereinigung, S. 111). - April 1996 Grundsteinlegung gemeinsamen Klärwerks für Guben und Gubin in Gubin (Neiße-Echo, Nr. 9/1996; Gubener Heimatbrief 2/1996, S. 70). - 2.6.1996 Einrichtung einer Zugverbindung von Guben nach Zielona Góra/Grünberg in Schlesien (LR, 20.4.1996; Gubener Heimatbrief 2/1996, S. 71). - 4.5.1997: „(Europatag Guben und Gubin) die Neißeinsel (Schützenhausinsel) für tausende Bürger über eine Pontonbrücke von der deutschen und eine Behelfsbrücke von der polnischen Seite zu einem kulturellen Begegnungstag kurzzeitig“ geöffnet (Wilke, S. 28; vgl. Bericht von Joachim Knak mit zahlreichen Abb. in: Gubener Heimatbrief 2/1997, S. 25-30). - 2.5.1998 „Offizielle Inbetriebnahme des gemeinsamen Klärwerks in Gubin" (Guben nach der Wiedervereinigung, S. 113; vgl. Gubener Heimatbrief 1/1998, S. 74 f.; 2/1998, S. 73 f.). - 22.8.1998 „In Guben bzw. Gubin werden deutsche und polnische Soldaten im Beisein der beiden Vertreidigungsminister vereidigt “ (Guben nach der Wiedervereinigung, S. 113). - 18.9.1998 „Offizielle Einweihung der neuen Brücke zwischen Gubin und der Schützenhausinsel“ (ebd.). - 7.5.1999 „Abnahme der neuen Neißebrücke am zukünftigen Grenzübergang [„Guben-Süd“ - P. B.] bei Schlagsdorf-Sekowice (Schenkendorf)“ (ebd., S. 114; Baubeginn Frühjahr 1997: Gubener Heimatbrief 2/197, S. 59; Bericht zum Baufortschritt: ebd. 1/1998, S. 76-78);. - 7.7.1999 „Einweihung der neuen Egelneißebrücke zwischen Laternengasse und Kirchstraße“ (Guben nach der Wiedervereinigung, S. 114). - 8.6.2000 Feierliche Eröffnung des Grenzübergangs Guben-Süd (Gubener Heimatbrief 2/2000, S. 70).

BevölKerungszahlen: 1925: 40 636, 1939: 45773, 1945: östlich der Neiße ca. 37 000, westlich 8000; Guben (Deutschland): 1946: 25297, 1964: 25 492; Gubin (Polen): 1950: 4300, 1966: 14300 (Städtebuch, S. 227). - [Westteil:] 1945: 24.5.: ca. 13000 (Sebastian I, S. 36), 26.6.: 18578 (ebd., S. 40), 2.7.: 20860 (ebd., S. 42), 31.12.: 25852 (ebd., S. 48). - 1.9.1945: 25379 (Guben in der Sowjetischen Besatzungszone, S. 62). - 1946: 31.1.: 26126 (Sebastian II, S. 29), 1.3.: 26404 (ebd., S. 30), 31.3.: 26484 (ebd., S. 32), 30.4.: 26683 (ebd., S. 33), 30.6.: 26885 (ebd., S. 35), 31.7.: 27131 (ebd., S. 36), 31.8.: 26364 (ebd., S. 37), 30.9.: 26364 (ebd., S. 38), 31.10.: 26307 (ebd., S. 38), $30.11 .: 25458$ (ebd., S. 39), 31.12.: 25505 (ebd.). „Die stark schwankenden Einwohner- und Mitgliederzahlen sind nur durch den ständigen Zugang von Umsiedlern aus den Gebieten östlich von Oder und Neiße und deren Abgang in andere Gebiete Deutschlands zu erklären.“ (ebd.). - 29.10.1946: 25297 Einwohner, davon aus Ostpreußen: 27, Hinterpommern 42, Ostbrandenburg 1254, Schlesien 463, Tschechoslowakei 29, Polen 60, Danzig 18, Rumänien 3, Baltikum 13, Sowjetunion 2 (Volkszählung 1946). - Juli 1946: 16442 „Umsiedler“ (BLHA, Rep. 203 MdI, Nr. 1074, Bl. 52; Abb.: Mietk, S. 66). - „1947: 26.7.: 25600 Einwohner (Sebastian III, S. 23). - 31.12.1948: Gesamtbevölkerung: 25 282, davon „Umsiedler und Evakuierte“: 14948 (Grandke, S. 46). - Eingemeindung von Vertriebenen: 30.4.1947: 
16263 (Oehlsen, S. 102), Juni 1948: 15254 (ebd., S. 103), Febr. 1949: 15109 (ebd., S. 104), 30.9.1950 („nach den neuen Kreisgrenzen ab 1.7.1950“): - (ebd., S. 105).

Katholiken (Erzbistum Breslau/Erzbischöfliches Amt Görlitz): 1925: 1789, 1946: 1015 (Städtebuch, S. 227, siehe auch Heimatlexikon, S. 64). - Siehe ausführlich zur kath. Gemeinde in den Jahren 1945/46 die Quellenedition „Unsere Herzen bluten“.

FlüChtlings-/Umsiedlerlager (INSGeSAmt): „Seit Ende Mai wurden täglich tausende von Flüchtlingen durch Guben geschleust. Zuerst standen als Flüchtlingslager die ehemaligen Hotels ,Berliner Hof' und ,Kronprinz' zur Verfügung, später kam das Borsig-Lager hinzu." (Stadtverwaltung Guben, Archiv 185, Bericht vom 27.5.1946, in: Gubener Heimatkalender 44, 2000, S. 65).[Ab 20.6.] 1945 wurden in Guben vorübergehend acht (Behelfs-)Lager eingerichtet, von denen aber nur das „Borsiglager“ Bestand hatte (Arlt, S. 126). - 1.7.1945: „In Guben befanden sich 7 Lager für Umsiedler. Diese waren in der Pestalozzischule, Lokal, Feldschlößchen', im Borsig-Lager (auf dem Gelände des heutigen Chemiefaserkombinates ,Wilhelm Pieck' Schwarza, Chemiefaserwerk Guben), im Wilke-Stift, in Liehr's Hotel und in den Kindergärten in der Cockerillstraße (heute August-Bebel-Straße) und in der Alten Poststr. (heute Cyrankiewiczstraße) eingerichtet. Von den 841 Insassen waren 803 aus Guben." (Sebastian I [erschienen 1972], S. 42). - 4.5.1946: „Es besteht heute in der Grenzstadt Guben nur noch das Auffanglager Borsig, [...].“ (Bericht der Stadtverwaltung vom 4.5.1946, in: Guben 1945/1946, S. 74).

Flüchtlingslager Hotel/Gaststätte „Berliner Hof“, Berliner Straße 2a (Gebäude steht noch 2018): Wohl schon Ende Mai 1945 beschlagnahmt und zumindest der Saal als Flüchtlingslager genutzt, vor dem 1.7.1945 aber bereits aufgelöst und durch andere Unterkünfte (Liehr's Hotel, Borsiglager usw.) ersetzt (Stadtverwaltung Guben, Archiv 185, Bericht vom 27.5.1946, in: Gubener Heimatkalender 44, 2000, S. 65; Werner Möhring, in: Lausitzer Rundschau, 17.8.2005).

FlüChtlingslager Hotel „Zum KronPrinz“ (später „Volkshaus“), Berliner Straße 6, am Bahnhof (später und heute: Bahnhofstraße 6) [1847 als Bahnhofshotel erbaut, 1865 und 1903 Aus- und Erweiterungsbauten, im Ersten Weltkrieg Reservelazarett (LR, 1.10.2014)]: Wohl schon Ende Mai 1945 beschlagnahmt und zumindest der Saal als Flüchtlingslager genutzt, vor dem 1.7.1945 aber bereits aufgelöst und durch andere Unterkünfte (Liehr's Hotel, Borsiglager usw.) ersetzt (Stadtverwaltung Guben, Archiv 185, Bericht vom 27.5.1946, in: Gubener Heimatkalender 44, 2000, S. 65; Werner Möhring, in: Lausitzer Rundschau, 17.8.2005; Abb. des Saals vor 1933 in: Gubener Heimatbrief 1/2000, S. 9). - „Im Krieg war der Saal belegt mit internierten Franzosen. Nach der Vertreibung 1945 war der Saal Flüchtlingslager [...]“ (Otto Schulze, in: Märkischer Bote, 2.1.2010). - 5.5.1946 Rede Pieck im Hotel „Zum Kronprinz“ (siehe oben Ereignisse). - „Die Gaststätte Kronprinz befand sich in der Bahnhofstraße bzw. Berliner Straße. Später haben wir sie selbst nach dem Krieg als ,Volkshaus' erlebt mit Theatervorführungen bis ca. 1957 [richtig: 1945-1950 Spielstätte des Stadttheaters - P. B.] und später als Tanzlokal (Abi-Ball 
1959).“ (Bärbel Koschack, in: Märkischer Bote, 2.1.2010). - Anf. 1950er Jahre Umbenennung in „Volkshaus“, bis etwa 1990 als Tanzgaststätte beliebt, dann mehrjähriger Leerstand, 1999 Verkauf an den Gemeinnützigen Berufsbildungsverein (GBV), der saniert und bis 2012 als Ausbildungsstätte nutzt (Informationen von Andreas Peter, in: LR, 1.10.2014; Wiedereröffnung nach Sanierung 2001: LR, 18.1.2001; Gubener Heimatbrief 1/2001, S. 66-68 mit Abb.), dann weitgehend Leerstand, vorübergehend Nutzung für Discos, 2016 Verkauf an Rheinland-Immobilienverwaltungs AG (Rivag) mit Sitz in Guben, die zu Hostel mit 100 Betten, Gemeinschaftsräumen, Küche und Ballsaal umbauen will (LR, 11.3.2016; www.riv.ag/Guben-Volkshaus.htm [29.6.2017]).

FlÜCHTLINGS-/UMSIEDleRlager „Liehr's Hotel“ (Durchgangslager), Berliner Straße 3A (spätere Bahnhofstraße 3a), dreigeschossiges Gebäude: Ursprünglich (noch 1936) privates Hotel [1914: 35 Betten; 1930: „Liehrs Bahnhofs-Hotel“], 1939 als Bahnhofshotel (mit Bahnhofskasse) im Eigentum der Deutschen Reichsbahn erwähnt (Der Märkische Bote, 24.4.2010; Adressbuch Guben 1930). - Am 29.5.1945 „ergab sich die Notwendigkeit, die Isolierstation des Städtischen Krankenhauses (Uferstraße 12) dort [in „Liehr's Hotel“] unterzubringen. 50 Betten wurden belegt.“ (Der Märkische Bote, 24.4.2010; vgl. Sebastian I, S. 36). - [1945: ] „Zwecks Beratung und Weiterleitung der Umsiedler wurde am Bahnhof das der Reichsbahn gehörige frühere ,Liehrs Hotel' beschlagnahmt und als Durchgangslager eingerichtet. Cirka 400 Flüchtlinge fanden Platz." (Bericht der Stadtverwaltung vom 4.5.1946, in: Guben 1945/1946, S. 74). - 1.7.1945 als Lager/Notunterkunft für Flüchtlinge erwähnt (Sebastian I, S. 42). - Ab Okt. 1945 Durchgangslager für Vertriebenentransporte: „Hier wurden die Umsiedler aufgenommen und dann zum Borsig-Lager überwiesen." (Sebastian I, S. 46). - 15.12.1945: „Lierchs [richtig: Liehrs, P. B.] Hotel“ und „Borsigbaracken“ haben zusammen eine Aufnahmkapazität für 2000 Personen (Töpler, Menschenwurm, S. 472). - Kapazität am 31.12.1945 (Lager „Guben Liehrs-Hotel“): 300 (BArch, DO 2/45, Bl. 41). - Bis Januar 1946 wurden in Liehr’s Hotel 45311 „Umsiedler“ aufgenommen und betreut (Sebastian II, S. 30). - „Da seit Januar 1946 der Zugang an Umsiedlern bedeutend nachgelassen hat, ist das Durchgangslager ,Liehrs Hotel' am 15.021946 geschlossen und das Gebäude der Reichsbahn als Eigentümer wieder übergeben worden." (Bericht der Stadtverwaltung vom 4.5.1946, in: Guben 1945/1946, S. 74). - „Die große Aufschrift ,Liehrs BahnhofHotel' prangte noch in den 1950er Jahren am Hausgiebel. [...] Später [wohl 1946 - P. B.] zog wieder die Bahnhofkasse ein und blieb hier bis zur Wende. 1992 nutzte eine Versicherung das Gebäude. 1997 brannte der Dachstuhl ab, später erfolgte der Abriss. Die Firma Leichtmetallbau und Glaserei Dulitz besitzt heute das Gelände [...].“ (Der Märkische Bote, 24.4.2010).

FlÜCHTLINGS-/UMSIEDLERLAGER BORSigLAGER (WALDSIEDLUnG), Schlagsdorfer Weg (bis 1945 Zwangsarbeiterlager des Rüstungskonzerns Rheinmetall-Borsig innerhalb von dessen Werksgelände „am linken äußersten Ende des Geländes“ [Augustyniak, Rheinmetall-Borsig, S. 84; siehe auch Augustyniak, Zwangsarbeiter; Gunia, Kriegsgefangene]; 1945: 14 Wohnbaracken, 1 Sanitätsbaracke, Wirtschaftsräume, Entlausungsanstalt [Heimatlexikon, S. 111]): 
„20.6.1945 „Das Barackenlager auf dem Borsiggelände wird Quarantäne- und Wohnlager“ (Guben in der Sowjetischen Besatzungszone, S. 62). - 1.7.1945 als Lager/Notunterkunft für Flüchtlinge erwähnt (Sebastian I, S. 42). - 1945 wurde im Borsig-Lager „eine Notunterkunft für 1400 Flüchtlinge geschaffen" (Stadtverwaltung Guben, Archiv 185, Bericht vom 27.5.1946, in: Gubener Heimatkalender 44, 2000, S. 65). - „Im ,Borsiglager‘ vom Juli bis Oktober 1945 tägl. 400-500 Personen [...] betreut“ (Heimatlexikon, S. 111; Quelle: Stadtverwaltung Guben, Archiv 185, Bericht vom 27.5.1946, Abdruck in: Gubener Heimatkalender 44, 2000, S. 65). - Der am 1.8.1945 in das Lager eingewiesene Gerhard Eichner (Guben) berichtet in seinen Erinnerungen: „Das Lager war mit einem Drahtzaun eingezäunt. Darüber waren zwei Stränge Stacheldraht. Auf der nördlichen Seite des Zaunes befanden sich zwei Türen, in der linken hinteren Ecke stand ein Wachturm (dieser war aber bereits abgerissen). Es gab ungefähr 30 Baracken. Die Eingänge waren an den beiden Stirnseiten und durch einen Mittelgang miteinander verbunden. Link sund rechts des Ganges befanden sich die Stuben für jeweils 16 Personen. Das Mobiliar bestand aus 8 Doppelstockbetten, einem langen Tisch und Hocker. Dort, wo französische Zwangsarbeiter lebten, waren die Möbel gestri- [S. 85] chen, bei den sowjetischen und polnischen Gefangenen waren sie aus rohem Holz." (Augustyniak, Rheinmetall-Borsig, S. 84f.). - Ab Okt. 1945 das hauptsächliche Durchgangslager in Guben für die Vertriebenentransporte aus Polen. „Dort blieben sie solange, bis ein Transport [zur Weiterleitung, P. B.] zusammengestellt war. Das dauerte in der Regel 8 bis 14 Tage." (Sebastian I, S. 46). - [1945/46 (Erinnerungen eines evang. Pfarrers):] „Im ehemaligen Borsig-Lager hielt ich Andachten bei den Insassen eines Altersheimes aus Sommerfeld, die von zwei Diakonissen betreut wurden. [...] Nachdem dort die Insassen im wahrsten Sinne des Wortes, ausgestorben' warten, zogen Wolhynien-Deutsche ein, denen ich auch wöchentlich eine Andacht hielt.“ (Seefeld, S. 23). - „In der Zeit von November [1945] bis Februar 1946 bestand die tägliche Durchschnittsbelegschaftsstärke 1200 Köpfe. An Verpflegung wurden ausgegeben: 122776 Portionen Essen und kalte Kost, 120000 Portionen Kaffee und 42500 Brote à 1 1/2 Kg." (Stadtverwaltung Guben, Archiv 185, Bericht vom 27.5.1946, in: Gubener Heimatkalender 44, 2000, S. 65).15.12.1945 „Lierchs [richtig: Liehrs, P. B.] Hotel“ und „Borsigbaracken“ zusammen für 2000 Personen vorgesehen (Töpler, Menschenwurm, S. 472). - Bis Januar 1946 wurden im BorsigLager 72320 „Umsiedler“ aufgenommen und betreut (Sebastian II, S. 30). - „Im ,Borsiglager [...] vom November 1945 bis Februar 19461200 Personen betreut u. verpflegt (tägl. 1 Liter warmes Essen, 200 Gramm Brot)“ (Heimatlexikon, S. 111). - Kapazität am 31.12.1945 (Lager „Guben-Borsig-Werke“): 2000 (BArch, DO 2/45, Bl.41). - Kapazität am 1.1.1946: 1400 (BLHA, Rep. 203 MdI, Nr. 1163, Bl. 49). - 14.2.1946 Auffanglager „Borsiglager“, Kapazität: 1400 (Oehlsen, S. 28). - 1946 Belegungsstärke: 1000 (Kaminsky, S. 159). - 30.4.1946 als eines der verbleibenden Umsiedlerlager genannt (DAB, I/9-15-1 Flüchtlingsseelsorge 1945-1951, unfol., [30.6.1946], [Anlage 3]). - 4.5.1946: „Noch heute wohnen 218 Gubener dort, desgleichen beherbergt das Lager noch ein Altersheim. [...] Es besteht heute in der Grenzstadt Guben nur noch das Auffanglager Borsig, das mit seinen Einrichtungen als Vorbild eines Flüchtlings- beziehungsweise Umsiedlerlagers anzusprechen ist. Ein Teil des Lagers wird heute als Quarantänelager benutzt. Näh- 
und Schuhmacherstellen sind vorhanden. Vor allem wurde eine Entlausungsanstalt, wo täglich 180 Personen mit Gepäck entlaust und gebadet werden können, eingerichtet. [...]." (Bericht der Stadtverwaltung vom 4.5.1946, in: Guben 1945/1946, S. 74). - 24.8.1946 Umsiedlerlager Borsig, Kapazität: 1200 (SAPMO-BArch, DY 34/27880, Bl. 291). - 1.1.1947 Kapazität: 1000 (Oehlsen, S. 101). - 7.2.1947 Borsiglager in „Waldsiedlung“ umbenannt (Sebastian III, S. 22). - 1947 Schließung des Lagers „Borsig“ bevorstehend (SAPMO-BArch, DY 34/27745, B1. 92). - „Die Baracken dienten [...] später als Altersheim bzw. Kindergarten." (Augustyniak, Zwangsarbeiter, S. 50, hier Foto von Baracken um 1950: „Links im Vordergrund Teile der Gärtnerei Rautenberg, die dann in der Alten Poststraße ihren Sitz hatte"). - 1948 Altersheim Waldsiedlung erwähnt (Noack). - Ab 1960 auf diesem Gelände Errichtung des 1964 eröffneten großen Chemiefaserwerks (Augustyniak, Rheinmetall-Borsig, S. 84, 87).

Flüchtlingslager Pestalozzischule, Friedrich-Engels-Straße 72, Ecke Pestalozzistraße: Zuvor bereits ab 22.1.1945 Schulbetrieb geschlossen und als Notlazarett (Kriegslazarett) genutzt (Bäro, S. 25; 100 Jahre Pestalozzischule Guben, S. 100). - „Am 20.06.1945 wurde die Schule plötzlich mit ungefähr 180 Flüchtlingen, die von den Polen aus dem östlichen Stadtteil vertrieben waren, belegt. In kurzer Zeit waren das Gebäude und die Aborte wieder völlig verschmutzt. In der Kochküche wurde täglich für die Flüchtlinge gekocht. Als diese nach ungefähr vier Wochen die Schule räumen mussten, wobei allerlei mitgenommen wurde, begann die schon einmal geleistete Arbeit von neuem." (100 Jahre Pestalozzischule Guben, S. 102). 1.7.1945 als Lager/Notunterkunft für Flüchtlinge erwähnt (Sebastian I, S. 42).

FlüChtlingSlager „FeldsChlösschen“ (Restaurant), Kaltenborner Straße: 1.7.1945 als Lager/Notunterkunft für Flüchtlinge erwähnt (Sebastian I, S. 42). - 5.7.1945 „Bunter Abend“ mit Musik, Tanz und Vorführung heiterer Kurzstücke (Guben 1945/1946, S. 99). - 25.4.1946 Kundgebung zur Frage „Geht es über die Grenze?", in der der Bevölkerung diese Hoffnung gezielt genommen werden sollte (Blöß, Grenzen und Reformen, S. 62, nach BLHA, Rep. 250 Guben, Nr. 27, Bl. 76).

FlüChtlingslager Naemie-Wilke-Stift, Friedrichstraße (heute Dr.-Ayrer-Straße) 1-4: Im Zweiten Weltkrieg Reserve-Lazarett 101 (Nieschalk, S. 58). - 1.7.1945 „Wiedereröffnung des teilzerstörten Wilkestifts [als Krankenhaus]“ (Heimatlexikon, S. 67). - 1.7.1945 als Lager/ Notunterkunft für Flüchtlinge erwähnt (Sebastian I, S. 42). - Situation im August 1945 bei Rückkehr des Stiftsvorstehers: „Das Haus war voll belegt mit Flüchtlingen, darunter zahlreiche sieche und sterbende Personen. Es fehlte an Nahrung, Medizin und Wäsche." (Rose/Dill, S. 109). - 1945 Herrichtung als geplantes Krankenhaus des Kreises anstelle des den Anforderungen nicht genügenden provisorischen städtischen Krankenhauses (ebd.). Chefarzt 19451949: Dr. Franz Ayrer (Heimatlexikon, S. 77) [1.5.1948 Ehrenbürger, verstorben 28.3.1949 (Guben in der Sowjetischen Besatzungszone, S. 63)]. - „Auf Bitte der Stadt Guben 1946 Eröffnung eines Altersheimes" (Heimatlexikon, S. 77). 
Flüchtlingslager Kindergarten Cockerillstrasse (heute August-Bebel-Straße), gegenüber der Pestalozzischule, ehem. Gemeindehaus der Stadt- und Hauptkirche: 26.5.1945 als Kindergarten eröffnet (Guben 1945/1946, S. 71). - 1.7.1945 als Lager/Notunterkunft für Flüchtlinge erwähnt (Sebastian I, S. 42); bis vor wenigen Jahren noch als Kindergarten genutzt, 2017 Teilnutzung als Flüchtlingsunterkunft (Mitteilung Andreas Peter, Guben, 30.3.2017).

Flüchtlingslager Kindergarten Alte Poststrasse (heute Cyrankiewiczstraße; Betriebskindergarten der gegenüberliegenden Firma „Gubener Wolle“): 12.5 .1945 eröffnet „zur Unterbringung der Kinder, deren Mütter im Arbeitseinsatz standen" (Bericht der Stadtverwaltung von 1946, in: Guben 1945/1946, S. 71). - 1.7.1945 als Lager/Notunterkunft für Flüchtlinge erwähnt (Sebastian I, S. 42); 2017 Leerstand, Hauseigentümer: GuWo Gubener Wohnungsgesellschaft mbh (Mitteilung Andreas Peter, Guben, 30.3.2017).

KRANKENHÄUSER: „Vor 1945 gab es in Guben zwei Krankenhäuser und etwa vierzig Ärzte. Im Mai 1945 war ein Krankenhaus völlig und das Naemi-Wilke-Stift teilzerstört. Provisorisch wurden zwei Villen (jetzt Städtische Kinderkrippe) als Krankenhaus eingerichtet." (Böhme, S. 39).

Altersheim „Herberge zur Heimat“, Wilkestraße 36 (Standort seit 1936 [Fritzschka, S. 77]): „Durch den Zustrom [ab 20.6.1945 - P. B.] vieler alter, gebrechlicher und anhangloser Leute wurde ein Altersheim dringend benötigt, das in der ehemaligen, Herberge zur Heimat' hergerichtet wurde. Ihm folgte am 8. Juli 1945 die Gründung eines zweiten Altersheims in Atterwasch [Kr. Guben, westlich der Stadt]." (Bericht der Stadtverwaltung von 1946, in: Guben 1945/1946, S. 72). - „Zu Beginn des 2. Weltkrieges ist die Herberge [...] bereits wesentlich Alters- und Siechenheim gewesen. Während der Kriegsjahre kam es zu erzwungenen Einschränkungen dieses Dienstes, weil ausländische Arbeiter und Umsiedlerdeutsche in einen Teil der Unterkünfte eingewiesen wurden. Bei Kriegsschluß - nach den Kämpfen um Guben - waren die Gebäude teilweise schwer beschädigt und die Heimbewohner in alle Winde zerstreut. / Nach fünfähriger Übergangszeit, in der die Stadt die Verwaltung übernommen und die größten Kriegsschäden beseitigt hatte, um wieder alte sowie heimlos gewordene Menschen aufnehmen zu können, wurde die Herberge mit 27 Insassen im Jahre 1950 dem Verein als früherem Besitzer und damit in die Obhut der Inneren Mission zurückgegeben. / Unter der Leitung des neuen Hausvaters Illert und seiner Frau wurde die schwere Wiederaufbauarbeit angepackt. Die Not unter den Alten und Hilfsbedürftigen war in Guben so groß, daß die Herberge, der es an Geld, Inventar und Arbeitskräften fehlte, 1952 mit 67 Betten überbelegt werden mußte. [...]. (Hoffmeister, S. 54). 1998/99 Neubau (Guben nach der Wiedervereinigung, S. 114), 2000 eröffnet als „Evangelisches Seniorenzentrum Herberge zur Heimat" (Alten- und Pflegeheim/Betreutes Wohnen).

FRIEDHÖFE: 1945: „Ende 1945 war der Sprucker Friedhof [Westfriedhof, Bethanienstraße 10] voll belegt. Ein neuer an der Cottbuser Chaussee [Waldfriedhof] wurde angelegt. Eine Baracke diente als Leichenhalle. [...]." (Seefeld, S. 22). - 1995 (anlässlich des ersten Bundestreffens des Gubener Heimatbundes e. V. in Guben): „Am Vormittag des gleichen Tages [29.4.1995] enthüll- 
ten Bürgermeister Gottfried Hain und Prof. Dr. [Otto] Hockwin [1. Vorsitzender des Gubener Heimatbundes e. V.] im Beisein vieler Heimatbundmitglieder auf dem Waldfriedhof einen Gedenkstein für alle Gubener Toten, deren Gräber wir nicht mehr besuchen können oder die in fremder Erde ruhen.“ (Wilke, Heimatbund, S. 37; vgl. Heimatlexikon, S. 50); Inschrift: „Allen Toten/unserer/Heimat/in ehrendem/Gedenken“ und, kleiner, rechts unten „Gubener/Heimatbund e.V./Bundestreffen/April 1995“ (Materne, 60 Jahre, S. 28f.; Gubener Heimatbrief 2/1995, S. 22 mit Abb.; siehe auch: Festschrift zum 50jährigen Jubiläum des Gubener Heimatbundes e. V.). - 2013: „Es ist erklärter Wille der Stadtverordnetenversammlung, dass die Friedhöfe als identitätsstiftende öffentliche Einrichtungen erhalten bleiben." (Lausitzer Rundschau, 27.4.2013).

StRASSENUMBENENNUNGen: 5.5.1950 Frankfurter Straße in Straße der Freundschaft (Guben zu Zeiten der DDR, S. 72). - 8.7.1951 Breslauer Straße in Blumenweg, Danziger Straße in Elsterweg, Schlesische Straße in Gartenstraße (Der Kreis Guben im Jahre 1951, S. 81), zuvor entsprechender Beschluss der Stadtverordnetenversammlung am 29.6.1951 (Mitteilung Andreas Peter, Guben, 30.3.2017), laut 2000 publizierter Zeittafel Umbenennung bereits 11.5.1951 (Guben zu Zeiten der DDR, S. 72).

StÄdtepartnerschaften: 19.1.1991 Gubin [poln. Ostteil von Guben] und gleichzeitig mit Laatzen (Niedersachsen) (Heimatlexikon, S. 97; Guben nach der Wiedervereinigung, S. 110). Die Kontakte Laatzens nach Guben waren von dem 1928 in Guben geborenen Laatzener Ratsherrn Rolf Brönstrup geknüpft worden (Crossener Heimatgrüße 42, 1990, Nr. 4, S. 20); 1.9.1990 Vorvertrag in Guben unterzeichnet, 3.10.1990 Unterzeichnung in Laatzen (Aus unserer Heimat 2/1990, S. 24-30), 19.1.1991 Unterzeichnung in Gubin (Jajeśniak-Quast/ Stokłossa, S. 102 mit Foto).

VERTRIEBENENVERBÄNDE NACH 1990: (1) 22.6.1991 Gründung der Regionalgruppe Guben des (1952 in Hannover gegründeten) Gubener Heimatbundes e.V. in „Kermers Weinstube“ (Kupferhammerstraße 78) im Beisein des Gubener Bürgermeisters Bernd Balzarek (CDU), des Stadtverwaltungsdezerneten Dr. Peter Lohmann und des Superintendenten Walter Delbrück (konstituierende Sitzung mit 45 Mitgliedern aus Guben, Initiatoren: Hans Joachim Just, Dr. Michael Gretzinger als stellv. Vorsitzender und der nicht anwesende Johannes Knak), anschließend Eröffnung einer ersten Kontaktstelle in der Wilkestraße 5 (www.gubener-heimatbund.de [29.6.2017]; Festschrift zum 50jährigen Jubiläum des Gubener Heimatbundes e. V., S. 4; vgl. auch: Guben 1945/1946, S. 82; Guben nach der Wiedervereinigung, S. 110; Heimatlexikon, S. 49; Materne, 60 Jahre, S. 26, 28; siehe auch: Peter, 50 Jahre); 12.10 .1991 weiteres Treffen mit 102 Teilnehmern in der Bergschänke in Bresinchen (ebd.) auf Einladung von Rosemarie Kroll (Guben) (Gubener Heimatbrief 1/2006, S. 12); 2.5.1992 3. Regionaltreffen in Guben (Universum) mit 200 Teilnehmern (ebd.); 24./25.4.1993 Regionaltreffen in Guben mit über 400 Teilnehmern, darunter auch auswärtigen Gästen (ebd.). - Leiter der Regionalgruppe Guben (nach Angaben in: Gubener Heimatbrief, ergänzt durech Mitteilungen A. Peter und www. 
gubener-heimatbund.de): 1991-1996 Rosemarie Kroll, Guben (†2005); 1996-2011 Lutz Materne, Guben (*1940 Guben, † 2011); 2012 Annett Lücht, Guben (*1974 Herzberg/Elster); 2014-2016 Andreas Peter, Guben (*1963 Guben), seit 2018 Katrin Zeptner, Guben. - Seit 1992 regelmäßige Regionaltreffen in Guben (Wilke, Heimatbund, S. 36), seit 1995 auch Bundestreffen des Gubener Heimatbundes e. V. in Guben (Heimatlexikon, S. 49). 28.4. bis 1.5.1995 erstes in Guben veranstaltetes Gubener [Bundes-]Heimattreffen aller 14 Regionalverbände mit 400 Teilnehmern im Saal der Betriebsgaststätte im Industriegelände Forster Straße (Wilke, Heimatbund, S. 36) [Vorsitzende des Gubener Heimatbundes (nach Angaben in: Gubener Heimatbrief, ergänzt nach www.gubener-heimatbund.de): 1992-2000 Prof. Dr. Otto Hockwin, St. Augustin (*1925 Guben, + 2002 St. Augustin, 2000 Ehrenbürger von Guben); 2000-2006 Dr. Hubert Förster, Krefeld ( ${ }^{*} 1927$ Guben[-Ost]); 2006-2011 Lutz Materne, Guben (siehe oben); 2012-2014 Jan Kuberski, Guben (*1986 Guben); 2014-2015 Andreas Peter, Guben (siehe oben); 2016-2018 Heidelinde Fabig geb. Weber (*1940 Guben), Guben, seit 2018 Margit Geike]. - 29.9.1995 Eröffnung einer „Heimatstube“ in Guben durch den Gubener Heimatbund (siehe unten), zudem 2002 Verlagerung des Heimatarchivs von Hamburg nach Guben (Materne, 60 Jahre, S. 29; siehe auch Kabisch, Archiv). - 2. bis 5.5.2002 Feiern des 50-jährigen Bestehens des Gubener Heimatbundes in Guben mit Festveranstaltung im ehem. Volkshaus, Festvortrag "Zuhaus in Guben“ von Dr. Helmut Jendreiek (ebd.). - 2004 10. Bundestreffen in Guben (ebd., S. 30). - 2011 Übernahme der Herausgeberschaft und Redaktion des Gubener Heimatkalenders durch den Gubener Heimatbund e. V. zusätzlich zum weiter erscheinenden Gubener Heimatbrief (Gubener Heimatbrief 1/2012, S. 6, 12 f.). - 2012 Feiern des 60-jährigen Bestehens des Gubener Heimatbundes mit Festveranstaltung am 5.5. in der „Alten Färberei“ (ebd., S. 31). - 6. bis 8.5.2016 64. Bundestreffen im Jugend- und Begegnungszentrum Fabrik e. V. in Guben mit 78 Teilnehmern (Mitglieder und Gäste) (Bericht von Ingrid Giebler: www.gubener-heimatbund. de/butr64.php [4.4.2017]). - 5. bis 7.5.2017 65. Bundestreffen des Gubener Heimatbundes in Guben mit 72 Teilnehmern (Bericht: http://www.gubener-heimatbund.de [29.6.2017]). - (2) $B d V$-Kreisverband Guben, 18.10.1994 erwähnt mit Jürgen Gräber als Vorsitzendem (Akten der BdV-Landesgeschäftsstelle).

Heimatstube des Gubener Heimatbundes, Berliner Straße 35 (Haus der Volkssolidarität, 1. Etage): Ort der Pflege des Andenkens an die Geschichte der ehem. deutschen Bewohner der östlichen Stadthälfte, seit 1995 in Guben (anfangs als „Treff Heimatbund“ bezeichnet), ab 29./30.9.1995 zunächst in der Uferstraße 38, Haus II (geöffnet an der Tagen pro Woche; Bericht über Eröffnungsfeier: Gubener Heimatbrief 1/1996, S. 48 mit Abb.; Ein-Jahres-Bilanz: ebd. 1/1997, S. 69; siehe auch ebd. 1/2001, S. 9f. mit Abb.), ab 1.11.2002 Gasstraße 13, seit Herbst 2011 am heutigen Standort (Guben nach der Wiedervereinigung, S. 112; www.gube ner-heimatbund.de/heimatst.php [29.6.2017]).

Crossener Heimatstube („Kreis Crossen a.O. Gedenk- und Heimatstube“), Frankfurter StraBe 1 (unmittelbar am Grenzübergang): 4.10.2014 eröffnet; Träger: Heimatkreis Crossen/Oder 
in der Landsmannschaft Berlin-Mark Brandenburg e. V., Betreuer: Klaus Koruhn (http://www. heimatkreis-crossen-oder.de/H_stb.html 84.7.2017]).

Archivalische Quellen und Auskünfte: BArch, DO 2 ZVU, Nr. 39, Bl.32-33 (Lager, 1945). - BLHA, Rep. 6 B Züllichau-Schwiebus, Nr. 3 (Verlegung der Kreisverwaltung Züllichau nach Guben, Calau und Neuruppin; Abwicklung der Geschäfte, 1945). - BLHA, Rep. 202 G Amt für Information, Nr. 170, Bl. 578. - BLHA, Rep. 203 MdI, Nr. 1122 (Umsiedler- und Heimkehrerstatistiken, 1945-1946; enthält: Erfassung der Umsiedler in den einzelnen Kreisen der SBZ zum 1. Dez. 1945 sowie statistische Berichte der einzelnen Gemeinden, hier Stadtkreis Guben). BLHA, Rep. 250 Landratsamt Guben/Frankfurt (Oder), Nr. 284 („Protokoll über das Heimkehrertreffen in Guben“, 1949). - Stadtarchiv Guben. - Auskünfte Andreas Peter, Guben. - Siehe auch Quellenteil, Abschnitt 4.1 (S. 1281 ff.).

Gedruckte Quellen: Brandenburgische Gemeinden 1945, S. 67-69. - Guben 1945/1946. Berichte, Dokumente, Diskussionen. Hrsg. von Andreas Peter. 2., durchges. u. erw. Aufl. Guben 1997. - Kriegstagebuch des OKW 4,2. Stadtverwaltung Guben, Archiv 185. Volksbildungsamt, Abtl. Presse und Rundfunk: Vfg. 1. Vermerk für den Rundfunkbericht. Umsiedler. Guben, dem 27. Mai 1946. In: Gubener Heimatkalender 44 (2000), S. 65. - Töpler, Menschenwurm, S. 450, 472 u. ö. (siehe S. 664). - Wille I, S. 43, 412 f., II, S. 305 f. - Erinnerungsberichte (Auswahl) $[\mathrm{GHK}=$ Gubener Heimatkalender]: Dokumentation der Vertreibung I/1, S. 29 E-31 E, 431; I/2, S. 691, 721; I/3, S. 90, 109, 225 f., 228. - Brüllke, Wolfgang: Die Taschenuhr. In: GHK 61 (2017), S. $72-73$ [Vertreibung aus dem Ostin den Westteil der Stadt Juni 1945]. - Fuhrmann, Elfriede: Erinnerungen an meine Kindheit in Guben. In: Gubener Heimatbrief (2013), S. 25-26. - Hauske, Marianne (geb. Mühle): Das Kriegsende am Ostfriedhof. In: Gubener Heimatbrief (1995)1, S. 15. - Jendreiek, Helmut: Die ersten Gubener Nachkriegswochen. T. 1-2. In: Gubener Heimatbrief (1999)2, S. 29-40; (2000)1, S. 31-38; gekürzte Fassung in: Gubener Heimatkalender 41 (1997), S. 33-48. Kabisch, Winfried: Der schwere Anfang in Guben nach 1945. In: Gubener Heimatbrief (1995)1, S. 12-14. - Krausch, H[einz]-D[ieter]: Wilhelm Pieck und die Gubener - ein Erlebnisbericht. In: Gubener Heimatbrief (1997)1, S. 55. Möhring, Werner: Weltfriedenstag 1949. In: GHK 33 (1989), S. 28-30. - Ders.: Ein früher Versuch der Aussöhnung. T. 1 und 2. In: Gubener Heimatbrief (2007)1, S. 71-74. - Noack, Wolfgang: Erinnerungen an das Altersheim Waldsiedlung. In: GHK 57 (2013), S. 89. - Pflaum, Herbert: Meine Kindheit in Boberhöh. Flucht und Vertreibung im Jahr 1945. [Privatdruck]. Eichwalde bei Berlin 2014, S. 27 f., 37 f. - Seefeld, Erich: Als evangelischer Pfarrer in Guben 1945-1946. In: GHK 40 (1996), S. 21-24. - Unsere Herzen bluten. Tagebücher und Aufzeichnungen aus der katholischen Gemeinde in Guben 1945/46. Im Auftr. der kath. Gemeinde Guben und des Bistums Görlitz zsgest. u. bearb. von Winfried Töpler. T. 1-2. Cottbus 2013. - Wittchen, Luzie: Erinnerungen an die Heimat. In: Gubener Heimatbrief (1994)2, S. 59. - Zeitungsberichte und Vertriebenenpresse [GHK = Gubener Heimatkalender]: Aus unserer Heimat. Rundbrief des Gubener Heimatbundes für den Stadt- und Landkreis Guben 1984-1990. - Dartsch, Winfried: Das Jahr 1949 im Spiegel der Presse. In: GHK 32 (1988), S. 68-72. - Guben empfängt Wilhelm Pieck (Artikel des „Neuen Deutschland“ vom 7. Mai 1946, Auszug). In: GHK 44, 2000, S. 67. - Gubener Heimatbrief. Hrsg.: Gubener Heimatbund e. V. 1985-2017 [u. a. mit Berichten, Fotos und Teilnehmerlisten der Bundestreffen des Gubener Heimatbundes e. V.]. - Kleine Chronik unserer Heimatstadt im Jahr 1969. Zsgest. von Heinz Mattke. In: GHK 15 (1970), S. 39-40. - Der Kreis Guben im Gründungsjahr der DDR 1949. Zsgest.: W. Dartsch. In: GHK 33 (1989), S. 21-28 [Meldungen aus der „Märkischen Volksstimme“]. - Der Kreis Guben im Jahre 1950. Zsgest.: W. Dartsch. In: GHK 34 (1990), S. 28-34 [wie vor]. - Der Kreis Guben im Jahre 1951. Zsgest. von W. Dartsch. In: GHK 35 (1991); S. 79-82 [wie vor]. - Rund um den dicken Turm. Gubener Heimatbrief 1 (1957) - 65 (1984). - Wille I, S. 458.

Literatur [GHK = Gubener Heimatkalender]: Ansorge, Hermann: Oder-Neiße-Friedensgrenze. In: GHK 29 (1985), S. 33-37. - Arlt, Gernod: Gubener Oberbürgermeister 1945 bis 1951. In: GHK 50 (2006), S. 126-128. Ast/Mauersberger, S. 127. - Augustyniak, Manfred: Zur Geschichte der Zwangsarbeiter in Guben. In: GHK 49 (2005), S. 46-53. - Ders.: Rheinmetall-Borsig in Guben - eine Rüstungsschmiede. In: GHK 50 (2006), S. 81-87. Ders.: Das Ende der NS-Diktatur in Guben. In: GHK 54 (2010), S. 47-52. - Ders. / Möhring, Werner: Zum Wiederaufbau der Verwaltung der Stadt Guben 1945/46. In: GHK 40 (1996), S. 10-16. - Bäro, Heinz u. Günter: Schule und Jugend 1945/46. In: GHK 40 (1996), S. 25-32. - Bahl, Peter: Eine Stadt in zwei Ländern. In: Landesgeschichtliche Vereinigung für die Mark Brandenburg. Mitteilungsblatt 106 (2005), S. 73-76. - Blöß, Wolfgang: Grenzen und Refor- 
men in einer Umbruchgesellschaft. Berlin 2014. - Ders. Kreise und Gemeinden, S. 13. - Böhme, Renate: 19481978 - 30 Jahre Poliklinik Guben. In: GHK 22 (1978), S. 39-40. - Buschmann, Gerhard: Vor 50 Jahren: Grundsteinlegung zum „Chemiefaserkombinat Guben“. In: GHK 54 (2010), S. 61. - Czabatror, Jerzy: Zur Entwiclung in Gubin nach Ende des Krieges. In: GHK 54 (2010), S. 53-56. - Dietrich, Siegfried: 40 Jahre Wohnungsbau in unserer Stadt. In: GHK 33 (1989), S. 12-20. - Dziadek, Anna / Quiel, Günter: Anno 2014. In: GHK 59 (2015), S. 119-125. - Festschrift zum 50jährigen Jubiläum des Gubener Heimatbundes e. V. 1952-2002. Guben 2002. - Franzke, Werner: Der Wiederaufbau des Gesundheitswesens in unserer Stadt. In: GHK 12 (1967), S. 59-64. - Fritzschka, J.: Vom Soldatenquartier zum Altenpflegeheim. In: Gubener Heimatbrief (1994)2, S. 77. - 50 Jahre Volkssolidarität. In: GHK 40 (1996), S. 33-34. - Grünitz, Paul: Die militärischen Ereignisse im Land- und Stadtkreis Guben vom Januar bis April 1945. In: GHK 39 (1995), S. 17-34. - Guben in der Sowjetischen Besatzungszone. Zeittafel 1945-1949. In: GHK 44 (2000), S. 62-63. - Guben nach der Wiedervereinigung. In: GHK 44 (2000), S. 110-114. - Guben unter dem Nationalsozialismus. In: GHK 44 (2000), S. 44-45. - Guben zu Zeiten der DDR. In: GHK 44 (2000). S. 72-77. - Gubener Heimatbrief. Hrsg.: Gubener Heimatbund e.V. 1985-2017. - Gunia, Gerhard: „Bis fünf Minuten nach zwölf ...“ Die Stadt Guben im zweiten Weltkrieg. In: GHK 11 (1966), S. 36-42. - Ders.: Zerstörung und Neubeginn einer Niederlausitzer Stadt. In: GHK 29 (1985), S. 18-25. - Ders.: Kriegsgefangene wurden zu Zivilarbeitern. Der Raum Guben im II. Weltkrieg. In: GHK 44 (2000), S. 55-56. - Ders.: Die Neissestadt ohne Brücken. In: GHK 44 (2000), S. 64. Hahn, Gottfried: Zum Geleit. Anno 1995 - 50 Jahre nach dem Zweiten Weltkrieg. In: GHK 39 (1995), S. 8. - Heimatlexikon für Guben und Umgebung. Guben [2002]. - Helas, Horst: Zu seinem 130. Geburtstag - Nachdenken über Wilhelm Pieck. In: GHK 50 (2006), S. 54-56. - Hockwin, Otto: Der Gubener Heimatbund in Guben. In: Gubener Heimatbrief (1999)1, S. 63-69. - Hoffmeister, Joachim: 100 Jahre Herberge zur Heimat in Guben. In: GHK 15 (1970), 50-54. - 100 Jahre Pestalozzischule Guben 1902-2002 in Wort und Bild. Guben 2002. - Jajeśniak-Quast, Dagmara / Stokłossa, Katarzyna: Geteilte Städte an Oder und Neiße. Frankfurt (Oder) - Słubice, Guben - Gubin und Görlitz - Zgorzelec 1945-1995. Berlin 2000 (dazu Rezension von Andreas Peter in: Gubener Heimatbrief (2000)2, S. 97-98). - Kabisch, Winfried: Archiv des Gubener Heimatbundes eine Fundgrube. In: Gubener Heimatbrief (2001)2, S. 39-41. - Ders.: Eine Hauptabfuhrstrecke für Reparationsgüter führte über Guben. In: Gubener Heimatbrief (2002)1, S. 40-47. - Ders.: Die Brücken unserer Stadt. In: Gubener Heimatbrief (2007)1, S. 26-31; (2007)2, S. 40-43; (2008)1, S. 39-44. - Karge, Paul / Hirte, Horst: Unvergeßlicher Tag. Grundsteinlegung zum Großvorhaben unseres Siebenjahrplanes. In: GHK 6 (1961), S. 47-48. - Kirsch, Rita: Wie ein Großbetrieb das Leben in Guben veränderte. In: GHK 44 (2000), S. 104-108 [Chemiefaserwerk]. - Knak, Johannes: Unser Heimatbund - seine Entstehung und Aufgaben. In: Gubener Heimatbrief (1996)1, S. 7-9. [Gubener Heimatbund]. - Korsan, Katarzyna: Beiderseits der Oder. Die Geschichte eines Deutschen aus Guben. In: Grenzerfahrungen. Hrsg. von Alicja WancerzGluza. Hamburg 2003, S. 343-356 [Hubert Grajewski]. - Krogmann, Wolfgang: Das künftige Gesicht unserer Stadt. In: GHK 15 (1970), S. 31-32 [Wohnungsbau]. - Lengauer, Hans Georg: Soldatengräber an der Neißefront. In: Gubener Heimatbrief (2017)1, S. 56-61. - Machnik, Ferdinand: Guben erhielt den Namen Wilhelm Piecks. In: GHK 7 (1962), S. 29-32. - Materne, Lutz: Weihe eines Gedenksteines auf dem früheren Ostfriedhof. In: Gubener Heimatbrief (2004)1, S. 25-27. - Ders.: 60 Jahre Gubener Heimatbund. In: GHK 56 (2012), S. 26-31. - Möhring, Werner: Die Demontagen in Guben nach 1945. In: GHK 43 (1999), S. 48-53. - Ders.: Wohnungsbau in Guben nach dem II. Weltkrieg. In: GHK 48 (2004), S. 21-24. - Müller, Erich: Transporte, Lager, Ansiedlung im Warthegau: Das Schicksal der galizien- und wolhyniendeutschen Umsiedler nach ihrem Grenzübertritt 1939/40. In: Zeitweiser der Galiziendeutschen 43 (2005), S. 104-157. - Margarete Nieschalk: Lazarettstadt Guben. In: Gubener Heimatbrief (1994)2, S. 58. - Opitz, Erich: Tragische Folgen eines Weltkrieges. In: Jahrbuch für Gubener Geschichte 2012/13 (2013), S. 133-171. [Minen- u. Sprengstofftote im Raum Guben 1945-1950; Verbrechen gegen Kriegsende u. in der Nachkriegszeit 1945-1949, mit detaillierter Opferliste]. - Peter, Andreas: Der Juni-Aufstand im Bezirk Cottbus. In: Deutschland Archiv 27 (1994), S. 585-594 [v. a. am Beispiel des Kr. Guben]. - Ders.: Schmerzhafte Wunden europäischer Geschichte. In: Gubener Heimatbrief (2000)2, S. 97-98. - Ders.: 50 Jahre Gubener Heimatbund. In: GHK 46 (2002), S. 31. - Remus, Barbara: Gewachsenes Miteinander zwischen Guben und Gubin. In: Gubener Heimatbrief (2001)1, S. 62-64. - Richter, Ute: 70 Jahre Volkssolidarität. In: GHK 59 (2015), S. 36-38. - Rose, Wolfgang / Dill, Hans-Dieter: Das Naemi-Wilke-Stift in der SBZ/DDR. In: Das Naemi-Wilke-Stift in Guben. Berlin 2005, S. 109132. - Schatte, Hartmut: Kowalski trifft Schmidt ... In: GHK 50 (2006), S. 90-93. - Ders.: Der Schmerz ist gewi- 
chen, die Erinnerung bleibt. In: GHK 59 (2015), S. 82-87 [Besuch des Gubeners Heinz Meschke in seinem Heimatort Wallwitz, Kr. Guben, nach 1990]. - Schmichen, Günter: Wilhelm Pieck bleibt unvergessen. In: GHK 6 (1961), S. 28-32. - Schulz, Arno: Bahnüberquerungen in Guben in vergangenen Zeiten und heute. In: GHK 61 (2017), S. 107-114. - Schulz, Gisela: Aus dem Leben der Ortsgruppe 18 der Volkssolidarität in Guben. In: GHK 55 (2009), S. 77-80. - Schulz, Günter: Ein Werk des Friedens an der Friedensgrenze. In: GHK 29 (1985), S. $378-43$ [VEB Chemiefaserwerk]. - Sebastian, Günter: Guben im Jahre 1945. In: GHK 17 (1972), S. 35-48 [ausführlich; ab 24. April]. Ders.: Zeittafel zur Geschichte Gubens nach 1945 (II): Guben im Jahre 1946. In: GHK 18 (1973), S. 29-39. - Ders.: Zeittafel: Zur Geschichte Gubens nach 1945 (III): Guben im Jahre 1947. In: GHK 19 (1974), S. 22-27. - Stephan, Ulrich: Guben und die Oder-Neiße-Grenze. In: GHK 39 (1995), S. 40-47. - Stichling, Hans-Werner: Die "SchubertGruppe“ oder: Späte Opfer stalinistischen Terrors in Guben. In: Gubener Heimatbrief (1998) 1, S. 28-33. - Stokłossa, Katarzyna: Integration durch Zwang 1948-1953. Die Oder-Neiße-Grenze und die mühsame Integration. In: Vertreibung, Neuanfang, Integration. Christoph Kleßmann / Burghard Ciesla / Hans-Hermann Hertle (Hrsg.) Potsdam 2001, S. 74-88. - Dies.: Die Oder-Neiße-Grenze im Bewußtsein der Bewohner von Guben und Gubin (1945-1972). In: Grenzen im Ostblock und ihre Überwindung. Helga Schultz (Hg.). Berlin 2001, S. 113-134. - Waack, Christoph: Stadträume und Staatsgrenzen. Geteilte Grenzstädte des mittleren und östlichen Europa im Kontext lokaler Alltagswelten, nationaler Politik und supranationaler Anforderungen. Leipzig 2000, S. 56-61. - Wendler, Simone: Abschied vom Haus der Eltern in gerade mal zehn Minuten. Gubener erinnern sich an die Vertreibung aus dem Ostteil der Stadt. In: Gubener Heimatbrief (2005)1, S. 100-102. - W[ilke], J[ana]: Heimatbund tagte in Guben. In: GHK 40 (1996), S. 36-37. - Wilke, Jana: Kleine Insel in der Lausitzer Neiße. In: Jahrbuch für Gubener Geschichte 1 (2011/12), S. 2748. - Winkler, Joachim: Aus der Geschichte der Achenbachbrücke. In: Gubener Heimatbrief (2010)2, S. 33-36. - Die Zusammenarbeit deutscher und polnischer Arbeiter im CFG. In: GHK 22 (1978), S. 25-27 [Chemiefaserwerk Guben].

\section{Güstebieser Loose}

Landgemeinde (bis 1945 Ortsteil der östlich der Oder gelegenen Gemeinde Güstebiese [Kr. Königsberg/Nm.], seit 2003 Ortsteil von Neulewin), bis 15.3.1946 (Rest-)Kr. Königsberg/ Nm., 1946-1952 Kr. Oberbarnim, 1952-1990 Kr. Bad Freienwalde (Bez. Frankfurt/Oder), 1990-1993 Ldkr. Bad Freienwalde, 1993 Ldkr. Märkisch-Oderland

Ereignisse nach Kriegsende: 1945 Abtrennung von der Gemeinde Güstebiese (ehem. Kr. Königsberg/Nm.) durch die neue Grenzziehung an der Oder (Blöß, Kreise und Gemeinden, S. 148). - 3.10.1950 Zuweisung von westlich der Oder gelegenen Flächen der nun polnischen Gemeinde Güstebiese/Gozdowice an die Gemeinde Güstebieser Loose (ebd., S. 31).

EREIGNISSE NACH 1990: 4./5.7.2003 deutsch-polnische Festveranstaltung zum 250-jährigen Bestehen des Oderkanals Güstebiese-Hohensaaten mit Einweihung eines Gedenksteins auf deutscher Seite, dabei Festansprache des aus Güstebiese stammenden Mitinitiators Prof. Bertold Jonas (Bremen); unter den Anwesenden auch „der vollzählige Vorstand des Heimatkreisvereins Königsberg/Nm.“ (Jonas, S. 116).

BEVÖLKERUNGSZAHLEN: 1925: 400, 1939: 400, 29.10.1946: 383, 1950: 446, 1964: 383 (HGV MOL, S. 30 f.). 
Gedruckte Quellen und Literatur: Dokumentation der Vertreibung I/1, S. 389-392 (Güstebiese und Umgebung, Jan./Febr. 1945). - Jonas, Bertold: Deutsch-polnische Begegenung über die Oder. Das große Fest zwischen Güstebieser Loose und Güstebiese/Gozdowice. in: Königsberger Kreiskalender 2004, S. 115-121. [2003].

\section{Guhlsdorf}

Landgemeinde (ab 1972 Ortsteil von Groß Warnow), bis 1952 Kr. Westprignitz, 1952-1990 Kr. Perleberg (Bez. Schwerin), 1990-1993 Ldkr. Perleberg, 1993 Ldkr. Prignitz

BevölkerungSZAhlen: 1925: 131, 1939: 107, 1946: 168, 1964: 118 (HOL I, S. 301).

Katholiken: Der aus dem Erzbistum Breslau stammende Erzpriester Maximilian (Max) Kauschke (geb. 1874) war 1949 in Guhlsdorf (als Flüchtlingspfarrer) eingesetzt, als „Priester auswärtiger Bistümer" weiterhin dem Bistum Breslau zugeordnet (Schematismus Berlin 1949, S. 142). Er wurde „mit einem Teil“ seiner „bisherigen Gemeinde aus Schlesien hier angesiedelt“ (Schwillus/Brühe, S. 355). Dabei handelt es sich um die kath. Kirchengemeinde Kamöse, Kr. Neumarkt in Schlesien (Ostpriesterverzeichnis 2, 1949, S. 42).

Literatur: Schwillus/Brühe, S. 355.

\section{Gusow}

Landgemeinde (seit 31.12.1997 Gusow-Platkow), bis 1950 Kr. Lebus, 1950-1952 Kr. Seelow (ab 1952 Bez. Frankfurt/Oder), 1990-1993 Ldkr. Seelow, 1993 Ldkr. Märkisch-Oderland

EREIGNISSE: „1945 kamen unzählige Flüchtlinge durch Gusow und Platkow. Es fehlte an allem, Hunger, Unterernährung und Seuchen waren die Folgen. Viele Menschen starben an Typhus. Das Sterberegister für 1945 weist mehrere hundert Tote aus. /,Am 29.6.1945 traf der erste Flüchtlingstreck in Platkow ein und hoffte auf Aufnahme. So ging es weiter, täglich zogen Hunderte durch Platkow, kaum einer wusste wohin er sollte. Die Einwohnerzahl stieg dadurch bis 1949 auf 1348 an, davon waren ca. 450 Umsiedler." (Eine Chronik, S. 46). - Okt. 1945 Umsiedlerlager in Gusow erwähnt (BArch, DO 2/39). - 1946/48 war der aus Schlesien vertriebene KPD/SED-Funktionär und (seit 1946) Neubauer in Worin (Kr. Lebus) Bernhard Grünert (1906-1997; geb. Bergen, Kr. Schweidnitz) Bürgermeister von Gusow (Wikipedia, 11.12.2019).

BeVÖLKerungSZAHLEN: 1925: 1218, 1939: 1417, 1946: 1549, 1964: 1392 (HOL VII, S. 161).

Katholiken (bis 1994 Erzbistum Breslau/Erzbischöfliches Amt Görlitz, dann Erzbistum Berlin): 1954: 48 (Schematismus Görlitz 1954, S. 36).

Archivalische Quellen: BArch, DO 2 ZVU, Nr. 39, Bl. 8 (Lager, 1945). 
Literatur: Eine Chronik. 775 Jahre Platkow 1229-2004. 600 Jahre Gusow 1405-2005. Gusow-Platkow (2004). Ein leidgeprüftes Land. Bearb. von Fritz Knüppel. 2. Aufl. Barsinghausen 1990, S. 160 f.

\section{Haage}

Landgemeinde (seit 31.12.2002 Ortsteil von Mühlenberge), bis $1952 \mathrm{Kr}$. Westhavelland, 19521990 Kr. Nauen (Bez. Potsdam), 1990-1993 Ldkr. Nauen, 1993 Ldkr. Havelland

EREIGNISSE: „Viele Flüchtlinge kamen, versuchten eine Bleibe zu finden oder zogen weiter. [...] Für viele war das Schloß das erste neue Zuhause. Wer im Dorf einen Raum übrighatte, mußte Flüchtlinge aufnehmen. So wurden dann oft Einfamilienhäuser von 2 bis 3 Familien bewohnt." (Amtsbereich Friesack, S. 107).

EREIGNISSE NACH KRIEGSENDE: 1946 in der Bodenreform 50 neue Eigentümer berücksichtigt, davon 24 Umsiedler (HOL III, S. 148). - 1947 „bauten 13 Umsiedler ihre Häuser, fast alle als Typenbau Wohnung/Stall unter einem Dach.“ (Amtsbereich Friesack, S. 107), viele Bauern und Neusiedler flüchten jedoch in den fünfziger Jahren in den Westen, um „dem Zwangseintritt in die LPG zu entgehen" (ebd.).

BevölkeRungSZAHLEN: 1925: 459, 1939: 374, 1946: 601, 1964: 407 (HOL III, S. 148).Febr. 1948: 705, davon „112 Flüchtlinge von jenseits $d[$ er] Oder, 408 Reichsdeutsche, 1 Schweizer, 170 Wolhynier, 14 Rumänien-Deutsche." (Amtsbereich Friesack, S. 121; vgl. S. 107).

Literatur: Amtsbereich Friesack. Horb am Neckar 1996, S. 102-115 (Kap. 2.7 Haage), 121. - Z., W.: Flüchtlinge fanden im Ländchen Friesack eine neue Heimat. In: Friesacker Quitzow-Kurier, Nr. 34, 2010 (Online-Ausg., o. S.).

\section{Halbe}

Landgemeinde, bis 1952 Kr. Teltow, 1952-1990 Kr. Königs Wusterhausen (Bez. Potsdam), 1990-1993 Ldkr. Königs Wusterhausen, 1993 Ldkr. Dahme-Spreewald

EREIGNisSe BIS KRIEGSENDE: 23./24.4. bis 1. Mai 1945 „Kesselschlacht von Halbe“: „Nach dem Zusammenbruch der 9. Armee im Raum Frankfurt/Oder und bei Cottbus wurden die kaum noch kampffähigen Reste der Truppe in einem Waldstück zwischen Märkisch Buchholz und Halbe durch die Rote Armee im sogenannten Kessel von Halbe eingeschlossen. Entgegen einem ,Führerbefehl' entschied sich der kommandierende General der 9. Armee, General Theodor Busse, nicht nach Norden in Richtung Berlin, sondern nach Westen auszubrechen. Die verschiedenen Versuche forderten bis zum Ende der Kämpfe am 1. Mai 1945 ungefähr 40000 Tote auf deutscher Seite. Diese wurden begraben, wo man sie fand: in Gärten, in den Wäldern, an Straßenrändern und auf den Feldern. [...] Neben den Soldaten befanden sich Tausende Flüchtlinge in diesem Kessel. Insgesamt ist von 200000 eingeschlossenen Menschen auszugehen.“ (Geschichte vor Ort, S. 52). - „Mit in den Kessel geriet eine unbekannte Zahl von 
Evakuierten aus den Gebieten beiderseits der Oder und Neiße, von Flüchtlingen aus Orten, die die Front überrollt hatte, von Angehörigen des Wehrmachtgefolges sowie von Zwangsarbeitern, Kriegsgefangenen und Häftlingen des Dritten Reiches. [...] Das Schicksal der in dieses Inferno geratenen Zivilbevölkerung ist ein besonderes Kapitel. [...] Es wird vermutlich nie in allen Einzelheiten geklärt werden können.“ (Lakowski/Stich, S. 62). - „Mitten in das Chaos der Kämpfe gerieten Tausende Flüchtlinge, meist Frauen, Kinder und Alte sowie die ortsansässige Zivilbevölkerung." (Danyel/Kaule/Zündorf, S. 75). - [Erinnerungen eines deutschen Soldaten:] Ende April 1945: „Wir gelangten durch den Strug ([...] große Fläche am Ortsrand von Halbe) [...] zur Baruther Straße. Dort bot sich uns ein furchtbarer Anblick. Alles staute sich, Flüchtlinge, Soldaten, Pferdefuhrwerke, Armeefahrzeuge. Alles wollte nach Westen und keiner kam weiter. Ein unüberschaubarer Pulk aus Menschen, Tieren und Technik. Und mittenrein schoss die sowjetische Luftwaffe. Überall Tote und Verletzte und ein ohrenbetäubender Lärm. Schreie, Geschützdonner und Flugzeugmotoren: Und über die Lebenden und die Sterbenden fuhren deutsche Panzer - es war die Hölle. Wenn ein Augenblick Zeit zum Durchatmen war, wurden von uns in aller Eile die Toten im Waldboden verscharrt." (Brösemann, S. 99).

EReignisse NACH KRIEgSEnde: „In Köthen, Halbe, Leibsch und Neuendorf hatten sich Bürger elternlose Kinder angenommen.“ (Müller, S. 397). - „In vielen Ortschaften des Halber Kessels fanden kleine Kinder Aufnahme, die ihre Angehörigen verloren hatten. Man musste ihnen neue Namen geben, beispielsweise nach den Orten, wo man sie fand. So kam der kleine Peter Neuendorf zu seinem Familiennamen. Ein Mädchen wurde nach seiner Fundstelle Inge Postkeller genannt." (Waldfriedhof Halbe, S. 8).

BeVÖLKeRUngSzAHLEN: 1925: 1 120, 1939: $1229,1946: 1202,1964: 1208$ (HOL IV, S. 100).

WALdFriedhof Halbe (eingerichtet 1951): „Zu den auf dem Friedhof Bestatteten gehören Angehörige der Deutschen Wehrmacht, der Waffen-SS, der Hitlerjugend, zahllose Flüchtlinge und Zivilisten, verschleppte sowjetische und ukrainische Zwangsarbeiter, Opfer der Wehrmachtsjustiz sowie im Jahr 1952 umgebettete Tote des sowjetischen Speziallagers Nr. 5 in $[\rightarrow]$ Ketschendorf. Es handelt sich um eine der größten Kriegsgräberstätten der Bundesrepublik Deutschland mit über 22300 Kriegs- [S. 53] opfern und etwa 6000 Opfer des Speziallagers. Für letztere wurden im Mai 2004 Namenstafeln angebracht. Die genaue Anzahl der hier bestatteten deutschen Soldaten ist unbekannt. Bei den ungefähr 8000 namentlich bekannten Toten handelt es sich fast ausschließlich um Angehörige der Wehrmacht, die durch erhaltene Soldbücher und Erkennungsmarken im Gegensatz zu den Zwangsarbeitern und Zivilisten identifizierbar waren. Es ist dem unermüdlichen Engagement von Pfarrer Ernst Teichmann (1906-1983) zu verdanken, dass die Regierung der DDR 1951 die Genehmigung zum Bau eines ,Zentralfriedhofs Halbe“ erteilte." (Geschichte vor Ort, S. 52 f.; siehe auch Teichmann). - „Im Grabfeld VI (Reihe 7) ist eine Steintafel mit der Aufschrift ,NOEL' zu sehen - ein französischer Mädchenname, der eigentlich Weihnachten oder auch Christkind bedeutet. Dieses Synonym für Freude, Geburt und Neubeginn steht hier für das Gegenteil, den [S. 11] Tod. Noel war ein etwa 
zehn Jahre altes Mädchen, das in den letzten Apriltagen 1945 in der Nähe von $[\rightarrow]$ Baruth ums Leben kam. Man kennt nur seinen Vornamen. Nachforschungen ergaben, dass die kleine Noel zu einer Familie gehörte, die sich in Cottbus mit einem Flüchtlingstreck den zurückweichenden deutschen Truppen angeschlossen hatte und später in den Kessel um Halbe geraten war. Die Suche nach Eltern oder Verwandten blieb vergeblich, und da sich nie jemand nach dem Schicksal des Mädchens erkundigte, ist anzunehmen, dass die gesamte Familie im Inferno des Kessels ums Leben kam. Möglicherweise gehörten Noels Eltern zu den vielen unbekannten Toten, die auf dem Waldfriedhof in Halbe ihre letzte Ruhestätte erhielten. [...]." (Waldfriedhof Halbe, S. $10 \mathrm{f}$.).

Archivalische Quellen: Kreisarchiv Dahme-Spreewald, A-4 Gemeinde Halbe, Nr. 82 (betr. auf einem Grundstück am Oberen See in Halbe stehende Baracken, 1949-1950; enthält u. a.: Nutzung der Baracken durch Flüchtlingsfamilien); Nr. 254 (Umbettung Kriegstoter auf die Kriegsgräberstätte Waldfriedhof Halbe (Zubettungen vom Hartmannsdorfer Waldfriedhof in [ $\rightarrow$ ] Lübben), 1951-1952; enthält: „Soldaten- und Umsiedlergräber [wohl Gräber von Soldaten und Flüchtlingen]“, 3 Bl.).

GeDRUCKTE QUelLen Und LiteratuR: Brösemann, Herbert: Ich war 18. Kriegserinnerungen. In: Heimatkalender Königs Wusterhausen und Dahmeland 2017, S. 96-100. - Danyel, Jürgen / Kaule, Martin / Zündorf, Irmgard: Brandenburg 1945-1990. Berlin 2018, S. 75 („Waldfriedhof Halbe“). - Führling, Günter G.: Endkampf an der Oderfront. Erinnerung an Halbe. 2., überarb. Aufl. München 1996. - Geschichte vor Ort: Erinnerungskultur im Land Brandenburg für die Zeit von 1933 bis 1990. Konzept der Landesregierung. Stand: 15. Januar 2009 (Entwurf). [Potsdam] (2009), S. 52-54 (www.mwfk.brandenburg.de [17.10.2016]). - Lakowski, Richard / Stich, Karl: Der Kessel von Halbe 1945. Hamburg u. a. 2009. - Müller, Franz: Chronik der Stadt Märkisch Buchholz. Berlin 2001. - 1945. Das Jahr in der Region Dahme-Spreewald. Dokumentation zur Geschichte. T. 2. Zeuthen 2010, S. 7. - Herbert Pietsch: Tote Soldaten auf dem Zentral-Waldfriedhof in Halbe. In: Der 8. Mai 1945 als historische Zäsur. Hrsg. von Arnd Bauerkämper, Christoph Kleßmann, Hans Misselwitz. Potsdam 1995, S. 185-200. - [Teichmann, Ernst:] Ernst Teichmann, Pfarrer vom Waldfriedhof Halbe. Briefe und Aufzeichnungen 1950 bis 1983. Hrsg. von Rainer Potratz u. Meinhard Stark. Potsdam 1997. - Töpler, Menschenwurm. - Waldfriedhof Halbe. [Hrsg.:] Volksbund Deutsche Kriegsgräberfürsorge e. V. Kassel (2005). - Wilke, Dorothea: Der Krieg ist aus. Die letzten Kriegstage und das Ende in der Kesselschlacht von Halbe. In: Zeitgebunden. Brücken zur Vergangenheit. Hrsg. vom Seniorenbeirat der Stadt Cottbus. Cottbus 2010, S. 47-51.

\section{Hathenow}

Landgemeinde, bis 1950 Kr. Lebus, 1950-1990 Kr. Seelow (ab 1952 Bez. Frankfurt/Oder), 1990-1993 Ldkr. Seelow, 1993 Ldkr. Märkisch-Oderland

EREIGNISSE NACH KRIEGSENDE: 3.10.1950 Zuweisung von westlich der Oder gelegenen Flächen der nun polnischen Gemeinde Ötscher/Owczary (ehem. Kr. Weststernberg) an die Gemeinde Hathenow (Blöß, Kreise und Gemeinden, S. 32).

BeVÖLKERUNGSZAHLEN: 1925: 360, 1939: 364, 1946: 274, 1964: 214 (HOL VII, S. 173). 


\section{Havelberg}

Stadtgemeinde, bis 1952 Kr. Westprignitz (Provinz Mark/Land Brandenburg), 1952-1990 Kr. Havelberg (Bez. Magdeburg), 1990-1993 Ldkr. Havelberg (Land Sachsen-Anhalt), 1993 Ldkr. Stendal (Land Sachsen-Anhalt)

EREIGNISSE vor 1933: Juli 1921 Schließung des Kriegsgefangenenlagers des Ersten Weltkrieges. „In den Baracken fanden zunächst Aussiedlern aus den Ostgebieten des Deutschen Reiches, die durch den Versailler Vertrag an Polen und Litauen abgetreten werden mußten, erste Unterkunft. [...] Die meisten Gebäude aber wurden nach und nach abgerissen." (Ball, S. 154).

EReignisse bis KRIEgSende: [Wohl Anf. 1945:] „Ein überlanger Personenzug trifft ein, so lang, daß erst über ,Blumeiers' hinaus die letzten Wagen auf der freien Strecke zum Stehen kommen. Ein Zug voller Menschen, vorwiegend Frauen und Kinder. ,Flüchtlinge' heißt es, die in Havelberg und den umliegenden Dörfern untergebracht werden mußten. Mir fiel die ungewohnte Kleidung vieler Frauen auf. Sie trugen dunkle Kopftücher und lange dunkle Röcke. Noch Monate später erkannte ich Flüchtlinge in Havelberg an ihrer Kleidung." (Plath, S. 39). - 2.5.1945 Einmarsch der Roten Armee (Kriegsende und Nachkriegszeit in Havelberg [I], S. 4).

EReignisSe NACH KRIEgSENDE: [1945:] „Flüchtlinge [...] bevölkerten in großer Zahl die Stadt und die umliegenden Dörfer. [...] Als die Schulen wieder öffneten, fielen mir die oft um einen Kopf größeren Jungen in meiner Klasse auf, Flüchtlingskinder! Durch den Schulausfall während der Flucht mußten sie zurückgestuft werden. Ein großer Teil der Flüchtlinge zog nach der zögernd einsetzenden Stabilisierung der politi- [S. 57] schen Lage, nach dem Zusammenfinden von Familienangehörigen, nach der Rückkehr der Männer aus dem Krieg und den Kriegsgefangenenlagern weiter, vornehmlich in Richtung Westen. Gerade begonnene Schülerfreundschaften fanden ein jähes Ende." (ebd., S. 56f.). - 1946: „Gründung der chemisch-pharmazeutischen Fabrik durch den heimatvertriebenen Apotheker Blaßhofer" (Christopeit/Reichel/Buchholz, S. 25); vgl. Firmenanzeige (in der Rubrik „Chemische Fabriken“): „Chem. Pharm. Laboratorium/Apotheker/P. Blaßhofer \& Co./K.G./(2) Havelberg, Uferstraße 1“ (Wirtschafts-Wegweiser [erstellt 1946, gedruckt 1949], S. 63), ähnlich auch erw. („Steinstraße 1 und Uferstraße) in: Branchen-Adressbuch Provinz Brandenburg mit Groß-Berlin. Ausg. 1947 [1946], S. 88; auch erw. als Chemisches Laboratorium „P. Blaßhofer \& Co. K. G.“ in: Branchen-Adressbuch Land Brandenburg [1948], S. 155) [Es handelt sich um Paul Blasshofer, über den sein Sohn Christian B., Essen, freundlicherweise am 28.7.2018 mitteilte: „Mein Vater Paul Blasshofer, seine Ehefrau Erna Blasshofer und 3 Kinder sind Ende 1944 vor den näherrückenden russischen Truppen aus Rippin in Westpreußen (später Danzig-Westpreußen - im Regierungsbezirk Marienwerder) [Rypin (Polen), 1939-1945 Rippin] nach Havelberg geflohen. Im Februar 1945 wurde hier mein jüngster Bruder geboren. / Es erfolgte die Gründung einer chemisch-pharmazeutischen Fabrik in Gebäuden im Bereich der Wilsnacker Straße/vor dem Steintor. Unser Wohnort, das Büro, das Labor und u. a. eine Versandabteilung befanden sich in der Uferstraße 1 in Havelberg. Auf der von meinem Vater angepachteten, unserem 
Wohnhaus gegenüberliegenden Spülinsel, wurde der in der Nachkriegszeit so wertvolle ,Alleskönner für die Gesundheit - Sanddorn' kultiviert und im Betrieb weiter verarbeitet. In Erinnerung geblieben ist mir auch unsere Ichthyol-Salbe. / 1953 hat das DDR-Regime meinen Vater enteignet. / Die Fabrik ist verstaatlicht worden. / Meine Eltern und 4 Kinder sind dann nach $[\rightarrow]$ Potsdam gezogen. Hier hat mein Vater als Betriebsleiter den gerade aus der DDR geflohenen Fabrik-Eigentümer (Herstellung von Pertussin) ersetzt. Die Wohnung des ,Republikflüchtigen' befand sich in der Behlertstraße in Potsdam direkt neben der Fabrik. Hier sind wir also gelandet und haben in Teilbereichen dieser umfänglichen Wohnanlage viele Jahre lang die gesamte Habe der ,Republikflüchtigen'vor Augen gehabt./Es hat dann noch bis 1958 gedauert, bis meine Mutter ihren Apotheker davon überzeugen konnte, dass es in diesem Staat keine Zukunft für ihn gibt. Der brasilianische Pass meiner Mutter machte es möglich, dass uns unter schwierigsten Bedingungen die Auswanderung nach Brasilien genehmigt worden ist. / Wir sind aber dann plangemäß nur bis Essen gekommen! / Hier hat mein Vater eine Apotheke eröffnet./ 1980 ist mein Vater verstorben.“]. - 1948: „Die Schlesische Dampferkompanie in Havelberg wird enteignet.“ (ebd., S. 26). - 20.5.1951 (lt. Polizeibericht): „illegale Zusammenkunft“ einer „Umsiedlerorganisation Landsberger Heimatvertriebene“ im Ausflugslokal Müggenbusch bei Havelberg. „Das Ziel dieser Versammlung bestand darin, eine feste Organisationsform zu schaffen, um im Kreis $[\rightarrow]$ Westprignitz die Umsiedlerorganisation ins Leben zu rufen. Vor der Auflösung wurde die Hetzschrift ,Ostbrandenburg-Neumark' Landesverband der Heimatvertriebenen, Berlin SW 11, be- [S. 397] schlagnahmt. Bei dieser Zusammenkunft war ferner eine Krankenpflegerin des Krankenhauses der Inneren Mission in Havelberg anwesend." Letztere hält eine Begrüßungsansprache, insgesamt ungefähr 22 Teilnehmer (Wille III, S. 396 f., BArch, DO 1/11/1887, Bl. 36, vgl. Edition im Quellenteil, Nr. 233).

Bevölkerungszahlen: 1925: 5418, 1939: 5739, 1945: 7861 (davon 2046 „Umsiedler“), 1964: 6672 (Städtebuch, S. 236). - „Am 2. November [1945] beherbergt die Stadt 7174 Einwohner. Darunter sind nur 1796 Männer, aber 3476 Frauen und 1902 Kinder. 2122 Neubürger sind Vertriebene aus den Ostgebieten. Bis Jahresende kommen noch 687 weitere Vertriebene hinzu." (Christopeit/Reichel/Buchholz, S. 25).

Katholiken: 1925: 122, 1946: 542 (Städtebuch, S. 236). „Am 15.5.1939 wurde Havelberg mit etwa 300 Katholiken seelsorglich selbständige Kuratie. 1953 hatte sich ihre Zahl verdreifacht." (Brühe, S. 20).

Gedruckte Quellen: Dokumentation der Vertreibung I/1, S. 359. - Plath, Lothar: Erinnerungen an das Kriegsende und die Nachkriegsjahre in Havelberg. In: Kriegsende und Nachkriegszeit in Havelberg [I]. Havelberg 1992, S. 37-84. - Wille III, S. $111 \mathrm{f}$. (Tätigkeitsbericht des Kreisumsiedlerausschusses für 1946). - Wirtschafts-Wegweiser für Wittenberge und die Kreise West- und Ostprignitz. Branchen-Adreßbuch. Potsdam (1949), S. XI (Dienststellen der Stadt), 49-134 (Firmen).

LiterAtur: Ball, Sabine: Ein Kriegsinternierungslager in Havelberg 1914-1921. In: Havelberg - kleine Stadt mit großer Vergangenheit. Hrsg. von der Stadt Havelberg. Halle 1998, S. 145-157. - Brühe, Matthias: Katholische Kirche zwischen Prignitz und Havelland. Berlin 2000, S. 20. - Christopeit, Gerald / Reichel, Antje / Buchholz, Torsten: Havelberger Geschichte in Daten. In: Havelberg - kleine Stadt mit großer Vergangenheit. Hrsg. von der Stadt Havelberg. 
Halle 1998, S. 10-30. - Kriegsende und Nachkriegszeit in Havelberg [I]-[II]. Hrsg.: Heimatverein Havelberg e.V. Havelberg 1992-1994. - Steiner, Edgar: Flüchtlinge und Vertriebene im Elb-Havel-Winkel. In: Kriegsende und Nachkriegszeit in Havelberg [II]. Havelberg 1994, S. 77-79.

\section{Heiligengrabe}

Landgemeinde (seit 1928 mit Techow), bis 1952 Kr. Ostprignitz, 1952-1990 Kr. Wittstock (Bez. Potsdam), 1990-1993 Ldkr. Wittstock, 1993 Ldkr. Ostprignitz-Ruppin

EREIGNISSE BIS KRIEGSENDE: 2.5.1945 Besetzung durch die Rote Armee. „In der Abtei hatten sich in der Hauptsache unsere Stiftsleute mit ihren Angehörigen und Flüchtlinge, sowie Frl. Ehrecke und die beiden alten Baltinnen unter Obhut von Frl. v. Wintzingerode, die Frl. v. Alvensleben als Hausdame vertrat, zusammengefunden, die alle im Kreuzgang der Dinge harrten, die da kommen würden." (Bericht der Äbtissin Armgard von Alvensleben, März 1946; Neese I, S. 329).

EREIGNisSe NACH KRIEgSEnde: 1945 „Zustrom zahlreicher Flüchtlinge“ (Lebenswerke, S. 139). - 1.8.1946 Auszug der Sowjetarmee aus dem Stift (Neese I, S. 324). - „Im August 1946 wurden nach langwierigen Verhandlungen mit der Obersten sowjetische[n] Militär-Administration die Stiftsgebäude wieder freigegeben, in denen dann kurz darauf die Diakonissen des Mutterhauses ,Friedenshort' aus Miechowitz [1936 umbenannt in Mechtal] (Kreis Beuthen, Oberschlesien) eine neue Heimat fanden." (Kiekebusch, S. 458); im Kloster Stift Heiligengrabe finden [1946?] ferner Diakonissen aus dem schlesischen Diakonissenmutterhaus Grünberg in (Nieder-)Schlesien Aufnahme (Handbuch der deutschen evangelischen Kirchen, S. 358). 1946: „pachtweise Überlassung der Abtei und sonstiger stiftseigener Gebäude und Grundstücke an das Diakonissenmutterhaus ,Friedenshort““ (Neese VI, S. 215). „Das Kloster wird zur neuen Heimat der aus Oberschlesien vertriebenen Diakonissen des ,Friedenshortes.“ (Lebenswerke, S. 71). - 1946 (Bericht der Stiftsdame Hedwig v. Saenger): [Im Stift anwesend sind:] „Eine ganze Reihe von Mechtaler Schwestern vom ,Friedenshort", viele Kinder aus den Kinderheimaten und außerdem allerlei hilfreiche Geister, die den Schwestern helfen, die Abtei wieder bewohnbar zu machen. [...] [S. 324] [...] die Friedenshort[-]Schwestern haben Mut und Gottvertrauen und sind Arbeit gewohnt. Sie haben schon manche der vielen Hindernisse überwunden und einzelne Räume schon recht wohnlich gestaltet. Im Neubau z. B. wohnt [...]. Im anderen Flügel sind in den Lernsälen eine Menge Jungens untergebracht, größere Mädchen drüben im Schulhaus. In der Abteiküche wird bereits wieder für etwa 50 Menschen gekocht." (Neese I, S. 323 f.). - 2.2.1947 (Pastor Beuster an Oberkirchenrat): „Der Friedenshort kann sich nicht weiter beschränken, er muß Platz halten für die in Kürze aus Schlesien eintreffenden über 50 Menschen und weitere 50 aus einer Notunterkunft und 20 Alte ...“ (ebd., S. 249 nach EZA 22/271). - 21.4.1947: „Der Friedenshort ist im Stift untergebracht und die Pfleglinge, $z$. Zt. sind 150 Diakonissen und Kinder hier, mindestens 150 weitere aus Schlesien ausgewiesene werden noch erwartet. (ebd., S. 250). - 9.5.1947 (Sitzung in Heiligengrabe): „Die Friedenshort-Oberin: in der jetzigen Lage ist es unmöglich, 2-3000 Menschen in Heiligengrabe zu ernähren, da jegliches landwirtschaftliches Gelände nicht bereitgestellt wird. 
[...].“ (ebd., S. 251). - 16.5.1947: „Der kirchliche Raum in Kolonie Heidelberg, als Betsaal und für Gottesdienste und Amtshandlungen genutzt, ist übergegangen an die Bauernhilfe, dort besitzt jetzt der Arbeiter Kapinski aus Lodz, ernster Bibelforscher.“ (ebd.). - 30.6.1947: „Im Stiftsgelände befinden sich fast 100 heimat- und elternlose Kinder, Opfer des Krieges.“ (ebd.). Sept./Okt. 1947 in der Bodenreform enteignet obwohl Kircheneigentum (ebd., S. 211-218, $252 \mathrm{f}.) .-$ 13.11.1947: „Gartengrundstücke (Stiftshauptmannsgarten) sind dringend notwendig für die Friedenshort-Ernährung mit 100 Waisen." (ebd., S. 253). - 18.11.1955 Bericht der Äbtissin: „Der Friedenshort half wesentlich durch Einsatz von Kindern und Jugendlichen bei der Ernte in Rapshagen [Heiligengraber Stiftsgut]." (ebd., S. 256). - 18.11.1948 (Rundbrief der Äbtissin Armgard von Alvensleben): „Obgleich das Stift erneut als Kirchengut anerkannt ist, gibt es noch so manche Schwierigkeiten zu überwinden. Trotzdem wollen wir dankbar zurückblicken und froh sein, daß die Abtei und ein Teil der Stiftsdamenhäuser abgemietet wurde von dem Diakonissenhaus ,Friedenshort'. Damit herrscht in Heiligengrabe ein Geist, wie er von jeher gewesen ist, d. h. ein Geist, der gewillt ist, dem Nächsten zu dienen und zu helfen. / Zu berichten wäre, daß der Rest der Stiftsdamen[-]Wohnungen, die dem Stift gehören, erneut bezogen ist. Ein Teil der Häuser ist mit Kindern aus dem Friedenshort belegt, während ein anderer Teil noch mit Flüchtlingen besetzt ist." (Neese I, S. 326).

LiterATUR: Berlin und Brandenburg. Stuttgart 1995, S. 222. - Handbuch der deutschen evangelischen Kirchen 1918 bis 1949. Bd. 1. Göttingen 2010, S. 358 (Kaiserswerther Verband deutscher Diakonissen-Mutterhäuser). - Kieckebusch, Werner von: Chronik des Klosters zum Heiligengrabe von der Reformation bis zur Mitte des 20. Jahrhunderts. Berlin 2008. - Lebenswerke. Frauen im Kloster Stift zum Heiligengrabe zwischen 1847 und 1945. Hrsg. im Auftr. des Kloster Stift zum Heiligengrabe von Simone Oelker u. Astrid Reuter sowie von der Deutschen Stiftung Denkmalschutz. Bonn 2002. - Stift Heiligengrabe. Ein Erinnerungsbuch. Hrsg. von alten Stiftskindern i. A. Nora Neese. T. I. Salzgitter 1992 (S. 290-345 u. a. Berichte aus den Jahren 1945-1948], T. VI. Salzgitter 2005 [S. 249-271 Kap. „Das Klosterstift nach dem Zusammenbruch 1945" (nach Akten des EZA)], S. 23 (Friedenshort-Schwestern), S. 35, 44 (Diakonissenhaus Friedenshort).

\section{Hennigsdorf}

Landgemeinde (seit 1962 Stadt), bis 1952 Kr. Osthavelland, 1952-1990 Kr. Oranienburg (Bez. Potsdam), 1990-1993 Ldkr. Oranienburg, 1993 Ldkr. Oberhavel

EREIGNISSE NACH KRIEGSENDE: 1945 (Bericht der Stadtverwaltung vom 22.12.1945, verfasst von Josef Syma): „Seit Mai 1945 betreibt die Gemeinde ein eigenes Behelfskrankenhaus, welches nach einer raschen Entwicklung zum Bezirkskrankenhaus erhoben und allen Erfordernissen Rechnung tragen wird. / Eine besondere Flüchtlingsfrage besteht her bisher noch nicht, da die hier verbliebenen Flüchtlinge sesshaft und somit aufgesogen wurden. Aber die Zahl der Fürsorgeberechtigten ist so hoch, dass nur die Hälfte der vom Kreis vorgeschriebenen Unterstützungssätze gezahlt werden können und die Unterstützten hierdurch einer besonderen Härte unterliegen. Die vorgesehene Aufnahme von mehreren Tauend Umsiedlern wird die Lage noch wesentlich verschärfen. Deshalb sind seit geraumer Zeit Vorbereitungen im Gange, um diesen Unglücklichen eine neue Heimat zu geben. Seitens der 
Parteien des antifaschistischen Blocks wurden Sammlungen von allerlei Hausgerät, Kleidungsstücken und dergleichen mit grossem Erfolg durchgeführt und dem Umsiedlerausschuß zugeführt. Nähstuben wurden eingerichtet und unter Leitung antifaschistischer Frauen Kleidungsstücke aus alten Sachen für die Bedürftigen angefertigt. / Mit der Anstrengung aller Kräfte werden wir auch dieses Problem lösen." (Brandenburgische Gemeinden 1945, S. 75). - 1946: In einem Bericht über die erfolgte Vermittlung „der arbeitsfähigen Umsiedler“ im Kreis Osthavelland in Beschäftigungsverhältnisse „werden besonders das Hüttenwerk Hennigsdorf und die LEW [Lokomotivbau-Elektrotechnische Werke, P. B.] Hennigsdorf erwähnt.“ (Oehlsen, S. 91). - 1962 Gründung des Kammerchors Hennigsdorf durch den in Berlin (Ost) ansässigen, bis 1945 in seiner Geburtsstadt Breslau ansässigen (katholischen) Sänger und Gesangspädagogen Leo Wistuba (1921-1994), Mitglied des CDU-Zentralvorstandes (Wilde, S. 173, 180).

BevöLKerungszahlen: 1910: 2400, 1925: 7 565, 1939: 12983, 1946: 13 071, 1964: 20604 (Städtebuch, S. 242). - Bericht der Gemeindeverwaltung vom 22.12.1945 (verfasst von Josef Syma): 1912 2 000, 1933 10.110. „Durch Übersteigerung der Industrie während der Naziherrschaft ist die Bevölkerungsziffer bis zum 31.1.1944 auf22 339 angestiegen, sodass eine ganze Barackenstadt errichtet werden musste, um die benötigten Arbeitskräfte unterzubringen. Die Höchstzahl wurde jedoch infolge des Zustroms von Flüchtlingen im April 1945 mit 29000 Einwohnern erreicht. Nachdem eine Stabilität eingetreten zu sein scheint, notierte man am 30.11.45 in Hennigsdorf 13885 Einwohner." (Brandenburgische Gemeinden 1945, S. 74).

Katholiken: 1925: 1620, 1946: 3450 (Städtebuch, S. 242). - [Nach Kriegsende:] „In den kommenden Monaten helfen einige Flüchtlingspriester in der Seelsorge aus." (75 Jahre kath. Kirchengemeinde ..., S. 20). - „Pfr. [Josef Maria] Zawacki [geb. 1888 Potsdam] konnte hier [im Flüchtlingslager in den ehemaligen Zwangsarbeiter-Baracken der A.E. G. - P. B.] im Juni 1947 in einer Kantinenbaracke vor etwa 800 Gläubigen zum ersten Mal die Hl. Messe feiern." (ebd., S. 22). - „Mit ihrer heimatvertriebenen Familie kam die 1921 geborene Marta Krause 1946 aus dem Sudetenland nach Hennigsdorf-Neubrück.“ Sie half regelmäßig „bei den Küsterdiensten in der Kapelle in Stolpe-Süd, zog 1961 selbst dort ein“ und war dann ,jahrelang im Caritaskreis der Pfarrgemeinde aktiv“, sie „wurde als ,Tante Marta' gemeindeweit bekannt“ (ebd., S. 57).

UMSIEDlerlager, Apfelallee 8: „In der unmittebaren Nachkriegszeit waren in den ehemaligen Zwangsarbeiter-Baracken der A.E. G. Flüchtlingslager eingerichtet worden.“ (75 Jahre kath. Kirchengemeinde ..., S. 22). - 1945 existiert angeblich ein Lager für 10000 Menschen (erwähnt 17.12.1945) (BLHA, Rep. 206, Nr. 2965, unfol.). - 17./19.12.1945 Lager Spandauer Allee erwähnt mit Lagerleiter Behrendt und Kapazität 5000 (BArch, DO 2/39, Bl. 89). - Kapazität am 31.12.1945: 5200 (BArch, DO 2/45, Bl. 40). - Kapazität am 1.1.1946: 500 (BLHA, Rep. 203 MdI, Nr. 1163, Bl. 50). - 1946 Quarantänelager. Baracken (BLHA, Rep. 230 Bernau, Nr. 287). - 1946 Belegungsstärke: 1500 (Kaminsky, S. 159). - 1946 Ankunft eines Transports mit 805 Vertriebenen aus Reichenberg in Böhmen (Jun, S. 250; vgl. den [identischen?] im Juni 
1946 eingetroffenen „Antifa-Transport“ aus Tschechoslowakei, der im Juli in Bernau eingemeindet wird: Christopeit, S. 83). - 4.10.1946: Ankunft eines Flüchtlingszugs mit 591 Personen aus dem Kr. Waldenburg [in Schlesien] in $\rightarrow$ Cottbus und Weiterleitung nach Hennigsdorf (Töpler, Menschenwurm, S. 544). - 1.1.1947 Lager, Kapazität: 2000 (Oehlsen, S. 101). - 1947 Schließung bevorstehend (SAPMO-BArch, DY 34/27745, B1. 92).

Lagerpersonal 1.11.1946: Lagerleiter: Josef Mahovsky [auch: Mahowski] (CDU, FDGB), geb. 21.4.1917; Lagerarzt: Dr. med. Graudenz, geb. 24.10.1889; Stellv. Lagerleiter: Georg Henschke (SED, FDGB), geb. 6.8. 1899; Bauleiter/Techniker: Andreas/Andree Duda (parteilos, FDGB), geb. 10.11.1916; Wirtschaftsleiter: Richard Bregulla (CDU, FDGB), geb. 21.9.1989; [Leiter der Lagerpolizei: Hermann Henningsen (parteilos, FDGB), geb. 13.4. 1897. - Personal 12.11.1946[?]: Lagerleiter: Josef Mahovsky, geb. 21.4.1917; Wirtschaftsleiter: Richard Bregulla, geb. 21.9. 1898; Lagerarzt: Werner Lauterbach (BLHA, Rep. 230 Bernau, Nr. 287, Bl. 19, $21-22,62-69,87-88)$.

StÄDtePARTNERSCHAften: (1) 1977 (1995 bekräftigt) Kralupy nad Vltavou (Kralup an der Moldau) in Tschechien (Mittelböhmen). - (2) 2012 Środa Wlkp. (Schroda) in Großpolen (http://www.hennigsdorf.de [4.11.2016]).

ARchivalische Quellen: BArch, DO 2 ZVU, Nr. 39, Bl. 89 (Umsiedlerlager, 1945). - BLHA, Rep. 250 Landratsamt Osthavelland, Nr. 853 (Berichte über Besichtigungen der Umsiedlerlager Falkensee und Hennigsdorf, 1946).

Gedruckte Quellen und Literatur: Brandenburgische Gemeinden 1945, S. 73-76. - Brühe, Matthias: Katholische Kirche zwischen Prignitz und Havelland. Berlin 2000, S. 21. - 75 Jahre Katholische Kirchengemeinde zu den hl. Schutzengeln Hennigsdorf. Hennigsdorf 2002. - Schwillus/Brühe, S. 324 - Töpler, Menschenwurm, S. 544. - Wilde, Eberhard: Leo Wistuba. In: Lebensbilder aus Hennigsdorf. Hennigsdorf 2000, S. 173-188.

\section{Herzberg}

Landgemeinde, bis 1950 Kr. Beeskow-Storkow, 1950-1990 Kr. Fürstenwalde (Bez. Frankfurt/ Oder), 1990-1993 Ldkr. Fürstenwalde, 1993 Ldkr. Oder-Spree

EREIGNISSE NACH KRIEGSENDE: In der Bodenreform 73 ha von 242 ha an 11 Umsiedler vergeben (HOL IX, S. 113).

EREIGNISSE NACH 1990: 10.6.1990 erstes gesamtdeutsches Heimattreffen der ehem. Bewohner des Kirchspiels Beutnitz (Kr. Crossen) (poln. Bytnica) in der Konsumgaststätte bzw. Gaststätte Simke, organisiert durch Dieter Schilling (Beeskow) u. a., mit ca. 220 Teilnehmern, darunter 42 aus Westdeutschland u. 12 West-Berliner (Crossener Heimatgrüße 42, 1990, Nr. 1, S. 6; Nr. 2, S. 10; Bericht: 42, 1990, Nr. 4, S. 30), 2. Treffen im Juni 1991 (ebd. 42, 1990, Nr. 6, S. 15).

BeVÖLKERUNGSZAHLEN: 1925: 650, 1939: 774, 1946: 1 126, 1964: 826 (HOL IX, S. 114). 


\section{Himmelpfort}

Landgemeinde (seit 2003 Ortsteil von $\rightarrow$ Fürstenberg/Havel), bis 1952 Kr. Templin, 19521990 Kr. Gransee (Bez. Potsdam), 1990-1993 Ldkr. Gransee, 1993 Ldkr. Oberhavel

EREIGNisse bis KRIEgSende: Das Ende des Krieges wurde mit dem Rückzug der Luftwaffe eingeläutet, die in Himmelpfort stationiert war. Sie war in Baracken in der Hasenheide untergebracht. / Ihrer Flucht in Richtung Westen schlossen sich noch andere an [...]." (Himmelpfort, S. 71).

EREIGNISSE NACH KRIEGSENDE: 1945: „Die größeren Häuser requirierte der russische Generalstab für sich als Unterkunft. Aber auch Flüchtlinge, die aus allen Richtungen kamen, beanspruchten Unterkünfte." (Himmelpfort, S. 71). - 1945 (Bericht des Bürgermeisters vom 25.11.1945): „Für die Flüchtlingsbetreuung sind jetzt Auffanglager Alte Mühle, Haus Eichberg und Barackenlager vor dem Dorf zum Bahnhof gelegen, Herrichtungsarbeiten von der [S. 80] Gemeinde im Gange. [...] Im allgemeinen ist die Bevölkerung, der Zeit entsprechend, zufrieden und der Gesundheitszustand als gut zu bezeichnen, durch das Bemühen der Gemeinde ist es einem hier Angestellten gelungen, Impfserum für Typhus herbei zu schaffen, worauf die gesamte Bevölkerung 3 mal gegen Typhus von Herrn Dr. Jugert geimpft werden konnte. [...] Durch das hier im April angtriebene Flüchtlingsvieh, konnte die Gemeinde bisher einigermaßen den Milch[-] und Fleischbedarf decken." (Brandenburgische Gemeinden 1945, S. 79f.).

BevölkeRUngSZAHLEN: 1925: 728, 1939: 737, 1946: 822, 1964: 802 (HOL VIII, S. 436).

UMSIEDLERLAGER: Kapazität am 31.12.1945 (Lager „Lychen-Himmelpfort“): 2000 (BArch, DO 2/45, Bl. 40) [vgl. aber die Angaben beim Lager $\rightarrow$ Lychen, das wohl mit dem Lager Himmelpfort identisch ist]. - 24.8.1946 Umsiedlerlager „Himmelfahrt“ [so!] im Kr. Templin, Kapazität: 800 (SAPMO-BArch, DY 34/27880, Bl. 291).

Gedruckte Quellen und Literatur: Brandenburgische Gemeinden 1945, S. 79-80. - Himmelpfort. Historischer Überblick. Überarb. Ausg. Gransee 2009.

\section{Hirschluch $\rightarrow$ Storkow-Hirschluch}

\section{Hohen Neuendorf}

Landgemeinde (seit 1999 Stadtrecht), bis 1952 Kr. Niederbarnim, 1952-1990 Kr. Oranienburg (Bez. Potsdam), 1990-1993 Ldkr. Oranienburg, 1993 Ldkr. Oberhavel

EREIGNISSE NACH 1990: 17.9.2005 „8. Ostdeutscher Kulturtag“ des BdV-Landesverbandes Brandenburg in der Stadthalle (Akten der BdV-Landesgeschäftsstelle).

BeVÖLKERUNGSZAHLEN: 1925: 7 052, 1939: 9976, 1946: 9352, 1964: 9773 (HOL VI, S. 395). 


\section{Hohenwutzen}

Landgemeinde (seit 2003 Stadtteil von $\rightarrow$ Bad Freienwalde/Oder), bis 15.3.1946 (Rest-)Kr. Königsberg/Nm., 1946-1952 Kr. Oberbarnim, 1952-1990 Kr. Bad Freienwalde (Bez. Frankfurt/Oder), 1990-1993 Ldkr. Bad Freienwalde, 1993 Ldkr. Märkisch-Oderland

EREIgnisse nach KriegSende: In den ersten Märztagen 1945 Teil-Sprengung der dem Straßen-, Fußgänger- u. Eisenbahnverkehr dienenden Oderbrücke (v.-Saldern-Brücke) (Schneider, S. 14; Schöning, S. 148).

EREIGNISSE NACH KRIEGSENDE: 3.10.1950 Zuweisung von westlich der Oder gelegenen einwohnerlosen Flächen der nun polnischen Gemeinde Niederwutzen/Osinów-Dolny (ehem. Kr. Königsberg/Nm.) an die unmittelbar an der Oder-Grenze gelegene Gemeinde Hohenwutzen (Blöß, Kreise und Gemeinden, S. 31). - 1950er Jahre: Gründung der LPG „Friedensgrenze" (Sobottka-Heese, S. 1). - 1957 Bau einer neuen Straßenbrücke über die Oder, die aber als Grenzübergang (bis auf wenige Ausnahmen) gesperrt bleibt (Schöning, S. 148-151). - 1.3.1993 Eröffnung eines Grenzübergangs für den Straßenverkehr nach Polen (Oder-Brücke) (ebd., S. 151). - 19.6.1993 Gedenkstein-Enthüllung (s. u.).

BeVÖLKERUNGSZAHLEN: 1925: 847, 1939: 1052, 29.10.1946: 904, 1950: 1075, 1964: 1000 (HGV MOL, S. 18).

Gedenkstein (am Ortseingang auf der Bundesstraße 158) mit Inschrift „Oderland - Heimatland. Zur Erinnerung an den Kreis Königsberg in der Neumark. 19.6.1993“. Enthüllung: 19.6.1993 (Bluhm, mit Abb.; Mahn- und Gedenkstätten Brandenburg, mit Abb.). Die Aufstellung wurde vom „Heimatkreis Königsberg/Neumark e. V.“ (Planung seit 21.7.1992) initiiert, konnte aber erst nach mehrmonatigen Auseinandersetzungen mit der Gemeinde Hohenwutzen und der Gemeinde Parstein, aus der der Findling beschafft wurde, umgesetzt werden (Bluhm).

Quellen und Literatur: Bluhm, Hans-Gottfried: Fünf Jahre Gedenkstein für den Heimatkreis Königsberg/Neumark. In: Königsberger Kreiskalender 1998 (1997), S. 155-160. - Der Gedenkstein und die Parsteiner - von der einstweilige[n] Verfügung bis zur kostenlosen Fernsehwerbung. Die unendliche, unglaubliche Geschichte des Findlings der Königsberger. In: Märkischer Informationsdienst 1993, Nr. 12, S. 12-13. - Gedenkstein-Einweihung beim Treffen des HK Königsberg/Nm. In: Märkischer Informationsdienst 1993, Nr. 7/8, S. 6-8. - Mahn- und Gedenkstätten Brandenburg. Hrsg.: BdV (http://www.bund-der-vertriebenen.de [20.9.2016]). - Schneider, Joachim: Die Oder während der Kriegshandlungen im Frühjahr 1945. In: Historischer Verein zu Frankfurt (Oder) e.V. Mitteilungen 2001, H. 2, S. 7-21, hier S. 14 (Saldernbrücke). - Schöning, Wilfried: Die Brücke über die Oder bei Hohenwutzen. In: Königsberger Kreiskalender 1996 (1995), S. 148-153 [Mit detaillierter Beschreibung der Brückenkonstruktion von 1957]. - Sobottka-Heese, K(athrin): Die Gründung der LPG „Friedensgrenze“ und der Aufbau der Rinderzucht in Hohenwutzen. In: Hohenwutzener Heimatzeitung 18/19 (2016/17), S. 1-4. 


\section{Jahnberge}

Wohnplatz (1937-1952 Wohnplatz von Brädikow, 1952-2003 Wohnplatz/Ortsteil von Warsow, seit 2003 Ortsteil von Wiesenaue), bis 1952 Kr. Westhavelland, 1950-1990 Kr. Nauen (Bez. Potsdam), 1990-1993 Ldkr. Nauen, 1993 Ldkr. Havelland

EREIGNISSE BIS KRIEGSENDE: „Historische Bindungen gab es nicht, so daß der heutige Ortsteil [von Wiesenaue] seine ganz eigene Geschichte hat." (Amtsbereich Friesack, S. 134). - 1937 von der Siedlungsgenossenschaft „Eigene Scholle“ gegründet: Anlage von Verwaltungsgebäude und Wirtschaftsgebäuden (Speicher und Maschinenhalle) sowie Baracken für RAD und ab 1940 für Fremd-/Zwangsarbeiter; kurz vor Kriegsende Verwaltungsgebäude abgebrannt (ebd., S. 134 f.).

EREIGNISSE NACH KRIEGSENDE: „1945 menschenleerer Ort, der nur von Flüchtlingen aus Ostpreußen und Wolhynien neu besiedelt wurde, die durch die Bodenreform großzügig Siedlungs-, Land- und Waldflächen erhielten." (W.Z., Flüchtlinge). - 1947 in Warsow (!) Bodenreformland vergeben an 75 Eigentümer, davon 59 Umsiedler (HOL III, S. 409), in Jahnberge 42 Siedler mit Neubauernstellen berücksichtigt (Amtsbereich Friesack, S. 136), 1949-1953 Bau von Häusern für die Neubauern, 1951/52 Einrichtung eines kleinen Konsumladens in alten Baracken sowie Bau von Feuerwehrdepot und Kirche, 1953 Schule (40 Schüler, 1969 geschlossen). „Von den damaligen Eigentümern der 42 Neubauernstellen sind heute [1996] noch 8 bzw. deren Kinder in Jahnberge." Nach Abwanderung nach Westdeutschland Wiederbesetzung der meisten frei gewordenen Stellen (ebd.), nach 1990 besonders Abwanderung der Jugend (ebd., S. 137).

BevöLKeRUngszahlen (für Warsow!): 1925: 180, 1939: 194, 1946: 454, 1964: 347 (HOL III, S. 409). - Jahnberge; 1969: 151, 1996: 83 (Amtsbereich Friesack, S. 137).

Literatur: Amtsbereich Friesack. Horb am Neckar 1996, S. 134-137 (Kap. „Der Ortsteil Jahnberge“). - Blöß, Wolfgang: Kommunale Strukturen im Spannungsfeld gesellschaftlicher Umwälzungen. Berlin 2018, S. 270-272. - Z., W.: Flüchtlinge fanden im Ländchen Friesack eine neue Heimat. In: Friesacker Quitzow-Kurier, Nr. 34, 2010 (OnlineAusg., o.S.).

\section{Jamlitz}

Landgemeinde, bis 1944 Kr. Lübben, 1945 Kr. Guben, [1945-?] 1950-1952 Kr. Lübben, 1952-1990 Kr. Beeskow (Bez. Frankfurt/Oder), 1990-1993 Ldkr. Beeskow, 1993 Ldkr. Dahme-Spreewald

EREIGNISSE BIS KRIEGSENDE: 1.1.1945 auf Verfügung des Reichsministers des Innern vom 22.11.1944 wegen Einrichtung des Waffen-SS-Truppenübungsplatzes „Kurmark“ Eingliederung in den Kr. Guben (Grundriß, S. 140).

BeVÖLKeRUNGSZAHLEN: 1925: 471, 1939: 377, 29.10.1946: 856, 1950: 935, 1964: 722 (HGV LDS, S. 18 f.). - „Anfang Oktober 1945 lebten in Jamlitz in den umliegenden anderen Baracken 
außerhalb des sowjetischen Speziallagers etwa 1326 Vertriebene, wovon nur 501 Personen bei der sowjetischen Kreiskommandantur und dem Sozialamt $[\rightarrow]$ Lübben registriert waren. Jamlitz selbst hatte zu dieser zeit 388 Einwohner. Ende Oktober waren nur noch 918 Vertriebene in Jamlitz wohnhaft, davon 521 registrierte." (Weigelt, Flucht, S. 15, nach Quellen im Kreisarchiv LOS).

LAGER JAMLITZ (auch „Jamlitz-Lieberose“ wegen der unmittelbaren Nähe zur Stadt $\rightarrow$ Lieberose [z. B. Wille I, S. 66]; auf dem ehem. Truppenübungsplatz der Waffen-SS): Das ehem. KZNebenlager („Arbeitslager“) „Lieberose“ (Außenlager des KZ Sachsenhausen) wurde im Febr. 1945 aufgelöst; nur einzelne Baracken dienten nach Kriegsende 1945 vorübergehend, „für wenige Monate“, als Flüchtlingsunterkünfte bzw. als Vertriebenenlager, bis Ende August 1945 das sowjet. Speziallager Nr. 6 aus der Dammvorstadt von $\rightarrow$ Frankfurt (Oder) hierher verlegt wurde (Geschichte vor Ort, S. 39; Weigelt, Jamlitz, S. 33; Zitat: Weigelt, Bahnhof). - „Auf Anweisung des Bürgermeisters Hans Grünberg sollen ehemalige NSDAP-Mitglieder die Baracken des KZ's im Mai 1945 gesäubert haben. Nachfolgend sind einige Baracken mit Vertriebenen belegt worden, in welchem Umfang, ist unbekannt." (Weigelt, Umschulungslager, S. 27). - Sommer 1945: Beispiel für vorübergehende Unterbringung einer Vertriebenenfamilie aus Amtitz, Kr. Guben, vertrieben am 20.6.1945 und zunächst nach $\rightarrow$ Groß Gastrose gelangt: „Nach Rücksprache mit den West- $[\rightarrow]$ Gubener Behörden, die kopflos waren, da sie von der Vertreibung völlig überrascht wurden, mußten wir nach Jamlitz. Dort wurden wir in die Baracken des ehem. Konzentrationslagers eingewiesen. Am 23. August verließen wir den Ort wieder, weil das Lager als Internierungslager eingerichtet wurde." (Faßke, S. 69). - 28./29.6.1945 übernachtete in leer stehenden Lagerbaracken ein Vertriebenen-Treck aus dem Kr. Crossen (Pflaum, S. 38). - Zwischen 25.8. und 19.9.1945 plante die Provinzialregierung überdies die Einrichtung eines großen Auffangbzw. Quarantänlagers für 15000 Vertriebene in den noch stehenden Baracken des ehem. KZ (SS-Lagers) Jamlitz, nachdem der sowjet. Marschall Schukow am 19.7.1945 befohlen hatte, die Deutschen von östlich der Oder und südlich der Warthe im „Raum zwischen Cottbus, Lübben, Seelow und Beeskow“ anzusiedeln (ebd., S. 28f.). Hierzu waren mehrere große Auffanglager geplant, Jamlitz sollte das größte werden. „Cottbus könne so etwas von der Last der Vertriebeneneinquartierung genommen werden. Die Besatzungsmacht wolle Lebensmittel liefern, auch Medikamente und Impfstoffe seien von höherer Stelle schon zugesagt. Die Cottbuser Ärzte hätten sich zur Verfügung zu halten." (ebd., S. 28) Das NKWD kam der Entscheidung jedoch bereits am 13.9.1945 zuvor und brachte 3465 eigene Gefangene aus dem aufgelösten sowjet. Speziallager Nr. 6 in der ehem. Dammvorstadt von $\rightarrow$ Frankfurt (Oder) (Słubice), zunächst zur Herrichtung der Baracken, hier unter (Słubice, S. 117-119). Bevor Jamlitz dann in der Folge (bis April/Mai 1947) ausschließlich als sowjet. Internierungslager (Speziallager Nr. 6 als Nachfolger des Lagers in Słubice) genutzt wurde, waren aber auch bereits Vertriebene untergebracht worden: „Anfang Oktober 1945 wohnten in Jamlitz und den umliegenden Baracken etwa 1300 Vertriebene. Jamlitz selbst hatte nur 388 Einwohner. Ende Oktober waren nur noch 500 Vertriebene in Jamlitz registriert." (ebd., S. 29). Insofern ist die Angabe bei Wenzel (S. 138), in Jamlitz 
sei tatsächlich bis „zum 18. September 1945“ ein (Flüchtlings-)Lager „für 15000 Personen“ entstanden, irrig (vgl. auch die vorsichtige Erwägung einer Nutzung im Bericht Dr. Gotthard Eberleins vom 25.9.1945: „Dort wäre Platz für etwa 15000 Menschen. [...] Bisher sind dort etwa 1000 deutsche Kriegsgefangene untergebracht." [Wille I, S. 245]). - [Aktennotiz der ZVU, o. D., wohl 28.9.1945:] „Nach Mitteilung des Major Iwanzow, fällt das Lager Jamlitz für Umsiedlerzwecke nunmehr endgültig aus, weil es von der N.K.W.D. benötigt wird." (BArch, DO 2/38, Bl. 93). 11.10.1945: Auf einem Priesterkonvent in Cottbus heißt es: „Nach den Einweisungen der Flüchtlinge scheint uns in Jamlitz-Lieberose noch ein Lokalist notwendig zu sein (Pfarrei $[\rightarrow]$ Beeskow).“ (Töpler, Menschenwurm, S. 438).-12.10.1945 in Befehl der SMA Brandenburg als eines von drei im Bezirk Lübben für die Aufnahme von „deutschen Umsiedlern“ geeigneten Lagern genannt, die dafür hergerichtet werden sollen (Wille I, S. 66). - 1947 Auflösung des sowjet. Speziallagers und Abriss der Baracken. Anschließend siedelten sich „vor allem Vertriebene aus Schlesien“ an (Andreas Weigelt laut Berliner Morgenpost, 20.5.2016) und "errichteten Häuser“ (Glasmacher). - „In den 1950er Jahren sind die Reste des für das ,Waldlager' Jamlitz charakteristischen alten Kiefernbestandes gefällt und das Gelände weitgehend mit Einfamilienhäusern bebaut worden." (Weigelt, Jamlitz, S. 42).

FRIEDHOF: Gedenkstein für die Vertriebenen aus Braschen (Kr. Crossen): Findling mit Metallbuchstaben-Inschrift (Versalien) „Zum Gedenken/an Braschen und seine/deutsche Bewohner/bis 1945“ (Crossener Heimatgrüße), eingeweiht 6.6.1999 anlässlich des von etwa 60 ehemaligen Braschenern besuchten 15. Braschener Heimattreffens (Weigelt, Flucht, S. $12 \mathrm{f}$.). Hierbei handelt es sich das Dorf Braschen, „nur 25 Kilometer hinter Guben gelegen, das mit etwa 600 Einwohner am 23. Juni 1945 vollständig von der polnischen Verwaltung per Befehl geräumt und die Menschen in Richtung Guben vertrieben wurden. Sie kanen wenige Tage später in Jamlitz an. Wenn im Raum Lieberose von den damals Heimatlosen gesprochen wird, dann klingt noch heute der Ortsname Braschen besonders im Ohr. / [... Ein großer Teil der Flüchtenden durchquerte Jamlitz. Während dieser Flucht sind Braschener auch in Lieberose gestorben und hier beerdigt worden. (ebd., S. 9). „Fast alle Braschener, die am 23. Juni 1945 ausgewiesen wurden, mußten erst einmal in den Baracken des ehemaligen KZ Jamlitz Quartier beziehen. Die Zustände waren furchtbar." (ebd., S. 11). Die Mehrheit der etwa 560 ehemaligen Braschener lebte später im östlichen Teil der DDR.“ (ebd., S. 12).

GedRuckte Quellen: Faßke, Joachim: Vor 50 Jahren. Flucht, Heimkehr und Vertreibung. In: Gubener Heimatbrief (1995)2, S. 68-69. - Flucht, Vertreibung, Neubeginn 1945. Schicksale und Berichte aus dem Raum Lieberose. Lieberose 2006. - Pflaum, Herbert: Meine Kindheit in Boberhöh. Flucht und Vertreibung im Jahr 1945. [Privatdruck]. Eichwalde bei Berlin 2014, S. 38. - Töpler, Menschenwurm. - Totenbuch Sowjetisches Speziallager Nr. 6, Frankfurt/ Oder 1945, Jamlitz 1945-1947. Im Auftr. der Evang. Kirchengemeinde Lieberose und Land hrsg. u. bearb. von Andreas Weigelt. 2. Aufl. Lieberose 2009. - Wille I, S. 66, 245, 303, 329.

Digitale Quellen: Fotografien von 205 Grabsteinen (Aufnahmen: L. Richter, 2016) und Lebensdaten der 235 Bestatteten (z. T. mit Angabe des Wohn-/Herkunftsortes) des Gräberfeldes Internierungslager-Friedhof Jamlitz in der Online-Grabsteindatenbank des Vereins für Computergenealogie e.V. (genealogy.net [19.1.2017]), darunter Erich 
Felsch (1900-1947) aus Posen, Schuhmachermeister Karl Grimm (1904-1947) aus Guben, Adalbert u. Albert Napieralla (1892-1946) aus Bentschen.

LITERATUR: Geschichte vor Ort: Erinnerungskultur im Land Brandenburg für die Zeit von 1933 bis 1990. Konzept der Landesregierung. [Potsdam] (2009), S. 39 (www.mwfk.brandenburg.de [17.10.2016]). - Flucht, Vertreibung, Neubeginn 1945. Schicksale und Berichte aus dem Raum Lieberose. Lieberose 2006. - Glasmacher, André: Gegen das Vergessen (Flurstück 411). In: Jüdische Allgemeine, Nr. 8, 21.2.2008. - Grundriß zur deutschen Verwaltungsgeschichte 1815-1945. Reihe A. Bd. 5: Brandenburg. Bearb. von Werner Vogel. Marburg/Lahn 1975, S. 140. - Mietk, S. 20. - Orte des Erinnerns. Hrsg. von Anna Kaminsky. 3., überarb. u. erw. Aufl. Berlin 1996, S. 203 f. - Słubice. Historia, topografia, rozwój/Geschichte, Topografie, Entwicklung. Słubice 2003. - Weigelt, Andreas: Jamlitz - Speziallager Nr. 6 (September 1945 - April 1947). In: Jörg Morré: Speziallager des NKWD. Potsdam 1997, S. 33-42. - Ders.: „Umschulungslager existieren nicht“. Zur Geschichte des sowjetischen Speziallagers Nr. 6 in Jamlitz 1945-1947. Potsdam 2001. - Ders.: Flucht, Vertreibung, Neubeginn 1945. In: Flucht, Vertreibung, Neubeginn 1945. Lieberose 2006, S. 2-23. - Ders.: Mein Bahnhof Jamlitz (2008), http://home.snafu.de/karuna/jamlitz/mein_bahnhof.html [15.10.2016]. - Wenzel, Mario: Die Aufnahme und Versorgung von Flüchtlingen und Vertriebenen in Eberswalde 1945-1948. In: Eberswalder Jahrbuch 2015, S. 136-145, hier S. 138 (irrig).

\section{Jerischke-Pusack}

Landgemeinde, bis 1946 (Rest-)Kr. Sorau, 1.4.1946-1990 Kr. Spremberg (Bez. Cottbus), 1990-1993 Ldkr. Spremberg, 1993 Ldkr. Spree-Neiße

EREIGNISSE NACH KRIEGSENDE: 3.10.1950 Zuweisung der westlich der Neiße gelegenen einwohnerlosen Flächen der nun polnischen Gemeinde Groß Särchen (ehem. Kr. Sorau) an die Gemeinde Jerischke (Blöß, Kreise und Gemeinden, S. 32).

BevÖLKERUNGSZAHLEN (Jerischke): 1925: 179, 1939: 174, 29.10.1946: 280, 1950: 278, 1964 : 220 (HOV SN, S. 22 f.).

GedenKstein an der ehemaligen (1945 zerstörten) Neißebrücke von Groß Särchen, enthüllt 9.9.1995; Inschrift: „Unsere Brücke zum Einst. Dank dem Gestern, Aussöhnung im Heute, Segen dem Morgen. Arbeitskreis Sorau - Heimatfreunde Groß- u. Klein Särchen." (Mahn- und Gedenkstätten Brandenburg, mit Abb.).

Quellen und Literatur: Mahn- und Gedenkstätten Brandenburg. Hrsg.: BdV (www.bund-der-vertriebenen.de [20.9.2016]).

\section{Jeserig (bei Brandenburg)}

Landgemeinde, bis 1952 Kr. Zauch-Belzig, 1952-1990 Kr. Brandenburg-Land (Bez. Potsdam), 1990-1993 Ldkr. Brandenburg, 1993 Ldkr. Potsdam-Mittelmark

BevöLKeRUnGSZAHLEN: 1925: 510, 1939: 1034, 1946: 1219, 1964: 1014 (HOL V, S. 176).

Katholiken: Nach dem II. Weltkrieg kam aus der Ordensgemeinschaft der Missionare der hl. Familie „der aus Schlesien vertriebene P. [ater] Alfons Engler MSF nach $[\rightarrow]$ Lehnin, er konnte 
auch seinen Mitbruder P. Gregor Smelz MSF zur Mitarbeit gewinnen.“ 1953 (wegen der Gläubigenzahl u. der großen Fläche) Herauslösung aus der Gemeinde Lehnin u. Bildung einer eigenen Lokalie in Jeserig; ,ihr erster und letzter eigener Seelsorger war P. Gregor Smelz MSF (1953-59), der auf dem Nachbargrundstück in einem angemieteten Haus wohnte, das von P. Engler aus einem Holzschuppen massiv errichtet worden war. Mit damals etwa 400 Katholiken wurde die Gemeinde zum 1.5.1956 seelsorglich selbständige Kuratie, aber seit 1959 von P. Engler mitbetreut, bis sie 1965 offiziell wieder mit Lehnin vereinigt wurde“. Sitz: Potsdamer Straße 21 ; kleiner kath. Friedhof im benachbarten $\rightarrow$ Schenkenberg (Brühe, S. 22), wo die Jeseriger Gemeinde bis zu ihrem eigenen Kapellenbau Gast im evang. Betsaal war; Jeseriger Kapelle (St. Josef) erbaut 1952-1953 (Nitschke, S. 32).

Literatur: Brühe, Matthias: Katholische Kirche zwischen Havel und Dahme. Berlin 1999, S. 22. - Nitschke, Johannes: 150 Jahre Pfarrkirche „Heilige Dreifaltigkeit“ Brandenburg an der Havel. Brandenburg an der Havel [2001], S. 32. - Schwillus/Brühe, S. 304.

\section{Jeserig/Fläming (bei Brück)}

Landgemeinde, bis 1952 Kr. Zauch-Belzig, 1952-1990 Kr. Belzig (im Bez. Potsdam), 19901993 Ldkr. Belzig, 1993 Ldkr. Potsdam-Mittelmark

EREIGNisSe BIS KrIEgSENDE: „Seit Ende 1944/Anfang 1945 kamen Umsiedler (damals Flüchtlinge und heute Vertriebene genannt) in Jeserig an. [...]. (Dorbritz, S. 77). - 4.5.1945 Einmarsch der Roten Armee (Dorbritz/Kästner/Neuendorf, S. 75).

EREIGNISSE NACH KRIEGSENDE: „[...] Es ging nicht nur um die Unterbringung, sondern auch um Arbeitsplätze. Jeserig hatte 475 Ein- [S. 78] wohner, davon waren 170 Umsiedler. Sie wurden nicht immer mit offenen Armen empfangen [...]. Wohlwollend gemeint war die erste gemeinsame Weihnachtsfeier 1946 in Sperfelds Saal mit Chor, kleinen Geschenken und einer eindrucksvollen Ansprache von Landrat [Richard] Sydow.“ (Dorbritz, S. 77 f.). - Bei der Bodenreform in Jeserig 1945 ,verweigerte die Gemeindebodenkommission anfänglich die Abgabe von Grund und Boden an Heimatvertriebene“, die KPD-Kreisleitung forderte deshab am 12.10.1945 vehement deren Berücksichtigung (Helle, S. 233); Umsiedler lt. HOL bei der Bodenreform jedoch nicht gesondert erwähnt (HOL V, S. 173).

BevölkeRungSZAHLEN: 1925: 258, 1939: 306, 1946: 475, 1964: 366 (HOL V, S. 173).

Katholiken: 1953 zur benachbarten Pfarrei bzw. Kuratie $[\rightarrow]$ Wiesenburg gehörig; Jeserig war „eine damals fast rein katholische Siedlung von Umsiedlern“ (Brühe, S. 47; identisch: Schwillus/Brühe, S. 201).

Literatur: Brühe, Matthias: Katholische Kirche zwischen Havel und Dahme. Berlin 1999, S. 47. - Christopeit. Dorbritz, Gerhard: Erinnerungen an die Nachkriegszeit. In: Ders. / Helga Kästner/Ernst Neuendorf: Jeserig/Fläming. Wiesenburg 2003, S. 76-81. - Helle, Matthias: Nachkriegsjahre in der Provinz. Berlin 2011, S. 233. - Schwil- 
lus/Brühe, S. 201. - Senst, Gerhard: Aus den Dörfern Jeserig und Niederwerbig. In: ... schwere Kämpfe in und um Treuenbrietzen (OKW-Bericht). 1945. Treuenbrietzen 1995, S. 79-83.

\section{Jeserigerhütten}

Landgemeinde, bis 1952 Kr. Zauch-Belzig, 1952-1990 Kr. Belzig (im Bez. Potsdam), 19901993 Ldkr. Belzig, 1993 Ldkr. Potsdam-Mittelmark

EREIGNISSE NACH KRIEGSENDE: 1948 Erwähnung der von sudetendeutschen Vertriebenen gegründeten „Holzverarbeitungsgenossenschaft Jeserigerhütten“ (Christopeit, S. 86).

Bevölkerungszahlen: 1925: 157, 1939: 135, 1946: 213, 1964: 239 (HOL V, S. 179).

LITERATUR: Christopeit.

\section{Joachimsthal}

Stadtgemeinde, bis 1952 Kr. Angermünde, 1952-1990 Kr. Eberswalde (Bez. Frankfurt/Oder), 1990-1993 Ldkr. Eberswalde, 1993 Ldkr. Barnim

EREIGNISSE BIS KRIEGSENDE: 27.4.1945 Einmarsch der Roten Armee (Festschrift 400 Jahre Schorfheidestadt Joachimsthal, S. 45).

Bevölkerungszahlen: 1925: 2089, 1939: 3650, 1946: 4 105, 1964: 3838 (Städtebuch, S. 248).

Katholiken: 1946: 241 (Städtebuch, S. 249).

UMSIEDLERLAGER: Okt. 1945 erwähnt (BArch, DO 2/39, Bl. 11). - Kapazität am 31.12.1945: 2500 (BArch, DO 2/45, Bl. 40). - Kapazität am 1.1.1946: 600 (BLHA, Rep. 203 MdI, Nr. 1163, Bl. 50).

Städtepartnerschaften: (1) Sept. 1996 Golczewo, Polen (Gülzow, ehem. Kr. Cammin, Pommern). - (2) (Amt Joachimsthal:) 2007 Moryn, Polen (Mohrin, ehem. Kr. Königsberg/ Neumark, Provinz Brandenburg) (Auskunft des Amtes, 23.8.2018).

Archivalische Quellen: BArch, DO 2 ZVU, Nr. 39, Bl. 11 (Lager, Okt. 1945). - Siehe auch Quellenteil, Nr. 215. LiterAtUR: Festschrift 400 Jahre Schorfheidestadt Joachimsthal. Altenhof 2004.

\section{Jocksdorf}

Landgemeinde (heute Ortsteil von Neiße-Malxetal), bis 1945 Kr. Sorau, 1945-1946 (Rest-)Kr. Sorau bzw. Kr. Forst, 1.4.1946-1950 Kr. Cottbus, 1.7.1950-1990 Kr. Spremberg (ab 1952 Bez. Cottbus), 1990-1993 Ldkr. Spremberg, 1993 Ldkr. Spree-Neiße 
EREIGNisSe BIS KRIEgSEnde: Anfangs stand den „Kameraden der Jocksdorfer Freiwilligen Feuerwehr [...] lediglich eine von Pferden gezogene Handdruckspritze zur Verfügung, die von vier Kameraden wechselseitig bedient werden musste. [... zu ihrer ersten Motorspritze kamen sie durch die Kriegswirren 1945. Flüchtlinge führten diese in einem Treck aus Richtung Seidelsdorf mit und ließen sie aus ungeklärten Umständen im [Groß] Schacksdorfer Wald stehen, wo sie die Jocksdorfer Kameraden später sicher stellten." (Gerd Kunisch: Sieben Jahrzehnte zum Wohle der Dorfgemeinschaft. In: LR, 8.6.2004).

BEVÖLKERUNGSZAHLEN: 1925: 249, 1939: 228, 29.10.1946: 271, 1950: 275, 1964: 238 (HGV SN, S. 22 f.).

UMSIEDLERLAGER: Im „Verzeichnis der errichteten und vorgesehenen Umsiedlerlager im Verwaltungsbezirk Cottbus“ vom 15.12.1945 mit „Personenzahl“ 1000 genannt (Töpler, Menschenwurm, S. 472), für entsprechende Bereitstellung vorgesehen auch schon lt. Bericht vom 24.10.1945 (ebd., S. 450).

Gedruckte Quellen: Töpler, Menschenwurm, S. 450, 472.

\section{Jüterbog}

Stadtgemeinde (bis 29.5.1945 und 1952-1993 Kreissitz), bis 1946 Kr. Jüterbog-Luckenwalde, 1946-1952 Kr. Luckenwalde, 1952-1990 Kr. Jüterbog (Bez. Potsdam), 1990-1993 Ldkr. Jüterbog, 1993 Ldkr. Teltow-Fläming

EReignisse bis Kriegsende: 2.4.1945 Einmarsch der Roten Armee (Schulze, Jammerbock III, S. 653).

EREIGNisSe NACH KRIEgSEnde: 18.8.1945 (Stichtag) Anordnung eines Flüchtlingsstopps „von Seiten der Umsiedlerstelle in $[\rightarrow]$ Luckenwalde" und Verbot einer Weiterleitung aus der Stadt Jüterbog, so dass das Flüchtlingslager in den „Fuchsbergkasernen“ (s.u.) zum „Dauerlager" wurde (Schulze, Jammerbock IV, S. 136). - 24.9.1945 Todesfall einer ca. 46-jährigen Flüchtlingsfrau aus Königsberg/Nm. in Jüterbog (Krätzner, S. 23, nach Angaben in der „Heimatkartei“). - 1946 (Bericht der Kreisverwaltung über „Umsiedlergenossenschaft“): „In Jüterbog eine Produktiv- und Handelsgenossenschaft der Kunstblumen- und Früchteindustrie gebildet, die 40 Personen beschäftigt." (BLHA, Rep. 203 MdI, Nr. 1074, zitiert nach: Oehlsen, S. 90), 15.3.1947 noch erwähnt als „Umsiedlergenossenschaft“ (Heimarbeit) „Produktiv-u. Handelsgenossenschaft der Kunstblumen- u. Früchte-Industrie [/] Jüterbog, Planeberg Nr. 3/Krs. Luckenwalde [/] ppa. Hubert Beer, Jüterbog, Promenade 37 [/] Belegschaft 50 [/] könnten bei genügendem Material 200 beschäftigen" (BLHA, Rep. 333, Nr. 574, Bl. 105), 1948 noch erwähnt als (von sudetendeutschen Vertriebenen gegründete) „Produktions- und Handelsgenossenschaft der Kunstblumen und -früchteindustrie Jüterbog" (Christopeit, S. 86). - Ende Juli 1948 im Verzeichnis (von der Landesregierung) verbotener Suchdienste erwähnt: „Schlesiersuchdienst“, Jüterbog, Mönchenstr. 37 („Ma- 
terial im Okt. 1946 [vom staatl. Suchdienst] übernommen") (BLHA, Rep. 203 MdI, Nr. 1197, Bl. 41). - 1949 wohnt in Jüterbog der vor 1945 in Beuthen/OS. als Apotheker u. Pharmazierat (sowie als Mitglied des Führerbeirates der deutschen Apothekerschaft) wirkende Fritz Melcher (1877-1960) (Mitteilung Jochen Schröder, Stuttgart, 11.8.2018; siehe auch oben Anm. 1449).

EREIGNISSE NACH 1990: Der stellv. Vorsitzende des Landesverbandes Brandenburg der Landsmannschaft Berlin-Mark Brandenburg, Henrik Schulze (Jüterbog), führte 1993 nach der Amtsniederlegung des Landesvorsitzenden Ullrich Kohlstock (Forst/L.) vorübergehend die Geschäfte des Vorsitzenden (Märkischer Informationsdienst 1993, Nr. 7/8, S. 18).

BevölkerungSzAHLEN: 1925: 9678, 1939: 12595, 1946: 15 137, 1964: 14281 (Städtebuch, S. 252).

Katholiken: 1925: 286, 1946: 1678 (Städtebuch, S. 253). - Kirchengemeinde: 1953: 3500 (Brühe, S. 23). 1962 zur Pfarrei erhoben (ebd.).

(Kreis-)UMSiedlerlager KaSerne, ehemalige Kasernengebäude der Fußartillerie-Schießschule (Abb. in: Schulze, Jammerbock I, S. 85-91 mit Lageplan; Buchinger/Cante, S. 192), auf den Fuchsbergen beim ehem. Militär-Bahnhof und Güterbahnhof der Kleinbahn („FuchsbergKaserne“): „bereits ab Ende 1944 (sind) Teile des Geländes als Notquartier für Flüchtlinge genutzt worden“ (Schulze, Jammerbock III, S. 81). - „Vor allem die Fuchsbergkasernen dienten als Notunterkunft für Flüchtlinge und Vertriebene. Allein von Mai 1945 bis Januar 1946 wurden hier 104000 Personen, durchgeschleust und verpflegt'. Insgesmt war es eine dreiviertel Million Menschen, die das Jüterboger Auffanglager zeitweilig zu betreuen hatte." (Schulze, Jammerbock IV, S. 32). - 12.10.1945 in Befehl der SMA Brandenburg als eines von drei im Bezirk Luckenwalde für die Aufnahme von „deutschen Umsiedlern“ geeigneten Lagern genannt („Kasernen Fuchsberge, wie das Dorf Zinna neben der Stadt Jüterbog, Altlager [Altes Lager]"), die dafür hergerichtet werden sollen (Wille I, S. 66), zuvor war am 6.10.1945 eine entsprechende dringende Bitte der Provinzialregierung an die SMA gerichtet worden (BArch, DO 2/39, Bl. 2). 17.12.1945 als eines von drei brandenburgischen Auffanglagern erwähnt (BLHA, Rep. 206, Nr. 2965, unfol.). - Kapazität am 31.12.1945 (Lager „Jüterbog-Fuchsberg“): 400 (BArch, DO 2/45, Bl. 41). - Kapazität am 1.1.1946: 3000 (BLHA, Rep. 203 MdI, Nr. 1163, Bl. 49). - 1946 Belegungsstärke („Jüterbog Kaserne“): 3000 (Kaminsky, S. 159). - „Im Februar 1946 taten noch 30 Polizisten im Umsiedlerlager Dienst.“ (Schulze, Jammerbock IV, S. 33). - (14.2.1946 Kreis- und Quarantänelager, Kapazität: 3000 (Oehlsen, S. 28); 14.2.1946 4.00 Uhr morgens Eintreffen des ersten Antifa-Transportes aus der ČSR (Gablonz/Jablonec n. N.) auf dem Bahnhof Jüterbog, ,in den Kasernen auf den Fuchsbergen untergebracht, zwecks einer dreitägigen Quarantäne“, anschließend Ansiedlung in Dorf Zinna ( $\rightarrow$ Neuheim) (Schmutzer, Dorf Zinna Neuheim, S. 15; Fischer, S. 18). - 21.3.1946 Vermerk im Jüterboger Ratsprotokoll, „daß im Umsiedlerlager ein akuter Fall von Fleckfieber aufgetreten ist und viele an Krätze erkrankt waren. [...].“ (Schulze, Jammerbock IV, S. 32). - 30.4.1946 als eines der verbleibenden Umsiedlerlager 
genannt (DAB, I/9-15-1 Flüchtlingsseelsorge 1945-1951, unfol., [30.6.1946], [Anlage 3]). Für Dez. 1946 „Schließung der Zentralküche in den Fuchsbergen“ vorgesehen. [...] „Das Massenquartier bestand bis 1948.“ Ab 1948 beanspruchte „die Rote Armee die Fuchsbergkasernen für sich“ (Schulze, Jammerbock IV, S. 33). „Am 23. März 1948 schrieb das Stadtbauamt an den Vorsitzenden des Sozialausschusses, Fritz Imme: ,Entsprechend der Anweisung der Kreiskommandantur muß das Dauerlager in den Fuchsbergen bis zum 28. d. Mts. geräumt werden. Um die Familien unterbringen zu können, ist zunächst eine Einweisung in die Räume des alten Landratsamtes [S. 137] erfolgt.“" (Schulze, Jammerbock IV, S. 136 f.). - 2002 Abriss der ehem. Kasernenanlage (Berliner Morgenpost, 18.6.2002), teilweise Konversion zu Wohnzwecken.

Umsiedlerlager Altes Lager (bei Jüterbog): 6.10.1945 in der o.g. Bitte der Provinzialregierung an die SMA um Überlassung bezeichnet als „Altes Lager (Barbara-Lager)“ mit „40 Baracken für ca. 1000 Umsiedler" (BArch, DO 2/39, Bl. 2). - Demnach dürfte sich die nur allgemein „Jüterbog“ lautende Bezeichnung für ein weiteres Umsiedlerlager (zusätzlich zur Kaserne Fuchsberg) mit der Belegungsstärke 1000 für das Jahr 1946 hierauf beziehen (Kaminsky, S. 159).

StÄDtePartnerschaften: Nach 1973 Kontakte mit Głubczyce, Polen (Leobschütz, Oberschlesien) (Trzcielińska-Polus, S. 538).

VERTRIEBENENVERBÄNDE NACH 1990: (1) BdV-Kreisverband Jüterbog, gegründet 1991 (Märkischer Informationsdienst 8/1994, S. 14), 1996: BdV-Kreisverband Luckenwalde, Jüterbog, Teltow-Flämig, Zossen, Sitz $\rightarrow$ Luckenwalde (BdV-Handbuch 1996, S. 218). 1.10.2009 26 Mitglieder. - (2) BdV-Regionalverband e.V. Alte Heimat, Jüterbog, 24.3.2009 Beschluss zur Eigenständigkeit u. Ablösung („Auslösung“) vom Kreisverband Teltow-Fläming, 28.7.2009 (Mitgliederversammlung) Satzung errichtet, 17.8.2010 eingetragen beim Amtsgericht Potsdam (VR 7575); 5.2.2009 24 aktive u. 6 Passivmitglieder, 1.10.2009 26 Mitglieder; 17.9.2013 in der Mitgliederversammlung in der Gaststätte „Schmied zu Jüterbog“, Markt 12, Auflösung beschlossen (14 Mitglieder anwesend, 8 entschuldigt). - Vorsitzende: 2009 Dr. Ursel Bachmann, Jüterbog (*1944) (noch 2010 erwähnt), letzter Ansprechpartner: Waltraud Kießling, Jüterbog (Akten der BdV-Landesgeschäftsstelle).

ARChivalische Quellen: BArch, DO 2 ZVU, Nr. 39, Bl.2. - BArch, DO 2/50, Bl. 189 (Umsiedler-Ausschuss, 1946), Bl. 223 (ZVU-Dienstreise, 2.7.1947).

Gedruckte Quellen und Literatur: Brühe, Matthias: Katholische Kirche zwischen Havel und Dahme. Berlin 1999, S. 23. - Buchinger, Marie-Luise / Cante, Macus: Stadt Jüterbog mit Kloster Zinna und Gemeinde Niedergörsdorf. Worms am Rhein 2000 (Denkmale in Brandenburg, Bd. 17.1). - Christopeit. - Fischer, L(othar): Neuheim eine Heimatstadt des Friedens. In: Heimatkalender des Kreises Jüterbog 1986, S. 17-21. - Krätzner, S. 23. - „Die Russen sind da“. Peter Böthig u. Peter Walther (Hg). Berlin 2011. - Schulze, Henrik: Jammerbock I: von den Anfängen bis 1918. Hoppegarten 2014 (Militärgeschichte Jüterbog, 1792-2014, [Bd. 2]). - Ders.: Jammerbock III: 1935-1945. Hoppegarten bei Berlin 2016 (Militärgeschichte Jüterbog, 1792-2014, [Bd. 3]). - Ders.: Jammerbock IV: 1945-2014. Jüterbog 2018, S. 32 f., 136f. (Militärgeschichte Jüterbog, 1792-2014, [Bd. 4]). - Töpler, Menschenwurm. - Trzcielińska-Polus. - Wille I, S. 66, 260, 459; II, S. 47 f. 


\section{Kahnsdorf (Kr. Luckau) $\rightarrow$ Cahnsdorf}

\section{Kantdorf $\rightarrow$ Spremberg-Cantdorf}

\section{Kartzow}

Landgemeinde (1974-2003 Ortsteil von Fahrland; seit 2003 Ortsteil von $\rightarrow$ Potsdam), bis 1939 Kr. Osthavelland, 1939-1952 Stadtkr. Potsdam, 1952-1990 Kr. Potsdam-Land (Bez. Potsdam), 1990-1993 Ldkr. Potsdam, 1993-2003 Ldkr. Potsdam-Mittelmark, 2003 Stadtkr. Potsdam

EREIGNISSE NACH KRIEGSENDE: „Das Gutshaus des Rittergutes diente von 1945 bis 1949 als Unterkunft für Umsiedler und wurde danach im Jahr 1949 zum Kindergenesungsheim umgebaut.“ (Wikipedia, Kartzow [6.1.2017]). - In der Bodenreform unter 73 Personen 16 „Umsiedler" berücksichtigt (HOL VII, S. 169).

1925: 203, 1939: 215, 1946: 270, 1964: 170 (HOL III, S. 170).

\section{Katerbow}

Landgemeinde (seit 1997 Ortsteil von Temnitzquell), bis 1952 Kr. Ruppin, 1952-1990 Kr. Neuruppin (Bez. Potsdam), 1990-1993 Ldkr. Neuruppin, 1993 Ldkr. Ostprignitz-Ruppin

EREIGNISSE NACH KRIEgSENDE: „Das Leben im und nach dem Kriege war hart, aber im Gegensatz zu den vielen evakuierten Berlinern und den Flüchtlingen vor allem aus Schlesien - Katerbow hatte jetzt bestimmt das Dreifache an Einwohnern - doch noch erträglich. Ich entsinne mich vieler Menschen, die nur für Monate oder Wochen im Dorf verweilten, bis sich die Familien, die durch die Kriegsereignisse auseinandergerissen waren, wieder zusammen fanden und in ihre alte Heimat zogen oder in der Fremde eine neue Existenz aufbauen mussten. Alle hatten es sehr schwer, sich mit den neuen und sehr eingeschränkten Lebensbedingungen zurecht zu finden, Viele kamen nur mit dem im Dorfe an, was sie tragen konnten. Meistens fehlte der Familienvater, weil er im Krieg gefallen, vermisst oder in Gefangenschaft war. / Auch wir hatten mehrmals Einquartierungen, sei es durch schlesische Flüchtlinge oder Soldaten der Sowjetarmee. Und immer noch trafen Trecks mit Flüchtlingen aus Ostpreußen, Hinterpommern oder Schlesien ein. Da die Unterbringung wahrscheinlich vom sowjetischen Kommandanten befohlen war, gab es manchmal bei den Einwohnern wenig Verständnis für die schreckliche Lage der Menschen. Alle mussten zusammenrücken, um den ,Umsiedlern' - so wurden sie in der DDR offiziell genannt - ein wenig möblierten Wohnraum zu geben. Die Küchen wurden dann im Schichtwechsel benutzt. Manche Trecks waren aber auch nur auf der Durchreise und fuhren nach wenigen Tagen zu einem unbekannten Ziel weiter, nachdem sie mit Lebensmitteln und Futter für die Pferde versorgt waren.“ (Glimm, S. 33). - „Der alte Schulraum war noch vorhanden, aber 
[ab 1947] ungenutzt und unansehnlich. Nach dem Krieg haben sich Umsiedler aus dem Warthegau daraus eine Bleibe gemacht." (ebd., S. 22). - Ende Juli 1948 im Verzeichnis (von der Landesregierung) verbotener Suchdienste erwähnt: Fritz Trispel, „Suchdienst Katerbow“, Katerbow Krs. Ruppin (BLHA, Rep. 203 MdI, Nr. 1197, Bl. 41).

BEVÖLKERUNGSZAHLEN: 1925: 336, 1939: 376, 1946: 652, 1964: 353 (HOL II, S. 116).

Literatur: Glimm, Peter: Damals in Katerbow (Teil 1). In: Historischer Verein der Grafschaft Ruppin e. V. Mitteilungsblatt 16 (2006), S. 21-36.

\section{Kerkwitz}

Landgemeinde (1998 Zusammenschluss mit $\rightarrow$ Groß Gastrose zu Gastrose-Kerkwitz, seit 2003 Ortsteil von Schenkendöbern), bis 1952 Kr. Guben, 1952-1990 Kr. Guben (Bez. Cottbus), 1990-1993 Ldkr. Guben, 1993 Ldkr. Spree-Neiße

BevöLKeRUnGSZAHLEN: 1925: 487, 1939: 528 (HOL NL II, S. 218); 29.10.1946: 629, 1950: 659, 1964: 612 (HGV SN, S. 27).

EREIGNISSE NACH 1990: 1994 Zweitägiges erstes Heimattreffen der ehem. Bewohner von Tzschernowitz/Schernewitz (Kr. Guben) [poln. Czarnowice] in der Gaststätte Seifer und im "Jägerhof “ mit Gedenkgottesdienst in der Kerkwitzer Kirche (Bericht aus LR in: Gubener Heimatbrief 2/1994, S. 107). - 30.9.1995 2. [Heimat-] Treffen der vertriebenen ehem. Bewohner des Kirchspiels Starzeddel (Kr. Guben) (poln. Starosiedle) in der Gaststätte „Jägerhof “ mit 215 Teilnehmern (Bericht von Lonni Fürste mit Teilnehmerliste [ohne Wohnortangabe]: Gubener Heimatbrief 1/1996, S. 63-68) [1. Treffen 1994 in $\rightarrow$ Neuzelle; 3. Treffen wegen der starken Resonanz verlegt in größere Gaststätte in $\rightarrow$ Kolkwitz (Kr. Guben)]; 27.9.1997 4. Treffen im „Dorfkrug“ in Kerkwitz mit 125 Teilnehmern (Bericht von Lonni Fürste mit Teilnehmerliste [ohne Wohnortsangabe]: Gubener Heimatbrief 1/1998, S. 84-87); 26.9.1998 5. Treffen im „Dorfkrug“ in Kerkwitz mit 121 Teilnehmern (Bericht von Lonni Fürste mit Teilnehmerliste [ohne Wohnortsangabe]: Gubener Heimatbrief 1/1999, S. 85-88).

\section{Ketschendorf $\rightarrow$ Fürstenwalde-Ketschendorf}

\section{Ketzin/Havel}

Stadtgemeinde, bis 1952 Kr. Osthavelland, 1952-1990 Kr. Nauen (Bez. Potsdam), 1990-1993 Ldkr. Nauen, 1993 Ldkr. Havelland

EREIGNISSE: „Im späten 19. Jh. zahlr. kath. Zuwanderer aus Schlesien, nach 1945 Flüchtlinge u. Vertriebene“ (Städtebuch, S. 257). 
EReignisSe Bis KRIEgSEnde: Jan. 1945: „Zum Ende des Monats kamen die Trecks der Flüchtlinge in $[\rightarrow]$ Paretz an. Zumeist wurden sie nach Ketzin geleitet. Doch als dort alle Quartiere belegt waren, hieß es, der Rest kommt nach Paretz [...].“ (Schellhorn, S. 71).

EREIGNiSSE NACH KRIEgSEnde: 15.10.1945 Einrichtung einer Entlausungsstation beschlossen, 19.10.1945 Typhuspflichtimpfung. „Der Zu- und Umzug der Flüchtlinge hielt das ganze Jahr 1945 an." (Damaschke/Damaschke/Bergemann, S. 63). - 1945 (Bericht der Stadtverwaltung vom Nov. oder Dez. 1945, unterzeichnet von Bürgermeister [Karl] Reckling): „Ich nähere mich jetzt einer Gruppe Frauen, die auf die Eröffnung eines Lebensmittelgeschäftes warten. Ihre Unterhaltung, die in den verschiedensten [S. 84] Mundarten geführt wird, - Ketzin hat viele Flüchtlinge aufgenommen -, dreht sich wie überall heute um Fragen der Ernährung. [...] / Zu dieser Zeit, als in Ketzin Tausende von Flüchtlingen weilten, als hunderte fremdländischer Arbeiter die Stadt bevölkerten, übernahm der Bürgermeister Reckling, von der russischen Kommandantur beauftragt, die Führung der Geschäfte der Stadt Ketzin. Seiner unermüdlichen Arbeit und der rührigen Tätigkeit seiner Mitarbeiter, der Herren Paul Gutsche (in der Lebensmittelversorgung), Otto Hüber (im Wohnungsamt), Josef Reiter (Arbeitsamt) und Willi Baganz (als Polizeichef) ist es zu verdanken, daß die Stadt Ketzin heute als friedlich aufbauende Stadt erscheint. Aber der Weg dahin war weit und für die verantwortlichen Männer oft unsagbar schwer. / Da war zunächst die Hauptschwierigkeit zu überwinden - die Ernährung für die rund 9000 Menschen, die sich damals in Ketzin befanden, zu sichern. [...] / [S. 85] Ein beinah unlösbar scheinendes Problem waren die Flüchtlinge und ihre Versorgung. Die große Anzahl von Ortsfremden aus den letzten Tagen des Kampfes ist zwar zusammengeschrumpft. Trotzdem hat Ketzin heute noch eine Einwohnerzahl von 5300 Menschen, gegenüber 3200 bis 3400 zu Beginn des Krieges. Für rund 2000 Menschen mußte hier Wohnraum geschaffen werden. Da hieß es für die Ketziner zusammenrücken und sich bescheiden. $95 \%$, so sagt mir der Bürgermeister, sind in Privatquartieren untergebracht worden, ein kleiner Teil lebt in Gemeinschaftslagern. Not und Elend dieser Armen sind groß. Die Stad that versucht, so gut sie konnte, Abhilfe $z u$ schaffen. Eine Gemeinschaftsküche wird eingerichtet, in der die Leute zweimal am Tage gegen geringes Entgeld [so!] schmackhaftes warmes Essen empfangen. Ein Spinnstofflager, daß [so!] die Stadt aus sichergstellten Kleidungsstücken und Stoffen errichtete, lieferte ihnen die nötigsten Bekleidungsgegenstände. Auch in geldlicher Hinsicht werden die Flüchtlinge von der Stadt unterstützt." (Brandenburgische Gemeinden 1945, S. 83-85). - 27.11.1946 mehrere mit „Umsiedler(n)“ belegte Barackenunterkünfte erwähnt („Barackenunterkunft in Vorketzin“, „Baracke Thälmannstraße“ u. a.). „Der Ort Ketzin ist überbelegt und kann weitere Umsiedler kaum noch aufn[ehmen]." (BLHA, Rep. 230 Bernau, Nr. 292, Bl. 175; vgl. Quellenteil, Nr. 74).

Bevölkerungszahlen: 1925: 3256, 1939: 3415, 1946: 5107, 1964: 4179 (Städtebuch, S. 257). - Ende April 1945: 5675, davon 4014 Einheimische, 930 Flüchtlinge, 624 Personen mit 2. Wohnsitz (zum Teil Berliner Bombengeschädigte, die hier ein Gartengrundstück hatten, bzw. Schiffer), 98 Ausländer (zum Teil noch ehemalige „Fremdabeiter“) (Damaschke/Damaschke/Bergemann, S. 63). 
Katholiken: 1925: 267, 1946: 712 (Städtebuch, S. 257). - Rückgang der Zahl nach 1918. „Erst nach dem II. Weltkrieg nahm sie durch Flüchtlinge wieder zu und lag 1953 bei 1600 .” (Brühe, S. 23; weitgehend textidentisch: Schwillus/Brühe, S. 334).

Archivalische Quellen: BLHA, Rep. 230 Oberlandratsamt Bernau, Nr. 292, Bl. 175 (siehe Quellenteil, Nr. 74).

Literatur: Bergemann, Helmut / Damaschke, Alfred: Ketzin 1945. Die letzten Tage des Krieges - die ersten Tage des Friedens. Berlin 1996 (Schriften des Heimatmuseums Ketzin, 4) [mit Quellenanhang (S. 34-74)]. - Brandenburgische Gemeinden 1945, S. 83-86. - Brühe, Matthias: Katholische Kirche zwischen Prignitz und Havelland. Berlin 2000, S. 23. - Damaschke, Alfred / Damaschke, Elisabeth / Bergemann, Helmut: Ketzin. Berlin 1997. - Schellhorn, Karin: Chronik eines Umbruchs - Paretz 1945. In: Paretz. Hrsg. von Matthias Marr. Magdeburg 1991, S. 71-76 [nach Augenzeugenberichten]. - Schwillus/Brühe, S. 334.

\section{Kiekebusch}

Landgemeinde (seit 2003 Ortsteil von $\rightarrow$ Cottbus), bis 1952 Kr. Cottbus, 1952-1990 Kr. Cottbus (Bez. Cottbus), 1990-1993 Ldkr. Cottbus, 1993 Ldkr. Spree-Neiße

BeVÖLKerungSzAHLEN: 1925: 534, 1939: 925, 1946: 781, 1950: 849, 1964: 777 (HGV SN, S. $10 \mathrm{f}$.).

Ehemaliger FriedhoF: „Seit Jahrzehnten kämpft der Kiekebuscher Dieter Bartusch gegen das Vergessen. Vor allem der ehemalige Friedhof an der Turnstraße lässt ihm keine Ruhe. Vier Soldaten der deutschen Wehrmacht sind im Jahr 1997 auf dieser geschlossenen Ruhestätte für eine Umbettung auf dem Georgenberg in $[\rightarrow]$ Spremberg exhumiert worden. Mindestens 23 zivile Kriegsopfer aber liegen noch namenlos unter Kiekebuscher Erde. / [...] „Den Opfern der Kriege 1914-18 und 1939-45 zum Gedenken. Den Lebenden zur Mahnung" steht auf der Tafel am Findling. Die drei Gladiolen im Töpfchen davor sind verwelkt - vergessen fast wie mindestens 23 zivile Opfer. Sie hatten zum Teil Grabsteine auf dem alten Kiekebuscher Friedhof. ,Hier neben dem Findling waren die Kindergräber - meine Schwester Renate, die 1945 an Rachendiphtherie gestorben war, lag hier', erinnert sich Dieter Bartusch. / [...] / Flüchtlinge und Vertriebene liegen in Kiekebusch begraben: ,Nachdem die Brücke der Autobahn zerstört war, kamen die Züge aus Görlitz nicht mehr durch die Trümmer. Die Menschen mussten hier aussteigen und zum Cottbuser Bahnhof laufen. Wir haben mit Handwagen beim Gepäck geholfen. Manchmal wurden Verstorbene aus dem Zug gereicht', erinnert sich Bartusch. Anneliese Karnal, das Kind einer aus Glogau geflüchteten Frau, wurde 1945 nur wenige Tage alt und in Kiekebusch beigesetzt. Albert Schober aus Glogau war 59, als er hier an Ruhr starb. Die 70-jährige Auguste Rutschke aus Crossen traf ein Hirnschlag. Paul Weiß war über 70, als er nach der Vertreibung aus Breslau unterernährt im Mai 1946 in Kiekebusch starb. ,Sie hatten Typhus, Diphtherie, Lungenembolie, Herzschwäche, Unterleibsentzündung - sie sind alle Opfer dieses Krieges', sagt Bartusch. / Die Kiekebuscher haben heute einen neuen, größeren Friedhof. In den 60- und 70er-Jahren hatte eine Lehrerin mit Schulkindern die Gräber der zivilen Opfer gepflegt. ,Die Lehrerin war selbst Vertriebene, sagt Bartusch. Die vier Soldaten wurden 1997 umgebettet. 2001 [...] wurde der alte Friedhof beräumt 
und zur Grünfläche [...]. Eine Gedenkstätte sollte entstehen, der Findling wurde aufgestellt. Derweil ließ der Volksbund Deutsche Kriegsgräberfürsorge einen Plan mit zwei Kreuzgruppen aus Granit, Hochkreuz, Namenstafeln und immergrüner Hecke fertigen. [...] Bartusch kümmerte sich um die Namen der Opfer. / Die Einigung auf eine Lösung aber brauchte Zeit. 2003 wurde Kiekebusch Ortsteil von Cottbus. Die zivilen Opfer seien nie Bestandteil der offiziellen Gräberliste gewesen, heißt es nun von der Stadtverwaltung Cottbus. Jan Gloßmann, Sprecher der Stadt: ,Die Nutzungsberechtigten der Grabstätten haben nach Ablauf der Ruhefristen die Gräber der Angehörigen beziehungsweise zivilen Opfer eingeebnet. Mit einem Beschluss vom 19. August 2004 hat sich der damalige Ortsbeirat für eine Gedenktafel für alle Opfer der Kriege ausgesprochen.' Die Tafel wurde befestigt, das Thema ad acta gelegt. / Dass ein dauerndes Ruherecht für zivile Kriegsopfer nicht vom Gesetzgeber vorgesehen sei, wie Gloßmann mitteilt, sieht Bartusch anders. Nach dem Gesetz über die Erhaltung der Gräber der Opfer von Krieg und Gewaltherrschaft bleiben Kriegsgräber dauerhaft bestehen, sagt er. Neben den Soldaten gehören auch verstorbene Flüchtlinge, Vertriebene, Tote nach Bombenangriffen und Zivilpersonen, die in der Zeit vom 1. September 1939 bis 31. März 1952 an den Folgen des Krieges starben, zu den Kriegsopfern. Eine Tafel mit ihren Namen wünscht er sich für Kiekebusch. Er wird nicht müde, gegen das Vergessen mit Politikern auf kommunaler, Landes- und Bundesebene zu sprechen.“ (Igel-Allzeit).

UngedRuckte Quellen: Auskünfte Dieter Bartusch (Kiekebusch), 18.7.2017.

Gedruckte Quellen und Literatur: Annett Igel-Allzeit: Ein Kiekebuscher kämpft gegen das Vergessen. In: LR online, 1.9.2016.

\section{Kienitz}

Landgemeinde, bis 1950 Kr. Lebus, 1950-1952 Kr. Seelow, 1952-1990 Kr. Seelow (Bez. Frankfurt/Oder), 1990-1993 Ldkr. Seelow, 1993 Ldkr. Märkisch-Oderland

EREIGNISSE BIS KRIEGSENDE: [Bericht eines ab 28. Jan. 1945 auf Urlaub auf seinem Hof am Oderdamm befindlichen Soldaten:] „Anfang Februar 1945 wurden die Einwohner Kienitz-Dorf von den Russen evakuiert und über die Oder geschafft. [...] Am 31. Januar morgens kamen über die zugefrorene Oder die Russen in Kolonnen über den Fährweg in Richtung Dorf Kienitz zu Fuß und auch mit Fahrzeugen. [...] Der Brückenkopf wurde bis Amt Kienitz erweitert. [...] [S. 99] [...] Einige Tage vorher [vor dem 2. Febr.] kamen noch mehrere Familien aus dem Kreis Gnesen und wurden auch untergebracht. Auch diese mußten weiter. [...] Nach meiner Rückkehr aus amerikanischer Gefangenschaft habe ich erfahren, daß die über die Oder geschafften Einwohner von Dorf Kienitz bis nach Schneidemühl mußten, ohne verpflegt zu werden. Es sind auch längst nicht alle zurückgekommen. 4 Personen wurden verschleppt und nur 2 kamen wieder. Einige wurden gleich erschossen und 2 14jährige Jungen mitgenommen." (Raabe, S. 98 f.). - 8.2.1945 Zerstörung der Brücke durch deutschen Luftwaffenangriff (Schneider, S. 16f.). 
BevöLKerungszahlen: 1925: 1966, 1939: 1261, 1946: 1019, 1964: 1041 (HOL VII, S. 217). - 19.4.1946: 270 Flüchtlinge im Ort (Strenge/van Tankeren, S. 189).

Gedruckte Quellen und Literatur: N. N.: Erinnerungen an den Einmarsch der Russen in Kienitz und ins Oderbruch aufgrund von Berichten nacherzählt. In: ebd., S. 100-102. - Raabe, Moritz: Die ersten Russen in Kienitz Ein leidgeprüftes Land. Bearb. von Fritz Knüppel. 2. Aufl. Barsinghausen 1990, S. 98-99. - Schneider, Joachim: Die Oder während der Kriegshandlungen im Frühjahr 1945. In: Historischer Verein zu Frankfurt (Oder) e. V. Mitteilungen 2001, H. 2, S. 7-21, hier S. 16 f. (Brücke). - Strenge, Sigrid / Tankeren, Marga van: Letschiner Chronik. Bd. 5. Letschin 2011.

\section{Kietz (b. Küstrin) $\rightarrow$ Küstrin-Kietz}

\section{Kirchhain}

Stadtgemeinde (22.5.1950 Zusammenschluss mit $\rightarrow$ Doberlug zu Doberlug-Kirchhain), bis 1952 Kr. Luckau, 1952-1990 Kr. Finsterwalde (Bez. Cottbus), 1990-1993 Ldkr. Finsterwalde, 1993 Ldkr. Elbe-Elster

Ereignisse bis Kriegsende: Anf. Jan. 1940 besteht in Kirchhain ein Auffanglager für 250 umgesiedelte Wolhynien- und Galiziendeutsche (Müller, S. 124). „Im [kath.] Pfarrhaus fanden während der ersten Kriegsjahre einige Volksdeutsche aus Galizien Unterschlupf, die vorher zusammengedrängt im Schützenhaus untergebracht waren." (Homagk, S. 48). - 22.4.1945 Einmarsch der Roten Armee (Homagk, S. 48).

EREIGNISSE NACH KRIEGSENDE: 15.3.1947 Erwähnung einer „Umsiedlergenossenschaft“ (Heimarbeit) für Näherinnen in Kirchhain („14 Frauen mit eigenen Nähmaschinen“) (BLHA, Rep. 333, Nr. 574, Bl. 105).

BevöLkerungszahlen: 1925: 5 109, 1937: 5 950, 1946: 7636 (Städtebuch, S. 102). - Doberlug-Kirchhain: 1955: 9789, 1964: 9100 (ebd.).

Katholiken (Erzbistum Breslau/Erzbischöfliches Amt Görlitz): 1925: 115, 1946: 767 (Städtebuch, S. 102). - April 1945 Flucht des Kuratus aus der Stadt in Richtung Westen. „Das durch Flucht des Geistlichen freigewordene Pfarrhaus wurde zeitweilig von Flüchtlingsfamilien und einer russischen Dolmetscherin bewohnt. / Im Zuge der Vertreibung der Deutschen aus den deutschen Ostgebieten mach dem Krieg vergrößerte sich die Zahl der in Kirchhain und Umgebung gestrandeten Flüchtlinge, unter denen nicht wenige Katholiken waren. In der Hoffnung wieder in die Heimat zurückzukehren, haben Familien aus Schlesien, dem Sudetenland, aus dem Ermland, aus Danzig und der freien Prälatur Schneidemühl in der Kirchhainer Gemeinde Aufnahme finden können." (Homagk, S. 48). - 22.4.1945: „Der katholische Geistliche Herr Dr. Felix Haase [1882-1965] aus Breslau wird hiermit beauftragt, bis aufweiteres die katholische Pfarrseelsorge in Kirchhain Niederlausitz zu übernehmen." (Beauftragung durch den Erzbischöflichen 
Commissarius in Finsterwalde; Töpler, Menschenwurm, S. 322; Haase, bis 1945 o. Prof. u. Dekan der Theol. Fakultät der Univ. Breslau, war 1945/46 auch in Calau u. Vetschau zur Aushilfe eingesetzt, ging 1946 in den Westen [ebd., S. 641]). - „Aus Schlesien kam schließlich am 4. Juli 1945 Pfarrer Leo Golisch nach Kirchhain [offiziell berufen 6.7.1945 (Töpler, Menschenwurm, S. 344)]. Er organisierte den systematischen Ausbau der Seelsorge unter den sehr schwierigen Nachkriegsverhältnissen. Die besondere Herausforderung stellte die Zahl der Gläubigen dar, die von 500 im letzten Kriegsjahr auf rund 2200 im Jahr 1947 angestiegen war. Kurzerhand ernannte das Erzbischöfliche Amt in Görlitz den Flüchtlingspfarrer Heribert Titze zum zweiten Pfarrer in Kirchhain. Da es nun zwei Pfarrer in Kirchhain gab, fand auch in den umliegenden Dörfern, monatlich ein Gottesdienst statt. Ebenso konnte nun auch in diesen Außenstationen der Religionsunterricht erteilt werden. / Im Jahr 1948, als sogar ein dritter Sonntagsgottesdienst aufgrund steigender Zahlen der Kirchenbesucher eingeführt werden musste, wurde am 1. Juli die nicht selbständige Kuratie Kirchhain zu einer selbständigen Kuratie erhoben. Dies bedeutete, dass die Katholiken in Kirchhain und Umgebung (19 Orte) aus der Pfarrgemeinde Finsterwalde ausgepfarrt und zu einer selbständigen Kirchengemeinde vereinigt wurden. [...] / Pfarrer Golisch wurde im September 1948 nach $[\rightarrow$ ] Tröbitz berufen." (Homagk, S. 49); Golisch (geb. 1894 Skorschenno [Kr. Preuß. Stargrad], gest. 1964) wirkte bis 1945 zuletzt als Pfarrer in Hirschfeldau (Kr. Sagan), ab 1948 als Pfarrer in Tröbitz und ab 1953 als Hausgeistlicher in Wittichenau (Schematismus Görlitz 1954, S. 64), Anf. 1949 wohnte er in Kirchhain Am Hagwall 5 (Ostpriesterverzeichnis 2, 1949, S. 28); Titze (geb. 1907 Niederhermsdorf, Kr. Waldenburg/ Schlesien) wirkte 1944/45 als Pfarrer in Lamsdorf [Kr. Falkenberg/OS.], ab 1949 Caritasdirektor in Cottbus, 1953 Pfarrer in Senftenberg (Schematismus Görlitz 1954, S. 66). - 1948-1952 Kaplan (wohnt 1949 Am Hagwall 5): Johannes Langer (geb. 1918 Potsdam), früher Kaplan in Oberschreiberhau (Schlesien), ab 1952 Kuratus in $\rightarrow$ Lübbenau (Schematismus Görlitz 1954, S. 68; Ostpriesterverzeichnis 2, 1949, S. 51). - 1949-1963 Kuratial-Pfarrer Stephan Wagner (geb. 1910 Reichenau, Kr. Frankenstein/Schlesien, gest. 1963), zuvor seit 1939 in Cottbus: „Als ein jährlicher Höhepunkt des Gemeindelebens ist seit dieser Zeit das Fronleichnamsfest anzusehen. Die damals individuell gestalteten und geschmückten Altäre aller zur Gemeinde gehörenden Landsmannschaften sind hierbei besonders hervorzuheben." (Homagk, S. 50). [Diese] „Altäre gestalteten: Alt-Kirchhainer, Schlesier, Sudetendeutsche, Ermländer.“ (ebd., S. 58, Anm. 28).

UMSIEDLERLAGER KINDERHEIM: Im „Verzeichnis der errichteten und vorgesehenen Umsiedlerlager im Verwaltungsbezirk Cottbus“ vom 15.12.1945 ohne „Personenzahl“ genannt (Töpler, Menschenwurm, S. 472).

Gedruckte Quellen und Literatur: Homagk Mathias: 100 Jahre Gemeindegeschichte. In: „Ich gehe mit dem Gedanken um, in Kirchhain einen Betsaal zu bauen ..... Hrsg. von dems. u. Kathleen Hirschnitz. Halle/Saale 2008, S. 44-49. - Müller, Erich: Transporte, Lager, Ansiedlung im Warthegau: Das Schicksal der galizien- und wolhyniendeutschen Umsiedler nach ihrem Grenzübertritt 1939/40. In: Zeitweiser der Galiziendeutschen 43 (2005), S. 104157. - Töpler, Menschenwurm, S. 322, 342, 344, 472 u. ö. 


\section{Kirchmöser}

Landgemeinde (seit 1952 Ortsteil von Brandenburg), bis 1950 Kr. Jerichow II (Provinz Sachsen bzw. Land Sachsen-Anhalt), 1.7.1950-1952 Kr. Westhavelland (Land Brandenburg), seit 1952 Stadtkr. Brandenburg (bis 1990 Bez. Potsdam)

EREIGNISSE BIS KRIEGSENDE: „Als 1944 die Kämpfe an der Weichsel entbrannten, sollten zwei Gießereien aus Warschau-Praga nach [S. 127] Kirchmöser verlagert werden. Dazu kam es jedoch nicht mehr. In den letzten Kriegstagen siedelten Eisenbahner der Ausbesserungswerke Schneidemühl und Danzig mit ihren Familien nach Kirchmöser über. Am 26. und 27. Januar 1945 trafen drei Räumungszüge aus dem RAW Schneidemühl über Kreuz [/Ostbahn, Netzekr.], $[\rightarrow]$ Küstrin, $[\rightarrow]$ Strausberg und $[\rightarrow]$ Brandenburg in Kirchmöser ein. Neben den Eisenbahnern mit ihren Familien wurden auch wichtige Werkzeuge, Maschinen und Werkstoffe mitgebracht und dem RAW Brandenburg-West übergeben. Die Versorgung und Unterbringung der Flüchtlinge war jedoch ein Problem." (Menzel/Menzel/Schulze, S. 126f.).

EReignisse NaCh KriegSende: 24.11.1946 Flüchtlingszug aus Preußisch Holland (Ostpreußen) mit 1790 Personen und Zielort Kirchmöser passiert $\rightarrow$ Cottbus (Töpler, Menschenwurm, S. 545).

UMSIEDLERLAGER: 20.7.1946 W. Leichnitz als Umsiedler-Lagerbetreuer in Kirchmöser/Havel erwähnt (BLHA, Rep. 333, Nr. 574, B1. 35). - 31.12.1946: „Wenn man sich das Gesamtbild der gegebenen Lage vor Augen hält, wenn man ersehen muß, unter welch düsteren Verhältnissen Umsiedler derzeit im Lager zu Kirchmöser verbringen, besser: leben, deren Kinder von Haus zu Haus gehen und um ein Stückchen Brot betteln müssen, die kalte Mauern um sich haben, weder Kleidung, noch Federbetten, Wäsche und Geschirr mitnehmen durften, dann haben wir wirklich Grund dazu, Gott zu danken und sich mit dem bescheidenen Los zufrieden zu geben." (Tagebuch Emil Kämpf [sudetendeutscher Vertriebener, in Kirchmöser in Privatunterkunft wohnend], S. 432).

Gedruckte Quellen und Literatur: Blöß, Kreise und Gemeinden, S. 46. - Menzel, Stefan / Menzel, Walter/ Schulze, Jörg: Die Eisenbahn in Brandenburg an der Havel. Stendal 2017. - Tagebuch Emil Kämpf (Vertriebener aus dem Sudetenland) [Auszüge]. In: „Die Russen sind da“. Peter Böthig u. Peter Walther (Hg). Berlin 2011, S. 431-434, 436-437. - Töpler, Menschenwurm. - Wirtschafts-Wegweiser für Brandenburg (Havel) mit Plaue und Kirchmöser. Branchen-Adressbuch. Potsdam [1948?].

\section{Klein Kölzig}

Landgemeinde (1969 Stadtrecht), bis 1945 Kr. Sorau, 1945-1946 (Rest-)Kr. Sorau bzw. Kr. Forst, 1.4.1946-1952 Kr. Spremberg, 1952-1990 Kr. Forst (Bez. Cottbus), 1990-1993 Ldkr. Forst, 1993 Ldkr. Spree-Neiße

BEVÖLKERUNGSZAHLEN: 1925: 431, 1939: 425, 29.10.1946: 426, 1950: 480, 1964: 411 (HGV SN, S. 22 f.). 
UMSIEDLERLAGER (im Gutshaus): Kapazität am 31.12.1945 (Lager „Kl. Kölzig-Schloss“): 120 (BArch, DO 2/45, Bl. 40, 41). - Kapazität am 1.1.1946: 120 (BLHA, Rep. 203 MdI, Nr. 1163, B1. 51).

Gedruckte QueLLen: Wille I, S. 193 f.

\section{Klein Köris}

Landgemeinde (seit 1971 Ortsteil von Groß Köris), bis 1952 Kr. Teltow, 1952-1990 Kr. Königs Wusterhausen (Bez. Potsdam), 1990-1993 Ldkr. Königs Wusterhausen, 1993 Ldkr. DahmeSpreewald

EReignisse BIS KriegSende: Anf. Jan. 1940 besteht in Klein Köris ein Auffanglager für 210 umgesiedelte Wolhynien- und Galiziendeutsche (Müller, S. 122/124).

BevöLKERUNGSZAHLEN: 1925: 360, 1939: 591, 1946: 901, 1964: 735 (HOL IV, S. 143).

LiterAtur: Müller, Erich: Transporte, Lager, Ansiedlung im Warthegau: Das Schicksal der galizien- und wolhyniendeutschen Umsiedler nach ihrem Grenzübertritt 1939/40. In: Zeitweiser der Galiziendeutschen 43 (2005), S. 104157.

\section{Kleinmachnow}

Landgemeinde, bis 1952 Kr. Teltow, 1952-1990 Kr. Potsdam-Land (Bez. Potsdam), 19901993 Ldkr. Potsdam, 1993 Ldkr. Teltow-Fläming

EREIGNISSE NACH KRIEGSENDE: 1945: „Zu dieser Zeit waren in Kleinmachnow sehr viele Flüchtlinge untergebracht. Diese Problematik bereitete der Nachkriegsverwaltung große Schwierigkeiten, galt es doch für alle Menschen Lebensmittel und für die Kinder Milch zu beschaffen.“ (Der Landkreis Potsdam, S. 59). - 1945: „Am Vormittag des 24. Dezember kam ein großer Transport mit Flüchtlingen in Kleinmachnow an. Er war lange unterwegs gewesen, und die Menschen waren in einem besonders elenden Zustand. So hieß es denn, alle Kräfte zur Hilfeleistung zu mobilisieren. Die Frauen kümmerten sich wieder um Kleidung und Essen, um die Unterbringung und die Säuberung. - Mir gelang es, bis zum Abend eine Weihnachtsfeier in der Eigenherdschule vorzubereiten, so daß die Flüchtlinge wenigstens am Heiligen Abend durch Kerzenschein, Weihnachtslieder und kleine Geschenke einen Hoffnungsschimmer auf eine bessere Zeit vermittelt bekamen." (Bloch, S. 65).

EREIGNISSE NACH 1949: Von 1962 bis 1976 lebte in Kleinmachnow (bis 1968 Förster-FunkeAllee 26, dann Fontanestraße 20) die Schriftstellerin Christa Wolf (geb. 1929 Landsberg/Warthe), die in ihrem 1976 erschienenen autobiographischen Roman „Kindheitsmuster“ auch das Thema der Flucht 1945 behandelt und über ihren ersten Besuch im Heimatort nach dem Krieg (1971) reflektiert. 1976 zog die Familie nach in Berlin (Ost) (Wohnadressen nach Potsdamer 
Neueste Nachrichten, 9.1.2012). - Bis kurz nach der Wende lebte in Kleinmachnow auch die Redakteurin und Schriftstellerin Gisela Heller geb. Hielscher (geb. 1929 Breslau), sie wohnt jetzt in $\rightarrow$ Teltow.

BeVÖLKerungszahlen: 1925: 1000, 1939: 12565, 1946: 11792, 1964: 13821 (HOL IV, S. 174). - 1945 sollen sich 16000 Menschen in Kleinmachnow aufgehalten haben (Lange, Kleinmachnow, S. 57).

Katholiken: [1945]: „Die Gemeinde, die vor dem II. Weltkrieg schon 1600 Katholiken zählte, war durch Flüchtlinge und Vertriebene auf weit über 2000 Katholiken gewachsen. 1946 wurde in einem Einfamilienhaus am Grasweg ein Kindergarten gegründet, der dort bis heute besteht. In $[\rightarrow]$ Stahnsdorf entstand 1948 eine Tochtergründung, beide Gemeinden wurden zum 1.1.1955 Kuratie, Kleinmachnow dann zum 1.4.1960 auch Pfarrei. [...].“ (Brühe, S. 24; textähnlich: Schwillus/Brühe, S. 352).

Gedruckte Quellen und Literatur: Bloch, Peter: Zwischen Hoffnung und Resignation. Köln 1986. - Brühe, Matthias: Katholische Kirche zwischen Havel und Dahme. Berlin 1999, S. 24. - Lange, Herbert: 75 Jahre Gemeinde Kleinmachnow. In: Zwischen Havelland und Fläming 1995, S. 51-58. - Ders.: Kleinmachnow. In: Der Landkreis Potsdam 3/4 (1993), S. 57-60. - Schwillus/Brühe, S. 352.

\section{Klein Warnow}

Landgemeinde (ab 1972 Ortsteil von Groß Warnow), bis 1952 Kr. Westprignitz, 1952-1990 Kr. Perleberg (Bez. Schwerin), 1990-1993 Ldkr. Perleberg (Land Brandenburg), 1993 Ldkr. Prignitz

EREIGNISSE NACH KRIEGSENDE: 1946 in der Bodenreform keine Umsiedler genannt (HOL I, S. 933).

BevölkerungSZAHLEN: 1925: 155, 1939: 153, 1946: 208, 1964: 152 (HOL I, S. 933).

Katholiken: „Im Gebiet der Pfarrei [ $\rightarrow$ ] Perleberg wurde in Klein-Warnow 1946 der aus Schlesien heimatvertriebene Pfr. Robert Stosiek mit einem Teil seiner bisherigen Gemeinde angesiedelt. Bis zu seinem Tod [1956] bestand hier eine Seelsorgstelle, die zuletzt noch etwa 100 Katholiken zählte.“ (Brühe, S. 56). Bei der „bisherigen Gemeinde“ handelt es sich um die kath. Kirchengemeinde Namslau in Schlesien (Ostpriesterverzeichnis 2, 1949, S. 83). Der Geistliche Rat Robert Stosiek (geb. 1872 Oberglogau), früherer Pfarrer von Namslau (Schlesien) und nach 1945 als „Priester auswärtiger Bistümer“ weiterhin dem Erzbistum Breslau zugeordnet (Schematismus Berlin 1949, S. 146), starb am 1.6.1956 in Klein Warnow. [Nachruf seines $\rightarrow$ Wittenberger Amtsbruders: ] „Seit 1946 betreute er die mit ihm umgesiedelten Landsleute in Kl. Warnow und Umgegend. Er war uns ein vorbildlicher hilfsbereiter Priester und väterlicher Freund. An der Beerdigung in Klein Warnow nahmen außer den Geistlichen des Dekanats teil der Kapitelsvikar Dr. Piontek aus Görlitz sowie Prälat Drews aus Berlin." (Bolwin, S. 212). 
Literatur: [Bolwin, Jacob:] Chronik der Missionspfarrei Wittenberge. Wittenberge [2006]. - Brühe, Matthias: Katholische Kirche zwischen Prignitz und Havelland. Berlin 2000, S. 56. - Schwillus/Brühe, S. 355.

\section{Klessin}

Landgemeinde (seit 1946 [zw. März und Sept.] Ortsteil von Podelzig), bis 1950 Kr. Lebus, 1950-1990 Kr. Seelow (Bez. Frankfurt/Oder), 1990-1993 Ldkr. Seelow, 1993 Ldkr. MärkischOderland

EReignisse bis Kriegsende: [Aus dem Clessiner Tagebuch des dortigen Gutsbesitzers Otto v. Albedyll, geführt Jan. bis April 1945:] „[Jan. 1945:] [...] Inzwischen war der Russe bis vor Posen gelangt und in Ostpreußen tief eingebrochen, so daß wir uns schon mit dem Gedanken befaßten, Sachen zu packen. / Überall waren große Flüchtlingstrecks im Anmarsch. Am 29.1. kamen 25 Flüchtlinge aus Wreschen. / [...] Die Straßen waren voller Flüchtlinge. [...] Der Ostwall war anscheinend überlaufen. Wir packten und fuhren einige notwendige Sachen nach Plötzenhof, da bereits flüchtende Soldaten über die zugefrorene Oder zurückfluteten. Der Ostwall war also wirklich überlaufen und hatte nicht standgehalten. Nun lag die Oderlinie offen. Der Volkssturm wurde aufgeboten, um die Oder zu halten. Wo blieben die Soldaten, von denen die Garnisonen alle überfüllt waren? Es schwirrten die tollsten Gerüchte, man merkte, daß alles kopflos war. / Es kam ein Zug Küstriner Pioniere, der im Clessiner Hause unterkam und den Oderraum sichern sollte. Was konnten diese 18 Mann schon machen? / Wir waren jede Nacht unten an der Oder, wo zurückflutende Soldaten in Haufen übers Eis kamen. Sehr oft hatten sie schon keine Waffen mehr. Ein furchtbares Bild. / Am Abend des 1. Februar meldete sich ein Major aus Podelzig, der den Auftrag hatte, an der Oder eine Front aufzubauen. [...] / [S. 33] Die Nacht war sehr unruhig, da die über die Oder kommenden Soldaten die Nachricht mitbrachten, daß russische Panzer schon in den gegenüberliegenden Dörfern waren. Das Wetter schlug um und auf dem Odereis war bereits etwas Wasser. Überall auf den Straßen war eine fürchterliche Glätte. / Am 2. Februar abends sprach ich in Podelzig mit unserem Landrat Kreuzberger, der mir geraten hatte, wegen der Räumung von Clessin mit dem Kreisleiter zu sprechen, damit Frauen und Kinder in Sicherheit kämen. Ein dorthin entsandter Bote brachte nachts die Nachricht, ich werde an die Wand gestellt, würde ich eigenmächtig etwas unternehmen. Also mußten Frauen und Kinder dableiben. / [...] [Sonntag, 4.2.1945:] Noch immer waren die Frauen und Kinder da, ein unerhörter Skandal! / [...] [S. 34] 13.30 Uhr nachmittags schlugen zwei Granaten ins Hausdach ein, eine weitere am Eingang von dem Zweifamilienhaus hinter dem Hof. / Frauen und Kinder in Panik. Ich ließ anspannen und mußte energisch werden. Ich ließ den Feldscheunenweg fahren, da der Pflasterweg schon unter Feuer lag, weil vor Podelzig Artillerie aufgefahren war. / Die Flüchtlinge konnte ich nicht losschicken, denn ich hatte kein Pferd mehr im Stall. Die Truppen nahmen die Pferde, weil sie keinen Sprit mehr hatten. / Ich verzweifelte fast angesichts der Lage. So mußte also auch Clessin zugrunde gehen. [...] Es war kein Räumungsbefehl gegeben worden. Wir verbrachten die unruhige Nacht im Keller des Hauses. [... [ [Montag, 5.2.1945:] Um 7 Uhr traf ich den Artillerie-Beobachter im Hause, der mich aufforderte, sofort zu räumen, aber erst gegen 9 Uhr kamen die Wagen und Pferde. Daher 
fuhren wir mit unserem Zweispänner-Kastenwagen, beladen mit 25 Flüchtlingen, als letzte aus Clessin fort. Die meisten gingen zu Fuß, da auch die Habe der Flüchtlinge mit mußte. Es war ein furchtbar schwerer Moment, es ging über Mallnow nach Alt-Mahlisch. In Mallnow trafen wir die Podelziger, die den Räumungsbefehl nicht nach Clessin weitergegeben hatten. In Alt-Mahlisch kamen alle in der Schule unter. [...] / Am nächsten Morgen, 6.2.45, ging der Treck nach Bülstringen [bei Haldensleben in der Provinz Sachsen, P. B.], das dieser nach $6 \frac{1}{2}$ Tagen unbeschadet erreichte. Die Flüchtlinge kamen in den nächsten Tagen auch weiter. / [...]." (v. Albedyll, S. 32-34). - 23.2.1945 Einmarsch der Roten Armee (ebd., S. 37).

BevölKerungszahlen: 1925: 180, 1939: 126 (HOL, S. 220).

Gedruckte Quellen und Literatur: Albedyll, Otto v.: Clessiner Tagebuch 1945. In: Ein leidgeprüftes Land. Bearb. von Fritz Knüppel. 2. Aufl. Barsinghausen 1990, S. 31-40. - Blöß, Kreise und Gemeinden, S. $20,81$.

\section{Kliestow}

Landgemeinde (1947-1950 und seit 1952 Ortsteil von $\rightarrow$ Frankfurt/Oder), bis 1947 Kr. Lebus, 1947-1950 Stadtkr. Frankfurt (Oder), 1950-1952 Kr. Frankfurt (Oder), seit 1952 Stadtkr. Frankfurt (Oder) (1952-1990 Bez. Frankfurt/Oder)

EREIGNISSE NACH KRIEGSENDE: In der Bodenreform 160,9 ha von 355,9 ha an 39 „Umsiedler“ vergeben (HOL VII, S. 223).

LPG „FRIEDENSGRENZE“: [gegründet 1958?]. - [1972]: „Die Genossenschaftsbauern der LPG „Friedensgrenze" Kliestow haben in den letzten Jahren durch Um- und Ausbau vorhandener Gebäude ein Milchviehkombinat für 1200 Milchkühe geschaffen, in dem bei äußerst rationeller Nutzung der Grundmittel und geringem Aufwand an manueller Arbeit mit bestem ökonomischen Erfolg eine industriemäßige Milchproduktion organisiert wird. Die Anlage zählt zu den größten der DDR und kann als Beispiel für all die Kooperationen und Genossenschaften dienen, die nach rationelleren Möglichkeiten der Milchproduktion in der vorhandenen Bausubstanz suchen. / Die LPG „Friedensgrenze bewirtschaftet 616 ha LN [Landwirtschaftliche Nutzfläche, P. B.], davon sind 386 ha Wiese und Weide und 228 ha Ackerland in Wechselnutzung. Der Betrieb liegt am nördlichen Stadtrand von Frankfurt, entlang der Oder, und ist mit 500 ha dem Abwasserverwertungsgebiet der Stadt Frankfurt (Oder) angeschlossen. [...] Im Jahre 1963 wurde ein Stall $93 m \times 12$ für 160 Milchkühe in Anbindehaltung errichtet. [...]. In den folgenden Jahren schuf die Baubrigade der LPG daraus durch Erweiterungsbauten und Umbau eine Laufstallanlage für 1200 Milchkühe [...] Der Ausbau der Anlage ist damit noch nicht abgeschlossen." (Mothes/Zeihn/Glanz, S. 345).

BEVÖLKERUNGSZAHLEN: 1925: 382, 1939: 702 (HOL VII, S. 223).

Literatur: Mothes, E. / Zeihn, K. / Glanz, J.: Technologie und Ökonomie einer Laufstallanlage für 1200 Milchkühe. In: Deutsche Agrartechnik 22 (1972), S. 345-349. [LPG „Friedensgrenze“]. 


\section{Klinkengrund $\rightarrow$ Belzig}

\section{Königs Wusterhausen}

Stadtgemeinde, bis 1952 Kr. Teltow, 1952-1990 Kr. Königs Wusterhausen (Bez. Potsdam), 1990-1993 Ldkr. Königs Wusterhausen, 1993 Ldkr. Dahme-Spreewald

EREIGNISSE BIS KRIEGSENDE: 1940-1945 Unterbringung von altersheimbedürftigen Umsiedlern aus Lettland und Estland“ u. a. in der Landesanstalt Königs Wusterhausen (Fürsorge und Wohlfahrtspflege, S. 62). - [Anf. 1945:] „Die Front rückt näher und Königs Wusterhausen wird von ununterbrochenen Flüchtlingskarawanen durchzogen. Die Menschen aus dem Osten Deutschlands, die oft nur das Nötigste oder das nackte Leben retten können, finden in der [katholischen] Kirche seelsorgerischen Beistand und im Pfarrhaus eine warme Nachtstätte und etwas zu Essen. Pausenlose Luftangriffe, die vor allem Berlin gelten, zwingen die Menschen stundenlang im Keller auszuhalten. [...] / Am 20. April herrscht Geschützdonner schon rund um die Stadt. Die Straßen sind von Flüchtlingen, zurückflutenden Truppen und mitgeführtem Material vestopft. [...].“ (Seyer, S. 35). - 26.4.1945 Einmarsch der Roten Armee (ebd., S. 36).

EREIGNISSE NACH KRIEGSENDE: „Erst am 30. April wird ein Stadtkommandant eingesetzt und die Lage normalisiert sich langsam. Auch die Zahl der Flüchtlinge verringert sich allmählich. / [...] Kurze Zeit später kommt es wieder zu Flüchtlingsdramen. Diesmal sind es die Flüchtlinge aus den polnisch besetzten Gebieten, die dort nach Kriegsende vertrieben werden. Auch sie leiden an Hunger und Krankheiten, die Beerdiungen am Ort nehmen kein Ende. [...].“ (ebd., S. 36).

Bevölkerungszahlen: 1925: 4818, 1939: 6562, 1946: 6614, 1964: 8922 (Städtebuch, S. 262).

Katholiken: 1925: 327, 1946: 520 (Städtebuch, S. 261). - „Damals [vor 1945] lebten hier etwa 1850 Katholiken, nach dem II. Weltkrieg stieg ihre Zahl zeitweilig auf das Doppelte." (Brühe, S. 25; textidentisch: Schwillus/Brühe, S. 329). - „Mit Kriegsende ist ein Wandel in der Gemeinde zu spüren. [...] Viele Vertriebene und Aussiedler siedeln sich im Ort an, Einheimische ziehen dafür in andere Gegenden." (Seyer, S. 37).

(Kreis-)UMSIEdLeRlager: 30.9.1945 Auffanglager für Flüchtlinge erwähnt, nach dreiwöchiger Quarantänezeit Entlassung u. a. nach $\rightarrow$ Waltersdorf (Sychold, S. 71). - Kapazität am 31.12.1945: 500 (BArch, DO 2/45, Bl. 40). - Kapazität am 1.1.1946: 1000 (BLHA, Rep. 203 MdI, Nr. 1163, Bl. 49). - 14.2.1946 Kreis- und Quarantänelager, Kapazität: 1000 (Oehlsen, S. 28). - 30.4.1946 als eines der verbleibenden Umsiedlerlager genannt (DAB, I/9-15-1 Flüchtlingsseelsorge 1945-1951, unfol., [30.6.1946], [Anlage 3]).

UMSIEDlerlager An der Eisenbahn: Kapazität am 1.1.1946: 500 (BLHA, Rep. 203 MdI, Nr. 1163, Bl. 50). 
Kinderheim: Zwischen 1945 und 1948 bestand eine Patenschaft der SED-Betriebsgruppe oder des SED-Betriebsrats der Zentralverwaltung für deutsche Umsiedler für das Kinderheim in Königs Wusterhausen (BArch, DO 2/6).

StÄdtepartnerschaften: 1974 Přibram, Tschechien (Pribram, Mittelböhmen).

Archivalische Quellen: BArch, DO 2 ZVU, Nr. 6 (ZVU: SED-Betriebsgruppe und Betriebsrat. - Sitzungen, Protokolle, 1945-1958; enthält u. a.: Patenschaft mit dem Kinderheim in Königswusterhausen). - BArch, DO 2/39, B1. 98-99 (Umsiedlerlager, Dez. 1945). - Kreisarchiv Dahme-Spreewald, A-1 Kreistag und Rat des Kreises Königs Wusterhausen, Nr. 322 (33. Sitzung des Rates, 24. Dez. 1953; enthält u. a.: Überplanmäßige Verausgabung von Mitteln für Zahlung von Erziehungsbeihilfen für Umsiedlerkinder).

Gedruckte Quellen und Literatur: Adamy, Kurt/Hübener, Kristina: Königs Wusterhausen in der Zeit der Weimarer Republik und des Nationalsozialismus (1918-1945). In: Königs Wusterhausen. Hrsg. von Kurt Adamy, Kristina Hübener, Marko Leps. Berlin 1998, S. 123-174. - Brühe, Matthias: Katholische Kirche zwischen Havel und Dahme. Berlin 1999, S. 25. - Fürsorge und Wohlfahrtspflege in Brandenburg (1800-1952). Hrsg. von Margot Beck. Berlin 2002. - 1945. Das Jahr in der Region Dahme-Spreewald. Dokumentation zur Geschichte. T. 2. Zeuthen 2010, S. 220-229 (S. 220 f.: Zeitzeugenbericht [Interview 2006] der Litauendeutschen Frau Kugel, ca. 1935 in deutsche Ostgebiete umgesiedelt, von dort 1945 nach Königs Wusterhausen, Notunterkunft und weiterer Werdegang). Schwillus/Brühe, S. 329. - Seyer, Norbert: Ein Jahrhundert St. Elisabeth Königs Wusterhausen. Königs Wusterhausen 2009. - Stier, Frank / Zabel, Marco: Königs Wusterhausen von 1945 bis zur Gegenwart. In: Königs Wusterhausen. Hrsg. von Kurt Adamy, Kristina Hübener, Marko Leps. Berlin 1998, S. 175-226 [ohne Behandlung des Flüchtlingszuzugs]. - Sychold, Erich: Chronik Waltersdorf. Waltersdorf (2001). - Wille III, S. 431.

\section{Königs Wusterhausen-Zernsdorf $\rightarrow$ Zernsdorf}

\section{Körbiskrug}

Wohnplatz von $\rightarrow$ Zeesen (seit 2003 als Gemeindeteil von Zeesen Ortsteil der Stadt $\rightarrow$ Königs Wusterhausen), bis 1952 Kr. Teltow, 1952-1990 Kr. Königs Wusterhausen (Bez. Potsdam), 1990-1993 Ldkr. Königs Wusterhausen, 1993 Ldkr. Dahme-Spreewald

BeVÖLKERUNGSZAHLEN: 1925: 430 (HOL IV, S. 141).

UMSIEDLERLAGER: Kapazität am 31.12.1945 (Lager „Körbeskrug b. Bestensee“): 300 (BArch, DO 2/45, Bl. 40).

\section{Kolkwitz}

Landgemeinde, bis 1952 Kr. Cottbus, 1952-1990 Kr. Cottbus (Bez. Cottbus), 1990-1993 Ldkr. Cottbus, 1993 Ldkr. Spree-Neiße

EREIGNisSE NACH 1990: „In Kolkwitz bei Cottbus [... trafen sich die Vertriebenen aus dem Kreis Freystadt [in Schlesien]. Kolkwitz wurde von den Organisatoren deshalb gewählt, weil es 
dort eine Gaststätte mit einem besonders großen Saal gibt. Der Raum war in den Jahren nach der ,Wende' stets hoffnungslos überfüllt.“ (Schneider, S. 32). - Ab 1991 auch jährliche „Heimattreffen des ehem. Sorauer Landes" in Kolkwitz, ab 2006 fortgeführt in $\rightarrow$ Forst (Newsletter Sorauer Land, Nr. 1/Senioren-Union der CDU $\rightarrow$ Cottbus, Sept. 2015; Sorauer Sommerfelder Hefte 16, 2016, Nr. 2, S. 3). - 1993 erstes Pförtener Heimattreffen in Form eines Klassentreffens, später in Forst (Lausitzer Rundschau, 12.6.2008). - 28.9.1996 3. [Heimat-]Treffen des Kirchspiels Starzeddel (Kr. Guben) (poln. Starosiedle) in der Gaststätte „Zur Eisenbahn“ mit 133 Teilnehmern (Bericht von Joachim Faßke u. Lonni Fürste in: Gubener Heimatbrief 1/1997, S. 78-80; S. 80-82: Teilnehmerliste) [1. Treffen 1994 in $\rightarrow$ Neuzelle, 2. Treffen in $\rightarrow$ Kerkwitz (Kr. Guben)]. - 6.9.2003 „Heimattreffen der Bewohner des ehemaligen Kreises Freystadt" (Schlesien) in der Gaststätte „Zur Eisenbahn“ (Lausitzer Rundschau, 26.8.2003).

BevölKerungszahlen: 1925: 2418, 1939: 2945, 29.10.1946: 3271, 1950: 3759, 1964 : 3395 (HGV SN, S. 22 f.).

MAssengrab bei Der LungenheilstätTe (diese ab 1953 als Klinikum Teil des Bezirkskrankenhauses Cottbus bzw. des Carl-Thiem-Klinikums in $\rightarrow$ Cottbus, 2007 Klinikum-Standort Kolkwitz geschlossen), Am Klinikum: (Nach 8.) Mai 1945 Beisetzungen in 12 Massengräbern hinter der Anstalt (darunter auch mindestens 147 Flüchtlinge): „Nach alten Lageskizzen ließe sich das Massengrab hinter der ehemaligen Gärtnerei des Klinikums ziemlich genau bestimmen. Das Gelände [...] ist heute Privateigentum und eingezäunt. [...] Es sieht ja keiner, dass das Gräber von 147 Menschen sind, die die Strapazen des Zweiten Weltkrieges nicht überlebt haben.“ (Annett Igel, in: LR, 8.9.2012). - „Nach dem Zweiten Weltkrieg wurde das Gebäude der Kolkwitzer Heilstätte weiter zur Behandlung Tuberkulosekranker genutzt. Aufgrund kriegsbedingter Kapazitätsengpässe mussten zwischen 1945 und 1946 auch nicht-lungenkranke Patienten des zerstörten Städtischen Krankenhauses Cottbus aufgenommen werden." (Jüttemann, S. 103).

GedenKstein AUf DeM Friedhof (eingeweiht 13.11.2011): Inschrift: „Wir gedenken der 147 zivilen Opfer/von Krieg und Vertreibung, / die hinter der Friedhofshalle der ehemaligen/Lungenheilstätte Kolkwitz ihre letzte/Ruhestätte gefunden haben.//Wenn das Licht erlischt, bleibt die Trauer. /Wenn die Trauer vergeht, bleibt die Erinnerung./Dies ist das einzige Paradies, aus dem wir/nicht vertrieben werden können." (BR 9 (2011), Nr. 8, S. 10; Klein/Herrnbeck, S. $204 \mathrm{f}$. mit Abb.; Foto von 2013 in BdV-Landesgeschäftsstelle). „Ein großer Granitstein aus dem Tagebau $\rightarrow$ Welzow-Süd erinnert jetzt auf dem Kolkwitzer Friedhof an 147 Menschen, die im Jahr 1945 die Strapazen der Flucht nicht überlebt haben. Sie ruhen in zwölf Massengräbern am Klinikum [ehem. Lungenheilstätte, siehe oben, P. B.]. Einige Kilometer entfernt von ihren Gebeinen wird am morgigen Volkstrauertag [13.11.2011] der Gedenkstein eingeweiht. / Kinder, Frauen, Männer aus Brandenburg, Schlesien und Oberschlesien liegen in den Massengräbern am Klinikum, sagt Dieter Bartusch vom Volksbund Deutsche Kriegsgräbervorsorge [zugleich Beisitzer im Vorstand des BdV-Landesverbandes Brandenburg (LR, 30.11.2012), P. B.]. Der 
kalte Winter hatte ihnen zugesetzt, viele waren unterernährt in Kolkwitz angekommen, litten an Verletzungen. Sie waren zu geschwächt, um das Lazarett der Lungenheilanstalt wieder lebend verlassen zu können. ,1945 konnte der alte Friedhof am Klinikum die Verstorbenen nicht mehr aufnehmen. Es blieb nur Zeit, sie in Massengräbern hinter der Friedhofskapelle der ehemaligen Lungenheilanstalt zu bestatten', sagt Bürgermeister Fritz Handrow (CDU). / Und sie wurden in den Jahrzehnten danach fast vergessen, nichts weist am Klinikum auf ihr Schicksal hin. ,14 Jahre habe ich darum gekämpft, dass etwas in Kolkwitz an diese Vertriebenen erinnert. Richtig ins Rollen kam die Diskussion darüber, als das Klinikum im Sommer 2000 sein 100-jähriges Bestehen feierte', sagt Dieter Bartusch. In Unterlagen zur Lungenheilanstalt im Carl-Thiem-Klinikum hat er Hinweise auf diese zivilen Kriegsopfer gefunden, und auch im Kirchenbuch von 1945 wurde er fündig. Über 600 Gebeine von Kriegsopfern hat er auf diese und ähnliche Weise schon identifizieren können. Und auch die Namen aus Kolkwitz will er in den Publikationen der Vertriebenenorganisationen veröffentlichen lassen. ,Es gibt immer noch viele Menschen, die ihre Angehörigen im Zweiten Weltkrieg verloren haben und wissen wollen, wo sie beigesetzt wurden', sagt Bartusch. [Das Publikationsvorhaben wurde inzwischen zurückgestellt, die Übergabe der Namenliste auch der zivilen Toten an den Volksbund ist vorgesehen (Mitteilung D. Bartusch, 18.7.2017) - P.B.] Zudem hofft er immer noch, dass die 147 Gebeine zum Stein auf den Kolkwitzer Friedhof umgebettet werden können. ,Genug Platz vor dem Stein ist da. Nur ist das sehr teuer. Auch alle 147 Namen auf einer Tafel zu nennen, scheiterte an den Kosten', sagt Dieter Bartusch. Dass das Gebiet, auf dem sich die Massengräber am Klinikum noch befinden, jetzt eingezäunt ist, beunruhigt den 77-Jährigen: ,Es sieht ja keiner, dass das Gräber sind. Nicht, dass dann irgendwann, wenn keiner mehr da ist, der Bescheid weiß, etwas darauf errichtet wird ...' Nach dem Kriegsgräbergesetz haben alle, die bis zum 31. März 1952 durch die Kriegswirren gestorben sind, ein ewiges Ruherecht. / Wie die Steine in $[\rightarrow]$ Werben und an der $[\rightarrow]$ Potsdamer Nikolaikirche ist auch der Stein in Kolkwitz eine Schenkung aus dem Tagebau. Das Bergbauunternehmen Vattenfall hatte im Sommer zudem den Transport und das Aufstellen übernommen. Der Findling wiegt fünfeinhalb Tonnen und steht in seiner ganzen Breite von über zwei Metern vor einer Gruppe Robinien rechts neben der Kolkwitzer Trauerhalle. / Am morgigen Volkstrauertag, 13. November, um 14 Uhr wird der Gedenkstein auf dem Kolkwitzer Friedhof eingeweiht. Fritz Handrow freut sich über möglichst viele Gemeindevertreter, die kommen. Auch die Bürger sind herzlich eingeladen, sagt Fritz Handrow.“ (Annett Igel, in: LR, 12.11.2011).

QuelLen und Literatur: Bericht über das 3. Treffen des Kirchspiels Starzeddel am 28.9.1996 in Kolkwitz. in: Gubener Rundbrief (1997)1, S. 78-83 (mit Teilnehmerliste). - Jüttemann, Andreas: Die preußischen Lungenheilstätten 1863-1934. Diss. FU Berlin 2015 (www.diss.fu-berlin.de [5.6.2017]). - Klei, Alexandra / Herrnbeck, Christian: Überall Geschichte. Nationalsozialismus und Kriegsende 1945 - Denkmale, Erinnerungszeichen und historische Orte im Landkreis Spree-Neiße. Berlin 2005. - Kriegsopfer erhalten Gedenkstein. Tonnenschwerer Findling auf dem Kolkwitzer Friedhof aufgestellt. In: BR 9 (2011)8, S. 10. - Kriegsopfer erhielten Gedenkstein in Kolkwitz. Dieter Bartusch: Jahrelanges Ringen führte zum Erfolg. In: ebd. 9 (2011)11, S. 12. - Lausitzer Rundschau, 12.11.2011, 8.9.2012. - Schneider, Gerold: Seelsorge für Heimatvertriebene in der ehemaligen DDR. In: Kirche und Heimat. Bonn 1999, S. 26-33. - Töpler, Menschenwurm, S. 466. - Auskünfte Dieter Bartusch (Kiekebusch), 18.7.2017. 


\section{Krayne}

Landgemeinde (seit 2003 Ortsteil von Schenkendöbern), bis $1952 \mathrm{Kr}$. Guben 1952-1990 Kr. Guben (Bez. Cottbus), 1990-1993 Ldkr. Guben, 1993 Ldkr. Spree-Neiße

EReignisse NACH KriegSende: „Als am 14. Mai 1945 die Russen in Krayne eintrafen, stießen sie bereits auf die ersten zurückgekehrten Dörfler. Man fand nur noch wenig Kleinvieh vor, viele Häuser waren durch abziehende deutsche Truppen und Flüchtlinge geplündert worden. [...] / Fast unhaltbar wurde der Zustand für das 22-Häuser-Dorf, als polnisches Militär - im Vorgriff auf die Beschlüsse der Potsdamer Konferenz vom August 1945 - bereits [S. 102] am 20. Juni 1945 begann, Deutsche aus den Gebieten östlich der Neiße gewaltsam zu vertreiben. [...] In Krayne trafen vor allem Flüchtlinge aus [Groß und/oder Klein] Drenzig, Döbern, Vettersfelde [alle im Ostteil des Kr. Guben] und Tschernitz [Kr. Sorau] ein, die auf die Gehöfte aufgeteilt wurden, insgesamt mehr als 30 Familien. An Namen überliefert sind: Richter, Jänisch, Müller, Huhnt, Schütze, Fechtner, Riedel, Jurk, Peter, Gronke, Tilgner, Linke, König, Bär, Schulz, Walter, Händel, Lehmann, Bög, Küpper, Neumann, Krüger, Rademacher, Kleemann, Hoffmann, Kuhbein, Bartke, Kramer und Klein. Nicht alle wurden in Krayne seßhaft. [...] [S. 103] [...] [Bodenreform:] In jedem Dorf wurde eine Bodenkommission gebildet, der die Aufteilung des enteigneten Landes oblag. Die Krayner Kommission bestand aus Willi Riedel und Gustav Neumann, beide aus Drenzig[,] sowie Willi Rademacher aus Pohlo [im Ostteil des Kr. Guben], alles Heimatvertriebene. [...]. [S. 104] In Krayne wurden also rund 130 ha Land versiedelt. Da Willi Riedel kurz nach der Siedlung verstarb, übernahm Richard Lehmann aus Döbern das Neubauernland. Die Neubäuerin Elfriede Küpper stammte aus Drenzig. In Krayne errichtete man keine typisierten Neubauernhäuser, der benötigte Wohnraum entstand durch den Umbau von Wirtschaftsgebäuden des ehemaligen Gutes. [...].“ (Schatte, S. 101-104).

BevölKeRUngSZAHLEN: 1925: 127, 1939: 114 (HOL NL II, S. 222); 29.10.1946: 201, 1950: 204, 1964: 167 (HGV SN, S. 27).

GedRUCKTe QUeLlen und Literatur: Schatte, Hartmut: Krayne. Teichperle der Niederlausitz. [Cottbus] 2005. Schulz, Gisela: Aus dem Leben der Ortsgruppe 18 der Volkssolidarität in Guben. In: Gubener Heimatkalender 55 (2009), S. 77-80, hier S. 77 (Kinderheim Krayne). - Töpler, Menschenwurm, S. 472.

\section{Kremmen}

Stadtgemeinde, bis 1952 Kr. Osthavelland, 1952-1990 Kr. Oranienburg (Bez. Potsdam), 19901993 Ldkr. Oranienburg, 1993 Ldkr. Oberhavel

EREIGNisSE BIS KRIEgSENDE: [Anf. April 1945]: „Kolonnen der zurückflutenden Wehrmacht verließen die Stadt in westlicher Richtung, gefolgt von den Flüchtlingsströmen der Evakuierten aus den Ostgebieten, die auf Pferdewagen oder oft nur auf Handwagen ihre wenige Habe gerettet haben." (Henniger, S. 43). - 23.4.1945 Fliegerangriff: „Auf dem Marktplatz wurden ein 
Flüchtling [und zwei weitere Personen (...)] getötet.“ (ebd., S. 43 f.). - 24.4.1945 Einmarsch der Roten Armee (polnische Truppen) (ebd., S. 45), in der Stadt wohnende Flüchtlinge erwähnt (ebd., S. 47).

EREIGNISSE NACH KRIEGSENDE: [Mai] 1945: „Nach und nach kehrten die geflüchteten Kremmener Bürger in ihre zum Teil verwüsteten oder von Umsiedlern besetzten Wohnungen zurück. [... Im Mai 1945 übernahm Otto Engels die Leitung der Kremmener Polizei. Unterstützt wurde er von einigen Alteingesessenen und Umsiedlern, die als Hilfspolizisten fungierten. Als Dolmetscher fungierte Frau Sonnenberg, eine Baltendeutsche, die der Krieg nach Kremmen verschlagen hatte. [...] Es gab jedoch bald Versorgungsprobleme, waren doch zu den etwa 3000 Kremmener Einwohnern ca. 1000 Umsiedler gekommen. Auch die Unterbringung dieser Ärmsten und die Beschaffung von Kleidung und Mobiliar belastete die deutsche Verwaltung sehr. [...] [S. 50] [...] / In der Schule und im Landhaus wurden in Massenquartieren Umsiedler notdürftig untergebracht, bis ihnen durch das Wohnungsamt Wohnraum vermittelt werden konnte. Da Typhus und Ruhr auftraten, wurde am Bahnhof im Büro Schlüter eine Seuchenstation eingerichtet. [...]./Im August wurde die Schule von Flüchtlingen geräumt und wieder hergerichtet $[. .$.$] / Am 1. Oktober 1945$ begann der Unterricht in acht Klassen. [...] Unter den Schülern befanden sich viele Umsiedlerkinder. Die meisten wußten nichts über den Verbleib ihrer Väter, sie waren erbärmlich gekleidet. Am jammervollsten war der Zustand ihres Schuhwerks, besaßen doch viele nur ein paar Holzpantinen. Fast alle, mit Ausnahme einiger einheimischer Bauernkinder, sahen verhungert aus.“ (Henniger, S. 49 f.). - 1945 (Bericht der Stadtverwaltung vom Nov. oder Dez. 1945, verfasst von H. Wille): „Ein Problem für die Stadt bildet die Unterbringung von Flüchtlingen, die bisher in Stärke von 1000 Personen innerhalb der Stadt untergebracht sind. Eine weitere Zahl von Umsiedlern ca. 1400 müssen noch untergebracht werden, was an die Organisationskunst der zu[-] [S. 102] ständigen Verwaltungsteile große Anforderungen stellt. Bei der Behandlung dieses Problems tritt die unbedingte Notwendigkeit der durchgeführten Bodenreform besonders auffällig in Erscheinung. Eine erhebliche Anzahl landarmer Bauern und Flüchtlinge konnte durch Aufteilung der Güter untergebracht werden, wobei den Flüchtlingen eine neue Heimat geschaffen wurde. Um der drohenden Seuchengefahr zu begegnen, wurde ein Hilfskrankenhaus im ehemaligen Forsthaus eingerichtet." (Brandenburgische Gemeinden 1945, S. 101).

BeVÖLKeRUNGSZAHLEN: 1925: 3 170, 1939: 3304, 1946: 3605, 1964: 3301 (Städtebuch, S. 264).

Katholiken: 1925: 108, 1946: 298 (Städtebuch, S. 265). - „1953 wohnten 1000 Katholiken in Kremmen und Umgebung." (Brühe, S. 24).

UmSiedlerlager Amalienfelde (ehem. Gut bei Kremmen, bereits vor 1945 eingemeindet): Kapazität am 31.12.1945 (in Liste Lager „Amalienfelde“ eingeordnet beim Kr. Niederbarnim, es folgt Lager „Oranienburg“): 100 (BArch, DO 2/45, Bl. 40). 
Gedruckte Quellen und Literatur: Brandenburgische Gemeinden 1945, S. 99-102. - Brühe, Matthias: Katholische Kirche zwischen Prignitz und Havelland. Berlin 2000, S. 24. - Henniger, Gerhard: 700 Jahre Stadt Kremmen. Kremmen [1998].

\section{Kromlau}

Landgemeinde (seit 1999 Ortsteil von Gablenz), bis 1945 Kr. Sorau, 1945-1946 (Rest-)Kr. Sorau bzw. Kr. Forst, 1.4.1946-1952 Kr. Spremberg, 1952-1990 Kr. Weißwasser (Bez. Cottbus), 1990-1994 Ldkr. Weißwasser (Land Sachsen), 1994-2008 Ldkr. Niederschlesischer Oberlausitzkr., 2009 ldkr. Görlitz (Land Sachsen)

UMSIEDLERLAGER: Im „Verzeichnis der errichteten und vorgesehenen Umsiedlerlager im Verwaltungsbezirk Cottbus“ vom 15.12.1945 ohne „Personenzahl“ genannt (Töpler, Menschenwurm, S. 472), für entsprechende Bereitstellung vorgesehen auch schon lt. Bericht vom 24.10.1945 (ebd., S. 450).

\section{Krugau}

Landgemeinde (seit 2003 Ortsteil der Gemeinde Märkische Heide), bis 1952 Kr. Lübben, 1952-1990 Kr. Lübben (Bez. Cottbus), 1990-1993 Ldkr. Lübben, 1993 Ldkr. Dahme-Spreewald

BevölKerungszahlen: 1925: 433, 1939: 370, 1946: 694, 1950: 693, 1964: 384 (HGV LDS, S. 26 f.). - 1.5.1946: 666, davon 358 Ortsansässige, 308 „Umsiedler“ (Becken, S. 32).

UMSIEDLERLAGER (bis 1945 Barackenlager des Reichsarbeitsdienstes) [vmtl. östlich von Krugau auf militärischem Gelände: hier bis 1945 Panzernebenzeugamt mit Heeresmunitionsdepot (MUNA), später NVA-Kaserne, heute "Spreewaldkaserne“ mit Sanitätsmateriallager der Bundeswehr (Wikipedia, Krugau, 19.9.2016)]: 12.10.1945 in Befehl der SMA Brandenburg als eines von drei im Bezirk Lübben für die Aufnahme von „deutschen Umsiedlern“ geeigneten Lagern genannt, die dafür hergerichtet werden sollen (Wille I, S. 66). - 24.10.1945 vom Landratsamt in Bericht erwähnt mit Kapazität ,für 2000 Mann" (Töpler, Menschenwurm, S. 451). 19.11.1945: Kapazität 2000 Personen (Mietk, S. 19). - Im „Verzeichnis der errichteten und vorgesehenen Umsiedlerlager im Verwaltungsbezirk Cottbus“ vom 15.12.1945 mit „Personenzahl“ 2000 genannt (Töpler, Menschenwurm, S. 472). - 1945 „Errichtung eines Quarantänelagers in Krugau, das von Dr. [Karl oder Richard?] Michel und Lagerschwestern betreut wurde. Alle [in den Kr. Lübben geleiteten] Flüchtlinge und Heimkehrer mussten dieses Lager passieren, sofern sie nicht schon vorher ohne Krankheitssymptome im Land Brandenburg ansässig waren und an Immunisierungen teilgenommen hatten. Der Quarantänenachweis war Vorbedingung für die Anmeldung im Einwohneramt und für den Erhalt einer Lebensmittelkarte. Die höchste Frequentierung erreichte das Lager im Sommer 1946, als 1100 Sudetendeutsche die Quarantä- 
ne durchliefen, ehe sie in die Gemeinden des Kreises [Lübben] eingewiesen wurden“" (Liebert, S. 51). - Kapazität am 31.12.1945 (irrtümlich bezeichnet als Lager „Kargau“): 2000 (BArch, DO 2/45, Bl. 40). - Kapazität am 1.1.1946: 1500 (BLHA, Rep. 203 MdI, Nr. 1163, Bl. 51). 1946 Belegungsstärke: 2000 (Kaminsky, S. 159). - 24.8.1946 Umsiedlerlager, Kapazität: 1200 (SAPMO-BArch, DY 34/27880, B1. 291).

ARChivalische QueLLEn: BLHA, Rep. 250 Landratsamt Lübben, Nr. 306 („Verwaltung des Umsiedlerlagers (ehem.
Munitionsanstalt) Krugau“, 1946-1947); Nr. 598 („Umsiedlerlisten vom Lager Krugau und von den Gemeinden“,
1946); Nr. 601 („,Verwaltung des Lagers Krugau und Eingemeindung der Umsiedler“, 1946-1947); Nr. 604 („Tätig-
keit der Umsiedlergenossenschaften Krugau und Straupitz“, 1947-1949); Nr. 605 (desgleichen, 1948-1950). - Kreis-
archiv Dahme-Spreewald, A-1 Kreistag und Rat des Kreises Lübben, Nr. 1531 (Krugau, 1946-1953; enthält u. a.:
Umsiedlergenossenschaft).

GedRUCKTe QuelLen und Literatur: Becken, Jörg: Lübben nach dm Inferno. [Cottbus] 2010. - Liebert, Bodo: Lübben - der Wiederaufbau ab 1945. Die Reanimation des todkranken Gesundheitswesens. In: Lübbener Heimatkalender 2018 (2017), S. 39-60. - Töpler, Menschenwurm, S. 472. - Wille I, S. 66, 303.

\section{Küchensee}

Wohnplatz (seit 1950 Ortsteil der Stadt $\rightarrow$ Storkow), bis 1950 Kr. Beeskow-Storkow, 19501952 Kr. Fürstenwalde, 1952-1990 Kr. Beeskow (Bez. Frankfurt/Oder), 1990-1993 Ldkr. Beeskow, 1993 Ldkr. Oder-Spree

(Kreis-)Umsiedlerlager: Bei $\rightarrow$ Storkow, an der Chaussee Beeskow-Storkow, $2 \mathrm{~km}$ vom Bahnhof Storkow, im „unübersichtlichen Gelände“ (BLHA, Rep. 230 Bernau, Nr. 287, Bl. 17, 25, 34), am Küchensee gelegen (Tschechne, S. 42). Das ehem. Ausbildungslager der SS, ab 28.4.1945 (sowjet.) Kriegsgefangenenlazarett Küchsenee (für verwundete deutsche Soldaten, vgl. Lange, S. 54-56; rd. 400 Verwundete aus dem Kessel von $\rightarrow$ Halbe sind hier 1945 verstorben [Städtebuch, S. 490]; Tschechne, S. 42: „von hohem Maschendrahtzaun umgeben“) wurde im Okt. 1945 beschlagnahmt und als Umsiedlerlager hergerichtet (BLHA, Rep. 250 BeeskowStorkow, Nr. 867, unfol., Bericht vom 1.11.1945), Herrichtung als Umsiedlerlager für 1500 Personen ist laut Bericht vom 11.12.1945 nun „endgültigfertig gestellt“ (ebd.) [Das in der Findbucheinleitung BLHA, Rep. 356 Umsiedlerlager Küchensee und der Übersicht über die Bestände des Brandenburgischen Landeshauptarchivs. T. III/1. Berlin 2001, S. 84, genannte Eröffnungsdatum 26.8.1946 muss auf einem Irrtum beruhen.]. - 21.10.1945 Herrichtung einer Außenstation der kath. Pfarrei Storkow im Flüchtlingslager durch Pfarrer Paulus Dubianski (Töpler, Menschenwurm, S. 494). - Nov. 1945 sowohl als „Lager Küchensee“ als auch als „Umsiedlerheim am Küchensee“ bezeichnet (BLHA, Rep. 256 Küchensee, Nr. 16, unfol.); Dez. 1945 „Lagerleitung des Umsiedlerheims Küchensee“ (ebd.), Jan. 1946 sowohl als „Umsiedlerheim Küchensee“ als auch als „Flüchtlingslager Küchensee“ bezeichnet (ebd.). - Kapazität am 31.12.1945: 1500 (BArch, DO 2/45, Bl. 40). - Kapazität am 1.1.1946: 1600 (BLHA, Rep. 203 MdI, Nr. 1163, Bl. 49). 1946 Quarantänelager. Holzbaracken. Kapazität 1946 bis 1700 Personen (BLHA, Rep. 230 
Bernau, Nr. 287, Bl. 18); provisorisches Krankenhaus in der benachbarten Villa „Seeburg“ am Küchensee (heute Restaurant), benachbart auch Friedhof (Soldaten u. Flüchtlinge) (Rölke, S. 34). - 1946 Belegungsstärke: 1600 (Kaminsky, S. 159), außerdem auch Heimkehrerlager mit Belegungsstärke 100 (ebd., S. 160). - 14.2.1946 Kreis- und Quarantänelager, Kapazität: 1600 (Oehlsen, S. 28). - 30.4.1946 als eines der verbleibenden Umsiedlerlager genannt (DAB, I/9-15-1 Flüchtlingsseelsorge 1945-1951, unfol., [30.6.1946], [Anlage 3]). - 24.8.1946 Umsiedlerlager, Kapazität: 1500 (SAPMO-BArch, DY 34/27880, B1.291). - 1.1.1947 Lager, Kapazität: 1800 (Oehlsen, S. 101). - 9.6.1947 Quarantänelager, Kapazität: 1 500, Belegung: 1543, Quarantäne beendet am 18.6. (SAPMO-BArch, DY 34/27880, B1. 239). - 1947 DEFA-Dokumentarfilm in der Kino-Wochenschau „Der Augenzeuge 1947/76“ (14 Minuten) zeigt u. a. Baracke und Krankenstation im Quarantänelager Küchensee (www.defa-stiftung.de, www.progress-film.de [10.7.2018]); 13.10 .1947 für 14.10. Aufführung des „auf Veranlassung der Landesregierung Brandenburg hergestellte(n) Film(s),Küchensee“" [tatsächlich aber nur kurze Sequenz von 1 Minute, 26 Sekunden innerhalb o.g. Films) in Berlin vorgesehen (BArch, DO 2/38, Bl. 302); 14.10.1947 „Telefonischer Anruf [der ZVU] bei Herrn [Paul] Sch midt, Produktionsleiter der Wochenschauen, wegen Uraufführung des Films, Küchensee'. / Herr Schmidt teilt mit, dass es sich nicht um eine Uraufführung, sondern um eine Probevorführung des Films handelt, an der nur einige besonders interessierte Stellen teilnehmen sollen./Die für heute geplante Vorführung musste aus technischen Gründen um eine Woche verlegt werden. [...].“ (ebd., Bl. 303). Inhaltangabe: „Umsiedlerlager Küchensee bei Storkow (41 m) [...]; Quarantänestation: Totale auf an Zaun angebrachte Schilder: ,Kreis-Umsiedlerlager Küchensee - Zutritt strengstens verboten!', ,Quarantänelager - Das Betreten des Geländes ist verboten! Die Lagerleitung' (deutsch und kyrillisch); v.E. vom Lagerleben, darunter Schwenk über Lagergelände mit Umsiedlern, Kiosk ,Zeitungen, Zeitschriften' und langen Baracken; Totale auf in Regal gelagerte Arzneien der Krankenstation; Lagerarzt bei der Behandlung und Untersuchung von Umsiedlern; Krankenschwester auf Krankenstation gibt im Bett liegender alter Frau Medizin; Frau beim Wäschewaschen mit Waschbrett im Freien; Männer beim Rasieren an Waschbecken im Freien; Lagerkoch mit Kochmütze in Lagerküche bei der Zubereitung von Fleisch; Verteilung von gekochten Kartoffeln und gebratenem Fleisch; Umsiedler Paul Sattler (Drucker und Grafiker) beim Sortieren seines Zeichenmaterials sowie an seinem neuen Arbeitsplatz als Faktor mit Kollegen an Druckmaschine in einer Druckerei in Potsdam-Babelsberg [...]; Menschen, darunter Arthur Sörgel, im Umsiedlerlager an Schalter mit Namenszug ,Postannahme - Telegrammannahme 14-17 Uhr' anstehend und an seinem neuen Arbeitsplatz als Klavierspieler in einem Orchester mit Stehgeiger in Storkow [...] während eines Konzerts; Totale auf applaudierende Zuschauer; Totale auf Ehepaar Goldene Hochzeit mit Blumen und Zahl ,50` auf dem Tisch im Freien und umringt von Umsiedlern im Lager feiernd; Totale auf Kinder mit Erzieherinnen im Umsiedlerlager an langen Tischen im Freien Kirschen essend; Totale auf Kinder auf Kettenkarussel aus Holz und angetrieben per Muskelkraft von den Kindern“. (www.defa-stiftung.de, Filmdatenbank [10.7.2018]). - 23.10.1947 „Küchensee Krs. Beeskow-Storkow“ als Zielpunkt für 
den 2. Transport aus dem sowjet. Teil Ostpreußens vorgesehen (Wille II, S. 117). - Ende Okt. 1947 Transport aus dem sowjetisch besetzten Teil Ostpreußens (2 300 Personen) (I. Aktion) (Wille II, S. 136), Anf. April 1948 II. Aktion (1661 Personen) (ebd.), III. Aktion Ende Aug. (2 027) und Okt. 1948 (2 130) (S. 137); April 1948 Ankündigung bevorstehenden 14-tätigen Quarantäneaufenthalts eines Transports aus dem sowjetisch besetzten Teil Ostpreußens (Wille II, S. 127). - Jan. 1948 (Anf./Ende) laut Lagerbestandsmeldung vom 10.2.1948 im Lager 0 / 0 Insassen (BLHA, Rep. 203 MdI, Nr. 1115, Bl. 7). - 25.11.1947 „Aufnahmefähigkeit von 1500 Mann, Quarantänelager für Umsiedler“ (BLHA, Rep. 302, VP, Nr. 9, Bl. 43). - 31.12.1947, Jan./Febr. 1948 Umsiedlerlager Küchensee eines von 7 verbleibenden Lagern in Brandenburg (BLHA, Rep. 203 MdI, Nr. 1198, Bl.28v). - 3.6.1948 Eröffnung eines Erholungsheims für Heimkehrer im Umsiedlerlager Küchensee Umsiedlerlager (BLHA, Rep. 203 MdI, Nr. 1198, Bl.34). - Aug. 1948 Stempel „Heimkehrer-Erholungsheim Küchensee Kreis Beeskow-Storkow“ (Rep. 256 Küchensee, Nr. 166, unfol.). - Okt./Nov. 1948 Umsiedlerlager Küchensee eines von 5 Lagern in Brandenburg (BLHA, Rep. 203 MdI, Nr. 1198, Bl. 46). - „Seit Ende 1948 wurden zunehmend auch heimatlose Heimkehrer aufgenommen und vierwöchige Erholungsaufenthalte für Heimkehrer durchgeführt." (Hartisch). - 22.2. bis 14.3.1949 vorübergehende Aufnahme von Kindertransporten (ca. 850 Kinder) zur Weiterleitung in die britische Zone (Weidner, S. 72-75). - 26.4.1949 noch in Lagerliste genannt (BLHA, Rep. 203 MdI, Nr. 1198, Bl. 66). Im Juni 1949 ist das Umsiedlerlager Küchensee aufgelöst worden. Lagerleiter zuletzt: Halbach; Aufnahmekapazität zuletzt: 1500 Personen; „Verwendungszweck: Zeitweilige Aufnahme von Umsiedlern bis zu ihrer Eingemeindung. Das Kartenmaterial des Lagers Küchensee ist durch die Landesreg.[ierung] - Abt. Umsiedler u. Heimkehrer - für den "Suchdienst" sichergestellt." (BLHA, Rep. 203 MdI, Nr. 1198, Bl. 69v); „1950 endgültig aufgelöst“ (Bretschneider). - Anschließend Errichtung einer Polizeischule im ehem. Lager (BLHA, Rep. 250 Beeskow-Storkow, Nr. 824, unfol., Schreiben vom 17.9.1949).

LAGERPERSONAL: Lagerleiter: Febr. 1946 Kurt Neubacher, zuvor Fred Burggraf, Nov. 1946 Fritz Piepenburg [vgl. Lager Fürstenwalde!] (BLHA, Rep. 230 Bernau, Nr. 287, Bl. 18), 22.7.1946 der „ehemalige Lagerleiter Zirkel“ erwähnt (BArch, DO 2/38, Bl. 290); 1.8.1946 Piepenburg als „Nachfolger des verhafteten bisherigen ersten Lagerleiters, Kurt Neubacher" bezeichnet (ebd., Bl. 295); Lagerarzt Dr. [Wolfgang] Gattig [geb. 1911] „hat täglich nur wenig Zeit für das Lager, da er neben seiner Haupttätigkeit im Krankenhaus Hubertushöhe noch mit vielen Kreisaufgaben betraut ist." (ebd., Bl. 296). - 15.11.1946: Lagerleiter: Fritz Piepenburg; Wirtschaftsleiter: Leo Kunz; Lagerarzt: Dr. [Rulemann] v. Hoff (BLHA, Rep. 230 Bernau, Nr. 287, B1. 17, 34) [v. Hoff war bereits vor 1945 Arzt in Storkow (Reichs-Medizinal-Kalender 1937, T. 2, S. 161)]. - Lagerpersonal am 1.1.1948: Lagerleiter: Piepenburg; Wirtschaftsleiter: Kunz; Lagerarzt: Dr. v. Thal (BLHA, Rep. 333, Nr. 575, Bl. 27 [Liste der leitenden Angestellten]). - Lagerleiter Febr./März 1949 (lt. Weidner, S. 75): Leo Kunz (zuvor in Kyritz). - Lagerleiter laut BLHA-Findbuch Rep. 256 Umsiedlerlager Küchensee, S. 1: „Herr Zirkel, Herr Piepenburg (ab 1946), Herr Liebelt, Herr Heidlas (ab Juni 1949 kommissarisch).“ - „Im Lager waren durchschnittlich 27 Angestell- 
te beschäftigt. Es verfügte u. a. über Kindergarten, Lagerbibliothek, Sanitätsbaracke, Küche und Werkstätten. Für schulpflichtige Kinder wurde der Unterricht im Lager abgehalten." (Torsten Hartisch in: BLHA-Findbuch Rep. 256 Umsiedlerlager Küchensee).

Katholiken: 21.10.1945 Eröffnung einer Außenstation für vierzehntätigen kath. Gottesdienst im Flüchtlingslager (6-13 Besucher) durch den kath. Pfarrer (Lokalisten) [Paul] Dubianski in $\rightarrow$ Storkow (Bericht Dubianski vom 31.1.1946, in: Töpler, Menschenwurm, S. 494).

Archivalische Quellen: BArch, DO 2 ZVU, Nr. 38, Bl. 284-290, 294-313 (Lager Küchensee, 25.2. - 22.7.1946, 1.8.1946-16.3.1949). - BLHA, Rep. 203 MdI, Nr. 1180 (Umsiedlertransporte aus Polen und der Sowjetunion, 1949; enthält u. a.: Transporte über Küchensee). - Rep. 230 Oberlandratsamt Bernau, Nr. 287, Bl. 17-18, 31-43. - BLHA, Rep. 256 Umsiedlerlager Küchensee (4,8 lfm, 1945-1950). - BLHA, Rep. 333 SED-Landesleitung Brandenburg, Nr. 578 („Heimkehrerlager“, 1946-1949; enthält u. a.: Küchensee).

Gedruckte Quellen: Töpler, Menschenwurm, S. 494, 609. - Wille I, S. 260 f. - Erinnerungsberichte: Dokumentation der Vertreibung I/2, S. 862. - Below, Ruth: Wie ich zu meiner neuen Heimat fand. In: Geschichten aus sieben Jahrzehnten. Storkower Zeitzeugen berichten. Storkow 2005, S. 52-53 [1946 Quarantäneaufenthalt im Lager Küchensee]. - Hübner, Hans: Meine Kindheit und der schwere Anfang in Kiekebusch. In: Ingelore Kundoch / Dietrich Kundoch / Hans-Jürgen Nossack: Chronik Kiekebusch. Schönefeld [2009], S. 47-51, hier S. 48 f. [4.-18.6.1947 Quarantäneaufenthalt im Lager Küchensee (Vertriebenenfamilie aus Kr. Hirschberg/Schlesien)]. - Lange, Günter: Glück oder Schutzengel. In: Damals und heute. Storkower Zeitzeugen berichten. Storkow 2003, S. 54-56 [Genesungsaufenthalt als deutscher Soldat im sowjetischen Kriegsgefangenenlazarett Küchensee, 2.5. bis 1.9.1945]. - Rölke, Hildegard: Erinnerungen an den Aufenthalt im Flüchtlingslager Küchensee. In: ebd., S. 33-34 [Ostpreußin, aus Lager Angermünde kommend, ab 9.2.1946 vierwöchiger Aufenthalt im Lager Küchensee, beschreibt Wohnsituation]. - Weidner, Dagmar: 1949: Tage in Küchensee. In: ebd., S. 72-75 [Betreuung von Kindertransporten im Lager Küchensee, 21.2. bis 14.3.1949].

Literatur: HOL IX, S. 261 (Art. Storkow, ohne Erwähnung des Lagers). - Ast/Mauersberger, S. 45 (Fotos). - Müller, Wolfgang: Nachkriegsjahre in Eichwalde. Eichwalde [2007], S. 108, 110 (Einweisungen aus dem Lager Küchensee nach Eichwalde, 1947/48). - Tschechne, Gerd: Das Kriegsende in und um Storkow (Mark). Storkow (Mark) 2005, S. 42. - Übersicht über die Bestände des Brandenburgischen Landeshauptarchivs. T. III/1. Berlin 2001, S. 84. - Weigelt, Andreas: (Außenlager) Storkow. In: Der Ort des Terrors. Hrsg. von Wolfgang Benz u. Barbara Distel. Bd. 3. München 2006, S. 274-275.

\section{(Küstrin-)Altdrewitz}

Bis 1945 Landgemeinde im Kr. Königsberg/Nm., seit 1945 zu Polen (Kostrzyn)

Durchgangslager FÜR UMSIEDler 18.10.1945 errichtet (BLHA, Rep. 211, Nr. 1976, Bl. 42), 21.10.1945 bis 13.11.1945 nachgewiesen. - Lager-Sanitäts-Bereitschaft, Chefarzt Dr. H. Wagner (berichtet täglich in deutscher und russischer Sprache 31.10. bis 13.11.1945 an den Umsiedlerleiter des Flüchtlingsdurchgangslagers $\rightarrow$ Küstrin-Neustadt sowie nachrichtlich an den Landrat $\rightarrow$ Lebus, Kreiskommandantur $\rightarrow$ Seelow und Ortskommandantur Küstrin).

Archivalische Quellen: BLHA, Rep. 211 Ministerium für Gesundheitswesen, Nr. 1076, Bl. 21-34, 67-77 (vgl. Quellenteil, Nr. 30). - BArch, DO 2/105 (Berichte); DQ1/81 (Berichte). 
Gedruckte Quellen und Literatur: Gespräche mit ehemaligen Küstrinern über Küstrin, Vertreibung und Neuanfang in Küstrin-Kietz und anderswo. Aufgez. u. bearb. von Siegfried Neubauer. Bd. 1-7. Petershausen bzw. ab Bd. 4 Frankfurt (Oder) 1999-2018. - Steinhauf, Andy: Das Auffanglager Küstrin/Alt-Drewitz 1945. In: www.cuestrin.de [online seit 5.9.2019].

\section{Küstrin-Kietz}

Landgemeinde (1929-1945 Stadtteil von Küstrin, Kr. Königsberg/Nm., seit 31.12.1997 [mit $\rightarrow$ Gorgast und Manschnow] Ortsteil von Küstriner Vorland), 1945-1946 (Rest-)Kr. Königsberg/Nm. 1946-1950 Kr. Lebus, 1950-1990 Kr. Seelow (Bez. Frankfurt/Oder), 1990-1993 Ldkr. Seelow, 1993 Ldkr. Märkisch-Oderland, seit 31.12.1997 Ortsteil der Gemeinde Küstriner Vorland (mit $\rightarrow$ Gorgast und Manschnow)

Ortsname: bis 1929 Kietz, 1929-1946 Küstrin-Kietz, 1946-1954 Kietz b. Küstrin, April bis Juli/Aug. 1954 vorübergehend „Friedensfelde“ (lokal, nichtamtlich), 1954-1991 Kietz, seit 3.10.1991 Küstrin-Kietz (Blöß, Kreise und Gemeinden, S. 142; Rogge, S. 63, Steinhauf/www. cuestrin.de).

EREIGNISSE BIS KRIEGSENDE: 31.1.1945 In Libbenichen (Kr. Lebus) einquartierte „Flüchtlinge aus Kietz bei Küstrin“ erwähnt, die am 8. Febr. weiterreisen (Ein leidgeprüftes Land, S. 152). 30.3.1945 Einmarsch der Roten Armee in Küstrin-Kietz (Kohlase, S. 150). - Der Ortsteil Kietz war bei Kriegsende zu $98 \%$ zerstört (ebd., S. 151).

EREIGNISSE NACH KRIEgSENDE: Ende Juni 1945 Durchzug von Vertriebenen aus dem Kr. Oststernberg: „Am 30. Juni gegen zehn Uhr habe ich meine Frau in eine Decke gewickelt auf dem Friedhof in Küstrin-Kietz beerdigt. Sie liegt in einem Massengrab am Weg vom Eingang rechts und wurde dort unter der Nummer 256 registriert." (Gerlach, S. 577; vgl. Schicksal in Zahlen, S. 175: Kriegsgräberstätte mit ca. 205 Kriegstoten). - 15.3.1946 (Datum des Inkrafttretens) der westlich der Oder gelegene Teil von Küstrin durch Beschluss des Präsidiums der Provinzalverwaltung vom 25.1.1946 über die Auflösung des Restkr. Königsberg/Nm. dem Landkr. Lebus zugewiesen, aber schon zuvor vom Lebuser Landrat in die Verwaltung seines Landkr. einbezogen (Blöß, Kreise und Gemeinden, S. 142). - Zu Küstrin-Kietz gehört auch die „Oderinsel“ (ehemals zu Küstrin-Altstadt) sowie ein bis 1990 für den Militärverkehr genutzter Grenzbahnhof (Danyel/ Kaule/Zündorf, S. 48). - 1949 wurde hier in einem Wagen der Goßner-Mission mit der Aufschrift „Evangelische Kirche Brandenburg“ „u. a. die Christenlehre gehalten“ (Kirchen im Oderbruch, S. 29, Foto 170). - 1962-1974 Wasserversorgung der Gemeinde Kietz durch das polnische Wasserwerk Kostrzyn (Bräuning 2020).

EREIGNISSE NACH 1990: [Nach 1990]: „In Kietz dient das frühere Wohnhaus des Superintendenten von Küstrin als Kirchsaal für die Gemeinde." (Kirchen im Oderbruch, S. 79). 30.5.1992 „Eröffnung des Eisenbahnüberganges Küstrin-Kietz/Kostrzyn (Küstrin-Neustadt) für den Schienenpersonenverkehr. [...].“ (MOZ.de, 9.3.2017 [18.8.2018]; Stadt Müncheberg, 
S. 17; Dawidowski, S. 101: „Damit endete der Dornröschenschlaf der geteilten Stadt. [...],Am 30. Mai 1992 war es dann soweit. Gegen 8 Uhr wurde die Menschenmenge auf dem Bahnhofsvorplatz in Küstrin-Kietz immer größer. Einwohner und Gäste, Interessierte und ehemalige Einwohner versammelten sich hier. Gegen 9 Uhr fuhr ein Sonderzug mit Eisenbahnfreunden aus Berlin ein, natürlich mit Dampflok und historischen Waggons. Gegen 9.15 Uhr traf die polnische Prominenz mit dem Wojewoden Zbiegniew Pusz an der Spitze ein. Um 9.30 Uhr fuhr der Sonderzug mit dem Ministerpräsidenten Stolpe und Hemjö Klein, Mitglied-Vorstand DR/DB [Deutsche Reichsbahn/ Deutsche Bundesbahn], ein. [...] Nach 47 Jahren Unterbrechung wird wieder der Reisezugverkehr auf der alten ,Ostbahn' aufgenommen. [...] Die Fahrt führte vom Bahnhof Küstrin-Kietz über die Odervorflutbrücke, über die Oderbrücke, über die Warthevorflutbrücke, über die Warthebrücke zum Bahnhof Küstrin-Neustadt (Kostrzyn) und dauerte fünf Minuten' [...]. Kostrzyns Bürgermeister Wladyslaw Mysona empfing dort den ersten Reisezug. Stolpe überreichte Mysona einen rot-weißen Regenschirm, ein Symbol gemeinsamer Landesfarben." (Ulf Grieger in: MOZ. de, 9.3.2017, darin Zitat Martin Rogge, Vorsitzender des Vereins für die Geschichte Küstrins [18.8.2018]). - 21.11.1992 Grenzöffnung auch für den Straßenübergang (MOZ.de, 9.3.2017 [18.8.2018]; Dawidowski, S. 101). [Bericht 2017:] „[...] Die alte sechsfeldrige Brücke war im Krieg zerstört worden. Vor 70 Jahren wurde die Brücke teilweise aus Resten der alten wieder aufgebaut. Der polnische Brückenteil war ein Stahlbetonüberbau und sanierungsfähig. Auf der deutschen Seite bestand die Brücke aus zwei Feldern einen Stahlfachwerkbogenkonstruktion und einem Brückengerät der Wehrmacht. Da keine Sanierung mehr möglich war, wurde eine Behelfsbrücke aus dem Katastrophenbestand des Bundes errichtet. / [...] / Auf deutscher Seite errichtete man bis zur Odermitte eine Behelfsbrücke aus vorgefertigten Teilen als Durchlaufkonstruktion. Ende Juli erfolgte der teilweise Abriss der alten Stahlkonstruktion für den bevorstehenden Einschub der neuen Brücke. Die neue wurde zu einem Block von etwa 20 Metern montiert und dann in die alte Brücke eingeschoben. [...] / [..] Viele Menschen beiderseits der Oder begegneten sich an diesem Tag [21.11.1992]. Getrübt wurde die Freude auf polnischer Seite dadurch, dass Polen noch immer nur mit Pass nach Deutschland einreisen durften. / ,Auf der Flußmitte wurde der historische Augenblick vollzogen. Brandenburgs Ministerpräsident Manfred Stolpe und der Wojewode von Gorzow Zbiegniew Pusz durchschnitten das Band und gaben den Verkehr auf dieser Straße frei', berichtete Martin Rogge. Und er fragte: ,Was mag wohl den Menschen bei dieser Szene durch den Kopf gegangen sein: Trecks von Flüchtlingen, Festung Küstrin, Rückzug der Wehrmacht, Einnahme durch die Rote Armee, Kriegsgefangene, Vertriebene nach Westen, geteilte Stadt, eine Brücke - eine Hoffnung, Markt, Einkaufen ... ? / [...]." (Ulf Grieger in: MOZ. de, 9.3.2017 [18.8.2018]). - 2008 Start des privaten Internetportals www.cuestrin.de (Titel: „Küstrin - Die Stadt an Oder und Warthe. Die Geschichte der ehemaligen Festungs- und Garnisonstadt auf Cuestrin.de“) des in Küstrin-Kietz aufgewachsenen Andy Steinhauf (geb. 1977), Frankfurt (Oder), mit einer laufend wachsenden Zahl historischer Themenbeiträge, auch zu Küstrin-Kietz, z. B. dessen Bahnhof, und zum Auffanglager Küstrin/Alt-Drewitz 1945. - Bevölkerungsgeschichtliche Bilanz 2019: „In Küstrin-Kietz sind die meisten zugezogen. Irgendwann. 
Sie kamen [1945] als aus dem Ostteil der Stadt Küstrin Vertriebene, [nach 1945] als Eisenbahner oder, in jüngerer Zeit sind das immer mehr, als polnische Bürger, die im boomenden Industriegebiet Kostrzyn-Słubice Arbeit haben und auf Wohnungssuche sind. Wohnungen sind rar im Grenzgebiet Polens. Meist bringen die Zugezogenen Kinder mit, die in Manschnow betreut und beschult weren. Ein Prozess, der ungesteuert läuft." (Grieger 2020, S. 74).“

BeVÖLKeRUNGSZAHLEN: 1925: 715, 1939: 900, 29.10.1946: 1 156, 1950: 1419, 1964: 1350 (HGV MOL, S. 22f.).

Katholiken (bis 1994 Erzbistum Breslau/Erzbischöfliches Amt Görlitz, dann Erzbistum Berlin): 1954: 60 (Schematismus Görlitz 1954, S. 36).

Gemeindepartnerschaft der Gemeinde Küstriner Vorland: Kostrzyn, Polen (Küstrin) (wikipedia.org/wiki/Kostrzyn_nad_Odrą [14.12.2019]).

Archivalische Quellen: BArch, DO 2 ZVU, Nr. 39, Bl. 3, 5.

Gedruckte Quellen und Literatur: Blöß, Kreise und Gemeinden, S. 142. - Bräuning, Uwe: Die Entnazifizierung in Küstrin-Kietz 1945-1950; ders.: Zerbrechlich wie Glas - als Küstrin-Kietz in den Fokus deutsch-polnischer Beziehungen geriet; ders.: Kietz Kreis Seelow - Ein Dorf unter Spionageverdacht; veröffentlicht 2016 auf https://ku estrinkietz.wordpress.com [6.1.2017]. - Ders.: Wasser für Kietz - vom jähen Ende eines grenzüberschreitenden Projektes. In: Jahrbuch Märkisch-Oderland 27 (2020 [2019]), S. 94-96. - Danyel, Jürgen / Kaule, Martin / Zündorf, Irmgard: Brandenburg 1945-1990. Berlin 2018, S. 47 f. („Grenzbahnhof und Garnison Küstrin-Kietz“). - Dawidowski, Rudolf: Gedanken zur Öffnung des Grenzüberganges Küstrin. In: Königsberger Kreiskalender 1994 (1993), S. 101104. - Fudel, Torsten: Der Krieg an der Oder. Seelow 2011. - Gerlach, Otto: Meine Erlebnisse beim Einmarsch der Russen im Jahr 1945. In: Heinz W. Linke / Heinz Paschke: Das Sternberger Land. Iserlohn 1988, S. 575-578. - Gespräche mit ehemaligen Küstrinern über Küstrin, Vertreibung und Neuanfang in Küstrin-Kietz und anderswo. Aufgez. u. bearb. von Siegfried Neubauer. Bd. 1-7. Petershausen bzw. ab Bd. 4 Frankfurt (Oder) 1999-2018. - Grieger, Ulf: Die vereinten Zugezogenen. In: Jahrbuch Märkisch-Oderland 27 (2020 [2019]), S. 74-76. - Kirchen im Oderbruch und ihre Schicksale seit dem Frühjahr 1945. Berlin 1992, S. 79, 169 f. - Kohlase, Fritz: Küstrins Untergang im Jahre 1945. In: Königsberger Kreiskalender 2006, S. 145-152. - Kriegstagebuch des OKW 4,2, S. 1161. - Ein leidgeprüftes Land. Bearb. von Fritz Knüppel. 2. Aufl. Barsinghausen 1990. - Lissner, Wilhelm: Verwehte Spuren. Münster 2006, S. 88-94 [Kriegsgefangenenlager Küstrin-Kietz, 1945]. - Rogge, Martin: Seit dem 3. Oktober 1991 wieder: KüstrinKietz. in: Königsberger Kreiskalender 1993 (1992), S. 63-67. - Rohr, Joachim: Der Kietzer Friedhof. In: Königsberger Kreiskalender 1995 (1994), S. 60-66. - Schicksal in Zahlen 5. Aufl. Kassel 1997. - Stadt Müncheberg von 1991 bis 2014. Müncheberg 2015. - Steinhauf, Andy: Die wirschaftliche Entwicklung in Küstrin-Kietz von 1945 bis 1995. Ein Report. Frankfurt (Oder) 2018. - Ders.: Die Geschichte der Stadt Küstrin auf www.cuestrin.de: Ein Arbeitsbericht. In: Arbeitsbericht der Arbeitsgemeinschaft ostdeutscher Familienforscher (2019)4, S. 30-31. - Töpler, Menschenwurm, S. 487 f. - Waack, Christoph: Stadträume und Staatsgrenzen. Geteilte Grenzstädte des mittleren und östlichen Europa im Kontext lokaler Alltagswelten, nationaler Politik und supranationaler Anforderungen. Leipzig 2000, S. 56-61. - Wille I, S. 260 f., 459 


\section{Küstrin-Neustadt}

Stadtgemeinde, bis 1945 Kr. Königsberg/Nm., seit 1945 zu Polen (Kostrzyn)

EReignisse bis KRIEgSende: [1945:] „Die Städte $[\rightarrow$ ] Frankfurt/Oder und Küstrin wurden zu Festungen erklärt. Während der Vorstoß auf Frankfurt/Oder östlich der Stadt schon bei Kunersdorf scheiterte, gelang es vorgeprellten russischen Einheiten beiderseits Küstrin die zugefrorene Oder zu überschreiten und Brückenköpfe zu bilden. Ende Januar drangen Panzerspitzen in Küstrin-Neustadt rein und richteten überall große Verwirrung an, besonders unter den vielen Flüchtlingstrecks, die auf die Küstriner Brücken bei ihrer Flucht in Richtung Westen angewiesen waren. Die Neustadt wurde dann am 2./3. Februar von den Russen besetzt." (Ein leidgeprüftes Land, S. 17).

DURChgANGSLAGER FÜr UMSIEDLER (Lager I und II): Auch als „Durchgangslager für Umsiedler Küstrin“ und „Flüchtlingsdurchgangslager Küstrin“ bezeichnet. - 1.12.1945 zwei Flüchtlingsumsiedlerlager erwähnt (der kath. Pfarrer Alois Pech, z. Zt. in Wiesenburg (Mark), will sich „sofort nächste Woche nach dort begeben, um möglichst bald nach dort zu übersiedeln und seelsorglich zu arbeiten " (Gespräche, Bd. 7, S. 126). - 11.11. bis 3.12.1945 nachgewiesen, Lager dann geschlossen, anschließend Lager in $\rightarrow$ Wriezen. - Lager-Sanitäts-Bereitschaft, Chefarzt Dr. H. Wagner (berichtet täglich in deutscher und russischer Sprache 11.11.-4.12.1945 an den Umsiedlerleiter des Flüchtlingsdurchgangslagers Küstrin-Neustadt sowie nachrichtlich an den Landrat des Kr. Lebus [bis 15.11.: Landrat/Kommandantur], Kreiskommandantur Seelow, [bis 15.11. auch: Lagerverwaltung] und Ortskommandantur Küstrin). - Personal am 1.12.1945: Leiter („Umsiedlerleiter für das Flüchtlingsdurchgangslager Küstrin"): Rühe; Lager-Oberarzt für Lager I: Med. Rat Dr. [Rudolf] Görlach (i.V.: Dr. [Otto] Kalteis [Bl. 35: er im Lager eingetroffen 28.11.]); Abt.-Ärzte: Dr. Knapp, Dr. Kaminski; Lager-Oberarzt für Lager II und Stellvertreter (des Chefarztes): Dr. [Giuliano?] Moretti [auch 30.11.1945 anwesend, führt seit 18.10. Entbindungen $\operatorname{durch}(\mathrm{Bl} .42)]$.

Archivalische Quellen: BArch, DO 2 ZVU, Nr. 39, Bl. 34-38, 58, 63-84 (beide Küstriner Lager, 1945). - BArch, DO 2/105 (Umsiedlerlager Küstrin und Wriezen. Berichte der Schutzpolizei Küstrin-Neustadt, 1945-1949, enthält u. a.: Plan des Lagers Küstrin). - BLHA, Rep. 211 Ministerium für Gesundheitswesen, Nr. 1076, Bl. 2-23, 35-66 (vgl. Quellenteil, Nr. 34-36).

Gedruckte Quellen und Literatur: Ein leidgeprüftes Land. Bearb. von Fritz Knüppel. 2. Aufl. Barsinghausen 1990. - Gespräche mit ehemaligen Küstrinern über Küstrin, Vertreibung und Neuanfang in Küstrin-Kietz und anderswo. Aufgez. u. bearb. von Siegfried Neubauer. Bd. 1-7. Petershausen bzw. ab Bd. 4 Frankfurt (Oder) 1999-2018. Wille I, S. $260 \mathrm{f}$. 


\section{Kuhbier (Kr. Ostprignitz) $\rightarrow$ Kuhsdorf}

\section{Kuhsdorf}

Landgemeinde (seit 31.12.2002 Ortsteil von Groß Pankow), bis 1952 Kr. Ostprignitz, 19521990 Kr. Pritzwalk (Bez. Potsdam), 1990-1993 Ldkr. Pritzwalk, 1993 Ldkr. Prignitz

1.2.1945: „Die ersten Trecks aus dem Warthegau ziehen durch den Ort." (Tagebuch Pfarrer Salefsky in Chronik Kuhsdorf, S. 129). - 5.2.1945: „Täglich fahren jetzt Flüchtlinge aus dem Warthegau durch den Ort. Sie sind Mitte Januar zu Hause aufgebrochen bei starker Kälte und viel Schnee. Viele sind unterwegs umgekommen - vor allem Kinder.“ (ebd.). - 10.2.1945: „In Kuhbier übernachten über 2000 Flüchtlinge; jedes Haus ist mit 30-40 und mehr Menschen belegt. Viele bleiben trotz strömenden Regens auf ihren Wagen liegen - teilweise auch aus Furcht vor Diebstahl. In der Pfarrscheune waren 20 Pferde untergebracht, im Stall 14. Wir haben wie auch an den Vortagen Frauen mit Kindern aufgenommen.“ (ebd.). - 16.2.1945: „Die Kuhsdorfer Schule ist mit zwei Flüchtlingsfamilien aus dem Kreise Leslau belegt. Die Bänke sind in den Kirchturm gestellt und im Schulraum ist Stroh geschüttet. [...]. Auch die Schulen in [Groß] Pankow und Kuhbier sind belegt.“ (ebd.). - 28.2.1945: „So fahren noch täglich $d[i e]$ Trecks aus dem Osten. Sie werden nach Osthannover weitergeleitet." (ebd., S. 130). - 4.3.1945: „In der Nacht brennt die volle Scheune von Reinhold Krugmann-Kuhsdorf ab. [...] Unvorsichtigkeit von Treckkutschern soll die Ursache des Brandes sein." (ebd.). - 15.3.1945: „Nur noch vereinzelt Flüchtlingswagen fahren hier durch. Die Trecks werden anders geleitet." (ebd.). 18.3.1945: „Sonntag Judica. In der dicht gefüllten Kuhsdorfer Kirche wurden heute 5 Mädchen und 6 Knaben - darunter auch 3 Flüchtlingskinder - aus Kuhsdorf und Mesendorf konfirmiert. [...]." (ebd.). - 15.4.1945: „Die Flüchtlinge füllen die Kirchen.“ (ebd., S. 131). - 16.4.1945: „Flüchtlinge aus Wittenberge, das von Artillerie beschossen wird, kommen nach Kuhsdorf und Kuhbier. Es sind vor allem ausländische Arbeiter, auch Frauen und Kinder, meistens Franzosen, aber auch Polen und andre. Sie haben seit Tagen nichts mehr gegessen. Das Elend auf den Straßen ist unendlich groß." (ebd.).

BevöLKeRUngSZAHLEN: 1925: 193, 1939: 275, 1946: 450, 1964: 308 (HOL I, S. 454).

Gedruckte Quellen und Literatur: Chronik der Pfarre zu Kuhsdorf. Transkribiert und vervielfältigt von Agnes u. Henning v. Kopp-Colomb. Haltern 2008, S. 128-131: Tagebuchaufzeichnungen von Pfarrer Herbert Salefsky, Jan. bis April 1945.

\section{Kuschkow}

Landgemeinde (seit 2003 Ortsteil der Gemeinde Märkische Heide), bis 1952 Kr. Lübben, 1952 1990 Kr. Lübben (Bez. Cottbus), 1990-1993 Ldkr. Lübben, 1993 Ldkr. Dahme-Spreewald

BEVÖLKERUNGSZAHLEN: 1925: 528, 1939: 506, 29.10.1946: 756, 1950: 667, 1964: 565 (HGV LDS, S. 26f.). - 1.5.1946: 662, davon 491 Ortsansässige, 171 „Umsiedler“ (Becken, S. 32). 
FLÜCHTLINGSLAGER (bis 1945 Barackenlager des Reichsarbeitsdienstes): 1945 erwähnt (Becken, S. 28). - 2.7.1945 Kurzaufenthalt eines am 23.6.1945 aus der Neumark Vertriebenen in Rot-Kreuz-Baracke in Kuschkow (Tagebuch Heinz Kayser im Archiv des Hauses Brandenburg in Fürstenwalde, hier nach Auswertung in http://www.zeitstimmen.de [25.5.2017]).

LiterATUR: Becken, Jörg: Lübben nach dem Inferno. [Cottbus] 2010.

\section{Kyritz}

Stadtgemeinde, bis 1952 Kr. Ostprignitz (Kreissitz), 1952-1990 Kr. Kyritz (Bez. Potsdam), 1990-1993 Ldkr. Kyritz, 1993 Ldkr. Ostprignitz-Ruppin

EREIGNISSE BIS KRIEGSENDE: „Die Flüchtlingsleitstelle befand sich damals [Febr. 1945] an der heutigen Ecke Prinzenstraße/Maxim-Gorki-Straße, der früheren Friedrichstraße." (Leske, S. 6). Die Flüchtlinge aus Stadt u. Kreis Meseritz kamen „vornehmlich in die Gegend um Kyritz/ Perleberg" (Stadt und Kreis Meseritz. [Bd. 1], S. 341).

EREIGNISSE NACH KRIEGSENDE: 2.9.1945 Verkündung des Bodenreformbeschlusses in einer Rede Wilhelm Piecks auf der Kreisbauernkonferenz des Kr. Ostprignitz im Kinosaal der Gaststätte „Zum Schwarzen Adler“ (später „Zum Prignitzer“) am Markt, Maxim-Gorki-Str. 25 (abgerissen) (Ast/Mauersberger, S. 86; Schmeissner, T. II, S. 79f.; Redetext: Stephan, S. 54-66). „Die Rede des damaligen KPD-Vorsitzenden Wilhelm Pieck ließ Kyritz zu einem Wallfahrtsort sozialistischer Geschichtsschreibung werden." (Ast/Mauersberger, S. 86). Hölzerne Gedenktafel am Haus nach 1989 entfernt (Abb. ebd.), noch erhalten ist das Bodenreform-Denkmal vor dem ehemaligen Kreiskulturhaus „Wilhelm Pieck“, Leninallee 8 [seit 1991 wieder Perleberger Straße] (ebd., Historischer Führer, S. 249; Abb.: Schmeissner, T. II, S. 77).

EREIGNISSE NACH 1990: 13.1. bis 17.3.2018 Ausstellung „Flucht-gestern und heute“ im Kulturhaus Kyritz, offizielle Eröffnung am 20. Jan. in Gegenwart der Bürgermeister von Kyritz und Wusterhausen und über 50 Gästen (BR 16 (2018)2, S. 6), zuvor gezeigt in $\rightarrow$ Oranienburg. „Die Idee zu der Wanderausstellung kommt aus Oranienburg (Oberhavel). Dort entstand sie in Zusammenarbeit unter anderem mit dem Bund der Vertriebenen (BdV) und dem Netzwerk Schule. Mehrere Oranienburger Schüler führten unter der Leitung ihrer Lehrerin Dagmar Jurat insgesamt 20 Interviews mit ihren Großeltern, vor allem aber auch ihnen zunächst völlig fremden MenschenGeflüchtete von Gestern und Heute. Sie sprachen gemeinsam über persönliche Erfahrungen zum Thema Flucht und Vertreibung. / Die verschiedenen Lebenswege der Befragten wurden dann auf 20 Schautafeln verewigt. Auf zehn Tafeln befinden sich hierbei die Geschichten von Fluchtopfern nach 1945, darunter der Kyritzer Alfons Zeh [geb. 1938 Obrawalde, Kr. Meseritz], der auch Mitglied im $B d V$ ist. Alfons Zeh bietet Führungen für Schulklassen durch die Ausstellung an, um auch den jungen Leuten dieses Thema näher zu bringen. / Auf den anderen Aufstellern berichten Flüchtlinge aus der gegenwärtigen Zeit von ihren Erfahrungen - so der 17-jährige Syrer Adnan Faour, der am Sonnabend 
im Kulturhaus auch anwesend war." (M.A.Z., Ostprignitz-Ruppin, 17.1.2018). Ausstellung anschließend gezeigt in $\rightarrow$ Neuruppin.

BevöLKerungszahlen: 1925: 5391, 1939: 6077, 1946: 8679, 1963: 8467 (Städtebuch, S. 269).

Katholiken: 1925: 167, 1946: 726 (Städtebuch, S. 269). 1953 (H1.-Geist-Gemeinde): 2700 (Brühe, S. 25).

UMSIEDLERLAGER (im ehem. Wanderheim): Okt. 1945 erwähnt als Umsiedlerlager („Wanderheim") [also vmtl. identisch mit dem später als Kinderheim/-dorf genutzten Gebäude, s. u.] (BArch, DO 2/39, Bl. 6-7). - Kapazität am 1.1.1946: 800 (BLHA, Rep. 203 MdI, Nr. 1163, B1. 50).

UMSIEDLERLAGER (in der evang. Kirche): „Das [katholische] Gotteshaus blieb im II. Weltkrieg unbeschädigt und diente zeitweilig auch der evangelischen Gemeinde zum Gottesdienst, als deren Kirche als Flüchtlingslager genutzt wurde." (Brühe, S. 25; textidentisch: Schwillus/Brühe, S. 330).

Kinderdorf, ab 1952 „Ernst Thälmann“, Perleberger Straße 62: Ab April 1949 Kinderheim „Kinderdorf Kyritz“ der Volkssolidarität Land Brandenburg, v.a. für Kindertransporte aus Ostpreußen (ab 1951 u.a. auch „Wolfskinder“), zuvor Standort einer Polizeieinheit (Gebäude eines ehemaligen Wanderarbeiterheims), diese 1949 im Tausch mit dem bisherigen Kinderheim-Standort nach $\rightarrow$ Pinnow (Kr. Angermünde) verlegt (Leiserowitz, S. 7, 36 f., 76 u. ö.; Winterberg, S. 180-188). - 1960 als Spezialkinderheim mit Kapazität von 200 Plätzen erwähnt (Sachse), noch 1987 erwähnt, heute Standort einer Seniorenresidenz (Sachse). - Nach 1990 jährliche Treffen ehemaliger Heimkinder, meist in einem Hotel im benachbarten Bantikow (BR 9 (2011), Nr. 8, S. 19; 15 (2017), 5, S. 10; 6, S. 11; 16 (2018), 5, S. 11): „Von ehemals 270 Heimkindern kommen etwa 30 noch einmal im Jahr zusammen. Beim Treffen im Mai [2015] waren sogar drei ehemalige Erzieherinnen dabei.“ (Möbius, S. 6). - 2018 Ausstellung des Heimatvereins Kyritz über das frühere Kinderheim (Bels). - 17.9.2019 Einweihung einer InfORMATIONSSTELE vor dem Haus, die „an die Geschichte dieses Gebäudes als Auffangstelle für heimatlose Kinder und Kinderheim nach dem Zweiten Weltkrieg“ erinnert, im Beisein von „etwa 20 Zeitzeugen, die als ostpreußische Kinder das Schicksal der ,Wolfskinder“ erleben mussten“, darunter „Heinrich Kenzler, der 1949 mit 14 Jahren zu den ersten gehörte, die in der Kyritzer Einrichtung Aufnahme fanden. In seinem Redebeitrag anlässlich de Einweihung der Info-Stele bekannte er: [... , Hier in Kyritz wurden aus uns wieder Menschen gemacht.“ [...] Es war die Gemeinschaft der Wolfskinder, von der die Initiative ausging, mit der Stele einen Erinnerungspunkt für das öffentliche Gedenken zu schaffen. So erinnerte der Vorsitzende der Kyritzer Stadtverordnetenversammlung Thomas Settegast (SPD) daran, dass der Begriff,Wolfskinder' erst in den 1990er Jahren publik wurde. Es gehe nun darum, die Erinnerung an diese Geschichte nicht wieder verblassen zu lassen." (BR 17 (2019)11, S. 11). 
StÄDtepartnerschaften: 2006 Wałcz, Polen (Deutsch Krone).

VERTRIEBENENVERBÄNDE NACH 1990: (1) BdV-Kreisverband Kyritz, (später:) BdV-Kreisverband Altkreis Kyritz e. V., gegründet 23.3.1991, 6.7.1991 Satzung errichtet, 27.8.1992 eingetragen beim Amtsgericht Kyritz (VR 419). 1996 Sitz Perleberger Str. 13 (BdV-Handbuch 1996, S. 218); 2009 Sitz Mühlenstr. 1 (Akten der BdV-Landesgeschäftsstelle); 2012 Informationsveranstaltung in $\rightarrow$ Wusterhausen, 1.5.2014 Geschäftsstelle Mühlenstr. geschlossen (MAZ, Kyritzer Tageblatt, 25.4.2014) u. Kontaktadresse nach Wusterhausen verlegt (MAZ, 12.7.2014).Mitgliederzahlen: Dez. 2005: 272, Dez. 2009: 205, Okt. 2010: 190, Ende 2013: 143. 2013/14 vorübergehend in Aufösung, hat rund 150 Mitglieder (MAZ, Kyritzer Tageblatt, 18.11.2013). Vorsitzende: (1992) Ernst-W. Draeger, Kyritz, (1996/97) Rosemarie Franz geb. Rachner, Wusterhausen/D. (geb. 1940), dann bis 2000 Horst Schnick, Wusterhausen/D. (geb. 1934, aus Groß Golmkau, Kr. Dirschau), dann bis zum Rücktritt am 28.8.2004 Helmut Hein, Neustadt/D. (geb. 1948) (MAZ, 6.10.2004), 2004-2014 wieder Schnick (anfangs u. zuletzt kommissarisch) (Akten wie vor), ab 2014 Sebastian Groß (Finanzbuchhalter in Wusterhausen/D., aus Demerthin, 201444 Jahre alt) (BR 12 (2014)8, S. 8; MAZ, 12.7.2014). - (2) 2006 Gründung des Vereins „Flämmchen e. V“" durch die 2002 nach Kyritz gekommene Kindergärtnerin Natalie (Natalyia) Schmidt (Vorsitzende) und neun weitere Spätaussiedler als „Hilfe und Unterstützung für Spätaussiedler“ (www.kyritz.de [16.6.2018]). „Ziel des Vereins ist es den Kontakt zwischen den Einheimischen und den Neubürgern zu fördern." (BR 4 (2006)1, S. 14).

Archivalische Quellen: BArch, DO 2 ZVU, Nr. 39, Bl. 6-7 (Umsiedlerlager „Wanderheim“, 1945).

GedRUCKTE Quellen: Wirtschafts-Wegweiser für Wittenberge und die Kreise West- und Ostprignitz. Branchen-Adreßbuch. Potsdam (1949), S. XIII (Dienststellen der Stadt), 49-134 (Firmen). - ERINnERUngsberichte: Bolduan, Waltraud: Das Kinderheim in Kyritz - Rettungsanker nach Flucht und Elend. In: BR 9 (2011)3, S. 10-11. - Leske, Arthur: Erinnerungen eines Schönermarkers an schicksalhafte Tage. In: BR 14 (2016) 8, S. 6-7. - Uhlemann, Karin: Kinderheim Kyritz: Jeder von uns erlernte einen Beruf. In: BR 9 (2011)5, S. 13. - Dies.: Erinnerungen an eine Kindheit ohne Eltern. In: ebd. 10 (2012)7, S. 6.

Literatur: Bels, Sandra: Erinnerung an die Wolfskinder. Heimatverein Kyritz eröffnete Ausstellung über das frühere Kinderheim in Kyritz. In: BR 16 (2018), 5, S. 11. - Brühe, Matthias: Katholische Kirche zwischen Prignitz und Havelland. Berlin 2000, S. 25. - Historischer Führer. Stätten und Denkmale der Geschichte in den Bezirken Potsdam, Frankfurt (Oder). Leipzig u. a. 1987. - Informationsstele erinnert an das Schicksal der Wolfskinder. In: BR 17 (2019)11, S. 11. - Leiserowitz, Ruth: Von Ostpreußen nach Kyritz. Potsdam 2003. - Möbius, Dagmar: Ehemalige Heimkinder treffen sich jährlich in der Ostprignitz. Kriegskinder und ihre Schicksale. (Erstdruck in: Der Märker, 8./9.5.2015). In: BR 13 (2015) 5, S. 6-7. - Noetzel, Andreas: Bemerkungen zur demokratischen Bodenreform am Beispiel der Region Kyritz. In: Jahrbuch Ostprignitz-Ruppin 25 (2016), S. 217-237 [betr. auch Stadt Kyritz]. Sachse, Christian: Informationen zu Brandenburger Spezialheimen, Fassung vom 19.6.2012, www.christian-sachse. de (27.4.2016). - Schmeissner, Dorte: Kyritz, die Stadt der Bodenreform. T. I. In: Jahrbuch Ostprignitz-Ruppin 15 (2006), S. 77-87. - Dies.: Dass. T. II. In: ebd. 17 (2008), S. 77-92. - Schwillus/Brühe, S. 330. - Stephan, Herbert: Die demokratische Bodenreform - erster Schritt auf dem Wege zur endgültigen Befreiung der Bauern (dargestellt am Beispiel des Landkreises Ostprignitz im ehemaligen Land Brandenburg). Kyritz 1965. - Stadt und Kreis Meseritz. [Bd. 1]. O. O. [1972]. - Winterberg, Sonya: Wir sind die Wolfskinder. München/Zürich 2012. 


\section{Lauta}

Landgemeinde (1965 Stadtgemeinde), bis 1952 Kr. Calau (ab 1950 Kr. Senftenberg), $1952-$ 1990 Kr. Hoyerswerda (Bez. Cottbus), 1990-1993 Ldkr. Hoyerswerda (Land Sachsen), 1993 Ldkr. Bautzen (Land Sachsen)

EReignisse Nach Kriegsende: Gründung zweiter Privatbetriebe durch sudetendeutsche Vertriebene, „die ,Sudetendeutsche Glasveredlung und Export Gebr. Reile und die ,Glasveredlungsstätte Sudetenland Carl Kindermann', beide im Lautawerk" (Christopeit, S. 86). - 1951 muss die glasverarbeitende „Umsiedlergenossenschaft Gablauta“, deren Namen an die Herkunft der Arbeiter aus dem böhmischen Gablonz erinnerte“, ihren Namen ändern (Ther, S. 493).

BevöLkerungszahlen: (Lautawerk:) „1948 stieg die Einwohnerzahl nach Aufnahme von c[a]. 2000 Umsiedlern auf 9002 ." (HOL NL II, S. 313).

Literatur: Christopeit. - Ther, Philipp: Von Schlesien in die Lausitz. Ein Beispiel der Integration von Vertriebene in der DDR. In: „Wach auf, mein Herz, und denke“. Berlin/Opole 1995, S. 488-494.

\section{Lebus}

Stadtgemeinde, bis 1950 Kr. Lebus (Kreissitz), 1950-1990 Kr. Seelow (Bez. Frankfurt/Oder), 1990-1993 Ldkr. Seelow, 1993 Ldkr. Märkisch-Oderland

EREIGNISSE 1945: „Zum Jahreswechsel 1944/45 wurde in Lebus der Schulbetrieb eingestellt. Im Schulgebäude brachte man Flüchtlinge und Soldaten unter. Ab Mitte Dezember hatte der Eisgang auf der Oder eingesetzt. Um den 4. Januar herum kam das Eis auf der Höhe von Lebus zum Stehen, die Oder war nun bis zum 3. Februar zu Fuß passierbasr." (Hunger, S. 9). „Am 5.2.1945 mußte [...] Lebus wegen des starken Artilleriebeschusses geräumt und die Einwohner auf die zurückliegenden Dörfer verteilt werden." (Ein leidgeprüftes Land, S. 20). 12.2.1945 Einmarsch der Roten Armee (Schneider, Kämpfe um Lebus, S. 35). [Aus dem Bericht einer zu diesem Zeitpunkt in Potsdam evakuierten Lebuserin über nach ihrer Rückkehr nach Lebus Anf. Juli 1945 dort erhaltene Informationen:] „Ich erfuhr aus Erzählungen, daß bereits am Nachmittag des 12.2.45 die etwa 200 zurückgebliebenen Lebuser zusammengetrieben und alle Nichtarbeitsfähigen über die Oder gebracht wurden. Die Arbeitsfähigen mußten schanzen oder Tote beerdigen. Da Lebus im Verlauf der Kämpfe etwa dreimal den Besitzer gewechselt hatte, trieb man die Zivilbevölkerung rechts der Oder immer weiter nach Osten zurück. Am Pfingssonnabend 1945 trafen die Überlebenden wieder in Lebus ein und mußten sofort mit den Aufräumungsarbeiten beginnen. Da es kein Brot gab, zogen Frauen und Kinder zur Kommandantur, um den Kommandanten um Zuteilung zu bitten. Die Antwort lautete, Lebus hätte 4000 tote Russen gekostet, da brauchte auch kein Lebuser übrig zu bleiben. Soweit aus Erzählungen der damals Zurückgebliebenen." (Ein leidgeprüftes Land, ebd., S. 30). - „Lebus war von Februar bis April 1945 Kampfgebiet und wurde zu 95 Prozent zerstört.“ (Hunger, S. 8). - „Die letzte Fähre verkehrte am 3. Februar 
[...].“ (ebd., S. 10). - 5.3.1945 Teilzerstörung der Oderbrücke durch Wehrmachtsverband (Schneider, S. 16).

EREIGNISSE NACH KRIEgSENDE: Der Lehrer und ehem. Leiter der Volksschule in Königsbach (Bukowiec) bei Lodz (1939-1945 Wartheland) Karl Meier (ca. 1886-1966) kam 1945 nach Vahldorf bei Magdeburg, wurde dort Leiter der Volksschule und Fachlehrer für Russisch. „Nach der Pensionierung zog er nach Lebus/Oder und betätigte sich dort bis zu seinem Tode als Organist in der evangelischen Kirche. / Von Lebus aus besuchte der des öfteren die ehemaligen Königsbacher, die sich in Großgörschen bei Leipzig angesiedelt hatten, und hatte brieflichen und persönlichen Kontakt zu seinen ehemaligen Schülern in der Bundesrepublik Deutschland.“ (Heike, S. 261).

BevölKerungszahlen: 1925: 3112, 1939: 3037, 1946: 1498, 1964: 1754 (Städtebuch, S. 278).

Katholiken: 1946: 40 (Städtebuch, S. 278).

Gedruckte Quellen und Literatur: Heike, Otto: 150 Jahre Schwabensiedlungen in Polen 1795-1945. Leverkusen 1979. - Hunger, Manfred: Das Kriegsende 1945 in Lebus. in: Jahrbuch Märkisch Oderland 2020 (2019), S. 8-13. - Ein leidgeprüftes Land. Bearb. von Fritz Knüppel. 2. Aufl. Barsinghausen 1990, S. 20, 27-30. - Schneider, Joachim: Die Oder während der Kriegshandlungen im Frühjahr 1945. In: Historischer Verein zu Frankfurt (Oder) e. V. Mitteilungen 2001, H. 2, S. 7-21, hier S. 14 (Brücke Lebus/Göritz). - Ders.: Die Kämpfe um Lebus im Frühjahr 1945. In: ebd. 2007, H. 1, S. $27-48$.

\section{Leegebruch}

Landgemeinde, bis 1952 Kr. Osthavelland, 1952-1990 Kr. Oranienburg (Bez. Potsdam), 1990-1993 Ldkr. Oranienburg, 1993 Ldkr. Oberhavel

EReignisse BIS KRIEgSEnde: Mai 1936 „Baubeginn für die Heinkelsiedlung in Leegebruch“ (Leegebrucher Geschichte). Anwerbung von Arbeitern für die im benachbarten $\rightarrow$ Oranienburg errichteten Heinkel-Werke in ganz Deutschland, die dann bis 1939 u. a. auch aus Ostpreußen und Schlesien kamen, Ausbau der Landgemeinde Leegebruch zu einer Werkssiedlung.

Ereignisse NACH KriegSende: April 1946: „Neben anderen Umsiedlern treffen in Leegebruch Antifatransporte aus dem böhmischen Nixdorf ein.“ (Leegebrucher Geschichte).„Gründung der ,Genossenschaft der Messerschmiede Leegebruch“ (GML) mit Josef Kittel als Leiter." (ebd.; siehe unten). - 11.6.1946 wendet sich der seit 1945 in Leegebruch lebende und wirkende pensionierte evangelische Flüchtlingspfarrer Hans Wackernagel hilfesuchend an das Konsistorium: „Da nun ja an anderen Orten die Wohnungsnot ... sehr groß ist, wurden hierher nun trotz der herrschenden Lebensmittel- und Verdienstnot viele Flüchtlinge gebracht. Diese armen, heimatlosen Menschen kommen nun hier wieder in die denkbar größte Armut. [...].“ (Dieck/ Poldrack, S. 29). - 1947 für die Bodenreform 2 landlose Bauern und 1 Umsiedler“ erwähnt 
(HOL III, S. 105). - 23.4.1948 (Schreiben des Evang. Konsistoriums an die evang. Gemeinde Leegebruch): „Wir haben der Kirchengemeinde Leegebruch die Glocke Nr. 133 aus der Gemeinde Niederkränig [poln. Krajnik Dolny; ehem. Kr. Königsberg/Nm.] leihweise überlassen“ (Dieck/ Poldrack, S. 43).

EREIGNISSE NACH 1990: Durch Beschluss der Gemeindeverwaltung ist Leegebruch eine der Patengemeinden der Stiftung „Zentrum gegen Vertreibungen“ (http://www.z-g-v.de/ [23.6.2017]).

BevöLkerungszahlen: 1925: 230, 1939: 5074 [„größtes Dorf Deutschlands“], 1946: 5 554, 1964: 5389 (HOL III, S. 207).

MessersCHMIEDE: „Nach Kriegsende gingen viele [Heinkel-Arbeiter-]Familien wieder in ihre Heimat zurück, es kamen aber auch viele als Vertriebene aus den ehemaligen Ostgebieten. Prägend waren die neuen Bürger aus dem nordböhmischen Dorf Nixdorf (Miulášovice). Bis 1918 waren in Nixdorf die größten Stahlwaren- und Messerfabriken Österreich-Ungarns. Da einer der neuen Bürger aus seiner kleinen Schlosserei eine Drehbank, einen Schleifstein, eine Bohrmaschine sowie Kleinwerkzeuge mitgebracht hatte, konnte eine Produktionsstätte auf dem zur Verfügung gestellten Gelände am Ortseingang von Leegebruch geschaffen werden. 16 Vertriebene schlossen sich zusammen und gründeten am 1. August 1946 die Genossenschaft der Messerschmiede Leegebruch (GML)." (wikipedia.org/wiki/Leegebruch [5.6.2017], Vgl. Christopeit, S. 84f.). - 15.3.1947 Erwähnung der „Umsiedlergenossenschaft“ „Genossenschaft der Messerschmiede“ mit „Belegschaftsstärke 50“ (BLHA, Rep. 333, Nr. 574, Bl. 105). - 1947 DEFADokumentarfilm in der Kino-Wochenschau „Der Augenzeuge 1947/38“ behandelt u.a. die Messerschmiede-Umsiedlergenossenschaft Leegebruch (DEFA-Stiftung, Filmdatenbank).1948 „produziereten im sogenannten ,märkischen Solingen' 86 Arbeiter insgesamt 24 Sorten Küchen-, Tafel- und Taschenmesser." (Pape, S. 125). - Auf einer Maikundgebung in den 1950er Jahren schwenkte ein Mitarbeiter unter einem SED-Banner auch „die aus Nixdorf herübergerettete Fahne des dortigen Arbeiter-Turnvereins“ (Funke, mit Foto). - 1.8.1954 „Einweihung eines Gedenksteins für die Gründer der Messerschmiede“ (Leegebrucher Geschichte). - 1.10.1955 „Umwandlung der GML in ,VEB (K) Messerschmiede Leegebruch' nach erfolglosen Protesten der Belegschaft. Josef Kittel wird abgelöst“ ' (ebd.). - 7.10.1984 „Der ,Karl-Marx-Orden“ wird an die Belegschaft der Messerschmiede verliehen“ (ebd.). - „Die Belegschaft der Messerschmiede erhält den Orden ,Banner der Arbeit““ (ebd.). - 1.7.1990 „Gründung der Messerschmiede Leegebruch GmbH“ als Rechtsnachfolger (ebd.). - Am 14. Februar 1991 verkaufte die Treuhand die Geschäftsanteile der Messerschmiede Leegebruch GmbH zu 100\% an die Firma Siegfried Schumacher GmbH Gummersbach. Am 17.06.1991 beschloss die Gesellschaftsversammlung den Firmennamen auf,Adler Messer GmbH' zu ändern. Nach der Deutschen Einheit wurde die freie Marktwirtschaft spürbar. Der Betrieb musste weitere Entlassungen durchführen. Von 1994 bis 1997 erfolgte schrittweise die Auslagerung von Produktionsabschnitten nach Mikolasovice in Tschechien, die eine weitere Reduzierung von Arbeitskräften nach sich zog. Jetzt findet kei- 
ne Produktion von Schneidwaren in Leegebruch mehr statt. Mit dem Verkauf von Gebäuden und Grundstücken entstand auf dem Gelände ein Gewerbepark, in dem sich klein- und mittelständische Betriebe ansiedelten. [...] / Die Messerschmiede Leegebruch hatte in den Jahre von 1946 bis zum Verkauf 1991, als größter Betrieb von Leegebruch, einen erheblichen Anteil an der sozialen und kulturellen Gestaltung des Ortes, und wurde durch die hervorragende Entwicklung über Ländergrenzen hinaus bekannt. Im Jahre 2001 erfolgte der Abriss der Hauptgebäude durch die Supermarktkette ,Lidl \& Schwarz““ (Funke). - „Nur eine auf Initiative des Geschichtsvereins [Geschichtsverein Leegebruch e. V.] aufgestellte Tafel am einstigen Standort Eichenallee (heute Lidl) informiert Vorübergehende an diese Vergangenheit." (Unger, Erinnerung). - Dauerausstellung zur Firmengeschichte im neuen Gemeindezentrum für 2018 geplant (ebd.).

Literatur: Augsten, Gisbert: Die katholische Kirche St. Petrus zu Leegebruch. Ein historischer Abriss und eine Würdigung aus Anlass des 50. Jahrestages der Kirchweihe. Leegebruch 2000. - Christopeit. - Dieck, Rosemarie / Poldrack, Nele: Die evangelische Kirchengemeinde Leegebruch von ihren Anfängen bis 2008. Leegebruch 2015. - Funke, Alfred: Die Messerschmiede - das märkische Klein-Solingen. In: Leegebruch. Hrsg.: Arbeitsgruppe Heimatgeschichte im Kulturverein Leegebruch. 2. Aufl. Leegebruch [2003], S. 85-92. - Ders.: Ein Leegebrucher Wahrzeichen die Messerschmiede. Leegebruch 2007. - Ders.: Ein Leegebrucher Wahrzeichen - die Messerschmiede. Bildband. Leegebruch 2008. - Ders.: Die Messerschmiede. In: Messer Magazin (2011)2 (www.geschichtsverein-leegebruch. de [5.6.2017]). - Leegebrucher Geschichte. Hrsg.: Geschichtsverein Leegebruch e.V. In: www.cake-media.de/leege bruch/verein.html [5.6.2017]). - Pape, Petra: Flüchtlinge und Vertriebene in der Provinz Mark Brandenburg. In: Sie hatten alles verloren. Hrsg. von Manfred Wille u. a. Wiesbaden 1993, S. 110-132. - Unger, Ulrike: Erinnerung an 70 Jahre Messerschmiede Leegebruch. Geschichte erhält Platz im neuen Gemeindezentrum. In: Leegebruch Journal 30 (2016), S. 6-7. - Dies.: Mit der Wende kam das Ende. In: Oranienburger Generalanzeiger (OGA), 1.8.2016.

\section{Lehnin}

Landgemeinde (seit 1.4.2002 Ortsteil von Kloster Lehnin), bis 1952 Kr. Zauch-Belzig, 19521990 Kr. Brandenburg-Land (Bez. Potsdam), 1990-1993 Ldkr. Brandenburg, 1993 Ldkr. Potsdam-Mittelmark

EREIGNISSE NACH KRIEGSENDE: 1946 bei der Bodenreform kein Umsiedler berücksichtigt (1 Neusiedler) (HOL V, S. 221).

Bevölkerungszahlen: 1925: 2 644, 1939: 3 001, 1946: 3978, 1964: 3336 (HOL V, S. 222).

Katholiken: „Nach dem II. Weltkrieg stieg ihre Zahl durch Vertriebene auf weit über 1000 , erster Seelsorger am Ort war 1946 kurzzeitig Franz Müller. Zeitweilig konnte man damals die Lehniner Klosterkirche mitnutzen. Seelsorglich selbständige Kuratie wurde die Gemeinde 1956 [...].“ (Brühe, S. 26). - „P. Alfons Engler MSF [geb. 1907 (Anschriftenverzeichnis des Klerus der Grafschaft Glatz 1945-1950, S. 3)] kam als Vertriebener aus Habelschwerdt/Schlesien und wurde am 1.12.46 zum Lokalkaplan ernannt, er wirkte hier bis zu seinem Tod 1982.“ (ebd.). „Marx und Engler prägten jahrzehntelang das Leben der Gemeinde.“ (Schwillus/ Brühe, S. 304). - „Am 19.3.1948 konnte auf dem später von der Familie Völker übereigneten 
Grundstück eine aus einem Pferdestall und einer Wagenremise umgebaute schlichte Kapelle eingeweiht werden. Ihren Namen erhielt sie in Anlehnung an den Orden P. Englers, die Missionare der hl. Familie.“ (ebd.; textähnlich: Schwillus/Brühe, S. 304). - „Das 1950-51 erbaute Pfarrhaus wurde nach der Wende ausgebaut und 1995 als ,Pater-Engler-Haus für Kinder- und Gruppenfreizeiten wiedereröffnet." (ebd.).

Krankenhaus Luise-Henriette-Stift: 28.10.1944: „15 Flüchtlingskinder aus Ostpreußen werden im Stift aufgenommen." (100 Jahre Diakonissenmutterhaus, S. 140). - 13.2.1945: „Neun Diakonissen aus dem Posener Mutterhaus gelangen auf der Flucht nach Lehnin." (ebd.). - 20.3.1945 auf Aufforderung der Provinzialregierung in Potsdam (wegen Zunahme der in Brandenburg eintreffenden Insassen von Krankenhäusern und Heimen unter den Flüchtlingen) Beschluss des Vorstandes des Diakonissenmutterhauses Luise-Henrietten-Stift zur Einrichtung eines Ausweichkrankenhauses für die Städte Potsdam und Brandenburg in seinen Gebäuden und den vom Reichsamt „errichteten und wieder verlassenen weiträumigen Baracken“ (später Krankenhaus Luise-Henriette-Stift genannt) und Berufung der zum Mutterhaus gehörenden Diakonissen aus dem Krankenhaus „Hubertus“ in Berlin-Schlachtensee zum Dienst im Lehniner Krankenhaus, daraufhin 27.3.1945 Eintreffen der Schlachtenseer Krankenschwestern unter Leitung ihrer Oberin Diakonisse Bertha Varchmin. - 7.4.1945 Dienstantritt des aus dem Diakonissen-Mutterhaus in Posen geflüchteten, während des Krieges in Lazaretten tätigen Chirurgen Dr. Gustav Schülke als Leiter des einzurichtenden Ausweich- bzw. Notkrankenhauses (Brandt, S. 81; 100 Jahre Diakonissenmutterhaus, S. 140; Schmiechen, S. 9), 15.4.1945 Arbeitsaufnahme des Krankenhauses, bald auch eines Kinderheims; Betreuung zahlreicher Flüchtlinge u. Waisenkinder, Geburten von Flüchtlingskindern, Beisetzung verstorbener Patienten im Konventgarten (Massengrab) (Sommermeyer, S. 17). - 23.4.1945 Rote Armee im Stift (100 Jahre Diakonissenmutterhaus, S. 140). - 28.4.1945: „die Posener Schwestern blieben über Nacht schon im Lindenhaus“ (Tagebuch, S. 102). - 30.4.1945: „Wir haben insgesamt 379 Personen, die im L.H. Stift verpflegt werden." (ebd., S. 109). - Juni 1945 Ruhrepidemie (Isolierstation in Baracke III bis Okt. 1958).

GedRUCKTe Quellen: Tagebuch der Diakonissen im Luise-Henrietten-Stift Lehnin [Auszüge]. In: „Die Russen sind da“. Peter Böthig u. Peter Walther (Hg). Berlin 2011.

Literatur: Brandt, Günther: Das Lehniner Krankenhaus. In: 100 Jahre Diakonissenmutterhaus Luise-Henriette in Lehnin. Unna [2011], S. 81-87 (mit Abb.). - Brühe, Matthias: Katholische Kirche zwischen Havel und Dahme. Berlin 1999, S. 26. - 100 Jahre Diakonissenmutterhaus Luise-Henriette in Lehnin. Unna [2011]. - Luise-Henriette-Stift. Lehnin 1970. - Nitschke, Johannes: 150 Jahre Pfarrkirche „Heilige Dreifaltigkeit“ Brandenburg an der Havel. Brandenburg an der Havel [2001], S. 31 f. - Schmiechen, Ernst: Fünfzig Jahre Diakonissenmutterhaus Luise-HenrietteStift in Lehnin (Mark) 1911-1961. [Lehnin (Mark) 1961]. - Schwillus/Brühe, S. 304. - Sommermeyer, Ruth: Die Diakonissengemeinschaft des Luise-Henrietten-Stifts. In: 100 Jahre Diakonissenmutterhaus Luise-Henriette in Lehnin. Unna [2011], S. 13-24 (mit Abb.). 


\section{Leibchel}

Landgemeinde (seit 26.10.2003 Ortsteil von Märkische Heide), bis 1952 Kr. Lübben, 19521990 Kr. Lübben (Bez. Cottbus), 1990-1993 Ldkr. Lübben, 1993 Ldkr. Dahme-Spreewald

BevöLKERUNGSZAHLEN: 1925: 266, 1939: 238, 29.10.1946: 459, 1950: 452, 1964: 315 (HGV LDS, S. 26 f.). - 1.5.1946: 414, davon 208 Ortsansässige, 206 „Umsiedler“ (Becken, S. 32).

UMSIEDLERLAGER Kinderheim: 24.10.1945 (Bericht des Landratsamtes betr. Unterbringungsplanung des Kreises für Flüchtlinge): „[...]. Ausserdem ist das Kinderheim Leipchen [richtig: Leibchel] auszubauen.“ (Töpler, Menschenwurm, S. 451). - „Die elternlosen Kinder des Kreises [Lübben] wurden nach Leibchel in das von der Roten Armee beschlagnahmte Gutshaus gebracht. Die Kommandantur und Landrat Hille richteten hier bis Ende 1945 ein Kinderheim für 90 Waisenkinder ein. Außerdem wurden 39 Amtsvormundschaften aufgenommen und 450 Pflegekinder betreut.“ (Becken, S. 29). - Im „Verzeichnis der errichteten und vorgesehenen Umsiedlerlager im Verwaltungsbezirk Cottbus“ vom 15.12.1945 ohne „Personenzahl“ genannt (Töpler, Menschenwurm, S. 472).

Gedruckte Quellen und Literatur: Becken, Jörg: Lübben nach dem Inferno. [Cottbus] 2010. - Töpler, Menschenwurm, S. 451, 472.

\section{Lenzen (Elbe)}

Stadtgemeinde, bis 1952 Kr. Westprignitz, 1952-1990 Kr. Ludwigslust (Bez. Schwerin), 19901992 Ldkr. Ludwigslust (Land Mecklenburg-Vorpommern), 1992-1993 Ldkr. Perleberg (Land Brandenburg), 1993 Ldkr. Prignitz

Bevölkerungszahlen: 1925: 2709, 1939: 2700, 1946: 3480, 1964: 3147 (Städtebuch, S. 282).

Katholiken: 1925: 33, 1946: 119 (Städtebuch, S. 283).- 1946: „Auf wiederholte Bitten der in Lenzen und Umgegend angesiedelten katholischen Flüchtlinge wurde am Feste Christi Himmelfahrt durch Kaplan Hawlitzky $([\rightarrow]$ Bad Wilsnack) in Lenzen der erste Gottesdienst gehalten und zwar in einer stillgelegten Kegelbahn. 60 Erwachsene und 20 Kinder waren erschienen. Außer in Lenzen wurden späterhin an jedem 5. Sonntag im Monat auch in Deibow und Mellen hl. Messen gelesen. Für den Gottesdienst in Lenzen hatte die evang. Gemeinde ihre Kirche zur Verfügung gestellt.، (Bolwin, S. 194). - 1.1.1947 Ernennung des Kaplans Heribert Rosal (Berlin-Reinickendorf) zum Kaplan in $[\rightarrow]$ Wittenberge $u$. Beauftragung mit der seelsorgerlichen Betreuung der kath. Flüchtlinge in Lenzen u. Umgebung (ebd., S. 195). - 1947 Erwähnung „,von vertriebenen sudetendeutschen Katholiken [...]. Die erste hl. Messe fand an Christi Himmelfahrt 1946 im Schützenhaus statt. Später konnte man die Sakristei der evangelischen Katharinenkirche nutzen. Schließlich gelang es, den Sitzungssaal der Stadtsparkasse in 
der Hamburger Str. 23 zu mieten und ihn als Gottesdienstraum herzurichten. Am 8.9.1947 wurde er eingeweiht [...] Das Marien-Patronat ging auf eine Anregung aus der Gemeinde zurück [...].“ (Brühe, S. 27); Gottesdienste im gemieteten Sitzungssaal der Stadtsparkasse lt. Pfarrer Bolwin ab 1.6.1947 (Bolwin, S. 194). - Lokalie Lenzen zu selbständiger Kuratie erhoben (ebd., S. 206).

Gedruckte Quellen und Literatur: [Bolwin, Jacob:] Chronik der Missionspfarrei Wittenberge. Wittenberge [2006]. - Brühe, Matthias: Katholische Kirche zwischen Prignitz und Havelland. Berlin 2000, S. 27. - Schwillus/ Brühe, S. 355 f. - Wille II, S. 366. - Wirtschafts-Wegweiser für Wittenberge und die Kreise West- und Ostprignitz. Branchen-Adreßbuch. Potsdam (1949), S. XI f. (Dienststellen der Stadt), 49-134 (Firmen).

\section{Letschin}

Landgemeinde, bis 1950 Kr. Lebus, 1950-1990 Kr. Seelow (ab 1952 Bez. Frankfurt/Oder), 1990-1993 Ldkr. Seelow, 1993 Ldkr. Märkisch-Oderland

EREIGNISSE VOR 1933: „600 ostpreußische Flüchtlinge trafen hier am 9. November 1914 um Mitternacht ein, wurden in den beiden Sälen der Gasthöfe übernachtet [so!] und am nächsten Tage in die Quartiere verteilt." (Strenge/van Tankeren, Bd. 5, S. 180; S. 181 f.: Namenliste der Quartiergeber und der Flüchtlinge). Diese Kriegsflüchtlinge blieben meist bis 1915, in Einzelfällen bis 1917 am Ort. „Eine Familie zog nach $[\rightarrow]$ Seelow, eine nach Hannover.“ (ebd., S. 182). - 1918-1923 Zuwanderung mehrerer Familien aus den Provinzen Posen und Westpreußen (ebd., S. 182-184).

EREIGNISSE VOR UND NACH KRIEgSENDE: Ab Jan. 1945 Ankunft zahlreicher Flüchtlingsfamilien, darunter mehrerer bessarabiendeutscher Familien aus dem „Warthegau“, weiterer Familien aus dem Kreis Welun sowie aus Gurten [bei Posen], Neudamm/Neumark, Schlesien u. a. (Strenge/van Tankeren, S. 186-189, mit unvollständiger, aber detaillieter Namenliste, auch der nach Kriegsende hinzugekommenen Vertriebenen, meist mit Angaben bis zur Gegenwart). „Das Dorf war schwer zerstört, über 50 \% der Gebäude unbewohnbar, Wege und Felder waren vermint. / Nur langsam kehrte ein Teil der Letschiner Einwohner aus den Fluchtorten zurück, viele kamen nie mehr zurück. [...]. [S. 48] [...] Die heimkehrenden Einwohner hatten oftmals nur das retten können, was sie auf dem Leib trugen oder besaßen nur so wenig, daß alles [...] in eine Aktentasche paßte. [...] / Ende 1945 brach in Letschin, wie im ganzen Kreis Seelow, eine Typhusepidemie aus. Zeitweise waren bis zu 400 Einwohner erkrankt, 56 verstarben. Die Not wurde durch eine ausbrechende Ruhr noch verstärkt, die noch einmal 39 Letschiner dahinraffte. Hunger und Entkräftung forderten weitere Opfer, noch einmal starben 49 Letschiner.“ (Gill, S. 47). - 1945/46 in der Bodenreform 419,3 ha (von 814,6 ha) an 92 Umsiedler vergeben, ferner 58 ha (von 587,3 ha Waldzulage von Neuhardenberg-Hermersdorf) an 29 Umsiedler (HOL VII, S. 245, Wirth, S. 24f.). - 21.7.1968: Durchführung eines Glaubenstages für bessarabiendeutsche Flüchtlinge durch den „Besuchsdienst im Evangelisch Kirchlichen Gnadauer Gemeinschaftswerk in der DDR“ (Keller/Baumann, S. 217). 
BevölKerungszahlen: 1925: 3 190, 1939: 3023, 1946: 2 876, 1964: 2774 (HOL VIII, S. 246). - 19.4.1946: 516 Flüchtlinge im Ort (Strenge/van Tankeren, Bd. 5, S. 189).

EReignisSe NACH 1990: Das Amt Letschin ist eine der Patengemeinden der Stiftung „Zentrum gegen Vertreibungen“ (http://www.z-g-v.de/ [23.6.2017]).

Katholiken: (bis 1994 Erzbistum Breslau/Erzbischöfliches Amt Görlitz, dann Erzbistum Berlin): 1954: 132 (Schematismus Görlitz 1954, S. 36).

Strassenumbenennungen: Die bereits vor 1945 existierende Küstriner Straße wurde 1979 umbenannt in Straße der Freundschaft (Mitteilung der Gemeinde Letschin, Edgar Petrick, 26.6.2018), 2000 (durch Beschluss der Gemeindevertretung Letschin) Rückbenennung in Küstriner Straße (Mitteilung der Letschiner Heimatstuben, 22.6.2018).

GedRuckte QuelLen: Elske, Gerhard: [Lebenslauf]. In: Müncheberger Lebensläufe. T. 3. Müncheberg 2012, S. 1924 [1932-1960 in Letschin wohnhaft].

Literatur: Amt Letschin. Horb am Neckar 1995, S. 14. - Gill, Manfred: Letschin 1336-1986. Letschin 1985 (Heimatkalender). - Keller, Herbert / Baumann, Arnulf: Bessarabischer Brüderbesuchsdienst in der DDR. In: Jahrbuch der Deutschen aus Bessarabien 59 (2008), S. 216-223. - Strenge, Sigrid / Tankeren, Marga van: Letschiner Chronik. Bd. 1. Letschin 2001. Bd. 5. Letschin 2011. - Wirth, Gisela: Zum 30. Jahrestag der Durchführung der demokratischen Bodenreform in Letschin. In: Heimatkalender für die Gemeinde Letschin 1 (1975/76), S. 21-27.

\section{Leuthen}

Landgemeinde (seit 2003 Ortsteil der Stadt $\rightarrow$ Drebkau), bis 1952 Kr. Cottbus, 1952-1990 Kr. Cottbus-Land (Bez. Cottbus), 1990-1993 Ldkr. Cottbus, 1993 Ldkr. Spree-Neiße

EREIGNISSE NACH KRIEGSENDE: „In der Nachkriegszeit wurden im Schloss Flüchtlinge untergebracht." (Wikipedia, 8.7.2018).

BevÖLKERUNGSZAHLEN: 1925: 577, 1933: 749, 1939: 756, 1946: 956, 1950: 1004, 1964: 956 (HGV SN, S. 14f.).

KINDERHEIM: 1951 lt. Schreiben des Ministeriums für Volksbildung, HA Unterricht und Erziehung, Berlin, vom 16.4.1951 $\rightarrow$ „Kyritz“ und „Leuthen bei Cottbus“ als Heime in Brandenburg (neben fünf weiteren in den anderen Ländern der DDR) „in Aussicht genommen“ für Teilkontingente zur „die Unterbringung des in Bischofswerda erwarteten Kindertransportes von 286 Kindern“ aus dem sowjetischen Teil Ostpreußens (BArch, DO 1/8405, unfol.). [Möglicherweise ist die Angabe „Leuthen bei Cottbus“ geographisch jedoch nicht zu wörtlich zu nehmen. Dann nämlich könnte es sich bei dem o a. Kinderheim auch um das in Groß Leuthen (!) im Kr. Lübben handeln, das nach 1945 für Kriegswaisen (im „Schloss“), dann als „Landeskinderheim“ (erwähnt 1950), später (wohl schon ab 1948, ab spätestens 1952) als „Spezialkinderheim“ für schwererziehbare Kinder genutzt wurde (www.christian-sachse.de/spezialheime_brandenburg.pdf, S. 108 u. ö.). 
Gemeindepartnerschaft: Nietkowice, Polen (ehem. Deutsch Nettkow, Kr. Crossen [19371945 umbenannt in Straßburg/Oder]) (www.drebkau.de [8.7.2018]).

\section{Liebenwalde}

Stadtgemeinde, bis 1952 Kr. Niederbarnim, 1952-1990 Kr. Oranienburg (Bez. Potsdam), 1990-1993 Ldkr. Oranienburg 1993 Ldkr. Oberhavel

EREIGNISSE BIS KRIEGSENDE: 1944/45: „während des Winters 1944/45, der sehr kalt und schneereich war, durchzogen lange Flüchtlingstrecks aus Ostpreußen die kleine Stadt. ,Die Hand-und Pferdewagen vollgepackt mit dem letzten Hab und Gut, obenauf sitzend frierende Kinder", so die Erinnerungen einer damaligen Liebenwalderin. ,Wenn die Dunkelheit nahte, wurden diese armen Menschen in der Schule und in den Sälen der Gaststätten untergebracht." (Lehmann, S. 181).

BEVÖLKERUNGSZAHLEN: 1925: 2577, 1939: 2966, 1946: 3708, 1964: 3375 (Städtebuch, S. 286).

Katholiken: 1925: 67, 1946: 299 (Städtebuch, S. 287).

LiteratuR: Lehmann, Jörg: Die Stadt Liebenwalde. Karwe 2004.

\section{Lieberose}

Stadtgemeinde, bis 1952 Kr. Lübben, 1952-1990 Kr. Beeskow (Bez. Frankfurt/Oder), 19901993 Ldkr. Beeskow, 1993 Ldkr. Dahme-Spreewald

EREIGNISSE BIS KRIEgSENDE: Die Stadt wird kurz vor Kriegsende zur „Festung“ erklärt und erleidet in der Folge schwere Zerstörungen (Töpler, Menschenwurm, S. 295).

EREIGNISSE NACH KRIEGSENDE: „1945 Unterbringung von 800 Flüchtlingen“ (Städtebuch, S. 290). - 1945 (Bericht der Stadtverwaltung vom Nov. oder Dez. 1945): [S. 110:] „Eine umfangreiche, durch die Flüchtlingsnot erforderliche Neugründung ist die Einrichtung eines Krankenhauses. [...] Für aus Gefangenschaft durchziehende Soldaten wurde ein Unterkunftsheim mit Verpflegung eingerichtet. [...] [S. 112:] „10. Die Sorge für die Flüchtlinge. Im Mai bis Juni d.J. zogen Tausende von Rückwanderer durch Lieberose, die hier sämtlich verpflegt werden mussten. Acht Wochen lang erhielten täglich tausend Familien ein warmes Mittagessen und Unterkunft in den Lieberoser Wohnungen. An Durchziehende wurden in dieser Zeit täglich 500 Portionen Brot gegeben, sodass die Stadt alle Vorräte, die von dem deutschen Militär zurückgelassen und von dem russischen Heer der Stadt überlassen worden waren, restlos an Hilfsbedürftige, ortsfremde Flüchtlinge abgegeben sind [so!]. Z.Zt. sind fast 800 Flüchtlinge in Dauerwohnungen untergebracht und erhalten Verpflegung und Heizung. Alles irgendwie verwendbare Militärgut war sorgfältig vor dem Verrotten geschützt und zu neuem Gebrauch hergerichtet worden. Den meisten Familien konnte auf diese Weise eine geschlos- 
sene kleine Wohnung zugewiesen werden, wo sie Ruhe und Kraft zur täglichen Arbeit finden konnten." (Brandenburgische Gemeinden 1945, S. 110, 112).

Bevölkerungszahlen: 1925: 1444, 1939: 1665, 1946: 2495, 1964: 1829 (Städtebuch, S. 290).

Katholiken (Erzbistum Breslau/Erzbischöfliches Amt Görlitz): 1850: 13, 1946: 230 (Städtebuch, S. 290).

LAGER: Bei dem in der Literatur genannten ehem. KZ-Nebenlager Lieberose (auch „JamlitzLieberose") handelt es sich um das Lager im Lieberose unmittelbar östlich benachbarten $\rightarrow$ Jamlitz.

Gedruckte Quellen und Literatur: Brandenburgische Gemeinden 1945, S. 105-113. - Töpler, Menschenwurm. - Flucht, Vertreibung, Neubeginn 1945. Schicksale und Berichte aus dem Raum Lieberose. Lieberose 2006.

\section{Lindenberg}

Landgemeinde (heurte Ortsteil von Groß Pankow), bis 1952 Kr. Ostprignitz, 1952-1990 Kr. Pritzwalk (Bez. Potsdam), 1990-1993 Ldkr. Pritzwalk, 1993 Ldkr. Prignitz

BevöLKeRUngSZAHLEN: 1925: 450, 1939: 394, 1946: 742, 1964: 417 (HOL I, S. 521).

Archivalische Quellen: BLHA, Rep. 203 MdI, Nr. 167 („Beschwerdesache Pfarrer [August] Mascher über Aufenthalt einer Umsiedlerfamilie im Pfarrhaus zu Lindenberg, Kr. Ostprignitz“, 1951).

\section{Lindow}

Stadtgemeinde, bis 1952 Kr. Ruppin, 1952-1990 Kr. Neuruppin (Bez. Potsdam), 1990-1993 Ldkr. Neuruppin, 1993 Ldkr. Ostprignitz-Ruppin

Bevölkerungszahlen: 1925: 1923, 1939: 2248, 1946: 3414, 1964: 2517 (Städtebuch, S. 293).

Katholiken: 1905: 32, 1946: 285 (Städtebuch, S. 294). - „Nach dem II. Weltkrieg wurde Lindow zum 1.7.1949 selbständige Kuratie, in der 1953 etwa 750 Katholiken wohnten. Bis 1965 wirkte hier Pfr. Carl Demmer (1947-65).“ (Brühe, S. 28; verkürzt auch in: Schwillus/Brühe, S. 335). Demmer (geb. 1902 Berlin) war bis 1945 Pfarrer in Pyritz (Pommern) (Ostpriesterverzeichnis 2, 1949, S. 20; Schematismus Berlin 1949, S. 67).

StÄdtepartnerschaften: 2010 Břesnice, Tschechien (Bresnitz, Südböhmen). - Lindower Ortsteil Banzendorf seit 1.9.2001 mit Jemiołów, Polen (Petersdorf, ehem. Kr. Oststernberg, Provinz Brandenburg) (BR 12 (2014) 1, S. 14). - 2014 Start eines Projektes zur Geschichte der „Vertreibung der Deutschen und der Polen“ am Beispiel von Petersdorf mit Zeitzeugen- 
befragung und geplanter deutsch-polnischer Ausstellung in Lagow und Lindow, koordiniert durch den ehemaligen Lindower Bürgermeister Peter Wilbers als Vorstandsmitglied des Vereins für internationale Beziehungen der Stadt Lindow (Aufruf „Zeitzeugen gesucht" in: BR 11 (2013)12, S. 15).

Literatur: Brühe, Matthias: Katholische Kirche zwischen Prignitz und Havelland. Berlin 2000, S. 28. - Schwillus/ Brühe, S. 335. - Wille I, S. 372.

\section{Lobetal}

Landgemeinde (seit 31.12.2002 Ortsteil von $\rightarrow$ Bernau), bis $1950 \mathrm{Kr}$. Oberbarnim, 1950-1952 Kr. Niederbarnim, 1952-1990 Kr. Bernau (Bez. Potsdam), 1990-1993 Ldkr. Bernau, 1993 Ldkr. Barnim

BeVÖLKerungszahlen: 1925: 219, 1939: 371, 1946: 664, 1964: 618 (HOL VI, S. 339).16.8.1946: „Stammbevölkerung: 88, Umsiedler: 232 Heimins[assen] $33 \mathrm{Kdh}$. (i[m] Kinderheim)“ (BLHA, Rep. 230 Bernau, Nr. 20, Bl. 3).

FlÜChtLINGSLAGER: Abb. „Zugewucherte Baracke des ehemaligen Lagers Lobetal bei Bernau“ in BR 10 (2012) 2, S. 11.

FRIEDHOF (nördlich des Melchesees): „Auf dem Lobetaler Friedhof [...] wurde 1995 ein Mahnmal für die ,mehr als 600 Flüchtlinge und Bewohner' errichtet, die 1945-1947,Opfer der Folgen nationalsozialistischer Gewaltherrschaft' wurden. Sie starben [S. 303] vor allem an Seuchen und Unterernährung und ruhen hier in einem Massengrab. Unter ihnen waren auch Menschen, die in den letzten Kriegstagen erschossen wurden, Flüchtlinge und Menschen, die im Chaos der Kriegs- und Nachkriegszeit verzweifelten und ihrem Leben ein Ende setzten. Die von Friedrich Schötschel gestaltete Betonscheibe, die sich im nördlichen Teil des Friedhofs befindet, ist in der Mitte symbolhaft durchbrochen. Ein Gitterwerk hält ein bronzenes Herz; der sich ausweitende Riß geht mitten durch die Inschrift. Bemerkenswert ist, daß - anders als bei den vielen anläßlich des fünfzigjährigen Kriegsendes entstandenen Friedhofs-Denkmälern - hier nicht pauschal von den ,Opfern des Krieges' gesprochen, sondern die NS-Herrschaft als Ursache des Krieges benannt wird. [...].“ (Gedenkstätten NS II, S. 303 f.).

\section{Luckau}

Stadtgemeinde, bis 1952 Kr. Luckau, 1952-1990 Kr. Luckau (Bez. Cottbus), 1990-1993 Ldkr. Luckau, 1993 Ldkr. Dahme-Spreewald

EREIGNISSE BIS KRIEGSENDE: Im Februar 1945 befand sich der Sitz des evakuierten „Provinzialstraßenbauamt Crossen (Oder)" in Luckau, Rathaus, II. Stock (BLHA, Rep. 6B Züllichau-Schwiebus, Nr. 169). - 20.4.1945 Einmarsch der Roten Armee (Jannaschke, S. 29; Mietk, S. 230). 
EREIGNISSE NACH KRIEGSENDE: u.a. 27.6.1945 Wohnungseinweisung von 13 Vertriebenen aus Christianstadt am Bober (Kr. Sorau) bei Einheimischen (H. Rieger, S. 18-21). - „Flüchtlinge kamen in langen Trecks durch Luckau. Ziemlich geschlossene Gemeinden waren die aus Woltersdorf [richtig: Waltersdorf] bei Sprottau und aus Ketzelsdorf im Sudetengau, bei letzterer war der Geistliche mit. Sie zogen in Richtung Westen, weil hier kein Aufnahmegebiet war. [...]/Gegenwärtig halten sich im Seelsorgebezirk noch Ausgewiesene aus Freystadt, Fraustadt, Grünberg, Woltersorf b. Sprottau und Sorau auf, meist alte gebrechliche Leute, die nicht weiteren Märschen gewachsen waren. Sie haben im hiesigen evangelischen Gemeindehaus Aufnahme und Pflege gefunden." (Töpler, Menschenwurm, S. 380). - Aufnahme fanden hilfsbedürftige Flüchtlinge 1945-1947 besonders im „Haus Bethesda“ (erwähnt in Sonderausstellung des Niederlausitz-Museums Luckau zu Bürgerstiftungen 2017; Mitteilung der Kuratorin Dr. Silke Kamp, 11.7.2017). - 1945 Typhusepidemie: „Da auch in Luckau eine große Anzahl von Flüchtlingen aus den deutschen Ostgebieten lagerten, drohte die Durchseuchung der gesamten Bevölkerung mit Typhus zu einer großen Gefahr zu werden. Aus diesem Grunde rangen [S. 28] sich die deutschen provisorischen Gesundheitsbehörden zusammen mit der sowjetischen Administration zu einem einschneidenden Entschluss durch: Das gesamte Dorf $[\rightarrow]$ Cahnsdorf bei Luckau wurde zwangsgeräumt für die Flüchtlinge, welche in Quarantäne standen und das Dorf nicht ohne Genehmigung verlassen durften. Ein weiteres Behelfskrankenhaus [neben denen im Luckauer Stadtgebiet und dem Seuchenkrankenhaus im Schloss Waltersdorf] mit ursprünglich 739, später 1359 Betten wurde dort eingerichtet. Alle ambulant tätigen Ärzte von Luckau und Umgebung mussten ehrenamtlich Dienst tun. Speziell für die Tätigkeit in den Behelfskrankenhäusern waren die Ärzte Dr. Fritz Kissner, Dr. Swobodzinski [vmtl. Franz S., lt. Reichs-Medizinal-Kalender 1937 Arzt in Tütz (Grenzmark), P. B.], Dr. Konrad Bolle und Dr. Ruttig vorgesehen. Etwa 7000 Flüchtlinge durchliefen das Quarantänelager in Cahnsdorf, welches im Dezember 1945 wieder aufgehoben wurde - einerseits begründet durch den Rückgang der Seuchengefahr, andererseits durch den massiven Widerstand der betroffenen, einheimischen Bevölkerung zusammen mit den lokalen Behörden.“ (Wagner, S. 28). - 1945-1955 war der ehem. Triebeler Oberpfarrer Hans Klahre (1878-1957) evang. 3. Pfarrer in Luckau, der 1952 ein Treffen seiner ehem. Kirchengemeinde in $\rightarrow$ Cottbus leitete (BArch, DO 1727887, Bl. 80-81, vgl. Bericht im Quellenteil, Nr. 238).

BevölkerungSzAHLEN: 1925: 4394, 1939: 4812, 1946: 6145, 1964: 6307 (Städtebuch, S. 298). - 1.12.1945: 6423, davon 4088 „Altansässige Einwohner“ [davon 1041 männlich, 1969 weiblich, 1078 Kinder unter 14 Jahren], 197 „Umsiedler mit festem Wohnsitz in Luckau“ [davon 51 männlich, 76 weiblich, 70 Kinder], 2138 „Umsiedler ohne festen Wohnsitz“ [davon 483 männlich, 1104 weiblich, 551 Kinder] (Mietk, S. 233 [nach BLHA, Rep. 203 MdI, Nr. 1134, Bl. 75]).

Katholiken (Erzbistum Breslau/Erzbischöfliches Amt Görlitz): 1925: 113, 1946: 466 (Städtebuch, S. 298). - 1948-1949 Filiale der Grauen Schwestern für ambulante Pflege in der Brauhausgasse 14. - Kaplan war 1949 der bis 1945 in Neiße (Schlesien) wirkende Rudolf Fuhrmann (1913-1975) (Ostpriesterverzeichnis 2, 1949, S. 26). 
StÄDtepartnerschaften: 6.12.1991 Ślawa, Polen (Schlawa [1937-1945 Schlesiersee] bei Glogau, Schlesien) (Mitteilung der Stadtverwaltung, 11.9.2018).

VerTRIEBENENVERBÄNDE NACH 1990: BdV-Kreisverband Lübben/Luckau, gegründet 1993 (LR, 25.3.2003), Sitz: $\rightarrow$ Lübben.

ArChivalische Quellen: BArch, DO 2 ZVU, Nr. 50, Bl. 223 (ZVU-Dienstreise, 2.7.1947).

Gedruckte Und sonstige Quellen und Literatur: Jannaschke, Theo: 1945 - Luckau in den letzten Tagen des 2. Weltkrieges. In: Luckauer Heimatkalender 6/7 (1974/75), S. 25-29. - Mertens, Johannes: Die Berliner Ordensprovinz der Grauen Schwestern von der heiligen Elisabeth 1859-1991. Reinbek bei Hamburg 1992, S. 480-483. - Mietk, Thomas: Roter Stern über Luckau 1945 bis 1989/90. In: Luckau. Helga Tuček/ Thoma Mietk (Hg.). Berlin 2018, S. 228-273. - Rieger, Christian: Erinnerungen an Weißack. In: Luckauer Heimatkalender 49 (2017), S. 79-82. [Kindheitserinnerungen eines Vertriebenen]. - Rieger, Helmut: Licht und Brot in Luckau. In: Luckauer Heimatkalender 32 (2000), S. 18-21 [Wohnungseinweisung von Christianstädter Familien 1945]. - Töpler, Menschenwurm, S. 380 f. u. ö. - Wagner, Hans: 100 Jahre Krankenhaus Luckau (1903-2003). In: Luckauer Heimatkalender 36 (2004), S. 24-36. - Wille I, S. 459. - Mitteilung Dr. Silke Kamp (Berlin), 11.7.2017.

\section{Luckenwalde}

Stadtgemeinde (ab 29.5.1945 Verwaltungssitz des Kreises), bis 1946 Kr. Jüterbog-Luckenwalde, 1946-1990 Kr. Luckenwalde (ab 1952 Bez. Potsdam), 1990-1993 Ldkr. Luckenwalde, Ldkr. Teltow-Fläming

Ereignisse bis Kriegsende: Anf. 1945: „Endlose Trecks von Flüchtlingen zogen durch die Stadt, Tag und Nacht." (100 Jahre Katholische Pfarrgemeinde Luckenwalde, S. 21). - 22.4.1945 Einmarsch der Roten Armee (Maetz, S. 211; Der Zweite Weltkrieg in Luckenwalde, unpagin. [S. 23]).

EREIGNISSE NACH KRIEGSENDE: 1.6.1945: Seuchenlazarett auf dem Grundstück der kath. Kirche Lindenstraße 6 eingerichtet (bis März 1946) (Maetz, S. 214). - Okt. 1945: Bei Schulbeginn Unterricht teilweise im Freien, da die Schulräume „z. T. noch durch Umsiedler belegt sind“ (ebd., S. 215). - 10.6.1947: „Die Stadt erwartet in der nächsten Zeit 300 Umsiedler.“ (ebd., S. 221). 13.7.1947 Heimattreffen von Vertriebenen aus dem Kreis Brieg (Schlesien) mit 5 Teilnehmern (Briegische Briefe, Jg. 1, 1947, S. 176), Jan. 1948 erneut mit 7 Teilnehmern (ebd. Jg. 2, 1948, Nr. 7/8, S. 12). - 24.7.1947: „Es sind 1500 Umsiedler (Flüchtlinge) aus der Waldenburger Gegend (Niederschlesien) eingetroffen." (Maetz, S. 221). - 5.8.1947 Tod des Brieger Ehrenbürgers, Stadtältesten und ehemaligen Stadtrats Bäckermeister Paul Mende (geb. 1883 Brieg) im Bürgerhospital Luckenwalde (GenWiki/Brieg [6.7.2017]). - 25.9.1948: „Ein Transport mit 250 Umsiedlern trifft in Luckenwalde ein. 70 Personen davon bleiben in Luckenwalde." (ebd., S. 225).

EREIGNISSE NACH 1990: 27.5.2000 „3. Ostdeutscher Kulturtag“ des BdV-Landesverbandes Brandenburg) im Stadttheater (Akten der BdV-Landesgeschäftsstelle) „mit 520 Plätzen voll besetzt (BdV-Notizen 1 (2003)4, S. 4). 
BevölKerungszahlen: „1925: 24769, 1939: 28 813, 1946: 30979 (Flüchtlinge!), 1964: 29215“ (Städtebuch, S. 304). - 1945/46 starke Bevölkerungszunahme bes. durch Flüchtlinge (Städtebuch, S. 304). - 15.11.1945: 28205 Einwohner, davon 5879 Flüchtlinge (Maetz, S. 217). - 7.11.1947: 5834 „Umsiedler“ (ebd., S. 222). - 10.12.1948: „22\% der Einwohner sind Umsiedler" (ebd., S. 226).

Katholiken: 1925: 1 102, 1937: 1400, 1946: 2767 (Städtebuch, S. 305). - „Pfr. Georg Kubiak, der die Gemeinde von 1943-49 leitete, als sie auf 4000 Katholiken anwuchs, trat 1949 in den Benediktinerorden ein." (Brühe, S. 28) [Kubiak, geb. 1904 Görlitz, war vor 1945 Pfarrer in Gollnow, Kr. Naugard (Schematismus Berlin 1940, S. 75)]. - [Nach Kriegsende 1945:] „Ein ganz großer Erfolg wurde die Caritas-Sachspende für die Flüchtlinge. Etwa 120 Personen konnten mit Wäsche und Kleidungsstücken bedacht werden. - Auch an das Spielzeug für die Flüchtlingskinder wurde gedacht. In einer eigenen Andacht brachten die ortsansässigen Kinder bei einem Opfergange Spielzeug für unsere Flüchtlingskinder zum Altar." (100 Jahre Katholische Pfarrgemeinde Luckenwalde, S. 22).

NotUnterküNFTe: Am 5.9.1946 werden drei Barackenlager und sieben weitere Notunterkünfte erwähnt: Lager Baruther Tor/Krähenheide (8 Baracken), Lager Schützenstraße (etwa 8 Baracken), Lager Industriegelände (etwa 5 Baracken), Lager Mozartstraße, Lager Treuenbrietzener Tor Nr. 18 und 19 [s. u.], Sportecke, Evang. Vereinshaus (Dahmer Straße), Carl-Stift, Jugendheim Industriestraße, ehem. Fabrikgelände Kyburg (Maetz, S. 218 f.). „Für die Nutzung einer Baracke in der Mozartstraße durch Flüchtlinge werden vom Magistrat Mieten festgelegt. Sie betragen monatlich pro Zimmer 9,00 RM, 2,00 RM für Möbelnutzung und 3,00 RM für Strom und Wasser." (ebd., S. 219).

UMSIEDLERLAger Treuenbrietzener Tor: Im Spätherbst 1945 kommen per Bahn Vertriebenentransporte aus Ostpreußen in das Lager, in dem schlechte Bedingungen herrschen und viele Menschen sterben (Degen, Kap. 10), teilweise nur zur Durchschleusung. - 27.12.1945 „Durchschleusungslager Luckenwalde" erwähnt (BArch, DO 2/39, Bl. 93). - Kapazität am 31.12.1945 (Lager „Treuenbrietzen[er] Tor" ): 4000 (BArch, DO 2/45, Bl. 41). - Kapazität am 1.1.1946: 2000 (BLHA, Rep. 203 MdI, Nr. 1163, Bl. 51). - 1946 Belegungsstärke: 3000 (Kaminsky, S. 159). - 24.8.1946 Umsiedlerlager Treuenbrietzener Tor, Kapazität: 800 (SAPMO-BArch, DY 34/27880, Bl. 291). - 1.1.1947 Lager, Kapazität: 1200 (Oehlsen, S. 101). - Lt. Anordnung vom 15.9.1947 haben sich in der Bodenreform enteignete und daraufhin ausgewiesene Großgrundbesitzer, die nicht bei Verwandten oder Bekannten außerhalb des Zauch-Belziger Kreisgebietes unterkommen können, zwecks weiterer Unterbringung im „Umsiedlerlager Luckenwal-

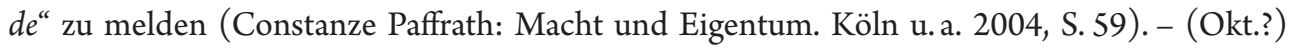
1947 Schließung bevorstehend (SAPMO-BArch, DY 34/27745, Bl. 92).

Kriegsgräberanlage „EHrenfeld Mohrungen“ auf dem WALdFriedhof LuCKenWALDE, südlich der Kapelle (Straße des Friedens): 1945/46 Beisetzung „,von 585 Toten in wenigen 
Wochen“ im sogenannten Mohrungen-Feld: zivile Kriegsopfer, „vorwiegend Flüchtlinge aus den ehemaligen Ostgebieten wie dem namengebenden Kreis Mohrungen im ehemaligen Ostpreußen“, die mit Vertriebenentransporten nach Luckenwalde gekommen waren. „Lange Zeit war diese Fläche nicht gekennzeichnet, und erst 1996 wurden eine kleine Gedenktafel und zwölf steinerne Kreuze aufgestellt. Angesichts der hohen Zahl von 585 hier beigesetzten Kriegsopfern erschien uns aber auch diese Form des Gedenkens nicht ausreichend, so daß im Jahr 2003 beschlossen wurde, die Gedenkanlage gebührend umzugestalten." (Ansprache des für den Neugestaltungsentwurf verantwortlichen Landschaftsarchitekten Dr. Joachim Jacobs, Berlin, bei der Einweihung 2004, s. u.). 30.9.2004 feierliche (Wieder-)Einweihung nach der Neugestaltung, nun sechs Stelen mit Bronzetafeln mit den Namen der Beigesetzten, soweit noch bekannt, und einer gesonderten, vom BdV gespendeten Bronzetafel mit der Versalien-Inschrift: „Heimat-/Zuspruch// und/Tröstung. /Wir ehren/unsere Toten.//Heimatvertriebene/aus dem/Kreis Mohrungen/in Ostpreussen/und anderen/Heimatgebieten/im Osten.//Die von/1945 bis 1947/im/Luckenwalder/Umfeld/durch Krieg und/Flucht ihr Leben verloren.//BdV Teltow-Flaming." (Mahn- und Gedenkstätten Brandenburg, mit Abb.; Bericht mit Texten der Ansprachen und Grußworte von 2004 in: Mohrunger Heimatkreis-Nachrichten 104, 2004, S. 29-33). - Zur Einweihung siehe auch BR 2 (2004)5, S. 15 mit Fotos; längerer Auszug aus der Eröffnungsansprache der Luckenwalder Bürgermeisterin Elisabeth Herzog-von der Heide und 3 Fotos des Ehrenfeldes auch: in Der Zweite Weltkrieg in Luckenwalde, unpagin. [S. 35].

Strassenumbenennungen (nach Kriegsende): Beuthener Straße (seit 1935, zuvor ab 1930 teilweise „Die Welle“) in Zum Freibad sowie 1950 die (1930 als Straße I bis VII angelegten) Straßen einer Siedlung, die 1939 nach „grenzlanddeutschen“ Orten bzw. Landschaften benannt worden waren: Danziger Straße (Eschenweg), Graudenzer Straße (Buchenweg), Flensburger Straße (Ahornallee), Masurenstraße (Akazienallee), Memeler Straße (Birkenstraße), Posener Straße (Eichenstraße) (Maetz, S. 337-346).

StÄdtepartnerschaften: Nach 1973 Kontakte mit Brzeg, Polen (Brieg, Schlesien) (Trzcielińska-Polus, S. 538).

Vertriebenenverbände NACH 1990: (1) BdV-Kreisverband Luckenwalde, Jüterbog, TeltowFlämig, Zossen, Sitz 1996: Am Markt 12, Luckenwalde (BdV-Handbuch 1996, S. 168), später (schon 19.2.1996 erwähnt) BdV-Kreisverband Teltow-Fläming, Sitz Luckenwalde; 25.10.1996 Satzung errichtet, 30.7.1997 eingetragen beim Amtsgericht Luckenwalde (VR 371); Geschäftsstelle: 2001 Am Markt 12, 2008 Upstallweg 6; Vorsitzende: 1992-2002 Dr. Elimar Schwarz (geb. 1928, Lehrer i. R., Rentner, Luckenwalde), 2002-2007 Jens-Michael Knaak (geb. 1969, Rechtsanwalt in Luckenwalde; Pressesprecher der Jungen Union, Kreisverband Teltow-Fläming; auch Schatzmeister des BdV-Landesverbandes), 2007-2009 Mirko Boche (geb. 1972, Versicherungsvertreter; anschließend im Kreisverband Luckenwalde), 2009 Arbeit eingestellt; im Kreisverband existierte ferner ein Ortsverband Luckenwalde und Nuthe-Urstromtal (als Vorsitzende erwähnt: 2001 Alfons Domke [s. u.], 2002 Frank, 2008 Dr. Elimar Schwarz) (Akten der 
BdV-Landesgeschäftsstelle). - (2) BdV-Regionalverband Luckenwalde und Umgebung e. V., Sitz Luckenwalde, gegründet 18.8.2001 (Gründungsversammlung, Satzung errichtet), 16.5.2002 Neuanmeldung beim Amtsgericht Luckenwalde, 25.7.2003 ebd. eingetragen, 2003 bei Jahreshauptversammlung 9 Mitglieder anwesend; Vorsitzende: 2001-2003 Alfons Domke (geb. 1941, Dipl. oec., Luckenwalde, anschließend Beisitzer), 2003-(2006) Hans Hinderlich (geb. 1934, Trebbin OT Schönhagen, Rentner), ab 2008 (noch 2018) Heinz Fröhlich (geb. 1931 Grünberg in Schlesien, Dipl.-Päd., i. R., Rentner, Luckenwalde, zuvor stellv. Vorsitzender, desgl. 1996 im BdV-Kreisverband Teltow-Fläming; 1994 auch Vorstandsmitglied des BdV-Landesverbandes, 1998 dessen stellv. Vorsitzender) (Akten der BdV-Landesgeschäftsstelle). - (3) BdV-Regionalverband Mark Brandenburg, gegründet 30.9.2003 in Luckenwalde, Vorsitzender: Jens-Michael Knaak (s. o.), stellv. Vorsitzender: Dr. Elimar Schwarz (s. o.); Tätigkeit aber bald wieder eingestellt (Akten u. Mitteilung der BdV-Landesgeschäftsstelle). - (5) BdV-Landesverband Brandenburg e. V. (Sitz und Geschäftsstelle $\rightarrow$ Potsdam; Träger mehrerer u. a. für Spätaussiedler tätigen Migrationsberatungsstellen, u. a. in Luckenwalde) (brandenburger-rundschau. de [10.10.2016]).

Archivalische Quellen: BArch, DO 2 ZVU, Nr. 39, Bl. $93-97$ (Lager, Dez. 1945).

Gedruckte Quellen und Literatur: Brühe, Matthias: Katholische Kirche zwischen Havel und Dahme. Berlin 1999, S. 27-28. - Degen, Ilmar: Flucht, Vertreibung und Deportation am Beispiel des Kreises Mohrungen/Ostpreußen. Wunstorf 2001. - Dokumentation der Vertreibung III, S. 299. - Feierliche Wiedereinweihung der Kriegsgräberstätte „Ehrenfeld Mohrungen“ auf dem Waldfriedhof Luckenwalde am 30. September 2004. In: Mohrunger Heimatkreis-Nachrichten Jg. 33, Ausg. 104 (2004), S. 29-33. - 100 Jahre Katholische Pfarrgemeinde Luckenwalde. Luckenwalde 1951. - Maetz, Dietrich: Chronik der Stadt Luckenwalde. Luckenwalde 2016 [für die Jahre 1945 ff. insbes. basierend auf der Datensamlung von Werner Grubert, Luckenwalde 2015]. - Mahn- und Gedenkstätten Brandenburg. Hrsg.: BdV (www.bund-der-vertriebenen.de [20.9.2016]). - Schwillus/Brühe, S. 331. - Töpler, Menschenwurm. - Trzcielińska-Polus. - Wille II, S. 306. - Der Zweite Weltkrieg in Luckenwalde!? Ausstellungskatalog. Text u. Bildausw.: Roman Schmidt. (Luckenwalde 2015).

\section{Ludwigsfelde}

Landgemeinde (1965 Stadtrecht), bis 1952 Kr. Teltow, 1952-1990 Kr. Zossen (Bez. Potsdam), 1990-1993 Ldkr. Zossen, 1993 Ldkr. Teltow-Fläming

BevölKerungszahlen: 1925: 134, 1933: 224, 1939: 3256, 1946: 5 806, 1964: 12212 (Städtebuch, S. 311).

UMSIEDLERLAGER: Das gelegentlich als „Umsiedlerlager Genshagen-Ludwigsfelde“ bezeichnete Lager befand sich im 1997 nach Ludwigsfelde eingemeindeten und diesem unmittelbar benachbarten $\rightarrow$ Genshagen (Kr. Teltow).

Katholiken: 1946: 1080. - „1947 zählte man durch Flüchtlinge und Vertriebene 1700 Katholiken. Die Kuratie wurde zum 1.10.1947 seelsorglich und zum 1.7.1950 auch vermögens- 
rechtlich selbständig.“ (Brühe, S. 29). „1952 lagen Baupläne für eine Kirche vor, durften aber nicht ausgeführt werden." (Schwillus/Brühe, S. 301).

Literatur: Brühe, Matthias: Katholische Kirche zwischen Havel und Dahme. Berlin 1999, S. 29. - Schwillus/Brühe, S. 301 .

\section{Lübben/Spreewald}

Stadtgemeinde, bis 1952 Kr. Lübben, 1952-1990 Kr. Lübben (Bez. Cottbus), 1990-1993 Ldkr. Lübben, 1993 Ldkr. Dahme-Spreewald

EREIGNisSe BIS KRIEGSENDE: Anf. Jan. 1940 besteht in Lübben ein Auffanglager für 300 umgesiedelte Wolhynien- und Galiziendeutsche (Müller, S. 124). - „Am 24. Januar [1945] wurde der Stamm [des Lazaretts Birnbaum] verladen und gelangte über Frankfurt an der Oder nach Lübben im Spreewald.“ (Hielscher, S. 13). - 19.4.1945 (Tagebucheintragung Ursel Treichel): „Seit Tagen, eigentlich schon seit Beginn des Jahres, verstärkt im Vormonat März, fuhren Pferdegespanne mit Flüchtlingen von $[\rightarrow]$ Beeskow und $[\rightarrow]$ Straupitz her kommend, durch die Stadt, nur manchmal anhaltend, weiter nach Westen." (Ebert, Lübben und die Niederlausitz, Bd. 2, S. 9). 25.4.1945 Ende der Kampfhandlungen im Stadtinnern, 27.4.1945 im unmittelbaren Umland (Liebert 2018, S. 39). - 1945 beim Einmarsch der Roten Armee ca. 500 Tote unter Zivilbevölkerung (Städtebuch, S. 314). - Die Stadt gilt bei Kriegsende als schwer zerstört (Töpler, Menschenwurm, S. 295). „Die Kreisstadt Lübben ist auf Grund des Krieges zu $78 \%$ zerstört worden.” (Schreiben des Stadtbauamtes vom 11.6.1947; Neitmann/Schröder/Weirauch, S. 167).

EREIGNISSE NACH KRIEGSENDE 1945: Ab Juni 1945 ständig steigender Zustrom von Flüchtlingen, kritische Gesundheitssituation, Seuchengefahr, Typhus- und Diphterieepidemie (Liebert 2018, S. 44-47). - „Die rasante Zunahme der Einwohnerzahl durch rückkehrende Lübbener und einwandernde Flüchtlinge führte zu einer völlig ungelenkten Belegung der noch erhaltenen Wohnungen und jeglicher Räumlichkeiten, die den obdachlosen Menschen ein Minimum am Schutz boten.“ (Liebert 2019, S. 32). - „Gemeinsam mit dem [sowjetischen] Wirtschaftskommandanten Bratschenko wurden überall in der Stadt Unterbringungsmöglichkeiten für die stetig steigende Zahl der Einwohner gesucht. Dabei wurden vorrangig die bisher militärisch genutzten Standorte überprüft. Neben der Jägerkaserne wurden das Lager des Reichsarbeitsdienstes in der Majoransheide, die Gefangenenlager Frauenberg und Pfaueninsel, das Stabshelferinnenheim Wiesenweg, die Postbauten und das Waldlager $[\rightarrow]$ Börnichen auf ihre Nutzbarkeit überprüft. Weiterhin erfolgte die Untersuchung auch in den im Kreisgebiet befindlichen Militärstandorten und Gefangenenlagern. davon waren die MUNA $[\rightarrow]$ Krugau, die Lager $[\rightarrow]$ Jamlitz, $[\rightarrow]$ Lieberose sowie andere Standorte betroffen[,] in denen nach Unterbringungsmnöglichkeiten und noch vorhandenen Materialbeständen gesucht wurde. [...]/Die Inspekltion der Militärobjekte diente auisschließlich dem Ziel, Unterbringungsräume für den nicht endenden Flüchtlingsstrom zu finden, Schulen, Sparkassengebäude und Räume des Fi- 
nanzamtes waren inzwischen zu überbelegten Massenquartieren geworden. Deshalb wurden Baracken an den Militärstandorten in der Majoransheide, auf der Pfaueninsel, am Frauenberg und im Wiesenwg kurzfristig zu Flüchtlingsunterkünften umgenutzt. Auf Initiative des Bahnhofskommandanten wurden mit Unterstützung der sowjetischen Wirtschaftsoffiziere 250 Plätze im Kasernengelände bereitgestellt und eine Unterkunft für elternlose Kinder ausgebaut. Der Frauenberg wurde auf Befehl des Kreiskommandanten für nicht transportfähige Alte und Kranke sowie für Wöchnerinnen eingerichtet. Im September war er mit 300 Personen völlig überbelegt, daraus resultierten an diesem Standort, wie auch in allen übrigen Massenquartieren völlig unzureichende hygienische Verhältnisse, die eine schnelle Verbreitung infektiöser Krankheiten begünstigten und krasse Auswirkungen auf das Gesundheitswesen im Kreis hatten [...]. (ebd., S. 33). -11.6.1945 Todesfall einer 80-jährigen Flüchtlingsfrau aus Königsberg/Nm. in Lübben (Krätzner, S. 23, nach Angaben in der „Heimatkartei“). - 20.6.1945 Flüchtlingsheime/-lager erwähnt (Liebert 2018, S. 45). - Juli 1945 zahlreiche Flüchtlinge auf dem Bahnhof Lübben (Wille I, S. 34). - 17.9.1945 (Bericht des kath. Pfarrers Franz Janissek [geb. 1904 Namslau, ab 1942 in Lübben, zuvor Kaplan in Schlesien] über die Situation in Lübben): „grausige Not in der Stadt, die in Trümmern liegt. Die beiden Seelsorgsschwestern und eine Caritas-Krankenschwester sind ständig unterwegs. Das Elend in Lübben ist geradezu gräßlich. Flüchtlinge haben mir erzählt, $[\rightarrow]$ Cottbus sei ein Paradies dagegen. Hier bekommen die armen Leute nichts. Jetzt schickt man sie nach Cottbus und von dort nach $[\rightarrow]$ Königswusterhausen nach Bescheinigungen zum Verenden natürlich." (Töpler, Menschenwurm, S. 414). - „Da sich der Flüchtlingsstrom in den Sommermonaten noch verstärkte und die Unterbringungssituation eklatant verschärfte, wurden von der Kommandantur rigorose Maßnahmen angeordnet, die die Aufenthaltsdauer für Flüchtlinge in der Stadt auf 48 Stunden begrenzte, sofern nicht Ausnahmen durch ärztliche Atteste bestätigt wurden. Zur Überwindung dieser beklagenswerten Zustände erhielt das Bauamt von der Militärverwaltung die Freigabe für Baracken aus dem Waldlager Börnichen, dem Lager des Reichsarbeitsdienstes und aus Privatbesitz, die an neuen Standorten im Hasensprung, in der Deichsiedlung, an der Schweineweide und am Ostbahnhof kurzfristig für die Wohnnutzung aufgebaut wurden." (Liebert 2019, S. 33). - Nov. 1945349 und Dez. 19452000 Transporte durch Lübben geführt (Neitmann/Schröder/Weirauch, S. 166). - „Auch zu Beginn des Jahres 1949 waren die in der Stadt bestehenden Wohnverhältnisse nur geringfügig verbessert. Wie in den Vorjahren herrschte Wohnungsnot, es gab es noch Massenquartiere und viele Wohnprovisorien mit katastrophalen hygienischen Bedingungen, die nicht immer winterfest waren “ (Liebert 2019, S. 50).

EREIGNISSE 1950/51: 1950 inoffizielles Treffen von aus Sommerfeld/NL (Kr. Crossen, ehem. Provinz Brandenburg) Vertriebenen: „In Lübben/Spreewald wurde am Himmelfahrtstag eine aus Sommerfeld stammende Glocke, die vor der Vernichtung bewahrt geblieben und der dortigen Kirche zugeteilt worden ist, feierlich geweiht. Ueber 200 Landsleute kamen zum Teil von weither herbeigeeilt, um an dem Festgottesdienst teilzunehmen, nachmittags versammelte man sich in zwei Gaststätten, um noch ein wenig in zwanglosem Geplauder heimatliche Erinnerungen zu pllegen." (Crossener Heimat- 
grüße, Nr. 10, 1950; vgl. auch Nr. 11, 1950). - 1950 Heimattreffen von Vertriebenen aus Grünberg in Schlesien in der evang. Kirche unter Leitung des Pfarrers Dr. Friedrich Böhm $(\rightarrow$ Strausberg) mit ca. 1000 Teilnehmern (BArch, DO 1/27887, Bl. 41). Ein gleichartiges Treffen für in den Kreisen Lübben und umliegenden Kreisen „Senftenberg, Spremberg, Cottbus und Frankfurt/ Oder" ansässigen Grünberger wurde für den 29.7.1951 geplant und ist vmtl. auch durchgeführt worden: vormittags Gottesdienst in der Kirche, nachmittags im Lokal „Wendenfürst“ (ebd.; siehe auch Quellenteil, Nr. 234). - 16.8.1950 lt. Polizeibericht ist Marta Gawel (Schwester des herausgebenden Superintendenten [Heinrich] Gawel in Essen), Lübben, Luckauer Str. 2, zuständig für die Sammlung von „Geldspenden, die die Herausgabe des [Steinauer] Rundbriefes möglich machen“, zuständig (BArch, DO 1/27886, Bl. 100).

EREIGNISSE NACH 1990: 28.5.2005 Heimattreffen der ehemaligen Laubnitzer und Hermsdorfer aus dem Kreis Sorau im Gasthof „Lindengarten“ in Lübben-Treppendorf (29.5. gemeinsame Fahrt in die Heimatorte in Polen) (Lausitzer Rundschau, 12.4.2005).

BEVÖLKERUNGSZAHLEN: 1925: 7866, 1939: 10816, 1946: 9433, 1964: 12300 (Städtebuch, S. 314). - 10.5.1945: 2066 (Liebert 2019, S. 37). - 1945: Mai: 2 516, Juni: 5411, Juli: 8361, Aug.: 8 803, Sept.: 9369, Okt.: 9603, Nov.: 10292, Dez.: 10328 (Ebert, Lübben und die Niederlausitz, Bd. 2, S. 104; Neitmann/Schröder/Weirauch, S. 166). - 31.12 .1945 (einschl. Flüchtlinge): 10537 (Liebert 2019, S. 37). - 27.7. 1946: 10 026, davon [S. 41] 8209 Lübbener, 1442 Flüchtlinge, 375 Heimkehrer) (Liebert 2019, S. 40 f.). - Registrierte Flüchtlinge 1945: Mai: -, Juni: 460, Juli: 672, Aug.: 923, Sept.: 1 223, Okt.: 939, Nov.: 1230, Dez.: 1686 (ebd.). Verpflegte Durchzugsflüchtlinge 1945: Mai: 2939, Juni: 3 170, Juli: 5 820, Aug.: 14087, Sept.: 22 900, Okt.: 4337, Nov.: -, Dez.: 533 (ebd.).

Katholiken (Erzbistum Breslau/Erzbischöfliches Amt Görlitz): 1925: 333, 1946: 730 (Städtebuch, S. 315). - 1946-1949 wirkt als Kaplan in Lübben (wohnt 1949 Am Kleinen Hain 43) der bis 1945 in Küstrin und kurzzeitig 1945/46 in $\rightarrow$ Birkenwerder wirkende Kaplan Alfons Kuschbert (geb. 1911 Neisse) (Ostpriesterverzeichnis 2, 1949, S. 50), ab 1.4.1949 in $\rightarrow$ Straupitz (Schematismus Görlitz, S. 68). - 1948-1951 ist der aus Breslau gebürtige, zuvor seit 1945 als Kaplan in Wittichenau (Kr. Hoyerswerda) wirkende Bernhard Kaßner (geb. 1913) Kaplan, anschließend in Weißwasser (Schematismus Görlitz 1954, S. 68).

FlÜCHTLINGS-/UmSIEdLERLAGER: 1945 als Sammellager in Lübben genutzt: Baracken des ehem. Reichsarbeitsdienstes sowie die Jägerkaserne (Becken, S. 28); in der ehem. Jägerkaserne (1 500 Personen) „befand sich schon seit Juni 1945 ein Durchgangslager“ (Mietk, S. 18). „Dort [im Kasernenbereich] und im Lazarett verstarben sehr viele Flüchtlinge. Von Mitte August bis Mitte November 1945 starben etwa 60 Typhuskranke, die Erzpriester Janissek im Totenbuch der katholischen Kirche vermerkte, im Beerdigungsbuch der Paul-Gerhardt-Kirche sind es für den gleichen Zeitraum noch einmal rund 130 Personen, fast ausschließlich Flüchtlinge, darunter besonders viele Kinder aller Altersstufen. Das betraf Flüchtlinge, die ihren letzten 
Beistand von den beiden großen Lübbener Kirchen erhielten. Hinzu kommen noch Flüchtlinge, die ohne kirchliche Unterstützung beerdigt wurden." (Ebert, Lübben und die Niederlausitz, Bd. 2, S. 73). - 17.9.1945 (Bericht des kath. Pfarrers Franz Janissek über die Situation in Lübben): „Fast täglich: Beerdigungen, Krankenbesuche, besonders in den riesigen Flüchtlingslagern. / Die Kaserne hat allein ca. 15 Hauptgebäude und 8 Baracken. Dazu noch 2 große Flüchtlingslager, das Kreiskrankenhaus und das Landeskrankenhaus. [...] Jeden Montag abend 19 Uhr Flüchtlingsgottesdienst im Freien auf dem Kasernenhof. Letzten Montag waren es 200 Kommunionen." (Töpler, Menschenwurm, S. 414). - Im „Verzeichnis der errichteten und vorgesehenen Umsiedlerlager im Verwaltungsbezirk Cottbus“ vom 15.12.1945 mit „Personenzahl“ 700 genannt (Töpler, Menschenwurm, S. 472). - Kapazität am 31.12.1945 (Lager „Lübben“): 1500 (BArch, DO 2/45, B1. 40). - [Lager Jägerkaserne]: Kapazität am 1.1.1946: 1500 (BLHA, Rep. 203 MdI, Nr. 1163, B1. 51). - 1946 Belegungsstärke: 800 (Kaminsky, S. 159). - „Dazu gab es einige kleinere Lager in Lübben auf der Pfaueninsel (Baracke des ehemaligen Kriegsgefangenenlagers mit einer Gesamtfassung von 120 Flüchtlingen) und im Stabshelferinnenheim (Wiesenweg/ehemals Trüschels Fabrik, mit einer Gesamtfassung von 550 Flüchtlingen), die nicht lange bestanden bzw. dann wegen ihrer geringen Größe nicht mehr als ,Lager' in den Berichten definiert worden waren. Nur zwischen Oktober und Dezember 1945 gab es Zählungen über Flüchtlinge in den Lagern Pfauennsel und Wiesenweg“: ehem. Stabshelferinnenheim: 499 bis 611, Pfaueninsel: 70 bis 96 Flüchtlinge (Mietk, S. 19). - Juli 1946 Beanspruchung des Areals der Jägerkaserne, zweier Gebäude der Landesklink und der Bahnhofstraße 31, des ehemaligen Landwehrlagers im Wiesenweg sowie von Telien des RAD-Lagers in der Majoransheide durch die sowjetische Besatzungsmacht. „Die Nachricht glich einer Katastrophe, da alle Standorte durch Flüchtlinge belegt waren. Die Tragweite und die Folgen des Befehls wurden erst sichtbar, als binnen weniger Tage der Beschluß noch präzisiert wurde. Danach war das Kasernengelände bis zum 01. Juli 46 von allen Privatpersonen zu räumen. [... In Abstimmung mit dem Landratsamt und mit Unterstützung der Militärverwaltung mußten die Flüchtlinge, quasi über Nacht, in das Kreisgebiet umgesiedelt werden, wobei ein Teil auch in die bereits überbelegten Räumlichkeiten der Stadt eingewiesen wurde. [...] (Liebert 2018, S. 40). - Auflösung der Lager: ehem. Stabshelferinnenheim: Mai 1946; Jägerkaserne: Juni 1946; Pfaueninsel: keine Angaben (Mietk, S. 19).

StÄNDISChes Landhaus: „Im Ständischen Landhaus, das die Kampfhandlungen im April ohne Zerstörung von Gebäudeteilen überstanden hatte, wohnen von 1945 bis 1949 viele Umsiedlerfamilien, Flüchtlinge, Vertriebene und Familien, die ihre Wohnungen durch Brand oder Bombenschäden verloren hatten (1949 noch 38 Familien)." [Außerdem sind hier Behörden untergebracht.] (Ebert 2003, S. 494; vgl. auch Becken, S. 28).

FlÜChtLINGS-MASSENGRÄBER AUf DEM FrIEDhof AM WASSERTURM: „Insgesamt weist die Gräberliste der Lübbener Stadtverwaltung 688 Flüchtlinge auf. / Doch auch diese Zahl ist ungenau. Leider wurden nicht alle toten Flüchtlinge dort am Wasserturm (Westteil des Lübbener Friedhofgeländes, d. Verf.) bestattet. Es gab außerdem noch einen sogenannten ,Kinderfried- 
hof: Wieviele Kinder dort bestattet wurden, ist nicht bekannt. / Da die Flüchtlingsgräber in der Folgezeit von niemandem gepflegt wurden und auch nur wenige hölzerne Namentafeln trugen, verwilderte die Fläche und verwitterten die Tafeln. Eine spätere Friedhofverwaltung ebnete die Fläche ein, so daß zunächst die genaue Grablage nicht mehr bekannt war. Nur noch in den kirchlichen Bestattungsbüchern und in städtischen Sterbelisten fand sich der Hinweis: ,Flüchtlingsgrab am Wasserturm. / Erst im Jahre 1996 begann die Lübbener Stadtverwaltung, den sicher mehr als 700 unbekannten Flüchtlingen die längst fällige Ehre zu erweisen und eine Gedenkstätte zu errichten. / Die Rasenfläche am Wasserturm wurde eingefaßt und mit einem Gedenkstein versehen, der die Worte trägt ,Zum Gedenken an die Flüchtlinge, die an den Folgen des 2. Weltkrieges gestorben sind.' / Weitere Flüchtlings- und auch Soldatengräber werden heute noch auf dem Kommunalen Friedhof in Steinkirchen und in Lübben-Nord, rechts der Hartmannsdorfer Straße vor der Trasse der ehemaligen Spreewaldbahn im Bereich des ehemaligen Friedhofs der früheren ,Brandenburgischen Idiotenanstalt' vermutet.“ (Ebert, Lübben und die Niederlausitz, Bd. 2, S. 73). - „Wie geschwächt diese Menschen durch Mangelernährung und Krankheiten wie Tuberkulose, Diphterie und Typhus waren, davon zeugt das Gräberfeld auf dem Lübbener Friedhof mit über 600 von Mai - Dezember 1945 gestorbenen Flüchtlingen." (Becken, S. 29, mit Abb. von zwei Beispielseiten 40 [Mai, Juli und Dez. 1945] und 43 [7. bis 16. Juli 1945, Nachtrag 28. Okt. 1945] aus dem Totenbuch der Friedhofsverwaltung für das Gräberfeld der Flüchtlinge, überschrieben „Massengräber Flüchtlinge“ und „2te Reihe Kinderfriedhof", bzw. „3te Reihe Kinderfriedhof").

Gedenkstein: Auf dem Friedhof befindet sich am Gräberfeld der Flüchtlinge und Vertriebenen ein aufrecht stehender Stein mit Inschrift (Versalien, Text s. o.) (Becken, S. 28 mit Abb.).

StäDtepartnerschaften: 1993 Wolsztyn, Polen (Wollstein, ehem. Provinz Posen).

VertriebenenVERBÄNDE NACH 1990: BdV-Kreisverband Lübben/Luckau, Sitz Lübben, gegründet 1993 (LR, 25.3.2003; Akten der BdV-Landesgeschäftsstelle), zuvor bereits 1989/90 BdV in Lübben (Amtsblatt für den Landkreis Dahme-Spreewald Jg. 13, 2006, Nr. 43, S. 2), 24.4.1993 Satzung errichtet, 18.4.1994 eingetragen beim Amtsgericht Lübben (VR 179); 1996 BdV-Kreisverband Lübben, Luckau, Dahme/Spreewald erwähnt mit Sitz in $\rightarrow$ Lübben, Lehmmühlengasse 5 (BdV-Handbuch 1996, S. 168), 2002 Umzug der Geschäftsstelle von Lohmühlengasse 2 nach Bahnhofstr. 42 (Zimmer 26), von der Stadtverwaltung kostenlos zur Verfügung gestellt. 18.12.2002 Weihnachtsfeier im „Lindengarten“ in Treppendorf (LR, 6.12.2002, 25.3.2003); zum 31.12.2009 aufgelöst (Akten wir vor). - Mitgliederzahlen: 16.3.2002 GesamtMitgliederversammlung im Sitzungssaal des Landratsamtes Lübben mit 43 Teilnehmern von insgesamt 100 Mitgliedern, 2006111 Mitglieder (Akten wir vor). - Vorsitzende: 1993-(2004) Werner Gäbler, Lübben (geb. 1934, Bau- u. Möbeltischler, im Vorruhestand), (2007)-2009 Manfred Walther (geb. 1948 Parchim, Rechtsanwalt u. Notar in Berlin; war 1989 Rechtsanwalt in Lübben; siehe auch $\rightarrow$ Potsdam/BdV-Landesvorsitzender) (Akten wie vor). - Jahresrückblick 2002 des Vorsitzenden Werner Gäbler (nach Zeitungsbericht): „Im Mittelpunkt stand im 
Vorjahr erneut die Pflege des kulturellen Erbes und die erfolgreiche Integration von Aussiedlern. Die Arbeit mit den Russland-Deutschen [Spätaussiedler, P. B.] hat in Lübben eine besondere Bedeutung. Der BdV betreut diese beispielsweise im Aussiedlerheim der Stadt. / Mehr als 200 Gespräche wurden laut Gäbler im vergangenen Jahr geführt, viele davon auch in der Kleiderkammer. ,Diese Brücke zur Verständigung wurde gern angenommen', betonte der Vorsitzende. Die Aussiedler hätten das Angebot nicht nur für den eigenen Bedarf sondern auch für ihre Familien in der Heimat genutzt und so eine Verbindung hergestellt. Doch die Brücke zur Verständigung ist unterbrochen. Die ABM-Stelle in der Kleiderkammer lief Ende Februar dieses Jahres aus. ,Einen neuen Antrag lehnte das Arbeitsamt ab', zeigte sich Werner Gäbler enttäuscht. Seiner Ansicht nach ist dieses Verhalten ,ein Schlag gegen die Spätaussiedler'. Der BdV sucht jetzt nach anderen Lösungen. So sichern Vorstandsmitglieder vorerst stundenweise die Betreuung der Kleiderkammer. Auf Dauer werde dies jedoch kaum machbar sein, befürchtet der Vorsitzende." (LR, 25.3.2003).

Archivalische Quellen: BArch, DO 1 Ministerium des Innern der DDR, Nr. 27886, Bl. 100 (Marta Gawel, 1950). - BArch, DO 1/27887, Bl. 39-41 (Grünberger Treffen 1950/51). - Auskünfte: Manfred Walther (Berlin) u. Eckhard Tolzmann (Lübben), 6.8.2018.

GedRUCKTE QUelLen und Literatur: Becken, Jörg: Lübben nach dm Inferno. Die Jahre 1945-61. [Cottbus] 2010 (S. 82: Auszug aus Klassenbuch der $12 \mathrm{~b}$ des Abiturjahrgangs 1958 mit Angabe der Geburtsorte, darunter 2 aus Kr. Crossen, 1 aus Kr. Sorau, 2 aus Niederschlesien, 1 aus Königsberg, 2 aus Reichenberg/Sudetenland). - Ebert, Rolf: Lübben und die Niederlausitz. Bd. 2: Lübben im April/Mai 1945. Lübben 1997. - Ders.: Zur Geschichte der Stadt Lübben (Spreewald). Lübben 2003. - Hielscher, Karl A.: Das Kriegsende 1944/45 für den Kreis Birnbaum. In: Birnbaum/Warthe. Hrsg. von Margarete Becker u. a. Hemmingen 1977, S. 9-18. - Krätzner, S. 23. - Liebert, Bodo: Lübben - der Wiederaufbau ab 1945. Lübbener Heimatkalender 2018 (2017), S. 39-60; 2019 (2018), S. 28-53; 2020 (2019), S. 116-150. - Maziul, Eckart: Steinkirchen im April/Mai 1945. In: Lübbener Heimatkalender 2020 (2019), S. 108-111. - Mietk, Thomas: Neuanfang im Kreis Lübben. Beitrag zur Flüchtlings- und Vertriebenenforschung am Ende des Zweiten Weltkrieges. Lübben 2010. - Müller, Erich: Transporte, Lager, Ansiedlung im Warthegau: Das Schicksal der galizien- und wolhyniendeutschen Umsiedler nach ihrem Grenzübertritt 1939/40. In: Zeitweiser der Galiziendeutschen 43 (2005), S. 104-157. - Neitmann, Klaus / Schröder, Kathrin / Weirauch, Kärstin: „Ist eine Zierde des Landes gewest". Lübben (Spreewald) im Spiegel archivalischer Quellen. Berlin 2006. - Renke, Herbert: Der Heimat Glocke klingt nun wieder. In: Crossener Heimatgrüße, Nr. 11, 1950, unpagin. (S. [7]). - Sommerfelder Glocke in Lübben. In: ebd., Nr. 10, 1950, unpagin. (S. [6]). - Töpler, Menschenwurm. - Wille I, S. 34, 459.

\section{Lübbenau (Spreewald)}

Stadtgemeinde, bis 1950 Kr. Calau (ab 1950 Kr. Senftenberg), 1.7.1950-1952 Kr. Lübben, 1952-1990 Kr. Calau (Bez. Cottbus), 1990-1993 Ldkr. Calau, 1993 Ldkr. OberspreewaldLausitz

EREIGNISSE NACH KRIEGSENDE: 15.3.1947 Erwähnung einer „Umsiedlergenossenschaft“ (Heimarbeit) „Genossenschaft für Holzbearbeitung“ mit 15 Arbeitern (BLHA, Rep. 333, Nr. 574, B1. 105).

BevöLKerungSZAHLEN: 1925: 4650, 1939: 4 190, 1946: 5626, 1964: 16287 (Städtebuch, S. 319). 
Katholiken (Erzbistum Breslau/Erzbischöfliches Amt Görlitz): 1925: 85, „1945: ca. 1200 Kath. (Flüchtlinge!)“; 1946: 438 (Städtebuch, S. 320). - Ab 1952 wirkt als Kaplan und ab 1954 als Kuratitalpfarrer in Lübbenau der vor 1945 als Kaplan in Oberschreiberhau (Schlesien) tätige Johannes Langer (geb. 1918 Potsdam), zuvor Kaplan in $\rightarrow$ Kirchhain (Schematismus Görlitz 1954, S. 68; Ostpriesterverzeichnis 2, 1949, S. 51).

UMSIEDLERLAGER: 24.10.1945 vom Landratsamt in Bericht erwähnt mit Kapazität „700 Mann“ nach „Räumung von den jetzt dort dauernd untergebrachten Umsiedlern und deren Einweisung in Ortsquartiere" (Töpler, Menschenwurm, S. 451). - Kapazität am 31.12.1945: 250 (BArch, DO 2/45, Bl. 41). - Kapazität am 1.1.1946: 350 (BLHA, Rep. 203 MdI, Nr. 1163, Bl. 51).

StÄdtepartnerschaften: (1) 1981 (erneuert 1.4.2000) Nowogród Bobrzański, Polen (Naumburg am Bober, Schlesien). - (2) 1.4.2000 Pniewe, Polen (Pinne, ehem. Kr. Samter, Provinz Posen). - (3) 21.10.2005 Świdnica, Polen (Schweidnitz, Schlesien) (www.luebbenauspreewald.de [31.8.2016]).

Archivalische Quellen: BLHA, Rep. 333 SED-Landesleitung Brandenburg, Nr. 574, Bl. 105.

Gedruckte Quellen und Literatur: Blöß, Kreise und Gemeinden, S. 14. - Töpler, Menschenwurm, S. 414, 451.

\section{Lychen}

Stadtgemeinde, bis 1952 Kr. Templin, 1952-1990 Kr. Templin (Bez. Neubrandenburg), 19901993 Ldkr. Templin (Land Brandenburg), 1993 Ldkr. Uckermark

EREIGNISSE BIS KRIEgSENDE: 1945 (Bericht der Stadtverwaltung vom Nov. oder Dez. 1945, verfasst von Gustav Metscher): „In den letzten Kriegsjahren hatte die Einwohnerschaft viel Elend zu sehen bekommen. Grosse endlose Flüchtlingszüge wurden hier durchgeschleust, Tag um Tag, Woche um Woche. Die Bevölkerung gab ihr Letztes her, um die Not lindern zu helfen. Der Friedhof nahm viele viele derjenigen Heimatlosen auf in seinen Frieden, die hier ihre letzte Ruhestätte fanden. Die Räume der Stadtschule wurden in Notquartiere für die müden Wanderer [so!]. Monatelang setzte dadurch der Unterricht aus. / [...] [S. 118] Unsagbar gross wurde das Elend der Einwohner. Die meisten Einwohner, die sich in die Wälder geflüchtet hatten, fanden, als sie zurückkehrten, nichts mehr von ihrem Hab und Gut. Alles war begraben unter den Trümmern oder verbrannt in den Flammen. Sie hatten keine Bleibe mehr. So drängte sich alles zusammen in den Häusern, die noch stehen geblieben waren. Viele von diesen Häusern waren aber inzwischen von der Roten Armee beschlagnahmt worden." (Brandenburgische Gemeinden 1945, S. 117 f.).

BevölKerungszahlen: 1925: 3867, 1939: 4332, 1946: 3649, 1964: 3562 (Städtebuch, S. 324).

KATHOLIKEN: 1925: 122, 1946: 193 (Städtebuch, S. 324). 
UMSIEDLERLAGER: 14.11.1945 als überfüllt erwähnt (Wille I, S.318). - Kapazität am 1.1.1946: 2000 (BLHA, Rep. 203 MdI, Nr. 1163, Bl. 51) [Wohl aber identisch mit dem für den 31.12.1945 erwähnten Lager „Lychen-Himmelpfort“ ( $\rightarrow$ Himmelpfort).]

Gedruckte Quellen: Brandenburgische Gemeinden 1945, S. 117-120. - Wille I, S. 318.

\section{Märkisch Buchholz}

Stadtgemeinde (Name seit 1937 Märkisch Buchholz, zuvor Wendisch Buchholz, 1945-1949 jedoch zeitweilig wieder Wendisch Buchholz, ab 1949 nur noch Märkisch Buchholz), bis 1950 Kr. Beeskow-Storkow, 1950-1952 Kr. Lübben, 1952-1990 Kr. Königs Wusterhausen (Bez. Potsdam), 1990-1993 Ldkr. Königs Wusterhausen, 1993 Ldkr. Dahme-Spreewald

EREIGNISSE BIS KRIEGSENDE: „In Leibsch waren schon ab Ende Januar [1945] durchziehende Schwarzmeerdeutsche und andere Flüchtlinge, die mit Fuhrwerken und teils mit Handwagen kamen, zu versorgen.“ (Müller, S. 384). - Die Stadt wird kurz vor Kriegsende zur „Festung“ erklärt und erleidet in der Folge schwere Zerstörungen (Töpler, Menschenwurm, S. 295). [Gegen Ende April 1945:] „Was sich dann in diese kleinen märkischen Ortschaft und ihrer Umgebung abspielte, vermag ich kaum in Worte zu fassen. Es übertraf alles bisher Erlebte. Der Ort war vollgestopft mit Fahrzeugen jeglicher Art. Wehrmachtstransporte und Flüchtlingstrecks standen dicht gedrängt in den Straßen, als der Beschuss einsetzte. (...)."]. (Wilke, S. 50). - 29.4.1945 Einmarsch der Roten Armee (ebd., S. 384).

EREIGNISSE NACH KRIEgSENDE: Ab Spätsommer 1945 Aufnahme von Heimatvertriebenen in Buchholz und Köthen (Müller, S. 397, mit Statistik). „In Köthen, Halbe, Leibsch und Neuendorf hatten sich Bürger elternlose Kinder angenommen." (ebd.). - 1945 Bodenreform (ebd., S. 394f., 401, auch zu den umgebenden Dörfern), Neubauern sind vor allem „Heimatvertriebene und ehem. Arbeiter“ (ebd., S. 412). - „Eine Betondachsteinproduktion betrieb der heimatvertriebene Alfred Wenzel von 1946-1953 in den Räumen des enteigneten Baubetriebes an der Eisenbahnstraße, Flurst[ück]. 7/31. Den Kies gewann Wenzel auf dem Nachbargrundstück Flurst. 7/30، (ebd., S. 407). - Von 1949 bis 1984 lebte in Märkisch Buchholz (und Ost-Berlin) der bekannte, aus Böhmen stammende Schriftsteller Franz Fühmann (1922-1984) (Danyel/ Kaule/Zündorf, S. 76).

BevölKerUngSZAHLEN: 1925: 995, 1939: 1081, 1946: 1027,1948 etwa 160 Flüchtlinge, 1964: 915 (Städtebuch, S. 329).

Katholiken (Erzbistum Breslau/Erzbischöfliches Amt Görlitz): 1925: 33, 1946: 51 (Städtebuch, S. 329).

Literatur: Danyel, Jürgen / Kaule, Martin / Zündorf, Irmgard: Brandenburg 1945-1990. Berlin 2018, S. 76 f. Müller, Franz: Chronik der Stadt Märkisch Buchholz. Berlin 2001 [S. 377-384 ausführliche Schilderung der letzten 
Kriegstage]. - Richter, Hans: Franz Fühmann. In: Böhmen. Hrsg. von Frank-Lothar Kroll. Berlin 2000, S. 127-150. Wilke, Dorothea: Der Krieg ist aus. In: Zeitgebunden. Cottbus 2010, S. 47-51.

\section{Mahlow}

Landgemeinde (seit 2003 Ortsteil von Blankenfelde-Mahlow; vgl. $\rightarrow$ Blankenfelde), bis 1952 Kr. Teltow, 1952-1990 Kr. Zossen (Bez. Potsdam), 1990-1993 Ldkr. Zossen, 1993 Ldkr. Teltow-Fläming

Strassenumbenennungen (nach Kriegsende): Beuthener Straße in Mendelssohnstraße, Bromberger Straße in Tschaikowskystraße, Warschauer Straße in Josef-Haydn-Straße, Oppelner Straße in Eichendorffstraße, Graudenzer Straße in Mozartstraße (Wölfle-Fischer, S. 98).

LiterAtur: Wölfle-Fischer, Susanne: 725 Jahre Mahlow. [Mahlow] 2011.

\section{Marquardt}

Landgemeinde (seit 2003 Ortsteil von $\rightarrow$ Potsdam), bis 1952 Kr. Osthavelland, 1952-1990 Kr. Potsdam-Land (Bez. Potsdam), 1990-1993 Ldkr. Potsdam, 1993-2003 Ldkr. Potsdam-Mittelmark, 2003 Stadtkr. Potsdam

EREIGNISSE NACH KRIEGSENDE: „1945 [:] Der vom Landrat des Kreises [ $\rightarrow$ ] Osthavelland vorgegebene Abriss des Marquardter Schlosses zur Gewinnung von Baumaterial für Wohnungen wird nicht vollzogen. Im Schloss werden stattdessen Flüchtlingsfamilien aus den ehemaligen deutschen Ostprovinzen untergebracht. / Mit Genehmigung des Bürgermeisters werden auf den Hauptflächen des Parkes Kartoffeln und Gemüse angebaut.“ (Grittner, S. 54). - „1946[:] Die Einwohnerzahl hat sich durch den Zuzug von vertriebenen Familien aus Schlesien, Ostpreußen, Pommern, der Neumark und dem Sudetenland von 422 (1939) auf 528 (1946) erhöht." (ebd. S. 54f.).

MÄrkische GehöRlosenschule: Die am 20.1.1945 durch Zugtransport nach $\rightarrow$ Pritzwalk (Ankunft: 21.1.) evakuierte Gehörlosenschule Posen (Kinder u. 11 Begleitpersonen) wurde im Februar 1946 von der Provinzialverwaltung Brandenburg übernommen, mangels Weiterbildungsmöglichkeiten in Pritzwalk aber im Aug. 1946 als nunmehrige „Märkische Gehörlosenschule in das Schloss Marquardt verlegt. Situation bei Ankunft: „Das Schloß, ehemaliges Ausflugsziel und Luxusgaststätte, ist völlig verwüstet. Für die Bedürfnisse der Schule hatte man es notdürftig hergerichtet. Einfache Tische, Bänke, Hocker und Betten sind das Mobiliar. Durch die Nutzung einer ehemaligen Lazarettbaracke kann die unerträgliche Enge vorerst übewunden werden. Es ist eine erste Stätte der Ruhe und des Friedens für die kriegserschöpften Kinder und gleichzeitig Keimzelle einer Gehörlosenschule in Brandenburg. / Der eisige Winter 1946/47 bringt große Schwierigkeiten mit der Heizung. Die Baracke muß abgerissen und verheizt werden. Das Wasser friert in. Einzig der Kamin in der Halle wärmt die erstarrten Räume. Im 
Eßsaal sind 5 Klassen zusammengestellt. [... Z Zu Beginn des Jahres 1947 ist ein Schulbetrieb nicht mehr möglich. Die Kinder werden aus den Weihnachtsferien nach Marquardt nicht mehr zurückgerufen. Es wird beschlossen, die Schule nach $[\rightarrow]$ Eberswalde zu verlegen. [...] Am 21.4.1947 kommen die Kinder nach Eberswalde.“ (Pelzer/Pelzer, S. 14).

BevÖLKERUNGSZAHLEN: 1925: 476, 1939: 422, 1946: 528, 1964: 414 (HOL III, S. 234).

Gedruckte Quellen und Literatur: Adreßbuch Groß-Potsdam 1949, S. 880-881. - Grittner, Wolfgang: Marquardt. Illustrierte Zeittafel zur Ortsgeschichte 1313-2016. [Marquardt] 2017. - Pelzer, Rotraut / Pelzer, Susanne: Das Gehörlosenschulwesen der Provinz Brandenburg. In: Pritzwalker Heimatblätter 2 (1989), S. $12-14$.

\section{Meyenburg}

Stadtgemeinde, bis 1952 Kr. Ostprignitz, 1952-1990 Kr. Pritzwalk (Bez. Potsdam), 1990-1993 Ldkr. Pritzwalk, 1993 Ldkr. Prignitz

BevölKeRUngszahlen: 1925: 2 165, 1939: 2222, 1946: 3329, 1964: 3040 (Städtebuch, S. 333).

Katholiken: 1925: 47, 1946: 332 (Städtebuch, S. 333). - „Nach dem II. Weltkrieg wurden Tausende Vertriebene in der Prignitz angesiedelt, unter ihnen auch Katholiken. Wegen der allgemeinen Wohnungsnot musste die bisherige Kapelle aufgegeben werden. Die Gottesdienste wurden in evangelischen Kirchen gehalten, bis in Meyenburg ein Grundstück erworben und hier am 8.7.1951 ein Gottesdienstraum benediziert werden konnte. [...]. / Die Pläne gingen auf Kurt Reuter (1948-54) zurück, der seit Oktober 1948 [aus $\rightarrow$ Pritzwalk kommend] als erster Priester in Meyenburg ansässig war. Zunächst war er als ,Flüchlingsseelsorger' ernannt und hatte bei einer katholischen Familie gewohnt. Zum 1.7.1953 wurde Meyenburg mit etwa 900 Katholiken seelsorglich, 1959 auch vermögensrechtlich selbständige Kuratie. [...]./ Die Mariahilf-Ikone wurde von einem der Vertriebenen angefertigt. [...].“ (Brühe, S. 29). - „In den umliegenden Orten, vor allem dort, wo landwirtschaftliche Güter enteignet wurden, wurden weitere 1200 Katholiken angesiedelt. [...] In Meyenburg und anderen Orten wurden katholische Gottesdienste nunmehr in evangelischen Kirchen abgehalten, dank des Entgegenkommens evangelischer Kirchengemeindem, z. B. in Frehne, Penzlin und Retzow, hier übrigens in einer Gaststätte.“ (1899-1999, S. 11). - „Reuter reiste zunächst als ,wandernde Kirche‘ per Fahrrad und später mit einem leichten Motorrad als ,Rucksack- und Wanderpriester' und wurde schließlich am 15. Oktober [1948] in Meyenburg bei Familie Biesenthal in der Freyensteiner Straße 9 ansässig." (ebd., S. 12). - Pfarrer [Fritz] Krusche (Pritzwalk) [geb. 1892 Bunzlau] bittet am 1810.1947 bei der Stadtverwaltung Meyenburg um einen „Wohn- und Amtsraum“ für den neu nach Meyenburg gekommnen Pfarrer Reuter: „Die Katholiken der Stadt Meyenburg gehören zur kath. Kirchengemeinde $[\rightarrow]$ Pritzwalk. [...] Zahl der Katholiken in Meyenburg selbst und Umgebung mehr als verzehnfacht [...]. Nun ist der für Meyenburg vorgesehene Pfarrer bereits eingetroffen: Herr Pfarrer Kurt Reuter, der aus Pommern (Swinemünde) ausgewiesen wurde. [...]." (ebd., S. 10). 
EvAKuIERUngSort: Im Februar 1945 befand sich der Sitz der evakuierten „KrankenhausSchule (?) Züllichau (?)“ in Meyenburg (Ostprignitz) (BLHA, Rep. 6B Züllichau-Schwiebus, Nr. 169).

Gedruckte Quellen und Literatur: Brühe, Matthias: Katholische Kirche zwischen Prignitz und Havelland. Berlin 2000, S. 29. - 100 Jahre Katholische Kirche in Meyenburg. 1899-1999. [Meyenburg 1999]. - Schwillus/Brühe, S. 357. - Wirtschafts-Wegweiser für Wittenberge und die Kreise West- und Ostprignitz. Branchen-Adreßbuch. Potsdam (1949), S. XIII (Dienststellen der Stadt), 49-134 (Firmen).

\section{Michendorf}

Landgemeinde, bis 1952 Kr. Zauch-Belzig, 1952-1990 Kr. Potsdam-Land (Bez. Potsdam), 1990-1993 Ldkr. Potsdam, 1993 Ldkr. Potsdam-Mittelmark

EReignisse bis Kriegsende: April 1945 Einmarsch der Roten Armee, kampflose Übergabe (Strich, S. 30).

EREIGNisSE NACH KRIEGSENDE: 1945 (Bericht der Gemeindeverwaltung vom Nov. oder Dez. 1945): „Gegenwärtig zählt die Stadt [!] infolge von Zuwanderung durch Flüchtlinge und aus Berlin über 3000 Einwohner. Aber unter diesen 3000 befinden sich etwa 900 Kinder und Jugendliche." (Brandenburgische Gemeinden 1945, S. 130). - 1946 in der Bodenreform Umsiedler nicht gesondert berücksichtigt (HOL V, S. 268).

BEVÖLKERUNGSZAHLEN: 1925: 1490, 1939: 2 526, 1946: 3 055, 1964: 2989 (HOL V, S. 269).

Katholiken: „Zum 1.3.45 wurde Otto Hoffmann [1891 Berlin] als erster Seelsorger angestellt und eine Lokalie entstand. Die Zahl der Katholiken nahm durch Flüchtlinge bald zu. In der ehemaligen Remise wurde am 2.7.1946 die bescheidne St.-Josefs-Kapelle benediziert. Damals zählte man etwa 450 Katholiken.“ 1952 Kuratie (Brühe, S. 30; textähnlich, aber gekürzt: Schwillus/Brühe, S. 332).

Gedruckte Quellen und Literatur: Adreßbuch Groß-Potsdam 1949, S. 881-893. - Brandenburgische Gemeinden 1945, S. 127-130. - Brühe, Matthias: Katholische Kirche zwischen Havel und Dahme. Berlin 1999, S. 30. Schwillus/Brühe, S. 332. - Strich, Hans-Joachim: Kleine Michendorfer Chronik. In: Zwischen Havelland und Flänming 2000, S. 27-33.

\section{Mildenberg}

Landgemeinde (seit 2003 Ortsteil der Stadt $\rightarrow$ Zehdenick), bis 1952 Kr. Templin, 1952-1990 Kr. Gransee (Bez. Potsdam), 1990-1993 Ldkr. Gransee, 1993 Ldkr. Oberhavel

KATHOLIKen: „Ab 1943 vermehrten evakuierte und wohl auch ausgebombte Berliner die Zahl der Gemeindeglieder, vor allem aber waren es die bis Kriegsende die Flüchtlinge aus dem Osten 
und in den Folgejahren die Heimatvertriebenen aus den ehemaligen deutschen Gebieten." (75 Jahre, S. 25).

Literatur: 75 Jahre Katholische Kirche Heilig Kreuz in Mildenberg. 1937-2012. Templin (2012).

\section{Mittenwalde}

Stadtgemeinde, bis 1952 Kr. Teltow, 1952-1990 Kr. Königs Wusterhausen (Bez. Potsdam), 1990-1993 Ldkr. Königs Wusterhausen, 1993 Ldkr. Dahme-Spreewald

Ereignisse bis Kriegsende: April 1945 (Bericht der Stadtverwaltung vom Nov. oder Dez. 1945): „Mittenwalde im April 1945. [...] In Mittenwalde sind Tausende von Flüchtlingen untergebracht und ein übernatürlicher Waffenlärm hat sich entfaltet." (Brandenburgische Gemeinden 1945, S. 130).

EREIGNisSe NACH KRIEGSEnde: Ende 1945 (Bericht der Stadtverwaltung vom Nov. oder Dez. 1945): „Ernst Neumann und Alfred Gehrmann als Beisitzer haben, wie man es von ihnen erwartete, die kleinen sozialen Fragen, wie Flüchtlingsproblem, Materialfragen, Zurückführung deutscher Soldaten, Beleuchtung und sonstige Fragen zur Zufriedenheit gelöst." (Brandenburgische Gemeinden 1945, S. 139). - In der Region Mittenwalde/Ragow leben noch in den 1950er Jahren besonders viele Vertriebene aus Ziebingen (Kr. Weststernberg) (Schieche/Jaeschke, S. 320).

Bevölkerungszahlen: 1925: 3060, 1939: 3136, 1946: 3432, 1964: 2599 (Städtebuch, S. 337).

Katholiken: 1925: 105, 1946: 282 (Städtebuch, S. 338).

Gedruckte Quellen und Literatur: Brandenburgische Gemeinden 1945, S. 133-140.- Schieche, Manfred / Jaeschke, Gerhard: Ziebingen. Eisenhüttenstadt u. a. 2001.

\section{Mönchwinkel}

Landgemeinde (seit 2003 Ortsteil von $\rightarrow$ Grünheide/Mark), bis 1950 Kr. Niederbarnim, 1950-1990 Kr. Fürstenwalde (ab 1952 Bez. Frankfurt/Oder), 1990-1993 Ldkr. Fürstenwalde, 1993 Ldkr. Oder-Spree

EREIGNISSE NACH KRIEGSENDE: 1946 (Bericht der Kreisverwaltung Oberbarnim): „Im Kreis Oberbarnim verdankt in Mönchswinkel eine Kunstgewerbliche Werkstatt ihr Entstehen der Initiative einer Umsiedlerin. Die Bevölkerung des Dorfes begrüßt dieses Unternehmen und unterstützt es, weil hierdurch auch die Einheimischen, besonders die Frauen, Erwerbsmöglichkeiten haben." (BLHA, Rep. 203 MdI, Nr. 1074, zitiert nach: Oehlsen, S. 91).

BevöLKeRUngSZAHLEN: 1939: 382, 1946: 355, 1964: 355 (HOL VI, S. 374). 


\section{Mörz}

Landgemeinde, bis 1952 Kr. Zauch-Belzig, 1952-1990 Kr. Belzig (Bez. Potsdam), 1990-1993 Ldkr. Belzig, 1993 Ldkr. Potsdam-Mittelmark

EREIGNISSE BIS KRIEgSENDE: Jan. 1945 einer von vielen Orten im Umland von $\rightarrow$ Belzig, in denen Flüchtlinge einquartiert wurden. 21.1.1945: „In der Gaststätte Bergemann wurde unsere Familie noch mit zwei anderen Familien abgesetzt. Dort waren schon die Bauern erschienen, die je eine Familie zugewiesen bekamen, um sie in ihre Wohnungen zu bringen. [...]." (Weiß, Von Bessarabien nach Belzig, S. 115).

BevÖLKeRUngSZAHLEN: 1925: 288, 1939: 283, 1946: 403, 1964: 291 (HOL V, S. 274).

Gedruckte Quellen (Erinnerungsberichte): Weiß, Arthur: Von Bessarabien nach Belzig. Leipzig 2012.Ders.: Die letzten Kinder Bessarabiens. Leipzig 2014.

\section{Müllrose}

Stadtgemeinde, bis 1950 Kr. Lebus, 1950-1952 Kr. Frankfurt, 1952-1990 Kr. Fürstenberg bzw. (ab 1961) Eisenhüttenstadt (Bez. Frankfurt/Oder), 1990-1993 Eisenhüttenstadt, 1993 Ldkr. Oder-Spree

EReignisse NACH Kriegsende: 1945 (Bericht der Stadtverwaltung vom Nov. oder Dez. 1945): „Der Gebäudebestand der Stadt Müllrose hat durch die kriegerischen Einwirkungen verhältnismäßig wenig gelitten. [...] Bedauerlich dagegen ist die Sprengung der herrlichen Brücken über den Oder-Spreekanal. Im Zuge der Reichsstraße Frankfurt (Oder) - Leipzig wurde mit größer Beschleunigung eine Notbrücke hergestellt. Gegen den Herbst hin konnte dann auch die neue Eisenbahnbrücke über den Kanal dem Verkehr übergeben werden. [...] [S. 144] Neben der Arbeit dieser Männer [städt. Amtsleiter] ist besonders die segensreiche Tätigkeit der Frauen vom Roten Kreuz anzuerkennen (Schwester Elise Küster, Schwester Mathy Wittchen, Frau Käthe Heinisch), die unter teilweisem Beistand von Dr. [Erich] Klimpel und Heilstätten-Chefarzt Dr. [Harry] Zemmin monatlich in rund 300 Fällen Hilfe reichen. [...] Müllrose ist wegen der Nähe der Oderbrücken bei Frankfurt und Fürstenberg ein Durchgangsort ersten Ranges, so daß hier auch viele Flüchtlinge und heimkehrende Kriegsgefangene vom RK Rat und Hilfe suhen. Vonseiten der Stadt aus ist für sie gesorgt durch eine Verpflegungsstelle und Massenquartiere. / Aus Müllrose selbst werden ab September 1945 rund 130 Bedürftige dauernd unterstützt. / Sehr zu wünschen läßt noch die hiesige Verkehrslage. Zwischen Müllrose und Frankfurt verkehrt zwar täglich ein Zugpaar, aber leider so, daß der Morgenzug nicht nach Frankfurt (Oder) fährt (um von dort aus ev[tl]. weiter reisen zu können), sondern von Frankfurt kommt, und daß der Nachmittagszug nicht von Frankfurt kommt, sondern nach Frankfurt geht. Die Anschlüsse nach Cottbus und nach Beeskow-Königswusterhausen fehlen überhaupt noch." (Brandenburgische Gemeinden 1945, S. 143 f.). 
EREIGNISSE NACH 1949: Vor 1990 „in der Spätzeit der DDR“ inoffizielle Heimattreffen von in der näheren Umgebung von Frankfurt (Oder) wohnhaften ehem. Bewohnern der Gemeinde Ziebingen (Kr. Weststernberg), zunächst in privatem Rahmen auf dem Anwesen der Familie Dietrich in Müllrose, Kirchhofgasse 6, dann mit größerer Beteiligung jährlich und getarnt als „Klassentreffen“ in der Gaststätte „Am Kanal“, organisiert von einem fünfköpfigen Komitee, nach 1990 weitergeführt zunächst in $\rightarrow$ Frankfurt (Oder), dann in $\rightarrow$ Weißenspring. Dazu Bericht von 1995: Es „,beschlossen noch vor der Wende in der DDR einige Ziebinger der Geburtsjahrgänge 1922/23, die in der näheren Umgebung von Frankfurt (Oder) wohnen, sich halbjährlich zu treffen. Sie versammelten sich bei der Familie Dietrich in Müllrose. Durch den ,Buschfunk', den die Staatsmacht nicht zu unterbinden vermochte, breiteten sich Informationen über diese Wiedersehen aus. Bald fragten Angehörige anderer Jahrgänge an, ob sie teilnehmen könnten. Da das kleine Anwesen der Dietrichs einem solchen Ansturm nicht gewachsen war, beschloß an, sich als, Schulklasse' nur noch einmal jährlich zu versammeln und die zweite Veranstaltung als Treffen aller ehemaligen Ziebinger zu organisieren. / Dafür wurde ein Komitee gebildet, in dem die Damen Edith Dietrich, geb. Raasch, Bischof, geb. Oberhauser, und Sack, geb. Kanisch, sowie der Heimatfreund Sack und als Vertreterin der jüngeren Generation Edith Dietrichs Tochter Marianne zu arbeiten begannen. Es wurde eine Anschriftenliste angelegt sowie ein geeignetes Trefflokal gesucht und mit der Gaststätte ,Am Kanal' in Müllrose gefunden. Weiter verschickte man die Einladungen und traf mit dem Wirt die notwendigen Vereinbarungen, die insbesondere Speis' und Trank betrafen. Dadurch sahen sich noch in der Spätzeit der DDR viele Ex-Ziebinger in dem Städtchen am Oder-Spree-Kanal wieder. [...] / [...] dann kam der November 1989, in dem der Eiserne Vorhang verschwand. Durch persönliche Kontakte und jetzt mögliche Presseveröffentlichungen setzte ein Anfragesturm hinsichtlich der heimatlichen Zusammenkünfte ein. Viele ehemalige DDR-Bürger trauten sich erst jetzt, die Beziehungen zur Heimat wiederherzustellen. Aus den alten Bundesländern kamen Briefe von Landsleuten, die Kontakte mit Bekannten von früher aufnehmen wollten. Da die Müllroser Gaststätte der erwarteten großen Teilnehmerzahl nicht gewachsen erschien, wich man zunächst nach Frankfurt (Oder) aus. Auch dort wurde es eng. Deshalb wählte die Gruppe der Organisatoren eine Gaststätte in Weißenspring, einem zwischen Müllrose und Brieskow-Finkenheerd gelegenen Dorf, als neuen Treffpunkt. Dort lassen jetzt jährlich einmal über 160 Heimatfreunde, die aus allen Teilen Deutschlands anreisen, ihr Ziebingen auferstehen." (Crossener Heimatgrüße 47, 1995, Nr. 6, S. 19). - 1.7. bis 9.11.2003 (verlängert bis 9.1.2004): (Sonder-)Ausstellung „Fremde - Heimat - Müllrose. Flüchtlinge und Vertriebene in Müllrose und Umgebung nach dem 2. Weltkrieg“ [auch „... 1945-1950“]. Eine Ausstellung des Kulturland Brandenburg e. V. in Zusammenarbeit mit dem Amt Schlaubetal, Müllrose“ im „Haus des Gastes“, Kietz 5: „Wegen der übergroßen Nachfrage [...] bis zum 9. Januar 2004 verlängert.“ (Lausitzer Rundschau, 7.11.2003).

Bevölkerungszahlen: 1925: 2609, 1939: 2693, 1946: 2 197, 1964: 3056 (Städtebuch, S. 348). - 1933: 2700, Ende 1945: 2360 („bei ständiger Zunahme“) (Brandenburgische Gemeinden 1945, S. 143). 
Katholiken: 1925: 91, 1946: 372 (Städtebuch, S. 348).- „Schon der Breslauer Schematismus von 1871 verzeichnet für Müllrose monatlichen Gottesdienst. In den 30er Jahren des 20. Jh. wurde im Ort von den Frankfurter Pfarrgeistlichen für einige ortsansässige Katholiken gelegentlich die hl. Messe in der Schule gehalten. Nach dem II. Weltkrieg [...] siedelten sich Vertriebene aus dem Sudetenland und aus Schlesien an. Alle 14 Tage wurde nun Sonntagnachmittag in der ev. Kirche Eucharistie gefeiert. / Unter großen Schwierigkeiten wurde dann im Hofgebäude eines Privatgrundstücks in der Nähe des Maktplatzes eine Kapelle eingerichtet, zu deren Einweihung 1968 extra Kardinal Alfred Bengsch kam, damit der Raum, wie es in der Chronik der zuständigen Frankfurter Gemeinde heißt, ,den staatlichen Behörden gegenüber so etwas wie eine ,kirchliche Sanktion' bekommt.' Argwöhnisch wurde das Baugeschehen vorher genauestens beobachtet. [...]. Einen eigenen katholischen Seelsorger gab es in Müllrose seit der Reformation nicht mehr." (Brühe, S. 36).

Gedruckte Quellen und Literatur: Brandenburgische Gemeinden 1945, S. 143-144. - Brühe, Matthias: Katholische Kirche zwischen Uckermark und Oderland. Berlin 1998, S. 36. - Das Schicksal der Flüchtlinge. In: Lausitzer Rundschau, 7.11.2003. - Schwillus/Brühe, S. 317. - Wie die Treffen der Ziebinger wuchsen. Beginn mit DDR-Buschfunk - 96 wieder mit Fahrt in die Heimat. In: Crossener Heimatgrüße 47 (1995), Nr. 6, S. 19.

\section{Müncheberg}

Stadtgemeinde, bis 1950 Kr. Lebus, 1950-1952 Kr. Seelow, 1952-1990 Kr. Strausberg (Bez. Frankfurt/Oder), 1990-1993 Ldkr. Strausberg, 1993 Ldkr. Märkisch-Oderland

EREIGNisSe BIS KRIEgSEnde: 18.1.1945: Müncheberg wird als neue Befehlszentrale für die Trecks aus dem Kr. Wollstein/Posen bestimmt (Dokumentation der Vertreibung I/ 1, S. 385). „1945 liegt Müncheberg an der Marschroute der Roten Armee, die Stadt wird geräumt.“ (Brühe, S. 37; vgl. Schwillus/Brühe, S. 306). - 19.4.1945 Einmarsch der Roten Armee (Chronik. T. 1, S. 4).

EREIGNISSE NACH KRIEgSENDE: „Die wenigen in der Stadt zurückgebliebenen Einwohner (nicht einmal 50) sehen ihre Stadt in Trümmern: mehr als 300 Häuser, 72 Geschäfte sowie Produktionsstätten und soziale Einrichtungen sind zerstört. / 400 Müncheberger Bürger sind als Soldaten auf den Schlachtfeldern des 2. Weltkrieg[s] gefallen und von Mai bis Dezember werden weitere 736 Müncheberger und Flüchtlinge durch Hunger, Typhus und andere Seuchen dahingerafft.“ (Chronik. T. 1, S. 4). - 1945: „Nur wenige Müncheberger kehren zurück. Dafür siedeln sich Flüchtlinge an, vor allem Schlesier und Ostpreußen." (Brühe, S. 37; vgl. Schwillus/ Brühe, S. 306). - 1.7.1945 (Flüchtlingstreck aus Landsberg/W.): „So erreichen wir Müncheberg, auch hier erwartet uns niemand. Mit Mühe und Not finden wir ein Quartier. Die Leute sind sehr nett. In einer Bodenkammer ohne Fenster legen wir uns zur Ruh', d. h. wir sitzen auf einem Sofa zu dritt." (Tagebuch Hildegard Burmeister, S. 282). - Anf. Juli 1945 (Erinnerungsbericht einer am 25.6. aus Rogsen, Kr. Meseritz, Vertriebenen): „In Müncheberg gingen wir, da wir schon über eine Woche 
unterwegs waren, zur Volksküche und baten um etwas warmes Essen, es wurde uns abgelehnt. In Müncheberg stand ein Zug mit Flüchtlingen aus West- und Ostpreußen. Mein Mann und ich als einzige von den vielen Menschen, die die Straße zogen, stiegen in den Zug und fuhren bis Berlin-Alexanderplatz." (Dokumentation der Vertreibung I/2, S. 685). - Okt. 1945 (aus Bericht an Landrat): „Von den zu Kriegsende vorhandenen Häusern sind nur 83 bewohnbar. [...].“ (Chronik. T. 1, S. 8). - Typhusepidemie: „Bis Ende 1945 waren ca. 150 Personen an Typhus verstorben. (ebd., S. 12). - 1.4.1955 „Gründung der Landwirtschaftlichen Produktionsgenossenschaft (LPG) ,Prof. Dr. Rübensam' mit 86 Mitgliedern unter dem Vorsitz des parteilosen Neubauern Otto Krey (Umsiedler aus Ostpreußen)“ (Müncheberg 1232-2007, S. 153); lt. Chronik. T. 1, S. 51, jedoch: „Erster Vorsitzender wird Bruno Kärger, der 1956 von Otto Krey aus Philippinenhof abgelöst wird“, der bis zu seinem Tod 1972 im Amt blieb (ebd., S. 103); tatsächlich stammte K. aus Westpreußen (!), lebte zwar schon seit 1937 in Müncheberg, kam aber 1946 aus brit. Gefangenschaft in Niedersachsen als sogen. „Umsiedler“ nach Philippinenhof (Müncheberger Lebensläufe. T. 5, S. 95).

Bevölkerungszahlen: „1925: 4284, 1939: 4926 (auch andere Angaben), April 1945: ca. 50 Einwohner in geräumter Stadt, 1946: 4084, 1964: 5289“ (Städtebuch, S. 353). - 1.5.1945: „etwa 400, davon 100 Männer, 160 Frauen und 140 Jugendliche und Kinder" (Chronik. T. 1, S. 5). - Okt. 1945 (aus Bericht an Landrat): „Von den rund 5000 Einwohnern sind ca. 3600 zurückgekehrt. Dazu kommen 600 Flüchtlinge." (ebd., S. 8). - 30.10 .1945 (erste Einwohnerzählung): 4000, davon 600 „Umsiedler“ (ebd., S. 10). - 1.12.1945: 3400 „zuzüglich 600 Übersiedler / davon mit festem Wohnsitz in der Stadt 300 (200 männlich, 280 weibl., 120 Kinder unter 14 Jahren). Von den 600 Umsiedlern stammen aus den deutschen Ostgebieten 500 (180 männliche, 220 weibliche und 200 Kidner), aus West- und Süddeutschland 50 und 50 aus der sowjetischen Besatzungszone." (ebd.). - 10.9.1946: 4003, 29.10.1946: 4084 (davon 1.1778 männlich) (ebd., S. 15). - 30.6.1947: 4347. „Davon 3390 Stammeinwohner und 957 Umsiedler“ (ebd., S. 16). - 25.11.1947: neben 4383 Stammeinwohnern „noch 1001 Umsiedler, in der Hauptsache Frauen (679) und Kinder" (ebd., S. 16). - Dez. 1947: 4415; 1.1.1948: 4084 (ebd., S. 17). - 28.9.1948: 4536 (ebd., S. 20). - Dez. 1948: 4566 (ebd., S. 21). - 14.9.1949: 4566; 30.9.1949: 4557, „darunter 3482 Stammeinwohner und 1075 Umsiedler aus den ehemaligen deutschen Ostgebieten“ (ebd.). - 31.12.1949: 4535, „unter ihnen zahlreiche Umsiedler“ (ebd., S. 25). - Dez. 1949: „4557 Müncheberger, unter denen sich 3482 Stammeinwohner und 1075 Umsiedler aus den ehemaligen deutschen Ostgebieten befanden" (Müncheberg 1232-2007, S. 147). - 20.3.1950: 4558 (Chronik, S. 26). - 1.2.1951: 5284, „davon 1401 Umsiedler“ (ebd., S. 27). - Juni 1952: 4603 (ebd., S. 32). - Dez. 1952: 4538 (ebd., S. 34).

Katholiken: 1925: 229, 1946: 272 (Städtebuch, S. 353). - „[Am 1.1.] 1947 beginnt Pfr. Alfons Lochowitz [geb. 1895 in Paulsdorf, Kr. Rosenberg/Oberschlesien, aber nicht zu den Flüchtlingspfarrern zählend, da bis 1945 in Finow tätig] seinen Dienst, am 1.1.1948 wird Müncheberg auch vermögensrechtlich selbständig, 1949 kann die Kirche neu benediziert werden.“ 
(Schwillus/Brühe, S. 306; Ergänzungen in Klammern nach Schematismus Berlin 1947, S. 144, und 1949, S.65). - 1994 Namengebung „St. Hedwig“ für die neue, mit Buckow fusionierte Pfarrgemeinde (ebd.).

Strassenumbenennung: 1948 Küstriner Straße umbenannt in Seelower Straße (Müncheberg 1232-2007, S. 148; Mitteilung Frank Geißler, Verein für Heimatgeschichte der Stadt Müncheberg e. V., 15.8.2018).

StÄdtepartnerschaften: 8.5.1998 Witnica, Polen (Vietz/Ostbahn, ehem. Kr. Landsberg/ Warthe, Neumark) (Müncheberger Nachrichten, 5 (2012), Nr. 5, S. 1; Stadt Müncheberg, S. 87).

Ungedruckte Quellen: Auskünfte des Vereins für Heimatgeschichte der Stadt Müncheberg e. V. (Prof. Christoph Bernard, 17.7.2018; Frank Geißler, 15.8.2018).

Gedruckte Quellen und Literatur: Brühe, Matthias: Katholische Kirche zwischen Uckermark und Oderland. Berlin 1998, S. 37. - Chronik der Stadt Müncheberg in den Jahren 1945 bis 1989/90. T. 1-2. Müncheberg 2012, in T. 1 u. a.: Christpoph Bernard / Heinz Butschke: Unter sowjetischer Verwaltung (S. 14-17), Hans Dallmann: Müncheberg ab 1945 (S. 18-20). - Dokumentation der Vertreibung I/1, S. 385; I/2, S. 231, 685. - Müncheberg 1232-2007. Müncheberg [2007]. - Stadt Müncheberg von 1991 bis 2014. Müncheberg 2015. - Müncheberger Lebensläufe. T. 1-5. Müncheberg 2008-2018. - Schwillus/Brühe, S. 306. - Tagebuch Hildegard Burmeister [Auszüge]. In: „Die Russen sind da“. Peter Böthig u. Peter Walther (Hg). Berlin 2011, S. 280.

\section{Nauen}

Stadtgemeinde, bis 1952 Kr. Osthavelland, 1952-1990 Kr. Nauen (Bez. Potsdam), 1990-1993 Ldkr. Nauen, 1993 Ldkr. Havelland

EReignisse BIS Kriegsende: Ende Jan. 1945 Evakuierung der „Crossener Sparkasse“ aus Crossen/Oder nach Nauen und Einrichtung einer provisorischen Niederlassung ebd. (Pflaum, S. 15). - 24.4.1945 Einmarsch der Roten Armee (Al Diban, S. 40).

EReignisse NaCh KRIEgSEnde: 8.12.1945 (Bericht der Stadtverwaltung): „Es besteht in der Berlinerstraße 35 seit Sommer 1945 in der ehemaligen Villa des Bürgermeisters ein Flüchtlingskinderheim sowie ein Tageskindergarten. Im Kinderheim werden elternlose Flüchtlingskinder ganz betreut, d.h. sie schlafen und essen dort. Außerdem noch Kinder von Müttern, die krank sind und wo keine andere Person vorhanden ist. Im Tageskindergarten werden Kinder aufgenommen vom 3. Lebensjahr an, sie bekommen dort ihr Mittagessen uind werden bestens versorgt. Unser Umsiedlerheim in der Ketzinerstraße wird auch von der Fürsorge betreut, mittels einer Pflegerin. Alle diese Heime werden von der Stadtverwaltung besonders berücksichtigt in Fragen der Brennung und anderen Bedürfnissen des täglichen Lebens. In der Schüzenstraße befindet sich unser Altersheim, wo Antifaschisten tatkräftig am Werk sind. Die Betreuung der durchziehenden Opfer des Faschismus lag ebenfalls in den Händen der Sozialfürsorge. Abschließend soll gesagt sein, daß beschlagnahmtes Hamstergut und dergleichen ebenfalls durch die soziale Fürsoge, wenn vorhanden, zu wohltätigen Zwecken verwandt wird. Bei 
einer Belegschaft von 6 Personen ist es eine große aber dankenswerte Arbeit, die dort geleistet wird. In Verbindung damit möchte ich nicht versäumen, über das Flüchtlingsproblem zu schreiben. Es sind hier in Nauen 2700 Flüchlinge, welche jetzt hier am Wiederaufbau mit teilnehmen, In Kürze kommen noch 5000 neue Flüchtlinge und zwar davon 2500 für die Stadt. Baracken stehen bereit bzw. werden fertiggestellt. 1000 können nach Reinigung in Privatwohnungen noch [S. 149] untergebracht werden, es muß eben zusammengerückt werden. Die KPD Ortsgruppe Nauen hat die Initiative ergriffen, es wird gesammelt für die Flüchtlinge, Decken, Eßgeschirre, Töpfe usw." (Brandenburgische Gemeinden 1945, S. 148 f.). - Ab 1951 amtierte in Nauen der aus Kürtow (Kr. Arnswalde) vertriebene Pfarrer Hans-Georg Furian (geb. 1903 Kürtow, gest. Nauen 9.3.1968) als Superintendent u. Krankenhausseelsorger (700 Jahre Arnswalde Neumark. Wunstorf 1969, S. 140), zuvor Superintendent u. Pfarrer in $\rightarrow$ Fehrbellin (Pfarralmanach 1953, S. 156).

EREIGNISSE NACH 1990: 2018 Schüler des Gymnasiums am Leonardo da Vinci Campus Nauen befassen sich in Zusammenarbeit mit "grenzgänger | forschung \& training“ mit dem Thema „Migration in der brandenburgischen Geschichte und Gegenwart“ und präsentieren die Ergebnisse ihrer Arbeit in der Ausstellung „Brandenburg in Bewegung“ (29.6. bis 22.7.2018) im HBPG in $\rightarrow$ Potsdam. Im Programmheft von „Kulturland Brandenburg“ für das 2. Halbjahr 2018 heißt es dazu: „Französische Hugenotten, böhmische Reformierte, jüdische Glaubensflüchtlinge aus Österreich, Schweizer Bauern, schlesische und preußische Vertriebene oder russische Spätaussiedler - sie alle sind Teil unserer heutigen Gesellschaft. Viele der Brandenburgerinnen und Brandenburger blicken auf eine bewegte Familiengeschichte zurück, die ihren Ursprung außerhalb der Region hat. $\mathrm{Ob}$ Sprache, Speisen oder Städtebau: unser Alltag ist geprägt durch Zuwanderung und durch Einflüsse verschiedener europäischer Kulturen." (Druckfassung, S. 44, online S. 45 [18.8.2018]).

BevöLKeRUNGSZAHLEN: 1925: 9605, 1939: 11 907, 1946: 13 106, 1964: 12095 (Städtebuch, S. 358). - „1933, also zu Beginn der Hitlerherrschaft hatte Nauen 10200 Einwohner, heute 13200 davon sind 2700 Flüchtlinge." (Brandenburgische Gemeinden 1945, S. 148). - [1945 ff.] „Durch die hohe Zahl von fast 3500 Umsiedlern aus den östlichen Gebieten wuchs die Einwohnerzahl sprunghaft auf fast 14000 an." (Al Diban, S. 41).

Katholiken: 1925: 781, 1946: 1592 (Städtebuch, S. 358). - Nach 1950 [1953?]: über 3000 (Brühe, S. 32; Schwillus/Brühe, S. 334). - 22.8.1946 „Pfr. Westphal, Hans, Nauen Kr. Osthavelland, Gartenstr. 71" [Pfarrhaus] erwähnt in einer Aufstellung der außerplanmäßig eingesetzten „Flüchtlingsgeistlichen“ (DAB, I/9-15-1 Flüchtlingsseelsorge 1945-1951, unfol.). - 1949 wohnt im Pfarrhaus Gartenstr. 71 der aus dem Bistum Königgrätz stammende und bis 1945 als Pfarrer in Abtsdorf bei Zwittau (Böhmen) wirkende Dechant Heinrich Rücker (geb. 1891 Schatzlar, Sudetenland bzw. Böhmen) (Schematismus Berlin 1949, S. 145; Ostpriesterverzeichnis 2, 1949, S. 71).

VERTRIEBENENVERBÄNDE NACH 1990: BdV-Kreisverband Nauen; 1996 erwähnt mit Sitz Berliner Str. 3 (BdV-Handbuch 1996, S. 168); 14.6.2001 VR-Eintragung beim Amtsgericht Nauen, 
31.8.2001 Sitz Berliner Str. 3, Vorsitzender: (1992 erwähnt) Horst Kuhse, Nauen (geb. 1930) (Akten der BdV-Landesgeschäftsstelle).

Gedruckte Quellen und Literatur: Al Diban, Martina: In Nauen durch die Jahrhunderte. Falkensee 1995. Brandenburgische Gemeinden 1945, S. 147-150. - Brühe, Matthias: Katholische Kirche zwischen Prignitz und Havelland. Berlin 2000, S. 31-32. - Pflaum, Helmut: Meine Kindheit in Boberhöh. Eichwalde bei Berlin 2014, S. 15. „Die Russen sind da“. Peter Böthig u. Peter Walther (Hg). Berlin 2011. - Schwillus/Brühe, S. 333-334.

\section{Nauen-Bergerdamm $\rightarrow$ Bergerdamm}

\section{Nennhausen}

Landgemeinde, bis 1952 Kr. Westhavelland, 1952-1990 Kr. Rathenow (Bez. Potsdam), 19901993 Ldkr. Rathenow, 1993 Ldkr. Havelland

EReignisse NACH Kriegsende: Nach der Enteignung 1945 „diente das ehemalige Herrenhaus als Flüchtlingsheim, Zentralschule und ab 1959 als Kulturhaus [...].“ (Andreae/Geiseler, S. 212). - „Im Zuge der Bodenreform 1945/46 wurden 827 ha Fläche an 133 landarme und landlose Bauern und 31 Flüchtlingsfamilien übergeben." (Das Havelland um Rathenow und Premnitz, S. 261; vgl. HOL III, S. 252).

BevöLKerungSZAHLEN: 1925: 1006, 1939: 907, 1946: 1 178, 1964: 1024 (HOL III, S. 253).

Literatur: Andreae/Geiseler, S. 212. - Das Havelland um Rathenow und Premnitz, S. 248.

\section{Neuenhagen b. Berlin}

Landgemeinde, bis 1952 Kr. Niederbarnim, 1952-1990 Kr. Strausberg (Bez. Frankfurt/Oder), 1990-1993 Ldkr. Strausberg, 1993 Ldkr. Märkisch-Oderland

EREIGNISSE NACH 1990: 1995 Zeitzeugenarbeit des Seniorenbeirates mit einem Wettbewerb begonnen (Seniorenbeiräte im Land Brandenburg, S. 23 f.), in der Folge Herausgabe von Broschüren („Lebenszeit“), zu denen auch Vertriebene mehrfach Erinnerungen beisteuern.

BevölKerungszahlen: 1925: 4560, 1939: 11 997, 1946: 11656,1964 : 13025 (HOL VI, S. 397).

StÄDtePARTNERSChaften: Mai 2005 Świebodzin (Schwiebus, bis 1945 Kr. ZüllichauSchwiebus [Provinz Brandenburg]), zuvor bereits in den 1990er Jahren Kontakte und Begegnungen der Seniorengruppen beider Orte (Skotnicki, S. 85 f.).

Gedruckte Quellen und Literatur: Lebenszeit I-XVI. Neuenhagen 1996-[2018] (siehe Quellenverzeichnis, Abschnitt 2.4.1). - Siek, Erich: Kindergartentradition in Neuenhagen. In: Jahrbuch Märkisch-Oderland 27 (2020 [2019]), S. 88-89. - Skotnicki, Jutta: Die höchste Jesus-Statue der Welt blickt auf Neuenhagens Partnerstadt. In: Le- 
benszeit XIV. Neuenhagener Geschichten. Neuenhagen o.J. [ca. 2012], S. 85-90. - Seniorenbeiräte im Land Brandenburg. Potsdam 1999. - Vogel, Georg: Die Volkssolidarität in Neuenhagen. In: Lebenszeit. T. III. Zeitzeugen berichten. Hrsg. vom Landesseniorenbeirat Brandenburg u. dem Seniorenbeirat Neuenhagen. Neuenhagen [1998], S. 117-120.

\section{Neu Fahrland $\rightarrow$ Potsdam-Neu Fahrland}

\section{Neuhardenberg}

Landgemeinde (1949-1990 umbenannt in Marxwalde), bis $1950 \mathrm{Kr}$. Lebus, 1950-1952 Kr. Seelow, 1952-1990 Kr. Seelow (Bez. Frankfurt/Oder), 1990-1993 Ldkr. Seelow, 1993 Ldkr. Märkisch-Oderland

Bevölkerungszahlen: 1925: 1229, 1939: 1182, 1946: 1423, 1964: 1926 (HOL VII, S. 295).

UMSIEDLERLAGER: 17.10.1945, „ehemaliges RAD-Barackenlager, in dem z.Zt. etwa 60 Umsiedler wohnen. [...] Infolge der Kleinheit [...] zur massenweisen Unterbringung von Umsiedlern nicht geeignet." (BArch, DO 2/39, Bl. 3). - Kapazität am 31.12.1945: 400 (BArch, DO 2/45, Bl. 40).

\section{Neuheim (Dorf Zinna)}

Landgemeinde (bis 1951 „Dorf Zinna“; seit 1997 Ortsteil von $\rightarrow$ Jüterbog), bis 1946 Kr. Jüterbog-Luckenwalde, 1946-1952 Kr. Luckenwalde, 1952-1990 Kr. Jüterbog (Bez. Potsdam), 1990-1993 Ldkr. Jüterbog, 1993 Ldkr. Teltow-Fläming

EREIGNISSE BIS KRIEGSENDE: DorfZinna 1937 als Siedlung wegen Einbeziehung in den Wehrmachts-Schießplatz Jüterbog aufgelöst (HOL X, S. 373, Gebäude aber nur teilweise beseitigt (Schmutzer).

EREIGNISSE NACH KRIEGSENDE: 12.10.1945 in Befehl der SMA Brandenburg als eines von drei im Bezirk Luckenwalde für die Aufnahme von „deutschen Umsiedlern“ geeigneten Lagern genannt, die dafür hergerichtet werden sollen (Wille I, S. 66). - 1946 Neuaufbau unter dem alten Namen, Ansiedlung von „Antifa-Umsiedlern“ aus der Tschechoslowakei und einzelnen anderen Vertriebenen (Schmutzer); „Umsiedler aus Gablonz angesiedelt“ (HOL X, S. 377; vgl. Christopeit, S. 85 f.); vier Tage zuvor, 14.2.1946, Ankunft des ersten Zugs aus Gablonz und Reichenberg in Jüterbog (Schulze, Jammerbock IV, S. 259 nach Schmutzer); 24.4.1946 feierliche Neugründung des Ortes (Schulze, Jammerbock IV, S. 259). - In der Bodenreform 226 ha von 878 ha an 19 Umsiedler vergeben (HOL X, S. 377). - 15.12.1949 Kreistagssitzung Luckenwalde mit Tagesordnungspunkt „Beschlußfassung über die Namensänderung der Gemeinde Dorf Zinna in ,Neuheim " (BLHA, Rep. 250 Luckenwalde, Nr. 108, Bl. 303), aber erst 1951 umbenannt (HOL X, S. 373). - 21.7.1952 feierliche Verleihung des Titels „Dorf des Friedens - Neuheim 
auf Friedenswacht“ an das Dorf Neuheim (Schmutzer, S. 45). - Siehe auch Wohnungsbau „Тур 53/4 Neuheim“ (BLHA, Rep. 511 Hochbauproj. Pdm, Nr. 1005).

Bevölkerungszahlen: 1925: 405, 1939: -, 1946: 491, 1964: 430 (HOL X, S. 378).

UMSIEDLERLAGER: Kapazität am 31.12.1945 (Lager „Dorf Zinna“): 1000 (BArch, DO 2/45, Bl. 41).

UMSIEDLERGENOSSENSCHAFT (SPÄTER VEB GABLONA): 30.9.1946 Gründung der Genossenschaft durch überwiegend sudetendeutsche Glashandwerker/-arbeiter aus Gablonz/Böhmen (Gründungsprotokoll, Bl.2): 32 Personen, eingetragene Genossenschaft mit beschränkter Haftpflicht, „zwecks Aufbau der Glas u. Schmuckindustrie“, Vors. der Gründungsversammlung: Franz Maschke, Schriftührer Josef Hysek, beide auch in Vorstand gewählt an erster und zweiter Stelle, Firma „Genossenschaft für Glas u. Bijouterie-Industrie Dorf-Zinna“, Sitz DorfZinna (BLHA, Rep. 260 AG Jüterbog, Nr. 30 [Genossenschaftsregister-Akte des Amtsgerichts Jüterbog]; ebd., Bl.3-13: Statut mit (Bl.13v) 30 Unterschriften (Liste der Genossen); Bl. 1 Anmeldung als „Produktiv- und Handelsgenossenschaft für Glas und Bijouterie“ in Dorf Zinna). - 4.4.1951 Übergabe der von der Rechtsabteilung der VVB Glas-Keramik Land Brandenburg, Eichwalde, bearbeiteten Angelegenheiten und sonstigen Akten an den Rat des Kreises Luckenwalde als neuen Rechtsträger „im Zuge der Reorganisstion der VVB (L) und der damit bedingten Auflösung der VVB Glas-Keramik“ (BLHA, Rep. 250 Luckenwalde, Nr. 328, unfol., mit Übergabe-Protokoll mit Anlage Aufstellung der übergegebenen Akten, dabei Grundbuchauszüge betr. Grundstücke Pad. 12 Blatt 418 Dorf Zinna und Band VIII, Blatt 291); am selben Tag Übergabe der Planungsunterlagen betr. Gablona Dorf Zinna von der Planungsabteilung der VVB Glas-Keramik Land Brandenburg an den Rat des Kreises Luckenwalde (ebd.). - 20.7.1952 Übergabe des Fabrikneubaus des VEB Gablona in Neuheim bei Jüterbog (Schmutzer, S. 45). - Laut Eintragung vom 11.10.1952 ist die Firma erloschen („von Amts wegen zu löschen“). „Der VEB [Gablona Neuheim] ist als völlig neues Werk anzusehen." (BLHA, Rep. 260 AG Jüterbog, Nr. 30, Bl. 39). 1960576 Beschäftigte (464 Produktionsarbeiter) (HOL X, S. 377). - 1983 Bezeichnung „VEB Gablona-Schmuckwaren“ (ebd.).

Archivalische Quellen: BArch, DO 2 ZVU, Nr. 39, Bl. 2. - BArch, DO 2/50, Bl. 185-186 (Dorf Zinna), Bl. 223 (ZVU-Dienstreise, 2.7.1947). - BLHA, Rep. 250 Landratsamt Luckenwalde, Nr. 327 („Übernahme von Maschinen der Firma Krüger/Senst in DorfZinna in die Glas- und Bijouterie-Genossenschaft“, 1948-1949); Nr. 328 („Übergabe des Werkes „Gablona“, Kristall und Bijouterie, Dorf Zinna, von der VVB(L) Glas-Keramik an den Rat des Kreises sowie weitere Bearbeitung von Rechtsangelegenheiten dieses Werkes“, 1950-1952). - Siehe auch Quellenteil, Nr. 203.

Gedruckte Quellen und Literatur: Ast/Mauersberger, S. 74-76 (Kapitel „Neuheim - die Geschichte eines Dorfes“, mit 3 Fotos). - Blöß, Wolfgang: Kommunale Strukturen im Spannungsfeld gesellschaftlicher Umwälzungen. Berlin 2018, S. 166-169. - Christopeit. - Fischer, L(othar): Neuheim - eine Heimatstadt des Friedens. In: Heimatkalender des Kreises Jüterbog 1986, S. 17-21. - Gedenkstätten NS II, S. 265. - Hoorn, Heike van: Neue Heimat im Sozialismus. Essen 2004. - Dies.: Die Schaffung einer politischen Lebenswelt. Das Antifa-Umsiedlerdorf Zinna/Neuheim in Brandenburg. In: Politik vor Ort. Innsbruck u. a. 2007, S. 149-159. - Pragal, Peter: Von Gablonz nach Neuheim. Wie Sudetendeutsche ,Antifa-Umsiedler' in Brandenburg ihre industrielle Tradition fortsetzten. http://www. 
kulturforum.info/de/startseite-de/1019554-themen/6992-von-gablonz-nach-neuheim (aufgerufen 27.5.2016). Schmutzer, Hans: ... auferstanden aus Ruinen. Geschichte des Dorfes Dorf Zinna - Neuheim. Hrsg.: Dorfklub Neuheim und Betrieb VEB Gablona. [Neuheim 1966]. - Schulze, Henrik: Jammerbock IV: 1945-2014. Jüterbog 2018, S. 33, 258-260 (Militärgeschichte Jüterbog, 1792-2014, [Bd. 4]). - Vier Jahrzehnte Gablona Schmuckwaren Neuheim. In: Heimatkalender des Kreises Jüterbog 1986, S. 21-25. - Wille I, S. 66.

\section{Neu Künkendorf}

Landgemeinde (seit 2003 Ortsteil von $\rightarrow$ Angermünde), bis 1952 Kr. Angermünde, 19521990 Kr. Angermünde (Bez. Frankfurt/Oder), 1990-1993 Ldkr. Angermünde, 1993 Ldkr. Uckermark

BevÖLKERUNGSZAHLEN: 1925: 524, 1939: 443, 1946: 623, 1964: 464 (HOL VIII, S. 548).

UMSIEDLERLAGER: Kapazität am 31.12.1945 (Lager „Neu-Künkendorf, Gutsherrenhaus“): 200 (BArch, DO 2/45, Bl. 40). - Kapazität am 1.1.1946: 200 (BLHA, Rep. 203 MdI, Nr. 1163, B1. 50).

\section{Neuküstrinchen}

Landgemeinde (seit 2003 Ortsteil von Oderaue), bis 1946 (Rest-)Kr. Königsberg/Nm., 19461952 Kr. Oberbarnim, 1952-1990 Kr. Bad Freienwalde (Bez. Frankfurt/Oder), 1990-1993 Ldkr. Bad Freienwalde, 1993 Ldkr. Märkisch-Oderland

EREIGNISSE NACH KRIEGSENDE: 3.10.1950 Zuweisung von westlich der Oder gelegenen Flächen der nun polnischen Gemeinde Altküstrinchen/Stary Kostrzynek (ehem. Kr. Königsberg/ Nm.) an die Gemeinden Neuküstrinchen und $\rightarrow$ Neuranft (Blöß, Kreise und Gemeinden, S. 31). - 1987 erstes, als „Dorffest“ deklariertes Heimattreffen vertriebener ehemaliger Bewohner von Alt-Küstrinchen (Stary Kostrzynek, Polen) im Kulturhaus nit 89 Teilnehmern (,Alle wussten Bescheid', freut sich Ingeborg Kiene noch heute über den Coup."), ab 1990 Fortsetzung in $\rightarrow$ Altglietzen (Märkische Onlinezeitung, 11.7.2011 [20.9.2016]).

BevölKeRUnGSZAHLEN: 1925: 298, 1939: 239, 29.10.1946: 498, 1950: 296, 1964: 221 (HGV MOL, S. 30 f.).

\section{Neulietzegöricke}

Landgemeinde (seit 2003 Ortsteil von Neulewin), bis 1946 (Rest-)Kr. Königsberg/Nm., 15.3.1946-1952 Kr. Oberbarnim, 1952-1990 Bad Freienwalde (Bez. Frankfurt/Oder), 19901993 Ldkr. Bad Freienwalde, Ldkr. Märkisch-Oderland 
EREIGNISSE NACH KrIEgSENDE: 3.10.1950 Zuweisung von westlich der Oder gelegenen Flächen der nun polnischen Gemeinde Alt Lietzegöricke/Stare Łysogórki (ehem. Kr. Königsberg/ Nm.) an die (unmittelbar an der Oder gelegene) Gemeinde Neuküstrinchen (Blöß, Kreise und Gemeinden, S. 31).

BeVÖLKeRUNGSZAHLEN: 1925: 458, 1939: 361, 29.10.1946: 574, 1950: 615, 1964: 401 (HGV MOL, S. 30 f.).

GedRUCKTe QuelLen: Dokumentation der Vertreibung I/1, S. 390 (Umgebung, Jan./Febr. 1945).

\section{Neu Lindenberg}

Wohnplatz/Ortsteil von Lindenberg (mit diesem seit 2003 Ortsteil von Ahrensfelde), bis 1952 Kr. Niederbarnim, 1952-1990 Kr. Bernau (Bez. Frankfurt/Oder), 1990-1993 Ldkr. Bernau, 1993 Ldkr. Barnim

Katholiken: „Katholiken, die durch Flucht und Vertreibung in die Nähe Berlins gekommen waren, erbauten 1959 in dem zur Pfarrei Berlin-Falkenberg gehörenden Ort Neu-Lindenberg die Bruder-Klaus-Kapelle. Wegen des schönen bleiverglasten Kreuzwegs in den Fenstern fanden viele Jahre lang dort regelmäßig Sühnekreuzwege des Dekanats Berlin-Weißensee statt. 1995 wurde die Kapelle aufgelöst und das Grundstück verkauft." (Brühe, S. 52).

Literatur: Brühe, Matthias: Katholische Kirche zwischen Uckermark und Oderland. Berlin 1998, S. 52.

\section{Neupetershain}

Landgemeinde, bis 1952 Kr. Calau, 1952-1990 Kr. Calau (Bez. Cottbus), 1990-1993 Ldkr. Calau, 1993 Ldkr. Oberspreewald-Lausitz

EReignisse NACH KRIEgSende: „In Petershain werden auf Anweisung der Selbstverwaltung etwa zwanzig Familien, vorwiegend aus dem reichlich einhundert Kilometer entfernten niederschlesischen Raum um Grünberg (heute Zielona Góra) angesiedelt. Sie finden Bleibe auf dem verlassenen Gutshof oder in nicht oder nicht voll belegten Höfen. Mit der trügerischen Hoffnung auf Rückkehr. 1946 erhalten sie im Zuge der Bodenreform ,Junkerland in Bauernhand eigenen Grund und Boden und sogar weitestgehend standardisierte Neubauernhäuser. Mensch und Vieh unter einem Dach, getrennt durch eine Futterküche.“ (Kittan, S. 243).

BeVÖLKERUNGSZAHLEN: 1925: 2862, 1939: 3238, 29.10.1946: 3657, 1950: 3822 , 1964 : 3060 (HGV OSL, S. 10 f.).

Katholiken (Erzbistum Breslau/Erzbischöfliches Amt Görlitz): Herbst 1947: „Einrichtung der Lokalie Neupetershain mit eigenem Seelsorger Kuratus Franz Grabisch“, 1953 Pfarrkuratie (Zur Geschichte der Pfarrei St. Josef). Grabisch (1901-1967) war bis 1945 Pfarrer in der Stadt 
Bischofstal [Ortsname bis 1936: Ujest], Kr. Groß Strehlitz (Oberschlesien) (Ostpriesterverzeichnis 2, 1949, S. 29), sein Grab auf dem Friedhof Neupetershain wurde 1997 eingeebnet und der Grabstein in der Pfarrkirche Neupetershain aufgestellt (Zur Geschichte der Pfarrei St. Josef). - Im Herrenhaus wurde ab 1933 von den „Mägden Mariens von der unbefleckten Empfängnis“ aus Poremba (Oberschlesien) das „St.-Barbara-Stift“ geführt und nach 1945 „zur Unterbringung von Kleinkindern genutzt“ (Palais \& Park Neupetershain). - „Von 1987 bis 1989 bewohnten die Mägde Mariens das Pfarrhaus. [...] Nach dem Krieg hatten sich die katholischen Flüchtlinge, die aus Schlesien nach Neupetershain gekommen waren, um die Schwestern geschart. Damals zählte die Gemeinde fast 600 Katholiken [...]." (Tag des Herrn, 49. Jg., 1999, Ausg. 14).

Quellen und Literatur: Kittan, Horst: Die Russen kommen. Cottbus 2011. - Palais \& Park Neupetershain, www. palais-park-neupetershain.de [17.1.2017]. - Zur Geschichte der Pfarrei St. Josef in Welzow, www.st-antonius-gross raeschen.de [17.1.2017].

\section{Neuranft}

Landgemeinde (1974-2003 Ortsteil von $\rightarrow$ Neuküstrinchen; seit 2003 Ortsteil von Neulewin), bis 1946 (Rest-)Kr. Königsberg/Nm., 15.3.1946-1952 Kr. Oberbarnim, 1952-1990 Bad Freienwalde (Bez. Frankfurt/Oder), 1990-1993 Ldkr. Bad Freienwalde, 1993 Ldkr. MärkischOderland

EREIGNISSE NACH KRIEGSENDE: 3.10.1950 Zuweisung von westlich der Oder gelegenen Flächen der nun polnischen Gemeinde Altküstrinchen/Stary Kostrzynek (ehem. Kr. Königsberg/ Nm.) an die Gemeinden $\rightarrow$ Neuküstrinchen und Neuranft (Blöß, Kreise und Gemeinden, S. 31).

Bevölkerungszahlen: 1925: 80, 1939: 76, 29.10.1946: 229, 1950: 137, 1964: 144 (HGV MOL, S. 30 f.).

\section{Neurochlitz}

Landgemeinde (1949 gegründet; seit 2002 Ortsteil von Mescherin), 1949-1950 Kr. Löcknitz (Land Mecklenburg), 1950-1952 Kr. Angermünde (Land Brandenburg), 1952-1990 Kr. Angermünde (Bez. Frankfurt/Oder), 1990-1993 Ldkr. Angermünde (Land Brandenburg), 1993 Ldkr. Uckermark

EREIGNISSE NACH KRIEGSENDE: 1948 auf brach liegendem ehemaligem (vorpommerschem) Gutsland (auf Beschluss des Rates des Kr. Löcknitz) neu angelegt und 7.10.1949 offiziell gegründet (Namengebung nach dem Herkunftskreis der Siedler Rochlitz in Sachsen). „In der Umgebung waren allerdings die Menschen, die bereit waren, ein neues Dorf zu bauen, nicht zu finden. Man wandte sich nach Sachsen, an den Kreis Rochlitz. Die Werbung zeigte ein gu- 
tes Ergebnis. Der größte Teil der neuen Bürger des zu bauenden Dorfes waren Umsiedler, die vorläufig im Kreis Rochlitz eine neue Heimat gefunden hatten; aber auch Altbürger meldeten sich. In Neurochlitz nahmen die Arbeit auf: 29 Altbürger aus dem Kreis Rochlitz und 174 Umsiedler, die zum größten Teil im Kreis Rochlitz lebten. Nur wenige der neuen Bürger der jungen Gemeinde Neurochlitz kannten sich früher schon. [...] / Die Familien der Siedler kamen in den Monaten April und Mai 1949 nach Neurochlitz. In selbstgebauten Holzbaracken wohnten sie bis etwa Dezember 1949, dann waren die massiven Häuser fertiggestellt. Die Bürger hatten beim Bau ihrer Häuser tatkräftig mitgearbeitet, so konnte dann im Dezember 1949 der Bau des Dorfes im allgemeinen als abgeschlossen gelten, wenn auch noch manches fehlte. / Das Dorf wurde mitten auf dem Acker gebaut. [... Beiderseits der Straße von Gartz (Oder) nach $[\rightarrow]$ Rosow [...] liegt nun das Dorf. Insgesamt wohnen 40 Neubauernfamilien dort. Die Einwohnerzahl beträgt jetzt etwa 210.“ (Berkenkamp, S. 107).

EREIGNISSE NACH 1990: 2019 Dokumentarfilm über Neurochlitz von Claudia Baradoy (Autorin) und Riccardo Wittig (Kamera, Schnitt) (23.8.2019 Uraufführung im überfüllten Kulturhaus Neurochlitz) (MOZ, 28.8.2019).

BevöLkerungszahlen: 1958: ca. 210 (Berkenkamp, S. 107); 2001: 150 (Der Landschleicher, 9.9.2001); 2011: „knapp 140“ (Prutean).

LiterATUR: Berkenkamp: Entstehung und Entwicklung der Gemeinde Neurochlitz. In: Heimatkalender des Kreises Angermünde 1959, S. 107-108. - Mohaupt, Heinz: Das 50jährige Neurochlitz. In: Angermünder Heimatkalender 1999, S. 45-49. - Prutean, Steff, in: Potsdamer Neueste Nachrichten, 29.4.2011.

\section{Neurüdnitz}

Landgemeinde (seit 2003 Ortsteil von Oderaue), bis 15.3.1946 (Rest-)Kr. Königsberg/Nm., 1946-1952 Kr. Oberbarnim, 1952-1990 Kr. Bad Freienwalde (Bez. Frankfurt/Oder), 19901993 Ldkr. Bad Freienwalde, 1993 Ldkr. Märkisch-Oderland

EREIGNISSE NACH KRIEGSENDE: 3.10.1950 Zuweisung von westlich der Oder gelegenen Flächen der nun polnischen Gemeinde Alt Rüdnitz/Stara Rudnica (ehem. Kr. Königsberg/Nm.) an die Gemeinde Neurüdnitz (Blöß, Kreise und Gemeinden, S. 31). - Febr. 1945 Zerstörung der Eisenbahnbrücke über die Oder durch Tieffliegerangriff (Schlasse, S. 44). - April 1945 Sprengung der Straßenbrücke (ebd.). - 1952-1955 Wiederaufbau der Eisenbahnbrücke nach Zäckerick (poln. Siekierki), die jedoch bis 1989 militärischer Nutzung vorbehalten blieb (ebd., S. 47 f.). - 2005 Eintragung der Strombrücke als Technisches Denkmal in das Denkmalverzeichnis des Landes Brandenburg (ebd., S. 80). - Stand 2019: Planung einer Wiedereröffnung der Eisenbahnbrücke als (touristischer) Grenzübergang für Fußgänger und Radfahrer im Jahr 2021 (S. 7, 82).

BEVÖLKERUNGSZAHLEN: 1925: 515, 1939: 432, 29.10.1946: 667, 1950: 571, 1964: 461 (HGV MOL, S. 30 f.). 
Literatur: Schlasse, Heike Eva: Die Oderdrücke bei Neurüdnitz. Ein Denkmal der Verkehrsgeschichte und des Kalten Krieges. Petersberg 2019.

\section{Neuruppin}

Stadtgemeinde, bis 1952 Kr. Ruppin, 1952-1990 Kr. Neuruppin (Bez. Potsdam), 1990-1993 Ldkr. Neuruppin, 1993 Ldkr. Ostprignitz-Ruppin

EReignisse Bis KRIEgSENDE: Anf. 1945 Kreisverwaltung Züllichau nach $\rightarrow$ Guben, $\rightarrow$ Calau und $\rightarrow$ Neuruppin evakuiert (BLHA, Rep. 6 B Züllichau-Schwiebus, Nr. 3), deren Akten nach Neuruppin (Übersicht BLHA, T. 2, S. 515). - 25. bis 30.4.1945: „Fluchtbewegungen aus der mit Flüchtlingen aus Berlin und den Ostprovinzen überfüllten Stadt und aus [S. 260] den Militärlazaretten in Richtung Westen“" (Heinrich, Zeittafel, S. 259f.). - 1.5.1945 Einmarsch der Roten Armee (Meier, S. 237).

EReignisse NACH KriegSENDE: 1945: „Die Kasernen, in denen viele Flüchtlinge und später die Umsiedler untergekommen waren, wurden nun von den sowjetischen Truppen beansprucht.“ (Meier, S. 237). - „Die alltägliche Versorgung der Bevölkerung, die Unterbringung der Umsiedler und Flüchtlinge und der Aufbau demokratischer Strukturen beschäftigten die Mitarbeiter der Stadtverwaltung rund um die Uhr.“ (ebd., S. 238). - 1.6.1945: „Gestern Abend kamen von Altruppin und dem Schloßgarten nahe der Wittstocker Allee sicher 100 Flüchtlingswagen voll Gepäck und Menschen, ein trauriges Bild. Es hieß, sie seien nicht über die Oder gekommen und mußten zurück. Andere [S. 204] sagen, es seien Ukrainer. Wann werden diese Wanderungen ein Ende haben?“ (Tagebuch Elisabeth Buchholtz, S. 203f.). - „Bis 1947 kamen noch 8239 Umsiedler in die Stadt. [...] Typhus, Tuberkulose, Lungenentzündung, Diphterie, Krebs und Unfälle wurden als häufige Todesursachen verzeichnet. Die Auswirkungen der schlechten hygienischen Bedingungen gerade für die Umsiedler und die mangelhafte Ernährung spiegeln sich in diesen Todesursachen ebenso wider wie die schlechten medizinischen Versorgungsmöglichkeiten. [...] Ernährungsstörungen waren ebenfalls eine häufige Todesursache. / In der einstigen Landesklinik erhöhte sich die Patientenzahl ab Mai 1945 innerhalb von wenigen Monaten von 600 auf 1350 Kranke. Seuchen breiteten sich aus. Es mangelte an Medikamenten, an Nahrungsmitteln und an Fachpersonal.“ (ebd., S. 240). - Juli 1945 Eintreffen eines Trecks am 29.6.1945 aus Bomst [ehem. Kr. Züllichau-Schwiebus (Provinz Brandenburg), zuvor bis 1938 Kr. Bomst (Provinz Grenzmark Posen-Westpreußen) - P.B.] ausgewiesener alte Leute, Frauen und Kinder (Barkau, S. 25). - 31.7.1945 Ankunft einer Familie aus Bomst: „In Neuruppin kamen wir auf den Hof von den Kasernen in der Fehrbelliner Strasse. Die ganzen Kasernen hingen voller Menschen, alle Räume waren überfüllt. Wir hatten nur auf dem Hof Platz. [...] Wir haben auch nichts zu essen bekommen. Aber es waren dort Wasserhähne, wir haben uns Wasser abkochen können. [...] [S. 108] [...] In Neuruppin waren ja schon viele Bomster angekommen [...].“ (Preuß, S. 107 f.). „Im Sommer 1946 zogen die Berliner Verbandskrankenhäuser wieder nach Berlin. Dafür traf ein Transport mit geistig Kranken aus dem Sudetenland ein. [...].“ (Meier, S. 240). 
EREIGNISSE NACH 1990: Ab 1991 jährliche Treffen des „Heimatkreises Züllichau-Schwiebus“, anfangs mit über 2000 Teilnehmern aus dem gesamten Bundesgebiet, inzwischen mit altersbedingt sinkenden Teilnehmerzahlen (MAZ, 19.9.2016); 25.7.1993 Treffen im „Freizeitpark Gildenhall“ mit über 3000 Teilnehmern (Meißner, S. 8). „Auf dem ersten Treffen nach der Wende (1991) waren es unerwartet 1500 Teilnehmer. [...] 1992 kamen zur Überraschung der Organisatoren 1000 weitere Heimatfreunde hinzu. Und nun in diesem Jahr [1993] eine erneute Steigerung auf 3000.“ (ebd.); 1994 Treffen der Züllichau-Schwiebuser in Gildenhall mit Grußwort des anwesenden Ministerpräsident Manfred Stolpe (Märkischer Informationsdienst 1994, Nr. 6/7, S. 1-5); 27.7.2008 Grußwort des Landtagspräsidenten Gunter Fritsch auf dem Treffen in Gildenhall (www.landtag.brandenburg.de), 25.7.2011 Jahrestreffen im „Seehotel Gildenhall“ in Alt Ruppin, Wuthenower Straße 10 (Märkische Onlinezeitung, 23. u. 25.7.2011 [20.9.2016]), 2015 „25. Heimattreffen des Krises Züllichau-Schwiebus“ im Kulturhaus Stadtgarten Neuruppin (Karl-Marx-Straße 103) mit 350 Teilnehmern (MAZ, 28.6.2015), zuletzt am 18.9.2016 im Stadtgarten mit "gut 250" Teilnehmern in Anwesenheit des Neuruppiner und des polnischen Züllichauer Bürgermeisters (MAZ, 19.9.2016). - 2002 Treffen der ehemaligen Bewohner von Dürrlettel (Kr. Meseritz) in Neuruppin (Heimatgruß Meseritz 162, 2002, S. 4 f., mit Gruppenbild: 37 Personen). - Ab 26.3.2018 Wanderausstellung „Flucht - gestern und heute“ (20 Schautafeln) in der Kreisverwaltung Ostprignitz-Ruppin, zuvor in $\rightarrow$ Kyritz (www.fluchtgestern-und-heute.de [22.4.2018]).

BevöLKerungszahlen: 1925: 18245, 1939: 24559 (u. a. ca. 4000 Militärpersonen), 1946: 26040, 1964: 22453 (Städtebuch, S. 364).

Katholiken: 1925: 1015, 1936: 2491 (Städtebuch, S. 365). - Alt Ruppin (1993 eingemeindet): 1925: 2041, 1939: 3007 , 1946: 3369, 1964: 2926 (ebd., S. 364). - „Nach dem II. Wekltkrieg gehörten etwa 1500 Katholiken zu Neuruppin [...]. 1953 lag die Katholikenzahl bei etwa 3400 , nachdem bereits $1949[\rightarrow]$ Lindow mit $[\rightarrow]$ Rheinsberg seelsorglich ausgegliedert worden war." (Brühe, S. 34; leicht verkürzt auch in: Schwillus/Brühe, S. 335).

UMSIEDleRlageR: Kapazität am 1.1.1946: 300 (BLHA, Rep. 203 MdI, Nr. 1163, Bl. 50). 1946 Ankunft eines Transports mit 1085 Vertriebenen aus Reichenberg in Böhmen (Jun, S. 251). - 26.7.1946 Ankunft eines Transports mit 1222 Vertriebenen aus Althabendorf bei Reichenberg in Böhmen (ebd.).

StÄDtepartnerschaften: (1) Nach 1973 Kontakte mit Namysłów, Polen (Namslau, Schlesien) (Trzcielińska-Polus, S. 538). - Städtepartnerschaftsverträge: (2) 1994 Nymburk, Tschechien (Nimburg in Mittelböhmen). - (3) 2005 Babimost, Polen (Bomst, bis 1945 Kr. Züllichau-Schwiebus [Provinz Brandenburg], zuvor bis 1938 Kr. Bomst [Provinz Grenzmark Posen-Westpreußen]).

VERTRIEBENENVERBÄNDE NACH 1990: (1) BdV-Kreisverband Neuruppin, gegründet 1991 (Märkischer Informationsdienst 8/1994, S. 14); 1993-2010 als Sitz erwähnt: Franz-Künstler-Str. 8 
(Akten der BdV-Landesgeschäftsstelle; BdV-Handbuch 1996, S. 168). 13.11.1996 Satzung beschlossen. 2003 bestehen folgende Gruppen: Landsberg, Rheinsberg, Schlesien, ZüllichauSchwiebus, Pommern/Ostpreußen; 6.5.2011 Feier des 20jährigen Bestehens im Tempelgarten; Anfang 2013 Auflösungsbeschluss, zuletzt knapp 70 Mitglieder (MAZ, 18.11.2013), anschließend bestehen Heimatgruppen als lose Zusammenschlüsse weiter (s. u.). - Mitgliederzahlen: 1991: 180; 2005133 zahlende Mitglieder; 2008: 135 Mitglieder; 2012: 101 (3 Lindow, 1 Dechtow, 2 Gnewikow, 1 Nietwerder, 1 Wildberg, 1 Molchow, 1 Stöffin, 1 Repente, 1 Darritz, 2 Radensleben, 1 Ribbeckshorst, 19 Rheinsberg, 1 Kleinzerlang, 2 Osterne/Badingen, 3 Dierberg, 1 Altruppin, alle anderen Neuruppin) (Akten der BdV-Landesgeschäftsstelle). - 1. Vorsitzende: 1991-1996 Rudolf Fitzner, Kränzlin (geb. 1928 Waldruh [Tschöplau], Kr. Freystadt/Schlesien, gest. 2009), Gründer (BR 6 (2009)1, S. 10), (1999)-2002 Werner Gotthardt, Neuruppin (geb. 1929, aus Barten, Ostpreußen, 1945 aus Kriegsgefangenschaft nach Wittenberge gekommen [Vater dann Tierarzt ebd.], lernt Schlosser, später Ingenieur, ab 1956 in Neuruppin (ausführlich Jeanette Schäfer in: MAZ, 26.3.2008 mit Bild), 2002 (1998?)-2010 Johanna Franke geb. Roß, Neuruppin (geb. 1932 Schwente, Pommern, gest. 2010 Neuruppin) (ebd. 8 (2010)7, S. 11; 8 (2010)9, S. 11; Interview mit ihr, geführt von Jeanette Schäfer: MAZ 26.3.2008), 2010-2013 Inge Stark, Neuruppin bzw. Darritz (geb. 1934; Leiterin der $\rightarrow$ Rheinsberger Gruppe) (Akten der BdV-Landesgeschäftsstelle). - (2) 2013 „Vertriebenen Heimatgruppen Neuruppin“ (Leitung: Inge Stark), 2015 „BdV Heimatgruppen Neuruppin Rheinsberg“" (Leitung: Inge Stark) (Akten der BdV-Landesgeschäftsstelle).

Gedenkstein auf dem Evang. Friedhof, Gerhart-Hauptmann-Straße 61: „Der in der Nähe der Friedhofskapelle [...] [S. 26] stehende Stein erinnert an die Opfer der Vertreibung und der Luftangriffe auf Neuruppin, bei denen auch Vertriebene Opfer wurden. / Auf dem Friedhof befinden sich zwei Gräberfelder, die den Vertriebenen und ihren Toten gewidmet sind. Das den Flüchtlingen gewidmete Gräberfeld wird durch einen schlichten Würfel mit der Inschrift ,2. Weltkrieg - Gräber der Flüchtlinge' und separaten Tafeln mit den Namen der Umgekommenen oder Verstorbenen bestimmt. Ein weiteres Gräberfeld, ebenfalls mit Gedenkstein versehen, nimmt die Kinder auf. So fanden 471 Vertriebene hier ihre letzte Ruhe, darunter 176 Kinder - die Bilanz der Jahre 1945 bis 1946." (Johanna Franke: BdV übernahm Sanierung. In: BR 3 (2005) 2, S. 25-26). - „Die Gestaltung des Friedhofs bezieht 1100 Kriegsgräber aller Opfergruppen ein. Sie beginnt mit Soldatengräbern des 1. und 2. Weltkrieges, Flüchtlingsgräbern als geschlossenes Grabfeld, Kindergräbern, Gräber russischer und polnischer Zwangsarbeiter. Die Opfer vom Todesmarsch, 77 Häftlinge aus dem KZ Sachsenhausen, fanden vor dem hohen Kreuz ihre letzte Ruhe. Auf dem Soldatenfriedhof, der ein Kennzeichen für den Friedhof ist, sind ebenfalls die Gräber der Verfolgten des Naziregimes zu finden. / Steine, Stelen und Skulpturen wurden vom Bildhauer Wieland Schmiedel aus Crivitz bei Schwerin entworfen: 8 Schriftblöcke, die Mutter, Grenzstein, zerschlagene Platte, Trauernde, Holzkreuz." Einer der quaderförmigen Steinblöcke trägt auf der Oberseite die Versalien-Inschrift „2. Weltkrieg/Gräber der/Flüchtlinge" (www.kirchenkreis-wittstock-ruppin.de/93.html, mit Fotos [19.7.2017]). 2004 im Auftrag des BdV saniert (BR 3 (2005) 2, S. 25 f., mit Bild). 
Archivalische Quellen: BArch, DO 1 Ministerium des Innern der DDR, Nr. 27887, B1. 45 (Teinahme von Neuruppinern an „Umsiedlertreffen“ in Berlin, 1951). - BLHA, Rep. 6 B Züllichau-Schwiebus, Nr. 2 (Abwicklungsgeschäfte der Kreisverwaltung Züllichau in Neuruppin, 1944-1945; enthält u. a.: Verzeichnis über den Verbleib der Beamten und Angestellten der Kreisverwaltung Züllichau-Schwiebus); Nr. 3 (Verlegung der Kreisverwaltung Züllichau nach Guben, Calau und Neuruppin; Abwicklung der Geschäfte, 1945). - Siehe auch Quellenteil, Nr. 235.

Gedruckte Quellen und Literatur: Barkau, Margarete: Erlebnisse in Bomst. In: Vor 50 Jahren. Als Flucht und Vertreibung im Kreis Züllichau-Schwiebus begannen. O. O. 1995, S. 23-25. - Brühe, Matthias: Katholische Kirche zwischen Prignitz und Havelland. Berlin 2000, S. 33-34. - Christopeit, Gerald: Ders.: Die Vertriebenen im Gründungsjahr der DDR - Versuch einer Standortbestimmung anhand ihrer Lage im Land Brandenburg 1949. In: 50 Jahre Flucht und Vertreibung. Hrsg. von Manfred Wille. Magdeburg 1997, S. 256-270, hier S. 266 f. - Dokumentation der Vertreibung I/1, S. 359, 381. - Heinrich, Gerd: Zeittafel. In: Fontanestadt Neuruppin 1256-2006. Neuruppin 2006, S. 255-263. - Lebensgeschichten Neuruppiner Frauen. Norderstedt [2006]. - Meier, Brigitte: Fontanestadt Neuruppin. Karwe 2004. - Meißner, Lothar: Besucherrekord bei den Züllichau-Schwiebusern. Über 3000 Heimatfreunde trafen sich in Gildenhall. In: Märkischer Informationsdienst 1993, Nr. 7/8, S. 8-9. - Modrau, Marianne: Erlebnisse in Lanken. Zsgest. von Karl-Heinz Graff. In: Vor 50 Jahren (wie vor), S. 27-32, hier S. 31. - Preuß, Ruth: [Lebensgeschichte]. In: Lebensgeschichten Neuruppiner Frauen. Norderstedt [2006], S. 84-120. - Schwillus/Brühe, S. 335. Tagebuch Elisabeth Buchholtz [Auszüge]. In: „Die Russen sind da“. Peter Böthig u. Peter Walther (Hg). Berlin 2011. - Trzcielińska-Polus. - Übersicht über die Bestände des Brandenburgischen Landeshauptarchivs (Staatsarchiv Potsdam). T. 2. Weimar 1967, S. 515. - Wille I, S. 372; II, S. 206; III, S. 108.

\section{Neuseddin}

Landgemeinde (seit 5.12.1993 Ortsteil von Seddiner See), bis 1952 Kr. Zauch-Belzig, 19521990 Kr. Potsdam-Land (Bez. Potsdam), 1990-1993 Ldkr. Potsdam, 1993 Ldkr. Potsdam-Mittelmark

EREIGNISSE NACH KRIEgSENDE: „Hier im Ort wurden die Flüchtlinge leichter integriert. Der große Rangierbahnhof bot vielen auch trotz großer Zerstörung am 20. April 1945 wieder Arbeit." (Cimbal, S. 41).

BevöLKerungszahlen: 1925: 650, 1939: 1026, 1946: 1484, 1964: 1731 (HOL V.S. 411).

Gedruckte Quellen und Literatur: Cimbal, Hanswerner: Zweite Heimat Neuseddin. In: Heimatgruß. Zeitschrift für Mitglieder und Freunde des Heimatkreises Meseritz e. V. und der Heimatkreisgemeinschaft Birnbaum 181, 2007, S. 40-41. - Klewitz, Fritz: Die Ereignisse im Raum von Neuseddin. In: Um Beelitz harter Kampf. 1945. Beelitz 1999, S. 127-143.

\section{Neustadt (Dosse)}

Stadtgemeinde, bis 1952 Kr. Ruppin, 1952-1990 Kr. Kyritz (Bez. Potsdam), 1990-1993 Ldkr. Kyritz 1993 Ldkr. Ostprignitz-Ruppin

EREIGNISSE NACH 1990: 22.9.2001 „4. Ostdeutscher Kulturtag“ des BdV-Landesverbandes Brandenburg in der Graf von Lindenau-Halle (Akten der BdV-Landesgeschäftsstelle). - Seit 2012 jährliche „Namslauer Heimattreffen“ der „Namslauer Heimatfreunde e.V.“ im Park Hotel 
Neustadt, Prinz-von-Homburg-Str. 35, 4.10.2012 mit 60 Teilnehmern, gebürtig aus Stadt u. Kreis Namslau, überwiegend aus Schmograu (Namslauer Heimatruf, H. 215, 2012, S. 51-54 Kurzbericht mit Teilnehmerliste: 36 Teilnehmer, „die meisten aus der Region“), 2. Treffen 2013 (ebd., H. 219, 2013, S. 20-22 Bericht mit Teilnehmerliste); Ankündigung für 3. Treffen 2014 ebd., H. 222, 2014, S. 58; 4. Treffen 2015; 5. Treffen 1.10.2016.

Bevölkerungszahlen: 1925: 1458, 1939: 1362, 1946: 2 152, 1964: 3515 (Städtebuch, S. 371).

Katholiken: 1925: 138, 1946: 297 (Städtebuch, S. 372). - Kuratie: 1911: 1300, 1939: 350 Katholiken. „Nach dem II. Weltkrieg [...] stieg die Katholikenzahl durch die Flüchtlinge und lag 1953 bei 1500 . Zeitweilig bestanden in $[\rightarrow]$ Wusterhausen $(1945-46)$ und in $[\rightarrow]$ Sieversdorf (1946-60) Seelsorgstellen." (Brühe, S. 35).

HAupt- UND LANDGestüt (1946-1948 Arthur-von-Weinberg-Gestüt“): „1943 waren aufgrund der Kriegslage im Osten Landbeschäler aus Rastenburg [Ostpreußen] nach Neustadt evakuiert worden. Kurze Zeit später kam die gemischtfarbene Stutenherde (ca. 80 Stuten) aus Trakehnen-Bajohrgallen [Ostpreußen] in Neustadt an. Und im Oktober 1944 erreichte der erst 16-jährige Reitbursche Otto Fiege mit zwei Hauptbeschälern [...] aus Trakehnen das Gestüt. Am 2.3.1945 traf Dr. Martin Heling mit den Hengsten des Landgestüts Georgenburg [Ostpreußen] nach sechsmonmatiger Odyssee über das Eis des Frischen Haffs via Danzig in Neustadt ein. 59 der evakuierten Hengste verblieben in Neustadt, 100 Hengste erreichten schließlich Celle. Mit den Pferden kam auch das ostpreußische Personal nach Neustadt. [...]." (Dochow, S. 64). Nach dem Einmarsch der Roten Armee mussten jedoch alle Pferde bis auf einem lahmenden Hengst abgegeben werden. (ebd., S. 66). - „In Zirke [Kr. Birnbaum] wurden die beiden Gestüte am Morgen des 21. Januar [1945] in Marsch gesetzt und gelangten in das brandenburgische Gestüt Neustadt an der Dosse [...]. Nach Kriegsende mußten sie an die östlichen Mächte ausgeliefert werden." (Hielscher, S. 13). - Ab Sept. 1945 Neueinrichtung des Gestüts durch den ehem. Neustädter Tierzuchtamtsleiter Gustav Condereit (1886-1972) (ebd., S. 69), 1945-1948 Landstallmeister (ebd., S. 203), der jedoch die DDR 1953 verlässt (ebd., S. 74). April 1946 Übernahme von 30 wertvollen, aus dem Landgestüt Marienwerder (Westpreußen) zunächst in das Landgestüt Halle-Kreuz evakuierten Junghengsten, darunter Trakehner (ebd., S. 71). Einige Stuten Trakehner Abstammung wurden in den ersten Nachkriegsjahren hinzuerworben bzw. aus Enteignungen zugewiesen (ebd., S. 72 f.). - Leiter des Hengstdepots war 1956-1959 der vor 1933 in Trakehnen tätige Horst Katerbitz (ebd., S. 106). - Direktor des Tierzuchtgutes war 1965-1991 Heinz Hoppe (geb. 1931 Großendorf, Hinterpommern, 1947 nach Sachsen vertrieben, besuchte 1949-1953 landwirtschaftliche Fachschule in Zug bei Freiberg/Sachsen, 1953 Zootechniker im VEG Groß Langerwisch, dann Direktor des VEG Kammermark im Kr. Pritzwalk, währenddessen Studium in Bernburg, Dipl.-Landwirt, 1994-1996 Landstallmeister in Neustadt/D.). 
GedenKstÄTte AUf DEM FRIEDHOF: 20.5.1998 eingeweihtes Hochkreuz mit Inschrift „Im / Geden-/ken/an/die Opfer der Vertreibung/des/II./Welt-/krie-/ges“ (Mahn- und Gedenkstätten Brandenburg, mit Abb.; BR 12, 2014, Nr. 9, S. 5 mit Abb.).

Quellen und Literatur: Brühe, Matthias: Katholische Kirche zwischen Prignitz und Havelland. Berlin 2000, S. 35. - Christopeit, Gerald: Ders.: Die Vertriebenen im Gründungsjahr der DDR - Versuch einer Standortbestimmung anhand ihrer Lage im Land Brandenburg 1949. In: 50 Jahre Flucht und Vertreibung. Hrsg. von Manfred Wille. Magdeburg 1997, S. 256-270, hier S. 267. - Clough, Patricia: In langer Reihe über das Haff. Die Flucht der Trakehner aus Ostpreußen. München 2004. - Dochow, Gudrun (Hrsg.): Haupt- und Landgestüt Neustadt (Dosse). Vom preuBischen Gestüt zum Sanssouci der Pferde. Neustadt (Dosse) 2013. - Hielscher, Karl A.: Das Kriegsende 1944/45 für den Kreis Birnbaum. In: Birnbaum/Warthe. Hrsg. von Margarete Becker u. a. Hemmingen 1977, S. 9-18. - Mahnund Gedenkstätten Brandenburg. Hrsg.: BdV (www.bund-der-vertriebenen.de [20.9.2016]). - Namslauer Heimatruf 214 (2012) - 222 (2014). - Wille I, S. 372. - Auskünfte Edeltraud Hoppe, Kyritz (Namslauer Heimatfreunde e. V.), 21.9.2016.

\section{Neuzelle}

Landgemeinde, bis 1950 Kr. Guben, 1.7.1950-1952 Ldkr. Frankfurt (Oder), 1952-1990 Kr. Fürstenberg bzw. (ab 1961) Kr. Eisenhüttenstadt-Land (Bez. Frankfurt/Oder), 1990-1993 Ldkr. Eisenhüttenstadt, 1993 Ldkr. Oder-Spree

EREIGNISSE NACH 1945: [Okt. 1945:] „Viele [S. 35] Flüchtlinge aus den Gebieten östlich von Oder und Neiße, Vertriebene, aus aus Bessarabien und dem Gebiet um Odessa, waren in Neuzelle und auf dem Gut Wellmitz untergebracht. Diese hatten Schwierigkeiten mit der deutschen Sprache, so kamen sie an Wochenenden zu einer Neulehrerin in die Wohnung und erhielten Nachhilfehunterricht." (Schneider, S. 34f.). - „Den Lehrerchor gab es nicht mehr, nachdem ein aus Ostpreußen gekommener Lehrerkollege das Lied dirigierte: ,Wenn ich den Wandrer frage ...', denn da hieß es zum Schluß: ,Ich kann nicht nach Hause, hab' keine Heimat mehr.' Das galt als Provokation!" (ebd., S. 41).

EREIGNISSE NACH 1990: 21.5.1994 1. [Heimat-] Treffen [der vertriebenen ehem. Bewohner] des Kirchspiels Starzeddel (Kr. Guben) (poln. Starosiedle) in Saal und Biergarten der Gaststätte „Kummerower Hof“ in Neuzelle mit ca. 150 Teilnehmern, organisiert von Lonni Fürste (Cottbus) (Bericht in: Gubener Heimatbrief 2/1994, S. 90-93), in den folgenden Jahren regelmäßige Treffen, wegen der starken Resonanz verlegt in größere Gaststätten in $\rightarrow$ Kerkwitz bzw. $\rightarrow$ Kolkwitz (Kr. Guben).

Bevölkerungszahlen: 29.10.1946: 2733 (Volks- u. Berufszählung 1946, S. 14).

Katholiken (Erzbistum Breslau/Erzbischöfliches Amt Görlitz): „Hier befinden sich in einer ehemaligen Zisterzienser-Klosterkirche die Gräber von Verwandten der hl. Hedwig. In den Jahren 1945/46 entwickelte sich dorthin eine - wohl von Schlesiern getragene - Hedwigswallfahrt [...], die aber sicherlich wieder erloschen ist.“ (Schroubek [1968], S. 154). - „Neuzelle wurde neben Görlitz nach dem zweiten Weltkrieg im deutschen Restteil der Erzdiözese Breslau zu einem geistlichen Schwerpunkt und Wallfahrtsort. Seit 1947 pilgerten vor allem jugendliche 
Christen alljährlich zur Schutzmantelmadonna in die Neuzeller Stiftskirche. / Ein großer Schritt zum Neuanfang war die Errichtung des Erzbischöflichen Pastoralseminars Bernhardinum in Neuzelle, welches das verlorene Pastoralseminar Albertinum in Breslau[-]Carlowitz [für das gesamte Gebiet der SBZ - P. B.] ersetzen sollte.“ (Homagk, S. 29). - Der (ab 1914) letzte deutsche Pfarrer von Bösdorf (Kr. Neisse, Schlesien), Geistlicher Rat Heinrich Werner (geb. 1867 Grosch[o]witz, Schlesien), war „nach der Vertreibung [ab 1946] Hausgeistlicher im St. Florianstift in Neuzelle, [...], starb dort am 24.9.1960، (Bögner, S. 143; ergänzt nach Schematismus Görlitz 1958, S. 55, und 1961, S. 114). - 1949 wohnt im Florianstift der aus Lesten [Tschirnau, Kr. Guhrau] (Schlesien) vertriebene Geistliche Rat Paul Kuchel (geb. 1883) (Ostpriesterverzeichnis 2, 1949, S. 41).

St. Florian-Stiftung (kath. Waisenhaus), Frankfurter Straße 12: „Nach dem Ende des Zweiten Weltkrieges gab diese Flüchtlingskindern, vor allem aus Schlesien, ein Zuhause." (Neuzelle einst und jetzt, S. 69).

Priesterseminar Bernhardinum (im Gebiet Görlitz, dem Restteil der Erzdiözese Breslau): 1947 in den Verhandlungen zwischen Kapitelsvikar Prälat Dr. Ludwig Cuno (1881-1949, ab 1.6.1946 in Görlitz, zuvor im Bischöfl. Generalvikariat in Breslau) und Ministerialdirekor Dr. Kurt Grünbaum (1892-1982) vorübergehend (nicht umgesetzte) gemeinsame Planung von Kirche und Provinzialregierung, das Erzbischöfliche Amt aus Görlitz (Amtsräume sowie Dienstwohnungen für die Mitglieder des Domkapitels von Breslau) nach Neuzelle zu verlegen (erwähnt 12.6.1947; Müller, S. 36). - 1.7.1947 Mietvertrag zwischen dem Erzbischöflichen Amt Görlitz und der Provinzalregierung Brandenburg über die Vermietung von Wohn- und Wirtschafsräumen in den Klostergebäuden von Neuzelle für die Errichtung enes Priestereminars (ebd., S. 36). - 2.5.1948 Priesterseminar gegründet (mit zweijähriger Verzögerung „vor allem wegen der feindseligen Haltung der Verwaltungsstellen im Land Brandenburg“). „Im Priesterseminar wurden die letzten beiden Jahre der Priesterausbildung, d. h. nach dem Theologiestudium (bis 1952) in den Westsektoren, abgeleistet. Zwischen 1949 und 1970 wurden 130 Priester auf den Titel von Breslau geweiht, auch einige, die in den Westzonen ausgebildet worden waren, die aber vor dem Krieg im Erzbistum Breslau geboren waren." (Hecklau, S. 82; Gründungsdatum nach Müller, S. 37). „Das Neuzeller Priesterseminar wurde bewußt in die Tradition des Priesterseminars in Breslau gestellt, wobei sich diese Kontinuität auch in der Berufung der beiden leitenden Personen, des Regens und des Spirituals, manifestierte." (Dahlmann/Reith, Elitenwanderung, S. 118): Daher hatte man „für das Amt des Regens den ehemaligen Regens des Pastoralseminars von Breslau-Carlowitz, Msgr. Dr. Paul Ramatschi [1898-1975; im Amt 1948-1967], und für das Amt des Spirituals den ehemaligen Spiritual des Theologenkonvikts von Breslau, Herrn Pfarrer Erich Puzik [im Amt 1948-1967], ausersehen“ (Priesterseminar Bernhardinum Neuzelle, S. 7; Amtszeiten S. 12). - 1952 Erweiterung durch Ausbau des Scheunenteils (Müller, S. 37). - 1966-1970 Innenausbau und 1977-1982 Dachgeschossausbau (ebd.). - 1.4.1985 Trägerwechsel: Aus dem diözesanen Pastoralseminar 
wird das Interdiözesane Pastoralseminar Bernhardinum, unterhalten „von den Diözesen Berlin und Dresden/Meißen sowie der Apostolischen Administratur Görlitz und den Apostolischen Administratoren in Erfurt und Schwerin“ (Müller, S. 37). - 1993 Schließung: „,im Rahmen von Umstrukturierungs- und Rationalisierungsmaßnahmen am 1.9.1993 nach Erfurt an das dortige Priesterseminar verlegt“ (ebd.).

Gedruckte Quellen und Literatur: Blöß, Kreise und Gemeinden, S. 13. - Bögner, Josef: Heimatchronik der Pfarrgemeinde Baumgarten Kreis Frankenstein - Schlesien. Bad Oeynhausen 1982. - Hecklau, Svenja: Aufbau der Seelsorge im Gebiet Görlitz 1945-1972. In: Vertriebene finden Heimat in der Kirche. Hrsg. von Rainer Bendel. Köln u. a. 2008, S. 79-93. - Homagk, Mathias: Der Neubeginn - Vom „Restteil“ des Erzbistums Breslau zum Bistum Görlitz. In: „Ich gehe mit dem Gedanken um, in Kirchhain einen Betsaal zu bauen ..."Halle/Saale 2008, S. 27-35. Müller, Wolfgang: Das Priesterseminar Bernhardinum. In: 725 Jahre Neuzelle. Eisenhüttenstadt 1993, S. 35-37. Neuzelle einst und jetzt. Frank Mangelsdorf (Hg.). Texte Janet Neiser. Berlin 2018. - Priesterseminar Bernhardinum Neuzelle 1948-1988. Neuzelle 1988. - Schneider, Hildegard: Erinnerungen an die ersten Schuljahre in Neuzelle nach dem Ende des Krieges 1945. In: Heimatkalender Eisenhüttenstadt und Umgebung 14 (1996), S. 34-42. - Schroubek, Georg R.: Wallfahrt und Heimatverlust. Marburg 1968. - Töpler, Menschenwurm.

\section{Neu Zittau}

Landgemeinde (seit 2003 Ortsteil von Gosen-Neu Zittau durch Fusion mit $\rightarrow$ Gosen), bis 1950 Kr. Beeskow-Storkow, 1950-1990 Kr. Fürstenwalde (ab 1952 Bez. Frankfurt/Oder), 19901993 Ldkr. Fürstenwalde, 1993 Ldkr. Oder-Spree

EREIGNISSE NACH KRIEGSENDE: 1946 Unterbringung von 37 sudetendeutschen Textilfacharbeitern („Antifa-Familien aus der Tschechoslowakei“; überwiegend aus Warnsdorf/Varnsdorf, vier Personen aus Obergrund/Horní Podluží bei Warnsdorf) im Amtsbezirk Neu Zittau (BLHA, Rep. 256 Küchensee, Nr. 29). - 1948 Erwähnung der von sudetendeutschen Vertriebenen gegründeten „Genossenschaft für handwerkliche Erzeugnisse Neuzittau“ (Christopeit, S. 86). -

BeVÖLKERUNGSZAHLEN: 1925: 1 148, 1939: 1 851, 1946: 2015, 1964: 1671 (HOL IX, S. 312).

Katholiken: „Nach dem II. Weltkrieg kamen Vertriebene auch nach Neu-Zittau, das zur Pfarrei Erkner gehörte. Für sie konnte in einer Druckerei, deren Besitzerin katholisch war, ein dem hl. Adalbert gewidmeter Kapellenraum eingerichtet werden. Seelsorger am Ort war von 194553 Dr. Johannes Maier [geb. 1888 Hammerstein (Schematismus Berlin 1949, S. 143; Ostpriesterverzeichnis 2, 1949, S. 54)], der frühere Offizial des Bistums Danzig. In den 60er Jahren wird der Ort noch als ,Seelsorgestelle' geführt. 1991 wurde die Kapelle aufgegeben." (Brühe, S. 52). - 22.8.1946 „Kons[istorial-]Rat Dr. Maier, Johs., Neuzittau b/Berlin, Berlinerstr. 29“ erwähnt in einer Aufstellung der außerplanmäßig eingesetzten „Flüchtlingsgeistlichen “ (DAB, I/915-1 Flüchtlingsseelsorge 1945-1951, unfol.).

Archivalische Quellen: BLHA, Rep. 250 Landratsamt Beeskow-Storkow, Nr. 881 („Einbürgerung von Umsiedlern“, 1947-1950; enthält auch: „Gründung der Textilgenossenschaft Neu Zittau durch Umsiedler“, 1948). - BLHA, Rep. 256 Umsiedlerlager Küchensee, Nr. 29 (enthält u. a.: Liste von 37 im Amtsbezirk Neu-Zittau untergebrachten 
Textilfacharbeitern, 16./22. Juli 1946); Nr. 329 („Eingemeindungen von Umsiedlern im Amtsbezirk Neu-Zittau und Ketschendorf“; enthält: „Umsiedlerlisten“, Juli 1946).

Literatur: Brühe, Matthias: Katholische Kirche zwischen Uckermark und Oderland. Berlin 1998, S. 52. - Christopeit. - Oehlsen, S. 84. - Schwillus/Brühe, S. 314.

\section{Niederfinow}

Landgemeinde, bis 1950 Kr. Angermünde, 1.7.1950-1952 Kr. Oberbarnim, 1952-1990 Kr. Eberswalde (Bez. Frankfurt/Oder), 1990-1993 Ldkr. Eberswalde, 1993 Ldkr. Barnim

EReignisse Bis Kriegsende: April 1945 Flucht der Einwohner in die Uckermark und nach Mecklenburg (Schiefelbein, S. 107-114). - 26.4.1945 Einmarsch der Roten Armee (ebd., S. 107).

Bevölkerungszahlen: 1.8.1947: 1448 Einwohner, davon 444 Männer, 689 Frauen und 315 Kinder. „Der hohe Einwohnerstand resultiert aus der Zuweisung von 300 Flüchtlingen vom Umsiedleramt Angermünde." (Schiefelbein, S. 121).

GedRuckte Quellen und Literatur: Dokumentation der Vertreibung I/2, S. 492. - Eberswalde 1945. Begleitheft zur Sonderausstellung im Stadt- und Kreismuseum. Eberswalde 1995, S. 67 f. (Schiffshebewerk). - Schiefelbein, Siegfried: Niederfinow - Ein Ort mit schwebenden Schiffen. Niederfinow 2008.

\section{Niemegk}

Stadtgemeinde, bis 1952 Kr. Zauch-Belzig, 1952-1990 Kr. Belzig (Bez. Potsdam), 1990-1993 Ldkr. Belzig, 993 Ldkr. Potsdam-Mittelmark

EReignisSe BIS KRIEgSEnde: Febr. bis April 1945 (aus dem Protokoll des Niemegker Schuldirektors und NSDAP-Ortsgruppenleiters Adolf Kewitz vom 18.5.1945): „Ich selbst hatte mit der Unterbringung von Flüchtlingen und der Betreuung derselben zu tun." (Dalitz, S. 132). - Febr. 1945 Flüchtlingstransport aus Schwiebus mit Feuerwehrfahrzeugen nach Niemegk und Dabendorf überführt (BLHA, Rep. 6 B Züllichau-Schwiebus, Nr. 169). - [Ca. April 1945:] „Kurz vor Niemegk wurde eine Gruppe Flüchtlinge noch von Tieffliegern erschossen. Viele Tote." (Sewerin, S. 101). - 25.4.1945 Beginn einer Massenflucht der Bevölkerung aus Niemegk, besonders nach $\rightarrow$ Belzig (Dalitz, S. 161). - 2.5.1945 Einmarsch der Roten Armee (ebd., S. 163). - Engpässe in der Lebensmittelversorgung vor und nach Kriegsende führen zu vermehrter Kleingartennutzung. „Das war besonders für die vielen Umsiedlerfamilien äußerst schwierig, denn die Kleingärten wren alle schon seit längerer Zeit durch Niemegker Bürger gepachtet. Es fanden sich noch Flächen, worauf die Erschließung von Kleingärten möglich war und so richtete die Stadt z. B. in der Nachbarschaft zum Behelfsheim auf dem Schützenplatz, am Bahnhof und sogar in den Schießbahnen der Schießstände mehrere Gärten ein. An anderen Stellen gab es auch noch kleine Brachflächen dafür." (Dalitz, S. 137). 
EREIGNisSe NACH KRIEGSENDE: 1.12.1945 (Bericht der Stadtverwaltung): „Herzeleid und Kummer und Sorge ist durch die Kriegswirren in jede Familie eingzogen. Im Jahre 1933 zählte Niemegk 2500 jetzt 4200 Einwohner. Die höhere Einwohnerzahl ergibt sich aus den Flüchtlingen, die aufgenommen und untergebracht werden mußten. Die Flüchtlinge machen der Stadtverwaltung große Sorgen. Ihr Gesundheits- und Ernährungszustand ist nicht besonders gut. Das Heranschaffen des täglichen Bedarfs macht große Schwierigkeiten, da nicht genügend Lastkraftwagen zur Verfügung stehen und sich der Brennstoffmangel sehr bemerkbar macht. Aber für alles wurde bisher doch ein Ausweg gefunden, um wenigstens die größte Not zu beheben." (Brandenburgische Gemeinden 1945, S. 155). - 1945-1949 praktiziert in Niemegk, Werderstr. 1, der in Berlin aufgewachsene Arzt Dr. Joachim Niepelt (geb. 1917), dessen Familie nach Niemegk evakuiert war und der in seinen Erinnerungen u. a. Erlebnisse mit Flüchtlingen aus dem Banat u. Siebenbürgen schildert.

BevölKerungszahlen: 1925: 2386, 1939: 2979, 1946: 3257, 1964: 2743 (Städtebuch, S. 375).

Katholiken: 1925: 17, 1946: 269 (Städtebuch, S. 375).

Archivalische Quellen: BLHA, Rep. 6 B Züllichau-Schwiebus, Nr. 169 (Umsiedlungsaktion im Kreise ZüllichauSchwiebus, 1945; enthält u.a.: Namentliche Liste des aus Schwiebus mit Feuerwehrfahrzeugen nach Niemegk und Dabendorf (Kr. Zauch-Belzig) überführten Flüchtlingstransports, Febr. 1945).

Gedruckte Quellen und Literatur: Brandenburgische Gemeinden 1945, S. 155-156. - Dalitz, Siegfried: „Helft unseren Kranken!“ Das Gesundheitswesen nach 1945. In: Zwischen Havelland und Fläming 1994, S. 81-83. - Ders.: Die Chronik der Stadt Niemegk. Bd. 8. Niemegk 2008 (S. 113-213: Zweiter Weltkrieg und Kriegsende). - Niepelt, Joachim: Was, Sie kennen den Fläming nicht? Episoden aus der Landdoktorzeit in Niemegk 1945 bis 1949. 2., erw. u. bearb. Aufl. Belzig 2004. - Sewerin, Gertraud: Krankenschwester vom DRK. In: „.. das Glockengeläut ist einzustellen“. 1945 - das Jahr zwischen Krieg und Frieden. T. 1: Belzig und Umgebung. Belzig 1995, S. 101-102.

\section{Noßdorf $\rightarrow$ Forst-Noßdorf}

\section{Oderberg/Mark}

Stadtgemeinde, bis $1950 \mathrm{Kr}$. Angermünde, 1.7.1950-1952 Kr. Oberbarnim, 1952-1990 Kr. Eberswalde (Bez. Frankfurt/Oder), 1990-1993 Ldkr. Eberswalde 1993 Ldkr. Barnim

EREIGNISSE: 1945 Todesfall eines Flüchtlings aus Königsberg/Nm. in Oderberg (Krätzner, S. 26, nach Angaben in der „Heimatkartei“). 27.4.1945 Eimmarsch der Roten Armee (Fleischer, S. 127 f.). - 1945 (Bericht der Stadtverwaltung von Nov. oder Dez. 1945): „Oderberg wurde [...] in den letzten Tagen des Aprils 1945 zu einer toten Stadt. [...] Welche Schwierigkeiten ergaben sich nicht schon allein beim Bau der von den SS-Formationen zerstörten Brücke? Im ganzen Kreis Angermünde ist keine Brücke anzutreffen, die der Oderberger Freiheits-Brücke - so [S. 161] heisst die neue Holzbrücke nun - gleichkommt. [...] Gewaltig ist die Arbeit, die all diese Männer übernommen [Bürgermeister und Amtsleiter] haben, denn Oderberg gehört zu dem Notstandsgebiet an der Odergrenze. 
Viele der schweren Schäden sind heute bereits behoben. Die beschädigten Häuser wurden instand gesetzt, Schutt und Trümmer aufgeräumt, die Wasserversorgung repariert, das elektrische Leitungsnetz wieder hergestellt. Jahrelang wird vielleicht die bis auf die kleinste Brücke zerstörte Eisenbahnstrecke Bad Freienwalde-Oderberg-Angermünde unbenutzt bleiben müssen, Verbindung mit Berlin wurde durch Dampfverkehr geschaffen. / Typhus und Seuchen fordern Opfer. Schutzimpfungen fanden statt. Alle Aufräumarbeiten sind in Frage getellt und die Gesundheuit der Bevölkerung gefährdet, wenn die Ernährung nicht einigermaßen sichergetellt ist. Die Stadtverwaltung sucht Mittel und Wege, dem Elend zu steuern und eine geordnete Lebensmittelversorgung zu sichern. Vieles harrt noch weiterer Lösung, wie Schule, Flüchtlingszuzug, Wohnungsknappheit, wirtschaftlicher Aufschwung." (Brandenburgische Gemeinden 1945, S. 155). - „Bis zum 1. Mai 1945 waren insgesamt 120 Oderberger in ihre Stadt zurückgekehrt.“ (Fleischer, S. 128). - „Im Sommer 1945 beauftragte der Stadtkommandant die Ortsverwaltung, mit dem Bau einer Notbrücke aus Holz zu beginnen.“ (ebd., S. 128). - „Im August 1945 begann die Stadtverwaltung Oderberg mit dem Umbau der leer stehenden Unterkunftshäuser im ,Steinlager' zu Wohnungen für die Flüchtlinge, die von östlich der Oder kamen. Die ehemaligen Waschräume in den Häusern wurden notdürftig zu Küchen umgebaut und die großen Aufenthaltsräume mit Trennwänden versehen. Ab Oktober 1945 kamen dann verstärkt zahlreiche Flüchtlinge mit ihrer wenigen Habe nach Oderberg, um eine neue Heimat zu sichen. Die Flüchtlinge erhielten für die ersten Tage ihrer Anwesenheit in Oderberg Gemeinschaftsverpflegung und zwar ,regelmäßig in Form von Grütze. / Bekanntmachung der Stadtverwaltung am 19. November 1945: ,Oderberg erwartet in den nächsten Tagen viele hundert Flüchtlinge, die untergebracht werden müssen. Die allermeisten von diesen haben großen Mangel an Kleidung, Wäsche u.s.w. Es geht die dringende Bitte an jeden einzelnen, so viel wie möglich bereit zu halten für die Armen." (ebd., S. 130).

Bevölkerungszahlen: 1925: 3178, 1939: 3559, 1946: 3768, 1964: 4111 (Städtebuch, S. 378). - 1.8.1945: 1958 (Fleischer, S. 129).

Katholiken: 1925: 40, 1946: 213 (Städtebuch, S. 378).

FlüChtlingSlager SChule: Eine 24-jährige Frau aus Hohensalza, „zur Zeit in Oderberg, Mark, Flüchtlingslager Schule“, stirbt am 18.1.1945 an Lungentuberkulose und Kreislaufschwäche im Kreiskrankenhaus Angermünde (Stadtarchiv Angermünde, Standesamt Angermünde, Sterberegister, Nr. 56/1945).

UMSIEDLERLAGER: Kapazität am 31.12.1945: 2000 (BArch, DO 2/45, Bl. 40). - Kapazität am 1.1.1946: 2000 (BLHA, Rep. 203 MdI, Nr. 1163, Bl. 50). - 1946 Belegungsstärke: 2000 (Kaminsky, S. 159). - 30.1.1946 (Bericht der Zentralverwaltung für Umsiedler): „Zirka $30 \mathrm{~km}$ südlich von Angermünde, mit der Bahn bequem zu erreichen, befindet sich das Lager Oderberg, das eine Aufnahmefähigkeit von 3000 Personen hat und z. Zt. unbenutzt ist" (Kotsch, S. 132).

GedRuCKTE Quellen und Literatur: Brandenburgische Gemeinden 1945, S. 159-161. - Fleischer, Horst: Abriss der Chronik Oderbergs. T. 4: Von 1930 bis 1949. In: Eberswalder Jahrbuch 2004/05 (2004), S. 119-133. - Krätzner, S. 26. 


\section{Oranienburg}

Stadtgemeinde, bis 1952 Kr. Niederbarnim, 1952-1990 Kr. Oranienburg (Bez. Potsdam), 1990-1993 Ldkr. Oranienburg, 1993 amtsfreie Stadt im Ldkr. Oberhavel

EREIGNISSE NACH 1990: Durch Beschluss der Stadtverwaltung ist Oranienburg eine der Patengemeinden der Stiftung „Zentrum gegen Vertreibungen“ (www.z-g-v.de/ [23.6.2017]). - Ab 14.3.2010 (Wander-)Ausstellung „Meine Ostpreußen“ im Regine-Hildebrandt-Haus in Oranienburg, anschließend in $\rightarrow$ Zehdenick gezeigt (konzipiert u. gestaltet von Angelika u. Olaf Pasenau, $\rightarrow$ Gransee). - 28.9.2013 [letzter] „15. Ostdeutscher Kulturtag“ des BdV-Landesverbandes Brandenburg in der Sporthalle des Luise-Henriette-Gymnasiums (Akten der BdV-Landesgeschäftsstelle). - 2015 Gedenkstein-Aufstellung (s.u.).- 21./22.6.2014 Zeitzeugengespräch „Folgen des II. Weltkriegs - Kriegskinder - Wolfskinder. Treffen der Generationen“ im ehem. Pharmasaal, Heinrich-Byk-Str. 1 mit Berichten von „Wolfskindern“ und Beteiligung von Schülern und Lehrern aus Oranienburg sowie Gästen aus Litauen (Veranstalter: BdV-Kreisverband Oberhavel e.V., Projektleiter: Hans-Joachim Speckmann), gefördert mit Mitteln der Brandenburgischen Landeszentrale für politische Bildung (www.politische-bildung-brandenburg. de/node/10219 [5.6.2017]. „Erstmals ist es dem BdV-Kreisverband des Landkreises Oberhavel $(\mathrm{OHV})$ am 21. Juni gelungen, Zeitzeugen und die nachfolgenden Generationen zu einem öffentlichen Gespräch zusammenzubringen, über das es noch Vieles aufzuarbeiten gibt." (Hans-Joachim Speckmann, in: Preußische Allgemeine Zeitung, Nr. 29, 2014). - 4.6.2016 Festumzug anlässlich der 800-Jahrfeier der Stadt mit vom BdV gestalteten Transparenten „Während Flucht $u$. Vertreibung kamen 3 Millionen Deutsche ums Leben“ (an Treck-Handwagen), „Oranienburg 1945. Eine Stadt in Trümmern. 40000 vertriebene Deutsche suchen hier ein Obdach" und "Kriegsende 1945: 15 Millionen deutsche Flüchtlinge suchen eine Bleibe. Bei der Vertreibung fanden 3 Millionen Menschen den Tod." (BR 14 (2016)8, S. 10 f.). - Ab 13.8.2017 Wanderausstellung (20 Schautafeln) „Flucht gestern und heute" in der Stadtkirche St. Nicolai (Hauptschiff), anschließend (8.11.2017 bis 5.1.2018) gezeigt in der Kreisverwaltung Oberhavel (www.facebook.com/netzwerkschule2015/ [22.4.2018]; Focus online, Regional Brandenburg, 8.11.2017), dann in $\rightarrow$ Kyritz.

BevöLkerungszahlen: 1925: 14723, 1939: 29232, Jan. 1945: 34 186, 1946: 18633, 1964 : 20246 (Städtebuch, S. 382).

Katholiken: 1925: 811, 1946: 1868 (Städtebuch, S. 382). - 1939 (Herz-Jesu-Pfarrgemeinde!): 2700 (Brühe, S. 37).

UMSIEDLERLAGER: Kapazität am 31.12.1945: 350 (BArch, DO 2/45, Bl. 40). - Kapazität am 1.1.1946: 250 (BLHA, Rep. 203 MdI, Nr. 1163, Bl. 50).

Städtepartnerschaften: (1) Nach 1973 Kontakte mit Prudnik, Polen (Neustadt, Oberschlesien) (Trzcielińska-Polus, S. 538). - (2) 7.10.1974 Städtepartnerschaft mit Mělník, Tschechien (Melnik, Mittelböhmen). 
VERTRIEBENENVERBÄNDE NACH 1990: (1) BdV-Kreisverband Oberhavel e. V. (Sitz Oranienburg, eingetragen beim Amtsgericht Neuruppin, VR 1725; veranstaltet ebd. jährlich „Tag der Heimat“), gegründet 1990, feiert 16.9.2000 10-jähriges Bestehen (Brandenburg-Nachrichten 4, 2000). „Der Verein umfasst die Kreisgruppen der Landsmannschaften der Ostpreußen, Westpreußen, Pommern, Schlesier, Ostbrandenburger und Sudetendeutschen und führt diese." Daher offiziell (2002 erwähnt) „BdV-Kreisverband Oberhavel mit den Kreisgruppen LM Ostpreußen/Weichsel-Warthe, LM Pommern, LM Schlesien-Berlin/Mark Brandenburg, LM Berlin-Mark Brandenburg/Sudetendeutsche LM, LM Westpreußen“; 1996 erwähnt als Kreisverband Oranienburg mit Sitz Stralsunder Str. 1 (BdV-Handbuch 1996, S. 168), 2002 Geschäftsstelle: Stadtverwaltung, Schloßplatz 2; langjähriger Vorsitzender von der Gründung bis 2011: Karl Prihoda, Leegebruch (1932-2015) aus Schüttenitz bei Leitmeritz; 2011 Joachim Stöcker zum Vorsitzenden gewählt (BR 9 (2011)6, S. 9), verfasst Erklärung: „Im Vorstand des BdV Oberhavel wird kein bekennendes NPD-Mitglied akzeptiert." (ebd. 9 (2011)10, S. 14). Geschäftsführender Vorstand 2017: Vorsitzender: Hans-Joachim Speckmann, Kremmen (seit 2013), stellv. Vorsitzender: Jürgen Funk (seit 2013), Schatzmeisterin: Christel Hensel (www.politische-bildung-brandenburg.de [2.6.2017]); 2014 Veranstalter eines "Treffens der Generationen“ (siehe oben). - (2) Landsmannschaft Ostpreußen, Kreisgruppe Oranienburg e.V. bzw. Kreisgruppe Oberhavel, Sitz Oranienburg (siehe auch $\rightarrow$ Schmachtenhagen), 8.5.1993 Satzung errichtet, 16.12.1994 eingetragen beim Amtsgericht Oranienburg (VR 483), ab Mai 2017 nur noch „Ostpreußengruppe Oranienburg/Oberhavel“, nicht mehr Landsmannschaft Ostpreußen-Kreisgruppe Oranienburg (Akten der BdV-Landesgeschäftsstelle); Mitgliederzahlen: 200578 Mitglieder, davon 42 über 70 Jahre (Auskunft der Landsmannschaft OstpreuBen, Hamburg), 12.2.2013: 55, 2014: 59, 2016: 29 (Akten der BdV-Landesgeschäftsstelle); Vorsitzende: (1994) Horst Haut (gest. 2010), (2009) Dagmar Jakob, Oranienburg; bis 2012 Horst Trimkowski langjähriger Vorsitzender, zuletzt 2011 wiedergewählt (BR 9 (2011)4, S. 11); 2012-2013 Eva Haut (BR 10 (2012)6, S. 11; 11 (2013)3, S. 8); seit 2013 Elard von Gottberg (geb. 1973) (BR 11 (2013)3, S. 8); sonstige Vorstandsmitglieder 2016: stellv. Vorsitzender: Heinrich Kenzler (geb. 1934 Kalaushöfen, Kr. Fischhausen, Ostpreußen, „Wolfskind“), Schatzmeister: Reinhard Groß (Aileen Hohenstein, in: Märkische Onlinezeitung, 11.4.2016) (Akten der BdV-Landesgeschäftsstelle). - (3) Kreisgruppe Pommern (Pommersche Landsmannschaft im Kreis Oberhavel innerhalb des BdV e.V.), 20.3.1999 Satzung angenommen (123 Mitglieder in Oranienburg anwesend); sonstige Mitgliederzahlen: 1.1.2006: 115, 1.1.2014: 77, 1.1.2015: 76 (Akten BdV-Landesgeschäftsstelle). - (4) Landsmannschaft Schlesien, Kreisgruppe Oberhavel: Vorsitzende 2011 Silke Taube (BR 10 (2012)6, S. 11). [Vgl. Landsmannschaft Schlesien - Oberund Niederschlesien - Landesgruppe Berlin Mark Brandenburg e. V., Sitz Berlin, 29.8.1995 Satzung errichtet, 7.6.1996 eingetragen beim Amtsgericht Charlottenburg (VR 2944 Nz)]. - (5) Kreisgruppe Oberhavel der Sudetendeutschen; 31.12.2006: 10 Mitglieder, Vorsitzender: Karl Prihoda (s. o.). - (6) Kreisverband Oberhavel /Landsmannschaft Westpreußen, 200913 Mitglieder.

Gedenkstein für Flüchtlinge und Vertriebene (auf der Grünfläche hinter der Stadtbibliothek): Basaltsein mit weißer Inschrift: „Gewidmet den Menschen, die infolge des 2. Weltkrieges aus 
ihrer / Heimat fliehen mussten, vertrieben wurden oder ihr Leben verloren. / Ihr Schicksal ist uns Verpflichtung, die Ursachen von Kriegen, Flucht/und Vertreibung in der heutigen Welt zu bekämpfen und zu ächten // Die Einwohnerschaft der Stadt Oranienburg", geschaffen von dem Oranienburger Steinbildhauermeister Ömür Güldas, aufgestellt 2015 durch Stadtverwaltung und BdV Oberhavel, Einweihungsfeier am 20.6.2015 (Märkische Onlinezeitung, Oranienburger Generalanzeiger, 22.6.2015). - Abb.: BR 13 (2015)8, S. 9.

Gedruckte Quellen und Literatur: Brühe, Matthias: Katholische Kirche zwischen Prignitz und Havelland. Berlin 2000, S.36-38. - Dokumentation der Vertreibung I/1, S.381; I/2, S. 492. - Schwillus/Brühe, S.336. Trzcielińska-Polus.

\section{Paaren im Glien}

Landgemeinde (heute Ortsteil der Gemeinde Schönwalde-Glien), bis 1952 Kr. Osthavelland, 1952-1990 Kr. Nauen (Bez. Potsdam), 1990-1993 Ldkr. Nauen, 1993 Ldkr. Havelland

EREIGNISSE NACH KRIEgSENDE: 1947 in der Bodenreform 3 Umsiedler berücksichtigt (HOL III, S. 262).

EREIGNISSE NACH 1990: 5.6.1999 „2. Ostdeutscher Kulturtag“ des BdV-Landesverbandes Brandenburg in der Brandenburghalle mit Grußwort des Ministerpräsidenten Stolpe und Ansprache der BdV-Präsidentin Erika Steinbach (Akten der BdV-Landesgeschäftsstelle).

Bevölkerungszahlen: 1925: 565, 1939: 523, 1946: 631, 1964: 537 (HOL III, S. 262).

Katholiken: „Erhalten ist die aus einer Baracke entstandene Kapelle in Paaren [...]. Sie wurde errichtet für katholische Heimatvertriebene, die in der Umgebung angesiedelt worden waren.“ (Schwillus/Brühe, S. 305). - „Wie in vielen anderen Orten wurden hier nach dem II. Weltkrieg Vertriebene aus Schlesien, dem Sudetenland und der Prälatur Schneidemühl angesiedelt. Kirchlich gehörten die Katholiken nun zur Gemeinde $[\rightarrow]$ Brieselang, deren Seelsorger anfangs im Gutshaus Perwenitz, später in den evangelischen Dorfkirchen 14-tägig die Hl. Messe feierte. / 1964 gelang es einem Ehepaar, am östlichen Ortsausgang von Paaren ein Grundstück zu erwerben, auf dem zwei vom Caritasverband überlassene Baracken aufgestellt und sogar mit einem massiven Vorbau versehen werden konnten, da der damalige Bürgermeister einen ,vernünftigen' Blick wünschte. Unter fleißiger Mithilfe der Gemeinde entstand eine Kapelle, die am 24.10.1965 benediziert wurde. Sie trägt ein Kreuz auf dem Giebel sowie den Schriftzug ,St. Joseph' 1966 wurde der Tabernakel aufgestellt und ein Kreuzweg eingeweiht, 1971 wurde die Barackenkapelle auch ummauert." (Brühe, S. 39).

Literatur: Brühe, Matthias: Katholische Kirche zwischen Prignitz und Havelland. Berlin 2000, S. 39. - Schwillus/ Brühe, S. 305. 


\section{Päwesin}

Landgemeinde (seit 1960 Ortteil von Ketzin), bis 1952 Kr. Westhavelland, 1952-1990 Kr. Brandenburg-Land (Bez. Potsdam), 1990-1993 Ldkr. Brandenburg, 1993 Ldkr. Potsdam-Mittelmark

Bevölkerungszahlen: 1925: 625, 1939: 528, 1946: 736, 1964: 841 (HOL III, S. 268).

UMSIEDLERLAGER: Kapazität am 31.12.1945 (Lager „Päverin“ [so!]): 300 (BArch, DO 2/45, Bl. 40; vgl. oben Tabelle 2).

Archivalische Quellen: Siehe Quellenteil, Nr. 123.

\section{Paretz}

Landgemeinde (seit 1960 Ortteil von Ketzin), bis 1952 Kr. Osthavelland, 1952-1990 Kr. Nauen (Bez. Potsdam), 1990-1993 Ldkr. Nauen, 1993 Ldkr. Havelland

EREIGNISSE BIS KRIEGSENDE: 1945: „Paretz wird Zufluchtsstätte von ca. 200 Flüchtlingen aus den Ostgebieten Deutschlands“ (Damaschke/Damaschke/Bergemann, Ketzin, S. 61). - „Der Januar im Jahre 1945 führte ein eisiges Regiment. Zum Ende des Monats kamen die Trecks der Flüchtlinge in Paretz an. Zumeist wurden sie nach $[\rightarrow]$ Ketzin geleitet. Doch als dort alle Quartiere belegt waren, hieß es, der Rest kommt nach Paretz [...]. So wurden sie auf die Einwohner von Paretz verteilt. Jeder, der ein Zimmer, eine Kammer frei hatte, wurde aufgefordert, Flüchtlinge aufznehmen. [...]. [S. 72] [...] Im alten Gasthof zu Luisens Zeiten, versorgte eine Feldküche die Flüchtlinge mit warmem Essen. / Als Bürgermeister amtierte in dieser Zeit Hermann Meineke. Bei ihm erfolgte die Anmeldung, erhielt man Lebensmittelkarten und Bezugsscheine für Kleidung. [...] Für die Flüchtlinge gab es in den ersten Monaten keine Arbeit. [...].“ (Schellhorn, S. 71 f.). - 24.4.1945: „Laufend trafen neue Flüchtlinge ein. Vor allem kamen sie über den Schwarzen Weg in Paretzhof, also aus Richtung Falkenrehde, in den Ort. Auch hielten sich etliche städtische Verwandte der Paretzer Bürger hier auf. Sie waren z. B. aus Berlin geflüchtet." (ebd., S. 73). - 24.4.1945 abends Einmarsch der Roten Armee (ebd.), ab 24./25.4.1945 dient ihr das Schloss als Lazarett (ebd., S. 74) bis zu ihrem Abzug Mitte 1946 (Lucas/Hoffmeister, S. 13).

EREIGNISSE NACH KRIEGSENDE: [Bilanz im Mai 1945:] „Etliche Flüchtlinge waren geblieben, nicht weitergezogen." (ebd., S. 75). - 1947 Einzug von Flüchtlingen in das Schloss, nachdem es „mehrere Monate leer gestanden hatte; März 1948 übereignet die SMAD Schloss und Gut an die Zentrale Vereinigung der gegenseitigen Bauernhilfe (ZVdgB), die es 1948-1950 zur Bauernschule (später Bauernhochschule „Edwin Hoernle“) ausbaut (Lucas/Hoffmeister, S. 13). 1947 in der Bodenreform 83 neue Eigentümer berücksichtigt, davon 21 Umsiedler (HOL III; S. 270). 
Bevölkerungszahlen: 1925: 422, 1939: 382, 1946: 579 (HOL III, S. 270).

Literatur: Damaschke, Alfred / Damaschke, Elisabeth / Bergemann, Helmut: Ketzin. Berlin 1997, S. 61. - Lucas, Karin / Hoffmeister, Titia: Paretz. 2., verb. Aufl. Überarb. von Matthias Marr. Berlin [1993]. - Schellhorn, Karin: Chronik eines Umbruchs - Paretz 1945. In: Paretz. Hrsg. von Matthias Marr. Magdeburg 1991, S. $71-76$ [nach Augenzeugenberichten].

\section{Parmalager $\rightarrow$ Spremberg-Cantdorf}

\section{Paulinenaue}

Landgemeinde, bis 1952 Kr. Westhavelland, 1952-1990 Kr. Nauen (Bez. Potsdam), 1990-1993 Ldkr. Nauen, 1993 Ldkr. Havelland

EReignisse NACH Kriegsende: „Der Paulinenauer Betrieb [das Gut Paulinenaue - P. B.] wurde der Sowjetischen Militäradministration (SMA) des Landes Brandenburg unterstellt und diente bis Mai 1949 als Versorgungsgut der Roten Armee. Die Verwaltung übernahmen sowjetische Wirtschaftsoffiziere, die mit ihren Stäben in das Gutshaus zogen. Neuer Wirtschaftsleiter wurde Fritz Haarstrich, der als Umsiedler nach Paulinenaue kam.“ (Wacker, S. 10). - 27.7.1945 Einzug des aus Königsberg in Ostpreußen bzw. Kutschlau bei Schwiebus geflüchteten Bodenkundlers Prof. Dr. Eilhard Alfred Mitscherlich (1874-1956), bis 1941 Direktor des Instituts für Pflanzenbau an der Universität Königsberg und seitdem bis 1945 mit Forschungen auf dem Familiengut Kutschlau befasst, in Paulinenaue (Amtsbereich Friesack, S. 155-161), ab 1.6.1949 (bis 1956) Direktor des in Paulinenaue gegründeten Instituts zur Steigerung der Pflanzenerträge, nach Mitscherlichs Tod ab 1957 Institut für Grünland- und Moorforschung (ab 1972 Institut für Futterproduktion) der Akademie der Landwirtschaftswissenschaften (Wojahn, S. $16 \mathrm{f}$., 21; Wacker, S. 49; BBL, S. 285 f.). - 1947 in der Bodenreform 174 neue Eigentümer berücksichtigt, davon 23 Umsiedler (HOL III, S. 272).

BevölkerungSZAhlen: 1939: 717, 1946: 1053, 1964: 994 (HOL III, S. 272).

LiterATUR: Amtsbereich Friesack. Horb am Neckar 1996, S. 143-167 (Kap. 2.11 Paulinenaue). - Andreae/Geiseler, S. 230. - Wacker, Günther: Paulinenaue. Eine Ortschronik aus dem Havelland. Digitalisierte Version der ersten Ausgabe von 1984 (http://archiv.paulinenaue.info/allgemeines/chroniken/wacker.pdf [7.1.2017]). - Wojahn, Eberhard: Über Entwicklung und Aufgaben des Institutes für Futterproduktion Paulinenaue der Akademie der Landwirtschaftswissenschaften der DDR. In: Wanderungen durch den Kreis Nauen 3. Nauen (1984), S. 16-27. 


\section{Peitz}

Stadtgemeinde, bis 1952 Kr. Cottbus, 1952-1990 Kr. Cottbus-Land (Bez. Cottbus), 19901993 Ldkr. Cottbus, 1993 Ldkr. Spree-Neiße

EREIGNISSE NACH 1990: 1991 gewann „die Evangelische Flüchtlingsseelsorge mit ihren Integrationsmodellen zusammen mit der Kirchengemeinde in Peitz bei dem Bundeswettbewerb 1991 für ,Vorbildliche Integration von Aussiedlern' unter 221 Bewerbern als einzige Institution in Berlin und Brandenburg eine Goldplakette" (Köhler, S. 430).

BevöLKeRUngSZAhlen: „Nach 1945 starker Zustrom von Heimatvertriebenen, Verdopplung der Einwohnerzahl“ (Städtebuch, S. 390); nach den Gesamteinwohnerzahlen Zunahme jedoch etwas geringer: 1925: 3058, 1939: 3528 , 1946: 5045, 1964: 4471 (ebd.).

Katholiken: 1925: 69, 1946: 639 (Städtebuch, S. 391). - Pfarrer war 1949 der bis 1945 in Schönbrunn, Kr. Sagan (Schlesien), amtierende Josef Felis (geb. 1904) (Ostpriesterverzeichnis 2, 1949, S. 23). - 1991-2005: Während der Existenz der Landesstelle für Aussiedler (siehe unten) gab es unter deren Adresse in Peitz eine „Caritas-Kreisstelle Cottbus/Kath. Aussiedlerhilfe“, deren Initiator war der 1986-1994 in Peitz amtierende Pfarrer Horst Andreas (geb. 1925) (Mitteilung Lehmann).

STÄDTEPARTNERSCHAFTEN: (1) 1994: „Die drei ehemaligen brandenburgischen Festungsstädte Peitz, Küstrin und Spandau, vertreten durch ihre Bürgermeister sowie den Volksbildungsstadtrat von Spandau, unterzeichneten jetzt eine Vereinbarung über städtepartnerschaftliche und kulturelle Zusammenarbeit. Mit einem Festakt soll die Abmachung nach Bestätigung durch den Küstriner Stadtrat am 23. April in Küstrin besiegelt werden." (Vor Partnerschaft mit Küstrin. In: Märkischer Informationsdienst 1994, Nr. 2, S. 8). - 3.8.2001 Städtepartnerschaft mit Kostrzyn, Polen (Küstrin). - (2) (Amt Peitz:) 26.2.2000 Partnerschaft mit Zbąszynek, Polen (Neu Bentschen, ehem. Kr. Meseritz, Provinz Posen; 1938-1945 Prov. Brandenburg) (www.peitz.de [23.8.2018]).

Vertriebenenverbände NACH 1990: 1996 erwähnt BdV-Kreisverband [ $\rightarrow$ ] Cottbus, Dammzollstr. 27 in Peitz (BdV-Handbuch 1996, S. 218).

Landesstelle für Aussiedler des Landes Brandenburg, Peitz-Malxebogen, Juri-Gagarin-Str. 7 (gegründet 1991, Landesoberbehörde, mit angeschlossenem Plattenbau-Wohnheim [590 Betten] und Schule), Leiter 1991-2003: Rainer Zwiers (zuvor Ausländerdezernent in der Bezirksverwaltungsbehörde Cottbus, später Abteilungsdirektor im Landesamt für Soziales und Versorgung in $\rightarrow$ Cottbus), 2003-2006 Hannelore Mudra (anschließend Abteilungsdirektorin im Landesamt für Soziales und Versorgung in Cottbus) (Auskunft Landesamt, 15.6.2017). „Nach 1990 erlebte die ,Landestelle für Aussiedler des Landes Brandenburg in Peitz einen großen Zulauf. Die noch lebenden Vertriebenen konnten nun eine finanzielle Entschädigung beantragen. Viele wurden so erst wieder daran erinnert, daß sie Vertriebene sind.“ 
(Kotsch, S. 137). - 1993 Herausgabe einer Willkommensbroschüre (Informationsbroschüre für Neubürger: „Das mit Unterstützung des Bundesinnenministeriums entstandene Büchlein stellt die Kleinstadt, ihr Umfeld und ihre Geschichte vor. Enthalten sind auch Angaben über wichtige Wirtschaftsbereiche. Zudem werden touristische Ziele wie Spreewald, Forster Rosengarten und die Stadt Cottbus vorgestellt.“ (Neues Deutschland, 24.7.1993). - 1996: „In der Landesstelle für Aussiedler in Peitz sollen auch weiterhin alle Aussiedler und Spätaussiedler betreut werden, die Brandenburg erreichen. Eine Übertragung dieser Aufnahme- und Anerkennungsverfahren von der zentralen Landesstelle auf die Landkreise und kreisfreien Städte soll es nicht geben. Das wäre ,weder sachgerecht, wirtschaftlich noch effektiv', heißt es im Prüfbericht der Landesregierung, der gestern im Landtag vorgelegt wurde. Laut Bericht werden dem Land Brandenburg monatlich 600 bis 700 Spätaussiedler zugewiesen. Seit 1991 durchliefen 22500 Menschen die Landesstelle." (Berliner Zeitung, 14.8.1996). - 10.12.1996 Verordnung über die Auflösung der beim Innenministerirum ressortierenden eigenständigen Landesoberbehörde „Landesstselle für Aussiedler“ und der Landesreinrichtung „Ausländeraufnahmeheim“ in Blumberg, in Kraft getreten am 1.1.1997 (GVBl. II/96, [Nr. 41], S. 864), die Behörde (einschließlich Wohnheim und Schule) wird jedoch, nun beim Arbeits- und Sozialministerium ressortierend, bis 2005 weitergeführt als „Landesvertriebenen- und Aussiedleramt“ (Jubiläum, S. 20; Mitteilung Dr. Ilona Schulz, 7.6.2017), dem Landesamt für Soziales und Versorgung (Cottbus) nachgeordnet. - 2003: „Alle Rußlanddeutschen, die nach Deutschland wollen, kommen zunächst in das zentrale Lager in Friedland in Niedersachsen. Von dort werden sie auf die Bundesländer verteilt. So kamen Klara und ihre Kinder und Kindeskinder nach Brandenburg in die Landesstelle für Aussiedler in Peitz nahe Cottbus. Sie wohnen in einem Plattenbau am Rande der kleinen Stadt mit Blick auf die riesigen Kühltürme des Kraftwerkes Jänschwalde. In der DDR-Zeit waren hier sogenannte Vertragsarbeiter, aus Polen vor allem, untergebracht, die mit am Kraftwerk bauten. Als die letzten Montagearbeiter auszogen, übernahm die Landesstelle das gesamte Gebäude.“ (Frank Pergande, in: F.A.Z., 29.4.2003). - 2004 „Landesschule für Aussiedler“ noch erwähnt (LR 17.12.2004). - Dez. 2005 „Auf Grund des Rückgangs der Aufnahme von Spätaussiedlern kommt es zur Schließung der zentralen Erstaufnahmeeinrichtung des Landesvertriebenen- und Aussiedleramtes in Peitz" (Jubiläum, S. 22); die Aufgaben der Behörde (zuletzt 13 Mitarbeiter) wurden von der (inzwischen ebenfalls aufgelösten) Abt. 6 des Landesamtes für Soziales und Versorgung in $\rightarrow$ Cottbus übernommen (Mitteilung Schulz; Der Tagesspiegel, 17.11.2005), 1.4.2006 „Umzug der Abteilung Landesvertriebenen- und Aussiedleramt von Peitz nach Cottbus mit einem Aktenumfang von ca. drei km Länge“ (Jubiläum, S. 23). - Verlegung der Mitarbeiter nach Cottbus zum 25.9.2006 (LR, 15.9.2006).

Gedruckte Quellen: Töpler, Menschenwurm.

QUeLlen (zur Landesstelle für Aussiedler): BLHA, Rep. 1610 Landesamt für Soziales und Versorgung. - Auskünfte Dr. Ilona Schulz, Spremberg, 7.6.2017. - Mitteilung Jutta Lehmann, Caritasverband der Diözese Görlitz e. V., Regionalstelle Cottbus, 8.6.2017. - Auskünfte Landesamt für Soziales und Versorgung, 15.6.2017. 
Literatur (zur Landesstelle für Aussiedler): Jubiläum. 20 Jahre Landesamt für Soziales und Versorgung. Cottbus 2011. - Köhler, Jürgen: Notaufnahme. Evangelische Flüchtlingsseelsorge. Berlin 1991, S. 413-430. - Kotsch, Detlef: Vertriebene und Vertriebenenpolitik in Brandenburg nach dem Zweiten Weltkrieg. In: Die Herkunft der Brandenburger. Hrsg. von Klaus Neitmann u. Jürgen Theil. Potsdam 2001, S. 127-137. - Kühl, Vilma: Eine Familiengeschichte Wolgadeutscher. In: Heimatkalender Bad Liebenwerda 56 (2004/05), S. 77-87. - Märkischer Informationsdienst 1994, Nr. 9, S. 15. - Pergande, Frank: Leben in Deutschland lernen. Aussiedler in fremder Umgebung. In: Frankfurt Allgemeine Zeitung, 29.4.2006.

\section{Perleberg}

Stadtgemeinde, bis 1952 Kr. Westprignitz (Kreisstadt), 1952-1990 Kr. Pritzwalk (Kreisstadt; bis 1990 im Bez. Schwerin), 1990-1993 Ldkr. Pritzwalk (Land Brandenburg), 1993 Ldkr. Prignitz (Kreisstadt)

Ereignisse bis KriegSende: Die Flüchtlinge aus Stadt u. Kreis Meseritz kamen „vornehmlich in die Gegend um Kyritz/Perleberg“ (Stadt und Kreis Meseritz. [Bd. 1], S. 341). - „Am 1.02.45 trifft der erste Flüchtlingszug in Perleberg ein. [...] Die Flüchtlinge müssen wieder fort, der Zug wurde falsch geleitet.“ (Hoppe, S. 68). - 6.2.1945: „Flüchtlinge über Flüchtlinge! In Perleberg beginnt nun die Arbeit in der Flüchtlingsbetreuung. Am 9.02.45 treffen die ersten Wagen ein. [...] [S. 69] [...] In der Mädchenschule in der Wilsnacker Straße wird die Flüchtlingszentrale eingerichtet. Unterricht ist nunmehr endgültig vorbei. Alle Räume werden benötigt, und wir Lehrer haben täglich vollen Einsatz im Flüchtlingsdienst.“ (ebd., S. 68f.). - [Ende Febr. oder Anf. März 1945:] „Der Flüchtlingsstrom wächst täglich, in unserer Stadt sind lange Wagenkolonnen. Der Schulhof gleicht nachts einer Wagenburg. [...] In den Schulräumen liegen Hunderte eng gedrängt auf Stroh. Alle werden verpflegt, registriert und weitergeleitet. Bei uns bleiben die Kreise Samter, Kolmar, Czarnikau, Stadt Meseritz, später auch Stadt Küstrin. Die Versprengten kommen ratlos auf unsere Suchstelle, hier befindet sich die Kartei für alle Durchreisenden. [...].“ (ebd., S. 69). - „Am 4.4.[1945] soll der Unterricht in der Mädchenschule wieder beginnen, nachdem der wochenlange Flüchtlingsstrom abgeebbt ist. Aber ein großer Bombenangriff auf Perleberg um 10 Uhr vormittags vereitelt alles. [...] Am Schützenhaus im Wald bei den Schießsständen fielen die Bomben mitten in die Flüchtlinge vom Flugplatz, Bäume liegen kreuz und quer, Krater an Krater, es gab sehr viele Tote. [...]." (ebd., S. 70). - 2.5.1945 Einmarsch der Roten Armee (ebd., S. 89; Brandenburgische Gemeinden 1945, S. 167: „um die Mittagszeit“). - Zeitzeuge erwähnt einzelne anwesende Flüchtlinge aus Oberschlesien, Zielenzig (Neumark) und Breslau (Hoppe, S. 89).

EREIGNiSSE NACH KRIEGSENde: 20.7.1945 (Flüchtling aus Woldenberg/Nm.): „[... ] Perleberg. Wegen Quartier zur Polizei und Wirtschaftsamt. 2 Mal. Für Kino, Kaffee, Tanz ist hier schon gesorgt. Flüchtlinge? [S. 303] Ich bekomme aber selbst ein Quartier bei Gärtnerei Förster. Sehr freundlich, sauber und hilfsbereit, sogar Feldbettstellen werden noch aufgestellt. Obwohl schon 9 Flüchtlinge aus dem Netzebruch, Fam. Stolz und Grützmacher, einige Tage dort sind! [...]." (Tagebuch Prochnow, S. 302 f.). - 1945: „Endlose Trecks ziehen durch die Straßen. Flüchtlinge sind es aus allen deutschen 
Gauen. Weiter geht ihr Weg, weiter auf der Straße des Elends. Auch in Perleberg wird für sie in mehreren Lagern gesorgt. Großküchen werden eingerichtet und das Rote Kreuz ist Tag und Nacht unermüdlich tätig. Manche Not kann gelindert werden, manches Dunkel wird wieder hell, manche Sorgenfalte glättet sich. Aber auch manches Leid wird von dem weißen Laken des Todes überdeckt. Zu klein wird der Friedhof. Das große Sterben hat begonnen. Und kranke Seelen folgen Särgen nach. Aber dennoch muß und wird es aufwärts gehen!“ (Brandenburgische Gemeinden 1945, S. 167). „Nähstuben helfen den Flüchtlingen und den zurückgekehrten Soldaten.“ (ebd., S. 170). - Karl Rodewald „kam als Umsiedler aus Lodz, er hatte dort russisch und polnisch unterrichtet. Jetzt [nach Kriegsende 1945] war er Dolmetscher für die Kommandantur und an unserer Knabenschule Lehrer" (Hoppe, S. 131). 2.8.1945: „Der Kriegskommandant hatte kürzlich verfügt, daß die Stadt Perleberg von der weiteren Belegung mit Flüchtlingen ausgenommen bleibt." (Bericht des Landrates, Wille I, S. 101). - Spätsommer 1945 „Flüchtlingsehepaar Streese aus Landsberg an der Warthe“ erw. (Hoppe, S. 131). 1946 befand sich die „Flüchtlingsleitstelle“ im Rathaus (Wirtschafts-Wegweiser, S. XII). - Seit 1948 jährliche Durchführung von Glaubenstagen für bessarabiendeutsche Flüchtlinge durch den „Besuchsdienst im Evangelisch Kirchlichen Gnadauer Gemeinschaftswerk in der DDR“ (Keller/Baumann, S. 217, 221). - 1.2.1949 Übernahme der Leitung der staatl. Apotheke der Kreispoliklinik sowie des Ehrenamtes des Kreisapothekers des Kr. Westprignitz durch den 1945 aus Küstrin geflüchteten Apotheker Heinrich Frigge (1901-1953), 1952 Kreisapotheker des Kr. Perleberg (Biela, S. 35). - 22.7.1949 „Heimkehrerkonferenz“ in Perleberg (BLHA, Rep. 202 A, Nr. 526). - 25.9.1955 stirbt in Perleberg der evang. Pfarrer Otto Walther (geb. 1871), bis Jan. 1945 Pfarrer in Marwalde, Kr. Osterode (Ostpreußen). „Er fand eine neue Zuflucht in Perleberg. Aber auch nachdem er 1946 in den Ruhestand getreten war, hat er nicht gerastet, sondern seinem Sohn, der die Pfarrstelle Perleberg versieht, immer wieder in Predigt und Unterricht geholfen. Am 28. Juni 1955 durfte er, geistig und körperlich frisch, den Tag seines sechzigjährigen Amtsjubiläums feiern." (Nachruf in: Ostpreußenblatt, F. 45, 5.11.1955); [der erw. Sohn: Gerhard Walther (geb. 1902), vor 1945 Pfarrer in Groß Lenkeningken (Kr. Ragnit, Ostpreußen), ab 1947 kommissarisch in Quitzow bei Perleberg (Pfarralmanach 1953, S. 164]

EREIGNisSe NACH 1990: Seit 2001 (zuvor in $\rightarrow$ Pritzwalk) regelmäßig (in ungeraden Jahren) „Kleines Heimatkreistreffen der Meseritzer und Birnbaumer" des Heimatkreises Meseritz e. V. und der 2001 in den Verein integrierten Heimatkreisgemeinschaft Birnbaum im Hotel „Neuer Hennings Hof“ in Perleberg, Hennings Hof 3 (in geraden Jahren als „Großes Heimattreffen“ in Paderborn), 2001 und 2003 mit jeweils 800 Teilnehmern (www.heimatkreis-meseritz.de [20.9.2016]), 2009 „Großes Heimatreffen der Meseritzer und Birnbaumer" am selben Veranstaltungsort mit mehreren hundert Teilnehmern (MAZ, 14.5.2009), 15./16.5.2015 8. Heimatreffen am selben Veranstaltungsort mit etwa 180 Teilnehmern (www.heimatkreis-meseritz.de [20.9.2016]), 20.5.2017 desgleichen.

BEVÖLKERUNGSZAHLEN: 1925: 10348, 1939: 12 342, 1946: 13 701, 1964: 13118 (Städebuch, S. 395). 
Katholiken: 1925: 356, 1946: 1002 (Städebuch, S. 395). - „1939 hatten 850 Katholiken zur Pfarrei gehört. Nach dem II. Weltkrieg konnten für die Heimatvertriebenen zwei zusätzliche Seelsorgstellen eingerichtet werden: In $[\rightarrow]$ Guhlsdorf wirkte 1946-54 und in $[\rightarrow]$ Klein-Warnow 1946-56 jeweils ein Priester, die mit einem Teil ihrer bisherigen Gemeinde aus Schlesien hier angesiedelt wurden. Mit diesen Seeslorgstellen wurden 1953 in der Pfarrei Perleberg nach offiziellen Angaben etwa 1900 Katholiken gezählt." (Brühe, S. 41).

VERTRIEBENENVERBÄNDE NACH 1990: BdV-Kreisverband Perleberg e. V., gegründet 1991 (Märkischer Informationsdienst 8/1994, S. 14), Satzung errichtet 13.4.1992, beim Amtsgericht Perleberg (VR 199) eingetragen 11.8.1992; 1992 erwähnt mit Sitz Reetzer Str. 5 (Akten der der BdV-Landesgeschäftsstelle), 1996 erwähnt mit Sitz Mühlenstr. 12 (BdV-Handbuch 1996, S. 168); Vorsitzende: 1992-1999 Ernst Maaß (Perleberg, geb. 1934), 1999-2011 Roland Draeger (Perleberg) (Akten wie vor), 2003 im geschäftsführenden Vorstand insgesamt 5 Vorstandsmitglieder, im erweiterten Vorstand die Sprecher der 8 Landsmannschaften (BdV-Notizen 1 (2003)3, S. 8); Aug. 2006326 Mitglieder, 2012 aufgelöst (Akten wie vor; zur Auflösung auch: MAZ, 18.11.2013). - Ein auf Initiative dieses Kreisverbandes aufgestellter Gedenkstein befindet sich an der $\rightarrow$ Plattenburg.

Archivalische Quellen: BLHA, Rep. 202 A, Nr. 526 (Presseartikel und Ansprachen des Ministerpräsidenten Dr. Steinhoff, 1949; enthält u. a.: Zusammenstellung von Fakten 1917-1949 für die Heimkehrerkonferenz am 22. Juli 1949 in Perleberg).

Gedruckte Quellen: Wille I, S. 101. - Wirtschafts-Wegweiser für Wittenberge und die Kreise West- und Ostprignitz. Potsdam (1949). - Zeitzeugen-/Erinnerungsberichte: Brandenburgische Gemeinden 1945, S. 165-170 (Verf.: Hans Bremer). - Hoheisel, Wilhelm: Aus dem Treckbericht der Elsenauer. In: Heimatbuch für den Kreis Eichenbrück-Wongrowitz. Bd. 2. Wendisch Evern 1978, S. 121-129 [11.2.1945 Aufenthalt in Perleberg]. - Hoppe, Albert: Perleberg 1945 - Tagebuchaufzeichnungen. In: Mitteilungen des Vereins für Geschichte der Prignitz 14 (2014), S. 63-132. - 1945. Das Jahr in der Region Dahme-Spreewald. Dokumentation zur Geschichte. T. 2. Zeuthen 2010, S. 224 f.: Zeitzeugenbericht [Interview 2006] Frau Loeser geb. Ostrowski, 1940 aus der Bukowina nach Zirke bei Birnbaum umgesiedelt, von dort Jan. 1945 in den Kr. Soldin geflüchtet, 1946 Transport nach Brandenburg, Unterkunft bei Verwandten in Perleberg). - Tagebuch Ernst Prochnow [Auszüge]. In: „Die Russen sind da“. Peter Böthig u. Peter Walther (Hg). Berlin 2011, S. 302 f.

Literatur: Biela, Paul: Schicksale deutscher Apotheker aus Ostbrandenburg am Ende des Zweiten Weltkrieges. Frankfurt (Oder) 2017. - Brühe, Matthias: Katholische Kirche zwischen Prignitz und Havelland. Berlin 2000, S. 40-41. - Keller, Herbert / Baumann, Arnulf: Bessarabischer Brüderbesuchsdienst in der DDR. In: Jahrbuch der Deutschen aus Bessarabien 59 (2008), S. 216-223. - Schwabe, Karl-Heinz: Chronik des Krankenhauses Perleberg Reetzer Straße -. [Perleberg 2000]. [Masch.]. - Stadt und Kreis Meseritz. [Bd. 1]. O. O. [1972]. 


\section{Pinnow}

Landgemeinde, bis 1952 Kr. Angermünde, 1952-1990 Kr. Angermünde (Bez. Frankfurt/ Oder), 1990-1993 Ldkr. Angermünde, 1993 Ldkr. Uckermark

UMSIEDLERLAGER: „Das Verwaltungs- und Fabrikareal [eines ehem. Munitionslagers der Wehrmacht] diente einige Monate [richtig: 2 Jahre - P. B.] lang als Durchgangslager für Flüchtlinge und Vertriebene aus den deutschen Ostgebieten." (Kaule/Wolle, S. 76). - 1945 bereits erwähnt (Kreisarchiv Barnim, B.II.Finow 15541). - Kapazität am 31.12.1945: 4000 (BArch, DO 2/45, Bl. 40). - Kapazität am 1.1.1946: 2000 (BLHA, Rep. 203 MdI, Nr. 1163, Bl. 49). 6.1.1946 66-jähriger „Flüchtling aus dem Lager Pinnow“ (geb. in Sagan) im Kreiskrankenhaus Angermünde an „Erfrierung“ gestorben (Stadtarchiv Angermünde, Standesamt Angermünde, Sterberegister, Nr. 38/1946). - 26.1.1946 Bericht der ZVU (Born) über Kontrollfahrt: Lager Pinnow. „Hier selbst Bahnstation. z.Zt. mit ca. 680 Umsiedlern belegt. Es besteht aus 9 Stein- und 2 Holzbaracken. Es können dort etwa 3000 Umsiedler untergebracht werden." (BArch, DO 2/38, Bl. 11). - 30.1.1946 (Bericht der Zentralverwaltung für Umsiedler): „Lager Pinnow, das sich in einem musterhaften Zustand befand" (Kotsch, S. 132). - Jan./Febr. 1946 Vertriebenentransport aus Hinterpommern über Angermünde ins Lager gelangt (Sonnemann, S. 28 f., mit Beschreibung des Lebens im Lager). - 14.2.1946 Auffanglager, Kapazität: 2000 (Oehlsen, S. 28). 1946 Heimkehrerlager, Belegungsstärke: 2000 (Kaminsky, S. 160, siehe u. a.: SAPMO-BArch, DY 34/27781, Bl. 154-155). - 30.4.1946 als eines der verbleibenden „Umsiedlerlager“ genannt (DAB, I/9-15-1 Flüchtlingsseelsorge 1945-1951, unfol., [30.6.1946], [Anlage 3]). 24.7.1946 in Liste der Lager für „Ostheimkehrer“ als „Waldlager Pinnow“ genannt mit Kapazität 1500 („wird auf 2000 erhöht") und Bestimmung "f[ür] Heimatlose“ („Krankenbetten: 1500 “) (BArch, DO 2/45, Bl.76). - 24.8.1946 Heimkehrerlager, Kapazität: 1600 (SAPMO-BArch, DY 34/27880, Bl.291). - 1.1.1947 Lager, Kapazität: 1200 (Oehlsen, S. 101). - 9.6.1947 Quarantänelager, Kapazität: 1200, Belegung: 45 (SAPMO-BArch, DY 34/27880, Bl. 239).25.11.1947 in Befehl der SMA Brandenburg in Liste „der [zum 30.12.1947] zu schließenden Lager" aufgeführt (BLHA, Rep. 203 VP, Nr. 9, Bl. 43v), anschließende Nutzung als Kinderheim sowie für Lehrwerkstätten vorgesehen (Oehlsen, S. 32). - Anfang 1948 bereits aufgelöst (Rep. 256 Küchensee, Nr. 217). - Ab 1952 Umnutzung als Objekt der Kasernierten VP, 1956 Übergabe an NVA, ab 1965 „VEB Instandsetzung Pinnow“ (Kaule/Wolle, S. 76), seit 2006 Telefonund Raketenmuseum (Industrie- und Gewerbegebiet 9) (ebd., S. 77).

Kinderheim „Kinderdorf Pinnow“: 1947-1949 Kinderheim „Kinderdorf Pinnow“, v. a. für Kindertransporte aus Ostpreußen („Wolfskinder“), 1949 im Tausch mit Standort einer Polizeieinheit nach $\rightarrow$ Kyritz verlegt (Leiserowitz, S. 7, 36 f., 76 u. ö.).

Archivalische Quellen: BArch, DO 2/38, Bl. 11. - BLHA, Rep. 204 A, Nr. 2120: „Früheres Umsiedlerlager Pinnow (ehem. Offiziershaus und Badehaus)", 1947-1950. - BLHA, Rep. 250 Landratsamt Angermünde, Nr. 518 (Umsiedlerbetreuung 1946-1947; enth. u. a. Einbruchsdiebstähle im Lager Pinnow); Nr. 522 (Wirtschaftsberichte und Zugangsmeldungen des Lagers Pinnow, 1946); Nr. 523 (Personalangelegenheiten des Lagers Pinnow, 1946-1947); 
Nr. 524-530 (Gehaltslisten der Angestellten des Lagers Pinnow, 1946-1947). - BLHA, Rep. 333 SED-Landesleitung Brandenburg, Nr. 578 („Heimkehrerlager“, 1946-1949; enthält u.a.: Pinnow). - Kreisarchiv Barnim, B.II.Finow (Stadt Finow), Nr. 15541 (Übersicht der Flüchtlinge aus dem Lager Pinnow, 1945, 3 Bl.). - SAPMO-BArch, DY 34/27781, Bl. 154-155 (Lager).

Gedrucke Quellen und Literatur: Kaule, Martin/Wolle, Stefan: 100 Orte der DDR-Geschichte. Berlin 2018, S. 76 f. - Leiserowitz, Ruth: Von Ostpreußen nach Kyritz. Potsdam 2003. - Sachse, Christian: Informationen zu Brandenburger Spezialheimen, Fassung vom 23.5.2012, www.christian-sachse.de (27.4.2016). - Sonnemann, Lothar: Bittere Medizin. Jacobsdorf 2002.

\section{Plattenburg}

Wohnplatz/Ortsteil (1928-1963 von Groß Leppin, 1963-2001 von Kletzke, seit 2001 Landgemeinde), bis 1952 Kr. Westprignitz, 1952-1990 Kr. Perleberg (Bez. Schwerin), 1993 Ldkr. Prignitz

EREIGNISSE: „Plattenburg war 1945 eine der zentralen Sammelstellen des Kreises Westprignitz für Flüchtlinge und Vertriebene aus Ost- und Westpreußen, Ostbrandenburg, Pommern, dem Warthegau, dem Netzedistrikt und Schlesien." (www.heimatkreis-meseritz.de [19.9.2016]).

GedenKstÄTte: 8.7.1995 Einweihung/Enthüllung eines Gedenksteins (Findling) „auf Initiative des ,Bundes der Vetriebenen "“ (Heimatgruß Meseritz 215, 2015, S. 12; BR 3 (2005)4, S. 17 mit Foto) mit der Inschrift (Metallbuchstaben) „Zur Erinnerung an Opfer und Leid durch Flucht und Vertreibung als Folge des 2. Weltkrieges / BdV Perleberg 1995“ vor dem Knappenhaus der Burg, deren Gebäude nach 1945 als Flüchtlingsunterkunft dienten. Seitdem am Volkstrauertag jährliche Kranzniederlegungen durch Mitglieder des BdV Perleberg sowie Heimatfreunde des Heimatkreises Meseritz e. V. (www.heimatkreis-meseritz.de [19.9.2016]; Heimatgruß Meseritz 181, 2007, S. 5; Mahn- und Gedenkstätten Brandenburg, mit Abb.). - 15.11.2015 (Volkstrauertag): „Der Betreuer des Heimatkreises Meseritz für die Prignitz, Herybert Schulz, informierte, daß auf Anraten des ehemaligen Landrates Lange der Heimatkreis die Patenschaft über diese Gedenkstätte übernommen hat. Die Begründung war, daß der Vertriebenenverband Perleberg nicht mehr als Verein existiert, da er sich aufgelöst hatte." (Heimatgruß Meseritz 215, 2015, S. 12).

Quellen und Literatur: Mahn- und Gedenkstätten Brandenburg. Hrsg.: BdV (www.bund-der-vertriebenen.de $[20.9 .2016])$.

\section{Plaue/Havel}

1931-1952 Stadtgemeinde im Kr. Westhavelland, seit 1952 Ortsteil von $\rightarrow$ Brandenburg/Havel (bis 1990 Bez. Potsdam)

EReignisSe NACH KriegSEnde: 14./15.10.1945 Bodenreform (Deichgräber, S. 127), unter 181 neuen Eigentümern 4 Umsiedler berücksichtigt (HOL III, S. 288). - 14.7.1946 (Bericht 
der Stadtverwaltung:) „Auf dem Gebiete des Wohnungswesens lassen sich die Schwierigkeiten nicht vollends beheben, weil einmal durch Angehörige der Roten Armee etwa 60 Wohnungen belegt sind und außerdem der Zuzug der für Plaue anfallenden Flüchtlinge anhält." (ebd., S. 152). - „Am 30. Oktober 1946 trafen weitere deutsche Umsiedler aus der Tschechoslowakei hier ein. Insgesamt waren es 30 Personen: 5 einzelne, 3 Familien à 2, 5 Familien à 3 und 1 Familie zu 4 Personen. Sie wurden sofort nach Eintreffen in die für sie bereitgestellten Wohnräume eingewiesen. / Die Umsiedler führten als Gepäck nur das Allernotwendigste mit, so daß die Quartiergeber verpflichtet wurden, die Unterkünfte wohnbar herzurichten. Damit die Angekommenen schnellstens in ihre Quartiere kamen, waren die Mitglieder des hiesigen Umsiedler- und Frauenausschusses angewiesen worden, helfend mitzuwirken. [...] / Der am 23. August 1946 unserer Stadt zugewiesene Umsiedlertrupp aus der Tschechoslowakei bestand aus 185 Personen, 65 wurden nach Briest überwiesen, 120 verblieben in Plaue." (ebd., S. 164). - Tätigkeitsbericht der Stadtverwaltung für 1946 (17.1.1947): Anf. 1946 4604, Ende 19464721 Einwohner. Einwohnermeldeamt: „An Flüchtlingszuwachs ist insgesamt ein Zugang von rund 770 zu verzeichnen.“ (ebd., S. 178). Wohnungsamt: „[...] Das dem Wohnungsamt angegliederte Umsiedlerwesen brachte erhebliche Mehrarbeit. Im Jahre 1946 mußten zweimal zugewiesene Umsiedlerfamilien mit 147 Personen untergebracht werden. In Plaue sind bisher 771 Umsiedler aufgenommen worden.“ (ebd., S. 183). - Zeitgenössischer Bericht „Wieder kamen Umsiedler nach Plaue“: „Mitte April 1947 gab der Bürgermeister bekannt, daß weitere 300 Umsiedler für Plaue vorgesehen sind, die schon am 20. April [S. 192] eintreffen sollten. Sehr schwer war es, auch nur annähernd den benötigten Wohnraum zu beschaffen, der möbliert bereitgestellt werden sollte. Am 14. Mai kam der erste Trupp von 30 Flüchtlingen an, sie befanden sich in einer erbarmungswürdigen Verfassung und standen buchstäblich vor einem nichts. Deshalb wandte sich der Bürgermeister in einem Aufruf an die Einwohner Plaues, mit der Bitte, die Vorratskammern zu überprüfen und diverse Weckgläser mit Inhalt zur Linderung der Not dieser Flüchtlinge abzugeben.“ (ebd., S. 191 f.). - Tätigkeitsbericht der Stadtverwaltung für 1947 (S. 203-207): Sozialamt: „Im Berichtsjahre wurden auf Antrag in 128 Fällen Umsiedlerbeihilfen gewährt." (S. 204). - 15.3.1947 Erwähnung einer „Umsiedlergenossenschaft“ (Heimarbeit) für Glasveredelung in Plaue (BLHA, Rep. 333, Nr. 574, Bl. 105). - Rechenschaftsbericht der Stadtverwaltung für 1948 (S. 231-235): Wohnungsamt: „Besonders schwierig war die wohnraummäßige Unterbringung von 39 zugewiesenen Umsiedlern, die nichts hatten und auf möblierte Wohnungen angewiesen waren. [...].“ (S. 233)

BevöLKerungszahlen: 1925: 2754, 1939: 3730, 1942: 5000, 1946: 4679, 1952: 4200 (Städtebuch, S. 54).

Katholiken: 1928: 159, 1946: 648 (Städtebuch, S. 55). - Lokalie: 1649: 1600 (Schematismus Berlin 1949, S. 71). - Regelmäßiger Gottesdienst seit 1944. „Seit 1947 bestand am St.-JakobusAltersheim eine Lokalie, die mit ihren damals etwa 750 Gläubigen unter dem Patronat der Rosenkranzkönigin stand. Aus Schlesien vertriebene Borromäerinnen wirkten hier bis 1969, erster eigener Geistlicher war seit dem 1.7.1947 [Kaplan] Edgar Maniera aus dem Erzbistum Breslau. Arme Schulschwestern vom 3. Orden des hl. Franziskus (Vöcklabrucker Franziskanerinnen) [die be- 
reits seit 1929 im St.-Marien-Krankenhaus in Brandenburg/Havel tätig waren (vgl. Brühe, S. 20), P. B.] führten das Altersheim bis zu seiner Auflösung 1991 weiter, wobei auch die zuletzt etwa 120 Katholiken zählende Gemeinde in die Muttergemeinde St. Bernhard/Brandenburg zurückgegliedert wurde." (Brühe, S. 45 [Zitat]; Schwillus/Brühe, S. 303; Schematismus Berlin 1949, S. 143). Sitz des St. Jakobus-Altersheims (auch „St. Jakobus-Rentnerheim“): Brandenburger Staße 4-5; 19494 Mitglieder (Borromäerinnen); Sitz der Lokalie: Kirchstr. 8; Lokalkaplan: Pfarrvikar Edgar Maniera (Schematismus Berlin 1949, S. 71, 91, 143). - Maniera (geb. 1911) war bis 1945 Pfarrer in Schmottseifen, Kr. Löwenberg in Schlesien (Ostpriesterverzeichnis 2, 1949, S. 54).

UMSIEDLERLAGER: Kapazität am 31.12.1945: 300 (BArch, DO 2/45, Bl. 40). - Kapazität am 1.1.1946: 300 (BLHA, Rep. 203 MdI, Nr. 1163, Bl. 50).

Gedruckte Quellen und Literatur: Brühe, Matthias: Katholische Kirche zwischen Havel und Dahme. Berlin 1999, S. 45. - Deichgräber, Albert: Chronik der Stadt Plaue (Havel). T. 2. [Wiesbaden 1969]. - Nitschke, Johannes: 150 Jahre Pfarrkirche „Heilige Dreifaltigkeit“ Brandenburg an der Havel. Brandenburg an der Havel [2001], S. 34. Schwillus/Brühe, S. 303. - Wirtschafts-Wegweiser für Brandenburg (Havel) mit Plaue und Kirchmöser. BranchenAdressbuch. Potsdam [1948?].

\section{Podelzig}

Landgemeinde, bis 1950 Kr. Lebus, 1950-1990 Kr. Seelow (ab 1952 Bez. Frankfurt/Oder), 1990-1993 Ldr. Seelow, 1993 Ldkr. Märkisch-Oderland

EREIGNISSE BIS KRIEGSENDE: „Ende Januar [1945] war hier auch etwas Aufbruchstimmung. An der Oder wurde gekämpft. Trecks kamen durch unseren Ort. Teils wurden die Wagen von Ochsen gezogen und dies bis von Dirschau aus. [...] Im Dorf hörte man schon die Einschläge der feindlichen Artillerie." (Wendisch, S. 147).

EREIGNISSE BIS KRIEGSENDE: In der Bodenreform 221 ha von 997 ha an 35 „Umsiedler“vergeben, außerdem 26,5 ha von 80 ha Waldzulage der Gemeinde Alt Madlitz an 10 „Umsiedler“vergeben (HOL VII, S. 354). - [Bericht einer im März 1946 aus dem Fluchtort Strasburg/ Uckermark nach Podelzig zurückgekehrten Podelziger Bauersfrau:] „Podelzig war fast zu $100 \%$ zerstört. Es wohnten wenig Menschen zu der Zeit dort. Es kamen Flüchtlinge und auch Berliner nach Podelzig und siedelten. Wir hatten ca. 50 ha. Unser Land war voller Bunker und Stellungen. Unser Viehbestand begann 1946 mit 2 Hühnern. 1947 bekamen wir elektrisches Licht. Die Eisenbahn fuhr erst später. Vom Kriegsgefangenenlager [ $\rightarrow$ Frankfurt/Oder-] Gronenfelde holte mein Mann sich entlassene Soldaten die nicht wußten, wohin. So schafften wir die Arbeit. Doch von dem auf uns ausgeübten Druck, dem wir Altbauern ausgesetzt waren, will ich nicht weiter berichten, dies ist genügend bekannt. Am 26. November 1952 wurden wir auf unserer Flucht in den Westen verhaftet. Wir kamen in das Gefängnis Frankfurt/Oder. Am 3. Januar 1953 wurde ich entlassen. [...] Im Juni 1954 mußten wir in den Westen fliehen. Mein Mann sollte erneut verhaftet werden. In Kirchwerder bei Bergedorf (Hamburg) fanden wir ein neues Zuhause. Unsere Heimat bleibt Podelzig." (Wendisch, S. 149). 
BeVÖLKeRUngSzAHLEN: 1939: 851, 1946: 784, 1964: 1237 (HOL VII, S. 354).

Literatur: Wendisch, Otto: Erlebnisse in Podelzig und auf der Flucht. Nach Berichten seiner Frau aufgezeichnet. In: Ein leidgeprüftes Land. Bearb. von Fritz Knüppel. 2. Aufl. Barsinghausen 1990, S. 147-149.

\section{Podelzig-Klessin $\rightarrow$ Klessin (Kr. Lebus)}

\section{Postheim (Kr. Templin) $\rightarrow$ Templin, Postheim}

\section{Potsdam}

Stadtgemeinde, seit 1809 Stadtkreis (1952-1990 Bezirksstadt im gleichnamigen Bez.)

EREIGNISSE VOR 1939: Im Ersten Weltkrieg wird nach den Kriegszerstörungen in ostpreußischen Städten ein „Kriegshilfsverein Potsdam für Gr. Rominten und Dubeningken (Kreis Goldap)“ gegründet (Die Ostpreußenhilfe, S. 68).

EREIGNISSE BIS KRIEgSENDE: Jan. 1945 „die ersten Flüchtlingstrecks aus den Ostgebieten in der Stadt“ (Potsdam und das Jahr 1945, S. 7). - „Immer mehr Flüchtlinge [...] trafen seit Januar 1945 ein. Die Stadt war mit Flüchtlingen überfüllt." (Potsdam. Ausgewählte Ergebnisse, S. 3). - Jan. 1945 (Erinnerungen der Flakhelferin Ursula Borstorff): „Bei unseren Gängen durch die Stadt erlebte ich im eisigen Januar 1945 die endlosen Trecks aus dem Osten. [... .." (Baller/Reinholz, S. 350). - Anf. 1945 verschafft der hilfsweise in der Garnisonverwaltung beschäftigte und dort u. a. mit der Registrierung von aus den Ostgebieten kommenden Flüchtlingen betraute evang. Pfarrer Günther Brandt (1912-1986) auch untergetauchten Juden neue Papiere, da diese z.T. nur auf der Grundlage der mündlichen Aussagen der Flüchtlinge ausgestellt wurden (Pfarrer Günther Brandt, S. 2, 5, 15). - 22.1.1945: „die Schule in Klein-Glienicke muss 200 Flüchtlinge aus dem Osten aufnehmen“ (ebd., S. 436). - 27.1.1945: „In Potsdam beginnen ,Zimmerkontrollen, um benötigten Wohnraum für die Flüchtlinge aus Schlesien und Ostpreußen zu erfassen“ (ebd., S. 348). - 27.1.1945: „Die ,Potsdamer Tageszeitung' schreibt [...] erstaunlich offen über die Trecks, die sich durch die Stadt schieben und teilweise in Auffanglager untergebracht werden. Sie verwendet den offiziellen Ausdruck ,Rückgeführte.“ (Kapuste, S. 69). - 27.1.1945: „In Potsdam beginnen ,Zimmerkontrollen', um benötigten Wohnraum für die Flüchtlinge aus Schlesien und Ostpreußen zu erfassen“ (Baller/Reinholz, S. 348). Febr. 1945: Potsdam wird (gemeinsam mit den Kreisen Niederbarnim u. Osthavelland) zum Aufnahmegebiet für die zu evakuierende Bevölkerung des Kreises Grünberg in Schlesien bestimmt (BLHA, Rep. 6 B Kreisverwaltung Züllichau-Schwiebus, Nr. 169, unfol.). - 19.2.1945: „Flüchtlinge aus den ehemals östlichen Gebieten des Deutschen Reichs erhalten in Potsdam 0,5 kg Zucker und 125 g Seifenpulver als Sonderzuteilung“ (ebd., S. 354). - Im Februar 1945 befand sich der Sitz der evakuierten Dienststelle des „Kommandeurs der Gendarmerie bei der 
Regierung Frankfurt (Oder)“ in Potsdam, Allee nach Sanssouci 6 (BLHA, Rep. 6B ZüllichauSchwiebus, Nr. 169). - Febr./März 1945: Foto (Bildarchiv Preußischer Kulturbesitz, Berlin) „Wagen eines Flüchtlingstrecks vor dem Rathaus auf dem Alten Markt von Potsdam“ (Abb.: Meinicke, S. 475). - März 1945: Foto „Flüchtlingstreck in der Charlottenstraße“ (Potsdam und das Jahr 1945, S. 35). - 8.3.1945: „In der Hohenzollernstraße haben sie eine 4. Klasse (für Flüchtlingskinder) eingerichtet." (Tagebucheintrag Ada U., abgedruckt in: Potsdamer Neueste Nachrichten, 1.4.1995). „Unsere 4. Flüchtlings-Klasse ist im Parterre. Meine Banknachbarin ist Christa B., Flüchtlingskind aus Schneidemühl im Warthegau." (Erinnerungsprotokoll Grida U., ebd.). - 1945 (erwähnt 14.4.) Flüchtlinge u.a. untergebracht im Regierungsgebäude (heute „Stadthaus“, Friedrich-Ebert-Straße 79/81) (Schiller, S. 56). - 14.4.1945 schwerer Bombenangriff (Potsdam und das Jahr 1945, S. 8 f., 67; Baller/Reinholz, S. 372-277). - 24.4.1945 Sprengung der Langen Brücke (Potsdam. Ausgewählte Ergebnisse, S. 4). - 24.-30.4.1945 Einmarsch der Roten Armee (ebd., S. 10 f., 68 f.), 24.4.1945 bereits in Babelsberg und Teltower Vorstadt, 25.4. in Krampnitz und Nedlitz, kurz zuvor Sprengung der dortigen Havelbrücken, 27.4. in Bornim und Bornstedt sowie Jägervorstadt, dann auch im Stadtzentrum (Potsdam. Ausgewählte Ergebnisse, S. 4), 28.4.1945 Sprengung der Glienicker Brücke durch deutsche Truppenreste, Einsetzung eines sowjetischen Stadtkommandanten, Restkämpfe in Eiche und Geltow noch bis 30.4.1945 (ebd., S. 5).

EReignisse NACH KRIEgSende: 1945: „Potsdam wird Sitz der Provinzialverwaltung Mark Brandenburg (Arbeitsaufnahme: 29.6., Bestätigung durch SMAD: 4.7.1945) (Potsdam und das Jahr 1945, S. 73; Baller/Reinholz, S. 401), Tagungsort: Sitzungsaal im ehem. Regierungsgebäude Spandauer Str. 32/34 (1946 Friedrich-Ebert-Str. 32-34, heute Haus-Nr. 79/81) (Potsdam und das Jahr 1945, S. 15). - 17.7. bis 2.8.1945 Berliner (Potsdamer) Konferenz im Schloss Cecilienhof: Im „Potsdamer Abkommen“ vom 2.8.1945 u. a. Festlegung der Ausweisung Deutscher aus den Ostgebieten (ebd., S. 16). - Aug. 1945: „zeitweise Zuzugssperre für Heimatvertriebene, da innerhalb der Stadt fast 20000 Einwohner infolge der Beschlagnahmungen durch die Besatzungsmacht obdachlos geworden waren“ (Wittenberg, S. 76). - „Im September-Oktober 1945 setzte der Hauptstrom der Umsiedler ein. Bis zum 1. Juli 1946 wurden 52391 Flüchtlinge insgesamt hier durchgeschleust. [...]." (ebd., S. 23, Schreiben des Oberbürgermeisters vom 24.9.1946). 1.10.1945 (Tagebuchaufzeichnung): „Nachricht, dass man als Flüchting nicht nach Potsdam hineinkäme, das Flüchtlinge sofort wieder aus der Stadt heraus müssten [...]." (Keppler, S. 96). [1945/46?]: „Der von meinen Schwiegereltern als Flüchtling aus Ostpreußen aufgenommene Musikdirektor Ludwig Baues schloß sich der CDU an und wurde Stadtverordneter." (Goerke, S. 123). Baues, der bis 1948 auch Leiter des „Potsdamer Männerchors“ war (Wirth, Potsdamer Kulturkalender, S. 480), wurde am 29.3.1950 zusammen mit Bürgermeister Erwin Köhler (CDU) und dessen Frau verhaftet und „verstarb nach einigen Tagen Haft im Zuchthaus $[\rightarrow]$ Cottbus“ (Agethen, S. 185). - 18.10.1946 Premiere des DEFA-Spielfilms „Freies Land“ (Regie: Milo Harbich) im Kino „Charlott“, der das Flüchtlingsschicksal am Beispiel eines Dorfes in der Westprignitz behandelt (wikipedia, www.defa-stiftung.de/milo-harbich [10.7.2018]) . - 1947-1950 
lebte der 1940-1945 als Dramaturg in Breslau tätige Schriftsteller Hugo Hartung (1902-1972) in Potsdam, er ging anschließend zunächst nach West-Berlin (Melchert, S. 184-187; wikipedia). - 14.8.1948 Übernahme der Charlottenhof-Apotheke (ab 1950 „Park-Apotheke“), Geschwister-Scholl-Str. 63, durch den 1946 aus Schlesien vertriebenen ehemaligen (bis 1945) Besitzer der Löwen-Apotheke in Züllichau Josef Kolodziej (1898-1972) (Biela, S. 13). - 1949 liest der damals als Volontär bei der „Tagespost“ in Potsdam tätige und in der Kolonie Alexandrowka 11 wohnhafte Schriftsteller Horst Bienek (1930-1990) aus Gleiwitz (ab 1955 in der Bundesrepublik lebend, 1975-1982 Romanfolge „Gleiwitz“) eine „Breslauer Novelle“ (Wirth, Das geistig-literarische Klima, S. 35; wikipedia).

EREIGNISSE NACH 1990: 11.9.1994: Bei der Landtagswahl erhält (unter den sonstigen Parteien) die UWVB („Unabhängige Wählergemeinschaft der Vertriebenen und anderer Benachteiligter“) 180 (Zweit-)Stimmen, 1990 war sie noch nicht vertreten, 1999 ist sie nicht mehr vertreten (Statistischer Informationsdienst Landeshauptstadt Potsdam, Nr. 8/1999, S. 7). - 1995 (und 2003) Bekräftigung der 1973 geschlossenen Städtepartnerschaft mit Opole, Polen (Oppeln, Oberschlesien). - 29.8.1998 „1. Ostdeutscher Kulturtag“ des BdV-Landesverbandes Brandenburg auf dem Alten Markt (Akten der BdV-Landesgeschäftsstelle). - 2003 Einweihung eines Gedenksteins für die Opfer von Flucht und Vertreibung neben dem Alten Rathaus, Am Alten Markt (Potsdamer Neueste Nachrichten, 14.11.2003). - 2003 „Rußlanddeutsche heute - Identität und Integration“ („I. Potsdamer Forum“) im Alten Rathaus, veranstaltet vom Deutschen Kulturforum östliches Europa (www.kulturforum.info [7.6.2017]). - 2.9.1994 „Abschied und Ankunft": Lesung aus einem deutschen und einem polnischen autobiographischen Werk zu Flucht und Vertreibung (Ursula Höntsch aus Berlin und Joanna Konopińska aus Breslau) in der Villa Kellermann (Kulturbund), Mangerstr. 34-36, veranstaltet von der Deutsch-Polnischen Gesellschaft Brandenburg e. V. in Kooperation mit der Gesellschaft für interregionalen Kulturaustausch e. V., Berlin, mit Unterstützung der Brandenburgischen Landeszentrale für politische Bildung (www. dpg-brandenburg.de [4.6.2018]). - 1994 „Gemeindetag der Rußlanddeutschen“: „Etwa 2000 in Berlin und im Land Brandenburg untergebrachte Aussiedler aus der ehemaligen Sowjetunion waren mit Sonderbussen gekommen." (Renate Oschlies, in: Zeit online, 9.9.1994). - 16.4.2015 Diskussionsveranstaltung „Brandenburger Forum“ der Konrad-Adenauer-Stiftung (in Kooperation mit dem BLHA) zum Thema „Vertriebene in Brandenburg - ,Kalte Heimat' oder gelungene Integration?"“ mit Vorträgen von Dr. Peter Bahl (Berlin) und Prof. Dr. Michael Schwartz (Berlin) im Restaurant Le Manège, Neuer Markt 9 a/b (Quelle: Programm). - 27.6. bis 27.9.2018 (Wander-)Ausstellung (des Zentrums zur Erforschung des Genozids und Widerstandes in Litauen) „Wolfskinder: Auf dem Brotweg von Ostpreußen nach Litauen 1945-1948“ in deutscher u. litauischer Sprache mit „22 mobilen Ständen und 10 Video-Monitoren“ im Foyer des Landtages Brandenburg, Alter Markt 1; Eröffnung mit Grußwort des litauischen Botschafters Darius Semaška (Text: BR 16 (2018) 8, S. 5-6) sowie Reden der Direktorin des Zentrums zur Erforschung des Genozids und Widerstandes in Litauen, Birute Terese Burauskaite (Text: BR 16 (2018) 8, S. 1-4), u. des Landtagsvizepräsidenten Dieter Dombrowski (CDU) (dritte deutsche 
Station nach Weimar u. Berlin, zuvor in Regierung, Parlament u. mehreren Städten Litauens gezeigt; BR 16 (2018) 7, S. 8 f.).

BevölkerungszAHLEN: 1925: 67300, 1939: 126000, 28.2.1945: 119378 („außerdem 40 000-50 000 Obdachlose [Bombenangriff 14.4.1945] u. Flüchtlinge“), 1946: 113600 (Städtebuch, S. 403). 1945 ff. „Zuzug aus den ehem. dt. Ostgebieten u. aus anderen Gebieten der SBZ bzw. DDR“ (ebd.). - 20.2.1945: „Die Stadt war überfüllt mit Frauen und Kindern [...] und mit 30000 Ostflüchtlingen“ (Bestehorn, S. 181). - 28.2.1945: 30000 Flüchtlinge aus den Ostgebieten in Potsdam registriert (Baller/Reinholz, S. 356). - [Sommer] 1945: „etwa 15000 Flüchtlinge aus dem Osten jenseits von Oder und Neiße in der Stadt" (Entscheidung für den Glauben, S. 5). - 1.9.1945 (Einwohnerstatistik): 125117 Einwohner, davon 12113 Flüchtlinge und Umsiedler (1 305 aus Berlin, 3037 aus der Mark Brandenburg, 1804 aus Ostpreußen, 857 aus Westpreußen, 865 aus Pommern, 1679 aus Schlesien, 1825 aus dem „Warthegau“ und Polen, 88 aus der CSR bzw. dem „Sudetengau“, 10 aus Jugoslavien, 56 aus Österreich, 587 aus dem „Westen“), 39 sonstige Ausländer (Potsdam und das Jahr 1945, S. 23; Baller/Lück, S. 245). - Juli 1946: 25158 „Umsiedler“ (BLHA, Rep. 203 MdI, Nr. 1074, Bl. 52; Abb.: Mietk, S. 66). - „Bis 1. Juli 1946 wurden 52391 Flüchtlinge durch Potsdam geschleust und zumeist in anderen Landesteilen, Mecklenburg, Thüringen, aber auch in den Kreisen Jüterbog, Prenzlau und ZauchBelzig untergebracht.“ (Uhlemann, S. 314). - „Am 24. September 1946 sind noch 9547 Flüchtinge in Potsdam ansässig." (Potsdam und das Jahr 1945, S. 23, Bericht des Oberbürgermeisters vom 24.9.1946). - 29.10.1946: 113568 Einwohner, davon aus Ostpreußen: 2391, Hinterpommern 2 137, Ostbrandenburg 3573 , Schlesien 2 924, Tschechoslowakei 406, Polen 1430, Danzig 360, Rumänien 127, Baltikum 501, Sowjetunion 96 (Volkszählung 1946). - 31.12.1948: Gesamtbevölkerung: 120569, davon „Umsiedler und Evakuierte“: 12526 (Grandke, S. 46). - Eingemeindung von Vertriebenen: 30.4.1947: 25745 (Oehlsen, S. 102), Febr. 1949: 13034 (ebd., S. 104), 30.9.1950 (Stadt Potsdam, „nach den neuen Kreisgrenzen ab 1.7.1950“): 11987 (ebd., S. 105).

Katholiken: 1925: 4600, 1946: 9800, 1964: 6600 (Städtebuch, S. 404). - Gemeinde: um 1955: 6500 (Brühe, S. 33). - Am 14.4.1945 befindet sich u. a. „Pfarrer Scherer (Flüchtling aus Unruhstadt)" im Luftschutzkeller des beim Bombenangriff an diesem Tag völlig zerstörten Pfarrhauses [Charlottenstraße 54] (Burda, S. 164 [Zitat]; Schwillus/Brühe, S. 342). - Von Mai 1947 bis Juli 1949 wirkte der als Kuratus aus Greifenberg in Pommern vertriebene Pfarrer Geistliche Rat Alfred Kurts (geb. 1909 Berlin, gest. 1969) als Hausgeistlicher im St. Josefs-Krankenhaus, Allee nach Sanssouci 7 (Ostpriesterverzeichnis 2, 1949, S. 48; www.mater-dolorosa-lankwitz.de [17.1.2017]). - 1952 Fronleichnamsprozession (von FDJ-Fanfarenzug gestört): „Die Fronleichnamsaltäre standen an den Außenseiten der Kirche. Der Gottesdienst war gut besucht, da zu dieser Zeit die Innenstadt durch die vielen aus dem Osten stammenden Flüchtlinge übervölkert war. [...]“ Augenzeugenbericht Horst Wylezalek, hier nach: Entscheidung für den Glauben, S. 18).

Авт. VII A Umsiedler und Heimkehrer (bzw. bis 1946 „Amt für deutsche Umsiedler“ der Abt. VII Arbeit und Sozialwesen) im Ministerium für Arbeit und Sozialwesen der Provinzial- 
bzw. Landesregierung Brandenburg (siehe auch oben den Abschnitt „Umsiedlerverwaltung“ im Teil 1, Kapitel III. 1): Sitz am 20.10.1945 noch im ehem. Regierungsgebäude (heute Stadthaus) Spandauer Str. 32/34 [heute: Friedrich-Ebert-Str. 79/81)] (BLHA, Rep. 16 Nl Spiegelberg, Nr. 5, Bl. 1), auch 17.12.1945 noch Spandauer Str. 32/34 (Briefkopf in BLHA, Rep. 206, Nr. 3036, unfol.); dann umgezogen auf das Regierungsgelände im Süden der Stadt (andere Regierungsdienststellen bleiben jedoch im Stadthaus): 1946 Alte Zauche 67, Haus I (Potsdamer Wirtschafts-Wegweiser 1946, S. 5); 1946/48 Alte Zauche 67, Haus II bzw. 2 [heute Heinrich-Mann-Allee 103] (u. a. BLHA, Rep. 203 MdI, Nr. 1195, Bl.65; BLHA, Rep. 230 Bernau, Nr. 292, Bl. 4; BLHA, Rep. 256 Umsiedlerlager Küchensee, Nr. 217, unfol., 16.11.1948; Branchen-Adressbuch Provinz Brandenburg mit Groß-Berlin. Ausgabe 1947. Berlin (1946), unpagin.), 13.8.1948 Umzug ,in ein anderes Haus innerhalb des Regierungsgeländes Alte Zauche" (BLHA, Rep. 203 MdI, Nr. 1198, Bl. 34v), Okt. 1948 in Haus 1 b (BLHA, Rep. 203 MdI, Nr. 1198, Bl. 62). - 6.9.1950 erwähnt mit Sitz Saarmunder Str. 23, Haus 9, dies auf am 18.10. und 17.11.1950 genutzten Briefbögen durchgestrichen und korrigiert in Heinrich-Mann-Allee 107 (BArch, DO 1/8207, unfol.). - Das als Nachfolgebehörde fungierende Referat Bevölkerungspolitik saß Dez. 1950/Jan. 1951 HeinrichMann-Allee 107, Haus 9, deren Leiter Kuhn ebd. in Zimmer 18 (ebd.).

Provinzial- bzw. Landesbeauftragte des Suchdienst für vermisste Deutsche in Der Sowjetischen Besatzungszone Deutschlands (erwähnt 1946-1949): Sitz (offenbar stets bei der Abt. Umsiedler) Potsdam, Alte Zauche 67, Haus 2 (erwähnt 1947), später (1949) Haus 9 Zimmer 32 (im Amt für Deutsche Umsiedler); Provinzialannahmestelle: Hebbelstr. 6 (erwähnt 13.9.1946).

Auffanglager am Obelisk (im Bunker unter dem Winzerberg, Schopenhauerstr.): 4.2.1945 Nutzung für Flüchtlinge (aus Küstrin) nachgewiesen (Gespräche mit ehemaligen Küstrinern, T. 6, S. 221).

UMSiedlerlager/Aufbaulager LuftschiffHafen, Zeppelinstraße 110: Nach dem Bombenangriff vom 14.4.1945 befindet sich hier in den aus dem Kaiserreich stammenden Shedhallen und Lagerräumen eines der Auffanglager für obdachlos gewordene Potsdamer (Mihan, S. 185). - „Für die nicht in Einzelräumen unterzubringenden Notfälle [obdachloser Einheimischer und Zuwandernder] richtete die Stadtverwaltung Massenunterkünfte ein. Eine solche befand sich etwa ab Frühsommer 1945 in der Lindenstraße 29, einem Gebäudetrakt, der zum Großen Militärwaisenhaus Potsdam gehörte, heute Teil des Hotels am Großen Waisenhaus. In dem Gebäude befand sich auch eine Dienststelle der Besatzungsmacht. Als sich Probleme mit der Nutzung der dort befindlichen Entlausungsstelle ergaben, ließ die Ärztin der sowjetischen Kommandantur wissen, dass das Flüchtlings- bzw. Umsiedlerheim nicht in der Stadt bleiben könne und nach außerhalb verlegt werden solle. Auf der Suche nach einem geeigneten Ausweichstandort verständigten sich das Sozial- und das Wohnungsamt der Stadt auf den Luftschiffhafen, konkret auf das frühere Gasthaus Schiemann - das Wirtshaus zum Luftschiffhafen. Es war beabsichtigt, das neue Flüchtlingsheim mit allen erforderlichen hygienischen Einrich- 
tungen auszustatten. / Im Oktober 1945 erfolgte der Umzug von der Lindenstraße zum Wirtshaus Luftschiffhafen. In der amtlichen Sprachregelung handelte es sich nunmehr um ein Umsiedlerlager. Postalisch führte es die Anschrift Zeppelinstraße 100. [...]./ Das Lager bestand aus dem Wirtshaus Luftschiffhafen und einigen bereits vorhandenen schadhaften Baracken. Der Vorschlag, weitere Baracken, die am Straßenbahndepot und Am Brunnen standen, zum Luftschiffhafen umzusetzen, ließ sich nicht realisieren. [...].“ (Lambrecht/Sperfeld, S. 201; Lage des Wirtshauses siehe Lageplan ebd., S. 193). - Kapazität am 31.12.1945 (Lager „Potsdam, Zeppelinstr. 63“): 360 (BArch, DO 2/45, Bl.41). - Kapazität am 1.1.1946: 350 (BLHA, Rep. 203 MdI, Nr. 1163, Bl. 49). - 14.2.1946 Kreis- und Quarantänelager „Luftschiffhafen“, Kapazität: 3.50 (Oehlsen, S. 28). - „Im Potsdamer Lager wurden bis 1. Juli 194612165 Personen verpflegt, entlaust und von Ärzten betreut. Diese wurden weiter befördert nach Mecklenburg, Thüringen und in die Kreis Jüterbog, Prenzlau, Zauch-Belzig. Der Rest von 80 Personen wurde Anfang Juli 1946 nach Brandenburg/Havel überführt. [...]." (Potsdam und das Jahr 1945, S. 23, Schreiben des Oberbürgermeisters vom 24.9.1946). - „Offiziell ist das für Männer und Frauen gedachte Umsiedlerlager schon zum 1. Juli 1946 wieder aufgelöst worden. Real bestand es weiter und sollte jetzt vorübergehend Heimkehrer aufnehmen. [...] Das Potsdamer [Heimkehrer-] Lager war die kleinste dieser Notunterkünfte [in der Provinz Mark Brandenburg], die mitunter mehrere Tausend Bewohner hatten. / Das frühere Wirtshaus beziehungsweise Restaurant Luftschiffhafen blieb weiter das Hauptgebäude der Einrichtung. Anfangs war auch der Begriff Überbrückungslager üblich [...]. / Anfangs befanden sich etwa 70 Heimkehrer im Lager Luftschiffhafen, von denen 20 aber bald privat unterkamen. Bis September 1947 stieg die Zahl der dort lebenden Heimkehrer jedoch auf etwa 140 an. [...]./ Die Potsdamer Stadtverwaltung hatte die arbeitsfähigen Männer des Lagers zur Übernahme von Tätigkeiten verpflichtet, faktisch als Gegenleistung für kostenlose Unterkunft und Verpflegung. Diese Arbeitskräfte waren auf verschiedenen Potsdamer Baustellen und bei der Besatzungsmacht eingesetzt. Aus diesem Grund trug die Einrichtung im Potsdamer Luftschiffhafengelände bald die Bezeichnung Aufbaulager. [...].“ (Lambrecht/Sperfeld, S. 202). - 1947 „Aufbaulager“ Zeppelinstr. 110 (der Abt. Sozialwesen des Rates der Stadt unterstellt), hier auch Sitz des städtischen „Heimkehrer- und Umsiedler-Ausschuß“" (Adressbuch 1947, T. 1, S. 23). - In Aktennotiz 12.4.1948 wieder als Umsiedlerlager bezeichnet (BLHA, Rep. 201, Nr. 403, Bl. 4). - 13.4.1948: „Die Massenunterkunft der Stadt Potsdam im Aufbaulager Luftschiffhafen beherbergt zur Zeit 125 alleinstehende Männer (ehemalige Umsiedler und Heimkehrer, bei denen eine Familien-Zusammenführung wegen des Wohnraummangels bisher nicht möglich war, Dienstverpflichtete, Anhanglose und Ledige). Sie sind sämtlich im Wiederaufbau der Stadt Potsdam und im Dienst der Besatzungsmacht tätig. 30 weitere Dienstverpflichtete muß das Lager wegen Wohnraummangel aufnehmen. [Bl.21v] Außerdem besteht ein Aufnahmesoll von 200 neuen Umsiedlern für die Stadt Potsdam. Der Weiterbestand eines Lagers ist durch die Notlage somit zur Zeit bedingt. Die Unterbringung ist jedoch in jeder Hinsicht unzureichend und beschämend für die Landeshauptstadt Potsdam. Für die Instandsetzungsarbeiten steht kein Baumaterial zur Verfügung.“ (ebd., Bl. 21). - Am 15.4.1948 „leben [im Lager] zur Zeit 
125 heimatlose Männer (ehemalige Umsiedler bezw. Heimkehrer und Dienstverpflichtete), die ausschließlich für den Wiederaufbau der Stadt Potsdam und für die Besatzungsmacht arbeiten" (ebd., Bl. 18). - Belegung am 28.4.1948: 130 Mann, davon 41 Heimkehrer, 68 Arbeitseingewiesene, 21 weitere Arbeitseingewiesene, die aber eigene Quartiere haben und nur zur Verpflegung ins Lager kommen (ebd., Bl.3). - Auf dem Gelände Zeppelinstr. 110 (Luftschiffhafen) befinden sich auch (1946 erwähnt) die „Betreuungsstelle für Umsiedler“ der Abt. Sozialwesen des Magistrats (Potsdamer Wirtschafts-Wegweiser 1946, S. 8) und (1947 erwähnt) mit derselben TelefonNr. wie das Aufbaulager der „Heimkehrer- und Umsiedler-Ausschu $\beta^{“}$ [der Stadt Potsdam] (Adressbuch Groß-Potsdam 1947, T. 1, S. 23). - Nach mehreren Berichten und auch öffentlicher Kritik an den schlechten hygienischen Verhältnisen im Lager (1948) erfolgt im Frühjahr 1949 eine Instandsetzung und die Wiedereröffnung (Mitte Mai 1949 Eröffnungsfeier) des „Aufbaulagers“ als „Potsdamer Facharbeiterheim, auch Facharbeiterwohnheim genannt“. Dieses wurde 1951 aufgelöst und das Hauptgebäude von der Bau-Union übernommen. „Erst im Februar 1953 wurde festgelegt, dass das Gebäude von der Bau-Union für das Ministerium des Innern beziehungsweise für die KVP zu räumen ist." (Lambrecht/Sperfeld, S. 203).

St.Josefs-Krankenhaus, Allee nach Sanssouci 7 (Brandenburger Vorstadt): [1945: ] „Flüchtlinge kamen zu jeder Tageszeit ins Krankenhaus und wurden von den Schwestern mit Rat und Tat, aber auch - soweit vorhanden - mit Lebensmitteln versorgt." (Rose, S. 138).

EntlausungSanstalten: 1946 werden drei Standorte erwähnt: Krankenhaus Hermannswerder; Städt. Krankenhaus, Neue Königstr. 129; Babelsberg, Gartenstr. 55 (Potsdamer Wirtschafts-Spiegel 1946, S. 14).

Evangelische ERlöserkirchgemeinde, Nansenstraße 6 (Brandenburger Vorstadt): 1945: „Änderung der Zusammensetzung der Erlösergemeinde durch den Flüchtlingsstrom aus den Gebieten jenseits der Oder und Neiße und dem Sudetenland. Die Heimatvertriebenen werden in die Gemeinde integriert. / Aufstellung eines ,Barmherzigen Brotkorbs' und Sammlung anderer Nahrungsmittel zur Linderung der Not der Flüchtlinge, [S. 50] entlassenen Kriegsgefangenen und Verwundeten. Die Frauenhilfe richtet einen ,Barmherzigen Kleiderschrank' ein. / Starke Zunahme der kirchlichen Beerdigungen, so daß die Pfarrer ,kaum vom Friedhof' kommen." (Knaack, S. 49f.).

Schloss Cecilienhof, Im Neuen Garten 11: 17.7. bis 2.8.1945 Tagungsort der Berliner (Potsdamer) Konferenz: Im „Potsdamer Abkommen“ vom 2.8.1945 u. a. Festlegung der Ausweisung Deutscher aus den Ostgebieten (Potsdam und das Jahr 1945, S. 16). - 10.1.1952 Übergabe des Schlosses an die Landesregierung Brandenburg durch die SMAD, Einrichtung einer Gedenkstätte zum „Potsdamer Abkommen“ (Schloß Cecilienhof, S. 198; Orte des Erinnerns, S. 225; Potsdam. Ausgewählte Ergebnisse, S. 8).

Gedenkstein, Am Alten Markt: 15.11.2003 Einweihung eines Gedenksteins (Findling mit Inschriften-Metallplatte, Versalien) für die Opfer von Flucht und Vertreibung durch den Lan- 
desverband Brandenburg des BdV neben dem Alten Rathaus (Potsdamer Neueste Nachrichten, 14.11.2003; Foto kurz vor Aufstellung in: BR 9 (2011) 8, S. 10; Foto der Inschriftentafel: ebd. 13 (2015) 3, S. 4) mit dem Albert-Schweitzer-Zitat (ganz unten in kleinerer Schrift auch in englischer Sprache wiederholt): „In schlimmster Weise vergeht / man sich gegen das Recht, / indem man Völkerschaften / das Recht auf das Land, / das sie bewohnen, / in der Art nimmt, / dass man sie zwingt, / sich anderswo anzusiedeln. // Albert Schweitzer //Bund der Vertriebenen / Landesverband Brandenburg//[...]“. Einweihung mit Ansprache von Markus Meckel MdB vor etwa 150 Anwesenden und ökumenischem Gottesdienst in der unmittelbar benachbarten Nikolaikirche; die Potsdamer Kampagne gegen Wehrpflicht, Zwangsdienste und Militär und die Potsdamer Antifa-Gruppe bezogen verbal ablehnend Stellung (Baller/Lück, S. 244 f.; Auskünfte Eberhard Clemens/BdV-Landesverband, 18.7.2007; ausführender Steinmetzmeister: Peter Brunzel, Cottbus, aus Sommerfeld/NL, Kr. Crossen, stammend). - 2003-2005 mehrfach mit Parolen („Deutsche Täter sind keine Opfer“, „Nazis raus“) beschmiert (MAZ, 1.12.2003, 2.3.2005, BR 3 (2005) 2, S. 24-25 u. ö.).

StÄdtepartnerschaften: 6.6.1973 Opole, Polen (Oppeln, Oberschlesien), 7.4.1995 und 2003 bekräftigt ([1991:] „soll auch in Zukunft, dann jedoch frei von verordneter ,Brüderlichkeit', zwanglos fortgeführt werden. [...] Gerade Potsdam als Hauptstadt des an Polen angrenzenden Landes Brandenburg sieht sich vor eine besondere Aufgabe gestellt, wenn es darum geht, einen Beitrag zum besseren Verständnis zwischen deutschen und polnischen Mitbürgern zu leisten." (Partnerschaften, S. 52). - 1987 „Dni Poczdamu w Opolu“ (Tage der Stadt Potsdam in Oppeln), u.a. mit einer Potsdam-Fotoausstellung von Werner Taag (Trzcielińska-Polus, S. 535). „Mit der Ausgestaltung der Partnerschaft befasst sich der Opole-Club Potsdam. Ansprechpartner ist der Vorsitzende Frank Kupferschmidt“ (Stand: Juni 2016; www.potsdam.de). - 26.8.2018 „feierliche Einweihung der Opolestraße im Potsdamer Stadtteil Bornstedt“ „im Rahmen des 45. Jubiläum[s] der Städtepartnerschaft zwischen Potsdam und Opole“ (maz-online.de, 26.8.2018).

VertriebenenVerbände NACH 1990: (1) BdV-Landesverband Brandenburg e.V., Sitz: Potsdam; gegründet 1991 (Akten der BdV-Landesgeschäftsstelle; Märkischer Informationsdienst 8/1994, S. 14); „setzte die Arbeit des am 14. Dezember 1990 konstituierten Gründungsausschusses fort" (BdV-Handbuch 1993, S. 274); Geschäftsstelle: 1991-1998: Heinrich-Mann-Allee 103, Haus 16 (BdV-Handbuch 1993, S. 274; desgl. 3. Aufl. 1996, S. 168; Akten wie vor), 1998-2013 Zum Kahleberg 4, seit 2013, nach Umzug in das angrenzende Hauptgebäude, Zum Jagenstein 3 (Akten wie vor); Träger einer zunächst v. a. für Spätaussiedler, dann aber für Migranten allgemein tätigen Migrationsberatungsstelle am Ort der Geschäftsstelle) (brandenburger-rundschau.de [10.10.2016]). 25.1.1991 Gründungsversammlung im Deutschlandhaus in Berlin-Kreuzberg, Stresemannstr. 90 in den Räumen des Landesverbandes Berlin (Gründungsprotokoll mit 30 Unterschriften; Vorsitzender: Dr. Reinhard Anders [s.u.], 1. stellv. Vorsitzende: Marianne Kühn-Berger [s.u.], 2. stellv. Vorsitzender: Dieter Lüdtke, Schatzmeister: Werner Schulze, Schriftführer: Johanna Anders), zugleich Satzung angenommen, 12.3.1991 eingetragen beim 
Amtsgericht Potsdam (VR 401), 24.6.1995 neue Satzung errichtet (Akten wie vor); 29.6.1991 „durch den BdV-Bundesvorstand als ordentliches Mitglied des Bundes der Vertriebenen aufgenommen“ (BdV-Handbuch 1993, S. 274). - 1. Vorsitzende (lt. Mitteilung der BdV-Landesgeschäftsstelle vom 21.6.2018, Personalia ergänzt nach deren Akten): a) 12.3.1991-7.10.1991 Dr. Reinhard Anders (geb. 1940 Seifersdorf, Ldkr. Liegnitz, ev., aufgewachsen in Petersdorf, Kr. Goldberg, 1945 Flucht, nach Rückkehr in Heimatdorf Petersdorf 1948 Vertreibung, über Forst ins Lager Falkensee, von dort eingemeindet in $\rightarrow$ Frankenfelde b. Luckenwalde; Tierarzt in Meinsdorf, 1991 Mitarbeiter des Ministeriums für Landwirtschaft in Potsdam; CDU; Synodale; bis 1990 CDU-Volkskammer-Abgeordneter [Selbstauskunft, 3.8.2018]); b) 7.10. 91-27.4.1993 (Edeltraut-)Marianne Kühn-Berger geb. Berger (geb. 1927 Breslau, gest. 29.12.2016, Grab in Zühlen b. Rheinsberg; 1946 Vertreibung; Künstlerin [Kostümgestalterin, bekannte Malerin, Grafikerin, Glaskünstlerin u. a.] in Wilhelmshorst bzw. ab 1992 in Neuruppin, zahlreiche Ausstellungen (www.kühn-berger.de [3.8.2018]); ab 2007 Mitglied der Partei Die Linke [Nachruf von Otto Theel: Märkische Linke 1/2017, S. 3 mit Bild]); c) 27.4.1993-24.6.1995 Reinhard Stober (geb. 1928 Neusalz/Oder, gest. 2007, Diplom-Lehrer in Luckenwalde); d) 24.6.199523.3.1998 Erwin Brauer (kommissarisch); e) 23.3.1998-18.9.2002 Erwin Brauer (geb. 1946 Klein Podel, Kr. Stolp/Pommern, gest. 2011, Dipl.-Ing. in Potsdam, CDU [Kurznachruf in BR 9 (2011) 6, S. 12]); f) 18.9.2002-30.7.2008 Manfred Walther (geb. 1948 Parchim, Eltern aus der Bukowina, 1940-1945 in Breslau; Rechtsanwalt u. Notar in Berlin; ab Mai 1990 Staatssekretär im DDR-Justizministerium u. bis 3.10.1990 kommissarischer Justizminister, 1990-1994 MdL Brandenburg u. stellv. CDU-Fraktionsvorsitzender; siehe auch $\rightarrow$ Lübben); g) seit 30.7.2008 Harald Heerwagen (geb. 1946 Jena, Mutter aus Hinterpommern; Abbruchunternehmer in Potsdam, jetzt Rentner). Die Nennung von Manfred Walther für 1996 (BdV-Handbuch 1996, S. 167) ist zu korrigieren. Die Phase vom 24.6.1995 bis 23.3.1998 „war geprägt durch eine Reihe vereinsinterner Streitigkeiten und Unregelmäßigkeiten. In der Vorstandswahl von 1995 war Manfred Walther als Landesvorsitzender gewählt worden. In den Verfahren Amtsgericht Potsdam (AZ. 60VR 401) und Landgericht (AZ. 5T 350/96) zur Sache wurde die Unwirksamkeit der Landeswahlversammlung vom 24.06.1995 durch die Gerichte festgestellt und der stellvertretende Landesvorsitzende Erwin Brauer aus dem Vorstand c) als allein handlungsbefugtes Organ benannt." (Mitteilung der BdV-Landesgeschäftsstelle wie vor). 2003 Gedenkstein-Einweihung (siehe oben). - (2) BdVKreisverband Potsdam, gegründet 1991 (Amtsgericht Potsdam, VR 1799), 1996/98 erwähnt mit Sitz Heinrich-Mann-Allee 103, Haus 16 (BdV-Handbuch 1996, S. 168); 2003353 Mitglieder, aufgelöst zum 31.12.2017; Vorsitzende (Akten der BdV-Landesgeschäftsstelle): 19942005 Harry Horlitz (geb. 1936 Leitersdorf, Kr. Crossen, gest. 2018 Potsdam; Kriminalpolizist a. D. in Potsdam, 1945 mit Treck über Frankfurt/O. nach Potsdam u. Paaren, dann nach Falkenrehde gekommen, 1954 zur Kasernierten VP, 1959 zur Schutzpolizei nach Potsdam, 1962 zur Kriminalpolizei [Nachruf von Volker Oelschläger in MAZ, 2018); 2005-2008 Harald Heerwagen, Potsdam (s. o. beim Landesverband) (BR 2 (2004)2, S. 6 f.; 3 (2005)6, S. 18), 2009 vakant (amtierender Vorsitzender: Fritz Philipp), 2010-2017 Fritz Philipp, Lehrer in Potsdam 
(geb. 1934 Plichten, Kr. Osterode, Ostpreußen, gest. 2018) (BR 11 (2013)2, S. 5 ; 13 (2015)12, S. 10). - (3) Memelland-Gruppe Potsdam, Mai 1991 als nicht selbständige Gruppe in der Arbeitsgemeinschaft der Memellandkreise (AdM) gegründet von dem in Memel geborenen Arno Baar (Potsdam-Babelsberg) im Zusammenwirken mit Viktor Kittel (Westerland/Sylt), stellv. Bundesvorsitzender der AdM, Zusammenkünfte in Potsdam in loser Folge, meist einmal pro Monat („Herr Baar hielt Vorträge und zeigte/erklärte ihm zur Verfügung gestellte Mappen der memelländischen und speziell der Geschichte der Stadt Memel“), nach Baars Tod Tätigkeit 1998 beendet (Mitteilungen H.-J. Froese, Landsmannschaft Ostpreußen, 27.8. und 14.9.2017). - (4) Landsmannschaft Ostpreußen, Landesgruppe Brandenburge. V. (LO LG Brandenburg) (Sitz Potsdam), neugegründet 2015, Satzung datiert 24.10.2015, in das Vereinsregister beim Amtsgericht Potsdam (Az. VR 8602 P) eingetragen 10.3.2016 (Stand 2017: Vorsitzender: Hans-Jörg Froese (geb. 1957) [auch stellv. Bundessprecher der Landsmannschaft Ostpreußen e.V. und seit 2010 Präsident der PRUSSIA, Gesellschaft für Heimatkunde Ost- und Westpreußens e. V.], Werder/Havel; stellv. Vorsitzender: Kai Lüdemann, Potsdam; Schatzmeister: Reinhard Grunenberg, Berlin), bei Veranstaltungen teilweise Kooperation mit der Prußen-Stiftung TOLKEMITA (Potsdam) (lolgbrandenburg.wordpress.com/ [4.7.2017]; BR 14 (2016)4, S. 11; Mitteilungen H.-J. Froese, 5./12./19.7.2017). - (5) Sudetendeutsche Landsmannschaft, Landesgruppe Brandenburg e. $V$., Sitz Potsdam; 23.4.1995 Satzung beschlossen, 16.12.1996 eingetragen beim Amtsgericht Potsdam (VR 1627), als Landsmannschaft noch erwähnt 1999 u. 2002 . Vorsitzende 1996 (?): Waltraud Steinmetzger (vgl. $\rightarrow$ Premnitz!); Landesobmann 2002: Dr. Herbert Fechtner, Guben (Akten der BdV-Landesgeschäftsstelle). - (6) Ost- und Mitteldeutsche Vereinigung der CDU Brandenburg, Landesvorsitzender seit 2012: Jesko von Samson-Himmelstjerna (Potsdam), geb. 1973 (www.brandenburg-cdu.de [10.7.2018]).

Wissenschaftliche Vereine: (1) Arbeitsgemeinschaft ostdeutscher Familienforscher e.V. (AGoFF) (Sitz Herne, 1927 begründet in Breslau): 1998-2007 befand sich die AGoFF-Forschungsstelle Mittelpolen-Wolhynien in Potsdam, Hessestr. 16; Leiter: Mario Seifert (geb. 1956 Potsdam [Vater aus Sorau (bereits vor 1945 westlich von Oder/Neiße lebend), Mutter aus Stettin (bis 1945 dort, dann Bad Freienwalde)]), der 2000-2017 zugleich Schriftführer der AGoFF war und seit 2018 deren stellv. Schriftführer ist (agoff.de [30.7.2018]; Auskünfte M. Seifert, 14.9.2018). - (2) Verein für Geschichte Schlesiens e. V. (Sitz: Würzburg, 1846 gegründet in Breslau): Zweiter Vorsitzender war 2007-2020 Prof. Dr. Andreas Klose, Potsdam (zugleich 2010 bis 2020 Schriftleiter der vom Verein herausgegebenen „Schlesischen Geschichtsblätter“).

Deutsches Kulturforum östliches Europa e. V. (Sitz Potsdam): Gegründet Dez. 2000 als gemeinnütziger Verein, „gefördert von der Beauftragten der Bundesregierung für Kultur und Medien (BKM) aufgrund eines Beschlusses des Deutschen Bundestages." Selbstdarstellung („Kurzprofil“): „Das Deutsche Kulturforum östliches Europa engagiert sich für eine zukunftsorientierte Auseinandersetzung mit der Geschichte jener Gebiete im östlichen Europa, in denen früher Deutsche gelebt haben bzw. heute noch leben. / Im Dialog mit Partnern aus Mittel- und Osteuropa will das Kulturforum die 
Geschichte dieser Regionen als verbindendes Erbe der Deutschen und ihrer östlichen Nachbarn entdecken und einem breiten Publikum anschaulich vermitteln. [...].“-Zahlreiche Veranstaltungen, v. a. Ausstellungen (u.a. im $\rightarrow$ Haus der Brandenburgisch-Preußischen Geschichte in Potsdam), Lesungen, Vorträge und Podiumsdiskussionen, werden deutschlandweit durchgefürt, darunter besonders auch in Potsdam. (Alle Angaben nach www.kulturforum.info [14.4.2017]). - Seit 2003 wird die Buchreihe „Potsdamer Bibliothek östliches Europa“ herausgegeben.

Haus der Brandenburgisch-Preussischen Geschichte (HBPG), Am Neuen Markt: Gegründet 2003 von der Landesregierung. U. a. gelegentliche Sonderausstellungen mit Bezug zu den Vertreibungsgebieten (http://www.hbpg.de/Ausstellungsarchiv.html [14.4.2017]): 17.2. bis 9.4.2006 „Die Neumark. Begegnung mit einer historischen Landschaft“ (zweisprachige deutschpolnische Tafel-Wanderausstellung, in Kooperation mit dem $\rightarrow$ Deutschen Kulturforum östliches Europa). - 8.2. bis 6.4.2008 „Oberschlesien im Objektiv. Historische und aktuelle Fotografien aus dem Muzeum w Gliwicach (Gleiwitz), dem Schlesischen Museum zu Görlitz und der Berliner Initiative europareportage. Präsentiert vom Haus der Brandenburgisch-Preußischen Geschichte und dem Deutschen Kulturforum östliches Europa“. - 12. bis 18.3.2010 „Eine europäische Odyssee. Königsberg Oelsnitz/Erzgeb. - Potsdam - Stockholm - Kaliningrad. Eine biografische Kunstinstallation im Haus der Brandenburgisch-Preußischen Geschichte“ von Hanna Sjöberg (Berlin) und Dorothea Bjelfvenstam (Stockholm) [Lebensgeschichte eines im Juli 1945 aus Königsberg i. Pr. nach Potsdam gekommenen Kindes]. - 4.2. bis 13.3.2011 „Landsberg an der Warthe/Gorzów Wielkopolski. Zwei Namen - Eine Geschichte/jedno miasto - wspólna historia". Ausstellung des Brandenburgischen Landeshauptarchivs und des Staatsarchivs Gorzów Wielkopolski“. - 16.11.2012 bis 6.1.2013 „Struktur und Architektur. Das postindustrielle Kulturerbe Oberschlesiens. Eine Ausstellung von Europareportage Berlin in Zusammenarbeit mit dem Deutschen Kulturforum östliches Europa und dem Schlesischen Museum Kattowitz/Muzeum Ślaskie w Katowicach im Rahmen des 5. Europäischen Monats der Fotografie“. - 7.9.2018 bis 20.1.2019 „Szenische Ausstellung“ „Beiderseits der Oder. Geschichtsraum, Grenzraum, Begegnungsraum“ (Kuratoren: Julia Bork, Thomas Wernicke): „Zur Vorbereitung der Ausstellung ging 2018 ein Team des Hauses der Brandenburgisch-Preußischen Geschichte (HBPG) gemeinsam mit Studierenden des Masterstudiengangs Bühnenbild_Szenischer Raum der Technischen Universität Berlin auf Spurensuche beiderseits der Oder. Sie trafen Menschen aus Polen und Deutschland, deren Lebens- und Familiengeschichten geprägt sind durch Flucht, Vertreibung oder Umsiedlung während des Zweiten Weltkriegs bzw. nach der Spaltung Europas in der Nachkriegszeit. Die Gesprächspartner berichteten, wie die Heimat der Vorfahren nur in familiären Erinnerungen weiter besteht, wie das neue Zuhause als Ort des Geborgenseins gelebt wird, und wie sie sich dem gemeinsamen kulturellen Erbe und damit auch den Nachbarn jenseits der Oder öffnen." (Auszug aus dem Austellungsflyer, Text auch online: www.hbpg.de/ausstellungen/beiderseits-der-oder.html [20.8.2018]; vgl. Thomas Wernicke/Julia Bork: Beiderseits der Oder. In: MuseumsJournal Berlin \& Potsdam 3/2018, S. 78-79).

Archivalische Quellen und Auskünfte: BArch, DO 2 ZVU, Nr. 50, Bl. 204 (Lager Luftschiffhafen, 1947). BLHA, Rep. 201 Landtag, Nr. 403 (Mängel im Aufbaulager Luftschiffhafen, Zeppelinstraße in Potsdam, und Schaf- 
fung von Wohnraum für Umsiedler, 1947-1948). - BLHA, Rep. 203 MdI, Nr. 1123 (Umsiedler- und Heimkehrerstatistiken, 1945-1946; enthält: Erfassung der Umsiedler in den einzelnen Kreisen der SBZ zum 1. Dez. 1945 sowie statistische Berichte der einzelnen Gemeinden, hier Stadtkreis Potsdam). - BLHA, Rep. 333 SED-Landesleitung Brandenburg, Nr. 577 („Heimkehrerlager“, 1946-1949; enthält u. a.: Potsdam/Luftschiffhafen). - Bildarchiv PreuBischer Kulturbesitz (bpk), Berlin: Fotoserie (4 Bilder) von Arthur Grimm: Flüchtlingstreck aus den Ostgebieten auf dem Alten Markt, Febr./März 1945; Fotoserie (4 Bilder) von Hilmar Pabel: Treck schlesischer Flüchtlinge bei Potsdam, Frühjahr 1945. - Stadtarchiv Potsdam, Rat der Stadt Potsdam/Oberbürgermeister, Nr. 33 (Berichte des Sozialamtes, 1945-1953; enthält: Berichte der Betreuungsstelle für Rückwanderer, Berichte der Abteilung Umsiedler-Heimkehrer, Tätigkeitsberichte des Sozialamtes); Nr. 47 (Tätigkeitsberichte der Oberstaatsanwaltschaft, Mai 1945 - Juli 1946; enthält u. a.: Rechtsprechung im Fall Wolf, ehemaliger Leiter der Betreuungsstelle für Rückwanderer); Nr. 406 (Tätigkeit des Heimkehrer- und Umsiedler-Auschusses, 1947-1948). - Mitteilungen Hans-Jörg Froese (Landsmannschaft Ostpreußen e. V. und Vorsitzender von deren Landesgruppe Brandenburg), Werder/Havel, 27.8. und 14.9.2017. - Siehe auch Quellenteil, Nr. 209-213, 217, 220.

Gedruckte Quellen: Töpler, Menschenwurm.- Adressbücher: Adressbuch Groß-Potsdam 1947. T. 1: Behörden, Organisationen, Verkehr, Industrie, Wirtschaft, Freie Berufe. Potsdam (1947). - Adressbuch Groß-Potsdam 1949. Potsdam (1948). - Potsdamer Wirtschafts-Spiegel 1946. - Potsdamer Wirtschafts-Wegweiser. Potsdam (1946). - Erinnerungsberichte: Dokumentation der Vertreibung I/2, S. 732. - Bestehorn, [Friedrich]: Potsdams Schicksal im Frühjahr 1945. Aufzeichnungen vom Oktober 1995 [vielm. 1945! - P. B.] über die Monate April/Mai 1945. In: Werner Mihan: Die Nacht von Potsdam. Berg am Starnberger See 1997, S. 181-184 [Oberbürgermeister, Aufzeichnnungen über seine Tätigkeit April/Mai 1945]. - Burda, August: Pfarrchronik vom 14./15. April 1945 bis 9. Mai 1945. In: Werner Mihan: Die Nacht von Potsdam. Berg am Starnberger See 1997, S. 163-175 [Küster der Kath. Kirche, zeitgenöss. Aufzeichnungen]. - Gespräche mit ehemaligen Küstrinern. Bd. 6. Frankfurt (Oder) 2017, S. 221223. - Goerke, Heinz: Am Puls der Medizin. Hildesheim u. a. 1996. - Grabner, Sigrid: Jahrgang ,42. Mein Leben zwischen den Zeiten. (Erstdruck Leipzig 2003) Kisslegg 2011. - Helms, Friedrich: Tagebuch. Wilhelmshorst 1945. Hrsg. von Tobias Wimbauer. Hagen-Berchum 2009 [Betr. auch Potsdam]. - Keppler, Günter: Tagebuchaufzeichnungen aus dem Jahre 1945. In: Potsdam 1945. Potsdam 2005, S. 95-117. - Potsdam 1945. Persönliche Aufzeichnungen und Erinnerungen. Potsdam 2005. - „Die Russen sind da“. Peter Böthig u. Peter Walther (Hg). Berlin 2011. - Solbrig, Erika, geb. Adam: Flucht und Vertreibung 1945. Augenzeugenbericht. In: BR 15 (2017) 5, S. 6-7. - Siehe auch die (bis 2018) 20 Anthologien des Zirkels "Zeitzeugen“ beim Seniorenbeirat der Stadt Potsdam (Quellenverzeichnis, 2.4.1, unterschiedliche Titel).

Literatur: Agethen, Manfred: Franz Schleusener - ein Opfer kommunistischer Gewaltherrschaft in Brandenburg. In: Historisch-politische Mitteilungen S. 15 (2008), 167-189. - Arlt, Klaus: Die Straßennamen der Stadt Potsdam. 2. Aufl. Potsdam 2010. - Baller, Kurt: Potsdamer Daten des 20. Jahrhunderts. Potsdam 2000. - Ders. / Lück, Siegfried: Gedenktafeln, -steine und Stelen in Potsdam. Barleben 2016, S. 244 f. - Ders. / Marlies Reinholz: Potsdam im Zweiten Weltkrieg. Magdeburg 2010. - Beevor, Antony: Berlin 1945. München 2002, Abb. 15 nach S. 272 [Foto „Hungrige Vertriebene sammeln Bucheckern in einem Wald bei Potsdam“ von Hilmar Pabel / Bildarchiv Preußischer Kulturbesitz]. - Biela, Paul: Schicksale deutscher Apotheker aus Ostbrandenburg am Ende des Zweiten Weltkrieges. Frankfurt (Oder) 2017. - Entscheidung für den Glauben. Potsdam 2009. - Huber, Edi: Zwischen Krieg und Frieden - das Jahr 1945. [Forsetzungsserie mit wechselnden Artikeltiteln, dabei Auszüge aus dem Tagebuch von Ada U. und Tochter Grida U.] In: Potsdamer Neueste Nachrichten, 28.1., 25.2., 1.4., 29.4., 23.9., 21.10., 23.12.1995. [Betr. v. a. die im Febr. 1945 in Potsdam untergekommene Flüchtlingsfamilie U. aus Kalisch]. - Kapuste, Eberhard: Die Gemeinde Eiche in den Jahren 1918 bis 1945. [Potsdam 2014] [Ortsteil Eiche, 1935-1952 sowie seit 1993 nach Potsdam eingemeindet]. - Knaack, Rudolf: 100 Jahre Erlöserkirche in Daten. In: Die Erlöserkirche in Potsdam 1898-1998. Potsdam 1998, S. 25-69 [Brandenburger Vorstadt]. - Lambrecht, Rainer / Sperfeld, Horst: Der Potsdamer Luftschiffhafen. Geschichte und Geschichten eines besonderen Stadtraums. Potsdam 2019, S. 200-203: Umsiedler- und Heimkehrerlager Luftschiffhafen. - Meinicke, Wolfgang: Die Aufnahme von Vertriebenen in der Sowjetischen Besatzungszone Deutschlands. In: „Wach auf, mein Herz, und denke“. Berlin/Opole 1995, S. 475-487, hier S. 475. - Melchert, Monika: Der Zeitgeschichtsroman nach 1945 am Beispiel von Werner Wilk und Hugo Hartung. In: „Hoffnung und Erinne- 
rung“. Potsdamer Literatur 1945 bis 1950. Hrsg. von Mathias Iven. Milow/Berlin 1998, S. 178-187. - Mihan, Werner: Die Nacht von Potsdam. Berg am Starnberger See 1997. - Oehlsen, S. 9 (Foto „Treck schlesischer Flüchtlinge bei Potsdam, Frühjahr 1945"). - Onnen, Hans-Joachim: Profile aus Potsdam und dem Landkreis Potsdam-Mittelmark. Bd. 1-3. Potsdam 1998-2000. - Orte des Erinnerns. Hrsg. von Anna Kaminsky. 3., überarb. u. erw. Aufl. Berlin 1996, S. 224-226 [Gedenkstätte zum Potsdamer Abkommen im Schloss Cecilienhof]. - Die Ostpreußenhilfe im Ersten Weltkrieg. Husum 2006. - Pfarrer Günther Brandt. Eine Dokumentation zum 100. Geburtstag. Potsdam 2012. - Partnerschaften. Die Stadt Potsdam und ihre Partnerstädte. In: Potsdam heute [1] (1991), H. 1, S. 52-53. - Potsdam. Ausgewählte Ergebnisse der Entwicklung der Stadt seit der Befreiung vom Hitlerfaschismus durch die ruhmreiche Sowjetarmee. Potsdam 1975. - Potsdam und das Jahr 1945. Potsdam 1995. - Rose, Wolfgang: Die SBZ-Zeit und die DDR-Zeit 1945 bis 1990. In: St. Josefs-Krankenhaus Potsdam-Sanssouci 1862-2012. Eckart Frantz (Hrsg.). Berlin 2012, S. 135-174. - Schiller, Gertraud: Im havelländischen Tal der Wublitz. Bd. 1. Potsdam 2013. - Schloß Cecilienhof und die Potsdamer Konferenz 1945. Berlin u. a. 1995. - Schwillus/Brühe, S. 341-343. - Seniorenbeiräte im Land Brandenburg. Potsdam 1999, S. 49 f. - Trzcielińska-Polus. - Uhlemann, Manfred: Neubeginn in Potsdam. In: Brandenburg im Jahr 1945. Potsdam 1995, S. 297-332, bes. S. 31 f. - Wirth, Günter: Der andere Geist von Potsdam. Frankfurt am Main 2000. - Ders.: Das geistig-literarische Klima in Potsdam 1945 bis 1950. In: „Hoffnung und Erinnerung “. Potsdamer Literatur 1945 bis 1950. Hrsg. von Mathias Iven. Milow/Berlin 1998, S. 16-39 [erwähnt z. B. den im Kulturbund tätigen früheren Breslauer kath. Theologen Prof. Dr. Max Rauer (S. 19) und die Lesung einer „Breslauer Novelle" auf einer Kulturbund-Veranstaltung junger Autoren 1949 durch Horst Bienek, damals Volontär bei der „Tagespost“ in Potsdam (S. 35)]. - Ders.: Potsdamer Kulturkalender 1945 bis 1950. In: ebd., S. 473-492. - Wittenberg, Hannes: Russen in Potsdam zwischen 1945 und heute. In: Ankommen in Potsdam. Hrsg.: ArchitraV e. V. Potsdam 2018, S. $72-81$.

\section{Potsdam-Babelsberg (Stadtkr. Potsdam)}

EREIGNISSE NACH 1945: „Am 11.4.1948 wurden bei einem Gedenkgottesdienst in Berlin-Babelsberg [so!] die Namen von 260 Arnswaldern verlesen, die seit 1945 verstorben waren." (700 Jahre Arnswalde Neumark, S. 17). - Der (aus Ostpreußen stammende) Potsdamer Bürgermeister Hermann Gerigk (CDU) „spricht als solcher (und, der auch Umsiedler ist') am 5.10.1950 auf einer ,Umsiedlerversammlung' in Babelsberg" (BLHA, Rep. 202 G, Nr. 162, Bl. 217; vgl. Textabdruck im Quellenteil, Nr. 223).

Katholiken: 1939: etwa 2000, 1950: etwa 3000 (Schwillus/Brühe, S. 344).

UMSIEDLERLAGER: Kapazität am 31.12.1945: 230 (BArch, DO 2/45, Bl. 41).

LiteratUR: 700 Jahre Arnswalde Neumark. Wunstorf 1969.

\section{Potsdam-Bornstedt (Stadtkr. Potsdam)}

EREIGNISSE NACH 1945: „Die Flüchtlinge oder ,die Vertriebenen; wie man sie nannte, waren ein großes Problem.“ (Hanke, S. 262). - In der evangelische Kirchengemeinde Bornstedt amtierte als Gemeindepfarrer von 1954 bis 1974 der aus Schlesien zunächst nach Thüringen geflüchtete Willi Hanke (1910-1988), zuletzt auch Superintendent des Kirchenkreises Falkensee (ebd., S. 262-269, 271). 
UMSIEDLERLAGER: Kapazität am 1.1.1946: 800 (BLHA, Rep. 203 MdI, Nr. 1163, Bl. 50).

Strassennamen: 2018 Opolestraße (Opole, Polen/Oppeln, Oberschlesien); siehe oben Potsdam/Städtepartnerschaften.

Literatur: Hanke, Willi: „Bornstedt nahe bey Sanssouci“. Geschichte der Evangelischen Kirchengemeinde Potsdam-Bornstedt. Potsdam 2006.

\section{Potsdam-Marquardt $\rightarrow$ Marquardt}

\section{Potsdam-Neu Fahrland (Stadtkr. Potsdam)}

Landgemeinde (1952-2003; 1939-1952 und seit 2003 Ortsteil von $\rightarrow$ Potsdam), bis 1939 Kr. Osthavelland, 1939-1952 Stadtkr. Potsdam, 1952-1990 Kr. Potsdam-Land (Bez. Potsdam), 1990-1993 Ldkr. Potsdam, 1993-2003 Ldkr. Potsdam-Mittelmark, 2003 Stadtkr. Potsdam

EREIGNISSE NACH KRIEgSENDE: [Fahrland:] „Nur wenige Einwohner waren aus dem Ort geflohen, mancher Heimatvertriebene kam neu dazu. [... ] Die Umsiedler wurden im alten Amtshaus und anderen leerstehenden Häusern aber auch auf großen Wirtschaften untergebracht. [...]." (800 Jahre Fahrland, S. 23).

BevÖLKeRUnGSZAHLEN: 1925: 334, 1964: 1020 (HOL III, S. 91).

UMSIEDLERLAGER: Kapazität am 1.1.1946: 400 (BLHA, Rep. 203 MdI, Nr. 1163, Bl. 50).

Literatur: 800 Jahre Fahrland. Hrsg. von Claus Wartenberg. Fahrland (1997).

\section{Premnitz}

Landgemeinde (3.11.1962 Stadtrecht), bis 1952 Kr. Westhavelland, 1952-1990 Kr. Rathenow (Bez. Potsdam), 1990-1993 Ldkr. Rathenow, 1993 Ldkr. Havelland

EREIGNISSE BIS KRIEGSENDE: 28.1.1945: Der erste von vier Evakuierungszügen aus Woldenberg/Nm. mit dem Ziel Anklam wird über Berlin umgeleitet und bringt 450 Woldenberger nach Premnitz (Mai, Situation, S. 4; BR 15 (2017)8, S. 11). „Es war die größte zusammenhängende Flüchtlingsgruppe in Premnitz. In den nächsten Monaten trafen immer wieder kleinere Gruppen in Premnitz ein." (ebd. 8 (2010)12, S. 8). - 2.5.1945 Kampfloser Einmarsch der Roten Armee (Premnitz, S. 6).

EREIGNISSE NACH KRIEGSENDE: „Ein größerer Anstieg war dann aber 1946 zu verzeichnen, hier waren es hauptsächlich Vertriebene aus dem Sudetenland. So 2 bis 3 Tausend Menschen hatte die Stadt aufzunehmen. Die Zahlen schwanken, viele Vertriebene zogen weiter, immer neue kamen hinzu. Premnitz hatte zu Beginn des Jahres 1945 ca. 5000 Einwohner (Fabrikar- 
beiter und Bauern). In den Jahren 1945 bis 1947 stieg die Einwohnerzahl ständig durch den Flüchtlingsstrom an. Durch den Betrieb der IG-Farben in Premnitz gab es viele Baracken, z. B. das Mädchenheim, die Steinbaracke am Tor 2, die Holzbaracken am Säuregraben sowie die Quartiere im alten Kraftwerk am Tor 11. In den kleinen Zimmern von etwa $18 \mathrm{~m}^{2}$ lebten häufig 4-6 Personen, Durch die schlechten hygienischen Verhältnisse traten viele Krankheiten auf, von denen häufig Kinder schwer betroffen waren. [...]." (Wolfgang Bornstädt in: Brandenburger Rundschau 8 (2010) 12, S. 8). - 1946 Anforderung von Arbeitskräften aus dem Umsiedlerlager $\rightarrow$ Küchensee für die Agfa-Kunstseidenfabrik in Premnitz (BLHA, Rep. 206, Nr. 3036).

BevölkerungSzahlen: 1925: 1906, 1939: 3846, 1946: 6387, 1964: 10087 (Städtebuch, S. 415). - 1940: 3932, 1945: 5250 (Mai, Situation, S. 4).

Katholiken: 1925: 131, 1946: 1614 (Städtebuch, S. 415). - Nach 1918 „kamen durch die Industrieansiedlung katholische Arbeiter aus dem Rheinland und aus Schlesien nach Premnitz, nach dem II. Weltkrieg dann auch vertriebene Sudetendeutsche.“ (Brühe, S. 43; nahezu textidentisch in: Schwillus/Brühe, S. 346). - „Durch die Zuwanderung von Heimatvertriebenen nach 1945 vergrößerte sich die Gemeinde immer mehr.“ (Nitschke, S. 31). - „Nach dem Zweiten Weltkrieg hatte die katholische Gemeinde zunächst eine kleine Baracke des Chemiefaserwerkes für Gottesdienste angemietet. Die Gemeinde war damals durch die Umsiedler auf über 2000 Mitglieder angewachsen. Viele Gläubige setzten sich für einen Neubau ein. [...]. (Borgmann/Sebastian, S. 55). - „Der Zuzug von Heimatvertriebenen, vor allem von Sudetendeutschen aus Nordböhmen, führte 1945/46 zu einer Vergrößerung der katholischen Kirchgemeinde. Die kleine Kapelle, 1937 eingeweiht, war zu klein. Mitte der siebziger Jahre lebten in Premnitz ca. 1300 Katholiken.“ (Premnitz, S. 84, mit Bild der Kapelle). „Mit finanzieller Förderung durch das Bonifatiuswerk wurde 1977 mit dem Bau einer neuen katholischen Kirche begonnen. Es wurde von staatlichen Stellen auferlegt, dass das Gebäude nicht sofort als Kirche zu erkennen ist, also keinen Turm bekommt. Das Kreuz befindet sich an der Rückseite. Am 1 . April 1978 wurde die Kirche ,Zur unbefleckten Empfängnis Mariens` durch Kardinal Alfred Bengsch konsekriert.“ (ebd., S. 85).

FlÜChtlings-/Umsiedlerlager, am Tor 2 (ehem. „Volksdeutschen-Lager“): Aug. 1946 nachgewiesen durch Einweisung von sudetendeutschen Vertriebenen aus Böhmisch-Leipa (Mai, Situation, S. 5 mit Foto einer Baracke, etwa 1947), eine von ihnen berichtete später: „In ein Zimmer wurden 3 Familien mit insgesamt 11 Personen eingewiesen. Es gab nur eine Bettstelle, für alle anderen wurden Strohsäcke gestopft. Im Winter wurden wir in eine Heimstraßen-Baracke eingewiesen." (ebd.).

FlüChtlings-/UMSIEdLeRLAGER, Heimstr., Beethovenstr. (Mackensenstr.)/Liebigstr., südlich der Werkbahn an der Städtebahn (bis 1945 Unterkunft für die Arbeiterinnen des IG-Farben-Werks, „Mädchenheim“): 10 Baracken (à 20 Zimmer für je 3 bis 4 Personen) u. 3 Luftschutzbunker, unmittelbar angrenzend an abgetrenntes Lager für eine Aufklärungseinheit der 
Roten Armee (11 Baracken, 2 Luftschutzbunker, Kameradschaftshaus [ab 1947 Kinderhort], Kulturhaus); „Heimleiter“ des Flüchtlingslagers (1945): Herr Schmidt (Bornstädt, S. 44-53; Luftaufnahme ebd., S. 45; Grundriss-Skizze 1945/46 nach der Erinnerung für beide Lager: ebd., S. 47; siehe auch Mai, Situation, S. 5-7; Luftaufnahme S. 6). - „Infolge der schlechten hygienischen Bedingungen waren viele Notquartiere durch Ungeziefer befallen. In den Heimstraßenbaracken kam es zu einem umfangreichen [S. 7] Flohbefall. In den Holzbaracken, z. B. in der Seuchenbaracke, hatten sich Wanzen eingenistet. [...] / Diese Notquartiere mussten über Jahre von vielen Familien bis zum Beginn des Wohnungsbaues Anfang der 50er Jahre genutzt werden." (Mai, Situation, S. 6f.).

VERTRIEBENENVERBÄNDE NACH 1990: Sudetendeutsche Landsmannschaft, Landesgruppe Brandenburg, 1996 erwähnt mit Sitz in Premnitz, Mozartstr. 12 (Waltraud Steinmetzger) (BdVHandbuch 1996, S. 114, 168).

Strassenumbenennung: 2010 Benennung des Busplatzes an der Fabrikenstraße in Woldenberger Platz auf Anregung des aus Woldenberg/Nm., Kr. Friedeberg/Nm. (poln. Dobiegniew) vertriebenen Premnitzers Wolfgang Bornstädt (geb. 1936) (von 2007) und einstimmigen Beschluss der Stadtverordneten (offizieller Festakt mit Schild-Enthüllung durch Bürgermeister Roy Wallenta [parteilos] u. Initiator E. Bornstädt am 12.11. vor 80 Zuschauern) (BR 8 (2010)12, S. 8-9; Bernd Geske: Woldenberger Platz ist eingeweiht. In: MAZ, Westhavelländer, 13./14.11.2000, S. 13). „Der Woldenberger Platz in Premnitz trägt bis zum heutigen Tag die einzige Ortsbezeichnung im Westhavelland, die an Flucht und Vertreibung am Ende des Zweiten Weltkriegs erinnert.“ (Märkische Allgemeine, 14.6.2013). „Es gebe keine Zahlen, hatte Bürgermeister Roy Wallenta vor der Enthüllung des Namensschildes gesagt, doch nach seinem gefühlten Erleben hätten bis zu 30 Prozent der Premnitzer einen persönlichen Hintergrund, der auf Flucht und Vertreibung zurück gehe." (ebd.). - Am Straßenschild befindet sich eine Erläuterungstafel: „Woldenberg/Neumark, heute Dobiegniew (Republik Polen)/12-14 Millionen Deutsche und deutschstämmige Angehörige verschiedener Staaten wurden im Ergebnis des zweiten Weltkrieges aus ihrer angestammten Heimat vertrieben. Auch in Premnitz fanden viele Vertriebene eine neue Heimat. Vertreibungen von Menschen sind ein Unrecht, das bis heute in vielen Teilen der Welt geschieht." (Simone Weber: Zeitzeugen werden immer weniger [mit Foto]. In: moz.de, 21.6.2017 [16.6.2018]). - In der Gegend des Woldenberger Platzes stand ein Teil der nach Kriegsende von Vertriebenen bewohnten Baracken (BR 8 (2010)12, S. 10).

Archivalische Quellen: BLHA, Rep. 206 Ministerium für Wirtschaft und Arbeit, Nr. 2997, Nr. 3036. - Bildarchiv Preußischer Kulturbesitz (bpk), Berlin: Fotoserie (6 Bilder) von Herbert Hensky: Baracken als Notunterkünfte für Vertriebene neben dem Chemiefaserwerk Premnitz, Okt. 1949.

Gedruckte Quellen und Literatur: Gebietsverband Rathenow des BdV beging „Tag der Vertreibung“. In: BR 15 (2017) 8, S. 11. - Borgmann, Lutz / Sebastian, Jürgen: Kirchen im Havelland. Potsdam 1994, S. 55. - Bornstädt, Wolfgang: Erinnerungen an die Flucht aus Woldenberg und den Neuanfang in Premnitz. In: Die letzten Tage im Krieg und die ersten Wochen im Frieden in der Region um Rathenow. T. 3. Hrsg.: Rathenower Heimatbund e. V. 2., unveränd. Aufl. Rathenow 2018 (1. Aufl. 2015), S. 14-54. - Brühe, Matthias: Katholische Kirche zwischen Prignitz und 
Havelland. Berlin 2000, S. 42. - Mai, Jürgen: Die Situation der Flüchtlinge in der Region am Beispiel von Premnitz. In: Die letzten Tage im Krieg und die ersten Wochen im Frieden in der Region um Rathenow. T. 3. Hrsg.: Rathenower Heimatbund e. V. 2., unveränd. Aufl. Rathenow 2018 (1. Aufl. 2015), S. 4-8. - Ders.: Neubeginn im Premnitzer Werk. In: ebd., S. 9-10 [Kunstseidenwerk]. - Nitschke, Johannes: 150 Jahre Pfarrkirche „Heilige Dreifaltigkeit“ Brandenburg an der Havel. Brandenburg an der Havel [2001], S. 31. - Oehlsen, S. 29 (Abb. 7 „Baracken als Notunterkünfte für Vertriebene in Premnitz 1949“). - Premnitz. Jahrzehnte im Rückblick. 2. Aufl. Horb am Neckar 2010. - Schwillus/ Brühe, S. 346.

\section{Prenzlau}

Stadtgemeinde (Kreissitz), bis 1952 Kr. Prenzlau, 1952-1990 Kr. Prenzlau (Bez. Neubrandenburg), 1990-1993 Ldkr. Prenzlau, 1993 Ldkr. Uckermark

EREIGNisse vor 1939: „Auf dem Prenzlauer Friedhof befindet sich ein Grabstein, der auf das Schicksal der Wolgadeutschen aufmerksam macht. Er trägt die Inschrift: ,Hier ruhen drei Erwachsene und 66 Kinder - Wolgadeutsche, verstorben auf dem Treck 1928 bis 1933'. [...] In Deutschland wurden die Aussiedler [aus der Sowjetunion] vorläufig in drei Lagern untergebracht, in Hammerstein, in Mölln und in Prenzlau. In Prenzlau brachte man so 1800 Wolgadeutsche in der ein Jahr zuvor freigezogenen Roten Kaserne unter. Die Entbehrungen der langen Reise forderten Opfer. 66 Kinder und 3 Erwachsene verstarben. Sie wurden in einem Massengrab auf dem Prenzlauer Friedhof beigeetzt." (Theil, Stadtlexikon, S. 210).

EREIGNISSE BIS KRIEGSENDE: 1940-1945 Unterbringung von altersheimbedürftigen Umsiedlern aus Lettland und Estland"u. a. in der Pflegeanstalt Prenzlau (Fürsorge und Wohlfahrtspflege, S. 62). - 1944 halten sich bereits zahlreiche Flüchtlinge in der Stadt auf (Theil, Stadtlexikon, S. 300). - [Im Krieg:] „große Masern-Epidemie in der Kaserne Grabowstraße, wo eine große Zahl Umsiedler mit vielen Kindern untergebracht waren und eine erschreckende Sterblichkeit herrschte." (Ohnesorge, S. 342). - 20.1.1945 Evakuierung der Kreisverwaltung Eichenbrück (Wongrowitz) aus dem Reichsgau Wartheland mit dem Ziel Prenzlau, Übergabe des Verwaltungsgutes an das Landratsamt Prenzlau, dann aber auch $\rightarrow$ Templin (Nebelung, S. 89). - (Ende Jan./ Anf. Febr. 1945: „Durch die Uckermark und die Stadt Prenzlau ziehen in ständig zunehmendem Strom Flüchtlingstrecks aus Ost-, Westpreußen und Pommern.“ (Chronik, S. 473), ab Jan. Flüchtlingstrecks, die „ununterbrochen durch die Stadt rollten oder bei Einbruch der Dunkelheit anhielten, um warme Getränke und Reinigungsmöglichkeuten zu suchen" (Ohnesorge, S. 342), Kreiskrankenhaus überfüllt (ebd., S. 343). Jan. bis März 1945 Todesfälle von Flüchtlingen aus dem „Warthegau“ (darunter auch Deutschbalten), ab 1.2.1945 auch aus Ostpreußen, ab 15.2. auch aus Hinterpommern (Kr. Pyritz, Greifenhagen, Saatzig), im März auch aus Küstrin, in Prenzlauer Flüchtlingslagern (s.u.) und zahlreich im Kreiskrankenhaus, hier auch von evakuierten Berlinern, sowie in der Brandenburgischen Pflegeanstalt (Hermann-Göring-Straße 2) (Stadtarchiv Prenzlau, Standesamt Prenzlau, Sterberegister 1945); 5.2.1945 (nachts 1 Uhr) Tod einer 80-jährigen Flüchtlingsfrau aus Ostpreußen auf dem Hauptbahnhof an Altersschwäche (Nr. 116) und 
(8 Uhr) einer 86-Jährigen Flüchtlingsfrau aus Westpreußen („mit Flüchtlingszug hier angekommen") „im Durchgangsraum auf dem Hauptbahnhof" an "Schlagaderverhärtung, Kreislaufschwäche“ (Nr. 127); 6.2.1945 Zwei Totgeburten von Flüchtlingskindern im Kreiskrankenhaus (Nr. 131, 132). - 12.2.1945 Beurkundung des am 10.2. „auf dem Wagen im Flüchtlingstreck unbekannten Orts" eingetretenen Todesfalls einer 35-jährigen Flüchtlingsfrau aus dem Kr. Zempelburg (Nr. 149), 14./16./17./19./21./24.2. und 2./3./4./6./7./10./13.3. weitere gleichartige Fälle (meist aus „Warthegau“ bzw. Posen und Westpreußen, 28.2. auch Ostpreußen, im März auch aus Hinterpommern) vom 12., 13., 15., 19., 21., 22., 23. und 28.2. und 1./2./4./5./6.3. beurkundet, teilweise später genauere Angaben in Nachträgen oder beim zuständigen Standesamt I in Berlin beurkundet (ebd., Nr. 163, 174, 176 [„,in der Nähe von Schmölln“], 179, 180 [„Prenzlau, Brüssower Chaussee 6“], 181, 183, 191, 210 [„auf dem Kraftwagen im Flüchtlingstreck in der Nähe von Stettin“], 229 [Edmund Metschulat, „wohnhaft in Beijewonnen in Litauen“, 8 Monate alt, „auf einem Wagen im Flüchtlingstreck unbekannten Orts", Geburtsdatum, -ort und Eltern unbekannt], 230, 231, 232, 267 [Ostpreuße, „auf einem Wagen im Flüchtlingstreck vor Prenzlau“], 269, 278 [aus Kr. Labiau], 284 [Säugling, aus Kr. Elbing], 301, 302 [Kleinkind aus Kr. Thorn an „Brechdurchfall" am 2.2. „bei Schmölln auf einem Treckwagen"], 303, 309 [70 Jahre alt, aus Kr. Saatzig, 5.3. „im Treckwagen durch Fliegerbeschuß gefallen“], 311 [14 Jahre alt, aus Kr. Tilsit-Ragnit, 5.3. „auf dem Treckwagen auf der Reichsautobahn bei Altdamm"], 219 [7.3., 73-jähriger Bauer aus Kr. Naugard, „im Treckwagen vor Prenzlau“]), 323 [5.3.73-jährig, aus Kr. Preußisch Eylau, „in Wollin Kreis Prenzlau im Treckwagen“, „Starker Darmkatarrh mit Kreislaufschwäche“], 347). - 15.2.1945 Tod einer „etwa 70 Jahre“ alten unbekannten Flüchtlingsfrau „in Prenzlau in der Nähe der Eisenbahnbrücke an der Angermünder Straße auf einem Flüchtlings-Treckwagen " [angegebene Todesursache: „Altersschwäche“] (ebd., Nr. 225). - 20.2.1945 nachmittags (Tagebuch einer Flüchtlingsfrau aus Küstrin, geb. 1909): „Wir sind zum, Mansfeld Werk' geführt worden. In der großen Betriebshalle wurden wir das erste Mal bewirtet. In drei großen Hallen wurden wir Flüchtlinge aufgeteilt. [...]. Die [S. 37] Arbeitsmaiden bewirteten uns freundlichst. Es gab eine Brotsuppe und zwei Scheiben Brot. Zur Quartiervergabe kam es erst am nächten Tag. Schlafen wir auf Stühlen - ist egal - gewohnt sind wir es ja. Um 17 Uhr hatten wir Fliegeralarm. Doch bei dem Stimmengewirr haben wir wenig gehört. Trotzdem blieben wir in der Halle." (Ammon, S. 36f.). - 20.2.1945 (23 Uhr) Tod eines 5 Monate alten Flüchtlingskindes aus dem Kr. Graudenz „in Prenzlau, Hermann-Göring-Straße, auf dem Treckwagen“ [Todesursache „Brechdurchfall“ durchgestrichen] (Stadtarchiv Prenzlau, Standesamt Prenzlau, Sterberegister 1945, Nr. 207). - 21.2.1945 (Tagebuch einer Flüchtlingsfrau aus Küstrin): „Heute gingen wir in die Stadt, um etwas einzukaufen. Es gab so wenig wie bei uns. Brötchen gab es auch nicht mehr. Mit Wurst usw. sah es auch mies aus. In der Stadt hoben sie schon Panzergräben [...] aus. Es war ein großes Treiben in der Stadt. Trecks und Flüchtlinge belebten sämtliche Straßen. [...]." (Ammon, S. 37). - 28.2.1945 Tod des ersten bessarabiendeutschen Flüchtlings aus Kr. Schwetz im Kreiskrankenhaus, 67-jährig an „Erfrierung der Füße, Lungenentzündung“ (Stadtarchiv Prenzlau, Standesamt Prenzlau, Sterberegister 1945, Nr. 283). - 19.4.1945 erster Bombenangriff (Chronik, S. 475). - 25.4.1945 morgens 4.00 Uhr schwerer Bombenangriff; nachmittags Aufruf 
der NSDAP-Kreisleitung zum Verlassen der Stadt „strahlenförmig nach Westen“ (Handzettel und Lautsprecherdurchsagen), Massenflucht der Bevölkerung über Berliner Chaussee u. Neubrandenburger Straße nach Westen (ebd., S. 476; Zimmermann, S. 14; Engler, S. 275). - 25.4.1945 (Tagebuch Fähnrich z. S. Peter Meyer-Ranke): „Morgens am 25. April waren wir in Prenzlau, einer ausgestorbenen Stadt, die zwei Tage später von den Russen besetzt wurde. Wir fuhren gleich zum Bahnhof, das große Lazarett war schon geräumt. Dort stand ein Lazarettzug, das heißt sechs Viehwagen und acht alte Personenwagen 3. Klasse. Der Zug hätte eigentlich am Abend vorher abfahren sollen, doch es kam keine Lok.“ (Kempowski, Echolot, S. 121). - 27.4.1945 Einmarsch der Roten Armee. „Nach Erlöschen der Feuersbrünste ist Prenzlau zu etwa 85 \% zerstört.“ (Chronik, S. 477 f.; vgl. Drewes). - 28.4.1945 Rückkehr der in die umgebenden Waldgebiete geflohenen Einwohner. „Die Innenstadt ist unpassierbar." (ebd., S. 478).

Ereignisse NACH Kriegsende: Aug./Sept. 1945 Typhusepidemie (Wille I, S.421).17.8.1945 Todesfall einer 71-jährigen Flüchtlingsfrau aus Königsberg/Nm. in Prenzlau (Krätzner, S. 25, nach Angaben in der „Heimatkartei“).- 22.10.1945 „Feldberg in Mecklenburg ist der Aufnahmepunkt von Prenzlau [d.h. für nach Prenzlau gehende Vertriebenentransporte]." (BArch, DO 2/39, Bl. 10). - 1949: „Volkssolidarität und DFD richten in der Bergstraße 10a ein Waisenheim für 40 Kinder ein.“ (Theil, Stadtlexikon, S. 307). - „Immerhin fiel Vertretern des DDR-Innenministeriums noch 1960 negativ auf, dass das überwiegend aus Vertriebenen bestehende Evangelische Frauenwerk des Kreises Prenzlau sich noch immer mit Themen wie „Schlesien einst und jetzt“ oder „Die Zukunft gehört uns beschäftigte." (Schwartz, Vertriebene, S. 568 f., hier nach Engler, S. 275 f.).

EREIGNISSE NACH 1990: Einweihung einer Gedenktafel (s. u.).

BEVÖLKERUNGSZAHLEN: 1925: 21 565, 1939: 26858, Juni 1945: 11323, 1946: 17 669, 1964: 20368 (Städtebuch, S. 419). - 1944 halten sich, „nachdem hier bereits zahlreiche Flüchtlinge ankamen, fast 30000 Personen in Prenzlau auf.“ (Theil, Stadtlexikon, S. 300). - Anf. Mai 1945 „nur noch 500 Einwohner vorhanden“ (ebd.). - 16.5.1945: 8104 (ebd., S. 301). - 27.12.1945: 16062, darunter 600 Flüchtlinge (Theil, Stadtlexikon, S. 303). - Aug. 1946: 17200, 1.1.1948: 19323 (Chronik, S. 481).

Katholiken: 1925: 930, 1946: 1176 (Städtebuch, S. 420). - [Nach 1945: „NNeben dem Wiederaufbau [der Maria-Magdalenen-Kirche] muß sich Pfarrer Herbert Fleischer [geb. 1904 Berlin] (1939-54) auch um etwa 3000 katholische Flüchtlinge kümmern, die zu den bisher 1500 Gemeindemitgliedern dazukommen. 1947 zählt er 1000 (!) Kinder im Religionsunterricht in der 1.-8. Klasse!“" (Brühe, S. 40; nahezu textidentisch in: Schwillus/Brühe, S. 345).

Flüchtlingslager Mansfeldwerke (im Norden der Stadt, östlich der Stettiner Straße): 21.1.1945 Tod einer 55-jährigen Flüchtlingsfrau aus Litzmannstadt [Lodz] im Lager (die Anzeigende, vmtl. die Tochter, weist sich durch „Ausweis der deutschen Volksliste“ aus) (Stadtarchiv Prenzlau, Standesamt Prenzlau, Sterberegister 1945, Nr. 70). 
FlÜCHTLINGSLAGER Lindenstrasse 791 (am Westrand der Altstadt): 26.1.1945 Tod eines 10 Monate alten Flüchtlingsjungen aus Leslau [Włocławek] im Lager, angezeigt durch die Mutter (Stadtarchiv Prenzlau, Standesamt Prenzlau, Sterberegister 1945, Nr. 76). - 1.2.1945 Tod eines 95-jährigen Flüchtlings aus Ostpreußen im Lager (ebd., Nr. 105). - 1.3.1945 Tod eines mit seiner Mutter im Lager untergebrachten Flüchtlingskleinkinds aus dem Kr. Angerburg im Kreiskrankenhaus an Bronchialasthma (Nr. 270). - 4.3.1945 Tod eines mit seiner Mutter im Lager untergebrachten Flüchtlingskinds aus dem Kr. Leipe im Kreiskrankenhaus an Meningitis tuberculosa (Nr. 293). - 7.3.1945 (8.30 Uhr) Tod eines 87-jährigen Flüchtlings aus dem Kr. Wehlau „auf dem Treckwagen vor dem Hause Lindenstraße 791“ („Die Anzeigende hat sich durch Trecklaufzettel ausgewiesen“) (Nr. 312). - Weitere Todesfälle von Flüchtlingen im Lager: 9.3.1945 (Nr. 327 [82 Jahre alt, aus Kr. Naugard]).

FlüChtlingslager Kreuzstrasse 18 (im westlichen Teil der Altstadt): 4./6./7./10./11./ 12./15./18./21./24./26./27./28.2. und 2./4./5./6./8./9./10./11./13./15./16.3.1945 Todesfälle von, meist alten, Flüchtlingen aus „Warthegau“bzw. Posen (u.a. aus Leslau [Włocławek]) und Westpreußen, ab 15.2. bis März auch aus Hinterpommern (Kr. Pyritz u. Greifenhagen), am 27.2. auch aus Küstrin, ab 2.3. auch aus Ostpreußen, im Lager (Stadtarchiv Prenzlau, Standesamt Prenzlau, Sterberegister 1945, Nr. 110 [gebürtig aus Narva/Estland], 121, 136, 143 [aus Altersheim Schneidemühl], 145, 154, 155, 173, 201, 220, 241, 250, 251, 255, 263 [94 Jahre alt], 277, 285, 300 [Frau aus Kr. Bromberg, 68 Jahre alt, an „Durchfall, Kreislaufversagen“], 307, 325, 326 [Bessarabiendeutsche aus Kr. Wirsitz], 329 [Russlanddeutsche (geb. in Alexandrowka) aus Rosenberg in Westpreußen], 330, 336, 337, 361, 378, 379). - Die genannten Sterbefälle werden beim Standesamt anfangs zumeist vom Hilfsschullehrer Karl Krüger, wohnhaft in Prenzlau (6./8.2.) angezeigt, ab 10.2. fast stets (außer wenn durch Verwandte des Verstorbenen) von der in Prenzlau wohnhaften Schülerin Hildegard Macknow (ausgewiesen durch Kennkarte), weshalb anzunehmen ist, dass sie selbst in der Lagerbetreuung eingesetzt oder Tochter des Lagerbetreuers war, denn am 26.2.1945 zeigt der Hilfsschullehrer Martin Macknow, wohnhaft in Prenzlau (Nr. 250), an (vmtl. ihr Vater), vom 27.2. bis 16.3. jedoch zumeist wieder Hildegard Macknow, am 2.3.1945 vorübergehend wieder Karl Krüger (Nr. 277).

FlüChtlingslager Klosterstrasse 28 (ehem. Logengebäude, April 1945 zerstört [Schicksale, Bd. 1, S. 131]; im westlichen Teil der Altstadt): Jan. 1945 Säuglings- u. Kleinkinderstation durch die NSV eingerichtet (Ohnesorge, S. 343). - 16./19./21./23./28.2. und 7./12./13./15.3.1945 Todesfälle von Flüchtlingen, meist alten Leuten und Säuglingen, vor allem aus dem „Warthegau“ bzw. Posen, ab 23.2. auch aus Ostpreußen, im März auch aus Hinterpommern, im Lager (Stadtarchiv Prenzlau, Standesamt Prenzlau, Sterberegister 1945, Nr. 189 [aus Netzekr.], 194 [aus Kr. Hohensalza], 209 [aus Kr. Alt-Burgund; anzeigender Ehemann „ausgewiesen durch Ausweis der deutschen Volksliste“], 217 [Säugling aus Kr. Deutsch Krone], 226 [desgl. aus Kr. Wirsitz], 227, 249 [aus Kr. Preußisch Holland], 268 [80-jährige Flüchtlingsfrau aus Kr. Altburgund an Kreislaufschwäche, offenbar kurz vor Aufnahme in das Lager: „in Prenz- 
lau, Klosterstraße 28 auf einem Treckwagen“], 321 [aus Kr. Samland], 359 [aus Kr. Cammin]), 376, 377). - Die genannten Sterbefälle werden beim Standesamt zumeist von der „Verwaltungsleiterin Marga Heimann, wohnhaft zur Zeit in Prenzlau“, angezeigt (ausgewiesen durch „Ausweis der Hitler-Jugend“), weshalb anzunehmen ist, dass sie die Lagerleiterin war. - 11.3.1945 Tod eines Flüchtlings im Flüchtlingslager Klosterstraße 27 (!) (Nr. 342).

FlÜCHTLINGSLAger NSV-Kindergarten Am UCKerSeE: 26.2.1945 Todesfälle von Flüchtlingen, meist alten Leuten und Säuglingen, vor allem aus dem „Warthegau“ bzw. Posen (Stadtarchiv Prenzlau, Standesamt Prenzlau, Sterberegister 1945, Nr. 252 [Säugling aus Kr. Neumark; Kindesvater „durch Ausweis der deutschen Volksliste ausgewiesen“]).

Flüchtlingslager Sternstrasse 583 (im südlichen Teil der Altstadt): 26.2.1945 Todesfälle von Flüchtlingen, meist alten Leuten und Säuglingen, vor allem aus dem „Warthegau“ bzw. Posen (Stadtarchiv Prenzlau, Standesamt Prenzlau, Sterberegister 1945, Nr. 265 [43-jähriger Flüchtling aus dem Kr. Dramburg, verstorben im Kreiskrankenhaus), 4.3.1945 Kleinkind aus Kr. Leipe (Nr. 583).

FlÜChtLINGSheim, Uckerwiek 813a (am Südrand der Altstadt): Innerhalb des 1927 geschlossenen, aber 1945 reaktivierten Städtischen Krankenhauses (Stadtkrankenhauses) im Dominikanerkloster befand sich von mindestens Januar bis November 1946 ein gesondertes „Flüchtlingsheim“ (1./2.1.1946 als „Flüchtlingskrankenhaus“ bezeichnet, als „Flüchtlingsheim“ am 14.1. und 17./18./25./28.2. und 11.3. und 16./24.4.1946 und 13./19.5. und 23.6. und 21.7. und 6.9. und 15./30.11. und gleichzeitig [außer 1./2./14.1. und 24.4. und 13.5. und 21.7. und 6.9. und 15.11.] auch als „Flüchtlingslager“ bezeichnet (Stadtarchiv Prenzlau, Standesamt Prenzlau, Sterberegister, Jg. 1946A, Nr. 21, 23, 71, 262, 272, 340, 341, 380, 547, 572, 582; Jg. 1946B, Nr. 678, 702, 803, 804, 848, 930, 1037, 1078). Hier verstarben in diesem Zeitraum zahllose Flüchtlinge, bei einigen von ihnen ist das Flüchtlingsheim auch als Wohnadresse (teilweise auch als „Pflegeheim“, ab 17.6.1946 auch als „Altersheim“ bezeichnet) angegeben, im Haus lebten aber auch einige Einheimische („Pflegeheim“).

StÄdtisches Pflegeheim: 3.3.1945 Todesfall einer 65-jährigen Rentnerin aus dem Kr. Randow (Stadtarchiv Prenzlau, Standesamt Prenzlau, Sterberegister).

FlüChtlingSlager Zuckerfabrik (Stettiner Vorstadt, westlich der Stettiner Straße, nördlich der Bahnhöfe): 8.3.1945 erster Todesfall (offenbar noch vor der Ausladung): 87-jähriger Flüchtling aus Hinterpommern, an „Alterschwäche“ in "Prenzlau, Zuckerfabrik im Treckwagen“ (Stadtarchiv Prenzlau, Standesamt Prenzlau, Sterberegister 1945B, Nr. 348). - 24.1. und 10./25./26.3. und 8.4.1946 Lager erwähnt (ebd., Jg. 1946A, Nr. 122, 365, 448, 458, 520).

Kreiskrankenhaus, Stettiner Straße 121 (nördlich der Altstadt in der Stettiner Vorstadt, 1927 eröffnet): Ab Jan. 1945 Aufnahme- u. Todesort zahlreicher Flüchtlinge (Näheres siehe oben Ereignisse bis Kriegsende); 20.4.1945 evakuiert (Gutzschebauch, S. 125). Nach Ein- 
marsch der Roten Armee (27.4.1945) von dieser beschlagnahmt. „Nach der Freigabe durch die durch Rote Armee musste das leergeräumte Krankenhaus wieder in Betrieb genommen werden. Mangels Betten dienten alte spendierte Matratzen und Strohsäcke den Patienten als Krankenlager. Zunächst wurde das Krankenhaus Seuchenkrankenhaus. Die Patienten wurden wegen Tuberkulose, Syphilis, Fleckfieber und Typhus behandelt.“ (ebd.). Unter den Ärzten befand sich „Dr. Stümke, der aus der Pommerschen Frauenklinik Stettin und der Frauenklinik Frau[e]ndorf flüchten musste, weil die nachrückenden Polen aus dem Osten die Kliniken vereinnahmten. Dr. Stümke gelang es, Instrumente, Verbrauchsmaterial, Wäsche und Medikamente nach Prenzlau mitzunehmen, unterstützt durch einen Offizier der Roten Armee. / Er verließ 1948 tief enttäuscht Prenzlau und ging nach Parchim [...]“ (ebd.). - Sehr viele Flüchtlinge, darunter solche aus dem Lager [ $\rightarrow$ Prenzlau-] Birkenhain bei Prenzlau und dem Lager Quenz bei $\rightarrow$ Brandenburg/Havel, verstarben 1946 im Kreiskrankenhaus (Stadtarchiv Prenzlau, Standesamt Prenzlau, Sterberegister, Jg. 1946).

Strassenumbenennungen: 5.5.1950 Stettiner Straße (zentrale Ausfallstraße nach Norden) und Baustraße in Leninstraße (Theil, Stadtlexikon, S. 180; Chronik, S. 484; Engler, S. 287), Baustraßenteil der Leninstraße 1964 in Georg-Littmann-Straße (Theil, Stettiner Straße, S. 149), 1992 komplette Rückbenennung in Stettiner Straße (ebd.).

StÄdtepartnerschaften: Juli 2010 Barlinek, Polen (Berlinchen, ehem. Kr. Soldin/Neumark, Provinz Brandenburg).

VertriebenenVerbände NACH 1990: BdV-Kreisverband Prenzlau e. V. (1996 erwähnt mit Sitz in Prenzlau, Diesterwegstr. 443; BdV-Handbuch 1996, S. 169) bzw. ab 1998 BdV-Kreisverband Uckermark e. V. (so erwähnt 1995/99 in Akten der BdV-Landesgeschäftsstelle), gegründet 1990; 5.7.1991 als BdV-Kreisverband Prenzlau e. V. Satzung errichtet, 9.7.1992 eingetragen als Bund der Vertriebenen Prenzlau e. V. mit Sitz Prenzlau beim Kreisgericht Prenzlau (VR 112). - 28.3.1995 1080 Mitglieder (ohne Angermünde/Schwedt), zahlende 1369; davon Altkreise: Angermünde: 500 zahlende; Schwedt: 200, Templin: 180 (insgesamt 280), Prenzlau: 489 (ingesamt 800) (Akten wie vor). - 3.9.1994 Großveranstaltung „Tag der Heimat“ in Prenzlau im Saal des neuen Kreishauses, Grabowstr. - Vorsitzende: 1991/92 Armin Rötche (geb. 1933), Schlosser in Schenkenberg; 26.8.1992 bis 2006: Gertrud Rothgänger, Prenzlau (geb. 1935) (Rötche nun 2. Stellvertreter) (Akten der BdV-Landesgeschäftsstelle), später vom BdV abgespalten (Austritt aus Landesverband 1.12.2002) und 2006 (Beschluss 18.2.) als vom BdV unabhängiger Verein „Heimatvertriebene in der Uckermark e.V.“ (HVU) (Sitz Prenzlau) neu gegründet (13.3.2006 beim Amtsgericht Prenzlau, VR 2585, als Fortsetzung [Rechtsnachfolger] eingetragen) (Akten der BdV-Landesgeschäftsstelle; Berliner Morgenpost, 17.1.2007); Schriftgut des HVU mit BdV-Kreisverbands-Vorakten im Stadtarchiv Prenzlau (Laufzeit 1990-2008).

Gedenktafel für die Opfer von Flucht und Vertreibung, auf dem Platz der Einheit an einer halbrunden Mauer in Blickrichtung Uckersee: Inschrift: „Vertreibung ist Unrecht./Die Opfer 
haben Anspruch darauf, / daß die Überlebenden ihr Vermächtnis/bewahren./Die Heimat bleibt unvergessen./BdV Uckermark." (Gedenkorte der Stadt Prenzlau; Mahn- und Gedenkstätten Mecklenburg-Vorpommern).

Archivalische Quellen: BArch, DO 2 ZVU, Nr. 39, Bl. 10, 41 (Umsiedlerlager, 1945). - Stadtarchiv Prenzlau, Standesamtsregister 1945-1946 (www.ancestry.de).

Gedruckte Quellen: Ammon, Margarete: Tagebuch. In: Gespräche mit ehemaligen Küstrinern. Bd. 6. Frankfurt (Oder) 2017, S. 29-50 (S. 36 f., 43 f.). - Dokumentation der Vertreibung I/1, S. 39, 190; I/2, S. 714, 839, 865. - Kempowski, Walter: Das Echolot. 2. Aufl. München 2005. - Drewes, Wilhelm: Einnahme, Zerstörung und Besetzung der Stadt Prenzlau durch die Sowjets am 27.04.1945. In: Mitteilungen des Uckermärkischen Geschichtsvereins zu Prenzlau 26 (2019), S. 159-163 [Zeitzeugenbericht, Verf. [1885-1967), war städt. Angestellter]. - Ohnesorge, Lena: Erinnerungen an das Medizinalwesen in Prenzlau vor 1945. In: Prenzlau. Barendorf 1984, S. 333-343. - Wiede, Walter: Wieder ein neues Ziel - Fürstenwerder -. Umsiedler 1945 unterwegs. In: ebd., S. 94-104, hier S. 95 [Aufenthalt im Flüchtlingslager Prenzlau Ende Sept. oder Anf., Okt. 1945]. - Wille I, S. 420-422.

LiteratuR: Brühe, Matthias: Katholische Kirche zwischen Uckermark und Oderland. Berlin 1998, 39-40. - Chronik der Stadt Prenzlau in Auszügen: 1945-1984. In: Prenzlau. Barendorf 1984, S. 473-500. - Engler, Harald: Das „sozialistische“ Prenzlau in der SBZ und der DDR (1945 bis 1990). In: Geschichte der Stadt Prenzlau. Horb am Neckar 2009, S. 274-339. - Fürsorge und Wohlfahrtspflege in Brandenburg (1800-1952). Hrsg. von Margot Beck. Berlin 2002. - Gedenkorte der Stadt Prenzlau. Projektleitung: Jörg Dittberner. (Prenzlau) o.J. - Grandke, Sarah: „Als die Füße nass und kalt waren, erkannte ich den Ernst der Lage." Flucht und Vertreibung 1944/45 und die schwierige Nachkriegszeit. Prenzlau 2008. 64 S. - Gutzschebauch, Jürgen: Das Krankenhaus Prenzlau feierte 90. Geburtstag. In: Heimatkalender Prenzlau 61 (2018), S. 123-133. - Krätzner, S. 25. - Mahn- und Gedenkstätten MecklenburgVorpommern. Hrsg.: BdV (www.bund-der-vertriebenen.de [10.10.2016]). - Nebelung, (Paul-Friedrich): Der Landkreis Eichenbrück (Wongrowitz) im Reichsgau Wartheland. in: Heimatbuch für den Kreis Eichenbrück-Wongrowitz. [Bd. 1]. Lüneburg [1967], S. 87-89. - Putz, Jakob: Wie aus Fremden Nachbarn wurden. Nachbarschaften zwischen Vertriebenen und Uckermärkern nach dem zweiten Weltkrieg. Wettbewerbsbeitrag (am Christa-und-Peter-ScherpfGymnasium Prenzlau) zum Thema: Vertraute Fremde - Nachbarn in der Geschichte. Prenzlau 2013 (www.uckermaerkischer-geschichtsverein.de/online-lesesaal) [Zeitzeugenbefragung]. - Schicksale deutscher Baudenkmale im Zweiten Weltkrieg. 2. Aufl. Bd. 1. Berlin [1980]. - Schwillus/Brühe, S. 345. - Theil, Jürgen: Prenzlauer Stadtlexikon und Geschichte in Daten. Prenzlau 2005. - Ders.: Die Stettiner Straße im Wandel der Zeit. In: Mitteilungen des Uckermärkischen Geschichtsvereins zu Prenzlau 26 (2019), S. 149-158. - Zimmermann, Wilhelm: Zehn Tage im April 1945. Die Zerstörung der Stadt Prenzlau im Zweiten Weltkrieg. Buchholz i. d. Nordheide 1992.

\section{Prenzlau-Birkenhain}

(Kreis-)Umsiedlerlager Birkenhain (Flüchtlingslager Birkenhain), im Prenzlauer Stadtforst (Große Heide), Flur 46, Flurstück 22/1: Durchgangs- und Quarantänelager, bestehend aus drei Baracken (bis Kriegsende von Wehrmacht und SS genutzt, u.a. ab 1943 Quartier für den Persönlichen Stab des Reichsführers SS Heinrich Himmler), ergänzt durch gegenüber liegendes „Hotel Birkenhain“, hier auch Sitz der Lagerverwaltung, etwa 600 LagerInsassen (Hacker, S. 33; Engler, S. 275 f.). - 18.10.1945 Einrichtung des Quarantänelagers „in dem alten SS-Lager Birkenhain“ im Gange, "Heißluft-Entlausungsanlage wird gebaut" (Wille I, S. 422). - Kapazität am 31.12.1945: 3000 (BArch, DO 2/45, Bl. 40). - Kapazität am 1.1.1946: 1000 (BLHA, Rep. 203 MdI, Nr. 1163, Bl. 49). - 9./11./21 2. und 2./9./10./11./20./27.3. und 
24.4. und 4.6. und 5.7.1946 „Flüchtlingslager Birkenhain“ als Aufenthaltsort (Wohnung) genannt bei Sterbefällen von Flüchtlingen im Kreiskrankenhaus Prenzlau (Stadtarchiv Prenzlau, Standesamt Prenzlau, Sterberegister, Jg. 1946A, Nr. 220, 224, 298, 344, 363, 372, 381, 382, 421, 446, 582, 742, 832), 16./17.3.1946 desgleichen als „Lager Birkenhain“ (ebd., Nr. 405, 407). 14.2.1946 Kreis- und Quarantänelager, Kapazität: 1500 (Oehlsen, S. 28). - 2.3.1946 Todesfall eines Lagerinsassen durch Flecktyphus im Kreiskrankenhaus (Stadtarchiv Prenzlau, Standesamt Prenzlau, Sterberegister, Jg. 1946A, Nr. 344). - 1946 Belegungsstärke: 1500 (Kaminsky, S. 159). - 30.4.1946 als eines der verbleibenden Umsiedlerlager genannt (DAB, I/9-15-1 Flüchtlingsseelsorge 1945-1951, unfol., [30.6.1946], [Anlage 3]). - 13.5.1946 Prüfungskommission bemängelt Unsauberkeit im Lager, mangelhafte Ausstattung und fehlende Ausrüstung, beantragt Beschaffung von 1000 Pritschen (,ursprünglich für 450 Personen eingerichtet“) (Hacker, S. 33); „unmenschliche hygienische Bedingungen im Lager, offenbar gab es keine Waschmöglichkeiten und auch keine Toiletten" (Engler, S. 275f.). - 20.6.1946 Flüchtlingstransport mit ca. 300 Personen eingetroffen (Hacker, S. 33). - 6.7.1946 Flüchtlingstransport mit ca. 220 Personen eingetroffen (Hacker, S. 33). - 24.7.1946 in Liste der Lager für „Ostheimkehrer“ genannt mit Kapazität 2000 (BArch, DO 2/45, Bl. 76). - Juli 1946 Verkauf einer „Baracke von 10 Meter" an eine Neubäuerin durch das Finanzamt Prenzlau (Hacker, S. 34). - 24.8.1946 Umsiedlerlager, Kapazität: 900 (SAPMO-BArch, DY 34/27880, Bl. 291). - 1.1.1947 Lager, Kapazität: 500 (Oehlsen, S. 101). - 1947 Schließung bevorstehend (SAPMO-BArch, DY 34/27745, B1. 92). - Aug. 1947 Lager aufgelöst, Weiternutzung der Baracken durch benachbartes Krankenhaus als Außenstelle (Hacker, S. 34, 36; Theil, S. 25). - „Die ,Himmlerbaracke' überdauerte die Zeit und war Flüchtlingslager, Tbc-Baracke, Kindergenesungsheim, Außenstation des Kreiskrankenhauses Prenzlau, Internat der Sonderschule, Quartier für den Aufbaustab des Armaturenwerks in Prenzlau, Wohnheim für vietnamesische Lehrlinge und in den 80er Jahren bis 1990 Kinderferienheim der Großbäckerei Pasewalk. 1991 wurde das Grundstück mit der Baracke an die Stadt Prenzlau rückübertragen. 1996 [1t. Hacker, S. 53: 1997 - P. B.] wurde die Baracke unter Denkmalschutz gestellt. 2004 wurde die Arbeitsgemeinschaft ,Historische Baracke Birkenhain im Uckermärkischen Geschichtsverein gegründet, um die Sicherung und spätere Nutzung der von den Häftlingen erbauten Baracke zu übernehmen." (Timm, S. 586).

Archivalische Quellen: BArch, DO 2 ZVU, Nr. 39, Bl. 10 (1945). - BLHA, Rep. 250 Landratsamt Prenzlau, Nr. 1085 („Berichte über die Lage des Kreises“, 1945-1949; enthält u. a.: „Bericht über das Umsiedlerlager Birkenhain“, 1947). - Stadtarchiv Prenzlau, Standesamtsregister 1945-1946 (www.ancestry.de).

Literatur: HOL VIII, S. 85 (ohne Erwähnung des Lagers). - Engler, Harald: Das „sozialistische“ Prenzlau in der SBZ und der DDR (1945 bis 1990). In: Geschichte der Stadt Prenzlau. Horb am Neckar 2009, S. 274-339, hier S. 275 f. - Hacker, Anne: Birkenhain als Flüchtlingslager. Die Baracke als eine Zwischenstation zum neuen Leben in der „Zwangsheimat“ Deutschland. In: Birkenhain. Ein historischer Ort. Autoren: Judith Drescher u. a. Hrsg.: Uckermärkischer Geschichtsverein zu Prenzlau e. V. Prenzlau 2007, S. 30-36. - Theil, Jürgen: Prenzlauer Stadtlexikon und Geschichte in Daten. Prenzlau 2005, S. 25. - Timm, Marion und Reinhard: (Außenlager) Prenzlau. In: Der Ort des Terrors. Hrsg. von Wolfgang Benz u. Barbara Distel. Bd. 4. München 2006, S. 585-587. - Wille I, S. 422. 


\section{Prenzlau-Bündigershof}

EREIGNISSE NACH KRIEgSENDE: In der Bodenreform 162 ha (von 227 ha) an 21 Umsiedler vergeben (HOL VIII, S. 160).

FLÜCHTLINGSLAGER: 17.2.1945 (Stunde unbekannt) Tod eines etwa 70 Jahre alten Flüchtlings aus Flatow im Lager an „Altersschwäche“ (Stadtarchiv Prenzlau, Standesamt Prenzlau, Sterberegister 1945, Nr. 228).

\section{Pritzerbe}

Stadtgemeinde, bis 1952 Kr. Westhavelland, 1952-1990 Kr. Brandenburg-Land (Bez. Potsdam), Kr. Westhavelland), 1990-1993 Ldkr. Brandenburg, 1993 Ldkr. Potsdam-Mittelmark

EREIGNISSE BIS KRIEGSENDE: 28.4.1945 Havelfähre von der Wehrmacht auf Grund gesetzt (Blasek, S. 31). - 2.5.1945 Einmarsch der Roten Armee (Das Havelland um Rathenow und Premnitz, S. 93).

EREIGNISSE NACH KRIEGSENDE: „Unmittelbar nach Kriegsende wird eine neue Fähre aufgebaut“ (Blasek, S. 31). - August 1947 als Mitglied des Wohnungsausschusses erwähnt: „Umsiedler Schrape“" (ebd., S. 50).

BevöLKerungszahlen: 1925: 1646, 1939: 1614, 1946: 1943, 1964: 1567 (Städtebuch, S. 427).

Katholiken: 1925: 28, 1946: 277 (Städtebuch, S. 427).

UMSIEDLERLAGER: Kapazität am 31.12.1945: 300 (BArch, DO 2/45, Bl. 40). - Kapazität am 1.1.1946: 250 (BLHA, Rep. 203 MdI, Nr. 1163, Bl. 50).

Literatur: Blasek, Willi: Chronik der Stadt Pritzerbe 948-1998. Pritzerbe 1998. - Das Havelland um Rathenow und Premnitz. Köln u. a. 2017.

\section{Pritzwalk}

Stadtgemeinde, bis 1952 Kr. Ostprignitz, 1952-1990 Kr. Pritzwalk (Bez. Potsdam), 1990-1993 Ldkr. Pritzwalk, 1993 Ldkr. Prignitz

EReignisse BIS KRIEgSende: 1943 Einquartierung des „Marien-Krankenhauses“ aus dem ausgebombten Hamburg in der Schule am Giesensdorfer Weg (Rehberg/Simon, S. 197). 31.1.1945: „Die ersten Flüchtlinge aus dem Osten - aus dem Kreise Meseritz - kommen mit der Bahn in Pritzwalk an.“ (Chronik Kuhsdorf, S. 129). - Anf. 1945 „befanden sich [in der Stadt] viele Frauen und Kinder, die aus den Ostgebieten flohen und hier eine vorläufige Bleibe erhielten“ (S. 136); „die Stadtverwaltung musste Quartiere für die zahlreichen Flüchtlinge und für 
Wehrmachtseinheiten bereitstellen." (ebd., S. 138). - 1945 wurde Pritzwalk als Evakuierungsort für Flüchtlinge aus Mogilno (Wartheland, ehem. Provinz Posen) vorgegeben (www.heimatkreis-mogilno.de [20.9.2016]). - 29.1.1945 Evakuierung des größten Teils der Bewohner von Politzig (Kr. Meseritz) mit der Eisenbahn nach Pritzwalk (Stadt und Kreis Meseritz. [Bd. 1], S. 145, 148). - Febr. 1945 Durchzug eines Trecks aus Filehne (Dokumentation der Vertreibung I/1, S. 378). - 15.4.1945 „Explosion auf dem Bahnhof, zahlreiche Opfer und weitreichende Zerstörungen Pritzwalks“ (Rehberg/Simon, S. 197). - „Viele Flüchtlinge waren bereits aus dem Osten hierher gekommen. Darunter die jüngste Schwester meiner Mutter mit drei Kindern aus Sorau, die sich nun auch hier im Hause aufhielten." (Hüning, S. 11). - 2.5.1945 Einmarsch der Roten Armee (Rosenbaum, S. 30).

EREIGNisse NACH Kriegsende: Laut Meldung des Bürgermeisters an den Landrat vom 6.6.1945 befinden sich in Pritzwalk 7196 Ortsansässige und 3402 Flüchtlinge, darunter „1 101 Erwachsene, 317 Kinder von 6-14, 124 Kinder von 3-6 und 156 Kinder unter 3 Jahren aus dem Osten“, „Gemeinschaftsverpflegungseinrichtungen sind vorhanden“; für die „Flüchtlingsdurchgangslager" wurde das Ausschussmitglied der KPD Olga Speich, Hausfrau aus Lodz, verantwortlich gemacht (Simon, S. 23). - Frühjahr 1946 Zuteilung eines halben Morgens Bodenreformland an der Straße nach Buchholz an „Umsiedler“, „vermutlich die spätere Gartenanlage“ (Rehberg/ Simon, S. 151; vgl. HOL I, S. 687 [ohne Zuordnung zu „Umsiedlern“]). - 1.7.1947 Eröffnung des von vertriebenen Unternehmern aus Meseritz wiedergegründeten Tiefbauunternehmens Friedrich und Georg Schulz im benachbarten Neu Krüssow (Kr. Ostprignitz; ab 1950 Wohnplatz von Wilmersdorf, mit diesem 2002 nach Pritzwalk eingemeindet). „Auf Anweisung von Partei und Regierung der DDR wurde der Familienbetrieb Schulz bei voller Auftragslage am 1.10.1958 zm VEB (K) Tiefbau Pritzwalk umfunktioniert." (Schulz, S. 29). - 1951 TomaszowerTreffen (von Vertriebenen aus Tomaszów Maz., Polen) mit Pfarrer Seeberg in Pritzwalk (Heimatbote. Mitteilungsblatt für die Glieder der Evangelisch-Augsburgischen Kirche ... 3/1951); Heinrich Seeberg (1907-1974) war bis Jan. 1945 der letzte deutsche Pfarrer im Kirchspiel Tomaschow (Mittelpolen) (Eduard Kneifel: Die evangelisch-augsburgischen Gemeinden in Polen 1555-1939. Vierkirchen [1971], S. 330) und vom 12.3.1945 bis 1969 Pfarrer in Brotterode bei Schmalkalden (Thüringen), von wo aus er auf der Grundlage einer „Kartei mit etwa 500 bis 600 Familien“ „1947-1955 Rundbriefe an die ehemaligen Gemeindemitglieder“ versandte. „Die Rundbriefe wurden 1955 durch die DDR-Regierung verboten, da sie als ,revanchsistisch“ bezeichnet wurden.“ (Art. „Seefeld, Heinrich Wilhelm“ von Stefan Balzer in: wiki.wolhynien. net [22.8.2018]).

EREIGNISSE NACH 1990: 1995 erstes eigenständig organisiertes Heimattreffen der Meseritzer und Birnbaumer in der Prignitz in Pritzwalk, 1997 zweites Treffen, 1999 erstmals mit einer Delegation des Heimatkreises Meseritz, danach abwechselnd mit dem sogenannten Großen Heimattreffen (in Paderborn) in $\rightarrow$ Perleberg (Heimatgruß Meseritz 173, 2005, S. 7) . - 6./7.6.1998 Kreistreffen der Kreisgemeinschaft Wehlau e.V. (Ostpreußen) im Hotel „Pritzwalker Hof“, Ha- 
velberger Straße 59 (Wehlauer Heimatbrief 59, 1998, S. 5, 56-58), 30.5.1999 desgleichen am selben Ort (Wehlauer Heimatbrief 60, 1999, S. 16f., 44).

BevöLKerungszahlen: 1925: 8478, 1939: 8923, 1946: 9416, 1964: 9874 (Städtebuch, S. 430).

Katholiken: 1925: 327, 1946: 606 (Städtebuch, S. 431). - Pfarrgemeinde: 1939: 500, 1953: 1900 (Brühe, S. 43). - Ab 1.7.1947 war der (1946 aus Swinemünde vertriebene) Pfarrer Kurt $\rightarrow$ Reuter in Pritzwalk Administrator, ab 1954 Kuratus; ab 15.10.1948 hatte er seinen Sitz im zu Pritzwalker Gemeinde gehörenden $\rightarrow$ Meyenburg und war dort „Flüchtlingspfarrer“ (1960 versetzt nach $\rightarrow$ Eberswalde).

FLÜCHTLINGSLAGER (Havelberger Straße 59): 1945/46 Flüchtlingslager Gaststätte Sengbusch (heute „Pritzwalker Hof “), Leiter 1945: Wilhelm Struck (Pritzwalker Heimatblätter 16, 2015, S. 23 mit Abb., 25 f.). - Als Flüchtlingslager erwähnt 4.9.1945 (Dutkowski/Lohkamp, S. 143).

GeHÖRLOSENSCHULE (Evakuierung): 21.1.1945 Eintreffen der am 20.1. evakuierten Gehörlosenschule Posen (Zugtransport: Kinder u. 11 Begleitpersonen): „In Pritzwalk war unsere Aufnahme in aller Eile vorbereitet worden. Zum Schlafen waren die Kinder in der Hilfsschule auf Stroh untergebracht. In einem, Lokal wurde ein Tagesraum zur Verfügung gestellt, in dem die Kinder essen und sich während des Tages aufhalten." (Tagebuch des stellv. Direktors, in Pelzer/Pelzer, S. 13). „Im Februar 1946 übernimmt das Land [Provinzialverwaltung] Brandenburg die Gehörlosenschule in Pritzwalk und besetzt freie Schülerstellen mit seinen Kindern.“ (ebd.). - Aug. 1946 mangels Weiterbildungsmöglichkeiten am Ort Verlegung als nunmehrige „Märkische Gehörlosenschule“ nach $\rightarrow$ Marquardt bei Potsdam (Pelzer/Pelzer, S. 13 f.).

StÄDtepartnerschaften: Nach 1973 Kontakte mit Kietrz, Polen (Katscher, Oberschlesien) (Trzcielińska-Polus, S. 538).

Vertriebenenverbände nach 1990: BdV-Kreisverband Pritzwalk, Sitz Pritzwalk, 1993 Hagenstr. 19 (Akten der BdV-Landesgeschäftsstelle), 1996 ebd. (BdV-Handbuch 1996, S. 169); 1990 als einer der ersten im Land Brandenburg gegründet von Herrn [Gerhard?] Stelter sen. u. Johanna Lichteblau (s.u.). 6.8.1990 erste Zusammenkunft in Pritzwalk (140 Teilnehmer), 3.9.1990 Wahlversammlung (220 Teilnehmer), 8.11.1990 zweite große Versammlung (230 Teilnehmer). „1992 nahm der Kreisverband Verbindung zur deutschen Minderheit in Pommern auf. Es wurde und werden regelmäßig Fahrten in die Heimat vorgenommen, dabei wurde der Kontakt zum Deutschen Freundeskreis in Sensburg (Masuren) und Breslau aufgenommen." Ab 1993 e. V. (Kreisbzw. Amtsgericht Perleberg, VR 119). „Im Jahr 1999 waren 560 Vertriebene im Kreisverband organisiert“. 28.10.2000 Festveranstaltung zum 10jährigen Bestehen im Hotel „Pritzwalker Hof“, Havelberger Str. 59 (Zitate nach: „Tag der Heimat“. 10-jähriges Bestehen des BdV-Kreisverbandes Pritzwalk. Potsdam (2000). [6] Bl.; Exemplar in Akten der BdV-Landesgeschäftsstelle); 2008 Sitz Gartenstr. 12. - 20.8.2006 293 Mitglieder, davon in Einzelgruppen: Brandenburg 63, 
Pommern 46, Ost- u. Westpreußen 51, Schlesien 47, „Warthe-Weichsel“ 68; 1.1.2008: 240 Mitglieder (Stadt Pritzwalk mit Dörfern 120, Amt Meyenburg 40, Amt Putlitz 45, Amt Groß Pankow 35, insgesamt 40 Dörfer); Altersstruktur: 43 bis 70 Jahre alt, 4771 bis 75 Jahre alt, 7076 bis 80 Jahre alt, 80 über 80 Jahre alt (Akten der BdV-Landesgeschäftsstelle). - 2011 Mitgliederversammlung mit 79 Teilnehmern (40 als krank gemeldet, 5 aus anderen Gründen abwesend) (ebd.). - 201370 Mitglieder (MAZ, 18.11.2013). - 2015 noch erwähnt (Akten wie vor). - Vorsitzende: 1990-2005 Johanna Lichteblau (geb. 1932 Schönau, Kr. Goldberg in Schlesien, gest. 2005, kath., 1947 vertrieben, kam nach Buchholz bei Pritzwalk, später Wirtschaftsleiterin des Kreiskrankenhauses Pritzwalk, 1993-2002 auch Vorstandsmitglied des BdV-Landesverbandes) (Nachruf mit Bild: BR 3 (2005)3, S. 36 f.; siehe auch ebd. 8 (2010)5, S. 20); ab 2005 zunächst zwei gleichberechtigte Vorsitzende: Siegfried Stelter (bis 2008), Pritzwalk (geb. 1939), u. Irmgard Langer (bis 2012), Gerdshagen OT Giesenshagen (geb. 1940); ab 2012 kommissarisch Ingrid Benn, Pritzwalk (geb. 1937) (Akten der BdV-Landesgeschäftsstelle).

Strassenumbenennungen: Die nach 1918 geschaffenen Benennungen wie Danziger Straße und Thorner Straße wurden nach 1945 umbenannt (Runde, S. 18).

GedRUCKTE Quellen: Dokumentation der Vertreibung I/1, S. 378.

Literatur: Brühe, Matthias: Katholische Kirche zwischen Prignitz und Havelland. Berlin 2000, S. 43. - Chronik der Pfarre zu Kuhsdorf. Transkribiert und vervielfältigt von Agnes u. Henning v. Kopp-Colomb. Haltern 2008, S. 129. Dokumentation der Vertreibung I/1, S. 378. - Dutkowski, Ilse / Lohkamp, Giesela: Die große und die kleine Katastrophe 1945. In: Pritzwalker Heimatblätter 15 (2013), S. 143-144. [Explosion am Bahnhof 4.9.1945]. - Hüning, Ilse: Erlebnisbericht vom Kriegsende im April und Mai 1945. In: Pritzwalker Heimatblätter 16 (2015), S. 11-14 [nach Tagebuchaufzeichnungen]. - Pelzer, Rotraut / Pelzer, Susanne: Das Gehörlosenschulwesen der Provinz Brandenburg. In: Pritzwalker Heimatblätter 2 (1989), S. 12-14. - Rehberg, Rolf / Simon, Wolfgang: Illustrierte Geschichte Pritzwalks. Pritzwalk 2006. - Rosenbaum, Katja: Hasso Nädtke - Mit 14 im März 1945 in Pritzwalk. In: Pritzwalker Heimatblätter 16 (2015), S. 30-31. - Runde, Dorothea: Straßennamen Pritzwalks im Wandel der Zeit. In: Pritzwalker Heimatblätter 7 (1996), S. 12-21. - Schulz, Herybert: Die Obra - ein Nebenfluß der Warthe. Gründung des Tiefbauunternehmens Schulz. Neubeginn westlich der Oder. In: Heimatgruß. Zeitschrift für Mitglieder und Freunde des Heimatkreises Meseritz e. V. und der Heimatkreisgemeinschaft Birnbaum 196 (2011), S. 28-29. - Simon, Wolfgang: Folgen des Krieges - dargestellt anhand ausgewählter Beispiele. In: Pritzwalker Heimatblätter 16 (2015), S. 17-24. Stadt und Kreis Meseritz. [Bd. 1]. O. O. [1972]. - Trzcielińska-Polus.

\section{Putlitz}

Stadtgemeinde, bis 1952 Kr. Westprignitz, 1952-1990 Kr. Pritzwalk (Bez. Potsdam), 19901993 Ldkr. Pritzwalk, 1993 Ldkr. Prignitz

EREIGNISSE BIS KRIEGSENDE: „Im Verlauf des 2. WK Aufnahme von Bombengeschädigten aus Hamburg u. Flüchtlingen aus Ostgebieten“ (Städtebuch, S. 435). - [April 1945]: „Die vermehrt durchziehenden Trecks der Flüchtlinge und Soldaten in Richtung Elbe zeigten an, dass das Ende des Krieges bevorstand. Putlitz war übervölkert. Die Einwohnerzahl hatte sich von etwa 2100 Bewohnern auf ca. 3800 erhöht, nahezu das Doppelte der Einwohnerzahl vor dem Kriege.“ 
(Köhler/Dannehl, S. 41; ähnlich Köhler, S. 145). - 3.5.1945 Einmarsch der Roten Armee; Erschießung einer sechsköpfigen Flüchtlingsfamilie in einem Haus in der Perleberger Straße. „Der Tod dieser Flüchtlinge wurde später standesamtlich auf den 3. Mai 1945 datiert. Die sechs erwachsenen Toten wurden in Decken gehüllt und ohne Begräbniszeremonie auf dem Friedhof bestattet. / Erst nach der Wende, im Jahr 2009, erfuhren wir durch flugbegeisterte Kölner, die in Putlitz weilten, dass jene Flüchtlingsfamilie zu einem Dr. Eichenberger (Jahrgang 1897) gehörte, der im Ersten Weltkriege einen der wenigen Zeppeline gefolgen hatte, schwer verwundet worden war und vom Kaiser 1917 höchste Auszeichnungen erhalten hatte." (Köhler/Dannehl, S. 41).

BevöLKerungszahlen: 1925: 2095, 1939: 2069, 1946: 2763, 1964: 2337 (Städtebuch, S. 435).

Katholiken: 1925: 51, 1946: 120 (Städtebuch, S. 435 f.).

Gedruckte Quellen und Literatur: Köhler, Christel: Putlitz bei Kriegsende 1945. In: Pritzwalker Heimatblätter 15 (2013), S. 145-148. - Dies. / Dannehl, Herbert: Putlitz am Ende des Zweiten Weltkrieges. In: Pritzwalker Heimatblätter 16 (2015), S. 40-42. - Wirtschafts-Wegweiser für Wittenberge und die Kreise West- und Ostprignitz. Branchen-Adreßbuch. Potsdam (1949), S. XIIf. (Dienststellen der Stadt), 49-134 (Firmen).

\section{Quenz-Lager $\rightarrow$ Brandenburg an der Havel (Stadt)}

\section{Radensdorf (Lausitz)}

Landgemeinde (seit 1993 Ortsteil von $\rightarrow$ Lübben), bis 1952 Kr. Lübben, 1952-1990 Kr. Lübben (Bez. Cottbus), 1990-1993 Ldkr. Lübben, 1993 Ldkr. Dahme-Spreewald

Bevölkerungszahlen: 1925: 476, 1933: 438, 1939: 423, 1950: 566, 1946: 573, 1964: 419 (HGV LDS, S. 22 f.). - 1.5.1946: 526, davon 377 Ortsansässige, 149 „Umsiedler“ (Becken, S. 33).

LiterAtUR: Mietk, Thomas: Als alles zu Ende war. Nachkriegsjahre in Radensdorf. In: Lübbener Heimatkalender 2016, S. 102-111.

\section{Radensleben}

Landgemeinde (seit 1993 Ortsteil von $\rightarrow$ Neuruppin), bis 1952 Kr. Ruppin, 1952-1990 Kr. Neuruppin (Bez. Potsdam), 1993 Ldkr. Ostprignitz-Ruppin

EReignisse BIS KRIEgSende: Febr. 1945 Zwischenstation eines Trecks aus Filehne: „Wir bekamen saubere Privatquartiere und durften über Sonnabend-Sonntag dort bleiben. Schon der Empfang in dem Dorf war sehr nett." (Dokumentation der Vertreibung I/1, S. 378).

BevöLKeRUngSZAHLEN: 1925: 536, 1939: 431, 1946: 712, 1964: 628 (HOL II, S. 205). 


\section{Ragösen}

Landgemeinde (seit 2002 Ortsteil von (Bad) Belzig), bis 1952 Kr. Zauch-Belzig, 1952-1990 Kr. Belzig (Bez. Potsdam), 1990-1993 Ldkr. Belzig, 1993 Ldkr. Potsdam-Mittelmark

EREIGNISSE BIS KRIEgSENDE: 2.5.1945 Einmarsch der Roten Armee (Ragösen, S. 6).

EReignisse NACH KriegSende: Aug. 1945: In „einem großen Hause am Bahnhof sind die Mieter durchweg Vertriebene“, die keine Miete zahlen können (Ragösen, S. 19). - Febr. 1946: Der Antifa-Ausschuss befasst sich mit der „Frage der unterernährten Flüchtlingskinder“ (ebd., S. 19f.). - Suppenküche: „im Pfarrhaus wurde eine warme Mahlzeit zubereitet, welche an die Flüchtlingskinder ausgegeben wurde“ (ebd., S. 39). - „1947 lebten etwa 400 Personen hier im Ort, die ihre Heimat im Osten [...] verlassen mussten. [...] Einige blieben hier, fanden auch bald Arbeit und bescheidenen Wohnraum. Einige heirateten hier und lebten sich so allmählich in die neue Heimat ein, die sie gezwungen waren zu akzeptieren. [... .“ (ebd., S. 54).

Bevölkerungszahlen: 1925: 827, 1939: 803, 1946: 1045, 1964: 827 (HOL V, S. 350). „Nach Kriegsende 1945 stieg die Einwohnerzahl Ragösens durch den Zustrom heimatlos gewordener Menschen auf 1 100.“ (Wikipedia, 17.1.2017).

Katholiken: „1945 kamen mit den Flüchtlingstrecks auch viele Bürger, die katholischen Glaubens waren (meist aus dem Sudetenland). Unter den Vertriebenen war ein katholischer Pfarrer, der im Haus des Kaufmanns Spiesecke wohnte. Es wurde durch Vereinbarungen beider Pfarrer möglich, dass am Sonntag nach dem evangelischen Gottesdienst auch eine katholische Messe zelebriert werden konnte. Auch katholische Taufen und Eheschließungen fanden in der [evangelischen] Kirche statt.“ (Ragösen, S. 41). - In Ragösen, Bahnhofstr. 1, lebte 1949 der dem Bistum Erzbistum Breslau angehörende, vor 1945 in Berzdorf ([Kr. Strehlen], Schlesien) wirkende Pfarrer Bruno Glomptner (geb. 1906 Oppersdorf, Kr. Neisse) (Schematismus Berlin 1949, S. 141; Ostpriesterverzeichnis 2, 1949, S. 28)

LiteRATUR: Ragösen. Beiträge zur Geschichte. T. 2: 1945 bis 1991. Ragösen 2002, S. 19f., 39, 41, 54 („Vom Schicksal der Flüchtlinge“).

\section{Rangsdorf}

Landgemeinde, bis 1952 Kr. Teltow, 1952-1990 Kr. Zossen (Bez. Potsdam), 1990-1993 Ldkr. Zossen, 1993 Ldkr. Teltow-Fläming

EREIGNISSE NACH KRIEGSENDE: 1945: „Einrichtung eines Notkrankenhauses zur Vermeidung von Seuchen im heutigen Volkshaus in der Seebadstraße, 1946 Verlegung in das jetzige Gebäude des Rates der Gemeinde.“ (600 Jahre Rangsdorf, S. 54). - „Sorgen bereitete auch die Unterbringung der Umsiedler und der ausgebombten Berliner, die in Rangsdorf Zuflucht gesucht 
hatten. Freistehende Häuser geflohener Mitglieder der Nazipartei sowie alle brauchbaren Lauben wurden belegt, unterbesetzte Räume neu verteilt.“ (ebd., S. 33).

BeVÖLKeRUngSzAHLEN: 1925: 462, 1939: 4 120, 1946: 4922, 1964: 5377 (HOL IV, S. 225).

Katholiken: „Zum 1.11.1945 wurde der heimatvertriebene Schneidemühler Priester Albrecht Prause (1945-54) zum Lokalkalplan ernannt, er bezog eine Wohnung in der Goethestr. 3b. Für die Namensgebung der Kapelle sorgte Pfr. Albert Haucke von der Muttergemeinde $[\rightarrow$ ] Zossen, als 1954-57 Paulus Henzel in Rangsdorf wirkte, der ein großes, von Vertriebenen mitgebrachtes Kreuz hatte anbringen lassen und sie daher Hl.-Kreuz-Kapelle nennen wollte. In dieser Zeit wurden etwa 450 Katholiken gezählt. [...].“ 1963 Kuratie (Brühe, S. 36). - Albrecht Prause (geb. 1910 Lissa) war vor 1945 Pfarrer in Groß Butzig, Kr. Flatow (Ostpriesterverzeichnis 2, 1949, S. 66; Schematismus Berlin 1949, S. 145).

Literatur: Brühe, Matthias: Katholische Kirche zwischen Havel und Dahme. Berlin 1999, S. 36. - 600 Jahre Rangsdorf. Rangsdorf [1975].

\section{Rathenow}

Stadtgemeinde (Kreissitz), 1925-1950 kreisfreie Stadt (mit Sitz des Landratsamtes Westhavelland), 1.7.1950-1952 Kr. Westhavelland, 1952-1990 Kr. Rathenow (Bez. Potsdam), 19901993 Ldkr. Rathenow, 1993 Ldkr. Havelland

EREIGNisSe BIS KRIEgSENDE: Febr. 1945: Rathenow wird zum Aufnahmegebiet für die zu evakuierende Bevölkerung der Stadt Posen und des Kreises Schieratz [Sieradz] (Wartheland) bestimmt (BLHA, Rep. 6 B Kreisverwaltung Züllichau-Schwiebus, Nr. 169, unfol.). - Im Febr. 1945 befand sich der Sitz der evakuierten Stadtsparkasse Schwiebus in Rathenow (ebd.).Vom 2. Febr. bis 26. April 1945 befand sich die Ausweichstelle der evakuierten Stadtsparkasse zu Mohrin (Kr. Königsberg/Nm.) in der Kreissparkasse Rathenow (Bein, S. 81-86). 11.3.1945: „Rathenow mit Flüchtlingen total überfüllt“ (Information für einen herannahenden Flüchtlingstreck, der deswegen in Richtung $\rightarrow$ Brandenburg/Havel weiterziehen sollte; nach Treckbericht in: Ein leidgeprüftes Land, S. 189). - 24.4.1945 (Tagebuch des Rathenower Superintendenten Heimerdinger): „Dienstag, den 24. April beginnt die Beschießung der Stadt Rathenow. In der Superintendentur waren außer mir und meiner Frau untergebracht: ein altes Ehepar aus Ostpreußen, Gerbig, mit gelähmter Tochter, die aus der Heimat Königsberg nach Lebus geflüchtet und dann hierher evakuiert waren. [...].“ (Heimerdinger, S. 2). - „In unserer Stadt befanden sich eine unübersehbar große Zahl von Rückwanderern und Flüchtlingen aus dem Osten. Am 25. April begann der sinnlose Kampf um Rathenow, der mit der Zerstörung unserer Innenstadt und ihrer Kulturgüter endete. Nie wird festzustellen sein, wie viele Menschen bei diesen Kämpfen umkamen.“ (Guthjahr, S. 57). - 25.4.1945: „Bewohner werden in den Wald getrieben, um die Kampflinie nicht zu behindern.“ (ebd., S. 77). - 4.5.1945 (Tagebuch Heimerdinger): „Am 4. Mai drangen die Russen in unseren Stadtteil und unser Haus ein und forderten sofortiges Verlassen 
der Wohnung. Mit einigen Gepäckstücken gingen wir nach Stechow [...].”! (Heimerdinger, S. 3). 6.5.1945 Einmarsch der Roten Armee (Das Havelland um Rathenow und Premnitz, S. 192). $90 \%$ der Innenstadt-Bebauung waren bei Kriegsende zerstört (ebd.). - „Rathenow war zu über $60 \%$ zerstört, von der Altstadt waren noch $10 \%$ erhalten geblieben." (Mewes, S. 33).

EREIGNISSE NACH KRIEGSENDE: „Nach und nach kehrte auch die geflohene und evakuierte Bevölkerung nach Rathenow zurück." (Mewes, S. 33). - 25.5.1945 (Tagebuch des Rathenower Superintendenten Heimerdinger): „Heute hatte ich 7 Beerdigungsfeiern zu halten. [...] Darunter war ein 14jähriges Mädchen aus der Schwabenkolonie am Dnjepr. Von dort im Treck nach Deutschland befördert, dann in Posen angesiedelt, jetzt hier untergebracht, an TBC gestorben und wie so viele den Strapazen erlegen. Der Vater schon 1937 in Russland verschleppt, ohne dass eine Kunde von ihm die Angehörigen erreichte." (Heimerdinger, S. 11). - 25.5.1945 (Tagebuch wie vor): „Heute trafen Heimkehrer aus Landsberg an der Warthe bei uns ein - mit Empfehlung meines Freundes Scharf, mit dem sie seit der Invasion und der Verdrängung aus seinem Haus bei Professor Borngräber zusammen gehaust haben, eine Mutter mit 9 Kindern und einer ländlichen Magd, alle aus Bonn am Rhein. Sie sind in 14 Tagen $180 \mathrm{~km}$ weit zu Fuß mit schwerem Handwagen hierher gezogen, von Kartoffeln lebend, in Scheunen nächtigend, aber alle gesund aussehend. Die Frauen freilich immer wieder von den Russen vergewaltigt.“ (ebd., S. 13). - 1.6.1945 (Tagebuch wie vor): „Die Beerdigungen nehmen nachträglich $z u$. Ich begleitete gestern 6 und heute 7 Personen zur letzten Ruhe, zum größeren Teil solche, die aus den Gärten oder aus dem Walde jetzt nach vier Wochen umgebettet wurden, an geweihter Stätte. Die [S. 13] Exhumierten mussten freilich in Massengräbern bestattet werden. [...].“ (ebd., S. 12 f.). - „Im Juni [1945] befanden sich noch 8600 Flüchtlinge aus Frankfurt/Oder, Lebus, Posen und Riga in der Stadt." (Rathenow. Chronik 1216-2007, S. 23). - 10.7.1945 (Tagebuch Heimerdinger, wie oben): „Infolge der Unterernährung grassiert eine epidemische Darmerkrankung, die [der!] meistens die alten und die kleinen Kinder massenweise zum Opfer fallen. Ebenso verheerend wirkt sich nachträglich die Flucht der Einwohner in die Wälder während oder nach der Beschießung aus. Die Alten haben die Kälte, Aufregung unf Überanstrengung in den Tagen der Flucht zunächst vielfach überstanden. Heimgekehrt kränkeln sie und starben dann nach einigen Wochen. Noch niemals soind bei uns sonntags so viele Abkündigungen von Verstorbenen verlesen worden, wie den letzten Wochen." (Heimerdinger, S. 17). - 13.7.1945 (Tagebuch wie vor): „Auf dem Hof der Polizeistelle liegen Hunderte von Flüchtlingen aus dem Sudetenland, die binnen 10 Min. zum Verlassen ihrer Wohnungen gezwungen wurden und seit dem von Ort zu Ort zogen - von einer Stadt zur anderen abgeschoben, weil diese auch ihre eigenen Einwohner nicht ernähren kann. Wohin? fragt sie mein Schwager, in den Hungertod sagt die Frau. Die Tschechei wird restlos von Deutschen gesäubert, ebenso unsere Ostprovinzen. In Liegnitz durften nur Facharbeiter zurückbleiben. [...].“ (ebd., S. 18) „Vor einigen Tagen hatte ich am Grab eines der vor 13 Jahren nach hier versetzten westpreußischen Siedler zu sprechen." (ebd., S. 19). - 30.7. und 9.9.1945 2 Todesfälle von Flüchtlingen/Vertriebenen (vermutlich Ehepaar) aus Königsberg/ Nm. in Rathenow (Krätzner, S. 23, nach Angaben in der „Heimatkartei“). - 1.9.1945 (Tagebuch Heimerdinger wie oben): „Der Typhus wälzt sich auf Rathenow zu, sagte mir gestern der Medizinalrat. So sind die vier apokalyptischen Reiter dann vollzählig: Krieg-Hunger-Seuche und Tod. Die Zahl 
der Todesopfer infolge Hungers wächst ständig. Seit 8 Wochen kein Fleisch und kein Fett und das bei dem [den!] bereits vorher ausgemergelten Körpern! Wie sollen die der Seuche widerstehen. Schon jetzt haben wir ständige Beerdigungen von den Typhus zum Opfer gefallenen." (Heimerdinger, S. 20). [1945/46] (Grundschule in Rathenow-West): „Die Schülerzahl wuchs durch die Kinder der Umsiedler, und so wurden viele Neulehrer eingestellt." (Otto-Seeger-Grundschule). - Der Lehrer (für Russisch und Geografie) Theodor Muchin (geb. 1918 Arzis/Bessarabien, gest. 2007), 1941 in den „Warthegau“ umgesiedelt, lebte nach Entlassung aus sowjetischer Kriegsgefangenschaft von 1948 bis zu seinem Tod in Rathenow (Biografie, verfasst von Heinz-Walter Knackmuß 2011, www.rathenow-fks.org [4.6.2017]). - „Das Jahr 1953 brachte keine spürbare Linderung der verheerenden Wohnungsnot. Wer noch glücklicher Besitzer einer eigenen Heimstatt war, bekam Untermieter zwangseingewiesen. Ganze Familien mußten dann in einem Zimmer zusammengepfercht leben, weil sie ihr Zuhause durch Kriegseinwirkung verloren hatten." (Guthjahr, S. 65). - „17.6. bis 25.6.1953 der Ausnahmezustand verhängt.“ (ebd., S. 67).

EREIGNISSE NACH 1990: 2003 Gedenksteineinweihung (s.u.).- 27.9.2008 „11. Ostdeutscher Kulturtag" des BdV-Landesverbandes Brandenburg in der Havellandhalle (Akten der BdVLandesgeschäftsstelle). - 8. bis 27.4.2014 Wanderausstellung „Fromme und tüchtige Leute ... Die deutschen Siedlungen in Bessarabien (1814-1940)" im Kulturzentrum Rathenow, konzipiert von PD Dr. Ute Schmidt (Berlin) u. Ulrich Baehr, 24.4.2014 Begleitveranstaltung (Film u. Gespräch) ebd. (Mitteilungsblatt des Bessarabiendeutschen Vereins 69, 2014, H. 4, S. 4).

BEVÖLKERUNGSZAHLEN: 1925: 27 588, 1939: 32 124, 1946: 28 974, 1964: 28961 (Städtebuch, S. 440). - Juli 1946: 2485 „Umsiedler“ (BLHA, Rep. 203 MdI, Nr. 1074, Bl. 52; Abb.: Mietk, S. 66). - 29.10.1946: 27566 Einwohner, davon aus Ostpreußen: 351, Hinterpommern 451, Ostbrandenburg 289, Schlesien 498, Tschechoslowakei 136, Polen 435, Danzig 99, Rumänien 49, Baltikum 438, Sowjetunion 31 (Volkszählung 1946). - 1946 „27934 Einwohner davon 3211 Umsiedler" (Rathenow. Chronik 1216-2007, S. 23). - 31.12.1948: Gesamtbevölkerung: 27 864, davon „Umsiedler und Evakuierte“: 3218 (Grandke, S. 46). - Eingemeindung von Vertriebenen: 30.4.1947: 2897 (Oehlsen, S. 102), Juni 1948: 12033 (ebd., S. 103), Febr. 1949: 3348 (ebd., S. 104).

Katholiken: 1925: 1001, 1946: 1910 (Städtebuch, S. 441). - Kuratie: 1928: etwa 1800 (Brühe, S. 44). - „Viele Heimatvertriebene suchten nach dem Krieg auch in Rathenow und den umliegenden Dörfern eine neue Heimat. Zwölf Außenstationen mussten eingerichtet werden." (Nitschke, S. 30).

Umsiedlerlager Magazininsel (Rathenow-West, von Havel und zwei Archen umflossen), ehem. Liegenschaft der Wehrmacht, Ende 1945 von den sowjetischen Besatzungsbehörden dem Kr. Westhavelland und der Stadt Rathenow zugesprochen (Blöß, Grenzen, S. 154), bis 1950 jedoch (als Teil der Gemeinde Neue Schleuse) zum Kr. Jerichow II im Land SachsenAnhalt gehörig, erst dann offiziell zum Kr. Westhavelland im Land Brandenburg gehörig (Blöß, 
Kreise und Gemeinden, S. 122) und erst 1952 offiziell als „Rathenow-West" nach Rathenow eingemeindet (Das Havelland um Rathenow und Premnitz, S. 193): „Als Ende 1945 „der Umsiedlerstrom immer größer und die Unterbringung der Menschen immer dringender geworden war, überließen die sowjetischen Stellen die Insel dem Landkreis Westhavelland und der Stadt Rathenow. Beide investierten daraufhin erhebliche Mittel in den Aufbau eines Auffanglagers für Umsiedler, es konnte am 1. Februar [!] 1947 eröffnet werden." (Blöß, Grenzen, S. 154). Kapazität am 31.12.1945: 2000 (BArch, DO 2/45, Bl. 40 [hier als Lager „Rathenow“ mit Fassungsvermögen 2000 beim Landkreis Westhavelland aufgeführt], Bl. 41 [hier als Lager „Rathenow-Magazinstr." (!) mit Fassungsvermögen 2000 beim Stadtkr. Rathenow aufgeführt; beide Lager sind aber offensichtlich identisch sein]). - Kapazität am 1.1. [!] 1946: 1800 (BLHA, Rep. 203 MdI, Nr. 1163, Bl. 49). - 14.2.1946 Kreis- und Quarantänelager „Magazininsel“, Kapazität: 1800 (Oehlsen, S. 28). - 1946 Belegungsstärke: 1500 (Kaminsky, S. 159). - 30.4.1946 als eines der verbleibenden Umsiedlerlager genannt (DAB, I/9-15-1 Flüchtlingsseelsorge 1945-1951, unfol., [30.6.1946], [Anlage 3]). - Anf. Aug. 1946 Ankunft eines Transports aus dem Sudetenland (u. a. eine Frau aus Böhmisch Leipa) am Bahnhof Rathenow Nord u. Fußmarsch „zum Quarantänelager auf der Magazininsel“, 16.8. geplante Einweisung nach Döberitz, Rückkehr ins Lager nach Aufnahmeverweigerung durch den Bürgermeister (Die letzten Tage, T. 3, S. 5). - 24.8.1946 Umsiedlerlager Rathenow, Kapazität: 1500 (SAPMO-BArch, DY 34/27880, Bl. 291). - 1946 beschließt die Gemeindevertretung von Neue Schleuse „auf Antrag ihrer SED-Fraktion einstimmig, dafür Sorge zu tragen, daß 200 in Neue Schleuse lebende Umsiedler auf der Magazin-Insel untergebracht werden“ (Blöß, Grenzen, S. 154). - 14.10.1946 Transport aus Namslau (Schlesien) im Lager Rathenow eingetroffen (amtlicher Bericht vom 16.10. siehe Quellenanhang Nr. 54; darin Lagerleiter Rückwald und Lagerarzt Stock erw.); Zeitzeugenbericht: „Dort wurden wir in großen Steinbaracken untergebracht. Die Verpflegung war hundsmiserabel. Unsere Mutter hatte einen Beutel mit Mehl dabei, so dass sie die Wassersuppe ein bißchen andicken konnte. Wir waren froh als die 14 Tage vorbei waren. Nun hieß es, auf zum Bahnhof. [...]." [Weitertransport nach $\rightarrow$ Rhinow] (Gospodarek, S. 50). - 1.1.1947 Kapazität: 1450 (Oehlsen, S. 101). - 1947 Schließung (SAPMO-BArch, DY 34/27745, Bl. 92). - „Nachdem es zum 1. Februar 1947 aufgelöst worden war, wurde die Insel zum Aufnahmeort für die der Stadt Rathenow zugewiesenen Umsiedler bestimmt, die in der zu 80 \% zerstörten Stadt kein menschenwürdiges Unterkommen finden konnten. Zu diesem Zweck sollten Wohnungen eingerichtet werden. Darüber hinaus nutzte die Konsumgenossenschaft Rathenow Lagerräume und betrieb eine Großbäckerei. [...].“ (Blöß, Grenzen, S. 154). - 3.6.1948 Besichtigung der Insel durch den sachsen-anhaltischen Ministerpräsidenten Hübener und den Landrat von Jerichow II, den Oberbürgermeister von Rathenow u. a.: „Unterdessen war die Bäckerei abgebrannt, und Rathenow hatte seine Absicht aufgegeben, in den zwar unversehrten, aber wenig geeigneten anderen Bauten auf der Insel Wohnungen für Umsiedler zu schaffen." (ebd., S. 155).

StÄdtepartnerschaften: (1) Nach 1973 Kontakte mit Kluczbork, Polen (Kreuzburg, Oberschlesien) (Trzcielińska-Polus, S. 538). - (2) 1991 Städtepartnerschaft mit Złotów, Po- 
len (Flatow, ehem. Provinz Westpreußen; 1938-1945 Provinz Pommern) (www.rathenow.de [25.8.2018]).

VeRTRIEBENENVERBÄNDE NACH 1990: (1) BdV-Kreisverband Rathenow e. V. (später [14.5.1996 bereits erwähnt] BdV-Gebietsverband Rathenow e. V.), 1990 gegründet, 16.4.1991 eingetragen beim Kreisgericht Rathenow (VR 200). Geschäftsstelle 1993 Schopenhauerstr. 11, 1996 erwähnt mit Sitz Berliner Str. 22 (BdV-Handbuch 1996, S. 169), 1.1.1997-1999 Forststr. 50 (im Gebäude des DRK), 2000-2005 Forststr. 44 (AWO-Haus), 2005-2010 Jahnstr. 4, 2010-2018 Jahnstr. 1 (Lutherhaus). - Mitgliederzahlen: „Mitte der 1990er Jahre hatte er 250 Mitglieder. Heute sind es nur noch 130, viele von ihnen sind 65 Jahre und älter." (BR 11 (2013) 6, S. 5). Ende 1998 260 voll zahlende Mitglieder u. 6 Neuaufnahmen, insgesamt 266; Aug. 2006: 191; 31.12.2017: 77 (Akten der BdV-Landesgeschäftsstelle). - Begeht jährlich „Tag der Heimat“ im Lutherhaus der Evang. Kirchengemeinde, Jahnstraße 1 (u.a. MAZ, 20.10.2013), ferner regelmäßig „eine Gedenkkundgebung zum Volkstrauertag am Denkmal im Fontanepark und Fahrten in die Heimat" (BR, Juni 2013). 1999 „geplante Vorhaben/Aktivitäten für 1999“: u. a. jeweils drei Treffen/Zusammenkünfte der LM Ostpreußen in der Volkssolidarität, Friedrich-Engels-Str. 4, der LM Westpreußen/Danzig und Weichsel-Warthe, der LM Pommern und Ostbrandenburg, der LM Schlesien in der Volkssolidarität, dezentrale Treffen in Rhinow (Frühjahrs- u. Adventstreffen) und Nennhausen (Frühjahr), 2000 Planung für Treffen in Stölln u. Nennhausen (desgl. 2002). 12.10.2002 „Tag der Heimat“ in Rathenow (Bericht von H. König in: Der Vertriebene, Dez. 2002). [2009:] „Wie alljährlich hatte der Bund der Vertriebenen, Gebietsverband Rathenow, zum Volkstrauertag am Sonntag, dem 15. November, um $10 \mathrm{Uhr}$ am Gedenkstein Forststraße/Fontaneplatz eingeladen. $Z u$ dieser öffentlichen Gedenkfeier erschienen zahlreiche Heimatvertriebenen und weitere Interessenten insbesondere auch der Bürgermeister Ronald Seeger. Die musikalische Umrahmung erfolgte durch eine Bläsergruppe der Musikschule Rathenow mit mehreren Liedern." (MAZ, Westhavelländer, 18.11.2009). [2015:] „In diesem Jahr besteht der Bund der Vertriebenen in Rathenow 25 Jahre. ,Das erste Treffen fand nach einem Gründungsaufruf im Clubraum des Kulturhauses statt', erinnert sich Ursula Brommauer. ,Der Saal platzte aus allen Nähten.' 1990 wurde der BdV Rathenow mit über 300 Mitgliedern gegründet. Heute sind es noch 115 Mitglieder. Der Gründungsvorsitzende war Klaus Eichler. Als er nach einem Jahr wegzog, übernahm Ursulas Ehemann Albrecht Brommauer diese Funktion. Als Ostpreuße leitete er auch die [Kreisgruppe der] OstpreußenLandsmannschaft. Nach fünfJahren übernahm [1996] Herbert Kapahnke den Vorsitz." (Märkische Onlinezeitung (MOZ), 4.12.2015). - 2000 Ausschreibung für „Ambulante Betreuung von Spätaussiedlern im Landkreis Havelland“, jährlich befristete Spätaussiedlerbetreuung per ABM bis 2002, dann SAM noch 2003 bis ca. 2005. - Vorsitzende: bis 28.3.1992 Christoph Eichler, 21.4.1993 erwähnt als amtierender Vorsitzender: Albrecht Brommauer, Rathenow (Rücktritt 10.4.1996), dann amtierender Vorsitzender (noch 1997) der stellv. Vorsitzende Herbert Kapahnke, Semlin (geb. 5.12.1939 Kamehlen, Kr. Karthaus, Westpreußen, war über Dänemark zunächst nach Schleswig-Holstein gelangt), dieser 2003 als Vorsitzender erwähnt, zuletzt auch Landesobmann Brandenburg der Landsmannschaft Westpreußen, starb am 11.9.2015 in Sem- 
lin (Traueranzeige in: MAZ, 19.9.2015; www.westpreussen-online.de [31.5.2017]); seit 2016 (noch 2018) Alfred Hinz, Rathenow (geb. 1936 Königsberg/Nm.). - (2) Landsmannschaft Westpreußen e. V., Landesgruppe Brandenburg, 1996 erwähnt mit Sitz in Semlin, Dorfstr. 53 (Herbert Kapahnke) (BdV-Handbuch 1996, S. 138, 168). „Im Oktober 1995 und fortsetzend im März 1996 bildete sich auch eine Landesgruppe der LM Westpreußen mit gewähltem Vorstand (Vorsitz Herbert Kapahnke) und beschlossener Satzung (auch von der Bundesgeschäftsstelle in Münster genehmigt). Trotz etlicher Aktivitäten ist eine Weiterentwicklung bisher nicht erfolgt. (kein Finanzhaushalt mit finanzieller Abrechnung, auch nicht extra eingetragener Verein)." (Kapahnke, 4.7.2002, in Akten der BdV-Landesgeschäftsstelle). Inzwischen mit dem Ausscheiden Kapahnkes aufgelöst (Mitteilung T.A. Fischer, Berlin, 10.7.2018).

Gedenkstein im Fontanepark, Südost-Ecke Forststraße/Rosa-Luxemburg-Straße (gegenüber dem Wohn- und Pflegezentrum): 2003 errichtet vom BdV-Gebietsverband Rathenow, der hier jährlich am Volkstrauertag Treffen veranstaltet, auch für 13.11.2017 wiederum vorgesehen (MAZ, 8.11.2013; Auskünfte E. Kapahnke und BdV-Landesgeschäftsstelle).

Archivalische Quellen und Auskünfte: BLHA, Rep. 203 MdI, Nr. 1124 (Umsiedler- und Heimkehrerstatistiken, 1945-1946; enthält: Erfassung der Umsiedler in den einzelnen Kreisen der SBZ zum 1. Dez. 1945 sowie statistische Berichte der einzelnen Gemeinden, hier Stadtkreis Rathenow). - BLHA, Rep. 250 Landratsamt Westhavelland, Nr. 66 („Tätigkeit des Kreisausschusses bzw. Ortskomitees Rathenow der Deutsch-Polnischen Gesellschaft für Frieden und gute Nachbarschaft", 1951-1952). - Auskünfte Elisabeth Kapahnke (stellv. Vorsitzende des BdV-Gebietsverbandes Rathenow), Rathenow-Semlin, 31.5.2017. - Auskünfte BdV-Landesverband Brandenburg, 18.7.2017.

Gedruckte Quellen und Literatur: Bein, Otto: Stadtsparkasse zu Mohrin. In: Kreiskalender für den Heimatkreis Königsberg-Neumark 10 (1962), S. 75-86. - Blöß, Kreise und Gemeinden, S. 26, 122. - Blöß, Wolfgang: Grenzen und Reformen in einer Umbruchgesellschaft. Berlin 2014, S. 151-156 [Neue Schleuse und Magazin-Insel]. Ders.: Kommunale Strukturen im Spannungsfeld gesellschaftlicher Umwälzungen. Berlin 2018, S. 254 f. - Brühe, Matthias: Katholische Kirche zwischen Prignitz und Havelland. Berlin 2000, S. 44. - Die letzten Tage im Krieg und die ersten Wochen im Frieden in der Region um Rathenow. T. 1-3. Hrsg.: Rathenower Heimatbund e. V. [Red.:] HansJürgen Wodtke u. a. 2. Aufl. (T. 1.: 4. Aufl.) Rathenow 2014-2018. - Gospodarek, Gerhard: Erinnerungen an Schwirz. In: Namslauer Heimatruf 216 (2013), S. 37-50. - Guthjahr, Rudolf: Havelstadt Rathenow. Kleine Stadtchronik. Rathenow 1991. - Das Havelland um Rathenow und Premnitz. Köln u. a. 2017. - Heimerdinger, Georg: Die ersten Tage des Friedens - das Tagebuch des Superintendenten Georg Heimerdinger. Rathenow o.J. [Tagebuch 17. Mai bis 1. Sept. 1945 mit Rückblick auf die Geschehnisse ab 24. April 1945]. - Krätzner, S. 23. - Kranert, Gudrun: 1945 - Ende des Zweiten Weltkrieges. In: Heimatjahrbuch für Falkensee und Umgebung 2018 (2017), S. 66-72. - Ein leidgeprüftes Land. Bearb. von Fritz Knüppel. 2. Aufl. Barsinghausen 1990, S. 189. - Mewes, Fritz: 8. Mai - 60. Gedenktag zum Ende des 2. Weltkrieges. In: Rathenower Heimatkalender 49 (2005 [2004]), S. 31-34. - Müller, Günter: Letzte Kriegstage in Rathenow 1944/1945. Erinnerungen eines Soldaten. Potsdam 2009 [Nur allgemein für die Situation in der Stadt von Interesse, ohne Bezug zu Flüchtlingen]. - Nitschke, Johannes: 150 Jahre Pfarrkirche „Heilige Dreifaltigkeit" Brandenburg an der Havel. Brandenburg an der Havel [2001], S. 29 f. - Otto-Seeger-Grundschule. 100 Jahre Schulgebäude, [2008] (www.grundschule-rathenow-west.de/seite/26050/schulgeschichte [7.1.2017]). - Rathenow. Chronik 1216-2007. Nordhorn 2007. - Rathenow in Flammen. Kriegskinder auf den Spuren ihrer Geschichte. Klaus Weidt (Hg.). Böttingen 2015. - Schwillus/Brühe, S. 346. - Tagebuch Hildegard Burmeister [Auszüge]. In: „Die Russen sind da“. Peter Böthig u. Peter Walther (Hg). Berlin 2011, S. 310 f. - Trzcielińska-Polus. 


\section{Ravensbrück}

Landgemeinde (seit 15.10.1950 Ortsteil von $\rightarrow$ Fürstenberg/Havel, nach Kriegsende 1945 bereits der sowjetischen Kommandantur Fürstenberg/Havel zugeschlagen [Blöß, Grenzen, S. 165]), bis 1950 Kr. Templin, 1952-1990 Kr. Gransee (Bez. Potsdam), 1990-1993 Ldkr. Gransee, 1993 Ldkr. Oberhavel

Ereignisse NACH Kriegsende: Abtransport von Baracken des KZ Ravensbrück (BLHA, Rep. 250 Templin, Nr. 270), wohl u. a. nach $\rightarrow$ Fürstenberg/Havel für das Flüchtlings-/Barackenlager Berliner Straße (Stegemann, S. 236). - „Die Häftlingsbaracken wurden in den ersten Jahren nach dem Krieg fast alle abgebaut und an Flüchtlinge und Vertriebene verkauft, die sie an anderer Stelle in der Region wieder aufbauten und darin noch viele Jahre, manche sogar Jahrzehnte wohnten.“ (Leo, S. 514). - In der Bodenreform 15 ha von 157 ha an 4 „Umsiedler“ vergeben (HOL VIII, S. 800).

BevölkerungSZAhlen: 1925: 694, 1939: 783, 1946: 937 (HOL VIII, S. 800).

Archivalische Quellen: BLHA, Rep. 250 Landratsamt Templin, Nr. 270 (Bereitstellung von Baracken für Schaffung von Unterkünften für Umsiedler, 1945-1948; enthält u. a.: Abtransport von Baracken aus dem ehemaligen KZ Ravensbrück).

Literatur: Blöß, Kreise und Gemeinden, S. 26. - Blöß, Wolfgang: Grenzen und Reformen in einer Umbruchgesellschaft. Berlin 2014, S. 165 f. - Leo, Annette: Ravensbrück - Stammlager. In: Der Ort des Terrors. Hrsg. von Wolfgang Benz u. Barbara Distel. Bd. 4. München 2006, S. 473-520. - Stegemann, Wolfgang: Die Nachkriegszeit 1945 bis 1948 in Zeitdokumenten. In: Ders. / Wolfgang Jacobeit: Fürstenberg/Havel, Ravensbrück. Bd. 2. Teetz 2004, S. 223-257.

\section{Reichenwalde}

Landgemeinde, bis 1950 Kr. Beeskow-Storkow, 1950-1990 Kr. Fürstenwalde (ab 1952 Bez. Dresden), 1990-1993 Ldkr. Fürstenwalde, 1993 Ldkr. Oder-Spree

EREIGNISSE BIS KRIEGSENDE: „Mit Schwinden der Mitarbeiterzahlen durch Einberufung und Kriegsverpflichtungen kommen ab 1938 immer mehr Volksdeutsche, Evakuierte, Flüchtlinge und Kriegsgefangene, Franzosen und Russen, in den Landwirtschaften der Arbeiterkolonien [Außenstelle Arbeiterkolonie Reichenwalde der Hoffnungstaler Anstalten Lobetal, P. B.] und als Helfer in der Betreuung zum Einsatz.“ (Schneider, S. 81). - Jan. 1945: „Schwarzmeerdeutschen, seit Wochen auf der Flucht vor der nach Westen ziehenden Roten Armee, wurde eine Unterkunft in freien Wohnräumen zugewiesen. In vielen Familien lebten Verwandte aus Berlin und anderen Städten, auch Flüchtlinge aus den östlichen Gebieten.“ (ebd., nach Schulchronik Reichenwalde). - [Bericht vom 5.2.1945,] „dass Hausvater Koch im Januar 1945 in der Reichenwalder Kolonie ,unerhörte Mengen' von Flüchtlingen zu versorgen hatte. ,Vor drei Tagen musste er 2500 beköstigen, darunter 1500 russische Gefangene und 1000 Soldaten." (ebd., nach 
Schreiben von Pastor Braune, Hoffnungtaler Anstalten in Lobetal, an Pastor Bodelschwingh). 26.4.1945 Einmarsch der Roten Armee (ebd., S. 82).

BevölKerungszahlen: 1925: 573, 1939: 697, 1946: 799, 1964: 681 (HOL IX, S. 214).

Literatur: Schneider, Inge: Reichenwalde in den letzten Kriegswochen des Jahres 1945. In: Gerd Tschechne: Das

Kriegsende in und um Storkow (Mark). Storkow (Mark) 2005, S. 81-84.

\section{Reitwein}

Landgemeinde, bis 1950 Kr. Lebus, 1950-1990 Kr. Seelow (ab 1952 Bez. Frankfurt/Oder), 1990-1993 Ldkr. Seelow, 1993 Ldkr. Märkisch-Oderland

EREIGNISSE BIS KRIEgSENDE: 2./4.2.1945 Einmarsch der Roten Armee in Reitwein, die Bevölkerung flieht in Richtung Rathstock, Hathenow und Podelzig. „Die noch in Reitwein verbliebenen Einwohner wurden am 7.2. über die Oder nach Göritz und weiter östlich getrieben. Viele kamen dabei ums Leben, besonders alte Menschen, die solchen winterlichen Gewaltmarsch nicht mehr aushielten." (Ein leidgeprüftes Land, S. 19).

EReignisse NACH KRIEgSende: [Ca. 28.] 7. 1945 (Treck von Vertriebenen aus dem Kr. Meseritz: „Als wir in Reitwein waren, gab es ein großes Gewitter, es goß in Strömen und im ganzen Dorf fanden wir kein trockenes Plätzchen. Der Ort war völlig zerstört. Unter der großen Treppe im $S c h l o \beta$ verbrachten wir die Nacht. Überall waren Menschen voll Hunger und ohne Hoffnung." (Becker, S. 34). - 22.3.1947 Deichbruch an der Oder löst Hochwasser-Katastrophe aus (Ein leidgeprüftes Land, S. 265). - 3.10.1950 Zuweisung von westlich der Oder gelegenen Flächen der nun polnischen Gemeinde Göritz/Górzyca (ehem. Kr. Königsberg/Nm.) an die Gemeinde Reitwein (Blöß, Kreise und Gemeinden, S. 31).

BeVÖLKERUNGSZAHLEN: 1925: 1078, 1939: 835, 1946: 859, 1964: 789 (HOL VII, S. 371).

Katholiken (bis 1994 Erzbistum Breslau/Erzbischöfliches Amt Görlitz, dann Erzbistum Berlin): 1954: 38 (Schematismus Görlitz 1954, S. 36).

FRIEDHOF: GEDENKSTÄTTE (am Volkstrauertag 2006 eingeweiht) aus vier silbernen, mit Inschriften versehenen Kunststoffplatten auf Granittafeln, davon drei für die gefallenen Soldaten, eine für die zivilen Opfer, darunter die aus den deutschen Ostgebieten Vertriebenen, „die im Spätsommer 1945 über die Oder nach Reitwein kamen“, hier „erschöpft und entkräftet“ starben und in „etwa 80 Gräbern [...] auf dem Reitweiner Friedhof beigesetzt“ wurden (Märkische Oderzeitung, 2.11.2006, nach Forschungsergebnissen von Hermann Kaiser). Inschrift der Tafel für die zivilen Opfer: „Im Gedenken der zivilen Opfer im Jahr 1945, den Flüchtlingen und Vertriebenen sowie den Reitweinern nah und fern der Heimat/Die Gemeinde Reitwein" (www.denkmalprojekt.org).

QUELLEN UND LiterATUR: Becker, Lieselotte: Flucht und Vertreibung aus Strese. In: Heimatgruß (Meseritz) 215 (2015), S. 32-35. - Dokumentation der Vertreibung I/2, S. 680. - Ein leidgeprüftes Land. Bearb. von Fritz Knüppel. 
2. Aufl. Barsinghausen 1990, S. 18-21, 41-65. - Im Gedenken an gefallene Reitweiner. In: Märkische Oderzeitung, 2.11.2006. - www.denkmalprojekt.org [16.10.2006].

\section{Reppinchen}

Landgemeinde, bis 1952 Kr. Zauch-Belzig, 1952-1990 Kr. Belzig (im Bez. Potsdam), 19901993 Ldkr. Belzig, 1993 Ldkr. Potsdam-Mittelmark

EREIGNisSe NACH KRIEgSEnde: „Durch Flüchtlinge und Umsiedler erhöhte sich die Einwohnerzahl nach Kriegsende um 30 Prozent auf 774. Aber bereits 20 Jahre später war die Einwohnerzahl wieder auf das Vorkriegsniveau abgesunken. Hier sind die Auswirkungen der Umwälzungen, die sich in der Landwirtschaft der inzwischen gegründeten DDR vollzogen, deutlich ablesbar. Hinzu kommt, dass in Reppinichen kein zusätzlicher Wohnungsbau für die Umsiedler und Flüchtlinge stattfand, so dass die fast 200 zusätzlichen Einwohner in den vorhandenen Gebäuden unterkommen mussten." (Kästner). - Bei der Bodenreform Umsiedler nicht gesondert erwähnt (HOL V, S. 361).

BevölKerungSZAhlen: 1925: 590, 1939: 597, 1946: 774, 1964: 592 (HOL V, S. 361).

Katholiken: „Zum 1.10.1946 wurde Dechant Johannes Krowarz aus dem Bistum Leitmeritz mit der Wahrnehmung der Seelsorge in dem am westlichen Rand der Kuratie $[\rightarrow]$ Belzig gelegenen Ort beauftragt. 1949 hatte er seinen Sitz bereits in $[\rightarrow$ ] Wiesenburg." (Brühe, S. 46).

Literatur: Brühe, Matthias: Katholische Kirche zwischen Havel und Dahme. Berlin 1999, S. 47. - Kästner, Helga: Reppinchen. T. 2. (/www.helga-kaestner.de/reppinichen2.htm [7.1.2017]).

\section{Rheinsberg}

Stadtgemeinde, bis 1952 Kr. Ruppin, 1952-1990 Kr. Neuruppin (Bez. Potsdam), 1990-1993 Ldkr. Neuruppin 1993 Ldkr. Ostprignitz-Ruppin

BevöLKerungszahlen: 1925: 3269, 1939: 3722, 1946: 4215, 1964: 4215 (Städtebuch, S. 446).

Katholiken: 1925: 61, 1946: 208 (ebd.). - „Nach 1945 kamen durch die Flüchtlingsströme viele Katholiken in die Region“ (Schädler, S. 240). - 22.8.1946 „Pfr. Abendroth, Herbert, Rheinsberg/Mark, Strelitzerstr./Villa Irene“ erwähnt in einer Aufstellung der außerplanmäßig eingesetzten „Flüchtlingsgeistlichen“ (DAB, I/9-15-1 Flüchtlingsseelsorge 1945-1951, unfol.). „Nach dem II. Weltkrieg nahm der zuvor in Odermünde-Pölitz bei Stettin tätige P. Alois Becher [!] OMI (1946-54) in der Dr.-Martin-Henning-Str. 6 Wohnung, die Gottesdienste feierte er in der Brauthalle der evangelischen Kirche. Die damit entstandene Lokalie wurde 1949 der neu gegründeten Kuratie Lindow zugeordnet und zählte 1953 über 400 Katholiken. Seit 1954 galt sie als aufgelöst, allerdings wohnte hier noch ein Ruhestandspriester.“ (Brühe, S. 45). Der bis 
1945 im Ordenshaus in Stettin wirkende Pater Aloys Becker [!] (Orden der „Oblaten der Unbefleckten Jungfrau Maria“ [OMI]) (geb. 1909) wohnte 1949 in Rheinsberg/Mark, Strelitzer Str. 6 (Ostpriesterverzeichnis 2, 1949, S. 103).

UMSIEDLERLAGER: Kapazität am 1.1.1946: 800 (BLHA, Rep. 203 MdI, Nr. 1163, Bl. 50).

Literatur: Brühe, Matthias: Katholische Kirche zwischen Prignitz und Havelland. Berlin 2000, S. 45. - Schädler, Verena: Katholischer Sakralbau in der SBZ und in der DDR. Regensburg 2013. - Schwillus/Brühe, S. 318. - Wille I, S. 372 .

\section{Rhinow}

Stadtgemeinde, bis 1952 Kr. Westhavelland, 1952-1990 Kr. Rathenow (Bez. Potsdam), 19901993 Ldkr. Rathenow 1993 Ldkr. Havelland

EREIGNISSE NACH KRIEGSENDE: 1945 wohnen acht Flüchtlingsfamilien als Mieter der Gutsbesitzerin von der Hagen im Herrenhaus (Andreae/Geiseler, S. 253). - 1946 (Bericht der Kreisverwaltung über eine „Umsiedlergenossenschaft"): „Im Kreis Westhavelland ist in Rhinow mit Hilfe von zehn Webern eine Webereigenossenschaft entstanden, die in der Lage sein wird, im kommenden Jahr 40 Arbeiter zu beschäftigen." (BLHA, Rep. 203 MdI, Nr. 1074, zitiert nach: Oehlsen, S. 90), 15.3.1947 „Weberei-Genossenschaft" noch erwähnt mit 43 Arbeitern (BLHA, Rep. 333, Nr. 574, Bl. 105), auch 1948 noch erwähnt als von Sudetendeutschen gegründete „Webereigenossenschaft Rhinow und Umgebung“ (Christopeit, S. 86). - 1946 Einsatz von „Umsiedlern“ und Kriegsgefangenen in der Firma „Bastfaser, Rhinow“ (BLHA, Rep. 206, Nr. 2997). - Herbst 1946 Ankunft eines Vertriebenen-Transports aus dem Kr. Namslau (Schlesien) (nach Quarantänezeit im Lager $\rightarrow$ Rathenow) auf dem Bahnhof Rhinow und Verteilung auf umliegende Dörfer, u. a. Görne (Gospodarek, S. 48, 50). - 1956-1988 war die aus Lodz vertriebene Ruth Fleischmann (geb. 1926) Lehrerin in Rhinow, die sich hier auch als Ortschronistin stark engagierte und dafür 2006 zur Ehrenbürgerin ernannt wurde (Schmidt).

BevölKerungSzAHLEN: 1925: 1292, 1939: 1563, 1946: 2451, 1964: 1875 . „Zunahme der Einwohnerzahl [...] 1945 durch Flüchtlinge u. Vertriebene“ (Städtebuch, S. 450).

Katholiken: 1925: 27, 1946: 268. „Zunahme der kath. Einwohner durch Flüchtlinge u. Vertriebene nach 2. WK“ (Städtebuch, S. 450). - „Kurzzeitig bestanden nach dem II. Weltkrieg von heimatvertriebenen Priestern betreute Seelsorgestellen in Rhinow (1945/46), [...]." (Schwillus/Brühe, S. 330). - „Auf Bitten des damals zuständigen Pfarrers von $\rightarrow$ Rathenow wurde am 11.11.1946 der aus der Diözese Leitmeritz stammende Pfr. Heinrich Marschner mit der Wahrnehmung der Seelsorge in Rhinow und Umgebung beauftragt. Er verließ den Ort jedoch wieder im Sommer 1947. Später wurde Rhinow in die Pfarrei $\rightarrow$ Neustadt/Dosse umgepfarrt." (Brühe, S. 56).

ARchivalische Quellen: BLHA, Rep. 206 Ministerium für Wirtschaft und Arbeit, Nr. 2997. 
Gedruckte Quellen und Literatur: Andreae/Geiseler, S. 253 f. - Brühe, Matthias: Katholische Kirche zwischen Prignitz und Havelland. Berlin 2000, S. 56. - Christopeit. - Gospodarek, Gerhard: Erinnerungen an Schwirz. In: Namslauer Heimatruf 216 (2013), S. 37-50. - Oehlsen, S. 90. - Schmidt, Christin: Rhinows Ehrenbürgerin wird 90. In: Märkische Allgemeine, 10.9.2016. - Schwillus/Brühe, S. 330.

\section{Rittgarten}

Landgemeinde (1979-2001 Ortsteil von Schapow, seit 2001 von Nordwestuckermark), bis 1952 Kr. Prenzlau, 1952-1990 Kr. Prenzlau (Bez. Neubrandenburg), 1990-1993 Ldkr. Prenzlau (Land Brandenburg), 1993 Ldkr. Uckermark

EREIGNISSE NACH KRIEGSENDE: Zwischen 1.5. und 31.12.1945: „107 Umsiedler und Flüchtlinge fanden Aufnahme. Sie wurden in den Herrenhäusern in Rittgarten und Augustfelde untergebracht.“ (Schulchronik, S. 128). - [1946]: „Im Ort befinden sich 23 Siedler, welchen je nach Familienangehörigen 5 bis 8 ha Land zugeteilt worden sind. Da es an Zucht- und Zugtieren fehlt, wird das Land vorerst nicht gemeinsam beabeitet. Um kein Gefühl der Benachteiligung bei der Landzuteilung aufkommen zu lassen, werden die vermessenen Landstücke später verlost. / Durch Neusiedler hat die Gemeinde einen Zuwachs von 13 Personen erhalten." (Schulchronik, S. 129). - 1.7.1946: „Durch Zuzug weiterer Umsiedler hat sich die Anzahl der Schüler auf 66 erhöht." (ebd.). - In der Bodenreform 236 ha (von 396,5 ha) an 35 Umsiedler vergeben (HOL VIII, S. 819). - [1946:] „Seit dem 1.9. amtiert hier eine Neulehrerin, Frl. Irmtraud L.“ (Schulchronik, S. 130). - „Im Berichtsmonat [Mai 1947] sind wieder 3 Siedlungen aufgegeben worden." (ebd., S. 133).

BevöLKerungszahlen: 1925: 135, 1939: 209, 1946: 408, 1964: 277 (HOL VIII, S. 820). 1.5.1945: 66, 31.12 .1945 (nach Eingemeindung des ehem. Rittergutes Augustfelde): 222 (Schulchronik, S. 127 f.).

Gedruckte Quellen und Literatur: Schulchronik der Gemeinde Rittgarten ab 01.01.1946. In: Die Uckermark 1945. T. 1. Prenzlau 1995, S. 127-135.

\section{Roddan}

Landgemeinde, bis 1952 Kr. Westprignitz, 1952-1990 Kr. Perleberg (Bez. Schwerin), 19901993 Ldkr. Perleberg, 1993 Ldkr. Prignitz

BeVÖLKeRUngSZAHLEN: 1925: 238, 1939: 192, 1946: 289, 1964: 199 (HOL I, S. 745).

ARChIVAlische Quellen: Kreisarchiv Prignitz, Rat der Gemeinde Roddan, G 00088 (Verzeichnisse über Umsiedler und Evakuierte sowie Volks- und Berufszählung, 1945-1950). 


\section{Rosow}

Landgemeinde (seit 2002 Ortsteil von Mescherin, Amt Brandenburgisch-Vorpommern), bis 1939 Kr. Randow (Provinz Pommern), 1939-1945 Kr. Greifenhagen (Provinz Pommern), 1945-1950 Kr. Randow (Land Mecklenburg), 1950-1952 Kr. Angermünde (Land Brandenburg), 1952-1990 Kr. Angermünde (Bez. Frankfurt/Oder), 1990-1993 Ldkr. Angermünde, 1993 Ldkr. Uckermark

EREIGNISSE NACH KRIEGSENDE: „Nach dem zweiten Weltkrieg lag zwischen den beiden Orten [Rosow und Stettin, P. B.] plötzlich eine Grenze. Zahlreiche Flüchtlinge aus dem Osten fanden in Rosow eine neue Heimat, während auf der anderen Seite der Oder Vertriebene aus dem Baltikum und dem ehemaligen Ostpolen sesshaft wurden." (Janowski, S. 94).

GedëCHTNISKIRCHE Rosow: 2003 Gründung des „Fördervereins Gedächtniskirche Rosow deutsch-polnischen Gedenkstätte für Flucht, Vertreibung und Neuanfang “ auf Initiative von Karl Lau, Kirchenältester und seit der Wende ehrenamtlicher Bürgermeister von Rosow (Dez. 2006 Bundesverdienstkreuz am Bande), 2006-2007 Sanierung des 1945 ausgebrannten, Anfang der 1950er Jahre notdürftig wiederhergestellten Kirchengebäudes und Ausbau zu einer „deutschpolnischen Gedenkstätte für Flucht, Vertreibung und Neuanfang“. Das Projekt wurde unterstützt vom „Förderkreis Alte Kirchen Berlin-Brandenburg“, dessen Geschäftsführer Bernd Janowski (geb. 1957) 2007 schrieb: „Angesichts des polnischen EU-Beitritts werden Nachkriegsschicksale der heutigen Grenzlinie dokumentiert, Kultur- und Diskussionsveranstaltungen, Konzerte und Lesungen finden bereits jetzt statt und Menschen begegnen einander, die sich trotz räumnlicher Nähe leider noch immer ziemlich fremd geblieben sind. - Gibt es dafür einen bessereen Ort als ein Kirchengebäude?" (Janowski, S. 94). - Aus der Projektbeschreibung des Fördervereins: „Flucht, Vertreibung, Evakuierung, Umsiedlung, wie immer es zu verschiedenen Zeiten und von verschiedenen Seiten genannt wurde, ein Thema, das in der sowjetischen Besatzungszone, der späteren DDR weitgehend als Tabu galt. / Diese Ereignisse und die damit verbundenen einschneidenden Erlebnisse durften nicht offen oder gar gemeinschaftlich dargestellt werden. Und so blieb das Thema Flucht bis in die Gegenwart erhalten. Im Westen, der späteren Bundesrepublik Deutschland, wurde das Thema zu leicht und zu lange von den Ursachen abgekoppelt. Die Ostsiegermacht Sowjetunion wurde als alleiniger Urheber dieser Nachkriegssituation gesehen. Die Initiatoren dieses Projektes wenden sich gegen die Wiederbelebung dieser Diskussion/Wir möchten die Geschehnisse von damals aus der Sicht der Betroffenen festhalten, uns aber auf den Blick nach vorn konzentrieren [...] / Diese Gedenkstätte veranschaulicht die geschichtlichen Abläufe, die sich hier besonders konzentriert am Kriegsende abgespielt haben. Hierdurch ergibt sich die besondere Aufgabe darin, mit dem Abstand von mehr als einem halben Jahrhundert, insbesondere der jüngeren Generationen unsere Geschichte darzustellen. Dabei werden exemplarisch die Ereignisse der Nachkriegssituation auch überregionale Bedeutung haben. Durch die besondere Nähe zu unserem Nachbarland Polen wird diesem Projekt auch eine grenzüberschreitende Wirkung und Einbeziehung angestrebt. / Der politische Umbruch in Deutschland nach 1989/90 führte in vielen Gemeinden und Städten Findung einer eigenen Identität zur Heimat, Tradition und Geschichte. Es war 
eine überfällige Hinwendung zu Themen, die in den Jahren nach 1945 bis zum Ende der 80er Jahre im östlichen Teil Deutschlands keine Rolle mehr zu spielen schien, da der politisch ideologische Druck hier deutliche Einschränkungen auferlegte. In unserer Gedenkstätte Rosow soll die Flucht aus der damaligen deutschen östlichen Heimat, aus Hinterpommern und Preußen dargestellt werden. [...]/Man braucht nur auf die Karte zu schauen und man sieht die Straßen, die Autobahnen, die Bahnlinien in Richtung Süden und Westen. Neben der demographischen Notwendigkeit so eine Begegnungsstätte zu schaffen, um den Betroffenen noch die Möglichkeit zu geben ihre Betroffenheit zeigen zu können und an die Nachwelt weiterzugeben, ist die Situation, die Atmosphäre für einen solchen Gedächtnisort an der Grenze zu Polen so günstig wie nie zuvor, weil diese Grenze sich in einer entspannten, immer weniger spürbaren Bedeutung befindet. [...]/Wir Initiatoren sagen, dass eine Kirche ein guter, angemessener Ort für die Darstellung und Begegnung mit diesem Thema ist. Wir denken sogar, dass eine Kirche ein besonders geeigneter Ort dafür ist. / Ein symbolischer Ort des Leides und der Hoffnung. Ein ,Schutz' gegen unerwünschten Eifer und ein Vertrauensangebot für interessierte Befürworter unseres Projektes. Die Thematik lässt auch keine ,Kombination' in, bzw. mit, schon bestehenden, geförderten Einrichtungen zu, weder auf Reiterhöfen noch in volkskundlichen oder technischen Museen. [...] / Flüchtlinge, Vertriebene, Umgesiedelte und deren Nachkommen leben auf beiden Seiten der Oder in dieser Region. - Der Wunsch, das Interesse an der Darstellung dieses Themas besteht auf beiden Seiten. Ohne die öffentliche und gemeinsame Darstellung der deutschen und polnischen Schicksale, bleiben diese Ereignisse mit ein Grund für gegenseitige Vorbehalte und Mißverständnisse und behindern den jetzt notwendigen Integrationsprozess. - Wir möchten mit unserem Projekt einen <atmosphärischen> Beitrag für mehr Offenheit und Miteinander leisten." (www.rosow.de).

Literatur: Janowski, Bernd: Ein Zeichen der Versöhnung. Die Gedächtniskirche Rosow. In: Offene Kirchen 2007, S. 94. - www.rosow.de/html/das_projekt.html [25.5.2017].

\section{Rüdersdorf}

Landgemeinde, bis 1950 Kr. Niederbarnim, 1.7.1950-1990 Kr. Fürstenwalde (ab 1952 Bez. Frankfurt/Oder), 1990-1993 Ldkr. Fürstenwalde, 1993 Ldkr. Märkisch-Oderland

EReignisse bis Kriegsende: 21.4.1945 Einmarsch der Roten Armee (Köhler, S. 158; Hennickendorf 1945, S. 43).

EREIGNisSe NACH KRIEgSEnde: „Aus dem Osten waren große Ströme Flüchtlinge nach Rüdersdorf gekommen und fanden im ehemaligen Zwangsarbeiterlager erste Unterkunft." (Köhler, S. 159). - Aug. 1945: „Große Sorgen bereitet eine Typhusepidemie und die Versorgung der zahlreichen Flüchtlinge.“ (Aus der Rüdersdorfer Ortschronik, o. S.). - „Nach dem II. Weltkrieg [...] siedelten sich auch hier Vertriebene an." (Brühe, S. 41). - 1946 in der Bodenreform 204 ha (von 920 ha) an 29 Umsiedler vergeben (HOL V, S. 459). - 1974 Ansiedlung einer Spätaussiedlerfamilie aus Oberschlesien (Bericht des Familienvaters in: 100 Jahre Pfarrkirche Hl. Familie Rüdersdorf, S. 65-67). 
EREIGNISSE NACH 1990: 4.7.2010 Festumzug zur 775-Jahr-Feier: „30 Bilder umfasste der Bergfestumzug anlässlich der 775-Jahr-Feier von Rüdersdorf. Volkssolidarität [VS] und Bund der Vertriebenen (BdV) waren für die Bilder „Kriegsende in Rüdersdorf“ und „Vom schweren Anfang nach dem Krieg" verantwortlich. / Zunächst erfolgten umfangreiche Recherchen im Internet, in Archiven der Heimatvereine und des Bundesverbandes der Volkssolidarität, die ja bereits in der Nachkriegszeit eine entscheidende Rolle in der allgemeinen Betreuung gespielt hatte. [... / So kam es auch 14-tägig zum Treffen in einer Altrüdersdorfer Gaststätte, wo sich Anwohner einbrachten, aber auch eine ganze VS-Familie. Unser Vorstandsmitglied Helga Just mit Tochter und Schwiegersohn, seine Schwestern nebst Familien und Freunden - insgesamt 10 Personen - waren dabei. Sie bildeten zusammen mit anderen die Darsteller der Gruppe der Heimkehrer und Flüchtlinge. Sie waren in entsprechender Kleidung, mit Handwagen, Gepäck und typischen Utensilien ausgerüstet, die Trümmerfrauen mit Kopftuch und Hammer.“ (Radoy, S. 48).

Bevölkerungszahlen: 1935: 3692, 1939: 11 507, 1946: 10 824, 1964: 11751 (HOL V, S. 459).

Katholiken: [Amtszeit von Pfarrer Alfred Kionka (geb. Rydultau, Kr. Rybnik), 1936-1949:] „Infolge Vertreibung Deutscher aus den von Polen besetzten Gebieten kamen nach Kriegsende viele heimatvertriebene Familien auch nach Rüdersdorf. Sie wurden von der Gemeinde aufgenommen und, so weit es möglich war, unterstützt, sodass sie hier eine zweite Heimat fanden. Das Pfarrhaus stand allen, die Rat und Hilfe brauchten, jederzeit offen." (100 Jahre Pfarrkirche Hl. Familie Rüdersdorf, S. 28).

(Kreis-)UMSiedlerlager: „Das Areal des riesigen Zwangsarbeiterlagers der Preussag wurde 1945-50 für Umsiedler und Kriegsflüchtlinge aus dem Osten - sie wurden in den Baracken des Lagers untergebracht - und von 1951 bis 1992 von Strafvollzugseinrichtungen des Landes Brandenburg genutzt. Gebäudereste des Lagers sind heute noch vorhanden (Adresse: Am Bruch 6).“ (Gedenkstätten NS II, S. 342). - Kapazität am 31.12.1945: 1000 (BArch, DO 2/45, B1. 40). - 1.1.1946 Kapazität: 1500 (BLHA, Rep. 203 MdI, Nr. 1163, Bl. 49). - 14.2.1946 Kreis- und Quarantänelager, Kapazität: 1500 (Oehlsen, S. 28). - 24.8.1946 Umsiedlerlager, Kapazität: 1500 (SAPMO-BArch, DY 34/27880, B1.291). - 1946 Belegungsstärke: 1500 (Kaminsky, S. 159). - Nov. 1946 Quarantänelager. Holzbaracken. Kapazität: 1600 Personen, 61 Planstellen (Lagerpersonal: 13.11.1946: Lagerleiter: Franke; 12.11.1946: Lagerarzt: Dr. May; 6.11.1946 Betriebsratsvorsitzender: Gründel) (BLHA, Rep. 333, Nr. 575). - 1.1.1947 Kapazität: 1500 (Oehlsen, S. 101). - 9.6.1947 Quarantänelager, Kapazität: 1 500, Belegung: 1590, Quarantäne beendet am 16.6. (SAPMO-BArch, DY 34/27880, Bl. 239) - 23.10.1947 „Rüdersdorf Krs. Niederbarnim“ als Zielpunkt für den 14. Transport aus dem sowjetischen Teil Ostpreußens vorgesehen (Wille II, S. 117). - 25.11.1947 in Befehl der SMA Brandenburg in Liste "der [zum 30.12.1947] zu schließenden Lager" aufgeführt (BLHA, Rep. 203 VP, Nr. 9, Bl. 43v). - Dez. 1947 Auflösung (BLHA, Rep. 250 Niederbarnim, Nr. 1101; Rep. 256 Küchensee, Nr. 140), Anf. 1948 bereits aufgelöst (Rep. 256 Küchensee, Nr. 217). 
VERTRIEBENENVERBÄNDE NACH 1990: 1993 BdV-Regionalverband Fürstenwalde/Rüdersdorf und Umgebung e.V. (1. Vorsitzender: Hermann Schmück, $\rightarrow$ Fürstenwalde [geb. 1920], 2. Vorsitzender: Reinhold Bujok, Rüdersdorf [1928-2015], Spätaussiedler aus Beuthen/OS); 2000 Trennung in zwei Verbände, hier: BdV-Kreisverband Amt Rüdersdorf und Umgebung e. V. (Vorsitzender: 2000-2014 Reinhold Bujok, dann Dieter Janke, Rüdersdorf [geb. 1946]) (10 Jahre Bund der Vertriebenen, S. 12f.), 5.2.2000 Satzung errichtet, 25.11.2003 eingetragen beim Amtsgericht Strausberg (VR 735) (Akten der BdV-Landesgeschäftsstelle). 21.11.2012: 47 Mitglieder. - Der Verband gibt gemeinsam mit dem in $\rightarrow$ Fürstenwalde ansässigen Kreisverband Oder-Spree ein Informationsblatt heraus: „Feelinchen. Informationsblatt des Bundes der Vertriebenen Oder-Spree e. V. und Amt Rüdersdorf und Umgebung e.V." (anfangs zwei-, später dreimonatlich; 2017 erschienen Nr. 121 und 122; siehe auch Keller). Vorsitzender (2017): Dieter Janke, Rüdersdorf (Feelinchen 121, 2017, S. 17).

Heimatstube des BdV-Kreisverbandes: 2014 Umzug der in von der Gemeinde kostenlos zur Verfügung gestellten Räumen befindlichen Heimatstube in ein Ersatzdomizil neben dem Rathaus vorgesehen (BR 13 (2015) 1, S. 9).

GeDENKSTEIN auf dem alten Kalkberger Friedhof: 26.8.2000 aufgestellt durch den BdV-Kreisverband Amt Rüdersdorf e. V. auf Initiative von dessen Vorsitzendem Reinhold Bujok, Enthüllung durch den Bürgermeister und den BdV-Kreisvorsitzenden, Weihe/Segnung durch den kath. u. den evang. Pfarrer (1998 Antrag auf Genehmigung, 1999 Zustimmung des Gemeinderats per Mehrheitsbeschluss zu einer reduzierten Form mit Inschrift ohne die vorgeschlagenen Wappen der ehem. ostdeutschen Provinzen). Inschrift: „Zum Gedenken der Opfer gegen Flucht, Vertreibung und Gewalt" (10 Jahre Bund der Vertriebenen, S. 23-33 mit Abb.; BrandenburgNachrichten 4, 2000). U. a. 19.11.2010 Kranzniederlegung am Gedenkstein im Beisein von Vereinsmitgliedern und Rüdersdorfer Bürgern sowie des Bürgermeister, seines Stellvertreters und von Gemeindevertretern aller Fraktionen sowie u. a. einer Delegation aus Strzelce Krajeńskie (ehem. Friedeberg/Neumark) (www.ruedersdorf.de [10.10.2016]).

Archivalische Quellen: BLHA, Rep. 230 Oberlandratsamt Bernau, Nr. 287, B1. 23 bis 30. - BLHA, Rep. 250 Landratsamt Niederbarnim, Nr. 1101 (Kreisumsiedlerlager Rüdersdorf, 1946-1948; enthält u. a.: Versorgungsfragen; Auflösung des Lagers Rüdersdorf im Dezember 1947; namentliche Aufstellung von 65 Personen, die aus dem Lager Postulicz [richtig: Potulice (dt. Potulitz)] (Polen) nach Rüdersdorf kamen; Belegungsmeldungen). - BLHA, Rep. 256 Küchensee, Nr. 140.

Gedruckte Quellen und Literatur: HOL VI, S. 454-459. - Aus der Rüdersdorfer Ortschronik. In: Rüdersdorfer Heimatblätter Nr. 2 (1984), o. S. - Brühe, Matthias: Katholische Kirche zwischen Uckermark und Oderland. Berlin 1998, S. 41. - Bujok, R[einhold]: 10 Jahre BdV-Arbeit in Rüdersdorf und Umgebung. In: BdV-Notizen 1 (2003)2, S. 8-10. - Gedenkstätten NS II, S. 341-342. - Hennickendorf 1945. [Hennickendorf 2005]. - 100 Jahre Pfarrkirche Hl. Familie Rüdersdorf 1905 bis 2005. Rüdersdorf bei Berlin 2005. - Köhler, Eva: Rüdersdorf. Berlin 1994. - Radoy, Renate: Umzug zum Jubiläum von Rüdersdorf. Volkssolidarität und BdV gestalteten zwei eindrucksvolle Bilder. In: Volkssolidarität im Barnim aktuell 2 (2010)4, S. 48-49. - Rüdersdorf. Zeitzeugen berichten. Hrsg. vom Seniorenbeirat Rüdersdorf. Rüdersdorf 1998. - Rüdersdorf. Zeitzeugen berichten. Vorkriegszeit, Kriegszeit, Nachkriegszeit. Hrsg. 
vom Seniorenbeirat Rüdersdorf. Vorw.: Peter Gutsche. Rüdersdorf o.J. - Schwillus/Brühe, S. 347. - 10 Jahre Bund der Vertriebenen in Rüdersdorf und Umgebung. Rüdersdorf 2002.

\section{Rühstädt}

Landgemeinde, bis 1952 Kr. Westprignitz, 1952-1990 Kr. Perleberg (Bez. Schwerin), 19901993 Ldkr. Perleberg, 1993 Ldkr. Prignitz

EREIGNISSE BIS KRIEGSENDE: „Vereinzelt kamen [ab 1939] Umsiedler, wie Familie Tatjuk, die durch das NS-Umsiedlungsprogramm ihre Heimat [Wolhynien] verlassen hatten, in Rühstädt an." (Transitzone Dorf, S. 60). - [1945:] „In der Ortschronik wird berichtet, dass das Dorf mit Flüchtlingen aus den Ostgebieten überfüllt gewesen sei: ,Jedes Haus, jedes Zimmer war überbelegt.“ Anfang Mai 1945 Einmarsch der Roten Armee (ebd., S. 64). - „Ausgebombte Flüchtlinge aus [S. 69] Hamburg fanden im Schloss und im Amtshaus bis in den Sommer 1945 hinein Unterschlupf.“ (ebd., S. 67, 69). - „Ab 1952 beherbergte das Feierabendheim [im Gutshaus] oin den ersten Jahren überwiegend Flüchtlinge, die im Zuge der Bodenreform neugesiedelt hatten. Insgesamt wurden 102 pflegebedürftige, meist alleinstehende Menschen aufgenommen. [...] Kinder der Flüchtlingsfamilien zog es meist in die umliegenden Städte [...].“ (ebd., S. 76).

BevöLKeRUNGSZAHLEN: 1925: 539, 1939: 355, 1946: 612, 1964: 602 (HOL I, S. 768).

Archivalische Quellen: Kreisarchiv Prignitz, Rat der Gemeinde Rühstädt, G 00478 (Bodenreform, 1946-1948; enthält u. a.: Verzeichnis der Umsiedler und Evakuierten).

Gedruckte Quellen und Literatur: Lindemann, Stefan: Findbuch zum Pfarrarchiv Rühstädt. In: Mitteilungen des Vereins für Geschichte der Prignitz 7 (2007), S. 24-68. - Transitzone Dorf. Ein Ort zwischen Bodenreform und Kollektivierung. Hrsg. von: Projektgruppe Umsiedlerin: Maria Hetzer [u. a.]. O. O. 2015. [Am Beispiel von Abbendorf und Rühstädt].

\section{Saalow}

Landgemeinde (seit 2003 Ortsteil von Am Mellensee), bis 1952 Kr. Teltow, 1952-1990 Kr. Zossen (Bez. Potsdam), 1990-1993 Ldkr. Zossen, 1993 Ldkr. Teltow-Fläming

UMSiedlerlager (zuvor Lazarett): Auch als „Umsiedlerlager des Kreises Teltow Saalow“ bezeichnet. - Bei $\rightarrow$ Zossen, Landkreis Teltow. An der Straße Saalow-Gadsdorf, 3 km vom Bahnhof Zossen. - Quarantänelager, Holzbaracken. - Kapazität am 31.12.1945: 1200 (BArch, DO 2/45, Bl. 40). - 1946 Belegungsstärke: 800 (Kaminsky, S. 159). - U. a. Juli 1946 Eintreffen eines Vertriebenentransports aus dem Sudetenland am Bahnhof Saalow (Rotzer). - 24.8.1946 Umsiedlerlager, Kapazität: 800 (SAPMO-BArch, DY 34/27880, Bl. 291). - 11.11.1946: Lagerleiter: Kleemann. Wirtschaftsleiter: Försterling. Lagerarzt: Inatowitz. - 1.1.1947 Kapazität: 1200 (Oehlsen, S. 101). - April oder Mai 1947 Übernahme von Medikamenten, Arznei- und Verbandsmitteln aus dem aufgelösten Umsiedlerlager $\rightarrow$ Eberswalde (Wenzel, S. 144). - 9.6.1947 
Quarantänelager, Kapazität: 2000, Belegung: 0 (SAPMO-BArch, DY 34/27880, Bl. 239).25.11.1947 in Befehl der SMA Brandenburg in Liste „der [zum 30.12.1947] zu schließenden Lager" aufgeführt (BLHA, Rep. 203 VP, Nr. 9, Bl. 43v).

BevöLKerungszahlen: 1925: 404, 1939: 517, 1946: 962, 1964: 1705 (HOL IV, S. 242).

Quellen: BLHA, Rep. 230 Oberlandratsamt Bernau, Nr. 287, Bl.44-51. - Auskünfte Augustin Rotzer, Teltow, 4.3.2017 (Juli bis Sept. 1946 mit den Eltern als Vertriebener aus dem Sudetenland im Lager befindlich, dann mit 19 Sudetendeutschen nach $\rightarrow$ Teltow eingemeindet).

Literatur: Wenzel, Mario: Die Aufnahme und Versorgung von Flüchtlingen und Vertriebenen in Eberswalde 19451948. In: Eberswalder Jahrbuch 2015, S. 136-145, hier S. 144.

\section{Saarow $\rightarrow$ Bad Saarow}

\section{Sachsendorf}

Landgemeinde, bis 1950 Kr. Lebus, 1950-1990 Kr. Seelow (ab 1952 Bez. Frankfurt/Oder), 1990-1993 Ldr. Seelow, 1993 Ldkr. Märkisch-Oderland

EREIGNISSE BIS KRIEgSEnde: [Aus Tagebuchaufzeichnungen des Gutsbesitzers:] 24.1.1945: „Täglich kommen Flüchtlinge aus der Gegend östlich Posens in das Dorf." (Schmelzer, Evakuierung, S. 111). - 26.1.1945: „Mehr und mehr Flüchtlinge kommen bei hohem Schnee und 4 Grad Kälte per Bahn und per Gespann aus den Ostprovinzen ins Dorf. Die Straßen sind voll von zurückgehenden Militärautos aus der Etappe. [...] [S. 112] In Sachsendorf erwartet mich eine Kosakenschwadron, die unbedingt untergebracht werden will. [...] Gleichzeitig mit den Kosaken trifft der Treck der Familie von Sprenger aus Sprengersfeld [e], Kreis Gnesen, nach 14tägiger Fahrt ein. / Die Russen haben inzwischen ihre Front bis unmittelbar an die Festung Schneidemühl, bis Bentschen und in Oberschlesien bis fast an Breslau vorgetrieben. Da Zeitungen uns selten erreichen und das Aussetzen des elektrischen Stroms das Radio stillgelegt hat, werden wir nur spärlich mit Nachrichten versorgt. [...]." (Ebd., S. $111 \mathrm{f}$.$) . -$ 30.1.1945: „Täglich verstärkt sich der Strom der das Dorf passierenden Flüchtlinge. Wagen an Wagen ziehen diese Unglücksmenschen - nun schon seit gut zwei Wochen unterwegs - durch das Dorf. Es ist schon lange nicht mehr möglich, sie alle unterzubringen. Bei uns im Gutshaus sind alle Fremdenzimmer längst belegt, das Eßzimmer ist Strohlager geworden. Alle übrigen Räume sind dichtbelegt, Ställe, Scheunen und alle nur möglichen Räume des Hofes stehen voller Flüchtlingspferde. Furchtbar das Elend dieser von Haus unf Hof Vertriebenen, die kaum mit dem Nötigsten versehen einem ungewissen Schicksal entgegenziehen. / Seit zwei Wochen in Schnee und Kälte auf eiliger Flucht vor den ständig hinter ihnen herrollenden Feindpanzern. Oft Tag und Nacht durchfahrend, um doch noch schneller wie diese über die Oder zu kommen. Oft sinken sie abends so zermürbt in ihre Quartiere, daß sie sich schwören, nun auch keinen Schritt mehr weiterzuziehen, und doch müssen sie nach einem Tage Rast weiter, um denen Platz zu machen, die nach ihnen kommen. Und es sind so viele, daß wir schließlich nur noch die 
behalten, die das Dorf bei Eintritt der Dunkelheit erreichen. Wer so früh kommt, daß er den nächsten Ort noch bei Tageslicht erreichen kann, muß weiterziehen. / Rührend ist die Bescheidenheit dieser Leute, die mit allem zufrieden und für alles dankbar sind. Und man kann ihnen nur so wenig bieten, da es zuviele sind. Nur wärmende Nahrung, Futter für ihr übermüdetes Vieh und Ruhe für Mensch und Zugtier. / Schlimmer noch wie diesen Flüchtlingen ist es denen ergangen, die ihre Heimat per Bahn verlassen mußten. Völlig unzureichende Vorkehrungen waren durch die Behörden getroffen worden. In Güterzügen - vielfach in offenen Waggons - wurden die Leute fortgeschafft, so daß Hunderte von Kleinkindern bei der Kälte erfroren. Unendlich viele Familienangehörige haben sich verloren und keine Ahnung, was aus den anderen geworden ist. / Inzwischen sind die Russen bis auf $50 \mathrm{~km}$ Luftlinie von uns jenseits der Oder angekommen. Wir Sachsendorfer beginnen nun, uns mit dem Gedanken vertraut zu machen, daß auch wir uns auf die Flucht begeben [S. 114] müssen. Die Nachrichten der in Mengen über die Oder zurückflutenden Soldaten, die nachts jenseits der Oder aufleuchtenden Brände, Schauergeschichten der Flüchtlinge beunruhigen die Bevölkerung. / Ich lasse die Ackerwagen nachsehen, sie mit Plandächern versehen. Vorerst nur aus Vorsicht, für den Fall, daß ...' Man will es noch nicht glauben, daß auch wir unsere Heimat verlassen müssen. Für jeden von uns wurde ein Rucksack genäht und ein Koffer mit dem Nötigsten gepackt, dem im Ernstfalle nur noch Mundvorrat hinzuzufügen war." (Ebd., S. $113 \mathrm{f}$.). 2.2.1945: „In Sachsendorf ist alles teilweise noch von Flüchtlingen oder schon wieder von Soldaten belegt." 3.2.1945: „Mittags kommt eine Reihe Bauerngespanne aus $[\rightarrow]$ Reitwein, unter ihnen der Bauer Adolf Gahr, dessen Gehöft diesseits Göritz unmittelbar an der Oder liegt." (Ebd., S. 114). - 4.2.1945: „Die Russen hatten sich inzwischen in Reitwein ungeachtet des kniehohen das Odereis überflutenden Wassers verstärkt. Auch den $[\rightarrow]$ Kienitzer Brückenkopf hatten sie verstärkt und die aus Tucheband und $[\rightarrow]$ Golzow durch unser Dorf ziehenden Flüchtlingsgespanne behaupteten, sie ständen schon an der Straße Golzow/Tucheband. Es wäre höchste Zeit für uns, sich auf den Weg zu machen. [...]." (Ebd., S. 115). „Es bestand die Anordnung, den Ort nicht ohne Räumungsbefehl zu verlassen. Durch die Erzählungen der Flüchtlinge aus den östlichen Kreisen, die ebenfalls diese Anordnung erhalten hatten, jedoch niemals oder zu spät auf den Weg gebracht worden waren, war das Vertrauen der Bevölkerung in die Fürsorge der Partei restlos erschüttert. Am liebsten wäre jeder, kaum daß er den Wagen bestiegen hatte, auf und davon gefahren. Es bedurfte großen Zuredens, die Leute zu bewegen, bis zum Morgen zu warten, damit alle geschlossen abrücken könnten. / Die restlichen Bonner Evakuierten waren inzwischen mit den letzten aus Dolgelin gehenden Zügen abgereist. / Über Nacht in Reitwein sichtbar werdende Brände, Artilleriefeuer, das eine Antwort der Russen erwarten ließ, Gefechtslärm, dazu die üblen Nachrichten von Flüchtlingen und Soldaten über das unmenschliche Auftreten der Russen ließen den Ortsgruppenführer und mich beschließen, am Morgen ohne einen Räumungsbefehl abzurücken. / Die ganze Nacht über wurde gepackt und gegen Morgen waren wir endlich fertig. Da die dörflichen Gespanne schon abmarschiert waren, gab ich ebenfalls Abmarschanweisung. Um 7 Uhr des 5. Februar 1945 zogen die letzten Gespanne meines Trecks vom Hofe, der zusammen mit den Vorwerken an die 540 Gespanne und etwa 395 Menschen umfaßte." (Ebd., S. 116).

EReignisse NACH KRIEgSende: 1946 Der DEFA-Spielfilm „Freies Land“ (Regie: Milo Harbich) behandelt das Flüchtlingsschicksal am Beispiel eines Dorfes in der $\rightarrow$ Westprignitz u. 
thematisiert daneben auch die Lage im „Notstandsgebiet Lebus“ am Beispiel von Sachsendorf (u. a. gezeigt: „Volksschule Sachsendorf"), Premiere 19.10.1946 in $\rightarrow$ Potsdam (wikipedia, www. defa-stiftung.de/milo-harbich [10.7.2018]).

BevöLKerungszahlen: 1925: 857, 1939: 814, 1946: 827, 1964: 887 (HOL VII, S. 381).

LiterATUR: Schmelzer, Hans-Adolf: Die Evakuierung des Dorfes und Gutes Sachsendorf 1945. In: Ein leidgeprüftes Land. Bearb. von Fritz Knüppel. 2. Aufl. Barsinghausen 1990, S. 111-132 [Tagebuchaufzeichnungen des Gutsbesitzers]. - Schmelzer, Hans-Jürgen: Verlorene Felder. Stunde Null im Oderbruch 1945/46. Berlin 2016.

\section{Sachsendorf-Werder $\rightarrow$ Werder (Oderbruch)}

\section{Sagast}

Landgemeinde, bis 1952 Kr. Westprignitz, 1952-1990 Kr. Pritzwalk (Bez. Potsdam), 19901993 Ldkr. Pritzwalk, 1993 Ldkr. Prignitz

Ereignisse bis Kriegsende: Ende Febr. 1945 Endpunkt eines Trecks aus Filehne (Netzekr. Pommern [ehem. Grenzmark Posen-Westpreußen]) (Dokumentation der Vertreibung I/1, S. 378 f.).

BevölkerungSZAHLEN: 1925: 335, 1939: 309, 1946: 494, 1964: 332 (HOL I, S. 774).

\section{Schenkenberg}

Landgemeinde, bis 1952 Kr. Zauch-Belzig, 1952-1990 Kr. Brandenburg-Land (Bez. Potsdam), 1990-1993 Ldkr. Brandenburg, 1993 Ldkr. Potsdam-Mittelmark

EREIGNISSE VOR 1945: „Ab 1925 wurden um das Vorwerk herum auf 554 Hektar 153 Ansiedlungen geplant. Nach dem Ersten Weltkrieg sollten hier, wie auch in anderen Teilen Deutschlands staatlich gestützt, Siedlungsgesellschaften für Umsiedler und Flüchtlinge aus ehemals deutschen Gebieten neue Existenzmöglichkeiten erschließn. Die Siedler kamen aus der Ukraine, Polen, Pommern, Westpreußen, Schlesien sowie aus dem rheinisch-westfälischen Raum. / Die ersten Häuser wurden 1925 errichtet. Am 30. September 1928 wurde auch die politische Gemeinde Schenkenberg gegründet. Bis 1930 erfolgte der Aufbau von 226 typisierten Siedlerstellen für Bauern, Gärtner und Arbeiter. Die Wohnhäuser waren hauptsächlich einfache Doppelhäuser in zwei Typen - mit Satteldach und Doppelgaube, gerundetem Giebel mit kleiner Gaube und Nebengelassen für die Kleintierhaltung. [...]." (Groch/Strehlau, S. 129). 1926 Bau einer großen Siedlung für Optanten aus Polen, deutschstämmige Siedler aus Russland, Ruhr-Umsiedler u. a. durch die Siedlungsgesellschaft Arbeiterheimstätten in Berlin-Adlershof, 1927 weitergeführt durch die Siedlungsgesellschaft Deutsch-Land mbH in Berlin und 
die Deutsche Kultur- und Siedlungs-Gesellschaft mbH ebd. (Unverricht, S. 18-22; HOL V, S. 388). - „Ab 1943 wurden in Schenkenberg Familien aus dem zerbombten Berlin aufgenommen." (Groch/Strehlau, S. 131).

EREIGNISSE NACH KRIEGSENDE: „Wie schon nach dem Ersten Weltkriege wurden auch nach dem Zweiten Weltkriege wieder Umsiedler auas den ehemaligen deutschen Ostgebieten, der Tschechoslowakei, der Sowjetunion und den Balkanländern in der Gemeinde angesiedelt.“ (Groch/Strehlau, S. 131). - [Tagebuchauszüge:] 12.5.1945: „Die Sorge um das tägliche Brot wächst. Es sieht so aus, als ob einstweilen überhaupt kein Brot mehr an gewöhnliche Deutsche verteilt werde. Die zunächst in der Schule und dann in der Baracke untergebrachten deutschstämmigen Flüchtlinge vom Schwarzen Meer ... werden bevorzugt.“ (Schaper, S. 65). - 6.6.1945: „Am Abend kommt die Sensation. / Wir sitzen mit Frau Bober in unserem Wäldchen, da kommen zwei Männeken auf unser Grundstück [Waldstraße, später Kindergarten, P.B.], eines davon mit roter Armbinde, und eröffnen uns, daß eine Flüchtlingsfamilie bei uns einquartiert werde. Wir fragen nach deren Kopfzahl, und sie antworten etwas verschämt: Zehn Personen, die elfte soll noch bei uns geboren werden. Es sind deutschstämmige Flüchtlinge vom Schwarzen Meer./Von dem Schreck müssen wir uns zunächt etwas erholen...." (ebd., S. 72). - 7.6.1945: „Wir haben das Gefühl, daß die Leute (die Einquartierung) trotz ihrer im ersten Augenblick Schreck erregenden Menge uns nicht mehr Opfer auferlegen, als unter den heutigen Umständen ein jeder billigerweise auf sich nehmen muß." (ebd.). - 8.6.1945: „Ich liege noch im Bett, da erscheint Herr Dietrich, alter Kommunist und Mitglied der Schenkenberger Regierung [Antifaschistisches Komitee, P. B.], und erklärt sehr ungezogen und diktatorisch, wie hätten unserer Einquartierung außer dem Stall nicht die kleine Schlafkammer, sondern unser Schlafzimmer einzuräumen. / Das lehne ich rundweg ab. ..." (ebd.). - 20.6.1945: „(Über die elfköpfige Einquartierung) Wir haben jetzt wenigstens jemand, der gelegentlich vorkommende Arbeiten ausführen, Holz hacken kann und dergleichen. Wer würde uns sonst das Wasser aus dem Bruch holen? Vom Wasserwerk gibt es keins mehr.“ (ebd., S. 74). - 27.6.1945: „Um 10 Uhr gibt es eine Überraschung. Ein Gesandter vom Komitee verkündet kurz und bündig, um 12 Uhr mittags müsse unsere Einquartierung marschfertig zur Umsiedlung nach Groß-Kreu[t]z sein. Nachdem ihr ganzer Kram zusammengepackt und auf den schon um 7 Uhr vorgefahrenen Leiterwagen verfrachtet ist, kommt der Gegenbefehl: Wieder abladen! In Groß-Kreu[t]z besteht keine Unterkunftsmöglichkeit./[S. 75] Für die Ernährung unserer kleinen Siedlung würde der Abtransport von hundertachtzig Schwarz-MeerDeutschen eine merkliche Entlastung bedeuten." (ebd., S. 74f.).

BEVÖLKERUNGSZAHLEN: 1925: 110, 1939: 772, 1946: 784, 1964: 666 (HOL V, S. 388).

Gedruckte Quellen und Literatur: Groch, Wolfgang / Strehlau, Reinhold: 90 Jahre Siedlerdorf Schenkenberg. In: Zwischen Havel und Fläming 2018 (2017), S. 129-132. - Schaper, [Carl]: Das Kriegsende. In: Wilfried Unverricht: Schenkenberg. Schenkenberg 1998, S. 60-75 [Tagebuchauszüge, 22.4. bis 3.7.1945, Verf. ist der bei Verwandten in Schenkenberg evakuierte Berliner Rechtsanwalt Dr. Carl Schaper]. 


\section{Schlepzig}

Landgemeinde, bis 1952 Kr. Lübben, 1952-1990 Kr. Lübben (Bez. Cottbus), 1990-1993 Ldkr. Lübben, 1993 Ldkr. Dahme-Spreewald

EREIGNISSE NACH KRIEGSENDE: „Nach dem II. Weltkrieg ließen sich zahlreiche ostpreußische Umsiedler im Ort nieder." (Spree-Wasserwanderatlas, S. [8]).

BeVÖLKeRUnGSZAHLEN: 1925: 874, 1939: 814, 29.10.1946: 1239, 1950: 1 191, 1964: 828 (HGV LDS, S. 10 f.). - 1.5.1946: 1028, davon 824 Ortsansässige, 204 „Umsiedler“ (Becken, S. 33).

UMSIEDLERLAGER (bis 1945 Barackenlager des Reichsarbeitsdienstes): 12.10.1945 in Befehl der SMA Brandenburg als eines von drei im Bezirk Lübben für die Aufnahme von „deutschen Umsiedlern“ geeigneten Lagern genannt („Waldlager Schlepig-Wernichen“ [Schlepzig-Börnichen]), die dafür hergerichtet werden sollen (Wille I, S. 66). - 24.10.1945 vom Landratsamt in Bericht erwähnt mit Kapazität „500-800 Mann“ (Töpler, Menschenwurm, S. 451). - Im „Verzeichnis der errichteten und vorgesehenen Umsiedlerlager im Verwaltungsbezirk Cottbus" vom 15.12.1945 zusammen mit dem Umsiedlerlager $\rightarrow$ Börnichen mit „Personenzahl“ 500-800 genannt (Töpler, Menschenwurm, S. 472).

ArChIVAlische Quellen: Kreisarchiv Dahme-Spreewald, A-4 Gemeinde Schlepzig, Nr. 16 (Aufstellungen über Zuteilungen aus der Bodenreform, 1945-1950; enthält auch: Verzeichnis der Umsiedler).

LiterATUR: Becken, Jörg: Lübben nach dem Inferno. [Cottbus] 2010, S. 28, 33. - Spree-Wasserwanderatlas (http:// www.schlepzig.de/wasserwandern/wasserwanderatlas.pdf [6.1.2017]). - Töpler, Menschenwurm, S. 472. - Wille I, S. 66 .

\section{Schmachtenhagen}

Landgemeinde (seit 2003 Ortsteil von $\rightarrow$ Oranienburg), bis 1952 Kr. Niederbarnim, 19521990 Kr. Oranienburg (Bez. Potsdam), 1990-1993 Ldkr. Oranienburg, 1993 Ldkr. Oberhavel BevöLKerungszahlen: 1925: 963, 1939: 1479, 1946: 1598, 1964: 1526 (HOL VI, S. 482).

VeRTRIEBENENVERBÄNDE NACH 1990: Landsmannschaft Ostpreußen e. V., Landesgruppe Brandenburg, 1996 erwähnt mit Sitz in Schmachtenhagen, Oranienburger Chaussee 7 (Horst Haut) (BdV-Handbuch 1996, S. 78, 167; Haut war 1995-2008 Vorsitzender [Auskunft der Landsmannschaft Ostpreußen, Hamburg]), siehe aber auch $\rightarrow$ Oranienburg. 


\section{Schmellwitz}

Landgemeinde (seit 1.7.1950 Ortsteil von $\rightarrow$ Cottbus), bis $1950 \mathrm{Kr}$. Cottbus, seit 1950 Stadtkr. Cottbus (1950-1990 Bez. Cottbus)

EREIGNisSE NACH KrIEgSENDE: Ende Juli 1948 im Verzeichnis (von der Landesregierung) verbotener Suchdienste erwähnt: Helmut Rekus, Schmellwitz Kr. Cottbus, Schulstr. 36 (BLHA, Rep. 203 MdI, Nr. 1197, Bl. 41).

\section{Schöneiche b. Berlin}

Landgemeinde, bis 1950 Kr. Niederbarnim, 1.7.1950-1990 Kr. Fürstenwalde (Bez. Frankfurt/ Oder), 1990-1993 Ldkr. Fürstenwalde, 1993 Ldkr. Oder-Spree

EREIGNISSE BIS KRIEGSENDE: 7.8.1944 Aufnahme aus den Ostgebieten evakuierter Schüler in den Schulen in Schöneiche und Fichtenau (Felber/Jerratsch/Martini, S. 137). - 22.4.1945 Einmarsch der Roten Armee (ebd., S. 140).

EReignisse NACH KrIEgSEnde: Mai 1945: „Seuchen wie Ruhr, Typhus und vor allem Tuberkulose verbreiten sich.“ (Felber/Jerratsch/Martini, S. 145). „In Schöneiche sind etwa 2200 Umsiedler einzugliedern“; Schule: Die Kinder sind sehr unruhig. ,Flüchtlingskinder kamen und gingen. Es kehrt vorerst keine Ruhe ein, da fortwährend Schüler in ihre alte Heimat zurückgehen oder wieder nach Schöneiche heimkehren.“ (ebd., S. 146). - 28.9.1945: Ankündigung des stellvertretenden Bürgermeisters, „dass in nächster Zeit 2000 Flüchtlinge eintreffen. ,Es handelt sich in der Hauptsache um Volksdeutsche, die jetzt ,Heim ins Reich' kommen.' Jeder verfügbare Wohnraum soll gemeldet werden, in dem Flüchtlinge untergebracht werden können. Die ehemaligen Angehörigen der NSDAP und deren Gliederungen werden aufgefordert, Einrichtungsgegenstände, Haushaltsartikel, Kleider, Wäsche usw. zur Verfügung zu stellen." (ebd., S. 150). - 24.10.1945 (Bericht des Bürgermeisters über die Bodenreform): Es wurden 40 ha (von $392 \mathrm{ha}$ ) an 5 Umsiedler vergeben (ebd., S. 152). - Dez. 1945 Bürgermeister führt Rückgang der Einwohnerzahl von 10100 auf 9791 darauf zurück, „dass Umquartierte und Bombengeschädigte bis Oktober nach Berlin zurückgekehrt seien, da sie sonst ihr Wohnrecht in Berlin verlören. Außerdem seien viele Flüchtlinge in entsprechende Auffanggebiete zurückgekehrt." (ebd., S. 154). - 1946: Konradheim in der Friedrichshagener Straße dient als Typhusstation, das Schloss als Lazarett, Quarantänestation und Wohnhaus (ebd., S. 154). - 25.1.1946 Schließung der Seuchenstation. „Insgesamt gab es 100 Typhuskranke““ (ebd.). - 12.5.1946: „Der Lagerleiter des Kreisumsiedlerlagers $\rightarrow$ Rüdersdorf informiert den Bürgermeister der Gemeinde Schöneiche, dass ,167 Umsiedler zur Eingemeindung nach Schöneiche und Kleinschönebeck überwiesen werden. ,Die Umsiedler kamen aus verschiedenen Berliner Quarantänelagern. Sie sind seuchen- und läusefrei. Die Umsiedler erhielten für 2 Tage Brot, da keine andere Marschverpflegung auf Grund der schnellen Räumung des Lagers beschafft werden konnte.' Die Umsiedler sollen von der Straßenbahnhaltestelle Grätzwalde abgeholt werden." (ebd., S. 155). 
EREIGNisSe NACH 1990: 1998 zieht die im „Förderkreis Alte Kirchen Berlin-Brandenburg e. V. als Autorin u. Redakteurin (früher hauptberuflich als Redakteurin der „Märkischen Union“ in $\rightarrow$ Potsdam, dann der „Neuen Zeit“ in Berlin-Ost) tätige Journalistin Eva Gonda (geb. 1936 Landsberg/W.) von Berlin-Köpenick nach Schöneiche, wo sie u. a. in der Evang. Kirchengemeinde aktiv ist (von Wedel-Schunk).

Bevölkerungszahlen: 1925: 1140, 1939: 9153, 1946: 8799, 1964: 9983 (HOL VI, S. 492). - Laut Flüchtlingsstatistik vom 15.7.1946 befanden sich in der Gemeinde Schöneiche einschließlich Münchehofe 878 Flüchtlinge (154 Jungen u. 142 Mädchen im Alter bis 15 Jahre, 160 Männer u. 422 Frauen im Alter über 15 Jahre) (Felber/Jerratsch/Martini, S. 156).

Katholiken: Der aus dem Ermland (Freudenberg, Kr. Rößel) vertriebene Pfarrer Franz Friedrich (geb. 1886) war nach 1945 (erwähnt 1946/49) Hausgeistlicher im (seit 1926 von Franziskanerinnen betriebenen) Theresienheim Schöneiche, Königstraße 18 (Schematismus Berlin 1947, S. 37, 150; 1949, S. 37, 141; Ostpriesterverzeichnis 2, 1949, S. 25 ).

Kinderheim St. Konrad (zuvor Johannes-Hoever-Haus), Friedrichshagener Straße 67: „Nach 1945 wurde der zum Teil kriegsgeschädigte und ausgeplünderte Gebäudekomplex wieder der katholischen kirche übereignet. Zwei Nonnen begannen im Auftrag des Bistums Berlin und mit der Unterstützung des in Schöneiche ansässigen Bernhard Machnik mit dem Aufbau des ,Konradheimes. Bernhard Machnik war zu der Zeit zunächst freier Sachbearbeiter für Wohlfahrtspflege und Flüchtlingsfragen, später Syndikus im Caritasverband. Schwerpunkt seiner Arbeit war das Auffinden von elternlosen Flüchtlingskindern in Deutschland mit alliierter Reisegenehmigung für alle deutschen Besatzungszonen." (Cajar, S. 17). - „Nach dem Zweiten Weltkrieg übernahm der Berliner Caritasverband in Schöneiche bei Berlin ein Haus von den Franziskanerbrüdern in der Friedrichshagener Straße 67. Dort hatten die Franziskaner 1924 in der ehemaligen Gaststätte Roland ein Kindererholungsheim eingerichtet, das sie Johannes-Höver-Haus nannten. Der Caritasverband führte das Haus weiter und übertrug die Leitung am 14. Juli 1947 den Marienschwestern. Sie sollten Kinder aufnehmen, die an den Folgen der Unterernährung in den Kriegs- und Nachkriegsjahren litten. / Am 16. Juli 1947 kamen vier Schwestern nach Schöneiche. Sie waren aus Schlesien vertrieben worden und brachten nur wenige Habseligkeiten mit. Das Haus fanden sie in völlig verwahrlostem Zustand vor. Es gab keinen Strom, kein Licht, kein Gas, kein Wasser, keine sanitären Anlagen, keine Türen, die Fenster waren mit Pappe vernagelt und es fehlte an Möbeln und Geschirr. Im Ort konnte man nichts kaufen. Lebensmittel gab es nur auf Marken, welche die Schwestern als neu Zugezogene noch nicht bekamen; so hatten sie nichts zu essen und mussten vom St. Antonius-Krankenhaus in Friedrichshagen mit versorgt werden. / Angesichts der Kinder, die hier aufgenommen werden sollten, setzte eine große Hilfsaktion ein. Die Schwestern des St. Antonius-Krankenhauses brachten auf einem Handwagen die nötigsten Dinge. Auch die Einwohner von Schöneiche spendeten, was sie entbehren konnten, vor allem Haus- und Küchengeräte. / Nach knapp drei Wochen trafen am 4. August 1947 die ersten Kinder ein. Für sie standen 45 Luftschutzbetten 
bereit, aber es fehlte noch an Strohsäcken, Kissen, Bettwäsche, Kleiderschränken und Waschgelegenheiten. Die Kinder mussten sich zum Teil auf dem Hof an der Wasserleitung waschen, was sie im Hochsommer auch mit Begeisterung taten. Zum Wäschewaschen mussten die Schwestern in das St. Antonius- [S. 507] Krankenhaus fahren, da sie in Schöneiche weder einen Bottich noch eine Wäscheleine besaßen. Erst allmählich konnten sie die notwendigen Dinge von Nachbarn erwerben. Holz zum Kochen der Wäsche suchten sie im Wald. Bei den Bauern erbettelten sie Stroh für die Betten. Der Caritasverband lieferte neue Decken, gebrauchte Handtücher und einige Papiersäcke, aus denen die Schwestern Kissenbezüge und Strohsäcke nähten. [...] Die Situation besserte sich gegen Ende des Jahres 1947, als die öffentliche Unterstützung einsetzte und die Schwestern die nötigsten Einrichtungsgegenstände kaufen konnten. / Einen Raum richteten die Schwestern als Kapelle ein. [...] / [...] Im Herbst 1947 erhielt die Niederlassung drei Parzellen Gartenland, die sie bewirtschaften konnte. Es kamen weitere Schwestern für die landwirtschaftliche Arbeit, und bis Ende 1947 wuchs der Konvent auf zehn Schwesterm. Sie arbeiteten im Kinderheim, in der Landwirtschaft und in der ambulanten Krankenpflege. [...] / [... Das Haus war weiterhin im Unstand und unbeheizt. Bis November 1947 schlug der Regen in die Schlafzimmer. Es fehlte an Kohlen, und erst Ende des [S. 508] Jahres kam die erste Zuteilung von Brennholz. Ein wohlwollender Schreiner fertigte die nötigsten Möbel für die Kinder an. / Das Haus diente nun als Erholungsheim für Kinder, als Waisenhaus und als Kommunikantenanstalt. Kurzzeitig arbeiteten die Schwestern von Mai 1948 bis Februar 1949 in der Seelsorgehilfe in der Pfarrei. Nebenbei gingen sie auch der ambulanten Krankenpflege nach. 1949 waren 15 Schwestern in der Niederlassung." (Mertens, Bd. 2, S. 506-508). 1950 Namengebung „Kinderheim St. Konrad“, 1952 staatliche Anerkennung als Kinderkurheim durch den Rat des Bezirkes Frankfurt (Oder) und Spezialisierung auf langfristige Heimplätze für tuberkulosegefährdete Kinder (ebd., S. 508). - Ab 1953 Nutzung zunächst eines Teils, später aller der Räume durch das Bischöfliche Vorseminar (ab 1972 Sprachenkurs/-seminar für Priesteramtskandidaten), nach und nach Reduzierung der Kinderbetreuung, 1958 Entlassung der letzten Heimkinder, Konzentration der Schwesternarbeit auf die Betreuung des Vorseminars und die ambulante Krankenpflege (1964 10 Schwestern) (ebd., S. 509). 1988 noch 4 Schwestern, 28.7.1990 Auflösung der Marienschwestern-Niederlassung (ebd., S. 510).

Gedruckte Quellen: Zeidler, Hans: Als Ostpreußen verloren ging. Ein Schlesier im Krieg. Berlin 1998, S. 61f. [(Neu-)Lehrer in Schöneiche].

Literatur: Brühe, Matthias: Katholische Kirche zwischen Uckermark und Oderland. Berlin 1998, S. 42. - Cajar, Wolfgang: Geschichte der Gesundheitsfürsorge in Schöneiche. [Schöneiche] 2018. - Felber, Christina / Jerratsch, Ines / Martini, Helge: Schöneiche bei Berlin. Schöneiche bei Berlin 2000. - Mertens, Johannes: Geschichte der Konregation der Marienschwestern von der Unbefleckten Empfängnis 1945-1999. Bd. 2. Berlin 2000, S. 506-510. Schwillus/Brühe, S. 347. - Wedel-Schunk, Theda von: Eva Gonda - engagiert für „Alte Kirchen“. In: Offene Kirchen 2016, S. 92-93. 


\section{Schönholz}

Ortsteil von Neuwerder (seit 1928), bis 1952 Kr. Westhavelland, 1952-1990 Kr. Rathenow (Bez. Potsdam), 1990-1993 Ldkr. Rathenow, 1993 Ldkr. Havelland

EReignisse NACH KRIEgSENDE: „Die Gutsbesitzerfamilie Lange wurde 1945 enteignet, worauf Neusiedler das bescheidene Herrenhaus in Besitz nahmen. Die Wohnhäuser und Wirtschaftsgebäude ließ man danach verfallen, so daß sie wegen ihres schlechten Bauzustandes um 1970 schließlich abgerissen werden mußten.“ (Andreae/Geiseler, S. 262). - „1945 wurde das Gut enteignet. Noch im selben Jahr siedelten 34 bessarabische Flüchtlingsfamilien aus Kat[1] ebug (nahe dem Schwarzen Meer) nach Schönholz über und bekamen je ein Stück Land. So sollten wohl die meisten der heutigen Schönholzer bessarabische Wurzeln haben." (Das westhavelländische Schönholz, o. S.). - „In Schönholz waren die Bessarabier [... in der Mehrheit. Die meisten von ihnen stammten aus der Heimatgemeinde Katleburg, in Bessarabien eine ,Pachtgemeinde“ (Schmidt, S. 507). - Feste wurden „in Schönholz bis zum Beginn der 60er Jahre“ in bessarabiendeutschem Stil begangen und entsprechende alte Lieder dazu gesungen. „Hier wurden in den ersten Jahren viele Hochzeiten nach bessarabischem Brauch gefeiert." (ebd., S. 521). - In der gesamten Gemeinde Neuwerder (!) 1947 in der Bodenreform 57 neue Eigentümer berücksichtigt, davon 52 Umsiedler (HOL III, S. 414). - 1966/67 Bau eines evangelischen Gemeindezentrums für Schönholz (und Neuwerder) an der Dorfstraße. „Voraussetzung für die Baugenehmigung war die staatliche Auflage, keinen Friedhof anzulegen. Das Grundstück hatte die kleine Gemeinde - vorwiegend Rumäniendeutsche aus Bessarabien - von der Evangelischen Kirchengemeinde $[\rightarrow]$ Rhinow erhalten. Seitdem gehört die Schönholzer Kirche zu gleichen Teilen der Evangelischen Kirchengemeinde Rhinow und der Landeskirchlichen Gemeinschaft Schönholz/Rathenow.“ (Borgmann/Sebastian, S. 69 mit Abb.).

Neubauernhaus (Typen-Wohnstallhaus): „aus der Zeit der Bodenreform für Vertriebene (Umsiedler) aus Bessarabien, teilweise aus Abbruchmaterial eines ehemaligen Vorwerks zum Gut Hohennauen errichtet, um 1947“ (Dorfentwicklung in Brandenburg, S. 16, mit Abb.).

Bevölkerungszahlen: 1925: 102 (HOL III, S. 341). - Neuwerder insgesamt: 1925: 86, 1939: 106, 1946: 381, 1964: 239 (ebd., S. 414).

Literatur: Andreae/Geiseler, S. 262. - Borgmann, Lutz / Sebastian, Jürgen: Kirchen im Havelland. Potsdam 1994, S. 69. - HOL III, S. 341 (ohne Erwähnung der Flüchtlingsansiedlung). - Dorfentwicklung in Brandenburg. Hrsg.: Ministerium für Landwirtschaft, Umweltschutz und Raumordnung (MLUR) des Landes Brandenburg in Verb. mit Märkische Akademie ländlicher Raum e.V. Potsdam 2002, S. 16. - Schmidt, Ute: Die Deutschen aus Bessarabien. 3. Aufl. Köln/Weimar/Wien 2006, S. 507, 521. - Das westhavelländische Schönholz wurde 1945 zur neuen Heimat von 34 bessarabischen Familien. In: Märkische Oderzeitung, 4.1.2011. 


\section{Schönwalde}

Landgemeinde (seit 31.12.2001 Ortsteil der Gemeinde Schönwald), bis 1.7.1950 Kr. Luckau, 1950-1990 Kr. Lübben (ab 1952 Bez. Cottbus), 1990-1993 Ldkr. Lübben, 1993 Ldkr. DahmeSpreewald

BeVÖLKERUNGSZAHLEN: 1925: 842, 1939: 1015, 29.10.1946: 1420, 1950: 1297, 1964: 1073 (HGV LDS, S. 30 f.).

FLÜCHTLINGSLAGER (bis 1945 Barackenlager des Reichsarbeitsdienstes): 1945 erwähnt (Becken, S. 28).

LiterATUR: Becken, Jörg: Lübben nach dem Inferno. [Cottbus] 2010. - Blöß, Kreise und Gemeinden, S. 14.

\section{Schönwalde (heute: Schönwalde-Glien)}

Landgemeinde, bis 1952 Kr. Osthavelland, 1952-1990 Kr. Nauen (Bez. Potsdam), 1990-1993 Ldkr. Nauen, 1993 Ldkr. Havelland

EREIGNISSE NACH KRIEGSENDE: 1947 in der Bodenreform 14 Umsiedler berücksichtigt (HOL III, S. 343). - 15.3.1947 Erwähnung einer „Umsiedlergenossenschaft“ (Heimarbeit) „Antifa-Genossenschaft eGmbH, Erzeugung u. Verkauf von Strick- u. Wirkwaren sowie Malerbedarfsartikel, [/] Schönwalde b. Nauen/Krs. Osthavelland, Ernst Bernweisler, Schönwalde [/] Belegschaft versucht noch Maschinen aus der CSR zu bekommen." (BLHA, Rep. 333, Nr. 574, Bl. 105), 1948 noch erwähnt als von Sudetendeutschen gegründete „Gewerbegenossenschaft Schönwalde" (Christopeit, S. 86).

BeVÖLKERUNGSZAHLEN: 1925: 350, 1939: 3 022, 1946: 3 525, 1964: 3796 (HOL III, S. 343).

Katholiken: „Zehn Jahre nach der Gründung der Siedlung Schönwalde entstand dort zum 1.10.1942 auch eine seelsorglich selbständige Kirchengemeinde.“ (Brühe, S. 48) - „Als der aus der Grafschaft Glatz heimatvertriebene Pfarrer Rochus Bernatzky in ein Hennigsdorfer Flüchtlingslager kam, konnte ihn Pfr. [Josef Maria] Zawacki [Pfarrer in $\rightarrow$ Hennigsdorf] dazu bewegen, die neue Kuratie zum 15.11.1946 zu übernehmen.“ (ebd., S. 21). - „1946 „kam der aus Schlesien vertriebene Pfr. Rochus Bernatzky (1946-70) mit einem Teil seiner bisherigen Gemeinde nach Schönwalde. Unter Einbeziehung der alten Kapelle entstand nach Plänen von F. Linke ein Neubau, der am 3.11.1951 benediziert werden konnte. Die Katholikenzahl lag damals bei etwa 1200, im Jahre 1957 wurde die Gemeinde auch vermögensrechtlich selbständig." 1997 Kuratie aufgelöst (Brühe, S. 48; textähnlich: Schwillus/Brühe, S. 315). - Rochus Bernatzky (geb. 1903 Mittelsteine, Kr. Neurode) war bis 1945 Pfarrer der kath. Gemeinde Wölfelsgrund, Kr. Habelschwerdt (Grafschaft Glatz/Schlesien) (Anschriftenverzeichnis des Klerus der Grafschaft Glatz 1945-1950, S. 2; Ostpriesterverzeichnis 2, 1949, S. 14; Schematismus Berlin 1949, S. 139). Er hielt auch nach 1945 stets Kontakt zu den in alle Welt vertriebenen Wölfelsgrundern 
und nahm ab 1947 regelmäßig und aktiv an den in den Westzonen organisierten Wölfelsgrunder Treffen teil. Offenbar hat er dabei zumeist die Heilige Messe gehalten, nachweislich schon am 8. August 1947 beim Treffen in Engelskirchen, auch bei der Wallfahrt nach Werl 1970 war er dabei (Chronik zu Wölfelsgrund, S. 548 f. mit Foto). Am 29. Januar 1978 wurde im Rahmen eines solchen Heimattreffens in Kreutzberg/Ahr feierlich sein 50. Priesterjubiläum begangen (ebd., S. 554). Letztmalig nahm er 1991 teil (ebd., S. 438, 563), am 6. Februar 1997 verstarb er in Refrath bei Köln (ebd., S. 577, Faksimile des Totenzettels mit Lebensweg).

Archivalische Quellen: BLHA, Rep. 333 SED-Landesleitung Brandenburg, Nr. 574, Bl. 105.

Literatur: Brühe, Matthias: Katholische Kirche zwischen Prignitz und Havelland. Berlin 2000, S. 48. - Christopeit. - Die Chronik zu Wölfelsgrund, Kreis Habelschwerdt, Grafschaft Glatz in Schlesien. Zusammenstellung, Ausarbeitung und Ergänzung von Leonhard Prause. [Wenden 2005], S. 548 (Engelskirchen), 549 (Werl, mit Foto). - 75 Jahre Katholische Kirchengemeinde zu den hl. Schutzengeln Hennigsdorf. Hennigsdorf 2002, S. 21, 65. - Schwillus/ Brühe, S. 315 .

\section{Schwanebeck-Gehrenberge}

Wohnplatz/Ortsteil der Landgemeinde Schwanebeck (dieses seit 2003 Ortsteil von Panketal), bis 1952 Kr. Niederbarnim, 1952-1990 Kr. Bernau (Bez. Frankfurt/Oder), 1990-1993 Ldkr. Bernau, 1993 Ldkr. Barnim

EREIGNISSE NACH KRIEGSENDE: In Schwanebeck insgesamt in der Bodenreform 55 ha von 295 ha an 5 Umsiedler vergeben (HOL VI, S. 519).

Katholiken: „Pfarrer (Kuratus) der Kuratie „Maria Hilfe der Christen“ in der Siedlung Gehrenberge, Kolpingstr. 16, war ab 1.7.1947 der bis 1945 in Tirschtiegel amtierende Propst Franz Düllick (geb. 1903 Schneidemühl) (Ostpriesterverzeichnis 2, 1949, S. 21; Schematismus Berlin 1949, S. 61, 140).

\section{Schwarzheide}

Landgemeinde (1967 Stadtrecht), bis 1952 Kr. Calau (ab 1950 Kr. Senftenberg), 1952-1990 Kr. Senftenberg (Bez. Cottbus), 1990-1993 Ldkr. Senftenberg, 1993 Ldkr. OberspreewaldLausitz

BevöLKerungszAhlen: 1925: 3638, 1939: 5898, 1946: 7449, 1964: 8173 (Städtebuch, S. 463).

Katholiken (Erzbistum Breslau/Erzbischöfliches Amt Görlitz): 1946: 1031 (Städtebuch, S. 463). - Pfarrer war 1949 der bis 1945 im nun polnischen Teil des Erzbistums Breslau wirkende Kuratus Richard Frost (geb. 1910) (Ostpriesterverzeichnis 2, 1949, S. 26). 
FRIEDHOF SCHWARZHEIDE-WEST: „1946 grub man im [Brabag-]Werksgelände fünf männliche Leichen aus, vermutlich ehemalige KZ-Häftlinge. Sie wurden in einem Sammelgrab bestattet, in dem Flüchtlinge und deutsche Soldaten beerdigt worden waren. Um alle diese Toten zu ehren, wurde 1965 links von der Trauerhalle und vor dem Sammelgrab ein Denkmal errichtet, ein auf mehreren Stufen ruhender Findling mit der Inschriftentafel: ,Gewidmet den namenlosen Opfern des Faschismus / Ihr bleibt uns unvergessen“" (Gedenstätten NS II, S. 347).

\section{Schwedt/0der}

Stadtgemeinde, bis 1952 Kr. Angermünde, 1952-1961 Kr. Angermünde (Bez. Frankfurt/ Oder), 1961-1993 Stadtkreis (bis 1990 Bez. Frankfurt/Oder), 1993 Ldkr. Uckermark

EREIGNISSE BIS KRIEGSENDE: 22.1.1945: „Eintreffen der ersten Ostflüchtlinge“ (Wir wollten eigentlich nicht fliehen ..., S. 13). - 26.1.1945: „Beginn der Krise in Schwedt - der Treck aus dem Osten beginnt: Immer größere und längere Kolonnen von Trecks ziehen mit Pferd und Wagen bei Kälte, Schnee und Matsch durch die Straßen der Stadt. Nach den Erzählungen der Flüchtlinge sind viele - vor allem alte Menschen - unterwegs erfroren." (ebd., S. 15). - 30.1.1945: „Der Flüchtlingsstrom hält an. Die Flüchtlinge kommen jetzt nur noch mit Handwagen, Karren, Fahrrädern oder mit einem Bündel auf dem Rücken. Die Alten, Gebrechlichen und Kranken sollen sich in der Knabenschule melden. Aus Angst vor einer Trennung von den Angehörigen im Treck wird die Anordnung kaum befolgt.“ (ebd., S. 17). - 31.1.1945: „Der Fliegerhorst in Königsberg [Neumark] wird gesprengt, die Bevölkerung flieht nach Schwedt. Es herrscht Tauwetter - besonders die Flüchtlingstrecks leiden unter Schnee, Dreck, fehlendem Wasser und der Verkehrsnot. Die Flüchtlingskolonnen wurden registriert und für bestimmte Kreise zur Weiterfahrt eingeteilt.“ (ebd., S. 18). - 1.2.1945: „Der Flüchtlingsstrom ebbt ab - er soll in die Neumark umgeleitet worden sein, Telefonsperre für Schwedt" (ebd., S. 30). - 2.2.1945: „Flüchtlingsströme aus den geräumten Orten jenseits der Oder ziehen durch Schwedt.“ (ebd.). - 2./3.2.1945: Langer Flüchtlingstreck aus Nahausen (Kr. Königsberg/Nm.) flieht über Schwedt weiter in den Kr. Templin (Köhler, S. 99-101). - 3.2.1945: „Das zusammengetriebene Vieh aus der Neumark wird über die Brücke und durch Schwedt gebracht." (Wir wollten eigentlich nicht fliehen ..., S. 30). - 4.2.1945 „Den ganzen Tag hört man Kanonendonner von der Neumark her." (ebd., S. 31). - 4.2.1945: Standgericht (Kriegsgericht) verhängt in Schwedt Todesurteil gegen den zur Beschaffung von Waffen und Munition für seine Truppe nach Schwedt gekommenen Bürgermeister von Königsberg/Nm., Kurt Flöter, wegen unerlaubten Verlassens seiner Stadt, Vollstreckung durch Erhängen an einer Kastanie auf der Schwedter Schlossfreiheit (Chronik, S. 120; Brandenburgische Gemeinden 1945, S. 3; Wir wollten eigentlich nicht fliehen ..., S. 26, 31). - 7.2.1945: „Die Evakuierung von Frauen und Kindern mit Sonderzügen nach $[\rightarrow]$ Perleberg/Westprignitz beginnt. In der Nacht kommen Einwohner von Nipperwiese [Kr. Greifenhagen/Pommern] über das Eis der Oder, um sich in Sicherheit zu bringen." (Wir wollten eigentlich nicht fliehen ..., S. 31).- 10.2.1945: „Bei der Durchschleusung der Trecks 
aus der Neumark helfen auch Angehörige des Volkssturms.“ (ebd.). - 12.2.1945: „Beginn des Abtransportes aller transportfähigen Bewohner, um Platz für den Katastrophenfall zu haben. Für das Schwedter Krankenhaus wird eine Ausweichstelle im Gasthaus ,Waldfrieden' geschaffen.“ (ebd., S. 32). - 14.2.1945 „Trecks aus Richtung Königsberg bringen die alarmierende Nachricht, dass der Anmarsch der Roten Armee nicht mehr aufzuhalten sei. Die Schanzarbeiten in und um Schwedt werden fieberhaft fortgesetzt.“ (ebd.). - 20.2.1945: „Die Evakuierung von Frauen und Kindern wird ab jetzt behördlich angeordnet." (ebd., S. 33; vgl. Chronik, S. 121). - 21.2.1945: „Der für die Evakuierung bereitgestellte Zug ist schon lange vor der Abfahrt überfüllt." (Wir wollten eigentlich nicht fliehen ..., S. 33). - 23.2.1945: Abends Treck der Nipperwieser Einwohner durch Schwedt.“ (ebd., S. 34). - 27.2.1945: „Oder zur Hauptkampflinie erklärt“ (ebd., S. 36); militärischer „Räumungsbefehl für den Schwedter Brückenkopf“ (ebd., S. 37). - Nacht 1./2.3.1945: „Der Brückenkopf Schwedt wurde planmäßig aufgegeben und die Oderbrücke bei Niederkränig gesprengt.“ (ebd., S. 40). - 2.3.1945: „Die Meglitzbrücke ist gesprengt.“ (ebd., S. 46). - 5.3.1945: „Alle Dörfer der Neumark und die Oderranddörfer sind zum größten Teil geräumt. Nur vereinzelt kommen die Flüchtlinge zu Fuß und mit Handwagen über die Schwedter Brücke.“ (ebd., S. 47). - 6.3.1945: „Etwa 7000 Leute haben Schwedt schon verlassen." (ebd.). - 30.3.1945: Beginn der Räumung der Stadtviertel an der Oder, zwangsweise Unterbringung der Bevölkerung in Wohnungen der Stadtmitte (ebd., S. 51; Chronik, S. 121). 2.4.1945 morgens Sprengung der Stadtbrücke durch Wehrmachtspioniere (Wir wollten eigentlich nicht fliehen ..., S. 52, 58 f.; Chronik, S. 121). - 14.4.1945: „Der größte Teil der Zivilbevölkerung hat die Stadt verlassen." (Wir wollten eigentlich nicht fliehen ..., S. 62). - 19.4.1945: „Um 4 Uhr früh fährt der letzte Zug aus Schwedt.“ (ebd., S. 63). - 26.4.1945 Besetzung der Stadt durch sowjetische Truppen, angeblich nur noch 26 Bewohner anwesend (ebd., S. 72, 75, 78). - „Am Ende des Krieges waren mehr als 85 Prozent der Stadt zerstört.“ (Rössler, S. 131). „Die Lage an der Oder, durch die Schwedt plötzlich zur Grenzstadt wurde, sorgte dafür, daß die Stadt in besonderem Maße von den Flüchtlingsströmen betroffen war." (Springer, S. 31).

EREIGNISSE NACH KRIEGSENDE: 10.5.1945: „Der sowjetische Stadtkommandant beruft den parteilosen Ackerbauern Kurt Wendt (Flüchtling aus Ostpreußen) zum Bürgermeister“, der noch im Mai durch einen Schwedter abgelöst wird (Wir wollten eigentlich nicht fliehen ..., S. 83). - Juni 1945 Typhusepidemie (Chronik, S. 122). - 9.7.1945 (Treck aus Woldenberg/ Nm.): „Vor Schwedt wird halt gemacht, weil der Zug nicht in die Stadt darf. Von einem aufgestellten Stadtbeamten bekommen wir die Auskunft, daß an Fürsorge von einer Stelle nicht zu denken ist. Jeder kann ziehen, wohin er will, und sich zu essen suchen. [...] und ich gehen aber zu Beruhigung der Menschen in die Stadt, zur russischen Kommandantur, wo man uns abweist. Dann zum Bürgermeisteramt, wo man uns auch abwimmelt. Für Alte und Kranke, die unterwegs liegen, gibt es noch keine Fürsorge." (Tagebuch Prochnow, S. 291). - 3.8.1945: „Wiederinbetriebnahme des Krankenhauses und Eröffnung eines Kinderheimes [siehe unten]." (Wir wollten eigentlich nicht fliehen ..., S. 88).6.9.1945: „Beginn der Bodenreform in Schwedt“, Durchführung auch den umliegenden Gütern am 4. und 7.10.1945 (ebd., S. 90, 93). - 1.11.1945: „Täglich verkehrt ab 14.00 Uhr einmal ein 
Zug nach Angermünde.“ (ebd., S. 95). - 1.12.1945: Der aus der Neumark stammende Michael Wolter wird von der sowjetischen Kommandantur als Bürgermeister eingesetzt, amtiert aber offenbar nur kurz (Chronik, S. 123). - 3.10.1950 Zuweisung von westlich der Oder gelegenen einwohnerlosen Flächen der nun polnischen Gemeinde Niederkränig/Krajnik Dolny (ehem. Kr. Königsberg/Nm.) an die Stadt Schwedt/Oder (Blöß, Kreise und Gemeinden, S. 31). - „Angesichts einer derartigen Situation der Stadt [wirtschaftliche Stagnation bzw. Rückgang - P. B.] mußten insbesondere junge Menschen die Perspektiven für ihr zukünftiges Leben vor allem außerhalb der Stadt suchen, und dies galt nicht nur für potentielle Republikflüchtlinge, für Vertriebene und Kriegsflüchtlinge, die nach einem mehr oder minder kurzen Aufenthalt weitzerzogen." (Springer, S. 33). - 1973 Öffnung des Grenzübergangs nach Niederkränig/Krajnik Dolny (Otto, S. 42).

EREIGNISSE NACH 1990: Heimattreffen von Vertriebenen aus dem Kr. Königsberg/Nm. (König, S. 103).

BevÖLKERUNGSZAHLEN: 1925: 8976, 1939: 10640 (ständige Bevölkerung: 9 161), 16.4.1945: 26, 1946: 5961, 1964: 19090 (Städtebuch, S. 466). - 1944: „Per 1. Oktober beträgt die Zahl Einwohner 9205. Dazu kommen 868 Flüchtlinge und Schwedter Bürger, deren Wohnungen durch Bomben zerstört wurde.“ (Chronik, S. 120). - Juni 1945: „Es sind mehr als 1000 Einwohner registriert." (Wir wollten eigentlich nicht fliehen ..., S. 84). - 30.6.1945: 3909 (ebd., S. 86). - Ende Juli 1945: 5001 (ebd., S. 88). - Bevölkerungszahl mit Stand 11.8.1945: „1224 Männer, 2249 Frauen, 1521 Kinder und 263 Flüchtlinge“ (Stadtarchiv Schwedt/Oder, Akte Allg. Verwaltung, Bürgermeister, Aug. 1945 bis Juni 1946, hier zit. nach: Zeitensprünge, S. 65). - 30.9.1945: 5023 (Wir wollten eigentlich nicht fliehen ..., S. 92). - Nov. 1945: 5233 (davon 91,7\% bereits vor dem Krieg, Rest „Umsiedler“) (Springer, S. 33). - 19486680 Einwohner (Chronik, S. 125). - 1949: 6790, 1955: 6418, 1957: 6209 (Springer, S. 33). - Ab 1960 (Erdölverarbeitungswerk) starke Bevölkerungszunahme. 1974 kamen 42,1\% der Zuwanderer aus dem Bezirk Frankfurt/Oder und 15,4\% aus dem Bezirk Neubrandenburg (ebd., S. 162; der Anteil Vertriebener wird im Kapitel „Bevölkerungsentwicklung und Beschäftigtenstruktur“ [S. 160-167] nicht thematisiert).

Katholiken: 1925: 423, 1946: 257 (Städtebuch, S. 467). - Administrator ist ab 20.2.1946 Kuratus Werner Jahr (geb. 1903 Grünberg/Schlesien), der bis 1945 in Gollnow (Kr. Naugard, Pommern) wirkte (Schematismus Berlin 1947, S. 67; Ostpriesterverzeichnis 2, 1949, S. 39). „Von 1853-95 und noch einmal von 1905-1911 war Schwedt für die Seelsorge im jenseits der Oder gelegenen Königsberg/Neumark zuständig, das heutige Chojna, zu dessen polnischer Gemeinde in den letzten Jahren Kontakte geknüpft wurden." (Schwillus/Brühe [2009], S. 348).

Katholisches Kinderheim St. Hedwig (Fabrikstraße 2, im Krebsschen Waisen- und Kommunikanten-Stift [Eigentümer]): In Schwedt bestand von 1909 bis 1991 ein Kinderheim der Hedwigschwestern, das bis 1946 deren Mutterhaus Breslau unterstand (Name „St. Hedwig“ 
wohl erst 1946). Die Schwestern, die von Febr. bis Juni 1945 in $\rightarrow$ Perleberg evakuiert waren, gingen u. a. auch der ambulanten Krankenpflege nach (Mertens, S. 528 f.). „Das Kinderheim hatte [im Nov. 1946] dreißig Plätze. Die Kinder besuchten die Schule des Ortes." (ebd., S. 529). - Am 3.8.1945 „nimmt das katholische Kinderheim der Hedwigsschwestern über 70 Kinder, die die Schwestern als Waisen oder Flüchtlinge entlang der Oder aufgelesen haben, in ihre Obhut" (Chronik, S. 122). - 1946 Hedwigschwestern in Schwedt (Oder): Waisenhaus, Seelsorgehilfe: 5 Mitglieder (Schematismus Berlin 1947, S. 102).

Flüchtlings-/UmsiedleRLAGER: Kinder orthodoxer Konfession aus „Schwedt, Oder, Flüchtlingslager" sterben am 18. und 29.1.1945 im Kreiskrankenhaus $\rightarrow$ Angermünde (Stadtarchiv Angermünde, Standesamt Angermünde, Sterberegister, Nr. 41/1945, 67/1945). - 25.9.1945: Zur Unterbringung der Flüchtlinge aus dem Osten in einem Durchgangslager werden 2 Baracken instandgesetzt, ebenso die ausbaufähigen Kasernen. Die Unterbringungsmöglichkeiten in der Stadt sind erschöpft, zumal die russische Kommandantur erheblichen Wohnraum für sich benötigt." (Wir wollten eigentlich nicht fliehen ..., S. 91). - 22.10.1945 Kapazität: 4000. Lagerleiter: Albert Bartelt (BArch, DO 2/39, Bl. 10). - Ende Dez. 1945 Bericht der ZVU: „Die Weiterleitung der in den Lagern Angermünde und Schwedt befindlichen restlichen Umsiedler wird Anfang Januar 1946 vor sich gehen." (BArch, DO 2/38, Bl. 1). - Kapazität des Umsiedlerlagers am 1.1.1946: 1000 (BLHA, Rep. 203 MdI, Nr. 1163, B1. 50).

StÄDtepartnerschaften: (1) 1994 Chojna, Polen (Königsberg/Neumark, ehem. Kreisstadt in der Provinz Brandenburg) und (1a) Gryfino, Polen (Greifenhagen in Pommern). - (2) 2000 Moryn, Polen (Mohrin, ehem. Kr. Königsberg/Neumark, Provinz Brandenburg). - (3) 2004 Koszalin, Polen (Köslin, ehem. Provinz Pommern).

Archivalische Quellen: BArch, DO 2 ZVU, Nr. 38, Bl. 1; DO 2/39, Bl. 10-11 (Lager, 1945).

Gedruckte Quellen: Brandenburgische Gemeinden 1945, S. 3. - Dokumentation der Vertreibung I/1, S. 377. Tagebuch Ernst Prochnow [Auszüge]. In: „Die Russen sind da“. Peter Böthig u. Peter Walther (Hg). Berlin 2011, S. 291.

Literatur: Brühe, Matthias: Katholische Kirche zwischen Uckermark und Oderland. Berlin 1998, S. 43-44.Chronik der Stadt Schwedt/Oder in Daten, Dokumenten und Bildern. Schwedt/Oder [2010]. - Köhler, Erich: Das Flüchtlingselend neumärkischer Familien. In: Königsberger Kreiskalender 2002, S. 96-104. - Mertens, Johannes: Geschichte der Kongregation der Hedwigschwestern 1930-2000. Manuskript. Berlin 2004, S. 528-531. - Otto, Gerhard: Deutsch-polnische Kontakte und Beziehungen entlang der Oder. In: Königsberger Kreiskalender 1996 (1995), S. 41-44. - Rössler, Katrin: Kriegsende und Zerstörung. Schwedt von 1933 bis 1945: Leben im Dritten Reich. Red.: Anke Grodon u. a. Schwedt/Oder [2013?], S. 129-133. - Schneider, Joachim: Die Oder während der Kriegshandlungen im Frühjahr 1945. In: Historischer Verein zu Frankfurt (Oder) e.V. Mitteilungen 2001, H. 2, S. 7-21, hier S. 14 (Brücke). - Schwillus/Brühe, S. 348. - Springer, Philipp: Verbaute Träume. Herrschaft, Stadtentwicklung und Alltag in der sozialistischen Industriestadt Schwedt. Berlin 2006. - Wir wollten eigentlich nicht fliehen ... Schwedt im Frühjahr 1945. Hrsg.: Stadtmuseum Schwedt/Oder. Schwedt/Oder 2007. - Zeitensprünge. 750 Jahre Schwedter Geschichte. Schwedt/Oder 2016. 


\section{Seehausen}

Landgemeinde, bis 1952 Kr. Angermünde, 1952-1990 Kr. Prenzlau (Bez. Neubrandenburg), 1990-1993 Ldkr. Prenzlau (Land Brandenburg), 1993 Ldkr. Uckermark

EREIGNISSE NACH KRIEGSENDE: „In der Gemeinde Seehausen lebten im Februar 1959 von insgesamt 542 Einwohnern 361 ,Umsiedler' (67 Prozent), die vormals aus Fraustadt (Niederschlesien) stammten. Sie kamen 1945 geschlossen nach Seehausen, waren vorwiegend Einzelbauern und fast durchweg Katholiken. Verbindungen zu westdeutschen Vertriebenenorganisationen seien bisher nicht feststelbar; jedoch sei der Einfluß der katholischen Kirche groß. Teilnahme an ,Umsiedlertreffen in Westberlin' und Zusammenkünfte auf dem Gebiet der DDR erfolgten nicht. Der ,Umsiedler [B.M.]' trat offen gegen die Oder-Neiße-Grenze auf; die anderen äußerten ihre Meinung dazu nicht. In der Gemeinde bestand noch keine LPG. ,Es wird von den Umsiedlern und den ehemaligen Landarbeitern des Dorfes aktiver Widerstand bei der Gründung einer LPG geleistet. Die Gemeinde Seehausen ist durch vier geheime Mitarbeiter [des MfS] abgesichert." (Bericht der MfS-Kreisdienststelle Prenzlau vom 26.2.1959 [BStU, MfS BV Neubrandenburg XX 260], zit. nach Amos, S. 53). - 1961 werden „Umsiedler“ in Seehausen, die sich der Gründung einer LPG widersetzen, vom Ministerium für Staatssicherheit durch einen „Inoffiziellen Mitarbeiter“ überwacht (Inoffizielle Mitarbeiter, S. 93).

BevÖLKeRUNGSZAHLEN: 1925: 492, 1939: 370, 1946: 610, 1964: 454, 1971: 346 (HOL VIII, S. 915).

Gedruckte Quellen und Literatur: Amos, Heike: Die Vertriebenenpolitik der SED 1949 bis 1990. München 2009. - Inoffizielle Mitarbeiter des Ministeriums für Staatssicherheit. T. 1. Hrsg. von Helmut Müller-Enbergs. 3. Aufl. Berlin 2001.

\section{Seelow}

Stadtgemeinde (seit 1950 Kreissitz), bis 1950 Kr. Lebus, 1950-1990 Kr. Seelow (ab 1952 Bez. Frankfurt/Oder), 1990-1993 Ldkr. Seelow, 1993 Ldkr. Märkisch-Oderland

EREIGNISSE BIS KRIEGSENDE: 1.2.1945: „Hunderte Flüchtlinge wanderten durch die Straßen der Stadt.“ (Fudel, S. 15). - Febr. 1945: Seelow wird als Zwischenstation (wohl Durchschleusungspunkt) für die in den Kreis Ostprignitz zu evakuierende Bevölkerung der Kreise Mogilno und Obornik (Wartheland) bestimmt (BLHA, Rep. 6 B Kreisverwaltung Züllichau-Schwiebus, Nr. 169, unfol.).

EREIGNISSE NACH KRIEGSENDE: 30.6.1945 (Flüchtlingstreck aus Landsberg/W.): „In Seelow sollte das Lager sein und die erste Verpflegung, aber keine Spur von alledem." (Tagebuch Hildegard Burmeister, S. 280). - 25.9.1945 (Bericht Dr. Gotthard Eberlein): „Bei [ $\rightarrow$ ] Küstrin besteht keine Möglichkeit für ein großes Lager einzurichten. Seelow ist völlig durch die Kriegsereignisse zerstört. Es hätte Platz für etwa 100000. Wir können aber dort keine Baracken bauen. Wenn entsprechende 
Baracken geliefert werden könnten, könnten wir in der Nähe von Seelow ein großes Barackenlager aufstellen. Wie haben aber keine Arbeitskräfte, Der Kreis ist menschenleer." (Wille I, S. 245). - „Da es bis zu Weihnachten 1945 so gut wie keine Lebensmittel zur Verteilung gab, brach eine Hungersnot aus. Der Hunger-Typhus tat sein übriges, so daß nach den damaligen Berichten ca. 500-600 Seelower Bürger in kurzer Zeit starben [...]. / Die Rückkehr der Zivilbevölkerung setzte nur sehr zögerlich ein, frühestens etwa Mitte bis Ende Mai 1945, vielfach noch später." (Ein leidgeprüftes Land, S. 159).

Bevölkerungszahlen: 1925: 3220, 1939: 3082, Jan. 1945: 3400, April 1945: 152, Dez. 1945: etwa 1000, 1946: 2757, 1964: 4503 (Städtebuch, S. 472).

Katholiken (bis 1994 Erzbistum Breslau/Erzbischöfliches Amt Görlitz, dann Erzbistum Berlin): 1930: 91, 1946: 145 (Städtebuch, S. 472). - 1954: 144 (Schematismus Görlitz 1954, S. 36). Bis 1994 (als ehem. Teil der Erzdiözese Breslau) Exklave der Apostolischen Administratur Görlitz, dann an das Erzbistum Berlin übergeben. - „Hier wagte Alois Pech, seit 1942 Pfarrer von Küstrin, wo Kirche und Pfarrhaus [1945] ebenfalls restlos vernichtet worden waren, den Neuanfang seiner damals zum Erzbistum Breslau gehörenden Gemeinde. Seelow war zuvor schon eine Außenstation zunächst von $[\rightarrow]$ Frankfurt, dann von Küstrin gewesen, 1946 konnte er sich hier bei einer katholischen Familie einmieten. / Am Hang, an dem die Bundesstraße 1 in das Oderbruch hinabführt, liegt das Grundstück mit dem ,Gemeindehaus' [Küstriner Str. 26]. Im ersten Stock [...] konnte später ein größerer Raum als Kapelle gemietet werden. Vorher wurde im Schützenhaus, dann in einem Gasthaussaal die hl. Messe gefeiert. / Ganz allmählich konnte die Seelsorge wieder aufgebaut werden. 1948 wude in zwei Gottesdiensten an einem Tag 157 Personen die Firmung gespendet. Vor allem Flüchtlinge aus Schlesien, Ostpreußen und dem Warthegau bildeten die neue Gemeinde, Pfr. Pech nannte sie ,Pfarrei Küstrin - Sitz Seelow'. 1949 wird der ,Sitz' nach [ $\rightarrow$ ] Golzow verlegt." 1961 Kauf von Grundstück und Gebäude, Erweiterung der Kapelle im ersten Stock, 1962 von Bischof Ferdinand Piontek benediziert. Gemeinde ab 1989 von Frankfurt (Oder) aus pastoriert (Brühe, S. 45); Kapelle 2004 aufgegeben (Schwillus/Brühe, S. 317). Zu Pfarrer Pech in Seelow siehe auch dessen Jahresbericht 1945 in: Gespräche, Bd. 7, S. 121-126.

Gedenkstätte Seelower HöHen: Die bislang auf die militärischen Kriegsereignisse des Jahres 1945 konzentrierte Gedenkstätte bezieht seit 2017 auch den Themenkomplex „Flucht und Vertreibung“ stärker in ihre Arbeit ein. Die neue Gedenkstättenleiterin Kerstin Niebsch erklärte, man habe „damit begonnen, in der Gedenkstätte auch Filme zu zeigen, die sich intensiv mit den Themen Krieg, Flucht und Vertreibung auseinandersetzen. ,Das wird sehr gut angenommen', so Kerstin Niebsch. Zudem sammele man Erfahrungen von anderen Einrichtungen, um das im Archiv noch befindliche Material von Zeitzeugen-Erinnerungen so aufzuarbeiten, dass es von den Besuchern, gerade auch durch die jüngere Generation, gut nacherlebbar wird.“ (Ulf Grieger: Gedenkstättenfilm soll überarbeitet werden, in: MOZ, 31.3.2017, www.gedenks taette-seelower-hoehen.de/aktuell [31.5.2017]). - 6. bis 8.10.2016 deutsch-polnische Tagung des Museumsverbandes des Landes Brandenburg „Alte Heimat - Neue Heimat. Deutsche und 
polnische Museen westlich und östlich der Oder nach dem Zweiten Weltkrieg" in der Gedenkstätte Seelow und dem Museum Festung Küstrin (Muzeum Twierdzy Kostrzyn): „Die diesjährige Herbsttagung des Museumsverbandes widmet sich einem im wahrsten Sinne des Wortes grenzüberschreitendem Thema. In drei Panels werden polnische und deutsche Wissenschaftler und Museumsmitarbeiter darüber diskutieren, welchen Niederschlag die Umbruchsituation beiderseits der Oder nach 1945 vor allem in der Museumslandschaft gefunden hat. Spiegeln sich der massenhafte Zuzug von „Umsiedlern“ in den Museen westlich der Oder wider? Unter welchem Blickwinkel betrachteten die Neusiedler in den nun westpolnischen Regionen die einst deutschen Museumssammlungen? Wie veränderte sich dieser Blick im Laufe der Jahre? Welche ganz praktischen Möglichkeiten gibt es heute für eine grenzüberschreitende Zusammenarbeit von Museen?“ U.a. sprach Dr. Reinhard Schmook (Oderlandmuseum Bad Freienwalde) über „Neue Heimat links der Oder - Vom Flüchtlingsalltag in den ersten Nachkriegsjahren“. (Programm: www.museen-brandenburg.de [31.5.2017]; www.hsozkult.de, 27.9.2016 [31.5.2017]; Druck in: Museumsblätter 30 (2017), S. 26-33).

FriedenSWALd AUf DEM KRUGBERG: „1991 auf Initiative des Bürgermeisters Gernot Schmidt, des Schriftstellers Martin Stade, des Journalisten Eberhard Grasshoff sowie des Aktionskünstlers Ben Wargin zum Gedenken an die Toten des Zweiten Weltkrieges und der Vertriebenen auf dem Krugberg in der Nähe der Straße nach Werbig gepflanzt. Dort befinden sich auch 13 Skulpturen als Ergebnis eines Bildhauersymposiums als ,Zeichen für den Aufbau eines gemeinsamen Hauses Europa““ (wikipedia.org/wiki/Seelow [31.5.2017]). - „Der Friedenswald auf dem Krugberg in Werbig wurde der Anfang einer Kette von Friedenswäldern, die über Polen (am 24. Oktober 1992 östlich der Oder nahe dem kleinen Dorf Gorzyca (ehemals Göritz)), bis Russland (am 7. April 1994 in Brest) [reichen].“ (www.seelow.de [31.5.2017]).

Gedenkstein vor DEM StÄDtischen Friedhof: 25.9.2004 eingeweiht (errichtet vom $\mathrm{BdV}$ ); behauener, aufrecht stehender Findling mit metallener Inschriftenplatte: „Zum Gedenken an alle, die im Krieg, bei Flucht und Vertreibung ihr Leben gelassen haben. Ihr Opfer mahnt zur Völkerverständigung und zu Frieden." (Abschrift der Inschrift und Foto von 2006 von Michael Elstermann: www.denkmalprojekt.org [31.5.2017]; Auskünfte M. Schimmel; BR 2 (2004)5, S. 16 mit Fotos).

Strassenumbenennungen: Küstriner Straße (vor 1900 Cüstriner Straße) 1946 oder 1948 umbenannt in Clara-Zetkin-Straße, 1991 oder 1993 rückbenannt (Mitteilung Michael Schimmel, Berlin, 2.7.2018).

StÄDtepartnerschaften: 1998 (Partnerschaftsvertrag „Nach jahrelanger Freundschaft“) Kostrzyn, Polen (Küstrin) und Międzychód, Polen (Birnbaum, ehem. Provinz Posen) (www. seelow.de [31.8.2016]).

VertriebenENVERBÄNDE NACH 1990: BdV-Kreisverband Seelow (ab 1993 Kreisverband Märkisch-Oderland, zuletzt Kreisverband Märkisch-Oderland, Seelow-Strausberg e.V., Sitz Seelow, 
so noch 2013 erwähnt); 1996 erwähnt als „Kreisverband Märkisch Oderland, Seelow“ mit Sitz in Seelow, Hinterstr. 12 d (BdV-Handbuch 1996, S. 168). 24.5.1997 Satzung errichtet, 11.8.1998 eingetragen beim Amtsgericht Frankfurt (Oder) (VR 692), 8.1.2014 liquidationslose Auflösung zum 31.12.2014 von Mitgliederversammlung beschlossen, 18.12.2014 Büro in Seelow geschlossen (Akten der BdV-Landesgeschäftsstelle). - Mitgliederzahlen: 20.11.2006: 435, 28.10.2009: 260 (Akten wie vor), 2012 rund 230 Mitglieder (Märkische Oderzeitung, 15.10.2012); 2009 bei Wahlversammlung im Waldhotel in der Diedersdorfer Waldsiedlung 72 Mitglieder anwesend (Märkische Onlinezeitung, 1.12.2009). - Vorsitzende: 1992-2011: Kurt Struwe, Agraringenieur-Pädagoge, $\rightarrow$ Küstrin-Kietz, 1995/2009 in Golzow (geb. 1928), 2011/12 kommissarisch Willi Steffen (geb. 1939) (BR 9(2011)6, S. 9), 2012-2014 Gerhard Kaminski, Wilmersdorf (geb. 1948) (Märkische Oderzeitung, 15.10.2012) (Vorsitz niedergelegt 23.1.2014) (Akten wie vor).

ARChivalische Quellen und Auskünfte: BArch, DO 2 ZVU, Nr. 39, Bl. $34-38$ (Stadt Seelow, 1945). - Auskünfte Michael Schimmel (Berlin), 12.7.2017.

Gedruckte Quellen und Literatur: Brühe, Matthias: Katholische Kirche zwischen Uckermark und Oderland. Berlin 1998, S. 45. - Fudel, Torsten: Der Krieg an der Oder. Seelow 2011. - Gespräche mit ehemaligen Küstrinern über Küstrin, Vertreibung und Neuanfang in Küstrin-Kietz und anderswo. Aufgez. u. bearb. von Siegfried Neubauer. Bd. 7. Frankfurt (Oder) 2018. - Ein leidgeprüftes Land. Bearb. von Fritz Knüppel. 2. Aufl. Barsinghausen 1990, S. 158-159 (Erinnerungen Seelower Frauen, nacherzählt). - Schwillus/Brühe, S. 317. - Tagebuch Hildegard Burmeister [Auszüge]. In: „Die Russen sind da“. Peter Böthig u. Peter Walther (Hg). Berlin 2011, S. 280. - Töpler, Menschenwurm, S. 487 f. u. ö.

\section{Selchow}

Landgemeinde (seit 2003 Ortsteil von $\rightarrow$ Schönefeld), bis 1952 Kr. Teltow, 1952-1990 Kr. Königs Wusterhausen (Bez. Potsdam), 1990-1993 Ldkr. Königs Wusterhausen, 1993 Ldkr. Dahme-Spreewald

EREIGNisse: 27.4.1945 Einmarsch der Roten Armee (Weise, S. 37). - 1945-1949 Bodenreform (ebd., S. 38-40).

Bevölkerungszahlen: 1925: 514, 1939: 484, 1946: 560, 1964: 522 (HOL IV, S. 278).1.7.1945: 565 Einwohner. 15.10.1945 190 „Umsiedler“ aus den ehem. Ostgebieten (50 Männer, 75 Frauen, 65 Kinder) (Weise, S. 37). - 3.11.1945: 180 Umsiedler (38/78/64), 5.1.1946: 190 (50, 75, 65) (ebd., S. 41). - 27.6.1946: 152 „Umsiedler“ (24 „Umsiedlerfamilien“ mit und 15 ohne festen Wohnsitz) (ebd., S. 45). - Wohnberechtigte „Umsiedler“: 18.12.1945: 194, 31.5.1946: 97, 30.11.1946: 160, 3.2.1947: 162, 6.8.1947: 250 (ebd., S. 45). 


\section{Selterhof $\rightarrow$ Treuenbrietzen}

\section{Senftenberg}

Stadtgemeinde (seit 1947 Kreissitz), bis 1952 Kr. Calau (1950 in Kr. Senftenberg umbenannt), 1952-1990 Kr. Senftenberg (Bez. Cottbus), 1990-1993 Ldkr. Senftenberg, 1993 Ldkr. Oberspreewald-Lausitz (Kreissitz)

EREIGNISSE BIS KRIEGSENDE: Die Stadt gilt bei Kriegsende als relativ unbeschadet geblieben (Töpler, Menschenwurm, S. 295).

EREIGNISSE NACH KRIEGSENDE: [1945:] „Die vielen Umsiedler konnten in fünf Umsiedlerheimen untergebracht werden." (Forkert, S. 78).

EREIGNISSE NACH 1949: „Eine größere polnische Kolonie existierte außer in Berlin (Ost) auch in Senftenberg, wo polnische Fachkräfte im Braunkohletagebau und den damit verbundenen Industrien beschäftigt waren." (Meister, S. 555) [Hierunter ist ein nennenswerter Anteil von Oberschlesiern zu vermuten - P.B.]. - 1961 fristlose Entlassung des Spielleiters am „Theater der Bergarbeiter" in Senftenberg B(ernhard) K(laus) Tragelehn (geb. 1936 Dresden) wegen seiner Regie-Verantwortung bei der Uraufführung der (unmittelbar anschließend als „konterrevolutionär“ verbotenen) Komödie „Die Umsiedlerin oder das Leben auf dem Lande“ von Heiner Müller in der FDJ-Studentenbühne der Hochschule für Ökonomie in Berlin-Karlshorst, er wird „zur Bewährung in den Braunkohletagebau geschickt“ (Schulz, S. 273f.).

EREIGNISSE NACH 1989: 2006 Heimattreffen von Vertriebenen aus Osselwitz, Kr. Guhrau (Schlesien), und Umgebung im Senftenberger Vereinsheim „Neue Erde“ mit 38 Teilnehmern, organisiert von Kurt Kosmehl (geb. 1931, aus Niederschlesien), Senftenberg (BR 4 (2006)2, S. 22); er 1995/96 erwähnt als 1. stellv. Vorsitender des BdV-Kreisverbandes Senftenberg (Akten der BdV-Landesgeschäftsstelle).

BevÖLKERUNGSZAHLEN: 1925: 17 472, 1939: 17 566, 1946: 17783, 1964: 24053 (Städtebuch, S. 476).

Katholiken (Erzbistum Breslau/Erzbischöfliches Amt Görlitz): 1925: 2710, 1946: 3104 (Städtebuch, S. 477). - Pfarrer war 1949 der bis 1945 in Freiwaldau (Sudetenland) amtierende Geistliche Rat Prof. Josef Ehrlich (geb. 1885) (Ostpriesterverzeichnis 2, 1949, S. 22). - Im Josefshaus lebte 1949 ferner der bis 1945 in Obermois (Niederschlesien) wirkende Kaplan Paul Gärtner (geb. 1914) (ebd., S. 27). - 1952-1953 war der aus Breslau gebürtige Bernhard Kaßner (geb. 1913) Kaplan und Administrator (anschließend Kuratital-Pfarrer in $\rightarrow$ Tröbitz (Schematismus Görlitz 1954, S. 68). - Ab 1953 war Pfarrer der aus Niederhermsdorf (Kr. Waldenburg in Schlesien) gebürtige, aber bereits vor 1945 in die Niederlausitz gekommene Heribert Titze (1907-1971), der zuvor ab 1949 Caritas-Direktor in $\rightarrow$ Cottbus gewesen war (ebd., S. 44, 66). 
UMSIEDLERLAGER: 24.10.1945 vom Landratsamt in Bericht erwähnt mit Kapazität „700 Mann“ nach „Räumung von den jetzt dort dauernd untergebrachten Umsiedlern und deren Einweisung in Ortsquartiere“ (Töpler, Menschenwurm, S. 451). - Im „Verzeichnis der errichteten und vorgesehenen Umsiedlerlager im Verwaltungsbezirk Cottbus" vom 15.12 .1945 mit „Personenzahl“ 700 (ebd., S. 472). - Kapazität am 31.12.1945: 350 (BArch, DO 2/45, Bl. 41). - Kapazität am 1.1.1946: 350 (BLHA, Rep. 203 MdI, Nr. 1163, Bl. 51).

Strassenumbenennungen: Ende der 1930er Jahre erhält ein Stadtviertel „Straßenbezeichnungen nach Städten aus dem besetzten Sudetengebiet und wird somit zum Sudetenviertel, heute Blumensiedlung" (Kober, S. 36).

StÄDtepartnerschaften: 1992 Nowa Sól, Polen (Neusalz an der Oder, Schlesien); 1996 Veszprém, Ungarn (Wesprim); 1996 Žamberk, Tschechien (Senftenberg in Böhmen).

VertriebenenVERBÄNDE NACH 1990: BdV-Kreisverband Senftenberg, 1994 bereits erwähnt (Aklten der BdV-Landesgeschäftsstelle), 1996 erwähnt mit Sitz in Niemtsch, Seestr. 6 (BdVHandbuch 1996, S. 169), 14.6.1995 Satzung errichtet („Bereiche: $[\rightarrow]$ Calau, $[\rightarrow]$ Großräschen, Ruhland, Senftenberg"), 31.1.1996 eingetragen beim Amtsgericht Senftenberg (VR 594), später (wohl ab spätestens 2000, aber auch schon 1994 so) BdV-Kreisverband Oberspreewald-Lausitz, Sitz Senftenberg. - 1994 Großveranstaltung „Heimatvertriebene und Aussiedler im zusammenwachsenden Deutschland“ in der Sporthalle, 1995 festliche Gedenkveranstaltung „50 Jahre Ende des Zweiten Weltkrieges/50 Jahre Flucht und Vertreibung“ in der „Neuen Bühne“. 28.2.2013 Verein erloschen (Akten). - Mitgliederzahlen: Nov. 2005: 58, mehrheitlich aus Niederschlesien; Ende 2002: 78, beitragszahend: 48 (H. Lipske an BdV-Landesverband, 9.12.2002: „Der Rückgang der zahlenden Mitglieder (Erlebnisgeneration) ergibt sich aus den Sterbefällen bzw. Einweisungen in Pflegeheime, wodurch sie an unseren Veranstaltungen nicht mehr teilnehmen können."). - Vorsitzende: (18.10.1994 erwähnt) Günther Zappe. Lauchhammer (geb. 1922), 1995-(2008, 2013?) Helmut Lipske, Niemtsch (geb. 1932, gest. 2013, aus Niederschlesien, Mitglied seit 1.12.1991) (BR 11 (2013)8, S. 6; Akten der BdV-Landesgeschäftsstelle).

Literatur: Forkert, Werner: Senftenberger Rundblicke. T. 3. Senftenberg 2008. - Kober, Steffen: Aus der Geschichte der Senftenberger Straßennamen. In: Kippensand 5 (2017), S. 33-36. - Meister, Hans-Peter: Zuwanderung aus Schlesien nach Berlin und Brandenburg ab 1950. In: „Wach auf, mein Herz, und denke“. Berlin/Opole 1995, S. 543556. - Schulz, Kristin: Heiner Müller: Die Umsiedlerin oder Das Leben auf dem Lande (1961). In: Handbuch Nachkriegsliteratur. Berlin/Boston 2013, S. 270-275. - Ther, Philipp: Die Vertriebenenpolitik in der SBZ/DDR 19451953 am Beispiel des Kreises Calau-Senftenberg. In: Jahrbuch für brandenburgische Landesgeschichte 46 (1995), S. 159-168. - Töpler, Menschenwurm, S. 334, 451, 472 u. ö. 


\section{Senzke}

Landgemeinde, bis 1952 Kr. Westhavelland, 1952-1990 Kr. Nauen (Bez. Potsdam), 1990-1993 Ldkr. Nauen, 1993 Ldkr. Havelland

EREIGNISSE BIS KRIEGSENDE: „Im Januar 1945 waren bereits die ersten Umsiedler auf das Bredower Gut gekommen. Ihre Heimat waren Wolhynien und Bessarabien. Nach ihrem langen Weg war Senzke und $[\rightarrow]$ Haage ihre neue Heimat. Zuerst wurden diese Menschen bei Bauern untergebracht. Dort halfen sie in der Landwirtschaft. [...]." (Amtsbereich Friesack, S. 94). „Am 26. April fanden im Raum Senzke heftige Kämpfe statt.“ (Mewes, S. 33).

EReignisse NACH Kriegsende: [Plünderung des Herrenhaus]; „später zogen Flüchtlinge und Umsiedler vorübergehend in das Gebäude ein.“ (Andreae/Geiseler, S. 284). - „Nach dem Zweiten Weltkrieg, als Senzke zur Heimat vieler Flüchtlinge und Heimatvertriebenen wurde, diente das Herrenhaus zunächst Wohnzwecken. Nachdem den neuen Einwohnern im Zuge der so genannten Bodenreform am nördlichen Ortsrand Neubauernhöfe errichtet wurden und das Haus vorübergehend leer stand, sollte es abgerissen werden. Dem engagierten Einschreiten von Senzker Bürgern ist es zu verdanken, das das Herrenhaus erhalten blieb. Es diente später als Schule." (Das Havelland um Rathenow und Premnitz, S. 248). - Am 2. September [1945] verkündet Wilhelm Pieck [...] die Durchführung der Bodenreform. Im Anschluß daran wurde das Gut versiedelt. Diejenigen Umsiedler, die ein Stück Land erhalten hatten, wurden im Schloß untergebracht. Auf ihren Siedlungen begannen sie Häuser zu bauen. Das war auch notwendig, denn im Schloß wurde eine Schule eingerichtet und der Platz wurde gebraucht. Bis zur Fertigstellung ihrer Häuser wohnten einige Familien noch in leerstehenden Häusern und Wohnungen. / 1950. Das Schloß, das für den Ausbau als Schule gedacht war, war noch von 18 Umsiedlerfamilien (Neubauern) belegt. Kellerräume, Flure und Kammern wurden zum Teil als Stallungen genutzt. [...] / Auf Befehl der sowjetischen Kommandantur in Rathenow sollte dieser Herrensitz, nach dem die 18 Umsiedlerfamilien ausgezogen waren, abgerissen werden." (Amtsbereich Friesack, S. 94). - 1947 in der Bodenreform 72 neue Eigentümer berücksichtigt, davon 44 Umsiedler (HOL III, S. 356).

BevöLKerungSzAHLEN: 1925: 293, 1939: 225, 1946: 472, 1964: 322 (HOL III, S. 356).

Literatur: Andreae/Geiseler, S. 284. - HOL III, S. 355 f. - Amtsbereich Friesack. Horb am Neckar 1996, S. 88-101 (Kap. 2.6 Senzke). - Das Havelland um Rathenow und Premnitz. Köln u. a. 2017. - Mewes, Fritz: 8. Mai - 60. Gedenktag zum Ende des 2. Weltkrieges. In: Rathenower Heimatkalender 49 (2005 [2004]), S. 31-34.

\section{Sieversdorf}

Landgemeinde, bis 1952 Kr. Ruppin, 1952-1990 Kr. Kyritz (Bez. Potsdam), 1990-1993 Ldkr. Kyritz, 1993 Ldkr. Ostrignitz-Ruppin

EReignisse NACH KriegSende: Herbst 1945 Einweisung von mindestens drei Familien aus dem Kr. Namslau bei Sieversdorfer Bauern nach Quarantäneaufenthalt im Lager Magazininsel 
in $\rightarrow$ Rathenow (Hoppe). - 1946 bei der Bodenreform (72 ha, 36 Siedler) keine Umsiedler genannt (HOL II, S. 251).

BevölkeRUngSZAHLEN: 1925: 1093, 1939: 1019, 1946: 1510, 1964: 927 (HOL II, S. 251).

Katholiken: - „Kurzzeitig bestanden nach demn II. Weltkrieg von heimatvertriebenen Priestern betreute Seelsorgestellen in [...] und in Sieversdorf (1946-60).“ (Schwillus/Brühe, S. 330). - „Etwa sechs Kilometer von Neustadt/Dosse entfernt übernahm der aus dem Erzbistum Breslau heimatvertriebene Pfr. Anton Jendritzko (1946-55) die Seelsorge. Ihm folgte, als die Lokalie damals über 800 Katholiken zählte, Pfr. Erwin Ungar (1955-60), der danach Pfarrer der Muttergemeinde wurde, womit die Seelsorgestelle Sieversdorf zu bestehen aufhörte." (Brühe, S. 56). - Beide blieben als „Priester auswärtiger Bistümer“ weiterhin ihren Heimatbistümern zugeordnet, der vor 1945 in Kaulwitz, Kr. Namslau (Schlesien) wirkende Jendritzko (geb. 1906 Pilchowitz, Kr. Rybnik) dem Erzbistum Breslau (Schematismus Berlin 1949, S. 142; Ostpriesterverzeichnis 2, 1949, S. 40), der zuvor ab 1946 in $\rightarrow$ Frankfurt (Oder) als Kaplan und vor 1945 in Kladno (Böhmen) amtierende Ungar (geb. 1915 Mährisch-OstrauWitkowitz) dem Erzbistum Prag (Schematismus Berlin 1949, S. 64, 147; Ostpriesterverzeichnis 2, 1949, S. 87).

Quellen und Literatur: Brühe, Matthias: Katholische Kirche zwischen Prignitz und Havelland. Berlin 2000, S. 56. - Schwillus/Brühe, S. 330. - Auskünfte Edeltraud Hoppe (Namslauer Heimatfreunde e. V.), Kyritz, 21.9.2016.

\section{Simmersdorf}

Landgemeinde (heute Ortsteil von Groß Schacksdorf), bis $1945 \mathrm{Kr}$. Sorau, 1945-1946 (Rest-) Kr. Sorau bzw. Kr. Forst, 1.4.1946-1952 Kr. Cottbus, 1952-1990 Kr. Forst (Bez. Cottbus), 1990-1993 Ldkr. Forst, 1993 Ldkr. Spree-Neiße

EREIGNISSE NACH 1990: Seit 1990 regelmäßige Heimattreffen der vertriebenen ehem. Bewohner der Kleinstadt Gassen (Kr. Sorau), bis 2002 (organisiert von Helmut Schüttke) im „Gasthaus Sacro" in $\rightarrow$ Forst, ab 2003 in der Gaststätte „Kaminstube“ in Simmersdorf, Dorfstraße 1: 2003 13. Treffen mit 60 Teilnehmern aus dem gesamten Bundesgebiet (LR, 29.8.2003), 21.8.2004 14. Treffen (ebd.), 28.8.2005 15. Treffen in der Gaststätte „Kaminstube“, Dorfstraße 1 (LR, 19.8.2005), 2008 18. Gassener Heimattreffen, organisiert von Heinz Schlabe (Jüterbog) u. Käte Lehmann (Meschede) (LR, 26.8.2008).

Bevölkerungszahlen: Simmersdorf: 1925: 289, 1939: 379 (HOL NL II, S. 402). - Groß Schacksdorf-Simmersdorf: 1925: 778, 1939: 843, 29.10.1946: 981, 1950: 990, 1964: 1667 (HGV SN, S. 11).

UMSIEDLERLAGER HOLZSTOFFWERKE: Im „Verzeichnis der errichteten und vorgesehenen Umsiedlerlager im Verwaltungsbezirk Cottbus“ vom 15.12.1945 mit „Personenzahl“ 250 genannt (Töpler, 
Menschenwurm, S. 472), für entsprechende Bereitstellung vorgesehen auch schon lt. Bericht vom 24.10.1945 (ebd., S. 450).

Gedruckte QuelLen: Töpler, Menschenwurm, S. 450, 472.

\section{Sonnewalde}

Stadtgemeinde, bis 1952 Kr. Luckau, 1952-1990 Kr. Finsterwalde (Bez. Cottbus), 1990-1993 Ldkr. Finsterwalde, 1993 Ldkr. Elbe-Elster

EREIGNiSSE NACH 1990: Publikationsvorhaben der „Sonnewalder Heimatblätter“: „Es gibt bereits einen Bericht über die vielen Flüchtlinge 1945 und wie sie in Sonnewalde untergekommen sind." (LR, 27.2.2006) [Druck bisher nicht nachweisbar].

Bevölkerungszahlen: 1925: 1081, 1939, 1 163, 1946: 1498, 1964: 1274 (Städtebuch, S. 481).

Katholiken (Erzbistum Breslau/Erzbischöfliches Amt Görlitz): 1925: 26, 1946: 133 (Städtebuch, S. 482). - Kuratus in Sonnewalde war 1948-1959 der bis 1945 in Brunzelwaldau (Kr. Freystadt in Schlesien) amtierende Felix Barnert (1883-1961), zuvor Kaplan in $\rightarrow$ Finsterwalde (Ostpriesterverzeichnis 2, 1949, S. 12; Töpler, Menschenwurm, S. 637).

Gedruckte Quellen: Töpler, Menschenwurm, S. 668.

\section{Sophienthal}

Landgemeinde, bis 1950 Kr. Lebus, 1950-1990 Kr. Seelow (ab 1952 Bez. Frankfurt/Oder), 1990-1993 Ldkr. Seelow, 1993 Ldkr. Märkisch-Oderland

EREIGNISSE NACH KRIEGSENDE: 3.10.1950 Zuweisung von westlich der Oder gelegenen Flächen der nun polnischen Gemeinde Klewitz/Chlewice (ehem. Kr. Königsberg/Nm.) an die Gemeinde Sophienthal (Blöß, Kreise und Gemeinden, S. 32).

Bevölkerungszahlen: 1925: 348, 1939: 246, 1946: 402, 1964: 331 (HOL VII, S. 411). 19.4.1946: 57 Flüchtlinge im Ort (Strenge/van Tankeren, S. 189).

Katholiken (bis 1994 Erzbistum Breslau/Erzbischöfliches Amt Görlitz, dann Erzbistum Berlin): 1954: 5 (Schematismus Görlitz 1954, S. 36).

LiterATUR: Strenge, Sigrid / Tankeren, Marga van: Letschiner Chronik. Bd. 5. Letschin 2011. 


\section{Sorno}

Landgemeinde, bis 1952 Kr. Calau (1950 in Kr. Senftenberg umbenannt, 1952-1973 Kr. Senftenberg (Bez. Cottbus), 1971/73 abgebaggert (devastiert)

EReignisse NaCH Kriegsende: „Bei den Feierlichkeiten zum Tag der Arbeit [nach 1949, P.B.] griff ein Vertriebener in dem kleinen Dorf Sorno Stalin sowie die DDR-Regierung an. $\operatorname{Er}$ [S. 492] wurde sofort von der Staatssicherheit verhaftet. Der Informationsdienst registrierte diesen Mann als ,Arbeiter (Umsiedler)', als ob der Zusatz in Klammern sein Verhalten erklären würde." (Ther, S. $492 \mathrm{f}$.).

Literatur: Ther, Philipp: Von Schlesien in die Lausitz. Ein Beispiel der Integration von Vertriebene in der DDR. In: „Wach auf, mein Herz, und denke“. Berlin/Opole 1995, S. 488-494.

\section{Sperenberg}

Landgemeinde (seit 2002 Ortsteil von Am Mellensee), bis 1952 Kr. Teltow, 1952-1990 Kr. Zossen (Bez. Potsdam), 1990-1993 Ldkr. Zossen, 1993 Ldkr. Teltow-Fläming

EREIGNisse 1945 NACH KRIEgSEnde: 5.12.1945 (Bericht der Gemeindeverwaltung): „Durch den Abzug der vielen militärischen Einrichtungen wurden verschiedene massive Gebäude, Kasernen und Baracken für die einheimische Bevölkerung und für zivile Bedürfnisse frei, so dass Sperenberg heute etwa 400 Flüchtlinge unterbringen konnte. Die meisten stammen aus dem Osten und haben hier eine vorläufige Heimat gefunden." (Brandenburgische Gemeinden 1945, S. 186).

BeVÖLKERUNGSZAHLEN: 1925: 144, 1939: 2030, 1946: 2 180, 1964: 1840 (HOL IV, S. 286).

Katholiken: „[...] aus alten Ställen umgebaute und am 24.9.1951 konsekrierte Kapelle in Sperenberg [Hauptstraße 4], in deren Umgebung sich nach dem II. Weltkrieg Flüchtlinge aus Ostpreußen angesiedelt hatten.“ (Brühe, S. 37). - „Für die in der Umgebung angesiedelten Katholiken aus Ostpreußen war 1949-69 ein eigener Seelsorger angestellt." (Schwillus/Brühe, S. 358). - „1954 wurde Sperenberg mit damals etwa 800 Katholiken vermögensrechtlich selbständige Kuratie." (Brühe, S. 37).

Gedruckte Quellen und Literatur: Brandenburgische Gemeinden 1945, S. 185-187. - Brühe, Matthias: Katholische Kirche zwischen Havel und Dahme. Berlin 1999, S. 37. - Schwillus/Brühe, S. 358.

\section{Spremberg}

Stadtgemeinde, bis 1952 Kr. Spremberg, 1952-1990 Kr. Spremberg (Bez. Cottbus), 19901993 Ldkr. Spremberg, 1993 Ldkr. Spree-Neiße

EReignisSe bis Kriegsende: Anf. Jan. 1940 besteht in Spremberg ein Auffanglager für 250 umgesiedelte Wolhynien- und Galiziendeutsche (Müller, S. 124). - Anf. Febr. 1945 Durchzug 
eines Flüchtlingstrecks aus Neusulzfeld bei Lodz nach Bayern; vorherige Station Bad Muskau, nachfolgende Hoyerswerda (Schöler, S. 87). - 12.2.1945 Treckbefehl für Benau (Kr. Sorau): „Der Bestimmungsort für Benau war Spremberg." (Dokumentation der Veretreibung I/1, S. 480). - 14./18.4.1945 Verlegung des Krankenhauses nach $\rightarrow$ Senftenberg und Klettwitz, teilweise Rückkehr am 9.5. (Wiesner, S. 55 f.). - „18.-20.4.1945 Kämpfe um die zur Festung erklärte Stadt, am 20./21.4. Einmarsch der Roten Armee“ (Städtebuch, S. 487). - 19.4.1945: „Bei Spremberg überschritt der Gegner die Spree.“ (Kriegstagebuch des OKW 4,2, S. 1251). 23.4.1945 Ende der „seit dem 16. April 1945 andauernden“ Kampfhandlungen. „Im Ergebnis der Kämpfe ist das Stadtzentrum zu 85 \% zerstört." (Festschrift, S. 167). - Die Stadt gilt bei Kriegsende als schwer zerstört (Töpler, Menschenwurm, S. 295).

EREIGNISSE NACH KrIEgSENDE: Mai 1945 Einrichtung eines Behelfskrankenhauses (Ambulatorium) in den leeren Räumen einer ehemaligen Arztpraxis in der Kesselstraße nach Beschlagnahmung des Krankenhausgebäudes als Magazin für die Rote Armee (bis Dez. 1946). „Etwa sechs Wochen wurde an dieser Behandlungsstelle, der einzigen im Kreise Spremberg, vielen Kranken geholfen." (Wiesner, S. 56); Juli 1945 Eröffnung weiterer Behelfsstandorte (z. T. bis Ende 1947) in Wohnhäusern in der späteren Karl-Marx-Straße (ehem. Schnabelsche Villa auf dem Schomberg, später Feierabendheim) und Drebkauer Straße 3, 4, und 17/18 sowie einer Turnhalle ebd. (ebd., S. 57). - 20.7.1945 (Bericht Pfarrer Adamski): „unsere hiesige Ernährungslage ist so schlecht, unsere, Vorräte' durch Plünderung u. sehr viele! Durchreisende so erschöpft, dass wir niemand mehr aufnehmen können. [...].“ (Töpler, Menschenwurm, S. 359). - 15.3.1946 Ankunft eines Transports mit 1171 Vertriebenen aus Böhmisch Leipa in Böhmen (Jun, S. 254). - 26.9.1946 Ankunft eines Transports mit 1281 Vertriebenen aus Asch in Böhmen (ebd.). - 15.3.1947 Erwähnung zweier „Umsiedlergenossenschaften“ (Heimarbeit): (1) „Spremberger Textilgenossenschaft eGmbH. [/] Josef Hartmann, Spremberg, Bergstrasse 16a [/] keine Maschinen vorhanden“ und (2) „Konfektionsschneiderei [/] Belegschaft unbekannt" (BLHA, Rep. 333, Nr. 574, Bl. 105). - 1948 Erwähnung der von sudetendeutschen Vertriebenen gegründeten „Textilgenossenschaft Spremberg“ (Christopeit, S. 86). - 1947/48 wirkt der aus dem Sudetenland stammende spätere DDR-Außenminister Oskar Fischer (geb. 1927 Asch/Böhmen) nach seiner 1946 erfolgten Entlassung aus sowjetischer Kriegsgefangenschaft als FDJ-Kreisvorsitzender in Spremberg, zuvor 1946/47 Schneider ebd., anschließend 1949/50 FDJ-Landesvorsitzender Brandenburg, 1950/51 MdL Brandenburg (Christopeit, S. 83; Wer war wer in der DDR? 5. Ausg. Bd. 1. Berlin 2010); gest. 2020.

BevöLKERUNGSZAHLEN: 1925: 12 726, 1939: 13 945, 1946: 17498, 1964: 23443 (Städtebuch, S. 485).

Katholiken (Erzbistum Breslau/Erzbischöfliches Amt Görlitz): 1925: 720, 1946: 1414 (Städtebuch, S. 485).

UMSIEDLERLAGER FABRIK, Berliner Str.: „Okt. 1945 Auffanglager für Flüchtlinge in Spremberg“ (Städtebuch, S. 487). - „Umsiedlerlager (Durchgangslager)“ ab Ende Okt. 1945 (erster Trans- 
port hauptsächlich Schlesier und bes. Breslauer), „besteht aus dem einzigen noch vorhandenen massiven Gebäude einer ehemaligen Fallschirmfabrik und etwa 10 Holzbaracken, welche früher von Ostarbeitern, dann von italienischen Kriegsgefangenen bewohnt gewesen waren" (DAB, I/9-15-1 Flüchtlingsseelsorge 1945-1951, unfol., [8.3.1946]). - Dez. 1945 eines von drei Auffanglagern (erwähnt 17.12.1945) (BLHA, Rep. 206, Nr. 2965, unfol.). - Kapazität am 31.12.1945 (Lager „Spremberg, Berliner Str. I“): 1500 (BArch, DO 2/45, Bl. 41). - 14.2.1946 Auffanglager, Kapazität: 2000 (Oehlsen, S. 28). - 1946 Belegungsstärke: 1500 (Kaminsky, S. 159). - 8.3.1946 Bericht über die katholische Flüchtlingsfürsorge in Spremberg (DAB, I/9-15-1 Flüchtlingsseelsorge 1945-1951, unfol., [8.3.1946]). - 30.4.1946 als eines der verbleibenden Umsiedlerlager genannt (DAB, I/9-15-1 Flüchtlingsseelsorge 1945-1951, unfol., [30.6.1946], [Anlage 3]). 1946 eines von zwei Auffanglagern, in denen die Entlausung vorgenommen wird (erwähnt 17.6.1946) (BLHA, Rep. 206, Nr. 2965, unfol.). - 1.1.1947 Lager, Kapazität: 1500 (Oehlsen, S. 101).

StÄDtepartnerschaften: 12.6.1999 Szprotawa, Polen (Sprottau, Schlesien).

VertriebenenVerbände NACH 1990: BdV-Kreisverband Spremberg, gegründet 1991 (Märkischer Informationsdienst 8/1994, S. 14), 1992 Satzung errichtet, kein e. V., 1996 erwähnt mit Sitz Artur-Becker-Ring 13 (BdV-Handbuch 1996, S. 169); 28.5.2002 Veranstaltung zum 10jährigen Bestehen des BdV in Spremberg; Verband erwähnt 2002 (LR, 11.12.2002); dann BdV-Gebietsverband Spremberg, 200728 wahlberechtigte Mitglieder bei Mitgliederversammlung anwesend; noch 2018 erwähnt (Akten der BdV-Landesgeschäftsstelle). Vorsitzende: (1993)-2006 Wilfried Effenberger, Spremberg (geb. 1935 Markersdorf, gest. 2006, kath.) (BR 4 (2006)2, S. 31), ab 2006 (anfangs kommissarisch; 2018 noch erwähnt) Renate Drichel, Spremberg OT Schwarze Pumpe (geb. 1939 Kaaso, Kr. Guben; Mitglied seit 1994). - BdV-Stadtverband Spremberg: 2004 Feier des 10-jährigen Bestehens (BR2 (2004)2, S. 17). 201062 Mitglieder, 2015 noch erwähnt (Akten wie vor).

GedenKanlage auf dem Waldfriedhof, 2006: Bronzetafel auf liegendem Stein mit VersalienInschrift „61 Kinder/haben an dieser Stelle/des Waldfriedhofes/ihre letzte Ruhestätte gefunden/Sie konnten 1945 und 1946/von den durch Spremberg/kommenden Flüchtlingszügen/aus dem Osten Deutschlands / nur noch tot geborgen werden" (Klein/Herrnbeck, S. 206 f. mit Abb.; commons.wikimedia.org/wiki/File:Gedenkstein_Flüchtlingskinder_1945-1946_in_Spremberg.jpg).

GedenKanlage „Hürden überwinden“ auf dem Georgenberg, 2009: Über vier Wege mit Rampen und Treppen erreichbares Plateau, darauf ineinander verschachtelte Steinportale, umspannt von einem Bronzeband: „Die Stadt Spremberg gedenkt aller Opfer von Krieg und Gewaltherrschaft" (Klein/Hermbeck, S. 208 f. mit Abb.; wikipedia.org/wiki/Datei:Denkmalanlage_ Hürden_überwinden_Spremberg.JPG; LR online, 4.4.2008, 13.2.2009). 
Archivalische Quellen: BLHA, Rep. 250 Landratsamt Spremberg, Nr. 389 („Umsiedlertransporte in Spremberg“, 1945); Rep. 333 SED-Landesleitung Brandenburg, Nr. 574, Bl. 105 („Umsiedlergenossenschaften“, 1947).

Gedruckte Quellen Dokumentation der Vertreibung I/1, S. 480, 485. - Kriegstagebuch des OKW 4,2, S. 1251. Töpler, Menschenwurm. - Wille I, S. 260; II, S. 47 f., 56 (Erinnerungen eines Sudetendeutschen).

LiterAtur: Ast/Mauersberger, S. 18. - Christopeit. - Festschrift 700 Jahre Stadt Spremberg. Hrsg.: Stadt Spremberg. Spremberg 2000. - Kaczmarek, Günther: Die Befreiung des Kreises Spremberg vom Hitlerfaschismus im April 1945. Spremberg 1980. - Klei, Alexandra / Herrnbeck, Christian: Überall Geschichte. Nationalsozialismus und Kriegsende 1945 - Denkmale, Erinnerungszeichen und historische Orte im Landkreis Spree-Neiße. Berlin 2005. - Müller, Erich: Transporte, Lager, Ansiedlung im Warthegau: Das Schicksal der galizien- und wolhyniendeutschen Umsiedler nach ihrem Grenzübertritt 1939/40. In: Zeitweiser der Galiziendeutschen 43 (2005), S. 104-157. - Schöler, Heinrich Artur: Neu-Sulzfeld/Nowosolna. Erlangen 2009. - Stein, Jürgen: Die Entwicklung des Spremberger Krankenhauses - ein Beispiel für den Fortschritt der medizinischen Betreuung in unserer Region. In: Festschrift 700 Jahre Stadt Spremberg. Hrsg.: Stadt Spremberg. Spremberg 2000, S. 127-151. - Wiesner, H.: Die Entwicklung des Spremberger Krankenhauses seit 1945. In: Heimatkalender für den Kreis Spremberg 1959, S. 55-61.

\section{Spremberg-Cantdorf}

Landgemeinde Cantdorf (seit 1.1.1946 Ortsteil von Spremberg), bis 1952 Kr. Spremberg, 1952-1990 Kr. Spremberg (Bez. Cottbus), 1990-1993 Ldkr. Spremberg, 1993 Ldkr. SpreeNeiße

EREIGNISSE BIS KRIEGSENDE: Anf. Jan. 1940 besteht in „Castorf über Spremberg“, womit wohl nur Cantdorf gemeint sein kann, ein Auffanglager für 250 umgesiedelte Wolhynien- und Galiziendeutsche (Müller, S. 124). - 19.4.1945 Einmarsch der Roten Armee (Kaczmarek, S. 9).

BEVÖLKERUNGSZAHLEN: 1925: 892, 1939: 899 (HOL NL II, S. 137).

Umsiedlerlager Parma (Parmalager), im ehem. „Schützenhaus Parma“ (1881 eingeweihtes Vergnügungslokal), Berliner Straße 10: 24.10.1945 erwähnt als Lager „Parma“ des Ldkr. Spremberg für 1000 Mann (Töpler, Menschenwurm, S. 451). - Im „Verzeichnis der errichteten und vorgesehenen Umsiedlerlager im Verwaltungsbezirk Cottbus“ vom 15.12.1945 mit „Personenzahl“ 1000 genannt (Töpler, Menschenwurm, S. 472). - Kapazität am 31.12.1945 (Lager „Paragma Lg. $I^{\prime \prime}$ ): 3000 (BArch, DO 2/45, Bl. 41). - Kapazität am 1.1.1946: 2000 (BLHA, Rep. 203 MdI, Nr. 1163, Bl. 49). - 24.8.1946 Umsiedlerlager Parma, Kapazität: 1500 (SAPMO-BArch, DY 34/27880, Bl.291). - 1947 Schließung bevorstehend (SAPMO-BArch, DY 34/27745, B1. 92). - Danach offenbar wieder gastronomisch genutzt. Nach Mitteilung von Manfred Gnida „endete in Verbindung mit dem Tod des letzten Inhabers Ernst Kantor die gastliche Geschichte dieses Vergnügungslokals. Später beherbergte dieser Ort Rinder und Schweine, dann war die GHG Kurzwaren, die BHG und zuletzt eine Firma für Schädlingsbekämpfung dort ansässig. 1993 erfolgte der Abriss. An der Stelle sollte der Wohnpark ,Spreeaue` errichtet werden, leider wurde daraus nichts. Heut ist dieser Ort ein Schandfleck. Gestrüpp, Ruinen- und Mauerreste bilden den Anblick." (Märkischer Bote, 20.10.2010). 
UMSIEDLERLAGER WilHelmSTAL: Im „Verzeichnis der errichteten und vorgesehenen Umsiedlerlager im Verwaltungsbezirk Cottbus“ vom 15.12.1945 unter „Wilhemsthal“ [!] mit „Personenzahl“ 500 genannt (Töpler, Menschenwurm, S. 472).

GedRuckte QuelLen und Literatur: Kaczmarek, Günther: Die Befreiung des Kreises Spremberg vom Hitlerfaschismus im April 1945. Spremberg 1980. - Müller, Erich: Transporte, Lager, Ansiedlung im Warthegau: Das Schicksal der galizien- und wolhyniendeutschen Umsiedler nach ihrem Grenzübertritt 1939/40. In: Zeitweiser der Galiziendeutschen 43 (2005), S. 104-157. - Töpler, Menschenwurm, S. 451, 472.

\section{Spremberg-Trattendorf}

Landgemeinde Trattendorf (seit 1.1.1946 Ortsteil von Spremberg), bis 1952 Kr. Spremberg, 1952-1990 Kr. Spremberg (Bez. Cottbus), 1990-1993 Ldkr. Spremberg, 1993 Ldkr. SpreeNeiße

EREIGNISSE BIS KRIEGSENDE: 19.4.1945 Einmarsch der Roten Armee (Kaczmarek, S. 9).

BeVÖLKERUNGSZAHLEN: 1925: 997, 1939: 1974 (HOL NL II, S. 158).

UMSIEDleRlager TratTendorf: 24.10 .1945 erwähnt als Lager „Trattendorf“ des Ldkr. Spremberg für 500 Mann (Töpler, Menschenwurm, S. 451). - Im „Verzeichnis der errichteten und vorgesehenen Umsiedlerlager im Verwaltungsbezirk Cottbus“ vom 15.12.1945 mit „Personen$z a h l^{\prime \prime} 500$ genannt (Töpler, Menschenwurm, S. 472).

GedRuckte QuelLen und Literatur: Kaczmarek, Günther: Die Befreiung des Kreises Spremberg vom Hitlerfaschismus im April 1945. Spremberg 1980. - Töpler, Menschenwurm, S. 451, 472.

\section{Stahnsdorf}

Landgemeinde, bis 1952 Kr. Teltow, 1952-1990 Kr. Potsdam-Land (Bez. Potsdam), 19901993 Ldkr. Potsdam, 1993 Ldkr. Potsdam-Mittelmark

EREIGNISSE BIS KRIEGSENDE: 1939 wird ein (Beobachtungs-)Lager der Deutschen Reichsbahn in der Alten Potsdamer Landstraße erwähnt, in dem sich u. a. Wolhynien- und Galiziendeutsche, aber auch Sudetendeutsche und Wehrmachtsangehörige aufhielten (Kubatzki, S. 89). 22.4.1945 Einmarsch der Roten Armee (Böhm, S. 83). - 2.5.1945 Nach erneuten Kampfhandlungen mit deutschen Truppen endgültige Einnahme durch die Rote Armee (Böhm, S. 86; Geschichte(n) aus 750 Jahren Stahnsdorf, S. 168 f.).

EReignisse NACH Kriegsende: 31.10.1946 Wahl (mit den Stimmen von CDU und LDP) des 1946 aus Königsfelde bei Stettin nach Abtretung des Stettiner Raumes an Polen als Flüchtling nach Stahnsdorf gekommenen Kaufmanns Friedrich Bender (CDU) zum (ersten freigewählten) Bürgermeister (28.2.1947 von der Kreiskommandantur bestätigt, 14.3.1947 Amtseinführung), 28.4.1950 Amtsenthebung auf Betreiben der SED wegen angeblicher Ablehung 
der Oder-Neiße-Grenze (Bender lehnte die nachträgliche Grenzziehung bei Stettin ab) und „antisowjetischer Haltung“, geht nach West-Berlin und gründet dort 1953 den Stahnsdorfer Heimatverein) (Geschichte(n) aus 750 Jahren Stahnsdorf, S. 180 f.). - 1954 Bestattung des am 16.12.1954 in Einbeck verstorbenen letzten Direktors der Zuckerfabrik Arnswalde auf dem Waldfriedhof (700 Jahre Arnswalde Neumark. Wunstorf 1969, S. 77).

Bevölkerungszahlen: 1925: 1700, 1939: 5408, 1946: 6375, 1964: 6407 (HOL IV, S. 293). - Laut Rechenschaftsbericht des Gemeindevorstandes vom Sept. 1946 sind „1 096 Umsiedler und 410 ausgebombte Berliner Bürger in Stahnsdorf untergebracht" (Geschichte(n) aus 750 Jahren Stahnsdorf, S. 176).

Katholiken: „Die Friedhofskirche diente anfangs auch den Katholiken Stahnsdorfs als Gottesdienststätte, als ihre Zahl nach dem II. Weltkrieg auf etwa 1000 anstieg und zum 15.8.1948 der Heimatvertriebene Johannes Aßmann (1948-53) als eigener Geistlicher kam. Bis dahin bestand eine seelsorgliche Einheit mit $\rightarrow$ Kleinmachnow. / Zum Patronatsfest am 25.3.1950 konnte in der heutigen Fr.-Naumann-Straße eine Holzbaracke als Kapelle benediziert werden. Ein weit vorangetriebener Kirchbau ließ sich aus politischen Gründen nicht verwirklichen. [...].“ (Brühe, S. 38; nahezu textgleich in: Schwillus/Brühe, S. 352). Der Schlesier Johannes Aßmann (geb. 1909 Deutsch Wartenberg) war bis 1945 Pfarrer in Steinseifersdorf, Kr. Reichenbach in Schlesien (Ostpriesterverzeichnis 2, 1949, S. 11; Handbuch des Erzbistums Breslau für das Jahr 1934, S. 172; Schematismus Berlin 1949, S. 139).

Literatur: Böhm, Jürgen: Das Ende des II. Weltkrieges in Stahnsdorf bei Berlin. In: Brandenburgisches Genealogisches Jahrbuch 10 (2016), S. 83-104 (mit namentlichem Verzeichnis der deutschen Toten bei Kriegsende, darunter auch einzelne aus den Ostgebieten gebürtige Zivilisten, wobei unklar bleibt, ob sie Flüchtlinge waren). - Brühe, Matthias: Katholische Kirche zwischen Havel und Dahme. Berlin 1999, S. 38. - Geschichte(n) aus 750 Jahren Stahnsdorf. Stahnsdorf 2014. - Kubatzki, Rainer: Zwangsarbeiter- und Kriegsgefangenenlager. Berlin 2001. - Schwillus/Brühe, S. 352 .

\section{Stavenow}

Wohnplatz/Ortsteil der Landgemeinde Karstädt, bis 1952 Kr. Westprignitz, 1952-1990 Kr. Perleberg (Bez. Schwerin), 1990-1993 Ldkr. Perleberg (Land Brandenburg), 1993 Ldkr. Prignitz

EReignisse Bis KriegSende: Febr. 1945 Zwischenstation eines Trecks aus Filehne [Netzekr., Pommern (ehem. Provinz Grenzmark Posen-Westpreußen)] (Taufe eines kleinen Jungen, „der auch mit seiner Mutter auf der Flucht war. Paten waren die Quartierwirtin und eine Frau aus unserem Treck."] (Dokumentation der Vertreibung I/1, S. 378). 


\section{Stechow}

Landgemeinde (seit 31.12.2002 Ortsteil von Stechow-Ferchesar), bis 1952 Kr. Westhavelland, 1952-1990 Kr. Rathenow (Bez. Potsdam), 1990-1993 Ldkr. Rathenow, 1993 Ldkr. Havelland

EREIGNISSE NACH KRIEgSENDE: „In dem Herrenhaus kamen [nach Kriegsende] Flüchtlingsfamilien unter." (Andreae/Geiseler, S. 288). - 1946 in der Bodenreform unter 129 neuen Eigentümern 31 Umsiedler beücksichtigt (HOL III, S. 373; Das Havelland um Rathenow und Premnitz, S. 234).

EREIGNISSE NACH 1990: Seit 2009 finden, initiiert von Anika Teubner (geb. 1984), einer in Rathenow lebenden Urenkelin bessarabiendeutscher Flüchtlinge, in der „Kulturscheune“ der Gaststätte „Stadt Rathenow“ in Stechow jährliche Treffen (2012/14: „Bessarabische Zusammenkunft") des 2009 gegründeten Regionalverbandes Havelland des Bessarabiendeutschen Vereins e. $V$. statt, die von vielen im Havelland (u. a. in $\rightarrow$ Falkensee, Ferchesar, $\rightarrow$ Premnitz, $\rightarrow$ Rathenow) wohnenden Bessarabiendeutschen und ihren Nachfahren besucht werden: 11.10.2009 1. Treffen (260 Teilnehmer aus einem 80-km-Umkreis, Grußwort des Rathenower Bürgermeisters), 2. Treffen 2010, 3. Treffen 2011, 4. Treffen 30.9.2012, 5. Treffen 2013, 19.10.2014 6. Treffen (240 Teilnehmer), 11.10.2015 7. Treffen (rund 150 Teilnehmer), 9.10.2016 „8. Treffen der Bessarabiendeutschen im Havelland") (www.bessarabien.de, www.mein-bessarabien.de [12.9.2016]). 8.10.2017 Regionaltreffen der Bessarabiendeutschen in Stechow (150 Teilnehmer; Vorsitzende des Regionalverbandes: Dagmar Schubert) (BR 15 (2017) 12, S. 11).

BeVÖLKeRUnGSZAHLEN: 1925: 541, 1939: 542, 1946: 801, 1964: 556 (HOL III, S. 374). - „In der unmittelbaren Nachkriegszeit beherbergte Stechow rund 360 Flüchtlinge und Vertriebene, wodurch sich die Einwohnerzahl fast verdoppelt hatte." (Das Havelland um Rathenow und Premnitz, S. 234).

Gedruckte Quellen und Literatur: Andreae/Geiseler, S. 288. - Das Havelland um Rathenow und Premnitz. Köln u. a. 2017. - Schubert, Dagmar: Schlange stehen in Havelland und der Lüneburger Heide. In: Mitteilungsblatt des Bessarabiendeutschen Vereins 70 (2015), H. 1, S. 20 [Bericht über Treffen in Stechow u. Uelzen, 2014, mit Abb.]. - Seeger, Dieter: Befreiung (Rathenow, Ferchesar, Stechow). In: Die letzten Tage im Krieg und die ersten Wochen im Frieden in der Region um Rathenow. T. 1. Hrsg.: Rathenower Heimatbund e. V. 4. Aufl. Rathenow 2014 (1. Aufl. 2006), S. 69-75 [Erlebnisbericht; Kriegsende in Stechow; S. 71: bessarabiendeutsche Flüchtlinge Ende April 1945 in Stechow].

\section{Storkow}

Stadtgemeinde, bis 1950 Kr. Beeskow-Storkow (Kreissitz in $\rightarrow$ Beeskow), 1950-1952 Kr. Fürstenwalde, 1952-1990 Kr. Beeskow (Bez. Frankfurt/Oder), 1990-1993 Ldkr. Beeskow, 1993 Ldkr. Oder-Spree

EREIGNISSE BIS KRIEgSENDE: „Die ersten zivilen Flüchtlinge aus dem Kampfgebiet jenseits der Oder durchfluteten im Januar 1945 für einige Tage auf Straßen und Eisenbahn die Mark. 
Auch Storkow wurde von dem Strom berührt, und einige Familien wurden auf amtliche Einweisung im Städtchen seßhaft. Dann riß diese traurige Welle ab, und die Storkower atmeten erleichtert auf.“ (Becker, S. 17). - März 1945: „Der Marktplatz war vollgepfropft mit Fuhrwerken von Flüchtlingen. Die Front war an der Oder aus der Erstarrung aufgebrochen, rollte nun nach Westen und trieb jetzt die endlosen Trecks der Flüchtenden vor sich her. [...] Am Nachmittag ging es auf Befehl weiter ins Ungewisse. Die Storkower staunten: das war also die wahre Kriegslage. Und wenn die [S. 18] Flüchtenden hier nicht bleiben sollten, dann war wohl Storkow auch gefährdet.“ (Ebd., S. 17f.). - „Bereits im Februar 1945 wurden auch die beiden Schulen für die Unterbringung von Flüchtlingen ausgeräumt. [...] Die Schulräume waren mit Stroh ausgelegt. Zur Information, als Betreuer und Aufsicht waren alte Lehrer, die nicht weiter Verwendung fanden, eingeteilt worden. Ältere Schüler [...] waren als Boten, Betreuer, Helfer und Begleiter (z.B. zu den Behörden) eingeteilt.“ (Kühne, S. 57). - „20.4.1945: [Bombenangriff]: „Die meisten Bomben fielen in die Gärten am Rande der Stadt. Eine jedoch traf die Badeanstalt mit ihren Wannen- und Brausebädern und riss sie auseinander. Flüchtlinge aus den Kriegsgebieten an der Oder hatten hier eine vorläufige Unterkunft gefunden. Für viele wurde es im Leben die letzte. Wer mit dem Schrecken davonkam, verlor die kleine, mühsam mitgeschleppte Habe." (Tschechne, S. 22) . - 26.4.1945 Einmarsch der Roten Armee (Tschechne, S. 11, 38).

EReignisSe NACH KRIEgSENDE: 1945-1954 ist der zuvor bis 1945 an der Medizinischen Akademie Danzig tätig gewesene Chirurg Dr. Wolfgang Gattig (geb. 1911) Chefarzt des Kreiskrankenhauses Hubertushöhe (siehe Quellenteil, Nr. 42). - 1.5.1946 Wohnungseinweisung einer hinterpommerschen Vertriebenenfamilie unmittelbar aus dem Lager ( $\rightarrow$ Küchensee?) (Sonnemann, S. 30).

BevölkerungSZAhlen: 1925: 3563, 1939: 4316, 1946: 4747, 1964: 4798 (Städtebuch, S. 490). - „Das Kampfgeschehen in der zur Festung ausgebauten Stadt führte dazu, dass die monatliche Sterberate des Jahres 1945 mit 157 toten Zivilsten im April ihr grausiges Maximum erreichte. Wie viele von den etwa 4000 Stammbewohnern im April 1945 überhaupt noch im Ort waren, ist schwerlich feststellbar, ebenso wenig wie viele Fremde sich aufhielten." (Jürgen Pfeiler, hier zitiert nach Tschechne, S. 45).

Katholiken (Erzbistum Breslau/Erzbischöfliches Amt Görlitz): 1925: 88, 1946: 323 (Städtebuch, S. 490). - Pfarrer (anfangs Lokalist, ab 1947 Kuratial-Pfarrer) war vom 8.9.1945 bis 1958 der zuvor (ab 1940) in Landsberg/Warthe amtierende und von dort 1945 vertriebene Pfarrer Paul Dubianski (1906-1963) (Ostpriesterverzeichnis 2, 1949, S. 21; Töpler, Menschenwurm, S. 492-495; Zysnarski, S. 76), seit Anf. Dez. 1945 unterstützt von seiner ehemaligen Pfarrsekretärin aus Landsberg/W. als Pfarrhelferin (ebd., S. 495), 1958 in den Ruhestand getreten, dann wohnhaft in Gehren, Kr. Luckau (Schematismus Görlitz, 1961, S. 76). - 2012 Von Kaplan Martin Dutzschke (Cottbus) angeregtes und geleitetes Schulprojekt mit Film über den 1944/45 im KZ Dachau inhaftierten Dubianski (Lausitzer Rundschau, 7.11.2012). 
BAHnHOF: In der Regel wurden hier von 1945 bis 1949 die ankommenden Vertriebenen-Eisenbahntransporte für das benachbarte Lager $\rightarrow$ Küchensee ausgeladen.

Waisenhaus Storkow (Flüchtlingskinderheim): Ende Mai 1945 in der Villa Schaudt am See für Waisenkinder eingerichtet. Leitung: Frau Noack; Betreuer: Ehepaar Hellwig; Ende Juni 194530 betreute Kinder (Becker, S. 58-60: Kapitel „Die Herberge der Unschuldigen“).“1946 betreibt die SED Wahlwerbung mit dem Hinweis auf das von „Genossen der S.E.D.“ eingerichtete Waisenhaus (Abb. des Wahlplakats ebd., nach S. 217). - Als die Oberschule 1948 ein Internat benötigte, siedelte das Kinderheim in eine Villa auf der anderen Seite des Sees über [...]." (ebd., S. 141).

StÄdtepartnerschaften: [2004?] Opalenica (Opalenitza, vor 1918 Kr. Grätz, Provinz Posen); seit 2003 Kontakte und Begegnungen von Seniorengruppen aus Storkow und Opalenica (König).

Archivalische Quellen: BLHA, Rep. 250 Landratsamt Beeskow-Storkow, Nr. 919 („Liste der in Storkow aufgenommenen Umsiedler“, 1945).

Gedruckte Quellen: Töpler, Menschenwurm, S. 492-495 u.ö. - Erinnerungsberichte: Dokumentation der Vertreibung I/2, S. 862. - Das Alte stürzt. Es ändert sich die Zeit und neues Leben blüht aus den Ruinen. Storkower Zeitzeugen berichten aus ihrem Leben. Storkow 2013. - Brücken bauen / budowa mostów. Hrsg.: Seniorenbeirat Storkow (Mark) / Seniorenorganisation Opalenica. Storkow (Mark)/Opalenica 2005. - Damals und heute. Storkower Zeitzeugen berichten. Storkow 2003. - Drei tolle Tage nach über 800 Jahren. Storkower Zeitzeugen berichten über die Feierlichkeiten zum 800. Jahrestag der Ersterwähnung unserer Stadt im Jahre 1209 und erzählen weitere Geschichten. Storkow 2011. - Gelebte Geschichte. Storkower Zeitzeugen berichten aus 8 Jahrzehnten. Storkow 2007. - Geschichten aus sieben Jahrzehnten. Storkower Zeitzeugen berichten. Storkow 2005. - Kühne, Horst: KriegNachkrieg in Storkow. Eine Erinnerung. In: Gerd Tschechne: Das Kriegsende in und um Storkow (Mark). Storkow (Mark) 2005, S. 56-65. - Sonnemann, Lothar: Bittere Medizin. Jacobsdorf 2002. - Storkower Zeitzeugen berichten. Erlebnisse, Erinnerungen, Erfahrungen, Erkenntnisse. [H. 1]-2. Storkow 1999-2001. - Ein Stück des langen Weges. Storkower Zeitzeugen berichten anlässlich des 800. Jahrestages der Ersterwähnung unserer Stadt. Storkow 2009.

Literatur: Becker, Franz: Die große Wende in einer kleinen Stadt. Frankfurt (Oder) 1965. - König, Horst: Zwei Jahre Seniorenvereinbarung Storkow - Opalenica. In: Brücken bauen / budowa mostów. Storkow (Mark)/Opalenica 2005, S. 12-15. - Tschechne, Gerd: Das Kriegsende in und um Storkow (Mark). Storkow (Mark) 2005. - Zysnarski, Jerzy: Duchowni landsberskich kościołów przed 1945 r. [Die Geistlichen der Landsberger Kirchen bis 1945]. In: Nadwarciański Rocznik Historyczno-Archiwalny 9 (2002), S. 49-77.

\section{Storkow-Hirschluch}

Wohnplatz von $\rightarrow$ Storkow

EREIGNISSE NACH KRIEgSEnde: „28. April [1945] und weitere Tage“: „In Hirschluch war eine Halle für Flüchtlinge bereitgestellt worden. Wir bekamen Plätze auf einer Holzbank, die rund um die Halle lief. Durch die Enge war es warm und vor allem trocken, es gab auch etwas zu essen. Abends versuchten wir alle zu schlafen. Da es eng war, kroch ich unter die Bank, vergraben in Mänteln und Decken. In der Nacht wurde es hell. Russen mit Karabinern und Scheinwerfern standen in der Halle und 
forderten: ,Frau komm!' Ich rührte mich nicht. [...]." (Kriegserinnerungen der damals 18-jährigen Ilse Hendzlik geb. Gutsche, Niederschrift 2005, in: Tschechne, S. 43-44, hier S. 43).

Jugendheim Hirschluch der Evangelischen Kirche in Berlin-Brandenburg, Hirschluch 1, Storkow (Jugendrüstzeitheim, 1925 gegründet): „In der unmittebaren Vor- und Nachkriegszeit wurde das Jugendheim für sehr unterschiedliche Zwecke in Anspruch genommen. Sudetendeutsche wurden einquartiert und aus dem Johannesstift Berlin-Spandau vor dem Bombenkrieg evakuierte Altersheimbewohner. Wehrmachtssoldaten waren hier vor dem Abmarsch in Richtung Polen stationiert, und dann wurden die Gebäude auch als Lazarett für Verwundete genutzt. Deutsche Flüchtlinge aus dem Posener Gebiet fanden Aufnahme und zum Kriegsende hin auch Bewohner der wegen der Kämpfe um $[\rightarrow]$ Fürstenwalde geräumten Samariteranstalten $[\rightarrow$ Fürstenwalde-] Ketschendorf. So lebten im April 1945 an die 600 Menschen auf dem Heimgelände. Unglücklicherweise geriet am 24. April 1945 eine Baracke in Brand und dabei fanden 23 Anstaltsinsassen den Tod; sie wurden zunächst in einem Massengrab beerdigt und erst in späteren Jahren nach Fürstenwalde überführt. Ende April 1945 besetzten sowjetische Truppen Hirschluch und hielten sich eine Zeit lang dort auf, sie richteten ein Großwäscherei ein, wo deutsche Frauen zu arbeiten hatten (aber auch Verpflegung erhielten). Im Mai und Juni grassierten Ruhr und Typhus, dann wurden an die 500 Italiener vor dem Abstransport in ihre Heimat in Hirschluch zusammengezogen. / Anfang 1946 lebten neben den Heimmitarbeitern, die langsam die Heimunterkünfte wieder für den Gastbetrieb herrichteten, immer noch 13 Flüchtlingsmütter mit 36 Kindern in den Gebäuden. Aber schon im Sommer 1946 kamen doch wieder erste Erholungssuchende, vor allem Großstädter.“ (Kuhn, S. 80).

LiterATUR: Kuhn, Günter: Mehr als 75 Jahre „Hirschluch“. In: Kreiskalender Oder-Spree 2002, S. 78-81. - Tschechne, Gerd: Das Kriegsende in und um Storkow (Mark). Storkow (Mark) 2005, S. 43 f. [Kriegserinnerungen von Ilse Hendzlik geb. Gutsche].

\section{Storkow-Küchensee (Wohnplatz) $\rightarrow$ Küchensee}

\section{Strasburg (Uckermark)}

Stadtgemeinde, bis 1950 Kr. Prenzlau (Provinz/Land Brandenburg), 1.8.1950-1952 Kr. Pasewalk (Land Mecklenburg), 1952-1990 Kr. Strasburg (Bez. Neubrandenburg), 1990-1994 Kr. Strasburg (Land Mecklenburg-Vorpommern), 1994 Ldkr. Uecker-Randow (Land Mecklenburg-Vorpommern)

EREIGNISSE BIS KRIEGSENDE: Ab 1945 zahlreiche Flüchtlinge in der Stadt (Schulz, S. 445). 28.4.1945 mittags Einmarsch der Roten Armee (ebd., S. 435 f.). - Stadt durch Kriegseinwirkung zu 48 bis $55 \%$ zerstört. 
EREIGNISSE NACH KRIEGSENDE: 1945 nach Kriegsende Typhusepidemie: „Ein großer Teil (der Einwohner), darunter viele Flüchtlinge, stirbt eines jämmerlichen Todes, wovon der alte Friedhof mit seinen Massengräbern und der daneben neuaufgelegte Friedhof eine bedeutende, stumme Rede geben könnte." (Schulz, S. 435). - 17.6.1945 Befehl zur Einrichtung einer Seuchenstation in der Villa Stenzel (Zuckerfabrik) angesichts der Typhusepidemie (ebd., S. 445). - Ab Mai 1946 Waisenhaus Lemmersdorf (80 Kinder, 10 Schwestern) (ebd., S. 443). - 28.11.1946 bis 1948 Bürgermeister: Anton Bigalke (CDU), aus Deutsch Krone, vor 1933 Zentrum (ebd., S. 453). - In der Bodenreform 1132 ha von 2471 ha an 125 „Umsiedler" verteilt (HOL VIII, S. 972). - „Viele Zwangsumsiedler aus dem Osten suchten in ihrem Elend Zuflucht bei der Kirche. Daraus erwuchs eine hoffnungsvolle Gemeindearbeit in allen Glaubensgemeinschaften der Stadt. Dies wurde noch verstärkt dadurch, dass viele der neuen Strasburger aus den kirchlichen Erweckungsgebieten jenseits der Oder kamen. Eine zehntägige Evangelisation im August 1949 brachte eine Besucherzahl von bis zu 390 Menschen in der [evang.] Kirche zusammen." (Riedel, S. 49). - Ende Juli 1948 im Verzeichnis (von der Landesregierung) verbotener Suchdienste erwähnt: Kläske, Strasburg/Uckermark („,t. Schrb. Bürgerm. d. Stadt Strasburg v. 7.8. 47 vernommen und Material beschlagnahmt“) (BLHA, Rep. 203 MdI, Nr. 1197, Bl. 41).

BevölKerungszahlen: 1925: 6287, 1939: 6786, 1946: 6994, 1964: 7531 (HOL VIII, S. 973). - Anf. 1945: 6700, Mai 1945: ca. 4000, Anf. 1946: 7 156, 30.8.1947: 7160 (davon 1844 Umsiedler und Heimkehrer) (Schulz, S. 443).

Katholiken: „Nach dem II. Weltkrieg kamen Flüchtlinge, das Gemeindeleben blühte neu auf." (Brühe, S. 36).

FlÜCHTLINGSLAgeR: [Auszüge aus dem Tagebuch von Ada U., einer Mutter mit Kindern, 1940 aus der Bukowina über Jauer in Schlesien nach Kalisch umgesiedelt, Ende Jan. 1945 per Güterzug aus Kalisch gelüchtet:] 1.2.1945: „Halbtot vor Hunger und Schlaflosigkeit nach fünf Tagen Bahnfahrt endlich im Flüchtlingslager Strasburg/Uckermark. [...].“- 5.2.1945: „Diesmal aber ist es ein Notlager. Es ist schrecklich in der großen Halle, vielleicht 300 Leute schlafen hier. Aber immer noch besser als zwischen den Fronten." - 17.2.1945: „Wir sind in eine Schule umgezogen, ,nur ' fünf Familien in einem Raum. Alle schlafen auf Stroh. Die Kinder haben Läuse. [...].- 18.2.1945: „Wir fahren nach $[\rightarrow]$ Potsdam. Die Mutter von Rosi K., Gridas kleiner Freundin, hat uns alle eingeladen." (Abdruck in: Potsdamer Neueste Nachrichten, 25.2.1995).

StÄDtepartnerschaften: 2004 Drawsko Pomorskie, Polen (Dramburg, ehem. Provinz Pommern).

Gedruckte Quellen: Ada U.: [Tagebuchauszüge. Forsetzungsserie mit wechselnden Artikeltiteln]. In: Potsdamer Neueste Nachrichten, 28.1., 25.2., 1.4., 29.4., 23.9., 21.10., 23.12.1995. [Aufenthalt im Flüchtlingslager Strasburg, Febr. 1945].

Literatur: Brühe, Matthias: Katholische Kirche in Vorpommern. Neuaufl. Berlin 2000, S. 36. - Riedel, Christhart: Kirchliches Leben in Strasburg. In: Festschrift 750 Jahr Stadt Strasburg (Um.). Hrsg von Anette Görl. Milow 2000, S. S. 42-51. - Schulz, Erwin: Chronik der Stadt Strasburg (Uckermark). Milow 2000. 


\section{Straupitz}

Landgemeinde, bis 1952 Kr. Lübben, 1952-1990 Kr. Lübben (Bez. Cottbus), 1990-1993 Ldkr. Lübben, 1993 Ldkr. Dahme-Spreewald

EREIGNISSE NACH 1990: Seit 1992 jährliche Heimattreffen der ehemaligen Einwohner von Tschausdorf (Kr. Crossen, ehem. Provinz Brandenburg), zunächst organisiert von Gustav Birkner (Straupitz), ab ca. 1994/95 von Hermann Mertke (Groß Leuthen, geb. ca. 1934), ab 2015 von Petra Resag (Schenkendöbern), anfangs im großen Saal der Sportlergaststätte mit 180 Teilnehmern aus ganz Deutschland, jedoch überwiegend aus der Region, nach Teilnehmerrückgang ab ca. 1995 im Gasthaus „Zur Byttna“, u. a. 6.9.2003 (Lausitzer Rundschau [LR], 26.8.2003), 5.9.2009 16. Heimattreffen (LR, 13.8.2009), Sept. 2010 17. Heimattreffen mit rund 20 Teilnehmern (LR, 7.9.2010 u. 18.8.2011), 3.9.2011 18. Heimattreffen (LR, 18.8.2011), Sept. 201423. Heimattreffen ebd. mit 40 Teilnehmern (28 gebürtige Tschausdorfer und Angehörige) (LR, 25.9.2014).

BeVÖLKERUNGSZAHLEN: 1925: 1 106, 1939: 963, 29.10.1946: 1638, 1950: 1648, 1964: 1454 (HGV LDS, S. 10 f.). - 1.5.1946: 1648, davon 988 Ortsansässige, 660 „Umsiedler“ (Becken, S. 33).

Katholiken: 1949 wohnt in Straupitz Nr. 43 der aus Sommerfeld/Niederlausitz (Kr. Crossen) vertriebene Pfarrverweser Josef Hoffmann (geb. 1908) (Ostpriesterverzeichnis 2, 1949, S. 37). - Ab 1.4.1949 wirkt in Straupitz, zunächst als Lokalist, ab 1954 als Kuratialpfarrer, der bis 1945 in Küstrin und 1945/46 in $\rightarrow$ Birkenwerder eingesetzte Kaplan Alfons Kuschbert (geb. 1911 Neisse), zuvor bis 1949 in $\rightarrow$ Lübben (Ostpriesterverzeichnis 2, 1949, S. 50; Schematismus Görlitz, S. 68).

FriedHof: Grabstein der Hebamme Wilhelmine Hahn (1874-1952) „aus Preichow Kr. Krossen“ (Inschrift). „Dankbare ehemalige Einwohner der Ortschaften um den Jähnsdorfer See und im Staatsforst Braschen [Kr. Crossen] legten hier noch in den späten 50er und in den 60er Jahren des öfteren Blumen nieder." (Klinke, S. 182 mit Abb.). „Die Vertreibung im Juni 1945 führte sie mit der Tochter und deren zwei Kindern nach Straupitz im Spreewald. [...] Ihrer Beerdigung wohnten zahlreiche Heimatfreunde bei." (ebd.).

Archivalische Quellen: BLHA, Rep. 250 Landratsamt Lübben, Nr. 604 (Tätigkeit der Umsiedlergenossenschaften Krugau und Straupitz, 1947-1949); Nr. 605 (desgleichen, 1948-1950). - Kreisarchiv Dahme-Spreewald, A-1 Kreistag und Rat des Kreises Lübben, Nr. 1588 (Straupitz, 1945-1956; enthält u. a.: Umsiedlergenossenschaft). Sonstige Quellen: Auskünfte Herrmann Mertke, Groß Leuthen, 20.9.2016.

GedRUCKTE QUELLEN UND Literatur: Becken, Jörg: Lübben nach dem Inferno. [Cottbus] 2010. - Klinke, Helmut: Der Südkreis schätzte „Hebamms Mutter“. In: Wanderungen durch Südostbrandenburg an und jenseits der OderNeiße-Grenze 1996/97 (1996), S. 181-182. - Töpler, Menschenwurm. 


\section{Strausberg}

Stadtgemeinde, bis 1952 Kr. Oberbarnim, 1952-1990 Kr. Strausberg (Bez. Frankfurt/Oder), 1990-1993 Ldkr. Strausberg, 1993 Ldkr. Märkisch-Oderland

EREIGNisSe BIS KRIEgSENDE: 21.4.1945 morgens Einmarsch der Roten Armee (Barthel, S. 201).

EREIGNisSe NACH KRIEgSENDE: 1945: „Ab Juli kamen [...] ständig Umsiedler nach Strausberg, die teilweise hier blieben, zum größten Teil aber nach kurzer Zeit weitergeleitet wurden. Der Wohnraum war knapp.“ (Barthel, S. 206). - [Sommer] 1945: „Eine Volksküche versorgte täglich etwa 1400 Personen, darunter viele Umsiedler, die in einem ,Flüchtlingslager" untergebracht waren." (ebd., S. 211). - 25.9.1945 „Bei Strausberg besteht keine Möglichkeit für ein Lager." (Wille I, S. 245, Suche nach Standort für große Lager). - Ab Sept./Okt. 1945 Bodenreform (ebd., S. 216f.). - Nach Kriegsende wird der bis 1945 als Superintendent in Grünberg in Schlesien wirkende evangelische Pfarrer Dr. Friedrich Böhm (1882-1963) Superintendent in Strausberg; er organisiert 1950/51 Grünberger Heimattreffen in $\rightarrow$ Lübben (BArch, DO 1/27887, Bl. 39-42). - 1948: „Die Märkische Volkssolidarität führte mehrere Sammlungen von Möbeln, Hausrat und Kleidung durch, um den Umsiedlern zu helfen, kam aber nur zu bescheidenden Ergebnissen.“ (ebd., S. 222; nach Bericht des Ortsausschusses der Märkischen Volkssolidarität vom 2.6.1948 über die Lage der Umsiedler). - „Bis 1949 hatten sich für 14 aufgegebene Neubauernstellen keine Nachfolger mehr gefunden; im Frühjahr 1950 waren 23 Stellen unbesetzt [...].“ (ebd., S. 225). - 1952: „Im Juli wurden in Strausberg 52 Jugendliche für die Kasernierte Volkspolizei geworben [...]." (ebd., S. 227).

EREIGNISSE NACH 1990: 23.9.2006 „9. Ostdeutscher Kulturtag“ des BdV-Landesverbandes Brandenburg in der Akademie der Bundeswehr (Akten der BdV-Landesgeschäftsstelle).

BeVÖLKerungszahlen: 1925: 9239, 1939: 11674, 1946: 9716, 1964: 17688 (Städtebuch, S. 495). - Anf. Mai 1945: 2-3000, Ende Juni 1945: etwa 10000 (nach Rückkehr der meisten Geflohenen) (Barthel, S. 206); Dez. 1955: 13000 (ebd., S. 236).

KATHOLIKEN: 1925: 422, 1946: 772 (Städtebuch, S. 496).

FlÜCHTLINGSLAgER/UMSIEDLERLAger (im Hauptgebäude des Brandenburgischen Landesjugendheims, Wriezener Straße, heute Hausnummern 28 bis 30 A, jetzt u. a. Oberstufenzentrum): „In einem der Gebäude des Landesjugendheims wurden im Mai 1945 gefangen genommene Generale der Wehrmacht vorübergehend untergebracht (Generals-Sammellager)“ (Mitteilung Barthel, 7.1.2017, aufgrund der Zeitzeugenaussage eines 1945 dort vor der Ausfliegung der Generale in die Sowjetunion untergebrachten Adjutanten eines Generals). - Sommer 1945 „Flüchtlingslager“ erwähnt (Barthel, S. 211). - „28.6.1945: Im Landesjugendheim [offenbar in einem Teil] sind internierte Italiener untergebracht (die in der Folgezeit durch Plünderungen in der Stadt unangenehm auffielen); 2.7.1945: Die Flüchtlinge sollen als Landarbeiter 
auf einige umliegende Dörfer verteilt werden (auf 6 Dörfer je 10); 9.7.1945: Die Küche gab zuletzt täglich bis zu 2500 Portionen aus; der Bedarf stieg vor allem infolge des Flüchtlingsstroms. Die Küche versorgt Krankenhaus, Altersheim, Entbindungsheim und Flüchtlingslager; z. T. muss im Freien gekocht werden; 16.7.1945: Im Flüchtlingslager (= Durchgangslager) herrschen katastrophale Zustände: Gestorbene, die fast verwest sind, liegen herum; dort sind auch Kinder ohne Eltern; alte Leute, die in ihrem eigenen Kot liegen, und keiner kümmert sich darum. Der Flüchtlingsstrom [aus Berlin und aus dem Osten] hat nachgelassen. Zur Betreuung im Flüchtlingslager sind zwei Rot-Kreuz-Schwestern eingesetzt.“ (Exzerpte von Dr. Rolf Barthel, Strausberg, aus Akte Stadtarchiv Strausberg, alte Nr. 347 „Magistratssitzungen Mai bis Dezember 1945“) - „18.10.1945: Sitzung des Antifa-Aktionsausschusses: Durch das städtische Flüchtlingslager liefen bisher 2641 Personen, etwa 1000 sind noch im Lager, 39 sind verstorben.“ (wie vor, alte Nr. 250 „Verschiedenes“). - 23.10.1945 Sammellager Strausberg (im Landesjugendheim) erwähnt mit Kapazität: 2000 Personen, Lagerleiter: Georg Sydow (BArch, DO 2/39, Bl. 14). - „Im November befanden sich etwa 500 Umsiedler in Strausberg; 14.12.1945: Im Umsiedlerlager befinden sich z.Zt. etwa 290 Personen; allein im Oktober durchliefen etwa 2000 Personen das Lager. (Sie wurden in andere Landesteile weitergeleitet, u. a. nach Mecklenburg und in die Provinz Sachsen).“ (Exzerpte Barthel, wie oben, alte Nr. 83 „Sozialwesen“). Kapazität am 31.12.1945: 2000 (BArch, DO 2/45, Bl. 40). - Kapazität am 1.1.1946 („Umsiedlerlager"): 2000 (BLHA, Rep. 203 MdI, Nr. 1163, Bl. 50). - 10.1.1946 Flüchtlingslager als in Gebäuden des Landesjugendheims erwähnt in „Schreiben des des Strausberger Magistrats vom 10.1.1946 an den Präsidenten der Provinzialverwaltung (Exzerpt Barthel aus Akte Stadtarchiv Strausberg, alte Nr. 77 „vermischte Akten“). - „Über das Ende dieses Durchgangslagers habe ich nichts gefunden. Es [...] fehlen zwischen 1946 und 1954 fast alle Akten." (Mitteilung Barthel, 7.1.2017).

STRASSENUMBENENNUNGen: 14.7.1950 Bromberger Straße in Gorkistraße (der in West-OstRichtung verlaufende Teil später in Uhlandstraße umbenannt), Kleine Bromberger Straße in Uhlandstraße (später der Gorkistraße zugeordnet), Danziger Straße in Goethestraße, Dirschauer Straße in Bruno-Bürgel-Straße, Gnesener Straße in Tolstoistraße, Graudenzer Straße in Heinestraße (später Heinrich-Heine-Straße), Lissaer Straße in Lessingstraße, Thorner Straße in Schillerstraße, Tilsiter Straße in Freiligrathstraße (Béringuier, S. 18).

StÄdtepartnerschaften: (1) 1978 Dębno, Polen (Neudamm, ehem. Kr. Königsberg/Neumark, Provinz Brandenburg), 1992 erneuert (www.stadt-strausberg.de/partnerstaedte-paten schaften [23.8.2018]). - (2) 1998 Terezín, Tschechien (Theresienstadt, Nordböhmen).

Archivalische Quellen: BArch, DO 2 ZVU, Nr. 39, Bl. 11, 14 (Lager, 1945). - Stadtarchiv Strausberg, alte Nr. 77, 83, 250, 347 (Exzerpte Dr. Rolf Barthel, Strausberg, mitgeteilt 7.1.2017).

Literatur: Barthel, Rolf: Geschichte der Stadt Strausberg. Berlin 1987. - Béringuier, Claus: Sammlung zur Geschichte und Herkunft Strausberger Namen. Strausberg 2008 (Akanthus-Mitteilungen, H. 21). - Brühe, Matthias: Katholische Kirche zwischen Uckermark und Oderland. Berlin 1998, S. 53 (Strausberg-Vorstadt). 


\section{Stützkow}

Landgemeinde (seit 1973 Ortsteil von $\rightarrow$ Schöneberg), bis 1952 Kr. Angermünde, 1952-1990 Kr. Angermünde (Bez. Frankfurt/Oder), 1952-1990 Ldkr. Angermünde, 1993 Ldkr. Uckermark EREIGNISSE NACH KRIEGSENDE: In der Bodenreform 33 ha von 103 ha an Umsiedler vergeben (HOL VIII, S. 977). - 3.10.1950 Zuweisung von westlich der Oder gelegenen einwohnerlosen Flächen der nun polnischen Gemeinde Peetzig/Oder (Piasek) (ehem. Kr. Königsberg/Nm.) an die Gemeinde Stützkow sowie weiterer Teile an die Gemeinde $\rightarrow$ Criewen (Blöß, Kreise und Gemeinden, S. 31).

BeVÖLKERUNGSZAHLEN: 1925: 139, 1939: 191, 1946: 189, 1964: 117 (HOL VIII, S. 978).

\section{Teltow}

Stadtgemeinde, bis 1952 Kr. Teltow, 1952-1990 Kr. Potsdam-Land (Bez. Potsdam), 19901993 Ldkr. Potsdam, 1993 Ldkr. Potsdam-Mittelmark

EREIGNISSE BIS KRIEGSENDE: 22.4.1945 Einmarsch der Roten Armee. „Am Ende des zweiten Weltkrieges war eine chaotsche Situation in Teltow entstanden, die einer langen Zeit des Aufbaus bedurfte." (Wachs, S. 24).

EREIGNISSE BIS KRIEGSENDE: Sept. 1946 Einweisung von 20 Sudetendeutschen aus dem Lager $\rightarrow$ Saalow in Wohnungen in Teltow (anfangs vorübergehend auf Dachboden der Brauerei, Alte Potsdamer Straße, untergebracht), die überwiegend dauerhaft in Teltow verblieben sind. Nach Teltow sind u. a. auch Schlesier gekommen (Rotzer).

EREIGNISSE NACH 1990: Kurz nach der Wende zog die Redakteurin und Schriftstellerin Gisela Heller geb. Hielscher (geb. 1929 Breslau) von $\rightarrow$ Kleinmachnow nach Teltow, wo sie seitdem lebt.

BEVÖLKERUNGSZAHLEN: 1925: 5434, 1939: 12 131, 1946: 10 950, 1964: 13080 (Städtebuch, S. 501). - 1936: 10087 (Wachs, S. 24).

Katholiken: 1925: 475, 1946: 1434 (Städtebuch, S. 501). - „Zum 1.4.1959 wurde Teltow mit damals etwa 1800 Katholiken Pfarrei.“ (Brühe, S. 39).

UMSIEDLERLAGER: 1946 Belegungsstärke: 3000 (Kaminsky, S. 159).

Evangelisches Diakonissenhaus Berlin-Teltow, Lichterfelder Allee 45: 20.4.1945 [Tagebuch der Oberin Anna von Noel]: „Flüchtlinge aus Fürstenwalde 3 Erwachsene und 5 Kinder aufgenommen. [...].“ (Wieke, S. 132). - „Die Familie von Pfarrer Blochwitz, die aus der Neumark geflohen war und im Teltower Diakonissenhaus Zuflucht gesucht hatte, brachte sich nach einem Vergewaltigungsversuch an der Frau des Pfarrers gemeinsam um." (ebd., S. 135) [Es kann sich 
nur um Gottfried Blochwitz (geb. 1903 Frankfurt/O.) handeln, ab 1930 Pfarrer in Neumühl bei Küstrin (Otto Fischer, Pfarrerbuch, T. 2/1, S. 65]. - „Eine unaufschiebbare Aufgabe war die Aufnahme und Versorgung der Flüchtlinge, die nach dem Kriegsende in zunehmender Zahl im sowjetischen Besatzungsgebiet strandeten. Wir hatten ja schon im Lauf des letzten Jahres einzelne Personen oder auch ganze Familien aufnehmen können, dazu kamen die Königsberger, Posener und Danziger Schwestern, deren Mutterhäuser zerstört waren. In diesem Sommer [1945] kamen noch die durchreisenden Flüchtlinge dazu, die meist ein unbeschreiblich jammervolles Bild boten. Wir hielten ständig Räume in einem eigens dafür hergerichteten Haus bereit, wo die armen Menschen wenigstens für eine Nacht - länger durften sie in Teltow nicht bleiben - Ruhe und eine warme Mahlzeit fanden.“ (ebd., S. 136, Zitat aus Erinnerungen von Schwester Erna Meyer).„Von den Schwestern in den Außenstationen hatte man wochen- und monatelang nichts gehört, [...] Umso größer war die Freude, als Mitte Juli 1945 Schwester Ida Brosius mit einer Gruppe von geistig behinderten Waisenkindern aus Züllichau in Teltow ankam. [...] [S. 137] [...] Auch die Tochteranstalt Siloah in [Berlin-] Pankow Niederschönhausen hatte ein wechselvolles Schicksal erlitten. Als Berlin immer schwerer bombardiert wurde, hatte man alle Insassen des Heims [... aus Berlin heraus- und in Hammer bei Schwiebus untergebracht. [...] Kaum hatten sich alle dort eingelebt, mussten sie vor der heranrückenden Roten Armee, die Ende Januar 1945 bereits die Oder erreicht hatte, erneut fliehen. Zurück nach Siloah.“ (ebd., S. 136f.). - „Als Herausforderung und Hilfe zugleich erwies sich die 1948 erfolgte Aufnahme und Vereinigung mit den aus Kreuzburg in Oberschlesien stammenden Diakonissen. Diese waren noch kurz vor Kriegsende nach der Evakuierung ihres Mutterhauses geflohen und seitdem mit Patienten und Hilfsbedürftigen auf der Suche nach einer neuen Heimat. Mit ihnen nahm die Zahl engagierter Schwestern deutlich zu. Sie brachten mit ihren speziellen Fachkenntnissen in Gemeindediakonie und Krankenpflege auch ein eigenes Profil in die Arbeit ein, was den neuen Aufgaben in Teltow sehr entgegenkam. [...] Dagegen füllte sich das Kinderheim schnell wieder mit Säuglingen oder Kleinstkindern, die im Krieg oder auf der Flucht ihre Eltern ganz oder vorübergehend verloren hatten." (Röder, S. 12). - Die am 8. Juli 1948 vollzogene Vereinigung mit dem („aus Kreuzburg O./Schl. verdrängten“ [gedruckte Bekanntmachung von „Kuratorium und Vorstand des Diakonissenhauses Teltow“, „Teltow, den 8. Juli 1948“, abgebildet in: Diakonissenhaus, S. 43]) Diakonissenmutterhaus Kreuzburg (Oberschlesien) wurde zunächst auch im Namen der Teltower Einrichtung erkennbar: „Evangelisches Diakonissenhaus Teltow-Kreuzburg“. Die Diakonisse Luise von Werdeck (1898-1982), die 1939, aus dem Lutherstift $\rightarrow$ Frankfurt (Oder) kommend, Oberin des Kreuzburger Mutterhauses geworden und nach der Flucht 1945 mit den Schwestern zunächst in Sachsen-Anhalt untergekommen war, wurde 1948 in Teltow Oberin der vereinigten Mutterhäuser (bis 1969) (Diakonissenhaus, S. 43, 53, 84). „Sie war 30 Jahre im Oberinnenamt und hat die beiden Schwesternschaften stark geprägt. Das Zusammenwachsen der beiden Schwesternschaften war ihr Verdienst, aber auch die Schwestern von beiden Seiten waren guten Willens. In ihrem Ruhestand blieb sie die Seelsorgerin der Schwestern und war auch sehr um die Feierabendschwestern bemüht. Ihr Wirken bezog sich nicht nur auf die Schwestern und die Anstaltsgemeinde, es war ein großer Kreis von Menschen, 
für den sie zur Verfügung stand.“ (ebd., S. 84). Der aus Kreuzburg nach Teltow gekommene Pastor Friedrich Steinwachs (1891-1969) war seit 1929 Vorsteher der Diakonissenanstalt Kreuzburg gewesen und nun 1948-1963 Vorsteher und - neben dem (bereits ab 1927 in Teltow wirkenden) Direktor Alfred Fritz (geb. 1886) - 2. Pfarrer im Diakonissenhaus Teltow (Pfarralmanach 1950, S. 61; 1953, S. 59; 1956, S. 71; Diakonissenhaus, S. 54 mit Bild). - In einer nach 2000 angelegten Einfamilienhaussiedlung südlich des Diakonissenhauses wurden mehrere Straßen nach Pfarrern und Oberinnen benannt, darunter (bis 2003 Privatweg) Friedrich-Steinwachs-Weg und (bis 2013 Privatstraße) Luise-von-Werdeck-Straße.

StÄdtepartnerschaften: Mai 2006 Żagań, Polen (Sagan, Schlesien).

Quellen: Auskünfte Augustin Rotzer, Teltow, 4.3.2017 (Juli bis Sept. 1946 mit den Eltern als Vertriebener aus dem Sudetenland im Lager befindlich, dann mit 19 Sudetendeutschen nach Teltow eingemeindet); Evang. Diakonissenhaus Berlin Teltow Lehnin, Sekretariat (Stephan Gellbach), 9.1.2020 (Geburtsjahr L.v. Werdeck); Stadt Teltow, Öffentlichkeitsarbeit (Jürgen Stich), 9.1.2020 (Straßennamen).

Literatur: Brühe, Matthias: Katholische Kirche zwischen Havel und Dahme. Berlin 1999, S. 39. - Diakonissenhaus Teltow 1841-1991. Geschichtlicher Rückblick auf 150 Jahre Ev. Diakonissenhaus Berlin-Teltow und 60 Jahre Diakonissenmutterhaus „Bethanien“ in Kreuzburg/Oberschlesien. Hrsg. vom Hausvorstand des Evang. Diakonissenhauses Teltow. (Teltow) 1991. - Röder, Hans-Jürgen: Im Angesicht der Mauer. Diakonisches Leben im DDR-Sozialismus. Hrsg. vom Evang. Diakonissenhaus Berlin Teltow Lehnin. Berlin 2016. - Schwillus/Brühe, S. 352. - Wachs, Reiner: Das letzte Jahrhundert der Entwicklung Teltows. In: Potsdamer Land 1 (1990), S. 21-29 [ohne Hinweis auf Flüchtlinge]. - Wiebach, Albert: Schwerer Anfang. In: 700 Jahre Stadt Teltow. Teltow 1965, S. $16-17$ [Erinnerungen des ersten Nachkriegs-Bürgermeisters ab 30.4.1945, ohne Hinweis auf Flüchtlinge]. - Wieke, Thomas: Alles kann anders kommen jederzeit. 175 Jahre Evangelisches Diakonissenhaus Berlin Teltow Lehnin. Hrsg. vom Evang. Diakonissenhaus Berlin Teltow Lehnin. Berlin 2016.

\section{Telz}

Landgemeinde (seit 2003 Ortsteil von $\rightarrow$ Mittenwalde), bis 1952 Kr. Teltow, 1952-1990 Kr. Zossen (Bez. Potsdam), 1990-1993 Ldkr. Zossen, 1993 Ldkr. Dahme-Spreewald

BeVÖLKERUNGSZAHLEN: 1925: 390, 1939: 489, 1946: 595, 1964: 388 (HOL IV, S. 308).

Kinderheim „Kinderfreude“ (Landheim der Berliner Stadtmission für „gefährdete Mädchen“), gegründet 1910: „[...] nach dem zweiten Weltkrieg wurden die Mädchen auf behördlichen Wunsch auf andere Heime verteilt oder entlassen. Um der Not der Flüchtlingskinder willen wurde das Telzer Heim noch 1946 Waisenhaus. Die zugewiesenen Kinder kamen meist völlig verstört, an Leib und Seele verkommen, im Heim an, das selbst auch noch Spuren des Krieges und der Zerstörung aufwies. Nun begann für Schwester Elisabeth Staaden und ihre Mitarbeiterinnen die neue Aufgabe: den Kindern Eltern und Geschwister zu ersetzen, ihnen in jeder Hinsicht Mutter zu sein. Mit den Jahren fanden sich inzwischen die überlebenden Verwandten." (Fünfundsiebzig Jahre Berliner Stadtmission, S. 128; Gebäude-Abb. S. 127).

Literatur: Fünfundsiebzig Jahre Berliner Stadtmission. Berlin 1952, S. 127-134. 


\section{Templin}

Stadtgemeinde, bis 1952 Kr. Templin, 1952-1990 Kr. Templin (Bez. Neubrandenburg), 19901993 Ldkr. Templin, 1993 Ldk. Uckermark

EREIGNISSE BIS KrIEgSENDE: Anf. Jan. 1940 besteht in Templin ein Auffanglager für 1000 umgesiedelte Wolhynien- und Galiziendeutsche (Müller, S. 124). - 20.1.1945 Evakuierung der Kreisverwaltung Eichenbrück (Wongrowitz) aus dem Reichsgau Wartheland mit dem Ziel $\rightarrow$ Prenzlau, Übergabe des Verwaltungsgutes an das Landratsamt Prenzlau, bald darauf aber auch an das Landratsamt Templin (Nebelung, S. 89). - „In der Bürgerschule waren seit Anfang [Januar] 1945 Flüchtlinge untergebracht. Unterricht wurde nur noch für zwei bis drei Stunden im Joachimsthalschen Gymnasium abgehalten. / Im Februar erreichen erste Flüchtlingskolonnen aus dem Osten die Stadt. Fuhrwerke verstopften die Straßen und wurden in Richtung Zehdenick weitergeleitet." (Makowitz/Knitter/Kunze, S. 213; vgl. S. 450 f.; vgl. Bestmann). - Febr. 1945 Zwischenhalt eines Trecks aus Filehne: „Hunderte von Menschen waren in einem Kinosaal zusammengefercht. [...].“ (Dokumentation der Vertreibung I/1, S. 378). - Treck aus Nahausen (Kr. Königsberg/Nm.): „Um den 6. Februar war Templin erreicht, das für die Aufnahme der Flüchtlinge aus dem Kreis Königsberg vorgesehen war." Anschließend Aufteilung auf die Kreisdörfer $\rightarrow$ Beenz und $\rightarrow$ Bredereiche (Köhler, S. 100). - 23.4.1945 „Verstopfung der Straßen durch Wehrmachtsfahrzeuge und Flüchtlingskolonnen“" (Makowitz/Knitter/Kunze, S. 451). - 27.4.1945 Flucht der Mehrheit der Einwohner (Makowitz/Knitter/Kunze, S. 215, 452). - 27./28.4.1945 Einmarsch der Roten Armee (ebd., S. 216; vgl. S. 564). - 27.4.1945 Todesfall einer 63-jährigen Flüchtlingsfrau (Witwe) aus Königsberg/Nm. in Templin (Krätzner, S. 24, nach Angaben in der „Heimatkarte““). - 30.4.1945 Bürgerschule durch Brandstiftung zerstört (ohne Turnhalle) (ebd., S. 217, 452). - 1.5.1945 Rückkehr erster Einwohner (ebd., S. 452), Verschleppung von Männern u. Jugendlichen, teilweise zur Zwangsarbeit nach Ostpreußen, Rückkehr nach mehreren Monaten (ebd., S. 219).

EREIGNisSE NACH KRIEgSENDE: „Nach Templin kamen infolge der Kriegsauswirkungen ca. 2500 Flüchtlinge. Am 25. Juli 1945 erhielt der Bürgermeister Brandt vom Landrat die Richtlinie, dass alle wiederkehrenden Ortsansässigen, die Evakuierten aus Polen jenseits von Oder und Neiße und dem Sudetengebiet, die im Januar und Februar in die Stadt kamen, in Templin aufgenommen werden müssen. Deshalb sollten die Ortsansässigen ihre Wohnansprüche einschränken. / So wurde in der $[\rightarrow]$ Engelsburg bei Ahrensdorf ein Flüchtlings- und Heimkehrerlager eingerichtet, später wurde es Kreisaltersheim. Ebenso wurden das Postheim und die Baracken des Reichsarbeitsdienstes in der Dargesdorfer Straße am Abzweig nach Ludwigsdorf für Heimkehrer nutzbar gemacht. In der Heimstraße 9 nutzte man die damaligen Behelfsheime weiter. Berliner, deren Wohnungen nicht zerstört waren, mussten nach Berlin zurückkehren. [...].“ (ebd., S. 226). - Juli 1945 Einrichtung einer Typhusstation im Krankenhaus (ebd., S. 453). - 30.9.1945 Todesfall einer Flüchtlingsfrau aus Königsberg/Nm. in Templin (Krätzner, S. 25, nach Angaben in der „Heimatkartei“). - 25.10.1947 „Aufruf, zur ,Umsiedlerwoche“ Mobiliar, Hasurat usw. abzugeben“ (ebd., S. 458). - 8.11.1947 „Aufruf zur Einschränkung der 
Wohnansprüche, um die Unterbringung der Umsiedler zu verbessern.“ (ebd., S. 458). - In der Bodenreform 217 ha (von 491 ha) an 22 Umsiedler vergeben (HOL VIII, S. 1001). - Ab 1948 wurden sowohl für die Stadt als auch für den Kreis keine Zuzugsgenehmigungen mehr ausgestellt.“ (Makowitz/Knitter/Kunze, S. 226). - „Viele Flüchtlingsfamilien [S. 79] blieben in Templin. In den vorhandenen Wohnungen lebten oft fremde Menschen dicht beieinander, aber das Wenige, was sie hatten, wurde redlich geteilt." (Krzywinsky, S. 78 f.). - Der gelernte Buchhändler Friedrich Scholz-Padiéra (geb. 20.6.1900 Beelitz, gest. 28.8.1969 Templin), kam 1945 als Flüchtling aus Schlesien nach Templin, war ebd. als Antiquitätenhändler tätig, „engagierte sich hier für die kulturellen Angelegenheiten, insbesondere für den Wiederaufbau der historischen Altstadt, für die Schaffung des Museums und im Bereich der Denkmalpflege als Vorsitzender des Kreisdenkmalausschusses. [...]“ (Makowitz/Knitter/Kunze, S. 566).

BevölKerungszahlen: 1925: 7562, 1939: 8619, 1946: 9970, 1964: 10998 (Städtebuch, S. 505). - 6.4.1945: 10398 (Makowitz/Knitter/Kunze, S. 451), Juli 1945: ca. 11500 (ebd., S. 454), 6.4.1946: 10398 („polizeilich gemeldet“, ebd., S. 455), 14.5.1946: 10762, davon 2548 „zugezogen“ (ebd., S. 222).

Katholiken: 1925: 198, 1946: 666 (Städtebuch, S. 505). - „Die Wiederbenutzung der HerzJesu-Kirche sollte sich mehr als segensreich auswirken, als 1945/46 der Strom der Flüchtlinge und Heimatvertriebenen den Kreis Templin erreichte, denn da wurde sie für viele von ihnen zu einem Ort der Zuflucht und geistlichen Beheimatung. Für die auf dem Lande Wohnenden hielt Pfarrer Ueberholz [geb. 1891 Berlin] schon bald wieder in der Heilig-Geist-Kapelle in Lychen und dazu in verschiedenen Dörfern Stationsgottesdienste ab. Da alle 5 Bahnstrecken demontiert waren, musste es per Fahrrad geschehen, in derr Hungerzeit eine enorme Belastung." (75 Jahre Herz-Jesu-Kirche Templin, S. 22).

(Kreis-)Umsiedlerlager Postheim: 1908 Post- und Genesungsheim eingeweiht, bis 1914 Errichtung von 18 weiteren Häusern mit insgesamt 188 Wohnungen, insbesondere von Berlinern für Erholungsaufenthalt genutzt (1938 5800 Personen in 27 Häusern mit 235 Wohnungen). 1915/16 vorübergehend Notquartier für 150 Familien aus dem russisch besetzten Teil Ostpreußens, 1923 Beschlagnahmung von Wohnungen durch die Regierung Potsdam für 200 Flüchtlingsfamilien aus Westpreußen (später in neuerrichteten Siedlungsbauten in Waldstraße und Märkischem Viertel angesiedelt). Im Zweiten Weltkrieg Einzug der „Volksdeutschen Mittelstelle“ (VoMi) und 1943 des in Berlin ausgebombten „Volksbunds für das Deutschtum im Ausland“ (VDA), in Templin Vereinigung mit der VoMi. Aufstellung von Baracken für aus Slowenien zwangsumgesiedelte Deutsche sowie für osteuropäische Zwangsarbeiter. 1945 Plünderungen und Beschädigungen zum Kriegsende, dann mehrwöchige Einquartierung sowjetischer Truppen, anschließend 1945 notdürftige Instandsetzung als Lager für Flüchtlinge („später erhielten rund 190 Familien hier eine Unterkunft“ [Makowitz/Knitter/Kunze, S. 221]). - 25.7.1945: „Richtlinie des Landrates an den seit 2. Mai amtierenden Bürgermeister Hans Brand und an alle Templiner: Aufnahme von Flüchtlingen, so auch im Postheim." (Kun- 
ze, S. 87). - Okt. 1945 erwähnt (BArch, DO 2/39, Bl. 11). - Kapazität am 1.1.1946: 1500 (BLHA, Rep. 203 MdI, Nr. 1163, Bl. 49). - 14.2.1946 Kreis- und Quarantänelager, Kapazität: 2000 (Oehlsen, S. 28). - 1946 Belegungsstärke: 1000 (Kaminsky, S. 159). - 30.4.1946 als eines der verbleibenden Umsiedlerlager genannt (DAB, I/9-15-1 Flüchtlingsseelsorge 19451951, unfol., [30.6.1946], [Anlage 3]). - 24.7.1946 in Liste der Lager für „Ostheimkehrer“ als Lager „Dawersdorfer Str.“ [richtig: Dargersdorfer Str.] genannt mit Kapazität 500 (BArch, DO 2/45, Bl. 76). - 24.8.1946 Umsiedlerlager, Kapazität: 1000 (SAPMO-BArch, DY 34/27880, Bl. 291). - „1946: Im Nebenhaus des ,Casino' werden 40 Plätze für Tbc-Kranke geschaffen." (Kunze, S. 87). - 1.1.1947 in Templin zwei Lager, Kapazität: 1200 bzw. 800 (Oehlsen, S. 101). - [Lagerinsassen:] „Viele von ihnen suchten sich später im Templiner Stadtgebiet und in umliegenden Dörfern ihre Bleibe.“ (Maaß/Völker, S. 24). - „Das Heim wurde nach Auszug der Flüchtlinge nach $[\rightarrow]$ Engelbsurg bei Ahrensdorf verlegt, wo am 2. Januar 1948 ein Altersfeierabendhaus öffnete." (Makowitz/Knitter/Kuntze, S. 229). - 25.2.1949: „Das Haus Nr. 3 im Postheim wurde Kreisalters- und TBC-Heim.“ (ebd., S. 460). - 1.11.1946 „Übergabe des ehemaligen Posterholungsheims mit 26 Häusen an den FDGB, Vergabe der restlichen noch zweckentfremdet durch die Kommunale Wohnungsverwaltung" (Makowitz/Knitter/Kuntze, S. 456; vgl. Kunze, S. 87), nach 1949 und auch nach 1990 Mischnutzung der gesamten Siedlung Postheim: Dauerwohnungen, Erholungsstätten und Ferienhäuser (ebd., S. 274f.).

Waldhof(schule), Röddeliner Str. 36 (heute Behinderteneinrichtung der Stephanus-Stiftung): Febr. 1945: „Die Waldhofschule wurde beschlagnahmt und dort die Isolierstation des zerstörten Krankenhauses untergebracht. Zusätzlich mussten dort Flüchtlinge aufgenommen werden.“ (Makowitz/Knitter/Kunze, S. 213). - 27./28.4.1945 „Beim Vormarsch der Roten Armee zum Waldhof wurde der Leiter und Superintendent Buchhol[t]z mit einem Gewehrkolben niedergeschlagen, weil er sich schützend vor Flüchtlingsfrauen stellte, die sich dort aufhielten. Er starb am 3. Mai an den Folgen der Verletzung.“ (ebd., S. 216; vgl. S. 564) [Dr. Karl Buchholtz (geb. 1891 Dresden), ab 1934 Pfarrer in Templin (Otto Fischer, Pfarrerbuch, T. 2/1, S. 104)]. 28.4.1945 (Bericht des Leiters des Waldhofs, Daniels): „Im Laufe des Tages stellten sich noch mehrere Flüchtlingsfamilien ein, denen ich ebenfalls Obdach gewährte." (Knitter, S. 119).

Forstschule (Röddeliner Str.): Das Gebäude diente „während des Krieges als Lazarett und am Ende sowie nach dem Krieg für einige Monate als Flüchtlingsunterkunft", später Polytechnische Oberschule V (Makowitz/Knitter/Kuntze, S. 266f.).

Städtepartnerschaften: 19.10.1977 Polczin Zdrój, Polen (Bad Polzin, ehem. Kr. Belgard/ Pommern), 1997 erneuert (Makowitz/Knitter/Kuntze, S. 555).

VertriebenENVERBÄNDE NACH 1990: BdV-Regionalverband Templin e. V., 21.12.96 i. G. (in Gründung): Vollversammlung. u. Delegiertenwahl in der Templiner Gaststätte „Stadt Templin“ mit 63 Teilnehmern (Einladungen gingen in die Amtsbereiche Templin-Stadt, Templin-Land, $\rightarrow$ Lychen, $\rightarrow$ Boitzenburg u. Gerswalde), Satzung errichtet, 11.8.1998 Eintragung beim Amts- 
gericht Prenzlau (VR 590). - Mitgliederzahlen: 31.12.2005: 68, 2012: 38. Verband noch 2018 erwähnt (Akten der BdV-Landesgeschäftsstelle). - Vorsitzende: 1996-2017 Dr. Hans-Georg Engel, Tierarzt in Hassleben (geb. 1936 Dürwangen, Kr. Rößel, Ostpreußen, gest. 2019 Templin) (zuvor [erwähnt 1994] Schriftführer im Kreisverband $\rightarrow$ Prenzlau/Templin u. Hauptmitarbeiter für den Altkreis Templin), ab 2017 (2018 noch erwähnt) der bisherige 1. stellv. Vorsitzende Reinhard Franke, Templin OT Klosterwalde (geb. 1946 Nimptsch, Kr. Reichenbach).

Archivalische Quellen: BArch, DO 2 ZVU, Nr. 39, Bl. 11 (Lager, Okt. 1945).

Gedruckte Quellen und Literatur: HOL VIII, S. 991, 1002 („Postgenesungsheim“ im Art. Templin, ohne Erwähnung des Lagers). - Bestmann, Christa: Wege und Irrwege durch die letzten Tage des 2. Weltkrieges. In: Templiner Heimatkalender 2016 (2015), S. 41-48. - Brandenburger Rundschau 17 (2019) 4, S. 11 (Todesanzeige H.-G. Engel). - Dokumentation der Vertreibung I/1, S. 378. - 75 Jahre Herz-Jesu-Kirche Templin 1935-2010. Templin (2010). - Knitter, Eitel: Die Geschehnisse am Waldhof Templin 1945 (nach einem Bericht vom 5. Mai 1945). In: Templiner Heimatkalender 2000 (1999), S. 119-120. - Köhler, Erich: Das Flüchtlingselend neumärkischer Familien. In: Königsberger Kreiskalender 2002, S. 96-104. - Krätzner, S. 24f. - Krzywinsky, Ursula: So erlebte ich als Vierzehnjährige das Kriegsende in Templin. In: Templiner Heimatkalender 2002 (2001), S. 73-79 [Febr.-Dez. 1945; ihre Mutter nimmt Anf. März 1945 aus Rummelsburg in (Hinter-)Pommern geflüchtete Verwandte auf]. - Kunze, Martin: Das Postheim - Zur Chronik einer Templiner Perle. Teil 2. In: Templiner Heimatkalender 2016 (2015), S. 87-94. Maaß, Helmut / Völker, Hubert: 100 Jahre Postheim in Templin. In: Templiner Heimatkalender 2006 (2005), S. 2226. - Makowitz, Bärbel / Knitter, Eitel / Kunze, Martin: Templin. 2. Aufl. Strasburg (Um.)/Berlin 2013. - Müller, Erich: Transporte, Lager, Ansiedlung im Warthegau: Das Schicksal der galizien- und wolhyniendeutschen Umsiedler nach ihrem Grenzübertritt 1939/40. In: Zeitweiser der Galiziendeutschen 43 (2005), S. 104-157. - Nebelung, (Paul-Friedrich): Der Landkreis Eichenbrück (Wongrowitz) im Reichsgau Wartheland. in: Heimatbuch für den Kreis Eichenbrück-Wongrowitz. [Bd. 1]. Lüneburg [1967], S. 87-89. - „Die Russen sind da“. Peter Böthig u. Peter Walther (Hg). Berlin 2011. - Schwillus/Brühe, S. 353.

\section{Teupitz}

Stadtgemeinde, bis 1952 Kr. Teltow, 1952-1990 Kr. Königs Wusterhausen (Bez. Potsdam), 1990-1993 Ldkr. Königs Wusterhausen, 1993 Ldkr. Dahme-Spreewald

EReIGNisSe BIS KRIEgSende: 27.4.1945 Einmarsch der Roten Armee (Rose, Teupitz am See, S. 240).

EREIGNisSe NACH KRIEgSENDE: Frühsommer 1945: Flüchtlingstreck in Teupitz (Foto von Josef Donderer [Bildarchiv Preußischer Kulturbesitz], Abb. in: Rose, Teupitz von 1952 bis in die jüngste Vergangenheit, S. 250). - Noch 1952 befinden sich im Schloss Wohnungen für Flüchtlingsfamilien (ebd., S. 255).

BevöLKerungszahlen: 1925: 3654 (davon 1400 Landesheilanstalt), 1939: 3038 Einwohner, „1945 mit Flüchtlingen kurzzeitig ca. 5000“, 1946: 1550 (Städtebuch, S. 510). - 1925: 3019, 1939: 3 988, 29.10.1946: 2622, 1950: 2695, 1964: 2286 (HGV LDS, S. 10 f.).

Katholiken (Erzbistum Breslau/Erzbischöfliches Amt Görlitz): 1925: 83, 1946: 136 (Städtebuch, S. 511). - 12.10.1945 Bericht des kath. Pfarrers Franz Janissek ( $\rightarrow$ Lübben): „[...] 
Herrn Kaplan Josef Hawellek habe ich das Gebiet um Teupitz zugewiesen. [...] Er nimmt Wohnsitz in Schwerin [...]. Er findet in Teupitz, Gross Köris und Schwerin [...] Entgegenkommen und Unterstützung der Gemeindemitglieder. [...] Da in Teupitz die Anstaltskapelle zerschossen und das Inventar vernichtet ist, wird er in der evgl. Kirche zelebrieren. Er wird weiter einmal monatlich des Sonntags Nachmittag in $[\rightarrow]$ Halbe (Schule), Oderin (evgl. Kirche) und Briesen (Schule) Gottesdienste halten. Der Herr Bürgermeister von Teupitz schreibt mir zu dieser Frage u. a. ,... Der Errichtung einer kath. Pfarrstelle in der Stadt Teupitz und Besetzung durch einen Flüchtlingspfarrer stehe ich sehr positiv gegenüber. [...]؛ Vor 10 Tagen fand hierselbst in der evgl. Kirche ein kath. Gottesdienst (Anm. ,von Königswusterhausen') statt, der besonders in den Kreisen der Flüchtlinge grossen Anklang fand. [...].“ (Töpler, Menschenwurm, S. 430)

LANDESANSTALT: 1940-1945 „Unterbringung von altersheimbedürftigen Umsiedlern aus Lettland und Estland“" u. a. in der Landesanstalt Teupitz (Fürsorge und Wohlfahrtspflege, S. 62). In der Landesanstalt Teupitz befinden sich 19453000 Menschen, darunter zahllose Flüchtlinge (auch aus der Umgebung), „die hauptsächlich in den Kellern Zuflucht gesucht hatten“ (Rose, Anstaltspsychiatrie, S. 30). - 22.9.1945: Lt. Bericht des Kath. Flüchtlingsdienstes Berlin „ist in der Landesheilanstalt eine katholische Kapelle vorhanden" (Töpler, Menschenwurm, S. 423).

Archivalische Quellen: Kreisarchiv Dahme-Spreewald, A-4 Stadt Teupitz, Nr. 165 (Ortsumsiedlerausschuss, 1947-1949; enthält u. a.: Protokolle); Nr. 481 und 607 (Wiederhergestelltes Fragment der Einwohnermeldekartei der Stadt Teupitz A-P und Q-Z; enthält u. a.: Flüchtlinge, 1945). - C-2 K (Karten), Nr. K-60 (Plan der Stadt Teupitz mit Eintragung der Baugebiete [usw.], 1947 - ca. 1955; enthält u. a.: „Ergänzungen mit Bleistift (noch durch den Zeichner, etwa um die Entstehungszeit des Rohlings): An der Grenze zur Schweriner Gemarkung geplante Umsiedler- und Heimkehrersiedlung, aufzubauen im Zuge der Bodenreform (mit Namen der Siedler) [...].“ (laut Archivdatenbank).

GedRUCKTE QUELlen und Literatur: Fürsorge und Wohlfahrtspflege in Brandenburg (1800-1952). Hrsg. von Margot Beck. Berlin 2002. - 1945. Das Jahr in der Region Dahme-Spreewald. Dokumentation zur Geschichte. T. 2. Zeuthen 2010, S. 220-229 (S. 222 f.: Zeitzeugenbericht [Interview 2007] der Rumäniendeutschen Frau Mattigka geb. Pahl, 1939 aus der Bukowina nach Lissa umgesiedelt, von dort auf Umwegen 1945 nach Teupitz; Großvater aus Wolhynien). - Rose, Wolfgang: Anstaltspsychiatrie in der DDR. Berlin 2005, S. $29 \mathrm{ff}$. - Ders.: Teupitz am See 1905-1945. In: Teupitz. Eine märkische Stadt im Wandel der Zeiten. Heinrich Krause / Karsten Kuhl (Hrsg.). Berlin 2007, S. 193-246. - Ders.: Teupitz von 1945 bis in die jüngste Vergangenheit. In: Teupitz (wie vor), S. 247-291. Töpler, Menschenwurm, S. 423 u. ö.

\section{Trattendorf $\rightarrow$ Spremberg-Trattendorf}

\section{Trebbin}

Stadtgmeinde, bis 1952 Kr. Teltow, 1952-1990 Kr. Luckenwalde (Bez. Potsdam), 1990-1993 Ldkr. Luckenwalde, 1993 Ldkr. Teltow-Fläming

Bevölkerungszahlen: 1925: 3556, 1939: 3979, 1946: 4554, 1964: 4011 (Städtebuch, S. 514). 
Katholiken: 1925: 109, 1946: 347 (Städtebuch, S. 514). - „1947 gehörten 1500 Katholiken zu Trebbin." (Brühe, S. 40).

Literatur: Brühe, Matthias: Katholische Kirche zwischen Havel und Dahme. Berlin 1999, S. 40. - Schwillus/Brühe, S. 301.

\section{Treuenbrietzen}

Stadtgemeinde, bis 1952 Kr. Zauch-Belzig, 1952-1990 Kr. Jüterbog (Bez. Potsdam), 19901993 Ldkr. Jüterbog, 1993 Ldkr. Potsdam-Mittelmark

EReignisSe bis Kriegsende: 21.4.1945 Einmarsch der Roten Armee (... schwere Kämpfe, S. 23 f.). - „Am 21. April 1945 von der Roten Armee besetzt, am 23. April nach ungeklärten Vorfällen Massenerschießungen von Zivilisten u. zeitweiliger Rückzug der Sowjets, für wenige Stunden Stadt wieder in dt. Hand." (Städtebuch, S. 520).

EREIGNisSE NACH KRIEGSENDE: „164 Flüchtlinge und Heimkehrer sind in den Jahren 1946 bis 1948 verstorben und fanden ihre letzte Ruhestätte auf dem evangelischen Friedhof in Treuenbrietzen." (... schwere Kämpfe, S. 12).

BeVÖLKeRUnGSZAHLen: 1925: 5793, 1939: 8447, 1946: 8569, 1964: 7166 (Städtebuch, S. 518).

Katholiken: 1925: 138, 1946: 853 (Städtebuch, S. 518). - „Als erster eigener Seelsorger kam mit Vertriebenen Propst Hubert Bönigk (1945-55) aus der Prälatur Scheidemühl. Die Gemeinde wude 1948 seelsorglich und 1955 mit damals etwa 1100 Katholiken vermögensrechtlich selbständig. Zunächst konnte man wechselweise die beiden evangelischen Stadtkirchen nutzen, dann eine umgebaute Kegelbahn und bis 1973 einen Tanzsaal.“ (Brühe, S. 41; identisch: Schwillus/Brühe, S. 201). - 22.8.1946 „Bönigk, Hubert, Treuenbrietzen, Großstr. 10“ erwähnt in einer Aufstellung der außerplanmäßig eingesetzten „Flüchtlingsgeistlichen“ (DAB, I/9-15-1 Flüchtlingsseelsorge 1945-1951, unfol.). - Hubert Bönigk (geb. 1906 Wonno, Kr. Löbau, Westpreußen) war bis 1945 Pfarrer in Meseritz (Ostpriesterverzeichnis 2, 1949, S. 16; Schematismus Berlin 1949, S. 70, 130).

UMSiedlerlager Selterhof (später „Heimkehrerlager Selterhof“; ehem. zentrales „Fremd““ bzw. Zwangsarbeiterlager der an der Straße nach Jüterbog gelegenen Munitonsfabrik [Werk S] der Firma Treuenbrietzener Metallwarenfabrik Kopp \& Co. und zweier weiterer Rüstungsbetriebe), zwischen Treuenbrietzen und Frohnsdorf an der Straße nach Lüdendorf, „nahe der Straße nach Jüterbog, dort, wo ein Weg über die Bahngleise in Richtung Lüdendorf führt; das Werk befand sich nördlich, das Lager südlich des Weges.“ Lagergelände „circa 700 mal 300 Meter“ groß (Gedenkstätten NS II, S. 358): „Nach Kriegsende wurden auch im Werk Selterhof die Maschinen abgebaut und die Gebäude geprengt. Das Barackenlager blieb erhalten und gab zunächst vielen Flüchtlingen aus den Ostgebieten eine Unterkunft.“ (... schwere Kämpfe, S. 12; vgl. ähnlich: 
Schulze, S. 271). - 6.10.1945 Umsiedleramt Brandenburg bezeichnet „Unterkunftsbaracken der Fabrikteile , $A^{\prime}$ und , $B^{\prime}$ des ehemaligen Industriewerkes Kopp in Treuenbrietzen“ als geeignet für „Aufnahme von Siedlern. Die beiden Lager befinde sich an der Straße Potsdam-Beelitz-Treuenbrietzen-Jüterbog, sind nicht belegt und haben eine Kapazität von insgesamt 6000 Personen." (BArch, DO 2/39, Bl. 1). - 1945 Einrichtung als eines von vier Quarantänelagern des Kr. Zauch-Belzig; Kapazität Mitte Nov. 1945: 3000 (Helle, S. 296), ab Ende 1945 eines von zwei verbleibenden Quarantänelagern des Kreises (ebd., S. 297). - Kapazität am 31.12.1945: Lager „Treuenbrietzen, Koppwerke A“: 4000, Lager „Koppwerke B“: 4000 (BArch, DO 2/45, B1. 40). - Kapazität (als Umsiedlerlager) am 1.1.1946: 2000 (BLHA, Rep. 203 MdI, Nr. 1163, Bl. 49). - 1946 Belegungsstärke („Treuenbrietzen“): 1000 (Kaminsky, S. 159). - 30.4.1946 als eines der verbleibenden Umsiedlerlager genannt (DAB, I/9-15-1 Flüchtlingsseelsorge 1945-1951, unfol., [30.6.1946], [Anlage 3]). - „Das ehemalige Lagerareal wurde 1946-48 von Flüchtlingen aus dem Sudetenland und aus den Karpaten genutzt" (Gedenkstätten NS II, S. 358). - 29.6.1946 Ankunft eines Transports mit 1110 Vertriebenen Karpatendeutschen, überwiegend Oberzipsern, aus dem Lager Poprad (Deutschendorf) in der Slowakei (Jun, S. 254; vgl. Die Karpatenpost 68, 2017, 7, S. 4), anschließend teilweise Ansiedlung in $\rightarrow$ Brück und Umgebung. - 14.7.1946 Ankunft eines Transports mit 1110 Vertriebenen aus Prag-Modřany (ebd.). - 28.7.1946 Ankunft eines Transports mit 1110 Vertriebenen aus St. Joachimsthal in Böhmen (ebd.). - 16. bis 31.8.1946 134 Kriegsgefangene (Heimkehrerlager) (Oehlsen, S. 35). - 19.8.1946 Ankunft eines Transports mit 1110 Vertriebenen aus Tetschen in Böhmen (Jun, S. 254) . 24.8.1946 Umsiedlerlager Selterhof, Kapazität: 1500 (SAPMO-BArch, DY 34/27880, Bl. 291) - 5.9.1946: Ankunft eines Flüchtlingszugs mit 1250 Personen aus [dem Kr.] Reichenberg-Land [Böhmen] in $\rightarrow$ Cottbus und Weiterfahrt nach Treuenbrietzen (Töpler, Menschenwurm, S. 541). - 9.9.1946: Ankunft eines Flüchtlingszugs mit 1011 Personen aus Langenbielau, Kr. Reichenbach [Schlesien] in Cottbus und Weiterfahrt nach Treuenbrietzen (ebd., S. 542). - 1.1.1947 Kapazität: 2700 (Oehlsen, S. 101). - Laut Bericht der Abt. Umsiedler und Heimkehrer der Provinzialregierung befanden sich am 2.4.1947 bei einer Besichtigung durch Herrn Münchenhagen „Rumänien-Deutsche“ im Lager und führte der Lagerleiter „darüber Klage, dass die Stadtverwaltung in Jüterbog das Lager als Obdachlosenheim benutzt" (BLHA, Rep. 203 MdI, Nr. 1198, Bl. 5). - 9.6.1947 Quarantänelager, Kapazität: 1500, Belegung: 366 (SAPMO-BArch, DY 34/27880, Bl. 239). - 23.10.1947 „Treuenbrietzen Krs. Belzig“ als Zielpunkt für den 5. Transport aus dem sowjet. Teil Ostpreußens vorgesehen (Wille II, S. 117). - Nov. 1947 Transport aus dem sowjetisch besetzten Teil Ostpreußens (1972 Personen) (I. Aktion) (Wille II, S. 136).25.11.1947 „Aufnahmefähigkeit von 1500 Mann - Quarantänelager für Umsiedler“ (BLHA, Rep. 302, VP, Nr. 9, Bl. 43). - 31.12.1947, Jan./Febr. 1948 Umsiedlerlager Selterhof eines von 7 verbleibenden Lagern in Brandenburg (BLHA, Rep. 203 MdI, Nr. 1198, Bl. 28v). - Lagerpersonal am 1.1.1948: Lagerleiter: Rissmann; Wirtschaftsleiter: Gräber; Lagerarzt: ... [?] (BLHA, Rep. 333, Nr. 575, Bl. 27 [Liste der leitenden Angestellten]). - Jan. 1948 (Anf./Ende) laut Lagerbestandsmeldung vom 10.2.1948 im Lager 29 / 0 Insassen (BLHA, Rep. 203 MdI, Nr. 1115, Bl. 7). - April 1948 Ankündigung bevorstehenden 14-tätigen Quarantäneaufenthalts eines Transports aus dem 
sowjetisch besetzten Teil Ostpreußens (Wille II, S. 127). - 3.9.1948: „Im Heimkehrerlager Treuenbrietzen befinden sich zur zeit ca. 800 Heimkehrer, welche aus England über Frankreich gekommen sind. Unter ihnen befinden sich ca. 200 Heimkehrer, welche ihre Angehörigen in den jetzt von Polen besetzten Gebieten haben." (SAPMO-BArch, DY 34/27880, Bl. 139. - Okt./Nov. 1948 Heimkehrerlager Selterhof/Treuenbrietzen eines von 5 Lagern in Brandenburg (BLHA, Rep. 203 MdI, Nr. 1198, Bl. 46). - 26.4.1949 Heimkehrerlager Selterhof eines von 5 Lagern in Brandenburg, soll wahrscheinlich im Sommer 1949 aufgelöst werden (BLHA, Rep. 203 MdI, Nr. 1198, Bl. 66). Bis 1948 für Flüchtlinge genutzt, „danach von der Kasernierten Volkspolizei der DDR (KVP), ab Mitte der 50er Jahre bis in die 90er Jahre als sowjetisches Kasernengelände." (Gedenkstätten NS II, S. 358). - 26.4.1949 "Selterhof (Heimkehrerlager)" noch in Lagerliste genannt, soll aber voraussichtlich „im Sommer 1949 aufgelöst werden“ (BLHA, Rep. 203 MdI, Nr. 1198, Bl. 66). Juni 1949 Heimkehrerlager Selterhof in Auflösung befindlich (SAPMO-BArch, DY 34/27880, B1. 5). - „Das genaue Datum der Auflösung des Quarantänelagers ist nicht bekannt. Vermutlich kurz darauf übernahm die KVP [Kasernierte Volkspolizei] das Objekt. Ab 1949 lag die 8. VPBereitschaft Berlin/Brandenburg in Selterhof.“ (Schulze, S. 271). „Ende 1950 soll die Bereitschaft nach $\rightarrow$ Premnitz verlegt worden sein. (ebd., S. 272). Bis mindestens Sept. 1953 befand sich hier dann „eine Polit-Schule der KVP“, die nach Potsdam verlegte, als „die Sowjetarmee aus das Objekt Selterhof beanspruchte“ (ebd.). Nutzung durch diese bis 1994 (ebd., S. 274). „Ab 2005 wurden die oberirdischen Unterkünfte, die zum Teil noch aus der Zeit der deutschen Munitionsfabrik stammten, abgerissen, um einer Photovoltaik-Anlage Platz zu machen. Die unterirdischen Bunkerräume blieben erhalten. [...].“ (ebd., S. 275).

Umsiedlerlager Landesanstalt Treuenbrietzen: Einrichtung als eines von nur noch zwei Quarantänelagern des Kr. Zauch-Belzig zw. Mitte Nov. 1945 u. 1.1.1946 (Helle, S. 296f.). Kapazität am 1.1.1946: 2000 (BLHA, Rep. 203 MdI, Nr. 1163, Bl. 49). - 24.7.1946 in Liste der Lager für „Ostheimkehrer“ als genannt mit Kapazität „in beschleunigtem Ausbau 1600: Krankenbetten: 1600" (BArch, DO 2/45, Bl. 76). - 24.8.1946 Umsiedlerlager Landesanstalt, Kapazität: 1500-3000 (SAPMO-BArch, DY 34/27880, Bl. 291). - 16.10.1946 befinden sich laut Kontrollbericht des Leiters des Kreis-Sozialamtes Belzig, Bräunig, nach einer Begehung durch Landrat [Richard] Sydow, Kreis-Umsiedleramtsleiter Ziegenhagen u. Dr. Pawlitzki 1449 „Internierte“ im Lager, Lagerarzt: Dr. Klehr (Text abgedruckt in: Helle, S. 348). - 1.1.1947 Lager „Landesanstalt“, Kapazität: 3000 (Oehlsen, S. 101). - 1947 Schließung bevorstehend (SAPMO-BArch, DY 34/27745, Bl.92). - Siehe auch das Kapitel „Flecktyphus im Quarantänelager“ in den Erinnerungen des Niemegker Arztes J. Niepelt, S. 44-47.

Archivalische Quellen: BArch, DO 2 ZVU, Nr. 39, Bl. 2 (Lager, 1945). - BArch, DO 2/50, Bl. 235 -236 (Eingemeindung aus Lager Treuenbrietzen-Selterhof. Bericht 4.7.1947) - BLHA, Rep. 333 SED-Landesleitung Brandenburg, Nr. 577 („Heimkehrerlager“, 1946-1949; enthält u. a.: Selterhof).

GedRuckte QuelLen: Gregor, Walli: Internierungslager Selterhof. In: Barbara-Meldung 23 (2011), S. 20-22 [Lagerleben 1946]. - Niepelt, Joachim: Was, Sie kennen den Fläming nicht? Episoden aus der Landdoktorzeit in Niemegk 1945 bis 1949. 2., erw. u. bearb. Aufl. Belzig 2004. - Stechbart, Monika: Rinnsteinkinder. Berlin 2007. 
Literatur: Brühe, Matthias: Katholische Kirche zwischen Havel und Dahme. Berlin 1999, S. 41. - Gedenkstätten NS II, S. 358-359. - Helle, Matthias: Nachkriegsjahre in der Provinz. Berlin 2011, S. 296 f. - Schulze, Henrik: Jammerbock IV: 1945-2014. Jüterbog 2018 (Militärgeschichte Jüterbog, 1792-2014, [Bd. 4]), S. 271-275 (S. 271 Zitat aus Bericht der „Mitte 1946 aus Schlesien“ vertriebenen Walli Gregor nach deren Privatdruck „Die Flucht. Zwei Jahre meines Lebens“, 18.9.2004). - ... schwere Kämpfe in und um Treuenbrietzen (OKW-Bericht). 1945. Das Jahr zwischen Krieg und Frieden. Treuenbrietzen und Umgebung. Treuenbrietzen 1995. - Schwillus/Brühe, S. 201.

\section{Tröbitz}

Landgemeinde, bis 1952 Kr. Luckau, 1952-1990 Kr. Finsterwalde (Bez. Cottbus), 1990-1993 Ldkr. Finsterwalde, 1993 Ldkr. Elbe-Elster

BevölKeRUnGSZAHLEN: 1925: 985, 1939: 882 (HOL NL I, S. 136); 29.10.1946: 1278, 1950: 1301, 1964: 1120 (HGV EE, S. 11).

Katholiken (Erzbistum Breslau/Erzbischöfliches Amt Görlitz): 8.7.1945: „Herr Pfarrer Joseph Volkmer aus Neuwaldau Kreis Freystadt, Niederschlesien, von den Polen vertrieben, wird hiermit beauftragt, die katholische Seelsorge in Tröbitz und Umgegend zu übernehmen." (Beauftragung durch den Erzbischöflichen Kommissar; Töpler, Menschenwurm, S. 345). Volkner (geb. 1893) war später Kuratus in Könnern/Saale (Schematismus Görlitz 1958, S. 95). - 1.11.1948 Kuratie Tröbitz errichtet (Schematismus Görlitz 1954, S. 17). - Ab 1953 war der aus Breslau gebürtige (zuvor ab 1952 als Kaplan und Administrator in $\rightarrow$ Senftenberg wirkende) Bernhard Kaßner (geb. 1913) Kuratital-Pfarrer in Tröbitz (ebd.).

Gedruckte Quellen: Töpler, Menschenwurm.

\section{Velten}

Stadtgemeinde (seit 1935 Stadtrecht), bis 1952 Kr. Osthavelland, 1952-1990 Kr. Oranienburg (Bez. Potsdam), 1990-1993 Ldkr. Oranienburg, 1993 Ldkr. Oberhavel

EReignisSe BIS KRIEgSEnde: 23.4.1945 Einmarsch der Roten Armee (Dahms, S. 95).

EREIGNISSE NACH KRIEGSENDE: 1945: „Die Versorgung der Veltener, der Evakuierten, der vielen Flüchtlinge aus den Ostgebieten und der Rückkehrer war in den ersten Tagen das größte Problem." (Dahms, S. 96). - 1947 für die Bodenreform keine Umsiedler erwähnt (HOL III, S. 400).

Bevölkerungszahlen: 1925: 7646, 1939: 8753, 1946: 10391, 1964: 9834 (Städtebuch, S. 525).

Katholiken: 1925: 521, 1946: 1118 (Städtebuch, S. 526). - „Mit dem Eintreffen der ersten Heimatvertriebenen aus den verlorenen Ostgebieten und aus der Czechoslovakei, unter denen viele Katholiken in unserer Gemeinde eine neue geistliche Heimat finden sollten, markiert sich 
der Beginn eines neuen Abschnitts unserer Geschichte. / Das damit erfolgte sprunghafte Wachstum unserer Gemeinde wird deutlich an der Zahl der Erstkommunionkinder: $1944 \rightarrow 8$ / 1945 $\rightarrow 11 / 1946 \rightarrow 15 / 1947 \rightarrow 17 / 1948 \rightarrow 37$ / Der größte Teil der neuen Gemeindeglieder war auf den Dörfern im Gebiet untergebracht worden. Um ihnen Sonntagsgottesdienst zu ermöglichen, wurden sog. Außenstationen eingerichtet. Dafür stellten die evangelischen Gemeinden das sei hier dankbar hervorgehoben - bereitwillig ihre Kirche zur Verfügung. / Mit dem Fahrrad zuerst, dann mit dem Motorrad und dank guter Beziehungen des Pfarrers schon recht bald mit einem alten Opel wurden zwischen zwei Gottesdiensten in Velten zwei Dörfer mit dem Meßkoffer aufgesucht. Das war in der Regel Vehlefanz und abwechselnd Schwante und Eichstädt. / Diese Aufgabe fiel einem neuen Pfarrer zu, Pfarrer Franz Busch [geb. 1904 Rüschendorf, Kr. Vechta], der nach dem Verzicht des schwerkranken Pfarrers [Paul] Breuer [geb. 1882 Wittgendorf, Kr. Landeshut] am 31. März 1946 die Pfarrei aus den Hände des Pfarrverwesers Dr. [Karl] Harmuth [geb. 1895 Sagan] übernahm. [... ]. / Die Haupt-Seelsorgearbeit unter den Heimatvertriebenen auf den Dörfern scheinen aber die Schönstätter Marienschwestern geleistet zu haben, die mit dem Fahrrad hinausfiuhren, um in den Wohnungen Religionsunterricht zu geben; bei dem Streßprogramm am Sonntag fand der Pfarrer mit Sicherheit keine Zeit für ein persönliches Wort. / Überhaupt ist es im Rückblick verwunderlich, daß die Gläubigen möglichst gut versorgt wurden, aber ein eigenes Gemeindeleben auf den Außenstationen offensichtlich gar nicht angestrebt wurde. Es wurden ja sogar die Ministranten aus Velten mitgebracht. [...].“ (100 Jahre St. Joseph Velten, S. 50; biographische Daten ergänzt nach Schematismus Berlin 1947). - 1953 in der Gemeinde 3000 Katholiken gezählt, 1955 noch Kirchbauplanung in Vehlefanz, dann starker Rückgang (Brühe, S. 49).

Literatur: Brühe, Matthias: Katholische Kirche zwischen Prignitz und Havelland. Berlin 2000, S. 49. - Dahms, Paul: Velten. Velten 2009. - 100 Jahre St. Joseph Velten. Festschrift. Velten 1996.

\section{Vetschau (Spreewald)}

Stadtgemeinde, bis $1950 \mathrm{Kr}$. Calau (1950 in Kr. Senftenberg umbenannt), 1952-1.7.19501952 Kr. Lübben, 1952-1990 Kr. Calau (Bez. Cottbus), 1990-1993 Ldkr. Calau, 1993 Ldkr. Obersprewald-Lausitz

EReignisse BIS KriegSende: Anf. Jan. 1940 besteht in „Brandenmühle [Brandmühle] bei Vetschau" ein Auffanglager für 200 umgesiedelte Wolhynien- und Galiziendeutsche (Müller, S. 124).

EREIGNisSe NACH KRIEGSENDE: 8.7.1945 (Tagebucheintrag einer schlesischen Flüchtlingsfrau): „Viele Schlesier warten auch hier in Vetschau auf ihre Rückkehr nach Schlesien, die Polen sollen angeblich wieder heraus aus Schlesien. Aber etwas genaues weiß man nicht." (MOB, AGoFF-Archiv, B 42-00016, S. 12). - (Ehem. Villa des Unternehmers Ferdinand Griebenow (1848-1910) zwischen Bahnhof und Schönebegker Straße, mit „Griebenow-Park“): „Die Villa wurde 1960 
gesprengt, nachdem sie zunächst als Krankenhaus für Kriegsverwundete und für die Unterkunft von Flüchtlingen gedient hatte." (Vetschauer Persönlichkeiten, S. [2]).

Bevölkerungszahlen: 1925: 3025, 1939: 2990, 1946: 4064, 1964: 7494 (Städtebuch, S. 528).

Katholiken (Erzbistum Breslau/Erzbischöfliches Amt Görlitz): 1925: 148, 1964: 302 (Städtebuch, S. 528). - 1945/46 war der ehem. Breslauer Univ.-Prof. Dr. theol. Felix Haase $(\rightarrow$ Kirchhain) zur Aushilfe in $\rightarrow$ Calau und Vetschau eingesetzt (Töpler, Menschenwurm, S. 641). - Pfarrer war 1949 der bis 1945 in Raudten (Kr. Lüben, Schlesien) amtierende Josef Beyer (geb. 1905) (Ostpriesterverzeichnis 2, 1949, S. 14).

UMSIEDLERLAGER (Fageb-Baracken): 24.10.1945 vom Landratsamt bezeichnet als „im Aufbau mit 700 Mann" (Töpler, Menschenwurm, S. 451).

Archivalische Quellen: Martin-Opitz-Bibliothek (MOB) Herne, AGoFF-Archiv, B 42-00016 (Fluchttagebuch).

Gedruckte Quellen und Literatur: Blöß, Kreise und Gemeinden, S. 14. - Müller, Erich: Transporte, Lager, Ansiedlung im Warthegau: Das Schicksal der galizien- und wolhyniendeutschen Umsiedler nach ihrem Grenzübertritt 1939/40. In: Zeitweiser der Galiziendeutschen 43 (2005), S. 104-157. - Töpler, Menschenwurm, S. 451 u. ö. - Vetschauer Persönlichkeiten (www.vetschau.de [7.1.2017]).

\section{Vierraden}

Stadtgemeinde, bis 1952 Kr. Angermünde, 1952-1990 Kr. Angermünde (Bez. Frankfurt/ Oder), 1990-1993 Ldkr. Angermünde, 1993 Ldkr. Uckermark

EREIGNISSE NACH KRIEGSENDE: In Vierraden ist nach 1945 (bis mindestens 1982) eine wolhyniendeutsche Familie (Mathes) nachweisbar (forum.wolhynien.de, 15.8.2007 [7.1.2017]).

Bevölkerungszahlen: 1925: 1297, 1939: 1228, 1946: 1004, 1964: 888 (Städtebuch, S. 531).

KATHOLIKEN: 1925: 5, 1946: 17 (Städtebuch, S. 532).

\section{Wachow}

Landgemeinde (seit 2003 Ortsteil der Stadt $\rightarrow$ Nauen), bis 1952 Kr. Westhavelland, 1952-1990 Kr. Nauen (Bez. Potsdam), 1990-1993 Ldkr. Nauen, 1993 Ldkr. Havelland BevöLKeRUNGSZAHLEN: 1925: 817, 1939: 758, 1946: 1 131, 1964: 1407 (HOL III, S. 405).

UMSIEDLERLAGER: Kapazität am 31.12.1945: 200 (BArch, DO 2/45, Bl. 40). 


\section{Walddrehna}

Landgemeinde (seit 2003 Ortsteil von Heideblick), bis 1952 Kr. Luckau, 1952-1990 Kr. Luckau (Bez. Cottbus), 1990-1993 Ldkr. Luckau, 1993 Ldkr. Dahme-Spreewald

BEVÖLKERUNGSZAHLEN: 1925: 554, 1939: 668, 29.10.1946: 727, 1950: 721, 1964: 611 (HGV LDS, S. 18 f.).

UMSIEDLERLAGER: 16.11.1945 (Zeitungsbericht): „Ein weiteres Durchgangslager für Umsiedler entsteht zur Zeit in Walddrehna." (Töpler, Menschenwurm, S. 462). - Kapazität am 31.12.1945: 500 (BArch, DO 2/45, Bl. 41). - Kapazität am 1.1.1946: 500 (BLHA, Rep. 203 MdI, Nr. 1163, Bl. 51)

\section{Waldsieversdorf}

Landgemeinde, bis 1950 Kr. Lebus, 1950-1952 Kr. Seelow, 1952-1990 Kr. Strausberg (Bez. Frankfurt/Oder), 1990-1993 Ldkr. Strausberg, 1993 Ldkr. Märkisch-Oderland

EREIGNISSE NACH KRIEGSENDE: In der Bodenreform 205,2 ha von 2867 ha an 24 Umsiedler vergeben (HOL VII, S. 406).

EREIGNISSE NACH 1990: 12.4.2015 19. Treffen der im östlichen Teil Brandenburgs wohnhaften Heimatvertriebenen aus der Grafschaft Glatz: „Es kamen 40 Personen von $[\rightarrow]$ Cottbus bis $[\rightarrow]$ Bernau, von $[\rightarrow]$ Königs Wusterhausen bis $[\rightarrow]$ Frankfurt/Oder, aus Berlin und dem Umland. Sie feierten zunächst mit Großdechant Franz Jung [kath. Visitator für Priester und Gläubige aus der Grafschaft Glatz] in der Heilig-Geist-Kapelle in $[\rightarrow]$ Buckow einen Gottesdienst, der mit Musik aus der Schubert-Messe umrahmt wurde. [...]. Anschließend ging es nach Waldsieversdorf zum Mittagessen im CVJM-Haus. Danach konnten alle bei eine DVD-Vorführung noch einmal die Jubiläumsfeier des Großdechanten miterleben. Auch der gemütliche Teil mit Vorträgen auf,Pauersch' kam nicht zu kurz [...]. Nach der gemeinsamen Kaffeetafel traten alle wieder den Heimweg an." (Rundbrief des Großdechanten, H. 3/2015, S. 20 f.); 20. Treffen 2016 ebd. (www.grafschaft-glatz.de [20.9.2016]).

LiteratuR: Heinze: 19. Treffen der Grafschafter in Buckow-Waldsieversdorf. In: Rundbrief des Großdechanten, H. 3/2015, S. 20-21.

\section{Waltersdorf}

Landgemeinde, bis 1952 Kr. Teltow, 1952-1990 Kr. Königs Wusterhausen (Bez. Potsdam), 1990-1993 Ldkr. Königs Wusterhausen, 1993 Ldkr. Dahme-Spreewald

EREIGNisSe BIS KRIEGSEnde: 25.4.1945 Einmarsch der Roten Armee (Sychold, S. 67). - [Bei Kriegsende:] „Das Dorf war überfüllt mit Flüchtlingen und Evakuierten aus Berlin.“ (ebd.). 
EREIGNISSE NACH KRIEgSENDE: 12.5.1945 Sitzung des Gemeinderates: „Die Schwarzmeerdeutschen sollten sich beim Kommandanten in $[\rightarrow]$ Eichwalde melden. Vorher sollte die Gemeinde bei Ihnen [so!] Haussuchungen nach Waffen und Plünderungsgut durchführen." (ebd., S. 68). - 8.7.1945 Sitzung des Gemeinderates: „Bisher wurden fast jede Nacht 100 und mehr Flüchtlinge bei den einzelnen Bauern untergebracht. Die Bauern wehren sich dagegen, so könne es nicht weitergehen, daß sie sich nach ihrer schweren Tagesarbeit noch um das Nachtlager für Flüchtlinge zu kümmern haben. Es wurde beschlossen, daß ein Raum für Flüchtlinge zurecht gemacht wird. / [S. 70] Das ehemalige Gefangenenlager für Franzosen (mit Kochgelegenheit, auf dem Grundstück Praatz) oder die große Scheune im Pfarrhof sollen in Ordnung ghebracht werden. Zum Saubermachen der Räumlichkeiten sollen in erster Linie die Nazi-Frauen und Frauen von Nazis herangezogen werden. Den Flüchtlingen ist ein Strohlager zu geben, etwa Kartoffeln und Gemüse. Brotausgabe muß abgelehnt werden, ebenso ihre Aufnahme in die Gemeinde." (ebd., S. 69f.). - 15.9.1945 Ratssitzung (Bericht über Gespräche beim Kommandanten): „Künftig sollen Flüchtlinge auch in die Bauernhöfe eingesetzt werden." (ebd., S. 71). - 30.9.1945 Rechenschaftsbericht des Bürgermeisters: „In nächster Zeit müssen wir mit einem Zuzug von Flüchtlingen rechnen, und zwar in einer Höhe von ungefähr $20 \%$ der jetzigen Einwohnerzahl. Diese Flüchtlinge kommen aus dem Auffanglager $[\rightarrow]$ Königs Wusterhausen, wo sie eine Quarantäne von 3 Wochen durchgemacht haben und seuchenfrei entlassen werden." (ebd.). - 12.1.1946 Gemeinderatssitzung: „Das Barackenlager der HeinkelWerke für Fremdarbeiter und Gefangene ist von der Bodenreform beschlagnahmt worden, um den Neubauern Gelegenheit zur Besorgung von Steinen aus den Bunkern zu geben." (ebd.). - 3.3.1946 Öffentliche Versammlung (Bericht): „[...] Im Zusammenhang mit der Bodenreform war die Frage der Lösung des Wohnungsproblems für die Neubauern außerordentlich schwierig, [S. 72] zumal von verschiedenen Volksgenossen wenig Verständnis dafür aufgebracht wurde, daß den Neusiedlern nach ihrer Verpflichtung zur Sicherstellung der Volksernährung auch der notwendige Wohn-, Stall- und Scheunenraum zur Verfügung gestellt werden muß. Wenn die Gemeindeverwaltung aus diesen Gründen gezwungen war, verschiedentlich Wohnungstausch anzuordnen und dabei einige Einwohner etwas härter angefaßt wurden, so haben diese Leute das ihrem eigenen Verhalten zuzuschreiben." (ebd., S. 71 f.). - 1947 Einquartierung einer sowjetischen Armeeinheit (ebd., S. 72), 31.8.1947 Gutshaus von der Sowjetarmee übernommen (ebd., S. 73).

BevÖLKeRUngSzAHLEN: 1925: 1016, 1939: 1 156, 1946: 1250, 1964: 1117 (HOL IV, S. 333).

Archivalische Quellen: Kreisarchiv Dahme-Spreewald, A-4 Gemeinde Waltersdorf, Nr. 4 (Flüchtlingswesen, 1946-1955; enthält u. a.: „Liste Flüchtlinge“, Wohnungszuweisungen).

LITERATUR: Sychold, Erich: Chronik Waltersdorf. Waltersdorf (2001). 


\section{Wandlitz}

Landgemeinde, bis 1952 Kr. Niederbarnim, 1952-1990 Kr. Bernau (Bez. Frankfurt/Oder), 1990-1990 Kr. Bernau, 1993 Ldkr. Barnim

EReignisse: Ab/nach 1945 „zogen Flüchtlinge in die Region.“ (Brühe, S. 48). - In der Bodenreform 34 ha von 392,5 ha an 6 Umsiedler vergeben (HOL VI, S. 596).

BeVÖLKeRUNGSZAHLEN: 1925: 1 802, 1939: 2 482, 1946: 3 151, 1964: 3272 (HOL VI, S. 597).

LiterATUR: Brühe, Matthias: Katholische Kirche zwischen Uckermark und Oderland. Berlin 1998, S. 48.

\section{Wandlitzsee}

Wohnplatz/Ortsteil von $\rightarrow$ Wandlitz

EREIGNISSE NACH KRIEGSENDE: „Im Januar 1945 mußten [Hedwig-]Schwestern und Kinder aus dem St. Klemens-Hofbauer-Stift in Glogau (Głogów) vor der heranrückenden Front flüchten. Sie gingen zunächst nach $[\rightarrow]$ Döbern und von dort weiter nach Wandlitzsee in Brandenburg. / Nachdem in $[\rightarrow]$ Bad Saarow eine neue Niederlassung [der Hedwigschwestern] entstanden war, siedelten die Schwestern und Kinder aus Wandlitzsee am 8. Mai 1946 dorthin über." (Mertens, S. 535).

LiterATUR: Mertens, Johannes: Geschichte der Kongregation der Hedwigschwestern 1930-2000. Manuskript. Ber$\operatorname{lin} 2004$, S. 535.

\section{Warsow (Kr. Westhavelland) $\rightarrow$ Jahnberge}

\section{Weißack}

Landgemeinde (ab 1997 Ortsteil von Berstequell, dieses seit 31.12.2001 Ortsteil von Heideblick), bis 1952 Kr. Luckau, 1952-1990 Kr. Luckau (Bez. Cottbus), 1990-1993 Ldkr. Luckau, 1993 Ldkr. Dahme-Spreewald

BEVÖLKERUNGSZAHLEN: 1925: 265, 1939: 259, 29.10.1946: 325, 1950: 329, 1964: 306 (HGV LDS, S. 18f.).

KREISKINDERHEIM (Dorfstraße 46): „Im Schloß [...] war im Jahr 1949 das staatliche Heim für elternlose Kinder und bedürftige infolge des Krieges eingerichtet worden. / Bis 1978 leitete Anneliese Göbel das Heim. [... . / In den Nachkriegsjahren war die Führung des Kinderheimes vor große Probleme gestellt. Die jüngsten Kinder waren zwei Jahre alt. [...]." (Knuth/Voigt, S. 22). Bericht eines ehem. Heimkindes: „Eine Schlafstatt hatte jeder, Bettbezüge waren Illusion, braune Decken, keine Federn, nur einem Strohsack unterm Po. In den Räumen keine Möbel nur zwei 
Bänke und ein Tisch. [...]." (ebd.). - Heute Kinderheim „Eichenhof“ (Träger seit 1991: Arbeiter-Samariterbund, Ortsverband Luckau/Dahme e. V.).

Literatur: Knuth, Reinhard/Voigt, Detlef: 50 Jahre Kinderheim Weißack. in: Luckauer Heimatkalender 32 (2000), S. 22-26. - Rieger, Christian: Erinnerungen an Weißack. In: Luckauer Heimatkalender 49 (2017), S. 79-82. [Kindheitserinnerungen eines Vertriebenen an die Teilnahme in einem FDJ-Ferienlager 1946].

\section{Weissagk}

Landgemeinde (nordwestlich von $\rightarrow$ Forst), bis 1946 (Rest-)Kr. Sorau, 1.4.1946-1952 Kr. Cottbus, 1952-1985 Kr. Cottbus (Bez. Cottbus), 1985 abgebaggert (devastiert)

UMSIEDLERLAGER: Kapazität am 31.12.1945: 2000 (BArch, DO 2/45, B1. 41). - Kapazität am 1.1.1946: 1500 (BLHA, Rep. 203 MdI, Nr. 1163, Bl. 51).

\section{Weißenspring}

Landgemeinde (heute Ortsteil von Groß Lindow), bis 1945 Kr. Lebus, nach Kriegsende 19451.10.1947 Stadtkr. Frankfurt (Oder), 1947-1950 Kr. Lebus, 1.7.1950-1952 Kr. Frankfurt (Oder), 1952-1990 Kr. Fürstenberg/Oder bzw. (ab 1961) Kr. Eisenhüttenstadt-Land (Bez. Frankfurt/Oder), 1990-1993 Ldkr. Eisenhüttenstadt, 1993 Ldkr. Oder-Spree

EREIGNISSE NACH 1990: Bald nach 1990 Fortsetzung der zuvor kurzzeitig in $\rightarrow$ Frankfurt (Oder) und vor 1990 in $\rightarrow$ Müllrose durchgeführten jährlichen und nun gesamtdeutschen Heimattreffen von ehem. Bewohnern von Ziebingen (Kr. Weststernberg, ehem. Provinz Brandenburg) in einer Gaststätte in Weißenspring mit jeweils über 160 Teilnehmern, nachgewiesen noch mindestens bis Juni 1995 mit Ankündigung für 1996, organisiert durch Edith Dietrich, Müllrose; 1995 auch gemeinsame Busreise mit 70 Teilnehmern nach Ziebingen (Crossener Heimatgrüße 47, 1995, Nr. 6, S. 19).

Gedruckte Quellen und Literatur: Wie die Treffen der Ziebinger wuchsen. In: Crossener Heimatgrüße 47 (1995), Nr. 6, S. 19.

\section{Welzow}

Landgemeinde (1969 Stadtrecht), bis 1952 Kr. Spremberg, 1952-1990 Kr. Spremberg (Bez. Cottbus), 1990-1993 Ldkr. Spremberg, 1993 Ldkr. Spree-Neiße

EREIGNISSE BIS KrIEgSENdE: 20.4.1945 Einmarsch der Roten Armee (Kaczmarek, S. 9).

BevölKerungSZAHLEN: 1925: 6230, 1939: 7072, 1946: 7304, 1964: 7016 (Städtebuch, S. 538). 
Katholiken (Erzbistum Breslau/Erzbischöfliches Amt Görlitz): 1925: 839, 1946: 895 (Städtebuch, S. 538). - 1946 „Erfassung der Flüchtlinge und Vertriebenen“ (Zur Geschichte der Pfarrei St. Josef).

(Kreis-)UMSiedlerlager FlugPlatz: 24.10 .1945 erwähnt als Lager „Flugplatz Welzow“ des Ldkr. Spremberg für 3000 Mann (Töpler, Menschenwurm, 451). - Im „Verzeichnis der errichteten und vorgesehenen Umsiedlerlager im Verwaltungsbezirk Cottbus“ vom 15.12.1945 als „Welzow / Flugplatz“ mit „Personenzahl“ 3000 genannt, diese Zahl in einer zweiten Fassung jedoch „durch Streichung zweier Nullen geändert zu 30“ (ebd., S. 472, 474). - Kapazität am 31.12.1945 (Lager „Welzow N.L. II“): 1500 (BArch, DO 2/45, Bl.41). - Kapazität am 1.1.1946: 2000 (BLHA, Rep. 203 MdI, Nr. 1163, Bl. 49). - 14.2.1946 Kreis- und Quarantänelager, Kapazität: 2000 (Oehlsen, S. 28). - 1946 Belegungsstärke: 3000 (Kaminsky, S. 159). - 25.2.1946 mit Kapazität 2000 als eines der verbleibenden Umsiedlerlager genannt (BArch, DO 2/45, Bl. 67).30.4.1946 als eines der verbleibenden Umsiedlerlager genannt (DAB, I/9-15-1 Flüchtlingsseelsorge 1945-1951, unfol., [30.6.1946], [Anlage 3]). - 24.8.1946 Umsiedlerlager, Kapazität: 2000 (SAPMO-BArch, DY 34/27880, Bl. 291).

Gemeindepartnerschaft: 7.10.1999 Maszewo, Polen (Massow bei Naugard, Pommern) (Auskunft der Stadtverwaltung, 5.9.2018).

Gedruckte Quellen und Literatur: Kaczmarek, Günther: Die Befreiung des Kreises Spremberg vom Hitlerfaschismus im April 1945. Spremberg 1980. - Richter, Margarete: Der schöne Sirup. In: Lebenszeit. T. IV. Zeitzeugen berichten. Hrsg. vom Seniorenbeirat der Gemeinde Neuenhagen bei Berlin. Neuenhagen [1998], S. 9-13. - Töpler, Menschenwurm, S. 451, 472, 474. - Zur Geschichte der Pfarrei St. Josef in Welzow <http://www.st-antonius-gross raeschen.de/Chronik\%20St.Josef\%20Welzow.html [17.1.2017]>.

\section{Wendisch Buchholz $\rightarrow$ Märkisch Buchholz}

\section{Werben (Spreewald)}

Landgemeinde, bis 1952 Kr. Cottbus, 1952-1990 Kr. Cottbus (Bez. Cottbus), 1990-1993 Ldkr. Cottbus, 1993 Ldkr. Spree-Neiße

EREIGNISSE BIS KRIEGSENDE: „Das RAD-Lager war schon zum Jahresende 1944 geräumt worden. Die letzten Arbeitsmaiden verließen Werben Anfang Januar mit unbekanntem Ziel in Richtung Westen. Es kamen immer mehr Flüchtingstrecks in Werben an. Nachdem die Menschen mit Speisen und Getränken versorgt waren, zogen die meisten mit ihren Pferdewagen Richtung Westen weiter." (Ramoth, S. 42, Erinnerungsbericht von Erwin Gollasch). - 15.4.1945: „Das Schwesternhaus war schon mit Flüchtlingen belegt." (Ramoth, S. 37, Erinnerungen der evang. Kirchenmitarbeiterin Karnauke aus $\rightarrow$ Cottbus, tätig in der Frauenhilfe). - 22.4.1945 Einmarsch der Roten Armee (ebd., S. 38, 43 f.). 
EREIGNISSE NACH KRIEGSENDE: „Die Geschichte des Dofes Werben nach 1945 wurde weitgehend auch von den Heimatvertriebenen mit geschrieben. [...] [S. 46] [...] Werben wurde zu einem wichtigen Sammel- und Durchzugsort für die Heimatvertriebenen auf der Suche nach einer Bleibe in den Gebieten unweit der Neißelinie. Während ein Teil bis nach Westdeutschland weiterzog, verblieben viele Füchtlinge in unserer Region - in der Hoffnung, bald wieder in die Heimat zurückzukehren. [...] Die Heimatvertriebenen, die in dieser Region blieben, kamen meist aus dem östlichen Teil der Lausitz mit den Kreisen Sorau, Sommerfeld und Teilen des Kreises Guben, aus dem Kreis Crossen oder aus Niederschlesien. / Von den Kreisbehörden wurden die Flüchtingsfamilien auf die einzelnn Gemeinden aufgeteilt, viele suchten sich aber aus eigener Initiative eine Bleibe. Auch die Gemeinde Werben nahm zunächst an die 700 Flüchtlinge auf. Eine größere Anzahl wurde im ehemaligen Barackenlager des RAD (Reichsarbeitsdienst), im Gemeindehaus der Kirche sowie im [Guts-]Haus von Schönfeldt untergebracht. / Auch Heinrich Schulz, der spätere Kreisvorsitzende des Bundes der Vertriebenen, war mit den Großeltern und der Mutter aus Grünberg vertrieben worden. Er erinnert sich: ,Wir lebten dort in diesem Lager, wie die Menschen überall, unter ärmlichsten Verhältnissen. Der Hunger war unser ständiger Begleiter. In Folge der Entbehrungen starben Dutzende von ihnen, geschwächt, krank, vom Typhus dahingerafft. Auch der Großvater von Heinrich Schulz war darunter." (Ramoth, S. 45 f.). - „Bereits im Spätsommer 1945 kam die Frauenhilfsarbeit wieder in Gang. [...] Da die Gemeinde eine neue Schwester dringend nötig hatte, hat das Mutterhaus Hedwig Bormann, bis dahin in Cottbus-Sandow stationiert, für Werben freigegeben. Die Aufgaben waren enorm. Werben war überfüllt mit Flüchtlingen und Heimatvertriebenen. Frau von Schönfeldt setzte ihre Kräfte voll in der Flüchtlingsfürsorge ein, nachdem sie [...] aus ihrem Haus ausgewiesen wurde. [...] Die Frauenhilfe veranstaltete schon 1945 zwei Weihnachtsfeiern für die Flüchtlinge; eine für die jüngeren und eine für die älteren. [...]. (ebd., S. 38).

Bevölkerungszahlen: 1925: 1438, 1939: 1511 (HOL NL II, S. 112); 29.10.1946: 1949, davon 814 männlich (Gemeindestatistik 1946, S. 13); 1950: 1992, 1964: 1590 (HGV SN, S. 31).

Katholiken (Erzbistum Breslau/Erzbischöfliches Amt Görlitz): 66 (Gemeindestatistik 1946, S. 13).

Auffanglager: Auffanglager für Flüchtlinge in ehem. Baracken des (Ende 1944/Anf. Jan. 1945 geräumten) RAD-Lagers (Ramoth, S. 42, 46f., 95; BR 14 (2016) 9, S. 11). - „In den letzten Kriegsmonaten 1945 ,landeten“ viele vor der Roten Armee Geflohene oder Evakuierte aus Niederschlesien und dem Südostwinkel der Niederlausitz in Werben. Darunter waren etwa 50 Göhrener [aus Göhren (Kr. Crossen)]. Sie fanden Notunterkunft in den Baracken eines Arbeitsdienst-Lagers und in einer Turnhalle. Viele blieben zunächst am Ort, weil sie hoffen, nach Kriegsende in die nahe Heimat zurückkehren zu können. Hunger und schlechte hygienische Lebensbedingungen verursachten eine Typhusepidemie unter den Heimatvertriebenen. Zur Bestattung der Verstorbenen wurde ein besonderer Friedhof [s. u., Waldfriedhof] an der 
Chaussee von Werben nach Cottbus angelegt. [...]." (Crossener Heimatgrüße 47, 1995, Nr. 1, S. 27). - 13.6.1945 vom Kreisrat neben anderen ehem. RAD-Lagern im Kreis zur Beschlagnahmung und Unterbringung der Flüchtlinge vorgeschlagen (Wille I, S. 42).

WALDFRIEDHOF: Zum ehem. Auffanglager (s. o.) gehöriger Friedhof an der Chaussee zwischen $\rightarrow$ Cottbus und Burg, April/Mai 1945 eingerichtet, da der Gemeindefriedhof nicht mehr ausreichte (auch für Verstorbene aus dem Cottbuser Seuchenkrankenhaus, von dem sich Teile in Werben befanden, und aus einem im Lager untergebrachten Cottbuser Altenheim), 1945-1952 insgesamt 402 Bestattungen. Am Friedhofstor ehemals kleines Schild „Memento mori“. Friedhof in den fünfziger und sechziger Jahren noch von Angehörigen und Bekannten gepflegt (v. a. Hertha und Dieter Bartusch), dann verwahrlost, von der Volkspolizei für die Ausbildung von Hunden genutzt (Ramoth, S. 46 f., Scheer, S. 147; Crossener Heimatgrüße 47, 1995, Nr. 1, S. 27). „Anfang der 80er Jahre wurde Hertha Bartusch weggejagt, als sie weiterhin Gräber von Göhrenern pflegen wollte." (ebd., S. 27). Ab 1993 wiederhergestellt (ebd., S. 28), einige wenige Originalgrabsteine (u. a. Vertriebene aus den Kreisen Crossen, Grünberg und Namslau) noch vorhanden (s. Digitale Quellen). - „Ab Juli 1945 wurden dann auch die verstorbenen Heimatvertriebenen meistenteils hier beerdigt.“ (Ramoth, S. 47). „Insbesondere sind dort mindestens 20 frühere Einwohner des großen Dorfes Göhren bei Sommerfeld begraben." (Crossener Heimatgrüße 47, 1995, Nr. 1, S. 27). - 14.11.1998 (Volkstrauertag) Einweihung einer Erinnerungsstätte auf dem Waldfriedhof durch den BdV in Verbindung mit dem Volksbund Deutsche Kriegsgräberfürsorge (großes Holzkreuz und vier liegende Namenstafeln auf ovaler gepflasterter Fläche) (Scheer, S. 147). „Unter großer Teilnahme von Einwohnern des Amtes Burg wurde am Sonnabend auf dem Waldfriedhof Werben eine Gedenkstätte für die Opfer von Krieg und Vertreibung eingeweiht. An der Veranstaltung zum Volkstrauertag nahmen Brandenburgs Landtagspräsident Dr. Herbert Knoblich und der 1. Beigeordnete des Landkreises, Dr. Hans Schönherr, teil." (Lausitzer Rundschau, Elbe-Elster-Rundschau, 16.11.1998). „In bewegenden Worten hatte Inge Sonntag [geb. Borbs, Viersen] als Betroffene vor den mehr als 100 Anwesenden berichtet, wie sie als Vertriebene unmittelbar nach dem Krieg auf dem Werbener Waldfriedhof [1946 an Cholera] ihren Großvater [Bäckermeister Friedrich Borbs aus Göhren (Kr. Crossen)] begraben mußte. Eine ärmliche Beerdigung ohne Sarg, nur in ein Bettlacken konnten sie den Toten wickeln. In kurzer Zeit hatte sie vier Angehörge verloren." (Ramoth, S. 48; ergänzt nach Crossener Heimatgrüße 47, 1995, Nr. 1, S. 28; Todesursache nach ebd., Nr. 2, S. 41). - „Die Gedenkstätte beindruckt durch ihre Schlichtheit. Unter dem großen Kreuz befinden sich die Platten mit den Namen der Menschen, die hier ihre letzte Ruhestätte fanden. Jährlich zum Volkstrauertag werden hier Kränze niedegelegt.“ (ebd.). - 2003 Neugestaltung und Einweihung eines Gedenksteins (Findling) mit Inschriftenplatte (Versalien): „Auf diesem Friedhof ruhen / 402 Opfer / von Flucht und Vertreibung, / die in den Jahren 1945 bis 1952/ihr Leben gelassen haben.//Der Vertriebenenverband hat 1994 / auf diese jetzige Gedenkstätte aufmerksam gemacht. / Die Anlage wurde mit Fördermitten des Landes Brandenburg/sowie mit Unterstützung des Amtes Burg (Spreewald), / der Gemeinde Werben, / des Volksbundes Deutsche Kriegsgräberfürsorge / und Soldaten der Bundeswehr hergerichtet." 
(BR 2 (2004)2, S. 19 mit Foto; 12 (2014)7, S. 4 mit Foto; Klein/Herrnbeck, S. 210 f. mit Foto; Foto von L. Richter 2013 auf: grabsteine.genealogy.net [8.9.2016]). - 2014 Sanierung (Erneuerung des Zauns) der Gedenkstätte durch den Bauhof des Amtes Burg/Spreewald (Meldung vom 31.7.2014, www.werben-im-spreewald.de [8.9.2016]; BR 12, 2014, 7, S. 4).

Archivalische Quellen: Evang. Kirchenbuch Werben (darin 1945/46 zahlreiche Todesfälle von Flüchtlingen im „Ausweich-Pflegeheim“, meist mit Bestattungsort „Friedhof am Altersheim Werben“).

Digitale Quellen: Namentliche Erfassung der auf dem Waldfriedhof Beigesetzten und Fotos (Aufnahmen: L. Richter, 2013) der Anlage sowie der einzelnen Gedenktafeln und Grabsteine in der Online- Grabsteindatenbank des Vereins für Computergenealogie e. V. (genealogy.net [8.9.2016]), darunter neben den Gedenktafeln auch zeitgenössische Grabsteine, u. a. für Bäckermeister Friedrich Borbs (o. D.) aus Göhren bei Sommerfeld, Gustav Schulz $\left({ }^{*} 1868\right.$, +21.2.1946) aus Göhren Kr. Crossen, Erna Schwarz (*1930, + 31.10.1945) aus Langenwaldau Krs. Liegnitz.

Gedruckte Quellen und Literatur: Klei, Alexandra / Herrnbeck, Christian: Überall Geschichte. Nationalsozialismus und Kriegsende 1945 - Denkmale, Erinnerungszeichen und historische Orte im Landkreis Spree-Neiße. Berlin 2005. - Ramoth, Siegfried: Das Gemüsedorf Werben im Wandel eines Jahrhunderts. Cottbus 2001 (bes. S. 45-48 Kap. „Heimatvertriebene“; S. 48: Liste der 1952 „hier ansässige(n) Vertriebenen-Betriebe“). - Scheer, Regina: Der Umgang mit den Denkmälern. Eine Recherche in Brandenburg. [Potsdam] 2003, S. 147. - Ein vergessener Friedhof im Spreewald. In: Crossener Heimatgrüße 47 (1995), Nr. 1, S. 27-28. - Wille I, S. 42.

\section{Werder (Havel)}

Stadtgemeinde, bis 1952 Kr. Zauch-Belzig, 1952-1990 Kr. Potsdam-Land (Bez. Potsdam), 1990-1993 Ldkr. Potsdam, 1993 Ldkr. Potsdam-Mittelmark

EREIGNISSE BIS KRIEGSENDE: 23.1.1945: „Es sind nach heute fernmündlich und durch die NSV. und die NSDAP. eingegangenen Mitteilungen sofort bezw. in den nächsten Tagen etwa 600 Personen (Flüchtlinge und Fliegergeschädigte) in der Stadt Werder (Havel) unterzubringen. Mit einem noch viel größeren Mehr muß gerechnet werden. [...] Es sollen zunächst belegt werden: Potsdamer Straße, Berliner Straße, Ed. Lehmannstraße, Kugelweg, Moosfennstraße, Brandenburger Straße. [...]." (Vermerk des Leiters des Quartieramtes, Faksimile in: Pape/Schultze, S. 106). - „Einer im Archiv vorgefundenen Liste konnte entnommen werden, dass in der Zeit vom in der Zeit vom 23. Januar bis 7. April 19451240 Erwachsene und 154 Kinder in Werder Zuflucht suchten und mit Wohnraum und allem Lebensnotwendigen zu versorgen waren." (ebd., S. 102). - „Alfred Schultze aus der Kemnitzer Straße bereichtete, dass dort an manchen Tagen ganze Trecks ,parkten. Ein dienstbeflissener Blockwart vermittelte den Flüchtlingen Unterkünfte und für die Pferde Unterstellmöglichkeiten. Letztere wurden nachts in einem Gewächshaus der ehemaligen Gärtnerei Große untergestellt. Die Wagen verblieben auf der Kemnitzer Straße. Auch aus dem Ortsteil Petzow ist bekannt, das sich die vorübergehend durchziehende Flüchtlinge mit ihren Pferdefuhrwerken aufhielten. / In den letzten Monaten des Krieges wurden der Bahnhof unserer Stadt und die Vulkanfiber-Fabrik zum ,Umschlagplatz für Flüchtlinge. Denn diese blieben ja nicht alle in Werder, sondern wurden auch in die umliegenden Gemeinden ein- [S. 104] gewiesen. [...] Im Speisesaal der genannten Fabrik - die Küche diente [...] als Volksküche - erhiel- 
ten die Ankommenden eine warme Mahlzeit und Getränke.“ (ebd., S. 103 f.). - Flüchtlingssammelstelle: Die NSV richtete ,in der ehemaligen Gaststätte ,Mokka Efti' in der Straße Unter den Linden 18 (heute ,Ristorante Pané Vino') [...] eine Kleinkinder- und Krankensammelstelle für durchreisende und ankommende Flüchtlinge“ ein (ebd., S. 104). - Ende April 1945 Einmarsch der Roten Armee (Lambrecht/Meissner, S. 83 f.).

EREIGNISSE NACH KRIEGSENDE: 1945 (Bericht der Stadtverwaltung): „[... ] eine große Zahl von Flüchtlingen strömte nach Werder ein." (Brandenburgische Gemeinden 1945, S. 191). - „Obwohl die Stadt weitgehend unzerstört geblieben ist, bedrängten sie nach Kriegsende keine geringeren Wohnungsprobleme als jene Kommunen, in denen ganze Stadtteile in Trümmern lagen. Schon im Frühjahr 1945 begann der Zustrom von Flüchtlingen aus den Ostgebieten. Diese wurden zunächst wahllos dort untergebracht, wo noch Platz war. „Es musste überall zusammengerückt werden“, resümierte das Wohnungsamt 1948. Ein für später geplanter Ausgleich ließ sich durch den anhaltenden Zugang von Flüchtlingen indes nicht mehr realisieren. / Aber erst mit der Errichtung der Sperrgebiete für die Besatzungsmacht steigerte sich der Wohnraummangel zu einer wirklichen Notsituation." (Lambrecht/Meissner, S. 90). - 19.10.1945 Plan zur Unterbringung von „6600 Umsiedler(n) nicht allein in der Stadt Werder/Havel, sondern vornehmlich in den zur Bürgermeisterei Werder/Havel gehörenden Landgemeinden" (Wille II, S. 186).

EREIGNISSE NACH 1990: Ab Herbst 1992 Weststernberger Heimattreffen im Saal der Gaststätte „Friedrichshöhe“, Hoher Weg 85, veranstaltet vom „Heimatkreis Weststernberg e. V.“, 1993 mit „an die 750“ Teilnehmern mit Grußwort des Werderaner Bürgermeisters Werner Große (Märkischer Informationsdienst 1993, Nr. 10/11, S. 14), 1995 mit ca. 600 Teilnehmern (Heimatbrief Weststernberg 15/1995, S. 12). Im Bericht über das Treffen von 1995 heißt es zum ersten Treffen 1992: „Alle Teilnehmer waren damals von der großen Besucherzahl überrascht. Heute wissen wir, daß mindestens 30 bis $40 \%$ der Vertriebenen aus dem Kreis Weststernberg in der Region Frankfurt (Oder) - Berlin - Brandenburg leben. Seit Kriegsende gab es zahlreiche Kontakte der Heimatfreunde untereinander, auch über die Grenze hinweg zwischen der DDR und der Bundesrepublik. [...]." (ebd.).

BevöLKerungszahlen: 1925: 7696, 1939: 11314, 1946: 11310, 1964: 9784 (Städtebuch, S. 540). - 1945: 14000 (Brandenburgische Gemeinden 1945, S. 191).

Katholiken: 1925: 289, 1946: 845 (Städtebuch, S. 540). - „Zum Kriegsende strömten in mehreren Wellen Millionen deutscher Flüchtlinge aus dem Gebiet östlich von Oder und Neiße und dem Sudetenland nach Westen. So wundert es nicht, dass sich auch im Einzugsbereich der Pfarrgemeinde Werder viele Flüchtlinge niederließen. Ein Teil von ihnen ging nach einer gewissen Zeit weiter nach Westen, in die sogenannten ,Westzonen', aber viele blieben. Wo sollten sie auch hin? Sie fanden in der Pfarrgemeinde ,Maria Meeresstern' in Werder eine neue Heimat. Gerade die Schlesier fanden hier im Pfarrer einen Landsmann. Auch die Lieder in der Heiligen Messe waren wie in der alten Heimat, denn bis 1930 gehörte die Delegatur Berlin zum Erzbis- 
tum Breslau." (Heckmann, S. 34) [Pfarrer war 1938-1966 der gebürtige Oberschlesier Hugo Makosch (ebd., S. 47)].

GedRuckte Quellen: Adreßbuch Groß-Potsdam 1949, S. 797-842: Verzeichnis der Einwohner, Firmen, Organisationen und Behörden der Stadt Werder. - Brandenburgische Gemeinden 1945, S. 191-192 (Verf.: H. Simon). - Tagebuch Elsa Grätsch (aus Breslau) [Auszüge]. In: „Die Russen sind da“. Peter Böthig u. Peter Walther (Hg). Berlin 2011, S. 70, 198, 201, 203, 205-207, 210, 213 f. - Wille II, S. 186.

LiterATUR: Heckmann, Dieter, und Zeitzeugen: 100 Jahre katholische Kirche „Maria Meeresstern“ Werder a.d. Havel 1906-2006. 2., erw. Aufl. Potsdam 2013. - Lambrecht, Rainer / Meissner, Klaus-Peter: Havelauen. Potsdam 2012. - Pape, Kurt / Schultze, Alfred: Werder (Havel) 1945. Potsdam 2015.

\section{Werder (0derbruch)}

Wohnplatz von $\rightarrow$ Sachsendorf (seit 2003 Ortsteil von Lindendorf), bis 1950 Kr. Lebus, 19501952 Kr. Seelow, 1952-1990 Kr. Seelow (Bez. Frankfurt/Oder), 1990-1993 Ldkr. Seelow, 1993 Ldkr. Märkisch-Oderland

EReignisse NACH Kriegsende: April 1946 Ansiedlung von über 50 DobrudschadeutschenFlüchtlingsfamilien aus Rumänien (1940 von dort in den Raum Posen/Wartheland umgesiedelt) auf Bodenreformland in dem unbewohnten, weitestgehend kriegszerstörten Ort, zunächst in Notunterkünften, dann in (überwiegend 1951 fertiggestellten) Wohnhäusern (Baudis 2016; Marx, S. 109; Schmook, S. 30-32). - „Mit eisernem Erfolgswillen packten die entwurzelten Flüchtlinge die schwierigsten Aufgaben an und schufen meistens in verwandtschaftlicher Gemeinschaftsarbeit ein neues Zuhause. / Es entstand ein schönes Dorf mit ca. 400 Einwohnern, mit neuen Wohnhäusern und Stallanlagen, Schöpfbrunnen, Backöfen, Gemüse- und Blumengärten, einer Verkaufsstelle für Lebensmittel und Kurzwaren, einem Erntekindergarten und einer Bauernstube. [...]. Die großartigen Leistungen der Neusiedler in dem abgelegenen Dörfchen wurden mehrmals in der Tagespresse gelobt und gewürdigt. In unglaublich kurzer Zeit vollzog sich ein rasanter Aufschwung, aber die Zwangskollektivierung der Landwirtschaft bewirkte eine krasse Veränderung. Viele Famlien wurden republikflüchtig, und bis zur Wendezeit war das entlegene Oderbruchdörfchen fast leergezogen und zu einem unscheinbaren, vergessenen Ort geworden. [...].“ (Baudis 2013, S. 11).

Katholiken (bis 1994 Erzbistum Breslau/Erzbischöfliches Amt Görlitz, dann Erzbistum Berlin): 1954 (Sachsendorf mit Ortsteil Werder): 64 (Schematismus Görlitz 1954, S. 36).

Literatur: Baudis, Anna: Werder - ein fast vergessenes Dörfchen im Oderbruch. In: Mitteilungsblatt des Bessarabiendeutschen Vereins 68 (2013), H. 4, S. 11-12. - Dies.: Werder wurde Heimstatt für Flüchtlinge. In: Märkische Oderzeitung, 5.5.2016. - Marx, Wolf-Rainer: Der Pfarrer predigte im Soldatenmantel. Der schnelle Wiederaufbau zerstörter Kirchen im Oderbruch. In: Offene Kirchen 2015, S. 108-110. - Oehlsen, S. 81 (Foto einer Vertriebenenfamilie beim Dachdecken in Werder). - Schmook, Reinhard: Neue Heimat links der Oder - Vom Flüchtlingsalltag in den ersten Nachkriegsjahren. in: Museumsblätter. Mitteilungen des Museumsverbandes Brandenburg 30 (2017), S. 26-33. - Vom Schwarzen Meer nach Werder. In: Märkische Oderzeitung [MOZ], 19.4.2006. 


\section{Werneuchen}

Stadtgemeinde, bis 1952 Kr. Oberbarnim, 1952-1990 Kr. Bernau (Bez. Frankfurt/Oder), 1990-1993 Ldkr. Bernau, 1993 Ldkr. Barnim

EReignisse NACH KRIEgSende: Sept. 1945 drei Todesfälle von Flüchtlingen aus Königsberg/ Nm. in Werneuchen (Krätzner, S. 25, nach Angaben in der „Heimatkartei“). - Mai 1949 bekundet der Vorsitzende der SED-Ortsgruppe Werneuchen in einer Sitzung des Kreisverbandes Oberbarnim sein Unverständnis darüber, „daß ein sozialistischer Staat [Polen] fremdes Land okkupieren könne“ (Blöß, Grenzen und Reformen, S. 70).

BevöLKerungSZAHLEN: 1925: 2773, 1939: 4095, 1946: 4218, 1964: 3908 (Städtebuch, S. 543).

Katholiken: 1925: 89, 1946: 285 (Städtebuch, S. 544). - „Nach dem II. Weltkrieg kamen auch nach Werneuchen und Umgebung katholische Vertriebene, die Gemeinde blieb aber unter 1000 Seelen." (Brühe, S. 49; identisch: Schwillus/Brühe, S. 299).

Lager Werneuchen/Weesow (Sowjetisches Speziallager Nr.7), Mai bis August 1945: Das Lager diente wie die anderen Speziallager als Sammel- und Durchgangslager für vom NKWD Verhaftete. Ein direkter Bezug zur Gruppe der Flüchtlinge und Vertriebenen bestand also nicht. Es ist aber davon auszugehen, dass sie unter den Insassen (geschätzt wird eine Gesamtzahl von 9000 bis 13700 Internierten) zumindest dann vertreten war, wenn Transporte aus weiter östlich gelegenen Lagern aufgenommen wurden. So trafen Häftlinge u. a. „im August 1945 aus Frankfurt/Oder (2 000) und im November aus Posen [!] (2000) ein“ (Morré, S. 81). Im Totenbuch (s. u.), das in vielen Fällen die Geburtsorte nennt, finden sich zahlreiche in den Ostgebieten geborene Personen, ohne dass man im einzlnen weiß, ob sie zu den Vertriebenen zählten.

Gemeindepartnerschaft: 1996 Dziwnów (Berg-Dievenow) bei Cammin, Pommern; 1998 Ustronie Morskie (Henkenhagen) bei Kolberg, Pommern.

Gedruckte Quellen und Literatur: Blöß, Wolfgang: Grenzen und Reformen in einer Umbruchgesellschaft. Berlin 2014. - Brühe, Matthias: Katholische Kirche zwischen Uckermark und Oderland. Berlin 1998, S. 49. - Krätzner, S. 25. - Morré, Jörg: Werneuchen/Weesow - Speziallager Nr. 7 (Mai - August 1945). In: Ders.: Speziallager des NKWD. Potsdam 1997, S. 78-82. - Schwillus/Brühe, S. 299. - Totenbuch sowjetisches Speziallager Nr. $7 /$ Nr. 1 in Weesow und Sachsenhausen 1945-1950. Hrsg. von der Gedenkstätte und Museum Sachsenhausen/Stiftung Brandenburgische Gedenkstätten. Bearb. von Ines Reich. Berlin 2010. 


\section{Weskow}

Landgemeinde, seit 1.1.1946 Ortsteil von $\rightarrow$ Spremberg, bis 1945 Kr. Spremberg, 1952-1990 Kr. Spremberg (Bez. Cottbus), 1990-1993 Ldkr. Spremberg, 1993 Ldkr. Spree-Neiße

UMSIEDLERLAGER: 1946 wird ein Umsiedlerlager „Westow“, Belegungsstärke ohne Angabe, erwähnt (Kaminsky, S. 159). Ungeklärt ist, ob das nicht auffindbare, offensichtlich verschriebene „Westow“ identisch ist mit Weskow.

\section{Wiesenau}

Landgemeinde (bis 1919 Krebsjauche), bis 1952 Kr. Guben, 1952-1990 Kr. Fürstenberg/Oder bzw. (ab 1961) Kr. Eisenhüttenstadt-Land (Bez. Frankfurt/Oder), 1990-1993 Ldkr. Eisenhüttenstadt, 1993 Ldkr. Oder-Spree

EREIGNISSE BIS KRIEGSENDE: 5./6.2.1945 (nachts) Einmarsch der Roten Armee. „Etwa 500 Menschen, meist Frauen und Kinder sowie Alte, befanden sich noch im Ort ... [...] Die Einwohner wurden am 7. Februar 1945 in mehrere Keller [...] gesperrt [...]. Dann wurden sie gezwungen, über die damals mit Eis bedeckte Oder in das bereits besetzte Gebiet östlich des Flusses zu wandern. [...] In diesen Monaten starben 25 Einwohner östlich der Oder, manche Schicksale blieben ungeklärt. Viele der Frauen wurden vergewaltigt.“ (600 Jahre Wiesenau, S. 38).

EREIGNISSE NACH KRIEGSENDE: „Nach Beendigung der Kampfhandlungen wanderten die Vertriebenen [S.39] zurück, in der Hoffnung, ein normales Leben beginnen zu können [...] Viele Einwohner aus den östlich der Oder gelegenen Dörfern, die vor den russischen Truppen über den Fluss nach Westen geflohen waren, zogen ebenfalls, diesmal von West nach Ost, in ihre Heimatorte. Diese Züge begegneten sich unterwegs. Während die Wiesenauer wenigstens in ihrem Ort bleiben konnten, mussten die Kunitzer, $[\rightarrow]$ Aurither und alle anderen ihre Dörfer nach wenigen Tagen wieder verlassen [...]. So kamen viele Menschen der Nachbardörfer als Flüchtlinge nach Wiesenau, auf die Kunitzer Loose und die Thälmannsiedlung [ErnstThälmann-Siedlung (zu [ $\rightarrow$ ] Ziltendorf)].“ (600 Jahre Wiesenau, S. 38 f.). - Aug.-Sept. 1945 Höhepunkt einer Typhusepidemie (ebd., S. 39). - 3.10.1950 Zuweisung von westlich der Oder gelegenen Flächen der nun polnischen Gemeinde Kunitz/Kunice (ehem. Kr. Weststernberg) (anteilig; vgl. $\rightarrow$ Brieskow-Finkenheerd und $\rightarrow$ Frankfurt/Oder) an die Gemeinde Wiesenau (Blöß, Kreise und Gemeinden, S. 31).

BevölkerungSZAhlen: 1925: 1385, 1939: 1602 (HOL NL II, S. 223). - 26.6.1945: 1137 („Die russische Kommandantur verlangt ..., S. 21). - 20.7.1945: „Die Gemeinde Wiesenau zählt z.Z.1215 Einwohnr. Anfang Mai sind die ersten Einwohner nach Wiesenau zurückgekehrt. Ungefähr 500-600 Einwohner, die fast alle zurückgekehrt sind, waren im Orte. [...] Die Sterblichkeit ist erschreckend hoch [...].“ (Ebd., S. 33). - 24.7.1945: 1246 (ebd., S. 38). 
GedRuckte Quellen: „Die russische Kommandantur verlangt...“ Eine regionale Quellensammlung der ersten Nachkriegsjahre für Fürstenberg (Oder) und Umgebung 1945-1949. Eisenhüttenstadt 2003.

Literatur: 600 Jahre Wiesenau 1368-2018. Hrsg.: Gemeinde Wiesenau. Red.: Hans-Dieter Walz u.a. Wiesenau 2018. - Wargenau, Katalin: Feste feiern - Traditionen bei den Aussiedlerfamilien in Wiesanu, Ortsteil Kunitz-Loose. In: Heimatkalender Eisenhüttenstadt und Umgebung 12 (1994), S. 91-92.

\section{Wiesenburg/Mark}

Landgemeinde, bis 1952 Kr. Zauch-Belzig, 1952-1990 Kr. Belzig (im Bez. Potsdam), 19901993 Ldkr. Belzig, 1993 Ldkr. Potsdam-Mittelmark

BEVÖLKERUNGSZAHLEN: 1925: 2002, 1939: 1 172, 1946: 2 136, 1964: 1742 (HOL V, S. 469).

Katholiken: Pfarrer Pech aus dem zerstörten Küstrin hält sich im Juli 1945 in Wiesenburg auf (Töpler, Menschenwurm, S. 364). - Der aus dem Bistum Ermland stammende Pfarrer Paulinus Pienski (geb. 1886 Krojanke, Kr. Flatow) war 1946 als außerplanmäßiger Flüchtlingsgeistlicher in Wiesenburg (St. Elisabeth-Kapelle im Schloss) eingesetzt, Adresse Görzker Straße 8 (DAB, I/9-15-1, Aufstellung vom 22.8.1946; Schematismus Berlin 1947, S. 75, 152), 1949 war er Pfarrer im Maria-Elisabeth-Heim in $\rightarrow$ Altenhof am Werbellinsee (Schematismus Berlin 1949, S. 63, 144). - 1948 folgte ihm (bis 1953) der zuvor in $\rightarrow$ Reppinchen (Kr. ZauchBelzig) als Seelsorger eingesetzte, aus der Diözese Leitmeritz stammende (vor 1945 Pfarrer in Gersdorf/Böhmen) Dechant Johannes Krowarz (geb. 1883 Lorenzdorf), Adresse wie vor (Brühe, S. 47; Ostpriesterverzeichnis 2, 1949, S. 48; Schematismus Berlin 1949, S. 70, 143). 1950 Kapelle im Schloss gekündigt, Neubau „auf dem inzwischen erworbenen Grundstück Görzker Str. 8“, 1952 geweiht (Hl. Elisabeth), 1.5.1953 vermögensrechtlich selbständige Kuratie mit etwa 700 Katholiken, „zu der auch das nahegelegene $[\rightarrow]$ Jeserig (Fläming), eine damals fast rein katholische Siedlung von Umsiedlern gehörte“; 1960er Jahre etwa 450 Katholiken, letzter „eigener Seelsorger von Wiesenburg war Ludwig Kirschner [geb. Brandenburg 1925] (1960-66), ab 1966 vom $\rightarrow$ Belziger Pfarrer mitbetreut, 1.4 .1968 beide Gemeinden zur Kuratie Belzig-Wiesenburg vereinigt, 1998 Wiesenburger Kapelle aufgegeben u. 1999 entwidmet (Brühe, S. 47).

Literatur: Brühe, Matthias: Katholische Kirche zwischen Havel und Dahme. Berlin 1999, S. 47. - Nitschke, Johannes: 150 Jahre Pfarrkirche „Heilige Dreifaltigkeit“ Brandenburg an der Havel. Brandenburg an der Havel [2001], S. 31. - Schwillus/Brühe, S. 201.

\section{Wildau}

Landgemeinde, bis 1952 Kr. Teltow, 1952-1990 Kr. Königs Wusterhausen (Bez. Potsdam), 1990-1993 Ldkr. Königs Wusterhausen, 1993 Ldkr. Dahme-Spreewald

EREIGNISSE BIS KRIEGSENDE: 24.4.1945 Einmarsch der Roten Armee (Schiller, S. 12). 
EReignisse bis Kriegsende: [Mai] 1945: „Eine der ersten Gemeindeschwestern wird Erika Sappek, eine Kriegerwitwe, allein stehende Flüchtlingsfrau aus Breslau mit vier Kindern.“ (Schiller, S. 14).

BevölKeRUngszahlen: 1925: 4390, 1939: 5 664, 1946: 5 166, 1964: 8397 (HOL IV, S. 347).

Gemeindepartnerschaft: 16.8.1995 Rewal, Polen (Rewahl, ehem. Kr. Greifenberg, Pommern) (www.rewal.pl [25.8.2018]).

LiterATUR: Schiller, Werner: Kriegsende und Neuanfang. Aus Dokumenten von Zeitzeugen. In: Wildauer Heimatbuch. T. 2. Horb am Neckar 2001, S. 9-17.

\section{Wilhelmshorst}

Landgemeinde, bis 1950 Kr. Zauch-Belzig, 1950-1952 Stadtkr. Potsdam, 1952-1990 Kr. Potsdam-Land (Bez. Potsdam), 1990-1993 Ldkr. Potsdam, 1993 Ldkr. Potsdam-Mittelmark

BevöLKeRUnGSZAHLEN: 1925: 304, 1939: 1313, 1946: 1532, 1964: 2008 (HOL V, S. 473).

KATHOLIKEN: „Nach dem II. Weltkrieg kamen Vertriebene, unter ihnen Dechant Anton Heimann [geb. 1872 Bukarest (Schematismus Berlin 1949, S. 141)] (1946-49) aus der Diözese Leitmeritz. 1950 wurde die Gemeinde seelsorglich, 1959 vermögensrechtlich selbständige Kuratie. 1954 erbte sie das Haus Heideweg 5 und nutzt es seitdem für die damals etwa 800 Katholiken als Pfarrund Gemeindehaus.“ (Brühe, S. 43). - „Seit 1946 wirken aus Schlesien vertriebene Schwestern der Mägde Mariens in Wilhelmshorst, in den 50er Jahren hatten sie sogar ihr Provinzialat im Haus Immaculata im Ravensbergweg 4/6. Daneben unterhieten sie im Nebengebäude Föhrenhang 22 ein Altersheim mit einer eigenen Kapelle. [...]." (ebd.; textähnlich: Schwillus/Brühe, S. 332).

Gedruckte Quellen und Literatur: Adreßbuch Groß-Potsdam 1949, S. 903-908. - Brühe, Matthias: Katholische Kirche zwischen Havel und Dahme. Berlin 1999, S. 43. - Helms, Friedrich: Tagebuch. Wilhelmshorst 1945. Hrsg. von Tobias Wimbauer. Hagen-Berchum 2009. - 100 Jahre Wilhelmshorst 1907-2007. Hrsg. von Rainer Paetau. Wilhelmshorst 2007. - Schwillus/Brühe, S. 332.

\section{Wilsnack $\rightarrow$ Bad Wilsnack}

\section{Wittenberge}

Stadtgemeinde, 1922-1950 Stadtkr. (zuvor Kr. Westprignitz), 1.7.1950-1952 Kr. Westprignitz, 1952-1990 Kr. Perleberg (Bez. Schwerin), 1990-1993 Ldkr. Perleberg (Land Brandenburg), 1993 Ldkr. Prignitz

EREIGNISSE BIS KRIEGSENDE: 1945: „Die aus dem Westen nach Ostdeutschland Evakuierten sowie die Bewohner aus den Ostgebieten fliehen vor dem anrückenden Feind, lange Trecks durchziehen täg- 
lich die Stadt in der Richtung nach Westen und alle noch nicht als Lazarett eingerichteten Schulräume sind mit Flüchtlingen belegt. Die Kirche ist an den Sonntagen überfüllt, so werden am 1. Ostertage 791 Kommunionen ausgeteilt." (Bolwin, S. 187). - Jan. 1945: „Zahlreiche Bürger, die in Hamburg ihre Wohnung durch Bombenabwurf verloren hatten, und Flüchtlinge aus den Ostgebieten waren jetzt in unserer Stadt untergebracht. Im Schulgebäude am Schulplatz 5 wurden laut Stammrolle 1555 Flüchtlinge, darunter 459 Kinder einquartiert. Hier ist der Unterricht jetzt stark eingeschränkt." (Muchow, S. 4). - 30.1.1945: Ankunft von vier Güterzügen mit rund 10000 Flüchtlingen aus Osterode (Ostpreußen) und Umgebung, u. a. die evakuierte Belegschaft des dortigen Reichsbahnausbesserungswerks (RAW) (Abfahrt in Osterode 21.1.1945), Unterbringung in vom RAW Wittenberge bereitgestellten Notunterkünften (Sembritzki, S. 9). - Ab 5.2.1945: „Für die Schüler der Bürgerschule II (Schulplatz 5) ist bis auf weiteres kein Unterricht, weil im Schulgebäude Flüchtlinge untergebracht werden.“ (ebd., S. 5). - 22.2.1945 Bombenangriff(ebd., S. 5 f.; Chronik, S. 163; Bolwin, S. 187). -5./6.3.1945: „Ein Lazarett aus Küstrin wird nach Wittenberge verlegt und hier in der Jahnschule (B III/IV) einquartiert." (Muchow, S. 6; vgl. Chronik, S. 164) „Die Turnhalle in der Scheunenstraße wurde nach Bombenangriffen und nach Sterbefällen unter den in der benachbarten Schule einquartierten Flüchtlingen jetzt auch notdürftig als ,Leichenaufbewahrungsstätte benutzt." (Muchow, S. 7). - 15.3.1945 Bombenangriff (ebd., S. 8 f.; Chronik, S. 164). - 15.3. u. 10.4.1945 Bombenangriff (ebd., S. 13 f.; Chronik, S. 165; Bolwin, S. 188). 3.5.1945 Einmarsch der Roten Armee (Chronik, S. 169; Bolwin, S. 190).

EReignisse NaCH Kriegsende: [Nach Kriegsende 1945 (Notiz des kath. Pfarrers):] „Tausende von Heimatvertriebenen und Evakuierten aus dem Westen sind in Wittenberge zusammengeströmt und größtenteils in Sammellagern notdürftig untergebracht. Sämtliche Schulen sind besetzt. Es herrscht unbeschreibliches Elend, das durch den Ausbruch von Typhus und Ruhr ein entsetzliches Ausmaß annimmt. Alte Leute und Kleinkinder sterben wie die Fliegen an Hunger und Seuchen. Zugleich muss ich Schwerkranke versehen und Verstorbene beerdigen. [...] 222 Beerdigungen habe ich im Jahre 1945 gehalten. / Die Notkapelle ist an den Sonntagen beängstigend voll. (Bolwin, S. 291). 16.5.1945: „In einem Bericht über die ,Zustände unter den Hunderten von Flüchtlingen, die nahezu acht Tage auf dem Wittenberger Bahnhof auf ihren Weitertransport nach Berlin warten;, wird auf die unhaltbaren Zustände unter den Wartenden verwiesen, viele leiden unter schweren Durchfallerkrankungen." (Chronik, S. 172). - 17.5.1945 Bekanntmachung des Oberbürgermeisters: „Alle Flüchtlinge, deren Heimat diesseits der Elbe liegt, müssen sich wieder nach ihrem Heimatort begeben.“ (ebd.). - 22.5.1945 „Bürgermeister Saarfels aus Grabow informiert, daß am 23.05. ein Transport von 1200 Flüchtlingen Wittenberge passieren wird. Die Flüchtlinge sind mit Verpflegung für drei Tage (bis 25.05.) ausgestattet.“ [Fußnote: „Der Transport passiert Wittenberge reibungslos.“] (ebd., S. 173). - Mai 1945: „Allein im Mai 1945 verstarben in Wittenberge 199 Personen, darunter 20 Säuglinge, an Typhus und anderen Seuchen. Im Barackenlager an der Tivolistraße war Typhus ausgebrochen. Seine Bewohner wurden dann in die Räume des ehemaligen Rüstungsbetriebes ,Mechanische Werkstätten VöLCK' (früher einmal Zigarettenfabrik Rustin) in der Perleberger Straße/Ecke Krausestraße verlegt. Damit begann die 
Nutzung dieses Gebäudekomplexes als Hilfskrankenhaus (Seuchen-Krankenhaus). Eine große Impfaktion wurde durchgeführt.“ (Muchow, S. 44). - Juni 1945: „Die Flüchtlingsunterkünfte in den Schulhäusern in der Scheunenstraße werden in die Baracken des Zellwollewerkes an der Lenzener Straße (Mühlenberg) verlegt.“ (ebd., S. 45). - 11.6.1945 „Ausweisung aller Ausländer, die ihren Wohnsitz westlich der Elbe haben, aus der Stadt.“ (Muchow, S. 45). - 29.6.1945: „Oberbürgermeister [Johann] Haacken gibt bekannt: „Die aus den Provinzen Pommern und Schlesien sowie aus der Lausitz und den Gebieten westlich der Oder und östlich der Elbe sich in Wittenberge aufhaltenden Personen müssen den hiesigen Stadtkreis bis zum 5.7. ds. Js. verlassen. Der Termin der Abreise in das Gebiet östlich der Oder wird später bekanntgegeben." (Muchow, S. 46; vgl. Chronik, S. 178). - 16.7.1945: „Der Oberbürgermeister weist das Polizeikommissariat an: $\mathrm{Ab}$ sofort sind sämtliche Zugangsstraßen zur Stadt Wittenberge abzusperren. Flüchtlinge sind unter allen Umständen von der Stadt fernzuhalten. Sie sind sofort an die umliegenden Dörfer und Ortschaften weiterzuleiten.“ (Chronik, S. 179). - 23.7.1945 „Bildung eines permanenten Flüchtlingsausschusses. 1. Vorsitzender: Peter Beyer, Bahnstraße 3; 2. Vors. Schubert." (ebd., S. 180). - 30.8.1945 „Aufruf an die Kleingärtner, Flüchtlinge[n] und heimkehrende[n] Soldaten in den überfüllten Krankenhäusern durch Spenden von Obst und Gemüse zu helfen.“ (ebd., S. 183; Muchow, S. 51). - 1.9.1945 (Vertriebenen-Bahntransport, aus Pritzwalk kommend, auf der Durchreise in das Lager Flüchtlingslager Goldbeck im Kr. Osterburg/Altmark:) "In einer Schule in Wittenberge wurden wir registriert und bekamen einen Passierschein" (Becker, S. 35). - 10.9.1945 Einladung zu einer Versammlung durch den „Aktionsausschuß Bodenreform" (Chronik, S. 183; Muchow, S. 52). - 15.9.1945 Bekanntmachung über den Wiederbeginn des Schulunterrichts am 1.10. („Die Beschulung der Flüchtlingskinder wird besonders geregelt“) (Chronik, S. 183; Muchow, S. 52). - Sept. 1945 Typhus-Impfung aller Bürger zwischen 6 und 55 Jahre wegen der Typhusepidemie, die „bereits viele Opfer gefordert hat" (Chronik, S. 184) . - 8.10.1945 Beginn des ersten Neulehrerkursus in der Provinz Brandenburg in Wittenberge (Muchow, S. 54). - 10.10.1945 Beginn der Durchführung der Bodenreform (Muchow, S. 54). - 12.10.1945 „Anordnung \# 320/100: Alle Umsiedler und Flüchtlinge aus Rußland, Estland, Litauen, Lettland und Polen sowie sämtliche Ausländer, die in den Jahren 1939-1945 nach Wittenberge gekommen sind, haben sich bis Montag, den 15.10.45, im Rathaus zwecks Registrierung zu melden." (ebd., S. 185).- 24. bis 30.10.1945 erneute Typhus-Impfung (ebd.). - 4.12.1945 Unterrichtsbeginn der oberen Jahrgänge der Volksschulen („Einschulung der Flüchtlingskinder erfolgt ab 10.12.45. Meldung bei den Schulleitern der Bürgerschule 2, Schulplatz 4/5.)“ (Muchow, S. 58). - Ende Juli 1948 im Verzeichnis (von der Landesregierung) verbotener Suchdienste erwähnt: Cibis, Gewerbelehrer, Wittenberge, Feldstr. 14 b. Hecht (BLHA, Rep. 203 MdI, Nr. 1197, Bl. 41). - 16.5.1949: „Die Baracke in der Tivolistraße, die bisher als Quarantänestation für Umsiedler und Heimkehrer diente, wird Unterkunft eines neuen Kindergartens. Als dessen Leiterin wird Hildegard Wypyrczyk eingesetzt." (Chronik, S. 223).

EREIGNISSE NACH 1990: 21.9.2002 „Tag der Heimat" im Restaurant „Zur alten Zellwolle“ mit ca. 302 Teilnehmern (Akten BdV-Landesgeschäftsstelle). 
BEVÖLKERUNGSZAHLEN: 1925: 25 625, 1939: 27 834, 1946: 31 485, 1964: 32439 (Städtebuch, S. 546). - 1.7.1945: 39587 Einwohner (darunter 9940 Kinder bis zu 14 Jahren), davon etwa 6000 Flüchtlinge (Muchow, S. 47; Chronik, S. 178). - 31.1.1946: „38 860 Einwohner. Davon sind 8146 Umquartierte und 119 Ausländer“ (Chronik, S. 192). - Juli 1946: 4893 „Umsiedler“ (BLHA, Rep. 203 MdI, Nr. 1074, Bl. 52; Abb.: Mietk, S. 66). - 29.10.1946: 31485 Einwohner, davon aus Ostpreußen: 2331, Hinterpommern 634, Ostbrandenburg 381, Schlesien 945, Tschechoslowakei 160, Polen 433, Danzig 262, Rumänien 57, Baltikum 124, Sowjetunion 33 (Volkszählung 1946). - 31.12.1948: Gesamtbevölkerung: 32 801, davon „Umsiedler und Evakuierte“: 6548 (Grandke, S. 46). - Eingemeindung von Vertriebenen: 30.4.1947: 4886 (Oehlsen, S. 102), Juni 1948: 6319 (ebd., S. 103), Febr. 1949: 6530 (ebd., S. 104).

Katholiken: 1925: 983, 1946: 2487 (Städtebuch, S. 547). - Gemeinde bestand schon im 19. Jh., seit 1891 Pfarrei. „1939 zählte man in der Gemeinde 1700 Katholiken, ihre Zahl stieg durch die Vertriebenen nach dem II. Weltkrieg stark an: Nachdem schon 1939 in $[\rightarrow]$ Havelberg und dann 1947 in $[\rightarrow]$ Bad Wilsnack und 1953 in $[\rightarrow]$ Lenzen Tochtergründungen enstanden waren, verblieben 1953 noch 3000 Katholiken bei der Muttergemeinde." (Brühe, S. 51). - 1919-1951 hatten die Breslauer Marienschwestern eine Niederlassung auf dem Pfarrgrundstück zwecks ambulanter Krankenpflege sowie Pflege- u. Bildungsarbeit (Bolwin, S. 129-131, 198f., 201 f.).

Umsiedlerlager Wittenberge: Kapazität am 1.1.1946: 1000 (BLHA, Rep. 203 MdI, Nr. 1163, Bl. 50).

ReichsbahnausbesserungSWERK WitTEnberge: 30.1 .1945 (vgl. oben Ereignisse bis Kriegsende) Ankunft der evakuierten Belegschaft des Reichsbahnausbesserungswerks (RAW) Osterode (Ostpreußen) in Wittenberge (Sembritzki, Flucht per Bahn, S. 9). „Viele der deutschen Firmenangehörigen [des RAW Osterode] fanden nach dem 2. Weltkrieg im RAWWittenberge eine Fortsetzung ihrer Beschäftigung." (Geschichte der Stadt Ostróda - Osterode, www. ostpreußen.de [22.8.2017]). „Ab Januar 1945 kamen Flüchtlingsfamilien aus dem Paten-RAW in Osterode nach Wittenberge und fanden hier eine neue Heimat. Viele Angehörige dieser Familien sind auch heute [2001] noch mit dem Werk oder der Eisenbahn verbunden. / Nach Kriegsende musste das RAW Wittenberge wieder bei Null anfangen." (Sembritzki, 125 Jahre Eisenbahnwerkstätten, S. 105).

STRASSENumbenennungen: 1948 Rückbenennung von 1938 umbenannten Straßen: Bromberger Straße (Dallminer Straße), Danziger Straße (Motricher Straße), Posener Straße (Nebeliner Straße), Thorner Straße (Postliner Straße) (Chronik, S. 3, 9, 11).

Archivalische Quellen: BLHA, Rep. 203 MdI, Nr. 1125 (Umsiedler- und Heimkehrerstatistiken, 1945-1946; enthält: Erfassung der Umsiedler in den einzelnen Kreisen der SBZ zum 1. Dez. 1945 sowie statistische Berichte der einzelnen Gemeinden, hier Stadtkreis Wittenberge).

GedRUCKTE QueLLen und Literatur: Becker, Lieselotte: Flucht und Vertreibung aus Strese. In: Heimatgruß (Meseritz) 215 (2015), S. 32-35. - [Bolwin, Jacob:] Chronik der Missionspfarrei Wittenberge. Wittenberge [2006]. Brühe, Matthias: Katholische Kirche zwischen Prignitz und Havelland. Berlin 2000, S. 50-51. - Chronik der Stadt 
Wittenberge. Im Auftr. der Stadtverwaltung Wittenberge erarb. durch Hans Joachim Eichel, Heinz Muchow u. Günter Rodegast. Wittenberge 1997. - Dokumentation der Vertreibung I/1, S. 359, 364; I/2, S. 721. - Muchow, Heinz: Wittenberg 1945. Eine Chronologie. Wittenberge 1991. - Rodegast, Günter: „Umsiedler“ in Wittenberge. Eine Dokumentation. In: Prignitzer Heimat 29 (2001), S. 14-17. - Ders.: 6000 Flüchtlinge in der Stadt. Die Gesundheitslage in Wittenberge 1945. In: Prignitzer Heimat 58 (2015), S. 54-55. - Schwillus/Brühe, S. 354-356. - Sembritzki, Mario: 125 Jahre Eisenbahnwerkstätten in Wittenberge - Tradition, die verpflichtet. In: Jahrbuch des Prignitzer Heimatvereins Wittenberge 1 (2001), S. 105-114. - Ders.: Flucht per Bahn aus Ostpreußen. Wie die Belegschaft des Reichsbahn-Ausbesserungswerkes Osterode mit vier Zügen nach Wittenberge kam. In: BR 14 (2016) 8, S. 8-9 (Erstdruck in: Schweriner Volkszeitung, 10.2.2015). - Wille II, S. 397 f. (Seidenraupenzucht in der Stadtrandsiedlung, 1947). - Wirtschafts-Wegweiser für Wittenberge und die Kreise West- und Ostprignitz. Branchen-Adreßbuch. Potsdam (1949), S. VII-XI (Dienststellen des Stadtkreises), 3-47 (Firmen).

\section{Wittstock}

Stadtgemeinde, bis 1952 Kr. Ostprignitz, 1952-1990 Kr. Wittstock (Bez. Potsdam), 1990-1993 Ldkr. Wittstock, 1993 Ldkr. Ostprignitz-Ruppin

EREIGNISSE BIS KRIEGSENDE: 1940-1945 Unterbringung von altersheimbedürftigen Umsiedlern aus Lettland und Estland“ u. a. in der Pflegeanstalt Wittstock (Fürsorge und Wohlfahrtspflege, S. 62). - 25.4.1945: „In der Stadt ebbt der Durchstrom ab. Viele Trecks, die nach Norden ziehen." (Tagebuch eines 1945 verstorbenen Arztes, in: Kempowski, Echolot, S. 151).

EReignisse NACH KriegSende: (ca. Nov./Dez.) 1945 (Bericht der Stadtverwaltung): „Nach Fortfall des bisherigen städtischen Krankenhauses wurde behelfsmäßig ein anderes in der Stadt eingerichtet, ausserdem bestehen mehrere Isolierstationen." (Brandenburgische Gemeinden 1945, S. 197).

BevölKerungszahlen: 1925: 7681, 1939: 9010, 1946: 9460, 1964: 10292 (Städtebuch, S. 552). - (ca. Nov./Dez.) 1945 (Bericht der Stadtverwaltung): „gegenwärtig 9840 Personen, von denen 2101 Flüchtlinge und Evakuierte sind" (Brandenburgische Gemeinden 1945, S. 196).

Katholiken: 1925: 10, 1946: 839 (Städtebuch, S. 552). - Pfarrgemeinde: Die 1939 angegebene Zahl von 800 Gemeindemitgliedern war 1953 auf das Dreifache gestiegen [...]. (Brühe, S. 52). - Kuratie: „Wurden 1939 gerade 500 Katholiken gezählt, so lag ihre Zahl 1950 bei 1900.“ (Schwillus/Brühe, S. 357).

StÄdtepartnerschaften: Nach 1973 Kontakte mit Krapkowice, Polen (Krappitz, ehem. Kr. Oppeln, Oberschlesien) (Trzcielińska-Polus, S. 538).

VertriebenenVerbände NACH 1990: BdV-Kreisverband Wittstock, 1996 erwähnt mit Sitz Meyenburger Chaussee 25 (BdV-Handbuch 1996, S. 169); noch 1997 als solcher erwähnt, ab 1997 (bis zuletzt) BdV-Bereichsverband Wittstock/Dosse e. V., Sitz Wittstock, 20.1.1997 dessen Satzung errichtet, 27.10.1998 eingetragen beim Amtsgericht Neuruppin (VR 768 OPR), 18.11.1999 Satzungsänderung (eingetragen 25.4.2000); zum 1.1.2010 aufgelöst (4.12.2009 
Mitteilung an BdV-Landesverband, dass „ab 1. Januar 2010 nicht mehr besteht“). - Mitgliederzahlen: 13.3.1997 47 anwesend, 200345 Teilnehmer bei Jahreshauptversammlung, 30.11.2005: 37 Mitglieder, 31.10.2006: 34, 30.9.2007: 32, 30.9.2008 31 (Akten wie vor), zuletzt 25 Mitglieder (MAZ, 18.11.2013). - Vorsitzende: 1995 Horst Kähler, Wittstock; (13.2.1996 u. 1998 erwähnt) Herbert Müller, Wittstock (geb. 1929); 2001-2005 Wilhelm Stürmer, Freyenstein (geb. 1930, gest. 2005); ab 2005 Hannelore Krieglstein, geb. Siewert (geb. 1935), 2009 in Vollversammlung H. Krieglstein mit anderen als Liquidatoren gewählt (Akten wie vor).

Gedruckte Quellen und Literatur: Brandenburgische Gemeinden 1945, S. 195-198.- Brühe, Matthias: Katholische Kirche zwischen Prignitz und Havelland. Berlin 2000, S. 52. - Fürsorge und Wohlfahrtspflege in Brandenburg (1800-1952). Hrsg. von Margot Beck. Berlin 2002. - Kempowski, Walter: Das Echolot. 2. Aufl. München 2005. - Schwillus/Brühe, S. 357. - Trzcielińska-Polus.

\section{Wriezen/Oder}

Stadtgemeinde, bis 1952 Kr. Oberbarnim, 1952-1990 Kr. Bad Freienwalde (Bez. Frankfurt/ Oder), 1990-1993 Ldkr. Bad Freienwalde, 1993 Ldkr. Märkisch-Oderland

EREIGNisSe BIS KRIEgSEnde: Ca. 30.1.1945 (Erinnerungsbericht eines Treckführers aus Eitelsdorf/Nowawies, Kr. Znin in Posen): „[... F Fahrt über Wriezen, wo der Volkssturm mit Panzerfäusten bereitstand. In Wriezen ist eine Litzmannstädter Familie, welche bei mir evakuiert war und mit meinem Wagen mitgekommen ist, Ehepaar und zwei Kinder, von der NSV. übernommen, weil der Frau die Beine erfroren sind." (Dokumentation der Vertreibung I/1, S. 359). - 1945 unmittelbar im Kampfgebiet gelegen. „In den letzten Kriegstagen wird die Wriezener Altstadt fast völlig zerstört [...]. (Brühe, S. 51). - 19.4.1945 Einmarsch der Roten Armee. „Nach der Eroberung war Wriezen, das seit den letzten Januartagen Frontstadt war, ein einziges Trümmerfeld. Nur wenige Häuser waren stehengeblieben, darunter auch das Krankenhaus." Die Stadt ist von der Zivilbevölkerung geräumt (Wriezen, S. 19).

EREIGNISSE NACH KRIEGSENDE: [Juni 1945]: „Acht Wochen nach dem Ende der Kampfhandlungen strömten dann Zehntausende von Deutschen von jenseits der Oder durch die zerstörte Stadt, die zeitweilig zum Sperrgebiet erklärt wurde, da Typhus grassierte und Hunderte hinwegraffte." (Wriezen, S. 19). - 17.12.1945: Aus einem nach Stendal weiterfahrenden Vertriebenentransportzug aus Ostpreußen werden in Wriezen 18 Tote ausgeladen (Wille I, S. 325). - März 1947 Räumung der Stadt wegen des nach dem Deichbruch bei $\rightarrow$ Reitwein drohenden OderHochwassers (ebd.). - 1948: „Auf Zuweisung des Ev. Konsistoriums der Mark Brandenburg erhielt die Ev. Kirchengemeinde Wriezen am 23.04.1948 die Glocke 110 aus der Gemeinde Werblitz (heute Verbnica [richtig: Wierzbnica]) bei Soldin.“ (sharingheritage.de/kulturerbejahr/ europaweites-glockenlaeuten/; 6.12.2019; frdl. Hinweis Prof. Dr. Joachim Zdrenka, 5.12.2019).

Bevölkerungszahlen: 1925: 7326, 1939: 7746, 1946: 4804, 1964: 5491 (Städtebuch, S. 557). 
KATHOLIKEN: 1925: 229, 1946: 237 (Städtebuch, S. 557).

(KREIS-)UMSIEDLERLAGER WRIEZEN (Kreisquarantänelager), auf dem zuvor zuletzt als Kriegsgefangenenlager genutzten Hof der NSKK-Panzerfahrschule, hinter dem 1945/46 als Typhusstation genutzten Rathaus, Freienwalder Straße 50 (Schmook): Provinzialgesundheitsamt, 18.10.1945: „Auf Grund der örtlichen Verhältnisse [...] kommt als Auffanglager in dem [...] Gebiet lediglich das ehemalige OT-Lager in Wriezen in Frage, wofür jedoch bisher noch keinerlei Vorbereituntgen getroffen worden sind. Vorbereitende Aufnahmemöglichkeiten zur Unterbringung von Umsiedlern bestehen in dem gesamten bezeichneten Gebiet nicht, mit Ausnahme einer Turnhalle in Wriezen (100-150 Umsiedler Fassungsraum).“ (Wille I, S. 414). - 22.10.1945 Lagerleiter Bogatzki erwähnt (BArch, DO 2/39, Bl. 10). - 23.10.1945 Durchangslager Wriezen erwähnt mit Kapazität 1500 Personen, Lagerleiter: Erich Mitschke. Umfang: 4 Baracken auf dem Gelände der Motorsportschule (900 Personen), 1 Turnhalle (300), 1 Baracke (100), 1 Schuppen (100), 1 Saal (100). (BArch, DO 2/39, Bl. 13). - 3.11.1945 Lagerleiter Wolff erwähnt (ebd., Bl. 3940). - Dez. 1945 findet im Lager eine Seuchen- u. Hygiene-Inspektion durch die Hauptabt. Sanitätswesen der Zentralverwaltung für Gesundheit statt (Wille I, S. 423). - 18.12.1945 (Bericht des Schutzpolizeikommandos): Umsiedlerlager besteht aus Lager I und II (I: „Lager I befindet sich in der ehemaligen NSKK-Sportschule [...] in unmittelbarer Nähe des Hafen-Anschlussgleises. Es besteht aus 5 Wohnbaracken mit einem Fassungsvermögen von ca. 700 Personen. [...]. Hinzu kommen eine Turnhalle, in der etwa 150 Personen und der Saal des Gesellschaftshauses, in dem ca. 120 Personen Unterkunft finden würden. Insgesamt könnten 970 Personen im Lager I untergebracht werden. / [...] / Das Lager II besteht aus 13 Wohnbaracken mit einem Fassungsvermögen von ca. 1270 Personen. / [...] / Der Lagerbestand des Lagers Wriezen beträgt zur Zeit 240 Personen, dem gegenüber steht das Verwaltungspersonal mit 135 Personen." (BArch, DO 2/105, unfol.). 21.12.1945 7. Transport (1131 Personen), 27.12.1945 8. Transport (1849), 30.12.19459. Transport (758), 21.1.1946 10. Transport (1415), 24.1.1946 11. Transport (64) (ebd., Bericht der Schutzpolizei, Einsatz-Kommando Wriezen vom 31.1.1946). - Kapazität am 31.12.1945 (Lager „Wriezen-Motorsportschule“): 1800 (BArch, DO 2/45, Bl. 40). - Kapazität am 1.1.1946: 1000 (BLHA, Rep. 203 MdI, Nr. 1163, Bl. 49). - 18.1.1946 (in $\rightarrow$ Freienwalde u. Wriezen): „Hygienische Verhältnisse gänzlich unzulänglich [...]. Einfache Strohschütten, keine Decken, keine Bettwäsche, keine Waschschüsseln, keine Seife. Ernährung ebenfalls unzureichend, Abortanlagen unzulänglich (in Wriezen keine Bedachung) [...]." (Wille I, S. 423). - 14.2.1946 Kreis- und Quarantänelager, Kapazität: 1000 (Oehlsen, S. 28). - 1946 Belegungsstärke: 800 (Kaminsky, S. 159). - 30.4.1946 als eines der verbleibenden Umsiedlerlager genannt (DAB, I/9-15-1 Flüchtlingsseelsorge 1945-1951, unfol., [30.6.1946], [Anlage 3]). - 24.8.1946 Umsiedlerlager, Kapazität: 1000 (SAPMO-BArch, DY 34/27880, Bl. 291). - In Lagerliste vom 1.1.1947 nicht aufgeführt (Oehlsen, S. 101).

STÄDTISCHER FriedhoF: 1945 fanden hier „zahlreiche Flüchtlinge und Vertriebene die letzte Ruhestätte“ (Kirchen im Oderbruch, S. 146). 
StÄDtepartnerschaften: [Nach 1990] Mieszkowice, Polen (Bärwalde/Neumark, ehem. Kr. Königsberg/Neumark, Provinz Brandenburg).

Archivalische Quellen: BArch, DO 2 ZVU, Nr. 39, Bl. 10, 13, 31, 39-40, 55-57 (Umsiedlerlager, 1945). - BArch, DO 2/105: Umsiedlerlager Küstrin und Wriezen, 1945-1949.

Quellen und Literatur: Brühe, Matthias: Katholische Kirche zwischen Uckermark und Oderland. Berlin 1998, S. 50-51. - Dokumentation der Vertreibung I/1, S. 359. - Fiddecke, Marlies: Dr. Hans Schmorell - Arzt in Wriezen und Pazifist. In: Jahrbuch Märkisch-Oderland 25 (2018), S. 51-53 [Geb. 1897 Memel, Chirurg und Gynäkologe, 1935-1953 Leiter des Krankenhauses in Wriezen]. - Kirchen im Oderbruch und ihre Schicksale seit dem Frühjahr 1945. Berlin 1992, S. 143-146. - Wille I, S. 260, 423. - Wriezen. Die Stadt mußte von 1945 bis 1957 zweimal geräumt werden. In: Berlin-Brandenburger Kurier. Sondernr. für die Kreise Ober- und Niederbarnim [1958], S. 19-20. - Auskünfte Dr. Reinhard Schmook, Oderlandmuseum Bad Freienwalde, 15.10.2016.

\section{Wünsdorf}

Landgemeinde (seit 2003 Ortsteil der Stadt $\rightarrow$ Zossen), bis 1952 Kr. Teltow, 1952-1990 Kr. Zossen (Bez. Potsdam), 1990-1993 Ldkr. Zossen, 1993 Ldkr. Teltow-Fläming

EReignisse NaCh Kriegsende: (ca. Nov./Dez.) 1945 (Bericht des Gemeindevorstehers): „Wünsdorf war Heeresstandort und ist durch den Kriegsausgang in seiner Bedeutung stark benachteiligt. Alle Wehrmachtsanlagen sind aufgelöst; über das Schicksal der nicht beschädigten Gebäude besteht noch keine Klarheit. Zur Zeit ist der Ort von Truppen der Roten Armee stark besetzt. Die wirtschaftliche Entwicklung ist noch stark beeinträchtigt. Die Unterbringung der vielen russischen Offiziere in Privatquartiere und die Unterbringung der Flüchtlinge und und ausquartierten Bevölkerung macht erhebliche Schwierigkeiten." (Brandenburgische Gemeinden 1945, S. 201).

BeVÖLKeRUnGSZAHLEN: 1925: 1 138, 1939: 3 153, 1946: 3383, 1964: 2574 (HOL IV, S. 354).

\section{Wußwerk}

Landgemeinde (seit 2003 Ortsteil der Gemeinde Alt Zauche-Wußwerk), bis 1952 Kr. Lübben, 1952-1990 Kr. Lübben (ab 1952 Bez. Cottbus), 1990-1993 Ldkr. Lübben, 1993 Ldkr. DahmeSpreewald

BeVÖLKERUNGSZAHLEN: 1925: 261, 1939: 273, 29.10.1946: 386, 1950: 363, 1964: 257 (HGV LDS, S. 14f.).

FLÜCHTLINGSLAGER (bis 1945 Barackenlager des Reichsarbeitsdienstes): 1945 erwähnt (Becken, S. 28).

LITERATUR: Becken, Jörg: Lübben nach dem Inferno. Die Jahre 1945-61. [Cottbus] 2010. 


\section{Wusterhausen/Dosse}

Stadtgemeinde, bis 1952 Kr. Ruppin, 1952-1990 Kr. Kyritz (Bez. Potsdam), 1990-1993 Ldkr. Kyritz, 1993 Ldkr. Ostrignitz-Ruppin

EREIGNISSE NACH KRIEGSENDE: 29.7.1946 ist der erste Transport mit Umsiedlern aus der Tschechoslowakei im Kreis Ruppin eingetroffen und in den Bezirk Wusterhausen zwecks Eingemeindung weitergeleitert worden.“ (Wille II, S. 205). - 1948: Zur „Umsiedler“-Problematik und ihrer Aufnahme durch die „Einheimischen“ dreht der Regisseur Arthur Pohl für die DEFA den Spielfilm „Die Brücke“ „in [ $\rightarrow$ ] Zehdenick an der Havel und zum großen Teil in Wusterhausen/Dosse“; Premiere 28.2.1949 in Berlin (Wikipedia [26.6.2018]; www.defa-stiftung.de/1949 [10.7.2018]).

EREIGNISSE NACH 1990: Seit ca. 2000 jährliche „Heimattreffen der Schweriner“ (Vertriebene aus dem ehem. Kreis Schwerin/Warthe [zuletzt Provinz Brandenburg, zuvor bis 1938 Provinz Grenzmark Posen-Westpreußen]), anfangs in der „Dossehalle“ (Zur Dossehalle 6) mit über 300 Teilnehmern aus dem gesamten Bundesgebiet, am 2.7.2016 im „Stadtsaal“ mit rund 40 Teilnehmern aus dem gesamten Bundesgebiet, „vor allem aber aus dem Kyritzer Altkreisgebiet selbst. Denn hierher verschlug es am Ende des Zweiten Weltkriegs sehr viele Bewohner des damaligen Kreises Schwerin an der Warthe [...]." (MAZ, 3.7.2016).

BevölkerungSZAHLEN: 1925: 2671, 1939: 2 863, 1946: 4040, 1964: 3227 (Städtebuch, S. 561).

Katholiken: 1925: 57, 1946: 333 (Städtebuch, S. 561). - „Kurzzeitig bestanden nach dem II. Weltkrieg von heimatvertriebenen Priestern betreute Seelsorgestellen in [...], Wusterhausen (1945-46) [...].“ (Schwillus/Brühe, S. 330). - „Nach dem II. Weltkrieg war hier von Oktober 1945 bis Januar 1946 der aus der Prälatur Schneidmühl heimatvertriebene Pfr. Karl Joseph Hawlitzky als Lokalkaplan tätig; er übernahm dann die Gemeinde $\rightarrow$ Bad Wilsnack." (Brühe, S. 56).

StÄDtepartnerschaften: 19.10.2014 (Absichtserklärung unterzeichnet) Przytoczna, Polen (Prittisch, ehemals Kr. Schwerin/Warthe), auf Anregung von Fleischermeister Klaus Ribbe (Vorsitzender des Wusterthausener Gewerbevereins), dessen Mutter aus Prittisch stammt. „Die Region ist einer ganzen Reihe von Wusterhausenern aus ihrer Kindheit gut bekannt." (www.wuster hausen.de [7.7.2017]; MAZ, 12.7.2014).

VERTRIEBENENVERBÄNDE NACH 1990: BdV-Kreisverband Wusterhausen 2005 erwähnt (BR 3 (2005)2, S. 30). - 25.2.2012 Informationsveranstaltung des BdV-Kreisverbandes $[\rightarrow]$ Kyritz im Klubraum der Pro Seniorenpflege in Wusterhausen mit „mehr als 50 BdV-Mitglieder(n)“ und Referat des Bundestages-Referenten für Vertriebene und Flüchtlinge Sven Oole (geb. 1970) (CDU) aus Berlin (BR 10 (2012)3, S. 16). - 2014 mit dem Wechsel des Vorsitzenden zu dem in Wusterhausen tätigen Sebastian Groß Kontakadresse von Kyritz nach Wusterhausen, Am Markt 1, verlegt (MAZ, 12.7.2014). 
Gedruckte Quellen und Literatur: Brühe, Matthias: Katholische Kirche zwischen Prignitz und Havelland. Berlin 2000, S. 56. - Schwillus/Brühe, S. 330. - Wille I, S. 372.

\section{Wustermark}

Landgemeinde, bis 1952 Kr. Osthavelland, 1952-1990 Kr. Nauen (Bez. Potsdam), 1990-1993 Ldkr. Nauen, 1993 Lkr. Havelland

BevöLKeRUnGSZAHLEN: 1925: 873, 1939: 1 038, 1946: 1340, 1964: 1831 (HOL III, S. 426).

Katholiken: „Schon bald nach Ende des II. Weltkriegs wurde in Wustermark in der evangelischen Kirche für hier angesiedelte Heimatvertriebene monatlich Hl. Messe gefeiert. Zuständig war Pfr. Karl Joseph Hawlitzky aus $[\rightarrow]$ Dallgow-Döberitz, der nun zusammen mit seiner Pfarrhelferin Sr. Tabitha Heuss die Nutzung des Gebäudes für die katholischen Christen erreichen konnte. Die Gemeinde spendete Stühle für die Ausstattung. [...].“ 1968 nach $\rightarrow$ Nauen umgepfarrt (Brühe, S. 53).

Literatur: Brühe, Matthias: Katholische Kirche zwischen Prignitz und Havelland. Berlin 2000, S. 53.

\section{Wustrau}

Landgemeinde (1974-2003 Ortsteil von Wustrau-Altfriesack, seit 2003 von Fehrbellin), bis 1952 Kr. Ruppin, 1952-1990 Kr. Neuruppin (Bez. Potsdam), 1990-1993 Ldkr. Neuruppin, 1993 Lkr. Ostprignitz-Ruppin

FlÜChtLINGSLAGER: Das am Dorfrand befindliche Lager des Reichsarbeitsdienstes wurde im Zweiten Weltkrieg als Gefangenenlager für muslimische Soldaten der Ostlegionen (Tataren) und danach als Flüchtlingslager genutzt. Eine Monographie zum Gefangenenlager wird von Dr. Stephan Theilig vorbereitet (Märkische Allgemeine, 7.5.2017; Mitteilung Dr. St. Theilig, 17.8.2017).

GedenksteIN (Findling) in Grünanlage nahe dem Eingang zum „Brandenburg-PreußenMuseum“: Inschrift (in Versalien): „Den Opfern der Vertreibung aus Preussen 1945-1950 / Pommern Westpreussen Ostpreussen Memelland Ostbrandenburg Schlesien" (Abb. in: wikipedia/Liste der Vertriebenendenkmale in Brandenburg [20.9.2016]). - Der vom Museumsgründer, dem Berliner Bankier Ehrhardt Böddecker (1925-2016), persönlich initiierte und gestiftete Stein wurde gleichzeitig mit der Eröffnung des Museums im Sept. 2000 präsentiert (angefertigt August 2000 in Rheinsberg von der Firma Steinmetzbetrieb Scherhag; Steinmetz: Tilo Walz); „unbearbeiteter Findling (2,8 t), Beschriftung tief eingemeißelt und mit dunkelbrauner Farbe farbig ausgetönt" (Auskunft des Museumsleiters Dr. St. Theilig aus der Datenbank des Museums, 12.9.2017). 


\section{Wutike}

Landgemeinde (seit 2002 Ortsteil von Gumtow), bis 1952 Kr. Ostprignitz, 1952-1990 Kr. Kyritz (Bez. Potsdam), 1990-1993 Ldkr. Kyritz, 1993 Ldkr. Prignitz

EREIGNISSE BIS KrIEgSENDE: Vor Kriegsende 1945 Einweisung zahlreicher Flüchtlinge bei Bauern und in der Schule, u. a. eine Familie aus Dombrowice in Polen (siehe Bericht von Anna Glass), aber auch Bombenkriegsevakuierte aus Berlin (Gass, S. 126, 128)

EREIGNISSE NACH KRIEGSENDE: Unterrichtsausfall bis Sept. 1945 durch Belegung der Schule mit Flüchtlingen (ebd., S. 144).

BevÖLKERUNGSZAHLEN: 1925: 494, 1939: 483, 1946: 817, 1964: 591 (HOL I, S. 1019).

Gedruckte Quellen: Glass, Anna: Als Flüchtlinge in Brandenburg. In: Die Vergangenheit lebt in uns. Potsdamer erinnern sich. Hrsg. von Franz Fabian. Milow 2007, S. 126-146 [Erinnerungsbericht des Kindes einer Flüchtlingsfamilie].

\section{Zaatzke}

Landgemeinde (seit 2003 Ortsteil von $\rightarrow$ Heiligengrabe), bis $1952 \mathrm{Kr}$. Ostprignitz, 1952-1990 Kr. Wittstock (Bez. Potsdam), 1990-1993 Ldkr. Wittstock, 1993 Ldkr. Ostprignitz-Ruppin

EREIGNISSE NACH KRIEGSENDE: 1947 Durchführung eines „Landsberger Kirchentages“ für Vertriebene aus Stadt und Kreis Landsberg/Warthe (Ehemalige Kirchengemeinden von Landsberg ..., Jan. 1948, S. 3).

BeVÖLKERUNGSZAHLEN: 1925: 462, 1939: 515, 1946: 780, 1964: 648 (HOL I, S. 1022).

LiterATUR: Ehemalige Kirchengemeinden von Landsberg, Warthe, Stadt und Land, 1. Monatsbericht, Jan. 1948 , S. 3.

\section{Zäckericker Loose}

Landgemeinde (bis 1945 Ortsteil der östlich der Oder gelegenen Gemeinde Zäckerick [Kr. Königsberg/Nm.], seit 2003 Ortsteil von Oderaue), bis 15.3.1946 (Rest-)Kr. Königsberg/Nm., 1946-1952 Kr. Oberbarnim, 1952-1990 Kr. Bad Freienwalde (Bez. Frankfurt/Oder), 1990_ 1993 Ldkr. Bad Freienwalde, 1993 Ldkr. Märkisch-Oderland

EReignisse NACH Kriegsende: 1945 Abtrennung von der Gemeinde Zäckerick durch die neue Grenzziehung an der Oder (Blöß, Kreise und Gemeinden, S. 148). - „Nach dem Kriegsende siedelten sich Vertriebene aus den nun polnisch verwalteten ostdeutschen Gebieten an. So wohnten 1946391 Einwohner im Ort." (Wikipedia, Zäckericker Loose, 5.1.2017). - Am 12.6.1946 bestehen im Ort drei von Vertriebenen eingerichtete [Ein-Mann-]Handwerksbetriebe („Umsiedlerbetriebe“) (Wille II, S. 365). - 3.10.1950 Zuweisung von westlich der Oder 
gelegenen Flächen der nun polnischen Gemeinde Zäckerick/Siekierki (ehem. Kr. Königsberg/ Nm.) an die Gemeinde Zäckericker Loose (Blöß, Kreise und Gemeinden, S. 31).

BeVÖLKeRUnGSZAHLEN: 1925: 400, 1939: 400, 29.10.1946: 475, 1950: 391, 1964: 316 (HGV MOL, S. 30 f.).

LiterATUR: Schneider, Joachim: Die Oder während der Kriegshandlungen im Frühjahr 1945. In: Historischer Verein zu Frankfurt (Oder) e. V. Mitteilungen 2001, H. 2, S. 7-21, hier S. 14 (Brücken bei Zäckerick).

\section{Zeesen-Körbiskrug $\rightarrow$ Körbiskrug}

\section{Zehdenick}

Stadtgemeinde, bis 1952 Kr. Templin, 1952-1990 Kr. Gransee (Bez. Potsdam), 1990-1993 Ldkr. Gransee, 1993 Ldkr. Oberhavel

EREIGNISSE BIS KRIEGSENDE: 29.4.1945 Einmarsch der Roten Armee (Städtebuch, S. 567).

EReignisse NACH Kriegsende: 1945: „Einige Tanzsäle, wie z.B. das Schützenhaus, dienten der notdürftigen Unterkunft von Umsiedlern. Diese Menschen sollten verpflegt und nach und nach in Wohnungen eingewiesen werden. Immer wieder waren es die Mitglieder des antifaschistischen Frauenausschusses, die uneigennützige Hilfe leisteten. Große Körbe voller Schnitten wurden zubereitet. Überall, wo eine größere Kochgelegenheit bestand, wurde Essen gekocht. Die Zutaten gaben zuerst die Organe der Roten Armee. Fleißige Ausschußmitglieder trugen Lebensmittelspenden für die Umsiedlerbetreuung zusammen. / Es gab skrupellose Einwohner der Stadt, die sich an Hab und Gut von Familien, die Zehdenick vorübergehend verlassen hatten, bereicherten. Sie fingen an, Schwarzmarktgeschäfte mit lebennotwendigen Gütern zu betreiben. $[\ldots][\ldots]$ So hatte z.B. der Sattler und Polsterer Luther eine größere Menge von Stoffen gehortet. Die Volkskontrolle beschlagnahmte diese und beauftragte den Frauenausschuß mit der Verteilung an die Umsiedler. / [S. 111] Das größte Schieberlager wurde beim Drogisten Hein gefunden. [...] Der Warenbestand an Textlien und Lebensmitteln wure auf mehrere Tausend Mark geschätzt. Dadurch konnte Hunderten von Umsiedlern geholfen werden. / An anderen Stellen wurden Kleidungsstücke sichergestellt, die ebenfalls an Hilfsbedürftige ausgegeben werden konnten. Bei Chlupke (heute PGH Holzschuhmacher) konnte die Kriminalpolizei einige Nähmaschinen sicherstellen. Auf Veranlassung von Johanna Sühring und Frieda Wagner wurden diese zum Bekleidungswerk geschafft, um dort in der Aktion ,Aus Alt mach Neu' für Umsiedler und Notleidende Kleider und Anzüge herzustellen. Später wurde am Markt durch den Frauenausschuß eine Nähstube geschaffen, die die gleiche Aufgabe hatte./ 1947 wurde eine Volksküche errichtet, wo viele Umsiedler, die keine Kochgelegenheit hatten, ein warmes Mittagessen erhielten. Initiatoren dieser Einrichtung waren wieder Mitglieder des Frauenausschuses. Die Leitung hatte die Freundin Hanna Sühring. Mitarbeiter waren die Freundinnen 
Kahle, Jetzki, Norbert, Rau und Schmidt. Sie versorgten täglich 180 bis 200 Einwohner mit warmem Essen. Daß dies nicht einfach war, kann man sich vorstellen." (Rau/Wegener, S. 10 f.). Okt. 1945: „Ein Umsiedlerlager mit 300 Personen befindet sich auf der Ziegelei Prerauer an der Waldstraße. Zahlreiche Personen sterben dort an Typhus. [...].“ (Gatzke, S. 166). - 7 „Umsiedlerfamilien" sind 1946 in Baracken des ehem. RAD-Lagers untergebracht (BLHA, Rep. 333, Nr. 574, B1. 32-34). - Ende Juli 1948 im Verzeichnis (von der Landesregierung) verbotener Suchdienste erwähnt: Maria Pollanetz, Zehdenick/Ha[vel]., Hauptstr. 35 (BLHA, Rep. 203 MdI, Nr. 1197, Bl. 41). - 1948: Zur „Umsiedler“-Problematik und ihrer Aufnahme durch die „Einheimischen“ dreht der Regisseur Arthur Pohl für die DEFA den Spielfilm „Die Brücke“ „in $[\rightarrow]$ Zehdenick an der Havel und zum großen Teil in Wusterhausen/Dosse“; (Gatzke, S. 167) Premiere 28.2.1949 in Berlin (Wikipedia [26.6.2018]; www.defa-stiftung.de/1949 [10.7.2018]).

EREIGNISSE NACH 1990: Ab 16.11.2010 (Wander-)Ausstellung „Meine Ostpreußen“ in der CDU-Geschäftsstelle, anschließend 2011 in $\rightarrow$ Erkner u. zuvor in $\rightarrow$ Oranienburg gezeigt (konzipiert u. gestaltet von Angelika u. Olaf Pasenau, $\rightarrow$ Gransee).

BeVÖLKERUNGSZAHLEN: 1925: 9 182, 1933: 11 173, 1938: 12 460, 1939: 12 544, 1945: 13218 („Nach Aufnahme zahlreicher Umsiedler“), 1946: 13246, 1964: 12358 (Städtebuch, S. 565; Festschrift 1967, S. 142). - „Im Oktober [1945] hat Zehdenick 13218 Einwohner, davon 2744 Umsiedler und Evakuierte aus Berlin.“ (Gatzke, S. 166). - 1952: „Durch den Umsiedlerzustrom steigt die Bevölkerung auf 18000 ، (ebd.).

Katholiken: 1925: 989, 1946: 1449 (Städtebuch, S. 565). - „Nach 1945 war ein großer Zuzug von Ostflüchtlingen, die nun den neuen Stamm der [Katholischen Kirchen-] Gemeinde bildeten.“ (Kort/Giering, S. 60). - „In der Amtszeit von Pfr. Joseph Eismann (1937-50) wuchs die Gemeinde durch Zuzug von Flüchtlingen von 1100 auf weit über 2000 Katholiken." (Brühe, S. 54; textähnlich in: Schwillus/Brühe, S. 353).

UMSIEDLERLAGER: Okt. 1945: „Ein Umsiedlerlager mit 300 Personen befindet sich auf der Ziegelei Prerauer an der Waldstraße. Zahlreiche Personen sterben dort an Typhus. [...]. (Gatzke, S. 166). - 1948: „Das Kloster wird als Unterkunft für Flüchtlinge genutzt.“ (ebd., S. 167).

Städtepartnerschaften: 10.3.2007 Siemiatyce (Podlachien, Polen) (wikipedia/Zehdenick [3.8.2018]).

GedRUCKTe QUellen und Literatur: Brühe, Matthias: Katholische Kirche zwischen Prignitz und Havelland. Berlin 2000, S. 54. - Dokumentation der Vertreibung I/1, S. 359. - Gatzke, Margitta: Zeittafel von 1945 bis 1989. In: Festbuch 800 Jahre Zehdenick. Karlshagen 2016, S. 166-169. - Kort, Eberhard / Giering, Gregor: Aus der Chronik der Katholischen Kirchengemeinde „Maria Himmelfahrt“ in Zehdenick. In: Festschrift 775 Jahre Zehdenick. Zehdenick 1992, S. 57-63. - Rau, Lucie / Wegener, Frieda: 20 Jahre DFD in Zehdenick. In: Festschrift zur 750-Jahr-Feier der Havelstadt Zehdenick. Zehdenick 1967, S. 109-112. - Entwickung der Einwohnerzahlen der Stadt Zehdenick. In: ebd., S. 142. - Schwillus/Brühe, S. 353. 


\section{Zelliner Loose}

Landgemeinde (bis 1945 Ortsteil der östlich der Oder gelegenen Gemeinde Zellin [Kr. Königsberg/Nm.], seit 2003 Ortsteil von $\rightarrow$ Letschin), bis 15.3.1946 (Rest-)Kr. Königsberg/Nm., 1946-1950 Kr. Oberbarnim, 1.7.1950-1990 Kr. Seelow (ab 1952 Bez. Frankfurt/Oder), 19901993 Ldkr. Seelow, 1993 Ldkr. Märkisch-Oderland

EReignisse NACH KRIEgSende: 1945 Abtrennung von der Gemeinde Zellin durch die neue Grenzziehung an der Oder (Blöß, Kreise und Gemeinden, S. 148). - 3.10.1950 Zuweisung von westlich der Oder gelegenen Flächen der nun polnischen Gemeinden Alt Blessin/Stary Błeszyn und Zellin/Czelin (ehem. Kr. Königsberg/Nm.) an die Gemeinde Zelliner Loose (Blöß, Kreise und Gemeinden, S. 31 f.).

BeVÖLKerungszahlen: 1925: 100, 1939: 103, 29.10.1946: 83, 1950: 112 (HGV MOL, S. $26 f$.).

GeDRUCKTE QuelLen: Dokumentation der Vertreibung I/1, S. 390 (Zellin).

\section{Zernitz}

Landgemeinde (seit 1997 Ortsteil von Zernitz-Lohm), bis 1952 Kr. Ostprignitz, 1952-1990 Kr. Kyritz (Bez. Potsdam), 1990-1993 Ldkr. Kyritz, 1993 Ldkr. Ostprignitz-Ruppin

BevöLKeRUngSZAHLEN: 1925: 585, 1939: 674, 1946: 1 163, 1964: 919 (HOL I, S. 1043).

Gemeindepartnerschaft: Nach 1973 Kontakte mit Baborów bei Opole, Polen (Bauerwitz, ehem. Kr. Leobschütz, Oberschlesien) (Trzcielińska-Polus, S. 538).

\section{Zernsdorf}

Landgemeinde (seit 2008 Stadtteil von $\rightarrow$ Königs Wusterhausen), bis 1952 Kr. Teltow, 19521990 Kr. Königs Wusterhausen (Bez. Potsdam), 1990-1993 Ldkr. Königs Wusterhausen, 1993 Ldkr. Dahme-Spreewald

EREIGNisSe NACH KRIEgSEnde: Keine Bodenreform (HOL IV, S. 370).

BevölKeRUngSZAHLEN: 1925: 948, 1939: 1 638, 1946: 2 125, 1964: 2205 (HOL IV, S. 370).

UMSIEDLERLAGER: Kapazität am 31.12.1945: 800 (BArch, DO 2/45, Bl. 40). - Kapazität am 1.1.1946: 600 (BLHA, Rep. 203 MdI, Nr. 1163, Bl. 50). 


\section{Zeschdorf-Alt Zeschdorf $\rightarrow$ Alt Zeschdorf}

\section{Zeuthen}

Landgemeinde, bis 1952 Kr. Teltow, 1952-1990 Kr. Königs Wusterhausen (Bez. Potsdam), 1990-1993 Ldkr. Königs Wusterhausen, 1993 Ldkr. Dahme-Spreewald

EReignisse bis Kriegsende: „Das größte Problem waren die Flüchtlinge. Sie kamen aus Schlesien und Pommern mit Hand- und Pferdewagen, mit Kühen und Ziegen. Es waren Tausende, die durch [S. 346] Zeuthen zogen oder in Zeuthen blieben. [...].“ (Zeuthen, Bd. 1, S. 345 f.). 25.4.1945 Einmarsch der Roten Armee (Zeuthen, Bd. 1, S. 349 f.; Bd. 2, S. 56).

EREIGNISSE NACH KRIEGSENDE: „Ein weiterer starker Eindruck der ersten Wochen und Monate waren die Tausende von Flüchtlingen, die - soweit ich mich entsinne - erst nach dem 8. Mai durch Zeuthen zogen bzw. zum Teil hier blieben. Meist blieben die Flüchtlinge aus einem bestimmten Ortzusammen und wurden wieder gemeinsam einem Ort zugewiesen. / Erster Aufnahmeort war die Schule. Dann fand eine Versammlung auf der Dorfaue statt, wo die Flüchtlinge auf die Häuser verteilt wurden. Auch ich bekam zu ,meinem' einquartierten Rotarmisten noch Flüchtlinge dazu. / Der erste Bürgermeister (SPD) und der Kommandant hatten angeordnet, daß ein Flüchtlingskomitee zu bilden sei. Ich arbeitete dort mit, und wir sammelten und verteilten u. a. Hausrat und Kleidung. Ein Altersheim, das wir einrichten wollten, kam damals trotz großer Nachfrage leider nicht zustande. Aber auf Befehl des Kommandanten ein Kindergarten, und zwar in der Villa am See, in der vorher das ,Rote Komitee' gearbeitet hatte." (Zeuthen, Bd. 2, S. 204, Interview mit Hertha Elwert 1985, 1945 SPDMitglied, dann von der SED mit der Organisation der Gewerkschaftsarbeit beauftragt). - „Die ankommenden Flüchtlinge wurden in der Schule gesammelt, das mitgebrachte Vieh auf der Wiese am Graben angebunden. In der Dorfaue erfolgte die Verteilung auf die Häuser, fast jedes Haus nahm Flüchtlinge auf. Viele dieser Flüchtlinge waren so geschwächt, daß sie starben. Die Anzahl derer war so groß, daß eine normale Bestattung nicht mehr möglich war. So wurden die Toten auf dem Friedhof in Zeuthen in Massengräbern (zumeist ohne Sarg) beigesetzt. (H.G. Schrader nach Augenzeugenberichten; in: 1945. Das Jahr in der Region Dahme-Spreewald. T. 2, S. 18).

BevölKerungszahlen: 1925: 2023, 1939: 4 135, 1946: 4 166, 1964: 9085 (HOL IV, S. 372); 1950: 4817 (HGV LDS, S. 35).

Archivalische Quellen: ELAB, Flüchtlingsbuch (evang. Kirchenbuch), 1948-1951.

Gedruckte Quellen und Literatur: 1945. Das Jahr in der Region Dahme-Spreewald. Dokumentation zur Geschichte. T. 1-2.Zeuthen 2009-2010. - Zeuthen. Geschichte und Geschichten. Zsgest. von Hans-Georg Schuster. Bd. [1]-2. Horb am Neckar 1998-2001 [Erlebnisberichte aus den Jahren 1945/46: Bd. 1, S. 345-348; Bd. 2, S. 202-214]. 


\section{Ziesar}

Stadtgemeinde, bis 1950 Kr. Jerichow I (Provinz Sachsen bzw. Land Sachsen-Anhalt), 19501952 Ldkr. Burg (Land Sachsen-Anhalt), 1952-1990 Kr. Brandenburg-Land (Bez. Potsdam), 1990-1993 Ldkr. Brandenburg, 1993 Ldkr. Potsdam-Mittelmark (Land Brandenburg)

BeVÖLKERUNGSZAHLEN: 1925: 2513, 1939: 2 802, 1946: 3598, 1948: 3768, 1964: 2954. „Zuwanderung [...] nach 1945 über 1000 Flüchtlinge u. Vertriebene (v. a. aus Schlesien, Pommern, Böhmen)“ (Städtebuch, S. 570).

Katholiken: 1939: 50, 1946: 505, 1948: 549. „deutl. Zunahme der Zahl der kath. Einwohner nach 1945 durch Flüchtlinge“ (Städtebuch, S. 570).

\section{Ziltendorf}

Landgemeinde, bis 1952 Kr. Guben, 1952-1990 Kr. Fürstenberg/Oder bzw. (ab 1961) Kr. Eisenhüttenstadt-Land (Bez. Frankfurt/Oder), 1990-1993 Ldkr. Eisenhüttenstadt, 1993 Ldkr. Oder-Spree

EReignisse NACH Kriegsende: Vertriebene aus Kreutz (poln. Krzyż) im Kr. Grünberg in Schlesien wurden anfangs in Ziltendorf einquartiert, bis sie im benachbarten $\rightarrow$ Aurith Land zugeteilt erhielten (Aurith - Urad, S. 29). - 3.10.1950 Zuweisung von westlich der Oder gelegenen Flächen der nun polnischen Gemeinde Aurith/Urad (ehem. Kr. Weststernberg) an die Gemeinde Ziltendorf (Blöß, Kreise und Gemeinden, S. 31), nun deren Ortsteil $\rightarrow$ Aurith. 1995/96 Neubau einer evang. Kirche (Vorgänger 1945 zerstört) und Einbau von zwei im Zweiten Weltkrieg auf den Hamburger „Glockenfriedhof“ gelangten Glocken aus ehemaligen neumärkischen Dorfkirchen (die größere aus Drehnow bei Crossen/Oder) (Fromm, S. 89).

BEvöLKerungSZAHLEN: 1925: 1431, 1939: 1414 (HOL NL II, S. 281). - 26.6.1945: 1000 („Die russische Kommandantur verlangt ..., S. 21). - 24.7.1945: 1146 („Die russische Kommandantur verlangt ..., S. 38). - 17.8.1945: 1008 , davon 215 Flüchtlinge (ebd., S. 48).

GedRuckte Quellen: „Die russische Kommandantur verlangt ...“ Eine regionale Quellensammlung der ersten Nachkriegsjahre für Fürstenberg (Oder) und Umgebung 1945-1949. Eisenhüttenstadt 2003.

Literatur: Aurith - Urad. Zwei Dörfer an der Oder - dwie wioski nad Odra. 2., korr. Aufl. Potsdam 2009, S. 29. Fromm, Günter: Bodenreform 1945/46 in Ziltendorf - Ortsteile Thälmannsiedlung und Aurith. In: Heimatkalender Eisenhüttenstadt und Umgebung 15 (1997), S. 80-86. - Ders.: Ziltendorf hat wieder eine Kirche. In: ebd., S. 87-89. Schneider, Joachim: Die Oder während der Kriegshandlungen im Frühjahr 1945. In: Historischer Verein zu Frankfurt (Oder) e. V. Mitteilungen 2001, H. 2, S. 7-21, hier S. 17 f. (Überflutung). 


\section{Zinna (Dorf) (Kr. Jüterbog-Luckenwalde) $\rightarrow$ Neuheim}

\section{Zossen}

Stadtgemeinde, bis 1952 Kr. Teltow, 1952-1990 Kr. Zossen (Bez. Potsdam), 1990-1993 Ldkr. Zossen, 1993 Ldkr. Teltow-Fläming

EREIGNisSe BIS KRIEgSENDE: April 1945 weicht das Ende Jan. nach $\rightarrow$ Finsterwalde evakuierte Reserve-Lazarett Meseritz nach Zossen aus. „Dort war seines Bleibens nur kurze Zeit. Dann setzte es sich weiter über $[\rightarrow]$ Nauen nach Mecklenburg ab.“ (Hielscher, Bl. 16).

EREIGNISSE NACH KRIEGSENDE: 1970-1988 war Superintendent des evang. Kirchenkreises Zossen der zuvor ab 1959 in Libbenichen (Kr. Lebus) als Pfarrer wirkende spätere Propst HansOtto Furian (geb. 1931 Arnswalde, gest. 2002 Berlin), Sohn des Pfarrers u. Superintendenten Hans-Georg F. in $\rightarrow$ Nauen (wikipedia).

Bevölkerungszahlen: 1925: 4841 (5229 mit Wohnplätzen), 1939: 5928, 1946: 5958, 1964: 4964 (Städtebuch, S. 575).

Katholiken: 1925: 234, 1946: 512 (Städtebuch, S. 575). - Pfarrei: 1939: etwa 1 100, nach 1945: über 4000 (Schwillus/Brühe, S. 358). - 22.8.1946 „Pfr. Krause, Albrecht, Zossen/Mark, Bahnhofstr. 35“ erwähnt in einer Aufstellung der außerplanmäßig eingesetzten „Flüchtlingsgeistlichen“ (DAB, I/9-15-1 Flüchtlingsseelsorge 1945-1951, unfol.), aber bereits seit 1935 hier Pfarrer (bis 1961) (Schwillus/Brühe, S. 358). - Ab 1.4.1949 Pfarrei, zuvor Kuratie, 1950 Kapelle vergrößert, Tochtergemeinden 1951 in $\rightarrow$ Sperenberg u. 1963 in $\rightarrow$ Rangsdorf gebildet (Brühe, S. 44).

FLÜCHTLINGSLAGER (im Wald bei Zossen): 1945 erwähnt; im Wald befinden sich zwei ungekennzeichnete Massengräber für die Toten des Lagers (Scheer, S. 147).

StÄdtepartnerschaften: Nach 1973 Kontakte mit Nysa, Polen (Neisse, Schlesien) (Trzcielińska-Polus, S. 538).

VERTRIEBENENVERBÄNDE NACH 1990: (1) BdV-Kreisverband Luckenwalde, Jüterbog, TeltowFläming, Zossen, Sitz $\rightarrow$ Luckenwalde, erwähnt 1996 (BdV-Handbuch 1996, S. 218); 2001 erwähnt als $B d V$-Kreisverband Teltow-Fläming (Berliner Morgenpost, 17.1.2007). - (2) BdVRegionalverband Zossen, 12.6.2009 Gründungsversammlung mit 26 anwesenden Mitgliedern, Jan. 2010: 49 zahlende Mitglieder, Vorsitzende: Gisela König, Zossen (Akten der BdV-Landesgeschäftsstelle).

Quellen und Literatur: Brühe, Matthias: Katholische Kirche zwischen Havel und Dahme. Berlin 1999, S. 44. Scheer, Regina: Der Umgang mit den Denkmälern. [Potsdam] 2003, S. 147. - Hielscher, Alexander Karl: Das Kriegsende 1945 im Westen des Warthelandes und im Osten der Kurmark. Typoskript. [Bielefeld 1986] (Archiv der Landesgeschichtlichen Vereinigung für die Mark Brandenburg, Berlin). - Schwillus/Brühe, S. 358. - Trzcielińska-Polus. 


\section{Zützen}

Landgemeinde (seit 1.8.2001 Ortsteil von $\rightarrow$ Schwedt/Oder), bis $1952 \mathrm{Kr}$. Angermünde, 1952-1990 Kr. Angermünde (Bez. Frankfurt/Oder), 1952-1990 Kr. Angermünde, 1993 Ldkr. Uckermark

EReignisse NACH Kriegsende: „In der SED-Ortsgruppe Zützen (Kr. Angermünde) wurde im Septem- [S. 71] ber 1949 die Meinung vertreten, die Oder-Neiße-Linie sei ungerecht, sie müsse unbedingt beseitigt werden. [...]." (Blöß, Grenzen und Reformen, S. 70 f.). - 3.10.1950 Zuweisung von westlich der Oder gelegenen einwohnerlosen Flächen der nun polnischen Gemeinde Niedersaathen/Zatoń Dolna (ehem. Kr. Königsberg/Nm.) an die Gemeinde Zützen (Blöß, Kreise und Gemeinden, S. 31).

BevölKeRUngSZAHLEN: 1925: 280, 1939: 180, 1946: 267, 1964: 261 (HOL VIII, S. 1184).

LITERATUR: Blöß, Wolfgang: Grenzen und Reformen in einer Umbruchgesellschaft. Berlin 2014. 
Teil 3

Quellenedition 



\section{Vorbemerkung}

Die Auswahl der edierten zeitgenössischen Quellentexte ist in erster Linie auf eine - nach Möglichkeit repräsentative - Zusammenstellung von für die Thematik typischen Schriftstücken aus Behördenakten gerichtet: Berichte, Reden, Pressextexte sowie behördeninterne und -externe Schreiben. Im Vordergrund stehen die im Brandenburgischen Landeshauptarchiv befindlichen Überlieferungen der brandenburgischen Provinzial- bzw. Landesregierung und der Landratsämter, hinzu treten aus kirchlichen Archiven entsprechende Überlieferungen evangelischer und katholischer kirchlicher (Ober-)Behörden, wobei im staatlichen wie im kirchlichen Bereich die lokale Verwaltungsebene zumeist durch die von dort eingehenden Berichte und Schreiben vertreten ist. Die im Bundesarchiv befindlichen Überlieferungen der zentralen SBZ-/DDR-Verwaltung (Zentralverwaltungen, Ministerien) sind nur in Einzelfällen ergänzend hinzugenommen worden. Nicht berücksichtigt werden konnten die Überlieferungen der Zentrale und der Bezirksverwaltungen des MfS.

Eine solche Sammlung kann nur teilweise Vollständigkeit in der Behandlung aller Facetten bieten, da regionale Unterschiede nur unvollständig abgebildet werden und insgesamt der stets zielgerichtete und daher oftmals einseitige Blick der Verwaltung dominiert. Insbesondere musste auf eine vollständige Behandlung der Regionen und Kreise des geographisch weiten Untersuchungsraumes verzichtet werden. Diese ist jedoch zumindest immer dann gewährleistet, wenn Statistiken oder Berichte das gesamte Gebiet der Provinz bzw. des Landes abdecken. Bei den lokalen und aus den Kreisen kommenden Berichten musste dagegen ebenso wie bei als typisch erkannten Einzelfällen eine stichprobenartige Auswahl getroffen werden. Nach Möglichkeit sind dabei aber die (Groß-) Landschaften im Norden und Süden sowie einzelne mittlere Bereiche um Berlin/Potsdam jeweils beispielhaft, d. h. vornehmlich durch Quellen aus den Kreisen Angermünde, Beeskow-Storkow, Cottbus, Guben, Jüterbog-Luckenwalde und Teltow sowie der Stadt Potsdam, stellvertretend für alle anderen Stadt- und Landkreise gewählt worden.

Selbstzeugnisse (Zeitzeugenberichte), die für den darstellenden Teil der Arbeit eine wesentliche weitere Quelle bilden, dort aber nahezu ausschließlich aus gedruckt zugänglichen Beispielen gewählt wurden, konnten im Quellenteil grundsätzlich nicht berücksichtigt werden. Ausnahmsweise aufgenommen wurden Auszüge aus zwei beiläufig entdeckten, bisher wohl kaum breiter bekannten und insgesamt noch unpublizierten Texten, zum einen der zeitgenössische Bericht der Lehrerin und Biesenthaler NS-Ortsfrauenschaftsleiterin Klara Stephan über die Betreuung von Flüchtlingstransporten und -trecks in Biesenthal im Januar und Februar 1945 (Quelle 1), zum anderen eine Passage aus den nicht zeitgenössischen, 1964 verfassten Erinnerungen des Landrats des Kreises Jüterbog-Luckenwalde Fritz Ludwig an die Jahre 1945 bis 1949 (Quelle 157). 


\section{Editionsgrundsätze}

Die Texte werdern grundsätzlich buchstabengetreu wiedergegeben. Offenkundig versehentliche Schreibfehler sind in der Regel stillschweigend korrigiert, Verstöße gegen die Grammatik in der Regel unverändert übernommen und nur, wo dies für das Verständnis nötig erscheint, durch [so!] gekennzeichnet. Fehler bei der Interpunktion wurden nur in gewichtigen Fällen, die den Lesefluss stören, stillschweigend korrigiert. Punkte als Markierungen innerhalb mehr als dreistelliger Zahlen (z.B. 12.568) werden durch halbe Leerzeichen (12568) wiedergegeben. Der besseren Übersicht wegen sind Tabellen mit Rahmen versehen, Tabellentitel und Texte in Spaltenköpfen in Fettdruck geändert worden.

In Typoskripten vorgenommene Hervorhebungen in Form von Unterstreichungen und Sperrungen u. a. werden, auch bei Familiennamen, wenn der Übersichtlichkeit dienend, (nur hier im Editionsteil in Quellentexten) kursiv wiedergegeben, wenn zu vernachlässigen, weggelassen. Zwischen Unterstreichung und Sperrung in der Vorlage wird dabei, sofern nicht besondere Gründe vorliegen, nicht unterschieden.

Ein Absatz wird, insbesondere im Rahmen der Formalbeschreibung von Schriftstücken, wenn nötig, durch Schrägstrich / gekennzeichnet.

(Nur) Zusätze des Herausgebers stehen in eckigen Klammern []. Auslassungen in der Vorlage sind daher durch ... kenntlich, Weglassungen des Herausgebers stets durch [...]. 


\section{III. Übersicht über die edierten Quellentexte}

$1 \quad$ Ankunft und Erstaufnahme (1945-1950)

1.1 Flüchtlingsstrom und Vertriebenentransporte (1945-1950)

(1) Bericht der Lehrerin und NS-Ortsfrauenschaftsleiterin Klara Stephan über die Betreuung von Flüchtlingstransporten und -trecks in Biesenthal im Januar und Februar 1945. - [Biesenthal, 1945] (Auszug)

(2) Evakuierungsplan für die Kreise des Reichsgaus Wartheland und sowie angrenzende Kreise der Neumark und Niederschlesiens. - Februar 1945

(3) Bericht über die Situation der Flüchtlinge auf dem Bahnhof Cottbus. - Finsterwalde, 8. Juli 1945

(4) Bericht des Landrats des Kreises Beeskow-Storkow über die Unterbringung von Flüchtlingen. - Beeskow, 11. August 1945

(5) Forderung des Kreises Beeskow-Storkow nach einem Aufnahmestopp wegen Überbelegung. - Beeskow, 25. August 1945

(6) Rundschreiben der Provinzialverwaltung an die Landräte und Oberbürgermeister zur Vorbereitung auf die Aufnahme weiterer Flüchtlinge und Heimkehrer. - Potsdam, 25. August 1945

(7) Bericht über die Tätigkeit des Flüchtlingsausschusses des Kreises Beeskow-Storkow. Beeskow, 1. September 1945

(8) Bedrängte Wohnraumsituation im Durchgangsort Forst (Lausitz). - Forst (Lausitz), 8. September 1945

(9) Bericht über die Tätigkeit der Flüchtlingsbetreuungsstelle des Kreises Beeskow-Storkow für die Zeit vom 1. bis 10. September 1945. - Beeskow, 11. September 1945

(10) Bericht des Gesundheitsamtes des Kreises Beeskow-Storkow über die Situation der Flüchtlinge im Kreis. - Beeskow, 11. September 1945

(11) Bericht über die Tätigkeit der Flüchtlingsbetreuungsstelle des Kreises Beeskow-Storkow für die Zeit vom 11. bis 20. September 1945. - Beeskow, 24. September 1945

(12) Vorübergehende Unterbringung deutscher Vertriebener aus Serbien und Bulgarien in Forst (Lausitz). - Potsdam, 28. September 1945

(13) Bericht der Zentralverwaltung für deutsche Umsiedler über die Lage in Forst (Lausitz). - Berlin-Friedrichsfelde, 25. Oktober 1945

(14) Bericht über die Tätigkeit der Umsiedlerbetreuungsstelle des Kreises Beeskow-Storkow. - Beeskow, 30. Oktober 1945

(15) Meldung aus Angermünde über tägliche Flüchtlingsströme aus Polen. - Berlin-Friedrichsfelde, 2. Dezember 1945 
(16) Bericht des Umsiedlerbetreuers des Landkreises Beeskow-Storkow. - Beeskow, 8. Dezember 1945

(17) Bericht des Gemeindevorstehers von Pieskow über die durch sowjetische Einquartierung verminderte Aufnahmefähigkeit für „Umsiedler“. - Bad Saarow-Pieskow, 19. Dezember 1945

(18) Ärztlicher Bericht über einen vom Lager Angermünde nach Thüringen weitergeleiteten Vertriebenentransport aus Polen. - Gera, 1. Januar 1946

(19) Beschwerde des Präsidenten der Zentralverwaltung für deutsche Umsiedler über die Zustände im Umsiedlerlager Angermünde. - [Berlin-Friedrichsfelde], 29. Januar 1946

(20) Rede der Leiterin des Umsiedleramtes der Provinzialverwaltung, Sendhoff, vor Mitgliedern der KPD und SPD. - [Potsdam, Februar 1946]

(21) Protokoll einer Referentenbesprechung im Amt für Arbeit und Sozialwesen der Provinzialverwaltung Mark Brandenburg. - Potsdam, 17. Juni 1946 (Auszug)

(22) Gemeindestatistik des Kreises Beeskow-Storkow über Vertriebenenzahl und Zerstörungsgrad. - Bernau, 26. Juli 1946

(23) Gemeindestatistik des Kreises Niederbarnim über Vertriebenenzahl und Zerstörungsgrad. - Bernau, 16. August 1946

(24) Tabelle der Herkunftsgebiete (Stand: 31. Dezember 1947)

(25) Bericht über eine Besprechung mit dem für Umsiedlerfragen zuständigen sowjetischen Major Kaplan über die Aufnahme bevorstehender Transporte aus Polen. - Potsdam, 30. März 1949

(26) Bericht über die Aufnahme eines Vertriebenentransportes im Kreis Luckenwalde. Luckenwalde, 1. August 1949

(27) Pressetext des Informationsdienstes des Rates des Kreises Luckenwalde über Empfang und Einweisung eines Vertriebenentransportes. - Luckenwalde, 5. August 1949

(28) Bericht der Abt. Arbeit und Sozialfürsorge über die Besichtigung eines Vertriebenentransportes aus Polen im Lager Gronenfelde bei Frankfurt (Oder). - Potsdam, 24. Februar 1950

(29) Sammeltransporte aus Königsberg in Ostpreußen in den Quarantänelagern und Personalsituation im Lager Fürstenwalde. - Berlin, 11. Juni 1951 (Auszug)

\subsection{Durchgangslager (1945-1951)}

(30) Zehntägiger Krankenbericht des Chefarztes des Durchgangslagers für Umsiedler Küstrin-Altdrewitz Dr. H. Wagner an die Provinzialregierung Mark Brandenburg, Abt. Provinzial-Gesundheitsamt, Potsdam. - (Küstrin-)Altdrewitz, 31. Oktober 1945

(31) Eidesstattliche Erklärung eines Vertriebenen wegen Diebstahlsverdachts. - Flüchtlingsheim am Küchensee, 7. November 1945

(32) Schreiben der Umsiedlerbetreuungsstelle des Kreises Beeskow-Storkow an die Lagerverwaltung in Küchensee. - [Beeskow], 9. November 1945 
(33) Bericht über die Demolierung eines Lagers durch die sowjetische Besatzungsarmee. Beeskow, 9. November 1945

(34) Zusammenfassender Lagebericht über das Umsiedlerlager Küstrin anlässlich von dessen Liquidation. - Küstrin, 1. Dezember 1945

(35) Zusammenfassender Lagebericht über die Geburtshilfliche Station im Umsiedlerlager Küstrin anlässlich von dessen Liquidation. - Küstrin, 30. November 1945

(36) Zusammenfassender Tätigkeitsbericht über ärztliche Tätigkeit im Flüchtlingslager Küstrin anlässlich von dessen Liquidation. - Küstrin-Neustadt, 3. Dezember 1945

(37) Bericht über den Mord an einem ostpreußischen Flüchtling in der Nähe des Flüchtlingslagers Forst Zinna. - Luckenwalde, 10. Dezember 1945

(38) Bericht des Kreissozialamtes über den Stand der Vorbereitung von Durchgangslagern in Bad Saarow und Pieskow. - Beeskow, 13. Dezember 1945

(39) Bericht über das Umsiedlerlager Wriezen und Tätigkeitsbericht des dortigen Schutzpolizeikommandos. - Wriezen, 18./19. Dezember 1945.

(40) Anweisung der Provinzialverwaltung Mark Brandenburg zur Versorgung eines Transportes im Umsiedlerlager Küchensee. - [Küchensee], 2. Februar 1946

(41) Verzeichnis der am 1. Januar 1946 in Tätigkeit gewesenen Lager für „Umsiedler“. [Potsdam, 1946]

(42) Aufnahme von Transporten im Umsiedlerlager Küchensee, 7. und 9. Februar 1946. [Küchensee], 10. Februar 1946

(43) Bescheinigung des Polizeileiters des Umsiedlerlagers Küchensee für die Landesanstalt Teupitz über eine geistesgestörte Lagerinsassin. - Küchensee, 10. Februar 1946

(44) Anweisung der Provinzialverwaltung zur Versorgung eines Transportes im Umsiedlerlager. - [Küchensee], 12. Februar 1946

(45) Protokoll der Vernehmung einer des Diebstahls Verdächtigten im Lager Küchensee. Küchensee, 18. Februar 1946

(46) Lagebericht des Lagerarztes des Kreisumsiedlerlagers Glöwen für die Monate Januar bis März 1946. - Glöwen, 25. März 1946

(47) Protokoll einer Verhandlung über einen Transport zum Lager Küchensee. - Küchensee, 11. April 1946

(48) Protokoll der Vernehmung eines Diebstahlzeugen im Lager Küchensee. - Küchensee, 16. April 1946

(49) Schreiben des Umsiedlerlagers Küchensee an die Lagerleitung des Lagers in Berlin NW 21, Kruppstraße. - [Küchensee], 20. April 1946

(50) Tätigkeitsbericht des Umsiedlerlagers Küchensee für die Zeit vom 1. bis 10. Mai 1946. - [Küchensee], 10. Mai 1946 (Auszüge)

(51) Überweisungen von „Umsiedlern“ in das Umsiedlerlager Küchensee durch das Amt für Arbeit und Sozialwesen des Kreises Beeskow-Storkow. - [Beeskow], Februar bis Juni 1946 
(52) Schreiben des Umsiedlerlagers Küchensee an den Landrat des Kreises Beeskow-Storkow. - Küchensee, 8. Juli 1946

(53) Tagesberichte des Umsiedlerlagers Küchensee. - [Küchensee], 8. Juli bis 26. September 1946

(54) Bericht des Umsiedlerlagers Rathenow-Magazininsel über den Transport aus dem Kreis Namslau (Schlesien) vom 14. Oktober 1946. - Rathenow, 16. Oktober 1946

(55) Stellungnahme des Betriebsrates des Kreisumsiedlerlagers Rüdersdorf zur geplanten Personalreduzierung. - Rüdersdorf, 6. November 1946

(56) Stellungnahme des Lagerarztes des Kreisumsiedlerlagers Rüdersdorf zur geplanten Reduzierung des Sanitätspersonals. - Rüdersdorf, 12. November 1946

(57) Stellenplan des Kreisumsiedlerlagers Rüdersdorf. - Rüdersdorf, 11. November 1946

(58) Bericht des Umsiedlerlagers Agneshof in Falkensee. - Falkensee, 11. November 1946

(59) Bericht über die Stimmung der Vertriebenen im Quarantänelager Quenz. - [O. O.], [April] 1947

(60) Bericht über eine Informationsveranstaltung im Umsiedlerlager Küchensee. - Potsdam, 13. August 1947

(61) Tätigkeitsbericht der Abteilung Umsiedler und Heimkehrer im Amt für Arbeit und Sozialwesen des Kreises Beeskow-Storkow über die Betreuung eines Transportes aus Stettin im Umsiedlerlager Küchensee. - Beeskow, 10. Oktober 1947

(62) Anzahl der Lager und ihre Verringerung in den Jahren 1945, 1946, 1947, 1948. - Potsdam, 23. Juni 1948

(63) Verringerung des Lagerpersonals in den einzelnen Lagern. - Potsdam, 23. Juni 1948

(64) Bericht über Lagerverwaltung und Unterkunft 1946 bis 1948. - Potsdam, 23. Juni 1948

(65) Programm eines gemeinsamen „Bunten Abends“von Vertriebenen und Kriegsheimkehrern im Heimkehrer-Erholungsheim Küchensee. - Küchensee, [4. September 1948]

(66) Erfahrungsbericht des Lagerleiters des Umsiedlerlagers Küchensee über den Transport U 19123 aus Ostpreußen. - Küchensee, [13. September 1948]

(67) Erfahrungsbericht des Lagerleiters des Umsiedlerlagers Küchensee über Ankunft und Aufnahme des Transports 19219 aus Königsberg in Ostpreußen. - Küchensee, [24.] Oktober 1948

(68) Bericht des Lagerleiters über die Betreuung eines Vertriebenentransports aus Lodz im Umsiedlerlager Küchensee vom 30. Oktober bis 12. November 1948. - Storkow, 16. November 1948

(69) Ausschreibung zur Teilnahme an einer Ausstellung der Arbeiten von Kindern und Jugendlichen im Umsiedlerlager Küchensee. - Küchensee, 8. März 1949

(70) Unterschriftensammlung zur Ächtung der Atomwaffe im Quarantänelager Fürstenwalde. - Potsdam, 20. Oktober 1950 
(71) Bericht über die Behandlung der Sammeltransporte aus Königsberg in Ostpreußen in den Quarantänelagern Fürstenwalde, Wolfen und Bischofswerda. - Berlin, 5. Juni 1951 (Auszug)

(72) Mitgliederwerbung für die DDR-Massenorganisationen unter den aus Königsberg in Ostpreußen Ausgewiesenen in den Quarantänelagern. - Potsdam, 5. Oktober 1951 (Auszug)

\section{Versorgung, Eingliederung, Gleichstellung (1945-1951)}

2.1 Wohnung (1946-1949)

(73) Kontrollberichte zur Wohnsituation der Flüchtlinge und Vertriebenen in den Gemeinden des Kreises Osthavelland auf Anordnung der SMA. - [Verschiedene Orte], 27. November 1946 (Auszüge)

(74) Protokoll der 7. Sitzung des Wohnungsausschusses bei der Provinzialverwaltung Mark Brandenburg. - Potsdam, 2. Juli 1947 (Auszüge)

(75) Protokoll der 2. Tagung der Leiter der Wohnungsämter. - Potsdam, 10. April 1947 (Auszug)

(76) Beschwerde wegen unzureichenden Wohnraums. - Potsdam, 23. Februar 1948

(77) Eingabe Einheimischer wegen Wohnraums. - Heinsdorf, 3. März 1948

(78) Antwort (auf Nr. 77). - Luckenwalde, 12. April 1948

(79) Berichtsanforderung über die Situation im Aufbaulager Luftschiffhafen in Potsdam durch Landtagspräsident Friedrich Ebert. - Potsdam, 12. April 1948

(80) Dringlichkeitsantrag des Umsiedlerausschusses des antifaschistischen Blocks Potsdam an die Stadtverordnetenversammlung von Potsdam wegen Wohnraums für „ehemalige Umsiedler, Heimkehrer und Dienstverpflichtete“. - Potsdam, 15. April 1948

(81) Eingabe der Gemeindevorsteherin von Raßmanssdorf bei Beeskow wegen Unmöglichkeit der Aufnahme weiterer Vertriebenen. - Raßmannsdorf, 23. April 1948

(82) Bericht über die Wohnsituation eines Vertriebenen in Rathenow. - Rathenow, 8. Dezember 1948

(83) Bericht über die Überprüfung der Wohnsituation im Kreis Teltow durch die Abt. Umsiedler und Heimkehrer der Landesregierung. - [Potsdam], [Dezember 1948]

(84) Bericht über die Überprüfung der Wohnsituation in der Gemeinde Werder bei Strausberg durch die Abt. Umsiedler und Heimkehrer der Landesregierung. - Potsdam, 13. Dezember 1948

(85) Anordnung der Landesregierung Brandenburg zur Verbesserung der Wohnverhältnisse. - Potsdam, 9. Juli 1949 (Auszüge)

(86) Beschwerde einer Vertriebenen über Schikanierung durch ihren Vermieter. - Beeskow, 29. Juli 1949 
(87) Überprüfung der Wohnverhältnisse der Vertriebenen in der Gemeinde Sauen im Kreis Beeskow-Storkow. - Beeskow, 26. September 1949

\section{$2.2 \quad$ Versorgung (1945-1949)}

(88) Schreiben des Landrates des Kreises Westprignitz, Abt. Rechtswesen, an den Bürgermeister in Uenze. - Perleberg, 27. Juni 1946

(89) Leserbrief eines in der Lagerbetreuung tätigen Vertriebenen an die Zeitung „Der Morgen“. - Kirchmöser/Havel, 20. Juli 1946

(90) Antrag auf Zuteilung von Bezugsscheinen für Kleidung für einen Mitarbeiter der Umsiedlerabteilung. - Potsdam, 3. August 1946

(91) Antrag eines Mitarbeiters der Umsiedlerabteilung auf Zuteilung einer Schlafcouch. Potsdam, 9. Mai 1947

(92) Bericht über eine Besprechung zur Vorbereitung der „Umsiedlerwoche“ in Luckenwalde. - Luckenwalde, 6. Oktober 1947

(93) Bericht über eine Veranstaltung zur „Umsiedlerwoche“ in Jüterbog. - Luckenwalde, 27. Oktober 1947

(94) Bericht über eine Veranstaltung zur „Umsiedlerwoche“ in Luckenwalde. - Luckenwalde, 29. Oktober 1947

(95) Bericht des Bürgermeisters von Deibow über die „Umsiedlerwoche“ an den Landrat des Kreises Westprignitz. - Deibow, 9. November 1947

(96) Bericht des Vorsitzenden des Ortsumsiedlerausschusses Wolfshagen an den Landrat des Kreises Westprignitz. - Wolfshagen, 12. November 1947

(97) Bericht des Vorsitzenden des Ortsumsiedlerausschusses Breese an den Landrat des Kreises Westprignitz. - Breese, 14. November 1947

(98) Bericht des Geschäftsführers des Ortsumsiedlerausschusses in Postlin an den Landrat des Kreises Westprignitz. - Postlin, 18. November 1947

(99) Monatsbericht des Umsiedlerausschusses in Leibsch im Kreis Beeskow-Storkow für Dezember 1947. - Leibsch, 2. Januar 1948

(100) Tätigkeitsbericht des Umsiedlerausschusses Havelberg. - Havelberg, 14. Januar 1948

(101) Schreiben des Landrates des Kreises Westprignitz an den Minister für Arbeit und Sozialwesen in Potsdam wegen von Neusiedlern genutzten Gutshausinventars. - Perleberg, 2. Februar 1948

(102) Tätigkeitsbericht des Umsiedlerausschusses Hohenvier (Kreis Westprignitz). - Hohenvier, 19. Februar 1948

(103) Tätigkeitsbericht des Umsiedlerausschusses Toppel (Kreis Westprignitz). - Toppel, 1. März 1948

(104) Tätigkeitsbericht des Umsiedlerausschusses - Lütkendorf bei Putlitz (Kreis Westprignitz). Lütkendorf, 3. März 1948 
(105) Bericht der Gemeindevorsteherin von Raßmanssdorf bei Beeskow über die Betreuung der Vertriebenen. - Raßmannsdorf, 25. Mai 1948

(106) Auskunftsersuchen des Umsiedlerausschusses der Gemeinde Dannenreich im Kreis Beeskow-Storkow an die Provinzialregierung. - Dannenreich, 7. Juni 1948

(107) Schreiben des Rates des Kreises Westprignitz, Abt. VI/Rechtswesen an Ernst Bazer in Erpfingen, Kr. Reutlingen, wegen Möbelnutzung durch Vertriebene. - Perleberg, 9. Juni 1949

(108) Schreiben des Rates des Kreises Westprignitz, Abt. VI/Rechtswesen an den Rat der Gemeinde in Uenze wegen Möbelnutzung durch Vertriebene. - Perleberg, 9. Juni 1949

(109) Arbeitsbericht des Frauenreferates des Rates des Kreises Luckenwalde. - Luckenwalde, 12. November 1948 (Auszug)

(110) Pressetexte des Informationsdienstes des Rates des Kreises Luckenwalde. - Luckenwalde, 3. Oktober 1949

\subsection{Eingliederungs- und Gleichstellungsbemühungen} (1945-1949)

(111) Besprechung der Leiter der Sozialämter bei den Landratsämtern am 17. Dezember 1945. - Potsdam, 21. Dezember 1945 (Auszug)

(112) Reaktion der Zentralverwaltung für deutsche Umsiedler auf den Plan zur Errichtung einer „Arbeitsgemeinschaft deutscher Flüchtlinge in Finsterwalde. - [Berlin], 14. Mai 1946

(113) Befehl der SMA Brandenburg zur Ergreifung verstärkter Maßnahmen zur Gleichstellung der Vertriebenen mit den Einheimischen. - Potsdam, 11. November 1946

(114) Befehl der SMA Brandenburg zur Ergreifung verstärkter Maßnahmen zur Gleichstellung der Vertriebenen mit den Einheimischen. - Potsdam, 7. März 1947

(115) Protokoll einer Konferenz zum Thema „Soziale Betreuung der Landarbeiter“ im Ministerium für Arbeit und Sozialwesen Brandenburg. - Potsdam, 11. März 1947 (Auszug)

(116) Protokoll einer Besprechung zur sozialen Betreung der Land- und Forstarbeiter in der Landesregierung Brandenburg. - Potsdam, 9. August 1947 (Auszug)

(117) Rede des Landrats des Kreises Niederbarnim, Max Paatz, vor Heimkehrern auf der Heimkehrertagung am 6. September 1948 in Bernau. - [Bernau, 1948] (Auszüge)

(118) Protokoll einer SED-Konferenz über Umsiedlerfragen. - Potsdam, 26. Februar 1949 


\section{$2.4 \quad$ Arbeitsmarkt (1945-1948)}

(119) Monatsberichte des Kreisarbeitsamtes Teltow. - Mahlow 1945-1947 (Auszüge)

(120) Monatsberichte des Kreisarbeitsamtes Beeskow über „Umsiedler“. - Beeskow 19461947

(121) Bereitstellung von Arbeitskräften für die Agfa-Kunstseidenfabrik in Premnitz aus Umsiedlerlagern. - Potsdam/Berlin, Juli-August 1946

(122) Protokoll der Besprechung der Abteilung Wirtschaft und der Abteilung Arbeit und Sozialwesen mit der Industrie- und Handelskammer. - Potsdam, 27. Juli 1946 (Auszug)

(123) Einsatz von Vertriebenen bei der Müllabfuhr. - Rathenow, 24. August 1946

(124) Jahresberichte von Arbeitsämtern über den Einsatz von „Umsiedlern“ als Arbeitskräfte im Jahr 1946. - [Verschiedene Orte], 7. bis 20. Dezember 1946 (Auszüge)

(125) Jahresbericht des Kreisarbeitsamtes Neuruppin über den Einsatz der Arbeitskräfte 1946. - Neuruppin 13. Dezember 1946 (Auszüge)

(126) Monatlicher Situationsbericht des Arbeitsamtes Kyritz für den Kreis Ostprignitz. - Kyritz, 19. Dezember 1946 (Auszug)

(127) Bericht der Abt. Arbeit und Sozialfürsorge des Landesvorstandes Brandenburg der SED an die Abt. Arbeit und Sozialfürsorge des Zentralsekretariats der SED, Genossen Belke, in Berlin. - [Potsdam], 15. März 1947

(128) Bericht des Informationsdienstes des Rates des Kreises Luckenwalde über die Genossenschaft für Glas- und Bijouteriewaren in Dorf Zinna. - Luckenwalde, 9. August 1947

(129) Antrag eines vertriebenen Reichsbahners auf Entnazifizierung. - Nauen, Oktober 1947

(130) Bericht über die Arbeitsmarktlage im Land Brandenburg. - Berlin, 27. Oktober 1947 (Auszüge)

(131) Listen der durch „Umsiedler“ errichteten Industrie- und Handelsbetriebe in den Kreisen. - [Potsdam], 6. November 1947 (Auszüge)

(132) Berichterstattung über „Umsiedlergenossenschaften“. - Potsdam, 8. April 1948

(133) Belieferung und Benennung der „Umsiedlergenossenschaft Neuzittau“. - Potsdam, 24. Mai 1948

(134) Bericht über die „Umsiedler-Genossenschaft“ für Kunstblumen in Jüterbog. - Luckenwalde, 15. Juni 1948

\subsection{Bodenreform und Neubauernprogramm (1946-1951)}

(135) Umfrage zur Berücksichtigung der Flüchtlinge und Vertriebenen bei der Bodenreform. - Potsdam, 20. Juni 1946

(136) Berücksichtigung der Flüchtlinge und Vertriebenen im Kreis Beeskow-Storkow bei der Bodenreform. - Beeskow, 8. August 1946

(137) Berücksichtigung der Flüchtlinge und Vertriebenen im Kreis Teltow bei der Bodenreform. - Mahlow, 22. August 1946 
(138) Bericht eines Mitglieds des SED-Provinzialverbandes Brandenburg über seinen Besuch in Dorf Zinna. - Potsdam, 29. Oktober 1946

(139) Pressebericht des Informationsdienstes des Kreises Luckenwalde über die Durchführung des Neubauernprogramms. - Luckenwalde, 10. Juni 1948

(140) Pressebericht des Informationsdienstes des Kreises Luckenwalde über den Rückstand bei der Errichtung von Neubauernhäusern. - Luckenwalde, 16. September 1948

(141) Pressetext des Rates des Kreises Luckenwalde über die Sollerfüllung bei der Pflichtablieferung aus dem Neubauerndorf Dorf Zinna (Neuheim). - Luckenwalde, 6. August 1949

(142) Bericht des Bürgermeisters der Stadt Potsdam über ländliche Besitzverhältnisse und Wohnsituation in einzelnen Ortsteilen. - Potsdam, 18. November 1949

(143) Bericht über Selbstverpflichtungen der Neubauern von Dorf Zinna (Neuheim). [Dorf Zinna], Ende Juli/Anf. August 1951

\section{$3 \quad$ Vertriebenenverwaltung und Kirchen (1945-1949)}

3.1 Provinzial-/Landesregierung, Kreise, Städte und Gemeinden (1946-1949)

(144) Verzeichnis der Kreisbeauftragten für Umsiedler in Brandenburg. - [Berlin], [1946]

(145) Vorschlagsliste der SED für die Mitglieder des Provinzialausschusses für Heimkehrer und Umsiedler. - Potsdam, 14. August 1946

(146) Protokoll der Konferenz der Abteilung Arbeit und Sozialwesen mit dem Vizepräsidenten Rücker. - Potsdam, 12. Oktober 1946 (Auszug)

(147) Arbeitsplan der Abteilung Umsiedler und Heimkehrer im Amt für Arbeit und Sozialwesen des Kreises Beeskow-Storkow für Januar 1947. - [Beeskow, Dezember 1946] (Auszug)

(148) Jahresbericht der Abteilung Umsiedler und Heimkehrer im Amt für Arbeit und Sozialwesen des Kreises Beeskow-Storkow für 1946. - Beeskow, 7. Janauar 1947

(149) Tätigkeitsbericht der Abteilung Umsiedler und Heimkehrer im Amt für Arbeit und Sozialwesen des Kreises Beeskow-Storkow für Januar 1947. - Beeskow, 4. Februar 1947

(150) Bericht über die Tagung der Kreisumsiedlerämter am 25. September 1947 in Potsdam. - Potsdam, 29. September 1947

(151) Aufgabenbereich und Entwicklung der für Umsiedler und Heimkehrer zuständigen Provinzialbehörde. - Potsdam, 23. Juni 1948

(152) Protokoll der 3. Schulungstagung für Gemeindevertreterinnen im Kreis Luckenwalde. - Luckenwalde, 30. Juni 1948 (Auszüge)

(153) Aufgabenformulierung für die Abteilung Umsiedler und Heimkehrer der Landesregierung Brandenburg für das Jahr 1949. - [Potsdam, 1948]

(154) Beurteilung des Leiters der Abteilung Umsiedler und Heimkehrer Erich Friedrichs. Potsdam, 18. Februar 1949 
(155) Protokoll der Sitzung des Kreisumsiedlerausschusses Oberbarnim am 9. März 1949. Bad Freienwalde, 23. März 1949

(156) Beurteilung des Haushaltsreferenten der Abteilung Umsiedler und Heimkehrer Carl Gaedtke. - Potsdam, 23. Juni 1949

(157) Erinnerungen des Landrats des Kreises Jüterbog-Luckenwalde Fritz Ludwig an die Jahre 1945 bis 1949. - [O. O., Niederschrift 1964] (Auszüge)

\subsection{Suchdienst für vermißte Deutsche in der SBZ (1946-1949)}

(158) Einrichtung von Annahmestellen für Suchanträge des Suchdienstes für vermißte Deutsche in Potsdam. - Potsdam, 19. November 1946

(159) Rundfunkmeldungen des Suchdienstes zur Familienzusammenführung von aus den Vertreibungsgebieten stammenden Kriegsheimkehrern. - Potsdam, 6. Dezember 1946

(160) Arbeitsbericht der Landesbeauftragten für Brandenburg des Suchdienstes für vermißte Deutsche in der SBZ. - Potsdam, Anf. Juli 1947 (Auszug)

(161) Verzeichnis in der SBZ verbotener Suchdienste (Auszug für Brandenburg). - [Berlin, Ende Juli 1948]

(162) Arbeitsbericht der Landesbeauftragten für Brandenburg des Suchdienstes für vermißte Deutsche in der SBZ. - Potsdam, 7. Oktober 1948 (Auszüge)

(163) Anfrage wegen Veröffentlichung in der Suchzeitung des Suchdienstes. - Neuruppin, 1. Juli 1949

(164) Antwort der Landesbeauftragten des Suchdienstes wegen Veröffentlichungen in der Suchzeitung. - Potsdam, 3. August 1949

(165) Rundschreiben der Suchdienst-Landesbeauftragten an die Räte der Landkreise und Städte zur Ermittlung von in Altersheimen wohnenden Flüchtlingen aus den Vertreibungsgebieten. - Potsdam, 4. September 1949

\subsection{Kirchen (1945-1948)}

\subsubsection{Evangelische Kirche (1945-1948)}

(166) Bericht der Gemeinschaft evangelischer Schlesier über die Aufnahme der Gemeindeglieder und Pfarrer in das Kirchengebiet Berlin-Brandenburg ab 1945. - Berlin, [1972]

(167) Protokoll der Sitzung des Hauptvorstandes des Gustav-Adolf-Werks der evangelischen Kirche für Berlin und Brandenburg. - Berlin, 31. August 1946 (Auszug)

(168) Rundschreiben des Konsistoriums betr. die kirchliche Registrierung und das kirchliche Beurkundungswesen der Evakuierten, Flüchtlinge und Umsiedler. - Berlin-Charlottenburg, 16. Mai 1947

(169) Rundbrief des evangelischen Bischofs von Berlin Otto Dibelius an die Pfarrer seiner Landeskirche betr. Flüchtlingsbetreuung. - Berlin, 14. Februar 1948 


\subsubsection{Katholische Kirche (1945-1947)}

(170) Bericht über die seelsorgliche Betreuung der vertriebenen Schwarzmeerdeutschen durch das katholische Pfarramt in Cottbus. - Cottbus, [September 1945]

(171) Bericht über die katholische Flüchtlingsfürsorge in Spremberg. - Spremberg, 8. März 1946

(172) Bericht über die katholische Flüchtlingsbetreuung in Wittstock und Umgebung. Wittstock, 14. Mai 1946

(173) Bericht eines katholischen Pfarrers über die Situation der Flüchtlinge und Vertriebenen in den brandenburgischen Randgebieten Berlins, besonders in Petershagen. - [Petershagen], [Dezember 1946]

(174) Bericht über die katholische Flüchtlingsseelsorge in Brandenburg an der Havel. [Brandenburg an der Havel], Jan. 1947

(175) Bericht über die katholische Flüchtlingsseelsorge im Quenz-Lager in Brandenburg an der Havel. - Brandenburg an der Havel, Jan. 1947

(176) Bericht über die katholische Flüchtlingsseelsorge im Raum Schwedt/Oder. - Schwedt, Jan. 1947

(177) Bericht über die katholische Flüchtlingsseelsorge in Döberitz. - [Berlin-Wilmersdorf], Jan. 1947

(178) Bericht über die katholische Flüchtlingsseelsorge in Zehdenick. - [Zehdenick], Jan. 1947

\section{4 Überwachung der Bevölkerung durch Informanten und Volkspolizei (1946-1953)}

4.1 Allgemeine und politische Stimmungsund Informationsberichte (1946-1950)

(179) Allgemeiner Stimmungsbericht des Informationsdienstes beim Landrat des Kreises Guben. - Guben, 14. Februar 1946 (Auszüge)

(180) Politischer Stimmungsbericht des Informationsdienstes beim Landrat des Kreises Guben. - Guben, 27. Februar 1946 (Auszüge)

(181) Politischer Stimmungsbericht des Informationsdienstes beim Landrat des Kreises Guben. - Guben, 15. Oktober 1946 (Auszüge)

(182) Bericht der Abt. Presse und Information über eine unveröffentlichte Leserzuschrift der „Märkischen Volksstimme“ zur Situation deutscher Facharbeiter in einer polnischen Fabrik im Vertreibungsgebiet. - Potsdam, 5. August 1946

(183) Stimmungsbericht eines Informationsdienstmitarbeiters in der Firma C. Lehmann's Wwe. \& Sohn in Guben an den Informationsdienst beim Landratsamt des Kreises Guben. - Guben, 5. November 1946 (Auszug) 
(184) Stimmungsbericht eines Informationsdienstmitarbeiters in Guben an den Informationsdienst beim Landratsamt des Kreises Guben. - Guben, 6. November 1946 (Auszug)

(185) Stimmungsbericht eines Informationsdienstmitarbeiters in Guben an den Informationsdienst beim Landratsamt des Kreises Guben. - Guben, 7. November 1946

(186) Monatliche „Politische Stimmungsberichte“ des Rates des Kreises Luckenwalde an die Landesregierung Brandenburg, Abt. Inneres, auf der Grundlage von Berichten des Informationsdienstes. - Luckenwalde, 1946-1948 (Auszüge)

(187) Stimmungsbericht des Informationsdienstes des Kreises Luckenwalde. - Luckenwalde, 12. April 1947 (Auszug)

(188) Stimmungsbericht des Informationsdienstes in Kerkwitz (Kreis Guben) an das Landratsamt - Guben, Informationsdienst. - Kerkwitz, 5. Mai 1947

(189) Politischer Stimmungsbericht aus der Stadt Guben. - Guben, 16. Mai 1947 (Auszug)

(190) Stimmungsbericht des Informationsdienstes beim Landrat des Kreises Guben. - Guben, 24. September 1947 (Auszüge)

(191) Politischer Stimmungsbericht aus der Lederfabrik Emanuel Meyer in Guben. - Guben, November 1947

(192) Stimmungsbericht des Informationsdienstes des Rates des Kreises Guben an das Informationsamt der Landesregierung Brandenburg in Potsdam. - Guben, 24. November 1947 (Auszüge)

(193) Stimmungsbericht des Informationsdienstes des Rates des Kreises Guben an das Informationsamt der Landesregierung Brandenburg in Potsdam, Seestr. 43. - Guben, 28. November 1948 [vielmehr 1947]

(194) Stimmungsbericht des Informationsdienstes des Rates des Kreises Guben an das Informationsamt der Landesregierung Brandenburg in Potsdam. - Guben, 2. Dezember 1947 (Auszüge)

(195) Stimmungsbericht des Informationsdienstes beim Landrat des Kreises Guben an den Landrat über die Londoner Friedenskonferenz und Äußerungen zum Friedensvertrag. - Guben, 3. Dezember 1947 (Auszüge)

(196) Stimmungsbericht des Informationsdienstes beim Landrat des Kreises Guben an den Landrat zur Londoner Konferenz. - Guben, 4. Dezember 1947 (Auszug)

(197) Stimmungsbericht eines Informationsdienstmitarbeiters in Kaltenborn (Kreis Guben) an den Landrat des Kreises Guben, Abt. Informationsdienst. - Kaltenborn, 14. Dezember 1947

(198) Bericht des Kreisbauamtes des Kreises Guben über Übergriffe der sowjetischen Grenzpolizei an Oder und Neiße. - Guben, 11. Februar 1948

(199) Stimmungsbericht eines Informationsdienstmitarbeiters in Atterwasch (Kreis Guben) an den Informationsdienst beim Landratsamt des Kreises Guben. - Atterwasch, 16. Februar 1948 (Auszug) 
(200) Stimmungsbericht des Informationsdienstes des Rates des Kreises Guben an das Informationsamt der Landesregierung Brandenburg in Potsdam, Seestr. 43. - Guben, 24. Februar 1948 (Auszüge)

(201) Stimmungsbericht des Informationsdienstes des Rates des Kreises Guben an den Informationsdienst der Landesregierung Brandenburg in Potsdam, Seestr. 43, über die in der Zeit vom 12. bis 22. Mai 1948 durchgeführten öffentlichen und Betriebsversammlungen des Informationsdienstes. - Guben, 25. Mai 1948 (Auszüge)

(202) Stimmungsbericht des Informationsdienstes des Rates des Kreises Guben an den Informationsdienst der Landesregierung Brandenburg in Potsdam, Seestr. 43, über das Volksbegehren. - Guben, 1. Juni 1948 (Auszüge)

(203) Bericht über eine Aussprache der „Umsiedler“ der Gemeinde Kloster Zinna. - Luckenwalde, 3. September 1948

(204) Stimmungsbericht des Informationsdienstes des Rates des Kreises Guben an das Informationsamt der Landesregierung Brandenburg in Potsdam. - Guben, 30. Oktober 1948 (Auszüge)

(205) Stimmungsbericht des Informationsdienstes des Rates des Kreises Guben an das Informationsamt der Landesregierung Brandenburg in Potsdam. - Guben, 16. März 1949 (Auszüge)

(206) Monatliche Stimmungsberichte des Informationsdienstes des Rates des Kreises Luckenwalde an Kreisrat Jentsch. - Luckenwalde, 1948 (Auszüge)

(207) Halbmonatliche Stimmungsberichte des Informationsdienstes des Rates des Kreises Luckenwalde an Kreisrat Jentsch. - Luckenwalde, 1949 (Auszüge)

(208) Pressetext des Informationsdienstes des Rates des Kreises Luckenwalde über einen Schülerwettbewerb zur Bekämpfung der Kartoffelkäferplage in Petkus. - Luckenwalde, 5. August 1949

(209) Politischer Monatsbericht des Oberbürgermeisters der Stadt Potsdam an den Innenminister des Landes Brandenburg. - Potsdam, 12. August 1949 (Auszug)

(210) Bericht über die Stimmung der Bevölkerung in Potsdam. - Potsdam, 28. Oktober 1949 (Auszug)

(211) Bericht über eine Betriebsversammlung im Karl-Marx-Werk in Potsdam am 4. November 1949. - Potsdam, 5. Oktober 1949

(212) Politischer Monatsbericht des Oberbürgermeisters der Stadt Potsdam an den Innenminister des Landes Brandenburg. - Potsdam, 12. November 1949 (Auszug)

(213) Politischer Monatsbericht des Oberbürgermeisters der Stadt Potsdam an den Innenminister des Landes Brandenburg. - Potsdam, 15. Dezember 1949 (Auszug)

(214) Bericht über die Lage der „Umsiedler“ im Kreis Angermünde. - [Angermünde], 15. April 1950

(215) Bericht über die Stimmung im grenznahen Oberförstereibezirk Joachimsthal. - Angermünde, 17. Juni 1950 
(216) Bericht über eine Kundgebung für deutsch-polnische Freundschaft. - [Cottbus], Juli 1950

(217) Protokoll der außerordentlichen Sitzung der Stadtverordnetenversammlung von Potsdam anlässlich des Tages der deutsch-polnischen Freundschaft. - Potsdam, 22. Juli 1950

(218) Bericht über den „Tag für Frieden und gute Nachbarschaft mit der Volksrepublik Polen“ im Kreis Angermünde. - Angermünde, 24. Juli 1950

(219) Bericht des Informationsdienstes des Rates des Kreises Cottbus über die GrenzlandFriedenskundgebung in Guben am 10. September 1950. - Cottbus, 11. September 1950 (Auszug)

(220) Bericht des Informationsdienstes der Stadt Potsdam an die Abt. Informationskontrolle der Landesregierung. - Potsdam, 18. September 1950 (Auszug)

(221) Bericht über eine Betriebswahlversammlung im VEB Gubener Schuhfabrik am 28. September 1950. - Guben, 9. Oktober 1950

(222) Bericht über den Auftritt Wilhelm Piecks auf einer Wahlkundgebung in Guben am 2. Oktober 1950. - Cottbus, 3. Oktober 1950 (Auszug)

(223) Bericht über eine „Umsiedlerversammlung“ in Potsdam-Babelsberg am 5. Oktober 1950. - [Potsdam, Okt. 1950]

\section{2 Überwachung von Vertriebenentreffen und Kontakten} zu westdeutschen Vertriebenenorganisationen (1947-1953)

(224) Bericht eines Mitglieds des SED-Ortsverbandes Brieselang über eine kirchliche Vertriebenenversammlung in Berlin-Tempelhof. - Brieselang, 10. März 1947

(225) Informantenbericht über ein Meseritzer Vertriebenentreffen in Berlin-Charlottenburg. - Berlin, 9. August 1948

(226) Polizeibericht über Verbindungen einzelner Personen zur „Kreisgemeinschaft Angerburg“. - Berlin, 5. März 1950

(227) Bericht des Informationsamtes der Stadt Frankfurt (Oder) über ein Trebschener Heimattreffen in Berlin-Nikolassee. - Frankfurt (Oder), 18. April 1950

(228) Polizeibericht über Kontakte von Brandenburgern zum „Heimatwerk für die Katholiken Danzigs und Westpreußens“. - [Berlin], 30. Juni 1950

(229) Polizeibericht über ein Crossener Vertriebenentreffen in Berlin-Kreuzberg. - Berlin, 31. Oktober 1950

(230) Polizeiliche Beobachtung eines ostpreußischen Vertriebenen in der Ostprignitz. Potsdam, 1. November 1950

(231) Brandenburgischer Polizeibericht über ein Oststernberger Vertriebenentreffen in Berlin-Oberschöneweide. - Berlin, 27. November 1950

(232) Berliner Polizeibericht über ein Oststernberger Vertriebenentreffen in Berlin-Oberschöneweide. - Berlin, 30. Dezember 1950 
(233) Polizeibericht über ein Landsberger Vertriebenentreffen bei Havelberg. - Potsdam, 1. Juni 1951

(234) Polizeiberichte über ein Grünberger Vertriebenentreffen in Lübben. - Potsdam, 9. Juni 1951

(235) Polizeibericht über die Teilnahme von Neuruppinern an einem Neubentschener Vertriebenentreffen in Berlin. - Potsdam, 18. Juli 1951

(236) Polizeibericht über brandenburgische Teilnehmer eines Vertriebenentreffens in BerlinZehlendorf. - Potsdam, 25. April 1952

(237) Polizeibericht über die Beschlagnahmung einer karpatendeutschen Vertriebenen-Flugschrift in Potsdam. - Potsdam, 26. April 1952

(238) Polizeibericht über das kirchliche Triebeler Vertriebenentreffen in Cottbus am 6. Juli 1952. - Cottbus, 6. Juli 1952

(239) Polizeibericht über Maßnahmen zur Kontrolle brandenburgischer Teilnehmer eines Landsberger Vertriebenentreffens in West-Berlin am 28. Dezember 1952. - Frankfurt/ Oder, 4. Januar 1953

(240) Polizeibericht über Verbindungen aus Schmergow republikflüchtiger bessarabiendeutscher Bauern zum Vertriebenenverband der Dobrudschadeutschen. - Potsdam, 4. Februar 1953

\section{$5 \quad$ Aussiedlung Deutscher aus Polen (1950-1965)}

(241) Benachrichtigung der Kreise und Städte wegen Aussiedlung noch in Polen befindlicher deutscher Staatsangehörigen. - Potsdam, 1. Januar 1950

(242) Summarische Branchenstatistik der aus Polen in den Bezirk Cottbus ausgesiedelten Arbeitskräfte. - Cottbus, 12. August 1965

(243) Vorbereitung der Familienzusammenführung für eine deutsche Familie aus dem polnischen Teil Ostpreußens. - Frankfurt (Oder), 17. Dezember 1965

(244) Bericht des Rates des Bezirkes Cottbus über Eintreffen und Weiterleitung von Aussiedlern aus Polen. - Cottbus, 31. Dezember 1965

\section{Vertriebenenverbände nach 1990 (1991-2018)}

\subsection{Satzungen (1991-2018)}

(245) Satzung des BdV-Landesverbandes Brandenburg. - Potsdam, 12. März 1991 (Auszug)

(246) Erklärung des BdV-Landesvorstandes Brandenburg zur Satzung des Landesverbandes. - Potsdam, 11. September 1993 (Auszug)

(247) Satzung des BdV-Landesverbandes Brandenburg. - Berlin, 24. Juni 1995 (Auszug)

(248) Satzung des BdV-Landesverbandes Brandenburg. - [Potsdam], 18. Juli 2008 (Auszug) 
(249) Satzung des BdV-Kreisverbandes Brandenburg/Havel. - Brandenburg, 22. Oktober 1991 (Auszug)

(250) Satzung des BdV-Kreisverbandes Lübben/Luckau. - Lübben, 24. April 1993 (Auszug)

(251) Satzung des BdV-Kreisverbandes Eberswalde, Bad Freienwalde, Bernau. - Eberswalde, 19. April 1997 (Auszüge)

(252) Satzung des BdV-Kreisverbandes Amt Rüdersdorf und Umgebung. - [Rüdersdorf], 5. Februar 2000 (Auszüge)

(253) Satzung des BdV-Kreisverbandes Oder-Spree. - Fürstenwalde, 10. Februar 2000 (Auszüge)

(254) Satzung des BdV-Kreisverbandes Potsdam-Mittelmark mit der Kreisgruppe Ostpreußen/Westpreußen in Brandenburg a.d. Havel. - Brandenburg a.d. H., 16. Juli 2000 (Auszug)

\subsection{Protokolle, Berichte und Reden (1992-2011)}

(255) Protokoll der Vertriebenenversammlung des Kreises Finsterwalde am 21. März 1992. Finsterwalde, 21. März 1992

(256) Bericht des Aussiedlerbetreuers des BdV-Kreisverbandes Brandenburg/Havel über die Aussiedlerbetreuung in den Monaten April bis Juni 1999. - Damsdorf, 30. Juni 1999

(257) Veranstaltungsplanung des BdV-Kreisverbandes Brandenburg/Havel für das Jahr 2000. - Brandenburg, 21. Februar 2000

(258) Veranstaltungsplanung des BdV-Kreisverbandes Eberswalde, Bad Freienwalde, Bernau für das Jahr 2003. - Eberswalde, 29. Januar 2003

(259) Tätigkeitsbericht des BdV-Regionalverbandes „Alte Heimat“ Jüterbog für die Jahre 2007-2010. - Jüterbog, 31. Mai 2011

(260) Zeitungsinterview mit der Vorsitzenden des BdV-Kreisverbandes Neuruppin Johanna Franke. - Neuruppin, März 2008

(261) Rede von Wolfgang Bornstädt beim Festakt zur Namensgebung des Woldenberger Platzes in Premnitz. - Premnitz, 12. November 2010 


\title{
IV. Quellentexte (1945-1965)
}

\section{$1 \quad$ Ankunft und Erstaufnahme (1945-1950)}

\subsection{Flüchtlingsstrom und Vertriebenentransporte (1945-1949)}

\author{
(1) Bericht der Lehrerin und NS-Ortsfrauenschaftsleiterin Klara Stephan über \\ die Betreuung von Flüchtlingstransporten und -trecks in Biesenthal im Januar \\ und Februar 1945. - [Biesenthal, 1945] (Auszug)
}

Archiv des Heimatvereins Biesenthal e. V. - Manuskript, 15 Bl.; Schulheft DIN A 5, außen auf Etikett von der Verfasserin stammende Aufschrift „Kriegstagebuch / K. Stephan“. - Bemerkung: Es handelt sich um eine nachträgliche, aber zeitgenössische Niederschrift in Form eines Erinnerungsberichts. Die Verfasserin (geb. 1885) war von 1912 bis 1945 Volksschullehrerin in Biesenthal und 1945 als NS-Ortsfrauenschaftsleiterin für die Flüchtlingsbetreuung zuständig.

[...] [Bl. 8r] [...] Als im August 1944 der Russe in Ostpreußen einzufallen begann, ahnten wir noch nicht, wie weit er ins Reich vorstoßen würde. Die Ostpreußischen Grenzgebiete mußten evakuiert werden, und allmählich rückte die Front im Reich vor. Es mußten bei uns beizeiten Maßnahmen getroffen werden, Flüchtlinge [B1. 8v] aufzunehmen, um den Ärmsten[,] die all ihr Hab und Gut hinter sich lassen müssen, eine Heimstatt zu geben.

Der Ortsamtsleiter der NSV, jetzt Pg. Konrektor Weber, hatte den Auftrag, ein Durchgangslager in der Schule zu schaffen, und es wurde mit unserer Hilfe alles Notwendige vorbereitet. Am 22.1.45 kam die Nachricht, daß Flüchtlinge aus Ostpreußen bei uns in Biesenthal ankommen würden. Schon am 23.1. frühmorgens hieß es, daß der Transport am selben Abend eintreffen würde. Zuerst sollten es 200, dann 800 Flücht- [B1. 9r] linge sein, und als es soweit war, waren es 2000 ! Alles war bereit, sie zu empfangen und aufzunehmen. Heißer Kaffee war da, Berge von Broten hatten wir zurecht gemacht, Suppe wurde gekocht, Milch für die Säuglinge und Kleinkindernahrung standen bereit. Die „Dienststelle Paula“2205 hatte ihre Omnibusse zur Bahn geschickt, und von den Männern des Volkssturmes geleitet und unterstützt, kamen die Flüchtlinge mit Sack und Pack in die Klassenräume, die mit Stroh belegt, schön durchgeheizt, auf sie warteten. Bei der grimmigen [Bl. 9v] Kälte wurde die Wärme besonders angenehm empfunden, denn die Fahrt durch Tage und Nächte, zum Teil in offnen Güterwagen, war sehr schlimm gewesen, und viele Kranke befanden sich dazwischen und bedurften sofort besonderer Betreuung, die ihnen durch das DRK zuteil wurde.

Wir glaubten, mehrere Tage Zeit zu haben, um alle Flüchtlinge in Familien unterzubringen, aber schon am andern Tage [23.1.1945] kam die Weisung, das Lager so schnell wie möglich wieder frei zu machen, da neue Flüchtlinge, - diesmal [Bl. 10r] Trecks aus dem Warthegau, - auf dem Wege hierher waren. 
Drei Wochen ${ }^{2206}$ lang riß dann die Kette der Trecks nicht ab. Man muß das gesehen und erlebt haben, wie vom Vormittag an Wagen an Wagen sich reihte bis zum späten Abend. Beschreiben läßt es sich kaum. Manche hatten ein Dach über ihre Wagen gezimmert, manch nur Gestelle darüber mit Teppichen belegt, viele fuhren ganz offen, was bei zeitweiligem Schneesturm ganz schlimm war. Alte Leute über 80 Jahre und Kinder bis zum Säugling herunter, - einer war erst 12 Tage alt, - sie alle [Bl. 10v] mußten die Flucht ertragen, so gut oder so schlecht es eben ging. Diejenigen, die noch keine weite Strecke hinter sich gebracht hatten, mußten weiterfahren, waren aber dankbar, wenn sie für Augenblicke anhalten durften, um heißen Kaffee zu bekommen oder gar Suppe, wenn es gerade so klappte. Die ab 16 Uhr eintrafen, blieben zur Nacht, anfangs immer 800-1 000 Menschen, für die wir sorgten, so gut wir konnten.

Am Morgen begann unsere Arbeit um 7 Uhr mit der Ausgabe des Frühstücks. Ehe dann die Wagen zur Weiterfahrt [Bl. 11r] bereit waren, hatten die Leute tausend Wünsche. Oft war die Frauenschaft allein anwesend, sodaß wir manchen Verband erneuerten, wenn niemand vom DRK da war, und telefonisch bei der NSV oder der Polizei oder dem Ortsbauernführer Sachen erledigten. Ähnlich war es natürlich auch bei der Ankunft am Nachmittag. Wie oft ich an solchen Tagen zum und vom Telefon durch die Schule gelaufen bin, das kann sich niemand vorstellen. Dabei hielten einen dauernd Menschen an und baten um Auskünfte, und jedem wollte man doch gerecht werden. [Bl. 11v] Einmal waren 3 Mütter von der vorigen Rast nochmal nach Hause gefahren und nicht rechtzeitig zurück, als der Treck weiterging. Ihre Kinder wurden mitgenommen, und ich mußte nun die Mütter verständigen, wo diese geblieben waren, aber keiner wußte eine Telefonnummer, nicht einmal, wo das Dorf telefonisch angeschlossen war. Ich konnte ihnen trotzdem bald mitteilen, daß sie am andern Morgen bis $1 / 29$ Uhr hier in Biesenthal sein sollten. Daß sie dann erst um $1 / 211$ Uhr ankamen und sich erst einen Wagen nach Lanke besorgen [Bl. 12r] mußten, war dann nicht unsere Schuld.

Nie werde ich vergessen, wie eine Mutter ihr 2 Monate altes Kind tot bei sich hatte. Ich redete mit ihr, aber auf alles sagte sie zunächst nur: „Ich will ja bloß ein Särgel2207, ich will's ja bei mir behalten." Schließlich war sie dann so weit, daß sie mit einer Bekannten zusammen die amtlichen Schritte tat und es hier in der Halle zurückließ. Ja, man konnte viel Jammer miterleben, und das belastete einen seelisch natürlich. Immer wieder sagte man sich: [Bl. 12v] Wenn Du das wärst! Aber auch heiteres kam vor. Einmal wollte ich fast einem Fohlen ins Leben helfen! Ich trieb aber den Ortsbauernführer doch auf, und nachher meldete er mir: „Die Stute ist untergebracht!“ Die ganze Zeit merkte man mal wieder: Die NS Frauenschaft ist Mädchen für alles! Große Arbeit machte uns in der gleichen Zeit das Volksopfer.

Die Sammlung begann bei uns am 28.1., dem Sonntag, an dem die Männer des Volkssturms mit Wagen durch die Stadt fuhren und die von der Bevölkerung bereit- [Bl. 13r] gelegten Sachen 
abholten. In Heilands Kegelbahn warfen sie uns dann alles durch die Fenster, zunächst schon etwas vorsortiert, dann aber bald wild durcheinander, weil eben zuviel kam. Das Ergebnis war hervorragend, aber uns wurde anders beim Anblick der Berge, die sich türmten, wenn wir an das Sortieren dachten, das unsere erste Aufgabe war. In der eiskalten Kegelbahn waren Füße und Hände immer wie abgestorben, aber ein treuer Stamm von Frauen arbeitete unentwegt daran, Überblick in den reichen Segen zu bringen. Wenn die Flüchtlinge Zeit übrig ließen, ging's [Bl. 13v] immer wieder ins Volksopfer. Wir begrüßten es, daß bald die Weisung kam, die tragfähigen Sachen sofort an bedürftige Flüchtlinge auszugeben. Das Wirtschaftsamt übernahm alles und gab Bezugsscheine aus, und wir verlegten nun einen Teil unserer Arbeit in den Sitzungssaal des Rathauses, wo Frau Schmidt sehr bald mit Hilfe einiger Frauen und junger Mädels ein richtiges Warenhaus entstehen ließ, in das die Flüchtlinge strömten. Ich selbst sortierte mit andern immer noch weiter und war zunächst nach wie vor mit der Flücht- [Bl. 14r] lingsbetreuung an die Schule gebunden, es war ein dauerndes Hin und Her, man mußte schon unermüdlich sein, und das sind wir wirklich gewesen.

Schließlich kam der Tag, an dem keine Flüchtlinge mehr eintrafen und auch das Sortieren und aufs Rathaus Schaffen der Sachen des Volksopfers hörte auf, und es blieb als Hauptsache die Ausgabe der Sachen. Der Betrieb wurde auch immer größer, da die auf den umliegenden Dörfern untergebrachten Flüchtlinge auch hierher kamen, um Sachen zu empfangen. Wir gaben uns die größte Mühe, jeden zu be- $[\mathrm{Bl} .14 \mathrm{v}]$ friedigen, meistens glückte es auch. Natürlich waren auch Unzufriedene und Meckerer dazwischen und solche, die andern nichts gönnten und alles selbst gebrauchen konnten. An manchem Tag gab’s Ärger und mancher verbitterte Mensch machte sich und uns das Leben schwer. Mußten wir, die wir noch nichts verloren hatten, sie nicht mit Geduld und Liebe tragen? Wir versuchten es immer wieder. Nur wenn dann wirklich mal freches Pack anrückte, das klaute und Bezugsscheine fälschte, wurden wir schließlich auch mal grob. Es gibt eben überall [Bl. 15r] solche und solche. An einem Vormittag platzte es mir mal so raus: „Herrschaften, was ist das heute gemütlich bei uns, es hat uns heute noch niemand ausgeschimpft!" Da waren die netten Leute, die gerade bei uns waren baß erstaunt und konnten nicht begreifen, wie das möglich wäre. Die dankbaren entschädigten uns immer wieder für allen Kummer. Und ihre Freundlichkeit werden wir nie vergessen. Wie viele haben uns in der Schule immer wieder versichert, es sei hier der erste Ort, in dem sie wirklich gut aufgenommen und [Bl. 15v] betreut werden. Eine Frau hat uns beim Abschied mal richtig abgeküßt. Es war uns manches unbegreiflich, was sie von andern Orten erzählten. Wir haben immer wieder versucht zu beruhigen, und fast immer war das garnicht schwer, wenn die armen Menschen merkten, daß man es gut mit ihnen meinte. 


\section{(2) Evakuierungsplan für die Kreise des Reichsgaus Wartheland sowie angrenzende} Kreise der Neumark und Niederschlesiens. - Febr. 1945

BLHA, Rep. 6 B Kreisverwaltung Züllichau-Schwiebus, Nr. 169, unfol. - Typoskript mit wenigen Bleistiftergänzungen, $1 \mathrm{~S}$.

\section{Aufnahmegebiete der Kreise des Warthegaus und Niederschlesien[s].}

\begin{tabular}{|c|c|}
\hline Konin, Lentschütz, Turek & Westhavelland [Bleistiftzusatz:] (Rathenow) \\
\hline Wielun & Guben, Beeskow \\
\hline Lask & Cottbus \\
\hline Schieratz & Rathenow \\
\hline Kempen und Ostrowo & Spremberg \\
\hline Kalisch & Sorau \\
\hline Litzmannstadt (Land) & Lübben \\
\hline Litzmannstadt (Stadt) & Cottbus \\
\hline Leslau und Hermannsbad & Königsberg NM \\
\hline Hohensalza (Stadt) & Angermünde \\
\hline Hohensalza (Land) & Prenzlau \\
\hline Dietfurt & Templin \\
\hline Altburgund und Eichenbrück & Ruppin [hiervor Abhakungshaken] \\
\hline Kolmar & Westpriegnitz \\
\hline Waldrode und Kutno & Soldin \\
\hline Warthbrücken und Gnesen & Landsberg (Warthe) \\
\hline Mogilno und Obornick & Ostpriegnitz [Bleistiftzusatz:] (Seelow) \\
\hline Samter und Birnbaum & Westpriegnitz [Bleistiftzusatz:] (Bad Freienwalde) \\
\hline Posen (Stadt) & Rathenow \\
\hline Posen (Land) und Grätz & Kreis Belzig \\
\hline Wreschen & Calau \\
\hline Schroda, Schrimm, Kosten & Jüterbog, Luckenwalde \\
\hline Jarotschin & Sorau \\
\hline Gostin und Lissa & Luckau \\
\hline Krotoschin und Rawitsch & Kollin 2208 \\
\hline Wollstein & Osthavelland [Bleistiftzusatz:] (Nauen) \\
\hline Züllichau-Schwiebus-Bomst & Templin-Angermünde-Prenzlau-Ruppin [hiervor Abhakungshaken] \\
\hline Crossen & Teltow-Osthavelland \\
\hline Grünberg (Schles) & Potsdam-Niederbarnim und Osthavelland \\
\hline Freystadt (Schles.) & Brandenburg, Zauch-Belzig \\
\hline Fraustadt & Sorau \\
\hline
\end{tabular}

2208 [Unidentifiziert. Alle gleich oder ähnlich lautenden Ortsnamen liegen weitab von den anderen Evakuierungskreisen. Eher unwahrscheinlich: die kleine Gemeinde Kollin (Collin), Kr. Pyritz (Pommern).] 


\section{(3) Bericht über die Situation der Flüchtlinge auf dem Bahnhof Cottbus. - Finsterwalde, 8. Juli 1945}

DAB, I/9-15-1 Flüchtlingsseelsorge 1945-1951, unfol., 8.7.1945. - Typoskript, 2 Bl. - Abschrift, Bl. 1 oben: Abschrift, r. o. Finsterwalde, den 8.7.1945; darunter Überschrift Reisevermerk/ über die Flüchtlingsnot in den zu den RBD’en [= Reichsbahndirektionen] Halle und Berlin gehörenden Gebieten“. - Bl. 2 masch. „gez. Kobert / RA“2209. Teildruck nach Parallelüberlieferung (BLHA, Rep. 211, Nr. 1067, Bl. 9) bereits in: Wille I, S. 34-35, Nr. 8 (hier fehlen die Schlussabsätze, in denen Kobert Vorschläge formuliert).

Das Flüchtlingselend, hervorgerufen durch eine neue Welle aus dem Osten, beherrscht das Gesamtleben in den Gebieten südöstlich und südlich von Berlin. Die Tragödien hungernder und sterbender Menschen wickeln sich zu einem großen Teil auf den Bahnhöfen oder in deren Nähe ab. Es ist schwierig, sich ein genaues, zusammenhängendes Gesamtbild über die Ausmaße und Auswirkungen der im Osten entstandenen Katastrophe zu verschaffen, da die Einzelschicksale, die man beobachtet, so grausam sind und die gehetzten Menschen sehr unvollständige Angaben machen.

Aus den Beobachtungen muß jedoch folgendes als feststehend angesehen werden:

Es sollen etwa 7000000 Deutsche, die östlich der Oder und der Lausitzer Neiße sowie in den tschechischen Gebieten (Mährisch-Ostrau-Schönbrunn usw.) wohnen, von den Polen oder Tschechen vertrieben werden. Die Leute werden von den Polen oder Tschechen aufgefordert, sich innerhalb kürzester Frist (es werden Zeiten von $1 / 4$ bis 2 Stunden genannt) in Marsch zu setzen. Es kann nur das Notwendigste mitgenommen werden. Als zugelassene Traglasten wurden 12 bis $16 \mathrm{~kg}$ angegeben. Wenn es gelingt, mit Karren, Handwagen und Pferdefuhrwerken abzuziehen, so werden die Pferde und Wagen beim Überschreiten der Oder bzw. Neiße restlos abgenommen und die übrigen Sachen geplündert. Hungernd und mit abgerissenem oder ohne Schuhwerk und häufig nur notdürftig gekleidet sammeln sich die Menschen auf den Bahnhöfen und versuchen, mit irgend einer Möglichkeit weiterzukommen. Die Russen machen bei der Mitfahrt in Russenzügen keine Schwierigkeiten, im Gegenteil wurde sogar beobachtet, daß russische Soldaten Brot an Kinder verteilten. Die Menschen umlagern jeden Zug[,] der nach dem Westen oder Süden bereitgestellt wird. Sie liegen auf den Wagendächern und den beladenen Kohlenwagen und hängen sich an die Trittbretter der Wagen und die hervortretenden Teile der Lok an. Auf Sicherheit kann keine Rücksicht genommen werden.

Durch den Bahnhof Cottbus werden auf diese Weise täglich etwa 6000 Menschen durchgeschleust. Kranke und Sterbende liegen tagelang auf den zerstörten Bahnsteigen oder in den Ruinen der Bahnhofsgebäude herum. Die Toten werden ohne Sarg neben den Gleisen beerdigt. 42 solcher Gräber befinden sich auf der Südseite des Bahnhofs. Das Rote Kreuz hat auf dem Bahnhof eine Notküche eingerichtet, aus der in der Mittagszeit eine dünne Kartoffelsuppe verabreicht wird. Die Zuteilungen reichen aber bei weitem nicht aus, so daß es an der Ausgabestelle zu Auseinandersetzungen zwischen den Flüchtlingen kommt. In der Stadt Kottbus bestehen 
weitere Notküchen. Ähnliche Zustände wie in Cottbus haben wir auf Bahnhof Lübben festgestellt.

Wir haben bei der Durchreise die auf den Straßen und Bahnhöfen lagernden und herumziehenden Flüchtlinge beobachtet.

Die Ernährungslage ist infolge dieser Zustände in dem gesamten Gebiet[,] besonders aber auf den Knotenbahnhöfen und in den Städten äußerst kritisch. Die Lebensmittelzuteilungen sind äußerst gering und unregelmäßig.

Durch den verlorenen Krieg ist das Nachrichten- und Transportwesen in einem derartigen Maße lahmgelegt, daß anzunehmen ist, daß bei den zuständigen Stellen des Reiches und der Besatzungsmächte kein oder höchstens nur ein unvollständiges Bild über dieses Elend besteht. Auch die Reichsbahn als Reichsstelle und als größtes deutsches Transportunternehmen hat hier helfend einzugreifen.

Wir schlagen daher vor, sofort folgende Schritte zu unternehmen:

1.) Bei den zuständigen Stellen wäre anzuregen, daß zur Beseitigung der Lebensmittel- und Bekleidungsnot ähnlich wie nach dem Weltkriege ${ }^{2210}$ die internationalen karitativen Organisationen eingeschaltet werden. [Bl. 2] Wir denken hierbei an Untersuchung der katastrophalen Zustände durch das Internationale Rote Kreuz, Anforderung von Hilfe bei den amerikanischen und englischen Quäkerverbänden sowie bei den Religionsgesellschaften (z.B. Deutsche Bischöfe, Karitasverband, Innere Mission, High Church usw.).

2.) Bei den Reichs- und Provinzialstellen ist zu fordern, daß die Unterbringung der Flüchtlinge, die jetzt zum großen Teil ohne Ziel von [Ort] zu Ort teils auf der Landstraße teils auf der Eisenbahn sich bewegen, geregelt wird.

3.) Wir müssen umgehend das Erforderliche veranlassen, die Flüchtlinge dem Aufkommen entsprechend und nach den Unterkunftsorten im Reiche oder Flüchtlingszonen abzufahren, damit die Stauungen auf den Knotenbahnhöfen vermieden werden.

Wir weisen hierbei darauf hin, daß gerade durch diese Stauungen die an sich schon ungünstige Lebensmittellage der Städte noch vergrößert wird. Außerdem gestatten die Knotenbahnhöfe, die größtenteils zerstört sind, kein längeres Ansammeln der Flüchtlinge. (Nähere Ausführungen hierüber im Reisebericht über Feststellungen in Cottbus und Finsterwalde.)

\section{(4) Bericht des Landrats des Kreises Beeskow-Storkow über die Unterbringung von Flüchtlingen. - Beeskow, 11. August 1945}

BLHA, Rep. 250 Landratsamt Beeskow-Storkow, Nr. 867, unfol. - Typoskript (Durchschlag), 1 Bl. - L. o.: „Landratsamt / Flüchtlingsbetreuung“. - R. o. Datierung „Beeskow, den 11.8.1945“. - Adresse: „An den / Herrn Präsidenten der Provinzial- / verwaltung Mark Brandenburg, / Sozialabteilung / Potsdam. “ - Kein Betreff. - Keine Unterschrift. 
Seit dem Beginn des Flüchtlingsstromes sind in der Stadt Beeskow ca. 1 500, im gesamten Kreise einschl. Stadt Beeskow, ca. 10000 Flüchtlinge untergekommen. Die Notwendigkeit, Erntearbeiter sowie Kräfte für den Wiederaufbau zu gewinnen, erleichterte diesen Vorgang. Im Gefolge der Flüchtlinge kam eine Typhusepidemie, der zeitweise täglich 3-4 Menschen zum Opfer fallen. Diese Typhuswelle hat auch auf das flache Land übergegriffen, schwillt aber, je weiter nach Westen, immer mehr ab.

Für die Alten, Siechen und Kinder ist in Neuendorf bei Beeskow ein Altersheim mit einer Abteilung für Waisenkinder im Entstehen, das in der nächsten Woche eröffnet werden kann. Aus den Reihen der Flüchtlinge sind 2 Frauen zur Betreuung derjenigen kranken Flüchtlinge gewonnen worden, die im Krankenhaus nicht mehr Unterkunft finden können. Im Kreise wird demnächst in den einzelnen Dörfern die Einrichtung von Gemeindehäusern angebahnt werden, in denen Alte und Schwache ein Unterkommen finden, denn die Stadt Beeskow kann in ihrem Altersheim nicht alle Alten und Siechen aufnehmen.

Bei der Bemessung der Zahl der unterzubringenden Flüchtlinge bitte ich zu berücksichtigen, daß der Kreis Beeskow stark gelitten hat unter Kampfhandlungen, sowohl Dorf wie Stadt, daß z. B. in Beeskow von 902 Häusern 128 ganz, 234 teilweise zerstört sind, während andere Kreise vom Kriege wenig, u.[nter] U.[mständen] fast garnicht berührt worden sind.

\section{(5) Forderung des Kreises Beeskow-Storkow nach einem Aufnahmestopp wegen Überbelegung. - Beeskow, 25. August 1945}

BLHA, Rep. 250 Landratsamt Beeskow-Storkow, Nr. 824, unfol. - Typoskript (Durchschlag), 1 Bl. - L. o. nur: „II“, da für Ausfertigung Kopfbogen benutzt. - R. o. Datierung „25. August [194]5“. - Adresse: „An den / Herrn Präsidenten / der Provinzialverwaltung / Mark Brandenburg, Sozialabteilung / Potsdam / Spandauerstr. 34“. - Bezug: AZ VII/2 vom 30.7.45. / Betr.: Ostflüchtlinge.“ - O.1. handschriftlich „Herrn Göring“. - Unterzeichnet mit Paraphe: „In Vertretung/ K“. - R.u. „Gö“. - Verfügung: „1.) [Adresse] / 2.) Z.d.A.“

Unter Bezugnahme auf das o. a. Schreiben und die durch den hiesigen Einsatzleiter mit der Provinzialrätin Frau Sendhoff am 21.8.[19]45 in Potsdam gehabten Besprechung wird mitgeteilt, dass die Aufnahmefähigkeit des Kreises Beeskow-Storkow nunmehr erschöpft ist. Bei dem überaus starken Zugang von Ostflüchtlingen aus den für den hiesigen Kreis zuständigen Gebieten hat gerade in den letzten Tagen eine äusserst starke Belegung erfolgen müssen.

Unter Berücksichtigung der im Kreise eingetretenen umfangreichen Kriegsschäden sowie der Verluste der durch die russische Besatzung in Anspruch genommenen Unterbringungsmöglichkeiten wie ganze Dörfer, Güter, besonders erhaltene Baulichkeiten (Schlösser), ist der Kreis nicht in der Lage, 60 \% der Bevölkerung an Flüchtlingen aufzunehmen. Der gesamte nördliche Teil des Kreises, mit einem erheblichen Teil der gesamten Einwohnerschaft besetzt, muss ebenfalls für die Belegung mit Flüchtlingen ausfallen, weil ausser den erheblichen Kriegsschäden umfangreiche Industrie besteht und für die schon ansässigen Einwohner Ernährungsschwierigkeiten auftauchen. Weiter muss bemerkt werden, dass in mehreren Gebieten des Kreises eine Typhus-Epidemie und neuerdings auch Diphterie-Epidemie ausgebrochen ist, die nach Aus- 
kunft des Gesundheitsamtes noch ständig im Ansteigen begriffen ist. Diese Epidemien erfordern aus gesundheitlichen Gründen strenge Sperrmassnahmen.

Z.Zt. ist die Einsatzleitung damit beschäftigt, genaues Zahlenmaterial über die Belegung mit Ostflüchtlingen und Evakuierten zu sammeln und entsprechende Aufstellungen zu fertigen, die nachgereicht werden.

Wie bereits eingangs erwähnt, ist der Kreis nicht mehr in der Lage, irgendwelche Ostflüchtlinge aufzunehmen. Es wird um möglichst umgehende Mitteilung gebeten, wohin die [Flüchtlinge] aus den Teilen südlich der Warthe in Brandenburg gelegenen Gebieten (Oststernberg, Weststernberg, Züllichau-Schwiebus, Schwerin, Meseritz und Crossen) weiterzuleiten sind. Bis zum Eingang dieser erbetenen Auskunft werden Ostflüchtlinge aus den genannten Kreisen von hier aus ebenfalls nach der Provinz Sachsen weitergeleitet, wie das mit den aus Schlesien stammenden Flüchtlingen gemäss der am 21.8. persönlich erteilten Auskunft geschehen muss.

Im Anschluss hieran wird erneut darauf aufmerksam gemacht, dass der Herr Oberbürgermeister in Cottbus nach wie vor die Flüchtlinge nach Beeskow leitet mit der festen Zusage, dass diese im hiesigen Kreise Aufnahme finden werden. Neuerdings sendet Cottbus Ostflüchtlinge sogar direkt in einzelne Dörfer des Kreises. Hierdurch entsteht bei den betreffenden Flüchtlingen erhebliche Verwirrung, weil diese im Kreise Beeskow erfahren müssen, dass die in Cottbus gemachten Zusagen nicht zutreffend waren. Es wird gebeten, das Erforderliche zu veranlassen, dass solche Fälle in Zukunft vermieden werden.

\section{(6) Rundschreiben der Provinzialverwaltung an die Landräte und Oberbürgermeister} zur Vorbereitung auf die Aufnahme weiterer Flüchtlinge und Heimkehrer. - Potsdam,

\section{August 1945}

BLHA, Rep. 250 Landratsamt Beeskow-Storkow, Nr. 867, unfol. - Typoskript (Vervielfältigung mit beglaubigendem Rundstempel der „Provinzialverwaltung Mark Brandenburg“, masch. in Adresse eingefügt „Beeskow“), 1 Bl. - L. o.: „Der Präsident / der Provinzialverwaltung / Mark Brandenburg / Az. VII/2“. - R. o. Datierung „Potsdam, den 25. August 1945. / Spandauer Str. 34.“- Adresse: „An / den Herrn - Landrat - [gestrichen: „Oberbürgermeister"] - / in Beeskow / An die Herren / Landräte und Oberbürgermeister / der kreisfreien Städte in der Provinz Brandenburg“. Betreff: „Betrifft: Flüchtlingswesen und heimkehrende Soldaten.“- Unterschrift: „gez. Dr. Steinhoff./ Beglaubigt: [...? / Angestellter.“ - Eingangsstempel des Landratsamtes Beeskow, 7. Sept. 1945; Paraphen und Verfügungen „II / Gö. / ..., r. o. „Göring“.

Es ist möglich, dass noch etwa 100000 weitere Flüchtlinge in allernächster Zeit in der Provinz Mark Brandenburg untergebracht werden müssen. Ausserdem ist eine grössere Anzahl verwundeter Soldaten entlassen, die als Heimkehrer die Mark Brandenburg aufsuchen.

Die Situation erfordert die höchste Aktivität der Landräte, um durch Sofortmassnahmen zu erreichen, dass heimkehrende Soldaten und Flüchtlinge für den Winter vor Eintritt der schlechten Witterung untergebracht sind. 
Als Sofortmassnahme ist ein Ausschuss bei jedem Landratsamt zu bilden, bestehend aus:

dem Dezernenten für das Flüchtlingswesen,

dem Kreisarzt,

den Vertretern der politischen Parteien.

Dieser Ausschuss hat in dem Kreis systematisch Suchaktionen zu veranlassen nach:

Brachland,

Wiesen, die umgearbeitet werden können,

Umsiedlergelände,

herrenlosen Gütern, die sich zur Aufteilung eigenen und Wohnraum.

Es ist sofort eine Quarantänestation bereit zu stellen für Entlausung und Untersuchung wegen Seuchengefahr.

Es ist sofort ein allgemeiner Flüchtlingspass anzufertigen nach beiliegendem Muster. ${ }^{2211}$

Alle 10 Tage, angefangen am 1. September 1945 sind genaue Berichte über die Bildung des Ausschusses und die aufgenommenen Arbeiten der Provinzialverwaltung einzureichen.

\section{(7) Bericht über die Tätigkeit des Flüchtlingsausschusses des Kreises Beeskow-Storkow. - Beeskow, 1. September 1945}

BLHA, Rep. 250 Landratsamt Beeskow-Storkow, Nr. 867, unfol. - Typoskript (Durchschlag), 2 Bl. - L. o. Absender: „Der Landrat / des Kreises Beeskow-Storkow / Flüchtlingsausschuss.“ - R. o. Datierung: „Beeskow, den 1. September 1945“. - Bl. 2 Unterschrift „Der Arbeitseinsatzleiter / [gez.] Göhring“; links daneben Paraphe „M.“ - Überschrift: „Bericht/über die Tätigkeit des Flüchtlingsausschusses im Kreise Beeskow-Storkow.“

In der Zeit bis 31. August 1945 war ein äußerst starker Zustrom an Flüchtlingen zu verzeichnen, der gelegentlich die Zahl von 700 Flüchtlingen je Tag erreichte. Hierbei konnte festgestellt werden, daß diese Flüchtlinge aus allen Teilen des von den Polen besetzten Gebietes, vornehmlich jedoch aus Schlesien, stammten. Da nach den Anweisungen der Provinzialverwaltung nur aus den südlich der Warthe gelegenen 6 Kreisen Brandenburgs (Oststernberg, Weststernberg, Züllichau-Schwiebus, Schwerin/Warthe, Meseritz und Crossen/Oder) stammende Flüchtlinge im Kreise Beeskow-Storkow Aufnahme finden sollten, wurden laut weiterer Anweisung der Provinzialverwaltung die aus Schlesien stammenden Flüchtlinge in die Provinz Sachsen und die aus dem Gebiet nördlich der Warthe und dem Warthegau stammenden Flüchtlinge nach Mecklenburg weitergeleitet.

Leider mußte festgestellt werden, daß die Flüchtlinge in den Nachbarkreisen (Cottbus, Lübben, Lebus) nicht gleich von dort aus in die oben genannten Gebiete weitergeleitet, sondern völlig unnötig erst in den Kreis Beeskow-Storkow verwiesen wurden. - So wurden täglich vom Ober- 
bürgermeister in Cottbus eine sehr erhebliche Anzahl von Flüchtlingen aus allen Räumungsgebieten wahllos in einzelne Orte des Kreises Beeskow-Storkow gesandt mit der festen Zusicherung, hier bestimmt Unterkunft zu finden, während diese Orte wegen Überbelegung längst nicht mehr aufnahmefähig oder sogar wegen Seuchen (Typhus etc.) gesperrt waren. Es gelangt dem Flüchtlingsausschuss ferner zur Kenntnis,

1. Dass der Kreis Zauch-Belzig von bereits bis zu acht Wochen dort untergebrachten Flüchtlingen geräumt und diese zum grossen Teil in den Kreis Beeskow-Storkow geleitet wurden.

2. Dass die Eisenbahndirektion Halle/Saale durch Anschlag bekannt gab, dass Flüchtlinge aus Schlesien in den Kreisen Beeskow-Storkow, Lübben, Cottbus und Lebus Aufnahme finden müssen.

3. Dass die Flüchtlings[-] und Invalidenleitstelle Kreis Luckenwalde-Jüterbog Flüchtlinge aus Schlesien angeblich gemäss Anordnung der Administration der roten Armee nach Beeskow sendet.

4. Dass das Landratsamt des Kreises Dessau-Köthen ebenfalls Flüchtlinge aus Schlesien in die Provinz Brandenburg, jedoch vornehmlich in den Kreis Beeskow-Storkow, entsendet.

5. Dass der Bezirksbürgermeister des Bezirks Berlin-Lichtenberg aus allen Gebieten stammende Flüchtlinge von dort in den Kreis Beeskow leitet.

Hierdurch musste bei den Flüchtlingen erhebliche Verwirrung entstehen, weil diese im Kreise Beeskow-Storkow erfahren müssen, dass die ihnen anderweitig gemachten festen Zusagen nicht zutreffend waren. Es ist deshalb eine einheitliche Lenkung des Flüchtlingsstromes dringend erforderlich, zumal alle Flüchtlinge jetzt bereits viele Wochen wandern und von den einzelnen Stellen hin- und hergeschickt worden sind, ohne zu einem Ziel zu gelangen.

Für die Errechnung des Flüchtlingssolls muss eine derzeitige Stammeinwohnerschaft von 55000 Personen im Kreise Beeskow-Storkow zu Grunde gelegt werden. Von dieser Zahl sind etwa 25000 Einwohner abzuziehen, da sich diese in Gebieten befinden, die wegen starker Industrialisierung und völlig unzureichender Ernährungsmöglichkeiten als ausgesprochene Notstandsgebiete oder durch erhebliche Kriegsschäden nicht aufnahmefähig sind. Hierdurch verbleibt somit für die Errechnung des Flüchtlingssolls eine Einwohnerzahl von ca. 30000 Personen. Bisher sind im Kreise Beeskow-Storkow etwa 14000 Flüchtlinge einschliesslich Evakuierter aufgenommen worden. Demnach ist die Aufnahmemöglichkeit des Kreises fast erschöpft. Es fehlen seitens der Provinzialverwaltung Angaben darüber, wohin fortan Flüchtlinge aus allen Gebieten (also auch aus den südlich der Warthe gelegenen sechs Kreisen Brandenburgs) weiterzuleiten sind.

Z.Zt. wird an der Aufstellung der nach Herkunftsorten geordneten Listen der gesamten im Kreise Beeskow-Storkow aufgenommenen Flüchtlinge für die geplante Suchaktion gearbeitet. 


\section{(8) Bedrängte Wohnraumsituation im Durchgangsort Forst (Lausitz). - Forst (Lausitz), 8. September 1945}

BArch, DO 2 Zentralverwaltung für deutsche Umsiedler, Nr. 38, Bl. 91. - Typoskript, Durchschlag. - Oben „Abschrift“. - O.1.: „Der Oberbürgermeister der Stadt Forst (Lausitz). - Adresse: „An / die Provinzial-Verwaltung / Mark Brandenburg / Potsdam / Spandauerstraße 32-34“. - Datum: „Forst (Lausitz) / 8. Sept. 1945“. - Betreff: „Räumung der Ausländerviertel.“ - Unterzeichnet „Der Oberbürgermeister / i. A. Unterschrift“.

Wie wir wiederholt darauf hingewiesen haben, ist die weitere Besetzung der Ausländer-Viertel nicht mehr tragbar. / Forst war vor der Besetzung durch die Rote Armee eine Stadt von 42000 Einwohnern. / $20 \%$ des ursprünglichen Wohnraums sind durch die Verlegung der polnischen Westgrenze bis an die Neisse, verloren gegangen. Weitere / $40 \%$ sind durch die Kriegseinwirkung völlig zerstört und auf lange Sicht hin nicht mehr aufzubauen. / Von den restlichen 40\% des Wohnraums sind ungefähr / $20 \%$ durch Einräumung von Ausländer-Viertel der Bevölkerung entzogen. / In den restlichen $20 \%$ des verbliebenen Wohnraumes ist die augenblickliche Gesamt-Bevölkerung von ca. 25000 Einwohnern untergebracht. / Die Art der Unterbringung (es wohnen verschiedentlich in 2 Zimmern 3 Familien) ist sittlich und hygienisch nicht mehr tragbar.

In den letzten Tagen wurden weitere, ursprünglich der Bevölkerung zur Verfügung stehende, Wohnblocks geräumt, und zwar für russische Truppenteile. / Die Ungewissheit der Bevölkerung und die dadurch entstehende dauernde Unruhe, daß jeder Forster täglich damit rechnen kann, daß sein Haus geräumt werden muß, läßt ein Aufbauen der Wirtschaft und das gewünschte Ingangbringen des Handels und Wandels einfach nicht zu. / Dieser verheerende Zustand wirkt sich auf die seelische und, bedingt durch die äußerste Lebensmittelknappheit, auch auf die körperliche Haltung der Bevölkerung vernichtend aus.

Wir bitten die Provinzial-Verwaltung, Mark Brandenburg, bei der Sow [jetischen] militärischen Administration vorstellig zu werden und die sofortige Räumung der Ausländer-Viertel und das Verbot für den weiteren Zuzug von Ausländern zu erwirken. / Weiterhin bitten wir zu erwirken, daß nicht fortlaufend Einquartierungen russischen Militärs erfolgen, da der Wohnraum[,] der unserer geplagten Bevölkerung zur Verfügung steht, nicht einmal den allermindesten Anforderungen genügt. ${ }^{2212}$

2212 Daraufhin (Durchschlag Bl. 94) Schreiben des Präsidenten der Privinzialverwaltung Mark Brandenburg, Potsdam, 28.9.1945, an „den stellvertr. Chef / der Sowjetischen Militärischen Administration / Herrn Generalmajor der Garde Sharow, / z. Hd. v. Herrn Major Iwanzow / Zimmer 125 / Potsdam" mit der dringenden Bitte, „mit Rücksicht auf die kommende große Masseneinwanderung der Umsiedler durch Forst die in Forst untergebrachten Zivilausländer und Truppenteile der Roten Armee anderweitig, evtl. auf die polnische Seite, zu verlegen. / Wie gefährdet Forst ist, ergibt sich aus der Tatsache, daß z. Zt. täglich 20 Todesfälle gezählt werden." 
(9) Bericht über die Tätigkeit der Flüchtlingsbetreuungsstelle des Kreises Beeskow-Storkow für die Zeit vom 1. bis 10. September 1945. - Beeskow,

\section{September 1945}

BLHA, Rep. 250 Landratsamt Beeskow-Storkow, Nr. 867, unfol. - Typoskript (Durchschlag), 1 Bl., mit Unterschrift. - L.o. Absender: „Der Landrat/ des Kreises Beeskow-Storkow / Flüchtlingsbetreuungsstelle“. - R. o. Datierung: „Beeskow, den 11. September 1945.“ - Bl. 2 Unterschrift „... Jung[?]“. - Überschrift: „Bericht/über die Tätigkeit der Flüchtlingsbetreuungsstelle des Kreises Beeskow-Storkow für die Zeit / vom 1. bis 10. September 1945.“

Auch in der Berichtszeit hat der im Bericht vom 1.9. bereits vermerkte Zustrom an Flüchtlingen nicht nachgelassen. Die Zahl von 700 Flüchtlingen je Tag wurde wiederum häufig erreicht. Die Flüchtlinge stammten mit wenigen Ausnahmen aus den südlich der Warthe gelegenen Teilen der Provinz Brandenburg und aus Schlesien. Die in der Versammlung der Vertreter der Kreise am 4.9.[19]45 in Potsdam gemeldeten Flüchtlinge aus Polen, Ungarn und dem Balkan sind bisher nicht eingetroffen.

Die in dem Bericht vom 1.9. Absatz 2 beanstandeten Maßnahmen der Nachbarkreise und anderer Flüchtlingsbetreuungsstellen (Weiterleiten der dort eintreffenden Flüchtlinge nach dem Kreise Beeskow-Storkow) mußte leider auch in der Berichtszeit dauernd beobachtet werden.

Am 6.9. begab sich der Leiter der Flüchtlingsbetreuungsstelle (Göhring) zur Sozialabteilung der Provinzialverwaltung, um von dort weitere Richtlinien einzuholen. In der mit der Provinzialrätin Frau Sendhoff geführten Verhandlung wurden die neuen Richtlinien über die Weiterleitung der Flüchtlinge auf den vorgesehenen Wegen durchgesprochen.

Um für den Kreis Beeskow-Storkow eine möglichst einheitliche Regelung zu erzielen, wurden nunmehr die aus den südlich der Warthe gelegenen Teilen Brandenburgs eintreffenden Flüchtlinge im Kreise Beeskow-Storkow aufgenommen. Da die Zahl dieser Flüchtlinge die in dem aufgestellten Plan beabsichtigte Höhe erreichte, wurden alle übrigen aus anderen Gebieten, insbesondere aber aus Schlesien stammenden Flüchtlinge, auf dem nunmehr vorgeschriebenen Wege zur nächsten Leitstelle Fürstenwalde weitergeleitet. Leider mußte festgestellt werden, daß Fürstenwalde über die neuen Aufgaben noch nicht orientiert zu sein schien, da es die ersten nach dort überwiesenen Flüchtlinge kurzerhand in den Kreis Beeskow-Storkow zurückschickte. Es wurde darauf die Betreuungsstelle Fürstenwalde mit einem ausführlichen Schreiben auf die neuen von der Provinzialverwaltung festgesetzten Richtlinien hingewiesen.

In der Berichtszeit wurden insgesamt 3315 Flüchtlinge für dauernd im Kreise aufgenommen. Hierzu kommt eine erheblich Anzahl von solchen Flüchtlingen, die auf Grund ärztlicher Bescheinigungen, wegen Ermüdungserscheinungen oder Reparaturen an kleinen Fahrzeugen für mehrere Tage Aufnahme fanden. Die Zahl dieser Flüchtlinge kann mit etwa 250 angegeben werden.

Laut Mitteilung des Gesundheitsamtes ist außer den im Bericht vom 1.9. genannten Schwierigkeiten über die Unterbringung weiterer Flüchtlinge durch die herrschende, dem Höhepunkt zustrebende Typhusepidemie außerordentlich erschwert. Nicht nur, daß die Flüchtlinge als erste den Typhus hier einschleppten, verbreiteten sie in auch laufend weiter durch ihr unhygieni- 
sches Verhalten, ihre völlige Unterernährung und die zum Teil unmöglichen Wohnverhältnisse, in denen sie sich befinden. Etwa $80 \%$ aller Typhuserkrankten rekrutiert sich aus dem Flüchtlingsstrom. Die Krankenhäuser und Privatquartiere sind mit Typhuserkrankten überbelegt, so daß eine Isolierung infolge der fast unüberbrückbaren Schwierigkeiten, die sich bei der Erweiterung von Krankenhäusern (Betten-, Medikamenten-, Nahrungsmittelmangel) ergeben, unmöglich sein wird. Hinzu kommt, daß viele Ortschaften des Kreises beträchtliche Kriegsschäden aufweisen und der mangelhaften Verkehrsmöglichkeiten wegen eine sanitäre Versorgung nicht nur schwierig, sondern stellenweise ganz unmöglich ist. Das Gesundheitsamt ist weiter der Auffassung, daß auf Grund der in etwa $1 \frac{1}{2}$ Monaten zu erwartenden ungünstigen Witterungslage und [durch] die damit in Verbindung stehenden grippösen Erkrankungen weitere Einweisungen von Flüchtlingen rechtzeitig abzustoppen seien. Ferner berichtet das Gesundheitsamt, daß es der anfallenden Zahl von erforderlichen Entlausungen durch den völligen Mangel von wirksamen Entlausungsmitteln nicht mehr gewachsen sei.

Die Gesamtzahl der im Kreise untergebrachten Flüchtlinge beträgt am 10.9.[19]45 = 17475 .

Die in der Besprechung in Potsdam in Aussicht gestellten Flüchtlingspässe sind bisher nicht eingetroffen. Ebenso ist bisher ein Bericht über die Tagung am 4.9. nicht eingegangen.

Für den 12. und 14.9.[19]45 sind Tagungen der Gemeindevorsteher des Kreises anberaumt, in denen Flüchtlingsfragen und die damit verbundenen Aufgaben der einzelnen Gemeinden besprochen werden sollen. Ferner ist gegebenenfalls die Bildung von Kommissionen geplant, die zur Ermittlung von Wohnraum und anderen Unterbringungsmöglichkeiten in den einzelnen Gemeinden eingesetzt werden sollen. Diese Kommissionen werden sich voraussichtlich zusammensetzen aus

Vertreter des Kreises

1 Vertreter der Gemeinde (Amtsbürgermeister)

1 Polizeiorgan,

1 Vertreter aus den Flüchtlingen der einzelnen Gemeinden.

In der geplanten Suchaktion sind Bekanntmachungen in den einzelnen Gemeinden veröffentlicht worden, in denen die Flüchtlinge aufgefordert werden, nähere Angaben über etwaig gesuchte Personen $[\mathrm{zu}]$ machen.

[Darunter handschriftliche Notiz, unterzeichnet mit Paraphe „Gö“ für Göhring: ]

Zählung am 17/9. abends 15129 ohne 3 Städte 


\section{(10) Bericht des Gesundheitsamtes des Kreises Beeskow-Storkow über die Situation} der Flüchtlinge im Kreis. - Beeskow, 11. September 1945

BLHA, Rep. 250 Landratsamt Beeskow-Storkow, Nr. 867, unfol. - Typoskript, 1 Bl., mit Kopierstift-Unterschrift. L. o. Absender: „Gesundheitsamt.“ - R. o. Datierung: „Beeskow, den 11. September 1945.“ - Unterschrift „Die Leiterin des Gesundheitsamtes / [gez.: ] Dr. Horlbeck / Medizinalrätin.“2213 - Überschrift: „Ergänzungsbericht zum Bericht des Herrn Landrats in Beeskow vom 11.9.1945 über die Tätigkeit der hiesigen Flüchtlingsbetreuungsstelle."

Außer der im Bericht angegebenen hohen Belegungsziffer des Kreises und der durch die Nachbarkreise gegebenen Schwierigkeiten ist eine weitere Unterbringung der Flüchtlinge durch die herrschende, dem Höhepunkt zustrebende Typhusepidemie äußerst schwierig. Nicht nur, daß die Flüchtlinge als erste den Typhus hier einschleppten, verbreiten sie ihn auch laufend weiter durch ihr unhygienisches Verhalten, ihre völlige Unterernährung und die zum Teil unmöglichen Wohnverhältnisse, in denen sie sich befinden. Etwa $80 \%$ aller Typhuserkrankten rekrutiert sich aus dem Flüchtlingsstrom. Die Krankenhäuser und die Privatquartiere sind mit Typhuskranken überbelegt, sodaß eine Isolierung infolge der fast unüberbrückbaren Schwierigkeiten, die sich bei der Erweiterung von Krankenhäusern (Betten-, Medikamenten-, Nahrungsmittelmangel) ergeben, unmöglich wird. Hinzu kommt, daß durch die vergangenen Kriegshandlungen alle Ortschaften des Kreises beträchtlich in Mitleidenschaft gezogen sind und durch die mangelhaften Verkehrsmöglichkeiten eine sanitäre Versorgung der Einheimischen und der Flüchtlinge nicht nur schwierig, sondern teilweise ganz unmöglich ist. Mit Rücksicht auf die in ca. 11/2 Monat einsetzende ungünstige Witterungslage und die dann zu erwartenden grippösen Erkrankungen sind weitere Zuweisungen von Flüchtlingen rechtzeitig abzustoppen. Auch sind wir hier der anfallenden Zahl von Entlausungen durch das völlige Fehlen von wirksamen Entlausungsmitteln nicht mehr gewachsen.

[Handschriftliche Notiz auf der Rückseite (Kopierstift):]

Flüchtlingsbewegung.

$\begin{array}{lrr}\text { 31.8.[19]45 = } & 14160 \\ \text { Zugang } & 1-10.9 \cdot[19] 45: & 3315=17475 \\ " & 11 .-20.9 .[19] 45: & 2705=20180\end{array}$

(11) Bericht über die Tätigkeit der Flüchtlingsbetreuungsstelle des Kreises BeeskowStorkow für die Zeit vom 11. bis 20. September 1945. - Beeskow, 24. September 1945

BLHA, Rep. 250 Landratsamt Beeskow-Storkow, Nr. 867, unfol. - Typoskript (Durchschlag) mit (Kopiersift-) Unterschrift [...?]. - L o.: „Der Landrat / des Kreises Beeskow-Storkow / Flüchtlingsbetreuungsstelle“. - R. o.: Beeskow,

2213 [Dr. med. Else Horlbeck (geb. 1911 Greiz). Vgl. ihre Personalakten als Leiterin des Gesundheitsamtes (Laufzeit 1945-1947): BLHA, Rep. 211, PA 20, sowie als Medizinalrätin (1938-1945): BLHA, Rep. 2A I Pers 2298/6, ferner für die Jahre 1938-1944 (Wohnort: Ketschendorf!) ihre Ärztekammerakte: BLHA, Rep. 72 Ärztekammer, Nr. 1395.] 
den 24. September 1945.“ - Am oberen Blattrand Bleistiftvermerk „Entwurf“. - Überschrift: „Bericht/ über die Tätigkeit der Flüchtlingsbetreuungsstelle des Kreises Beeskow-Storkow für die Zeit/vom 11. bis 20. September 1945.“

Der starke Zustrom an Flüchtlingen hat in den letzten Tagen der Berichtszeit etwas nachgelassen. Die Gründe hierfür werden unten erwähnt. Der aus dem Balkan gemeldete Flüchtlingsstrom ist bisher nicht in Erscheinung getreten. es wurden nach wie vor sämtliche aus den südlich der Warthe gelegenen Teilen der Provinz Brandenburg eintreffenden Flüchtlinge im Kreise Beeskow-Storkow aufgenommen und nur die aus den anderen Gebieten stammenden Flüchtlinge, die fast ausschließlich aus Schlesien kamen, auf dem vorgeschriebenen Weg Nr. 3 in die nördlichen Teile der Provinz Brandenburg weitergeleitet.

Die im Bericht vom 11.9. erwähnte Tatsache, dass Fürstenwalde die nach dort geleiteten Flüchtlinge zurückschickte, wurde auch auf verschiedene an die Flüchtlingsstelle gerichtete Schreiben nicht abgestellt, worauf am 17.9. eine persönliche Rücksprache in Fürstenwalde erfolgte. Hierbei mußte festgestellt werden, daß die Flüchtlingsstelle in Fürstenwalde über die ihr zugedachten Aufgaben bisher nicht unterrichtet war. Auf Grund dieser Rücksprache wurde durch den Bürgermeister in Fürstenwalde die von der Provinzialverwaltung vorgesehene Weiterleitung der Flüchtlinge, die auch im Kreise Lebus keine Aufnahme finden konnten, zugesagt.

Der Kreis Lübben schien über das Ergebnis der in der Tagung vom 4.9. festgelegten Richtlinien nicht orientiert zu sein. Aus dem Kreise Lübben wurden in großer Anzahl Flüchtlinge nach Beeskow entsandt, um sich in dem in Beeskow vermuteten Sammellager Flüchtlingspässe ausstellen und in den Kreis Lübben einweisen zu lassen. Da jedoch Beeskow weder als Sammel- noch als Auffanglager vorgesehen war und hierdurch eine völlig unnötige Belastung der Flüchtlinge eintrat, erfolgte am 13.9. eine persönliche Besprechung mit dem Referenten für das Sozialwesen und dem Herrn Landrat in Lübben. Auf Grund dieser Besprechungen wurde das Entsenden dieser Flüchtlinge nach Beeskow eingestellt.

Laut Mitteilung des Gesundheitsamtes ist die Anzahl der Typhuserkrankungen weiter gestiegen, während die Diphterieerkrankungen etwas zurückgegangen sind. Die gesamte Seuchenlage hat sich damit im ganzen nicht wesentlich geändert.

Das vorgesehene Altersheim in Neuendorf bei Beeskow wurde weiter ausgebaut; leider war es bisher nicht möglich, die dringend benötigten Decken zu beschaffen, so dass die Aufnahmefähigkeit des Altersheims beschränkt ist.

In den am 12. und 14.9. stattgefundenen Tagungen der Gemeindevorsteher wurde diesen die Dringlichkeit der Flüchtlingsfrage und das in Potsdam festgelegte Aufnahmesoll bekanntgegeben. In den einzelnen Amtsbürgermeisterbezirken werden Kommissionen gebildet zur Ermittlung von Unterbringungsmöglichkeiten in den einzelnen Dorfgemeinden. Das Ergebnis dieser Aktion ist noch nicht bekanntgeworden, verspricht aber Erfolg.

Die Errichtung einer Sammelunterkunft als Quarantäne für solche Flüchtlinge, die im Kreise Beeskow Aufnahme finden, ist eingeleitet. Eine Sanitätsstation zwecks ärztlicher Betreuung sowie eine Gemeinschaftsküche sind hierbei vorgesehen und werden angegliedert. 
Erhebliche Schwierigkeiten bei der Einrichtung dieser Räume entstehen vornehmlich durch den Mangel an Glas. In der Berichtszeit wurden insgesamt 2705 Flüchtlinge im Kreise aufgenommen. Die Gesamtzahl der im Kreise untergebrachten Flüchtlinge beträgt am 20.9.1945 = 20180 Personen.

Die Flüchtlingspässe sind auch bisher nicht eingetroffen.

Die Aufstellung der für die Suchaktion im Kreise erforderlichen und nach Herkunftsorten geordneten Kartei ist nahezu abgeschlossen.

Neuerdings werden aus verschiedenen Orten der Nachbarkreise Lebus und Lübben aus dem Gebiet südlich der Warthe stammende Flüchtlinge, die bereits wochen- und zum Teil monatelang dortselbst untergebracht waren, ausgewiesen und zur Aufnahme in den Kreis BeeskowStorkow verwiesen. Hierdurch entsteht neue Verwirrung und Unruhe bei den Flüchtlingen und die Landstraßen werden erneut bevölkert. Der Kreis Beeskow-Storkow muß es ablehnen, alle diese aus den Nachbarkreisen abgeschobenen Flüchtlinge aufzunehmen und hat sowohl die abschiebenden Gemeinden wie auch die Landräte dieser Kreise entsprechend benachrichtigt. Es wird dringend gebeten, auch seitens der Provinzialverwaltung das Erforderliche zu veranlassen, diese Ausweisungen zu unterbinden.

Aus verschiedenen Gründen mußte der Eindruck entstehen, daß in anderen Landkreisen die Bedeutung der Flüchtlingsfrage nicht in dem erforderlichen Umfange angesehen und Belangen der Ernährungslage des eigenen Kreises der Vorrang eingeräumt wird. Wenn verhindert werden soll, daß sich die Flüchtlingsangelegenheit zu einer unabsehbaren Katastrophe mit Revolten und ähnlichen Ereignissen und Übergriffen entwickelt, dann kann nicht dringend genug gefordert werden, die einzelnen Landkreise auf die ungeheure Gefahr hinzuweisen.

\section{(12) Vorübergehende Unterbringung deutscher Vertriebener aus Serbien und Bulgarien in Forst (Lausitz). - Potsdam, 28. September 1945}

BArch, DO 2 Zentralverwaltung für deutsche Umsiedler, Nr. 38, B1.92. - Typoskript, Durchschlag. - O. handschriftlich „Abschrift“. - R. o. handschriftlich: „Baier“. - Überschrift: „Vermerk: Fernmündl. Durchgabe durch Herrn Vizepräs. Bechler.“ - Darunter 1. o.: „Der Präsident / der Provinzialverwaltung/Mark Brandenburg / Abt. Arbeit u. Sozialwesen / Az. VII/2“. - R. o.: „Potsdam, den 28. Sept. 1945 / Spandauerstr. 34 / Schmi/Lo.“ - Adresse: „An / den stellvertr. Chef / der sowj. Mil[itärischen] Administration / Herrn Generalmajor der Garde Sharow / z. Hd. v. Herrn Major Iwanzow / in Potsdam“. - Betreff: „Deutsche Umsiedler“. - Bezug: „Bezug auf unser heutiges Schreiben wegen der Stadt Forst/L.“ - R. u. „Unterschrift“. - L. u.: „Gef[ertigt]. Lo. / ab 28.9. Lo.“

Soeben wird mir gemeldet, daß sich in Forst/Lausitz in der Nähe des $\mathrm{Ba}[\mathrm{h}]$ nhofs ein Lager mit 9200 Serben und Bulgaren (Volksdeutsche) befinden. Der dortige Kommandant soll verfügt haben, daß diese Serben und Bulgaren in die Stadt Forst eingebürgert werden sollen. Durchweg haben diese Volksdeutschen durch Generationen hindurch in Jugoslavien und Bulgarien gelebt, weshalb ich bitte in Erwägung zu ziehen, ob es nicht angebracht wäre, diese Serben und Bulgaren in ihre ehemaligen Heimatgebiete zurückzuführen. 
Es steht jedenfalls fest, daß die Stadt Forst nicht in der Lage ist, diese Menschen ernähren zu können, da die Lebensmittelrationen der dortigen Bevölkerung bereits so niedrig sind, daß daraus größere Gefahren entstehen können. Ferner kommt in Betracht, daß Forst als Hauptlager für den Übergang des kommenden Flüchtlingsstromes der deutschen Umsiedler von der Zentralverwaltung vorgesehen ist und wäre es dringend notwendig, dieses Lager, in dem sich zur Zeit die 9200 Serben und Bulgaren befinden, für den besagten Zweck frei zu machen.

Wenn eine sofortige Rückführung nicht möglich ist, wäre es dringend notwendig, die Serben und Bulgaren in ein Lager mehr im Innern der Provinz Brandenburg zu verlegen. ${ }^{2214}$ / Da jedoch auch in den anderen Bezirken der Provinz Brandenburg die Ernährungslage für die Bevölkerung durchweg außerordentlich schlecht ist, bitte ich Sie um Bereitstellung von Lebensmitteln für diese 9200 Serben und Bulgaren.

\section{(13) Bericht der Zentralverwaltung für deutsche Umsiedler über die Lage in Forst (Lausitz). - Berlin-Friedrichsfelde, 25. Oktober 1945}

BArch, DO 2 Zentralverwaltung für deutsche Umsiedler, Nr. 38, Bl. 95-97. - Typoskript, Durchschlag, 3 S. - S. 11. o.: „Abt. II / (Verteilung u. Abrechnung)“ [der ZVU]. - R. o.: „B[er]1[i]n-Friedrichsfelde, den 25.10.45“ - Überschrift: „Bericht über die Lage in Forst.“ - S. 3 (Bl. 97) mit Kopierstift unterzeichnet [gez.] „Baier“. - S. 1 (Bl. 95) r. o.: (rot) „Tgb.-Nr. 3/36/45 g / Blatt 13 / Kr. 1/2.“, darunter (grün) Paraphe vom 27.10., l. daneben (grün: „Herrn Wolter / Nach Kenntnisnahme zurückgeben“. - Ganz o. Kopierstift-Überschrift „Brandenburg“.

Forst ist unmittelbarer Grenzort und wird durch die Neiße in 2 Teile zerlegt. Die Polen benutzen Forst als Überleitungsstation. Die Umsiedler werden von den Polen auf polnischem Gebiet ausgeladen. Diese müssen dann über die Brücke den Weg nach Forst diesseits nehmen. / Ein Auffanglager besteht bisher in Forst nicht, die Gemeindeverwaltung hat sich bisher auch dagegen gewehrt, ein solches zu errichten, da sie nicht in der Lage sind, durch ein Lager festgehaltene Umsiedler zu verpflegen. / Die bisher in Forst aus Polen eingetroffenen Umsiedler werden weder registriert, noch zahlenmäßig festgestellt, geschweige denn in irgendeiner Form ärztlich betreut. Die Menschen haben sich meist in den Ruinen der Häuser aufgehalten und, solange es die Witterung zuließ, auch dort genächtigt. Ab und zu hat die Gemeindeverwaltung durch Polizeimaßnahmen diese Leute veranlaßt, Forst zu verlassen und weiterzureisen. Sie sind dann meist in Richtung Cottbus und weiter in das Innere gezogen. / In letzter Zeit wurden einige Quartiermöglichkeiten für die Nacht durch die Gemeindeverwaltung bereitgehalten, darunter das Hotel Kaiserhof. Am letzten Sonntag (21.10.45) sollen etwa 4000 Personen in Forst eingetroffen sein, wovon sie 2000 nach Cottbus abgeschoben haben sollen. Die übrigen sind in anderen Richtungen weitergezogen.

2214 [Aktennotiz o. D., wohl 28.9.1945 (BArch, DO 2/38, B1. 93):] Frau Sendhoff, Potsdam teilt[,] mit, dass Major Iwanzow die Entscheidung über die 9270 Umsiedler bekanntgegeben hat. Diese bleiben endgültig in Deutschland und werden in der Masse zirka 8000 nach Prenzlau zwecks Arbeitseinsatzgeschickt. Verhandlungen mit der Reichsbahn sind aufzunehmen. 
Von den 9260 Deutschen aus Jugoslavien, die seit einigen Wochen in Forst untergebracht sind, wurden in den letzten Tagen 380 Personen nach Luckenwalde und 2200 Personen nach Belzig weitergeleitet. / Die letzten Instruktionen lauten, daß diese Umsiedler nach Stralsund weitergeleitet werden sollen. Wer den Befehl herausgegeben hat, daß der Abtransport nach Luckenwalde bezw. Belzig vorgenommen werden sollte, konnte nicht ermittelt werden. / Es ist nun angeordnet worden, daß die noch in Forst verbliebenen 6680 Deutschen aus Jugoslavien per Sammeltransport nach Stralsund/Meckl. weitergeleitet werden sollen. Um diese Sammeltransporte durchzuführen, wurde mit der RBD Cottbus verhandelt. In Cottbus befinden sich keine Waggons. Die Waggons können nur beschafft werden durch die Zentralwaggonstelle der Zentralverwaltung für Verkehr. Bei Abtransport von je 1000 Personen wären unter Berücksichtigung des Gepäcks, das diese Umsiedler bei sich haben, 30 Güterwagen nötig. Wenn man berücksichtigt, daß jeder Transport mindestens 4 Tage bis zum Zielbahnhof gebraucht, und der Rücktransport des leeren Zuges voraussichtlich ebenso viel Zeit in Anspruch nimmt, so würden mindestens 6 Wochen vergehen, bis der letzte Abtransport durchgeführt ist. [B1. 96]

Die Stadtverwaltung wie auch der Stadtkommandant drängen darauf, daß diese Menschen schnellstens abtransportiert werden. Diese Menschen sind z. Zt. untergebracht in Wohnungen, mehrerer Straßenzüge von Forst. Diese Straßenzüge mußten seinerzeit geräumt werden, um alle Rückwanderer aus dem Osten, die von der Hitler-Regierung aus den von Deutschen besetzten Gebieten nach Deutschland zur Arbeit zwangsverschleppt wurden, unterzubringen. Dieser Rücktransport über Forst wurde abgeschlossen und die Deutschen aus Jugoslavien anschließend darin untergebracht. Um die in Forst verbliebene deutsche Bevölkerung wieder mit genügendem Wohnraum zu versehen, ist es zwingend notwendig, den Abtransport zu beschleunigen. Das ist auch notwendig in Anbetracht der Wiederingangsetzung der Produktion und ebenso notwendig aus hygienischen Gründen. Die Sterblichkeitsziffer im Ort beträgt bei einer Einwohnerschaft von 26200 täglich 35 und einer Geburtenziffer von 2 pro Tag, wovon meist noch 1 Kind nach einer Woche stirbt. Wenn diese sozialen Verhältnisse nicht geändert werden, würde Forst in ca. $28 \mathrm{Mo}-$ naten ausgestorben sein. Berücksichtigt muß noch werden, daß die Stadtverwaltung an die Bevölkerung in 15 Wochen bisher nur 3 Pfd. Brot pro Person ausgeben konnte. / Um den Abtransport beschleunigen zu können, wäre es notwendig, täglich mindestens 1 Zug von 1000 Personen zu organisieren. Das würde erfordern 180 Wagen, die schnellstens bereitgestellt werden müßten. Dann wäre in 1 Woche der Abtransport aller Umsiedler aus Jugoslavien durchgeführt.

Da Forst als Auffangbecken in Aussicht genommen war, wurden von der Provinzialverwaltung mit Unterstützung der Zentralverw[altung] für Gesundheitswesen ca. 20 Ärzte und ausreichendes Sanitätspersonal nach Forst entsandt. / Bei der Einstellung der Stadtverwaltung (für Forst kommt ein Auffanglager nicht in Frage) wurden die Ärzte bis auf 1 sowie das Sanitätspersonal wieder zurückgeschickt. Das Sanitätspersonal war unter den Versorgungsbedingungen nicht bereit, in Forst zu bleiben. / In Forst fehlen ${ }^{2215}$ auch fast alle notwendigen Medikamente. Zur 
Behandlung von Kranken unter den Umsiedlern stehen keine Mittel zur Verfügung. Frl. Dr. Zimmermann erklärte mir, daß sie in den Apotheken nicht die notwendigsten und einfachsten Medikamente erhalten konnte. Die Bevölkerung von Forst ist bisher noch nicht geimpft worden, da es an den notwendigen 40 L[iter] Typhusserum fehlt. / Da also alle Voraussetzungen für ärztliche Betreuung fehlen, erfolgt keine organisierte hygienische Abwehr. Es wird also nur der behandelt, der von sich aus den Arzt aufsuchen muß. Selbst Typhuskranke können in Forst nicht untergebracht werden, weil die zur Verfügung stehenden 200 Betten mit Forster Bürgern belegt sind. Folglich müssen die Typhuskranken mit den anderen mitwandern. / [Bl. 97] Die in unserem Rundschreiben Nr. 1 umrissenen Aufgaben waren in Forst nicht bekannt. Ebenso hatte der Arzt, Frl. Dr. Zimmermann, keine Instruktionen oder Anweisungen über die dem Arzt in Forst gestellten Aufgaben.

Nach Rücksprache mit dem Vertreter des Oberlandrats in Cottbus wurde vereinbart, daß sofort alle Maßnahmen getroffen werden, um in Forst ein Auffanglager für ca. 5000 Personen zu schaffen. Es wurde ferner zugesagt, daß sofort ein Verpflegungsreservelager für 5000 Personen geschaffen werden soll. / Es wurde ferner vereinbart, daß ein Ausschuß für die Gemeinde Forst gebildet werden soll, der sich mit all diesen Aufgaben und deren Durchführung befaßt.

Nachsatz: / Die meisten Umsiedler verlassen Forst mit den fahrplanmäßigen Zügen wie jeder andere Zivilreisende.

\section{(14) Bericht über die Tätigkeit der Umsiedlerbetreuungsstelle des Kreises Beeskow-Storkow. - Beeskow, 30. Oktober 1945}

BLHA, Rep. 250 Landratsamt Beeskow-Storkow, Nr. 867, unfol. - Typoskript (Durchschlag). - L. o. Absender: [fehlt wegen Verwendung eines Kopfbogens in der Ausfertigung: „Der Landrat des Kreises Beeskow-Storkow“] / „VII/U / Sozialamt - / Umsiedlerbetreuungsstelle“. - R. o. Datierung: „[Beeskow, den] 30. Oktober 1945“.- Keine Unterschrift oder Paraphe. - Überschrift: „Bericht/über die Tätigkeit der Umsiedlerbetreuungsstelle des Kreises BeeskowStorkow vom 21.10. bis 30.10.1945.“

In den letzten 10 Tagen war der Umsiedlerstrom schwach. Es handelte sich lediglich um Umsiedler, welche bis vor kurze[r] Zeit unter den Russen im polnischen Gebiet gearbeitet hatten. Diese Umsiedlerfamilien werden jetzt vom Russen bei ihrem Abzuge mitgenommen. Der Anfall beträgt im hiesigen Kreis ungefähr 1000 Personen, welcher sich laufend erhöht. Diese Umsiedler sind aber nicht in den Kreis Beeskow-Storkow eingewiesen, da lt. Anordnung des Herrn Oberlandrats in Bernau und auf Befehl der russischen Militäradministration jegliche Einweisungen gesperrt sind. Die hiesige Umsiedlerbetreuungsstelle steht daher in folgender schwierigen Lage: Einmal drängen die Umsiedler mit der Aufnahme, dazu kommt die Unterstützung der Russen, und auf der anderen Seite steht das Aufnahmeverbot des Herrn Oberlandrats in Bernau und der Befehl der russischen Militäradministration. Die Umsiedler befinden sich noch im hiesigen Kreis und werden teilweise vom Russen ernährt. Der restliche Teil der Umsiedler stiehlt sich das Essen zusammen. 
In der Berichtszeit wurden 106 Umsiedler aufgenommen. Somit ein Gesamtbestand von 21361 Umsiedlern. Die Aufnahmen setzen sich wie folgt zusammen:

5 Aufnahmen ins Altersheim,

$21 \quad$ auf Grund eines ärztlichen Attestes,

$54 \quad$ kurzfristig Eingewiesene wegen Krankheit[,]

12 Kriegsgefangene[,] die aus russischer Gefangenschaft entlassen sind und deren Familienangehörige hier eingewiesen sind.

14 Verwandtenaufnahmen 1. Grades, die bis jetzt von dem ${ }^{2216}$ Polen zur Arbeit zurückgehalten wurden und deren Angehörige im hiesigen Kreise eingewiesen sind.

$\overline{106}$

Das schwarze Wandern von Umsiedlern blüht immer noch. Einige Umsiedlerfamilien pilgern vom Kreis zu Kreis, weil sie mit ihrer ersten zugewiesenen Unterkunft nicht zufrieden waren. Es müssen m.E. an diese Umsiedlerfamilien strenge Bestrafungsmaßstäbe angelegt werden, da durch dieses undisziplinierte Umherwandern eine geregelte Umsiedlerfürsorge in Frage gestellt ist. Vornehmlich erscheinen diese Familien aus dem Kreise Guben.

Die Seuchenlage im Kreise Beeskow-Storkow ist weiterhin unverändert.

\section{(15) Meldung aus Angermünde über tägliche Flüchtlingsströme aus Polen. -} Berlin-Friedrichsfelde, 2. Dezember 1945

BArch, DO 2 Zentralverwaltung für deutsche Umsiedler, Nr. 38, Bl. 14. - Typoskript, Durchschlag. - O.1. „Sekr./1“, o. r. „Berlin-Friedrichsfelde, 2.12.1945“. Überschrift „Aktennotiz“. - R. o. handschriftlich (rot) „Tgb.-Nr. 3/47/46 g / Blatt 1./.13 / Ko. 3/4.“, darunter Stempel „zu den Akten“. - Unterzeichnet mit Kopierstift [gez.] „P. Schulz“, l.u. Paraphe und Verteiler.

Stadt Angermünde, Herr Schäfer, meldet am 2.12.45 10.30 Uhr vormittags fernmündlich, dass festgesetzte Flüchtlingsströme durchschnittlich 1500 pro Tag aus Scheune b. Stettin ${ }^{2217}$ von den Polen nach Angermünde gesandt werden. Diese Menschen kommen in einem unglaublichen Zustand an. Vollkommen verdreckt, verlaust, zerschlagen, vollkommen ausgeplündert, der grösste Teil ohne Handgepäck und ohne Verpflegung, halb verhungert in Angermünde an. Diese Flüchtlinge gehören an und für sich nach Mecklenburg. Es bestehen keine Unterbringungsmöglichkeiten mehr in Angermünde, da alle zur Verfügung stehenden Räume, wie Schulen, Gastwirtschaften und sonstige Gebäude überbelegt sind. Verpflegungsschwierigkei-

2216 [Handschriftlich korrigiert aus:] den.

2217 [Der Bahnhof Stettin-Scheune erhielt die Funktion „der ,nördlichen Drehscheibe für Vertreibung gen Westen, Repatriierung gen Osten und als Ankunftsort polnischer Siedler." (Holz, Evakuierte, Flüchtlinge und Vertriebene auf der Insel Rügen [wie Anm. 19], S. 122). Siehe auch Willi Neuhoff: Stettin-Scheune 1945. Drehscheibe und Schicksalsort für Flüchtlinge, Heimkehrer und Vertriebene. Hrsg. von Heinz Jonas. Woltersdorf 1995.] 
ten bestehen, Gruppen der Umsiedler versuchen infolgedessen sich ungeordnet nach Berlin durchzuschlagen. Für Angermünde besteht dadurch grösste Seuchengefahr. Eine Abänderung dieser Zustände war bisher nicht möglich, auch nicht durch Eingreifen des russ. Kommandanten. Es herrscht grosses Massensterben täglich. Zur Zeit des Anrufes wieder 20 Tote. Im Augenblick über 6000 Umsiedler in Angermünde. Zwei von der Zentralverwaltung Berlin zugesagte Züge, davon einer aus Mecklenburg, der andere aus Berlin, bisher nicht eingetroffen. Angermünde bittet daher sofort um die Gestellung von Zügen, zum Abtransport dieser Flüchtlinge nach Mecklenburg, da eine Verpflegung, ärztl. Betreuung und Registrierung nicht mehr möglich ist.

\section{(16) Bericht des Umsiedlerbetreuers des Landkreises Beeskow-Storkow. - Beeskow,} 8. Dezember 1945

BLHA, Rep. 250 Landratsamt Beeskow-Storkow, Nr. 867, unfol. - Typoskript, 1 Bl., mit Stempel und KopierstiftUnterschrift. v L. o. Absender: „Jaensch / Umsiedlerbetreuer“. - R. o. Datierung: „Beeskow, den 8. Dezember 1945“. Überschrift: „Bericht/vom 6.12.1945 vor [handschriftlich korrigiert aus „mit“] dem Herrn Bürgermeister und den Bezirksleitern.“ - Rückseite Unterschrift: [gez.] „Jaensch“, u.l. Adresse: „Der / Umsiedlerbetreuungsstelle in Beeskow/ Mark / zur Kenntnisnahme übersandt.“

1. Die Schießhalle ist z. Zt. mit nur eingewiesenen Umsiedlern belegt. Die Krankheitsfälle haben nachgelassen. Die an Typhus erkrankten Erwachsenen und Kinder sind aus dem Krankenhaus entlassen und sehen ihrer Genesung entgegen. Seit 8 Tagen ist die Schießhalle zur großen Freude der Insassen mit elektrischem Licht versehen. Leider haben sich zur allgemeinen Klage die Kopf- und Kleiderläuse, sowie Ratten und Mäuse eingenistet. Trotz Aufstellung von Fallen ist nur ein geringer Erfolg zu verzeichnen. Herr Eichberg war beauftragt, mit Zelio-Paste versehene Brocken auszulegen. Da er z. Zt. dieses Rattengiftmittel nicht zur Verfügung hat, konnte er den Auftrag nicht ausführen.

2. In der Turnhalle ist nur noch die linke hintere Seite mit eingewiesenen Umsiedlern belegt. Davon ist ein kleines Zimmer vermietet, während die andere Familie noch mietefrei (da ohne Einkommen) wohnt. Nach Rücksprache mit Herrn Krost werden jetzt die anderen Räume instandgesetzt, sodass zwei Wohnungen in absehbarer Zeit bezogen werden können. Aus dem vorderen Teil der Turnhalle muss eine Beeskower Familie ziehen, da dieser Raum Jugendheim, also seiner früheren Bestimmung zugeführt wird.

3. Im Forsthaus bleiben im Durchschnitt nur noch 3-5 Soldaten über Nacht, da der Zustrom der Gefangenen nachgelassen hat. Das dort eingerichtete Kinderheim ist aufgelöst, dafür hat das Waisenhaus diese Aufgabe mit übernommen. Das Waisenhaus hat bis zu 14 Kinder aufgenommen und betreut z. Zt. 11 Waisen bezw. Halbwaisen. Im Waisenhaus können auch Kinder aus den Nachbarbezirken bezw. Berlin aufgenommen werden, natürlich gegen einen höheren Tagespreis.

4. In Bahrensdorf in der Feuerwehrschule sind z. Zt. befristet 24 Personen eingewiesen, die sich in den Baracken aufhalten. Sie werden nach wie vor von Schwester Helene betreut. 
Die auf dem Gesundheitsamt eingesetzten Helferinnen versehen den Gesundheitsdienst für den ganzen Stadtbezirk durch regelmässige Begehungen der Wohnungen um die Typhusfälle, bezw. mit ansteckenden Krankheiten behafteten Personen in das Krankenhaus einweisen zu lassen. Diese Begehungen der Häuser haben eine Unterbrechung erfahren, durch die Schutzimpfungen gegen Typhus in den letzten Wochen, wodurch sich auch in unserem Kreise ein Rückgang der Typhuserkrankungen bemerkbar gemacht hat, während noch in den Monaten vorher über 600 Personen daran erkrankt waren, sind im letzten Monat 238 Fälle gemeldet, also nur $1 / 3$.

Anfang November habe ich von Frau Dr. Horlbeck ${ }^{2218}$ den Auftrag erhalten, die Fertigstellung der Entlausung voranzutreiben. Ich habe [mich] gleich daraufhin mit Herrn Wittmeyer (Abt. Bauwesen beim Landratsamt) in Verbindung gesetzt und jeweils regelmässig die Bauhandwerker aufgesucht und um dringende Ausführung der ihnen aufgetragenen Arbeiten gebeten. Es ist mir dann auch gelungen, etwas Schwung in die Sache zu bringen. Die Heiß-Kessel-Anlage für warmes Wasser und Duschanlage ist abgenommen und ist betriebsfähig. Im Duschraum sind auch zwei Badewannen und ein Waschtisch für die Kopfentlausung untergebracht. Die einzelnen Räume sind mit eisernen Öfen versehen. Die Öfen der Kleiderentlausungskammer mussten umgebaut werden, da es für [so!] die zur Abtötung der Läuse erforderlichen Hitzegrade nicht erbrachte. Inzwischen ist der Umbau erfolgt und dieser Mangel abgestellt. Als letztes konnte ich gestern das erforderliche Thermometer heranbesorgen. Die Entlausung könnte sofort in Betrieb gesetzt werden, wenn das nötige Brennmaterial geliefert werden würde. Leider ist es mir trotz mehrmaliger Rücksprache mit Herrn Ketelhohn nicht gelungen, Holz bezw. Kohlen heranzubesorgen. Die gestern angefahrenen Stubben sind vollständig nass und können zur Anheizung nicht gebraucht werden. Gestern wurde mir vom Landratsamt der Bescheid erteilt, dass nächste Woche mit Lieferung von trockenem Brennholz zu rechnen ist, sodass wir dann sofort mit der Entlausung beginnen können.

\section{[Nachtrag]}

Typoskript, 1 Bl., ohne Unterschrift. R.o.: Datierung: „Beeskow, den 13. Dezember 1945“.

Bei dem heutigen Telefongespräch mit dem stellvertretenden Amtsbürgermeister von BadSaarow teilte dieser folgendes mit: / Die Herrichtung der Barackenlager in der Gemeinde BadSaarow ist nur möglich, wenn der Amtsbezirk Bad-Saarow genügend Unterstützung bekommt, d.h., zur Behebung der Schäden in den Baracken werden nach Schätzung der zuständigen Herren ca. 40-50 Handwerker benötigt, welche im Amtsbezirk Bad-Saarow nicht vorhanden sind. Ferner fehlen in den vorhandenen Baracken sämtliche Fensterrahmen. Glas oder Holz zur Behebung der Schäden ist nicht vorhanden. Auch sind sämtliche in den Baracken vorhanden gewesenen Öfen und Betten von den russischen Kommandos entnommen worden. / Der 
zuständige Herr fragt an, wie sich die hiesige Dienststelle zu dieser Sachlage stellt, d. h., ob der Landrat in der Lage ist, die benötigten Handwerker, Öfen, Betten, Bretter usw. zur Verfügung zu stellen.

\section{(17) Bericht des Gemeindevorstehers von Pieskow über die durch sowjetische} Einquartierung verminderte Aufnahmefähigkeit für „Umsiedler“. Bad Saarow-Pieskow, 19. Dezember 1945

BLHA, Rep. 250 Landratsamt Beeskow-Storkow, Nr. 867, unfol. - Typoskript, 1 Bl., mit Stempel und KopierstiftUnterschrift. - L.o. Absender: „Gemeindeamt.“- Darunter Adressen/Verteiler: „1.) Dem Herrn Landrat, Umsiedlerstelle / 2.) Dem Herrn Amtsbürgermeister Bad Saarow.“- R.o. Datierung: „Bad Saarow-Pieskow, den 19. Dezember 1945.“- R.u. Stempel „Gemeinde Bad Saarow / [größer:] Pieskow“; Unterschrift „Gemeindeamt/ [gez.: Henk[?] / Der Gemeindevorsteher." - In der Akte folgt unmittelbar eine zweite, textidentische Ausfertigung (Durchschlag mit Stempel und Unterschrift) mit Unterstreichung des oben erstgenannten Empfängers sowie Eingangsstempel des Landratsamtes Beeskow vom 24. Dez. 1945 und grünem Verteiler „VII“ (für Sozialamt).

Das seither in Pieskow auf dem Gelände der ehemaligen Heeresabnahme [einquartierte] russische Batl. hat heute verfügt, dass es folgende Gebäude bis auf weiteres belegt:

1.) Schloss Pieskow mit allen Nebengebäuden

2.) Wassersportheim mit allen Baracken

3.) Dorfanger mit allen Baracken

4.) Posterholungsheim mit allen Nebengebäuden.

Die zwischen diesen angeführten Hauptgebäuden liegenden Bauernhäuser erhalten Einquartierung.

Wie mir der Kommandeur des betreffenden Batl. mitteilt, ist die Massnahme im Einverständnis mit dem Kommandanten von Bad Saarow erfolgt. Der Umzug ist bereits im Gange. Die schweren Schäden, besonders an Zentralheizungen, Fenstern usw., die durch die frühere Einquartierung entstanden sind, müssen von der Gemeinde Pieskow beseitigt werden.

Durch diese plötzliche Umbelegung ist über die Hälfte des in Aussicht genommenen Raumes für die Unterbringung von Umsiedlern ausgefallen. Es bleiben nur noch die Baracken am Kronprinzendamm und die Baracken des Lagers Dr. Gildemeister, soweit sie bewohnbar sind. Es können höchstens in diesen Baracken 800 Mann untergebracht werden, soll die Belegung einigermassen menschenwürdig sein.

Es wird gebeten, aus vorstehenden Ausführungen den einzig möglichen Schluss zu ziehen und zu verfügen, dass Pieskow auf keinen Fall mehr als 800 Umsiedler zur vorübergehenden Unterbringung erhält. 


\section{(18) Ärztlicher Bericht über einen vom Lager Angermünde nach Thüringen weitergeleiteten Vertriebenentransport aus Polen. - Gera, 1. Januar 1946}

BArch, DO 2 Zentralverwaltung für deutsche Umsiedler, Nr. 38, Bl. 3-4. - Typoskript, Durchschlag, 2 S. - O. „Abschrift“. - R. o.: „Gera, den 1.1.1946“. Darüber handschriftlich (rot) „3/01/46 g / Bl. 2.“, daneben Eingangsstempel „28.1.46“. - Überschrift: „Bericht/ des leitenden Arztes beim Amt für Umsiedler Gera über den Transport vom 30.12.1945 aus Angermünde.“ - S. 2 (Bl. 4) r. o. handschriftlich (rot) „3/01/46 g/ Bl. 3.“, daneben Eingangsstempel „28.1.46“. - Unterschrift „gez. Dr. Vollrath.“ - U.1. (nicht Durchschlag) „2 Abschriften gefertigt, für / Sanitäts-Abteilung / 28.1.1946 Reimann“. - Teildruck (zeitlich falsch eingeordnet): Wille I, S. 399. - Bemerkung: Diese Berichtsabschrift bildet die Anlage zu einem Schreiben des Landes Thüringen, Landesamt für Kommunalwesen, Weimar, 19.1.1946, an die ZVU in Berlin-Friedrichsfelde betr. „Umsiedlertransport Angermünde-Berlin-Gera 7008“ (Bl. 2), in dem der Bericht kurz zusammengefasst wird („spricht bereits derart für sich selbst, daß sich zusätzliche Bemerkungen erübrigen“) und mitgeteilt wird, dass der Transport „dem Lager Gera am 26.12.45 durch ein Telegramm des Magistrats Berlin (Hauptsozialamt) folgenden Inhalts angekündigt worden (war): ,Sonnabend fahren 2000 Umsiedler von Berlin nach Gera.' Abfahrtszeit und Zug-Nr. wurden nicht angegeben. [...].“ Zudem sei „in diesen Tagen schon wieder ein Transport aus Angermünde eingetroffen, der einige Tote enthielt. Näherer Bericht hierüber steht noch aus.“ Die „Ausführungen des Dr. med. Vollrath“ seien „dem Landespräsidenten Dr. Paul wie auch dem I. Vizepräsidenten des Landes Thüringen zur Kenntnisnahme zugeleitet“ worden; „auch die SMA. Weimar wurde unterrichtet.“ - Bl. 5: Am 21.1.1946 schrieb der „Präsident des Landes Thüringen“, Dr. [Rudolf] Paul, aus Weimar an ZVU in Berlin-Friedrichsfelde u. a.: „Wie Sie aus dem Bericht ersehen wollen, sind die Menschen dieses Transportes im höchsten Masse menschenunwürdig behandelt worden und das Land Thüringen hat Wochen[,] vielleicht sogar Monate nötig, um diese armen Menschen wieder auf den normalen Gesundheitszustand zu bringen." - Lt. Schreiben des Gesundheitsamtes Gera (kommissarischer Amtsarzt Dr. [Klaus] Rauh) an das thüringische Landesgesundheitsamt handelte es sich bei dem Transport um „Umsiedler“, „die fast ausnahmslos aus polnischem Gebiet stammen. [...] Der Zug fuhr am 26.12. von Angermünde ab und war am 30.12. abends in Gera; war also 5 Tage unterwegs. Während dieser 5 Tage fuhr der Zug durch Berlin und hielt auf mehreren Berliner Bahnhöfen. Trotzdem hat sich kein Mensch irgendwie um den Zug und seine Insassen gekümmert." (Bl. 6). Die ZVU führte daher eine Kontrolle in Angermünde durch und fand untragbare Verhältnisse vor (Bl. 7-12), forderte eine Schließung und schlug die Verteilung auf andere Lager sowie Neueinrichtung am Ort (siehe dazu auch das nachfolgend abgedruckte Schreiben des ZUV-Präsidenten an den Präsidenten der Provinzialverwaltung Brandenburg vom 29.1.1946].

Es ist schwer, sachlich zu bleiben bei der Beurteilung dieses Transportes, der in seiner Beschaffenheit, Versorgung und Betreuung einen derartigen Abgrund von Not und Elend aufriß, daß Anstrengung dazu gehört, nicht hinauszuschreien vor Schmerz und Empörung über soviel unverschuldetes Menschenleid. Es ist müßig, bei der Ergründung der wahren Ursachen dieser schrecklichen Verhältnisse stehen zu bleiben. Wir haben nur die Folgen zu sehen und uns mit ihnen auseinander zu setzen.

Die Versorgung des Transportes war in jeder Beziehung mangelhaft. In Angermünde war die Verpflegung nur für 3 Tage und nicht einmal an alle ausgehändigt worden, bei der einmaligen Verpflegung unterwegs waren ebenfalls nicht alle bedacht worden, so daß ein großer Teil während der einwöchigen Fahrt hungern mußte und sich notdürftig mit gestohlenen Kartoffeln und Wasser ernährte. Die Folgen waren sehr eindeutig: Zahlreiche Hungerödeme und Durchfälle mußten festgestellt werden. Im Allgemeinen befanden sich die Leute in einer körperlichen Verfassung, die jeder Beschreibung spottet. Das übliche Bild der Unterernährung, Erschöpfung, Übermüdung, Verdreckung, Verlausung, Verkrätzung, der Abgestumpftheit und Indolenz gegen alle äußeren Einflüsse war riesig ins Grauenhafte verzerrt. 
Es befanden sich in dem Zug 3 Tote und etliche Sterbende, von denen keiner Notiz nahm, um die sich niemand kümmerte und deren Identität oft nicht feststellbar war. Ein Arzt begleitete den Zug überhaupt nicht, die zugeteilte Schwester konnte der Aufgabe, einen solchen Zug sanitär allein zu betreuen, nicht gewachsen sein. Erschütternd wiederum das Bild der zahlreichen Alten, die unter den Verhältnissen am meisten zu leiden hatten und oft den Eindruck machten, als ob sie auf der Flucht vor allem Schrecklichen doch nur dem Tod entgegenwankten.

Der Zug selbst bestand aus ungeheizten Wagen, die größtenteils ohne Fenster waren. Notdürftig waren Abdichtungen aus Pappe, Stroh und Lumpen hergestellt worden. Die einzelnen Wagen starrten vor Dreck und Unrat und es war mehrstündige Arbeit erforderlich, sie für den Weitertransport wieder einigermaßen zu säubern. [B1. 4]

Welchen Einfluß das auf den Gesundheitszustand der Umsiedler, dieser in Lumpen gehüllten Jammergestalten hatte, beweisen folgende Zahlen: $90 \%$ waren verlaust, / $60 \%$ mit Krätze behaftet, / 3 Personen starben während des Transportes, / 7 Personen kurz nach dem Entladen, / 10 weitere liegen im Sterben, / 6 Personen waren geschlechtskrank, / 8 tuberkuloseverdächtig, / 11 typhusverdächtig, / 25 Krankenhauseinweisungen wurden vorgenommen, weitere sind noch erforderlich, / 94 Kranke wurden in die Krankenstation aufgenommen, darunter schwere Fälle von Pneumonie und Grippe, / über 200 Leichtkranke konnten auf der Station keine Aufnahme mehr finden und mußten ambulant behandelt werden.

Es wird eindringlich darauf hingewiesen, daß mit solchen Transporten, die durch ihre starke Verlausung alle als fleckfieberverdächtig anzusehen sind, die bisher geordnete sanitäre Betreuung im Übernahmelager Gera vollständig zerstört wird und mit größter Wahrscheinlichkeit Seuchen eingeschleppt werden, die das ganze Land überfluten. Dringend notwendig ist die sofortige Vergrößerung und Verbesserung der Entlausungsanlage in der Panzerkaserne, die solchen Aufgaben keineswegs gewachsen ist. Weiterhin wird erneut darauf hingewiesen, daß die Belastung des Personals durch diese Transporte in kürzester Zeit zu schweren gesundheitlichen Schädigungen und zum körperlichen Zusammenbrechen führen wird. Es müssen deshalb noch genügend Ersatzkräfte bereitgestellt werden, um die erhöhte Arbeit zu bewältigen.

(19) Beschwerde des Präsidenten der Zentralverwaltung für deutsche Umsiedler über die Zustände im Umsiedlerlager Angermünde. - [Berlin-Friedrichsfelde], 29. Januar 1946

BArch, DO 2 Zentralverwaltung für deutsche Umsiedler, Nr. 38, Bl. 9-10. - Typoskript, Durchschlag, 2 S. - L. o. nur (da in Ausfertigung Kopfbogen verwendet): „Der Präsident“ [der ZVU] / „-R“. - R. o.: 29. Januar 46“. - Adresse: „An den / Herrn Präsidenten / der Provinzialverwaltung/Mark Brandenburg/Potsdam“. - S. 2 [Bl. 10] unterzeichnet „Zentralverwaltung für / deutsche Umsiedler / gez. Engel / Der Präsident“. - S. 2 [Bl. 10] u.1. „Abschrift/an die Provinzialverwaltung / Mark Brandenburg - Umsiedleramt -, Potsdam, / Herrn Dr. Eberlein.“

Sehr geehrter Herr Präsident Steinhoff!

Auf Grund von Berichten aus Sachsen und Thüringen und auf Grund von Klagen aus Umsiedlerkreisen aus dem Gebiet Angermünde führten wir eine Kontrolle der Lager in und um Angermünde am Sonnabend, dem 26. Januar 1946 durch. Die dabei getroffenen Feststellungen sind 
derart, dass man nicht mehr von einer Nachlässigkeit oder von Fehlern sprechen kann. Diese unverantwortliche, leichtsinnige und fehlerhafte Arbeit lässt sich nur noch als Schädlingsarbeit qualifizieren, bewusste oder unbewusste. Die beiliegenden Berichte aus Gera über Transporte, die aus Angermünde nach dort geschickt wurden[,] $]^{2219}$ und der Bericht der Kontrolle vom 26.1. zeigen Ihnen[,] Herr Präsident, die Notwendigkeit, mit schärfsten Mitteln zu reagieren. Unser Kampf, Ausbreitung von Seuchen zu verhindern, wird illusorisch, wenn immer wieder Transporte aus den Ostgebieten über das ganze Land geschickt werden, die weder entlaust noch sanitär betreut sind, trotzdem alle Voraussetzungen an Ort und Stelle vorhanden sind, um diese Arbeit durchzuführen. Seit mehr als 4 Monaten wird das Gebiet um Angermünde immer wieder von uns als Brennpunkt bezeichnet und verlangt, dass alle notwendigen Voraussetzungen geschaffen werden, um die ankommenden Umsiedler organisatorisch zu erfassen und sanitär zu betreuen. Die Berichte der Kontrolleure Ihres Umsiedleramtes, die uns während dieser ganzen Zeit zugingen, waren reine Augenwischerei und waren voll von Versprechungen, die sich niemals realisierten. Dabei muss ich leider nun auch feststellen, dass von allen Ländern und Provinzen die Mark Brandenburg als die schlechteste und schwächste bezeichnet werden muss. Welche Bedeutung diese Feststellung für die gesamte Zone hat, ist ohne Weiteres klar, denn gerade Brandenburg hat als Seuchenschleuse und Auffang für die aus Osten einströmenden Umsiedler eine ungeheure Bedeutung im Landesmasstabe. Alle Versuche, beratend und helfend Ihrem Umsiedleramt zur Seite zu stehen, halte [S. 2 (Bl. 10)] ich jetzt für gescheitert, ich glaube, dass es notwendig sein wird, eine grundsätzliche neue Einstellung zur Umsiedlerfrage in Ihrer Verwaltung durchzuführen. Wenn es mir irgend möglich ist, möchte ich in den nächsten Tagen nach Potsdam kommen, um mit Ihnen[,] Herr Präsident, diese Frage eingehend zu besprechen. Zum speziellen Fall Angermünde habe ich heute mit Frau Oberprovinzialrätin Sendhoff und Herrn Friedrichs vom Umsiedleramt vereinbart, dass sofort eine Kommission nach Angermünde in Marsch gesetzt wird, zur Überfügung der Verhältnisse und Abstellung der Übelstände[,] und um eine Anzeige an die Staatsanwaltschaft gebeten, die Verantwortlichen für die dortigen Zustände zur Bestrafung zu bringen. Ich halte es für absolut notwendig, dort exemplarisch zu bestrafen, da die dortigen Zustände nicht mehr mit Unvermögen zu erklären sind. Es ist ohne Weiteres zu erwarten dass, wenn unsererseits nicht ganz energische Massnahmen ergriffen werden, die SMA ihrerseits den russischen Staatsanwalt für diesen Fall interessieren wird. Im Interesse des Aufbaues einer deutschen Selbstverwaltung scheint es mir geraten, erst unsererseits alle uns zur Verfügung stehenden Mittel aufzuwenden, um solche Misstände zu liquidieren.

Ich hoffe, Sie[,] Herr Präsident[,] recht bald besuchen zu können[,] und werde mich rechtzeitig bei Ihnen anmelden. 


\section{(20) Rede der Leiterin des Umsiedleramtes der Provinzialverwaltung, Sendhoff, vor Mitgliedern der KPD und SPD. - [Potsdam, Februar 1946]}

BLHA, Rep. 333 SED-Landesleitung Brandenburg, Nr. 574, Bl. 5-14. - Undatiertes Typoskript (Durchschlag) mit wenigen redaktionellen (Tinten-)Ergänzungen (u. a. die gesamte Überschrift), ohne Unterschrft; wohl Abschrift aus Wortprotokoll der gesamten Sitzung (Beiträge anderer Redner und Diskutanten wohl nur in Auswahl) übernommen. - Teildruck (nur Absätze 1 und 2 und etwa zur Hälfte Absatz 4) unter dem Titel „Schwierigkeiten bei der Einrichtung von Auffanglagern in der Provinz Mark Brandenburg und Appell an die einheimische Bevölkerung, den eintreffenden Vertriebenen bereits in den Lagern zu helfen (Auszüge aus einer Rede der Leiterin des Umsiedleramtes der Provinzialverwaltung, Sendhoff, vor Mitgliedern der KPD und SPD)“: Wille I, S. 337 f., Nr. 201 (mit der inzwischen veralteten Signatur BLHA, Rep. 330/IV-2/6.1/574, Bl. 200-203).

Von den Umsiedlern und zurückkehrenden Kriegsgefangenen in der Provinz Mark Brandenburg

Referat der Ministerialrätin Genossin Sendhoff:

Ich begrüsse es, dass in diesem Kreis einmal zur Umsiedlerfrage Stellung genommen wird, weil ich mir davon gute Auswirkungen für diese Aktion verspreche. Gerade in diesen Wochen ist eine gewisse Pause eingetreten und ist jetzt Zeit, die Schwächen und Mängel der Vergangenheit in dieser Arbeit zu untersuchen und Abhilfe zu schaffen, damit wir für den neuen Strom der Umsiedler, den wir im April/Mai mit Beginn der wärmeren Jahreszeit erwarten, gut vorbereitet sind.

Im vergangenen Jahr waren bis zum 1. Oktober ca. 637000 Umsiedler in die Provinz eingeströmt, z. T. in Trecks, die aber in unorganisierten Transporten kamen. Diese Umsiedler wurden in die Gemeinden aufgenommen und eingewiesen. Ein grosser Teil der Umsiedler - es wurden damals mehrere Hunderttausend geschätzt - zogen von einem Kreis in den anderen, bettelten sich durch, suchten auch die einzelnen Lager, die damals bestanden, auf und hielten sich in dem einfachen Bestreben, wenn diese Gebiete geöffnet oder wieder freigegeben würden, möglichst nahe der Grenze zu sein, um zuerst wieder in die Heimat zu kommen.

$\mathrm{Ab}$ Oktober v.J. trat eine neue Lage ein. Es setzten organisierte Transporte, die von Polen kamen, ein, die in Brandenburg aufgefangen wurden und dann weitergeleitet werden sollten nach Mecklenburg, spätere Teile nach Thüringen und Sachsen. Um diese Aufgaben zu bewältigen, wurden an den Grenzen Auffanglager geschaffen und in den Kreisen Kreislager. In den Auffanglagern, wo die Umsiedler einströmten, wurden sie ärztlich untersucht, entlaust, registriert und dann geschlossen in Transporten mit Zügen nach den anderen Provinzen befördert. Auf diese Art wurden bis Januar 1946 eine Viertel Million Menschen durchgeschleust; ausserdem wurden 50000 Menschen nach Ableistung einer 14tägigen Quarantäne in der Provinz eingemeindet. - Es ergaben sich in den Auffanglagern ungeheure Schwierigkeiten. Zum Beispiel war ein Haupt-Einschleuspunkt Küstrin. Diesseits der Oder ist das ganze Gebiet zerstört und es bestand keine Möglichkeit, dort Lager einzurichten, weil dort weder Wasser, noch Licht, noch Raum vorhanden waren. Wir waren deshalb gezwungen, auf der Ostseite der Oder in Küstrin die vorhandenen Baracken und Militärunterkünfte, die noch gut erhalten waren, [Bl. 6] als La- 
ger einzurichten. Es wurden dort laufend zeitweise bis zu 30000 Menschen beherbergt. Ihre Fortschaffung war so schwer, weil die Gestellung der Eisenbahnzüge nicht klappte. Infolge Zusammenstössen auf dem ostseitigen Gebiet musste dann Ende Dezember das Lager innerhalb von 5 Tagen geräumt werden. Weitere Einschleuspunkte waren Forst, Frankfurt und Spremberg. In Forst waren die Verhältnisse ebenfalls unzuträglich, weil auch dort infolge der Zerstörungen nur mangelhafte Lagermöglichkeiten waren. Es kamen auch dort weniger organisierte Transporte an, vielmehr handelte es sich um von den Polen über die einzige über die Oder führende Brücke wild hineingestossene Menschen, die oftmals bis zu einer Stärke von 1000 Personen ankamen. Die Menschen waren total verhungert, ausgeplündert und mißhandelt, verseucht und verdreckt.

In der Provinz bestanden ausser den 5 Auffanglagern bis jetzt 91 Kreislager, die im Verlaufe der letzten Monate ausgebaut wurden. In diesen Lagern bestanden Lagerausschüsse, die die Betreuung der Umsiedler vornahmen. In den Orten selbst bestand ein Umsiedlerausschuss und ebenfalls waren solche in den Kreisen vorhanden. Diese Umsiedlerausschüsse setzten sich zusammen aus Vertretern der vier antifaschistischen Parteien, meistens jedoch nur der beiden Arbeiterparteien, Vertretern der Gewerkschaft, dem Frauenausschuss, dem Lagerleiter und den verantwortlichen Personen der Sozialabteilungen. Es zeigte sich jedoch bei der ganzen Aktion, dass diese Ausschüsse nicht so arbeiteten, wie es sein sollte. Ich habe mehrfach in der Provinz mit solchen Ausschüssen gesprochen, auch Besichtigungen durchgeführt und immer wieder festgestellt, dass die Vertreter dieser Ausschüsse ihre Tätigkeit darin sahen, sich in bestimmten Zeitabständen von den Lagerleitern einen Bericht geben zu lassen über die Arbeit und diesen Bericht dann zu kritisieren. Selten ließen sie sich im Lager selbst sehen. Die Ausschüsse als solche hatten nicht erkannt, welche grosse politische Bedeutung die Umsiedlerfrage für uns hatte. Wir haben ihnen immer wieder klargemacht, dass es darauf ankommt, auch den letzten Brandenburger Bürger davon zu überzeugen, dass es nicht sein Verdienst ist, wenn er noch ein Dach über dem Kopf hat und dass es seine Pflicht und Schuldigkeit ist, den Umsiedlern, die ebenso viel oder ebenso wenig schuld an dem Elend sind, das wir durchmachen, zu helfen, dass wir die Pflicht haben, den Umsiedlern nicht nur zu einer neuen Heimat zu verhelfen, sondern [Bl. 7] ihnen auch ihr seelisches Gleichgewicht wiederzugeben und neuen Mut zum Leben. Wir dürfen in ihnen nicht lästige Eindringlinge und lästige Esser sehen, sondern müssen ihnen das Bewusstsein geben, dass sie auf unsere Hilfe rechnen können. Wir müssen sie erziehen zu Menschen, die tatkräftig helfen am Wiederaufbau des neuen Deutschland. Die Umsiedlerausschüsse haben die unbedingte Pflicht, in den Lagern laufende Kontrollen durchzuführen. In den Lagern selbst sind nur wenige als bezahlte Kräfte eingesetzt, wie z. B. der Lagerleiter, die Verantwortlichen in der Küche, die Verantwortlichen für die Ernährung, der Verantwortliche für die Registratur und einige andere Personen. Die Hilfskräfte müssen aus der Masse der Umsiedler gewonnen werden. Da es sich aber um grosse Mengen Lebensmittel handelt, die genauestens verteilt werden müssen und über die bis zum letzten Gramm abgerechnet werden muss, ist eine unbedingte genaue Kontrolle dieser Verwaltung notwendig. 
Von den 683000 Umsiedlern, die in die Provinz eingeströmt sind und untergebracht wurden, sind fast alle Kreise betroffen. Die Stärke der Unterbringung ist aus der vorliegenden Karte ${ }^{2220}$ zu ersehen. Nach dem Beschäftigungsverhältnis ergibt sich folgendes Bild: Es wurden untergebracht

$\begin{array}{llrl}\text { in der Landwirtschaft } & \text { rund } & 220000 & \text { Pers., } \\ \text { in der Industrie } & \text { rund } & 72000 & \text { Pers., } \\ \text { im Handel } & \text { rund } & 35700 & \text { Pers., } \\ \text { in den Ämtern } & \text { rund } & 2800 & \text { Pers., } \\ \text { im Handwerk } & \text { rund } & 48500 & \text { Pers. }\end{array}$

Die Zahl der Nichtbeschäftigten beträgt rund 290 000, davon entfallen auf Kinder etwa 190000. Ueber das im Zuge der Bodenreform an Umsiedler verteilte Land liegt bis jetzt eine Meldung vor, wonach an 6509 Umsiedler 40305 ha Land verteilt wurde. Die Zahl der nichtbeschäftigten Menschen setzt sich zum grossen Teil aus alten und kranken Personen zusammen. Die Krankenhäuser sind von Umsiedlern überfüllt; es handelt sich meistens um Menschen, die an Altersschwäche dahinsiechen. Hinzu kommt ein grosser Teil Waisenkinder, die in Waisenhäusern untergebracht sind. Wir haben eine ganze Anzahl Waisenhäuser, die nur mit Flüchtlingskindern belegt wurden. Es ist leider eine Tatsache, dass uns die Transporte aus dem Osten nicht viel Arbeitskräfte aber viel Wohlfahrtsempfänger bringen. Das bedeutet für ganze Gemeinden eine Katastrophe. Es zeigt sich, dass Gemeinden durch die Umsiedler derart finanziell überlastet sind, dass manche von ihnen vor dem Bankrott stehen. Die letzten Transporte sahen [Bl. 8] z.B. folgendermassen aus: Ein Transport von 1100 Personen umfasste 50 alte Männer, ca. 450 Frauen, davon die Hälfte über $50 \mathrm{~J}$., ca. 550 Kinder, von denen 80 Waisenkinder waren. Unter den Männern befanden sich 6, die fast erblindet[,] und 2, die ganz erblindet waren. So sieht also ein üblicher Umsiedlertransport aus. Trotz allem muss man immer wieder sehen, dass es sich um Menschen handelt, die ein Recht darauf haben, wieder irgendwo eine Heimat, ein Dach über dem Kopf zu finden. Man muss immer wieder davon ausgehen, dass man das Möglichste herausholen muss, um aus diesen Menschen Arbeitskräfte zu gewinnen. Es muss dafür gesorgt werden, dass bei der Ueberzahl der Frauen mit Kindern Kindergärten entstehen, um dadurch die Frauen zu entlasten und sie für die Arbeit freizumachen. Wir können diese Frauen mit Kindern nicht nur als Wohlfahrtsempfänger übernehmen.

Im Moment sollen 1 1/2 Millionen Umsiedler, von Polen kommend, in die englische Zone transportiert werden. Die ersten organisierten Züge von Osten nach Westen sind Anfang voriger Woche gerollt. Es besteht jedoch die Gefahr, dass wegen zu wenig Aufnahmebereitschaft im Westen der Pole erneut wieder nach Brandenburg einschleusen wird und wir müssen dann den Aufgaben gewachsen sein. Die anderen Provinzen haben den Vorzug, dass sie nicht direkt der 
Einschleuspunkt sind und sie nutzen ihn so, dass sie sich nach Möglichkeit gegen die Aufnahme sperren. Die Provinz Brandenburg ist einfach gezwungen, weil die Menschen hereingepumpt werden, diese jetzt zu versorgen. Das ist besonders zu unterstreichen, weil unsere Provinz an sich am schlechtesten daran ist, einmal durch die Zerstörungen durch die Kriegsereignisse und weil sie auch ernährungsmässig am schlechtesten dasteht. Wenn man rechnet, dass die $1 / 4$ Million Umsiedler, die nur durchgeschleust wurden, durchschnittlich mindestens 10 Tage in Brandenburg ernährt wurden, so kann man sich vorstellen, welche Lebensmittelmengen Brandenburg aufbringen musste.

Für die aus der Tschechoslowakei und Österreich im April/Mai einsetzenden Transporte sollen, wie uns von der Zentralverwaltung gesagt wurde, besser organisierte Verhältnisse geschaffen werden. Die Züge sollen nicht wahllos, sondern geordnet eintreffen. Daraus ergibt sich nach Vorschlag der Zentralverwaltung und auch der SMA Karlshorst, dass ein grosser Teil der vorhandenen Lager in der Provinz aufgelöst werden kann. Es bleiben in der Provinz Brandenburg 22 Lager bestehen, die durchschnittlich 1500 Personen fassen. Die [Bl. 9] übrigen Lager werden aufgelöst und ihre Bestände an Ausstattung usw. benutzt, die der kommenden Unterbringung dienen sollen, gut auszustatten. Es wird durch die Auflösung der Lager ein Apparat frei, der bezahlt wurde, und können wir auf diese Art eine beachtliche Summe Geldes sparen. Ein Teil der Lager kann auch benutzt werden, sofern es sich um feste Bauten handelt, um Umsiedlern als Dauerunterkunft zu dienen. Gute Kleinlager können auch dazu benutzt werden, um dort handwerkliche Betriebe einzurichten. Auffanglager befinden sich jetzt in Spremberg, Forst, Guben und Angermünde. Ein neues Auffanglager wird noch eingerichtet in Frankfurt. Die anderen Lager sind Kreislager, die zur Ableistung der Quarantäne dienen. Wir glauben, dass wir mit diesen Lagern den Anforderungen gewachsen sein werden. Notwendig ist jedoch, dass die Lager vorschriftsmässig ausgestattet werden. - Es ist ausserdem noch das Quenzlager in Brandenburg, dass zur Unterbringung und Aufnahme von Kriegsgefangenen dient. Alle Lager müsse in eine reine und eine unreine Station aufgeteilt werden. Es ist unbedingt notwendig, dass die Umsiedler, die entlaust sind, in saubere Räume kommen. Solange entlauste und nicht entlauste Umsiedler zusammen sind und entlauste Umsiedler in die alten Räume zurückgehen, ist eine Entlausung vollkommen zwecklos. Die Lager müssen eben zur Hälfte getrennt werden. Es muss dafür gesorgt werden, dass in den Lagern Pritschen aufgestellt werden, die ja bereits von den aufgelösten Lagern zur Verfügung stehen. Es ist unbedingt darauf zu achten, dass das Stroh erneuert wird, um Seuchengefahr zu vermeiden. Die Ausschüsse müssen es sich zur ernsten Aufgabe machen, regelmässig strenge Kontrollen in den Lagern durchzuführen. Diese Vertreter sollen gleichzeitig in den Lagern ein politische Propaganda machen und Lagerversammlungen abhalten, um mit den Umsiedlern zu sprechen. Die Umsiedler kommen vielfach völlig erschöpft an. Man sieht, dass sie nicht nur körperlich, sondern auch seelisch vollkommen zu Grunde gehen. Es müsste eine selbstverständliche Aufgabe der Ausschüsse sein, sich mit diesen Menschen in jeder Beziehung helfend zu befassen. 
Die Umsiedler machen eine 14tägige Quarantäne durch. Es ist unbedingt notwendig, die Registrierung der Umsiedler zweckmässigerweise so durchzuführen, dass man gemeinsam mit den Arbeitsämtern feststellen kann, welche Arbeitskräfte sich unter den Umsiedlern [Bl. 10] befinden, welche Berufe sie ausüben, um gleich Massnahmen zu schaffen, diese Arbeitskräfte in entsprechende Orte zu transportieren, wo sie gleich ihrem Beruf entsprechend arbeiten können. Die Frauenausschüsse haben bereits in den vergangenen Monaten vorbildliche Arbeit geleistet in der Betreuung der Umsiedler und werden auch in den kommenden Monaten das Gleiche leisten. Wir haben viele Lager, denen Näh- und Flickstuben, auch Schusterwerkstätten angegliedert sind. Es muss möglich sein, das notwendigste Werkzeug zu beschaffen, damit die schadhafte Kleidung und das schadhafte Schuhzeug der Umsiedler dort ausgebessert werden kann.

Nun etwas zu den Kriegsgefangenen. Bis Anfang des Jahres sind im Osten rund 25000 Kriegsgefangene in Frankfurt/Oder entlassen worden. Diese sollten, sofern es sich nicht um Berliner und Brandenburger handelt, nach dem Quenzlager in Brandenburg und von dort in die anderen Provinzen mittels Transporten gebracht werden. Die notwendige Arbeit unter den Kriegsgefangenen ist m. E. in politischer Beziehung noch weniger von den Parteien und Ausschüssen erkannt worden als in der Umsiedlerfrage. Wir müssen uns darüber klar sein, dass die Kriegsgefangenen nach ihrer Entlassung die Arbeiter in unseren Betrieben sein werden, dass sie in vorderster Front stehen müssen beim Wiederaufbau und es unbedingt notwendig ist, dass wir diese Menschen auf ihre Aufgabe vorbereiten. Praktisch war es so, dass es immer sehr schwer war, die Kriegsgefangenen von Frankfurt/Oder überhaupt nach Brandenburg hinzubekommen. Wenn in Frankfurt/ Oder 1500 Personen in einen Zug eingeladen wurden, kamen im Quenzlager in Brandenburg nur 50 an, die übrigen waren unterwegs ausgestiegen. Im Lager selbst haben die beiden ArbeiterParteien Versammlungen unter den Gefangenen abgehalten. Im Quenzlager selbst hat sich namentlich die KPD sehr darum bemüht, Eintritt in die russischen Lager zu bekommen[,] und ist dies nach vieler Mühe auch gelungen. Heute ist es bereits so, dass im Kriegsgefangenenlager eine Art Betriebsgruppe, ein Aktiv, besteht. Es zeigte sich sowohl im Lager Frankfurt wie auch im Quenzlager in Brandenburg, dass die Kriegsgefangenen mit sehr grossen Illusionen kommen. Sie sind der Ueberzeugung, dass sie dem Versprechen Hitlers zufolge den Zuschuss von 300 Mark und einen neuen Anzug sofort nach ihrer Entlassung bekommen. Sie glauben auch, dass ihnen dies zusteht, da sie schliesslich an der Front für Deutschland gekämpft haben. Sie können nicht sofort begreifen, [Bl. 11] wie grundlegend sich alles geändert hat. Es war ein ungeheurer Wissensdurst bei allen Kriegsgefangenen festzustellen und die Genossen werden förmlich mit Fragen überschüttet. Diese Menschen wollen alles wissen. Ich habe schon mehrmals versucht, auch gelegentlich einer Konferenz der vier Provinzen, dem Major Isakow ${ }^{2221}$ von Karlshorst den Vorschlag zu machen, dass die Kriegsgefangenen nicht in Frankfurt/Oder die Entlassungspapiere bekommen sollten, sondern erst im Quenzlager in Brandenburg. Es hat sich als unbedingt

2221 [Oberst Isakow war ab 1945/46 Chef der Abteilung für deutsche Umsiedler der SMAD (Foitzik, Sowjetische Militäradministration (wie Anm. 1094), S. 462).] 
notwendig erwiesen, dass die Kriegsgefangenen nochmals entlaust werden und eine Quarantäne durchmachen, da durch sie sofort Seuchen in die Provinz eingeschleust werden.

Ein Teil der Kriegsgefangenen ist aus dem Westen gekommen und wurde im Quenzlager untergebracht. Bei diesen Soldaten zeigten sich noch grössere Illusionen, allerdings nach der anderen Richtung hin. Sie glaubten nach allem, was man ihnen vor der Grenze gesagt hatte, dass in der russischen Zone die Offiziere gleich erschossen und die anderen Soldaten zum grössten Teil nach Sibirien verschleppt würden. Sie waren höchst erstaunt, dass sie ausgerechnet vom Russen sehr freundlich behandelt wurden und auch ohne weiteres ihre Papiere ausgehändigt erhielten. Ebenso erstaunt waren sie, dass sie in geheizten Räumen untergebracht wurden und täglich ihre warme Mahlzeit bekamen. Alles dies hatten sie niemals für möglich gehalten. Sie hatten sich aber trotz aller Schrecknisse, die man ihnen voraussagte, freiwillig gemeldet nach der russischen Zone, weil ihre Sehnsucht nach der Familie und der Drang nach Gewissheit über die Heimat stärker waren als jede Propaganda. Sie hatten im Westen monatelang unter Zelten auf kahlem Ackerboden zubringen müssen und auch nicht regelmässig warme Mahlzeiten erhalten. Auch um diese Menschen hatten sich die beiden Arbeiterparteien stark bemüht und hier war gleich eine Aufgeschlossenheit festzustellen. Wir hatten im Quenzlager auch die Möglichkeit geschaffen, durch einen Vertreter des Arbeitsamtes diese Menschen gleich in Arbeit zu vermitteln. Es war dies allerdings nur zu einem geringen Teil möglich, weil diese Gefangenen, genau so wie die Entlassenen aus Frankfurt/Oder nicht in der Lage sind, sofort zu arbeiten, sondern erst eine kurze Ruhezeit durchmachen müssen.

Für die Umsiedler aus Ost und West sowie für die Kriegsgefangenen besteht infolge der gemachten Erfahrungen die unbedingte Notwendigkeit, Massnahmen zu ergreifen, um die Gefahr des Flecktyphus [B1.12] zu bekämpfen. Wir haben hier in Brandenburg bereits in verschiedenen Lagern einige Typhus-Fälle. In Brandenburg Stadt allein sind 42 solcher Fälle zu verzeichnen. Das ist eine sehr ernste Gefahr. Es hat sich erwiesen, dass dieser Flecktyphus hereingeschleppt wurde durch Umsiedler und Kriegsgefangene. Da die Krankheit sich erst innerhalb 3 Wochen entwickelt, erkennt man sie nicht sofort. Darum müssen unbedingt sowohl die Umsiedler wie auch die entlassenen Kriegsgefangenen die Quarantänezeit durchmachen. Nach dem Befehl der russischen Besatzungsmacht müssen bestimmte Massnahmen ergriffen werden. Wir haben jetzt zusammen mit dem Gesundheitsamt und der Polizei Vorschriften ausgearbeitet und allen Kreisen bekanntgegeben, damit das Möglichste getan wird, diese furchtbare Krankheit von Brandenburg fernzuhalten. Es ist unbedingt notwendig, dass

1.) die Lager aufgeteilt werden in reine und unreine Stationen,

2.) die Umsiedler bezw. Kriegsgefangenen in der ersten Woche dreimal entlaust werden und nach Schluss der Quarantäne nochmals.

Die Ausschüsse müssen unbedingt dafür sorgen in Zusammenarbeit mit der Lagerleitung, dass die Entlausungsanlagen ständig in Ordnung sind. 
3.) An den Grenzen der Provinz müssen die Wege und Stationen von Polizei überwacht werden, damit jeder Mensch, der die Grenze übertritt, kontrolliert wird. Nur wer nachweisen kann, dass die letzte Entlausung nicht länger als 5 Tage zurückliegt, kann vorschriftsmässig durchgelassen werden.

4.) Auf allen Stationen dürfen Fahrkarten an Nichtansässige ebenfalls nur dann verkauft werden, wenn eine Entlausung nicht länger als 5 Tage zurückliegt.

Auch hier muss seitens der Polizei stark kontrolliert werden. Alle Menschen, die aufgefangen werden und nicht nachweisen können, dass sie entlaust sind, müssen in ein Lager geschafft und gezwungen werden, erforderlichenfalls eine Quarantänezeit durchzumachen. Es sind harte Massnahmen notwendig, wenn wir die Seuche erfolgreich bekämpfen wollen. Die Massnahme des Kartenverkaufs nur bei Nachweis der Entlausung wird auch in anderen Provinzen durchgeführt, sodass man nicht zu befürchten braucht, dass von anderen Städten Menschen herkommen und die Seuche mitbringen.

5.) Neue Lebensmittelkarten dürfen an Nichtortsansässige nur ausgehändigt werden, wenn sie durch ordnungsmässige Papiere nachweisen, dass die letzte Entlausung nicht länger als 5 Tage zurückliegt.

Nur wenn wir ganz hart und unerbittlich alle diese Massnahmen durchführen, ist ein Erfolg in der Bekämpfung des Flecktyphus gesichert. [Bl. 13]

[Sozialversicherung und Umsiedler $]^{2222}$

\section{Genosse Kienast}

nimmt vom Standpunkt der Sozialversicherung zu der Umsiedlerfrage Stellung. Wenn die Genossin Sendhoff berichtet, dass 683000 Umsiedler untergebracht worden sind, dann kann man bestimmt annehmen, dass 100-150000 Rentner in dieser Zahl enthalten sind. Nimmt man nun noch die Kriegsbeschädigten hinzu, so kommen zu der bereits für Brandenburg feststehenden Zahl der Altrentner in Höhe von 200000 noch weitere 200-250 000 Unterstützungsberechtigte. Es ergäbe sich somit eine Gesamtzahl von 400-500 000 Rentnern. Augenblicklich sind aber nur etwas über 500000 pflichtversichert, von denen die Sozialversicherungsanstalt Einnahmen aus Sozialabgaben erzielt. Das bedeutet also, dass die finanzielle Basis der neuen Sozialversicherungsanstalt überbelastet wird. Selbstverständlich wird es Aufgabe der SozialversicherungsAnstalt sein, den Umsiedlern auf alle Fälle zu helfen. Sie sollen nicht als fünftes Rad am Wagen betrachtet werden. Selbstverständlich kann man aber nur im Rahmen des Möglichen helfen. Im Hinblick auf die neue Steuererhöhung wäre es ohne weiteres möglich, die Umsiedler durch die Sozialversicherungs-Ordnung zu erfassen und zu betreuen, wenn ein provinzieller und überprovinzieller Kostenträger ermittelt wird, d.h. also, wenn provinzielle Mittel für die Umsiedler der Sozialversicherungsanstalt zur Verfügung gestellt werden. Eine weitere Möglichkeit der 
Hilfe besteht darin, dass man die Umsiedlerausschüsse beauftragt, örtlich festzustellen, welche Umschulungsmöglichkeiten für die Umsiedler gegeben sind. Entsprechende Berichte wären einzureichen, damit die Sozialversicherungsanstalt im provinziellen Maßstab planen und die Umschulungskräfte einsetzen kann. Es lassen sich überall in den verschiedensten Ortschaften zumindest in grösseren Betrieben betriebsnahe Schulungen durchführen. ${ }^{223}$

Genosse Seibt ...2224

Genossin Sendhoff 225

betont nochmals, wie notwendig es ist, einen Lastenausgleich sowohl zwischen den Gemeinden wie auch zwischen den Provinzen zu schaffen. Das, was Provinz Brandenburg hat tragen müssen bei der Durchschleusung der $1 / 4$ Million Umsiedler sowie bei der Durchschleusung von Kriegsgefangenen, ist eine überprovinzielle [Bl. 14] Angelegenheit. Man kann auch nicht erwarten, dass die Provinz Brandenburg den ganzen sogenannten Lagerrest schluckt. Bei der Aufteilung der Zentralverwaltung für deutsche Umsiedler im Oktober v.J. hinsichtlich der zu erwartenden Umsiedler blieb ein Rest von 780000 Menschen, der nicht aufgeteilt war. Auf Anfrage wurde gesagt, das sei der sogenannte Lagerrest, die Kranken, Siechen, Alten und zum anderen Teil seien es Faschisten, die isoliert werden müssten. Es wird von vornherein mit $25 \%$ Kranken gerechnet, dafür ist ein Lagerausgleich unbedingt notwendig.

Ich muss nochmals darauf hinweisen, dass da, wo die Umsiedler eingemeindet werden, ihnen unbedingt Arbeitsmöglichkeiten geschaffen werden müssen. Sind sie in der Landwirtschaft beschäftigt, darf es nicht so sein, dass sie zwar einen Sommer hart arbeiten dürfen, dann im Winter den Bauern lästig sind und der öffentlichen Fürsorge zur Last fallen. In Henningsdorf ${ }^{226}$ bei Berlin ist ein sehr schönes Beispiel, wie man den Menschen helfen kann. Dort hat man mit dem Bau eines Lagers gleichzeitig Räume geschaffen, um die Umsiedler in Handwerksbetrieben, in Handwebereien und Werkstätten zu beschäftigen. Es gibt Möglichkeiten, Töpfereien einzurichten, Werkstätten zur Herstellung von Holzschuhen, Handwebereien oder Werkstätten für landwirtschaftliche Geräte zu schaffen. Auch hier muss man sagen, dass da, wo ein Wille ist, auch ein Weg gefunden wird.

2223 [Handschriftlicher redaktioneller Zusatz am Ende von Bl. 13:] Sozialversicherung u. Umsiedler von Kienast als letztes bringen.

2224 [Text fehlt in der Vorlage. - Gemeint ist wohl Kurt Seibt (1908-2002), Sekretär der SED-Landesleitung und MdL.]

2225 [Handschriftlicher redaktioneller Zusatz am Rande:] Schlusswort der Frau Sendhoff am Schluss der Seite 8 anhängen [d.h. nach ihrem obigen Haupttext und vor dem Redebeitrag Kienast].

2226 [Richtig: Hennigsdorf.] 


\section{(21) Protokoll einer Referentenbesprechung im Amt für Arbeit und Sozialwesen der Provinzialverwaltung Mark Brandenburg. - Potsdam, 17. Juni 1946 (Auszug)}

BLHA, Rep. 206 Ministerium für Wirtschaft und Arbeit, Nr, 2965, unfol. - Typoskript (Durchschlag), 2 Bl. (Vollständigkeit nicht gesichert), ohne Unterschrift. - Auf 1. S. o.1. „Provinzialverwaltung / Mark Brandenburg / Amt für Arbeit u. Sozialwesen / Akz./VII Gor., r. o. „Potsdam, den 17. Juni 1946 / Alte Zauche 67 / Haus I“. - Überschrift „Protokoll!“, darunter Anwesenheitsliste.

$[\ldots][2 . \mathrm{Bl}].[\ldots]$

Herr Friedrichs (Umsiedler)

Die Provinz Brandenburg ist durch Hereinströmen der Umsiedler sehr stark belastet. 50000 Umsiedler aus der Tschechoslowakei sind zu erwarten. 23 Lager haben wir zur Verfügung, davon 2 Auffanglager, Fürstenberg ${ }^{2227}$ und Spremberg. Dort wird die Entlausung vorgenommen. Jeden 3. Tag könnte dort ein Transport von 1500 Menschen durchgeschleust werden. Die Quarantänezeit dauert 5 Tage, kann sich aber durch Fleckfieber usw. verlängern.

Viele Menschen aus den westlichen Zonen kommen nach der russischen Zone. Dies darf nur mit Zuzugsgenehmigung geschehen. Die S. M. A. hat eine Verfügung erlassen, nach der neu hinzuziehende ohne Genehmigung nach dem Grenzort zurückgeschickt werden müssen.

Dr. Eberlein

wünscht eine besondere Betreuung der entlassenen jugendlichen Kriegsgefangenen in den Lagern. [/] Zur Entnazifizierung. Es geht nicht an, daß sich Angehörige der N.S.D.A.P. im Westen entnazifizieren lassen und dann nach hier zurückkehren. Über dieses Thema ist eine eingehende Besprechung vorgeschlagen.

\section{(22) Gemeindestatistik des Kreises Beeskow-Storkow über Vertriebenenzahl und Zerstörungsgrad. - Bernau, 26. Juli 1946}

BLHA, Rep. 230 Oberlandratsamt Bernau, Nr. 20, Bl. 6-9. - Typoskript, 4 Bl. -Bl. 6: Begleitschreiben auf Kopfbogen „Der Landrat / des Kreises Beeskow-Storkow“ / Geschäftszeichen: „VII/U/C 3“ / [masch.: ] „Amt für Arbeit und Sozialwesen“. - R. o. Datierung: „Beeskow, den 26. Juli 1946“. - Adresse: „Herrn / Oberlandrat / in Bernau“. - Stempel „Der Landrat des Kreises Beeskow-Storkow / Umsiedler-Betreuungsstelle“ und Bleistift-Unterschrift „I.A. [...?]“. Eingangsstempel „Der Oberlandrat / Eing.: 1. Aug. 1946“, darin handschriftliche Nr. „6571“; grüne Paraphe „H[?]“ und Zuständigkeitsvermerk „VII“. - Bl. 7-9: [Anlage:] Tabelle.

In der Anlage überreichen wir Ihnen eine Aufstellung über die Stammeinwohner, Umsiedler und Prozentsatz der Zerstörung der Gemeinden des Kreises Beeskow-Storkow. ${ }^{2228}$

[Bl. 7] 


\begin{tabular}{|c|c|c|c|c|}
\hline Lfd. Nr. & Gemeinde & Stammeinwohner & Umsiedler & Grad der Zerstörung \\
\hline 1. & Beeskow & 5570 & 2152 & $66 \%$ \\
\hline 2. & Storkow & 3245 & 1765 & $40 \%$ \\
\hline 3. & Wendisch-Buchholz & 867 & 147 & $90 \%$ \\
\hline 4. & Ahrensdorf & 139 & 98 & $40 \%$ \\
\hline 5. & Alt-Golm & 165 & 147 & - \\
\hline 6. & Alt-Schadow & 227 & 234 & $30 \%$ \\
\hline 7. & Alt-Stahnsdorf & 277 & 209 & - \\
\hline 8. & Bad-Saarow & 1391 & 670 & $40 \%$ \\
\hline 9. & Behrensdorf & 104 & 103 & - \\
\hline 10. & Neu-Behrensdorf & 207 & 176 & - \\
\hline 11. & Bindow & 398 & 562 & $6 \%$ \\
\hline 12. & Birkholz b. Beeskow & 106 & 128 & - \\
\hline 13. & Birkholz b. W[endisch]-Buchholz & 151 & 183 & \\
\hline 14. & Blossin & 131 & 151 & $15 \%$ \\
\hline 15. & Bornow & 191 & 81 & $5 \%$ \\
\hline 16. & Braunsdorf & 265 & 105 & - \\
\hline 17. & Briescht & 215 & 139 & - \\
\hline 18. & Buckow & 415 & 355 & - \\
\hline 19. & Bugk & 173 & 153 & $15 \%$ \\
\hline 20. & Dahmsdorf & 117 & 85 & $5 \%$ \\
\hline 21. & Dannenreich & 175 & 111 & $2 \%$ \\
\hline 22. & Diensdorf & 201 & 160 & $5 \%$ \\
\hline 23. & Dolgenbrodt & 128 & 216 & $5 \%$ \\
\hline 24. & Drahendorf & 72 & 70 & $3 \%$ \\
\hline 25. & Falkenberg & 186 & 119 & $15 \%$ \\
\hline 26. & Friedersdorf & 1131 & 677 & $5 \%$ \\
\hline 27. & Friedrichshof & 167 & 81 & - \\
\hline 28. & Giesensdorf & 115 & 141 & $8 \%$ \\
\hline 29. & Glienicke & 705 & 446 & $5 \%$ \\
\hline 30. & Görsdorf b. Beeskow & 249 & 96 & - \\
\hline 31. & Görsdorf b. Storkow & 301 & 154 & $6 \%$ \\
\hline 32. & Görzig & 216 & 262 & - \\
\hline 33. & Gosen & 711 & 183 & $4 \%$ \\
\hline 34. & Gross-Eichholz & 152 & 109 & $15 \%$ \\
\hline 35. & Gross-Rietz & 288 & 188 & $5 \%$ \\
\hline 36. & Gross-Schauen & 128 & 97 & $10 \%$ \\
\hline 37. & Gross-Wasserburg & 136 & 171 & $30 \%$ \\
\hline 38. & Hartmannsdorf & 551 & 345 & $5 \%$ \\
\hline
\end{tabular}




\begin{tabular}{|c|c|c|c|c|}
\hline Lfd. Nr. & Gemeinde & Stammeinwohner & Umsiedler & Grad der Zerstörung \\
\hline 39. & Hermsdorf & 170 & 136 & $35 \%$ \\
\hline 40. & Herzberg & 656 & 484 & $\begin{array}{r}- \\
{[\mathrm{Bl} .8]} \\
\end{array}$ \\
\hline 41. & Hohenbruck [Hohenbrück] & 82 & 79 & - \\
\hline 42. & Kablow & 552 & 286 & - \\
\hline 43. & Kablow-Ziegelei & 257 & 166 & $15 \%$ \\
\hline 44. & Kehrigk & 111 & 113 & $80 \%$ \\
\hline 45. & Ketschendorf & 6417 & 870 & - \\
\hline 36. & Kirchhofen & 46 & 46 & - \\
\hline 37. & Klein-Schauen & 98 & 94 & - \\
\hline 48. & Klein-Rietz & 66 & 59 & $30 \%$ \\
\hline 49. & Köthen & 105 & 111 & $5 \%$ \\
\hline 50. & Kohlsdorf & 135 & 112 & $25 \%$ \\
\hline 51. & Kolberg & 336 & 120 & - \\
\hline 52. & Kolpin & 303 & 105 & $12 \%$ \\
\hline 53. & Kossenblatt & 423 & 331 & $15 \%^{2229}$ \\
\hline 54. & Krausnick & 598 & 234 & $15 \%$ \\
\hline 55. & Krügersdorf & 105 & 135 & - \\
\hline 56. & Kummerow & 63 & 76 & - \\
\hline 57. & Kummersdorf & 316 & 153 & $2 \%$ \\
\hline 58. & Kunersdorf & 31 & 52 & - \\
\hline 59. & Langewahl & 679 & 208 & $45 \%$ \\
\hline 60. & Lebbin & 121 & 53 & - \\
\hline 61. & Leibsch & 234 & 148 & - \\
\hline 62. & Limsdorf & 123 & 146 & - \\
\hline 63. & Lindenberg & 481 & 451 & - \\
\hline 64. & Markgrafpieske & 775 & 399 & $10 \%$ \\
\hline 65. & Märkisch-Rietz & 357 & 265 & $15 \%$ \\
\hline 66. & Merz & 183 & 91 & - \\
\hline 67. & Möllendorf & 109 & 79 & - \\
\hline 68. & Münchehofe & 265 & 228 & $35 \%$ \\
\hline 69. & Neu-Boston & - & - & - \\
\hline 70. & Neubrück & 371 & 191 & $3 \%$ \\
\hline 71. & Neuendorf b. Beeskow & 100 & 87 & $5 \%$ \\
\hline 72. & Neuendorf b. W[endisch]-Buchholz & 229 & 141 & $45 \%$ \\
\hline 73. & Neu-Golm & 204 & 123 & - \\
\hline
\end{tabular}

2229 [15 durchgestrichen und links daneben gesetzt:] $\downarrow$ 


\begin{tabular}{|c|c|c|c|c|}
\hline Lfd. Nr. & Gemeinde & Stammeinwohner & Umsiedler & Grad der Zerstörung \\
\hline 74. & Neu-Reichenwalde & - & - & - \\
\hline 75. & Neulübbenau & 417 & 233 & $30 \%$ \\
\hline 76. & Neu-Schadow & 158 & 61 & $30 \%$ \\
\hline 77. & Neu-Zittau & 1580 & 208 & $3 \%$ \\
\hline 78. & Neu-Stahnsdorf & 74 & 39 & - \\
\hline 79. & Niederlehme & 2156 & 529 & $\begin{array}{r}2 \% \\
{[\text { Bl. } 9]} \\
\end{array}$ \\
\hline 80. & Oegeln & 130 & 85 & - \\
\hline 81. & Petersdorf & 372 & 144 & $6 \%$ \\
\hline 82. & Pieskow & 304 & 203 & $4 \%$ \\
\hline 83. & Pfaffendorf & 311 & 278 & $2 \%$ \\
\hline 84. & Philadelphia & 231 & 275 & $6 \%$ \\
\hline 85. & Prieros & 610 & 275 & $6 \%$ \\
\hline 86. & Radinkendorf & 126 & 158 & $2 \%$ \\
\hline 87. & Radlow & 128 & 99 & $9 \%$ \\
\hline 88. & Ragow & 208 & 113 & - \\
\hline 89. & Ranzig & 136 & 152 & - \\
\hline 90. & Rauen & 1477 & 537 & $10 \%$ \\
\hline 91. & Rassmannsdorf & 59 & 68 & - \\
\hline 92. & Reichenwalde & 536 & 393 & - \\
\hline 93. & Rietz-Neuendorf & 63 & 62 & - \\
\hline 94. & Rieplos & 200 & 120 & - \\
\hline 95. & Sauen & 139 & 127 & $5 \%$ \\
\hline 96. & Schneeberg & 205 & 130 & - \\
\hline 97. & Schwenow & 67 & 41 & $4 \%$ \\
\hline 98. & Schwerin & 62 & 63 & - \\
\hline 99. & Selchow & 291 & 156 & - \\
\hline 100. & Spreenhagen & 729 & 385 & $15 \%$ \\
\hline 101. & Streganz & 142 & 82 & $15 \%$ \\
\hline 102. & Stremmen & 158 & 227 & $5 \%$ \\
\hline 103. & Tauche & 253 & 281 & - \\
\hline 104. & Werder & 112 & 74 & $3 \%$ \\
\hline 105. & Wernsdorf & 1270 & 334 & $2 \%$ \\
\hline 106. & Wilmersdorf & 224 & 99 & - \\
\hline 107. & Wochowsee & 39 & 82 & $8 \%$ \\
\hline 108. & Wulfersdorf & 196 & 66 & $6 \%$ \\
\hline 109. & Sabrodt & 148 & 128 & $5 \%$ \\
\hline 110. & Trebatsch/Rocher & 259 & 216 & $6 \%$ \\
\hline
\end{tabular}




\begin{tabular}{|c|l|c|c|c|}
\hline Lfd. Nr. & \multicolumn{1}{|c|}{ Gemeinde } & Stammeinwohner & Umsiedler & Grad der Zerstörung \\
\hline 111. & Sawall & 129 & 107 & $6 \%$ \\
\hline 112. & Wolzig & 387 & 158 & - \\
\hline & zusammen & 49153 & 24322 & \\
\hline
\end{tabular}

\section{(23) Gemeindestatistik des Kreises Niederbarnim über Vertriebenenzahl und Zerstörungsgrad. - Bernau, 16. August 1946}

BLHA, Rep. 230 Oberlandratsamt Bernau, Nr. 20, Bl. 2-5. - Typoskript, 4 Bl. - Bl. 2: Begleitschreiben. Absender 1. o. „Der Landrat / des Kreises Niederbarnim / VII/10a H/Ha." R. o. Datierung „Bernau/b. Berlin, den 16.8.46“. - Adresse: „An den / Herrn Oberlandrat Bezirksverwaltung Berlin / z. Hd. v. Frau Dr. Hartung / Bernau“. - Betreff: „Betr.: Einwohner-Umsiedler, Zerstörungsgrad der einzelnen Gemeinden.“ - Unleserliche Bleistift-Unterschrift mit vorangestelltem masch. „I. A.“ und Frakturschrift-Stempel „Landrat / des Kreises Niederbarnim“. - R. o. Eingangsstempel „Der Oberlandrat / Eing.: 19. Aug. 1946“ / [darin handschriftlich: „T 8689“; o. Mitte (Kopierstift-)Zuständigkeitsvermerk „VII“. - Bl. 3-5: Anlage: Tabelle.

In obiger Angelegenheit gebe ich Ihnen die gewünschte Aufstellung, die ich auch gleichzeitig nach Potsdam ${ }^{2230}$ einreiche. Die noch ausstehenden Angaben einzelner Gemeinden lasse ich sofort nach Eingang folgen. ${ }^{2231}$

\section{Anlage.}

$[\text { B1. 3] }]^{2232}$

\begin{tabular}{|l|c|c|c|}
\hline \multicolumn{1}{|c|}{ Gemeinde } & $\begin{array}{c}\text { Stamm- } \\
\text { bev[ölkerung] }\end{array}$ & Umsiedler & Grad der Zerst[örung] \\
\hline Bernau & 12414 & $\begin{array}{c}1116+155 \\
\text { Tsch[echen] }\end{array}$ & 8\% zerst. (?) $)^{2233}$ \\
\hline $\begin{array}{l}\text { Lobethal } \\
\text { [Lobetal] }\end{array}$ & 88 & $\begin{array}{c}\text { 232 Heimins[assen] } \\
\text { 33 Kdh. (i[m] Kinder- } \\
\text { heim) }\end{array}$ & nicht. \\
\hline Zepernick & 8230 & 998 & $0,75 \%$ zerst. \\
\hline Birkholz & 416 & 153 & $20 \%$ zerst. \\
\hline Lindenberg & 1567 & 373 & nicht zerst. \\
\hline Schönow & 3450 & 150 & $5 \%$ zerst. \\
\hline Schwanebeck & 2470 & 242 & 2 [zerst.] \\
\hline
\end{tabular}

2230 [Wohl an Abt. Inneres I Statistisches Amt.]

2231 [In der Akte nicht enthalten.]

2232 [Die nachfolgende Tabelle enthält in der Vorlage keine Tabellenrahmen. In der Edition weggelassen wurde die letzte Spalte „Bemerkungen“, da sie in allen Fällen leer gelassen worden ist. Die hier kursiv gesetzten Ortsnamen sind im Original lediglich unterstrichen; ihre Hervorhebung bezieht sich auf die Amtsbezirkssitzorte. Bis auf wenige Ausnahmen sind die Zahlen mit Bleistift abgehakt.]

2233 [Das Fragezeichen steht über „zerst.“; die urspr. Eintragung „nicht zerstört“ ist durchgestrichen.] 


\begin{tabular}{|c|c|c|c|}
\hline Gemeinde & $\begin{array}{c}\text { Stamm- } \\
\text { bev[ölkerung] }\end{array}$ & Umsiedler & Grad der Zerst[örung] \\
\hline Alt-Landsberg & 4746 & 1006 & $1,3 \%$ zerst. \\
\hline Löhme & 292 & 121 & nicht zerst. \\
\hline Seefeld & 574 & 177 & $5 \%$ zerst. \\
\hline Krummensee & 176 & 172 & $\begin{array}{c}34 \text { Gebäude besetzt, beschäd }[\text { igt }] \\
\text { bzw. zerstört }\end{array}$ \\
\hline Seeberg & 444 & 161 & $50 \%$ zerst. \\
\hline \multicolumn{4}{|l|}{ Birkenwerder } \\
\hline \multicolumn{4}{|l|}{ Bergfelde } \\
\hline \multicolumn{4}{|l|}{ Borgsdorf } \\
\hline \multicolumn{4}{|l|}{ Hohen Neuendorf } \\
\hline \multicolumn{4}{|l|}{ Stolpe } \\
\hline \multicolumn{4}{|l|}{ Schönfliess } \\
\hline Börnicke & 309 & 175 & $10 \%$ zerst. \\
\hline Erkner & 6530 & 217 & $83 \%$ zerst. \\
\hline Grünheide & 2399 & 265 & $10 \%$ zerst. \\
\hline \multicolumn{4}{|l|}{ Mönchwinkel } \\
\hline \multicolumn{4}{|l|}{ Spreeau } \\
\hline Herzfelde & 2592 & 179 & $2,7 \%$ zerst. \\
\hline Rehfelde & 2053 & 232 & 4,- $\%$ zerst. \\
\hline Werder & 398 & 252 & nicht zerst. \\
\hline Hennickendorf & 2281 & 230 & $1 \%$ zerst. \\
\hline Zinndorf & 218 & 155 & $\begin{array}{c}5 \% \text { zerst. } \\
{[\text { Bl. } 4]}\end{array}$ \\
\hline Kienbaum & 191 & - & $10 \%[$ zerst. $]$ \\
\hline \multicolumn{4}{|l|}{ Lichtenow } \\
\hline Kagel & 679 & 47 & $20 \%$ zerst. \\
\hline Hoppegarten & 3450 & 336 & $22 \%$ zerst. \\
\hline \multicolumn{4}{|l|}{ Liebenwalde } \\
\hline Hammer & 766 & 286 & $5 \%$ zerst. \\
\hline Neuholland & 610 & 6 & $40 \%$ zerst. \\
\hline Kreuzbruch & 151 & 162 & nicht zerst. \\
\hline \multicolumn{4}{|l|}{ Mühlenbeck } \\
\hline \multicolumn{4}{|l|}{ Glienicke } \\
\hline Schildow & & & \\
\hline
\end{tabular}




\begin{tabular}{|c|c|c|c|}
\hline Gemeinde & $\begin{array}{c}\text { Stamm- } \\
\text { bev[ölkerung] }\end{array}$ & Umsiedler & Grad der Zerst[örung] \\
\hline \multicolumn{4}{|l|}{ Schönwalde } \\
\hline Schönerlinde & 800 & 440 & nicht zerst. \\
\hline Neuenhagen & 10869 & 1680 & $\begin{array}{c}\mathrm{v}[\mathrm{on}] 3590 \text { Häusern d.h. } \\
5300 \text { Wohn[un]g[en] } 100 \text { Häuser } \\
\text { tot[al] zerstört[,] } 250 \mathrm{schw[er]} \\
\text { beschäd[igt, } 800 \text { leicht besch[ädigt] }\end{array}$ \\
\hline Ahrensfelde & 1617 & 154 & $10 \%$ zerst. 1 \\
\hline \multicolumn{4}{|l|}{ Dahlwitz-Hoppegarten ${ }^{2234}$} \\
\hline Eiche & 789 & 141 & $30 \%$ zerst. \\
\hline Hönow & 2340 & 117 & $25 \%$ zerst. \\
\hline Mehrow & 183 & 25 & $60 \%$ zerst. \\
\hline Oranienburg & 17128 & 615 & $25 \%$ zerst. \\
\hline Bernöwe & 163 & 28 & $7 \%$ zerst. \\
\hline Friedrichsthal & 1845 & $170+13$ Tsch $[$ echen $]$ & $1 / 2 \%$ zerst. \\
\hline \multicolumn{4}{|l|}{ Freienhagen } \\
\hline Germendorf & 931 & 84 & $3 \%$ zerst. \\
\hline Lehnitz & 1508 & 203 & $35 \%$ zerst. \\
\hline Malz & 510 & 30 & $1 \%$ zerst. \\
\hline Nassenheide & 1213 & 123 & - \\
\hline Sachsenhausen & & & {$[\mathrm{Bl} .5]$} \\
\hline Petershagen & 5625 & 362 & $1 \%$ zerst. \\
\hline \multicolumn{4}{|l|}{ Bruchmühle } \\
\hline Eggersdorf & 2843 & 238 & $15 \%$ zerst. \\
\hline Fredersdorf & 3713 & 680 & $2 \%$ zerst. \\
\hline \multicolumn{4}{|l|}{ Vogelsdorf } \\
\hline Rüdersdorf & 9739 & 1012 & $19 \%$ zerst. \\
\hline Woltersdorf & 5245 & 660 & nicht zerst. \\
\hline Schöneiche & 8319 & 880 & $15 \%$ [zerst.] \\
\hline \multicolumn{4}{|l|}{ Münchehofe } \\
\hline $\begin{array}{l}\text { Gross-Schöneberg } \\
\text { [vielmehr Gross-Schönebeck!] }\end{array}$ & 2073 & $472+61$ Tsch $[$ echen $]$ & nicht zerst. \\
\hline Klandorf & 333 & $134+6$ Tsch $[$ echen $]$ & nicht zerst. \\
\hline Liebenthal & 383 & 110 & nicht zerst. \\
\hline
\end{tabular}




\begin{tabular}{|c|c|c|c|}
\hline Gemeinde & $\begin{array}{c}\text { Stamm- } \\
\text { bev[ölkerung] }\end{array}$ & Umsiedler & Grad der Zerst[örung] \\
\hline Schluft & 170 & 98 & nicht zerst. \\
\hline Eichhorst & 474 & 146 & $2 \%$ zerst. \\
\hline Wandlitz & 2570 & 436 & 8 Häuser zerst. \\
\hline Basdorf & 2619 & 138 & nicht zerst. \\
\hline Klosterfelde & 2379 & 406 & 2 Häuser zerst. \\
\hline Lanke & 200 & - & $25 \%$ zerst. \\
\hline Marienwerder & 1350 & 34 & $4 \%$ zerst. \\
\hline Prenden & 407 & 55 & $1 / 2 \%$ zerst. \\
\hline \multicolumn{4}{|l|}{ Ruhlsdorf } \\
\hline Sophienstädt & 313 & 19 & nicht zerst. \\
\hline Schmachtenhagen & 1500 & 50 & nicht zerst. \\
\hline Stolzenhagen & 965 & $238+12$ Tsch $[$ echen $]$ & nicht zerst. \\
\hline Wensickendorf & 1067 & 148 & nicht zerst. \\
\hline Zerpenschleuse & 1741 & 150 & $1,3 \%$ zerst. $^{2235}$ \\
\hline Zühlsdorf & 1243 & 66 & $1,3 \%$ zerst. \\
\hline Blumberg & 1673 & 418 & $7 \%$ zerst. \\
\hline
\end{tabular}

\section{(24) Tabelle der „Herkunftsgebiete der Umsiedler“. - Potsdam, 31. Dezember 1947}

BLHA, Rep. 203 MdI, Nr. 1152, 15-19. - Bl. 16: Tabellenvordruck im Format DIN A 3 quer (Aufnahmekreise im Land Brandenburg), handschriftliche Tabellenköpfe (Herkunftsländer), maschinenschriftliche Zahlenangaben und Tabellentitel „Herkunftsländer der Umsiedler. (Stand 31.12.47)“. - Bl. 17: Maschinenschriftliche Tabelle der Herkunftsländer nach Formblatt 7 und 1. - Bl. 18: „Erläuterung zur Aufstellung über Herkunftsgebiete“ (Typoskript mit wenigen handschriftlichen Ergänzungen des Paraphierenden, l. u. datiert Potsdam, den 4. Februar 1948, r. u. Paraphe Fm[?] 3/2.). - Bl. 19: Desgleichen (Durchschlag).

[Bl. 16]

Herkunftsgebiete der Umsiedler. (Stand 31.12.47)

\begin{tabular}{|l|r|r|r|r|r|r|r|r|r|r|r|r|r|r|}
\hline & Polen & CSR & $\begin{array}{c}\text { Oester- } \\
\text { reich }\end{array}$ & $\begin{array}{c}\text { Un- } \\
\text { garn }\end{array}$ & $\begin{array}{c}\text { Jugo- } \\
\text { sla- } \\
\text { vien }\end{array}$ & $\begin{array}{c}\text { Rumä- } \\
\text { nien }\end{array}$ & $\begin{array}{c}\text { Bel- } \\
\text { gien }\end{array}$ & $\begin{array}{c}\text { Nor- } \\
\text { wegen }\end{array}$ & UdSSR & $\begin{array}{c}\text { Ita- } \\
\text { lien }\end{array}$ & $\begin{array}{c}\text { Hol- } \\
\text { Iand }\end{array}$ & $\begin{array}{c}\text { Däne- } \\
\text { mark }\end{array}$ & $\begin{array}{c}\text { Lett- } \\
\text { land }\end{array}$ & $\begin{array}{c}\text { Grie- } \\
\text { chen- } \\
\text { land }\end{array}$ \\
\hline $\begin{array}{l}\text { L a n d kre i s e : } \\
\text { Angermünde }\end{array}$ & 23004 & 197 & - & - & - & - & - & - & 855 & - & - & 815 & - & - \\
\hline $\begin{array}{l}\text { Beeskow- } \\
\text { Storkow }\end{array}$ & 16410 & 1176 & 31 & 8 & - & 38 & - & 2 & 1540 & - & - & 48 & - & - \\
\hline
\end{tabular}




\begin{tabular}{|c|c|c|c|c|c|c|c|c|c|c|c|c|c|c|}
\hline & Polen & CSR & $\begin{array}{l}\text { Oester- } \\
\text { reich }\end{array}$ & $\begin{array}{l}\text { Un- } \\
\text { garn }\end{array}$ & $\begin{array}{c}\text { Jugo- } \\
\text { sla- } \\
\text { vien }\end{array}$ & $\begin{array}{c}\text { Rumä- } \\
\text { nien }\end{array}$ & $\begin{array}{l}\text { Bel- } \\
\text { gien }\end{array}$ & $\begin{array}{c}\text { Nor- } \\
\text { wegen }\end{array}$ & UdSSR & $\begin{array}{l}\text { Ita- } \\
\text { lien }\end{array}$ & $\begin{array}{l}\text { Hol- } \\
\text { land }\end{array}$ & $\begin{array}{c}\text { Däne- } \\
\text { mark }\end{array}$ & $\begin{array}{l}\text { Lett- } \\
\text { land }\end{array}$ & $\begin{array}{c}\text { Grie- } \\
\text { chen- } \\
\text { land }\end{array}$ \\
\hline Calau & 27937 & 3479 & 15 & 26 & - & 85 & - & - & 418 & - & - & 27 & - & - \\
\hline Cottbus & 19167 & 1605 & 2 & - & - & 9 & - & 2 & 461 & - & - & 56 & - & - \\
\hline Guben & 14061 & 16 & - & - & - & - & - & - & - & - & - & 10 & - & - \\
\hline Luckenwalde & 21054 & 4146 & 72 & 18 & - & 481 & - & - & 914 & - & - & 25 & - & - \\
\hline Lebus & 29466 & 84 & - & - & - & - & - & - & 258 & - & - & 44 & - & - \\
\hline Lübben & 13260 & 2487 & - & - & - & - & - & - & 848 & - & - & 52 & - & - \\
\hline Luckau & 26212 & 4299 & 47 & 20 & 4 & 47 & - & - & 986 & - & - & 30 & - & - \\
\hline Niederbarnim & 29480 & 2407 & 35 & 10 & - & 19 & - & 1 & 2327 & - & - & 229 & - & - \\
\hline Oberbarnim & 20703 & 616 & - & - & - & - & - & - & 2248 & - & - & 110 & - & - \\
\hline Osthavelland & 23664 & 9484 & - & - & - & - & - & - & 4410 & - & - & 141 & - & - \\
\hline Ostprignitz & 32835 & 3514 & 54 & 28 & - & 579 & - & - & 1202 & - & - & 52 & - & - \\
\hline Prenzlau & 22175 & 1814 & - & - & - & - & - & - & 232 & - & - & 79 & - & - \\
\hline Ruppin & 28853 & 3610 & 23 & 30 & - & 251 & - & - & 2750 & - & - & 92 & - & - \\
\hline Spremberg & 9228 & 174 & 1 & - & - & - & - & - & 295 & 1 & - & 15 & - & 2 \\
\hline Teltow & 31933 & 2606 & 39 & 19 & - & 82 & - & - & 2440 & 1 & - & 146 & - & - \\
\hline Templin & 23660 & 441 & - & - & - & 138 & - & - & 100 & - & - & 71 & - & - \\
\hline Westhavelland & 23029 & 2607 & - & - & - & 727 & - & - & 2084 & - & - & 64 & - & - \\
\hline Westprignitz & 24508 & 5882 & - & - & - & - & - & - & 250 & - & - & 41 & 1 & 1 \\
\hline Zauch-Belzig & 29549 & 4418 & 48 & 41 & - & 628 & 1 & 12 & 1489 & 4 & 1 & 138 & - & - \\
\hline $\begin{array}{l}\text { St a d tkreis: } \\
\text { Brandenburg }\end{array}$ & 6339 & 496 & 2 & - & - & 8 & - & - & - & - & - & 114 & - & - \\
\hline Cottbus & 10886 & 1357 & 15 & 7 & - & 10 & - & 2 & 596 & 2 & - & 55 & - & 1 \\
\hline Eberswalde & 2532 & 140 & 13 & 1 & - & - & - & - & 225 & 1 & - & 520 & - & - \\
\hline Forst & 1650 & - & - & - & - & - & - & - & - & - & - & - & - & - \\
\hline Frankfurt/Oder & 12349 & 68 & 6 & - & - & 15 & - & 1 & 19 & 1 & - & 94 & - & - \\
\hline Guben & 14559 & - & - & - & - & - & - & - & - & - & - & - & - & - \\
\hline Potsdam & 8069 & 1262 & 35 & 7 & - & 51 & - & - & 243 & - & - & 31 & - & - \\
\hline Rathenow & 1749 & 171 & 5 & - & - & 7 & - & - & 40 & - & - & 108 & - & - \\
\hline Wittenberge & 5154 & 49 & - & - & - & - & - & - & 44 & - & - & 63 & - & - \\
\hline insgesamt & 553474 & 58605 & 441 & 215 & 4 & 3175 & 1 & 20 & 27274 & 10 & 1 & 3270 & 1 & 4 \\
\hline
\end{tabular}

\begin{tabular}{|c|c|c|c|c|c|c|c|c|}
\hline amerik. & britisch & franz. & $\begin{array}{c}\text { Mecklen- } \\
\text { burg }\end{array}$ & $\begin{array}{c}\text { Branden- } \\
\text { burg }\end{array}$ & $\begin{array}{c}\text { Sachsen- } \\
\text { Anhalt }\end{array}$ & $\begin{array}{c}\text { Land } \\
\text { Sachsen }\end{array}$ & $\begin{array}{c}\text { Thürin- } \\
\text { gen }\end{array}$ & Berlin \\
\hline- & - & - & - & 530 & - & - & - & 762 \\
\hline 7 & 20 & 20 & 207 & 1583 & 20 & 11 & - & 2879 \\
\hline
\end{tabular}




\begin{tabular}{|c|c|c|c|c|c|c|c|c|}
\hline amerik. & $\begin{array}{c}\text { Zonen } \\
\text { britisch }\end{array}$ & franz. & $\begin{array}{l}\text { Mecklen- } \\
\text { burg }\end{array}$ & $\begin{array}{l}\text { Branden- } \\
\text { burg }\end{array}$ & $\begin{array}{c}\text { Sachsen- } \\
\text { Anhalt }\end{array}$ & $\begin{array}{c}\text { Land } \\
\text { Sachsen }\end{array}$ & $\begin{array}{c}\text { Thürin- } \\
\text { gen }\end{array}$ & Berlin \\
\hline 100 & 168 & 100 & - & 300 & 700 & 676 & 600 & 400 \\
\hline- & - & - & - & - & - & - & - & 311 \\
\hline- & - & - & - & - & - & - & - & - \\
\hline 63 & 116 & 25 & 143 & 1328 & 134 & 124 & 46 & 1905 \\
\hline- & - & - & - & 1109 & - & - & - & 520 \\
\hline 15 & - & 41 & - & - & - & - & - & 487 \\
\hline - & - & - & - & - & - & - & - & 2.055 \\
\hline 85 & 129 & 19 & 48 & 773 & 18 & 19 & 13 & 3237 \\
\hline- & - & - & 30 & 745 & 230 & 140 & 820 & 243 \\
\hline- & - & - & - & - & - & - & - & 5649 \\
\hline 104 & 442 & 35 & 356 & 1954 & 121 & 121 & 60 & 2628 \\
\hline- & - & - & 1829 & 1234 & - & - & - & 658 \\
\hline 209 & 1408 & 14 & 115 & 2.015 & 206 & 218 & 110 & 9.827 \\
\hline- & - & - & - & - & - & - & - & 138 \\
\hline 126 & 23 & 20 & 48 & 1.725 & 113 & 100 & 97 & 7900 \\
\hline- & - & - & - & - & - & - & - & 1311 \\
\hline- & - & - & - & - & - & - & - & 1232 \\
\hline- & - & - & - & 2.014 & - & - & - & 2.331 \\
\hline 50 & 83 & 12 & 141 & 3.208 & 160 & 292 & 75 & 3.529 \\
\hline- & 623 & - & - & - & - & - & - & - \\
\hline 355 & 166 & 101 & 139 & 2.099 & 667 & 565 & 226 & 1.233 \\
\hline 45 & 124 & 6 & - & - & - & - & - & 105 \\
\hline- & - & - & - & - & - & - & - & 3 \\
\hline- & - & - & - & - & - & - & - & 100 \\
\hline- & - & - & - & - & - & - & - & - \\
\hline 25 & 77 & 34 & 32 & 388 & 70 & 22 & 20 & 737 \\
\hline 18 & 60 & 3 & 94 & 569 & 29 & 22 & 24 & 149 \\
\hline 19 & 100 & 4 & 162 & 446 & - & 46 & 21 & 86 \\
\hline 1.221 & 3.539 & $\underline{434}$ & 3.344 & $\underline{22.020}$ & 2.468 & $\underline{2.356}$ & 2.112 & $\underline{50.415}$ \\
\hline
\end{tabular}

Potsdam, den 31. Januar 1948

[Bl. 17]

\begin{tabular}{|l|c|c|}
\hline \multicolumn{1}{|c|}{ Land } & Formblatt 7 & Formblatt 1 \\
\hline $\begin{array}{l}\text { 1) } \\
\text { Polen }\end{array}$ & 553474 & 557341 \\
\hline
\end{tabular}




\begin{tabular}{|c|c|c|}
\hline Land & Formblatt 7 & Formblatt 1 \\
\hline Tschechoslowakei & 58605 & 61226 \\
\hline Österreich & 441 & 064 \\
\hline Ungarn & 215 & 1718 \\
\hline Jugoslavien & 4 & 4 \\
\hline Rumänien & 3715 & 1267 \\
\hline Belgien & 1 & 1 \\
\hline Norwegen & 20 & 3 \\
\hline UdSSR & 27274 & 20910 \\
\hline Jtalien & 10 & - \\
\hline Holland & 1 & 1 \\
\hline Dänemark & 3270 & 2967 \\
\hline Griechenland & 4 & 4 \\
\hline \multirow[t]{2}{*}{ Lettland } & 1 & 1 \\
\hline & $\underline{646495}$ & $\underline{645309}$ \\
\hline $\begin{array}{l}\text { 2) } \\
\text { amerik. Zone }\end{array}$ & 1221 & 4865 \\
\hline brit. Zone & 3539 & 46214 \\
\hline \multirow{2}{*}{ franz. Zone } & 434 & 695 \\
\hline & $\underline{5194}$ & $\underline{51774}$ \\
\hline $\begin{array}{l}\text { 3) } \\
\text { Mecklenburg }\end{array}$ & 3344 & 17337 \\
\hline Brandenburg & 22020 & 25103 \\
\hline Sachsen-Anhalt & 2468 & 2750 \\
\hline Land Sachsen & 2356 & 6354 \\
\hline Thüringen & 2112 & 7995 \\
\hline \multirow[t]{2}{*}{ Berlin } & 50415 & 51739 \\
\hline & $\underline{82715}$ & $\underline{111278}$ \\
\hline 1) & 646495 & 645278 \\
\hline 2) & 5194 & 51774 \\
\hline 3) & 82715 & 111278 \\
\hline insgesamt & 734404 & $\begin{array}{l}\frac{808361}{\text { [abzüglich] Abwanderungen }} \\
\mathrm{n}[\text { ach] d }[\text { em] Westen[:] } \\
\frac{-50463}{757898}\end{array}$ \\
\hline
\end{tabular}


[Bl. 18]

\section{Erläuterung zur Aufstellung über Herkunftsgebiete}

Die Gegenüberstellung von Formblatt 7 (Kreismeldung) und Formblatt 1 (SMA) zeigt deutlich eine Veränderung in den einzelnen Herkunftsgebieten. Für diese Feststellung gibt es zweierlei Begründung.

1. Die bisherigen Unterlagen, auf die das Formblatt 1 aufgebaut ist, waren nicht ausreichend oder die Erhebungen der einzelnen Gemeinden mangelhaft. Den einzelnen Bürgermeister kann aber nicht ausschließlich allein der Vorwurf einer mangelnden Erhebung treffen. Es ist zu beobachten, daß die Umsiedler aus irgendwelchen persönlichen Gründen Angaben zu verschleiern suchen, wobei nicht festzustellen ist, ob dies aus rein wirtschaftlichen oder politischen Erwägungen heraus geschieht.

2. Innerhalb der Umsiedler ist eine ständige Bewegung durch Ab- und Zugänge. Bekanntlich unterscheiden jedoch die Meldebehörden nicht zwischen alteingesessener Bevölkerung und Umsiedlern, so daß auch hierin gewisse Schwierigkeiten liegen, die notwendigen Feststellungen zu treffen.

Bei den Gesamtzahlen der aus den Ostgebieten eingemeindeten Umsiedler mit 646495 (Formbl. 7) und 645309 (Formbl. 1) ist der Unterschied nicht wesentlich. Die einzelnen Gebiete hingegen weisen z.T. nicht geringe Abweichungen auf. Besonders augenfällig erscheint das Verhältnis in den Angaben über Angekommene aus der UdSSR, die im Formblatt 7 um 7000 höher liegen. Diese Feststellung liegt jedoch in einer Anordnung der SMA begründet, nach der die angekommenen Umsiedler aus Kaliningrad (rd. 6000) unter Mecklenburg zu verbuchen waren. Bei einem Vergleich mit den Angaben ist diese Verschiebung klar zu erkennen.

Die im Formblatt 7 höhere Angabe über Dänemark-Rückkehrer läßt sich ebenfalls begründen. Im Formblatt 1 sind die regulären Übernahmen der Dänentransporte gebucht. Neben diesen Transporten sind jedoch weitere Umsiedler über Quarantänelager in Mecklenburg eingeströmt, z. T. mit Zuzugsgenehmigung, die im Formblatt 1 nicht erfaßt werden konnten. Diese Bewegung ist erst später durch eingehende Anträge auf Zuzugsgenehmigung von Personen, die von einzelnen Gemeinden nicht aufgenommen wurden, erkannt worden.

Die Angaben der Einzelgänger über ihr Herkunftsgebiet ist [so!] meist zweifelhaft. Einzelgänger, die einen nicht unerheblichen Anteil in der Umsiedlerbewegung haben, konnten, besonders in der ersten Zeit, ihre Aussage über ihr Herkunftsgebiet zwischen dem Quarantänelager und dem Eingemeindungsort ändern.

Die verringerten Zahlenangaben in der Übernahme aus den Zonen ist [so!] zu erklären, daß es sich [zum] größten Teil um Evakuierte handelte, die [handschriftlich ergänzt: inzwischen] in ihre Heimat zurückkehrten. [Handschriftlich ergänzt: (S. auch Angaben unter „Abgang“ in andere Zonen.)] 
Die gleiche Begründung trifft auch für die verminderten Zahlen bei den anderen Ländern der sowjetischen Zone zu.

Die Differenz zwischen 734081 Umsiedler (Formbl. 7) und 757898 (Formbl. 1) mit 23817 ergibt sich aus der natürlichen Bewegung von $\mathrm{Zu}$ - und Abzügen, durch Sterbefälle und Geburten. Diese Bewegung ist in dem Formblatt 1 nicht zu erkennen. Das Formblatt 1 ist eine Fortschreibung aller ordnungsgemäß gebuchten Zugänge und kann somit nur bis zum Abschluß der Quarantäne als korrekte Aufzeichnung herangezogen werden.

\section{(25) Bericht über eine Besprechung mit dem für Umsiedlerfragen zuständigen} sowjetischen Major Kaplan über die Aufnahme bevorstehender Transporte aus Polen. Potsdam, 30. März 1949

BLHA, Rep. 333 SED-Landesleitung Brandenburg, Nr. 574, Bl. 403-404. - Abschrift der Abt. Werbung, Presse, Rundfunk vom 12.4.1949, für diese unterzeichnet „i.A. [gez.] Maillard“. - Typoskript (Durchschlag), 2 Bl. - Verteiler: Arb. u. Sozial / Kommunal [rot unterstrichen] / Org.-Abtlg. / Werb. u. Presse“. - Oben in Rot: „Kommunal“ / „Gen. Mü“.

$[\ldots]$

Bericht.

Über die Rücksprache mit Major Kaplan am 29.3.[19]49 und der [so!] damit in Verbindung durchzuführenden Massnahmen.

Nach einem Abkommen zwischen der polnischen Militärmission, Oberstleutnant Gebert und Oberst Somow von der SMAD Karlshorst werden in der Zeit vom 10. April bis 10. August 24000 Umsiedler aus Polen nach der sowjetischen Zone überführt. Die 24000 Umsiedler werden in 20 Transporten in Stärke von 1200 bis 1500 Mann über Frankfurt/Oder nach der sowj. Zone eingeschleust. Die Transporte verteilen sich auf die Monate wie folgt:

$$
\begin{array}{lll}
\text { April }=3 & \text { Juli }=5 \\
\text { Mai }=5 & \text { August }=2 \\
\text { Juni }=5 &
\end{array}
$$

Von diesen 20 Transporten übernimmt das Land Brandenburg 1 Transport im Mai, 1 im Juni und $1 \mathrm{im}$ Juli. Die Transporte werden bis Frankfurt/Oder von polnischem Personal begleitet. Ab Frankfurt/Oder begleitet den Transport ins Quarantänelager nur 1 polnischer Transportbegleiter. Zusätzlich ist deutsches Personal und, soweit als notwendig, Polizei und Sanitätspersonal mitzubringen.

Den Umsiedlertransporten wird ab Gronenfelde seitens der polnischen Regierung für 3 Tage Marschverpflegung mitgegeben. Aus dieser Marschverpflegung wird für die Transporte in Gronenfelde ein warmes Essen gekocht wie seinerzeit in Forst. Die restliche Marschverpflegung, die die Transporte mithaben, soll nach Möglichkeit bis zum Quarantänelager in bestimmten Zeitabständen abgegeben werden, damit die Umsiedler nicht alles auf einmal verzehren. Es wurde Major Kaplan aber vorgeschlagen, dass von Frankfurt bis Thüringen ungefähr 1-2 Tage 
Reisezeit besteht und es tragbar wäre, wenn die Marschverpflegung ab Frankfurt/O bis zum Quarantänelager in einer einmaligen Ausgabe an die Umsiedler abgegeben wird.

Für jeden Transport werden von Polen aus folgende Begleitpapiere mitgegeben:

1.) Ein Dokument in dreifacher Ausfertigung, in dem alles Wesentliche über den Transport enthalten ist, z. B. Zug-Nr., Transport-Nr., Anzahl der Umsiedler und mitgebrachte Verpflegung (3 Tage). Gleichzeitig soll in diesem Dokument festgelegt sein, wieviel Umsiedler polnische Personalpapiere mitbekommen haben. An Hand der Angaben im beschriebenen Dokument ist der Transport von der deutschen Übernahmestelle (Lagerleitung) zu überprüfen und die Richtigkeit der darin enthaltenen Angaben zu bescheinigen bezw. zu korrigieren. Bei der Überprüfung des Transportes soll insbesondere darauf geachtet werden, wieviel Umsiedler prozentual keinen Ausweis (polnischen) mitbekommen haben und in diesem Dokument vermerkt werden. Ein Exemplar verbleibt im Lager, ein Exemplar wird an die Umsiedlerabteilung der Landesregierung und von hier aus dem Leiter der Umsiedlerabteilung, Major Kaplan, gegeben. Für den weiteren Transport ab Gronenfelde soll von der Lagerleitung ein neuer Transportschein ausgestellt werden, in dem die für den Transport notwendigen Angaben (Zug-Nr., übernommene Verpflegung usw.) enthalten sind. [Bl. 404]

2.) Ist jedem Transport eine vollständige Namensliste der Transportteilnehmer mit 4 Spalten mitgegeben, in denen Vor- und Zuname, Geburtstag und Beruf enthalten sind. Die Namensliste geht mit der deutschen Transportbegleitung oder auch mit der polnischen ins Quarantänelager mit und wird dort abgegeben.

3.) Wird ein Sanitätspass mitgegeben, der gleichfalls ins Quarantänelager mitgeht und vorschriftsmässig vom übernehmenden Arzt aus Gronenfelde zu überprüfen ist.

Die Richtigkeit aller gemachten Angaben bezgl. der Anzahl der Personen, Kranken usw., Anzahl der Personen, die keine Personalpapiere haben, kann über die Wagenältesten am besten überprüft werden.

Nach dem Abkommen über die Rückführung der Umsiedler soll unter Punkt 11 vermerkt sein, dass

a) in jedem Transport nicht mehr als 75-100 arbeitsunfähige Personen mitkommen,

b) Bettlägerig- und Infektionskranke überhaupt nicht mit dem Transport mitgeführt werden dürfen,

c) in jedem Transport soll sich ein Krankenwagen für die zu behandelnden Petsonen befinden.

Zuwiderhandlungen gegen diese vorstehend angeführten Bestimmungen müssen gleichfalls auf dem Dokument zu 1) vermerkt werden.

Weiterhin ist in dem Abkommen vermerkt worden, dass die Umsiedler ihre bewegliche Habe, so z.B. ihre eigenen Betten, Wäsche und Kleidung ohne Gewichtsbeanstandung mit nach Deutschland bringen können. Über besondere Vorkommnisse bezgl. grober Vernachlässigung 
vorstehender Bestimmungen ist ein Protokoll zu fertigen, wenn die Angaben der Umsiedler glaubhaft und Beschwerden berechtigt erscheinen, damit sie der Umsiedlerabteilung der SMA des Landes Brandenburg zugeleitet werden können, damit für die nachkommenden Transporte die aufgezeigten Mängel abgestellt werden können. Ein Abkommen bezgl. der Übernahme von weiteren 75000 Umsiedlern ab August wird evtl. noch abgeschlossen.

Betr.: Übernahme von Heimkehrern aus der UdSSR.

Bis Ende des 2. Quartales sollen ungefähr 100000 Heimkehrer übernommen, bis Ende März ungefähr 23000 und der Rest davon bis Ende Juni übernommen werden. Die Transporte aus der Hornkaserne sollen auch Sonntags nach Gronenfelde übernommen und für schnellsten Abtransport soll gesorgt werden. Die Reichsbahn Berlin soll von der SMAD Karlshorst Anweisungen erhalten haben, allen Transportanforderungen aus dem Lager Gronenfelde nachzukommen. Wenn Gronenfelde ab und wann nicht in der Lage ist, die Heimkehrer abzutransportieren, soll ein jeweiliger Transport nach Fürstenwalde gehen und von dort abgewickelt werden. Das Letztere wäre jedoch eine ungünstige Regelung.

Betr: Polen-Heimkehrer.

Im April und Mai kommen je 2 Transporte über Frankfurt/O., die im Heimkehrerlager Fürstenwalde ihre Quarantäne abzuleisten haben und von dort nach ihren Heimatorten entlassen werden.

Betr. Zivil-Internierte.

Zivil-Internierte sind sofort von Frankfurt/O. mit den Heimkehrern gemeinsam in ihre Heimat zu entlassen.

Potsdam, den 30. März 1949

gez. Unterschrift.

(26) Bericht über die Aufnahme eines Vertriebenentransportes im Kreis Luckenwalde. Luckenwalde, 1. August 1949

BLHA, Rep. 250 Landratsamt Luckenwalde, Nr. 108, Bl. 433. - Typoskript, 1 Bl., mit Unterschrift „I.A. [gez. (Bleistift)] Krause“. - L.o. Absenderstempel mit Aktenzeichen: „Der Rat des Kreises / Luckenwalde / Arbeit u. Sozialwesen / Az.: VII/4 - Kr./N.“, darunter Adresse „An den / Rat des Kreises Luckenwalde / Informationsdienst - / im Hause“. - R. o.: Datierung: „Luckenwalde, den 1.8.49 / Goethestr. 1“. - Betreff: „Betr.: Bericht über Aufnahme und Unterbringung des am 10.7.49 angekommenen Umsiedler-Transportes“.

Wieder einmal nahm der Kreis Luckenwalde einen Umsiedler-Transport in Stärke von 120 Personen auf. / Die Vorarbeiten waren vom Kreiswohnungsamt so gut geregelt, dass die Eingemeindung ohne Schwierigkeiten vonstatten ging.

Als der Transport in Jüterbog ankam, wurde er vom Kreiswohnungsamt übernommen. Der stellv. Bürgermeister der Stadt Jüterbog, Herr Schönfeld[,] und Herr Stadtrat Gebhart waren ebenfalls am Bahnhof, um die für Jüterbog aufzunehmenden Umsiedler zu empfangen. Nach kurzem Aufenthalt wurden die Umsiedler per Wagen mit ihrem Gepäck zur Stadt gefahren. Im 
Kulturheim war ein geschmackvolles Essen angerichtet, Pilzsuppe, Gulasch und Pilze, Salzkartoffeln und Süßkraut, hinterher Kaffee, Brot mit Quark.

Der stellv. Bürgermeister Schönfeld begrüsste die Umsiedler und wies darauf hin, daß nach langer schwerer Leidenszeit, die die Folge des verbrecherischen Hitlerregimes war, endlich der Tag gekommen ist, wo sie wieder ansässig werden und eine neue Heimat bekommen sollen. Er brachte zum Ausdruck, daß die Stadt die Umsiedler nicht als Eindringlinge, sondern als vollwertige Mitbürger begrüßt, die auch Anteil nehmen müssen an den Geschehen ihrer neuen Heimatstadt.

In der Frage zur „Einheit Deutschlands“ wies Herr Schönfeld darauf hin, dass gerade die Umsiedler im eigensten Interesse dazu Stellung nehmen müssen, damit die Möglichkeit geschaffen wird, ihnen in ausreichendem Maße helfen zu können. Teilweise mit Tränen in den Augen nahmen die Umsiedler Kenntnis von den Ausführungen.

Herr Stadtrat Gebhart sicherte den neuen Bürgern jede Hilfe zu.

Nach Abschluß dieser kleinen Feierlichkeit ging es per Wagen zur neuen Wohnung.

Die Ortschaften Bochow, Rohrbeck und Dennewitz holten ihre neuen Bürger ebenfalls vom Bahnhof Jüterbog ab.

Die für den Bezirk Luckenwalde vorgesehenen Umsiedler wurden per Bahn nach Luckenwalde gebracht. Auch hier war das Wohnungsamt der Stadt Luckenwalde zur Stelle. Schnellstens wurden die schriftlichen Formalitäten erledigt und schon ging es zur Unterkunft. Zu begrüßen wäre es gewesen, wenn auch die Stadtväter Luckenwaldes einen herzlichen Empfang bereitet hätten. [Bl. 433v]

Die neuen Bürger der Gemeinde Berkenbrück waren enttäuscht, als sie noch allein auf dem Bahnhof auf ihr Abholen warteten. Aber auch sie kamen auf ihre Kosten, denn Herr Bürgermeister Bart hatte auch gute Vorarbeiten geleistet und empfing sie mit einem guten Essen.

Sämtliche Aufnahmen gingen ohne Schwierigkeiten vonstatten. Lediglich in Rohrbeck stellte sich die Schwester des Besitzers F.[... M.[...], Frau A. Sch.[...], der Aufnahme ablehnend gegenüber und ließ die Umsiedler vor dem Eingang stehen. Erst nachdem der Wohnungsausschuß und der Bürgermeister Frau Sch. auf die Folgen ihres Verhaltens aufmerksam machten und die angesammelte Bevölkerung eine drohende Haltung über die ungebührlichen Äußerungen der Frau Sch.[...] und ihres Sohnes [...], der die Oberschule besucht, einnahmen, bequemte sich Frau Sch.[...], die Umsiedler einzulassen. Hoffen wir, dass in der Zwischenzeit die Familie F. [...] M.[...] dieses schlechte Verhalten der Umsiedler-Familie gegenüber auf eine andere Art und Weise wieder gutgemacht hat. -

\section{(27) Pressetext des Informationsdienstes des Rates des Kreises Luckenwalde} über Empfang und Einweisung eines Vertriebenentransportes. - Luckenwalde,

\section{August 1949}

BLHA, Rep. 250 Landratsamt Luckenwalde, Nr. 108, Bl. 432. - Typoskript (Durchschlag, außer der Verfügung), 1 Bl., mit Kugelschreiber-Paraphe „Ki“ des Informationsdienstmitarbeiters Hans Kirstein. - O.1. Absenderstempel: „Der 
Rat des Kreises / Luckenwalde / Informationsdienst“. - O. r. Datierung „Luckenwalde, den 5. Aug. 1949“. - U.1. Verfügung: „2. Verteiler: / Volksstimme / Tagespost / 3. Z.d.A.“- - Der Text fußt auf dem Bericht des Referates Arbeit und Sozialwesen vom 1.8.1949 (siehe dort).

Unsere Hilfe den Umsiedlern!

Im Rahmen der Nationalen Front gilt es, den vom Kriege am meisten Betroffenen, den Umsiedlern, in erster Linie zu helfen. Diese Hilfe und Unterstützung hat überall dort einzusetzen, wo sie erforderlich ist.

So wurde der letzte im Kreise Luckenwalde angekommene Umsiedlertransport dank der guten Vorbereitungen des Kreiswohnungsamtes in Jüterbog sofort von Vertretern der Stadtverwaltung herzlich empfangen und auch gut bewirtet. In einer kurzen Begrüssungsansprache wies Stadtrat Schönfeld darauf hin, dass nach langer, schwerer Leidenszeit, die die Folge des verbrecherischen Hitlerkrieges war, endlich der Tag gekommen ist, an dem auch die Umsiedler wieder sesshaft werden und eine neue Heimat bekommen. Die Stadt Jüterbog betrachtet sie nicht als Eindringlinge, sondern als vollwertige Mitbürger, denen jede Hilfe zuteil werden wird. Im ureigensten Interesse muss sich jeder Umsiedler zur Einheit Deutschlands bekennen und die Nationale Front zur Beseitigung des nationalen Notstandes stärken. Diese Forderung ist unerlässlich.

In der Stadt Luckenwalde erfolgte gleichfalls die Einweisung in bereits vorbereitete Unterkünfte sofort. Hier wäre es aber wünschenswert gewesen, wenn die Stadtväter genau wie in Jüterbog einen Empfang mit Essen vorbereitet hätten. Sämtliche Einweisungen in die einzelnen Dörfer gingen ohne Schwierigkeiten vonstatten. Lediglich in der Gemeinde Rohrbeck stellte sich die Schwester des Bauern F.[...] M.[...], Frau A.[...] Sch.[...], der Aufnahme ablehnend gegenüber und liess die Umsiedler vor dem Eingang stehen. Erst nachdem der Wohnungsausschuss und der Bürgermeister auf die Folgen dieses Verhaltens aufmerksam machten und die mittlerweile angesammelte Bevölkerung ihrer Empörung über dieses unsoziale Verhalten und die ungebührlichen Aeusserungen der Frau Sch.[...] und ihres Sohnes, der die Oberschule besucht, Ausdruck verlieh, bequemte sie sich dazu, die Umsiedler einzulassen. Wir wollen nur hoffen, dass in der Zwischenzeit die Familie M.[...] dieses verwerfliche Verhalten von Frau Sch. wieder gutgemacht hat und diese deutschen Schwestern und Brüder als gleichberechtigt betrachten und behandeln.

Wenn wir nicht wollen, dass die Umsiedler willige Werkzeuge einer deutsch-feindlichen Politik werden, müssen wir ihnen mit dem notwendigen Verständnis entgegenkommen und ihnen helfen, wo wir nur können, damit sie bei uns heimisch werden. Wir brauchen heute jeden einzelnen zum Wiederaufbau unserer zerstörten Wirtschaft und dazu gehören auch die Umsiedler.

\section{(28) Bericht der Abt. Arbeit und Sozialfürsorge über die Besichtigung} eines Vertriebenentransportes aus Polen im Lager Gronenfelde bei Frankfurt (Oder). Potsdam, 24. Februar 1950

BLHA, Rep. 333 SED-Landesleitung Brandenburg, Nr. 574, Bl. 422. - Typoskript mit Bleistiftunterschrift „Habermann“. - L.o. „Abt. Arbeit u. Sozialfürsorge“; r. o. Datierung und Geschäftszeichen: „Potsdam, den 24.2.1950 / Ha/ 
Kl.,, darunter in blauem Buntstift „Ha / Rücksprache“. - Am Ende „Verteiler / Gen. Kieling / Org.-Instrukteurabt. / Kultur- und Erziehung“.

\section{Bericht}

über die Besichtigung des Transportes der zurückgeführten Umsiedler aus Polen am 20.2.1950 in Gronenfelde bei Frankfurt/Oder.

Der Transport wurde in Gronenfelde von der polnischen Delegation übergeben und in das Quarantänelager Wolfen-Sachsen weitergeleitet. Der Transport umfaßte 789 Personen, davon sehr viel alte Leute und junge Frauen mit Kindern. Es befanden sich wenig Männer unter dem Transport, die beruflich fast ausschließlich in der Landwirtschaft tätig waren. Einige jüngere, 21jährige Männer waren sich vollkommen unschlüssig darüber, welchen Beruf sie einschlagen werden.

Durch Gen. Heinze, Ministerium des Innern, Bevölkerungspolitik, Berlin, und Gen. Kuhn, Landesregierung Brandenburg, Abt. Umsiedler, wurde festgestellt, daß die getroffenen Vereinbarungen zwischen den polnischen und deutschen Behörden in Berlin restlos eingehalten worden sind.

In dem Zuge wurden zum 1. Mal wieder deutsche Zeitungen ausgegeben. Sämtliche Personen waren über die Entwicklung der Deutschen Demokratischen Republik, bezw. deren Bildung nicht orientiert. Sie haben in Polen angeblich keine deutschen Zeitungen lesen können und in den polnischen Zeitungen sind die deutschen Geschehnisse wenig berührt worden.

Es handelt sich zum großen Teil um ehemalige „Volksdeutsche“ aus Kongreßpolen. Die Stimmung war allgemein gut, Mißstimmung über die Umsiedlung war nicht zu verzeichnen. Teilweise wurde mit Augenzwinkern die Meinung vertreten: „Mal sehen, wo es besser ist, ob im Osten oder Westen."

Dieser Transport wird von Wolfen aus aufgeteilt auf die gesamte DDR. Sämtliche Personen haben die Zuzugsgenehmigung zu Angehörigen. Durchweg waren alle Personen gut eingekleidet und führten sie auch einige bewegliche Sachen mit sich. - Für Brandenburg entfallen aus diesem Transport ungefähr 50 Personen.

Die Kinder (10-14 Jahre) haben nur in dem letzten Dreivierteljahr polnische Schulen besucht und haben durchschnittlich 3-5 Jahre den Schulbesuch versäumt. Besonders schwierig ist es bei den 16jährigen, die noch keine abgeschlossene Schulbildung demzufolge haben.

Zusammenfassend ist zu sagen, daß, da es sich um ehemalige Volksdeutsche handelt, in den Quarantänelagern unbedingt sofort eine gute ideologische Aufklärung einsetzen muß. Ebenso ist es erforderlich, daß die nachfolgenden Transporte so aufgeteilt werden, daß die Volkdeutschen nicht in großen Gruppen zusammen bleiben, damit die Hetze gegen die Oder/Neiße/ Grenze nicht neue Nahrung trägt. [B1. 422v]

Auf unser Befragen, wie es ihnen in Polen ergangen ist, wurde durchweg ausweichend geantwortet. Es wurde aber von allen Befragten betont, daß sie seit 1945 in Kellerwohnungen hausten, 
ihnen die Sachen abgenommen worden sind und sie nur im Haushalt und in der Landwirtschaft arbeiten durften. Sämtliche Personen befanden sich in einem guten allgemeinen Zustand. In einem Sanitätswagen wurden 5 Kranke mitgebracht, die durch eine Schwester betreut worden sind und in Gronenfelde einem deutschen Arzt übergeben wurden.

Von dem deutschen Transportleiter wurde erwähnt, daß in den nachfolgenden Transporten dies stimmt mit den Besprechungen in Berlin überein - u. a. Epileptiker und Sieche mitgeführt werden. Außerdem erklärte er, daß in diesem Transport Personen sind, die bei einer evtl. Option für Polen erst hätten eine Strafe absitzen müssen für den ehemaligen Verrat, den sie an Polen begangen hätten. Es befanden sich namentlich unter den alten Leuten Personen, deren vorhergehende Generation polnischer Staatsangehörigkeit waren.

Besondere Beachtung muß den Kindern zugewandt werden. Hier ist es erforderlich, daß die anhanglosen Kinder möglichst im Kinderdorf untergebracht werden. Grundsätzlich muß dafür gesorgt werden, daß sie noch die unterbrochene Schulzeit nachholen bezw. eine[n] einigermaßen ordentlichen Schulabschluß erhalten.

Außerdem ist erforderlich, daß in den Quarantänelagern eine Berufsberatung eingerichtet wird, da sich sämtliche jüngeren Männer [handschriftlich hinzugesetzt: u. Frauen] über ihren zukünftigen Beruf nicht im klaren waren und hier durch eine gute Berufsberatung diese sofort in unsere Mangelberufe gelenkt werden müssen.

Weiter müssen die Jugendorganisationen sich sofort der Kinder und Jugendlichen annehmen, da ich festgestellt habe, daß gerade bei der Jugend ein Haß gegen Polen besteht.

Der nächste Transport kommt am 24.2.1950 in Gronenfelde an und wird in das Quarantänelager Fürstenwalde-Brandenburg gehen. Die Transporte für Westdeutschland werden über Forst gelenkt.

\section{(29) Sammeltransporte aus Königsberg in Ostpreußen in den Quarantänelagern und Personalsituation im Lager Fürstenwalde. - Berlin, 11. Juni 1951 (Auszug)}

BArch, DO 1 Ministerium des Innern der DDR' Nr. 8408, unfol. - Typoskript. - O.1.: „MdI-Abt. Bevölkerungspolitik“. - O. r.: „Berlin, den 11.6.1951 / Bü/Kr.“ - Überschrift: „Aktennotiz“. - U.r. unterzeichnet [gez.] „Büttner“. - Am 1. Rand diverse Bleistift-Randvermerke, o.r. Vermerk „z. d.A."vom 14.11.1951.

Nach telefonischer Rücksprache mit dem Min. für Staatssicherheit am 11.6.1951, 9.30 Uhr, wurden folgende Vereinbarungen getroffen:

\section{Aktion Kaliningrad}

a) In Wolfen kann mit der Eingemeindung der Repatrianten für die DDR sofort begonnen werden.

b) Sämtliche Westrepatrianten sind erneut für ein Verbleiben in der DDR zu bearbeiten. Sollte trotz aller Bemühungen und auch bei Abgabe des Versprechens, die Angehörigen aus Westdeutschland nach hier zu übersiedeln, kein Erfolg zu erzielen sein, so können die Repatrianten 
einzeln bzw. in Familien zur Schleusung gebracht werden. Unter keinen Umständen darf jedoch ein Sammeltransport zusammengestellt werden.

Über die tägliche Abschleusung ist von den Lagern zu berichten. Eine Kopie der Meldungen ist an Stasi weiterzugeben.

c) Vom Ministerium für Staatssicherheit wird nochmals daraufhingewiesen, dass der Lagerleiter und der Wirtschaftsleiter von Fürstenwalde, sowie der Kreisarzt nicht weiter tragbar sind. Nähere Feststellungen werden uns noch zugehen. Es wird für angebracht gehalten, Veränderungen vorzunehmen. Um den Arzt wird sich Stasi selbst kümmern. / [...]

\subsection{Durchgangslager (1945-1949)}

(30) Zehntägiger Krankenbericht des Chefarztes des Durchgangslagers für Umsiedler Küstrin-Altdrewitz Dr. H. Wagner an die Provinzialregierung Mark Brandenburg, Abt. Provinzial-Gesundheitsamt, Potsdam. - (Küstrin-)Altdrewitz, 31. Oktober 1945

BLHA, Rep. 211 Ministerium für Gesundheitswesen, Nr. 1076, Bl. 34. - Typoskript (Durchschlag mit Paraphe), 1 S. [Schreibweise Altdrevitz offenkundig irrtümlich in Analogie zur russischsprachigen Fassung des Schreibens.]

Unter den eingetroffenen 4000 Umsiedlern befanden sich nach Feststellung nachstehende Erkrankungen, die von uns stationär aufgenommen wurden:

\begin{tabular}{|lr|lc|}
\hline Infektionskranke & 23 & chirurg. Fälle & 3 \\
\hline Ruhrverdacht & 4 & innere Fälle & 35 \\
\hline Typhus & 13 & & 17 \\
\hline Typhus-Abdominalis & 3 & Sterbefälle & \\
\hline Diphterie & 3 & Todesursache: Altersschwäche. & \\
\hline
\end{tabular}

Ambulant wurden in einer von uns eingerichteten Lagerrevier-Sprechstunde täglich 70-80 Personen beraten. Heute, dem 31.10 .45 sind die Untersuchungen für den Abtransport über 1500 Mann beendet.

\section{(31) Eidesstattliche Erklärung eines Vertriebenen wegen Diebstahlsverdachts. -}

\section{Flüchtlingsheim am Küchensee, 7. November 1945}

BLHA, Rep. 256 Umsiedlerlager Küchensee, Nr. 16, unfol. - Typoskript (1 S.) mit eigenhändiger Unterschrift („v.g.u.“) „Emma Kergel geb. Fietze“. Über „Pelzmantel“ handschriftlich „Plench-“. - „einen Pelzmantel (getragen)“ unterstrichen.

Ich erkläre hiermit an Eidesstatt, dass mir Frau Jenny List, geb. am 16.11.1879, verstorben im Barackenlager am Küchensee, Storkow/Mark, den 18.10.1945, einen Pelzmantel (getragen) für den Fall ihres Ablebens unwiderruflich zugesprochen hat, den ich sofort nach ihrem Tode an mich genommen habe. Ich selbst hatte es unterlassen, von dieser getroffenen Abmachung die Lagerleitung in Kenntnis zu setzen. Der Zuspruch erfolgte ohne Beisein von Zeugen. 


\section{(32) Schreiben der Umsiedlerbetreuungsstelle des Kreises Beeskow-Storkow an die Lagerverwaltung in Küchensee. - [Beeskow], 9. November 1945}

BLHA, Rep. 256 Umsiedlerlager Küchensee, Nr. 29, unfol. - Schreiben des Sozialamtes / Umsiedlerbetreuungsstelle, VII/U/Kü. [beim Landratsamt des Kreises Beeskow-Storkow] an die Lagerverwaltung in Küchensee bei Storkow/ Mark mit Unterschrift „Peibi[ck?]“. - Typoskript (Durchschlag), 2 S.

Wir weisen darauf hin, dass der Kreis Beeskow-Storkow in Ausführung des Befehls des Marschalls Shukow 20000 Umsiedler, deren Festansiedlung im kommenden Frühjahr geplant ist, den Winter über unterbringen muß. Die Zeit des Eintreffens der Hauptmasse dieser Heimatlosen ist nicht bekannt. Da mit dem überraschenden Anlauf des Hauptstroms gerechnet werden muß, sind sofort Maßnahmen zu treffen, dass diese in Küchensee geordnet durchgeschleußt werden.

1.) Die Personen sind aufzunehmen und statistisch nach folgenden Gesichtsprunkten zu erfassen:
I. Bauhandwerker
a) einzelne
b) mit Familie
II. Landwirte
a) einzelne
b) mit Familie
c) mit Familie und Vieh
III. Waldarbeiter
a) einzelne
b) mit Familie

IV. Facharbeiter aller Art, jede Branche gesondert.
V. Landarbeiter
VI. ungelernte Arbeiter
a) einzelne
b) mit Familie
a) einzelne
b) mit Familie.

a) einzelne

b) mit Familie

Alle Angaben sind nach Alter und Geschlecht zu machen. Vordrucke sind von den einzelnen Lagerleitern selbst anzufertigen.

2.) $\mathrm{Zu}$ melden sind sofort alle Seuchenverdächtigen und Seuchenkranken. Weiterhin alle nicht marschfähigen und pflegebedürftigen Personen. Alle Angaben sind getrennt nach Alter und Geschlecht zu machen.

3.) Der Arzt hat laufend Unterricht und Informationen zur Bewältigung der Arbeit zu erteilen.

4.) Zwischen dem Arzt, Lagerleiter und Leiter der Umsiedlerbetreuungsstelle des Kreises werden laufend gemeinsame Besprechungen zur Klärung etwaiger Differenzen stattfinden.

5.) Die Verpflegung wird seitens der Provinzialverwaltung zentral gesteuert, Anweisungen erfolgen in Kürze.

6.) Für jedes Lager ist vor dem Eintreffen der Umsiedler bereitzustellen:

a) Der Beauftragte des Leiters der Umsiedlerbetreuungsstelle des Kreises.

b) Büro für Registrierung und Schreibarbeit. 
c) Eine Anzahl von Hilfs- und Schreibkräften.

d) Betreuer und Ordner

e) Kinderbetreuerin

f) Küchenpersonal.

7.) Die Umsiedler sin, soweit sie arbeitsfähig sind[,] zur Arbeit aller Art heranzuziehen, auch in gewerbliche Betriebe.

8.) Jeder Umsiedler oder Haushaltsvorstand einer Familie erhält schon vor der Abgangsstation einen Umsiedlerpass, wer keinen hat, muss im Kreislager einen bekommen. Ohne Paß erfolgt grundsätzlich keine weitere Betreuung der Umsiedler, Vordrucke hierfür werden vom Kreis zur Verfügung gestellt.

9.) Von der Lagerverwaltung ist eine Lagerordnung herauszugeben und dieselbe sichtbar in jeder Baracke mindestens zweimal anzubringen.

10.) Die Umsiedler sind nach dem Eintreffen sofort, noch bevor mit den vorstehenden Punkten begonnen wird, zu entlausen und zu desinfizieren.

11.) In sämtlichen Entscheidungen, betreffend der Lagerverwaltung und der Umsiedler behält sich der Kreisumsiedlerausschuß in Verbindung mit dem Leiter der Umsiedlerbetreuungsstelle des Kreises das Recht der entgültigen [so!] Bestimmung vor.

\section{(33) Bericht über die Demolierung eines Lagers durch die sowjetische Besatzungsar-} mee. - Beeskow, 9. November 1945

BLHA, Rep. 250 Landratsamt Beeskow-Storkow, Nr. 867, unfol. - Typoskript (Durchschlag, außer Adresse), 1 Bl. - L.o. [Es fehlt „Der Landrat des Kreises Beeskow-Storkow“, da in Ausfertigung Kopfbogen verwendet]: „VII/U / - Sozialamt - / Umsiedlerbetreuungsstelle“. - R. o.: Datierung: „9. November 1945“. - Adresse: „An die Provinzialverwaltung in Potsdam / Herrn Oberlandrat in Bernau / An die Zentralverwaltung für deutsche Umsiedler Bln.-Friedrichsfelde“. - Rückseite Paraphen „M.“ (rot) und „Pei.“ (Kopierstift).

Auf Grund der am 6.11.1945 stattgefundenen Sitzung in Bernau und der nach dieser gehabten Besprechung mit dem Herrn Direktor Schlaffer von der Zentralverwaltung wird folgendes mitgeteilt:

Das frühere SS-Lager „Fuchsbau“ bei Ketschendorf im Kreise Beeskow-Storkow ist bereits zweimal zur Aufnahme von Umsiedlern hergerichtet worden. Ein drittes Mal dasselbe einzurichten wird auf Grund der gehabten Kosten und [durch] fortlaufendes willkürliches Abreißen der roten Armee, von hier vorläufig nicht vorgenommen. Dieses wahhllose Abreißen geschieht durch das in der Nähe liegende politische Gefangenenlager der N.K.W.D. Die dort abgerissenen Barackenteile werden zu Brennholz verwandt.

Dieses Lager, das eine Unterbringungsmöglichkeit von 25000 Personen hat, sieht somit der endgültigen Vernichtung entgegen. Wir hatten diese fest ausgebauten Baracken in unserer Kalkulierung mit einbezogen und gedacht, hier einen Großteil der für den Kreis Beeskow-Storkow 
zugewieseneen Umsiedler fest anzusiedlen. Dies wird dadurch völlig über den Haufen geworfen. Damit wird die Umsiedlerunterbringung im Kreise Beeskow-Storkow in Frage gestellt.

Es wird gebeten, dass von dortseits eine Kommission, am besten Herr Direktor Schlaffer persönlich, zur Besichtigung dieses Großlagers entsandt wird. Täglich ziehen die Russenkommandos mit 150-200 Häftlingen hinein, und räumen weiter aus. Während der Zeit des Ausräumens darf sich ein Deutscher im Gelände nicht sehen lassen, entweder es wird geschossen, oder er läuft Gefahr, mitgenommen zu werden. Jeder Tag, der hier versäumt wird, kostet uns Tausende von Mark. Ebenfalls bitten wir, die zuständige russische Stelle zu mobilisieren, damit diese dort regelnd eingreift. Am besten einen zuständigen russischen Offizier sofort mitbringen.

Ein Auto zur Besichtigung wird vom Kreise zur Verfügung gestellt.

Auf Grund der heute stattgefundenen telefonischen Rücksprache, wird noch hinzugefügt, dass der Kreiskommandant des Kreises Beeskow-Storkow von der Maßnahme, dass das SS-Lager „Fuchsbau“ für die Unterbringung von Umsiedlern vorgesehen ist, unterrichtet ist.

Der Abbruch geht laufend weiter. Die hiesige Behörde ist völlig machtlos. Eine Verbindungsaufnahme mit dem Leiter des politischen Gefangenenlagers in Ketschendorf ist einfach nicht möglich. Wir bitten erneut, diese Angelegenheit als sehr dringend zu behandeln, damit von dort aus schnellstmöglichst eine Abhilfe dieses zeitigen Übelstandes erfolgt.

\section{(34) Zusammenfassender Lagebericht über das Umsiedlerlager Küstrin anlässlich von dessen Liquidation. - Küstrin, 1. Dezember 1945}

BLHA, Rep. 211 Ministerium für Gesundheitswesen, Nr. 1076, Bl. 36-41. - Bericht des Chefarztes Dr. H. Wagner an die Provinzialregierung Mark Brandenburg, Abt. Provinzialgesundheitsamt, Potsdam, Alte Zauche, mitunterzeichnet vom Umsiedlerleiter für das Flüchtlingsdurchgangslager Küstrin, Rübe, und den Lagerärzten Dr. Moretti ${ }^{2236}$ (LagerOberarzt für Lager II und Stellvertreter [des Chefarztes]), Dr. Otto Kalteis in Vertretung für den Lager-Oberarzt für Lager I Medizinalrat Dr. [Rudolf] Görlach und dem Abteilungsarzt Dr. Knapp ${ }^{2237}$. - Typoskript, 6 S.

Wie der Lagerleitung und mir durch die Abgeordneten der Zentralverwaltung und russ[ischen] Administration Berlins bekannt gegeben wurde, sind Anordnungen zur Liquidation des Umsiedlerlagers Küstrin erlassen worden. Zu begrüßen ist damit die endgültige Klärung der territorialen Frage, die uns in letzter Zeit viel Kopfzerbrechen machen mußte.

Wie wir Ihnen ja laufend in unseren Lageberichten schilderten, wurde unsere hiesige Aufbauarbeit zur Durchführung der von Ihnen gestellten Aufgaben durch ständige Differenzen mit der polnischen Bevölkerung aufs höchste erschwert. Die zur Sicherheit der Umsiedler eingesetzte deutsche Polizei konnte die täglichen Überfälle von polnischen Banden sowie laufenden

2236 [Vmtl. identisch mit: Giuliano Moretti (geb. 1912, gest. ca. 1986), 1942 in Zürich zum Dr. med. promoviert, zuletzt Facharzt für Augenheilkunde in Muralto bei Locarno (Schweiz).]

2237 [Randbemerkung von Dr. Knapp über den Abt.-Arzt Dr. Kaminski, dessen Unterschrift fehlt:] Bezüglich Dr. Kaminski kann ich mir kein sicheres Urteil erlauben, da ich erst 3 Tage hier bin. 
Ausplünderungen der Lagerinsassen und besonders unserer Krankenstationen trotz ständiger Rücksprache mit der polnischen Kommandantur mangels Waffengewalt nicht verhindern.

Die zur Lagerliquidation getroffenen Maßnahmen sind bereits ausgeführt und besteht eine Sperre für das weitere Eintreffen der Umsiedler von Seiten der polnischen Bahnkommission.

Der heutige Lagerbestand an Umsiedlern beträgt: 19551.

Die Abtransportmöglichkeit ist allerdings ein Problem für sich, und glaube ich kaum, daß in der von der Zentralregierung festgesetzten Zeit die Lagerliquidation stattfinden kann. Die Umsiedler werden von hier, soweit sie der Lage gewachsen sind, zu Fuß bis nach Wriezen (ca. $50 \mathrm{~km}$ ) in Marsch gesetzt, teilweise auch, besonders nicht gehfähige, alte Leute und Kinder, mit Zügen von hier abtransportiert. Es muß vorausgesetzt werden, daß der Abtransport mit der Bahn ein äußerst schlechter ist, bedingt durch den dauernden Ausfall von Lokomotiven, die durch die russische ${ }^{2238}$ Bahnverwaltung für andere Zwecke beschlagnahmt werden. Die beladenen Züge stehen tagelang auf dem hiesigen Bahnhof, und kann ich ärztlicherseits, was den Gesundheitszustand der Bevölkerung anbetrifft, nicht für gut heißen. Es besteht in erster Linie die Kältegefahr in den nicht heizbaren Waggons und der zu schnelle Aufbrauch der von uns ausgegebenen Reiseverpflegung. Weiterhin die örtlich bedingte schlechte Versorgung mit warmem Essen und dergl[eichen]. Aus diesen Umständen heraus habe ich veranlaßt, daß die hier stationär untergebrachten Kranken, sowie die sich noch unter der Bevölkerung befindenden Leichtkranken, bis zur endgültigen Räumung des Lagers hier festgehalten werden, um dann durch einen Pendelzugverkehr nach dem Lager Wriezen abtransportiert zu werden.

Durch den Vertreter der russ[ischen] Administration ist mir bekannt geworden, daß das Lager in Wriezen seit einigen Tagen im Aufbau begriffen ist und in ca. 10 Tagen angeblich fertig gestellt sein soll. Näheres über die Lagerverwaltung und ärztliche Versorgung dort ist mir unbekannt, und weiß ich nicht, ob wir dort weiterhin die Versorgung und den Aufbau der Krankenstation übernehmen sollen.

Für die Sicherstellung der Unterbringungsmöglichkeit der kranken Bevölkerung werde ich erst dann den Abtransport nach Wriezen einleiten, wenn ich mich überzeugt habe, daß dort die Unterbringungsmöglichkeit sowie Versorgung gewährleistet ist. [Bl. 37]

Betreffs des Abtransportes der jetzigen gesunden Bevölkerungsschicht ist mir mit Hilfe russ[ischer] Unterstützung eine Verbesserung für die Entlausungsmöglichkeit gegeben worden. Von der russ. Administration ist mir 1 russ. Arzt mit 5 Unterärzten und 1 fahrbaren Entlausungsanlage für diesen Zweck zu Hilfe gekommen, und ist es mir somit möglich gewesen, die gesamte abgehende Bevölkerung in Zusammenarbeit mit unserer schon geschaffenen Entlausungsanlage zu entseuchen. Für den Transport wird an die Bevölkerung zur weiteren Profylaxe von Ungeziefer Duolit ausgegeben. (5 gr. Pro Kopf). 
Die Bevölkerung wird von den Außendienst tuenden Ärzten genauestens abgangsuntersucht und registriert. Teilweise Lücken haben sich wegen zu großem Papiermangel ergeben.

Die Überwachung des infrage kommenden Abtransportes mit der Bahn wird von unserem AuBendienst in Form von Waggonmusterungen und deren Desinfektion, sowie die Möglichkeit der Transportversorgung (Wasser und dergl.) getätigt. Begleitpersonal in Form von ärztlichem Hilfspersonal, das von mir genauestens über die ärztlichen Transportvorschriften belehrt worden ist, übernimmt die Betreuung der Transporte. Ärzte können für diesen Zweck von hier nicht abgegeben werden.

Die Verpflegung der Abtransporte ist von unserer Lagerleitung den Umständen entsprechend bestens geregelt worden. Die persönliche Zusammenarbeit mit dem Umsiedlerleiter, Herrn Rübe, ist bestens und erspart mir in dieser Hinsicht viele Unannehmlichkeiten, da sich unsere Arbeit in eine Parallele zieht.

Die Verladung der Transporte ist allerdings eine äußerst schwierige, da mir jegliches Krankentransportmittel mangelt. Ich habe Sie in jedem meiner Berichte dringendst ersucht, mir diesbezüglich Krankentransportmittel zu Hilfe zu senden, mußte aber immer wieder feststellen, daß Sie mir in keiner Weise Unterstützung zukommen ließen. Die Umleitung der Kranken, sowie den An- und Abtransport derselben schon durch die örtlich bedingte Lage unserer beiden entfernten Läger und der Bahnstation habe ich unter äußersten Schwierigkeiten nur mit Handwagen und Transportkommandos sowie Krankentragen getätigt. Die Umstände, die sich hierbei ergaben, waren bestimmt keine erfreulichen. Wenn z. B. des Nachts, ohne Beleuchtung die Kranken ausgeladen oder aus den Lägern zwecks stationärer Behandlung umtransportiert wrden mußten und dazu unter ständiger Gefahr der Ausplünderung und Überfälle, so können Sie sich ungefähr von unserer Arbeit ein kleines Bild machen. Trotzdem konnten wir in dieser schwierigen Lage, die sich auch auf unsere übrige Tätigkeit auswirkte, in den 4 Wochen unserer hiesigen Arbeit folgenden Aufbau des Lager-Sanitätswesens verzeichnen:

Wie ich bereits oben anführte, haben wir hier 2 Teillager, in denen die Bevölkerung untergebracht ist. Die Entfernung beträgt min. $3 \mathrm{~km}$.

A.) Das erste war mir die Schaffung eines Außendienstes zur:

1.) von Ein- und Abgangsuntersuchungen der Umsiedler, die von den zuständigen LagerOberärzten getätigt wurden. Hierunter entfällt das sofortige Aussondern von Kranken, die Isolation derselben sowie Quarantäne.

Die sofortige Isolation von Verlausten und Verseuchten in gesonderten Unterkünften, sowie die sofortige Durchführung der uns möglichen schubweisen Entlausung in unserer improvisierten Entlausungsanlage.

Die Ausführung der Desinfektion durch die uns zur Verfügung stehenden Mittel (Chlorkalk, Duolit und Kresolseifenlösung). [Bl. 38] 
2.) Die Kontrolle der Küchen und Lebensmittelanlagen sowie des Lebensmitteltransportdienstes. Anlegung von Küchen-Kontrollbüchern. Laufende ärztliche Überwachung des Küchenpersonals und der in Lebensmittelbetriebsanlagen Beschäftigten und deren listenmäßige Erfassung. Die Überprüfung und Organisation zum Ausbau von Latrinen und neuen Wasseranlagen sowie Abwässerungsanlagen.

Die vorgefundenen Wasseranlagen waren äußerst schlecht und für die Zahl der Lagerbesatzung eine mehr wie geringe. Dazu kommt, daß polnische Banden die Wasserentnahme laufend störten, sodaß sich dieser Zustand ebenso bei uns in der Sanitäts-Bereitschaft äußerst schlecht auswirken mußte. Es kommt laufend vor, daß die nötige Reingung sowie Versorgung der Kranken durch die Küche nicht gewährleistet ist, daß die Entlasungsanlage stundenlang mangels Wasser außer Betrieb gesetzt ist.

3.) Die Überwachung der allgemeinen Hygiene in den Unterkünften und der Öffentlichkeit. Die Überprüfung der Ausführung meiner öffentlich bekanntgemachten Erlasse an die Bevölkerung. Diesbezüglich ist mitzubedenken, daß die eintreffenden Umsiedler körperlich und geistig vollkommen vernachlässigt sind, und der Wille zur Sauberkeit und Ordnung nur unter Zuhilfenahme gröbster Strenge wachgerufen werden kann. In einem Massenbetrieb von 32000 Menschen sind das bestimmt keine Kleinigkeiten, und mußte ich diesbezüglich sogar einige Verantwortliche der Umsiedler bestrafen. Bekanntmachungen über Seuchengefahr und dergleichen wurden von mir erlassen.

4.) Die unbedingt erforderliche Verbesserung der Unterkünfte durch einen aufgestellten Arbeitseinsatzdienst.

Die zu Anfang des Lagerbestandes 70 \% zerstörten Unterkünfte sind bis zu $50 \%$ bereits instand gesetzt worden und für den Kälteeinsatz gesichert. Die Umstände, die sich hierbei ergaben, waren äußerst schwierige. So schon die Beschaffung von Lagerstätten und Stroh, das oft km-weit herangetragen werden mußte, und uns hierfür keinerlei Transportmittel zur Verfügung standen. Werkzeuge und sonstige Materialien wurden dauernd von polnischen Banditen in Überfällen gestohlen, und waren unsere Handwerker auf die primitivsten Mittel angewiesen. So konnte auch die nach mühseliger Kleinarbeit fertig gestellte Bäckerei trotz unserer stärksten Einwände bei der polnischen Kommandantur von der Miliz beschlagnahmt werden.

5.) Die Ausführung der internen Krankenüberwachung sowie die dauernde Durchkämmung unserer Kontrollen zur Aussonderung neu anfallender Kranken und deren Meldung. Die Arbeit hierbei wurde durch die eingesetzten Blockleiter unterstützt. Diesbezüglich entfallen die Verhängung von Quarantänen, die Unterkünfte, Desinfektion usw.

6.) Die Errichtung von 2 Ambulatorien in jeweiligen Lagerbereichen und die ärztliche Betreuung der sich im Lager befindenden Umsiedler. Bisher konnte leider nur eine teilweise Notbehandlung stattfinden, im Übrigen aber mußte sich die ärztliche Tätigkeit auf Beratung einstellen. 
7.) Die Aufstellung eines Transport-Überwachungsdienstes, wie ich oben schon schilderte, der mit der ärztlichen Betreuung der Transporte beauftragt wurde. Hierunter entfallen die Waggondesinfektion und Musterungen, die Prüfung auf Infektionsgefahr, die Aufstellung von Isolierwagen, Stellung der Begleitmannschaft und Belehrung derselben. Die in dem Rundschreiben der Zentralverwaltung vom 26.10.45 angeordneten Transportärzte [B1.39] sowie Reise-Apotheke und dergleichen konnte in Ermangelung des Personals sowie des Materials nicht gestellt werden. In allen anderen Punkten aber habe ich mich bemüht, mit den praktischen Ausführungen den Anordnungen nachzukommen.

8.) Die Aufstellung eines Bestattungsdienstes und Kontrolldienstes der anfallenden Toten.

Darunter entfällt die Aufstellung eines nur mit primitivsten Beförderungsmitteln ausgerüsteten Bestattungs-Kommandos, das aus den Umsiedlern von mir herausgezogen wurde, sowie für je ein Lager eingeteilten Friedhofs, der hygienisch einwandfrei von den Unterkünften richtig abgesondert gelagert wurde. Die Aufstellung einer Toten-Registration für spätere Nachforschungen sowie die Verwaltung von Nachlaßsachen, die von mir der allgemeinen Sozialfürsorge übergeben wurden.

Zusammenfassend zu Punkt A) betreffs des allgemeinen Gesundheitszustandes der Bevölkerung ist zu bemerken:

Die ankommenden Umsiedler, die schon naturgemäß zu $80 \%$ unterernährt sind, sind durch Ausplünderung von polnischer Miliz und Banden ihrer Bekleidung und Lebensmittel zum größten Teil beraubt. Es kommt vor, daß große Teile tagelang auf den Transporten ohne Lebensmittel sind und schon bei Eintreffen im hiesigen Lager sich daraus erschrecklich hohe Sterbezahlen stellen. Die Bevölkerung ist zu $25 \%$ total verlaust und zu $60 \%$ verdreckt. Der Prozentsatz von Kleinkindern erstreckt sich auf 25-30\%, der der altersschwachen und kaum mehr transportfähigen Leute auf $35 \%$.

Die vorgesehene Impfung der Bevölkerung kann in Ermangelung von Impfstoff nicht durchgeführt werden.

Zur Verpflegung der Bevölkerung bestehen in beiden Lagern je eine Großküche. Die tägliche Leistung dieser Küchen zusammen beträgt: 19000 Portionen. So kam es vor, daß bei einem Lagerbestand von über 30000 Menschen die Bevölkerung nicht täglich versorgt werden konnte.

Wie mir von der Lagerleitung bekannt ist, bieten sich in der Beschaffung von Lebensmitteln äußerste Schwierigkeiten, und ist die Verpflegung der Umsiedler eine sehr schlechte. Die Aufstellung von Lebensmittel-Magazinen und Bäckereien konnte in diesen durch die Transport- und Nachschubfrage bedingten Mißständen auch keine große Hilfe bringen.

Als zweite Notwendigkeit war mir die Schaffung eines

B) Innendienstes, der von mir im Lager II zentral verwaltet wird.

Für die Verwaltung entfallen:

Die Organisation und Überwachung des gesamten Lager-Sanitätswesens. 
Aufstellung von täglichen Krankenverschieblichkeitsmeldungen an das Dezernat des Gesundheitswesens beim Landrat in Seelow. Die Aufstellung 10-tägiger Krankenverschieblichkeitsmeldungen, nachrichtlich an das Provinzial-Gesundheitsamt, Potsdam, sowie 15-tägige Kranken-Dekadenberichte an die russ. Administration in Berlin. Weiter die allgemeinen Lageberichte, nachrichtlich an Landräte, Provinzialverwaltung und Zentralverwaltung.

1.) Die Aufstellung von Krankenstationen:

Im Lager I wurde von mir

1 Altersstation von 200 Betten nebst Ambulatorium ausgebaut. Für diese Station kommen nur nicht infektiöse Alterskrankenerscheinungen in Frage. [B1. 40]

Im Lager II, und das ist der Hauptsitz für die stationäre Krankenbehandlung, befinden sich:

1 Infektions-Abteilung mit 60 Betten

1 Innere und Chirurg. Abteilung mit 72 Betten incl. 1 gynäkologischen Unterabteilung nebst 1 chirurg. Ambulatorium

1 sich noch im Ausbau befindende Zahnstation, besetzt mit einem Dentisten

1 Heim zur Aufnahme von schwereren nicht infektiösen Alterskrankenerscheinungen incl. 1 Waisenkinderstation mit 100 Betten.

Der Ausbau dieser Stationen ist in kürzester Zeit aufs beste geschehen und können den Umständen entsprechend als einwandfreie Betriebe angesehen werden. Schwierigkeiten ergeben nur dabei die Heizungsfrage.

Die stationäre Behandlung beschränkte sich auf ein Minimum durch die von uns aus den Trümmern der Stadt herausgeholten Medikamente und die aus den Privatpraxissen der Ärzteschaft beschafften Instrumente und Hilfsmittel, die aber in keiner Art und Weise zufriedenstellend sind.

Wie ich Ihnen ja bereits mitgeteilt habe, können wir kaum die notdürftigste Wund- und Notbehandlung durchführen, und mußte ich leider feststellen, daß trotz meiner dauernden Bitte an Sie, um Unterstützung in Form von Medikamenten, Instrumenten und Verbandsstoffen, keinerlei Unterstützung Ihrerseits eingetroffen ist. So mußten beispielsweise die Entbindungen unter äußerster Schwierigkeit in Ermangelung von Instrumenten mit der Hand ausgeführt werden. Weitere Hilfsmittel zur Krankenbehandlung fehlen gänzlich, diesbezüglich auch Notbeleuchtungskörper und muß in den wenigen Stunden des Tages das möglichste ausgeführt werden. Unsere Arbeitszeit für chirurgische Eingriffe und dergleichen, sowie verwaltungstechnische Arbeiten ist leider in Ermangelung von Beleuchtungskörpern eine äußerst kurze und schwierige.

Die Behandlung der Infektionskranken ist ebenso katastrophal, da jegliche Sera fehlen. Die hohen Todeszahlen sind daher nicht verwunderlich. 
2.) Die Organisation und der Einsatz von Ärztepersonal und ärztlichem Hilfspersonal.

z. Zt. befinden sich in beiden Lagern insgesamt 5 Ärzte. Davon 3 von der ProvinzialRegierung verpflichtete und 2 aus den Umsiedlerkreisen von mir herausgegriffene und ebenfalls dienstverpflichtete Ärzte. Insgesamt sind seit Lagerbestand 8 Ärzte eingetroffen, davon sind 3 durch Krankheit und zu große körperliche Beanspruchung ausgefallen. Dr. Zöbisch ${ }^{2239}$, Dr. Warnecke und Dr. Görlach haben bei mir ihren Dienst vorbildlich erfüllt, und muß ich bedauern, daß diese 3 Kollegen aus Gesundheitsrücksichten nach Potsdam zurückgesandt werden mußten.

Aus der Ärzteschaft hat sich Herr Dr. Moretti in der Organisation und Aufbau seiner Inneren und Chirurg.-gynäkologischen Abteilung besonders bewährt. Er erfüllt hier seinen Dienst mehr wie vorbildlich.

Ein gewisser Dr. Kaminski, der sich aus den Umsiedlerkreisen eingefunden hat, füllt seinen Dienst hier zur allgemeinen Unzufriedenheit aus. Die Ärzteschaft hat beschlossen, ihn zur Rechenschaft zu ziehen, und werde ich an Sie unsere Beschlüsse und Entscheidungen mitteilen und Ihnen den Fall übergeben.

Zur Diensteinteilung war es notwendig, für je 1 Lager 1 Lageroberarzt einzusetzen, ihm zur Hilfe 1 Abteilungsarzt oder 1 Assistenzarzt.

Das ärztliche Hilfspersonal, bestehend aus Schwestern, Helferinnen, Sanitäter, Angestellte und Arbeiter ist von mir für die [B1. 41] Dauer des Lagerbestandes dienstverpflichtet worden.

Der Personalbestand ist:

Schwestern 29

Helferinnen 15

Sanitäter 2

Angestellte u. 4

Arbeiter 9

Für das Personal sind von mir Unterkünfte geschaffen worden, die für die Arbeitenden für ihre persönlichen Wünsche nachkommen. Eine allgemeine Personalfürsorge ist ebenfalls eingerichtet in Form von Betreuung, Beratung, Schaffung von Postverbindungen, Nachforschungen für Angehörige, Sorge für Personalangehörige und dergleichen. Nachlaßsachen von Toten werden desinfiziert und in einwandfreiem Zustande, soweit erforderlich, an das Personal ausgegeben.

Personaluntersuchungen sowie Registrierung der Unterschungsergebnisse in der Personalkartei ist erfolgt. Wir haben erfreulicherweise aus den Trümmern der Stadt noch etwas Impfstoff gefunden, und so konnte ich unser Personal gegen Ruhr und Cholera impfen.

2239 [Vmtl. Karl Zoebisch, lt. Reichs-Medizinal-Kalender 1937 (T. 2, S. 229) Fürsorgearzt am Gesundheitsamt Berlin-Lichtenberg.] 
Lt. heutiger Rücksprache mit Herrn Landrat Papke ist es mir möglich, das dienstverpflichtete Personal als Lohn für die schwierige Arbeit an der Außenstelle unseres Landes in Seelow (Kreis Lebus) unterzubringen und den Leuten die Gewähr einer Existenzmöglichkeit zu bieten.

Das, was hier zu tun war, wurde von uns den Umständen gemäß mit bestem Willen ausgeführt, und bedaure ich nur, daß uns von Ihnen keinerlei Unterstützung zuteil wurde. Wir hätten bestimmt um vieles mehr leisten können.

\section{(35) Zusammenfassender Lagebericht über die Geburtshilfliche Station} im Umsiedlerlager Küstrin anlässlich von dessen Liquidation. Küstrin, 30. November 1945

BLHA, Rep. 211 Ministerium für Gesundheitswesen, Nr. 1076, Bl. 42. - Bericht des Lageroberarztes Dr. Moretti ${ }^{2240}$ (wohl Anlage zum Bericht des Chefarztes Dr. H. Wagner an die Provinzialregierung Mark Brandenburg, Abt. Provinzialgesundheitsamt, Potsdam, Alte Zauche). - Typoskript mit eigenhändiger Unterschrift, $1 \mathrm{~S}$.

Seit Errichtung des Lagers vom 18.10.[19]45 bis zum heutigen Tage wurde 1 Infektionsstation, 1 Innere-Abteilung, 1 Chirurg[ische]. Abteilung einschl[ießlich]. 1 Wöchnerinnenstube errichtet.

Bevor wir in der Lage waren, diese Station für Geburtshilfe zu errichten, will ich eine kurze Schilderung, unter welchen Schwierigkeiten und wie mit den primitivsten Mitteln eine Entbindung zu Stande kam, geben. / Die Wöchnerinnen, die zur Entbindung kamen, waren bereits von den Polen total ausgeplündert, sodaß sie nicht über die für das Kleinkind benötigte Wäsche (Windeln, Hemdchen, Jäckchen) verfügten. Auch kein Bett stand zur Verfügung. Die Niederkommende mußte auf nacktem Stroh gebettet werden.

Wenn ich, meistens nachts, zu einer Wöchnerin gerufen wurde, bot sich mir folgendes Bild. / In einem halb verfallenen Wohnraum, Fenster nur notdürftig mit Brettern vernagelt, lag auf einem Strohlager die zu entbindende Frau. Selbiger Raum war überfüllt von anderen Flüchtlingen und Kindern. / Die Mitbewohner dieses Raumes wurden von mir während der Entbindung hinausgeschickt. Die Wöchnerin wurde von mir untersucht und entbunden. Wasser und Seife, Wasserbehälter etc. waren meist nur spärlich vorhanden. Die zur Entbindung benötigten Instrumente fehlten. Zur Abnabelung benutzten wir eine einfache Schere. Zum Abbinden der Nabelschnur nahmen wir weißes Band. Eine Höllensteinlösung war nicht vorhanden. Sterile Nabelbinden fehlten ebenfalls. Der Säugling wurde nur notdürftig abgewaschen und in Tücher gehüllt. Die Mutter konnte nur notdürftig versehen werden. Zum größten Teil konnten die Entbindungen nur bei Notbeleuchtung (Ofenfeuer) getätigt werden. Trotz dieder schwierigen Verhältnisse erfreuen sich Mütter und Kinder der besten Gesundheit.

Seit dem 18.10.[19]45 wurden von mir bis zum heutigen Tage 30 Entbindungen getätigt, die alle normal verliefen. / Ich kann nur von einem einzigen Sterbefall berichten, wo der Embryo unglücklicherweise eine Becken-Querlage hatte, die Wöchnerin außerdem vom Russen einen 
Bauchschuß abbekam und gleichfalls mit einer schweren Go. ${ }^{2241}$ belastet war. Zur Rettung von Mutter und Kind wäre nur der Kaiserschnitt möglich gewesen, der aber auf Grund der fehlenden Instrumente undurchführbar war.

Die Wöchnerinnen erthalten täglich eine Zusatznahrung.

\section{(36) Zusammenfassender Tätigkeitsbericht über ärztliche Tätigkeit im Flüchtlingslager Küstrin anlässlich von dessen Liquidation. - Küstrin-Neustadt, 3. Dezember 1945}

BLHA, Rep. 211 Ministerium für Gesundheitswesen, Nr. 1076, Bl. 35. - Bericht des Lagerarztes Dr. Otto Kalteis [an die Provinzialregierung Mark Brandenburg, Abt. Provinzialgesundheitsamt, Potsdam, Alte Zauche]. - Typoskript mit eigenhändiger Unterschrift, $1 \mathrm{~S}$.

\section{Bericht}

über meine ärztl. Tätigkeit im Flüchtlingslager Küstrin.

Gleich nach meinem Eintreffen im Lager am 28.11.[19]45 wurde ich mit der Leitung des ärztl[ichen] Aussendienstes im Lager II betraut. Es war meine Aufgabe die Kranken in den einzelnen Blocks des Lagers ärztl[ich] zu betreuen und zu versorgen.

Da im ganzen Lager II rund 10000 Flüchtlinge untergebracht waren, war die Anzahl der ambulanten Kranken eine recht grosse, besonders wenn berücksichtigt wird, dass die Lagerinsassen zu einem grossen Teil aus überalterten Menschen und aus Kindern bestehen, die schon vor ihrem Eintreffen im hiesigen Lager auf dem Transport den grössten Strapazen und Entbehrungen ausgesetzt waren. Von den Polen fast ihrer ganzen Habe beraubt, nur mit den dürftigsten Lebensmitteln versehen, oft nach langen Fussmärschen, kamen die Flüchtlinge in einem recht schlechten Gesundheits- und Ernährungszustand im Lager an.

Am meisten betroffen waren die alten Leute, die besonders an allgemeinen Schwäche- und Erschöpfungszuständen litten, bei denen aber auch sehr viele Fälle von Herzmuskelschwäche mit Dekompensationserscheinungen festgestellt werden konnten. Die Erkältungskrankheiten nahmen in Folge der verhältnismäßig günstigen Witterung nur einen leichteren Verlauf und beschränkten sich im wesentlichen auf Katarrhe der oberen Luftwege. Bei den Kleinkindern und Säuglingen zeigten sich in Folge des Milchmangels und des Mangels an geeigneter Kindernahrung gehäuft Ernährungsstörungen. Auch bei den Erwachsenen und alten Leuten traten gehäuft Darmkatarrhe unspezifischer Art mit schweren Durchfällen auf. Typhus, Dysenterie und sonstige Infektionskrankheiten traten verhältnismässig selten auf. Alle Fälle von Infektionskrankheiten wurden sofort im Infektionshaus des Lagers isoliert.

In den Tagen vor Auflösung des Lagers wurden aus der Belegschaft des Lagers zum Zwecke des Abtransprtes die Kranken, die Familien mit Kindern und die nicht marschfähigen alten Leute herausgesucht. Diese sollen in Zügen oder Autos über die Grenze geschafft werden. 
Im allgemeinen kann gesagt werden, dass die Zahl der Kranken trotz der schlechten Unterkünfte und Verpflegungsverhältnisse verhältnismässig klein war. Die Behandlung der Kranken war allerdings in Folge des fast gänzlichen Mangels an Medikamenten eine sehr schwierige.

\section{(37) Bericht über den Mord an einem ostpreußischen Flüchtling in der Nähe des Flüchtlingslagers Forst Zinna. - Luckenwalde, 10. Dezember 1945}

BLHA, Rep. 250 Landratsamt Luckenwalde, Nr. 104, B1.69. - Typoskript (Durchschlag, außer der Verfügung), 1 Bl., unterzeichnet (masch.) „Der Landrat“, Kopierstift-Unterschrift „Dr. Ludwig“. - O. 1. Absender und Tagebuch-Nr.: „Der Landrat / des Kreises Luckenwalde-Jüterbog / - Kreiskriminalpolizei - / Tgb.Nr. 1844/45“. - R. o. Datierung/ Aktenzeichen: „Luckenwalde, den 10. Dez. 1945 / Li./Rö.“ - U.1. Verfügung: „Dem Herrn Landrat / zur Kenntnis und zum Verbleib“, darunter handschriftlicher Bleistiftvermerk „Z.d.A.“

\section{Bericht!}

Betr.: Mord an dem z. Zt. stellungslosen Rudolf Zinnau, geb. am 2.11.1909 zu Königsberg (Ostpr.), jetzt wohnhaft in Grüna, Dorfstr. 24 c, Krs. Luckenwalde-Jüterbog.

Am 8.12.1945, gegen 17,00 Uhr, wurde die Kreiskripo durch den Leiter des Geschäftszimmers der Kreispolizei, Herrn Dichte, benachrichtigt, dass eine männliche Leiche in der Staatl. Försterei Zinna (ehemaliger Schiessplatz) aufgefunden worden sei. [...] Gegen 18,00-19,00 Uhr wurde nun die Leiche aufgefunden, die in einem Graben lag, der sich mitten im Walde befand und durch Schneewehen vom Schnee vollständig bedeckt war. [...]

Der Ermordete war mit einem Handwagen in den Wald gefahren, um Holz zu holen. In diesem Walde wird sehr viel gewildert und herumgeschossen von Soldaten der Roten Armee und Zivilrussen. Der Genannte muss von irgendeiner Person gestellt worden sein, in der Annahme, er sei ein ausgewichener Kriegsgefangener. Begründung über diese Annahme ist, dass der Ermordete einen Mantel vom ehemaligen Arbeitsdienst trug, sowie Sportstrümpfe und den Anschein erweckte, dass er ein ehemaliger Offizier gewesen sein muss und vielleicht aus dem Flüchtlingslager Forst Zinna entwichen sei. Der Gestellte hat nun nach Aufforderung durch den Anrufenden das Dickicht des Unterwaldes verlassen müssen.

Der Anrufende und der Gestellte sind nun gemeinschafttlich den Waldweg zum Flüchtlingslager gegangen. Auf diesem Wege muss zwischen den Genannten ein Zusammenstoss stattgefunden haben. Der Mörder hat hier dem Zinna den tödlichen Schuss beigebracht und sein Opfer dann in den dortigen Graben gerollt. / [...]

\section{(38) Bericht des Kreissozialamtes über den Stand der Vorbereitung von Durchgangslagern in Bad Saarow und Pieskow. - Beeskow, 13. Dezember 1945}

BLHA, Rep. 250 Landratsamt Beeskow-Storkow, Nr. 867, unfol. - Typoskript, 1 Bl., mit (Tinten-)Unterschrift. R.o. Datierung: „Beeskow, den 13. Dezember 1945.“- Rückseite Unterschrift: [gez.] „Mertel / Hauptsachbearbeiter im / Sozialamt." 


\section{Bericht über die Besichtigung der Durchgangslager in Bad-Saarow und Pieskow}

Am gestrigen Tage, Mittwoch den 12. Dezember wurde Unterzeichneter zu einer dienstlichen Besichtigungsfahrt mit dem zuständigen sowjetischen Offizier Agapitow abkommandiert. Es wurde zunächst das Auffanglager Saarow und im Anschluss daran das Auffanglager Pieskow besichtigt. Beide Orte können in zusammen 73 Baracken Umsiedler, die in den nächsten Tagen erwartet werden, aufnehmen. Zu diesem Zweck war eine sofortige Herrichtung dieser Baracken angeordnet worden.

\section{Ergebnis der Besichtigung Saarow.}

Es handelt sich um das ehemalige Barackengelände der früheren Wehrmacht. In keiner der Baracken war bisher etwas geschehen. Auf dem Gemeindeamt in Saarow wurde dann endlich festgestellt, daß die Baracken angeblich allmählich herzurichten seien und es seien schon das frühere Angestelltenheim und das frühere Versuchshaus hergerichtet, die jedoch nicht besichtigt wurden. Der Offizier, [er] handelt im Auftrage der sowjetischen Militäradministration, ordnete in Saarow auf dem Gemeindeamt die sofortige Inangriffnahme zur Herstellung und Bereitstellung der rund 53 Baracken des ehemaligen Wehrmachtsgeländes von Saarow an. Es wurde weiter festgestellt, daß ein Herr Dreyer [handschriftlich korrigiert aus „Drescher"] aus Saarow der angebliche Verbindungsmann zwischen Kreisverwaltung und Amt Saarow sei und dafür verantwortlich sei.

\section{Ergebnis der Beschtigung Pieskow.}

Dort waren bereits 2 Baracken hergerichtet. Der für diesen Ort eingesetzte Kriegsbeschädigte Siegert leitet die Instandsetzungsarbeiten der Baracken und wurde vom Offizier zum Lagerkommandanten bestellt.

Aus den Anordnungen des Offiziers habe ich entnommen, daß 9000 Umsiedler nach Saarow und 2000 nach Pieskow in kürzester Zeit kommen und in diesen Baracken untergebracht werden müssen. Ich habe hierbei festgestellt, daß in Saarow die Handhabung dieser Arbeiten völlig oberflächlich und unwichtig behandelt wird. Im Gegensatz hierzu steht Pieskow. Es muß also eine diesbezügliche Anordnung schon erlassen sein. Mit der Herrichtung der Baracken, d.h.: Saubermachen der Baracken ist es jedoch nicht getan. Es müssen sofort in allen Baracken Beleuchtungskörper für elektrisches Licht angebracht werden, des weiteren für Heizung (Aufstellung von Öfen), für Möbelstücke, Tische und Stühle, sowie Betten zumindest Strohsäcke, sowie Einrichtung der Küchen Vorkehrungen getroffen werden.

\section{(39) Bericht über das Umsiedlerlager Wriezen und Tätigkeitsbericht des dortigen Schutzpolizeikommandos. - Wriezen, 18./19. Dezember 1945.}

BArch, DO 2 Zentralverwaltung für deutsche Umsiedler, Nr. 105, unfol. - Typoskript, 1 S. mit 1 Anlage (1 S.). - L. o. „Schutzpolizei / Einsatz-K[omman]do. / Küstrin-Neustadt“. - R. o.: „Wriezen, den 18. Dezember 1945.“ - Eigenhändige Bleistift-Unterschrift „Witthuhn“ / „Hptm. d. Sch.P. u. / Leiter des Kdos.“ [Werner Witthuhn, Hauptwachtmeister; vgl. www.cuestrin.de]. - Anlage: Kopf wie vor, jedoch abweichendes Datum „19. Dez. 1945“. 


\section{Bericht über das Umsiedlerlager Wriezen.}

Das Umsiedlerlager Wriezen besteht aus den Lagern I und II.

Lager I befindet sich in der ehemaligen NSKK-Sportschule und liegt in unmittelbarer Nähe des Hafen-Anschlussgleises. Es besteht aus 5 Wohnbaracken mit einem Fassungsvermögen von ca. 700 Personen. Um diese geringe Aufnahmefähigkeit zu erhöhen, wurden in den Räumen zwei übereinander liegende Lagerstätten eingebaut. Die dafür erforderlichen Arbeiten sind noch nicht abgeschlossen. Hinzu kommen eine Turnhalle, in der etwa 150 Personen und der Saal des Gesellschaftshauses, in dem ca. 120 Personen Unterkunft finden würden. Insgesamt könnten 970 Personen im Lager I untergebracht werden.

Da die Fenster zum größten Teil fehlten, wurden die Öffnungen mit Brettern vernagelt und nur kleine Glasscheiben eingesetzt. Aus diesem Grunde kann eine geregelte Entlüftung durch Öffnen der Fenster nicht stattfinden. In den Räumen befinden sich teils gemauerte, teils eiserne Öfen. Die Abortanlagen sind in einer primitiven Bauart errichtet und zum größten Teil nicht überdacht. Ebenso fehlt eine räumliche Trennung der Anlagen für Männer und Frauen.

Das Lager II besteht aus 13 Wohnbaracken mit einem Fassungsvermögen von ca. 1270 Personen.

Der bauliche Zustand der Baracken ist durch Fremdeinwirkung stark herabgesetzt. In allen Baracken fehlen die Fenster und zum Teil auch die Fensterrahmen und die Türen. Für einige Unterkünfte ist eine Zentralheizungsanlage vorhanden. In den anderen Baracken fehlt jede Möglichkeit zum Heizen der Räume.

Die sanitären Anlagen in den Unterkünften sind nicht benutzbar, und die Abortanlage im Freien ist vollkommen unzulänglich.

Eine Benutzung der vorhandenen Kücheneinrichtung ist zur Zeit nicht möglich, da die Feuerungsanlage beschädigt ist und die Kessel nicht mehr vorhanden sind.

Durch die Außerbetriebsetzung des Wasserwerkes und das Fehlen von Brunnen im Lagergelände, ist die Versorgung mit Wasser in Frage gestellt. Das Lager aufnahmebereit zu machen, würde mehrere Wochen in Anspruch nehmen. Die von der Lagerleitung angegebene Frist von zwei Wochen dürfte kaum einzuhalten sein.

Durch die große Entfernung des Lagers II vom Bahnhof würde sich der An- und Abtransport der Umsiedler sehr schwierig gestalten. Ein Anschlußgleis besteht hier nicht.

Der Lagerbestand des Lagers Wriezen beträgt zur Zeit 240 Personen, dem gegenüber steht das Verwaltungspersonal mit 135 Personen.

1 Anlage. 
[Anlage: ]

Tätigkeitsbericht/ des K[omman]dos. in Wriezen.

Bei meinem Eintreffen im Umsiedlerlager Wriezen 6.12.45, habe ich folgende Verhältnisse vorgefunden. / Das Lager besteht aus 5 Wohn- und 1 Wirtschaftsbaracke, mit einer Aufnahmefähigkeit von ca. 700 Personen.

Die Stadtpolizei Wriezen konnte den Schutz des Lagers nicht übernehmen, weil die ihr zur Verfügung stehenden Kräfte nicht ausreichten. Es war daher eine Lagerpolizei in Stärke von 1-12 eingesetzt worden, die für den Ordnungsdienst und die Bewachung des Lagers, sowie für den An- und Abtransport der Umsiedler zu sorgen hatte. Diese Einrichtung war für die hiesigen Verhältnisse ausreichend, und demzufolge sollte das K[omman]do. Küstrin innerhalb von 8 Tagen aufgelöst und nach den Standorten entlassen werden. Diese Anordnung war von dem seinerzeitigen Lager-Kdt. Oblt. Kutzenko getroffen worden. Der neue Lager-Kdt. Oblt. Tschebattero befahl, daß ein Teil des Kdos. Küstrin in Stärke von 1-7 in Wriezen verbleiben sollte. Mein dagegen erhobener Einspruch wurde mit der Begründung abgelehnt, daß er wie in Küstrin, auch hier besonderen Wert auf die Zusammenarbeit mit meinem Kdo. lege. Das Kdo. übernahm daraufhin die Funktionen der Lagerpolizei Wriezen, die als solche aufgelöst ist, deren Angehörige aber weiter als Blockleiter beschäftigt sind.

Das Aufgabengebiet des Kdos. in Wriezen ist eng begrenzt und besteht hauptsächlich in der Stellung von Sicherheitswachen für das provisorische Tank- und Lebensmittellager und für die hier benötigten Kraftfahrzeuge. / Die Kraftfahrzeuge, haben heute den Befehl zur sofortigen Rückkehr nach ihren Standorten erhalten. / Ferner werden täglich Kontrollgänge durch die Baracken durchgeführt. Die Holz- und Kohlenausgabe wird durch den jeweiligen diensthabenden Wachtposten kontrolliert.

Am 17. und 18.12. wurde das Kdo. zur Betreuung eines auf dem Bahnhof Wriezen abgestellten Umsiedler-Transportzuges eingesetzt. Der Zug bestand aus 55 Wagen mit 4485 Personen. Unter der organisatorischen Leitung des Kdos. wurde warmes Essen und Marschverpflegung für 3 Tage ausgegeben.

Aus dem oben gegebenen Bericht ist zu ersehen, daß ein weiteres Verbleiben des Kdos. in Wriezen nicht erforderlich ist. Ich bitte daher um Auflösung des Kdos.

\section{(40) Anweisung der Provinzialverwaltung Mark Brandenburg zur Versorgung eines Transportes im Umsiedlerlager Küchensee. - [Küchensee], 2. Februar 1946}

BLHA, Rep. 256 Umsiedlerlager Küchensee, Nr. 29, unfol. - Aktenvermerk des Umsiedlerlagers Küchensee, betitelt „Telefonische Durchsage der Provinzialverwaltung Mark Brandenburg in Potsdam vom 2.2.1946 13.45 Uhr“. Vermerk u.1.: „Aufgenommen: Schmidt.“ - Typoskript ohne Unterschrift, 1 S.

Der Kreis Beeskow-Storkow bekommt in den nächsten Tagen 1500 Umsiedler in das Lager Küchensee zugewiesen. Diese Umsiedler haben eine 14tägige Quarantäne in Berlin durchgemacht. Diese Umsiedler sind im Kreise Beeskow-Storkow einzuweisen und beruflich zu erfassen. Die 
Umsiedlerausschüsse sind dafür einzusetzen. Sie bekommen Marschverpflegung und dann reguläre Einwohnerverpflegung.

\section{(41) Verzeichnis der am 1.1.1946 in Tätigkeit gewesenen Lager für „Umsiedler“. - [Potsdam, 1946]}

BLHA, Rep. 203 MdI, Nr. 1163, Bl.49-51. - Bleistift-Manuskript in Tabellenform. Abkürzungen und Wiederholungsstriche wurden aufgelöst. Nr. 1-26 auf Bl. 49, Nr. 27-55 auf Bl. 50, Nr. 56-67 auf Bl. 51.

\begin{tabular}{|c|c|c|c|c|}
\hline Lfd. Nr. & Kreis & Bezirk & Benennung des Lagers & Kapazität \\
\hline 1 & Angermünde & Eberswalde & Pinnow & 2000 \\
\hline 2 & Guben & Cottbus & Borsiglager & 1400 \\
\hline 3 & Forst & Cottbus & Forst, Kaiserhof & 500 \\
\hline 4 & Spremberg & Cottbus & Pharmalager [so! $]^{2242}$ & 2000 \\
\hline 5 & Brandenburg & Brandenburg & Quenz & 4000 \\
\hline 6 & Spremberg & Cottbus & Welzow & 2000 \\
\hline 7 & Luckau & Cottbus & Finsterwalde & 2200 \\
\hline 8 & Sonnenwalde & Cottbus & Jüterbog & 3000 \\
\hline 9 & Beeskow-Storkow & Bernau & Küchensee & 1600 \\
\hline 10 & Teltow & Bernau & Königswusterhausen & 1000 \\
\hline 11 & Niederbarnim & Bernau & Bernau & 1000 \\
\hline 12 & Osthavelland & Bernau & Falkensee & 1500 \\
\hline 13 & Oberbarnim & Eberswalde & Wriezen & 1000 \\
\hline 14 & Eberswalde & Eberswalde & Eberswalde & 1500 \\
\hline 15 & Templin & Eberswalde & Postheim & 1500 \\
\hline 16 & Prenzlau & Eberswalde & Birkenhain & 1000 \\
\hline 17 & Westprignitz & Brandenburg & Glöwen & 2000 \\
\hline 18 & Zauch-Belzig & Brandenburg & Belzig, Bergholzerstr. & 1000 \\
\hline 19 & Zauch-Belzig & Brandenburg & Treuenbrietzen, Selterhof & 2000 \\
\hline 20 & Rathenow-Stadt & Brandenburg & Rathenow, Mag.insel & 1800 \\
\hline 21 & Potsdam & Brandenburg & Luftschiffhafen & 350 \\
\hline 22 & Niederbarnim & Bernau & Rüdersdorf & 1500 \\
\hline 23 & Zauch-Belzig & Brandenburg & Belzig, Lübnitzerstr. & 1800 \\
\hline 24 & Zauch-Belzig & Brandenburg & Klinkengrund & 1500 \\
\hline 25 & Zauch-Belzig & Brandenburg & Treuenbrietzen, Landesanstalt & 2000 \\
\hline 26 & Zauch-Belzig & Brandenburg & Belzig, Schützenhaus & 400 \\
\hline 27 & Zauch-Belzig & Brandenburg & Belzig, Bornerstr. & 1200 \\
\hline 28 & Westprignitz & Brandenburg & Bad Wilsnack & 200 \\
\hline 29 & Westhavelland & Brandenburg & Friesack & 400 \\
\hline
\end{tabular}




\begin{tabular}{|c|c|c|c|c|}
\hline Lfd. Nr. & Kreis & Bezirk & Benennung des Lagers & Kapazität \\
\hline 30 & Westhavelland & Brandenburg & Pritzerbe & 250 \\
\hline 31 & Westhavelland & Brandenburg & Plaue & 300 \\
\hline 32 & Westhavelland & Brandenburg & Döberitz & 150 \\
\hline 33 & Ostprignitz & Brandenburg & Kyritz & 800 \\
\hline 34 & Ruppin & Brandenburg & Rheinsberg & 800 \\
\hline 35 & Ruppin & Brandenburg & Neuruppin & 300 \\
\hline 36 & Ruppin & Brandenburg & Grün[e]berg & 500 \\
\hline 37 & Stadt Wittenberge & Brandenburg & Wittenberge & 1000 \\
\hline 38 & Niederbarnim & Bernau & Oranienburg & 250 \\
\hline 39 & Niederbarnim & Bernau & Gross Schönebeck & 500 \\
\hline 40 & Potsdam & Potsdam & Bornstedt & 800 \\
\hline 41 & Potsdam & Potsdam & Neu Fahrland & 400 \\
\hline 42 & Osthavelland & Bernau & Hennigsdorf & 500 \\
\hline 43 & Teltow & Bernau & Königswusterhausen, An der Eisenbahn & 500 \\
\hline 44 & Teltow & Bernau & Zernsdorf & 600 \\
\hline 45 & Teltow & Bernau & Genshagen-Ludwigsfelde & 1500 \\
\hline 46 & Angermünde & Eberswalde & Angermünde, Kaisergarten & 1500 \\
\hline 47 & Angermünde & Eberswalde & Britz & 1000 \\
\hline 48 & Angermünde & Eberswalde & Joachimsthal & 600 \\
\hline 49 & Angermünde & Eberswalde & Oderberg & 2000 \\
\hline 50 & Angermünde & Eberswalde & Neu Künkendorf & 200 \\
\hline 51 & Angermünde & Eberswalde & Gramzow & 1000 \\
\hline 52 & Angermünde & Eberswalde & Altenhof/Schorfheide & 600 \\
\hline 53 & Angermünde & Eberswalde & Schwedt & 1000 \\
\hline 54 & Oberbarnim & Eberswalde & Freienwalde & 1300 \\
\hline 55 & Oberbarnim & Eberswalde & Straußberg [Strausberg] & 2000 \\
\hline 56 & Templin & Eberswalde & Engelsburg & 1500 \\
\hline 57 & Templin & Eberswalde & Lychen & 2000 \\
\hline 58 & Lübben & Cottbus & Börnichen & 800 \\
\hline 59 & Lübben & Cottbus & Krugau & 1500 \\
\hline 60 & Lübben & Cottbus & Lübben & 1500 \\
\hline 61 & Luckau & Cottbus & Weissagk & 1500 \\
\hline 62 & Luckau & Cottbus & Walddrehna & 500 \\
\hline 63 & Luckenwalde & Cottbus & Luckenwalde, Treuenbr. Tor & 2000 \\
\hline 64 & Luckenwalde & Cottbus & Baruth & 400 \\
\hline 65 & Forst & Cottbus & Klein-Kölzig & 120 \\
\hline 66 & Calau & Cottbus & Senftenberg & 350 \\
\hline 67 & Calau & Cottbus & Lübbenau & 350 \\
\hline
\end{tabular}


(42) Aufnahme von Transporten im Umsiedlerlager Küchensee,

\section{7. und 9. Februar 1946. - [Küchensee], 10. Februar 1946}

BLHA, Rep. 256 Umsiedlerlager Küchensee, Nr. 29, unfol. - Bericht des Lagerleiters/Umsiedlerbetreuungsstelle „bezüglich der Arbeit in den Kontroll-Sammel-Versandpunkten der Provinz Brandenburg vom 10.2.1946“ (r. o.: „Formblatt 4“). - Typoskript (Durchschlag) mit Paraphe des Lagerleiters Pi[epenburg] und Stempel „Der Landrat des Kreises Beeskow-Storkow / Umsiedler-Betreuungsstelle“, 1 S.

[a] Lfd. Nr.

[b] Benennung der ausgeführten Arbeit

[c] Bezeichnung d[er] Provinzkontrollversandpunkte

[d] Zusammen [Zahl der Personen]

[e] Bemerkung [Spalte leer]

[a] [b]

1. Eingang von Umsiedlungstransporten

Transport Nr. 17159 von Berlin-Schles. Bhf. eingeg[angen] 7.2.[19]46

Transport Nr. 4011 aus Pinnow eingeg[angen] 9.2.[19]46

2. Gesamte Besichtigung der Umsiedler

Der Transport aus Berlin war frei von Kranken und Seuchenverdächtigen.

1509 Umsiedler wurden auf die Gemeinden verteilt. 2 Mann gestorben.

3. Bei der Besichtigung festgestellte Infektionskranke Transport Nr. 17159

4. Isolierte Infektionskranke

Transport Nr. 4011

5. Festgestellte Verlauste

Transport Nr. 17159

6. Durchgeführte Sanitätsbetreuung

Transport Nr. 17159

918

7. In Quarantäne genommen

\section{Bemerkungen:}

1.) Der Infektionen unter den Umsiedlern, unternommene Massnahmen zur Isolierung, Quarantäniesierung, Desinfektion.

Die schweren Infektionskrankheiten werden in dem zum Lager gehörenden Krankenhaus „Seeburg“ behandelt. Alle anderen Erkrankten sind [in] einer besonderen Baracke untergebracht. Die ärztliche Betreuung liegt in den Händen von Herrn Dr. Gattig, Hubertushöhe. ${ }^{2243}$

2243 [Dr. med. Wolfgang Gattig (geb. 1911 Nehesdorf, Kr. Luckau), 1945-1954 Chefarzt des Kreiskrankenhauses Hubertushöhe (bei Storkow), zuvor 1939-1945 an der Medizinischen Akademie Danzig tätig (1944 Habilitation ebd.), 1954-1956 Schiffsarzt (Chirurg) der Olympic Whaling Company Panama (Walfangflotte 
Alle mit dem Transport Nr. 4011 aus Pinnow angekommenen Umsiedler (1 857) werden 12 Tage in Quarantäne behalten.

Alle Umsiedler werden in der bestehenden Desinfektionsanstalt (Dampf) entlaust. Läusepulver wurde dem Lager trotz Antrag beim Gesundheitsamt nicht zur Verfügung gestellt.

(43) Bescheinigung des Polizeileiters des Umsiedlerlagers Küchensee für die Landesanstalt Teupitz über eine geistesgestörte Lagerinsassin. - Küchensee, 10. Februar 1946

BLHA, Rep. 256 Umsiedlerlager Küchensee, Nr. 16, unfol. - Typoskript (Durchschlag) ohne Unterschrift, 1 S.

Hiermit wird bescheinigt, dass die am 12.3.1931 geborene Irmgard $B[\ldots]$ völlig geistesgestört ist und hier im Gemeinschaftslager Küchensee nicht betreut werden kann. B. bedeutet eine Gefahr für das ganze Lager. Um Aufnahme wird gebeten.

\section{(44) Anweisung der Provinzialverwaltung zur Versorgung eines Transportes im Umsiedlerlager. - [Küchensee], 12. Februar 1946}

BLHA, Rep. 256 Umsiedlerlager Küchensee, Nr. 16, unfol. - Aktenvermerk des Umsiedlerlagers Küchensee, betitelt „Fernmündliche Durchsage der Prov. Verwaltung Potsdam am 12.2.[19]46 um 13.45 Uhr“. - Typoskript ohne Unterschrift, $1 \mathrm{~S}$.

Der Transport von Umsiedlern aus Tangermünde, 1857 Personen, der am 8.2.[19]46 nach dem Lager Küchensee geleitet wurde, hat dort eine 3-wöchentliche Quarantäne durchzumachen. Eine Einweisung in das Kreisgebiet hat vorläufig nicht zu erfolgen. Weitere Anweisungen von der Prov.[-]Verwaltung sind abzuwarten. Eine Lebensmittelzuteilung ist bereits angewiesen. Die Versorgung hat vorläufig aus Kreisbeständen zu erfolgen.

\section{(45) Protokoll der Vernehmung einer des Diebstahls Verdächtigten}

\section{im Lager Küchensee. - Küchensee, 18. Februar 1946}

BLHA, Rep. 256 Umsiedlerlager Küchensee, Nr. 16, unfol. - Typoskript (1 S.) mit eigenhändigen Unterschriften („v.g.u."), links der der Vernehmenden [Lagerleiter] [Kurt] Neubacher, rechts der der Vernommenen (Hildegard D[...]). Über der Überschrift „Protokoll“ handschriftlich vom Vernehmenden: „Entwurf“.

Aufgefordert erscheint im Büro Frau $D[\ldots]$ und gibt folgendes zu Protokoll.

Zur Person: $\quad$ Ich heiße Hildegard D[...], bin am 4.12.1916 in Witzen ${ }^{2244}$ geboren und bin seit dem 24. September 1945 im Umsiedlerlager Küchensee.

Onassis), 1956-1960 Vertragsarzt beim Versorgungsamt Hamburg, dann Facharzt u. Dozent für Chirurgie in Hamburg (Chirurgenverzeichnis. 4. Aufl. Heidelberg 1958, S. 235; desgl. 6. Aufl. Berlin/Heidelberg 1980, S. 177).]

2244 [Witzen im Kr. Sorau (Ostteil).] 
Zur Sache: Am 13.2.[19]46 habe ich mir zu meinem Hochzeitstag von der Küche 2 Kuchen backen lassen. Die Zutaten hierfür hat mein Mann von Mecklenburg, von Verwandten geholt. Ich erkläre an Eidesstatt, dass ich zu diesem Zweck aus der Küche keine Zutaten erhalten habe.

(46) Lagebericht des Lagerarztes des Kreisumsiedlerlagers Glöwen für die Monate Januar bis März 1946. - Glöwen, 25. März 1946

BLHA, Rep. 250 Landratsamt Westprignitz, Nr. 261, unfol. - Typoskript (Durchschlag), 2 S. - Adressiert an die „Provinzialverwaltung Mark Brandenburg, Amt für Deutsche Umsiedler, Potsdam“.

Bericht über die sanitäre Arbeit im Umsiedlerlager Glöwen vom 1.1.1946 bis 20.3.1946

Um zunächst eine Übersicht zu geben, werden die im Schreiben der Provinzialverwaltung, Amt für Deutsches Umsiedlerwesen (Az.: VII/2/Ges.Wesen) erhobenen Fragen beantwortet:

1) Seit Beginn der Umsiedleraktion wurden vom hiesigen Lager 18 Kranke den öffentlichen Krankenanstalten überwiesen.

2) Seit dem 1.1.1946 wurden 13766 Umsiedler durchgeschleust.

3) 1008 Umsiedler wurden in dieser Zeit im Krankenrevier des Lagers ärztlich betreut.

4) Den Verlausungsgrad der Umsiedler kann man allgemein schlecht angeben. Transporte aus dem Osten (Danzig etc.) waren teilweise bis zu $40 \%$ verlaust. Bei Transporten aus dem Westen fanden sich keine Kleiderläuse. Bei Transporten, die hier im Lager aus der Mark Brandenburg zusammengestellt wurden, um nach dem Westen geleitet zu werden, fanden sich nur ganz vereinzelt Läuse. Auf 3000 Umsiedler 1 Fall.

Der Seuchenstand war im allgemeinen ein günstiger. Fleckfieber kam überhaupt nicht vor. Bauchtyphusfälle waren nur wenige, im ganzen wurden zwei einwandfreie und 4 Verdachtsfälle von Typhus einer öffentlichen Krankenanstalt überwiesen. Diphteriefälle waren 3 zu verzeichnen. Paratyphus, Ruhr, Scharlach wurden nicht beobachtet. Weiter wurden erkannt 6 Fälle von inaktiver Lungentuberkulose, 2 Fälle von Syphilis und 8 Fälle von Gonorrhoe.

Das Lager verfügt über eine ausgezeichnete Badeeinrichtung. 2 Wannen und zahlreiche Duschbäder, die ständig in Gebrauch waren und rege benutzt wurden, besonders im Zusammenhang mit Läuse- und Krätzebekämpfung.

Die ärztliche Betreuung wird durchgeführt durch einen Lagerarzt, der dem Lager neben seiner Tätigkeit in Allgemein-Praxis für Glöwen und Umgebung (ärztliche Betreuung von 5-6000 Menschen) und als Sprengelarzt zur Verfügung steht. In Zeiten starker Lagerbelegung konnte der Arzt all seinen Aufgaben nicht voll und ganz gewachsen sein. Deshalb ist anzustreben, dem Lager, wenigstens bei starker Belegung, noch einen Hilfsarzt zur Verfügung zu stellen, was auch vom Amtsarzt Perleberg und Beamten der Provinzialverwaltung Brandenburg ebenfalls für notwendig befunden wurde. 
Für die sanitäre Betreuung im Krankenrevier und Lager stehen dem Lagerarzt 1 Sanitätshelfer und 5 Schwestern zur Verfügung, von denen eine Vollausbildung mit Staatsexamen hat.

Dem Krankenrevier konnte bisher an ärztlichen Instrumenten, Untersuchungs- und Behandlungsgerät, noch nichts geliefert werden. Die Hilfsmittel, die vorhanden sind, wie Spritzen, elektrischer Sterilisator, einige Instrumente und Bestrahlungsapparate wurden von der AllgemeinPraxis des Lagerarztes abgezweigt und zur Verfügung gestellt, da ohne diese eine Behandlung nicht möglich ist. Nach anfänglichen grossen Schwierigkeiten wurden nun auch dem Krankenrevier Medikamente geliefert. An Verbandsmitteln herrscht nach wie vor grosser Mangel, besonders fehlt es an Binden.

Die gemäss Verfügung der Provinzialverwaltung vom 21.1.1946 geforderte reine und unreine Seite ist zur Durchführung gelangt.

Dagegen fehlt es im Lager immer noch an einer Entlausungsanlage, die bei Vollbelegung den Anforderungen gerecht wird. Die beiden vorhandenen elektrischen Heissluftkästen reichen für eine ordnungsgemässe Entlausung von zahlreichen Umsiedlern nicht aus. Der Ausbau der früher noch vom Lazarett herstammenden teilweise zerstörten Entlausungsanlage muss umgehend, wie seit Monaten gefordert, in Angriff genommen werden. Nur der zu dieser Anlage gehörige Heissluftraum für die Kleiderentlausung ist betriebsfertig, allerdings auch nur bei Beheizung mit Briketts. Da bei Holzheizung nur Temperaturen bis $60^{\circ}$ entstehen, müsste die Anlage auf Holz umgebaut werden (mehr Züge!) oder Briketts zur Verfügung gestellt werden. Die Kesselanlage der Waschräume, ebenfalls die An- und Auskleideräume der reinen und unreinen Seite, müssten wieder hergestellt werden (Wände abdichten, da für nackte Menschen zu kalt!)

Ein weiterer wunder Punkt im Lager sind die Klosettanlagen, die keineswegs den Anforderungen genügen. Bei Belegung sind die Klosetts meist verstopft und die vom Lagerarzt seit Monaten geforderten Latrinen sind immer noch nicht gebaut, sodass man bei Belegung im Lager und Umgebung über Haufen menschlicher Exkremente stolpert. Ein Zustand, der nicht nur im höchsten Grad unhygienisch, sondern unsere ganze der Seuchenabwehr dienende Arbeit illusorisch macht.

\section{(47) Protokoll einer Verhandlung über einen Transport zum Lager Küchensee. - Küchensee, 11. April 1946}

BLHA, Rep. 256 Umsiedlerlager Küchensee, Nr. 29, unfol. - Abschrift (Typoskript), 1 S. [Reihenfolge der Unterschriften, anders als im Kopf: Sudaref, [Kurt] Neubacher, [Fritz] Piepenburg].

Verhandlung den 11.4.[19]46.

Die Unterzeichneten, der Lagerleiter von Küchensee, Herr Neubacher, der Leiter vom Sozialwesen, Herr Piepenburg, und der Beauftragte der Kreiskommandantur Oberleutnant Sudaref haben an der Verhandlung teilgenommen, über Folgendes:

Am 10.4.[19]46 um 19.15 Uhr ist ein Transport mit Umsiedler[n] mit sämtlichen Papieren in Storkow eingeftroffen. In diesem Transport Nr. 17162 befanden sich 1344 Mann. Der Trans- 
port war in Berlin zusammengestellt, und sollte in die englische Zone abgeleitet werden. Da er in der englischen Zone nicht aufgenommen wurde, ist er von dort[,] der Grenzstadt Völpke, hierher geleitet worden mit einer Stärke von 900 Mann. Während der Fahrt hatten die Umsiedler 3 Tage keine Verpflegung, es hat sich ein Toter darunter befunden. Die Stadt Storkow hat 2 LKWs eingesetzt und von einer Entfernung $6 \mathrm{~km}$ von der Ausladungsstelle bis zum Lager die Umsiedler hingebracht. Bei der Ausladung der Umsiedler hat die Polizei von Storkow beigestanden, Die Ausladung dauerte von 19.15 Uhr bis 1.00 Uhr.

Die Verhandlung wurde mit den Unterzeichneten aufgestellt. [...].

\section{(48) Protokoll der Vernehmung eines Diebstahlzeugen im Lager Küchensee. -}

\section{Küchensee, 16. April 1946}

BLHA, Rep. 256 Umsiedlerlager Küchensee, Nr. 16, unfol. - Typoskript mit den eigenhändigen Unterschriften des Zeugen und des vernehmenden Lagerleiters [Kurt] Neubacher, $1 \mathrm{~S}$.

\section{Vernehmung}

Aufgefordert erscheint heute hier Herr Eugen $S[\ldots]$ und gibt folgendes zu Protokoll:

Zur Person: Ich heisse Eugen $S[\ldots]$, geb. 27.3.22 in Lodsch und befinde mich seit dem 10.4.[19]46 im Umsiedlerlager Küchensee.

Zur Sache: Seit dem 10.4. waren Waldemar [korrigiert aus: Ludwig] $L[\ldots]$ und ich einmal mit den hier im Lager ansässigen Gerda und Charlotte J[... ] zusammen.

Am Sonnabend den 13.4. zirka $20 \mathrm{Uhr}$ habe ich mir von Frl. J[... ] ein Bügeleisen geliehen. Als ich dasselbe zurück brachte, blieb ich noch eine geraume Zeit bei Frl. J[... ] im Zimmer. Nach zirka 30 Minuten erschien Herr L. L[... ] im Zimmer und trug unter seiner Jacke einige Wäsche und Bekleidungsstücke. Ich erkannte diese als nicht sein Eigentum, da es sich zum grössten Teil um Damenwäsche handelte. L. übergab diese Wäschestücke den beiden Mädels. Wie weit Frl. C. und G. J[... über den Diebstahl informiert waren, kann ich nicht sagen, da ich diese garnicht danach gefragt habe.

Am 10.4.[19]46 wurde von der hiesigen Lagerpolizei eine Durchsuchung sämtlicher Baracken nach [einem] einer Frau gestohlenen Koffer mit Wäschestücken veranstaltet. Ich vermutete sofort dass es sich um die von L. an Frl. J[...] übergebenen Wäschestücke handelte und habe das am 16.4. der Lagerführung gemeldet.

L. hat mich gebeten über diese Sache Stillschweigen zu bewahren, dass ich jedoch nich getan habe. 


\section{(49) Schreiben des Umsiedlerlagers Küchensee an die Lagerleitung des Lagers}

\section{in Berlin NW 21, Kruppstraße. - [Küchensee], 20. April 1946}

BLHA, Rep. 256 Umsiedlerlager Küchensee, Nr. 29, unfol. - Durchschlag (Typoskript), 1 S., unterzeichnet mit Paraphe „Pi“ [Piepenburg]. Die Zahl 36 handschriftlich eingefügt.

Sie erhalten heute 36 Umsiedler. Diese gehören zu den Ihnen am 19.4. überwiesenen Transport und sind auf den dorthabenden Listen namentlich verzeichnet. / Wir machen Sie ferner darauf aufmerksam, dass viele Einzelreisende bei Ihnen eintreffen werden, trotzdem wir diese Leute darauf hingewiesen haben, dass ohne Einreisegenehmigung eine Uebersiedlung in die englische Zone nicht möglich ist.

\section{(50) Tätigkeitsbericht des Umsiedlerlagers Küchensee für die Zeit} vom 1. bis 10. Mai 1946. - [Küchensee], 10. Mai 1946 (Auszüge)

BLHA, Rep. 250 Landratsamt Beeskow-Storkow, Nr. 869, unfol. - Typoskript (Durchschlag) ohne Unterschrift (nur masch. „Umsiedlerbetreuungsstelle“) 2 Bl. Gesamter Kopf fehlt. - Überschrift: „Bericht über die Tätigkeit des Umsiedlerlagers Küchensee in der Zeit vom 1.5.-10.5.1946.“

Am 2.5. traf im Umsiedlerlager Küchensee ein Transport von 967 Umsiedlern ein. Der Transport kam von Berlin Schlesischen Bahnhof und war aus verschiedenen Berliner Lagern zusammengestellt. Der Gesundheitszustand des Transportes war gut. Ein Teil der Umsiedler fuhr auf eigenen Wunsch und eigener Gefahr nach Thüringen, Sachsen oder nach Berlin. Der Rest von 784 Umsiedlern wurde auf Anordnung der Provinzialverwaltung - Amt für deutsche Umsiedler - eingemeindet.

Es erhielten die Amtsbezirke Niederlehme 159 Umsiedler[,] Ketschendorf 298 Umsiedler[,] Friedersdorf 133 Umsiedler[,] Markgrafpieske 149 Umsiedler[,] Wend[isch]-Buchholz 45 Umsiedler[.] Der Amtsbezirk Neu-Zittau[,] der noch eine Aufnahmefähigkeit von 2000 Umsiedlern hat[,] wurde unberücksichtigt gelassen, da die Ernährungsschwierigkeiten laut Ansagen des Amtsbürgermeisters zu grosse sind. Im Lager verbleiben 56 Umsiedler, welche ihre Quarantäne durchmachen. Während der Lagerzeit wurde am 5.5. im Rahmen der Umsiedlerbetreuung ein Varietéabend mit anschliessend Tanz veranstaltet. Die Artisten waren unter den Umsiedlern vorhanden. Dort wurde ferner Bier und Alkohol ausgeschenkt.

$[\ldots][$ Bl. v] $[\ldots]$

Aufgaben des Umsiedlerlagers Küchensee für die nächste Zeit

Laut Mitteilung der Provinzialverwaltung trifft in den nächsten Tagen ein Transport von 1500 Umsiedlern aus der Tschechoslowakei ein. Es ist der Umsiedlerbetreuungsstelle und der Lagerleitung zur Aufgabe gemacht, das Lager schnellstens aufnahmefähig zu machen. Ferner die Lebensmittel und Medikamente sicher zu stellen. 
Die in Bad-Saarow lagernden Barackenteile sind schnellstens nach Küchensee zu transportieren und dort wieder aufzustellen. Das in der Försterei Tschinka bei Alt-Schadow liegende Brennholz 400 mtr. ist schnellstens anzufahren.

Das Personal, insbesondere die Lagerpolizei ist zu vervollständigen um ein geregeltes Arbeiten und eine sichere Bewachung des Lagers zu gewährleisten.

Zur Bewältigung dieser Aufgaben benötigen wir die Gestellung von Lkw’s.

Es wird der Umsiedlerbetreuungsstelle von der russischen Behörde mangelndes Interesse vorgeworfen, dieses muss aber schärfstens zurückgewiesen werden, da die Umsiedlerbetreuungsstelle laufend Lkw's beantragte, diese aber nicht gestellt werden konnten. Um strengere Massnahmen zu verhindern müssen dem Umsiedlerlager Küchensee jetzt laufend Fahrzeuge gestellt werden. Die o. a. 1500 Umsiedler werden nach der Verfügung der Provinzialverwaltung nach Ableistung einer 3-wöchigen Qauarantäne im Kreise Beeskow-Storkow eingemeindet werden. Da aber in den einzelnen Amtsbezirken schon Schwierigkeiten bei der Unterbringung bestehen, ist es dringend notwendig einen von der Provinzialverwaltung Mark Brandenburg vorgeschlagenen Kreisumsiedlerausschuss zu bilden.

\section{(51) Überweisungen von Umsiedlern in das Umsiedlerlager Küchensee durch} das Amt für Arbeit und Sozialwesen des Kreises Beeskow-Storkow. - [Beeskow], Februar bis Juni 1946

BLHA, Rep. 256 Umsiedlerlager Küchensee, Nr. 29, unfol. - 22 Einzelschreiben. - Typoskripte (Durchschläge) mit Paraphe, je $1 \mathrm{~S}$.

14.2.1946: Betrifft: [... (4 Namen mit Geburtsdaten)]. Obenstehende Personen bitten wir in dss Lager aufzunehmen und zum Personenbestand anzurechnen.

5.3.1946: Es wird hiermit gebeten Frau Margarete $\mathrm{M}[\ldots]$ in das Lager in Quarantäne zu nehmen. Frau $\mathrm{M}[\ldots]$ kommt direckt [so!] aus dem Osten.

28.3.1946: Es wird hiermit Frau Minna R[... geb. 10.7.00 in das Umsiedlerlager Küchensee zur Ableistung ihrer Quarantänezeit überwiesen. Nach Ablauf der Quarantänezeit bitten wir Frau R. in die Gemeinde Braunsdorf zu überwiesen.

2.4.1946: Hiermit werden folgende Personen [... (2 Namen mit Geburtsdaten)] in das Umsiedlerlager eingewiesen, zwecks Ableistung ihrer Quarantänezeit.

6.4.1946: Hiermit wird Herr Günther J[... ] geb. 28. Juni 1928 zur Ableistung seiner Quarantänezeit in das Lager überwiesen.

18.4.1946: Folgende unten aufgeführte Personen werden ausnahmsweise dem Lager Küchensee zugewiesen zur Verteilung in die Gemeinden: [... (3 Namen mit Geburtsdaten und -orten)]. Dieselben müssen ihre Quarantäne noch ableisten.

20.4.1946: Hiermit wird Herr Siegfried S. geb. 12.6.28 in das Lager eingewiesen zwecks Ableistung seiner Quarantänezeit. Herr Sch. kommt direkt aus dem östlich der Oder liegendem Gebiet. 
24.4.1946: Hiermit wird Herr Paul S. geb. 5.2.75 in das Lager zwecks Ableistung seiner Quarantänezeit aufgenommen. P. Sch. kommt direkt aus den besetzten polnischen Gebieten.

27.4.1946: Hiermit wird Ihnen zur Ableistung der Quarantäne Frau Emma B. geb. 27.6.00 [und] Horst B [...] geb. 13.2.38 überwiesen. Es wird gebeten, wenn die Möglichkeit besteht, genannte Personen für immer im Lager als Arbeitskräfte zu behalten.

29.4.1946: Hiermit wird Herr Heinz S. geb. 28.1.1920 und Frau Anni S. geb. 19.7.22 in das Lager eingewiesen, zwecks Ableistung ihrer Quarantäne. Obige Personen kommen direckt [so!] aus den Ostgebieten.

8.5.1946: Hiermit werden folgende Personen [... (4 Namen mit Geburtsdaten)] in das Umsiedlerlager eingewiesen, zwecks Ableistung ihrer Quarantänezeit. Obige Personen kommen direkt aus den östlichbesetzten Gebieten.

9.5.1946: Hiermit werden folgende Personen in das Umsiedlerlager Küchensee eingewiesen, zwecks Ableistung der Quarantänezeit: [... (4 Namen mit Geburtsdaten)]. Die genannten Personen sind Einzelgänger und kommen direkt aus dem Osten.

13.5.1946: Hiermit wird Herr D[... ] Emil in das Lager eingewiesen zur Ableistung seiner Quarantänezeit. Herr D. kommt aus den Ostgebieten und ist nach Ableistung seiner Quarantänezeit zum Arbeitseinsatz in Kossenblatt vorgesehen.

24.5.1946: Hiermit wird Herr Heinz Z[ ... ] in das Lager Küchensee eingewiesen zwecks Ableistung seiner Quarantänezeit.

24.5.1946: Hiermit wird Ihnen Herr Richard S[... in das Umsiedlerlager überwiesen, zwecks Ableistung seiner Quarantäne. Herr S. kommt aus polnischer Gefangenschaft.

29.5.1946: Hiermit wird Herr Gerhard H[... ] geb. am 28.6.29 in das Lager eingewiesen, zwecks Ableistung seiner Quarantäne. Es wird gebeten Herr H. nach der Quarantäne an das Arbeitsamt Beeskow zu verweisen.

29.5.1946: Hiermit werden folgende Personen in das Lager eingewiesen, zwecks Ableistung Ihrer Quarantänezeit: [... (3 Namen mit Geburtsdaten)].

31.5.1946: Hiermit wird Herr Gustav R[... geb. am 6.6.03 in das Lager eingewiesen, zwecks Ableistung seiner Quarantänezeit.

3.6.1946: Hiermit wird Herr Karl P[...] geb. am 3.5.06 in das Umsiedlerlager, zwecks Ableistung seiner Quarantäne, eingewiesen. Herr P. kommt direkt aus dem Gebiet jenseits der Oder.

4.6.1946: Hiermit wird Herr Karl L[...] in das Lager eingewiesen zwecks Ableistung seiner Quarantäne. Herr L. kommt aus der Schweiz.

6.6.1946: Hiermit wird Frl. Johanna B. geb. 9.3.24 in das Umsiedlerlager Küchensee eingewiesen, zwecks Ableistung ihrer Quarantäne.

11.6.1946: Hiermit wird Herr Günther G[...] geb. am ...[?] 9. 29 in das Lager eingewiesen, zwecks Ableistung seiner Quarantänezeit. 


\section{(52) Schreiben des Umsiedlerlagers Küchensee an den Landrat des}

\section{Kreises Beeskow-Storkow. - Küchensee, 8. Juli 1946}

BLHA, Rep. 256 Umsiedlerlager Küchensee, Nr. 29, unfol. - Typoskript (1 S.) auf (ergänztem und abgeändertem) Kopfbogen des Landrates des Kreises Beeskow-Storkow mit eigenhändiger Unterschrift des Lagerleiters Piepenburg. U.1. handschritlicher Bleistiftvemerk von anderer Hand „Der Transport ist bis zu den Gemeindewahlen schon längst eingemeindet!“

Bei einer hier im Lager Küchensee erfolgten Aussprache wurde u. a. angefragt, wie es mit dem Wahlrecht der neu angekommenen Umsiedler ist. Nach den bestehenden Wahlverordnungen sind nur die wahlberechtigt, welche 3 Monate in einem Ort wohnen. Diese Bedingung kann von den Umsiedlern nicht erfüllt werden, da sie ja erst nach Ablauf ihrer 14tägigen Quarantäne eingemeindet werden.

Wir bitten von dort aus um Nachricht bzw. Weiterleitung dieser Frage an die Provinzialverwaltung.

\section{(53) Tagesberichte des Umsiedlerlagers Küchensee. - [Küchensee], 8. Juli bis}

\section{September 1946}

BLHA, Rep. 256 Umsiedlerlager Küchensee, Nr. 217, unfol. - Typoskript (Durchschläge), meist auf Kopfbogen der Kreisverwaltung Beeskow-Storkow, jeweils unterzeichnet vom Lagerleiter Piepenburg.

Sonntag, 7.7.1946 (Niederschrift 8.7.1946)

Der am 4.7. eingetroffene Transport aus der Tschechoslowakei hat sich hier sehr gut eingelebt. Die Umsiedler sind sehr sauber und sehr arbeitsam. Allerdings besteht bei der vorgesehenen Verteilung in den Kreis die Schwierigkeit, dass viele Familien in die amerikanische Zone gehen wollen, wie aus [dem] besonderen Bericht hervorgeht.

Der Chor der Umsiedler gab am Abend ein Konzert [,] an welchem das gesamte Lager teilnahm, Neben Volksliedern wurden musikalische Vorträge gebracht und zum Abschluß ein gemeinsames Volkslied gesungen. Bei dieser Gelegenheit wurde ein Fass Bier ausgeschenkt.

Da die meisten Umsiedler katholischen Glaubens sind, wurde am Sonntagnachmittag Kirche mit anschliessend[er] Beichte abgehalten.

Montag, 8.7.1946 (Niederschrift 9.7.1946)

Am Montag[,] den 8.7.1946 veranstalte[re] die Konzertgruppe der Umsiedler einen Tanzabend, an welchem die gesamte Jugend sich rege beteiligte. An Kinder und werdende Mütter wurden pro Kopf 300 gr. Kirschen oder Aepfel ausgegeben. Die Entlausung der Umsiedler ist im [so!] vollem Gange.

\section{Dienstag, 9.7.1946 (Niederschrift 9.7.1946)}

Wegen des grossen Erfolges wurde der Tanzabend wiederholt. Es gelangte bei dieser Gelegenheit $50 \mathrm{~L}$ Trinkbran[n]twein zur Ausgabe. Wiederum erhielten alle Kinder bis zu 14 Jahren, sowie werdende Mütter 500 gr. Obst (Johannisbeeren). Mit der Schutzimpfung gegen Typhus 
wurde begonnen. Am Nachmittag fand eine Besichtigung durch den Dezernenten des Amtes für Arbeit und Sozialwesen Herrn Jung und der Leiterin des Kreisfrauenausschusses Frau Powallka statt. Dabei erfolgte eine Prüfung der Lebensmittelbestände. Die Prüfung hat ergeben, dass diese stimmten. Mit der Schuhfabrik in Storkow wurde erneut vereinbart, dass diese täglich 10 Paar Schuhe reparieren.

Mittwoch, 10.7.1946 (Niederschrift 12.7.1946)

Am 10.7. fand eine Besichtigung des Lagers durch den Verbindungsoffizier der Kreiskommandantur, Leutnant Sudareff[,] und einem russischen Offizier der Kommandantur Storkow statt. Die Besichtigung verlief zur vollsten Zufriedenheit. Bei dieser Gelegenheit wurde uns mitgeteilt, dass dem Lager von der Kreiskommandantur 15 T. Briketts bewilligt worden sind. Am Abend fand eine Wiederholung des Tanzabends statt.

Donnerstag, 11.7.1946 (Niederschrift 12.7.1946)

Am Donnerstag[,] den 11.7. fand die erste Sitzung des neu gebildeten Umsiedlerausschusses statt. Im Umsiedlerausschuss ist jede Baracke durch eine Frau und einen Mann vertreten. Nach der Einleitung durch den Lagerleiter sprach Herr Dezernent Jung zu den Anwesenden über die Pflichten und Aufgaben des Umsiedlerausschusses. Es wurden verschiedene Kommissionen der Küchenkontrolle gebildet, welche täglich wechseln. Ferner Kommissionen für die Sauberhaltung des Lagers. Für Anfang nächster Woche ist ein politischer Vortrag vorgesehen. Die anschliessende Besichtigung durch den Dezernenten Herrn Jung und der Leiterin des Frauenausschusses Beeskow, Frau Powalka, verlief zur vollsten Zufriedenheit. Am Abend fand erneut eine Tanzveranstaltung statt.

Sonntag, 14.7.1946 (Niederschrift 15.7.1946)

Am Sonntag[,] den 14.7. veranstaltete die Künstlergruppe des Lagers ein Frühkonzert. Es gelangten neben Volksliedern, Solovorträgen der Trompete, Geige usw. Rezitationen zum Vortrag. Am Nachmittag wurde ein katholischer Gottesdienst mit anschliessender Beichte abgehalten.

Am Sonnabend wurden 125 Ltr. Bier ausgeschenkt. Ausserdem bekamen alle Kinder bis zum 14. Lebensjahr $250 \mathrm{~g}$. Kirschen und je 4 Personen eine Gurke.

Donnerstag, 18.7.1946 (Niederschrift 22.7.1946)

Die Quarantänezeit des am 3.7.[19]46 hier eingetroffenen Transportes ist heute beendet. Alle Umsiedler wurden 3 mal entlaust und geimpft. Alle 1200 Umsiedler wurden im Kreise Beeskow-Storkow eingemeindet. Allerdings sind viele Facharbeiter dem Landesarbeitsamt zum überbezirklichen Ausgleich überwiesen.

Zum Abschluss veranstaltete noch einmal der Chor und die Musikgruppe einen Konzertabend, der bei den Zuhörern reichen Beifall fand. Bei dieser Gelegenheit wurden 77 Ltr. Starkbier ausgegeben. Vom Kreisfrauenausschuss wurden uns von der Kreisfrauenausschussleiterein Frau Powalka zusätzlich $6 \mathrm{~kg}$ Mehl, $50 \mathrm{~kg}$ Schoten und 3,75 Kg Gurken übergeben. 
Freitag, 19.7.1946 (Niederschrift 22.7.1946)

Heute wurde mit der Verteilung der Umsiedler begonnen. Die Gestellung der Fahrzeuge für den Abtransport liess sehr zu wünschen übrig. Es wurden eingemeindet in den Amtsbezirk Merz 84 Umsiedler, Friedersdorf 49 Umsiedler, Storkow 100 Umsiedler, Neu-Zittau 679 Umsiedler, Bad Saarow 67 Umsiedler, Ketschendorf 58 Umsiedler, Krausnick 60 Umsiedler, Trebatsch 28 Umsiedler, Lindenberg 11 Umsiedler, Markgrafpieske 32 Umsiedler.

Montag, 22.7.1946 (Niederschrift 24.7.1946)

Am 22.7.1946 wurde die Verteilung der Umsiedler fortgesetzt. Die Gestellung der LKW's liess viel zu Wünschen übrig, sodass die für Neu-Zittau bestimmten Umsiedler noch nicht alle an Ort und Stelle transportiert werden konnten.

Die Firma Schröder, Alt-Stahnsdorf, ist mit zwei Arbeitern bei dem Barackenbau beschäftigt.

Auf Vereinbarung mit der Stadt Storkow und dem Kreisgesundheitsamt wurden 19 Umsiedler des Schwenkelagers Storkow zur Entlausung nach Küchensee gebracht.

\section{Sonnabend, 23.7.1946 (Niederschrift 24.7.1946)}

Heute wurde die Verteilung der Umsiedler abgeschlossen. Es befinden sich zur Zeit noch $39 \mathrm{Um}$ siedler im Lager. Neben 16 Kranke[n] und Nichttransportfähige[n], befinden sich 12 alte Leute, welche unbedingt in ein Altersheim überwiesen werden müssen[,] und eine Familie[, die] wegen eines damals aufgetretenen Masernfall[s] eine 10-tägige Quarantäne durchmachen müssen.

Da das Lager wieder schnellstens aufnahmefähig sein muss, muss unbedingt dafür gesorgt werden, dass die alten Leute in ein Altersheim aufgenommen werden.

Die im Lager befindlichen arbeitsfähigen Leute sind dabei[,] die Baracken zu säubern. Firma Range, Philadelphia, ist dabei[,] die defekten Kochkessel zu reparieren.

\section{Montag, 25.7.1946 (Niederschrift 25.7.1946)}

Heute fuhren sämtliche zur Verfügung stehenden LKW's des Kreises Beeskow-Storkow Umsiedler und Gepäck vom Bahnhof Beeskow zum Lager. Der letzte Lastzug mit Gepäck traf hier um 2.45 Uhr ein. Damit hat das Ausladen bezw. das Überführen der Umsiedler von Beeskow nach Storkow 28 Stunden gedauert. Wir bitten[,] in Zukunft die zuständigen Stellen darauf hinzuweisen, daß dem Lager Küchensee der nächstgelegene Bahnhof Storkow ist. Es läßt sich nicht öfter durchführen, daß die so dringend benötigten LKW's 28 Stunden für das Umsiedlerlager Küchensee fahren.

Bei dem Transport wurde festgestellt, daß ein ganzes Altersheim evakuiert wurde. Die alten Leute sind in einer besonderen Baracke untergebracht und werden von einer Schwester betreut.

Sonnabend, 26.7.1946 (Niederschrift 26.7.1946)

Der neuangekommene Transport wurde eingewiesen und die Registrierung vorgenommen. Ein Todesfall durch Altersschwäche. Verpflegungsstärke: 1217. 
Sonntag und Montag, 27.7. und 28.7.1946 (Niederschrift 28.7.1946)

Am 27.7.[19]46 wurde die Registrierung der Umsiedler fortgesetzt. Ferner auf Anordnung der Provinzialverwaltung sämtliche Textilfacharbeiter herausgesucht und namhaft gemacht. 500 Umsiedler wurden entlaust. Es gelangten 3 Kasten Brause zum Verkauf.

28.7. [19]46. Am 28.7. hielt der katholische Pfarrer Gottesdienst mit anschließend[er] Beichte ab. Sonst keine besonderen Ereignisse.

Dienstag und Mittwoch, 29.7. und 30.7.1946 (Niederschrift 30.7.1946)

Am 29.7. wurden die restlichen 700 Umsiedler entlaust. Eine von den Umsiedlern gebildete Tanzkapelle spielte am Abend in einem provisorisch eingerichteten Gemeinschaftsraum.

30.7.1946. Am 3[0].7. fand eine Besichtigung des Lagers durch die Kreisärztin Medizinalrätin Dr. Horlbeck ${ }^{2245}$ statt. Die Besichtigung ergab, daß die sanitären Anlagen sowie die Unterkunftsmöglichkeiten der Umsiedler in bester Ordnung waren.

Belegungsstärke: 1218. 132 wurden durch den Lagerarzt, Dr. Gattig ${ }^{2246}$, gegen Typhus schutzgeimpft.

\section{(54) Bericht des Umsiedlerlagers Rathenow-Magazininsel über den Transport aus} dem Kreis Namslau (Schlesien) vom 14. Oktober 1946. - Rathenow, 16. Oktober 1946

BLHA, Rep. 333 SED-Landesleitung Brandenburg, Nr. 574, Bl. 52. - Typoskript (1 S. mit Rückseite), Abschrift (ohne Unterschriften). B1. 52v 1.u. „gez. Rückwald (Lagerleiter)“ und r. u. „gez. Stock (Lagerarzt)“. Eingangsstempel vom 30.10.[1946]. - B1. 52r 1. o. „Umsiedlerlager Rathenow-Magazininsel“, r. o. Datierung „Rathenow, den 16.10.1946“. Überschrift: „Bericht / über Transport aus dem Kreise Namslau vom / 14.10.1946.“

Mit einem Umsiedlertransport, der am 14 d.M. hier eintraf, kamen 1139 Umsiedler aus dem Kreise Namslau/Schles. (jetzt Polen). Die Umsiedler waren 5 Tage unterwegs, wurden nur unzulänglich verpflegt und kamen in schlechter Allgemeinverfassung hier an. Der größte Teil hatte nur sehr wenig Gepäck herrüberretten können.

Bei der Gesamtuntersuchung der Umsiedler dieses Transportes fand sich herabgesetzter Ernährungs- und Kräftezustand. Ein großer Teil der Umsiedler, und zwar über $25 \%$, war an Scabies ${ }^{2247}$ oder anderen auf Unreinlichkeit zurückzuführende[n] Hautkrankheiten erkrankt. Ein weiterer Teil war kopfverlaust.

Schon am ersten Tage mußten 48 Patienten auf die Revierbaracken verlegt werden. Hierbei handelte es sich zum größten Teil um Altersgebrechlichkeit, Altersschwachsinn und eine verhältnismäßig große Zahl von Asthma-bronchiale-Kranken. Einzelne Fälle zeigen besonders krass, daß schon seit gut einem Jahr völlig unzureichende ärztliche Versorgung für die deutsche

2245 [Dr. Else Horlbeck, Leiterin des Gesundheitsamtes des Kr. Beeskow-Storkow (siehe Anm. 2213).]

2246 [Siehe Anm. 2243.]

2247 [Krätze.] 
Zivilbevölkerung bereitgestellt wurde. Ein Fall von Mamma-Carcinom zeigt schwerste Zerfallserscheinungen, wie sie in der hiesigen Zone schon seit langem nicht beobachtet wurden. Zwei Krüppelkranke und mehrere alte, sich nicht mehr selbst helfenkönnende Personen waren völlig verschmutzt und ungepflegt. Völlig vernachlässigt ist auch ein Teil von Magen-Carcinom.

Die Umsiedler gaben übereinstimmend an, daß seit fast einem Jahr keinerlei ärztliche Behandlung für sie vorhanden war. Daraus erklärt sich, daß unter den Männern des Transportes ein großer Teil wegen Leistenbrüchen für schwere Arbeit nicht einsatzfähig ist. Ebenso ist ein großer Teil der Frauen nur bedingt arbeitsfähig, da sie an Herzkrankheit, Frauenleiden, Magenbeschwerden usw. erkrankt sind.

Sofort nach Eintreffen des Transportes wurde mit der stationären und ambulanten Behandlung der Umsiedler begonnen. Es zeigte sich, daß mindestens jeder zweite Umsiedler in irgendeiner Weise ärztlich zu versorgen war. Bei der ambulanten Behandlung fielen die impetigenösen und Sacbies-Erkrankungen, ferner jauchende Unterschenkel-Geschwüre, Furunkulose und Pyodermien $^{2248}$ auf.

Bei der Generaluntersuchung bot sich bei einem großen Teil der Umsiedler das Bild der Unterernährung mit Oedemen an den Unterschenkeln, Blutunterdruck, Blässe und allgemeiner Schwäche. Die Kinder im Pubertätsalter hatten vergrößerte Schilddrüsen, eine Erscheinung, die auch auf Mangelerkrankungen zurückzuführen ist. Die Mädchen waren hiervon häufiger befallen als die Knaben. Die festgestellten Thyerotexikosen gaben übereinstimmend an, daß die für diese Krankheit typischen Symptome erst im letzten Jahr bei schwerer Arbeit und mangelhafter Ernährung aufgetreten waren. [B1.52v]

Die Zahl der aus Polen verwiesenen arbeitsfähigen Männer ist äußerst gering, denn der Transport war hauptsächlich aus kranken Frauen, Kindern, Kranken und Gebrechlichen zusammengestellt.

Die Bekleidung fast aller Umsiedler ist mangelhaft und dürfte für den Winter kaum ausreichen.

\section{(55) Stellungnahme des Betriebsrates des Kreisumsiedlerlagers Rüdersdorf zur geplanten Personalreduzierung. - Rüdersdorf, 6. November 1946}

BLHA, Rep. 230 Oberlandratsamt Bernau, Nr. 287, Bl. 26. - Anlage zu einem Schreiben des Kreisumsiedlerlagers Rüdersdorf, Rüdersdorf, 13. Nov. 1946, an die Provinzialverwaltung Mark Brandenburg, Amt für deutsche Umsiedler, Abt. VII A (Fin.), Potsdam „über den Herrn Landrat des Kreises Niederbarnim, Dezernat Sozialwesen, Bernau“ („Bezug: Dort[ige] Verfg. v. 1.11.46 Az. Fl./Sg. Betr.: Personal der Umsiedlerlager“) [ebd., Bl. 25]. - Typoskript (Durchschlag), 1 Bl. - Abschrift, datiert o.r. „Rüdersdorf b. Berlin d. 6. Nov. 1946“. - O.1.: „Kreisumsiedlerlager Rüdersdorf“. - Adresse: „Der Provinzialverwaltung der Mark Brandenburg / Amt für deutsche Umsiedler / z. Hd. v. Herrn Friedrichs / Potsdam / über / Landrat des Kreises Niederbarnim / Dezernat Sozialwesen / Bernau“. - Betreff: „Betr.: Reduzierung des Lagerpersonals.“ - Masch. Unterschrift „Der Betriebsrat: / I. A. gez. Gründel“.

$\mathrm{Zu}$ der von der Provinzialverwaltung angeordneten Personalreduzierung nimmt der Betriebsrat des hiesigen Umsiedlerlagers wie folgt Stellung: 
Die fristlose Entlassung aller Kartoffelschälerinnen hat zur Folge, dass wir dadurch [Ersatzkräfte] aus den Reihen der Umsiedlerfrauen einsetzen müssen. Bei der ersten Belegung des Lagers waren wir gezwungen Umsiedlerfrauen einzusetzen. Seitens des damaligen Lagerarztes wurde diese Massnahme beanstandet mit der Begründung, dass es durch den Einsatz dieser Frauen zu einer Masseninfektion kommen könnte. Auch wäre dann der ganze Quarantänegedanke in seinen Grundfesten erschüttert.

Ebenfalls ist es arbeitsmässig auf keinen Fall tragbar, sämtliche Angestellte der Registrierstelle zu kündigen. Nach der von Ihnen angeordneten Reduzierung bliebe kein Angestellter für die Registrierstelle übrig. Da gerade diese Abteilung mit der wichtigste Bestandteil der Lagerverwaltung ist, ist die Entlassung dieser Leute nicht tragbar. Falls sie dennoch gefordert wird, sieht sich der Betriebsrat gezwungen, die Verantwortung hinsichtlich einwandfreier Abwicklung der Registrierung abzulehnen.

Schon die Reduzierung der Lagerpolizei bringt derartige Schwierigkeiten mit sich, dass die Lagerordnung dadurch stark in Mitleidenschaft gezogen wird. Gerade bei dem zur Zeit im Lager befindlichen Transport ist die Anwesenheit der Polizei im Lager dringend erforderlich, da sich[,] wie von uns und auch durch den Herrn Landrat festgestellt wurde, faschistische Tendenzen unter den Umsiedlern stark bemerkbar machen. Der Herr Landrat hat auch demzufolge schärfste Ueberwachung angeordnet. Diese Ueberwachung ist nicht durchführbar, wenn auf der anderen Seite Personalabbau im stärksten Masse gefordert wird.

Wenn die Lagerleitung bisher alle Transporte hervorragend abgewickelt hat, ich glaube, dass diese Feststellung seitens der Provinzialverwaltung unterstrichen werden kann, so ist das darauf zurück zu führen, dass das gesamte Lagerpersonal täglich mehr als 12 Stunden einschl. Sonntags gearbeitet hat. Die geforderte Reduzierung würde zur Folge haben, dass dann den gestellten Anforderungen in dieser Weise nicht mehr entsprochen werden könnte.

An Hand dieses Schreibens wird gebeten, die angeordnete Reduzierung nochmals einer Prüfung zu unterziehen und uns mitzuteilen, ob es bei den festgelegten Kündigungen verbleibt oder aber die Personalreduzierung soweit infrage kommt wie es tragbar ist, um alle anfallenden Arbeiten ordnungsgemäss und auch termingemäss ausführen zu können.

\section{(56) Stellungnahme des Lagerarztes des Kreisumsiedlerlagers Rüdersdorf zur geplanten Reduzierung des Sanitätspersonals. - Rüdersdorf, 12. November 1946}

BLHA, Rep. 230 Oberlandratsamt Bernau, Nr. 287, Bl. 27. - Anlage zu einem Schreiben des Kreisumsiedlerlagers Rüdersdorf, Rüdersdorf, 13. Nov. 1946, an die Provinzialverwaltung Mark Brandenburg, Amt für deutsche Umsiedler, Abt. VII A (Fin.), Potsdam „über den Herrn Landrat des Kreises Niederbarnim, Dezernat Sozialwesen, Bernau“ („Bezug: Dort[ige] Verfg. v. 1.11.46 Az.Fl./Sg. Betr.: Personal der Umsiedlerlager“) [ebd., Bl. 25]. - Typoskript (Durchschlag), 1 Bl. - Abschrift, datiert o.r. „Rüdersdorf b. Berlin d. 12.11.46“. - O.1.: „Kreisumsiedlerlager Rüdersdorf / Sanitätsstation Dr. M/Ha.“- Adresse: „An die / Lagerleitung“. - Betreff: „Betr.: Abbau des Personals.“ - Masch. Unterschrift „F. d. R.d.A.: Der Lagerarzt / Dr. May (Stempel)“. 
Auf der hiesigen San [itäts-]Station werden 11 Kräfte beschäftigt. Für diese sind folgende Arbeiten: Die Entlausung (Morgens 6 Uhr bis Abends 22 Uhr) durchgehend, das tägliche Begehen der Baracken. Nachsehen nach Ungeziefer, ferner das Kontrollieren der Abortanlagen und Abwässerungen und dann der Dienst in der Sanitätsbaracke selbst. In der Sanitätsbaracke befinden sich 80 Betten, deren Insassen betreut werden müssen, d.h. Sauberhalten, Essen herbeiholen, austeilen, Verbände und Umschläge verabreichen, die ärztlichen Verordnungen ausführen, d.h. Fiebermessen $2 \times$ täglich und Medikamente verabreichen. Nachts ist immer eine Schwester als Nachtwache in der Baracke.

Dieser angegebene mannigfaltige Dienst verteilt sich folgendermassen: Für die Entlausung 1 Heizer, 2 Sanitäter und 2 Schwestern, die schichtweise in der Entlausungsarbeit eingeteilt sind. Zusätzlich müssen immer je 2 mit einem Sanitäter aus der Baracke täglich sämtliche Baracken begehen, nach Ungeziefer suchen, Aborte usw. überwachen.

Eine Sanitätsperson ist dauernd in dem vom Lager getrennten Steinhaus[,] in der die Quarantäne für Einzelgänger abgeleistet wird, stationiert.

Die restlichen 3 weiteren Sanitätspersonen stehen für den Dienst in der Sanitätsbaracke zur Verfügung. Sie haben den Dienst zu verrichten um die Kranken, die zum Teil hilflos sind (2 Schwestern)[,] während die 3. Schwester zur Hilfe des Lagerarztes bestimmt ist, d.h. sie macht Verbände, gibt die Medikamente aus, die in verschlossenen Schränken verwahrt sind, ist verantwortlich für die eingeschlossenen Medikamente und für die im Schrank verschlossenen Spenden des internationalen Roten Kreuzes. Ausserdem muss noch eine von den 3 Schwestern den Nachtdienst versehen.

Sämtliche Sanitätspersonen sind von Früh bis abend pausenlos beschäftigt. Die Arbeit ist zeitweise so, dass noch aushilfsweise eine Schwester von Bernau, nachdem der Kreisarzt sich von der Notwendigkeit überzeugt hatte, hierher versetzt worden war. Die verantwortungsvolle Arbeit, die das Sanitätspersonal in diesem Quarantänelager für Umsiedler, die im schlechtesten Gesundheitszustand meistens hier eintreffen, ist derartig verantwortungsvoll und anstrengend für jeden Einzelnen, dass keiner entbehrt werden kann.

Ausser dem reinen Sanitätspersonal ist noch eine Schreibkraft auf der San.-Station eingesetzt und zwar obliegt ihr die Führung der Krankengeschichten sowie die Erledigung des gesamten Schriftverkehrs des Arztes und der Stat[ion] im Allgemeinen, wie Terminmeldungen, Medikamentenanforderungen und Führung der verschiedenen Statistiken und erforderlichen Bücher.

\section{(57) Stellenplan des Kreisumsiedlerlagers Rüdersdorf. - Rüdersdorf,}

\section{November 1946}

BLHA, Rep. 230 Oberlandratsamt Bernau, Nr. 287, Bl. 28. - Typoskript (Durchschlag), 1 Bl. - Abschrift (r. o.: „Muster 3“), datiert o. r. „Rüdersdorf/b. Berlin d. 11.11.46“. - O.1.: „Kreisumsiedlerlager Rüdersdorf“. - Überschrift: „Rahmenetat Nr. ... / für Kreisumsiedlerlager Rüdersdorf / Uebernahmepunkte mit einer Kapazität bis zu 1600 Personen.“ 


\begin{tabular}{|c|c|c|c|c|}
\hline Lfd. Nr. & Stellenbezeichnung & Stellenzahl & Monatsvergütung & Bemerkungen \\
\hline 1 & Lagerleiter & 1 & 457,67 & \\
\hline 2 & Stellvertr. Lagerleiter & 1 & 357,67 & \\
\hline 3 & Lagerarzt & 1 & 200,-Pausch[al] & (Nebenamtl[ich] eingesetzt) \\
\hline 4 & Leiter d. Wirtschaftsabt. & 1 & 357,67 & \\
\hline 5 & Rechnungsführer & 1 & 357,67 & \\
\hline 6 & Lebensmittelverwalt[er] & 1 & 357,67 & \\
\hline 7 & Lagerverwalter & 1 & 357,67 & \\
\hline 8 & Leiter d. San[itäts]-Stat[ion] & 1 & 357,67 & \\
\hline 9 & Sekretärin & 1 & 246,34 & \\
\hline 10 & Verw.-Angestellter & 1 & $263,-$ & \\
\hline 11 & Koch & 1 & 283,84 & \\
\hline 12 & Stationsschwester & 1 & 225,50 & \\
\hline 13 & $\begin{array}{l}\text { Leiter d. Lagerpol[izei] } \\
\text { u. Dolmetscher }\end{array}$ & 1 & $250,-$ & \\
\hline 14 & Hilfsschwestern & 2 & $374,-$ & \\
\hline 15 & Verw[altungs]-Angestellte & 1 & 182,84 & \\
\hline 16 & Koch & 1 & 248,84 & \\
\hline 17 & Sanitäter & 3 & 774,84 & \\
\hline 18 & Lageraufseher $\mathrm{x}$ ) & 10 & 2594,18 & \\
\hline 19 & Lageraufseherinnen & 8 & 1877,88 & \\
\hline 20 & Verw[altungs-]Angestellte & 4 & 712,88 & \\
\hline 21 & Hilfsschwestern & 2 & $350,-$ & \\
\hline 22 & Botinnen & 2 & $240,-$ & \\
\hline 23 & Küchenfrauen & 7 & $1680,-$ & \\
\hline 24 & Heizer & 1 & $360,-$ & \\
\hline 25 & Küchenfrauen xx) & 7 & $840,-$ & \\
\hline
\end{tabular}

x) 1 Lageraufseher, 3 Lageraufseherinnen zum 30.11. gekündigt.

xx) Küchenfrauen zum Kartoffelschälen und Gemüseputzen nur vorübergehend halbtags eingesetzt.

\section{(58) Bericht des Umsiedlerlagers Agneshof in Falkensee. - Falkensee,}

\section{November 1946}

BLHA, Rep. 230 Oberlandratsamt Bernau, Nr. 287, Bl. 71-73. - Typoskript (Durchschlag), 3 Bl. - O.1. Stempel „Quarantäne-Lager / Agneshof / Falkensee“. - R. o. Datierung: „Falkensee, den 10.11.1946“. - Überschrift: „Lagerbericht des Umsiedlerlagers Agneshof, Falkensee“. - Bl. 73 u. Unterschrift: „[gez.] Richter / Lagerleiter“. 
1) Art der Lagerbaulichkeiten ${ }^{2249}$ : Umsiedler- und Quarantänelager

2) Art der Lagerbaulichkeiten: Steinbaracken

3) Kapazität: 1600 / reine Seite 750 / unr[eine] Seite 750

4) Anzahl der Betten: 1600

5) Pritschen:-

6) Notlager: -

7) Anzahl der Strohsäcke: 1100

8) Anzahl der Decken: 500

9) Wieviel Unterkunftsräume sind vorhanden: 133 alle heizbar

10) Allgemeinzustand der Baulichkeiten und der Unterkunftsräume: bis auf Fensterscheiben und Ofenrosten in Ordnung.

11) Grösse der Sanitätsstation:

a) wieviel Kranken- und Isolierbetten: 22 Krankenbetten / 100 Isolierbetten

b) Behandlungsräume: 2

12) Grösse der sanitären Einrichtungen:

a) Entlausungsanlagen: Kapazität 10-20 Pers. pro Stunde je nach Gepäck

b) Bade- und Duscheinrichtungen: 120 Personen pro Stunde

13) Ist eine Waschküche vorhanden: ja.

14) Ist ein Aufenthaltsraum oder Speisesaal vorhanden: ein Aufenthaltsraum (gleichzeitig Speisesaal) ist vorhanden.

15) Grösse der Küchenanlage: 9 Kessel mit je 300 Litern

16) Ist ein besonderer Raum für Kinder (Kindergarten) vorhanden mit einer hauptamtlichen Kindergärtnerin: nein

17) Grösse und Zustand des Vorratsraumes für Lebensmittel: Der Vorratsraum für Lebensmittel hat eine Grösse von 27 qm. Der Raum ist gegen Diebstähle gesichert, Kellerräume sind vorhanden. [B1.72]

18) Arbeiten Handwerker im Lager und welche Werkstätten existieren: Schlosserei, Tischlerei

a) Die Handwerker arbeiten auf eigne Rechnung.

b) Mit Material werden sie von den Firmen, bzw. vom Lager versorgt. 
19) Wie funktioniert die Lagerverwaltung:

a) Eine genaue Registrierung der Lagerdurchgänge wird vorgenommen.

b) Das Arbeitsamt wird herangezogen.

c) Das Lager wird durch Antifa-Parteien und Frauenausschuss unterstützt.

20) Wie wird die Lagerordnung aufrecht erhalten?

a) Polizeikräfte stehen nicht zur Verfügung.

b) Die Ordnung wird durch bezahlte Lagerordner aufrecht erhalten.

c) Aus den Reihen der Umsiedler werden Ordner mit herangezogen.

21) In welcher Form werden die Umsiedler während der Quarantänezeit beschäftigt?

a) Die Umsiedler werden in der Küche zum Kartoffelschälen und Gemüseputzen herangezogen.

b) Zur Sauberhaltung des Lagers werden ebenfalls Umsiedler herangezogen.

c) Durch Stubenälteste werden die Umsiedler bei der Aufrechterhaltung der inneren Ordnung herangezogen.

22) Werden im Lager bestimmte Veranstaltungen durchgeführt?

a) Sowie Transporte im Lager anwesend sind werden Redner der Antifa-Parteien herangezogen, die über politische und wirtschaftliche Themen sprechen.

b) Die Berufsfragen werden bei Diskussionen mit erörtert und es wird auf Mangelberufe hingewiesen.

c) Es werden bunte Abende veranstaltet.

d) Mit Zeitungen wird das Lager beliefert.

23) Von wem und wann wurde das Lager im letzten Quartal kontrolliert?

a) 7.9.46 Präsident Engels [Engel]

3.10.46 Herr Wolter und Herr Scholz ） Zentralverwaltung

7.10.46 Vizepräsident Tschesnow ） Berlin

28.10.46 Vizepräsident Tschesnow

b) 4.9.46 Herr Schöning ） Provinzialverwaltung

4.10.46 Herr Friedrichs ） Potsdam

31.10.46 Herr Haslinger

c) 6.8.46 Herr Wetschorek, Oberlandratsamt Bernau

12.8.46 russ. Major mit Polizeichef von Bernau 
7.9.46 Herr Dr. Lind vom „Internationalen Roten Kreuz“

28.10.46 3 Herren vom „Internationalen Roten Kreuz“ [Bl. 73]

d) 29.8.46 Herr Milark )

3.10.46 Herr Milark ） Landratsamt Bernau

31.10.46 Herr Milark, Herr Ulm )

e) - - -

f) 29.8.46 Herr Dr. Christe

3.10.46 Herr Dr. Christe Kreisarzt

31.10.46 Herr Dr. Christe

g) 4.10.46 Major Somow und Kapitän Kaplan SMA

28.10.46 Major Stuttland SMA Karlshorst

24) Welche Mängel wurden bei diesen Besichtigungen festgetellt und welche sind davon abgestellt worden?

Von Herrn Wolter (Zentralverwaltung Berlin) wurde beanstandet, dass das Brot zahlenmässig und nicht gewichtsmässig empfangen wurde. Das Brot wird vom 4.10.46 ab gewichtsmässig vom Bäcker empfangen. Ausserdem wurde beanstandet, dass kein Lagerausschuss bestände. Ein Lagerausschuss wurde sofort gebildet.

25) Welche Mängel weist das Lager zur Zeit auf und wer ist verantwortlich für deren Abstellung.

Es steht nicht genügend Heizmaterial und kein Gemüse zur Verfügung. Holz ist vorhanden, jedoch kein Fahrzeug zum Heranschaffen, da die Fahrzeuge zum Rübentransport benötigt werden, bzw. keinen Brennstoff haben.

26) Allgemeine Charakteristik des Lagers und Einklassifizierung?

Falkensee ist als A-Lager einklassifiziert.

27) In welcher Weise wird die Evakuierung des Lagers nach beendeter Quarantäne durchgeführt?

Die Evakuierung nach beendeter Quarantäne erfolgt

a) durch die Eisenbahn

b) durch Lastkraftwagen. 


\section{(59) Bericht über die Stimmung der Vertriebenen im Quarantänelager Quenz. - O. O., [April] 1947 \\ BLHA, Rep. 333 SED-Landesleitung Brandenburg, Nr. 574, Bl. 114 (alt 369). - Typoskript (Durchschlag) mit Ko- pierstift-Unterschrift „Pokriefke“.}

\section{Stimmungsbericht}

In der Zeit vom 13. bis 31.3.1947 befanden sich im Lager „Quenz“

\section{Personen.}

Sie kamen in zwei Transporten zu 365 Personen und 125 Personen. Davon: Männer: 347, Frauen 109 und Kinder 32.

Bei dem ersten Transport von 365 Personen handelt es sich um Zivilinternierte, die aus Rußland über Frankfurt/Oder entlassen worden sind und hier im Lager nach Ableistung ihrer Quarantänezeit eingemeindet werden sollen. Ein Teil, der im Westen seine Angehörigen hat, erwartet seine Zuzugsgenehmigung von dort. Sie setzen sich aus den verschiedensten Berufsschichten zusammen und waren in den von Polen besetzten Gebieten beheimatet. (Ost- und Westpreußen und Schlesien). Mit einigen Ausnahmen sind alle Mitglied der N. S.D.A.P., Frauenschaft und B.D.M. gewesen. Ihre Stimmung bringen sie in Versammlungen und Diskussionen wie folgt zum Ausdruck:

Ein Teil berichtet, daß sie in der Gefangenschaft sehr gut behandelt und auch verpflegt wurden, der andere Teil äußert sich, es nicht gut gehabt zu haben. Letzteres bringen vor allem die Frauen zum Ausdruck. Da sie alle sehr schlecht bekleidet sind, hauptsächlich Männer, so können sie nicht verstehen, warum sie jetzt[,] aus der Gefangenschaft entlassen, hier im Lager nicht von der deutschen Behörde die notwendigsten Bekleidungsstücke erhalten. Sie äußern, daß sie in die von Polen besetzten Gebiete zurück möchten. Sie glauben immer noch, daß doch ein Teil wieder deutsch wird. Daß sie die Zuzugsgenehmigung für die Orte, wo sie wohnen wollen, haben müssen, begreifen sie nicht. Den heutigen politischen Verhältnissen gegenüber sind sie mißtrauisch. Es ist daher schwer und wird lange dauern, sie für die demokratische Neuordnung zu erziehen. Durch die Versammlungen, Sitzungen und Besprechungen wie Diskussionen wird den Insassen doch vieles schon verständlich und werden sie durch diese politische Aufklärungsarbeit für das öffentliche Leben vorbereitet. Durch die Heranziehung von einigen Umsiedlern zur Mitarbeit im Antifa-Ausschuss werden wir in unserer Arbeit unterstützt und können in grösserem Umfange auf die Umsiedler einwirken. Weiter beweisen wir ihnen, daß alles in ihren [so!] Interesse getan wird, indem wir diese Antifa-Ausschuss-Mitarbeiter als Kontrollorgane einsetzen. Bei der Ausgabe der Kalt- und Warmverpflegung, sowie [Bl. 114v] in den Kartoffelund Gemüseputzräumen, für die Sauberkeit im Lager, und der Abfertigung in der Registratur.

Beim zweiten Transport, der erst am 13.3.[19]47 angekommen ist, sind wir dabei, ihre Einstellung zu den Verhältnissen in der hiesigen Zone festzustellen, und Berichte über die Verhältnisse in den Westzonen zu sammeln. 
(60) Bericht über eine Informationsveranstaltung im Umsiedlerlager Küchensee. Potsdam, 13. August 1947

BLHA, Rep. 233 SED-Landesleitung Brandenburg, Nr. 574, Bl. 172. - Typoskript (Durchschlag) mit (Kopierstift-) Unterschrift des Leiters der Abt. Umsiedler „Friedrichs“. - U.1. Datierung und Geschäftszeichen: „Potsdam, den 13. August 1947. / Fri./Re.“ - Überschrift: „Bericht über die Fahrt nach Küchensee / am 11.8.1947.“ - R. o. Verteilervermerk (Kopierstift, vmtl. vom Unterzeichneten): „SED“.

Die zu $18.00 \mathrm{~h}$ angesetzte Versammlung wurde auf $20.00 \mathrm{~h}$ vertagt, da um $18.00 \mathrm{~h}$ noch die Diskussion über das Referat des Informationsdienstes im Kreis im Gange war. Es handelt sich bei dem Transport um überaus interessierte und rege Menschen, die überwiegend in Schlüsselstellungen tätig waren.

Als Vertreter des Landrates erschien der Kreisrat - - - 2250 (Vertreter der LDP). In einem etwa einstündigen Referat habe ich das gesamte Umsiedlerproblem dargelegt und gleichzeitig die am Nachmittag gestellten Fragen berücksichtigt.

Es sind einige Tage zuvor andere Vorträge gehalten worden, u. a. auch von der Kreisleitung der SED. Die Ausführungen sind bei der Eigenart des Transportes nicht immer richtig aufgenommen worden bezw. ist nicht der richtige Ton oder die richtige Ausdrucksweise gefunden worden.

Zusammenfassend kann man sagen, daß man bei den meisten Referenten die Feststellung machen muß, daß sie sich nicht in die Psyche eines Umsiedlers hineinversetzen. Es handelt sich bei den Umsiedlern um Menschen, die erst wenige Stunden auf deutschem Boden stehen und nichts weiter wissen, als das, was ihnen gelegentlich der englische Sender aufzeigte. Diese Umsiedler sind mit Parolen aller Art gefüttert. Sie hören von angeblichen Verschleppungen.

Eine besondere Stellung nimmt offenbar die LDP in Storkow ein. Wie mir von der Lagerleitung berichtet wurde, hat der Vorsitzende der LDP in Storkow als Diskussionsredner im Lager ausgeführt: „Wenn unsere Politik maßgebend wäre, hättet Ihr dort bleiben können." So und ähnlich sprachen jetzt und auch schon bei anderen Transporten die Diskussionsredner der LDP.

Die Umsiedler dieses Transportes sind andererseits sehr aufgeschlossen und zeigen guten Willen, sich hier einzureihen.

Es liegt nun bei uns und nicht zuletzt bei den übrigen Abteilungen, daß dieser Personenkreis richtig eingemeindet wird.

(61) Tätigkeitsbericht der Abteilung Umsiedler und Heimkehrer im Amt für Arbeit und Sozialwesen des Kreises Beeskow-Storkow über die Betreuung eines Transportes aus Stettin im Umsiedlerlager Küchensee. - Beeskow, 10. Oktober 1947

BLHA, Rep. 250 Landratsamt Beeskow-Storkow, Nr. 869, unfol. - Typoskript (Durchschlag) mit Paraphe [...?], 1 Bl. - L. o.: „Der Landrat/des Kreises Beeskow-Storkow/Amt für Arbeit und Sozialwesen / Abt. Umsiedler und Heimkehrer / Az.: VIIA/U/C 3. Schd.“ - R. o. Datierung: „Beeskow, den 10.10.1947“. - Überschrift: „Bericht/ über 
die Tätigkeit der Abteilung Umsiedler und Heimkehrer im Amt für Arbeit und Sozialwesen des Landratsamts für den Monat September 1947.“ - Kopierstift-Unterschrift: „I. A. [gez.] ... [?].

In der Berichtszeit traf am 4.9.1947 ein Transport aus Stettin, unter der Transport-Nr. 122/7083 in Stärke von 1490 Personen im Umsiedlerlager Küchensee ein.

Der Transport wurde während der 14-tägiggen Quarantänezeit laufend kulturell von sämtlichen Organisationen betreut. Es fanden statt:

4.9.47 20 Uhr Umsiedlerversammlung (Begrüssung, Bekanntgabe der Lagerordnung).

ca. $800 \mathrm{P}$.

5.9.47 10 Uhr Beratungsstunde des Suchdienstes (Herr Bierwald)

ca. $100 \mathrm{P}$.

12 Uhr Umsiedlerausschussitzung

$20 \mathrm{Uhr}$

$$
\text { Beginn des Kindergartens täglich ca. } 100 \text { Kinder }
$$

Beginn des Schulunterrichtes täglich ca. 250 Kinder

7.9.47 $6 \mathrm{Uhr} \quad$ kath. Gottesdienst

$12 \mathrm{Uhr} \quad$ Umsiedlerausschussitzung

8.9.47 10 Uhr Umsiedlerausschussitzung (Arbeitsvermittlung)

$20 \mathrm{Uhr} \quad \mathrm{Gr}[\mathrm{oßer}]$ bunter Abend mit Kapelle Steiner

ca. $600 \mathrm{P}$.

9.9.47 10.45 Uhr Vortrag des Informationsdienstes über „Aktuelle Tagesfragen“

(Herr Springer Beeskow)

ca. $550 \mathrm{P}$.

$15 \mathrm{Uhr} \quad$ Frauenversammlung mit anschliessender Beratungsstunde

(Fr. Noack Frauenausschuss Storkow)

ca. $450 \mathrm{P}$.

10.9.47 16 Uhr Versammlung der VdgB (Referent Kreisvorstand Klehr, Beeskow

u. Juhnke, Beeskow)

ca. $600 \mathrm{P}$.

20.30 Uhr Kundgebung des Antifa-Blocks „Wie sieht der Umsiedler

das neue Deutschland“.

ca. $600 \mathrm{P}$.

Anschl[ießend] Tanz [Bl.v]

11.9.47 10 Uhr FDGB-Versammlung (Refer. Kreisvorstand Junker, Storkow) ca. 300 P.

$12 \mathrm{Uhr} \quad$ Umsiedlerversammlung (Eingemeindung Krs. Teltow) ca. $400 \mathrm{P}$.

15 Uhr Kinderfest, Märchenvorstellung der Volksbühne

„Rotkäppchen“ ca.500 P.

19 u. 21 Uhr Filmvorführungen „Kein Platz für Liebe“ und

der Augenzeuge

ca. $500 \mathrm{P}$.

12.9.47 10 Uhr Vortrag über Sozialversicherung (Ref. Dienststellenleiter Stein, Storkow)

ca. $200 \mathrm{P}$. 
16 Uhr Schmalfilmvorfürhungen der Kreisbildstelle (Kulturfilme) ca. 200 P.

$20 \mathrm{Uhr} \quad$ CDU-Versammlung (Ref. Kreisvorstand Gröschke, Beeskow) anschl[ießend] Tanz ca. $250 \mathrm{P}$.

13.9.47 10 Uhr ev. Gottesdienst ca. $400 \mathrm{P}$.

19 Uhr Besichtigung durch Frau Dau, Potsdam

$20 \mathrm{Uhr} \quad$ Umsiedlerversammlung Ref. Lagerleiter „Aktuelle Tagesfragen u. Eingemeindung" ca. 800 P.

14.9.47 10 Uhr Umsiedlerausschussitzung

15.9.57 10 Uhr Vortrag über Geschlechtskrankheiten $\quad 150$ P.

20 Uhr Gr[oßer] bunter Abend mit eignen Kräften des Transportes einschl. Tanz mit Kapelle Steiner ca.700 P.

16.9.47 16 Uhr Schmalfilmvorführungen der Kreisbildstelle (Märchenfilm) ca.500 P. $20 \mathrm{Uhr} \quad$ Umsiedlerversammlung (Ref. Herr Münchenhagen, Potsdam) ca. 400 P.

$21 \mathrm{Uhr}$ Gesangs-Solistenabend des Storkower Chors ca.500 P. 17.9.47 20 Uhr Abschiedsabend mit der FDJ-Spielgruppe und der Kapelle Steiner ca. 700 P. Nach Ablauf der Quarantäne, am 18.9.1947 wurde der Transport nach den Kreisen Niederbarnim, Teltow, Lübben, Cottbus und Calau weitergeleitet. Eingemeindet wurden von diesem Transport $10 \underline{8}$ Personen. / An Einzelgänger[n] wurden durch Umzüge und Heimkehrer 72 Personen aufgenommen, somit hat der Kreis einen Gesamtbestand von 23766 Umsiedler[n] zu verzeichnen.

Auf Kontrollfahrten im Kreis musste immer wieder festgestellt werden, dass einige Bürgermeister, vornehmlich die Bürgermeister der Gemeinden Neulübbenau, Tauche, Schneeberg und Buckow in keiner Weise Interesse an der Lösung der Umsiedlerfrage haben. Denn sonst könnte es nicht möglich sein, dass in der Gemeinde Buckow eine Frau auf dem Hausboden, ohne einem Bett schlafen musste und in den übrigen Gemeinden Wohnungsumquartierungen zum Wohle der Umsiedler, garnicht oder erst nach Monaten erledigt werden.

Die am 23.9.1947 durchgeführte Kontrolle der Zentralverwaltung im Umsiedlerlager Küchensee verlief ohne jede Beanstandung. 
(62) Anzahl der Lager und ihre Verringerung in den Jahren 1945, 1946, 1947, 1948. Potsdam, 23. Juni 1948

BLHA, Rep. 203 MdI, Nr. 1166, Bl. 3. - Auszug aus „Historischer Bericht. Beginn der Umsiedlung 1945 bis einschl. Mai 1948“, Abschnitt „A. Organisatorische Arb[eit]. Punkt 2“. [Potsdam, 23. Juni 1948]. - Typoskript (Durchschlag), 1 S.

\begin{tabular}{|l|c|c|}
\hline \multicolumn{1}{|c|}{ Jahre } & Anzahl der Lager & Kapazität \\
\hline 1945 bis März 1946 & 84 & 128000 \\
\hline April bis September 1946 & 29 & $45-48000$ \\
\hline Oktober bis Dezember 1946 & 25 & 44500 \\
\hline 1947 & 13 & 24500 \\
\hline Januar bis Juni 1948 & 7 & 13390 \\
\hline
\end{tabular}

(63) Verringerung des Lagerpersonals in den einzelnen Lagern. -

Potsdam, 23. Juni 1948

BLHA, Rep. 203 MdI, Nr. 116, Bl. 3. - Auszug aus „Historischer Bericht. Beginn der Umsiedlung 1945 bis einschl. Mai 1948“, Abschnitt „A. Organisatorische Arb[eit]. Punkt 4“. [Potsdam, 23. Juni 1948]. - Typoskript (Durchschlag), 1 S.

\begin{tabular}{|l|c|c|}
\hline \multicolumn{1}{|c|}{ Jahre } & Lagerpersonal It. Rahmenetat & Iststärke \\
\hline Jahr 1945 bis März 1946 (lt. Haushaltsplan) & 4200 & $\begin{array}{c}\text { Iststärke } \\
\text { ist } \\
\text { April bis September 1946 }\end{array}$ \\
$\begin{array}{l}\text { Oktober bis Dezember 1946 } \\
\text { Januar bis August 1947 (einschl. Sanitätsstation } \\
\text { Gronenfelde) }\end{array}$ & $\begin{array}{c}\text { zu } \\
\text { ermitteln }\end{array}$ \\
\hline $\begin{array}{l}\text { September bis Dezember 1947 (einschl. Sanitäts- } \\
\text { station Gronenfelde) }\end{array}$ & 580 & 616 \\
\hline $\begin{array}{l}\text { Januar bis März 1948 (einschl. San.Station Gro- } \\
\text { nenfelde) }\end{array}$ & 646 & 379 \\
\hline April bis Juni 1948 & 430 & 238 \\
\hline
\end{tabular}

(64) Bericht über Lagerverwaltung und Unterkunft 1946 bis $1948 .-$ Potsdam, 23. Juni 1948

BLHA, Rep. 203 MdI, Nr. 116, Bl. 9. - Auszug aus „Historischer Bericht. Beginn der Umsiedlung 1945 bis einschl. Mai 1948“, Abschnitt „A. Organisatorische Arb[eit]. Punkt 6: Aufbesserungsprozess in den Lagern, Rückgang der Mängel und Verstöße in den Lagern“. [Potsdam, 23. Juni 1948]. - Typoskript (Durchschlag), 1 S.

Lagerverwaltung (Personalien)

1946 ungenügend ausgebildetes Lagerpersonal

1947 Fortschritte durch geeignete Schulung

1948 Befriedigender Stand der Qualifikation des Lagerpersonals

2251 [Davor handschriftlich eingefügt:] Planstärke. 
Unterkunft.

1946 Erhebliche Mängel am baulichen Zustand als auch an der Inneneinrichtung der Lager. Z. B. waren nur 25-30\% der Barackenfenster verglast, während 75\% mit Pappe oder Holzverkleidung versehen werden mußten. Erhebliche Schäden an den Dächern. Unvollständiges Inventar in Unterkunftbaracken und Küchen. Knappheit an Brennstoffen.

1947 Restlose Durchführung der Winterfestmachung der Lager. Ergänzung des Inventars aus aufgelösten Lagern und durch Neubeschaffung. Vermehrung der Bettenzahl anstelle reiner Strohlager. Ausreichende Brennstoffversorgung.

1948 Weitere Instandsetzung der inzwischen wieder beschädigten Dächer. Verglasung aller Fenster mit Fensterglas oder Igelit. Vervollständgung der Innenausstattung der Baracken, insbes. Belieferung mit Decken und Strohsäcken. Z. Zt. durchaus befriedigende Lagerzustände.

Verpflegung.

von 1946-1948 Verbesserung der Verpflegung-Portionssätze. Nach und nach Verstärkung der Kontrolle des Lebensmittelverbrauches.

Kriminalität.

$1946=22$ gemeldete Fälle,

$1947=16 "$ " ,

$1948=$ bis jetzt 4

(65) Programm eines gemeinsamen „Bunten Abends“ von Vertriebenen und Kriegsheimkehrern im Heimkehrer-Erholungsheim Küchensee. [Küchensee, 4. September 1948]

BLHA, Rep. 256 Umsiedlerlager Küchensee, Nr. 166, unfol. - Typoskript, 1 S., rechts unten paraphiert „Rf.“; offenbar Anlage zum Bericht vom 2. Oktober 1948 über die Heimkehrerbetreuung im September 1948.

\author{
Programm \\ vom \\ „Bunten Abend“ \\ „SO SIND WIR“
}

Ausgeführt von: Baracke I

1.) Einführungslied: Es weht der Wind ...

2.) Ansprache

3.) Lustspiel: Die Räuber

4.) Volkstanz 
5.) Lied:

Herr Maier kam nach Hause ...

6.) Lustspiel:

Ein Paar Klumpen

7.) Lustspiel:

Familie Schiefmund

8.) Lied:

Jetzt kommen die lustigen Tage

9.) Lustspiel:

Der Volkswagen

10.) Volkstanz

Mein Mann der fährt zur See ...

11.) Lied:

Ich brauch keinen Mann ...

12.) Lustspiel:

Das Denkmal

13.) Lied

Ja, so Zwei, wie wir Zwei ...

14.) Lustspiel:

Die Bauersfrau

15.) Lustspiel

Junge Hunde

16.) Lustspiel:

ALA ist gross

17.) Lustspiel:

Der Fahrkartenverkauf

18.) Schlusslied:

SO SIND WIR ...

Alle Angehörigen des Umsiedlerlagers „Küchensee“ sind hiermit herzlichst für Freitagabend eingeladen.

\section{(66) Erfahrungsbericht des Lagerleiters des Umsiedlerlagers Küchensee über den Transport U 19123 aus Ostpreußen. - Küchensee, [13. September 1948]}

BLHA, Rep. 256 Umsiedlerlager Küchensee, Nr. 217, unfol. - Typoskript (Durchschlag), 2 S., Überschrift: „Erfahrungsbericht über den Transport U 19 123“; S. 1 1. o. Stempel „Umsiedlerlager / Küchensee / bei Storkow/Mark“, r. o. paraphiert „Sch.“; S. 2 Unterschrift des Lagerleiters Piepenburg, Stempel „Der Landrat des Kreises Beeskow-Storkow / Umsiedlerlager Küchensee“. - Anlagen: Tagesberichte (Typoskript), 3 S. (siehe unten) sowie (nicht in die Edition aufgenommen): Bericht über FGDB-Versammlung im Lager am 4.9.1948, Liste von auf einer Versammlung des Arbeitsamtes gestellten Fragen, Bericht über SED-Versammlung am 7.9.1948 im Lager, Aufstellung über abgegebene Zeitungen und Zeitschriften, statistischer Bericht über kulturelle und politische Betreuung.

Der am 28.8. [1948] hier eingetroffene Transport war in einem guten Gesundheitszustand. Die Umsiedler führten wenig Gepäck mit sich, was damit begründet wurde, dass sie alle entbehrlichen Sachen in Ostpreussen gegen Lebensmittel eingetauscht hatten.

Mit Hilfe der MVS und der FDJ ging die Ausladung sehr schnell von statten, zumal die Umsiedler sehr diszipliniert waren. Um 15 Uhr war der gesamte Transport im Lager. Die am gleichen Tage durchgeführte Registrierung konnte noch am selben Abend beendet werden, da sich die Umsiedler sofort nach Eintreffen zur Registrierungsstelle begaben. Die wichtigste Frage, welche die Umsiedler gleich nach dem Eintreffen stellten, war die nach der Aufwertung des alten Geldes bezw. Auszahlung der Kopfquote. Im Durchgangslager Pasewalk wurde den Umsiedlern bekanntgegeben, dass sie sofort nach ihrem Eintreffen pro Kopf DM 70,- ausgezahlt er- 
halten. Als wir bekannt gaben, dass dieses nicht der Fall ist, waren die Leute sehr erregt. Die auf Veranlassung der Landesregierung ausgezahlten DM 5,- pro Familie waren zu gering, um die notwendigsten Besorgungen zu machen, denn hierbei kamen besonders die grossen Familien schlecht weg, die damit noch nicht einmal die notwendigsten Bedürfnisse wie Haare schneiden und Post erledigen konnten. Dankenswerterweise setzte sich der Leiter des Sozialamtes Beeskow [,] Herr Mertel, dafür ein, dass vom Kreis das Geld zur Auszahlung der Unterstützung nach Befehl 92 zur Verfügung gestellt wurde. Insgesamt wurden 30365,- DM Unterstützungen gezahlt. Diese Auszahlung wurde von den Umsiedlern sehr begrüsst, denn hierdurch wurde bewiesen, dass die bei der Begrüssung versprochene Hilfe durch den Rat des Kreises keine leeren Worte waren. Das Programm der kulturellen Betreuung war, wie aus beiligenden Bericht ersichtlich, sehr reichhaltig und fand Beifall bei den Umsiedlern. Besonders tat sich der FDJKreisvorstand Seelow hervor, dessen Kulturreferent der Lagerleitung zwei Truppen vermittelte, welche wirklich überdurchschnittliches Können zeigten. Besonders erfreut waren die Umsiedler darüber, dass es im Lager einen Kindergarten und Schulstunden für alle Kinder gab. Hier wurde den Kindern geboten, was sie jahrelang entbehren mussten.

Die Versorgung der Umsiedler war geregelt. Obwohl die Freigaben verspätet eintrafen, hatte der Kreis uns die benötigten Lebensmittel zur Verfügung gestellt, dabei auch für die Umsiedler Gemüse, was ihnen nach den Sätzen und den Freigaben nicht zusteht. Schwierigkeiten bereitete lediglich die Zusatzkost für werdende u. stillende Mütter. Diese wurde vom Kreis nicht freigegeben, da keine entsprechenden Unterlagen vorhanden sind, wonach diese Freigaben erfolgen sollen. Der Suchdienst wurde von den Umsiedlern stark in Anspruch genommen. Insgesamt wurden 227 Suchanträge gestellt.

Die von der MVS zur Verfügung gestellten Textilien trafen sehr spät ein, doch konnte die Ausgabe noch rechtzeitig erfolgen. Die Bedürftigkeit wurde durch einen Verteilerausschuss geprüft, der auch die Ausgabe vorgenommen hat.

Wichtig für die Betreuung neuer Transporte wäre, dass dem Lager von der Landesregierung Material für Schuhreparaturen zur Verfügung gestellt wird. Denn gerade die Schuhfrage ist die brennen[d]ste. Aus dem Kreis konnte kein Schuhmachermaterial beschafft werden, da dieses über die Handwekskammer verteilt wird und wir da nicht berücksichtigt werden können, da kein gewerbsmässiger Schuhmacher im Lager tätig ist.

Der Abtransport der Leute ging schnell und reibungslos von statten. Lediglich der gestellte Sonderzug kam mit reichlicher Verspätung an, sodass in Berlin die Anschlusszüge nach Angermünde und Wriezen nicht erreicht wurden. Für die in Berlin übernachteten Umsiedler wurde durch Vermittlung der Transportführer bestens gesorgt. Der Abtransport vom Bahnhof Friedrichstrasse in die an der S[-] B [ahn] gelegenene Orte der Kreises Niederbarnim war gut organisiert. Nach den Berichten der Transportführer war das gesamte Bahnhofspersonal auf dem Bahnhof Friedrichstr. hilfsbereit. In allen Orten war die Aufnahme gut vorbereitet, d.h. die Umsiedler wurden mit Mittagessen u. dgl. erwartet. Es erhielten in Glienicke, neben dem Mittagessen, alle 
Kinder von 1-14 Jahren einen Riegel Schokolade. Ausserdem konnten in der Gastwirtschaft kostenlos Getränke verzehrt werden.

Am 11. nachmittags, $16 \mathrm{Uhr}$, war das Lager geräumt.

Tagesberichte über die Betreuung des Transportes U 19-123 für die Zeit v. 28.8.-9.9.[1948]

[Typoskript (Durchschlag), 3 S., S. 1 1. o. Stempel „Umsiedlerlager/Küchensee / bei Storkow/Mark“. Am Schluss Unterschrift des Lagerleiters Piepenburg und Stempel „Der Landrat des Kreises Beeskow-Storkow / Umsiedlerlager Küchensee"]

28.8.

Am 28.8. gegen 12 Uhr traf der Transport auf dem Bahnhof Storkow ein. Entgegen den gegebenen Anordnungen war der Transport 2030 Personen stark. Es wurden von uns 1215 Personen ausgeladen. Bei der Ankunft waren Vertreter der MVS und der FDJ zur Stelle, die den Umsiedlern beim Entladen und beim Transport ins Lager behilflich waren. Um 15 Uhr war der gesamte Transport im Lager und in den Baracken eingewiesen. Die Registrierung wurde noch am gleichen Tage vorgenommen.

29.8 .

Um 10 Uhr begrüsste die Lagerleitung die erschienenen Umsiedler in einer Versammlung und gab ihnen die Lagerordnung bekannt. Allgemein interessierende Fragen, wie Zuzugsgenehmigungen, Verbleib elternl[oser] Kinder usw. wurden sofort geklärt. Abends um 19 Uhr traf sich der gewählte Umsiedlerausschuss zu seiner 1. Sitzung. Hier wurden die Umsiedler auf die Bedeutung des Ausschusses sowie der Küchenkontrolle hingewiesen und mit ihren Pflichten und Rechte[n] vertraut gemacht. Auf vielfachen Wunsch fand am Abend um 20 Uhr ein kath. Gottesdienst statt, welchen Pfarrer Dubianski[,] $]^{2252}$ Storkow, abhielt. (120 Personen)

30.8.

Um den Umsiedlern die Möglichkeit zu geben, Telegramme und Briefe abzuschicken, wurden pro Familie DM 5,- ausgezahlt. Um 9 Uhr trafen sich die 2-7jährigen Kinder, um unter Leitung einer Kindergärtnerin zu spielen. Um 11 Uhr wurden die 10-14jährigen zusammengefasst, um mit ihnen 2 Stunden Schule abzuhalten. Nachmittags sangen und spielten die 7-10jährigen.

\section{8.}

Um 10 Uhr traf sich der Umsiedlerausschuss um die bisher gesammelten Erfahrungen auszutauschen. Die Lagerleitung übertrug dem Ausschuss neue Aufgaben, wie Seifenverteilung, Zigarettenverteilung u. dgl. Auch wurden die vorgesehenen Veranstaltungen besprochen. Abend [s], $20 \mathrm{Uhr}$, fand der offizielle Begrüssungsabend statt. Neben dem Lagerleiter sprach der Vertreter des Rates des Krs. Beeskow-Storkow, Herr Götze. Er versprach, dass der Krs. Beeskow-Storkow

2252 [Paul Dubianski (1906-1963), 1945-1958 kath. Pfarrer in Storkow, zuvor (ab 1940) Pfarrer in Landsberg/ Warthe und von dort 1945 vertrieben.] 
alles tun wird, um den Umsiedlern ihren Quarantäneaufenthalt so angenehm wie möglich zu gestalten. Anschliessend trat die Kabarett-Truppe Westphal auf, welche für ihre Darbietungen reichen Beifall erntete, dann wurde mit der Kapelle Kessler getanzt. Die Veranstaltung war von ca. 800 Umsiedlern besucht.

\section{9.}

8 Uhr kath. Gottesdienst (Pfarrer Dubianski, 120 Personen). Um 10 Uhr hielt Pfarrer Ro$\mathrm{kohl}^{2253}$, Storkow, einen ev. Gottesdienst mit Abendmahl ab, wozu 500 Personen erschienen waren. Im Anschluss an einer Besichtigung durch die Vertreter der Landesregierung Herrn Kuhn und Herrn Münchenhagen wurde eine Umsiedlerversammlung abgehalten, auf welcher Herr Kuhn zu den Umsiedlern sprach. (s. bes. Bericht). 15 Uhr Kinovorstellung mit dem Film „Frühling“. Abend[s] um 20 Uhr hielt die Lagerleitung eine Versammlung ab, unter dem Titel „Was der Umsiedler wissen muss?" Hier wurden alle interessierenden Probleme erörtert. Die Eingemeindung wurde bekanntgegeben und diskutiert, über Zuzugsmöglichkeiten, Sozialversicherungsangelegenheiten, Umsiedlerunterstützung, Arbeitseinsatzmöglichkeiten usw. gesprochen. In der Diskussion wurden alle noch unklaren Fragen beantwortet, sodass die Umsiedler über alle Fragen Auskunft erhielten.

\section{9 .}

Um 9.30 Uhr sprach ein Vertreter der Wismut-AG ${ }^{2254}$ über die Arbeitseinsatzmöglichkeiten im Erzbergbau. 200 Personen hörten den Ausführungen zu und etwa 12 alleinstehende junge Leute meldeten sich für den Erzbergbau. Neben der Werbung für Arbeitskräfte war dieser Vortrag gut, um die umgehenden Gerüchte über den Erzbergbau zu klären.

Die 3. Umsiedlerausschusssitzung fand um $16 \mathrm{Uhr}$ statt. Sie zeigte, dass die Umsiedler mit der Behandlung und den Einrichtungen des Lagers zufrieden waren. Eine von den Umsiedlern aufgestellte Kapelle führte abend[s] einen Tanzabend durch.

\section{9.}

Um 10 Uhr hielt Herr Bierwald eine Versammlung über den Suchdienst ab. Da die Umsiedler den Suchdienst wohl in Anspruch nehmen wollten, aber kein Geld hatten, wurde beschlossen, bei Mittellosigkeit Suchkarten kostenlos zur Verfügung zu stellen. Mit den Kindern von 10-14 wurde ein Spaziergang in den umliegenden Wäldern gemacht.

2253 [Rudolf Rokohl, geb. 1911, ab 1947 evang. Pfarrer mit Sonderauftrag für Kirchliche Rüstarbeit im Heim Hirschluch bei Storkow (Pfarralmanach 1953, S. 199).]

2254 [Die für den Uranerzabbau im Erzgebirge gegründete Sowjetisch-Deutsche Aktiengesellschaft (SDAG) Wismut (Aue).] 
4.9 .

Der FDGB hatte um 20.30 Uhr zu einer Versammlung geladen, zu welcher 350 Umsiedler erschienen waren. (s. b[esonderen] Bericht). Im Anschluss daran veranstalteten die Umsiedler mit eigenen Kräften einen bunten Abend.

5.9 .

Sonntag, dem 5.9. fand um 8 Uhr ein kath. u. um 10 Uhr ein ev. Gottesdienst statt. Um 20.30 Uhr wurde auf ausdrücklichen Wunsch der Umsiedler ein Tanzabend veranstaltet.

6.9 .

Herr Stein von der Sozialversicherungskasse, Kreisdirektion Beeskow, hielt einen Vortrag über Sozialversicherung ab. In der Diskussion beantwortete er die von den Umsiedlern gestellten persönl. Fragen. Um 16 Uhr traf sich der Umsiedlerausschuss zu einer erneuten Sitzung. Nach dem im Laufe des Tages die Vertreter der einzelnen Kreise erschienen waren, und ihre Eingemeindungsorte bekanntgegeben hatten, fand um 18 Uhr eine Verteilungsversammlung statt.

7.9.

Ueber Fragen des Arbeitseinsatzes und der Umschulung sprach der Vertreter des Kreisarbeitsamtes, Herr Hartmann, Beeskow, in einer um 11.30 Uhr abgehaltenen Versammlung. Nachmittags um 15 Uhr sprach Herr Bürgermeister Becker, Storkow, als Vertreter der SED zu den Umsiedlern (s. besond. Bericht). Die FDJ-Laiengruppe Storkow brachte den Umsiedlern abends ein buntes Programm, anschliessend wurde getanzt.

\section{9.}

Die Lagerleitung gab in einer Versammlung die genauen Orte bekannt und machte die einzelnen Familien namhaft, welche in diesen Orten eingemeindet werden. Um 18 Uhr sprach Herr Ministerialrat Friedrichs zu den Umsiedlern. Er umriss die bisher geleistete Arbeit in der Umsiedlerabteilung und wies die Umsiedler darauf hin, dass die Ursachen der Umsiedlung in den vergangenenen 12 Jahren zu suchen sind. Er erklärte den Umsiedlern die Einrichtung des neuen Staates und besonders die Einrichtung[en], welche den Umsiedlern bei ihrer Eingemeindung weiterhelfen werden und zur Verfügung stehen. Herr Ministerialrat Friedrichs forderte die Umsiedler auf, sich mit aller Kraft dafür einzusetzen, dass ihre Lebenslage gebessert wird, indem sie sich sofort der Wirtschaft und dem Wiederaufbau zur Verfügung stellen. Abend[s] um 20.30 Uhr fand eine Freilichtvorführung des Filmes „Razzia“ statt. ${ }^{225}$

9.9.

Um 20 Uhr fand der Abschiedsabend für den Transport statt. Als Vertreter der Landesregierung sprach Herr Münchenhagen zu den Umsiedlern. Er wünschte ihnen alles Gute und gab der 
Hoffnung Ausdruck, dass der Quarantäneaufenthalt in Küchensee ihnen in guter Erinnerung bleiben möge. Der Lagerleiter gab einen Bericht über die während des Transportes geleistete Arbeit und verabschiedete sich von den Umsiedlern mit den besten Wünschen für die Zukunft. Anschliessend fand ein Wunschkonzert mit der Kapelle Lienhard Eberswalde und dem Tenor Wilhelm Dubbick statt. Die Darbietungen fanden reichen Beifall. Anschliessend wurde getanzt.

Während der Berichtszeit besuchten 586 Kinder den Kindergarten, 981 Kinder die Schul- bezw. Spielstunden.

\section{(67) Erfahrungsbericht des Lagerleiters des Umsiedlerlagers Küchensee über Ankunft und Aufnahme des Transports 19219 aus Königsberg in Ostpreußen. - Küchensee, [24.] Oktober 1948}

BLHA, Rep. 256 Umsiedlerlager Küchensee, Nr. 217, unfol. - Typoskript (Durchschlag), 2 S., Überschrift: „Erfahrungsbericht über den Transport U 19219 v[om] 11.10-24.10.1948“; S. 1 1. o. Stempel „Umsiedlerlager / Küchensee / bei Storkow/Mark“, r. o. paraphiert Z.d. A. G.; S. 2 Unterschrift des Lagerleiters Piepenburg, Stempel „Der Landrat des Kreises Beeskow-Storkow / Umsiedlerlager Küchensee“. - Anlagen (Typoskripte [Durchschläge], 6 S., nicht in die Edition aufgenommen): Tagesberichte, Bericht über SED-Versammlung, Bericht über CDU-Versammlung, Bericht über Diskussionsabend der SED-Betriebsgruppe.

Der Transport traf am 11.10. aus Kaliningrad kommend hier ein. Um den Verkehr der fahrplanmässigen Züge nicht zu behindern, wurde der Transport geteilt. Der 1. Teil traf um 9.30 Uhr, der 2. Teil um 12.30 Uhr hier ein. Die Ausladung ging reibungslos von statten. Bei der Ausladung waren Mitglieder der CDU und des DFB zugegen. Die Überführung von Kranken und des Gepäcks ins Lager wurde durch Fahrzeuge der ATG vorgenommen. Der erste Eindruck des Transports war wenig gut. Die Umsiedler sahen abgespannt und schmutzig aus, was aber darauf zurückzuführen war, das[s] ein grosser Teil der Transportangehörigen schon 11 Tage unterwegs waren d. h. sie waren in Littauen [so!] aufgegriffen worden, von dort wurden sie nach Kaliningrad transportiert und nach einigen Tagen Wartezeit dann dem Transport angeschlossen. Der Transport war laut Angabe des Transportführer[s] in Kaliningrad nicht verpflegt worden sondern den Leuten wurde anheim gestellt, sich für die in ihrem Besitz befindlichen Rubel Lebensmittel einzukaufen. Die Personen, welche keine Rubel hatten, erhielten kurz nach der Abfahrt Brot ausgehändigt.

Der Gesundheitszustand des Transports war schlecht, da sehr viel alte Leute dabei waren[,] die krank und bettlägerig waren, ca 400 Personen waren verlaust.

Die Unterbringung des Transports bereitete einige Schwierigkeiten, da das Lager nicht auf 2100 Personen vorbereitet war. Durch Hinzunahme ehemaliger Angestellten[-]Wohnungen gelang es die Leute ordnungsgemäss unterzubringen. 2 Frauen, welche in Schneidemühl abhanden gekommen bezw. in Pasewalk ausgeladen wurden, kamen einen Tag später nach.

Die Registrierung wurde sofort vorgenommen. Leider musste später festgestellt werden, dass einige Personen falsche Namen angegeben hatten. Z. B. hatten Frauen die Namen der mit ihnen lebenden Männer angegeben, obwohl sie nicht verheiratet waren. Desgleichen wurde festge- 
stellt, dass elternlose Kinder auf die Namen der Pflegeeltern geschrieben waren. Nach wiederholtem Aufmerksammachen in den Versammlungen meldeten sich die Betreffenden und die Registrierungslisten wurden berichtigt.

Die während der Quarantänezeit durchgeführten Veranstaltungen wurden sehr gut besucht. Besonderen Anklang fand der Kindergarten bezw. der Unterricht für Kinder von 7-14 Jahren. Die eindrucksvollste Veranstaltung der Quarantänezeit war die am 22.10. stattgefundene SED Versammlung, auf welcher Herr Landrat Förster zu den Umsiedlern sprach. Interessant und sehr gut besucht war ebenfalls die von der SED Betriebsgruppe abgehaltene Versammlung. Hierbei zeigte es sich, dass die Umsiedler zum Teil sehr gut über die politische Lage in der Ostzone Bescheid wussten bezw. die ihnen übergebenen Zeitungen sehr eingehend studierten. Mit Rücksicht darauf, dass ein groser Teil der Umsiedler die Westzonen als Reiseziel hatten, ist es verständlich, dass die häufigste Diskussionsfrage war „Wann wird die Einheit Deutschlands hergestellt?" bezw. was können wur zur Beschleunigung dieser Einheit tun?

Im Übrigen liess die Disziplin der Umsiedler viel zu wünschen übrig, d.h. die gewählten Umsiedlerausschüse und Barackenältesten hatten es sehr schwer, ihre Anordnungen durchzusetzen. Durch den Umsiedlerausschuss wurden an die Lagerleitung Beschwerden bezw. Anzeigen gegen einige Transportangehörige wegen ihres Verhaltens während der vergangenen 3 Jahre gestellt. Den Beschuldigten wurde zur Last gelegt, Deutsche misshandelt zu haben bezw. durch Bedrohung mit Waffen erpresst und bestohlen zu haben. Die angestellten Ermittlungen der Kriminalpolizei ergaben, dass die Beschuldigten zu Recht bestanden und so wurden 6 Personen verhaftet. Diese befanden sich nach Abschluss der Quarantäne noch in Untersuchungshaft.

Während der Quarantänezeit wurden an Umsiedler Textilien aus einer Lieferung der MVS (s. besonderen Bericht) verteilt. Hierdurch konnte die grösste Not beseitigt werden. Für werdende und stillende Mütter stellte das ev. Hilfswerk zusätzlich Nährmittel zur Verfügung (s. besonderen Bericht).

Die ärztl. Untersuchungen ergaben, dass die festgestellten Krankheiten meistens chronisch waren. Infektionskrankheiten wurden nicht festsgestellt. Ein Scharlachkrankes Kind wurde ins Krankenhaus eingeliefert, desgleichen 5 geschlechtskranke Frauen.

Die Eingemeindung erfolgte unter Berücksichtigung der persönlichen Wünsche, und der in den Kreisen vorhandenen Wohn- und Unterbringungsmöglichkeiten.

45 alte Leute wurden ins Altersheim und 28 elternlose Kinder ins Kinderheim überwiesen.

Der Abtransport der Umsiedler mit den zur Verfügung gestellten Sonderzügen ging reibungslos von statten. Die Verladung geschah pünktlich, sodass die Züge zu der angeforderten Abfahrtzeit fertig beladen waren.

Beanstandungen während der Lagerzeit wurden von Seiten der Umsiedler nicht vorgebracht. Festzustellen wäre noch, dass zur ordnungsgemässen Unterbringung ca 200 Strohsäcke benötigt werden, um auch die vorhandenen Eisenbetten ausnutzen zu können, Desgleichen wäre 
es notwendig, dass der Abt. Handel u. Versorgung beim Rat des Krs. eine schriftliche Anweisung $^{2256}$ gegeben wird, dass den werdenden und stillenden Müttern während ihrer Lagerzeit Zusatzverpflegung zusteht, d.h. dass diese Zusatzverpflegung vom Kreis zur Verfügung gestellt werden soll.

(68) Bericht des Lagerleiters über die Betreuung eines Vertriebenentransports aus Lodz im Umsiedlerlager Küchensee vom 30. Oktober bis 12. November 1948. Storkow, 16. November 1948

BLHA, Rep. 256 Umsiedlerlager Küchensee, Nr. 217, unfol. - Typoskript (Durchschlag), 2 S. - S. 1 1.o. Vordruck „Umsiedlerlager Küchensee/Kreis Beeskow-Storkow/Geschäftszeichen ...“, r. o. datiert „Storkow (Mark), den 16.11.1948“; Adressenfeld: „An die Landesregierung Brandenburg / Der Minister für Arbeit u. Sozia[1] wesen / - Abt. Umsiedler u. Heimkehrer - / Potsdam / Alte Zauche 67. - S. 2 Unterschrift des Lagerleiters Piepenburg, Stempel „Der Landrat des Kreises Beeskow-Storkow / Umsiedlerlager Küchensee“; darunter handschriftlich „Abt. Umsiedler u. Heimkehrer / Beeskow / zur Kenntnisnahme überreicht“ sowie Unterschrift und Stempel wie vor. - 7 Anlagen (Typoskripte [Durchschläge], 13 S.; teils auf gedrucktem Kopfbogen wie vor, aber mit Geschäftszeichen „P./.K.", teils nur mit Stempel 1. o. „Umsiedlerlager / Küchensee / bei Storkow“; nur teilweise in die Edition aufgenommen):

[1.] Tagesberichte für die Zeit v. 30.10.-12.11.[1948] (2 S.).

[2.] Bericht über SED-Versammlung (1 S.). [Nicht in die Edition aufgenommen.]

[3.] Bericht über Versammlung mit Ministerialrat Friedrichs (1 S.). [Nicht in die Edition aufgenommen.]

[4.] Statistik der Eingemeindungen (3 S.).

[5.] Statistik der Einzelgänger mit Zuzugsgenehmigungen (1 S.).

[6.] Statistik der Transportabgänge durch Kopftausch, u. a. aufgeschlüsselt nach Berufsgruppen (3 S.).

[7.] Statistischer Bericht über die kulturelle und politische Betreuung (maschinenschriftlich ausgefüllter hektografierter Vordruck, 2 S.).

\section{Erfahrungsbericht des Transports 35/7079}

Der Transport wurde uns am 28.10. aus Forst gemeldet und traf hier am 30.10. gegen 9 Uhr ein. Der Transport war zusammengestellt in Lodz, nicht wie auf dem Sanitätspass vermerkt, in Waldenburg. Er bestand aus 280 Männern, 790 Frauen und 540 Kinder[n]. Eine Familie, 6 Pers[onen], war in Forst wegen Diphterieverdacht ausgeladen worden. Der Gesundheitszustand der Umsiedler war durchaus zufriedenstellend, obwohl 600 Transportangehörige aus dem Lager Potulice ${ }^{2257}$ bei Lodz kamen.

Der Bekleidungszustand des Transports war sehr unterschiedlich. Während die aus dem Lager kommenden schlecht bekleidet waren, führten die übrigen Transportangehörige[n] ausreichend Bekleidungsstücke mit. Auch Lebensmittel wurden von den Umsiedlern mitgeführt, sodass ein Teil der Umsiedler das ihnen gereichte Mittagessen zurückgaben und sich aus ihre[n] eigene[n] Vorräte[n] kochten. Dieses gab sich aber nach den ersten Tagen, als die Umsiedler merkten, dass das ihnen gereichte Essen gut und schmackhaft zubereitet war.

2256 [„Anweisung“ handschriftlich korrigiert aus „Genehmigung“.]

2257 [Polnisches „Zentrales Arbeitslager Potulice“, 1945-1950 überwiegend genutzt für deutsche Vertriebene.] 
In den polit. Versammlungen $u$. Diskussionen brachten die Umsiedler in den meisten Fällen wirtschaftliche Fragen zum Vortrag. Da ein grosser Teil der Umsiedler Pg. waren, stand die Frage, wie sieht es mit unserer Zukunft aus, im Vordergrund. Die angesetzten Versammlungen u. Veranstaltungen waren gut besucht.

Die von den Umsiedlern durchgeführten bunten Abende ${ }^{2258}$ hatten nicht immer den richtigen Ton, was sich daraus ergibt, dass die vorgebrachten Vorträge u. Sketch[e] meistens aus dem Lager stammten. Als beste Veranstaltung der Quarantäne ist der Abschiedsabend mit den Darbietungen des Prof. Schmidt ${ }^{2259}$ mit seinem Ensemble zu bezeichnen.

Die interessanteste Versammlung war der Diskussionsabend der SED-Betriebsgruppe, auf welchem sich die Umsiedler frei und offen aussprachen.

Besonderen Anklang fand, wie bei allen bisherigen Transporten, der von uns durchgeführte Kindergarten sowie der Unterricht für 10-14jährige.

Durch die Textilzuteilung der MVS konnten die Notstände, hinsichtlich der Bekleidung, beseitigt werden.

Die Eingemeindung der Umsiedler wurde nach ihren beruflichen Fähigkeiten vorgenonmmen, wobei berücksichtigt wurde, ob die jeweiligen Kreise Land- bezw. Stadtgemeinden zur Eingemeindung vorgesehen hatten. Die Textilfacharbeiter wurden in den Krs. Luckenwalde eingemeindet. Ein grosser Teil der Umsiedler war im Besitz von Zuzugsgenehmigungen oder erhielt diese während der Lagerzeit. So kam es, dass über 400 Personen auf Grund von Zuzugsgenehmigungen das Lager verliessen, sodass die Kreise nicht die vorgesehenen Transportstärken erhielten.

Der Abtransport der Umsiedler ging reibungslos von statten. Die gestellten Sonderzüge wurden an beiden Tagen pünktlich um 1.30 Uhr abgefertigt, sodass die vorgeschriebenenen Anschlusszüge in $\mathrm{B}[\mathrm{er}] \mathrm{l}[\mathrm{i}] \mathrm{n}$ ohne Schwierigkeiten erreicht wurden.

Die Aufnahmegemeinden waren von dem Eintreffen der Umsiedler rechtzeitig verständigt und war demzufolge der Empfang der Umsiedler vorbereitet.

Noch zu bemerken wäre, dass bei Einweisung von Einzelgängern, während eines Transports, die volle Quarantänezeit von 14 Tagen eingehalten wird, da es sonst der Lagerleitung sehr schwer fällt, den Umsiedlern des Transportes klar zu machen, dass eine Quarantäne von 14 Tagen unerlässlich ist. Z. B., während des letzten Transportes trafen Einzelgänger ein, die einen Tag nach dem Eintreffen eingemeindet wurden. Dieses erregte begreiflicherweise Missfallen bei den Transportangehörigen.

2258 [Laut beigefügtem statistischem Bericht wurden 3 Abende durchgeführt. Gesamtteilnehmerzahl: 2 100.]

2259 [Laut beigefügtem statistischem Bericht „Klavier, Okarinamusik u. Gesang“, 700 Teilnehmer.] 
[Anlage 1] Tagesberichte für die Zeit v. 30.10.-12.11.

30.10. Am 30.10. traf der Transport Nr. 35/7079 aus Lodz kommend in Storkow ein. Zur Ausladung waren Vertreter der MVS 2260 erschienen. Sofort nach der Ankunft im Lager wurde mit der Registrierung begonnen.

31.10. Vormittag fand eine Begrüssung durch die Lagerleitung statt.

1.11. 10 Uhr kath. Gottesdienst. 12 Uhr Umsiedlerversammlung. Hier wurde den Umsiedlern die Lagerordnung erläutert und über die Eingemeindung Auskunft erteilt.

2.11. Durch unseren Beauftragten Herrn Bierwald wurde eine Versammlung abgehalten, welche den Zweck hatte, die Umsiedler über den Suchdienst für vermisste Deutsche aufzuklären.

3.11. Auf Wunsche der Umsiedler fand um $8 \mathrm{Uhr}$ morgens wiederum ein kath. Gottesdienst statt, welcher von Pfarrer Dubianski, Storkow[,] abgehalten wurde.

4.11. Der Kreispolizeichef hielt am Vormittag eine Versammlung ab, mit dem Zweck, Kräfte für die Volkspolizei zu werben. 10 Umsiedler meldeten sich und wurden auch angenommen. Abends führte die Lagerleitung eine Umsiedlerversammlung unter dem Motto „Was der Umsiedler wissen muss" durch. Hier wurde den Umsiedlern die Entwicklung nach dem Zusammenbruch klar gestellt $u$. alle bestehenden Parteien $u$. Organisationen erläutert. Ausserdem wurden persönliche Probleme der Umsiedler, wie Zuzugsgenehmigungen, Geldeintausch, Eingemeindung usw. behandelt.

5.11. Am Abend sprach, anlässlich eines Tanzabends der Baracke I, der Vertreter der Landesregierung Herr Münchenhagen, zu den Umsiedlern.

6.11. Um 13 Uhr fand ein ev. Gottesdienst statt und abends erfreute die FDJ-Spielgruppe Storkow, die Umsiedler mit einem bunten Programm. Anschliessend wurde [durchgestrichen: mit lagereigenen Kräften] getanzt.

7.11. 10 Uhr kath. Gottesdienst. Abends um 20 Uhr hatten sich die Umsiedler zu einer Feierstunde, anlässlich des 31. Jahrestages der russ. Oktoberrevolution zusammengefunden. Der Lagerleiter wies auf die Bedeutung dieses Tages hin. An die Kreiskommandantur wurde ein Glückwunschtelegramm gesandt. Um 21 Uhr führte die Baracke XI einen bunten Abend durch.

8.11. Die SED-Betriebsgruppe des Lagers hatte die Umsiedler um 20 Uhr zu einem Diskussionsabend geladen. Nach einem Kurzreferat des Genossen [Leo] Kunz über die Lage der Umsiedler in der Ost- $\mathrm{u}$. in der Westzone wurde über allgemein politische Fragen diskutiert.

9.11. Vormittags 7 Uhr Bekanntgabe der Eingemeindungsorte. 10.30 Uhr Vortrag der Sozialversicherungskasse (Herr Siebert, Storkow). Hier wurden den Umsiedlern die Aufgaben der Sozialversicherung erläutert und Hinweise erteilt, welche Schritte zu unternehmen 
sind, um Alters- bezw. Witwen- $u$. Waisenrente zu erhalten. Abends um $20 \mathrm{Uhr}$ fand ein Tanzabend statt.

10.11. 8 Uhr kath. Gottesdienst. 11 Uhr ev. Gottesdienst. 16 Uhr Versammlung der SED, Referent Bürgermeister Becker (s. Bericht). Anschliessend sprach Herr Ministerialrat Friedrichs von der Landesregierung Potsdam zu den Umsiedlern. (s. Bericht). Um 19 u. 21 Uhr fanden zwei Zirkusvorstellungen statt.

11.11. Zur Abschiedsveranstaltung war Herr Prof. Schmidt mit seinem Ensemble erschienen. Nach dem der Lagerleiter einen kurzen Rechenschaftsbericht gegeben hatte, unterhielt Prof. Schmidt die Anwesenden 2 Std. mit einem bunten Programm.

12.11. Abtransport der Umsiedler mit Sonderzug Nr. - - - Die Verladung ging sehr flott von statten, das die ATG eine grosse Anzahl Fahrzeuge zum Abtransport der Umsiedler bereitgestellt hatte. Auch der Weitertransport der Umsiedler in Berlin war gut organisiert. Dasselbe ist für den Abtransport am 13. zu sagen.

Täglich fand eine Besprechung der Barackenältesten statt. Jeden 2. Tag eine Umsiedlerausschussitzung.

[Anlage 4 - Bericht über Eingemeindungen]

Der Transport Nr. 35/7079 wurde in nachstehend aufgeführte Orte eingemeindet.

\begin{tabular}{|c|c|c|c|c|}
\hline & Männer & Frauen & Kinder & insges. \\
\hline \multicolumn{5}{|l|}{ Niederbarnim } \\
\hline Petershagen & 5 & 4 & 3 & 12 \\
\hline Fredersdorf & - & 5 & 7 & 12 \\
\hline Woltersdorf & 4 & 8 & 8 & 20 \\
\hline Ruhlsdorf & 1 & 14 & 4 & 19 \\
\hline Eichhorst & 1 & 6 & 5 & 12 \\
\hline Stolzenhagen & 2 & 4 & 9 & 15 \\
\hline Borgsdorf & 13 & 43 & 22 & 78 \\
\hline Schildow & 2 & 1 & 1 & 4 \\
\hline Lindenberg & - & 4 & 7 & 11 \\
\hline Mühlenbeck & - & 2 & 1 & 3 \\
\hline Lanke & 3 & 3 & 4 & 10 \\
\hline Stolpe & 6 & 11 & 6 & 23 \\
\hline Klausdorf [Klandorf!] & 2 & 5 & 13 & 20 \\
\hline Wandlitz & 1 & 3 & - & 4 \\
\hline Neuenhagen & 1 & 1 & 3 & 5 \\
\hline [Zwischensumme] & 41 & 113 & 94 & 248 \\
\hline
\end{tabular}




\begin{tabular}{|c|c|c|c|c|}
\hline & Männer & Frauen & Kinder & insges. \\
\hline \multicolumn{5}{|l|}{ Kopfaustausch } \\
\hline Stralsund & 4 & - & - & 4 \\
\hline Bad Lausick & 1 & 3 & 3 & 7 \\
\hline Chemnitz & 2 & 1 & 1 & 4 \\
\hline Förderstedt & - & 2 & 1 & 3 \\
\hline [Summe] & 48 & 119 & 99 & 266 \\
\hline \multicolumn{5}{|l|}{ Osthavelland } \\
\hline Falkensee & 19 & 25 & - & 44 \\
\hline Nauen & 2 & 12 & 9 & 23 \\
\hline Wustermark & 1 & 4 & 2 & 7 \\
\hline Vehlefanz & - & 4 & 6 & 10 \\
\hline Hakenberg & 1 & 1 & 2 & 4 \\
\hline Dallgow & - & 4 & 7 & 11 \\
\hline Schönwalde & 2 & 3 & 5 & 10 \\
\hline Marwitz & - & 1 & 2 & 3 \\
\hline Leegebruch & 1 & 11 & 2 & 14 \\
\hline Gr[oß] Glienicke & 1 & 2 & 1 & 4 \\
\hline Fehrbellin & 2 & 3 & 4 & 9 \\
\hline Latzke [Lentzke!] & 2 & 5 & 3 & 10 \\
\hline Wansdorf & 1 & 4 & 1 & 6 \\
\hline Schwante & - & 2 & 3 & 5 \\
\hline Kremmen & 2 & 4 & 5 & 11 \\
\hline Bötzow & - & 8 & 4 & 12 \\
\hline [Summe] & 34 & 93 & 56 & 183 \\
\hline \multicolumn{5}{|l|}{ Calau } \\
\hline Spremberg & 1 & 2 & - & 3 \\
\hline Zerkwitz & - & 3 & 5 & 8 \\
\hline Bahnsdorf & - & 2 & 3 & 5 \\
\hline Zinnitz & - & 1 & 2 & 3 \\
\hline Sedlitz & 1 & 1 & - & 2 \\
\hline Raudin [Reuden?] & - & 1 & 3 & 4 \\
\hline Gr[oß] Kaschen [Koschen!] & - & 2 & 4 & 6 \\
\hline Hörlitz & 4 & 5 & 2 & 11 \\
\hline
\end{tabular}




\begin{tabular}{|c|c|c|c|c|}
\hline & Männer & Frauen & Kinder & insges. \\
\hline \multicolumn{5}{|l|}{ Kopfaustausch } \\
\hline Sassen & 1 & 2 & 1 & 4 \\
\hline Gaschwitz & - & 4 & - & 4 \\
\hline [Summe $]$ & 7 & 23 & 20 & 50 \\
\hline Luckenwalde & 20 & 74 & 36 & 130 \\
\hline \multicolumn{5}{|l|}{ Kopfaustausch } \\
\hline Prenzlau & 1 & 4 & 1 & 6 \\
\hline Neuruppin & - & 2 & - & 2 \\
\hline Mahlow & - & 1 & 1 & 2 \\
\hline Trebbin & 1 & 1 & - & 2 \\
\hline Ahrensdorf & - & 1 & 1 & 2 \\
\hline Gr[oß] Pillingsdorf & - & 1 & - & 1 \\
\hline Oberpöllnitz & - & 1 & 1 & 2 \\
\hline Rudolfstadt [Rudolstadt!] & - & 1 & - & 1 \\
\hline Bahn/Usedom [Balm!] & 1 & 1 & 1 & 3 \\
\hline Pirna & 1 & 1 & - & 2 \\
\hline Zwönitz & - & 1 & - & 1 \\
\hline Hoyerswerder [Hoyerswerda!] & - & 1 & 1 & 2 \\
\hline Böhlen & - & 1 & 1 & 2 \\
\hline Jessenigk [Jeßnigk?] & 1 & - & - & 1 \\
\hline $\mathrm{Ni}[\mathrm{e}]$ sky & 2 & - & - & 2 \\
\hline Calberwisch & - & 3 & - & 3 \\
\hline [Summe] & 27 & 94 & 43 & 164 \\
\hline Zauch-Belzig & 24 & 69 & 95 & 188 \\
\hline Rathenow & 13 & 59 & 45 & 117 \\
\hline \multicolumn{5}{|l|}{ Teltow } \\
\hline Gr[oß] Ziethen & 3 & 5 & 3 & 11 \\
\hline Stahnsdorf & 1 & 1 & - & 2 \\
\hline Zossen & 1 & 3 & 2 & 6 \\
\hline Blankenfelde & 2 & 5 & 1 & 8 \\
\hline Ludwigsfelde & - & 2 & 4 & 6 \\
\hline Rangsdorf & 3 & 14 & 4 & 21 \\
\hline Gr[oß] Beeren & 2 & 8 & 9 & 19 \\
\hline Selchow & 1 & 6 & 4 & 11 \\
\hline
\end{tabular}




\begin{tabular}{|c|c|c|c|c|}
\hline & Männer & Frauen & Kinder & insges. \\
\hline Mahlow & 1 & 2 & - & 3 \\
\hline Güterfelde & - & 3 & 4 & 7 \\
\hline Gallun & 1 & 2 & 1 & 4 \\
\hline Eichwalde & - & 10 & 8 & 18 \\
\hline Senzig & 1 & 7 & 3 & 10 \\
\hline Mittenwalde & - & 1 & 3 & 4 \\
\hline Brusendorf & - & 4 & 1 & 5 \\
\hline Schönefeld & 2 & 3 & 6 & 11 \\
\hline Zeuthen & 2 & 6 & 9 & 17 \\
\hline Schulzendorf & 1 & 5 & 6 & 12 \\
\hline Gräbendorf & 3 & 9 & 1 & 13 \\
\hline Miersdorf & - & 8 & 13 & 21 \\
\hline Bestensee & - & 2 & - & 2 \\
\hline Königswusterhausen & - & 2 & 1 & 3 \\
\hline [Zwischensumme] & 24 & 108 & 83 & 215 \\
\hline \multicolumn{5}{|l|}{ Kopfaustausch } \\
\hline Gera & 1 & - & - & 1 \\
\hline Radebeul & - & 1 & - & 1 \\
\hline Mirchhain [Kirchhain!] & - & 1 & 1 & 2 \\
\hline [Summe] & 25 & 110 & 84 & 219 \\
\hline \multicolumn{5}{|l|}{ Luckau } \\
\hline Bennersdorf [Hennersdorf?] & 1 & 4 & - & 5 \\
\hline Crienitz [Crinitz!] & - & 1 & 2 & 3 \\
\hline Beesdau & - & 1 & - & 1 \\
\hline Grunow [Gruhno!] & - & 2 & 2 & 4 \\
\hline $\mathrm{Kl}[$ ein] Krausnick [Krausnik!] & - & 2 & 2 & 4 \\
\hline Gr[oß] Krausnick [Krausnik!] & - & 2 & 2 & 4 \\
\hline Rückersdorf & 1 & 3 & - & 4 \\
\hline $\mathrm{Kl}[$ ein] Baran [Bahren!] & 1 & 3 & - & 4 \\
\hline Buchhain & 1 & 5 & - & 6 \\
\hline Lieskau & - & 1 & 3 & 4 \\
\hline [Summe] & 4 & 24 & 11 & 39 \\
\hline Kinderdorf Pinnow & 2 & 3 & 6 & 13 \\
\hline Altersh[eim] Saalow & - & 7 & - & 7 \\
\hline Spremberg, Blindenanst[alt] & 1 & - & - & 1 \\
\hline Polizeischule & 10 & - & - & 10 \\
\hline
\end{tabular}




\section{[Anlage 5]}

Einzelgänger mit Zuzugsgenehmigungen

\begin{tabular}{|c|c|c|c|c|}
\hline & insges. & Männer & Frauen & Kinder \\
\hline Sachsen & 22 & 4 & 12 & 6 \\
\hline Sachsen-Anhalt & 86 & 25 & 46 & 15 \\
\hline Mecklenburg & 89 & 30 & 43 & 16 \\
\hline Thüringen & 32 & 11 & 13 & 8 \\
\hline Berlin & 13 & 4 & 5 & 4 \\
\hline [Summe $]$ & 242 & 74 & 119 & 49 \\
\hline Krs. Templin & 4 & - & 3 & 1 \\
\hline Krs. Luckenwalde & 3 & - & 2 & 1 \\
\hline Krs. Ostprignitz & 14 & 2 & 9 & 3 \\
\hline Krs. Niederbarnim & 3 & 1 & 2 & - \\
\hline Krs. Westhavelland & 12 & 2 & 5 & 5 \\
\hline Krs. Eberswalde & 2 & - & 1 & 1 \\
\hline Krs. Ruppin & 6 & - & 2 & 4 \\
\hline Krs. Osthavelland & 12 & 1 & 5 & 6 \\
\hline Krs. Cottbus & 4 & - & 4 & - \\
\hline Krs. Prenzlau & 11 & 4 & 6 & 1 \\
\hline Krs. Westprignitz & 13 & 3 & 6 & 4 \\
\hline Krs. Brandenburg & 1 & - & 1 & - \\
\hline Krs. Teltow & 3 & 1 & 2 & - \\
\hline Krs. Angermünde & 7 & 1 & 4 & 2 \\
\hline Krs. Lebus & 9 & - & 4 & 5 \\
\hline Krs. Frankfurt & 1 & - & 1 & - \\
\hline Krs. Oberbarnim & 5 & - & 4 & 1 \\
\hline Krs. Beeskow-Storkow & 3 & - & 2 & 1 \\
\hline [Summe $]$ & 115 & 16 & 64 & 35 \\
\hline
\end{tabular}




\section{[Anlage 7]}

Statistischer Bericht für den Transport 35/7079 30.11.-12.11.1948

des Umsiedler-Heimkehrer-Lagers Küchensee

über die kulturelle und politische Betreuung

\begin{tabular}{|c|c|c|c|}
\hline \multirow{2}{*}{$\begin{array}{l}\text { Veranstaltungen } \\
\text { Kundgebungen }\end{array}$} & \multicolumn{2}{|c|}{ Gesamtzahl der } & \multirow{2}{*}{$\begin{array}{l}\text { Themen und Namen } \\
\text { der Referenten: }\end{array}$} \\
\hline & Veranstaltg: & Teilnehmer: & \\
\hline $\begin{array}{l}\text { politisch: } \\
\text { SED } \\
\text { CDU } \\
\text { LDP }\end{array}$ & $\begin{array}{l}3 \\
- \\
-\end{array}$ & $\begin{array}{r}1800 \\
-\end{array}$ & $\begin{array}{l}\text { 1) SED-Betriebsgr. Kunz, Piepenburg, „Dis- } \\
\text { kussion aller politischen Fragen“ } \\
\text { 2) Kreisvorstand, Bürgermeister Bäcker }{ }^{2261} \\
\text { „Ziele der SED“ } \\
\text { 3) SED Betriebsgruppe Revolutionsfeier zum } \\
\text { 31. Jahrestag der russ. Oktoberevolution. }\end{array}$ \\
\hline $\begin{array}{l}\text { überparteilich: } \\
\text { F D G B } \\
\text { FD J } \\
\text { MVS } \\
\text { D F D } \\
\text { Polizei }\end{array}$ & $\begin{array}{l}- \\
1 \\
- \\
- \\
1\end{array}$ & $\begin{array}{r}- \\
600 \\
- \\
- \\
100\end{array}$ & $\begin{array}{l}\text { Kreispolizeichef Dudlitz, Werbung für Volks- } \\
\text { polizei }\end{array}$ \\
\hline $\begin{array}{l}\text { Theater } \\
\text { Tanzab }[\mathrm{en}] \mathrm{d} \\
\text { Kino } \\
\text { Konzert } \\
\text { Zirkus } \\
\text { bunte Abende }\end{array}$ & $\begin{array}{l}2 \\
1 \\
2 \\
3\end{array}$ & $\begin{array}{r}800 \\
700 \\
500 \\
2100\end{array}$ & $\begin{array}{l}\text { Titel des Theaterstücks, Name u. Art der Vari- } \\
\text { ete-Veranstaltg. oder der Artistengruppe, Titel } \\
\text { der Filme, bei Konzerten Art (Gesang, Instru- } \\
\text { mentalmusik usw.) u. Veranstalter } \\
\text { eigene Kräfte des Transports } \\
\text { Prof. Schmidt, Klavier u. Okarinamusik u. } \\
\text { Gesang } \\
\text { eigene Kräfte des Transports }\end{array}$ \\
\hline $\begin{array}{l}\text { kirchliche: } \\
\text { ev. (auch Gottesdienst) } \\
\text { kath. }\end{array}$ & $\begin{array}{l}2 \\
4\end{array}$ & $\begin{array}{l}600 \\
400\end{array}$ & $\begin{array}{l}\text { Themen und Namen der Geistlichen oder an- } \\
\text { dere Vertreter der Kirche: } \\
\text { Pfarrer Rokohl } \\
\text { Pfarrer Dubianski }\end{array}$ \\
\hline Sonstige: & & & $\begin{array}{l}\text { Kurzer Hinweis auf Anlaß u. Art der Veranstal- } \\
\text { tung (Tanzveranstaltungen u. Feste:) }\end{array}$ \\
\hline Umsiedlerversl. & 2 & 1400 & $\begin{array}{l}\text { Lagerleitung, Begrüssung u. „Was der Umsied- } \\
\text { ler wissen muss“ }\end{array}$ \\
\hline Umsiedlerversl. & 1 & 700 & Ministerialrat Friedrichs „Umsiedlerprobleme“ \\
\hline Vortrag der Sozialv[er $]$ s. & 1 & 200 & Aufgaben der Sozialversicherung \\
\hline Vortrag über Suchd[ienst] & 1 & 200 & Bierwald \\
\hline
\end{tabular}


Wieviel und welche Zeitungen und Zeitschriften wurden im Kalendermonat abgegeben: welche Zeitung: Anzahl der Exemplare: welche Zeitschrift: Anzahl der Exemplare: „Tägl. Rundschau“ 300

„Neues Deutschland“ $\quad 300$

„Berliner Zeitung“ 60

„Tribüne“ 240

„Nationalzeitung“ 40

Welche Zeitungen werden besonders verlangt: ./.

Die Bibliothek umfaßt wieviel Bände: 521 Stück

Davon im Monat neu erworben: ./. Stück

Davon durch Spenden: ./. Stück

Bei Neuerwerbungen Titel, Verfasser und Anzahl der einzelnen Bücher: ./.

Welche Broschüren oder Büche sind zumeist gefragt und welcher Umsatz wurde bei den einzelnen erreicht:

„So können wir es schaffen“ 40

„Demokratische Schulreform“ 12

„Umsiedlerprobleme“ $\quad 50$

Welche Fragen wurden von Heimkehrern und Umsiedlern zumeist gestellt:

s. Versammlungsberichte

Sonstige Bemerkungen:

Kindergarten 2-6jährige Kinder 672

Spielstunden 7-10jährige Kinder 585

Schule 10-14jährige Kinder 755

(69) Ausschreibung zur Teilnahme an einer Ausstellung der Arbeiten von Kindern und Jugendlichen im Umsiedlerlager Küchensee. - Küchensee, 8. März 1949

BLHA, Rep. 256 Umsiedlerlager Küchensee, Nr. 164, unfol. (Rückseite). - Typoskript (Durchschlag) mit eigenhändiger Unterschrift des Lagerleiters. 


\section{Ausschreibung}

Alle Jugendlichen und Kinder im Umsiedlerlager Küchensee werden aufgefordert, an einer für Mitte nächster Woche vorgesehenen Ausstellung im Gemeinschaftshaus - Haus 4 - mitzuarbeiten.

$\mathrm{Zu}$ diesem $\mathrm{Zwecke}$ wird folgendes vorgeschlagen:

1) Für die Mädels werden Wolle und Stricknadeln zur Verfügung gestellt, die dann daraus Strümpfe, Socken, Handschuhe usw. anfertigen können.

2) Jungens können Bastelarbeiten, Schnitzereien, Zeichnungen usw. ausarbeiten.

3) Gruppen oder Zimmerbelegschaften können gemeinsame Arbeiten ausführen oder sich an einem Wettbewerb in Bezug auf Zimmerausgestaltung oder vorbildliche Reinlichkeit beteiligen.

Durch einen noch besonders zu bildenden Ausschuss werden dann die einzelnen Arbeiten begutachtet und prämiert. Für die ersten 3 Preise sind wertvolle Gegenstände vorgesehen. 10 weitere Trostpreise kommen ebenfalls zur Verteilung.

Die auszustellenden Gegenstände sind spätestens Mittwoch, den 16.3.[19]49 im Büro abzugeben.

$$
\begin{gathered}
\text { Keiner schliesse sich aus! Alle machen mit! } \\
\text { [gez. Unterschrift }] \\
\text { Lagerleiter. }
\end{gathered}
$$

\section{(70) Unterschriftensammlung zur Ächtung der Atomwaffe im Quarantänelager}

\section{Fürstenwalde. - Potsdam, 20. Oktober 1950}

BArch DO 1 Ministerium des Innern der DDR, Nr. 8207, unfol. - Typoskript, 1 S. - Abschrift (Anlage zum „abschriftlich Kenntnis von einer Information“ gebenden Schreiben desselben Absenders, Potsdam, 17.3.1950, unterzeichnet „Kuhn“, an das Ministerium des Innern der DDR, „Luisenstr. 46“, dort eingegangen 21.3.1950). - Gedruckter Briefkopf: o.1. (mit als Typoskript eingetragenem Geschäftszeichen) „Landesregierung Brandenburg / Der Minister d. Innern [korrigiert aus für Arbeit und Sozialwesen“] / Abt. Umsiedler [durchgestrichen: „und Heimkehrer“] / G.-Z. 1678/1/2 - 1 - „[...]. - Mitte: Wappen des Landes Brandenburg. - R. o.: „(2) Potsdam, den 20. Oktober 1950 / Heinrich-Mann-Allee 107 / Haus 9 / Zim. 18 [dafür durchgestrichen: „Alte Zauche 67“ / [...]. - Adresse: „An die / Deutsche Demokratische Republik / Minister des Innern / Hauptabteilung Staatliche Verwaltung / Abt. Bevölkerungspolitik / Berlin W 8 / Mauerstr. 25“. - Betreff: „Unterschriftensammlung zur Ächtung der Atomwaffe in den Quarantänelagern“ / Bezug: „Ihr Schreiben vom 11.10.50 Tgb.Nr. 8671/50 Ar.“ - U.r. eigenhändige Unterschrift (Typoskript) „Kuhn“. - O.r. Eingangsstempel, datiert „23. Okt. 1945“.

Wir geben Ihnen zur Kenntnis, dass es schon zu allen Zeiten bei uns üblich war, dass in den Quarantänelagern des Landes Brandenburg politische Arbeit geleistet wurde, die sich auch dahingehend auswirkt[,] dass Aktionen, die in Verfolg irgend welcher Ziele unter der Bevölkerung ausgelöst wurden, parallel auch in unseren Quarantänelagern durchgeführt wurden. Die 
Unterschriftensammlung zur Ächtung der Atomwaffe ist bei uns im Lager Fürstenwalde zur Durchführung gelangt bis zu dem Zeitpunkt, wo die Unterschriftensammlung dafür allgemein lief und dann später die ankommenden Umsiedler ab Mitte September Schwierigkeiten bei der Unterschriftensammlung machten, in dem sie sagten, sie sind für die genannte Aktion schon in der Volksrepublik Polen erfasst worden. Rücksprachen unserer Lagerleitung mit der poln. Transportleitung bestätigte[n] das. Von diesem Zeitpunkt ab wird die Unterschriftensammlung im Lager Fürstenwalde nicht mehr durchgeführt. Im Durchschnitt haben in Verfolg der durchgeführten Aktion $78 \%$ der Transportteilnehmer ihre Unterschrift für die Ächtung der Atomwaffe gegeben. Einen Transport 100\%ig für die Abgabe der Unterschriften zur Ächtung der Atomwaffe zu bewegen, ist uns nicht gelungen, es gab immer Frauen, die ohne Beisein ihres Mannes nichts mehr unterschreiben wollten oder auch Männer, die erklärten, nachdem sie sich in der Vergangenheit die Finger verbrannt hätten, nichts mehr künftig zu unterschreiben.

\section{(71) Bericht über die Behandlung der Sammeltransporte aus Königsberg} in Ostpreußen in den Quarantänelagern Fürstenwalde, Wolfen und Bischofswerda. Berlin, 5. Juni 1951 (Auszug)

BArch, DO 1 Ministerium des Innern der DDR, Nr. 8408, unfol. - Typoskript, Durchschlag. - O.1. „MdI-Abt. Bevölkerungspolitik“. - O. r.: „Berlin, den 5.6.1951 / Bü/Kr.“ - Überschrift: „Bericht / über die Dienstreise vom 28.5., 29.5., 30.5. und 1.6.51“. - Rücks. unterzeichnet „(Büttner)“ durch Paraphe [gez.] „B“.

In den Quarantänelagern Fürstenwalde, Wolfen und Bischofswerda Kontrolle der Kaliningrader-Transporte

\section{Fürstenwalde}

Gemeinsam mit dem Leiter des Ref. Bevölkerungspolitik, Herrn Kuhn, wurden die von dem berliner [so!] Beauftragten des Min. für Staatssicherheit geäusserten Mängel im Lager Fürstenwalde überprüft und dabei folgendes festgestellt:

a) Das Lagerpersonal zeigt ein schlechtes negatives Zusammenarbeiten. Der Lagerleiter hat es bisher nicht verstanden, eine geeignete Vertretung zu schaffen und eine strengere Anleitung und Kontrolle der administrativen Arbeiten im Lager durchzuführen. Angeblich ist es nicht möglich, geeignetes Personal einzustellen, da die infrage kommenden Menschen lieber in die Industrie oder nach Berlin gehen, weil dort höhere Verdienstmöglichkeiten gegeben sind.

b) Die politische Betreuung durch Herrn Bartol ist mangelhaft. Es fehlt an der nötigen Anleitung durch die Kreisleitung bzw. den Landesvorstand der SED.

c) Der verantwortliche Arzt Dr. Fiedler hat eine sehr negative Einstellung. Seine Überprüfung ist veranlasst worden.

d) Administrative Mängel bei der Essenausgabe, der regelmässigen Besprechung mit den Baracken- und Stubenältesten, der Einsammlung von überflüssigem Brot, in der Textilverteilung, Anlegung eines Sportplatzes, eine bessere Fürsorge der Repatrianten konnten an Ort und Stelle besprochen und sofort abgestellt werden. 


\section{Beschlussfassung}

Der Lagerleiter Piepenburg stellte im Anschluss daran selbst fest, dass eine personelle Veränderung notwendig ist und bat um seine Entlassung. Die Landesregierung Brandenburg ist bemüht, eine Klärung und evtl. Neubesetzung durch Herrn Kratschke, bisher Stützpunktleiter in Frankfurt/Oder, vorzunehmen.

Die Wahlvorbereitungen im Lager sind sorgfältig getroffen worden. Die ärztliche Betreuung der kranken Säuglinge und Kinder wurde veranlasst. / Die schulpflichtigen Kinder zeigen grossen Lerneifer und sind fleissige Schulgänger. / Die allgemeine Untersuchung auf Geschlechtskrankheiten wurde von den Repatrianten mit Befremden aufgenommen und z. T. abgelehnt. Eine Verstärkung des kulturellen Programms wird nach Rücksprache mit Herrn Bartol vorgenommen. / Die Repatrianten sind zum grössten Teil mit neuer Kleidung versorgt worden. Einige Ungerechtigkeiten bei der Verteilung konnten abgestellt werden. [Rücks.:]

\section{Wolfen}

Das Lager ist mit den vorhandenen Schwierigkeiten besser als Fürstenwalde fertiggeworden und hat in enger Zusammenarbeit mit Stasi, der Kreis[-] und Landesleitung der SED aufgetretene Mängel von vornherein beseitigt. / Ein Teil der elternlosen Kinder ist bereits nach Mecklenburg weitergeleitet worden. / Die Einkleidung soll erst am Ende der verlängerten Quarantäne durchgeführt werden. / Die allgemeine Untersuchung auf Geschlechtskrankheiten hat eine Reihe von neuen Infektionen ergeben./ Die Wahlvorbereitungen sind ebenfalls mit Sorgfalt getroffen worden. Die kulturelle Betreuung lässt durch die Mitarbeit der Gross-Betriebe nicht zu wünschen übrig.

\section{Bischofswerda}

Die Lagerleitung hat es verstanden, einen guten Kontakt mit den Repatrianten herzustellen und benutzt jede Gelegenheit für die Vorbereitung zur Wahl. - Z. B. trägt der grössere Teil der Umsiedler aus K. die blauen Friedensabzeichen, die sie aus eigenen Mitteln erworben haben. / Der Innenminister, Herr Hoffmann ${ }^{2263}$, hat sich ebenfalls stark in die allgemeine Betreuung mit eingeschaltet, besuchte die einzelnen Baracken und sprach anlässlich einer Kulturveranstaltung der Landesregierung Sachsen zu den Repatrianten. / Die Kontrolle der eingegangenen Post ergab ausserordentlich wichtige Einblicke in die Lebensverhältnisse der Umsiedler in Westdeutschland. Es wurde veranlasst, dass eine entsprechende Auswertung vorgenommen wird. / Die allgemeine Untersuchung auf Geschlechtskrankheiten ergab keinerlei Anlass zu irgendwelchen Klagen.

Auf Grund der ausserordentlichen personellen Belastung der beiden Lager Wolfen und Fürstenwalde wurde das Lagerpersonal der Thüringer Lager zur Unterstützung hinzugezogen. 
(72) Mitgliederwerbung für die DDR-Massenorganisationen unter den aus Königsberg in Ostpreußen Ausgewiesenen in den Quarantänelagern. - Potsdam, 5. Oktober 1951 (Auszug)

BArch, DO 1 Ministerium des Innern der DDR, Nr. 8408, unfol. - Typoskript. - O.1. Stempel „Landesregierung Brandenburg / Der Minister des Innern / Hauptabteilung Staatliche Verwaltung / Referat Bevölkerungspolitik / GZ: 1671/4“. - R. o.: „Potsdam, den 5. Oktober 1951 / Heinr[ich-]Mann-Allee 107, Haus 12 / Zim[mer] 170“. - Adresse: „An das / Ministerium des Innern / der Deutschen Demokr[atischen] Republik / HA Staatl. Verwaltung / Abt. Bevölkerungpolitik / Berlin W 8 / Mauerstr. 25“. - Betreff: „Sonderbericht über die Abwicklung der Kaliningrader Repatrianten-Transporte.“ - U.r. unterzeichnet „I.A. / gez. Kuhn / Beglaubigt / [gez.] Hoppe / Reg[ierungs]-Angest[ellter]“, mehrere Paraphen und Vermerk „z. d. A.. - O. r. Eingangsstempel „9. OKT. 1951, „B̈̈“ / 47579“.

In dem Bericht ${ }^{2264}$ ist angeführt, daß in Bischofswerda 230 Jugendliche ihre Aufnahme in die FDJ beantragten. Durch Rücksprache mit dem Kollegen Halm ist mir bekannt geworden, daß diese Jugendlichen nicht nur ihre Aufnahme beantragt haben, sondern in einer feierlichen Kundgebung auch die Mitgliedsbücher im Lager Bischofswerda erhalten haben. Auch in unserem Lager Fürstenwalde ist jederzeit für Mitglieder der demokratischen Massenbewegungen geworben worden, aber es wurde von hier die Anweisung erteilt, daß Mitgliedsbücher im Lager nicht ausgehändigt werden dürfen, sondern daß die Lagerinsassen sich nach ihrer Eingemeindung bei den örtlichen Organisationen für die Aufnahme in Partei und Massenorganisation melden sollen. Es wurde von hier festgestellt, daß Personen, denen im Lager Mitgliedsbücher ausgehändigt wurden, sich gleich daraufhin aus dem Lager entfernten und in einem Falle in Berlin in der Kuno-Fischer-Str. ${ }^{2265}$ als politischer Flüchtling auftauchten. Es wird als notwendig angesehen, die Lagerleitungen anzuweisen, wie sie sich gegenüber den Aufnahmegesuchen zu verhalten haben. / $[\ldots]$

\section{Versorgung, Eingliederung, Gleichstellung (1945-1951)}

\subsection{Wohnung (1946-1949)}

\section{(73) Kontrollberichte zur Wohnsituation der Flüchtlinge und Vertriebenen in den} Gemeinden des Kreises Osthavelland auf Anordnung der SMA. - 27. November 1946 (Auszüge)

BLHA, Rep. 230 Oberlandratsamt Bernau, Nr. 292, Bl. 151-175. - Typoskripte (Durchschläge). - Bemerkung: Als Beispiele abgedruckt sind: 1. ein vollständiger Bericht (Gemeinde Vehlefanz), 2. aus sämtlichen Berichten der Gemeinden des Beispielkreises Osthavelland jeweils nur die Antworten auf die Frage 15 nach der weiteren Aufnah-

2264 [„Sonderbericht“ des MdI, Abt. Bevölkerungspolitik, Berlin, vom 31.7.1951 „über die Betreuung und Abwicklung der Repatrianten-Transporte in den Quarantänelagern Bischofswerda, Wolfen und Fürstenwalde“, ebd., unfol.]

2265 [In der Kuno-Fischer-Straße 8 im (West-)Berliner Bezirk Charlottenburg befand sich von 1950 bis 1953 die Notaufnahmestelle für Flüchtlinge aus der DDR als erste Anlaufstelle. (Seit 2007 befindet sich an dem Gebäude eine entsprechende Gedenktafel.)] 
mekapazität und 3. auf die Aufforderung zur Angabe zu den einzelnen Familien. - Bl. 151: Begleitschreiben des Landrates des Kreises Osthavelland, Abt. Sachgebiet VII Arbeit und Sozialwesen, vom 27. Nov. 1946 (TyposkriptDurchschlag) an den Oberlandrat in Bernau; Anlage: Bl. 152-175: Abschriften der Kontrollberichte aus den einzelnen Gemeinden (Typoskript-Durchschläge, jeweils auf hektografiertem „Formblatt Nr. 8“, im Original meist vom Bürgermeister unterzeichnet), überwiegend undatiert (außer: Paaren/Glien 29.10.1946, Fehrbellin 5.11.1946, Bärenklau 7.11.1946).

\section{a. Beispiel Vehlefanz}

[Bl. 152]

Formblatt Nr. 8

Kontrollbericht des Arbeitsausschusses.

Ort: Vehlefanz Kreis: Osthavelland
1.) Einwohnerzahl:
a) Altortsansässige [Antwort:] 1.119

b) ehem. Umsiedler [Antwort:] 410

2.) Wieviel arbeitsfähige ehem. Umsiedler sind ohne Beschäftigung (ggf. welche Berufsgruppen)? [Antwort:] -

3.) Wieviel ehem. Umsiedler sind als selbständige Handwerker, Gewerbetreibende usw. tätig? [Antwort:] -

4.) Werden ehem. Umsiedler bei der Besetzung von Stellen in den Verwaltungen berücksichtigt? [Antwort:] nein

5.) Gibt es am Ort eine Kinderbetreuungsstelle? [Antwort:] ja Kindergarten

6.) Wie ist das Verhältnis zwischen Altortsansässigen und ehem. Umsiedlern? [Antwort:] normal, gut

7.) Ist ein Ortsumsiedlerausschuss gebildet worden? [Antwort:] Die Bildung erfolgt demnächst

8.) Welche Aufgaben sind diesem Ausschuß auf Grund dieser Kontrolle übertragen worden? [Antwort:] die vorgeschriebenen Aufgaben

9.) Welche Möglichkeiten bestehen für eine Heimindustrie? (Die ehem. Umsiedler und Bürgermeister sind hierfür zu interessieren. Durch Initiative des Bürgermeisters und durch Unternehmergeist der ehem. Umsiedler ist in einigen Kreisen hierin gute Arbeit geleistet worden.) [Antwort:] Wird in Erwägung gezogen.

10.) Ist durch bauliche Veränderung besserer und vermehrter Wohnraum am Ort zu schaffen? (Genaue Angaben, welche Baumaterialien dazu gebraucht werden) [Antwort:] ja erforderlich wäre Kalk, Zement, Mauersteine, Balken und Brettermaterial.

11.) Wieviel Textilien und Schuhwerk werden dem Ort monatlich zur Verfügung gestellt und wer erhält diese? [Antwort:] Stoff-Schuhwerk nur für Kinder in beschränkltem Umfange Ausgabe erfolgt in erster Linie nur an Flüchtlingskinder 
12.) Stehen der Gemeinde Baumaterialien zur Verfügung und wozu sollen diese verwendet werden? [Antwort:] In der Gemeinde sind keine Baumaterialien vorhanden.

13.) Erhält die Gemeinde Hausrat für die ehm. Umsiedler? (ggf. wieviel monatlich und ist die gerechte Verteilung sichergestellt) [Antwort:] ja, aber vollkommen ungenügend. Gerechte Verteilung ist sichergestellt.

14.) Welchen Schutz und welche Hilfe erhalten die Heimkehrer insbes. die Heimatlosen? [Antwort:] Die Betreuung erfolgt durch den Frauenausschuß in Form von Bekleidung usw. [Bl. 153]

15.) Wieviel Familien könnten noch in der Gemeinde untergebracht werden? (Diese Frage ist unter Berücksichtigung des Umstandes, daß noch weitere 50000 Umsiedler aufzunehmen sind, zu beantworten). [Antwort:] Es können keine Familien mehr hier untergebracht werden.

Für die Überprüfung der einzenen Unterkünfte und Wohnungen der ehem. Umsiedler sind unter Angabe des Namens der Familie, Größe der Familie genau Anschrift, ganz kurz nähere Angaben über die Wohnverhältnisse, wirtschaftliche Versorgung, tarifliche Entlohnung usw. zu machen.

In den Gemeinden möglichst viel Unterkünfte besuchen.

Der Bürgermeister

gez. Wolff

\section{b. Aufnahmekapazität (Frage 15)}

Vehlefanz [Bl. 153:] Es können keine Familien mehr hier untergebracht werden.

Staffelde [Bl. 155:] keine

Perwenitz [Bl. 157:] Keine Wohnmöglichkeiten - Die Gemeinde ist mit Flüchtlingen überlastet mit $95 \%$.

Paaren/Glien [Bl. 159:] Da im Verhältnis zur früheren Einwohnerzahl bereits 50 \% an Flüchtlingen aufgenommen wurden, ist keine Unterbringungsmöglichkeit mehr vorhanden.

Marwitz [Bl. 161:] Nur im äußersten Notfalle könnten noch einzelne untergebracht werden.

Markee [Bl. 163:] In der Gemeinde z. Zt. keine, da die meisten Häuser von der Roten Armee bewirtschaftet werden.

Markau [Bl. 165:] In der Gemeinde selbst keine[.] $75 \%$ der Wohnräume sind Eigentum des hiesigen Provinzialgutes und wird von diesem darüber verfügt.

Lentzke [Bl. 167:] Es können keine Umsiedler mehr untergebracht werden, da Lentzke bisher eine Einwohnerzahl von 565 Personen hatte und jetzt 872 Einwohner hat.

Deutschhof [Bl. 169:] Siedlungsland steht noch zur Verfügung[,] aber keine Wohnungsmöglichkeit

Fehrbellin [Bl. 171:] keine 
Bärenklau [Bl. 172:] Die Gemeinde besitzt 118 Einfamilienhäuser. Bisher wurden 256 Umsiedler untergebracht. Den am 1. d.Mts. hier eingetroffenen Umsiedler habe ich noch unter schwierigen Verhältnissen einen Wohnraum beschafft. Weitere Umsiedler können in der hiesigen Gemeinde nicht mehr aufgenommen werden.

Ketzin [Bl. 175:] Der Ort Ketzin ist überbelegt und kann weitere Umsiedler kaum noch aufn[ehmen].

\section{c. Angaben zu einzelnen Familien}

[Diese Angaben sind nur von 5 Gemeinden, und hier teilweise lediglich summarisch, geliefert worden, obgleich überall eine große Zahl von ansässigen „Umsiedlern“ angegeben wird.]

Perwenitz

[Bl. 157:] $10 \%$ der Umsiedler besitzen sehr schlechte Wohnverhältnisse, da z. Zt. keine Änderungen wegen Mangel an Baumaterial getroffen werden können.

\section{Lentzke}

[Bl. 167:] Die Überprüfung der Unterkünfte fand bei nachstehenden Umsiedlern statt.

$\begin{array}{ll}\text { Alois Philipp, } & 4 \text { Personen } \\ \text { Emma Dworschak } & 3 \text { Personen } \\ \text { Wenzel Pachl } & 4 \text { Personen } \\ \text { Rudolf Kraut } & 3 \text { Personen } \\ \text { Johann Maschek } & 3 \text { Personen } \\ \text { Martha Jahl } & 2 \text { Personen }\end{array}$

Die Wohnverhältnisse sind den derzeitigen Verhältnissen entsprechend, es mangelt zum Teil noch an Kochgelegenheiten und Wärmeöfen, sowie Brennmaterial. Ebenso schwierig ist die Beschaffung von Fensterglas, wodurch einige Wohnungen wohnlicher gestaltet werden könnten. Die meisten Umsiedler sind gegen tarifliche Entlohnung als Landarbeiter beschäftigt und erhalten zur wirtschaftlichen Versorgung die ihnen zustehenden Lebensmittelkarten, ältere Leute erhalten durch die Sozialversicherungskasse Alters-Invaliden- oder Witwen-Rente.

\section{Fehrbellin}

[B1. 171:] Letzte Angaben können noch nicht gemacht werden, da der Umsiedlerausschuß gestern neu gewählt wurde und seine Tätigkeit noch nicht begonnen hat.

Ketzin

[Bl. 175:] Barackenunterkünfte:

$\begin{array}{llcl}\text { Grünberger, Hildegard } & 4 & \text { Personen } & 22 \mathrm{qm} \\ \text { Kositz, Martha } & 7 & " & 79,5 \mathrm{qm}\end{array}$


Müller, Karge, Schulz[,]

Blümel, Polomka

Junge, Kappel

Wollbrügge, Pätschke

Drescher

$\begin{array}{rcc}15 & " & 115,-\mathrm{qm}^{2266} \\ 9 & " & 52 \mathrm{qm} \\ 9 & " & 52 \mathrm{qm} \\ 10 & " & 52 \mathrm{qm}\end{array}$

Hierbei handelt es sich besonders um große Barackenräume, die nur durch aufgestellte Schränke für die einzelnen Familien unterteilt sind. Durch Schaffung von Trennwänden sollen den Familien Räume mit mehr wohnlichem Charakter geschaffen werden.

Besonders schlimm steht es um die Barackenunterkunft in Vorketzin, wo in einem Raum, der vom Gefängnis Tegel als Außenstelle benutzt wurde, auf 50 qm 5 Familien mit 22 Personen untergebracht sind.

Die Familie Gottke, Baracke Thälmannstraße bewohnt mit 6 Personen nur 20-22 qm Raum.

Der Familie Oleniczak, Paretzerstraße steht mit 5 Personen nur ein Raum von 15 qm zur Verfügung.

Diesem Elend wäre nur durch Aufstellung von Baracken oder Behelfsheimen abzuhelfen.

(74) Protokoll der 7. Sitzung des Wohnungsausschusses bei der Provinzialverwaltung Mark Brandenburg. - Potsdam, 2. Juli 1947 (Auszüge)

BLHA, Rep. 206 Ministerium für Wirtschaft und Arbeit, Nr, 2965, unfol. - Vervielfältigtes Typoskript, 4 S., ohne Unterschrift.

\section{Protokoll}

der 7. Sitzung des Wohnungsausschusses bei der Provinzialregierung Mark Brandenburg am Mittwoch, den 2.7.1947 in Potsdam, Alte Zauche 67, Haus I.

Es waren anwesend: Herr Franz Fedler (i. V. von Frau Haalck) (CDU)/Herr Ernst Franz (FDGB) / Frau Lily Krantz (Frauenausschüsse)/ Herr Herbert Lieckefett (FDGB)/ Frau Elfriede Schneemann (i.V. von Frau Böttge) (Frauenausschüsse)/Herr Gustav Blüthner (LDP) / Herr Ferd. Genske (LDP) / Frau Else Bauer ${ }^{2267}$ (SED) / Herr Erich Ebert (CDU) / Frau Charlotte Walde (SED)

Der Vorsitzende, Herr Franz, eröffnete um 14 Uhr 30 die Sitzung und sprach als erstes über die Tagesordnung. Er beantragte drei Punkte: Die Aufgaben der Wohnungsämter und ihre Stellung zur Bevölkerung, die Wohnungsausschüsse und Beschwerden. [...]

2266 [115 handschriftlich korrigiert aus: $] 155$.

2267 [Geb. 1893 Potsdam, gest. 1950 Berlin (West), 1946-1950 MdL (SED, zuvor SPD) und 3. Vizepräsidentin des Landtags, 1946-1947 „innerhalb der Partei Leiterin der Abteilung Arbeit und Sozialfürsorge für die gesamte Provinz Brandenburg, Mitglied des Sekretariats des Landesverbandes der SED“, wohnt 1947 Potsdam, Schillerstr. 3 (Handbuch des Landtages 1947 (wie Anm. 1064), S. 54, 59 mit Bild, 121.] 
Herr Brehmer ${ }^{2268}$ sprach im Auftrage von Herrn Franz zu Punkt I der Tagesordnung.

Die Wohnungsämter sind die vom Gesetzgeber eingesetzten Stellen, die die Wohnraumversorgung durchzuführen haben. Durch die an uns herangetragenen Beschwerden der Bevölkerung stehen wir ständig mit den Wohnungsämtern in Verbindung und haben den besten Ueberblick über die Erledigung ihres Aufgabengebietes und ihre Arbeitsweise [... (Es folgt ein kurzer historischer Rückblick auf die Entstehung und Entwicklung der Wohnungsämter in Deutschland seit der Industrialisierung) ... J Je knapper der Wohnraum, desto strenger und gerechter muss er verteilt werden. Potsdam hatte z. B. schon immer ca. 46000 bis 48000 Familien mit Wohnraum zu versorgen und nur ca. 35000 Wohnungen zur Verfügung. Auch das Wohnungsgesetz konnte hier nur eine bedingte Wandlung schaffen. Der 2. Weltkrieg und [S. 2] seine katastrophalen Folgen besonders für die Wohnraumversorgung hat es dann mit sich gebracht, dass die Besatzungsmächte zur Behebung der grossen Not das Kontrollratsgesetz Nr. 18 (Wohnungsgesetz) vom 8.3.1946 erlassen haben. Die Flüchtlinge aus dem Osten und die Umgesiedelten waren unterzubringen und demzufolge musste sich jeder in seinen Wohnraumbedürfnissen einschränken. Die Wohnungsämter haben daher die Aufgabe, nicht nur den vorhandenen Wohnraum zu erfassen, sondern ihn auch vor allen Dingen gerecht zu verteilen. Die einströmenden Menschenmassen stehen gegenüber dem durch den Krieg stark mitgenommenen Wohnraumbestand in einem Verhältnis, das uns vor beinahe unlösbare Aufgaben stellt. Die Wohnungsämter stehen damit an erster Stelle des sozialen Aufgabengebietes und haben eine Verantwortung zu tragen, der sie sich gewachsen zeigen müssen. Alle an uns herangetragenen Beschwerden bedeuten ein Misstrauen der Bevölkerung gegen die Arbeitsweise der Wohnungsämter. Man muss sagen, dass gerade die Arbeit der Wohnungsämter die öffentliche Meinung stark beeinflusst und ein Versagen dieserr Stellen sich bei den Wahlen erheblich bemerkbar macht. Die Wohnungsbehörden müssen also dem Notstand der Bevölkerung durch Verständnis und Entgegenkommen Rechnung tragen. Unfreundliche Behandlung, ungenaue oder gar falsche Angaben der Wohnungsprüfer usw. müssen das Vertrauen der Bevölkerung zur Behörde untergraben. Es sollten daher gerade die Angestellten der Wohnungsämter nach ganz bestimmten Gesichtspunkten sorgfältig ausgewählt werden. Aus diesem Grunde wird beabsichtigt, Schulungskurse einzurichten, in denen sie fachlich, sozialpolitisch und psychologisch geschult werden. So vorgebildete Angestellte werden dem Publikum richtig entgegentreten und eine Beruhigung der Lage und ein Nachlassen der Beschwerden herbei führen. Ein grosses Uebel der Wohnungspolitik ist die Korruption. Besonders in den kleineren Gemeinden sind die Bürgermeister verwand $[t]$ schaftlich und freundschaftlich gebunden und nehmen aus diesen Erwägungen und Rücksichten heraus keine gerechte Wohnraumverteilung vor. Ein solches Verhalten gibt dann immer wieder Anlass zu Beschwerden, die an uns heranggetragen werden und in die sich eventuell sogar noch die politischen Parteien einschalten. Es entsteht eine Flut von Unwillen, die dann nur sehr schwer 
abzubiegen ist. Alle diese Fehler und Mängel müssen durch eine geeignete Schulung der Wohnungsbeamten beseitigt werden.

Das Wohnungsamt hat ferner die Aufgabe der Betreuung der Wohnungen in gesundheitlicher Hinsicht. Durch das enge Zusammenwohnen ist die Gefahr der Entstehung von Krankheiten und Seuchen sehr gross. Hier kann bei gutem Willen durch Umgruppierungen usw. Abhilfe geschaffen werden. Aus all den Ausführungen ist zu ersehen, dass die Aufgaben der Wohnungsämter sehr vielseitig und von allergrösster Bedeutung sind. Es ist daher wichtig, dass der richtige Mann am richtigen Platz steht.

Herr Fedler bemerkte zu den Ausführungen des Herrn Brehmer, dass viele Mängel bei den Wohnungsämtern nicht so leicht abzubiegen wären, weil eine gerechte Behandlung der Bevölkerung nicht nur eine Frage des Wissens[,] sondern auch vor allem des Taktes wäre, der, wenn nicht von Natur aus vorhanden, nur durch sehr sorgfältige Schulung anerzogen werden kann. Ferner vertrat er die Ansicht, dass man hier mehr Frauen einsetzen sollte. Besonders als Wohnungsprüferinnen wären Frauen besser in der Lage beurteilen zu können, welche Einengungen und Aenderungen in der gewohnten Unterbringung ohne besondere Belastung des [S. 3] häuslichen Lebens möglich wären, denn die Wohnung ist nun einmal das Reich der Frau.

$[\ldots]$

(75) Protokoll der 2. Tagung der Leiter der Wohnungsämter. - Potsdam, 10. April 1947 (Auszug)

BLHA, Rep. 206 Ministerium für Wirtschaft und Arbeit, Nr. 2965, unfol. - Typoskript (Durchschlag), 11 S. - Auf 1. S.l. u. Bleistiftunterschrift „Brehmer“. - 1. S.r. o. handschriftlich: „Herrn Fischer / zur Kenntnisnahme“, darunter dessen Paraphe „Fi“.

\section{Protokoll}

der 2. Tagung der Leiter der Wohnungsämter am 10. April 1947

vormittags 10 Uhr in Potsdam, Alte Zauche 67, Haus I.

Herr Brehmer ${ }^{2269}$ eröffnete um 11 Uhr die Sitzung und dankt für den regen Besuch (erschienen waren lt. Anwesenheitsliste 227088 Teilnehmer). Er begrüsst die Teilnehmer, insbesondere die Herren der Deutschen Verwaltung[,] und gab die Gründe bekannt, die die Tagung notwendig machten. Danach haben die Erfahrungen auf dem Gebiete der Wohnraumbewirtschaftung gezeigt, dass gerade bei den unteren Wohnungsbehörden noch immer Unklarheiten bei der Anwendung des Kontrollratsgesetztes Nr. 18 (Wohnungsgesetz) bestehen, die es notwendig machten, die Leiter der Wohnungsämter zu einer gemeinsamen Aussprache hierher zu laden, 
um die aufgetretenen Zweifels- und Streitfragen zu klären. Alsdann erteilte Herr Brehmer Herrn Ministerialrat Fischer ${ }^{2271}$ das Wort.

Herr Fischer erklärte, dass die Wohnraumbewirtschaftung eines der wichtigsten und brennendsten Probleme ist, das bisher auch im Laufe von Jahrzehnten nicht gelöst werden konnte. [...] So hat sich jetzt nach dem Zusammenbruch eine Wohnungskatastrophe entwickelt, dass wir vor einem Problem stehen, das fast nicht mehr zu meistern ist. Grosse Gebiete Deutschlands sind zerstört oder auf längere Zeit verloren gegangen, während auf der anderen Seite Hunderttausende von Flüchtlingen hereingeströmt sind, die Anspruch auf Wohnraum haben. So muss denn auf Grund des Wohnungsgesetztes heute zu den Fragen der Umsiedler besondere Stellung genommen werden. Die Verwaltungen tuen [so!] von sich aus alles, um eine gerechte Lösung zu finden. Sie ist daher eine unserer Hauptaufgaben.

Herr Brehmer dankt Herrn Fischer für seine Ausführungen, die als Leitmotiv für die Tagung gelten sollen. Er bedauert, dass Herr Minister Schwob ${ }^{2272}$ heute leider verhindert ist, der Sitzung beizuwohnen und übermittelt seinen Gruss. Sodann erteilt er Herrn Jagoczinski ${ }^{2273}$ von der Deutschen Verwaltung das Wort zu

Punkt I der Tagesordnung über die Stellung der Wohnungsämter und der mit ihren Aufgaben betrauten Dienststellen, sowie der Wohnungssausschüsse nach den Bestimmungen des Wohnungsgesetzes. $[\ldots][$ S. 2] [...]

Er nahm dann zu dem von den Wohnungsbehörden mit Recht geklagten Mangel an Arbeitskräften Stellung. Im Durchschnitt hat ein Angestellter 1300 Wohnungen zu bewirtschaften. Es gibt aber auch Gebiete, die über Gebühr Umsiedler aufnehmen mussten, so dass dort auf einen Angestellten der Wohnungsbehörde sogar 1460 Wohnungen kommen. [...]

Es erscheint ein Vertreter der russischen Besatzungsmacht, Kapitän [S. 3] Kaplan und wird von Herrn Brehmer begrüsst.

Dann melden sich 3 Teilnehmer zum Wort:

1.) In Wittstock gibt es täglich 80-100 Wohnungssuchende. [...]

3.) Ein Jahr lang sind in Erkner durch die Besetzung der Russen 100 Wohnungen beschlagnahmt worden, Sie können aber der öffentlichen Bewirtschaftung nicht nutzbar gemacht werden, da die Gemeinde E. von sich aus nicht in der Lage ist, Material für die abmontierten Fenster, Türen, sanitäre Anlagen usw. zu beschaffen. Es handet sich hier hauptsächlich um kleinere Wohnungen für Arbeiter.

$\mathrm{Zu}$ diesen Fragen erklärt Herr J., dass das Wohnungsamt nicht ein Staat im Staate sein darf. Es muss unbedingt harmonisch zusammenarbeiten mit den Bürgermeistern bezw. den betreffen-

2271 [Max Fischer, Leiter der Abt. Arbeit und Sozialwesen der Provinzialregierung.]

2272 [Fritz Schwob, Minister für Arbeit und Sozialwesen in der Provinzialregierung.]

2273 [Karl Jagodzinski (!), Deutsche Zentralverwaltung für Umsiedler (ZVU), Berlin.] 
den Gemeinderatsmitgliedern. Da, wie bereits schon erwähnt, der Bürgermeister bezw. Stadtrat für die Durchführung des Wohnungsgesetztes verantwortlich sind, kann natürlich der Leiter des Wohnungsamtes keinen Einspruch dagegen erheben, wenn der Bürgermeister eine Wohnung vergibt. [...] [S. 6]

$\mathrm{Zu}$ Punkt 3 Tagesordnung über die Erfassung von unterbelegten Wohnräumen in den Stadtund Landgemeinden führt Herr Brehmer aus, dass in den Dörfern noch längst nicht der ganze Wohnraum erfasst worden ist. Die Bürgermeister haben oft keine Übersicht über ihren Wohnraum und sind daher oftmals viele Räume überbeglegt. Nach dem Gesetz ist jeder Bürgermeister verpflichtet, eine Wohnungskartei anzulegen, aus der jederzeit der Wohnungsbestand ersichtlich ist. Die Angestellten des Ministeriums für Arbeit und Sozialwesen sollen daher angehalten werden, bei ihren Fahrten in die Provinz die Bürgermeister zu überpfüfen, ob solche Karteien vorhanden sind, damit evtl. die säumigen Bürgermeister in Strafe genommen werden können. Die Hinweise, dass kein Material für die Karteien vorhanden ist, können nicht als Entschuldigung gelten, da beim Deutschen Gemeindeverlag jederzeit Bestellungen auf Karten gemacht werden können, wie überhaupt sämtliche Formulare dort erhältlich sind. Bei kleinen Gemeinden genügt evtl. eine Handkartei oder Listenführung. Besonders tragisch liegen die Verhältnisse im Kreise Spremberg, der durch die Kampfhandlungen sehr zerstört wurde und weder über Geld noch Material verfügt, um Karteien anzulegen. Es wird dem Kreis nahe gelegt, sofort Karteien einzurichten, da nach dem Gesetz ihre Einrichtung zur Pflicht gemacht ist. Ohne Kartei würde eine zu grosse Korruption um sich greifen.

Hierzu antwortet Herr J. aufklärend, dass z. B. bei der Tagung der Wohnungsamtsleiter von Mecklenburg ein einheitliches Formblatt nach dem Entwurf der Stadt Greifswald eingeführt worden ist und zu diesem Zweck 16000 t Papier durch die deutsche Verwaltung [S. 7] zur Verfügung gestellt worden sind. Das könnte evtl. auch für Brandenburg heraushgeholt werden.

[...] Angermünde hat anstelle der Karteien Listen angelegt. [...]

Alsdann erteilte Herr Brehmer Herrn Ministerialrat Friedrichs, Leiter des Amtes für Deutsche Umsiedler, das Wort:

Nach seinen Ausführungen hat die Provinz bereist 700000 Umsiedler aufgenommen und sind in Kürze noch weitere 100000 unterzubringen. Alle Abteilungen, besonders die Wohnungsämter, müssen mithelfen, diese schwierige Aufgabe zu kösen. Noch hoffen die Umsiedler, dass [S. 8] sie vielleicht bald in ihre Heimat zurückkehren können, aber sie werden grosse Enttäuschungen erleben und dann nicht mehr mit den gegebenen Verhältnissen zufrieden sein. Die SMA verlangt von Herrn F. jeden Monat einen Bericht, was zu Gunsten der Umsiedler geschehen ist. Besonders interessieren dabei die Kreise Luckenwalde und Luckau und werden zu Gunsten der Umsiedler Kontrollen durchgeführt, die nicht immer sehr günstig für die Wohnungsbehörden in den Gemeinden ausfallen. Enges Zusammenarbeiten mit den Ortsumsiedlerausschüssen ist unbedignt notwendig. Ein Zuzug zu Familienangehörigen kann nur gestattet werden, wenn dadurch kein besonderer Wohnraum beansprucht wird. Eine Ausnahme hierbei machen nur die Facharbeiter, die überall 
dringend gebraucht werden. Bei der Entscheidung ist die Stellungnahme des Bürgermeisters unerlässlich, die letzte Entscheidung liegt bei dem Landrat. Den Neusiedlern fehlen dringend Wohnund Wirtschaftsräume, Die Beschaffung des Materials bereitet die grössten Schwierigkeiten, und soll es in erste Linie den Neusiedlern zur Verfügung gestellt werden. Leider müssen immer wieder Verschiebungen von Baumaterialien (Treuenbrietzen) festgestellt wedren.

Herr Brehmer dankt Herrn Friedrichs für seine Ausführungen und nimmt Bezug auf den Befehl 1467, der für uns beschämend ist, da er beweist, dass von uns nicht genügend getan worden ist, um unhaltbare Zustände zu beseitigen. Herr Brehmer betont, dass der Umsiedler nach seiner Einbürgerung Gemeindemitglied wird genau wie die Alteingesessenen und damit die gleichen Pflichten und Rechte erhält. Bei der Unterbringung von Umsiedlern und Flüchtlingen macht die Beschaffung von Hausrat und Mobiliar, insbesondere Betten, die grössten Schwierigkeiten. Hier macht sich das Verbot der Anwendung des Reichsleistungsgesetztes besonders bemerkbar. Wenn nicht bald ein Landesgesetz erlassen wird, das die Möglichkeit der Beschlagnahme von Mobiliar und Hausrat gibt, ist ein grosser Teil der Sachen nach den westlichen Zonen abgeschoben oder verkommt in Kellern und auf Böden. - Die Vertreter der Stadt Guben geben bekannt, dass sie eine Verordnung zur Beschlagnahme von Mobiliar herausgegeben haben, das ungenutzt auf Böden und Kellern steht. Die Stadtverwaltung übernimmt in diesem Fall die Verantwortung, wenn ein neues Gesetz die Herausgabe der Möbel an die Besitzer vorsehen sollte.

Der Stadtkreis Brandenburg hat eine eigene Ortssatzung herausgegeben, die er dem Referat Wohnungsfürsorge demnächst zur Verfügung stellen will.

Genau so dringend wie Möbel und Hausrat fehlen Öfen und Herde. Nach diesen Aussagen der Tagungsteilnehmer sind die Wirtschaftsämter angehalten, für eine bevorzugte Verteilung an Umsiedler Sorge zu tragen. [...]

Punkt 9 der Tagesordnung: Allgemeines. [...] [S. 11] [...]

Herr Brehmer weist noch einmal auf die genaue Einhaltung der Termine bei den abzugebenden monatlichen Meldungen hin, die leider noch viel zu wünschen übrig lässt und dem Referat durch die laufenden Anmahnungen eine grosse Mehrarbeit und Belastung entsteht. [...]

Abschliessend bemerkt Herr Brehmer, dass leider grosse Teile der Bevölkerung viel zu wenig mit dem Wohnungsgesetz und seiner Durchführungsverordnung bekanntgmacht worden sind. Zur Aufklärung der Bevölkerung sind Presseberichte, Vorträge und Rundfunksendungen unerlässlich. Die Kreise müssen vor allem auch eine dahingehende Schulung der Bürgermeister durchführen, um Fehlentscheidungen der unteren Wohnungsbehörden zu vermeiden.

Der Vertreter der russischen Besatzungsmacht, Herr Kapitän Kaplan[,] erklärt, dass er den ausführlichen Darlegungen des Herrn Brehmer nichts hinzuzufügen hätte und wünscht uns weitere Erfolge für die schwere aber dankbare Aufgabe einer gerechten Wohnraumverteilung und Wohnraumbeschaffung.

Schluss der Sitzung: 15 Uhr 30. 


\section{(76) Beschwerde wegen unzureichenden Wohnraums. - Potsdam, 23. Februar 1948}

BLHA, Rep. 250 Landratsamt Luckenwalde, Nr. 107, Bl. 156. - Typoskript mit Unterschrift „Im Auftrage: [gez.] Hawellek“. - L. o. Absender: Landesregierung Brandenburg/Minister des Innern/Informationsamt/GZ. 14493/1“. - R. o. Datierung: „Potsdam, den 23.2.1948 / Seestr. 43 / Tel. 5991/93“, darunter Eingangsstempel „25. Febr. 1948“. - Adresse: „An den / Rat des Kreises Luckenwalde / - Informationsdienst - / Luckenwalde“. - Betreff: „Betrifft: Umsiedlerbeschwerde D.[...]-Heinsdorf“. - L. u. Bleistiftvermerk „Süssenbach?“

Die uns übermittelte Beschwerde über unzureichende und gesundheitsschädliche Wohnverhältnisse der Familie A.[...] D.[..] in Heinsdorf haben wir der Abteilung Umsiedler und Heimkehrer mit der Bitte um Regelung zugeleitet. Wir erhielten nunmehr den Bescheid, dass die Familie D.[... umquartiert worden ist. Sie erhielt eine zusammenhängende Wohnung, die kopfzahlmässig auch ausreichend ist. Die ehemalige Wohnung wurde anderen Umsiedlerfamilien zur Verbesserung ihrer Wohnverhältnisse zugeteilt.

\section{(77) Eingabe Einheimischer wegen Wohnraums. - Heinsdorf, 3. März 1948}

BLHA, Rep. 250 Landratsamt Luckenwalde, Nr. 107, Bl. 157. - Handschriftliche (Kopierstift) Eingabe ohne Adresse, 1 Bl., unterzeichnet „Gruß / Frau Donath.", am Ende datiert „3/3.48.“

Bauer Willi Sch.[...]. in Heinsdorf Haus Nr. 10 / besteht aus 4 Zimmer[,] 1 Kammer und 1 Küche.

1 Z. hat die alte Bäuerin $73 \mathrm{~J}$. alt (Altenteil). Der alte Bauer ist am 17.2.[19]48 gestorben.

$1 \mathrm{Z}$. hat der junge Erbe + Sohn $43 \mathrm{~J}$. alt.

1 Z. und 1 Kammer haben 1/5 Köpfige Flüchtlings Familie

1 Z. hat die Bauers Familie als Wohn-Aufenthaltsraum, essen u.s.w. bei Kälte schläft der Kutscher drin.

In 4 Wochen ist Hochzeit, der Sohn ist aus der Gefangenschaft gekommen u. heiratet nun 1 Flüchtlingsmädchen welche 1 uneheliches Kind von 7 Jahren hat. Also sind es z.Z.t 8 Pers. in 1 Monat 10 Pers. Und diese Menschen haben alle nur 1 Küche für schlachten, waschen, kochen u. s. w. denn es ist keine Futterküche vorhanden. Nun kommt das Wohnungsamt u. will am 5.3. eine 4 köpfige Familie mit Schwein u.s. w. [Bl. 157v] in das 1 Zimmer setzen, welche nun auch noch an den Herd u. die Küche benützen wollen.

Die Hochzeit ist wegen den Tod des alten Bauern um 4 Wochen verschoben. Mit der Soll Abgabe stehen Sch.[...] an erster Stelle, waren auch keine ehemalig. P. G. Bitte belassen Sie den Leuten das 1 Zimmer, Sie jammern, aber sind zu unbeholfen, zu reden und zu schreiben, deswegen soll ich es für sie tun. Die Flüchtl[in]g[e]. wollten auch nicht in das Zimmer, sondern zum Bürgermstr. Jahn, da die Flüchtlingsfrau dort immer hilft, aber der will sie auch nicht. Und raus müssen sie aus dem Schloß, es wird abgerissen, Bitte zu helfen, diesesmal ist es ungerecht die Leute noch mehr zu beengen. 
(78) Antwort (auf Nr. 77). - Luckenwalde, 12. April 1948

BLHA, Rep. 250 Landratsamt Luckenwalde, Nr. 107, Bl. 158. - Typoskript (Durchschlag), 1 Bl., mit KopierstiftParaphe „WKu“ des Informationsdienstmitarbeiters beim Rat des Kreises Luckenwalde W. Kummer. - L. o. Adresse: „Herrn Willi Sch.[...] / Heinsdorf / [...].- R. o. Datierung: „Luckenwalde, den 12. April 1948“.

Bezugnehmend auf meinen Besuch in Heinsdorf muss ich Ihnen leider mitteilen, dass es mir nicht gelungen ist, das dritte Zimmer für Sie freizubekommen, In Heinsdorf sind leider besonders ungünstige Wohnverhältnisse durch die starke Belegung mit Flüchtlingen. Eine Umquartierung nichtsiedelnder Neubauern nach Zagelsdorf oder Prensdorf ist zur Zeit auch nicht möglich. Rücksprachen mit dem Leiter des Kreiswohnungsamtes, der sich auf ihren Fall genau entsinnen konnte, endeten ergebnislos, weil derselbe den Standpunkt vertritt, ein Zimmer für das Ehepaar und 1 Zimmer für Grossmutter und Enkelkind, ausser der grossen Wohnküche, wären vorübergehend ausreichend.

Hoffentlich werden die geplanten Bauvorhaben in Heinsdorf recht schnell durchgeführt, damit für alle eine Entlastung eintritt.

\section{(79) Berichtsanforderung über die Situation im Aufbaulager Luftschiffhafen} in Potsdam durch Landtagspräsident Friedrich Ebert. - Potsdam, 12. April 1948

BLHA, Rep. 201 Landtag, Nr, 403, Bl. 4. - Typoskript, 1 Bl., mit eigenhändiger blauer Buntstift-Paraphe „Eb“. - Datierung o. r.: „Potsdam, den 12.4.1948“, darunter Aktenzeichen „Eb/ne.“, darunter handschriftliches Eingangsdatum (roter Buntstift) „E 10.5.48“ (dafür gestrichen: 26.4.48“ [Bleistift]). - Überschrift: „Aktennotiz / an die Abteilung Arbeit und Sozialfürsorge“.

Durch Rücksprache mit verschiedenen heimatlosen Umsiedlern, die in dem Aufbaulager Luftschiffhafen in Potsdam untergebracht sind, gewann ich den Eindruck, dass dort vieles nicht in Ordnung ist. Ich habe deshalb über das Büro des Landtags von der Regierung einen Bericht angefordert, den ich in der Anlage ${ }^{2274}$ beifüge.

Aus diesem Bericht, den der Rat der Stadt Potsdam an die Regierung erstattete, ergibt sich, dass es der Stadt Potsdam nicht möglich war,

1. für den Ess- und Tagesraum dieses Umsiedlerlagers Heizmaterial zu besorgen,

2. eine Baracke ganz winterfest in Stand zu setzen.

Diese beiden beschämenden Tatsachen scheinen mir wieder einmal zu beweisen, dass die Stadtverwaltung Potsdam auch auf dem Gebiet der Betreuung der Umsiedler und Heimkehrer die Dinge an sich herankommen lässt, anstatt ihnen vorausplanend zu begegnen. Es kann mich niemand davon überzeugen, dass es den 100000 Einwohnern der Stadt Potsdam unmöglich ist, für diese heimatlosen Umsiedler Heizmaterial für einen Tagesraum und so viel Baumaterial zu besorgen, dass man eine Baracke völlig winterfest herstellen kann. 
Ich kann auch nicht einsehen, dass es eine Unmöglichkeit sein soll, diese heimatlosen Umsiedler - wenigstens die älteren unter ihnen - in Privathaushalten unterzubringen. Was in dem Bericht über die für die heimatlosen Umsiedler absolut notwendige Gemeinschaftsbetreuung gesagt wird, halte ich für nicht stichhaltig. Wenn die Männer in eine ordentliche Familie kommen, werden sie auch dort ordentlich betreut werden.

Unfassbar ist die in dem Bericht betonte Absicht, dass eine Verpachtung des Grundstücks, zwecks Errichtung eines Restaurants, vorgenommen und die Umsiedler dann aus irgendwelchen, mir nicht verständlichen kommunalpolitischen Gründen noch enger zusammengepfercht werden sollen, als das bisher schon der Fall war. Es erscheint mir fast unmöglich, dass unsere Genossen in der Potsdamer Stadtverwaltung solche Schildbürger sind; aber man kann es nicht wissen. [Bl. 4v]

Ich bitte, durch die Abteilung Arbeit und Sozialfürsorge die ganze Angelegenheit noch einmal ernsthaft zu überprüfen und mir beschleunigt Bericht zu geben, damit ich eventuell in meiner Eigenschaft als Präsident des Landtags die zuständigen Stellen der Stadt Potsdam auf ihre Pflicht aufmerksam machen oder im tatsächlichen Unvermögensfalle andere Stellen auf die Zustände aufmerksam machen kann.

\section{(80) Dringlichkeitsantrag des Umsiedlerausschusses des antifaschistischen Blocks Potsdam an die Stadtverordnetenversammlung von Potsdam wegen Wohnraums für „ehemalige Umsiedler, Heimkehrer und Dienstverpflichtete“. - Potsdam, 15. April 1948 2275}

BLHA, Rep. 201 Landtag, Nr, 403, Bl. 16-20. - Typoskript (Durchschlag), 5 Bl.: Bl. 16 Dringlichkeitsantrag von „Rat der Stadt Potsdam / Sozialamt / Abt. Umsiedler-Heimkehrer / Umsiedler-Ausschuß / Amtsstelle VIII/8 / Hebbelstraße 4“, Potsdam, den 17. April 1948, „An den Rat der Stadt Potsdam - Sozialamt/z.Hd. von Herrn Stadtrat Hausmann / Potsdam / zur Vorlage an die Stadtverordneten-Versammlung“ (auf Kopfbogen des Rates der Stadt Potsdam). - Bl. 17 („Blatt 2“): Beschluss des Umsiedlerausschusses, Potsdam, 15.4.1948, mit den Unterschriften der Vorsitzenden Fischer sowie der Mitglieder, für die SED [August] Deimling, Kupke, [E.] Struck, für die CDU M[argarete] Schöller, für die LDP Henschke, für den FDGB Bauer, Arlt. - Bl. 18-19: Begründung, S. 19 Unterschrift der Vorsitzenden Fischer und Gegenzeichnung durch Stadtrat Hausmann. - Bl. 20: [Anlage zum] „Antrag zur Schaffung von Wohnraum für Umsiedler“: „Aufstellung für den Bedarf an Baustoffen, Handwerkern und Kapital zur Wiederherstellung von 100 zur Zeit nicht bewohnten Wohnungen“, erstellt von Rat der Stadt Potsdam / Amtsstelle VI Sch“, Stempel: „Stadtbauamt / Abt. Wiederaufbau / f. d. ziv. Sektor“, Unterschrift „i.A. Dellmin[?]“.

[B1. 17]

Potsdam, den 15. April 1948.

Der Umsiedlerausschuß des antifaschistischen Blocks beschließt, der Vorsitzenden Frau Fischer (Abt. Umsiedler des Sozialamtes) den Auftrag zu erteilen, sich an die Stadtverordneten-Versammlung zu wenden mit folgenden Anträgen:

2275 [Hinweis: Einen fast gleichlautenden, etwas knapper gefassten Antrag hatte der Umsiedler-Ausschuss am 13. April 1948 an den Militärkommandanten der Stadt Potsdam Oberst Werin gerichtet (ebd., Bl. 21).] 
Die Stadtverordneten-Versammlung wolle beschließen,

1. daß die Beethovenschule ${ }^{2276}$, Potsdam-Babelsberg [Bleistift darübergeschrieben: „oder ein anderes Gebäude“], zur Einrichtung eines Heimes für ledige und anhanglose ehemalige Umsiedler, Heimkehrer und Dienstverpflichtete der Stadt Potsdam freigegeben wird,

2. daß der Rat der Stadt Potsdam einen Antrag an den Landtag richte mit dem Ersuchen, einen Beschluß zu erwirken, in dem die Landesregierung veranlaßt wird, der Stadt Potsdam Baumaterial zuzuweisen zum Ausbau von Wohnungen, da die an die Landesregierung gerichteten Anträge erfolglos geblieben sind, die Notlage der Umsiedler aber ein sofortiges Einschreiten dringend erfordert.

[Bl. 18]

\section{Begründung}

Mit Bezugnahme auf den anliegenden Beschlu $ß^{2277}$ des Umsiedlerausschusses des antifaschistischen Blocks vom 15. April 1948 reiche ich folgende Begründung der darin enthaltenen Anträge ein.

\section{Punkt I}

Die Aufgaben der Umsiedlerämter des Landes Brandenburg in diesem Jahr sind vorwiegend bevölkerungs- und wirtschaftspolitisch

1) Verbesserung der Wohnraumverhältnisse in den Städten durch Aus- und Erweiterungsbauten aller Art.

2) Beseitigung der Massenunterkünfte.

3) Sicherung der gerechten Wohnraumverteilung.

4) Zusammenführung der Familien.

$\mathrm{Zu}$ Punkt 2 und 4 bemerken wir folgendes:

In dem Aufbaulager der Stadt Potsdam am Luftschiffhafen leben zur Zeit 125 heimatlose Männer (ehemalige Umsiedler bezw. Heimkehrer und Dienstverpflichtete), die ausschließlich für den Wiederaufbau der Stadt Potsdam und für die Besatzungsmacht arbeiten.

Eine Anzahl von ihnen ist anhanglos und ledig, bei anderen war eine Zusammenführung infolge der Wohnungsnot bisher noch nicht möglich. Zur Unterbringung weiterer 30 Dienstverpflichteter ist das Lager gleichfalls auf Grund des Wohnraummangels wieder vorgesehen.

2276 [Ebd., Bl. 3: „Der Antrag, die Beethoven-Schule dafür zu bekommen, musste abgesetzt werden, da zur gleichen Zeit die Gewerbeschule das Gebäude übernommen hat.“ - Dennoch ist es „in den ersten Frühlingsmonaten“ zu einer teilweisen Belegung der Schule (Turnhalle) gekommen, wie eine Zeitzeugin, damals Schülerin der Beethovenschule, überliefert und beschrieben hat: Helga Bornstädt: In: Turnhalle wurde Notquartier. In: Gestern und heute. Erinnerungen von Mitgliedern des Zirkels „Zeitzeugen“ beim Seniorenbeirat der Stadt Potsdam. Potsdam 2005, S. 27-28.]

2277 [Siehe oben Bl. 17.] 
Für die Beseitigung einer Massenunterkunft wie der am Luftschiffhafen fehlen in Potsdam die Voraussetzungen. Derartige Einrichtungen bleiben für die nächste Zeit eine Notwendigleit, sie sind zeitbedingt. Ebenso geben wir zur Kenntnis, daß unserer Stadt ein weiteres Aufnahmesoll von 200 neuen Umsiedlern von der Landesregierung auferlegt worden ist. Ein Einspruch gegen diese Maßnahme ist zwecklos. Es ist unsere Pflicht, erwähnte Unterkünfte menschenwürdig zu gestalten. Die dort Untergebrachten haben ein Recht auf eine freundliche und hygienisch einwandfreie Behausung. Die Forderung wird immer dringender, für die ledigen Facharbeiter und Dienstverpflichteten ein Heim zu schaffen.

Wie uns mitgeteilt wird, ist die Beethovenschule in Babelsberg freigegeben worden. Dieses Gebäude möchsten wir als zweckentsprechend vorschlagen und bitten den Rat der Stadt Potsdam in Anerkennung der dringenden Notwendigkeit und der politischen Wichtigkeit dieser Maßnahme, die Beethovenschule in Babelsberg zur Einrichtung eines solchen Heimes zur Verfügung zu stellen.

[Bl. 19]

\section{Punkt II}

In dem Rundschreiben Nr. 89/VII/47 der Landesregierung Brandenburg - Minister für Arbeit und Sozialwesen, Abt. Umsiedler-Heimkehrer - und der Anordnung vom 16. Januar 1948 betreffend Auflösung der bestehenden Umsiedlerlager wird gefordert, daß von den Gemeinden Wohnraum in genügender Menge geschaffen wird, um den Umsiedlern menschenwürdigere Unterkünfte zu sichern. Die Notwendigkeit dieser Maßnahme ist uns voll bewußt, da wir auf den regelmäßigen Klagen in den täglichen Sprechstunden feststellen mußten, daß die Wohnungsnot und das Wohnungselend vieler Umsiedlerfamilien kaum noch zu überbieten sind.

Trotz besten Willens des Wohnungsamtes ist eine durchgreifende Besserung vorerst nicht zu erwarten. Die Wohnraumfrage in Potsdam ist katastrophal, da die Stadt als Landeshauptstadt übermäßig viel Wohnraum verbrauchen muß für Unterbringung von Geschäftsstellen, amtlichen Verwaltungsstellen, Verwaltungsstellen der Parteien und Körperschaften, die zum großen Teil in Wohnräumen untergebracht sind. Hinzu kommt, daß die Landesregierung viel freiwerdenden Wohnraum beansprucht zur Unterbringung ihrer zuziehenden Angestellten.

Anträge auf Zuteilung von Baumaterial zum Ausbau beschädigter Wohnungen sind von der Landesregierung mit der Begründung abgelehnt worden, daß alle anfallenden Materialien zunächst für die Durchführung des Befehls 209, der Erstellung von 9000 Neubauernhöfe[n], erforderlich sein werden. (Antrag vom 27. November 1947, Antwort vom 24. Januar 1948 - U/II $16608 / 4)$. Andererseits muß festgestellt werden, daß Baumaterial vorhanden ist, wenn es sich um Repräsentativbauten der Landesregierung handelt. Anträge des Herrn Oberbürgermeisters an den Landtagspräsidenten vom 9. September 1947 und 5. November 1947 sind abgelehnt worden, darunter einer mit der Begründung, daß die Stadt Materialien zum Ausbau des Landestheaters erhalten habe. Es ist ein unhaltbarer Zustand, daß die Landesregierung Forderungen stellt und deren Erfüllung gleichzeitig verhindert, zumindest die dahingehenden Bestrebungen nicht fördert. 
Eine Aufstellung der Abteilung Wiederaufbau des Stadtbauamtes für den Bedarf an Baustoffen, Handwerkern und Kapital zur Wiederherstellung von 100 nicht bewohnten Wohnungen wird beigefügt.

\section{(81) Eingabe der Gemeindevorsteherin von Raßmannsdorf bei Beeskow wegen} Unmöglichkeit der Aufnahme weiterer Vertriebenen. - Raßmannsdorf, 23. April 1948

BLHA, Rep. 250 Landratsamt Beeskow-Storkow, Nr. 869, unfol. - Manuskript mit Unterschrift, 1 Bl. - R. o. Datierung: „Rassmannsdorf, 25.5.48.“ - Anschrift: „An den / Rat des Kreises Beeskow-Storkow / Amt f. Arbeit u. Sozialfürsorge / Abtlg. Umsiedler + Heimkehrer / Beeskow.“ - Betreff: „Betr. Zuweisung von Umsiedlern.“ - Eingangsvermerk „Eg 25/3 48 / M“. - Unterschrift: „Blume, Gemeindevorsteherin“, Stempel der „Gemeinde Rassmannsdorf / Kreis Beeskow-Storkow“.

Auf Grund Ihres Schr[eibens] v. 19.3. erwidere ich folgendes: Die Gemeinde Rassmannsdorf ist z. Zt. mit fast $100 \%$ Umsiedlern gegenüber den Alteingesessenen belegt. Die 14 Häuser der Gemeinde bestehen zum überwiegenden Teil aus Stube und Küche. Auch 2 Notwohnungen, die keine menschenwürdige Unterkunft darstellen, sind z. zt. mit Umsiedlern besetzt. Ausbaufähige Wohnungen sind hier nicht vorhanden. Solange es noch Gemeinden gibt, die weniger als $95 \%$ Umsiedler beherbergen, muss der hiesige Umsiedlerausschuss eine weitere Aufnahme von Umsiedlern ablehnen. Ich bin mir wohl bewusst, dass diese heimatlosen Menschen, deren Schicksal auch das meine ist, eine neue Heimat finden müssen, aber die neue Unterbringung darf nicht derart primitiv und verletzend sein, dass sie den Heimatlosen auch noch den letzten Rest Mut nimmt. Ich bitte daher, von einer weiteren Zuweisung von Umsiedlern für meine Gemeinde abzusehen.

\section{(82) Bericht über die Wohnsituation eines Vertriebenen in Rathenow. - Rathenow,} 8. Dezember 1948

BLHA, Rep. 333 SED-Landesleitung Brandenburg, Nr. 574, Bl.372-373. - Typoskripte, 3 Bl. - Erste Anlage (B1. 373) zum Begleitschreiben des Rates des Kreises Westhavelland, Abt. Informationsdienst („Betr.: Wohnungsamt Rathenow"), an den Landesvorstand der SED, z. Hd. d. Genossen Globig, in Potsdam (B1. 372, auf Kopfbogen). Die zweite Anlage (Bl. 374) hier weggelassen, da einen Kriegs-Heimkehrer betreffend.

Anliegend übermitteln wir einen Bericht die Wohnungsangelegenheit $\mathrm{G}[\ldots] \mathrm{H}[\ldots]$, Rathenow, betreffend. Leider sind die Photos sehr spät fertig geworden. Der betreffende Photograph war längere Zeit nicht im Amt. Aus den kleinen Bildern könnt Ihr Euch ja einen Begriff machen, unter welchen Umständen die Umsiedler leben mussten. Durch unser sofortiges Eingreifen d. h. die gesamte Kommission konnte dem $\mathrm{H}[\ldots]$ plötzlich am nächsten Tage eine andere Wohnung zugewiesen werden, was zuerst über ein Jahr lang nicht möglich war. Der Oberbürgermeister Gen. Szillat ${ }^{2278}$ hat sich selbst davon überzeugen müssen, dass es dem Wohnungsamt wohl bekannt war, wie die Umsiedler hausen mussten.

2278 [Paul Szillat, geb. 1888 Berlin, SED, zuvor SPD, ab 1945 Oberbürgermeister von Rathenow, 1947 MdL und Mitglied des Zentralvorstandes der SED (Handbuch des Landtages 1947 (wie Anm. 1064), S. 56, 100).] 
Der zweite Bericht, den Arbeiter K[...] betreffend, zeigt ein typisches Heimkehrer-Schicksal auf. Das anliegende Photo zeigt ein Autowrack, das vor dem Eisenbahnwaggon des Ehepaars $\mathrm{H}[\ldots]$ lag. Hier hauste lt. Bericht der Arbeiter K[... 2 Monate auf einem Stroh- und Lumpenlager zusammengekauert nächtelang. Auch in diesem Fall konnte plötzlich noch am selben Tage dem Mann ein Zimmer nachgewiesen werden.

Wir bitten, diese Berichte mit den Photos ${ }^{2279}$ dem Landesvorstand der SED zu unterbreiten. Der Gen. Hähnel ist von diesen Zuständen unterrichtet, indem er selbst alles in Augenschein nahm.

Mit sozialistischem Gruß

[Unterschrift]

[Bl. 373r]

\section{So leben Umsiedler!2280}

Der Umsiedler G[... H H ...], von Beruf Straßenwärter jetzt Rentner, 68 Jahre alt, und seine 63 Jahre alte Ehefrau kamen im November 1946 aus Schlesien zu ihrer Tochter nach Rathenow, Frau H[...], [... (Adresse)]. Die Tochter lebt mit ihren 3 schulpflichtigen Kindern in einer Siedlungs-Kleinstwohnung und nahm die beiden alten Leute auf. Da der zur Verfügung stehende Wohnraum für 3 Erwachsene und 3 Kinder nicht ausreichte, unternahm H[... Schritte bei Wohnungsamt, um eines der damals leerstehenden Behelfsheime zu erhalten bezw. käuflich $\mathrm{zu}$ erwerben. Trotz mehrfacher Anträge und Vorstellungen beim Wohnungsamt wurde dem Rentner-Ehepaar nicht geholfen.

Auf dem Reichsbahn-eigenen Gelände, einem Schrottlagerplatz an der Verladestraße Ecke Schützenstraße entdeckte der Umsiedler $\mathrm{H}[\ldots]$ einen unbrauchbaren ausrangierten Güterwagen, den er als Notwohnung ausbaute. Verhandlungen mit der Bahnverwaltung gestatteten den beiden alten Leuten das Bewohnen des Güterwagens und des Schrottlagerplatzes gegen ein monatliches Entgelt (Miete) in Höhe von 10,- DM.

Im Juli 1947 bezog $\mathrm{H}[\ldots]$ mit seiner Frau diese menschenunwürdige Notwohnung und lebt bisher daselbst. Obwohl die Verwaltung - Wohnungsamt Herr Sch [...] und Herr F[... - hiervon Kenntnis hatten, wurde bisher seitens der Verwaltung in keiner Weise eingegriffen. Der Güterwagen, in dem $\mathrm{H}[\ldots]$ s hausen; denn von einem Wohnen in dieser Elendsbaracke kann keine Rede sein, ist in 2 Räume geteilt, der sogenannten Küche, in der eine argbeschädigte Kochmaschine, die anscheinend aus dem Schutt stammt, einem selbstgezimmerten Tisch und recht viel Gerümpel, unter anderem Töpfe, Kannen usw., die aus dem Schutt und Schrott geborgen wurden[, befindlich sind]. Das sogenannte Schlafzimmer besteht aus 2 eisernen Bettstellen, 1 Vertiko, Kisten und Gerümpel, das H[... ebenfalls aus dem Schrott barg.

2279 [Liegen nicht mehr bei.]

2280 [Diese Überschrift von unbekannter Hand handschriftlich hinzugesetzt.] 
Einen Winter haben $\mathrm{H}[\ldots]$ s bereits in dieser Bude zugebracht, sollte sich in diesem Jahre ein strenger Winter einstellen, und die bisher versagenden Stadtverwaltung-Wohnungsamtnichts unternehmen, kann man mit schweren Gesundheitsstörungen, wenn nicht gar mit dem Tode durch Erfrieren rechnen. Wenn man bedenkt, daß es in Rathenow noch Personen gibt, die über 2 Wohnungen verfügen (wie der Direktor des Krankenhauses, Herr A[...], der außer seiner Dienstwohnung im Krankenhaus noch eine eigene Zwei-Zimmerwohnung besitzt. Die Dienstwohnung ist unbenutzt. Herr A[...] fährt mit dem Dienstwagen täglich 4 mal von der Wohnung Heidefeldstraße nach dem Krankenhaus und zurück und verbraucht den Benzin, der eigentlich dem Krankentransport zusteht.), oder daß 2 Personen eine 3-Zimmerwohnung besitzen, oder daß gar ehemalige Nazis und sogar SS-Männer von dem Wohnungsamt bevorzugt behandelt werden, so können wir feststellen, daß in dem vorliegenden Falle $\mathrm{H}[\ldots]$ doch anscheinend eine Sabotage seitens des Wohnungsamtes vorliegen muß. Wo bleibt hier die vielgepriesene Humanität, von der so viel geredet wird? Den verantwortlichen Personen gehörte, gehörig zur Verantwortung gezogen zu werden, wenn nicht gar [Bl.373v] wegen Verbrechens gegen die Menschlichkeit den Prozeß zu machen.

Die am heutigen Tage eingesetzte Sonderkommission speziell für diesen Fall und bestehend aus dem Bürgermeister Weidland, dem Stadtpolizeichef Russow, dem Leiter der Kriminalpolizei - Herrn Träger -, der Leiterin des Informationsdienstes - Frau Ganke -, einem Mitglied der Wohnungskommission SED - Frau Bradler -, und DFD Frau Klicks und dem verantwortlichen Offizier - Oberleutnant Reemer - von der Kreiskommandantur war einstimmig der Auffassung, daß dem bisherigen Zustand eines Weiterwohnens in dieser Elendsbaracke ein Ende gesetzt werden muß.

Herr Oberleutnant Reemer gab der Frau den Auftrag, sich unverzüglich mit dem Oberbürgermeister in Verbindung zu setzen.

\section{(83) Bericht über die Überprüfung der Wohnsituation im Kreis Teltow durch die Abt.} Umsiedler und Heimkehrer der Landesregierung. - [Potsdam], o. D. [Dezember 1948]

BLHA, Rep. 333 SED-Landesleitung Brandenburg, Nr. 574, Bl. 375. - Typoskript (Durchschlag), 2 S., mit eigenhändiger Unterschrift [des leitenden Mitarbeiters in der Abt. Umsiedler und Heimkehrer der Landesregierung Brandenburg, Walter] Münchenhagen.

\section{Bericht über die Überprüfung des Kreises Teltow und des}

Lagers Fürstenwalde am 9.12. in Gegenwart von Herrn Wernsdorf.

Die Überprüfung in der Gemeinde Ahrensdorf ergab, daß die Umsiedlerfamilie W[...] inzwischen zur Bäuerin Th[...] umquartiert worden ist. Dadurch wurde wohl der freie Wohnraum belegt, aber nicht die Lösung geschaffen, die erstrebenswert ist. Eine Rücksprache bei der Kreisverwaltung am 9.11.[19]48 ergab, daß zur Bäuerin Th. die Umsiedlerfamilie L[... ] aus Gräbendorf eingewiesen werden sollte, da der Mann der Frau L[... L Landarbeiter ist und die Wirtschaft der Th. gut führen könnte. L[...] ist z. Zt. immer noch in Mecklenburg und erhält nach dort nicht die Zuzugsgenehmigung für seine Familie wegen der schwierigen Wohnraumlage in dem 
betreffenden Ort. Die Gemeinde Ahrensdorf hat sich aber sofort geweigert, die L[... ] aufzunehmen, da sie auf dem Standpunkt steht, daß A. bereits genügend Umsiedler hat. Die Kreisverwaltung (Herr Cochlovius) hat sich diesem Standpunkt gebeugt, und so lebt die Familie L[... immer noch getrennt. L. arbeitet weiter in Mecklenburg, und seine Frau mit Kind wohnt weiter in Gräbendorf.

Bei der anschließenden Rücksprache in Mahlow wurde Herr Cochlovius beauftragt, bis zum 1.1.1949 die Zusammenführung der Familie L[... ] zu bewerkstelligen.

Auch der Umsiedler J[... ] aus Gräbendorf, der von Beruf Schneider war, hat bisher noch keinen Arbeitsplatz nachgewiesen erhalten. So soll er jetzt in Zernsdorf Kreis Teltow Arbeit und Wohnung bekommen. - Auch hier wurde Herr C. beauftragt, bis zum 1.1. die vollzogene Umquartierung zu melden.

Bei Granzow in Zossen ist die Wohnraumangelegenheit augenblicklich so, daß die Abteilung MWD der Roten Armee in Zossen ein Haus benötigt und das Wohnungsamt dafür das Haus der Gärtnerei Granzow vorgeschlagen hat. Dadurch würde diese Streitigkeit eine schnelle und günstige Lösung finden.

Gegen den Bauern L[...] in Zossen ist wegen der Nichteinhaltung unserer damals getroffenen Anweisung zur Unterbringung der Umsiedlerfamilie nichts unternommen worden. - Auch hier wurde Herr C. beauftragt, bis zum 1.1. bei der Amtsanwaltschaft Zossen entsprechende Schritte einzuleiten.

Der angebliche Pole K[... ] hat sich in Gräbendorf bisher nicht wieder sehen lassen.

Auch in der Wohnraumangelegenheit Z[...], Gräbendorf, wurde Herr C. beauftragt, eine örtliche Überprüfung durchzuführen, um festzustellen, inwieweit Z. berechtigt war, das Wochenendhaus zu demontieren. Sollte diese Demontage ohne Berechtigung durchgeführt sein, wurde Herr C. beauftragt, auch hier entsprechende Maßnahmen zu ergreifen.

Bei einer anschließenden Rücksprache auf dem Kreisvorstand der S.E.D. wurden die Mängel in der Arbeit des Kreissozialamtes behandelt. Diese Stelle will sich in Zukunft stärker für dieses Aufgabengebiet interessieren. - Der Kreisvorstand wurde besonders auf den Vorfall W[...] in Groß Kienitz aufmerksam gemacht. / [B1.375v] [... $]^{2281}$

\section{(84) Bericht über die Überprüfung der Wohnsituation in der Gemeinde Werder bei Strausberg durch die Abt. Umsiedler und Heimkehrer der Landesregierung. - Potsdam, 13. Dezember 1948}

BLHA, Rep. 333 SED-Landesleitung Brandenburg, Nr. 574, Bl. 370-371. - Typoskript (Durchschlag), 4 S., mit eigenhändiger blauer Buntstift-Unterschrift [des leitenden Mitarbeiters in der Abt. Umsiedler und Heimkehrer der Landesregierung Brandenburg, Walter] Münchenhagen. 
Bericht über die Überprüfung der Gemeinde Werder bei Strausberg Kr. Niederbarnim, am 8. Dezember 1948.

Die Besichtigung wurde durchgeführt in Gegenwart des Bürgermeisters [Georg] Ritsche, SED und dem Mitglied des Wohnungsausschusses Topp (Ortsgruppenvorsitzender der SED, Neusiedler (Umsiedler).

Die Gemeindevertretung setzt sich zusammen aus 12 Mitgliedern, von denen 3 Umsiedler sind (2 SED, 1 CDU). Die Sitze verteilen sich auf die SED mit 7 und die CDU mit 5 Mitgliedern. Der Gemeinderat setzt sich aus 4 Personen zusammen, und zwar aus 2 SED, 1 CDU und 1 parteilosen Mitglied. Hiervon sind 2 Umsiedler. Die Gemeinde hat 683 Einwohner, von denen 279 Umsiedler sind, somit $40 \%$. Bis 1939 hatte die Gemeinde 420 Einwohner.

Durch die Bodenreform wurde eine Wirtschaft über 100 ha und 3 Höfe aktiver Nazis enteignet. Davon wurden 29 Neusiedlerstellen und 52 Kleinsiedlerstellen geschaffen. Von den 29 Siedlern sind 15 Umsiedler, und von den 52 Kleinsiedlern sind 42 Umsiedler. Durch den Befehl 209 werden 194811 Neubauten erstellt, davon 3 für Umsiedler. 6 Bauten sind bisher fertig. Imzuge des Bauprogramms 1949/50 müssen in der Gemeinde noch 11 Bauten erstellt werden, die restlos für Umsiedler bestimmt sind. An die landlosen Umsiedler kam lediglich 1 ha Gemeindeland zur Verteilung, dies wurde an 10 Umsiedler als Gartenland gegeben. Der Ortsausschuss der VdgB setzt sich aus 7 Mitgliedern zusammen. Von diesen sind 2 Großbauern; Umsiedler sind in dem Ausschuss 3 verrtreten. Die örtliche VdgB soll nach Aussagen des Bürgermeisters gut arbeiten. $65 \%$ der altortsansässigen Bevölkerung gehörten der NSDAP und deren Organen an. Bei den Gemeindewahlen 1946 hatte die Gemeinde 634 Einwohner, von denen 400 eingetragene Wähler waren. Abgegebene Stimmen insgesamt $384=96 \%$, davon SED $50 \%$, CDU $38 \%$, LDP $5,6 \%$, ungültige $6,4 \%$.

Der Wohnungsausschuss setzt sich aus 7 Mitgliedern zusammen, von denen 4 Umsiedler sind (alles Neubauern). 2 Mitglieder des Wohnungsauschusses gehören der SED an, 1 Mitglied der CDU und 1 Mitglied ist parteilos. Die Richtlinien der Deutschen Wirtschaftskommission über die Arbeit der Wohnungsausschüsse sind in Werder bei dem Bürgermeister und dem Wohnungsausschuss vollkommen unbekannt.

Der Umsiedlerausschuss setzt sich aus 7 Personen (alles Umsiedler) zusammen. Der Ausschuss hat keinerlei Arbeitsmöglichkeiten nach unseren gegebenen Richtlinien. Er besteht nur auf dem Papier bzw. werden die entsprechenden Fälle vom Bürgermeister mit dem Neubauern Topp erledigt.

Bei der Wohnraumkontrolle stellte ich folgendes fest:

Altbauer E[...] Sch [...], Haus Nr. [...], bewohnt mit seiner Ehefrau 2 Zimmer und 1 Angestellter besitzt ein weiteres Zimmer, insgesamt stehen diesen 3 Personen 56 qm Wohnfläche zur Verfügung. / [Bl.370v] 
Die Familie des Großbauern $\mathrm{H}[\ldots] \mathrm{K}[\ldots]$ besteht aus 2 Erw. und 2 Kindern sowie einer Angestellten. Diesen 5 Personen stehen 4 Zimmer mit insgesamt 102 qm Wohnfläche zur Verfügung. Die Geschwister V[...], Haus Nr. [...], bewohnen mit 3 Erw. und einer Hausangestellten 3 Zimmer von 54 qm Wohnfläche.

Der Ch[...] W[...], Haus Nr. [...], stehen mit 2 Personen 2 Zimmer mit 32 qm Wohnfläche zur Verfügung.

Der Bauer N[...], Haus Nr. [...], bewohnt mit 3 Erw. 3 Zimmer mit 52 qm Wohnfläche.

Der Bauer H[...], Haus Nr. [...], bewohnt mit 5 Erw. und 1 Kind 4 Zimmer mit 54 qm Wohnfläche.

Der Großbauer B[...], Haus Nr. [...], wohnt mit 5 Erwachsenen in 6 Zimmern mit 109 qm Wohnfläche.

Der Großbauer L[...], Haus Nr. [...], bewohnt mit 5 Erw. und 2 Kindern 5 Zimmer mit 100 qm Wohnfläche, (von den 5 Erw. sind 2 Angestellte, die in einem Zimmer schlafen.)

Der Bauer N[...], Haus Nr. [...], bewohnt mit 3 Erw. 3 Zimmer mit 55 qm Wohnfläche.

Demgegenüber stehen die Wohnverhältnisse der landlosen Umsiedler.

So bewohnt der Umsiedler W[...] mit 2 Erw. und 2 Kindern 1 Zimmer von 20 qm, das nur als Loch bezeichnet werden kann.

Der Umsiedler R[...] B [... ] bewohnt mit 2 Erw. und 2 Kindern 1 Zimmer von 20 qm Wohnfläche.

Der Umsiedler K[...] W[...] bewohnt mit 2 Erw. und 1 Kind 1 Zimmer von 16 qm Wohnfläche.

Der Umsiedler F[...] E[...] bewohnt mit 2 Personen 1 Zimmer von 11 qm Wohnfläche.

Der Umsiedler R[...] B [...] bewohnt mit 4 Erw. und 4 Kindern 2 Zimmer von 30 qm Wohnfläche.

Der Umsiedler $\mathrm{H}[\ldots] \mathrm{H}[\ldots]$ bewohnt mit 2 Erw. und 2 Kindern 1 Zimmer mit 17 qm Wohnfläche.

Die Umsiedlerin $\mathrm{M}[\ldots] \mathrm{R}[\ldots]$ bewohnt mit 1 Erw. und 2 Kindern 1 Zimmer mit 14,5 qm.

Der Umsiedler F[...] Sch[...] bewohnt mit 2 Erw. und 1 Kind 1 Zimmer von 18,5 qm Wohnfläche.

Im Gegensatz hierzu stehen wieder die Wohnverhältnisse der Umsiedler, die durch die Bodenreform Land erhalten haben. Durch die Schaffung der Neubauten werden deren Wohnverhältnisse bedeutend aufgelockert. Herr Topp, als Mitglied der Wohnungskommission, auf den krassen Gegensatz der altansässigen Bevölkerung, der landlosen Umsiedler und der Neusiedler in der Wohnraumverteilung aufmerksam gemacht, zuckte mit den Schultern und erklärte, daß die Wohnungskommission sich nicht noch unbeliebter machen könne. [Bl. 371r] 
Von den 16 Unterstützungsempfängern im Dorf sind 13 Umsiedler. Es gibt im Ort ca. 30 Arbeitslose, alles Umsiedlerfrauen. Für diese Frauen bestehen auch in der Umgebung durch die schlechten Fahrverbindungen keine Arbeitsmöglichkeiten. Genauso schwierig ist die Frage der Unterbringung jugendlicher Umsiedler in Lehrstellen. Zur Zeit arbeiten sie meistens gegen ein Butterbrot bei den Bauern.

Zur politischen Beeinflussung der Umsiedler durch die Westpropaganda ist zu bemerken, daß besonders die Frauen an den Treffen im Johannis-Stift in Spandau teilnehmen. Die Umsiedler stammen zum grossen Teil aus der Landsberger und Schweriner Gegend. Stark macht sich die reaktionäre Propaganda nicht bemerkbar, da von den entsprechenden Stellen nur im Stillen gearbetet wird. Allerdings machen sich derartige Strömungen sogar unter den Umsiedler-Neubauern bemerkbar, so hat selbst die Frau des Ortsgruppenvorsitzenden der SED und Neusiedlers Topp an einer Versammlung in Spandau teilgenommen. Der reaktionäre Einfluss unter den Umsiedlern ist hauptsächlich auf das Wirken der CDU-Ortsgruppe in Werder zurückzuführen. Der Vorsitzende der CDU, Reinhold Brechlin (Umsiedler und Neubauer), ist hier scheinbar der Kopf. So äußerte er sich in der Versammlung zur Durchführung des 2-Jahresplanes im eigenen Dorf, daß er im nächsten Jahr nicht 2 Schweine mehr haben wird als jetzt, wenn man ihm dieselben nicht gibt.

Zur Beschwerde Brandt ist folgendes zu sagen: [...] [Bl.371v] [...]

Betrachtet man die Gegenüberstellung der Wohnverhältnisse der Großbauern und der landlosen Umsiedler, so ist schon hieraus zu sehen, daß nicht nur eine Umquartierung grösseren Stiles durchgeführt werden müßte, sondern auch dem N. anderen Wohnraum zugeteilt werden kann. [...]

Insgesamt ist zu Werder zu sagen, daß es sich um eine Gemeinde handelt, in der es 3 Schichten gibt, 1. die Großbauern, 2. die Neusiedler (einschl. Umsiedler), die jetzt tonangebend sind, und 3. die Landlosen (meist Umsiedler), die von beiden anderen Gruppen ausgebeutet und traktiert werden.

\section{(85) Anordnung der Landesregierung Brandenburg zur Verbesserung der Wohnverhältnisse. - Potsdam, 9. Juli 1949 (Auszüge)}

BLHA, Rep. 250 Landratsamt Beeskow-Storkow, Nr. 824, unfol. - Druck, 1 Bl. - L. o.: „Landesregierung Brandenburg / Minister für Arbeit und Sozialwesen / Gesch.-Z.: II D - 6371 - 5“. - R. o.: „Potsdam, den 9. Juli 1949/Alte Zauche 67, Haus Ia“.- Überschrift: „Anordnung für die Durchführung einer Sonderaktion zur Verbesserung der Wohnverhältnisse der Umsiedler und der werktätigen Bevölkerung“. - Unterzeichnet „Schwob“. - Kopierstift-Eingangsvermerk „Eg 16/7 49 / Mtl“ [Mertel], daneben blaugrüner Sichtvermerk; am Ende Bleistiftvermerk „Vermerk: Wir fahren selbst hin in die Gemeinden u. geben gleich die Anweisungen. / Mtl.“

Die Wohnverhältnisse der Umsiedler und der werktätigen Bevölkerung sind nicht befriediegend. Den Umsiedlern ist im Durchschnitt nur die Hälfte des Wohnraumes der ortsansässigen Bevölkerung zugeteilt worden. Nach Feststellung einer Landeskontrollkommission steht den Umsiedlern und Industriearbeitern vielfach ein um 50\% geringerer Wohnraum zur Verfügung 
als der übrigen Bevölkerung. Diesen Zuständen muß abgeholfen werden. Zur Verbesserung der Wohnverhältnisse der Umsiedler und der werktätigen Bevölkerung müssen daher außergewöhnliche Maßnahmen ergriffen werden, für welche die nachstehende Anordnung gilt. / [...]

\section{(86) Beschwerde einer Vertriebenen über Schikanierung durch ihren Vermieter. -} Beeskow, 29. Juli 1949

BLHA, Rep. 250 Landratsamt Beeskow-Storkow, Nr. 824, unfol. - Typoskript (Durchschlag), 1 Bl. - L. o. ,- Sekretatiat des Landrats -,.. - R. o. Datierung „Beeskow, den 29.7.1949“. - Kopierstift-Unterschrift „E. G[...]“.

Hier erscheint Frau Emma G[...] aus Alt-Schadow und gibt folgendes zu Protokoll:

Wir sind Umsiedler aus Gumbinnen in Ostpreussen und wohnen seit 10. Mai 1946 bei dem Bauern R[... M [...]. Meine Familie besteht aus 4 Personen. Die Wohnung besteht aus 1 Zimmer, 1 Küche und 1 Kammer. Seit einer Überprüfung der Umsiedlerwohnungen in Alt-Schadow durch Herrn Mertel und Frau Förster werden wir laufend schikaniert, weil der Vermieter, Herr $\mathrm{M}[\ldots]$, annimmt, dass wir uns beschwert hätten. Die Grobheiten der Familie $\mathrm{M}[\ldots]$ arten sogar in Tätlichkeiten aus.

Ich bitte hierdurch um Überprüfung und wenn irgend möglich, um umgehende Abstellung dieses Mißstandes, da es unter diesen Umständen einfach unmöglich ist, weiter dort zu wohnen. Weiterhin ist die Wohnung auch zu klein und ich bitte um Zuweisung einer etwas grösseren.

\section{(87) Überprüfung der Wohnverhältnisse der Vertriebenen in der Gemeinde Sauen im Kreis Beeskow-Storkow. - Beeskow, 26. September 1949}

BLHA, Rep. 250 Landratsamt Beeskow-Storkow, Nr. 824, unfol. - Typoskript (Durchschlag), 1 Bl. - L. o.: „- Sekretariat des Landrats -“. - R. o. Datierung „Beeskow, den 26.9.1949“. - Adresse: „An die / Abteilung VII/Kreiswohnungsamt / im Hause.“ - Betreff: „Betr.: Unterbringung der Umsiedler im Ort Sauen.“ - Unterschrift: „gez. Brosien / Landrat." L. u. „Für die Richtigkeit: [gez.] Malskeit“.

Bei einer Überprüfung der Gemeinde Sauen durch mich musste ich feststellen, dass eine Vielzahl von Umsiedlern unter menschenunwürdigen Verhältnissen untergebracht worden ist. In einer darauf folgenden Abendversammlung wurde von mir eine Kommission gebildet, die die Überprüfung des gesamten vorhandenen Wohnraumes einschl. des Schlosses des Geheimrates Bier $^{2282}$ vornimmt. Ich erwarte, dass am Mittwoch, den 28.9.[19]49, ein Beauftragter des Kreiswohnungsamtes im Ort Sauen mit der dortigen Ortskommission die Dinge überpüft und nach den Wünschen der Ortskommission abändert. Vor allen Dingen ist darauf zu achten, dass das Haus Bier auf keinen Fall ohne weitere Belegung bleibt.

2282 [August Bier (1861-12.3.1949), ab 1912 (Wald-)Gutsbesitzer in Sauen, angesehener Mediziner (Chirurg) der Berliner Universität, als Emeritus ab 1933 regimenahe.] 


\section{$2.2 \quad$ Versorgung (1945-1949)}

(88) Schreiben des Landrates des Kreises Westprignitz, Abt. Rechtswesen, an den Bürgermeister in Uenze. - Perleberg, 27. Juni 1946

BLHA, Rep. 250 Landratsamt Westprignitz, Nr.257, Bl. 184. - Typoskript (Durchschlag). - L.o. „Der Landrat/ des / Kreises Westprignitz / Abteilung Rechtswesen/Akt.-Z: B 7 - Dr.W/Go.“ - R. o.: Perleberg, den 27. Juni 1946. - Darunter 1. Schreibverfügung: „1.) An den Herrn Bürgermeister/in Uenze.“ - O. Mitte behördeninterner Bearbeitungsstempel: „zur Kanzlei: / Kanzl. erl.[edigt]: / gefertigt: / gelesen: [für alle geltend (Klammer):] „27/6 Go“/ „ab: 28/6 Go.“- Rückseite: Weitere Schreibverfügung: „2) An/Frau Ilse von König/bei Herrn B[...]/in Kleinow.“ [Kurznachricht über ergangenes Ersuchen an Bürgermeister und Ankündgung, „nach Eingang des Berichts auf die Angelegenheit zurückzukommen“, 3) Wiedervorlageverfügung für 10.7.1946, unterzeichnet „I.A. [Paraphe], darunter handschriftlich „Herre nochmals vorladen. / 16/8 46 [gez. (Paraphe)].“ [Herre war der stellv. Bürgermeister der Gemeinde Uenze.]

Betrifft: Hausrat der Familie von König.

Nach dem Gesetz über die Bodenreform wurde der Grundbesitz und das landwirtschaftliche Zubehör der Gutsbesitzer enteignet. Unter die Enteignungsbestimmungen fielen jedoch nicht der Hausrat und das Mobiliar. Frau von König - z. Zt. wohnhaft in Kleinow bei dem Bauern $B[\ldots]$ - bittet um Herausgabe des Mobiliars. Sofern dieses Mobiliar nicht von der Besatzungsmacht als Beutegut in Anspruch genommen und an die Siedler verschenkt worden ist, ist dem Antrage stattzugeben. Sie wollen daher zunächst feststellen, wo sich Mobiliar befindet, das Frau von König gehört. Frau von König ist bereit, den Siedlern das zur Aufrechterhaltung ihres Hausstandes notwendige Mobiliar nach folgender Massgabe leihweise zur Verfügung zu stellen:

Bei den Flüchtlingsfamilien L[... ], F[...], S[... und evtl. G[...], die etwa im März/April 1945 als Flüchtlinge nach dort gekommen sind - nicht gesiedelt haben - und im Zuge der Freimachung der Gutshäuser für Siedler zu Bauern umquartiert sind, befinden sich Möbel, die Frau von König den Siedlern gegen Herausgabe der bei L[...] u. a. untergestellten Möbel leihweise zur Verfügung stellen will. Die Möbel aus dem Gutshaus, die von den Siedlern z. Zt. gebraucht werden, möchte Frau von König mit an ihren neuen Wohnsitz nehmen.

Ich ersuche, die Angelegenheit umgehend mit den in Frage kommenden Siedlern zu besprechen und mir über das Ergebmis bis zum 10. Juli ds. Js. Bericht zu erstatten.

\section{(89) Leserbrief eines in der Lagerbetreuung tätigen Vertriebenen an die Zeitung „Der} Morgen“. - Kirchmöser/Havel, 20. Juli 1946

BLHA, Rep. 333 SED-Landesleitung Brandenburg, Nr. 574, Bl.35. - Typoskript (Abschrift), 1 Bl. - Absender: „W. Leichnitz / Bahnhofstr. 2“. - Datierung: „Kirchmöser/Havel, den 20.7.1946“. - Adresse: „An die / Schriftleitung / „Der Morgen“ / Berlin W 8 / Taubenstr. 48/49“. - Betreff/Bezug: „Betr.: Umsiedlerbetreuung. Ihr Artikel Betreuung der Umsiedler und Heimkehrer von Vizepräsident Dr. Uhle ${ }^{2283}$ in Nr. 157 vom, 9.7.46.“

2283 [Reinhard Uhle (1890-1973), LDP, Vizepräsident der Landesverwaltung Sachsen für Justiz und auch für Gesundheit.] 
Obiger Artikel Ihrer Zeitung ist vielen tausend Umsiedlern „aus der Seele“ gesprochen. Ich bin in der Lagerbetreuung eines Rückführungslagers von etwas [so!] 2000 Umsiedlern tätig, die mit großem Interesse Ihren Artikel gelesen haben. Es erübrigt sich wohl, dem Referat etwas hinzuzufügen.

Wie jedoch diese Umsiedlerbetreuung in der Praxis aussieht, woll [so!] nachstehende Mitteilung zeigen:

Rund 2000 Umsiedler aus Schneidemühl mit etwa 300 Kindern sind bei uns untergebracht. Die Männer, meist Eisenbahner, haben in benachbarten Städten Beschäftigung gefunden. Frauen, Kinder, Arbeitsunfähige und Alte sind in wohnungswürdigen Unterkünften oder auch in Privatquartieren untergebracht.

Man hat nun behördlicherseits sehr schnell die Gemeinschaftsverpflegung abgeschafft, dafür den Leuten Lebensmittelkarten verabfolgt. Dadurch sind sie nun den einheimischen Bewohnern gleichgestellt und man hat ihnen die Umsiedlereigenschaft abgesprochen. Es ist aber nicht gelungen, alle Umsiedler in feste Wohnungen zu bringen. Die nun in Massenquartieren und Baracken wohnenden Siedler besitzen keine eigenen Kocheinrichtungen, sie kochen im Freien oder gemeinsam. In Privatquartieren sind sie auf die Mitbentzung der Küche des Grundmieters angewiesen. Sie können dann aber die Küche nur gelegentlich benutzen, sind also den Grundmietern gegenüber erheblich im Nachteil. Bei zwangsweiser Einweisung, die in der Praxis aber noch kaum vorgenommen ist, besteht von Anfang an eine Ungerechtigkeit, daß die Grundmieter, die ihr gesamtes Vermögen behalten durften, sich auch noch als die Herren der Wohnung aufspielen. Sie haben fast alle Kleinvieh, besitzen Hausgärten u. Pachtland, haben nicht nur ihre neuen, sondern auch ihre alten abgetragenen Sachen behalten. Sie können sich also jederzeit aus alten neue Sachen anfertigen lassen usw. Nun genießen sie auch noch den besonderen Schutz der Behörden. Ihr Eigentum wird unter allen Umständen geschützt, Feld- u. Gartendiebstähle werden besonders schwer bestraft. Jeder gerecht denkende Mensch wird diesem auch zustimmen. Wo aber gibt es ein Gesetz, daß die Gartenbesitzer verpflichtet, aus ihren Hausgärten auch nur ein Pfund Obst oder Beeren abzugeben?

On es die maßgebenden Stellen wissen, wie einem Umsiedlerkinde zu mute ist, das täglich die früchtebehangenen Bäume $u$. Beerensträucher sehen muß, aber nie auch nur einen Apfel oder Birne bekommt? Das in der Schule ansehen muß, wie die Kinder der Einheimischen täglich ihr Obst u. ihre Beeren vor den Augen der Umsiedlerkinder essen. Unsere Kinder haben während zwei Ernteperioden nicht ein Pfund Obst bekommen. [Bl. 35v]

Die Einheimischen erhalten neben ihren Gartenerzeugnissen auch noch dieselbe Menge Obst u. Gemüse u. werden von den einheimischen Geschäftsleuten auch noch bevorzugt bedient. Genau so verhält es sich mit der Ausgabe von Bezugscheinen. Einheimische können sich immer wieder aus alten Sachen neue machen lassen, während die Siedler keine alten Sachen besitzen. Sie werden aber, weil sie ja angeblich keine Umsiedler mehr sind, genauso behandelt. 
Wohl sieht man große Herden von Gänsen u. Enten durch die Dorfstraßen watscheln. Wir haben aber noch nie, auch nur ein Gramm Geflügelfleisch erhalten. Sind diese Güter nur für die Einheimischen als zusätzliche Nahrung gedacht?

Unsere Umsiedler hatten sich zusammengetan u. gemeinsam mit Zustimmung der Umsiedlerstelle beim Landratsamt einen Waggon Kartoffeln gekauft. Der Amtsvorsteher ließ die Kartoffeln zu Gunsten einer Werkküche beschlagnahmen. Unsere Umsiedler brachten unter Zurücklassung eigener Sachen eine Schreibmaschine mit, die im Lager dringend benötigt wurde. Die Maschine wurde bei der Polizei ordnungsmäßig auf Verlangen gemeldet. Auch sie wurde vom Amtsvorsteher beschlagnahmt $u$. ist für uns verloren.

Die Landbevölkerung erhält erheblich weniger Lebensmittel zugeteilt als die Stadtbewohner. Fast kein Gemüse, kein Obst, keine Fische usw. Es ist anzunehmen, daß der Gesetzgeber es haben will, daß sich die Landleute diese Dinge „an der Quelle“ selbst beschaffen, was ja auch richtig ist. Den Landleuten ist auf Grund ihrer Erzeugung die Beschaffung sehr leicht möglich.

Unsere auf dem Lande untergebrachten Umsiedler, die aber in der Industrie beschäftigt werden, können sich, obwohl sie auf dem Lande wohnen, nichts Zusätzliches kaufen, weil sie ja nichts zum Tauschen haben. Für Geld gibt es ja auf dem Lande schon längst nichts mehr.

Ährenlesen, Holzsammeln usw. ist bei schwerer Strafe verboten. Mühsam erstandenes Obst oder Gemüse wird rücksichtslos von der Polizei abgenommen. Fast immer trifft es den Umsiedler, die ja selbst nichts ernten können.

Warum werden bewußt zwei Klassen von Staatsbürgern geschaffen, die einen, die alles behalten durften und noch in jeder Weise geschützt werden, und andere, die Umsiedler oder Bombengeschädigte sind. Wenn es überhaupt noch einen Eigentumsbegriff gibt, warum nur für die Besitzenden? Wer hat unser Eigentum geschützt? Wie denkt man sich einen gerechten Ausgleich? Oder ist der Gedanke, daß die Umsiedler u. Ausgebombten die Alleinschuldigen am Kriege sind, auch schon Allgemeingut geworden? Warum sind die Sparkonten für Umsiedler immer noch gesperrt, obwohl die Einheimischen ihren Freibetrag längst erhalten haben. Gerade die Umsiedler gebrauchen ihr Geld zur Beschaffung des fehlenden Hausrats nötiger als alle anderen Volksgenossen. Sollten wir Umsiedler immer die „Gezeichneten“ im wahren Sinne des Wortses bleiben, weil wir in Lumpen gehüllt einhergehen müssen?

Wenn es möglich war, bei der Bodenreform einen Eingriff in das Privatvermögen der Besitzenden zu machen, dann müßte es doch auch möglich sein, diesen Eingriff bei den anderen Besitzenden zugunsten der Umsiedler u. Bombengeschädigten zu machen? Wir Umsiedler wären dankbar, hierüber noch einmal etwas zu hören.

Sollte die Veröffentlichung obigen Schreibens in Ihrer Zeitung nicht möglich sein, so bitte ich, das Schreiben dem Verfasser des Artikels in Nr. 157 zu übersenden.

Hochachtungsvoll! gez. Leichnitz 
(90) Antrag auf Zuteilung von Bezugsscheinen für Kleidung für einen Mitarbeiter der Umsiedlerabteilung. - Potsdam, 3. August 1946

BLHA, Rep. 601 VdN, Nr. 1562, unfol. - Typoskript (Durchschlag), 1 S., mit eigenhändiger Bleistift-Unterschrift „... [?]“ und Stempel „Referat Opfer des Faschismus Potsdam“. - Absender: „Der Magistrat der Stadt Potsdam / - Opfer des Faschismus -“. - Datierung o. r.: „Potsdam, den 3. Aug. 1946“. - Adressiert „An das Wirtschaftsamt Potsdam / Potsdam“. - Ohne Betreff. - Bleistiftvermerk auf Vorderseite o. 1.: „E“.

Herr Erich Kuhn, wohnhaft in Potsdam, Drevesstraße 1, ist anerkanntes Opfer des Faschismus. Es wird gebeten, ihm wenn es irgend möglich ist, Bezugscheine über Kleidungsstücke, vor allem für einen Anzug auszuhändigen. Herr Kuhn besitzt außer dem, was er auf dem Leibe hat, nichts anzuziehen. Er ist bei der Provinzialverwaltung beschäftigt und schon aus diesem Grunde erscheint es angebracht, Herrn Kuhn zu unterstützen.

\section{(91) Antrag eines Mitarbeiters der Umsiedlerabteilung auf Zuteilung einer Schlafcouch. - Potsdam, 9. Mai 1947}

BLHA, Rep. 601 VdN, Nr. 1562, unfol. - Typoskript, 1 Bl., mit eigenhändiger Kopierstift-Unterschrift „Kuhn“. - Absender: „Erich Kuhn 2284, [r. o.:] Drevesstr. 18/19 bei Schwarz“. - Datierung o. r.: „Potsdam, den 9. Mai 1947“. - Adressiert „An den Stadtausschuß O. d. F. / z. Hd. Frau Berg-André / Potsdam / Friedrich Ebert Str.“ - Betreff: „Antrag auf Zuteilung einer Schlafcouch“. - Bleistiftvermerk auf Vorderseite u. 1.: ,zurückstellen. 24.5.“

Der Unterzeichnete ist am 7.3.05 in Ostpreußen geboren. Ich war in Königsberg Mitglied der KPD und arbeitete bis zum 4.2.35 dort illegal. Dann wurde ich wegen Vorbereitung zum Hochverrat mit Zuchthaus bestraft. Die Zuchthausstrafe verbüßte ich in Wartenburg/Ostpr., anschließend war ich im K.Z.-Lager Sachsenhausen bei Oranienburg. / 1943 wurde ich dann zwangsläufig Soldat bei den $999^{2285}$ und war auf dem Peleponnes ${ }^{2286}$ auch wieder kurzfristig wegen illegaler Arbeit verhaftet. / Nach Rückkehr aus Jugoslawien im vergangenen Jahre verblieb ich in Potsdam, weil eine Rückkehr nach Königsberg nicht mehr möglich war. Bin jetzt bei der Provinzialverwaltung Abt. Umsiedler und Heimkehrer angestellt. / Ich wohne jetzt möbliert und sehr dürftig und besitze nichts, darum ersuche ich um Überlassung der Schlafcouch als eigene Schlafgelegenheit nach.

\section{(92) Bericht über eine Besprechung zur Vorbereitung der „Umsiedlerwoche“} in Luckenwalde. - Luckenwalde, 6. Oktober 1947

BLHA, Rep. 250 Landratsamt Luckenwalde, Nr. 105, Bl.311. - Typoskript (Durchschlag, außer Verfügung), 1 Bl., mit Kopierstift-Unterschrift des Informationsamtsmitarbeiters „W. Süßenbach“. - O.1. „Der Rat des Kreises / Luckenwalde / Allgem. Verwaltung / Az.: Ia/8 Sü/He.“ - O.r. Datierung „Luckenwalde, den 6. Oktbr. 1947. / Linden-Allee 3“. - Rücks. u.1. Verfügung: „2.) Verteiler: / Die Tagesspost/Märk. Volksstimme / Neues Deutschland / Informationsamt /3.) ZdA“. - Überschrift: „Besprechung zur Vorbereitung der ,Umsiedlerwoche“."

2284 [Näheres über ihn siehe oben im Kapitel III 1, Abschnitt „Umsiedlerverwaltung“.]

2285 [Bewährungsbataillon 999 (Strafbataillon bzw. -division) der deutschen Wehrmacht.]

2286 [Die (!) Peloponnes, Halbinsel in Griechenland.] 
Im Auftrage des Kreisumsiedlerausschusses Luckenwalde versammelten sich am Sonnabend, dem 4.10.47, die Vertreter der antifaschistischen Parteien, die Bürgermeister des Kreises, die kirchlichen Behörden und alle in Frage kommenden Dienststellen zu einer Besprechung über die Ende ds. Mts. stattfindende Sammelaktion zu Gunsten der Umsiedler und Ausgebombten. Erschienen wr ausserdem auch Herr Landrat Dr. Ludwig und Herr Ministerialrat Friedrichs von der Landesregierung Brandenburg.

Herr Krause von der Abtlg. Amt für Umsiedler gab einen umfangreichen Rechenschaftsbericht. Im Anschluss daran sprach Herr Ministerialrat Friedrichs über die nun stattfindende „Umsiedlerwoche“ vom 26.10-2.11.47. Herr Friedrichs führte u.a. aus: „Es muss eine umfangreiche Sammlung durchgeführt werden. In allen Zeitungen, auf allen öffentlichen Plätzen, in Veranstaltungen, sowie im Rundfunk wird auf die Bedeutung der Umsiedlerfragen hingewiesen werden." Vorschläge über die Durchführung dieser Umsiedlerwoche wurden vom Referenten reichlich gebracht.

Die im Anschluss stattgefundene Diskussion wurde von den Anwesenden lebhaft geführt. Besondere Ausführungen machte der Landrat, der noch einmal an den Sinn und Zweck dieser „Umsiedlerwoche“ erinnerte. Für die tüchtigsten und rührigsten Landgemeinden des Kreises wurde vom Landrat ein Ehrenpreis für vorbildliche Arbeit zur „Umsiedlerwoche“ ausgesetzt, der in Form von Textilien und anderen Gebrauchsgegenständen zur Verteilung gelangen wird. [Bl. $311 \mathrm{v}]$

Ausserdem wird sich auch an dem betreffenden Sonntag die gesamte Stadt- und Kreisverwaltung, vom Landrat bis zum Bürolehrling, an einer grossangelegten Holz-Einschlageaktion zur Verfügung stellen. Das geschlagene Holz wird ebenfalls unter die bedürftigsten Umsiedler zur Verteilung gelangen.

Zum Schlusse sprach Herr Ministerialrat Friedrichs noch einmal an alle die Bitte aus: „Keine Stunde und kein Tag darf während der „Umsiedlerwoche“ vorübergehen, um nicht noch einmal an die Herzen und Hände aller zu appellieren, damit den Umsiedlern wirklich geholfen werden kann!“

\section{(93) Bericht über eine Veranstaltung zur „Umsiedlerwoche“ in Luckenwalde. -}

\section{Luckenwalde, 29. Oktober 1947}

BLHA, Rep. 250 Landratsamt Luckenwalde, Nr. 105, Bl. 299. - Typoskript (Durchschlag, außer Verfügung), 1 Bl., mit Paraphe „WKu-,; des Informationsamtsmitarbeiters Werner Kummer; vereinzelte handschriftliche Korrekturen (Druckmanuskript, o. M. handschriftlich „Zeitung.“). - O.1. „Der Rat des Kreises / Luckenwalde / Allgem. Verwaltung / Az.: Ia/8 Sü/He.“ - O.r. Datierung „Luckenwalde, den 29. Oktbr. 1947./ Linden-Allee 3“. - U.1. Verfügung [Verfügung „1.)“ neben Überschrift]: „2.) Verteiler: / Die Tagespost / Märk. Volksstimme / Neues Deutschland / 3.) ZdA“.

Grossveranstaltung zur Umsiedlerwoche.

Die SED Ortsgruppe Luckenwalde hat am Montag, den 27.10.47 die Bevölkerung zu einem grossen bunten Abend im „Bürgerhof“ eingeladen. Die sozialistische Spielgemeinschaft und 
eine erzgebirgische Heimatlieder-Singgruppe des Landessenders Sachsen übernahmen die Ausgestaltung des Abends.

Stadtrat Andres führte in seiner Begrüssungsansprache u. a. aus: „Ich danke all denen, die mitgeholfen haben, den Umsiedlern ihr schweres Los zu erleichtern. Vieles ist schon für sie getan worden, aber viel mehr muss noch getan werden. Die Umsiedler müssen eingegliedert werden und als gleichberechtigte Bürger unter uns wohnen; dafür werden wir arbeiten. Dass schon viel geschafft ist, beweist, dass bereits in der Stadt- und Kreisverwaltung 240 Umsiedler als Angestellte beschäftigt sind. Gern wollen wir beim Aufbau ihrer neuen Heimat weiter unsere Pflicht erfüllen und ihnen helfen. Wir wenden uns in dieserr „Umsiedlerwoche“ an alle Einwohner der Stadt: „Geben Sie, was Sie noch Entbehrliches besitzen! Geben Sie es mit freudigem Herzen!“, damit diese Aktion auch ihren vollen Erfolg verspricht."

Im Mittelpunkt des bunten Abends aber stand die Ansprache des Landtagsabgeordneten Völz, SED. ${ }^{2287}$ „Können die Umsiedler in unserer Heimat eine neue Heimat finden? Sie werden eine neue Heimat finden! Dafür werden alle demokratischen Parteien und Verwaltungsstellen sorgen und sich einsetzen. Im Gegensatz zur Westzone, wo verantwortungslose Elemente ein verbrecherisches Spiel mit den Umsiedler[n] treiben, ihnen immer wieder eine Rückgliederung nach dem Osten versprechen. Beweisen wir in der Ostzone, dass wir es ernst meinen und ihnen hier ein neues Heim schaffen. Wir reden nicht von Neubürgern, wie in der Westzone, sondern wir helfen überall an der Verschmelzung mit den Alteingesessenen. Unser oberstes Ziel ist Befreiung aus materieller und seelischer Not. Eine eingehende Betreuung, Schaffung neuer Wohnräume, Sammlung von Textilien, Möbeln und Hausrat und nicht zuletzt Unterstützung auf finanzielle Art. Das ist unsere Hilfe. Unser Wunsch ist auch, dass es nun endlich dazu kommen möge, dass das Wort „Umsiedler“ und alle „Umsiedlerausschüsse“ fortfallen, denn ihre Not ist auch unsere Not, sie zu überwinden geht uns alle an!

Wir müssen die Umsiedlung aus den Folgen einer verbrecherischen Politik des Naziregimes betrachten. 15 Millionen Deutsche mussten ihre Heimat verlassen. Sie sind die Opfer dieses verbrecherischen Spiels. Im wesentlichen aber sei gesagt, dass in diesem Jahr der Abschluss der grossen Umsiedlung erfolgt.

Aufgabe der Umsiedlerwoche ist, die Abseitsstehenden aufmerksam zu machen, denn ihr Schi $[\mathrm{c}]$ ksal ist auch unser Schi[c]ksal. Deshalb ist unsere Parole: „Die Umsiedler werden bei uns eine neue Heimat finden!“

Die vorgetragenen Lieder und Rezitationen von der Singegruppe des Landesenders Sachsen ernteten nieendenwollenden Beifall. Mit den Liedern „Schlafe, schlafe süsser Knabe[“] v. Schubert $^{2288}$ und „Feierabend“ von A. Günther ${ }^{2289}$ wurde der bunte Abend beschlossen.

2287 [Otto Völz (geb. 1901 Stettin), SED (zuvor SPD), ab 1945 Zweiter Bürgermeister von Strausberg, Miterrichter und Hauptgeschäftsführer der Industrie- und Handelskammer für Brandenburg.]

2288 [„Schlafe, schlafe, holder süßer Knabe, Wiegenlied von Franz Schubert, 1816.]

2289 [„Feieromd“, bekanntes erzgebirgisches Volkslied von Anton Günther, 1903.] 


\section{(94) Bericht über eine Veranstaltung zur „Umsiedlerwoche“ in Jüterbog. - Luckenwalde, 27. Oktober 1947}

BLHA, Rep. 250 Landratsamt Luckenwalde, Nr. 105, B1. 300. - Typoskript (Durchschlag, außer Verfügung), 1 Bl., mit Kopierstift-Unterschrift des Informationsamtsmitarbeiters „W. Süßenbach“, daneben Stempel „Der Landrat des Kreises Luckenwalde / Informationsdienst“ (Druckmanuskript, o. M. handschriftlich „Zeitung“). - O.l. „Der Rat des Kreises / Luckenwalde / Allgem. Verwaltung / Az.: Ia/8 Sü/He.“ - O.r. Datierung „Luckenwalde, den 27. Oktbr. 1947. / Linden-Allee 3“. - Rücks. u.1. Verfügung [Verfügung „1.)“ neben Überschrift]: „2.) Verteiler: / Informationsamt / Märk. Volksstimme / Die Tagespost / Neues Deutschland / 3.) ZdA“.

[...] [Vorangestellt ist ein separater Bericht „30 Jahre sozialistischer Aufbau in der Sowjet-Union“.]

Erste Grossveranstaltung zur Umsiedlerwoche.

In Jüterbog wurde durch eine Gemeinschaftsveranstaltung des Kulturbundes, des Stadtchores und der FDJ aus Dorf-Zinna die Umsiedlerwoche festlich eröffnet. Ein Mitglied des Umsiedlerausschusses leitete die festliche Stunde mit den Worten ein: „Wir Umsiedler sind Ausgebombte, die vom Schi[c]ksal so hart betroffenen, wollen mithelfen am Aufbau des neuen demokratischen Deutschlands, wir wünschen aber auch volles Verständnis uns gegenüber und eine tatkräftige Unterstützng“.

Lieder wie „Im schönsten Wiesengrunde“ oder „O Täler weit, o Höhen“, vorgetragen vom Stadtchor, ernteten reichen Beifall. Else Mendel-Oberüber ${ }^{2290}$ (Violine) und Addi Schmidt (Klavier) brachten den Walzer in A-Dur von Johannes Brahms und die 2 ungarischen Tänze von BrahmsJoachim zum Vortrag. Ein nicht endenwollender Beifall war der Dank für die Darbietungen.

Gleichzeitig fand im Saal eine Ausstellung von den Umsiedlern des Dorfes Zinna über die Erzeugnisse der Produktiv- und Handelsgenossenschaft für Glas[-] und Bijouterieindustrie statt. Besondere Beachtung fanden die statistischen Aufzeichnungen, aus denen hervorging, dass die Belegschaft von Mai [19]46 von 50 Arbeitern bis 1.10.[19]47 auf über 250 gestiegen sind. Für 1 Million Reichsmark Erzeugnisse wurden seit der Gründung umgesetzt. 50 000.- RM wurden an Löhnen für die dort be- [Bl.300v] schäftigten Umsiedler ausgezahlt. In der Entwicklung der Landwirtschaft konnte ebenfalls erfreulicherweise die Feststellung gemacht werden, dass es auch hier vorwärts gegangen ist. Der Anfang war sehr schwer. Eine Ziege war der Bestand, während jetzt 42 Ziegen im Dorfe gezählt werden. Ebenfalls beachtenswert ist die Schafzucht. Von den anfänglichen 2 Schafen im Dorf sind es nun 32 Stück. Pferde und Kühe konnte fast jeder einzelne erhalten.

Eine ähnliche Entwicklung zeigt die Beschaffung von Ackergeräten. 6 Pflüge waren der Anfang, während nun 32 vorhanden sind. Ackerwagen war 1 vorhanden, jetzt jedoch stehen 36 zur Verfügung. Bevölkerungsmässig stieg die Kopfzahl der Gemeinde von 280 auf 537.

Auch der Rundfunk war Zeuge der Veranstaltung, besuchte die Ausstellung und führte im Anschluss daran Gespräche mit Umsiedlern und Mitgliedern der Kreisverwaltung Luckenwalde. 


\section{(95) Bericht des Bürgermeisters von Deibow über die „Umsiedlerwoche“ an den Landrat des Kreises Westprignitz. - Deibow, 9. November 1947}

BLHA, Rep. 250 Landratsamt Westprignitz, Nr. 256, Bl. 51. - Adressiert: An den Herrn Landrat, Abt. Arbeit u. Sozialwesen VII/4 - Umsiedler - in Perleberg. - Typoskript mit eigenhändiger Unterschrift des Bürgermeisters Höger. Eingangsstempel Landrat in Perleberg 15. Nov 1947 (No. 99616).

\section{Bericht über die Umsiedlerwoche}

1. Besprechung in der Sitzung der Gemeindevertretung.

2. Besprechung mit den Parteien u. Organisationen.

3. Anbringung von Bekanntmachungen und Plakaten.

4. Strassenumzüge durch die Jugend.

5. Es ist die Wahrnehmung gemacht worden, dass die Umsiedler mit Möbeln versehen sind und dass ihnen von den Bauer[n] alle Wirtsch[afts-] Geräte zur Verfügung gestellt werden, die sie selbst besitzen.

6. Daher alles gute Beispiele.

7. Schlechte Beispiele keine.

8. Die hiesigen Umsiedler und Flüchtlinge wohnen mietefrei in den mit allem Mobiliar ausgestatteteten Altsitzerwohnungen und Bauernstuben. Zum Teil müssen sie noch deren Küchen mitbenutzen. Wegen Beschaffung von Kochherden habe ich bereits berichtet. Da die hiesige Gemeinde mit Umsiedlern überlastet wuirde, mussten die Altsitzer ihre Wohnungen verlassen und sehr beengt untergebracht werden. Wo noch einzelne Möbelstücke fehlten, ist durch die Sammlung Ausgleich geschaffen worden. Es fehlen aber noch drei Kleiderschränke. Hoffentlich kann uns höheren Ortes dazu verholfen werden, indem Möbelfabrikanten angewiesen werden, solche gegen Geld zu liefern. Die eingesammelten 190,- RM werden dazu verwendet. Es können wohnliche Verbesserungen erst vorgenommen werden, wenn Baumaterialien werden vorhanden sein. Zur Zeit gibt es leider noch nicht mal einen Nagel zu kaufen. Leibliche Not ist aber noch viel vorhanden, weil es viel zu wenig Kleidung gibt. Die Seelische Not ist aber noch riesengross.

\section{(96) Bericht des Vorsitzenden des Ortsumsiedlerausschusses Wolfshagen an den Landrat des Kreises Westprignitz. - Wolfshagen, 12. November 1947}

BLHA, Rep. 250 Landratsamt Westprignitz, Nr. 256, Bl. 65. - Manuskript mit eigenhändiger Unterschrift des Vorsitzenden des Umsiedlerausschusses [Fandung?]; Eingangsstempel Landrat in Perleberg 15. Nov 1947.

\section{Bericht über die Umsiedlerwoche der Gemeinde Wolfshagen}

Auf Anregung des Vorsitzenden des Umsiedlerausschusses haben SED- und Gemeindeversammlung stattgefunden, wo über die Umsiedlerwoche beraten wurde.

In der SED-Versammlung wurde beschlossen, dass alteingesessene Genossen (soweit sie in der Lage wären) Spenden im Gemeindebüro abgeben sollten, eventuell sich persönlich für die 
Sammlung einzusetzen. / In der Gemeindeversammlung wurden vom Bürgermeister die alteingesessenen Gemeindemitglieder auf die Not der Umsiedler hingewiesen und aufgefordert, sich reichlich an der Spende zu beteiligen. Auch sind Propagandablätter ausgehängt und ausgegeben worden.

Trotz der vielen Hinweise auf den Ernst der Sache sind die Spenden ausgeblieben. Die SED in den Ortsteilen Wolfshagen und Hellburg hat versagt. - Ausser dem Ortsgruppenleiter, der ein Paar Lederschuhe und Ledergamaschen gespendet hat, sind keine weiteren Spenden eingegangen. Im Ortsteil Wolfshagen sind von den ansässigen Bewohnern keine Spenden eingegangen. Wenn auch nur von diesen Bewohnern eine kleine Anzahl vorhanden ist, so ist doch festgestellt worden, dass bei etlichen doch noch verschiedene Möbelstücke und Hausgerät auf dem Boden als Gerümpel aufbewahrt werden. Also ist anzunehmen, dass sie für die Umsiedler nichts übrig haben. / Ebenso ist es im Ortsteil Hellburg. / In den Ortsteilen Dannhof und Horst war das Ergebnis in D. befriedigend, in H. sehr mäßig. / Die gespendeten Sachen von den Ortsteilen Dannhof und Horst sind an diejenigen Umsiedler verteilt worden, welche nicht gesiedelt haben. Es handelt sich hier hauptsächlich um alte Leute und alleinstehende Frauen mit Kindern. Viele Umsiedler, die noch dringend Hausgerät gebrauchen, mussten unberücksichtigt bleiben.

\section{(97) Bericht des Vorsitzenden des Ortsumsiedlerausschusses Breese an den Landrat des Kreises Westprignitz. - Breese, 14. November 1947}

BLHA, Rep. 250 Landratsamt Westprignitz, Nr. 256, Bl. 60. - Manuskript mit eigenhändiger Unterschrift des Vorsitzenden des Ortsumsiedlerausschusses „Kurt Rellech[?], Kl[ein] Breese Perlebergerstr. 20“. - Adressiert: „An den Herrn Landrat, Abt. für Arbeit u. Sozialwesen VII/4 - Umsiedler -,.. [Randvermerk: „Interessant. 8.“].

Trotzdem mir der hiesige Bürgermeister wiederholt versprochen hat, die bei der Besichtigung der Umsiedlerwohnungen festgestellten Mängel zu beseitigen, ist bis heute nichts geschehen. Die Umsiedler wohnen nach wie vor 5 und 6 Personen in einem Zimmer[,] schlafen 3 Personen in einem Bett[,] zum Teil sogar noch auf dem Fußboden, haben keine Fensterscheiben, keinen Keller und sind ein Teil der Wohnungen nicht winterfest. Eine Umquartierung wird nicht vorgenommen, trotzdem hier noch genügend Wohnraum vorhanden ist. Wenn eine größere, gute Wohnung mal frei wird, dann wird dieselbe einem Einheimischen zugewiesen, auch wenn es eine einzelstehende Person ist. Auch in der Umsiedlerwoche wurde nichts unternommen, weil nach Ansicht des Bürgermeisters die Einheimischen schon zu viel durch den Krieg verloren haben und auch nur das Nötigste besitzen. Einige, wenige Sachen sind wohl auf Grund der Propaganda in Rundfunk und Presse gespendet worden. Es wird jedenfalls vom Bürgermeister nichts getan, um das Los der Umsiedler zu verbessern.

Ich bitte daher den Herrn Landrat, einen Vertreter vom Umsiedleramt nach Breese zu schicken, der sich persönlich von den hiesigen Mißständen überzeugen kann. 


\section{(98) Bericht des Geschäftsführers des Ortsumsiedlerausschusses in Postlin an den Landrat des Kreises Westprignitz. - Postlin, 18. November 1947}

BLHA, Rep. 250 Landratsamt Westprignitz, Nr. 256, Bl. 112. - Typoskript mit eigenhändigen Unterschriften, 1. der des Bürgermeisters Schmetsdorf, r. der des Geschäftsführers des Umsiedlerausschusses Hochschultz.

Betrifft: Bericht über die Umsiedlerwoche in der Gem[einde] Postlin

Aus Anlaß der Hilfswoche für Umsiedler[,] die von der Landesregierung vom 26.10-2.11. festgesetzt wurde, war der Ortsumsiedlerausschuß der Gemeinde Postlin am 22.10. unter dem Vorsitz unseres Bürgermeisters Schmetsdorf zu einer Sitzung zusammengetreten, um über die zu ergreifenden Vorbereitungen und Maßnahmen für eine günstige Abwicklung der Woche zu beraten. Da uns von der Behörde so gut wie gar keine Propagandamittel zur Verfügung stenden [so!], waren wir auf uns selbst angewiesen und wurde die Woche zunächst mit einer kleinen Bekanntmachung eingeleitet, die die Bevölkerung auf die Aktion aufmerksam machen sollte. An diese schloß sich nach einigen Tagen ein vom Geschäftsführer verfaßter Aufruf, in dem die Dorfbewohner auf die Zwecke und Ziele der Woche in umfassender Weise hingewiesen wurden. Dieser Aufruf wurde an allen maßgeblichen Stellen verteilt und diente gleichzeitig als Propagandamittel. Die Sammelaktion begann am 26.10. und erstreckte sich nicht nur auf Möbel und Hausgerät, sondern auch auf Naturalien und Lebensmittel, da auf der Sitzung am 22. beschlossen war, den Umsiedlern am Ende der Woche, dem 2. Nov.[,] ein gemeinschaftliches Eintopfessen zu geben[,] und am Abend des gleichen Tages ein geselliges Beisammensein mit Tanz, welches noch durch eine kleine Verlosung von Hausgeräten und Lebensmitteln abwechslungsreicher gestaltet wurde.

Das Ergebnis der Hausgerätesammlung war ein ganz klägliches, da im ganzen 2 alte Schränke, 1 Sofa, 1 Küchentisch, 1 Federbett zur Verfügung gestellt wurden und es allgemein hieß, man habe nicht mehr. Die Lebensmittelsammlung ergab trotz ihres beschränkten Ausmaßes doch so viel, daß das Eintopfessen auch ohne Fett am 2.11. steigen konnte und an ca. 180 Umsiedler mit Frau und Kind bewirtet wurden. Auch der gesellige Abend verlief im Einklang mit der einheimischen Bevölkerung gemütlich und zufriedenstellend und wogte der Tanz unter den Klängen unserer vorzüglichen Dorfkapelle bis gegen Mitternacht hinunter und fand dadurch einen zufriedenstellenden Abschluß.

Man kann sich trotz allem jedoch des Eindrucks nicht erwähren [so!], daß die Bevölkerung dem Umsiedlertum immer noch fremd gegenübersteht, man völlig verständnislos und uninteressiert an den Leiden und Entbehrungen der Umsiedler vorübergeht und man nicht einsehen will, daß es gleichberechtigte Menschen sein sollen, die sich von der einheimischen Bevölkerung nur dadurch unterscheiden, daß sie für das Land ihre ganze Existenz geopfert haben und hier in der Fremde nur als lästiger Zuwachs angesehen werden. 
(99) Monatsbericht des Umsiedlerausschusses in Leibsch im Kreis Beeskow-Storkow für Dezember 1947. - Leibsch, 2. Janauar 1948

BLHA, Rep. 250 Landratsamt Beeskow-Storkow, Nr. 869, unfol. - Typoskript ohne Unterschrift, 1 Bl. - L. o.: „Umsiedlerausschuss. / 160 Umsiedler.“ - R.o. Datierung: „Leibsch, den 2.Januar 1948.“- Anschrift: „An das / Amt für Umsiedler / Beeskow.“ - Überschrift: „Monatsbericht/Dezember 1947.“ - Eingangsvermerk mit Paraphe M.[?] „19.1.47“.

Am 3.12. fand im Gasthaus Krüger die monatliche Versammlung statt. Bei der allgemeinen Aussprache klagten die Umsiedler, (die meisten arbeiten im Freien), über die schlechte Arbeitskleidung. Vor allen Dingen Arbeitsschuhe fehlen. Ebenso für unsere älteren Frauen dickere Strümpfe oder Wolle zum Anstricken. Sie haben bis jetzt noch keine Strümpfe bekommen, da wir nur seidene hatten, und es nichts für diese Frauen ist. Unsere Schulkinder über 10 Jahre besuchen die Einheitsschule in Neulübbenau. Sie haben also einen weiten Schulweg. Für sie sind auch nie Strümpfe und Schuhe bei der Verteilung. Die dafür in Frage kommenden Grössen gibt es scheinbar nicht mehr. Strickwolle für bedürftige Schulkinder ist für 19 angefordert und geliefert worden. Nun bekamen wir aber noch 5 Kinder dazu, welche nichts weiter hatten, als was sie auf dem Leibe hatten. Die Wolle wurde nun an diese Kinder ausgegeben, dadurch fehlt es uns aber für die andern, welche nach Neulübbenau zur Schule gehen. Wäre es nicht möglich, dass wir die Wolle für die 5 Kinder nachgeliefert bekommen?

Für die 3 neuen Familien fehlen dringend Betten und Schlafdecken.

Es wurde fleissig für die Weihnachtsfeier gesammelt und gearbeitet. Jedes Umsiedlerkind, sowie die alten Leute sollten beschenkt werden. Von [Bl. v] den Stammeinwohnern wurden Spielzeug, Wäsche und Kinderkleidung gespendet. Ferner wurden vom Umsiedlerausschuss und Frauenreferat die Textlien vom November, die Wolle für 19 Schulkinder, Geschirr und Hausschuhe für die Bescherung bestimmt.

Die Pakete wurden vom Frauenreferat gepackt und eingestellt. Für Geschenke wurden ca. Mk. - - - ausgegeben. Leider kam für Dezember keine Textilienzuteilung. Das Geschirr und die Babysachen waren sehr gefragt.

Es wäre sehr wünschenswert, wenn Leibsch seine Zuteilung selbst bekommen würde. Mit Krausnick klappt es nicht immer. Wir brauchten noch für einige alte Leute Geschenke. Die Sachen waren in Krausnick. Der Wagen, welcher wöchentlich das Brot für Leibsch holt, sollte sie mitbringen. Es wurde mit Krausnick telefoniert, dass der Wagen kommt, es soll alles fertig sein. Leider war es nicht der Fall, und der Vorsitzende musste am Sonntag bei Glatteis fahren, damit wir zu unserer Zuteilung kamen.

Am 4. Advent war dann die Dorfweihnachtsfeier. Der Saal war dicht besetzt. Die Schule und die Jungmädel teilten sich das Programm. Geboten wurde:

Weihnachtsgedichte

Krippenspiel
Im Spielzeugladen

Märchen im Walde 
Weihnachtsliederpotpourri Das gläserne Herz.

Die 4 Jahreszeiten

Nach einem gemeinsam gesungenen Weihnachtslied kam der Weihnachtsmann und verteilte aus 2 grossen Säcken die Geschenke. Damit die kleinen Kinder der Stammeinwohner nicht leer ausgingen, machten die Eltern auf Anregung der Lehrerin selbst kleine Pakete, welche verteilt wurden.

Es war für alle eine gelungene Überraschung.

Der Umsiedlerausschuss will sich im neuen Jahr weiter bemühen, recht vielen zu helfen und Freude zu spenden. Wir hoffen aber auch auf grösste Unterstützung des Umsiedleramtes.

\section{(100) Tätigkeitsbericht des Umsiedlerausschusses Havelberg. - Havelberg,}

\section{Januar 1948}

BLHA, Rep. 250 Landratsamt Westprignitz, Nr. 254, Bl. 107. - Typoskript mit eigenhändiger Unterschrift des Vorsitzenden („Der Umsiedlerausschuß / Eckert“).

Die Wohnungsfrage, als eine der brennensten, hat in letzter Zeit Veranlassung gegeben 18 Wohnungen als besonders schlecht herauszustellen. Die Besichtigung ergab, dass hier unbedingt Besserung geschaffen werden muss. Die Beschaffung von Kochherden stellt den Umsiedlerausschuss vor weitere Schwierigkeiten. Die Materialbeschaffung ist schwierig. Trotzdem wiederholt an die Kreisverwaltung dieserhalb appelliert wurde, ist Lieferung bezw. Antwort ausgeblieben. / Erneut angekommenen Umsiedlern konnte leider nicht das notwendigste gegeben werden, sodass sie z.T. ohne Betten und Decken nächtigen müssen. / Der Mangel an Kochtöpfen ist katastrophal, weshalb an die umgehende Lieferung der Töpfe für die seit langer Zeit an das Kreissozialamt [zu liefernden] 283 Stahlhelme erinnert wird. Weitere Stahlhelme liegen bereit. / Die Anfragen der Umsiedler wegen dringenden Bedarfs an Strohsäcken wollen nicht verstummen. Hier muss unbedingt schnellstens geholfen werden, weshalb ich bitte, meine an die Kreisverwaltung gerichteten Anträge und Bitten zu erledigen.

Erfreulicherweise kann erneut berichtet werden, dass Umsiedler mit Erschließung von Gewerbe bzw. Fertigungsbetrieben rührig voranschreiten. Ein Schmiedebetrieb mit spezieller Anfertigung von Hufnägeln sowie ein Fertigungsbetrieb von Holznägeln für Schuhgewerbe arbeiten bereits zur Zufriedenheit und versorgen Havelberg und darüber hinaus mit den Erzeugnissen. Leider kann man sich des Eindrucks nicht erwehren, dass die heimischen Betriebe (Konkurrenz) oder auch andere Stellen gerade den Umsiedlern hierbei Schwierigkeiten machen und die Eröffnung solcher Betriebe zu hintertreiben suchen, obwohl die erteilten Gewerbekonzessionen ein [im!] Verhältnis zum Anteil der Umsiedler an der Gesamtbevölkerung der Stadt verschwindend gering sind.

Nach wie vor steht der Umsiedlerausschuss jeden Mittwochabend im Rathaus den Umsiedlern zur Verfügung, Diese Abende werden rege in Anspruch genommen. 
(101) Schreiben des Landrates des Kreises Westprignitz an den Minister für Arbeit und Sozialwesen in Potsdam wegen von Neusiedlern genutzten Gutshausinventars. Perleberg, 2. Februar 1948

BLHA, Rep. 250 Landratsamt Westprignitz, Nr. 257, B1. 350. - Typoskript auf Kopfbogen des Landrats mit eigenhändiger Unterschrift „v. Zerssen“. - Betrifft: „Schloß Kletzke“. - Bezug: „Verfg. vom 29. Januar 1948 [...]“.

Ihr Schreiben betreffs der aus dem Schloß Kletzke entnommenen Gegenstände ist von mir zur weiteren Erledigung dem Chef der Kreispolizei übergeben worden. Ob sich für dieses Schreiben eine rechtliche Unterlage findet und ob vor allen Dingen das Wort „entwendet“ von Herrn Stege bewiesen werden kann, entzieht sich meiner Beurteilung. Das Schloß Kletzke war lange Zeit durch Einheiten der Roten Armee besetzt. Die Siedler werden möglicherweise die bei ihnen befindlichen Gegenstände als Geschenke der Besatzungsmacht bezeichnen. Ob sich der von Ihnen gewünschte Zweck gegen eine unter den Siedlern und Umsiedlern des Dorfes Kletzke entstehende Unruhe rechtfertigt, lasse ich dahingestellt. Im allgemeinen ist hier im Kreise diese Frage so behandelt worden, daß wir Gebrauchtsgegenstände und Möbel ohne künstlerischen Wert den Siedlern und Umsiedlern belassen haben. Sollten allerdings Altbauern oder sonstige in Kletzke beschäftigte Personen sich in den widerrechtlichen Besitz von Gegenständen aus dem Schloß gesetzt haben, so begrüße ich die Fortnahme dieser Gegenstände.

\section{(102) Tätigkeitsbericht des Umsiedlerausschusses Hohenvier (Kreis Westprignitz). -} Hohenvier, 19. Februar 1948

BLHA, Rep. 250 Landratsamt Westprignitz, Nr. 254, B1. 57. - Typoskript mit eigenhändiger Unterschrift des Vorsitzenden A[rtur] Pickert. - Adressiert: „An den Herrn Landrat / Abt. VII/4 - Umsiedler -“. Antwort auf [„Bezug:“] „Rundschreiben Nr. 70/48 [des Landratsamtes] vom 28. Januar [19]48“.

1) Sitzung der Umsiedler: Am Mittwoch, dem 18.10.[19]48 fand eine Umsiedlerversammlung statt zum Zwecke der Neuwahl des Vorstandes. Gewählt wurde zum Vorsitzenden Herr Artur Pickert, als Beisitzer Fräulein Else Kusche und Herr Paul Epphard. Als Delegierter für die geplante Kreisumsiedlertagung wurde Herr Pickert bestimmt.

2. Monatsbericht. Der Ausschuß hat sich im vergangenen Monat wie immer an der Verteilung der Bezugsscheinwaren beteiligt. Er erstattete Bericht über die durch die Neuregelung der Verteilung geschaffene Lage, daß nämlich der FDGB jetzt rund $3 / 4$ der anfallenden Waren zur Verteilung an die werktätige Bevölkerung einschließlich der Knechte und Mägde bei den Bau[ern] bekommt, für die arbeitslose und die bäuerliche besitzende Bevölkerung etwa 1/4 durch die Gemeinde verteilt wird. Er führte aus, wie trostlos durch diese Regelung die Aussichten der Umsiedler geworden sind, bezugsscheinpflichtige Waren zu erhalten, da deren überwiegende Mehrheit nicht in Arbeit steht. Für die Gemeinde Hohenvier ergibt sich das Bild, daß 30 Personen durch den FDGB betreut werden, dagegen 140 durch die Gemeinde, daß also auf 30 Personen nach der oben angeführten Quote die dreifache Menge an Bezugsscheinen entfällt wie auf die übrigen 140. Die Versammlung hatte wohl Verständnis dafür, daß die werktätige Bevölkerung bevorzugt behandelt wird und daß alles, was an Berufskleidung erzeugt wird, restlos 
ihr zur Verfügung zu stellen ist, daß aber auf die sonstige Bekleidung sie den gleichen Anspruch hat. Die Hälfte der hiesigen Umsiedler mußte seiner Zeit Polen mit $40 \mathrm{~kg}$ Gepäck verlassen, konnte nur das Notwendigste von ihrer Habe mit nach Deutschland nehmen und sieht nun die Möglichkeit, sich ein neues Stück Wäsche oder Kleidung zu schaffen, in weite Ferne gerückt. Hier liegt nach Ansicht der Versammlung eine Härte vor, die zu mildern, das Umsiedleramt bestrebt sein müßte.

Auch in der Wohnungsfrage sieht der Umsiedlerausschuß mit Sorge in die Zukunft. Zur Zeit sind die hier untergebrachten Familien befriedigend untergebracht. Durch die Räumung der Schlösser usw. von den in diesen untergebrachten Familien steht den Gemeinden eine neue Zuweisung von Familien bevor. Der Wohnraum in der Gemeinde ist schon stark in Anspruch genommen, so daß zu befürchten steht, daß wieder die Umsiedler mit ihrem beschränkten Raum noch enger zusmmenrücken müssen.

Die Versorgung der Umsiedler mit Brennholz ist insoweit durchgeführt, als jeder Haushalt $2 \mathrm{c}[\mathrm{b}] \mathrm{m}$ Holz zu angemesenem Preis erhalten hat. Bei größerem Bedarf ist es gestattet, Holz in der nahe gelegenen Waldung zu lesen.

Vielen hiesigen Umsiedlern ist es aufgefallen, daß in den Perleberger Geschäften in Wirtschaftsartikeln reichlicher bedient wird als sie mit ihrem Haushaltspaß. Eine Gleichstellung ist erwünscht.

\section{(103) Tätigkeitsbericht des Umsiedlerausschusses Toppel (Kreis Westprignitz). -} Toppel, 1. März 1948

BLHA, Rep. 250 Landratsamt Westprignitz, Nr. 254, B1. 31. - Typoskript mit eigenhändiger Unterschrift des Vorsitzenden [Meinecke?].

Die im Dezember eingetroffenen Umsiedler aus Tilsit kamen ohne jegliche Sachen und Geldmittel an. Da es alles alte Leute waren, mußte die Gemeinde fast an allen Unterstützung zahlen. Durch eine Sammelaktion wurde Gemüse eingebracht 2 Ztr. Kohlrüben, 1 Ztr. Mohrrüben, 50 Pfd. r[ote] Beete und Zwiebeln, die sofort gerecht verteilt wurden. Da die Gemeinde über keinen Wald verfügt, war die Beschaffung von Brennholz schwierig. Die Bauerngespanne fuhren für alle Familien vorerst Buschholz an. Ein Antrag an das Forstamt war erfolgreich, sodass jede Familie noch 1-2 rm Klobenholz bekommen kann. Durch eine Zuteilung an Geschirr konnte jede Familie Tassen, Töpfe und Einweckgläser erhalten. Durch die Gemeinde wurden 3 Öfen angeschafft, die aufgestellt wurden. Hier fehlt es an Ofenrohr. Ein Einwohner hat vorerst einige Enden zur Verfügung gestellt, die er aber gern wieder zurück haben möchte. Vielleicht wäre es möglich Ofenrohr zu beschaffen, oder ein paar Tafeln Schwarzblech der Gemeinde zukommen zu lassen.

Es fehlt dringend Schuhwerk und Bekleidungsstücke. Durch die jetzige Kartoffelsperre sind die Umsiedler in Not, da sie erst 1 Ztr. erhalten haben.

Betr.: Meldekarten: Die Meldekarten wurden am 26.2.1948 nach Potsdam gesandt. 


\section{(104) Tätigkeitsbericht des Umsiedlerausschusses Lütkendorf bei Putlitz (Kreis Westprignitz). - Lütkendorf, 3. März 1948}

BLHA, Rep. 250 Landratsamt Westprignitz, Nr. 254, Bl. 33-35 - Manuskript mit eigenhändiger Unterschrift des Bürgermeisters W. Langfeldt sowie für den Umsiedlerausschuss den Unterschriften von dessen Vorsitzendem Brose und Schriftführer Neuwald. Bl. 33 oben adressiert „An den / Herrn Landrat, / Perleberg“.

\section{Bericht des Umsiedlerausschusses}

Wie gemeldet trat der Ausschuß am 22.2. unter Anwesenheit des Bürgermeisters zusammen. Frau Ruth Kruppa lehnte die Mitarbeit ab, für sie trat über Ersuchen des Bürgermeisters Frau Schulleiterin Kaatz in den Ausschuß ein.

Programmgemäß wurde zuerst der Zweck und die Aufgaben an hand der Rundschreiben und einiger Hefte der Zeitschrift „Neue Heimat“2291 besprochen.

Sodann wurde als 2. Punkt der Tagesordnung die Wohungsfrage behandelt. Die Unterbringung der Umsiedler war hier von Anbeginn an, wie auch durch viele Eingaben in Perleberg bekannt, sehr mangelhaft, weil der Ort für seine Größe zu stark mit Flüchtlingen belegt war; erreicht doch heute noch die Zahl der Umsiedler jene der einheimischen Bevölkerung. Trotz vieler Bemühungen konnte auch im Laufe der Zeit nur wenig an diesem Zustande verbessert werden. So führt die Gemeinde, wie aus dem Schreiben vom 24.2. an den Kreiswohnungsausschuß ersichtlich, seit mehr als $1 / 2$ Jahr einen Briefwechsel[,] um für 10 Familien bessere Wohnverhältnisse zu schaffen, machte Vorschläge zum Ausbau von 2 Wohnungen und stellte die bessere Unterbringung von 2-4 Familien als besonders [Bl. 34] dringend in den Vordergrund, leider bisher ohne Erfolg. Da die Möglichkeit der Beschaffung besserer Wohnungen sehr beschränkt ist, würde wohl nur durch Unterbringung einiger Familien in Orten mit einem geringeren Hundertsatz von Umsiedlern eine Verbesserung zu erzielen sein.

Zur Versorgung mit Brennholz wurden $60 \mathrm{~m}^{3} \mathrm{Holz}$ geschlagen, wodurch die in Betracht kommenden Familien 1-2 $\mathrm{m}^{3}$ zugeteilt erhielten. Da das Fällen der Bäume erst zu Anfang Dezember erfolgte, mußte von vielen das Holz in nassem Zustande verwendet werden. Um diesem Übelstande in Zukunft abzuhelfen, wurde der Bürgermeister ersucht[,] im laufenden Jahre das Holzschlagen früher anzuordnen. Dabei stellte sich heraus, daß die Gemeinde keinen schlagfähigen Wald besitzt und auch die Besitzer über nur geringe[,] für die Versorgung der Umsiedler unzureichende Waldbestände verfügen; deshalb an die übergeordneten Stellen gerichtete Eingaben um Hilfe blieben bisher erfolglos.

Zum Besuch der Umsiedlertagung am 27.2. wurden 2 Delegierte bestimmt, doch konnten diese wegen Einstellung des Zugverkehrs Putlitz-Berge nicht fahren; sodaß nur der Gemeindesekretär daran teinehmen konnte. Für künftige Tagungen wäre es wünschenswert, diese erst $11^{\mathrm{h}}$ be-

2291 [Zeitschrift „Die Neue Heimat. Illustrierte Monatszeitschrift“. Hrsg.: Hauptabteilung für Deutsche Umsiedler im Sowjetischen Okkupationsgebiet, erschienen in Berlin (Deutscher Zentralverlag) 1947-1949.] 
ginnen zu lassen, damit die Abgesandten der weiter entfernten Gemeinden nicht allzuspät nach Beginn der Tagung eintreffen oder, wenn möglich, einen Sonder-Triebwagen bereit zu stellen.

Auf Anregung des Herrn Bürgermeisters beschloß die Gemeindevertretung[,] täglich [Bl. 35] 201 Magermilch an die nicht Landwirtschaft treibende Bevölkerung abzugeben. An einer am 26.2. stattgefundenen Versammlung des Ausschusses, in welcher auch der Bürgermeister zugegen war, wurde die Verteilung der Magermilch wie nachstehend festgesetzt:

Kinder von 1-5 und von 10-14 Jahren sowie alte Leute über 65 Jahre des nicht Milchkühe haltenden Bevölkerungsteils erhalten $1 / 4$ l, Kinder von 5-10 Jahren $1 / 21$ täglich.

Dadurch hat die Bauernschaft die Ernährungslage der in Betracht kommenden Familien in dankenswerter Weise verbessert.

\section{(105) Bericht der Gemeindevorsteherin von Raßmanssdorf bei Beeskow über die Betreuung der Vertriebenen. - Raßmannsdorf, 25. Mai 1948}

BLHA, Rep. 250 Landratsamt Beeskow-Storkow, Nr. 869, unfol. - Manuskript mit Unterschrift, 1 Bl. - R. o. Datierung: „Rassmannsdorf, 25.5.48.“ - Anschrift: „An den / Rat des Kreises Beeskow-Storkow / Amt f. Arbeit u. Sozialwesen / Umsiedlerbetreuungsstelle / Beeskow.“ - Betreff: „Betr. Umsiedlerbetreuung.“ - Eingangsvermerk „M 27/5 48“. - Unterschrift: „Blume, Gemeindevorsteherin“, daneben Stempel der „Gemeinde Rassmannsdorf / Kreis Beeskow-Storkow“.

Wie ich von Herrn J. Langas erfahre, wird Ihrerseits Klage darüber geführt, dass von der Gemeinde Rassmannsdorf keine Berichte über die Umsiedlerbetreuung eingehen. Ich berichtete Ihnen aber schon vor längerer Zeit, dass in diesem Jahr wieder aus gemeindeeigenem Wald Holz geschlagen werden konnte, das zu ganz geringen Preisen an die Umsiedler abgegeben wurde. / Von den für die Gemeinde bestimmten Textilien werden $60 \%$ an Umsiedler, der Rest an Stammeinwohner verteilt. / Jedes Umsiedlerschulkind erhält täglich 1 Ltr. Milch kostenlos. / Der Stellmacher J. Langas, der selbst Umsiedler ist, hat bereits für alle Umsiedler mindestens 1 Paar Holzpantoffel hergestellt und zu geringem Preis abgegeben. [Bl. v] / Den Umsiedlern, die Land gesiedelt haben, wird durch gegenseitige Hilfe jede Unterstützung durch Stellen von Gespannen, Maschinen und Geräten zuteil.

\section{(106) Auskunftsersuchen des Umsiedlerausschusses der Gemeinde Dannenreich im Kreis Beeskow-Storkow an die Provinzialregierung. - Dannenreich, 7. Juni 1948}

BLHA, Rep. 250 Landratsamt Beeskow-Storkow, Nr. 869, unfol. - Typoskript (Abschrift), 1 Bl. - Oben: „Abschrift!“ - L. o.: „Umsiedlerausschuss / Dannenreich / Krs. Beeskow-Storkow“. - R. o. Datierung: „Dannenreich, den 7. Juni 1948“. - Anschrift: „An die / Provinzialregierung / Mark Brandenburg, Abt. Sozialwesen / Potsdam“. - U.1.: „Gemeinde Dannenreich / gez. Unterschrift“. - U.r.: „Für den Umsiedlerausschuss / zeichnet / Josef Neumann / Erwin Krüger“.

Die Umsiedler der Gemeinde Dannenreich haben in der letzten Versammlung dem Ausschuss folgende Fragen vorgelegt:

1.) Bekommen alls Umsiedler die einmalige Unterstützung von 300,- RM? Presse und Rundfunk haben wiederholt eine 95\%ige Auszahlung von gestellten Anträgen bekannt- 
gegeben. In der Gemeinde, die etwa 100 Umsiedler bei 200 Altbürgern beherbergt, haben bisher ..... Leute die Unterstützung von 300 RM resp. 100 RM bekommen. 14 Umsiedler sind abgelehnt worden, da sie ein monatliches Einkommen von über 90 RM haben. Diese sind aber keineswegs Großverdiener. Soweit hier bekannt ist, spricht der Befehl der SMA hierüber davon, nicht kleinlich in der Auszahlung der Beträge zu sein. Eine Auszahlung der Sparkonten der Umsiedler ist nicht möglich, da deren Banken jenseits der Oder liegen.

Wie soll ein Umsiedler mit beispielsweise 300 RM Monatsgehalt sich von dem Verdienst Gelder für die Anschaffung von Möbel und Hausrat etc. abzweigen? Ist diese Unterstützung nicht überhaupt für Anschaffung von Gebrauchsgegenständen gedacht? Warum bekommen nicht alle Umsiedler, auch wenn sie 50,- RM Wochenlohn haben, die einmalige Unterstützung?

2.) Die Volkssolidarität soll sich für Umsiedler allerorts tatkräftig eingeschaltet haben. Die Umsiedler in der Gemeinde haben bis heute von keiner Stelle eine Zuweisung von auch nur dem notwendigsten Hausgerät (Decken, Betten etc.) erhalten. Es gibt 53 Umsiedler, die unter keiner Decke schlafen. Es dauer[t] nicht mehr lange, dann ist die einzigste Schüssel im Hause Speisetrog, Waschgefäss und Nachtgeschirr zugleich. Wann endlich sind zum notdürftigsten Leben die elementarsten Voraussetzungen gegeben. Auf dem Schwarzmarkt zu kompensieren, ist kein Umsiedler in der Lage.

Entfällt bei den örtlichen Textilienzuteilungen ein festgetzter Prozentsatz auf die Umsiedler?

3.) Allen Schulkindern wurde bis zum 1. III. [19]48 ein Brötchen als Schulspeisung verabfolgt. Bei den Umsiedlerkindern war dies Brötchen das Frühstück. Da die Schule nicht städtischen Charakter hat, wurde die Brötchenaktion eingestellt.

Wir bitten um Beantwortung der Fragen, um der Versammlung gelegentlich Aufklärung zu geben.

\section{(107) Schreiben des Rates des Kreises Westprignitz, Abt. VI/Rechtswesen an} Ernst Bazer in Erpfingen, Kr. Reutlingen, wegen Möbelnutzung durch Vertriebene. Perleberg, 9. Juni 1949

BLHA, Rep. 250 Landratsamt Westprignitz, Nr. 257, Bl. 536. - Typoskript (Durchschlag). - [Siehe auch Nr. 108.]

Auf Ihre Eingabe vom 5. März 1949 hat mir der Rat der Gemeinde Uenze mitgeteilt, daß er Ihr Eigentumsrecht an den Möbeln anerkenne, Ihr Besitzrecht jedoch solange bestreite, wie die Umsiedler, die im Besitz der Gegenstände seien, diese unbedingt benötigten. Zur Klärung des von Ihnen später geltend zu machenden Herausgabeanspruchs empfehle ich Ihnen im Einvernehmen mit dem Rat der Gemeinde Uenze eindeutig festzulegen, wo sich die einzelnen noch vorhandenen Möbel befinden. Der Rat der Gemeinde Uenze hat Durchschrift dieser Mitteilung erhalten. 
(108) Schreiben des Rates des Kreises Westprignitz, Abt. VI/Rechtswesen an den Rat der Gemeinde in Uenze wegen Möbelnutzung durch Vertriebenen. Perleberg, 9. Juni 1949

BLHA, Rep. 250 Landratsamt Westprignitz, Nr. 257, Bl. 536. - Typoskript (Durchschlag).

[Unter Beifügung einer Abschrift des vorstehenden Schreibens (Nr. 107) an Bazer] Zur gefälligen Kenntnisnahme übersandt. Zwecks Vermeidung evtl. Schadensersatzansprüche empfehle ich den Verbleib der Möbelstücke eindeutig festzulegen und dem Bazer eine Abschrift dieser Aufstellung zu geben. Wie aus meiner Antwort an Bazer hervorgeht, wird zwar das Eigentumsrecht anerkannt, das Besitzrecht jedoch bestritten. Das heißt, daß die Möbel den bedürftigen Umsiedlern zur Zeit nicht weggenommen werden dürfen, daß diese aber grundsätzlich verpflichtet sind, dem Eigentümer Möbelmiete zu zahlen.

\section{(109) Arbeitsbericht des Frauenreferates des Rates des Kreises Luckenwalde. -} Luckenwalde, 12. November 1948 (Auszug)

BLHA, Rep. 250 Landratsamt Luckenwalde, Nr. 301. - Typoskript mit Unterschrift (Tinte) „Frieda Janis“. - Kopf o.1.: „Der Rat / des Kreises Luckenwalde / - Frauenreferat -,, o. r.: „Luckenwalde, den 12.11.47 / Markt 11 / Tel. 2142 App. 83“, darunter Eingangsstempel „13. Nov. 1947“. - Überschrift „Arbeitsbericht für den Monat Oktober 1947“. - Fast textidentisch, jedoch mit Stempel des Demokratischen Frauenbundes Deutschlands, Kreis Luckenwalde, Unterschrift von Alida Rosenborn für die Ortsgruppe und Datum 5.11.1947 sowie Eingangsstempel vom 13.11.1947: ebd., Bl. 302.

Wie wir schon im vorigen Monat ${ }^{2292}$ berichteten, haben wir sehr viel Mühe mit der Errichtung von Kindergärten und wir können leider noch von keinem Erfolg berichten.

Die Kommissionen haben sich sehr eingearbeitet, besonders die Kommission für Spinnstoffabteilung, so daß wir mit einer Anzahl Frauen von Frauenausschuß und vom Demokratischen Frauenbund sehr viel zu tun haben, alle Anträge auf die Bedürftigkeit zu prüfen.

In der Umsiedlerwoche hat sich der DFD und der Frauenausschuß ebenfalls eingeschaltet. Wir sind eifrig dabei, alle gespendeten Sachen aus der Stadt zusammen zu holen. Dabei haben wir viele Frauen[,] die selbst Umsiedler sind, herangezogen. Die grösseren Sachen wie Bettgestelle, Kommoden[,] Tische usw. lassen wir von den Umsiedlern selbst abholen, damit der Spender sieht[,] wo seine Sachen hinkommen.

Am 12.10.[19]47 haben wir unsere Werbeveranstaltung durchgeführt, die auch gut ausgefallen war. Am 11.10.[19]47 haben wir für 1000 Bedürftige je einen Liter warmes Essen ausgegeben. $/[\ldots]$

Von einer Luckenwalder Firma haben wir vier Handwagen erwerben können, die wir jetzt gegen eine Leihgebühr stunden- oder tageweise zur Verfügung stellen. Diese Einrichtung ist von

2292 [In der Akte, Bl. 286-308, enthalten sind die Tätigkeitsberichte für Juni 1947 sowie für die Monate August 1947 bis Juni 1948.] 
der Bevölkerung begrüßt worden und es wird reger Gebrauch davon gemacht. Diese Wagen dienten und dienen uns auch oft bei den Sammlungen für die Umsiedler. / [...

\section{(110) Pressetexte des Informationsdienstes des Rates des Kreises Luckenwalde. -} Luckenwalde, 3. Oktober 1949

BLHA, Rep. 250 Landratsamt Luckenwalde, Nr. 108, Bl. 373. - Typoskript (Durchschlag, außer der Verfügung), 1 Bl., mit Kugelschreiber-Paraphe „Ki“ des Informationsdienstmitarbeiters Hans Kirstein. - O. r. Datierung „Luckenwalde, den 3. Okt. 1949. - U.1. Verfügung: „2. Verteiler: / Volksstimme / Tagespost / 3. Z.d.A.“.

So etwas gibt es noch!

Auf einer Gemeindeversammlung in Hohenseefeld brachte ein Umsiedler aus Niederseefeld zur Sprache, dass der Bauer, bei dem er wohnt, ihm verboten hat, das Wasser aus der Küche im Haus zu entnehmen. Er ist also gezwungen, sein benötigtes Koch- und Waschwasser aus dem Viehstall zu holen.

Von einer anderen Seite wurde ausgeführt, dass es Besitzer gibt, die ihren im Hause einwohnenden Umsiedlern den Hausschlüssel verweigern, sodass sie praktisch des nachts eingesperrt sind und weder ins Haus hinein noch heraus kommen.

Wer diese beiden kurzen Notizen liest, der wird sich fragen, ja, gibt es denn so etwas überhaupt? Jawohl, solche Dinge kommen heute noch vor. Beide Bauern sollten sich aber einmal genau überlegen, dass die Umsiedler genauso wie die Alteingesessenen deutsche Menschen sind, denen der verbrecherische Hitlerkrieg besonders schwer mitgespielt hat und denen wir unsere besondere Fürsorge und Unterstützung zuteil werden lassen müssen. Solche Schikanen, anders kann man diese Dinge nicht bezeichnen, werden von allen anständigen Menschen schärfstens verurteilt und wir sollten uns freuen, wenn es nur dieses Hinweises bedarf und diese Mängel sofort abgestellt werden.

Spenden für Umsiedler.

Auf einer Einwohnerversammlung in Hohenseefeld spendete die SED-Betriebsgruppe der Landesregierung Brandenburg zur Beschaffung von Textilien für bedürftige Umsiedlerkinder 200.- DM. Dieser Spende schloss sich die Kreisvereinigung der gegenseitigen Bauernhilfe des Kreises Luckenwalde mit 100.- DM an und stellte gleichzeitig Textilien für diesen Zweck zur Verfügung. 


\subsection{Eingliederungs- und Gleichstellungsbemühungen (1945-1949)}

\section{(111) Besprechung der Leiter der Sozialämter bei den Landratsämtern am 17. Dezember 1945. - Potsdam, 21. Dezember 1945 (Auszug)}

BLHA, Rep. 206 Ministerium für Wirtschaft und Arbeit, Nr. 2965, unfol. - Typoskript (teilweise Durchschlag), 7 B1. - Vollständigkeit des Protokolls (außer beim Punkt „Umsiedlerfragen“) nicht gesichert. - Die hier (mit Ausnahme der am Schluss stehenden Aufzählung der Altersheime) weggelassenen Teile betreffen andere bzw. allgemeine, von anderen Referenten vorgetragene Themen (v. a. Lohn- und Arbeitsbedingungen, Arbeits- und Unfallschutz, Umschulung, Frauen und Mütter, Sozialversicherung).

[1. Bl.]

\section{Besprechung}

der Leiter der Sozialämter bei den Landratsämtern

am 17. XII. 1945.

Es waren anwesend Vertreter aus den Kreisen [Außer Luckau sämtlich mit Bleistift abgehakt]: Brandenburg / Wittenberge / Westprignitz / Rathenow / Luckau [nicht abgehakt] / Lübben / Cottbus / Kyritz / Belzig/M. / Frankfurt/O. / Luckau-Land / Guben-Stadt / Beeskow-Storkow / Luckenwalde / Neuruppin / [handschriftlich hinzugesetzt:] Eberswalde

Die Umfrage bei den nicht zu der Konferenz erschienenen Vertreter[n] der Sozialämter und die Begründung hierfür erfolgte auf besonderer Verfügung.

$$
\begin{aligned}
& \text { Pdm., den 21.12.[19]45 } \\
& \text { [handschriftl. gez.: ] Lootz }
\end{aligned}
$$

$[\ldots]$

[4. Bl.]

Umsiedlerfragen:

Frau Sendhoff ${ }^{293}$ begann mit ihren Ausführungen, daß das Schmerzenskind der Provinzialverwaltung die Ums[iedler].-Abt. ist. Die Kreise Angermünde, Lebus und Forst sind am schlimmsten betroffen. Vom Ende Oktober bis jetzt sind ungefähr 162000 Menschen durchgeschleust worden. Wir müssen uns immer wieder vor Augen halten, daß es sich bei der Betreuung der Ums[iedler] nicht um Kartoffelsäcke[,] sonderrn um lebende Menschen handelt. Die Lager sind in einem Zustand, daß man nicht begreifen kann, daß Menschen als Lagerleiter solche Verantwortung übernehmen können. Es ist eben unbeschreiblich und die Menschen müssen schon von vornherein spüren, daß sie als großes Laster ${ }^{2294}$ [so!] hierher kommen. Diese Menschen haben genausoviel

2293 [Magda Sendhoff (1899-1963), Oberprovinzialrätin und Leiterin der Umsiedlerabteilung der Provinzialverwaltung Mark Brandenburg in Potsdam.]

2294 [Gemeint ist „als große Last“.] 
oder wenig Schuld an all ihrem Leid wie wir und das bedeutet, diesen Leuten zu helfen, nicht nur, daß sie etwas in den Magen bekommen, entlaust oder untersucht werden, sondern man muß diesen Menschen Lebensmut geben und wir wollen ihnen helfen und sind bereit, ihnen einen neuen Arbeitsplatz, Wohnung und Heimat zu geben und am Wiederaufbau Deutschlands zu helfen. Die ganze Provinz muß noch stark auf das Neue vorbereitet werden. Ein neuer Strom von Ums [iedlern] - die aus der Tschechei kommen - und in die engl. u. amerika. Zone gehen, kommt durch d. Prov[inz] Brandenburg. Dafür müssen die Auffanglager Forst, Spremberg und Jüterbog diese Massen bewältigen, aber auch die Kreislager müssen herangezogen werden. Diese Kreislager können als Dauerlager am Ende benutzt werden, vor allem muß der neue Strom vorbereitet werden. Eine neue Welle von Westevakuierten kommt aus Westdeutschland in die Provinz rein. Wir werden sehr, sehr viel Arbeit bekommen, auch wenn es Stopp gegeben ist. Die besten Beweise in den letzten Wochen sind in Angermünde gegeben, dort treffen trotzdem täglich Züge mit Ums[iedlern] ein. Wenn die einzelnen Kreise Ums[iedler] bekommen oder aufnehmen, die heute noch wahllos umherwandern, ohne von uns eine Meldung zu haben, so müssen diese zusätzlich aus dem Soll genommen werden. Um dieses [so!] zu entgehen, muß immer erst Rücksprache mit uns genommen werden, denn es kann nicht angehen, daß immer noch Flüchtlinge aufgenommen werden, die in irgendeinem Ort Verwandte zu wohnen haben und denken, daß sie bei denen bleiben können. Generell kann das nicht durchgeführt werden. Vorläufig bleibt es dabei, daß die Ums[iedler,] die nach dem 15.10. gekommen sind, nicht für die Prov[inz] Br[andenburg]. zuständig sind sondern nur durchgeschleust werden müssen, bis jetzt kamen sie nach Mecklenburg und neuerdings geht es nach Sachsen. Für die Ums[iedler], die aus der Tschechei kommen und in der Prov[inz] bleiben, muß Arbeit geschaffen werden. Ein Beispiel dafür: Hennigsdorf ist nur ein kleiner Ort und hat ein Lager geschaffen für 10000 Menschen. Die Handwerker bekommen Arbeit in den handwerklichen Betrieben. - Ein unsagbares Elend herrscht unter den Kgf. ${ }^{2295}$, die nach Brandenburg kommen. Der Gesundheitszustand ist sehr schlecht. Über Frankfurt/O. kommen noch 1000000 Kgf., diese sind in ganz Deutschland beheimatet. Für diese soll ein besonderes Referat eingerichtet werden, bei der SMA u.Z. V. ${ }^{2296}$ soll in dieser Angelegenheit verhandelt werden. Das ist eine Aufgabe, die nicht nur Brandenburg [5. Bl.] anbetrifft, sondern das ganze Reich. Mit diesen Kgf. muß gesprochen werden und man muß ihnen Hilfe zukommen lassen.

Die Frauenausschüsse fangen jetzt erst an zu arbeiten, bis jetzt wurde noch keine praktische Arbeit geleistet. Die Frauen müssen sich in verstärktem Maße um die Kgf. kümmern, da sie dem Neuaufbau gegenüber vollständig fremd sind. Besondere Rücksprache muß genommen werden und auch andere Lager sind dafür hinzuzuziehen.

Für die hochschwangeren Frauen muß noch viel mehr gesorgt werden, bis jetzt waren annähernd 100 Geburten, sie müssen Frauenanstalten zugeführt werden. In Luckenwalde mußte die Polizei Geburtshelfer spielen, zumindest muß aber eine besondere Unterkunft für diese Frauen vorhan-

2295 [Kriegsgefangenen].

2296 [(Deutsche) Zentralverwaltung.] 
den sein. Wir müssen alles tun für die Ums[iedler], die Unterbringung muß menschenwürdig sein und Weiterleitung muß reibungslos vor sich gehen. Die Marschverpflegung darf nicht eher herausgegeben werden, bevor das Lager nicht sauber gemacht worden ist. Es geht nicht an, daß in einzelnen Lagern noch nicht mal die Säuglinge eine Suppe bekommen. Wenn keine Milch vorhanden ist, kann man von den Nährmitteln für kleine Kinder wenigstens eine Schleimsuppe kochen.

Die Frauenausschüsse sind den Sozialämtern angegliedert. Es muß eine Referentin bei den Frauenausschüssen sein, besonders bei der Betreuung der Umsiedler.

\section{Diskussionen}

Luckau: Bei der Durchschleusung der Ums[iedler] nach Mecklenburg sind große Schwierigkeiten entstanden. Polen schreiben Humanität vor und [wir] üben sie in Mecklenburg nicht aus. Mecklenburg gibt den Ums[iedlern] nichts, keinen Kaffe[e,] keine Suppe ect. [so!], Beschwerden des Transportführers wurden nicht angenommen. Die Leute kehren nach Luckau zurück und sagen, wenn man sie dort nicht aufnimmt, dann scheiden sie aus dem Leben aus, außerdem könnten sie ihre Verwandten aufsuchen, und bei denen wohnen. In Mecklenburg bestehen große Mißstände.

\section{Cottbus Stadt- und Guben Stadt}

wurden besichtigt und kontrolliert. In Cottbus war alles verpflegungstechnisch gesehen einwandfrei, nur Mängel waren an Stroh und Bettwäsche vorhanden, denn diese Sachen gibt es im Landkreis Cottbus sehr schlecht. Cottbus ist Grenzkreis, von den Geburten sterben $60 \%$ weg, wenn das so weitergeht, ist der Kreis innerhalb 60 Jahren ausgestorben. Die Russen verlangen restlose Ablieferung der Milch. Die Kinder bekommen nur $1 / 4$ ltr, alles andere muß abgeliefert werden und so ist es sehr schlecht, für die Ums[iedler]-Kinder Milch zu bekommen.

\section{Stadt Guben:}

In Guben sind sehr schlechte und erschütternde Zustände. Die Ums[iedler]-Ausschüsse haben nicht gearbeitet. Bei den Austeilungen der Verpflegung werden die Ums[iedler] betrogen. Der Kontrolleur hat das Essen probiert, 1 ltr. Essen ließ er sich geben, es sollte Kartoffelsuppe sein, sie wahr [so!] sehr dünn und nur 2 Kartoffelstückchen drin enthalten u. Suppengrün u. Wasser. Das Essen ist sehr schlecht, 300 gr. stehen den Ums[iedlern]. zu und so wenig bekommen sie nur. Brot selbst war richtig verteilt. Zucker bekamen sie auch nur 7 g., Fett war nicht da und Nährmittel nicht aufzufinden. Wo lagert dieses? Oberb[ür]g[er] $\mathrm{m}[\mathrm{ei}] \mathrm{st}[\mathrm{er}]$. hat versprochen, daß es besser wird, dafür sollen die Frauenausschüsse eingesetzt werden. Flüchtlinge kommen noch und noch, der Stopp macht sich nicht bemerkbar. Die Polen sind gemein, sie treiben die Menschen in die Neiße und schlagen sie, erschütternd ist es in diesen Grenzkreisen. Der Kommandant nimmt keinen Transport ab, bevor ihn die Polen nicht richtig übergeben haben. Mit den Kgf. ${ }^{2297}$ ist es ein trauriges Kapitel. Kriegsbeschädigte kommen und haben nichts anzuzie- 
hen und müssen, da sie krank sind, behandelt werden, wo sollen die Grenzstädte diese Mittel [6. Bl.] hernehmen für die Kgf.? Von andern Kreisen müßte Wäsche und Oberkleidung gesammelt werden, um es dort den Kgf. auszuhändigen. Nach Forst-Guben u. Cottbus kommen tägl. Kgf., ohne geschlossene Züge. (es kommt daher, da das Lager Sagan aufgelöst worden ist).

Wittenberge:

Flüchtlinge bekamen kein warmes Essen. 2 Tage 6000 Flüchtlinge durchgekommen, Ernährungsamt bewilligt keine Verpflegung. Wo kann diese beschafft werden? Was soll mit den Leuten werden, die nach Mecklenburg beschafft ${ }^{2298}$ werden sollen? Sitzen in Wittenbegre fest, weil keine Bahn fährt.

$[\ldots][$ 7. B1.] [...]

Herr Kienast. [Zum Thema Sozialversicherung]

[...] / Altersheime befinden sich in Forst, Spremberg, Wittenberge, Cottbus, Brandenburg, Wittstock, Luckenwalde.

\section{(112) Reaktion der Zentralverwaltung für deutsche Umsiedler auf den Plan} zur Errichtung einer „Arbeitsgemeinschaft deutscher Flüchtlinge in Finsterwalde. [Berlin], 14. Mai 1946

BArch, DO 2 Zentralverwaltung für deutsche Umsiedler, Nr. 50, Bl. 423. - Typoskript (Durchschlag), 1 S., unterzeichnet mit Paraphe „Chw“. - L. o.: „abgesandt am [Datumsstempel:] 14.5.46“, darunter „Org./O-Chw./Bl.“; r. o.: Datierung „14.5.1946“. - Adresse: „Herrn / Alwin Schulz / Finsterwalde/N.L. / Goethe-Str. 11“. - „Betr.: Arbeitsgemeinschaft deutscher Flüchtlinge. / Bezug: Ihr Schreiben vom 29.4.1946““- L. u. Verteiler: „Präsident / Vizepräsident [mit Bleistift unterstrichen] / Presse / 2 × Org.Abt.“ - R.u. „Zentralverwaltung für deutsche Umsiedler / I.A. / [gez.: ] Chw“.

Auf Ihr Schreiben ${ }^{2299}$ teilen wir Ihnen mit, dass wir der Errichtung einer Arbeitsgemeinschaft deutscher Flüchtlinge ablehnend gegenüber stehen. Die Zusammenfassung der Umsiedler in besonderen Organisationen würde zu einer Isolierung dieser Bevölkerungsgruppe führen. Das Interesse der Umsiedler besteht jedoch darin, sich so schnell wie möglich den örtlichen Verhältnissen ihrer jetzigen Unterbringungsorte anzupassen und sich so eng wie möglich mit der alteingesessenen Bevölkerung zu verbinden. Unsere Verwaltung tritt mit allem Nachdruck dafür ein, dass die Umsiedler nicht nur die gleichen Pfichten sondern auch die gleichen Rechte wie die Altbevölkerung besitzen.

Die bereits in der sowjetischen Zone bestehenden demokratischen Organisationen haben nicht nur die Aufgabe sondern auch die Pflicht, sich der Umsiedler besonders anzunehmen und ihnen die Wege zur Errichtung einer neuen Existenz zu ebnen. Besondere Umsiedler-Organisa-

2298 [Gemeint ist "geschafft".]

2299 [Ebd., Bl. 422: Schreiben von Stadtrat a. D. Alwin Schulz, Finsterwalde N. L., vom 29.4.1946, mit dem ausführlich, aber doch allgemein begründeten Antrag auf „Genehmigung und Zulassung der Organisation Arbeitsgemeinschaft deutscher Flüchtlinge“.] 
tionen würden die leider vielfach zu beobachtenden Gegensätze zwischen der alten und neuen Bevölkerung nicht überbrücken, sondern zum Schaden der Umsiedler nur vergrößern.

Das sich jetzt über die ganze sowjetische Besatzungszone erstreckende Werk „Volkssolidarität“ wird allen Notleidenden, also auch den Umsiedlern, Hilfe bringen.

Wir bitten Sie darum, den Gedanken an besondere Umsiedler-Organisationen fallen zu lassen und die bereits vorhandenen Möglichketen, den Umsiedlern mit Rat und Tat zu helfen, zu fördern.

\section{(113) Befehl der SMA Brandenburg zur Ergreifung verstärkter Maßnahmen zur Gleichstellung der Vertriebenen mit den Einheimischen. - Potsdam, 11. November 1946}

BLHA, Rep. 230 Oberlandratsamt Bernau, Nr. 292, Bl. 4-5. - Typoskripte. - Bl. 4 Anschreiben (Rundschreiben): B1. 4r 1. o. Absender „Provinzialverwaltung / Mark Brandenburg / Amt für deutsche Umsiedler / Az.: VIIa Fri/Re.“ Darunter Adresse: „An den Herrn Oberlandrat in Bernau“. - R. o. Datierung: „Potsdam, den 11.11.1946 / Alte Zauche 67“. - Darunter Eingangsstempel „Der Oberlandrat/Eing.: 13. Nov. 1946“ mit handschriftlicher Nr. „19149“ und blauer Paraphe „F“[G?] und Abt.-Zuständigkeit „VII“. - Bl. 4v Bleistiftunterschrift „Friedrichs“. - Bl. 4r unten roter Buntstiftvermerk „geschrieben an alle 4 Kreise / 15/11.46 mit Abschriften der Anlagen“. - Bl. 5 Anlage (Befehl der SMA).

In der Anlage wird ein Befehl der Verwaltung der Sowj[etischen] Militäradministration der Provinz Mark Brandenburg übersandt mit dem Ersuchen, allen Landräten, Oberbürgermeistern und Kenntnis zu geben und die angeordneten Nachprüfungen sofort durchführen zu lassen. Über das Ergebnis ist bis zum 22. Nov. d.J[ah]r[e]s zu berichten.

Der Befehl der SMA beweist erneut, daß die Ortsumsiedlerausschüsse, wie sie von uns angeordnet wurden, in den einzelnen Gemeinden entweder nicht gebildet wurden oder ihre Tätigkeit nicht mit dem nötigen Ernst nach den von uns gegebenen Richtlinien durchführen. Die Ortsumsiedlerausschüsse haben in ihren Gemeinden dafür zu sorgen, daß die ehem. Umsiedler der alteingesessenen Bevölkerung gleichgestellt werden. Sie haben die Fürsorge für diese ehem. Umsiedler zu übernehmen und sich zeigenden Ungerechtigkeiten mit allen ihnen zu Gebote stehenden Mitteln zu beseitigen. Mit Verfügung vom 25.8.1946 wurden von uns Kontrollberichte der Ortsumsiedlerausschüsse nach Formblatt 8 angefordert. Die hier vorliegenden lassen erkennen, daß die Beantwortung der gestellten Fragen äußerst flüchtig und oberflächlich erfolgte. Im Nachsatz des Formblattes 8 heißt es wie folgt:

„Für die Überprüfung der einzelnen Unterkünfte und Wohnungen der ehem. Umsiedler sind unter Angabe des Namens und der Familie, Größe der Familie, genaue Anschrift, ganz kurze nähere Angaben über die Wohnverhältnisse, wirtschaftliche Versorgung, tarifliche Entlohnung usw. zu machen." In dieser Hinsicht blieben fast alle Fragebogen unbeantwortet. In den meisten Fällen wurde das Formblatt offenbar nur von dem zuständigen Gemeindevorsteher oder Bürgermeister ausgefertigt, nicht von dem Ortsumsiedlerausschuss bezw. einer Arbeitskommission des Ausschusses. [Bl. 4v] 
Die Kreis- und Ortsumsiedlerausschüsse haben durch die Arbeitskommission der Ausschüsse zu überprüfen, ob die anfallenden Güter aller Art (Kleidung, Hausrat und Mobiliar) in erster Linie und nach Möglichkeit ausschließlich den ehem. Umsiedlern zur Verfügung gestellt werden. Mit dem Aufruf vom 9. Sept. 1946 zu den Aufgaben der Umsiedlerausschüsse wurden eine Reihe Anregungen für die Arbeit gegeben. Es ist dafür zu sorgen, daß spätestens bis zum 22.11. d.J $[\mathrm{ah}] \mathrm{r}[\mathrm{e}] \mathrm{s} .^{2300}$ aus allen Gemeinden die geforderten Berichte hier vorliegen.

Besonders eingehende Berichte erwarten wir über die Gemeinden und Städte Ketzin, Wittenberge, Brandenburg, Luckenwalde, Jüterbog und Potsdam sowie über den Kreis Ostprignitz.

\section{Anlage}

[B1. 5]

\section{UdSSR}

Verw. d. SMA d. Prov. Brandenburg

6.11.[19]46

Nr. 7538 Potsdam.
Abschrift

An den

Präs. d. Prov. Verwaltung der

Prov. Brandenburg

Dr. Steinhoff

Die in einer Anzahl von Städten und Dörfern der Prov. Brandenburg vorgenommene Nachprüfung der Arbeitsverhältnisse und Lebensbedingungen der Umsiedler hat Klagen der Umsiedler über die schweren Lebensbedignugen ergeben, und zwar:

1. Die Lebenshaltung der zur dauernden Niederlassung Umgesiedelten ist schlechter als die der eingesessenen Bevölkerung, nämlich: nicht genügend Möbel und Haushaltungsgegenstände, weniger Wohnfläche und häufig werden überhaupt keine Wohnungen zur Verfügung gestellt.

2. Die alteingesessenen Einwohner verhalten sich mit Verachtung gegenüber den Umsiedlern, betrachten sie als lästige Ausländer und halten sie für Menschen 2. Klasse.

3. Den Umsiedlern wird nicht rechtzeitig Arbeit verschafft, sondern sie werden für private Arbeiten bei den örtl. Bauern ausgenutzt.

4. Die Umsiedler erklären: „Wir Flüchtlinge sind arme und bedauernswerte Menschen geworden. Die Behörden werfen uns jedesmal solche Worte ins Gesicht: Ihr habt kein Anrecht auf eine Wohnung, Ihr habt nichts anderes verdient, Euch soll Hitler eine Wohnung geben“.

Die o[ben] dargelegten Fälle zeugen davon, dass (sowohl die Prov. Verwaltung) wie auch die örtl. Behörden für die Fragen der Arbeitsbeschaffung und der Lebensbedingungen für Umsiedler wenig Interesse haben und letzteren keinerlei Unterstützung gewähren. 
Ich ordne an:

1. Innerhalb 10 Tagen eine Untersuchung über die Arbeitsverhältnisse und Lebensbedingungen der Umsiedler durchzuführen und Massnahmen zur Verbesserung der Lage der Umsiedler zu ergreifen.

Besondere Aufmerksamkeit ist auf folgende Städte zu richten: Ketzin, Wittenberge, Brandenburg, Luckenwalde, Jüterbog, Ostprignitz und Potsdam.

2. Eine Kontrolle über die ordnungsmässige Einordnung der zur dauernden Niederlassung Umgesiedelten und ihre Versorgung mit allem Notwendigen auf gleicher Stufe mit den Alteinwohnern zu errichten.

3. Unter der eingesessenen Bevölkerung eine umfangreiche Aufklärungstätigkeit über die Verbesserung der gegenseitigen Beziehungen mit den Umsiedlern und grössere Unterstützung bei der Einrichtung ihrer Lebensverhältnisse durchzuführen.

Über das o[ben] Dargelegte benachrichtigen Sie mich bis zum 30.11.[19]46.

Stellvert[retender]. Chef der Verw[altung]. d. Prov. Brandenburg Gardegeneralmajor (Sschistow ${ }^{2301}$ )

Übers[etzt]. Dom. ${ }^{2302}$ Prestin

geschr[ieben]. Hühne.

(114) Befehl der SMA Brandenburg zur Ergreifung verstärkter Maßnahmen zur Gleichstellung der Vertriebenen mit den Einheimischen. - Potsdam, 7. März 1947

BLHA, Rep. 333 SED-Landesleitung Brandenburg, Nr. 574, Bl. 100. - Abschrift (Typoskript).

Abschrift

UdSSR

Verw. d. SMA d. Prov. Brandenburg

7.3.[19]47

Nr. 1467 Potsdam.
An den

Min.-Präsidenten der Provinzialre-

gierung der Prov. Brandenburg

Dr. Steinhoff

Während der Jahre 1945 und 1946 sind in der Prov. Brandenburg aus Polen, der Tschechoslowakei und anderen Staaten etwa $700 \mathrm{t}[\mathrm{a}] \mathrm{us}$ [end] deutsche Umsiedler angekommen. Im Verhältnis zur Gesamtbevölkerungszahl der Provinz machen die Umsiedler 28 \% der ganzen Bevölkerung aus. Die deutschen Selbstverwaltungsorgane haben eine erhebliche Arbeit hinsichtlich der Un-

2301 [Wladimir Afanasjewitsch Tschistow, Generalmajor, 1947 Chef der Abt. Kommandanturdienst der SMADLandesverwaltung Brandenburg, Aug. 1947 bis Okt. 1949 stellv. Chef der SMA-Landesverwaltung Brandenburg (Foitzik, Sowjetische Militäradministration, wie Anm. 1094, S. 480).] 
terbringung der Umsiedler geleistet. Jedoch gibt es in den Angelegenheiten der Regelung der Arbeits- und Lebensverhältnisse der Umsiedler noch grosse Mängel:

1. Die Unterbringung der Umsiedler am ständigen Wohnsitz ist schlechter als die der Stammbevölkerung, wie z.B. unzureichende Zahl von Möbeln, Haushaltsgegenständen und dergl. Die Umsiedler leben in schlecht eingerichteten Wohnungen, hausen in Dachkammern, Keller- und uneingerichteten Räumen, zur gleichen Zeit, wo die Alteinwohner eine Wohnfläche über jegliche Norm hinaus einnehmen und sich auf jede Weise der Einquartierung von Umsiedlern bei ihnen widersetzen. Fälle des Widerstandes gegen die Überlassung von Wohnungen ereigneten sich in den Dörfern: Jenickendorf ${ }^{2303}$, Ilmannsdorf ${ }^{2304}$, Waltersdorf, Kreis Luckenwalde und anderen Bezirken.

Bei dem in der Prov. vorhandenen durchschnittlichen Wohnraum auf den Kopf der Bervölkerung von 7,7 qm ist in einer Anzahl von Kreisen die Wohnfläche erheblich grösser, wie z. B. in Frankfurt/Oder - 11,63 qm, Cottbus - 10,3 qm, Kreis Spremberg - 10,3 qm, Kreis Osthavelland 10,8 qm, Stadt Brandenburg - 10,0 qm, Kreis Zauch-Belzig - 10,1 qm. Trotzdem hausen die Umsiedler, wie oben angegeben, in Dachräumen, nicht eingerichteten Baracken und dergl. So ist z.B. durech eine Untersuchung der ordnungsmässigen Unterbringung von 32 Familien, die im Bezirk Cottbus als ständigen Wohnsitz seßhaft geworden sind, festgestellt worden, die Wohnfläche, auf der die Umsiedler untergebracht sind, ist äusserst unzureichend, es liegen Fälle vor, daß in einem Zimmer 2 und mehr Familien wohnen (Kreis Luckau).

2. Die örtl. Organe treffen keine konkreten Maßnahmen zur bevorzugten Unterbringung der Umsiedler in Arbeitsstellen unter Berücksichtigung ihrer Fachkenntnisse. Viele Umsiedler arbeiten nicht in ihrem Arbeitsfach. Es sind erst wenig Umsiedler, besonders Jugendliche, zu einer Betriebsschulung herangezogen worden.

3. Es wird die geringschätzige Einstellung der Alteinwohner gegenüber den Umsiedlern nicht in gebührender Weise bekämpft. Die Alteiwohner betrachten die Umsiedler als lästige Ausländer, halten sie für „Fremde“ und „Zugereiste“.

4. Das Ansiedeln der Umsiedler nach Ablauf der vorgeschriebenen Quarantänefrist geht durch die örtl. Organe langsam vor sich, was sich auf den moralischen und materiellen Zustand der Umsiedler auswirkt (Im Lager Forst befinden sich seit Januar 88 Umsiedler, die bisher nicht angesiedelt sind). Die örtl. Organe erweisen den Betagten und Invaliden keine Unterstützung und schaffen keine normalen Lebensbedingungen für die Umsiedler (Kr. Cottbus). [Bl. 100v]

5. Die Umsiedler werden nicht rechtzeitig mit Heizmaterial versorgt und erhalten keine Bezugsscheine auf Industriewaren, Kr. Luckau, Luckenwalde u. a. 
6. Es sind Fälle festgestellt, daß die Ärzte es ablehnen, Kranken Hilfe zu erweisen. So z.B. weigerte sich in Cottbus der Arzt $\mathrm{M}[\ldots]$ indem er es durch die Kälte begründete, zu dem Kranken B $[\ldots]$, Rudolf in die Baracke zu kommen.

7. Im Kr. Luckenwalde sind Fälle vorgekommen, daß Umsiedler, die aufgrund der Bodenreform Land zugeteilt erhalten hatten, die Übernahme wegen Fehlens von landw. Inventar und Zugkraft jetzt verweigern. Alle diese Mängel sind darauf zurückzuführen, daß viele Arbeiter der örtl. Selbstverwaltungsorgane noch nicht die wichtige Bedeutung der mit der Umsiedlerung [so!] der Deutschen und ihrer Einordnung in den Arbeitsprozeß zusammenhängenden Fragen begriffen haben und die Kontrolle schlecht und unwirksam durchführen. Man muß begreifen, daß die Angelegenheiten der deutschen Umsiedler und ihre Lebens- und Arbeitsverhältnisse eine ungeheure Bedeutung für die weitere Entwicklung der Demokratisierung Deutschlands und im besonderen der Prov. Brandenburg haben. Zur Beseit[ig] ung der vorhandenen Mängel und gründlichen Verbesserung der Arbeit mit den Umsiedlern,

$$
\text { ordne ich an: }
$$

1. Unter Ihre persönliche Kontrolle die Arbeit der örtl. Selbstverwaltungsorgane in Sachen der Unterbringung und allgemeinen Versorgung der Umsiedler zu nehmen.

2. Zu Ansiedlung der Umsiedler die Aufbauarbeiten für die Reparatur des zerstörten Wohnraums in Gang zu bringen und allgemeinen Tarif für Wohnungsmieten festzusetzen.

3. Von den örtl. Organen zu verlangen, die Arbeit bezügl. der Errichtung von Gewerbegenossenschaftsbetrieben und von Betrieben industriellen Typs in Gang zu bringen und zu dieser Maßnahme in 1. Linie die Umsiedler heranzuziehen.

4. Durch die örtl. Organe alle Invaliden, Betagten und Waisen in Heimen und Internaten unterzubringen und ihnen normale Lebensbedingungen zu schaffen.

5. Zu berücksichtigen, daß im Laufe des Jahres [19]47 die Aufnahme von deutschen Umsiedlern aus Polen und anderen Städten sowie von Kriegsgefangenen andauern und die ungeschwächte Aufmerksamkeit wegen ihrer Ansiedlung und Arbeitsbeschaffung erfordern wird.

Über den Stand der Arbeit mit den Umsiedlern, ihre Unterbringung, Einordnung in den Arbeitsprozess und materielle Sicherstellung ist monatlich am 1. eines jeden Monats, beginnend mit dem 1. April [19]47, zu berichten.

$$
\text { Chef der Verwaltung }
$$

der SMA der Prov. Brandenburg

Gardegeneralmajor (Scharow ${ }^{2305}$ ) 


\title{
(115) Protokoll einer Konferenz zum Thema „Soziale Betreuung der Landarbeiter“
} im Ministerium für Arbeit und Sozialwesen Brandenburg. - Potsdam, 11. März 1947 (Auszug)

BLHA, Rep. 206 Ministerium für Wirtschaft und Arbeit, Nr. 2965, unfol. - Typoskript ohne Unterschrift, 5 Bl. (dabei 2 Durchschläge, davon eine im Schriftbild differierende Abschrift, 1 Bl. Anwesenheitsliste mit Unterschriften).

\author{
Protokoll \\ über
}

„Soziale Betreuung der Landarbeiter am 11.3.47

Anwesend waren:

$\begin{array}{ll}\begin{array}{l}\text { Herr Fischer }{ }^{2306} \\ \text { Frau Przyjemski }\end{array} & \text { Abt. VII } \\ \text { Herr Einhorn } & \text { Abt. VII - Ref.: Frau und Kind } \\ \text { Herr Brehmer } & \text { Abt. VII - Ref.: Kulturelle Betreuung } \\ \text { Herr Thiele } & \text { Abt. VII - Ref.: Wohnungsfürsorge } \\ \text { Herr Schmidt } & \text { Märkische Volkssolidarität } \\ \text { Herr Beuster } & \text { SED - Landesverband Potsdam } \\ \text { Herr Münchenhagen } & \text { Gewerkschaft, Land- u. Forstwirtschaft } \\ \text { Herr Gehrmann } & \text { Abt. Umsiedler u. Heimkehrer } \\ \text { Frau Dr. Müller } & \text { Abt. III, Ref.: Land[wirtschaft] u. Forsten } \\ \text { Frau Fleischer } & \text { Abt. Gesundheitswesen }\end{array}$

Trotz Einladung waren nicht erschienen die Vertreter der VdgB, der LDP und der CDU.

Bei der Eröffnung der Sitzung wies Herr Gehrmann darauf hin, dass es z. Zt. eine der dringendsten Forderungen ist, die soziale Lage der Landarbeiter zu überprüfen. Herr Spillner als Leiter des Ausschusses „Soziale Betreuung der Landarbeiter“ hat bereits zu dieser Frage Stellung genommen. Da Herr Spillner auf Dienstreise ist, um für die Landarbeiter Textilien zu besorgen, bin ich als sein Vertreter zur Leitung der Konferenz bestellt.

Das wichtigste Problem der sozialen Bereuung der Landarbeiter muss schnellstens einer Lösung entgegengeführt werden. Notwendig dabei ist, die SMA von der Dringlichkeit der Aktion zu überzeugen. Min.Dir. Wegener ist ebenfalls an der Lösung dieses Problems stark interessiert und wünscht, dass der Auschuss eng mit ihm zusammen arbeitet. 
Wenn Herr Spillner Textilien besorgt, so wird damit längst nicht der Bedarf der notleidenden Landarbeiter gedeckt sein. Es wird Aufgabe des zu bildenden Ausschusses sein, gerade auf diesem Gebiete sich besonders für die Landarbeiter einzusetzen.

In den zu bildenden Ausschuss soll nach Möglichkeit je 1 Vertreter des FDGB, der antifaschistischen Parteien, der VdgB, den Frauenausschüssen, der Abteilung VII - Arbeit und Sozialwesen - berufen werrden. Es geht nicht an, dass einige hunderttausend Landarbeiter der Provinz Mark Brandenburg nicht gesehen werden oder nicht gesehen werden wollen. Die „Soziale Betreung der Landarbeiter" ist ausserdem noch eine politische Aufgabe[,] die gelöst werden muss. Was bisher für die Landarbeiter getan wurde, ist ausserordentlich kläglich.

Ich nehme an, dass auch Sie einige Vorschläge vorzubringen haben. [2. Bl.]

Herr Fischer.

Wir haben uns schon auf der 1. Sitzung mit dem Problem der „Sozialen Betreuung der Landarbeiter" beschäftigt. Dabei wurde festgestellt, dass die Wohnungsverhältnisse sehr schlecht sind. Solange dem Landarbeiter und dem Umsiedler nicht eigener Wohnraum, auch wenn er noch so bescheiden ist, zur Verfügung steht, wird die soziale Betreuung der Landarbeiter negativ bleiben. Die z. Zt. äusserst ungesunden und asozialen Wohnverhältnisse der Landarbeiter und Umsiedler beeinträchtigen stark die Arbeitsmoral derselben. Auch ist das Verhältnis der Umsiedler, die speziell zur Frühjahrsbestellung als Landarbeiter eingesetzt werden sollen, zu ihren Arbeitgebern, den Bauern, bei dem [so!] sie in Kost und Logie [so!] untergebracht sind, oft ein sehr gespanntes. Der zum grössten Teil hungrige und sandige Boden der Mark Brandenburg zwingt den märkischen Bauern zu härtester Arbeit und grosser Anstrengung, Der Existenzkampf hat ihn hart, ja sogar geizig gemacht. Er zeigt nicht das Verständnis für die Nöte der Umsiedler, die bei ihm einquartiert sind und zum Teil selbst früher Bauern waren, Die Verhältnisse sind oft derart gespannt, dass diese Umsiedler und ehemaligen Bauern es vorziehen, sich freiwillig zur Oderregulierung zu melden, die z. Zt. eine der schwierigsten Arbeiten ist, als wie beim Bauern Hofdienst zu leisten.

Um dem Wohnungselend auf dem Lande zu steuern, müssen alle Mittel erwogen weden, die geeignet sind, diesen Rückstand zu beseitigen. Man müsste dem Gedanken näher treten, ein Preisausschreiben herauszugeben über den Bau von Kleinstwohnungen, wobei die Bauverhältnisse den örtlichen Verhältnissen angepasst sein müssen. Auf alle Fälle müsste man Fachleute dafür interessieren.

Die Lage des Landarbeiters hat sich durch die Deputatfrage nicht zu seinen Gunsten gebessert. Der Landarbeitertarif ist aufgekündigt worden.

Ebenso notwendig wie die Linderung der materiellen Nöte der Landarbeiter ist die „Kulturelle Betreuung“ derselben. In den seltensten Fällen ist ein Radio vorhanden, Zeitungen kommen sehr unregelmässig und wenn, meistens sehr veraltet zum Landarbeiter. Hier muss seitens des Ref.: „Kulturelle Betreuung der Werktätigen“ eingegriffen werden. 
Ich halte es für notwendig, dass nicht nur der Ausschuss für die „Soziale Betreuung der Landarbeiter" die Probleme überprüft, sondern dass vielmehr auf dem Dienstwege die Landräte und Oberbürgermeister angewiesen werden, sich ebenfalls um diese Frage zu kümmern; und dass die nachgeordneten Dienststellen veranlasst werden, über die von ihnen veranlassten Massnahmen zu berichten.

Frau Fleischer.

Als ich von der letzten Sitzung kam, hatten wir vom Provi-Frauenausschuss ${ }^{2307}$ sofort Rundschreiben an die Frauenausschüse für die Gemeinden herausgegeben, mit dem Aufruf, Bekleidungsstücke für die Landarbeiter zu sammeln. Bisher war diese Aktion leider erfolglos. Ich bin der Meinung, dass man immer wieder bei der SMA in dieser Angelegenheit vorsprechen müsste.

Auch für die „Kulturelle Betreuung“ haben wir Bücher gekauft und wollen eine Wanderbibliothek gründen.

Es müsste dafür gesorgt werden, dass die Selbstversorger zusätzlich Lebensmittelkarten erhalten. [3. Bl.]

Frau Przyjemski.

Ich bin der Meinung, dass die Wohnungsämter über die Landräte angewiesen werden müssten, jede einzelne Wohnung darauf zu überprüfen, wieviel Zimmer jeder Familie zur Verfügung stehen. Es müsste dann so wie in Berlin sein, dass, sofern genügend Raum vorhanden ist, Umsiedler eingewiesen werden.

\section{Herr Brehmer.}

Ich kann aus Erfahrung sagen, dass die Umsiedler, sobald sie in den Gemeinden eingemeindet sind, als Eindringlinge angesehen werden. Die Bürgermeister selbst leisten den meisten Widerstand, nur um keine Umsiedler einzugemeinden. Die Bodenreform ist zum grossen Teil schuld daran. Das Land wurde nur an bekannte und befreundete Familien aufgeteilt und an solche, die schon Land hatten. Die Umsiedler selbst wurden in den seltensten Fällen bedacht.

Die Landräte müssen anfangen, die Bürgermeister ordentlich zu schulen. Sie haben auch die Möglichkeit die Bürgermeister in Strafe zu nehmen, tun es aber trotzdem nicht.

Die Arbeit der Bürgermeister muss nicht durch die Landräte sondern auch durch die politischen Parteien überprüft werden.

Frau Przyjemski.

Man müsste bei den Landräten eine Kommission zusammenstellen, die nur für die Überprüfungen der Wohnungsverhältnisse verantwortlich ist. 
Herr Beuster.

Das Bauprogramm wird hinderlich sein an der Beschaffung von Wohnungen für Umsiedler. Es wird wenig dabei herauskommen. Für die Landarbeiter muss noch ein Sonderweg beschritten werden. Wir sind uns darüber im klaren, dass wir uns auf den Wohnraum beschränken müssen, der im Augenblick vorhanden ist.

Für die in der Forst tätigen Umsiedler müssen ebenfalls Wohnungen geschaffen werden, da sonst das Arbeitsprogramm nicht durchgeführt werden kann. An den sozialen Stellen muss mindestens 1 Mann sein, der sich nur mit den Landarbeitern befasst.

Die Frage der Selbstversorgung ist zu klären, da die Selbstversorger weniger haben als wir in der Stadt.

Von zuständiger Stelle wurde mir gesagt, dass, wenn wir jetzt, nachdem die Lebensmittelkarte 6 abgeschafft wurde, den Selbstversorgern noch Lebensmittelkarten geben, die ganze Lebensmittelversorgung in Frage gestellt wäre.

Wichtig ist, dass sich alle Organisationen der Landarbeiter annehmen, das Herausfinden von bisher noch unbewohntem Wohnraum, von Baracken und der Bau von Blockhäusern.

Abschliessend möchte ich noch sagen, dass man bei der Forst in den letzten Monaten eine wesentliche Besserung bei der Textilversorgung festgestellt hat. [4. Bl.]

Herr Münchenhagen.

Die Abt. Umsiedler und Heimkehrer ist von sich aus bemüht, die Frage der Umsiedler zu lösen. Wir haben Kreiskonferenzen einberufen um diese Fragen ausführlich zu besprechen. Durch die Witterungsverhältnisse bedingt, waren diese Konferenzen schlecht besucht.

Bei den stattfindenden Konferenzen haben wir die Arbeit des FDGB und die der antifaschistischen Parteien sehr vermisst; nur die SED war - wie heute - vertreten.

Dem Vorschlag von Herrn Fischer, betr.: des Preisausschreibens stimme ich zu.

Herr Brehmer.

Zur Wohnraumverteilung hätte ich noch folgendes zu sagen: Eine Wohnungskartei wäre das einzige, woran der Bürgermeister feststellen kann, wieviel Wohnraum zur Verfügung steht. Dieser Aufgabe haben sich aber die Bürgermeister bisher bewusst entzogen.

Frau Fleischer.

Bei dem Bau von Notwohnungen ist darauf zu achten, dass für die Mieter kein gesundheitlicher Schaden entstehen kann.

Frau Dr. Müller.

Ich bin der Ansicht, dass fremde Personen feststellen müssen, wieviel Wohnraum in den einzelnen Gemeinden vorhanden ist. 


\section{Herr Gehrmann.}

Es wird wenig daran gedacht, dass man die Häuser auch noch ausbauen kann. In unserem Haus ist der Boden für eine Pförtner-Wohnung ausgebaut worden. Der Ausbau - 1 Stube und 1 Küche - kam RM 350,--

\section{Herr Brehmer.}

Es muss ein Propagandazug durch die Presse stattfinden, Wir müssen uns weiter mehr mit der Innen- als mit der Aussenpolitik befassen. Der Rundfunk bringt nicht die Probleme, die für das Interesse der Bevölkerung sind. Es muss auf die Not der Umsiedler und Landarbeiter hingewiesen werden.

\section{Herr Schmidt.}

Ich begrüsse die heutige Zusammenkunft auf das herzlichste. Die Landarbeiterfrage liegt auch uns am meisten am Herzen. Durch die Vielseitigkeit der uns auferlegten Arbeiten konnten wir uns den eigentlichen Problemen nicht so annehmen, wie es erforderlich war. Ich bedaure, dass die Vertreter der CDU und der LDP nicht anwesend sind. [5. Bl.]

Unsere Hauptsorge ist nicht die Wohnungsbeschaffung sondern die Verpflegung. Hier muss eine Lösung gefunden werden, um den Landarbeitern die Lebensmittelkarte zu geben. An die Regierung wurde der Antrag gestellt, bei der SMA zu beantragen, dass die Landarbeiter Lebensmittelkarten bekommen.

Die Leute, die nur auf dem Lande wohnen, um besser leben zu können, müssen wieder ausgewiesen werden und dafür sollen die Landarbeiter dort Wohnung nehmen.

Ich möchte davor warnen, die Barackenfrage zu sehr in Angriff zu nehmen, da damit zu viel Schwierigkeiten verbunden sind und auch zu viel Gelder ausgegeben werden.

An den schlechten Wohnverhältnissen haben die Umsiedler zum Teil selbst schuld. Sie glaubten anfangs den Gerüchten, dass sie wieder in ihre Heimat zurück könnten und wollten sich nirgends ansiedeln. Die Ausarbeitungen für Rundfunk und Presse müssen wir von uns aus machen, um diese Frage alsbald in den Äther zu bringen; diese Massnahme muss sofort in Angriff genommen werden.

Herr Thiele.

Es ist sehr wichtig, dass dieses Protokoll dem Landesausschuss der Parteien, die heute hier nicht anwesend sind, zugeschickt wird und dass diese bis zu einem bestimmten Tage dazu Stellung nehmen.

\section{Herr Gehrmann.}

Von allen Anwesenden möchte ich einen kurzen Bericht haben, ob evtl. noch Vorschläge zu den angeschnittenen Fragen zu machen sind. 
Herr Fischer.

Zum Abschluss ist zu sagen, dass ein engerer Arbeitsausschuss zu bilden ist, dessen Führung Herrn Gehrmann übertragen wird, Weitere Mitglieder sind: Herr Brehmer, Herr Beuster, Frau Fleischer und die VfgB.

Die nächste Zusammenkunft ist am Mittwoch, den 9. April 1947.

Potsdam, den 15.3.[19]47/Sa.-

(116) Protokoll einer Besprechung zur sozialen Betreuung der Land- und Forstarbeiter in der Landesregierung Brandenburg. - Potsdam, 9. August 1947 (Auszug)

BLHA, Rep. 206 Ministerium für Wirtschaft und Arbeit, Nr. 2965, unfol. - Typoskript (Durchschlag), 3 Bl. - Auf 3. Bl. masch. „Im Auftrage: / gez. Gehrmann“ und u. 1. (Bleistift) „Ka. / 11/8. 47“. - Auf 1. Bl. o. 1.: „-2243-“; r. o. Eingangsstempel „Arbeit und Sozialwesen / Eing. 14 AUG. 1947“, Kenntnisnahme-Bleistifthaken der Abt. VII.; Durchschlagverteiler-Anschrift 1. o.: „An die Abt. VII / Ref. Wohnungsfürsorge / z. Hd. Herrn / Zimmermann / Alte Zauche.“

\section{Protokoll}

Zur Sitzung für soziale Betreuung der Land- und Forstarbeiter am Sonnabend, dem 9.8.[19]47

Ort: Landesregierung Brandenburg, Friedrich-Ebert-Str., Zimmer 340. / Beginn: 9 Uhr.

Anwesend waren: Herr Grabowski, Abt. VII, Ref. Arbeits- u. Unfallschutz / Herr Rother, [desgleichen] / Herr Wöhling, Sachbearbeiter Landwirtschaft, SED / Herr Zimmermann, Abt. VII, Wohnungsfürsorge / Frau Grothe, Abt. IV, Provi-Frauenausschuss ${ }^{2308}$ / Herr Beuster, FDGB, I. G. - Land und Forst / Herr Fölber, [desgleichen] / Herr Jahn, Abt. VII a - Umsiedler und Heimkehrer / Herr Gehrmann, Abt. III, Ref. Land- und Forstarbeiterfragen / Herr Spiller, [desgleichen]

I.

Herr Gehrmann eröffnete die Sitzung und bat Herrn Grabowski vom Arbeitsschutzamt um Erläuterungen über die eingeleiteten Massnahmen zur bevorstehenden Arbeitsschutzkampagne vonseiten des Ref. Arbeitsschutz. [...] [2. B1.] [...]

II.

Herr Gehrmann führte aus: In allen Dörfern und landwirtschaftlichen Grossbetrieben sollen auf Vorschlag der deutschen Zentralverwaltung Fürsorgerinnen eingesetz $[t]$ werden. In erster Linie soll hierdurch der Landbevölkerung im Punkte Wohnungsfürsorge geholfen werden. Man denkt bei der Fürsorgerin an eine erste ärztliche Hilfe, an Kinderbetreuung usw. Die Wahl der Fürsorgerin ist überhaupt eine grosse Charakterfrage, da sie zu allen schwierigen Fragen ihres Wirkungskreises als Beraterin hinzugezogen werden wird, denn sie hat ja Zutritt in jedes Haus. 
Für die Landesregierung ist der Einsatz von Fürsorgerinnen neben der Frage des geschulten Menschenmaterials in der Hauptsache ein Finanzierungsproblem, das vom Ministerium für Arbeit und Sozialwesen gelöst werden muss.

Herr Zimmermann, Ref. Wohnungsfürsorge, äusserte sich wie folgt: Es seien schon andere wichtige Pläne aus Geldmangel abgelehnt worden, er habe wenig Hoffnung bei unserem o.g. Fürsorgeplan.

Herr Beuster schlug daraufhin vor, diese Aktion mit dem Einsatz von weniger Fürsorgerinnen, und zwar zunächst in allen Landkreisen eine, zu beginnen, oder man sollte die ausgesprochenen Notstandsgebiete zuerst bedenken.

Herr Gehrmann sah auch eine Möglichkeit, die Land- und Forstarbeiter evtl. im Landratsamt durch einen besonderen Sachbearbeiter zu betreuen, der speziell in dieser Richtung zu arbeiten hat.

Herr Jahn sprach sich für die Übertragung der Aufgaben einer Fürsorgerin auf die schon bestehenden Umsiedler- und Heimkehrerausschüsse aus, die in $90 \%$ aller Gemeinden des Landes Brandenburg bereits gut funktionierten. In ihnen befinden sich Vertreter sämtlicher Organisationen. Der Umsiedlerauschuss setzt sich nicht etwa nur aus Umsiedlern zusammen, es soll ja endlich der Punkt erreicht werden, dass Altbauern und Umsiedler gleichgeschaltet ${ }^{2309}$ sind.

Herr Zimmermann knüpfte hieran an, dass künftig darauf geachtet werden soll, dass auch die Wohnungsausschüsse einen Umsiedler bzw. einen Flüchtling enthalten, die Belange dieser Menschen würden dadurch wesentlich besser gewahrt. [3. Bl.]

Herr Gehrmann bedeutete, dass auch die gerechte Überwachung der Textilienverteilung eine Aufgabe der zu schaffenden sozialen Einrichtung sei, er berichtete einige Vorkommnisse, wo z. B. die Textilien nicht weit über das Haus des Bürgermeisters hinaus gekommen waren. Die Umsiedler und Flüchtlinge müssen vor allen Dingen immer dahingehend beeinflusst werden, in ihrer jetzigen Umgebung endlich eine zweite Heimat zu sehen und nicht mit der Möglichkeit einer Rückkehr in ihre östliche Heimat zu rechnen. Nur so kann der Aufbaugedanke gefördert werden. Die weiteren Schritte zu Punkt II wurden von der Entscheidung des Herrn Ministers Schwob abhängig gemacht, die erst abgewartet werden muss.

III.

Die Beteiligung der Landarbeiter an dert Prämierung der Bauern für gute Leistungen wurde dann kurz zur Diskussion gestellt.

Grundsätzlich waren alle massgeblichen anwesenden Vertreter mit der Beteiligung der Arbeiter an der Prämierung der Bauern einverstanden. Man ist der Meinung, dass es auch bei der heutigen Bauernpolitik möglich sein muss, dem Arbeiter einen Prämienanteil zukommen zu 
lassen. Diese Frage muss mit dem FDGB und der VdgB. geklärt werden, damit von hier aus Anweisungen an die Kreise und an die kreisfreien Städte herausgegeben werden. Diese beiden Massenorganisationen haben diese Frage so schnell wie möglich zu lösen.

IV.

Herr Spiller berichtete über die letzten Erfolge in der Textilienverteilung. In der letzten Zeit wurde eine Reihe von Herrenanzügen zur Verfügung gestellt, die nun zum grossen Teil anlässlich des Erntewettbewerbs den Prämienträgern kostenlos ausgegeben werden sollen. Vom 3. Quartal an sollen die Textilzuwendungen über die Landratsämter erfolgen. Der FDGB soll nach wie vor bei der Verteilung mit eingeschaltet werden. Das Referat wird sich aber zur Aufgabe machen, zu überprüfen, wieviel Material tatsächlich an die Kreise ausgegeben wird, und darauf zu achten, dass die Land- und Forstarbeiter, die zum grossen Teil Umsiedler sind, ihrer Notlage entsprechend besonders berücksichtigt werden.

Arbeitsbekleidung ist bisher leider nicht zu erreichen gewesen.

\section{(117) Rede des Landrats des Kreises Niederbarnim, Max Paatz, vor Heimkehrern auf der Heimkehrertagung am 6. September 1948 in Bernau (Auszüge)}

BLHA, Rep. 250 Landratsamt Niederbarnim, Nr. 104, unfol. - Typoskript (Durchschlag), 16 Bl. - Auf 1. Bl. o. 1. Stempel „Der Landrat/ des Kreises Niederbarnim / Sekretariat“. - R. o. Datierung „Bernau, den 6. Sept. 1948.“ - Überschrift: „Referat / des Herrn Landrats Paatz zur Heimkehrertagung am 6.9.1948“.

Liebe Heimkehrer!

[...] / [10. Bl.] [...] Tausende und aber Tausende Umsiedler - 46000 - hat der Kreis Niederbarnim aufgenommen und steht heute wieder vor der Tatsache, 5000 neue aufzunehmen. Menschen, die heimatlos, entwurzelt durch die Welt gehen, müssen wir [11. Bl.] wieder eine neue Heimat schaffen. Daß wir dazu das Eigentum derer verwenden, die uns in dieses Elend stürzten, dürfte selbstverständlich sein. Es handelt sich darum, den Umsiedlern mit den Mitteln eine neue Heimstatt zu schaffen, die wir uns aus dem Befehl $124^{2310}$ holen. [...]

Heute befinden sich im Kreise insgesamt 532 Neubauerngehöfte. Außerdem wurden von 1945 bis heute 217 Gehöfte erstellt. [... ] Im Zuge des Jahres 1948 werden bis 31.12. gemäß dem [12. Bl.] Neubauernprogramm 600 neue Gehöfte entstehen, eine Arbeit, die in ihrer Leistung und Auswirkung von wenigen verstanden worden ist. [...] Steine holen wir uns von den Schlössern, aus den Trümmern und den Ruinen, denn wir sind der Meinung, daß alle Dinge, die an die damalige Zeit der Güter und Gutsverwalter erinnern, ausgelöscht werden müssen, und wir damit den Menschen, die ihre Heimat verloren haben, eine neue Heimat schaffen. / [...]

2310 [Befehl des Obersten Chefs der Sowjetischen Militärverwaltung und Oberbefehlshabers der Gruppe der sowjetischen Besatzungstruppen in Deutschland, Nr. 124 vom 30. Oktober 1945 über die Beschlagnahme und provisorische Übernahme einiger Eigentumskategorien in Deutschland.] 


\section{(118) Protokoll einer SED-Konferenz über Umsiedlerfragen. - Potsdam, 26. Februar 1949}

BLHA, Rep. 333 SED-Landesleitung Brandenburg, Nr. 574, Bl. 385-395. - Typoskript (Durchschlag) ohne Unterschrift. - Bl. 395 Datierung: „Potsdam, den 16. Februar 1949“. - Bl. 385 Überschrift: „Protokoll / der Konferenz über die Umsiedlerfragen / am 16.2.1949 im Club- und Konferenzhaus.“ - R. o. Bleistift-Verteiler „ZS“ [= Zentralsekretariat].

Genosse Mickin eröffnete die Tagung und tadelte den schlechten Besuch, der beweist, daß der Frage des Umsiedlerproblems nicht genügend Aufmerksamkeit zukommt, da gewisse reaktionäre Kreise der anderen Parteien immer wieder versuchen z. B. die Frage der Ostgrenze als nicht geklärt hinzustellen.

\section{Referat Genosse Artur Voigt ${ }^{2311}$ :}

Genosse Voigt wies in seinem Referat auf die unterschiedliche Behandlung des Umsiedlerproblems in den Westzonen und in unserer Zone hin. Er wies darauf hin, daß das Umsiedlerproblem nicht erst mit Kriegsende begann, sondern schon gleich nach 1933. Er erinnerte hierbei an die $\mathrm{KZ}$ und die Judenverfolgung, an den Überfall auf friedliebende Völker, Verschleppung in andere Länder zum Zweck der Arbeitsleistung und zur bewußten Aussiedlung und Besiedlung ihrer Heimatgebiete mit deutschen Elementen. / Diese Dinge werden zu wenig beachtet.

Er stellte dann die Frage[,] ob das Umsiedlerproblem das Problem einer bestimmten Grenze ist[,] und erläuterte in diesem Zusammenhang die Stellung unserer Partei zur Oder-NeißeGrenze.

„Als erste Aufgabe steht vor uns der Kampf um einen gerechten Frieden und um die Einheit Deutschlands" betonte der Gen. Voigt in seinem Referat.

Um die Umsiedler absolut nicht seßhaft werden zu lassen, versucht man jetzt mit allen Mitteln die [so!] immer wieder in Unruhe zu versetzen. So wird das Gerücht verbreitet, daß $4 \frac{1}{2} 2$ Millionen Umsiedler aus der sowjetischen Zone herausgenommen werden sollen und gegen Umsiedler aus den westlichen Zonen ausgetauscht. Es muß den Menschen klargemacht werden, daß es sich hier um mehr als um eine bewußte Lüge handelt.

Hierbei taucht die Frage auf, wer der eigentliche Feind der Umsiedler ist und wer verhindert, daß die Umsiedler seßhaft werden. / Die Angehörigen der Kreise der Großgrundbesitzer, Monopolkapitalisten, der besitzenden Klasse und ihre Trabanten, sowie die Kreise um Schumacher sind die bewußten Stellen, die die Politik begrüßen, die die Seßhaftmachung der Umsiedler durch Gerüchte zu verhindern suchen.

Genosse Voigt kam dann auf die verschiedenartige Auffassung zum Umsiedlerproblem zu sprechen und versuchte eine Klärung dieser unterschiedlichen Meinung herbeizuführen. Er sagte:

2311 [Richtig: Vogt. - Art(h)ur Vogt war Leiter der Hauptabteilung Umsiedler und Heimkehrer in der Deutschen Verwaltung des Innern (siehe auch Anm. 1024).] 
„Dies entspringt aus der verschiedenartigen Einstellung zu einigen entscheidenden Grundfragen.

Es bestehen zwischen der Ostzone und den westlichen Zonen nicht nur verschiedenartige Auffassungen zur demokratischen Entwicklung in der Richtung, den [so!] die Verwaltung zu gehen hat, Diese Entwicklung ist hier in der Ostzone nahezu abgeschlossen und wir führen jetzt den Kampf um die Festigung dieser demokratischen Errungenschaften. [Bl. 386]

Wir sind aber dabei nicht stehen geblieben, sondern haben versucht die gesellschaftlichen Verhältnisse in den entscheidenden Phasen zu ändern. Das ist der entscheidendste Unterschied zu den westlichen Zonen. Wenn wir uns dort den Staatsapparat ansehen, so stellen wir fest, daß die Macht in denselben Händen liegt wie vor 1933 und von 1933 - [19]45. Hieraus entspringt die Hetze gegen die SU und gegen die Kräfte des Fortschritts in Deutschland.“

Im Gegensatz zur Westzone gehen wir hier in der Ostzone daran die Arbeitslosigkeit zu beseitigen, alle verfügbaren produktionsfähigen Kräfte einzuschalten in den Produktionsprozß zur Besserung des Lebens der Gesamtheit.

In den Westzonen steht für die Umsiedler nicht die Frage „Neue Heimat, neues Leben“, sondern die Frage der Propagierung der Losung „Euch kann nur geholfen werden, wenn Ihr in Eure Heimat zurückgeht.“

Der Referent wies weiter darauf hin, daß die Kirche versucht sich überall in der Umsiedlerbetreuung an die Spitze zu stellen. Es werden Heimattreffen veranstaltet, zu deren Teilnahme sogar Oberbürgermeister und Landräte die Fahrzeuge und Brennstoff zur Verfügung stellen. Das muß bekämpft werden.

Gen. Voigt wies darauf hin, daß die großen Erfolge in der Umsiedlerarbeit nur erzielt werden konnten, indem sich alle Mitarbeiter von den Landesämtern bis zu den Dorfgemeinschaften einschalteten und bereit mitarbeiteten.

Es gibt kein Problem von solchem Ausmaß[,] das unter so schweren Bedingungen und Voraussetzungen gelöst werden mußte und gelöst wurde, wie das Umsiedlerproblem.

Diese große Frage kann man aber nicht unabhängig von allen die Bevölkerung betreffenden Fragen lösen. Wir müssen also versuchen, sie in die Gesamtstruktur unserers Volkes einzubauen.

Man kann das Umsiedlerproblem schon aus dem Grunde nicht mehr gesondert behandeln, da auch viele der Alteingesessenen arm geworden sind durch den Krieg. Das bedeutet keienswegs eine Liquidierung der Umsiedlerbetreuung, sondern Aufgehen dieser bisherigen Körperschaften in schon bestehende.

In seinen weiteren Ausführungen ging der Gen. Voigt auf die Frage der Stellung unserer Partei zur Bevölkerung ein und stellte fest, daß wir noch nicht das Vertrauen genießen wie wir es haben müssen.

Im Vordergrund unserer Arbeit steht immer das Problem „Mensch“. Die Sorge um den Menschen muß das Hauptmotiv in der Umsiedlerbetreuung sein. 
Bei der Neugestaltung des Umsiedlerproblems steht nun die Frage die fähigen Kräfte, die bisher in der Umsiedlerarbeit tätig waren, herauszunehmen und an anderen Stellen einzusetzen.

Die Erfahrungen haben gezeigt, daß bisher nicht genügend Aufmerksamkeit den besonderen Verhältnissen der Umsiedler gewidmet wurde. Man hat nicht danach gefragt[,] kommt Ihr vom Land oder kommt Ihr aus der Stadt, sondern man hat sie da untergebracht [,] wo man sie räumlich unterbringen konnte. Nun muß hier regulierend eingegriffen werden, damit die Menschen, die aus den Industriegebieten kommen[,] auch wieder in der Industrie arbeiten können und die in der Landwirtschaft tätig waren[,] nun auch wieder in der Landwirtschaft eine Beschäftigung finden werden. Hier werden sich Umquartierungen ergeben, die aber dazu beitragen[,] den Umsiedlern nun endlich eine neue Heimat zu geben, wo sie neben Wohnung auch eine entsprechende Arbeit finden. [B1. 387]

Zum Schluß wies der Gen. Voigt auf dire Mitarbeit der Umsiedler an der Erfüllung des Zweijahresplanes hin und hob die vorbildliche Hlfe in der Umsiedlerfrage durch die „Märkische Volkssolidarität" hervor.

Genosse Mickin verlas die in der Anlage I beigefügte Entschließung und bat um rege Diskussion zum Referat und zu der Entschließung.

[Bl. 388]

Diskussion:

Gen. Mickin dankt dem Gen. Voigt für das Referat und verliest anschliesend eine Entschliessung, die von den Anwesenden Genossen angenommen wird.

Gen. Qualzek, ZS.

Alle Organisationen sollen das Ziel haben, den besonderen Schwerpunkt auf die Umsiedlerfragen zu legen. Es ist notwendig, dass wir Rechenschaft ablegen, über die von uns geleistete Arbeit. Durch die Aufnahme der Umsiedler hat sich vieles in unserer Bevölkerungspolitik geändert.

Einen [so!] Teil der Umsiedler ist es ge[g]lückt, sich in das Gesellschaftsleben einzureihen. Noch ist aber nicht erreicht, dass sich alle Umsiedler in ihrer neuen Heimat wohl fühlen. Sie sind mit dem augenblicklichen Stand noch unzufrieden.

Die reaktionären Kräfte haben es verstanden[,] die Umsiedler von unserer politischen Linie abzubringen, Es lag an uns, denn wir haben den Umsiedlern keine politische Klarheit verschafft. Unsere Genossen in den Verwaltungsstellen fassten die Umsiedlerfrage als eine Ressortsfrage auf.

Wenn jetzt die Umsiedlerausschüsse aufgelöst werden, kann man denken, jetzt werden sie vergessen und es gibt keine Stelle mehr, wohin sie sich wenden können. Wir müssen den 
Umsiedler[n] klar machen, dass sich unsere wirtschaftliche Lage bessern muss und dass sie uns dabei helfen können.

Um den Umsiedler[n] ebenfalls eine gute berufliche Ausbildung zu geben, müssen Lehrlingswerkstätten errichtet werden und Lehrlingsheime, denn auch sie sollen zu Qualitätsarbeitern ausgebildet werden. Dies ist Arbeit der Massenorganisation, wo wir uns aber einschalten müssen. Aber leider fehlen uns noch die finanziellen Mittel, um diese Massnahmen durchführen zu können.

In der Westzone befinden sich 6 $1 \frac{1}{2}$ Mill. Umsiedler, die aber noch keine richtige Heimat dort gefunden haben. Man beabsichtigt dort auch nicht, ihre Lage zu verbessern. Uns ist bekannt, dass an der Spitze der Westzone nicht Ostvertriebene stehen, sondern unserer Grossbauern. Selbst in unserer [so!] Reihen wird noch immer über die Oder-Neiße-Grenze diskutiert. Darüber gibt es keine Diskussion mehr. Solange wir diesen Gedanken in unserer [so!] Reihen nicht zurückdrengen [so!], werden wir sehr ernst über diese Dinge reden müssen. Genosse Pieck und Ulbricht haben auf der Parteikonferenz darüber gesprochen, dass den Umsiedlern nicht das Gefühl aufkommen soll, Ihre Arbeit wäre eine Ressortarbeit, sondern sämtliche Verwaltungen werden sich besondern [!] um sie bemühen, z. B. Arbeitseinsatz, Entwicklung des Wirtschaftslebens, soziale Hilfe der Alten. [Bl.389] Wir wollen die Umsiedler nicht als isolierte Gruppe behandeln und nicht wie im Westen.

Ich hoffe, dass wir in der Diskussion erleben und hören welche Fehlen [so!] wie bisher gemacht haben und wie wir sie jetzt beseitigen können.

Vom ZS wird ein Programm ausgearbeitet. Darüber aber jetzt zu diskutieren ist nicht notwendig und erforderlich. Das ist ein Programm, das unserer ganzen Partei zugeht.

\section{Gen. Zindler, Potsdam}

Ich will gleich beleuchten, das Programm kommt spät, aber es kommt. Die Umsiedlerfrage ist eine eminent wichtige Frage. Ich will zu Themen sprechen, die nicht angenehm sind, die aber gesagt werden müssen. Man muss annehmen, dass ich ein Schumachermann ${ }^{2312}$ bin, aber nein, ich bin und bleibe Sozialist. Wir als Umsiedler haben am meisten geopfert im Krieg. Die Umsiedlerwoche in Potsdam hat sich als Entrümplungswoche gezeigt. Wir haben 87000.- RM gesammelt[,] ich allein 2000.- RM abgeliefert. Was mit dem Geld geschehen ist, ist bis heute noch nicht bekannt geworden. Durch Zufall habe ich hinter [so!] herum erfahren, dass von den 87 000.- RM nur 880.- RM existieren. Durch die Währungsreform ist uns das Geld verloren gegangen. Man sollte es sich vorher überlegt haben, ob man das Geld nicht 1:1 aufwerten kann. Ich liebe meine Heimat und darum gebe ich mich mit der Oder-Neisse-Grenze nicht zufrieden. Wer hat Schuld, dass die Umsiedlung vorgenommen werden musste?

Gen. Voigt: Wir wagen nicht zu sagen, wer die Schuld hat!

2312 [Siehe dazu oben Anm. 1189.] 
Gen Zindler: Wir haben dem Landtag aufgetragen, sich mit der Umsiedlerfrage zu befassen. Genosse König, der damit beauftragt wurde, hat noch nichts von sich hören lassen. Es müssen Voraussetzungen geschaffen werden, dass sich die Umsiedler hier heimisch fühlen. Der Umsiedler wird immer zur Oder-Neisse-Grenze schielen.

Den Umsiedlern fehlt das Geld, sich neue Möbel anzuschaffen und überhaupt einen neuen Hausstand zu gründen.

\section{Gen. Haak, Oberbarnim:}

Vor einem Monat habe ich die Umsiedlerstelle übernommen und gesehen, dass diese Aufgabe eine politische ist. Die Ansicht von meinem Vorredner ist auch noch bei anderen Genossen vertreten. Die Partei hat gesagt, dass wir die Oder-Neisse-Grenze anerkennen und da gibt es keine Diskussion mehr. Es ist notwendig, dass jeder Parteifunktionär seine Aufgabe kennt und den anders denkenden Genossen Aufklärung über diese Frage gibt. [Bl. 390] Wir müssen ihnen klar machen, dass sie hier als freie Menschen leben und dass man drüben im Westen unseren Aufbau hemmen will. Von reaktionären Kräften, die die Umsiedlerausschüsse bildeten, wurde den Umsiedlern erklärt, sie müssen wieder zurück. Sie haben mit reiner Westpolitik gearbeitet, also darf man das Umsiedlerproblem nicht vernachlässigen. Viele Umsiedler leben in schlechten Wohnungen und Baracken, wo es durchregnet, da muss es als erstes unserer Aufgabe sein, einzugreifen und zu helfen. Hier haben die Gemeinderäte versagt. Wo gut gearbeitet wurder, sind die Umsiedler auch gut untergebracht. Mit Hilfe der VSB ${ }^{2313}$ sind wir gut vorangekommen, es ist bei uns so, dass die VSB, die christliche Bewegung und die CDU die Oberhand hat.

Der Landesregierung müssen Fehler unterlaufen sein, denn wir bekommen Möbel zugewiesen, die kein Umsiedler sich leisten kann.

Wir in unserem Kreis sollen noch 500 Umsiedler aufnehmen. Dann ist aber die Auflösung des Umsiedlerausschusses ein bischen übereilt. Die Verwaltung wird dann noch nicht in der Lage sein die Unterbringung zu veranlassen. Sonst begrüsse ich aber die Auflösung der Umsiedlerausschüsse. Aufklärungsarbeit fehlt unter den Umsiedlern, damit ihnen klar gemacht wird, dass sie nicht mehr Flüchtlinge sind, sondern deutsche Menschen in einem einigen Deutschen Vaterland. Wir dürfen als Partei niemals die klare Linie verlassen. Wir müssen uns an die Parteidiszilpin halten und klar unseren Weg gehen.

Gen. Hoffmann, Landesvorstand Brandenburg

Bei dem Gen. Zindler hat man den Eindruck wirklich, er sei ein Schumachermann. Er schiebt das Umsiedlerproblem auf andere Leute. Die Selbstkritik fehlt. Wir müssen zu allen Aufgaben klar und kritisch Stellung nehmen und somit unsere Arbeit verbessern. / Der Bau von Arbeiterhäusern muss genau so angestrebt werden, wie der Bau von Neubauernhäuser[n]. / Verschiebungen von Arbeitskräften müssen vorgenommen werden.

$2313 \quad$ VSB $=$ Volkssolidarität Brandenburg. $]$ 
Gen. Kupke, Sozialamt Potsdam

Jeder hat nach seiner Heimat Sehnsucht. Wir sind Deutsche und hier ist unser Vaterland, ganz gleich ob in Schlesien oder im Land Brandenburg. Was die 87000.- RM angeht[,] so kann ich sagen, dass doch von dem Geld auch etwas angeschafft wurde für die Umsiedler. Leider ist es aber so, dass die Preise zu hoch sind.

Zu der Verschiebung von Arbeitskräften frage ich gleich, warum stellt man uns nicht da hin, wo wir hingehören? Man darf nicht das Gefühl [Bl. 391] aufkommen lassen, dass sie sich hier als Umsiedler fühlen. Es gibt unter den Umsiedlern auch noch eine ganze Reihe von Nazis, die unter den Umsiedlern Unstimmigkeiten hervorrufen. Die Wohnungsnot ist die grösste Not unter den Umsiedlern, die wir nicht vergessen dürfen.

Gen. Kuhn, Landesregierung

Begrüsst den Beschluss des Zentralsekretariats, der die Auflösung der Umsiedlerämter vorsieht. Die Umsiedler sind gleichberechtigte Bürger. Mit der Arbeit nach $3 \frac{1}{2}$ Jahren sind wir nicht zufrieden, denn man hätte mehr leisten können, wenn man mehr Erfahrung gehabt hätte. Die Umsiedlerstelle ist eine Aufgabe der gesamten Verwaltung. Die Wohnraumfrage war die wichtigste Frage der Umsiedler. Wir haben auch noch nicht verstanden die Wohnraumfrage zu lösen. Die Umsiedler sollen jetzt dort untergebracht werden, wo sie gleich Arbeit finden und wo sie benötigt werden. Nach dem Runderlass Nr. 275 vom 6.12. ist eine Zwangsumqua[r]tierung vorzunehmen.

In der Presse hat man die schlechten Zustände geschildert, die zwar nicht immer auf Wahrheit beruhen, aber zumindest zu $75 \%$.

Die CDU nimmt in Brandenburg eine Abseitsstellung in der Frage der Umsiedlung ein.

Eine Gesetzgebung in der Sache der Umsiedlerfrage ist meines Erachtens nicht notwendig, denn sie muss aus der Einstellung der Bewohner selbst herauskommen.

Gen. Löwenstein, Sozialamt ${ }^{2314}$

Gen. Zindkers [Zindler!] hat recht, wenn er beanstandet, dass das Geld abgewertet wurde. Die Schuld liegt aber nicht beim Umsiedleramt, sondern bei der Landesregierung. Mit Herrn Friedrich[s] habe ich in der Angelegenheit gesprochen und er hat mir die Versicherung gegeben, dass das Geld 1:1 aufgewertet wird. Gen. Pauli hat die Wichtigkeit der Umsiedlerfrage erkannt. Er gab kurzen Rechenschaftsbericht über die Arbeit des Umsiedlerrausschusses.

Gen. Hix, Handwerkskammer

Umsiedler in den Genossenschaften. Ihnen wurde in erster Linie Material zur Verfügung gestellt. 
Gen. Hoffmann, Landesvorstand

Wir sind auf einer Arbeitstagung der Partei, wo das Problem der Umsiedler besprochen werden soll und Richtlinien für die weitere Arbeit festgelegt werden sollen. [Bl. 392]

\section{Genossin Voss}

Frage der Kredite wurde aufgeworfen.

In Berlin fand jetzt das 5. Treffen der Pommern statt. Solchen Treffen muss man auch eine besondere Bedeutung beimessen, denn dort wird das Problem besprochen, wie sie am besten in ihre Heimat zurückkommen und dass es überhaubt [so!] der Fall ist. Der Beratungsausschuss muss diese Aufgabe übernehmen, um solche Treffen zu unterbinden.

Gen. Klank, Abtlg. Wirtschaftsplanung

Wir lassen uns von dem Grundsatz leiten, dass die einzelnen Wirtschaftsstätten rentabel sein müssen, darum auch die Produktionsgenossenschaften. Bei dem Wohnungsbau wird noch immer der Befehl 209 bevorzugt und zwar aus politischen Gründen. Eine Verschiebung von Arbeitskräften wird in diesem Jahr vorgenommen werden.

Gen. Brehmer, Wohnungsfürsorge

Das Umsiedlerproblem ist ein Wohnungsproblem. Schlechte Arbeit wird in den kleinen Gemeinden geleistet, sie weigern sich Umsiedler aufzunehmen.

Gen. Engelbrecht, Handwerkskammer

Wo bleibt in unserer Arbeit die führende Rolle der Partei. Man sollte den Ausdruck Umsiedler nicht mehr anwenden, denn sie sind gleichberechtigte Bürger. Die Umsiedlergenossenschaften sollen nicht in die Handwerksgenossenschaften mit eingereiht werden.

Auf jeder Konferenz wird immer wieder die Oder-Neisse-Frage aufgeworfen, wir müssen viel mehr darüer diskutieren, wie erreichen wir die Einheit Deutschlands.

Gen. Wendel

Führte nur die Schwächen in Bezug auf die Wohnungsfürsorge an.

Gen. Bittner, DWK

Genossesnchaften, die nicht rentabel arbeiten, werden aus den Genossenschaften ausgeschlossen.

Wir versuchen für die Umsiedler alle Punkte frei zu bekommen, damit sie das kaufen können, was sie am dringendsten benötigen.

Die Auflösung der Umsiedlerausschüsse ist von allen Genossen anerkannt. Die Arbeit der Umsiedlerausschüsse wird auf die Wohnungs- und Sozialausschüsse verteilt. Sie haben ihr[en] Gesichtskreis erweitert. Zum 31.3. werden nun die Umsiedlerämter aufgelöst, und diese Arbeit wird nun auf die Verwaltungen übertragen. Die Umsiedlerwoche war Aufgabe aller Parteien. [Bl. 393] 
Schlußwort Gen. Voigt

„An die Spitze aller Betrachtungen müssern wir die Frage der Ursache der Lage[,] in der wir uns heute befinden[,] stellen,“ dies waren die Worte[,] die der Gen. Voigt zu der stattgefundenen Diskussion sagte.

Er wies dann auf die Kriegsgefangenen hin, die noch zurückkommen werden[,] und betonte in diesen Ausführungen, daß z. B. in Polen der anfängliche Haß sich nunmehr gewandelt hat und die Kriegsgefangenen dort in sehr anständigen Verhältnissen leben. Die Kriegsgefangenen haben gezeigt, daß sie willig sind beim Aufbau der durch den Hitlerkrieg angerichteten Schäden[,] und die polnische Bevölkerung hat erkannt, daß es auch noch ein anderes Deutschland gibt als das[,] was ihnen diese ungeheuren Schäden zugefügt hat.

Er wies dann auf die Hetzen in der Westtagespresse gegen unsere Volkspolizei hin und gegen sowjetische Offiziere, die ihre Pflicht taten. Wenn dann die Zeitung schreibt: „So lange dieses System besteht, kann es in der Welt keinen Frieden geben“, so hat dies eine unverkennbare Ähnlichkeit mit der Goebbel[s]'schen Kriegspropaganda.

Er führte weiter aus, daß wir uns ernsthaft mit der Frage beschäftigen müssen, woher es kommt, daß die Heimatsehnsucht bei den Umsiedlern noch immer überwiegt. Hier muß neben der Verwirklichung des Befehls 209 für möglichst menschenwürdige Wohnraumverhältnisse für die Umsiedler gesorgt werden. Wenn man ihnen einigermaßen gute Lebensbedingungen schafft, sollte da nicht die Heimatliebe auch zur neuen Heimat entstehen?

Es wurde in der Diskussion schon gesagt, daß überall[,] wo Deutschland ist und überall da[,] wo für den Sozialismus gekämpft wird, unsere Heimat sei.

In Bezug auf die in der Diskussion angeschnittene Frage der Möbel läßt sich im Moment keine Änderung herbeiführen, da die Produktionskosten sich nicht senken lassen.

Er erwähnte dann, daß den Gerüchten über die von der Besatzungsmacht gestohlenen Uhren bis zur gestohlenen Heimat ganz energisch entgegengetreten werden muß, denn oft werden diese Gerüchte von Leuten verbreitet, die weder ein Fahrrad, noch etwas anderes unter den Kriegseinwirkungen verloren haben.

Der Referent ging dann auf die Wohnraumnot ein und stellte fest, daß auch hier im Lande Brandenburg noch genügend Wohnraum vorhanden sei und daß er nur richtig ausgenutzt werden müsse. Auch dieses Problem wird, wie vieles andere, dadurch, daß es nun gemeinsam von einer Stelle bearbeitet wird, sicher besser gelöst werden, als wenn das Umsiedler-Problem getrennt behandelt wird und immer jede Dienststelle ihre Sonderinteressen hat.

Die vorgeschlagene Entschliessung wurde einstimmig angenommen. 


\subsection{Arbeitsmarkt (1945-1948)}

\section{(119) Monatsberichte des Kreisarbeitsamtes Teltow. - Mahlow 1945-1947 (Auszüge)}

BLHA, Rep. 230 Oberlandratsamt Bernau, Nr. 221, unfol. - Typoskripte (Durchschläge). - Jeweils im Wesentlichen gleichlautend: Lo. (anfangs Stempel) „Arbeitsamt Teltow“. Kopierstift-Unterschrift „Loppuch“, ab August 1946 „Hußock“. - Begleischreiben: Briefkopf (gedruckter Kopfbogen) „Der Landrat des Kreises Teltow / Abtlg.: Arbeitsamt / [Az.]: „- 5200 - [Wechselnde Bearbeiterkürzel]. - R. o.: „Mahlow, den“ [Datum]. - Adresse: „An die / Provinzialverwaltung Mark Brandenburg/ - Landesarbeitsamt - / Potsdam / Am Kanal 31 [ab April 1946: „Alte Zauche 67“]“. - Betreff: „Betrifft: Berichterstattung gemäss Verwaltungs-Vorschrift Nr. 1.“ - Unten: „Vorstehende Durchschrift dem Herrn Oberlandrat / Bernau / zur Kenntnis übersandt unter Befügung des Monatsberrichts für [...] in doppelter Ausfertigung.“ - Eingangsstempel: „Der Oberlandrat [Datum]“. - Editorischer Hinweis: Auslassungskennzeichnung [...] hier nur, wenn Absätze nicht vollständig wiedergegeben werden.

\section{[a] Monatsbericht für Dezember 1945. - Mahlow, den 30. Dezember 1945}

Nach den getroffenen Feststellungen waren ca 25000 Umsiedler polizeilich erfasst. Von diesen hat aber ein beträchtlicher Teil den Kreis Teltow wieder verlassen. Die Sesshaftgewordenen sind, soweit sie arbeitsfähig waren, bereits in feste Arbeitsverhältnisse eingesetzt. Beim Eintreffen der für den Kreis Teltow bestimmten Umsiedler aus Ungarn und der Slowakei sind Vorkehrungen für die einsatzmässige Erfassung getroffen. Jedoch lassen die Demontagemassnahmen der Industriebetriebe im Arbeitsamtsbezirk eine Einsatzplanung z. Zt. nicht zu.

\section{[b] Monatsbericht für Januar 1946. - Mahlow, den 30. Januar 1946}

Die Bodenreform ist im Kreise Teltow fast restlos durchgeführt. Ueber den Erfolg lässt sich z. Zt. Endgültiges noch nicht sagen, da hierfür die Zeit noch verfrüht ist. Auf den Arbeitseinsatz hat sich die Bodenreform bisher kaum ausgewirkt. Von den Umsiedlern konnten nur vereinzelt Kräfte den Neubauern zugeführt werden.

In der Umsiedlerfrage allgemein und der $\mathrm{Zu}$ - bezw. Abwanderung von Umsiedlern sind nennenswerte Aenderungen nicht eingetreten. Ueber die zu erwartenden Umsiedler, die bereits im Dezember [19]45 dem Kreis Teltow zugeführt werden sollten, liegt auch bis heute noch nichts Bestimmtes vor.

\section{[c] Monatsbericht für Februar 1946. - Mahlow, den 23. Februar 1946}

Ueber die oftmals übertriebenen Kräfteanforderungen der Roten Armee und von ihr geführten Betriebe ist bereits im Monatsbericht für Januar 1946 ausführlich hingewiesen worden. Wie bereits im Vormonat, hat sich auch in diesem Monat im Kreise Teltow die fast restlos durchgeführte Bodenreform arbeitseinsatzmässig kaum ausgewirkt. Ein nennenswerter Zugang von Umsiedlern ist nicht erfolgt, dagegen wurde eine grössere Anzahl ehemaliger Kriegsgefangener durch das Umsiedlerlager Königs Wusterhausen geschleust, und fast 100\%ig vermittelt. 


\section{[d] Monatsbericht für Monat März 1946. -Mahlow, den 23. März 1946}

Von den im Berichtsmonat eingetroffenen 308 Umsiedlern (69 Männer, 239 Frauen) konnte der männliche arbeitseinsatzfähige Teil fast restlos vermittelt werden. Die Frauen fanden[,] soweit geeignet, in der Landwirtschaft Verwendung.

Die Bodenreform ist auf den Arbeitseinsatz bisher ohne Einwirkung geblieben. [...]

Den Anforderungen der Besatzungsarmee konnte im allgemeinen nachgekommen werden. Auch der durch die Rückführung der Bessarabiendeutschen nach Russland aufgetretene Bedarf an landwirtschaftlichen Arbeitskräften dürfte sich decken lassen.

\section{[e] Monatsbericht für Monat April 1946. - Mahlow, den 25. April 1946}

Von den im Berichtsmonat eingetroffenen Umsiedlern konnte der überwiegende Teil in Arbeitsplätze eingewiesen werden. /

Die Bodenreform ist auch weiterhin auf den Arbeitseinsatz ohne Einwirkung geblieben.

\section{[f] Monatsbericht für den Monat Juli 1946. - Mahlow, den 26. Juli 1946}

[...] Die Bodenreform wirkte sich bisher noch nicht aus.

Die Annahme, dass noch grössere Transporte von entlassenen Kriegsgefangenen eintreffen könnten, hat sich leider nicht bestätigt. Auch die Einsetzung der Umsiedler zeigte nicht den erwarteten Erfolg. Die Transporte kamen hier erst an, als sie mehrere Lager passiert hatten und die voll einsatzfähigen Arbeitskräfte und Spezialwerker bereits ausgesiebt worden sind, z. B. konnten von einem 600 Personen starken Transport nur 40 geeignete männliche Arbeitskräfte eingesetzt werden, der Rest bestand aus nicht einsatzfähigen Personen, fast nur aus beschränkt einsatzfähigen Frauen und Greisen und Kindern. Erfreulicherweise soll das bei den jetzt eintreffenden Transporten, die aus der Tschechoslowakei kommen, nicht mehr der Fall sein.

Die Gesamtbevölkerung des Kreises Teltow beträgt 174671 und hat sich, im Vergleich zum Vormonat (174 114), durch den Zuzug von Umsiedlern etwas erhöht. [...]

\section{[g] Monatsbericht für den Monat Juni 1946. - Mahlow, den 1. Juli 1946}

Der letzte grössere Umsiedlertransport von 684 Personen setzte sich zusammen aus: 90 Männern, 349 Frauen, 245 Kindern. Die Männer konnten zum grössten Teil in ihrem Beruf, die Frauen, soweit einsatzfähig, in der Landwirtschaft Verwendung finden.

\section{[h] Arbeitslenkungsbericht für den Monat August 1946. - Mahlow, den 29. August 1946}

Die Bodenreform hat sich bisher nicht entscheidend auf den Arbeitseinsaatz ausgewirkt, es steht aber fest, dass ein gewisser Prozentsatz an Handwerkern dadurch der Arbeitsplanung verlorengeht.

Die Gesamtbevölkerung des Kreises Teltow beträgt 174886 Personen und hat sich im Vergleich zum Vormonat (174671) durch den Zuzug von Umsiedlern und Rückkehrern etwas erhöht. [... 
[i] Arbeitseinsatzbericht für den Monat September 1946. Mahlow, den 23. September 1946

Ich habe bereits in meinem Vormonatsbericht auf die katastrophale Arbeitseinsatzlage in meinem Bezirk hingewiesen und gebeten, mich bei der Abgabe von Arbeitskräften für den zwischenbezirklichen Ausgleich zu verschonen; [...].

Die durch die Aerztekommission erwartete Besserung und Gewinnung von weiteren Arbeitskräften ist nicht eingetreten; es kann vielmehr gesagt werden, dass das Ergebnis äußerst schlecht ist.

Die Gesamtbevölkerung des Kreises Teltow beträgt 175944 Personen und hat sich im Vergleich zum Vormonat (174886) durch den Zuzug von Umsiedlern und Rückkehrern erhöht. Davon entfallen auf Männer 51 636, Frauen 80794, Kinder unter 14 Jahren männlich 21300, Kinder unter 15 Jahren weiblich 22 214. [...] Monatlicher Zugang der Umsiedler und Rückkehrer: 298 Männer, 333 Frauen, insgesamt 631 Personen.

[j] Arbeitseinsatzbericht für den Monat November 1946. Mahlow, den 23. November 1946

Im Berichtszeitraum stieg die Zahl der Gesamtbevölkerung des Kreises Teltow auf 178686 Personen [...]. Insgesamt wurden bisher 30611 Umsiedler aufgenommen. [...]

\section{[k] Arbeitseinsatzbericht für den Monat Dezember 1946. -} Mahlow, den 21. Dezember 1946

Im Berichtsmonat stieg die Zahl der Gesamtbevölkerung des Kreises Teltow auf 179467 Personen [...]. Insgesamt wurden bisher 30716 Umsiedler aufgenommen. [...]

\section{[1] Arbeitseinsatzbericht für den Monat Januar 1947. - Mahlow, den 25. Januar 1947}

Im Berichtsmonat stieg die Zahl der Gesamtbevölkerung des Kreises Teltow auf 179953 Personen [...]. Insgesamt wurden bisher 30716 Umsiedler aufgenommen. [...]

\section{(120) Monatsberichte des Kreisarbeitsamtes Beeskow über „Umsiedler“. -} Beeskow 1946-1947

BLHA, Rep. 230 Oberlandratsamt Bernau, Nr. 221, unfol. - Typoskripte (Durchschläge, ab Mai 1946 auf gedruckten Kopfbögen). - Jeweils im Wesentlichen gleichlautend: L o.: Briefkopf „Der Landrat/ des Kreises Beeskow-Storkow / Kreisarbeitsamt / Akz.: VII/A/5“. - R. o.: Beeskow, den [Datum] / Tel.: 245“. - Adresse: „Der / Provinzialverwaltung / Mark Brandenburg / - Landesarbeitsamt - / Potsdam.“ - „Bezug: Provinzialverwaltung Mark Brandenburg, Abt. VII für Arbeit und Sozialwesen, Az. VII/7/Re./Sa. vom 17.12.45 und Az. VII/7/83 Rö/Sa. v. 7.3 .46 (Verw. Verfg. Nr. 35). - Betr.: Monatsbericht (Umsiedler).“ - Überschrift: „Monatsbericht/(Betr. Umsiedler)“.- Unten Durchschrift-Adresse: „Nach dem Abgang: / Dem Oberlandrat der Bezirksverwaltung Berlin / - Arbeit und Sozialwesen - / Bernau / Abdruck mit der Bitte um Kenntnisnahme vorgelegt.“ - Stempel „Arbeitsamt / Beeskow-Storkow“. Unterzeichnet bis Mai 1946 „Jung“, danach „I. A. Svenson“. - I. d. R. mit Eingangsstempel „Der Oberlandrat“ / Datum. 


\section{[a] Beeskow, den 23. Februar 1946}

Im Kreise Beeskow-Storkow sind z.Zt. 23259 Umsiedler erfasst. 12635 Personen sind voll bezw. bedingt arbeitsfähig (54,4\%). 10604 Personen sind Kinder und alte Leute bezw. nicht mehr einsatzfähige Personen. Die im Kreise Beeskow-Storkow erfassten Umsiedler sind zum größten Teil auf dem Land untergebracht. Es befinden sich z. Zt. 9210 Umsiedler in Arbeit. Ein Teil der Umsiedler hat im Kreise gesiedelt. Im Monat Februar sind zwei Umsiedlertransporte im Kreise eingetroffen und zwar:

$$
\begin{aligned}
& 950 \text { Männer } \\
& 1274 \text { Frauen } \\
& \frac{1162 \text { Kinder }}{3386}
\end{aligned}
$$

Der größte Teil dieser arbeitseinsatzfähigen Umsiedler konnte noch nicht in Arbeit vermittelt werden, da sie erst die vorgeschriebene Quarantäne im Umsiedlerlager durchmachen müssen. Vom Arbeitsamt sind Maßnahmen ergriffen, dass die betr. Umsiedler nach Möglichkeit entsprechend ihres Berufes in Arbeit eingesetzt werden. Die Verteilung auf die einzelnen Gemeinden des Kreises wird diesbezüglich mit der Umsiedlerbetreuungsstelle des Kreises durchgeführt.

\section{[b] Beeskow, den 26. März 1946}

Im Kreise Beeskow-Storkow sind z. Zt. an Umsiedlern erfasst:

\begin{tabular}{lr} 
Männer: & 6340 \\
Frauen: & 7749 \\
Kinder: & 9395 \\
\hline Insges.: & 23484
\end{tabular}

12681 Personen sind voll bezw. bedingt arbeitsfähig (54\%). 10803 Personen sind Kinder und alte Leute bezw. nicht mehr einsatzfähige Personen. Die im Kreise Beeskow-Storkow erfassten Umsiedler sind zum größten Teil auf dem Lande untergebracht. Es befinden sich z. Zt. 10296 Umsiedler in Arbeit. Ein großer Teil davon hat im Kreis gesiedelt. Der im Monat Februar im Kreise eingetroffene Umsiedlertransport ist nach Ablauf der Quarantäne aus dem Umsiedlerlager entlassen und auf 3 Amtsbezirke des Kreises verteilt worden. Die Vermittlung in Arbeit wird laufend soweit möglich fortgesetzt.

\section{[c] Beeskow, den 26. April 1946}

Im Kreise Beeskow-Storkow sind z. Zt. an Umsiedlern erfasst:

\begin{tabular}{lr} 
Männer: & 6355 \\
Frauen: & 7899 \\
Kinder: & 9546 \\
\hline Insges.: & 23800
\end{tabular}


12801 Personen sind voll bezw. bedingt arbeitsfähig (53\%). 11119 Personen sind Kinder und alte Leute bezw. nicht mehr einsatzfähige Personen. Es befinden sich z. Zt. 11018 Umsiedler in Arbeit. Im Monat April ist ein Umsiedlertransport von 794 Personen, der für den Westen (engl. Zone) bestimmt war, im Kreise eingetroffen. Der Transport wurde nach neuer Zusammenstellung nach dem Westen weitergeleitet. Es blieben im Kreise 144 Personen, die nach Beendigung der Quarantäne zum größten Teil in Landgemeinden eingewiesen wurden. Die Unterbringung in Arbeit wurde bei der Verteilung auf die einzelnen Gemeinden weitgehendst berücksichtigt. 5 Familien wurden dem Kreis Lebus überwiesen, um dort zu siedeln.

\section{[d] Beeskow, den 27. Mai 1946}

Im Kreise Beeskow-Storkow sind z. Zt. an Umsiedlern erfasst:

\begin{tabular}{lr} 
Männer: & 6781 \\
Frauen: & 9737 \\
Kinder: & 8565 \\
\hline Insges.: & 25083
\end{tabular}

12830 Personen sind voll bezw. bedingt arbeitsfähig (53\%). Es befinden sich z. Zt. 11030 Umsiedler in Arbeit. Im Monat Mai sind im Kreise Beeskow-Storkow 1242 neu aufgenommen worden. Die Unterbringung in Arbeit der neu hinzukommenden Umsiedler stößt immer mehr auf Schwierigkeiten, da im Kreise großer Wohnraummangel besteht und somit eine Unterbringung am Arbeitsort selten möglich ist. Die Heranführung der Arbeitskräfte zum Arbeitsplatz ist infolge Fehlens von Verkehrseinrichtungen kaum möglich.

\section{[e] Beeskow, den 26. Juli 1946}

Im Kreise Beeskow-Storkow sind z. Zt. an Umsiedlern erfasst:

\begin{tabular}{lr} 
Männer: & 6352 \\
Frauen: & 11027 \\
Kinder: & 7517 \\
\hline Insges.: & 24896
\end{tabular}

10136 Personen sind voll bezw. bedingt arbeitsfähig. Es befinden sich z. Zt. 8236 Umsiedler in Arbeit. Im Umsiedlerlager des Kreises befand sich ein Umsiedlertransport (1200 Personen, Antifa-Umsiedler) aus der Tschechoslowakei, die nach Ablauf der Quarantäne am 19. und 20.7.[19]46 auf die einzelnen Orte des Kreises verteilt wurden, Am 16.7.[19]46 waren diese Umsiedler durch das Arbeitsamt in Arbeitsfragen beraten und soweit möglich in Arbeit vermittelt worden. Der größte Teil dieser Umsiedler sind Facharbeiter bezw. Hilfskräfte der Textilindustrie, die im Kreise in ihrem Beruf nicht untergebracht werden können, da im Kreise Beeskow-Storkow Textilindustrie nicht vorhanden ist. Gem[äß] Mitteilung der Umsiedlerbetreuungsstelle Beeskow vom 24.7.[19]46 sind diese Textilfachkräfte dem Amt für Deutsche 
Umsiedler, Potsdam[,] gemeldet worden, um eine evtl. Weiterleitung dieser Kräfte nach dem Lande Sachsen zu erwirken.

[f] Beeskow, den 24. Sept[ember] 1946

Im Kreise Beeskow-Storkow sind z. Zt. an Umsiedlern erfasst:

\begin{tabular}{lr} 
Männer: & 7304 \\
Frauen: & 11449 \\
Kinder: & 7240 \\
\hline Insges.: & 25993
\end{tabular}

13768 Personen sind voll bezw. bedingt arbeitsfähig. Es befinden sich z. Zt. 9198 Umsiedler in Arbeit. Im Umsiedlerlager des Kreises befindet sich seit dem 13.9.[19]46 ein Umsiedlertransport aus Kaaden (1218 Personen). Dieser Transport wird wahrscheinlich nicht im Kreise verbleiben[,] sondern in andere Bezirke weitergeleitet werden.

Der im Monatsbericht vom 26.8.[19]46 erwähnte Transport aus der Tschechoslowakei ${ }^{2315}$ ist am 31.8.[19]46 nach Osthavelland weitergeleitet worden.

\section{[g] Beeskow, den 24. Okt[ober] 1946}

Im Kreise Beeskow-Storkow sind z. Zt. an Umsiedlern erfasst:

\begin{tabular}{lr} 
Männer: & 7329 \\
Frauen: & 11488 \\
Kinder: & 7244 \\
\hline Insges.: & 26061
\end{tabular}

13813 Personen sind voll bezw. bedingt arbeitsfähig. Es befinden sich z. Zt. 12068 Umsiedler in Arbeit. Im Umsiedlerlager des Kreises befindet sich seit dem 15.10.[19]46 ein Umsiedlertransport aus Namslau (Schlesien) (1778 Personen). Ob eine Eingemeindung im Kreise Beeskow-Storkow vorgenommen wird, steht noch nicht fest.

\section{[h] Beeskow, den 24. November 1946}

Im Kreise Beeskow-Storkow sind z. Zt. an Umsiedlern erfasst:

\begin{tabular}{lr} 
Männer: & 6409 \\
Frauen: & 10471 \\
Kinder: & 6392 \\
\hline Insges.: & 23272
\end{tabular}

2315 [Vermutlich ist der Bericht vom 26.7. gemeint, denn es liegen spezielle „Berichte betr. Umsiedler“ in der Akte für diese Monate nur zweimonatlich vor, während der Transport in dem allgemeinen Monatsbericht - diese allgemeinen Berichte liegen, wenn auch mit Lücken, monatlich vor - vom 26.8. nicht erwähnt wird.] 
11837 Personen sind voll bezw. bedingt arbeitsfähig. Es befinden sich z. Zt. 11199 Umsiedler in Arbeit. Im Umsiedlerlager des Kreises befinden sich z. Zt. 553 Umsiedler. Nach Auskunft der Umsiedlerbetreuungsstelle Beeskow werden diese Umsiedler in den nächsten Tagen in andere Kreise weitergeleitet.

\section{[i] Beeskow, den 20. Dezember 1946}

Im Kreise Beeskow-Storkow sind z. Zt. an Umsiedlern erfasst:

\begin{tabular}{lr} 
Männer: & 6439 \\
Frauen: & 10543 \\
Kinder: & 6412 \\
\hline Insges.: & 23394
\end{tabular}

11867 Personen sind voll bezw. bedingt arbeitsfähig. Es befinden sich z. Zt. 11205 Umsiedler in Arbeit. Im Umsiedlerlager des Kreises Beeskow-Storkow befinden sich z. Zt. keine Umsiedler.

\section{[j] Beeskow, den 21. Januar 1947}

Im Kreise Beeskow-Storkow sind z. Zt. an Umsiedlern erfasst:

\begin{tabular}{lr} 
Männer: & 6478 \\
Frauen: & 10561 \\
Kinder: & 6423 \\
\hline Insges.: & 23462
\end{tabular}

12504 Personen sind voll bezw. bedingt arbeitsfähig. Es befinden sich z. Zt. 11597 Umsiedler in Arbeit. Im Umsiedlerlager Küchensee bei Storkow befindet sich seit dem 1.1.[19]47 ein Umsiedlertransport in Stärke von 1790 Personen. Von diesem Transport sind bezw. werden 600 Personen in den Kreis Beeskow-Storkow eingemeindet. Der Rest wird wie folgt weitergeleitet:

$\begin{array}{ll}\text { Kreis Teltow } & 200 \text { Personen } \\ \text { Kreis Luckenwalde } & 500 \text { Personen } \\ \text { Kreis Spremberg } & 400 \text { Personen }\end{array}$

Die Registrierung usw. der Umsiedler dieses Transportes gem[äß] Rundschreiben Nr. 102 vom 4.12.[19]46 ist durchgeführt und bereits am 10.1.[19]47 dem Landesarbeitsamt mit Schreiben des Kreisarbeitsamtes Az.VII/A/17 unter Beifügung der Registrierungslisten gemeldet worden. 


\section{(121) Bereitstellung von Arbeitskräften für die Agfa-Kunstseidenfabrik in Premnitz aus Umsiedlerlagern.}

a) Berlin, 24. Juli 1946

BLHA, Rep. 206 Ministerium für Wirtschaft und Arbeit, Nr. 3036, unfol. - Typoskript (Durchschlag), 2 S., Abschrift mit masch. Unterschrift „gez. Dischereit“. - L. o.: „Deutsche Verwaltung für Arbeit und Sozialfürsorge der Sowjetischen Besatzungszone in Deutschland / Abt. II - Erfassung und Arbeitslenkung der Bevölkerung.“ - R. o.: „Berlin, den 24. Juli 1946 / Di./Gro.“ - Darunter Verteiler (Kopierstift): „Ref. 3“. - Betreff: „Betrifft: Bereitstellung von Arbeitskräften für das Werk Agfa-Seide in Premnitz."

\section{Niederschrift}

über die Dienstreise des Referenten Dischereit vom 18.-20.7.46 zur Aussprache mit der Betriebsleitung des Werkes und mit den Leitern der Arbeitsämter in Rathenow und Brandenburg.

Um die Möglichkeiten der Bedarfsabdeckung und die Frage der Unterbringung ortsfremder Kräfte zu überprüfen, habe ich in der Angelegenheit mit den vorgenannten Stellen persönlich Fühlung genommen und dabei auch die Arbeitsstelle besichtigt. / Die Aussprache im Werk und die Besichtigung der Arbeitsstelle erfolgte unter Beteiligung des Leiters des Arbeitsamtes Rathenow, Herrn Renziehausen.

Das Werk beschäftigt zur Zeit 1473 männliche und 1268 weibliche Arbeitskräfte. Von dieser Gesamtbelegschaft mit 2741 Kräften fehlten infolge Krankheit und durch sonstiges Fernbleiben 603 Personen, so daß die tatsächliche Betriebsstärke 2138 Beschäftigte umfasste.

Zur Erfüllung der vorliegenden Produktionsaufgaben benötigt das Werk weitere 200 gesunde männliche und 200 weibliche Arbeitskräfte. / Die 200 männlichen Arbeitskräfte werden für den chemischen Teil des Betriebes erfordert. Die zu leistende Arbeit bedingt ein fortlaufendes Bewegen und den laufenden Transport von Spulen, die[,] in einer Rahmenfassung abgestellt, ein Gesamtgewicht von ca. 80 Pfd. haben. / Es ist dem Werk nicht damit gedient, wenn der Bedarf zahlenmässig durch Kräfte gedeckt wird, die von vornherein nur vorübergehend arbeiten wollen oder aus gesundheitlichen oder anderen Gründen nicht in der Lage sind, die anfallenden Arbeiten zu leisten. Die Leute müssen gesund auf den Füssen sein; die Einwirkungen der Säure schliessen auch eine Beschäftigung von chronisch Lungen- und Magenleidenden aus. / Die 200 Frauen werden für die Zwirnerei, Haspelei und Sortierung benötigt.

Das Werk ist bemüht, die Belegschaftsmitglieder in der Sorge um die Ernährung und Bekleidung zu unterstützen. / Das Werk bemüht sich auch um die Unterbringung der ortsfremden Arbeitskräfte. / Die Unterbringung der fremden Kräfte erfolgt in Privatquartiere. Die Leute müssen sich in Selbstverpflegung beköstigen. Das Werk liefert ein markenfreies Mittagessen; der Preis beträgt zur Zeit RM -,50.

Diese Art der Unterbringung und Verpflegung lässt für die Abdeckung des Bedarfes nur die Ansetzung von Umsiedlern und Heimkehrern zu. Für diese Bedarfsabdeckung spricht auch die 
Art der Arbeit, die für eine volle Leistungsfähigkeit eine längere Zeit der Eingewöhnung erfordert. Für eine Zuführung von Kräften im Wege des überbezirklichen Ausgleichs ist die für die Unterbringung und Verpflegung getroffene Regelung nicht geeignet. Diese Tatsache ist den Herren der Werkleitung und der Betriebsvertretung, die bei der Besprechung zugegen war, auch bekannt gegeben worden.

Das Werk steht wegen der Zuweisung von Umsiedlern mit dem Hauptamt für Sozialfürsorge Berlin - Abteilung Arbeitsvermittlung - in dauernder Verbindung. Für den 24. ds. Mts. sind dem Werk 20 männliche und 40 weibliche Kräfte aus den Lagern in $\mathrm{Bu}$ [c]kow und Rudow zugesagt worden.

Das Arbeitsamt in Rathenow wird bestrebt bleiben, aus der Fluktuation anfallende Kräfte der näheren Umgegend dem Werk laufend zuzuweisen.

In dem Werk sind ca. 250 Arbeitskräfte beschäftigt, die in dem angrenzenden Bezirk des Arbeitsamtes Genthin wohnen. Genthin gehört zum Bezirk des Provinzialamtes Sachsen in Halle. Das Arbeitsamt Genthin soll bei eintreffendem Bedarf auf die bei Agfa-Seide beschäftigten Kräfte zurückgreifen und für andere Aufgaben einweisen. Da es sich bei diesen Leuten ausschliesslich um eingearbeitete Kräfte handelt, bittet das Werk, von einer Abziehung dieser Kräfte für die Folge Abstand zu nehmen.

Befremdend war der Umstand, dass das für den Betrieb zuständige Arbeitsamt in Rathenow von der Anforderung des Werkes erst durch meine Anwesenheit Kenntnis erhielt. Dieser Zustand ist einfach ein Unding.

Jede Anforderung ist an das für den Sitz des Betriebes zuständige Arbeitsamt zu leiten. Kann das Arbeitsamt den angemeldeten und von ihm nach Prüfung der Verhältnisse anerkannten Bedarf im eigenen Bezirk nicht abdecken, so hat es nach Prüfung der Vermittlungsreife der Arbeitsplätze von sich aus den zwischenbezirklichen Ausgleich einzuleiten. Es trägt auch gegenüber den veranlassenden Stellen und den abgebenden Ämtern die Verantwortung für die Vermittlungsreife, insbesondere für die Aufnahme und die Unterbringung der zugewiesenen Kräfte.

Das Rundschreiben Nr. 37 des Landesamtes für Arbeit in Potsdam betreffend de Zuweisung von Arbeitskräften im zwischenbezirklichen Ausgleich für das Werk Agfa-Seide ist gleichfalls ohne Prüfung der örtlichen Verhältnisse veranlasst worden.

\section{b) Potsdam, 5. August 1946}

BLHA, Rep. 206 Ministerium für Wirtschaft und Arbeit, Nr. 3036, unfol. - Bleistift-Manuskript, 1 Bl., mit Unterschrift „Sattler“. - L. o.: „VII/7/32/Sa.", r. o.: „Potsdam, den 5.8.46.“ - R. u. Sichtvermerk: „ges. Th.[?]“.

1) Vermerk: Umsiedlerstelle, Frau Steeger, ruft an und teilt folgendes mit:

Nach Premnitz sind 39 männliche und 56 weibliche Fachkräfte mit 108 Angehörige[n] vermittelt. Die Kräfte kommen aus dem Lager Küchensee. Mit dem Treuhänder Herrn Langbein der Agfa-Seide ist abgesprochen worden, dass Agfa die restlichen Fachkräfte sich laufend aus dem 
Lager holt, eingemeindet, und bei der Agfa einsetzt. Demnach ist nach Mitteilung von Frau Steeger der Bedarf für Premnitz abgedeckt und die Angelegenheit somit erledigt.

5/8.46./Sattler.

\section{c) Potsdam, 7. August 1946}

BLHA, Rep. 206 Ministerium für Wirtschaft und Arbeit, Nr. 3036, unfol. - Typoskript, 1 Bl., mit Kopierstift-Unterschrift „I.A. Lisch[?]“.- L. o. „Amt für deutsche Umsiedler / Az.VII/2/Ste./Scha.“; r. o. „Potsdam, den 7. Aug. 1946“. Adressierung: „Mitteilung an Landesarbeitsamt Herrn Westphal“. - R. o. 2 Namenskürzel mit Kenntnisnahmestrichen „La.[?]“ / „Ste.[?]“. - L. u. Bearbeitungsvermerk/Verfügung: „1) Kenntn.[is] gen.[ommen] /2) zdA (Agfa S. Premnitz)“/ Paraphe „Th[?]“.

Am 2.8. wurde in einer persönl[ichen] Rücksprache Agfa-Seide Premnitz Herrn Langbein, folgendes abgesprochen: / 39 Männer Textilfachkräfte / 56 Frauen dto. / zuzügl[ich] 108 Angehörige, die bereits im Kreise Beeskow-Storkow eingemeindet sind, werden insges[amt] von der Agfa-Seide Premnitz übernommen. / Für Transportraum wird Herr Götze resp. Herr Langbein im Einvernehmen mit diesem besorgt sein. / Es ist ferner Herrn Langbein im Einverständnis mit Herrn Friedrichs gestattet, in die einzelnen Lager zu gehen, um die männl[ichen] Kräfte, die für seinen Betrieb benötigt werden, selbst auszuwählen. / Zur Bedingung wurde die Unterbringung der Arbeitskräfte und deren Familien gemacht.

\section{d) Potsdam, 16. August 1946}

BLHA, Rep. 206 Ministerium für Wirtschaft und Arbeit, Nr. 3036, unfol. - Typoskript, 1 Bl. - Unten Datierung „Brandenburg (Havel), den 16.1.1946“; darunter handschriftlich (Bleistift) „not. P. 22.1.46 / z. Vorgang ,Premnitz؛ P.“ - O. r. Eingangsstempel: „Prov.Verw. Mark Brandenburg / 22.[?]01.46[?] [...]“.- Überschrift: „Aktenvermerk“. [Absender ist das Arbeitsamt Brandenburg/Havel.]

Am 14.1.1946 erschienen auf dem Arbeitsamt der Bürgermeister von Premnitz mit 2 Betriebsratsmitgliedern der Agfa-Kunstseidenfabrik Premnitz und forderten die Gestellung von 300 männlichen und 200 weiblichen Arbeitskräften, und zwar sollten diese sofort, spätestens am Mittwoch, bereitstehen. Über Unterbringungsmöglichkeiten konnte nichts Bestimmtes gesagt werden. Wir mußten auch den Herren erklären, daß wir Arbeitskräfte von hier z.Z. nicht stellen können, da wir sehr hohe Anforderungen für anderweitige Zwecke, insbesondere für die Besatzungsbehörde in der Stadt Brandenburg, erfüllen müssen. Wir haben ihnen vorgescholagen, aus dem Umsiedlerlager ${ }^{2316}$ von den dort befindlichen Kriegsgefangenen zu versuchen, Leute heranzuziehen. Der zufällig anwesende Leiter der Einsatzstelle des Arbeitsamtes im Umsiedlerlager, Herr Suhr, versprach, für Mittwoch 50 Männer zu stellen. Dieses Versprechen konnte er so jedoch nicht halten, da am Dienstag sämtliche Kriegsgefangenen und auch sämtliche Zivilinsassen nach ihren weiteren Bestimmungsorten abtransportiert wurden. Heute, Mittwoch, den 16.1.1946, kamen der Bürgermeister von Premnitz und 1 Betriebsratsmitglied der Agfa- 
Kunstseidenfabrik und wollten dann die versprochenen Leute abholen. Der Unterzeichnete ist dann mit ihnen nach dem Lager gefahren und dort wurde folgendes abgesprochen:

Die Lagerverwaltung stellt aus den jetzt angemeldeten Kriegsgefangenen 300 Personen ab, insbesondere solche, die nicht in ihre Heimat zurückkehren können, weil diese abgetrennt ist (Ostgebiete, Schlesien). Die Bedingungen, mit welchen die vermittelten Leute in Premnitz beschäftigt und unterbgebracht werden, sind folgende:

Zunächst werden sie in Baracken untergebracht. Es sollen bis zu 300 angesiedelt werden, d.h., die dort eingesetzten Männer sollen, nachdem sie ihre Familie gefunden haben, die nach dorthin nachholen können, sollen dann Wohnraum und sogar ein Stück Gartenland im Laufe des Sommers zugewiesen bekommen.

Es wurde weiter zugesagt, daß Arbeitskleidung und auch Schuhwerk für diese Leute beschafft wird. Die sonstige Entlohnung nach Tarif. Der Bürgermeister der Stadt Premnitz erklärte, daß er die Zusicherung vom Landrat habe, diese Leute fest anzusiedeln. Sie sollen dann auf das allgemeine Ansiedlungssoll des Kreises Westhavelland angerechnet wrden.

(122) Protokoll der Besprechung der Abteilung Wirtschaft und der Abteilung Arbeit und Sozialwesen mit der Industrie- und Handelskammer. - Potsdam, 27. Juli 1946 (Auszug)

BLHA, Rep. 206 Ministerium für Wirtschaft und Arbeit, Nr. 2965, unfol. - Typoskript (Durchschlag), 5 Bl., auf Bl. 5 Kopierstiftunterschrift „I. V. Fischer“.

\section{Protokoll}

über die Sitzung zwischen der Abt. Wirtschaft, der Industrie- und Handelskammer und der Abt. Arbeit und Sozialwesen am 27. Juli 1946.

Anwesend waren:

Herr Dr. Schleusener ${ }^{2317}$

Herr Dr. Eberlein

Herr Fischer ${ }^{2318}$

Herr Dr. Tonn

Herr Piperek

Herr Schmidt

Herr Völz

Herr Dipl.-Ing. Eickhoff

Herr Eckstein
Leiter d. Abt. Industrie- u. Handelskammer

Leiter der Abt. Arbeit und Sozialwesen

stellv. Leiter der Abt. Arbeit und Sozialwesen

Referent d. Glas- und Grobkeramikindustrie

Bergbaureferent

Referent d. Textilindustrie

Geschäftsführer d. Industrie- u. Hand[els-].Kammer Industrie- u. Hand[els-].Kammer Industrie- u. Hand[els-].Kammer

2317 [Dr.-Ing. Harald Schleusener (1911-2000), Sohn des CDU-Politikers Frank Schleusener (1876-1950).]

2318 [Siehe Anm. 2271.] 


$\begin{array}{ll}\text { Herr Walpuski } & \text { Referent - Landesarbeitsamt - Arbeitseinsatz } \\ \text { Frau Steger } & \text { Referent Umsiedler. }\end{array}$

Innerhalb der Provinz Brandenburg sind bis zum heutigen Tage 9 Umsiedlertransporte eingemeindet worden. Hierzu kommen noch 40000 Umsiedler hinzu, von denen sich ca. 15000 ihren Lebensunterhalt durch Arbeit selbst verdienen müssen. Ein zweckentsprechender Arbeitseinsatz scheitert überall an fehlendem Wohnraum. Auch arbeitsmäßig bedeutet die Unterbringung Schwierigkeiten. Dadurch besteht die große Gefahr einer Abwanderung nach dem Westen. Lt. Befehl der SMA muß dieses mit allen Mitteln verhindert werden - das kann nur durch eine soziale Hilfe geschehen -.

Die Unterbringung in landwirtschaftliche Betriebe ist wegen Über[be]setzung ausgeschlossen. Die SMA hat erklärt, daß sie die Herausziehung der Jugendlichen aus den landwirtschaftlichen Betrieben wünsche und dieselben an die Maschinen zu stellen sind.

Lt. Befehl der SMA sind die Textilkräfte der Umsiedler möglichst an einem Ort zu belassen, damit bei Bedarf sofort der Abtransport erfolgen kann.

Die Unterbringungsmöglichkeiten im Bezirk Senftenberg sind sehr schwierig. Es muß versucht werden Baracken, auch gegen den Willen des Bürgermeisters, zu errichten. / Der Bürgermeister von Rüdersdorf weigert sich Arbeitskräfte aufzunehmen, obgleich ihm die Lieferung von Baracken und Lebensmitteln zugesagt wurde. / Die Stadt Cottbus kann keine Arbeitskräfte mit Familienangehörigen aufnehmen, da durch eine russische Panzerarmee viele Straßenzüge und Häuser besetzt worden sind. / Der Bürgermeister von Templin lehnt die Unterbringung von Arbeitskräften ab, trotzdem Unterkünfte vorhanden sind, die nur einer Ausstattung bedürfen. [2. Bl.] / Die Unterbringungsmöglichkeiten in der Grube Finkenhe[e]rd/Frankfurt/O (Bergbau) von ca. 100 Werkwohnungen, sind von dem Bürgermeister der Stadt beschlagnahmt worden, da er dieselben mit seinen eigenen Arbeitskräften besetzt hatte. Außerdem stand der Grube Finkenhe[e]rd noch ein ehemaliges Ausländerlager für ca 2000 Insassen zur Verfügung, an welchem nur kleine Reparaturen notwendig waren.

Es wird darauf hingewiesen, daß durch das inzwischen herausgegebene Kontrollratswohnungsgesetz die Frage der Werkwohnungen dahingehend geklärt worden ist, daß sie ihrem ursprünglichen Zweck wieder zugeführt werden nmüsen.

Für die Einstellung der Provinz Brandenburg bezügl. der Unterbringung ist es bezeichnend, daß die Bürgermeister für unverheiratete Arbeitskräfte Wohnraum zur Verfügung stellen wollen, während sie Arbeitskräfte mit Familienangehörigen ablehnen.

Es wird die Frage aufgeworfen, ob die Arbeitskräfte mit ihren Familienangehörigen an den Orten wohnraummäßig untergebracht werden können[,] wo sie gebraucht werden, oder ob sie nach Sachsen zum Aufbau der Wirtschaft weitergeleitet werden sollen. 
Die Provinz Sachsen hat sich bereit erklärt, von der Provinz Brandenburg Umsiedler, mit einer unbegrenzten Anzahl von Familienmitgliedern, zu übernehmen. / Der Kupfer-Schiefer-Bergbau Mannsfelde ${ }^{2320}$, Sitz Eisleben, hat Arbeits- und Unterbringungsmöglichkeiten für 4000 Familien. / Die Textilindustrie Sachsen stellt den Antrag, Umsiedler mit Familienangehörigen sofort nach dorthin zu leiten.

Es wird die Frage aufgeworfen, ob die Beschaffung der Arbeitskräfte und der Unterkünfte derselben, Aufgabe der Abt. Arbeit und Sozialwesen sei. / Nach Rücksprache mit der Abt. II, die die Verteilung der Baustoffe unter sich hat, wird der Frage näher getreten werden. (Die Abt. II hat in Eberswalde und Freienwalde sämtliche Baracken und Baumaterialien eingezogen).

Die Industrie- und Handelskammer wird Zahlen und Unterlagen einreichen, an welchen Orten die Unterbringungsmöglichkeiten sichergestellt sind und an welchen nicht.

Der Bergbau in der Provinz Brandenburg benötigt für 3000 Menschen 100 Baracken und verpflichtet sich, dieselben bei Gestellung sofort abzuholen und binnen 8 Wochen aufzustellen.

Von der Abt. Wirtschaft wird erklärt, daß Feststellungen getroffen worden sind[,] in welchen Bezirken Arbeitskräfte benötigt werden. Der Bedarf muß unbedingt sichergestellt werden.

Zur Sicherstellung der Unterbringung wäre die Herausgabe einer Notverordnung von Seiten der Provinzialverwaltung notwendig. [3. Bl.]

Ziegelproduktion [...] Für die Grobkeramikherstellung bieten die Umsiedler aus der Tschechoslowakei keine guten Voraussetzungen.

Glas-Industrie [...] Der Bedarf muß aus den vorhandenen Umsiedlern gedeckt werden. [...]

\section{(123) Einsatz von Vertriebenen bei der Müllabfuhr. - Rathenow, 24. August 1946}

BLHA, Rep. 230 Oberlandratsamt Brandenburg, Nr. 22, Bl. 25. - Typoskript (Durchschlag), 1 Bl. - L. o. Absender: „Der Landrat / des Kreises Westhavelland / Amt für deustche Umsiedler“. - R. o. Datierung „Rathenow, den 24. August 1946“; Aktenzeichen „- VII/300 Zi/Sr -“. - Adresse: „An die / Provinzialverwaltung / Mark Brandenburg / Abt. VII/Arbeit und Sozialwesen / Erfassung und Arbeitseinsatz der/Bevölkerung (Landesarbeitsamt) / Potsdam / Alte Zauche 67 / durch Herrn Oberlandrat“. - Betreff: „Betrifft: „Arbeitskräfte für die Berliner Müllabfuhr in Päwesin“.Bl. 25v: Stempel „Der Landrat / Rathenow-Westhavelland“, [masch.] „i/A.“ [gez. (Tinte)] „Olterburg[?]“.- Bl. 25r o. „Abschrift“. - Verfügung/Bearbeitungsvermerk: „1/“...[? (Paraphe)] weitergereicht/2.) z.d.A. (VII/12 WH.) $27 / 8$. ... [? (Unterschrift, eventuell Paraphe für „Bernhardt“)]“.

Unter Bezugnahme auf dortige Verfügung gem. 31.5.[19]46 - VII/7/32 Wa/Pa -, welche erst jetzt zur Kenntnis des Umsiedleramtes gelangte, wird mitgeteilt, dass von den jetzt eintreffenden Umsiedler-Transporten aus der Tschechoslowakei entsprechende Arbeitskräfte für die Berliner Müll- [Bl. 25v] abfuhr nach Päwesin zugewiesen werden. 


\section{(124) Jahresberichte von Arbeitsämtern über den Einsatz von „Umsiedlern“ als Arbeitskräfte im Jahr 1946. - [Verschiedene Orte], 7. bis 20. Dezember 1946 (Auszüge)}

BLHA, Rep. 206 Ministerium für Wirtschaft und Arbeit, Nr. 2997, unfol. - Typoskripte. - [Die Jahresberichte folgen dem Schema des Berichtes des Kreisarbeitsamtes Neuruppin (siehe unten Nr. 126) gemäß Anforderung durch das Rundschreiben des Referats Erfassung und Arbeitseinsatz der Bevölkerung der Abt. VII Arbeit und Sozialwesen der Provinzialverwaltung (siehe ebd.). Aus den Berichten über den Arbeitskräfteeinsatz insgesamt werden hier nur die jeweiligen Antworten zur Frage nach dem Einsatz von „Umsiedlern“ wiedergegeben. - Die Akte enthält nur Berichte der Städte und Kreise aus dem Oberlandratsbezirk Brandenburg, entsprechende Berichte anderer Bezirke liegen in der Rep. 206 nicht vor.]

B. Arbeitseinsatz bei Industrie, Handel und Gewerbe.

2. Wie wurden die Umsiedler und ehemaligen Kriegsgefangenen eingesetzt; Gesamtzahl der Zuweisungen aus dem genannten Personenkreis.

3. Fälle der Absage der Arbeitslosen oder Zugewiesenen vom Arbeitseinsatz wegen Nichtbereitstellung von Wohnraum

a) allgemein

b) Umsiedler

4. Wieviel Umsiedler und Erwerbsbeschränkte sind eingesetzt und für welche Arbeiten?

5. Welche Schwierigkeiten haben sich bei der Vermittlung dieses Personenkreises ergeben und welche Massnahmen sind zur Behebung der Mängel getroffen worden?

\section{[a] Arbeitsamt des Kreises Westprignitz. - Perleberg, 10. Dezember 1946}

$\mathrm{Zu}$ 2.) Die Umsiedler und ehem. Kriegsgefangenen wurden in erster Linie, soweit es irgend möglich war, in ihren erlernten Berufen untergebracht. Wo das nicht möglich war, wurden die [sie!] in der Landwirtsch[aft,] Baugewerbe und andere Betriebe eingewiesen. Gesamtzahl der Zuweisungen aus dem genannten Personenkreis - 4235

$\mathrm{Zu}$ 3.) Vermittlungen und Zuweisungen erfolgten nur dann, wenn die Wohnungsfrage geklärt war.

$\mathrm{Zu}$ 4.) Es sind 4327 Umsiedler und Erwerbsbeschränkte eingesetzt worden. Der größte Teil der Umsiedler in der Landwirtschaft, der Rest im Baugewerbe, Sägewerken und Ziegeleien. Die Erwerbsbeschr[änkten] haupts[ächlich] in kaufm. Berufe, als Wachmänner und Boten oder für andere leichte Arbeiten. in Teil befindet sich auch in der Umschulung.

$\mathrm{Zu}$ 5.) Wie zu A 1 der rein landwirtsch. Charakter des Kreises erwähnt, konnten besonders die im Herbst eingetroffenen Umsiedler nicht alle in ihre Berufe untergebracht werden, denn ein großer Teil kommt aus Wirtschaft [s]- und Industriezweigen, die hier nicht vorhanden sind. (Textil- und Glasindustrie) Die Verkehrsverbindungen erschweren und machen teilweise die Vermittlung der in den Dörfern untergebrachten Umsiedler unmöglich. Der Gesundheitszustand läßt einen Einsatz nur bedingt zu. Die Bekleidung, besonders das Schuhwerk und die 
Berufsbekleidung, sind unzureichend. Wie schon erwähnt, wurde der größte Teil berufsfremd eingesetzt. Die Mängel in Bezug auf Kleidung konnten durch Sammelaktionen bezw. Spinnstoffausgaben und Fürsprache beim Kreissozialamt soweit als möglich behoben werden.

\section{[b] Arbeitsamt des Kreises Ostprignitz. - Kyritz, 20. Dezember 1946}

$\mathrm{Zu}$ 2.) Die Umsiedler und ehemaligen Kriegsgefangenen wurden zu ca. $85 \%$ in der Landwirtschaft, der Rest in ihre bisher erlernten Berufe untergebracht, sofern die Zuführung in den erlernten Berufen wie Weber, Glasbläser, Bildhauer usw. nicht möglich war. Die Gesamtzahl der Umsiedler beträgt ca. 43 000. Die Gesamtzahl der ehemaligen Kriegsgefangenen beträgt im Monat ca. 200.

$\mathrm{Zu}$ 3.) Fälle der Absagen der Arbeitslosen oder Zugewiesenen vom Arbeitsamt wegen Nichtbereitstellung von Wohnraum sind nicht zu verzeichnen, da die zustündigen Dienststellen über den bestehenden Wohnungsmangel unterrichtet waren.

$\mathrm{Zu}$ 4.) Es sind im Kreise etwa

$\mathrm{Zu} 4$ a) Umsiedler 22306

$\mathrm{Zu} 4$ b) Erwerbsbeschränkte ca. 2000

für landwirtschaftliche Arbeiten, Hilfsarbeiten in den kleineren Handwerksbetrieben und der Stärkefabrik Kyritz vermittelt worden.

Zu 5.) Die Schwierigkeiten der Vermittlung der Kräfte bestehen darin, dass [den] in den 137 Landgemeinden untergebrachten Umsiedlern, nachdem die landwirtschaftlichen Arbeiten beendigt worden sind, zum grössten Teil andere Arbeiten während der Wintermonate nicht zugewiesen werden können, da die Überweisung in andere Gemeinden wegen des überall herrschenden Wohnraummangels nicht möglich ist, so dass die Lenkung der Arbeitskräfte örtlich geschehen muss. Es werden sich aber Möglichkeiten bieten, diese Kräfte zu Gelegenheitsarbeiten, wie Holzeinschlag und Arbeiten bei der Roten Armee[,] während der Wintermonate heranzuziehen.

\section{[c] Arbeitsamt des Kreises Westhavelland. - Rathenow, 10. Dezember 1946}

$\mathrm{Zu}$ 2.) Eingesetzt wurden sie zum Teil in der Landwirtschaft, Agfa Seide Werk, Premnitz, und in der Bastfaser, Rhinow, vor allen Dingen führten wir sie den Mangelberufen zu. Umsiedler und Kriegsgefangene insgesamt: 4506 Personen.

$\mathrm{Zu} 3$ a.) Leider war das Kreisarbeitsamt Rathenow nicht in der Lage, die nich immer fehlenden Fachkräfte in Rathenow aufzunehmen, da unsere Stadt zu $52 \%$ zerstört ist und es uns bisher aus diesem Grunde noch nicht möglich war, Wohnungen, wegen Mangel an Baumaterialien, auszubauen.

$\mathrm{Zu} 3$ b.) Wir mussten Spezialfachkräfte, welche wir auf dem Wege der Umsiedler zugewiesen erhielten, z. B. Kunstglasindustriearbeiter, nach Thüringen verlagern. 
Zu 4.) 3225 Umsiedler[,] 2824 Erwerbsbeschränkte[.] Diese wurden der Landwirtschaft (Bodenreform), der Rathenower Optik, der Firma Bastfaser, Rhinow, dem Agfa Seide Werk, Premnitz, in allen möglichen Berufen, zugeführt.

$\mathrm{Zu}$ 5.) Bei den Antifa-Familien, welche wir aus der Tschechei zugewiesen erhielten, machte uns der grosse Wohnraumanspruch dieser Familien viele Schwierigkeiten, da jede Familie eine komplette Wohnung verlangte. Diese Durchführung gelang uns nur in wenigen Fällen.

\section{[d] Arbeitsamt des Kreises Zauch-Belzig. - Belzig (Mark), 8. Dezember 1946}

$\mathrm{Zu}$ 2.) Umsiedler und Heimkehrer wurden ihren Berufen entsprechend eingesetzt. Zahlen können nicht gemeldet werden.

$\mathrm{Zu}$ 3.) Fehlanzeige. Es könnten aber noch mehr Arbeitskräfte vermittelt werden, wenn genügend Wohnraum vorhanden wäre.

$\mathrm{Zu}$ 4.) Kann nicht gemeldet werden.

$\mathrm{Zu}$ 5.) Mangel an warmer Bekleidung und Handwerkszeug. (Kreisumsiedlerausschuß beabsichtigt eine Sammlung durchzuführen.)

\section{[e] Arbeitsamt der Stadt Brandenburg/Havel. - Brandenburg/Havel, 7. Dezember 1946}

[Zu 2.)] Die Umsiedler, die nach Brandenburg überwiesen wurden, sind ihren zuständigen Berufszweigen, d.h. der Fa. Skomski, zugewiesen. Aus der Kriegsgefangenschaft kehrten zurück 5257, davon wurden in Arbeit gebracht 4978.

[Zu 3.)] Eine Absage der Zugewiesenen wegen Wohnraum ist hier nicht bekannt, $[\mathrm{Zu} 4)$.$] die Umsiedler sind restlos eingesetzt. Erwerbsbeschränkte sind bis auf 713$ Frauen restlos eingeetzt.

[Zu 5.)] Die Verhandlungen wegen der Schwerbeschädigten - aufgrund der Anordnung vom 2.9.1946 - sind im Augenblick noch nicht abgeschlossen, weil einzelne Arbeitgeber sich noch nicht dazu durchringen können, Schwerbeschädigte einzustellen. Die ihnen gestellte Frist läuft am 15.12.1946 ab und dann setzen Zwangsmassnahmen des Arbeitsamtes ein.

\section{[f] Arbeitsamt der Stadt Wittenberge. - Wittenberge, 18. Dezember 1946}

$\mathrm{Zu}$ 2.) Ortsansässige Kriegsgefangene wurden ihren früheren Arbeitsstellen zugeführt. Umsiedler und alle anderen Kriegsgefangenen wurden im Produktionsprozess eingereiht.

Zu 3.) Enthällt.

Zu 4.) Umsiedler 1581, Erwerbsbeschränkte 377, ihrer Beschädigung entsprechend in Handwerks- und Grossbetrieben.

Zu 5.) Keine. 
(125) Jahresbericht des Kreisarbeitsamtes Neuruppin über den Einsatz der Arbeitskräfte 1946. - Neuruppin 13. Dezember 1946 (Auszüge)

BLHA, Rep. 206 Ministerium für Wirtschaft und Arbeit, Nr. 2997, unfol. - Typoskript (Durchschlag), 3 Bl. (5 S.) mit Unterschrift. - 1. Bl.: Absenderstempel „Kreisarbeitsamt Ruppin / Neuruppin“, Aktenzeichen „II/1-43-“, r. o. Datierung „13. Dezember 1946.“, darunter Sachbearbeiterkürzel „Ko.“- Adresse: „An / die Provinzialverwaltung Mark Brandenburg / Abt. VII Arbeit und Sozialwesen / - Landesarbeitsamt - / Potsdam / Alte Zauche 67, Haus 1.“- Betreff: „Betr.: Aufstellung des Jahresberichtes 1946 über den Arbeitseinsatz der Arbeitskräfte in der Provinz Mark Brandenburg.“ - Bezug: „Vorg.: Rundschreiben Nr. 100 vom 25.11.1946 v Az. VII/7/32 Wa/Pa. -“ [Das hektografierte Rundschreiben des Referats Erfassung und Arbeitseinsatz der Bevölkerung der Abt. VII Arbeit und Sozialwesen der Provinzialverwaltung liegt der Akte bei; diesem sind die unten in eckigen Klammern hinzugefügten Fragen entnommen.] - Letzte (5. S.) u.: „Der Leiter des Amtes: / [Stempel] In Vertretung / [gez.:] Zeise[?]“.- Separates Begleitschreiben (1 Bl.) desselben Absenders mit Unterschrift „I. A. Ruß“, Neuruppin 16. Dez. 1946, zur Übersendung des o. g. Berichts „in doppelter Ausfertigung“ „An den Herrn Oberlandrat des Verwaltungs- / bezirks Brandenburg, / Abt. VII Arbeit und Sozialfürsorge, / Brandenburg/Havel, / Burghof 5." (Eingangsstempel 21. Dez. 1946).

\section{A. Ausführung der Befehle über die Gestellung von Arbeitskräften}

$[\ldots][$ S. 2] [...]

$Z u$ 3: [Ursachen bei Nichterfüllung der einzelnen Befehle und Anordnungen] Die Erfüllung der einzelnen Befehle und Anordnungen scheitert vor allem am Nichtvorhandensein von Fachkräften und daran, dass auch die ungelernten Kräfte des Kreises in den Arbeitsprozess des Wiederaufbaues eingegliedert sind. Eine der Hauptursachen für die Nichterfüllung einzelner Befehle und Anordnungen ist der geradezu katastrophale Gesundheitszustand der Bevölkerung. Von 100 für den Odereinsatz durchgeführten amtsärztlichen Untersuchungen waren lediglich 27 vollarbeitseinsatzfähige Kräfte festgestellt worden, während 47 eine 50 \%-ige Erwerbsbeschränkung aufwiesen und der Rest sich als völlig unbrauchbar für jeden Arbeitseinsatz herausstellte. Um die für den Odereinsatz nach Rundschreiben Nr. 80 angeforderten 159 Arbeitskräfte zusammenzubekommen, mussten ca. 600 Menschen im Alter von 1-50 Jahren aus den Karteien herausgesucht und einer amtsärztlichen Untersuchutng zugeführt werden. Handelte es sich bei überbezirkliche Abstellungen, so waren oftmals das Nichtvorhandensein von Kleidung, Schuhen und warmen Decken die Ursachen, weshalb Arbeitskräfte aus sozialen Gesichtspunkten nicht abgestellt werden konnten. / [...]

$\mathrm{Zu}$ 6: [Wurden die Unterbringungsmöglichkeiten für Neuarbeiter geprüft? Wo und welche Mängel sind dabei festgestellt worden; wie wurden diese beseitigt?] Obwohl bereits grosser Bedarf an Neuarbeitern besteht, konnten solche im überbezirklichen Ausgleich nicht angefordert wedren, da keine Unterbringungsmöglichkeiten bestehen. Die Zuzugsgenehmigungen in den Kreis sind überall erschwert, in die Stadt Neuruppin überhaupt nicht zu erhalten, da ein grosser Teil des Wohnraums der Stadt russischen Belangen zur Verfügung gestellt werden musste. Da die Bevölkerung des Kreises bereits auf engstem Wohnraum, zusammengepresst lebt, konnte dieser Mangel nicht beseitigt werden. / [...] [S. 3] [...] 


\section{B. Arbeitseinsatz bei Industrie, Handel und Gewerbe.}

$\mathrm{Zu}$ 1: [Wieviel Arbeitsstellen sind während der Okkupation Deutschlands im Jahre 1946 vermittelt worden] Insgesamt sind während der Zeit der Okkupation im Kreise Ruppin im Jahre 194617630 Arbeitsstellen vermittelt worden. Davon in männliche Stellen 5377, in weibliche Stellen 12253.

$\mathrm{Zu} 1$ a: [ür die Hauptwirtschaftszweige] Für die Hauptwirtschaftszweige wurden insgesamt 2234 Stellen, davon 1553 männliche und 651 weibliche Stellen vermittelt.

$\mathrm{Zu} 1$ b: [alle sonstigen Stellen.] In sonstige Stellen wurden 15396 Kräfte eingewiesen, davon 3794 männliche und 11602 weibliche Kräfte.

$\mathrm{Zu}$ 2: [Wie wurden die Umsiedler und ehemaligen Kriegsgefangenen eingesetzt; Gesamtzahl der Zuweisungen aus dem genannten Personenkreis.] Nach bisherigen Feststellungen fanden im Amtsbezirk des Kreisarbeitsamtes Ruppin 48596 Umsiedler Aufnahme. Vollarbeitsfähig davon waren männlich 5909 und weiblich 10321 Personen.

Im Berichtsjahr 1946 sind 5123 Umsiedler in den Kreis gekommen, von denen 3867 durch das Arbeitsamt in Arbeit eingewiesen wurden. 641 Heimkehrer aus der Kriegsgefangenschaft wurden im Berichtsjahr gleichfalls in Arbeit vermittelt. Bei den Einweisungen der Umsiedler in unseren Kreis handelte es sich vorwiegend um ungelernte Arbeitskräfte. Bemühungen des Arbeitsamtes, aus den Umsiedlerlagern Facharbeitskräfte in den Kreis zu bekommen, schlugen fehl, obwohl das Arbeitsamt Vertreter in einzelne Lager schickte, um die im Kreis benötigten Fachkräfte zu erhalten.

$\mathrm{Zu}$ 3: [Fälle der Absage der Arbeitslosen oder Zugewiesenen vom Arbeitseinsatz wegen Nichtbereitstellung von Wohnraum] Fälle der Absage kamen nicht vor, da

a) [allgemein] örtliche Arbeitszuweisungen erfolgten und

b) [Umsiedler] die Umsiedler infolge Mangels an Bekleidung und Schuhwerk gleichfalls an ihrem Einsatzort in Arbeit eingewiesen werden mussten und ihnen ausserdem lange Anmarschwege nicht zugemutet werden konnten.

$\mathrm{Zu}$ 4: [Wieviel Umsiedler und Erwerbsbeschränkte sind eingesetzt und für welche Arbeiten?] Insgesamt wurden 5360 Umsiedler und Erwerbsbeschränkte vorwiegend für ländliche Arbeiten eingesetzt.

$\mathrm{Zu}$ 5: [Welche Schwierigkeiten haben sich bei der Vermittlung dieses Personenkreises ergeben und welche Massnahmen sind zur Behebung der Mängel getroffen worden?] Schwierigkeiten in der Betreuung der Umsiedler und Erwerbsbeschränkten sind darin zu erblicken, dass dieser Personenkreis meist nicht in feste Arbeitsverhältnisse, sondern fast immer nur in saisonedingte Arbeit wie Frühjahrsbestellung, Holzeinschlag, Erntearbeiten und Herbstbestellung, eingewiesen werden konnten. Die Wohnungsschwierigkeiten erschweren auch die Möglichkeiten eines planvolleren Einsatzes der Umsiedler. 
$\mathrm{Zu}$ 6: [Was ist geschehen, um die Arbeitslosen der sogenannten „toten Berufe“ (Hausangestellte, kaufm. Berufe u. a.) unterzubringen. Anzahl der nicht vermittelten Arbeitslosen dieser Berufe; Vorschläge, um diesen Personenkreis unterzubringen.] In den Städten wurden die Angehörigen der sogenannten toten Berufe in der Hauptsache zu den täglichen Anforderungen der Grossfirmen und der Roten Armee, Be- und Entladen von Waggons, Aufräumungsarbeiten, eingesetzt. Auf dem Lande wurden diese Kräfte durch die Ortsbürgermeister zu allen anfallenden Arbeiten herangezogen. In den Städten und Dörfern ist im Übrigen dafür Sorge getragen worden, dass dieser Personenkreis nach Möglichkeit in handwerkliche Berufe umgeschult, bzw. als Anlernlinge eingesetzt wurden. [S. 4]

$\mathrm{Zu}$ 7: [Wieviel Frauen sind zum Arbeitseinsatz gebracht; für welche Arbeiten; welche Schwierigkeiten sind hierbei aufgetreten; welche Massnahmen sind zur Überwindung der Mängel getroffen worden?] Im Kreise Ruppin sind 12253 Frauen in feste Arbeit eingewiesen worden. Schwierigkeiten traten nur bei den Zwangsarbeitseinweisungen für Aufräumungsarbeiten der Stadtbauämter auf, da der Gesundheitszustand der Frauen infolge unzureichender Ernährung schweren körperlichen Arbeiten entgegensteht. Die Anforderungen der Roten Armee an Frauen zu allen vorkommenden Arbeiten belaufen sich täglich auf etwa 200-250, wobei [bei] der Auswahl der Kräfte ebenfalls auf den schlechten Bekleidungszustand der Frauen Rücksicht genommen werden musste. Zur Überwindung der Mängel konnte von seiten des Arbeitsamtes nichts unternommen werden, da sich Bekleidungs- und Ernährungsschwierigkeiten ausserhalb des Zuständigkeitsbereichs des Arbeitsamts bewegen.

C. Bewegung der Arbeitskräfte durch zwischen- bzw. überbezirklichen Ausgleich.

$\mathrm{Zu}$ 1: [Wieviel Arbeiter und Angestellte sind aus anderen Ländern oder Provinzen in die Mark Brandenburg gekommen?] In den Kreis Ruppin sind aus anderen Ländern und Provinzen insgesamt 5123 Kräfte zugezogen. / [...]

Zu 1 d: [Welche Schwierigkeiten sind aufgetreten?] Sowohl in den Städten als auch in den Dörfern, die z. T. heute mit $100 \%$ mehr Menschen belegt sind als im Jahre 1939, wurde die Bevölkerung so eng zusammengedrückt, dass gewisse Gefahren für die Volksgesundheit bestehen. / $[\ldots]$

$\mathrm{Zu}$ 4: [Ursachen der vorgenommenen Vermittlungen; welche Schwierigkeiten traten auf; wie wurden diese beseitigt?] Als Ursache der vorgenommenen Vermittlungen sind Wieder-AufBauvorhaben und wie schon im Punkt 3) erwähnt, die Oderregulierungsanforderungen anzusehen. Beim Heranziehen der Kräfte für die Oderregulierung traten insofern oftmals Schwierigkeiten auf, als die Bevölkerung für solche Einsätze nicht mehr über die nötige Kleidung und Schuhwerk verfügt. Auch Decken sind nicht vorhanden. Der Gesundheitszustand der Bevölkerung ist, wie schon einmal in diesem Bericht erwähnt, ein derart schlechter, dass bei diesen überbezirklichen Einsätzen die Auswahl der infragekommenden Leute ungemein schwer fällt, da von 500 amtsärztlich Untersuchten nur 100-120 als körperlich geeignet für den Einsatz be- 
urteilt wurden. Die Beseitigung dieser Zustände liegt ausserhalb der Einwirkungsmöglichkeiten eines Kreisarbeitsamtes. / [...]

\section{(126) Monatlicher Situationsbericht des Arbeitsamtes Kyritz für den Kreis Ostprignitz. - Kyritz, 19. Dezember 1946 (Auszug)}

BLHA, Rep. 230 Oberlandratsamt Brandenburg, Nr.22, Bl. 117-118. - Typoskript (Durchschlag), 2 Bl. - L.o. Absender und Aktenzeichen: „Arbeitsamt Kyritz/L./O.“- R.o. Datierung „Kyritz, den 19.12.1946“. - Adresse: „An die / Provinzialverwaltung Mark Brandenburg/Abt. VII Arbeit und Sozialwesen / - Landesarbeitsamt/Potsdam / und / Herrn Oberlandrat / Abt. Statistisches Amt / Brandenburg/Havel“. - Betreff: „Betr.: Monatsbericht (Situatoonsbericht). - Eingangsstempel „24. Dez. 1946“. - Bl. 118 u. Stempel „Arbeitsamt Kyritz / Ostprignitz“, unterzeichnet masch. „Der Leiter des Arbeitsamtes“ [gez. (Kopierstift)] „I.A. Bernhardt“.

[...] [Bl. 118]

Zahl der im Kreise Ostprignitz aufgenommenen Flüchtlinge:

$\begin{array}{lcc} & \text { Männlich } & \text { Weiblich } \\ \text { bis 14 Jahren } & 7434 & 6650 \\ \text { 14- bis 18 Jahren } & 1930 & 2251 \\ \text { 18- bis 60 Jahren } & 7349 & 12941 \\ \text { über 60 Jahre } & 1762 & 2900\end{array}$

Die Zahl der im Berichtsmonat aufgenommenen Flüchtlinge aus den polnisch besetzten Gebieten beträgt ... Umsiedler, davon entfallen auf:

$\begin{array}{ll}\text { Männer } & 23 \\ \text { Frauen } & 30 \\ \text { Kinder } & 21\end{array}$

Hiervon sind in den Arbeitsprozess eingegliedert:

Männer 22

Frauen 20

Berufliche Aufgliederung der Ostumsiedler ist:

$\begin{array}{lr}\text { Landwirtschaft } & 18 \\ \text { Bauarbeiter } & - \\ \text { Handwerkl. Berufe } & 8 \\ \text { Ungelernte Arb[eiter] } & 16\end{array}$

Das Aufnahmesoll des Kreises beträgt 40000. 


\section{(127) Bericht der Abt. Arbeit und Sozialfürsorge des Landesvorstandes Brandenburg der SED an die Abt. Arbeit und Sozialfürsorge des Zentralsekretariats der SED, Genossen Belke, in Berlin. - [Potsdam], 15. März 1947}

BLHA, Rep. 333 SED-Landesleitung Brandenburg, Nr. 574, Bl. 103-106. - Typoskript (Durchschlag) mit eigenhändiger Paraphe Su. [Bezug/Zeichen des Adressaten:] IVa Be./K. [Bezugnahme auf Schreiben vom:] 13.2.[19]47. [Eigenes Zeichen:] Su./g. [Datum:] 15.3.1947. Vermerk auf Bl. 1 oben (blauer Buntstift): „Gen. Wernsdorf A 24.3./47.

Werte Genossen!

Betr. Umsiedlerausschüsse: Seit langem sind in unserer Provinz Kreis- und Ortsumsiedlerausschüsse in überparteilicher Zusammensetzung gebildet worden. Es war anfangs so, dass diese Ausschüsse immer nur auf dem Papier standen. Aber dadurch, dass wir immer wieder auf unsere Kreisvorstände einwirkten, diese Ausschüsse zu gut funktionierenden Hilfsinstrumenten zur Lösung aller Umsiedlerfragen zu gestalten, haben wir endlich erreicht, dass fast jeder Ausschuss aktiv arbeitet, wenn der eine oder andere auch schwächer ist. Die Umsiedlerausschüsse arbeiten in engster Verbindung mit den zuständigen Verwaltungsstellen, die ebenfalls rührig sind, und es trat die irrige Meinung auf, dass jetzt die Verwaltungen nur noch allein in Funktion treten können. So schrieb uns ein Genosse aus Eberswalde, dass dem Ausschuss nicht mehr eine solche Bedeutung beigemessen werden kann, weil die Behörde ihm die Arbeit vorwegnimmt. Wir haben selbstverständlich sofort korrigiert. Euren Vorschlag, dass der Umsiedlerausschuss in stärkerem Masse wie bisher selbst Versammlungen einberufen soll, haben wir weitergegeben.

Betr. Wohnraumbeschaffung: Hierfür sind Euch bereits Berichte zugegangen. Wir möchten nur noch ergänzend dazu berichten, dass von den Umsiedlerausschüssen als Unterkünfte wie [so!] Baracken, hergerichtet wurden. Viele Umsiedler sind als Untermieter untergebracht, wodurch sich auch in diesen Fällen die Hausratbeschaffung erledigt hat. Die Bevölkerung leistet oftmals bei der Unterbringung von Umsiedlern grossen Widerstand und es bedarf schon einer starken Persönlichkeit, um sich durchzusetzen. So war es ein Pfarrer, der neun Zimmer mit drei Personen zur Verfügung hatte und nicht eins dafür [davon] für Umsiedler abgeben wollte. Erst durch lange Diskussionen und Druck der Verwaltung wurde es aber nachher doch erreicht. In Zernitz blieben von einem neuen Transport 13 Frauen mit Kindern auf der Strasse. Auch sie mussten zwangsweise als Untermieter einquartiert werden. Der Umsiedlerausschuss macht sich oft unbeliebt. Wir haben aber feststellen können, sofern er selbst von der Notwendigkeit seiner Aufgaben durchdrungen ist und eine gute Aufklärungsarbeit leistet, trägt er doch unbedingt seinen Teil dazu bei, die Umsiedler einigermassen unterzubringen. [Bl. 104]

Betr. Facharbeiterumschulung: Hierzu müssen wir berichten, dass die männlichen Umsiedler in den meisten Fällen in kürzester Zeit vom Arbeitsamt vermittelt werden können. Die Transporte werden zur Eingemeindung bereits so gelenkt, dass den Berufsgruppen der Umsiedler Rechnung getragen wird. Die Zahlen unseres Landesarbeitsamtes für Facharbeiterumschulung stimmen. Wir haben in unserem Verhältnis - Industrie- und Landgemeinden - keine solche umfangreichen Möglichkeiten, wie Provinzen oder Länder mit grossen Industrien. Viele Umsiedler arbeiten als Landhelfer, wenn sie nicht, wie es bei uns in hohem Masse ist, Neubauern sind. Schwierigkeiten 
haben wir darin, die Umsiedlerfrauen mit Kindern in ausgesprochenenen Landgemeinden im Winter Arbeit zu geben. Im Sommer arbeiten sie auf dem Felde. Ein Teil arbeitet in den neugeschaffenen Genossenschaften, der andere Teil fällt der allgemeinen Fürsorge zur Last.

Wie wir Euch bereits berichtet haben, ist in Angermünde im ehemaligen Umsiedlerlager eine neue Fachumschulungswerkstatt geschaffen worden. Wir werden aber dieser Frage noch grössere Bedeutung beimessen.

Betr. Hausratbeschaffung für Umsiedler: Mit diesem Problem haben wir uns seit Wochen beschäftigt und erwogen, diese Beschaffung durch kein Gesetz zu erzwingen. Wir sind zu der Ansicht gelangt, dass man auf freiwilliger Grundlage mit allen Parteien und Organisationen, an der Spitze die Volkssolidarität, mehr erreichen wird. Nach Diskussionen haben wir festgestellt, dass die CDU und LDP diesem Gesetz nicht zustimmen werden. Sie sehen darin eine Beschlagnahme und „Eingriff in das private Besitztum“. Die Verantwortung aber können wir nicht allein übernehmen und werden nun eine grosszügige Aktion in gemeinschaftlicher Verantwortung auf freiwillige Hausratsspende für die Umsiedler durchführen. An einem Sonntag soll diese Aktion starten und glauben [wir] auch damit Erfolg zu haben. Endesunterzeichnete wird in dieser Frage erst noch einmal persönlich bei Euch vorsprechen.

Betr. Bezugsscheinpflichtige Waren: Wir haben in dieser Richtung gemeinsam mit dem Amt für deutsche Umsiedler dahingehend auf die Verwaltungen eingewirkt, dass die Umsiedler in erster Linie bei der Bezugscheinverteilung berücksichtigt werden. Bisher haben wir immer angewiesen, 60 \% aller Bezugscheine sollen an Umsiedler ausgegeben werden. Das kann aber nicht generell für alle Gemeinden angewandt werden, sonst hiesse es eine soziale Schicht gegen die andere auszuspielen. In den Landgemeinden kann der Umsiedler mehr erhalten an Bezugscheinen, als in den Industriegemeinden, wo der Arbeiter vornehmlich erst einmal mit Arbeitskleidung versehen werden muss. Bei unseren Überprüfungen haben wir feststellen können, dass eine gerechte Verteilung unter Berücksichtigung der Umsiedler vorgenommen wird.

Antif. Umsiedler, die Neubauernstellen übernehmen wollen: Sofern uns solche antifaschistischen Umsiedler bekannt waren, haben wir sie unserer Landwirtschaftsabteilung gemeldet, die das Adressenmaterial zur Weiterleitung gesammelt hat.

Befehl Nr.304: Darüber haben wir Euch vor einigen Tagen einen ausgi[e]bigen Bericht übermittelt, ${ }^{2321}$ ergänzen denselben aber noch mit Angaben aus dem Stadtkreis Eberswalde.

Der vorgeschriebene Prüfungsausschuss besteht aus einem Vertreter des Sozialamtes, des Umsiedlerausschusses und der Finanzverwaltung. Insgesamt wurden bis zum 11.1.[19]47 Anträge für

\begin{tabular}{lrr}
330 Erwachsene über & RM & 99000,- \\
99 Kinder über & RM & $9900,-$ \\
\cline { 2 - 3 } & RM & $108900,-$
\end{tabular}


zur Zahlung durch die Sozialversicherungskasse angewiesen. Die Auszahlungen selbst sind vorschriftsmässig in drei Monaten vorgenommen. Bis Weihnachten wurden RM 10 820,- zur Auszahlung gebracht. [Bl. 105]

In Abständen drängen wir immer wieder bei unserer Abt. Arbeit und Sozialfürsorge bei den Kreisvorständen auf eine schnellere und nicht engherzige Abwicklung dieser Anträge.

Wir werden Euch weiterhin auf dem Laufenden halten.

Jugendliche Umsiedler: In dieser Frage arbeiten wir mit allen Stellen wir FDJ, Arbeitsamt, Jugendfürsorge und Sozialamt zusammen. Die meisten der jugendlichen Umsiedler und Heimkehrer sind bei Bauern als Landhelfer untergekommen, ein kleinerer Teil als Lehrlinge in allen Industriezweigen.

Umsiedlergenossenschaften-Heimarbeit: In der Provinz Brandenburg haben wir 16 Umsiedlergenossenschaften, die wir Euch nachstehend bekanntgeben. Ergänzende Angaben erhaltet Ihr Anfang des nächsten Monats.

1.) Produktiv- u. Handelsgenossenschaft für Glas- u. Bijouterie-Industrie [/] Zinna/Krs. Luckenwalde [/] Arbeitsstärke unbekannt.

2.) Genossenschaft der Messerschmiede [/] Leegebruch/Krs. Osthavelland [/] Belegschaftsstärke 50

3.) Produktiv- u. Handelsgenossenschaft der Kunstblumen- u. Früchte-Industrie [/] Jüterbog, Planeberg Nr. 3/Krs. Luckenwalde [/] ppa. Hubert Beer, Jüterbog, Promenade 37 [/] Belegschaft 50 [/] könnten bei genügendem Material 200 beschäftigen

4.) Spitzenklöppel Genossenschaft m.b.H. [/] Grünheide i.M./Krs. Niederbarnim (Herr Singer) [/] Belegschaft 22 Arbeiter und weitere Heimarb[eiter]

5.) Antifa-Genossenschaft eGmbH, Erzeugung u. Verkauf von Strick- u. Wirkwaren sowie Malerbedarfsartikel, [/] Schönwalde b. Nauen/Krs. Osthavelland, Ernst Bernweisler, Schönwalde [/] Belegschaft versucht noch Maschinen aus der CSR zu bekommen.

6.) Metallgiesserei Genossenschaft, Cottbus - Josef Berger [/] Belegschaft 4 Arbeiter

7.) Schneidwarengenossenschaft Dahme/Krs. Luckenwalde [/] Belegschaft 12 Arbeiter

8.) Möbel- und Erzeugungs-Genossenschaft [/] Grünheide/Mark/Niederbarnim [/] Belegschaft 16 Arbeiter

9.) Weberei-Genossenschaft, Rhinow/Krs. Westhavelland [/] Belegschaft 43 Arbeiter

10.) Spremberger Textilgenossenschaft eGmbH. [/] Josef Hartmann, Spremberg, Bergstrasse 16a [/] keine Maschinen vorhanden

11.) Genossenschaft für Holzbearbeitung Lübbenau/Krs. Calau [/] Belegschaft 15 Arbeiter 
12.) Strohflechterei in Gollnitz/N.-L. ${ }^{2322}[/]$ Belegschaft 20 Arbeiter - weitere 50 Arbeiter sind mit der Herstellung von Bürsten beschäftigt

13.) Glasveredlung in Plaue/Krs. Westhavelland [/] Arbeitsstärke unbekannt

14.) Weberei in Burow/Krs. Westhavelland ${ }^{2323}[/] 4$ Frauen mit eigenen Webstühlen

15.) Näherinnen in Kirchhain/Krs. Luckau [/] 14 Frauen mit eigenen Nähmaschinen

16.) Konfektionsschneiderei Spremberg [/] Belegschaft unbekannt

\section{Planungen:}

Textilgenossenschaft Falkensee/Krs. Osthavelland

Sparteriegenossenschaft in Sallgast/Krs. Luckau

[Bl. 106]

Wirkerei und Weberei, Kuhblank bei Perleberg/Krs. Westprignitz

Handschuhmacher, Bad Wilsnack/Krs. Westprignitz

Fabrik Elektr. Heizkörper, Ossack/N.-L.

Glasveredelung, Eichwalde/Krs. Teltow

Gurtweberei, Friesack/Krs. Westhavelland

Weberei in Alexanderdorf/Krs. Teltow

Möbelfabrik, Calau

Möbelfabrik in Glau/Kr.Luckenwalde

Privat Tischlerei, Heinrichsfelde bei Kyritz

Korbflechterei in Heinrichsfelde b. Kyritz

Holzmöbel in Miersdorf b. Zeuthen/Krs. Teltow

Waagenbau, Josef Philipp, Dahme/Krs. Luckenwalde

Gen[ossenschaftliche] Treibriemenweberei, Dahme/Krs. Luckenwalde

Gürtlerei für Kleinkunst, Elsholz/Krs. Zauch-Belzig

Privat:

Hausarbeitsgemeinschaft Lenzen (Elbe) b. Krinitz/Westprignitz.

Eure Stellungnahme zu den Produktivgenossenschaften teilen wir. Nach einer Diskussion in unserer Abteilung über Euren Brief sind wir auch zu dem Schluss gekommen, dass man eine Sicherung durch Anteile über $60 \%$ von Verwaltungs- oder Regierungsstellen treffen muss.

2322 [Sicherlich verschrieben, es wird sich um Gollmitz (Kr. Luckau) handeln.]

2323 [Im Kr. Westhavelland nicht zu ermitteln. Wahrscheinlich Verwechslung mit Burow, Kr. Westprignitz.] 
Wir machen noch den Vorschlag, diese Produktivgenossenschaften dem Revisions- und Wirtschaftsverband anzuschliessen. Für eine Stellungnahme Eurerseits in dieser Hinsicht wären wir Euch dankbar.

$$
\begin{gathered}
\text { Mit sozialistischem Gruss! } \\
\text { Sozialistische Einheitspartei Deutschlands } \\
\text { Der Landesvorstand } \\
\text { Abt. Arbeit und Sozialfürsorge } \\
\text { [gez.] Su[cker] }
\end{gathered}
$$

(128) Bericht des Informationsdienstes des Rates des Kreises Luckenwalde über die Genossenschaft für Glas- und Bijouteriewaren in Dorf Zinna. Luckenwalde, 9. August 1947

BLHA, Rep. 250 Landratsamt Luckenwalde, Nr. 105, Bl.340. - Typoskript mit Bleistift-Parape „WKu“ (Werner Kummer). - Kopf o.1.: „Der Landrat/ des Kreises Luckenwalde / - Informationsdienst -“, o. r.: „Luckenwalde, den 9.8.1947. - U.1. handschriftlich von W. Kummer notierter Verteiler: „Inf. Amt / Volksstimme / Neues Deutschland“.

Bericht über die Genossenschaft für Glas- und Bijouteriewaren im Dorf Zinna.

Im Dorf Zinna sind unter den 560 Einwohnern viele ehemalige Sudetendeutsche Glasbearbeiter, zumeist aus Gablonz.

38 Spezialarbeiter haben sich zu einer Genossenschaft zusammengefunden und wollen ihre[r] bekannte[n], Gablonzer Schmuckwarenindustrie wieder den Ruhm in der Welt verschaffen, den sie einst in ihrer Heimat hatte.

Die Genossenschaft stellt Knöpfe, Ringe, Broschen, Anhänger, Ketten, imitierte Edelsteine, zumeist aus Glas mit Metallfassungen, her. Die Landesregierung hat eine grosszügige Planung vorgesehen, bis zum Herbst soll eine Fabrik entstehen, die 200 [korrigiert aus 20] Arbeiter beschäftigen und weiteren 200 Heimarbeitern Lohn und Brot sichern soll.

Im dritten Quartal sollen Schmuckwaren im Werte von 300000 RM hergestellt werden. Geplant ist vor allem, diese Gablonzer Schmuckwaren wieder zu exportieren. In diesem Zusammenhang ist der Bau von 30 Siedlungshäusern geplant, die Grundsteine sind bereits gelegt. Der Bau kann nur langsam fortgesetzt werden, da Facharbeiter und Materialschwierigkeiten bestehen.

Die einzelnen Handwerkszweige sind leider noch zerstreut in Wohnungen untergebracht, da die Fabrik, in der die Arbeitskräfte zusammengefasst arbeiten sollen, noch fehlt. Es sind 100 Arbeiter und viele Heimarbeiter in den einzelnen Kleinbetrieben beschäftigt, Der ungeheuren Nachfrage nach Schmuckwaren kann im Augenblick aus verschiedenen Gründen nicht Rechnung getragen werden. Wichtig vor allem ist ja der Export. Auf der Leipziger Messe werden die 
rührigen Genossenschaftler ebenfalls vertreten sein. Der Wille und die Zuversicht ist vorhanden, dieser Industrie wieder den alten Weltruf zu verschaffen.

Die Bauprojekte sind leider ins Stocken geraten. Es fehlen vor allen Dingen Spezialmaschinen, Exenter, Pressen und Balance, die die Umsiedler leider in Gablonz zurücklassen mussten. Das zur Verarbeitung notwendige Glas müsste in Spezialglasbrennereien für diese Artikel hergestellt werden. Leider muss man sich mit der Konsumware begnügen.

Schwierigkeiten bestehen auch in der Lieferung mit Heizmaterial. 12 to Steinkohle sind mindestens pro Jahr erforderlich, ausserdem noch zusätzlich $100 \mathrm{fm}$ Brennholz. Zur Verarbeitung fehlen auch Buntmetalle, vor allem Tomback ${ }^{2324}$. Fachkräfte, die zur Zeit in Thüringen brachliegen, könnten im Dorf Zinna fachlich günstiger eingesetzt werden. Der einzige Lastkraftwagen der Genossenschaft und des gesamten Ortes ist zur Zeit in Reparatur.

\section{(129) Antrag eines vertriebenen Reichsbahners auf Entnazifizierung. - Nauen, Oktober 1947}

BLHA, Rep. 203 MdI, Entnazifizierungskommission, Nr. 1414, unfol. - Manuskript, 1 Bl. - 2. Eingangsstempel: „[Bh]f Nauen / Eing.: 28. OKT. 1947“ (mit Paraphe „Wah“); „Reichsbahndirektion / Berlin / Eing. 29. Okt. 47 N.“ - [Hinweis: Der Antragsteller, geb. 14.3.1895 Grüntal Kr. Meseritz, war (laut in der Akte enthaltenem Fragebogen sowie Verhandlungsprotokoll der Entnazifizierungskommission) 1937-1945 Mitglied der NSDAP, 1933-1945 Mitglied der DAF und 1943-1945 Mitglied des Reichsbundes der deutschen Beamten. Er wurde nach der Entnazifizierungsverhandlung bei der Reichsbahn als Arbeiter belassen. Laut in der Akte enthaltenem Lebenslauf wohnte er von 1920 an in Nipter Kr. Meseritz „bis zur Flucht am 29.1.1945“.]

\section{Antrag auf Entnazifizierung}

Der Unterzeichnete, bittet um Bereinigung vom Nationalsozialismus und um Weiterbeschäftigung bei der Reichsbahn. Um meine Familie, mit drei unmündigen Kindern, sowie meine alte Mutter vor der wirtschaftlichen Notlage zu bewahren, bin ich, nach wiederholtem Druck, von Seiten der Reichsbahn und höheren Parteistellen, als Parteianwärter beigetreten. Da ich mich nicht Aktiv [so!] bei der Partei beteiligt habe, bitte ich dies, sowie meiner [so!] jetzigen bitteren Notlage als Ostflüchtling, zu berücksichtigen.

Jetzige Wohnung: Nauen, Holzmarkt Str. 1

Jetziger Dienstort: Güterabfertigung Nauen

$\mathrm{R}[$ eichsbahn $] \mathrm{b}[\mathrm{e}] \mathrm{t}[\mathrm{rieb}] \mathrm{s.}$-Ass [istent $]$ Gottlieb Linke

2324 [Tomback: Metallgemisch aus Kupfer, Messing und einem Anteil Zinn oder Zink zur Herstellung von Geräten und Schmucksachen.] 


\section{(130) Bericht über die Arbeitsmarktlage im Land Brandenburg. - Berlin, 27. Oktober 1947 (Auszüge)}

BLHA, Rep. 206 Ministerium für Wirtschaft und Arbeit, Nr. 3021, Bl. 216-219. - Hektografiertes Typoskript, 6 S. und tabellarischer Anlage (1 S.). - Bl. 216r: Im Briefkopf 1. o. „Deutsche Verwaltung für Arbeit und Sozialfürsorge der sowjetischen Besatzungszone Deutschlands / Abt. Ia - Erfassung und Arbeitslenkung der Bevölkerung“; r. o. „Berlin NW, den [...] / Dorotheenstr. 77-78 / Ba/An“; darunter Stempel: „Nur für den Dienstgebrauch“, Paraphe „Fr[?]“.Auf letztem Bl. u.1. masch. „gez. Ballschuh / Sachbearbeiter“, r. vervielfältigte Unterschrift „Donau“ / masch.: „Abschnittsleiter der Abt. IA“.

[Bl. 216-219: 27. Oktober 1947] [B1.216r:]

Bericht über die Arbeitsmarktlage im Landes Brandenburg im Monat September 1947

$$
\text { A. Erfassung und Zählung }
$$

\section{Gesamtbevölkerung}

Auch im Berichtsmonat trafen zahlreiche Umsiedler und Heimkehrer in Brandenburg ein, so daß die Bevölkerungszahl um weitere 12455 Personen auf 2 599,654 Personen gestiegen ist. Die Bevölkerung setzt sich zusammen aus

$$
\begin{aligned}
& 1109419 \text { männl. Personen }=42,7 \% \\
& 1490235 \text { weibl. Personen }=57,3 \%
\end{aligned}
$$

In diesen Zahlen sind 322936 Knaben und 33268 Mädchen, insgesamt 654204 Kinder = 25,2\% der Bevölkerung, enthalten. / [...]

[Bl. 217]

\section{B. Besondere Aufgaben der Arbeitslenkung}

\section{Umschulung}

In der Umschulung bzw. Anlernung befanden sich am Ende des Berichtsmonats:

\begin{tabular}{lccc} 
& Umschüler & Anlerner & Insgesamt \\
\cline { 2 - 4 } Männer & 2985 & 394 & 3379 \\
Frauen & 273 & 581 & 854 \\
\cline { 2 - 4 } Insgesamt & 3258 & 975 & 4233
\end{tabular}

\section{Umsiedler}

Bis zum Stichtag wurden in Brandenburg 671629 Umsiedler aufgenommen. Gegenüber dem Vormonat bedeutet dies einen Zugang um 15031 Personen. Die bisher aufgenommenen Ostumsiedler setzen sich zusammen aus

$$
\begin{aligned}
& 189703 \text { (28,2\%) Männern } \\
& 298635 \text { (44,5\%) Frauen } \\
& 183291(27,3 \%) \text { Kindern. [Bl. 217v] }
\end{aligned}
$$

Nach ihren Herkunftsländern gegliedert stammen 
531038 aus Polen und den polnisch besetzten Gebieten

56518 aus der Tschechoslowakei

84073 aus anderen Gebieten.

An eingetragenen Meldepflichtigen wurden gezählt:

145526 Männer $=76,7 \%$ der erw[erbstätigen] männl. Umsiedler

191272 Frauen $\quad=64,0 \%$ der erw[erbstätigen] männl. Umsiedler

insges. 336798 Personen $=50,1 \%$ der gesamten Umsiedler

In Beschäftigung stehen:

$$
\begin{aligned}
& 136355 \text { Männer }=93,7 \% \text { der eingetrag. männl. Umsiedler } \\
& 137828 \text { Frauen } \quad=72,1 \% \text { der eingetrag. weibl. Umsiedler } \\
& \text { insges. } 274183 \text { Personen }=81,4 \% \text { der eingetrag. Umsiedler }
\end{aligned}
$$

Im Vergleich zum Vormonat haben sich die eingetragenen Meldepflichtigen um 4410 (2831 Männer, 1579 Frauen) und die Erwerbstätigen um 3416 (2 508 Männer, 908 Frauen) erhöht.

Die soziale Gliederung der erwerbstätigen Umsiedler ist die folgende:

Unselbständig Beschäftigte

Selbst. Landwirte

mith[elfende] Fam.-Angeh[örige]

Freie Berufe

mith[elfende] Fam.-Angeh[örige]

Gewerbetreibende

mith[elfende] Fam.-Angeh[örige]

Handwerker

mith[elfende] Fam.-Angeh[örige]

Erwerbstätige

\begin{tabular}{rrrc} 
Männer & Frauen & Insgesamt & \% der Erwerbs[ätigen] \\
\hline 110857 & 118307 & 229164 & 83,6 \\
14274 & 3423 & 17697 & 6,5 \\
5035 & 12608 & 17643 & 6,4 \\
617 & 275 & 892 & 0,3 \\
51 & 121 & 172 & 0,1 \\
1483 & 475 & 1958 & 0,7 \\
176 & 568 & 744 & 0,3 \\
3487 & 1273 & 4760 & 1,7 \\
375 & 778 & 1153 & 0,4 \\
\hline 136355 & 137828 & 274183 & 100,0
\end{tabular}


Die nichterwerbstätigen Umsiedler setzen sich wie folgt zusammen.

Vollarbeitsf[ähige] Arbeitslose

Vollarbeitsf[ähige] Arbeitspfl[ichtige], die keine Arbeit suchen

Erwerbsbeschr[änkte] Arbeitslose

Erwerbsbeschr[änkte] Arbeitspf[lichtige], die keine Arbeit suchen

Arbeitsfähige, vorübergehend von der Arbeit Freigestellte

Dauernd Arbeitsunfähige

Schüler und Studenten

In kurzfristiger Lehrerausbildung

Nichterwerbstätige

[Bl. 218r]

3. Schwerbeschädigte $[\ldots]$

4. Heimkehrer $[\ldots]$

\begin{tabular}{rrr} 
Männer & Frauen & Insgesamt \\
\hline 101 & 1234 & 1335 \\
- & 836 & 836 \\
762 & 971 & 1733 \\
& & \\
215 & 798 & 1013 \\
& & \\
2549 & 44773 & 47322 \\
4509 & 4064 & 8573 \\
925 & 653 & 1578 \\
110 & 115 & 225 \\
\hline 9171 & 53444 & 62615
\end{tabular}

\section{(131) Listen der durch „Umsiedler“ errichteten Industrie- und Handelsbetriebe in den Kreisen. - [Potsdam], 6. November 1947 (Auszüge)}

BLHA, Rep. 333 SED-Landesleitung Brandenburg, Nr. 574, Bl.225r-238v (hier nur abgedruckt Bl.225r-226v, Bl. 230-231r, 236-237). - Typoskript, 26 S. - Bl. 225r o.1.: „II/14 - Gam/Ho“, r. o. Stempel „Industrie- u. Handelskammer / Mark Brandenburg“, darüber Bleistiftdatum „6.11.47“; oben Mitte Bleistiftvermerk „Herrn Hgf [Hauptgeschäftsführer] Völz“. - In der Akte steht ein kurzes Begleitschreiben („Betr.: Umsiedler-Aktion“) von „Else Mieth / b/Industrie- und Handelskammer / Land Brandenburg“, Potsdam, „Saarmunderstrasse 23“, vom 8.11.1947 zur Übersendung an die Kreisleitung der SED / z. Hd. der Genossin Walde / Potsdam / Waisenstrasse 17“ voran mit Eingangsstempel vom 11.11.1947. „Ich nehme an, dass Du das Material in Deinen Referaten (bezw. der Gen. Merker auf der am Dienstag, 11.11. stattfindenden Landeskonferenz) auswerten kannst." (Bl. 224a). - Hinweis: Die umfangreiche Liste, von der hier alle Industriebetriebe, aber von den Handelsbetrieben nur die ausgewählter Kreise beispielhaft wiedergegeben werden, enthält Betriebe [in eckigen Klammern die Anzahl] in folgenden Kreisen: [1.] Industriebetriebe: Luckenwalde Stadt (Bl. 225r [3]), Zauch-Belzig (Bl. 225r [7]), Ruppin (Bl. 225v [2]), Westprignitz (Bl. 225v [4]), Wittenberge (Bl. 225v [1]), Eberswalde Stadt (Bl.225v [1]), Oberbarnim (Bl.225v [1]), Angermünde (Bl.226r [1]), Frankfurt Stadt (B1. 226r [2]), Cottbus (Bl. 226r [7]), Guben Stadt und Land (Bl. 226v [5]). - [2.] Handelsbetriebe. Zauch-Belzig (Bl. Bl. 227r-229v [65]), Ruppin (Bl. 230r-231r [25]), Wittenberge (Bl. Bl. 231r-v [7]), Eberswalde Stadt (Bl. 231v [1]), Oberbarnim (Bl. 231v [2]), Angermünde (Bl. 232r [12]), Forst (Bl. 233r [10]), Lebus (Bl. 233r-v [6]), Frankfurt Stadt (Bl. 233v [7]), Guben Stadt und Land (Bl. 234r-235v [42]), Luckenwalde Stadt (Bl. 235v [8]), Cottbus (Bl. 236r-237v/r [das Blatt 237r/v wird unten in umgekehrter Seitenreihenfolge abgedruckt, da in der Akte falsch r-v foliiert] [46]), Teltow (Bl. 238v-r [Bl. 238 in der Akte falsch r-v foliiert] [19]), Beeskow-Storkow (Bl. 238r [3]). - Bei rund der Hälfte der Betriebe ist neben der aktuellen Anschrift auch der Sitzort in den Vertreibungsgebieten angegeben. 
[B1. 225r]

Aufstellung von Industrie-Betrieben[,]

die durch Umsiedler errichtet wurden

\begin{tabular}{|c|c|c|c|c|c|}
\hline \multirow{3}{*}{$\begin{array}{l}\text { Name u. Anschrift d. Betriebes } \\
\text { ggfs. früh. Name u. } \\
\text { Sitz des Betriebes } \\
1\end{array}$} & \multirow{3}{*}{$\begin{array}{c}\text { Art d. Betriebes } \\
\text { Rechtsform, Größe } \\
2\end{array}$} & \multicolumn{2}{|c|}{ Zahl d. Beschäftgt. } & \multirow{3}{*}{$\begin{array}{l}\text { Gründungs- } \\
\text { datum n.d. } \\
\text { Umsiedlung } \\
\quad 4\end{array}$} & \multirow{3}{*}{$\begin{array}{c}\text { Umsatz } \\
\text { seit der } \\
\text { Neugründg. } \\
\quad 5\end{array}$} \\
\hline & & insg. & Ums. & & \\
\hline & & \multicolumn{2}{|c|}{3} & & \\
\hline \multicolumn{6}{|c|}{ Kreis: Luckenwalde Stadt } \\
\hline $\begin{array}{l}\text { Kurt Mummert } \\
\text { Luckenwalde, Haag } 12\end{array}$ & $\begin{array}{l}\text { Kinderwagenfabr[ik,] } \\
\text { Handel- u. Reparatur- } \\
\text { werkstatt }\end{array}$ & 7 & 2 & 1.11 .45 . & RM 91461.- \\
\hline $\begin{array}{l}\text { Produktiv- u. Handelsgenossen- } \\
\text { schaft d. Kunstblumen- u. Früchte- } \\
\text { industrie } \\
\text { Jüterbog, Planeberg } 3\end{array}$ & e. G.m.b.H. & 56 & 56 & 28.8 .46 & RM 110000.- \\
\hline $\begin{array}{l}\text { Produktiv- u. Handelsge- } \\
\text { nossenschaft für Glas- u. } \\
\text { Bijouterieind[ustrie], Dorf Zinna }\end{array}$ & Gen.m.b.H. & 234 & 227 & 23.10 .46 & RM $800000 .-$ \\
\hline
\end{tabular}

Kreis: Zauch-Belzig

\begin{tabular}{|l|l|c|c|c|c|}
\hline $\begin{array}{l}\text { Franz Verwiebe } \\
\text { Belzig, Brandenburger-Str. 45 }\end{array}$ & Ziegelei & 30 & 5 & Sept. 1946 & RM 66428.- \\
\hline $\begin{array}{l}\text { Beelitzer Konservenfabr[ik], } \\
\text { Pächter Paul Zarbock, Beelitz } \\
\text { Virchow-Str. 100 }\end{array}$ & Konservenfabrik & 145 & 60 & Okt. 1945 & [RM] \\
\hline $\begin{array}{l}\text { Arno Ohmenzetter } \\
\text { Damsdorf }\end{array}$ & Tankholzzubereitung & 18 & 17 & Mai 19461.- & RM 15000.- \\
\hline $\begin{array}{l}\text { Richard Jentsch } \\
\text { Schwanebeck }\end{array}$ & Tankholzzubereitung & 3 & 3 & März 1946 & RM 3300.- \\
\hline $\begin{array}{l}\text { Adolf Bresch } 2325 \\
\text { Rietz ü. Brandenburg }\end{array}$ & $\begin{array}{l}\text { Dachstein-Fabrikation } \\
\text { Otto Kamm }\end{array}$ & 3 & 3 & Juni 1946 & keinen \\
\hline $\begin{array}{l}\text { Jeserigerhütten } \\
\text { Komm.Betriebsltr. Herbert Natho }\end{array}$ & $\begin{array}{l}\text { Holzverarbeitungsge- } \\
\text { nossenschaft }\end{array}$ & 15 & 15 & 1.9 .46$. & RM 38 198.- \\
\hline
\end{tabular}

Kreis: Ruppin

\begin{tabular}{|l|l|c|c|c|c|}
\hline $\begin{array}{l}\text { Schuhfabrik Hans Kaß } \\
\text { Neuruppin } \\
\text { früher Friedeberg/NM }\end{array}$ & Schuhfabrik & 47 & 16 & 1.9 .45$. & RM 76120.- \\
\hline $\begin{array}{l}\text { J. Mampe-Stargard } \\
\text { Neustadt/Dosse } \\
\text { früher Stargard/Pomm. }\end{array}$ & $\begin{array}{l}\text { Herstellung von Spiritu- } \\
\text { osen usw. }\end{array}$ & 33 & 25 & 1.8 .45$. & RM 1617810.- \\
\hline
\end{tabular}

2325 [1945 aus Prażuchy bei Kalisch nach Rietz geflüchtet, bis 1945 kleiner Dachsteinfabrikationsbetrieb in Prażuchy (freundliche Auskunft des Urenkels Dr. Harald Bresch, Berlin, 20.7.2018).] 


\begin{tabular}{|c|c|c|c|c|c|}
\hline \multirow{3}{*}{$\begin{array}{l}\text { Name u. Anschrift d. Betriebes } \\
\text { ggfs. früh. Name u. } \\
\text { Sitz des Betriebes } \\
1\end{array}$} & \multirow{3}{*}{$\begin{array}{c}\text { Art d. Betriebes } \\
\text { Rechtsform, Größe } \\
2\end{array}$} & \multicolumn{2}{|c|}{ Zahl d. Beschäftgt. } & \multirow{3}{*}{$\begin{array}{l}\text { Gründungs- } \\
\text { datum } \mathrm{n} . \mathrm{d} . \\
\text { Umsiedlung } \\
\mathbf{4}\end{array}$} & \multirow{3}{*}{$\begin{array}{c}\text { Umsatz } \\
\text { seit der } \\
\text { Neugrüindg. } \\
5\end{array}$} \\
\hline & & insg. & Ums. & & \\
\hline & & \multicolumn{2}{|c|}{3} & & \\
\hline
\end{tabular}

Kreis: Westprignitz

\begin{tabular}{|l|l|c|c|c|c|}
\hline $\begin{array}{l}\text { Wassermühle } \\
\text { Kl[ein] Leppin b/Glöwen }\end{array}$ & Getreidemühle & 7 & 3 & 1.1 .46$. & RM 277 000.- \\
\hline $\begin{array}{l}\text { Brennerei Ponitz } \\
\text { Ponitz ü. Perleberg }\end{array}$ & Kartoffelbrennerei & 3 & 3 & 1.2 .46$. & RM 40215.- \\
\hline $\begin{array}{l}\text { Brandenburgischer Bergbau } \\
\text { Grube Gülitz }\end{array}$ & Landeseig. Betrieb & 88 & 81 & 1.3 .46$. & $\begin{array}{l}\text { RM 657 000.- } \\
\text { RM 947 200.- }\end{array}$ \\
\hline Ziegelei Muggerkuhl & $\begin{array}{l}\text { Landeseig. Betrieb } \\
\text { Ziegelei }\end{array}$ & 25 & 17 & Nov. 1945 & $\begin{array}{r}\text { nicht zu } \\
\text { ermitteln }\end{array}$ \\
\hline
\end{tabular}

Kreis: Wittenberge

\begin{tabular}{|l|l|l|l|l|c|}
\hline $\begin{array}{l}\text { Rohde \& Böttcher } \\
\text { Wittenberge[,] Perleberger-Str. 56 } \\
\text { früher Stettin }\end{array}$ & $\begin{array}{l}\text { Herrenkleiderfabrik } \\
\text { K.G. }\end{array}$ & 35 & 25 & 1.8 .46$. & RM 100 000.- \\
\hline
\end{tabular}

\section{Kreis: Eberswalde Stadt}

\begin{tabular}{|l|l|l|l|l|l|}
\hline $\begin{array}{l}\text { Willy Sommerfeld } \\
\text { Eberswalde, Schützen-Str. 1, } \\
\text { früh[er] Graudenz }\end{array}$ & $\begin{array}{l}\text { Obst- u. Gemüsever- } \\
\text { wertung }\end{array}$ & 27 & 7 & 1.7 .46$. & RM 70 191.- \\
\hline
\end{tabular}

\section{Landkreis: Oberbarnim}

\begin{tabular}{|l|l|c|c|c|c|}
\hline $\begin{array}{l}\text { Fritz Knöschke } \\
\text { Bad Freienwalde } \\
\text { Eberswalder-Str. 27 } \\
\text { früh[er] Neudamm/NM. }\end{array}$ & o.H.G. & 15 & 5 & 1.6 .47$. & RM 15000.- \\
\hline
\end{tabular}

\section{[Bl. 226r]}

Landkreis: Angermünde

\begin{tabular}{|l|l|l|l|l|l|}
\hline $\begin{array}{l}\text { Bernhard Balzer } \\
\text { Inh. W. Balzer } \\
\text { Hohengüstow } \\
\text { früher Stettin }\end{array}$ & Straßen- u. Tiefbau & 20 & 17 & 1.4 .46$. & RM 82 447.- \\
\hline
\end{tabular}

\section{Kreis: Frankfurt Stadt}

\begin{tabular}{|l|l|c|c|c|c|}
\hline $\begin{array}{l}\text { Schütz \& Bethke } \\
\text { Frankfurt/O.[,] Lippehner-Str. } \\
\text { früh[er] Lippehne/NM. }\end{array}$ & Landmaschinenwerk & 70 & 20 & 1.6 .46$. & RM 70000.- \\
\hline $\begin{array}{l}\text { Robert Bohr } \\
\text { Frankfurt/O. } \\
\text { Am Graben 4 }\end{array}$ & Maschinenbau & 14 & 6 & 26.6 .45$. & RM 78 446.- \\
\hline
\end{tabular}




\begin{tabular}{|c|c|c|c|c|c|}
\hline \multirow{3}{*}{$\begin{array}{l}\text { Name u. Anschrift d. Betriebes } \\
\text { ggfs. früh. Name u. } \\
\text { Sitz des Betriebes } \\
1\end{array}$} & \multirow{3}{*}{$\begin{array}{c}\text { Art d. Betriebes } \\
\text { Rechtsform, Größe } \\
2\end{array}$} & \multicolumn{2}{|c|}{ Zahl d. Beschäftgt. } & \multirow{3}{*}{$\begin{array}{c}\text { Gründungs- } \\
\text { datum n.d. } \\
\text { Umsiedlung } \\
4\end{array}$} & \multirow{3}{*}{$\begin{array}{c}\text { Umsatz } \\
\text { seit der } \\
\text { Neugründg. } \\
5\end{array}$} \\
\hline & & insg. & Ums. & & \\
\hline & & \multicolumn{2}{|c|}{3} & & \\
\hline
\end{tabular}

Kreis: Cottbus

\begin{tabular}{|c|c|c|c|c|c|}
\hline $\begin{array}{l}\text { Walter Linke K. G. } \\
\text { Cottbus, Bautzener-Str. 35, } \\
\text { früh[er] Guben }\end{array}$ & Strumpfwarenfabr [ik] & 42 & 27 & 1.11 .45 . & RM $191085 .-$ \\
\hline $\begin{array}{l}\text { Emil Feige } \\
\text { Cottbus, Werner-Str. 62, früher } \\
\text { Lodz }\end{array}$ & Strumpfwarenfabr $[\mathrm{ik}]$ & 14 & 5 & 1.5 .46 & RM 34418.- \\
\hline $\begin{array}{l}\text { Wilhelm Rietschel } \\
\text { Cottbus, Strom-Acker-Str., früh[er] } \\
\text { Gräfenhain }\end{array}$ & $\begin{array}{l}\text { Sägewerk u. Holzhand- } \\
\text { lung }\end{array}$ & 26 & 20 & 1.7 .46 & RM $85000 .-$ \\
\hline $\begin{array}{l}\text { Adolf Rüdiger } \\
\text { Cottbus, Ottilienstr. } 5\end{array}$ & Sargfabrikation & 6 & 1 & 1.8 .46 & RM 51 506.- \\
\hline $\begin{array}{l}\text { Theodor Paul Horn KG. } \\
\text { Cottbus, Rud.Breitscheid-Str. } \\
52 \text { / früher Sorau/NL. }\end{array}$ & Betonwerke K. G. & 15 & 11 & 12.4 .46 & RM 14000.- \\
\hline $\begin{array}{l}\text { Berger \& Stumpe } \\
\text { Cottbus, Schiller-Str. 24, früh[er] } \\
\text { Trautenau/Böhmen }\end{array}$ & $\begin{array}{l}\text { Metallgießergenossen- } \\
\text { schaft }\end{array}$ & 5 & 4 & Nov.46. & $\begin{array}{l}\text { RM Betrieb } \\
\text { läuft erst an }\end{array}$ \\
\hline $\begin{array}{l}\text { Willi Hapke } \\
\text { Cottbus, Gnesener-Str. 12, früh[er] } \\
\text { Guben }\end{array}$ & $\begin{array}{l}\text { Strumpf- u. Strickwa- } \\
\text { renfabrik }\end{array}$ & 1 & & 18.3.47. & $”$ \\
\hline
\end{tabular}

[B1. 226v]

Landkreis: Guben Stadt und Land

\begin{tabular}{|l|c|c|c|c|c|}
\hline $\begin{array}{l}\text { Richard Methke } \\
\text { Guben, Uferstr. 4 u. } \\
\text { Grüne Wiese }\end{array}$ & Industriebetrieb & 50 & 28 & 10.12 .45$. & RM 115427.- \\
\hline $\begin{array}{l}\text { Hermann Jurk } \\
\text { Guben, Ufer-Str. 39 }\end{array}$ & $\cdots$ & 6 & 6 & 1.4 .47$. & \\
\hline $\begin{array}{l}\text { G. Hamann } \\
\text { Guben, Berliner-Str. 31 }\end{array}$ & $\cdots$ & 9 & 4 & 1.2 .47$. & RM 248 438.- \\
\hline $\begin{array}{l}\text { O. Wintsche } \\
\text { Guben, Wilke-Str. 37 }\end{array}$ & $\cdots$ & 10 & 9 & 1.12 .45$. & RM 187451.- \\
\hline $\begin{array}{l}\text { Schneider \& Lokai } \\
\text { Guben, früh[er] Breslau }\end{array}$ & $\cdots$ & 65 & 51 & 1.9 .46$. & RM 97 139.- \\
\hline
\end{tabular}




\begin{tabular}{|c|c|c|c|c|c|}
\hline \multirow{3}{*}{$\begin{array}{l}\text { Name u. Anschrift d. Betriebes } \\
\text { ggfs. früh. Name u. } \\
\text { Sitz des Betriebes } \\
1\end{array}$} & \multirow{3}{*}{$\begin{array}{l}\text { Art d. Betriebes } \\
\text { Rechtsform, Größe } \\
2\end{array}$} & \multicolumn{2}{|c|}{ Zahl d. Beschäftgt. } & \multirow{3}{*}{$\begin{array}{l}\text { Gründungs- } \\
\text { datum n.d. } \\
\text { Umsiedlung } \\
4\end{array}$} & \multirow{3}{*}{$\begin{array}{c}\text { Umsatz } \\
\text { seit der } \\
\text { Neugründg. } \\
5\end{array}$} \\
\hline & & insg. & Ums. & & \\
\hline & & \multicolumn{2}{|c|}{3} & & \\
\hline
\end{tabular}

[Bl. 227r]

$[\ldots] /[\mathrm{Bl} .230 \mathrm{r}][\ldots]$

Aufstellung von Handelsbetrieben[,]

die durch Umsiedler errichtet wurden

Kreis: Ruppin

\begin{tabular}{|c|c|c|c|c|c|}
\hline $\begin{array}{l}\text { Paul Bergemann, Ingenieurbüro, } \\
\text { Neuruppin } \\
\text { früh[er] Carl Bergemann, } \\
\text { Werkzeug- u. Maschinenfabrik } \\
\text { Landsberg/W. }\end{array}$ & Handelsbetrieb & 1 & 1 & 1.8 .46 & $\begin{array}{r}\text { RM 6302.- } \\
\text { (1/4 jährl.) }\end{array}$ \\
\hline $\begin{array}{l}\text { Willy Franzke, Opt[ische] Photogr. } \\
\text { Werkstätten } \\
\text { Neuruppin / früh }[\mathrm{er}] \text { Breslau }\end{array}$ & $\begin{array}{l}\text { Offenes Handelsge- } \\
\text { schäft }\end{array}$ & 6 & & 18.5.45. & $\begin{array}{r}\text { RM } 14 \text { 500.- } \\
\text { (1/4 jährl. })\end{array}$ \\
\hline $\begin{array}{l}\text { Erich Lange } \\
\text { Neuruppin / früh[er] Köslin }\end{array}$ & Holzhandel u. Transport & 3 & & 1.11 .45 & $\begin{array}{r}\text { RM } 6607 .- \\
(1 / 4 \text { jährl. })\end{array}$ \\
\hline $\begin{array}{l}\text { Otto Gehrmann } \\
\text { Neuruppin / früh [er] Bez.Kommis. } \\
\text { d. Ermländ. Feuersoziet[ät] in } \\
\text { Allenstein }\end{array}$ & $\begin{array}{l}\text { Handelsvertreter Bez. } \\
\text { Kommis.d.Prov. } \\
\text { Versich.Anst.Brandbg. }\end{array}$ & 2 & & 1.11 .45 & RM 2412.- \\
\hline $\begin{array}{l}\text { E.J. Scholz Wwe., Inh. G. Scholz, } \\
\text { Neuruppin } \\
\text { früh[er] E.J. Scholz Wwe } \\
\text { Inh. G. Scholz, Wollstein }\end{array}$ & $\begin{array}{l}\text { Großhandel } \mathrm{m}[\mathrm{it}] \text { Buch- } \\
\text { u. Papierwaren sowie } \\
\text { Büromaterialien }\end{array}$ & 7 & 7 & 4.12 .46 & $\begin{array}{r}\text { RM } 15 \text { 475.- } \\
\quad(1 / 4 \text { jährl. })\end{array}$ \\
\hline $\begin{array}{l}\text { Erich Schwark / Neuruppin } \\
\text { früh }[\mathrm{er}] \text { Stettin }\end{array}$ & $\begin{array}{l}\text { Offenes Handelsgesch. } \\
\text { Eisenwaren, Hausrat, } \\
\text { Spielwaren }\end{array}$ & 1 & 1 & 3.6.46. & $\begin{array}{r}\text { RM } 28 \text { 716.- } \\
\text { (1/4 jährl. })\end{array}$ \\
\hline $\begin{array}{l}\text { Franz Woelk } \\
\text { Neuruppin / früh[er] Stettin }\end{array}$ & $\begin{array}{l}\text { Großhandel mit Textil- } \\
\text { waren }\end{array}$ & 1 & 1 & Okt.46. & $\begin{array}{r}\text { RM 2939.- } \\
\text { (1/4 jährl.) }\end{array}$ \\
\hline $\begin{array}{l}\text { Ing. F. Woth, Ingenieurbüro, Neu- } \\
\text { ruppin / früh[er] Glogau. }\end{array}$ & $\begin{array}{l}\text { Handel u. Reparatur v. } \\
\text { Landmaschinen }\end{array}$ & 1 & 1 & 22.6 .45 & $\begin{array}{l}\text { RM 275.- } \\
(1 / 4 \text { jährl. })\end{array}$ \\
\hline $\begin{array}{l}\text { Wilhelm Krecklow / Neuruppin, } \\
\text { früh }[\mathrm{er}] \text { Johannes Kuhlo, Stettin } \\
{[\mathrm{B} 1.230 \mathrm{v}]}\end{array}$ & $\begin{array}{l}\text { Elektro- u. Rundfunk- } \\
\text { Großhandlg. }\end{array}$ & & & Juli 47 & $\begin{array}{r}\text { Juli } 47 \\
\text { angelauf[en] }\end{array}$ \\
\hline $\begin{array}{l}\text { Hedwig Mandelkow / Neuruppin, } \\
\text { früher Martin Mandelkow, Stettin }\end{array}$ & $\begin{array}{l}\text { Papier- u. Schreibwaren- } \\
\text { großhandl[un]g }\end{array}$ & & & Juli 1947 & $\begin{array}{r}\text { Juli } 47 \\
\text { angelauf[en] }\end{array}$ \\
\hline $\begin{array}{l}\text { Paul Hoppe vorm. Reinhold Kno- } \\
\text { bloch / Gransee, früher Reinhold } \\
\text { Knobloch, Landmasch. u. Reparat. } \\
\text { Werkstatt, Gransee }\end{array}$ & $\begin{array}{l}\text { Handel mit landwirt- } \\
\text { schaftlichen Maschinen }\end{array}$ & 16 & & 1.7 .46 & $\begin{array}{r}\text { RM } 51155 \\
(1 / 4 \text { jährl. })\end{array}$ \\
\hline
\end{tabular}




\begin{tabular}{|c|c|c|c|c|c|}
\hline \multirow{3}{*}{$\begin{array}{l}\text { Name u. Anschrift d. Betriebes } \\
\text { ggfs. früh. Name u. } \\
\text { Sitz des Betriebes } \\
1\end{array}$} & \multirow{3}{*}{$\begin{array}{l}\text { Art d. Betriebes } \\
\text { Rechtsform, Größe } \\
2\end{array}$} & \multicolumn{2}{|c|}{ Zahl d. Beschäftgt. } & \multirow{3}{*}{$\begin{array}{l}\text { Gründungs- } \\
\text { datum n.d. } \\
\text { Umsiedlung } \\
\quad 4\end{array}$} & \multirow{3}{*}{$\begin{array}{l}\text { Umsatz } \\
\text { seit der } \\
\text { Neugründg. } \\
5\end{array}$} \\
\hline & & insg. & Ums. & & \\
\hline & & \multicolumn{2}{|c|}{3} & & \\
\hline $\begin{array}{l}\text { Fritz Bruhn } \\
\text { Gransee }\end{array}$ & $\begin{array}{l}\text { Einzelhandelsgeschäft } \\
\text { m[it] Manufaktur u. } \\
\text { Kurzwaren }\end{array}$ & 8 & & 8.12 .45 & $\begin{array}{r}\text { RM } 24 \text { 706.- } \\
\text { (1/4 jährl. })\end{array}$ \\
\hline $\begin{array}{l}\text { Günter Dreikandt / Lindow, } \\
\text { früher C. \& G. Dreikandt OHG. } \\
\text { Landsberg/W. }\end{array}$ & $\begin{array}{l}\text { Handelsvertretung f. } \\
\text { Groß- u. Einzelhandel, } \\
\text { techn. Erzeugnisse }\end{array}$ & & & 1946 & $\begin{array}{l}\text { RM } 5 \text { 801.- } \\
\text { (1/4 jährl.) }\end{array}$ \\
\hline $\begin{array}{l}\text { Richard Laubsch / } \\
\text { Wusterhausen/D. } \\
\text { früh[er] Getreide, Saaten-[,] } \\
\text { Futter- u. Düngemittelgesch[äft], } \\
\text { Marienburg }\end{array}$ & $\begin{array}{l}\text { Großhandel mit Wirt- } \\
\text { schaftsartikel u. Kurzwa- } \\
\text { ren aller Art }\end{array}$ & & & 2.1 .46 & $\begin{array}{r}\text { RM 9556.- } \\
\text { (1/4 jährl.) }\end{array}$ \\
\hline $\begin{array}{l}\text { Horst Voigt / Wusterhausen/D. } \\
\text { früh[er] Handelsvertr. Horst Voigt, } \\
\text { Tilsit }\end{array}$ & $\begin{array}{l}\text { Handelsvertreter d. } \\
\text { Nahrungs- u. Genußmit- } \\
\text { telbranche, Art. d. tägl. } \\
\text { Bedarfs }\end{array}$ & & & 1.11 .46 & $\begin{array}{l}\text { RM 968.- } \\
\text { (1/4 jährl.) }\end{array}$ \\
\hline Hermann Witt / Wusterhausen/D. & Fuhrunternehmer & 1 & & 1.1 .46 & $\begin{array}{r}\text { RM ...8.- } \\
\text { [Die ersten } 2 \\
\text { Ziffern fehlen } \\
\text { (Loch im Pa- } \\
\text { pier).] } \\
(1 / 4 \text { jährl.) }\end{array}$ \\
\hline $\begin{array}{l}\text { Hans Krönert, Wustrau } \\
\text { früh[er] Prag bezw. Reichenberg/ } \\
\text { Aussig }\end{array}$ & $\begin{array}{l}\text { Handelsvetretung in } \\
\text { Werkzeugen, Haushalts- } \\
\text { u. Wirtschaftsartikel }\end{array}$ & 1 & & 1.1 .47 & $\begin{array}{l}\text { RM 134.- } \\
\text { (1/4 jährl.) }\end{array}$ \\
\hline $\begin{array}{l}\text { Willy Lenz, Groß-Mutz } \\
\text { früh }[\mathrm{er}] \text { in Pommern }\end{array}$ & Gemischtwarengeschäft & 1 & 1 & 1.3 .46 & $\begin{array}{r}\text { RM } 7441 .- \\
\text { (1/4 jährl.) }\end{array}$ \\
\hline $\begin{array}{l}\text { Ludwig Knodel } \\
\text { Löwenberg / früher Breslau } \\
{[\text { Bl. 231r] }}\end{array}$ & $\begin{array}{l}\text { Einzelhandelsvertretung } \\
\text { f. Schädlingbekämpfung } \\
\text { in d. Landwirtschaft u. } \\
\text { Desinfektor }\end{array}$ & & & 1.9 .45 . & $\begin{array}{r}\text { RM } 3224 .- \\
\text { (1/4 jährl.) }\end{array}$ \\
\hline $\begin{array}{l}\text { Willi Sindakowski } \\
\text { Altgarz, früher in Ostpreußen }\end{array}$ & Versicherungsvertreter & & & Febr.47 & $\begin{array}{l}\text { RM 587.- } \\
(1 / 4 \text { jährl.) }\end{array}$ \\
\hline Heinz Siegener / Dreetz & Drogerie OHG. & 1 & & 15.9 .45 & $\begin{array}{r}\text { RM 16359.- } \\
\text { (1/4 jährl.) }\end{array}$ \\
\hline $\begin{array}{l}\text { Anastasius Ladwig } \\
\text { Hohenofen, früher } \\
\text { Kolonialwar[en] u. Feinkostgesch., } \\
\text { Hammerstein/Westpr. }\end{array}$ & Off. Handelsgeschäft & & & 1.1.47. & $\begin{array}{r}\text { RM } 2 \text { 800.- } \\
\text { (1/4 jährl.) }\end{array}$ \\
\hline
\end{tabular}




\begin{tabular}{|c|c|c|c|c|c|}
\hline \multirow{3}{*}{$\begin{array}{c}\text { Name u. Anschrift d. Betriebes } \\
\text { ggfs. früh. Name u. } \\
\text { Sitz des Betriebes } \\
1\end{array}$} & \multirow{3}{*}{$\begin{array}{l}\text { Art d. Betriebes } \\
\text { Rechtsform, Größe } \\
2\end{array}$} & \multicolumn{2}{|c|}{ Zahl d. Beschäftgt. } & \multirow{3}{*}{$\begin{array}{l}\text { Gründungs- } \\
\text { datum n.d. } \\
\text { Umsiedlung } \\
\quad 4\end{array}$} & \multirow{3}{*}{$\begin{array}{l}\text { Umsatz } \\
\text { seit der } \\
\text { Neugründg. } \\
5\end{array}$} \\
\hline & & insg. & Ums. & & \\
\hline & & \multicolumn{2}{|c|}{3} & & \\
\hline $\begin{array}{l}\text { Karl Friedrich } \\
\text { Segeletz, früh[er] Leitung v. } 3 \\
\text { Vers[icherungs-]Agent[uren] d. } \\
\text { Vers[icherungs-] Ges[ellschaft] } \\
\text { Thuringia i.d. Neumark }\end{array}$ & $\begin{array}{l}\text { Beauftragter d. } \\
\text { Prov[inzial-] } \\
\text { Vers[icherungs-] } \\
\text { Anst[alt] }\end{array}$ & & & 1.1 .46$. & $\begin{array}{r}\text { RM } 1 \text { 000.- } \\
\text { (1/4 jährl.) }\end{array}$ \\
\hline $\begin{array}{l}\text { Josef Schymiezek } \\
\text { Sieversdorf, früher Tunskirch/OS. }\end{array}$ & $\begin{array}{l}\text { Handelsunternehmen f. } \\
\text { Uhren, Gold-Silberwa- } \\
\text { ren, Optik }\end{array}$ & & & 1.9 .45 . & $\begin{array}{r}\text { RM } 2782 .- \\
\text { (1/4 jährl.) }\end{array}$ \\
\hline $\begin{array}{l}\text { Heinz Steinhaus / Köritz b. } \\
\text { Neustadt/D. / früh[er] Greifen- } \\
\text { berg/Pomm. }\end{array}$ & $\begin{array}{l}\text { Durchführung von Au- } \\
\text { totransporten }\end{array}$ & 3 & & & $\begin{array}{r}\text { RM } 6500 .- \\
\text { (1/4 jährl.) }\end{array}$ \\
\hline
\end{tabular}

[...]/[Bl. 236r] [...]

Stadt- und Land-Kreis: Cottbus

\begin{tabular}{|c|c|c|c|c|}
\hline $\begin{array}{l}\text { Julius Hentschel } \\
\text { Cottbus, Sand-Str. } 37 \\
\text { früh[er] Trachtenberg/Schlesien } \\
\text { [Trachenberg!] }\end{array}$ & $\begin{array}{l}\text { Einzelhandel mit Tex- } \\
\text { tilwaren }\end{array}$ & 2 & April 1946 & $\begin{array}{l}\text { RM } 43 \text { 926.- } \\
\text { RM } 57 \text { 177.- }\end{array}$ \\
\hline $\begin{array}{l}\text { Emil Bednorz } \\
\text { Cottbus, Spremberg[er]-Str. } 1 \\
\text { früh[er] Hindenburg O/S. }\end{array}$ & $\begin{array}{l}\text { Einzelhandel mit Tex- } \\
\text { tilwaren }\end{array}$ & 4 & 1945 & $\begin{array}{l}\text { RM } 17 \text { 155.- } \\
\text { RM } 42656 .-\end{array}$ \\
\hline $\begin{array}{l}\text { Kaufstätte Gappa } \\
\text { Cottbus, Mühlen-Str. } 41 \\
\text { früh[er] Sudetenland }\end{array}$ & $\begin{array}{l}\text { Einzelhandel mit Textil- } \\
\text { waren, Haushaltsartikel }\end{array}$ & 6 & 1.2 .46 & RM 139 155.- \\
\hline $\begin{array}{l}\text { Rudolf Kupsch } \\
\text { Cottbus / Karl Liebknecht-Str. } 15\end{array}$ & $\begin{array}{l}\text { Einzelhandel mit Tex- } \\
\text { tilwaren }\end{array}$ & 2 & 20.12 .45 & RM $129666 .-$ \\
\hline $\begin{array}{l}\text { Walter Menzel } \\
\text { Cottbus, Bahnhof-Str. } 55 \\
\text { früh[er] Waldenburg/Schl[esien] }\end{array}$ & $\begin{array}{l}\text { Einzelhandel mit Tex- } \\
\text { tilwaren }\end{array}$ & 1 & Aug. 1946 & $\begin{array}{l}\text { RM } 37443 .- \\
\text { RM 29572.- }\end{array}$ \\
\hline $\begin{array}{l}\text { Stefan Runge } \\
\text { Cottbus, Dresdener-Str. } 155\end{array}$ & $\begin{array}{l}\text { Einzelhandel mit Tex- } \\
\text { tilwaren }\end{array}$ & 1 & 1.3 .46 & $\begin{array}{l}\text { RM 10357.- } \\
\text { RM 27 717.- }\end{array}$ \\
\hline $\begin{array}{l}\text { Karl Weiss } \\
\text { Cottbus, Berlin[er] Str. } 150\end{array}$ & $\begin{array}{l}\text { Einzelhandel mit Tex- } \\
\text { tilwaren }\end{array}$ & 1 & 25.9 .45 & $\begin{array}{l}\text { RM } 14505 .- \\
\text { RM } 47424 .-\end{array}$ \\
\hline $\begin{array}{l}\text { Emmy Just } \\
\text { Cottbus, Thälmannplatz } 59 \\
\text { früh[er] Bunzlau/Schl[esien] }\end{array}$ & $\begin{array}{l}\text { Einzelhandel mit Tex- } \\
\text { tilwaren }\end{array}$ & 1 & April 1946 & RM 27231.- \\
\hline $\begin{array}{l}\text { Eduard Dejardin } \\
\text { Cottbus, Mühlen-Str. } \\
\text { früh[er] Forst }\end{array}$ & Sanitätsgeschäft & 2 & 1.5 .46$. & $\begin{array}{l}\text { RM } 18 \text { 819.- } \\
\text { RM 24251.- }\end{array}$ \\
\hline
\end{tabular}




\begin{tabular}{|c|c|c|c|c|c|}
\hline \multirow{3}{*}{$\begin{array}{l}\text { Name u. Anschrift d. Betriebes } \\
\text { ggfs. früh. Name u. } \\
\text { Sitz des Betriebes } \\
1\end{array}$} & \multirow{3}{*}{$\begin{array}{l}\text { Art d. Betriebes } \\
\text { Rechtsform, Größe } \\
2\end{array}$} & \multicolumn{2}{|c|}{ Zahl d. Beschäftgt. } & \multirow{3}{*}{$\begin{array}{l}\text { Gründungs- } \\
\text { datum n.d. } \\
\text { Umsiedlung } \\
\quad 4\end{array}$} & \multirow{3}{*}{$\begin{array}{l}\text { Umsatz } \\
\text { seit der } \\
\text { Neugründg. } \\
5\end{array}$} \\
\hline & & insg. & Ums. & & \\
\hline & & \multicolumn{2}{|c|}{3} & & \\
\hline $\begin{array}{l}\text { Hans Radach } \\
\text { Cottbus, Berlin [er] Str. } \\
\text { früh[er] Hirschberg/Schl[esien] }\end{array}$ & Drogerie & & & 1.7 .47$. & \\
\hline $\begin{array}{l}\text { H. Scholz, Kronenapoth[eke] } \\
\text { Cottbus, Marien-Str. } \\
\text { früh[er] Sommerfeld } \\
{[\mathrm{Bl} .236 \mathrm{v}]}\end{array}$ & Apotheke (Leiter) & 10 & & & \\
\hline $\begin{array}{l}\text { Leo Wodarz } \\
\text { Cottbus, Dresdener-Str. } 45 \text {, } \\
\text { früh }[\mathrm{er}] \text { Breslau }\end{array}$ & $\begin{array}{l}\text { Radio- u. Elektro-Ma- } \\
\text { terial }\end{array}$ & & & 1946 & $\begin{array}{l}\text { RM } 11038 .- \\
\text { RM 11912.- }\end{array}$ \\
\hline $\begin{array}{l}\text { Walde-Verlag } \\
\text { Cottbus, Rud.Breitscheid-Str. } 79 \\
\text { früh[er] Frankes Verlag u. Drucke- } \\
\text { rei, Inh. O. Borgmeyer, Breslau }\end{array}$ & Verlag & 5 & & 30.5 .45 & $\begin{array}{l}\text { RM 37223.- } \\
\text { RM } 36 \text { 101.- }\end{array}$ \\
\hline $\begin{array}{l}\text { Rudolf Stach, Inh. R. Kastner, } \\
\text { Cottbus, Dresdener-Str. } \\
\text { früh[er] Fa. Kastner, Crossen }\end{array}$ & $\begin{array}{l}\text { Einzelhandel } \mathrm{m}[\mathrm{it}] \\
\text { Haus- u. Küchengeräten }\end{array}$ & 6 & & Mai 1945 & $\begin{array}{l}\text { RM 75 784.- } \\
\text { RM 204993.- }\end{array}$ \\
\hline $\begin{array}{l}\text { Fritz Felix } \\
\text { Cottbus, Tauben-Str. }\end{array}$ & $\begin{array}{l}\text { Einzelhandel m[it }] \\
\text { Haus- u. Küchengeräten }\end{array}$ & 2 & & Dez. 1945 & $\begin{array}{l}\text { RM } 23 \text { 783.- } \\
\text { RM 41 440.- }\end{array}$ \\
\hline $\begin{array}{l}\text { Erich Bartsch } \\
\text { Cottbus, Dresdener-Str. }\end{array}$ & $\begin{array}{l}\text { Einzelhandel m[it }] \\
\text { Haus- u. Küchengeräten }\end{array}$ & 1 & & 1.6 .46$. & $\begin{array}{l}\text { RM } 20016 .- \\
\text { RM 19973.- }\end{array}$ \\
\hline $\begin{array}{l}\text { Fritz Stein } \\
\text { Cottbus, Fr[iedrich-]Ebert-Str. } 1 \\
\text { früh[er] Schlesien }\end{array}$ & $\begin{array}{l}\text { Einzelhandel m[it }] \\
\text { Haus- u. Küchengeräten }\end{array}$ & 2 & & 1.5 .46 & RM $27453 .-$ \\
\hline $\begin{array}{l}\text { Erich Nebel } \\
\text { Cottbus, Marien-Str. } 6 \\
\text { früh[er] Schlesien }\end{array}$ & $\begin{array}{l}\text { Einzelhandel m[it }] \\
\text { Haus- u. Küchengeräten }\end{array}$ & 2 & & 6.12 .45 & $\begin{array}{l}\text { RM } 28264 .- \\
\text { RM 95 917.- }\end{array}$ \\
\hline $\begin{array}{l}\text { Gustav Anders } \\
\text { Cottbus, K[arl-]Liebknecht-Str. 9a, } \\
\text { früh[er] Warschau }\end{array}$ & $\begin{array}{l}\text { Einzelhandel m[it }] \\
\text { Haus- u. Küchengeräten }\end{array}$ & 1 & & Juni 1946 & $\begin{array}{l}\text { RM } 9179 .- \\
\text { RM } 26170 .-\end{array}$ \\
\hline $\begin{array}{l}\text { H.S. G. Henkel } \\
\text { Cottbus, Berlin[er] Str. }\end{array}$ & $\begin{array}{l}\text { Einzelhandel } \\
\mathrm{m}[\text { it }] \text { Haus- u. } \\
\text { Küchenger[äten }]\end{array}$ & 5 & & 23.3.46. & $\begin{array}{l}\text { RM } 21 \text { 774.- } \\
\text { RM } 43 \text { 891.- }\end{array}$ \\
\hline $\begin{array}{l}\text { Fritz Stelzer } \\
\text { Cottbus, Dresdener-Str. } 129\end{array}$ & $\begin{array}{l}\text { Einzelhandel } \\
\mathrm{m}[\text { it }] \text { Haus- u. } \\
\text { Küchenger[äten] }\end{array}$ & 3 & & 1.3 .46 & $\begin{array}{l}\text { RM 16360.- } \\
\text { RM 40 556.- }\end{array}$ \\
\hline $\begin{array}{l}\text { Haus der Geschenke } \\
\text { Cottbus, Sand-Str. } 3 \\
\text { (H.Schettler) } \\
\text { früh[er] Kattowitz O.S. }\end{array}$ & $\begin{array}{l}\text { Einzelhandel } \\
\mathrm{m}[\text { it }] \text { Haus- u. } \\
\text { Küchenger[äten] }\end{array}$ & 3 & & 1.5 .46 & $\begin{array}{l}\text { RM } 39 \text { 159.- } \\
\text { RM } 81492 .-\end{array}$ \\
\hline
\end{tabular}




\begin{tabular}{|c|c|c|c|c|c|}
\hline \multirow{3}{*}{$\begin{array}{l}\text { Name u. Anschrift d. Betriebes } \\
\text { ggfs. früh. Name u. } \\
\text { Sitz des Betriebes } \\
1\end{array}$} & \multirow{3}{*}{$\begin{array}{l}\text { Art d. Betriebes } \\
\text { Rechtsform, Größe } \\
2\end{array}$} & \multicolumn{2}{|c|}{ Zahl d. Beschäftgt. } & \multirow{3}{*}{$\begin{array}{l}\text { Gründungs- } \\
\text { datum n.d. } \\
\text { Umsiedlung } \\
4\end{array}$} & \multirow{3}{*}{$\begin{array}{l}\text { Umsatz } \\
\text { seit der } \\
\text { Neugründg. } \\
\quad 5\end{array}$} \\
\hline & & insg. & Ums. & & \\
\hline & & \multicolumn{2}{|c|}{3} & & \\
\hline $\begin{array}{l}\text { Georg Snoppek } \\
\text { Cottbus, K[arl-]Liebknecht-Str. 9a, } \\
\text { früh[er] Oberschles[ein }] \\
{[\mathrm{Bl} .237 \mathrm{v}]}\end{array}$ & $\begin{array}{l}\text { Einzelhandel } \mathrm{m}[\text { it }] \\
\text { Haus- u. Küchengeräten }\end{array}$ & 1 & & Juni 1947 & \\
\hline $\begin{array}{l}\text { Josef Kahlert } \\
\text { Cottbus, Dresdener-Str. } 1 \\
\text { früh[er]Neustadt O/S. }\end{array}$ & Papier- u. Schreibwaren & 1 & & 1.4.46. & \\
\hline $\begin{array}{l}\text { Walter Linke K. G. } \\
\text { Cottbus, Ostrower Damm } \\
\text { früh[er] Guben }\end{array}$ & $\begin{array}{l}\text { Großhandel mit } \\
\text { Strümpfen }\end{array}$ & 1 & & 1945 & RM 109772.- \\
\hline $\begin{array}{l}\text { Kurt Weger } \\
\text { Cottbus, Mühlen-Str. } 47 \\
\text { früh[er] Forst }\end{array}$ & Neuheiten-Großhandel & 2 & & 3.6.46. & \\
\hline $\begin{array}{l}\text { Peter Magnuszewski } \\
\text { Cottbus, Luisen-Str. } 14\end{array}$ & Handelsvertreter & & & Anfang 46 & RM 12543.- \\
\hline $\begin{array}{l}\text { Max Schleizer } \\
\text { Cottbus, Rud.Breitscheid-Str. } 1\end{array}$ & $\begin{array}{l}\text { Ambulantes Gewerbe } \\
\text { (Haushalts-Artikel) }\end{array}$ & & & 1946 & RM 23727.- \\
\hline $\begin{array}{l}\text { Emil Deckart Inh. Hinrichsen, } \\
\text { Cottbus[,] Sickingen-Str. } 49 \\
\text { früh[er] Triebel Krs. Sorau }\end{array}$ & $\begin{array}{l}\text { Ambulantes Gewerbe } \\
\text { (Manufakturwaren) }\end{array}$ & & & 1946 & \\
\hline $\begin{array}{l}\text { Franz Hardt } \\
\text { Cottbus, Gilden-Str. } 26 \\
\text { früh[er] Sudetenland }\end{array}$ & $\begin{array}{l}\text { Ambulantes Gewerbe } \\
\text { (Reisevarieté) }\end{array}$ & 3 & & 1945 & \\
\hline $\begin{array}{l}\text { Hermann Rätzel } \\
\text { Cottbus, Thälmannplatz } 8 \\
\text { früh[er] Pelplin/Westpr. }\end{array}$ & Helfer in Steuersachen & & & 3.12 .45 . & \\
\hline $\begin{array}{l}\text { Käte Effenberger } \\
\text { Madlow, Spree-Str. } 9 \\
\text { früh[er] Glogau }\end{array}$ & Helfer in Steuersachen & & & 15.2.46. & \\
\hline $\begin{array}{l}\text { Spreewald-Drogerie } \\
\text { J. Seifert, Burg-Dorf } \\
\text { früh[er] Breslau }\end{array}$ & Drogerie & 1 & & Dez. 1945 & $\begin{array}{l}\text { RM } 7 \text { 009.- } \\
\text { RM } 32 \text { 525.- }\end{array}$ \\
\hline $\begin{array}{l}\text { Wilna Bernhardt } \\
\text { Burg-Dorf }\end{array}$ & $\begin{array}{l}\text { Einzelhandel u. Koloni- } \\
\text { alwaren }\end{array}$ & & & 1.12 .45 & $\begin{array}{l}\text { RM } 1 \text { 766.- } \\
\text { RM 8336.- }\end{array}$ \\
\hline $\begin{array}{l}\text { Friedrich Krautz } \\
\text { Burg-Dorf } \\
{[\mathrm{B} 1.237 \mathrm{r}]} \\
\end{array}$ & $\begin{array}{l}\text { Sämereien } \\
\text { Futtermittel }\end{array}$ & & & Juni 46 & \\
\hline $\begin{array}{l}\text { Robert Kessler } \\
\text { Burg-Dorf }\end{array}$ & $\begin{array}{l}\text { Gemischtwaren u. Ei- } \\
\text { senhandel }\end{array}$ & & & 1.1 .46$. & $\begin{array}{l}\text { RM 7427.- } \\
\text { RM 24 574.- }\end{array}$ \\
\hline
\end{tabular}




\begin{tabular}{|c|c|c|c|c|c|}
\hline \multirow{3}{*}{$\begin{array}{c}\text { Name u. Anschrift d. Betriebes } \\
\text { ggfs. früh. Name u. } \\
\text { Sitz des Betriebes } \\
1\end{array}$} & \multirow{3}{*}{$\begin{array}{l}\text { Art d. Betriebes } \\
\text { Rechtsform, Größe } \\
2\end{array}$} & \multicolumn{2}{|c|}{ Zahl d. Beschäftgt. } & \multirow{3}{*}{$\begin{array}{l}\text { Gründungs- } \\
\text { datum n.d. } \\
\text { Umsiedlung } \\
4\end{array}$} & \multirow{3}{*}{$\begin{array}{l}\text { Umsatz } \\
\text { seit der } \\
\text { Neugründg. } \\
\quad 5\end{array}$} \\
\hline & & insg. & Ums. & & \\
\hline & & \multicolumn{2}{|c|}{3} & & \\
\hline $\begin{array}{l}\text { Herrmann \& Schilde } \\
\text { Peitz, Mittel-Str. } 14 \\
\text { früh[er] Grünberg/Schles. }\end{array}$ & Modehaus & 2 & & 1.3 .46 & $\begin{array}{l}\text { RM 1900.- } \\
\text { RM } 10107 .-\end{array}$ \\
\hline $\begin{array}{l}\text { Karl-Heinz Bartel } \\
\text { Peitz, Aug.Bebel-Str. 15a }\end{array}$ & Haushaltsartikel & 1 & & 16.12 .46 & $\begin{array}{l}\text { RM 10728.- } \\
\text { RM 14468.- }\end{array}$ \\
\hline $\begin{array}{l}\text { Kurt Oswald } \\
\text { Schmellwitz, Haupt-Str. } 38\end{array}$ & $\begin{array}{l}\text { Einzelhandel m[it }] \\
\text { Haushalts- u. Küchen- } \\
\text { geräten }\end{array}$ & 1 & & 1.11 .45 & $\begin{array}{l}\text { RM 2 468.- } \\
\text { RM 8393.- }\end{array}$ \\
\hline $\begin{array}{l}\text { Alexander Klecker } \\
\text { Schmellwitz, Park-Str. 15, } \\
\text { früh[er] C.S.R. }\end{array}$ & $\begin{array}{l}\text { Kleinhandel mit Tex- } \\
\text { tilwaren }\end{array}$ & 1 & & 23.6 .46$. & RM 1367.- \\
\hline $\begin{array}{l}\text { M. Vogel } \\
\text { Schmellwitz, Haupt-Str. 84, } \\
\text { früh[er] Schlesien }\end{array}$ & $\begin{array}{l}\text { Kleinhandel mit Papier- } \\
\text { u. Schreibwaren }\end{array}$ & 1 & & 1.4 .46$. & $\begin{array}{l}\text { RM } 2429 .- \\
\text { RM } 8943 .-\end{array}$ \\
\hline $\begin{array}{l}\text { Georg Hartert } \\
\text { Kunersdorf }\end{array}$ & $\begin{array}{l}\text { Einzelhandel mit Eisen- } \\
\text { waren, Haus- u. Küchen- } \\
\text { geräten }\end{array}$ & & & 1.3 .46 & $\begin{array}{l}\text { RM 6385.- } \\
\text { RM 22 226.- }\end{array}$ \\
\hline $\begin{array}{l}\text { Willi Natusch } \\
\text { Dissenchen }\end{array}$ & $”$ & 1 & & 15.6 .46$. & $\begin{array}{l}\text { RM 4 531.- } \\
\text { RM 8655.- }\end{array}$ \\
\hline $\begin{array}{l}\text { Boleslaus Pusowski } \\
{[S t] \text { röbitz }}\end{array}$ & $”$ & & & 15.4.46. & $\begin{array}{l}\text { RM } 1 \text { 920.- } \\
\text { RM } 4 \text { 155.- }\end{array}$ \\
\hline $\begin{array}{l}\text { Emma Schulz } \\
\text { Eichow / früh[er] Neusalz/Oder }\end{array}$ & $\begin{array}{l}\text { Gemischtwaren u. Ei- } \\
\text { senwaren }\end{array}$ & 1 & & 1945 & $\begin{array}{l}\text { RM 5383.- } \\
\text { RM } 27870 .- \\
\end{array}$ \\
\hline $\begin{array}{l}\text { Heinrich Stockmann } \\
\text { Dissen }\end{array}$ & Eisenwaren & 2 & & 1.3 .46 & $\begin{array}{l}\text { RM 2395.- } \\
\text { RM 10486.- }\end{array}$ \\
\hline
\end{tabular}

$[\mathrm{Bl} .238 \mathrm{r}][\ldots]$

\section{(132) Berichterstattung über „Umsiedlergenossenschaften“. - Potsdam, 8. April 1948}

BLHA, Rep. 250 Landratsamt Beeskow-Storkow, Nr. 881, unfol. - Typoskript (auf Kopfbogen) mit Unterschrift „Im Auftrage / [gez.] Zann[?]“, 1 Bl. - L. o. (Druck): „Provinzialregierung Mark Brandenburg / Der Minister für Arbeit und Sozialwesen / Abt. Umsiedler und Heimkehrer / GZ: [masch.] U II/2 6607/3 / [...]“. - R. o. Datierung: „(2) Potsdam, den 8. April 1948 / Alte Zauche 67 [...]“. - Dazwischen Wappen des Landes Brandenburg. - Adresse: „An den / Rat des Kreises Beeskow-Storkow / Abteilung Umsiedler / Beeskow. / Eilt sehr!" - R. daneben schräg aufgedruckter großer Stempel „Gebt den Umsiedlern / eine neue Heimat!“ - Eingangsstempel Landratsamt Beeskow 13. April 1948. - Diverse Paraphen und Abt.-Verfügung sowie Nr. - Betreff: „Betr:: Umsiedlergenossenschaften und -betriebe.“

Im Lande Brandenburg haben sich erfreulicherweise eine größere Anzahl Genossenschaften und Betriebe aus Umsiedlerkreisen gebildet, an deren Fortbestand und Erweiterung nicht nur die SMA stärkstens interessiert ist, sondern ihre Existenz beweist auch, daß seitens der Kreise an der Schaffung von Arbeits- und Produktionsmöglichkeiten z. T. mit gutem Erfolg gearbeitet 
wurde. Es ist aber festgestellt worden, daß in einzelnen Fällen von den Kreisumsiedlerstellen Unternehmen betreut werden, die ihrer Charakteristik nach nicht als Umsiedlerbetriebe gelten können. Aus diesem Grunde ist es notwendig, eine sorgfältige Überprüfung in dieser Richtung hin bei den folgenden in Ihrem Kreisgebiet registrierten Genossenschaften und Betrieben durchzuführen. Dabei fallen Betriebe, die hauptsächlich Umsiedler beschäftigen, in die Kategorie der Umsiedlerbetriebe:

$\begin{array}{ll}\text { Textilgenossenschaft } & \text { Neu Zittau } \\ \text { Strohflechterei } & \text { Kolberg } \\ \text { Installationsgeschäft } & \text { Philadelphia } \\ \text { Betrieb Erlebach } & \text { Neu-Zittau }\end{array}$

Über diese Betriebe bitten wir folgende Angaben zu machen:

1) genaue Anschrift des Betriebes

2) Falls Genossenschaft, wieiviel Mitglieder sind eingetragen?

3) Kann der Betrieb genossenschaftlich organisiert werden?

4) Ist der Betrieb von Umsiedlern gegründet?

5) Wieviel Kräfte beschäftigt der Betrieb insgesamt?

6) Wieviel Kräfte sind davon Umsiedler?

7) Welcher monatliche Umsatz wurde zuletzt erzielt?

8) Was wird produziert?

9) Welcher Materialbedarf besteht zurzeit?

10) Sind Kredite in Anspruch genommen, wie hoch und von wem?

Das Ergebnis Ihrer Umfrage ist uns sofort, spätestens jedoch bis zum 30.4. - notfalls telefonisch, durchzugeben.

Wir halten es für notwendig, daß die Kreissachbearbeiter gemeinsam mit dem Handwerksamt bezw. mit Vertretern der Kreisplanungsämter und der Gewerkschaft persönlich mit diesen Betrieben Fühlung nehmen, um sich ein Bild über den Entwicklungsstand, die soziale Betreuung, die Lohn- und Wohnverhältnisse der Beschäftigten zu machen. Durch solche gemeinsamen Besichtigungen wird erreicht, daß auftretende Schwierigkeiten mit den zuständigen Dienststellen an Ort und Stelle besprochen und geeignete Maßnahmen für ihre Behebung unternommen werden können.

Damit auch die SMA einen Einblick über die Entwicklung der Umsiedlerbetriebe erhält, sind in der monatlichen Berichterstattung lt. Befehl Nr. 31 - Verfügungen vom 6.2. und 8.4.1948 als Anlage zum Formblatt II - die Fragen 5, 6, und 7 nach dem jeweiligen neuesten Stand zu beantworten. 


\section{(133) Belieferung und Benennung der „Umsiedlergenossenschaft Neuzittau“. - Potsdam, 24. Mai 1948}

BLHA, Rep. 250 Landratsamt Beeskow-Storkow, Nr. 881, unfol. - Typoskript (auf Kopfbogen) mit Unterschrift „Im Auftrage / [gez.] Zann[?]“, 1 Bl. - L.o. (Druck): „Landesregierung Brandenburg/Minister für Arbeit und Sozialwesen / Abteilung Umsiedler und Heimkehrer / G[eschäfts]-Z[eichen]: [masch.] U II/2 6607/3/18/ [...]“. - R. o. Datierung: „(2) Potsdam, den 24. Mai 1948 / Alte Zauche 67 App. 288 [...]“.- Dazwischen Wappen des Landes Brandenburg. - Adresse: „An den / Rat des Kreises Beeskow-Storkow / Abt. Umsiedler / Beeskow“. - Eingangsstempel Landratsamt Beeskow 29. Mai 1948. - Diverse Paraphen und Abt.-Verfügung sowie Nr. - Betreff: „Betr.: Umsiedlergenossenschaft zur Erzeugung von Industrie- und Wirtschaftsartikeln, Neuzittau“. Bezug: Ihr Schr[eiben] v. 7.5.48, G[eschäfts]-Z[eichen] XVIII/U/C H.Sch. ${ }^{2326}$

Aus dem uns übermittelten Vorgang ist zu ersehen, daß die Genossenschaft, obwohl sie Lieferanweisungen dafür besitzt, das benötigte Stroh, die Weidenruten u. Birkenruten bisher noch nicht erhalten hat. Wir bitten sie, sich sofort mit dem dortigen Handwerksamt resp. mit dem Kreisplanungsausschuß wegen Lieferung dieses Materials in Verbindung zu setzen. Die Firmierung „Umsiedlergenossenschaft Neuzittau“ halten wir nicht für zweckmässig. Bekanntlich soll die Verschmelzung der Umsiedler mit den Alteingesessenen gefördert werden und die Bezeichnung „Umsiedler" schließlich aus dem Wortschatz verschwinden. Aus diesem Grunde bitten wir darauf hinzuwirken, daß die Genossenschaft wie folgt eingetragen wird:

Genossenschaft zur Erzeugung von Industrie- u. Wirtschaftsartikeln, Neuzittau.

Über das Ergebnis Ihrer Maßnahmen erbitten wir Bericht.

Gleichzeitig bitten wir, die Genossenschaft zu veranlassen, die beigefügten Fragebogen in doppelter Ausführung auszufüllen, sowie auch die Fragestellung lt. unserem Schreiben vom 8.4. zu beantworten und uns diese wieder zurückzusenden.

3 Anlagen 2327

\section{(134) Bericht über die „Umsiedler-Genossenschaft“ für Kunstblumen in Jüterbog. - Luckenwalde, 15. Juni 1948}

BLHA, Rep. 250 Landratsamt Luckenwalde, Nr. 105, Bl. 171-172. - Typoskript (Durchschlag), 2 Bl.; vereinzelte handschriftliche Korrekturen (Druckmanuskript für Zeitung). - O.1. Verf.-Name „Erwin Schleusener“, o. r. Datierung „Jüterbog, den 15. Juni 1948 / Mönchenstr. 29“. Bl. 172: Masch. Verf.-Kürzel „-es-“.

\section{Blumenwunder aus Papier}

Die nach Beendigung des Krieges zur Durchführung gelangten Umsiedlungen brachten u.a. auch viele Industriezweige der ehemaligen sudetendeutschen Schmuckwarenindustrie nach Deutschland. Glaswaren und Bijouterieartikel verschiedenster Art, künstliche Blumen und Früchte waren Erzeugnisse, die dieser Industrie einen Weltruf verschafft hatten. Mit der An-

2326 [XVIII“ bezeichnet die Abteilungsnummer der Abt. „Umsiedler und Heimkehrer“ im Ministerium für Arbeit und Sozialwesen (vgl. oben Anm. 1058).]

2327 [Fehlen.] 
kunft in Deutschland galt es, eine neue Industriegrundlage und damit einen neue Heimat zu schaffen. Auf genossenschaftlicher Basis schlossen sich die meisten dieser Umsiedler zusammen und begannen, fast vollkommen aus dem Nichts ihre alte Industrie wieder aufzubauen.

So haben sich auch einige Umsiedler aus Niedereinsiedel, deren neue Heimat Jüterbog wurde, zu einer Produktiv- und Handelsgenossenschaft der Kunstblumen- und -früchteindustrie zusammengeschlossen. Das kleine, unscheinbare Schild in der Turmstr. 7 in Jüterbog lässt den Vorübergehenden nicht ahnen, welch reges Schaffen sich in den Zimmern des ehemaligen Gasthofes heute abspielt und dass die schönsten Ladendekorationen, die Kunstblumen, die der Gärtner verarbeitet[,] und der herrliche Blumenschmuck, der bei Feierlichkeiten Tisch und Raum schmückt, aus diesem unscheinbaren Betrieb stammen.

Ein Gang durch die bereits zu engen und zu kleinen Räume des Betriebes macht uns mit dert Zauberwerkstatt dieser künstlichen Flora bekannt. Da ist zunächst einmal die Stanzerei. Mit eisernen Stempeln werden die verlangten Muster aus dem Papier herausgeschlagen. Sie kommen dann in die Färberei, wo jedes Stück seine natürliche Färbung erhält. Dann wird Blatt für Blatt, Blüte für Blüte in eine elektrisch geheizte Presse gelegt, die jdem Teil die gewünschte Form gibt. Selbst die feinsten Aederchen werden auf diese Aet naturgetreu nachgeahmt. Damit sind die wichtigsten Vorarbeiten beendet. Flinke und geschickte Hände stellen nun die einzelnen teile zusammen. Ein Stückchen feiner Draht, mit grünem Papier umwickelt, bildet den Stiel und gibt der fertigen Blume Halt und Gestalt. So kurz und einfach der ganze Vorgang auch ist, verlangt er dich eine langjährige Erfahrung und eine Geschicklichkeit, die nicht von heute auf morgen zu erlernen ist. Die Kunstfertigkeit dieses Industriezweiges ist so ausgeprägt, dass es schwer ist, zwischen den Naturprodukten und den künstlichen Erzeugnissen menschlicher Hände zu unterscheiden.

65 Mitarbeiter zählt dieser Genossenschaftsbetrieb und ist damit einer der grössten in Jüterbog. $87 \%$ davon sind Frauen, von denen über die Hälfte als Heimarbeiterinnen beschäftigt werden. Der Betrieb könnte bei einer entsprechenden Unterstützung durch die Stadtverwaltung, vor allem durch Lösung der Raumfrage, in kürzester Zeit auf 200 Betriebsangehörige erweitert werden. Leider - so betonen die Genossenschaftsmitglieder - haben die Stadtväter von Jüterbog die Bedeutung dieser Industrie, im einzelnen für die Zukunft der Stadt und im besonderen für den deutschen Export, noch nicht erkannt. Hat doch diese Industrie der Tschechoslowakei Devisen im Werte von Millionen eingebracht. Die Produktionsauflage diesen [so!] kleinen Betriebes, die 1947 120000.- RM betrug, 1948 auf 160000 .- RM gesteigert werden soll, von der Genossenschaft aber auf 200000 .- RM gesetzt worden ist, zeigt, welche Entwicklungsmöglichkeiten hier vorhanden sind. Gerade dieser [Bl. 172] Industriezweig, der nicht an örtliche Rohstoffvorkommen gebunden ist, könnte der Stadt Jüterbog, die durch ihre einseitige militärische Entwicklung keine wirtschaftliche Grundlage für die Zukunft hat, eine neue Basis schaffen. Aber auch die Lohngestaltung, die bereits auf einer beachtlichen Höhe steht, stellt die Leistungsfähigkeit unter Beweis. So beträgt der Akkordlohn für Frauen im Durchschnitt 1.- RM, für Männer - bei denen es sich in der Hauptsache um Fachkräfte handelt - bis zu 1.50 RM. Diese Löhne werden tatsächlich ausgezahlt, da sämtliche Abzüge von der Genossesnchaft getragen werden. Die Auswahl von 
mehr als 200 verschiedenen Blumensorten und die ebenso grosse Anzahl anderer Muster gehen vorerst einmal in die Ostzone. Aber auch der Anfang mit der Westzone ist gemacht. Allerdings ist der Verkehr mit dieser Zone und auch mit dem Ausland, wo sich bereits amerikanische Firmen für die Jüterboger Blumenindustrie interessieren, durch die Zerreissung Deutschlands und die damit entstandene wirtschaftliche Lage gehemmt. Deshalb hat auch besonders die Belegschaft dieses Betriebes den Kampf um die Einheit Deutschlands erkannt.

\subsection{Bodenreform und Neubauernprogramm (1946-1951)}

\section{(135) Umfrage zur Berücksichtigung der Flüchtlinge und Vertriebenen bei der Bodenreform. - Potsdam, 20. Juni 1946}

BLHA, Rep. 230 Oberlandratsamt Bernau, Nr. 290, Bl. 1. - Typoskript, 1 Bl. - L. o. Absender und Aktenzeichen: „Provinzialverwaltung / Mark Brandenburg / Amt für deutsche Umsiedler / Az.: VII/2/Stat. / Ma/Schu.“ - R. o. Datierung: „Potsdam, den 20. Juni 1946 / Alte Zauche 67.“ - Adresse: „An den / Herrn Oberlandrat / in Bernau“. - Betreff: „Betrifft: Umsiedler in der Bodenreform.“ - Eingangsstempel: „Der Oberlandrat / Eing.: 20. Jul. 1946“ mit grüner Paraphe „H[?]“ und Nr. „5708“, daneben Zuständigkeitsvermerk „VII“. - Bl. 1v Unterschrift „Im Auftrage:“ [gez.] „Friedrichs“; darunter r. Paraphe „[...?]“, 1. Bleistiftvermerk „Abschriften an alle Kreise / am 25.7. [Paraphe:] Kfr.[?]“.

Wir ersuchen um Einsendung einer [Bleistiftzusatz über der Zeile: Allgemeinen] Übersicht, welche Hilfe den Umsiedlern als Neubauern im Zuge der Bodenreform in den einzelnen Kreisen zuteil wurde. Nachstehende Fragen sind zu beantworten und weitere Einzelheiten hinzuzufügen, falls in dem einen oder anderen Kreis in dieser Hinsicht etwas besonderes geleistet werden konnte. Alle Angaben werden nur zahlenmäßig erwartet.

1.) An wieviel Ums[iedler] wurde von der gesamten, in der Bodenreform dem Kreise zur Verfügung stehenden Fläche Land abgegeben. Hierbei sind die Zahlen in Hektar sowohl für die Gesamtfläche als auch für an die Neubauern abgegebene einzusetzen, desgl[eichen] die Anzahl der Familien sowie deren Kopfstärke.

2.) Anzahl der Pferde, Kühe, Schafe, Schweine oder sonst [igen] Viehs.

3.) Anzahl der Traktoren, Dresch-, Drill- oder sonst[igen] landw[irtschaftlichen] Geräte, sowie landw[irtschaftlichen] Ausrüstungsgegenstände.

[B1. 1v]

Der Bericht wird bis zum 15.8. [zweimal handschriftlich korrigiert aus 27.7. bzw. zuvor 17.7.] 1946 hier erwartet.

\section{(136) Berücksichtigung der Flüchtlinge und Vertriebenen im Kreis Beeskow-Storkow bei der Bodenreform. - Beeskow, 8. August 1946}

BLHA, Rep. 230 Oberlandratsamt Bernau, Nr. 290, Bl. 3. - Typoskript (Durchschlag, außer Adresse) auf Kopfbogen, 1 Bl. - L. o. Absender und Aktenzeichen: „Der Landrat / des Kreises Beeskow-Storkow / [...] / Geschäftszeichen: III Bodenreform“. - R. o. Datierung: (2) Beeskow, den 8. Aug. 1946 / [...]“.- Adresse: „An den / Herrn Oberlandrat / der Bez[irks] Verwaltung Berlin / - Abt. Arbeit u. Sozialwesen / VII b -“. - Eingangsstempel: „Der Oberlandrat / Eing.: 
14. Aug. 1946“, darin Paraphe [...?], daneben Zuständigekitsvermerk „VII“. - Betreff: „Betrifft: Umsiedler in der Bodenreform.“ - „Bezug: Dortseitiges Schreiben des Oberlandrats der Bezirksverwaltung Berlin vom 23.7.1946, Abtlg. Arbeit und Sozialwesen, VII b, Az. Ko/Sch. - „Verfügung vom 25.7.1946 der Abteilung VII a, Abt. Arbeits- u. Sozialwesen VII b - Az. Ke/Sch.“- Bl. 3v Stempel „Der Landrat des Kreises Beeskow-Storkow“ und Unterschrift „In Vertretung:“ [gez.] „Forst[?]“ „Kreisrat.“, daneben Paraphe „Prü“.

Zu obigem Bezug mache ich Ihnen folgende Angaben.

1.) An wieviel Umsiedler wurde von der gesamten in der Bodenreform dem Kreise BeeskowStorkow zur Verfügung stehenden Fläche Land abgegeben:

$\begin{array}{lll}\text { Umsiedler: } & \text { Familien } & 869 \\ & \text { Hektar } & 7060,2664 \text { ha } \\ \text { Kopfstärke } & & 3108 \\ \text { Neubauern: } & \text { Familien } & 779 \\ & \text { Hektar } & 3132,27 \mathrm{ha} \\ \text { Kopfstärke } & & 2337\end{array}$

2.) Es wurde nachstehendes Vieh den Umsiedlern zur Verfügung gestellt:

$\begin{aligned} 145 & \text { Pferde } \\ 139 & \text { Milchkühe } \\ 33 & \text { Zuchtbullen } \\ 80 & \text { Schweine } \\ 13 & \text { Schafe und Ziegen } \\ 27 & \text { Geflügel }\end{aligned}$

3.) Anzahl der an die Umsiedler ausgegebenen, landwirtschaftlichen Geräte und Ausrüstungsgegenstände:

140 Pferdeflüge

84 Eggen

37 Kultivatoren

53 Häufelflüge

21 Drillmaschinen

15 Mähmaschinen

1 Rüben-Erntemaschine

89 Kartoffelsortiermaschinen [Bl.3v]

1 Rübenschneider

27 Wagen

1 Schlitten. 


\section{(137) Berücksichtigung der Flüchtlinge und Vertriebenen im Kreis Teltow bei der Bodenreform. - Mahlow, 22. August 1946}

BLHA, Rep. 230 Oberlandratsamt Bernau, Nr. 290, Bl. 2. - Typoskript auf Kopfbogen, 1 Bl. - L. o. Absender und Aktenzeichen: „Der Landrat/ des Kreises Teltow / Amtssitz Mahlow“ / Aktenzeichen III b -Dr.Ti.F.“ - R. o. Datierung: (1) Mahlow, den 22. August 1946 / Florapark, Tel. Mahlow 228“. - Adresse: „An den / Herrn Oberlandrat der / Bezirksverwaltung Berlin / Amtssitz Bernau“. - Eingangsstempel: „Der Oberlandrat / Eing.: 24. Aug. 1946“, darin Paraphe [...?], daneben Zuständigkeitsvermerk „VII“. - Betreff: „Betrifft: Verfügung vom 25.7.1946 der Abteilung VII a, Abt. Arbeits- u. Sozialwesen VII b - Az. Ke/Sch.“ - Bl. 2v Stempel „Der Landrat des Kreises Teltow“ und Unterschrift „i.A. [gez.] Johm[?]“.

Die in der Verfügung der Provinzialverwaltung vom 20.6.1946 gestellten Fragen ${ }^{2328}$ werden von mir wie folgt beantwortet:

1. Im Kreise Teltow sind im ganzen rd. 40678 ha Land verteilt worden. Davon haben erhalten:

\begin{tabular}{lrrr} 
Kulturart & $\begin{array}{r}\text { Umsiedler } \\
\text { ha }\end{array}$ & $\begin{array}{r}\text { Neubauern } \\
\text { ha }\end{array}$ & \multicolumn{1}{c}{$\begin{array}{r}\text { im ganzen } \\
\text { ha }\end{array}$} \\
\hline Anzahl & 194 & 923 & 1117 \\
\hline Ackerland & 812,62 & 2772,25 & 3584,87 \\
Garten & 0,36 & 5,06 & 5,42 \\
Wald & 136,30 & 1330.69 & 1466,99 \\
Wiesen & 150,46 & 625,75 & 776,21 \\
Sonstiges & 32,08 & 60,43 & 92,51 \\
\hline Insgesamt & 1131,82 & 4794,18 & $5925,-$ \\
\hline
\end{tabular}

Die übrigen Flächen sind an landarme Bauern, Kleinsiedler und andere, an der Bodenreform beteiligte Stellen (Provinzialgüter usw.) verteilt worden.

Über die Kopfstärke der Umsiedlerfamilien liegen mir Angaben nicht vor. Sie ist im Durchscnitt mit 4-5 Personen je Familie anzunehmen.

2. Bei der Verteilung von Vieh, die anlässlich der Bodenreform vorgenommen wurde, konnten die Umsiedler nicht berücksichtigt werden, weil nur in wenigen Gemeinden Vieh zur Verteilung gelangte und in diesen Gemeinden zufällig keine Umsiedler angesetzt sind.

3. Bei der Verteilung von landwirtschaftlichem Inventar sind die Umsiedler und Neubauern in folgender Weise berücksichtigt worden. [Bl. 2v:]

2328 [Siehe oben die „Umfrage zur Berücksichtigung der Flüchtlinge und Vertriebenen bei der Bodenreform“, Potsdam, 20. Juni 1946.] 


\begin{tabular}{lccc} 
& Umsiedler & Neubauern & insgesamt \\
\hline Pferdeflüge (sämtl[iche]) & 23 & 88 & 111 \\
Eggen, eiserne (sämtl[iche]) & 6 & 50 & 56 \\
Kultivatoren (sämtl[iche]) & 3 & 10 & 13 \\
Häufelflüge (sämtl[iche]) & 3 & 23 & 26 \\
sämtl[iche] Arten von Drillmaschinen & 2 & 7 & 9 \\
Mähmaschinen & 4 & 11 & 15 \\
Pferdeharken & 3 & 14 & 17 \\
Mähmaschinen & - & 9 & 9 \\
Kartoffelsämaschinen & - & 2 & 2 \\
Kartoffelerntemaschinen & 3 & 3 & 6 \\
Rübenerntemaschinen & - & 1 & 1 \\
Kartoffelsortiermaschinen & 2 & 2 & 4 \\
Häckselmaschinen, Rübenschneider & 2 & 8 & 10 \\
Separateggen & 1 & 3 & 4 \\
Wagen, Schlitten & 15 & 40 & 55 \\
andere Maschinen & 4 & 44 & 48.
\end{tabular}

\section{(138) Bericht eines Mitglieds des SED-Provinzialverbandes Brandenburg über seinen Besuch in Dorf Zinna. - Potsdam, 29. Oktober 1946}

BLHA, Rep. 333 SED-Landesleitung Brandenburg, Nr. 574, B1. 53 (alt 193). - Typoskript ohne Unterschrift. - O.1. Verfassername: „Kneler“, darüber Bleistiftzusatz: „Bericht“. - R. o. Datierung: „Potsdam, den 29.10.1946“, r. daneben Bleistiftvermerk (wohl Verteiler) „A“.

Am 23.10. besuchte ich das Dorf Zimma ${ }^{2329}$, welches jetzt mit Sudetendeutschen besiedelt ist. Ich bin beim Vorstand der SED gewesen und habe mich dort über das Leben und Treiben dieser Antifaschisten erkundigt. Wenn man mit den Genossen spricht, hört man bald heraus, dass dort eine gute Moral herrscht. Bei der Gemeindewahl $100 \%$ für die SED, bei der Landtagswahl von 327 Wahlberechtigten, 305 für die SED, 5 CDU, 3 LDP, und 7 ungültig und 7 gingen nicht wählen. Der Vorsitzende besprach mit mir, dass er alles tun will, um die letzten Gegner unserer Partei in diesem Dorf für uns zu gewinnen. Dann besuchte ich die Heimindustrie. Es werden Knöpfe, Kunstperlen aus Glas usw. hergestellt. Die ganze Arbeit beruht auf Kollektiv. Diese Arbeit geht nach Luckenwalde und von dort zur Abteilung Industrie und Gewerbe. Die Leute sind sehr zufrieden, dass sie wieder ein neues Heim gefunden haben, wo sie auch ihrer politischen 
Tätigkeit ungestört nachgehen können. Ich besuchte dann die Neubauern. Alle klagten, dass sie sehr schlechten Boden hätten und beim Ablieferungssoll mussten sie das gleiche abliefern. Sie arbeiten fleissig von morgens bis abends und erklärten mir, trotz aller Schwierigkeiten wollen sie das Soll erreichen bzw. erreicht haben. Ihr Los ist etwas schwer, da sie in einem abgelegenen Dorf leben und ihre politische Tätigkeit nur auf dieses Dorf begrenzt ist. Es wäre politisch wichtig, dass man diesen Parteikader durch die Kreisleitung Luckenwalde auf die Nebendörfer verteilen würde. Der Bürgermeister, sowie der Leiter der Heimindustrie und der Leiter der Neubauern und die Partei sprachen ihren Dank für den Besuch, der von der SED abgestattet worden ist, aus und hoffen, bei der Arbeitstagung der Heimkehrer und Umsiedler, die in Potsdam stattfinden soll, grossen Anteil zu haben.

\section{(139) Pressebericht des Informationsdienstes des Kreises Luckenwalde über die Durchführung des Neubauernprogramms. - Luckenwalde, 10. Juni 1948}

BLHA, Rep. 250 Landratsamt Luckenwalde, Nr. 105, Bl. 173-174. - Typoskript (Durchschlag) mit wenigen Bleistiftergänzungen und Bleistiftüberschrift, 2 Bl. - Bl. 1731. o. Stempel „Der Rat des Kreises / Luckenwalde / Informationsdienst“ Aktenzeichen „Ku/J.“ - R. o. Datierung „Luckenwalde, den 10. Juni 1948 / Bahnhofstr. 5. - Bl. 174 Stempel wie vor, keine Unterschrift. - U.1. Verteiler (Bleistuft): „Inf[ormations-] Amt / Neues Deutschl[and] / Potsd[amer] Sender / Volksstimme / Tägl[iche] Rundschau“.

Zur Durchführung des Neusiedler Bauprogramms in L[uc]k[en]walde

Den Neusiedlern wurden durch die Bodenreform Land, durch die Sachgebiete Landwirtschaft und Forsten Saatgut, Vieh und ein grosser Teil der Geräte, durch die Umsiedlerbetreuung in vielen Fällen Kleidung, Hausrat und Möbel zur Verfügung gestellt. Damit nun diese Neubürger wirklich sesshaft und mit dem neuen Boden verwurzelt werden, müssen wir ihnen zu einem eigenen Haus auf eigener Scholle verhelfen. Die ehemaligen Gutsarbeiter-Kasernen ersetzen auf die Dauer nicht den eigenen Hof.

Der Kreis Luckenwalde hat es sich zur Aufgabe gestellt, im Rahmen des Bodenreform-Bauprogramms $500^{2330}$ Neubauernhöfe zu errichten. Fünf Monate sind vergangen, der Stand des Bauvorhabens ist nicht befriedigend. Bis jetzt sind erst 348 Neubauernhöfe angefangen und $39^{2331}$ fertiggestellt. Um die Bauvorhaben besser voranzutreiben, hat der Landrat des Kreises Luckenwalde, Dr. Ludwig, alle mit der Durchführung des Bauprogramms Beauftragten in den letzten 14 Tagen zweimal zu einer Aussprache geladen. Die verantwortlichen Bürgermeister und Siedlungsausschüsse, die Bauabschnittsleiter, Baumeister, Architekten, Vertreter der Landbaugesellschaft, des Arbeitsamtes, der VdgB und der Blockparteien und anderer Organisationen wohnten den Sitzungen bei, um eine recht breite Baiss für diese so überaus wichtige Aufgabe zu schaffen.

2330 [„500“ handschriftlich korrigiert aus unleserlicher Zahl.]

2331 [,39“ handschriftlich korrigiert aus „11“.] 
Jeder Bauabschnittsleiter wurde in diesen Sitzungen aufgefordert, über den Stand der Bauten Bericht zu erstatten. Bürgermeister, die sich nicht genügend für die Durchführung des Bauvorhabens einsetzten, mussten sich in den Sitzungen verantworten. Die Ursache für das schlechte Voranschreiten, die Schwierigkeiten waren verschieden. Besonders der Norden des Kreises leidet unter Mangel an Arbeitskräften. Hier zeigt sich auch, dass dem Nachwuchs an Bauarbeitern nicht genügend Beachtung geschenkt wurde.

Weitere Schwierigkeiten ergeben sich in der Materialbeschaffung. Kalk, Zement, Dachziegel sind die Engpässe beim Rohbau. Auch Fahrzeuge zum Transport von Baumaterialien, besonders Spezialfahrzeuge für gelöschten Kalk, und Gespanne zum Heranfahren des nötigen Bauholzes fehlen. Dazu kommt die ungünstige Lage der Sägewerke, die oft bis $40 \mathrm{~km}$ vom Bauplatz entfernt liegen und trotz zugesagter Freistellung durch Reparationsaufträge zum Teil ausfallen. Besondere Schwierigkeiten ergeben sich in Heinsdorf-Blankensee[,] neuen Auftrieb erhielt Hohenalsdorf. Vorbildlich ist Gebersdorf.

Zum Facharbeitermangel ist zu sagen, dass Bauhandwerker, die für das Bauprogramm verpflichtet wurden und gleichzeitig auch Besitzer einer Wirtschaft sind, lieber in derselben arbeiten, um ihr Abgabesoll pflichtgemäss zu erfüllen.

Zwischen den Altbauern und den Neusiedlern besteht wenig Solidarität. Die Altbauern geben an, dass die Neusiedler in vielen Fällen kein Interesse für ihren Bau zeigen. Deshalb kann nicht verlangt werden. dass die Altbauern führend sind. So sagt ein Bauer aus Höfgen, dass sie den Neusiedlern aus Gräfendorf nicht mehr helfen werden, da diese sich an der Aufbauarbeit selbst nicht beteiligen. Derartige Klagen werden in vielen Fällen angeführt.

Um die gesetzten Termine einzuhalten und alle bestehenden Schwierigkeiten soweit als möglich zu beseititgen, wird empfohlen: [Bl. 174]

1. Alle Privatbauten im Kreise sind einzustellen, um Arbeitskräfte und zur Zeit nicht benötigtes Baumaterial freizumachen. Der gefasste Kreistagsbeschluss muss nun auch praktisch zur Auswirkung kommen. Die Bevölkerung wird aufgefordert, alle privaten Bauausführungen zu melden, von denen anzunehmen ist, dass es sich um Verstösse handelt.

2. Die Dörfer, die keine eigenen Bauvorhaben ausführen, müssen ihre Nachbardörfer durch Arbeitskräfte und Stellung von Gespannen weitgehendst unterstützen.

3. Der Sondereinsatz von freiwilligen Arbeitskräften ist leider noch zu gering. Hier hat die FDJ in vielen Fällen, besonders in den Ziegelstein-Putzaktionen in Gebersdorf, Markendorf und Dahme vorbildlich gearbeitet.

4. Die ganze Umsiedlerfamilie muss, wenn es sich um die Fertigstellung ihres Hauses handelt, mit gutem Beispiel vorangehen und sich mit ganzer Kraft einsetzen. Neusiedler, deren Haus als erstes durch die Mithilfe der ganzen Dorfgemeinschaft fertiggestellt wurde, müssen nun auch nach ihrem Einzug weiter an der gegenseitigen Hilfe interessiert sein und dürfen die anderen Neubauern nicht im Stich lassen. 
5. Im Interese einer gesicherten Durchführung des Bauprogramms müssen Neusiedler, die ihrer Aufgabe nicht gerecht werden, durch solche ersetzt werden, die mit grösserem Interese an die Arbeit herangehen.

Auf die planmässige Durchführung der Bauvorhaben haben unsere Bürgermeister grossen Einfluss. Wenn es hier gelingt, über den Weg der Selbsthilfe die ganze Dorfgemeinschaft zu beteiligen, dann sind wir trotz allern Materialschwierigkeiten bestimmt in diesem Jahr ein gutes Stück weiter gekommen.

\section{(140) Pressebericht des Informationsdienstes des Kreises Luckenwalde über den Rückstand bei der Errichtung von Neubauernhäusern. - Luckenwalde, 16. September 1948}

BLHA, Rep. 250 Landratsamt Luckenwalde, Nr. 105, B1. 93-94. - Typoskript (Durchschlag), 2 Bl. (rückwärts geordnet [„kaufmännische Heftung“). - Bl. 941. o. Stempel „Der Rat des Kreises / Luckenwalde / Informationsdienst“ Aktenzeichen „Ki/J.“ - R. o. Datierung „Luckenwalde, den 16. Sept. 1948 / Bahnhofstr. 5 / Tel.: 2142 App. 35 “. - Bl. 93 Stempel wie vor und Paraphe „Pl.“

[B1. 94]

Werden alle Neusiedler in diesem Jahre noch ein Dach über den Kopf bekommen?

Auf einer erweiterten Sitzung des Bauausschusses 209 wurde festgestellt, dass der Kreis Luckenwalde mit der Errichtung der für dieses Jahr geplanten Neubauernhäuser stark im Rückstand ist. Zweifellos sind hierfür technische Schwierigkeiten mit die Ursache, jedoch wurde auch festgestellt, dass ein Versagen der beteiligten Stellen ebenso mit die Schuld an dieser Entwicklung trägt.

Die Kreiskommandantur, die an dieser Sitzung beratend teilnahm, versprach, bei der Beseitigung der technischen Schwierigkeiten weitgehend zu helfen und betonte, dass es eine Angelegenheit der gesamten Bevölkerung des Kreises sein muss, dafür zu sorgen, dass nicht Menschen ohne Obdach vom kommenden Winter überrascht werden. Hinter dieser Aufgabe müssten alle anderen zurückstehen.

Es wurden 2 Ausschüsse gebildet. Die Leitung des technischen Ausschusses, der mit allen Vollmachten ausgestattet wurde, liegt in den Händen von Herrn Kreisrat Grün, der in einer Solidaritätsaktion mit den Angestellten seiner Stadtverwaltung bewiesen hat, wie man mit ein wenig Schwung, Elan und gutem Willen Engpässe überwinden und dern Neubauern neuen Mut geben kann. Allerdings wurde auch festgestellt, dass die Neubauern an manchen Stellen die Hände in den Schoss legen und darauf warten, dass die Altbauern und freiwilligen Helfer aus der Stadt ihnen ihr Haus erstellen. Eine solche Einstellung zu überwinden wird künftig die Aufgabe des 2. politischen Ausschusses sein, der sich aus allen Parteien und Massenorganisationen zusammensetzt und zu deren Leitung Herr Dalbert (SPD) berufen wurde. [Bl. 93]

Er wird dafür sorgen, dass Stadt- und Landbevölkerung, Alt- und Neubauern ohne Unterschiede der Parteizugehörigkeit alle Hände regen werden, um noch vor Einbruch des Winters jedem unserer Neubauern sein Dach über den Kopf zu sichern. 


\section{(141) Pressetext des Rates des Kreises Luckenwalde über die Sollerfüllung bei der Pflichtablieferung aus dem Neubauerndorf Dorf Zinna (Neuheim). - Luckenwalde, 6. August 1949}

BLHA, Rep. 250 Landratsamt Luckenwalde, Nr. 108, Bl. 431. - Typoskript, 1 Bl., mit masch. Unterschrift „Der Rat des Kreises Luckenwalde / gez. Dr. Ludwig / Landrat“ und eigenhändiger Kopierstift-Unterschrift „Dr. Ludwig“.U.1. Verfügung/Verteiler „Herrn Kirstein / An die Märkische Volksstimme / An die Redaktion der ,Täglichen Rundschau' / An die Redaktion der Ztg. ,Neues Deutschland“', darunter handschriftlicher Bleistift-Vermerk des Informationsdienstmitarbeiters Hans Kirstein „Tagespost / Durchgesprochen $13.40 \mathrm{Ki“}$

Mit dem heutigen 6.8.1949 haben die 3 Dörfer des Kreises Luckenwalde / Dorf Zinna / Holbeck / u. Wildau / ihre Getreideabgabe 100 \%ig beendet. Das Dorf Zinna ist reines Neubauerndorf und hat in dem Wettbewerb der Dörfer des Kreises Luckenwalde in der Pflichtablieferung den Sieg davon getragen.

\section{(142) Bericht des Bürgermeisters der Stadt Potsdam über ländliche Besitzverhältnisse und Wohnsituation in einzelnen Ortsteilen. - Potsdam, 18. November 1949}

BLHA, Rep. 202 G Amt für Information, Nr. 165, Bl.36-38. - Typoskript (Durchschlag, außer Adresse), 3 Bl. Bl. 36r Kopfbogen „Rat der Landeshauptstadt Potsdam / Amtsstelle I Bgm“, Datierung „Potsdam, den 18. November 1949“. - Roter Eingangsstempel „19. Nov. 1949“, blauer Haken und roter Sichtvermerk „I/5“; drei Adressen (die zweite rot unterstrichen): „1. An die / Landeskontrollkommission des Landes Brandenburg / Potsdam / Alte Zauche 28 / 2.) An den „Herrn Innenminister des Landes Brandenburg / Potsdam / Saarmunder Str. 23 / 3.) An den / Herrn Oberbürgermeister des Stadtkreises Potsdam / im Hause“. - Betreff: „Betr: Sonderkommission laut Kabinettsbeschluß vom 4.7.1949, veröffentlicht in den PMB-Nachrichten Nr. 238 vom 13.7.1949.“ - Bl. 38v Bleistiftunterschrift des Bürgermeisters [Erwin] „Köhler“ und roter Stempel „Rat der Landeshauptstadt Potsdam / ““ (mit Stadtwappen).

\section{Vierter zum 5.11.1949 fälliger Bericht}

In der Sitzung der Sonderkommission am 28.9.1949 war von dem Vorsitzenden der VdgB in Golm, Herrn Nitz, darauf hingewiesen worden, daß sich im Ortsteil Golm etwa 20 Morgen befänden, die vollkommen brach lägen.

Die Überprüfungen der Kommission im Oktober ergaben, daß es sich hierbei um 20 Morgen Wiesen handele, die in Kuhfort liegen und zum Gute Bornstedt gehören. Das Gut Bornstedt wird von der Besatzungsmacht bewirtschaftet. Bisher ist seitens der zuständigen Offiziere jede Verhandlung über eine Freigabe dieser Wiesen abgelehnt worden. Auf Grund der neuesten innerpolitischen Lage und der Erklärung des Vorsitzenden der sowjetischen Kontrollkommission soll jetzt nochmals versucht werden, wegen dieser - seitens der Besatzungsmacht nicht genutzten - Wiesen mit der Wirtschaftsleitung des Gutes in Verhandlungen zu kommen. [Bl. 36v]

In dem Bericht vom 15.10.49 ist auf Seite 2 erwähnt worden, daß der Neubauer und Umsiedler Gohlke in Bornim zu hohe Miete für seinen Wohnraum und zu hohe Pacht für sein Gemüseland bezahlen müsse. Nachprüfungen durch die Kommission haben dazu geführt, daß die Miete von DM 150,-- auf DM 93,-- reduziert worden ist, wohingegegen der Pachtpreis für das Gemüseland bei nochmaliger genauerer Nachrechnung doch als angemessen zu bezeichnen ist. 
Sitzung der Kommission am 7.10.49.

Es wurden behandelt die Feststellungen der Kommission in den Ortsteilen Teltower Vorstadt, Grube, Nattwerder, Schlänitzsee, Fahrland.

In der Teltower Vorstadt sind 128 Morgen aufgeteilt worden zu 476 Parzellen von $300 \mathrm{qm}$ bis zu 6 Morgen. / Trotz der bestehenden Vorschrift, nach welcher alle diejenigen, die noch anderweit beschäftigt sind, aus der Bodenreform nicht mehr als 2 Morgen zugeteilt erhalten sollten, durften, wie der Vorsitzende der Gemeindebodenkommission berichtet, auf Grund einer seinerzeitigen Rücksprache mit Minister Rau Flüchtlingen und Umsiedlern - vorwiegend solchen, die mit Viehbeständen hier eintrafen und eine Futtergrundlage nötig hatten - Landstücke bis zu 6 Morgen zugeteilt werden. / Zu überprüfen sind jedoch noch Landzuteilungen von je 6 Morgen an die Fuhrgeschäfte T. und M. / Ebenso sind noch Landzuteilungen an einen Regierungsangestellten $S c h[\ldots],[\ldots$ (Adresse)], zu überprüfen, die zunächst etwas undurchsichtig erscheinen. / Die Unterbringung der Umsiedler im Ortsteil ist gut.

In Grube haben einige Handwerker mehr als 2 Morgen zugeteilt bekommen. Die Fälle sind jedoch jeweils so gelagert, daß die Kommission zu dem Ergebnis kommt, es dabei bewenden zu lassen. [Bl. 37r] / Eine Jungbäuerin, Frau H[... ], deren Mann gefallen ist, hat 5 Morgen bekommen. Ihr Vater hat eine Wirtschaft von etwa 70 Morgen. Sie selbst arbeitet auf dem Hofe des Vaters mit, und von dort werden auch die 5 Morgen der Frau $\mathrm{H}[\ldots]$ mit bewirtschaftet. Der Fall soll an Ort und Stelle nochmals überprüft werden.

Die Umsiedlerfrage konnte durch Erstellung von Neubauerngehöften gut gelöst werden. Die Umsiedler sind gut untergebracht. / Das Gutshaus soll Schule werden, das alte Schulhaus will die VdgB übernehmen. Aus dem Gutshaus müssen 6 Familien ausquartiert werden. Das Wohnungsamt hat den Fall bereits aufgegriffen. Die Umquartierung macht aber mangels Ersatzraumes noch große Schwierigkeiten.

Die Zusammenarbeit mit der Bevölkerung ist gut. Jeden Monat werden 1 bis 2 gut besuchte Bauerversammlungen abgehalten. Schwierigkeiten macht nur das Holzfahren, weil weder Pferde- noch Wagenmaterial ausreichend vorhanden ist. Bemängelt wird ausserdem, daß die Stadtfuhrleute für ihre Pferde bei Sondereinsätzen extra Futter erhalten, während die Landbevölkerung nichts bekommt. / Die Besitzverhältnisse des Ortsvorstehers, des Vorsitzenden der Gemeindebodenkommission und der VdgB wurden durchgesprochen. Es ergaben sich keine Beanstandungen.

Über den Ortsteil Schlänitzsee soll in einer späteren Sitzung verhandelt werden.

\section{Ortsteil Fahrland}

3 Fälle von Landverpachtungen an Mitglieder der Gemeindebodenkommission müssen noch etwas eingehender überprüft werden, da diese Verpachtungen Unwillen in der Bevölkerung hervorgerufen haben.

An Umsiedlern hat Fahrland 236 Personen, deren Unterbringung nicht zu beanstanden ist. [Bl. 37v] / An landwirtschaftlichen Geräten fehlen im Orte vor allem Dreschkästen. Die vor- 
handenen haben eine zu geringe Leistungsfähigkeit. Das Kommissionsmitglied Wöhler von der VdgB will dafür sorgen, daß Abhilfe geschaffen wird. / Die Bauernversammlungen wurden laufend abgehalten und gut besucht, Schwierigkeiten bereiten die vielen Statistiken, die kurzfristig verlangt werden. / Auch für diese Gemeinde wurden die Besitzverhältnisse des Ortsvorstehers, des Vorsitzenden der Gemeindebodenkommission und der VdgB durchgesprochen. Es ergaben sich keine Beanstandungen.

Seitens der Kommissionsmitglieder Steudtner (Vertreter der Stadtverwaltung) und Krautz (Kriminalpolizei) wird ein Bericht über die Überprüfung der Wirtschaft des VdgB-Vorsitzenden der Gemeinde Bornstedt - Worgull - vorgelegt. Aus diesem geht u. a. hervor, daß Frau Worgull die beiden Kommissionsmitglieder als „Gesindel“ und "Schweine“ bezeichnet und ihren Mann aufgefordert hat, „das Gesindel vom Hofe zu werfen“. Wegen öffentlicher Beleidigung dieser beiden Kommissionsmitglieder wird Strafantrag bei der Staatsanwaltschaft gestellt werden. Der Vertreter der VdgB in der Kommission ist bereits gebeten worden, Herrn Worgull von seinem Posten als Vorsitzender der VdgB in der Gemeinde Bornstedt ablösen zu lassen. Hinzu kommt noch, daß Worgull seine Wirtschaft stark vernachlässigt und verwahrlosen läßt und somit allen anderen Landwirten ein recht schlechtes Beispiel gibt.

Am 18.10.49 fand eine Sitzung der Sonderkommission statt, auf der folgende Punkte besprochen wurden: / Der hauptamtlich seitens des Rates der Stadt angestellte Ortsvorsteher Metting in Golm hat durch die Bodenreform 2,47 ha zugeteilt erhalten, jedoch vor seiner Einstellung als Ortsvorsteher. Dazu gepachtet hat er 2,5 ha. Er bezieht ein Nettogehalt von DM 194.- und da er Angestellter ist (Ortsvorsteher), die Lebensmittelkarte III und die entsprechende Punktkarte. Hierin wird ein ungerechtfertigter Vorteil gegenüber danderen Neubauern gesehen. Ausserdem wird darauf hingewiesen, daß Metting zur Zeit, als er noch Vorsitzender der Kreisvereinigung der gegen- [Bl. 38r] seitigen Bauernhilfe war, bei der Aufteilung von Vieh und Geräten auf seinen Antrag hin Pferd und Wagen erhalten hat. Hierzu hätte er sich die Bestätigung der übergeordneten Stelle - des Landesverbandes der VdgB - einholen müssen. Dieses habe er jedoch nicht getan. - Der Kreissekretär der VdgB will die Angelegenheit noch weiter überprüfen.

Der Kommissionsvorsitzende ist ersucht worden, folgenden Fall in dem Bericht an die Landeskontrollkommission mit aufzunehmen: / Herr Z[... - z. Zt. in gehobener Stellung beim Landespreisamt tätig - habe 1945 oder [19]46 durch die Bodenreform in Heesen ${ }^{2332}$, Bahnstation Gutengerbedorf ${ }^{233}$, Kr. Ruppin, folgende Ländereien erhalten:

4 Morgen Ackerland

2 Morgen Wiese

4 Morgen Obstgarten

5 Morgen Wald,

2332 [Muss heißen: Häsen.]

2333 [Muss heißen: Gutengermendorf.] 
ausserdem 2 Kühe, 2 Schweine und Federvieh. Das Vieh sei bei einem Fräulein P[... ] in Gutengerbedorf ${ }^{2334}$ untergestellt. / Es wird die Frage aufgeworfen, unter welchen Umständen s[einer].z[ei]t. diese Zuteilungen erfolgt sind und ob sie mit der jetzigen Stellung des Herrn Z[...] in Einklang zu bringen sind. Es wird für richtig gehalten, daß entweder die Landeskontrollkommission selbst oder die Sonderkommission des Kreises Ruppin eine Überprüfung dieses falles vornimmt.

Von den Kommissionsmitgliedern werden noch verschiedene Landzuteilungen in Golm an Gewerbetrebende zur Sprache gebracht, die noch an Ort und Stelle überprüft werden sollen.

Überprüfungen in Golm am 24.10.1949

2 Milchhändler und 1 Stellmacher haben aus der Bodenreform mehr als 2 Morgen Land erhalten und zwar über 2 ha. Es handelt sich durchweg um kinderreiche Familien, ausserdem um Bodenklasse 7. Da alle Beteiligten ihr Land gut bestellen und sich eines guten Rufes in der Gemeinde erfreuen, soll keine Änderung beantragt werden. [Bl. 38v]

Es bestätigt sich, daß ein Umsiedler mit 5-köpfiger Familie sehr schlecht untergebracht ist, wohingegen bei dem Bauern, bei dem er arbeitet, an einer nahezu fertiggestellten aufgestockten Wohnung nicht weitergearbeitet wird, weil der Bauer kein Interesse daran hat, den Umsiedler bei sich aufzunehmen, Wohnungsamt und Bauamt sind angewiesen worden, sich sofort dieses Falles anzunehmen.

Des weiteren wurde festgestellt, daß die fraglichen 2 leerstehenden Wochenendhäuser am Zernsee (S. 3 des Berichtes vom 15.10.49) sich zu einer Zwangsvermietung nicht eignen, da sie in einem Überschwemmungsgebiet liegen und nahezu die Hälfte des Jahres dadurch unbewohnbar sind.

Am 24.10.1949 fanden noch Besichtigungen und Besprechungen in Grube statt. Der Fall H[... muß bereinigt werden, ebenso muß versucht werden, eine Möglichkeit zur Umquartierung der 6 Familien aus dem Gutshause zu finden damit dieses Schule werden kann, wohingegen die alte Schule für die VdgB genutzt werden soll.

\section{(143) Bericht über Selbstverpflichtungen der Neubauern von Dorf Zinna (Neuheim). - [Dorf Zinna], Ende Juli/Anf. August 1951}

BLHA, Rep. 250 Landratsamt Luckenwalde, Nr. 108, Bl.24-27. - Typoskript (Durchschlag), 4 Bl., ohne Unterschrift. - Verfasser ist vermutlich der Vorsitzende der VdgB von Dorf Zinna, dessen auf der Feierstunde gehaltene Rede (B1. 28-30) beigeheftet ist.

Industriearbeiter und Bauern sind natürliche Verbündete für den Kampf um den Frieden. Unter dieser Losung steht die gesamte Arbeit der Siedlungsgemeinde Dorf Zinna. Dorf Zinna, wo kein Bauer den Boden bearbeiten durfte, sondern die Bauern ausgesiedelt wurden und ein einstmals blühendes Dorf in eine tote Gemeinde verwandelt war, ist auferstanden, aus Ruinen, die uns 12 Jhre Hitlerdiktatur zurückliess. 
Umsiedler aus der Tschecho-Slowakei und zwar aus der Gegend von Gablonz haben im Jahre 1946 in Dorf Zinna Heimat gefunden. Unter schwierigen Verhältnissen und ohne Klagen und Murren gingen die Gablonzer Glasarbeiter daran, sich ihre alte Industrie aufzubauen. Sie gründeten eine Produktionsgenossenschaft und nahmen die Produktion auf. Vom Rohstoff bis zum fertigen Schmuckstück wird alles in eigenen Werkstätten hergestellt. Auf Wunsch der einzelnen Mitglieder der Genossenschaft wurde diese dann im Jahre 1950 in das Eigentum des Volkes überführt. Der volkseigene Betrieb Gablona ist durch seine umfangreiche und vor allen Dingen einzigartige Fabrikation über die Grenzen Deutschlands hinaus bekannt und geschätzt. Auf der Leipziger Herbst- bezw. Frühjahrsmesse ist es Schweden, das immer wieder seinen Bedarf für Lüsterbehang bei der Gablona in Dorf Zinna deckt. Aber nicht nur Industriearbeiter fanden eine sofortige Arbeit und eine gesicherte Existenzgrundlage in Dorf Zinna, auch Bauern pflügten und bearbeiteten wieder den während der Nazizeit jahrelang brachgelegenen Boden. Auf Grund des vorbildlich aufgestellten Dorfwirtschaftsplanes, dem Gesetz des Dorfes, sollte das Soll in Roggen bis zum 30.7.51 vorfristig abgeliefert werden. Mit dieserr Zielsetzung waren aber die Bauern noch nicht zufrieden, sondern sie setzten sich zusammen und kamen nach eingehender Diskussion überein, dass es unbedingt ermöglicht werden muss, den Termin noch früher zu erfüllen.

In engster Zusammenarbeit mit der MAS Fröhden, durch Unterstützung des Patenschaftsbetriebes VEB Plüschweberei Kloster Zinna und der Industriearbeiter aus der Gemeinde selbst gelang es durch Gemeinschaftsarbeit und gemeinsame Ablieferung bereits am 20.7.51 das gesamte Getreidesoll (Futtergetreide wurde ausgetauscht für Roggen) vorfristig zu erfüllen. Mit dieser grossartigen Leistung ist die Gemeinde Dorf Zinna die erste Gemeinde des Kreises Luckenwalde und darüber hinaus die erste Gemeinde der Deutschen Demokratischen Repulik, die das gesamte Getreidesoll vorfristig erfüllte. Mit dieser Leistung gaben sich aber die Bauern nicht zufrieden. Sie wissen, dass zur Sicherung der Volksernährung und zur Festigung des Friedens auch die neue Schälfurche und der Zwischenfruchtanbau gehören. Am 28.7.51 konnte Dorf Zinna melden: Schälfurche auf der gesamten Getreideanbaufläche zu $60 \%$ erfüllt, Zwischenfruchtanbau mit $300 \%$ übererfüllt. [Bl. 24v]

Zur Unterstützung der III. Weltfestspiele der Jugend und Studenten in Berlin ${ }^{2335}$ sind die Neubauern von Dorf Zinna folgende Verpflichtungen eingegangen: / [...] [Folgt namentliche Liste von 16 Personen mit Mengen- und Gewichtsangaben zu den Selbstverpflichtungen nebst Summenbildung $][\ldots][\mathrm{Bl} .25 \mathrm{r}][\ldots]$

Im Rahmen einer Feierstunde, bei der das Kreiskulturorchester und das Kreiskulturensemble für die III. Weltfestspiele mitwirkten, wurde den Bauern vom Landrat des Kreises eine Geldprämie von DM 1000.- für ihre Leistungen überreicht. Im Namen der Landesregierung Brandenburg dankte der Minister für Landwirtschaft Beseler ${ }^{2336}$ den Bauern und überreichte Bü- 
cher im Werte von DM 250.-. Das VEAB Kreiskontor übergab den Bauern DM 100.- und die Vereinigung der Verfolgten des Naziregimes übergaben gleichfalls DM 100.-. Die Prämie von DM 1000.- werden die Bauern nun nicht unter sich aufteilen. Sie werden genau so, wie ihre Leistung nur durch Gemeinschaftsarbeit ermöglicht wurde, eine Gemeinschaftseinrichtung schaffen - ein Dorfwaschhaus mit elektrischer Waschmaschine wird für dieses Geld erstellt werden, um den Frauen der gesamten Gemeinde die schwere Arbeit des Waschens wesentlich zu erleichtern.

Durch gemeinsame Arbeit von Industriearbeitern und Bauern wurde die erste Getreideernte des Volkswirtschaftsplanes 1951 vorfristig erfüllt. Durch gemeinsamen konsequenten Kampf für den Frieden errichtete sich Dorf Zinna ein besseres Leben in Wohlstand und im Glück. Die Bauern von Dorf Zinna gaben die Versicherung ab, alles daranzusetzen, um ihre [Bl. 25v] Leistungen zu steigern. Sie wissen, sie schaffen damit die Voraussetzungen für die Steigerung des Lebensstandartes [so!] der gesamten Bevölkerung und leisten damit einen entscheidenden Friedensbeitrag.

Ihre Losung lautet: „Vorwärts zu neuen Erfolgen,

Wir Bauern von Dorf Zinna

Stehen auf Friedenswacht.“

[B1. 26-27 Doppel der Selbstverpflichtungsliste, jedoch mit geändertem Kopf:]

[B1. 27] Selbstverpflichtungen der Bauern von Dorf-Zinna zu Ehren der Weltjugendfestspiele in Berlin vom 5.-19.8.51 und zu Ehren des gesamtdeutschen Bauerntages am 3.12.1951 in Leipzig. / [...]

\section{Vertriebenenverwaltung und Kirchen (1945-1949)}

\subsection{Provinzial-/Landesregierung, Kreise, Städte und Gemeinden (1946-1949)}

\section{(144) Verzeichnis der Kreisbeauftragten für Umsiedler in Brandenburg. - [Berlin], [1946]}

BArch, DO 2 Zentralverwaltung für deutsche Umsiedler, Nr. 50, Bl. 179. - Typoskript. - Offenbar erstellt von der ZVU. - Undatiert [aus dem Zusammenhang erschlossen: 1946]. - Die Tabelle umfasst 6 Spalten, von denen die beiden letzten hier weggelassen wurden, da sie keine individuellen Angaben enthalten. In der 5. Spalte „Umsiedlerausschuss“ heißt es für alle Kreise und Städte „Umsiedlerausschüsse sind in jedem Kreis vorhanden.“ In der 6. Spalte „Betreuung d. Umsiedler durch Sozialamt, Wohnungsamt usw.“ heißt es für alle: „In sämtlichen Kreisen und kreisfreien Städten befinden sich Sachbearbeiter f. Umsiedlerfragen, die den Sozialämtern unterstellt sind.“ - Auf Bl. 103 finden sich die Angaben der 1. bis 3. Spalte gleichlautend im Rahmen einer Gesamtliste für mehrere SBZ-Länder (Bl. 103-106), der Titel „Kreisbeauftragte für Umsiedler“ findet sich nur hier. - Abkürzung: Oberbgmstr. = Oberbürgermeister. 


\begin{tabular}{|c|c|c|c|}
\hline Stadt und Landkreis & $\begin{array}{l}\text { Ort der Umsiedler[-] } \\
\text { Betreuungsstelle }\end{array}$ & $\begin{array}{l}\text { Name des Verantwort- } \\
\text { lichen f. d. Umsiedler- } \\
\text { betreuungsstellen }\end{array}$ & $\begin{array}{l}\text { Unterstellungs- } \\
\text { verhältnis }\end{array}$ \\
\hline Angermünde & Angermünde & Herr Wolter & Landrat \\
\hline Angermünde & Pinnow & Herr Wolter & Landrat \\
\hline Beesk[ow-]Storkow & Küchensee & Herr Götze & Landrat \\
\hline Calau & & Herr Laurisch & Landrat \\
\hline Cottbus & & Herr Apelt & Oberlandrat \\
\hline Guben & Guben & Herr Winkler & Oberbgmstr. \\
\hline Luckenwalde & Luckenwalde & Herr Krause & Landrat \\
\hline Lebus & Fürstenwalde & Herr Bergemann & Landrat \\
\hline Luckau & Finsterwalde & Herr Liebig & Landrat \\
\hline Lübben & & Herr Sömisch & Landrat \\
\hline $\mathrm{N}[\mathrm{ie}] \mathrm{d}[\mathrm{er}]$-Barnim & Rüdersdorf & Herr Köhler & Landrat \\
\hline $\mathrm{Ob}[\mathrm{er}]-$ Barnim & & Herr Laube & Landrat \\
\hline Osthavelland & Falkensee & Herr Mielack & Landrat \\
\hline Osthavelland & Hennigsdorf & Herr Mielack & Landrat \\
\hline Ostprignitz & & Herr Scholz & Landrat \\
\hline Prenzlau & & Herr Karstädt & Landrat \\
\hline Ruppin & & Herr Schmidt & Landrat \\
\hline Spremberg & Spremberg & Herr Greischel & Landrat \\
\hline Teltow & Saalow & Herr Nikolai & Landrat \\
\hline Templin & Postheim & Herr Lehmann & Landrat \\
\hline Templin & Engelsburg & Herr Lehmann & Landrat \\
\hline Westhavelland & Rathenow & Herr Zimmermann & Landrat \\
\hline Westprignitz & Glöwen & Herr Naujoks & Landrat \\
\hline Zauch-Belzig & Belzig, Lübnitzer Str. & Herr Ziegenhagen & Landrat \\
\hline Zauch-Belzig & Treuenbrietzen-Landesanstalt & Herr Ziegenhagen & Landrat \\
\hline Zauch-Belzig & Treuenbrietzen-Selterhof & Herr Ziegenhagen & Landrat \\
\hline Zauch-Belzig & Belzig-Klinkengrund & Herr Ziegenhagen & Landrat \\
\hline Brandenburg & Quenz & Herr Boldt & Oberlandrat \\
\hline Cottbus & & Herr Lucke & Oberbgmstr. \\
\hline Eberswalde & Eberswalde & Herr Lück & Oberbgmstr. \\
\hline Forst & Forst & Herr Müller & Oberbgmstr. \\
\hline Frankfurt/O. & Gronenfelde & Herr Koch & Oberbgmstr. \\
\hline Potsdam & & Herr Reising & Oberbgmstr. \\
\hline Rathenow & & Frau Streuber & Oberbgmstr. \\
\hline Wittenberge & & Herr Dierke & Oberbgmstr. \\
\hline
\end{tabular}




\section{(145) Vorschlagsliste der SED für die Mitglieder des Provinzialausschusses für Heimkehrer und Umsiedler. - Potsdam, 14. August 1946}

BLHA, Rep. 333 SED-Landesleitung Brandenburg, Nr. 574, Bl. 40. - Typoskript (Durchschlag), 1 Bl., mit Paraphe „Su“ (Gerda Sucker). - Kein Absender, da in Ausfertigung offenbar Kopfbogen verwendet. - Adresse: „An die / Provinzialverwaltung / zu Hd. Herrn Friedrichs / Potsdam“. - Geschäftszeichen „Su/zo“, darunter „Arbeit und Sozialfürsorge“. - Datierung: „14. August 1946“. - Betreff: „Betrifft: Provinzialausschuss für Heimkehrer und Umsiedler.“ - Unterschrift „Sozialistische Einheitspartei Deutschlands / Der Provinzialvorstand / Abt. Arbeit und Sozialfürsorge / [gez.] Su“. - L. u. Paraphe „S.“ - Hinweis: Vorausgegangen ist ein von Sucker und Bauer unterzeichnetes Schreiben vom 10.8.1946 an das Sekretariat der SED (ebd., Bl. 39), in dem mit Bleistift die noch nicht namentlich benannten Vertreter der LDP und der CDU eingetragen, der „Sachbearbeiter der Abt. Heimkehrer“ der Provinzialverwaltung, Herr Friedrichs, gestrichen und als Vertreter der Abt. Arbeit [und Sozialwesen] der für Wohnungswesen zuständige Herr Menz hinzugefügt ist. - Am linken Rand der untenstehenden Personenliste ist mit Bleistift hinzugesetzt: „Einverständnis lt. Sekr. Sitzung am 12/8.46“.

Wir haben uns bemüht, die Vorschläge für den Provinzialausschuss zusammenzustellen und geben sie Ihnen wie folgt bekannt:

Herbert Thiele

SED

Ferdinand Genske / Potsdam, Waldemarstr. 23 a

LDP

Frau Martha Scharf 337 / Bergfelde (über Bürgermeisterei)

CDU

Frau Emmi Plinz $z^{2338}$

Frauenausschuss

Herr Eckart

FDGB

Fritz Schiller

FDJ

Kollege Krüger

Betriebsrat RAW

Herr Menz

Abt. Arbeit, Provinzialverw.

Wohnungswesen (Name ist noch zu benennen)

Wir bitten Sie, bei diesen Sitzungen eine Vertreterin unserer Abt. Arbeit und Sozialfürsorge Frau [Else] Bauer ${ }^{2339}$ oder Frau [Gerda] Sucker ${ }^{2340}$ beratend teilnehmen zu lassen.

Die erste Sitzung ist von Ihnen einzuberufen und wir schlagen hierfür vor, den Zeitpunkt im Laufe der nächsten Woche zu wählen. / Die erste Sitzung wird sich mit der Konstituierung des

2337 [Geb. 1904 Aschersleben, 1947 MdL Brandenburg, „Orts-, Kreis- und Landesleiterin der Frauenorganisation Königin-Luise-Bund“, wohnt Bergfelde, Siegelstr. 32 (Handbuch des Landtages 1947 (wie Anm. 1064), S. 56, 109).]

2338 [Geb. 1915 Danzig, 1946-1947 MdL Brandenburg (SED, zuvor SPD). „Frauenleiterin des Landesvorstandes [der SED]“, wohnt Potsdam, Margaretenstr. 8 (Handbuch des Landtages 1947 (wie Anm. 1064), S. 55, 108).]

2339 [Siehe Anm. 2267.]

2340 [Geb. 1907 Berlin, 1947 MdL Brandenburg (SED, zuvor KPD), „freireligiös, [...]; Mitglied des Sekretariats des Landesvorstandes der SED. Mitbegründerin und Vorsitzende der Märkischen Volkssolidarität für das Land Brandenburg“, wohnt Potsdam, Gontardstr. 125 (Handbuch des Landtages 1947 (wie Anm. 1064), S. 56, 99 mit Bild).] 
Ausschusses befassen und einen instruktiven Bericht entgegen nehmen./Zur Vorbereitung dieser Sitzung halten wir noch eine Rücksprache mit uns für zweckmässig.

\section{(146) Protokoll der Konferenz der Abteilung Arbeit und Sozialwesen mit dem Vizepräsidenten Rücker. - Potsdam, 12. Oktober 1946 (Auszug)}

BLHA, Rep. 206 Ministerium für Wirtschaft und Arbeit, Nr, 2965, unfol. - Typoskript (Durchschlag), 3 S., ohne Unterschrift. - Auf 1. S. o.1. „Abt. Arbeit und Sozialwesen“, r. „Potsdam, den 12.10.1946/ Hö“. - Überschrift: „Protokoll über die Sitzung mit Herrn Viz[e-].Präs. Rücker am 10.10.46. / Konferenz der Abt. VII“.

Herr Fischer ${ }^{2341}$

Die Struktur der Abt. VII besteht nach dem Sokolowski-Plan jetzt aus 3 Ministerialräten, die auf fachlichem Gebiet Stellvertreter des Abteilungsleiters sind. Die Umsiedler-Abteilung wird von der Abt. VII losgelöst und selbständig. Der Suchdienst wird der Ums[iedler-]Abt. angegliedert. Die Schwierigkeiten in der Abt. VII bestehen hauptsächlich in der Unterabt. Sozialfürsorge. Die Erstellung von Statistiken wird zu leicht genommen. Es muß eine einheitliche Statistik mit der Abt. V und den anderen zuständigen Stellen vereinbart werden, damit die SMA küntig zufriedengestellt wird. / Eine einwandfreie Arbeit der Abteilung kann nur dann gewährleistet werden, wenn kollektiv gearbeitet wird. Die Leiter der einzelnen Unterabteilungen dürfen nicht zu selbständig in Bezug auf den Schriftverkehr mit der SMA und dem Präsidium sein. / Es ist notwendig, daß jeden Donnerstag eine Abteilungsleiterbesprechung stattfindet, um ein allgemeines Bild zu erhalten und die auftretenden Schwierigkeiten nach Möglichkeit zu beseitigen. / [...] [S. 3]

Herr Friederichs / sprach über die noch zu erwartenden 50-75 000 Umsiedler.

Herr Brehmer / führte die Interesselosigkeit der Wohnungsämter in Bezug auf Unterbringungsmöglichkeiten an. Die Baracken sind nicht richtig erfasst und werden unzweckmäßig von den Gemeinden ausgenutzt. / [...]

(147) Arbeitsplan der Abteilung Umsiedler und Heimkehrer im Amt für Arbeit und Sozialwesen des Kreises Beeskow-Storkow für Januar 1947. [Beeskow, Dezember 1946] (Auszug)

BLHA, Rep. 250 Landratsamt Beeskow-Storkow, Nr. 869, unfol. - Typoskript (Durchschlag) ohne Unterschrift, 2 Bl. - Überschrift: „Arbeitsplan für den Monat Januar 1947 / Abteilung Arbeit und Sozialwesen VII“. - Wiedergegeben ist nur der Abschnitt 1.) zur Betreuung der „Umsiedler und Heimkehrer“.

1.)

Weiterführung der Umsiedleraktion, insbesondere Aufnahme der den Lagern des Bezirkes zugewiesenen Umsiedlertransporte.

Eingemeindung der Umsiedler, Wohnraum- und Arbeitsbeschaffung für die. 
Überwachung der notwendigen Maßnahmen durch Kreisumsiedlerausschuß und Ortsumsiedlerausschüsse in den Gemeinden, unter besonderer Berücksichtigung des Befehls der SMA über Kontrolle der Unterbringung, Versorgung und Arbeitsverhältnisse der Umsiedler.

Kontrolle der angeordneten sanitären Maßnahmen in den Umsiedlerlagern zur Verhütung von Seuchenerkrankungen. (Vergleiche Anweisung an die Lagerärzte Nr. 10).

Dekadenabrechnung über Transportbewegungen, Lebensmittelverbrauch und Versorgung der Umsiedler. (Berichterstattung gem. Verfg. der Provinzialverwaltung, Amt für deutsche Umsiedler, vom 15.11.1946, nach Wirtschaftsbericht B mit Anlage).

Wöchentliche Berichterstattung gem. Formblatt 1 über sanitäre Arbeit in den Umsiedlerlagern und

monatliche Berichterstattung gem. Formblatt 7 über die Eingemeindung der Umsiedler und ihre Berufsgliederung und nach Formblatt 8 über die Tätigkeit der Arbeitsausschüsse.

Monatliche Abgabe der Protokolle der Wirtschaftsprüfungskommission und der Kreisärzte über die Umsiedlerlager.

Betreuung der Heimkehrer, insbesondere weitere Werbung von Patenstellen für elternlose, junge Heimkehrer.

Bearbeitung der Anträge auf Zahlung einer einmaligen Unterstützung an arbeitsunfähige und mittellose Umsiedler gem. Befehl Nr. 314 der SMA und Runderlass Nr. 117 der Provinzialverwaltung. / [...]

\section{(148) Jahresbericht der Abteilung Umsiedler und Heimkehrer im Amt für Arbeit} und Sozialwesen des Kreises Beeskow-Storkow für 1946. - Beeskow, 7. Janauar 1947

BLHA, Rep. 250 Landratsamt Beeskow-Storkow, Nr. 869, unfol. - Typoskript (Durchschlag) mit Unterschrift „I.A. [gez.] Götze“, 1 Bl. - L. o.: Gedruckter Kopfbogen „Der Landrat/des Kreises Beeskow-Storkow / Amtssitz Beeskow / Aktenzeichen [masch.:] VII/U/C 3. / Amt für Arbeit und Sozialwesen / Abt. Umsiedler und Heimkehrer“. - R. o. Datierung: „Beeskow, den 7.1.[194]7“. - Überschrift: „Jahresbericht - 1946“. - Unterschrift „I.A. [gez.] Götze“, danbeen Stempel „Der Landrat des Kreises Beeskow-Storkow / Umsiedlerbetreuungsstelle“.

Die Abt. Umsiedler und Heimkehrer im Amt für Arbeit und Sozialwesen wurde Anfang des Jahres 1946 auf Grund der verstärkten Aussiedlung der Deutschen aus den besetzten Gebieten mit neuen verantwortungsvollen Aufgaben betraut.

Das Umsiedlerlager Küchensee wurde daraufhin neu reorganisiert und hat mit einem Stammpersonal von 36 Arbeitskräften insgesamt 3090 Männer[,] 5429 Frauen[,] 3084 Kinder durchgeschleust. Von denen waren mit Krankheiten behaftet 1 Lungen-TBC, 5 Knochen-TBC[,] 3 Ruhr[,] 3 Masern[,] 32 Go. $^{2342}$ [,] 2 Lues[,] 123 verschiedenen. Insgesamt hat der Kreis einen 
derzeitigen Bestand von 25475 Umsiedler[n]. Von denen sind: 20034 in festen Wohnungen[,] 3270 in Notwohnungen[,] 171 in Baracken untergebracht.

Um diesen Umsiedlern, die in unserem Kreis eine neue Heimat gefunden haben, mit den Stammeinwohnern gleichzustellen und Ihnen am Aufbau einer Existenz zu helfen, wurde in jeder Gemeinde unseres Kreises ein Umsiedlerauschuss gegründert, der die Interessen der Umsiedler in jeder Hinsicht vertritt und mit den ebenfalls gegründeten Wohnungsausschüssen Hand in Hand für die Verbesserung der Wohnungsverhältnisse arbeitet.

Als Anfang August vorigen Jahres auf die Bitte der SED von der U.d.S.S. R. 120000 deutsche Kriegsgefangene entlassen wurden, war es notwendig, diesen Heimkehrern, die mitunter jahrelang von der Heimat fern waren, zielewusst zu lenken und ihnen das Wiedereinfinden in geordnete Verhältnisse zu erleichtern. Es wurde die Abt. Heimkehrer ins Leben gerufen, die bisher für die Betreuung von 1138 aufgenommenen Heimkehrern, von denen 75 Heimatlose waren, die unserer besonderen Betreuung unterstehen, aus besonderen Mitteln RM 38 806,37 ausgegeben hat. Für kranke Heimkehrer wurde ein Krankenhaus in Friedersdorf eingerichtet.

Am 15.11.1946 wurde eine Annahmestelle für den Suchdienst für vermisste Deutsche eingerichtet, um den Umsiedlern das Wiederfinden ihrer Angehörigen zu erleichtern. Angenommen wurden bisher 80 Suchanträge. [Bl. v]

Arbeitsplan für das Jahr 1947

Für das Jahr 1947 ist geplant die Arbeits- und Wohnungslage der Umsiedler noch weiter zu bessern um den Umsiedlern einen wirklich festen Wohnsitz und ausreichende Existenzmöglichkeit zu geben. Verbunden ist damit, nach vollzogener Existenzmöglichkeit die Mitarbeit am Aufbau unseres Vaterlandes für eine wirkliche Demokratie.

Im Umsiedlerlager Küchensee ist vorgesehen die Verbesserung der sanitären Einrichtung.

Weitere Planungen ergeben sich aus der Entwicklung des Umsiedlerwesens.

\section{(149) Tätigkeitsbericht der Abteilung Umsiedler und Heimkehrer im Amt für Arbeit und Sozialwesen des Kreises Beeskow-Storkow für Januar 1947. - Beeskow, 4. Februar 1947}

BLHA, Rep. 250 Landratsamt Beeskow-Storkow, Nr. 869, unfol. - Typoskript (Durchschlag) mit Kopierstift-Unterschrift, 1 Bl. - L.o. (fehlt Landkreisname wegen Verwendung eines Kopfbogens) „VII/U/C 3. / Amt für Arbeit und Sozialwesen / Abt. Umsiedler und Heimkehrer“. - R. o. Datierung: „4.2.[194]7“. - Oben mittig (Kopierstift) Verteiler „Landrat“. - Überschrift: „Bericht über die Tätigkeit der Abt. Umsiedler und Heimkehrer in der Zeit vom 1.1. bis 31.12.1947“. - Unterschrift: „I.A. Go ...[?]““

Im Monat Januar war ein verstärkter Zustrom an Heimkehrern und Umsiedlern zu verzeichnen. Der Kreis hat einen Gesamtbestand von 24065 Umsiedler[n].

Von dem am 1.1.1947 eingetroffenen Transport Nr. 171/393 aus Schlawe/Pommern wurden in unserem Kreis bisher 453 Personen eingemeindet. Der Rest des Transportes wurde wie folgt weitergeleitet: 


$\begin{array}{ll}\text { Kreis Teltow } & 197 \\ \text { Kreis Spremberg } & 397 \\ \text { Kreis Luckenwalde } & 378 .\end{array}$

Die von dem Transport verbliebenen Waisenkinder wurden nach Perleberg und die alten Leute in das Siechenhaus Teupitz weitergeleitet.

Die kulturelle Betreuung des Transportes während der Lagerzeit war vorbildlich und wurde unter Beteiligung der Parteien, FDJ und Frauenausschuss durchgeführt.

Für den Suchdienst für vermisste Deutsche in der sowjetischen Besatzungszone wurden in unserem Kreis vier weitere Annahmestellen (Ketschendorf, Friedersdorf, Wend[isch]-Buchholz, Neu-Zittau) eingerichtet.

Die lfd. Termine wurden ordnungsgemäss erledigt.

\section{(150) Bericht über die Tagung der Kreisumsiedlerämter am 25. September 1947 in Potsdam. - Potsdam, 29. September 1947}

BLHA, Rep. 333 SED-Landesleitung Brandenburg, Nr. 574, Bl. 199 (alt 298). - Typoskript. - U.1. KopierstiftParaphe „We“ für Wernsdorf. - O.1. Name des Berichterstatters: „Wernsdorf“. - R. o. Datierung: „Potsdam, den 29.9.1947“. - Überschrift: „Bericht von der Tagung der Kreisumsiedlerämter am 25.9.1947 in Potsdam.“ „Kreisumsiedlerämter“ mit Bleistift unterstrichen und rechts daneben gesetzt „Landes-Umsiedler-Ausschuß“. - R.o. (blaue Tinte): „Seibt / 30.9.47.“2343

Herr Minister Schwob eröffnete die Tagung. Er ging auf das Umsiedlerproblem kurz ein, auf die Notwendigkeit der angekündigten Sammlung und betonte, dass die endgültige Lösung aller Fragen mit der Einheit Deutschlands verbunden ist.

Danach sprach Herr Ministerialrat Friedrichs. Er gab an Hand von Beispielen einen Bericht über die Arbeit der einzelnen Kreise und seiner Abteilung. Er beklagte sich, dass allgemein die Abteilung nicht die Anerkennung der anderen Dienststellen geniesst, da dass [so!] Umsiedlerproblem nicht ernst genug genommen wird. Er wird alles daran setzen, diese Anerkennung zu erringen.

Da die Umsiedlung als beendet betrachtet werden kann, stehen folgende Aufgaben im Vordergrund. Es gilt, die Umsiedler zu verringern, d. h. ihnen die neue Heimat zu schaffen, so dass sie sich nicht mehr als Umsiedler fühlen. / Es müssen neue Arbeitsstätten geschaffen werden, da ja nicht immer Arbeitsstätte und Wohnmöglichkeit zusammenliegen. / Eine Vermehrung der Umsiedlergenossenschaften muss angestrebt werden. / Berichterstattung und Mitarbeit der Kreise muss besser werden. Die besten 10 Orte jedes Kreises sollen genannt werden. Eine bevorzugte Belieferung mit Hausrat und Spinnstoffen dieser Orte, wo Umsiedlerausschuss gut arbeitet, wird durchgeführt. 
In der Diskussion kommt zum Ausdruck, dass auch die Kreisumsiedlerämter gegenüber den Landräten auf zu wenig Verständnis stossen und mit grossen Schwierigkeiten zu kämpfen haben. So ist es die Benzinfrage, die überall zu Ungunsten der Umsiedlerämter bearbeitet wird. Nur Luckenwalde kann von einer guten Zusammenarbeit berichten.

Von der Zentralverwaltung sprach Vizepräsident Daub, der eine klare politische Richtlinie gab. Die Zentralverwaltung für Umsiedler wird für die „Umsiedlerwoche“ Referenten stellen.

Nach der Bekanntgabe der Richtlinien für die Sammelaktion sprachen die einzelnen Kreise zu dieser Angelegenheit. Es war zu ersehen, dass sich alle Kreise schon damit beschäftigt haben und zum Teil einige Vorschläge machten. Westprignitz will Hauslisten ausgeben, in denen sich alle entweder so oder so eintragen sollen. Potsdam lässt bei jeder Kinovorstellung einen Vertreter des Umsiedlerausschusses sprechen. Spremberg hatte schon eine derartige Sammlung, Es sind immer die gleichen, die etwas geben. Ein grosser Teil verschliesst sich. Luckau will massgebende Personen sammeln lassen. Brandenburg lässt Hausobleute sammeln. Herr Friedrichs bringt dann noch zum Ausdruck, dass in der nächsten Sitzung des Landtags zur Umsiedlerwoche Stellung genommen wird und sicher Beschlüse gefasst werden, die der Sammlung eine grosse Unterstützung sein werden.

\section{(151) Aufgabenbereich und Entwicklung der für Umsiedler und Heimkehrer zuständigen Provinzialbehörde. - Potsdam, 23. Juni 1948 (Auszug)}

BLHA, Rep. 203 MdI, Nr. 1166, Bl. 1. - Auszug aus „Historischer Bericht. Beginn der Umsiedlung 1945 bis einschl. Mai 1948“, Abschnitt „A. Organisatorische Arb[eit]“. Potsdam, 23. Juni 1948. - Typoskript (Durchschlag), 2 S.

\section{$\mathrm{ZuA} 1$.}

Nach dem am 1.7.1945 begonnenen Neuaufbau der Provinzialverwaltung für Brandenburg, der späteren Landesregierung, wurde unter anderem befehlsgemäß in der Abteilung VII - Arbeit und Sozialwesen - eine besondere Unterabteilung VII/2 - Amt für deutsche Umsiedler - für die sich nach immer mehr verstärkende Umsiedler- und Heimkehrer-Aktion gebildet. Dieser Abteilung oblag der Auffang, die Erfassung und Lenkung aller Umsiedler und Heimkehrer und zwar sowohl der zahlreichen Einzelgänger, wie auch der in Transporten eintreffenden, die Durchführung einer Quarantäne, die Verteilung und Weiterleitung nach anderen Ländern oder in die Heimatorte und neuen Wohnorte innerhalb Brandenburgs. Bis zur Eingemeindung bezw. bis zum Abtransport nach anderen Ländern mußten die Massen der Umsiedler und Heimkehrer untergebracht, verpflegt, in sanitärer, wirtschaftlicher und kultureller Beziehung betreut, sowie mit Transportzügen oder Lastkraftwagen an- und weitertransportiert werden. Bei den Eingemeindungen mußten die Unterbringungs- und Arbeitsbeschaffungsmöglichkeiten berücksichtigt, auch mußte späterhin für die Verbesserung der Unterbringung und Schaffung neuer Beschäftigungsmöglichkeiten gesorgt werden.

Entsprechend diesen nur im allgemeinen aufgezählten großen Aufgaben wurde diese Unterabteilung in folgende Arbeitsgebiete eingeteilt: 
I. Leitung des gesamten Amts,

II. Organisation, Bevölkerungspolitik, Ansiedelung, Transport und Statistik,

III. Wirtschaft und Versorgung,

IV. Heimkehrer,

V. Verwaltung und Finanzen,

VI. Gesundheitswesen,

VII. Suchdienst.

Diese Einteilung ist während der ganzen Berichtszeit im allgemeinen aufrecht erhalten worden bis auf IV - Heimkehrer -, welches Arbeitsgebiet anfangs 1947 aufgegeben worden ist und seither von den anderen Arbeitsgebieten mit bearbeitet wird. Ferner ist das Personal des Arbeitsgebietes VI - Gesundheitswesen - im Februar 1948 an das Landesgesundheitsamt abgegeben worden, von wo aus dieses Arbeitsgebiet jetzt miterledigt wird.

Am 1.10.[19]46 ist die damalige Unterabteilung Amt für deutsche Umsiedler, zur unabhängigen und selbständigen Abteilung für Umsiedler und Heimkehrer im Ministerium für Arbeit und Sozialwesen erhoben worden.

Das zur Durchführung der vielfachen Organisationsarbeiten seit 1945 vorgesehene und notwendige Planpersonal der Abteilung, ist aus der nachfolgenden Zusammenstellung zu A 1 zu ersehen. [Bl. 1v:]

ZuA 2.

Als ausführende bezw. mitwirkende Organe für die Bewältigung der unter A 1 erwähnten zahlreichen Aufgaben wurden die Stadt- und Landkreise bestimmt, die auftragsgemäß zunächst zahlreiche Lager einrichteten. Meist handelte es sich um ehemalige Arbeitslager, Wehrmachtlager und dergl., aber auch um Schulen, Säle, Fabrikräume u. s. w., die oft nur wenig gute und zahlenmäßig nur geringe Unterbringungsmöglichkeiten boten. Ende des Kalenderjahres 1945 waren insgesamt 84 Lager mit einer angeblichen Belegungsfähigkeit für 128000 Personen erfaßt.

Nachdem die Umsiedleraktion in geregelte Bahnen gelenkt worden war, wurde zunächst veranlaßt, daß alle weniger guten und vor allem die kleinen Lager aufgegeben, andere ausgebaut und in ihren Einrichtungen verbessert wurden. Ferner wurden Anzahl und Kapazität fortan je nach dem Umfang der Umsiedler- und Heimkehreraktionen den Bedürfnissen angepaßt. In Auswirkung dieser Maßnahmen schwankten die Zahlen im Frühjahr und Sommer zunächst noch. Seit Juni 1946 konnte aber die im Winter 1945/46 bereits stark herabgesetzte Anzahl der Lager nach und nach ständig weiter vermindert werden und dementsprechend auch das Lagerstammpersonal.

Es wurde unterschieden Umsiedler-, Auffanglager, Quarantänelager und Heimkehrerlager.

Näheres über die Anzahl der Lager und das Lagerpersonal ist aus der nachstehenden Tabelle zu A 2 zu ersehen. 
[Bl. 2: Stellenplan der Abteilung Umsiedler und Heimkehrer der Landesregierung Brandenburg]

[Bl. 3: siehe Lager]

[Bl. 4, 6-8: siehe Statistiken]

[Bl. 5: Übernahme der Heimkehrer]

[Bl. 9: siehe Lager]

[Bl. 10: Finanzierung]

[Bl. 11:]

Punkt 8

Anwendung verschiedener Gesetze und Bestimmungen, Sonderrechte für Umsiedler.

$[\ldots]$

(152) Protokoll der 3. Schulungstagung für Gemeindevertreterinnen im Kreis Luckenwalde. - Luckenwalde, 30. Juni 1948 (Auszüge)

BLHA, Rep. 250 Landratsamt Luckenwalde, Nr. 287. - Typoskript (Durchschlag), 2 S, Abschrift ohne Unterschrift. Bl. 287r o.: „Abschrift“. - L. o. „Der Rat des Kreises / Luckenwalde / Abt. Volksbildung / - Referat Frau -“. - R. o. Datierung „Luckenwalde, den 30.6.1948 / Carlstr. 17“. - Darunter Eingangsstempel „13. Juli 1948“. - Überschrift: „Protokoll".

Zu der am 30.6.1948, 9 Uhr, im Lokal Grassow, Luckenwalde einberufenen 3. Schulungstagung für Gemeindevertreterinnen waren erschienen: / Frau [Frieda] Janis, Kreisfrauenreferentin sowie die eingeladenen Referenten, Herr Kreisrat Jentsch und der Leiter der Abt. Arbeit und Sozialwesen, Herr Schulze. / Es waren weiterhin 20 Gemeindevertreterinnen und 24 interessierte Frauen (des DFD, der Parteien usw.) aus dem gesamten Kreisgebiet anwesend.

Für die Tagung waren folgende Punkte vorgesehen:

1.) Das Wohnungsgesetz und Umsiedlerfragen.

2.) Heimkehrerfragen.

3.) Diskussion.

Die Schulungstagung wurde durch das verspätete Eintreffen verschiedener Gemeindevertreterinnen erst um 10 Uhr durch Frau Janis eröffnet. / Nach der Begrüssung der Anwesenden durch Frau Janis, erteilte diese dem Leiter der Abt. Arbeit u. Sozialwesen, Herrn Schulze, zu Punkt 1 der Tagesordnung, das Wort.

Herr Schulze wies zu Anfang erst einmal auf die Gründe hin, die den Anlass zur Gesetzgebung des Kontrollratgeetzes Nr. 18 (Wohnungsgesetz) gaben und ging dann auf die Aufgaben der Wohnungsbehörden ein, die ihnen gemäss des Wohnungsgesetzes obliegen. / Zusammengefasst erörterte Herr Schulze alle Wohnungsangelegenheiten, die auf Grund des Kontrollratgesetzes Nr. 18 durch die Wohnungsbehörden geregelt werden können, streifte die Zwangsmaß- 
nahmen auf Grund dieses Gesetzes und erklärte die Fälle, in denen die Wohnungsbehörden kein direktes Wohnungsrecht haben. / Er ging dann dazu über, das Wohnungs- und UmsiedlerProblem des Kreises Luckenwalde zu behandeln und brachte zum Ausdruck, dass in bezug auf Wohnraum und Betreuung für Umsiedler alles getan wird, was menschenmöglich ist. / Es wurde weiterhin zum Ausdruck gebracht, dass es in erster Linie die Aufgabe unserer Frauen sein müsste, die bei den polit. Parteien oder anderen Organisationen in Arbeit stehen, den Verwaltungsbehörden bei ihrer Arbeit in Wohnungs- und Umsiedlerfragen behilflich zu sein. / Herr Schulze schloss mit dem Versprechen, dass von der Abt. Arbeit und Sozialwesen des Kreises auch weiterhin alles getan wird, die Lage der Umsiedler-Familien, die in Notstände[n] leben, $\mathrm{zu}$ verbessern und diesen das Leben so zu gewährleisten, wie es ihnen gegenüber den Alteingesessenen zusteht.

Im Anschluss an dieses Referat wurden allgemein-interessierende Fragen gestellt, die durch den Referenten beantwortet wurden. / Nach einer kurzen Diskussion wurde Herrn Kreisrat Jentsch, durch Frau Janis, das Wort zu Punkt 2 der Tagesordnung erteilt. / [...]

Nach kurzer Diskussion in Heimkehrerfragen, wurde von den Anwesenden das Ernährungsproblem in erregter Debatte erörtert. / Herr Kreisrat Jentsch wies auf die Gründe hin, die dazu beitrugen, dass die Ernährungslage z. Zt. unser Leben so schlecht gestaltet und gab Auskunft über die gestelten Fragen.

Um 13.00 Uhr wurde der offizielle Teil der Schulungstagung durch Frau Janis geschlossen und ein Mittagessen für die Anwesenden ausgegeben.

\section{(153) Aufgabenformulierung für die Abteilung Umsiedler und Heimkehrer der Landesregierung Brandenburg für das Jahr 1949. - [Potsdam, 1948]}

BLHA, Rep. 333 SED-Landesleitung Brandenburg, Nr. 574, Bl.383. - Überschrift „Aufgaben der Abteilung Umsiedler und Heimkehrer für das Jahr 1949 und der gesamten Verwaltung“. - Abschrift (Typoskript), 2 S., maschinenschriftlich unterzeichnet „In Vertretung / gez. Kuhn“; Bl. 383v l.u. handschriftlicher Vermerk von „Mu.“: „Z.d.A.“

Die Aufgaben der Umiedler- und Heimkehrerabteilung der Landesregierung beschränken sich im Jahre 1949 auf die Übernahme der Heimkehrer- und Umsiedlertransporte, die aus dem Osten, der SU und Polen, kommen. Die Zahlen der zu übernehmenden Heimkehrer, soweit sie nach den Erklärungen der Gewahrsamsländer zu beachten sind, stehen ungefähr fest. Eine Änderung ergibt sich für das Jahr 1949 in der Übernahme der Heimkehrer- und Umsiedlertransporte dadurch, dass sämtliche Transporte über das Lager Gronenfelde nach der sowjetischen Zone eingeschleust werden. Der 2. Durchschleusungspunkt im Lande Brandenburg, Forst, wurde mit Ende des Jahres 1948 geschlossen. Über Forst gehen künftig nur die PolenHeimkehrer-, sowie Umsiedler- und Kindertransporte, die im Transitverkehr durch die sowjet. Zone nach dem Westen geleitet werden. Das Lager Gronenfelde hat demzufolge im Jahre 1949 eine grössere Aufgabe zu bewältigen als im Jahre 1948. Die technischen Vorbereitungen für die reibungslose Übernahme und Weiterleitung der Heimkehrer- und Umsiedlertransporte in Gronenfelde sind getroffen und die Durchschleusungskapazität des Lagers reicht aus, um über 
dieses Lager allein 1949 die gesamten noch ausstehenden Heimkehrer und Umsiedler in der sowjetischen Zone zu übernehmen.

Die Kinderaustauschtransporte von Ost nach West und umgekehrt werden mit Hilfe des Zentralen Jugendamtes Berlin und der Landesjugendfürsorge im laufenden Jahr stärkere Ausmaße annehmen, 800 Kinder, die zur Zeit im Lager Küchensee, Krs. Beeskow-Storkow gesammelt sind, gehen in 2 Transporten, am 7. und 8. März, von dort nach der engl. Zone ab. Im Lager Fürstenwalde werden gegenwärtig in jedem Monat 2 Heimkehrertransporte aus Polen übernommen, sie leisten dort ihre 14tätige Quarantäne ab und werden anschliessend nach ihren Heimatgemeinden in der sowjet. Zone entlassen.

Über die zu übernehmenden Umsiedlertransporte bestehen zwar keine festen Zahlen, doch soll nach Verlautbarung der Deutschen Verwaltung des Innern auch die Umsiedlung 1949 beendet werden.

Wir haben auch für die Übernahme der Umsiedler, die das Land Brandenburg 1949 zu übernehmen hat, die Vorbereitungen, soweit wir es als Umsiedlerabteilung der Landesregierung tun können, getroffen. Den Land- und Stadtkreisen sind die Übernahmezahlen bekannt und wurden diese angehalten, den erforderlichen Wohnraum bereitzuhalten. Stärker denn je werden die Umsiedler nach ihren erlernten Berufen (Mangelberufe) zur Eingemeindung nach dort gelenkt werden, wo Facharbeiter gebraucht werden; denn je schneller die Umsiedler untergebracht und versorgt werden, nehmen sie auch teil am Arbeitsprozess zum Wiederaufbau unserer Wirtschaft, die die dringendsten Nöte der gesamten Bevölkerung zu befriedigen hat.

Für die gesamte Verwaltung besteht für das Jahr 1949 die Aufgabe, sich mit der Umsiedlerfrage allgemein zu beschäftigen, sowie auch der Rückführung der Heimkehrer und deren Eingliederung ins normale Leben stärkere Beachtung zu schenken. Ab 1.4. d.Js. wird es in den Kreisen keine besonderen Umsiedlerämter und -Auschüsse mehr geben. Die Sozial- und Wohnungsausschüsse werden künftig in engster Zusammenarbeit mit dem Kreis und der Gemeindeverwaltung die Aufgaben zu lösen haben, die mit der Eingemeindung der Umsiedler in Zusammenhang stehen.

Eine der wichtigsten Arbeiten der Kreise und Gemeinden des Landes Brandenburg mit ist es, die Umsiedlerfamilien, die in den kleinen und kleinsten Gemeinden des Landes sitzen, im Jahre 1949 nach dorthin zu bringen, wo Erwerbsmöglichkeiten vorhanden und weitere Entwicklungsmöglichkeiten den Kindern der Umsiedler gegeben sind. Die Schaffung von [Bl.383v] Lehrlingsheimen in den grösseren Gemeinden unseres Landes muss vorangetrieben werden, um den Jugendlichen unter den Umsiedlern die handwerkliche Ausbildung zu ermöglichen.

Ideologische Aufklärungsarbeit unter den Umsiedlern muss im Jahre 1949 systematisch geleistet werden. Die Einflüsse des Westens, mit Hilfe der Umsiedler die Frage der Revision der Ostgrenzen zu stellen, müssen zunichte gemacht werden. Überall dort, wo sich unter den Umsiedlern Tendenzen breit machen, sich in Landsmannschaften unter der Obhut gewisser kirchlicher Dienststellen, die ihren Sitz im Westen Berlins haben, zusammenzufinden, muss mit verständ- 
nisvoller Aufklärungsarbeit entgegengewirkt werden. Es muss den Umsiedlern weitgehendst klargemacht wedren, dass gewisse Kreise die Umsiedler nur zum Chauvinismus erziehen wollen, um die gesellschaftlichen Veränderungen in der sowjetischen Zone zu beseitigen, die auch vielen Umsiedlern zum Segen gereichen. Unter Auslösung einer breiten Aufklärungskampagne müssen sämtliche Umsiedler, die durch die Bodenreform Land erhalten haben, aus ihrer Lethargie herausgerissen und zu den aktivsten Teilnehmern des Neubauernprogramms nach Befehl 209 gemacht werden. Wenn jeder Umsiedler-Neubauer in kürzester Zeit über sein eigenes Gehöft verfügt, ist die Verwurzlung seiner Familie mit der neuen Heimat gewährleistet und die Gedanken werden nicht mehr in der Vergangenheit verharren, sondern mutvoll in die Zukunft schauen. Er wird mitarbeiten an der Wiedergesundung unserer Wirtschaft und unserer neuen demokratischen Ordnung und auch zum Kampf um die Einheit Deutschlands seinen Teil beitragen.

Stärkere Anteilnahme der Kreise und Gemeinden muss auch der Rückkehr der Heimkehrer geschenkt werden. Es kommen jetzt die körperlich wie seelisch gesunden Kräfte nach langen Jahren in die Heimat zurück. Sie haben in ihren Gewahrsamsländern aktiv am Aufbau teilgenommen, und wir erwarten, dass sie auch in der Heimat so schnell wie möglich in vorderster Front beim Wiederaufbau unserer Wirtschaft stehen. Sie werden trotz des guten Willens, den sie zur Teilnahme an unserer Arbeit nach ihrer Rückkehr aus der Gefangenschaft mitbringen, aber nur dann die Hoffnungen, die wir in sie setzen, erfüllen, wenn sie in der Heimat entsprechend empfangen und geleitet werden. Stärke und stärkste Mitarbeit der demokratischen Massenorganisationen mit dem FDGB an der Spitze und der Blockparteieen sind notwendig, den Heimkehrern das Wissen um das neue Deutschland zu vermitteln.

\section{(154) Beurteilung des Leiters der Abteilung Umsiedler und Heimkehrer Erich Friedrichs. - Potsdam, 18. Februar 1949}

BLHA, Rep. 203 MdI, PA 276, unfol. - Typoskript (Durchschlag), 2 Bl., mit eigenhändiger Bleistift-Unterschrift „Pötsch“. - Absender: „Abteilung Personal / P 1 e /Pö.“ - Datierung o. r.: „Potsdam, den 18. Februar 1949“. - Adressiert auf Bl. 2 u.: „Herrn Min. Dir. Henschel z[ur] Kenntnis“. - Überschrift: Beurteilung: Erich Friedrichs, Leiter der Abteilung Umsiedler und Heimkehrer." - Diverse rote Anstreichungen sowie Bleistiftvermerk des Empfängers auf Vorderseite o. 1.: „Frl. Brandt / z.d.A. Friedrichs / 22/II H“.

F. kommt politisch über das Niveau eines Verwaltungsangestellten[,] welcher der Weimarer Zeit und [der] des Naziregimes angehörte, nicht hinaus. Wenn F. auch nicht der NSDAP angehörte, so ist aus gesprächsweisen Unterhaltungen des Leiters des Landeswohnungsamt[es] Herrn Bre[h]mer, welcher F. aus jener Zeit kennt, bekannt, daß F. bei der Ausgestaltung „kultureller" Veranstaltungen der Offiziere u. a. regen Anteil nahm und musikalisch mitwirkte.

Trotz regelmäßigen Besuch[s] der Parteiveranstaltungen ist F. politisch unklar, was seinen besonderen Ausdruck in der Grenzfrage Oder/Neiße findet. In politischen Unterhaltungen sagte F., daß man den Siedlern den Glauben an eine evtl. Rückführung nicht nehmen soll, da man nicht weiß, ob die Zukunft nicht doch mal eine andere Entwicklung nimmt. Oder, vielleicht wird es mal anders. 
Seit Stellungnahme Ulbricht und Grotewohl zur Grenzfrage ${ }^{2344}$, hat sich F. diesbezüglich revidiert. Jedoch wird eine innere Überzeugung bezweifelt. F. fehlt das Klassenbewußtsein und infolge dessen kann er keine positive politische Stellungnahme beziehen. Seine Referate sollen inhaltlich politisch negativ sein und sich mehr auf die rein menschliche Seite bezügl. Hilfe für die Umsiedler beziehen.

F. hat sich von Anfang an nur auf alte Verwaltungsangestellte gestützt oder solche[,] die ihm hörig sind. Die proletarischen Kräfte zog F. nur soweit an sich, soweit sie für F. [B1. 2] nutzbringend erschienen, um bei bestimmten Fragen gegenüber der Verwaltung seine Schwächen nicht in Erscheinung treten zu lassen. Auf Vorhalt, der Zusammenarbeit mehr Hauptgewicht beizumessen, äußerte F., daß ihm die BGL oder Betriebsgruppe nur im Wege ständen. Angesetzte Besprechungen fanden oft infolge Fischers ${ }^{2345}$ Abwesenheit nicht statt und man führte das eben darauf zurück, weil F. die [so!] Zusammenarbeit aus dem Wege ging.

Bezügl. der 15 prozentigen Prämienabgabe an die Partei, bereitete F. als einzigster der Abt. Schwierigkeiten. Sein arbeitsmäßiges Verhalten trug nicht zur Stärkung der Abt. bei. Durch seine Methoden wurde manch gute Kraft abgestoßen. F. wird fachlich als oberflächlich beurteilt. Gegenüber dem Publikum läßt er es an Rechtsbelehrungen fehlen. F. war nie bemüht, aus den gemachten Erfahrungen praktische Vorschläge zu bringen. Seine Fachkenntnisse gehen über den Stand eines Verw[altungs-]. Insp[ektors]. von früher nicht hinaus. Er ist ein Karrireist [so!]. Bezügl. Bewirtschaftung der Mittel in der Abt. achtet F. auf Sauberkeit um keine Korruption aufkommen zu lassen. Die seinerzeitige Einstellung seines Schwagers als Leiter des Transportwesens, fand in der Abt. keine Zustimmung. Derselbe ging dann von dort nach der DWK. Dasselbe trifft für seine Frau ${ }^{2346} \mathrm{zu}$, welche als Landesbeauftragte des Suchdienstes Berlin in der Abt. arbeitet.

In seinem moralischen Leben, haben Frauen einen starken Einfluß. Mit der Leiterin der Umsiedler-Abt. Sozialamt Potsdam, Frau Fischer, unterhielt F. ein intimes Verhältnis. „Dienstliche“ Fahrten wurden des öfteren von beiden ausgeführt. Ein Weiterbestehen des Verhältnis[ses] konnte noch nicht festgestellt werden.

Zur Abrundung seiner charakterlichen Beuteilung sei erwähnt, daß er in Wohngemeinschaft mit seinen Eltern lebt und den Charakter seines Haushalts bezügl. Konsumgenossenschaft von seinem Vater (nom[ineller]. Pg.) bestimmen läßt.

Gelegentlich starken Alkoholgenusse[s], verliert F. die Beherrschung und kommt äußerst redselig politsch (negativ) aus sich heraus.

2344 [Ulbricht hatte sich im November 1948 für eine Anerkennung der Oder-Neiße-Grenze als „Friedensgrenze“ ausgesprochen, im „Neuen Deutschland“ war der Begriff schon im März 1948 verwendet worden.]

2345 [„Fischers" ist rot durchgestrichen.]

2346 [Gertrud Friedrichs.] 


\section{(155) Protokoll der Sitzung des Kreisumsiedlerausschusses Oberbarnim}

\section{am 9. März 1949. - Bad Freienwalde, 23. März 1949}

BLHA, Rep. 333 SED-Landesleitung Brandenburg, Nr. 574, Bl. 405-406. - Protokoll-Abschrift. Überschrift: „Protokoll über die Sitzung des Kreisumsiedlerausschusses Oberbarnim am 9.3.49 lt. Schreiben des Rates des Kreises Oberbarnim - Amt f. Arbeit und Sozialfürsorge - Bad Freienwalde vom 23.3.49." Vermerk o.1. „Abschrift! Ma." - Typoskript (Durchschlag), 2 S., ohne Unterschrift.

Geladen waren: Frau Rooft, Frau Pestka, Frau Schulz, Frau Becker, Herr Jäschke, Herr Pohl, Herr Reetz, sowie Herr Willi Riedler. Erschienen waren Herr Riedler vom FDGB, Herr Jäschke von der CDU, Herr Reetz von der VdgB und Herr Pohl SED. Entschuldigt waren Frau Rooft und Frau Schulz. Die übrigen nicht anwesenden Mitglieder fehlten unentschuldigt.

Tagesordnung:

1.) Verlesung des Protokolls der letzten Sitzung.

2.) Neue Wege der Umsiedlerbetreuung in der Ostzone.

3.) Verteilung von 20 Schränken.

4.) Verschiedenes.

Zu Anfang der Sitzung gab Herr Haack, Sachbearbeiter der Kreisumsiedlerstelle bekannt, dass Herr Pratsch, Leiter des Amtes für Arbeit und Sozialfürsorge und gleichzeitig Mitglied des Kreisumsiedlerausschusses, auf Grund eines 14-tägigen Schulbesuchs bei der DWK am Erscheinen verhindert ist und der Sachbearbeiter der Umsiedlerstelle bei dieser Sitzung gleichzeitig in seiner Eigenschaft als stellvertr. Abteilungsleiter fungiere und damit Herrn Pratsch vertrete.

Danach wurde zu Punkt 1 der Tagesordnung, Verlesung der Protokolle der letzten Sitzung geschritten. Dieses wurde von Herrn Haack verlesen und erläutert. Betreffend Errichtung von Gemeinschaftswaschküchen für Umsiedler in den Gemeinden wurde ein Abschlussbericht nach den Meldungen der Städte und Gemeinden gegeben. Die Angelegenheite H. Reetz VdgB konnte durch die Anwesenheit von Herrn Reetz und durch das diesbezügliche Schreiben des Kreisausschusses der VdgB positiv geklärt werden. Das Protokoll wurde von Herrn Jäschke und Herr[n] Riedler unterschrieben.

Punkt 2. Herr Haack verlas sodann seinen Bericht über die Konferenz des Landesvorstandes Brandenburg (Tagung vom 16.2.[19]49) [,] wo Herr Voigt ${ }^{2347}$, Leiter der Abteilung Umsiedler und Heimkehrer, besonders zu den Problemen der fortschrittlichen Umsiedlerbetreuung Stellung nahm. Herr H. gab u. a. bekannt, dass die Auflösung aller Umsiedlerausschüsse bis Mitte April 1949 geplant ist und die Aufgaben der Umsiedlerausschüsse auf die Sozialkommissionen und Wohnungsausschüsse übergehen sollen. Der Sachbearbeiter teilte ausserdem mit, dass das Umsiedlerproblem in der Ostzone in Zukunft nicht mehr ressortmässig, sondern von den ge- 
samten Verwaltungsbehörden bearbeitet werden soll und dadurch folglich die Umsiedlerämter in den Kreisen und Ländern in absehbarer Zeit in Fortfall kommen.

Nach diesem Bericht gab es eine sehr heftige[,] leider sehr negative Diskussion über die Potsdamer Beschlüsse und deren Auswirkungen für die Umsiedler. Herr Jäschke stellte die Behauptung auf, in den Potsdamer Beschlüssen wäre kein $\$ vorhanden, welcher die Umsiedlung von Deutschen aus den Ostgebieten vorschreibt. Herr Jäschke stellte die Behauptung auf, diese hätten die Russen und Polen allein veranlasst. Herr Haack widerlegte die Behauptung, doch wurde ihm nicht Glauben geschenkt, obwohl er konkrete Tatsachen anführte (Abs. 13 der Potsdamer Beschlüsse).

Herr Riedler vom FDGB nahm dazu eine schwankende[,] zu Herrn Jäschke hinneigende Stellungnnahme ein. Herr J. fordert einen Lastenausgleich mit der Begründung, den Umsiedlern müsste alles erstattet werden, da sie ja keine Schuld an dem verlorenenen Krieg und an der Auswirkung hätten. Herr Haack widerlegte die Ausführungen von Herrn Jäschke und führte konkrete politische und wirtschaftliche Tatsachen an und wies besonders auf die Worte des Herrn Voigt bei der o. a. Umsiedlertagung [Bl. 406] hin. Herr J. versuchte darauf, die Landesregierung betr. der Umsiedlerbetreuung teilweise anzugreifen und kam auf die Angelegenheit

Punkt 3 Möbelzuteilung für Umsiedler (20 Schränke) zu sprechen. Der Sachbearbeiter erklärte hierzu die Zusammenhänge der Bestellung o. a. Wohnzimmerschränke (tel. Anruf der Landesregierung), sowie die Bezahlungsbedingungen der Firma Pracht, Luckenwalde. Er gab bekannt, dass der Schrankpreis je Schrank 326,- DM vom Landespreisamt genehmigt ist. Die Höhe des Preise wurde jedoch von allen Ausschussmitgliedern heftig kritisiert und der Landesregierung der Vorwurf gemacht, solche Preise zu genehmigen bezw. die Schränke für die Kreise zu bestellen.

Nach längerer Diskussion, in der Herr Haack die Stellungnahme der Landesregierung (Leiter der Abteilung Umsiedler u. Heimkehrer Herrn Kuhn) erläuterte, wurde von Herrn Riedler der Antrag eingebracht, die Landesregierung durch einen formgerechten Antrag der Kreisumsiedlerstelle zu bitten, die Kosten für die Schränke vorläufig zu übernehmen und die Gesamtsumme auf das Konto der Umsiedlerstelle, Finanzamt Bad Freienwalde, zu überweisen. Herr Haack gab bekannt, dass bereits 6 Schränke verkauft worden sind. 3 Schränke mit Genehmigung des Kreisrates an die FDJ für ihr Jugendheim und 3 Schränke auf Ratenzahlung an Umsiedler.

Der o. a. Antrag wurde abgestimmt. Alle anwesenden Auschussmitglieder stimmten für den Antrag von Herrn Riedler. Herr Haack enthielt sich bei der Abstimmung seiner Stimme auf Grund seiner Tätigkeit des Ausschuss [so!]. (Am 18.3.49 hat die Kreiskasse auf Anweisung des Herrn Kreisrates Schulz für Herrn Pracht, Luckenwalde, Möbelfirma, persönlich die Gesamtsumme auf die Schränke per Scheck ausgehändigt. Der Betrag geht vorschussweise zu Lasten des Kreisamtes für Arbeit und Sozialfürsorge.)

$\mathrm{Zu}$ Punkt 4 - Verschiedenes - wurden nur frühere Verteilungsangelegenheiten, Umsiedlerunterstützungen und allg. Umiedlerfragen besprochen. Der Sachbearbeiter der Kreisumsiedlerstelle schloss nach Erledigung aller Tagesordnungspunkte die Sitzung gegen $16 \mathrm{Uhr}$. 


\section{(156) Beurteilung des Haushaltsreferenten der Abteilung Umsiedler und Heimkehrer Carl Gaedtke. - Potsdam, 23. Juni 1949}

BLHA, Rep. 203 MdI, PA 487, Bl. 5. - Typoskript, 1 Bl., mit eigenhändiger Bleistift-Unterschrift „Beier“ und Stempel „Landesregierung Brandenburg / Minister des Innern / Hauptabt. Personal u. Schulung“. - O.1.: „P 8 - 1321“. - Überschrift: „Vermerk“. - Datierung o. r.: „Potsdam, den 23. Juni 1949“.

Herr Karl ${ }^{2348}$ Gaedtke wurde zu einer Aussprache gebeten. Er ist trotz seiner 70 Jahre noch geistig rege und geht als alter Beamter in seinen [so!] Beruf als Haushaltsreferent in der Abteilung Umsiedler und Heimkehrer auf. Er ist sehr interessiert an dem Umsiedlerproblem, um diesen Menschen wieder zu einer neuen Heimat zu verhelfen. Er ist politisch sehr interessiert und Mitglied der CDU, weil er überzeugt ist von der Notwendigkeit, auch Politik zu betreiben. Er ist dafür, daß die Einheit Deutschlands erstrebt wird, bezweifelt aber bei der Lethargie der Massen, daß es gelingen könnte, große Teile des Volkes für die Nationale Front zu gewinnen. Als Mitglied der CDU nimmt er an den Versammlungen seiner Partei teil, gibt auch an, bei dem zahlreichen Publikumsverkehr Einfluß auf die Menschen in Bezug auf den Kampf um die Einheit Deutschlands zu nehmen. Er scheint unter dem Einfluß des Kollegen Kuhn ${ }^{2349}$ (SED) zu stehen, was sicherlich mit der Eigenschaft aller Berufsbeamten zusammenhängt, sich vor dem Übergeordneten zu beugen. An Arbeitsbesprechungen und der politischen Schulung nimmt er teil; die Nationale Front bejaht er, um einmal das Volk an politische Fragen heranzuführen. Er scheint besonders beeinflußt zu sein von der Not der Umsiedler und hält ein allgemeiens Interesse des deutschen Volkes am Kampf um die Einheit für ausgeschlossen.

\section{(157) Erinnerungen des Landrats des Kreises Jüterbog-Luckenwalde Fritz Ludwig an die Jahre 1945 bis 1949, [Niederschrift 1964] (Auszüge)}

BLHA, Rep. 16 Nachlass Fritz Ludwig, Nr. 1. - Typoskript, 74 Bl. - Titel: „Erinnerungen eines brandenburgischen Landrats der Jahre 1945-49.“

[B1. 12]

\section{Landrat}

[Bl. 13] [1945] [...] Die alles beherrschende Aufgabe war die Sicherung des materiellen Lebens der Bevölkerung. Sie war auch die schwerste, obgleich der Kreis relativ intakt aus dem Kriege hervorgegangen war. Daß die Bevölkerung niemals hungerte, war der sowjetischen Militäradministration zu verdanken, die das fehlende Getreide für das wichtigste Nahrungsmittel - das Brot - bereitstellte. Andere Aufgaben, die Beseitigung jedes nazistischen Einflusses, den Aufbau einer demokratischen Verwaltung, die Ingangsetzung der Produktionsbetriebe und vieles andere mehr, was zur Normalisierung des Lebens der Bevölkerung gehörte, liefen daneben. Es bedurfte der unermüdlichen und selbstlosen Arbeit vieler Aktivisten der ersten Stunde, um den

2348 [Er selbst schreibt jedoch stets Carl.]

2349 [Erich Kuhn, Referent bei der Abt. Umsiedler und Heimkehrer der Landesregierung Brandenburg.] 
Forderungen des Lebens dieser Tage gerecht zu werden. Daß es erfolgreich geschah, war der Hilfe der Kreiskommandantur, ihrem Kommandanten Oberstleutnant Besrutschenko und seinen Mitarbeitern, mit denen uns bald ein echtes Vertrauensverhältnis verband, zu danken. Das „Haus am Platze“, um mich des Ausdrucks des sowjetischen Romans von E. Kasakewitsch ${ }^{2350} \mathrm{zu}$ bedienen, war eine Villa in der Schützenstraße $e^{2351}$, gegenüber dem heutigen Kreis-Kulturhaus. Vom Inhalt dieser hier anfänglich mehrmals in der Woche stattfindenden Besprechungen geben folgende Notizen eine Vorstellung, die ich meinen Aufzeichnungen entnehme:

Aufzeichnungen aus meinem Heft „Kommandantur“:

16. X. 1945 - $10 \mathrm{Uhr}$

1. Bericht über Todesfälle im Kreise, Zahl u. Ursache an Komm[andantur] bis morgen.

2. Es gibt Fälle von Bandenunwesen in Jänickendorf, Woltersdorf, Ruhlsdorf und Berkenbrück. [Bl. 14]

3. Umsiedlerlager Treuenbrietzener Str. ${ }^{2352}$ ist mit 174 Umsiedlern belegt. Major der Abt. Ketsch verlangt Bestätigung des Kommandanten zur Übernahme. - Zinna und Felgentreu soll mit Umsiedlern belegt werden. Boden aufteilen. Evtl. Baracken aufstellen. Häuser kontrollieren und Schäden sofort reparieren. 1 Monat Quarantäne. Küchen und Sanitätstsstellen einrichten!

4. 1000 to Kartoffeln bei Bauern kaufen und für die Dörfer Stangenhagen und Bärwalde lagern.

5. In den Dörfern überprüfen lassen, wer keine Ernte hat (bis 19. X. 7 Uhr abends melden).

18. X. - $10 \mathrm{Uhr}$

Kommandant

$[\ldots]$

4. Neubauern haben keine Lebensmittel bis zur Ernte. Sie müssen bis dahin versorgt werden. Alten Besitzern belassen, soviel sie brauchen, das andere sollen sie an die Neubauern verkaufen. - Bis 25. X. Bericht darüber.

5. Neubauern können zusätzlich 4 ha Wald bekommen, Altbauern bis 15 ha Boden können bis 3 ha Wald dazu haben. Durch Anschlag in den Dörfern bekannt machen. 12000 ha Wald stehen zur Verfügung.

2350 [Emmanuil G. Kasakewitsch (1913-1962), sowjet. Schriftsteller. In dem 1956 (in der DDR 1957) publizierten Roman „Das Haus am Platz“ werden die aus seinem Roman „Frühling an der Oder“ bekannten Hauptpersonen „nach ihrem Einsatz im Krieg nun als Mitarbeiter einer sowjetischen Ortskommandantur gezeigt.“ (Anne Hartmann/Wolfram Eggeling: Sowjetische Präsenz im kulturellen Leben der SBZ und frühen DDR 1945-1953. Berlin 1998, S. 340).]

2351 [In Luckenwalde.]

2352 [Altes Lager westlich Jüterbog.] 
6. Kann man bis 1. Nov. Bodenreform abschließen?

[...] [Bl. 15]

Die Bodenreform

[...] [Bl. 16] [...]

Der Großgrundbesitz war im Kreis Luckenwalde mit 76 Gütern stark vertreten. Ihr Land wurde unter 793 Umsiedler, 517 landlose und 1595 landarme Bauerrn aufgeteilt. Am 25. Oktober waren von den 76 Gütern bereits 69 aufgeteilt. Die Gutshäuser wurden im [Bl. 17] Sinne der besten Nutzung behandelt. Zum Teil wurden sie abgerissen und dienten als Baumaterial für Neubauernhäuser, andere wurden sozialen Zwecken zugeführt. [...]

[Bl. 33] [...

\section{Aufnahme der Umsiedler}

Aus der Aufnahme der in regelmäßigen Abständen aus dem Osten eintreffenden Umsiedlertransporte, die in Jüterbog stattfand, erwuchs dem Kreis eine Fülle von Aufgaben bezüglich ihrer Versorgung, gesundheitlichen Betreuung, Einkleidung, Zuweisung von Wohnungen sowie Einbeziehung in den Arbeitsprozeß und in das gesellschaftliche Leben. Ein Teil der bäuerlichen Umsiedler erhielt durch die Bodenreform eine neue, ihrer alten entsprechende Existenz. Die Erfahrung bei den Wahlen, daß die Dörfer mit hoher Umsiedlerbevölkerung überwiegend SED wählten, läßt erkennen, welche politisch auflockernde Wirkung dieses Element hatte. Aber auch wirtschaftlich bereicherte es den Kreis. Eine große Gruppe sudetendeutscher Antifaschisten kam mit gesamtem Mobiliar einschließlich ihrer Werkzeuge und begründete neue Industrien. [B1. 34] Sie besiedelten das von den Nazis in den Schießplatz Jüterbog einbezogene und daher entvölkerte Dorf Zinna (1948: 593 Einwohner) und begründeten dort die Bijouteriewarenherstellung, in Jüterbog die Kunstblumenfabrikation, in Dahme eine Messerschmiede- und Treibriemenfabrikation. So wurde der Kreis durch eine ganze Palette neuer Produktionsarten und -stätten bereichert. Insgesamt fanden 32865 Umsiedler aus dem Osten im Kreis Luckenwalde eine neue Heimat. Damit stieg die Einwohnerzahl des Kreises auf 104639 (1.1.1948), davon waren $31 \%$ Umsiedler. Die Stadt Luckenwalde nahm rund 7000 auf und wuchs damit auf 32138 (1.12.1948) gegenüber 27328 (1930). Hier betrug der Anteil der Umsiedler also nur rund $22 \%$. Das erklärt sich aus der Tatsache, daß der bäuerliche Anteil unter den Umsiedlern überwog.

[Handschriftlicher Nachtrag, Bl.33v:] Dorf Zinna wurde 1961 [1951!] in „Neuheim“ umbenannt. Der von den Umsiedlern geschaffene Betrieb, jetzt „Gablona“[,] nahm einen schnellen Aufschwung. Als ich ihn im Juni 1964 besuchte, nannte mir der Leiter des VEB Gablona, Gen[osse] Kraus, zu meiner Zeit noch Buchhalter, einige markante Zahlen. Gablona beschäftigt jetzt ca 700 Arbeitskräfte, in der Mehrzahl Frauen, die zum Teil aus den benachbarten Orten - Jüterbog, Grüna, Kloster Zinna u. a. - in 3 Autobussen zur Arbeit herangefahren werden. Der Jahresumsatz betrug 1963 über 33 Mill. Mark. Exportiert werden die Erzeugnisse in mehr als 30 Länder. 
[B1. 35]

Mißhelligkeiten

[...] [Bl. 37] [...] Schmerzlich waren Fälle, wo man sich von Mitarbeitern aus politischen oder moralischen Gründen trennen mußte, besonders Genossen, die in der Nazizeit unbeugsam gewesen waren, Verfolgung und Zuchthaus auf sich genommen hatten, wie mein langjähriger Polizeichef. In anderen Fällen waren Wirtschaftsvergehen zu verfolgen. Viel Aufsehen erregte der Fall M. [hier handschriftlich korrigiert in W., nachfolgend jedoch unkorrigiert] M. hatte mit großem kaufmännischem und organisatorischem Geschick die Textilversorgung im Lande Brandenburg aufgebaut und zwar als Privatunternehmer. Er war auch Initiator der Zinnaer Bijouteriearbeiter aus dem Sudetenland, wohin er nach seiner Befreiung aus dem KZ Auschwitz verschlagen worden war. Nach einer im Kapitalismus üblichen Manier hatte er mit der Zinnaer Bijouterie-Genossenschaft einen Vertrag geschlossen, in dem er sie verpflichtete, für einen ihr gewährten hohen Kredit ihre gesamte Produktion ausschließlich durch ihn zu verkaufen, und sich von dem Verkaufserlös eine Provision von $15 \%$ ausbedungen. Aus der [Bl. 38] über ihn verhängten Untersuchungshaft in Potsdam gelang es ihm, nach Westberlin zu entweichen, so daß der Prozeß in seiner Abwesenheit geführt wurde.

\subsection{Suchdienst für vermißte Deutsche in der SBZ (1946-1949)}

\section{(158) Einrichtung von Annahmestellen für Suchanträge des Suchdienstes für vermißte Deutsche in Potsdam. - Potsdam, 19. November 1946}

BLHA, Rep. 203 MdI, Nr, 1195, Bl. 65. - Typoskript (Durchschlag) mit (r. u.) Bleistift-Unterschrift der Provinzialbeauftragten des Suchdienstes „Schmidt“ [darüber masch.: „Die Provinzialbeauftragte“]. - Absender: Amt für deutsche Umsiedler/Die Provinzialbeauftragte / Az.: VIIa Schm/Ar. - Adresse „An das Informationsamt in Potsdam, / Seestr. / z. Hd. des Herrn Aulich.“ - R. o. Datierung: „Potsdam, den 19.11.46. Alte Zauche 67.“

Hierdurch bitten wir Sie, folgendes durch Presse und Rundfunk bekanntzugeben:

Bei den Umsiedlerämtern der Provinz Mark Brandenburg sind Annahmestellen von Suchanträgen des Suchdienstes für vermißte Deutsche errichtet worden.

Folgende Annahmestellen bestehen in Potsdam:

Amt für deutsche Umsiedler, Potsdam, Alte Zauche 67 - Haus II

$\begin{array}{lll}\text { Sprechzeit: } & \text { Montag - Freitag } & \text { von 9-16 Uhr }\end{array}$

Frauenausschuß Potsdam, Brandenburger - Ecke Jägerstr.

Sprechzeit: Montags von 14-16 Uhr

Aufbaulager Potsdam, Luftschiffhafen, Zeppelinstr. 110,

Sprechzeit: Montag-Sonnabend von 9-12 Uhr. 


\section{(159) Rundfunkmeldungen des Suchdienstes zur Familienzusammenführung von aus den Vertreibungsgebieten stammenden Kriegsheimkehrern. -} Potsdam, 6. Dezember 1946

1. Schreiben der Provinzialbeauftragten Brandenburg des Suchdienstes für vermißte Deutsche in der SBZ an den Landessender Potsdam. [Potsdam], 6. Dezember 1946

BLHA, Rep. 203 MdI, Nr, 1195, Bl. 62. - Typoskript (Durchschlag ohne Unterschrift oder Paraphe). Schreiben „An den Landessender / Potsdam / Kapellenbergstr. 4“. - R. o. Datierung: 6.12.46, links daneben Aktenzeichen „Ku./Di.“ U.1. Vermerk „4 Anlagen“ [fehlen] sowie „gef. Di. ab ... 12.46“.

In den Krankenhäusern von Potsdam und Babelsberg liegen Heimkehrer, die über Frankfurt/O. aus russischer Kriegsgefangenschaft entlassen sind. Die kranken Heimkehrer stammen aus Gebieten, die außerhalb der heutigen Grenzen Deutschlands liegen und wissen nichts von ihren Angehörigen. / Wir bemühen uns die Heimkehrer wieder mit ihren Angehörigen zusammenzuführen und bitten Sie, uns dabei behilflich zu sein, indem Sie durch den Landessender Potsdam, die Namen der Heimkehrer mit der alten Heimatanschrift, die auf den Listen mit aufgeführt ist, bekanntgeben. / Aus jeder der 4 Listen ist zu ersehen, in welchem Krankenhaus sich die Heimkehrer jeweilig befinden.

2. Antwortschreiben des Landessenders Potsdam. Potsdam, 6. Dezember 1946

BLHA, Rep. 203 MdI, Nr. 1195, Bl. 61. - Typoskript auf gedrucktem Kopfbogen (mit Wappen der Provinz Brandenburg). Absender „Landessender Potsdam / Kapellenbergstraße 4 / [masch.: ] Sendeleitung I b /Da“. - „An den Suchdienst für vermisste Deutsche / Potsdam / Alte Zauche 67“. - R. o. Datierung: (2) Potsdam, den 11. Dezember 1946“. R. u. Unterschrift „Der Intendant/i.A. [gez., Bleistift] Dannenberg[?]“, mittig Stempel „Landessender Potsdam“.

Unter Bezugnahme auf Ihr Schreiben vom 6. ds. Mts. teilt der Landessender Potsdam mit, dass täglich, ab heute bis Sonnabend, eine Heimkehrerliste nach den Nachrichten um 13.45 und 22.15 Uhr verlesen wird.

(160) Arbeitsbericht der Landesbeauftragten für Brandenburg des Suchdienstes für vermißte Deutsche in der SBZ. - Potsdam, Anf. Juli 1947 (Auszug)

BLHA, Rep. 203 MdI, Nr. 1198, Bl. 10-11. - Typoskript (Durchschlag) mit (Bl. 11 u.) Bleistift-Unterschrift der Landesbeauftragten „gez. Friedrichs“.

\section{Arbeitsbericht Monat Juni 1947}

[...] [Bl. 10] [...]

10.) Öffentliche Meinung

$[\ldots][$ Bl. 11] [...]

Herr Bruno R[... ] aus Neckarhausen Kr. Nürtingen, Raidwangerstr. 229 kam hier Anfang Juni schwarz über die Zonengrenze um seinen Jungen zu suchen, nachdem sämtliche Suchanträge bei allen nur erdenklichen Stellen (auch bei uns) ohne Erfolg geblieben waren. Herr R. war auch in Berlin und kam nachdem nach Potsdam. Er war in Sachsen und in Mecklenburg und wollte 
von Lager zu Lager gehen, da ihm bekannt war, daß sein Junge mit 8 Kindern zusammen in Begleitung einer kath. Schwester aus der Tschechoslowakei in Forst angekommen ist. Von Forst aus fehlte jede Spur, da sich die Gruppe dort anscheinend vom Transport abgesetzt hatte. Da Herr R. hier seine vielen bis dahin erfolglosen Bemühungen und die Verzweiflung seiner Frau sehr anschaulich schilderte, baten wir ihn uns Nachricht zu geben, falls er seinen Jungen findet. Wir erhielten nun am 27.6. die Nachricht, daß er den Jungen in einem Kinderheim in Aschersleben gefunden hat. $[\ldots]$

Im Kreis Prenzlau sprach ich einen alten Umsiedler, der noch immer seine Frau sucht. Der Mann arbeitet bei einem Bauern, erhält nur wenig bares Geld und hat alles, was er bisher verdient hat (etwas über 200.- RM) [,] bei den verschiedensten Suchstellen, auch Pfarrern u.s.w. ausgegeben ohne eine Nachricht zu bekommen. Er stellte nun noch einen Suchantrag, weil er gehört hatte, daß durch den zusammengefaßten Suchdienst in Berlin schon viele Leute sich gefunden hätten.

Im Kreis Luckenwalde hat sich ein Umsiedler-Ehepaar im Walde beim Pilzesammeln gefunden.

$[\ldots]$

\section{(161) Verzeichnis in der SBZ verbotener Suchdienste (Auszug für Brandenburg). - [Berlin, Ende Juli 1948]}

BLHA, Rep. 203 MdI, Nr. 1197, Bl. 41-48. - Typoskript (Durchschlag), 8 Bl., ohne Angabe der erstellenden bzw. veranlassenden Stelle (offensichtlich der „Suchdienst für vermißte Deutsche in der SBZ“, Berlin), ohne Unterschrift, undatiert [(wohl kurz) nach 27.7.1948]. - Bl. 41 (= Bl. 1): Brandenburg, Bl. 42 (= Bl. 2): Mecklenburg, Bl. $42-44$ (= Bl. 2-4): Sachsen, Bl. 44-45 (= B1. 4-5) Sachsen-Anhalt, Bl. 45-46 (= Bl. 5-6): Thüringen, Bl. 47-48 (= Bl. 1-2): „Verbotene Suchdienste in den Westzonen“. Dreispaltige Tabelle (Spaltentrennung hier wiedergegeben durch Gedankenstriche) ohne Tabellenkopf mit Angaben zu [1.] Bezeichnung des Suchdienstes, [2.] Sitz/Anschrift, [3. (nur Bl. 41-48)] Verbleib.

[Bl. 41]

\section{Verbotene Suchdienste}

\section{Brandenburg}

Caritas-Suchdienst der Diözese Breslau/Zweigstelle Cottbus - Cottbus, Lausitzer Str. 59 / [ohne Angabe zum Verbleib]

Cibis, Gewerbelehrer - Wittenberge, Feldstr. 14 b. Hecht / [ohne Angabe zum Verbleib]

Hilfswerk der evangelischen Kirche - Eberswalde, Eisenbahnstr. 84 - 1t. Schrb. Oberlandrat, Bez.Verw. Eberswalde, v. 26.11.46 darauf hingew[iesen]., dass Sucharbeit nur von uns ausgeführt wird.

Kläske - Strasburg/Uckermark - lt. Schrb. Bürgerm. d. Stadt Strasburg v. 7.8.47 vernommen und Material beschlagnahmt. 
Oberlandrat Bezirksverwaltung Cottbus, Referat für Arbeit u. Sozialwesen - Cottbus / KarlLiebknecht[-]Str. - Material am 7.11.46 übernommen.

Pfitzner - Blankenfelde Post Mahlow üb. Berlin, Steigerwaldweg 15 / [ohne Angabe zum Verbleib]

Maria Pollanetz - Zehdenick/Ha[vel]., Hauptstr. 35 / [ohne Angabe zum Verbleib]

Helmut Rekus - Schmellwitz Kr. Cottbus / Schulstr. 36 / [ohne Angabe zum Verbleib]

Schlesiersuchdienst - Jüterbog / Mönchenstr. 37 - Material im Okt. 1946 übernommen

Fritz Trispel / Suchdienst Katerbow - Katerbow Krs. Ruppin / [ohne Angabe zum Verbleib]

Umsiedlerlager „Quenz“ - Brandenburg/Havel - lt. Schr. Quenz v. 28.11.46 aufgelöst

Wietzke / Schreibbüro, Auskunftei - Brandenburg/Havel, Gotthardwinkel 1 - lt. Arb.Ber. Potsdam v. 7.11.47 aufgelöst u. Material ausgelief[ert].

\section{(162) Arbeitsbericht der Landesbeauftragten für Brandenburg des Suchdienstes für vermißte Deutsche in der SBZ. - Potsdam, 7. Oktober 1948 (Auszüge)}

BLHA, Rep. 203 MdI, Nr, 1198, Bl. 42-43. - Typoskript (Durchschlag) mit (Bl. 43 u.) Bleistift-Unterschrift der Landesbeauftragten „Friedrichs“, darunter Stempel „Suchdienst für vermißte Deutsche / in der sowjetischen Besatzungszone Deutschlands / Beauftragter für die Provinz Mark Brandenburg“. - Bl. 42 o.1. „G. Friedrichs / Landesbeauftragte für Brandenburg“, o. r. „Potsdam, den 7.10.48“.

Arbeitsbericht.

Gegliedert nach den, mit Rundschreiben No 7 vom 8. Mai 1947, vorgeschriebenen Richtlinien. Berichtszeit: August/September 1948

1. Offizielle Beziehungen.

a) Die Dankschreiben zum zweijährigen Bestehen des Suchdienst sind dem Ministerpräsidenten, dem Minister des Innern und dem Minister für Arbeit und Sozialwesen übergeben worden.

Außerdem erhielten das Schreiben die Abteilungsleiter der Landespolizei, des Statistischen Landesamtes und des Amtes für Umsiedler. Die Landessekretariate der SED, der CDU und der LDP erhielten ebenfalls je ein Exemplar und ebenso die Märkische Volkssolidarität, der Demokratische Frauenbund, der Rundfunk und der Allgemeine Deutsche Nachrichtendienst, sowie der Informationsdienst der Landesregierung und das Landesjugendamt. Die drei Brandenburger Zeitungen: Märkische Volksstimme, Tagespost und Märkische Union wurden auch bedacht und dazu kommen noch 21 Kreisräte und 9 Oberbürgerneister. Somit sind rund 50 Exemplare in Brandenburg verteilt worden und alle maßgebenden Stellen und Organe sind an ihre Mithilfe bei unserer Arbeit erinnert worden.

Durch die im Zuge der Sparmaßnahmen erfolgten Personaleinschränkungen ergeben sich jetzt für unsere Arbeit ziemlich große Schwierigkeiten. Angefangen in meiner Dienststel- 
le in der Abt. für Umsiedler, Frl. Dieterich meine Stenotypistin hat am 15.8. ihre Stellung hier aufgegeben und wurde nicht mehr durch eine andere Kraft ersetzt. Die übrigen Stenotypistinnen der Abteilung wurden angewiesen für mich mitzuarbeiten, aber da sie alle eigentlich überlastet sind, bin ich ziemlich auf mich allein angewiesen. Noch schlechter sieht es aber in den Kreisen aus. Allen Kreisumsiedlerämtern wurde das Personal stark eingeschränkt und die Angestellten müssen oft mehrere Sachgebiete zugleich übernehmen. Natürlich werden alle auftretenden Mißstände nun damit entschuldigt und man kann schwer etwas dagegen sagen. Z. B. die Meldekarten-Aktion ist dadurch wieder stark ins Schleppen geraten.

2. Annahmestellen

An der, von den Kreis-Umsiedler-Ämtern gemeldeten Zahl von 998 Annahmestellen im Land Brandenburg hat sich im Berichtszeitraum nichts geändert.

\section{3.) Werbung}

a) Presse: Die drei Brandenburger Tageszeitungen, Märkische Volksstimme (SED), Tagespost (SED) und Märkische Union (CDU) brachten ausführliche anerkennende Artikel zum zweiten Jahrestag des Suchdienst und würdigten einmütig seine Verdienste. Anlage 1 [fehlt]

b) Rundfunk: Der Landessender Potsdam übernimmt das Berliner Programm in Bezug auf die Suchdienstsendungen und kann daher um Überschneidungen zu vermeiden nur selten zusätzlich Sendungen für uns bringen. [Bl. 42v]

Anläßlich der Woche des Kindes vom 26.9. bis 2.10. wurde vom Rundfunk die Gesamtzahl der Erfolgsmeldungen aus der Kinderkartei genannt. Man schlägt mir vor eine Rundfunkreportage im Landesmaßstab über die Arbeit in Brandenburg zu bringen, da man beim Landessender möglichst solche Dinge senden will, die Brandenburg direkt betreffen. Hierzu werde ich mit Herrn Adolph [Informationsabt.] noch Rücksprache nehmen. Leider existiert kein statistisches Material über Erfolgsmeldungen aus dem Land Brandenburg,

c) Bildreklame: Die neuen Diapositive wurden Mitte August an die Kreis-Umsiedler-Ämter verteilt mit der Auflage sie im Kreis in alle Kinos gelangen zu lassen. Bisher stehen die Berichte über den Einsatz noch aus. Ohne mindestens eine Anmahnung geht es da nie ab.

d) Plakataushang: Plakate sind letztmalig zu Beginn des Monats August verteilt und soweit ich mich überzeugen konnte, noch überall angebracht und auch noch in einigermaßen gutem Zustand.

e) Veranstaltungen: An folgenden Veranstaltungen wurde im Berichtsmonat teilgenommen: 

6.8 .
Sitzung der Märkischen Volkssolidarität Potsdam
9.8-6.9.
Urlaub
19. +20.9 .
Bürgermeister-Konferenz in Calau (700 Jahrfeier in Lauta)
26.9.
Tagung der Gemeindevertreter in Groß-Räschen

Im September wurden 4 Umsiedler-Transporte übernommen, die sämtlich im Quarantänelager Falkensee bezw. Küchensee besucht wurden. Zweck und Ziel des Suchdienstes wurde hier den Umsiedler[n] klar gemacht und auf die Benutzung der Suchpostkarte sogleich nach der Eingemeindung hingewiesen.

4. Erfassung.

a) Sämtliche Kreis-Umsiedler-Ämter sind nach dem letzten Rundschreiben jetzt noch einmal telefonisch an ihre Pflicht zur Ausfüllung der Meldekarten erinnert worden. Alle versicherten mir, daß die Meldungen erfolgen, einzelne Kreise wie z.B. Angermünde sind dazu übergegangen die ihnen zugewiesenen Umsiedler gleich im Kreis-Umsiedleramt zu erfassen und die Meldungen gar nicht erst den Gemeinden zu überlassen, weil sie fürchten, daß die Karten dort nicht ordnngsgemäß ausgefüllt werden.

b) entfällt

c) entfällt

d) Die Erfassung durch Kindervermißtenkarte soll nun nach Angabe des Landesjugendamtes am 1.12. erfolgen. Die Vorverhandlungen waren wieder ins Stocken geraten, weil die zentrale Wirtschaftskomm [ission] mit der Erfassung bei der Lebensmittelkarten-Ausgabe nicht einverstanden war. Nach Klärung geht das Landesjugendamt jetzt erst an die Ausarbeitung der Arbeitsrichtlinien. Vom Landesjugendamt werde ich laufend informiert. AuBer den von mir beschafften 8000 Kindersuchformularen hat das Landesjugendamt noch 20000 Stück in Auftrag gegeben. Nach Angabe des Statistischen Landesamtes haben wir 5137 elternlose Umsiedlerkinder im Land Brandenburg. Danach müßten ca. 12-15000 Stück ausreichend sein.

e) Totenmeldeformulare will ich versuchen noch in diesem Quartal in Druck zu geben. Die Schwierigkeiten sind jetzt nicht mehr allein bei der Papierbeschaffung, sondern mein Kampf geht um die Kostenübernahme, die man jetzt mit Rücksicht auf die rigorosen Spar-[Bl. 43] maßnahmen ablehnt. Wenn ich die 20000 Exemplare der Handzettel „Suchst Du Deine Abgehörigen - Kriegsgefangene suchen ihre Angehörigen“ aus der Druckerei erhalten habe und die Rechnung vom Amt hier bezahlt ist, werde ich den neuen Auftrag über 10000 Stück Totenmeldeformulare versuchen durchzubringen.

5. Lager

Der Stand der Heimkehrer- und Umsiedlerlager ist unverändert bei 6 Lagern geblieben. 
6. Rundschreiben der Beauftragten

25.9. Rundschreiben an die Kreis-Umsiedler-Ämter zwecks Nachforschung nach den Kindern Helmut Pietsch und Hans-Dieter Pillkahn aus Königsberg mit gleichzeitigem nochmaligen Hinweis auf Ausfüllung der Meldekarten. Anlage 2 [fehlt]

2.10. Schreiben an die Kreise Teltow, Cottbus, Templin und Ruppin wegen der dort aufgetauchten verbotenen Suchdienste. Anlage 3 [fehlt]

7. Tätigkeit anderer Suchdienste

Der Caritas-Verband entfaltet immer noch eine rege Tätigkeit. Zu den 4 im Land Brandenburg bekannt gewordenen Suchdiensten habe ich bereits berichtet, daß die Abschlußmeldung der Auflösung bis zum 31. ds. Mts. erfolgen wird.

Bei einem davon, dem Suchdienst in Katerbow [,] handelt es sich um eine unserer Annahmestellen. Der Herr Fritz Trispel hat sich Kopfbogen „Suchdienst Katerbow“ angeschafft, im übrigen aber nach unseren Weisungen gehandelt. Gebühren hat er außer den Rm. 2 für die von ihm verauslagten Suchpostkarten keine kassiert.

8. Suchzeitung.

Ein Hinweis, daß die Suchzeitung wieder zu haben ist, ist in der hiesigen Presse erschienen.

9. Suchpostkarten.

Auf Ihre Meldung, daß aus dem Lager Falkensee alte unfrankierte Suchpostkarten eingegangen seien, erfahre ich aus dem Lager, daß auf dem Postamt Falkensee keine Suchpostkarten mehr vorrätig seien. Bei der Postdirektion wurde dieserhalb moniert. Vielleicht wäre es aber zweckmäßiger sich an die OPD Berlin zu wenden, da Falkensee zu GroßBerlin gehört ${ }^{2353}$.

10. Öffentliche Meinung.

Bericht in Vorbereitung.

11. Beschaffung von Materialien.

Fehlanzeige.

(163) Anfrage wegen Veröffentlichung in der Suchzeitung des Suchdienstes. Neuruppin, 1. Juli 1949

BLHA, Rep. 203 MdI, Nr. 1196, Bl. 12. - Typoskript auf gedrucktem Kopfbogen des Rates des Kreises Ruppin, Bleistiftunterschrift „Lampe“, davor masch. „I.A.“- L. o. Absendervermerk und Aktenzeichen: „- Suchdienst - / VII/5 Lg./Okr.“ - R.o. Datierung: „(2) Neuruppin, den 1.Juli 1949./Schinkelstr. 5/6. App. 29.“ - Adresse: „An den 
Suchdienst für vermisste Deutsche, Berlin W 8, Kanonierstr.“ - Rücks. Absenderstempel „Der Rat des Kreises Ruppin / Abt. Sozialwesen / Kreisumsiedleramt", Eingangsstempel Berlin vom 4.7.1949 und Weiterleitung nach Potsdam, 11.7.1949. - Vorders. Bearbeitungsvermerke aus Berlin und Potsdam, dabei, offenbar aus Berlin, rot „Eilt“. - [Antwort siehe unten.]

Unter dem 29.3.49 ist Ihnen nachstehendes Schreiben zugestellt worden, worauf wir noch keine Antwort erhalten haben:

„Von einigen Annahmestellen unseres Kreises gehen wiederholt Anfragen ein, wonach vorsprechende Umsiedler behaupten, dass sie bereits vor Jahresfrist und länger Suchanträge gestellt haben, jedoch noch keine Veröffentlichung in der Suchzeitung erfolgt ist. Wir bitten um Aufklärung, wie sich dieses verhält, damit wir den anfragenden Annahmestellen Auskunft geben können. Desgleichen bitten wir uns für die Gemeinden Propagandamaterial und Fotolisten für vermisste Kinder zwecks Propagierung zuzustellen.“

Wir bitten nochmals um Beantwortung.

\section{(164) Antwort der Landesbeauftragten des Suchdienstes wegen Veröffentlichungen in der Suchzeitung. - Potsdam, 3. August 1949}

BLHA, Rep. 203 MdI, Nr. 1196, Bl. 10. - Typoskript (Durchschlag) mit Paraphe „Orl.“ der Landesbeauftragten des Suchdienstes Orlowski auf Rückseite. - Oben masch. Absenderzusatz zum (hier fehlenden Kopfbogen): „Potsdam, Alte Zauche 67, Haus 9, Zimmer 32, Ruf: 4281-431-.“- Adresse: „An den Rat des Kreises Ruppin in Neuruppin / Schinkelstr. 5/6“. - R. o. Datiertung: „den 3. August 1949“. - Aktenzeichen: „6680-Be.Orl.“ - Betreff: „Ihre Anfrage wegen Veröffentlichung in der Suchzeitung und Übersendung von Sonderdrucken“" [Bl. 12] [Zeichen u. Datum der Anfrage:] VII/5 Lg./Okr.- v. 1.7.49“ [Siehe oben]. - Oben Schreibverfügung „1.) “, Rücks. unten Ablageverfügung „2.) ZdA."

Sie erhalten anliegend wiederum einige Sonderdrucke und Fotolisten zur bestmöglichsten Verwendung. Das mit Schreiben vom 1. Juli 1949 angeforderte Propagandamaterial schicke ich gleich mit und bitte, es nach Ihrem Dafürhalten zu verwenden. Ferner teile ich Ihnen folgendes mit: Der „Suchdienst“ veröffentlicht 14-tägig in der Suchzeitung gegen 2000 Namen. Es liegen aber nicht 100 oder 1000, sondern Millionen Anträge vor, demgemäß kann eine Veröffentichung nicht so schnell erfolgen, wie es der Außenstehende annimmt. Selbstverständlich werden zunächst die ältesten Eingänge berücksichtigt. [B1. 10v] Sie wollen Ihren Bescheid an die Annahmestellen Ihres Kreises dahingehend formulieren, daß die s. Zt. eingegangenen Suchanträge ordnungsgemäß sind und die Antragsteller mit dem Augenblick eines positiven Erfolges mit Bescheid rechnen können. Über termingemäße Veröffentlichungen können wir keine Zusage machen. Die Umsiedler können versichert sein, daß ihre Anträge keineswegs vernachlässigt worden sind. Ich selbst bin Umsiedlerin aus dem Osten und habe mich bei der Einarbeitung für die Arbeit beim Suchdienst davon überzeugen können, daß meine im Jahre 1946 beim Suchdienst gestellten Anträge nach meinen Angehörigen ordnungsmäßig bearbeitet worden sind, dennoch ist weder eine Veröffentlichung noch ein Zwsichenbescheid erfolgt, weil dieses bisher wegen der Fülle der Arbeit nicht möglich war.

Ich bitte Sie, in diesem Sinne auf die Antragsteller einzuwirken. 
(165) Rundschreiben der Suchdienst-Landesbeauftragten an die Räte der Landkreise und Städte zur Ermittlung von in Altersheimen wohnenden Flüchtlingen aus den Vertreibungsgebieten. - Potsdam, 4. September 1949

BLHA, Rep. 203 MdI, Nr. 1196, Bl. 4r-v. - Typoskript (Durchschlag) mit (r.o.) Bleistift-Abgangsvermerk und Paraphe der Landesbeauftragten des Suchdienstes Orlowski „ab 4.9.49 Orl“. - L. o. Stempel „Suchdienst für vermißte Deutsche in der sowjetischen Besatzungszone Deutschlands / Beauftragte für das Land Brandenburg“, darunter Aktenzeichen „6680-Be.Orl. - R. o. Datierung: „Potsdam, den 13. Juli [handschriftlich geändert in 4.9.] 1949. Alte Zauche 67, Haus 9, Zimmer 32, Ruf : 4281-431-.“ - Adresse „An den Rat des Kreises / Abteilung Arbeit und Sozialwesen - Suchdienst - / in“, darüber Schreibverfügung „1.) An die Räte der Landkreise und Städte des Landes Brandenburg.“, Rücks. Wiedervorlage-Verfügung „2) Wv. nach Eing. d. Bescheides.“ - „Betreff: Feststellung der Anzahl der in Ihrem Kreis vorhandenen Altersheime und Erfassung von Flüchtlingen, die sich in Altersheimen befinden.“

Ich bitte Sie mir mitzuteilen, wieviel Altersheime in Ihrem Kreise vorhanden sind, wo sich diese Altersheime befinden, wieviel Personen aus den Ostgebieten hier Aufnahme gefunden haben und ob alle umgesiedelten Personen in den Altersheimen Ihres Kreisverwaltungsbereiches durch die Meldekarte des „Suchdienst für vermißte Deutsche [B1. 4v] der SBZ. Deutschlands Berlin W 8, Kanonierstr. 35 ["] erfaßt worden sind. / Es ist unbeding erforderlich, alle Flüchtlinge, die sich in Altersheimen befinden, zu erfassen. / Ich bitte deshalb, die in den Altersheimen Ihres Verwaltungsbereiches lebenden Flüchtlinge durch die Meldekarte des „Suchdienst“ zu erfassen und die Meldekarten dem „Suchdienst“ oder der Landesbeauftragten des Suchdienst für Brandenburg in Potsdam, Landesregierung, Alte Zauche 67, Haus 9, Zimmer 32 zu übersenden. / Ich bitte um Bescheid, daß Sie meine Anweisung durchgeführt haben.

\subsection{Kirchen (1945-1948)}

\subsubsection{Evangelische Kirche (1945-1948)}

(166) Bericht der Gemeinschaft evangelischer Schlesier über die Aufnahme der Gemeindeglieder und Pfarrer in das Kirchengebiet Berlin-Brandenburg ab 1945. - Berlin, [1972]

ELAB, Best. 1 Konsistorium, Nr. 2453, unfol., hektografiertes Typoskript (60 S.) „Dokumentation über die Aufnahme der Pfarrer und Gemeindeglieder aus den zerstreuten Evangelischen Kirchen des Ostens in die westlichen Gliedkirchen; hier: Bericht zur Frage der Aufnahme in den Raum der Evangelischen Kirche in Berlin-Brandenburg und der sich daraus ergebenden Folgeerscheinungen für die in dies Kirchengebiet Aufgenommenen, wie auch aus der Sicht der aufnehmenden Landeskirchen“, erstellt von Kirchenrat Walter Schian, „Vorsitzender des Berliner Konvents der Hilfskomitees der zerstreuten evangelischen Ostkirchen“, [1972], Anlage 7) Schlesien (S. 43-50) (Kopf S. 43: „Gemeinschaft evangelischer Schlesier, Landesarbeitsgemeinschaft Berlin / Der Vorsitzende: Kirchenrat Walter Schian / 1 Berlin 38 / Teutonenstraße 9 / [...]“; zusätzliche Verf.-Angabe S. 47 u.: „gez. Schian“); daraus hier abgedruckt der Abschnitt „III. Aufnahme der Gemeindeglieder und Pfarrer in das Kirchengebiet Berlin-Brandenburg“ (S. 44-47).

Etwa ab Oktober 1945 konnten gezielte Maßnahmen für die Aufnahme der Gemeindeglieder und Pfarrer eingeleitet werden. Das Konsistorium selber ist dabei als Kirchenregiment weniger direkt in Erscheinung getreten. Es hat aber zwei Organisationen nach Möglichkeit unter- 
stützt, das ist einmal der Kirchendienst Ost unter seinem damaligen Leiter Dr. Kammel und die Dienststelle des neu gegründeten Hilfswerks, die ihren Dienstsitz in der Waltharistraße in Berlin Drei-Linden für das Gebiet Berlin-Brandenburg ${ }^{2354}$ hatte und deren Zentrale für den gesamten Flüchtlingsbereich aus den früheren deutschen Ostgebieten in Berlin-Charlottenburg, Lietzenburger Straße, lag.

Unter Leitung von Bischof D. Dr. Dibelius nahm man sich der Betreuung der Flüchtlinge besonders an. Seit Herbst 1945 ergingen die ersten Rundschreiben.

Da diese Flüchtlingskreise und Pfarrer alle aus einer Provinzialkirche kamen, die ja zur AltpreuBischen Union gehörte, so ergaben sich auch keine Schwierigkeiten, wie sie etwa bei der Aufnahme in Lutherische Landeskirchen der Fall gewesen sind. Die Pfarrer hatten untereinander engen Kontakt und kamen im Rahmen von schlesischen Kirchentagen, wie sie die Leitung des schlesischen Pfarrervereins in Halle, Leipzig und Wittenberg organisierte, zusammen. Auf diesen Kirchentagen zeigte es sich, daß die Aufnahme der wenigen schlesischen Pfarrer in Berlin-Brandenburg so gut wie reibungslos verlief, nur ein Fall ist bekannt, wo von dem örtlichen Gemeindekirchenrat von dem betreffenden Pfarrer ausdrücklich eine schriftliche Erklärung verlangt wurde, daß er sich zu der Unierten Kirche hielte. Aufs Ganze gesehen, ist unter Führung von Bischof Dr. Dibelius die Aufnahme dieser wenigen Pfarrer, sobald sie sich meldeten, umgehend erfolgt und die Einsetzung in verwaiste Pfarrämter ist meistens in wenigen Tagen ebenfalls erfolgt. Die wirtschaftliche Versorgung wurde nach den Bestimmungen der Berlin-Brandenburgischen Kirche in vollem Umfange gewährleistet. Darüberhinaus hat Bischof Dr. Dibelius aus ihm persönlich zur Verfügung stehenden Fonds auch wirtschaftliche Eingliederungshilfen gegeben.

Gerade dieser Pfarrerkreis hat sich dann seinerseits der vertriebenen Gemeindeglieder aus eigener Initiative angenommen, wobei verständlicherweise der Dienst an diesen Vertriebenen unabhängig von ihrer früheren Zugehörigkeit zu den einzelnen Kirchengebieten im ehemaligen Osten erfolgte. Wie reibungslos [S. 45] die Aufnahme durchgeführt wurde, zeigt der Fall des letzten Superintendenten von Grünberg in Schlesien Dr. Böhm ${ }^{2355}$, der sofort als Superintendent in Straußberg ${ }^{2356}$ eingesetzt wurde. Die Kirchenleitung war froh, durch den Krieg entstandene Lücken in der Pfarrerbesetzung schließen zu können, und nahm nicht nur schlesische Pfarrer, die nach Berlin-Brandenburg verschlagen wurden, sofort auf, sondern streckte Fühler aus, um auch ihrerseits Pfarrer aus anderen Kirchengebieten in der russisch besetzten Zone nach Berlin-Brandenburg zu bekommen. Hier ist der Fall des Berichterstatters, Pfarrer Walter Schian, zu nennen, der in das Kirchengebiet der Sächsisch-Anhaltischen Kirche verschlagen war und schon zum 1. Oktober 1945 als Pfarrer in Belzig eingesetzt wurde. Zugleich wurde dieser mit der Verwaltung der freigewordenen Superintendentur des Kirchenkreises Belzig beauftragt, in die er

2354 [Hilfswerk der Evangelischen Kirchen in Deutschland, Hauptbüro Brandenburg, Waltharistr. 2-4, BerlinNikolassee (Pfarralmanach 1950, S. 296).]

2355 [Dr. Friedrich Böhm (1882-1963), ab 1913 Superintendent in Grünberg.]

2356 [Strausberg (bei Berlin).] 
nach einem Jahr endgültig berufen wurde. Diese Pfarrer haben ihrerseits ihnen bekannte Amtsbrüder nach Berlin-Brandenburg geholt, und der zuständigen Kirchenleitung für die Besetzung vakanter Pfarrstellen vorgeschlagen. Diesen Vorschlägen ist, soweit feststellbar, in allen Fällen sofort entsprochen worden; auch hier gab es keinerlei Schwierigkeiten bei deren wirtschaftlicher Sicherstellung, sie waren von Anfang an den alteingesessenen Pfarrern gleichgestellt.

Die schlesischen Pfarrer haben, soweit wie möglich, Kontakt mit ihren früheren Gemeindegliedern aus den schlesischen Gemeinden gehalten und diesen in Form von Rundbriefen und persönlichen Besuchen eifrig gepflegt. Doch ist die Zahl der seit Oktober 1945 bis 1947 auf diese oder jene Weise nach Berlin-Brandenburg gekommenen Pfarrer nicht groß gewesen. Man wird wohl diese Zahl auf etwa weitere 12 schätzen können.

Eine besondere Erschwernis lag nicht bei den kirchlichen Dienststellen, sondern bei der russischen Besatzungsmacht, die Pfarrer und Gemeindeglieder aus den Vertreibungsgebieten stärker unter Kontrolle hielt. Zu Flüchtlingstreffen ist es in diesen ersten Jahren nur vereinzelt gekommen. Der Versand der Heimatbriefe an Gemeindeglieder wurde ernstlich behindert.

Schließlich macht sich auch die unterschiedliche Entwicklung in West-Berlin und Ost-Berlin sowie dem russisch besetzten Brandenburg bemerkbar. In West-Berlin fanden sich schlesische Pfarrer in einem besonderen Bruderkreis zusammen, die in dem damaligen Diakonissen-Mutterhaus Bethanien am Mariannenplatz ${ }^{2357}$ Aufnahme fanden. Daß es gerade dieses Haus war hing damit zusammen, daß der damalige Anstaltsvorsteher, Pastor Langer ${ }^{2358}$, früher in Schlesien tätig war und gern diese ehemaligen Amtsbrüder in den Räumen des Mutterhauses zusammenkommen ließ, zumal ja Bethanien eine große Zahl von Gemeindeschwestern-Stationen in Schlesien besetzt hatte.

Nur aus West-Berlin ist bekannt, daß es schlesische Heimat-Gottesdienste gab. Die politische Lage ergab, daß solche eigenen Heimat-Gottesdienste, jedenfalls was die Schlesier betraf, im Übrigen Kirchengebiet nicht durchgeführt werden konnten. Die Entwicklung im Brandenburgischen Kirchengebiet und Ost-Berlin stand eher unter sich verschärfender Beobachtung als unter Lockerung. In West-Berlin dagegen sammelte sich ein Kreis schlesischer Pfarrer, der ab 1949 von dem als geschäftsführenden Direktor des Vereins zur Errichtung Evangelischer Krankenhäuser aus Belzig nach Berlin berufenen Superintendenten Schian im Evangelischen Krankenhaus Hubertus ${ }^{2359}$ geleitet wurde. Der Kreis kam anfangs im Januar zusammen, später am Pfingst-Dienstag. Diesem Kreis schlossen sich mehr und mehr schlesische Pfarrer aus dem Brandenburgischen Kirchengebiet an. Solange der Verkehr zwischen der russischen Besatzungszone und West-Berlin einigermaßen reibungslos lief, stieg der [S. 46] Besuch erheblich an, zumal auch die Angehörigen der

2357 [Central-Diakonissenhaus Bethanien, Mariannenplatz 1-3, Berlin-Kreuzberg (jetzt „Künstlerhaus Bethanien").]

2358 [Wilhelm Langer (1887-1970), Kirchenrat, Pfarrer und Anstaltsvorsteher des Central-Diakonissenhauses Bethanien in Berlin-Kreuzberg, Mariannenplatz 1-3, zuvor 1923-1945 Stadtmissionsleiter in Breslau (Pfarralmanach 1950, S. 40; Dietmar Neß: Schlesisches Pfarrerbuch. Bd. 1. Leipzig 2014, S. 253 f.).]

2359 [Spanische Allee 10-14, Berlin-Nikolassee.] 
Pfarrer mit geladen wurden. Am letzten Treffen dieser Art, am Pfingst-Dienstag 1961, haben etwa 80 Personen teilgenommen. Von diesem Kreis gingen Impulse aus, die auf die Arbeit der Pfarrer und ihrer Gemeinden, was die Flüchtlinge betraf, gute Auswirkungen hatte[n].

Die Eingliederung der Vertriebenen in den Gemeinden in Brandenburg hat in manchen Fällen auf Mitarbeit in den Gemeindekirchenräten, wie auch auf das Kirchengemeindeleben befruchtenden Einfluß gehabt. Dies geschah im wesentlichen aus eigener Initiative und nicht auf irgendeinen kirchenregimentlichen Akt hin. Tendenzen, etwa eigene schlesische Personalgemeinden zu schaffen, sind nicht bekannt. Sie wären nicht zum Tragen gekommen, da die Zahl der vertriebenen Schlesier in Berlin-Brandenburg nach wie vor gering war und erst etwa seit Mitte der fünfziger Jahre durch Zuzug aus dem Westen, vor allem nach West-Berlin, stärker wurde. Hier in West-Berlin war es dann die 1951 gegründete Landesarbeitsgemeinschaft evangelischer Schlesier für Berlin, die im Rahmen der Aufgaben und Richtlinien der Zentrale dieser Gemeinschaft in Hannover ihre Arbeit tat. Es gelang der Berliner Landesgruppe, etwa 400 bis 500 Adressen evangelischer Schlesier in West-Berlin zusammenzubekommen, von denen rund 100 offizielle beitragszahlende Mitglieder sind, Einige der zur Gemeinschaft gehörenden schlesischen Pfarrer hatten Kontakt mit den sich bildenden Vertriebenenkreisen und haben führend in Zusammenarbeit mit den Landsmannschaften in der Betreuung der ehemaligen Flüchtlinge, wie sie in Kirchenkreisen bzw. politischen Kreisen gesammelt waren, mitgewirkt.

Als Besonderheit ist vor allem die Lage in West-Berlin hervorzuheben, das ja über 2 Millionen Einwohner hatte, und, wie so oft in diesen großen weltstädtischen Ballungsräumen, durch keine allzugroße kirchliche Haltung der Bevölkerung belastet war. Die Zahl der zugezogenen Flüchtlinge war verhältnismäßig klein und wurde daher bald von dem wenig kirchlichen Geist der alten Reichshauptstadt aufgesogen. Der Einfluß der Flüchtlingsgruppen war und blieb gering. Es ist nichts bekannt, daß etwa bei der Wahl von Gemeindekirchenratsmitgliedern oder Mitgliedern der Kreissynoden oder der Provinzialsynode als besonderer Gesichtspunkt die Zugehörigkeit zu einer ehemaligen evangelischen Ostkirche geltend gemacht wurde.

Mit der erheblichen Verschärfung der Spannungen zwischen Ost und West, die dann den Höhepunkt im Bau der Mauer fanden, verminderten sich die Möglichkeiten der Arbeit im steigenden Maße.

Hervorzuheben ist, daß aber von den Vertriebenenkreisen aus gerade auf dem Gebiet des Arbeitsfeldes der Diakonie Initiativen, wie etwa der Fürsorge der Aufnahme von alten Menschen ausging. Schlesische Mutterhäuser haben zwar in Berlin keine Aufnahme gefunden, dagegen Mutterhäuser in Lehnin ${ }^{2360}$ und Potsdam-Babelsberg ${ }^{2361}$. Weiterhin konnten ältere schlesische Flüchtlinge in Altersheimen oft untergebracht werden.

2360 [Offenbar im Krankenhaus Luise-Henriette-Stift, bisher nicht näher zu klären.]

2361 [Offenbar im Oberlinhaus, bisher nicht näher zu klären.] 
Seit dem Mauerbau hat sich die Arbeit ganz auf Berlin beschränkt. Finanziert wurde diese Arbeit weitgehend durch Spenden und Mitgliederbeiträge. In einigen seltenen Fällen gelang es, speziell für die schlesische Arbeit von der Kirchenleitung einmal einen Zuschuß zu erhalten. Doch sind das in den Jahren 1961 bis 1972 wohl nur etwa 1000,- DM gewesen. Im wesentlichen mußte sich [S. 47] die Arbeit selbst tragen. Ein Besuchsdienst für erkrankte oder ältere schlesische Gemeindeglieder wurde eingerichtet und dankbar aufgenommen.

Versuche, unter der Jugend Nachwuchs zu gewinnen, kamen auf Berliner Boden nicht zur Auswirkung. Schmerzlich war, daß man oft auf völliges Unverständnis, gerade bei der Pfarrerschaft, für die Probleme der Vertriebenen stieß. Es ist ja nicht nur mit der wirtschaftlichen Integrierung abgetan, sondern gerade auf dem Gebiet der inneren seelischen Vereinsamung liegen ja die tieferen Probleme.

Das schlesische Heimatbewußtsein ist stark ausgeprägt, die meisten schlesischen Gemeindeglieder wußten, auch wenn die sich da oder dort weniger um ihre Kirche gekümmert hatten, doch, daß die schlesische Kirche erhebliche Leidenszeiten in der Zeit der Gegenreformation durchgemacht hatte. Die Namen der schlesischen Friedenskirchen und Gnadenkirchen sowie der Bethäuser waren auch Gemeindegliedern bekannt, die vielleicht nicht sich völlig mit ihrer Kirche verbunden wußten. Für die kirchlichen Gemeindeglieder waren sie ein wesentlicher Bestandteil ihrer Gemeindegeschichte und erinnerten an die Bedrückung, wie sie die evangelische Kirche in Schlesien durchzustehen hatte. Die Eroberung Schlesiens durch Friedrich den GroBen wurde allgemein als eine Wende für die evangelische Kirche in Schlesien angesehen. In den Kirchen hing das Bild Friedrichs des Großen ebenso oft, wie auch dort der schlesische Adler angebracht war. Man war dankbar, aus dem katholischen Österreich ausgegliedert zu sein und sich nunmehr dem protestantischen Preußen zugehörig fühlen zu können. Der Historiker mag dazu manche Randbemerkung machen, aber für das kirchliche Bewußtsein der evangelischen Gemeindeglieder war dies wesentlich. Der Evangelische Schlesier war daher innerlich etwas bestürzt über die Entfremdung in der Kirche, wie er sie in Berlin vorfand. Dazu kam, daß der Schlesier auch ein starkes Bewußstein vom kulturellen Erbe seiner Heimat mitbrachte, angefangen von den Sagen um die Gestalt des „Rübezahl“ im Riesengebirge über die Großzahl der schlesischen Liederdichter hin, deren Lieder auch heute im Gesangbuch enthalten sind (Klepper $^{2362}$ ). Eine Gestalt wie Kurt Ihlenfeld stand ihm mit seinen Romanen, die teils in Schlesien, teils in Berlin spielten, nabe. Ebenso Gestalten wie Gerhart Hauptmann, der ja weit über Schlesien hinausgewirkt hat.

Aus allen diesen Schilderungen ergibt sich, daß eine echte Eingliederung, vor allem auf dem Gebiet der inneren seelischen Haltung, in diesem neuen Raum bis zum heutigen Tage große Probleme mit sich bringt. 


\section{(167) Protokoll der Sitzung des Hauptvorstandes des Gustav-Adolf-Werks der evangelischen Kirche für Berlin und Brandenburg. - Berlin, 31. August 1946 (Auszug)}

ELAB, Best. 29 Kirchenkreis Kölln-Land I, Nr. 554, unfol. - Typoskript (Durchschlag), 3 Bl., ohne Unterschrift. B1. [1]: L. o. „Gustav Adolf-Werk/ der ev. Kirche / für Berlin u. Brandenburg“; r. o.: „Berlin-Lichterfelde.West, d. 31.8.46 / Augustastr. 24“, hierunter handschriftlich datierter und numerierter Eingangsstempel „Superintendentur Kölln-Land I / Berlin-Lichterfelde, den 11.9.1946 / Tgb.Nr. 1537“; Überschrift: „Niederschrift / der Sitzung des Hauptvorstandes am 5. Juli 1946."

[...] [Bl. 2] [...]/Zu Punkt II der Tagesordnung ${ }^{2363}$ erstattet die Geschäftsführerin ${ }^{2364}$ einen Arbeitsbericht über die Zeit seit der letzten Hauptvorstandssitzung (28.6.[19]45):

Das Schwergewicht der Arbeit lag in der Flüchtlingsfürsorge, besonders in der Betreuung der aus dem Osten vertriebenen Pfarrer, ihrer Familien und Gemeinden. In der Flüchtlingsfürsorgearbeit wurden eingestellt: 2 Seelsorger (Pfr. Lic. [Harald] Kruska aus Posen und Pastor Dr. [Walter] Taube aus Danzig) und 2 Fürsorgerinnen (Blümner und Gock). Betreut wurden 5 Lager und zeitweise mehrere Bahnhöfe.

Der Geschäftsstelle selbst lag die persönliche Betreuung der „wandernden Diaspora“ ob: Versand von Lesepredigten, Unterrichtshilfen, theologischen Büchern und Schriften und der ev. Wochenzeitschrift „Die Kirche“. Regelmässiger Verkehr zur Zeit mit etwa 600 Anschriften. Finanzielle und materielle Unterstützung mit gesammelten Bekleidungsstücken. Vortragstätigkeit, Veranstaltung von Rüsttagen, um die Arbeit am Gustav Adolf-Werk von neuem auf eine biblische Besinnung zu gründen, damit von da her den Gustav Adolf-Freunden neue Kraft und Liebe erwachse. Die früheren Wege der Werbetätigkeit (Druckschriften, GA-Bote) sind zur Zeit noch nicht wieder gegeben. Für diese gegenüber früher viel mehr Kräfte beanspruchende Tätigkeit wurde zur Unterstützung der Geschäftsführerin Frl. Stempel als Mitarbeiter Herr Scherer eingestellt, dem auch die Buchführung obliegt.

Die Flüchtlingsfürsorge hat schliesslich zur Errichtung eines Gustav Adolf-Kinderheimes in Pulsnitz/Sachsen und zur Betreuung von Flüchtlingskindern überhaupt (Unterbringung in sonstigen Heimen) geführt. Insgesamt 21 Kinder werden z. Zt. von dem Gustav Adolf-Werk Berlin betreut.

Die neuesten Berichte aus Österreich und von D. Zoeckler ${ }^{2365}$ werden bekanntgegeben. / [...]

2363 [Geschäftsbericht.]

2364 [M. Stempel.]

2365 [Dr. theol. Theodor Zoeckler (1867-1949), ev.-luth. Pfarrer in Stanislau in Galizien, dort Gründer der diakonischen „Zöcklerschen Anstalten“, 1924-1939 Superintendent u. Kirchenpräsident der Evang. Kirche A(ugsburgischen) und H(elvetischen) B(ekenntnisses) in Kleinpolen, 1939-1943 im „Wartheland“, 19431945 nochmals in Stanislau, Jan. 1945 Flucht, lebte dann bis zum Tod in Stade, 1946 Gründer des Hilfskomitees der Galiziendeutschen A. u. H. B. im Diakonischen Werk der EKD e.V.] 
(168) Rundschreiben des Konsistoriums betr. die kirchliche Registrierung und das kirchliche Beurkundungswesen der Evakuierten, Flüchtlinge und Umsiedler. Berlin-Charlottenburg, 16. Mai 1947

ELAB, Best. 29 Kirchenkreis Kölln-Land I, Nr. 367, unfol. (16.5.1947). - Typoskript, hektografiert, 1 S. - O.1. Absender „Ev. Konsistorium / der Mark Brandenburg“, darunter „K. I Nr. 8341/47“. - R. o. „Berlin-Charlottenburg, den 16. Mai 1947 / Jebensstr. 3“. - Betreff: „Betr: Die kirchliche Registrierung und das kirchliche Beurkundungswesen der Evakuierten, Flüchtlinge und Umsiedler.“ v U.1. „An die / Herren Superintendenten unseres Aufsichtsbereichs / und an die Herren kirchlichen Archivpfleger.“ - U.r. Unterschrift (Tyoskript) „gez. Dr. von Arnim“ [Hans Ludwig v.A., Präsident des Konsistoriums]. - O.r. Eingangsstempel mit handschriftlichen Einträgen: „Superintendentur KöllnLand I / Berlin-Lichterfelde, den 28. V. 1947 / zu Tgb. Nr. 135.2“.

Obwohl das Seßhaftwerden der Evakuierten, Flüchtlinge und Umsiedler an den neuen Wohnorten noch nicht überall zum Abschluß gekommen ist und sich die fluktuierende Bevölkerung in den Städten, zumal in den Großstädten noch nicht endgültig übersehen läßt, erscheint es kirchlich dringend erforderlich, an die Registrierung der neuen Gemeindeglieder und Gäste heranzugehen, weil diese Registrierung die Grundlage und die Kontrolle für das Durchdringen der Wortverkündigung, die seelsorgerliche Erfassung, den kirchlichen Unterricht und die kirchlichen Amtshandlungen bildet. Die kirchliche Registrierung der neuen Gemeindeglieder besteht 1.) in ihrer karteimässigen Erfassung („Flüchtlingskartei“) und 2.) in dem „Flüchtlingsbuch".

1.) Die karteimäßige Erfassung aller neuen bzw. vorübergehenden Gemeindeglieder (Evakuierten, Flüchtlinge und Umsiedler) soll sofort beginnen. Dabei soll als Muster die übliche Form der am Ort gebrauchten Seelenkartei bzw. Gemeindekartei zu Grunde gelegt werden, die Flüchtlingskartei als solche aber von der Gemeindekartei getrennt gehalten werden. Sobald der gegenwärtige Bestand der Evakuierten, Flüchtlinge und Umsiedler etc. vollständig erfasst ist, wird die Flüchtlingskartei in eine genau alphabetisch geordnete Liste geschrieben und von dieser Liste eine Durchschrift an das Konsistorium gesandt. Eine andere Durchschrift der Liste wird dem „Flüchtlingsbuch“ vorangeheftet. ${ }^{2366}$

2.) Das „Flüchtlingsbuch“ enthält alle genauen Eintragungen über die kirchlichen Beurkundungen und Amtshandlungen aller Art an Evakuierten, Flüchtlingen und Umsiedlern und gibt genauen Einblick in ihre kirchlichen Verhältnisse. Zugrunde gelegt ist dabei die Anordnung über das „Verfahren bei Unmöglichkeit, Bescheinigungen über Taufe und Kirchenzugehörigkeit beizubringen“" (Kirchl. Amtsblatt 1946 Nr. 10/11 S. 55 f.) Jede der zeitlich auf einander folgenden Beurkunungen und Eintragungen im Flüchtlingsbuch erhält eine besondere Nummer, die von Jahr zu Jahr neu zu zählen ist. Das „Flüchtlingsbuch“ enthält keine Rubriken; es werden in jedem einzelnen Falle zu jeder Eintragung so viel Beweismittel (Urkundenabschriften, Zeugenaussagen, eidesstattliche Versicherungen usw.) beigebracht wie möglich ist. Zu dem Flüchtlingsbuch

2366 [Am linken Rand dieses Absatzes Bleistiftkommentar:] „Fluktuation kurzzeitig [...] Z. Zt. kaum durchführbar / Papier + Schreiber fehlen“. 
wird ein alphabetisches Register über alle in den Eintragungen vorkommenden Familiennamen laufend geführt.

Die Amtshandlungen an den Evakuierten, Flüchtlingen und Umsiedlern usw. werden überdies in kürzester Form in die üblichen Tauf-, Trau-, Sterbe-, Konfirmanden- usw. Register der Kirchengemeinde eingetragen. Dabei ist auf die ausführliche Eintragung im Flüchtlingsbuch unter Angabe von Jahrgang und Nummer hinzuweisen. Wir erwarten von allen Kirchengemeinden zu Beginn des Jahres 1948 einen Bericht über die Anlegung des Flüchtlingsbuches, darüber hinaus von den Landgemeinden die Einsendung der Flüchtlingsliste und von den Stadtgemeinden einen Bericht über die Art und Weise, wie sie - etwa durch das Finanzamt, das Einwohnermeldeamt oder andere Dienststellen - über Namen, Zahl, Leistungsfähigkeit usw. der neuen Gemeindeglieder dieser Art unterrichtet werden.

\section{(169) Rundbrief des evangelischen Bischofs von Berlin Otto Dibelius an}

\section{die Pfarrer seiner Landeskirche betr. Flüchtlingsbetreuung. - Berlin, 14. Februar 1948}

ELAB, Best. 1 Konsistorium, Nr. 2453, unfol., Abschrift, hektografiertes Typoskript (2 S.) in „Dokumentation über die Aufnahme der Pfarrer und Gemeindeglieder aus den zerstreuten Evangelischen Kirchen des Ostens in die westlichen Gliedkirchen; hier: Bericht zur Frage der Aufnahme in den Raum der Evangelischen Kirche in Berlin-Brandenburg und der sich daraus ergebenden Folgeerscheinungen für die in dies Kirchengebiet Aufgenommenen, wie auch aus der Sicht der aufnehmenden Landeskirchen“, erstellt von Kirchenrat Walter Schian, „Vorsitzender des Berliner Konvents der Hilfskomitees der zerstreuten evangelischen Ostkirchen“, [1972], Anlage zu Punkt 1) (= S. 28-29). S. 1: Briefkopf 1. „Der evangelische Bischof / von Berlin“, darunter Aktenzeichen/Tagebuch-Nr. „K. I Nr. 812/48“, r. o.: „Berlin, den 14. Februar 1948 / Charlottenburg 2, / Jebensstraße 3“.

Meine Lieben Brüder!

Es ist niemand unter uns, dessen Gedanken nicht täglich zu unseren Flüchtlingen aus dem Osten gehen und zu den äußeren und inneren Nöten, in denen sie stehen. Ich brauche kein Wort darüber zu verlieren, wie sehr diese Umsiedler, die ja nun längst gleichberechtigte Glieder unserer Kirchengemeinden geworden sind, einer besonders nachgehenden Seelsorge bedürfen und wieviel Schwierigkeiten innerer Art bei ihnen nach Abhülfe verlangen. Dabei lehrt die Erfahrung immer wieder, daß die Flüchtlinge leichter auf einen Pfarrer hören, der selbst aus dem Osten vertrieben wurde, als auf den eingesessenen, dem gegenüber sie allzu leicht das Vorurteil haben, daß er sie nicht recht verstehen könne.

Aus einer Besprechung dieser ganzen Fragen ist ein Beschluß der Kirchenleitung erwachsen, daß in jedem Kirchenkreis ein Pfarrer aus dem Osten zum Vertrauensmann für die seelsorgerlichen Aufgaben an den Umsiedlern bestellt werden soll. Diese Vertrauensmänner sollen in Fühlung mit den Ortsgeistlichen und den übrigen Amtsbrüdern, den Kreisstellen der Inneren Mission und des Hilfswerks sowie den sonstigen Umsiedlerbetreuern darauf bedacht sein, sich der seelischen Nöte und der kirchlichen Anliegen der Umsiedler anzunehmen, sie gelegentlich um Gottes Wort zu sammeln - nicht um eine Absonderung von der eingesessenen Gemeinde zu unterstützen, - sondern im Gegenteil um ihnen den Eingang in das kirchliche Leben und die kirchliche Sitte der Gemeinde, in der sie nun einmal wohnen, zu erleichtern. Die Gefahr, daß 
die Flüchtlinge aus dem Osten sich gesondert zusammenschließen und dann einer Freikirche beitreten, ist größer, als mancher glaubt. Wir haben in anderen Provinzen derartige Fälle bereits in erheblichem Ausmaß.

Ich bitte Sie daher, einen solchen Vertrauensmann für jeden Kirchenkreis zu berufen und den Namen an den Leiter des Kirchendienstes Ost, Herrn Pfarrer Lic. Dr. Kammel, Berlin-Dahlem, Reichensteiner Weg 24, mitzuteilen.

Pfarrer Dr. Kammel ist beauftragt, die gesamte Betreuung der Umsiedler in unserer Kirchenprovinz zusammenzufassen. An ihn bitte ich, etwaige Fragen zu richten und ihm bis zum 1.10.1948 mitzuteilen, was in dieser Angelegenheit an Erfahrungen, Wünschen und Anregungen sich in Ihrem Kirchenkreis ergeben hat.

Neben dieser allgemeinen kirchlichen Betreuung aller Umsiedler soll die besondere landsmannschaftliche Zusammenfassung weiter einhergehen. Es sollen also gelegentlich Schlesier von schlesischen Pfarrern beucht werden, die Ostpreußen von ostpreußischen und so fort.

Die beteiligten leitenden Stellen sind in dieser Frage völlig einmütig, sodaß Reibungen nicht zu befürchten sind. In jedem Falle aber soll Seelsorge und Wortverkündigung im Mittelpunkt stehen. Daneben wird immer wieder auf die Fragen einzugehen [S. 29] sein, die die Umsiedler besonders beschäftigen: Volkstum, Union, Einzelschuld und Gesamtverantwortung.

Ich bitte Gott, daß aus einer solchen liebevollen und verständnisvollen Arbeit an den Flüchtlingen ein wirklicher Segen für unsere Gemeinden erwachsen möchte. Wir wissen alle, daß die Umsiedler von Hause her an treue Kirchlichkeit gewöhnt sind. Bei vielen ist diese Kirchlichkeit durch die schweren Erlebnisse der Flucht erschüttert worden, bei anderen hat sie sich umso mehr vertieft. Aus einer solchen vertieften Kirchlichkeit könnte in unseren Gemeinden eine reiche Frucht erwachsen.

In herzlicher Verbundenheit

Ihr getreuer

gez. D. Dr. Dibelius

\subsubsection{Katholische Kirche (1945-1947)}

(170) Bericht über die seelsorgliche Betreuung der vertriebenen Schwarzmeerdeutschen durch das katholische Pfarramt in Cottbus. Cottbus, [September 1945]

DAB, I/9-15-1 Flüchtlingsseelsorge 1945-1951, unfol., [Okt. 1945]. - Typoskript (Durchschlag), 4 Bl. - Ohne Datum, Verfasserangabe, Unterschrift und Adresse. - Verfasser ist Erzpriester Bruno Broß, Cottbus (siehe unten im Text); vgl. den verschiedene kleinere Textvarianten berücksichtigenden Druck nach der Überlieferung im Bistumsarchiv Görlitz in: Winfried Töpler: Der zehntausendfüßige Menschenwurm. In: Vertriebene finden Heimat in der Kirche. Köln u. a. 2008, S. 291-635, hier S. 410-413. 
Die seelsorgliche Betreuung der Schwarzmeerdeutschen durch das katholische Pfarramt in Cottbus Wer die Verhältnisse der hiesigen Seelsorge näher kennt, wird feststellen müssen, daß die kath. Pfarrei Cottbus mit ihren mehr als 80 eingepfarrten Ortschaften ausserordentlich starken Diasporaeinschlag aufweist. Hinzu kommt die zusätzliche Belastung durch den schier endlosen Zustrom der aus Ober- und Niederschlesien, aus der Grafschaft Glatz und aus dem Sudetengau ausgewiesenen Flüchtlingsdeutschen, dann aber auch für die Zeit von Mitte Juli bis Anfang September die seelsorgliche Betreuung der Schwarzmeer-Deutschen. Was letztere anlangt, so wurden diese s[einer] Z[eit] von der deutschen Wehrmacht bei dem im Jahre 1944 beginnenden Vormarsch der Russen evakuiert und im März des gleichen Jahres nach dem Warthegau gebracht. Nach der Besetzung des deutschen Ostens durch die Russen im Februar 1945 verfügten diese ihre vorübergehende Unterbringung in Luckenwalde und bald danach von Juli bis Anfang September in den Wartelagern in und um Cottbus zwecks Rückführung nach Rußland.

Die Geschichte dieser Auslandsdeutschen, insbesondere ihrer Auswanderung aus der deutschen Heimat und ihrer Ansiedlung in Rußland mag durch ein paar Gedankenstriche angedeutet werden. Vor etwa 150 Jahren rief die weitblickende und unternehmende Kaiserin Katharina II. von Rußland, der Abstammung nach eine deutsche Prinzessin von Anhalt-Zerbst, nach ihrem Regierungsantritt im Jahre 1762 deutsche Ansiedler aus dem Elsaß und Schwabenlande nach Rußland in der Absicht, das damals verhältnismässig schwach besiedelte, aber fruchtbare Gebiet an der Wolga, am Schwarzen Meer, in der Dobrudscha und Krim durch deutschen Kolonistenfleiß nutzbar und ihrer groß angelegten Agrarpolitik dienstbar zu machen. Das Angebot war für die in sehr genügsamen Verhältnissen lebenden Familien umso verlockender, als ihnen ein weit ausgedehntes Areal im Ausmaß von 100 bis 1000 ha pro Familie zur selbständigen Bewirtschaftung überlassen wurde. Trotz der nunmehr fast 4 Generationen überdauernden Loslösung von ihrer angestammten Heimat und den mannigfachen religiös-politischen Wandlungen im zaristischen wie sowjetischen Rußland, legten diese Auslandsdeutschen ein äusserst zähes Festhalten am Erbgut ihrer deutschen Herkunft in Sprache, Sitte, völkischem Brauchtum, vor allem aber in ihrer religiösen Haltung an den Tag; eine Zähigkeit, an der [Bl. 2] selbst die tiefeinschneidenden und radikalen antichristlichen Verfolgungsmaßnahmen abprallten, die im Jahre 1932 mit steigender Heftigkeit einsetzten. Ja, fast möchte es scheinen, als ob gerade dieser Druck eine Reaktion ausgelöst habe, die geradezu eine Erhöhung der Spann- und Sehkraft ihres tiefgläubuigen Sinnes zur Folge hatte. Dieser Beobachtung konnte sich niemand entziehen, der z.Z. ihres Aufenthaltes in Cottbus den tiefreligiösen Sinn und Eifer in den Übungen der Frömmigkeit wahrnehmen konnte. Eine frische religiöse Welle schien die Gemeinde von Cottbus überflutet zu haben. Diese rege Beteiligung am Gottesdenst wochentags und sonntags in überfüllter Kirche, dieser Andrang bei den Beichtstühlen und an der Kommunionbank, dieses verständnisvolle Miterleben des Kirchenjahres mit seinen Festgezeiten und heiligen Bräuchen, diese Vorliebe für das Rosenkranzgebet und andere kirchliche Andachten, der kindlich-fromme Gebrauch der Sakramentalien, vorab des Weihwassers, diese Singfreudigkeit in Pflege des kirchlichen Volksliedes und eines geschulten Choralgesanges, diese Opfer- und Gebefreudigkeit, die 
von der eigenen Ration absparte zu Gunsten der hungernden Flüchtlinge, die von unserer Pfarrcaritas betreut wurden - man sprach damals: halb Cottbus lebe von ihrem Brote - dies alles und vieles andere kennzeichnet so recht den innig-frommen, opferwilligen und kirchenfreudigen Geist eines urwüchsigen, von moderner Kompliziertheit unangekränkelten Volksgemüts.

Unwillkürlich drängt sich die Frage auf, wie denn diese verfolgten Glaubensbrüder unter dem Druck einer so radikalen Verfolgungspolitik sich zu solch mannhaftem Bekennertum erschwingen konnten? Man vergesse nicht, daß diese mutigen Kämpfer nach der im Jahre 1932 erfolgten Verbannung ihres Bischofs und ihrer Priester fast ganz auf sich allein angewiesen waren. Und wenn ihnen auch später während ihrwer Asylzeit in Rumänien manch schätzenswerte und dankenswerte Hilfe durch den dortigen Bischof Markus Glaser ${ }^{2367}$ und seine Priesterschaft zuteil wurde, so konnte es sich doch nur um einen vorübergehenden Notbehelf handeln. Nein, der tiefste Grund ihrer vorbildlichen religiösen Haltung war etwas anderes: Eine stark ausgeprügte, lebendige und bewußt gepflegte Traditionsverundenheit. Von ihr gingen starke, erzieherische Kräfte aus in das Familienleben und in das daraus entspringende Familienapostolat. Dieses brachte jene wetterfesten, [Bl. 3] willenstarken und kernhaft frommen Söhne und Töchter hervor, die das religiöse Erbgut ihrer Väter und Vorväter in heiliger Pietät entgegennahmen und von Geschlecht zu Geschlecht weitergaben. Welchen Segen dieses innerhäusliche Apostolat vorab auf die Kinderwelt und heranwachsende Jugend ausübte, davon konnten sich die Katholiken von Cottbus tagtäglich durch eigenen Augenschein überzeugen. Welch ein Schauspiel war es zu sehen, wenn diese ernst veranlagte und für alles Religiöse empfängliche Jugend mit einem wahren Heißhunger nach religiöser Belehrung und nach dem Empfang der hl. Sakramente verlangte! Solch ungestümem Herzensdrange konnte sich der seeleneifrige Pfarrer von Cottbus nicht verschließen, zumal er unter ihnen nicht wenige vorfand, die selbst über das 20 . Lebensjahr hinaus noch nie gebeichtet und kommuniziert hatten. Sein Entschluß stand fest, dem Hunger dieser darbenden Seelen nicht länger zu wehren, sondern ihnen ohne Verzug den Weg zum Heilandsherzen zu bahnen.

Da man täglich auf einen Abtransport der Schwarzmeer-Deutschen gefaßt sein mußte, war eine Vorbereitung auf Erstbeicht[e] und Erstkommunion nur möglich auf dem Wege von Schnellkursen. Mancherlei Schwierigkeiten drohten seinen Plan zu durchkreuzen. Vor allem war es die strenge Überwachung des Lagers durch russische Posten. Besuch und Verlassen desselben war nur den Inhabern von Passierscheinen erlaubt; diese aber erhielten nur die wenigsten. Kinder[n] und Jugendlichen blieben sie ganz verwehrt. Aber man wußte Rat. Wenn alles Bitten nichts half, dann wurden künstliche Ausgänge durch Gartenzäune und Kellerlöcher geschaffen; und dann kamen sie helleuchtenden Auges in den Unterricht und meldeten siegesfroh: „Es ist uns wieder einmal geglückt.“ Dank dieser Zusammenarbeit gelang es Pfarrer Broß ${ }^{2368}$ mit Un-

2367 [Markus Glaser (1880-1950), 1942 bis 1948 röm.-kath. Bischof und Apostolischer Administrator der Diözese Iaşi (Jassy).]

2368 [Bruno Broß (1898-1970), Geistlicher Rat, 1939-1969 kath. Pfarrer in Cottbus.] 
terstützung zweier Flüchtlingspriester und einer hiesigen Schwester aus der Genossenschaft der Mägde Christi ${ }^{2369}$ innerhallb von drei Wochen in drei größeren und zwei kleineren Vorbereitungsgruppen etwa 280 Kinder und Jugendliche zum Tische des Herrn zu führen. In dem Bemühen, der jungen Brautschar des eucharistischen Heilandes dem Erstkommuniontag die Charakternote eines unvergesslichen Gedenktages aufzudrücken, gedachte Pfarrer Broß die heilige Feier durch reiche liturgische Umrahmung recht ausdrucksvoll zu gestalten. In diesem Bestreben unterstützten ihn die hochbeglück- [Bl. 4] ten Eltern der Erstkommunikanten im edelsten Wetteifer durch Beschaffung von Festkleidern, Kerzen, geschmackvollen Blumenschmuck für Kopfschleier, Haarschmuck, Kerzen und Gewandung. Ein ergreifendes Schauspiel bot sich den Festteilnehmern, als der in musterhafter Ordnung und andachtiger Haltung nahender Festzug durch ein dichtgedrängtes Spalier neugieriger Zuschauer, unter priesterlicher Führung und unter den K[1]ängen des Kirchenchors der Schwarzmeer-Deutschen dem festlich geschmückten Gotteshaus zuschritt. Der Ablauf der Feier mit feierlichem Orgelklang, Festansprache, Erneuerung der Taufgelübde, Chor- und Choralgesang und zwischendurch eingelegten Kindergebeten schuf eine äusserst weihevolle Athmosphäre. Als Nachklang der vormittägigen Hauptfeier war nachmittags zu Ehren der Heilandsmutter eine eindrucksvolle Schlußandacht mit feierlicher Weihe an das reinste Herz Mariä vorgesehen, Eine theophorische Prozession mit sakramentalem Segen krönte die Festfeier.

Die Festveranstaltungen sind vorüber. In der Pfarrkirche von Cottbus ist es wieder stiller geworden. Die Schwarzmeer-Deutschen sind inzwischen in ein anderes Wartelager überführt worden. Aber der in Cottbus gestiftete Segen wird bleiben. Schweren, aber dankerfüllten Herzens nahmen unsere Glaubensrüder vom Schwarzen Meer von uns allen Abschied.

Möge der Heiland, der ihnen und ihren Kindern vom Tabernakel der Pfarrkirche zu Cottbus aus so viel himmlisches Glück ins Herz gelegt hat, ihnen als treuer Weggenosse das weitere Geleite geben in seiner Liebe, seiner kraftspendenden Gnade und seinem Frieden! So wechselvoll ihr Lebenslos sich künftighin auch gestalten mag, die eucharistische Verbundenheit, die im sakramentalen Gotteszelt von Cottbus einen so verheißungsvollen Auftakt genommen, wird sie über alle irdischen Schicksalswendungen, Mühen und Sorgen hinweg im felsenfesten Vertrauen auf Gottes gütige und weise Führung aufrecht erhalten, gestützt auf das Heilandswort: „Kommet her zu mir, die ihr mühselig und beladen seid, ich werde euch erquicken."2370

\section{(171) Bericht über die katholische Flüchtlingsfürsorge in Spremberg. - Spremberg, 8. März 1946}

DAB, I/9-15-1 Flüchtlingsseelsorge 1945-1951, unfol., [8.3.1946]. - Typoskript, 1 Bl. Bericht, dabei: 1 Bl. Typoskript-Anschreiben: Absender 1.o., gedruckt: „Katholisches Pfarramt/Spremberg Nd.-L./[...]“, r.o. Datierung „Spremberg Nd.-L., den 8. März 1946“, darunter r. Adresse „An Seine Eminenz den hochwürdigsten Herrn, Herrn Kardinal Dr. von Preysing, Bischof von Berlin / in Berlin“, 1. „Tgb.Nr. 61/46“. - Ganz o. 1. Bleistiftvermerk zur Referats- 
zuständigkeit: „Flüchtlinge“, davor (durchgestrichen): „Ostfragen“.- Bericht: Absender 1.o., gedruckt: „Kath. Pfarramt / Spremberg Nd.-L. / [...]“, r. o. Datierung „Spremberg Nd.-L., den 8.3.1946 / Bergstraße 21“; u.r. Unterschrift (Tinte) „Adamski“ [Dr. Roman Adamski].

\section{Ew. Eminenz}

erlaube ich mir, obwohl zum Erzbistum Breslau gehörig, da die gegenwärtige traurige organisatorische Lage des Erzbistums Breslau es nicht als zweckmässig erscheinen lässt, einen kurzen Bericht über den Stand der hiesigen Umsiedlerfürsorge bezw. das hiesige Umsiedlerlager zu überreichen. Die seelsorgliche Gewissensnot hat mich dazu schon längst getrieben; aber erst heute bin ich infolge eines günstigen Umstandes in der Lage, durch einen vertrauenswürdigen Boten diesen Bericht des hiesigen Lagers in die Hände Ew. Eminenz gelangen zu lassen.

Da die Verhältnisse des hiesigen Lagers typisch für die vielen anderen Lager sind, bin ich der bescheidenen Meinung, dass ein solcher Bericht Ew. Eminenz gelegen kommen könnte. Ich bitte herzlich wie dringend, von diesem Bericht in jeder Form Gebrauch machen zu wollen und bin

Ew. Eminenz

$$
\begin{aligned}
& \text { ehrfurchtsvoll ergebenster } \\
& \text { [gez.] Dr. Adamski, Pfarrer }
\end{aligned}
$$

\section{Bericht über die Flüchtlingsseelsorge in Spremberg}

Seit Ende Oktober 1945 ist auch das in Spremberg L[ausitz] befindliche Umsiedlerlager (Durchgangslager) von sogen. Umsiedlern besetzt. Das Lager besteht aus dem einzigen noch vorhandenen massiven Gebäude einer ehemaligen Fallschirmfabrik und etwa 10 Holzbaracken, welche früher von Ostarbeitern, dann von italienischen Kriegsgefangenen bewohnt gewesen waren. Welcher Art der Zustand des Lagers ist, kann man sich deshalb leicht vorstellen. Dass guter Wille vorhanden und alle Anstrengungen seitens der Lagerleitung, der Aerzte und des Pflegepersonals, welche unter $\mathrm{Au}[\mathrm{f}]$ sicht der deutschen und russischen Behörden arbeiten, gemacht werden, darüber besteht kein Zweifel. Trotzdem müsste manches verbessert werden. Die Entlausungsanlagen bedürfen dringend einer gründlichen Ueberholung bezw. Erneuerung und Erweiterung. Die Krankenbaracke ist, schwach ausgedrückt, primitiv. Ein Kleidermagazin und eine Apotheke sind m.W. nicht vorhanden; die Aerzte bitten sehr um Medikamente. Die Umsiedler nächtigen auf Strohlagern, in den Baracken in rohen Holzbettstellen mit Papierstrohsäcken. Bettwäsche, Krankenbekleidung etc sind nicht vorhanden; die Kranken schlafen in ihren Decken, Kleidern bezw. Lumpen. In mehreren Baracken fehlen die Fensterscheiben ganz oder teilweise. Von dem allgemeinen Zustand des Lagers soll hier nicht die Rede sein.

Der erste Transport (hauptsächlich Schlesier und Breslauer), der Ende Oktober 1945 hier eintraf, zählte gegen 1000 Mann (auch Frauen u. Kinder). Dann kamen Insassen eines Altersheimes aus Sorau und kleinere Gruppen, welche sich bis Mitte Dezember im Lager aufhielten. Mitte Januar 1946 erschien plötzlich ein grosser Transport von ca 1200 Personen (Oberschlesier, Schlesier, Sudetendeutsche, Oesterreicher, Polen), von denen noch ca 350 anwesend sind. 
Diese Umsiedler kamen aus dem polnischen Lager Jaworzno bei Trzebnica ${ }^{2371}$ (Richtung Krakau), wo sie mit Konzentrationslagermethoden behandelt worden waren! und [von wo sie] völlig ausgeplündert, krank, siech, erschöpft und verzweifelt ankamen. 50 waren schon unterwegs gestorben. Vom ersten Transport starben 31 (meistens Frauen), vom letzten sind 38 katholisch, mehrere protetantisch beerdigte [so!] worden (meistens Männer). Die Todesursachen waren Dysenterie, Altersschwäche, Typhus, Lungenleiden, Herzschwäche. Kirchliche Stellen, Katholiken und Protestanten (Einzelpersonen) halfen durch Speisungen, Bekleidung, Lebensmittel, Geld. Bei der Notlage der hiesigen Bevölkerung ist das leider nur in beschränktem Umfange möglich gewesen. Die Umsiedler wurden nach Möglichkeit häufig besucht, vor allem die Kranken. Regelmässig fanden katholische und protetantische Gottesdienste statt, es wurde Beichtgelegenheit geboten, die Kranken wurden versehen, die Toten kirchlich eingesegnet bezw. beerdigt. An den Gottesdiensten beteiligten sich 2-300 Personen. Es wurde Post nach Schlesien durch Herrn Caritasdirektor Zinke ${ }^{2372}$ vermittelt.

Die Lagerleitung ist immer um genügende Verpflegung - sie kann bei den bestehenden anormalen Verhältnissen nur knapp sein - und wirklich ausreichende Beheizung bemüht gewesen.

Es muss zusammenfassend gesagt werden: für eine bessere Organisation und Anlage des Lagers und eine erfolgreichere Betreuung der Umsiedler ist noch viel finanzielle und sonstige Hilfe (Medikamente, Bekleidung) nötig. Die physischen und psychischen Leiden der Umsiedler sind masslos erschütternd. Die Tatsache und Notwendigkeit solcher Lager überhaupt ist die grösste Kulturschande Europas im 20. Jahrhundert, ein Kainszeichen für Christentum und Humanität!

\section{(172) Bericht über die katholische Flüchtlingsbetreuung in Wittstock und Umgebung, - Wittstock, 14. Mai 1946}

DAB, I/9-15-1 Flüchtlingsseelsorge 1945-1951, unfol., [14.5.1946]. - Typoskript, 3 Bl. - O.1. Datierung „Wittstock/Dosse, den 14. Mai 1946.“ Darunter Adresse „An das Bischöfl. Ordinariat / in Berlin“. R. o. Absender: „kath. Pfarramt.“ - Betreff: Zu dem dortigen Schreiben vom 25.4.46. betr. Flüchtlingsbetreuung.“ - Eingangsstempel des Bischöfl. Ordinariats Berlin vom 30. Mai 1946, J[ournal]-Nr. 1478. Zuständigkeitsvermwerk „Flüchtlingsseelsorge“. O. Vermerk in Rot „H[ochwürdigsten] H[errn] Gen[eral] Vic[ar] / Bitte z[ur] Sitzung / We ${ }^{2373}$ 1/6 46.“ L. o Vermerk in Rot „Hilfsgeistl[icher]“, darüber Stempel „Ad acta“. - Bl. 3: Unterschrift: „das katholische Pfarramt / [gez.] [Karl] Hullin / Pfarrer, geistl. Rat.“; unten Vermerk (Tinte): „HH. Gen. Vicar. / mit Bitte die Angelegenheit Wittstock z. Sitzung zu bringen. / Anstellung eines Hilfsgeistl. (Flüchtlingspriester dringend notwendig) / Wohnung vorhanden im Pfarrhaus. (Kost ebenda) / Monatl. Zuschuß z. Anstellung 150 M. / Paderborn ist angeschrieben aber noch keine Äußerung. / 1/6 46. [gez.] We. - Darunter Kopierstiftvermerk „Kpl. Langer, Carl ${ }^{2374}$ nach Wittstock dekretiert. / a. a. 7/6 Pi“, dabei Stempel „ad acta“. - Im Text mehrfach rote Unterstreichungen, offensichtlich von Ordinariatsrat Weber.

2371 [Polnisches „Zentrales Arbeitslager Jaworzno“ (bei Kattowitz) für „Volksfeinde“, 1945 bis 1949 betrieben.]

2372 [Johannes Zinke (geb. 1903), Leiter des Diözesan-Caritasverbandes Cottbus-Görlitz (Schematismus Görlitz 1954, S. 6).]

2373 [Paul Weber, geb. 1881 Kanth (Schlesien), Ordinariatsrat.]

2374 [Karl Langer, geb. 1913 Berlin, Kaplan, Okt. 1946 an St. Carolus Borrmomäus in Berlin-Grunewald tätig.] 
Bericht über den gegenwärtigen Stand der Flüchtlingsbetreuung:

Die genaue Zahl der kath. Flüchtlinge zu erfassen ist schwierig. Es sind solche aus den Kreisen Meseritz, Landsberg u Schwerin/W, ferner aus Schles[ien] u Bukowina. Diese wollen alle nicht hier bleiben, da sie keine Beschäftigung u keine richtige Wohnung haben, sie gehen $\mathrm{u}$ andere kommen wieder, noch nichts sicheres u bestimmtes. Beispielsweise hörte ich durch Anfrage bei einem Katholiken in Freienstein ${ }^{2375}$, dass dort nur 3 Katholiken wären, die Schule gab mir eine Zahl der kath. Kinder mit 12 an, tatsächlich waren es 70 Ungarn aus der Bukowina, als ich nach einer Woche hinfuhr, um sie aufzusuchen, erfuhr ich, dass sie vor etwa 3 Tagen nach Eisenach/ Sachsen abgereist waren. Die Zahl beträgt gegenwärtig schätzungsweise etwa 2500[,] davon 1000 in Wittstock. Grössere geschlossene Gruppen sind in Ganz (17 km) etwa 100, Fretzdorf $(12 \mathrm{~km})$ 100, Grabow $(14 \mathrm{~km})$ 100, mittlere Gruppen bis 50 in 5 Ortschaften, Rest zerstreut in anderen Gemeinden. Darunter sind 250 Schulkinder, von diesen 130 in Wittstock selbst. Angaben beruhen auf den Meldungen der Schulen.

\section{Gottesdienstregelung.}

Infolge der weiten Entfernungen, Mangel an Schuhen u Kleidern, Mangel an Verkehrsmitteln, sind ein grosser Teil schon ein Jahr nicht zum Gottesdienst gewesen. Ich habe versucht, Laiengottesdienste einzurichten, zunächst in den einzelnen Familien, dann mehreren Familien gemeinsam, dann die ganze Ortschaft zusammen, aber das klappt nicht ganz, denn zu diesem Zwecke muss der Pfarrer persönlich da sein um dies zu organisieren, das ist mir allein aber unmöglich, da ich am Sonntage am Orte festgehalten werde, Sonntag auch der Zugverkehr ruht, Wochentags die Leute nicht anzutreffen sind; sie müssen auch periodisch wenigstens einmal im Viertel[jahr] eine hl. Messe hören. Zu diesem Zwecke muss hier ein Hilfsgeistlicher her. [Bl. 2]

\section{Schulunterricht.}

Ich habe die Eltern ermahnt, vorläufig selbst ihren Kindern das Notwendigste so gut wie sie es nur können, beizubringen. Die 20 kleinen Kathechismen [so!] die ich erhielt[,] reichten zu diesem Zwecke nicht aus.

Ich habe an einzelnen Schulen Laienhelfer angestellt, Berlinche[n] 6 Kinder, Dransee 8 Kinder, Ganz 12 Kinder, Fretzdorf 18 Kinder, je ein Mädchen von 18 Jahren, Herzsprung, 6 Kinder, Königsberg 8 Kinder, Christdorf 9 Kinder, Grabow 20 Kinder, eine alte ehemalige Oberlehrerin aus dem Sudetenland, Blandiko[w] u Papenbruch 28 Kinder einen Herr, ehemaligen Führer der kath. Jugendbewegung. Gadow mit 12 Kinder[n] sowie eine Anzahl von Dörfern fehlen noch. Ich habe auch gehört, dass die Gläubigen den prot[estantischen] Unterricht sowie den Gottesdienst besuchen, um nur, wie sie sagen einen einigermasse[n] Ersatz zu haben. Es muss also dringend die Entsendung einer Hilfskraft beschleunigt werden. Dies[e] muss den Unterricht 
besuchen, organiesieren [so!] u zum Teil auch selbst erteilen, bezw. überwachen. Dieser Zustand ist nur vorübergehend denkbar.

Eine Seelsorgshelferin, wie dort vorgeschlagen, kann ich hier nicht brauchen, ich kann sie nicht bei den unsicheren Zeiten allein auf die weiten leeren Strassen senden. Es kommt also hier nur ein Geistlicher in Frage.

Wohnung unterhalt.

Ein Zimmer im Pfarrhause ist durch Wegzug der Familie Rhein freigeworden, das Wohnungsamt hat diese für den Hilfsgeistlichen freigegeben, einer Zuzugsgenehmigung stehen keine Hindernisse entgegen. Verpflegung erhält er im Pfarrhause, desgl. die notwendigsten Möbel, von Eleganz u. dergl. muss er allerdings absehen, ein Fahrrad ist unbedingt nötig, Gesundheit, Ertragung von Strapazen u. vor allem Liebe u. Begeisterung sind unablässige Bedingungen.

\section{Besoldung}

Wenn von dort $150 \mathrm{M}$ monatl, wie für die Helferin angeboten, dem Hilfsgeistlichen gegeben, könnte die hiesige Gemeinde einen monatl. Zuschuss von $50 \mathrm{M}$ gewähren, dazu kämen noch Stipendien von etwa $100 \mathrm{~m}$. Ich selbst habe hier 10 Jahre lang jährl. $1800 \mathrm{M}$ Gehalt bezogen. [B1. 3]

Ich habe auch hier mit dem Wohnungsamt über die Frage einer Schwesternstation verhandelt. Dasselbe hat nichts einzuwenden, leider ist hier aber infolge der starken Besatzung die Wohnungsfrage sehr brennend $u$ vorläufig eine passende Wohnung nicht vorhanden. Die grauen Schwestern ${ }^{2376}$ aus Frankfurt, die hier mit ihrem Kinderheim in einem Dorfe Wulfersdorf evakuiert waren, haben einen guten Eindruck auf die Bevölkerung hinterlassen, u wären gern bereit, die Station hier zu übernehmen (Mutterhaus Tempelhof ${ }^{2377}$ ).

Eine Abschrift dieses Berichts sende ich gleichzeitig an den Bonifactius-Verein für das kath. Deutschland in Paderborn Neuhäuserstr. 22.

Abschliessend bemerke ich noch, dass ich bisher an 2 Aussenstationen alle vier Wochen, allerdings nur wochentags Gottesdienst halte.

Ich bitte um dringende Behandlung des Falles u[nd] hoffe, dass alles nicht wieder, wie schon einmal, durch neuhinzukommende Ereignisse über den Haufen geworfen wird.

2376 [Graue Schwestern von der hl. Elisabeth (Schematismus des Bistums Berlin für das Jahr 1947, S. 68 101).]

2377 [St. Joseph-Krankenhaus, Bäumerplan 24, Berlin-Tempelhof (Schematismus des Bistums Berlin für das Jahr 1947, S. 60, 101).] 


\section{(173) Bericht eines katholischen Pfarrers über die Situation der Flüchtlinge und Vertriebenen in den brandenburgischen Randgebieten Berlins, besonders in Petershagen. - [Petershagen], [Dezember 1946]}

DAB, I/9-15-1 Flüchtlingsseelsorge 1945-1951, unfol., [Dez. 1946]. - Typoskript (Durchschlag), 3 Bl. - Undatierte Abschrift ohne Unterschrift; Bl. 3 r. u. masch.: „Bericht gegeben von / Herrn Pfarrer Hering.“ - Überschrift Bl. 1 o.: „Bericht über die Notlage der Randgebiete von Groß-Berlin mit besonderer Berücksichtigung der Kuratiegemeinde Petershagen bei Berlin."

Die besondere Not der Randgebiete von Groß-Berlin ist nicht so sehr eine seelsorgliche als eine leibsorgerische. Die katholischen Kirchengemeinden der „Bannmeile“ umfassen keine territorial so gewaltigen Gebiete wie etwa die Kirchengemeinden Brandenburgs und Pommerns. So sind auch die zahlreichen Flüchtlinge aus den Ostgebieten räumlich ohne allzugroße Schwierigkeiten erreichbar, wenn auch ihre Betreuung für den Seelsorger, der meist völlig auf sich allein gestellt ist, eine kaum noch zu bewältigende neue Belastung ${ }^{2378}$ bedeutet.

Aber die eigentliche Not der Einheimischen wie der Flüchtlinge in unseren Gemeinden ist eine materielle. Sie besteht

1. in den katastrophalen Ernährungsverhältnissen,

2. in dem fast völligen Mangel an Verdienstmöglichkeiten,

3. in dem Mangel an Wohnraum,

4. in dem völligen Mangel an Kleidung und Gebrauchsgütern,

5. in dem fast völligen Mangel an Heizmaterial.

Die Territorien, von denen hier die Rede ist, gehören nicht mehr zum Stadtgebiet von GroßBerlin. Da sie jedoch ausgesprochene Siedlungsgebiete für die Stadt gewesen sind, gibt es in ihnen kaum noch nennenswerte Landwirtschaft. Sie sind also völlig außerstande, sich selbst $\mathrm{zu}$ versorgen. Sie wurden in normalen Zeiten auschließlich von Berlin aus versorgt. Ihre Bevölkerung arbeitete zum allergrößten Teil in der Stadt. Nun sind diese Gebiete, die sämtlich zur russischen Zone gehören, fast hermetisch von der Stadt abgeschlossen. Daher die erbärmlichen Ernährungsverhältnisse und der Mangel an Gebrauchsgütern, daher die fehlende Verdienstmöglichkeit für die meisten Einwohner derselben. Der verfügbare Wohnraum ist äußerst beschränkt und besteht vielfach nur in Wohnlauben, die oft nur für den Sommer gebaut worden sind, und die nun von den Flüchtlingen auch in der bittersten Winterkälte bewohnt werden müssen.

Unsere Ernährungsverhältnsse haben sich folgendermaßen entwickelt: Von Mai [19]45 bis Februar [19]46 haben wir von 125-175 Gramm Brot und ca. 300 gr. Kartoffeln pro Tag leben müssen. Das war buchstäblich alles! Nicht einmal Salz hatten wir zu den Kartoffeln! Von Febru-

2378 [Der Verf. des Berichts, Pfarrer Bernhard Hering, war selbst erst wenige Jahre, zuvor am 7.11.1940, verhaftet und am 28.8.1941 entlassen worden.] 
ar bis September [19]46 hatten wir auf dem Papier 950 Kalorien, in Wirklichkeit bekamen wir nur etwa 500! Erst seit September 1946 haben wir auf dem Papier 1150 Kalorien, die jedoch meist auch heute noch nicht voll zugeteilt werden. Die Berliner Bevölkerung dagegen hat in der ganzen Zeit regelmäßig ihre 1550 Kalorien gehabt und oft noch mehr durch Sonderzuteilungen. Auch heute noch beträgt unsere Brotration nur 200 Gramm für den Normalverbraucher.

Die Folgen dieser Hungersnot wearen diese: Schon im Winter 1945/46 starben die meisten der Alten und Kranken, Der Rest ist in diesem Winter dran! Kinder werden kaum noch geboren. Alle Menschen sind total unterernährt. Hungerödeme, Skorbut, Hautinfektion und alle anderen Mangelkrankheiten grassieren. Anfang 1946 erhob sich die Gefahr einer Typhusepidemie, die nur durch wiederholte Impfungen der gesamten Bevölkerung gebannt weren konnten. Alle schlimmen Instinkte wurden entfesselt: Schleichhandel, Wucher, Betrug, Unterschlagung, Diebstahl, Raub, Plünderung, Vergewaltigung, Prostitution. Dazu ständig wachsende Verbitterung, Hoffnungslosigkeit, Verzweiflung. [Bl. 2]

Die Lage der Flüchtlinge: Am furchtbarsten sind die s[eine]r. Zeit aus Ostpreußen nach Rußland Deportierten und von dort wegen Erkrankung nach Deutschland zurückgeführten dran. Sie sind fürchterlich unterernährt, leiden an den Nachwirkungen schwerer Krankheiten und besitzen buchstäbdlich nur das, was sie auf dem Leibe haben, und das sind ausnahmslos Fetzen. Da unsere ausgeplünderte einheimische Bevölkerung auch nur noch das Allernotwendigste besitzt, kann niemand mehr ihnen wirksam helfen. Sie müssen weiter in ihren Lumpen herumlaufenund - sterben!

Einige Einzelfälle, die jedoch für viele andere stehen:

1. Familie St[...]. Vater 57 Jahre, kriegsbeschädigt aus dem ersten Weltkrieg, hat nur ein Bein. Mutter 47 Jahre schwer rheumakrank. - 8 Kinder im Alter von 6-16 Jahren.

Die Familie war in Jordan, Krs. Züllichau-Schwiebus ansässig, wo sie eine eigene kleine Landwirtschaft besaß. Kurz vor Ankunft der Russen (30. Januar [19]45) flüchtete die Mutter mit den 7 jüngeren Kindern über Frankfurt/Oder - Freienwalde nach Petershagen. Mitnehmen konnten sie nur Handgepäck. Der Vater und [der] älteste Sohn blieben. Der Sohn wurde im Juli [19]45 ausgewiesen und gelangte per Treck zu seiner Familie nach Petershagen. Einiges Geld hatte Frau St $[\ldots]$ bei der Flucht noch mitnehmen können. Bald aber war es alle.

In Petershagen fand die Familie Unterkunft in einem alten baufälligen Sommerhäuschen. Die Folge: Die Mutter erkrankte wieder schwer an Rheuma. Dann gelang es, der Familie eine etwas bessere Wohnung zu verschaffen.

Verdienstmöglichkeit besteht kaum. Der invalide Vater sucht etwas durch Holzmachen bei den Leuten zu verdienen. Von der polit. Gemeinde erhält die Familie, - wie alle Flüchtlinge, - 15,Mark im Monat. 
2. Familie Th[...]. Mutter 40 Jahre. 3 Kinder im Alter von 6 bis 10 Jahren.

Die Familie war in Liegnitz ansässig. Im Februar wurde sie von deutschen Behörden gezwungen, Liegnitz zu verlassen. Si[e] ging unter Mitnahme eines Handwagens mit dem notwendigsten Gepäck 20 km zu den Eltern des Mannes nach Goldberg/Schles. Im Februar noch wurde Goldberg von den Russen eingenommen. Plünderungen, Vergewaltigungen der Mutter, schließlich Selbstmordversuch von 11 Personen durch Öffnung der Pulsadern, der jedoch vergeblich blieb, da die Kälte das Blut gerinnen, bezw. erfrieren ließ.

Mit Frau Th $[\ldots]$ und ihren drei Kindern waren aus Liegnitz auch die alten Eltern derselben, Vater 71, Mutter 70 Jahre[,] geflüchtet, die in Petershagen bei Berlin ansässig waren, aber von dort wegen der Bombenangrffe nach Liegnitz gegangen waren. Die Großmutter war in Goldberg 3 Tage vor Ankunft der Russen an den Strapazen gestorben. Sie mußte in einer Holzkiste beerdigt werden, ohne Priester.

Ende Februar wurde die Einwohnerschaft Goldbergs von den Russen auf die Landstraße getrieben. Frau Th $[\ldots]$ ging mit den Kindern und ihrem alten Vater nach Liegnitz zurück. Dort fand sie ihre Wohnung völlig ausgeplündet vor. Mehrmals wurde sie aus dieser Wohnung ver- [Bl. 3] jagt. Im März wurde auch die Bevölkerung der Stadt Liegnitz von den Russen vertrieben nach einem Dorfe $12 \mathrm{~km}$ von Liegnitz. Dort fanden sie Quartier in einer Scheune, in der sie drei Monate hausen mußten. Unter den dort zusammengetriebenen Deutschen grassierten Ruhr, Typhus, Läuseplage, Selbstmorde. Es starben ca. $10 \%$.

Im Juni [19]45 konnten die Vertriebenen nach Liegnitz zurückkehren, wurden jedoch von dort alsbald wiederum vertrieben, jetzt durch die Polen. In einem Fußmarsch von rd. 150 km gelangte die Familie Th[...] mit ihrem Handwägelchen schließlich nach Sachsen. Unterwegs wurde sie nicht weniger als fünfmal ausgeplündert. Über die deutsche Grenze durfte nur $20 \mathrm{~kg}$ Handgepäck pro Kopf mitgenommen werden. Von Sachsen gelangte Familie Th. dann per Bahn nach Petershagen. Hier fand sie das Heim der Großeltern völlig ausgeplündert vor. Nur noch einige Betten waren vorhanden. So hatte jedes der Familienmitglieder nur noch das, was es auf dem Leibe trug[,] und eine Wolldecke. Auch von Geldmitteln war die Familie völlig entblößt. Sie erhielt von der polit. Gemeinde ebenfalls pro Monat 15,- M. Seit November [19]46 bekommt der Großvater, der mittlerer Beamter war, wieder eine Pension von monatl. 90,- Mark.

Frau Th $[. .$.$] erkrankte infolge der ausgestandenen Strapazen und Entbehrungen im Septem-$ ber [19]46 schwer und liegt seitdem im Krankenhaus. Das jüngste ihrer Kinder konnten wir in einem Kinderheim unterbringen, das zweitjüngste fand in einer orstansässigen Familie Aufnahme, der älteste, zehnjährige Junge haust mit dem alten, fast blinden Großvater zusammen und versorgt diesen. Eine unserer Frauen schaut ab und zu nach dem Rechten.

3. Frau Maria L[... ], 31 Jahre, stammt aus Deppen, Kr. Heilsberg, Ostpr. Dort waren ihre Eltern, landwirtschaftl. Arbeiter, mit 7 Kindern ansässig. Maria befand sich in Guttstadt in Stellung. Von dort wurde sie im Januar [19]45 nach wiederholten Vergewaltigungen durch die Russen nach dem Lager Stalinhorst bei Moskau deportiert. Fußmarsch und dreiwöchentliche Bahn- 
fahrt, auf der in jedem Waggon 4-11 Personen starben. In Stalinhorst wurden die Deportierten, fast alles Frauen und Mädchen, zu Waldarbeiten, Torfstechen, Kanalarbeiten verwendet, bei denen sie bis zu den Knien im Wasser stehen mußten. Viele erkranken an Typhus, Grippe, Nervenfieber, Lungenentzündung. $40 \%$ starben. Die Verpflegung war sehr schlecht, weil der Lagerleiter alles verschob. Oft wurden die Deportierten geschlagen und mit Bunkerhaft bestraft. Ärztliche Betreuung bestand zwar, doch fehlte es fast völlig an Medikamenten. Läuse- und Wanzenplage. Badegelegenheit war alle 14 Tage, jedoch ohne Seife. Kleidungsstücke erhielten nur die Schwerstarbeiterinnen. Die meisten hatten kein Hemd. Maria L[...] erkrankte schwer an Rheuma, Typhus und Nervenfieber. Sie ist auch heute noch arbeitsunfähig.

Entlassen wurden meist nur Kranke und Schwache, und zwar ab August [19]46. Unter diesen gelangte auch Maria L[...] in vierzehntägiger Bahnfahrt (Viehwagen) nach Frankfurt/Oder und über das Quarantänelager nach Petershagen. In Frankfurt erhielten die Rückgeführten je zwei Hemden und zwei Soldaten-Unterhosen, einzelne auch Uniformstücke. M. L[...] kam hier an mit Gummi-Überschuhe[n] an den Füßen, einem zerlumpten Rock und Pullover, einer alten Mütze und einem Mantel, der nur noch aus Sackleinwandflicken bestand. Von ihrer Familie weiß Maria L[... ] nichts. Aus den Deportiertenlagern weiß M. L[... ] noch zu berichten, daß in einzelnen derselben durch deportierte deutsche Priester Gottesdienst gehalten werden konnte.

\section{(174) Bericht über die katholische Flüchtlingsseelsorge in Brandenburg an der Havel. - [Brandenburg an der Havel], Jan. 1947}

DAB, I/9-15-1 Flüchtlingsseelsorge 1945-1951, unfol., [Jan. 1947. - Typoskript, 1 Bl. - Abschrift. Eine von mehreren Anlagen („Berichte und Situationsbilder aus der Flüchtlingsseelsorge des Bistums Berlin“) zum Schreiben des Caritas-Verbandes für Berlin, Berlin-Wilmersdorf, 25. Jan. 1947, an den Bischof von Berlin, Kardinal von Preysing. Überschrift: „Flüchtlingsseelsorge in Brandenburg/H.“

Der vorläufig noch immer anhaltende Zustrom von Ausgewiesenen aus dem Osten, insbesondere aus Schlesien[,] stellt uns vor Aufgaben, denen wir immer weniger gewachsen sind. Das Elend hat ein Ausmaß längst angenommen, dem wir mir den bescheidenen Mitteln, die von kirchlichen Stellen eingesetzt werden können[,] nach dieser ungeheuren Verarmung in keiner Weise mehr gewachsen sind. Immer wieder kommen Hunderte an, die nicht mehr haben, als sie auf dem Leibe tragen. Auch wenn formell ihnen gestattet wird, bei der Ausweisung Gepäck mitzunehmen - und Gott sei Dank bringen ja auch einige noch einen Koffer mit - aber unzählige sind total ausgeplündert; mutwillig haben die Plünderer ihr bischen Papiergeld noch vor ihren Augen zerrissen und in die Oder geworfen. Bei 17 Grad Kälte kam eine Frau an, wie mir von einer Helferin in der Bahnhofsmission erzählt wurde, die nur mit einem Hemd und einem Unterrock und einem ganz leichten Überwurf bekleidet war; die Frau schrie unerträglich vor rasenden Schmerzen durch die Erfrierungen. Füsse und Unterkörper waren entsetzlich angeschwollen. Im Nachbardorf Schmerzke ist eine Frau, die mit 10 Kindern hier ankam, von denen erst eines beim Bauern arbeiten kann, alle anderen noch zu klein sind; ein Kind ist auf der 
Flucht geboren; ein Notstand, der uns öfter begegnet, diese Kinder, die auf der Flucht zur Welt gekommen sind, für die die ausgewiesene Mutter nichts tun konnte, sind natürlich eine besondere Sorge. Aber es läßt sich wenig helfen, weil doch auch die einheimische Bevölkerung seit 1939 - Ausbruch des Krieges - so gut wie nichts mehr an Wäsche und Kleidung kaufen konnte.

Außerhalb des Stadtgebietes gehören zur Pfarrei Brandenburg aus dem Kreis Westhavelland 16 Ortschaften; aus dem Kreis Zauch-Belzig 30 Ortschaften; die Pfarrei hat einen Durchmesser von etwa 30-40 km; auf dieser Fläche werden etwa 5000 Flüchtlinge angekommen sein; und der Zustrom hält immer noch an; kurz vor Weihnachten kamen an einem Morgen hier im Durchgangslager wieder über 3000 Ausgewiesene an; fast alle in größter Armut. Es ist vorläufig bei allem guten Willen noch ganz unmöglich, die Flüchtlinge in der Seelsorge oder durch die Caritas einigermaßen vollständig zu erfassen. Wir müssen allein zu Schulen und zum Gottesdienst jeden Monat etwa $900 \mathrm{~km}$ auf dem Rade zurücklegen in der Pfarrei; wir haben an 8 Stellen ausserhalb Gottesdienst und an 15 Stationen Unterricht. Es müßte an viel mehr Stellen Religionsunterricht gehalten werden, weil die Kinder bei dem schlechten Schuhzeug und der ganz ungenügenden Ernährung weite Wege zum Religionsunterricht und zur Kirche nicht zurücklegen können. Bei 5 und 6 Grad über Null liefen manche Kinder noch barfuß. In Göttin ist eine Familie, die 7 Kinder hat, das Jüngste ist auch auf der Flucht geboren, der Vater arbeitslos, früher Lehrer, kommt für schwere Arbeit nicht in Frage, da er nur einen Arm hat. Weiterverwendung als Lehrer ausgeschlossen; treu katholische Leute, sie wohnen $4 \mathrm{~km}$ von der Kirche entfernt, können aber wegen Schuhmangel nie kommen; andererseits ist es ganz unmöglich, daß wir auch alle $3 \mathrm{~km}$ Gottesdienst einrichten. Vielfach gehen die Leute in die protestantische Kirche, weil die [so!] Gottesdienst haben wollen und wir keinen dort mehr einrichten können. Oft wird ihnen auch von protestantischer Seite geholfen, während unsere Hilfsmöglichkeiten viel zu gering sind. Oft höre ich von Familien, die zu 7 Personen in einem Zimmer sitzen, das keinen Ofen hat, bei 17 Grad Kälte! und keine Aussicht auf Arbeit! Die Leute sind immer wieder in Gefahr zu verzweifeln.

Eine große Sorge ist der Mangel an Fahrrädern und brauchbarem Flickzeug. Bei der Eroberung sind unzählige Fahrräder verloren gegangen. Mir hatte ein wohlmeinender Mann später aus alten Teilen ein Fahrrad [S. 2] zusammengebaut; natürlich ist die Bereifung schon sehr schlecht. $\mathrm{Zu}$ Fuß kann man auch nicht gehen, weil es keine Stiefelsohlen mehr gibt, auch nicht für uns Geistliche. Wir könnten unendlich viel Segen stiften, wenn wir selbst Stiefelsohlen hätten und an arme Leute, besonders an Kinder Stiefelsohlen als Liebesgaben ausgeben könnten. Wenn statt Rauchwaren Stiefelsohlen in einigen Liebesgabenpaketen wären, dann wäre vielen geholfen. - Eine große Not ist auch die an religiösem Lesestoff. Vor allem brauchten wir Biblische Geschichten und Gesangbücher, damit ein einheitliches Singen erzielt würde beim Gottesdienst. Sehr schmerzlich fühlen wir heute die Ausplünderung unserer Borromäusbibliotheken von etwa 900 Bänden; fast alles haben uns die Nazis fortgenommen, vieles einfach verschleudert, manches vielleicht auch in die Lazarette gegeben. Jedenfalls haben wir heute nur noch einen sehr dürftigen Rest unserer früher reichen und gediegenen Borromäusbücherei, und wir möchten so gern den Flüchtlingen Lesestoffleihen. Wie gut wäre es, wenn wir katholische Bibe- 
lausgaben mit Anmerkungen verschenken könnten - die Protestanten haben solche Ausgaben aus dem Ausland geschenkt bekommen; wenn die Leute nun wenig zu lesen haben, werden sie umso intensiver lesen und das könnte ein Gewinn in religiöser Hinsicht werden. Wie gut wäre es, heute, wenn wir billige Ausgaben des guten alten Goffine ${ }^{2379}$ hätten.

\section{(175) Bericht über die katholische Flüchtlingsseelsorge im Quenz-Lager in Brandenburg an der Havel. - Brandenburg an der Havel, Jan. 1947}

DAB, I/9-15-1 Flüchtlingsseelsorge 1945-1951, unfol., [Jan. 1947. - Typoskript, 1 Bl., unten Ms.-Zusatz „Bericht vom $\mathrm{H}$ [ochwürdigen] $\mathrm{H}$ [errn] Kuratus Höhle ${ }^{2380}$, Brandenburg/Jan. 47.“ Abschrift. Eine von mehreren Anlagen („Berichte und Situationsbilder aus der Flüchtlingsseelsorge des Bistums Berlin“) zum Schreiben des Caritas-Verbandes für Berlin, Berlin-Wilmersdorf, 25. Jan. 1947, an den Bischof von Berlin, Kardinal von Preysing. - Überschrft: „Ein Bericht aus dem Quenz-Lager in Brandenburg/Havel“.

Zahlreiche Menschen mit kleinen Bündeln beladen ziehen die Straße vom Bahnhof zum Lager. Da weiß ich, ein neuer Transport ist gekommen. Diesmal sind es meist Ostpreußen. Schon lange hatte man ihnen in der Heimat ihre Besitzungen weggenommen. Die Polen haben alles an sich gerissen. Jetzt, nachdem sie den Polen noch die ganze Herbstarbeit auf den Feldern getan haben, jetzt müssen sie plötzlich fort. Fünf Tage waren sie auf der Eisenbahn. An der Grenze wurden sie noch gründlich ausgeplündert. Die Meisten von ihnen haben nur das, was sie anhaben und ein Bündel, was man mit einer Hand leicht tragen kann.

Viele alte Leute zwischen 80 und 90 Jahren. Viele Kinder, etwa 1000 bei 3500 Leuten. Viele Kinder sind Vollwaisen und werden von Bekannten und Verwandten mitgeschleppt. Wohin, wie lange, das weiß keiner. Wenig Leute im besten Alter, die hat der Krieg verschlungen, Männer wie Frauen.

„Meine Frau und meine Schwiegertochter haben die Polen vor meinen Augen aufgehängt", erzählt ein alter Mann. / „Unserer Mutter haben sie die Kehle durchgeschnitten, und wir standen dabei“ erzählt ein 12jähriges Mädchen.

Das Lager ist einfach. Die Leitung gibt sich alle Mühe, aber die Not ist zu groß. In den einzelnen Räumen sind etwa 40 Personen zusammen. Große und Kinder. Betten mit etwas Stroh, manchmal auch mit einer Matratze. In einem Bett liegt eine 92jährige sterbende Frau, daneben sitzt ein 4jähriges spielendes Kind. Eine alte Frau hockt auf ihrem Bündel, man hat ihr alles weggenommen, jetzt läßt sie das Bündel nicht mehr los, das will sie behalten.

Gegen 16 Uhr wird es dunkel. Es gibt Stromsperren, mehrere Stunden, und wenn der Strom da ist, dann fehlen die elektrischen Birnen. Sie sind irgendwann gestohlen, und ein Ersatz war noch nicht möglich. Da sitzen nun die Menschen in der Dunkelheit 40 bis 45 in einem Raum, vom Säugling bis zum Greis, etwa 15 Stunden lang, bis der Morgen kommt.

2379 [Das in zahlreichen Auflagen und Ausgaben erschienene „Katholische Unterrichts- und Erbauungsbuch“ (Handpostille) des Prämonstratensers Leonhard Goffiné.]

2380 [Theobald Höhle (geb. 1909 Dormund-Hörde), seit 1943 Kuratus in Brandenburg/Havel (St. Bernhard).] 
Kleidung, Schuhe und Wäsche, was für eine Not. „Wenn man doch wenigstens mal ein Hemd zum Wechseln hätte, um dieses waschen zu können“, sagt ein Mann, der früher 400 Morgen besaß. Die Verpflegung geht nach Karte 4, wie die Leute sonst sie auch haben, aber andere Leute haben einen kleinen Garten, oder mal hier und da Bekannte, diese Menschen haben nichts. Mittags nur Kohlsuppen. Wie freuen sich die Menschen über eine Schnitte trocken Brot. Eine Frau sagt mir strahlend: „O, Herr Pfarrer, ich habe was Feines bekommen.“ Meine Gemeindeschwester hatte ihr drei Schnitten Brot gegeben.

Kirchlich sind die Menschen ergreifend. Manche sehen nach 2 Jahren zum ersten Male wieder einen Priester. Ich hatte Beichtzeit angesagt. Da standen sie, 40 Mann hintereinander, in Reihen zu 8 Personen. Gottesdienst sollte sein. Sonntags Mittags um zwei Uhr. In der Nähe wurde gesprengt, die Leute mußten an den gegenüberliegenden Zaun des Lagers, wegen der Steine. Die Sprengung kam endlich um 16.15 Uhr. Um 16.30 fingen wir den Gottesdienst an. Eine große völlig leere Baracke, vorn ein Tisch mit zwei Kerzen, sonst alles dunkel. Ein ergreifendes Hochamt. Etwa 500 hl. Kommunionen. Kaum einer ging. Um 18 Uhr waren wir fertig. Über vier Stunden hatten die Leute gestanden und ausgehalten. Was sie alles haben wollten: Weihwasser, Rosenkränze, Heiligenbilder, Kreuze. Christlicher Wandschmuck. Ihnen fehlt das Kreuz in ihrem Wohnraum, das haben sie immer so gehabt. Einige haben wenigstens einen kleinen Corpus noch mitgebracht, das ganze Kreuz war ihnen zu groß.

\section{(176) Bericht über die katholische Flüchtlingsseelsorge im Raum Schwedt/Oder. -}

\section{Schwedt, Jan. 1947}

DAB, I/9-15-1 Flüchtlingsseelsorge 1945-1951, unfol., Jan. 1947. - Typoskript, 1 Bl., oben Ms.-Zusatz „berichtet von $\mathrm{H}[\mathrm{errn}]$ Kuratus Jahr ${ }^{2381}$, im Januar 47.“ Abschrift. Eine von mehreren Anlagen („Berichte und Situationsbilder aus der Flüchtlingsseelsorge des Bistums Berlin") zum Schreiben des Caritas-Verbandes für Berlin, Berlin-Wilmersdorf, 25. Jan. 1947, an den Bischof von Berlin, Kardinal von Preysing. - Überschrift: „Aus dem Gebiet Schwedt/Oder“.

Neue Flüchtlinge aus der Tschechoslowakei sind in einem Dorfe angekommen; sie haben nur, was sie auf dem Leibe tragen, auch nicht einmal Geld. Zum Schlafen, da sie keine Bettstellen noch Federbetten oder Decken haben, ist $3 / 4$ des Raumes mit Stroh ausgefüllt, ein Brett davorgeschlagen, damit es nicht im ganzen Raume verstreut wird. Stühle bestehen in Gestalt alter Kisten, einen Tisch gibt es nicht, ebenso wenig wie einen Schrank. Handwerker sind darunter, für die es keine passende Arbeitsstätte im Dorfe gibt. Und jetzt, im Winter, auch keine sonstige Arbeit, um sich Geld zu verdienen, um wenigstens die kartenmäßigen Lebensmittel erwerben zu können.

Zur hl. Messe sind sie wohl vollständig anwesend; alle finden in den Schulbänken nicht Platz, viele müssen stehen. Als sie ihre heimischen Weihnachtslieder singen, da sehe ich manche Träne tropfen.

In dem zu $85 \%$ zerschossenen Städtchen Gartz/Oder ist in dem zufällig stehen gebliebenen Altersheim eine Flüchtlingsfrau von 75 Jahren untergebracht, die mich um die hl. Kommunion 
bat. Vorsichtiger Weise nehme ich zwei hl. Hostien mit. Im Flur des Heimes werde ich von einer Insassin angehalten: sie sei katholisch, es seien bereits 9 katholische Insassen im Hause, alles Flüchtlinge, und als sie hört, daß ich die hl. Kommunion mithabe, macht sie das halbe Haus rebellisch; 6 kommen, um die hl. Kommunion zu empfangen, 2 bettlägerige lassen darum bitten. Trotz Teilung konnte ich wegen des kleinen Formates der Hostien nicht allen gerecht werden. Unter vielen Tränen baten sie mich, doch bald wiederzukommen. Ich verspreche ihnen, in 14 Tagen hl. Messe dort zu feiern.

Also mache ich mich wieder auf den Weg; inzwischen ist es kalt geworden, wozu mein Sommermantel wenig paßt. Aber einen Wintermantel besitze ich nicht. In meiner einzigen dünnen, vielfach gestopften schwarzen Hose friere ich auf dem $21 \mathrm{~km}$ weiten Weg sehr, so daß ich mich erst mal kurz erwärmen muß, ehe ich mit Beichthören beginnen kann. Inzwischen haben sich aus umliegenden Dörfern an die 50 Menschen versammelt; alle leichten Möbel werden aus dem Zimmer herausgeräumt, so dicht stehen die Menschen, auch noch im Nebenraum, daß für mich selbst kaum noch Platz bleibt. Als ich ein Wort von der Heimat spreche, geht ein Aufschluchzen durch die Gläubigen. Da ich jeden Sonntag bereits auf einer Aussenstation in, habe ich den versammelten Gläubigen für jeden Monat an einem Wochentage die hl. Messe versprochen. Möge es nur nicht so kalt bleiben, wie jetzt.

\section{(177) Bericht über die katholische Flüchtlingsseelsorge in Döberitz. - [Berlin-Wilmersdorf], Jan. 1947}

DAB, I/9-15-1 Flüchtlingsseelsorge 1945-1951, unfol., [Jan. 1947]. - Typoskript, 1 Bl. - Abschrift. - Eine von mehreren Anlagen („Berichte und Situationsbilder aus der Flüchtlingsseelsorge des Bistums Berlin“) zum Schreiben des Caritas-Verbandes für Berlin, Berlin-Wilmersdorf, 25. Jan. 1947, an den Bischof von Berlin, Kardinal von Preysing. Überschrift: „Flüchtlingsarbeit in Döberitz“.

Seit einigen Monaten wird die immerhin schon erhebliche Zahl an Flüchtlingen, die sich auf die einzelnen Ortschaften verteilen und sehr viel Not und Elend durchkosteten[,] durch einen starken Zustrom vermehrt. In manchen Orten sind bis zu 30 Familien auf einmal hinzugekommen. Aus dem Sudetenland, aus Schlesien, aus dem Warthegau oder gar aus Masuren sind unsere Leutchen. Manchmal sind sie schon drei- oder viermal geflüchtet. Von den Deutschen zwangsevakuiert, vor den Russen geflohen, dann wieder zurück und von den Polen aufs neue ausgewiesen, dann wochen- und monatelang im Lager verbracht und schließlich in einer ehemaligen Stallkammer oder auf einem Bodenraum, mit Steinboden und durchlässigen Wänden ohne rechte Heizung, ohne Kleidung und auch ohne Betten gelandet. Frauen, die über das Schicksal ihrer Männer noch nichts wissen, hausen oft mit 5-6 Kindern auf einem ganz engen Raum, schlafen one Decken auf dem nackten Boden. Den Kindern fehlt oft das Notwendigste au Kleidung. Manchmal sind es die Kinder aus verschiedenen Familien, weil die Eltern oder die Mutter unterwegs oft nach furchtbarster Vergewaltigung auch noch ermordet wurde, oder am Wege liegen geblieben ist. 
Mancher Heimkehrer, der jetzt froh ist endlich seine Familie wiedergefunden zu haben, muß sich von der Untreue seiner Frau überzeugen, die sich den Soldaten der Besatzungsmacht völlig verschrieben hat. Auch seinen Kindern kann er oft garnicht mehr Vater sein. Furchtbare Ehetragödien und Familienszenen sind die Folge und das seelische Erleben der Kinder wird in frühester Jugend schon vergiftet. / Manche Mutter sucht ihr Kind, das sie verloren hat, und manche alte Frau muss für ihre Enkel sorgen, da ihre Tochter unterwegs ermordet, verunglückt oder verschleppt worden ist.

\section{(178) Bericht über die katholische Flüchtlingsseelsorge in Zehdenick. - [Zehdenick], Jan. 1947}

DAB, I/9-15-1 Flüchtlingsseelsorge 1945-1951, unfol., [Jan. 1947]. - Typoskript, 1 Bl. - Abschrift ohne Verfasserangabe und Unterschrift (Verf. ist entweder der Zehdenicker Pfarrer Joseph Eismann, geb. 1905, oder eine in der Caritasarbeit tätige Katholikin aus der Gemeinde). Eine von mehreren Anlagen („Berichte und Situationsbilder aus der Flüchtlingsseelsorge des Bistums Berlin“) zum Schreiben des Caritas-Verbandes für Berlin, Berlin-Wilmersdorf, 25. Jan. 1947, an den Bischof von Berlin, Kardinal von Preysing, diese jedoch in der Akte falsch abgelegt bei 1946. Überschrift: „Bericht aus Zehdenick“.

Die Pfarrei Zehdenick, Mark Brandenburg, liegt $60 \mathrm{~km}$ nördlich Berlin, zählt jetzt etwa 2000 Katholiken unter 24000 Andersgläubigen und umfaßt 2 Städte (ausser Z. noch Liebenwalde) und 18 Dörfer. Von den 2000 Katholiken sind etwa 800 Flüchtlinge aus dem Osten, Bombengeschädigte usw. In einem Dorf (Falkenthal), welches früher nur 2 Katholiken zählte, heute 85, war zu Weihnachten zum 1. Mal seit 400 Jahren wieder hl. Messe in der alten, jetzt evang. Dorfkirche. Der Pfarrer (in der Pfarrei Z. ist nur 1 Geistlicher tätig) hat im Jahre 1946 nur mit dem Fahrrad $2600 \mathrm{~km}$ zurückgelegt. Im Sommer hatte die Pfarrei 81 Kommunionkinder, welche zu einem grossen Teil - mangels neuer Kleidung - mit geliehenen Kleidern und Schuhe[n] versorgt wurden. Ebenso war es zur Firmung am 30. Sept., beim Besuch des Herrn Cardinals v. Berlin ${ }^{2382}$, als 175 Firmlinge gezählt wurden. Im Laufe des Jahtres 1946 wurden 2600.- RM für Caritaszwecke ausgegeben, Die Spenden an Geld waren - trotz der Armut der Gemeindemitglieder - ziemlich reichlich. Was aber fehlt ist Kleidung und vor allem Schuhe, Schuhe, Schuhe! Besonders für die Kinder. Die Pfarrei hat viele kinderreiche Familien und zählt 370 kath. Schulkinder von 6-14 Jahren. Die erste Hilfe von ausserhalb traf vor Weihnachten ein und bestand in $16 \mathrm{~kg}$ Fett und 4 Büchsen Milch aus der Papstspende. (Mußte aus Berlin geholt werden). Die Spende wurde vor Weihnachten an 72 Familien und Einzelpersonen, besonders Alte und Lungenkranke, verteilt. Die Tuberkulose ist rapide im Steigen, die Unterernährung allgemein groß. Sehr viele Familien sind ohne Verdiener, unter den Flüchtlingen nur $12 \%$ Männer. - Kathol. Bauern hat die Gemeinde nicht einen einzigen, nur einige Umsiedler auf parzellierten Gütern, welche aber alle sehr ärmlich leben. Hilfe aus der Gemeinde ist weder für Lebensmittel noch für Kleidung und Schuhe zu erwarten, obgleich die Caritasgruppe immer wieder bittet und sammelt geht. 
Familie $N[\ldots]$.

Zehn Kinder und das Kind der ältesten Tochter brachte Frau N[... ] nach der Flucht aus Danzig mit nach Zehdenick. Der Mann, Fischermeister, war kurz vor der Flucht gestorben. Mit 12 Personen wohnten sie 1945 in einem Raum der Ziegelei - in Etagenbetten, auf Strohsäcken. Jetzt haben sie 2 Räume. Die 3 ältesten Töchter arbeiten, die jüngeren gehen zur Schule - oder auch nicht, weil sie auf Betteltour sind. Alle kommen fleissig zur Kirche. Wir helfen, wo wir können[,] und Frau N[... ] ist tapfer und arbeitet. Doch wer gibt Kleidung, Bettzeug, Schuhe, Essen? Wann werden die Kinder nicht mehr in die Häuser betteln gehen? Sind sie nicht ständig in Gefahr zu lügen, zu stehlen, die Schule zu schwänzen? Kriegsnot! / [...]

\section{$4 \quad$ Überwachung der Bevölkerung durch Informanten und Volkspolizei (1946-1953)}

\subsection{Allgemeine und politische Stimmungs- und Informationsberichte (1946-1950)}

\section{(179) Allgemeiner Stimmungsbericht des Informationsdienstes beim Landrat des Kreises Guben. - Guben, 14. Februar 1946 (Auszüge)}

BLHA, Rep. 250 Landratsamt Guben/Frankfurt(Oder), Nr. 83, Bl. 122-125. - Typoskript (Durchschlag), 4 Bl., mit eigenhändiger Unterschrift „Sicker“. - Bl. 122 1. o.: „Der Landrat des Kreises Guben / - Informationsdienst -“; r. o.: „Guben, den 14. Februar 1946“. - Überschrift: „Allgemeiner Stimmungsbericht“. - B1. 125 masch. Unterschrift „Der Landrat / I. A. [gez. (Kopierstift)] Sicker / Informationsdienst“.

[Bl. 122] [...] Berücksichtigen wir, dass jetzt auf der Westseite der Stadt Guben über 26000 Einwohner durch die unglückliche Grenzziehung leben, wenn vor dem Zusammenbruch nur 8000 Menschen wohnten. Darum hatte Guben als Grenzstadt insbesondere unter den [so!] Flüchtlingsstrom zu leiden. Bis heute sind 39 grosse und kleine Betriebe unter Selbstverwaltung wieder in Gang gesetzt worden. Auch 358 handwerkliche Betriebe haben ihre Tätigkeit wieder aufgenommen. [...]

[B1. 123] Gerüchte werden besonders im Landkreis verbreitet, die Engländer hätten die Beziehungen zur Sowjetunion abgebrochen - bald würde hier unser Gebiet eine englische Besatzungszone werden - die Wiedereinführung der Sperrzeit bedeutet, dass sich Polen und die Sowjetunion in einen baldigen Kriegskonflikt befinde - auch sollte es diesmal bestimmt am 2. Februar d.J[a]hr[e]s über die Neisse gehen.

Das letztere war besonders in Guben vorherrschend, Auch unsere Neusiedler im Landkreis, die flüchten mussten am 20.6.1945 von der Ostseite[,] zeigen nicht den richtigen Arbeitswillen auf ihrer erhaltenen Scholle. Glauben sie noch heute es geht eines schönen Tages wieder über die Neisse. Die wahren Urheber dieser Gerüchte-Verbreitung konnten noch nicht festgestellt werden. $[\ldots]$ 
[Bl. 124] Herr Kreisarzt Dr. Hasse wies besonders auf die Durchführung der angeordneten Massnahmen für den Gesundheitszustand hin. Fürstenberg müsse unbedingt den Bau einer Entlausungsanstalt sofort nachholen. Die Frage der Geschlechtskrankheiten ist nicht nur eine rein ärztliche Frage, sondern eine politische. (Erziehung der Jugend) [...].

(180) Politischer Stimmungsbericht des Informationsdienstes beim Landrat des Kreises Guben. - Guben, 27. Februar 1946 (Auszüge)

BLHA, Rep. 250 Landratsamt Guben/Frankfurt(Oder), Nr. 83, Bl. 128-129. - Typoskript, 2 Bl. - Bl. 1281. o.: „Der Landrat / - Informationsdienst -,; r. o.: „Guben, den 27. Februar 1946“. - Überschrift: „Politische Stimmungsberichte.“ - Bl. 129 masch. Unterschrift „Der Landrat / I. A. [gez. (Bleistift)] Pfandke / Informationsdienst.“

[Bl. 128] [...] Wenn wir hier im Stadt- und Landkreise Guben einen wöchentlichen Zeitungsvertrieb von 60700 Exemplaren buchen können, (Stadt Guben allein 55000 Exemplare - Fürstenberg 3000 - Neuzelle 2700 Exemplare) so stellen wir, ganz nüchtern gesehen, eine politische Unaktivität fest. Dies kommt besonders stärker in ländlichen Gebieten zum Ausdruck.

Politische Tagesfragen, wie „Vereinigung der Großmächte U.S. O.“, sowie „Prozeß der Kriegsverbrecher in Nürnberg", nimmt die Bevölkerung so teilnahmslos hin. Keine konkrete Fälle hört man, wo Resolution gefaßt oder die Forderung von Betriebsbelegschaften oder sonstiger Volksschichten erhoben werden, was mit den Kriegsverbrechern in Nürnberg und mit den aktiven Faschisten geschehen soll.

Die Flüsterpropaganda und die Gerüchte sind hier in unserer Grenzstadt und auch im Landkreis stets auf der Tagesordnung. Immer ein bestimmter Termin wird verbreitet, dann geht es wieder auf die Ostseite von Guben.

Einiges: „Die russische Besatzungstruppe soll abziehen und unser Gebiet von Engländern besetzt werden.“ „Es sind Heringe und Zwiebeln nach Guben gekommen, aber der Russe hätte alles beschlagnahmt. Guben soll aussterben! Es steht fest, daß im Frühjahr das Massensterben beginne.“ „In anderen Orten haben die Einwohner $150 \mathrm{~kg}$ Kartoffeln erhalten und wir in unserem Notstandsgebiet nur 65 kg.“ „Der Pole und der Balkan bereiten einen Krieg gegen die Sowjet-Union vor. Dann wird es uns besser gehen.“ Äusserung des Herrn Zeschke, Groß-Breesen, Mitglied der Liberal-Demokratischen Vereinigung, am 23. Februar 1946 in einer öffentlichen Versammlung dieser Partei in Kaltenborn: „Güteraufteilung wäre zu übereilt durchgeführt! Auch müßte man den Besitzer entschädigen oder bezahlen.“

[...] Der Frauenausschuß beim Magistrat der Stadt Guben hat seine Arbeit für die Interessen der Frauen verstärkt aufgenommen. Im Flüchtlingslager Kontrollen durchgeführt und Verfehlungen abgestellt. $[\ldots]$

\section{(181) Politischer Stimmungsbericht des Informationsdienstes beim Landrat} des Kreises Guben. - Guben, 15. Oktober 1946 (Auszüge)

BLHA, Rep. 250 Landratsamt Guben/Frankfurt(Oder), Nr. 83, Bl. 134-136. - Typoskript (Durchschlag außer Adresse), 3 Bl. - Bl. 122 1. o.: „Landratsamt / - Informationsdienst -“; r. o.: „Guben, den 15. Okt. 1946“. - Adresse: 
„An / Herrn Landrat Nitschke, / i[m] Hause.“ - Überschrift: „Politischer Stimmungsbericht". - Bl. 136 masch. Unterschrift „Der Landrat - Informationsdienst - / I. A. [gez. (Kopierstift)] Sicker“.

[Bl. 134] Der Informationsdienst führt zur Zeit öffentliche Versammlungen im Landkreis Guben durch und wollen wir einige Stimmungsbilder zum Vortrag bringen:

Gemeinde Gross-Drewitz: Büttner, Waldarbeiter, parteilos./Was sagt Molotow zur Ostfrage? Wir sind Flüchtlinge, wir haben nichts und bekommen auch nichts. Aber die heimkehrenden Kriegsgefangenen erhalten bald ihren Bezugsschein für Anzugstoff usw. und daheim haben sie den Schrank voll Sachen. Hier müsste auch geprüft werden. Es geht eben ungerecht zu. [...]

\section{(182) Bericht der Abt. Presse und Information über eine unveröffentlichte}

\section{Leserzuschrift der „Märkischen Volksstimme“ zur Situation deutscher Facharbeiter} in einer polnischen Fabrik im Vertreibungsgebiet. - Potsdam, 5. August 1946

BLHA, Rep. 333 SED-Landesleitung Brandenburg, Nr. 574, Bl. 38. - Typoskript, 1 Bl., ohne Unterschrift (unvollständig?). - Absender 1. o.: „Abt. Presse und Information“. - Datierung r. o.: „Potsdam, den 5. Aug. 1946“, darunter Geschäftszeichen „Hü/sl“. - Keine Eingangs- und Bearbeitungsvermerke.

Die Märkische Volksstimme übersandte uns zur Kenntnisnahme eine Zuschrift aus dem Leserkreis, in dem [so!] die Zustände in einer Textilfabrik des von Polen besetzten Gebietes geschildert werden. Es wird darin die grosse Not, in der sich die deutschen Facharbeiter befinden, eindringlich dargelegt. Wie der Einsender schreibt, bekommen die Arbeiter bei einer Arbeitszeit von 46 Stunden in der Woche nur 40 Stunden bezahlt. Bei einem Stundenlohn von 1 Zloty, also 40 Zloty Wochenlohn, der nicht einmal ausreicht, um ein Brot zu kaufen, da dieses 46 Zloty kostet. Dagegen hat ein polnisches Mädchen, das die gleiche Arbeit an derselben Maschine leistet, für die gleiche Zeit 1001 Zloty, oder in Stundenlohn umgerechnet, 10,8 Zloty verdient. Ausserdem werden die polnischen Arbeitskräfte bei der Zuteilung von Produkten weitgehend bevorzugt.

Von einer sozialen Gerechtigkeit kann unter solchen Umständen wirklich nicht mehr gesprochen werden, und man muss sich darüber wundern, dass die deutschen Arbeitskräfte weiterhin unermüdlich für das Werk tätig sind. Dabei sollen die Arbeitsleistungen, die gegen die unserer Facharbeiter in gar keinem Verhältnis stehen, unberücksichtigt bleiben. / Man kann es unter diesen Umständen ohne weiteres verstehen, wenn der Einsender den Wunsch äussert, möglichst bald dort wegzukommen, um hier in unserer Zone in den Arbeitsprozess eingereiht zu werden. An eine Veröffentlichung in der Presse oder Auswertung durch den Rundfunk ist wohl aus leicht begreiflichen Gründen m. E. nicht zu denken. / [...] 


\section{(183) Stimmungsbericht eines Informationsdienstmitarbeiters in der Firma C. Lehmann's Wwe. \& Sohn in Guben an den Informationsdienst beim Landratsamt des Kreises Guben. - Guben, 5. November 1946 (Auszug)}

BLHA, Rep. 250 Landratsamt Guben/Frankfurt(Oder), Nr. 82, Bl. 31. - Manuskript mit eigenhändiger Unterschrift [gez.] „Mit proletarischem Gruß Kurt Flamm“. Eingangsvermerk vom 6.11.1946, Beantwortungsvermerk des Informationsdienstleiters Sicker vom 7.11.1946.

Werter Genosse Sicker! [...] Die breite Masse unserer Belegschaft begrüßt die 31 Punkte die Genosse Stalin abgegeben hat. ${ }^{2383}$ Nur über den einen Punkt herrscht sehr, sehr große Enttäuschung und das ist die Grenzziehung; die den meisten Gefolgschaftsmitgliedern am Herzen liegt, da doch der größte Teil von über der Neiße ist. Wir wollen es alle nicht glauben daß wir auf die Dauer so eng beisammen wohnen sollen und der ertragreiche Boden drüben ist, den wir für unsere Ernähurng so dringend brauchen. [...

\section{(184) Stimmungsbericht eines Informationsdienstmitarbeiters in Guben an den Informationsdienst beim Landratsamt des Kreises Guben. - Guben, 6. November 1946 (Auszug)}

BLHA, Rep. 250 Landratsamt Guben/Frankfurt(Oder), Nr. 82, Bl. 42-43, hier Bl. 43. - Manuskript (auf Rückseite von Blankobogen der Fa. Rheinmetall-Borsg AG, Werk Guben) mit eigenhändiger Unterschrift [gez.] „Dr. Paul Heymann" [Studienrat in Guben, Pestalozzistraße 8]. Eingangsvermerk vom 7.11.1946.

[...] Es ist müßig, von einer Einheit Deutschlands zu sprechen wie Stalin es getan hat ${ }^{2384}$, solange die Ostprovinzen, Preußen, Pommern, Posen, Schlesien u. ein Teil von Brandenburg, vom Reich abgerissen und den Polen u. Russen überlassen sind. Wenn früher das Volk im Besitze dieser Kornkammern sich nicht ernähren konnte, sondern noch dazu auf Lebensmitteleinfuhr angewiesen war, so ist jetzt erst recht eine ausreichende Ernährung völlig unmöglich geworden trotz der Bodenreform, die zwar den Bauern, aber nicht der Gesamtheit Vorteile gebracht hat. Das deutsche Volk ist zum Hinsiechen, vielleicht sogar zum Hungertode verurteilt; darüber können alle Reden ausländischer Staatsmänner über die Notwendigkeit der Einheit Deutschlands nicht hinwegtäuschen. Die Ostprovinzen sind uns nötiger als z. B. das Saargebiet!

2383 [„Antworten auf die am 23. Oktober 1946 vom Präsidenten der amerikanischen Nachrichtenagentur United Press, Ilhug Baillie, gestellten Fragen / 29. Oktober 1946“ (J.W. Stalin: Werke. Bd. 15. Dortmund 1979, S. 61-63, hier S. 62:) „18. Frage: Hält Rußland die Westgrenzen Polens für beständig? / Antwort: Jawohl.“]

2384 [Wie vor, S. 61: „9. Frage: Glauben Sie, dass die vier Besatzungszonen in Deutschland in der nächsten Zeit hinsichtlich der Wirtschaftsverwaltung vereinigt werden müssen, um Deutschland als friedliche Wirtschaftseinheit wiederherzustellen und um den vier Mächten die Bürde der Besatzung zu erleichtern? / Antwort: Man muss nicht nur die wirtschaftliche, sondern auch die politische Einheit Deutschlands wiederherstellen." 


\section{(185) Stimmungsbericht eines Informationsdienstmitarbeiters in Guben an den Informationsdienst beim Landratsamt des Kreises Guben. - Guben, 7. November 1946}

BLHA, Rep. 250 Landratsamt Guben/Frankfurt(Oder), Nr. 82, B1. 57. - Typoskript mit eigenhändiger Unterschrift [gez.] „Alfred Tietz“ [im Landratsamt dessen Adresse hinzugesetzt: „Cottb[user]. Platz No. 20“]. Eingangsvermerk vom 9.11.1946.

Betreffs des Interviews Stalins und des Pressekorrespondenten über die 31 Fragen wird im allgemeinen die Antwort Stalins begrüßt, daß Deutschlands wirtschaftliche und politische Einheit gefordert wird. ${ }^{2385} \mathrm{Da}$ aber die westliche Grenze Polens von Stalin als endgültig anerkannt wird, hat große Unzufriedenheit ausgelöst. Wörtlich wurde gesagt, daß der Pole gar kein Interesse an dem Gebiet hat, das er von Deutschland erhalten hat. Der Pole will sein ihm von Rußland abgetrenntes Gebiet zurückhaben und uns unser Gebiet sofort freigeben. Wenn Deutschland gezwungen ist, die Millionen Flüchtlinge unterzubringen und zu ernähren, wird es nie gesunden können und die Folge wäre, es würde ein ewiger $\mathrm{Haß}$ gesät. Wenn man also von russischer Seite so handelt, werden sie in Deutschland nie Freunde erwerben. Es wird aber auch von verschiedenen Seiten gewünscht mit Rußland in Freundschaft zu leben, da Deutschland und Rußland in Freundschaft alles schaffen könnten was beiden Staaten von Nutzen sein würde, so gar beide Staaten von der Welt unabhängig machen würde. Hier aber wäre es der Sieger, der uns zeigen müßte, daß er Gnade vor Recht ergehen lassen müßte. So die Stimmung unter den Leuten.

(186) Monatliche „Politische Stimmungsberichte“ des Rates des Kreises Luckenwalde an die Landesregierung Brandenburg, Abt. Inneres, auf der Grundlage von Berichten des Informationsdienstes. - Luckenwalde, 1946-1948 (Auszüge)

BLHA, Rep. 250 Landratsamt Luckenwalde, Nr. 106. - Typoskripte (Durchschläge). - Rubriken nach Richtlinien der Provinzialverwaltung Mark Brandenburg, Abt. Inneres, mitgeteilt zuletzt am 10.4.1946 (Bl. 3).

14.11.1946 [Bl. 109-110]

Unterzeichnet in Vertretung des Landrats durch Kreisrat Pietsch.

[Bl. 109v] Zu 7.) [c) Arbeit der Frauenausschüsse]

Die Frauenausschüsse, insbesondere die der Städte, haben in der vergangenen Zeit in den ihr [so!] zugewiesenen Arbeitsgebieten grosses geleistet. Sie haben Nähstuben errichtet, in denen alte Kleidung umgearbeitet und an die Hilfsbedürftigen ausgegeben wurden. Sie haben weiter nach besten Kräften Umsiedler und heimkehrende Kriegsgefangene betreut, die Arbeit in den Kindergärten in weitgehen[d]stem Masse unterstützt und sich schliesslich auch um die Freilassung antifaschistisch gesinnter Kriegsgefangener bemüht. 
14.12.1946 [Bl. 106-108]

Unterzeichnet in Vertretung des Landrats durch Kreisrat Pietsch.

[Bl. 107r] Zu 7.) [c) Arbeit der Frauenausschüsse]

Die Frauenausschüsse sind neben ihrer sonstigen Arbeit mit der Vorbereitung von Weihnachtsfeiern für die Alten, Kinder, Umsiedler und auch für die heimgekehrten Kriegsgefangenen beschäftigt. Neben praktischen Geschenken wird auch, soweit als möglich, für den Magen gesorgt werden.

13.2.1947 [Bl. 101-103]

Unterzeichnet in Vertretung des Landrats durch Kreisrat Pietsch.

[Bl. 101v] Zu 7.) [c) Arbeit der Frauenausschüsse]

[...] Aus Auslandsspenden konnten erst kürzlich in den Umsiedlerlägern, wenn auch im beschränkten Umfange, Süssigkeiten verteilt werden. [...]

[Bl. 102v] Zu 11.) Welche Gerüchte waren während der Berichtszeit im Umlauf?]

[...] Auf grossen Plakaten, die innerhalb der Stadt Luckenwalde zum Aushang kamen, wurde ein Bühnenball des Stadttheaters [...] angekündigt. [...] Doch die Bemerkung, dass der Eintritt 15.- RM beträgt und dunkler Anzug, also Abendtoilette gefordert wird, entfesselte unter der arbeitenden Bevölkerung der Industrie einen Sturm. / Hören wir Frau E[... ], 40 Jahre alt, Inhaberin einer Leihbücherei, SED, Luckenwalde, was sie dazu sagt: „Ist es nicht eine Herausforderung gegenüber der arbeitenden Bevölkerung RM 15.- Eintritt zu verlangen und Kostüm oder dunkler Anzug zu wünschen, und dies in einer Zeit, wo hunderte von Flüchtlingen nicht einmal das Notwendigste besitzen?" / [...]

15.4.1947 [Bl. 98-99]

Unterzeichnet in Vertretung des Landrats durch Kreisrat Pietsch.

[B1. 98v] Zu 4.) [Welche Versammlungen wurden durchgeführt?]

Von der SED ist in einer grösseren Anzahl der Gemeinden des Kreisgebietes zu den Moskauer Friedensverhandlungen in öffentlichen Versammlungen Stellung genommen worden. Der Besuch und die Anteilnahme sind als gut zu bezeichnen. Interessiert hat besonders [bei] den Umsiedlern aus den Ostgebieten die Frage der Westgrenze Polens. Noch immer besteht in den Umsiedlerkreisen die Hoffnung, eines Tages in die von ihnen verlassene Heimat zurückkehren zu können.

13.5.1947 [Bl. 96-97]

Unterzeichnet in Vertretung des Landrats durch Kreisrat Pietsch.

[Bl. 96r] [Zu 1.) [Politische Stimmung der Bevölkerung] [...]

Was sagt der Bürgermeister Roch aus Kaltenborn? [...] „Schwer haben es die Neusiedler. Ich habe darum jedem Altbauern eine Patenwirtschaft, d. h. also, einen Neusiedler angehängt. Jeder 
Altbauer ist verpflichtet, dem Neusiedler mit Gespannen und sonstigen Kleinigkeiten zu helfen. Altbauern, die nicht spurten, habe ich energisch angefasst. [...].“

14.7.1947 [Bl. 92-93]

Unterzeichnet in Vertretung des Landrats durch Kreisrat Pietsch.

[Bl. 92r] [Zu 1.) [Politische Stimmung der Bevölkerung] [...]

Grosse Sorge bereitet der Bevölkerung und auch der Verwaltung noch immer das Fehlen der Kartoffeln. Der Ausgleich durch Frischgemüse ist nicht in vollem Umfang herbeizuführen; ganz abgesehen davon, dass sich die Bevölkerung vom Einkauf des Frischgemüses zurückhält, weil sie noch immer der Meinung ist, die bisher nicht ausgelieferten Kartoffeln noch zu empfangen. Bei der Landbevölkerung, besonders in den Orten Mückendorf, Zesch, Görsdorf und Prensdorf, bekam ein Vertreter des Informationsdienstes als erste Frage vorgelegt: „Was sollen wir Neusiedler essen? Bekommen wir auch für den Monat Juli noch das Leihgetreide?" In Mückendorf [Bl. 92v] und Görsdorf bezogen ungefähr die Hälfte der Bewohner Leihgetreide. In Prensdorf ist es $1 / 3$. In diesen Ortschaften sind viele Neusiedler und Flüchtlinge, die seit Monaten Leihgetreide bezogen und nicht als Selbstversorger und auch nicht als Normalverbraucher kartenmässig anzusprechen sind. Durch den Fortfall des Leihgetreides für den Monat Juli ist die Versorgung mit Brot für 9000 Bewohner des Kreises in Frage gestellt.

[Bl. 93] Zu 7.) [c) Arbeit der Frauenausschüsse; d) Arbeit der Vereinigung der gegenseitigen Bauernhilfe]

Der Frauenausschuss hat sich besonders beschäftigt mit den am 27.6.[19]47 eingetroffenen rund 1500 Flüchtlingen. Daneben geht die Schulspeisung weiter, wenn auch unter erschwerten Umständen. Die Nähstube schafft unermüdlich für Heimkehrer, Flüchtlinge und, soweit es geht, auch für die Einwohnerschaft. / Das Kreissekretariat der gegenseitigen Bauernhilfe ist neu besetzt worden, und zwar mit einem Neusiedler, aus dessen Arbeit man einen Auftrieb erwartet.

13.11.1947 [B1. 81-82]

Unterzeichnet in Vertretung des Landrats durch Kreisrat Pietsch.

[Bl. 81] [Zu 1.) [Politische Stimmung der Bevölkerung] [...]

„Wenn wir den jetzt beschrittenen Weg weitergehen“, so sagt die Neusiedlerin, Frau D[...], aus demselben Ort [Heinsdorf], 34 Jahre alt, „müssen wir den Bankerott anmelden; denn ich kann einfach nicht verstehen, dass man uns Neusiedler, wenn wir unsere Beschwerden und Sorgen an den Mann bringen wollen, nicht anhört? Wir baten schon seit längerer Zeit um eine Überprüfung der Wohnverhältnisse in unserer Gemeinde. Trotz tausendfacher Schreiben und Bitten wird einfach nichts getan." / [...] 


\subsubsection{8 [Bl. 74-76]}

Unterzeichnet in Vertretung des Landrats durch Kreisrat Pietsch.

[Bl. 75] [Zu 4.) (Welche Versammlungen wurden durchgeführt?)] [...]

Von den in den Versammlungen anwesenden Umsiedlern, besonders aus Schlesien, wurden wiederholt Anfragen betr. endgültiger Grenzfestsetzung der Oder-Neisse-Linie gemacht. Unverständlicherweise hoffen die ehemaligen Anwohner dieser Gebiete auf eine Revidierung der Grenzen und Rückkehr in die Heimat. Laufenden Aufklärungen der deutschen Dienststellen stehen diese Bewohner zum Teil verständnislos gegenüber. Diese Leute können sich noch immer nicht mit der Umsiedlung abfinden und stellen betr. Rückkehr oft in naiver Weise diesbezügliche Fragen. Durch geschickte Propaganda der Westmächte werden die Hoffnungsschimmer im Herzen der Umsiedler immer wieder geweckt. Der Aufbau einer neuen Existenz in der jetzigen Heimat leidet darunter. / [...]

\subsubsection{8 [Bl. 71-73]}

Unterzeichnet von Landrat Dr. [Fritz] Ludwig.

[Bl. 71] [...]

$\mathrm{Zu} \mathrm{1.)} \mathrm{[Politische} \mathrm{Stimmung} \mathrm{der} \mathrm{Bevölkerung]}$

Unangenehm beeindruckt wird die Stimmung der Bevölkerung zur Zeit durch nachteilige Begleiterscheinungen in der Lebensmittelversorgung. Kartoffe[1]n, Gemüse und Brot sind die Hauptnahrungsmittel der Bevölkerung und gerade hier ergeben sich für grössere Teile Unzuträglichkeiten. Durch eine Anordnung der Landesregierung sollen sämtliche Vorräte an Speisekartoffeln als Saatkartoffeln Verwendung finden. Leider werden von dieser Aktion grössere Teile der Stadtbevölkerung betroffen, die bisher nicht in der Lage waren, Kartoffeln einzukellern. In Mitleidenschaft gezogen werdne in erster Linie Umsiedler und Untermieter, die räumlich nicht in der Lage waren, Kartoffeln auf Vorrat zu beziehen. [...] / Die Frauen geben in Gesprächen der Erwartung Ausdruck, daß wenigstens den Kindern zu Ostern zumindest ein Ei zugestanden wird. [...]

$$
\text { 13.6.1948 [B1. 58-63] }
$$

Unterzeichnet von Landrat Dr. Ludwig.

[Bl. 59] [...]

$[\mathrm{Zu}$ 1. (Politische Stimmung der Bevölkerung)] [...]

In den letzten, vom Informationsdienst durchgeführten Versammlungen auf dem Lande wurden in der Diskussion folgende Stimmen laut: / Durch das Volksbegehren für die Einheit Deutschlands wird immer wieder die Frage der Ostgrenzen und die Lostrennung der Ostgebiete aufgeworfen. Die Bevölkerung sagt, wir können nicht verstehen, dass wir hier Hunger leiden müssen, während im Osten riesige Gebiete brach liegen, unausgenutzt bleiben und einer immer stärkeren Verwilderung anheimfallen. 
Frau $\mathrm{N}[\ldots]$ in Langenlipsdorf sagt: / Jeder Deutsche wird selbstverständlich für ein einiges Deutschland sein, aber gerade deshalb verstehe ich nicht, warum die Ostgebiete nicht dazu gehören sollen. Weshalb wird ein Unterschied zwischen den Ostgebieten und dem Westen gemacht? Was im Osten richtig ist, sollte dann auch im Westen richtig sein oder umgekehrt, was wir im Westen ablehnen, müssen wir auch im Osten ablehnen.

Die Bevölkerung, besonders die aus den evakuierten Gebieten, hat für die politischen Gründe dieser Massnahme kein Verständnis. / [...]

14.7.1948 [Bl. 54-57]

Unterzeichnet in Vertretung des Landrats durch Kreisrat Ziebarth.

[Bl. 55] [...]

1.) $[$ Politische Stimmung der Bevölkerung] [...]

Von den Umsiedlern aus den Ostgebieten wird die Frage nach einer Aufwertung ihrer Sparguthaben gestellt. Die Umsiedler, die ihr ganzes Hab und Gut verloren haben, wünschen, soweit durch vorhandene Sparbücher ein Guthaben nachgewiesen werden kann, dass dieses ebenfalls aufgewertet wird. Die Verkündung der Währungsreform in der Ostzone wurde verhältnismässig ruhig aufgenommen und als gerecht empfunden. / [...]

16.11.1948 [Bl. 35-39]

Unterzeichnet von Landrat Dr. Ludwig.

[Bl. 38] [...]

$\mathrm{Zu}$ 9.) [Übergriffe von Angehörigen der Roten Armee]

In Luckenwalde wird seitens der Bevölkerung Klage geführt, dass [B1. 39] eine militärische Einheit in sehr unverständlicher Weise 21 Familien aus ihren Wohnungen wies, ohne dass der freigemachte Wohnraum voll beansprucht wurde. [...] / Gerade gegenwärtig wird diese ständige Wohnraumfreimachung sehr hart für die deutsche Bevölkerung empfunden, da laufend neue Umsiedlertransporte in Luckenwalde eintreffen. Der Kreis Luckenwalde hat von Juli bis November 600 Umsiedler aufnehmen müssen und es sind weitere Transporte angesagt. / Neuerdings geht man von seitens der Besatzungsmacht so weit, ganze Strassenzüge durch meterhohe Bretterzäune abzusperren, trotzdem es sich zum Teil um Durchgangsstrassen zu den Gemeinden des Kreises handelt. / [...]

(187) Stimmungsbericht des Informationsdienstes des Kreises Luckenwalde. Luckenwalde, 12. April 1947 (Auszug)

BLHA, Rep. 250 Landratsamt Luckenwalde, Nr. 106, B1. 208-209. - Typoskript (Durchschlag), 2 Bl. - Bl. 2081. o. „Der Landrat/ des Kreises Luckenwalde/Informationsdienst“. - R. o. Datierung „Luckenwalde, den 12.4.1947“. Darunter Eingangsstempel „14. April 1947“. - Überschrift: „Stimmungsbericht“. - Bl. 209 u. Kopierstift-Unterschriften „[gez.] R. Caspar, [gez.] E. Süßenbach / Informationsdienst“. 
Frau Sch[...], Flüchtling aus Schlesien, jetzt in Niebendorf, vertritt folgende Ansicht: Durch die Aussprachen von Amerika und England auf der Moskauer-Friedenskonferenz ${ }^{2386}$, rechne ich bestimmt auf eine Rückkehr nach Schlesien. Es heisst doch ausdrücklich in den [so!] Potsdamer Abkommen: „Die Häupter der drei Regierungen bekräftigen ihre Auffassung, dass die endgültige Festlegung der Westgrenze Polens bis zu der Friedenskonferenz zurückgestellt werden soll.“ / ["]Ich glaube deshalb bestimmt, dass wir noch einmal nach Schlesien zurückkehren werden.["] Bei der Erzählung derartiger Gerüchte taucht oft das Datum des 31 Okt. [19]47 auf, welches der Termin für die Heimkehr sein soll. / Diese oben angeführte Meinung wird nicht nur von Schlesiern vertreten. sondern auch von den Sudetendeutschen. Der Informationsdienst erhielt vor einiger Zeit wieder einen Aufruf an die Sudetendeutschen, von einem Flüchtling ausgehändigt, der fest von der Existenz des Alliierten Kontrollrats, welcher sich mit derartigen Dingen beschäftigen soll, überzeugt war.

\section{(188) Stimmungsbericht des Informationsdienstes in Kerkwitz (Kreis Guben) an das Landratsamt Guben, Informationsdienst. - Kerkwitz, 5. Mai 1947}

BLHA, Rep. 250 Landratsamt Guben/Frankfurt(Oder), Nr. 82, Bl. 152. - Manuskript mit eigenhändiger Unterschrift „[gez.] M. Albinus, Kerkwitz [von anderer Hand, offenkundig im Landratsamt, hinter dem Namen hinzugesetzt: S.E.D.)“. - Eingangsvermerk vom 8.5.1947.

1. Die Stimmung der Flüchtlinge ist durch den Abbruch der Verhandlungen in Moskau ${ }^{2387}$ auf den 0 Punkt gesunken. Sie hatten alle geglaubt, daß die Oder-Neiße-Linie Deutschland wieder zugesprochen würde. Es ist doch bald unmöglich soviel Menschen auf engen Raum zusammen zu drängen. Wenn das deutsche Volk nicht vernichtet werden soll, dann muß [es] wenigstens soviel Lebensraum erhalten, daß es leben und arbeiten kann. Nur so können wir wieder langsam vorwärts kommen und unsere Schuld wieder gut machen.

2. Die Kundgebung zum 1. Mai war hier wenig besucht. Im allgemeinen war hier wenig Interesse für den 1. Mai zu beobachten.

\section{(189) Politischer Stimmungsbericht aus der Stadt Guben. - Guben, 16. Mai 1947}

\section{(Auszug)}

BLHA, Rep. 250 Landratsamt Guben-Frankfurt (Oder), Nr. 85, unfol. - Typoskript (auf Kopfbogen mit masch. Vermerk „Abschrift!“), 2 Bl. - O.1.: „Der Oberbürgermeister / der Stadt Guben / [...]“.- R. o. Datierung: „Guben, den 16. Mai 1947“. - Adresse: „An die / Provinzialregierung Mark Brandenburg / Abt. Inneres, / Potsdam.“- „Unser Zeichen / HV.Nr. I St 5/47“. - „Betr.: Politischer Stimmungsbericht. / Bezug: Erlaß vom 10. April 1946. - Az.: Her 257/ St. -“. - Eingangsvermerk „E. 20./5.“ - Abschriftliche Unterschrift „I. V. / gez. Koschack, / Stadtrat.“ - Auf dem 2. Bl. u. Adressierung der Abschrift an „Herrn Sicker, Informationsdienst, Guben, Landratsamt“ „mit der Bitte um Kenntnisnahme“, unterzeichnet „I. V. [gez.] Koschack/ Stadtrat.“ 
[...] / In weiten Kreisen der Gubener Bevölkerung hat der Ausgang der Moskauer Konferenz $z^{2388}$ Enttäuschung hervorgerufen. So gespannt man hier den Verhandlungen gerade in Bezug auf die vorläufige Grenzziehung folgte, weil gerade Guben als geteilte Grenzstadt äußerst daran interessiert war, so ist durch die Neuansetzung der Konferenz im Herbst ds. Js., wo all diese Fragen nochmals zur Beratung stehen, die Enttäuschung auch verständlich. Waren doch annähernd 15000 Gubener der Ostseite, die jetzt auf der restlichen Westseite ihre Heimat gefunden haben, besonders an den Verhandlugen interessiert. Weiter wird mit großem Interesse die Politik in Frankreich verfolgt. Das wieder in Erscheinungtreten dè Gaulès ${ }^{2389}[$ so!] am politischen Horizont wird in weiten Kreisen der Arbeiter mit einer gewissen Beunruhigung aufgenommen. Zu den täglichen Fragen des Lebens stehen in erster Linie die Sorgen um Kartoffeln und Kohle. In parteilichen sowie auch in betrieblichen Veranstaltungen tritt nach Haltung eines Referates immer wieder in der Diskussion die Frage der Ernähung in den Vordergrund. / [...]

\section{(190) Stimmungsbericht des Informationsdienstes beim Landrat des Kreises Guben. - Guben, 24. September 1947 (Auszüge)}

BLHA, Rep. 250 Landratsamt Guben/Frankfurt(Oder), Nr. 83, Bl. 195-198. - Tgb.-Nr. 311 S/Sch.; Typoskript (Durchschlag), 4 Bl. - Bl. 1951. o.: „Der Landrat/Informationsdienst/ Tagb.Nr. 311 S/Sch.“ - R. o.: Guben, den 24. Septbr. 1947.“ - Adresse: Herrn / Landrat Nitschke / Guben.“ - Überschrift: „Stimmungsbericht“. - Bl. 193 Unterschrift „I.A. [gez. (Kopierstift)] Sicker“.

[B1. 195] Stimmungsbericht über Ernährungsfragen, Kontingent-Ablieferung, Befehl 201, Forster Bahnlinie und sonstige Stimmungen.

Mitarbeiter Kurt Gassan - Ziltendorf (- $)^{2390}$ : / Die Stimmung in unserer Gemeinde ist im Augenblick sehr gedrückt. Der Bauer klagt, weil er viel abgeben muss und der Arbeiter, weil er so wenig zugeteilt erhält. Die Klagen der Flüchtlinge gehen dahin, dass der Bauer Kuchen backen kann und der Umsiedler hat kein Bett zum Zudecken, keinen Schrank, keinen Tisch. Zum grossen Teil wohnen Umsiedler mit 5 und mehr Personen in einem kleinen Raum. Jeder anständige Umsiedler arbeitet, was in seinen Kräften steht und das Dorf ist von früh bis in die Nacht hinein von Hamsterern bevölkert. Wo haben diese Leute die Zeit her, um täglich diese Fahrten zu unternehmen? Und will der Umsiedler etwas haben, so bekommt er nichts, denn die Preise, die von den Hamsterern geboten werden, kann kein Flüchtling bezahlen. Er wohnt zwar auf dem Lande und arbeitet, aber zu kaufen bekommt er nichts. Die letzte Hoffnung der Umsiedler ist die, dass es noch einmal zurück geht, sonst verliert alles den Mut, denn es geht nicht an, dass die Einheimischen noch fast alles haben und der Umsiedler nichts, aber auch garnichts. / Warum wird nichts unternommen, dass die noch vorhandenen Sachen auch mit den Flüchtlingen geteilt werden? Das ist die Frage, welche von den Umsiedlern immer wieder gestellt wird. / [...] [Bl. 197]

[Wie vor.]

2389 [Charles de Gaulle (1890-1970), französ. General und Politiker.]

2390 [Der eingeklammerte Strich bezieht sich auf das Fehlen einer Parteizugehörigkeit.] 
Bürgermeister Riechert-Sembten (SED):

In politischer Hinsicht erwartet die Bevölkerung durch die bevorstehende Friedenskonferenz eine endgültige Festlegung der Grenzen und besonders der Ostgrenzen. Die Flüchtlinge leben in einer fast unerträglichen Spannung und werden immer wieder durch Gerüchte über Heimkehr beunruhigt. Das enge Zusammenleben und die Wohnungsfrage bereiten der Gemeindeverwaltung und dem Umsiedlerausschuss immer wieder Sorgen und Schwierigkeiten. Eigennützige und die Not der Zeit nicht verstehende Ortsansässige müssten in die rechte Bahn gelenkt werden! [...]

Mitarb. Ella Bietsch bei der Fa. C. G. Wilke 2391 (SED):

[...] Warum bekam der [aus dem Amt entfernte - P. B.] Herr Oberbürgermeister Schwarz seine sämtlichen Möbel mit, während es sonst nicht gestattet ist, Möbel aus der Stadt zu entfernen. Wir haben noch einen Teil Flüchtlinge, die nicht einmal ein Bett haben. / [...]

(191) Politischer Stimmungsbericht aus der Lederfabrik Emanuel Meyer in Guben. Guben, November 1947

BLHA, Rep. 250 Landratsamt Guben-Frankfurt (Oder), Nr. 85, unfol. - Typoskript ohne Unterschrift, 1 Bl. - Hinweis: Es handelt sich um den Bericht eines lokalen Informanten (Mitarbeiter des Informationsdienstes), der anschließend textidentisch in den (umfangreicheren) Gesamtbericht des Leiters des Informationsdienstes des Landratsamtes Guben, Sicker, datiert Guben, 24. November 1947, aufgenommen wurde (in der Akte ebenfalls enthalten, unfol.; siehe nachfolgendes Dokument Nr. 192). - Überschrift: „F[irm] Emnauel Meyer, Guben“.

Betr[iebs-]Leiter Fengler: Wir müssen so schnell als möglich ein einiges Deutschland werden, da sonst Wirtschaft und Bevölkerung zugrunde gehen und dass wir den Flüchtlingen, die ja nicht selbst geflüchtet sind, sondern ausgewiesen wurden, ihre Heimat wiedergeben. Also Wiedergabe der alten Grenzen!

Betriebsratsvor[itzender] Fellert: / Betriebs-Gruppenleiter der SED Klinke: Die Londoner Konferenz, wo unsere Vertreter gehört werden, muss klar zum Ausdruck bringen, dass wir ohne den Osten nicht leben können und dass man uns nicht als Flüchtlinge behandelt, da wir ja nicht selbst geflüchtet sind, sondern ausgewiesen wurden. Sonst versprechen wir uns von der Londoner Konferenz nichts, da hier 2 verschiedene Weltanschauungen aufeinandertreffen, die sich über Deutschland nicht einig werden können.

Unsere Gedanken sind oft in London und wir hoffen, dass die uns führenden Männer der Welt uns nicht enttäuschen werden und uns helfen, ein einiges Deutschland zu werden und dass bald die Zonengrenzen fallen und uns unser altes Deutschland wieder zugesprochen wird.

Abteilung Färberei: Mit grossem Interesse schauen wir auf die Londoner Konferenz, da dort unser Schicksal entschieden wird. Wir wünschem, dass endlich die alten Grenzen wieder hergestellt werden und unser Lebensstandart [so!] gehoben wird. 
Sonstige Arbeiter des Betriebes: Unser einiger Wunsch ist der, dass so schnell als möglich entschieden wird, was zu unseren Gunsten sein kann, nämlich unser Lebensstandart [so!] gebessert wird, dass uns der Osten zurückgegeben wird, der vieler Arbeiter Heimat ist.

\section{(192) Stimmungsbericht des Informationsdienstes des Rates des Kreises Guben an das Informationsamt der Landesregierung Brandenburg in Potsdam. - Guben, 24. November 1947 (Auszüge)}

BLHA, Rep. 250 Landratsamt Guben/Frankfurt(Oder), Nr. 83, Bl. 209. - Abschrift (Typoskript, Durchschlag) für Landrat Nitschke, im Hause, mit eigenhändiger Unterschrift „i. A. [gez.] Sicker“.- Dieser für die Landesregierung zusammengestellte Gesamtbericht des Kreises führt beim Rat des Kreis gesammelte Berichte aus einzelnen Gemeinden und Firmen, teilweise gekürzt, zusammen (vgl. als Beispiel den obigen textidentischen Einzelbericht, Nr. 192).

\section{Stimmungsbericht}

über die Londoner Konferenz ${ }^{2392}$, den Marshall-Plan und zu der Sache Dr. Friedensburg ${ }^{2393}$. $[\ldots]$

\section{Emanuel Meyer, Lederfabrik, Guben}

Betriebsleiter Fengler: Wir müssen so schnell als möglich ein einiges Deutschland werden, da sonst Wirtschaft $\mathrm{u}$. Bevölkerung zugrunde gehen und dass wir den Flüchtlingen, die ja nicht von selbst geflüchtet sind, sondern ausgewiesen wurden, ihre Heimat wiedergeben. Also Wiedergabe der alten Grenzen!

Betriebsratsvors. Fellert und Betr.Gruppenleiter der SED Klinke: Die Londoner Konferenz, wo unsere Vertreter gehört werden, muss klar zum Ausdruck bringem, dass wir ohne den Osten nicht leben können und dass man uns nicht als Flüchtlinge behandelt, da wir ja nicht selbst geflüchtet sind, sondern ausgewiesen wurden. Sonst versprechen wir uns von der Londoner Konferenz nichts, da hier 2 verschiedene Weltanschauungen aufeinander treffen, die sich über Deutschland nicht einig werden können.

Unsrere Gedanken sind oft in London und wir hoffen, dass die uns führenden Männer der Welt uns nicht enttäuschen werden und uns helfen, ein einiges Deutschland zu werden, dass bald die Zonengrenzen fallen und uns unser altes Deutschland wieder zuugesprochen wird.

Abteilung Färberei: Mit grossem Interesse schauen wir auf die Londoner Konferenz, da dort unser Schicksal entschieden wird. Wir wünschen, dass endlich die alten Grenzen wieder hergestellt werden und unser Lebensstandart [so!] gehoben wird!

Sonstige Arbeiter im Betriebe: Unser einziger Wunsch ist der, dass so schnell als möglich entschieden wird, was zu unseren Gunsten sein kann, nämlich, dass unser Lebensstandart [so!] gebessert wird, dass man uns den Osten zurückgibt, der vieler Arbeiter Heimat ist! / [... ] 
(193) Stimmungsbericht des Informationsdienstes des Rates des Kreises Guben an das Informationsamt der Landesregierung Brandenburg in Potsdam, Seestr. 43. Guben, 28. November [1947]

BLHA, Rep. 250 Landratsamt Guben/Frankfurt(Oder), Nr. 83, Bl. 210. - Tgb.-Nr. 347 S/Sch.; Abschrift (Typoskript, Durchschlag) für Landrat Nitschke, Guben, mit eigenhändiger Unterschrift „i. A. [gez.] Sicker“. - [Datierung 28.11.1948 irrtümlich, muss lauten 28.11.1947.]

Stimmen über die Londoner Konferenz..$^{2394}$

Revierförster Laskus - SED - Gem[einde] Schernsdorf.

Soweit ich mit der hiesigen Bevölkerung in Berührung gekommen bin, und soweit ich mit den [einen] oder anderen über die Aussichten zur Londoner Konferenz gesprochen habe, musste ich feststellen, dass man im grossen u. ganzen sich über diese Frage der so wichtigen Konferenz gar keine Gedanken macht. Die wirtschaftlichen Sorgen der einzelnen Menschen in der hies[igen] Gemeinde sind zu gross, um noch Raum für Fragen zu lassen, die ausserhalb ihres Gesichtskreises liegen. Da wir hier mit einheimischen Menschen u. Umsiedlern zu tun haben, ist auch die Stimmung unterschiedlich. Die einen erwarten von der Londoner Konferenz, dass die Flüchtlinge wieder nach ihrer Heimat zurückkehren dürfen, damit sie wieder grössere Bewegungsfreiheit in ihren Dörfern haben. Wir alle erwarten von der Konferenz ein Verständnis für unsere Not u. einen Friedensentwurf, der uns aufatmen lässt und der Hoffnung Raum gibt, in einem geeinten Deutschland unter einer Zentralregierung ohne kostspielige Länderregierungen den demokratischen Wiederaufbau durchführen zu können. Dass wir für den Krieg büssen müssen, sehen wir ein, doch soll die uns auferlegte Busse auch erträglich sein.

C. Lehmann's Ww. u. So[hn]

Nach Aeusserung des Betriebsrats-Vors. u. 1 Kollegen ist die Mehrheit der Belegschaft der Auffassung, dass sie von der Londoner Konferenz trotzdem vieles erwartet. Aber die Grundfrage bleibt für sie immer noch - die Grenzfrage! Da sie als Betrieb hart an der Neisse liegen und ihr Blick tägl. dort hinüberschweift, werden sie natürlich den Gedanken der alten Heimat niemals los. Sie erwarten doch eine Grenzänderung auf dieser Londoner Konferenz.

(194) Stimmungsbericht des Informationsdienstes des Rates des Kreises Guben an das Informationsamt der Landesregierung Brandenburg in Potsdam. Guben, 2. Dezember 1947 (Auszüge)

BLHA, Rep. 250 Landratsamt Guben/Frankfurt(Oder), Nr. 83, Bl. 211. - Tgb.-Nr. 347/S/Sch.; Typoskript (Durchschlag) für Landrat Nitschke, im Hause, mit eigenhändiger Unterschrift „i. A. [gez.] Sicker“. 


\section{Stimmungsbericht}

über die Londoner Friedenskonferenz ${ }^{2395}$ und Aeusserungen zum Friedensvertrag $[\ldots]$

Gustav Pfeiffer, Korbweiden-Fabrik, Wellmitz (SED):

Ich habe bisher noch keinen Menschen gefunden, der optimistisch an einen Erfolg der Londoner Konferenz glaubt. Allerdings haben die letzten Meldungen aus London, wie ich bei meiner letzten Fahrt feststellte, die optimistische Stimmung durch den bisher guenstigen Verlauf der Konferenz gehoben. Allgemein erzählt man sich besonders unter Flüchtlingen, dass die Grenzfrage auf die Tagesordnunng gesetzt wurde; es herrscht die Meinung vor, dass man uns endlich sagen sollte, woran wir sind.

Luise Pietsch, Guben, Deulowitzer Str. 15 (b.d. Fa. CG. Wilke, Hutfabr.) (SED):

An der Konferenz ist starke Teilnahme; jeder ist gespannt auf die Berichte in den Tageszeitungen. Auch von seiten der Frauen herrscht starke Teilnahme.

\section{(195) Stimmungsbericht des Informationsdienstes beim Landrat des Kreises Guben} an den Landrat über die Londoner Friedenskonferenz und Äußerungen zum Friedensvertrag. - Guben, 3. Dezember 1947 (Auszüge)

BLHA, Rep. 250 Landratsamt Guben/Frankfurt(Oder), Nr. 83, Bl. 212. - Typoskript (Durchschlag) mit eigenhändiger Unterschrift „i. A. [gez.] Sicker“.

Herta Schmidt, Guben, B. G. H. ${ }^{2396}$, S.E.D.

Die Belegschaft unserer Fa. der Berlin-Gubener-Hutfabrik verfolgt aufmerksam den Verlauf der Londoner Konferenz ${ }^{2397}$. Unser Hauptaugenmerk ist auf eine baldige Regelung der Ost- und Westgrenze gerichtet und insbesondere auf die endgültige Festlegung der Ostgrenze.

Stadtrat Schwadtke, Guben, L. D.P.

Ich bin der Meinung, dass nun endlich die Grenzfrage gelöst und die Grenzen wie 1937 festgelegt werden und es zu einer Einheit Deutschlands kommen wird, denn es ist doch der größte Wunsch der Flüchtlinge, zur Heimat zurückkehren zu dürfen.

\section{(196) Stimmungsbericht des Informationsdienstes beim Landrat des Kreises Guben} an den Landrat zur Londoner Konferenz. - Guben, 4. Dezember 1947 (Auszug)

BLHA, Rep. 250 Landratsamt Guben/Frankfurt(Oder), Nr. 83, Bl. 213-214. - Typoskript (Durchschlag) mit eigenhändiger Unterschrift „i. A. [gez.] Sicker“. 
Karl Raschke, Koch im Altersheim - Waldsiedlung:

Ich hege die Hoffnung, dass bei der jetzigen Zusammenkunft der Aussenminister ${ }^{2398}$ das Urteil für Deutschland günstig ausfallen und es zu einer Einigung kommen wird. Von dieser Konferenz hängt ja alles ab. Ohne die Beseitigung der Zonengrenzen und ohne eine Einheit kann Deutschland nicht bestehen. Gerade wir Flüchtlinge setzen ja unsere ganz Hoffnung auf eine Rückkehr in die Heimat.

\section{(197) Stimmungsbericht eines Informationsdienstmitarbeiters in Kaltenborn (Kreis Guben) an den Landrat des Kreises Guben, Abt. Informationsdienst. - Kaltenborn, 14. Dezember 1947}

BLHA, Rep. 250 Landratsamt Guben/Frankfurt(Oder), Nr. 82, Bl. 144. - Manuskript mit eigenhändiger Unterschrift [gez.] „Mattigk“. - Eingangsvermerk vom 15.12.1947.

Bericht 1: Stimmung auf dem Lande zum deutschen Volkskongreß. ${ }^{2399}$

Bauern, Arbeiter u. Umsiedler wünschen ein einheitlich demokratisches Deutschland u. einen gerechten Frieden. Freien Handel über die Zonengrenzen hinaus.

Bericht 2: Londoner Konferenz.

In den Nachrichten $u$. in der Presse werden die Berichte über die Konferenz der Außenminister ${ }^{2400}$ mit Interesse verfolgt, doch über die deutsche Ostgrenze, was für die Umsiedler das Wichtigste ist, wurde bisher wenig beraten. Die Vorschläge des Außenministers Molotow's werden allgemein begrüßt.

\section{(198) Bericht des Kreisbauamtes des Kreises Guben über Übergriffe der sowjetischen Grenzpolizei an Oder und Neiße. - Guben, 11. Februar 1948}

BLHA, Rep. 250 Landratsamt Guben/Frankfurt(Oder), Nr. 83, Bl. 234. - Typoskript, 1 Bl. - L. o.: „Der Landrat / Kreisbauamt -, - R. o.: „Guben, den 11. Februar 1948 / Wo/Pr.“ - Adresse: „An die / Abteilung Hauptverwaltung / im Hause“.- Betreff: „Betr: Uebergriffe der Besatzungsmacht.“- Mit eigenhändiger Kopierstift-Unterschrift [gez.] „Wolf“ / [masch.: ] „Kreisbaumeister“. - Verfügung der Personalabteilung des Rates des Kreises, Kreisinspektor Schulze, 12. Februar 1948: „1.) Beitrag zum Politischen Stimmungsbericht. / 2.) W[ieder]v[orlage] 5.3.48.“ [beides abgehakt].

Laufende Beschwerden der längs der Oder und Neisse gelegenen Ortschaften zwangen mich bisher, fast wöchentlich Eingaben an die örtliche Kreiskommandantur, wegen zahlreicher Uebergriffe der russischen Grenzpolizei, zu unternehmen. / Besonders die Ortschaften Schlagsdorf, Klein-Gastrose, Gross-Gastrose, sind bei den Willkürmassnahmen der einzelnen ständig wechselnden Grenzposten, hiervon am meisten betroffen. Diese Gemeinden müssen als einzigste Zufahrtstrasse nach Guben einen Weg zwischen Bahnstrecke Guben - Gross-Gastro-

2398 [Siehe Anm. 2392.]

2399 [Erster „Deutscher Volkskongress für Einheit und gerechten Frieden“ auf Initiative der SED in Berlin (Admiralspalast), 6./. Dezember 1947.]

2400 [Siehe Anm. 2392.] 
$\mathrm{se}^{2401}$ hart an der Neisse gelegen, täglich passieren, Auf diesem Wege werden den Leuten die Ausweise, wohlgemerkt ordnungsmässige Ausweise, abgenommen, sie selbst zurückgeschickt oder eingesperrt und auf das übelste belästigt. / Gespannkräfte und auch die Personen dieser Gemeinden weigern sich künftighin nach Guben zu fahren, da die Zustände trotz laufender Beschwerden sich nicht bessern. Betonen möchte ich nochmals, dass es für diese Gemeinden nur diesen einen einzigen Weg nach Guben gibt.

\section{(199) Stimmungsbericht eines Informationsdienstmitarbeiters in Atterwasch (Kreis Guben) an den Informationsdienst beim Landratsamt des Kreises Guben. - Atterwasch, 16. Februar 1948 (Auszug)}

BLHA, Rep. 250 Landratsamt Guben/Frankfurt(Oder), Nr. 82, Bl. 71-72. - Manuskript mit eigenhändiger Unterschrift „[gez.] Rudi Brilke [Rudolf Brilke, Junglehrer], Atterwasch No. 28“. - Eingangsvermerk vom 19.2.1948 $(145 / 48)$.

[Bl. 72v] Nicht immer war es möglich die Berichte laufend an das Inf[ormations-] Büro zu senden, weil eine so große und kaum zu bewältigende Arbeit auf jeden Schulamtsbewerber liegt. Ich werde bestrebt sein, auch weiterhin Berichte die für das Informationsbüro von großer Wichtigkeit sind, zu verfassen und ins Büro zu schicken. [...]

$[\mathrm{Bl} .71 \mathrm{v}]$ Wie ist die Stimmung der Bevölkerung ${ }^{2402}$ : Ich kann wohl mit recht sagen, sie ist mehr als ausreichend. Nur in Kürze befürchte ich eine, ich möchte nicht sagen eine Katastrophe, so doch eine starke Aufregung. Bitte hören sie: In unserm Dorf soll am 21.2. eine kleine Geselligkeit zu stande kommen. Zu diesem Fest soll ein kleiner Stier geschlachtet und die Teilnehmer damit bewirtet werden. Alles ganz gut und schön. An diesem Fest aber, was die V.D. G. B. ${ }^{2403}$ gibt, werden nur seine Mitglieder teilnehmen. Also nur Bauern, nicht aber Umsiedler. Ich möchte nicht sagen, daß den Bauern ein solches Fest nicht zu gönnen ist, weil sie fast alle ihr Schwein geschlachtet haben, nein, ich und alle Umsiedler sind der Ansicht, daß durch diese seperaten [so!] Feste keine Einigung im ganzen Reich erzielt wird. In jeder Gemeinde wird es nach einem solchen Fest zwei Gruppen Menschen geben: Bauern, die besitzenden[,] und Flüchtlinge, die vertriebenen. Das was die Partei in unserm Dorf versucht auszugleichen, vernichtet die V.D. G. B. Ich bin erstaunt darüber, das[s] unser Landrat die Genehmigung zur Schlachtung eines Rindes zu diesen Zwecken gibt. Gerade er hat in vielen Referaten darauf hingewiesen, daß wir die Flüchtlinge für uns gewinnen müssen, und versuchen müssen den Flüchtlingen das zu geben was sie verloren haben. Wir können ihnen nicht viel geben, das Zugehörigkeitsgefühl aber bestimmt. Es wurde auch von unserem Ortsgruppenleiter der S.E.D. angeregt auch die Flüchtlinge mit diesem Fleisch zu bewirten. Der Vorsitzende und auch die Mitglieder der V.D. G. B. hätten gegen [Bl. 71r] diesen Plan nichts einzuwenden. Er wurde jedoch in Guben direkt verboten.

2401 [Darüber handschriftlich eingefügt:] u. Reißel [dafür gestrichen: „und“.]

2402 [Zusatz vom Landratsamt:] zu den örtlichen Fragen.

2403 [VdgB.] 
Die arbeitende Bevölkerung und Umsiedler unseres Dorfes fragt sich mit Recht: „Mit welchem Recht entnimmt die V.D. G. B. ein Rind aus der Wirtschaft und verbraucht es für die Mitglieder. Wir fordern dann aber auch erhöhte Belieferung unser[er] Lebensmittelkarten."

Über diese Frage erbitte ich mir schnellstens Bescheid, weil täglich Rückfragen an meine Person gestellt werden. Persönlich habe ich an diesem Fall größtes Interesse. / [...]

(200) Stimmungsbericht des Informationsdienstes des Rates des Kreises Guben an das Informationsamt der Landesregierung Brandenburg in Potsdam, Seestr. 43. Guben, 24. Februar 1948 (Auszüge)

BLHA, Rep. 250 Landratsamt Guben/Frankfurt(Oder), Nr. 83, Bl. 230. - Abschrift (Typoskript, Durchschlag) für Landrat Nitschke im Hause, mit eigenhändiger Unterschrift [gez.] „Sicker“.

Mitarbeiter der Verwaltung in Fürstenberg/Oder:

Das Scheitern der Londoner Konferenz ${ }^{2404}$ hat unter der Bevölkerung wie eine Bombe eingeschlagen. Ein grosser Teil hatte geglaubt, dass es in letzter Minute noch zur Einigung kommen und endlich die Zonengrenzen fallen würden. [...]

Ein Mitglied der Gemeindevetretung aus Deulowitz, Kr. Guben:

[...] Ist einmal den Flüchtlingen Gelegenheit geboten, wieder ihren heimatlichen Boden zu bewirtschaften, würde sich das auf die allgemeine Ernährungslage nur zum Vorteil auswirken. $[\ldots]$.

(201) Stimmungsbericht des Informationsdienstes des Rates des Kreises Guben an den Informationsdienst der Landesregierung Brandenburg in Potsdam, Seestr. 43, über die in der Zeit vom 12. bis 22. Mai 1948 durchgeführten öffentlichen und Betriebsversammlungen des Informationsdienstes. Guben, 25. Mai 1948 (Auszüge)

BLHA, Rep. 250 Landratsamt Guben/Frankfurt(Oder), Nr. 83, Bl. 257-260. - Abschrift (Typoskript, Durchschlag, 4 B1.) für Landrat Nitschke, im Hause, mit eigenhändiger Unterschrift „i. A. [gez.] Sicker“.

Thema: „Warum Volksbegehren?“ / Referent: Karl Sicker.

Oeffentliche Gemeindeversammlung in Atterwasch am 12. Mai 1948, 20 Uhr.

Besucherzahl: 36. Männer 32. Frauen 4. Jugendl[iche]. -. Altbauern 12. Neubauern -. Umsiedler 20 .

Zur Diskussion wurde die Frage gestellt: Könnten Kriege verhindert werden? / Zur Frage der Entnazifizierung kann man es von seiten der Verwaltung nicht verstehen, dass auf jedem Formular, Fragebogen usw. zu lesen ist: „Bist du Mitglied der NSDAP. oder Mitglied irgend einer 
Gliederung gewesen? Wenn nun die Entnazifizierung beendet ist, warum ist diese Frage immer wieder zu lesen? / Die SED hat ja auch einmal erklärt, sie würde dafür eintreten, dass man die jetzige Ostgrenze einer Revision unterziehen müsste. Die Polen haben grosse deutsche Gebiete, welche sie nicht restlos bewirstchaften, besetzt. Die Frage der Ostgrenze müsste als erster Punkt gestellt werden. Alle 4 Siegermächte haben Schuld, dass sie uns nicht wieder die alten Gebiete, die ja unsere Heimat sind, zurückgeben!

Oeffentl. Gemeindeversammlung in Taubendorf am 13. Mai 1948, 20 Uhr.

Besucherzahl:24. Männer 18. Frauen -.Jugendl[iche]6.Altbauern6. Neubauern2.Umsiedler 12. [B1. 258] Zur Aussprache meldeten sich Vertreter der SED., VdgB. und Umsiedler. / Das Brotund Futtergetreide, was jetzt Sowjet-Russland für die Ostzone liefert, ist doch unser Getreide; der Russe hat es doch von unserem genommen! Was macht das schon pro Kopf der Bevölkerung aus? / Wir Umsiedler wollen in unsere Heimat! Russland sollte als Beispiel vorangehen und zeigen, dass es die Ostgrenze ändern kann. / Ein Jugendlicher äusserte sich in dem Sinne, als er erklärte: „Uns ist es egal, ob ein Kaiser oder ein Dr. Schumacher ${ }^{2405}$ regiert, und wenn es nicht anders geht als durch Krieg, die Hauptsache, wir kommen zurück zur Heimat!“

Oeffentliche Gemeindeversammlung in Grano am 14. Mai 1948, 20 Uhr

Besucherzahl: 46. Männer 30. Frauen 10. Jug[en] dl[iche]. 6. Altbauern 15. Neubauern 10. Umsiedler 15 .

Zur Diskussion: [...] Das Neusiedlerprogramm ist gut, aber was wird kommen? Dieses Jahr wird es noch so gehen mit den Bauten, aber nächstes Jahr werden wir den Neusiedlern kein Bauholz mehr zur Verfügung stellen können. Praktisch gesagt: Wir haben keinen Wald mehr. Die Alliierten sollten uns mal 10 Jahre allein, frei arbeiten lassen und uns nicht mit Reparationen belasten.

\section{Oeffentl. Gemeindeversammlung in Bresinchen am 19. Mai 1948, 20 Uhr}

Besucherzahl: 51. [B1.259] Männer 35. Frauen 10. Jugendl[iche]. 6. Altbauern 20. Neubauern -. Umsiedler 20.

Zur Diskussion meldete sich ein Umsiedler: „Wird man die Umsiedler, die alle ihr Hab und Gut verloren haben, einmal entschädigen? Eine Waffenschmiede will kein einziger, denn ein jeder will in seine Heimat zurück.

Betriebsversammlung der Fa. Rennert \& Donath (VeB.), am 20.5.[19]48, 15.30 Uhr

Besucherzahl: 33. Männer 26, Frauen 4, Jugendl[iche]. 3.

Zur Diskussion. Allen liegen eben die Ostgrenzen am Herzen, wollen wir doch zurück in die Heimat. Im Grunde genommen haben wir jetzt keine Heimat. Wir sehen ein, dass der Kampf wohl

2405 [Dr. Kurt Schumacher (1895-1952), ab 1946 SPD-Parteivorsitzender in den Westzonen, Scharfer Gegner einer Vereinigung mit der KPD.] 
zuerst geführt werden muss für ein einheitliches, demokratisches Deutschland. Es ist selbstverständlich, dass sich ein jeder in die Listen zum Volksbegehren einzeichnet. Es könnte trotzdem manches besser sein, denn zuviel wandert noch in die deutschen Kanäle. Es fehlt an den wirklichen Volkskontrollen. / [...]

(202) Stimmungsbericht des Informationsdienstes des Rates des Kreises Guben an den Informationsdienst der Landesregierung Brandenburg in Potsdam, Seestr. 43, über das Volksbegehren. - Guben, 1. Juni 1948 (Auszüge)

BLHA, Rep. 250 Landratsamt Guben/Frankfurt(Oder), Nr. 83, Bl. 261. - Abschrift (Typoskript, Durchschlag) für Landrat Nitschke, im Hause, mit eigenhändiger Unterschrift „i. A. [gez.] Sicker“.

Eine Stimme aus Fürstenberg/Oder: Fürstenberg/O. ist Grenzstadt geworden. Von den 9225 Einwohnern sind 3600 Umsiedler. Von diesen wird immer wieder die Meinung vertreten, wenn wir uns einzeichnen in die Liste zum Volksbegehren, haben wir endgültig unser Urteil unterschrieben, unser Schicksal besiegelt und wir kommen nie in unsere Heimat zurück! Andere sagen wieder: „Was werden wir uns einzeichnen, besser wird es ja doch nicht und mehr bekommen wir auch nicht". / [...]/

Stimmen der Umsiedler aus Guben: „Ja, wenn sie uns würden sagen, wie können wieder über die Neisse, dann würde ich unterschreiben. Wir wissen nicht, was die Unterschrift bedeutet. Es wird im allgemeinen gesagt, wenn wir uns einzeichnen, dann unterschreiben wir unser eigenes Todesurteil. Dann unterschreiben wir, dass wir mit der jetzigen Ostgrenze einverstanden sind. Dieser Gedanke kreist sehr stark unter den Umsiedlern. Ja für die Einheit und einen gerechten Frieden bin ich auch, aber wir wollen doch auch unsere Heimat zurück. / Andere sagen, „wir

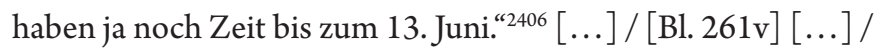

1 Stimme aus Kieselwitz: Beim Volksbegehren ist es hier vorgekommen, dass sich einige Umsiedler nicht eintragen, weil sie glauben, sie bekennen sich zu der jetzigen Ostgrenze.

\section{(203) Bericht über eine Aussprache der „Umsiedler“ der Gemeinde Kloster Zinna. - Luckenwalde, 3. September 1948}

BLHA, Rep. 250 Landratsamt Luckenwalde, Nr. 105, Bl. 116-118. - Typoskript (Durchschlag), 3 Bl., mit TintenParaphe „Pl“ des Informationsdienstmitarbeiters Plath, vereinzelte handschriftliche und maschinenschriftliche Korrekturen. - O.1. Stempel „Der Rat des Kreises / Luckenwalde / Informationsdienst“, darunter Aktenzeichen „Pl/J““ O.r. Datierung „Luckenwalde, den 3. Sept. 1948 / Bahnhofstr. 5 / Tel.: 2142 App. 35“. - Bl. 118 u.: Wiederholung des o. g. Stempels.

Die Umsiedler der Gemeinde Kloster Zinna versammelten sich am 27.8. zahlreich zu einer vom Amt für Umsiedler der Kreisverwaltung einberufenen Aussprache. Nach wenigen einleitenden Worten des Versammlungsleiters begann bereits die Aussprache, zu deren Beginn darauf hingewiesen wurde, dass man an dieser Stelle sagen solle, was zu sagen ist, sonst müsste man selbst die 
Schuld der Unabänderlichkeit auf sich nehmen. Nun - die Umsiedler haben von dieser Aufforderung reichlich Gebrauch gemacht und es war eine Freude, zu hören, in welch sachlicher Form sie ihre vielseitigen Klagen und Beschwerden vorbrachten. In ebenso erfreulich sachlicher Form erfolgten allerdings auch die kurzen Antworten und man kann feststellen, dass ein grosser Teil der Anwesenden mit der Sicherheit die Versammlung verlassen konnte, dass in seinem Falle entweder durch den Rat der Gemeinde oder durch das Amt für Umsiedler Abhilfe geschaffen werden kann.

Ein sehr guter Vorschlag aus der Versammlung war der Gedanke, einen Gemeinschaftskeller für diejenigen Umsiedler zu schaffen, die bei ihren Wohnungen keine Einkellerungsmöglichkeiten für Holz und Kartoffeln haben, wodurch oft in den Wohnräumen sich Feuchtigkeit bildet und dieser ausserdem zu stark eingeschränkt wird. Der Bürgermeister von Kloster Zinna stellte fest, dass ein der Gemeinde gehörender und für diese Zwecke geeigneter Keller in Kaltenhausen vorhanden sei, jedoch müsse nach seiner Auffassung evtl. durch Lattenverschläge eine Unterteilung dieses Raumes zur Verhinderung von Diebstählen geschaffen werden.

Sehr erfreut wurde die Meldung aufgenommen, dass Materialien zur Instandsetzung (nicht zum Ausbau) von Wohnungen beim Umsiedleramt [Bl. 117] vorhanden sind. Die Mitteilung des Versammlungsleiters, dass trotz wiederholter Hinweise in seinen Mitteilungsblättern die Gemeinde Kloster Zinna derartiges Material bislang noch nicht angefordert habe, quittierten die Versammlung mit erstaunten Ausrufen. Auch hier musste man den Eindruck gewinnen, dass diese Umsiedlerversammlung durchaus dazu beigetragen hat, das Verhältnis zwischen dem Amt für Umsiedler und dem Neubürger noch enger zu gestalten und andererseits zwischen Altund Neubürgern manche Schranke niederzureissen.

Wie überall blüht auch in Kloster Zinna der Neid. Bei der Verteilung von Bezugscheinen für Spinnstoffe und Schuhwaren glaubt man noch immer, Bevorzugungen einzelner feststellen zu müssen. Wir sind derselben Meinung wie ein Angestellter der Gemeindeverwaltung, der die Veröffentlichung der Bezugscheinempfänger am Schwarzen Brett vorschlug. Der Einwand, dass nicht alle empfangenen Bezugscheine eingelöst würden und dass deshalb gelegentlich durch dieses Veröffentlichen ein falches Bild entstehen könne, wurde hinfällig, als derselbe Angestellte berichten konnte, dass bei den letzten Verteilungen kaum noch uneingelöste Bezugscheine zurückgekommen seien, von 200 ausgegebenen Bezugscheinen höchstens 3 Stück.

Im allgemeinen wurde Klage darüber geführt, dass die Altbürger den Umsiedlern nicht immer mit dem nötitgen Verständnis entgegenkämen. Der Versammlungsleiter wies darauf hin, dass das Verständnis auf beiden Seiten da sein müsse; Hilfsbereitschaft auf der einen Seite erfordere auch einen gewissen Anpassungswillen auf der anderen. Und wenn wir auch nicht ganz seine Worte unterschreiben wollen, dass 20 Männer in einem Raum sich besser vertrügen, als 2 Frauen auf einem Herd, so wollen wir doch der Frage des eigenen Herdes an dieser erschwerten Verständigung nicht die [Bl. 118] geringste Schuld beimessen. Umso erfreulicher ist es, dass das Amt für Umsiedler die Möglichkeit hat, Herde zur Verfügung zu stellen, allerdings für den ziem- 
lich klotzigen Preis von 120.- DM. Es wurde übrigens darauf hingewiesen, dass gegebenenfalls zum Erwerb eines solchen Herdes auch eine soziale Beihilfe gewährt werden kann.

Eine grosse Sorge für die Umsiedler ist die Frage nach Handwagen. Wir greifen die in der Versammlung gegebene Anregung auf, sich die Haltung des Demokratischen Frauenbundes in Luckenwalde zum Vorbild zu nehmen und entweder durch die Gemeinde oder durch die VdgB oder den FDGB 2-3 Handwagen zu beschaffen, die den Umsiedlern in der Reihenfolge der Anforderung abwechselnd leihweise überlassen werden können.

Als besonders erfreulich stellen wir fest, dass ein spät gekommener Gast, der versuchte, mit Hetzparolen die Versammlung aufzuputschen, durch die eisige Ablehnung aller Anwesenden sich veranlasst sah, das Lokal sehr schnell weider zu verlassen. Dieser Umstand lässt uns hoffen, dass die Umsiedler von Kloster Zinna in Kürze so weit sein werden, wie der Versammlungsleiter es von der Gemeinde Wahlsdorf berichten konnte, in der der Verschmelzungsprozess zwischen Alt- und Neusiedlern so weit fortgeschritten ist, dass man den einen vom andern nicht mehr unterscheiden kann.

\section{(204) Stimmungsbericht des Informationsdienstes des Rates des Kreises Guben an das Informationsamt der Landesregierung Brandenburg in Potsdam. - Guben, 30. Oktober 1948 (Auszüge)}

BLHA, Rep. 250 Landratsamt Guben/Frankfurt(Oder), Nr. 83, Bl. 301-304. - Tgb.-Nr. 998/48 S/Sch.; Abschrift (Typoskript, Durchschlag) für „Herrn Landrat Nitschke, im Hause!“) mit eigenhändiger Unterschrift „i. A. [gez.] Sicker“.

[Bl. 301] Stimmungsbericht über die in der Zeit vom 7.-23. Oktober 1948 durchgeführten öffentlichen und Betriebsversammlungen des Informationsdienstes. / Thema: „Wer ist der Friedensstörer der Welt?" / Referenten: [...] und der Unterzeichnete, Abt.Leiter Sicker, Inf[ormations-] Dienst.

Oeffentl[iche Gemeindeversammlung in Kobbeln, 7.10.[1948]. - Anwesend: 25 Männer.Ref[erent]: Sicker.

Warum hat uns der Russe als Flüchtling nicht in Polen geduldet, warum hat er uns nicht behalten? Wir sehnen uns doch nach unserer Heimat. Wir wissen ja auch, dass wir den Krieg verloren haben und alles wieder gutmachen wollen, aber der Russe soll uns wieder nach dem Osten zurücklassen. An dem Russen liegt es einzig und allein. Wir würden den Russen umarmen und küssen, wenn er unsere Heimat wiedergibt, an die wir doch so hängen. Er hätte alle Umsiedler für sich, wenn er das durchführen würde. (Der allgemeine Gedanke besteht, der Russe unterdrückt uns.) Müssen wir Umsiedler den Krieg allein bezahlen? [...]

Oeffent [iche] Gemeindeversammlung in Lawitz, 8. Okt. [1948]. - Anwesend: 62 Besucher, davon 45 Männer, 7 Frauen, 10 Jugendliche. - Referent: Sicker.

Die unglückliche Grenzziehung für die Umsiedler ist immer wieder ein Anlass zur Aussprache. Man sollte uns eben nicht soweit zurückjagen, denn wir sind doch nicht allein Schuld an diesem 
Krieg. Wie sieht nun das geeinte Deutschland aus? Die Grossmächte werden sich nicht mehr einig. Es wird immer gesagt, ohne den Westen können wir nicht leben, Westdeutschland gehört zu uns. Aber was wird mit dem Osten? Was wird mit den Gebieten, die uns verloren gegangen sind? Ohne die Ostgebiete können wir auch nicht leben. Wenn es nicht anders wird, gehen wir doch alle [Bl. 302] zugrunde. Es ist besser, wir lassen den Amerikaner herkommen. Das Verfahren bezgl. Reparationsholz nimmt kein Ende. - Was wird überhaupt mit unserem Wald. Wenn das so weiter geht und der Russe schleppt immer mehr Holz heraus, dann sind wir in einigen Jahren. Der russische Wald reicht ihnen doch zu, aber immer von uns. Hat denn der Russe keine Einsicht?

Oeffent [iche] Gemeindevers[ammlung] Kaltenborn, 9.10.[19]48. - Anwesend: 43 Pers[onen], davon 32 Männer, 5 Frauen und 6 Jugendliche. - Ref[erent]: Sicker.

(Obwohl diese Gemeinde dicht an Stadt Guben grenzt und dort Industriearbeiter wohnen, war die Aussprache eine klägliche. Die Besucher haben bestimmte Hemmungen, sie glauben, sich dem Inf.Dienst gegenüber nicht offen aussprechen zu können, weil [man] die Auffassung vertritt, dem einzelnen könnten persönliche Nachteile entstehen.) / 1 Umsiedler stellte die Frage: „Wie stellt sich die Sowjet-Union zur Frage der Abrüstung?“ Vertreter der Sowjetunion sprachen auf den Konferenzen wohl von Abrüstung, man rüstet aber auf! / [...] [Bl. 303]

Oeff[entliche] Gem[einde.] Vers[ammlung] Kl[ein] Gastrose, 16.10.[1948]. - Anwesend: 24 Pers[onen], davon 18 Männer, 1 Frau und 5 Jugendl[iche]. Ref[erent]: Sicker.

Es kamen Stimmen der Umsiedler zum Ausdruck, dass nur der Russe daran Schuld ist, wenn wir nicht mehr über die Neisse bezw. Oder kommen. Ohne Ostgebiete können wir unsere Lebenslage aber nicht bessern. Solange der Russe hier ist, wird es nicht besser!

Kulke, Erich, Umsiedler: Die Menschen im Westen haben es besser; sie können sich alles kaufen. Uns ist es sch ... egal, und wenn wie Schulden machen; wer das einmal bezahlen muss, soll uns gleich sein, die Hauptsache: wir haben zu essen. Es fehlen uns Fleisch, Fett usw. Wir werden es erleben, dass die vier Mächte zu keiner Einigung kommen - eher kommt es zum Kriege! Wo soll das hinführen, man besitzt kein richtiges Hemd mehr! Kein Paar vernünftige Schuhe hat man - man erhält keine Gebrauchsgüter. Man lässt ja alles hier verkommen. Das müsste einmal mit dem Teufel zugehen (Ganz verärgert und aufgeregt, schlägt sogar mit der Faust auf den Tisch).

Auch Stimmen der Altbauern gehen dahin, dass der Russe ebenfalls einsehen müsste, dass man den Umsiedlern ihre Heimat wiedergeben müsste. Auf so einem engen Raum zusammengepfercht zu werden, ist für die Dauer ein unerträglicher Zustand. / [... 
(205) Stimmungsbericht des Informationsdienstes des Rates des Kreises Guben an das Informationsamt der Landesregierung Brandenburg in Potsdam. Guben, 16. März 1949 (Auszüge)

BLHA, Rep. 250 Landratsamt Guben/Frankfurt(Oder), Nr. 83, B1. 306. - Tgb.-Nr. 183/49 S/Sch.; Abschrift (Typoskript, Durchschlag) für Landrat Nitschke, im Hause, mit eigenhändiger Unterschrift „i.A. [gez.] Sicker“.

Stimmungsbericht über die augenblickliche Verbreitung von Gerüchten.

Seit ungefähr 8 Tagen schwirren wieder politische Gerüchte in unserer Grenzstadt umher, desgl[eichen] im Landkreisgebiet und in den Nachbarstädten. Diese Gerüchte haben sich seit dem vergangenen Montag in verstärktem Masse ausgebreitet. Bestimmte Parolen werden in gewissen Abständen vom Westen her in unsere Grenzbevölkerung hineingeworfen.

Was wird nun alles erzählt? -

In der Stadt Frankfurt/O. ist sehr viel russisches Militär eingetroffen. Verschiedene Strassen der Stadt sind geräumt worden, damit die Soldaten Quartier erhalten. Unsere Grenzstädte Guben, Fürstenberg/O., Frankfurt/O. und Forst werden geräumt. Die Bevölkerung soll nach Königsberg/Ostpr. kommen; andere erzählen, es ginge nach Mecklenburg. Die Rote Armee wird all die angeführten Grenzstädte besetzen und darüber hinaus auch noch den Landkreis belegen. Gestern abend, also am 13.3., soll der Rat der Stadt zusammengetreten sein, um über das Abrücken der Bevölkerung Stellung zu nehmen, sowie darüber, wie die Räumung vor sich gehen soll. Zu diesem Zweck soll die Bevölkerung die Möglichkeit erhalten, für die III. Dekade das Brot abzuholen.

Auf Grund dieser Gerüchte hört man auch, dass es ängstliche Gubener Einwohner gibt, die ihre Koffer bereits gepackt haben; 3 Familien haben auf Grund dieser Gerüchte hin Guben mit dem Handwagen verlassen! Viele können überhaupt nicht mehr schlafen, andere sagen: „Wenn das Wahrheit wird, können wir uns ja das Leben nehmen!“

Nachts sollen schon Kanonentransporte gehen. Eine der Mütter äusserte sich, dass sie einen 3. Weltkrieg nicht mehr mitmachen könne. Stalin solle u. a. geäussert haben, dass es ohne einen Krieg nicht ginge!“

(Die Angst vor dem Kriege und der Atombombe ist grösser, als das Interesse beides zu bekämpfen).

$[\ldots]$

(206) Monatliche Stimmungsberichte des Informationsdienstes des Rates des Kreises Luckenwalde an Kreisrat Jentsch. - Luckenwalde, 1948 (Auszüge)

BLHA, Rep. 250 Landratsamt Luckenwalde, Nr. 106-107. - Typoskripte (Durchschläge bzw. Vervielfältigungen) mit Unterschrift [gez.] „Plath“. - Stempel „Der Rat des Kreises / Luckenwalde / Informationsdienst“, Zeichen „Pl/J.“ - Adressiert an „Herrn Kreisrat Jentsch / im Hause“. 


\subsubsection{8 [Bl. 316] / Tätigkeitsbericht (Monat August 1948)}

$[\ldots] /[\ldots]$ Ausserdem wurde eine Umsiedlerversammlung im Kreis vom Informationsdienst beschickt und ausgewertet. / Ferner wurden besucht: / [...]/ Eine zwanglose Umsiedlerversammlung (ehemalige Landsberger) ${ }^{2407} /[\ldots]$ / Am 28.8. kam ein Transport von 90 Umsiedlern in Luckenwalde an, die zum Teil in Luckenwalde, zum Teil im Kreisgebiet untergebracht wurden. Der Informationsdienst war auf dem Bahnhof und später bei der Abfertigung der Umsiedler zugegen. Zwei Tage nach der Ankunft begleitete der Informationsdienst den zuständigen Sachbearbeiter bei 6 Umsiedlerbesuchen. / [...] [B1. 317]

[Anlage] Versammlungen im Monat August

[...] Die Umsiedlerversammlung in Kloster Zinna beschäftigte sich besonders lebhaft mit den Fragen der Unterbringung der Umsiedler und der Bereitstellung von Nebengelass. [...]

\section{(207) Halbmonatliche Stimmungsberichte des Informationsdienstes des Rates des Kreises Luckenwalde an Kreisrat Jentsch. - Luckenwalde, 1949 (Auszüge)}

BLHA, Rep. 250 Landratsamt Luckenwalde, Nr. 106. - Typoskripte (Durchschläge bzw. Vervielfältigungen) mit Unterschrift [gez.] „Kirstein“. - Stempel „Der Rat des Kreises / Luckenwalde / Informationsdienst“, Zeichen „Ki/J.“ - Adressiert an „Herrn Kreisrat Jentsch / im Hause“.

7.1.1949 [Bl. 170] / Die Stimmung bei einem Teil der Bevölkerung ist sehr schlecht und richtet sich gegen die SED und die Besatzungsmacht. [...] / Auf der Demonstration der Luckenwalder Arbeiterschaft gegen die Loslösung des Ruhrgebietes von Deutschland am 4.1. sprach der Kreissekretär der SED. Am Ende seiner Ausführungen wurde von den über $5 \frac{1}{2} 2$ Tausend ${ }^{2408}$ Anwesenden nur sehr geringer Beifall gespendet. Eine gleichzeitig abgefasste Resolution wurde zwar einstimmig angenommen, doch war deutlich zu erkennen, dass ein Teil sich jeglicher Stimme enthalten hat. / Am Schluss der Kundgebung konnten wir hören, wie ein der Sprache nach Oberschlesier zu seinem Nachbarn sagte: Die machen ein Geschrei um die Ruhr, aber das Gebiet, das uns am nächsten liegt, und das genau so wertvoll ist, von unserem Schlesien, da spricht niemand, das schweigt man tot. Die sind ja alle hier nur russenhörig. [Bl. 170v] [...]

25.1.1949 [Bl. 168-169] [Bl. 168r:] [öffentliche Handwerkerversammlung der NDB [NDP!] am 13.1.1949 in Luckenwalde] [... ] / Als der Redner über die Ostgrenze und in diesem Zusammenhang ebenfalls eingehend über die unerhörte Losreissung des Ruhrgebietes sprach, erfolgte aus der Menge ein Zuruf: „Was das Ruhrgebiet für unsere Wirtschaft bedeutet, ist Ostpreussen für unsere Ernährung." / Immer wieder muss man die Erfahrung machen, dass die Umsiedler nie die politische Notwendigkeit der im Osten erfolgten Grenzziehung anerkennen wollen und im Geheimen hoffen, doch noch einmal dorthin zurückkehren zu können. [...]

2407 [Hierzu fehlen nähere Ausführungen.]

2408 [Zahl durchgestrichen und am Rand mit Bleistift notiert „3 000“.] 
[Bl. 168v] [...] / Auf der Kreiskonferenz der VdgB am 21.1. in Luckenwalde meldeten sich viele Diskussionsredner, die zu dem Referat des Landesbauernsekretärs Neddermeyer Stellung nahmen. [...] / Der Neusiedler K[...] aus Schöbendorf legte Verwahrung dagegen ein, dass die Bauern nicht die Punktkarte bekommen. Er regte an, diese Frage einer gründlichen Überprüfung nach sozialen Gesichtspunkten zu unterziehen. Für die Heulieferung im Jahre 1947 nach Sachsen hat seine Gemeinde bis heute noch kein Geld bekommen. Weiter forderte er unter grösstem Beifall der Versammelten eine Ausgleichsdifferenzierung mit der ganzen Zone. [...] [Bl. 169r] / Der Neusiedler M[...] erhob gegen die sozialen Lasten Einspruch. Während er jährlich an die Krankenkasse 200.- DM und für seine Siedlung 250.- DM zu zahlen hätte, stehen nachweisbar nur 568.- DM Einnahmen gegenüber. Nun muss er aber noch Heu, Stroh und Saatgut kaufen. Dazu treten die Steuern, Feuerversicherung usw. „Wenn hier die Regierung nicht eingreift, gehen die Neusiedler alle vor die Hunde“, waren seine abschliessenden Worte. (Beifall).

[Bl. 169r] [...] / Auf der Gemeindeversammlung am 10.1. in Lichterfelde machte sich der Lehrer Z[...] aus Sernow zum Sprecher der Gemeinde und bemängelte die starke Belegung des Dorfes mit Neusiedlern. Er führte aus, dass in Luckenwalde noch 3-4 Personen 6-7 Zimmer bewohnen. Solange das noch der Fall ist, müssten alle dagegen schärfsten Protest einlegen. (Den Namen dieser Leute hat er aber auf unser Befragen nicht genannt.)

31.3.1949 [Bl. 161-162] [Bl. 161v:] [...] / Auf der ersten öffentlichen Versammlung der NDB [NDP!] in Dahme wurde über das Thema: „Was wollen wir National-Demokraten“ vom Kreisvorstand Luckenwalde aus gesprochen. Als erster Diskussionsredner [Bl. 162r] meldete sich ein ostpreussischer Umsiedler von 63 Jahren und brachte beiliegende Resolution ein, die aber vom Versammlungsleiter nicht zur Abstimmung gebracht wurde. ${ }^{2409}$ / Ein grosser Teil der Versammlungsteilnehmer waren Umsiedler und als sie die eindeutige Stellung der NDP zu der Grenzziehung im Osten hörten, erfolgten Zurufe aus der Menge: „Wir sind keine Umsiedler, wir sind mit Gummiknüppel und Maschinenpistole von Haus und Hof Vertriebene." Als daraufhin ein FDJ'ler in die Diskussion eingriff und auch seine eindeutige Stellungnahme klarlegte, antwortete der gleiche Zufrufer: „Wer in der Heimat sitzt, kann ja gut reden. Aber wer herausgetrieben wurde, der spricht anders. Wer das Potsdamer Abkommen unterschrieben hat, ist uns egal. Wir werden hier von den Alteingesessenen ausgenützt und an uns wird noch verdient." / [... $]$

2409 [Der mit „Friedensresolution“ überschriebene Text des Justizbeamten i. R. Karl K., datiert Dahme, 28.3.1949 (Bl. 163) enthält acht Punkte, in denen v. a. gefordert wird: weltweite Total-Abrüstung, sofortiger Friedensvertrag, Abzug der Besatzungstruppen, internationale Rüstungskontrolle, Gründung einer Polizei in allen Staaten der Welt, „welche die Ordnung und Sicherheit der Staatsbürger gewährleistet“ sowie „Rückgabe aller urdeutschen von Polen besetzten Ostgebiete“ und des besetzten Ruhrgebietes. „Denn ohne die Rückgabe dieser angeführten Gebiete, besonders des Ostens, wo die deutsche Bevölkerung heimatlos geworden und in einem landwirtschaftlich armen Gebiet Mitteldeutschlands angesiedelt worden ist, ist ein einheitliches demokratisches Deutschland für alle Zeiten undenkbar und würde dem deutschen 50 Millionen Volk nie eine gesichterte Lebensexistenz zuführen."] 
22.4.1949 [Bl. 155-156] / [Bl. 155v:] [...] / Die Versammlung der NDP Luckenwalde, auf der Dr. Korfes ${ }^{2410}$ über das Thema sprach: „Stalingrad, wie ich es erlebte und welche Lehren ich daraus zog", fand bei den über 200 Versammelten lebhaften Anklang. In der Diskussion war die Frage: „Ist es nicht möglich, ein Einvernehmen zwischen Russland und Deutschland zu erzielen, um die jetzt bestehende Ostgrenze zu verändern?" Immer wieder wird diese Frage von den Umsiedlern gestellt und es ist notwendig, dass mehr denn je in dieser Beziehung Aufklärungsarbeit geleistet wird. / [...]

23.8.1949 [Bl. 139-140] [Bl. 139v:] [...] / Einige Umsiedler, mit denen wir über die Ostgrenze sprachen und denn wir die Notwendigkeit der Grenzziehung klarlegten, äusserten sich: „Wilhelm Pieck hat im Jahre 1946 hier in Luckenwalde auf einer Versammlung verkündet, dass die SED für die Revision der Ostgrenze eintritt. Heute betrachtet die SED die Grenze als endgültig. Damals hat sie nur versucht, die Stimmen der Umsiedler zu fangen und viele Umsiedler sind darauf hereingefallen. Einige von uns haben dieses doppelzüngige Spiel erkannt und ihren Austritt aus der SED erklärt. Wenn man uns heimisch machen will, dann muss uns aber auch wirklich geholfen und nicht soviel darüber gesprochen und geschrieben werden.[“] / [...]

24.10.1949 [Bl. 131-132] [Bl. 131v:] [...] / Auf einer Versammlung in Werder ${ }^{2411}$, an der fast nur etwa 15 Umsiedler teilnahmen, wurde mit keinem Wort die Oder-Neisse-Grenze erwähnt. Diese Leute sind der Ansicht, dass es wegen der Grenze nicht lohnt, einen neuen Krieg zu entfachen, der uns als Deutsche nur noch tiefer ins Verderben stürzen würde als der letzte. Die Oder-Neisse-Grenze wurde von ihnen als Friedensgrenze betrachtet. Nur erwarten sie von der Deutschen Demokratischen Regierung, dass bald Anordnungen herauskommen, die ihnen helfen, die heute noch bestehenden materiellen Sorgen und Nöte zu verbessern.

24.11.1949 [Bl. 125-126] / [Bl. 126] [...] / Ein Umsiedler in der Gemeinde Waltersdorf äusserte sich: „Ich kann es nicht verstehen, dass Pieck und Grotewohl als deutsche Menschen dafür eintreten, dass wir auf die Gebiete östlich der Oder freiwillig verzichten. Sie müssten sich doch im Gegenteil dafür einsetzen, dass wir in unsere alte Heimat zurückkommen." / [...]

\section{(208) Pressetext des Informationsdienstes des Rates des Kreises Luckenwalde über einen Schülerwettbewerb zur Bekämpfung der Kartoffelkäferplage in Petkus. - Luckenwalde, 5. August 1949}

BLHA, Rep. 250 Landratsamt Luckenwalde, Nr. 108, B1. 434. - Typoskript, 1 Bl., mit masch. Unterschrift „Kirstein“ des Informationsdienstmitarbeiters Hans Kirstein. - O.1. Absenderstempel: „Der Rat des Kreises / Luckenwalde / In-

2410 [Dr. Otto Korfes (1889-1964), ,geriet 1943 als Generalmajor u. Kommandeur einer Infanteriedivision in Stalingrad in sowj(et). Kriegsgefangenschaft u. war dann Mitbegründer des Bundes Deutscher Offiziere (BDO) und des Nationalkomitees „Freies Deutschland“ (NKFD); (...). Nach Rückkehr 1948 wurde K. Gründungsmitglied der NDPD u. Dir(ektor) des Zentralarchivs der SBZ.“ (BBL, S. 234).]

2411 [Werder (Kr. Jüterbog-Luckenwalde).] 
formationsdienst“. - O.r. Datierung „Luckenwalde, den 5. Aug. 1949“. - U.1. Verfügung „Verteiler: / Volksstimme / Tagespost/3. Z.d.A..

\section{Schulkinder vorbildlich.}

Zur intensiven Bekämpfung des Kartoffelkäfers sind die Schulkinder der Gemeinde Petkus in einen Suchwettbewerb getreten. Die Bewertung wird nach Punkten vorgenommen. Für das Auffinden eines Käfers gibt es 30 Punkte, ein Eigelege 10 und eine Larve 1 Punkt. Wer am Ende der Aktion die meisten Punkte hat, ist Sieger. Für die 5 besten Sucher sind von der Gemeinde Preise ausgesetzt. An erster Stelle liegen bis jetzt [...]. Die Kinder der Umsiedler stehen bei diesen freiwilligen Suchen an erster Stelle. [... N Noch immer gibt es Bauern, die darüber leichtsinnig hinwegsehen und die Kartoffelkäfergefahr mit einer Handbewegung abtun. Die Schulkinder von Petkus haben diese Gefahr erkannt. [...] / Möge diese Erkenntnis der Schulkinder von Petkus, die die grosse Gefahr erkannt haben, zum Allgemeingut aller werden und dazu beitragen, dass auch in andereen Gemeinden gleiche Wettbewerbe gestartet werden. / [...]

\section{(209) Politischer Monatsbericht des Oberbürgermeisters der Stadt Potsdam an den Innenminister des Landes Brandenburg. - Potsdam, 12. August 1949 (Auszug)}

BLHA, Rep. 202 G Amt für Information, Nr. 164, Bl. 163-190. - Typoskript (Durchschlag ohne Unterschrift), 27 Bl. - Bl. 163 unvollständige Absenderangaben, da Ausfertigung auf Kopfbogen, Absender ist jedoch zweifellos „[Rat der Landeshauptstadt Potsdam]“, [„Amtsstelle“] (1.o. masch.:) „I/Obm“ [= Oberbürgermeister], r.o. Datierung „[Potsdam, den] 12. August [19]49“, kein Eingangsstempel. - Adresse: „An die / Landesregierung Brandenburg / Minister des Innern-/Potsdam/Saarmunder Strasse 23“.- Betreff: „Betr.: Politischer Monatsbericht/Bezug: AZ.Her.257 Ht.v.10.4.46 und AZ.I 257/Boe.Wei.v.28.5.46“. - Zahlreiche rote Unterstreichungen im Text, vereinzelt handschriftliche Worteinfügungen.

\section{$[\ldots][$ Bl. 172]}

SED verlangte Soforthilfe für Umsiedler, so berichtete die Märkische Volksstimme am 7. Juli 1949. Mit großer Erwartung sahen die Umsiedler der Realisierung dieser Ankündigung entgegen. Als es dann aber hieß, daß nur die Umsiedler mit einer Bevorzugung in der Textilversorgung zu rechnen hätten, die nach dem 1. Januar 1949 eingemeindet wurden, war die Enttäuschung groß. Es ist nicht zu verhehlen, daß der große Kreis der 1945 eingemeindeten Umsiedler diese Maßnahme als eine Ungerechtigkeit empfindet und darum sehr verstimmt ist.

\section{Hierzu 2 Stimmen:}

\section{Ein Ostpreusse:}

Wir haben alle Haus und Hof verloren und sind in Lumpen hergekommen. Ausserdem hatten die jetzt Gekommenen mehr Möglichkeiten, sich in Polen oder Tschechoslowakei Sachen anzuschaffen, die hier nicht zu haben sind, oder die wir nicht bezahlen können. Ich muß schon sagen, das ist sehr ungerecht. 
Ein Umsiedler aus Königsberg:

Da wird immer ein Lamento in Zeitungen und Rundfunk gemacht, und es steckt nichts dahinter. Die brauchen sich gar nicht zu wundern, wenn man immer mißgestimmter wird.

[Bl. 173] [...]

\section{(210) Bericht über die Stimmung der Bevölkerung in Potsdam. - Potsdam, 28. Oktober 1949 (Auszug)}

BLHA, Rep. 202 G Amt für Information, Nr. 165, Bl. 45-47. - Bl. 45 Begleitschreiben des Informationsdienstes beim Rat der Landeshauptstadt Potsdam, Potsdam, 19. Okt. 1949, an die Landesregierung Potsdam, Abt. Information, Potsdam, zur Übersendung der „Abschrift eines Berichtes, den wir auf Anforderung der Kommandantur gefertigt haben." (Blaue Buntstift-Unterschrift des Informationsdienstmitarbeiters [gez.] „Schmückert“, Eingangsstempel „Informationsamt / Eing.: 19.10.49. / GZ:-“. - Bl. 46-47 Typoskript (Durchschlag, Kopfbogenangaben fehlen) des Berichts, Bl. 46 o.1. „Informationsamt beim“, r. o. „18. Oktober [194]9“, darunter Eingangsstempel wie vor, darunter Bleistiftvermerk „erl. Fch[?] 20/10.49“. - Adresse: „An die/Hauptkommandantur/z. Hd. Major Stroilow/Potsdam“. - Betreff: „Bericht [handschriftlich in der Landesregierung geändert aus „Übersicht"] über die Stimmung der Bevölkerung [handschriftlich wie vor ergänzt: „in der Landeshauptstadt Potsdam] anläßlich der Bildung einer gesamtdeutschen Regierung. [handschriftlich wie vor ergänzt: „(20. Oktober 1949)“]., links daneben Abschreibeanordnung „6 x“; Bl. 47 u. (nachträglich für Abschrift eingeklammerte) Unterschrift „Schmückert“. - Bl. 48-50 drei Durchschläge einer vollständigen Abschrift, jedoch ohne die Adresse und die Unterschrift.

Einleitend ist zu sagen, dass fast sämtliche Bevölkerungsschichten nach wie vor die Forderung nach einer besseren Versorgung mit Lebensmitteln und Gebrauchsgegenständen in den Vordergrund ihres Denkens und Handelns stellen. Aus dem größten Teil der Gespräche und Diskussionen geht immer wieder folgende Redewendung hervor: „Macht bloß recht schnell, damit wir zu einem geregelten Dasein kommen.“

Die Meinung der einzelnen Schichten der Potsdamer Bevölkerung ist nach unseren Informationen folgende:

In Arbeiter- und Handwerkerkreisen wird der gegenwärtigen Entwicklung wohl allgemein rege Anteilnahme entgegengebracht. In der Diskussion gehen die Meinungen jedoch weit auseinander. Der immerhin größte Teil ist der Ansicht, dass man der Sowjetunion recht dankbar sein müsse ob des großzügigen Schrittes und der uns erwiesenen Freundschaft. [...] Ein anderer Teil verhält sich immer noch abwartend und reserviert. [...] [Bl. 47] [...]

Der größte Teil der Umsiedler ist mit der neuen politischen Lage in so fern nicht einverstanden, als er weder in der Erklärung der UdSSR noch in dem Regierungsprogramm seinen sehnsüchtigsten Wunsch berücksichtigt sieht, wieder in die Heimat zurückkehren zu können. Es wird immer wieder zum Ausdruck gebracht, dass man als ein ehrlicher Deutscher die Oder-NeißeGrenze nicht anerkennen könne, zumal Deutschland nach ihrer Meinung ohne die Ostgebiete nicht lebensfähig sei. Es gibt selbstverständlich unter den Umsiedlern auch Kreise, die nicht wieder in ihre Heimat zurückkehren wollen aus dem Grunde, weil sie sich hier eine annehmbare Existens [so!] und ein gemütliches Heim geschaffen haben. Dieser Kreis muß jedoch als der kleinere bezeichnet werden. 
Auch die Hausfrauen haben wohl in der überwiegenden Mehrzahl die Ereignisse zur Kenntnis genommen, sie sehen sie aber weniger von der politischen als von der Warte, dass sie nun ihren Männern und Kindern einer bessere Mahlzeit werden bereiten können. Die Abschaffung der Karte 4 steht im Mittelpinkt der Diskussionen unserer Hausfrauen. Man äussert sein Mißfallen darüber, dass die Abschaffung der Karte 4, die bereits im Oktober vollzogen werden sollte, nun noch wieder hinausgezögert wird. Ernste Stellungnahme hört man von dieser Seite selten. Bemerkenswert ist, dass gerade Hausfrauen mit mehreren Kindern sich mit politischen Fragen kaum beschäftigen.

\section{(211) Bericht über eine Betriebsversammlung im Karl-Marx-Werk in Potsdam} am 4. November 1949. - Potsdam, 5. Oktober 1949

BLHA, Rep. 202 G Amt für Information, Nr. 165, Bl. 39-40. - Typoskript (Durchschlag, außer Adresse), 2 Bl. - Bl. 39 o.1. „RAT DER LANDESHAUPTSTADT POTSDAM / - Informationsdienst“, daunter Adresse: „An die / Landesregierung Brandenburg/Abt. Information/Potsdam“. - R.o. Datierung und Aktenzeichen: „Potsdam, den 5. November 1949 / Schm./Kz“, darunter Eingangsstempel „Informationsamt / Eing.: 7.11.49. / GZ: -“. - Betreff: „Betr.: [handschriftlich in der Landesregierung ergänzt: „Bericht über eine“] Betriebsversammlung im Karl-Marx-Werk am 4. Nov. 1949 [handschriftlich wie vor hinzugefügt: „(Oder-Neiße-Grenze-Diskussion)“]. - L. daneben Abschreibeanordnung „6 x“, darunter Erledigungsvermerk „,erl. Fch[?] 8/11.49“. - Bl. 40 u. Blaue Buntstift-Unterschrift des Informationsdienstmitarbeiters [gez.] „Schmückert“. - Bl. 41r-v Durchschlag einer vollständigen Abschrift, jedoch ohne die Adresse und die Unterschrift.

Die Betriebsgruppe der SED im Karl-Marx-Werk führte am 4. November 1949 in Verbindung mit der Betriebsgewerkschaftsleitung eine Betriebsversammlung durch mit dem Thema: „OderNeiße-Grenze - Friedensgrenze“. Die Teilnehmerzahl belief sich auf ca. 1000. Die Leitung der Versammlung hatte Sozialdirektor Boulanger (SED).

Gen[osse] Hermann Axen vom Zentralsekretariat der SED Berlin gab mit einem kurzen Referat über Bedeutung unf Notwendigleit der Oder-Neiße-Grenze die Diskussionsgrundlage. In 6 Punkten zeigte er die Stellung der Partei und der Deutschen Demokratischen Regierung zur Oder-Neiße-Grenze auf.

Seine Ausführungen wurden mit großem Interesse verfolgt. Anschließend ergab sich eine rege Fragestellung seitens der Versammlung. Aus den ca. 30 gestellten Fragen seien einige herausgegriffen:

Würde Polen die Ostgebiete zurückgeben, wenn Frankreich das Saargebiet abtritt?

Warum haben die Polen sich so gehässig bei der Evakuierung benommen?

Besteht die Möglichkeit, daß man trotz der Grenze wieder in die Ostgebiete zurückkehren kann, bezw. daß diejenigen Deutschen, die noch dort sind, bleiben können?

Wie erzählt wird, kann Polen die Ostgebiete garnicht bearbeiten. Es wäre doch besser, wenn man sie uns zurückgeben würde. 
Besteht überhaupt die Möglichkeit, daß wir durch unsere Arbeit endlich Ruhe und Frieden bekommen? Andernfalls wäre es das beste, wenn Deutschland aufgelöst würde. [B1. 40]

Ich kenne die Polen genau und weiß, daß ein großer Teil von ihnen nazistisch eingestellt ist. Ich zweifele daran, daß jemals eine echte Freundschaft zustandekommt.

Die OdF werden gut versorgt. Warum gibt man den Umsiedlern nicht auch etwas mehr? Ich habe bei der Evakuierung alles verloren, wer ersetzt mir den Schaden?

Meiner Meinung nach brauchen wir die Ostgebiete noch nicht abschreiben, denn im Potsdamer Abkommen ist doch festgelegt, daß die Grenze im Osten Deutschlands im Friedensvertrag erst endgültig geregelt wird.

Der Wohnraummangel, der doch auch durch die Verluste der Gebiete im Osten bedingt ist, könnte doch gemildert werden, wenn sich die Besatzungsbehörden etwas einschränken würden.

Es steht in krassem Gegensatz zum Sozialismus, dass Rußland, Königsberg weiterhin besetzt hält.

Die Antworten des Referenten wurden des öfteren beifällig unterbrochen. Es war zu bemerken, daß seine Art den Anwesenden imponierte. Lautes Gelächter wurde allerdings hörbar, als der Referent gelegentlich einer Antwort darauf zu sprechen kanm, daß die Besatzungstruppen selbstverständlich bis zum Abschluß eines Friedensvertrages bleiben würden.

Dann gab Sozialdirektor Boulanger seine Stellungnahme zum Problem Oder-Neiße-Grenze. Als er in diesem Zusammenhang auf die Steigerung der Produktion zu sprechen kam und von „Eurem Werk“ und „Eurem Anteil“ an den Erträgen des Werkes sprach, erhob sich lautes Gelächter und abfällige Äusserungen wurden laut. Allerdings wurde man dann sehr nachdenklich, als B. an Hand von konkreten Beispielen aufzeigte, wo die Gewinne des Werkes verbraucht werden[,] z.B. 200 000,- DM für Gewinnung von Wohnraum für die Arbeiter, sowie mehrere tausend Mark für neue Maschinen, für den Kindergarten und für die Betriebsberufsschule.

Abschließend wurde dann eine Entschließung zur Abstimung gebracht; 3 Personen enthielten sich der Stimme.

\section{(212) Politischer Monatsbericht des Oberbürgermeisters der Stadt Potsdam an den Innenminister des Landes Brandenburg. - Potsdam, 12. November 1949 (Auszug)}

BLHA, Rep. 202 G Amt für Information, Nr. 164, Bl. 87-111. - Typoskript, 25 Bl., mit Unterschrift. - Bl. 28 Kopfbogen „Rat der Landeshauptstadt Potsdam, Amtsstelle“ (1. o. masch.:) „I/Obm“ [= Oberbürgermeister], r.o. Datierung „Potsdam, den 12. November 1949“, darunter. - Eingangsstempel „19. Nov.1949“, blauer Haken und roter Sichtvermerk „I/6“. - Adresse: „An die / Landesregierung Brandenburg / - Minister des Innern - / Potsdam / Saarmunder Strasse 23“. - Betreff: „Betr.: Politischer Monatsbericht / Bezug: AZ.Her.257 Ht.v.10.4.46 und AZ.I 257/Boe. Wei.v.28.5.46“. - Auf letztem Bl. (Bl. 111) u. masch. „Oberbürgermeister / I. V., daunter Bleistiftunterschrift „Köhler“, daneben roter Stempel „Rat der Landeshauptstadt Potsdam / 2“ (mit Stadtwappen). 


\section{$[\ldots][B l .94][\ldots]$}

Die Veröffentlichung des Regierungsprogramms erfolgte dann am 13. Oktober. Die vorherrschende Meinung: „Macht bloß recht schnell, damit wir zu einem geregelten Dasein kommen“, kann unbedingt als Einverständnis mit dem Regierungsprogramm gewertet werden. Im Einzelnen haben besonders die Hausfrauen die Abschaffung der Karte IV begrüßt. Beifällige Äusserungen wurden allgemein dem zu erwartenden gesteigerten Import von Lebensmitteln, wie auch der Sorge der Regierung um die Kriegsgefangenen und Rentner gezollt. Der größere Teil der Umsiedler, der sich jedenfalls infolge ungenügender Existenz hier nicht wohl fühlt, sieht in der konsequenten Haltung der Regierung zur Oder-Neiße-Grenze eine Zurücksetzung. Man ist der Ansicht, daß die Regierung mit der kompromißlosen Anerkennung der Oder-Neiße-Grenze einen Schritt zu weit gegangen ist und sich gegen den Willen des größeren Teils des deutschen Volkes festgelegt habe. Der Macht des Siegers sich beugend, bleibe uns im Augenblick nichts anderes übrig, aber für alle Zeiten und immer, damit könne man sich nicht einverstanden erklären. Der Revanche-Gedanke könne mit der Erklärung der Regierung im Volke nicht ausgelöscht werden. In anderen Teilen der Bevölkerung legt man die Erklärung der Regierung, wonach auch die private Unternehmer-Initiative der Entwicklung unserer Wirtschaft dienstbar zu machen sei, so aus, daß, wenn eine besondere Förderung der Unternehmer-Initiative seitens der Regierung nicht erwartet wird, dieses zu mindest aber unter keinen Umständen durch Volkseigene Handelsunternehmen usw. beeinträchtigt werden darf. [Bl. 95] [...].

\section{(213) Politischer Monatsbericht des Oberbürgermeisters der Stadt Potsdam an den Innenminister des Landes Brandenburg. - Potsdam, 15. Dezember 1949 (Auszug)}

BLHA, Rep. 202 G Amt für Information, Nr. 164, Bl. 28-41. - Typoskript (Durchschlag ohne Unterschrift), 14 Bl. Bl. 28 unvollständige Absenderangaben, da Ausfertigung auf Kopfbogen, Absender ist jedoch zweifellos „[Rat der Landeshauptstadt Potsdam]“, [„Amtsstelle“] (1.o. masch.:) „I/Obm“ [= Oberbürgermeister], r. o. Datierung „[Potsdam, den] 15. Dezember [194]9“, darunter Eingangsstempel „Informationsamt / Eing.: 17.12.49. / GZ.: -“. - Adresse: „An die / Landesregierung Brandenburg / - Minister des Innern - / Potsdam / Saarmunder Strasse 23“. - Betreff: „Betr.: Politischer Monatsbericht / Bezug: AZ.Her.257 Ht.v.10.4.46 und AZ.I 257/Boe.Wei.v.28.5.46“. - Auf letztem Bl. (Bl. 41) u. masch. „Oberbürgermeister“.

$[\ldots][\mathrm{Bl} .30][\ldots]$

Die Oder-Neiße-Grenze wird im Allgemeinen nur von dem kleinsten Teil der Potsdamer Bevölkerung als Friedensgrenze betrachtet. Nicht zu übersehen ist, daß sogar politisch organisierte Potsdamer davon sprechen, daß Deutschland ohne die Ostgebiete zum Verhungern verurteilt sei und, daß man sich vielleicht mit der Abtrennung abfinden würde, wenn die Grenze in dieser Form in einem Friedensvertrag festgelegt wird. Dann könne man ja nichts machen. In der breiten Masse der Bevölkerung geht man immer wieder mit Voreingenommenheit und Gehässigkeit an diese Frage heran. Man spricht davon, daß die „Pollacken“ keinerlei Anrecht auf Ostpreußen, Oberschlesien und auf die von deutscher Arbeitskraft geschaffene Industrie Oberschlesiens haben. Man rege sich hier über die Abtrennung des Ruhrgebietes durch die Amerikaner auf. Daß aber die Gruben Oberschlesiens für Deutschland genau so wichtig sind, 
wie die an der Ruhr, will man hier nicht wahrhaben. Einige Stimmen besagen, daß man einen Befreiungsaufstand, wie 1813 organisieren müsse. Nicht verwunderlich ist, daß man in diesem Zusammenhang vielfach auf das Wort RIAS stößt.

$[\ldots]$

\section{(214) Bericht über die Lage der „Umsiedler“ im Kreis Angermünde. - [Angermünde], 15. April 1950}

BLHA, Rep. 202 G Amt für Information, Nr. 170, Bl. 27-31. - Typoskript (Durchschlag), 5 Bl., vereinzelt handschriftliche Korrekturen, mit Kopierstift-Unterschrift des Leiters des Informationsdienstes des Rates des Kreises „Spangenberg“ (Bl. 31). - Bl. 27: Briefkopf fehlt, da Original auf Kopfbogen des Rates des Kreises, hier nur „- Informationsdienst -“; o.l. Aktenzeichen „Sp/B.“, o.r. Datierung und Tel.-Nr.: „15.4.1950 / [Tel. Apparat-Nr.:] 507 623 / [Zimmer Nr.:] 34“, darüber Eingangsstempel „Informationsamt/ Eing.: 17.4.50 / GZ.:“ - Betreff: „Betr:: Lage der Umsiedler im Kreise Angermünde.“

Im Kreise Angermünde befinden sich nach dem Stichtag vom 1. Januar 1950 (nachdem kein Zuzug) 28015 Umsiedler, d[as].s[ind]. bei ca. 82000 Gesamteinwohnern $32 \%$ der Gesamteinwohnerschaft, davon fallen ca. 7600 auf die 6 Städte des Kreises und $20700^{2412}$ sind in den Landgemeinden des Kreises untergebracht.

Die besondere Schwierigkeit liegt hinsichtlich der Umsiedlerfrage in der geringen Industrialisierung des Kreises, die bei einem nicht unwesentlichen Teil eine berufsfremde Beschäftigung notwendig mache.

Einen gewissen Ausgleich schuf die Bodenreform, wo aus der gesamt zu versiedelnden Fläche von 78160 ha rund 17000 ha, also ca. $22 \%$, an 1680 Umsiedler mit ca. 6600 Familienangehörigen, insgesamt 8280 Umsiedler, das sind ca. $25 \%$ der Gesamtumsiedler, versiedelt wurden.

Ein Teil ist in den ländlichen Gemeinden, in vielen Fällen mit Familienangehörigen, als landw[irtschaftlicher $]$ Arbeiter - und Arbeiterin tätig.

Nach Auszügen aus einigen Produktionsbetrieben und aus der Verwaltung muss ca. ein Prozentsatz von $40 \%$ festgestellt werden, der berufsfremd untergebracht ist. So kann man z. B. im Eisenwerk "Jonny Schweer" 2413 auf eine Gesamtbelegschaftsstärke von 40 Arbeitern und Angestellten 8 Umsiedler, von denen 2 berufsfremd sind, feststellen. Im Britzer Eisenwerk kommen auf 570 Beschäftigte 150 Umsiedler, mit 27 berufsfremden. Die Kreiskonsumgenossenschaft weist mit 428 Beschäftgten 128 Umsiedler auf, von denen 25 berufsfremd eingesetzt sind. Eine wesentlich höhere berufsfremden Quote weisen die Betriebe auf, die eine leichte Anlernmöglichkeit bieten, wie z.B. die UTVG, Schwedt (Uckermärkische Tabakverwertungs-Genossenschaft),

2412 [Drittletzte Ziffer schwer lesbar korrigiert.]

2413 [Muss heißen: Scheer. - Es handelt sich offenkundig um das Eisenwerk in der Stadt Angermünde, dass allerdings unter diesem Namen nicht zu ermitteln ist. Im Branchen-Fernsprechbuch (...) für den Bezirk der Oberpostdirektion Potsdam, 1. Ausg. 1951, S. 38 heißt es nur neutral „Eisengießerei und Maschinenfabrik Angermünde VEB“.] 
wo ausser einigen Fachleuten und 186 Arbeitern und Angestellten 19 Umsiedler berufsfremd eingesetzt sind. Das Schotterwerk Althüttendorf hat bei $162^{2414}$ Angestellten 42 Umsiedler, von denen nur 10 in ihrer ursprünglichen Berufsart arbeiten.

Somit liegt der Durchschnittswert der in der Industrie und Handel beschäftigten Personen bei ca. $20 \%$ bis $25 \%$ und davon ca. $35 \%$ - bis - $40 \%$ berufsfremd oder umgelernt.

Das Verhältnis von 25 \% Umsiedlern ist auch konstant in der Verwaltung des Kreises, wo von 522 Kreisangestellten einschl. Kreisverwaltung, 114 Umsiedler sind. Hier ist das prozentuale Verhältnis der in ihrer Berufsart, oder zumindest berufsnahen Art, arbeitenden, ca. 85 bis $90 \%$.

Von den hier vorhandenen 114 Umsiedlern sind 93 berufsverwandt verblieben, 10 haben sich aus Arbeitern, oder handwerklichen Berufen in die Verwaltungsarbeit eingearbeitet und 11 Angestellte sind berufsfremd aus dem frühreren Angestelltenverhältnis jetzt als Bote, Reinemachefrau oder so ähnlich tätig, d.h. dass auch verdienstmässig gesehen [Bl. 27v] 85-90\% der Umsiedler-Verwaltungsangestellten [sich] ihren früheren Einkommensverträgen nähern bezw. [diese] zum Teil sogar überschreiten.

Von diesen 114 Umsiedlern der Verwaltung sind 8 in leitender Funktion tätig.

Ein ähnliches Bild bietet hier die grösste Handelsorganisation[,] die Konsumgenossenschaft des Kreises. Von den 168 Umsiedlern liegen nur 33 knapp unter 200,- DM Netto monatlich, 2 bis 300,- DM monatlich, entfallen auf 129 Umsiedler, 3 - 400,- DM monatlich erhalten 4 Umsiedler und 2 Umsiedler haben einen Verdienst über 400,- DM. 12 Umsiedler haben davon leitende Funktionen inne.

Die Verdienstspannen in den Produktionsbetrieben liegen z. T. produktionsbedingt, wesentlich tiefer. Von 8 Umsiedlern der Eisengiesserei „Jonny Scheer“ liegen drei unter der Verdienstgrenze von 200,- DM, 4 zwischen 200,- und 300,- DM und einer in der Grenze zwischen 300,und 400,- DM. Von den 3 leitenden Angestellten des Betriebes [ist] 1 Umsiedler. Der grösste Industriebetrieb des Kreises Britzer Eisenwerk hat bei 150 Umsiedlern 102 unter 200,- DM, 40 zwischen 200,- und 300,- DM und 300,- bis 400,- DM 8 Umsiedler.

Die bisher höchst erreichte Netto-Verdienstspanne liegt bei 380,- DM. Die geringste Verdienstspanne bei 140,- DM Netto.

Das Schotterwerk Althüttendorf zeigt bei 42 Umsiedlern 40 Beschäftigte unter der 200,- DMGrenze und nur 2 über der 200,- DM-Grenze. Sehr tief liegen die Löhne der uckermärkischen Tabak-Verwertungsgenossenschaft, bei allen 19 Umsiedlern unter der 200,- DM-Grenze, zwischen $125,-$ bis $160,-$ DM.

Wenn sich also hier die prozentualen Durchschnittswerte der Verdienstspannen der Umsiedler aus den wesentlichen Industriebetrieben des Kreises ziehen, so liegt der Verdienst von 70 \% der 
Umsiedler unter der 200,- DM-Grenze, zwischen 200,-- und 300,- DM ca. $25 \%$ und nur $8 \%$ liegen über der 300,- DM-Verdienstgrenze.

Unter den 387 Umsiedlern dieser Industrieschwerpunkte befindet sich ein Aktivist im Britzer Eisenwerk, mit einer durchschnittlichen Verdienstspanne von 380,- DM Netto.

Eine starke Besetzung mit Umsiedlern zeigen die MAS-Stationen des Kreises mit 30 Umsiedlern bei 71 Gesamtbeschäftigten.

Die Arbeitslosenziffern bewegen sich bei Männern um 200, bei Frauen um 100.

Da entsprechend der Struktur des Kreises die Masse der Umsiedler sich in den ländlichen Gemeinden befindet und in den aufgezeigten Industrieschwerpunkten sonst nur die bereits erwähnten ca. 8000 Siedler mit Angehörigen eine selbständige Existenzgrundlage besitzen, so ist selbstverständlich bei einem grossen Teil der Umsiedler, die über eine durchschnittliche Verdienstspanne von 200,- und 250,- DM nicht hinauskommen, die materielle Sorge hinsichtlich des Wiedererwerbs der notwendigen Anschaffungen noch grosser Mangel vorhanden.

Bei selbst noch nicht ablehnender Haltung wird immer wieder die schwierige Versorgungslage von den Umsiedlern hervorgehoben.

So wurden in der Gemeinde Gramzow die Umsiedler R[... ], SED, B[...], ptl., P[...], ptl., $\mathrm{Z}[\ldots]$, SED, S[...], ptl., M[...], SED, S[...], ptl. befragt. Sie stehen alle auf dem Standpunkt, dass die allgemeine Versorgungslage noch verbessert werden müsste, besonders für den Kleinbauern und Werktätigen. Sie erkennen an, dass die HO als Gradmesser unserer Wirtschaft angesehen werden kann, hoffen aber, in ihrem Interessem, auf eine weitere Preissenkung. [B1. 28r]

So stehen auch die Umsiedler in Altenhof, wie uns Herr Prillwitz mitteilt, auf dem Standpunkt, dass zwar ihre Lage aufgrund dessen, da sie eben alles verloren haben, noch viele Mängel aufzuweisen hat. Sie geben aber zu, dass sich die Versorgung bisher entschieden verbesserte und bei einer weiteren Preissenkung auch sie wieder in erhöhtem Masse die Möglichkeit haben, sich wieder Anschaffungen zu machen.

So ist die Grundtendenz, dass wohl manche Klagen über Mangelerscheinungen noch vorhanden sind, insbesondere hinsichtlich Bekleidung und Möbeln, die Stimmung sich aber in Erkenntnis der stetigen Verbesserung hoffnungsvoller neutralisiert hat.

Wesentlich beigetragen zu dieser Neutralisierung hat die Verbesserung der Ernährungslage, weil die zum Teil noch nicht ausreichende Wohnungsfrage nicht noch durch den knurrenden Magen unterstrichen wird.

So sagt zum Beispiel der Umsiedler E[...] G[...], Lüdersdorf, ich fühle mich jetzt sehr gut in Lüdersdorf, hungern brauchen wir nicht mehr. Bei der Wohnraumverteilung bin ich gerecht behandelt worden. Ich war früher Arbeiter auf einem Kornschuppen und bin jetzt Ackerkutscher. Wöchentlich bekomme ich 25,- DM, Kost und alles frei. So hat sich nach meiner Auffassung die Lage seit 1945 bedeutend verbessert.“ 
Die allgemeine Verbesserung der Lage der Umsiedler drückt sich auch in der Senkung der Sozialunterstützungen aus, die im April 1949 noch in 1160 Fällen aufgewandt werden musste, während sie im Januar 1950 auf 602 Fälle, d. h. also fast um $45 \%$ abgesunken ist.

Schwierig ist noch die Wohnraumfrage, wo durch die Alteingesessenen auch jetzt noch nicht die nötige Vernunft und durch die örtlichen Wohnungsorgane noch nicht der notwendige politische Weitblick aufgebracht wird. Die politische Passivität liegt im wesentlichen in der Wohnraunmfrage insofern begründet, da die zweitrangige Behandlung den Umsiedler nicht zum Einheimischen werden lässt. So wurden z. B. im 1. Quartal 1950 durch das Wohnungsamt 272 Wohnungsstreitigkeiten, ausschliesslich von Umsiedlern, begutachtet, die aufgrund der vorhandenen Situation restlos zu Gunsten der Umsiedler entschieden werden könnten.

So wurde z.B. im Falle R[...], Angermünde, eine abgeschlossene Wohnung mit 2 Zimmern und Küche zugewiesen, die 2 Familienmitglieder wohnten bisher in einem Durchgangszimmer. Im Falle K[...], Golm, wohnten 5 Personen in 1 Zimmer. Der Familie wurden jetzt 2 Zimmer zugewiesen.

$\mathrm{A}[\ldots]$, Angermünde, wohnte mit 3 Personen in 1 Zimmer von ca. $12 \mathrm{qm}$, ihm wurde jetzt eine abgeschlossene Wohnung gegeben.

Diese Fälle wurden aber erst durch Eingreifen der Kreiswohnungsbehörde entschieden und beweisen somit die Unzulänglichkeit der örtlichen Wohnungskommissionen, wo der eine Alteingesessene den anderen Alteingesessenen nicht recht behelligen will. Die in den Wohnungskommissionen vorhandenen Umsiedler befanden sich bisher entweder als Neusiedler zu irgendeinem der Altbauern in einem Abhängigkeitsverhältnis oder ernährungsmässig. Trotz allen Bemühungen, wohnen nach dem Stand vom Januar 1950 noch ca. 1600 Familien, das entspricht also ca. 8000 Umsiedlern, in Untermiete. Inwieweit diese soziale Abhängigkeit gegenüber der Altbauernschaft auf die Simmung und damit auf die politische Einsicht und Aufgeschlossenheit der Umsiedler einwirkt, geht aus einigen Vergleichszahlen der Wahlergebnisse der Volksratswahlen im Kreise Angermünde hervor. [Bl. 28v]

In 21 Gemeinden des Kreises lag das Wahlergebnis unter 50\%. Dort standen 6997 Altbauern 733 Neubauern gegenüber, d. h. also $10 \%$ Neubauern (ca.). In 13 Gemeinden des Kreises lag das Wahlergebnis über $70 \%$. Dort standen 142 Altbauern 672 Neusiedlern gegenüber, d.h. ca. $78 \%$ waren Neubauern.

Damit ergibt sich, dass der entscheidende Faktor bei der stimmungsmässigen Beeinflussung bei gleicher Umsiedlerbesetzung von 30-40\% bis zu 60\% durch die Alteingesessenen ausgeht, die in der 1. Gruppe durch ihr soziales Unverständnis das einheimisch werden der neuhinzugekommenen Gemeindemitglieder ausschlossen und damit ihr politisches Interesse und ihre Aktivität beschränkten.

In dieser Hinsicht treten besonders bei den Umsiedler-Neubauern gewisse Bedenken auf, da sie glauben, dass sie mit der augenblicklichen Kreditlage und in Anbetracht dessen, dass sie sich ja 
alles wieder neu anschaffen müssen, ernste Bedenken haben, ob sie ihre Neubauten im Rahmen des Siedlerbauprogramms werden erfolgreich zu Ende führen können.

In mehr als einem Fall werden Stimmen laut, wie die des Umsiedlers E[... R [...]: „Unser Bau ist halb fertig, nun ist der Kredit gesperrt. Allein zu zahlen sind wir nicht in der Lage. 15000,DM wurden uns bewilligt, sind aber jetzt gesperrt. Mir ist klar, dass die DDR nicht gleich alles geben kann, denn sie haben ja genau so anfangen müssen, wie ich auf meiner Siedlung.

Dieser Fragenkreis der Umsiedler-Neubauten läuft natürlich wieder hinüber in die allgemeine Wohnraumfrage und Auflösung oder Nichtauflösung des Abhängigkeitsverhältnisses von den Alteingesessenen.

Wie krass diese Frage oft noch liegt, kommt in der Stellungnahme desselben Umsiedlers zum Ausdruck: „Einheimisch fühle ich mich allerdings in Lüdersdorf noch nicht. Wenn ich mir mal von meinem Nachbarn W[... etwas leihe, so fühlt er sich als Alteingesessener immer mir voraus."

Die Tochter eines Umsiedler-Neubauern aus derselben Gemeinde sagt: „Beschwerden haben wir nur gegen den Hauswirt W[...] A[... ] wegen unserer Viehhaltung. Er ist der Ansicht, wir brauchten kein Vieh. Auch hat er uns eine Bettstelle gegeben, die fordert er wieder.“

Aus der Gemeinde Blankenburg sagt der Umsiedler F[...]: „Die Wohnraumverteilung in der Gemeinde ist nicht gerecht durchgeführt. Herr L[...] mit 4 Personen 1 Zimmer, Herr Z[... 2 Personen 3 Zimmer."

Der Neusiedler $\mathrm{H}[\ldots]$ aus Lützlow: „Ich wohne mit 5 Personen in einem Zimmer und wäre dankbar, wenn ich eine andere Wohnung bekommen könnte.“

Diese Beispiele könnte man noch sehr zahlreich aus den meisten Gemeinden des Kreises fortsetzen.

Diese sozialen Verhältnisse sind es im wesentlichen, die den Gedanken an die ehemals „bessere“ Heimat nicht zur Ruhe kommen lassen und somit stark eine politische Passivität hervorrufen. Gleichfalls bedingt durch die sozialen Verhältnisse ist besonders in den ländlichen Gemeinden der überwiegende Teil noch nicht wieder im Besitz eines Radios.

So stösst man häufig auf starke Unkenntnis der gegenwärtigen politischen Begebenheiten, die in den Umsiedlern ein schiefes Bild der Lage entstehen lässt oder ihnen aus mangelndem Wissen die Notwendigkeit einer politischen Mitarbeit für sie nicht erkenntlich macht.

So sagt Frl. L[... S $[\ldots]$ aus Lüdersdorf: „Zu den Demontagen in Watenstedt-Salzgitter ${ }^{2415}$ kann ich nichts sagen; Radio haben wir nicht." [Bl. 29r]

2415 [Die interalliierte Reparationskommission hatte 1949 die Demontage von $90 \%$ der großen Eisenhütte Watenstedt-Salzgitter (ab 1951 Salzgitter) beschlossen, stellte diese aber nach Protesten 1950 ein. In WatenstedtSalzgitter lebten damals überdurchschnittlich viele Vertriebene.] 
Diese und ähnliche Äusserungen hörten wir zu wiederholten Malen auch bei anderen politischen Ereignissen, Gesetz zur Förderung der Jugend, Landarbeiter-Schutzgesetz usw. aus dem überwiegenden Teil unserer Gemeinden.

Die ländliche Struktur unseres Kreises führt dazu, dass der landarbeitende Mensch und somit auch ca. $3 / 5$ unserer Umsiedler, wenn er oft erst abends vom Felde, vom Holzfahren u. ä. zurückkehrt, das Zeitungslesen als eine Belastung empfindet, was daher in den meisten Fällen unterbleibt, während das gesprochene Wort durch ihn müheloser aufgenommen wird, daher vermisst der landbewohnende Umsiedler in starkem Masse das Vorhandensein eines Radios.

Wenn bei äusserlicher Betrachtung der kummunalen ${ }^{2416}$ [so!] Arbeit auch die Beteiligung der Umsiedler verhältnismässig stark erscheint, so kommen z. B. auf 66 Gemeinden des Kreises 623 Gemeindevertreter und Stadtverordnete[,] von denen 174 Umsiedler sind, d.h. also, dass das 3.el Verhältnis im Rahmen der Gesamteinwohnerschaft des Kreises im Rahmen der Struktur der Gemeindevertretungen fast gewahrt ist. So darf das nicht über den wirklichen Grad der politischen Aktivität hinwegtäuschen.

Wenn wir die parteipolitische Aufschlüsselung der obengenannten 174 Gemeindevertreter betrachten, so entfallen

$\begin{array}{cl}33 & \text { auf die CDU, } \\ 2 & \text { auf die LDP, } \\ 107 & \text { auf die SED und } \\ 32 \text { ptl. } & \end{array}$

Diese Zahlen ins Verhältnis gesetzt zu den Mitgliederstärken der Parteien bedeuten, dass bei der CDU 3,2 \% kommunal-politisch arbeitet und wenn wir Schätzungsweise die Parteilosen als stark sinnesverwandt hinzunehmen, fast $6 \%$.

Bei der SED wird nur ein Prozentsatz von 1,4\% erreicht. Die tiefere Begründung dürfte hier in der Frage der Oder/Neisse-Linie liegen.

Weiter unterbaut wird diese Analyse bei der Gegenüberstellung der Gesamtmitgliederzahlen der Parteien und Organisationen zu ihrem Umsiedleranteil. So hat die Demokratische Bauernpartei bei 724 Mitgliedern laut Stand vom 31.3.1950 398 Umsiedler, d. h. über 50 \%. Die CDU bei 1169 Mitgliedern 269 Umsiedler, also fast 25\%, dabei werden 22 Funktionäre aus Umsiedlern gestellt. Die N.D.P.D. hat bei 280 Mitgliedern im Kreise 69 Umsiedler, also nahezu 25\%. Die S. E. D. bei rd. 7000 Mitgliedern nur 800 Umsiedler. Bei der Gegenüberstellung der Zahlen der Demokratischen Bauernpartei dürfte das Resultat hauptsächlich durch die überwiegende Mehrzahl der Umsiedler auf dem Lande kommen, aber auch auf der weniger brüsken Betonung der Unabänderlichkeit der Oder/Neisse-Linie. Ganz klar ersichtlich ist dieser Prozentsatz bei der CDU, die diese Frage bisher grundsätzlich vermieden [hat] entscheiden $[\mathrm{d}]$ zu erörtern, und bei der N.D.P., wo 
der im Vordergrund stehende Nationalgedanke verquickt wird mit der Hoffnung der Herstellung der alten „Nationalen“ Grenzen. Die S.E.D., als die Partei, die die Oder/Neisse-Linie entscheidend als Friedensgrenze betont, hat einen Umsiedleranteil von nur ca. $11 \%$. Die gleiche Grundtendenz weisen die Zahlen der L. D.P. [auf] mit 188 Mitgliedern zu 35 Umsiedlern, ca. 16\%.

Ihre weitere besondere Unterstreichung erfährt die Tatsache in den Zahlen in der Ges[ellschaft] f[ür] deutsch-sowj[etische] Freundschaft. Die Meinung breiterer Bevölkerungsschichten und hier auch vornehmlich Umsiedler in ihrer besonderen Empfindlichkeit durch die verlorene Heimat betrachten die SED durchaus als Russenpartei. [B1. 29v]

Da die Oder/Neisse-Linie als Friedensgrenze aktiv nur durch die Einheitspartei deklariert wird, legt man diese Feststellung auch der sowjetischen Besatzungsmacht von Seiten der Umsiedler zur Last. Und so ergeben die Zahlen der Ges[ellschaft] f[ür] deutsch-sowj[etische] Freundschaft bei 3586 Mitgliedern nur einen Umsiedleranteil von 275 Mitgliedern, d. s. ca. $8 \%$. Wenn wir dabei berücksichtigen die allgemeine politische Inaktivität der Umsiedler auf dem Lande und dazu diesbezüglich eine Analyse aus einigen Produktionsbetrieben unseres Kreises zieht, so hat z. B. das Britzer Eisenwerk bei 150 Umsiedlern nur 18 Personen = ca. 11,6\%. Im Schotterwerk Althüttendorf [ist] bei 42 Umsiedler[n] keiner in der Ges. f. dtsch.-sowj. Freundschaft. In der Eisengiesserei "Jonny Scheer" von 8 Umsiedlern 2 - 25\%. Bei der UTVG Schwedt von 19 Umsiedlern 1 in der Gesellschaft.

Demgegenüber in den Verwaltungen - Verwaltung des Kreises mit 114Ums[iedler]-Angest[ellten] ca. 70 in der Gesellschaft, d.s. über 62\%, Konsumgenossenschaft Kreis Angermünde von 148 Umsiedlern 35 in der Gesellschaft f. deutsch-sowj. Freundschaft, d[as] sind ca. 20\%.

Somit ergibt sich aus vorstehenden Zahlen, dass die $8 \%$ der im Gesamtkreisgebiet der in der Gesellschaft für deutsch-sowjetische Freundschaft organisierten, sich in der Hauptsache auf die Verwaltungsangestellten und zu einem geringeren Prozentsatz in einem Durchschnittswert von $15-16 \%$ auf die metallverarbeitenden Produktionsbetriebe und zu einem verschwindend geringen Teil in die ländl[iche] Struktur, d.h. also auch in die Masse der Umsiedler verlagert.

Unter dieser Zusammenfassung darf selbstverständlich auch die Beteiligung der 486 Umsiedler in den Ortsausschüssen der Nationalen Front bei insgesamt 1204 Personen, d. s. ca. 40 \% nicht zu hoch in Rechnung gesetzt werden.

Eine weitere Ergänzung bildet die Gegenüberstellung der wahlberechtigten Umsiedler zu den Alteingesessenen in ihrer parteipolitischen Bindung. Bei einer Gesamteinwohnerschaft von rund 82000 Menschen sind Alteingesessenen Wahlberechtigte etwa 16200, Umsiedler ca. 15800 . Von den Umsiedlern sind parteipolitisch gebunden 1570, von den Alteingesesessenen etwa 7790. Das Verhältnis steht also gegenüber von $9 \%$ Umsiedlern gegenüber $19 \%$ bei den Alteingesessenen.

Eine kleine Stabilisierung, die aber auch mit der Beschwerlichkeit in der Jetztzeit zusammen hängen kann[,] geht aus den Zahlen der nach dem Westen geflüchteten hervor. Bei insgesamt 640 nach dem Westen illegal abgewanderten entfallen 420 Abwanderungen auf Umsiedler, d. h. 
also 2/3. Die Masse dieser Abwanderungen lag in der Zeit von Ende 1947 bis Ende 1948 - Anfang 1949. Die im letzten Halbjahr 1949 und in diesem Jahr abgewanderten ist geringfügig.

Das[s] ein Teil, wenn auch verhältnismässig kleiner, neben einer vollen Existenzfähigkeit, wie sie die Neusiedler $100 \%$ ig erhalten haben, $[\ldots]^{2417}$ geht aus den Gewerbegenehmigungen hervor, wo von 2800 Gewerbegenehmigungen vom Jahre 1945 - bis 1950288 auf Umsiedler mit rd. 1400 Angehörigen entfallen, also nahezu $10 \%$.

Dass trotz der aufgezeigten Mängel ein langsames aber stetiges Hineinwachsen in die „Einheimischen" erfolgt, zeigt das vorangeführte Beispiel und im weiteren auch die starke Verankerung auf schulischem Gebiet. Auf der Landwirtschafts-Schule des Kreises machen die Umsiedlerkinder 10-12\% der Gesamtschülerzahl aus. In den 3 Oberschulen des Kreises sind insgesamt 198 Knaben und 132 Mädchen, davon sind Umsiedler 49 Knaben und 52 Mädchen. Diese soziale Aufschlüsselung ergibt von

Arbeitern u. unselbständigen Handwerkern

Siedler[n] und Kleinbauern

Angestellte[n]

ehem. Beamte[n]

selbst. Handw[erker] u. Gew[erbe] Treibende

Freie Beruf[e]

$\begin{array}{rc}\text { Knaben } & \text { Mädchen } \\ 18 & 4 \\ 8 & 14 \\ 16 & 14 \\ 2 & 1 \\ 2 & 7 \\ 3 & 3\end{array}$

[Bl. 30r]

Somit hält sich das Verhältnis von Arbeitern und Siedlern gegenüber den Schülern und Schülerinnen von Angestellten und ehem. Beamten genau mit 50 - 50\% zu Waage. Bei der Berücksichtigung von Schulgeldbefreiung und Erziehungsbeihilfen sind erfreulicher Weise bei den Knaben 42 und bei den Mädchen 41 Kinder bedacht worden, so dass die Umsiedler in den Oberschulen mit ca. $98 \%$ die nötigen Mittel staatlicher seits bewilligt erhielten, um die Schule zu besuchen.

Zusammenfassend ist zur Lage und Stimmung der Umsiedler folgendes festzustellen:

Die Berufsmöglichkeit im Verhältnis zur Zahl der Umsiedler ist zu gering. Die Möglichkeit einer Umschulung ist auch schwach, da die Industrie als solche im wesentlichen fehlt (Landkreis).

Der somit in der überwiegenden Zahl berufsfremde Einsatz macht selbstverständlich auch nur eine „berufsfremde“ Bezahlung möglich, die die an sich schwierige materielle Lage der Umsiedler, die sich bis auf geringe Ausnahmen alles neu beschaffen müssen, auch stimmungsmässig weiterhin erklärlich macht.

Die gedrängten Wohnungsverhältnisse tun das übrige, um ihnen trotz der Bemühungen, den Begriff „Umsiedler“ im öffentlichen Leben verschwinden zu lassen, ihr Umsiedlerdasein wieder

2417 [Hier fehlt offenbar Text, ohne dass eine Lücke gelassen wäre.] 
vor Augen zu führen und damit den alten Heimatgedanken immer wieder neu zu wecken. Die Weckung des Heimatgedankens in Verbindung mit den politischen Spannungen im Weltmaßstab, zusammen mit der Flüsterpropaganda halten einen Hoffnungsschimmer wach, der sie in Widerstreit bringt, zwischen der Wirklichkeit und der Notwendigkeit, sich eine „neue“ Existenz zu schaffen und der vermeindlichen [so!] Möglichkeit, einer „Rückkehr“. Die Situation zwischen Hangen und Bangen verhindert in den überwiegenden Fällen einen festen Entschluss zum neuen Anfang und vor allem, zur Mitgestaltung des Neuen, d. h. also zur politischen Aktivität.

Durch die Verbesserung der Lebenslage der Werktätigen allgemein macht sich in langsam steigendem Masse eine Neutralisation des oppositionellen Widerstandes gegen ihr Schicksal bemerkbar, und bringt hier in dieser Form die Hoffnung, vielleicht doch eine neue Heimat zu finden.

Dieser Teil der Umsiedler muss aber zur Zeit als der bei weitem kleinere angesehen werden und es würde überzeugenderer Massnahmen bedürfen, um diesen Prozentsatz ausschlaggebend zu vergrössern.

Bei allen, selbst positiven Meinungsäusserungen der Umsiedler, zur Entwicklung in der DDR und insbesondere im Verhältnis gegenüber dem Westen, blickt doch bis auf wenige Fälle das „es könnte doch sein dass," durch.

Unter diesem Gesichtspunkt wird auch die Lage der Nationalen Front betrachtet. So sind z. B. einige Stimmen aus Altenhof, von den Umsiedlern G [... ], Schneidermeister, - A. S [...], Waldarbeiter - A[...], Hilfsförster - K[...], Waldfacharbeiter-Lehrling, - „Die Lage der Umsiedler in unserem Ort ist jetzt so, dass sie wohl alle eine Arbeit bekommen haben, um ihre Familien zu ernähren. Die Wohnraumfrage kann als gelöst angesehen werden (mit Vorbehalt). Der Verdienst gestattet ihnen die nötigsten Anschaffungen zu machen. Ein Teil hat allerdings immer noch die Hoffnung, in ihre alte Heimat zurückkehren zu können. Ein weiteres Zeichen der Verbesserung ist, dass sie sich schon jetzt feste Arbeitsstellen suchen und nicht mehr für das Essen beim Bauern arbeiten. Die Nationale Front wird z. T. mit gemischten Gefühlen betrachtet, weil sie eben immer noch der Rias-Propaganda Gehör schenken.["] [B1.30v]

Die Einschränkung und der leise Hoffnungsschimmer, selbst positiver Kräfte geht deutlich aus dem Bericht unseres Mitarbeiters Schöps, aus der Gemeinde Gramzow, hervor: Dort wurden

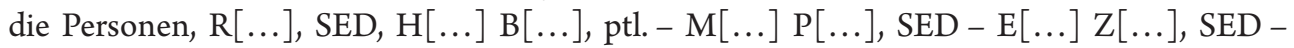
$\mathrm{A}[\ldots] \mathrm{S}[\ldots]$, ptl. - M[... $\mathrm{H}[\ldots]$, SED - und $\mathrm{P}[\ldots] \mathrm{S}[\ldots]$, ptl. befragt. ["]Die Befragten bejahen die Nationale Front und arbeiten auch mit, sie betrachten die Oder/Neisse-Linie als Friedensgrenze, wünschen aber, dass bei den späteren Friedensverhandlungen diese Grenzen noch einmal überprüft werden, denn sie haben alles in Schlesien bezw. Ostpreussen verloren. Da sie aber in Frieden mit allen Völkern leben wollen, erkennen sie die Oder/Neisse-Linie als Grenze an."

Die Einstellung zu ihrer materiellen Lage geht hier aus der Auffassung hervor, dass sie sich erst ganz einheimisch fühlen können, wenn die Entschädigung $100 \%$ ig erfolgt ist und wenn alle 
Angehörigen wieder zusammen sind. Die materielle Sorge bereit[et] ihnen die Kreditsperrung, weil viele von ihnen noch nicht mit dem Bauen fertig sind.

Eine andere Stimme gibt Herr H[...], aus Lützlow, ca. 56[?] Jahre a[lt,] parteilos, Neubauer: „Wenn die Nationale Front ihre Beschlüsse verwirklicht, ist es richtig, an der Oder/Neisse-Linie ist nichts zu ändern. Die wurde damals beschlossen. Eins fehlt mir noch und dass [so!] wäre eine Kleiderkarte. Ich war in meiner alten Heimat Bauer und bin jetzt Neusiedler. Ich wohne mit 5 Personen in 1 Zimmer und wäre dankbar, wenn ich eine andere Wohnung bekommen könnte.“

Er steht weiterhin auf dem Standpunkt, dass die Sache mit Watenstedt-Salzgitter als die grösste Sabotage an der deutschen Wirtschaft anzusehen sei. Auch die Versorgungslage wird als wesentlich verbessert seit 1945 bezeichnet. Die HO sei allerdings noch zu teuer.

Der Siedler E[...] G[...], aus Lüdersdorf; „Zur Nationalen Front kann ich nur ein geeintes Deutschland wünschen, wenn ich in meine Heimat könnte, würde ich wieder zurückgehen. Ich bin aber der Meinung[,] dass ich nicht wieder zurückkomme, da es doch die einheitliche Friedensgrenze sein soll. Ich war früher Arbeiter auf einem Kornschuppen und bin jetzt Ackerkutscher, wöchentlich bekomme ich 25,- DM[,] Kost und alles frei. Seit 1945 hat sich die Lage bedeutend gebessert."

Der Umsiedler $\mathrm{E}[\ldots] \mathrm{R}[\ldots]$ aus Lüdersdorf ist auch durchaus positiv eingestellt, aber auch er kämpft noch mit der alten Heimat. Er sagt: „Nach den Erlebnissen aus dem Hitlerkrieg ist es unbedingt erforderlich, die Einheit des ganzen deutschen Volkes zu erstreben, dafür bekommen wir Garantie durch die Nationale Front. Die Oder/Neisse-Linie müsste so sein wie 1937. Ich selbst kann nicht in meine Heimat, da ich hier bereits dank der DDR eine neue Heimat gefunden habe. Watenstedt-Salzgitter ist ungerecht, da hier nur Arbeitslosigkeit entsteht. Die Rüstungsindustrie kann ruhig abgebrochen werden. Die Riaspropaganda bezüglich der Rückführung: Vielleicht wäre es ganz gut, wenn die Umsiedler aus den Gebieten zurückkönnten. In der Wohnungskommission müssten mehr Umsiedler sein. Mir ist nicht klar, warum Neusiedler bebaute Grundstücke erhalten haben ohne Geld und sie sind nun nicht belastet wie ich mit Schulden. Warum diese Ungerechtigkeit. Ich selbst habe grosse Sorge um meinen Bau. Die Preise für dei HO müssen noch gesenkt werden, wer keine freien Spitzen hat, ist nicht in der Lage, sich dort etwas zu kaufen." [B1.31r]

Frau S[... ], Lüdersdorf, Umsiedlerin aus Klausdorf, Kr. Soldin: „Es ist richtig, dass die Grenzen fallen und Deutschland geeint wird für einen gerechten Frieden. Aber die Oder/Neisse-Linie ist keine Befriedigung, da wir hier noch keine Heimat gefunden haben, wegen des Wohnraummangels. Wir wohnen mit unseren 2 erwachsenen Kindern in einem Zimmer. Von WatenstedtSalzgitter haben wir keine Ahnung. Ebenso wenig von der Rias-Propaganda.“

Der Mann äusserte sich dazu: „Meine Einstellung zur DDR ist vertrauensvoll; denn ich hatte bisher mein Auskommen und mein Essen gehabt, dass ich aber keinen grösseren Wohnraum bekomme, ist mir unverständlich. Seit 2 Jahren habe ich eine grössere Wohnung beantragt, aber die Wohnungskommission hat sich noch nie bei mir sehen lassen. Meine jetzige Wohnung er- 
scheint mir menschenunwürdig, da beide Kinder über 14 Jahre alt sind. (Der Mann war früher Stellmacher, ist jetzt in seinem Beruf im Leistungslohn tätig, im FDGB organisiert, Kinder in der FDJ bezw. bei den Jungen Pionieren.)“

G[... E E [..], aus der Gemeinde Chorin, Umsiedler aus Schlesien: „Er ist begeisterter Anhänger der Nationalen Front. Es ist sehr schwer für ihn, dass er aus seiner Heimat fort musste, sieht aber die Notwendigkeit der Oder/Neisse-Linie ein und vertritt auch diese Meinung nach außen. Die Demontage in Watenstedt-Salzgitter verurteilt er auf das Schärfste. Er hat materielle Sorgen und möchte sich gern etwas anschaffen, hat aber das Geld nicht dazu. Er arbeitet zur Zeit als Stubbenroder mit 25,- bis 30,- DM in der Woche, war früher selbständiger Fleischer und Gastwirt. Steht zur Entwicklung in der DDR positiv. Ist Mitglied der SED und der Gesellschaft für deutsch-sowjetische Freundschaft.“

Der Umsiedler Z[...], neuhinzugekommener Umsiedler aus Prenzlau. [“]Er behauptet, von der Nationalen Front nichts zu verstehen, ihm ist alles gleich. Die Oder/Neisse-Linie interessiert ihn nicht, da sie ihn nicht betrifft. Schimpft über die Demontage im Westen. Er hat kein Radio, will aber, dass alle Ruhe und Frieden halten. Er möchte gern nach Prenzlau zurück. Ihm ist die Rente, die er bezieht, zu gering (57,- DM). Ist nirgends organisiert, nimmt am politischen Leben nicht teil.“

Frau T[...], Chorin. ["]Frau T[... ist Mitglied des DFD und steht zur Nationale[n] Front. Sie wäre gern in Pommern geblieben, hat sich aber mit der Oder/Neisse-Linie abgefunden. Ist gegen die Demontagen im Westen eingestellt. Die Siegermächte sollten endlich Ruhe geben und uns arbeiten lassen. Was der Rias sagt, hält die [so!] für dummes Gerede. Wenn es aber einmal möglich sein sollte, nach Hause zu kommen, dann will sie mit den Kindern fahren, würde aber auch hier bleiben. (Auch hier das schwankende Stimmungselement). Fühlt sich in Chorin einheimisch und sie hat keine Beschwerden gegen die Alteingesessenen. Materielle Sorgen hat sie nicht. Sie bekommt 120,- DM Rente für sich und die Kinder, davon verdienen 2 schon selbst. Bejaht die Entwicklung in der DDR. Die HO ist gut, müsste aber billiger werden.“

Herauszustellen wäre die Stimme des Umsiedler-Aktivisten $\mathrm{K}[\ldots] \mathrm{W}[\ldots]$, Schlosser, 40 Jahre, FDGB und Gesellschaft f[ür]. deutsch-sowjetische Freundschaft: „Ich begrüsse unsere demokratische Wirtschaftsentwicklung aus ganzem Herzen, insbesondere da ich selbst in einem volkseigenen Betrieb arbeiten kann. Jeder muss anerkennen, dass es hier bei uns im Osten vorwärts geht. Ich arbeite nicht allein, weil ich nur verdienen will, sondern weil ich weiss, dass ich gebraucht werde. Parteipolitisch habe ich mich noch nicht gebunden, dazu habe ich bei meiner Arbeit doch keine Zeit.“"

\section{(215) Bericht über die Stimmung im grenznahen Oberförstereibezirk Joachimsthal. - Angermünde, 17. Juni 1950}

BLHA, Rep. 202 G Amt für Information, Nr. 170, B1. 59. - Typoskript, 1 Bl., vereinzelt handschriftliche Korrekturen, mit Tinten-Unterschrift des Leiters des Informationsdienstes des Rates des Kreises [gez.] „Spangenberg“. - Gedruckter Kopfbogen „Der Rat des Kreises Angermünde“ (mit Kreiswappen), o.l. Geschäftszeichen „Sp/Le., o. r. Datierung 
„Angermünde, den 17.6.1950 / Telefon: Angermünde / Apparat Nr. 623 u. 507 / Zimmer Nr. 34 / - Informationsdienst -“. - Adresse: „An die / Landesregierung Brandenburg / - Amt für Information - / Abt. Informationskontrolle / Potsdam / Hebbelstr. 39“. - Betreff: „Betrifft: Schlechte Stimmung im Oberförstereibezirk Joachimsthal, Krs. Angermünde."

Am 14. Juli 1950 nahmen wir ${ }^{2418}$ zusammen mit dem Kreissekretär des FDGB, Kollegen Genz, an einer Betriebsversammlung der Oberförsterei Joachimsthal teil, die von ca. 300 bis 350 Menschen besucht war, vornehmlich Waldarbeiter und -arbeiterinnen.

Bereits die Ausführungen im Hauptreferat des Kol[legen]. Genz, hinsichtlich der Oder/Neisselinie führten zu zahlreichen gegnerischen Stellungnahmen. Etwa in der Form, dass man solange die Grenze nicht beseitigt sei, von einer freundschaftlichen Beziehung nicht sprechen könne, da z. Zt. dort drüben Disteln wüchsen und eine Stimme aus dem Hintergrund deutete den Begriff „Waffengewalt" an.

$\mathrm{Zu}$ einer ernsten Situation entwickelte sich der Abstimmungsversuch nach dem Arbeitsbericht des Forstamtsleiters Dr. Schöbitz, über eine Resolution wo der Forstamtsbezirk Joachimsthal mit einem polnischen Förstereibetrieb in Verbindung treten soll. Bei dem ersten Abstimmungsversuch erhoben sich nur ca. 6 bis 8 Hände von der gesamten Belegschaft, sonst eisiges Schweigen. Als Herr Dr. Ströbitz [Schöbitz!] einige Personen befragte warum sie sich denn zu dieser so wichtigen Frage so ablehnend verhielten, erhielt er keine Antwort, aber ca. 30 bis 40 Personen verliessen nach und nach den Saal, um wahrscheinlich einer weiteren Abstimmung zu entgehen. Da unter diesem Gesichtspunkt die Frage stand, wer die Oberhand behält, nahm der Kreissekretär des FDGB, Kol. Genz, [Bl. 59v] der Vorsitzende der Betriebsgruppe des Kreisforstamtes und wir noch einmal zu diesem Problem Stellung, mit dem Resultat, dass beim dritten Anlauf knapp $2 / 3$ der Hände zur Abstimmung in die Höhe schlichen und sich zur „Gegenprobe“ niemand meldete. Somit war eine formale Einstimmigkeit erreicht. Der Inhalt dieser Abstimmung muss aber als glatte Niederlage angesehen werden.

Inwieweit dergleichen Tendenzen, auch durch Genossen bzw. Kandidaten von der Partei unterstützt werden, geht aus einem Vorfall auf derselben Tagung hervor, wo durch Streichung von Investmitteln die Pflegearbeiten der Aufforstungskulturen in Frage standen. Der Vorsitzende der SED-Betriebsgruppe gab bekannt, dass die Betriesgruppe der SED sowie auch die NDP übereingekommen sei, diese Pflege in solidarischer [Arbeit?] zu erledigen, bzw. auch die Einwohnerschaft aufzurufen. Daraufhin stand der Leiter der Aussenstelle des Arbeitsamtes Joachismthal, Herr Pfeiffer, auf und erklärte, man könne doch nicht erwarten, dass die Leute ohne Bezahlung arbeiten würden.

Als von uns gegen eine solche Auffassung Stellung genommen wurde und die Bedeutung der Solidarität von 1945 bis zur Gegenwart dargelegt wurde und wir dabei selbstverständlich gezwungen waren, den Kollegen Pfeiffer sehr scharf zu rügen, hatte er den Saal von ca. 350 Versam- 
melten hinter sich, die sich dagegen verwahrten, daas man Pfeiffer wegen seiner Stellungnahme rügte.

Wir werden speziell die Angelegenheit Pfeiffer mit glecher Post dem Leiter des Arbeitsamtes Angermünde zusenden und bitten, die Landesstelle anzuhalten, sich auch von dort über das Veranlasste Rechenschaft geben zu lassen.

\section{(216) Bericht über eine Kundgebung für deutsch-polnische Freundschaft. - [Cottbus], Juli 1950}

BLHA, Rep. 202 G Amt für Information, Nr. 170, Bl. 267. - Typoskript, 1 Bl., ohne Unterschrift, zahlreiche handschriftliche Einfügungen und Streichungen zur Weiterverwendung. - L. o. Sichtvermerk „10c“ mit Haken.

Bericht über die Durchführung der Kundgebung für deutsche-polnische Freundschaft

1.) Forst:

Das Neisse-Vorgelände war für die große Kundgebung am 18.7.1950 mit Fahnen und Transparenten ausgeschmückt und von deutscher [dafür gestrichen: unserer] Seite waren 8-10000 Menschen auf den Beinen. Die Groß-Kundgebung wäre zu einem vollen Erfolg für deutschpolnische Freundschaft geworden, wenn von polnischer Seite ebenfalls eine große Delegation vorhanden gewesen wäre und das angekündigte Tanz-Ensemble der polnischen Freunde hier in Forst seine Aufführungen gezeigt hätte. Durch das Nichterscheinen des polnischen Ensembles hat der Wert der Kundgebung sehr viel verloren [Dafür gestrichen: Da dies nicht der Fall war, hat die Kundgebung nicht ihren Zweck erfüllt, die deutsch-polnische Freundschaft zu festigen]. Die Stimmung der Bevölkerung ist demzufolge etwas [dafür gestrichen: schwer] erschüttert [eingefügt: , zumal dies bereits das dritte Mal ist, wo polnische Delegationen wohl angekündigt waren, aber nicht erschienen sind]. Sie ist verstärkt worden durch den erschienenen Artikel in der Märkischen Volksstimme vom 19.7.50, der vom Auftreten des Kultur-Ensemble berichtete, welches gar nicht in Forst war. Am Ende der Kundgebung winkten die anwesenden polnischen Freunde, die am anderen Ufer der Neisse standen, und nachdem zuerst Kinder durch das Wasser wateten, gingen auch viele Erwachsene hinüber und suchten teilweise ihre ehemaligen Wohnungen auf und brachten kleine Gegenstände aus ihren Wohnungen mit hinüber. Zu Zwischenfällen ist es nicht gekommen.

2. Guben. 2419

Die Stadt Guben war mit Fahnen und Transpartenten geschmückt, worin die Freundschaft zum polnischen Volke zum Ausdruck kam. Am 21.7.50 fanden in 35 Betreben kurze Feierstunden statt. Am 22.7.50 um 20 Uhr fand in der Nähe der Neisse-Brücke eine große Veranstaltung statt. Die Vertreter der Parteien sprachen dort. Chöre der Jugend trugen zur kulturellen Umrahmung bei. Ein Telegramm an den polnischen Ministerpräsidenten wurde abgesandt. 


\section{Cottbus.}

In Cottbus fand die Kundgebung am 22.7.50 um 12,30 Uhr auf dem Altmarkt statt. Zirka 2500 Personen waren anwesend. Hierzu muß gesagt werden, daß die breite Masse der Stadt-Bevölkerung wenig Anteil nahm. Der größte Teil der Anwesenden setzte sich aus den Verwaltungsorganen, z. B. Stadt-, Kreis-Verwaltung, Verwaltung der Reichsbahn-Direktion und Amtsgericht zusammen. Die Volkspolizei und FDJ waren zahlreich vertreten. [Gestrichen: Die HO und Reichsbahn- (B1. 267v) Direktion sandten nur eine kleine Abordnung.] Zwei Tuchfabriken der Stadt nahmen fast geschlossen an dieser Kundgebung teil. Das äußere Bild des Kundgebungsortes war nicht zufriedenstellend ausgestaltet. [Gestrichen: Die FDJ sang einige Lieder. Zwei Rezitationen wurden vorgetragen.] Der Vorsitzende der Nationalen Front und der Bürgermeister der Stadt wiesen in ihren kurzen Referaten auf die Bedeutung der deutsch-polnischen Freundschaft und den Frieden hin. Zwei Resolutionen und ein Telegramm an den polnischen Ministerpräsidenten wurden einstimmig angenommen.

Die Kundgebung zeigte nicht den gewünschten Erfolg. Die Gründe hierfür sind in der schlechten Propagierung sowie in der ermangelnden Mitarbeit der einzelnen Parteien und Massenorganisationen zu finden. Das gesamte Stadtbild war für diesen besonderen Tag wenig ausgestaltet.

(217) Protokoll der außerordentlichen Sitzung der Stadtverordnetenversammlung von Potsdam anlässlich des Tages der deutsch-polnischen Freundschaft. Potsdam, 22. Juli 1950

BLHA, Rep. 202 G Amt für Information, Nr. 162, Bl. 185-186. - Typoskript (Durchschlag mit Unterschrift), 2 Bl. - Bl. 185 beglaubigte Abschrift, Überschrift „Abschrift“; 1.u. „F.d.R.d.A.: [gez.] Beinlich / Stadtangestellte“. R. o. Eingangsstempel „Informationsamt / Eing.: 29. Sep. 1950 / GZ.:“. - Bl. 186 Anlage „Entschliessung“. - Bl. 184 Begleitschreiben des Rates der Landeshauptstadt Potsdam, Information und Presse, Zeichen „Kz“, 28. Sept. 1950, an die Landesregierung Brandenburg, Amt für Information, Potsdam, Hebbelstr. 39, zur weisungsgemäßen Übersendung je einer Durchschrift der Protokolle der Ratssitzungen und Stadtverordentenversammlungen von Juli und Sept. 1950.

[Bl. 185]

56. (ausserordentliche) Sitzung der Stadtverordnetenversammlung am Sonnabend, dem 22. Juli 1950, um 13.00 Uhr

Anwesend vom Rat der Stadt: Herr Oberbürgermeister [Rudolf] Paul, Herr Bürgermeister [Hermann] Gerigk, Herr Stadtkämmerer [Max] Brauer, Herr Stadtrat Schönebeck

50 Stadtverordnete sind anwesend.

$\mathrm{Zu}$ Beginn der heutigen ausserordentlichen Sitzung der Stadtverordnetenversammlung anlässlich des Tages der deutsch-polnischen Freun[d]schaft singt der Chor der Humboldt-Schule drei Lieder: 
„Immer strebet zum Ganzen“2420, „Wir schwingen die Sense, den Hammer“2421 und „Ich rufe Euch alle".

Es folgt eine Rezitation von Herrn Karl Gadow ${ }^{2422}$ : „Starke Hände“ (von Wladislav Broniews$\left.\mathrm{ki}^{2423}\right)$.

Sodann spricht der Vorsitzende der Stadtverordnetenversammlung, Herr Spiegel ${ }^{2424}$, zur Einleitung der heutigen Sitzung und legt in kurzen Worten dar, welche Bedeutung der am 5./6. Juni 1950 zwischen der Polnischen Republik und der Deutschen Demokratischen Republik geschlossene Friedenspakt für beide Länder hat, und dass damit nicht nur eine feste Grundlage für die deutsch-polnische Freundschaft geschaffen, sondern gleichzeitig ein entscheidender Beitrag zur Stärkung des Friedenslagers in Europa geleistet wurde.

Der Vorsitzende erteilt nunmehr Herrn Minister Ingo von Koerber ${ }^{2425}$ das Wort.

Herr Minister von Koerber legt in seinem Referat die Gründe klar, die das jahrhundertelang zwischen Polen und Deutschland bestehende Missverhältnis zur Folge hatten, und welche Ursachen zur Abtretung deutscher Gebiete an Polen führten. Er bringt zum Ausdruck, dass mit dem Jahre 1945 eine Epoche verfehlter deutscher Machtpolitik ihr Ende fand. Er geht näher auf die Entwicklung, die sich in den letztvergangenen Jahren vollzogen hat, ein und führt aus, dass eine friedliche Zusammenarbeit beider Völker, ein Austausch in wirtschaftlicher und kultureller Beziehung, gefördert werden müsse.

Herr Minister von Koerber schliesst mit den Worten:

„Unsere Forderung sei für heute und für die Zukunft

für das deutsche Volk und für das polnische Volk,

das heute seinen nationalen Feiertag begeht:

Friede und gute Nachbarschaft!“

Der Vorsitzende verliest nunmehr eine Entschliessung, die einstimmig angenommen wird (Eine Niederschrift der Entschliessung wird dem Prtotokoll beigeheftet.).

2420 [„Immer strebe zum Ganzen und kannst du selber kein Ganzes werden, als dienendes Glied schließ an ein ganzes dich an!“ (Schiller).]

2421 [Volkslied von A. H. Illing, Komponist Eberhard Schmidt.]

2422 [Parteisekretär (Adressbuch Groß-Potsdam 1949, S. 116).]

2423 [Władysław Broniewski (1897-1962), polnischer Lyriker.]

2424 [Georg Spiegel, geb. 1895 Stuttgart, gest. 1960 Potsdam, SED (zuvor SPD), 19. Juli 1945-1947 Erster Bürgermeister der Stadt Potsdam, Herbst 1946-1950 Vorsitzender der Stadtverordnetenversammlung ebd., ab 1946 Mitglied des SED-Provinzialvorstandes Brandenburg und des SED-Kreisvorstandes Potsdam, 1949-1950 MdL (BBL, S. 374f.; wikipedia).]

2425 [Geb. 1890 Groß Plowenz, Kr. Strasburg in Westpreußen, gest. 1978 Dortmund-Barop (1970 Übersiedlung in die Bundesrepublik), 1946-1952 MdL (LDP/LDPD), 1949-1950 Finanz- und 1950-1952 Gesundheitsminister des Landes Brandenburg, 1948-1951 Erster Vorsitzender des LDP-Landesvorstandes; vgl. Handbuch des Landtages 1947 [wie Anm. 1064], S. 55, 78 mit Bild); wikipedia.] 
Zum Abschluss der Sitzung wird die erste Strophe der Nationalhymne gesungen. Die Sitzung ist um $14^{15} \mathrm{Uhr}$ beendet.

$\begin{array}{ll}\text { gez. Spiegel } & \text { gez. Beinlich } \\ \text { Vorsitzender } & \text { Schriftührer i.V. }\end{array}$

[Bl. 186]

\section{Entschliessung}

Nachdem die Sowjet-Armee mit Unterstützung der polnischen Freiheitskämpfer den grössten Teil Polens vom faschistischen Joch befreit hatte, wurde durch das Juli-Manifest des Polnischen Nationalen Befreiungs-Komitees am

\section{Juli 1944}

das neue demokratische Polen geschaffen.

Seit diesem Manifest, seit der Warschauer Aussenministerkonferenz, seit dem Abschluss verschiedener Handelsabkommen zwischen Polen und der Deutschen Demokratischen Republik und der gegenseitigen Ernennung der diplomatischen Vertretungen hat sich das freundschaftliche Verhältnis zwischen unseren beiden Völkern immer mehr gefestigt.

Mit dem Abkommen zwischen Polen und der Deutschen Demokratischen Republik vom 6. Juli 1950, in dem die Oder-Neisse-Grenze als unantastbare Friedensgrenze zwischen Polen und der Deutschen Demokratischen Republik festgelegt wurde, ist ein seit 700 Jahren bestehender Zustand der Zwietracht beseitigt worden. Das deutsche Volk hat den trügerischen Weg des „Dranges nach dem Osten" verlassen und an der Seite der Sowjet-Union, der volksdemokratischen Länder und der friedliebenden Menschheit der ganzen Welt den Weg des dauerhaften Friedens beschritten.

In der heutigen ausserordentlichen Stadtverordnetenversammlung der Landeshauptstadt Potsdam, am Tage der nationalen Wiedegeburt des demokratischen Polen, versichern die Stadtverordneten, dass sie sich, wo immer es auch sein mag, dafür einsetzen werden, dass dieser Weg des Friedens nie wieder verlassen wird. Nur in enger Verbundenheit und Freundschaft mit dem friedliebenden, demokratischen, nachbarlichen Polen, nur unter Führung des grossen SowjetVolkes in der Weltfriedensfront können die Kriegspläne des anglo-amerikanischen Imperialismus zertrümmert werden.

Friede und Einheit dem deutschen Volke!

Friede und Einheit dem ganzen koreanischen Volke!

Friede und Einheit allen unterdrückten Völkern der Welt! 


\section{(218) Bericht über den „Tag für Frieden und gute Nachbarschaft mit der Volksrepublik Polen“ im Kreis Angermünde. - Angermünde, 24. Juli 1950}

BLHA, Rep. 202 G Amt für Information, Nr. 170, Bl. 90-92. - Typoskript, 3 Bl., vereinzelt handschriftliche Korrekturen, am Schluss handschriftlicher siebenzeiliger Nachtrag Bleistift-Unterschrift des Leiters des Informationsdienstes des Rates des Kreises [gez.] „Spangenberg“ und Stempel des Informationsdienstes. - Gedruckter Kopfbogen „Der Rat des Kreises Angermünde“ (mit Kreiswappen), o.1. Geschäftszeichen „Sp/Le“, o.r. Datierung „Angermünde, den 24.7.1950 / Telefon: Angermünde / Apparat Nr. 623 u. 507 / Zimmer Nr. 34 / - Informationsdienst -“. - Adresse: „An die / Landesregierung Brandenburg / - Amt für Information - / Abt. Informationskontrolle / Potsdam / Hebbelstr. 39“. - Betreff: „Betr. Terminmeldung für den 26.7.1950, Punkt a) Ereignisse bei der Durchführung Analyse des Tages für Frieden und gute Nachbarschaft mit der Volksrepublik Polen.“

Bei nach dem neuen Stand 102 Gemeinden des Kreises Angermünde mit ca. 95000 Einwohnern, nahmen ca. 3700 Einwohner an den Feierlichkeiten der Deutsch-Polnischen Freundschaft teil. Das sind ca. $4 \%$. Davon fallen ca. 2100 auf männliche Teilnehmer, 600 auf weibliche und 800 auf Jugendliche. In 53 Gemeinden des Kreises wurden keine Feierstunden durchgeführt.

Die Referenten wurden in 41 Fällen durch die SED, in 2 Fällen durch die DBD und 2 durch die CDU, 1 Referent der LDP, 1 Referent der FDJ und in 2 Fällen durch Parteilose gestellt.

Als besonders gut gelungene Veranstaltung muss die Versammlung in Angermünde hervorgehoben werden, die vor allem durch die guten Darbietungen der Volkspolizei mit einer Versammlungsteilnehmerzahl von annähernd 500 Personen ihre besondere Note bekam. Abgeschlossen wurde die Veranstaltung durch den Film: „Die letzte Etappe!“

Um so weniger erfreulich waren dafür die an sich gut vorgeplanten Kundgebungen in den Odergemeinden Lunow, Stolzenhagen und Schwedt. Diese Veranstaltungen scheiterten durchweg an dem Benehmen unseres polnischen Nachbarn.

In der Gemeinde Lunow z. B. wurden gegenüber dem polnischen Ort Bellinschen ${ }^{2426}$ [so!] genau wie im Oktober vorigen Jahres Fahnenmaste errichtet, mit der polnischen, deutschen und roten Fahne und die Gesamtbedeutung des Tages durch Transparente unterstrichen. Um 19.00 Uhr marschierte ein Grossteil der Bevölkerung Lunow's und Lüdersdorfs mit Musik zur Oder hinaus. Wie uns Herr K[...] aus Lunow sagt, „mutete es [B1. 91] komisch an, dass sich im Dorf Bellinschen [so!] selbst die Bevölkerung auf den Strassen aufhielt, sich am Rande der Oder nur wenige Personen aufhielten. Ein stärkeres Aufgebot von polnischer Miliz vertrieb bei unserem Eintreffen die Zivilbevölkerung. Die versuchte Verbindung durch den Dolmetscher wurde erst nach längerer Zeit von der Militz [so!] beantwortet, dass heute nichts von Freundschaft bekannt sei und dass man nach Hause gehen solle."

Wie uns ein Teilnehmer aus Lüdersdorf, Herr P[..., ] mitteilt, vertritt man die Meinung, „dass solche Nachbarn nicht zu denken wären und sie würden ein zweites Mal dort nicht mehr hingehen. Wenn wir unter diesen Umständen unsere Bemühungen um die Freundschaft fortsetzen würden, so käme das dann einer Würdelosigkeit gleich.“ 
Ein solcher Standpunkt unserer polnischen Nachbarn gibt natürlich jenen Elementen Recht, die in der Gemeinde Pinnow z. B. kurz nach dem Aushang der Plakate diese wieder entfernte. Erwischt wurde niemand. ${ }^{2427}$

Wie uns vom Inf[ormations-] Dienst Frankfurt/Oder mitgeteilt wird, steht noch der grössere Teil der Bevölkerung auf dem Standpunkt, dass die Oder-Neisse-Grenze keine gerechte Grenze sei. Immer wieder taucht die Frage auf: „Kommen wir wieder zurück in unsere Heimat." Einen Schwerpunkt in der Oder-Neisse-Frage bilden die Eisenbahner, die nach Polen fahren und die immer wieder zum Ausdruck bringen, daß in Polen viele Gebiete brach liegen würden.

Da solche Ereignisse sehr schnell Runde zu machen pflegen, unterstützt sie die Argumentation gewisser Umsiedlerkreise, wie z. B. die des Arbeiters R[... ], 48 Jahre alt, parteilos, „dass es nicht gerechtfertigt sei, dieses Land jenseits der Oder abzutreten, auch die Regierung habe dazu kein Recht gehabt, denn sie sei nur Treuhänderin und könne nicht darüber verfügen, ohne dass ein ordentlicher Friedensvertrag vorhanden sei.“

Erweitert wird diese Auffassung durch den kaufmännischen Angestellten D[...], 38 Jahre alt, parteilos, „dass durch die Deutsch-Polnischen Bestrebungen die Kriegsgefahr noch erhöht werde, da solche Bestrebungen den Hass der andren Völker nur verstärken würde[n].“ (Rias)

Desgl[eichen]. vertritt der Gemüsehändler R[... ] die Auffassung[,] „dass man ja mit den Polen noch nie auf gutem Fusse gestanden hätte, und dass der polnische Nationalhass den Deutschen gegenüber nicht so schnell zu überwinden sei. Man würde ja jetzt noch laufend die Deutschen aus dem polnischen Gebiet hinausjagen." Und man sollte sich doch noch einmal überlegen, ob man nicht die Deutschen, die zurückwollten, zurücklassen sollte.

„Bis jetzt sei es so gewesen, dass die Umsiedler mit ihrem Hab und Gut und mit ihrer Heimat den verlorenen Krieg bezahlt hätten. Im Westen hätte man sie wenigstens etwas entschädigt.“” [B1. 92]

Einen etwas gemässigteren Standpunkt vertrat der erst kürzlich aus der russischen Gefangenschaft zurückgekehrte Arbeiter K[...], 48 Jahre, parteilos, „dass er, als er durch Polen zurückgefahren sei, überall gut bestellte Äcker gesehen hätte, bis auf einen Streifen an der Oder. Aber selbstverständlich müsse auch von seiten des Polen etwas getan werden, um das Freundschaftsverhältnis zu vertiefen.“

Dieselben Schwierigkeiten wie in Lunow traten in der Gemeinde Stolzenhagen auf, wo uns nur lakonisch gemeldet wurde: „Der Pole hat die Kundgebung verhindert.“

In der Gemeinde Schwedt versuchte man am Mittwoch bzw. am Montag [der] vergangenen Woche mit dem polnischen Grenzschutz über eine Veranstaltung ins Benehmen zu kommen.

2427 [Der folgende Absatz steht als handschriftlicher Bleistift-Nachtrag am Ende der letzten Seite (Bl. 92), die vorgesehene Position ist aber durch Einfügungszeichen gekennzeichnet.] 
An beiden Tagen liess man aber die Vertreter der deutschen demokratischen Parteien trotz Verabredung warten, ohne dass überhaupt jemand erschien.

Wie uns Frau $\mathrm{M}[\ldots]$ aus Gellmersdorf berichtet, wurde trotz guter Vorbereitung, Hauswerbung, die Deutsch-Polnische Veranstaltung in der Gemeinde Gellmersdorf ein nur mässiger Erfolg von nur ca. 60 bis 70 Teilnehmern. Da insbesondere unter den Frauen eine sehr grosse Ablehnung vorhanden sei und die „alte Heimat“ das Tagesgespräch wäre.

Die erstgenannte Zahl von 3700 Teilnehmern wird in ihrer Bedeutung auch dadurch geschwächt, da es sich bei ca. $25 \%$ dieser Gemeinden um Deutsch-Polnische Veranstaltungen in Verbindung mit den Schulentlassungsfeiern handelt, die dadurch einen grösseren Prozentsatz Menschen heranholten.

\section{(219) Bericht des Informationsdienstes des Rates des Kreises Cottbus über die Grenzland-Friedenskundgebung in Guben am 10. September 1950. - Cottbus, 11. September 1950}

BLHA, Rep. 202 G Amt für Information, Nr. 170, Bl. 333-334. - Typoskript (Durchschlag), 2 Bl. (3 S.) mit BleistiftUnterschrift [gez.] „Sommer“. Bl.333r o.1. „Fritz Sommer“, r. o. Datierung „Cottbus, d. 11. Sept. 1950/Dresdner Str. 84 a“. - grüne Paraphe „H[?], grün Unterschrift „B ... [?], rot Nr. „5“; blau Verfügung „Auswerten“. - Bl. 335-336: Gedrucktes Veranstaltungsprogramm.

\section{Machtvolles Grenzlandtreffen an der Neisse.}

In der Stadt Guben gestaltete sich der Gedenktag für die Opfer des Faschismus zu einem noch nie dagewesenen Ereignis. Bereits um 10,00 Uhr marschierte die Gubener Bevölkerung mit Kränzen und Blumensträussen, Transparenten in mehreren Demonstrationszügen, geführt von Fahnendelegationen und Musikchören zur Kundgebung auf den Sportplatz Reipo-Platz ${ }^{2428}$. Aus den verschiedensten Städten der Deutschen Demokratischen Republik waren Delegationen zu diesem Grenzlandtreffen gekommen, denen die in voller Stärke einschl. Spielmannszug und Fanfarenzug erschienene Cottbuser Schalmeienkapelle mit alten und neuen Kampfliedern der Arbeiterbewegung vorausspielte.

Leider werden die auswärtigen Freunde trotz der nachherkommenden Begeisterung einen etwas bitteren Geschmack mit nach Hause genommen haben, denn die Bahnhofsbetriebsgruppe hatte völlig daneben geschaltet. Sie hatte den Bahnhof auch nicht im geringsten zu ihrem Empfang vorbereitet, obwohl sie mehrere Tage bereits vorher darauf hingewiesen worden war.

Auf dem Sportplatz Reipo-Platz war eine Rednertribüne mit reichem Fahnenschmuck aller friedliebenden demokratischen Länder rechts und links daneben, vorbereitet. In der Mitte einer im Hintergrund aufgerichteten Wand war eine übergrosse Friedenstaube mit einem goldenen Lorbeerkranz umrahmt, auf schwarz-rot-goldenenm Hintergrund, festlich angebracht. Fast 10000 Friedensfreunde hatten sich zu dieser Kundgebung versammelt. Doch leider veränderte 
sich das nieselnde Wetter zu stärkerem Regenfall, sodass der grösste Teil der zu leicht angezogenen nach Hause gingen. Immerhin waren ca. 3000 Kämpfer für den Frieden zurückgeblieben, deren Ausharren auch ganz besonders belohnt wurde.

Eine polnische Delegation von 60 Wiederstandskämpfern [so!] und jungen Friedenskämpfern war ebenfalls angemeldet, deren Zug aber aus irgend einem Grunde nicht eintraf. Unsere Freunde aus Polen kamen deshalb, was keiner mehr erwartet hatte, zu Fuss über die über die Neisse hinwegführende Eisenbahnbrücke[,] reicht mit bestickten Fahnen, Blumen und kleinen Fähnchen versehen[,] und über ihren Köpfen trugen sie die Bilder von Generalissimus Stalin, Präsident Bierut ${ }^{2429}$ und Präsident Wilhelm Pieck. Ihr Eintreffen wurde von den Versammelten mit ungeheurer Begeisterung begrüsst und von unseren Jüngsten Arm in Arm auf die Tribüne begleitet. Herzlichstes Händeschütteln und ein gegenseitiges Austauschen von Abzeichen und Andenken und dann konnte man auf der Tribüne nicht mehr feststellen[,] wer Pole und wer Deutscher war, man sah nur noch Friedenskämpfer, aus deren Augen Liebe zur Heimat und Hass gegen die Kriegsbrandstifter hervorleuchtete.

In einer zündenden Ansprache übermittelte dann ein Vertreter der polnischen Gewerkschaft die Grüsse der polnischen Freiheits- und Friedenskämpfer. „Unser heutiges Beisammensein an der Friedensgrenze["], so betonte er, ["]ist ein Weg der deutsch-polnischen Freundschaft und Zusammenarbeit, den wir gemeinsam beschritten haben. In den vergangenen Jahr- [Bl.333v] hunderten wurden uns gegenseitige Feindschaft anerzogen. Erst durch den Sieg der Sowjetunion wurde uns die Möglichkeit gegeben, unsere heutige Freundschaft anzubahnen. Die Mitglieder der V.V.N. und die polnischen Freiheitskämpfer in Verbindung mit der FIAPP ${ }^{2430}$ waren besonders dazu berufen, diesen Kampf weiter zu führen. Die damaligen Hitlergenerale unter Führung der USA-Imperialisten schmieden bereits neue Waffen und sie machen garkein Hehl daraus, gegen wen sie diese Waffen schmieden.

Wir aber wollen den Frieden.

Wir besitzen die klare Erkenntnis, dass wirklicher Patriotismus der Weg zur gegenseitigen Achtung und Völkerverständigung ist. Unsere Waffe ist die Arbeit, unser Ziel ist der Wiederaufbau der Dörfer und Städte, die durch den Krieg so schwer gelitten haben. Der Lärm unserer Betrieb[e] und Fabriken wird den Lärm der Kriegshetzer zum Schweigen bringen.

So kämpfen die Mitglieder der VVN und die polnischen Freiheitskämpfer. So kämpfen Menschen, die den Frieden wollen, damit der Menschheit eine bessere und glücklichere Zukunft gesichert ist.

Es lebe die deutsch-polnische Freundschaft!

Es lebe die Freundschft mit der Sowjetunion!

2429 [Bolesław Bierut (1892-1956), 1947-1952 Staatspräsident der Republik Polen.]

$2430[$ FIAPP $=$ Fédération Internationale des Anciens Prisonniers Politiques (gegründet 1947 in Warschau, Sitz in Paris, Generalsekretariat in Warschau.] 
Es lebe die internationale Solidarität!

Es lebe der Weltfriedensfreund Stalin! [“]

Spontan erhob sich nach Beendigung seiner Worte der Beifall. Die polnischen Freunde riefen in Sprüchen die Namen Stalin, Bierut, Wilhelm Pieck und immer wieder: „Stalin, Bierut, Wilhelm Pieck“. Dazwischen wurden die genannten Namen von der Menge im einzelnen freudig aufgerufen. Und endlich wurde auch der letzte mitgerissen, sodass ein einziger Sprechchor von mehreren tausend Köpfen rief: „Stalin, Bierut“, Wilhelm Pieck!“.

Der Kamerad - - - vom Landesverband der VVN antwortete darauf: „Wir versprechen den polnischen Brüdern, alles zu tun, um mit ihnen im gemeinsamen Kampf den Frieden zu erzwingen."

\section{(220) Bericht des Informationsdienstes der Stadt Potsdam an die Abt.}

\section{Informationskontrolle der Landesregierung. - Potsdam, 18. September 1950 (Auszug)}

BLHA, Rep. 202 G Amt für Information, Nr. 162, Bl. 130-134. - Typoskript, 5 Bl., mit Unterschrift. - B1. 130 o.1. „Rat der Landeshauptstadt Potsdam/Information und Presse“, r. o. Datierung und Aktenzeichen: „Potsdam, den 18.9.50 / Schm./Kz“, darunter blauer Buntstiftvermerk „erledigt“ mut Paraphe „G“[?], am linken Rand blauer Buntstift-Verteiler[?] „G.“[?]. - Adresse: „An die/Landesregierung Brandenburg / Amt für Information / Abt. Informationskontrolle / Potsdam / Hebbelstrasse 39“. - Betreff: „Betr.: Analyse der Wahlvorbereitungen im Stadtkreis Potsdam. - Bl. 134 Blaue Buntstiftunterschrift des Informationsdienstmitarbeiters [(masch.:) „I.A.“] [gez.] „Schmückert“. - Diverse redaktionelle Bleistiftänderungen, zweifellos beim Empfänger vorgenommen, im hier abgedruckten Textauszug keine Änderungen. - Die hir abgedruckte Passage findet sich wortgleich auch im Politischen Monatsbericht des Oberbürgermeisters an den Innenminister vom 19. Oktober 1950 (Durchschlag ebd., Bl. 285-314, Zitat B1. 291):

$[\ldots][\mathrm{Bl} .132][\ldots]$

2. Oder-Neiße-Grenze:

Besonders schwierig und wenig erfolgreich ist die Diskussion um die Oder-Neiße-Linie als Friedensgrenze. Im großen gesehen denkt die Bevölkerung jedoch nicht daran, die Oder-NeißeLinie zu einer Frage des Krieges zu machen. Sie ist jedoch vielfach der Meinung, daß auf dem Wege von Verhandlungen eine Änderung geschaffen werden könnte. Aus Umsiedlerkreisen hört man immer wieder: „Auf allen Vieren würde ich rüberkrauchen“ oder „Bei der jetzigen Freundschaft mit Polen müßte es doch möglich sein, daß die Deutschen unter polnischer Regierung wieder in ihre Heimat zurück können“.

$[\ldots]$

\section{(221) Bericht über eine Betriebswahlversammlung im VEB Gubener Schuhfabrik} am 28. September 1950. - Guben, 9. Oktober 1950

BLHA, Rep. 202 G Amt für Information, Nr. 170, Bl. 385-386. - Typoskript (Abschrift), 2 Bl. - Bl. 385: „Abschrift“, 1. o. „Rat der Stadt Guben / Informationsdienst“, r. o.: Datierung „Guben, den 9. Oktober 1950.“ Adresse: „An den Rat des Kreises Cottbus / - Informationsdienst-/Cottbus“. - R. daneben Eingangsstempel „Informationskont- 
rolle / Eing.: 12. Okt. 1950 / Ausg. - / GZ.: -“, Sichtvermerk (Kopierstift) „G[?]“, Verfügung (grüner Buntstift) „z. d. A. / G.“ -Bl. 385 „I. A. / gez. Sicker“ [Informationsdienstleiter in Guben].

\section{Bericht über die am 28. September 1950 im VEB-Betrieb „Gubener Schuhfabrik" stattgefundene Betriebswahlversammlung.}

Anwesend 124 Belegschaftsmitglieder.

Kandidatenvorstellung: Simmack Irene, (SED) Lehrerin[,] aufgestellt vom Kulturbund, Stange, Max, (SED) von der VVN und Karge, Willi, LDP.

Kandidatin Simmack hielt das Kurzreferat über die Gesamtentwicklung seit 1945 und die Bedeutung der Oktoberwahlen. Zum Schluss ihrer Ausführungen rief die Kandidaten [gemeint ist „Kandidatin“] allen zu: „Jeder Wahlberechtigte muss am 15. Oktober 1950 seiner Wahl nachkommen und geben sie unserer Regierung ihr Vertrauen, indem sie die Kandidaten der Einheitsliste der Nationalen Front des Demokratischen Deutschland wählen.“

Kollege Petersilie, SED, bringt seine Freude zum Ausdruck, dass eine Lehrerin in unser Parlament einzieht. Er sagt unter anderem: Ich habe selbst noch einen schulpflichtigen Jungen, und ich glaube, wenn eine Lehrerin in unser Parlament kommt, wird sie sich immer wieder für die Interessen unserer Kinder einsetzen und versuchen, das herauszuholen, was herauszuholen ist. Auf der anderen Seite wird sie aber auch Rechenschaft ablegen müssen über ihre Tätigkeit. Es ist nicht alles glänzend in unserem Schulwesen, wenn irgendeine Lehrerin oder ein Lehrer ausfällt, ist die Vertretung sehr mangelhaft. Die Kinder sind sich fast selbst überlassen. Es ist deshalb angebracht, dass eine Lehrerin im Parlament sitzt, damit die immer wieder an der richtigen Stelle auf diese Uebelstände hinweist, und dadurch Abhilfe geschaffen wird.

Kollege Grosch ging auf die Ausführungen der Kandidaten [„Lernen und nochmals lernen[“] ein. Er sagte, dass die Kinder nicht nur politisch geschult werden sollen, sondern man solle ihnen das beibringen, was sie für das Leben brauchen. Die Kinder würden heute schon wieder politisch verhetzt werden und man würde wenig Rücksicht nehmen, auf die Kinder, die nicht so mitkämen. Lehrer sein, heisst Pädagoge sein. Dass Können und die Veranlagung des Menschen zu erkennen und danach das Kind zuu nehmen und vorwärts zu treiben. Es dürfte nicht passieren, dass das Kind vor dem Lehrer Angst hat, wie es schon wieder der Fall gewesen ist.

Kandidat Karge, Willi, LDP, stellte sich kurz vor und machte auch kurze Ausführungen über die Entwicklung von 1945 bis 1950. [Bl. 385v] Der Kandidat begrüsst auch, dass in der DDR für die Bildung des Volkes ungeheuere Mittel gestellt werden. Da sich niemand über seine Person zur Diskussion meldete, ergriff der Kandidat nochmals das Wort und sagte, es solle sich jeder zu Wort melden, auch wenn einmal etwas verkehrt gesagt wird. Deshalb brauche er keine Angst zu haben, dass er abgeholt werde. Das wäre Quatsch.

Grosch führte aus: „Es wird gesagt, man brauch keine Angst zu haben, abgeholt zu werden. Es ist kein Quatsch. Das beweisen die Vorgänge in letzter Zeit. Man verurteilt die Kriegsvorbereitungen in Westdeutschland, während die Ostsender von früh bis Abend Marschmusik spielen. 
Es ist verboten, von der Oder-Neisse-Linie zu sprechen und wer darüber spricht, ist ein Kriegshetzer. Im Radio der Ostsender spielt man das schöne Lied „In einem kühlen Grunde“. Auf der einen Seite verbietet man von der Heimat zu reden, auf der anderen erinnert man mit diesen Liedern immer wieder daran.

Kandidat Karge betont, dass der Gedanke der Oder-Neisse-Grenze von den Franzosen und dem Amerikaner unterstützt wurde. Er ist nicht von der Sowjetunion gekommen. Wer heute denkt, vom Westen Hilfe zu bekommen, hat verkehrt gedacht.

Kollege Kuppe, SED und BGL-Vorsitzender, führte aus, das[s] es der Amerikaner war, der die Ausweisung der Bevölkerung östlich der Oder-Neisse-Grenze veranlasst und sich dabei aktiv eingeschaltet hat. Die Oder-Neisse-Grenze wurde von allen vier Mächten auf der Konferenz in Jalta und Potsdam festgelegt und anerkannt. Heute stellen sich nun die Westmächte hin, als wenn sie von der Oder-Neisse-Grenze nie etwas gehört hätten. Sie wollen durch diese Methode die Umsiedler gegen die Sowjetunion aufhetzen vor ihren eigenen Kriegswagen spannen. Die Äusserungen des Kollegen Gro[s]ch sind reine Riashetze. Denn er musste doch erkennen, dass die Vorbereitungen der Westmächte auf einen neuen Krieg hinauslaufen. Ob er denn den zweiten Weltkrieg schon wieder vergessen hat, welcher der Welt 50 Millionen Tote und Verwundete gekostet hat.

Grosch erwiederte [so!]: Ich bin nicht für die Westmächte, ich habe auch den 2 . Weltkrieg nicht vergessen. Aber eines muss ich feststellen, dass die Feldwebel, die uns damals vorgeschickt haben, uns auch heute wieder vorschicken wollen. Es gibt Feldwebel, die Berufssoldat waren, und heute im FDGB sitzen. Das Parlament soll die Meinung des Volkes vertreten. Ich glaube, dass diese Abstimmung nicht die Meinung des Volkes bringt. Ich möchte mal feststellen, wer mit der Oder-Neisse-Grenze einverstanden ist. Das ganze Volk ist nicht gefragt worden. Wir haben auch Walter Ulbricht nicht [zu] Verhandlungen nach Warschau geschickt. Ich möchte feststellen, dass unsere Regierung keine legale Regierung ist, sondern eine illegale. Und was man mit der Oder-Neisse-Grenze getan hat, ist Landesverrat. Ich möchte ferner wissen, wir sind ein Volk von 60 Millionen im ganzen gerechnet, davon vielleicht 3 Millionen in der Ostzone, die vielleicht für die Regierung heute stimmen. Ich will weiter betonen, im Westen mögen es 5 Millionen sein, die für die Westmächte sind. Aber den anderen 52 Millionen[,] denen sind die Augen aufgegangen. Damals bei Adolf haben sie uns blind machen wollen, heute wollen sie und wieder blind machen. [Bl.386r]

Kandidat Karge erwiederte [so!], hier wird behauptet, eine Regierung[,] die uns aufgezwungen wird. Das ist Quatsch. 1945 wie der Krieg zu Ende war, kam dieser oder jener ran, der nicht die Interessen des Volkes wahrnahm, sondern auf seine Vorteile bedacht war.

Kollege Kuppe führte betreffs Berufssoldaten aus: Es ist nicht entscheidend[,] was einer früher war. Entscheidend ist, was er heute tut. Arbeitet er mit am Aufbau, oder stellt er sich dagegen.

Kollege Petersilie, Der überwiegende grosse und gewaltige Teil der Volkseigenen Betriebe erfüllt Tag für Tag seine Pflicht. 
Wir sind nicht in die Versammlung gekommen, um uns von einem einzelnen Menschen etwas vormachen zu lassen. Wenn dieser eine Mensch glaubt[,] für uns hier sprechen zu müssen, dann möchte ich ihm sagen, er spricht an der verkehrten Stelle. Wir wollen keine Demokratie nach dem Muster 1918 mit 28 Parteien und letzten Endes wissen wir alle, dass in diesem Parteikampf sich ein Volk zerfleischt und den Weg des Grauens geht. Davon müssen wir vollkommen genug haben und möchte dem lieben Kollegen noch eines zurufen: Wer sich noch heute bereit fühlt[,] für eine Nation einzustellen, die Phosphor auf die Menschen gegossen hat, gehört nicht in unsere Reihen. Das sind Verbrecher und nochmals Verbrecher[,] die nächtlicherweise mit ihren Flugzeugen gekommen sind und Frauen und Kinder getötet haben. Für die trete nicht ein einziges Mal ein.

Kollege Grosch nahm nochmals Stellung und erwiederte [so!] unter anderem: „Ich bin nicht für die Amerikaner, ich habe nur geäussert, wir sollten uns als Deutsche aus dem Schlamassel heraushalten, um nicht wieder zu verbluten. Ich habe im 2Jahrplan meine Pflicht erfüllt. Das dürfte meine Norm beweisen, denn im Wettbewerb stand ich an zweiter Stelle, Ich kann arbeiten, habe gearbeitet und werde noch arbeiten.["]

\section{(222) Bericht über den Auftritt Wilhelm Piecks auf einer Wahlkundgebung in Guben} am 2. Oktober 1950. - Cottbus, 3. Oktober 1950 (Auszug)

BLHA, Rep. 202 G Amt für Information, Nr. 170, Bl. 372-374. - Typoskript mit Unterschrift „Sommer“ (Bl. $374 r), 3$ Bl. - Bl. 372 Kopfbogen „Der Rat des Kreises Cottbus / Informationsdienst / Abt.: - Akt.-Z.: So/Mo“" r. o. Datierung „(2) Cottbus, den 3.10.1950. / Bahnhofstraße 24 / [Fernsprecher und Bankverbindungen]; Adresse: „An die / Landesregierung / Amt für Information / Abt. Informationskontrolle / Potsdam. - R. daneben Eingangsstempel: „Informationskontrolle / Eing.: 5. Okt. 1950 / Ausg. - / GZ.: -“, mittig Verfügung „Z.d. A. und Paraphe „G“[?].

\section{Bericht über den Besuch unseres Staatspräsidenten Wilhelm Pie[c]kzu der Wahlkundgebung} in Guben auf dem Reipoplatz ${ }^{2431}$ am 2.10.1950.

\section{$[\ldots][\mathrm{Bl} .373 \mathrm{v}][\ldots]$}

Dann ging der Präsident noch weiter auf die örtlichen Bestimmungen [gemeint ist sicherlich „Stimmungen“] der Bevölkerung ein. Er sagte: „Ich weiss, dass Euch die polnische Seite unserer Stadt noch sehr am Herzen liegt und sie nicht vergessen könnt. Auch ich wurde dort geboren und erzogen. Denkt aber immer daran, dass das polnische Volk $1 / 3$ seiner Bevölkerung durch den vergangenen Krieg verloren hat. Ihr wisst auch angesichts der Kriegshetze[,] die in Westdeutschland getrieben wird, dass man sich vor einem neuen Übergriff schützen muss. Die OderNeisse-Grenze bietet einen Teil dieses Schutzes. Man wusste aber auch, dass die Aussiedelung [B1. 374r] keine vorübergehende, sondern eine endgültige sein musste. Auf ${ }^{2432}$ das Geschrei in Westdeutschland, die Grenze zwischen Polen und Deutschland zu regeln[,] ist nur dazu angetan, um die Betroffenen in falsche und verlogene Hoffnungen zu halten. Damit will man die sich

2431 [Reichsbahn- und Post-Sportplatz, heute Lok-Sportplatz, Gasstraße.]

2432 [Muss heißen: „Auch“.] 
in Westdeutschland befindlichen Umsiedler in einer dauernden Unruhe belassen. Man lässt sie in den schlechtesten Verhältnissen leben und ihre Verzweiflung soll ausgenutzt werden, um sie als Kanonenfutter für den kommenden Krieg reif zu machen.

Aber Freunde, wir wissen, dass bei uns noch nicht alles in bester Ordnung ist. Aber wir geben uns die grösste Mühe, um unseren Umsiedlern so weit Hilfe zu geben, damit ihnen bewusst wird, dass sie gleichberechtigte Bürger unserer Republik sind.

Unser Verhältnis mit Polen ist im Gegensatz zu früher ein völlig anderes geworden. Polnische Maurer haben unseren Maurern gezeigt, wie man besser und schneller aufbauen kann. Unser Präsident stellte die Frage, ist das nicht besser, als der jahrzehnte alte Hass zwischen beiden Völkern? Hat nicht der Krieg auch unser Gut zerstört und uns zu Feinden gemacht? Der Frieden aber wird alles wieder aufbauen und uns zu weiterer Freundschaft bringen. Wir stellen deshalb die Entscheidung so, dass wir mit allen demokratischen Kräften den Frieden in der Welt mobilisieren. Wir haben durch den Krieg einen Teil unserer Heimat verloren. Wir haben aber die grosse Heimat des Friedens gewonnen.

Dann beleuchtete der Präsident noch einmal in Form einer Gegenüberstellung den Weg, den Westdeutschland eingeschlagen hat und den Weg, der bei uns beschritten worden ist und der von vielen Menschen in Westdeutschland heute bereits als der Richtige erkenntlich geworden ist. $[\ldots]$

\section{(223) Bericht über eine „Umsiedlerversammlung“ in Potsdam-Babelsberg am 5. Oktober 1950. - [Potsdam, Okt. 1950]}

BLHA, Rep. 202 G Amt für Information, Nr. 162, Bl. 217. - Typoskript (Durchschlag mit Unterschrift), 1 Bl. - In blauem Buntstift: Abschreibeverfügung „6 $x^{\prime \prime}$ und Erledigungsvermerk (durchschstrichene Paraphe „G“). - Bl. 217v handschriftlich (blauer Buntstift, keine eigenhändige Unterschrift!) ,gez. Mekas“ [Mitarbeiter der Abt. Informationskontrolle des Rates der Landeshauptstadt Potsdam ${ }^{2433}$ ], darunter masch. „I. A.“ - Vereinzelt Bleistiftunterstreichungen und redaktionelle Korrekturen des Empfängers (in der Edition nicht berücksichtigt). - Überschrift: „Bericht über eine Umsiedlerversammlung in Babelsberg."

Am 5.10.1950 führte der Wahlbezirksausschuss 32 in Babelsberg im Aufklärungslokal ${ }^{244}$ KarlGruhlstr. 55 eine Umsiedlerversammlung durch[,] bei der als Referent Herr Bürgermeister Gerigk, der auch Umsiedler ist, ein sehr beifällig aufgenommenes Referat [hielt].

Die 90 Anwesenden, zum grössten Teil Umsiedler aus den Kreisen Werktätiger, folgten den sehr anschaulich und sehr überzeugend gehaltenen Ausführungen des Referenten mit gespannter Aufmerksamkeit.

2433 [Adressbuch Groß-Potsdam 1949, S. 276: „Mekas, Gerhard, Polizeichef, N(eu)f(a)h(r)l(and). Ringstr. 22“, hier auch Hauseigentümer (ebd., S. 702).]

2434 [Gaststätte Alfred Hiemke (Adressbuch Groß-Potsdam 1947, T. 1, S. 116); heute Restaurant Otto Hiemke (restaurant-ottohiemke.de).] 
Bemerkenswert bei dem Referenten erschienen uns Redewendungen die [so!] wie: „Wir alle hier die christlich gesinnt sind und auch ich, der ich mich zur christlichen Weltanschauung bekenne“, oder „Wir wissen alle, dass der Frieden noch nicht erreicht ist, und das[s] fern von hier[,] aber politisch nahe[,] Blut fliesst und die Menschen dort wahrscheinlich nicht für ihre eigenen Interessen kämpfen. Anmerkun[g]: Meint Herr Gerigk etwa, dass die Nord-Koreaner auch für fremde Interessen kämpfen?

In gewissenmasse [so!] befremdlich muteten auch Aeusserungen Gerigks an wie: „Wenn man sich heute die Verhältnisse in Westberlin ansieht, so muss man feststellen, dass dort der Lebensstandart [so!] erheblich über den [so!] der damaligen Friedenszeit liegt. Übervolle Schaufenster, glänzende Ausstattung der Geschäfte usw; wir in unsere [so!] Republik sind allerdings arm und können das nicht bieten. Das Lebensniveau Westberlins liegt sogar bedeutend höher wir in den grossen Städten Westdeutschlands. Vor kurzem hatte ich einen Pfarrer aus Amsterdamm [so!] bei mir als Gast, der erzählte mir, dass sogar der Lebensstandart in Amsterdamm[,] dieser reichen Stadt[,] mit seinem [so!] riesigen Hafen und seinen grossen Handelsbeziehungen noch unter Westberlin liegt. Aber diese Erscheinungen in Westberlin sind trügerisch und von den Amerikanern künstlich herbei geführt. Anmerkung: Gerigk brachte in diesem Zusammenhang keinerlei Hinweise auf die schuldenfrei[e] Aufbauarbeit in der DDR und die grossen Verbesserungen des Lebens unserer Bevölkerung in den letzten Monaten. usw. Gerigk führte ferner u. a. aus, die Abtretungen [so!] der Ostgebiete ist ein[e] Preisgabe Deutscher Interessen, aber hervorgerufen durch die geschichliche Schuld des deutschen Volkes und der schweren politischen Fehler [Bl. 217v] der Vergangenheit.

Es traten insgesamt 15 Diskussionsredner auf. / Schwerpunkte der Diskussion waren: Wohnungs- und Möbelfragen, sowie Kredithilfe für Umsiedler. / Herr Gerigk liess aller vorgebrachten Beschwerden schriftlich festhalten und versprach jedem einzelnen[,] das[s] dieser bindend [so!] einer Woche von ihm einen Bescheid erhalten werde und nach massgabe [so!] der Möglichkeiten versucht wird Abhilfe zu schaffen.

\section{2 Überwachung von Vertriebenentreffen und Kontakten zu westdeutschen Vertriebenenorganisationen (1947-1953)}

\section{(224) Bericht eines Mitglieds des SED-Ortsverbandes Brieselang über eine kirchliche Vertriebenenversammlung in Berlin-Tempelhof. - Brieselang, 10. März 1947}

BLHA, Rep. 333 SED-Landesleitung Brandenburg, Nr. 574, Bl. 101 (alt 293). - Abschrift (Typoskript). - R. o. Datierung: „Brieselang, den 10.3.1947“, darüber mittig „Abschrift“. - O.1. Adresse: „An die / Kreisleitung der SED / Nauen“. - R. o. Bleistift-Verteiler: „Arb[eit] u. Soziales“. - Mit rotem Buntstift unterstrichen sind der 1., 3. und 4. Satz sowie „Mattern aus Bärwalde“. Der Hauptteil des Berichts von „Sämtliche Umsiedler“ bis „Auge zu werfen“ am linken Rand rot angestrichen und mit großem Ausrufungszeichen versehen.

Ich hatte Gelegenheit, am Sonntag, dem 9. d.Mts., einer Umsiedlerversammlung, die unter kirchlicher Leitung stand, in Tempelhof beizuwohnen. Will kurz den Verlauf der Versammlung 
schildern. / Als Einleitung Kirchengesang und Andacht. Dann sprach Pfarrer Heppner aus Sel$\operatorname{lin}^{2435} \mathrm{zu}$ den Tagesfragen der Umsiedler. Leider trat in seinen Ausführungen der Hass gegen Polen etwas zu stark in den Vordergrund. Sämtliche Umsiedler stimmten dem leider zu. Das ergibt sich auch aus einem Schreiben, das an den Alliierten Kontrollrat gerichtet werden soll. Es wurde allen Anwesenden erklärt, daß sie diesen Brief handschriftlich schicken sollen. In diesem Gesuch steht auch der Satz: [“] ... aus welcher uns die Polen vertrieben haben!["] Es trat dann auch ein Lehrer Mattern aus Bärwalde ${ }^{2436}$ auf, der ebenfalls in diese Kerbe hieb. Ich hatte Gelegenheit, mit verschiedenen Umsiedlern zu sprechen und sagte ihnen, daß es falsch wäre in den Umsiedlern jetzt Illusionen zu wecken, die nicht erfüllt werden können. Denn umso schwerer ist das Erwachen, wenn dem Wunsche nicht Rechnung getragen werden kann. Ich beabsichtige in diesem Schreiben an Euch, sämtliche Ortsgruppen zu veranlassen, auf die Umsiedlertagungen ein wachsames Auge zu werfen. Wir sind gern bereit, jedem Umsiedler mit Rat und Tat zur Seite zu stehen und sie zu unterstützen, wir möchten aber nicht, daß Umsiedler betrogen werden. Es sieht nachher so aus, als wenn sie alles wollen, und nur die Anderen Schuld wären, wenn es misslingt. Ich glaube, daß Ihr dem zustimmt ${ }^{2437}$ und dementsprechende Mitteilung an die anderen Ortsgruppen weiterleitet.

Mit sozialist[ischem]. Gruss!

gez. Laubsch

\section{(225) Informantenbericht über ein Meseritzer Vertriebenentreffen in Berlin-Charlottenburg. - Berlin, 9. August 1948}

BArch, DO 2 Zentralverwaltung für deutsche Umsiedler, Nr. 50, Bl. 512. - Typoskript, Durchschlag. - O.1.: „Abt. II Bü/Reu." [der ZVU]. - R. o.: „Berlin, den 9. August 1948“. - Unterschrift: „gez. Morche“.

Bericht/ über die am 8. August im Studentenhaus Berlin Hardenberg-Straße stattgefundene Versammlung ehemaliger Einwohner aus dem Kreis Meseritz.

Die obige Veranstaltung wurde von einem Dr. Mitschulat ${ }^{2438}$, wohnhaft B[er]1[in].-Mariendorf (ehem. Arzt aus dem Kreise Meseritz) einberufen. Als Zweck wurde angegeben, den ehemaligen Einwohnern des Kreises Meseritz Gelegenheit zu geben, sich in zwangloser Form zu treffen, Gedanken auszutauschen und einen Zusammenhalt nach Art der Landsmannschaften zu propagieren. In der Tat wurde bei der o. a. Veranstaltung weder ein Referat gehalten, noch fand irgendwie eine Begrüßungsansprache statt. Es war während der ganzen Zeit ein ewiges Kommen und Gehen von Menschen, die die Absicht hatten, Bekannte oder Angehörige zu treffen. Aus

2435 [Bei Bärwalde, Kr. Königsberg/Neumark.]

2436 [Kr. Königsberg/Neumark.]

2437 [Am linken Rand in rotem Buntstift, doppelt unterstrichen:] Ja!

2438 [Bisher nicht zu ermitteln. - Zur Arbeit der Meseritzer Heimatkreisbetreuer siehe: Stadt und Kreis Meseritz. [Bd. 1]. O. O. [1972], S. 342 f., sowie Heimatgruß. Zeitschrift für Mitglieder und Freunde des Heimatkreises Meseritz e. V. und der Heimatkreisgemeinschaft Birnbaum 1 (1949) ff.] 
den Gesprächen, die geführt wurden, wurden bestimmte politische Absichten oder sonstige Ziele nicht gehört. / Bei der obigen Zusammenkunft handelt es sich bereits um die 3. Veranstaltung.

gez. Morche

Nachsatz durch Herrn Morche: / Die Besucher dieser Veranstaltung kamen aus allen Teilen der sowjetischen Besatzungszone. Einige Orte, die ich in der Einzeichnungsliste vermerkt fand, wie z. B. Ludwigslust, Nauen, Wernigerode und Eisenach bestätigen diese Tatsache.

\section{(226) Polizeibericht über Verbindungen einzelner Personen zur „Kreisgemeinschaft Angerburg“. - Berlin, 5. März 1950}

BArch, DO 1 Ministerium des Innern der DDR, Nr. 27886, Bl. 88. - Typoskript auf Kopfbogen „Der Präsident der Volkspolizei in Berlin“, Abt. V (Vereine) Tgb.-Nr. 2600/50 / Berlin C 2, den 5. Dezember 1950. / Neue Königstraße 27-37 / [...].“- Adresse: „An das / Ministerium des Innern / Hauptverwaltung Deutsche Volkspolizei / Hauptabteilung VA / Berlin-Niederschönhausen / Seckendorffstr. 31“. - Betreff: „Umsiedlerorganisation (Kreisgemeinschaft Angerburg)“. - Bezug: Schreiben der HVDVP v. 26.9.1950 Az. 138616/50“. - Eingangsstempel VA 3 Tgb.-Nr. 19176, 7.12.[1950], mehrere Paraphen. - Auf Bl. 88v unterzeichnet „Im Auftrage: / [gez.] Peisel[?] / VP.-Kommandeur“.

Die in dem obigen Schreiben in Anlage aufgeführten Anschriften wurden eingehend überprüft. Den in Frage kommenden Personen wurde eröffnet, dass sie jede Verbindung mit dieser westlichen Umsiedlerorganisation zu unterlassen haben. In Fällen[,] wo ihnen Druckstücke zugesandt werden sollten, die von dieser Umsiedlerorganisation stammen, sind diese an die zuständige Verwaltungsdienststelle der Volkspolizei abzuliefern.

Bei der Überprüfung wurde festgestellt, dass 5 Personen von dem Bestehen der Kreisgemeinschaft Angerburg keine Kenntnis hatten. Weiteren 5 Personen wurden hin und wieder Werbeschreiben zugesandt, die sie unbeachtet liessen. Ausserdem sind 6 von den aufgeführten Personen nach Ausserhalb verzogen.

Nur in zwei Fällen konnten Verbindungen zur Kreisgemeinschaft Angerburg festgestellt werden. Es handelt sich um den / Ernst K[...], Berlin-Adlershof, Volkswohlstr. 112. / K. betreibt dort ein Schuhwarengeschäft mit Reparaturwerkstatt. Bei der Überprüfung wurden in seinem Geschäft noch weitere zwei Männer angetroffen die aus Ostpreussen gebürtig sind. Bei den [so!] Volkspolizei-Angehörigen[,] der den K[... ] aufsuchte[,] handelt es sich um einen Mann[,] der auch aus Ostpreussen stammt. Nachdem er seinen DPA2439 gezeigt hatte konnte er mit K[... ins Gespräch kommen. Dieser zeigte ihm eine Zeitschrift der Kreisgemeinschaft, die aus dem Westen stammte. In dem Inhalt wurde zum Ausdruck gebracht, dass bis zum Jahre 1952 alle Ostpreussen wieder in ihrer [so!] Heimat zurückgekehrt sein werden. Auf welche Weise das geschehen soll war jedoch nicht überzeugend dargelegt. Auf die von dem VP-Angehörigen an K[... gerichteten [so!] Frage wo denn der Bund seinen Sitz habe, schrieb K[... die Anschrift 
seiner Schwester / der Frau Gertrud K[...], / (13a) Rothenburg o/Tauber/Untere Schmiedegasse 7 / auf mit dem Hinweis, dass diese die Leiterin des Bundes der Heimatvertriebenen Ostpreussen für Bayern sei. Dort werden auch die Verzeichnisse über die vermissten Personen geführt. Der VP-Angehörige hatte in diesem Zusammenhang den K. nach seinem Onkel gefragt[,] der früher in Gumbinnen wohnte.

Auf die weitere Frage des VP-Angehörigen[,] wo denn der Bund in Groß-Berlin seinen Sitz habe, schrieb K. auf einen Zettel folgende Anschrift auf: / Bund der heimatvertriebenen Ostpreussen / Berlin-Lichterfelde-West, Margaretenstr. 28c / [Bl. 88v]

$\mathrm{K}[\ldots]$ gab noch den Rat bei schriftlichen Anfragen nur die Post des Westsektors zu benutzen, da in der DDR die SMA und die Volkspolizei „sehr hinter die Tätigkeit der Heimattreuen Verbände her sei“.

Ein weiteres Mitglied[,] das aktiv für diese Bewegung tätig ist[,] ist ein gewisser $F[\ldots]$ in BerlinJohannisthal, Almersweg 1, der in ständiger Verbindung mit $\mathrm{K}[\ldots]$ steht. Es konnte festgestellt werden, dass dieser ein sogenanntes Treffen organisieren sollte. Die Zusammenkunft jedoch war im Westsektor geplant. Der F. hat aber davon abgesehen[,] weil die Veranstaltung mit Westgeld hätte finanziert werden müssen. F[... ist gebürtiger Angerburger, gehört zweifellos dieser Organisation an und nimmt an den Veranstaltungen im Westsektor teil. Sonst aber leben er und seine Ehefrau sehr zurückhaltend.

Bei der Überprüfung der in der Anlage aufgeführten Personen konnte festgestellt werden, dass ihre Anschriften aus dem Kirchenbuch oder einem anderen Personalverzeichnis der Stadt Angerburg stammen. Zusammenkünfte, auch solche[,] die nicht angezeigt wurden, konnten bisher im demokratischen Sektor von Gross-Berlin nicht festgestellt werden. Es scheint festzustehen, dass alle Veranstaltungen dieser Organisation in Westberlin stattfinden.

\section{(227) Bericht des Informationsamtes der Stadt Frankfurt (Oder) über ein Trebschener Heimattreffen in Berlin-Nikolassee. - Frankfurt (Oder), 18. April 1950}

BLHA, Rep. 202 G Amt für Information, Nr. 170, Bl. 586. - Typoskript, 1 Bl. - L. o., doppelt unterstrichen, „Informationsamt“. - R. o.: „Frankfurt-Oder, den 18.4.1950“. - Eingangsstempel „Informationsamt / Eing.: 19.4.50. / GZ:“. - Betreff: „Versammlung der Bewohner des Ortes Trebschen-ehemals Odergebiet, jetzt polnisch in Nikolassee." - Unterzeichnet: „I.A. [gez.] Glombeck / (Glombeck) / Leiter des Informationsamtes“. - O. mehrere Bearbeitungsvermerke des Empfängers (Landes-)Amtes für Information: 1. o. (blauer Kopierstift): „10 d“, Mitte (rot): „Eilt / Neigmann / Mitteilung! / [Paraphe:] J.“, r. daneben (Kopierstift): „betr. Schr[ei]b[en] v. 23.3.50“. - Eine (im Bericht nicht angekündigte) Anlage (Bl. 587) bildet ein Exemplar des masch. vervielfältigten „Trebschener Heimatbriefes“ (1 Bl.) des u.g. Frankfurt Pfarrers [Richter], unterzeichnet „Euer Pastor“, datiert „Frankfurt-Oder, im März 1950“, in dem er u. a. auf den geplanten Gottesdienst hinweist. ${ }^{240}$

2440 [Siehe auch oben im Teil 1, Kapitel IV. 3, Abschnitt „Berlin als Bezugspunkt evangelischer Brandenburger“ mit Anm. 1924f.] 
An dem Treffen ${ }^{2441}$ nehmen 2 Familien aus Frankfurt-Oder teil. / Friedrich und Berta $M[\ldots]$, [... (Str. u. Hausnr.)] / Frau Sch [...], [... (Str. u. Hausnr.)] / Pfarrer Richter ${ }^{2442}$, ev., Marienkirchengemeinde Ffo. ${ }^{2433}$ hält die Ansprache in der ev. Kirche Nikolassee.

Im Gasthof der Kirche gegenüber findet dann das gemültliche Beisammensein statt. In Frankfurt-Oder sind keine Familien aus Trebschen ausser den beiden Genannten vorhanden. Vielmehr kommen aus den verschiedensten Orten diese Familien dorthin auch aus dem Westsektor Berlins. Die genannten Familienmitglieder sind im Alter von 45-50 und 54 Jahren. Sie bewohnen Stube und Küche und haben zum Teil schon Wohnungseinrichtungen sich selbst beschafft. $\mathrm{M}[\ldots]$ ist Zimmermann und ist augenblicklich bei dem Oderbrückenbau in Frankfurt-Oder beschäftigt. Sch[...] dagegen liegt augenblicklich im Krankenhaus. Nach Rücksprache mit den Familien wurde festgestellt, daß sie vom Sozialamt Frankfurt-Oder noch in keiner Hinsicht Unterstützung gefunden haben. Es ist ihnen in der Beschaffung ihrer jetzt vorhandenen Möbel keinerlei Zuwendung erteilt worden.

Der Grund der Teilnahme an dieser Zusammenkunft in Nikolassee ist nach Befragung „das Wiedersehen mit den ehemaligen Dorfbewohnern des jetzt polnischen Gebietes“.

Anmerkung des Informationsdienstes ${ }^{2444}$

Es haben bisher drei Zusammenkünfte der ehemaligen Trebschener Einwohner in Nikolassee stattgefunden. Das Treffen beginnt immer mit einem Gottesdienst vormittags um $10.00 \mathrm{Uhr}$.

\section{(228) Polizeibericht über Kontakte von Brandenburgern zum „Heimatwerk für die Katholiken Danzigs und Westpreußens“. - [Berlin], 30. Juni 1950}

BArch, DO 1 Ministerium des Innern der DDR, Nr. 27886, Bl. 45. - Typoskript, Durchschlag. - L. o. nur „VA“, da in der Ausfertigung Kopfbogen (der HV der DV, HA VA des MdI [der DDR], Berlin verwendet wurde). - R. o.: „30. Juni 1950 / 136911/50 / VA 3 - Hü.“ - Adresse: „An die / Landesbehörde der Volkspolizei / Brandenburg - VA 3 - / Potsdam“. - Betreff: „Umsiedlerorganisationen.“- Unterzeichnet „Leiter der Hauptabteilung VA/ [gez.] Lust / Chefinspekteur der Volkspolizei.“ - R. u. Bleistift-Paraphe vom 1.7. - Gleichlautende Schreiben mit den jeweiligen Adressenlisten für in den anderen Ländern ansässige Personen gingen am selben Tag an die zuständigen Landesbehörden der VP. ${ }^{2445}$

2441 [Dahinter handschriftlich eingefügt „23.4.50“, offenkundig vom selben Schreiber wie oben der Hinweis auf die Bezugnahme auf das Schreiben vom 23.3.1950.]

2442 [Hans Richter (geb. 1906 Dessau), 1932-1945 evang. Pfarrer in Trebschen (Kr. Züllichau-Schwiebus), ab 1947 Pfarrer der St. Marienkirche u. Seelsorger am Städt. Krankenhaus Reinmannstraße u. am Gerichtsgefängnis in Frankfurt (Oder) sowie Kreisbeauftragter für Männerarbeit ebd. (Pfarralamanch 1950, S. 236).]

2443 [Frankfurt (Oder).]

2444 [Unterhalb der Unterschrift.]

2445 [Durchschläge: Bl. 46 (Mecklenburg), Bl. 47 (Sachsen-Anhalt), Bl. 48 (Thüringen). Desgleichen bereits am 26.5.1950: Bl. 36 (Sachsen-Anhalt), 37 (Sachsen), 38 (Thüringen), 39 (Mecklenburg).] 
Nach Mitteilung der LBdVP Sachsen wurde in Dresden eine Frau Gertrud Bochmann ${ }^{2446}$ ermittelt ${ }^{2447}$, die in ständiger Verbindung mit einer im Westen bestehenden Umsiedlerorganisation - Heimatwerk der katholischen Umsiedler aus Danzig und Westpreußen - in Menden/ Westfalen steht und laufend Geldbeträge und Pakete an Bewohner der DDR im Auftrage dieser Organisation versendet.

In den bei ihr sichergestellten Unterlagen sind nachstehende Personen aufgeführt, die ihren Wohnsitz im Land Brandenburg haben und Empfänger der von der B. versandten Spenden waren bzw. mit ihr in Verbindung stehen.

[(...) Folgt Liste mit den Namen und den genauen Anschriften von 8 Personen in, Wittenberg/ Elbe $^{2448}$, Brandenburg/Havel, Görzig üb[er] Beeskow, Lychen, Perleberg/Westprignitz, Angermünde, Morwitz ${ }^{2449} \mathrm{~b}$. Velten, Nauen.]

Es ist zu überprüfen, ob die genannten Personen Mitglieder dieser Organsation sind, oder ob sie mit diese in Verbindung stehen. Es besteht die Möglichkeit, daß die Bochmann, nachdem ihr die weitere Tätigkeit für diese Organisation untersagt wurde, andere, mit ihr in Verbindung stehende Personen mit der Weiterführung betraut hat. Aus diesem Grunde sind obige Personen einer laufenden Überwachung zu unterziehen. Sollten bei der von dort durchzuführenden Überprüfung diesbezügliche Feststellungen getroffen werden, so wird um Bericht gebeten.

Die in Frage kommenden Personen sind darauf hinzuweisen, daß die Umsiedlerorganisation eine in der DDR verbotene Organisation ist, da sie durch die von ihr betriebenen Propaganda eine bewußte Hetze gegen die Oder-Neiße-Linie führt und somit die Interessen der Kriegstreiber vertritt.

2446 [Gertrud Bochmann, geb. 2.8.1898 Dresden, ledig, evang.-luth., Graphikerin (selbständige Gebrauchsgraphikerin). Sie selbst gehörte dieser „Umsiedlerorganisation“ nicht an. Deren Leiter war 1950 Dr. Josef Albert (Menden), der vor 1933 als Redakteur der „Sächsischen Volkszeitung“ in Dresden wirkte. Der Kontakt zwischen beiden rührte aus früherer Dresdner Bekanntschaft vor 1933 her („Ich tue es nur Dr. Albert zuliebe, da er uns so sehr gut bekannt ist.") B. beschäftigte ihre Schwester (geb. 1897), ebenfalls Graphikerin, bei ihrer Tätigkeit für A. als Hilfskraft. Der berichtende VP-Hauptmann vermutete, das das Graphiker-Gewerbe beiden „nur als Deckmantel dient und die Bochmanns mehr von der Tätigleit für das Heimatwerk leben" (Bericht des VP-Präsidiums Dresden, VA Referat VA 3, vom 9.5.1950, BArch, DO 1/27886, Bl. 32). In einem der Akte (Bl. 27) beiligenden Exemplar der gedruckten Mitteilungen des Heimatwerk für die Katholiken Danzigs und Westpreußens, 13. Rundschr. (Osternummer), Menden, Kr. Iserlohn, März/April 1950 (16 S.), heißt es im Impressum ausdrücklich (S. 16) „Spenden für die Ostzone: Frl. Gertrud Bochmann, Dresden, Bergstr. 59“. Weitere Druckschriften aus Menden in derselben Akte: Zentrale der Danziger Geistlichkeit. Viertes Rundschreiben, April/Mai 1947 (Bl. 1), Liste der zerstreuten Geistlichkeit der Diözese Danzig, April/Mai 1947 (Bl. 4).]

2447 [BArch, DO 1/27886, Bl. 29-30, 32-35.]

2448 [Gemeint ist Wittenberge/Elbe!]

2449 [Gemeint ist Marwitz!] 


\section{(229) Polizeibericht über ein Crossener Vertriebenentreffen in Berlin-Kreuzberg. -} Berlin, 31. Oktober 1950

BArch DO 1 Ministerium des Innern der DDR, Nr. 27886, B1. 140. - Typoskript auf Kopfbogen „Der Präsident der Volkspolizei in Berlin“ / „Abt. V Ref. 3/1 (Veranstaltungen)“. - R. o.: „Berlin, C 2, den 31. Oktober 1950 / Neue Königstraße 27-32 / [...]“. - Adresse: „An das / Ministerium des Innern / Hauptverwaltung Deutsche Volkspolizei / Hauptabteilung VA - / Berlin-Niederschönhausen / Seckendorffstr. 31“. - Betreff: „Veranstaltung für Heimatvertriebene - Crossener Treffen am 29.10.50 in B[er]1[i] n.-Neuköllnn ${ }^{2450}$, Hasenheide, Kliem’s Festsäle.“ - O. r. Eingangsstempel „VA 3“, „2.11.50 / Tgb.-Nr. 16255“, 2 Paraphen vom 3. und 6.11. und Vermerk „Ablegen“. - Bl. 140v: Unterschrift „Im Auftrage: / [gez.] „Paul“/ „VP-Kommandeur.“

An der Veranstaltung nahmen ca. 450 Personen teil. Es handelte sich meistens um Menschen, die bäuerlicher Arbeit nachgehen und zu ca. $90 \%$ in der DDR wohnen. Ca. 60 \% der Teilnehmer waren Frauen. Die überwiegende Anzahl waren über 40 Jahre alt, nur sehr wenige Jugendliche waren vertreten.

Der Leiter der Veranstaltung behandelte vor allen Dingen die Aufwertung der Uraltkonten. Es war auffällig, daß politische Dinge überhaupt nicht erwähnt wurden. Es muß sich um die erste oder um eine der ersten Zusammenkünfte dieses Kreises handeln. Die Besucher benutzten die Gelegenheit des Wiedersehens, um ihre persönlichen Erlebnisse auszutauschen und beachteten die Worte des Referenten fast gar nicht. Ein Diskussionsredner aus Potsdam erklärte, daß die Crossener, die in Potsdam wohnhaft [Bl. 140v] sind, an derartigen Zusammenkünften wenig Interesse hätten.

Auf der Veranstaltung wurde die „Stimme der Vertriebenen“ verkauft, wovon 1 Exemplar in der Anlage beigefügt ist."2451

\section{(230) Polizeiliche Beobachtung eines ostpreußischen Vertriebenen in der Ostprignitz. - Potsdam, 1. November 1950}

BArch, DO 1 Ministerium des Innern der DDR, Nr. 27886, B1. 81. - Typoskript auf Kopfbogen mit Vordruck, 1. o.: „Landesregierung Brandenburg“, darunter „G[eschäfts]-Z[eichen] [masch.:] Abt. VA, Ref. 3 Ke.“ - R.o. (Datum masch.): (2) Potsdam, den 1.11.50 / Bauhofstraße 11/13 / [...]. - Anschrift: „An die / Hauptverwaltung Deutsche Volkspolizei/Hauptabteilung Verwaltungspolizei/Berlin-Niederschönhausen/Seckendorffstrasse 31“. - Eingangsstempel der VA 3, Tgb.-Nr. 16438, 6.11.[1950], mehrere Paraphen. - Unterzeichnet „I.A. [gez.] Lebek“. - Betreff: „Kreisgemeinschaft Angerburg (Dr. med. Rosenfeld - Ganz Kr. Ostprignitz, Kinderklinik)“. - Bezug: unser Schreiben vom 22.8.50“ [In diesem Schreiben (B1. 78) wurden auf der Basis von Ermittlungen des VPKA Ruppin Druckschriften der „Kreisgemeinschaft Angerburg“ übersandt und mehrere mit dieser in Verbindung stehende Personen („,ehemalige Angerburger") mit Adressen (Neuruppin, Ganz sowie drei Orte in Sachsen-Anhalt) benannt, für die teilweise noch Ermittlungen „geführt“ bzw. (so bei Rosenfeld) „angestellt werden“, über die nach Abschluß eine „Charakteristik“ zugestellt werde.] - U.l. handschriftlicher Vermerk: „Bericht an M.d.I.“

2450 [Richtig wäre Berlin-Kreuzberg, da die Hausnummern 11-15 mit Kliems Festsälen zum Kreuzberger Teil der Straße gehören.]

2451 [BArch, DO 1/27886, Bl. 140. Die Anlage fehlt in der Akte.] 
Nachstehend erhalten Sie eine Charakteristik über Dr. med. Rosenfeld. / Dr. med. Max Rosenfeld ist am 28.8.[18]69 in Petrikau ${ }^{2452}$ [so!] Kreis Labiau geboren. / Sein erlernter Beruf ist Arzt, den er auch ausübt. / Seit dem 3.5. [19]49 wohnt er in Gr[oß] Pankow Kr. Ostprignitz. Er ist dort als leitender Arzt im Kinderkurhaus tätig. ${ }^{2453}$ Er lebt äußerst zurückgezogen vom öffentlichen Leben. In den Wochen vor der Oktober-Wahl zeigte das Kurhaus keinen Hinweis auf die Bedeutung der Wahl und auch keine Losung der Nationalen Front. In der Wahlkampagne sind der Arzt sowie seine Schwestern, es sind alles Diakonissen- und Bibelschwestern, trotz Aufforderung durch den Bürgermeister, nicht ein einziges mal zu einer Wahlversammlung erschienen. / Dies zeigt seine ablehnende Haltung gegenüber der heutigen Gesellschaftsordnung.

Vor längerer Zeit wurde dem Bürgermeister von Gr[oß] Pankow ein Brief ohne Absender zugesandt, der auf größere Mißstände im Krankenhaus hinweist. Daraus wurde entnommen, daß Krankenschwestern im Krankenhaus den Auftrag haben, die dort zu behandelnden Kinder streng religiös zu erziehen. Kirchliche Lieder sind an der Tagesordnung. Schwestern, die nicht damit einverstanden sind, wagen sich nicht zu äußern, da ihnen sonst mit der Entlassung gedroht wird. Dieser Brief wurde der örtlichen Stelle des M.f. S. übergeben.

Der Vater des Dr. R. ist in Angerburg verstorben, seine Mutter lebt jetzt noch in Nordenburg Kr. Angerburg ${ }^{2454}$.

\section{(231) Brandenburgischer Polizeibericht über ein Oststernberger Vertriebenentreffen in Berlin-Oberschöneweide. - Potsdam, 27. November 1950}

BArch DO 1 Ministerium des Innern der DDR, Nr. 27886, Bl. 159. - Typoskript auf Kopfbogen „Landespolizeibehörde / Brandenburg“, „GZ: Abt. VA, Ref. 3 Schm/K3.“- R. o.: „(2) Potsdam, den 27.11.50/Bauhofstraße 11/13 / [...]“. - Adresse: „An die / Hauptverwaltung Deutsche Volkspolizei / Hauptabteilung Verkehrspolizei / Berlin-Niederschönhausen / Seckendorffstrasse 31“. - Betreff: „Umsiedlerorganisation“. - Bezug: „Mitteilung des VPKA Westhavelland vom 16.11.50“. - Unterzeichnet „I.A. / [gez.] „Lebek“. - Eingangsstempel „VA 3“ vom 1.12.50 / „Tgb.Nr. 17824“, 1 Paraphe. - Bl. 160 Der Leiter der HA VA, Chefinspekteur der VP Lust, meldet dies daraufhin unter dem 4.12.1950 an das Präsidium der VP Berlin - V 3 -, erbittet Überprüfung und fordert bis 20.12.1950 Bericht an (Bl. 160). Bericht: Bl. 161 (siehe unten).

Durch Ermittlungen konnte festgestellt werden, daß am 12.11.50 um 15.00 Uhr in der ChristusKirche - Oberschöneweide ein Umsiedlertreffen für die ehemaligen Gebiete von Sta[r]pel ${ }^{2455}$, Burschen $^{2456}$ und Seeren ${ }^{2457}$ stattfand. Einberufer dieses Treffens war G. Lettenbauer, Berlin-

2452 [Irrtümliche Angabe. Gemeint ist „Petricken“.]

2453 [Das sogen. „Kinderkurhaus“ befand sich im Gutshaus, das 1945 zuerst Flüchtlingen als Unterkunft diente, „dann zeitweilig Typhus-Krankenhaus, dann mit Kindern belegt (war), [... . Dann Außenstelle des Kreiskrankenhauses Pritzwalk (freundliche Mitteilung Prof. Dr. Bernhard v. Barsewisch, Groß Pankow, 5.7.2018).]

2454 [Gemeint ist wohl Nordenburg im Kreis Gerdauen.]

2455 [Gemeint ist Starpel [!] (Kr. Züllichau-Schwiebus), unmittelbare Nachbargemeinde von Burschen (Kr. Oststernberg).]

2456 [Burschen (Kr. Oststernberg).]

2457 [Seeren (Kr. Oststernberg).] 
Oberschöneweide, Wilhelm Firlstr. ${ }^{2458} 20$. / Das VPKA Westhavelland bekam erst 2 Tage danach Kenntnis[,] sodaß von dort respektive der LBdVP keine weiteren Maßnahmen entwickelt werden konnten. / In der Anlage wird die Einladung beigefügt. ${ }^{2459}$ / 2 Anlagen.

\section{(232) Berliner Polizeibericht über ein Oststernberger Vertriebenentreffen in Berlin-Oberschöneweide. - Berlin, 30. Dezember 1950}

BArch DO 1 Ministerium des Innern der DDR, Nr. 27886, Bl. 161. - Typoskript auf Kopfbogen „Der Präsident der Volkspolizei in Berlin“, „Abt. V 3/1 (Vereine) Tgb.-Nr. 26.00/50“. - R. o. „Berlin C 2, den 30. Dezember 1950 / Neue Königstraße 27-37 / [...]“. - Adresse: „An das / Ministerium des Innern / Hauptverwaltung Deutsche Volkspolizei / Hauptabt. VA / Berlin-Niederschönhausen / Seckendorffstrasse 31“. - Betreff: „Umsiedlertreffen in Berlin-Oberschöneweide.“ - Bezug: „Dort[iges] Schreiben v. 4.12.50 - Az. 1904/50 - VA 3-Kl./Hü-“. - Unterzeichnet auf Rücks. „Im Auftrage / [gez.] „Paul“ / „VP.-Kommandeur“. - Eingangsstempel „VA 3“ vom 6.1.51 / „Tgb.-Nr. 188“, 3 Paraphen vom 4. und 6.1. - Antwort auf Berichtsanforderung (siehe oben).

Das Umsiedlertreffen für die ehemaligen Gebiete Sta[r]pel, Burschen und Seeren hat am Sonntag, den 12.11 .50 von 13 bis 17 Uhr im Gemeindehaus der Christuskirche in Berlin-Oberschöneweide, Firlstr. 15, stattgefunden. Einberuferin war die Frau Charlotte Kettenbauer ${ }^{2460}$ geb. Brose, geb. 29.1.12 in B [er]1[i] n-Weißensee, Bln-Johannisthal, Waldstr. 31 wohnhaft. Ihr Mann, der im Kriege gefallen ist, war der Pfarrer der Gemeinde Seeren Krs. Zielenzig ${ }^{2461}$. Bis zur Umsiedlung hat Frau K. [korrigiert aus „L.“ (auch im Folgenden)] sein Amt ausgeübt.

Die Zusammenkunft wurde in Form eines Gottesdienstes abgehalten und diente gleichzeitig dem Zweck nach vermißte Einwohner [so!] dieser Gebiete zu ermitteln. Der Frau K., die als Katechantin $^{2462}$ [so!] im Gemeindehaus der Christuskirche beschäftigt ist, wurde untersagt, weitere Umsiedlertreffen durchzu- [Bl.161v] führen. Die örtliche VP.-Dienststelle ist beauftragt worden, darauf zu achten, daß weitere Zusammenkünfte nicht mehr stattfinden. Der Frau K. sind für den Wiederholungsfall polizeiliche Zwangsmaßnahmen angedroht worden.

\section{(233) Polizeibericht über ein Landsberger Vertriebenentreffen bei Havelberg. -}

\section{Potsdam, 1. Juni 1951}

BArch, DO 1 Ministerium des Innern der DDR, Nr. 27887, B1. 37. - Typoskript auf Kopfbogen „Landespolizeibehörde Brandenburg“ / „G[eschäfts]-Z[eichen]: Abt.PM-Ref.2 - Schm/He.“ / (2) Potsdam, den 1.6.1951 / Bauhofstraße 11/13 / [...]“. - Adresse: „An die / Hauptverwaltung Deutsche Volkspolizei / - HA.PM-Ref.2 - / Berlin-Niederschönhausen“. - Betreff: „Umsiedlerorganisation“. - Bezug: „Hies[iges] Schreiben vom 23.5.1951“. - Bl. 37v unterzeichnet „Im Auftrag: / [gez.] Heckrodt / VP.-Oberrat“. - L. daneben: Eingangsstempel VA, 5.6.51, Paraphen. - Auszug gedruckt: Wille III, S. 397.

2458 [Muss heißen: „Firlstr.“ (nicht „Wilhelm-Firl-Str.“)]

2459 [Anlage fehlt.]

2460 [Muss heißen: „Lettenbauer“.]

2461 [Der Kreis hieß Oststernberg, Zielenzig war die Kreisstadt.]

2462 [Muss heißen: „Katechetin“.] 
Im Nachgang zu unserer Meldung vom 23.5.1951 wird der ausführliche Bericht des VPKA Westprignitz zur Kenntnisnahme übermittelt. / Am 20.5.1951 um 13.00 Uhr erhielt der VP.$\mathrm{W}$ [acht]m[eister] Liebsch von dem 3. VP.-Revier Gr[uppen]-Posten Havelberg, durch seine Mutter, welche aus der Nähe von Landsberg stammt, die Mitteilung, dass am 20.5.1951 um 14.00 Uhr in Müggenbusch, ungefähr $2 \mathrm{~km}$ von Havelberg entfernt, eine Zusammenkunft der Landsberger Heimatvertriebenen stattfinden sollte. Der Leiter des Gr.-P. Havelberg setzte sich daraufhin mit der örtlichen Parteileitung der SED in Verbindung, um die Zusammenkunft vom zivilen Sektor überwachen zu lassen. Der eingesetzte Vertrauensmann gab folgenden Bericht:

Ungefähr um 16.00 Uhr bemerkte ich, dass die im Ausflugslokal Müggenbusch im Freien sitzenden Personen die Tische zusammenrückten und sich dadurch der Charakter einer geplanten Zusammenkunft herausstellte. Ich stellte fest, dass ungefähr 22 Personen zusammengekommen waren. Eine Frau, die die Begrüssungsansprache hielt, war als Verantwortliche für die Zusammenkunft anzusprechen. Weiterhin bemerkte ich, dass ein Schreiben DIN A 4 herumgereicht wurde, das alle Teilnehmer der Zusammenkunft unterschrieben. Darüberhinaus stellte ich fest, dass sich unter den Anwesenden ein Parteigenosse aus Havelberg, namens B[...], befand. Daraufhin nahm ich mit dem Parteisekretär aus Havelberg Rücksprache und bat ihn, um nähere Einzelheiten der Zusammenkunft herauszustellen, einmal vorsichtig den B[...] anzusprechen. Dadurch gelang es den Namen der Frau, die die Leitung der Zusammenkunft hatte, zu erfahren. Es handelt sich um Frl. M[...], die Krankenschwester im Krankenhaus der Inneren Mission in Havelberg ist. Nach weiteren Angaben des B. handelte es sich bei obengenanntem Schreiben um eine Unterschriftensammlung für einen Pastor Wegener ${ }^{2463}$ aus Westberlin, dem damit der Dank für die Sorge um die Heimatgemeinde ausgedrückt werden sollte.

Weitere Personen, die uns namentlich bekannt sind und ebenfalls zu dieser Tagung anwesend waren, sind der Bürstenmacher Johannes $\mathrm{M}[\ldots]$ aus Havelberg, der, wie uns bekannt wurde, die Einladungskarten zu dieser Zusammenkunft austrug. Der Landwirt Otto J[... ] aus Havelberg, sowie der ebenfalls in Havelberg ansässige Rentner Otto J[... ]. Bei den dort anwesenden Personen handelt es sich um solche, die aus der Landsberger Gegend (Warthegau) ${ }^{2464}$ beheimatet waren.

Überdem stellte uns die Mutter des VP.-Wm. L[...] eine Zeitschrift zur Verfügung, deren Herausgeber die Landsmannschaft Ost-Brandenburg/Neumark im Berliner Landesverband der Heimatvertriebenen, Berlin SW $11[\mathrm{Bl} .37 \mathrm{v}]$ ist. In dieser Schrift, die stark kirchlichen Ein-

2463 [Georg Wegner (1892-1954), 1929-1945 evang. Pfarrer in Landsberg (Warthe), nach 1945 Pfarrer in BerlinReinickendorf, übernahm 1945 zusammen mit Else Schmaeling den (bald danach von Else und Paul Schmaeling betriebenen) Betreuungsdienst an den Landsberger Heimatvertriebenen (Heimatblatt der ehemaligen Kirchengemeinden Landsberg/Warthe, Stadt und Land 18 (1966), Nr. 7/8, S. 2 mit Bild; Jerzy Zysnarski: Duchowni landsberskich kościolów przed 1945 r. [Die Geistlichen der Landsberger Kirchen bis 1945]. In: Nadwarciański Rocznik Historyczno-Archiwalny 9, 2002, S. 49-77, hier S. 65 f.).]

[Irrige Angabe. Richtig: Neumark (allenfalls „Ostmark“).] 
schlag aufweist, tritt eine eminente Hetze gegen die Oder-Neiße-Grenze, als Friedensgrenze und gegen die SU auf.

Ein Bericht dieses Vorganges und das bekannte Exemplar wurden dem Amt f. Staatssicherheit zur Kenntnis und weiteren Bearbeitung übergeben.

\section{(234) Polizeiberichte über ein Grünberger Vertriebenentreffen in Lübben. - Potsdam, 9. Juni 1951}

BArch, DO 1 Ministerium des Innern der DDR, Nr. 27887, Bl. 39. - Typoskript auf Kopfbogen „Landespolizeibehörde / Brandenburg“, „GZ: Abtl. PM Ref. 2 b -Schm. - / A.z. 070357/3“. R. o.: „(2) Potsdam, den 9. Juni 1951 / Bauhofstraße 11/13 [...]“. - Adresse: „An die / Hauptverwaltung Deutsche Volkspolizei / - Hauptabteilung PM Ref. 2 b / Berlin-Niederschönhausen“. - Betreff: „Umsiedlertreffen in Lübben am 29.7.1951“. - Bezug: „Bericht des VPKA Senftenberg v. 7.6.1951“. - Unterschrift: „I.A. [gez.] Heckrodt“/„VP-Oberrat“. - Eingangsstempel der HVDV „14. JUNI 1951“ und der VA „14.6.51“, 2 Paraphen vom 14. und 18.6., ersterer mit Weiterleitungsvermerk „MdI/ MfSt“. [Eine kurze Meldung über das geplante Treffen ging dementsprechend am 19. Juni 1951 gleichlautend an das MdI, „Herrn Staatssekretär Warnke ${ }^{2465}$, Berlin W 8“, und an das MfS, „Herrn Insp[ektor] Pech, Berlin-Lichtenberg“ (Bl. 40).]

Durch Zusammenarbeit mit der Bevölkerung wurde in Erfahrung gebracht, das [s] am 29.7.1951 in Lübben ob[iges] Treffen stattfindet. Hierzu sollen ca 1000 Umsiedler teilnehmen. / Der Organisator dieses Treffens ist die ev. Kirche. Das Treffen wird in Form eines Gottesdienstes durchgeführt, auf welchem der Pf[arre ]r. Boehm ${ }^{2466}$, welcher ebenfalls Umsiedler ist, spricht. Nach dem Gottesdienst findet ein gemütliches Beisammensein statt. / Weitere Ermittlungen werden noch geführt.

BArch, DO 1 Ministerium des Innern der DDR, Nr. 27887, Bl. 41. - Typoskript auf Kopfbogen „Landespolizeibehörde / Brandenburg“, „GZ: Abtl. PM Ref. 2 b -Schm. - / A.z. 070357/3“ / (2) Potsdam, den 9. Juni 1951 / Bauhofstraße 11/13 [...]“.. - Adresse: „An die / Hauptverwaltung Deutsche Volkspolizei / - Hauptabteilung PM Ref. 2 b / Berlin-Niederschönhausen“. - Betreff: „Treffen der ehem. Bewohner des Krs. Grünberg/Schles, in Lübben“. - Bezug: „Schreiben der LBdVP-Brandenburg vom 9. Juni 1951“. - Unterschrift: „I. A. / [gez.] „Heckrodt“ / „VP.-Oberrat“.Eingangsstempel der HVDV „30. JUNI 1951“ und der VA „2.7.51“ mit 1 Paraphe vom 2.7. - Eine kurze Meldung über das geplante Treffen ging am 19. Juni 1951 gleichlautend an das MdI, „Herrn Staatssekretär Warnke, Berlin W 8“, und an das MfS, „Herrn Insp[ektor] Pech, Berlin-Lichtenberg“ (Bl. 40).

Nach eingehenden Ermittlungen kann zu dem geplanten Treffen der Grünberger im Kreis Lübben folgendes berichtet werden: / Am 29.7.1951 plant die ev. Kirche unter der Leitung des Pfarrers Böhm, ehem. Grünberg, jetzige Anschrift unbekannt, (angeblich Berlin-Straußberg ${ }^{2467}$ ) ein Treffen der Grünberger. / Die Organisation dieses Treffens soll die ev. Kirche inne haben. Die Zusammenkunft der Grünberger bezieht sich auf den Kreis Lübben und auf die umliegenden Anliegerkreise Senftenberg, Spremberg, Cottbus und Frankfurt/Oder. / Geplant ist in dem Tref-

2465 [Johannes Warnke (1896-1984), 1949-1952 Staatssekretär im Ministerium des Innern der DDR.]

2466 [Dr. Friedrich Böhm (1882-1963), ab 1913 evang. Pfarrer in Grünberg in Schlesien, 1927-1945 Superintendent ebd., nach 1945 Superintendent und Krankenhausseelsorger in Strausberg bei Berlin. Vgl. Pfarralmanach 1953, S. 201, 204; Clauss, Buch der Stadt Grünberg in Schlesien (wie Anm. 861), S. 105.]

2467 [Muss heißen: „Strausberg“.] 
fen vormittags ein Gottesdienst und nachmittags ein fröhliches Beisammensein in dem Ausflugslokal „Wendenfürst“ Lübben. ${ }^{2468}$ / Der Inhaber dieses Lokals ist ebenfalls gebürtiger Grünberger und heißt Max Flämming, geb. 29.12.[18]92 in Grünberg/Schles. Er ist Pächter dieses Lokals.

Im Jahre 1950 fand ebenfalls ein Treffen dieser Art unter der Leitung des Pfarrers Böhm in Lübben statt, woran ca. 1000 Personen teilnahmen.

Wir bitten dies zur Kenntnis zu nehmen, weitere Ermittlungen werden noch geführt.

\section{(235) Polizeibericht über die Teilnahme von Neuruppinern an einem Neubentschener Vertriebenentreffen in Berlin. - Potsdam, 18. Juli 1951}

BArch, DO 1 Ministerium des Innern der DDR, Nr. 27887, Bl. 45. - Typoskript (außer Adresse und Dienstgrad des Unterzeichneten Durchschlag) auf Kopfbogen „Landesbehörde der Volkspolizei Brandenburg“, „Abteilung: PM Ref. 2 / Aktenzeichen: 070365/51 Schm/He. / Potsdam, den 18.7.1951 / Bauhofstraße 11-13 / [...].“ - Adresse: „An die / Hauptverwaltung Deutsche Volkspolizei / - HA. PM - Ref. 2 - / Berlin-Niederschönhausen“. - Unterschrift: „Im Auftrage: / [gez.] Heckrodt / VP.-Oberrat“. - Eingangsstempel VA, 23.7.51, Paraphen.

Am 1.7.1951 fand in Berlin-Hermansthal ${ }^{2469}$ ein Umsiedlertreffen statt. ${ }^{2470}$ Hieran nahmen die ehemaligen Bewohner von Neuben[t]schen und Umgebung teil. Die Beteiligung betrug ca 1000 Personen. / Aus Neuruppin nahm der Kutscher Hermann G., geb. 7.2.1901 in Kuschten bei Neuben $[\mathrm{t}]$ schen, wohnhaft Neuruppin, [... ], teil. / Ferner Erich B[...], geb. 6.9.08 in Hoffmannsthal/Meseritz ${ }^{2471}$, wohnhaft in Neuruppin, [...], vom Beruf Friseur. / Das Ministerium f. Staatssicherheit in Neuruppin hat sich vorbehalten, diesen Vorgang selbst weiter zu bearbeiten.

\section{(236) Polizeibericht über brandenburgische Teilnehmer eines Vertriebenentreffens in Berlin-Zehlendorf. - Potsdam, 25. April 1952}

BArch, DO 1 Ministerium des Innern der DDR, Nr. 27887, Bl. 75. - Typoskript auf Kopfbogen „Landesbehörde der Volkspolizei Brandenburg“ „Abteilung: PM - Ref. 2 - / Aktenzeichen: 070928 He." / „Potsdam, den 25.4.1952 / Bauhofstraße 11-13 / [...]“. - Adresse: „An die/Hauptverwaltung Deutsche Volkspolizei/HA.PM-Ref.2-/Berlin W 8“. - Betreff: „Treffen ehem. Umsiedler“. - Bezug: „F[ern-]S[chreiben] des VPKA Seelow vom 22.4.1952“. - Eingangsstempel „Hauptverwaltung / Deutsche Volkspolizei / Eing.: 29. APR. 1952“, Paraphen und Vermerk „Z. d. A.“ - Bl. 75v unterzeichnet „Chef der Volkspolizei / Land Brandenburg / Stellv. op. / [gez.] Kotulan ${ }^{2472}$ / VP.-Inspekteur“.

Lt. Mitteilung des VPKA Seelow wurde am 21.4.1952 von dem VP.-Meister D[... ] im Triebwagen der Kleinbahn Fürstenwalde-Seelow, folgende Feststellung gemacht: / Im Wagen war zwischen einigen Fahrgästen ein Gespräch im Gange[,] aus welchem hervorging, dass sie am Sonnabend,

2468 [Gaststätte „Zum Wendenfürst“ in Lübben-Steinkirchen, Zum Wendenfürst 8; seit 1954 Jugendherberge.]

2469 [Vmtl. verschrieben, wahrscheinlich gemeint: Berlin-Neukölln, richtig jedoch Berlin-Kreuzberg (siehe folgende Anm.)]

2470 [Gemeint ist vmtl. das „Kreistreffen Meseritz“ am 1.7.1951 in Kliems Festsälen in Berlin-Kreuzberg, Hasenheide 15“. Vgl. Vorankündigungen in: Ostbrandenburg-Neumark 2 (1951), Nr. 12, o. S., u. 13, o. S., sowie den Kurzbericht ebd., Nr. 14, o.S. („etwa 1300 bis 1400 Teilnehmer“)]

2471 [Rybojadel (Kr. Meseritz), nach 1933 umbenannt in Hoffmannstal.]

2472 [Rudolf Kotulan (1906-1967), stellv. Chef der VP-Landesbehörde Brandenburg.] 
den 19.4.1952 und Sonntag, den 20.4.1952 an einem Treffen ehemaliger Umsiedler teilgenommen hatten. Dieses Treffen fand in Berlin-Zehlendorf (amerikanischer Sektor) statt. Aus diesem Gespräch ging hervor, dass sie im nächsten Jahr wieder in ihre alte Heimat zurückkehren könnten. Als sie bemerkten, dass ein VP.-Angehöriger im Wagen sass, brachen sie das Gepräch ab.

Bei den Leuten handelt es sich um umgefähr 10 Personen, die teils in Dolgelin und teils in Arensdorf wohnhaft sind. An dem Treffen sollen insgesamt 300 Personen teilgenommen haben. [Bl. $75 \mathrm{v}]$

Von seiten des VPKA Seelow wurde das M.f. S. und die Abt. K verständigt. Darüberhinaus wurden vom VPKA entsprechende Massnahmen getroffen, da die Möglichkeit des Einschleusens von Hetzmaterial besteht.

\section{(237) Polizeibericht über die Beschlagnahmung einer karpatendeutschen Vertriebenen-Flugschrift in Potsdam. - Potsdam, 26. April 1952}

BArch, DO 1 Ministerium des Innern der DDR, Nr. 27887, B1. 77. - Typoskript, Durchschlag. - L. o. „Volkspolizeipräsidium Potsdam / Abteilung PM Ref. 2 b 070914 / Sa/Ba.. - R. o.: „Potsdam, den 26.4.52.“ - Adresse: „An die / Landesbehörde der Volkspolizei / Brandenburg Abt. PM Ref. 2 b / Potsdam / Bauhofstr. 11-13“. - Betreff: „Tätigkeit einer Umsiedlerorganisation“. - Bezug: „ohne“. - Unterschrft: „Leiter des VPP.-Potsdam“ / [gez.] „Tsch“ (Paraphe für „Tschampel“ / „VP.-Kommandeur“ / daneben Gegenzeichnungsparaphe [...][?]. - U.1. „1 Anlage (Broschüre)“.

Durch die Pädagogin L[...], aus der Pädagogischen Fachschule für Heimerzieher in Potsdam, Lindenstr. 29, wurde am 22.4.52 beim Stubendurchgang die anliegende Broschüre ${ }^{2473}$ einer Flüchtlingsorganisation ehemaliger Sudetendeutscher ${ }^{2474}$ gefunden./Die wie sich danach herrausstellte [so!] dem Schüler der o.a. Schule Willi F[... geb. am 9.12.1932, wohnhaft in Stubbendorf, Krs. Grimmen Me[c]klenburg gehörte. Da es sich beim F. um einen aufrechten und fortschrittlichen jungen Menschen handelt, wurde mit F. offen über die Rolle der Art von Organisationen und über die Zweckmässigkeit der herrausgegebenen [so!] Schriften diskutiert, im Laufe der losen Unterhaltung gab F. folgendes an:

In letzten Osterfeiertagen weilte er in Stubbendorf bei seinen Eltern, was er hier wieder feststellen musste war, dass seine Eltern von irgend einer Stelle be[ein]flusst werden, denn sooft F. zu Hause weilte[,] erzählten die Eltern, dass es bald heimgeht und immer sogar mit genauen Daten. F. erwähnte weiter, dass in Mecklenburg vorallem in der Gegend von Schwerin ganze Dörfer von ehemaligen Sudetendeutschen bestehen, die durch irgendwelche Stellen zu Heimweh und Heimat zurückreise [so!] beeinflusst werden. Bezüglich der Organisation sagte F. folgendes: Die Organisationinitiatoren wie auch die Verfasser ${ }^{2475}$ der in der Broschüre vor-

2473 [BArch, DO 1/27887, Bl. 78: Broschüre „Wir aus der Hauerlandgemeinde Deutsch-Litta Kreis Kremnitz“, 24 S. (23 gezählte S.), DIN A 5.]

2474 [Irrtümliche Zuordnung. Tatsächlich handelt es sich um Karpatendeutsche aus der Slowakei.]

2475 [Eine herausgebende Körperschaft wird in der Broschüre nicht genannt, auch kein Druckort. Als Verfasser sind bei ihren jeweiligen Beiträgen angegeben: Franz Linkesch, Josef Engl (Schuldirektor), der in „Perach, im Dezember 1950“ ein Grußwort verfasst hat, sowie Thomas Wenzl („Unser letzter Bürgermeister“).] 
kommenden Artikel rekrutieren aus erzreaktionären und faschistischen Elementen, die F. noch aus seiner Heimat kennt. Die betreffende Organisationen werden nicht nur von den Deutschen ehemaligen „Sudetenländer“[,] die jetzt in Westdeutschland leben[,] ins Leben gerufen. Als Mitglieder fungieren dort auch Tschechen[,] die durch irgendwelche politischen bezw. andere Machenschaften nach ihrer Heimat nicht zurückkönnen.

Die in der anliegenden Broschüre von Seite 8 erwähnten Menschen ${ }^{2476}$ sind ehemalige Sudetendeutsche aus Deutsch-Litta ${ }^{2477}$ [,] an die im Jahre 1950 durch die Organisation eine Broschüre geschickt wurde bezw. weiter geschickt werden. Vermutlich stehen sie mit der schon erwähnten Organisation in Verdindung[,] da viele von der [so!] in der Broschüre erwähnten in der DDR wohnen, wär zu überprüfen in wie weit die Verbindungen von den einzelnen zu der Organisation noch bestehen und welche Tätigkeit sie aufweisen.

Um Kenntnisnahme und weitere Veranlassung wird gebeten.

1 Anlage (Broschüre)

\section{(238) Polizeibericht über das kirchliche Triebeler Vertriebenentreffen in Cottbus}

\section{am 6. Juli 1952. - Cottbus, 6. Juli 1952}

BArch, DO 1 Ministerium des Innern der DDR, Nr. 27887, B1. 80-81. - Typoskript, Durchschlag, 2 S. - 2 Überschriften: „Abschrift!", darunter „Bericht“. - L. o.: „Volkspolizeikreisamt-Cottbus / Abteilung PM 1“. - R. o.: Cottbus, den 6.7.1952“. - Bl. 81 Unterschrift 1.u. „F[ür] d[ie] R[ichtigkeit] d[er] A[bschrift] / [gez.] Beier / VP.-Kommissar", r. u.: „Abteilungsleiter PM / gez. Richter/VP.Oberkommissar“.

Das hier gemeldete Treffen der ehem. Triebela-[Triebeler] Gemeinde ${ }^{2478}$ in Cottbus am 6.7.1952 wurde von der Volkspolizei nicht genehmigt. Den [so!] schriftlichen Bescheid über die Ablehnung der Verantstaltung [so!] wurde dem Oberpfarrer Klahre ${ }^{2479}$ aus Luckau durch die Volkspolizei Luckau am 4.7.1952 gegen Behändigungsschein zugestellt. In der Annahme, daß trotzdem dieses Treffen der ehem. Triebeler-Kirchengemeinde in Cottbus statffinden wird, sind Vorbeugungsmaßnahmen dahingehend getroffen worden, daß einmal mit dem OP-Stab Luckau Rücksprache gehalten wurde, um von dort aus festzustellen, wieviel Personen sich auf die Bahn begeben zwecks Fahrt nach Cottbus. Des weiteren ist das vorgesehene Lokal Lindengarten ${ }^{2480}$ Cottbus verständigt worden, daß die Zusammenkunft in diesem Lokal von der Volkspolizei nicht genehmigt ist. Daraufhin wurden sämtliche bestellten Lebensmittel wieder abbestellt. Weiter er-

2476 [S. 8 bis 24 umfangreiche Liste der „Deutsch-Littaer“, jeweils mit aktuellem Wohnort, aber ohne genaue Anschrift.]

2477 [Deutsch-Litta (slowak. Kopernica) bei Kremnitz im „Hauerland“ (bis 1918 Ungarn, dann Tschechoslowakei, heute Slowakei), bis zur Vertreibung kurz nach 1945 überwiegend deutschsprachiges Dorf.]

2478 [Triebel im ehem. Kr. Sorau, Niederlausitz (poln. Trzebiel).]

2479 [Hans Klahre (1878-1957), 1917-1945 Oberpfarrer in Triebel, 1945-1955 evang. 3. Pfarrer in Luckau. Vgl. Uwe Czubatynski: Notizen zu einem biographischen Lexikon der Prignitz. In: Mitteilungen des Vereins für Geschichte der Prignitz 12 (2012), S. 103-130, hier S. 117.]

2480 [Lokal „Lindengarten“ (ehem. Schützenhaus) in Cottbus-Sandow, Lindenstr. 9.] 
folgte am Sonntag der Einsatz durch alle VP.-Angehörigen der Abteilung PM sowie ein Teil der Kameraden von der Abteilung K. Mit der [so!] Oberpfarrer Klahre selbst wurde am Sonntag früh, bevor der Gottesdienst in der Lutherkirche begann, eine persönliche Rücksprache durch den Leiter des Volkspolizeikreisamtes VP.Oberrat Kockjoy, geführt, in dem der Oberpfarrer Klahre nochmals darauf hingewiesen wurde, daß eine Zusammenkunft im Lokal Lindengarten nicht genehmigt ist und er die Anwesenden in der Kirche nach dem Gottesdienst auffordern möchte, sich anschließend wieder auf die Heimreise zu begeben. Die Trapo hatte außerdem die Aufgabe, festzustellen wieviel Personen und von wo sie mit den Zügen hier in Cottbus eintreffen. Durch Meldung der Trapo konnte festgestellt werden, daß aus verschiedenen Kreisen wie Frankfurt, Luckau, Lübben, Senftenberg u. Spremberg hier zu diesem Treffen ca. 200 bis 250 Personen frühmorgens mit den Zügen eingetroffen sind. Diese Personen begaben sich in kleineren Gruppen zu dem Wichernhaus in Cottbus und anschließend zur Lutherkirche zum Gottesdienst. In der Kirche selbst waren ca. 800 Personen versammelt, davon aber 50\% aus der Cottbuser Einwohnerschaft. Die kirchliche Handlung des Oberpfarrers sprach von Frieden und Einheit. Er sagte, jeder Tri[e]beler hat schweres durchgemacht, und die Heimat verloren, aber auch jeder hat heute wieder eine neue Heimat gefunden. Gott wird den Frieden erhalten, und für die Einheit sein, für den[,] der an Gott glaubt. Am Schluß der Predigt brachte er zum Ausdruck, daß er im Namen des Generalsuperintendanten ${ }^{2481}$ [so!] sagen möchte[,] daß die geplante Zusammenkunft nicht stattfindet. Jeder möge für sich gehen und dann in Frieden und Zufriedenheit mit Gottesliebe $^{2482}$ nach Hause fahren. Nach der Kirche bildeten sich einzelne Gruppen[,] die zum Teil sich zum Bahnhof begaben, und ein anderer Teil sich in den Straßen der Stadt verteilte. Eine geschlossene Zusammenkunft dieser ehemaligen Triebeler in Lokalen konnte nicht festgestellt werden.

Oberpfarrer Klahr[e] aus Luckau ist ein älterer Herr von 73 Jahren und hat die ehemalige Kirchengemeinde Triebel 27 Jahr lang betreut. Er selbst brachte zum Ausdruck, daß er nicht die Absicht habe, in irgend einer Form seiner ehemaligen Gemeinde irgendwelche Gedanken zu wecken, wo das Verlangen zur Rückkehr nach der ehemaligen Heimat wach gerufen wird. Im Gegenteil in seiner Predigt wird er zum Ausdruck bringen, daß sich jeder für den Frieden einsetzen soll und in seiner Heimat sich wohlfühlen soll. Das Treffen der ehemaligen Triebeler wurde von dem Superintendenten Schüler ${ }^{2483}$ aus Cottbus organisiert, der aber zur Zeit nicht anwesend ist.

Die einges[e]tzten VP-Angehörigen der Abteilung PM und K. hatten die Aufgabe, nach dem Gottesdienst festzustellen, in wieweit sich die ehemaligen Triebeler in größerer Anzahl in den Lokalen wieder getroffen haben. [Bl. 81]

2481 [Generalsuperintendent für die Neumark und die Niederlausitz in Cottbus war 1946-1972 Günter Jacob (1906-1993)

2482 [Vmtl. eher „Gottes Liebe“.]

2483 [Paul Schüler (geb. 1910), Superintendent in Cottbus, Pfarrer an der dortigen Lutherkirche, vor 1945 Pfarrer in Treuenbrietzen (selbst nicht zu den Vertriebenen zählend).] 
Bisher wurde von keinem VP.-Angehörigen diesbezüglich etwas gemeldet, sodaß angenommen werden kann, daß der größte Teil bereits die Heimreise z. T. mit Fahrrädern wieder angetreten hat, nur noch ein geringer Teil verschiedentlich Lokale aufgesucht hat um zu Mittag zu essen.

Nachsatz:

Bei der Rücksprache mit dem Oberpfarrer Klahre wurde von ihm bestätigt, daß er sofort nach dem Ablehnungsbescheid durch die VP. alles in die Wege geleitet hat, zur Benachrichtigung der eingeladenen Personen, um sie von dem Nichtstattfinden des Treffens zu unterrichten.

Die im Bericht aufgeführten Kreise wurden durch Fernschreiben des Volkspolizeikreisamtes verständigt, mit dem Hinweis, die Bahnhöfe und Zufahrtsstraßen nach Cottbus zu kontrollieren, um die Herfahrt besonders mit Omnibussen zu verhindern.

\section{(239) Polizeibericht über Maßnahmen zur Kontrolle brandenburgischer Teilnehmer eines Landsberger Vertriebenentreffens in West-Berlin am 28. Dezember 1952. - Frankfurt/Oder, 4. Januar 1953}

BArch, DO 1 Ministerium des Innern der DDR, Nr. 27887, Bl. 87. - Typoskript auf Kopfbogen „Bezirksbehörde der Deutschen Volkspolizei / Frankfurt“/ „Abteilung PM 2 / Aktenzeichen 070921 Schr./Scha. [...]“. - R. o.: „Frankfurt/Oder, den 4. Jan. 1953 (Wilhelm-Pieck-Straße 337“ / [...]“. - Adresse: „An die / Hauptverwaltung Deutsche Volkspolizei / Hauptabteilung PM Ref. 2 / Berlin W 8 / Glinkastr. 35“. - Betreff: „Umsiedlertreffen der ehem. Landsberger.“ - Bezug: „SSD. FS. Nr. 576 der HVDVP vom 16.12.1953“. - Unterzeichnet: „(k) Leiter der Abteilung PM / [gez.] „Passlack“ / „VP-Ob.Komm.“ - Eingangsstempel PM 7.1.53, 2 Paraphen vom 8. und 12.1.

Aufgrund des Fernschreibens ${ }^{2484}$ wurden sofort alle VPKA's angewiesen in Verbindung mit der Abteilung VK, K, S und Trapo entsprechende Maßnahmen zur intensiven Kontrolle und eventuellen Verhinderung der Teilnehmer zu treffen.

Nach erfolgten Einsatzbesprechungen in den Kreisen erfolgte die Festlegung der wichtigsten Kontrollpunkte auf Reichsbahngelände und den Verkehrsstraßen sowie die Einsatzzeiten und Stärken. Durch Absprache mit den Abteilungen Verkehr- der Kreise wurde dafür Sorge getragen, dass keine zusätzlichen Verkehrsmittel zum Einsatz gelangen.

Kontrollen wurden durchgeführt in der Zeit vom 27.12.52 17.00 Uhr schwerpunkt- und strukturmässig bis 29.12.52 19.00 Uhr. Diese Kontrollen zeigten, dass als Schwerpunkte die Kreise Fürstenwalde und Seelow anzusehen waren. Hier konnten etwa 110 Personen festgestellt werden, die ostwärts der Oder-Neiße-Grenze, zum größten Teil in Landsberg geboren wurden und von denen anzunehmen war, dass sie zu diesem Treffen fahren wollten. Sie wurden durch kleinere Beanstandungen zurückgehalten bzw. am rechtzeitigen Eintreffen gehindert.

2484 [Vgl. oben „Bezug“. Das Fernschreiben (BArch, DO 1727887, Bl. 85) informierte über das bevorstehende Treffen und ordnete die im Folgenden bestätigten Maßnahmen an.] 
Bei den Kontrollen der Rückfahrt konnte ein Mitführen von Hetzschriften nicht festgestellt werden. Jedoch war zu verzeichnen, dass in zwei Fällen im S-Bahnzug in Erkner Hetzmaterial gefunden wurde. Dieses Hetzmaterial wurde sofort von der Grenzbereitschaft sichergestellt.

Feststellungen über erfolgte Einladungen zu diesem Treffen konnten nicht getroffen werden. Es konnte jedoch informatorisch ermittelt werden, dass ein gewisser Schm[a] eling ${ }^{2485}$, wohnhaft in Westberlin, ein Initiator dieser Treffen ist. ${ }^{2486} \mathrm{Schm}[\mathrm{a}]$ eling ist ehem. Landsberger, hatte dort ein Zigarrengeschäft und war als großer Nazi bekannt. Er versucht auf diese Art[,] die ehem. Landsberger an sich zu ziehen und gegen die DDR zu hetzen.

[Handschriftlicher Bleistift-Zusatz am linken Rand beim 3. Absatz:] Frankfurt anweisen / d [aß] die Namen der / Landsberger[,] welche / nach Berlin fuhren / dem zuständigen / MfS mitgeteilt / werden.

\section{(240) Polizeibericht über Verbindungen aus Schmergow republikflüchtiger bessarabiendeutscher Bauern zum Vertriebenenverband der Dobrudschadeutschen. - Potsdam, 4. Februar 1953}

BArch, DO 1 Ministerium des Innern der DDR, Nr. 27887, Bl. 91. - Typoskript. - L. o.: „Bezirksbehörde Deutsche Volkspolizei / Potsdam / Abt. PM Ref. 2 b“. - R. o.: „Potsdam, d[en] 4.2.1953.“ - Adresse: „An die / Hauptverwaltung Deutsche Volkspolizei / - Hauptabteilung PM Ref. 2 b - / Berlin“. - Betreff: „Tätigkeit der Umsiedlerorganisation „Dobrucza-Deutsche““ - Bezug: „Bericht des VPKA Potsdam vom 26.1.1953“. - Bl. 91v Unterschrft: „(k) Leiter der Abteilung PM“ / [gez.] „Seifert“/„VP-Rat“. - Eingangsstempel DV „7. FEB. 1953“ und PM „7.2.53“ mit 1 Paraphe sowie Anordnungsvermerk „Bericht“.

Wie das VPKA Potsdam ermitteln konnte, wurden in der Zeit vom 20. bis 26.1.1953 folgende Kleinbauern republikflüchtig: [Folgen drei Namen] / Sämtliche Aufgeführten waren Umsiedler aus dem Gebiet von Bessarabien und der Volksrepublik Rumänien. Bei weiteren durchgeführten Ermittlungen wurde festgestellt, dass o. a. Personen mit dem westdeutschen Umsiedlerverein „Dobrucza-Deutsche“ in Verbindung standen. Weiter wurde festgestellt, dass der Vorstand

2485 [Paul Schmaeling (1893-1966), Bruder der ebenfalls für die Landsberger vertriebenen tätigen Else Schmaeling. Vgl. oben Anm. 1916; Nachrufe auf P. Sch.: Willy Heidenreich: „Der ist in tiefster Seele treu, der die Heimat liebt wie Du." In: Heimatblatt der ehemaligen Kirchengemeinden Landsberg/Warthe, Stadt und Land 18 (1966), Nr. 7/8, S. 1 (mit Bild); Erhard Schendel: Paul Schmaeling +. In: ebd., S. 2 (mit Bild E. und P. Sch.).]

2486 [Es handelt sich im die Weihnachtsfeier des „Heimatkreises Landsberg (Warthe) Stadt und Land“ im Grunewald-Casino in Berlin-Grunewald, Hubertusbader Str. („Beginn 14 Uhr"). Vgl. Ankündigung u. Einladung in: Ostbrandenburg-Neumark (1952), Nr. 24, S. 16 („Die Erwachsenen werden einen Unkostenbeitrag von 20 Pf. West bzw. Ost entrichten.“). Kurzbericht ebd. 4 (1953), Nr. 1/2, S. 7: „Wir sind es gewohnt, daß sich unsere Kreistreffen einer ständig wachsenden Beliebtheit erfreuen, aber trotzdem übertraf der Besuch unserer Weihnachtsfeier unsere kühnsten Erwartungen. Schon in den Vormittagsstunden strömten unsere Landsleute aus Ost und West zum Grunewald-Casino, so daß zur Einlaßzeit schon kein Platz mehr zu haben war. (...) Für die zahlreich erschienenen Kinder des Ostsektors und der Ostzone hatte der Weihnachtsmann noch besondere Überraschungen. (...) Wie die Jüngsten, so wurden auch die Ältesten bedacht, (...). Bei Tanz und Geselligkeit saß man bis in die Nachtstunden zusammen."] 
der NDPD Schmergow ${ }^{2487}$ [,] [Bl. 91v] Herr Knode, der Verbindungsmann zu dieser Organisation war. K. hatte Schriften der Organisation durch die Post empfangen und diese an ihm bekannte Umsiedler aus den angeführten Gebieten weitergegeben.

Der Vorgang wird von der Abteilung K weiterbearbeitet.

\section{$5 \quad$ Aussiedlung Deutscher aus Polen (1950-1965)}

\section{(241) Benachrichtigung der Kreise und Städte wegen Aussiedlung noch in Polen befindlicher deutscher Staatsangehörigen. - Potsdam, 1. Januar 1950}

BArch DO 1 Ministerium des Innern der DDR, Nr. 8207, unfol. - Typoskript, 1 S. - Abschrift (Anlage zum ,abschriftlich Kenntnis von einer Information“ gebenden Schreiben desselben Absenders, Potsdam, 17.3.1950, unterzeichnet „Kuhn“, an das Ministerium des Innern der DDR, „Hauptabt. Staatliche Verwaltung / Abt. Bevölkerungspolitik“ in „Berlin NW 7, Luisenstr. 46“, dort eingegangen 21.3.1950). - O.1. Stempel (mit als Typoskript eingetragenem Geschäftszeichen): „Landesregierung Brandenburg/Der Minister des Innern / Abt. Umsiedler und Heimkehrer / G.Z. 1677/3 - 1“. - Mitte: „Abschrift!“. - Darunter r.: „Potsdam, den 1. Januar 1950“, 1. „An / sämtl. Räte der Kreise und / Städte / Abt. Arbeit und Sozialwesen“. - Betreff: „Umsiedlung von deutschen Staatsangehörigen, die sich noch in Polen befinden, nach Ländern der DDR, und Einzelrückführung aus der CSR, Österreich und anderen Staaten." U.r. Unterschrift (Typoskript) „gez. Kuhn“.

Die Information, die Ihnen hierzu lt. Schreiben der damaligen Deutschen Verwaltung des Innern vom 24.5.49 über unsere Abteilung am 4.6.49 zuging, ist überholt.

Anträge auf Einzelrückführung aus Polen dürfen gegenwärtig nicht mehr gestellt werden, da die Provisorische Regierung der DDR eine Vereinbarung mit der Volksdemokratie Polen getroffen hat, nach der allen deutschen Staatsangehörigen, die noch in der Volksdemokratie Polen leben, 1950 Gelegenheit gegeben wird, nach Deutschland umzusiedeln, unabhängig davon, ob sie im Besitz einer Zuzugsgenehmigung sind oder nicht. Deutsche Staatsangehörige, die im Besitz einer Zuzugsgenehmigung nach den Ländern der Deutschen Demokratischen Republik sind, werden noch im 1. Quartal des Jahres 1950 nach hier umgesiedelt und anschliessend alle weiteren deutschen Staatsangehörigen, darunter auch solche, die ihre Angehörigen in den westlichen Besatzungszonen Deutschlands haben und die über die Länder der DDR zu diesen zureisen können.

Zuzugsgenehmigungen für deutsche Staatsangehörige in Polen sind somit nicht mehr notwendig, da der Zuzug solcher Personen, die sich bei ihrem späteren Eintreffen in den Ländern der DDR als Familienmitglieder wieder vereinigen wollen, ja durch die Anordnung der damaligen DWK vom 15.8.49 geregelt ist. (Zentralverordnungsblatt Teil 1 Nr. 71 vom 26.8.49, Seite 635.)

Vorstehende Regelung gilt auch für deutsche Staatsangehörige, die sich noch im Kaliningrader Gebiet befunden. Einzelrückführungsanträge können erst dann wieder gestellt werden, wenn die Umsiedlung aus den benannten Gebieten als beendet erklärt ist und in denselben noch deutsche Staatsangehörige verblieben sind. 
Für Personen deutscher Staatsangehörigkeit in den weiteren oben aufgeführten Ländern können Zuzugsgenehmigungen im Sinne der Familienzusammenführung gegeben werden, doch muss der Rückführungsantrag von den Interessenten für diese Personen jetzt über das deutsche Aussenministerium Berlin, Luisenstr. 56 gestellt werden.

\section{(242) Summarische Branchenstatistik der aus Polen in den Bezirk Cottbus ausgesiedelten Arbeitskräfte. - Cottbus, 12. August 1965}

BArch, DO 1 Ministerium des Innern der DDR, Nr. 14659, unfol. - Typoskript, 1 S. - Kopfbogen „Rat des Bezirkes Cottbus / [Typoskript:] Innere Angelegenheiten“ / 75 Cottbus, Neumarkt 5 / [...] Unser Zeichen 801102 / 75 Cottbus / 12.8.1965“. - Adresse: „Ministerium des Innern / Innere Angelegenheiten / zentrale Arbeitsgruppe / 108 Berlin 8 / Mauerstr. 29/32“. - [Betreff:] „Übersiedlung aus der VR Polen in die DDR“. - U.r. eigenhändige Unterschrift „Kaiser“ / „stellv. Abteilungsleiter“. - O.r. Eingangsstempel „13. Aug. 1965“ und handschriftliche Vermerke „8362 [...]“.

Zur Information und Auswertung teile ich Ihnen mit, daß von 1000 dem Bezirk Cottbus avisierten Übersiedlern bisher eingereist sind:

$\begin{array}{lcc}\text { Männer } & 53 \\ \text { Frauen } & 52 & \text { insgesamt: 178 Bürger } \\ \text { Kinder } & 73 & \text { äber die Zuführung von Arbeitskräften: } \\ \text { Aufschlüsselung ü } & \\ \text { Braunkohle } & 39 \\ \text { Energie } & 8 \\ \text { Chemie } & 3 \\ \text { Landwirtschaft } & 7 \\ \text { sonst. Berufe } & 31 \text { (Bauindustrie, örtl. Versorgungsbetriebe usw.) }\end{array}$

Insgesamt: 88 Arbeitskräfte

\section{(243) Vorbereitung der Familienzusammenführung für eine deutsche Familie aus dem polnischen Teil Ostpreußens. - Frankfurt (Oder), 17. Dezember 1965.}

BArch, DO 1 Ministerium des Innern der DDR, Nr. 14660, unfol. - Typoskript, 1 S. mit Anlage in zweifacher Ausfertigung (je 1 S.) - Kopfbogen „Rat des Bezirkes Frankfurt (Oder) / Land Brandenburg / Abteilung: [Typoskript: ] Innere Angelegenheiten / [...] / 12 Frankfurt (Oder), den 17.12.1965/Wilhelm-Pieck-Str. 3/4/ [...]." - Adresse: „Ministerium des Innern / Abt. Innere Angelegenheiten / Arbeitsgruppe I / 108 Berlin / Mauerstr. 29/32“. - [Betreff: ] „Übersiedlung aus der VR Polen in die DDR“. - U. eigenhändige Unterschrift „Schmidt / Abteilungsleiter“. - Eingangsstempel „21. Dez. 1965“ und handschiftlicher Vermerk [...].

Beiliegend übersenden wir Ihnen die Durchschriften einer Einladung, die dem Antragsteller / Sch [...], Helmut / über die Abt. Innere Angelegenheiten beim Rat des Kreises Bernau zugeschickt wurde. / Der Schwager des Herrn Schi., Herr B[...] Schönerlinde hatte sich um eine Einladung für seine Angehörigen bemüht und diese am 1.9.1965 erhalten. / Der Vorsitzende der LPG „Vereinte Kraft“ in Schönerlinde, Dr. Nau[,] befürwortete die Einreise, da die Betref- 
fenden Arbeit und Wohnung dort erhalten werden. / Herr Schi. hat sich jetzt schriftlich an die Abt. Innere Angelegenheiten beim Rat des Kreises mit der Bitte gewendet, diese Einladung zu bestätigen, da diese Forderung vom Konsulat in Gdansk erhoben wird. / Pm 67 b ${ }^{2488}$ liegen für diese Familie nicht vor.

Anlagen: [...] [Schreiben des Rates der Gemeinde Schönerlinde Kreis Bernau vom 30.11.1965 an den in Polen (Wojewodschaft Olsztyn) lebenden Antragsteller: sechs Monate gültige Einladung „zur Vorlage bei den zuständigen Behörden der Volksrepublik Polen“ für vier namentlich genannte Personen der Geburtsjahrgänge 1935, 1935, 1963 und 1965 mit der Bestätigung, „daß nach Genehmigung durch die zuständigen polnischen Behörden“ für diese „entsprechender Wohnraum sowie Arbeitsmöglichkeiten im Schönerlinde Kreis Bernau LPG „Vereinte Kraft“ zur Verfügung gestellt werden." ]

\section{(244) Bericht des Rates des Bezirkes Cottbus über Eintreffen und Weiterleitung von Aussiedlern aus Polen. - Cottbus, 31. Dezember 1965}

BArch, DO 1 Ministerium des Innern der DDR, Nr. 14659, unfol. - Typoskript, 2 S. - Kopfbogen „Rat des Bezirkes Cottbus / [Typoskript:] Innere Angelegenheiten“/ 75 Cottbus, Neumarkt 5/ [...] Unser Zeichen 801102 / 75 Cottbus / 31.12.1965“. - Adresse: „Ministerium des Innern/Innere Angelegenheiten/Arbeitsgruppe I/ 108 Berlin 8 / Mauerstr. 29/32“. - Betreff: „Übersiedlung aus der VR Polen in die DDR“. - S. 2 u. eigenhändige Unterschrift „Kaiser“ / „komm. Abteilungsleiter“. - S. 1 o. r. Eingangsstempel „4. Jan. 1966 / 34/66“ und handschriftlicher Vermerk „Für Bericht“.

Nachstehend geben wir Ihnen eine Aufstellung der Bürger, die über das $\mathrm{BH}^{2489}$ Koblenz eingereist sind:

[Folgt Tabelle mit 30 Namen und Vornamen, Personenzahl - insgesamt 117 Personen - Datum des Eintreffens im BH (unterschiedliche Daten zwischen 13.11.1964 und 30.12.1965), Datum der Weiterleitung (Unterschiedliche Daten zwischen 4.1. und 30.12.1965).]

Erklärungen:

1. Die Unterbringung der Ende des Jahres 1964 im Bezirksheim ${ }^{2490}$ eingetroffenen Familien war sehr schwierig. Einige Familien konnten sofort über die VVB Braunkohle arbeitsund wohnungsmäßig aufgenommen werden, so daß bei den verbliebenen Familien die Forderung auftrat, nur eine Neubauwohnung haben zu wollen. Durch persönliche Aussprachen konnte dieses Problem gelöst werden.

2. Frau $\mathrm{P}[\ldots]$ und Frau B $[\ldots]$ (lfd. Nr. 13 u. 23) haben im Bezirksheim entbunden, so daß die Weiterleitung verzögert wurde.

2488 [Nr. des Formular-Vordrucks für Anträge auf Einreise in die DDR.]

2489 [Bezirksheim.]

2490 [Hier: Bezirksheim Cottbus!] 
3. Die Familien $\mathrm{K}[\ldots]$ und $\mathrm{P}[\ldots]$ halten sich noch im Bezirksheim auf. Familie $\mathrm{K}[\ldots]$ war für das Kraftwerk Vetschau vorgesehen, jedoch sind die Wohnungen noch nicht fertig. Herr K. hat es bisher abgelehnt, im Kombinat Schwarze Pumpe, bei sofortiger Zuweisung einer Neubauwohnung, Arbeit aufzunehmen, Die Angelegenheit wird Anfang Januar 1966 geklärt.

Familie $\mathrm{P}[\ldots]$ (Ehemann nicht einsatzfähig wegen Krankheit) hat eine 21/2-ZimmerWohnung in Peitz abgelehnt, will durchaus in eine größere Stadt. Die arbeits- und wohnungsmäßige Unterbringung über einen Schwerpunktbetrieb ist nicht möglich, deshalb erfolgt am 3.1.66 die Unterbringung in Merzdorf Kreis Cottbus.

4. Einige Familien wie $\mathrm{Ch}[\ldots], \mathrm{Th}[\ldots], \mathrm{M}[\ldots]$ hätten nicht erst im Bezirksheim einreisen brauchen, da die Werke und Kreise die Aufnahme vorbereitet hatten.

Es kann eingeschätzt werden, daß große Anstrengungen unternommen werden, um eine schnelle Weiterleitung aus dem Bezirksheim zu veranlassen. In einigen Fällen wurde die Weiterleitung der Familien hinausgezögert, weil das Umzugsgut noch nicht eingetroffen war und die Kreise nicht in jedem Fall das Notwendigste in die Wohnungen stellen können. Das Verbleiben im Bezirksheim erfolgte dann im Einvernehmen mit den Bürgern.

\section{Vertriebenenverbände nach 1990 (1991-2018)}

\subsection{Satzungen (1991-2018)}

(245) Satzung des BdV-Landesverbandes Brandenburg. - Potsdam, 12. März 1991 (Auszug)

BdV-Landesgeschäftsstelle, Ordner Satzung/Geschäftsordnung, unfol. - Typoskript (Fotokopie), 9 Bl. - Bl. 1 Überschrift: „SATZUNG / Bund der Vertriebenen Landesverband Brandenburg e. V.“ - Undatiert. Bl. 9 heißt es jedoch im \ 15 Inkrafttreten: „Diese Satzung tritt mit der Eintragung in das Vereinsregister in Kraft." Darunter Vermerk des Registergerichts Kreisgericht Potsdam (mit Unterschrift u. Stempel): „Obige Satzung wurde am 12.3.91 ins [so!] Vereinsregister des Kreisgerichts Potsdam-Stadt unter 32 VR 401 registriert.“

[Bl. 1] [...]

\section{\$2 / Zweck und Ziele}

1. Der Landesverband ist überparteilich und überkonfessionell.

2. Auf der Grundlage der Charta der deutschen Heimatvertriebenen vom 5. August 1950 und des Grundgesetztes der Bundesrepublik Deutschland vom 23. Mai 1949 setzt sich der Landesverband für die Verwirklichung des Selbstbestimmungsrechtes der Völker, für das Recht auf die Heimat, ihre Wiedergewinnung und für die staatliche Einheit Deutschlands ein.

3. Der Landesverband vertritt die Belange der ihrer Heimat beraubten Deutschen gegenüber Behörden, kommunalen Körperschaften und der Öffentlichkeit in allen Angelegen- 
heiten, die mit der Vertreibung bzw. Aussiedlung aus der Heimat und der Wegnahme ihres Eigentums zusammenhängen, und nimmt ihre Interessen im Rahmen des $₫ 95$ BVFG (Bundesvertriebenengesetz) wahr. [B1.2]

4. Der Landesverband will, entsprechend des $\$ 96$ BVFG, dazu beitragen, das Kulturgut der Vertreibungsgebiete zu pflegen und zu erhalten, die Kenntnisse über diese Gebiete zu vertiefen und zu verbreiten, sowie die Verbindung mit den in der Heimat verbliebenen Landsleuten aufrechtzuerhalten.

\section{\$3 / Mitgliedschaft}

Mitglieder des Verbandes können alle natürlichen oder juristischen Personen werden, die sich zu dieser Satzung bekennen. / Alle Mitglieder des BdV-Landesverbandes, die bestimmten Vertreibungsgebieten entstammen, bilden innerhalb des Landesverbandes Landsmannschaften, die ihre eigenen Vorstände wählen und sich am Beitragsaufkommen beteiligen ( $\$ 5$ Ziff. 3), bilden. Das gleiche gilt für diejenigen Mitglieder des BdV-Landesverbandes, die - ohne entsprechende Abstammung - einer bestimmten Landsmannschaft anzugehören wünschen. / $\$ 4[\ldots]$

\section{(246) Erklärung des BdV-Landesvorstandes Brandenburg zur Satzung des Landesverbandes. - Potsdam, 11. September 1993}

BdV-Landesgeschäftsstelle, Ordner Satzung/Geschäftsordnung, unfol. - Typoskript (Fotokopie), 2 Bl. - Kopfbogen „BdV [Logo] Bund der Vertriebenen / [Landeswappen Brandenburg] Vereinigte Landsmannschaften und Landesverbände“, darunter 1.: „Landesverband Brandenburg e.V., r.: Heinrich-Mann-Allee 103 / Haus 16/14473 Potsdam / Tel.: [...]“. - Überschrift: „Erklärung des Landesvorstandes des BdV-Brandenburg zur Satzung des Landesverbandes“. - S. 2 am Textende datiert „Potsdam, den 11. September 1993“, darunter [gez.] Reinhard Stober / (Reinhard Stober) / Landesvorsitzender im Auftrage des Landesvorstandes“.

Der Vorstand des BdV-Brandenburg wurde am 18. Februar 93 auf der Landesversammlung des BdV-Brandenburg gewählt. / Er stellte fest, daß die Satzung des Landesverbandes nicht mehr aktuell ist und überarbeitet werden muß. Auf der erweiterten Vorstandssitzung am 11. September 93 wurde eine Kommission gebildet und beauftragt eine neue Satzung bis zum 15. Oktober 93 auszuarbeiten, die dann den Kreisvorsitzenden zugeleitet wird, damit sie von den Kreisvorständen diskutiert werden kann, um dann auf der Landesversammlung am 30. Oktober 93 in Potsdam angenommen zu werden.

Bei der Neufassung der Satzung muß zum Ausdruckkommen, daß die Satzung auf der Charta der Vertriebenen fußt, in der auf Rache und Vergeltung verzichtet wird. Formulierungen wie „... das Recht auf Heimat und ihre Wiedergewinnung“, dürfen so nicht in der Satzung stehen bleiben. / Wir wollen auf keinen Fall mit irreführenden Formulierungen zur Verunsicherung unserer Nachbarn beitragen und uns selbst in die Nähe von rechten und rechtsextremen Gruppen stellen lassen.

Aus diesem Grunde stellen wir fest: / Aus der geographischen Nähe zu Polen und der langen Grenze Brandenburgs zu Polen tragen die Vertriebenen in Brandenburg eine ganz besondere Verantwortung für eine Verständigung mit unseren Nachbarn. / Den Menschen, die heute in 
den Vertreibungsgebieten leben, muß die Angst vor einer neuen Vertreibung durch Deutsche genommen werden, in dem wir erklären: Wir wollen keine Vertreibung der dort lebenden Menschen.

Dies bedeutet jedoch nicht, daß wir, die Vertriebenen[,] zulassen, daß aus Unrecht Recht wird. / Nach der Haager Landkriegsordnung war die Vertreibung der Deutschen aus der angestammten Heimat ein Verbrechen. / Die entschädigungslose Enteignung des gesamten Besitzes der Vertriebenen macht sie zu den Verlierern des zweiten Weltkrieges. / Wir werden das Unrecht der Vertreibung und die Wegnahme unseres Eigentums nicht hinnehmen. [Bl. 2] Die Duldung der Vertreibung durch die damaligen Siegermächte ist in der Welt Beispiel für andere Vertreibungen mit den diese begleitenden Verbrechen geworden. Aus der Satzung muß ersichtlich werden, daß wir, der BdV-Landesverband Brandenburg[,] einen Ausgleich anstrebt, der beiden Seiten gerecht wird - den Vertriebenen und den heute in den Vertreibungsgebieten lebenden Menschen.

Wir fordern von der Landesregierung, daß sie bei der Bundesregierung Verträge einfordert, die diesen Forderungen der Vertriebenen Rechnung trägt [so!].

\section{(247) Satzung des BdV-Landesverbandes Brandenburg. - Berlin, 24. Juni 1995} (Auszug)

BdV-Landesgeschäftsstelle, Ordner Satzung/Geschäftsordnung, unfol. - PC-Ausdruck (Fotokopie), 9 Bl. - Bl. 1 Überschrift: „Satzung“. - Bl. 9 u. datiert „Berlin, ,Deutschlandhaus', den 24. Juni 1994“. Auf vorgeheftetem Beiblatt: „Neue Satzung u. Protokoll heute hier bei Amtsgericht Potsdam Handelsregister [!] hinterlegt. / VR 401 / [gez.] Leitzmann“, darunter Stempel des Amtsgerichts Potsdam, Nebenstelle Register, o. r. Eingangsstempel derselben Nebenstelle vom „06. Juli 1995“.

[Bl. 1] [...]

\section{$\$ 2 /$ Zweck}

1. Der Landesverband ist Mitglied des Bundes der Vertriebenen - Vereinigte Landsmannschaften und Landesverbände - e. V.: dessen Satzung er als für sich verbindlich anerkennt.

2. Der Zweck des Landesverbandes ist die Vertretung der ihm angeschlossenen Kreisverbände und der Landsmannschaften des Bundes der Vertriebenen bei der Erfüllung ihrer gemeinsamen Aufgaben.

3. Auf der Grundlage der Charta der deutschen Heimatvertriebenen vom 5. August 1950 und des Grundgesetztes der Bundesrepublik Deutschland vom 23. Mai 1949 setzt sich der Landesverband für die Verwirklichung des Selbstbestimmungsrechts der Völker, für das Recht auf die Heimat und die Wahrung der Rechte am Eigentum in der Heimat, für die Wahrung der nationalen und staatlichen staatlichen Einheit Deutschlands in einem freien und geeinten Europa, für die Erhaltung des Volkstums der Deutschen im Ausland und für die gesellschaftliche Integration der deutschen Aussiedler ein.

4. Er ist überparteilich und überkonfessionell. 
5. Der Landesverband hat die aus ihrer Heimat vertriebenen Deutschen sozial und wirtschaftlich zu fördern und ihre Anliegen gegenüber Regierung, gesetzgebenden Körperschaften und der Öffentlichkeit in allen Angelegenheiten zu vertreten, die mit der Vertreibung aus der Heimat und der Wegnahme ihres Eigentums zusammenhängen. Der Landesverband [Bl. 2] fördert die Bestrebungen der Mitglieder, das heimatliche Kulturgut zu erhalten, die Kenntnisse von Heimatgebieten zu vertiefen und zu verbreiten sowie die Verbindung mit den in der Heimat verbliebenen und den in anderen Ländern und Gebieten aufgenommenen Landsleuten aufrechtzuerhalten. / $\$ 3[\ldots]$

\section{(248) Satzung des BdV-Landesverbandes Brandenburg. - [Potsdam], 18. Juli 2008 (und 26. Mai 2018) (Auszug)}

BdV-Landesgeschäftsstelle, Ordner Satzung/Geschäftsordnung, unfol. - PC-Ausdruck, 7 Bl. - Bl. 1 Kopfbogen „BdV Bund der Vertriebenen / Vereinigte Kreisverbände und Landesgruppen der Landsmannschaften“; Überschrift: „Satzung / des Bundes der Vertriebenen - Landesverband Brandenburg e. V.“ - Bl. 7 u.: „Die Satzung wurde in der Landesversammlung am 18.07.2008 beschlossen.“ - Hinweis: Die abgedruckten Passagen sind in der 2018 gültigen Version der Satzung unverändert enthalten. Diese enthält lediglich eine Änderung vom 26.5.2018 zu dem bis dahin allgemein gehaltenen $\ 14$ Pkt. 5 (Vermögensübergang bei Auflösung), der nun als Empfänger des Vermögens das „Haus der Brandenburgisch-Preußischen Geschichte/Brandenburgische Gesellschaft für Kultur und Geschichte gemeinnützige GmbH, Schloßstraße 12, 14467 Potsdam“ benennt (Fassung vom 26.5.2018, S. 7).

[Bl. 1] [...]

\section{$\$ 2 /$ Zweck und Ziele}

Der Landesverband ist die Interessenvertretung seiner Mitglieder bei folgenden Aufgaben und Zielen:

1. Auf der Grundlage der Charta der deutschen Heimatvertriebenen vom 5. August 1950 und des Grundgesetztes der Bundesrepublik Deutschland setzt sich der Landesverband für die Verwirklichung des Selbstbestimmungsrechtes der Völker, für das Recht auf die Heimat und die Wahrung der Rechte am Eigentum der Heimat, für die Wahrung dieser Rechte in einem freien und geeinten Europa, für die Erhaltung des Volkstums der Deutschen im Ausland und für die gesellschaftliche Integration der deutschen Aussiedler ein. / Der Landesverband verfolgt insbesondere:

a) Verwirklichung einer gerechten Völker- und Staatenordnung, in der die Menschenrechte, das Recht auf Heimat und das Selbstbestimmungsrecht der Völker und Volksgruppen gewahrt werden und insbesondere Vertreibungen, Völkermord, völkerrechtswidrige Enteignungen sowie Diskriminierungen weltweit gebannt werden, und dort, wo sie erfolgten, im Rahmen der Möglichkeiten geheilt werden.

b) Fürsorge für deutsche Vertriebene, Aussiedler, Spätaussiedler und ihre Nachkommen.

c) Erhaltung und Entfaltung des kulturellen und wissenschaftlichen Erbes der Heimat. 
2. Der Landesverband verwirklicht diese Zwecke und Ziele durch:

a) Vertretung der Anliegen des genannten und betroffenen Personenkreises gegenüber Regierungen und Ämtern, gesetzgebenden Organen und der Öffentlichkeit.

b) Beratung, Betreuung und Unterstützung des genannten und betroffenen Personenkreises einschließlich von Zugewanderten/Migranten, um ihre gesellschaftliche und wirtschaftliche Eingliederung zu erleichtern,

c) Pflege, Förderung und Weiterentwicklung des kulturellen Erbes der Heimat als Teil der deutschen und europäischen Kultur, Vermittlung von Kenntnissen über das historische Ostdeutschland, die deutschen Siedlungsgebiete in Ost-, Ostmittelund Südosteuropa uns deren Geschichte. [B1.2]

d) Unterstützung und Zusammenarbeit mit den in der alten Heimat verbliebenen Deutschen und deren Nachkommen.

e) Förderung der Völkerverständigung durch partnerschaftliche Beziehungen zu der Bevölkerung unserer östlichen Nachbarstaaten auf der Basis von Wahrheit und Recht.

3. Er ist überparteilich und überkonfessionell. / $\$ 3[\ldots]$

(249) Satzung des BdV-Kreisverbandes Brandenburg/Havel. Brandenburg, 22. Oktober 1991 (Auszug)

BdV-Landesgeschäftsstelle, Aktengruppe BdV-Organisation, 07 KV Brandenburg, unfol. - Typoskript (Fotokopie), 6 S. - Satzungstext undatiert, aber S. 6: „\$ 13 Inkrafttreten / Diese Satzung tritt mit der Eintragung in das Vereinsregister in Kraft." S. 6 u. nachträglicher Vermerk des Kreisgerichts Brandenburg über Eintragung in das Vereinsregister, datiert „Brandenburg, den 22.10.1991“. - Außentitel und S. 1: „SATZUNG / Bund der Vertriebenen Kreisverband Brandenburg/Havel“. - Inhalt: 13 Paragraphen, vollständig abgedruckt werden hier nur $\$ 2$ und 3.

$[$ S. 1] $[\ldots]$

Zweck und Ziele

1. Der Verband ist überparteilich und überkonfessionell.

2. Auf der Grundlage der Charta der deutschen Heimatvertriebenen vom 5. August 1950 und des Grundgesetzes der Bundesrepublik vom 23. Mai 1949 setzt sich der Verband für die Verwirklichung des Selbstbestimmungsrechtes der Völker und für das Recht auf Heimat ein.

3. Der Verband vertritt die Belange der ihrer Heimat beraubten Deutschen gegenüber Behörden, kommunalen Körperschaften und der Öffentlichkeit in allen Angelegenheiten, die mit der Vertreibung bzw. Aussiedlung aus der Heimat und der Wegnahme ihres Ei- 
gentums zusammenhängen, und nimmt ihre Interessen im Rahmen des $\$ 95$ des BVFG (Bundesvertriebenengesetzes) wahr. [S. 2]

4. Der Verband will, entsprechend $\$ 96$ BVFG, dazu beitragen, das Kulturgut der Vertreibungsgebiete zu pflegen und zu erhalten, die Kenntnisse über diese Gebiete zu vertiefen und zu verbreiten, sowie die Verbindung mit den in der Heimat verbliebenen Landsleuten aufrechtzuerhalten.

\section{$\$ 3$}

\section{Mitgliedschaft}

Mitglieder des Verbandes können alle natürlichen oder juristischen Personen werden, die sich zu dieser Satzung bekennen. Alle Mitglieder des Verbandes, die bestimmten Vertreibungsgebieten entstammen, können innerhalb des Verbandes Landsmannschaften, die ihre eigenen Vorstände wählen und sich am Beitragsaufkommen beteiligen, ( $\$ 5$ Ziff. 3), bilden. Das gleiche gilt für diejenigen Mitglieder des Verbandes, die - ohne entsprechende Abstammung - einer bestimmten Landsmannschaft anzugehören wünschen. / $\ 4[\ldots]$

\section{(250) Satzung des BdV-Kreisverbandes Lübben/Luckau. - Lübben, 24. April 1993 (Auszug)}

BdV-Landesgeschäftsstelle, Aktengruppe BdV-Organisation, 24 KV Lübben/Luckau, unfol. - Druck, 7 S. DIN A 5. - Undatiert [Satzung 24.4.1993 errichtet]. Die Datierung ergibt sich u. a. aus der in derselben Akte (als Fotokopie enthaltenen) textidentischen Typoskript-Fassung, datiert „Lübben, d[en] 24.4.1993“, die dem Registergericht (Amtsgericht Lübben, VR 179) eingereicht worden war (Eintragung 18.4.1994). - Außentitel: „BdV / Satzung des Kreisverbandes Lübben/Luckau e. V. - des Bundes der Vertriebenen / Kreisverband Lübben/Luckau“, darunter Wappen mit dem brandenburgischen Adler. - Inhalt: 16 Paragraphen, vollständig abgedruckt wird hier nur $\$ 3$, der, ohne diese Überschrift zu benutzen, Zweck und Ziele nennt.

$[\mathrm{S} .3][\ldots]$

\section{$\$ 2$}

1. Der Kreisverband ist überparteilich und überkonfessionell.

2. Der Kreisverband vertritt die Belange der Vertriebenen gegenüber Behörden, kommunalen Körperschaften und der Öffentlichkeit in allen Angelegenheiten, die mit dem Verlust der Heimat in Zusammenhang stehen.

3. Der Kreisverband will das heimatliche Kulturgut erhalten, die Kenntnisse von den Vertreibungsgebieten vertiefen sowie die Verbindung mit den in den Vertreibungsgebieten verbliebenenen Landsleuten aufrechterhalten.

4. Mitglieder des Kreisverbandes können, die später im Kreisgebiet Lübben und Luckau eventuell bestehenden Ortsverbände des Bundes der Vertriebenen sein. / \$ 3 [...] 


\section{(251) Satzung des BdV-Kreisverbandes Eberswalde, Bad Freienwalde, Bernau. - Eberswalde, 19. April 1997 (Auszüge)}

BdV-Landesgeschäftsstelle, Aktengruppe BdV-Organisation, 10 KV Eberswalde, unfol. - PC-Ausdruck (Fotokopie), 8 S. - S. 1 Titel: „Satzung / des / Bundes der Vertriebenen / Kreisverband Eberswalde, Bad Freienwalde, Bernau“.S. 8 u.1. datiert „Eberswalde, den 19.04.1997“, darunter sieben eigenhändige Unterschriften, an erster Stelle die der Vorsitzenden [Martha-Maria] Schulz; am unteren Blattrand nachträglicher masch. Vermerk „Diese Satzung wurde am 19.04.1997 von der Delegiertenversammlung beschlossen.“ - S. 1 oben nachträglicher Vermerk des Registergerichts Amtsgericht Eberswalde über die Eintragung der Satzungsänderung (VR 404) am 7.8.1997. - Die Satzung enthält 17 Paragraphen. Weggelassen wurden hier aus dem $\$ 2$ die rein formal-organisatorischen und finanztechnischen Festlegungen (Sätze 5, 7 und 8).

$[$ S. 1] [...]

\section{$\$ 2$ \\ Zweck und Ziele}

(1) Der Kreisverband ist eine rechtlich selbständige Untergliederung des Bundes der Vertriebenen e. V. - Landesverband Brandenburg -, Heinrich-Mann-Allee 103, Haus 16, 14473 Potsdam, mit eigener Rechtspersönlichkeit. Er ist gleichzeitig Mitglied des Bundes der Vertriebenen e. V. - Landesverband Brandenburg - und ist für sein Gebiet Träger der Tradition des Bundes der Vertriebenen für Vereinigte Landsmannschaften und Landesverbände, Godesberger Allee 72/74, in Bonn.

(2) Auf der Grundlage der Charta der Deutschen Vertriebenen vom 05.08.1950, der Berliner Erklärung des Bundes der Vertriebenen vom Juni 1992 und des Grundgesetzes der Bundesrepublik Deutschland vom 23.05.1949 setzt sich der Kreisverband für die Verwirklichung des Selbstbestimmungsrechts der Völker, für das RECHT AUF HEIMAT und für VÖLKERVERSTÄNDIGUNG ein.

(3) Der Kreisverband will die Belange der Heimatvertriebenen in der Öffentlichkeit, gegenüber Behörden und kommunalen sowie sonstigen Körperschaften in allen Angelegenheiten vertreten, die mit der Vertreibung bzw. Aussiedlung und der Wegnahme ihres Eigentums zusammenhängen, ebenso mit der Wahrnehmung ihrer kulturellen Belange, und nimmt ihre Interessen wahr.

(4) Der Kreisverband will dazu beitragen, das Kulturgut (Sitten und Gebräuche) der ehemaligen Ostgebiete zu pflegen und zu erhalten, die Kenntnisse über diese Gebiete zu vertiefen und zu verbreiten sowie die Verbindung mit den in der Heimat verbliebenen Landsleuten und der dort lebenden Bevölkerung für gemeinsame Interessen auf allen Gebieten im Sinne gutnachbarschaftlicher Beziehungen zu gewinnen und zu unterstützen.

Des weiteren tritt er ein für die:

- Aufarbeitung der werte hinsichtlich von Kunst und Literatur, Sprachschatz und Tradition,

- Förderung der Kultur- u. Sprachpflege in den entsprechenden landsmannschaftlichen Verbänden, [S. 2] 
- $\quad$ Klärung von Rechtsansprüchen auf ehemaligen Wert und durch den Krieg aufgebürdeten Lasten,

- $\quad$ Unterstützung deutscher Minderheiten in den jeweiligen Heimatgebieten,

- $\quad$ Aussiedlerbetreuung u.a.m.

(5) $[\ldots]$

$\int 3$

Mitgliedschaft, Vereinsbeitritt

(1) Mitglied des Vereins kann jede natürliche Person werden, die ihre Hauptwohnung im Vereinsgebiet hat [...]. In Einzelfällen können darüber hinaus auch natürliche Personen Mitglieder werden, die ihren Sitz außerhalb des Vereinsgebietes haben, wenn Anknüpfungspunkte zum Vereinsgebiet bestehen. [...]

\section{(252) Satzung des BdV-Kreisverbandes Amt Rüdersdorf und Umgebung. -}

\section{[Rüdersdorf], 5. Februar 2000 (Auszüge)}

BdV-Landesgeschäftsstelle, Aktengruppe BdV-Organisation, 15.2 KV Rüdersdorf, unfol. - Typoskript (Durchschlag), 4 Bl. - Bl. 1 Titel: „SATZUNG / des Kreisverbandes Amt-Rüdersdorf und Umgebung“. - Bl. 4 enthält am Ende (ohne Unterschriften) die Namen der fünf Vorstandsmitglieder: „1. Herr Reinhold Bujok (Vorsitzender) / [... ]“, darunter steht „Beschluß der Mitgliederversammlung vom 05. Februar 2000“. - Die Satzung umfasst 10 Paragraphen.

$[$ S. 1] $[\ldots]$

\section{$\int 1$}

1. Der Bund der Vertriebenen Kreisverband Amt-Rüdersdorf und Umgebung, hat seinen Sitz in Rüdersdorf.

2. Er ist Mitglied des Bundes der Vertriebenen im Land Brandenburg e. V. und erkennt dessen Satzung als verbindlich an.

3. Der Kreisverband setzt sich zur Aufgabe, die Vertriebenen im Amt-Rüdersdorf und Umgebung zusammenzuschließen mit dem Ziel:

- der inneren Einheit Deutschlands zu dienen,

- das Recht auf die Heimat in Europa und auf der Welt als natürliches Menschenrecht zu vertreten und zu schützen,

- die Kenntnisse des historischen Siedlungsraumes der ehemaligen deutschen Ostgebiete entsprechend \$ 96 BVFG in Deutschland durch regelmäßige Informationsveranstaltungen $\mathrm{zu}$ verbreiten und gemeinsame kulturelle Aktionstaten, auch mit polnischen Kultureinrichtungen durchzuführen,

- die Geschichte der Vertreibung im Bewußtstein der Menschen aufrecht zu erhalten, 
- $\quad$ im Sinne Charta der deutschen Heimatvertriebenen von 1950 ein neues Kapitel deutsch-polnischer, deutsch-tschechischer Nachbarschaft zu beginnen,

- die sozialpolitischen Interessen der Heimatvertriebenen zu vertreten,

- $\quad$ sie in Rechts-, Steuer- und Wirtschaftsfragen gemäß \$95 BVFG unentgeltlich zu beraten und ihre Gleichstellung einzufordern.

\section{$\$ 2$}

Der Kreisverband ist überparteilich, überkonfessionell. und nicht auf wirtschaftlichen Gewinn aus. $[\ldots]$

\section{\3 Mitgliedschaft}

1. Mitglied kann jeder Deutsche werden. Die Mitgliedschaft wird durch die Annahme der schriftlichen Beitrittserklärung durch den Kreisverband erworben. / [...]

\section{(253) Satzung des BdV-Kreisverbandes Oder-Spree. - Fürstenwalde, 10. Februar 2000}

\section{(Auszüge)}

BdV-Landesgeschäftsstelle, Aktengruppe Kreisverbände, 15.1 KV Fürstenwalde, unfol. - PC-Ausdruck (Fotokopie), 4 Bl. - Bl. 1 Titel: „SATZUNG / des Kreisverbandes Oder-Spree des Bundes der Vertriebenen“. - Bl. 4 enthält am Ende die Datierung „Fürstenwalde, am 10. Februar 2000“, darunter den Satz „Die Charta der deutschen Heimatvertriebenen von 1950 und $§ 95$ BVFG sind integraler Bestandteil dieser Satzung und der Satzung als Anlage beigefügt.“ [Anlagen fehlen jedoch in dieser Akte], darunter (alles als Fotokopie) eigenhändige Unterschrift „Herm. Schmück / Vors.“, darunter „Beschluß der Mitgliederversammlung vom 10. Februar 2000“. - Der Text ist, abgesehen von geringfügigen redaktionellen Unterschieden, mit dem der Satzung des Kreisverbandes Amt Rüdersdorf identisch (s. o.), unterscheidet sich aber in dem dort fehlenden sechsten Unterpunkt des 3. Satzes („Rückkehr- und Aussiedlerrecht“).

$[$ S. 1] $[\ldots]$

$\int 1$

1. Der Bund der Vertriebenen Kreisverband Oder-Spree hat seinen Sitz in Fürstenwalde.

2. Er ist Mitglied des Bundes der Vertriebenen im Land Brandenburg e. V. und erkennt dessen Satzung als verbindlich an.

3. Der Kreisverband setzt sich zur Aufgabe, die Vertriebenen im Landkreis Oder-Spree zusammen zu schließen mit dem Ziel:

- der inneren Einheit Deutschlands zu dienen,

- $\quad$ das Recht auf die Heimat in Europa und auf der Welt als natürliches Menschenrecht zu vertreten und zu schützen,

- $\quad$ die Kenntnisse des historischen Siedlungsraumes der ehemaligen deutschen Ostgebiete entsprechend $\$ 96$ BVFG in Deutschland durch regelmäßige Informationsveranstaltungen zu verbreiten und gemeinsame kulturelle Aktionstaten, auch mit polnischen Kultureinrichtungen durchzuführen, 
- die Geschichte der Vertreibung im Bewußtstein der Menschen aufrecht zu erhalten,

- $\quad$ im Sinne Charta der deutschen Heimatvertriebenen von 1950 ein neues Kapitel deutsch-polnischer, deutsch-tschechischer Nachbarschaft zu beginnen,

- $\quad$ ein Rückkehr- und Aussiedlerrecht Deutscher in den Vertreibungsgebieten mit dazugehörigen Volksgruppen in Selbstverwaltung entsprechend europäischer Normen zu erreichen,

- die sozialpolitischen Interessen der Heimatvertriebenen zu vertreten,

- $\quad$ sie in Rechts-, Steuer- und Wirtschaftsfragen gemäß \$95 BVFG unentgeltlich zu beraten und ihre Gleichstellung einzufordern.

Der Kreisverband ist überparteilich, überkonfessionell und nicht auf wirtschaftlichen Gewinn aus. Er ist selbstlos tätig, er verfolgt nicht in erster Linie eigenwirtschaftliche Zwecke. Der Verein ist beim Amtsgericht Fürstenwalde eingetragen. / $\$ 2[\ldots]$

\section{\$3 / Mitgliedschaft}

1. Mitglied kann jeder Deutsche werden. Die Mitgliedschaft wird durch die Annahme der schriftlichen Beitrittserklärung durch den Kreisverband erworben. / [...]

\section{(254) Satzung des BdV-Kreisverbandes Potsdam-Mittelmark mit der Kreisgruppe Ostpreußen/Westpreußen in Brandenburg a. d. Havel. - Brandenburg a.d. H., 16. Juli 2000 (Auszug)}

BdV-Landesgeschäftsstelle, Aktengruppe BdV-Organisation, 7.1 KV Potsdam-Mittelmark, unfol. - PC-Ausdruck (Fotokopie), [4] S. - Satzungstext undatiert, aber S. [3]: „\$9 Inkrafttreten / Diese Satzung tritt mit der Eintragung ins Vereinsregister in Kraft." S. [4] beigegeben: Protokoll (Fotokopie) der „Fortgesetzte(n) Gründungsversammlung mit Satzungsänderung [...] vom 16. Juli 2000 in Brandenburg a. d. H.“ sowie Vermerk „Eintragung in das Vereinsregister ist am 16.08.2000 unter VR 741 erfolgt.“ - S. [1] u. [2] Überschrift „Satzung/Bund der Vertriebenen - Kreisverband Potsdam-Mittelmark/mit der Kreisgruppe Ostpreußen/Westpreußen in / Brandenburg a. d. Havel“.

$[\mathrm{S} .2][\ldots]$

\section{§ 1 Name, Sitz und Zweck}

1. Der Verein heißt „Bund der Vertriebenen (BdV), Kreisverband Potsdam-Mittelmark mit der Kreisgruppe Ostpreußen/Westpreußen in Brandenburg a.d. Havel“.

2. Der Verein ist Mitglied des Bundes der Vertriebenen - Vereinigte Landsmannschaften und Landesverbände e.V. Die landsmannschaftlichen Gruppen sind Mitglied der Landesgruppen e. V. im Land Brandenburg.

3. Zweck des Vereins ist die Förderung der Heimatpflege und Völkerverständigung, der Wissenschaft und Forschung, der Bildung und Erziehung zur Erhaltung der Kultur und Geschichte der ostdeutschen Vertreibungsgebiete als Teil des deutschen und europäischen Erbes. Auf der Grundlage der Charta der Vertriebenen vom 05. August 1950 und 
der Beschlüsse der UNO und Europaparlament setzt sich der Verein für die Interessen der ihrer Heimat beraubten Familien vor Behörden und in der Öffentlichkeit ein.

4. Der Satzungszweck wird verwirklicht durch kulturelle Veranstaltungen, thematische Beratungen, Studienfahrten, Materialsammlungen und Kontakte mit in der Heimat verbliebenen Deutschen und den jetzt dort lebenden Völkern, grenzüberschreitende Begegnungen und Zusammenarbeit mit hiesigen Körperschaften und Behörden. Der Verein verfolgt ausschließlich und unmittelbar selbstlose gemeinnützige Zwecke im Sinne von „Steuerbegünstigte Zwecke“ (\$\$ 51-68 AO). / \$ 2 ([...]

\subsection{Protokolle, Berichte und Reden (1992-2011)}

\section{(255) Protokoll der Vertriebenenversammlung des Kreises Finsterwalde} am 21. März 1992. - Finsterwalde, 21. März 1992 (Auszug)

BdV-Landesgeschäftsstelle, Ordner Protokolle 1991-1994, unfol. - Typoskript (Fotokopie), 2 Bl. - L. o. angeheftet Stempel „Erich Töppel / Eichenstraße 9 / O-7980 Finsterwalde“. - R. o. datiert „Finsterwalde, d[en] 21.3.92." - S. 2 unterzeichnet „Protokollant / [gez.] Töppel“.

Protokoll / zur Versammlung der Heimatvertriebenen des Kreises Finsterwalde in der Gaststätte Lindenhof Finsterwalde am 21.3.92

Versammlungsort: Saal der Gaststätte / Beginn: 13.10 Uhr / Ende: 16.00 Uhr / Teilnehmer: geschätzt ca. 400 Personen / Gäste: Frau Kühn-Berger ${ }^{2491}$, Vorsitzende des Landesverbandes Brandenburg / Herr Greschan ${ }^{2492}$, Geschäftsführer des Landesverbandes Brandenburg

Von Herrn Töppel, Organisator der Veranstaltung, wurde Zusammenkunft eröffnet. Es erfolgte die Vorstellung der Gäste vom Landesverband Brandenburg. Nach einführenden Darlegungen über Grund und Anliegen der Veranstaltung wurden die Gäste, die bereits vordem per Post Anfragen an verschiedene Instanzen und Adressen gerichtet hatten[,] darauf hingewiesen, daß ihre Briefe hier beantwortet werden. Eine Zusammenstellung der wesentlichsten Inhalte der Briefe wurden [so!] von Herrn Töppel an den Geschäftsführer Herrn Greschan übergeben. Frau Kühn-Berger ergriff nun das Wort und machte grundsätzliche Ausführungen zu folgenden Themen:

- $\quad$ Standpunkt zum Vertriebenenproblem der neuen Bundesländer

- $\quad$ Strukturelle Fragen - Begründung zur Ablehnung eines Zusammenschlusses mit dem BdV Berlin.

- Grundsätzliche Forderungen der Vertriebenen der ehem. DDR

- $\quad$ Entschädigung/Lastenausgleich

- Gleichbehandlung der Vertriebenen Ost/West

2491 [Marianne Kühn-Berger (1929-2016), 1991-1993 Vorsitzende des BdV-Landesverbandes.]

2492 [Walter Greschan.] 
- Zuerkennung unseres Status als Vertriebene

- $\quad$ Standpunkt zu dem verlorenen Besitz - kein neues Unrecht[,] keine Wiederinbesitznahme der Gebiete

- $\quad$ Notwendigkeit des Zusammenschlusses aller Vertriebenen zur Durchsetzung unserer Forderungen bei der Bundesregierung

- $\quad$ Fragen der Gründung eines Kreisverbandes in Finsterwalde.

In der Folge spricht Herr Greschan.

- $\quad$ Erläuterungen zu den gestellten Fragen.

- $\quad$ allgemeine Information zum Stand der gesetzlichen Regelungen

- $\quad$ Kritik an der Haltung des BdV der BRD beim Einigungsvertrag

- Grundsätzlich:

- Es gibt noch keine gesetzliche Regelung zu einem möglichen Lastenausgleich

- Deshalb gibt es auch noch keine Formulare oder Anträge

- $\quad$ Anträge, die derzeit in Umlauf gebracht werden[,] haben keine rechtliche Gültigkeit

- $\quad$ Einzige bestätigte Formulare sind Anträge auf Bestätigung als Vertriebene zur Rentenberechnung bei Notwendigkeit über den Lastenträger - Bearbeitung bei der Urkundenstelle des Kreises

- Bekanntgabe von Auskunftsstellen

Frau Kühn-Berger stellt die Frage zur Bildung eines Kreisverbandes an die Versammelten. Durch erheben von den Plätzen wird von den Versammelten in überwältigender Mehrheit die Zustimmung erklärt. Herr K[...] ergreift das Wort. In seinen Darlegungen schlägt er [S. 2] der Versammlung vor, eine Protestresolution zu verfassen und an die Bundesregierung zu senden. Sein Vorschlag wird allgemein begrüßt. Eine Ausarbeitung kam aus Zeitgründen nicht zustande und wird auf die nächste Hauptversammlung vertagt.

Frau Kühn-Berger verliest die wesentlichsten Auszüge aus dem Musterstatut und erbittet Bereitschaftserklärungen zur Mitarbeit im zu bildenden Vorstand. / Es kommt zu keiner öffentlichen Wortmeldung. / Es erfolgt die Ausgabe von begrenzt vorhandenen Beitrittsanträgen. Die Versammlung löst sich allgemein auf. Kurzfristig wird noch eine Spendenaktion zur Begleichung der Saalmiete durchgeführt. / Vom Unterzeichner werden die Anwesenden darauf hingewiesen, daß alle weiteren Maßnahmen von der Konstituierung eines Vorstandes abhängen und in der Presse veröffentlicht werden. 
Nachfolgend genannte Personen geben beim Unterzeichner Bereitschaftserklärungen zur Mitarbeit im Vorstand ab: / [... (Folgt Liste von 10 Namen.) $]$

Die Gäste des Landesverbandes Brandenburg übergeben Unterlagen für den Kreisverband und erklären sich bereit, bei der Gründungsversammlung Unterstützung zu geben.

Die Versammlung wird gegen 16.00 Uhr offiziell beendet.

\section{(256) Bericht des Aussiedlerbetreuers des BdV-Kreisverbandes Brandenburg/Havel über die Aussiedlerbetreuung in den Monaten April bis Juni 1999. - Damsdorf, 30. Juni 1999}

BdV-Landesgeschäftsstelle, Aktengruppe Kreisverbände, 7.0 KV Brandenburg/Havel, unfol. - Manuskript (Fotokopie), 2 Bl. - Datiert Bl. 1 o.r. „Damsdorf ${ }^{2493}$ 30.06.1999“, 1. o. Stempel „BUND DER/VERTRIEBENEN- / KREISVERBAND / BRANDENBURG“. - Bl. 2 u. unterzeichnet „Der Aussiedlerbetreuer des BdV-Kreisverbandes Brandenburg/Havel / [gez.] Siegfried Kaatz ${ }^{2494 “, ~ 1 . ~ u . ~ d e r s e l b e ~ S t e m p e l ~ w i e ~ a u f ~ B l . ~ 1 . ~-~ D a z u ~ A n s c h r e i b e n ~ z u r ~ U ̈ b e r s e n d u n g ~}$ des Berichts an die Aussiedlerbeauftragte des BdV-Landesverbandes (Renate Schulze), Manuskript, 1 S., datiert r. o. „Damsdorf, 06.08.1999“, unterzeichnet „Mit freundlichen Grüßen/ [gez.] Siegfried“, darunter Stempel des BdVKreisverbandes Brandenburg/Havel.

[Anschreiben:] Liebe Renate / Ich schicke Dir hier wieder meine etwas geänderten Unterlagen zur Betreuung für die Aussiedler. / Ich werde in Zukunft so wenig wie möglich die Betreuung durchführen. / Alle Fahrten werden mit dem Privat[-]PKW getätigt, der Sprit wird immer teurer und Bonn hält es nicht für nötig den Fahrpreis pro km. etwas zu erhöhen. Das Auto wird durch die ständigen Fahrten nicht besser. Ich habe im II/99 zwei Fahrten zur Ausländerbehörde nach Teltow gemacht. Das sind für eine Fahrt $120 \mathrm{~km}$. hin und zurück. Wenn aber nur Fahrten bis $100 \mathrm{~km}$ bezahlt werden, ist es eine Zumutung, die verbleibenden $20 \mathrm{~km}$ aus meine[r] Tasche zu bezahlen. Weiterhin ist es lt. meiner Aufzeichnung zur Betreuung zu ersehen, das[s] Ich nur auf sozialer Ebene berate und betreue.

Das mußte Ich mir mal von der Seele sprechen und würde es befürworten, auch Bonn davon zu unterrichten. / Die Regierung spricht immer von Integration der Aussiedler, aber die Betreuer möchten alles ehrenamtlich machen.

[Anlage]

Bericht über die Betreuung der Aussiedler durch den Aussiedlerbetreuer des BdV-Kreisverbandes Brandenburg/H. in den Monaten April, Mai und Juni 1999

Der Aussiedlerbetreuer betreut Aussiedler, die im überwiegenden Teil aus der ehem. SU. zu uns kommen. Sie wohnen in den Ü-Wohnheimen ${ }^{2495}$ in Michelsdorf, Wittstock, Wiesenburg, Wer-

2493 [Damsdorf (ehem. Kr. Zauch-Belzig, ab 1952 Kr. Brandenburg-Land, seit 1993 Ldkr. Potsdam-Mittelmark), seit 2002 Ortsteil der Gemeinde Kloster Lehnin.]

2494 [Siegfried Kaatz (geb. 1932) war außerdem 1997-2003 Vorsitzender des BdV-Kreisverbandes.]

2495 [Übergangswohnheime. - Siehe dazu: Ulrich Reitemeier: Aussiedler treffen auf Einheimische. Paradoxien der interaktiven Identitätsarbeit und Vorenthaltung der Marginalitätszuschreibung in Situationen zwischen Aus- 
der und Potsdam. Auch Aussiedler mit eigenem Wohnraum werden vom Betreuer aufgesucht und betreut. Es sind Männer und Frauen sowie Familien unterschiedlicher, sozialer Herkunft.

Für alle diese Menschen, die sich in ihrer neuen Umgebung einleben müssen[,] gibt es erhebliche Sprachschwierigkeiten und andere Probleme. Wegen ihrer sehr ungenügenden Sprachkenntnisse haben die Aussiedler große Schwellenängste gegenüber den Ämtern und Behörden, die auch nicht in jedem Fall Verständnis für die Aussiedler aufbringen. Der Aussiedlerbetreuer setzt sich dann dafür ein, um sie [so!] über diese Hürden hinweg zu helfen. Er ist ihr Ansprechpartner, die Vertrauensperson bei ihren Sorgen und Problemen und wird stets erwartet.

Bei fast allen ist es notwendig, das[s] der Betreuer Unterstützung und Hilfe bei Nachforschungen in Zusammenarbeit mit den Behörden zum Beschaffen von Dokumenten unternehmen muß, was mit Schwierigkeiten und mir viel Zeitaufwand getan werden muß. [Bl. 2] / Auch steht immer noch die Frage von Familienzusammenführungen an erster Stelle. Aber auch dieses wird von Jahr zu Jahr immer schwieriger,

Zur Betreuung gehört unter anderem auch das Begleiten zum Arbeitsamt, zur Leistungsabteilung, zum Sozialamt[,] zu den Rentenstellen und zu den Krankenkassen. / Auch hilft der Betreuer den Aussiedlern im Rentenalter beim Ausfüllen der Anträge. / Der Betreuer gibt Unterstützung beim [Be-]Antragen von Wohngeld und den Deutsch-Sprachlehrgängen. Weiterhin bemüht sich der Betreuer im Rahmen von Kleidersammlungen, den Aussiedlern viele gute Sachen zu bringen. Auch hat der Betreuer ständigen Kontakt zu der Heimleitung in den ÜWohnheimen. Die Arbeit des Betreuers besteht aus sehr viel Kleinarbeit und ein [so!] sich oft wiederholendes Bemühen bei den Ämtern und Behörden.

Aber unsere Hilfe und Unterstützung ist sehr wichtig für die Integration der Aussiedler. Durch persönliche Gespräche ist der Betreuer die Kontaktperson und der Ansprechpartner in allen Fragen und ein nützlicher Helfer für die Aussiedler.

\section{(257) Veranstaltungsplanung des BdV-Kreisverbandes Brandenburg/Havel für das Jahr 2000. - Brandenburg, 21. Februar 2000}

BdV-Landesgeschäftsstelle, Aktengruppe BdV-Organisation, 07 KV Brandenburg, unfol. - PC-Ausdruck, 1 S. - Datiert r. o. „Brandenburg, 21.02.2000“. - Überschrift: „Veranstaltungsplan des BdV-Kreisverbandes Brandenburg/H./für das Jahr 2000“. - U.1. [gez. (Kugelschreiber)] Kaatz / [PC-Ausdruck:] Siegfried Kaatz / Vorsitzender.

- 07.02.2000

- Monat März 2000

- Monat April 2000

- 28.-29.04.2000
Kränzchenrunde in Groß Kreutz (Strohhaus)

Tanznachmittag im Haus der Begegnung

Mitgliederversammlungen

Fahrt in die Heimat

siedlern und Binnendeutschen. Tübingen 2006, S. 97-105 (Wohn- und Lebensbedingungen im Übergangswohnheim).] 
- Monat Mai 2000

- 27.05.2000

- Monat Mai 2000

- 17.05.2000

- Monat Juni 2000

$-21.06 .2000$

- Monat Juli 2000

- Monat September 2000

$-30.09 .2000$

- Monat Oktober 2000

- Monat Dezember 2000
Kränzchenrunde in Groß Kreutz (Strohhaus)

III. Ostdeutscher Kulturtag in Luckenwalde

Tagesfahrt mit Bus-Unternehmen

Großveranstaltung in der Stadthalle

Dampferfahrt

Großveranstaltung im Schmöllner Weg

Kränzchenrunde in Groß Kreutz (Strohhaus)

Tag der Heimat und Erntedankfest in Berlin

Tag der Heimat in Brandenburg (TGZ) 2496

Kränzchenrunde in Groß Kreutz (Strohhaus)

Weihnachtsfeiern in der Stadt und im Landkreis

(258) Veranstaltungsplanung des BdV-Kreisverbandes Eberswalde, Bad Freienwalde, Bernau für das Jahr 2003. - Eberswalde, 29. Januar 2003

BdV-Landesgeschäftsstelle, Aktengruppe BdV-Organisation, 10 KV Eberswalde, unfol. - Typoskript auf fotokopiertem Vordruck-Kopfbogen „BdV Bund der Vertriebenen / BdV-Kreisverband Eberswalde, Bad Freienwalde, Bernau e. V.“ (1. o.) mit masch. Anschrift (r. o.) „16225 Eberswalde / Karl-Marx-Platz 8 / Tel. [...]“, 2 Bl. (und knappes Anschreiben, 1 Bl., zur Übersendung an den BdV-Landesverband in Potsdam, „z[um] Kahleberg 4“, datiert „29.01.2003“, unterzeichnet [Kugelschreiber] „i.A. [gez.] Kolberg“). - Überschrift: „Jahresbericht 2003“. - Bl. 2 u. 1. Stempel „BdV Bund der Vertriebenen / Kreisverband Eberswalde, / Bad Freienwalde, Bernau e. V. / Karl-Marx-Platz 8, 16225 Eberswalde“.

1. Geplante Veranstaltungen

1.1 Jahreshauptversammlung (Ende März)

1.2 Gesprächsrunden u. Abschluß der Arbeit mit dem Gymnasium in Bad Freienwalde (CD) März

1.3 Informationsveranstaltungen (drei)

1.4 Treffen mit politischen Entscheidungsträgern der Stadt Eberswalde (drei)

1.5 gemeinsame Veranstaltung mit der hiesigen Aussiedlergruppe „Kontakt“

2. Geplante Fahrten

2.1 Fahrt in die Masuren, Danzig, Pom[mersche] Schweiz (4 Tage)

2.2 Tagesfahrt mit dem Schiff bis Stettin

2.3 Treffen mit der deutschen Minderheit (zwei) 
2.4 Fahrt zum Pommerntreffen nach Bersenbrück ${ }^{2497}$ mit poln. Journalisten und der Minderheit (Juni)

2.5 Fahrt zum 6. Ostdeutschen Kulturtag 2498

2.6 Fahrt zum Tag der Heimat nach Berlin [B. 2]

3. Weihnachtsfeiern (vier) / mit Kulturprogramm und Info-Stunde

4. Öffentlichkeitsarbeit

4.1 Aufstellen eines Gedenksteines 1/2. Quartal

4.2 Gespräche und Vorschläge zur Vorbereitung der Stadt Eberswalde auf 750-JahrFeier unter Beteiligung der Vertriebenen

\section{(259) Tätigkeitsbericht des BdV-Regionalverbandes „Alte Heimat“ Jüterbog für} die Jahre 2007-2010. - Jüterbog, 31. Mai 2011

BdV-Landesgeschäftsstelle, Aktengruppe Kreisverbände, 23.2 KV Luckenwalde, unfol. - Typoskript (Fotokopie), 1 Bl. (2 S.). - O.1.: Stempel „Bund der Vertriebenen / Regionalverband e. V. / Alte Heimat / Jüterbog“. - R. o. Eingangsstempel der BdV-Landesgeschäftsstelle und handschriftliche Eingangsnr.: „Eingegangen 11. Nov. 2011/1154“, r. o. Paraphe „Hee“ des BdV-Landesvorsitzenden Harald Heerwagen. - S. 2 unter dem Text handschriftliche Notiz (Fotokopie): „31. Mai 2010 Kie [Paraphe der Schatzmeisterin Waltraud Kießling] / erstellt für das Finanzamt“.

Tätigkeitsnachweis - Übersicht

Unternehmungen aufgeschlüsselt ab 2007-2010

Unser Verein „Alte Heimat“ Regionalverband Jüterbog ${ }^{2499}$ wurde erst im Sept. 2010 wirksam. Vorher gehörten unsere Mitglieder dem Kreisverband Luckenwalde Teltow-Fläming ${ }^{2500}$ an. Unser Ausstieg aus dem Verband Luckenwalde wurde in einer Mitgliederversammlung beschlossen. Der Grund der Abwanderung war die schlechte Aktivität, so gut wie keine Informationen u. a. m. Zunächst versuchten wir eigenständig zu handeln, bis uns der Weg zu alleiniger Vereinsführung geebnet wurde.

Unsere Tätigkeit begann 2007 mit einem Erzähl-Café im Garten eines Mitgliedes. Dieses Unternehmen fand großen Anklang - 16 Mitglieder nahmen teil. Es wurde ein kleines Heimatfest.

- $\quad$ Als nächstes Unternehmen besuchten wir den Tierpark in Luckenwalde - allerdings nur mit 6 Mitgliedern.

- $\quad$ Um weitere Annäherung an weitere Verbände zu erhalten, wurde über das Land Berlin Kontakt hergestellt und zwar Teilnahme an einer Dampferfahrt mit Heimatfreunden.

2497 [Bersenbrück bei Osnabrück; seit 1958 Patenschaft des Landkreises Bersenbrück (seit 1972 Landkreis Osnabrück) für den ehem. Kreis Greifenhagen (Pommern), seit 1964 Patenschaft der Stadt Bersenbrück für die Stadt Greifenhagen (poln. Gryfino).]

2498 [In Brandenburg an der Havel.]

2499 [2013 Auflösungsbeschluss (Näheres siehe Ortsdokumentation Jüterbog).]

2500 [2009 Arbeit eingestellt (Näheres siehe Ortsdokumentation Luckenwalde).] 
- Im Jahr 2008 fanden wir Anschluß zum Raduga-Chor ${ }^{2501}$ der Aussiedler aus Russland, wir feierten zusammen den Frauentag[.] $]^{2502}$

- $\quad$ Im Juli unternahmen wir mit 13 Mitgliedern eine Rundfahrt ins Ländeken in unserer Region.

- $\quad$ Es folgte eine Fahrt nach Mellensee, dort wurde eine Bootsfahrt gemacht.

- Zum Jahresende organisierten wir einen weihnachtlichen Heimatabend und wieder mit den Frauen des Raduga-Chores.

- Das Jahr 2009 begann wie immer mit dem Frauentag gemeinsam mit dem Raduga[-] Chor, es ist eine gute Tradition geworden.

- Im weiteren Verlauf des Jahres nahmen wir an einem Vortrag über Augenkrankheiten teil.

- Zwischendurch bekamen wir eine Einladung des Chores und der Kreativgruppe der Aussiedler. Diese Zusammenkunft war von unseren Mitgliedern mit 21 Personen besucht worden und der Zusammenhalt noch mehr gefestigt wurde.

- Im Monat August besuchten wir das Museumsdorf Glashütte - 20 Mitglieder nahmen teil.

- $\quad$ Standard folgte dann wieder der Heimatabend zur Weihnachtszeit.

- Das Jahr 2010 fing dann wieder wie üblich mit der Frauentagsfeier an. Mit unseren Mitgliedern und den beiden Frauengruppen zählten wir 40 Pers[onen]. [S. 2]

- Im April organisierten wir einen Lichtbildervortrag über Ostpreußen, leider war dieser Vortrag nicht so gut besucht, es lag aber wohl auch daran, daß wir nur 2 Familien von dort bei uns im Verein haben.

- $\quad$ Im Monat Juni folgte nochmals ein Vortrag über Kräuter mit einem Spaziergang durch den Kräutergarten.

- $\quad$ Nicht zu vergessen waren unsere Zusammenkünfte im Garten mit dem Erzähl-Cafe sowie vorweihnachtliche Plausche[.]

\section{(260) Zeitungsinterview mit der Vorsitzenden des BdV-Kreisverbandes Neuruppin} Johanna Franke. - Neuruppin, März 2008

BdV-Landesgeschäftsstelle, Aktengruppe Kreisverbände, 26 KV Neuruppin, unfol., Zeitungsartikel (Fotokopie) aus: Märkische Allgemeine Zeitung, [Regionalausgabe Ostprignitz-Ruppin], 26.3.2008, mit Porträtfoto untertitelt „Vereinschefin Johanna Franke“. - Titel: „Verzicht auf Vergeltung / Vertriebene 135 Mitglieder im Bund organisiert“. - Die Fragen sind auch in der Vorlage kursiv gesetzt, der Name der Antwortenden jeweils halbfett. - Am Ende des Artikels: „,info Kontakt zum Bund der Vertriebenen gibt es über Johanna Franke, [Tel.] [...]. - Johanna Franke (Neuruppin), geb. 1932 in Hinterpommern, starb 2010 in Neuruppin.

2501 [Frauenchor Raduga, „Raduga - Altes Lager e.V.“, 1989 gegründet als „Frauenchor des Gemeinschaftswerkes Niedergoersdorf“" (Raduga, dt. Regenbogen). Vgl. chorraduga.jimdo.com (4.8.2018).]

2502 [Internationaler Frauentag (Weltfrauentag), 8. März.] 
Seit 17 Jahren gibt es in Neuruppin den Bund der Vertriebenen. ${ }^{2503}$ Der Verein ist eine Anlaufstelle für Vertriebene. Mit der Vorsitzenden sprach MAZ-Mitarbeiterin Jeanette Schäfer über die Ideologie und die Arbeit des Vereins.

MAZ: Wie viele Mitglieder gab es im Gründungsjahr 1991?/Johanna Franke: 180. Die MAZ hat damals groß über die geplante Gründung berichtet. Der schon gebildete Vorstand hat alle Interessenten aufgerufen, in den Stadtgarten zu kommen. Kurz darauf ist der Verein dem Landesverband des Bundes der Vertriebenen beigetreten.

Warum hat sich der Bund der Vertriebenen gegründet? / Franke: In den alten Bundesländern gab es die Landsmannschaften, die sich um die Vertriebenen kümmerten. Sie unterstützten in den neuen Bundesländern die Bildung der Vertriebenenverbände. Wir waren ein Anlaufpunkt für Vertriebene und Flüchtlinge.

Gab es Mitglieder, die Rachegefühle oder Wut wegen der Vertreibung heften? / Franke: Nein. Wir haben die Charta der deutschen Heimatvertriebenen als Grundlage unserer Arbeit festgelegt. Im Kern enthält sie den Verzicht auf Rache und Gewalt. Das ist für mich sehr wichtig.

Warum?/Franke: 15 Millionen Deutsche mussten 1945 ihre Heimat verlassen, 2,5 Millionen Menschen starben dabei. Das ist ein tragisches Ergebnis des von Deutschland begonnenen Zweiten Weltkrieges. Die Leitragenden sind wie immer die Menschen.

WievieleMitgliederhatderVerein derzeit? / Franke: 135. Abereswaren auch schon einmal 1000.

Wann war das? / Franke: Wenige Monate nach der Gründung. Es hieß, die Vertriebenen bekommen eine finanzielle Entschädigung, wenn sie ihre Herkunft als Vertriebener nachweisen konnten und in der DDR gemeldet waren.

Wo kommen die hier lebenden Vertriebenen her? / Franke: Unter anderem aus ZüllichauSchwiebus, Ostpreußen, Landsberg, Pommern und Schlesien.

Sie haben auch Mitglieder aus all diesen Gebieten?/Franke: Ja. Der Großteil unserer Mitglieder stammt aus Züllichau-Schwiebus. Schon vor der Vertreibung hat man geplant, die Bevölkerung aus gefährdeten Kreisen und Gemeinden möglichst geschlossen in einer anderen Region Deutschlands unterzubringen. Viele Schwiebuser sind in Brandenburg angesiedelt worden. Deshalb gibt es auch in Neuruppin jährlich das große Schwiebuser Treffen.

Und die anderen Betroffenen? / Franke: Die Gruppen haben sich von selbst gefunden. Man kommt ins Gespräch und findet Gemeinsamkeiten. Wir haben unsere Vereinsarbeit auf fünf Gruppen verteilt: Züllichau-Schwiebus, Schlesien, Landsberg, Pommern/Ostpreußen und eine gemischte Rheinsberger Gruppe. Die Gruppen unternehmen gemeinsam Ausflüge und treffen sich zweimal im Jahr, im Frühjahr und im Advent, zum gemütlichen Beisammensein. 
Wo hat der Verein seinen Sitz?/Franke: Wir haben im Haus der Begegnung ein mobiles Büro. Jeden ersten und dritten Mittwoch im Monat bietet der Vorstand eine Sprechstunde für Mitglieder und interessierte Bürger an.

Wird es den Bund der Vertriebenen eines Tages nicht mehr geben, weil die Generation der Betroffenen ausstirbt? / Franke: Das ist richtig. Doch wir freuen uns, dass noch heute Vertriebene kommen und Mitglied im BdV werden.

\section{(261) Rede von Wolfgang Bornstädt beim Festakt zur Namensgebung des Woldenberger Platzes in Premnitz. - Premnitz, 12. November 2010}

BdV-Landesgeschäftsstelle, Aktengruppe Kreisverbände, 32 KV Rathenow, unfol. - PC-Ausdruck (Fotokopie), 4 Bl. S. 4 handschriftlicher Vermerk von anderer Hand „Rede von Wolfgang Bornstädt (Woldenberg-Premnitz) bei der Namensgebung am Fr.[eitag] 12.11.2010“. - Der aus Woldenberg/Nm. stammende W. Bornstädt (geb. 1936) war der Initiator der Namengebung (Näheres siehe Ortsdokumentation Premnitz).

Sehr geehrter Herr Bürgermeister Wallenta, sehr geehrter Herr Kapahnke ${ }^{2504}$, sehr geehrter Herr Bader ${ }^{2505}$, sehr geehrte Premnitzer und Gäste, liebe Woldenberger und Schicksalsgenossen.

Wir werden heute an dieser Stelle einen [so!] Platz den Namen / „Woldenberger Platz“ / verleihen. / Dieser Name soll verdeutlichen, dass die Stadt Premnitz nach dem verheerenden 2. Weltkriege eine Geschichte von Flucht und Vertreibung hat. Nach Premnitz kamen ab 1945 tausende von Menschen[,] die ihre seit Jahren angestammte Heimat gewaltsam verlassen mussten.

Die Gruppe aus Woldenberg in der Neumark war die erste und größte Flüchtlingsgruppe, die am späten Nachmittag am Sonntag, den 28. Januar 1945, über Berlin den alten Bahnhof Premnitz erreichte. Es waren Tage mit sehr viel Schnee und Temperaturen zwischen -20 und $-10^{\circ} \mathrm{C}$. Es war ein Eisenbahnzug mit so genannten Berliner Personen-Wagen, wir waren ca. 400 Personen, ausschließlich Mütter mit ihren Kindern, vom Baby bis zum Halbwüchsigen. Die erste Nacht verbrachten wir in den Gasthöfen Müller, Strom, Lindenhof und Schilling sowie in der Schule in der heutigen Hauptstrasse. Am nächsten Tag wurden wir auf die uns zugewiesenen Quartiere verteilt, begleitet von den älteren Schülern der hiesigen Schule. Die Einquartierung erfolgte zwangsweise, auch für die Quartiergeber, entsprechend war die Begrüßung.

Da standen sie nun, unsere Mütter mit ihren 2, 3, 4, 5 und 6 Kindern. Alle was sie hatten trugen sie am Körper. Die Premnitzer Quartiergeber rückten zusammen, teilten ihren bescheidenen Wohnraum, ihre Küchen, Tassen, Teller und Betten mit uns, den Flüchtlingen.

Wo kommt ihr her? / Wir kamen aus Woldenberg in der Neumark, die Kleinstadt, ca. $300 \mathrm{~km}$ östlich von Premnitz entfernt mit 5500 Einwohnern mit gleicher Geschichte wie das Havelland, zur Mark-Brandenburg gehörig. Wir kamen unfreiwillig hier her, keiner konnte sich vor-

2504 [Herbert Kapahnke (1939-2015), Vorsitzender des BdV-Gebietsverbandes Rathenow.]

2505 [Werner Bader (1922-2014), Vorsitzender des Kulturfördervereins Mark-Brandenburg in Görne (Havelland), ehemaliger Vorsitzender der Landsmannschaft Berlin-Mark Brandenburg.] 
stellen, dass hier für uns endgültig die neue Heimat sein sollte. Die Woldenberger waren die erste Gruppe von Flüchtlingen in Premnitz. [S. 2]

Am 27. Januar gingen 4 Transporte in Richtung Westen, wir mussten flüchten vor der heranrückenden „Roten Armee“ von einer Stunde zur anderen, 3 Flüchtlingszüge aus Woldenberg kamen nach Anklam in Pommern, einer zufällig nach Premnitz. / Das Glück mit der Eisenbahn aus Woldenberg zu flüchten hatten leider nur die Hälfte der Woldenberger Bevölkerung, diese verließen bis auf einige Transportunfähige alte und kranke Menschen noch am 27. und 28. Januar 1945 die Stadt zu Fuß, einige wenige mit Pferd und Wagen. Es lagen ca. $50 \mathrm{~cm}$ Schnee bei $-20^{\circ} \mathrm{C}$. Die Straßen zur Oder waren verstopft durch Militär und Flüchtlinge. / Am 29. Januar erreichten die Soldaten der Roten Armee Woldenberg, eroberten sie kampflos, sofort wurde die Altstadt in Brand gesteckt. Am 30. Januar gegen Abend wurde der Himmel ganz rot und der größte Teil unserer schönen Stadt war nur noch ein Trümmerhaufen. / Die Flüchtlinge per Pferd und Wagen oder zu Fuß wurden ca. $40 \mathrm{~km}$ westlich von Woldenberg von der Roten Armee bei Berlinchen überrollt. Hier gab es viele Tote unter den Woldenberger Flüchtlingen. Grausame Vergewaltigungen der Frauen und Mädchen fanden statt, unwillige wurden erschlagen oder erschossen. Dieses Schicksal blieb uns erst einmal erspart[,] bis auch diese grausame Walze am 1. Mai 1945 Premnitz erreichte.

Wir glaubten nun wieder nach Woldenberg zurückkehren zu können. Das war wohl ein Irrtum, Woldenberg gehörte nach ca. 950 Jahren deutscher Geschichte zu Polen. Es begann für die meisten der ehemaligen Woldenberger ein Leben von größter Armut in den Baracken der Heimstrasse (Mädchenheim), Steinbaracken und Holzbaracken, auf diesem Platz[,] auf dem wir heute stehen.

Mit den Woldenbergern in Premnitz, das war erst der Anfang von Flucht und Vertreibung für diesen Ort. In steigendem Maße kamen Vertriebene aus allen Teilen des Ostens und Südostens Deutschlands nach Premnitz, aus Pommern, aus Schlesien, Ostpreußen und 1946 in großer Zahl aus dem Sudetenland. Geschätzt könnten es in Premnitz 3000 bis 4000 Vertriebene gewesen sein. Diese Jahre waren geprägt von Krankheit, Hunger und Kälte. [S. 3]

1949 wurden die BRD und die DDR gegründet und es wurde deutlich, unsere angestammte Heimat ist verloren. Eine große Zahl der Flüchtlinge verließ darauf hin Premnitz in Richtung Westen. Hier in der DDR galten wir als Umsiedler, über das wahre Schicksal durfte nicht gesprochen werden. Unsere Heimat, unseren Geburtsort und die Grabstätten unserer Eltern und Großeltern zu besuchen war uns verboten und unmöglich. Auch damit mussten wir uns abfinden.

Wir haben in Premnitz ein neues zu Hause gefunden, wir jüngeren gründeten Familien unter den gegebenen Verhältnissen. An der Entwicklung der Stadt Premnitz waren die Vertriebenen maßgeblich beteiligt. Mit dem Fall der Mauer vor 21 Jahren durften wir als Vertriebene nach 45 Jahren erstmalig öffentlich über dieses Thema, der völkerrechtswidrigen Vertreibung, sprechen, unsere Verwandten und Freunde die das Schicksal durch Zufall in den westlichen Teil unserer 
Heimat verschlagen hat, ungehindert besuchen. Auch in den neuen Bundesländern konnten nun Landsmannschaften des BdV gegründet werden. Angesichts dieser tief greifenden Ereignisse in die [so!] Geschichte für ca. 15 Mill. Vertriebener wollen wir heute diesen [so!] Platz den Namen „Woldenberger Platz“ geben. Die Stadt Woldenberg, die heute zu Polen gehört und den Namen Dobigniew trägt, soll unvergessen sei, stellvertretend für alle Städte und Dörfer, ob in Ostpreußen, Pommern, Schlesien oder dem Sudetenland, aber auch für viele weitere Vertreibungsgebiete in Europa nach dem 2. Weltkrieg[,] die dieses Schicksal tragen.

Einen herzlichen Dank an unseren Bürgermeister, Herrn Wallenta, den Vertretern aller 4 Fraktionen in der S. V. V. ${ }^{2506}$ [,] die dieser Namensgebung ein einstimmiges Ja gaben. Ein Dankeschön an den Gebietsvorstand des BdV, Land Brandenburg, vertreten durch Herrn Herbert Kapahnke.

Nicht vergessen soll die uneingeschränkte Unterstützung der Vertriebenengruppe aus Woldenberg sein, auch dafür einen herzlichen Dank. Gedankt sei auch allen anderen Unterstützern des Gedankens[,] in Premnitz einen Woldenberger Platz zu benennen[,] und nicht zuletzt gedankt soll werden der Lokalpresse der MAZ, die einen ganz wichtigen Beitrag zur Darstellung dieses Vorhabens geleistet hat und nach [S. 4] 65 Jahren dieser Geschehnisse um Flucht und Vertreibung bezogen auf die Stadt Premnitz eine umfangreiche Berichterstattung ermöglichte.

Der Woldenberger Platz steht für Erinnerung und Mahnung, dass sich diese Ereignisse nicht wiederholen, und somit soll dieser Platz ab heute den Namen / Woldenberger Platz / in Ehre tragen. 
Anhang 



\section{Abkürzungen}

Hier kursiv gesetzte Abkürzungen sind nur im Quelleneditionsteil zu finden.

\begin{tabular}{|c|c|}
\hline * & geboren; in Tabellen Fußnote \\
\hline+ & verstorben \\
\hline / & $\begin{array}{l}\text { Absatz [im Quellenteil (Teil 3)]; Zeilenwechsel [in Inschriftentexten in } \\
\text { Teil } 1 \text { und 2] }\end{array}$ \\
\hline // & Absatz [in Inschriftentexten in Teil 1 und 2] \\
\hline[] & Einfügung Peter Bahl \\
\hline Abb. & Abbildung \\
\hline $\mathrm{ABF}$ & Arbeiter-und-Bauern-Fakultät \\
\hline $\mathrm{ABM}$ & Arbeitsbeschaffungsmaßnahme \\
\hline Abs. & Absatz \\
\hline Abt. & Abteilung \\
\hline $\mathrm{ADN}$ & Allgemeiner Deutscher Nachrichtendienst \\
\hline$A k z$. & Aktenzeichen \\
\hline amerik. & amerikanisch \\
\hline amerikan. & amerikanisch \\
\hline Anm. & Anmerkung \\
\hline Anf. & Anfang \\
\hline App. & Apparat \\
\hline Art. & Artikel [nur in bibliographischen Angaben] \\
\hline$A T G$ & Autotransportgemeinschaft \\
\hline Aufl. & Auflage [nur in bibliographischen Angaben] \\
\hline AWG & Arbeiterwohnungsbaugenossenschaft \\
\hline$A z$. & Aktenzeichen \\
\hline $\mathrm{BBL}$ & Brandenburgisches Biographisches Lexikon (BBL). Potsdam 2002 \\
\hline $\mathrm{Bd}$. & Band \\
\hline BDM, B.D.M. & Bund Deutscher Mädel \\
\hline $\mathrm{BdV}$ & Bund der Vertriebenen \\
\hline bearb. & bearbeitet [nur in bibliographischen Angaben] \\
\hline Bearb. & Bearbeiter [nur in bibliographischen Angaben] \\
\hline Beitr. & Beitrag, Beiträge [nur in bibliographischen Angaben] \\
\hline Betr. & Betreff \\
\hline betr. & betrifft, betreffend \\
\hline bes. & besonders \\
\hline Best. & Bestand \\
\hline Bez. & Bezirk \\
\hline bezw. & beziehungsweise \\
\hline
\end{tabular}




\begin{tabular}{|c|c|}
\hline BGBl & Bundesgesetzblatt \\
\hline BGL & Betriebsgewerkschaftsleitung \\
\hline$B g m$ & Bürgermeister \\
\hline BHG & Bäuerliche Handelsgenossenschft \\
\hline Bl. & Blatt \\
\hline BLHA & Brandenburgisches Landeshauptarchiv \\
\hline brand. & brandenburgisch \\
\hline$B R D$ & Bundesrepublik Deutschland \\
\hline brit. & britisch \\
\hline $\mathrm{BStU}$ & $\begin{array}{l}\text { Der Bundesbeauftragte für die Unterlagen des Staatssicherheitsdienstes } \\
\text { der ehemaligen Deutschen Demokratischen Republik }\end{array}$ \\
\hline BVFG & Bundesvertriebenengesetz \\
\hline bzw. & beziehungsweise \\
\hline $\mathrm{CD}$ & Compact Disc \\
\hline $\mathrm{CDU}$ & Christlich-Demokratische Union Deutschlands \\
\hline d.Mts. & d(ies)es Monats \\
\hline DAF & Deutsche Arbeitsfront \\
\hline DDR & Deutsche Demokratische Republik \\
\hline$D D T$ & Dichlordiphenyltrichlorethan (Insektizid) \\
\hline DEFA & Deutsche Film AG \\
\hline ders. & derselbe [nur in bibliographischen Angaben] \\
\hline desgl. & desgleichen \\
\hline DFD (DFB) & Demokratischer Frauenbund Deutschlands \\
\hline dies. & dieselbe(n) [nur in bibliographischen Angaben] \\
\hline DRK & Deutsches Rotes Kreuz \\
\hline DSF & Gesellschaft für Deutsch-Sowjetische Freundschaft \\
\hline dto. & dito \\
\hline DWK & Deutsche Wirtschaftskommission \\
\hline E. & Ende \\
\hline ebd. & ebenda \\
\hline Eing. & Eingang \\
\hline eingel. & eingeleitet [nur in bibliographischen Angaben] \\
\hline EKD & Evangelische Kirche in Deutschland \\
\hline ELG & Einkaufs- und Liefergenossenschaft des Handwerks \\
\hline engl. & englisch \\
\hline erw. & erweitert [nur in bibliographischen Angaben] \\
\hline estn. & estnisch \\
\hline$e v$. , evang. & evangelisch \\
\hline evgl. & evangelisch \\
\hline
\end{tabular}


evtl. eventuell

F. Folge [nur in bibliographischen Angaben]

f. folgende (Seite)

f. für

Fa. Firma

FDGB Freier Deutscher Gewerkschaftsbund

FDJ Freie Deutsche Jugend

ff. fortfolgende (Seiten)

FH Fachhochschule

Fn. Fußnote

franz. französisch

französ. französisch

Frl. Fräulein

FS. Fernschreiben

g. Gramm

GBl. Gesetzblatt

GbR Gesellschaft bürgerlichen Rechts

geb. geboren

gen. genannt

Gen. $\quad$ Genosse [Mitglied der SED]

gepr. geprüft [nur in Berufsbezeichnungen]

ges.

gest. gestorben

gez. gezeichnet

GHDA Genealogisches Handbuch des Adels

GHG Großhandelsgesellschaft

GMB1 Gemeinsames Ministerialblatt

Gr., gr. Gramm

GST Gesellschaft für Sport und Technik

GVBl. Gesetz- und Verordnungsblatt

GZ Geschäftszeichen

H. Heft [nur in bibliographischen Angaben]

HA Hauptabteilung

Hd. Händen

HJ Hitlerjugend

hl. heilig

HO Handelsorganisation

hrsg., Hrsg. $\quad$ herausgegeben, Herausgeber

$\mathrm{HV} \quad$ Hauptverwaltung 


$\begin{array}{ll}\text { I.A., I/A. } & \text { Im Auftrag } \\ \text { ill. } & \text { illustriert [nur in bibliographischen Angaben] } \\ \text { i.M. } & \text { in (der) Mark [Brandenburg] } \\ \text { Ing. } & \text { Ingenieur } \\ \text { Inh. } & \text { Inhaber } \\ \text { insges. } & \text { insgesamt } \\ \text { I.V. } & \text { In Vollmacht } \\ \text { i.V. } & \text { in Vertretung } \\ \text { J. } & \text { Jahr } \\ \text { Jg. } & \text { Jahrgang } \\ \text { Jh. } & \text { Jahrhundert } \\ \text { K } & \text { Kriminalpolizei (Abt. K) } \\ \text { kath., kathol. } & \text { (römisch-)katholisch } \\ \text { Kdo. } & \text { Kommando } \\ \text { Kdt. } & \text { Kommandant } \\ \text { Kfz } & \text { Kraftfahrzeug } \\ \text { kg, Kg., Kg } & \text { Kilogramm } \\ \text { Kgf. } & \text { Kriegsgefangene } \\ \text { KG } & \text { Kommanditgesellschaft } \\ \text { KLV } & \text { Kinderlandverschickung } \\ \text { KPD } & \text { Kommunistische Partei Deutschlands } \\ \text { Kr. } & \text { Kreis } \\ \text { KVK } & \text { Karlsruher Virtueller Katalog } \\ \text { KVP } & \text { Kasernierte Volkspolizei } \\ \text { KZ } & \text { Konzentrationslager } \\ \text { l } & \text { Liter } \\ \text { l. } & \text { links } \\ \text { LBdVP } & \text { Landesbehörde der Volkspolizei } \\ \text { Ldkr. } & \text { Landkreis } \\ \text { LDP, L.D.P. } & \text { Liberal-Demokratische Partei } \\ \text { LDPD } & \text { Liberal-Demokratische Partei Deutschlands } \\ \text { lfd. } & \text { laufend } \\ \text { lfm } & \text { laufende Meter } \\ \text { lit. } & \text { litauisch } \\ \text { Lkw, LKW } & \text { Lastkraftwagen } \\ \text { LPG } & \text { Landwirtschaftliche Produktionsgenossenschaft } \\ \text { LR } & \text { Lausitzer Rundschau } \\ \text { lt. } & \text { laut } \\ \text { Ltr., ltr., ltr } & \text { Liter } \\ & \end{array}$


luth. lutherisch

LVG Lehr- und Versuchsgut

m.E. meines Erachtens

$M, M$. Mark

$m \quad$ Meter

MAS Maschinen-Ausleih-Station

masch. maschinenschriftlich

MAZ Märkische Allgemeine Zeitung

MdI, M.d.I. Ministerium des Innern

MdL Mitglied des Landtages

MfS, M.f.S. Ministerium für Staatssicherheit der DDR

Min. Ministerium

Min.Dir. Ministerialdirektor

Mk. Mark

MSF Missionarii a Sancta Familia (Missionare von der hl. Familie)

MWD Ministerstwo Wnutrennich Del ([sowjet.] Ministerium für innere Angelegenheiten)

NOZ Märkische Oderzeitung

MP Maschinenpistole

MTS Maschinen-Traktoren-Station

MVS Märkische Volkssolidarität

m. W. meines Wissens

MWFK Ministerium für Wissenschaft, Forschung und Kultur des Landes Brandenburg

ND Nachdruck, Neudruck

NDP(D), N.D.P. Nationaldemokratische Partei Deutschlands [in der SBZ/DDR]

Ndr. Nieder

NKFD Nationalkomitee „Freies Deutschland“

NKWD, Nadrodnyi Kommissariat Wnutrennich Del

N.K.W.D. ([sowjet.] Volkskommissariat für innere Angelegenheiten)

N.-L. Niederlausitz

NM., Nm. Neumark

N.N. Name unbekannt (nomen nescio)

NPD Nationaldemokratische Partei Deutschlands [nach 1990]

Nr. Nummer

NS nationalsozialistisch

NSDAP, Nationalsozialistische Deutsche Arbeiterpartei

N.S.D.A.P.

NSKK

Nationalsozialistisches Kraftfahrkorps 
NSV

NVA

o.

O.

Odf

o.J.

OMI

o. $\mathrm{O}$.

$O P$

$O P D$

OS., O/S., O.S.

Ostpr.

O. T., OT

OT

PA

P.B.

PDF

PDS

Pfd.

Pfr.

Pg., P. G.

$\mathrm{PGH}$

Pkw, PKW

PM, Pm

poln.

POS

ppa.

Pr.

Präs.

Prov.

ptl.

PVAP

$q m$

$\mathrm{r}$

r.

RAD

RAW

$R B D$

Red., red.
Nationalsozialistische Volkswohlfahrt

Nationale Volksarmee

oben

Oder

Opfer des Faschimsus

ohne Jahr [nur in bibliographischen Angaben]

Oblaten der Unbefleckten Jungfrau Maria

ohne Ort [nur in bibliographischen Angaben]

Operation

Oberpostdirektion

Oberschlesien

Ostpreußen

Organisation Todt

Ortsteil [im Dokumentationsteil]

Personalakte

Peter Bahl

Portable Document Format

Partei des demokratischen Sozialismus

Pfund

Pfarrer

Parteigenosse [Mitglied der NSDAP]

Produktionsgenossenschaft des Handwerks

Personenkraftwagen

Paß- und Meldewesen

polnisch

Polytechnische Oberschule

per procura

Preußen

Präsident

Provinz, Provinzial-

parteilos

Polnische Vereinigte Arbeiterpartei

Quadratmeter

recto [Blatt-Vorderseite]

rechts

Reichsarbeitsdienst

Reichsbahnausbesserungswerk

Reichsbahndirektion

Redaktion, redigiert 


\begin{tabular}{|c|c|}
\hline Ref. & Referat, Referent \\
\hline Rep. & Repositur \\
\hline RGBl & Reichsgesetzblatt \\
\hline$R K$ & (Deutsches) Rotes Kreuz \\
\hline$R M, R m$. & Reichsmark \\
\hline Rücks. & Rückseite \\
\hline russ. & russisch \\
\hline$S$ & Schutzpolizei \\
\hline S. & Seite(n) \\
\hline$s$. & siehe \\
\hline SAM & Strukturanpassungsmaßnahme \\
\hline SBZ & Sowjetische Besatzungszone Deutschlands \\
\hline $\begin{array}{l}\text { SED, SED. } \\
\text { slowak. }\end{array}$ & $\begin{array}{l}\text { Sozialistische Einheitspartei Deutschlands } \\
\text { slowakisch }\end{array}$ \\
\hline SMA, S.M.A. & Sowjetische Militäradministration \\
\hline SMAD & Sowjetische Militäradministration in Deutschland \\
\hline sowj., sowjet. & sowjetisch \\
\hline SPD & Sozialdemokratische Partei Deutschlands \\
\hline SS & Schutzstaffel [der NSDAP] \\
\hline SSD. & Staatssicherheitsdienst [MfS] \\
\hline SSR & Sozialistische Sowjetrepublik \\
\hline St. & Stück \\
\hline staatl. gepr. & staatlich geprüft [nur in Berufsbezeichnungen] \\
\hline Stasi & Staatssicherheitsdienst [MfS] \\
\hline Str. & Straße \\
\hline s.u. & siehe unten \\
\hline$S U$ & Sowjetunion \\
\hline SVK & Sozialversicherungskasse \\
\hline$t$ & Tonnen \\
\hline $\mathrm{T}$. & Teil [nur in bibliographischen Angaben] \\
\hline Tab. & Tabelle \\
\hline TAN & Technisch begründete Arbeitsnorm \\
\hline$T B C, T b c$. & Tuberculose \\
\hline Tel. & Telefon \\
\hline tel. & telefonisch \\
\hline $\mathrm{Tg} b .-\mathrm{Nr}$ & Tagebuch-Nummer \\
\hline to & Tonnen \\
\hline $\begin{array}{l}\text { Trapo } \\
\text { tschech. }\end{array}$ & $\begin{array}{l}\text { Transportpolizei } \\
\text { tschechisch }\end{array}$ \\
\hline
\end{tabular}


TU

u.

u.a.

u. a.m.

UdSSR,

U.d.S.S.R.

u.d.T.

u.E.

ukrain.

u. ö.

unfol.

UNO

usw., U. s.w.

$\mathrm{v}$

v. a.

v.J.

VdgB, V.D.G.B.

$\mathrm{VdH}(V D H)$

VdN

$V E A B$

VEB

$\operatorname{VEB}(\mathrm{K})$

VEG

VEG (P)

Verf., Verf.

Verfg.

Verw.

Vfg.

vgl.

vielm.

Viz.Präs.

VK

vmtl.

Vorders.

Vors.

VP, VP.

VPKA

$V P P$.
Technische Universität

unten, [in bibliographischen Angaben:] und

und andere(s), unter anderem

und anderes mehr

Union der Sozialistischen Sowjetrepubliken

unter dem Titel [nur in bibliographischen Angaben]

unsres Erachtens

ukrainisch

und öfter [nur in bibliographischen Angaben]

unfoliiert

United Nations Organization (Organisation der Vereinten Nationen)

und so weiter

verso [Blatt-Rückseite]

vor allem

voriges Jahr, vorigen Jahres

Vereinigung der gegenseitigen Bauernhilfe

Verband der Heimkehrer, Kriegsgefangenen und Vermisstenangehörigen

Deutschlands

Verfolgter des Naziregimes

Volkseigener Erfassungs- und Aufkaufbetrieb

Volkseigener Betrieb

(kreisgeleiteter) Volkseigener Betrieb

Volkseigenes Gut

Volkseigenes Gut (Pflanzenproduktion)

Verfasser/-in, [in Quellentexten:] Verfügung

Verfügung

Verwaltung

Verfügung

vergleiche

vielmehr

Vizepräsident

Verkehrskontrolle

vermutlich

Vorderseite

Vorsitzender

Volkspolizei

Volkspolizeikreisamt

Volkspolizeipräsidium 
VR

VS

VVB

VVN

W.

WK

Ww., Wwe.

Z.d.A.

zit.

ZS

Zsarb.

zsgest.

Ztr.

$z u H d$.
Vereinsregister [bei Angaben zu BdV-Verbänden]; Volksrepublik Volkssolidarität

Vereinigung Volkseigener Betriebe

Vereinigung der Verfolgten des Naziregimes

Warthe

Weltkrieg

Witwe

zu den Akten

zitiert [nur in bibliographischen Angaben]

Zentralsekretariat [der SED]

Zusammenarbeit [nur in bibliographischen Angaben]

zusammengestellt [nur in bibliographischen Angaben]

Zentner

Händen 


\section{Glossar}

Die im Zusammenhang mit der Eingliederung von Flüchtlingen und Vertriebenen („Umsiedlern") in den Quellen offiziell oder inoffiziell verwendeten, teils hierfür neu geschaffenen, teils neu definierten Begriffe sind nicht leicht zu normieren. Zeitlich und geographisch schwankt die Terminologie, Begriffe der Zeit vor Kriegsende sind bisweilen auch nach Mai 1945 weiter in Gebrauch, deren Begriffsinhalte schwingen beim Sprecher/Schreiber oder beim Hörer/Leser oft bewusst oder unbewusst mit. Auch KPD-/SED-Funktionäre sind bisweilen nicht frei von solchen jahrelang gehörten Vokabeln. Hinzu kommt, dass es Flucht- und Vertreibungsvorgänge vor und nach Kriegsende gab und ganz unterschiedliche Bevölkerungsgruppen, Staatsangehörigkeiten usw. betroffen waren; dies vereinfacht die Lage des rückschauenden Betrachters nicht. So gibt es nicht erst für Historiker Verständnisprobleme, sondern auch schon unter den Zeitgenossen. Die nachfolgende Zusammenstellung kann nur den (unvollständigen) Versuch bilden, bei Quellenstudien für Brandenburg ermittelte und im vorliegenden Buch begegnende Begriffe zu erläutern.

Alteingesessene - als Gegenteil von $\rightarrow$ „Umsiedler“ u. a. 1947 verwendet (BLHA, Rep. 203 MdI, Nr. 1196, Nr. 46); auch „eingesessene Bevölkerung“ (BLHA, Rep. 230 Bernau, Nr. 292, Bl. 5) und „bodenständige(n) Bevölkerung“ (BLHA, Rep. 333, Nr. 574, Bl. 22).

Alteinwohner - als Gegenteil von $\rightarrow$ „Umsiedler“ u. a. 1946 und 1947 in deutschen Übersetzungen von Befehlen der SMA Brandenburg verwendet (BLHA, Rep. 230 Bernau, Nr. 292, B1. 5; BLHA, Rep. 333, Nr. 574, B1. 100).

Altortsansässige - als Gegenteil von $\rightarrow$ „ehem. Umsiedler“ u. a. 1946 verwendet (BLHA, Rep. 230 Bernau, Nr. 292, u. a. Bl. 152).

Antifa-Transporte, Antifa-Umsiedler - Eisenbahntransporte geschlossener Gruppen von tschechischen (sudetendeutschen) Kommunisten und Sozialdemokraten deutscher Nationalität erfolgten 1945/46 in die SBZ (und die amerikanische Zone). Siehe dazu oben im Teil 1 den gesonderten Abschnitt im Kapitel I. 2.

Auffanglager - Der Begriff begegnet bereits vor Kriegsende, u. a. im Januar 1945, für Lager, die für (aus in Frontnähe geratenen ostdeutschen Städten) Evakuierte eingerichtet wurden, z.B. in Potsdam und Werben/Spreewald, außerdem in Potsdam für nach dem Bombenangriff vom 14.4.1945 obdachlos gewordene Einwohner. - Nach Kriegsende wird er von zentralen und lokalen Behörden häufig verwendet als konkretisierende Funktionsbezeichnung der $\rightarrow$ „Flüchtlingslager“ bzw. $\rightarrow$ „Umsiedlerlager“ in ihrer Eigenschaft als (Erst-)Aufnahmelager für ankommende Transporte (so belegt u. a. Sept. bis. Dez. 1945 und Febr. 1946).

Ausgewiesene - Teilweise für offiziell von polnischen oder tschechischen Diensststellen $\rightarrow$ Vertriebene (im Gegensatz zu $\rightarrow$ Flüchtlingen) verwendeter Begriff. Im Lager Küchensee wurden für einen am 9.2.1946 eingetroffenen Transport, der am 1.3.1946 abreiste, Vordrucke (Kreis-Druckerei Beeskow) zur Personenerfassung verwendet, die den Titel tragen „Per- 
sonalbogen für Ausgewiesene und $[\rightarrow]$ Heimkehrer" (überliefert in BLHA, Rep. 256 Küchensee, Nr. 82), so auch in maschinenschriftlichem Transportschein, Beeskow, 19.4.1946 (ebd., Nr. 29, unfol.).

Aussiedler - Personen deutscher Abstammung, die erst nach Ende der Vertreibungen aus den ehemaligen deutschen Ostgebieten oder aus anderen ostmittel- und osteuropäischen Siedlungs- bzw. (nach Umsiedlung, Deportation u. a.) letzten Wohnorten vor oder nach 1990 in die Bundesrepublik Deutschland übersiedelten, inoffiziell meist als $\rightarrow$ „Spätaussiedler“ bezeichnet, letzteres ab 1993 jedoch amtlich konkretisiert nur noch für nach 1992 zugezogene Aussiedler. In der DDR wurde für die meist aus Polen (Oberschlesien, gelegentlich Ermland und Masuren) Kommenden stattdessen offiziell von $\rightarrow$ „Übersiedlern“ bzw. von der „Übersiedlung von ehemaligen deutschen Staatsangehörigen in die DDR“" gesprochen. ${ }^{2507}$

Bürger der Vereinten Nationen - staatenlose $\rightarrow$ Flüchtlinge, die einen (auch im Potsdamer Abkommen genannten) Sonderstatus durch Schutz der Vereinten Nationen erhielten, von SMA und SED anerkannt (u. a. BLHA, Rep. 203 MdI, Nr. 1196, Bl. 40; siehe auch: BLHA, Rep. 250 Zauch-Belzig, Nr. 659: Namenslisten von Kindern der Vereinten Nationen, Flüchtlingen und Umsiedlern).

Durchgangslager (auch: „Flüchtlingsdurchgangslager“) - nach Kriegsende von zentralen und lokalen Behörden gelegentlich synonym verwendet bzw. als konkretisierende Funktionsbezeichnung der $\rightarrow$ „Flüchtlingslager“ bzw. $\rightarrow$ „Umsiedlerlager“ in ihrer Eigenschaft als Aufnahmelager für ankommende und entweder in eine andere Besatzungszone oder ein anderes Land weiterzuleitende bzw. nur zur Quarantäne und möglichst bald folgenden $\rightarrow$ Eingemeindung kurzzeitig aufgenommene Transporte (so u. a. Juni ${ }^{2508}$, Juli ${ }^{2509}$ und Nov. ${ }^{2510}$ 1945), teilweise aber auch noch konkreter zur Unterscheidung der unmittelbar an der Oder-Neiße-Grenze auf polnischem oder deutschem Territorium gelegenen Lager (Okt. bis Dez. „Flüchtlingsdurchgangslager“ (Küstrin-)Altdrewitz und Küstrin-Neustadt, 1945 und noch 1945, 1948 und 1949 „Durchgangslager“ Forst ${ }^{2511}$ ) und der zur Durchschleusung bzw. Entlassung dienenden $\rightarrow$ Heimkehrerlager (bes. Frankfurt-Gronenfelde).

Ehemalige Umsiedler - in der SBZ und DDR schon früh verwendte offizielle, kaschierende Bezeichnung für eingemeindete $\rightarrow$ Flüchtlinge und $\rightarrow$ Vertriebene in SBZ/DDR anstelle des ab spätestens 1952 meist vermiedenen Begriffs $\rightarrow$ „Umsiedler“2512

2507 Siehe im Teil 1 das Kapitel „Spätfolgen: Aussiedler nach 1950“. Ferner (mit weiterführender Literatur): Jannis Panagiotidis: Aussiedler/Spätaussiedler. In: Online-Lexikon zur Kultur und Geschichte der Deutschen im östlichen Europa, 2015. URL: ome-lexikon.uni-oldenburg.de/p32717 (Stand: 23.4.2015).

2508 Flüchtlingsdurchgangslager Pritzwalk. Wolfgang Simon: Folgen des Krieges - dargestellt anhand ausgewählter Beispiele. In: Pritzwalker Heimatblätter 16 (2015), S. 17-24, hier S. 23.

2509 Durchgangslager Blankenfelde (Kr. Teltow): Sterberegister Standesamt Blankenfelde, Nr. 190/1945.

2510 Durchgangslager Walddrehna: Töpler, Menschenwurm (wie Anm. 147), S. 462.

2511 1948: BLHA, Rep. 203 MdI, Nr. 1198, Bl. 28v, 34r, 46. - 1949: ebd., Bl. 66.

2512 Amos, Vertriebenenpolitik der SED (wie Anm. 12), S. 254. 
Eingemeindung, Eingemeindete - Die Aufnahme der $\rightarrow$ „Umsiedler“ als gleichberechtigte Bürger an einem neuem Wohnsitz nach Entlassung aus einem ( $\rightarrow$ Quarantäne-, $\rightarrow$ Durchgangs-)Lager. Am 9.11.1948 wurden z. B. im $\rightarrow$ „Umsiedlerlager Küchensee“ den am 30. Oktober aus Lodz eingetroffenen Vertriebenen ihre neuen Wohnorte, in die sie eingewiesen werden sollten, mitgeteilt: „Vormittags 7 Uhr Bekanntgabe der Eingemeindungsorte“2513

Einheimische, einheimische Bewohner - vielfach in der Literatur verwendet zur Unterscheidung von Flüchtlingen, Vertriebenen und anderen zeitweise im Ort befindlichen Personen, wie evakuierten, Kriegsgefangenen u.a., aber auch in zeitgenössischen Quellen häufig vorkommend, z. B. 1946: BLHA, Rep. 333, Nr. 574, Bl. 35. Definition im Merkblatt des Amtes für deutsche Umsiedler der Provinzialverwaltung Brandenburg vom 1.11.1946: „Als Einheimische (Stammbevölkerung) gelten alle Personen, die bereits im August 1939 in der Gemeinde ihren Wohnsitz hatten[,] und ihre inzwischen geborenen Kinder, ferner diejenigen Personen [,] die nach August 1939 einen neuen Aufenthaltsort aus eigenem Entschluß - nicht durch die Kriegsereignisse bedingtals ständigen Wohnsitz wählten." 2514

Ein- und Rückwanderer $\rightarrow$ Rückwanderer.

Einwohner (zugezogene) - Gegenbegriff zu „Umsiedler“, u. a. gebraucht in einer begrifflichen Festlegung der Umsiedlerabteilung der Landesverwaltung Sachsen vom 12.1.1946: „Diejenigen „Deutschen, die bis zum 1.10.1945 im Bundesland Sachsen polizeilich gemeldet waren, gelten als Einwohner (zugezogene Bevölkerung).'2515

Einzelgänger - Personen $(\rightarrow$ Vertriebene, $\rightarrow$ Evakuierte u. a. $)$, die allein und nicht im Rahmen eines offiziellen Gruppentransportes unterwegs waren, teils aus den Vertreibungsgebieten kommend, teils innerhalb der SBZ den Aufenthaltsort wechselnd. Ihre Gleichbehandlung bezüglich der Verpflichtung zu 14tägiger Quarantänezeit im Lager wird angemahnt in einem Bericht des Lagerleiters in Küchensee vom 16.11.1948. ${ }^{2516}$

Evakuierte - meist für während des Bombenkriegs aus den Städten aufs Land oder in kleinere Städte evakuierte Zivilisten gebraucht, aber auch für diverse andere unfreiwillige „Wanderungsgruppen " der Zeit vorkommend. Zwangsweise Evakuierungen Deutscher wegen der herannahenden Front (zu Unterscheiden von Umsiedlungsaktionen aus dem Baltikum oder Galizien; vgl. $\rightarrow$ „Rückgeführte“ und $\rightarrow$ „Rückwanderer“) begannen in osteuropäischen Siedlungsgebieten östlich der Reichsgrenzen schon 1943, in Südosteuropa 1944, in den Ostgebieten des Deutschen Reiches teilweise im Herbst 1944, wo sie aber, vielfach hinausgezögert und oft zu spät 
befohlen, erst ab Januar 1945 häufiger vorkamen (siehe auch $\rightarrow$ „Rückführungsfahrt“), dann in Zeitzeugenberichten eher als $\rightarrow$ Flucht bezeichnet. ${ }^{2517}$

Flucht - Der ohnehin sehr allgemeine Begriff wird in Zeitzeugenberichten nicht nur von $\rightarrow$ Flüchtlingen aus den Vertreibungsgebieten, sondern auch von westlich von Oder und Neiße lebenden $\rightarrow$ Einheimischen verwendet, die ihren Wohnort kurz vor dem Eintreffen der Roten Armee vorübergehend verließen, nach einigen Tagen, Wochen oder Monaten meist aber zurückkehrten.

Flüchtlinge - sowohl vor als auch nach Kriegsende offiziell und inoffiziell ${ }^{2518}$ auch in SBZ/DDR verwendeter Begriff für die Gesamtgruppe der Flüchtlinge und $\rightarrow$ Vertriebenen. Synonym und mit $\rightarrow$ „Umsiedler“ abwechselnd gebraucht u. a. in Stimmungsbericht des Landratsamtes Guben vom 24.9.1947 2519 , in der frühen Nachkriegszeit aber auch sehr häufig in Formulierungen von Privatpersonen begegnend. Am 8.9.1947 formuliert ein für Wohnungsfürsorge zuständiger Mitarbeiter der Landesregierung aber, offenbar zum Zwecke der Differenzierung, wobei ihm die fließenden Grenzen wohl bewusst waren: „einen Umsiedler bzw. einen Flüchtling“2520 - Im Protokoll des Wohnungsausschusses der Provinzialregierung Mark Brandenburg vom 2.7.1947 heißt es in der Wiedergabe eines Wortbeitrages von Brehmer „Die Flüchtlinge aus dem Osten und die Umgesiedelten“. ${ }^{2521}$ - In der deutschen Übersetzung eines Befehls der SMA Brandenburg von 1946 wird durchweg von „Umsiedlern“ gesprochen, in einem in dem Befehl wiedergegebenen Zitat heißt es dann aber als Selbstbezeichnung der Gruppe „Die Umsiedler erklären: ,Wir Flüchtlinge sind ...'“2522 - Im seit 1953 in West- und seit 1990 in Gesamtdeutschland geltenden Bundesvertriebenengesetz (BVFG) wird der Flüchtlingsbegriff v. a. für aus der SBZ/DDR (vor dem 1.7.1990) nach Westdeutschland Geflüchtete (auch „Sowjetzonenflüchtling“) verwendet, im Übrigen aber indirekt auch auf die ostdeutschen Flüchtlinge des Jahres 1945 bezogen, da bei der Definition des Begriffs Vertriebener $(\$ 1,1)$ als Ursache „Ausweisung oder Flucht“ genannt werden und in diversen weiteren Paragraphen das Begriffspaar der „Vertriebenen und Flüchtlinge“ als Gruppenbezeichnung vorkommt (z. B. im Titel ${ }^{2523}$ und im \$96).

Flüchtlingsdurchgangslager $\rightarrow$ Durchgangslager

Flüchtlingslager - sowohl vor als auch nach Kriegsende offiziell und inoffiziell verwendeter Begriff, ab Herbst 1945 offiziell ersetzt durch $\rightarrow$ „Umsiedlerlager“, ohne dass sich dass sogleich überall durchsetzte.

2517 Siehe (mit weiterführender Literatur): Martin Zückert: Evakuierung. In: Online-Lexikon zur Kultur und Geschichte der Deutschen im östlichen Europa, 2015. URL: ome-lexikon.uni-oldenburg.de/p32717 (Stand: 16.2.2015).

2518 Amos, Vertriebenenpolitik der SED (wie Anm. 12), S. 255.

2519 BLHA, Rep. 250 Landratsamt Guben, Nr. 82, Bl. 195.

2520 BLHA, Rep. 206 Ministerium für Wirtschaft und Arbeit, Nr. 2965, unfol.

2521 Ebd.

2522 BLHA, Rep. 230 Oberlandratsamt Bernau, Nr. 292, Bl. 5.

2523 „Gesetz über die Angelegenheiten der Vertriebenen und Flüchtlinge“. 
Heimatvertriebene - In der Bundesrepublik Deutschland offiziell, u.a. in \$ 2 BVFG (Bundesvertriebenengesetz) 2524 bis heute (unter Betonung des Wohnsitzes am 31.12.1937), sonst in Westdeutschland eher nur in den ersten Jahrzehnten nach 1945 öffentlich gebrauchter Begriff, der die Gruppe der aus ihren Siedlungsgebieten vertriebenen Deutschen von anderen Vertriebenen, v. a. den jüdischen und den nichtdeutschen Opfern der NS-Diktatur, unterscheiden helfen soll (in Westdeutschland auch Selbstbezeichnung, siehe z. B. „Block der Heimatvertriebenen und Entrechteten“ BHE). Der Begriff wurde in der westdeutschen Wissenschaft und Publizistik aber meist dennoch, ohne den umfassenderen Inhalt zu meinen, zu „Vertriebene“ verkürzt oder man gebrauchte das differenzierende Begriffspaar „Flüchtlinge und Vertriebene“, das sich bis heute in den meisten Veröffentlichungen findet. Der Begiff „Heimatvertriebener “ ist dagegen erst neuerdings (seit etwa 2000) in der wissenschaftlichen Literatur wieder etwas häufiger zu finden. ${ }^{2525}$ Auch die brandenburgische Landesregierung bzw. der Landtag Brandenburg verwenden ihn in ihrem Konzeptpapier von 2009. ${ }^{2526} \mathrm{Ob}$ er sich durchsetzen kann, vielleicht auch um die historische Gruppe nicht nur von vom Nationalsozialismus Verfolgten, sondern auch von heutigen (Flüchtlingen und) Vertriebenen zu unterscheiden, die ja aber ebenfalls ihre Heimat verlassen, bleibt abzuwarten.

Heimkehrer - aus der Kriegsgefangenschaft zurückkehrende Soldaten. Dies ist die durchgängig und deutschlandweit feststellbare Bedeutung, die auch in die Verwaltungssprache Eingang gefunden hatte, gelegentlich noch erweitert und konkretisiert zu „Kriegsheimkehrer“. Dennoch begegnet gelegentlich ein weniger konkreter Gebrauch des Begriffs, der aber wohl selten geblieben ist; so verwendet ein Zeitzeuge in seinem Bericht für von der vorübergehenden Flucht nach Mecklenburg 1945 zurückkehrende $\rightarrow$ einheimische Uckermärker den Begriff „Heimkehrer“ und bezeichnet sie nach Ankunft am Ursprungsort als „Heimgekehrte“2527.

Kreisumsiedlerlager $\rightarrow$ Umsiedlerlager

Kriegsheimkehrer $\rightarrow$ Heimkehrer

Lastenausgleich - Der Lastenausgleichsbegriff wurde in der SBZ - anders als in der Bundesrepublik Deutschland - für die Entschädigung der eingesessenen (!) Bevölkerung verwendet, wenn diese zu Abgaben zugunsten von $\rightarrow$ „Umsiedlern“ herangezogen wurde.

Lebenszeichen - vorgedruckte Postkarten für voneinander getrennte Verwandte, insbesondere noch in Lagern befindliche Kriegsgefangene, tragen diesen Aufdruck.

Märkische Volkssolidarität (MVS) - ab Frühjahr 1946 in Brandenburg fürsorgerisch tätig, besonders in der Betreuung von Kindern und alten Menschen.

2525 Beispielsweise in: Das Havelland um Rathenow und Premnitz (wie Anm. 105), S. 447 f.

2526 Geschichte vor Ort (wie Anm. 59), S. 79 („deutschstämmigen Heimatvertriebenen“).

2527 Die Uckermark 1945. T. 2. 2. Aufl. Prenzlau 1995, S. 4. 
Neubauer - In der SBZ ab 1945 verwendete Bezeichnung für Personen, denen Bodenreformland von mehr als fünf Hektar zugeteilt worden war und die nun hauptberuflich als Bauern wirtschafteten. Die Gruppe der Neubauern ist nicht auf die Vertriebenen $(\rightarrow$ „Neubauernumsiedler") beschränkt, sondern bestand sogar meist zum größeren Teil aus $\rightarrow$ Einheimischen. ${ }^{2528}$

Neubauernstelle - in der Bodenreform einem $\rightarrow$ Neubauern zugeteiltes und nun von ihm bewirtschaftetes Land, landwirtschaftlicher Betrieb eines Neubauern (Neubauernhof).

Neubauernumsiedler - gelegentlich begegnende zeitgenössische Variante zu $\rightarrow$ UmsiedlerNeubauer für in der Bodenreform mit Land versorgte, wegen Bedürftigkeit noch im Fokus der Verwaltung stehende Vertriebene (eigentlich), die nun als hauptberufliche $\rightarrow$ (Neu-)Bauern ihren Lebensunterhalt verdienen, u. a. am 21.2.1951 in einem Beschluss der brandenburgischen Landesregierung. ${ }^{2529}$

Neubürger - offizielle, kaschierende Bezeichnung für eingemeindete $\rightarrow$ Flüchtlinge und $\rightarrow$ Vertriebene in SBZ/DDR anstelle des ab spätestens 1952 meist vermiedenen $\rightarrow$ „Umsiedler“2530 Der Begriff „Neubürger“ wurde jedoch auch schon vor 1952 teilweise parallel zu „Umsiedler“ verwendet, bisweilen wurde seine Eignung auch bei SED- und Regierungsstellen unterschiedlich gesehen, so dass er weder ganz verschwand noch sich als alleiniger Ersatzbegriff für „Umsiedler" durchsetzen konnte. Der Begriff begegnet in den frühen Nachkriegsjahren gelegentlich auch in den Westzonen. ${ }^{2531}$

Neusiedler - in der Bodenreform mit Landzuteilung versehene, zuvor nicht selbständig in der Landwirtschaft tätig gewesene Personen, oft, aber nicht immer zugleich Vertriebene. Wie andere Begriffe ( $\rightarrow$ Neubürger) auch, sollte er aber letztlich vor allem zur Vermeidung der Begriffe $\rightarrow$ „Flüchtling“ und dann auch $\rightarrow$ „Umsiedler“ dienen. ${ }^{2532}$ Oft synonymer Gebrauch für $\rightarrow$ Neubauer.

Ostflüchtlinge - inoffizelle Bezeichnung in der DDR-Bevölkerung für die ostdeutschen Flüchtlinge und $\rightarrow$ Vertriebenen, jedoch seltener anzutreffen als das üblichere $\rightarrow$ „Flüchtlinge“ und das offizielle $\rightarrow$ „Umsiedler“2533

Ostumsiedler - Zur Unterscheidung von dem allgemeineren Begriff $\rightarrow$ „Umsiedler“, der formal auch Personen aus dem Ausland sowie $\rightarrow$ Evakuierte aus der Sowjetischen und den Westzo-

2528 Siehe auch (mit weiterführender Literatur): Ira Spieker: Neubauern. In: Online-Lexikon zur Kultur und Geschichte der Deutschen im östlichen Europa, 2012. URL: ome-lexikon.uni-oldenburg.de/55207.html (Stand: 3.6.2015).

2529 BLHA, Rep. 202A, Nr. 238, Bl. 55-56, hier nach Wille III (wie Anm. 196), S. 445, Nr. 519.

2530 Amos, Vertriebenenpolitik der SED (wie Anm. 12), S. 254.

2531 Siehe auch (mit weiterführender Literatur): Bernhard Parisius: Neubürger. In: Online-Lexikon zur Kultur und Geschichte der Deutschen im östlichen Europa, 2012. URL: ome-lexikon.uni-oldenburg.de/55207.html (Stand: 22.5.2015).

2532 Siehe auch (mit weiterführender Literatur): ebd.

2533 Amos, Vertriebenenpolitik der SED (wie Anm. 12), S. 255. 
nen einschloss, u. a. in Statistiken des Statistischen Landesamtes Brandenburg vom 31.12.1947 bis 8.4.1948 konkretisierend verwendet ${ }^{2534}$. In derselben Akte wahlweise im Text auch als „aus den Ostgebieten eingemeindete(n) Umsiedler" bezeichnet. ${ }^{2535}$ Unter dem 9.7.1946 moniert die „Zentralverwaltung für deutsche Umsiedler im sowjetischen Okkupationsgebiet", Berlin, in einem Schreiben an die SED Potsdam, die SED-Ortsgruppe Zehdenick habe in einem Schreiben vom 25.6.1946 von „Ostarbeitern“ gesprochen: „anscheinend ist sich die Ortsgruppe nicht darüber im klaren, dass es sich um, Ostumsiedler' handelt, also um Deutsche, die aus den jetzt polnisch besetzten Gebieten stammen “2536. Der Fall zeigt die Schwierigkeiten der Zentrale, lokalen Amtsträgern die unreflektiert weiter verwendte Terminologie der NS-Zeit abzugewöhnen („Ostarbeiter“ waren bis 1945 aus den besetzten Gebieten, insbesondere aus Polen und der Sowjetunion, stammende zivile Zwangsarbeiter).

Ostvertriebene - noch 1949 von einem Mitglied des Zentralsekretariats der SED auf einer SED-Konferenz verwendeter Begriff, allerdings für in den Westzonen lebende Personen. ${ }^{2537}$

Quarantänelager - Die Hauptfunktion der $\rightarrow$ Flüchtlings- bzw. $\rightarrow$ „Umsiedler-“ und $\rightarrow$ Heimkehrerlager benennende Bezeichnung: der (meist ca. 14tägige) Quarantäneaufenthalt vor der Weiterleitung bzw. $\rightarrow$ Eingemeindung.

Räumungsbefehl - von der Verwaltung und Zeitzeugen verwendet für die (meist im Januar 1945 verfügte) Evakuierung.

Reichsleistungsgesetz - „Gesetz über Sachleistungen für Reichsaufgaben“ vom 1. September $1939^{2538}$, bis Kriegsende eine der rechtlichen Grundlagen für die Enteignung $\rightarrow$ Einheimischer zugunsten von Flüchtlingen, Jan. 1946 im Landesblockausschuss Brandenburg als „mehr denn je dem Diebstahl gleichzusetzen" zurückgewiesen ${ }^{2539}$, aber noch am 2.8.1948 vom brandenburgischen Innenministerium weiterhin als Rechtsgrundlage berücksichtigt bzw. angewendet ${ }^{2540}$.

Repatrianten, Repatriierung (1) - in Polen seit 1944/45 Bezeichnung für die aus den sowjetisch gewordenenen polnischen Ostgebieten in die neuen Westgebiete Umgesiedelten (polnische Vertriebene, anfangs „Evakuierte“), zuständige Behörde war das „Staatliche Repatriierungsamt“ PUR (Państwowy Urząd Repatriacyjny), übersetzbar auch als Staatliche Umsiedlungsbehörde; entsprechend auch Bezeichnung der tschechischen Behörden für zurückkehrende Auslandstschechen und tschechische Auswanderer der Vorkriegszeit.

Repatrianten, Repatriierung, deutsche Repatrianten (2) - Repatriierung kommt auch vor als Bezeichnung der polnischen Behörden für die Ausweisung (Vertreibung) der deutschen

2535 Ebd., Bl. 18.

2536 BLHA, Rep. 333 SED-Landesleitung Brandenburg, Nr. 574, Bl. 32.

2537 Ebd., Bl. 388.

2538 RGBl. I 1939, S. 1645.

2539 Protokolle des Landesblockausschusses (wie Anm. 204), S. 21.

2540 Wille II (wie Anm. 196), S. 263 f. 
Restbevölkerung ab Herbst 1945 nach Deutschland. ${ }^{2541}$ Ferner gebrauchte das MdI der DDR den Begriff Repatrianten sowohl für Personen, die 1939-1945 zwangsweise (Zwangsarbeiter u. a.) im Deutschen Reich festgehalten worden waren und nun in ihre Heimatländer zurückkehrten, als auch später für deutsche Vertriebene, so 1951 für Ausgewiesene aus dem „Kaliningrader Gebiet“, z. B. „Repatrianten-Transport aus dem Kaliningrader Gebiet“2542. Im behördlichen Schriftverkehr der Abt. Bevölkerungspolitik des MdI mit dem für „Umsiedler“ zuständigen Referat Bevölkerungspolitik der Landesregierung Brandenburg zeigte sich 1950 die Verwendung unterschiedlicher Begriffe, indem der brandenburgische Referatsleiter Kuhn in seinen Antwortschreiben den Begriff „Repatrianten“ nicht durchgehend, aber mehrmals offenbar vermied und weiterhin von „Umsiedlern“ sprach, so werden (ein Beispiel von vielen!) mit Schreiben vom 4.9.1950 aus Berlin „Namenslisten der Repatrianten aus Polen“ angefordert, Kuhn spricht in seiner Antwort aber von „Umsiedlertransport-Listen“2543 Am 5.10.1951 sprich aber auch Kuhn von „Repatrianten-Transporte $(n){ }^{“ 2544}$ - Siehe auch $\rightarrow$ Westrepatrianten.

Rückführungsfahrt - u.a. im Januar und Februar 1945 im Sterberegister des Standesamtes Angermünde euphemistisch-bürokratisch verwendet für Evakuierung ( $\rightarrow$ Flucht) per Eisenbahn aus den Ostgebieten, z. B. aus Christburg (Kr. Stuhm) oder Königsberg in Preußen nach Angermünde. ${ }^{2545}$

Rückführungslager - seltenere Bezeichnung für „Umsiedlerlager“, in denen wegen des Bombenkrieges Evakuierte (aus den Gebieten westlich von Oder und Neiße!) nach Kriegsende auf die Möglichkeite zur Rückkehr in ihre Wohnorte warteten (z. B. gebraucht von einem in der Lagerbetreuung in Kirchmöser Tätigen: BLHA, Rep. 333, Nr. 574, B1. 35 ).

Rückführungspropaganda von Ostumsiedlern - Formulierung in einem Schreiben des SED-Zentralsekretariats vom 21.11.1947 für die Forderungen Vertriebener nach Genehmigung zur Rückkehr in die Heimat. ${ }^{2546}$

Rückgeführte - 1939/41 inoffiziell verwendet für aus der Sowjetunion in das Deutsche Reich Umgesiedelte (siehe sonst $\rightarrow$ Rückwanderer); außerdem aber 1944/45 offizielle Formulierung für während des Krieges nach Westen $\rightarrow$ evakuierte Bewohner in Frontnähe geratener ostdeutscher Städte und Landkreise, u. a. verwendet in Meldungen von Tageszeitungen, so im „Brandenburger Anzeiger“ Anfang $1945^{2547}$ und in der „Potsdamer Tageszeitung“ am 27.1.1945 2548 und

2541 Siehe z.B. „Unsere Heimat ist uns ein fremdes Land geworden ...“ (wie Anm. 195), Bd. 3. Marburg 2004, S. 234 f., 698.

2542 BArch, DO 1/8408, unfol.

2543 BArch, DO 1/8207, unfol.

2544 BArch, DO 1/8408, unfol.

2545 Stadtarchiv Angermünde, Standesamt Angermünde, Sterberegister, Jg. 1945.

2546 BLHA, Rep. 333 SED-Landesleitung, Nr. 574, Bl. 79, hier zitiert nach Wille III (wie Anm. 196), S. 353, Nr. 394.

2547 Wolfgang Kusior: Die Stadt Brandenburg im Jahrhundertrückblick. Berlin 2000, S. 67.

2548 Eberhard Kapuste: Die Gemeinde Eiche in den Jahren 1918 bis 1945. [Potsdam 2014], S. 69. 
ebenda am 16.3.1945 in einer Information über die Rechte der „Rückgeführten“: „Die Fürsorge für die Rückgeführten, insbesondere aus den jetzt von den Bolschewisten besetzten deutschen Gebieten, ist ohnehin Pflicht der Volksgemeinschaft. Rückgeführte Familien erhalten, solange ihre normalen Bezüge noch nicht wieder gezahlt werden bzw. für Mehraufwendungen und beim Ausfall ihrer Einnahmequellen, von der Gemeindeverwaltung ihres Aufenthaltsortes den Räumungsfamilienunterhalt. "

Rückkehrer - Ab 1945 Synonym für $\rightarrow$ „Heimkehrer“, d. h. aus der Kriegsgefangenschaft zurückkehrende deutsche Soldaten. ${ }^{2550}$ Vor 1945 aber auch inoffiziell für aus der Sowjetunion in das Deutsche Reich Umgesiedelte verwendet (siehe $\rightarrow$ Rückwanderer).

Rückwanderer - 1939/41 verwendet für aus der Sowjetunion in das Deutsche Reich $\rightarrow$ Umgesiedelte („Ein- oder Rückwanderer“, auch $\rightarrow$ „Rückkehrer“, $\rightarrow$ „Rückgeführte“, offiziell aber gemäß „Führererlass“ von 1939 meist „Umsiedler“). ${ }^{2551}$ - Nach Kriegsende wird „Rückwandern“ 1945 aber auch gebraucht für die „Bevölkerungsbewegung“ der aus den Ostgebieten Anfang 1945 Geflüchteten, die nach Ende der Kampfhandlungen vorübergehend in ihre Heimatorte östlich von Oder und Neiße zurückkehrten (und von dort später vertrieben wurden) ${ }^{2552}$, ebenso aber auch allgemein für alle durch die Kriegsereignisse an andere Orte gelangte Personen, die nun zurückkehren wollten: Im Juni 1945 muss die „Rückwanderung“ z. B. von der Kreiskommandantur Teltow genehmigt werden. ${ }^{2553}$

Spätaussiedler - Im nichtamtlichen Sprachgebrauch Personen deutscher Abstammung, die erst nach Ende der Vertreibungen aus den ehemaligen deutschen Ostgebieten oder aus anderen ostmittel- und osteuropäischen Siedlungs- bzw. (nach Umsiedlung, Deportation u.a.) letzten Wohnorten vor oder nach 1990 in die Bundesrepublik Deutschland (amtlich dort jedoch $\rightarrow$ „Aussiedler") oder die DDR (offiziell dort jedoch $\rightarrow$ „Übersiedler") kamen. Amtlich wird seit 1993 differenziert zwischen bis 1992 Zugezogenen „Aussiedlern“ und ab 1993 zugezogenen „Spätaussiedlern“ (Kriegsfolgenbereinigungsgesetz). In der Literatur wird jedoch vor wie nach 1993 meist der Begriff „Spätaussiedler“ als Sammelbegriff für beide Gruppen verwendet. ${ }^{2554}$

Stammbevölkerung $-\rightarrow$ Einheimische.

Stammeinwohner - als Gegenbegriff zu $\rightarrow$ „Flüchtlinge“ u. a. in einem Bericht der Flüchtlingsbetreuungsstelle des Kreises Beeskow-Storkow vom 4. Oktober 1945 verwendet. $^{2555}$

2549 Kurt Baller / Marlies Reinholz: Potsdam im Zweiten Weltkrieg. Eine Chronik. Magdeburg 2010, S. 364.

2550 Müller, Nachkriegsjahre in Eichwalde. (wie Anm. 177), S. 111.

2551 ELAB, 14/582, Bl. 9.

2552 Tagebuch vom Mai 1945, zitiert in: Der Speicher 17 (2015), S. 118.

2553 Schulzendorfer Nachrichtenblatt, Nr. 35, 12. Juni 1945.

2554 Siehe auch oben im Teil 1, Kapitel V, den Abschnitt „Spätaussiedler“ sowie (mit weiterführender Literatur): Panagiotidis, Aussiedler/Spätaussiedler (wie Anm. 2390).

2555 BLHA, Rep. 250 Landratsamt Beeskow-Storkow, Nr. 867, unfol. 
Suchdienst - Der „Suchdienst für vermisste Deutsche“ war ein wesentliches Element der „Umsiedler-Betreuung", diente aber auch allen anderen, die Verwandte in Folge der Kriegsereignisse vermissten. Laut Meldung der Kreis-Umsiedler-Ämter gab es im Aug./Sept. 1948 im Land Brandenburg 998 Annahmestellen. 2556

Übersiedler, Übersiedlung - offizieller Begriff in der DDR, verwendet ebenso für DDR-Bürger, die in die Bundesrepublik ausreisten, wie für $\rightarrow$ Aussiedler aus den polnischen Westgebieten, die in die DDR kamen. ${ }^{2557}$ In der Bundesrepublik bis 1990 und in Gesamtdeutschland ab 1990 offiziell als „Aussiedler“, inoffiziell als $\rightarrow$ „Spätaussiedler“ bezeichnet.

Umgesiedelte - inoffizielle Variante von $\rightarrow$ „Umsiedler“.

Umquartierte - In der NS-Zeit (1943-1945 belegt) und 1945 gelegentlich auch noch nach Kriegsende als Synonym für deutsche (Zwangs-) $\rightarrow$ Evakuierte, aber auch für $\rightarrow$ Umsiedler (1) bzw. (2) verwendet. ${ }^{2558} \mathrm{Vgl}$. Sachregister.

Umsiedler (1) - In der NS-Zeit sowie nach 1945 in Westdeutschland (und seit 1990 in Gesamtdeutschland) sowie in der Literatur wurde und wird der (in der Sowjetunion schon vor 1939 vielfach für staatlich angeordnete Aktionen angewandte) Begriff „Umsiedler“ hingegen konkreter verwendet für während des Zweiten Weltkrieges planmäßigen Umsiedlungen bestimmter Bevölkerungsgruppen ausgesetzt gewesene Personen, die aus der Sowjetunion, vom Balkan, aus Italien usw. in das Deutsche Reich („Heim ins Reich“) umgesiedelt wurden ${ }^{2559}$, z. B. die in den „Warthegau“2560 überführten Deutschbalten (Baltendeutschen) 1939/41 oder die Wolhynien- und Bukowinadeutschen 1939/40, die dort allesamt schon wenige Jahre später,

2556 BLHA, Rep. 203 MdI, Nr. 1198, Bl. 42.

2557 Schneider, Als Deutsche unter Deutschen? „Übersiedler aus der VR Polen“ (wie Anm. 23), S. 70 Anm. 5. U. a. verwendet 1965 vom Rat des Bezirkes Cottbus, Innere Angelegenheiten, für Personen/Familien aus Polen (BArch, DO 1/14659, unfol.).

2558 [Im Krieg:] Vorländer, NSV (wie Anm. 499), S. 520 (Nr. 296); ferner: Dokumentation über den Obernigker Treck 1945 einschließlich Aufenthalt in Wildstein/Egerland. Zsgest. von Ekkehard Loch u. Hellmut Seidel. Lüdenscheid/Deisenhofen 1998, S. 45 (Faksimile eines für „Sammelstelle:“ handschriftlich „Obernigk/Gemeindeplatz" [Kr. Trebnitz, Niederschlesien] ausgefüllten Formulars mit Vordruck-Überschrift: „Unsere Ortsgruppe wird umquartiert nach:“, Zielort [handschriftlich]: „Jauer (Stadt)“, mit gedruckter Liste: „Folgende Sachen sind vordringlich mitzunehmen:"), S. 46 (Faksimile eines vom NSDAP-Kreisleiter und vom NSV-Hauptamtsleiter gemeinsam unterzeichneten gedruckten Flugblatts „Umquartierte!“ an die Bevölkerung des niederschlesischen Kreises Jauer, „sich stündlich bereitzuhalten“, ausgenommen „die im Arbeitseinsatz stehenden“, wohl vom Jan. 1945). - [Nach Kriegsende:] Brandenburgische Gemeinden kurz nach dem Kriegsende von 1945. Aus eigenen Berichten der Gemeinden niedergeschrieben Ende 1945. Potsdam 2013 S. 22.

2559 Siehe u. a. die Formulierung in \$ 1,1 BVFG: „Vertriebener ist auch, wer als deutscher Staatsangehöriger oder deutscher Volkszugehöriger [...] aufgrund auf Grund der während des Zweiten Weltkrieges geschlossenen zwischenstaatlichen Verträge aus außerdeutschen Gebieten oder während des gleichen Zeitraumes auf Grund von Maßnahmen deutscher Dienststellen aus den von der deutschen Wehrmacht besetzten Gebieten umgesiedelt worden ist (Umsiedler)“.

2560 Hier zeitgenössisch z.B. 1941 auch „Deutscher Umsiedler“ auf Kennkarten (Laufzetteln) für Bukowinadeutsche, siehe Deutsches Historisches Museum Berlin, Inv. Nr.: Do2 91/15. 
1945, erneut, nun als $\rightarrow$ Flüchtlinge oder $\rightarrow$ Vertriebene, heimatlos wurden. Er ist hier also sowohl zeitgenössischer (Quellen-)Begriff als auch aktueller juristischer und wissenschaftlicher Terminus. Die Begriffe „Umsiedler“ und „Umsiedlung“ wurden zudem in Westdeutschland nach $1945 \mathrm{z}$. T. verwendet für Spätaussiedler ${ }^{2561}$ sowie für solche Flüchtlinge und Vertriebenen, deren ,freiwillige Umsiedlung“ aus überbelegten in andere Bundesländern gemäß „Umsiedlungsund Finanzierungsplan“ der Bundesregierung „gefördert werden“" sollte. ${ }^{2562}$

Umsiedler (2) - In SBZ/DDR offizielle Bezeichnung für $\rightarrow$ Flüchtlinge und $\rightarrow$ Vertriebene sowie sonstige im Zusammenhang mit den Kriegsereignissen aus ihrem angestammten Wohnort (also auch aus den 1945 bei Deutschland verbliebenen Ländern ${ }^{2563}$ ) $\rightarrow$ evakuierte oder zwangsweise überführte Personen. ${ }^{2564}$ Der Begriff wurde im September 1945 auf Befehl der Sowjetischen Militäradministration anstelle des bis dahin verwendeten Begriffs $\rightarrow$ „Flüchtlinge“ eingeführt und in der Folge von der KPD/SED durchzusetzen versucht. ${ }^{2565}$ Dies ist zwar weitestgehend gelungen (mit Auswirkungen bis in die rückblickende Terminologie der Bevölkerung in der Gegenwart sowie in archivischen Findmitteln), doch kam der Begriff „Flüchtling“ in der DDR im privaten Raum sowie in der belletristischen und autobiographischen Literatur weiterhin vor. Der „Umsiedler“-Begriff wird in der DDR öffentlich und offiziell nur bis etwa spätestens Mitte der 1950er Jahre, danach aber weiterhin zumindest in der internen Kommunikaton von Polizei und MfS benutzt sowie in der auf die Verhältnisse in der Bundesrepublik bezogenen Propaganda und auch in der wissenschaftlichen und der belletristischen Literatur. ${ }^{2566}$ Öffentlich wechselt man schon früh, aber nur bis 1952, zu den häufigen Varianten $\rightarrow$, ehemalige Umsiedler“ und $\rightarrow$ „Neubürger“.2567

2561 Warum die Deutschen nach Westdeutschland umgesiedelt werden wollen. In: Der Westpreuße 8 (1956), Nr. 17, S. 2.

2562 BGBl I 1955, S. 33; 1956, S. 490. L.: Umsiedlung von Vertriebenen und Flüchtlingen aus überbelegten Ländern. In: Der Westpreuße 8 (1956), Nr. 15, S. 2.

2563 Siehe z.B. die Festlegungen der Umsiedlerabteilung der Landesverwaltung Sachsen vom 12.1.1946 (Wille I [wie Anm. 196], S. 289), die zwischen „Einwohnern“ (nur, wenn „bis zum 1.10.1945 im Bundesland Sachsen polizielich gemeldet") und „Umsiedlern" unterscheidet. Siehe auch Punkt 2 in der folgenden Anm.

2564 Begriffsdefinition im Merkblatt des Amtes für deutsche Umsiedler der Provinzialverwaltung Brandenburg vom 1.11.1946: „Umsiedler ist jede Person deutscher Nationalität, welche ostwärts der Oder und Lausitzer Neiße, im Gebiet der CSR oder anderer Länder beheimatet war, jedoch nach Beginn des Krieges (September 1939) durch Waffenhandlungen, sonstige Kriegsmaßnahmen (Ausgebombte) oder Ausweisungsverfügungen gezwungen wurde, ihren Heimatort zu verlassen." / 2. Zu Umsiedlern zählen ferner diejenigen Personen, die während des Krieges[,] also ab September 1939 als Evakuierte, Ausgebombte, oder Betriebsverlagerte ihren Heimkatort verlassen mußten, der sich innerhalb der jetzigen deutschen Grenzen befindet. Hierzu rechnen auch die Personen, die in den westlichen Zonen (amerikanisch [e], englische, französische) beheimatet sind, bisher aber dorthin noch nicht zurückkehrten. (Evakuierte)" (Wille I [wie Anm. 196], S. 296, nach BLHA, Rep. 203 MdI, Nr. 1163, Bl. 48).

2565 Amos, Vertriebenenpolitik der SED (wie Anm. 12), S. 254. Siehe auch. Uta Bretschneider: Umsiedler (SBZ/ DDR). In: Online-Lexikon zur Kultur und Geschichte der Deutschen im östlichen Europa, 2013. URL: omelexikon.uni-oldenburg.de/61788.html (Stand: 28.8.2014).

2566 Ebd.

2567 Ebd. 
Umsiedler (3) - Abgesehen davon, dass der ohnehin allgemein gehaltene Begriff auch anderswo immer wieder in Gebrauch war und ist, werden die Begriffe „Umsiedlung“ und „Umsiedler“ in Brandenburg heute (wie schon zu DDR-Zeiten) konkret auch für die vom Braunkohlentagebau betroffenen Bewohner abgebaggerter Orte benutzt (z. B. Horno/Neu Horno). Nur am Rande sei darauf hingewiesen, dass der Begriff heute sogar bei der Rettung bedrohter Tiere Anwendung findet. So titelte eine Fürstenwalder Zeitung 2011: „Platz da für Umsiedler! Mit der Schaffung von Reptilien-Ersatzlebensraum ist der Weg für Kläranlagen-Erweiterung geebnet."2568

Umsiedlerausschuss (Orts-, Kreis-, Provinzialumsiedlerauschuss) - ab Oktober 1945 eingerichtete Gremien, die sich zur Unterstützung der Verwaltungen der Versorgung bedürftiger Flüchtlinge und Vertriebener annehmen und diese koordinieren und überwachen sollten. Im Vordergrund stand die Beschaffung von Wohnraum, Mobiliar, Kleidung und Haushaltsgegenständen, wozu u. a. Sammelaktionen wie die $\rightarrow$ „Umsiedlerwochen“ durchgeführt wurden. ${ }^{2569}$ Betroffene (Vertriebene) waren anteilig in den Ausschüssen vertreten. Die Umsetzung der Anordnung zur Einrichtung von Ortsumsiedlerausschüssen verlief in manchen Landgemeinden schleppend, bei Kontrollen war sie nicht selten noch gar nicht erfolgt.

Umsiedlerlager - In der SBZ Bezeichnung für die anfangs auch offiziell noch überwiegend als $\rightarrow$ Flüchtlingslager bezeichneten $\rightarrow$ Durchgangs- und $\rightarrow$ Quarantänelager, in die die Transporte zunächst geführt wurden, um von hier aus in Wohnquartiere eingewiesen („eingemeindet“) oder an andere Orte oder in eine andere Besatzungszone weitergeleitet zu werden. Die Zahl der Lager schwankte oft und stark und ist, wenn man alle kleinen lokalen Interimslager einbeziehen wollte, kaum noch festzustellen. Die Hauptlager standen unter der Verfügungsgewalt der zentralen Provinzial- bzw. Landesregierung, waren aber formal den Kreisverwaltungen (Landratsämtern) unterstellt. Theoretisch hatte jeder Landkreis ein „Kreisumsiedlerlager“, doch wurden je nach Kapazitätsbedarf (und Anforderung durch die Regierung) auch zusätzliche Lager eingerichtet.

Umsiedler-Neubauer - gelegentlich auch $\rightarrow$ „Neubauernumsiedler“, Bezeichnung für in der Bodenreform mit Land versorgte, wegen Bedürftigkeit noch im Fokus der Verwaltung stehende Vertriebene (eigentlich), die nun als hauptberufliche $\rightarrow$ (Neu-)Bauern ihren Lebensunterhalt verdienen, u. a. 1948 in einer Aufgabenformulierung für die Abteilung Umsiedler und Heimkehrer der Landesregierung Brandenburg für das Jahr 19492570 und am 15.4.1950 in einem Bericht des Amtes für Information über die Lage der „Umsiedler“ im Kreis Angermünde. ${ }^{2571}$

Umsiedlerwoche - vom 25. Oktober bis 2. November 1947 und erneut vom 22. bis 29. Februar 1948 in der gesamten SBZ durchgeführte Sammelaktion zugunsten der $\rightarrow$ „Umsiedler“, in der die $\rightarrow$ einheimische Bevölkerung in öffentlichen Veranstaltungen für das Integrationspro-

2568 Spree Wasser-Zeitung, Ausgabe Fürstenwalde, 16. Jg., Nr. 1, April 2011, S. 1.

2569 Siehe auch (mit weiterführender Literatur): Parisius, Neubürger (wie Anm. 2531).

2570 BLHA, Rep. 333 SED-Landesleitung Brandenburg, Nr. 574, Bl. 383v.

2571 BLHA, BLHA, Rep. 202 G Amt für Information, Nr. 170, Bl. 28v. 
blem sensibilisiert werden, vor allem aber $\rightarrow$ Einheimische Sachspenden (Kleidung, Hausrat usw.) leisten sollten und geleistet haben. ${ }^{2572}$

Volkssolidarität $\rightarrow$ Märkische Volkssolidarität

Westrepatrianten - Personen, die 1951 aus Ostpreußen ausgewiesen und in die DDR transportiert wurden, aber sogleich von dort zu Verwandten in Westdeutschland weitergeleitet wurden, nannte das MdI „Westrepatrianten aus den Kaliningrader Transporten“. ${ }^{2573}$ Vgl. $\rightarrow$ Repatrianten.

Wilde Vertreibung(en) - Nicht zeitgenössischer, nachträglich von Betroffenen eingeführter inoffizieller, inzwischen in der Geschichtswissenschaft aber allgemein gebräuchlicher Begriff für die noch vor der staatlichen Regelung durch das Potsdamer Abkommen (2. August 1945) zur Schaffung „vollendeter Tatsachen“ durchgeführten Vertreibungen aus den polnischen (ostdeutschen) Gebieten ${ }^{2574}$ (20. Juni bis Mitte Juli 1945) und tschechischen (sudetendeutschen) Gebieten $^{2575}$ (ab 5. Juni 1945).

Vertriebene - seit 1953 in Westdeutschland und seit 1990 in Gesamtdeutschland offizielle Bezeichnung in $\$ 1,1$ BVFG (Bundesvertriebenengesetz) ${ }^{2576}$ für die aus ihren Vorkriegswohnorten vertriebenen, d.h. (ab 1945) ausgewiesenen, (1939/45) umgesiedelten oder (ab 1933) geflüchteten deutschen Staatsangehörigen (vgl. aber auch $\rightarrow$ Heimatvertriebene) oder Volkszugehörigen, in der Literatur meist entweder als Oberbegriff für die Gesamtgruppe verwendet oder im Begriffspaar $\rightarrow$ „Flüchtlinge und Vertriebene“ für die zweite Gruppe, die nach Ende der Kampfhandlungen Ausgewiesenen, zur Unterscheidung von der ersten, den bereits (kurz) zuvor $\rightarrow$ Evakuierten bzw. Geflüchteten, im inoffiziellen Sprachgebrauch aber auch ungenauer synonymer Gebrauch vorkommend. In Westdeutschland und ab 1990 in Gesamtdeutschland auch Selbstbezeichnung, siehe z.B. „Bund der Vertriebenen“ BdV. In SBZ/DDR als westdeutscher Propagandabegriff bezeichnet und daher weder offiziell ( $\rightarrow$ „Umsiedler“, $\rightarrow$ „ehem. Umsiedler“, $\rightarrow$ „Neubürger“) noch inoffiziell ( $\rightarrow$ „Flüchtlinge“) in Gebrauch.

Zwangsevakuierte $\rightarrow$ Evakuierte.

2572 Bretschneider, Umsiedler (wie Anm. 2564). - Grundlegend: Schwartz, Kontrollierte Partizipation (wie Anm. 1113).

2573 BArch, DO 1/8408, unfol.

2574 Ruchniewicz, Wilde Vertreibung aus Polen (wie Anm. 530).

2575 Brandes, Wilde Vertreibung aus der Tschechoslowakei (wie Anm. 529).

2576 BGBl I 1953, S. 203. 


\section{Zeittafel 1944-2018}

Gekürzt zitierte Quellen und Literatur: Atlas = Zwangsumsiedlung, Flucht und Vertreibung 1939-1959. Atlas zur Geschichte Ostmitteleuropas. Bonn 2010. - Brisch/Buwert/Schieck = Brisch, Brigitte / Buwert, Wolfgang / Schieck, Martin: Frankfurt (Oder) 1945. Ausgewählte Daten, Dokumente, Fotos und Erinnerungen. Frankfurt (Oder) [1995]. Buwert = Buwert, Wolfgang: Festung Frankfurt (Oder): eine Stadt am Kriegsende. In: Brandenburg im Jahr 1945. Studien. Hrsg. von Werner Stang. Potsdam 1995, S. 38-83. - Foitzik = Inventar der Befehle des Obersten Chefs der Sowjetischen Militäradministration in Deutschland (SMAD) 1945-1949. Offene Serie. München u. a. 1995. - Hilgermann = Hilgemann, Werner: Atlas zur deutschen Zeitgeschichte 1918-1968. München/Zürich 1984. - Wille I-III = Die Vertriebenen in der SBZ/DDR. Dokumente. Hrsg. u. eingel. von Manfred Wille. T. 1-3. Wiesbaden 1996-2003.

\section{4}

16.10.1944 Überschreitung der ostpreußischen Grenze durch die Rote Armee (Atlas, S. 168).

20.10.1944 Beginn der Evakuierung der Bevölkerung aus den östlichen Kreisen Ostpreußens in die westlichen (Handbuch der Historischen Stätten Ost- und Westpreußen, S. LXIX)

\section{5}

12./14.1.1945Beginn der Offensive der Roten Armee in Richtung Oder (Weichsel-Oder-Operation), Frontdurchbruch an Weichsel und Narew (Buwert, S. 46; Atlas, S. 168)

13.01.1945 Sowjetische Offensive zur Eroberung Ostpreußens (Hilgemann, S. 205)

Mitte 1.1945 Tagung aller brandenburgischen [mit der Unterbringung, Verpflegung und Betreuung der Flüchtlingsströme beauftragten] NSV-Kreisamtsleiter im NSV-Gauamt in Frankfurt (Oder), Halbe Stadt 7 (Buwert, S. 57)

15.01.1945 Küstrin zur Festung erklärt (Kreis Königsberg/Neumark, S. 219)

19.01.1945 Sprengung der Eisenbahnbrücke bei Frankfurt (Oder) durch Wehrmachttruppen (Brisch/Buwert/Schieck, S. 7; Nachsprengung am 22.2.); Befehl zur Zwangsevakuierung Breslaus (Atlas, S. 168); Beginn der Zwangsevakuierung Küstrins (bis 21.2.) (Kreis Königsberg/Neumark, S. 219)

20.01.1945 Zwangsevakuierung der deutschen Bevölkerung der Stadt Posen, Eintreffen des Gauleiters und Reichsstatthalters Arthur Greiser aus Posen in Frankfurt (Oder) (Buwert, S. 50; Brisch/Buwert/Schieck, S. 4)

20.01.1945 Eintreffen des ersten Flüchtlingstrecks mit 60 Pferdefuhrwerken in Cottbus (Petzold, S. 108)

21.01.1945 Eintreffen der ersten Flüchtlingswelle aus Ost- und Westpreußen, dem Wartheland und der Neumark in Frankfurt (Oder) per Bahn und mit motori- 
sierten Fahrzeugen (Buwert, S. 49); Frankfurt (Oder) wird Durchgangsstadt für die Ostflüchtlinge (Brisch/Buwert/Schieck, S. 4)

22.01.1945 Frankfurt (Oder): Nachsprengung der Eisenbahnbrücke (Brisch/Buwert) Schieck, S. 7); HJ und BDM organisieren einen Bahnhofsdienst für die ankommenden Flüchtlinge (Brisch/Buwert/Schieck, S. 4)

23.01.1945 Sowjetische Truppen an der Oder in Niederschlesien (Hilgemann, S. 205)

25.01.1945 Eröffnung der Zentralstelle für vermißte Flüchtlinge in Frankfurt (Oder), Halbe Stadt 7 (Brisch/Buwert/Schieck, S. 4)

26.01.1945 Frankfurt (Oder) zur Festung erklärt [nicht 27.01.!] (Buwert, S. 49; Brisch/Buwert/Schieck, S. 4)

29.01.1945 Frankfurt (Oder): Lehrkräfte und Schüler der Alten Städtischen Oberschule werden zur Flüchtlingsbetreuung und für Kurierdienste eingesetzt (Brisch/Buwert/Schieck, S. 4)

30.01.1945 Untergang des aus Gotenhafen (Gdingen) kommenden, mit Flüchtlingen und Verwundeten besetzten Truppentransportschiffs „Wilhelm Gustloff“ vor der pommerschen Küste bei Stolpmünde

Ende 1.1945 Eintreffen der zweiten Flüchtlingswelle (Trecks mit Pferdegespannen und Fußgängern) in Frankfurt (Oder) (Buwert, S. 51)

31.01.1945 Die Rote Armee überschreitet die Oder bei Kienitz, Groß Neuendorf, Frankfurt (Oder) und Küstrin und bildet Brückenköpfe

02.02.1945 Die Rote Armee erreicht in Schiedlo (Kr. Guben) die Oder (Neißemündung) (Heimatkalender Eisenhüttenstadt 23, 2005, S. 259)

03.02.1945 Sprengung des Fliegerhorsts in Kunersdorf bei Frankfurt (Oder) (Wir waren damals 19. Frankfurt (Oder) 1995, S. 132)

04.02.1945 Beginn der systematischen Zwangsevakuierung der Zivilbevölkerung von Frankfurt (Oder) (Brisch/Buwert/Schieck, S. 7); Zwangsräumung der Dammvorstadt in Frankfurt (Oder) sowie von Beresinchen (Wir waren damals 19. Frankfurt (Oder) 1995, S. 131)

04.02.1945 „Wehrmachtspioniere sprengen [...] die große Oderbrücke bei Fürstenberg“ (70 Jahre Kriegsende in Fürstenwalde, o.S.).

04.02.1945 Standgericht (Kriegsgericht) verhängt in Schwedt (Oder) Todesurteil gegen den zur Beschaffung von Waffen und Munition für seine Truppe nach Schwedt gekommenen Bürgermeister von Königsberg/Nm., Kurt Flöter, wegen unerlaubten Verlassens seiner Stadt, Vollstreckung durch Erhängen an einer Kastanie auf der Schwedter Schlossfreiheit

04.02.1945 bis 11.02.1945 Konferenz von Jalta 
05.02.1945 Räumung der Gubener Vorstadt in Frankfurt (Oder) (Wir waren damals 19. Frankfurt (Oder) 1995, S. 131)

08.02.1945 Geheime Verlegung der Regierung Frankfurt (Oder) nach Westen auf Anordnung Himmlers; nur ein höherer Beamter soll in der Stadt verbleiben; der städtische Omnibusverkehr wird ausschließlich für den Transport der Flüchtlinge eingesetzt (Brisch/Buwert/Schieck, S. 7)

13.02.1945 Tod vieler Flüchtlinge beim Bombenangriff auf Dresden

15.02.1945 Schwerer Luftangriff auf den Bahnhof Cottbus, große Opferzahl (etwa $2000[?]$ ), darunter viele nicht registrierte Flüchtlinge (Menschen und Schicksale, S. 464; Töpler, Menschenwurm, S. 325)

24.02.1945 Befehl des NSDAP-Kreisleiters in Frankfurt (Oder) zur Zwangsevakuierung der Lebuser und der Gubener Vorstadt in Frankfurt (Oder) (Wir waren damals 19. Frankfurt (Oder) 1995, S. 133)

20.03.1945 Auflösung der Wehrbezirkskommandantur Frankfurt (Oder) und Verlegung nach Fürstenwalde (Brisch/Buwert/Schieck, S. 12)

31.03.1945 Kapitulation von Küstrin (Wir waren damals 19. Frankfurt (Oder) 1995, S. 134; Kreis Königsberg/Neumark, S. 219)

18.04.1945 (Abends) Beginn der Räumung des Brückenkopfes Dammvorstadt Frankfurt (Oder) (Brisch/Buwert/Schieck, S. 14)

19.04.1945 Sprengung der Oderbrücke in Frankfurt (Oder) durch die Wehrmacht [nicht 12.04.!] (Brisch/Buwert/Schieck, S. 14, 16)

21.04.1945 Aufhebung des Festungsstatus für Frankfurt (Oder) (Brisch/Buwert/Schieck, S. 14)

22.04.1945 (Abends) Rückzug der Wehrmachts- und Volkssturmverbände aus Frankfurt (Oder) (Brisch/Buwert/Schieck, S. 14)

23.04.1945 (Frühe Morgenstunden) Einmarsch der sowjetischen Truppen in Frankfurt (Oder) nach dreimonatiger Belagerung (Brisch/Buwert/Schieck, S. 14; Wir waren damals 19. Frankfurt (Oder) 1995, S. 136)

23.04.1945 Einzug der bereits in Zielenzig gebildeten sowjetischen Kommandantur für Frankfurt (Oder) in die Stadt (Brisch/Buwert/Schieck, S. 14)

04.05.1945 Fertigstellung einer provisorischen Oderbrücke in Frankfurt (Oder); beginnende Rückkehr von Frankfurtern in ihre Wohnungen in der Dammvorstadt (Brisch/Buwert/Schieck, S. 39)

05.05.1945 Die US-Armee verweigert fortan Flüchtlingen das Überqueren der Elbe.

06.05.1945 Befehl zur Evakuierung des Glatzer Beckens (Atlas, S. 168) 
07.05.1945 Die Rote Armee erreicht das Ostufer der Elbe in voller Breite.

08.05.1945 Bedingungslose Kapitulation der deutschen Wehrmacht, Kriegsende in Europa

15.05.1945 Polnische Beschriftung der Straßen in der Dammvorstadt Frankfurt (Oder) (Brisch/Buwert/Schieck, S. 39)

25.05.1945 Übergabe der Dammvorstadt Frankfurt (Oder) an die polnische Verwaltung (Brisch/Buwert/Schieck, S. 39)

27.05.1945 Beginn der Ausweisung der deutschen Bevölkerung der Dammvorstadt Frankfurt (Oder); Ende Mai Einrichtung eines Internierungslagers in der Dammvorstadt (Brisch/Buwert/Schieck, S. 39)

10.06.1945 Befehl des Oberbefehlshabers des Polnischen Heeres zur Verhinderung von Grenzübertritten in ihre Heimatorte strebender deutscher Flüchtlinge von der Westseite der Oder aus (Atlas, S. 184)

20.06.1945 Beginn der Ausweisungen („Wilde Vertreibungen“) der deutschen Bevölkerung aus dem östlich der Neiße gelegenen (Haupt-) Teil der Stadt Guben ${ }^{2577}$, am 23.6. aus Tamsel (Kr. Landsberg/Warthe), vom 26. bis 30.6. aus Landsberg/ Warthe (Landsberg an der Warthe [Bd. 1]. Bielefeld 1976, S. 323)

25.06.1945 Ausweisung der deutschen Restbevölkerung der Dammvorstadt Frankfurt (Oder) (Brisch/Buwert/Schieck, S. 42)

04.07.1945 Bildung der Provinzialverwaltung Brandenburg (Brisch/Buwert/Schieck, S. 45)

05.07.1945 Übergabe Stettins an die polnische Verwaltung durch die sowjetische Kommandantur

15.07.1945 Verstärktes Eintreffen durchziehender Flüchtingsströme aus dem Osten in Frankfurt (Oder) (Brisch/Buwert/Schieck, S. 45)

15.07.1945 bis 20.07.1945 Einstellung der „Wilden Vertreibungen“ durch polnische Kräfte (Atlas, S. 184)

17.07.1945 bis 02.08.1945 Potsdamer Konferenz (Hilgemann, S. 206): Festlegung der Oder-Neiße-Grenze; Beschluss zur „Überführung der deutschen Bevölkerung“ aus den Ostgebieten sowie aus der Tschechoslowakei und Ungarn in die vier Besatzungszonen („Potsdamer Abkommen“ vom 2.8.1945)

19.07.1945 SMAD-Befehl „Zur zweckmäßigen Verteilung der Bevölkerung in der Sowjetischen Besatzungszone“: „1. Alle Deutschen aus den polnischen Gebieten (östlich der Oder) folgendermaßen zu verteilen: / a) aus den Kreisen, die südlich des Flusses 
Warthe gelegen sind, zur Ansiedlung in die Landkreise Seelow, Cottbus, Lübben, Beeskow und Luckau weitzerzuleiten; / b) aus Landkreisen nördlich der Warthe in die nördlichen Landkreise der Provinz Mecklenburg zu leiten. / 2. Alle Deutschen aus der Tschechoslowakei und Jugoslawien sind zur Ansiedlung in die östlichen Kreise der Provinz Sachsen (die St[ädte] Schweidnitz [Schweinitz], Herzberg, Torgau, Liebenwerda) zu leiten. / [...]." (Wille I, S. 55; vgl. eben. S. 56)

02.09.1945 Rede des KPD-Vorsitzenden Wilhelm Pieck zum Bauernreformkonzept seiner Partei auf der Kreisbauernkonferenz des Kreises Ostprignitz in Kyritz

02.09.1945 Erste Bestattung auf dem Friedhof für Heimkehrer in Frankfurt (Oder) auf den Kiesbergen südlich des Hauptfriedhofes; bis zum 23.10.1946 werden dort 3.736 Heimkehrer bestattet (Brisch/Buwert/Schieck, S. 51)

03/04.09.1945 Erste zonale Konferenz zur besseren Koordinierung des Flüchtlings- und Vertriebenenproblems (zweitägige Beratung in Berlin mit den für Flüchtlingsfragen verantwortlichen leitenden Mitarbeitern der Landes- und Provinzialverwaltungen auf Anregung des Magistrats der Stadt Berlin, Hauptamt für Sozialwesen, und der Zentralverwaltung für Arbeit und Sozialfürsorge) (Wille I, S. 179f., 210-228)

06.09.1945 Verordnung zur Durchführung der Bodenreform in der Provinz Mark Brandenburg (8. und 11.9.1945 Ausführungsverordnung 1 und 2)

10.09.1945 bis 02.10.1945 Außenminister-Konferenz in London (Hilgemann, S. 206)

15.09.1945 Gründung der Zentralverwaltung für Flüchtlingswesen und Heimkehrer [in der SBZ], zehn Tage später in „Zentralverwaltung für deutsche Umsiedler“ (ZVU) umbenannt, auf Befehl Nr. 14 der SMAD vom 14.9.1945 (Oehlsen, S. 18; Wille I, S. 230f.)

21.09.1945 Sowjetisch-polnisches „Schweriner Grenzabkommen“ über den deutsch-polnischen Grenzverlauf bei Stettin (anschließende Übergabe des nunmehr gesamten „Stettiner Zipfels“ an Polen am 4.10.)

09.10.1945 Verfügung der Zentralverwaltung für deutsche Umsiedler (ZVU) über die Bildung von Umsiedlerausschüssen bei den Landratsämtern

20.11.1945 Der Alliierte Kontrollrat bestätigt den Plan für die Aussiedlung der deutschen Bevölkerung aus den Ostgebieten

16.12.1945 bis 26.12.1945 Außenminister-Konferenz in Moskau (Hilgemann, S. 206) 


\section{6}

10.01.1946 Bildung eines der Hauptabteilung für Arbeit und Sozialwesen angegliederten Provinzialumsiedlerauschusses

14.02.1946 Polnisch-britisches Abkommen über die Aussiedlung von Deutschen in die britische Besatzungszone (Atlas, S. 188)

19.02.1946 Abfahrt des ersten Transports aus Niederschlesien (Atlas, S. 188)

20.03.1946 Offener Befehl des Stellv. Chefs der SMAB Nr. 54 vom 20. März 1946: Überprüfung der Durchführung der Bodenreform in der Provinz Brandenburg (Überlieferung im BLHA: Rep. 202 A Büro des Ministerpräsidenten Nr. 82) (Inventar der Offenen Befehle der Sowjetischen Militäradministration des Landes Brandenburg. Ffm. 2002, S. 93)

22.04.1946 Zusammenschluss von KPD und SPD in der SBZ zur SED (Hilgemann, S. 206)

00.05.1946 Offener Befehl des Obersten Chefs der Sowjetischen Militäradministration in Deutschland (SMAD) (ohne Nr.) über die Organisation der materiellen Versorgung der deutschen Umsiedler (Foitzik, Nr. 420)

05.05.1946 Polnisch-sowjetisches Abkommen über die Aussiedlung der Deutschen in die sowjetische Besatzungszone (Atlas, S. 188)

19.07.1946 Einrichtung eines Suchdienstes für vermißte Deutsche in der SBZ, Berlin W 8, Kanonierstraße 35 (ab 1951 Glinkastraße), auf Befehl der SMA Nr. 204 anstelle aller anderen Organisationen (BLHA, Rep. 203 MdI, Nr. 1197, Bl. 40)

26.08.1946 Bildung eines „Provinzial-Umsiedler- und Heimkehrerausschusses“ als beratendes Organ für die Abteilung Amt für deutsche Umsiedler. Hauptaufgabe ist die Mitwirkung an der Sicherstellung bzw. Verbesserung der Wohnverhältnisse und Existenzgrundlagen sowie der Versorgung der Vertriebenen mit Mobiliar und Hausrat; zugleich Bildung eines Arbeitsausschusses aus den im Ausschuss tätigen Vertretern der drei „antifaschistischen Parteien“ und einem Vertrreter des Amtes für deutsche Umsiedler zwecks Überprüfung der einzelnen Gemeinden in enger Zusammeanarbeit mit den analog zu bildenden Kreis- und Bezirksausschüssen (BLHA, Rep. 230 Bernau, Nr. 292, Bl. 11).

09.09.1946 Aufruf des Provinzialumsiedlerausschusses „Zu den Aufgaben der Ortsumsiedlerausschüsse“ (erw. in BLHA, Rep. 203 MdI, Nr. 1198, Bl. 38)

01.10.1946 Anordnung der Bildung von Ortsumsiedlerausschüssen per Runderlass des Amtes für deutsche Umsiedler der Provinzialregierung Mark Brandenburg (erw. in BLHA, Rep. 203 MdI, Nr. 1198, Bl. 38).

15.10.1946 Offener Befehl des Obersten Chefs der Sowjetischen Militäradministration in Deutschland (SMAD) (Nr. 304) betr. einmalige Beihilfe für hilfsbedürftige Um- 
siedlerfamilien (Rep. 203 MdI, Nr. 1166, Bl. 12) bzw. betr. Hilfeleistung für Umsiedler (Foitzik, Nr. 623). Vgl. unten Gesetz vom 11.9.1947

18.10.1946 Premiere des DEFA-Spielfilms „Freies Land“ (Regie: Milo Harbich) im Potsdamer Kino „Charlott“, der das Flüchtlingsschicksal am Beispiel eines Dorfes in der Westprignitz behandelt und daneben auch das „Notstandsgebiet Lebus“ am Beispiel von Sachsendorf zeigt (beides bezogen auf das Frühjahr 1946; Darsteller sind neben professionellen Schauspielern Laiendarsteller mit Flüchtlingsschicksal und einheimische Bauern).

06.11.1946 Befehl Nr. 7538 der Verwaltung der SMA der Provinz Brandenburg zur Ergreifung von Maßnahmen zur Gleichstellung der Vertriebenen mit der eingesessenen Bevölkerung (BLHA, Rep. 230 Bernau, Nr. 292, Bl. 45).

03.12.1946 Ausweisung des größten Teils der noch zurückgebliebenen Bevölkerungsgruppe aus dem Kreis Landsberg/Warthe (Landsberg an der Warthe [Bd. 1]. Bielefeld 1976, S. 323)

\section{7}

25.02.1947 Auflösung des Landes Preußen durch den Alliierten Kontrollrat (Hilgemann, S. 206)

01.03.1947 Beginn der 14tägigen Herausgabe einer „Suchzeitung“ durch den Suchdienst für vermißte Deutsche in der SBZ, Berlin, mit jeweils ca. 1500 Suchanträgen und mit allgemeinen Beiträgen und Informationen zum Thema (Deutscher Zentralverlag G.m.b.H., Berlin C 2). Preis: RM 0,60 pro Nr. (BLHA, Rep. 203 MdI, Nr. 1195, Bl. 60)

\subsubsection{Hochwasserkatastrophe im Oderbruch}

\subsubsection{7-24.04.1947}

Moskauer Außenministerkonferenz (ohne Einigung über Anerkennung oder Korrektur der Oder-Neiße-Grenze zwischen den Westmächten und der UdSSR; offizielle Bezeichnung der Oder-Neiße-Grenze in der SBZ fortan als „Friedensgrenze“)

09.04.1947 Rundverfügung des brandenburgischen Ministers für Wirtschaftsplanung vom 9.4.1947 betr. Richtlinien zur Besetzung von Siedlerstellen: Bevorzugung von Umsiedlern gegenüber einem Teil der alten Bewerber (BLHA, Rep. 203 MdI, Nr. 1166, Bl. 12)

12.04.1947 Unterzeichnung eines neuen polnisch-sowjetischen Abkommens über die Aufnahme der restlichen in Polen verbliebenen Deutschen in die sowjetische Besatzungszone (Atlas, S. 188) 
22.04.1947 Tagung zur Auswertung der Ergebnisse der in den Monaten Februar und März durchgeführten Kreisdelegiertenkonferenzen der Ortsumsiedlerausschüsse (aller Länder und Provinzen der SBZ) in Potsdam (Wille III, Nr. 121)

05.05.1947 Ausweisung der letzten 600 Deutschen aus Landsberg/Warthe (Landsberg an der Warthe [Bd. 1]. Bielefeld 1976, S. 323)

11.09.1947 „Gesetz über die Aufnahme eines Kredites von 45000 000 RM für Auszahlung einmaliger Unterstützung an Umsiedler“ zur Durchführung des SMAD-Befehls Nr. 304 vom 15.10.1946 (GVBl. Brandenburg 1947, S. 23; Brandenburgische Gesetzsammlung 1945/1947, S. 252)

07.10.1947 Offener Befehl des Chefs der Verwaltung der SMAB Nr. 163 vom 7. Oktober 1947: Einrichtung von Neubauernwirtschaften (Überlieferung im BLHA: Rep. 202 A Büro des Ministerpräsidenten Nr. 88) (Inventar der Offenen Befehle der Sowjetischen Militäradministration des Landes Brandenburg. Ffm. 2002, S. 157)

11.10.1947 Runderlass Nr. 81/47 des brandenburgischen Ministers für Wirtschaftsplanung vom 11.10.1947 betr. Verteilung von Textilien und sonstigen Gebrauchsgegenständen unter Bevorzugung der Umsiedler (Rep. 203 MdI, Nr. 1166, Bl. 12). Vgl. unten 7.5.1948.

25.10.1947 bis 02.11.1947 „Umsiedlerwoche“ (Wille III, S. 262)

Nov. 1947 Ende der organisierten Massenaussiedlungen Deutscher aus Polen (Atlas, S. 188)

19.11.1947 Offener Befehl des Obersten Chefs der Sowjetischen Militäradministration in Deutschland (SMAD) (Nr. 255) über die Erhöhung der Zahl der QuarantäneLager für deutsche Umsiedler (Foitzik, Nr. 976)

25.11.1947 Offener Befehl des Chefs der Verwaltung der SMAB Nr. 202 vom 25. November 1947: Reduzierung der Lager für deutsche Umsiedler im Land Brandenburg (Überlieferung im BLHA: Rep. 202 A Büro des Ministerpräsidenten Nr. 85) (Inventar der Offenen Befehle der Sowjetischen Militäradministration des Landes Brandenburg. Ffm. 2002, S. 163)

25.11.1947 bis 15.12 .1947

Londoner Konferenz der Außenminister der Vier Mächte (von den Flüchtlingen mit Spannung verfolgt wegen der erhofften Grenzfragenregelung)

06.12.1947 bis 07.12.1947

Erster „Deutscher Volkskongress für Einheit und gerechten Frieden“ auf Initiative der SED in Berlin (Admiralspalast) 


\section{8}

1948/49 Aktion „Wir bauen auf“

21.01.1948 Rundverfügung Nr. 20/48 des brandenburgischen Ministers für Arbeit unf Sozialwesen betr. ausreichende Wohnraumverteilung, insbes. für mittellose Umsiedler (BLHA, Rep. 203 MdI, Nr. 1166, Bl. 12)

22.02.1948 bis 29.02.1948 erneute „Umsiedlerwoche“

09.03.1948 Befehl der SMAD zur Unterstellung der „Aufgaben für Umsiedlung“ unter die Deutsche Verwaltung des Innern zwecks Liquidierung einer gesonderten Umsiedler-Verwaltung (Amos, S. 21)

17.04.1948 Runderlass III 71/48 des brandenburgischen Ministers für Wirtschaftsplanung vom 17.4.1948 betr. Gartenland: Bevorzugung von Umsiedlern bei der Zuteilung von Gartenland zwecks ausreichender Versorgung mit Gemüse und festerer Bindung an ihre neue Heimat (BLHA, Rep. 203 MdI, Nr. 1166, Bl. 12)

07.05.1948 Erneuter Runderlass (Nr. 208/48) des brandenburgischen Ministers für Wirtschaftsplanung betr. Verteilung von Textilien und sonstigen Gebrauchsgegenständen unter Bevorzugung der Umsiedler (BLHA, Rep. 203 MdI, Nr. 1166, Bl. 12). Vgl. oben 11.10.1947.

\subsubsection{Auflösung der Zentralverwaltung für deutsche Umsiedler (ZVU)}

25.06.1948 SMAB-Befehl Nr.71 vom 25. Juni 1948: Durchführung des SMAD-Befehls Nr. 209 vom 9. Sept. 1947 über Maßnahmen zum wirtschaftlichen Aufbau der Neubauernwirtschaften im Land Brandenburg (Befehle der Sowjetischen Militäradministration des Landes Brandenburg 1945-1949. Frankfurt/Main 1997, S. 71).

Aug. 1948, Jan./Juni 1949

Werbefilm des Suchdienstes für vermißte Deutsche in der SBZ „Und alles wird wieder gut" läuft in den Kinos (BLHA, Rep. 203 MdI, Nr. 1196, Bl. 26, 28, 37, 38)

02.12.1948 Offener Befehl des Obersten Chefs der Sowjetischen Militäradministration in Deutschland (SMAD) (Nr. 189) über die Zahl der Quarantäne-Lager für deutsche Umsiedler und ehemalige Kriegsgefangene (Foitzik, Nr. 1212)

28.12.1948 Runderlass 314 der Zentralen Finanz-Verwaltung: Jedem Umsiedler, der nach der Währungsreform eingetroffen ist, wird eine Sonderunterstützung von DM 50,- ausgezahlt (erw. in BLHA, Rep. 333, Nr. 574, Bl. 402). 


\section{9}

16.02.1949 Konferenz über Umsiedlerfragen in Potsdam (BLHA, Rep. 202 C, Nr. 134 und Nr. 1235)

28.02.1949 Premiere des 1948 in Zehdenick und Wusterhausen/Dosse gedrehten, die Schwierigkeiten bei der Integration von „Umsiedlern“ in einer Kleinstadt thematiserenden DEFA-Spielfilms „Die Brücke“ in Berlin-Friedrichshain (Darsteller der „Umsiedler“: Jeannette Schultze, Karl Hellmer, Maria Besendahl)

15.04.1949 SMAB-Befehl Nr. 46 vom 15. April 1949: Beschleunigte Aufteilung der Ländereien aus dem Bodenreformfonds zur Kultivierung ungenutzter Landstücke in den Kreisen (Befehle der Sowjetischen Militäradministration des Landes Brandenburg 1945-1949. Ffm. 1997, S. 73).

01.05.1949 Verfügung der Deutschen Verwaltung des Innern, dass „die Erfassung aller durch die Kriegsereignisse umgesiedelten Personen, die jetzt in der sowj. Besz. ansässig und dort polizeilich gemeldet sind, auf der Meldekarte des Suchdienst nur noch von den polizeilichen Meldeämtern durchgeführt wird." (BLHA, Rep. 203 MdI, Nr. 1196, Bl. 22)

22.07.1949 Heimkehrerkonferenz in Perleberg (BLHA, Rep. 202A, Nr. 526)

26.08.1949 Runderlass des brandenburgischen Innenministers Bechler (Nr. 2 I/12) über die Auflösung der (kommunalen) Umsiedlerämter und -ausschüsse in Brandenburg (BLHA, Rep. 333, Nr. 574, Bl. 410; Michael Schwartz, Vertriebene und „Umsiedlerpolitik", München 2004, S. 227)

16.09.1949 Beschluss des Gemeinderates von Dorf Zinna zur Umbenennung der Gemeinde in Neuheim (Schmutzer, S. 44)

Okt. 1949 Einstellung der Tätigkeit der Umsiedlerausschüsse

16.10.1949 Erster „Tag der Heimat“ in West-Berlin

\section{0}

1950 Zwei größere Vertriebenentreffen in Lübben im kirchlichen Rahmen

02.01.1950 Vereinbarung zwischen der DDR und der VR Polen über die „Restumsiedlung aller deutschen Staatsangehörigen“ (Aktion zur Familienzusammenführung: 130000 Personen, Bahntransporte über Frankfurt (Oder) und Forst) (Atlas, S. 202; BLHA, Rep. 333, Nr. 574, Bl. 417-418)

03.02.1950 Rücktritt des (für die Umsiedlerverwaltung zuständigen) brandenburgischen Ministers für Arbeit und Sozialwesen Fritz Schwob (CDU) (Schwartz, S. 228) 
19.02.1950 Erster Transport mit Deutschen gemäß Vereinbarung vom 2.1.1950 verlässt Breslau (Atlas, S. 202)

22.02.1950 Bezeichnung der Oder-Neiße-Grenze als „Friedensgrenze“ in einer Erklärung der Regierung der DDR vor der Volkskammer

05.04.1950 Verordnung des MdI der DDR zur Beseitigung „, nicht mehr tragbarer Benennungen von Straßen, Wegen und Plätzen“ vom 30. März 1950 (insbes. nach ostdeutschen Städten) (GBl der DDR Nr. 39, 5.4.1950, S. 296)

06.06.1950 „Warschauer Deklaration“: Anerkennung der Oder-Neiße-Linie als endgültige Grenze durch Walter Ulbricht (Hilgemann, S. 207) (5./6.6.1950 Besuch einer Regierungsdelegation der DDR unter Leitung von W. Ulbricht in Warschau)

23.06.1950 Prager Abkommen zwischen DDR und ČSR über die Anerkennung der Aussiedlung der Sudeten- und Karpatendeutschen als „gerecht und unabänderlich“

06.07.1950 Görlitzer Abkommen zwischen DDR und VR Polen (auf Druck der UdSSR) über die Anerkennung bzw. endgültige Markierung der Oder-Neiße-Grenze (Bekanntmachung über die Ratifikation siehe 23.12.1950)

14.07.1950 Straßenumbenennungen in Strausberg bei an ostdeutsche Städte erinnernden Straßennamen

14.09.1950 „Umsiedlergesetz“: Gesetz über die weitere Verbesserung der Lage der ehemaligen Umsiedler in der Deutschen Demokratischen Republik vom 8. September 1950 (GBl der DDR Nr. 104, 14.9.1950, S. 971-973; auch in: Wille III, S. 423426, siehe dazu auch ebd. S. 406 f.; BArch, DO 1/15631, 15633, 15634, 15684, $15685,15688)$

30.09.1950 Erste Durchführungsbestimmung zum Gesetz über die weitere Verbesserung der Lage der ehemaligen Umsiedler in der Deutschen Demokratischen Republik vom 28. September 1950 (GBl der DDR Nr. 110, 30.9.1950)

02.10.1950 Ansprache Wilhelm Piecks auf einer Wahlkundgebung in Guben (Bericht: BLHA, Rep. 202 G, Nr. 170, Bl. 372-374).

18.10.1950 Zweite Durchführungsbestimmung zum Gesetz über die weitere Verbesserung der Lage der ehemaligen Umsiedler in der Deutschen Demokratischen Republik vom 11. Oktober 1950 (GBl der DDR Nr. 117, 18.10.1950)

15.11.1950 Anweisung über das Verfahren zur Durchführung des $\$ 5$ des Gesetzes über die weitere Verbesserung der Lage der ehemaligen Umsiedler (Ermäßigung des Pflichtablieferungssolls) vom 31. Oktober 1950 (GBl der DDR Nr. 129, 15.11.1950)

01.12.1950 Umbenennungen von Bahnhöfen in Berlin: Schlesischer Bahnhof in Ostbahnhof, Stettiner Bahnhof in Nordbahnhof 
23.12.1950 Bekanntmachung über die Ratifikation des Abkommens über die Markierung der festgelegten und bestehenden deutsch-polnischen Staatsgrenze vom 28. November 1950 (GBl der DDR, Nr. 143, 23.12.1950)

\section{1}

1951 „Polnische Regelungen für eine Familienzusammenführung polnischer Staatsangehöriger mit ihren Verwandten in der DDR" (Meister, Zuwanderung, S. 555).

27.01.1951 Unterzeichnung des Protokolls über die vollzogene Markierung der Oder-Neiße-Grenze durch die Außenminister Polens und der DDR im Haus der DSF in Frankfurt (Oder)

05.03.1951 Dritte Durchführungsbestimmung zum Gesetz über die weitere Verbesserung der Lage der ehemaligen Umsiedler in der Deutschen Demokratischen Republik vom 1. März 1951 (GBl der DDR Nr. 27, 5.3.1951)

31.03.1951 Vierte Durchführungsbestimmung zum Gesetz über die weitere Verbesserung der Lage der ehemaligen Umsiedler in der Deutschen Demokratischen Republik. Vom 20. März 1951 (GBl der DDR, Nr. 37, 31.3.1951)

10.05.1951 bis 12.05.1951 Transport von 3.695 Kaliningrader Deutschen (Ostpreußen) aus Litauen, Lettland, Weißrussland, der Ukraine und dem Kaliningrader Gebiet in die DDR

08.07.1951 Zeitungsmeldung über den Beschluss der Stadtverordnetenversammlung von Guben zur Umbenennung von Straßen: Schlesische Straße in Gartenstraße, Breslauer Straße in Blumenweg, Danziger Straße in Elsterweg (Meldung der „Märkischen Volksstimme" vom 8.7.1951, hier nach Gubener Heimatkalender 1991, S. 81).

08.09.1951 Änderung der Ersten Durchführungsbestimmung und Zweiten Durchführungsbestimmung zum Gesetz über die weitere Verbesserung der Lage der ehemaligen Umsiedler in der Deutschen Demokratischen Republik vom 29. August 1951 (GBl der DDR, Nr. 108, 8.9.1951)

\section{2}

03.04.1952 Studienreise einer „westdeutschen Umsiedler-Delegation“ im Land Brandenburg und Berlin (BLHA, Rep. 203 MdI, Nr. 1110)

06.07.1952 Kirchliches Triebeler Vertriebenentreffen in der Lutherkirche Cottbus mit ca. 800 Teilnehmern

20.07.1952 Übergabe des Fabrikneubaus des VEB Gablona in Neuheim bei Jüterbog (Schmutzer, S. 45) 
21.07.1952 Feierliche Verleihung des Titels „Dorf des Friedens - Neuheim auf Friedenswacht" an das Dorf Neuheim bei Jüterbog (Schmutzer, S. 45)

29.07.1952 Schaffung von 14 Bezirken in der DDR: Ordnung für den Aufbau und die Arbeitsweise der staatlichen Organe der Bezirke vom 24. Juli 1952 (GBl der DDR Nr. 101, 29.7.1952)

\section{3}

1953 Veröffentlichung der bereits 1950 in einer Zeitung vorabgedruckten Novelle „Die Umsiedlerin“ von Anna Seghers in Berlin (Ost)

27.01.1953 Einweihung der „Friedensglocke“ in Frankfurt (Oder) zur Erinnerung an das Abkommen über die „Oder-Neiße-Friedensgrenze“ zwischen DDR und VR Polen

17.06.1953 Volksaufstand in der DDR, teilweise werden am Rande Forderungen nach Revision der Oder-Neiße-Grenze erhoben (Eisenhüttenstadt)

\section{4}

25.01.-18.02.1954

Berliner Außenministerkonferenz der Vier Mächte (wegen der Unvereinbarkeit der Positonen zur Wiedervereinigung Deutschlands ohne Ergebnis geblieben), währenddessen heftige Auseinandersetzungen zwischen Stahlwerksarbeitern und SED-Funktionären in Fürstenberg/Eisenhüttenstadt: Sprechchöre mit Forderung nach Revision der Ostgrenze; Protestaktionen auch in Frankfurt (Oder), Guben und Görlitz

25.03.1954 Anerkennung der DDR als souveräner Staat durch die UdSSR (Hilgemann, S. 207)

\section{6}

17.01.1950 bis 20.01.1950 Erneute Gespräche zwischen DDR und VR Polen über die Fortsetzung der Ausreisen (Atlas, S. 202)

\section{9}

16.02.1959 Beendigung der organisierten Ausreisen von Deutschen aus Polen im Rahmen der Aktion zur Familienzusammenführung gemäß Vereinbarung vom 2.1.1950 (Atlas, S. 202) 


\section{1}

13.08.1961 Teilung Deutschlands und Bau der Berliner Mauer

30.09.1961 Uraufführung der in einem mecklenburgischen Dorf spielenden Komödie „Die Umsiedlerin oder das Leben auf dem Lande“ von Heiner Müller (basierend auf der Novelle von A. Seghers, siehe 1953) in der FDJ-Studentenbühne der Hochschule für Ökonomie in Berlin-Karlshorst, jedoch noch in der Nacht als „konterrevolutionär“ verboten (erst 1975 publiziert u. am 30.5.1976 unter dem Titel „Die Bauern“ an der Volksbühne in Berlin (Ost) wieder aufgeführt), der in Senftenberg tätige Regisseur B.K. Tragelehn wird fristlos entlassen (s. Ortsdokumentation Senftenberg).

\section{4}

20.03.1964 Straßenumbenennungen in Berlin-Friedrichshain: Breslauer Straße in Am Ostbahnhof, Königsberger Straße in Fredersdorfer Straße (www.berlingeschichte.de) strassen)

02.11.1964 Erste genehmigte Reisen von Rentnern aus der DDR zu Verwandten in der Bundesrepublik und West-Berlin (Beschluss des Ministerrates vom 9.9.1964)

1965 Straßenumbenennung in Frankfurt (Oder): Züllichauer Straße in Finkenheerder Straße (www.museum-viadrina.de/Strassenlexikon)

\section{0}

07.12.1970 Warschauer Vertrag zwischen der Bundesrepublik Deutschland und der Volksrepublik Polen: Anerkennung der Oder-Neiße-Grenze als westliche Staatsgrenze der VR Polen

\section{1}

16.07.1971 Vertrag zwischen der Deutschen Demokratischen Republik und der Volksrepublik Polen über die Zusammenarbeit auf dem Gebiet des Verkehrswesens (Bekanntmachung über das Inkrafttreten vom 2.2.1972 in GBl der DDR Nr. 3, 16.2.1972)

\section{2}

01.01.1972 Öffnung der Grenze zwischen DDR und VR Polen für den individuellen visafreien Reiseverkehr, u. a. Öffnung der Stadtbrücke in Frankfurt (Oder) für 
den direkten Übergang nach Polen (F. Ackermann: Die Stadtbrücke Frankfurt (Oder) - Stubice)

25.02.1972 Bekanntmachung über das Inkrafttreten von Durchführungsabkommen zum Vertrag zwischen der Deutschen Demokratischen Republik und der Volksrepublik Polen über die Zusammenarbeit auf dem Gebiet des Verkehrswesens vom 2. Februar 1972, darin u. a.: Abkommen über die Zusammenarbeit auf dem Gebiet der gemeinsamen Kontrolle des grenzüberschreitenden Verkehrs; Abkommen über die Zusammenarbeit auf dem Gebiet des grenzüberschreitenden Eisenbahnverkehrs (GBL der DDR Nr. 9, 25.2.1972)

03.03.1972 Straßenumbenennung in Berlin-Friedrichshain: Küstriner Platz in FranzMehring-Platz (www.berlingeschichte.de/strassen)

28.06.1972 Nach der Neuordnung der polnischen Diözesen wird der Jurisditktionsbezirk der für das bei Deutschland verbliebene Restgebiet der ehem. Erzdözese Breslau (mit den Niederlausitzer und neumärkischen Teilen) zuständige Erzbischöfliche Amt Görlitz in die Apostolische Administratur Görlitz umgewandelt. Das bisher noch dem (polnischen) Erzbischof von Breslau unterstellte Bistum Berlin wird aus dieser Erzdiözese herausgelöst und dem Papst direkt unterstellt.

1974 Wechsel mehrerer westlich der Oder gelegener (historisch neumärkischer) und durch die Grenzziehung isolierter katholischer Kirchengemeinden aus ihrer Breslauer bzw. Görlitzer Bistumszugehörigkeit in die des Bistums Berlin

1976 Autobiographischer Roman „Kindheitsmuster“ von Christa Wolf (geb. in Landsberg/Warthe) im Aufbau-Verlag, Berlin und Weimar, erschienen

\section{0}

Okt. 1980 Schließung der Grenze der DDR nach Polen für den visafreien Verkehr (bis 1991)

1985 Roman „Wir Flüchtlingskinder“ der Schlesierin Ursula Höntsch-Harendt im Mitteldeutschen Verlag, Halle/S. und Leipzig, erschienen

\section{0}

12.09.1990 Bestätigung der Oder-Neiße-Linie als deutsch-polnischer Grenze im Zwei-PlusVier-Vertrag (in Kraft getreten 15.3.1991)

03.10.1990 Beitritt der DDR zum Geltungsbereich des Grundgesetzes der Bundesrepublik Deutschland 


\subsubsection{Deutsch-polnischer Grenzvertrag}

14.12.1990 Konstituierung des Gründungsausschusses eines zu gründenden BdV-Landesverbandes Brandenburg

\section{1}

25.01.1991 Gründung des Bundes der Vertriebenen (BdV), Landesverband Brandenburg e. V. in Berlin (Sitz Potsdam, 12.3.1991 Eintragung in das Vereinsregister, Nr. 401, beim Kreisgericht Potsdam)

\section{4}

01.01.1994 Gesetz über eine einmalige Zuwendung an die im Beitrittsgebiet lebenden Vertriebenen (Vertriebenenzuwendungsgesetz - VertrZuwG): DM 4000 pro Person

1999 Einweihung des „Hauses Brandenburg“ in Fürstenwalde in Anwesenheit des Ministerpräsidenten Manfred Stolpe

\section{3}

15.11.2003 Einweihung des Gedenksteins für die Opfer von Vertreibung am Alten Markt in Potsdam (Initiator: Bund der Vertriebenen, Landesverband Brandenburg)

\section{5}

20.06.2015 Auf der Grundlage eines Bundesgesetzes von 2014 wird der 20. Juni (zugleich „Weltflüchtlingstag“) seit 2015 als Gedenktag für die Opfer von Flucht und Vertreibung begangen (u. a. Beflaggung öffentlicher Gebäude auch in Brandenburg).

2017-2018

2017-2018 Wanderausstellung „Flucht-gestern und heute“ in Oranienburg, Kyritz und Neuruppin 


\section{Quellen- und Literaturverzeichnis}

Online-Quellen (Internetseiten, PDFs, Datenbanken) sowie mündliche und schriftliche Auskünfte werden (mit wenigen Ausnahmen) nur in den Anmerkungen bzw. in den Quellen- und Literaturangaben im Teil 3 aufgeführt.

\section{Archivalische Quellen}

Brandenburgisches Landeshauptarchiv (BLHA), Potsdam

BLHA, Rep. 6 B Kreisverwaltung Züllichau-Schwiebus

BLHA, Rep. 16 Nachlass Fritz Ludwig

BLHA, Rep. 16 Nachlass Annemarie Spiegelberg

BLHA, Rep. 201 Landtag

BLHA, Rep. 202 G Amt für Information

BLHA, Rep. 203 Ministerium des Innern

BLHA, Rep. 203 Ministerium des Innern, Entnazifizierungskommission

BLHA, Rep. 206 Ministerium für Wirtschaft und Arbeit

BLHA, Rep. 211 Ministerium für Gesundheitswesen

BLHA, Rep. 230 Oberlandratsamt Bernau

BLHA, Rep. 250 Landratsamt Beeskow-Storkow

BLHA, Rep. 250 Landratsamt Guben/Frankfurt(Oder)

BLHA, Rep. 250 Landratsamt Luckenwalde

BLHA, Rep. 250 Landratsamt Niederbarnim

BLHA, Rep. 250 Landratsamt Westprignitz

BLHA, Rep. 256 Umsiedlerlager Küchensee

BLHA, Rep. 333 SED-Landesleitung Brandenburg

BLHA, Rep. $601 \mathrm{VdN}$

Bundesarchiv (BArch), Berlin-Lichterfelde

BArch, DO 1 Ministerium des Innern der DDR

BArch, DO 2 Zentralverwaltung für deutsche Umsiedler

Bundesarchiv-Lastenausgleichsarchiv (BArch-LAA), Bayreuth

BArch, OSTDOK (Ostdokumentation)

Bund der Vertriebenen (BdV), Landesverband Brandenburg e. V., Geschäftsstelle, Potsdam

Organisation 07 bis 39 (Ordner I/1-5); Kreisverbände 7.0 bis 39 (Ordner I/6-32); Ostdeutsche

Kulturtage (Ordner III/1-14); Protokolle 1991-1994 (Ordner II/1); Ordner Projekt Gedenkstein

(Ordner); Ordner Satzung und Geschäftsordnung

Deutsches Historisches Museum (DHM), Berlin

Sammlung Dokumente, Familienkonvolut Trinkaus-Sendhoff

Diözesanarchiv Berlin (DAB)

DAB, Abt. I Bischöfliches Ordinariat Berlin: I/3a (Protokollbücher), I/4 (Pfarreien und Seelsorgestellen), I/5 (Personalakten), I/9 (Flüchtlingsseelsorge) 
Evangelisches Landeskirchliches Archiv in Berlin (ELAB)

ELAB, Best. 1 Konsistorium der Evangelischen Kirche in Berlin-Brandenburg

ELAB, Best. 14 Evangelisches Konsistorium der Mark Brandenburg

ELAB, Best. 29 Kirchenkreis Kölln-Land I

Evangelisches Zentralarchiv in Berlin (EZA)

EZA, Best. 7 Evangelischer Oberkirchenrat

Gemeindearchiv Blankenfelde-Mahlow

Standesamt Blankenfelde, Sterberegister 1945-1946 (www.ancestry.de)

Landesgeschichtliche Vereinigung für die Mark Brandenburg e. V. (LGV), Archiv, Berlin

Best. C 1 Druckschriften

Best. C 3 Zeitungsausschnitte

Best. C 4 A Manuskripte

Martin-Opitz-Bibliothek, Herne

AGoFF-Archiv, Best. B 42 Vorlass Herbert Geisler, Nr. 16

Stadtarchiv Angermünde

Standesamt Angermünde, Sterberegister 1945-1946 (www.ancestry.de)

Stadtarchiv Frankfurt (Oder)

Best. II Stadtverordnetenversammlung, Nr. 913

Stadtarchiv Prenzlau

Standesamt Prenzlau, Sterberegister 1945-1946 (www.ancestry.de)

Stiftung Archiv der Parteien und Massenorganisationen der DDR im Bundesarchiv

SAPMO-BArch, DY 34 Bundesvorstand des FDGB, Abt. Sozialpolitik

Stiftung Brandenburg, Archiv, Fürstenwalde

Gemeinschaft der ehemaligen Aufbau-/Heimschüler von Drossen

Heimatbund Kreis Soldin/Neumark im Patenkreis Soltau

\section{Gedruckte Quellen}

\subsection{Quelleneditionen, archivische Findmittel und Beständeübersichten}

\subsubsection{Editionen}

Befehle der Sowjetischen Militäradministration des Landes Brandenburg 1945-1949. Bearb. von Klaus Geßner. Frankfurt am Main u. a. 1997 (Quellen, Findbücher und Inventare des Brandenburgischen Landeshauptarchivs, Bd. 4).

Bericht über die erste Sitzung des Provinzialverbandes der Mark Brandenburg am 16. und 17. Juni 1945 in Brandenburg/Havel (Auszüge). In: Die Uckermark 1945. Hrsg.: Gesamtschule mit gymnasialer Oberstufe „Carl Friedrich Grabow“ Prenzlau und Uckermärkischer Geschichtsverein zu Prenzlau e. V. T. 1. Prenzlau 1995, S. 110-115. [Enth. nur die Reden der Landräte der Kr. Templin u. Prenzlau]. 
Berichte der Landes- und Provinzialverwaltungen zur antifaschistisch-demokratischen Umwälzung 1945/46. Quellenedition. Hrsg.: Staatl. Archivverwaltung der DDR. Gesamtred.: Wolfgang Merker u. Hans-Joachim Schreckenbach. Bearb.: Gottfried Börnert u. a. Berlin 1989 (Publikationen der Staatlichen Archivverwaltung der DDR).

Brandenburgische Gemeinden kurz nach dem Kriegsende von 1945. Aus eigenen Berichten der Gemeinden niedergeschrieben Ende 1945. Potsdam 2013.

Chronik der ersten Jahre. Eine regionale Quellensammlung für Fürstenberg/Oder und Umgebung 1945-1949. Zsgest. von Bernd Bahro u. a. (Neuzelle 1994).

Chronik der Pfarre zu Kuhsdorf. Transkribiert und vervielfältigt von Agnes u. Henning v. Kopp-Colomb. Haltern 2008.

Dahl, Erich: Der Stadtkreis Angermünde nach dem Zusammenbruch des „Tausendjährigen Reiches“. In: Heimatkalender für den Kreis Angermünde 1960, S. 155-156 [Niederschrift Ende 1945 (noch vor Weihnachten)].

Dokumentation der Vertreibung der Deutschen aus Ost-Mitteleuropa. Hrsg. vom Bundesministerium für Vertriebene. In Verb. mit Adolf Diestelkamp u. a. bearb. von Theodor Schieder. Bd. 1-5. Beih. 1-3. Reg. 1953-1963.

Eberswalde 1945. Eine Zusammenstellung von Ereignissen mit Dokumenten und Erinnerungen. Begleitheft zur Sonderausstellung im Stadt- und Kreismuseum. Red.: Ingrid Fischer u. a. Eberswalde 1995 (Heimatkundliche Beiträge, 3).

Eberswalde 1945. Dokumente und Erinnerungen. Ein Anhang der 2. Auflage des Begleitheftes zur 1995 im Eberswalder Museum gezeigten Sonderausstellung. (Eberswalde) o.J.

Erschließung der Einwohnermeldebücher Groß Behnitz (mit Ortsteil Quermathen) 1950-1983. Mit einer Liste der „Russland-Flüchtlinge“ 1945/46. Bearb. von Stefan Lindemann unter Mitarb. von Nele Möbius. Potsdam 2015.221 S. [S. 197-198: Liste der Flüchtlinge aus Russland (und Litauen) 1945/46].

Erschließung des Gesamtkirchenbuches Klein Behnitz. Taufen 1902-1949. Beerdigungen 19341975. Trauungen 1932-1976. Konfirmationen 1912-1927. Bearb. von Stefan Lindemann. Brandenburg/H.-Potsdam 2004.

Guben 1945/1946. Berichte, Dokumente, Diskussionen. Hrsg. von Andreas Peter. 2., durchges. u. erw. Aufl. Guben 1997.

Inventar der Befehle des Obersten Chefs der Sowjetischen Militäradministration in Deutschland (SMAD) 1945-1949. Offene Serie. Im Auftr. des Instituts für Zeitgeschichte zsgest. u. bearb. von Jan Foitzik. München u. a. 1995 (Texte und Materialien zur Zeitgeschichte, Bd. 8).

Kriegstagebuch des Oberkommandos der Wehrmacht (Wehrmachtführungsstab) 1940-1945. Geführt von Helmuth Greiner u. Percy Ernst Schramm. Im Auftr. d. Arbeitskreises für Wehrforschung hrsg. von Percy Ernst Schramm. Bd. IV: 1. Januar 1944 - 22. Mai 1945. Eingel. u. erl. von Percy Ernst Schramm. 2. Halbbd. Frankfurt am Main 1961.

Lindemann, Stefan: Erschließung der Kirchenbücher Groß und Klein Behnitz. Taufen Groß Behnitz 1937-1992. Taufen Klein Behnitz 1950-1992. Konfirmationen Groß und Klein Behnitz 1927-2010. Beerdigungen Groß Behnitz 1952-2011. Beerdigungen Groß Behnitz 1976-2015. (Privatdruck) Vitte (Hiddensee)/Potsdam 2016.

-, -: Erschließung des Gesamtkirchenbuches Groß Behnitz (Teil 2). Taufen 1902-1936. Beerdigungen 1931-1951. Trauungen 1932-1959. Konfirmationen 1912-1926. (Privatdruck) Potsdam 2016.

Minia, [Günther]: Lager Cahnsdorf (Niederlausitz). Abschließender Bericht über das Auffanglager Cahnsdorf durch den Bevöllmächtigten für die Flüchtlingsfürsorge der deutschen Ev. Kirche der Niederlausitz, Superintendent Lic. Minia (Luckau). In: 700 Jahre Cahnsdorf 1297-1997. Cahnsdorf 1997, S. 15-17. 
1945. Das Jahr in der Region Dahme-Spreewald. Dokumentation zur Geschichte. Dokumentenausw.: Irmtraud Carl. [T. 1]-2. Zeuthen 2009-2010.

Probst, Richard: Caputh zum Kriegsende. In: Gedenken in Caputh. Den Opfern von Krieg und Gewalt. Ausgew. u. bearb. von Klaus Hugler. Caputh 2005, S. 57-61. [Zeitgenössischer Bericht, auf Aufforderung des Bürgermeisters verfasst im Sommer 1945, u. a. auch kurz zur Flüchtlingsproblematik].

Protokolle des Landesblockausschusses der antifaschistisch-demokratischen Parteien Brandenburgs 1945-1950. Eingel. u. bearb. von Fritz Reinert. Weimar 1994 (Veröffentlichungen des Brandenburgischen Landeshauptarchivs Potsdam, Bd. 30).

[Pündik]: Die politisch-ökonomischen Verhältnisse zum Zeitpunkt der Organisation und des Aufbaus der Militärkommandantur. Dokumentation über die Tätigkeit der sowjetischen Militärkommandantur Frankfurt (Oder) vom 20. Februar 1945 bis 1. Januar 1949 (Major Pündik). In: Wir waren damals 19. 50 Jahre 8. Mai in und um Frankfurt. Berichte, Dokumente, Recherchen, Tagebücher, Erinnerungen, Gespräche. Ein Lesebuch. Hrsg.: Jürgen Maerz. Frankfurt (Oder) 1995, S. 187-209.

Quellen zur Geschichte der Dörfer Groß und Klein Behnitz. Archivalische Quellen 1174/76-1989. Bearb. von Stefan Lindemann. Potsdam 2006 (Beiträge zur Geschichte der Dörfer Groß und Klein Behnitz (Havelland), Nr. 21).

Die Räumung des „Reichsgaus Wartheland“ vom 16. bis 26. Januar 1945 im Spiegel amtlicher Berichte. Bearb. von Joachim Rogall. Sigmaringen 1993.

(Rösch:) Rückblick auf das Heimkehrerlager Gronenfelde bei Frankfurt (Oder) vom 15.05.1950. In: Historischer Verein zu Frankfurt (Oder) e. V. Mitteilungen 1998, H. 2, S. 5-40. [Bericht des stellv. Lagerleiters].

„Die russische Kommandantur verlangt .... Eine regionale Quellensammlung der ersten Nachkriegsjahre für Fürstenberg (Oder) und Umgebung 1945-1949. Hrsg.: Bürgervereinigung „Fürstenberg (Oder) e. V. Verantw.: Erich Opitz. Eisenhüttenstadt 2003.

Schulchronik der Gemeinde Rittgarten ab 01.01.1946. In: Die Uckermark 1945. Hrsg.: Gesamtschule mit gymnasialer Oberstufe „Carl Friedrich Grabow“ Prenzlau und Uckermärkischer Geschichtsverein zu Prenzlau e. V. T. 1. Prenzlau 1995, S. 127-135.

Stadtverwaltung Guben, Archiv 185. Volksbildungsamt, Abtl. Presse und Rundfunk: Vfg. 1. Vermerk für den Rundfunkbericht. Umsiedler. Guben, dem 27. Mai 1946. In: Gubener Heimatkalender 44 (2000), S. 65.

Stalin, J.W.: Werke. Bd. 15; Mai 1945 - Dezember 1952. Dortmund 1979.

Töpler, Winfried [Hrsg.]: Berichte der katholischen Geistlichkeit aus dem Jahr 1945. T. 1-2. In: Niederlausitzer Studien 32 (2005), S. 102-125; 33 (2007), S. 122-137.

Töpler, Winfried: Der zehntausendfüßige Menschenwurm. Die Bewältigung der Kriegsfolgen und des schlesischen Flüchtlingsproblems im Gebiet des heutigen Bistums Görlitz. Texte aus dem Bistumsarchiv Görlitz. In: Vertriebene finden Heimat in der Kirche. Integrationsprozesse im geteilten Deutschland nach 1945. Hrsg. von Rainer Bendel (Forschungen und Quellen zur Kirchen- und Kulturgeschichte Ostdeutschlands, Bd. 38). Köln u. a. 2008, S. 291-635.

„Unsere Heimat ist uns ein fremdes Land geworden ..." Die Deutschen östlich von Oder und Neiße 1945-1950. Dokumente aus polnischen Archiven. Hrsg. von Włodzimierz Borodziej u. Hans Lemberg. Bd. 1: Zentrale Behörden, Wojewodschaft Allenstein. Marburg 2000 (Quellen zur Geschichte und Landeskunde Ostmitteleuropas, 4/I).

„Unsere Heimat ist uns ein fremdes Land geworden ..." Die Deutschen östlich von Oder und Neiße 1945-1950. Dokumente aus polnischen Archiven. Hrsg. von Włodzimierz Borodziej u. Hans Lemberg. Bd. 2: Zentralpolen, Wojewodschaft Schlesien (Oberschlesien). Marburg 2003 (Quellen zur Geschichte und Landeskunde Ostmitteleuropas, 4/II). 
„Unsere Heimat ist uns ein fremdes Land geworden ...“ Die Deutschen östlich von Oder und NeiBe 1945-1950. Dokumente aus polnischen Archiven. Hrsg. von Włodzimierz Borodziej u. Hans Lemberg. Bd. 3: Wojewodschaft Posen, Wojewodschaft Stettin (Hinterpommern). Marburg 2004 (Quellen zur Geschichte und Landeskunde Ostmitteleuropas, 4/III).

Unsere Herzen bluten. Tagebücher und Aufzeichnungen aus der katholischen Gemeinde in Guben 1945/46. Im Auftr. der katholischen Gemeinde Guben und des Bistums Görlitz zsgest. u. bearb. von Winfried Töpler. Hrsg.: Bistum Görlitz. T. 1-2. Cottbus 2013.

Urkunden-Sammlung zur Geschichte des Erzbistums Berlin von 1600 bis 1994. Hrsg. vom Bistumsarchiv Berlin. Verantw.: Heribert Rosal. Bd. 3: 1946-1994. Berlin 1994.

Die Vertriebenen in der SBZ/DDR. Dokumente. Hrsg. u. eingel. von Manfred Wille unter Mitarb. von Steffi Kaltenborn (T. 1: Steffi Kaltenborn, Gerald Christopeit. Manfred Jahn). Wiesbaden 19962003 (Studien der Forschungsstelle Ostmitteleuropa an der Universität Dortmund, Bd. 19,1-3): [T. 1. Ankunft und Aufnahme 1945. 1996. - [T.] 2. Massentransfer, Wohnen, Arbeit 1946-1949. 1999. [T.] 3. Parteien, Organisationen, Institutionen und die „Umsiedler“ 1945-1953. 2003.

Wieviel Einwohner hat der Kreis Guben? In: Gubener Heimatkalender 11 (1966), S. 126.

\subsubsection{Findmittel und Beständeübersichten}

Fürsorge und Wohlfahrtspflege in Brandenburg (1800-1952). Ein sachthematisches Quelleninventar aus dem Brandenburgischen Landeshauptarchiv, dem Geheimen Staatsarchiv Preußischer Kulturbesitz, dem Bundesarchiv und dem Archiv zur Geschichte der Max-Planck-Gesellschaft. Hrsg. von Margot Beck in Zsarb. mit Ulrike Kohl, Matthias Meissner u. Wolfgang Rose. Berlin 2002 (Schriftenreihe zur Medizin-Geschichte des Landes Brandenburg, Bd. 2).

Kurzübersicht über die Archivbestände der Kreise, Städte und Gemeinden im Land Brandenburg. Hrsg. von Uwe Schaper. Frankfurt am Main 2001 (Quellen, Findbücher und Inventare des Brandenburgischen Landeshauptarchivs, Bd. 10).

Landtag des Landes Brandenburg 1945-1952 (Rep. 201). Potsdam 1994 (Findbücher und Inventare des Brandenburgischen Landeshauptarchivs, 1).

Lindemann, Stefan: Findbuch zum Pfarrarchiv Legde. In: Mitteilungen des Vereins für Geschichte der Prignitz 6 (2006), S. 92-122

-, -: Findbuch zum Pfarrarchiv Rühstädt. In: Mitteilungen des Vereins für Geschichte der Prignitz 7 (2007), S. 24-68.

Übersicht über die Bestände des Brandenburgischen Landeshauptarchivs (Staatsarchiv Potsdam). T. 2: Behörden und Institutionen in der Provinz Brandenburg 1808/16 bis 1945. Weimar 1967 (Veröffentlichungen des des Brandenburgischen Landeshauptarchivs (Staatsarchiv Potsdam), Bd. 5).

Übersicht über die Bestände des Brandenburgischen Landeshauptarchivs Potsdam. T. 3,1: Behörden und Institutionen in der Provinz Mark Brandenburg - im Land Brandenburg 1945-1952. Bearb. von Torsten Hartisch u. a. Berlin 2001 (Veröffentlichungen des Brandenburgischen Landeshauptarchivs, Bd. 39).

Übersicht über die Bestände des Brandenburgischen Landeshauptarchivs Potsdam. T. 3,2: Staatliche Verwaltung, Wirtschaft, Parteien und Organisationen in den Bezirken Cottbus, Frankfurt (Oder) und Potsdam 1952-1990. Bearb. Rosemarie Posselt u. a. 2005 (Veröffentlichungen des Brandenburgischen Landeshauptarchivs, Bd. 50). 


\subsection{Druckschriften der Vertriebenenverbände}

\subsubsection{Periodika}

Arbeitskreis Bärwalde Nm. Kreis Königsberg Nm. Jahresbericht [1] (1967 [1968]) - 22 (1988 [1989]).

Aus unserer Heimat. Rundbrief des Gubener Heimatbundes für den Stadt- und Landkreis Guben (1990)2.

BdV-Notizen. Informationsblatt. [Hrsg.: ] Bund der Vertriebenen, Landesverband Brandenburg e. V. 1 (2003).

Brandenburger Rundschau. Informationen. Hrsg.: Bund der Vertriebenen Landesverband Brandenburg e. V. Vereinigte Kreisverbände und Landesgruppen der Landsmannschaften 2 (2004) - 17 (2019).

Brandenburgkurier. Märkischer Informationsdienst. Hrsg.: Landsmannschaft Berlin-Mark Brandenburg e. V. [30 (2016) ff.: Landsmannschaft Ostbrandenburg/Neumark e. V.], Fürstenwalde (Spree) 19 (2005) - 30 (2016).

Brandenburg-Nachrichten. Informationsblatt des Bundes der Vertriebene Landesverband Brandenburg e. V. 1 (1999), 4 (2000), 5 (2000).

Breslauer Nachrichten. Das Heimatblatt für alle ehemaligen Bewohner von Breslau und Schlesien [Untertitel ab Nr. 10: Mitteilungsblatt des Schlesier-Verbandes]. Cham/Opf. 1 (1949).

Briegische Briefe 1 (1947) - 2 (1948).

Bund der Vertriebenen - Kreisverband Potsdam-Mittelmark mit den Kreisgruppen Ostpreußen/Westpreußen. Heimatblatt 2017.

Crossener Heimatblatt 1 (1995) - 22 (2017).

Crossener Heimatgrüße 1 (1949) - 47 (1995).

Ehemalige Kirchengemeinden von Landsberg, Warthe, Stadt und Land. 1. Monatsbericht.

Feelinchen. Informationsblatt des Bundes der Vertriebenen Oder-Spree e. V. und Amt Rüdersdorf und Umgebung e. V. 121 (2017) - 122 (2017).

Frankfurt (Oder)-Sternberger Kurier [2] (1952) - 4 (1955).

Grünberger Rundbrief 2 (1948) - 48 (1953).

Grünberger Wochenblatt. Mitteilungsblatt für die früheren Bewohner der Stadt und des Kreises Grünberg in Schlesien 1953-1956.

Gubener Heimatbrief. Hrsg.: Gubener Heimatbund e. V. 1985-2017.

Heimatblatt der ehemaligen Kirchengemeinden Landsberg/Warthe, Stadt und Land 1949-2017.

Das Heimatblatt für Sorau N./L.-Stadt und Land. Monatsschrift für den Kreis Sorau (N.-L.) 1 $(1952 / 53)$.

Heimatblatt für deutsche Volksgemeinschaft. Frankfurt (Oder) - Sternberger Kurier 4 (1955).

Heimatbrief Weststernberg 15 (1995)

Heimatgruß. Zeitschrift für Mitglieder und Freunde des Heimatkreises Meseritz e. V. und der Heimatkreisgemeinschaft Birnbaum 1 (1949) - 218 (2016).

„Heimatgruß“ des Heimatkreises Meseritz. Register zu Nr. 1 (1949) - 211 (2014). Bearb. von Martin Sprungala. Hrsg.: Heimatkreis Meseritz e. V. Paderborn 2015.

Informationsblatt. Hrsg.: Bund der Vertriebenen Landesverband Brandenburg e. V. 1 (2003).

Karpatenblatt. Mesačnik Nemcov na Slovensku. Monatsblatt der Deutschen in der Slowakei 14 (2004)4; 20 (2011) 10.

Die Karpatenpost. Organ der Karpatendeutschen Landsmannschaft Slowakei 66 (2015) 4; 68 (2017) 3. Landsmannschaft Schlesien Nieder- und Oberschlesien. Rundbrief der Bundesgeschäftsstelle 1956. 
Märkischer Informationsdienst 1993, Nr. 6-7/8, 10/11-12; 1994, Nr. 1-6/7.

Mitteilungen. Hrsg.: „Heimatwerk“ für die Katholiken Danzigs und Westpreußens, 13. Rundschr. (Osternummer), Menden, Kr. Iserlohn, März/April 1950.

Mitteilungsblatt des Bessarabiendeutschen Vereins 67 (2012) - 71 (2016).

Monatsberichte der ehemaligen Kirchengemeinden von Landsberg (Warthe) Stadt und Land 1946 bis 1948. [Faks.-Nachdr.]. Hrsg. von der Bundesarbeitsgemeinschaft Landsberg (Warthe) Stadt und Land e. V. Red.: Dietrich Handt. Herford 2000 (Quellen und Darstellungen zur Geschichte des Landsberger Landes, H. 1).

Namslauer Heimatruf 214 (2012) - 222 (2014).

Neusalzer Nachrichten 41 (1965).

Ostbrandenburg-Neumark. Mitteilungsblatt der Landsmannschaft Ostbrandenburg-Neumark im Berliner Landesverband der Heimatvertriebenen 2 (1951) - 4 (1953).

Das Ostpreußenblatt 14 (1963) 24.

Rund um den dicken Turm. Gubener Heimatbrief 1 (1957) - 65 (1984)

Rundbrief des Großdechanten. Vergangenheit, Gegenwart, Zukunft der Grafschaft Glatz, H. 3/2015.

Schönfließer Heimatbrief. Rundbrief an alle Freunde und Bekannte aus Bad Schönfließ und Umgebung. Berlin, Nr. 2, Aug. 1950.

Sorauer Heimatblatt. Das Heimatblatt für Stadt und Land 2 (1953) - 4 (1955).

Unsere Märkische Heimat. Mitteilungsblatt der Landsmannschaft Ostbrandenburg-Neumark im Berliner Landesverband der Heimatvertriebenen 4 (1953) - 5 (1954).

Wehlauer Heimatbrief 59 (1998), 60 (1999).

Wir aus der Hauerlandgemeinde Deutsch-Litta Kreis Kremnitz. O. O. u. J.

\subsubsection{Einzelschriften}

Adressen aus der schlesischen Sparkassenorganisation. Ges. von Herrn Direktor Beck. 1. Adressen schlesischer Sparkassenleiter. In: Breslauer Nachrichten 1 (1949), Nr. 3-5.

Adressenliste der Braunsberger Gemeindeglieder. Stand: 25.11.1946.

Anschriften der Landsleute des Heimatkreises Schwerin (Warthe) e. V. (Stand: Januar 1992). Zsgest. u. hrsg. vom Heimatkreisbetreuer des Heimatkreises Schwerin (Warthe) e. V., Willi Pfeiffer, u. Käte Bornmann. Königswinter 1992.

Anschriften der Landsleute des Heimatkreises Schwerin (Warthe) in der Bundesrepublik Deutschland, Westberlin und im westlichen Ausland. Zsgest. vom Heimatkreisbetreuer des Kreises Schwerin (Warthe) Erich Klemt u. Käte Bornmann. Stand April 1979. Hattingen 1979.

Anschriften-Verzeichnis ehem. Einwohner von Friedeberg (Nm.), Alt-Karbe und Umgegend. Hrsg.: Flüchtlingsausschuß Friedeberg/Nm., Altkarbe und Umgegend. 2. Aufl. (Berlin) 1947.

Anschriftenverzeichnis der schlesischen kirchlichen Amtsträger. Hrsg. von [Gerhard] Hultsch. Düsseldorf 1953.

Anschriftenverzeichnis des Klerus der Grafschaft Glatz 1945-1950. Stand: 1. Juli 1950. Hrsg.: Generalvikar (Franz Xaver) Monse. Büren/Westf. 1950.

Aus der Geschichte der Vertriebenen in Berlin. Hrsg.: Berliner Landesverband der Vertriebenen e. V. Berlin-Charlottenburg (1954).

Baltische Totenschau 1939-1947. Zsgest. u. hrsg. von Georg Adelheim. 1. Aufl. Göttingen 1947 (ersch. 1948). Nachtrag 1952.

Bibliothek der Stiftung Brandenburg Stuttgart. Bestandskatalog 1991. Bearb. von Christian Assenbaum. Stuttgart 1991. 
Brieger Anschriften-Verzeichnis. Stadt und Landkreis Brieg. [Hrsg.:]Hrsg.: Stadt Goslar, Betreuungsstelle Brieg. 1 (1962) - 17 (1986).

Bund der Vertriebenen, Vereinigte Landsmannschaften und Landesverbände. Handbuch. 2. Aufl. Bonn 1993.

Bund der Vertriebenen, Vereinigte Landsmannschaften und Landesverbände. Handbuch. 3., überarb. Aufl. Bonn 1996.

Deutsch-baltisches Gedenkbuch. Unsere Toten der Jahre 1939-1947. Bearb. von Karin von Borbély. Hrsg.: Deutsch-baltische Genealogische Gesellschaft e. V. Darmstadt 1991.

Erinnerungsschrift an die Stadt Bad Schönfließ/Nm aus Anlaß ihres 675jährigen Bestehens 23. Juni 1956. Zsgest. von Benno Riech. Überreicht von Paul Lehmann. (Berlin) 1956.

Menschenrechte sind unteilbar. Die Brandenburger Vertriebenenseminare 1994-2000 als Beiträge zur Aufarbeitung von Vertreibungsverbrechen. Hrsg.: Landsmannschaft Ostpreußen, Landesgruppe Brandenburg e. V. und Bund der Vertriebenen-Landesverband Brandenburg e. V. Ziesar 2000.

2. Verzeichnis der heimatvertriebenen Priester aus dem Osten, soweit sie in den vier Zonen Deutschlands leben. Stand: 1.1.1949. Hrsg. vom Priesterreferat. Königstein/Ts., Hessen (1949).

Verzeichnis der schlesischen Apotheker und Berufsangehörigen. Zsgest. von Charlotte Groß. 2. Aug. Werl 1949.

10 Jahre Bund der Vertriebenen in Rüdersdorf und Umgebung. Hrsg. vom Bund der Vertriebenen Kreisverband Amt Rüdersdorf und Umgehbug e. V. Red.: R[einhold] Bujok u. a. Rüdersdorf 2002.

20 Jahre Bund der Vertriebenen Kreisverband Oder-Spree e. V. Hrsg.: Bund der Vertriebenen Kreisverband Oder-Spree e. V. Fürstenwalde (2012). 20 S.

\subsection{Sonstige zeitgenössische Druckschriften}

Adreßbuch der Stadt Sommerfeld (Niederlausitz) 1940.

Adreßbuch der Städte Potsdam, Nowawes und Werder 1936/37.

Adressbuch Groß-Potsdam 1947. T. 1: Behörden, Organisationen, Verkehr, Industrie, Wirtschaft, Freie Berufe. Potsdam (1947).

Adressbuch Groß-Potsdam 1949. Potsdam (1948).

Amtliches Fernsprechbuch für den Bezirk der Reichspostdirektion Potsdam. Hrsg. von der Reichspostdirektion Potsdam. Ausg. Febr. 1941. Stand vom 31. Oktober 1940.

Amtliches Gemeindeverzeichnis für das Deutsche Reich auf Grund der Volkszählung 1939. Hrsg. vom Statistischen Reichsamt. 2. Aufl. Berlin 1941 (Statistik des Deutschen Reiches, Bd. 550).

Bericht der Landesregierung über Projekte und Initiativen der kulturellen Bildung. [Potsdam] 2009 (Landtag Brandenburg, 4. Wahlperiode, Drucksache 4/7599).

Berliner Adreßbuch 1943.

Branchen-Adressbuch Provinz Brandenburg mit Groß-Berlin. Ausgabe 1947. Berlin (1946).

Branchen-Adressbuch Land Brandenburg. 2. Ausg. Berlin [1948].

Branchen-Fernsprechbuch. Handels-, Gewerbe- und Berufsverzeichnis für den Bezirk der Oberpostdirektion Potsdam. Stand: 1. März 1951. 1. Ausg. Berlin 1951. [Enthält auch „Behördenteil“ (S. 171-194)].

Branchen-Fernsprechbuch für die Bezirke Cottbus, Frankfurt (Oder), Potsdam 1961. Stand: Mai 1961.

Brandenburgische Gesetzsammlung 1945/1947. Hrsg. vom Landtag des Landes Brandenburg, Sekretariat des Präsidenten. Potsdam 1948.

Dartsch, Winfried: Das Jahr 1949 im Spiegel der Presse. In: Gubener Heimatkalender 32 (1988), S. 68-72. 
Einwohnerbuch Königsberg (Pr) 89 (1941).

Ein Jahr Bewährung der Mark Brandenburg. Rückblick und Rechenschaft. Hrsg. vom Präsidium der Provinzialverwaltung Mark Brandenburg. Potsdam 1946 (Schriften des Informationsamtes der Provinzialverwaltung Mark Brandenburg, H. 3). ND (mit Nachw. von Bernhard Bechler). Hrsg.: Rat des Bezirkes Potsdam u. a. Potsdam 1989. 58 S.

Endgültige Ergebnisse der Volks- und Berufszählung vom 29. Oktober 1946. Folge 1-8. In: Statistische Praxis 3 (1948), Beil. zu H. 5-12.

Guben empfängt Wilhelm Pieck (Artikel des „Neuen Deutschland“ vom 7. Mai 1946, Auszug). In: Gubener Heimatkalender 44, 2000, S. 67.

Handbuch des Erzbistums Breslau für das Jahr 1934.

Handbuch des Landtages des Landes Brandenburg. Potsdam 1947.

Handbuch für das katholische Schlesien. Hrsg. von Johannes Kaps. München 1951.

Klerusverzeichnis des Bistums Berlin. Hrsg. vom Bischöfl. Ordinariat Berlin [14.]1953 (Stichtag: 1. Februar 1953).

Der Kreis Guben im Gründungsjahr der DDR 1949. Zsgest.: W[infried] Dartsch. In: Gubener Heimatkalender 33 (1989), S. 21-28 [Ausgewählte Meldungen aus der „Märkischen Volksstimme“].

Der Kreis Guben im Jahre 1950. Zsgest.: W[infried] Dartsch. In: Gubener Heimatkalender 34 (1990), S. 28-34 [Ausgewählte Meldungen aus der „Märkischen Volksstimme“].

Der Kreis Guben im Jahre 1951. Zsgest. von W[infried] Dartsch. In: Gubener Heimatkalender 35 (1991); S. 79-82. [Ausgewählte Meldungen aus der „Märkischen Volksstimme“].

Landtag Brandenburg. 1. Wahlperiode 1990-1994. Volkshandbuch. Stand: Januar 1991. Rheinbreitbach 1991.

Landtag der Mark Brandenburg. 1. Wahlperiode. Drucksache 1-197: Stenographischer Bericht. 1.-26. Sitzung (1946/47).

Lausitzer Rundschau, 1990-2017.

Märkische Allgemeine Zeitung, 1990-2017.

Migrationsbericht des Bundesamtes für Migration und Flüchtlinge im Auftrag der Bundesregierung. Migrationsbericht 2011. Hrsg.: Bundesministerium des Innern. Berlin 2013.

Der Ministerat der Deutschen Demokratischen Republik 1990. Rheinbreitbach 1990.

Mitteilungsblatt der Abteilung Umsiedler und Heimkehrer im Ministerium für Arbeit und Sozialwesen der Landesregierung Brandenburg.

Nationalsozialistische Volkswohlfahrt. Art. in: Meyers Lexikon. 8. Aufl. Bd. 8. Leipzig 1940, Sp. $154-157$.

Oranienburger Generalanzeiger (OGA), 2013, 2015, 2016.

Orts- und Personenverzeichnis des Erzbischöflichen Amtes Görlitz. Hrsg. vom Erzbischöfl. Amt Görlitz. 2. Ausg. Stand vom 1. April 1954.

Orts- und Personenverzeichnis des Erzbischöflichen Amtes Görlitz. Hrsg. vom Erzbischöfl. Amt Görlitz. 3. Ausg. Stand vom 1. Januar 1958.

Orts- und Personenverzeichnis des Erzbischöflichen Amtes Görlitz. Hrsg. vom Erzbischöfl. Amt Görlitz. 4. Ausg. Stand vom 1. Januar 1961.

Pfarralmanach für die Kirchenprovinz Mark Brandenburg. Hrsg. vom Evang. Konsistorium der Mark Brandenburg. Nach dem Stande vom 1. April 1939. Berlin 1939.

Pfarralmanach für die Kirchenprovinz Mark Brandenburg. Hrsg. vom Evang. Konsistorium der Mark Brandenburg. T. 1: Die Berliner Kirchenkreise. Abgekürzte Ausg. nach dem Stande vom 1.5.1946. Berlin 1946. 36, VII S. - T. II: Die Kirchenkreise der Provinz. Abgekürzte vorläufige Ausg. nach dem Stande vom 1.10.1946. Berlin 1946. 
Pfarralmanach für die Kirchenprovinz Berlin-Brandenburg. Hrsg. vom Evang. Konsistorium BerlinBrandenburg. T. I: Die Berliner Kirchenkreise. Nach dem Stande vom 1.7.1948. Berlin 1948.

Pfarralmanach für die Kirchenprovinz Berlin-Brandenburg. Hrsg. vom Evang. Konsistorium BerlinBrandenburg. Nach dem Stande vom 1. April 1950. Berlin 1950.

Pfarralmanach für die Kirchenprovinz Berlin-Brandenburg. Hrsg. vom Evang. Konsistorium BerlinBrandenburg. Nach dem Stande vom 1. April 1953. Berlin 1953.

Pfarralmanach für die Kirchenprovinz Berlin-Brandenburg. Hrsg. vom Evang. Konsistorium BerlinBrandenburg. Berlin 1956.

Potsdamer Wirtschafts-Spiegel 1946. [Hrsg.:] Zentralvermittlung. Potsdam (1946).

Potsdamer Wirtschafts-Wegweiser. Branchen-Adressbuch. Hrsg.: Das Spezial-Archiv der deutschen Wirtschaft. Potsdam (1946).

Reichs-Medizinal-Kalender. T. 2: Verzeichnis der deutschen Ärzte und Heilanstalten 58 (1937).

Schematismus des Bistums Berlin für das Jahr ... [Hrsg.: B Bischöfliches Ordinariat [1947 ff.: Hrsg. vom Bischöflichen Ordinariat Berlin]. [9.]1940 (Stichtag: 15. April 1940). [10.]1941 (Stichtag: 1. April 1941). [11.]1947 (Stichtag 1. Oktober 1946). [12.]1949 (Stichtatg 1. Januar 1949). [13.]1951 (Stichtag: 1. Dezember 1950).

Schematismus für das Bistum Berlin. Hrsg. vom Bischöfl. Ordinariat Berlin [15.]1956 (Stichtag: 1. Februar 1956). 16.1958 (Abgeschlossen am 1. Februar 1958). 20.1965 (1963).

Schmutzer, Hans: ... auferstanden aus Ruinen. Geschichte des Dorfes Dorf Zinna - Neuheim. Hrsg.: Dorfklub Neuheim und Betrieb VEB Gablona. [Neuheim 1966].

Sozialberichterstattung. Sozialpolitik im Überblick. Hrsg.: Ministerium für Arbeit, Soziales, Gesundheit und Frauen des Landes Brandenburg, Öffentlichkeitsarbeit. Potsdam 1991.

Stadtverordnetenversammlung Potsdam. Hrsg.: Büro der Stadtverordnetenversammlung in der Stadtverwaltung Potsdam. Potsdam o.J. [nach 1991].

Statistischer Informationsdienst Landeshauptstadt Potsdam, Nr. 8/1999.

Taschenbuch des Berliner Lebens. Hrsg. von Walter Habel. Berlin-Grunewald 1957.

Verordnung zur Durchführung der Bodenreform in der Provinz Mark Brandenburg. Hrsg.: Provinzialverwaltung Mark Brandenburg. Potsdam 1945.

Verzeichnis der Bezirke, Kreise und Gemeinden der Deutschen Demokratischen Republik mit Zuständigkeitsbezeichnungen der Verwaltung und Gerichte. Zsgest. von Herbert Hempel. Berlin 1953.

Volks- und Berufszählung vom 29. Oktober 1946 in der sowjetischen Besatzungszone Deutschlands. [Hrsg.:] Deutsche Wirtschaftskommission für die sowjetische Besatzungszone, Statist. Zentralamt. Bd. I: Amtliches Gemeindeverzeichnis. Berlin 1948.

Volks- und Berufszählung vom 29. Oktober 1946 in der sowjetischen Besatzungszone Deutschlands. [Hrsg.: ] Deutsche Wirtschaftskommission für die sowjetische Besatzungszone, Statist. Zentralamt. Bd. II: Gemeindestatistik. H. 1: Land Brandenburg. Berlin 1948.

Wirtschafts-Wegweiser für den Kreis Niederbarnim. Branchen-Adreßbuch. Potsdam (1949).

Wirtschafts-Wegweiser für Wittenberge und die Kreise West- und Ostprignitz. Branchen-Adreßbuch. Potsdam (1949). 


\subsection{Erinnerungsberichte und sonstige Selbstzeugnisse}

\subsubsection{Sammlungen}

Das Alte stürzt. Es ändert sich die Zeit und neues Leben blüht aus den Ruinen. Storkower Zeitzeugen berichten aus ihrem Leben. Erlebnisse, Erinnerungen, Erfahrungen, Erkenntnisse. Hrsg. vom Storkower Ortsverband des Brandenburgischen Seniorenverbandes. Red.: Horst König u. a. Storkow 2013.

Auf Erlebtes zurück geschaut. Lebenserinnerungen und Erzählungen wurden aufgeschrieben von Mitgliedern des Zirkels „Zeitzeugen“ beim Seniorenbeirat der Landeshauptstadt Potsdam. [16. Anthologie]. Hrsg.: Seniorenbeirat in der Landeshauptstadt Potsdam. Stadtverwaltung, Fachbereich 3 für Soziales, Jugend, Gesundheit, Ordnung u. Umweltschutz der Landeshauptstadt Potsdam. Red.: Ortrun Heßke u. a. Potsdam 2014 (16. Heft).

Auf Spurensuche. Episoden und Dokumente aus 775 Jahren Ortsgeschichte Neuenhagen. Hrsg.: VorOrt - Kunst, Kultur und Kommunikation e. V., Gemeinde Neuenhagen bei Berlin. Neuenhagen 2006 (Jahrbuch 2006).

Aus unserem Leben. Lebenserinnerungen und Erzählungen wurden aufgeschrieben von Mitgliedern des Zirkels „Zeitzeugen“ beim Seniorenbeirat der Landeshauptstadt Potsdam. [18. Anthologie]. Hrsg.: Seniorenbeirat in der Landeshauptstadt Potsdam. Stadtverwaltung, Fachbereich 3 für Soziales, Jugend, Gesundheit, Ordnung u. Umweltschutz der Landeshauptstadt Potsdam. Red.: Edith Gaida u. a. Potsdam 2016 (18. Heft).

Briefe aus einem anderen Land. Briefe aus der DDR. Hrsg. von Hildegard Baumgart. Vorw. von Carola Stern. 2. Aufl. Hamburg 1971.

Brücken bauen/budowa mostów. Hrsg.: Seniorenbeirat Storkow (Mark)/Seniorenorganisation Opalenica. Red.: Horst König u. a. Storkow (Mark)/Opalenica 2005.

Damals und heute. Storkower Zeitzeugen berichten. Erlebnisse, Erinnerungen, Erfahrungen, Erkenntnisse. Hrsg. vom Seniorenbeirat des Amtes Storkow. Red.: Horst König. Storkow 2003.

„... das Glockengeläut ist einzustellen“. 1945 - das Jahr zwischen Krieg und Frieden. T. 1: Belzig und Umgebung. Hrsg. vom Förderkreis Museum Burg Eisenhardt e. V. Red.: Helga Kästner. Belzig 1995. [Berichte Einheimischer].

Drei tolle Tage nach über 800 Jahren. Storkower Zeitzeugen berichten über die Feierlichkeiten zum 800 . Jahrestag der Ersterwähnung unserer Stadt im Jahre 1209 und erzählen weitere Geschichten. Erlebnisse, Erinnerungen, Erfahrungen, Erkenntnisse. Hrsg. vom Storkower Ortsverband des Brandenburgischen Seniorenverbandes. Red.: Horst König, Reinhold Zielke. Storkow 2011.

Eisenhüttenstädter Lesebuch. Bd. 1-2. Hrsg. von Dagmar Semmelmann u. a. Berlin 2000-2004. [Gesprächsprotokolle].

Erfahrungen - Erkenntnisse. Lebenserinnerungen und Erzählungen - aufgeschrieben von Mitgliedern des Zirkels „Zeitzeugen“ beim Seniorenbeirat der Landeshauptstadt Potsdam. [14. Anthologie]. Hrsg.: Seniorenbeirat in der Landeshauptstadt Potsdam. Stadtverwaltung, Fachbereich 3 für Soziales, Jugend, Gesundheit, Ordnung u. Umweltschutz der Landeshauptstadt Potsdam. Red.: Ortrun Heßke u. a. Potsdam 2012 (14. Heft).

Erinnerung ist lebende Vergangenheit. Aufgeschrieben aus persönlicher Sicht von Mitgliedern des Zirkels „Zeitzeugen“ beim Seniorenbeirat der Stadt Potsdam. [9. Anthologie]. Hrsg.: Seniorenbeirat in der Landeshauptstadt Potsdam. Stadtverwaltung, Fachbereich 3 für Soziales, Jugend, Gesundheit, Ordnung u. Umweltschutz der Landeshauptstadt Potsdam. Red.: Erna Kreutz-Gralow u. a. Potsdam 2007 (9. Heft).

Erinnerungen an Flucht und Vertreibung. Berichte aus Heft 1 - Juni 1995 - des „Heimatblattes“ mit Ergänzungen durch spätere Berichte der Landsleute. Hrsg. von der Bundesarbeitsgemeinschaft 
Landsberg (Warthe) Stadt und Land e. V. Red.: Ursula Haase-Dresing. Herford 2005 (Quellen und Darstellungen zur Geschichte des Landsberger Landes, H. 3) (Heimatblatt der ehemaligen Kirchengemeinden Landsberg/Warthe Stadt und Land. Teil-Reprint mit Ergänzungen, T. 1).

Erinnerungen sind gehobene Schätze. Lebenserinnerungen und Erzählungen - aufgeschrieben von Mitgliedern des Zirkels „Zeitzeugen“ beim Seniorenbeirat der Landeshauptstadt Potsdam. [15. Anthologie]. Hrsg.: Seniorenbeirat in der Landeshauptstadt Potsdam. Stadtverwaltung, Fachbereich 3 für Soziales, Jugend, Gesundheit, Ordnung u. Umweltschutz der Landeshauptstadt Potsdam. Red.: Ortrun Heßke u. a. Potsdam 2013 (15. Heft).

Erlebnisse haben keine Altersgrenze. Generationsübergreifendes Projekt 1999 des Zirkels „Zeitzeugen“ beim Seniorenbeirat in der Stadt Potsdam und der Klasse $7 \mathrm{~b}$ der Voltaire-Grundschule in der Landeshauptstadt. [2. Anthologie]. Potsdam 1999.

Erlebt im vorigen Jahrhundert. Geschichten und Lebenserinnerungen - aufgeschrieben von Mitgliedern des Zirkels „Zeitzeugen“ beim Seniorenbeirat der Stadt Potsdam. [6. Anthologie]. Hrsg.: Seniorenbeirat der Stadt Potsdam. Stadtverwaltung, Fachbereich Soziales, Wohnen u. Senioren. Red.: Erna Kreutz-Gralow u. a. Potsdam 2004 (6. Heft).

Erlebte Geschichte. Aufgeschrieben aus persönlicher Sicht von Mitgliedern des Zirkels „Zeitzeugen“ beim Seniorenbeirat der Stadt Potsdam. [8. Anthologie]. Hrsg.: Seniorenbeirat in der Stadt Potsdam. Stadtverwaltung, Fachbereich 3 für Soziales, Jugend, Gesundheit, Ordnung u. Umweltschutz. Red.: Erna Kreutz-Gralow u. a. Potsdam 2006 (8. Heft).

Erlebtes bewahren. Lebenserinnerungen und Erzählungen. Aufgeschrieben von Mitgliedern der Arbeitsgruppe „Zeitzeugen“ beim Seniorenbeirat der Landeshauptstadt Potsdam. [20. Anthologie]. Hrsg.: Seniorenbeirat in der Landeshauptstadt Potsdam. Stadtverwaltung, Fachbereich 3 für Soziales, Jugend, Gesundheit, Ordnung u. Umweltschutz der Landeshauptstadt Potsdam. Red.: Edith Gaida u. a. Potsdam 2018 (20. Heft).

Flucht, Vertreibung, Neubeginn nach 1945. Schicksale und Berichte aus dem Raum Lieberose. Mit Beitr. von: Karl Beerfelde u. a. Hrsg. von der Evang. Kirchengemeinde Lieberose und Land. Red.: Andreas Weigelt. Lieberose 2006.

Gedenken in Caputh. Den Opfern von Krieg und Gewalt. Ausgew. u. bearb. von Klaus Hugler. Hrsg.: Evang. Kirchengemeinde Caputh. Caputh 2005. [Berichte Einheimischer].

Gelebte Geschichte. Storkower Zeitzeugen berichten aus 8 Jahrzehnten. Erlebnisse, Erinnerungen, Erfahrungen, Erkenntnisse. Hrsg. vom Seniorenbeirat der Stadt Storkow (Mark) anlässlich der 14. Brandenburgischen Seniorenwoche im Juni 2007. Red.: Horst König, Hans-Peter Höppener. Storkow 2007.

Gelebtes und Erlebtes. Senioren erinnern sich. [3. Anthologie]. Hrsg.: Seniorenbeirat in der Stadt Potsdam. Stadtverwaltung, Fachbereich Jugend, Soziales, Wohnen. Red.: Karl-Heinz Karge. Potsdam [2000].

Geschichten. Aus Nah und Fern. Zeitzeugen aus Strausberg erzählen. Hrsg.: Seniorenbeirat der Stadt Strausberg. Red.: Eva Emmrich. Strausberg 2006.

Geschichten aus dem Meer der Erinnerungen. Lebenserinnerungen und Erzählungen - aufgeschrieben von Mitgliedern des Zirkels „Zeitzeugen“ beim Seniorenbeirat der Landeshauptstadt Potsdam. [11. Anthologie]. Hrsg.: Seniorenbeirat in der Landeshauptstadt Potsdam. Stadtverwaltung, Fachbereich 3 für Soziales, Jugend, Gesundheit, Ordnung u. Umweltschutz der Landeshauptstadt Potsdam. Red.: Christa Kikels u. a. Potsdam 2009.

Geschichten aus sieben Jahrzehnten. Storkower Zeitzeugen berichten. Erlebnisse, Erinnerungen, Erfahrungen, Erkenntnisse. Hrsg. vom Seniorenbeirat der Stadt Storkow (Mark) anlässlich der 12. Brandenburger Seniorenwoche im Juni 2005. Red. u. Gestaltung: Horst König, Hans-Peter Höppner. Storkow 2005. 
Gespräche mit ehemaligen Küstrinern über Küstrin, Vertreibung und Neuanfang in Küstrin-Kietz und anderswo (Gesprächspartner in alphabetischer Reihenfolge). Aufgez. u. bearb. von Siegfried Neubauer. Ms.-Druck in kleiner Aufl. (Teilweise geringfügig verb. Nachaufl.). Bd. 1-7. Petershausen [ab Bd. 4: Frankfurt (Oder)] 1999-2018. [Bearb. geb. 1937 Berlin, aufgewachsen in Küstrin, Jan. 1945 Flucht nach Niederbayern, 1946 Übersiedlung nach Bonn, bereitet 2018 polnische Ausgabe aller Bände vor].

Gestern und heute. Erinnerungen von Mitgliedern des Zirkels „Zeitzeugen“ beim Seniorenbeirat der Stadt Potsdam. [7. Anthologie]. Hrsg.: Seniorenbeirat in der Stadt Potsdam. Stadtverwaltung, Fachbereich Soziales, Wohnen u. Senioren. Red.: Erna Kreutz-Gralow u. a. Potsdam 2005 (7. Heft).

Heiteres und Besinnliches. Geschichten und Lebenserinnerungen - aufgeschrieben von Mitgliedern des Zirkels „Zeitzeugen“ beim Seniorenbeirat der Landeshauptstadt Potsdam. [10. Anthologie]. Hrsg.: Seniorenbeirat in der Landeshauptstadt Potsdam. Stadtverwaltung, Fachbereich 3 für Soziales, Jugend, Gesundheit, Ordnung u. Umweltschutz der Landeshauptstadt Potsdam. Red.: Christa Kikels u. a. Potsdam 2008.

Hoffnung und Resignation/Nadzieje i rozczarowania. Alltag im Sozialismus/Dzien powszedni w socializmie. Deutsche und polnische Zeitzeugen berichten. Hrsg.: BRH Storkow u. a. Red.: Horst König u. a. Storkow/Opalenica 2007.

Kempowski, Walter: Das Echolot. Abgesang ,45. Ein kollektives Tagebuch. 2. Aufl. München 2005. [Tagebuchauszüge für 20., 25. und 30.4.1945, 8./9.5.1945].

Kriegsende und Nachkriegszeit in Havelberg [I]. Hrsg.: Heimatverein Havelberg e. V. Havelberg 1992 (Havelberger Regionalgeschichtliche Beiträge, Bd. 1).

Kriegsende und Nachkriegszeit in Havelberg [II]. Hrsg.: Heimatverein Havelberg e. V. Havelberg 1994 (Havelberger Regionalgeschichtliche Beiträge, Bd. 2).

Eine lähmende Angst überfällt uns. Erlebnisberichte zweier aus Ostpreußen vertriebener Frauen. In: Wir waren damals 19.50 Jahre 8. Mai in und um Frankfurt. Berichte, Dokumente, Recherchen, Tagebücher, Erinnerungen, Gespräche. Ein Lesebuch. Hrsg.: Jürgen Maerz. Frankfurt (Oder) 1995, S. 168-175. [Fluchterlebnisse innerhalb Ostpreußens 1944/45].

Lebendige Erinnerungen. Aufgeschrieben von Mitgliedern der Arbeitsgruppe „Zeitzeugen“ beim Seniorenbeirat der Landeshauptstadt Potsdam. [Heft Nr. 21]. Hrsg.: Landeshauptstadt Potsdam, Seniorenbeirat der Arbeitsgruppe „Zeitzeugen“. Red.: Edith Gaida u. a. Potsdam 2019.

Lebensgeschichten Neuruppiner Frauen. Aufgeschrieben von Heli Voss. Norderstedt [2006].

Lebenszeit [I.] Zeitzeugen berichten. Hrsg. vom Landesseniorenbeirat Brandenburg u. des [so!] „Verein zur Förderung der Brandenburgischen Seniorenwoche“. [Red.:] Günter Voigt. [Neuenhagen 1996].

Lebenszeit. T. II. Zeitzeugen berichten. Hrsg. vom Landesseniorenbeirat Brandenburg u. des [so!] „Verein zur Förderung der Brandenburgischen Seniorenwoche“. [Red.:] Günter Voigt. (Neuenhagen) [1997].

Lebenszeit. T. III. Zeitzeugen berichten. Hrsg. vom Landesseniorenbeirat Brandenburg u. dem Seniorenbeirat Neuenhagen. [Red.:] Günter Voigt. Neuenhagen [1998]

Lebenszeit. T. IV. Zeitzeugen berichten. Hrsg. vom Seniorenbeirat der Gemeinde Neuenhagen bei Berlin. [Red.:] Günter Voigt. Neuenhagen [1998].

Lebenszeit. T. V. Zeitzeugen berichten. Hrsg. vom Seniorenbeirat der Gemeinde Neuenhagen bei Berlin. [Red.: ] Günter Voigt. Neuenhagen 1999.

Lebenszeit. T. VI. Zeitzeugen berichten. Hrsg.: Seniorenbeirat der Gemeinde Neuenhagen. Red.: Günter Voigt. Neuenhagen 2000.

Lebenszeit VII. Hrsg.: Seniorenbeirat der Gemeinde Neuenhagen. Red.: Günter Voigt. Neuenhagen 2001.

Lebenszeit VIII. Neuenhagener Impressionen. Hrsg.: Seniorenbeirat der Gemeinde Neuenhagen. Red.: Günter Voigt. Neuenhagen 2002. 
Lebenszeit IX. Zu Hause in Neuenhagen. Hrsg.: Seniorenbeirat der Gemeinde Neuenhagen. Red.: Günter Voigt. Neuenhagen 2003.

Lebenszeit XIII. Neuenhagener Geschichten. Hrsg.: Seniorenbeirat u. Gemeinde Neuenhagen. Red.: Jutta Skotnicki, Marianne Wachtmann. Neuenhagen o.J. [ca. 2010].

Lebenszeit XIV. Neuenhagener Geschichten. Hrsg.: Seniorenbeirat u. Gemeinde Neuenhagen. Red.: Jutta Skotnicki, Marianne Wachtmann. Neuenhagen o.J. [ca. 2012].

Lebenszeit XVI. Neuenhagener Geschichten. Hrsg. von: Seniorenbeirat u. Gemeinde Neuenhagen bei Berlin. Red.: Marianne Wachtmann u. a. Neuenhagen bei Berlin [2018].

Ein leidgeprüftes Land. Der brandenburgische Kreis Lebus in den Wirren der Jahre 1945-1952. Ereignisse und Erlebnisberichte ehemaliger Kreisbewohner. Bearb. von Fritz Knüppel. Hrsg.: Heimatkreis Lebus. 2., durchges. Aufl. Barsinghausen 1990. [Berichte Einheimischer].

Die letzten Tage im Krieg und die ersten Wochen im Frieden in der Region um Rathenow. T. 1-3. Hrsg.: Rathenower Heimatbund e. V. [Red.:] Hans-Jürgen Wodtke u. a. 2. Aufl. (T. 1.: 4. Aufl.) Rathenow 2014-2018.

Meyer, Sibylle / Schulze, Eva: Wie wir das alles geschafft haben. Alleinstehende Frauen berichten über ihr Leben nach 1945. Hrsg. vom Senator für Familie und Gesundheit in Berlin. München 1984.

Müncheberger Lebensläufe. Autorenkollektiv. Hrsg. Verein für Heimatgeschichte der Stadt Müncheberg e. V.T. 1-5. T. 1-2: Zsgest. u. zumeist aufgeschrieben von Andreas Gehrke u. Frank Geißler. Textbearb.: [T. 1-3:] Andreas Gehrke. [T. 4-5:] Frank Geißler. Müncheberg 2008-2017.

Neun Zeitzeugen erzählen. Hrsg.: Seniorenbeirat Cottbus. Cottbus 2002 (Erinnerungen, Sichtweisen).

1945. Als Küstrin in Trümmer sank. Ich war dabei. Betrachtungen, Berichte und Briefe. Zsgest. u. bearb. von Fritz Kohlase. Überarb., erw. u. ill. 2. Aufl. Sehnde 2006.

Noa, Wolfgang: Leben in Preußen. Sieben Porträts. Berlin/Weimar 1983. 2. Aufl. 1985 (Edition Neue Texte). [S. 39-60: Paul Sch., geb. 1903; Okt. 1945 vertrieben aus Oberschlesien, Bahntransport nach Rostock, Übersiedlung nach Potsdam].

Potsdam 1945. Persönliche Aufzeichnungen und Erinnerungen. Begleitheft zur Sonderausstellung des Potsdam-Museums. Red.: Peter Herrmann. Potsdam 2005 (Veröffentlichung des Potsdam-Museums, 39).

rausgeschmissen. 13 Erinnerungen an Flucht und Vertreibung. Eine Dokumentation des ZeitGeschichte(n) e. V. - Verein für erlebte Geschichte. Red. Bearb.: Heidi Bohley, Wolfgang Kupke. 2. Aufl. Halle 2002.

Rückblicke auf Erlebtes. Lebenserinnerungen und Erzählungen - aufgeschrieben von Mitgliedern des Zirkels „Zeitzeugen“ beim Seniorenbeirat der Landeshauptstadt Potsdam. [13. Anthologie]. Hrsg.: Seniorenbeirat in der Landeshauptstadt Potsdam. Stadtverwaltung, Fachbereich 3 für Soziales, Jugend, Gesundheit, Ordnung u. Umweltschutz der Landeshauptstadt Potsdam. Red.: Ortrun Heßke u. a. Potsdam 2011.

Rüdersdorf. Zeitzeugen berichten. Hrsg. vom Seniorenbeirat Rüdersdorf. Rüdersdorf 1998.

Rüdersdorf. Zeitzeugen berichten. Vorkriegszeit, Kriegszeit, Nachkriegszeit. Hrsg. vom Seniorenbeirat Rüdersdorf. Vorw.: Peter Gutsche. Rüdersdorf o.J. [1999?].

„Die Russen sind da“. Kriegsalltag und Neubeginn 1945 in Tagebüchern aus Brandenburg. Peter Böthig u. Peter Walther (Hg). Mit einem Nachw. von Alexander Gauland. 2., durchges. Aufl. Berlin 2011. [Texte auch auf www.zeitstimmen.de].

Schlesien. Die letzten Tage im Kampf um Deutschlands reichste Provinz. Das Verbrechen der Vertreibung. [Zsgest. von Erich Kirschner]. Velen [1985].

Spuren aus ihrem Leben. Senioren erinnern sich. Hrsg.: Seniorenbeirat in der Stadt Potsdam. Stadtverwaltung, Fachbereich Jugend, Soziales, Wohnen. Red.: Erna Kreutz-Gralow u. a. [5. Anthologie]. Potsdam 2003 (5. Heft). 
Storkower Zeitzeugen berichten. Erlebnisse, Erinnerungen, Erfahrungen, Erkenntnisse. [H. 1]. Hrsg. vom Seniorenbeirat des Amtes Storkow. Red.: Horst König. Storkow 1999

Storkower Zeitzeugen berichten. Erlebnisse, Erinnerungen, Erfahrungen, Erkenntnisse. [H.] 2. Hrsg. vom Seniorenbeirat des Amtes Storkow. [Red.: Horst König]. Storkow 2001.

Ein Stück des langen Weges. Storkower Zeitzeugen berichten anlässlich des 800. Jahrestages der Ersterwähnung unserer Stadt. Erlebnisse, Erinnerungen, Erfahrungen, Erkenntnisse. Hrsg. vom Brandenburgischen Seniorenbeirat e. V., Ortsverband Storkow. Storkow 2009.

Die Uckermark 1945. T. 2. Hrsg.: Gesamtschule mit gymnasialer Oberstufe Carl Friedrich Grabow [und] Uckermärkischer Geschichtsverein zu Prenzlau e. V. 2. Aufl. Prenzlau 1995.

Um Beelitz harter Kampf. 1945. Das Jahr zwischen Krieg und Frieden. Beelitz und Umgebung. Hrsg.: Beelitzer Heimatverein. Red.: Hannelore Bothe / Fritz Klewitz. Beelitz 1999.

Vergangenes - Gegenwärtiges. Lebenserinnerungen und Erzählungen - aufgeschrieben von Mitgliedern des Zirkels „Zeitzeugen“ beim Seniorenbeirat der Landeshauptstadt Potsdam. [12. Anthologie]. Hrsg.: Seniorenbeirat in der Landeshauptstadt Potsdam. Stadtverwaltung, Fachbereich 3 für Soziales, Jugend, Gesundheit, Ordnung u. Umweltschutz der Landeshauptstadt Potsdam. Red.: Ortrun Heßke u. a. Potsdam 2010 (12. Heft).

Die Vergangenheit lebt in uns. Potsdamer erinnern sich. Hrsg. von Franz Fabian. Milow 2007.

Vertreibung aus dem Osten. Hrsg. von Hans-Jürgen Bömelburg, Renate Stößinger, Robert Traba. Olsztyn 2000. [Flucht und Vertreibung in deutschen und polnischen Augenzeugenberichten].

Vertreibung und Vertreibungsverbrechen 1945-1948. Bericht des Bundesarchivs vom 28. Mai 1974. Archivalien und ausgewählte Erlebnisberichte. Red.: Silke Spieler. Bonn 1989.

Vor 50 Jahren. Als Flucht und Vertreibung im Kreis Züllichau-Schwiebus begannen. Auszüge aus Tagebüchern, Briefen und Aufzeichnungen. Im Auftr. des Heimatkreises zsgest. von Lothar Meißner. O. O. 1995.

Was nicht vergessen werden sollte. Lebenserinnerungen und Erzählungen wurden aufgeschrieben von Mitgliedern des Zirkels „Zeitzeugen“ beim Seniorenbeirat der Landeshauptstadt Potsdam. [19.

Anthologie]. Hrsg.: Seniorenbeirat in der Landeshauptstadt Potsdam. Stadtverwaltung, Fachbereich 3 für Soziales, Jugend, Gesundheit, Ordnung u. Umweltschutz der Landeshauptstadt Potsdam. Red.: Edith Gaida u. a. Potsdam 2017 (19. Heft).

Wie es damals war. Lebenserinnerungen und Erzählungen wurden aufgeschrieben von Mitgliedern des Zirkels „Zeitzeugen“ beim Seniorenbeirat der Landeshauptstadt Potsdam. [17. Anthologie]. Hrsg.: Seniorenbeirat in der Landeshauptstadt Potsdam. Stadtverwaltung, Fachbereich 3 für Soziales, Jugend, Gesundheit, Ordnung u. Umweltschutz der Landeshauptstadt Potsdam. Red.: Ortrun Heßke u. a. Potsdam 2015 (17. Heft).

Wir waren damals 19. 50 Jahre 8. Mai in und um Frankfurt. Berichte, Dokumente, Recherchen, Tagebücher, Erinnerungen, Gespräche. Ein Lesebuch. Hrsg.: Jürgen Maerz. Frankfurt (Oder) 1995.

Zeitgebunden. Brücken zur Vergangenheit. Hrsg. vom Seniorenbeirat der Stadt Cottbus. Cottbus 2010 (Zeitzeugen erzählen).

Zeitstimmen. Literatur und Alltag in Brandenburg. Projekt des Brandenburgischen Literaturbüros, www.zeitstimmen.de [25.5.2017].

Zeitzeugen aus Strausberg berichten. Erinnerungen an Kindheit, Jugend und Kriegszeiten. Erlebnisse in Strausberg und anderswo. Wendezeiten - Zäsuren - erfüllte und zerstobene Träume. Hrsg. vom Seniorenbeirat der Stadt Strausberg. Strausberg (1999).

Zeitzeugen berichten. Aus der Sammlung der Arbeitsgruppe „Schreibende Senioren“ beim Seniorenbeirat in der Stadt Potsdam. [1. Anthologie]. Hrsg. vom Seniorenbeirat u. dem Dezernat Soziales, Jugend u. Gesundheit der Landeshauptstadt Potsdam. Potsdam [1998]. 
Zeitzeugen berichten. Erinnerungen, Erfahrungen, Erlebnisse, Erkenntnisse. [2]. Hrsg. von der Gemeinde u. dem Seniorenbeirat Fredersdorf-Vogelsdorf. Fredersdorf-Vogelsdorf 2001.

Zeitzeugen berichten. Erinnerungen, Erfahrungen, Erlebnisse, Erkenntnisse. [3]. Hrsg. vom Landesseniorenbeirat Brandenburg. Vorw.: Manfred Tippmann. O. O. [1999?].

Zeitzeugen berichten 2000. Rückblickend nach vorn schauen. Hrsg. vom Seniorenrat des Landes Brandenburg e. V. Vorw.: Paul Lucht. [Strausberg] o.J.

Zeitzeugen berichten 2003. Zuhause in Brandenburg. Hrsg. vom Seniorenrat des Landes Brandenburg e. V. Ausw. u. Red.: Sieglinde Heppener u. Paul Lucht. Cottbus 2003.

Zeitreisen durch ein Jahrhundert unternehmen Mitglieder des Zirkels „Zeitzeugen“ beim Seniorenbeirat der Stadt Potsdam. Senioren erinnern sich. [4. Anthologie]. Hrsg.: Seniorenbeirat der Stadt Potsdam. Stadtverwaltung, Fachbereich Jugend, Soziales, Wohnen. Red.: Helga Bornstädt u. a. Potsdam 2002 (4. Heft).

Zeitzeugen erzählen. Hrsg.: Seniorenbeirat Cottbus. Cottbus 2006 (Erinnerungen, Sichtweisen).

\subsubsection{Einzelberichte von Flüchtlingen, Vertriebenen und Spätaussiedlern}

Albrecht, Dorothea: Die letzten 24 Stunden in der Heimat Landsberg. Aus dem handschriftlichen Bericht übertr. von Matthias Lehmann. In: Heimatblatt der ehemaligen Kirchengemeinden Landsberg/Warthe Stadt und Land 50 (2015), S. 13-17. [Geb. 1930, Kaufmannstochter aus Landsberg/W., 30.1.1945 Evakuierung mit Personenzug über Küstrin nach Berlin, 31.1. Weiterfahrt vom Anhalter Bahnhof über Leipzig u. Regensburg nach Ingolstadt, Ankunft 1.2.1945].

Ambrosch, Rudolf [Rudi]: Kriegsgefangenschaft. In: Storkower Zeitzeugen berichten. [H. 1]. Hrsg. vom Seniorenbeirat des Amtes Storkow. Storkow 1999, S. 17-19. [Geb. 1926 Sudetenland, Kriegsheimkehrer].

Ambrosch, Rudi: Aus der Gefangenschaft in ein unbekanntes Land. In: Storkower Zeitzeugen berichten. [H. 1]. Hrsg. vom Seniorenbeirat des Amtes Storkow. Storkow 1999, S. 37-38. [Wie vor].

[Ammon, Margarete, geb. Gutsche:] Das Tagebuch der Margarete Ammon (geb. 1909). Transkription von Siegfried Neubauer. In: Gespräche mit ehemaligen Küstrinern. Aufgez. u. bearb. von Siegfried Neubauer. Bd. 6. Frankfurt (Oder) 2017, S. 29-50. [Zeitraum 12.1. bis 12.11.1945; lebt in Küstrin als gelernte Buchhändlerin mit ihrem Mann Ewald Ammon (Buch- u. Papierhandlung) bis zur Flucht (Zwangsräumung) am 19.2., mit (Militär-?)Fahrzeugen nach Altbleyen gebracht, dann zu Fuß nach Golzow (Oderbruch), mit „Omnibus der Luftwaffe“ nach Werbig („Auffangbahnhof"), 20.2. per Bahn weiter über Berlin-Lichtenberg, Eberswalde u. Angermünde nach Prenzlau (Bewirtung u. Unterbringung in großen Hallen des „Mansfeld Werk" (Schlafen auf Stühlen), 22.2. eigenständige Weiterfahrt (S. 37: „Die Abteile waren gerammelt voll, Flüchtlinge und frisch eingezogene Männer.") über Pasewalk (ebd.: „Bahnhof überfüllt mit Flüchtlingen"), Stralsund u. Rostock zu Freunden nach Bad Doberan (24.2.), 15.6. Befehl für die Flüchtlinge zum Verlassen des Ortes bis 18.6., Versuch der Rückkehr nach Küstrin über Rostock (ab hier per Bahn), Stralsund, Greifswald, Prenzlau (21./22.6. Übernachtung in offenem Güterwagen. „Drei Soldaten hatten sich einen alten Kinderwagen organisiert, Sie wollten noch ins Sudetenland."), Seehausen bei Prenzlau (hier 22.6. Lok abgehängt), zu Fuß (z. T. auf Autobahn) weiter (S. 44: „Die Ortschaften wurden mit Interesse besichtigt und aufgepasst, ob Küstriner auftauchten. In Prenzlau war nicht einer zu sehen. ") über Greiffenberg, Angermünde, Herzsprung, Serwest (Rast auf Strohlager), Eberswalde (S. 45: „Eberswalde ist ganz zerschossen. [...] Da bekommen wir zu hören: In Küstrin lassen die Polen niemanden hinein!"), 25.6.1945 Ankunft auf Stettiner Bahnhof in Berlin (Ausgehverbot), 26.6. zum Onkel nach Berlin-Rudow (S. 45: „Auch hier bekamen wir zu hören, Küstriner können nicht zurück. Aus - aus der Traum!"), entbehrungsreiches Leben in Berlin bis Jahresende (S. 46, 1.7.1945: „Wie ein Ausgestoßener komme ich mir vor, als hätte ich kein Recht zu leben auf dieser Welt: ,Flüchtlinge" $)$ ]. 
Baas, Friedrich-Karl: Angermünde und sein Krankenhaus im Herbst 1945 aus der Sicht eines Durchreisenden. Nachkriegszeit. In: Angermünder Heimatkalender 2016 (2015), S. 179-189.

Balschinat, Gretel: Meine Nachkriegsjahre in Wilhelmshorst. In: 100 Jahre Wilhelmshorst 1907-2007. Hrsg. im Namen der Freunde und Förderer der Wilhelmshorster Ortsgeschichte e. V. von Rainer Paetau. Wilhelmshorst 2007, S. 347-350. [Geb. ca. 1926 Königsberg i.Pr., Schneidermeistertochter, Ende Juni 1945 Flucht aus der Neumark nach Wilhelmshorst].

Barkau, Margarete: Erlebnisse in Bomst. In: Vor 50 Jahren. Als Flucht und Vertreibung im Kreis Züllichau-Schwiebus begannen. Auszüge aus Tagebüchern, Briefen und Aufzeichnungen. Im Auftr. des Heimatkreises zsgest. von Lothar Meißner. O. O. 1995, S. 23-25. [Geb. 1901 Bomst, Erlebnisse in Bomst ab 29.1.1945, 29.6.1945 polnischer Räumungsbefehl, 15-tägiger Treckmarsch der ausgewiesenen alten Leute, Frauen und Kinder nach Neuruppin, Verfasserin selbst erhält Unterkunft in Berlin (Aussagen vor Notar in Osnabrück 1952)].

Baumann, Reinhardt: Was ist Heimat? In: Zeitzeugen berichten 2003. Zuhause in Brandenburg. Hrsg. vom Seniorenrat des Landes Brandenburg e. V. Cottbus 2003, S. 18-19. [Geb. 1928, Russlanddeutscher aus dem Wolgagebiet, 1941 nach Kasachstan deportiert, nach 1990 als Spätaussiedler nach Senftenberg gekommen].

Becker, Lieselotte: Flucht und Vertreibung aus Strese. In: Heimatgruß. Zeitschrift für Mitglieder und Freunde des Heimatkreises Meseritz e. V. und der Heimatkreisgemeinschaft Birnbaum 215 (2015), S. 32-35. [Geb. 1930; 25./26.1.1945 Flucht (Zwangsevakuierung) mit Mutter, Großmutter und Geschwistern aus Strese (Kr. Meseritz) nach Brätz, 25.7.1945 Vertreibung, Treck über Reitwein u. Neutrebbin, 31.8. Ankunft in Pritzwalk, Bahnfahrt nach Wittenberge, Flüchtlingslager („Umsiedlungslager") Goldbeck, Wohnungseinweisung im Kr. Osterburg/Altmark, später Heirat in den Kr. Seehausen, Enteignung, Flucht in den Westen].

Bein, Otto: Stadtsparkasse zu Mohrin. In: Kreiskalender für den Heimatkreis Königsberg-Neumark 10 (1962), S. 75-86. [S. 81-85: Bericht Beins als ehem. Kassenleiter der Stadtsparkasse Mohrin über den letzten Geschäftstag am 31.1.1945 und die Evakuierung nach Rathenow].

Beißert, Elly: So kam ich nach Rüdersdorf. In: Rüdersdorf. Zeitzeugen berichten. Hrsg. vom Seniorenbeirat Rüdersdorf. Rüdersdorf 1998, S. 34-36. [Geb. 1923, später Verkäuferin/Rentnerin; 9.2.1945 Flucht aus Weißkirschdorf (Schlesien), Treck ins Sudetenland, nach einigen Wochen Rückkehr, da Pferde krank, Mitte Juni 1945 Vertreibung mit kleinem Wagen, Ausspannen kurz vor Jauer (Pferde beschlagnahmt), zu Fuß, den Wagen schiebend, weiter bis in den Raum Görlitz auf ein Rittergut, dort durch das „amerikanische Rote Kreuz" zurückgeschickt, Leben unter Polen im Heimatdorf („weiße Binde"), Anf. Aug. 1946 Vertreibung mit Leiterwagen nach Schweidnitz zum Bahnhof, Bahnfahrt bis Leipzig (14 Tage Aufenthalt in Kasernen), dann aufgeteilt auf Dörfer des Kr. Grimma, sie nach Köhra, 22.12.1947 Übersiedlung zu Verwandten nach Schöneiche bei Berlin, 1949 in Rüdersdorf Mann kennengelernt (Arbeiter im Chemiewerk), 1956 Umzug nach dort (Einfamilienhaus)].

Below, Ruth: Flucht, Vertreibung, schwerer Neuanfang. Gesprächsprotokoll, überarb. von Gerd Tschechne. In: Storkower Zeitzeugen berichten [H.] 2. Hrsg. vom Seniorenbeirat des Amtes Storkow. Storkow 2001, S. 52-56. Wiederabdr. u. d. T. „Flucht, Vertreibung, schwerer Anfang“ in: Brücken bauen / budowa mostów. Hrsg.: Seniorenbeirat Storkow (Mark) / Seniorenorganisation Opalenica. Storkow (Mark)/Opalenica 2005, S. 15-19. [Geb. 1929 Namslau (Schlesien), Schmiedtochter, Hauswirtschaftslehrling, 19.1.1945 Evakuierung (später Rückkehr), Okt. 1946 Vertreibung aus Krickau (Kr. Namslau), Güterzugfahrt über Forst u. Beeskow nach Storkow, Lager Küchensee, nach Unfall Aufnahme in Krankenbaracke, nach 14 Tagen Quarantäneaufenthalt Einweisung der Familie als Untermieter in Kehrigk (Kr. Beeskow-Storkow)].

-, -: Wie ich zu meiner neuen Heimat fand. Erzählt von G. F. Aufgeschrieben von Horst König. In:

Geschichten aus sieben Jahrzehnten. Storkower Zeitzeugen berichten. Hrsg. vom Seniorenbeirat der Stadt Storkow (Mark). Storkow 2005, S. 52-53. [Wie vor; Flucht, Verteibung, Lageraufenthalt u. erste 
Unterkunft wie vor, dann Schlosserin in VP-Dienststelle Küchensee II, lernt ebd. 1949 VP-Beschäftigten kennen (Heirat 1952), 1958 Umzug in Bauernhaus in Bugk bei Storkow, besucht später Heimatort u. hält Kontakt zu poln. Bewohnern].

Bisky, Lothar: So viele Träume. Mein Leben. Berlin 2005. 295 S. [Geb. 1941 Zollbrück, Kr. Rummelsburg, gest. 2013 Leipzig, Vater Landarbeiter in Lüllemin, Kr. Stolp, 1945 Flucht mit Mutter u. Bruder, dann zunächst Rückkehr, 1947 Vertreibung über Stettin nach Schleswig-Holstein, aufgewachsen in Brekendorf bei Eckernförde (schildert die deklassierend empfundenen Besitz-Unterschiede zwischen Einheimischen u. Flüchtlingen), Oberschulbesuch in Rendsburg, 1959 Übersiedlung in die DDR, Studium an der HumboldtUniv. zu Berlin, später Professor für Film- u. Fernsehwissenschaft (u. Rektor) an der Hochschule für Film und Fernsehen Potsdam, 1991-1993 PDS-Landesvorsitzender in Brandenburg, 2004-2005 Vizepräsident des Landtages Brandenburg].

Bitter (geb. Kopp), Margot: Unterwegs und Ankunft. In: Der Kreis Schubin. Geschichte, Erinnerungen, Skizzen. Hrsg. vom Heimatkreis Schubin - Altburgund e. V. Bergen 1990, S. 137-140. [Treck aus Salzdorf, Kr. Schubin (Wartheland) ab 20.1.1945 durch Neumark u. Prignitz bis nach Bergen, Kr. Celle; S. 137 Schilderung der Übernachtung u. vorübergehenden (5 Tage) Einquartierung in Hindenberg bei Gransee (Kr. Ruppin) ab 2.2.1945].

Bleich, Ute: Kampf dem Kartoffelkäfer - Kindheitserinnerung. In: Heimatkalender Prenzlau 58 (2015), S. 124-126 [geb. 1935 Breslau, lebte von April 1945 bis Aug. 1950 in Oberbösa/Thüringen, später in der Uckermark].

Bleschke, Otto: Deutsche Kriegsgefangene auf dem Truppenübungsplatz Wandern 1945 [Erlebnisbericht]. In: Heinz W. Linke / Heinz Paschke: Das Sternberger Land im Wandel der Zeiten. Iserlohn 1988, S. 591-592. [Aus Klein Rade (Kr. Weststernberg); als Wehrmachtssoldat 1945 in Berlin in sowjet. Kriegsgefangenschaft geraten u. am 8.5.1945 in großes Sammellager nach Frankfurt (Oder) marschiert, später in Wandern (Kr. Weststernberg), Ende Aug. 1945 entlassen, Marsch nach Frankfurt (Oder), dort Entlassung nach Strickscheid/Eifel zur Verlobten].

Bolduan, Erwin: [Lebenslauf]. Aufgeschrieben von Lieselotte Neuendorf. In: Müncheberger Lebensläufe. Hrsg. Verein für Heimatgeschichte der Stadt Müncheberg e. V.T. 3. Müncheberg 2012, S. 5-8. [Geb. 1902 Zizow (Kr. Rügenwalde), Bauernsohn, sechstes von sieben Kindern, ab 1920 Landwirtschaftsschule in Köslin, ab 1930 Gutsangestellter in Schwartow, Kr. Lauenburg (Pommern), 1932 Heirat mit einer Alt-Schlawerin, leben gemeinsam in Waldhof bei Schwartow (5 Kinder 1934-1941), April 1945 er von Roter Armee verschleppt, Familie noch bis Sommer 1946 in Waldhof, er übernimmt 1946 eine (Land-) Wirtschaft in Müncheberg, 1947 vorübergehend Aufbau einer Gaststätte in Philippinenhof bei Müncheberg, dann Neubauer ebd. (bewohnt mit Familie eine Hälfte des Gutshauses), 1955 Tod der Ehefrau, 1956 sein Hof in LPG eingegliedert, Umzug nach Müncheberg, Leiter der Viehwirtschaft in der LPG, 1969 Übersiedlung in die Bundesrepublik (Mölln)].

Bolduan, Waltraud: Das Kinderheim in Kyritz - Rettungsanker nach Flucht und Elend. Ehemalige Heimkinder berichten über ihr Schicksal. In: Brandenburger Rundschau 9 (2011) 3, S. 10-11. [Geb. 1939, Sägewerksbesitzertochter, Jan. 1945 Flucht mit fünf Geschwistern aus Wehlau (Ostpreußen), Vater von Russen inhaftiert, Lageraufenthalte mit Mutter, die 1947 an Hungertyphus stirbt, „Wolfskinder"-Leben in Litauen, 1948 Transport in die SBZ: Kinderheime Pinnow, Altenhof, Bad Saarow, Kyritz, hier Schulzeit; lebte 2011 in Schöneiche].

Bornstädt, Wolfgang: Erinnerungen an die Flucht aus Woldenberg und den Neuanfang in Premnitz. In: Die letzten Tage im Krieg und die ersten Wochen im Frieden in der Region um Rathenow. T. 3. Hrsg.: Rathenower Heimatbund e. V. 2., unveränd. Aufl. Rathenow 2018 (1. Aufl. 2015), S. 14-54. [Geb. 1936, aus Woldenberg/Nm., Flucht am 27.1.1945 per Bahn mit Mutter u. Geschwistern (Vater beim Volkssturm eingesetzt, dann vermisst) über Berlin (Schlesischer Bahnhof, Postbunker) nach Premnitz, Ankunft 28.1.; weitere Erlebnisse in Premnitz bis Sept. 1945; S. 47: Grundriss des Premnitzer Barackenlagers 1945/46 (Skizze nach der Erinnerung)]. 
Bräsike, Erhard: Meine Kindheit in Niederwutzen. In: Viadrus 6 (2014), S. 67-72. [Geb. 1941, Erlebnisse an der neuen Odergrenze 1945-1947].

Breske, Erika [geb. Roy]: Schlimme Erinnerungen an 1945. In: Heinz Materne / Hans Gerlach: GrossGandern und Klein-Gandern. Heimat im Sternberger Land. Wittingen/Bremen 1997, S. 146-148. [Geb. 1924 Groß Gandern (Kr. Weststernberg), aufgewachsen bis 1945 im Nachbarort Klein Gandern als Gastwirtstochter, nach Tod der Mutter Febr. 1945 über Lager Schwiebus in die Sowjetunion deportiert (Arbeitslager, Typhuserkrankung), Dez. 1945 mit Güterzug nach Berlin, untergekommen in Beeskow, dort später Kindergärtnerin].

Bretschneider, Dietlinde: Der Karnickelbraten. In: Zeitzeugen erzählen. Hrsg.: Seniorenbeirat Cottbus. Cottbus 2006, S. 63-65. [Geb. 1942 Zieditz bei Falkenau/Eger (Sudetenland), 1945 vertrieben (19622003 Lehrerin, lebt 2010 in Cottbus); hier: Kindheitserinnerung (nascht heimlich in der Speisekammer und wird bestraft). S. 63: „Wir waren Umsiedler aus dem Sudetenland. Die Nachkriegszeit war eine schwere Zeit. Wir hatten nur das Nötigste, und Fleisch stand bei uns nicht oft auf dem Speiseplan. Aber an den Festtagen zauberte Mutter ein Festessen auf den Tisch. (...)." S. 65: „So war ich stets hungrig und leicht zu verführen. Auch meine Eltern hungerten, um uns Kindern genügend Nahrung geben zu können. / Ich muss gestehen; ich esse noch immer gern Fleisch. Und - zu Ostern gibt es bei uns auch - Karnickelbraten nach Mutters Kochrezept, und immer muss ich an meine Nascherei aus der Kinderzeit denken!"].

-, -: Das Schweinereiten. In: ebd., S. 79-81. [(Wie oben); hier: Kindheitserinnerung].

-, -: Mutter. In: ebd., S. 111-112. [(Wie oben); hier: Dank an ihre Mutter. S. 111 : „Vertrieben - von der Heimat Hab und gut! Eine schwere Zeit stand für uns alle bereit. Von Mutter kamen nie Klagen. Still hat sie es ertragen (...)." ].

-, -: Cottbus, meine neue Heimat. In: ebd., S. 138-139. [(Wie oben); hier: Lobeshymne auf Cottbus (zuvor in Guben tätig, nach 1945 aufgewachsen in Thüringen)].

-, -: Meine Schulzeit. In: Zeitgebunden. Brücken zur Vergangenheit. Hrsg. vom Seniorenbeirat der Stadt Cottbus. Cottbus 2010, S. 80-83. [(Wie oben); hier: Dorfschule in Dorf bei Eisenach ab 1948].

Brüllke, Wolfgang: Die Taschenuhr. In: Gubener Heimatkalender 61 (2017), S. 72-73. [Geb. ca. 1936, Elternhaus in Guben (Ostteil), Febr. 1945 Treck-Evakuierung der Familie nach Osten zum Bober, dort Einmarsch der Roten Armee, Vater versteckt hier silberne Taschenuhr, die ihm ein Bekannter (Lokführer) 1947/48 auf einer Bahnfahrt zurückbringt; 3. Mai 1945 Rückkehr nach Guben, Juni 1945 Vertreibung in den westlichen Teil der Stadt].

Brzoska, Alfred: Ein Pfarrer schildert das furchtbare Martyrium seiner Gemeinde (Die Gemeinde Hennersdorf in der Russen- und Polenzeit). In: Schlesien. Die letzten Tage im Kampf um Deutschlands reichste Provinz. Das Verbrechen der Vertreibung. [Zsgest. von Erich Kirschner]. Velen [1985], S. 456-461. [Geb. 1892, 1932-1945 kath. Pfarrer in Hennersdorf (Kr. Ohlau), mit Angaben zum Verbleib der Gemeindemitglieder, u. a. in Sachsen, Mecklenburg und im Spreewald].

Buchholz, Meta, geb. Struwe: [Lebenslauf]. In: Müncheberger Lebensläufe. Hrsg. Verein für Heimatgeschichte der Stadt Müncheberg e. V.T. 1. Müncheberg 2008, S. 26-31. [Geb. 1921 Warnick (Kr. Landsberg/W.), Bauerntochter, aufgewachsen in Stolberg, 1942 Heirat mit Karl Buchholz, 1943 Tochter geboren, 31.1.1945 Flucht aus Stolberg mit Mutter u. Tochter zu Schwiegereltern nach Legde (Kr. Westprignitz), wo Schwiegervater Bürgermeister wird, Mai 1945 Rückkehr nach Stolberg, Juni 1945 mit Transportkarren über Manschnow (Kr. Lebus) nach Stolzenhagen (Kr. Niederbarnim) gelangt. „Dorthin hatte es schon viele Stolberger verschlagen." (S. 26), nach Rückkehr des Ehemannes aus sowjet. Gefangenschaft gemeinsam Neulehrerausbildung in Dallmin (später Fernstudium in Potsdam, Staatsexamina), ab Sept. 1946 beide als Lehrer in Neuhardenberg (im Schloss) u. ab 1948 bis zum Renteneintritt in Hermersdorf (beide Kr. Lebus) eingesetzt, beschreibt Aktivitäten wie Dorfklub, Theatergruppe u. Ausbau der Schule (mit Fotos)].

Bürkner, Eckhart: Der Geruch der Erde. Eine Familie erinnert sich. Jena u. a. 2001. [Erinnerungen seiner Eltern Herbert (geb. 1910) u. Margarete B. (geb. 1914) u. eigene frühe Kindheitserinnerungen (geb. 1941) 
an Flucht u. Vertreibung aus Tschöplowitz, Kr. Brieg (Schlesien): 20.1.1945 Evakuierung nach Hartau bei Zittau, Juni 1945 Rückkehr, Nov. 1946 Vertreibung, Aufenthalt im Umsiedlerlager Treuenbrietzen].

Bujok, Reinhold: 10 Jahre BdV-Arbeit in Rüdersdorf und Umgebung. In: 10 Jahre Bund der Vertriebenen in Rüdersdorf und Umgebung. Rüdersdorf 2002, S. 9-19. [Vorsitzender des BdV-Kreisverbandes Amt Rüdersdorf und Umgebung e. V.]

-, -: Aus der Heimat in ein neues Zuhause. In: 100 Jahre Pfarrkirche Hl. Familie Rüdersdorf 1905 bis 2005. Hrsg. von der Kath. Kirchengemeinde Hl. Familie in Rüdersdorf bei Berlin. Red.: Ariane Flemming u. a. Rüdersdorf bei Berlin 2005, S. 65-67. [Spätaussiedler aus Polen, geb. 1928 u. aufgewachsen in Beuthen/Oberschlesien, dort bis 1974 Elektromeister u. Familienvater, dann Ausreise der Familie in die DDR nach Rüdersdorf bei Berlin; kurze Schilderung des Lebens vor und nach der Ausreise, auch zu Integrationsschwierigkeiten (gest. 2015 Rüdersdorf)].

Burghause, Horst: [Interview]. Gespräche im Oktober 2001 und im Sommer 2005. In: Gespräche mit ehemaligen Küstrinern. Aufgez. u. bearb. von Siegfried Neubauer. Bd. 3. Petershausen 2005, S. 29-60. [Geb. 1928, Vater (aus Berlin) Berufssoldat (Feldwebel) bis 1936, dann Verwaltungsleiter, er aufgewachsen in Küstrin u. ab 1935 in Glogau, ab 1938 in Deutsch Krone, ab 1942 in Neustettin, 1944/45 Lehrgang u. Einsatz als Luftwaffenhelfer (Flakhelfer) in Vororten von Stettin u. in Neustettin, 1945 Flucht zur Mutter nach Berlin, Arbeit bei der Bahn, dann zum Onkel nach Gorgast, beim Versuch, per Bahn von Küstrin-Kietz nach Neustettin zurückzugelangen, nach Posen geraten, Sept. 1945 bis Dez. 1946 interniert in Posen u. Lager Potulice (Zwangsarbeit in Druckerei in Bromberg), als Jugendlicher in Amnestie entlassen, beim Versuch, in Küstrin die Grenze zu passieren, erneut interniert, über Stettin u. a. schließlich zur Entlassung Dez. 1946 nach Forst/L. transportiert, Weiterfahrt nach Frankfurt (Oder) mit Ziel Quarantänelager Wolfen (Sachsen), in Frankfurt aber mit anderen ausgerissen zur Tante nach Berlin u. dann nach Gorgast, ab 1.2.1947 Arbeit beim Brückenbau (Wiederaufbau der Oder-Eisenbahnbrücke) in Frankfurt (Onkel war hier Polier bei der aus Küstrin nach Frankfurt geflüchteten u. wiederöffneten Firma Christian Zölker, der späteren Frankfurter Bauunion), 1.8.1947 Wechsel zur Bahmeisterei Küstrin-Kietz, 1948/49 auf Bahnhof Golzow tätig in Fahrkartenausgabe u. Gepäckabfertigung, dann Meldung zur VP (Fachschule, Kriminalistikstudium, bis 1960 bei der Kriminalpolizei im VPKA Seelow, Entlassung, da Vater 1959 in Westen geflohen), dann bei der Bahn in Müncheberg (Ausbildung, Stellwerksmeister, Fahrdienstleiter), 1965-1971 Arbeitsökonom bei der Mitropa, 1971-1984 Sachbearbeiter bei der Bahn, dann Ausreise in die Bundesrepublik, 1991 Rückkehr nach Berlin, 2005 Besuch in Küstrin].

Burmeister, Hildegard: [Tagebuchauszüge 1945-1949]. In: „Die Russen sind da“. Kriegsalltag und Neubeginn 1945 in Tagebüchern aus Brandenburg. Peter Böthig u. Peter Walther (Hg). 2., durchges. Aufl. Berlin 2011. [Geb. 1926, Ende Juni 1945 aus Landsberg/W. vertrieben, lebt in Dorf im Havelland, 1951 in Ost-Berlin, 1954 Übersiedlung nach Niedersachsen].

Darge, Hans-Jürgen: [Lebenslauf]. In: Müncheberger Lebensläufe. Hrsg. Verein für Heimatgeschichte der Stadt Müncheberg e. V. T. 4. Müncheberg 2017, S. 2-15. [Geb. 1936 Liebenow (Kr. Greifenhagen), Vater staatl. gepr. Landwirt (Gastwirtssohn aus Müncheberg!), ab 1940 in Cadinen (Kr. Elbing), er hier 1942-1945 Schulbesuch, Jan. 1945 Flucht (Treck bis Mai, er Scharlach u. Gelenkrheumatismus), dann angesiedelt auf dem Friedrichshof bei Walkendorf (Mecklenburg), nach Rückkehr des Vaters aus Kriegsgefangenschaft Umzug nach Barth (Pommern), Vater wird 1946 Direktor des VEG Ober-Mützkow (Kr. Franzburg), er 1952 1/2 Jahr krank (Juli-Sept. Kur in Bad Berka, Thüringen), dann Umzug nach Weimar-Schöndorf, Okt. 1952-1954 Landwirtschaftliche Fachschule Eisenach (staatl. gepr. Landwirt), 1957-1958 Assistent im VEG Saatzucht Bernburg, 1959-1962 landwirtschaftliches Studium Hochschule Bernburg u. praktische Arbeit im VEG Bergen bei Wanzleben (Dipl.-Landwirt), 1959 Heirat (2 Söhne 1960/61), 1962-1965 Produktionsleiter im VEG Körbelitz (Kr. Burg), 1964 SED, 1965 stellv. Direktor des LVG Lietzen (bei Seelow), 1967-1981 dessen Direktor, 1981-1990 Direktor des VEG (P) Müncheberg (im Parteiauftrag), das "freundschaftliche Beziehungen mit Partnern in Bulgarien und Polen (Myślibórz/Soldin)" hatte (S. 12), 1990-1994 Geschäftsführer nach Umwandlung in Agrargesellschaft, 
ab 1994 Gesellschafter in GbR, bis 2006 Angestellter beim Sohn (Pächter), der Anteile des Vaters übernommen hatte, dann Rückzug ins Privatleben aus Enttäuschung über mangelnde Wertschätzung der vor 1990 geleisteten Arbeit durch Treuhandanstalt, dann Hobby Brieftaubenzucht; ab 1987 Vorsitzender des Kartoffelverbandes im Bezirk Frankfurt/Oder].

Dawidowski, Rudolf: Die Flucht der Familie Dawidowski nach Gorgast. In: 1945. Als Küstrin in Trümmer sank. Ich war dabei. Betrachtungen, Berichte und Briefe. Zsgest. u. bearb. von Fritz Kohlase. Überarb., erw. u. ill. 2. Aufl. Sehnde 2006, S. 379-380. [2.2.1945 Flucht aus Küstrin zu Bekannten nach Gorgast, 5.2.1945 Fortsetzung der Flucht mit Handwagen nach Golzow].

Dohna-Schlobitten, Alexander Fürst zu: Erinnerungen eines alten Ostpreußen. Berlin 1989. [Zieht Febr. 1945 als Treckführer auf dem Weg aus Ostpreußen u. a. durch die Uckermark].

Domscheit, Margarete, geb. Kehrer: Meine Müncheberger Geschichten. In: Müncheberger Lebensläufe. Hrsg. Verein für Heimatgeschichte der Stadt Müncheberg e. V.T. 1. Müncheberg 2008, S. 47-53. [Geb. 1935 Bessarabien (gest. 2015), Vater Jurist, 1940 Umsiedlung nach Deutschland, nach zweijährigen Lageraufenthalten wird der Vater Amtsrichter in Bromberg, Jan. 1945 Flucht nach Mecklenburg, dort Abitur, dann Studium in Leipzig (Kunstgeschichte u. klass. Archäologie, Ägyptologie; Eltern gehen in den Westen), daneben Gesangsausbildung fortgesetzt, dann tätig als Kunsthistorikerin, 1966 Heirat mit dem Premnitzer Arzt Wolfgang Domscheit (s.u.), ab 1974 in Müncheberg lebend, hier 1989 Sprecherin des „Neuen Forums", später Stadtverordnete (Bündnis 90/Die Grünen), Gleichstellungsbeauftragte, aktiv im kulturellen Leben der Stadt, Sängerin].

Domscheit, Wolfgang: [Lebenslauf]. In: Müncheberger Lebensläufe. Hrsg. Verein für Heimatgeschichte der Stadt Müncheberg e. V.T. 1. Müncheberg 2008, S. 54-59. [Geb. 1934 Königsberg/Ostpreußen, 18.3.1944 evakuiert nach Abschwangen (Kr. Preußisch Eylau), 31.10.1944 nach Polenz in Sachsen, Aug. 1945 fortgeschickt, nach Aufenthalten in Flüchtlingsdurchgangslagern 31.10.1945 in Ankunft in Horstdorf bei Oranienbaum, hier u. in Oranienbaum Schulbesuch bis 1948, 1949 Lehre als Stellmacher begonnen, dann aber ABF-Aufnahmeprüfung in Halle/S. bestanden, ab 1952 in Rostock, hier 1955 Abitur, dann Studium der Medizin in Greifswald, 1959 erste Ehe u. Sohn geboren, 1960 Staatsexamen, 1961 Promotion, 1961/62 am Kreiskrankenhaus Ilmenau, 1962-1966 Militärarzt in Erfurt, ab 1966 zweiter Arzt im Ambulatorium Premnitz, hier (nach Scheidung) 1966 zweite Ehe (mit Margarete D. geb. Kehrer, s. o.) u. 1967/68 Kinder geboren (u. a. die Publizistin u. Politikerin Anke Domscheit-Berg, geb. 1968 Premnitz), dann Gründung der Staatlichen Arztpraxis Bützer (Kr. Rathenow), 1970 Facharzt für Allgemeinmedizin, 1972-1974 Gründer u. Leiter des Landambulatoriums Milow (Kr. Rathenow), 1974-1982 leitender Arzt des Landambulatoriums Müncheberg (u. anschließend bis $2002 \mathrm{ebd}$. weiter als Arzt tätig). „Eine Odyssee, die 1944 in Königsberg begann, fand hier nach 30 Jahren ihr Ende." (S. 55), 1988 Ehrentitel Sanitätsrat, Aug. 1989 Mitglied des „Neuen Forum“, jahrelange Bemühungen um nikotinfreie Umwelt. S. 59 (mit Foto) über seine gute Bekanntschaft mit der ebenfalls aus Ostpreußen geflüchteten Elfriede Stachat (1906-2001), Frau des Müncheberger ev. Pfarrers u. (seit 1949) Superintendenten Friedrich Kurt Stachat (geb. 1892)].

Dosdall, Mafred: [Lebenslauf]. In: Müncheberger Lebensläufe. Hrsg. Verein für Heimatgeschichte der Stadt Müncheberg e. V. T. 1. Müncheberg 2008, S. 60-68. [Geb. 1942 Jastrow (Kr. Deutsch Krone), Sohn eines landwirtschaftlichen Beamten, Ende Jan. 1945 Flucht mit Eltern u. jüngerem Bruder nach Schwerin (Mecklenburg), Vater gerät in französ. Gefangenschaft, kehrt 1948 todkrank zurück u. stirbt 1950; beobachtet u. reflektiert früh: „Sprachregelung (...) in der SBZ: Wir sind gefälligst Umsiedler, keine Flüchtlinge." (S. 61); ab 1963 Chemiestudium in Greifswald, 1968 Diplom, dann im Hygieneinstitut in Neustrelitz tätig, 1969 beim Schnellreferatedienst Organische Chemie in Ost-Berlin, dieser später übernommen vom Ministerium für Wissenschaft u. Technik, Arbeitsvertrag „aus gesundheitlichen Gründen“ gelöst, lebt "unangepasst" in Ost-Berlin, ab 1970 in Dahmsdorf. "Schon als Kind war ich gerne auf dem Lande bei Verwandten und später dann sehr viel bei einer Familie aus der alten Heimat, die bei Neubrandenburg gesiedelt hatten." (S. 63). Siedelt sich 1974 in Dahmsdorf mit kleiner Landwirtschaft an, daneben u. a. 
Theater-Kleindarsteller in Berlin, vielfältige Aktivitäten, nach der Wende u. a. Vorsitzender der Interessengemeinschaft Märkische Schweiz e. V., 2003 Stadtverordneter in Müncheberg (später CDU)].

Düring (Frau): Das bittere Ende [Erlebnisbericht, verfasst 1970]. In: Heinz W. Linke / Heinz Paschke: Das Sternberger Land im Wandel der Zeiten. Iserlohn 1988, S. 631-636. [Aus Louisa (Warthebruch); 1.7.1945 Vertreibung: Viehwagentransport von Küstrin nach Mecklenburg (Flüchtlingslager Schwaan, Laage u. Letschow); Zuzugsgenehmigung zu Verwandten nach Bugk bei Storkow, dort Reinemachefrau, später Köchin im Ferienheim des FDGB im Schloss, zuletzt viele Jahre dessen Leiterin].

Duncklau, Heinz: Bad Freienwalde in den 50er Jahren. In: Viadrus 6 (2014), S. 118-120. [Geb. 1923 in Küstrin, 1945 zunächst nach Lübeck gelangt, Sommer 1946 illegale Übersiedlung nach Freienwalde zum Bruder, dort Lkw-Fahrer für die Autotransportgemeinschaft ATG, 1953 Flucht über West-Berlin nach Lübeck].

Eckhardt, Dieter: [Interview]. In: Gespräche mit ehemaligen Küstrinern. Aufgez. u. bearb. von Siegfried Neubauer. Bd. 4. Frankfurt (Oder) 2012, S. 43-60. [Geb. 1933 Küstrin-Alt Drewitz, Vater Sparkassensekretär in Küstrin, Mutter ab 1938 Stenotypistin ebd. (1938 geschieden), Schulbesuch in Küstrin (Friedrich-Gymnasium), 1.2.1945 Flucht der Familie per Bahn vom Altstädter Bahnhof über Kietz u. Gorgast nach Berlin zu Verwandten (hier eine Woche), dann in Brandenburg/Havel ansässig geworden, Schulabschluss nach 10. Klasse, Zimmererlehre, FDJ, GST, 1951 FDGB, 1952-1955 KVP in Ueckermünde, später Kraftfahrer bei der HO, ab 1967 Disponent u. 1968-1990 stellv. Direktor beim VEB Großhandel Obst und Gemüse; besuchte Küstriner Treffen in Berlin; Interview 2005 in Brandenburg/Havel geführt].

Ehlert, Vera: [Lebenslauf ihres Mannes Siegfried Ehlert]. In: Müncheberger Lebensläufe. Hrsg. Verein für Heimatgeschichte der Stadt Müncheberg e. V.T. 1. Müncheberg 2008, S. 69-74. [Geb. 1934 Preußisch Eylau (Ostpreußen), gest. 2005, Vater Sägewerksarbeiter, Winter 1944/45 Flucht der Familie über das Haff mit Ziel Niederfinow, wo Verwandte wohnten, Vater unterwegs von Sowjets verhaftet (seitdem vermisst), längerer Aufenthalt im Auffanglager Angermünde (Typhuserkrankung), dann nach Niederfinow gekommen, ebd. Schulbesuch bis 8. Klasse, 1950 Schlosserlehre im RAW Eberswalde u. Weiterbeschäftigung ebd. bis 1957, daneben im Abendstudium Ausbildung an der Ingenieurschule für Eisenbahnwesen in Dresden, nach Abschluss als Meister bis März 1958 im RAW, 1958-1960 NVA-Wehrdienst in Strausberg u. Brandenburg, 1959 Heirat mit einer staatl. gepr. Landwirtin aus Hoppegarten bei Müncheberg, 1960/62 zwei Kinder geboren, er ab 1965 im Meliorationsbau in Niederfinow bzw. ab 1966 als Meister u. Technologe in Rehfelde tätig (bis 1999), auch in der Freiwilligen Feuerwehr aktiv, 1993 ehrenamtlicher Bürgermeister von Hoppegarten, dann Stadtverordneter in Müncheberg].

Erlebnisse einer schlesischen Landfrau aus dem Kreis Wohlau (1944-1946). Hrsg. von Richard Hoppe. Wiesbaden 1978. [Vertreibung 26.10.1946, Fahrt im Viehwagen von Schlesien bis in Umsiedlerlager im Erzgebirge].

Faßke, Joachim: Vor 50 Jahren. Flucht, Heimkehr und Vertreibung. In: Gubener Heimatbrief (1995)2, S. 68-69. [Geb. 1929, gest. 2016, Bäckersohn, 20.6.1945 vertrieben aus seinem Heimatort Amtitz, Kr. Guben, schildert Kriegsende in Amtitz und Vertreibung, lebte später und bis zuletzt in Magdeburg, Ortsbetreuer für Amtitz im Gubener Heimatbund e. V.].

Fischer, Inge / Schläwe, Edeltraud: [Lebenslauf Elisabeth Schläwe geb. Matz, verfasst von den beiden Großnichten]. In: Müncheberger Lebensläufe. Hrsg. Verein für Heimatgeschichte der Stadt Müncheberg e. V.T. 2. Müncheberg 2008, S. 93-99. [Elisabeth Schläwe geb. 1894 Zicher (Kr. Königsberg/ Nm.), gest. 1995, zuletzt älteste Bürgerin von Müncheberg, Tochter eines Eisenbahners (Bahnhofsvorsteher in Ringenwalde), sieben Geschwister, bald nach Geburt Umzug nach Zicher (eigenes Haus), Heirat mit Kaufmann Otto Schläwe in Darrmietzel (1 Stieftochter), 7.2.1945 Flucht (Ehemann Ende März von den "Russen“ verschleppt, seitdem vermisst), bis Ende April in Ringenwalde, dann wieder in Darrmietzel, Juni 1945 Vertreibung (über Müncheberg, Neuruppin, Wittstock) bis nach Stuer (Mecklenburg), 1946 Übersiedlung nach Müncheberg zu Verwandten, sie arbeitet als Küchenhilfe auf dem Landhof (S. 95: „Sie war eine Institution in dieser Zeit."), dann VEG bis 1954 (ausführlich zum Leben im Alter u. ihrem Wesen, mit Bildern)]. 
Fischer, Inge: [Lebenslauf]. In: Müncheberger Lebensläufe. Hrsg. Verein für Heimatgeschichte der Stadt Müncheberg e. V.T. 5. Müncheberg 2017, S. 18-29. [Geb. 1931 Darrmietzel (Kr. Königsberg/ Nm.), Zimmerertochter (Zimmerei mit landwirtschaftlichem Nebenerwerb alter Familienbesitz; Vater 1938 zum Westwall-Bau, kehrt 1946 zurück), 30.1.1945 Treckvorbereitung (Pferdewagen), wegen Versorgung ostpreußischer Flüchtlinge verzögert bis 31.1., an diesem Tag Einmarsch der Roten Armee, 7./8.2.1945 mit Großfamilie nach Osten vertrieben (Handwagen): Neudamm („das lichterloh brannte"), Wusterwitz (Kr. Soldin), dann bis Ende April in Ringenwalde (verpflegt von Roter Armee, für die sie auch arbeiten), Ende April Heimweg nach Darrmietzel, Erntevorbereitung, Mitte Juni 1945 Vertreibung, Oderübergang (Behelfsbrücke; S. 22: „In der Oder konnte man kein Wasser sehen, die Oder war übersät mit Bergen von Koffern und Kisten mit den letzten Habseligkeiten, die den Flüchtenden aus den Händen geschlagen worden waren. Es herrschte großer Hass damals."), Unterkunft bei Verwandten in Berlin, dann Treck über Löwenberg, Neuruppin, Röbel (Mecklenburg) bis Stuer (Kr. Waren), hier Unterkunft mit ca. 100 anderen Flüchtlingen auf dem ehem. Gutshof, Einzug in kleines Haus, Sommer 1946 Rückkehr des Vaters aus Kriegsgefangenschaft, Okt. Umzug nach Müncheberg, wo Vater Zimmermann auf Gut Landhof Marienfeld wird, sie 1947-1949 Berufsschule für Hauswirtschaft, 1950 Kursus für Stenographie u. Schreibmaschine, 1951 Sachbearbeiter Bereich Handel u. Versorgung beim Rat des Kr. Seelow, 1951-1991 in der Bürgermeisterei Obersdorf bei Müncheberg tätig, 1954 Heirat mit Buchhalter aus Chemnitz (1955 Tochter), bis 1958 zu neun Personen in Drei-Zimmer-Wohnung, 1958 eigene Wohnung, 1962 Siedlungshaus u. eigenes Auto (S. 24: „Irgendwie wurden Haus und Grundstück in Müncheberg unser neues Darrmietzel und Müncheberg dadurch unsere neue Heimatstadt."), 1963-1965 Grundstudium für Kulturfunktionäre, zeitweise stellv. Bürgermeisterin in Obersdorf, 1970er Jahre Besuch in Heimatort Darrmietzel, 1991 Rentnerin, 2012 Witwe, 2017 nochmals Besuch in Darrmietzel (S. 29: „Es hat sich dort viel verändert, vor allem wurde viel gebaut. / Ich stellte erneut fest, dass ich eine neue Heimat gefunden hatte: Müncheberg.")].

Fischer, L(othar): Neuheim - eine Heimatstadt des Friedens. In: Heimatkalender des Kreises Jüterbog 1986, S. 17-21. [Verf., geb. 1905, laut Verfasserangabe "Parteiveteran“, war Leiter des ersten "AntifaTransports" aus dem Sudetenland, Abfahrt aus Gablonz/Jablonec n. N. 12.2.1946, 14.2.1946 Ankunft in Jüterbog, nach Quarantäne in den Fuchsbergkasernen Ansiedlung in Dorf Zinna (Neuheim), dort erster KPD-Parteisekretär].

Friedberg, Eva-Maria: Flucht aus Peisterwitz Kr. Ohlau. In: Lebenszeit [I.] Zeitzeugen berichten. Hrsg. vom Landesseniorenbeirat Brandenburg u. a. [Neuenhagen 1996], S. 36-39. [Geb. 1935 Peisterwitz, später Lehrerin; 1945 Flucht über Böhmen (Lager Melnik), Herbst 1946 im Quarantänelager in Ludwigslust (Mecklenburg)].

Friedrich, Gertrud: Vertreibung und Neubeginn. Erzählt von G. F. Aufgeschrieben von Horst König. In: Geschichten aus sieben Jahrzehnten. Storkower Zeitzeugen berichten. Hrsg. vom Seniorenbeirat der Stadt Storkow (Mark). Storkow 2005, S. 41-45. [Geb. 1929 Stretzin (Kr. Schlochau, Westpreußen), Schweizertochter, im Krieg wohnhaft in Berg Vorwerk bei Königswalde (Neumark), besucht 1944/45 Haushaltsschule in Potsdam, 9.5.1945 Rückkehr (mit Bruder) in Heimatort (Ankunft 13.5.), Landarbeit auf dem von der Roten Armee übernommenen Gut, 24.6.1945 Vertreibung, Fußmarsch über Küstrin nach Potsdam zur Tante, keine Zuzugsgenehmigung, ebenso in Beelitz-Heilstätten, Einweisung in Kreis Beeskow (Wohnung in Niederlehme), nach einem Jahr Einweisung nach Groß Schauen, weiterer Lebensweg in Wildau, Bad Saarow u. Storkow (Familiengründung 1956)].

Fuhrmann, Elfriede (geb. Ludewig): Erinnerungen an meine Kindheit in Guben. In: Gubener Heimatbrief (2013); S. 25-26. [Geb. ca. 1937, 21.2.1945 Flucht mit der Mutter (Vater in sowjet. Kriegsgefangenschaft verstorben) aus dem Nordostteil von Guben (Triftstraße 46, Ecke Finstere Gasse) mit Handwagen über Jamlitz nach Golßen, dort Unterkunft in Mansardenzimmer, Schulbesuch, Mai 1945 Rückkehr zu Fuß nach Guben, Juni 1945 Vertreibung, Neißeübergang über Holz-Notbrücke]. 
Gabloffsky, Werner: Kinderjahre in Landsberg/Warthe. In: Heimatblatt der ehemaligen Kirchengemeinden Landsberg/Warthe Stadt und Land 50 (2015), S. 33-41 [Geb. 1934 Landsberg/W., Arbeitersohn, verbleibt ab 30.1.1945 mit Mutter in Landsberg].

-, -: Erinnerungen an die Heimat Landsberg und Gorzów in Frieden und Krieg. In: Heimatblatt der ehemaligen Kirchengemeinden Landsberg/Warthe Stadt und Land 51 (2015), S. 48-55 [(Wie vor); Familie bis 1950 in sowjet. Diensten in Gärtnerei ebd., nach deren Abzug 1950 Ausweisung].

-, -: Erinnerungen an Wanderjahre und Beruf. In: Heimatblatt der ehemaligen Kirchengemeinden Landsberg/Warthe Stadt und Land 52 (2016), S. 41-48. [(Wie vor), 10.9.1950 Ausweisung per Bahn aus Landsberg/Warthe über Sammellager Breslau-Hundsfeld nach Sachsen: Lager Oelsnitz/V., über Lager Heiligenstadt Weiterfahrt nach Niedersachsen (Lager Friedland)].

Gasiecki, Joachim: Kinderjahre in Landsberg/Warthe. In: Heimatblatt der ehemaligen Kirchengemeinden Landsberg/Warthe Stadt und Land, H. 50 (2015), S. 33-41; H. 52 (2016), S. 20-27. [Geb. 1934 Landsberg/W., Arbeitersohn, verbleibt mit Mutter ab Ende Jan. 1945 in Landsberg, Ende Juni 1945 vertrieben, Treck über Küstrin u. Fort Gorgast nach Berlin].

Gedack, Otto: Erinnerungen am meinem ersten „1. Mai“. In: Damals und heute. Storkower Zeitzeugen berichten. Hrsg. vom Seniorenbeirat des Amtes Storkow. Storkow 2003, S. 57-58. [Geb. 1935, Dr. agr., Dipl.-Landwirt, Tierzüchter, Betriebsleiter; aus bessarabiendeutscher, 1942 als Bauern in Westpreußen angesiedelter Umsiedlerfamilie, als Kind 1945 evakuiert nach Mecklenburg, später in Storkow].

-, -: Wie ich die Bodenreform erlebte. In: ebd., S. 58-60. [Wie vor].

-, -: Appetit einst und heute. In: ebd., S. 146-148. [Wie vor; Ernährungssituation 1946-1954].

-, -: Deutsch-polnische Sichtweisen. In: Brücken bauen / budowa mostów. Hrsg.: Seniorenbeirat Storkow (Mark) / Seniorenorganisation Opalenica. Storkow (Mark)/Opalenica 2005, S. 52-55. [Wie vor; Erlebnisse 1942-1945 in Zielen bei Thorn Westpreußen, 20. Jan. 1945 Flucht über die Weichsel nach Westen; 1991 Reise in den (vorübergehenden) westpreußischen Heimatort; deutsch-polnisches Verhältnis, Schulddiskussion].

-, -: Stationen unserer Flucht 1945. In: Gelebte Geschichte. Storkower Zeitzeugen berichten aus 8 Jahrzehnten. Hrsg. vom Seniorenbeirat der Stadt Storkow (Mark). Storkow 2007, S. 24-28. [Wie vor; Erlebnisse ab Jan. 1945; 1952 Heirat mit „Flüchtlingsmädchen aus Stettin"].

-, -: Als es noch keine „Mauer“ gab. In: ebd., S. 91-92. [Wie vor; Leben in Berlin 1954-1959 während des Studiums an der Humboldt-Universität].

-, -: Erlebnisse und Erfahrungen als Agitator und Propagandist in der DDR. In: ebd., S. 99-100. [Wie vor; Junge Pioniere u. FDJ, 1950er Jahre, auch West-Berlin].

-, -: Wie ich die Bodenreform erlebte. In: Hoffnung und Resignation/Nadzieje i rozczarowania. Alltag im Sozialismus/Dzien powszedni w socializmie. Deutsche und polnische Zeitzeugen berichten. Hrsg.: BRH Storkoe u. a. Storkow/Opalenica 2007, S. 43-46. [Wie vor; Mecklenburg].

Gelfort, Hubertus: [Lebenslauf]. In: Müncheberger Lebensläufe. Hrsg. Verein für Heimatgeschichte der Stadt Müncheberg e. V.T. 1. Müncheberg 2008, S. 93-100. [Geb. 1942 Sagan (Schlesien), Vater Erich (u. Onkel) Ziegeleibesitzer in Sagan u. Flockenfabrikbesitzer in Müncheberg, daher 1945 Flucht nach Müncheberg. „Auch Mitarbeiter und Bekannte aus Schlesien kamen nach Müncheberg. Hunger und Not waren groß, so dass sich Vater, Onkel und Tante entschlossen, hier zu siedeln. Für Vater bot sich das an, denn er hatte die Landwirtschaft gelernt, obwohl er früher eher als Kaufmann arbeitete." (S. 93), Vater erhält Bodenreformland (zerstörter Hof des ehem. Ortsbauernführers, den er bis 1947 wieder aufbaut, daneben Einrichtung eines Kleinhandels auf dem Gelände der zerstörten Flockenfabrik am Münchehofer Weg, erst 1958 LPG-Mitglied), er dann Ausbildung zum Staatl. gepr. Landwirt, ab 1963 LPG-Mitarbeiter, 1966 LPG-Mitglied u. 1975 -Vorsitzender in Müncheberg, nach 1990 Agrargenosenschaft].

Gerlach, Otto: Meine Erlebnisse beim Einmarsch der Russen im Jahr 1945. Aufgeschrieben nach Notizen u. Erzählungen meines Vaters durch Karl Gerlach im Jahre 1968. In: Heinz W. Linke / Heinz 
Paschke: Das Sternberger Land im Wandel der Zeiten. Iserlohn 1988, S. 575-578. [Geb. ca. 1880, Landwirt aus Woxfelde (Kr. Oststernberg), Febr. bis März Aufenthalt in versch. benachbarten Dörfern, immer wieder von der Roten Armee vertrieben, 27.6.1945 Vertreibung durch Polen, Weg über Küstrin, Küstrin-Kietz (30.6., hier Tod u. Begräbnis der Ehefrau), Manschnow (1.7.), Golzow, Letschin (5./6.7.), Neu-Barnim (6./7. 7.), Wriezen (8./9.7.), Bad Freienwalde, Britz bei Eberswalde (10.7.), Vorweis [vmtl. verlesen, wahrscheinlich gemeint: Serwest] (12.7.), Crussow bei Angermünde (13.7. bis 21.12.), dann nach Berlin-Spandau zur Tochter; Schwiegertochter u. Enkel blieben in Crussow].

Glass, Anna: Als Flüchtlinge in Brandenburg. In: Die Vergangenheit lebt in uns. Potsdamer erinnern sich. Hrsg. von Franz Fabian. Milow 2007, S. 126-146. [Kind einer Flüchtlingsfamilie aus Dombrowice (Polen), vor Kriegsende 1945 bei Bauern in Wutike bei Kyritz zwangseingewiesen; schildert dortiges Leben bis Herbst 1945].

Glass, Kurt: Wo liegt Legde? [Norderstedt 2005].260 S. [Geb. 1934 Czernowitz (Bukowina/Rumänien), Vater Prokurist in dortiger Drogerie, besaß Einfamilienhaus; 1940 Umsiedlung nach Pforzheim, 1941 nach Lublin (Generalgouvernement), Vater hier Drogist; Jan./Febr. 1945 aus Evakuierungsort Wronke (Wartheland) Flucht mit Treck nach Bad Wilsnack, von hier Wohnungseinweisung nach Legde (Kr. Westprignitz), hier Schulbesuch (S. 39 Text eines schulischen Gutachtens, 1948), Tischlerlehre, Gesellenprüfung, Anstellung in Nachbarort, 1953 Flucht nach West-Berlin, Übersiedlung nach Stuttgart, nach 1990 Rückkehr nach Brandenburg als Investor].

Gleß, Karlheinz: Peetzig/Piasek - Erinnerungen an ein Dorf an der Oder. In: Vertreibung aus dem Osten. Hrsg. von Hans-Jürgen Bömelburg, Renate Stößinger, Robert Traba. Olsztyn 2000, S. 83-93. [Aus Peetzig (Kr. Königsberg/Nm.), Jan. 1945 Treck nach Gerswalde (Uckermark), Oderübergang bei Niederkränig, sieht den gehenkten Königsberger Bürgermeister in Schwedt/Oder, drei Monate Aufenthalt in Gerswalde, bei Heranrücken der Front Weiterfahrt nach Westen (Mecklenburg), kurz vor Schwerin Einmarsch der Roten Armee, Rückkehr über Stützkow (Kr. Angermünde) nach Peetzig, 17. Juni 1945 Vertreibung, Kutscher in Brüssow (Kr. Prenzlau), 1968 und 1993 Reisen in das Heimatdorf].

Göhler, Horst: Erinnerungen an unsere Vertreibung 1945 (1. Preisträger des Autorenwettbewerbs 2000). In: Gubener Heimatbrief (2001)2, S. 66-72. [Geb. 1929, aus Haaso (Kr. Guben); Anf. März 1945 Zwangsevakuierung nach Gersdorf (Kr. Crossen) östlich des Bober (dort Ankunft 15.3.), 8.5.1945 ebd. Kriegsende erlebt, 26727. 5. Rückkehr nach Haaso, 20.6. Vertreibung, 23.6. Aufnahme bei den Großeltern in Schernsdorf bei Fürstenberg/Oder, lebt dann in DDR, 1964/65 Besuche im Heimatort, freundschaftliche Kontakte zu den polnischen Bewohnern des Elternhauses].

Gonda, Eva: Fünf Monate im Jahr 1945. In: Heimatblatt der ehemaligen Kirchengemeinden Landsberg/ Warthe Stadt und Land 50 (2015), S. 17-19. [Geb. 1936 Landsberg/Warthe; wohnt mit Eltern in der Brückenvorstadt, Familie flieht nicht, erlebt 30.1.1945 Einmarsch der Roten Armee versteckt in Jutefabrik der Firma Max Bahr, Ende Juni 1945 Vertreibung (Treck mit Hand- u. Puppenwagen) über Warthe-Notbrücke u. Dühringshof (wo der Puppenwagen zurückbleibt)].

Gosdschick, Edeltraud, geb. Budach: Ich bin ein Kind von Heimatvertriebenen. Erinnerungen. In: Brandenburger Rundschau 15 (2017) 3, S. 7-9. [Geb. 1948 als Tochter eines neumärkischen, bis 1947 in sowjet. Kriegsgefangenschaft befindlichen Schiffers und dessen mit weiteren Verwandten 1945 auf Rat ihres Mannes nach Niederlehme (Kr. Beeskow-Storkow) geflüchteter Ehefrau; Erlebnisse als nachgeborenes Flüchtlingskind in Niederlehme bis 1963].

Gospodarek, Gerhard: Erinnerungen an Schwirz. In: Namslauer Heimatruf 216 (2013), S. 37-50. [Aus Schwirz, Kr. Namslau (Schlesien), Herbst 1946 Vertreibung, Bahn-Transport in Viehwaggons vom Bahnhof Namslau zum Lager Rathenow, nach 14 Tagen Quarantäne Weitertransport nach Rhinow, Einquartierung bei einer Bauernfamilie in Görne].

Grabner, Sigrid [geb. Hauf]: Jahrgang ,42. Mein Leben zwischen den Zeiten. (Erstdruck Leipzig 2003). Kisslegg 2011. 479 S. [geb. 1942 Tetschen-Bodenbach (Sudetenland), Tochter einer Deutschböhmin u. eines tschechischen Sprachlehrers, 13.7.1945 Vertreibung mit der Mutter aus Leitmeritz in die SBZ nach 
Dörstewitz bei Halle/Saale, ab 1947 in Merseburg aufgewachsen, 1961 Abitur in Halle/Saale, 19621967 Studium der Indonesienkunde u. Kulturwissenschaft an der Humboldt-Univ. in Ost-Berlin, 1972 Promotion ebd., ab 1974 freischaffende Schriftstellerin, 1994 Mitbegründerin des Brandenburgischen Literaturbüros (bis 1999 Geschäftsführerin), lebt seit 1976 in Potsdam (zuvor ab 1968 in Werder/Havel)].

Grätsch, Elsa: [Tagebuchauszüge]. In: „Die Russen sind da“. Kriegsalltag und Neubeginn 1945 in Tagebüchern aus Brandenburg. Peter Böthig u. Peter Walther (Hg). 2., durchges. Aufl. Berlin 2011. [Geb. 1908 Breslau, gest. 1992, Sekretärin, 1945 Flucht aus Schlesien nach Werder/Havel, Witwe mit drei Kindern, lebte später in Potsdam-Waldstadt].

Gregor, Walli: Internierungslager Selterhof. In: Barbara-Meldung 23 (2011), S. 20-22. [Auszug aus Dies.: Die Flucht. Zwei Jahre meines Lebens. Privatdruck für die Familie, 2004; hier: Zugtransport der Vertriebenen aus Schlesien nach Selterhof bei Treuenbrietzen, besonders dortiges Lagerleben 1946 bis zur Verlegung nach Spremberg am 24.12.1946].

Günther, Liesleotte: Meine erste große (unfreiwillige) Reise. In: Erlebnisse haben keine Altersgrenze. Generationsübergreifendes Projekt 1999 des Zirkels „Zeitzeugen“ beim Seniorenbeirat in der Stadt Potsdam und der Klasse $7 \mathrm{~b}$ der Voltaire-Grundschule in der Landeshauptstadt. [2. Anthologie]. Potsdam 1999, S. 37-40. [Geb. 1932 Görlitz, nach Ökonomiestudium bis 1990 im VEB Landbauprojekt in der Forschung tätig, nach Vorruhestand Rentnerin; schildert ihre Erlebnisse 1945: 6.2. Zwangsevakuierung mit Mutter u. weiteren Verwandten aus Görlitz per Bahn über Prag nach Brünn, von dort per Lkw weiter nach Selletau bei Brünn, Einquartierung in Schule, Ende April Flucht mit Wehrmachtssoldaten nach Westen aus Angst vor tschechischer Bevölkerung bis zur tschech.-bayerischen Grenze, erlebt am 1.5.1945 den Einmarsch der Amerikaner im Grenzort, 2.5. Ankunft in Deggendorf mit Lazarettzug (später Rückkehr nach Görlitz)].

-, -: Wie ich das Kriegsende erlebte. In: Erlebt im vorigen Jahrhundert. Geschichten und Lebenserinnerungen [6. Anthologie]. Hrsg.: Seniorenbeirat der Stadt Potsdam u. a. Potsdam 2004, S. 37-38. [Ähnliche Schilderung wie oben].

Hakus, Paul: Die Geschichte der Firma Schütz \& Bethke, gegr. 1857, in Lippehne, Kreis Soldin/Nemark. II. Teil: Frankfurt (Oder) 1946/47 bis 1971. In: Heimatblatt des Kreises Soldin/Neumark 63 (2011), Nr. 211, S. 10-11. [Ehem. Mitarbeiter der Firma in Lippehne, nach Evakuierung in Frankfurt (Oder)].

Hamann, Karl Heinrich: Erlebnisse in Tiborlager. In: Vor 50 Jahren. Als Flucht und Vertreibung im Kreis Züllichau-Schwiebus begannen. Auszüge aus Tagebüchern, Briefen und Aufzeichnungen. Im Auftr. des Heimatkreises zsgest. von Lothar Meißner. O. O. 1995, S. 73-74. [Geschehnisse im Grenzübungslager Tiborlager u. im Dorf Mittwalde bei Kriegsende; Ausweisung der letzten Einwohner 22./24.6.1945, Treck bis Fürstenberg/Oder, von dort Schwenk nach Süden; Verfasser später in Hamburg wohnhaft].

Hamsch, Siegfried: Erinnerungen und Ereignisse. Krieg - Vertreibung - Neuanfang. in: Jahrbuch für Gubener Geschichte 1 (2011/12), S. 190-208. [Geb. 1934 Tzschernowitz/Schernewitz, Kr. Guben (östlich der Neiße), Bäckermeistersohn, 14.2.1945 Flucht mit Familie nach Lindena bei Doberlug-Kirchhain (Bauerngehöft), bald nach 8.5.1945 zu Fuß Rückkehr in Heimatdorf, 20.6.1945 Vertreibung, bis August Aufenthalt in Bahro, dann 1945-1974 wohnhaft in Guben, Bäcker- u. Konditorlehre, 1954 Leiter des Heimatmuseums, 1956 Kreissekretär des Kulturbundes, 1974 Wechsel in das Bundessekretariat des Kulturbundes und Übersiedlung nach Ost-Berlin, 1992 Ruhestand].

Handreck, Elli (geb. Kitsching): Erinnerungen - 70 Jahre Verlust der Heimat [Gedicht]. In: Gubener Heimatbrief (2016)1, S. 26-27. [Geb. 1929 Markersdorf (Kr. Guben), nahe der Neiße (Ostufer), 1945 Flucht nach Finsterwalde, nach drei Monaten Rückkehr in Heimatort, 20.6.1945 Vertreibung, lebte 2016 in Taubendorf nahe der Neiße (Westufer, gegenüber ihrem Heimatort)].

Hartung, Hugo: Schlesien 1944/45. Aufzeichnungen und Tagebücher. München 1956. [Geb. 1902 Netzschkau/Vogtland, gest. 1972 München, Dr. phil., Schriftsteller, 1940-1945 Chefdramaturg in Breslau, lebte 1945-1947 in Neustadt/Orla, 1947-1950 in Potsdam (Immenseestr. 7), anschließend in WestBerlin, ab 1960 in München]. 
Hauk, Anton: Die Situation der Zivilbevölkerung. In: Vor 50 Jahren. Als Flucht und Vertreibung im Kreis Züllichau-Schwiebus begannen. Auszüge aus Tagebüchern, Briefen und Aufzeichnungen. Im Auftr. des Heimatkreises zsgest. von Lothar Meißner. O. O. 1995, S. 4-7. [Schilderung der Geschehnisse $z w .27$. u. 31.1.1945 als ehem. NSDAP-Kreisleiter u. zeitweiliger Landrat des Kr. Züllichau-Schwiebus, enger Kontakt mit den Behörden in Frankfurt (Oder)].

Hauske, Marianne (geb. Mühle): Das Kriegsende am Ostfriedhof. In: Gubener Heimatbrief (1995)1, S. 15. [Aus Guben (Ostteil), Bäckerstochter, Jan. 1945 Zwangsevakuierung an den Bober, 4.5.1945 Rückkehr; 1995 in Heilbronn wohnhaft].

Hein, Siegfried: „Heim ins Reich“ nach Seddin. In: Um Beelitz harter Kampf. 1945. Das Jahr zwischen Krieg und Frieden. Beelitz und Umgebung. Hrsg.: Beelitzer Heimatverein. Beelitz 1999, S. 64-65. [Geb.ca. 1929, als deutschstämmiger Bauernsohn polnischer Staatsangehörigkeit 1940 mit den Eltern aus einem Dorf in Polen auf einen Bauernhof „in der Gegend um Posen, der ehemals Polen gehörte“, umgesiedelt, von dort 20.1.1945 Flucht mit Wagen ( fünf Geschwister, Mutter, Großmutter und Tante mit zwei Kindern), nach 14 Tagen Ankunft in Seddin (Kr.Zauch-Belzig), dort notdürftig untergebracht, unmittelbar nach Eimarsch der Roten Armee aber mit der gesamten Einwohnerschaft aus dem Dorffortgetrieben, dann nach Stücken gegangen].

Helmann: Kriegsgeschehen in der Heimat und Vertreibung 1945 [Erlebnisbericht]. In: Heinz W. Linke / Heinz Paschke: Das Sternberger Land im Wandel der Zeiten. Iserlohn 1988, S. 593-596. [Aus Stenzig (Kr. Weststernberg); 26.6.1945 Familie aus Drossen vertrieben, Oderübergang bei Ötscher auf Notbrücke].

Herms, Toni: Flucht aus der Heimat. Bericht aus Schöneiche Kreis Wohlau - Schlesien. Hrsg. von Richard Hoppe. Wiesbaden 1976.

Hirschmann, Heinz: [Erinnerungen]. In: Neun Zeitzeugen erzählen. Hrsg.: Seniorenbeirat Cottbus. Cottbus 2002, S. 5-18. [Geb. 1931, bis 1945 in Neu Bentschen wohnhaft, Vater dort bei der Eisenbahn beschäftigt, später desgleichen in Falkenberg); er später Maurer, Bauingenieur, 1951 Heirat; drei Kinder, fünf Enkel; 26.1.1945 Flucht per Bahn, Sommer 1945 Vertreibung mit Großmutter, Mutter u. jüngerem Bruder „über verschiedene Irrwege bis Cottbus" (S. 5), „mit nur wenigen Sachen auf einem winzigen Handwagen“ (ebd.) dann bis nach Uebigau, wo der Vater arbeitet; schildert v. a. Kindheitserinnerungen (Wohnungseinrichtung in Neu Bentschen 1938; Bahnhof ebd.); zur DDR-Zeit Besuch in Neu Bentschen mit „Trabant"].

-, -: An der Zeitung komme ich nicht vorbei. In: Zeitzeugen erzählen. Hrsg.: Seniorenbeirat Cottbus. Cottbus 2006, S. 108-109. [(Wie oben); hier:].

-, -: Der unbekannte Straßenname. In: ebd., S. 125-126. [(Wie oben); hier:].

-, -: Gedanken über Brücken. In: ebd., S. 108-109. [(Wie oben); hier:].

-, -: Gedanken über Kirchen. In: ebd., S. 132-134. [(Wie oben); hier:].

Hirt, Alfred: Verlorene Heimat - Meine Kindheit. In: Lebenszeit VIII. Neuenhagener Impressionen. Hrsg.: Seniorenbeirat der Gemeinde Neuenhagen. Neuenhagen 2002, S. 35-41. [Geb. 1930 Kalin bei Kutno/Polen, Okt. 1947 ausgewiesen].

-, -: Mein Weg nach Neuenhagen. In: Lebenszeit IX. Zu Hause in Neuenhagen. Hrsg.: Seniorenbeirat der Gemeinde Neuenhagen. Neuenhagen 2003, S. 20-23. [(Wie vor) 1947 Eisenbahntransport über Forst (Lausitz), Lager Wernigerode, 1951 Übersiedlung nach Neuenhagen (Brandenburg)].

Höhne, Maria: Meine Kindheit in Polen. In: Auf Erlebtes zurück geschaut. Lebenserinnerungen und Erzählungen. [16. Anthologie]. Hrsg.: Seniorenbeirat in der Landeshauptstadt Potsdam u. a. Potsdam 2014, S. 27-29. [Geb. 1926 Zabridnow bei Lublin, Vater Kleinlandwirt, sie später Industriekaufmann; Kindheit in Sobutnow östlich des Bug in Polen (heute Weißrussland): „Bis zum September 1939, als der 2. Weltkrieg begann, hatten wir Kinder eine glückliche Kindheit."]

-, -: Kindheit im besetzten Polen. In: Wie es damals war. Lebenserinnerungen und Erzählungen. [17. Anthologie]. Hrsg.: Seniorenbeirat in der Landeshauptstadt Potsdam u. a. Potsdam 2015, S. 13-15. 
[Kindheit u. Besuch einer poln. Schule in Sobutnow (s.o.), dann 1939/40 in Internatsschule in Chetm bei Lublin].

-, -: Unsere Umsiedlung 1940. In: ebd., S. 24-27. [Von Sobudnow (Ostpolen) auf ein Gehöft nach

Kostschin bei Posen (Warthegau), besucht 1940-1941 deutsche Mittelschule in Posen, 1942 Sportlager

in Litzmannstadt (Lodz), sieht ebd. Ghetto, dann Besuch einer Frauenfachschule (mit Internat) in Posen,

März 1943 Tod der Mutter, Vater alleinerziehend mit 11 Kindern im Alter von 2 bis 20 Jahren, Okt. 1943 Tod des Vaters].

-, -: Schreck in der Adventszeit. In: Aus unserem Leben. Lebenserinnerungen und Erzählungen. [18. Anthologie]. Hrsg.: Seniorenbeirat in der Landeshauptstadt Potsdam u. a. Potsdam 2016, S. 93-95. [1960 mit Mann nach Jüterbog gezogen, er ebd. in der SED-Kreisleitung, Abt. Landwirtschaft tätig; schildert Wohnungsbrand 1968].

-,-: Mit siebzehn Jahren veränderte sich mein Leben. In: Was nicht vergessen werden sollte. [19. Anthologie]. Hrsg.: Seniorenbeirat in der Landeshauptstadt Potsdam u. a. Potsdam 2017, S. 10-12. [Berufstätigkeiten in Posen 1943].

Höntsch-Harendt, Ursula: Wir Flüchtlingskinder. Roman. Halle/Leipzig. 1985. 267 S. [Geb. 1934 Frankenstein/Schlesien, gest. 2000 Berlin; im Kern autobiographische Schilderung des Schicksals einer aus Schlesien in die SBZ gelangten Familie].

Höpfner, Rudi: Erinnerungen eines Flüchtlingskindes an Burg. In: Stog - Der Schober 2005 (2004), S. 91-94. [Bauernsohn aus Ostpreußen, mit Mutter und sechs Geschwistern als Kind in Burg im Spreewald bei einem Bauern untergekommen, beschreibt Kindheitserlebnisse bei Feldarbeit, in der Schule, zu Weihnachten usw. (2. Hälfte der 1940er Jahre)].

Hoheisel, Wilhelm: Aus dem Treckbericht der Elsenauer. In: Heimatbuch für den Kreis EichenbrückWongrowitz. Bd. 2. Wendisch Evern 1978, S. 121-129. [Treckführer; 20.1.1945 Marschbefehl, 29.1. Schwedt/Oder, über Templin nach Perleberg 11.2., weitere Übernachtungen in Nebelin u. Mödlich (Kr. Westprignitz), dann Weiterfahrt ins Lüneburgische].

Hora, Friedrich: Eine politische Biographie. T. 1 [1935-1961]. (Privatdr.) o. O. 2012. 543 S. [Autobiographie; geb. 1935 Klösterle/Eger (Sudetenland), Studienratssohn, 21.6.1945 Vertreibung aus Tetschen nach Pirna, mit Elbdampfer nach Dresden, Bahn-Transport über Chemnitz (Flüchtlingslager) nach Reichenbach/Vogtland, hier Schulbesuch bis 1954 (Vater ab 1946 in Reichenbach/V. wieder als Gymnasiallehrer tätig, 1946 CDU- u. 1947 DSF-Mitglied, engagiert sich in Nationaler Front, Mutter ab 1949 aktives DFD-Mitglied), 1949 Eintritt in FDJ (u.a. Zirkelleiter, propagandistische Tätigkeit) u. 1953 (als einziger in seiner Schulklasse) in SED, 1954-1959 Studium an der PH Potsdam, ab 1959 Lehrer für Deutsch u. Geschichte an der Georgij-Dimitroff-Oberschule (später EOS) in Falkensee, 1961-1971 Schulparteisekretär, 1960 Heirat in Frankfurt (Oder), Ehefrau später Direktorin der Oberschule „Ernst Thälmann“ in Falkensee; er später Prof.f. Didaktik an der PH Potsdam].

Hornstein, Erika von: Die deutsche Not. Flüchtlinge berichten. Köln/Berlin 1960.

Hübner, Hans: Meine Kindheit und der schwere Anfang in Kiekebusch. In: Ingelore Kundoch / Dietrich Kundoch / Hans-Jürgen Nossack: Chronik Kiekebusch. Die Geschichte eines märkischen Dorfes. Hrsg.: Gemeinde Schönefeld. Schönefeld [2009], S. 47-51. [Geb. 1941 Hirschberg im Riesengebirge (Schlesien), Vater Schweizer auf Gut Grunau Kr. Hirschberg, Ende Mai 1947 Vertreibung (mit Mutter u. Geschwistern, Vater war Soldat), Viehwaggon-Transport vom Bahnhof Hirschberg, 4. bis 18.6.1947 Quarantäneaufenthalt im Lager Küchensee, 19./20.6.1947 Weitertransport per Bahn nach Eichwalde, dort Ankunft 20. oder 21.6.1947, Wohnungseinweisung (1 Zimmer), Aug. 1947 Umzug nach Kiekebusch (Kr. Teltow) mit Genehmigung des dortigen Bürgermeisters, 1.9.1947 Einschulung, ab 1955 Lehre; Schwerpunkt der Erinnerungen sind die Ernährungssorgen der Kinderjahre in Eichwalde u. Kiekebusch 1947-1950].

Hübner, Werner: Kriegsodyssee und DDR-Karriere. In: Lebenszeit. T. II. Zeitzeugen berichten. Hrsg. vom Landesseniorenbeirat Brandenburg u. a. (Neuenhagen) [1997], S. 26-31. [Geb. 1922 Hermsdorf 
in Nordböhmen, Steinsetzer u. Sohn eines Steinsetzers, 1940-1945 Soldat (Waffen-SS), Mai 1945 Heirat in Böhmen, 1945/46 sowjet. Kriegsgefangenschaft, Sept. 1946 zur Familie nach Oschersleben, Formerlehre, FDGB, BGL, SED, Stadtverordneter, ab 1950 Studium an der Fachschule für Bauwesen in Magdeburg, ab 1954 Arbeitsvorbereiter im Straßenunterhaltungsbetrieb in Strausberg, dann Amtsleiter des Straßenbauaufsichtsamtes ebd., dann nach Besuch der Bezirksparteischule Direktor der Bezirksdirektion des Straßenwesens, ehrenamtlicher Parteisekretär, 1989 Rentner].

Jachnick, Erwin: Flucht und Vertreibung aus Ossig. In: Gubener Heimatbrief (1995)1, S. 60-73. [Aus Ossig, Kr. Guben; Erlebnisse von Jan. bis Juni 1945].

Jäzoch, Jutta (geb. Thiele): Zwangsarbeit mit 16 Jahren. In: Vor 50 Jahren. Als Flucht und Vertreibung im Kreis Züllichau-Schwiebus begannen. Auszüge aus Tagebüchern, Briefen und Aufzeichnungen. Im Auftr. des Heimatkreises zsgest. von Lothar Meißner. O. O. 1995, S. 96-100. [Geb. 1939, Ende Jan. 1945 in Kay, Kr. Züllichau-Schwiebus, von der Roten Amee zur Zwangsarbeit in verschiedenen Lagern, u. a. Potulice, verschleppt, Jan. 1949 Entlassung nach Deutschland, Transport über Frankfurt (Oder) in Quarantänelager nach Leipzig, Abholung durch die in Kuschkow (Kr. Lübben) ansässig gewordene Mutter].

Jendreiek, Helmut: Die ersten Gubener Nachkriegswochen. Das Schicksal einer Gubener Oberschülergruppe. In: Gubener Heimatkalender 41 (1997), S. 33-48. [Geb. 1928 Guben, gest. 2006, später Oberstudiendirektor in Heidelberg; gekürzte u. red. bearb. Fassung der beiden nachfolgenden Beiträge].

-, -: Die ersten Gubener Nachkriegswochen oder: Wir sind dabei gewesen damals ... (Teil 1). In: Gubener Heimatbrief (1999)2, S. 29-40.

-, -: Die ersten Gubener Nachkriegswochen oder: Wir sind dabei gewesen damals ... (Teil 2). In: Gubener Heimatbrief (2000)1, S. 31-38.

Just, Gustav: Deutsch, Jahrgang 1921. Ein Lebensbericht. Potsdam 2001. 277 S. (Schriftenreihe des Wilhelm-Fraenger-Instituts Potsdam, Bd. 2). [Geb. 1921 Reinowitz bei Gablonz (Sudetenland), gest. 2011 Prenden bei Bernau, kath., Vater Arbeiter (Maschinist in der Gablonzer Brauerei, Gewerkschafter, Organisationsleiter der Ortsgruppe der tschechoslowakischen Kommunistischen Partei), bei Kriegsende Offizier, im Lazarett in Tetschen-Bodenbach, Anf. 1946 Ausreise zu Schwiegereltern nach Bad Schmiedeberg, 1946-1957 SED, Arbeiter in Sachsen-Anhalt, Neulehrer, SED-Funktionär (Kreisvorstand Quedlinburg, Landesvorstand Sachsen-Anhalt, dann in der Kulturabteilung des SED-Zentralkomitees tätig, Journalist, 1957-1961 politischer Häftling, dann Schriftsteller, 1989 Gründer des SPD-Ortsvereins Prenden, ab 1990 SPD-Kreisvorsitzender in Bernau u. Mitglied des Kreistages, 1990-1992 Alterspräsident des Landtages Brandenburg].

Kaatz, Gebhard: [Lebenslauf]. In: Müncheberger Lebensläufe. Hrsg. Verein für Heimatgeschichte der Stadt Müncheberg e. V.T. 1. Müncheberg 2008, S. 110-117. [Geb. 1942 Landsberg/Warthe, April 1945 Flucht aus Hohensalza nach Müncheberg, wo der Großvater Otto Briesemeister (gest. 1929) bereits 1920-1929 als Zimmermeister u. Bauunternehmer tätig gewesen war; der aus einem Lazarett entlassene Vater, Walter K. (gest. 1972), Mechaniker, gründet am 14.7.1945 in Müncheberg eine Reparaturwerkstatt für Büro- u. Nähmaschinen (Fotos S. 110f.), er selbst wird Flugzeugtechniker (1970 Meisterprüfung) u. übernimmt 1971 die väterliche Firma als nunmehrige „Gebhard Kaatz Bürotechnik“, bleibt bis 1989 parteilos (dann Neues Forum), 1971 Heirat, Ehefrau arbeitet als Bürokraft u. Beraterin in der Firma, er 1993-2008 Stadtverordneter (parteilos), 2003 Umstellung zur GmbH („Kaatz GmbH Büroservice- \& -ausstattung"), da kinderlos].

-. -: „Firma Kaatz“ in Müncheberg - Beginn, Entwicklung und Fortbestand. In: Chronik der Stadt Müncheberg in den Jahren 1945 bis 1989/90. Hrsg.: Verein für Heimatgeschichte der Stadt Müncheberg e. V.T. 2: Beiträge aus Wirtschaft und gesellschaftlichem Leben. Müncheberg 2012, 34-38. [Ergänzte Fassung der firmengeschichtlichen Passagen im obigen Lebenslauf].

Kabisch, Winfried: Der schwere Anfang in Guben nach 1945. In: Gubener Heimatbrief (1995)1, S. 12 14. [Aus Guben (Ostteil), Sohn eines Geschäftsinhabers, Febr. 1945 evakuiert nach Potsdam-Babelsberg, nach Kriegsende Rückkehr, 20.6.1945 Vertreibung, 1995 in Frankfurt (Oder) wohnhaft]. 
Kämpf, Emil: [Tagebuchauszüge 1946/47]. In: „Die Russen sind da“. Kriegsalltag und Neubeginn 1945 in Tagebüchern aus Brandenburg. Peter Böthig u. Peter Walther (Hg). 2., durchges. Aufl. Berlin 2011. [Geb. 1888, gest. um 1955, 1945 aus Eidlitz (Sudetenland) nach Kirchmöser vertrieben, wohnt privat bei einem Hausbesitzer].

Kaleck, Martin / Wachtmann, Marianne: Der Krieg und die Wolfskinder. In: Lebenszeit XVI. Neuenhagener Geschichten. Hrsg. von: Seniorenbeirat u. Gemeinde Neuenhagen bei Berlin. Red.: Marianne Wachtmann u. a. Neuenhagen bei Berlin [2018], S. 59-62. [Schicksal des M. Kaleck, aufgeschrieben von M. Wachtmann: geb. 1936 Königsberg i.Pr. „als Sohn einfacher Eltern mit mehreren Geschwistern“ (S. 59), 1942-1944 Schulbesuch in Königsberg, Vater Mai 1945 in Lager verstorben; die Geschwister-Kinder ab 1946 allein in Litauen, verlieren sich, er kommt bei kinderlosem poln. Bauernehepaar unter, 1951 Ausreise in die DDR über Frankfurt (Oder) zur bereits 1947 aus Königsberg ausgewiesenen Mutter nach Sukow bei Schwerin, Grundschule bis 8. Klasse, Lehre als Elektromonteur, ab 1965 wohnhaft in Neuenhagen].

Kanzler, Magda, geb. Kirsch: Es war einmal ... wir waren Flüchtlinge in Freyenstein. [Teil 1]. In: Wir in Freyenstein 68 (2015), S. 3-4. [Geb. ca. 19237, Tochter des Fleischermeisters u. Gasthausbesitzers Fritz Kirsch in Wabnitz (Kr. Oels), 20.1.1945 als Kind mit Eltern u. Schwester Flucht (Dorftreck) ins Sudetenland, 15.6.1945 Aufbruch in die SBZ, 18.7.1945 Ankunft in Berlin, Meldung zum Ernteeinsatz in Kyritz, Zugfahrt vom Schlesischen Bahnhof aus nach Freyenstein, Unterkunft ebd. bei Bauern].

-, -: Meine Kinder- und Jugendjahre Teil 2. In: ebd. 103 (2018), S. 7-8. [Ausschließlich die Jahre in Schlesien vor der Flucht betreffend].

-, -: Lebenserinnerungen Teil 3. In: ebd. 103 (2018), S. 8-9. [Wie vor]; 104 (2018), S. 8 [Flucht u. anschließende Zerstreung der Familie].

-, -: Lebenserinnerungen Teil 4. In: ebd. 104 (2018), S. 8-9 [Nachdruck von Teil 1].

Karsch, Theodor: Ein Todesurteil für mich. In: Um Beelitz harter Kampf. 1945. Das Jahr zwischen Krieg und Frieden. Beelitz und Umgebung. Hrsg.: Beelitzer Heimatverein. Beelitz 1999, S. 47-48. [Als Flüchtling aus Jugoslawien am 23.1.1945 nach Buchholz (Kr. Zauch-Belzig) gekommen; Erlebnisse ebd. nach dem Einmarsch der Roten Armee].

Kasprzik, Horst (nach einem Bericht von Edith Schumacher): Unser Großvater blieb zurück. In: Zeitgebunden. Brücken zur Vergangenheit. Hrsg. vom Seniorenbeirat der Stadt Cottbus. Cottbus 2010, S. 62-64. [Sie geb. 1937 Mischlewitz bei Briesen, Westpreußen als Tochter deutscher Kleinbauern, Jan. 1945 Flucht, von der Roten Armee überrollt, einquartiert bei deutscher Familie in Somse (bei Berent), Rückkehr in Heimatdorf; Herbst 1945 per Bahn nach Westdeutschland von Graudenz, wo die Familie im Gedränge auf dem Bahnhof vom Großvater getrennt werden, den sie nicht wiedersehen].

Kautz, Ernst: Annäherung an einen Ort. In: Zeitzeugen berichten 2000. Rückblickend nach vorn schauen. Hrsg. vom Seniorenrat des Landes Brandenburg e. V. [Strausberg] o. J., S. 34-38. [Gemeinsame Reise des (als Lehrer in Niedersachsen lebenden) Autors mit seinem (in Pieskow lebenden, dort ebenfalls als langjähriger Lehrer tätig gewesenen) Onkel Hugo Kautz 1995 in den Heimatort Ludwigsberg/Lagowo, Kr. Kosten, in Polen (ehem. Wartheland). S. 35: „In all den Jahren, seit ich mit dem Bewusstsein lebte, Flüchtling zu sein, ja, sogar einen amtlichen Ausweis besaß, der mir diesen Status bestätigte, hatte ich mit gewünscht, einmal an dem Ort zu stehen, wo meine Füße zum ersten Mal die Erde berührt haben. "Beide 1940 aus Bessarabien nach dort umgesiedelt].

Kegler, Hartmut: Kriegsende und Nachkriegszeit in der westlichen Prignitz. In: Kriegsende und Nachkriegszeit in Havelberg [I]. Hrsg.: Heimatverein Havelberg e. V. (Havelberger Regionalgeschichtliche Beiträge, Bd. 1). Havelberg 1992, S. 91-93 [Febr. 1945 als Kind mit zwei Geschwistern, Mutter und Großeltern per Bahntransport aus Hirschberg im Riesengebirge nach Mellen (Kr. Westprignitz) gelangt, Unterbringung in der Mühle; Erlebisse in Mellen].

Keller, Erika: Erlebnisse aus dem zweiten Weltkrieg. In: Storkower Zeitzeugen berichten [H.] 2. Hrsg. vom Seniorenbeirat des Amtes Storkow. Storkow 2001, S. 46-49. Wiederabdr. in: Brücken bau- 
en / budowa mostów. Hrsg.: Seniorenbeirat Storkow (Mark) / Seniorenorganisation Opalenica. Storkow (Mark)/Opalenica 2005, S. 20-24. [Geb. 1926 Lodz, ebd. Lehre als Verwaltungsangestellte, 19.1.1945 Flucht über Posen nach Berlin zu Schwiegereltern, dann nach Etzin bei Ketzin vor den Bombenangriffen evakuierter Mutter u. Schwester, hier Kriegsende erlebt].

Keppler, Günter: Tagebuchaufzeichnungen aus dem Jahre 1945. In: Potsdam 1945. Persönliche Aufzeichnungen und Erinnerungen. Begleitheft zur Sonderausstellung des Potsdam-Museums. Red.: Peter Herrmann (Veröffentlichung des Potsdam-Museums, 39). Potsdam 2005, S. 95-117. [Geb. 1898 Schmarl bei Rostock, gest. 1988 Wiesbaden; Landwirt, 1937-1945 in Zemmin bei Stolp/Pommern, 1945-1948 Regierungsrat in der Provinzialverwaltung in Potsdam, wohnt Marienstr. 33, 1948 Flucht nach Koblenz, tätig bei Statistischen Bundesamt in Wiesbaden; Aufzeichnungen (1966 abgeschrieben und ergänzt) behandeln Flucht aus Pommern am 30.9.1945 nach Berlin/Potsdam und Leben u. Arbeiten in Potsdam bis 31.12.1945].

Kernchen, Herbert: Jugenderinnerungen an Fürstenwerder. In: Fürstenwerder Mosaik. T. 2: Die Vierziger und Fünfziger Jahre (Schriftenreihe des Uckermärkischen Geschichtsvereins Prenzlau e. V., Ortsgruppe Fürstenwerder, H. 2). Fürstenwerder 2002, S. 122-131. [Geb.ca. 1934, Sohn eines Polizeioffiziers u. NSDAP-Mitglieds, 1945 Flucht mit Mutter u. Schwester aus Freienwalde in Hinterpommern nach Barth in Vorpommern, hier Einmarsch der Roten Armee erlebt, Flüchtlingsrücktransport („in Barth in Ostseekähne eingeschifft und mit Schleppern über Stralsund nach Stettin geschleppt"), in Stettin kein Weitertransport, sondern Erwachsene „zum Aufräumen und Steineklopfen eingesetzt", Übernachtung in leerstehenden Häusern, nach ca. 4 Wochen Juli 1945 vertrieben, fünftägiger Fußmarsch zu Verwandten der Mutter nach Fürstenwerder (Uckermark), Mitte Juli 1945 Ankunft, Unterkunft beim Onkel (Bäckermeister), Aug. 1945 Typhus-Erkrankung, 1945-1948 Schulbesuch in Fürstenwerder, Schlosserlehrling bei der MAS Fürstenwerder, 1951 Flucht nach West-Berlin, lebt später in Hannover].

Klessen, Ursula: Viele hatten Typhus. In: Heinz Materne / Hans Gerlach: Gross-Gandern und KleinGandern. Heimat im Sternberger Land. Wittingen/Bremen 1997, S. 96-97. [Aus Groß Gandern (Kr. Weststernberg), Aufenthalt im Notkrankenhaus in Frankfurt (Oder) Juli 1945].

Klitzing, Anne v. (geb. v. Wedemeyer): Die Flucht. In: Menschen und Schicksale. v. Klitzing'sche Häuser im 19. Und 20. Jahrhundert (Die Familie von Klitzing, T. V). O. O. 1990, S. 196-204. [Geb. 1883 Schönrade (Kr. Friedeberg/Nm.), gest. 1965, Fideikommissherrntochter, Frau des Gutsbesitzers Hans v. K. (1874-1948); Erlebnisse auf dem Treck von Charlottenhof (Kr. Landsberg/W.) nach Westen, 30. Jan. bis März 1945, u. a. Neuhardenberg (Kr. Lebus), Haselberg (Kr. Oberbarnim), Bad Freienwalde/Oder].

Knospe, Marianne, geb. Redlich: [Lebenslauf]. Aufgeschrieben von Erich Knospe. In: Müncheberger Lebensläufe. Hrsg. Verein für Heimatgeschichte der Stadt Müncheberg e. V. T. 3. Müncheberg 2012, S. 49-62. [Geb. 1932 Rotschloß (Kr. Strehlen), Vater Melkermeister auf schlesischen Gütern: 1932-1937 Rotschloß, 1937-1940 Groß Kniegnitz (Kr. Reichenbach), 1940-1944 Seiffersdorf (Kr. Ohlau), sie ab 1940 Schulbesuch in Zottwitz bei Seiffersdorf, 1945 Flucht oder Vertreibung nach Pernitz bei Brandenburg/Havel, 1946-1947 Schulbesuch in Golzow, Arbeit beim Bauern, Lehrling bei einem Friseurmeister, 1950 Umzug nach Lehnin, wo 1950 zurückgekehrter Vater Arbeit bekam, 1951 Laborgehilfin beim Landesverband Brandenburg der VdgB, April 1951-1953 desgl. auf der Besamungsstation Müncheberg, 1952 Heirat, 1953-1962 4 Kinder, 1957-1991 Köchin im Kindergarten der Stadt Müncheberg; 1994 u. 2005 Besuche im Heimatdorf Seiffersdorf; S. 52-54 ausführlich auch zur schlesischen Heimat, aber (S. 54): „Als ihre Heimat bezeichnet Marianne nicht etwa Niederschlesien, sondern Müncheberg, wo sie bis heute etwa 62 Jahre ihres Lebens mit ihrem Mann verbrachte."].

Knuth, Reinhard: Wie ich Niederlausitzer wurde ... In: Luckauer Heimatkalender 47 (2015), S. 68-74. [Geb. in einem Gutsdorf im Kr. Züllichau-Schwiebus, Tagelöhnersohn, 31 1. 1945 Flucht mit Treck, 5.2. Ankunft in Waltersdorf, Kr. Luckau, 6.2.1945 Notunterkunft bei einem Bauern in Gehren, Kr. Luckau, Schulbesuch ebd., HJ-Dienst, Kriegsende, Hunger, 1948 Lehrling u. Konfirmation]. 
-, -: Erinnerungen an das Wintersportzentrum Gehren. In: Luckauer Heimatkalender 48 (2016), S. 43-47. [Verf. wie vor; Kindheitserlebnisse am Aufnahmeort].

Kohs, Marcel: Gerhard Begall: „Wie uns eine jüdisch-russische Ärztin half“. [Aufzeichnung nach Interview]. In: Pritzwalker Heimatblätter 16 (2015), S. 27-28. [Begall geb. 1930 in der Neumark, Bauernsohn, 1945 in Leimnitz (Kr. Züllichau-Schwiebus), 29.1.1945 zum Kriegseinsatz nach Schwiebus, 30.1.1945 in sowjet. Kriegsgefangenschaft geraten, zu Aufräumungsarbeiten nach Landsberg/Warthe deportiert, 28.3.1945 Transport in offenen Güterwagen nach Posen, 3.4.1945 Abtransport in die Sowjetunion (Lager Kathrinowka nördlich der Krim), Arbeit im Steinkohlebergwerk, 20.7.1947 Entlassung, Bahntransport nach Frankfurt (Oder), hier im Heimkehrer-Lazarett, dan Quarantänelager Pirna, nach einigen Wochen entlassen, Bahnfahrt über Wittenberge nach Pritzwalk, Fußmarsch nach Sadenbeck (Kr. Ostprignitz) zu seinen Eltern, später Eisenbahner in Pritzwalk].

Korsz, Erwin: Wie ich zum zweiten Mal Deutscher wurde. Aufgeschrieben von Horst König. In: Geschichten aus sieben Jahrzehnten. Storkower Zeitzeugen berichten. Hrsg. vom Seniorenbeirat der Stadt Storkow (Mark). Storkow 2005, S. 29-32. Wiederabdr. in: Brücken bauen / budowa mostów. Hrsg.: Seniorenbeirat Storkow (Mark) / Seniorenorganisation Opalenica. Storkow (Mark)/Opalenica 2005, S. 32-36. [Geb. 1932 Babziens, Kr. Rastenburg (Ostpreußen), Gutsarbeitersohn, Jan. 1945 Flucht (Treck) gescheitert, bleibt mit Mutter (gest. Mai 1946 an Typhus) u. zwei Schwestern in Ostpreußen („Wolfskinder"), er Traktorist auf Gut Sorquitten, 1955 zwangsweise poln. Staatsbürgerschaft, heiratet 1957, Bauer im Nebenerwerb, Dorfbürgermeister in Neberg (Kr. Sensburg), 1964 Zuzugsgenehmigung nach Storkow (DDR), wo Tante lebte, Verlust der poln. Staatsangehörigkeit (zwei Jahre lang staatenlos), erhält Arbeitsstelle in LPG Storkow u. Wohnung zugesichert unter der Verpflichtung, fünf Jahre in der Landwirtschaft zu arbeiten].

Krakau, Winfried: Flucht aus Schlesien. Mein langer Weg von Glogau nach Wilhelmshorst. In: 100 Jahre Wilhelmshorst 1907-2007. Hrsg. im Namen der Freunde und Förderer der Wilhelmshorster Ortsgeschichte e. V. von Rainer Paetau. Wilhelmshorst 2007, S. 345-346. [Geb.ca. 1929 Schlesien, Kartographensohn, 27.6.1945 aus Schlesien ausgewiesen, Flucht über Forst nach Luckau, 1952 Übersiedlung nach Wilhelmshorst].

Krause, Kurt: Erinnerungen an die Schreckenszeit vor 50 Jahren. In: Königsberger Kreiskalender 1996 (1995), S. 67-70. [Verf. stammt aus Neudamm/Neumark, lebt in Ketzin; 31.1.1945 evakuiert, nach vorübergehender Rückkehr in den Heimatort Juni 1945 vertrieben über Küstrin nach Berlin; 1993 Besuch im Heimatort].

Krebs, Gerhard: [Lebenslauf]. In: Müncheberger Lebensläufe. Hrsg. Verein für Heimatgeschichte der Stadt Müncheberg e. V. T. 5. Müncheberg 2017, S. 62-70. [Geb. 7.3.1946 Hostenice bei Aussig/ Elbe, Vater Fleischer (nach Vertreibung zunächst Waldarbeiter, später Forstingenieur u. Oberförster in Kröslin, Kr. Wolgast), Juni 1946 Vertreibung, Aufnahmelager bei Schwerin, dann Marnitz (Kr. Parchim), 1953-1963 Schulbesuch in Kröslin u. Wusterhusen (Kr. Wolgast), dann Lehre als Forstfacharbeiter mit Abitur in Bad Doberan, 1966-1969 Fachschule für Forstwirtschaft in Rabensteinfeld bei Schwerin, 1967 SED, 1968 Heirat (1969, 1970, 1977 Kinder), 1969 Staatl. Forstwirtschaftsbetrieb Templin (anfangs Wohnung in umgebauter Gartenlaube in Templin, dann Untermiete, dann Wohnung in Oberförstereigebäude), 1972-1991 Revierförster in Müncheberg, 1992-2011 Stadtförster ebd.].

Kreutz-Gralow, Erna: Advent und ein Karpfen. In: Zeitreisen durch ein. [4. Anthologie]. Hrsg.: Seniorenbeirat der Stadt Potsdam u. a. Potsdam 2002, S. 53-54. [Geb. 1928 Pilgramsdorf bei Pleß (Pielgrzymowice), Ost-Oberschlesien, Kleinbauerntochter (später Sachbearbeiterin u. Diplom-Lehrerin in der DDR); Kindheitserinnerungen aus einer Kolonie „Volksdeutscher“ bei Goldmannsdorf/Bzie (BeskidenVorland) im damals bis 1939 polnischen Ost-Oberschlesien].

-, -: Auf, auf zum Kickelhahn. In: ebd., S. 55-57. [Seniorengruppenreise nach Thüringen, 1998].

-, -: Ein Erlebnis, das mein Leben mitprägte. In: ebd., S. 57-59. [Erlebt während ihrer Zeit als Schülerin der Handelsschule in Rybnik am 3.1.1945 beim Bahnhof ihres Heimatorts Goldmannsdorf bewachten 
Marsch von Häftlingen aus dem KZ Auschwitz auf der Fernverkehrsstraße nach Jastrzemb mit einzelnen Erschießungen].

-, -: Der Wind weht über Stoppelfelder. In: 2003, S. 9-11. [Kindheitserinnerungen].

-, -: Endstation Lübeck. In: ebd., S. 2024. [Flucht aus Heimatort in Ost-Oberschlesien am 12.2.1945 mit

Wehrmachtseinheit über Prag u. allein weiter nach Hamburg u. Lübeck].

-, -: Frühling im Beskidenvorland. In: Erlebt im vorigen Jahrhundert. Geschichten und Lebenserinnerungen. [6. Anthologie]. Hrsg.: Seniorenbeirat der Stadt Potsdam u. a. Potsdam 2004, S. 8-11. [Kindheitserinnerungen].

-, -: Schwere Jahre [Rubrik „Erinnerungen an schwere Zeiten“]. In: ebd., S. 29-34. [12.2.1945 Flucht nach Lübeck, dort auch Eintreffen des Vaters, Erlebnisse dort u. Übersiedlung zur Mutter nach Lüderitz bei Stendal 1947 (Bahn-Transport über Duderstadt, dort Entlausung, Grenzübertritt, Personenzug nach Demker bei Stendal, Wiedersehensfreude)].

-, -: Eine Reise in den Winter. In: ebd., S. 85-89. [Busreise mit Potsdamer Seniorengruppe ins tschechische Erzgebirge 2002].

-, -: Status - Volkdeutsch. In: Gestern und heute. Erinnerungen von Mitgliedern des Zirkels „Zeitzeugen“ beim Seniorenbeirat der Stadt Potsdam. [7. Anthologie]. Hrsg.: Seniorenbeirat in der Stadt Potsdam. Stadtverwaltung, Fachbereich Soziales, Wohnen u. Senioren. Potsdam 2005, S. 10-14. [Kindheit in der o.g. Kolonie in Ost-Oberschlesien bis 1939].

-, -: Wie ich 1960 die Kultur aufs Land bringen sollte. In: ebd., S. 47-53. [Instrukteurin für Dorfklubarbeit in Stangenhagen bei Luckenwalde, Blankensee, Glau u. Göttin].

-, -: Winter im Vorland der Beskiden. In: ebd., S. 71-75. [Kindheitserlebnisse].

-, -: Weihnachten meiner Kindheit. In: Erlebte Geschichte. [8. Anthologie]. Hrsg.: Seniorenbeirat in der Stadt Potsdam u. a. Potsdam 2006, S. 25-28. [Kindheitserinnerungen aus Ost-Oberschlesien].

-, -: Der Weg zu meinem Beruf. In: ebd., S. 40-47. [1943-1945 Handelsschule in Rybnik (Oberschlesien), Mitte Jan. bis April 1945 Flucht nach Lübeck, 1946 in Lüderitz bei der Familie, Haushilfe bei Tierarzt, 1947 Schreibkraft im Gemeindeamt, 1948 Heirat mit dem Sohn eines selbständigen Gärtners, zwei Kinder, ab 1954 Hausfrau, dann Hilfserzieherin, in Schönhagen Kr. Luckenwalde, wo der Ehemann Lehrausbilder in einem Gartenbaubetrieb geworden war (er dann Instrukteur für Landwirtschaft bei der SED-Kreisleitung in Luckenwalde, 1956 Unfalltod), 1960 Instrukteurin für Dorfklubarbeit (s.o.), 1961-1964 Studium am Institut für Lehrerbildung in Potsdam, dann Lehrerin in Luckenwalde, 1970-1975 Fernstudium der Geschichte an der PH Potsdam, Diplom-Fachlehrer für Geschichte, wegen Gehörschadens vorzeitig aus dem Schuldienst ausgeschieden, Wohnheimleiterin an der Pädagogischen Fachschule für Kindergärtnerinnen in Luckenwalde, dann Erzieherin im Internat der Kinder-u. Jugendsportschule in Potsdam, wo bereits die Kinder lebten].

-, -: Ein unheimlicher Heimweg. In: ebd., S. 72-76. [Kindheitserlebnis in Ost-Oberschlesien].

-, -: Unser „Hofgarten“. In: Erinnerung ist lebende Vergangenheit. [9. Anthologie]. Hrsg.: Seniorenbeirat in der Landeshauptstadt Potsdam u. a. Potsdam 2007, S. 61-66. [Bei der Wohnung in Potsdam, Kiezstraße ab 1983].

-, -: Blau - Rot - Gelb. In: ebd., S. 80-84. [Besuch der Landesgartenschau in Rathenow 2006].

-, -: Geschichten, rund ums Autofahren. In: ebd., S. 103-108. [Lkw-Fahrschullehrgang als GST-Mitglied 1960, Pkw-Fahrschullehrgang und Anmeldung für Kauf eines „Trabant" 1972, Fahrprüfung 1974].

-, -: Episoden aus der Kindheit. In: Heiteres und Besinnliches. Geschichten und Lebenserinnerungen. [10. Anthologie]. Hrsg.: Seniorenbeirat in der Landeshauptstadt Potsdam u. a. Potsdam 2008, S. 11-16. [Elternhaus, erste Kinderjahre, Lebensumstände, u. Kindergartenzeit in Ost-Oberschlesien]. -, -: Anulka - meine Kurbekanntschaft. In: ebd., S. 84-90. [Kontakt zu einem polnischen Mädchen in Kolberg 2001]. 
-, -: Kinder- und Jugendjahre in Ostoberschlesien. In: Geschichten aus dem Meer der Erinnerungen. Lebenserinnerungen und Erzählungen. [11. Anthologie]. Hrsg.: Seniorenbeirat in der Landeshauptstadt Potsdam u. a. Potsdam 2009, S. 13-18. [Leben in der deutschen Minderheit, Schulbesuch, Zweiter Weltkrieg, Flucht].

-, -: Camping am Macha-See. In: ebd., S. 63-68. [Begleitung des EOS-Singeklubs nach Doksy am MáchaSee in der Tschechoslowaklei als Lehrerin der POS Ernst Moritz Arndt („Arndtschule“) in Luckenwalde, Juli 1966].

-, -: Wie Eichhörnchen mein Leben inspizierten. In: Vergangenes - Gegenwärtiges. Lebenserinnerungen und Erzählungen. [12. Anthologie]. Hrsg.: Seniorenbeirat in der Landeshauptstadt Potsdam u. a. Potsdam 2010, S. 53-56. [Handelsschule Rybnik ohne Abschluss verlassen wegen Kriegswirren u. Flucht, daher in schweren Nachkriegsjahren als Unqualifizierte in Niedriglohngruppe eingestuft; 1961 Besuch des Instituts für Lehrerbildung in Potsdam-Sanssouci, um Unterstufenlehrerin zu werden].

-, -: Wie ich als Kind die Getreideernte erlebte. In: ebd., S. 64-67. [Vater in Ost-Oberschlesien als Schnitter tätig].

-, -: „Wenn einer eine Reise tut ..." In: ebd., S. 83-88. [Busreise nach Wien 1990].

-, -: Die zwei Ungleichen. In: Rückblicke auf Erlebtes. Lebenserinnerungen und Erzählungen. [13.

Anthologie]. Hrsg.: Seniorenbeirat in der Landeshauptstadt Potsdam u. a. Potsdam 2011, S. 54-58. [Ab 1981 Erzieherin im Internat der Kinder-und Jugend-Sportschule (KJS) in Potsdam, beschreibt ihre Gartenarbeit im eigenen "Hofgarten"].

-, -: Gedanken zum 100. „Frauentag“. In: ebd., S. 59-62.

-, -: Meine Zeit als Lehrerin in Stülpe. In: Erfahrungen - Erkenntnisse. Lebenserinnerungen und Erzählungen. [14. Anthologie]. Hrsg.: Seniorenbeirat in der Landeshauptstadt Potsdam u. a. Potsdam 2012, S. 40-43. [Stülpe bei Luckenwalde, 1970er Jahre bis 1981].

-, -: Begegnungen vor der Wende. In: S. 87-91. [Erlebnisse u. Erfahrungen bei der ersten Westreise zur Schwester nach Bleckede (Niedersachsen) im Sept. 1989 nach langer Trennung; Okt. 1989 Besuch einer bei der Volkssolidarität in Miltern bei Tangermünde aktiven Cousine in Potsdam].

-, -: Meine Zeit als Schulgartenleiterin. In: Erinnerungen sind gehobene Schätze. Lebenserinnerungen und Erzählungen. [15. Anthologie]. Hrsg.: Seniorenbeirat in der Landeshauptstadt Potsdam u. a. Potsdam 2013, S. 57-60. [POS Ernst Moritz Arndt in Luckenwalde, 1964].

-, -: „Wohin soll denn die Reise geh'n ..." In: ebd., S. 64-67. [Begleitung einer Klassenfahrt nach Thüringen 1974].

Krockow, Christian Graf von: Die Stunde der Frauen. Bericht aus Pommern 1944 bis 1947. Nach einer Erzählung von Libussa Fritz-Krockow. 11. Aufl. Stuttgart/München 2000.

Kühl, Vilma: Eine Familiengeschichte Wolgadeutscher. In: Heimatkalender Bad Liebenwerda 56 (2004/05), S. 77-87. [Geb. 1950, Lehrerin in Fürstenwalde, Spätaussiedlerin, mit ihrer russlanddeutschen Familie 2000 aus Kasachstan über Peitz nach Finsterwalde gekommen].

Kühne, Horst: Krieg-Nachkrieg in Storkow. Eine Erinnerung. In: Gerd Tschechne: Das Kriegsende in und um Storkow (Mark). Dokumentation und Zeitzeugenberichte (Beiträge zur Geschichte der Stadt Storkow (Mark) und Umgebung, H. 4). Storkow (Mark) 2005, S. 56-65. [Geb. 1939, Schlossermeistersohn, aufgewachsen bis 1945 in der Dammvorstadt von Frankfurt (Oder), Anf. Febr. 1945 Zwangsevakuierung mit Mutter u. Geschwistern (Vater Soldat), 4.2.1945 Anmeldung in Storkow (Mark), Unterbringung bei den dort lebenden Großeltern, erlebt Kriegsende in Storkow].

Kulla, Barbara: Erinnerungen an die Umsiedlung aus unserer Heimat. In: Lebenszeit [I.] Zeitzeugen berichten. Hrsg. vom Landesseniorenbeirat Brandenburg u. a. [Neuenhagen 1996], S. 46-47. [Aufzeichnungen der Mutter, Katharina Vollmer, geb. 1900 Langenpfuhl, Kr. Oststernberg, 28.1.1945 Flüchtlinge aus den Kreisen Grätz, Samter, Schwiebus u. aus Bessarabien, Estland usw. im Haus untergebracht, 29.1.1945 Einmarsch der Roten Armee, 25.6.1945 vertrieben, Treck über Drossen zur Oder, allein 
zur Cousine weiter nach Altlandsberg (6.7.1945), in deren Haus aufgenommen, „das schon überfüllt von Flüchtlingen war"].

Kunert, Edith: Besuch in der alten Heimat. In: Lebenszeit. T. III. Zeitzeugen berichten. Hrsg. vom Landesseniorenbeirat Brandenburg u. dem Seniorenbeirat Neuenhagen. Neuenhagen [1998], S. 58-60. [Geb. ca. 1929 Alexandrow Kr. Lodz, 1945 Flucht].

Lange, Günter: Glück oder Schutzengel? In: Damals und heute. Storkower Zeitzeugen berichten. Hrsg. vom Seniorenbeirat des Amtes Storkow. Storkow 2003, S. 54-56. [Geb. 1926 Weichau/Schlesien, Kriegsende im Kessel von Halbe, verwundet im Gefangenenlazarett Lager Küchensee].

Langemark, Helene: Ich kann das Licht noch sehen. Ein Erlebnisbericht aus der Neumark 1945/46. Husum 1987. [Vertreibung über Stettin nach Schleswig-Holstein].

Lede, Elsbeth: [Lebenslauf]. Aufgeschrieben von Wolfgang Domscheit. In: Müncheberger Lebensläufe. Hrsg. Verein für Heimatgeschichte der Stadt Müncheberg e. V. T. 3. Müncheberg 2012, S. 63-66.

[Geb. 1922 Steinbockwerk (Sandow, Papierfabrik) (Kr. Weststernberg), hier aufgewachsen u. Schulbesuch bis 1937, dann Arbeit in Signierabteilung der örtlichen Papierfabrik, ca. 1939 Ausbildung zur Kindergärtnerin, RAD in Danzig, Pflichtjahr u. a. auf der "Wilhelm Gustloff" in Gotenhafen (Gdingen), 1941-1945 Leiterin eines Kindergartens in ihrem Heimatdorf Steinbockwerk, Jan. 1945 Kind geboren (stirbt nach 6 Monaten), nach Einmarsch der Roten Armee mit der Dorfbevölkerung nach Osten vertrieben, sie Typhus, noch vor Kriegsende zu Arbeit in Lazarett in Ziebingen verpflichtet (Versorgung deutscher Verwundeter unter sowjet. Aufsicht), von hier Flucht mit Verwundetentransport nach Berlin-Heiligensee, lernt Mann kennen, Umzug nach Müncheberg wegen Stellenanzeige, 2. Kind, verschiedene Tätigkeiten, 1956-1958 Schwesternausbildung in Neuenhagen, dann im Landambulatorium u. Entbindungsheim Müncheberg tätig].

Leder, Helmut: Ich war 16. In: Damals und heute. Storkower Zeitzeugen berichten. Hrsg. vom Seniorenbeirat des Amtes Storkow. Storkow 2003, S. 48-49. [Geb. 1929, erlebt 24.6.1945 Erschießungen Deutscher im Heimatort Anseith (Sudetenland)].

-, -: Ich war 16. In: Damals und heute. Storkower Zeitzeugen berichten. Hrsg. vom Seniorenbeirat des Amtes Storkow. Storkow 2003, S. 49-52. [Wie vor, Juli 1945 Vertreibung aus Anseith, Transport nach Sachsen-Anhalt, lebte später in Storkow].

Lehmann, Johannes: Erlebnisse in Muschten. In: Vor 50 Jahren. Als Flucht und Vertreibung im Kreis Züllichau-Schwiebus begannen. Auszüge aus Tagebüchern, Briefen und Aufzeichnungen. Im Auftr. des Heimatkreises zsgest. von Lothar Meißner. O. O. 1995, S. 32-40. [Geb. 1883, 1912-1945 evang. Pfarrer in Muschten; Erlebnisse ab 29.1.1945; 26.6.1945 Ausweisung, 29.6.1945 Übergang über die Oderbrücke in die Altstadt von Frankfurt (Oder). - L. wurde später (bis 1956) Pfarrer in Garlitz (Westhavelland) u. lebte dann bei seiner Tochter in Neumünster].

Leske, Arthur: Erinnerungen eines Schönermarkers an schicksalhafte Tage. In: Brandenburger Rundschau 14 (2016) 3, S. 6-7; 4, S. 6-7; 5, S. 6-7; 6, S. 6-7; 7, S. 6-7; 8, S. 6-7; 9, S. 10. [Geb. ca. 1936, gest. 2012 Schönermark, aus Alt Ruda (Kr. Hermmansbad/Ciechocinek) bei Hohensalza, Ende Jan. 1945 Flucht mit Eltern über Arnswalde und Dölitz (Kr. Pyritz) und die Uckermark in den angewiesenen Aufnahmekreis Ostprignitz, Flüchtlingsleitstelle Kyritz verweist nach Zernitz, ab Aug. 1945 in Schönermark, später langjähriger LPG-Vorsitzender ebd., nach 1990 aktives BdV-Mitglied, Kontakte mit einzelnen Bewohnern des Heimatortes bis zum Lebensende].

Lindner, Clemens: [Lebenslauf]. Aufgeschrieben von Karin Lindner [Ehefrau]. In: Müncheberger Lebensläufe. Hrsg. Verein für Heimatgeschichte der Stadt Müncheberg e. V. T. 3. Müncheberg 2012, S. 67-82. [Geb. 1933 Conradswalde (Kr. Elbing), drittes von fünf Kindern eines 1941 verstorbenen Bauern, 21.1.1945 zunächst mit Mutter, Tante u. 4 Schwestern Flucht mit Pferd u. Wagen, dann Umkehr u. nur mit Handgepäck über Frisches Haff bis auf die Frische Nehrung, Fußmarsch nach Danzig u. weiter bis nach Karstnitz (Kr. Stolp), hier Aufenthalt Frühjahr bis Herbst 1945, Okt. 1945 Vertreibung nach Karstädt bei Perleberg, Jan. 1946 Tod der Mutter, Onkel wird Vormund, ab 1948 landwirtschaftliche Lehre in Quitzow 
u. Landwirtschaftliche Fachschule in Perleberg, ab 1952 TAN-Sachbearbeiter im VEG Lindenberg (Kr. Beeskow), 1955-1958 Fachschule für Landwirtschaft in Eisenach, dann als staatl. gepr. Landwirt im VEG Müncheberg tätig, 1958 Abteilungsleiter, ab 1967 Leiter der Pflanzenproduktion im Lehr-u. Versuchsgut Müncheberg, 1968 Dipl.-Landwirt; 1960 SED; 1964 Heirat (kann keine Geburtsurkunde vorlegen), 1965-1975 drei Kinder; 2002 Besuch im Geburtsort].

Lindner, Ekkehard: Neulehrer in Frankfurt an der Oder. In: Schlesier in der DDR. Berichte von Flüchtlingen, Vertriebenen und Umsiedlern. Michael Parak (Hrsg.). Eine Veröff. des Schlesischen Museums zu Görlitz. Görlitz 2009. S. 48-61. [Geb. 1922 Rauscha (Kr. Görlitz), Apothekersohn aus Schlesien, 1945 Soldat, nach Entlassung aus sowjet. Kriegsgefangenschaft zu Fuß nach Schwedt/Oder gelangt, von hier Jan. 1946 zum Neulehrer-Ausbildungskursus in Frankfurt (Oder), anschließend 1946-1958 Lehrer ebd., nach mehrfacher Schikane als Regimegegner 1958 Flucht nach West-Berlin, Weiterleitung nach Niedersachsen, dort ab 1975 Volkshochschulleiter].

Löffler, Fritz: [Erlebnisbericht, zusammengestellt 1980]. In: Heimatkreis Soldin/Neumark. Hrsg. vom Heimatkreis Soldin/Neumark. Soltau 1981, S. 573-579. [Geb. ca. 1889, letzter deutscher Bürgermeister von Deetz, Kr. Soldin; Geschehnisse ab 2. Jan. 1945, Einmarsch der Roten Armee am 30. Jan., Vertreibung am 2.7.1945, Treck unter polnischer Bewachung durch den Kr. Pyritz (Brietzig), Oderübergang über Notbrücke bei Fiddichow (Kr. Greifenhagen/Pommern), dreitägiger Zwischenhalt in Passow (Kr. Angermünde), Weitertransport per Eisenbahn (offener Güterwagen), offenbar ab Bahnhof Angermünde, nach Berlin, Halte in Neukölln und Oberschöneweide; Versuch, beim älteren Bruder in Berlin-Gesundbrunnen unterzukommen, scheitert (Haus ist Ruine), Weiterfahrt vom Lehrter Bahnhof (mit Zwischenaufenthalt in Spandau-West) nach Schönhausen/Elbe, Elbübergang über Notbrücke nach Tangermünde].

Lorenz, Willy: [Tagebuchauszüge 1945-1949]. In: „Die Russen sind da“. Kriegsalltag und Neubeginn 1945 in Tagebüchern aus Brandenburg. Peter Böthig u. Peter Walther (Hg). 2., durchges. Aufl. Berlin 2011. [Geb. 1900, gest. 1981, Landwirtssohn, Landwirt u. Familienvater, bis 1945 in Frauendorf (Kr. Weststernberg), 22.6.1945 mit Familie von hier vertrieben, übernimmt Neubauernstelle in Bückwitz bei Wusterhausen/Dosse, 1956 Flucht nach Westdeutschland].

Lüderitz, Jörg: Heimat Brandenburg. Stationen meines Lebens. Berlin 2012. 217 S. [Geb. 1935 Rostin (Kr. Soldin/Nm.), Lehrersohn (und Enkel des Lehrers und neumärkischen Heimathistorikers Paul Biens [1874-1945] in Lippehne), 31.1.1945 Rote Armee in Rostin, Deportation der Mutter nach Russland, im Mai mit dem älteren Bruder Wechsel nach Lippehne zur Großmutter, 4.7.1945 Zwangsausweisung („wilde Vertreibung“) aus Lippehne, 14-tägige Flucht (Treck) in Richtung Berlin, kommt bei Verwandten in Rüdersdorf unter, wird später Buchhändler und betätigt sich als DDR-Bürger in der deutsch-polnischen Verständigung, reist schon ab 1968 u. später regelmäßig in die Neumark, nach 1990 ausgedehnte Vortragsu. Publikationstätigkeit zur Neumark].

-, -: Ein Bekenntnis zu Rüdersdorf. In: Rüdersdorf. Zeitzeugen berichten. Hrsg. vom Seniorenbeirat Rüdersdorf. Rüdersdorf 1998, S. 14-16. [Wie vor; hier: Aufnahme (mit Großmutter, Bruder u. weiteren Personen) in Rüdersdorf und Wieder-Trittfassen bis 1951; „unserer zweiten Heimat Rüdersdorf stets dankbar" für gütige Aufnahme].

-, -: Aus dem Kulturhaus in die Stasi-Haft. In: Rüdersdorf. Zeitzeugen berichten. Vorkriegszeit, Kriegszeit, Nachkriegszeit. Hrsg. vom Seniorenbeirat Rüdersdorf. Rüdersdorf o.J. [1999?], S. 51-53. [Wie oben; hier: Verhaftung 1957 wegen „Westkontakten“ (SPD-Jugendorganisation „Die Falken“ in West-Berlin; war aber schon 1956 in der DDR CDU-Mitglied geworden), 1959 Haftentlassung].

Lunkeit, Heinz: Böses Kriegsende - unerwarteter Neubeginn. In: Gelebte Geschichte. Storkower Zeitzeugen berichten aus 8 Jahrzehnten. Hrsg. vom Seniorenbeirat der Stadt Storkow (Mark). Storkow 2007, S. 46-49. [Geb. ca. 1923; 1941 Lehrling in Königsberg i. Pr., ab 1942 Wehrmachtssoldat, ab Aug. 1945 Arbeit als Autoschlosser u. Kraftfahrer für den sowjet. Stadtkommandanten in Storkow, der die noch in Ostpreußen befindliche verwitwete Mutter finden hilft]. 
-, -: Gedanken und Erinnerungen an das Storkower Schlepperwerk. In: Gelebte Geschichte. Storkower Zeitzeugen berichten aus 8 Jahrzehnten. Hrsg. vom Seniorenbeirat der Stadt Storkow (Mark). Storkow 2007, S. 49-52. [Wie vor; 1946-1948 Schlosser u. Kraftfahrer in den Storkow-Werken].

Lyhs, Dieter: Meine Kindheit im ländlichen, masurischen Umfeld. In: Damals und heute. Storkower Zeitzeugen berichten. Hrsg. vom Seniorenbeirat des Amtes Storkow. Storkow 2003, S. 8-11. Wiederabdr. in: Brücken bauen / budowa mostów. Hrsg.: Seniorenbeirat Storkow (Mark) / Seniorenorganisation Opalenica. Storkow (Mark)/Opalenica 2005, S. 55-59. [Geb. 1931, Bürgermeistersohn aus Saborowen/Reichenwalde (Kr. Lyck), 1944 Fluchtvorbereitung, später in Frankfurt (Oder)].

-, -: Flucht aus Ostpreußen (I). In: Damals und heute. Storkower Zeitzeugen berichten. Hrsg. vom Seniorenbeirat des Amtes Storkow. Storkow 2003, S. 38-40. Wiederabdr. in: Brücken bauen / budowa mostów. Hrsg.: Seniorenbeirat Storkow (Mark) / Seniorenorganisation Opalenica. Storkow (Mark)/ Opalenica 2005, S. 38-40. [Wie vor; August 1944 Evakuierung in die westliche Hälfte des Kreises Lyck].

-, -: Flucht aus Ostpreußen (II). In: Damals und heute. Storkower Zeitzeugen berichten. Hrsg. vom Seniorenbeirat des Amtes Storkow. Storkow 2003, S. 40-44. Wiederabdr. in: Brücken bauen / budowa mostów. Hrsg.: Seniorenbeirat Storkow (Mark) / Seniorenorganisation Opalenica. Storkow (Mark)/Opalenica 2005, S. 40-44. [Wie vor; 11.1.1945 Flucht aus Ostpreußen über Pillau, Gotenhafen (Gdingen) u. Stolp nach Stettin] (18.2.1945), 22.2.1945 Zugfahrt nach Berlin, am 23.2. bei Verwandten in Berlin-Marzahn untergekommen].

-, -: Kriegsende und Neubeginn. In: Damals und heute. Storkower Zeitzeugen berichten. Hrsg. vom Seniorenbeirat des Amtes Storkow. Storkow 2003, S. 61-62. [Wie vor; Berlin, März-Sept. 1945 Kinderlandverschickungslager in Bayern, 1946-1949 Bodenreform, Lehre u. FDJ-Ortsleitung in Delitzsch (Sachsen-Anhalt), 1949 Verpflichtungserklärung für Volkspolizei].

-, -: 1949 - das Jahr meiner Entscheidung. In: Geschichten aus sieben Jahrzehnten. Storkower Zeitzeugen berichten. Hrsg. vom Seniorenbeirat der Stadt Storkow (Mark). Storkow 2005, S. 55-57. [Wie vor; nach abgeschlossener Landmaschinenenschlosserlehre 1949 SED-Eintritt u. Verpflichtung zu dreijährigem Dienst in der Volkspolizei, Meldung in Weißenfels].

Martin, Lotte / Bitter (geb. Kopp), Margot: Unser Treck aus Salzdorf - Stationen einer Flucht. In: Der Kreis Schubin. Geschichte, Erinnerungen, Skizzen. Hrsg. vom Heimatkreis Schubin - Altburgund e. V. Bergen 1990, S. 135. [Während der Flucht vorgenommene kurze kalendarische Notizen, im März 1945 aufgezeichnet: Treck aus Salzdorf, Kr. Schubin (Wartheland) ab 20.1.1945 durch die Neumark, über die Oderbrücke in Schwedt nach Dobberzin (Kr. Angermünde) (2 Übernachtungen 30.1. bis 1.2.), Hindenberg bei Gransee (Kr. Ruppin) (Übernachtung im Saal 2.2., dann Aufteilung auf Bauernhöfe, 8.2. jedoch Weiterfahrt nach Schweinrich (Kr. Ostprignitz) u. bis 16.2. über Wittstock, Pritzwalk, Kuhbier (Kr. Ostprignitz), Perleberg, Sükow u. Nausdorf (beide Kr. Westprignitz) u. Lenzen/Elbe, Dömitz/Elbe bis Bergen, Kr. Celle].

Mertens, Sonja, geb. Prestel: [Interview]. In: Gespräche mit ehemaligen Küstrinern. Aufgez. u. bearb. von Siegfried Neubauer. Bd. 5. Frankfurt (Oder) 2013, S. 31-70. [Geb. 1932, Tochter eines Reichsbankbeamten, 31.1.1945 Flucht mit Familie aus Heimatort Küstrin in Lkw nach Manschnow, dann weiter nach Berlin mit Berliner Doppeldeckerbus (zurückkehrender Verwundetentransporter), später Sekretärin in Hennigsdorf (Eisenforschungsinstitut) u. Falkensee (Transformatorenwerk, dann Sonderschule); Heirat (1 Tochter); 1946 u. 1972 Besuche in Küstrin; Interview mit ihr u. ihrer Tochter 2006 in Berlin geführt (lebt in Altersheim in Berlin-Lichtenberg). S. 70: „Die Vertreibung wurde totgeschwiegen, wir durften darüber nicht sprechen. Wir hatten auch keine Möglichkeit, eine Verbindung zu finden zu anderen Küstrinern. Diese Kontakte sind alle erst nach der Wende entstanden. Erst da hatte man gemerkt, wie man vielfach dicht mit Küstrinern beisammen wohnte, ohne voneinander zu wissen. Es ist jetzt ein besonders wohltuendes Gefühl, wenn man über die Kriegserlebnisse offen sprechen kann - auch mit anderen Menschen, die nicht zur eigenen Familie gehören."]. 
Mierzwa, Rudolf: Als Spätaussiedler nach Guben. In: Jahrbuch für Gubener Geschichte 1 (2011/12), S. 209-214. [1974 als Kind aus Bobrek, Oberschlesien, als Spätaussiedler nach Guben gekommen, erfährt Ablehnung als Pole und "Pollacke"; thematisiert offizielle Tabuisierung des Themas in der DDR.]

Mietz, Alfred: [Lebenslauf]. In: Müncheberger Lebensläufe. Hrsg. Verein für Heimatgeschichte der Stadt Müncheberg e. V.T. 2. Müncheberg 2008, S. 28-33. [Geb. 1926 Dobersaul (Kr. Crossen), Vater dann Bauer in Kutzdorf bei Küstrin, ältestes von sechs Geschwistern, vertritt den Vater, als dieser Soldat wird, dann selbst RAD u. Soldat, amerikan. Gefangenschaft in Frankreich bis 1948, 1948 Entlassung zu den Eltern nach Bienenwerder bei Müncheberg, wo der Vater inzwischen eine von drei Neubauernstellen übernommen hatte („Trotzdem glaubten sie in der ersten Zeit, zurück in die Heimat in den Kreis Königsberg in der Neumark kommen zu können."); 1953 Heirat, 3 Kinder, er führt de facto den Hof (Vater Invalide), 1957 Land an neu gegründete LPG in Müncheberg übergeben, Übersiedlung nach dort; beschreibt dann ausführlich sein weiteres Leben als LPG-Mitglied bis 1990 (daneben u. a. Brigadier der Harzer im Forst)].

Mildner, Erika: Kindheit endete im Bombenhagel. Erinnerung an die vielen Toten von Swinemünde. In: Brandenburger Rundschau 12 (2014) 2, S. 10. [Geb. 1929 Swinemünde, als 15-Jährige Zeugin des Bombenangriffs im März 1945, 2014 Fahrt aus ihrem Wohnort Spremberg zur Gedenkfeier auf dem Golm (Usedom)].

Modrau, Marianne: Erlebnisse in Lanken. Zsgest. von Karl-Heinz Graff. In: Vor 50 Jahren. Als Flucht und Vertreibung im Kreis Züllichau-Schwiebus begannen. Auszüge aus Tagebüchern, Briefen und Aufzeichnungen. Im Auftr. des Heimatkreises zsgest. von Lothar Meißner. O. O. 1995, S. 27-32. [Hofbesitzerstochter, Erlebnisse 25.1. bis 10.4.1945 in Lanken u. Umgebung, dann Lagerhaft in Posen, 30.10.1945 Entlassung u. Bahnfahrt bis Schwiebus, Rückkehr in Heimatdorf, Ausweisung, 2.11.1945 Ankunft in Frankfurt (Oder), sogleich Weitertransport nach Berlin (Flüchtlingslager) und am selben Tag nach Neuruppin, 9.11.1945 Eintreffen bei der Familie].

Müller, Helga: Tagebuch [Auszüge]. In: Heinz Materne / Hans Gerlach: Gross-Gandern und Klein-Gandern. Heimat im Sternberger Land. Wittingen/Bremen 1997, S. 97. [2.2.1945 bis 13.1.1947 (Flucht, Vertreibung u. Verschleppung aus Groß Gandern (Kr. Weststernberg) über Lageraufenthalt in Russland u. Entlassung über Frankfurt (Oder) u. Berlin bis nach Hohenofen bei Neustadt (Dosse)].

Müller, Hubert: [Lebenslauf]. In: Müncheberger Lebensläufe. Hrsg. Verein für Heimatgeschichte der Stadt Müncheberg e. V. T. 2. Müncheberg 2008, S. 34-42. [Geb. 1935 Eichenau (Dembowitz) bei Allenstein (Ostpreußen), zweites von sechs Kindern eines Bauern (Familie evang. "christlich geprägt"), 28.11.1944 Evakuierung der "Kinderreichen“, kommt mit Mutter per Bahn nach einwöchiger Fahrt nach Dramburg (Pommern) (Vater beim Volkssturm in Ostpreußen geblieben), von dort Jan. 1945 Flucht zu Verwandten nach Langenstein bei Halberstadt (Ankunft 19.1.), Aug. 1945 Rückkehr des Vaters aus sowjet. Gefangenschaft, 1946 eigene Wohnung, 1949 Konfirmation, Schule bis 8. Klasse, dann Tischlerlehre in Halberstadt, 1952 Geselle, 1954-1956 Diakonschüler an den Neinstedter Anstalten bei Thale/Harz, 1956 Wechsel auf das Kirchliche Oberseminar in Potsdam-Hermannswerder (1960 Abitur), 1960-1965 Studium der evang. Theologie an der Univ. Greifswald, 1966-1967 Predigerseminar in Brandenburg/H., 1967 Heirat in Grünheide (Pfarrerstochter) u. Ordination in Magdeburg, 1967-1974 Pfarrer in Sommersdorf u. Sommerschenburg bei Marienborn (Kr. Oschersleben), 1974-1998 desgl. in Müncheberg].

Müllers, Renate: [Letzte Tage in der Heimat und Ereignisse der Flucht]. In: Heinz Materne / Hans Gerlach: Gross-Gandern und Klein-Gandern. Heimat im Sternberger Land. Wittingen/Bremen 1997, S. 97. [Geb. ca. 1925, aus Groß Gandern (Kr. Weststernberg), 29.1.1945 Flucht über Frankfurt (Oder) nach Schleswig-Holstein].

Nenast, Gertrud (geb. Will): Die Flucht im Jahre 1945/46 aus dem Landkreis Eichenbrück aus der Sicht meiner Mutter. In: Heimatbuch für den Kreis Eichenbrück-Wongrowitz. Bd. 4. Wendisch Evern 1993, S. 116-141. [Landwirtstocher aus Liebenau, 20. Jan. 1945 Flucht über Netzekreis und Neumark: Hochzeit, Woldenberg, Arnswalde (mit dem Ziel Oderübergang bei Schwedt), Regenthin, Granow, Berlinchen, 29. Jan. in Chursdorf von der Roten Armee eingeholt, versuchte Rückfahrt in Richtung 
Heimatort, Aufenthalte in Rogasen, Friedeberg/Nm. (Schanzeinsatz), Driesen, Brenkenhofswalde, von hier Vertreibung am 26. Juni, Marsch über Landsberg/W. nach Vietz, Oderübergang über Notbrücke bei Frankfurt (Oder) mit Ziel Schwanebeck und Potsdam, sechstägiger Marsch über Wriezen, Bad Freienwalde, Eberswalde und Bernau, 6. Juli Ankunft in Schwanebeck bei der Nichte der Mutter der Verfasserin, dort Arbeit auf dem Hof der Kusine, vorübergehend in Potsdam bei Vetter, Nov. Übersiedlung nach Thale/Harz zum Bruder, Mai 1946 Grenzübertritt nach Westen, Lager Friedland, dann wohnhaft u. Familiengründung in Westfalen].

Neumann, Christel (geb. Ziegler) / Neumann, Franz: [Lebensläufe]. In: Müncheberger Lebensläufe. Hrsg. Verein für Heimatgeschichte der Stadt Müncheberg e. V. T. 2. Müncheberg 2008, S. 43-50. [Ehepaar: Sie geb. 1930 Altkarbe (Kr. Friedberg/Nm.), ältestes von vier Kindern eines Buchdruckers, 1944/45 Freistelle an Lehrerbildungsanstalt, Ausbildung beendet, „weil meine Familie infolge der Kriegsereignisse nach Jeserig ins Brandenburgische zog. Vater pachtete dort eine Landwirtschaftsstelle" (S. 43); FDJ-Mitglied, Lehrerseminar Ludwigsfelde, 1950 Praktikum in Müncheberg, lernt hier ihren Mann kennen, dann bis 1990 Lehrerin ebd. (ausführlich). - Er geb. 1930 Süßenberg (Kr. Heilsberg, Ostpreußen), Bauernsohn aus alteingesessener Familie, ältestes von acht Kindern, Gymnasium Allenstein bis 18.1.1945, 2.2.1945 Einmarsch der Roten Armee, Vater (Volkssturmangehöriger) wird verschleppt (seitdem vermisst), er selbst in mehreren Lagern in Ostpreußen (Heilsberg, Bartenstein, Preußisch Eylau), dann bis 1948 bei Katharinenschwestern in Königsberg i. Pr., dann mit Gefangenentransport in die SBZ: zur Mutter nach Selbelang bei Nauen, dort Gespannführer auf dem VEG. „Zur Polizei und zur Wismut wollte ich nicht, da warnte man mich davor. So bewarb ich mich als Lehrer und wurde angenommen." (S. 45), Lehrerseminar Ludwigsfelde u. Cottbus, 1951-1990 Lehrer in Müncheberg (ausführlich), GST-Mitglied, kein Parteieintritt].

Nikoley, Horst: [Lebenslauf]. In: Müncheberger Lebensläufe. Hrsg. Verein für Heimatgeschichte der Stadt Müncheberg e. V.T. 2. Müncheberg 2008, S. 51-56. [Geb. 1930 Gramsdorf (Kr. Obornik), Vater Landwirt (ab 17.1.1945 im Volkssturm, vermisst), 21.1.1945 Zwangsevakuierung nach Westen in Richtung Ritschenwalde („um die minus 25 Grad“, S. 51), Flucht vor Roter Armee mit Pferdetreck bis an die Oder bei Küstrin, dann durch das Oderbruch u. bis Berlin-Weißensee (2./3.2.1945), dann Hohen Neuendorf, wo Bürgermeister Quartier u. Lebensmittelkarten verschafft („noch fünf oder sechs Pferdefuhrwerke", ebd.), weiter nach Mecklenburg bis mai 1945, dann gemeinsam mit Treck aus Trebnitz (Kr. Lebus) Rückmarsch bis Trebnitz, Unterkunft im dortigen „Schloss“. „Die Bodenreform symbolisierte für uns den Neuanfang in Trebnitz." (S. 52). 1955 Heirat, er dann ebd. Landwirt (später Facharbeiter für Schweinezucht), ab 1960 in LPG (ausführlich, auch zu MAS, MTS), daneben ab 1948 in der Freiwilligen Feuerwehr aktiv, später Autor einer Trebnitzer Dorfchronik].

Nitschke, Max: Erlebnisse in Züllichau. In: Vor 50 Jahren. Als Flucht und Vertreibung im Kreis Züllichau-Schwiebus begannen. Auszüge aus Tagebüchern, Briefen und Aufzeichnungen. Im Auftr. des Heimatkreises zsgest. von Lothar Meißner. O. O. 1995, S. 22-23. [Kaufmann in Züllichau, Erlebnisse 29.1. bis 4.7.1945, dann Ausweisungsbefehl, Bahntransport nach Cottbus, von dort Briefbericht an seine Familie].

Noack, Elvira (geb. Buchholz): Vom schweren Anfang in der sowjetischen Zone. In: Jahrbuch der Deutschen aus Bessarabien 47 (1996), S. 71-75. [Als Kind mit den Eltern aus Bessarabien in den „Warthegau" umgesiedelt, Jan. 1945 gemeinsame Flucht nach „P." (Westprignitz, Ortsname nicht ausgeschrieben!), Unterkunft bei Bauern im Kreis mehrerer bessarabiendeutscher Familien, 1. April 1946 Umzug in (nicht namentlich genanntes) Nachbardorf, dort Wohnung im Gutshaus, 1950 Hausbau, Vater Neubauer, LPGEintritt].

Noack, Jürgen: Wie ich in Fürstenberg (Oder) eine neue Heimat fand. In: Heimatkalender Eisenhüttenstadt und Umgebung 23 (2005), S. 198-206. [Geb. 1937, Schiffersohn aus Pollenzig, Kr. Crossen; Familie am 20.6.1945 von dort vertrieben].

Normann, Käthe von: Ein Tagebuch aus Pommern 1945-1946. 5. Aufl. München 1984. 
Olschowsky, Heinrich: Als Deutscher in Polen - als „Spätaussiedler“ in der DDR. In: „Wach auf, mein Herz, und denke“. Zur Geschichte der Beziehungen zwischen Schlesien und Berlin-Brandenburg von 1740 bis heute. Hrsg.: Gesellschaft für interregionalen Kulturaustausch e. V., Berlin, u. Verein Schlesisches Institut, Oppeln. Berlin/Opole 1995, S. 534-531. [Geb. 1939 Nakel (Kr. Oppeln), Sohn eines 1956 tödlich verunglückten Lehrers, 1958 mit der Mutter aus Oppeln nach Weimar ausgesiedelt, bis 1965 Studium der Slawistik u. Germanistik in Greifswald u. Berlin (Ost), wiss. Mitarbeiter an der Akademie der Wiss. der DDR in Berlin (Ost), 1979 Habilitation, 1988-1995 Prof. für Polonistik an der HumboldtUniversität zu Berlin].

Otto, Gerhard: Deutsch-polnische Kontakte und Beziehungen entlang der Oder. In: Königsberger Kreiskalender 1996 (1995), S. 41-44. [Verf. stammt aus Niederkränig (Kr. Königsberg/Nm.), lebt in Angermünde, beschreibt Reisen nach Polen 1966 (Stettin und Niederkränig) sowie häufiger ab 1973 (Oderübergang Schwedt-Niederkränig), private Kontakte mit zwei polnischen Familien und gegenseitige Besuche, später auch in den Heimatort der Ehefrau (Greifenhagen, Pommern), auch nach 1989].

Paech, Wolfgang: Geschehnisse ab Januar 1945. In: Heimatblatt der ehemaligen Kirchengemeinden Landsberg/Warthe Stadt und Land 51 (2015), S. 56-58. [Aus Jahnsfelde (Kr. Landsberg/W.), als Kind (wohl Juni?) 1945 mit Mutter u. Brüdern vertrieben, über Küstrin u. Berlin nach Kyritz zu einem Onkel; auf Betreiben des in britischer Gefangensachft befindlichen Vaters Genehmigung zur Übersiedlung in die Britische Zone].

Palm, Wolfgang: Ein mit der Stadt Königsberg/Nm. verknüpftes Arnswalder Vertriebenenschicksal (1945 bis 1947). In: Königsberger Kreiskalender 1995 (1994), S. 97-100. [Ausführlich kommentierter Abdruck eines brieflichen Erlebnisberichtes von Ursel Werk (geb. ca. 1929), Königsberg/Nm., 29.12.1946, an ihren älteren Bruder: 4.2.1945 Flucht (Gutstreck) mit der Mutter aus Stolzenfelde Kr. Arnswalde in den Raum Rostock, 3.5.1945 Rückkehr des Trecks in den Kreis Arnswalde, 17.5.1945 Ankunft in Arnswalde, 9.7.1945 Vertreibung aus Stolzenfelde (Fußmarsch in Richtung Oder), mit ausgewählten anderen Flüchtlingen dann aber durch Polen nach Königsberg/Nm. zum Arbeitseinsatz gezwungen und dort von Sowjetarmee bis Anfang 1947 festgehalten].

Parchert, Heinz: Die Nacht der Erinnerungen. In: Die Uckermark 1945. T. 2. 2. Aufl. Prenzlau 1995, S. 33-39. [Ehefrau aus Dorf in Hinterpommern, im März 1945 nach Prenzlau gekommen, heiratet Prenzlauer; „eigene Erlebnisse, die literarisch umgearbeitet wurden“.]

Peikert, Paul: „Festung Breslau“ in den Berichten eines Pfarrers. 22. Januar bis 6. Mai 1945. Hrsg. von Karol Jonca u. Alfred Konieczny. 3. Aufl. Berlin [Ost] 1970. [Geb. 1884 Langendorf, Kr. Neisse, gest. 1949 Bredenborn, Kr. Höxter, 1932-1945 kath. Pfarrer an St. Mauritius in Breslau].

Pekrul, Richard: Elternlos, aber Dank dem Schicksal gut betreut. Aus der Lebensgeschichte von Paul Pekrul. In: Brandenburger Rundschau 9 (2011) 8, S. 19. [Geb. 1942 Beberen, Kr. Leipe (Gau DanzigWestpreußen; poln. Bobrowniki), Vater im Krieg vermisst, Mutter bei der Geburt verstorben, vor Kriegsende 1945 Flucht mit Großeltern nach Berlin, Einweisung in Unterkunft nach Groß Pankow (Kr. Ostprignitz) (Dachboden des ehem. Guts-Wirtschaftsgebäudes), dann im Kinderheim in Bärensprung (Kr. Ostprignitz), ab 1950 im Kinderdorf Kyritz, später Dreher im Motorradwerk Zschopau].

Pfeiffer, Günter Wilhelm: Von Stoberau, meinem Heimatort, in die Fremde. Erinnerungen. In: Brandenburger Rundschau 13 (2015) 2, S. 16-17. [Geb. 1926 Stoberau (Kr. Brieg/Schlesien); hier: Ankunft als Kriegsheimkehrer in Frankfurt/Oder 10.12.1947, Erstversorgung u. Weiterleitung über Cottbus nach Pirna (Sachsen)]; 13 (2015) 3, S. 16-17. [ab 1947 Arbeiter im Rohrleitungsbau in Dresden, Schwarzheide-Ost u. ab 1951 in Brandenburg/Havel, Familiengründung in Bahnitz (Havelland) mit Einheimischer]; 13 (2015) 4, S. 16-17 [Arbeits- u. Familienleben: 1954-1956 Heizungsbauer in Premnitz, dann Meisterschule in Potsdam, 1958 Meisterprüfung, ab 1958 selbständiger Handwerker in Bahnitz, 1995 Gründung einer eigenen Heizungs- und Sanitärbau-Firma]; 13 (2015) 5, S. 16-17; 6, S. 17 [Leben als Rentner u. (ab 1990) Hausbesitzer in Rathenow]. 
Pfeiffer, Werner: Abgeholt. Chronik einer geraubten Jugend. Gütersloh 2000. [geb. 1929 Werro (Estland), 1941 Umsiedlung nach Schroda (Wartheland), 1945 Flucht nach Pommern, dort durch die Rote Armee von der Familie getrennt und zur Zwangsarbeit nach Russland verschleppt, Jan. 1946 nach Dahme (Mark) entlassen (hier setzt das Buch ein), wohin Mutter u. Schwester im Sommer 1945 als Vertriebene gelangt waren; als Schüler in Dahme 1947 vom NKWD verhaftet und in versch. Lager verbracht, 1954 aus Zuchthaus Waldheim entlassen, Flucht über West-Berlin in den Westen].

Pflaum, Herbert: Meine Kindheit in Boberhöh. Flucht und Vertreibung im Jahr 1945. [Privatdruck]. Eichwalde bei Berlin 2014. [Geb. 1937 Boberhöh (bis 1937 Deutsch Sagar), Kr. Crossen, Bauernsohn, 16.2.1945 Flucht mit Wehrmachts-Lkw nach Cottbus (Bahnhof), 17.2. Weiterfahrt per Wehrmachts-Lkw nach Vetschau, von dort per Bahn nach Berlin, Anhalter Bahnhof, warme Mahlzeit im "Haus Vaterland" erhalten, vom dortigen Aufnahmebüro für Flüchtlinge nach Kleinmachnow verwiesen, dort 19.2. Anmeldung im Aufnahmebüro der NSV für Flüchtlinge in der Eigenherd-Schule, 18.2. Wohnungseinweisung, 19.3. Weiterfahrt per Bahn nach Senftenberg (Unterkunft in Gasthof), 20.-23.4. Aufenthalt in Mückenberg, 26./27.4. wieder in Senftenberg, von hier aus 28.4. Rückmarsch (103 km) mit Handwagen in den Heimatort Boberhöh über Drebkau, Cottbus u. Guben, 30.4. bis 24.6. Aufenthalt in Boberhöh, 24.6. Vertreibung (Treck, ca. 400 Personen), Neißeübergang über provisorische Holzbrücke bei Guben, 25.-27.6. Übernachtung in Kiesgrube bei Reichenbach, Marsch in Richtung Lübben, 28./29.6. Übernachtung in Baracken des leerstehenden vormaligen KZ-Lagers Jamlitz, 1.7. Ankunft in vorläufigem Ziel Leeskow bei Bekannten, 9.-12.7. Weitermarsch über Zinnitz, Uckro u. Rosenthal nach Dahme/Mark, Unterkunft bei einem Großbauern in möbliertem Zimmer, kein Lageraufenthalt, ab 3.9. Schulbesuch in Dahme, Eltern übernehmen 1948 Siedlerstelle auf Bodenreformland in Niebendorf (1955 zurückgegeben), 21.3.1949 Übersiedlung nach dort, Verf. besucht dann Oberschule in Dahme bis zum Abitur, anschließend Studium an der Humboldt-Universität zu Berlin, Diplom-Mathematiker, lernt in Niebendorf seine spätere Frau kennen].

Plath, Lothar: Erinnerungen an das Kriegsende und die Nachkriegsjahre in Havelberg. In: Kriegsende und Nachkriegszeit in Havelberg [I]. Hrsg.: Heimatverein Havelberg e. V. (Havelberger Regionalgeschichtliche Beiträge, Bd. 1). Havelberg 1992, S. 37-84. [Geb. ca. 1939, erlebt das Kriegsende, aus einem Vorort von Stettin geflüchtet, als Kind mit der Mutter bei deren Mutter in Havelberg, Havelstraße; Zeitraum der Erinnerungen: etwa 1944 bis 1949].

Pöhl, Gustav [Erlebnisbericht]. In: Heinz W. Linke / Heinz Paschke: Das Sternberger Land im Wandel der Zeiten. Iserlohn 1988, S. 627-631. [Bürgermeister in Aurith (Kr. Weststernberg), Erlebnisse vom 24.12.1944 bis zur Vertreibung am 22.6.1945: Marsch über Kunitz, Reipzig, Schwetig zum Oder-Übergang nach Frankfurt (Oder)].

[Pohland, Gertrud:] Aus den Lebenserinnerungen von Gertrud Pohland. Zsgest. von Herbert Stertz. In: Kriegsende und Nachkriegszeit in Havelberg [II]. Hrsg.: Heimatverein Havelberg e. V. (Havelberger Regionalgeschichtliche Beiträge, Bd. 2). Havelberg 1994, S. 28-32. [1945-1949; Ehefrau eines Schiffers aus der Niederlausitz, 31.1.1945 Flucht über Fürstenberg (Oder) zu in Ketzin liegendem Kahn, Weiterfahrt mit Kahn nach Havelberg, Kriegsende auf der Elbe bei Räbel].

Posseldt, Gabriele: Unsere Besuche in Schwiebus. In: Was nicht vergessen werden sollte. [19. Anthologie]. Hrsg.: Seniorenbeirat in der Landeshauptstadt Potsdam u. a. Potsdam 2017, S. 89-91. [Reisen in die Heimatstadt des Ehemannes Klaus P., Schwiebus, 2002 u. 2009].

Preuß, Karl-Heinz: Die Gedanken sind frei. Lebensgeschichte eines Vertriebenen. Privatdruck o. O. [ca. 2009]. [Geb. 1932 Driesen/Neumark, Eltern aus der Provinz Posen stammend, Vater Reichsbahnarbeiter, 28.6.1945 Ausweisung; Fußmarsch bis nach Fürstenwalde zum Bruder der Mutter; Ende Juli Wechsel nach Berlin-Neukölln, Aug. 1945 nach Penkun, Malerlehre, dann Ausbildung bei der Volkspolizei, 1952 Dienstentlassung wegen verheimlichter Westverwandtschaft, anschließend Traktoristenausbildung in Palmnicken bei Füstenwalde, eingesetzt in Dörfern um Golßen, nach Lehrgängen Verwaltungsangestellter (Dispatcher) in einer MTS im Kr. Pasewalk, 1955 Heirat mit einer 1948 kennengelernten Vertriebenen aus dem Kr. Me- 
seritz, 1957 eigene Wohnung, bis 1971 versch. leitende Tätigkeiten in Pasewalk, u. a. beim Kreislandwirtschaftsrat, dann beim VEB Getreidewirtschaft in Bernau; S. 225-236: „Fahrt in die Heimat“ (ab 1968)].

Preuß, Ruth: [Lebensgeschichte. Bearbeitung eines mündlichen Berichts von 2002 nach Tonbandaufzeichnung durch H. Voss]. In: Lebensgeschichten Neuruppiner Frauen. Aufgeschrieben von Heli Voss. Norderstedt [2006], S. 84-120. [Geb. 1924 Bomst, Eltern besaßen kleine Landwirtschaft, Vater früh verstorben, wächst mit Stiefvater (Landwirt) auf; Hauswirtschaftslehre, 1941 beim RAD im Spreewald, 1942 Erntekindergartenleiterin im Kr. Züllichau-Schwiebus, Jan. 1945 Einmarsch der Roten Armee, ein Bruder wird erschossen, der andere und der Stiefvater nach Sibirien verschleppt; 27.6.1945 Vertreibung (ca. vierwöchiger Treck mit ca. 400 Personen bis Frankfurt/Oder), 31.7.1945 Ankunft im vorgesehenen Zielort Neuruppin, Einweisung auf Bauernhof in Seehof bei Wuthenow (Kr. Ruppin), später Säuglingsschwester und 1960-1974 Kindergartenleiterin in Neuruppin, dann Rentnerin; Kirchenmitglied, parteilos; 1991-2002 tätig im BdV-Kreisverband Neuruppin, organisiert Busreisen in die Heimat (Landsberg/W., Kr. Züllichau-Schwiebus u. a.), 2005 Ehrenbürgerin von Babimost/Bomst; schildert Lebensweg bis zur Gegenwart.].

Prochnow, Ernst: [Tagebuchauszüge]. In: „Die Russen sind da“. Kriegsalltag und Neubeginn 1945 in Tagebüchern aus Brandenburg. Peter Böthig u. Peter Walther (Hg). 2., durchges. Aufl. Berlin 2011. [Geb. 1887, Hotelbesitzer in Woldenberg/Nm., Anf. Juli 1945 vertrieben, Treckführer, gelangt über Zwischenhalte in Uckermark und Prignitz nach Mecklenburg].

Quast, Dora (geb. Praetsch): Das Hospital von Zielenzig von Februar bis September 1945 [Erlebnisbericht]. In: Heinz W. Linke / Heinz Paschke: Das Sternberger Land im Wandel der Zeiten. Iserlohn 1988, S. 599-596. [Krankenschwester, Sept. 1945 Vertreibung aus Zielenzig; Bahntransport über Reppen und Frankfurt (Oder) nach Berlin].

Regieli, Marta / Schurig, Leander: Endgültige Abreise ins Ungewisse. Über Flucht und Vertreibung und das Finden einer neuen Heimat. In: Stog - Der Schober 2018 (2017), S. 35-41. [Flucht des Landwirts Otto Schulze mit Familie aus Kriebau, Kr. Sorau, 1945, kurz vor Forst/L. von sowjet. Kommandanten zurückgeschickt, 23.6.1945 Vertreibung durch poln. Kommandanten, Einquartierung bei einem Bauern in Groß Machnow (Kr. Teltow) (S. 37: „Der Empfang in der Gastfamilie war sehr freundlich."); Herbst 1945 Übersiedlung nach Burg im Spreewald, weil sich dort „schon zehn Familien aus Kriebau (...) angesiedelt hatten" (ebd.), Tochter Erika Schulze übernimmt 1951 Bauernhof einer Kinderlosen in Müschen (Kr. Cottbus); Ehemann der Enkelin (L. Schurig) beschreibt gemeinsam mit der in Cottbus lebenden Urenkelin des aus Ostgalizien in das Schulzesche Haus in Kriebau gezogenen Michat Stojanowski (M. Regieli) die beiderseitigen Familiengeschichten u. die schon 1964 entstandenen freundschaftlichen Kontakte u. Besuche zwischen O. Schulze u.M. Stojanowski sowie zwischen den Nachfahren bis zur Gegenwart].

Reichert, Werner: Von der Neumark in die Prignitz. Lebenserinnerungen. In: Brandenburger Rundschau 11 (2013) 5, S. 18-19; 6, S. 18-19; 7, S. 19; 8, S. 18-19; 9, S. 18-19. [Geb. 1932 Wilkersdorf bei Küstrin (Kr. Königsberg/Nm.), Bauernsohn, 9.2.1945 Vertreibung aus Wilkersdorf nach Osten, zahlreiche Stationen in der Neumark, 6.5.1945 Rückkehr in den Heimatort, 20.6.1945 endgültige "wilde" Vertreibung, Flucht über Küstrin, Gorgast, Strausberg, Fangschleuse, Treuenbrietzen, Niemegk (2.7.1945), E. Juli bis Anf. Okt. Einweisung in Unterkunft bei einem Bauern in Preußnitz, ab Okt. 1945 auf Gut Schmerwitz, Schulbesuch u. (1947) Konfirmation in Schlamau, 1948-1949 Landarbeiter auf auf Gut Schmerwitz, 1949-1950 landwirtschaftliche Lehre ebd., 1950-1951 Landwirtschaftliche Schule in Calau, 1951-1953 Wirtschaftsgehilfe auf Gut Schmerwitz, 1953-1958 Wirtschaftsleiter ebd.; 1958-1963 Betriebsleiter auf Gut Seifersdorf bei Radeberg/Sachsen, 1963-1965 desgleichen auf Gut Schmerwitz, 1965-1990 Direktor des VEG Kantow (Kr. Kyritz), 1990-1996 weiterhin Verwalter auf diesem Gut bis zum Ruhestand; nach 1990 aktives Mitglied des BdV-Kreisverbandes Kyritz].

Reimnitz, Gisela: Jahre der Herausforderung. Lebenserinnerungen einer Gutsfrau. Mit einer Vorbem. von Michael Matthias Schardt. Paderborn 1991. 2. Aufl. 1992. [Geb. 1910, tagebuchartige Aufzeichnungen 1944-1945 u. Nachtrag 1952/61; 14.2. bis 6.3.1945 als Gutsfrau Treck von Reichersdorf (Kr. 
Guben) über Lübben, Jüterbog, Belzig, Genthin nach Rochau/Altmark, 1952 Flucht über West-Berlin nach Detmold].

Remenyi, Friedel (geb. Berndt): Geschichte eines Gutes in der Neumark. Kassel 2007 (Erzählen ist Erinnern, Bd. 69). [Geb. 1931, Landwirtstocher, Enkelin des Gutsbesitzers in Kemnath (Kr. Oststernberg), von dort Flucht 31.1.1945 über Frankfurt (Oder) nach Berlin, März 1945 per Bahn weiter nach Hitzacker (Niedersachsen); Kontakte von Mutter und Großmutter zu Kemnathern in der DDR (Brandenburg), mit Abdruck von entsprechenden Briefwechseln].

Rhinow, Hans-Ulrich: 1945: Ein dankbarer Rückblick auf meine kriegsbedingten Fluchtwege von Reppen nach Falkensee. In: Heimatjahrbuch für Falkensee und Umgebung 2015 (2014), S. 51-54. [Geb. 1932 Reppen, 1945 Schüler des Realgymnasium Frankfurt (Oder), wohnhaft in Reppen, 1.2.1945 Flucht mit Mutter aus Reppen per Bahn nach Frankfurt (Oder) und weiter nach Berlin, dort eingetroffen am 2.2.1945, zunächst bei Bekannten privat untergekommen, dann als inzwischen bombengeschädigte Flüchtlinge in eine verlassene Wohnung eingewiesen, 21.3.1945 Umzug in ein Zimmer in Falkensee-Finkenkrug, da in Falkensee viele Reppener untergekommen waren].

-, -: Meine Erlebnisse zum Kriegsende in Falkensee (April/Mai 1945). In: ebd., S. 55-60. [Autor wie vor].

Richter, Margarete: Der schöne Sirup. In: Lebenszeit. T. IV. Zeitzeugen berichten. Hrsg. vom Seniorenbeirat der Gemeinde Neuenhagen bei Berlin. Neuenhagen [1998], S. 9-13. [Geb. ca. 1935, aus Schlesien, lebt 1947 in Welzow; „Hamsterfahrt“ ins Oderbruch 1947].

Rieger, Christian: Erinnerungen an Weißack. Red., Bearb. des Textes u. Anm.: Lothar Treder-Schmidt. In: Luckauer Heimatkalender 49 (2017), S. 79-82. [Als Kind mit drei Brüdern, Mutter und Großmutter „durch die Auswirkumngen der Oder-Neiße-Grenzziehung nach Luckau gekommen, wo wir in der Bahnhofstraße 6 wohnten"; beschreibt seine durch seinen in der gerade gegründeten FDJ tätigen älteren Bruder Helmut ermöglichte Teilnahme an einem dreiwöchigen Ferienlager in Weißack während der Schulferien im Sommer 1946 (Unterkunft „in der ehemaligen Dorfkneipe")].

Rieger, Helmut: Licht und Brot in Luckau. In: Luckauer Heimatkalender 32 (2000), S. 18-21. [Aus Christianstadt/Bober, von dort am 24. Juni 1945 als Kind mit drei Geschwistern, Mutter und Großmutter sowie ehem. Haushälterin vertrieben, per Treck mit weiteren Christianstädter Bewohnern am 26. Juni in Forst (Lausitz) angekommen, am nächsten Tag Lkw-Transport mit 13 Christianstädtern nach Luckau, dort Wohnungseinweisung mehrerer Familien bei Einheimischen durch sowjet. Kommandantur, erste Schritte am neuen Wohnort (ungewohnt fettes Essen mit anschließenden Verdauungsproblemen; Brotkauf trotz fehlender Lebensmittelkarte); Mutter 1947 Mitarbeiterin des Amtsgerichts Luckau].

Risch, Theodor: Als Pfarrer im Netzebruch 1912-45. In: Erinnerungen an Stadt + Land Friedeberg Nm. Hrsg. von E(rhard) Schendel u. Hans Schauer. Berlin 1974, S. 263-277. [Geb. 1892, 1912-1919 evang. Pfarrer in Gottschimm, 1919-1945 in Gottschimmerbruch, beide Kr. Friedeberg/Nm., 1945 Vertreibung, anschließend 13 Jahre Pfarrer in Welsickendorf, Kr. Jüterbog-Luckenwalde, lebte zuletzt in Berlin-Spandau; beschreibt überwiegend Erlebnisse bis 1945].

Rölke, Hildegard: Wie ich das Jahr 1945 erlebte. In: Storkower Zeitzeugen berichten. Hrsg. vom Seniorenbeirat des Amtes Storkow. Storkow 1999, S. 27-30. - Auch in: Zeitzeugen berichten. Hrsg. vom Landesseniorenbeirat Brandenburg. O. O. [1999?], S. 52-53. - Wiederabdr. in: Brücken bauen / budowa mostów. Hrsg.: Seniorenbeirat Storkow (Mark) / Seniorenorganisation Opalenica. Storkow (Mark)/Opalenica 2005, S. 44-46. [Geb. 1929 Ostpreußen, Bauerntochter, August 1944 Evakuierung nach Pommern, Januar 1945 Rückkehr zur Familie nach Ostpreußen u. erneute Flucht nach Hinterpommern, Januar 1946 Vertreibung (aus Schleps bei Kolberg), 6.3.1946 Ankunft in Behrensdorf Siedlung (Kr. Beeskow-Storkow)].

-, -: Der erste Kindergarten. In: Storkower Zeitzeugen berichten. Hrsg. vom Seniorenbeirat des Amtes Storkow. Storkow 1999, S. 64-66. - Auch in: Zeitzeugen berichten. Erinnerungen, Erfahrungen, Er- 
lebnisse, Erkenntnisse. Hrsg. vom Landesseniorenbeirat Brandenburg. O. O. [1999?], S. 65-67. [Wie vor; Arbeit als Kindergärtnerin ab 1947].

-, -: Ein Erlebnis aus dem Hungerjahr 1946. In: Storkower Zeitzeugen berichten. Hrsg. vom Seniorenbeirat des Amtes Storkow. Storkow 1999, S. 68-69. [Wie vor; Hamstern in der Umgebung].

-, -: Eine Reise in die Vergangenheit. In: Storkower Zeitzeugen berichten. Hrsg. vom Seniorenbeirat des Amtes Storkow. Storkow 1999, S. 106-108. Wiederabdr. in: Brücken bauen / budowa mostów. Hrsg.: Seniorenbeirat Storkow (Mark) / Seniorenorganisation Opalenica. Storkow (Mark)/Opalenica 2005, S. 68-70. [Wie vor; Fahrt in ostpreußisches Heimatdorf 1992].

-, -: Eine unvergeßliche Hochzeitsreise. In: Storkower Zeitzeugen berichten 2. Hrsg. vom Seniorenbeirat des Amtes Storkow. Storkow 2001, S. 64-65. [Wie vor].

-, -: Mein 1. Heimattreffen. In: ebd., S. 89-90. [Wie vor].

-, -: Mein besonderes Filmerlebnis. In: ebd., S. 111-112. [Wie vor].

-, -: Kolberg - damals und heute. In: ebd., S. 124-126. - Auch in: Zeitzeugen berichten 2000. Hrsg. vom Seniorenrat des Landes Brandenburg e. V. [Strausberg] o.J., S. 21-24. - Wiederabdr. in. Brücken bauen / budowa mostów. Hrsg.: Seniorenbeirat Storkow (Mark) / Seniorenorganisation Opalenica. Storkow (Mark)/Opalenica 2005, S. 66-68. [Wie vor; Kuraufenthalt 2000 in der Station ihrer Flucht im März 1945].

-, -: Mein Pflichtjahr. In: Damals und heute. Storkower Zeitzeugen berichten. Hrsg. vom Seniorenbeirat des Amtes Storkow. Storkow 2003, S. 52-53. Wiederabdr. in: Brücken bauen / budowa mostów. Hrsg.: Seniorenbeirat Storkow (Mark) / Seniorenorganisation Opalenica. Storkow (Mark)/Opalenica 2005, S. 36-38. [Wie vor; August 1944 Evakuierung nach Pommern, Januar 1945 Rückkehr zur Familie nach Ostpreußen u. erneute Flucht nach Hinterpommern].

-, -: Mein 3. Heimattreffen. In: Damals und heute. Storkower Zeitzeugen berichten. Hrsg. vom Seniorenbeirat des Amtes Storkow. Storkow 2003, S. 145-146. [Wie vor; Treffen von Vertriebenen aus Bergenau/Krzywen (Kr. Treuburg/Marggrabowa), Ostpreußen, im Waldhotel Wandlitz 2002].

-, -: Erinnerungen an den Aufenthalt im Flüchtlingslager Küchensee. In: Geschichten aus sieben Jahrzehnten. Storkower Zeitzeugen berichten. Hrsg. vom Seniorenbeirat der Stadt Storkow (Mark). Storkow 2005, S. 33-34. [Wie vor; Jan. 1945 Vertreibung aus Evakuierungsort in Hinterpommern, Abfahrt vom Bahnhof Schivelbein mit Güterzug, Zwischenaufenthalte in den Flüchtlingslagern Pinnow u. Angermünde, 9.2.1946 Ankunft im Quarantänelager Küchensee bei Storkow, (6.3.1946) Eingemeindung in Behrensdorf Siedlung (Kr. Beeskow-Storkow), ab 1.5. tätig im Kinderheim Behrensdorf].

-, -: Eine unvergessliche Reise. In: Hoffnung und Resignation/Nadzieje i rozczarowania. Alltag im Sozialismus/Dzien powszedni w socializmie. Deutsche und polnische Zeitzeugen berichten. Hrsg.: BRH Storkoe u. a. Storkow/Opalenica 2007, S. 106-108 [Wie vor; Reise nach Ost- und West-Berlin 1951 (III. Weltfestspiele der Jugend].

-, -: Meine Ausbildung 1947/48. In: Gelebte Geschichte. Storkower Zeitzeugen berichten aus 8 Jahrzehnten. Hrsg. vom Seniorenbeirat der Stadt Storkow (Mark). Storkow 2007, S. 52-53. [Wie vor; Lehrgang als Erziehungshelferin in Brandenburg/Havel].

-, -: Eine unvergessliche Reise. In: Gelebte Geschichte. Storkower Zeitzeugen berichten aus 8 Jahrzehnten. Hrsg. vom Seniorenbeirat der Stadt Storkow (Mark). Storkow 2007, S. 119-122. [Wie vor; Reise in die Sowjetunion Okt. 1987].

Rosenbaum, Katja: Hasso Nädtke - Mit 14 im März 1945 in Pritzwalk. [Zusammenfassung nach Interview]. In: Pritzwalker Heimatblätter 16 (2015), S. 30-31. [Hasso Nädtke, geb. 1931 Züllchow (Kr. Randow, 1939 nach Stettin eingemeindet), Schneidermeistersohn, 7.3.1945 Flucht (Vater in französ. Gefangenschaft), Zugfahrt über Neustrelitz u. Wittstock nach Pritzwalk, Unterkunft bei nahen Verwandten; Familie später in Sadenbeck einquartiert, ab Febr. 1946 Schneiderlehre (ab Aug. beim entlassenen Vater), 
Heirat mit einer im Juni 1945 aus der Neumark vertriebenen Pritzwalkerin, er später Schneidermeister in Pritzwalk].

Rosenke, Adoline, geb. Müske: [Lebenslauf]. Aufgeschrieben von Hans-Jürgen Wolf. In: Müncheberger Lebensläufe. Hrsg. Verein für Heimatgeschichte der Stadt Müncheberg e. V. T. 3. Müncheberg 2012, S. 89-96. [Geb. 1920 Adolin (Kr. Nowograd-Wolynsk), Wolhynien (Westukraine), zweites von neun Kindern einer wolhyniendeutschen Kolonistenfamilie (Vater Landwirt, daneben Tischler u. Musiker), bald nach Geburt Umzug nach Kalenovke (Mittelukraine), 1935 Deportation in das Donbass, 1935 Zwangsverheiratung nach dem Willen des Vaters (S. 89: „Ich hatte keine schöne Kindheit und Jugend."), März 1942 Flucht vor der Roten Armee mit Ziel Berlin, zuvor Flüchtlingslager in Polen (hier Juli 1942 Geburt des dritten von sechs Kindern), Ende Dez. 1943 Ankunft in Berlin mit Bahn, per Lkw vom Bahnhof in Kaserne im Grunewald (Flüchtlingslager, Holzbaracken), nach einer Woche Einweisung in Barackenunterkunft auf Villengrundstück in Berlin-Marienfelde mit Gartenland, 1944 viertes Kind, dann wegen der Bombenangriffe Umzug nach Schöneiche, wo der Ehemann bei einem Bauern Arbeit bekommt u. als dessen Dolmetscher für die russ. u. poln. Zwangsarbeiter willkommen ist, April 1945 Einmarsch der Roten Armee, Fußmarsch zur Zwangsarbeit über Küstrin nach Sibirien befohlen, jedoch unterwegs Flucht nach Marienfeld bei Müncheberg, hier "hausten wir" bis Herbst 1945 im Gutshauskeller, dann in der Bodenreform Neubauernstelle erhalten, 1954 Kauf eines Grundstücks in der Müncheberger Siedlung, 1961 zwangsweise in LPG eingetreten (schildert S. 93-95 die vorausgehenden „Werbungen"); ehrenamtliche Arbeit im Gemeindekirchenrat bis Anfang 1970er Jahre, 1980 Rentnerin, 1996 Tod des Mannes].

Schaar, Max: Die Ausweisung aus Sternberg (Neumark) [Erlebnisbericht]. In: Heinz W. Linke / Heinz Paschke: Das Sternberger Land im Wandel der Zeiten. Iserlohn 1988, S. 616-627. [Lehrer, 24.6.1945 Vertreibung aus Sternberg; Fußmarsch (Treck) nach Frankfurt (Oder), Oderübergang über sowjet. HolzBehelfsbrücke; Trennung vom Treck und individuelle Weiterreise nach Berlin zu Angehörigen].

Schatta, Monika: Warum mein Herz für Deutsche und Polen schlägt. In: Das Alte stürzt. Es ändert sich die Zeit und neues Leben blüht aus den Ruinen. Storkower Zeitzeugen berichten aus ihrem Leben. Hrsg. vom Storkower Ortsverband des Brandenburgischen Seniorenverbandes. Storkow 2013, S. 54-83. [Geb. 1940, Melkermeisterochter aus Ostpreußen, gelernte Schneiderin, Fachverkäuferin, Dolmetscherin, Sortimentsrat, Rentnerin in Görsdorf; lebt bei Kriegsende mit Mutter u. Schwester auf dem Bauernhof der Großeltern in Schönwiese bei Allenstein (Vater an der Ostfront, desertiert, kehrt 1945 zurück), Kriegsende, leben unter Polen, erst 1957 Aussiedlung in die DDR (lebenslang enges Verhältnis $z u$ Polen u. der polnischen Sprache) über Grenzbahnhof Frankfurt (Oder) nach Berlin, Berufstätigkeit u. Familiengründung (3 Ehen), Übersiedlung nach Storkow].

Schietke, L. (Frau): Acht Jahre ist es her ... Erinnerungen an die Flucht aus Christianstadt. In: Das Heimatblatt für Sorau N./L.-Stadt und Land 1 (1953), Nr. 12, S. 8. [12.2.1945 Evakuierung (überwiegend Mütter mit Kindern) mit Eisenbahn (Viehwagen) aus Christianstadt über Grünberg/Schlesien, Crossen/ Oder, Guben, Halt u. NSV-Betreung vor Cottbus (Luftangriff), Senftenberg, Doberlug-Kirchhain, hier Ankoppeln an Eisenbahnerzug aus Christianstadt u. Naumburg, Weiterfahrt über Halle/S., Saalfeld/Th. nach Kronach u. Lichtenfels].

Schleusener, Werner: Der große Treck. In: Landsberg an der Warthe 1257 - 1945 - 1976. Stadt und Land im Umbruch der Zeiten. Hrsg. von Hans Beske u. Ernst Handke (Schriftenreihe der Bundesarbeitsgemeinschaft Landsberg (Warthe) Stadt und Land, Bd. 1). Bielefeld 1976 (3., unveränd. Aufl. 1995), S. 221-227. [Brieflicher Bericht eines Treckführers von 1945 über Ereignisse vom 28.1. bis 7.2.1945, Treck aus Merzdorf, Kr. Landsberg/W. 30.1.1945 über Küstrin nach Eberswalde u. weiter nach Magdeburg, eigene Flucht über Berlin nach Klein Wanzleben].

Schlösser, Udo: Unsere Flucht aus Landsberg. In: Heimatblatt der ehemaligen Kirchengemeinden Landsberg/Warthe Stadt und Land 49 (2014), S. 69-70. [Geb. ca. 1930, Sohn eines Berufsberaters beim Arbeitsamt Landsberg/Warthe, 30.1.1945 Flucht mit Eltern, Geschwistern, Großmutter u. Tante per 
Bahn über Küstrin nach Celle zu Verwandten, Ankunft 3.2.1945 (Auffanglager in Gastwirtschaft), 5.2. Wohnungszuweisung].

Schmidt, Lucia: Die Aussiedlung, neues Leben. In: Rüdersdorf. Zeitzeugen berichten. Hrsg. vom Seniorenbeirat Rüdersdorf. Rüdersdorf 1998, S. 17-18. [Geb. 1926, später Sachbearbeiterin/Rentnerin; 1.1.1947 Vertreibung aus Schlesien, 6.1. in Kohlfurt, zwischen Hoyerswerda u. Neuwiese ausgeladen und mit Gepäck auf Handwagen in Quarantänelager, Entlausung. „Viele Umsiedler wurden ohnmächtig vor Schwäche", viele kamen ins Lazarett (,wir wogen 35-40 kg“), erfolglose Unterkunftssuche auf Lausitzer Dörfern, dann Einweisung bei Bauernfamilie mit Polizeischutz, ein Jahr Arbeit bei Bauern, dann Schreibkraft, 1953 Heirat, Tochter geboren, nach Tod des Ehemannes Übersiedlung nach Rüdersdorf zur Familie der Tochter].

Schneider, Gerold: Vergangenheit, die nicht vergehen will. Irrwege deutsch-polnischer Nachbarschaft. Leipzig 1998. 323 S.; 2. Aufl. 1999. 339 S.; 4. Aufl. 2001. 339 S. - E-Book Berlin 2017. [Geb. 1927 Freystadt/Schlesien, gest. 2011), 1969-1987 kath. Pfarrer in Cottbus; Jugenderinnerungen 1945-1946 an die Erlebnisse im Krieg (u. a. Breslau) sowie Flucht, Lageraufenthalt und Vertreibung aus Schlesien über Forst (Lausitz) in die Britische Zone, vorübergehender Aufenthalt auf zerstörtem Bahnhof Cottbus].

Schneider, Karl-Heinz: Heimatbrief Weststernberg - eine Zeitung auf Spurensuche (Vortrag auf der Konferenz „Was ist Heimat?" im Collegium Polonicum, 18./19.11.2006). In: Transodra online (www.transodra-online.net/de/node/1391 [30.7.2018]). [Geb. 1936, aufgewachsen in Pulverkrug (Kr. Weststernberg), Journalist in Bernau; Erfahrungsbericht als Redakteur des „Heimatbriefs Weststernberg" (ab 1995)].

Scholz, Franz: Görlitzer Tagebuch. Chronik einer Vertreibung 1945/46. Ungek. Ausg. Frankfurt/M/ Berlin 1993. [Geb. 1909 Breslau, kath. Priester, 1940-1946 Kuratialpfarrer in Görlitz-Ost].

Schulz, Fritz: Meine Flucht vor den Russen. In: Heimatgruß. Zeitschrift für Mitglieder und Freunde des Heimatkreises Meseritz e. V. und der Heimatkreisgemeinschaft Birnbaum 217 (2016), S. 34-35. [Aus Tirschtiegel, Beamtensohn, als Schüler einer Lehrerbildungsanstalt im Jan. 1945 Flucht per Bahn von Neu Bentschen über Frankfurt (Oder) nach Eberswalde u. Finowfurt, März 1945 Fahrt über Berlin zur nach Lauscha/Unstrut evakuierten Mutter, 1954 Übersiedlung nach Westdeutschland].

[Schulz, Gerd:] Der Befreiung in Falkenrehde folgte ein furchtbares Kriegsende. Der Ortschronist Gerd Schulz erlebte als gerade angekommenes Flüchtlingskind die Befreiung seines neuen Heimatortes. In: Gertraud Schiller: Im havelländischen Tal der Wublitz. Bd. 1: Königliches Falkenrehde. Potsdam 2013, S. 56-58. [Mit Mutter 1945 aus Kunersdorf (Kr. Weststernberg) geflohen, Unterkunft im Regierungsgebäude (heute Stadthaus) in Potsdam, erlebt hier 14.4.1945 den Bombenangriff, dann zu Verwandten nach Falkenrehde, hier 24.4.1945 Einmarsch der Roten Armee erlebt].

Schulz, Herybert: Die Obra - ein Nebenfluß der Warthe. Gründung des Tiefbauunternehmens Schulz. Neubeginn westlich der Oder. In: Heimatgruß. Zeitschrift für Mitglieder und Freunde des Heimatkreises Meseritz e. V. und der Heimatkreisgemeinschaft Birnbaum 196 (2011), S. 28-29. [Geb. ca. 1932, Dipl.-Ing. Wasserbau, Enkel des Firmengründers aus Meseritz, nach 1945 in Neu Krüssow, Wiedergründung der Firma durch Vater u. Onkel ebd. 1947, 1958 in VEB (K) Tiefbau Pritzwalk umgewandelt, er selbst und sein Vater aber weiter im Betrieb beschäftigt, schildert beruflichen Lebensweg bis zum Renteneintritt].

Schulze, Siegfried: Vom Umsiedlerjungen zum Diplomingenieur. Aufgeschrieben von Jutta Hoppe. In: Ein Stück des langen Weges. Storkower Zeitzeugen berichten anlässlich des 800. Jahrestages der Ersterwähnung unserer Stadt. Hrsg. vom Brandenburgischen Seniorenbeirat e. V., Ortsverband Storkow. Storkow 2009, S. 58-61. [Geb. 1936 Pinnow (Kr. Weststernberg), kam 1945 „als Umsiedlerkind“ nach Hermsdorf bei Beeskow].

Siedler, Helga: Menschliche Schicksale und die Zufälle des Lebens. Ein Besuch in der Heimat ließ Freundschaften entstehen. In: Brandenburger Rundschau 11 (2013) 11, S. 18. [Witwe des als Sieben- 
jähriger aus Frauenburg in Ostpreußen geflüchteten Alois Siedler (Rüdersdorf), schildert gemeinsamen Besuch in Frauenburg 1989 und seitdem fortbestehende Kontakte].

Sivers, S[iegfried] von: Das Gefangenenlager in Schwiebus. In: Ostbrandenburg-Neumark 4 (1953), Nr. 8, S. 6-7; Nr. 9, S. 5-7; Nr. 12, S. 6; Nr. 13, S. 6-7; Nr. 14, S. 8-9; Forts.: Unsere Märkische Heimat 4 (1953), Nr. 19, S. 8-9; Nr. 20, S. 4-5; Nr. 21, S. 4-5; Nr. 22, S. 4-5; Nr. 23, S. 8-9; Nr. 24, S. 6-7; 5 (1954), Nr. 1/2, S. 4-7; Nr. 3, S. 4-5; Nr. 4, S. 6-8; Nr. 6, S. 4-5; Nr. 8, S. 4-5; Nr. 9, S. 5. Auszug wiederabgedr. in: Vor 50 Jahren. Als Flucht und Vertreibung im Kreis Züllichau-Schwiebus begannen. Auszüge aus Tagebüchern, Briefen und Aufzeichnungen. Im Auftr. des Heimatkreises zsgest. von Lothar Meißner. O. O. 1995, S. 79-95. [Geb. 1887 Randen/Livland, Arzt u. Schriftsteller, 1935-1945 prakt. Arzt in Berlinchen (Neumark), 20.2.1945 Verhaftung u. Verpflichtung als Lagerarzt im NKWD-Lager Schwiebus, dann Bahntransport über Frankfurt (Oder) u. Berlin bis Burxdorf bei Mühlberg/Elbe, per Lkw weiter ins Lager Mühlberg, Ende Aug. bis 20.10.1947 Stationsarzt im Sowjet. Speziallager Nr. 1. Mühlberg/Elbe, Aug. 1948 Übersiedlung nach Detmold, 1956 verstorben in Tegernsee; Erinnerungen an das Lager Schwiebus 1951 verfasst].

Solbrig, Erika, geb. Adam: Flucht und Vertreibung 1945. Augenzeugenbericht. In: Brandenburger Rundschau 15 (2017) 5, S. 6-7. [Geb. 1939 Krampe (Kr. Grünberg/Schlesien), Jan. 1945 Flucht mit Mutter u. zwei Geschwistern in Planwagen bis nach Golm bei Potsdam, Erstverpflegung ebd. im Kindergarten, Unterbringung in einem Zimmer bei Einheimischen, Erlebnisse bei Bombenangriffen und Einmarsch der Roten Armee in Potsdam, Ende 1946 Rückkehr des Vaters aus sowjet. Kriegsgefangenschaft, Nov. 1951 Flucht nach West-Berlin].

Sonnemann, Lothar: Bittere Medizin. Als Landarzt in Spreenhagen. Jacobsdorf 2002. [Geb. 1936 Köslin (Hinterpommern), Vater im Krieg vermisst, Mutter Schneidermeistertochter aus Köslin, Jan. 1946 Vertreibung mit Mutter und Großeltern, Eisenbahntransport nach Angermünde, Lageraufenthalt in Pinnow (und wahrscheinlich anschließend in Küchensee), 1.5.1946 Wohnungseinweisung in Storkow/Mark, nach Medizinstudium Arzt in Spreenhagen bei Storkow, Rostock und Frankfurt (Oder); autobiographische Erzählung mit fiktiven Dialogen].

Spitzer, Hartwig: Potsdamer Jahre. Erlebnisse und Gedanken. Von dem alten Osten in den Westen und zurück in den neuen Osten. Potsdam 2016.318 S. [Geb. 1929 Bromberg (Eltern aus Gnesen), 1944/45 Kriegshilfsdienst, 1945 Flucht mit Mutter und Geschwistern über Vorpommern nach Hessen, später Prof. für Regional- u. Umweltpolitik an der Univ. Gießen, 1997 Übersiedlung nach Potsdam, dort Mitglied des Gemeindekirchenrates u. Beirates der Friedenskirche; Schriftsteller].

Sproßmann, Heinz: Nach dem Kriege wurde die Uckermark meine neue Heimat. In: Chronik der uckermärkischen Dörfer Jagow mit Karlstein und Lauenhof, Kutzerow mit Dolgen, Taschenberg mit Uhlendorf und Taschenberger Ausbau. Milow u. a. 2013, S. 100-105. [Bauernsohn, 1.2.1945 als Schüler mit der Mutter Flucht (Treck) aus dem Heimatdorf Hainbach, Kr. Goldberg in Schlesien, 13./14.2.1945 Übernachtung in Lautawerk bei Hoyerswerda, dann Weiterfahrt bis ins Vogtland, 28.2. Ankunft in Rothenkirchen, Kr. Auerbach, erlebt hier Kriegsende mit dem Einmarsch der Amerikaner und 11.7. Einmarsch der „Russen“, 10.9.1945 Aufbruch (Treck) zur Rückkehr in die Heimat (Autobahn), in Greifendorf bei Döbeln Treckmarsch abgebrochen, da Neißegrenze geschlossen, dann 2 Jahre ebd. gelebt; 8.9.1947, „als klar war, dass es keine Heimkehr in unsere Heimat mehr geben wird“, Bahnfahrt (2 Waggons mit 12 Personen, Tieren, 2 Ackerwagen und Hausrat) in die Uckermark nach Jagow, „um dort zu siedeln" (bis Bahnhof Prenzlau, dann Kreisbahn); 1957 Heirat mit einem „Flüchtlingskind“ aus dem Kreis Naugard in Pommern. „Mit der Familiengründung [...(3 Kinder 1960-1965)] sind wir endgültig in der Uckermark angekommen."].

Stachowiak, Alfons: Meine Erinnerungen an das Kriegsende, die Flucht und die schwere Zeit danach. In: Die letzten Tage im Krieg und die ersten Wochen im Frieden in der Region um Rathenow. T. 2. Hrsg.: Rathenower Heimatbund e. V. 2. Aufl. Rathenow 2014 (1. Aufl. 2010), S. 13-19. [Geb. ca. 1932, aus Kalau (Kr. Meseritz), 14.6.1945 Vertreibung, Fußmarsch mit Mutter u. Geschwistern über 
Frankfurt (Oder) (Oder-Übergang auf Notbrücke) bis Berlin, Zugfahrt nach Rathenow, 10.7.1945 Einweisung in Schnitterkaserne in Böhne (Kr. Jerichow II), schildert weiteres (Über-)Leben bis Sommer 1946; Niederschrift Juni 2010].

Staske, Konrad: [Erinnerungen]. In: Neun Zeitzeugen erzählen. Hrsg.: Seniorenbeirat Cottbus. Cottbus 2002, S. 77-91. [Geb. 1927 in Niederschlesien (später Diplom-Landwirt); hier: Kindheits- u. Kriegserinnerungen; Kleingärtner in DDR- $u$. Nachwende-Zeit].

-, -: Erinnerungen an Osselwitz. In: Zeitzeugen erzählen. Hrsg.: Seniorenbeirat Cottbus. Cottbus 2006, S. 46-52. [(Wie oben); hier: Kindheits- und Jugenderinnerungen an sein Heimatdorf im Kr. Guhrau 1931-1944, 1944/45 Soldat u. engl. Gefangenschaft. S. 52: „Nach dem Krieg ging der Kampf ums Überleben weiter. / Dann kamen die berufliche Weiterbildung und die Verantwortung für die Familie. Da gab es kaum mehr Zeit an Osselwitz zu denken. (...). / Inzwischen war ich wieder mehrmals in Osselwitz. In unserem ehemaligen Haus, das 1931 erbaut wurde und sich in einem guten Zustand befindet, wohnen nette Leute. Sie haben das gleiche Schicksal wie wir als Vetriebene aus ihrer Heimat erlitten. / (...)."].

-, -: Als Siebzehnjähriger im Krieg. In: Zeitgebunden. Brücken zur Vergangenheit. Hrsg. vom Seniorenbeirat der Stadt Cottbus. Cottbus 2010, S. 15-18. [(Wie oben), hier: Einberufung zur Luftwaffe (Flugplatz Oels) 1944, weitere Ausbildung in Lüben u. in Holland, Okt. 1944 bei der 3. Fallschirmjägerdivision im Rheinland/Eifel eingesetzt, sechs Wochen Lazarettaufenthalt in Montabaur, 30.4.1945 bei Emden in Gefangenschaft geraten, Dez. 1945 aus brit. Gefangenschaft in Belgien entlassen, Arbeit bei einem Bauern].

Stiemke, Christa (geb. Meier): Lange verdrängt, aber unvergessen. Flucht - Vertreibung - neue Heimat. In: 100 Jahre Wilhelmshorst 1907-2007. Eine Waldsiedlung vor den Toren der Hauptstadt. Hrsg. im Namen der Freunde und Förderer der Wilhelmshorster Ortsgeschichte e. V. von Rainer Paetau. Wilhelmshorst 2007, S. 338-344. [Geb. 1938 Jauer (Schlesien), Schuhmachertochter, Sommer 1946 ausgewiesen, Aufenthalt im Lager Roederhof bei Belzig bis Spätherbst 1946].

Stöcker, Joachim: Westbesuch in der Uckermark - oder warum wir in der Ostzone blieben. Das Trauma der Flucht bestimmte das Handeln. In: Brandenburger Rundschau 9 (2011) 2, S. 13. [Geb. Adlig Baubeln, Kr. Tilsit (Ostpreußen), Schmiedsohn; als Kind 1949 erlebter Besuch des nun in Westdeutschland lebenen ehemaligen Gutsverwalters von Gut Adlig Baubeln, der die Familie des ehemaligen Guts-Hufschmieds zur Übersiedlung auf sein neues Gut bewegen wollte, für das er Arbeitskräfte suchte].

Stolpe, Manfred: Von Pommern nach Potsdam. Ein Leben im Gespräch. Das Interview mit Christoph Singelnstein und Jost-Arend Bösenberg. Berlin 2016. [Geb. 1936 Stettin, gest. 2019, Jurist, Gastwirtssohn aus Stettin-Altdamm, März 1945 Flucht mit der Mutter nach Greifswald, ebd. 1955 Abitur, dann Jura-Studium in Jena, 1959 Dipl.-Jurist, Umzug nach Potsdam u. Eintritt in den Dienst der Evang. Kirche Berlin-Brandenburg (Ostregion), 1982-1990 deren Konsistorialpräsident, 1990-2002 Ministerpräsident des Landes Brandenburg; S. 11-16: Kindheit in Stettin u. Flucht nach Greifswald].

Tamaschke, Grete: Auf der Flucht von Schlesien in den Spreewald und dann nach Fredersdorf. In: Zeitzeugen berichten [2]. Hrsg. von der Gemeinde u. dem Seniorenbeirat Fredersdorf-Vogelsdorf. Fredersdorf-Vogelsdorf 2001, S. 25-31. [Geb. ca. 1910, Tochter eines Tischlers; 1933 Heirat, lebt dann bis 1945 in Nettkow (Kr. Grünberg in Schlesien) mit drei Kindern u. Schwiegermutter, Ehemann vermisst, Ende Juli 1945 Vertreibung, Aufenthalt im Spreewald, Barackenwohnung in Laasow (Kr. Lübben) (mit Kindern, Mutter, Schwiegermutter, Schwägerin und deren beiden Kindern), Tätigkeit in Gärtnerei u. Forst, Brigadier, Aktivist, dann Verkäuferin (zuletzt Verkaufstellenleiterin) im Konsum im Spreewald u. ab ca. 1957 in Fredersdorf].

Thiede, Hans-Joachim: Schwere Tage im fünfundvierziger Jahr. Ein Tatsachenbericht. In: Niederlausitzer Studien 26 (1994), S. 89-95. [Geb. ca. 1933; ca. 20.2.1945 Flucht mit Eltern aus Wallwitz (Kr. Guben) nach Möllen am Schwielochsee, von hier aus 10.5.1945 Rückkehr in den Heimatort, Juli 1945 Vertreibung, dann westlich der Neiße „über ein Jahr bei einem Bauern“ in Treppeln (Kr. Guben), Okt. 1946 Weiterleitung über Cottbus nach Doberlug(-Kirchhain) zur Einweisung in Unterkunft]. 
Thiel, Anneliese: Meine Kindheit in den Masuren. In: Storkower Zeitzeugen berichten 2. Hrsg. vom Seniorenbeirat des Amtes Storkow. Storkow 2001, S. 11-14. [Geb. 1927 in Ostpreußen, Schneidertochter; Dorfleben].

-, -: Flucht, Kriegsende und Neubeginn. In: Storkower Zeitzeugen berichten 2. Hrsg. vom Seniorenbeirat des Amtes Storkow. Storkow 2001, S. 56-59. Wiederabdr. in: Brücken bauen / budowa mostów. Hrsg.: Seniorenbeirat Storkow (Mark) / Seniorenorganisation Opalenica. Storkow (Mark)/ Opalenica 2005, S. 24-28. [Wie vor; Flucht mit Freundin am 23. Jan. 1945 über Königsberg nach Pillau, 21-tägige Dampferfahrt nach Rügen, Dienstverpflichtung in Thüringen u. Bayern, US-Gefangenenlager in Kempten, dann auf Umwegen zur in der Altmark gelandeten Familie, Landzuteilung in der Bodenreform, 1947 Hausbau].

-, -: Mein erster Besuch im Westen. In: Storkower Zeitzeugen berichten 2. Hrsg. vom Seniorenbeirat des Amtes Storkow. Storkow 2001, S. 78-79. [Wie vor].

U., Ada: [Tagebuchauszüge. Forsetzungsserie mit wechselnden Artikeltiteln]. In: Potsdamer Neueste Nachrichten, 28.1., 25.2., 1.4., 29.4., 23.9., 21.10., 23.12.1995. [Geb. ca. 1905, Mutter von mehreren Kindern, 1940 aus der Bukowina über Jauer (Schlesien) nach Kalisch umgesiedelt, Anf. Jan. 1945 Flucht per Güterzug nach Strasburg/Uckermark, dort ab 1.2.1945 im Flüchtlingslager, 24.2.1945 bei Bekannten in Potsdam untergekommen].

Uhlemann, Karin (geb. Starke): Kinderheim Kyritz: Jeder von uns erlernte einen Beruf. Kindheitserinnerungen aus einer schweren Zeit. In: Brandenburger Rundschau 9 (2011) 5, S. 13. [Aus Nahrten, Kr. Guhrau, Schlesien; Vater seit 1942 in Russland vermisst, Mutter 1945 nach Flucht und Vertreibung an Typhus verstorben, bis 1952 bei einer Tante und Pflegeeltern, 1952-1955 im Kinderheim in Kyritz].

-, -: Erinnerungen an eine Kindheit ohne Eltern. Ehemalige Kyritzer Kinderheimbewohner pflegen ihre Tradition. In: Brandenburger Rundschau 10 (2012) 7, S. 6. [Wie vor, hier v. a. zum Treffen im Mai 2012].

Voigt, Günter: Die vier Leben der Emma H. In: Lebenszeit. T. IV. Zeitzeugen berichten. Hrsg. vom Seniorenbeirat der Gemeinde Neuenhagen bei Berlin. Neuenhagen [1998], S. 30-35. [Aufzeichnung nach den Erinnerungen der Bessarabiendeutschen Emma Hildebrandt, geb. ca. 1916 Gnadenthal bei Arzis; 19.1.1945 Flucht aus Moschen (Kr. Neumark) bis nach Buxtehude, Übersiedlung zur Mutter nach Letschin (Oderbruch), Übernahme einer Neubauernstelle, 1960 wegen Kollektivierung (LPG-Zwang) Flucht in den Westen (Bielefeld), 1964 Rückkehr].

-, -: Zum zweiten Mal vertrieben. In: Lebenszeit VII. Hrsg.: Seniorenbeirat der Gemeinde Neuenhagen. Neuenhagen 2001, S. 112-114. [Aufzeichnung nach den Erinnerungen der Bessarabiendeutschen Emma Hildebrandt (wie vor)].

-, -: Der lange Weg zurück. Nach Erzählungen von Waltraut Voigt. In: Auf Spurensuche. Episoden und Dokumente aus 775 Jahren Ortsgeschichte Neuenhagen. Hrsg.: VorOrt - Kunst, Kultur und Kommunikation e. V., Gemeinde Neuenhagen bei Berlin (Jahrbuch 2006). Neuenhagen 2006, S. 59-63. [Geb. 1930; aufgewachsen bis 1940 in Neuenhagen bei Berlin, 1940 mit Eltern nach Putzig bei Danzig gezogen, wo der Vater Bürgermeister wurde; 17.2. bis Ende Mai 1945 Flucht (mit dem Ziel Neuenhagen) über pommersche Dörfer nach Stettin, von dort per Bahn nach Berlin, dort zum Schlesischen Bahnhof gewiesen, wo jedoch kein Zug nach Strausberg ging, dann zu Fuß bis Neuenhagen zu Großeltern].

Warmbold, Alfred: Flucht, Heimkehr und Vertreibung 1945. Eine Zusammenfassung schriftlicher und mündlicher Berichte von Elli und Willi Döbber aus Neu Kunersdorf (Kr. Crossen/Ostbrandenburg) (Teil 1). In: Zeitschrift für Ostdeutsche Familiengeschichte 66 (2018), S. 321-334. [30.1.1945 Flucht der Familie mit Traktor u. zwei Anhängern aus Neu Kunersdorf, zunächst mit Ziel Frankfurt (Oder), dann Fürstenberg (Oder), hier 31.1.1945 Oder-Übergang, Weiterfahrt nach Frankfurt in Odernähe, bei Unfall Verlust eines Hängers, Rast in Müllrose (Übernachtung bei Einheimischen), dann „mit Tausenden von Flüchtlingen nach Südwesten weitergeleitet [...] nach Caminchen im Spreewald“ (S. 326). „Nach ungefähr fünf Tagen wurde uns mitgeteilt, daß die Bewohner von $\mathrm{Kr}$. Crossen im Umkreis von Zossen evakuiert wür- 
den." Weiterfahrt bis Mellensee, hier Wohnungszuweisung, vorübergehender Aufenthalt in Lüdersdorf, nach Kriegsende Rückkehr in Heimatort].

Weber, Emil: Erlebnisse in Dornau [Tagebuchauszüge]. In: Vor 50 Jahren. Als Flucht und Vertreibung im Kreis Züllichau-Schwiebus begannen. Auszüge aus Tagebüchern, Briefen und Aufzeichnungen. Im Auftr. des Heimatkreises zsgest. von Lothar Meißner. O. O. 1995, S. 41-65. [Pädagogikstudent, am 20.1.1945 aus seinem Studienort Posen in den Heimatort Dornau zurückgekehrt, Erlebnisse ab 29.1.1945; 6.7.1945 Ausweisung, Bahnfahrt nach Frankfurt (Oder), hier Ankunft 7.7.1945 (Wohnort der Schwiegereltern), Weiterfahrt mit Berliner Omnibus (Krankentransport) bis Ludwigsfelde, Weiterreise zur Familie nach Baden-Württemberg; später Professor].

Weber, Ernst-Günter: Vor 70 Jahren - Flucht aus Landsberg. In: Heimatblatt der ehemaligen Kirchengemeinden Landsberg/Warthe Stadt und Land 50 (2015), S. 6-9. [Geb. 1931, Beamtensohn aus Landsberg/W., 30.1.1945 Evakuierung mit Personenzug (Stehplätze) nach Berlin-Schlesischer Bahnhof, individuelle Weiterfahrt zu Verwandten nach Lautawerk (Kr. Calau), von dort April weiter nach Weißenfels/Saale zum Großvater, später Biologe in Magdeburg].

Weimann, Horst: Erlebnisse in Mühlbock. In: Vor 50 Jahren. Als Flucht und Vertreibung im Kreis Züllichau-Schwiebus begannen. Auszüge aus Tagebüchern, Briefen und Aufzeichnungen. Im Auftr. des Heimatkreises zsgest. von Lothar Meißner. O. O. 1995, S. 66-72. [Geb. 1934, kath., Erlebnisse seit der Räumung seines Heimatortes Schwiebus und Unterbringung mit der Mutter bei Verwandten in Mühlbock, Kr. Züllichau-Schwiebus, am 26.1.1945, ab 10.9.1945 zehntägiger Güterzug-Transport von Schwiebus nach Neuruppin, Wohnungseinweisung in Bechlin, Dez. 1945 Übersiedlung nach Niedersachsen].

Weinkauf, Harold: [Lebenslauf]. Aufgeschrieben von Ursula Weinkauf [Ehefrau] u. Hannelore Keil. In: Müncheberger Lebensläufe. Hrsg. Verein für Heimatgeschichte der Stadt Müncheberg e. V.T. 3. Müncheberg 2012, S. 111-118. [Geb. 1931 Tarnowke (Westpreußen), zweites von fünf Kindern eines Bauern, HJ, 1945 kurz vor Kriegsende Flucht zu Verwandten nach Gü(n)tershagen (Pommern), Vater unterwegs von der Familie getrennt u. nach Sibirien verschleppt, wo er wohl im Juni 1945 starb, Dez. 1945 Vertreibung (Mutter u. 4 Geschwister), Flüchtlingslager in Mecklenburg, dann zu Verwandten nach Wendefeld bei Gransee, wo er auf deren Bauernhof als Landarbeiter $u$. Traktorist arbeitet, Schulabschluss mit 8. Klasse, 1945 Konfirmation, Autoschlosser-Lehre bis 1951, ein Jahr Motorenschlosser in der MAS Oranienburg, 1952 Eintritt in die KVP: Fahrlehrer in Prenzlau, KFZ-technische Offiziersschule in Stahnsdorf, 1954 Unterleutnant, 1956 Dienst-Verpflichtung auf 10 Jahre in der NVA (Kraftfahrerausbilder in Prenzlau u. Stallberg), 1956 Heirat (3 Töchter), 1967 als Major der Reserve entlassen, Studium an der Ingenieurschule für Landmaschinentechnik in Berlin-Wartenberg, dann im Kreisbetrieb für Landtechnik in Trebus tätig, SED-Parteisekretär, Vaterländischer Verdienstorden in Bronze, 1975 Scheidung, ab 1975 Landmaschinenkonstrukteur im Forschungszentrum für Bodenfruchtbarkeit in Müncheberg (1988 Eilhard-Alfred-Mitscherlich-Preis), neue Ehe, 1992 Vorruhestand, 2007 Schlaganfall].

Weise, Kurt: Gerhard und Kurt Weise - Unsr neues Leben in Pritzwalk. In: Pritzwalker Heimatblätter 16 (2015), S. 25-26. [Brüder (Gerhard geb. 1943 Danzig), 20.7.1945 als Kinder mit der Mutter aus Danzig vertrieben (Vater 1945 von Russen verschleppt), 1.8.1945 Ankunft in Pritzwalk, Flüchtlingslager „Pritzwalker Hof", dann wechselnde Privatquartiere bei Pflegeeltern].

Weiß, Arthur: Von Bessarabien nach Belzig. Meine Memoiren. Leipzig 2012. [Geb. 1931 in Bessarabien als Maurer- und Bauernsohn, 2.10.1940 Umsiedlung nach Deutschland, Lageraufenthalt in Thüringen, Herbst 1941 Ansiedlung auf Bauernhof in Ziegelgrube/Ziegelnia Kr. Konin in Polen (Wartheland), Vater hier Bauer und Bürgermeister, 4.1.1945 13-tägige Flucht (Treck) mit Mutter und drei jüngeren Geschwistern nach Deutschland auf Anordnung der SS, Lageraufenthalt in Züllichau, 20.1.1945 14-tägiger Eisenbahntransport (anfangs Güter-, dann Personenwagen) bis Dresden (Aufnahmelager), 19.1.1945 Weitertransport per Bahn nach Belzig (Erstaufnahme in Kino), nach zwei Tagen Einquartierung der Flüchtlinge in umliegenden Dörfern, hier Mörz, Unterbringung in Kutscherstube auf einem Bauernhof, erlernt Schmiedeberuf.] 
-, -: Die letzten Kinder Bessarabiens. Neuanfang nach Krieg, Flucht und Vertreibung in der DDR.

Vier bewegende und tragische Geschwisterschicksale. Leipzig 2014. [Autor wie vor; schildert den eigenen Lebensweg und den der Geschwister in der DDR, die allesamt mit „Ausdauer, Fleiß und äußerster Sparsamkeit" wieder zu Eigentum, Wohlstand und auch beruflichem Aufstieg gelangen, aber mit der SED in Konflikt geraten].

Weiß, Konrad: Die SED-Propaganda wirkt noch nach. Deutsch-polnische Erfahrungen: Die persönlichen Kontakte haben Brücken gebaut. In: Frankfurter Allgemeine Zeitung, Nr. 161, 13.7.1996, Beilage „Ereignisse und Gestalten“ o. S. [Geb. 1942 Lauban, kath., Vater (Beamter) 1945 an den Folgen der Flucht verstorben, wächst in Genthin bei der Mutter (Arbeiterin) auf, 1963-1969 Studium in Potsdam, später DEFA-Filmregisseur, DDR-Bürgerrechtler; schildert sein Verhältns zu und seine Sicht auf Polen und das deutsch-polnische Verhältnis, bezieht dabei auch sein eigenes und das seiner Mutter zur schlesischen Herkunft ein].

Wernicke, Hilda: [Erinnerungen]. In: Neun Zeitzeugen erzählen. Hrsg.: Seniorenbeirat Cottbus. Cottbus 2002, S. 106-120. [Geb. 1926 Podletitz (Böhmen), 7.9.1945 vertrieben, (später Verkäuferin, Erzieherin, künstlerische Textilgestalterin), zieht 1996 von Hoyerswerda nach Cottbus (S. 106-109: „Meine neue Heimat Cottbus"); Familie, Jugenderinnerungen; S. 117-120: erster Besuch in der Heimat (S. 117: „Ich fuhr das erste Mal nach 15 Jahren, das war 1960, mit meinem Mann und den beiden Söhnen in meine angestammte Heimat. Der Zug brachte uns über Karlsbad in die Bergstadt Platten. Gedanklich erlebte ich an der Grenze zur Tschechoslowakei noch einmal, wie wir, Mutter und Schwester, noch vor dem Potsdamer Abkommen, mit unserem Handgepäck zwischen Menschen in Viehwagen gezwängt, nach Irgendwohin heimatverwiesen wurden. Damals lebten in meinem Heimatort Seestadtl, am Fuße des Erzgebirges, einst Tschechen und Deutsche friedlich nebeneinander. /(...)."]; hieraus das Familienkapitel „Der große und der kleine Fritz " bereits zuvor gedruckt in: Zeitzeugen berichten. Erinnerungen, Erfahrungen, Erlebnisse, Erkenntnisse. Hrsg. vom Landesseniorenbeirat Brandenburg. O. O. [1999?], S. 89-92.

-, -: Die neue Lada-Maschine. In: Zeitzeugen erzählen. Hrsg.: Seniorenbeirat Cottbus. Cottbus 2006, S. 8-10. [Kindheitserinnerung, 1934 (S. 10: „Wer weiß, bei welcher Familie oder auf welchem Schrottplatz diese Nähmaschine nach dem Krieg und der darauffolgenden Heimatvertreibung am 07.09.1945, wo wir alles liegen und stehen lassen mussten, gelandet ist und ob sie überhaupt noch existiert.")].

-, -: Der Gänsebraten. In: ebd., S. 14-16. [Heimatliche Kindheitserinnerung, Seestadtl, um 1940].

-, -: Das Hopfenflücken. In: ebd., S. 16-19. [Heimatliche Kindheitserinnerungen, Seestadtl, 1940].

-, -: Neuanfang 1945/46 auf die leichte Schulter genommen. In: ebd., S. 41-44. [S. 41: „Durch den

Vertriebenentransport nach Thüringen gekommen, für das Essen gearbeitet, Mutter, Schwester und ich getrennt untergebracht, kein Verdienst, wurde es ein unhaltbarer Zustand für uns. Es fehlte an der nötigsten Bekleidung. Wir wussten nichts über den Verbleib meiner Geschwister und der großen Verwandtschaft. Um einen Neuanfang zu finden, zogen wir mit unseren Habseligkeiten in das Bergbaugebiet Geiseltal (...)." Schildert dann die Arbeitsaufnahme in einer Brikettfabrik in Großkayna bei Weißenfels.].

-, -: Der kleine Sonnenstrahl. In: ebd., S. 70-71. [Gedicht].

-, -: Die Russen sind da! In: Zeitgebunden. Brücken zur Vergangenheit. Hrsg. vom Seniorenbeirat der Stadt Cottbus. Cottbus 2010, S. 42-43. [(Wie oben); schildert Erlebnisse als Sudetendeutsche bei Kriegsende, u. a. behördliche Vertreibungsankündigung].

-, -: Vertreibung aus der Heimat. In: ebd., S. 44-47. [(Wie oben); 7.9.1945 aus Seestadtl (bei Komotau, Sudetenland) mit Mutter u. Schwester vertrieben, 9.9.1945 Ankunft in Dörna, Kr. Mühlhausen. S. 46: „Dieses kleine Dorf war überfüllt mit Flüchtlingen aus Kroatien und Schlesien sowie mit Bombengeschädigten."].

Wieck, Michael: Zeugnis vom Untergang Königsbergs. Ein „Geltungsjude“ berichtet. Mit einem Vorw. von Siegfried Lenz. [Erstdruck 1989]. 7., veränd. Aufl. Heidelberg 2001. [Geb. 1928 Königsberg i.Pr., Musikersohn; 1945-1948 mit den Eltern im sowjet. Internierungslager Rothenstein in Königsberg, dann 
nach Deutschland entlassen, Aufenthalt im Quarantänelager Kirchmöser, von hier aus Flucht nach WestBerlin, Musikstudium, später Violinist].

Wiede, Walter: Wieder ein neues Ziel - Fürstenwerder -. Umsiedler 1945 unterwegs. In: Fürstenwerder Mosaik. T. 2: Die Vierziger und Fünfziger Jahre (Schriftenreihe des Uckermärkischen Geschichtsvereins Prenzlau e. V., Ortsgruppe Fürstenwerder, H. 2). Fürstenwerder 2002, S. 94-104. [Geb. 1927 Grünberg in Schlesien, 1944 (als Oberschüler) Flakhelfer, Mai 1945 aus US-amerikanischer Kriegsgefangenschaft in Sachsen Flucht über Dresden u. Spreewald nach Grünberg/Schlesien zu Mutter und Großeltern, Müllergehilfe für die Rote Armee, 25.9.1945 Vertreibung mit Mutter, Neißeübergang bei Guben, 26.9.1945 im Flüchtlingslager Cottbus „Flüchtlings-Paß“ ausgestellt (Abb. S. 103), Kurzbesuch bei Tante in Berlin (keine Zuzugsgenehmigung für Flüchtlinge), Entschluss, zum seit der Vorkriegszeit in Fürstenwerder (Uckermark) als Dachdeckermeister ansässigen Onkel zu gehen, Bahnfahrt bis Prenzlau, dort Übernachtung in Flüchtlingslager (Baracken), Okt. 1945 Unterbringung bei Bekannten des Onkels in Fürstenwerder, Berliner Straße (kleine Dachkammer), Arbeit bei Bauern, Dez. 1945 Übersiedlung nach Mecklenburg zu Bekanntem der Mutter aus Grünberg; lebt später in Berlin; 1993 Geburtsurkunde aus Zielona Góra (Grünberg) erhalten].

Winter, Heinz: Vertreibung. In: Storkower Zeitzeugen berichtenHrsg. vom Seniorenbeirat des Amtes Storkow. Storkow 1999, S. 27-30. [Geb. 1930, Juni 1945 Vertreibung aus Hänchen, Kr. Freystadt in Schlesien, per Treck in den Kr. Guben].

-, -: Wir irren umher und wussten nicht wohin. In: Storkower Zeitzeugen berichten 2. Hrsg. vom Seniorenbeirat des Amtes Storkow. Storkow 2001, S. 60-62. Wiederabdr. in: Brücken bauen / budowa mostów. Hrsg.: Seniorenbeirat Storkow (Mark) / Seniorenorganisation Opalenica. Storkow (Mark)/ Opalenica 2005, S. 49-52. [Wie vor; zwangsweise Arbeit im polnisch besetzten Gebiet bei Guben, dann erste Aufenthalte in Behelfswohnungen in Guben u. Umgebung sowie im Raum Cottbus, Arbeitssuche].

-, -: Mein Entschluss. In: Storkower Zeitzeugen berichten 2. Hrsg. vom Seniorenbeirat des Amtes Storkow. Storkow 2001, S. 71-72. [Wie vor].

-, -: Wie ich Storkower Bürger wurde. In: ebd., S. 72-73. [Wie vor].

-, -: Erinnerungen an Großvaterzeiten. In: Damals und heute. Storkower Zeitzeugen berichten. Hrsg. vom Seniorenbeirat des Amtes Storkow. Storkow 2003, S. 14-17. [Wie vor].

Winter, Waltraut: Anfang aus dem Nichts. In: Lebenszeit. T. IV. Zeitzeugen berichten. Hrsg. vom Seniorenbeirat der Gemeinde Neuenhagen bei Berlin. Neuenhagen [1998], S. 59-62. [Geb. ca. 1924; Vertreibung aus Schlesien 1946; Aufnahme in Sachsen].

-, -: Der lange Weg zurück. In: Lebenszeit. T. V. Zeitzeugen berichten. Hrsg. vom Seniorenbeirat der Gemeinde Neuenhagen bei Berlin. Neuenhagen 1999, S. 44-48. [(Wie vor); Okt. 1945 heimliche Rückkehr aus Kolkwitz bei Cottbus über Forst (Lausitz) zu ihren Eltern in den nun polnischen Heimatort im Kreis Reichenbach in Niederschlesien].

-, Waldtraut [Waltraut]: Drei Tage Hölle von Melnik. In: Lebenszeit IX. Zu Hause in Neuenhagen. Hrsg.: Seniorenbeirat der Gemeinde Neuenhagen. Neuenhagen 2003, S. 43-44. [(Wie vor); Flucht mit Freundin aus Schlesien am 8.5.1945 nach Tschechien].

Wirth, Alma: „Ausgesiedelt“. In: Kriegsende und Nachkriegszeit in Havelberg [II]. Hrsg.: Heimatverein Havelberg e. V. (Havelberger Regionalgeschichtliche Beiträge, Bd. 2). Havelberg 1994, S. 80-85. [Aus Neudorf bei Sebastiansberg (Sudetenland), Okt. 1946 „Antifa-Transport“, Aufenthalt im Quarantänelager Schönebeck/Elbe, dann Einweisung in Wohnung in Klietz, Kr. Jerichow II].

Wittchen, Luzie: Erinnerungen an die Heimat. In: Gubener Heimatbrief (1994)2, S. 59. [Vater Arbeiter in Gubener Hutfabrik, Mutter Spinnerin in Tuchfabrik Wolf ebd., kurz vor Kriegsende Flucht, Kessel von Halbe, Rückkehr nach Guben, Juni 1945 Vertreibung, Unterkunft im westlichen Stadtteil, weiteres Schicksal der Familie in der DDR].

Wodtke, Hans-Jürgen: Flucht aus Ostpreußen nach Böhne. In: Die letzten Tage im Krieg und die ersten Wochen im Frieden in der Region um Rathenow. T. 1. Hrsg.: Rathenower Heimatbund e. V. 4. Aufl. 
Rathenow 2014 (1. Aufl. 2006), S. 76-79 [Sohn einer damals 21-Jährigen, die 1945 mit ihrer Familie aus Sommerau bei Deutsch Eylau (Westpreußen, damals Ostpreußen) flüchtet, Treck über Marienburg, Dirschau, Stettin (Autobahn-Oderbrücken) nach Waren/Müritz (vorgegebenes Treckziel), dann Lösung vom hier aufgelösten Treck u. individuelle Bahnfahrt der Familie nach Rathenow, um zu Verwandten nach Möthlowshof bei Böhne (Kr. Jerichow II) zu gelangen (inoffizielles, privates Fluchtziel), 4.5.1945 Einmarsch der Roten Armee, Umzug zum Wilhelminenhof, hier 6.6.1946 Ankunft des Großvaters aus Gefangenschaft ("Zu diesem Zeitpunkt lebten auf dem Wilhelminenhof zwischen 70 und 80 Personen (heute 16 Personen). Es handelte sich dabei ausschließlich um Flüchtlinge, überwiegend Frauen und Kinder.")].

Wolf, Christa [geb. Ihlenfeld]: Kindheitsmuster. Roman. Berlin/Weimar 1976, zitiert nach der Ausgabe Darmstadt/Luchterhand 1977. [Geb. 1929 Landsberg/Warthe, Schriftstellerin, 1945 Flucht nach Mecklenburg, 1947 Umzug nach Bad Frankenhausen, 1949-1953 Studium in Jena und Leipzig; 1959 Umzug nach Halle/Saale, lebt 1962 bis 1976 in Kleinmachnow, dann in Ost-Berlin; der (autobiographisch zu verstehende) Roman ist zwar nicht gleichbedeutend mit einer Autobiographie, enthält aber viele wesentliche, ihr entsprechende Elemente; behandelt wird die Jugend im Heimatort und die Flucht, besonders aber auch das Erlebnis einer Wiederbegegnung mit der Vaterstadt anlässlich einer Reise 1971].

-, -: Erfahrungsmuster [1975]. In: Dies.: Fortgesetzter Versuch. Aufsätze, Gespräche, Essays. Leipzig 1979, S. 105-136. [Diskussion zum Roman "Kindheitsmuster"].

Wuntke, Hildegard: Flucht und Vertreibung. In: Storkower Zeitzeugen berichten 2. Hrsg. vom Seniorenbeirat des Amtes Storkow. Storkow 2001, S. 49-52. Wiederabdr. in: Brücken bauen / budowa mostów. Hrsg.: Seniorenbeirat Storkow (Mark) / Seniorenorganisation Opalenica. Storkow (Mark)/ Opalenica 2005, S. 46-49. [Geb. 1932 Berlin, Lehrerin, Studienrätin, Rentnerin in Storkow; aufgewachsen in Crossen/Oder, Jan. 1945 Flucht per Bahn (Güterzug) nach Berlin, Kellerwohnung in Falkensee (fälschlich Falkenberg genannt) bis zum Kriegsende, zu Fuß, Rückkehr nach Crossen, Juni 1945 Vertreibung, Fußmarsch über Frankfurt (Oder), Königs Wusterhausen u. Diedersdorf nach Wendisch Rietz (Kr. Beeskow-Storkow)].

-, -: Ich war Mitglied im DFD - ein Rückblick. In: Gelebte Geschichte. Storkower Zeitzeugen berichten aus 8 Jahrzehnten. Hrsg. vom Seniorenbeirat der Stadt Storkow (Mark). Storkow 2007, S. 130-133. [Wie vor, Leiterin der DFD-Ortsgruppe Selchow (Kr. Beeskow-Storkow), Tätigkeit der DFD-Kreisgruppe Beeskow].

-, -: Von einer, die auszog, das Lehren zu lernen - Erinnerungen einer Studienrätin aus den Jahren 1939 bis 1966. In: Gelebte Geschichte. Storkower Zeitzeugen berichten aus 8 Jahrzehnten. Hrsg. vom Seniorenbeirat der Stadt Storkow (Mark). Storkow 2007, S. 133-141. [Wie vor, Besuch des Elternhauses u. der Schule in Crossen/Oder 2005; Vertreibung Juni 1945, Sept. 1945 Unterkunft u. Schulbesuch in Wendisch Rietz, 1950 Neulehrerausbildung in Dallmin (Kr. Westprignitz), ab 1954 Lehrerin in Selchow (Kr. Beeskow-Storkow), 1966 „Verdienter Lehrer des Volkes"].

-, -: Lebensspuren neu und wieder entdeckt nach über 70 Jahren. In: Drei tolle Tage nach über 800 Jahren. Storkower Zeitzeugen berichten über die Feierlichkeiten zum 800. Jahrestag der Ersterwähnung unserer Stadt im Jahre 1209 und erzählen weitere Geschichten. Hrsg. vom Storkower Ortsverband des Brandenburgischen Seniorenverbandes. Storkow 2011, S. 104-114. [Wie vor; 1945 evakuiert nach Falkensee, Mai 1945 Rückkehr nach Crossen, Juni 1945 Vertreibung, Ankunft in Wendisch Rietz, später Lehrerin u. SED-Mitglied].

Zehbe, Luise: Meine Heimat ist jetzt polnisch. Neuwied 1985. [Bauerntochter aus der Neumark, im Zweiten Weltkrieg DRK-Schwester in Frankfurt (Oder), Landsberg/Warthe und Berlin, Flucht und Vertreibung, lebt dann in Schleswig-Holstein].

Zeidler, Hans: Als Ostpreußen verloren ging. Ein Schlesier im Krieg. Berlin 1998, 63 S. [Geb. 1920 Oberschreiberhau (Schlesien), nach Kriegseinsatz und Gefangenschaft Neulehrer in Schöneiche bei Berlin, wo er bis ins Alter ansässig bleibt]. 
Zimmermann, Irma: Lief das Leben aus den Händen. Haltepunkt Storkow - Vom verwundenden Leben der Irma Zimmermann. Aufgeschrieben von Wolfgang Geßler. In: Gelebte Geschichte. Storkower Zeitzeugen berichten aus 8 Jahrzehnten. Hrsg. vom Seniorenbeirat der Stadt Storkow (Mark). Storkow 2007, S. 65-77. [Aus Alexandrów bei Lodz, 1950 Ausreise in die DDR über das Lager Bischofswerda, über Freileben bei Lebusa u. andere Zwischenstationen nach Storkow gelangt, dort Gärtnerfamilie].

Zippan, Annelise, geb. Sanne: „Das Hochhaus am Kohlenweg“. Erinnerungen einer Küstriner Familie. In: Gespräche mit ehemaligen Küstrinern. Aufgez. u. bearb. von Siegfried Neubauer. Bd. 2. Petershausen 2004, S. 223-235. [Geb. 1932, Fleischertochter, 29.1.1945 Flucht der Familie aus Küstrin per Bahn begonnen, aber zurückgekehrt, mit Handwagen die Stadt verlassen, Güterzug nach Strausberg (Ankunft 3.2.1945), 5.2.1945 Anmeldung beim Gemeindeamt in Erkner, 21.4.1945 Einmarsch der Roten Armee, 1.6.1945 Versuch einer Rückkehr nach Küstrin, scheitert in Manschnow, Rückkehr nach Erkner, Schulbesuch, Alltagsleben, Versorgungsschwierigkeiten, Küstriner Treffen in Berlin-Lichterfelde (S. 234f.), später Besuch in Küstrin (S. 235: „ein Trümmerhaufen [...] Die Stadt ist nicht mehr das Küstrin aus den Kindertagen. Die neue Heimat war jetzt Erkner an der Spree.")].

\subsubsection{Einzelberichte Einheimischer}

Albedyll, Otto v.: Clessiner Tagebuch 1945. In: Ein leidgeprüftes Land. Bearb. von Fritz Knüppel. 2. Aufl. Barsinghausen 1990, S. 31-40. [Gutsbesitzer im Oderranddorf Klessin bei Podelzig, Kr. Lebus; Erlebnisse Jan. bis April].

Arnim, Clara von [geb. von Hagens]: Der grüne Baum des Lebens. Lebensstationen einer märkischen Gutsfrau in unserem Jahrhundert. In Zsarb. mit Peter-Anton von Arnim. 6. Aufl. Bern u. a. 1990. [Geb. 1909 Kassel; erlebt als Gutsherrin auf Gut Wiepersdorf (Kr. Jüterbog-Luckenwalde) von Jan. bis April 1945 durchziehende Flüchtlingstrecks, hilft bei deren Unterbringung und Betreuung].

Arnim-Kröchlendorff, Bertha von [geb. von Arnim]: Sommer 1945 in Kröchlendorff unter russischer Besatzung. Nach Notizen von Detlev v. Arnim-Kröchlendorff. In: Die Uckermark 1945. T. 2. 2. Aufl. Prenzlau 1995, S. 5-21. [Geb. 1885 Züsedom, gest. 24.11.1946 Berlin, Frau des Rittergutsbesitzers Detlev von A.-K., Landwirtin in Kröchlendorf; der Bericht setzt am 27.4.1945 in Kröchlendorf (Kr. Templin) ein und reicht bis zum 4.8.1945.]

Bandt, Marianne: Meine Stadt gestern und heute. In: Zeitzeugen berichten 2003. Zuhause in Brandenburg. Hrsg. vom Seniorenrat des Landes Brandenburg e. V. Cottbus 2003, S. 13-17. [Geb. 1928, Jugend in Frankfurt (Oder) und Umgebung westlich und östlich der Oder].

Bechler, Bernhard: Erinnerungen an die Bodenreform. In: Märkische Heimat. Beiträge zur Heimatgeschichte des Bezirkes Potsdam 4 (1985), S. 12-23. [Verf., geb. 1911 Grün/Vogtland, gest. 2002 Kleinmachnow, war 1945-1948 Leiter der Provinzialkommissionen für Entnazifizierung und Bodenreform in Brandenburg, 1946-1949 auch brandenburgischer Innenminister (SED)].

Berlin, Hermann: Meine Erlebnisse in Hammelspring im Jahre 1945. Aufgezeichnet aus dem Gedächtnis im Februar 2012. In: Templiner Heimatkalender 2014 (2013), S. 104-108. [Ab etwa Febr. „zogen fast täglich Flüchtlingstrecks mit Planwagen in Richtung Westen durchs Dorf. Oft wurden sie quartiermäßig für eine Nacht untergebracht. Es hieß, sie kämen aus Ostpreußen, später aus Posen oder aus dem Warthegau." (S. 105); 28.4. Durchzug von Flüchtlingsströmen aus Richtung Vietmannsdorf/Etashof. „Alle hatten Schwerin in Mecklenburg zum Ziel, weil dort bereits die Engländer sein sollten." (S. 106)].

Bestehorn, [Friedrich]: Potsdams Schicksal im Frühjahr 1945. Aufzeichnungen vom Oktober 1995 [vielm. 1945! - P. B.] über die Monate April/Mai 1945. In: Werner Mihan: Die Nacht von Potsdam. Berg am Starnberger See 1997, S. 181-184. [Obermagistratsrat in Potsdam; Bericht über seine Tätigkeit als Oberbürgermeister u. Leiter des städt. Wirtschafts- u. Ernährungsamtes im April/Mai 1945, gest. 13.1.1946]. 
Bestmann, Christa: Wege und Irrwege durch die letzten Tage des 2. Weltkrieges. Eine Familie auf der Flucht. In: Templiner Heimatkalender 2016 (2015), S. 41-48. [Eltern Hausbesitzer in Templin; erlebt als Kind Unterrichtsausfall in der Bürgerschule, als diese von Flüchtlingen belegt wird; 28.4.1945 Flucht der Familie in Richtung Hindenburg, auch zur Situation nach Rückkehr].

Bloch, Peter: Zwischen Hoffnung und Resignation. Als CDU-Politiker in Brandenburg 1945-1950. Hrsg. von Siegfried Suckut. Köln 1986. [Geb. 1900 Berlin, gest. 1984, Dr. rer. pol., bis 1940 Verleger in Berlin, wohnt ab 1938 in Kleinmachnow, Wolfswerder 46; 1946 bis April 1950 Mitglied des Landtages Brandenburg (CDU), ab Febr. 1948 Vorsitzender des Ausschusses für Wiederaufbau, Gesundheit und Umsiedler, Mai 1947 bis März 1950 Beisitzer und stellv. Landesvorsitzender der CDU Brandenburg, März 1950 Flucht nach West-Berlin].

Bornstädt, Helga: In: Turnhalle wurde Notquartier (Kindheitserinnerung). In: Gestern und heute. Erinnerungen von Mitgliedern des Zirkels „Zeitzeugen“ beim Seniorenbeirat der Stadt Potsdam. [7. Anthologie]. Hrsg.: Seniorenbeirat in der Stadt Potsdam u. a. Potsdam 2005, S. 27-28. [Geb. 1936 Nowawes (Potsdam-Babelsberg), Journalistin; erlebt ,in den ersten Frühlingsmonaten" 1945 Einquartierung von "Flüchtlingen von jenseits der Oder" in ihrer Beethoven-Schule in Potsdam-Babelsberg, darunter „Trecks aus Langenbielau und Breslau (...), Orten, in denen wir Verwandte hatten", Kontakt zu Gleichaltrigen, Ausräumung der Sportgeräte usw., Ausweichraum im "Eisenbahnerhotel“ in der Nähe des S-Bahnhofs Babelsberg].

Brösemann, Herbert: Ich war 18. Kriegserinnerungen. In: Heimatkalender Königs Wusterhausen und Dahmeland 2017, S. 96-100. [Geb. 1926 Halbe, Erlebnisse als Soldat im Raum Halbe April/Mai 1945].

Bruyn, Günter de: Zwischenbilanz. Eine Jugend in Berlin. 3. Aufl. Frankfurt am Main 1992. [1946-1949 Kontakt mit Flüchtlingen als Neulehrer in Garlitz (Westhavelland)].

Buchholtz, Elisabeth: [Tagebuchauszüge]. In: „Die Russen sind da“. Kriegsalltag und Neubeginn 1945 in Tagebüchern aus Brandenburg. Peter Böthig u. Peter Walther (Hg). 2., durchges. Aufl. Berlin 2011. [Geb. 1870, gest. 1964, lebt 1945 als Pfarrerwitwe in Neuruppin].

Burda, August: Pfarrchronk vom 14./15. April 1945 bis 9. Mai 1945. In: Werner Mihan: Die Nacht von Potsdam. Berg am Starnberger See 1997, S. 163-175 [Küster der Kath. Kirche Potsdam, zeitgenöss. Aufzeichnungen].

Dallorso, Inge (geb. Stuttrich): Befreiung Capuths vom Faschismus. In: Gedenken in Caputh. Den Opfern von Krieg und Gewalt. Ausgew. u. bearb. von Klaus Hugler. Caputh 2005, S. 50-57. [Aus alteingesessener Caputher Familie; Erinnerungen an Erlebnisse als junges Mädchen, aufgezeichnet 1985; erlebt Ankunft von Flüchtlingstrecks u. Versorgungsprobleme].

-, -: Das Ende des Faschismus und die Befreiung von Caputh. In: Wald-, Blütendorf und Strandbad Caputh. Heimatgeschichtliche Beiträge. Hrsg.: Rat des Kreises, Abt. Kultur. Red.: I. Lichtenberg u. a. Potsdam (1986), S. 11-14. [U.a. bei den Aussagen zu Flüchtlingen gekürzte Version].

Diebe, Johannes: Mein Leben, geb. 1927 in Guben. In: Gespräche mit ehemaligen Küstrinern. Aufgez. u. bearb. von Siegfried Neubauer. Bd. 2. Petershausen 2004, S. 28-74. [Geb. 1927 Guben, Vater Kesselschmied bei der Reichsbahn im RAW Guben, Mutter Hutarbeiterin in Hutfabrik Friedrich Wilke, eine ältere Schwester (Ausnäherin), Schulzeit, Ingenieurausbildung begonnn, 1944 Kriegsdiensteinstz in Schwarzheide, RAD in Genschmar, 15.1.1945 Einberufung zur Wehrmacht nach Küstrin (Panzergrenadier), Kriegsgefangenschaft in Landsberg/Warthe, Posen, Wyschni Wolotoschok bei Twer (Russland) (ausführlich), 23.4.1948 Ankunft im Heimkehrerlager Frankfurt (Oder), 25.4. Ankunft in Guben, schwieriges Wiedereinfinden in Zivilleben, 1948-1953 Techn. Leiter in "Lausitzer Strumpfwarenfabrik“ ebd., (1953 Betrieb geschlossen), 1950 Heirat (1951-1966 5 Kinder), 1954-1955 Lehrwerkstattleiter in Görlitz, 1955-1957 Einkäufer für Ober-u. Untertrikotagen in Cottbus (Konsum-Genossenschafts-Verband), 1957-1967 Werkmeister in Strickerei in Cottbus (ab 1961 PGH), 1962 privat Umzug nach Guben, 1964 Handwerksmeisterprüfung im Strickerhandwerk, 1967-1976 Meister in der Versuchsbateilung im Chemiefaserwerk in Guben, 1976 Herzinfarkt, danach andere Tätigkeiten im selben Betrieb, Wende, Familienleben]. 
Drewes, Wilhelm: Einnahme, Zerstörung und Besetzung der Stadt Prenzlau durch die Sowjets am 27.04.1945. In: Mitteilungen des Uckermärkischen Geschichtsvereins zu Prenzlau 26 (2019), S. 159-163 [Geb. 1885, gest. 1967, 1945 städt. Angestellter in Prenzlau].

Dutkowski, Ilse / Lohkamp, Giesela: Die große und die kleine Katastrophe 1945. In: Pritzwalker Heimatblätter 15 (2013), S. 143-144. [Geschwister (geb. Schönemann), eine von ihnen 1945 im Flüchtlingslager Havelberger Straße in Pritzwalk tätig, erleben am 4.9.1945 Explosion am Bahnhof].

Ehrich, Brigitte, geb. Lehmann: [Lebenslauf]. Aufgeschrieben von Annett Steffens-Pritzkuleit. In: Müncheberger Lebensläufe. Hrsg. Verein für Heimatgeschichte der Stadt Müncheberg e. V. T. 3. Müncheberg 2012, S. 9-18. [Geb. 1929 Schwiebus, ältestes von fünf Kindern, aufgewachsen in Schwiebus u. ab ca. 1932 in Frankfurt (Oder), Vater ebd. Böttcher in Ostquell-Brauerei, Schulbesuch in Frankfurt, BDM ebd. (Sport-Übungsplatz in Dammvorstadt), 1943 Lehre als Telefonistin bei der Post (abgebrochen, dann Pflichtjahr als Helferin in KLV im Seebad Horst bei Rewahl/Ostsee), 1944 wieder in Frankfurt (Fliegeralarme), dann zur in Cottbus evakuierten Mutter, hier 13.2.1945 Bombenangriff (Bahnhof u. Wohnung zerstört), dann in den Heimatort des Vaters Burg im Spreewald (Unterkunft in Schule, dann Baracke), dann bei einem Bauern in Byhleguhre (Kr. Lübben) („Billigure“), zu Fuß nach Frankfurt (Oder) zurück (Wohnung zerstört), Wohnungssuche: „Viele Menschen liefen hin und her." (S. 11); Großmutter kommt mit Treck aus Züllichau: (S. 12: „Wir waren nun 8 Personen in dieser Wohnung."); Trümmerarbeiten, FDJ-Mitglied, Arbeit in Fabriken, 1951 Verlobung mit einem Grenzpolizisten, Deutschlandtreffen in Berlin, 1952 Heirat, Geburt einer Tochter, Übersiedlung nach Berlin, 1953 nach Müncheberg, Ehemann hier bei der MTS Lehrlingsausbilder u. Fahrlehrer, sie 1957-1989 Pflegerin in Kinderkrippe].

Elske, Gerhard: [Lebenslauf]. Aufgeschrieben von Hans-Jürgen Wolf. In: Müncheberger Lebensläufe. Hrsg. Verein für Heimatgeschichte der Stadt Müncheberg e.V.T. 3. Müncheberg 2012, S. 19-24. [Geb. 1930 Fürstenfelde (Kr. Königsberg/Nm.), 1932 Umzug der Familie nach Letschin (Oderbruch), Sohn eines Schornsteinfegers, HJ, Vater im Volkssturm, 18.4.1945 Flucht nach Hagenow (Mecklenburg), Aug. 1945 Rückkehr nach Letschin, Bote im Gemeindebüro (Vater Silvester 1945 aus amerikan. Gefangenschaft entlassen), Jan. 1946 Lehre beim Vater, 1948 Paratyphus, 1949 Gesellen-, 1953 Meisterprüfung u. Heirat mit einer Arnswalderin, 1954 Geburt einer Tochter, 1960-1995 Bezirksschornsteinfegermeister in Müncheberg; Reisen an die Ostsee U. nach Ungarn sowie „Kurzreisen in die Heimat meiner Frau nach Arnswalde (heute Polen)“ (S. 22); 1991 Tod der Frau; er ab 1947 aktiv in Freiwilliger Feuerwehr (Letschin, dann Müncheberg)].

Emmrich, Eva: Mein viertes Schuljahr. In: Zeitzeugen aus Strausberg berichten. Hrsg. vom Seniorenbeirat der Stadt Strausberg. Strausberg (1999), S. 14-16. [Geb. ca. 1935, aufgewachsen in Frankfurt (Oder), Erlebnisse 1945/46, Evakuierung zu Verwandten nach Eberswalde, Rückkehr nach Kriegsende].

Eulenburg-Hertefeld, Marie Fürstin zu [geb. Freiin von Mayr-Melnhof]: Aufzeichnungen für meine Kinder über die letzten Monate des Zweiten Weltkrieges. In: Wend Graf zu Eulenburg-Hertefeld: Ein Schloß in der Mark. Erinnerungen an Liebenberg. Hrsg. von Dirk Klose. Stuttgart 1990, S. 175-191. [Geb. 1884; Jan. bis April 1945 Unterbringung durchziehender Flüchtlingstrecks in Schloss und Gut Liebenberg (Mark), Kr. Templin].

Fidus - Hugo Höppener: Tagebuch Januar bis Juli 1945. Hrsg. von Rolf F. Lang. Berlin-Friedrichshagen 1999 (edition friedrichshagen 1). [Geb. 1868, gest. 1948; lebt als Künstler (bes. Maler) in WoltersdorfSchönblick bei Berlin, erwähnt von 28. Jan. bis 2. April 1945 gelegentlich Vorkommnisse und Erlebnisse mit Flüchtlingen (S. 12, 16, 24, 31, 37, 47)].

Fritsche, Renate: Meine Kriegszeit in Pritzwalk und Flucht 1945. In: Pritzwalker Heimatblätter 16 (2015), S. 37-39 [Abitur 1942 in Perleberg, dann Studentin, 1944/45 kriegsdienstverpflichtet in ihrer Heimatstadt Pritzwalk. „Am 30. April 1945 bestiegen wir dann den letzten LKW, der durch einen Einsatz von allen anderen Autos noch übrig geblieben war, und fuhren in Richtung Parchim gen Norden. (...) Meine Großeltern wollten nicht mitgehen, sie seien zu alt (...).“ 2.5.1945 Ankunft in Lübeck].

Führling, Günter G.: Endkampf an der Oderfront. Erinnerung an Halbe. 2., überarb. Aufl. München 1996. [Verf. geb. in Forst (Lausitz)]. 
Glimm, Peter: Damals in Katerbow. Eine Kindheit im und nach dem 2. Weltkrieg in einem kleinen Dorf (Teil 2). Red. überarb. von Manfred Maronde. In: Historischer Verein der Grafschaft Ruppin e. V. Mitteilungsblatt 16 (2006), S. 21-36. [Geb. ca. 1937, aus alteingesesener Familie in Katerbow (Kr. Ruppin), erlebt dort durchziehende Trecks, Einquartierung schlesischer Flüchtlingsfamilien und Flüchtlingskinder als Mitschüler].

-, -: Damals in Katerbow. Eine Kindheit im und nach dem 2. Weltkrieg in einem kleinen Dorf (Teil 3). Red. überarb. von Manfred Maronde. In: Historischer Verein der Grafschaft Ruppin e. V. Mitteilungsblatt 17 (2007), S. 32-44. [Wie vor; u. a. Lebensmittel- u. Kleiderrationierung nach 1945, Grundversorgung von "Armen und Umsiedlern"; Situation der Neubauern].

Goerke, Heinz: Am Puls der Medizin. Arzt im 20. Jahrhundert. Eine Autobiographie. Hildesheim u. a. 1996. [Geb. 1917 Allenstein (Ostpreußen), ab 1919 in Potsdam aufgewachsen, bis 1950 Arzt ebd., nach 1945 Zeuge der schwierigen hygenisch-gesundheitlichen und Wohnsituation in der Stadt; Schwiegereltern nehmen ostpreußischen Flüchtling auf].

Gollasch, Erwin: Das Ende des Zweiten Weltkrieges. Erlebnisbericht. In: Siegfried Ramoth: Das Gemüsedorf Werben im Wandel eines Jahrhunderts. Ein Lausitzer Heimatbuch. Bearb. u. hrsg. von Jürgen Heinrich. Cottbus 2001 (Cottbuser Bücher, Bd. 9). Cottbus 2001, S. 39-44. [Geb. 1929 in Werben) Spreewald].

Grieger, Else: Fluchterlebnis. Ein bewegender Bericht einer Niederfinowerin. In: Siegfried Schiefelbein: Niederfinow - Ein Ort mit schwebenden Schiffen. Niederfinow 2008, S, 108-112. [1945 Damenfriseurin in Niederfinow, 20.4.1945 Flucht durch die Uckermark nach Mecklenburg, 17.7.1945 Rückkehr; Bericht verfasst am 18.7.1945].

Güldenhaupt, Günther: [Lebenslauf]. Aufgeschrieben von Edeltraud Schläwe. In: Müncheberger Lebensläufe. Hrsg. Verein für Heimatgeschichte der Stadt Müncheberg e. V.T. 3. Müncheberg 2012, S. 25-28. [Geb. 1929 Butterfelde bei Mohrin (Kr. Königsberg/Nm.), Vater Schweinezuchtmeister, ab 1938 auf dem Gut in Obersdorf bei Müncheberg, hier Schulbesuch, 1944/45 Flugzeugschlosser-Lehre in Königsberg/Nm., zum Kriegsende evakuiert in Oelsnitz (Vogtland), Ostern 1945 zurück nach Obersdorf, von hier Flucht vor Roter Armee in Richtung Neustadt/Dosse u. zurück, dann Arbeit beim Gleisbau in Müncheberg u. in Berlin, später bem Fernmeldewesen der Bahn ebd., 1955 Heirat mit „Flüchtling aus Selzig“ (Säpzig/ Stenzig, Kr. Weststernberg?) (2 Kinder 1955/61), ab 1967 im VEG Müncheberg/Obersdorf beschäftigt (Landarbeiter, dann Traktorist, später in Abt. Beregnung)].

Gutsche, Peter: Die Rüdersdorfer und ihre Kriegsgräber. In: Zeitzeugen berichten. [3]. Hrsg. vom Landesseniorenbeirat Brandenburg. O. O. [1999?], S. 23-24. [Friedhof Rudolf-Breitscheid-Straße; im Lazarett (altes Krankenhaus) Verstorbene].

Hagemann, Wolfgang: Meine Lehrzeit als „Umroller“ im Sommer 1945. In: Lebenszeit XIV. Neuenhagener Geschichten. Hrsg.: Seniorenbeirat u. Gemeinde Neuenhagen. Neuenhagen o.J. [ca. 2012], S. 45-49. [Als Kind am 21. April 1945 Flucht mit Mutter u. Bruder aus Neuenhagen nach Belzig, nach Kriegsende Rückkehr, Tätigkeit als Film-Umroller im örtlichen Kino, Erlebnisse mit der Roten Armee, Aufnahme von "Umsiedlern"].

Hamann, Wilhelm: Wie ich das Ende des II. Weltkrieges erlebte. In: Erlebte Geschichte. [8. Anthologie]. Hrsg.: Seniorenbeirat in der Stadt Potsdam u. a. Potsdam 2006, S. 13-22. [Geb. 1903 Forst/Lausitz, Kaufmann, bis 1945 Inhaber eines Großhandelsgeschäfts ebd., 1945 Volkssturm, ab 1955 Geschäftsführer einer ELG, 1959-1975 PGH-Mitglied, ab 1991 Heimbewohner im Hasenheyer-Stift in Potsdam; erlebt im Jan. 1945 Flüchtlingsdurchzug u. Einquartierung in Forst („Flüchtlinge aus Schlesien und dem sogenannten Warthegau", auch „ein großer Zug von KZ-Häftlingen"), 31.1.1945 heimliche Evakuierung von Ehefrau und Kindern nach Wittenberge].

Hammer: Als Treck-Arzt von Sagan nach Cottbus. In: Geschichte wird Erinnerung. Zum 50. Jahrestag der Befreiung im Land Brandenburg. Berichte, Dokumente, Essays, Fotos. Hrsg. vom Ministerium für Wissenschaft, Forschung und Kultur des Landes Brandenburg u. der Brandenburgischen Landes- 
zentrale für politische Bildung. Textausw. u. Red.: Annette Leo. Potsdam 1995, S. 140-141. [Auszug aus 1949 verfasstem Bericht des Cottbuser Arztes Dr. Hammer „Über die letzten Tage des Krieges und den Übergang zu einem normalen Gesundheitswesen" (BLHA, Rep. 211 Ministerium für Gesundheitswesen): nach Verschleppung von Cottbus nach Sagan, von dort 28.6.1945 als Treckarzt u. Treckführer ausgewiesener Deutscher aus Dörfern des Kreises Fraustadt über Sorau u. Triebel nach Cottbus zurückgekehrt, betr. insbes. Vorkommnisse vor dem Grenzübertritt].

[Hasse, Felix:] ... und an der anderen Seite das Ausland zu wissen. Aus der Chronik der katholischen Pfarrei. In: Wir waren damals 19. 50 Jahre 8. Mai in und um Frankfurt. Berichte, Dokumente, Recherchen, Tagebücher, Erinnerungen, Gespräche. Ein Lesebuch. Hrsg.: Jürgen Maerz. Frankfurt (Oder) 1995, S. 152-158. [Briefliche Berichte des Erzpriesters Hasse aus den Jahren 1946/47 über Ereignisse seit 23.4.1945].

Heimerdinger, Georg: Die ersten Tage des Friedens - das Tagebuch des Superintendenten Georg Heimerdinger. Rathenow o.J. [Geb. 1875 Schweidnitz (Schlesien), gest. 1967, Lehrersohn, 1907-1951 evang. Pfarrer in Rathenow, zuletzt Superintendent; Tagebuch 17. Mai bis 1. Sept. 1945 mit Rückblick auf die Geschehnisse ab 24. April 1945].

Helms, Friedrich: Tagebuch. Wilhelmshorst 1945. Mit e. Vorw. von Walter Kempowski. Hrsg. von Tobias Wimbauer. Hagen-Berchum 2009 [Geb. Blumenhagen (Kr. Springe), gest. 1955 Uelzen, 1945 Direktor der Filiale der Deutschen Bank in Potsdam, wohnt als Berliner Ausgebombter mit seiner Familie in Wochenendhaus in Wilhelmshorst; Tagebuchzeitraum: 20.4. bis 31.12.1945, auch zur Situation in Potsdam].

Hempel, Lucie: Hilfe in großer Not. In: Kriegsende und Nachkriegszeit in Havelberg [II]. Hrsg.: Heimatverein Havelberg e. V. (Havelberger Regionalgeschichtliche Beiträge, Bd. 2). Havelberg 1994, S. 30-32. [Wohnt als junge Mutter 1945 in Damelack bei Breddin (Kr. Ostprignitz), pflegt typhuskrankes Flüchtlingskind].

Herzog, Bernhard: Die misslungene Flucht Flieth - Schwerin. Erlebnisbericht aus den Jahren 1943-1945. In: Templiner Heimatkalender 2000 (1999), S. 113-118. [Bombenkriegsevakuierte Mutter mit Sohn aus Berlin, 1943-1945 bei befreundeter Familie in Flieth (Kr. Templin), Ende April 1945 Flucht nach Norden in Richtung Boitzenburg (mit polnischem Kutscher), Anf. Mai Rückkehr nach Flieth, Juni nach Berlin].

Höhne, Ilse: Reesdorf brennt. In: Um Beelitz harter Kampf. 1945. Das Jahr zwischen Krieg und Frieden. Beelitz und Umgebung. Hrsg.: Beelitzer Heimatverein. Beelitz 1999, S. 107-109. [Geb. 1931, Landwirtstochter in Reesdorf (Kr. Zauch-Belzig), erlebt ebd. Jan. bis April 1945 Flüchtlingseinquartierung, 26.4.1945 gemeinsame Flucht der Familie mit der einquartierten Flüchtlingsfamilie].

Hohenschild, Irmgard: Das Leben mit den Besatzern. In: Um Beelitz harter Kampf. 1945. Das Jahr zwischen Krieg und Frieden. Beelitz und Umgebung. Hrsg.: Beelitzer Heimatverein. Beelitz 1999, S. 83-85. [Beelitzerin, geb. ca. 1922, lebt 1945 ebd. mit ihrem zweieinhalbjährigen Sohn im Elternhaus (Ehemann noch in Kriegsgefangenschaft), im Haus u. a. zwei Flüchtlingsfamilien, die sich ihrer annehmen und sie und ihren Sohn beschützen].

Hollmann, Henriette: Ich war zwar erst sechs Jahre alt. In: „... das Glockengeläut ist einzustellen“. 1945 - das Jahr zwischen Krieg und Frieden. T. 1: Belzig und Umgebung. Hrsg. vom Förderkreis Museum Burg Eisenhardt e. V.: Belzig 1995, S. 117-118. [Erlebt als Kind Flüchtlingseinquartierung].

Hoppe, Albert: Perleberg 1945 - Tagebuchaufzeichnungen. In: Mitteilungen des Vereins für Geschichte der Prignitz 14 (2014), S. 63-132. [Geb. 1894 Groß Pankow bei Perleberg, gest. 1973 Perleberg, Lehrer, Anf. 1945 in Volkssturm, Stadtwachtdienst u. Flüchtlingsbetreuung eingesetzt].

Hüning, Ilse: Erlebnisbericht vom Kriegsende im April und Mai 1945. In: Pritzwalker Heimatblätter 16 (2015), S. 11-14. [Nach Tagebuchaufzeichnungen].

Jentsch, Willy: Im antifaschistischen Kampf gestärkt - für den Aufbau einer neuen Ordnung in Frankfurt/Oder. In: Wissenschaftliche Zeitschrift der Pädagogischen Hochschule Potsdam, Math.-Naturw. 
Reihe 10 (1966), S. 441-445. [Geb. Barschdorf(Schlesien) 1892, gest. 1966 Potsdam, gelernter Fleischer, früh in Gewerkschaft u. SPD tätig, zuletzt bis 1936 in Frankfurt (Oder), das er als „,meine Heimatstadt" bezeichnet (S. 442), 1938-1945 KZ Buchenwald, hier illegale Arbeit für die KPD, ab Ende Juni 1945 in Frankfurt (Oder), dort 1945/46 Organisationsleiter der KPD/SED, 1946-1950 Mitglied der SED-Kreisverwaltung, 1946-1948 Vors. des Kreisvorstandes der VdgB, 1946-1949 Bürgermeister u. stellv. Oberbürgermeister, 1949-1950 Oberbürgermeister].

Kalcher, Jutta: Unsere Flucht im April 1945. In: Hennickendorf 1945. [Hennickendorf 2005], S. 27-28. [20.4.1945 Zwangsevakuierung mit den Eltern aus Hennickendorf, Kr. Niederbarnim, Flucht nach Schwerin in Mecklenburg, Rückkehr 12.6.1945].

Karg, Otto: Was eine Großmutter ihrer Enkelin von der Flucht 1945 erzählt. In: Die Uckermark 1945. T. 2. 2. Aufl. Prenzlau 1995, S. 1-4 [27.4.1945 Flucht aus Parmen, Kr. Templin, nach Mecklenburg, nach Eintreffen der Roten Armee Rückkehr nach Parmen, S. 3: „Die Fahrt war aber noch schwieriger als die Flucht nach Westen."].

Kasack, Hermann: Dreizehn Wochen. Tage- und Nachtblätter. Aufzeichnungen aus dem Jahre 1945 über das Kriegsende in Potsdam. Hrsg. von Wolfgang Kasack. Mit einem Geleitw. von Walter Kempowski. Nachw. u. Erl. von Günter Wirth. Berlin 1996. [Geb. 1896 Potsdam, gest. 1966 Stuttgart, Schriftsteller, lebte 1920-1949 in Potsdam].

Kasprzik, Horst: Wie ich den Bombenangriff auf Cottbus erlebte. In: Zeitgebunden. Brücken zur Vergangenheit. Hrsg. vom Seniorenbeirat der Stadt Cottbus. Cottbus 2010, S. 18-21. [Geb. 1934 Cottbus, später Bote, Lehrling, Ingenieur (Fernmeldewesen), Dipl.-Ing. (Automatisierugstechnik), Dr.-Ing, (Informatik).]

Kieckbusch, Werner: Schulen und Schüler ohne Lehrer - Was tun? Erinnerungen an die Neulehrerausbildung an den Schulen im Altkreis Templin zwischen 1945 und 1952. In: Mitteilungen des Uckermärkischen Geschichtsvereins zu Prenzlau 22 (2015), S. 215-243.

Kiesewetter, Reinhard: Unser Bürgermeister in Philadelphia. In: Storkower Zeitzeugen berichten. Hrsg. vom Seniorenbeirat des Amtes Storkow. Storkow 1999, S. 54-56. [Geb. 1924; Erlebnisse als kommissarischer Gemeindesekretär in Philadelphia (Kr. Beeskow-Storkow) 1945/46].

Klitzing, Karl-Ludwig von: Atemlos. Erlebnisse eines Brandenburger Mediziners. Berlin 2014. [Geb. 1942, bis 1990 Klinikarzt in Frankfurt (Oder), u. a. Patientin mit Vertreibungstrauma].

Kn., F.: Reitwein. Erlebnisse eines Oderbruchbauern von 1945-1957. Aufzeichnungen aus den Jahren 1958-59. In: Ein leidgeprüftes Land. Bearb. von Fritz Knüppel. 2. Aufl. Barsinghausen 1990,

S. 51-65. [Reitwein, Kr. Lebus; auch zu einquartierten Flüchtlingstrecks].

Knitter, Eitel: Die Geschehnisse am Waldhof Templin 1945 (nach einem Bericht vom 5. Mai 1945). In: Templiner Heimatkalender 2000 (1999), S. 119-120. [Bericht des Leiters Daniels].

Köhler, Christel / Dannehl, Herbert: Putlitz am Ende des Zweiten Weltkrieges. In: Pritzwalker Heimatblätter 16 (2015), S. 40-42. [U.a. Durchzug von Flüchtlingstrecks, gewaltsamer Tod einer Flüchtlingsfamilie].

Krausch, H[einz]-D[ieter]: Wilhelm Pieck und die Gubener - ein Erlebnisbericht. In: Gubener Heimatbrief (1997)1, S. 55.

Kretschmer, N. N.: Tagebuch [im Stadtmuseum Cottbus]. In: www.zeitstimmen.de [25.5.2017]. [Nicht näher identifizierter Cottbuser, der im Juni und Juli 1945 den Zustrom von Vertriebenen in Cottbus erlebt].

Krzywinsky, Ursula: So erlebte ich als Vierzehnjährige das Kriegsende in Templin. In: Templiner Heimatkalender 2002 (2001), S. 73-79 [Febr. bis Dez. 1945; ihre Mutter nimmt Anf. März 1945 aus Rummelsburg in (Hinter-)Pommern geflüchtete Verwandte auf].

Lehmann, Werner: Damals um 1945 - aus meiner Kindheit in der Uckermark. In: Mitteilungen des Uckermärkischen Geschichtsvereins zu Prenzlau 22 (2015), S. 135-158.

Liß, Gerda: Jungmädelzeit. In: Um Beelitz harter Kampf. 1945. Das Jahr zwischen Krieg und Frieden. Beelitz und Umgebung. Hrsg.: Beelitzer Heimatverein. Beelitz 1999, S. 91. [„Treckdienst“ in Beelitz ab Anfang 1945]. 
Lissner, Wilhelm: Verwehte Spuren. Herbstliche Radwanderungen durch die Mark Brandenburg. Münster 2006. 94 S. [Verf. geb. 1929, 1945 Soldat u. Kriegsgefangener in der Mark Brandenburg; besucht 2002 seine Aufenthaltsorte von 1945; S. 88-94: Küstrin-Kietz: Auf der Oderbrücke. Erinnerungen 1945: Die stationären Kriegsgefangenenlager, 1945].

Manthey, Gerda: Endstation des Flüchtlingstrecks: Beelitz. In: Um Beelitz harter Kampf. 1945. Das Jahr zwischen Krieg und Frieden. Beelitz und Umgebung. Hrsg.: Beelitzer Heimatverein. Beelitz 1999, S. 91-92. [Geb. ca. 1931; Flüchtlingstreck (Mit drei Brüdern und Mutter) aus dem Oderbruch ab Febr. 1945 über Seelow, Diedersdorf, Wulkow; Unterbringung im Turnsaal in Beelitz-Heilstätten, dann im Kindergarten in der Nürnbergstraße in Beelitz, wo sie das Kriegsende erlebt].

Möhring, Werner: Weltfriedenstag 1949. In: Gubener Heimatkalender 33 (1989), S. 28-30. [Teilnehmer an deutsch-polnischer Freundschaftskundgebung am 1.9.1949 in Guben/Gubin als FDJ-Mitglied].

-, -: Ein früher Versuch der Aussöhnung. T. 1 und 2. In: Gubener Heimatbrief (2007)1, S. 71-74. [Wie vor].

Müller, Günter: Letzte Kriegstage in Rathenow 1944/1945. Erinnerungen eines Soldaten. Ausbildung, Einsatz und Ende der Kämpfe in und um Rathenow. Potsdam 2009. [Geb. 1927 Berlin, nur Erlebnisse als Soldat; später Neulehrer, dann Archivar in Potsdam].

Nickel, Irmgard: Nachkriegswirren in Altranft - unter der Herrschaft der Roten Armee. Eine Erzählung aus dem Buch „Aus meinem Leben - Zeitenwende“ von Irmgard und Ulrich Nickel, Kapitel 3.9. Nacherzählt von ihrem Sohn Ulrich Nickel. In: Bad Freienwalder Heimatkalender 57 (2013 [2012]), S. 55-58. [Geb. 1908, gest. 1978, Bäuerin aus Altranft, Erlebnisse Mai bis Okt. 1945].

Nickel, Ulrich: 1946 - Hoffnungsschimmer. In: Bad Freienwalder Heimatkalender 59 (2015 [2014]), S. 65-68). [geb. 1931 Altranft auf elterlichem Hof, schildert Bodenreform].

Niepelt, Joachim: [T. 1:] Was, Sie kennen den Fläming nicht? Episoden aus der Landdoktorzeit in Niemegk 1945 bis 1949. [T. 2:] Wanderungen durch die Mark ... en. Ein Wiedersehen nach 40 Jahren. 2., erw. u. bearb. Aufl. Belzig 2004. 106 S. [Geb. 1917, aufgewachsen in Berlin, Arzt, 1945 als verwundeter Soldat ins Lazarett nach Belzig gekommen, dann nach Niemegk zur dorthin evakuierten Familie, 1945-1949 Landarzt ebd., später Facharzt für Chirurgie u. Frauenheilkunde in Berlin (Ost), ab 1961 in Neuwied am Rhein; schildert auch Begegnungen mit Flüchtlingen, u. a. aus dem Banat u. Siebenbürgen (u.a.S. 18, 28, 34-36), S. 44-47 Besuch im Quarantänelager Treuenbrietzen); Niederschrift 1993 (T. 1) bzw. 2004 (T. 2) in Neuwied; Erstdruck von T. 1 Belzig 1993].

Noack, Wolfgang: Erinnerungen an das Altersheim Waldsiedlung. In: Gubener Heimatkalender 57 (2013), S. 89. [Geb. ca. 1941, Jugenderinnerungen (bis Anf. 1960er Jahre) an das Leben in der Siedlung als Sohn eines ab 1948 als Bürokraft im Altersheim tätigen Vaters, dessen Schwager und Frau ebd. Heimleiterwaren].

Nolte, Eva: Das also war der Krieg! In: Um Beelitz harter Kampf. 1945. Das Jahr zwischen Krieg und Frieden. Beelitz und Umgebung. Hrsg.: Beelitzer Heimatverein. Beelitz 1999, S. 29-31. [Beelitzerin, geb. ca. 1928/29; erlebt u. a. Ankunft von Flüchtlingstrecks und Einquartierung von Flüchtlingen im Haus Brauerstraße 4].

-, -: Wieder mit dem Handwagen unterwegs. In: ebd., S. 76-77. [(Wie vor), hier Erlebnisse vom 27.4. bis 7.5.1945 an wechselnden Zufluchtsorten in der Umgebung von Beelitz nach Ausweisung durch Rote Armee].

Nutsch, Eva-Maria: Mein Jahr Null. In: Storkower Zeitzeugen berichten 2. Hrsg. vom Seniorenbeirat des Amtes Storkow. Storkow 2001, S. 35. [Geb. 1927, aus Welzow (Kr. Spremberg), Einsatz als Krankenschwester in der Unfallstation der Welzower Kohlenwerke 1945/46 (Kriegsverletzungen, Typhus, Selbstmordversuche, Geschlechtskrankheiten, bes. Typhus-Impfungen)].

-, -: Jahrgang 1927. In: Damals und heute. Storkower Zeitzeugen berichten. Hrsg. vom Seniorenbeirat des Amtes Storkow. Storkow 2003, S. 44-46. [Wie vor; Januar 1945 Flucht als Arbeitsdienstmaid mit 
der Eisenbahn aus dem RAD-Lager Paradies vom Bahnhof Schwiebus über Crossen/Oder u. Berlin nach Potsdam u. weiter in den Heimatort Welzow].

-, -: Krankenhausalltag kurz nach dem Ende des II. Weltkrieges. In: ebd., S. 46-47. [Wie vor; 1947 Krankenschwesternausbildung im Städt. Krankenhaus Cottbus].

Ohnesorge, Lena [geb. Voss]: Erinnerungen an das Medizinalwesen in Prenzlau vor 1945. In: Prenzlau. Hauptstadt der Uckermark 1234-1984. Ein bürgerliches deutsches Lesebuch. Hrsg.: Heimatkreis Prenzlau. Barendorf 1984, S. 333-343. [Geb. 1898 Prenzlau, gest. 1987 Bochum, Fabrikantentochter, 1925 Heirat mit dem Prenzlauer Arzt Dr. Hans Ohnesorge (1892-1953), sie ab 1927 prakt. u. Anstaltsärztin in Prenzlau; ausführlich zum Jahr 1945].

Okun, Heidi: 72 Schüler in einer Klasse. In: Lebenszeit. T. II. Zeitzeugen berichten. Hrsg. vom Landesseniorenbeirat Brandenburg u. a. (Neuenhagen) [1997], S. 37-38. [Geb. ca. 1929, Neulehrerin, 1947 in einem ehem. Gutsdorf im Kr. Lebus eingesetzt, schildert schulische Situation in der einklassigen Dorfschule. „Die meisten meiner Schüler kamen aus „Umsiedlerfamilien“].

Peters, Curt: Friedrichsaue. Auszug aus einem Brief des Domänenpächters Curt Peters, Amt Friedrichsaue, an eine Bekannte vom Juni 1946. In: Ein leidgeprüftes Land. Bearb. von Fritz Knüppel. 2. Aufl. Barsinghausen 1990, S. 82-84. [Erlebnisse Jan. bis Sept. 1945, auch zu Flüchtlingstrecks].

Pfeiler, Jürgen: Als „Stalin“ ein Bulle war. Erinnerungen an unfreiwillige „Ferien auf dem Bauernhof“ und noch etwas mehr. In: Drei tolle Tage nach über 800 Jahren. Storkower Zeitzeugen berichten über die Feierlichkeiten zum 800. Jahrestag der Ersterwähnung unserer Stadt im Jahre 1209 und erzählen weitere Geschichten. Hrsg. vom Storkower Ortsverband des Brandenburgischen Seniorenverbandes. Storkow 2011, S. 84-93. [Anf. Febr. 1945 Flucht aus Frankfurt (Oder) über Cottbus nach Niederbayern].

Rabaschus, Gerhard: 1945 - Schlimmes Ende, schwerer Anfang. In: Storkower Zeitzeugen berichten. Hrsg. vom Seniorenbeirat des Amtes Storkow. Storkow 1999, S. 20-27. - Auch (ohne Titel) in: Zeitzeugen berichten. Erinnerungen, Erfahrungen, Erlebnisse, Erkenntnisse. [3]. Hrsg. vom Landesseniorenbeirat Brandenburg. O. O. [1999?], S. 43-46. [Geb. 1930; Kriegsende in Storkow: „Mitte oder Ende Januar 1945 [...], als immer mehr Ostflüchtlinge in unserer Schule in der Storkower Altstadt einquartiert wurden. Zunächst in der Turnhalle, dann auch in den Klassenräumen."].

Reglin, Fritz: Letzte Tage in Fürstenwerder, Flucht und Rettung unseres Hauses. In: Fürstenwerder Mosaik. T. 2: Die Vierziger und Fünfziger Jahre (Schriftenreihe des Uckermärkischen Geschichtsvereins Prenzlau e. V., Ortsgruppe Fürstenwerder, H. 2). Fürstenwerder 2002, S. 84-89. [Einquartierung von Flüchtlingen aus Ostpreußen, Posen und Berlin; eigene Flucht 26.4.1945, Rückkehr 10.5.1945].

Rocholl, Horst: Zwei Schildkröten (Andenken an Dr. Freund). In: Lebenszeit. T. III. Zeitzeugen berichten. Hrsg. vom Landesseniorenbeirat Brandenburg u. dem Seniorenbeirat Neuenhagen. Neuenhagen [1998], S. 86-87. - Wiederabdr. in: Zeitzeugen berichten. Hrsg. vom Landesseniorenbeirat Brandenburg. O. O. [1999?], S. 87-88. [Arzt erinnert sich an aus Schlesien vertriebenen Altlandsberger Kollegen].

-, -: Frieda Kretschmer (die Muttel von Buchholz). In: Lebenszeit. T. III. Zeitzeugen berichten. Hrsg. vom Landesseniorenbeirat Brandenburg u. dem Seniorenbeirat Neuenhagen. Neuenhagen [1998], S. 88-90. [Erinnerungen des Strausberger Kreisarztes an eine als DFD-Vorsitzende tätige Flüchtlingsfrau aus Schlesien].

Rohrlach, Peter P.: Die Landesgeschichtliche Vereinigung für die Mark Brandenburg. Eine persönliche Erinnerung aus den Jahren 1946-1996. In: Die Landesgeschichtliche Vereinigung für die Mark Brandenburg in Vergangenheit und Gegenwart. Aus Anlass ihres 125jährigen Bestehens bearb. u. hrsg. von Peter Bahl. Berlin 2009, S. 73-95. [Westkontakte während der Leipziger Messe].

Ruf, Johanna: Eine Backpfeife für den kleinen Goebbels. Berlin 1945 im Tagebuch einer 15-Jährigen. Die letzten und die ersten Tage. Hrsg. von Wieland Giebel. Berlin 2017. 117 S. [Geb. 1929/30, Tochter eines Hauswarts in Berlin-Südende, als BDM-Mitglied Anf. 1945 täglich Flüchtlingsbetreuung am Anhalter Bahnhof, dann bis 2.5. Verwundetenbetreuung im Lazarett unter der Reichskanzlei tätig, Mai 1945 desgleichen in 
sowjet. Durchgangslazarett Herzberge in Berlin-Lichtenberg, 25.5. bis 27.7.1945 desgleichen im Heimkehrerlager Kleist-Kaserne in Frankfurt (Oder) u. sowjet. Speziallager 6 in der Dammvorstadt, 28.7.1945 Entlassung und Rückkehr nach Berlin, später Krankenschwester in Berlin (West); Tagebuch von Jan. bis 28.7.1945].

Schäffer, Harry: Bestensee im Winter und Frühjahr 1945 und das Ende der nationalsozialistischen Herrschaft. In: Heimatkalender Königs Wusterhausen und Dahmeland 2014, S. 122-124. [Z. T. Zeitzeugenbericht, erwähnt auch Ankunft, Durchzug u. Unterbringung von „Ostflüchtlingen“].

Schaper, [Carl]: Das Kriegsende. In: Wilfried Unverricht: Schenkenberg. Schenkenberg 1998, S. 60-75. [Tagebuchauszüge, 22.4. bis 3.7.1945, Verf. ist der bei Verwandten in Schenkenberg evakuierte Berliner Rechtsanwalt Dr. Carl Schaper; erlebt u. a. Einquartierung von Schwarzmeerdeutschen].

Schendel, Erhard: Der kirchliche Betreuungsdienst. In: Erinnerungen an Stadt + Land Friedeberg Nm. Hrsg. von E(rhard) Schendel u. Hans Schauer. Berlin 1974, S. 381-385.

Schiefelbein, Siegfried: Kindliche Erinnerungen. In: Ders.: Niederfinow - Ein Ort mit schwebenden Schiffen. Niederfinow 2008, S, 112-114. [Geb. 1938 in Niederfinow, Flucht mit Einwohnertreck nach Bredereiche bei Lychen 1945].

Schladitz, Johanna [geb. Breuel]: Der Einmarsch der Roten Armee am 2. Mai 1945 in Buchholz: „Kein Mensch war zu sehen, niemand war auf der Straße. [Aufzeichnung nach Interview]. In: Pritzwalker Heimatblätter 16 (2015), S. 15-16. [Geb. 1924, Lehrerin; 1945 Zusammenleben mit Flüchtlingen, u.a. aus Wolhynien, in Buchholz (Kr. Ostprignitz)].

Schmelzer, Hans-Adolf: Die Evakuierung des Dorfes und Gutes Sachsendorf 1945. In: Ein leidgeprüftes Land. Bearb. von Fritz Knüppel. 2. Aufl. Barsinghausen 1990, S. 111-132 [Geb. 1902, gest. 1978 Krefeld, Gutsbesitzer in Sachsendorf (Kr. Lebus); Tagebuchaufzeichnungen, 20. Jan. bis 29. April 1945].

Schmelzer, Hans-Jürgen: Verlorene Felder. Stunde Null im Oderbruch 1945/46. Berlin 2016. [Geb. 1938 Frankfurt (Oder), Sohn des Vorigen; Ereignisse 1945/46].

Schneider, Hildegard: Erinnerungen an die ersten Schuljahre in Neuzelle nach dem Ende des Krieges 1945. In: Heimatkalender Eisenhüttenstadt und Umgebung 14 (1996), S. 34-42. [1945-1947, u.a. Unterbringung von Flüchtlingen und Vertriebenen in Neuzelle und auf Gut Wellmitz, aus Ostpreußen gekommener Lehrer].

Schob, Hedwig [geb. Kübelstein]: [Tagebuchauszüge]. In: „Die Russen sind da“. Kriegsalltag und Neubeginn 1945 in Tagebüchern aus Brandenburg. Peter Böthig u. Peter Walther (Hg). 2., durchges. Aufl. Berlin 2011. [Geb. 1904 Thalwinkel bei Namburg/Saale, gest. 1969, evang. Pfarrerstochter, verheiratet mit einem Siemens-Angestellten, wohnt 1940-1969 im eigenen Haus in Falkensee, erlebt hier 1945 Flüchtlingseinquartierung].

Schönig, Gertrud: Letzte Tage des Krieges. In: Zeitreisen durch ein Jahrhundert. [4. Anthologie]. Hrsg.: Seniorenbeirat der Stadt Potsdam. Stadtverwaltung, Fachbereich Jugend, Soziales, Wohnen (4. Heft) Potsdam 2002, S. 85-86. [Geb. 1928 Wittenberge; Flucht von Anne Wegener u. Eltern aus Wittenberge u. Rückkehr].

-, -: So fing es an. In: Spuren aus ihrem Leben. Senioren erinnern sich. Hrsg.: Seniorenbeirat in der Stadt Potsdam. Potsdam 2003, S. 47-54. [Teilnahme an Neulehrer-Lehrgang in Dallmin 1947/48].

Schönke, [Günther]: Die Frankfurter Schicksalstage (Vorfrühling 1945). In: Wir waren damals 19. 50 Jahre 8. Mai in und um Frankfurt. Berichte, Dokumente, Recherchen, Tagebücher, Erinnerungen, Gespräche. Ein Lesebuch. Hrsg.: Jürgen Maerz. Frankfurt (Oder) 1995, S. 130-139. [Um 1947 verfasster Bericht über den Zeitraum 16.1. bis 24.4.1945; Verf. (Dr. med.) war Oberstabsarzt und Zahnarzt in Frankfurt (Oder), wohnte Wilhelmsplatz 18].

[Schulze, Martha:] „Hoffentlich überstehen wir diese böse Zeit.“ Das Fluchttagebuch der Martha Schulze. Hrsg.: Bürgervereinigung „Fürstenberg (Oder)“ e. V. Red.: Erich Opitz. Eisenhüttenstadt [2013]. [Tagebuch 26.1.1945 bis 21.2.1948; geb. 1895 Frankfurt (Oder), 1945 Ehefrau eines Reichsbahnbetriebsassistenten in Fürstenberg (Oder), selbst ebd. Jan./Febr. 1945 als Blockfrau in der Flüchtlingsbetreuung 
eingesetzt, 5.2.1945 Evakuierung nach Gaschwitz bei Leipzig, Rückkehr 17.10.1945, weitere Erlebnisse in Fürstenberg (Oder) bis 21.2.1948].

Schulze, Sieglinde: Not macht erfinderisch. Kindheitserinnerungen aus der Nachkriegszeit. In: Heimatjahrbuch für den Landkreis Teltow-Fläming 23 (2016), S. 120-124. [Geb.ca. 1935, Einheimische in Glashütte bei Baruth, Kontakt zu Flüchtlingsfamilien].

Schuster, Manfred: Das Kriegsende 1945 in Schlabendorf. In: Luckauer Heimatkalender 47 (2015), S. 75-81. [Auch zu Anwesenheit u. Durchzug von Flüchtlingen].

Seefeld, Erich: Von August 1945 bis September 1946 als Pfarrer in Guben. In: Gubener Heimatbrief (1995) 1, S. 18-25. - Teildruck u. d. T.: Als evangelischer Pfarrer in Guben 1945-1946. In: Gubener Heimatkalender 40 (1996), S. 21-24. [Aus Templin, im August 1945 vom Oberkirchenrat nach Guben entsandt; Niederschrift der Erinnerungen 1981].

Seeger, Dieter: Befreiung (Rathenow, Ferchesar, Stechow). In: Die letzten Tage im Krieg und die ersten Wochen im Frieden in der Region um Rathenow. T. 1. Hrsg.: Rathenower Heimatbund e. V. 4. Aufl. Rathenow 2014 (1. Aufl. 2006), S. 69-75 [Erlebnisbericht eines damals Jugendlichen; wohnte in Siedlung in Rathenow, Kantstr.; erlebt Kriegsende im Fluchtort Stechow (Kr. Westhavelland); S. 71: bessarabiendeutsche Flüchtlinge Ende April 1945 als Russich-Dolmetscher in Stechow].

Seeger, Kurt: Ein Freienwalder erinnert sich an die Jahre 1945/46. In: Bad Freienwalder Heimatkalender 56 (2012 [2011]), S. 66-71. [Jugenderinnerungen an die Flucht aus Freienwalde am 20.4.1945 nach Klütz in Mecklenburg, Unterkunft zusammen mit vielen anderen Flüchtlingen in Klassenzimmern auf Stroh, die Rückkehr Juli sowie das Leben in den ersten Monaten danach].

Sewerin, Gertraud: Krankenschwester vom DRK. In: „,.. das Glockengeläut ist einzustellen“. 1945 - das Jahr zwischen Krieg und Frieden. T. 1: Belzig und Umgebung. Hrsg. vom Förderkreis Museum Burg Eisenhardt e. V. Red.: Helga Kästner. Belzig 1995, S. 101-102. [Belzigerin, nach Besuch eines DRKKrankenschwestern-Lehrgangs Einsatz in der Flüchtlings- und Verwundetenbetreuung in Belzig 1945, noch während des Krieges].

-, -: Die armen Kerle mußten ja irgendwie versorgt werden. In: ebd., S. 112-114 [Wie vor, hier Betreuung kranker und verwundter Soldaten in Belzig 1945 kurz vor und vor allem kurz nach Kriegsende].

Sielmann, Michael [Hrsg.]: Flucht und Vertreibung: Tagebuch von Ina Maria Ohnesorge (verh. Sielmann) vom 19.04.1945 bis zum 16.07.1945. In: Mitteilungen des Uckermärkischen Geschichtsvereins zu Prenzlau 25 (2018), S. 128-141. [Geb. 1927/28, Tochter des Prenzlauer Arztehepaars Dr. Hans und Dr. Lena Ohnesorge, Prenzlau; Erlebnisse auf der Flucht aus Prenzlau über Mirow (Mecklenburg) nach Lübeck und dortiger Aufenthalt].

[Spenn, Wilhelm:] Stunde Null. Ein Tagebuch aus Frankfurt an der Oder. Hrsg.: Harro Hess. Bad Münstereifel 1995. [Geb. 1874, gest. 1952, Buchbindermeister in Frankfurt (Oder), Tagebuch 1945-1949].

Stage, Hannelore: Mit Sandalen fing alles an (Erinnerungen an den Tag der Befreiung). In: Geschichten. Aus Nah und Fern. Zeitzeugen aus Strausberg erzählen. Hrsg.: Seniorenbeirat der Stadt Strausberg. Strausberg 2006, S. 12-14. [Geb. ca. 1941; 1945 Evakuierung aus Frankfurt (Oder) mit Mutter u. Geschwistern (Vater im Volkssturm eingesetzt), nach Kriegsende Rückkehr (Schubertstraße), Kindheitserlebnisse bis ca. 1950, u. a. Heimkehrerlager Gronenfelde].

Stellmacher, Gerda: Erlebnisse im Kriegs- und Nachkriegsjahr 1945. In: Bad Freienwalder Heimatkalender 56 (2012 [2011]), S. 63-65. [Geb. 1932 Bad Freienwalde; Kindheitserinnerungen an die Flucht aus Freienwalde Mitte April 1945 nach Finow und weiter nach Altenhof/Joachimsthal, Rückkehr am 3. Mai, Leben in den ersten Monaten danach unter sowjet. Besatzung, Typhusepidemie].

-, -: Kindheit von 1932 bis 1945 in Bad Freienwalde. In: Bad Freienwalder Heimatkalender 58 (2014 [2013]), S. 72-80. [Wie vor; Vater nach 1918 aus Westpreußen nach Bad Freienwalde gekommen, Familie lebte zunächst in Siedlungshaus in Posener Straße, dann in Eigenheim in Tornower Siedlung, vor 1945 Kontakte u. Besuche bei in Westpreußen verbliebenen Verwandten (Graudenz, Sehlen bei Tuchel), erlebt in 
Tornow im Krieg die Ansiedlung umgesiedelter Bessarabiendeutschen u. Donauschwaben, nach Kriegsende als Oberschülerin viele Flüchtlinge aus den Ostgebieten].

Targiel, Ralf-Rüdiger [Hrsg.]: Aufzeichnungen von Hans-Gotthard Merkel: Frankfurt im Februar/März 1945. In: Historischer Verein zu Frankfurt (Oder) e. V. Mitteilungen 1994, H. 2, S. 2-16. [Merkel, geb. 1885 Rostock, gefallen im Kessel von Halbe 29.4.1945, Oberst, 1942-1945 Wehrbezirkskommandeur in Frankfurt (Oder); tagebuchartige Aufzeichnungen (mit Lücken) 9.2. bis 24.3.1945].

[Teichmann, Ernst:] Ernst Teichmann, Pfarrer vom Waldfriedhof Halbe. Briefe und Aufzeichnungen 1950 bis 1983. Hrsg. von Rainer Potratz u. Meinhard Stark, Berlin-Brandenburgische Geschichtswerkstatt e. V. Potsdam 1997 (Brandenburgische Historische Hefte, 8).

[Thieme, Lotte:] Thieme, Hans und Lotte: Zechin und Friedrichsaue. Die Flucht aus der Heimat Ende Januar 1945. In: Ein leidgeprüftes Land. Bearb. von Fritz Knüppel. 2. Aufl. Barsinghausen 1990, S. 78-81. [Landwirtsfrau Lotte Thieme in Zechin, erlebt und versorgt Flüchtlinge aus Ostpreußen und Wartheland, führt dann selbst Treck nach Bernburg/Saale].

Thom, Fritz: Erinnerungen an das Ende des II. Weltkrieges und seine Folgen. In: Mitteilungen des Uckermärkischen Geschichtsvereins zu Prenzlau 22 (2015), S. 159-174.

Tyrolt, Margarete: Kreidezeichen an der Tür. In: Um Beelitz harter Kampf. 1945. Das Jahr zwischen Krieg und Frieden. Beelitz und Umgebung. Hrsg.: Beelitzer Heimatverein. Red.: Hannelore Bothe / Fritz Klewitz. Beelitz 1999, S. 31-32. [Beelitzerin, versorgt mit ihrer Schwester 1944/45 die Kranken aus den in Beelitz ankommenden Flüchtlingstrecks, erwähnt im Nachbarhaus einquartierte Schwarzmeerdeutsche].

Unger, Hans-Dieter: Der Treck endete für zwei Familien in Dänemark. In: Eberswalde 1945. Eine Zusammenstellung von Ereignissen mit Dokumenten und Erinnerungen. Begleitheft zur Sonderausstellung im Stadt- und Kreismuseum. Eberswalde 1995, S. 30-35 [Eberswalde-Finower Familie, die am 19.4.1945 nach Fürstenberg/Havel flieht und von hier per Bahn nach Warnemünde fährt, von dort per Schiff (Flüchtlingstransporter "Theresa Rus") nach Dänemark].

Völker, Elisabeth: Wie Gorgast für mich unvergeßlich wurde. In: 1945. Als Küstrin in Trümmer sank. Ich war dabei. Betrachtungen, Berichte und Briefe. Zsgest. u. bearb. von Fritz Kohlase. Überarb., erw. u. ill. 2. Aufl. Sehnde 2006, S. 381-387. [Bombenkriegsflüchtling aus Berlin, Sept. 1943 bis 5.2.1945 auf Bauernhof des Onkels in Gorgast, erlebt hier am 3.2.1945 Einmarsch der Roten Armee].

Weidner, Dagmar: 1949: Tage in Küchensee. In: Damals und heute. Storkower Zeitzeugen berichten. Hrsg. vom Seniorenbeirat des Amtes Storkow. Storkow 2003, S. 72-75. [Geb. 1931, Kindergärtnerin, 1949 Einsatz zur Kinderbetreuung im Umsiedlerlager Küchensee].

Weinkauf, Ursula: Otto Krey. Erinnerungen seiner 2. Ehefrau Ursula Weinkauf geb. Seidel. In: Müncheberger Lebensläufe. Hrsg. Verein für Heimatgeschichte der Stadt Müncheberg e. V.T. 5. Müncheberg 2017, S. 84-101. [Er geb. 1914 Fronau (Kr. Briesen), gest. 1972, lebte ab 1937 in Müncheberg, 27.3.1946 aus brit. Gefangenschaft entlassen u. 8.4.1946 vom Arbeitsamt Langenhagen bei Hannover an das Arbeitsamt Müncheberg verwiesen, kam dann als „Umsiedler" mit Familie nach Philippinenhof u. erhielt 11.9.1946 Bodenreformland, ab 1956 langjähriger Vorsitzender der LPG „Dr. Rübensam“ ebd., 1964 Witwer, zweite Heirat (mit der Verfasserin)].

Weiß, Waltraud: Ein Teller Wassersuppe. Auszüge aus einem Fürstenwalder Tagebuch deer Nachkriegszeit. In: Fürstenwalder Lesebuch. 725 Jahre Geschichte und Geschichten. 1272-1997. Stadt Fürstenwalde (Hrsg.). Red.: Anne-Gret Trilling u. a. Berlin 1997, S. 100-102. [1945 vorübergenend nach Königs Wusterhausen geflohen].

Wernitz, Wolfgang: Eine tragische Zeit für meine Familie. In: Um Beelitz harter Kampf. 1945. Das Jahr zwischen Krieg und Frieden. Beelitz und Umgebung. Hrsg.: Beelitzer Heimatverein. Red.: Hannelore Bothe / Fritz Klewitz. Beelitz 1999, S. 32-35 [Beelitzer, geb. 1934; Familie nimmt 1945 entfernte Verwandte aus Posen auf]. 
Weyer, Annemarie: Meine Fluchterlebnisse als Kind während der letzten Tage des 2. Weltkrieges und danach. In: Heimatkalender Prenzlau 58 (2015), S. 120-123. [Flucht aus Prenzlau ab 21./22.4.1945 nach Westen über Gollmitz, Fürstenberg/Havel, Wesenberg bis kurz vor Parchim und zurück].

Wiebach, Albert: Schwerer Anfang. In: 700 Jahre Stadt Teltow. 1265-1965. Teltow gestern, heute, morgen. Hrsg.: Rat der Stadt Teltow. Red.: Kurt Zimmermann. Teltow 1965, S. $16-17$ [Erinnerungen des ersten Nachkriegs-Bürgermeisters ab 30.4.1945].

Wilke, Dorothea: Der Krieg ist aus. Die letzten Kriegstage und das Ende in der Kesselschlacht von Halbe. In: Zeitgebunden. Brücken zur Vergangenheit. Hrsg. vom Seniorenbeirat der Stadt Cottbus. Cottbus 2010, S. 47-51. [Geb. 1928 Drebkau (arbeitet später im Finanzbereich); erlebt vor Kriegsende 1945 Flüchtlingsdurchzug in Drebkau (S. 47: „Flüchtlingstrecks durchzogen unser kleines Städtchen und verstärkten unsere Zukunftsängste.") u., selbst 12 Tage lang geflüchtet, in Märkisch Buchholz (S. 50: „Was sich dann [ca. Ende April] in diese kleinen märkischen Ortschaft und ihrer Umgebung abspielte, vermag ich kaum in Worte zu fassen. Es übertraf alles bisher Erlebte. Der Ort war vollgestopft mit Fahrzeugen jeglicher Art. Wehrmachtstransporte und Flüchtlingstrecks standen dicht gedrängt in den Straßen, als der Beschuss einsetzte. (...)."].

Winz, Ulrich: Mein Jahr 1945. In: Cottbuser Heimatkalender 1991, S. 60-66. [Kurzfassung nach eigenem, zeitgenössisch aufgeschriebenem Erlebnisbericht; geb. ca. 1935, wohnt 1945 im Elternhaus in Madlow bei Cottbus, 6.1.1945 Rückkehr von Besuch bei Großeltern in Sorau mit überfülltem Zug nach Cottbus, erlebt dann Kriegsende in Madlow, u. a. finden Jan./Febr. Verwandte aus Danzig, Ostpreußen u. Westfalen im Haus Unterkunft; Ende Juni Eintreffen der Großeltern aus Sorau; erlebt ab 1.10.1945 reibungslosen gemeinsamen Schulunterricht mit Flüchtlingskindern aus Schlesien u. Einheimischen].

(Wolff, Paul:) Wir müssen Neuenhagen verlassen - die letzten Kriegstage 1945. [Hrsg.: Irmgard Meincke]. In: Lebenszeit XIII. Neuenhagener Geschichten. Hrsg.: Seniorenbeirat u. Gemeinde Neuenhagen. Neuenhagen o. J. [ca. 2010], S. 12-15. [Ab 1902 Lehrer an der Dorfschule in Neuenhagen; Tagebuchauszüge 3. bis 29. April 1945 (veröffentlicht von der Enkelin): 21./25.4. Flucht zu Bekannten nach Berlin, Endkampf in Berlin-Moabit].

\section{Literatur}

\subsection{Nachschlagewerke}

Albinus, Robert: Lexikon der Stadt Königsberg Pr. und Umgebung. 2., erw. Aufl. Leer 1988.

Architekturführer DDR. Bezirk Frankfurt (Oder). Berlin 1987.

Atlas der Kirchenprovinz Pommern 1931. Maßstab 1 : 200 000. Nach der von Hans Christel Glaeser erarb. Karte der Kirchenprovinz Pommern neu hrsg. von der Arbeitsgemeinschaft für pommersche Kirchengeschichte. Mit einer Einf. von Norbert Buske. Schwerin 2005.

Barran, Fritz R.: Städte-Atlas Ostbrandenburg. Mit den früher brandenburgischen Landkreisen Arnswalde und Friedeberg/Nm. Leer 1990.

Barran, Fritz R.: Städte-Atlas Pommern. Leer 1989.

Barran, Fritz R.: Städte-Atlas Schlesien. Leer 1993.

Befreiung und Neubeginn. Literaturauswahl zur Befreiung der ehemaligen Provinz Brandenburg vom Faschismus. Bearb.: Dorothee Geßner. Hrsg.: Wissenschaftliche Allgemeinbibliothek des Bezirkes Potsdam. Potsdam 1985 (Literatur für Sie, 1/1985).

Beiträge zu einem Biographischen Lexikon der Deutschen aus dem Raum der Provinz Posen. Nach den 1978-1988 in der Zeitschrift „Der Kulturwart“ von Joachim Heinrich Balde herausgegebenen „Posener Biographien“. Hrsg.: Kommission für die Geschichte der Deutschen in Polen e. V. Durchges. 
von Helmut Neubach u. Wolfgang Kessler. Herne 2003 (Beiträge zur Geschichte der Deutschen in Polen und der deutsch-polnischen Beziehungen, 2).

Bestandsverzeichnis der deutschen Heimatvertriebenenpresse. Bearb. von Horst von Chmielewski u. Gert Hagelweide. Hrsg.: Stiftung Ostdeutscher Kulturrat OKR. München u. a. 1982.

Brandenburg an der Havel. Lexikon zur Stadtgeschichte. Hrsg. von Udo Geiseler u. Klaus Heß im Auftr. des Historischen Vereins Brandenburg (Havel) e. V. Berlin 2008 (Einzelveröffentlichungen der Brandenburgischen Historischen Kommission, Bd. 13).

Brandenburgisches Biographisches Lexikon (BBL). Hrsg. von Friedrich Beck u. Eckart Henning in Verb. mit Kurt Adamy, Peter Bahl u. Detlef Kotsch. Potsdam 2002 (Einzelveröffentlichung der Brandenburgischen Historischen Kommission, Bd. 5).

Chirurgenverzeichnis. Im Einvernehmen mit der Deutschen Gesellschaft für Chirurgie hrsg. von A. Hübner. 4. Aufl. Heidelberg 1958.

Chirurgenverzeichnis. Biographie und Bibliographie. Im Einvernehmen mit der Deutschen Gesellschaft für Chirurgie hrsg. von Herbert Junghanns. 6. Aufl. Berlin/Heidelberg 1980.

Czubatynski, Uwe: Notizen zu einem biographischen Lexikon der Prignitz. In: Mitteilungen des Vereins für Geschichte der Prignitz 12 (2012), S. 103-130.

Deutschbaltisches Biographisches Lexikon 1710-1960. Im Auftr. der Baltischen Historischen Kommission begonnen von Olaf Welding u. unter Mitarb. von Erik Amburger u. Georg von Krusenstjern hrsg. von Wilhelm Lenz. Köln/Wien 1970.

Evangelisches Pfarrerbuch für die Mark Brandenburg seit der Reformaton. Bearb. von Otto Fischer. T. 1-2. Berlin 1941.

Froh, Klaus / Wenzke, Rüdiger: Die Generale und Admirale der NVA. Ein biographisches Handbuch. Hrsg. vom Militärgeschichtlichen Forschungsamt. 2., durchges. Aufl. Berlin 2000.

Gemeindeverzeichnis für Mittel- und Ostdeutschland und die früheren deutschen Siedlungsgebiete im Ausland. In Verb. mit dem Statist. Bundseamt hrsg. vom Präs. des Bundesausgleichsamtes. Frankfurt am Main 1970.

Genealogisches Handbuch des Adels. Bd. 110: Freiherrliche Häuser. Bd. 19. Limburg an der Lahn 1996.

Grundriß zur deutschen Verwaltungsgeschichte 1815-1945. Reihe A: Preußen. Hrsg. von Walter Hubatsch. Bd. 2: T. 1: Provinz (Goßherzogtum) Posen. Bearb. von Dieter Stüttgen. T. 2: Provinz Grenzmark Posen-Westpreußen. Bearb. von Walther Hubatsch. Marburg/Lahn 1975.

Grundriß zur deutschen Verwaltungsgeschichte 1815-1945. Reihe A: Preußen. Hrsg. von Walter Hubatsch. Bd. 5: Brandenburg. Bearb. von Werner Vogel. Marburg/Lahn 1975.

Handbuch der Deutschen Evangelischen Kirchen 1918 bis 1949. Organe - Ämter - Verbände - Personen. Bd. 1: Überregionale Einrichtungen. Bearb. von Heinz Boberach, Carsten Nikolaisen u. Ruth Pabst. Göttingen 2010 (Arbeiten zur Kirchlichen Zeitgeschichte, Reihe A: Quellen, Bd. 18).

Heimatlexikon für Guben und Umgebung. Hrsg. vom Gubener Heimatkalender e. V. Gesamtleitung: Gernod Arlt. [Überarb. u. erw. Ausg.]. Guben [2002].

Hilgemann, Werner: Atlas zur deutschen Zeitgeschichte 1918-1968. München/Zürich 1984.

histomapberlin.de

Historischer Führer. Stätten und Denkmale der Geschichte in den Bezirken Potsdam, Frankfurt (Oder). Hrsg. von Lutz Heydick u. a. Leipzig u. a. 1987.

Historischer Handatlas von Brandenburg und Berlin. Lfg. 24: Verwaltungsgliederung 1815-1945. Bearb. von Gerd Heinrich. Berlin 1967.

Historisches Gemeindeverzeichnis des Landes Brandenburg 1875 bis 2005. Landkreis Dahme-Spreewald. Potsdam 2006 (Beiträge zur Statistik, 19.3). 
Historisches Gemeindeverzeichnis des Landes Brandenburg 1875 bis 2005. Landkreis Elbe-Elster. Potsdam 2006 (Beiträge zur Statistik, 19.4).

Historisches Gemeindeverzeichnis des Landes Brandenburg 1875 bis 2005. Landkreis Märkisch-Oderland. Potsdam 2006 (Beiträge zur Statistik, 19.6).

Historisches Gemeindeverzeichnis des Landes Brandenburg 1875 bis 2005. Landkreis OberspreewaldLausitz. Potsdam 2006 (Beiträge zur Statistik, 19.8).

Historisches Gemeindeverzeichnis des Landes Brandenburg 1875 bis 2005. Landkreis Spree-Neiße. Potsdam 2006 (Beiträge zur Statistik, 19.13).

Historisches Ortslexikon für Brandenburg. T. 1-11. Weimar 1962-1997 (Veröffentlichungen des Staatsarchivs Potsdam [ab Bd. 26: Brandenburgischen Landeshauptarchivs], ...).

T. 1: Prignitz. Bearb. von Lieselott Enders. 1. Aufl. 1962 (.., Bd. 3). 2., wesentlich erweiterte und überarbeitete Aufl. 1997 (..., Bd. 3).

T. 2: Ruppin. Bearb. von Lieselott Enders. 1970 (.., Bd. 7).

T. 3: Havelland. Bearb. von Lieselott Enders. 1972 (..., Bd. 11).

T. 4: Teltow. Bearb. von Lieselott Enders unter Mitarb. von Margot Beck. 1976 (..., Bd. 13).

T. 5: Zauch-Belzig. Bearb. von Peter P. Rohrlach. 1977 (..., Bd. 14).

T. 6: Barnim. Bearb. von Lieselott Enders unter Mitarb. von Margot Beck. 1979 (..., Bd. 16).

T. 7: Lebus. Bearb. von Peter P. Rohrlach. 1983 (..., Bd. 18).

T. 8: Uckermark. Bearb. von Lieselott Enders. 1986 (..., Bd. 21).

T. 9: Beeskow-Storkow. Bearb. von Joachim Schölzel. 1989 (..., Bd. 25).

T. 10: Jüterbog-Luckenwalde. Bearb. von Peter P. Rohrlach. 1992 (.., Bd. 26).

T. 11: Orts- und Personenregister der Teile I-X. Bearb. von Lieselott Enders. und Peter P. Rohrlach. 1996 (..., Bd. 31).

Historisches Ortslexikon für die Niederlausitz. Bearb. von Rudolf Lehmann. Bd. 1-2. Marburg 1979.

Historisches Ortschaftsverzeichnis Ostbrandenburg. Bearb. u. hrsg. vom Institut für Angewandte Geodäsie im Auftr. des Bundesministeriums des Innern unter der Leitung von Karl-A. Wegener. Frankfurt am Main 1994 (Reihe historischer Ortschaftsverzeichnisse für ehemals zu Deutschland gehörige Gebiete - Zeitraum 1914 bis 1945, Bd. 3).

Kauperts Straßenführer durch Berlin (https://berlin.kauperts.de/Strassen/).

Künkel, Ullrich: Bad Freienwalder Lexikon. 1. Ausg. [Rinteln] 1994.

Lexikon Alle Berliner Straßen und Plätze. Von der Gründung bis zur Gegenwart. Hrsg. von Hans-Jürgen Mende. Bd. 1-4. Berlin 1998.

Lexikon der Vertreibungen. Deportation, Zwangsaussiedlung und ethnische Säuberung im Europa des 20. Jahrhunderts. Detlef Brandes / Holm Sundhausen / Stefan Troebst (Hg.). In Verb. mit Kristina Kaiserová u. Krzysztof Ruchiewicz. Red.: Dmytro Myeshkov. Wien/Köln/Weimar 2010.

Müllers Verzeichnis der jenseits der Oder-Neiße gelegenen, unter fremder Verwaltung stehenden Ortschaften. Bearb. von M. Kaemmerer. ND Wuppertal 1980.

Neß, Dietmar: Schlesisches Pfarrerbuch. Bd. 1. Hrsg. vom Verein für Schlesische Kirchengeschichte. Leipzig 2014.

Online-Lexikon zur Kultur und Geschichte der Deutschen im östlichen Europa, 2012, ome-lexikon. uni-oldenburg.de/

Das Ortsbuch für das Deutsche Reich. Hrsg. in Verb. mit der Deutschen Reichsbahn u. Deutschen Reichspost. Berlin 1927. 
Ortsbuch für die Sudetengebiete (Ergänzung zur 7. Auflage von Müllers Großes Deutsches Ortsbuch). Enthält außer den Städten und sonstigen Gemeinden die nichtselbständigen Ortschaften pp. von einiger Bedeutung. Bearb. von Friedrich Müller. Wuppertal-Nächstebreck 1940.

Ortslexikon der Deutschen Demokratischen Republik. Bearb. von Karla Balkow u. Werner Christ. Berlin 1986.

Ostdeutsches Kulturgut in der Bundesrepublik Deutschland. Ein Handbuch der Sammlungen, Vereinigungen und Einrichtungen mit ihren Beständen. Bearb. von Wolfgang Kessler. Hrsg.: Stiftung Ostdeutscher Kulturrat OKR. München u. a. 1989.

Pfohl, Ernst: Orientierungslexikon der Tschechoslowakischen Republik, oro-, hydro- u. topographisches, statistisches u. wirtschaftskundliches Nachschlagewerk, Auskunftsbuch über jeden Ort der Republik, die verschiedensprachigen Namen, Lage, Einwohner, Denkwürdigkeiten, Bedeutung, Post- u. Eisenbahnstation, kommerziell-industrielle Tätigkeit nach verlässlichen amtlichen Daten. 3., neubearb. Aufl. Reichenberg 1931. ND u. d. T. Ortslexikon Sudetenland. Oro-, hydro- und topographisches, statistisches und wirtschaftskundliches Nachschlagewerk, Auskunftsbuch über jeden Ort, die verschiedensprachigen Namen, Lage, Einwohner, Denkwürdigkeiten, Bedeutung, Post- und Eisenbahnstation, kommerziell-industrielle Tätigkeit nach verläßlichen amtlichen Daten. Nürnberg 1987.

Posener Biographisches Lexikon. Bearb. von Wilfried Gerke. Lüneburg 1975.

Reitemeier, Ulrich: Auswahlbibliographie: Aufnahme- und Integrationsprozess von Spätaussiedlern in Deutschland. In: Aussiedler- und Minderheitenpolitik in Deutschland. Bilanz und Perspektiven. Hrsg. von Christoph Bergner u. Matthias Weber (Schriften des Bundesinstituts für Kultur und Geschichte der Deutschen im östlichen Europa, Bd. 38). München 2009, S. 263-287.

SBZ-Handbuch. Staatliche Verwaltungen, Parteien, gesellschaftliche Organisationen und ihre Führungskräfte in der Sowjetischen Besatzungszone Deutschlands 1945-1949. Im Auftr. des Arbeitskr. Geschichte und Politik der DDR an der Univ. Mannheim und des Inst. für Zeitgeschichte München hrsg. von Martin Broszat u. Hermann Weber. Mit Beitr. von Gerhard Brass u. a. München 1990. 2. (unveränd.) Aufl. 1993.

Silesia Sacra. Historisch-statistisches Handbuch über das evangelische Schlesien. Neu bearb. u. hrsg. von Gerhard Hultsch. Düsseldorf 1953.

SMAD-Handbuch. Die sowjetische Militäradministration in Deutschland 1945-1949. Bearb.: Jan Foitzik u. Tatjana W. Zarewskaja-Djakina unt. Mitarb. von Christiane Künzel u. Dina N. Nochotowitsch. Autoren: Burghard Ciesla u. a. Im Auftr. der Gemeinsamen Kommission zur Erforschung der Neuesten Geschichte der Deutsch-Russischen Beziehungen hrsg. von Horst Möller u. Alexandr O. Tschubarjan in Zsar. mit Wladimir P. Koslow u. a. München 2009.

Sprungalla, Martin: Historisches Ortsverzeichnis der Provinz Posen und der Wojewodschaft Poznań (Posen). Bad Bevensen 2007 (Beiträge zur Geschichte der Provinz Posen, Bd. 2)

Städtebuch Brandenburg und Berlin. Hrsg. von Evamaria Engel u. a. Stuttgart u. a. 2000 (Deutsches Städtebuch. Neubearb., Bd. 2).

Sudetendeutsches Ortsnamenverzeichnis. Amtliches Gemeinde- und Ortsnamenverzeichnis der nach dem Münchener Abkommen vom 29.9.1938 (Grenzfestegung vom 20.11.1938) zum Deutschen Reich gekommenen Sudetendeutschen Gebiete. Bearb. vom Sudetendeutschen Archiv u. Inst. für Landeskunde mit Unterstützung des Collegium Carolinum. Hrsgh. vom Inst. für Landeskunde in der Bundesanst. für Landeskunde u. Raumforschung. Bad Godesberg 1963.

Triest, Felix: Topographisches Handbuch von Oberschlesien. Teilbd. 1-2. Breslau 1864. ND Sigmaringen 1984 (Beiträge zur Geschichte und Landeskunde Oberschlesiens, Bd. 1).

Verdenhalven, Fritz: Namensänderungen ehemals preußischer Gemeinden von 1850 bis 1942 (mit Nachträgen bis 1950). Ein Schlüssel zu den Umbenennungen, Eingemeindungen und Zusammen- 
schlüssen von Stadt- und Landgemeinden während eines Jahrhunderts. Vornehmlich unter Benutzung amtlichen Materials. Unveränd. ND. Neustadt an der Aisch 1999.

Wegweiser für genealogische und historische Forschungen in ehemals deutschen Siedlungsräumen im östlichen Europa. Bearb. von Andreas Rösler in Zsarb. mit der Arbeitsgemeinschaft ostdeutscher Familienforscher. 6. Aufl. Zittau 2009.

wikipedia.org.

\subsection{Darstellungen}

Abraham-Diefenbach, Magdalena: Flucht, Vertreibung, Aussiedlung. Das östliche Brandenburg im Jahr 1945. In: Terra Transoderana. zwischen Neumark und Ziemia Lubuska. Bernd Vogenbeck u. a. (Bearb.) (Almanach. Europäische Grenzregionen neu entdecken, Bd. 1). Berlin 2008, S. 39-47.

Der 8. Mai 1945 als historische Zäsur. Strukturen, Erfahrungen, Deutungen. Hrsg. von Arnd Bauerkämper, Christoph Kleßmann, Hans Misselwitz. Potsdam 1995 (Protokolle).

800 Jahre Fahrland. Eine Festschrift. Fahrländer schreiben für Fahrländer. Hrsg. von Claus Wartenberg. Konzept u. Red.: Sonja Schnitzler. Fahrland (1997).

Ackermann, Felix: Die Stadtbrücke Frankfurt (Oder) - Słubice (1952-2002). In: Frankfurt an der Oder 1253-2003. Hrsg. von Ulrich Knefelkamp u. Siegfried Griesa. Berlin 2003, S. 311-320.

Adamy, Kurt / Hübener, Kristina: Königs Wusterhausen in der Zeit der Weimarer Republik und des Nationalsozialismus (1918-1945). In: Königs Wusterhausen. Eine illustrierte Orts- und Stadtgeschichte. Hrsg. von Kurt Adamy, Kristina Hübener, Marko Leps. Berlin 1998, S. 123-174.

Agethen, Manfred: Franz Schleusener - ein Opfer kommunistischer Gewaltherrschaft in Brandenburg. In: Historisch-politische Mitteilungen S. 15 (2008), 167-189.

Al Diban, Martina: In Nauen durch die Jahrhunderte. Geschichte und Geschichten. Falkensee 1995.

Altenhof, Schorfheide. (Eberswalde) 1956.

Amos, Heike: Die Vertriebenenpolitik der SED 1949 bis 1990. München 2009 (Schriftenreihe der Vierteljahrshefte für Zeitgeschichte, Sondernr.).

-, -: Vertriebenenverbände im Fadenkreuz. Aktivitäten der DDR-Staatssicherheit 1949 bis 1989. München 2011 (Schriftenreihe der Vierteljahrshefte für Zeitgeschichte, Sondernr.).

Amt Letschin. Mitte des Oderbruchs. Text u. Ausw. der Fotos: E. Kühn u. a. Horb am Neckar 1995.

Amtsbereich Friesack. Streifzüge durch Ländchen und Luch. Hrsg. von Fritz Beckmann im Auftr. des Amtsausschusses. Horb am Neckar 1996.

Andreae, Almut / Geiseler, Udo (Hg.): Die Herrenhäuser des Havellandes. Eine Dokumentation ihrer Geschichte bis in die Gegenwart. Berlin 2001.

Ansorge, Hermann: Oder-Neiße-Friedensgrenze. In: Gubener Heimatkalender 29 (1985), S. 33-37.

Appel, Heidemarie u. Martin: Geschichte der Glocken der evangelischen Friedenskirche zu Finow. in: Eberswalder Jahrbuch 2016, S. 58-61.

Arburg, Adrian v.: Deutschsprachige Antifaschisten: Aussiedlung aus der Tschechoslowakei. In: Lexikon der Vertreibungen. Zwangsaussiedlung und ethnische Säuberung im Europa des 20. Jahrhunderts. Detlef Brandes / Holm Sundhausen / Stefan Troebst (Hg.). Wien/Köln/Weimar 2010, S. 209-211.

Archäologie und Gedächtnis. NS-Lagerstandorte. Erforschen - Bewahren - Vermitteln. Interdisziplinäre Konferenz im Archäologischen Landesmuseum Brandenburg an der Havel 17. bis 19. September 2015. Hrsg.: Thomas Kersting u. a. Petersberg 2016 (Denkmalpflege in Berlin und Brandenburg, Arbeitsheft 4/2016).

Arlt, Gernod: Gubener Oberbürgermeister 1945 bis 1951. In: Gubener Heimatkalender 50 (2006), S. 126-128. 
Arlt, Klaus: Die Straßennamen der Stadt Potsdam. Geschichte und Bedeutung. 2., überarb. u. erw. Aufl. Potsdam 2010.

Arlt, Kurt: Zur Rolle der SMAD-Organe für innere Angelegenheiten. In: Wir waren damals 19. 50 Jahre 8. Mai in und um Frankfurt. Berichte, Dokumente, Recherchen, Tagebücher, Erinnerungen, Gespräche. Ein Lesebuch. Hrsg.: Jürgen Maerz. Frankfurt (Oder) 1995, S. 303-307.

Ast, Jürgen / Mauersberger, Kerstin: Zweite Heimat Brandenburg. Flucht, Vertreibung, Neuanfang. Berlin 2000.

Aufnahme - Integration - Beheimatung. Flüchtlinge, Vertriebene und die „Ankunftsgesellschaft“. Hrsg. von Josef Pilvousek u. Elisabeth Preuß. Berlin/Münster 2009 (Studien zur kirchlichen Zeitgeschichte, Bd. 3).

Augsten, Gisbert: Die katholische Kirche St. Petrus zu Leegebruch. Ein historischer Abriss und eine Würdigung aus Anlass des 50. Jahrestages der Kirchweihe. Leegebruch 2000 (Leegebrucher historische Blätter, H. 2).

Augustyniak, Manfred: Zur Geschichte der Zwangsarbeiter in Guben. In: Gubener Heimatkalender 49 (2005), S. 46-53.

-, -: Rheinmetall-Borsig in Guben - eine Rüstungsschmiede. In: Gubener Heimatkalender 50 (2006), S. 81-87.

-, -: Das Ende der NS-Diktatur in Guben. In: Gubener Heimatkalender 54 (2010), S. 47-52.

-, - / Möhring, Werner: Zum Wiederaufbau der Verwaltung der Stadt Guben 1945/46. In: Gubener Heimatkalender 40 (1996), S. 10-16.

Aurith - Urad. Zwei Dörfer an der Oder - dwie wioski nad Odra. Ein Buch von anschlaege.de. Text: Tina Veihelmann. Hrsg.: Deutsches Kulturforum östliches Europa. (Erstdr. 2006). 2., korr. Aufl. Potsdam 2009.

Aussiedler- und Minderheitenpolitik in Deutschland. Bilanz und Perspektiven. Hrsg. von Christoph Bergner u. Matthias Weber. München 2009 (Schriften des Bundesinstituts für Kultur und Geschichte der Deutschen im östlichen Europa, Bd. 38).

Autze, Rajan: Treibgut des Krieges. Flüchtlinge und Vertriebene in Berlin 1945. München 2001.

Bader, Werner: Patenschaften über Brandenburger Heimatvertriebene und politische Flüchtlinge aus Brandenburg. Eine Dokumentation des Kulturförderverein Mark-Brandenburg. Görne [2007].

Bäro, Heinz u. Günter: Schule und Jugend 1945/46. Versuch einer Zeitbeschreibung. In: Gubener Heimatkalender 40 (1996), S. 25-32.

Bahl, Peter: Das Kreisarchiv Gumbinnen. In: Gumbinner Heimatbrief 72 (1989), S. 39-41.

-, -: Eine Stadt in zwei Ländern. Besuch in Guben/Gubin. In: Landesgeschichtliche Vereinigung für die Mark Brandenburg. Mitteilungsblatt 106 (2005), S. 73-76.

-, -: Landesgeschichte in Berlin-Brandenburg heute. Institutionelle Anbindungen, Organisationsformen und Perspektiven. In: Landesgeschichtliche Vereinigung für die Mark Brandenburg. Mitteilungsblatt 110 (2009), S. 15-20.

-, -: Wozu noch Landesgeschichte? In: „Hie gut Brandenburg allewege“. Landeskundliche Beiträge. Festschrift auf 20 Jahre Die Mark Brandenburg. Hrsg. von Marcel Piethe. Berlin 2010, S. 132-138. -, -: Werner Vogel (1930-2016). In: Jahrbuch für brandenburgische Landesgeschichte 68 (2017), S. 317-320.

Ball, Sabine: Ein Kriegsinternierungslager in Havelberg 1914-1921. In: Havelberg - kleine Stadt mit großer Vergangenheit. Hrsg. von der Stadt Havelberg. Halle 1998, S. 145-157.

Baller, Kurt: Potsdamer Daten des 20. Jahrhunderts. Potsdam 2000.

-, - / Lück, Siegfried: Gedenktafeln, -steine und Stelen in Potsdam. Barleben 2016.

-, - / Reinholz, Marlies: Potsdam im Zweiten Weltkrieg. Eine Chronik. Magdeburg 2010. 
Balzer, Stefan: Zeittafel der geschichtlichen Entwicklung von Tomaszow-Maz., www.mittelpolen.de [20.9.2016]).

Barthel, Rolf: Geschichte der Stadt Strausberg. Monographische Gesamtdarstellung. Berlin 1987 (Studien zur Geschichte, Bd. 9).

-, -: Die Kampfhandlungen im April 1945. Die Befreiung der Orte des heutigen Kreisgebiets durch die Rote Armee. In: Heimatkalender für den Kreis Strausberg 3 (1990), S. 17-20.

Baudis, Anna: Werder - ein fast vergessenes Dörfchen im Oderbruch. In: Mitteilungsblatt des Bessarabiendeutschen Vereins 68 (2013), H. 4, S. 11-12.

-, -: Werder wurde Heimstatt für Flüchtlinge. In: Märkische Oderzeitung, 5.5.2016.

Baudisch, Rosemarie: 1945 bis 1952. Brandenburg in der SBZ/DDR. In: Ingo Materna / Wolfgang Ribbe: Geschichte in Daten. Brandenburg. München/Berlin 1995, S. 224-246.

Bauer, Friederike: Jede Karte ein Schicksal. Suchdienste nach dem Zweiten Weltkrieg in Deutschland. In: Das Archiv. Magazin für Kommunikationsgeschichte (2016) 1 (Themenheft „Die Post nach $1945^{\prime \prime)}$, S. 28-35.

Bauer, Herbert: Stalag III A. Das ehemalige Kriegsgefangenenlager des Zweiten Weltkrieges bei Luckenwalde. [Luckenwalde] [1996].

Bauerkämper, Arnd: Das Neubauernprogramm im Land Brandenburg. Voraussetzungen, Entwicklung und Auswirkungen 1947-1952. In: Jahrbuch für brandenburgische Landesgeschichte 45 (1994), S. $182-202$.

-, -: Die Bodenreform in der Provinz Mark Brandenburg. Wandel und Beharrung in der Agrarwirtschaft und ländlichen Gesellschaft 1945. In: Brandenburg im Jahr 1945. Studien. Hrsg. von Werner Stang unter Mitarb. von Kurt Arlt. Potsdam 1995, S. 265-296.

-, -: Flüchtlinge zwischen Ausschluß und Integration. Bodenreform und ländliche Gesellschaft in Brandenburg 1945-1948. In: 50 Jahre Flucht und Vertreibung. Gemeinsamkeiten und Unterschiede bei der Aufnahme und Integration der Vertriebenen in die Gesellschaften der Westzonen/Bundesrepublik und der SBZ/DDR. Hrsg. von Manfred Wille. Magdeburg 1997, S. 286-295.

-, -: Die vorgetäuschte Integration. Die Auswirkungen der Bodenreform und Flüchtlingssiedlung auf die berufliche Eingliederung von Vertriebenen in die Landwirtschaft in Deutschland 1945-1960. In: Geglückte Integration? Spezifika und Vergleichbarkeiten der Vertriebenen-Eingliederung in der SBZ/DDR. Hrsg. von Dierk Hoffmann u. Michael Schwartz (Schriftenreihe der Vierteljahrshefte für Zeitgeschichte, Sondernr.). München 1999, S. 193-214.

-, -: Scharfe Konflikte und „feine Unterschiede“. Vertriebene in der ländlichen Gesellschaft Brandenburgs von 1945 bis zu den frühen fünfziger Jahren. In: Vertreibung, Neuanfang, Integration. Erfahrungen in Brandenburg. Christoph Kleßmann / Burghard Ciesla / Hans-Hermann Hertle (Hrsg.) (Protokolle). Potsdam 2001, S. 123-150.

-, -: Ländliche Gesellschaft in der kommunistischen Diktatur. Zwangsmodernisierung und Tradition in Brandenburg 1945-1963. Köln/Weimar/Wien 2002 (Zeithistorische Studien, Bd. 21).

-, -: Gutachten für die Enquete-Kommission „Aufarbeitung der Geschichte und Bewältigung von Folgen der SED-Diktatur und des Übergangs in einen demokratischen Rechtsstaat im Land Brandenburg“" des Landtages Brandenburg. Agrargeschichte des Landes Brandenburg vor 1989. Korrigierte Fassung: Ausgabe 01.11.2012 (https://www.landtag.brandenburg.de/media_fast/5701/Gutachten\%20 Prof.\%20Bauerk\%C3\%A4mper_Agrargeschichte_korrigierte\%20Fassung\%20\%2801.11.12\%29. pdf).

Baum, Leonide: Wie haben sie es nur geschafft? (Im Osten). In: Jahrbuch der Deutschen aus Bessarabien 56 (2005), S. 30-35.

Beck, Friedrich: Quellen zur brandenburgischen Landesgeschichte. In: Brandenburgische Geschichte. Hrsg. von Ingo Materna u. Wolfgang Ribbe. Berlin 1995, S. 801-824. 
Becken, Jörg: Lübben nach dem Inferno. Die Jahre 1945-61. [Begleitband zur Ausstellung.] Hrsg.: Förderverein des Stadt- und Regionalmuseums Lübben (Spreewald) e. V. [Cottbus] 2010.

Becker, Franz: Die große Wende in einer kleinen Stadt. Zum 20. Jahrestag der Befreiung. Frankfurt (Oder) 1965.

Bederke, Jeanette: Fremde Oderbruch-Bewohner. Die Bevölkerungsstruktur im kriegszerstörten Landstrich änderte sich vor 60 Jahren grundlegend. In: Märkische Allgemeine, 22.3.2005. [Überwiegend nach einem Interview mit Dr. Reinhard Schmook].

Beer, Mathias: Bundesvertriebenengesetz (BVFG). In: Lexikon der Vertreibungen. Deportation, Zwangsaussiedlung und ethnische Säuberung im Europa des 20. Jahrhunderts. Detlef Brandes / Holm Sundhausen / Stefan Troebst (Hg.). Wien/Köln/Weimar 2010, S. 97-100.

Beer, Mathias: Die Vertreibung der Deutschen. Ursachsen, Ablauf, Folgen. In: Flucht und Vertreibung. Europa zwischen 1939 und 1948. Hamburg 2012, S. 24-65, 250-251.

Beevor, Antony: Berlin 1945. Das Ende. Aus dem Engl. übertr. von Frank Wolf. München 2002.

Bein, Otto: Stadtsparkasse zu Mohrin. In: Kreiskalender für den Heimatkreis Königsberg-Neumark 10 (1962), S. 75-86. [Verf. war 1924-1945 letzter Leiter, beschreibt Evakuierung nach Rathenow].

Beiträge zur Geschichte der demokratischen Bodenreform im Land Brandenburg. (Referate und Diskussionsbeiträge der am 29. September 1965 in Kyritz veranstalteten wissenschaftlichen Konferenz „20 Jahre Bodenreform - 20 Jahre sozialistische Agrarpolitik“). Hrsg. vom Staatsarchiv Potsdam u. der SED-Bezirksleitung Potsdam, Kommission zur Erforschung der Geschichte der örtlichen Arbeiterbewegung. Potsdam 1966.

Berendt, Thomas: Asylsuchende im Landkreis Märkisch-Oderland. In: Jahrbuch Märkisch-Oderland 24 (2017), S. 44. [Zur aktuellen Situation seit 2015].

Berg, Horst: Vom Nikolaus-Hospital zum Kreiskrankenhaus. Aus der Geschichte des Beeskower Gesundheitswesens. Beeskow 2002 (Beeskower Heimathefte, H. 6).

Bergemann, Helmut / Damaschke, Alfred: Ketzin 1945. Die letzten Tage des Krieges - die ersten Tage des Friedens. Berlin 1996 (Schriften des Heimatmuseums Ketzin, 4). [Mit Quellenanhang (S. 3474)].

Béringuier, Claus: Sammlung zur Geschichte und Herkunft Strausberger Namen. Strausberg 2008 (Akanthus-Mitteilungen, H. 21).

Berkenkamp: Entstehung und Entwicklung der Gemeinde Neurochlitz. In: Heimatkalender des Kreises Angermünde 1959, S. 107-108.

Berlin. Kampf um Freiheit und Selbstverwaltung 1945-1946. Hrsg. im Auftr. des Senats von Berlin. 2., erg. u. erw. Aufl. Berlin 1961 (Schriftenreihe zur Berliner Zeitgeschichte, Bd. 1).

Berlin. Ringen um Einheit und Wiederaufbau 1948-1951. Hrsg. im Auftr. des Senats von Berlin. Berlin 1962 (Schriftenreihe zur Berliner Zeitgeschichte, Bd. 3).

Berlin und Brandenburg. Mit Neumark und Grenzmark Posen-Westpreußen. Hrsg. von Gerd Heinrich. 3., überarb. u. erg. Aufl. Stuttgart 1995 (Handbuch der Historischen Stätten Deutschlands, Bd. 10).

Berlin, Hermann: Wie sich die Landwirtschaft in Hammelspring nach 1945 entwickelt hat. In: Templiner Heimatkalender 2016 (2015), S. 66-70.

Beske, Hans: Die Landsberger nach 1945. In: Landsberg an der Warthe 1257 - 1945 - 1976. Hrsg. von Hans Beske u. Ernst Handke (Bd. 1 der Schriftenreihe der Bundesarbeitsgemeinschaft Landsberg (Warthe) Stadt und Land). Bielefeld 1976, S. 251-265.

Bestensee. Die Chronik eines märkischen Ortes. Hrsg.: Gemeinde Bestensee. Autoren: Wolfgang Purann u. a. Bestensee 2006.

Bethke, Susann: Der Weg der Deutschen aus der Tschechoslowakei in die Sowjetische Besatzungszone Deutschlands (1945/46). In: Die Sudetendeutschen in der Sowjetischen Besatzungszone Deutsch- 
lands. Ankunft, Aufnahme und erste Integrationsversuche. Manfred Wille (Hrsg.) (Magdeburger Forschungen, 10: Geschichte). Magdeburg 1993, S. 5-27.

Der Bevölkerungsschwund in den märkischen Städten. In: Berlin-Brandenburger Kurier. Sondernr. für die Kreise Ober- und Niederbarnim [1958], S. 41-42.

Biela, Paul: Schicksale deutscher Apotheker aus Ostbrandenburg am Ende des Zweiten Weltkrieges. Flucht, Vertreibung, Verschleppung, Suizid. Frankfurt (Oder) 2017.

Bietz, Gerd-Dieter: Der Weg der Befreier Fürstenwaldes. In: Heimatkalender Kreis Fürstenwalde 1990, S. $16-18$.

Bilke, Jörg Bernhard: Unerwünschte Erinnerungen. Flucht und Vertreibung in der DDR-Literatur. In: Manfred Wille / Karlheinz Lau / Jörg Bernhard Bilke: Die Vertriebenen in Mitteldeutschland. Hrsg.: Bund der Vertriebenen (Deutschlandpolitische Schriftenreihe, 10). Bonn 1991, S. 15-23. -

Biskupek, Matthias: Was heißt eigentlich „DDR“? Böhmische Dörfer in Deutsch \& Geschichte. Berlin 2003.

Bleich, Ute: Kirchliches Leben zwischen 1930 und 1950. In: Fürstenwerder Mosaik. T. 2: Die Vierziger und Fünfziger Jahre (Schriftenreihe des Uckermärkischen Geschichtsvereins Prenzlau e. V., Ortsgruppe Fürstenwerder, H. 2). Fürstenwerder 2002, S. 57-65.

-, -: Kriegsopfer in Fürstenwerder. In: Fürstenwerder Mosaik. T. 2 [wie vor]. Fürstenwerder 2002, S. 72-81.

Blöß, Wolfgang: Brandenburgische Kreise und Gemeinden 1945-1952. Grenzänderungen, Eingemeindungen und Ausgemeindungen. Potsdam 2010 (Veröffentlichungen der Landesfachstelle Archive und öffentliche Bibliotheken im Brandenburgischen Landeshauptarchiv, Bd. 6).

-, -: Grenzen und Reformen in einer Umbruchgesellschaft. Vom Land Brandenburg zu den Bezirken 1945-1952. Berlin 2014 (Veröffentlichungen des Brandenburgischen Landeshauptarchivs, Bd. 66).

-, -: Kommunale Strukturen im Spannungsfeld gesellschaftlicher Umwälzungen, Die Grenzen von Gemeinden und Kreisen in Brandenburg 1945-1952. Berlin 2018 (Veröffentlichungen des Brandenburgischen Landeshauptarchivs, Bd. 71).

Bluhm, Hans-Gottfried: Heimatkreisarchiv jetzt im Oderlandmuseum Bad Freienwalde. In: Königsberger Kreiskalender 2005, S. 18-20.

-, -: Fünf Jahre Gedenkstein für den Heimatkreis Königsberg/Neumark. Eine Posse gerät zum würdigen Denkmal. In: Königsberger Kreiskalender 1998 (1997), S. 155-160. [Hohenwutzen].

Bluhm, Beatrix / Heydebrand, Detlev von / Stahl, Hans-Joachim: Schloss Boitzenburg in der Uckermark. Geschichte und Gegenwart. Angermünde 2011.

Bock, Michael: Die Todesmärsche jüdischer Frauen und Mädchen 1945 durch das Golßener Land. In: Luckauer Heimatkalender 50 (2018), S. 31-36.

Bögner, Josef: Heimatchronik der Pfarrgemeinde Baumgarten Kreis Frankenstein - Schlesien. Bad Oeynhausen 1982.

Böhm. Jürgen: Das Ende des II. Weltkrieges in Stahnsdorf bei Berlin. In: Brandenburgisches Genealogisches Jahrbuch 10 (2016), S. 83-104.

Böhme, Renate: 1948-1978 - 30 Jahre Poliklinik Guben. In: Gubener Heimatkalender 22 (1978), S. 39-40.

Bössneck, Ulrich / Köhler, Günter: Der Dietrich von Knorre - der Malakologe, Musologe und Naturschützer sowie einer der letzten klassischen Zoologen Deutschlands wurd 80 Jahre alt. In: Mitteilungen der Deutschen Malakolozoologischen Gesellschaft 100 (2019), S. 49-62.

Böttger, Marieta / Hamdali, Mohamed: Neue Heimat Eberswalde nach der politischen Wende 1990. Zuwanderung in den Barnim - Chancen und Probleme. In: Fremde Heimat Eberswalde. Zuwanderungen in Vergangenheit und Gegenwart. Begleitheft zur Sonderausstellung im Rahmen des Kultur- 
landes Brandenburg 2003 Europa (Heimatkundliche Beiträge). Überarb. 2. Aufl. Eberswalde 2008, S. 51-60. [Darin S. 53-60 Kapitel „Russlanddeutsche - Aussiedler/innen“].

[Bolwin, Jacob:] Chronik der Missionspfarrei Wittenberge. Wittenberge [2006].

Boldorf, Marcel: Fürsorge im Umbruch. Die Provinz Brandenburg zwischen Weimarer Republik und DDR-Länderreform. In: Fürsorge in Brandenburg. Entwicklungen - Kontinuitäten - Umbüche. Wolfgang Hofmann / Kristina Hübener / Paul Meusinger (Hg.) (Schriftenreihe zur Medizingeschichte, Bd. 15). Berlin 2007, S. 371-410.

Borgmann, Lutz / Sebastian, Jürgen: Kirchen im Havelland. Unterwegs im Raum Rathenow/Rhinow. Potsdam 1994.

Borowsky, Peter: Deutschland 1963-1969. Hannover 1983 (Edition Zeitgeschehen).

Bräuning, Uwe: Die Entnazifizierung in Küstrin-Kietz 1945-1950; ders.: Zerbrechlich wie Glas - als Küstrin-Kietz in den Fokus deutsch-polnischer Beziehungen geriet; ders.: Kietz Kreis Seelow Ein Dorf unter Spionageverdacht; veröffentlicht 2016 auf https://kuestrinkietz.wordpress.com [6.1.2017].

-, -: Wasser für Kietz - vom jähen Ende eines grenzüberschreitenden Projektes. In: Jahrbuch MärkischOderland 27 (2020 [2019]), S. 94-96.

Bräutigam, Helmut: Fremdarbeiter in Brandenburg in der NS-Zeit. Dokumentation zum ,Ausländereinsatz' im früheren Regierungsbezirk Potsdam 1939 bis 1945. Potsdam 1996 (Interkulturelle Beiträge, 17).

Brandenburg im Jahr 1945. Studien. Hrsg. von Werner Stang unter Mitarb. von Kurt Arlt. Potsdam 1995.

Brandenburg in der NS-Zeit. Studien und Dokumente. Hrsg. von Dietrich Eichholtz unter Mitarb. von Almuth Püschel. Berlin 1993.

Brandenburgische Geschichte. Hrsg. von Ingo Materna u. Wolfgang Ribbe. Berlin 1995.

Brandes, Detlef: Der Weg zur Vertreibung 1938-1945. Pläne und Entscheidungen zum ,Transfer ' der Deutschen aus der Tschechoslowakei und aus Polen. München 2001 (Veröffentlichungen des Collegium Carolinum, Bd. 94).

-, -: Wilde Vertreibung aus der Tschechoslowakei. In: Lexikon der Vertreibungen. Deportation, Zwangsaussiedlung und ethnische Säuberung im Europa des 20. Jahrhunderts. Detlef Brandes / Holm Sundhausen / Stefan Troebst (Hg.). Wien/Köln/Weimar 2010, S. 728-730.

Brandt, Günther: Das Lehniner Krankenhaus. Entwicklung vom Beginn 1945 bis zum Ende der DDR. In: 100 Jahre Diakonissenmutterhaus Luise-Henriette in Lehnin. Festschrift. Hrsg.: Evangelisches Diakonissenhaus Teltow Lehnin. Red.: Stefan Beier. Unna [2011], S. 81-87.

Brandt, Hans Jürgen: Maximilian Kaller (1880-1947). In: 75 Jahre Bistum Berlin. 20 Persönlichkeiten. Hrsg. von Michael Höhle (Wichmann-Jahrbuch des Diözesangeschichtsvereins Berlin, N. F. 8 , 2004/05). Heiligenstadt 2005, S. 75-86.

Braun, Michael: Erste Nachkriegsjahre in Hönow. In: Jahrbuch Märkisch-Oderland 25 (2018 [2017]), S. 46-48.

-, -: Die nicht ganz erste LPG in der DDR. In: Jahrbuch Märkisch-Oderland 27 (2020 [2019]), S. 39-45.

Braunschweig, Frieda: Aufbau der Schule in Passow nach 1945. in: Angermünder Heimatkalender 2020, S. 212-217.

Brekow, Frank: Die Kampfhandlungen um Brandenburg an der Havel im April und Mai 1945. In: Jahresbericht Historischer Verein Brandenburg (Havel) e. V. 20 (2010/11 [2011]), S. 41-52.

Bretschneider, Uta: Ostpreußen als Randnotiz? Selbst- und Fremdbilder von „Umsiedlern“ in der DDR. In: Jahrbuch deds Bundesinstitutts für Kultur und Geschichte der Deutschen im östlichen Europa 24 (2016), S. 193-214. 
Breyer, Richard: Ostbrandenburg unter polnischer Verwaltung. Frankfurt a. M./Berlin 1959 (Ostdeutschland unter fremder Verwaltung, Bd. 4).

Brisch, Brigitte / Buwert, Wolfgang / Schieck, Martin: Frankfurt (Oder) 1945. Ausgewählte Daten, Dokumente, Fotos und Erinnerungen. Frankfurt (Oder) [1995].

Bruch, Helma vom: Umbrüche im Leben der Frauen in der SBZ, der späteren DDR. In: Jahrbuch der Deutschen aus Bessarabien 56 (2005), S. 41-45.

Brühe, Matthias: Katholische Kirche zwischen Uckermark und Oderland. Ein Porträt der Kirchen und Gemeinden für Einheimische und Gäste. Zsgest. von Matthias Brühe. Hrsg. von der Pressestelle des Erzbistums Berlin. Berlin 1998.

-, -: Katholische Kirche zwischen Havel und Dahme. Ein Porträt der Kirchen und Gemeinden für Einheimische und Gäste. Zsgest. von Matthias Brühe. Hrsg. von der Pressestelle des Erzbistums Berlin. Berlin 1999.

-, -: Katholische Kirche zwischen Prignitz und Havelland. Ein Porträt der Kirchen und Gemeinden für Einheimische und Gäste. Zsgest. von Matthias Brühe. Hrsg. von der Pressestelle des Erzbistums Berlin. Berlin 2000.

-, -: Katholische Kirche in Vorpommern. Ein Porträt der Kirchen und Gemeinden für Einheimische und Gäste. Zsgest. von Matthias Brühe. Hrsg. von der Pressestelle des Erzbistums Berlin. Vollst. überarb. Neuaufl. Berlin 2000.

Buchinger, Marie-Luise / Cante, Macus: Stadt Jüterbog mit Kloster Zinna und Gemeinde Niedergörsdorf. Worms am Rhein 2000 (Denkmaltopographie Bundesrepublik Deutschland. Denkmale in Brandenburg, Bd. 17.1).

Bülow, Karl: Chronik der Stadt Bernau 1945-2000. T. 1: Landwirtschaft, Industrie, Handwerk. Bernau 2000.

-, -: Chronik der Stadt Bernau 1945-2000. Überarb. Fass. [in 1 Bd.]. Bernau 2007 (CD).

Bülow, Ursula Maria von: Flucht und Vertreibung aus dem schlesischen Kreis Oels. Eine Dokumentation. Würzburg 1996.

Buschmann, Gerhard: Vor 50 Jahren: Grundsteinlegung zum „Chemiefaserkombinat Guben“. In: Gubener Heimatkalender 54 (2010), S. 61.

Buwert, Wolfgang: Anmerkungen zum Stand der DDR-Geschichtswissenschaft und zur Befreiung und Zerstörung Frankfurts 1945. In: Historischer Verein zu Frankfurt (Oder) e. V. Mitteilungen 1991, H. 1, S. 11-24.

-, -: Ergänzungen zur Richtigstellung der Geschichte der Festung Frankfurt. In: Historischer Verein zu Frankfurt (Oder) e. V. Mitteilungen 1991, H. 1, S. 25-28.

-, -: Festung Frankfurt (Oder): eine Stadt am Kriegsende. In: Brandenburg im Jahr 1945. Studien. Hrsg. von Werner Stang unter Mitarb. von Kurt Arlt. Potsdam 1995, S. 38-83. [S. 46-51: Kapitel „Die Flüchtlinge kommen"]; auch in: Historischer Verein zu Frankfurt (Oder) e. V. Mitteilungen 1995, H. 2, S. 2-34.

-, -: Einige einleitende Bemerkungen zum nachstehenden „Rückblick auf das Heimkehrerlager Gronenfelde bei Frankfurt/Oder“. In: Historischer Verein zu Frankfurt (Oder) e. V. Mitteilungen 1998, H. 2, S. 2-4.

Cajar, Wolfgang: Geschichte der Gesundheitsfürsorge in Schöneiche. [Schöneiche] 2018 (Schöneicher Hefte, H. 20).

Christopeit, Gerald: Die Herkunft und Verteilung der Evakuierten, Flüchtlinge und Vertriebenen in der Provinz Mark Brandenburg und ihr Verhältnis zu der einheimischen Bevölkerung. In: Sie hatten alles verloren. Flüchtlinge und Vertriebene in der sowjetischen Besatzungszone Deutschlands. Hrsg. von Manfred Wille, Johannes Hoffmann u. Wolfgang Meinicke (Studien der Forschungsstelle Ostmitteleuropa an der Universität Dortmund, Bd. 13). Wiesbaden 1993, S. 86-109. 
-, -: Die Sudetendeutschen in der Provinz Mark Brandenburg 1945 bis 1948. In: Die Sudetendeutschen in der Sowjetischen Besatzungszone Deutschlands. Ankunft, Aufnahme und erste Integrationsversuche. Manfred Wille (Hrsg.) (Magdeburger Forschungen, 10: Geschichte). Magdeburg 1993, S. 80-93.

-, -: Verschwiegene vier Millionen. Heimatvertriebene in der Sowjetischen Besatzungszone und der DDR. In: Jahrbuch für deutsche und osteuropäische Volkskunde 38 (1995), S. 222-251.

-, -: Kerb und Klöppelspitzen im Kattenwinkel - Vertriebenensiedlungen in der SBZ/DDR? In: Jahrbuch für deutsche und osteuropäische Volkskunde 40 (1997), S. 76-99.

-, -: Die Vertriebenen im Gründungsjahr der DDR - Versuch einer Standortbestimmung anhand ihrer Lage im Land Brandenburg 1949. In: 50 Jahre Flucht und Vertreibung. Gemeinsamkeiten und Unterschiede bei der Aufnahme und Integration der Vertriebenen in die Gesellschaften der Westzonen/ Bundesrepublik und der SBZ/DDR. Hrsg. von Manfred Wille. Magdeburg 1997, S. 256-270.

-, -: Die Glasmanufaktur Derenburg - von der sudetendeutschen Umsiedlergenossenschaft zur staatlichen Glasmanufaktur Harzkristall. In: Jahrbuch für deutsche und osteuropäische Volkskunde 42 (1999), S. 118-145.

-, -: Die deutschen Heimatvertriebenen von Weichsel und Warthe in der SBZ/DDR und die Entwicklung nach der Wende 1989/90. In: Jahrbuch Weichsel-Warthe 50 (2004), S. 120-144.

Chronik der katholischen Kirchengemeinde St. Maria von Lourdes, Altlandsberg. Altlandsberg 2012.

Chronik der Stadt Müncheberg in den Jahren 1945 bis 1989/90. Hrsg.: Verein für Heimatgeschichte der Stadt Müncheberg e. V. Zsgest. von Frank Geißler. T. 1-2. Müncheberg 2012.

Chronik der Stadt Prenzlau in Auszügen: 1945-1984. In: Prenzlau. Hauptstadt der Uckermark 1234-1984. Ein bürgerliches deutsches Lesebuch. Hrsg.: Heimatkreis Prenzlau. Barendorf 1984, S. 473-500.

Chronik der Stadt Schwedt/Oder in Daten, Dokumenten und Bildern. Hrsg.: Stadt Schwedt/Oder, Der Bürgermeister, Fachbereich 7 Bildung, Jugend, Sport und Kultur. Schwedt/Oder [2010].

Chronik der Stadt Wittenberge. Im Auftr. der Stadtverwaltung Wittenberge erarb. durch Hans Joachim Eichel, Heinz Muchow u. Günter Rodegast. Wittenberge 1997.

Chronik der uckermärkischen Dörfer Jagow mit Karlstein und Lauenhof, Kutzerow mit Dolgen, Taschenberg mit Uhlendorf und Taschenberger Ausbau. Milow u. a. 2013.

Chronik Falkensee 1945-1961. Hrsg. vom Rat der Stadt Falkensee. Hrsg. vom Rat der Stadt Falkensee. Red. Bearb.: Kurt Ruppin. Falkensee (1983).

Chronik Katholische Pfarrgemeinde Heilige Dreifaltigkeit Brandenburg a. d. Havel 1903-2000 (www. hl-dreifaltigkeit.de/chronik/[20.9.2016]).

Die Chronik zu Wölfelsgrund, Kreis Habelschwerdt, Grafschaft Glatz in Schlesien. Zusammenstellung, Ausarbeitung u. Ergänzung von Leonhard Prause. [Wenden 2005].

Clauss, Ernst: Buch der Stadt Grünberg in Schlesien. Obst- und Rebenstadt des deutschen Ostens. Neubearbeitung u. Ergänzung der Stadtgeschichten von August Förster u. Hugo Schmidt. Frankfurt am Main 1957.2. Aufl. 1964.

Cwiertnia, Beate: Das Katechetenseminar in Görlitz und das Katechetinnenseminar in Cottbus. Katechet/Innen in der DDR. In: Vertriebene finden Heimat in der Kirche. Integrationsprozesse im geteilten Deutschland nach 1945. Hrsg. von Rainer Bendel (Forschungen und Quellen zur Kirchenund Kulturgeschichte Ostdeutschlands, Bd. 38). Köln u. a. 2008, S. 57-77.

Czabatror, Jerzy: Zur Entwicklung in Gubin nach Ende des Krieges. In: Gubener Heimatkalender 54 (2010), S. 53-56.

Czerny, Jochen: Der Aufbau des Eisenhüttenkombinates Ost 1950/51. Phil. Diss. A. Jena 1970.

-, -: Die Herausbildung sozialistischer Kollektive und Arbeiterpersönlichkeiten beim Aufbau des Eisenhüttenkombinats Ost (EKO). In: Jahrbuch für Geschichte 17 (1977), S. 419-563. 
Dahms, Paul: Velten. Ein Streifzug durch die Geschichte der Ofenstadt. Hrsg.: Stadt Velten. Velten 2009.

Dalitz, Siegfried: „Helft unseren Kranken!“ Das Gesundheitswesen nach 1945. In: Zwischen Havelland und Fläming 1994, S. 81-83.

-, -: Die Chronik der Stadt Niemegk. Bd. 8: Geschichten zur Geschichte der Stadt Niemegk. Niemegk 2008 (S. 113-213: Zweiter Weltkrieg und Kriegsende).

Damaschke, Alfred / Damaschke, Elisabeth / Bergemann, Helmut: Ketzin. Chronik einer kleinen Stadt im Havelland 1197-1945. Berlin 1997 (Schriften des Heimatmuseums Ketzin, 5).

Danyel, Jürgen / Kaule, Martin / Zündorf, Irmgard: Brandenburg 1945-1990. Der historische Reiseführer. Berlin 2018.

Dannenberg, Lars-Arne: Flucht und Vertreibung im Zittauer Zipfel 1945 bis 1950. In: Sächsische Heimatblätter 62 (2016), S. 155-162.

Dartsch, Winfried: Junkerland in Bauernhand. Zur demokratischen Bodenreform 1945/46 in Groß Breesen. In: Gubener Heimatkalender 29 (1985), S. 44-49.

„... das Glockengeläut ist einzustellen“. 1945 - das Jahr zwischen Krieg und Frieden. T. 1: Belzig und Umgebung. Hrsg. vom Förderkreis Museum Burg Eisenhardt e. V. Red.: Helga Kästner. Belzig 1995.

Daum, Linde / Adolf, Horst: Integration der Bessarabiendeutschen in der Sowjetischen Besatzungszone. In: Jahrbuch der Deutschen aus Bessarabien 56 (2005), S. 46-54.

DDR-Lesebuch. Von der SBZ zur DDR 1945-1949. Hrsg. von Ilse Spittmann, Gisela Helwig. Köln 1989 (Edition Deutschland Archiv).

Degen, Ilmar: Flucht, Vertreibung und Deportation am Beispiel des Kreises Mohrungen/Ostpreußen. Wunstorf 2001 (Veröffentlichungen aus dem Projektbereich Ostdeutsche Landesgeschichte an der Universität Bonn, 19).

Deichgräber, Albert: Chronik der Stadt Plaue (Havel). Im Auftr. der Stadtverwaltung geschrieben. T. 2 [1933-1949]. [Wiesbaden 1969].

Demps, Laurenz: Die Provinz Brandenburg in der NS-Zeit (1933 bis 1945). In: Brandenburgische Geschichte. Hrsg. von Ingo Materna u. Wolfgang Ribbe. Berlin 1995, S. 619-676.

-. -: Berlin im Bombenkrieg. In: Berlin 1933-1945. Michael Wildt / Christoph Kreutzmüller (Hg.). Berlin 2013, S. 357-371.

Deutsch Kroner Heimatkreis 1949-1980. In: Deutsch Krone. Stadt und Kreis. Hrsg. von Karl Ruprecht im Auftr. des Vereins Deutsch Kroner Heimathaus e. V. Bad Essen 1981, S. 341-348.

Diakonissenhaus Teltow 1841-1991. Geschichtlicher Rückblick auf 150 Jahre Ev. Diakonissenhaus Berlin-Teltow und 60 Jahre Diakonissenmutterhaus „Bethanien“ in Kreuzburg/Oberschlesien. Hrsg. vom Hausvorstand des Evang. Diakonissenhauses Teltow. (Teltow) 1991.

Dieck, Rosemarie / Poldrack, Nele: Die evangelische Kirchengemeinde Leegebruch von ihren Anfängen bis 2008. Leegebruch 2015 (Leegebrucher historische Blätter, H. 13).

Diefenbach, Matthias / Maćkowiak, Michał: Zwangsarbeit und Autobahn zwischen Frakfurt (Oder) und Poznań 1940-1945. Praca przymusowa i autostrada między Frankfurtem nad Odrą a Poznaniem 1940-1945. Die nationalsozialistischen Arbeitslager entlang der Reichsautobahnbaustelle für Juden, sowjetische Kriegsgefangene, Polizeihäftlinge und andere Zwangsarbeiter. Hrsg.: Institut für angewandte Geschichte - Gesellschaft und Wissenschaft im Dialog e. V. Frankfurt (Oder)-Poznań 2017.

Dietrich, Siegfried: 40 Jahre Wohnungsbau in unserer Stadt. In: Gubener Heimatkalender 33 (1989), S. $12-20$.

Dietze, Peter: Abschied von Werner Bader. In: Rathenower Heimatkalender 59 (2015 [2014]), S. 65-67.

Discher, Holm: Karl Voigt und Ernst Lösche - Ein Porträt der ersten Angermünder Landräte der Nachkriegszeit. In: Angermünder Heimatkalender 2016 (2015), S. 192-201. 
Dittmer, Gisela: Auf der Suche nach dem Verlorenen. Nach dem Krieg wird alles anders. In: 750 Jahre Seegefeld. Christliches Leben im Wind der Zeiten. Festschrift der Evang. Gemeinde Falkensee-Seegefeld zur 750-Jahr-Feier im Jahr 2015. Hrsg.: Gisela Dittmer. Falkensee 2015, S. 171-182.

Dittmer, Katja: Klinik für Frauenheilkunde und Geburtshilfe. In: Zeitreise durch die Geschichte des Klinikums Frankfurt (Oder). Die Entwicklung von 1945 bis 2002. Hrsg. von Ulrich Knefelkamp in Verb. mit Andreas Grahlemann. Berlin 2003, S. 53-56.

-, -: Klinik für Kinder- und Jugendheilkunde. In: Zeitreise durch die Geschichte des Klinikums Frankfurt (Oder). Die Entwicklung von 1945 bis 2002. Hrsg. von Ulrich Knefelkamp in Verb. mit Andreas Grahlemann. Berlin 2003, S. 48-52.

-, -: Kurzer Überblick über die Lazarette und Krankenhäuser unmittelbar nach dem Zweiten Weltkrieg. In: Zeitreise durch die Geschichte des Klinikums Frankfurt (Oder). Die Entwicklung von 1945 bis 2002. Hrsg. von Ulrich Knefelkamp in Verb. mit Andreas Grahlemann. Berlin 2003, S. 31-32.

Dochow, Gudrun (Hrsg.): Haupt- und Landgestüt Neustadt (Dosse). Vom preußischen Gestüt zum Sanssouci der Pferde. Neustadt (Dosse) 2013.

Dörr, Margarete: Vertrieben, ausgebombt, auf sich gestellt. Frauen meistern Kriegs- und Nachkriegsjahre. Frankfurt/Main 1998.

Dokumentation über den Obernigker Treck 1945 einschließlich Aufenthalt in Wildstein/Egerland. Zsgest. von Ekkehard Loch u. Hellmut Seidel. Lüdenscheid/Deisenhofen 1998.

Dorbritz, Gerhard: (Außenlager) Belzig. In: Der Ort des Terrors. Geschichte der nationalsozialistischen Konzentrationslager. Hrsg. von Wolfgang Benz u. Barbara Distel. Bd. 3: Sachsenhausen, Buchenwald. München 2006, S. 78-80.

-, -: Der 3. Mai 1945 - die kampflose Übergabe. In: „... das Glockengeläut ist einzustellen“. 1945 - das Jahr zwischen Krieg und Frieden. T. 1: Belzig und Umgebung. Hrsg. vom Förderkreis Museum Burg Eisenhardt e. V. Red.: Helga Kästner. Belzig 1995, S. 102-104.

-, -: Erinnerungen an die Nachkriegszeit. In: Ders. / Helga Kästner / Ernst Neuendorf: Jeserig/Fläming. Ein Dorf in der Brandtsheide. Beiträge zur Ortsgeschichte. Hrsg.: Gemeinde Wiesenburg, Ortsteile Jeserig. Red.: Helga Kästner. Wiesenburg 2003, S. 76-81.

-, -: Schicksale. Dokumentation über das Zwangsarbeiterlager Roederhof in Belzig. Belzig 2001.

Dorfentwicklung in Brandenburg. Hrsg.: Ministerium für Landwirtschaft, Umsweltschutz und Raumordnung (MLUR) des Landes Brandenburg in Verb. mit Märkische Akademie ländlicher Raum e.V. Konzeption u. Gestaltung: Norbert Rauscher. Potsdam 2002.

Drescher, Anne: Das Lager Wöbbelin nach Kriegsende 1945 bis 1948. Hrsg.: Der Landesbeauftragte für Mecklenburg-Vorpommern für die Unterlagen des Staatssicherheitsdienstes der ehemaligen DDR. Schwerin 2008.

Drieschner, Axel: Funktionen materieller Quellen für die zeithistorische Forschung. In: Archäologie und Gedächtnis. NS-Lagerstandorte. Erforschen - Bewahren - Vermitteln. Interdisziplinäre Konferenz im Archäologischen Landesmuseum Brandenburg an der Havel 17. bis 19. September 2015. Hrsg.: Thomas Kersting u. a. (Denkmalpflege in Berlin und Brandenburg, Arbeitsheft 4/2016). Petersberg 2016, S. 47-54.

Dziadek, Anna / Quiel, Günter: Anno 2014. In: Gubener Heimatkalendert 59 (2015), S. 119-125.

Eberlein, Hellmut: Zur Psychologie des Ostpfarrers. In: Jahrbuch für Schlesische Kirche und Kirchengeschichte, NF 32 (1953), S. 154-167.

Ebert, Rolf: Lübben und die Niederlausitz. Beiträge zur Geschichte einer Region im Land Brandenburg. Bd. 2: Lübben im April/Mai 1945. Untersuchungen und Betrachtungen zur Zerstörung der alten Spreewaldstadt am Ende des zweiten Weltkrieges sowie zu den ersten Maßnahmen ihres Wiederaufbaus. Lübben im Spreewald 1997. 
-, -: Zur Geschichte der Stadt Lübben (Spreewald). Chronologischer Abriss. Lübben 2003.

Eichler, Klaus: Zum ersten Kommandanten Sano des Entlassungslagers in der Horn-Kaserne Frankfurt (Oder) für kriegsgefangene deutsche Soldaten aus der Sowjetunion - Rudolf Voigt. In: Historischer Verein zu Frankfurt (Oder) e. V. Mitteilungen 2001, H. 1, S. 24-37.

-, -: Zu der Serie „Von der Festung zur Lazarettstadt - Frankfurt (Oder) 1945 bis 1949“. In: ebd. 2005, H. 2, S. 25-32.

-, -: Zur Studie „Unbekannte Grablagen verstorbener deutscher Kriegsgefangener in Frankfurt (Oder) aus der Zeit von 1945/50“ vom 15.04.12005. In: ebd., 2007, H. 1, S. 7-16.

-, -: Die wichtigsten Ereignisse für die Kaiserin-Witwe Hermine von Preußen in Frankfurt (Oder). In: ebd. 2008, H. 2, S. 31-32.

-, -: Zum Kreisverband der Heimkehrer, Kriegsgefangenen und Vermißtenangehörigen e. V. Frankfurt (Oder) mit seiner Auflösung zum 31.12.2009. In: ebd. 2010, H. 1, S. 26-29.

Eine Chronik. 775 Jahre Platkow 1229-2004. 600 Jahre Gusow 1405-2005. Hrsg.: Gemeinde GusowPlatkow. Gusow-Platkow (2004).

Eisenhüttenstädter Lesebuch. Profile 2002. Hrsg. u. verf. von Gudrun Prengel. Im Auftr. der Geschichtswerkstatt Eisenhüttenstadt e. V. Berlin 2002.

Eisfeld, Alfred: Die Rußlanddeutschen. Mit Beitr. von Detlev Brandes u. Wilhelm Kahle. München 1992 (Studienbuchreihe der Stiftung Ostdeutscher Kulturrat, Bd. 2).

Eisler, Cornelia: Verwaltete Erinnerung - symbolische Politik. Die Heimatsammlungen der deutschen Flüchtlinge, Vertriebenen und Aussiedler. München 2015 (Schriften des Bundesinstituts für Kultur und Geschichte der Deutschen im östlichen Europa, Bd. 57).

-, -: (Ost)brandenburgische Sammlungen in Westdeutschland. Zum Phänomen der Heimatstuben und -archive von Flüchtlingen und Vertriebenen in der Bundesrepublik Deutschland. In: Brandenburgische Archive 34 (2017), S. 35-41.

Das Ende des Zweiten Weltkrieges im Mai 1945. Erinnerungen an die Prignitzdörfer Boberow und Glövzin. Hrsg.: Manfred Müller. Schwerin 2006.

Engler, Harald: Von der Hauptsparkasse der Niederlausitz zur Sparkasse Dahme-Spreewald. In der Region für die Region seit 1824. Königs Wusterhausen/Potsdam-Bornim 2003.

-, -: Das „sozialistische“ Prenzlau in der SBZ und der DDR (1945 bis 1990). In: Geschichte der Stadt Prenzlau. Im Auftr. Der Stadt Prenzlau hrsg. von Klaus Neitmann u. Winfried Schich (Einzelveröffentlichungen der Brandenburgischen Historischen Kommission, Bd. 16). Horb am Neckar 2009, S. 274-339.

-, -: [Sammelrezension zum Thema Zwangsmigration und Vertreibung]. In: Jahrbuch für die Geschichte Mittel- und Ostdeutschlands 55 (2009 [2010]), S. 334-340.

Entscheidung für den Glauben. Potsdamer Katholiken berichten über ihre Erfahrungen im athistischen Staat DDR 1945 bsi 1989. Zsgest. u. bearb. von Manfred Gläser, Sigrid Grabner, Michael Kindler. Potsdam 2009.

Erbe und Auftrag der schlesischen Kirche/Dziedzictwo i posłannictwo śląskiego Kościoła. 1000. Jahre Bistum Breslau/1000 lat diecezji wrocławskiej. Hrsg. von Winfried König. Dülmen 2001.

Erinnerungen an Stadt + Land Friedeberg Nm. Hrsg. von E(rhard) Schendel u. Hans Schauer. Berlin 1974.

Die Erlöserkirche in Potsdam 1898-1998. Festschrift zur 100-Jahr-Feier am 4. Mai 1998. Hrsg. vom Gemeindekirchenrat der Erlöserkirchengemeinde Potsdam. Red.: Martin Kwaschik, Rudolf Knaack, Ewald Gerth. Potsdam 1998.

Ernst, Hans-Eberhard: Das Ende des Krieges - Greiffenberg 1945. In: Angermnünder Heimatkalender 2020, S. 203-211. 
Escher, Felix: Die katholische Kirche. In: Stahl und Brennabor. Die Stadt Brandenburg im 19. Und 20. Jahrhundert. Hrsg. von Gerd Heinrich u. a. (Bibliothek der Brandenburgischen und Preußischen Geschichte, Bd. 3). Potsdam 1998, S. 285-300.

-, -: Die katholische Kirche im 19. und 20. Jahrhundert. In: Tausend Jahre Kirche in Berin-Brandenburg. Hrsg. von Gerd Heinrich. Berlin 1999, S. 647-702.

-, -: (Art.) Katholische Kirche. In: Brandenburg an der Havel. Lexikon zur Stadtgeschichte. Hrsg. von Udo Geiseler u. Klaus Heß. Berlin 2008, S. 201-202.

Faehndrich, Jutta: Erinnerungskultur und Umgang mit Vertreibung in Heimatbüchern deutschsprachiger Vertriebener. In: Zeitschrift für Ostmitteleuropa-Forschung 52 (2003), S. 191-229.

-. -: Eine endliche Geschichte. Die Heimatbücher der deutschen Vertriebnenen. Köln u. a. 2011 (Visuelle Geschichtskultur, 5).

-, -: Heimatbuch. In: Online-Lexikon zur Kultur und Geschichte im östlichen Europa, 2013. URL: ome-lexikon.uni-oldenburg.de/55232.html (Stand 26.9.2013).

Feiber, Albert A.: Heimatbriefe als historische Quelle. In: Heimatzeitschriften. Funktionen, Netzwerke, Quellenwert. Tilman Kasten u. Elisabeth Fendl (Hg.) (Schriftenreihe des Instituts für Volkskunde der Deutschen des östlichen Europa, Bd. 18). Münster/New York 2017, S. 173-198.

Felber, Christina / Jerratsch, Ines / Martini, Helge: Schöneiche bei Berlin. Eine Chronologie durch die Geschichte. Schöneiche bei Berlin 2000.

Festschrift 700 Jahre Stadt Spremberg. Aus der Geschichte der Stadt Spremberg. Hrsg.: Stadt Spremberg. Spremberg 2000.

Festschrift 400 Jahre Schorfheidestadt Joachimsthal. Altenhof 2004.

Festschrift zum 50jährigen Jubiläum des Gubener Heimatbundes e. V. 1952-2002. Hrsg.: Gubener Heimatbund e. V. Verantw. Red.: Lutz Materne. Guben 2002.

Festschrift zur 750-Jahr-Feier der Havelstadt Zehdenick. Hrsg. vom Rat der Stadt Zehdenick. Zehdenick 1967.

Fiddecke, Marlies: Dr. Hans Schmorell - Arzt in Wriezen und Pazifist. In: Jahrbuch Märkisch-Oderland 25 (2018), S. 51-53.

Fisch, Bernhard / Klemeševa, Marina: Zum Schicksal der Deutschen in Königsberg 1945-1948 (im Spiegel bisher unbekannter Quellen). In: Zeitschrift für Ostmitteleuropa-Forschung 44 (1995), S. 391-400.

Fischer, Ingrid: Zuwanderung nach dem Zweiten Weltkrieg. In: Fremde Heimat Eberswalde. Zuwanderungen in Vergangenheit und Gegenwart. Begleitheft zur Sonderausstellung im Rahmen des Kulturlandes Brandenburg 2003 Europa (Heimatkundliche Beiträge). Überarb. 2. Aufl. Eberswalde 2008 (1. Aufl. 2003), S. 33-43. [Darin S. 33-37: Kapitel „Flüchtlinge, Vertriebene und Umsiedler"].

Fleischer, Horst: Abriss der Chronik Oderbergs. T. 4: Von 1930 bis 1949. In: Eberswalder Jahrbuch 2004/05 (2004), S. 119-133.

Flucht und Vertreibung. Europa zwischen 1939 und 1948. Mit e. Einl. von Arno Surminski. Hamburg 2012.

Flucht, Vertreibung, Neubeginn nach 1945. Schicksale und Berichte aus dem Raum Lieberose. Mit Beitr. von: Karl Beerfelde u. a. Hrsg. von der Evang. Kirchengemeinde Lieberose und Land. Red.: Andreas Weigelt. Lieberose 2006.

Foitzik, Jan: Sowjetische Militäradministration in Deutschland (SMAD) 1945-1949. Struktur und Funktion. Berlin 1999 (Quellen und Darstellungen zur Zeitgeschichte, Bd. 44).

Foitzig, Jan / Petrow, Nikita W.: Die sowjetischen Geheimdienste in der SBZ/DDR von 1945 bis 1953. Berlin u. a. 2009 (Texte und Materialien zur Zeitgeschichte, 17).

Forkert, Werner: Senftenberger Rundblicke. Interessantes aus der Senftenberger Geschichte. T. 3. Senftenberg 2008. 
Frankfurt an der Oder - Stadt der Heimkehrer. In: Geteilte Städte - Amputiertes Land (Sonderreihe der Zeitschrift „Berlin-Brandenburger Kurier“). Celle [1959], S. 24-29.

Franzke, Werner: Der Wiederaufbau des Gesundheitswesens in unserer Stadt. In: Gubener Heimatkalender 12 (1967), S. 59-64.

„Freiheit wollen wir!“ - Der 17. Juni 1953 im Land Brandenburg. Ausstellungskatalog. Hg.: Gabriele Schnell. Berlin 2003.

Fremde Heimat Eberswalde. Zuwanderungen in Vergangenheit und Gegenwart. Begleitheft zur Sonderausstellung im Rahmen des Kulturlandes Brandenburg 2003 Europa. Eberswalde 2003. Überarb. 2. Aufl. 2008 (Heimatkundliche Beiträge).

Fremde in Fürstenwalde. Fakten, Fragen, Fragmente. Eine Arbeit von Schülern des Geschwister-SchollGymnasiums. Hrsg. von der Kulturfabrik Fürstenwalde gGmbH. Red.: Florian Wilke. Fürstenwalde [2007].

Friedl, Gerhard: Juni 1945: Die Vertreibung der Deutschen aus Sommerfeld. In: Sorauer Sommerfelder Hefte 16 (2016), Nr. 1, S. 29; Nr. 2, S. 15-16.

Friemel, Franz Georg: Schlesische (und andere) Katholiken in der DDR. In: Erbe und Auftrag der schlesischen Kirche/Dziedzictwo i posłannictwo śląskiego Kościoła. 1000. Jahre Bistum Breslau/1000 lat diecezji wrocławskiej. Hrsg. von Winfried König. Dülmen 2001, S. 300-309.

Friske, Matthias / Niedrich, Hartmut: Altlandsberg. Glanz und Vergänglichkeit in acht Jahrhunderten. Neuenhagen 2000.

Fritzschka, J.: Vom Soldatenquartier zum Altenpflegeheim. „Herberge zur Heimat“ feiert 125jähriges Bestehen. In: Gubener Heimatbrief (1994)2, S. 77. (Nachdruck aus Neiße-Echo, Nr. 13/1994).

Fromm, Alexander: Die Jugend des Rudolf Bahro. Einstiger „Staatsfeind Nr. 1“ war ein Kind dieser Stadt. In: Heimatkalender Eisenhüttenstadt und Umgebung 18 (2000), S. 76-81.

Fromm, Günter: Bodenreform 1945/46 in Ziltendorf - Ortsteile Thälmannsiedlung und Aurith. In: Heimatkalender Eisenhüttenstadt und Umgebung 15 (1997), S. 80-86.

-, -: Ziltendorf hat wieder eine Kirche. In: Heimatkalender Eisenhüttenstadt und Umgebung 15 (1997), S. 78-89.

-, -: Nieder mit der Regierung! Der 17. Juni in Stalinstadt und Fürstenberg/Oder. In: Eisenhüttenstadt: „Erste sozialistische Stadt Deutschlands“. Hrsg.: Arbeitsgruppe Stadtgeschichte. Berlin 1999, S. $138-148$.

Fudel, Torsten: Der Krieg an der Oder. Ein Tagebuch. Vom Untergang der Festung Küstrin, den Ereignissen entlang der Reichsstraße 1 und die Schlacht um die Seelower Höhen. Seelow 2011.

Fünfundsiebzig Jahre Berliner Stadtmission. 9. März 1877-1952. Hrsg.: Berliner Stadtmission. Verf. im Auftr. des Vorstandes: Max Dietrich. Berlin 1952.

75 Jahre Bistum Berlin. 20 Persönlichkeiten. Hrsg. von Michael Höhle. Heiligenstadt 2005 (WichmannJahrbuch des Diözesangeschichtsvereins Berlin, N. F. 8, 2004/05).

75 Jahre Herz-Jesu-Kirche Templin 1935-2010. Hrsg.: Katholische Kirchengemeinde Herz Jesu. Red.: Th[omas] Höhle. Templin (2010).

75 Jahre Katholische Kirche Heilig Kreuz in Mildenberg. 1937-2012. Hrsg.: Katholische Kirchengemeinde Herz Jesu. Red.: Thomas Höhle. Templin (2012).

75 Jahre Katholische Kirchengemeinde zu den hl. Schutzengeln Hennigsdorf. Festschrift zum Jubiläum. Zsgest. von Matthias Brühe. Hennigsdorf 2002.

50 Jahre Volkssolidarität. In: Gubener Heimatkalender 40 (1996), S. 33-34.

Fürsorge in Brandenburg. Entwicklungen - Kontinuitäten - Umbüche. Wolfgang Hofmann / Kristina Hübener / Paul Meusinger (Hg.). Berlin 2007 (Schriftenreihe zur Medizingeschichte, Bd. 15). 
Fürstenwerder Mosaik. T. 2: Die Vierziger und Fünfziger Jahre. Red.: Ute Bleich u. a. Fürstenwerder 2002 (Schriftenreihe des Uckermärkischen Geschichtsvereins Prenzlau e. V., Ortsgruppe Fürstenwerder, H. 2).

Funke, Alfred: Die Messerschmiede - das märkische Klein-Solingen. In: Leegebruch. Hrsg.: Arbeitsgruppe Heimatgeschichte im Kulturverein Leegebruch. 2. Aufl. Leegebruch [2003], S. 85-92.

-, -: Ein Leegebrucher Wahrzeichen - die Messerschmiede. Leegebruch 2007 (Leegebrucher historische Blätter, H. 4).

-, -: Ein Leegebrucher Wahrzeichen - die Messerschmiede. Bildband. Leegebruch 2008 (Leegebrucher historische Blätter, H. 5).

-, -: Die Messerschmiede. In: Messer Magazin (2011)2, auch in: www.geschichtsverein-leegebruch.de [5.6.2017].

Furian, Hans-Otto: Vom Kirchenkampf zum Christuskampf. Kirchliches Leben in der östlichen Neumark 1933 bis 1945 (Zur Geschichte des Kirchenkampfes 3/1). Hrsg. im Auftr. der Kirchenleitung der Evang. Kirche Berlin-Brandenburg-schlesische Oberlausitz von Erich Schuppan. Berlin 2005.

Gansleweit, Klaus-Dieter: Zur Geschichte Steinsdorfs vom 18. bis 21. Jahrhundert. In: Niederlausitzer Studien 36 (2010), S. 123-159.

-, - / Opitz, Erich: Fürstenberg (Oder) im Wandel der Zeiten. T. 3. In: Fürstenberger Blätter 2 (2017), S. 6-24.

Gatzke, Margitta: Zeittafel von 1945 bis 1989. In: Festbuch 800 Jahre Zehdenick. Eine Zeitreise durch Vergangenheit und Gegenwart. Red.: Margitta Gatzke, Rainer Höll. Karlshagen 2016, S. 166-169.

Gaul, Anna-Maria: Zur Geschichte des Klinikums Frankfurt (Oder). In: Zeitreise durch die Geschichte des Klinikums Frankfurt (Oder). Die Entwicklung von 1945 bis 2002. Hrsg. von Ulrich Knefelkamp in Verb. mit Andreas Grahlemann. Berlin 2003, S. 11-27.

Gedenken in Caputh. Den Opfern von Krieg und Gewalt. Ausgew. u. bearb. von Klaus Hugler. Hrsg.: Evang. Kirchengemeinde Caputh. Caputh 2005.

Gedenkorte der Stadt Prenzlau. Projektleitung: Jörg Dittberner. (Prenzlau) o.J. (https://secure.service. brandenburg.de/sixcms/media.php/569/Flyer_Final_v1.02_Normalfassung_A4_Web.pdf).

Gedenkstätten für die Opfer des Nationalsozialismus. Eine Dokumentation. Bd. II: Bundesländer Berlin, Brandenburg, Mecklenburg-Vorpommern, Sachsen-Anhalt, Sachsen, Thüringen. Autorinnen: Stefanie Endlich (Berlin, Brandenburg) u. a. Bonn 2000.

Gefangene und Heimkehrer in Frankfurt (Oder) 1945-1950/56. Studien. Potsdam 1998. Wolfgang Buwert (Hg.). Brandenburgische Historische Hefte, 9).

Geglückte Integration? Spezifika und Vergleichbarkeiten der Vertriebenen-Eingliederung in der SBZ/ DDR. Hrsg. von Dierk Hoffmann u. Michael Schwartz. München 1999 (Schriftenreihe der Vierteljahrshefte für Zeitgeschichte, Sondernr.).

Geschichte der Deutschen Demokratischen Republik. Von einem Autorenkollektiv unter Leitung von Rolf Badstübner. Hrsg. vom Wiss. Beirat für Geschichtswissenschaft beim Ministerium für Hoch- u. Fachschulwesen unter Ltg. von Manfred Kossok. Berlin 1981.

Geschichte vor Ort: Erinnerungskultur im Land Brandenburg für die Zeit von 1933 bis 1990. Konzept der Landesregierung. Stand: 15. Januar 2009 (Entwurf). [Potsdam] (2009), http://www.mwfk. brandenburg.de/media/lbm1.a.1492.de/geschichtevorort.pdf [17.10.2016].

Geschichte vor Ort: Erinnerungskultur im Land Brandenburg für die Zeit von 1933 bis 1990. Konzept der Landesregierung. Ausgegeben: 04.05.2009. [Potsdam] 2009 (Landtag Brandenburg, 4. Wahlperiode. Drucksache 4/7529), http://www.mwfk.brandenburg.de/media_fast/4055/Konzept_ GeschichtevorOrt.pdf [17.10.2016]. 
Geschichte(n) aus 750 Jahren Stahnsdorf. Eine Chronik. Hrsg. vom Stahnsdorfer Heimatverein e. V. anlässlich des 750-jährigen Jubiläums. Stahnsdorf 2014.

Geteilte Städte - Amputiertes Land. Hrsg.: Ulrich Rühmland. Celle [1959] (Sonderreihe der Zeitschrift „Berlin-Brandenburger Kurier“).

Gill, Manfred: Letschin 1336-1986. Ein Streifzug durch die Geschichte des Oderbruchdorfes. Letschin 1985 (Heimatkalender Letschin 1985).

Der Glaube lebt. 50 Jahre Bistum Berlin 1930-1980. Hrsg. vom Bischöflichen Ordinariat Berlin unter Mitarb. von Peter Beier u. a. Leipzig 1980.

Goller, Alexander: Eine neue Heimat? Zur Aufnahme und Integration der Umsiedler im heutigen Eisenhüttenstadt. In: Transit - Transfer. Politik und Praxis der Einwanderung in die DDR 1945-1990. Kim Christian Priemel (Hrsg.) (Almanach des Institutts fürt Angewandte Geschichte). Berlin 2011, S. 25-50.

Goralczyk, Peter: Das Schicksal von Schlössern, Herrenhäusern und Burgen in der DDR-Zeit. In: Schlösser, Herrenhäuser, Burgen und Gärten in Brandenburg. Festschrift zum zwanzigjährigen Jubiläum des „Freundeskreises Schlösser und Gärten der Mark in der Deutschen Gesellschaft e. V.“ 2012. Sibylle Badstübner-Gröger (Hg.). Berlin 2012, S. 51-67.

Gräfe, Karl-Heinz: Kernprobleme ostdeutsch-polnischer Beziehungen 1945 bis 1949. In: Sächsische Heimatblätter 39 (1993), S. 260-261.

Gramlich, Sybille: Freileben. Das Neubauerndorf - Ein hoffnungsvoller Neubeginn. in: Brandenburgische Denkmalpflege 4 (1995), H. 1, S. 129-137.

-, -, u. a.: Stadt Frankfurt (Oder). Worms am Rhein 2002 (Denkmaltopographie Bundesrepublik Deutschland. Denkmale in Brandenburg, Bd. 3).

Grandke, Sarah: „Als die Füße nass und kalt waren, erkannte ich den Ernst der Lage." Flucht und Vertreibung 1944/45 und die schwierige Nachkriegszeit. Hrsg.: Uckermärkischer Geschichtsverein zu Prenzlau e. V. Prenzlau 2008. 64 S. (Schülerarbeiten zur Regionalgeschichte, H. 4).

Grenzerfahrungen. Jugendliche erforschen deutsch-polnische Geschichte. Hrsg. von Alicja WancerzGluza in Zsarb. mit Gabriele Bucher-Dinç. Hamburg 2003.

Grieger, Ulf: Die vereinten Zugezogenen. In: Jahrbuch Märkisch-Oderland 27 (2020 [2019]), S. 74-76.

Grittner, Wolfgang: Marquardt. Illustrierte Zeittafel zur Ortsgeschichte 1313-2016. [Marquardt] 2017.

Groch, Wolfgang / Strehlau, Reinhold: 90 Jahre Siedlerdorf Schenkenberg. In: Zwischen Havel und Fläming 2018 (2017), S. 129-132.

Grünitz, Paul: Die militärischen Ereignisse im Land- und Stadtkreis Guben vom Januar bis April 1945. Ein militärgeschichtlicher Abriß. In: Gubener Heimatkalender 39 (1995), S. 17-34.

Gruner, Petra: „... Steineklopfen wär’ auch möglich gewesen“. Der Neubeginn in der Erfahrung von Neulehrern. In: Der 8. Mai 1945 als historische Zäsur. Hrsg. von Arnd Bauerkämper, Christoph Kleßmann, Hans Misselwitz (Protokolle). Potsdam 1995, S. 128-151.

-, -: Die Neulehrer: Schlüsselsymbol der DDR-Gesellschaft. In: Aus Politik und Zeitgeschichte (1999)38, S. 25-31.

Guben in der Sowjetischen Besatzungszone. Zeittafel 1945-1949. In: Gubener Heimatkalender 44 (2000), S. 62-63.

Guben nach der Wiedervereinigung. Zeittafel 1991-1999. In: Gubener Heimatkalender 44 (2000), S. $110-114$.

Guben unter dem Nationalsozialismus. Zeittafel 1933-1945. In: Gubener Heimatkalender 44 (2000), S. 44-45.

Guben zu Zeiten der DDR. Zeittafel 1949-1990. In: Gubener Heimatkalender 44 (2000). S. $72-77$. 
Gunia, Gerhard: „Bis fünf Minuten nach zwölf ...“ Die Stadt Guben im zweiten Weltkrieg. In: Gubener Heimatkalender 11 (1966), S. 36-42.

-, -: Zerstörung und Neubeginn einer Niederlausitzer Stadt. Zum 40. Jahrestag der Befreiung. In: Gubener Heimatkalender 29 (1985), S. 18-25.

-, -: Zur Erinnerung an Wilhelm Pieck. In: Gubener Heimatkalender 40 (1996), S. 128-129.

-, -: Kriegsgefangene wurden zu Zivilarbeitern. Der Raum Guben im II. Weltkrieg. In: Gubener Heimatkalender 44 (2000), S. 55-56.

-, -: Die Neissestadt ohne Brücken. In: Gubener Heimatkalender 44 (2000), S. 64.

-, -: Gedanken zur Grenzöffnung 1972. In: Gubener Heimatkalender 44 (2000), S. 103.

-, -: Zwischen Bismarckturm und Borsigwerk. Beiträge zur Geschichte der Stadt Guben 1914-1944. Guben 2000.

Guski, Roman / Schlaier, Claudia: Projekt „Spurensicherung 1945“. Ansatz, Arbeitsschritte, Ausstellung. In: Museumsblätter. Mitteilungen des Museumsverbandes Brandenburg 27 (2015), S. 28-35.

Guthjahr, Rudolf: Havelstadt Rathenow. Kleine Stadtchronik. Rathenow 1991.

Gutzschebauch, Jürgen: Das Krankenhaus Prenzlau feierte 90. Geburtstag. Versuch einer Zeitreise von 1927-2017. In: Heimatkalender Prenzlau 61 (2018), S. 123-133.

Habel, Fritz Peter: Die Sudetendeutschen. 2., durchges. u. erw. Aufl. München 1998 (Vertreibungsgebiete und vertriebene Deutsche. Studienbuchreihe der Stiftung Ostdeutscher Kulturrat, Bd. 1).

Haberkern, Lisa: Heimatverlust im Familiengedächtnis. Eine Oral-History-Untersuchung unter Vertriebenenfamilien in Berlin und Brandenburg. Masterarbeit Europa-Univ. Viadrina Frankfurt (Oder) 2015.

Hacker, Anne: Birkenhain als Flüchtlingslager. Die Baracke als eine Zwischenstation zum neuen Leben in der „Zwangsheimat“ Deutschland. In: Birkenhain. Ein historischer Ort. Autoren: Judith Drescher u. a. Hrsg.: Uckermärkischer Geschichtsverein zu Prenzlau e. V. (Schülerarbeiten zur Regionalgeschichte, H. 3). Prenzlau 2007, S. 30-36.

Hahn, Eva / Hahn, Hans Henning: Die Vertreibung im deutschen Erinnern. Legenden, Mythos, Geschichte. Paderborn 2010.

Hahn, Gottfried: Zum Geleit. Anno 1995 - 50 Jahre nach dem Zweiten Weltkrieg. In: Gubener Heimatkalender 39 (1995), S. 8. [Geleitwort des Bürgermeisters der Stadt Guben; Eltern 1945 aus Grünberg in Schlesien nach Luckau vertrieben].

Hahn, Peter-Michael: Geschichte Brandenburgs. München 2009.

Halbrock, Christian: Evangelische Pfarrer der Kirche Berlin-Brandenburg 1945-1961. Amtsautonomie im vormundschaftlichen Staat? Berlin 2004.

Halicka, Beata: Das Zäsurjahr 1945 an der Mittleren Oder in den Erinnerungen von Deutschen und Polen. In: Schwierige Nachbarn? 300 Jahre deutsch-polnische Nachbarschaft. Groß Neuendorfer Gespräche 2006. Vorträge und Diskussionen. Hrsg. im Auftr. des Landfrauenvereins „Mittleres Oderbruch“ e. V. Groß Neuendorf von Wolfgang Michalka u. Reinhard Schmook. Berlin 2007, S. 59-73.

-, - / Diefenbach, Matthias: Neumark/Ostbrandenburg/Ziemia Lubuska. In: Online-Lexikon zur Kultur und Geschichte der Deutschen im östlichen Europa, 2018. URL: ome-lexikon.uni-oldenburg.de/ p38427 (Stand 23.01.2018).

Halter, Hans: Aktion Rote Faust (Felgentreu - ein „sozialistisches“ Flüchtlingsdorf). In: Die Flucht der Deutschen. Spiegel special 2/2002, S. 122-123.

Handt, Dietrich: Stiftung Brandenburg. In: Brandenburgkurier 20 (2006), Nr. 2, S. 2-6.

Hanke, Willi: „Bornstedt nahe bey Sanssouci“. Geschichte der Evangelischen Kirchengemeinde Potsdam-Bornstedt. Hrsg. im Auftr. der Evang. Kirchengemeinde Bornstedt von Jutta Erb-Rogg. Potsdam 2006. 
-, - / Bahl, Peter: Ahnen und Seitenverwandte der Geschwister Hanke (Schlesien und Ostpreußen). In: Archiv ostdeutscher Familienforscher, Bd. 15, 2003, S. 505-508.

Hanusch, Karin: Die Türme von Brück. In: Zwischen Havel und Fläming 2018 (2017), S. 48-51.

Hartelt, Konrad: Ferdinand Piontek (1878-1963). Leben und Wirken eines schlesischen Priesters und Bischofs. Köln u. a. 2008 (Forschungen und Quellen zur Kirchen- und Kulturgeschichte Ostdeutschlands, Bd. 39).

Hartisch, Torsten: Quellen des Brandenburgischen Landeshauptarchivs zur Ortsgeschichte in der Nachkriegszeit (http://blha.brandenburg.de/wp-content/uploads/2017/11/Hartisch_QuellenOrtsgeschichte-Nachkriegszeit.pdf [23.7.2018]).

Hartmann, Anne / Eggeling, Wolfram: Sowjetische Präsenz im kulturellen Leben der SBZ und frühen DDR 1945-1953. Berlin 1998 (edition bildung und wissenschaft, 7).

Hartwich, Mateusz J.: Reisen von DDR-Bürgern ins Riesengebirge in den 50er und 60er Jahren. In: Schlesier in der DDR. Berichte von Flüchtlingen, Vertriebenen und Umsiedlern. Michael Parak (Hrsg.). Eine Veröff. des Schlesischen Museums zu Görlitz. Görlitz 2009. S. 119-133.

Hausdorf, Walter / Noack, Siegrid: Frankfurt (Oder). Straßen, Wege, Plätze in ihrer historischen Entwicklung. In: Frankfurter Jahrbuch 2002, S. 3-166.

Haustein, Petra: Geschichte vor Ort: Erinnerungskultur im Land Brandenburg für die Zeit von 1933 bis 1990 (Konzept der Landesregierung). In: Landesgeschichtliche Vereinigung für die Mark Brandenburg. Mitteilungsblatt 111 (2010), 21-22.

Havelberg - kleine Stadt mit großer Vergangenheit. Hrsg. von der Stadt Havelberg. Halle 1998.

Das Havelland um Rathenow und Premnitz. Eine landeskundliche Bestandaufnahme. Hrsg. von Sebastian Kinder u. Haik Thomas Porada im Auftr. des Leibniz-Inst. für Länderkunde u. der Sächs. Akad. der Wiss. zu Leipzig. Köln u. a. 2017 (Landschaften in Deutschland, Bd. 74).

Hecklau, Svenja: Aufbau der Seelsorge im Gebiet Görlitz 1945-1972. In: Vertriebene finden Heimat in der Kirche. Integrationsprozesse im geteilten Deutschland nach 1945. Hrsg. von Rainer Bendel (Forschungen und Quellen zur Kirchen- und Kulturgeschichte Ostdeutschlands, Bd. 38). Köln u. a. 2008, S. 79-93.

Heckmann, Dieter, und Zeitzeugen: 100 Jahre katholische Kirche „Maria Meeresstern“ Werder a.d. Havel 1906-2006. 2., erw. Aufl. Potsdam 2013 (Heftreihe der Katholischen Propstei „St. Peter und Paul“ Potsdam, H. 9).

Hehn, Jürgen von: Die Umsiedlung der baltischen Deutschen - das letzte Kapitel baltisch-deutscher Geschichte. Marburg/Lahn 1984 (Marburger Ostforschungen, Bd. 40).

Heike, Otto: 150 Jahre Schwabensiedlungen in Polen 1795-1945. Leverkusen 1979.

Das Heimatbuch. Geschichte, Methodik, Wirkung. Matthias Beer (Hg.). Göttingen 2010.

Heimatbuch Cotzebant/Bötzow. Hrsg.: Heimatverein Bötzow e. V. Bötzow 2005.

Heimatbuch für den Kreis Eichenbrück-Wongrowitz. Geschichte, Sachberichte, Erzähltes, Bilder. Hrsg.: Eichenbrücker Vereinigung. Heimatkreisvereinigung Eichenbrück (Wongrowitz) in der Landsmannschaft Weichsel-Warthe. [Bd. 1]. Lüneburg [1967]. - Bd. 4: Von Lekno nach Lüneburg. Zusammenstellung u. Bearb. von Wilfried Gerke. Lüneburg 1993.

Heimatbuch für den Kreis Ostrowo/Provinz Posen mit angrenzenden Kreisen Kalisch und Kempen. Hrsg.: Heimatkreisgemeinschaft Ostrowo in der Landsmannschaft Weichsel-Warthe e. V. Zsgest. von Otto Käding. Kirchlengern 1983.

Heimatkreis Soldin/Neumark. Hrsg. vom Heimatkreis Soldin/Neumark. Soltau 1981.

Heimkehrer-Friedhöfe gezielt beseitigt. Ersatz: Zentrale Gedenkstätte - Trauerkapitel aus Frankfurts Stadtgeschichte. In: Wanderungen durch Südostbrandenburg an und jenseits der Oder-Neiße-Grenze. Jahrbuch 1996/97 (1996), S. 64-65. 
[Heine, Fritz:] Die Nationalsozialistische Volkswohlfahrt. [Verfasst 1944]. Hrsg.: Arbeiterwohlfahrt Bundesverband e. V. Bonn 1988.

Heinrich, Gerd: Staatsdienst und Rittergut. Die Geschichte der Familie von Dewitz in Brandenburg, Mecklenburg und Pommern. Mit einem Vorw. von Fritz-Jürgen von Dewitz. Bonn 1990.

-, -: Landesgeschichtliche Arbeiten und Aufgaben in Berlin-Brandenburg. Rückblicke und Ausblicke. In: Jahrbuch für die Geschichte Mittel- und Ostdeutschlands 39 (1990), S. 1-42.

-, -: Geschichtliche Einführung. In: Berlin und Brandenburg. Mit Neumark und Grenzmark PosenWestpreußen. Hrsg. von Gerd Heinrich. 3., überarb. u. erg. Aufl. (Handbuch der Historischen Stätten Deutschlands, Bd. 10). Stuttgart 1995, S. XV-CVI.

-, -: Alte Ordnungen und neue Anfechtungen. Die Kirche Berlin-Brandenburg im zerteilten Deutschland (1945 bis 1968). In: Tausend Jahre Kirche in Berlin-Brandenburg. Hrsg. von Gerd Heinrich. Berlin 1999, S. 763-842.

-, -: Land und Städte in Brandenburg und Berlin. II. Land und Städte in der Neuzeit bis zur Gegenwart. In: Städtebuch Brandenburg und Berlin. Hrsg. von Evamaria Engel u. a. (Deutsches Städtebuch. Neubearb., Bd. 2). Stuttgart u. a. 2000, S. XXXVI-L.

-, -: Preußische Herrensitze in Brandenburg. Brandenburgs alte Familien in den Stürmen des 20. Jahrhunderts. Traditionen, Vertreibung und Aufbau. In: Deutsches Adelsblatt 44 (2005), S. 89-96.

-, -: Militärischer Zusammenbruch 1945. In: Kulturatlas Brandenburg. Historische Landkarten. Geschichte der Mark im Überblick. Bearb. u. hrsg. von Gerd Heinrich. 2., erw. u. verb. Aufl. Berlin 2006, S. 52-53.

-, -: Zeittafel. In: Fontanestadt Neuruppin 1256-2006. Festschrift 750 Jahre Verleihung des Stadtrechts. Hrsg. von Gerd Heinrich, Peter Pusch u. Günter Rieger im Auftr. der Fontanestadt. Neuruppin 2006, S. 255-263.

Heise, Rosemarie: 40 Jahre Potsdamer Abkommen. In: Märkische Heimat 4 (1985), S. 4-13 (Nachdruck aus Archivmitteilungen 4/1985).

Helas, Horst: Zu seinem 130. Geburtstag - Nachdenken über Wilhelm Pieck. In: Gubener Heimatkalender 50 (2006), S. 54-56.

Helle, Matthias: Nachkriegsjahre in der Provinz. Der brandenburgische Landkreis Zauch-Belzig 1945 bis 1952. Berlin 2011 (Studien zur brandenburgischen und vergleichenden Landesgeschichte, Bd. 4).

Hempel, Karl-Heinz: Das Lager Elsterhorst. Erinnern - Gedenken - Mahnen. Hoyerswerda 2007 (Neue Hoyerswerdaer Geschichtehefte, Nr. 10).

Hennickendorf 1945. Ereignisse, Geschehnisse, Berichte. Hrsg.: Hennickendorfer Heimatfreunde e.V. [Hennickendorf 2005].

Henniger, Gerhard: 700 Jahre Stadt Kremmen. Wanderung durch Stadt und Geschichte. Begleitet von Petra Born u. Heiko Hohenhaus. Hrsg.: Stadt Kremmen. Kremmen [1998].

Hensen, Jürgen: Zur Geschichte der Aussiedler- und Spätaussiedleraufnahme. In: Aussiedler- und Minderheitenpolitik in Deutschland. Bilanz und Perspektiven. Hrsg. von Christoph Bergner u. Matthias Weber (Schriften des Bundesinstituts für Kultur und Geschichte der Deutschen im östlichen Europa, Bd. 38). München 2009, S. 47-61.

Herzig, Arno: Flucht und Vertreibung aus Schlesien. In: Flucht und Vertreibung. Europa zwischen 1939 und 1948. Hamburg 2012, S. 118-149.

Heß, Klaus / Richter, Anke: Die Stadt Brandenburg im Jahre 1945. In: Brandenburg im Jahr 1945. Studien. Hrsg. von Werner Stang unter Mitarb. von Kurt Arlt. Potsdam 1995, S. 195-222.

Heß, Klaus: Republik und NS-Diktatur: Die Stadtverwaltung und der Stadtkreis in der Phase des Ausbaus der Stadt zum zweitgrößten Industrieort der Provinz Mark Brandenburg (1918-1945). In: Stahl und Brennabor. Die Stadt Brandenburg im 19. Und 20. Jahrhundert. Hrsg. von Gerd Hein- 
rich u. a. (Bibliothek der Brandenburgischen und Preußischen Geschichte, Bd. 3). Potsdam 1998, S. 59-80.

-, -: Besatzungszeit und SED-Herrschaft (1945-1989). In: Stahl und Brennabor (wie vor), S. 149169.

-, -: Die Stadt Brandenburg nach Kriegsende im Jahr 1945. In: Jahresbericht Historischer Verein Brandenburg (Havel) e. V. 20 (2010/11 [2011]), S. 53-72.

Hetzke, Eberhard: Der Wiederaufbau des Städtischen Krankenhauses Cottbus nach seiner Zerstörung am 15. Februar 1945 in den Jahren 1945-1949. In: Geschichte und Gegenwart des Bezirkes Cottbus 16 (1982), S. 31-45.

-, -: Hilfsaktion „Rettet die Kinder“ in Cottbus im Jahre 1945. In: Geschichte und Gegenwart des Bezirkes Cottbus 19 (1985), S. 56-66.

-, -: Die epidemiologiche Lage nach dem zweiten Weltkrieg im Raum Cottbus, unter besonderer Berücksichtigung der Typhus- und Paratyphusepidmie des Jahres 1945. In: Geschichte und Gegenwart des Bezirkes Cottbus 23 (1989), S. 44-49.

-, -: Der Kampf der Ärzte nach dem Inferno. In: Cottbuser Heimatkalender 1990, S. 71-74.

Heye, Uwe-Karsten / Dalichow, Bärbel: „Wir wollten ein anderes Land“. Eine Familiengeschichte aus der DDR. München 2010.

Heyer, Jürgen / Peter, Hans-Ulrich: Dr. Dietrich von Knorre zum 60. Geburtstag. In: Anzeiger des Vereins Thüringer Ornithologen 3 (1999), S. 263.

Heymann, Hans-Christoph / Desjardins, Bodo / Schwerin, Detlef Graf von: 200 Jahre Wilhelmshayn 1816-2016. Vom Vorwerk zum Bauerndorf. Eine Chronik. Wilhelmshayn 2016.

Hielscher, Karl A.: Das Kriegsende 1944/45 für den Kreis Birnbaum. In: Birnbaum/Warthe. Hrsg. von Margarete Becker u. a. Hemmingen 1977, S. 9-18.

Hielscher, Alexander Karl: Das Kriegsende 1945 im Westen des Warthelandes und im Osten der Kurmark. Typoskript. [Bielefeld 1986] (Archiv der Landesgeschichtlichen Vereinigung für die Mark Brandenburg, Berlin).

Himmelpfort. Historischer Überblick. Überarb. Ausg. Gransee 2009.

Hinrichsen, Kerstin: Reine Reise nach L. In: Terra Transoderana. zwischen Neumark und Ziemia Lubuska. Bernd Vogenbeck u. a. (Bearb.). (Almanach. Europäische Grenzregionen neu entdecken, Bd. 1). Berlin 2008, S. 237-239.

Hirsch, Helga: Flucht und Vertreibung. Kollektive Erinnerung im Wandel. In: Aus Politik und Zeitgeschichte (2003)40/41, S. 14-26, bes. S. 21-23.

-, -: Schweres Gepäck. Flucht und Vertreibung als Lebensthema. Hamburg 2004.

Hirthe, Helmut: Das Heimkehrerlager in Frankfurt-Gronenfelde. In: Wir waren damals 19. 50 Jahre 8. Mai in und um Frankfurt. Berichte, Dokumente, Recherchen, Tagebücher, Erinnerungen, Gespräche. Ein Lesebuch. Hrsg.: Jürgen Maerz. Frankfurt (Oder) 1995, S. 282-284.

Hockwin, Otto: Der Gubener Heimatbund in Guben. In: Gubener Heimatbrief (1999)1, S. 63-69.

Höper, Eva-Maria: Frankfurt an der Oder. Der Architekt Martin Kießling (1879-1944). Städtebau der zwanziger Jahre zwischen Traditionalismus und Reformbewegungen. In: Brandenburgische Denkmalpflege 3 (1994)2, S. 81-93.

Hoffmann, Dierk: Vertriebenenintegration durch Arbeitsmarktlenkung? Zur Beschäftigungspolitik der SBZ/DDR (1945-1950). In: Geglückte Integration? Spezifika und Vergleichbarkeiten der Vertriebenen-Eingliederung in der SBZ/DDR. Hrsg. von Dierk Hoffmann u. Michael Schwartz (Schriftenreihe der Vierteljahrshefte für Zeitgeschichte, Sondernr.). München 1999, S. 173-192.

Hoffmeister, Joachim: 100 Jahre Herberge zur Heimat in Guben. In: Gubener Heimatkalender S. 15 (1970), 50-54. 
Hofmann Andreas R.: Die Nachkriegszeit in Schlesien. Gesellschafts- und Bevölkerungspolitik in den polnischen Siedlungsgebieten 1945-1948. Köln/Weimar/Wien 2000.

Hofmann, Jürgen: Heimatverlust und Neuanfang 1945/46. In: Besiedlung, Bevölkerung, Migration. Hrsg.: Heimatverein Marzahn-Hellersdorf e. V. Red.: Christa Hübner u. a. (Beiträge zur Regionalgeschichte, 13). Berlin 2016, S. 89-101, 186-188.

Holz, Martin: Evakuierte, Flüchtlinge und Vertriebene auf der Insel Rügen 1943-1961. Köln 2003 (Veröffentlichungen der Historischen Kommission für Pommern, Reihe V: Forschungen, Bd. 39).

Homagk, Mathias: Der Neubeginn - Vom „Restteil“ des Erzbistums Breslau zum Bistum Görlitz. In: „Ich gehe mit dem Gedanken um, in Kirchhain einen Betsaal zu bauen ..." Festschrift anlässlich des 100-jährigen Kirchweihjubiläums der katholischen Kirche in Kirchhain. Hrsg. von dems. u. Kathleen Hirschnitz in Zsarb. mit der katholischen Pfarrgemeinde Doberlug-Kirchhain. Halle/Saale 2008, S. 27-35.

-, -: 100 Jahre Gemeindegeschichte. In: ebd., S. 44-49.

Hoorn, Heike van: Neue Heimat im Sozialismus. Die Umsiedlung und Integration sudetendeutscher Antifa-Umsiedler in die SBZ/DDR. Essen 2004. [Diss. Münster 2002].

-, -: Die Schaffung einer politischen Lebenswelt. Das Antifa-Umsiedlerdorf Zinna/Neuheim in Brandenburg. In: Politik vor Ort. Sinngebung in ländlichen und kleinstädtischen Lebenswelten (Jahrbuch für Geschichte des ländlichen Raumes, 4). Innsbruck u. a. 2007, S. 149-159.

Huber, Edi: Zwischen Krieg und Frieden - das Jahr 1945. [Forsetzungsserie mit wechselnden Artikeltiteln] In: Potsdamer Neueste Nachrichten, 28.1., 25.2., 1.4., 29.4., 23.9., 21.10., 23.12.1995. [Betr. v. a. die im Febr. 1945 in Potsdam untergekommene Flüchtlingsfamilie U. aus Kalisch].

Hübner, Peter: „Durchhalten“ und „Durchkommen“. Niederlausitzer Industriearbeiter im Jahre 1945. In: Brandenburg im Jahr 1945. Studien. Hrsg. von Werner Stang unter Mitarb. von Kurt Arlt. Potsdam 1995, S. 136-166.

-, - : Vertriebenenintegration durch industrielle Erwerbsarbeit in den fünfziger und sechziger Jahren am Beispiel des Landes Brandenburg. In: Vertreibung, Neuanfang, Integration. Erfahrungen in Brandenburg. Christoph Kleßmann / Burghard Ciesla / Hans-Hermann Hertle (Hrsg.) (Protokolle). Potsdam 2001, S. 112-122.

100 Jahre Diakonissenmutterhaus Luise-Henriette in Lehnin. Festschrift. Hrsg.: Evangelisches Diakonissenhaus Teltow Lehnin. Red.: Stefan Beier. Unna [2011].

100 Jahre Katholische Kirche in Meyenburg. 1899-1999. [Meyenburg 1999].

100 Jahre Katholische Pfarrgemeinde Luckenwalde. Luckenwalde 1951.

100 Jahre Pestalozzischule Guben 1902-2002 in Wort und Bild. Hrsg.: Pestalozzi-Gymnasium Guben. Guben 2002.

100 Jahre Pfarrkirche Hl. Familie Rüdersdorf 1905 bis 2005. Hrsg. von der Katholischen Kirchengemeinde Hl. Familie in Rüdersdorf bei Berlin. Red.: Ariane Flemming u. a. Rüdersdorf bei Berlin 2005.

100 Jahre St. Joseph Velten. Festschrift. Velten 1996.

100 Jahre Wilhelmshorst 1907-2007. Eine Waldsiedlung vor den Toren der Hauptstadt. Hrsg. im Namen der Freunde und Förderer der Wilhelmshorster Ortsgeschichte e. V. von Rainer Paetau. Wilhelmshorst 2007.

120 Jahre Samariteranstalten 1892-2012. Fürstenwalde 2012 (Unterwegs dokumentiert, 2/2012).

Hunger, Manfred: Das Kriegsende 1945 in Lebus. in: Jahrbuch Märkisch Oderland 2020 (2019), S. $8-13$.

„Ich gehe mit dem Gedanken um, in Kirchhain einen Betsaal zu bauen ..." Festschrift anlässlich des 100-jährigen Kirchweihjubiläums der katholischen Kirche in Kirchhain. Hrsg. von Mathias Homagk 
u. Kathleen Hirschnitz in Zsarb. Mit der katholischen Pfarrgemeinde Doberlug-Kirchhain. Halle/ Saale 2008, S. 44-49.

I[llmann], N[orbert]: 100 Jahre Katholische Pfarrkirche „St. Peter und Paul“ in Eberswalde. [Hektografiertes Typoskript]. (Eberswalde) [1977].

Inoffizielle Mitarbeiter des Ministeriums für Staatssicherheit. T. 1.: Richtlinien und Durchführungsbestimmungen. Hrsg. von Helmut Müller-Enbergs. 3. Aufl. Berlin 2001 (Analysen und Dokumente, Bd. 3).

Instrumentalisierung, Verdrängung, Aufarbeitung. Die sowjetischen Speziallager in der gesellschaftlichen Wahrnehmung 1945 bis heute. Hrsg. von Petra Haustein, Annette Kaminsky, Volkhard Knigge u. Bodo Ritscher. Göttingen 2006.

Irmer, Thomas: Zwangsarbeit im „Beutelager“ - das KZ-Außenlager Glöwen. In: Havelberg - kleine Stadt mit großer Vergangenheit. Hrsg. von der Stadt Havelberg. Halle 1998, S. 169-180.

Isergebirgler und ihre Schmuckindustrie im Thüringer Wald, Harz und Brandenburg. Hrsg.: LeuteltGesellschaft e. V. Schwäbisch Gmünd 2000 (Jahresgabe für die Mitglieder der Leutelt-Gesellschaft, 2001; Gablonzer Bücher, 70).

Jaeschke, Gerhard / Schieche, Manfred: Ziebingen im Sternberger Land. Ein Ort und seine Menschen. Berlin/Eisenhüttenstadt 2002.

Jajeśniak-Quast, Dagmara / Stokłossa, Katarzyna: Geteilte Städte an Oder und Neiße. Frankfurt (Oder) - Słubice, Guben - Gubin und Görlitz - Zgorzelec 1945-1995. Berlin 2000.

Jannaschke, Theo: 1945 - Luckau in den letzten Tagen des 2. Weltkrieges. In: Luckauer Heimatkalender 6/7 (1974/75), S. 25-29.

Jeremicz, Jacek: Der Verlust der Heimat der Deutschen am Beispiel des ehemaligen Kreises Schwerin/ Warthe. In: Schwierige Nachbarn? 300 Jahre deutsch-polnische Nachbarschaft. Groß Neuendorfer Gespräche 2006. Vorträge und Diskussionen. Hrsg. im Auftr. des Landfrauenvereins „Mittleres Oderbruch“ e. V. Groß Neuendorf von Wolfgang Michalka u. Reinhard Schmook. Berlin 2007, S. 107-134.

Jonas, Bertold: Deutsch-polnische Begegenung über die Oder. Das große Fest zwischen Güstebieser Loose und Güstebiese/Gozdowice. in: Königsberger Kreiskalender 2004, S. 115-121. [2003].

Jubiläum. 20 Jahre Landesamt für Soziales und Versorgung. Aufbrüche, Kontinuitäten, Perspektiven. Hrsg.: Landesamt für Soziales und Versorgung. Red.: Kristina Hübener, Petra Schmoger. Cottbus 2011.

Jünemann, Andreas: Die preußischen Lungenheilstätten 1863-1934 (unter besonderer Berücksichtigung der Regionen Brandenburg, Harz und Riesengebirge). Diss. rer. med. FU Berlin. Berlin 2015 (www.diss.fu-berlin.de [5.6.2017].

Jugendarbeit in Brandenburg. Hrsg.: Landesjugendring Brandenburg e. V. und Landesjugendamt des Landes Brandenburg. Red.: Gerhard Mittelstädt, Bernd Mones. Potsdam/Bernau [2003].

Jun, Wilhelm: Die Flüchtlings-Transporte des Jahres 1946. Eine zusammenfassende statistische Darstellung der Transporte aus der Tschechischen Republik, Österreich, Ungarn und der Slowakei nach den Ländern der amerikanischen Besatzungszone (Bayern, Baden-Württemberg und Hessen) sowie der sowjetischen Besatzungszone (SBZ). Augsburg/Pohrlitz 2009 (http://sudetendeutschefamilienforscher.de/wp-content/uploads/2016/02/Verzeichnis_Vertreibungstransporte_1946_ V9.pdf [31.3.2017]).

„Junkerland in Bauernhand“? Durchführung, Auswirkungen und Stellenwert der Bodenreform in der Sowjetischen Besatzungszone. Hrsg. von Arnd Bauerkämper. Stuttgart 1996 (Historische Mitteilungen, Beiheft 20).

Just, Regine: Zur Lösung des Umsiedlerproblems auf dem Gebiet der DDR 1945 bis Anfang der fünfziger Jahre. In: Zeitschrift für Geschichtswissenschaft 35 (1987), S. 971-984. 
Kabisch, Winfried: Archiv des Gubener Heimatbundes eine Fundgrube. In: Gubener Heimatbrief (2001)2, S. 39-41.

-, -: Eine Hauptabfuhrstrecke für Reparationsgüter führte über Guben. In: Gubener Heimatbrief (2002)1, S. 40-47.

-, -: Die Brücken unserer Stadt. In: Gubener Heimatbrief (2007)1, S. 26-31; (2007)2, S. 40-43; (2008) 1, S. 39-44.

Kaczmarek, Günther: Die Befreiung des Kreises Spremberg vom Hitlerfaschismus im April 1945. Spremberg 1980 (Spremberg gestern und heute, 3).

Kästner, Helga: Das Jahr 1945 zwischen Krieg und Frieden in Belzig. In: Lokalhistorische Studien zu 1945 im Land Brandenburg. Zusammenbruch - Befreiung - Besatzung. Ergebnisse, Berichte und Dokumente aus dem Projekt. Hrsg.: Regionale Abeitsstellen für Ausländerfragen, Jugendarbeit und Schule, Brandenburg e. V. Red.: Hilde Schramm u. a. Potsdam 1996, S. 37-38.

-, - / Grünberg, Willi: 8000 Menschen nach Kriegsende in Belziger Quarantänelager. Maßnahmen zur Unterbringung und Versorgung in Bad Belzig, In: Bad Belzig Journal 7 (2017)1, S. $20-21$ (Chronik, T. 73).

Käthner, Klaus: Fritz Schulz - der erste Bürgermeister, als Friede ward an der Oder. In: Heimatkalender für den Stadt- und Landkreis Eisenhüttenstadt 1983, S. 16-18.

Kahlisch, Bertram: 25 Jahre Vereinsarbeit für die Heimatstadt Fürstenberg (Oder). In: Fürstenberger Blätter 2 (2017), S. 148-165.

Kaltenborn, Steffi: Herausbildung und Entwicklung der Umsiedlergenossenschaften in der Sowjetischen Besatzungszone Deutschlands nach dem zweiten Weltkrieg. In: Sie hatten alles verloren. Flüchtlinge und Vertriebene in der sowjetischen Besatzungszone Deutschlands. Hrsg. von Manfred Wille, Johannes Hoffmann u. Wolfgang Meinicke (Studien der Forschungsstelle Ostmitteleuropa an der Universität Dortmund, Bd. 13). Wiesbaden 1993, S. 178-192.

Kaminsky, Anna: Frauen in der DDR. Berlin 2016.

Kaminsky, Annette-Christine: „... es wird Zeit, daß wir nach Hause kommen ... “ In: Frankfurter Jahrbuch 1996/97 (1997), S. 147-162.

Kaplick, Otto: Geschichte der Neumark. in: Landsberg an der Warthe 1257 - 1945 - 1978. Aus Kultur und Geschichte im Spiegel der Jahrhunderte. Hrsg. von Hans Beske u. Ernst Handke (Schriftenreihe der Bundesarbeitsgemeinschaft Landsberg (Warthe) Stadt und Land, Bd. 2). Bielefeld 1978, S. $170-173$.

Kaps, Johannes: Die katholische Kirchenverwaltung in Ostdeutschland vor und nach 1945. In: Jahrbuch der Schlesischen Friedrich-Wilhelms-Universität zu Breslau 11 (1957), S. 7-39.

Kapuste, Eberhard: Die Gemeinde Eiche in den Jahren 1918 bis 1945. Hrsg.: Ortsbeirat Eiche. [Potsdam 2014].

Karge, Paul / Hirte, Horst: Unvergeßlicher Tag. Grundsteinlegung zum Großvorhaben unseres Siebenjahrplanes. In: Gubener Heimatkalender 6 (1961), S. 47-48.

Karner, Stefan: Die vergessenen Zwangsarbeiter. In: Flucht und Vertreibung. Europa zwischen 1939 und 1948. Hamburg 2012, S. 210-219, 255-256.

Kasten, Tilman: Heimatzeitschriften im Kontext der „Vertriebenenpresse“. Zur Einführung in das Thema und den Tagungsband. In: Heimatzeitschriften. Funktionen, Netzwerke, Quellenwert. Tilman Kasten u. Elisabeth Fendl (Hg.) (Schriftenreihe des Instituts für Volkskunde der Deutschen des östlichen Europa, Bd. 18). Münster/New York 2017, S. 9-38.

Kaule, Martin: Brandenburg 1933-1945. Der historische Reiseführer. Berlin 2012. 2., aktualis. Aufl. 2014.

-, - / Wolle, Stefan: 100 Orte der DDR-Geschichte. Berlin 2018. 
Keller, Herbert / Baumann, Arnulf: Bessarabischer Brüderbesuchsdienst in der DDR. In: Jahrbuch der Deutschen aus Bessarabien 59 (2008), S. 216-223.

Keller, Ines: Flüchtlinge und Vertriebene in der Lausitz. In: Niederlausitzer Studien 31 (2004), S. 88-91. -, -: „Jetzt bin ich hier und das ist gut so“. Lebenswelten von Flüchtlingen und Vertriebenen in der Lausitz. Bautzen 2005 (Lětopis 52, Sonderheft).

-, -: „Wenn man die Sprache braucht, dann lernt man sie auch. Bloß, wenn man sie nicht braucht, wird man sie auch nicht richtig lernen." - Anpassungsstrategien von Flüchtlingen und Vertriebenen in der Niederlausitz. In: Niederlausitzer Studien 33 (2007), S. 138-144.

-, -: Flüchtlinge und Vertriebene in der zweisprachigen (sorbischen) Lausitz. In: Volkskunde in Sachsen 23 (2011), S. 197-210.

Kerl, Brigitte: das Kriegsende 1945 in Falkensee. In: Heimatjahrbuch für Falkensee und Umgebung 2020 (2019), S. 51-54.

Kersten, Oliver: Die Nationalsozialistische Volkswohlfahrt insbesondere im Zweiten Weltkrieg. Magisterarbeit Freie Univ. Berlin 1993.

Kersting, Thomas / Schopper, Franz / Theune, Claudia: Tagungsresümee: Sicht der Archäologischen Denkmalpflege. In: Archäologie und Gedächtnis. NS-Lagerstandorte. Erforschen - Bewahren - Vermitteln. Interdisziplinäre Konferenz im Archäologischen Landesmuseum Brandenburg an der Havel 17. bis 19. September 2015. Hrsg.: Thomas Kersting u. a. (Denkmalpflege in Berlin und Brandenburg, Arbeitsheft 4/2016). Petersberg 2016, S. 173-175.

Kessler, Wolfgang: Ost- und südostdeutsche Heimatbücher und Ortsmonographien nach 1945. Eine Bibliographie zur historischen Landeskunde der Vertreibungsgebiete. Hrsg. von der Stiftung Ostdeutscher Kulturrat. München/New York 1979.

-, -: Die „ostdeutschen“ Heimatblätter in der Bundesrepublik Deutschland. Eine Annäherung. In: Heimatzeitschriften. Funktionen, Netzwerke, Quellenwert. Tilman Kasten u. Elisabeth Fendl (Hg.) (Schriftenreihe des Instituts für Volkskunde der Deutschen des östlichen Europa, Bd. 18). Münster/ New York 2017, S. 39-75.

Kibelka, Ruth: Wolfskinder. Grenzgänger an der Memel. 4. Aufl. Berlin 2003.

-, -: Ostpreußens Schicksalsjahre 1944-1948. Berlin 2016.

Kieckebusch, Werner von: Chronik des Klosters zum Heiligengrabe von der Reformation bis zur Mitte des 20. Jahrhunderts. Hrsg. von Brigitte Müller-Bülow zu Dohna u. Gabriele Simmermacher. Berlin 2008 (Studien zur Geschichte, Kunst und Kultur der Zisterzienser, Bd. 28).

Kienitz, Reinhard: Die Vertreibung der Hedwig-Schwestern. Geschichte der Caritas-Heimbildungsstätte (T. II). In: Ders.: Traumgehäuse. 60 Häuser mit bewegter Geschichte in Bad Saarow-Pieskow am „Märkischen Meer“. 4. Aufl. Bad Saarow 2014, S. 122-123. [Erstdr. in: Märkische Oder-Zeitung Sept. 2000].

Kießhauer, Rolf u. Inge: Friedrichshagener Straße, Wege und Plätze. Geschichte und Gegenwart. H. 2.: Zwischen Spree und Eisenbahn. Berlin-Friedrichshagen 1993.

Kießling, Martin: Ostmarkbauten. Städtebau in einer Mittelstadt. Stuttgart 1925.

Kikels, Christa / Kreutz, Karl: 20 Jahre Arbeitsgruppe „Zeitzeugen“ beim Senioreneirat der Landeshauptstadt Potsdam. In: Aus unserem Leben. Lebenserinnerungen und Erzählungen wurden aufgeschrieben von Mitgliedern des Zirkels „Zeitzeugen“ beim Seniorenbeirat der Landeshauptstadt Potsdam. [18. Anthologie]. Hrsg.: Seniorenbeirat in der Landeshauptstadt Potsdam. Stadtverwaltung, Fachbereich 3 für Soziales, Jugend, Gesundheit, Ordnung u. Umweltschutz der Landeshauptstadt Potsdam (18. Heft). Potsdam 2016. S. 6-8.

Kirche und Heimat. Die katholische Vertriebenen- und Aussiedlerseelsorge in Deutschland. Hrsg.: Sekretariat der Deutschen Bischofskonferenz. Bonn 1999 (Arbeitshilfen, 146). 
Kirchen im Oderbruch und ihre Schicksale seit dem Frühjahr 1945. Mit Bildern und historischen Anmerkungen. Hrsg. von Hans-Georg Rieger u. Günter-Alexander von Wittich im Namen des Heimatkreises Lebus. Berlin 1992.

Kirsch, Rita: Wie ein Großbetrieb das Leben in Guben veränderte. In: Gubener Heimatkalender 44 (2000), S. 104-108.

Kittan, Horst: Die Russen kommen. Russkie prichodjat. Eine Dorf- und Familiengeschichte. Cottbus 2011. [Petershain, Kr. Calau].

Klei, Alexandra (Text) / Herrnbeck, Christian (Fotos): Überall Geschichte. Nationalsozialismus und Kriegsende 1945 - Denkmale, Erinnerungszeichen und historische Orte im Landkreis Spree-Neiße. Hrsg.: werkraum bild und sinn e. V. Berlin 2005.

Kleine Chronik unserer Heimatstadt im Jahr 1969. Zsgest. von Heinz Mattke. In: Gubener Heimatkalender 15 (1970), S. 39-40.

Klemm, Bernhard: Frankfurter Denkmalgeschichte. Erzählt anhand von Schicksalen einzelner Denkmäler. In: Historischer Verein zu Frankfurt (Oder). Mitteilungen 1997, H. 1, S. 8-21.

-, -: Das Marienstift - aus der Geschichte einer katholischen Erziehungs- und Fürsorgeanstalt. In: Historischer Verein zu Frankfurt (Oder) e. V. Mitteilungen 2017, H. 2, S. 17-23.

Kliche, Manfred: Das Reichsarbeitsdienstlager in Raddusch. In: Stog - Der Schober 2010 (2009), S. 79-82.

Klier, Freya: Verschleppt ans Ende der Welt. Schicksale deutscher Frauen in sowjetischen Arbeitslagern. Frankfurt a. M. 1996.

-, -: Wir letzten Kinder Ostpreußens. Zeugen einer vergessenen Generation. Freiburg u. a. 2014.

Klinke, Helmut: Der Südkreis schätzte „Hebamms Mutter“. Wilhelmine Hahn war 44 Jahre im Bereich Seedorf-Scheegeln aktiv. In: Wanderungen durch Südostbrandenburg an und jenseits der OderNeiße-Grenze 1996/97 (1996), S. 181-182.

Klitzke, B [irgit]: Die Friedensbrücke - eine wechselhafte Geschichte. In: report e. Magazin für das Stadtzentrum Eberswalde 18 (2011) 2, S. 6.

Klose, Andreas: Die Grafschaft Glatz in der Sudetenkrise. In: Schlesische Geschichtsblätter 45 (2018), S. 1-23.

Kluchert, Ursula: Dallgow. Chronik eines Dorfes. Dallgow-Döberitz 2009.

Knaack, Rudolf: 100 Jahre Erlöserkirche in Daten. Ausgewählt von R. K. In: Die Erlöserkirche in Potsdam 1898-1998. Festschrift zur 100-Jahr-Feier am 4. Mai 1998. Hrsg. vom Gemeindekirchenrat der Erlöserkirchengemeinde Potsdam. Red.: Martin Kwaschik, Rudolf Knaack, Ewald Gerth. Potsdam 1998, S. 25-69.

Knak, Johannes: Unser Heimatbund - seine Entstehung und Aufgaben. In: Gubener Heimatbrief (1996) 1, S. 7-9. [Gubener Heimatbund].

Knauft, Wolfgang: Katholische Kirche in der DDR. Gemeinden in der Bewährung 1945-1980. Mainz 1980.

Kneifel, Eduard: Die evangelisch-augsburgischen Gemeinden in Polen 1555-1939. Eine parochialgeschichte in Einzeldarstellungen. Vierkirchen [1971].

Kober, Steffen: Aus der Geschichte der Senftenberger Straßennamen. In: Kippensand. Heimatkalender für das Senftenberger Gebiet 5 (2017), S. 33-36.

Köhler, Christel: Putlitz bei Kriegsende 1945. In: Pritzwalker Heimatblätter 15 (2013), S. 145-148.

Köhler, Erich: Das Flüchtlingselend neumärkischer Familien. Von einem Dorf im „fernen Osten“. In: Königsberger Kreiskalender 2002, S. 96-104. [Betr. Nahausen, Kr. Königsberg/Nm., und die teilweise Aufnahme der Flüchtlinge 1945 in Bredereiche bei Fürstenberg/Havel]. 
Köhler, Eva: Rüdersdorf. Die Kalkhauptstadt am Rande Berlins. Unter Mitarb. von Reinhard Kienitz. Berlin 1994.

Köhler, Günter: Notaufnahme. Evangelische Flüchtlingsseelsorge. Vierzig Jahre im Dienst für Umsiedler, Aussiedler und Übersiedler in Berlin. Berlin 1991.

König, Horst: Zwei Jahre Seniorenvereinbarung Storkow - Opalenica. In: Brücken bauen / budowa mostów. Hrsg.: Seniorenbeirat Storkow (Mark) / Seniorenorganisation Opalenica. Storkow (Mark)/ Opalenica 2005, S. 12-15.

Köstering, Susanne: DDR-Geschichte in brandenburgischen Museen. Wo stehen wir, wo geht es hin? In: Museumsblätter. Mitteilungen des Museumsverbandes Brandenburg 31 (2017), S. 8-15.

Kösters, Christoph: Katholiken in der Minderheit. Befunde, Thesen und Fragen zu einer sozial- und mentalitätsgeschichtlichen Erforschung ders Diasporakatholizismus in Mitteldeutschland und der DDR (1830/40-1961). in: Wichmann-Jahrbuch des Diözesangeschichtsvereins Berlin, N. F. 4 (1996/97 [1997]), S. 169-204.

Kohlase, Fritz: Küstrins Untergang im Jahre 1945. In: Königsberger Kreiskalender 2006, S. 145-152.

Korsan, Katarzyna: Beiderseits der Oder. Die Geschichte eines Deutschen aus Guben. In: Grenzerfahrungen. Jugendliche erforschen deutsch-polnische Geschichte. Hrsg. von Alicja Wancerz-Gluza in Zsarb. mit Gabriele Bucher-Dinç. Hamburg 2003, S. 343-356. [Auf der Basis eines Interviews mit dem 1937 in Guben (Ostteil) geborenen Hubert Grajewski, kath., Sohn eines aus Schneidemühl zugewanderten Bahnhofsangestellten, Mutter aus Dorf bei Guben, Febr. 1945 Evakuierung aus Guben und dreimonatiger Aufenthalt auf einem Bauernhof in Gehren bei Luckau, 2.5.1945 Rückkehr nach Guben, 20.6.1945 Vertreibung, seitdem wohnhaft im Westteil, 1967 erster Besuch in Ostteil, seitdem Freundschaft mit dem polnischen Gubiner Organisten Bernard Kusch].

Kort, Eberhard / Giering, Gregor: Aus der Chronik der Katholischen Kirchengemeinde „Maria Himmelfahrt" in Zehdenick. In: Festschrift 775 Jahre Zehdenick. Red.: Lothar Lauwaßer. Zehdenick 1992, S. 57-63.

Kossert, Andreas: Kalte Heimat. Die Geschichte der deutschen Vertriebenen nach 1945. 4. Aufl. München 2009.

-, -: Jeder vierte Brandenburger: Vertriebene und Flüchtlinge nach 1945. Eine Spurensuche. In: wir erben. europa in Brandenburg, brandenburg in europa. Hrsg.: Brandenburgische Gesellschaft für Kultur und Geschichte gGmbH, Kulturland Brandenburg, Potsdam. Konzeption: Christian MüllerLorenz u. Brigitte Faber-Schmidt. Red.: Christian Müller-Lorenz u. Dirk Schumann. Leipzig 2018, S. 139-143.

Kotsch, Detlef: Die Bezirke Potsdam, Frankfurt (Oder) und Cottbus in der DDR (1952 bis 1990). In: Brandenburgische Geschichte. Hrsg. von Ingo Materna u. Wolfgang Ribbe. Berlin 1995, S. 727-794.

-, -: Karrierewege in Brandenburg nach dem Zweiten Weltkrieg. Entstehung und Etablierung der neuen Eliten in den Jahren 1945-1960. In: Jahrbuch für brandenburgische Landesgeschichte 47 (1996), S. 149-191.

-, -: Das Land Brandenburg zwischen Auflösung und Wiederbegründung. Politik, Wirtschaft und soziale Verhältnisse in den Bezirken Potsdam, Frankfurt (Oder) und Cottbus in der DDR (1952 bis 1990). Berlin 2001 (Bibliothek der Brandenburgischen und Preußischen Geschichte, Bd. 8; zugl.: Brandenburgische Geschichte in Einzeldarstellungen, Bd. 8).

-, -: Vertriebene und Vertriebenenpolitik in Brandenburg nach dem Zweiten Weltkrieg. In: Die Herkunft der Brandenburger. Sozial- und mentalitätsgeschichtliche Beiträge zur Bevölkerung Brandenburgs vom hohen Mittelalter bis zum 20. Jahrhundert. Hrsg. von Klaus Neitmann u. Jürgen Theil unter Mitw. von Olaf Gründel (Brandenburgische Historische Studien, Bd. 9; Arbeiten des Uckermärkischen Geschichtsvereins zu Prenzlau e. V., Bd. 4). Potsdam 2001, S. 127-137. 
Kotzian, Ortfried: Die Umsiedler. Die Deutschen aus West-Wolhynien, Galizien, der Bukowina, Bessarabien, der Dobrudscha und in der Karpatenukraine. München 2005 (Vertreibungsgebiete und vertriebene Deutsche. Studienbuchreihe der Stiftung Ostdeutscher Kulturrat, Bd. 11).

Kracht, Walter: Stennewitz. Ein brandenburgisches Dorf in der Neumark wurde zum polnischen Stanowice. Berlin 2003.

Krätzner, Claus: Das Schicksal der Bevölkerung der Kreisstadt Königsberg in der Neumark zum Ende des Zweiten Weltkrieges im Spiegel der Heimatkartei. Eine Untersuchung zu den Vertreibungsverlusten und zur Seßhaftwerdung der Heimatvertriebenen aus der Kreisstadt Königsberg/Neumark. (Privatdruck) Hilchenbach 1999.

-, -: Das Schicksal der Einwohner der Kreisstadt Königsberg/Neumark am Ende des Zweiten Weltkrieges. In: Königsberger Kreiskalender 2002, S. 75-83.

Kranert, Gudrun: 1945 - Ende des Zweiten Weltkrieges. Deutschland wird aufgeteilt - Flüchtlingsströme erreichen auch Falkensee. In: Heimatjahrbuch für Falkensee und Umgebung 2018 (2017), S. 66-72.

Krause, G[eor]g: Heimatkreiskartei Ost-Sternberg. In: Frankfurt (Oder)-Sternberger Kurier 4 (1955), Nr. 2, S. 9-10.

Der Kreis Freystadt. Ein niederschlesisches Heimatbuch. Unter Mitarb. zahlr. Heimatfreunde gestaltet von L. Hildegard Rutkowski u. Hermann Otto Thiel. Hrsg. von dem Heimatbund Kreis Freystadt/ Niederschlesien. Scheinfeld 1969.

Kreis Königsberg/Neumark. Erinnerungen an einen ostbrandenburgischen Landkreis. Hrsg. vom Heimatkreis Königsberg/Neumark e. V. Berlin/Bonn 2006.

Der Kreis Schubin. Geschichte, Erinnerungen, Skizzen. Hrsg. vom Heimatkreis Schubin - Altburgund e. V. Bergen 1990.

Der Kreis Stuhm. Ein westpreußisches Heimatbuch. Hrsg. vom Kreisausschuß des Heimatkreises Stuhm. (Bad Pyrmont) 1975.

Kreis Züllichau-Schwiebus. Hrsg. im Auftr. der Heimatkreisvereinigung von Curt Schelenz. Frankfurt am Main 1970, 2. Aufl. 1975.

Krestin, Steffen: Cottbus - eine Stadt verändert ihr Gesicht. In: Preußen, Sachsen, Brandenburg. Nachbarschaften im Wandel. Hrsg. Brandenburgische Gesellschaft für Kultur und Geschichte gGmbH, Kulturland Brandenburg, Potsdam. Leipzig 2014, S. 46-55.

Kriegsende und Nachkriegszeit in Havelberg. [Bd.] [I]-[II]. Hrsg.: Heimatverein Havelberg e. V. Havelberg 1992-1994 (Havelberger Regionalgeschichtliche Beiträge, Bd. 1-2).

Krogmann, Wolfgang: Das künftige Gesicht unserer Stadt. In: Gubener Heimatkalender 15 (1970), S. 31-32. [Wohnungsbau].

Krügel, Max: Buckow im Landes Lebus. Berlin 1957.

Krüger, Bert / Schulz, Barbara: Das Gelände des KZ-Außenlagers Falkensee bei Berlin - Gedenkstätte und zeithistorisch-archäologischer Lernort. In: Archäologie und Gedächtnis. NS-Lagerstandorte. Erforschen - Bewahren - Vermitteln. Interdisziplinäre Konferenz im Archäologischen Landesmuseum Brandenburg an der Havel 17. bis 19. September 2015. Hrsg.: Thomas Kersting u. a. (Denkmalpflege in Berlin und Brandenburg, Arbeitsheft 4/2016). Petersberg 2016, S. 155-171.

Kruska, [Harald]: Zehn Jahre Kirchendienst Ost. In: Kirchliches Jahrbuch für die Evangelische Kirche in Deutschland 81 (1954), S. 198-228.

-, Harald: Der Kirchendienst Ost in Berlin. In: Die Unverlierbarkeit evangelischen Kirchentums aus dem Osten. Hrsg. von Carl Brummack. Ulm/Donau 1964, S. 97-106.

Kubatzki, Rainer: Zwangsarbeiter- und Kriegsgefangenenlager. Standorte und Topographie in Berlin und im brandenburgischen Umland 1939 bis 1945. Berlin 2001 (Berlin-Forschungen der Historischen Kommission zu Berlin, Bd. 1). 
Kühn, Detlef: Barbara Rommel †. In: Arbeitsbericht der Arbeitsgemeinschaft ostdeutscher Familienforscher e.V., Bd. 12, 2007, H. 2, S. 3.

Kühne, Lutz: Die Bodenreform im Kreis Beeskow-Storkow. In: Kreiskalender Oder-Spree 2006, S. 22-26.

Kuhn, Günter: Die Märker - ein mixtum compositum. Einwanderungen in der Mark durch die Jahrhunderte. In: Kirche auf märkischem Sand. Bilder aus der Evangelischen Kirche in Berlin-Brandenburg. Hrsg.: Leopold Esselbach. Berlin 1991, S. 22-29.

-, -: Mehr als 75 Jahre „Hirschluch“. Menschen begegnen, Gott erfahren. In: Kreiskalender Oder-Spree 2002, S. 78-81.

Kukla, D[ietrich]: Kreis Angermünde 1817-1993. In: Angermünder Heimatkalender 1994, S. 9-16.

-, Dietrich: Angermünde 1945. In: Angermünder Heimatkalender 1995, S. 38-49.

Kundoch, Ingelore / Kundoch, Dietrich / Nossack, Hans-Jürgen: Chronik Kiekebusch. Die Geschichte eines märkischen Dorfes. Hrsg.: Gemeinde Schönefeld. Schönefeld [2009].

Kunze, Martin: Das Postheim - Zur Chronik einer Templiner Perle. Teil 2: Vom Posterholungsheim zum dauerhaft bewohnten Ortsteil Templins, 1945 bis 1972. In: Templiner Heimatkalender 2016 (2015), S. 87-94.

Kusior, Wolfgang: Die Stadt Brandenburg im Jahrhundertrückblick. Streiflichter durch eine bewegte Zeit. Berlin 2000.

Lakowski, Richard: Das Ende der Naziherrschaft in Brandenburg. Mit einer Dokumentation. In: Brandenburg in der NS-Zeit. Studien und Dokumente. Hrsg. von Dietrich Eichholtz unter Mitarb. von Almuth Püschel. Berlin 1993, S. 411-442.

-, -: Planung und Realität des Kriegsendes. Fragen zum Thema Flucht und Vertreibung. In: Niederlage Sieg - Neubeginn. Kriegsende 1945. Werner Künzel, Richard Lakowski (Hg) (Protokolle). Potsdam 2005, S. 58-78.

-, - / Stich, Karl: Der Kessel von Halbe 1945. Das letzte Drama. (Erstdr. Berlin 1997). Hamburg u. a. 2009.

Lambrecht, Rainer / Meissner, Klaus-Peter: Havelauen. Dynamik zwischen Friedrichshöhe und Großem Zernsee. Potsdam 2012.

Lammert, Markus: Die Stadt der Vertriebenen. Görlitz 1945-1953. Görlitz 2012 (Neues Lausitzisches Magazin, Beiheft 10).

Lang, Karolina: Identität, Heimat und Vernetzung unter dem Schirm Gottes. Die ermländische Glaubensgemeinschaft im Nachkriegsdeutschland. In: Vertriebene finden Heimat in der Kirche. Integrationsprozesse im geteilten Deutschland nach 1945. Hrsg. von Rainer Bendel (Forschungen und Quellen zur Kirchen- und Kulturgeschichte Ostdeutschlands, Bd. 38). Köln u. a. 2008, S. 163-174.

Lange, Herbert: 75 Jahre Gemeinde Kleinmachnow. In: Zwischn Havelland und Fläming 1995, S. 51-58.

-, -: Kleinmachnow. In: Der Landkreis Potsdam 3/4 (1993), S. 57-60.

Lass, Edgar Günther: Flucht und Vertreibung. In: Der Kreis Treuburg. Ein ostpreußisches Heimatbuch. Zsgest. im Auftr. der Kreisgemeinschaft Treuburg von Rudolf Grenz. Lübeck 1971, S. 429-431.

Lau, Karlheinz: Ostdeutschland und die Vertriebenen im öffentlichen Bewußtsein und im Geschichtsbild der DDR bis 1989. In: Manfred Wille / Karlheinz Lau / Jörg Bernhard Bilke: Die Vertriebenen in Mitteldeutschland. Hrsg.: Bund der Vertriebenen (Deutschlandpolitische Schriftenreihe, 10). Bonn 1991, S. 9-14.

-, -: Ostbrandenburg nach 1945. In: Eberhard Völker [Hrsg.]: Pommern und Ostbrandenburger (Vertreibungsgebiete und vertriebene Deutsche. Studienbuchreihe der Stiftung Ostdeutscher Kulturrat, Bd. 9). München 2000, S. 147-166. 
Leben im Dritten Reich. Zwischen Einschulung und Einberufung. Hrsg.: Stadt Schwedt/Oder, Der Bürgermeister. Städtische Museen Schwedt/Oder, Stadtmuseum. Red.: Anke Grodon u. a. Schwedt/ Oder [2013?].

Lebenswerke. Frauen im Kloster Stift zum Heiligengrabe zwischen 1847 und 1945. Hrsg. im Auftr. des Kloster Stift zum Heiligengrabe von Simone Oelker u. Astrid Reuter sowie von der Deutschen Stiftung Denkmalschutz. Bonn 2002.

Leegebruch. Hrsg.: Arbeitsgruppe Heimatgeschichte im Kulturverein Leegebruch. 2. Aufl. Leegebruch [2003].

Leegebrucher Geschichte. Ortsgeschichte 1945-1989. Hrsg.: Geschichtsverein Leegebruch e. V. In: www.cake-media.de/leegebruch/verein.html [5.6.2017]).

Lehmann, Günter: Flüchtlinge und Soldaten 1945 in Groß-Breesen, Kr. Guben. In: Brandenburgische Genealogische Nachrichten 6 (2011), S. 14-21. [Chronologische Liste der im Ort Verstorbenen bzw. Beigesetzten, Jan. bis April 1945 (aus KB), überwiegend aus dem Ostteil des Kreises Guben und aus dem Ort selbst stammend; Groß Breesen liegt unmittelbar westlich der Neiße].

Lehmann, Jörg: Die Stadt Liebenwalde. Ein Streifzug durch die Geschichte der Ortsteile Freienhagen, Hammer, Kreuzbruch, Liebenthal, Liebenwalde und Neuholland. Karwe 2004.

Leibner, Max: Mein Heimatdorf Burschen, Kreis Ost-Sternberg. In: Frankfurt (Oder)-Sternberger Kurier 4 (1955), Nr. 6, S. 11.

Der Leidensweg der Karpatendeutschen 1944-1946. Eine Dokumentation. Hrsg. von der Arbeitsgemeinschaft der Karpatendeutschen aus der Slowakei. Red. von Adalbert Hudak. Stuttgart 1983, S. 82-85.

Leiserowitz, Ruth: Von Ostpreußen nach Kyritz. Wolfskinder auf dem Weg nach Brandenburg. Potsdam 2003.

Lemmen, Daniel J.: Reichsgau Wartheland. In: Online-Lexikon zur Kultur und Geschichte der Deutschen im östlichen Europa, 2014, ome-lexikon.uni-oldenburg.de/p32578 (Stand 18.12.2014).

Lengauer, Hans Georg: Soldatengräber an der Neißefront. In: Gubener Heimatbrief (2017)1, S. 56-61.

Leo, Annette: Ravensbrück - Stammlager. In: Der Ort des Terrors. Geschichte der nationalsozialistischen Konzentrationslager. Hrsg. von Wolfgang Benz u. Barbara Distel. Bd. 4: Flossenbürg, Mauthausen, Ravensbrück. München 2006, S. 473-520.

Leppin, Günther: Evangelisches Kirchentum im Kreis Züllichau-Schwiebus. In: Kreis Züllichau-Schwiebus. Hrsg. im Auftr. der Heimatkreisvereinigung von Curt Schelenz. Frankfurt am Main 1970, 2. Aufl. 1975, S. 48-52.

Liebert, Bodo: Lübben - der Wiederaufbau ab 1945. [T. 1]. Die Reanimation des todkranken Gesundheitswesens. In: Lübbener Heimatkalender 2018 (2017), S. 39-60.

-, -: Lübben - der Wiederaufbau ab 1945. [T. 2]. Die Schaffung von Wohnraum in den Jahren 1945 und 1949. In: Lübbener Heimatkalender 2019 (2018), S. 28-53.

-, -: Lübben - der Wiederaufbau ab 1945. [T. 3]. Wie entwickelten sich die Wohnverhältnisse von 1947 bis 1949? In: Lübbener Heimatkalender 2020 (2019), S. 116-150.

Liehr, Bärbel: Zur Geschichte der Gemeinde Golzow 1933-2000. Chronik. Hrsg.: Chronistenvereinigung Potsdam-Mittelmark e. V. T. II. [Nuthetal] 2003.

Linke, Heinz W. / Paschke, Heinz: Das Sternberger Land im Wandel der Zeiten. Hrsg.: Heimatkreisbetreuung West-Sternberg e. V. Iserlohn 1988 (Ostbrandenburger Heimatbuch I). [Darin, S. 575-636: Zusammenbruch und Vertreibung. Erlebnisberichte von 14 Betroffenen].

Lokalhistorische Studien zu 1945 im Land Brandenburg. Zusammenbruch - Befreiung - Besatzung. Ergebnisse, Berichte und Dokumente aus dem Projekt. Hrsg.: Regionae Abeitsstellen für Ausländerfragen, Jugendarbeit und Schule, Brandenburg e. V. Red.: Hilde Schramm u. a. Potsdam 1996. 
Loose, Ingo: Kredite für NS-Verbrechen. Die deutschen Kreditinstitute in Polen und die Ausraubung der polnischen und jüdischen Bevölkerung 1939-1945. München 2007 (Studien zur Zeitgeschichte, Bd. 75).

Lucas, Karin / Hoffmeister, Hoffmeister: Paretz. 2., verb. Aufl. Überarb. von Matthias Marr. Berlin [1993] (Schlösser und Gärten der Mark).

Ludwig, Andreas: Eisenhüttenstadt. Wandel einer industriellen Gründungsstadt in fünfzig Jahren Potsdam 2000 (Brandenburgische Historische Hefte, 14).

Ludwig, Bernhard: Hermine von Preußen. Die Geschichte eines ungewöhnlichen Lebens. In: Frankfurter Jahrbuch 2018, S. 6-85.

Machnik, Ferdinand: Guben erhielt den Namen Wilhelm Piecks. In: Gubener Heimatkalender 7 (1962), S. 29-32.

Maether, Bernd: Brandenburgs Schlösser und Herrenhäuser 1945-1952. Potsdam 1999 (Brandenburgische Historische Hefte, 12).

Maetz, Dietrich: Chronik der Stadt Luckenwalde. Hrsg.: Luckenwalder Heimatfreunde e. V. Luckenwalde 2016.

Mahn- und Gedenkstätten der deutschen Heimatvertriebenen. Hrsg.: Bund der Vertriebenen - Vereinigte Landsmannschaften und Landesverbände. Bearb.: Heinrich Kucharczyk. Bonn 2008.

Mai, Jürgen: Die Situation der Flüchtlinge in der Region am Beispiel von Premnitz. In: Die letzten Tage im Krieg und die ersten Wochen im Frieden in der Region um Rathenow. T. 3. Hrsg.: Rathenower Heimatbund e. V. 2., unveränd. Aufl. Rathenow 2018 (1. Aufl. 2015), S. 4-8.

-, -: Neubeginn im Premnitzer Werk. In: ebd., S. 9-10.

Makowitz, Bärbel / Knitter, Eitel / Kunze, Martin: Templin. Eine märkische Stadt im Wandel der Geschichte. Hrsg. von der Stadt Templin. 2. Aufl. Strasburg (Um.)/Berlin 2013.

Manegold, Bodo: Alt-Buckower Heimat-Chronik. Die Geschichte des Dorfes Buckow bei Berlin. T. 88. In: Buckower und Großziethener Prismagazin 2019, März/April, S. 17-19.

Marschner-Katzur, Lieselotte: Aus der Geschichte der Gemeinde Neuendorf bei Brück. O. O. 2009.

Marx, Wolf-Rainer: Der Pfarrer predigte im Soldatenmantel. Der schnelle Wiederaufbau zerstörter Kirchen im Oderbruch. In: Offene Kirchen 2015, S. 108-110.

Materna, Ingo: 1918 bis 1945. Brandenburg in der Weimarer Republik und während der NS-Herrschaft. In: Ders. / Wolfgang Ribbe: Geschichte in Daten. Brandenburg. München/Berlin 1995, S. 198-223.

Materne, Heinz / Gerlach, Hans: Gross-Gandern und Klein-Gandern. Heimat im Sternberger Land. Ein Beitrag in Wort und Bild, Wissen festzuhalten und Erinnerungen zu wecken, um das Werden und Sein sowie das Leben und Wirken der Menschen in unseren Heimatorten nicht aus dem Auge zu verlieren. [Privatdruck]. Wittingen/Bremen 1997.

Materne, Lutz: Weihe eines Gedenksteines auf dem früheren Ostfriedhof. In: Gubener Heimatbrief (2004)1, S. 25-27.

-, -: 60 Jahre Gubener Heimatbund. In: Gubener Heimatkalender 56 (2012), S. $26-31$.

Mau, Rudolf: Der Protestantismus im Osten Deutschlands (1945-1990). Leipzig 2005 (Kirchengeschichte in Einzeldarstellungen, IV/3).

Maziul, Eckart: Steinkirchen im April/Mai 1945. In: Lübbener Heimatkalender 2020 (2019), S. 108111.

Mehlhase, Torsten: Die SED und die Vertriebenen. Versuche der politischen Einflußnahme und der „Umerziehung“ in den ersten Nachkriegsjahren in Sachsen-Anhalt. In: Sie hatten alles verloren. Flüchtlinge und Vertriebene in der sowjetischen Besatzungszone Deutschlands. Hrsg. von Manfred Wille, Johannes Hoffmann u. Wolfgang Meinicke (Studien der Forschungsstelle Ostmitteleuropa an der Universität Dortmund, Bd. 13). Wiesbaden 1993, S. 159-177. 
-, -: Flüchtlinge und Vertriebene nach dem Zweiten Weltkrieg in Sachsen-Anhalt. Ihre Aufnahme und Bestrebungen zur Eingliederung in die Gesellschaft. Münster 1999. 454 S. (Geschichte, Bd. 22).

Mehnert, Elke: Vertriebene versus Umsiedler - der ostdeutsche Blick auf ein Kapitel Nachkriegsgeschichte. In: Landschaften der Erinnerung. Flucht und Vertreibung aus deutscher, polnischer und tschechischer Sicht. Elke Mehnert (Hrsg.) (Studien zur Reiseliteratur- und Imagologieforschung, Bd. 5). Frankfurt am Main u. a. 2001, S. 133-157.

Meier, Brigitte: Fontanestadt Neuruppin. Kulturgeschichte einer märkischen Mittelstadt. Karwe 2004.

Meier, Günter: Die Straßennamen von Blankenfelde 1918 bis 2002. Ein Spiegel der politischen Machtstrukturen in Deutschland. In: Heimatjahrbuch für den Landkreis Teltow-Fläming 9 (2002), S. 47-53.

Meinicke, Wolfgang: Zur Integration der Umsiedler in die Gesellschaft 1945-1952. In: Zeitschrift für Geschichtswissenschaft 10 (1988), S. 867-878.

-, -: Die Bodenreform und die Vertriebenen in der SBZ und in den Anfangsjahren der DDR. In: Sie hatten alles verloren. Flüchtlinge und Vertriebene in der sowjetischen Besatzungszone Deutschlands. Hrsg. von Manfred Wille, Johannes Hoffmann u. Wolfgang Meinicke (Studien der Forschungsstelle Ostmitteleuropa an der Universität Dortmund, Bd. 13). Wiesbaden 1993, S. 55-85.

-, -: Die Aufnahme von Vertriebenen in der Sowjetischen Besatzungszone Deutschlands. In: „Wach auf, mein Herz, und denke“. Zur Geschichte der Beziehungen zwischen Schlesien und Berlin-Brandenburg von 1740 bis heute. Hrsg.: Gesellschaft für interregionalen Kulturaustausch e. V., Berlin, u. Verein Schlesisches Institut, Oppeln. Berlin/Opole 1995, S. 475-487.

Meister, Hans-Peter: Zuwanderung aus Schlesien nach Berlin und Brandenburg ab 1950. In: „Wach auf, mein Herz, und denke“. Zur Geschichte der Beziehungen zwischen Schlesien und Berlin-Brandenburg von 1740 bis heute. Hrsg.: Gesellschaft für interregionalen Kulturaustausch e. V., Berlin, u. Verein Schlesisches Institut, Oppeln. Berlin/Opole 1995, S. 543-556.

Melchert, Monika: Der Zeitgeschichtsroman nach 1945 am Beispiel von Werner Wilk und Hugo Hartung. In: „Hoffnung und Erinnerung“. Potsdamer Literatur 1945 bis 1950. Texte und Betrachtungen. Zsgest. u. hrsg. im Auftr. des Urania-Vereins „Wilhelm Foerster“ Potsdam e. V. von Mathias Iven. Milow/Berlin 1998, S. 178-187.

Melis, Damian van: „Angabe nicht möglich“ - Integration statt Entnazifizierung der Flüchtlinge in Mecklenburg-Vorpommern. In: Geglückte Integration? Spezifika und Vergleichbarkeiten der Vertriebenen-Eingliederung in der SBZ/DDR. Hrsg. von Dierk Hoffmann u. Michael Schwartz (Schriftenreihe der Vierteljahrshefte für Zeitgeschichte, Sondernr.). München 1999, S. 161-170.

Mengel, Thomas: Das Schicksal der schlesischen Frauenklöster während des Dritten Reiches und 1945/46. Köln/Wien 1986 (Forschungen und Quellen zur Kirchen- und Kulturgeschichte Ostdeutschlands, Bd. 22).

Menschen und Schicksale. v. Klitzing'sche Häuser im 19. und 20. Jahrhundert. Hrsg.: Der Vorstand des v. Klitzing'schen Familienvereins e. V. im Auftr. des Familientages. Verantw. für Red.: Hans Ulrich v. Klitzing (Die Familie von Klitzing, T. V). (Kassel) 1990.

Mentzel, Klaus-Peter: Die Neubauernsiedlungen in Falkensee. In: Heimatjahrbuch für Falkensee und Umgebung 2018 (2017), S. 28-33.

-, -: Neubauernsiedlungen in Falkensee - Fortsetzung. In: Heimatjahrbuch für Falkensee und Umgebung 2020 (2019), S. 88-90.

Menzel, Stefan / Menzel, Walter / Schulze, Jörg: Die Eisenbahn in Brandenburg an der Havel. Stendal 2017.

Mertens, Johannes: Die Berliner Ordensprovinz der Grauen Schwestern von der heiligen Elisabeth 1859-1991. Hrsg. von der Berliner Ordensprovinz der Grauen Schwestern von der heiligen Elisabeth. Reinbek bei Hamburg 1992. 
-, -: Geschichte der Kongregation der Hedwigschwestern 1930-2000. Unveröff. Manuskript. Berlin 2004.

-, -: Geschichte der Konregation der Marienschwestern von der Unbefleckten Empfängnis 1945-1999. Bd. 1-2. Berlin 2000.

-, -: Geschichte der Konregation der Marienschwestern von der Unbefleckten Empfängnis in Berlin. In: Wichmann-Jahrbuch des Diözesangeschichtsvereins Berlin, N. F. 7 (2002/03 [2004]), S. 132-154.

Mewes, Fritz: 8. Mai - 60. Gedenktag zum Ende des 2. Weltkrieges. In: Rathenower Heimatkalender 49 (2005 [2004]), S. 31-34.

Micksch, Werner: Bewegung und Begegnung bei der Volkssolidarität in Guben. In: Gubener Heimatbrief (2005)1, S. 38-46.

Mietk, Thomas: Neuanfang im Kreis Lübben. Beitrag zur Flüchtlings- und Vertriebenenforschung am Ende des Zweiten Weltkrieges. Lübben 2010.73 S. (Einzelveröffentlichung des Kreisarchivs DahmeSpreewald, Bd. 1).

-, -: Als alles zu Ende war. Nachkriegsjahre in Radensdorf. In: Lübbener Heimatkalender 2016, S. 102-111.

-, -: Roter Stern über Luckau 1945 bis 1989/90. In: Luckau. Von der Hauptstadt der Niederlausitz zur Gartenstadt der Moderne. Helga Tuček / Thoma Mietk (Hg.) (Einzelveröffentlichungen des Kreisarchivs Dahme-Spreewald, Bd. 5; Einzelveröffentlichungen der Brandenburgischen Historischen Kommission, Bd. 19). Berlin 2018, S. 228-273.

Mihan, Werner: Die Nacht von Potsdam. Der Luftangriff britischer Bomber vom 14. Apruil 1945. Dokumentation und Erlebnisberichte. Berg am Starnberger See 1997.

Militärgeschichtliches Handbuch Brandenburg-Berlin. Im Auftr. des Militärgeschichtlichen Forschungsamtes hrsg. von Kurt Arlt, Michael Thomae u. Bruno Thoß. Potsdam 2010.

Möbius, Dagmar: Ehemalige Heimkinder treffen sich jährlich in der Ostprignitz. Kriegskinder und ihre Schicksale. (Erstdruck in: Der Märker, 8./9.5.2015). In: Brandenburger Rundschau 13 (2015) 5, S. 6-7.

Möller, Kathrin: (Art.) Flüchtling. In: Landeskundlich-historisches Lexikon Mecklenburg-Vorpommern. Hrsg. von der Geschichtswerkstatt Rostock e. V. und dem Landesheimatbund MecklenburgVorpommern e. V. Rostock 2007, S. 176-177.

Möhring, Werner: Die Demontagen in Guben nach 1945. In: Gubener Heimatkalender 43 (1999), S. 48-53.

-, -: Wohnungsbau in Guben nach dem II. Weltkrieg. In: Gubener Heimatkalender 48 (2004), S. 21-24.

Mohaupt, Heinz: Das 50jährige Neurochlitz. In: Angermünder Heimatkalender 1999, S. 45-49.

Morré, Jörg: Speziallager des NKWD. Sowjetische Internierungslager in Brandenburg 1945-1952. Mit

Beitr. von Gabriele Camphausen u. a. Eine Publ. der Brand. Landeszentrale für politische Bildung. Potsdam 1997.

-, -: „Umschulungslager existieren nicht“. Zur Geschichte des sowjetischen Speziallagers Nr. 6 in Jamlitz 1945-1947. Potsdam 2001.

Mothes, E. / Zeihn, K. / Glanz, J.: Technologie und Ökonomie einer Laufstallanlage für 1200 Milchkühe. In: Deutsche Agrartechnik 22 (1972), S. 345-349. [LPG „Friedensgrenze“].

Muchow, Heinz: Wittenberg 1945. Eine Chronologie. Wittenberge 1991.

Müller, Anne-Kathrin / Jeute, Gerson H.: Von den Schwierigkeiten ein Ende zu finden ... Neuzeit, Zeitgeschichte und Gegenwart als Themen der Archäologie in Berlin und Brandenburg. In: Feuerstein und Fluchttunnel. Archäologie in Berlin und Brandenburg seit der Wende. Publikation zu den Fachtagungen der Archäologischen Gesellschaft in Berlin und Brandenburg e. V. in Zsarb. mit dem Brandenburgischen Landesamt für Denkmalpflege und Archäologischen Landesmuseum und dem 
Landesdenkmalamt Berlin in Berlin am 22. September 2012 und in Prenzlau am 25. Mai 2013. Hrsg.: Michael Meyer u. a. Petersberg 2017, S. 243-258.

-, -: Die Qual der Wahl? Zum Umgang mit Funden aus Grabungen an zeitgeschichtlichen Komplexen. In: Archäologie und Gedächtnis. NS-Lagerstandorte. Erforschen - Bewahren - Vermitteln. Interdisziplinäre Konferenz im Archäologischen Landesmuseum Brandenburg an der Havel 17. bis 19. September 2015. Hrsg.: Thomas Kersting u. a. (Denkmalpflege in Berlin und Brandenburg, Arbeitsheft 4/2016). Petersberg 2016, S. 75-85.

Müller, Erich: Transporte, Lager, Ansiedlung im Warthegau: Das Schicksal der galizien- und wolhyniendeutschen Umsiedler nach ihrem Grenzübertritt 1939/40. In: Zeitweiser der Galiziendeutschen 43 (2005), S. 104-157.

Müller, Franz: Chronik der Stadt Märkisch Buchholz. Berlin 2001.

Müller, Johannes: Geschichte von Dorf und Rittergut Gross-Kammin bis 1925. [Privatdruck]. Heilbronn/Neckar 1997.

Müller, Wolfgang: Das Priesterseminar Bernhardinum. In: 725 Jahre Neuzelle. Festschrift zum Jubiläum der Klostergründung vor 725 Jahren. Verf. im Auftr. der Gemeinde Neuzelle von Peter Kaufmann u. a. Eisenhüttenstadt 1993, S. 35-37.

-, -: Der deutsche Restteil des Erzbistums Breslau die Diözese Görlitz. In: Erbe und Auftrag der schlesischen Kirche/Dziedzictwo i posłannictwo śląskiego Kościoła. 1000. Jahre Bistum Breslau/1000 lat diecezji wrocławskiej. Hrsg. von Winfried König. Dülmen 2001, S. 310-337.

Müller, Wolfgang: Nachkriegsjahre in Eichwalde. Zur Geschichte des Ortes von 1945 bis 1953. Eichwalde [2007].

-, -: Volkszählungen in Brandenburg nach dem Ende des 2. Weltkrieges. In: Heimatkalender Königs Wusterhausen und Dahmeland 2009, S. 130-132.

Müller-Pfeifruck, Sylvia: Die Kreuze für die Gefallenen des Zweiten Weltkriegs in der Stadtkirche Brüssow - Ein Forschungsbeitrag zu den Kriegergedächtnismalen in den evangelischen Kirchen des Landes Brandenburg. In: Jahrbuch für Berlin-Brandenburgische Kirchengeschichte 70 (2015), 236-261.

Müncheberg 1232-2007. Geschichte und Geschichten, Personen und Persönlichkeiten einer märkischen Kleinstadt. Hrsg.: Stadt Müncheberg. Müncheberg [2007].

Das Naemi-Wilke-Stift in der SBZ/DDR. In: Das Naemi-Wilke-Stift in Guben. Eine Stiftung zwischen Tradition und Moderne. Stefan Süß / Gottfried Hain (Hrsg.). Berlin 2005.

Nagel, Günter: Kriegsgefangenenlager in Dabendorf. In: Heimatjahrbuch für den Landkreis TeltowFläming 26 (2019), S. 43-48.

Nagelstutz, Stefan: „Umsiedler“ in der SBZ/DDR. Vertriebenenintegration in der SBZ/DDR 19451953. Saarbrücken 2009.

Natusch, Kurt: Altdöbern in der Niederlausitz. Eine Chronik in Daten. Altdöbern 1994.

Nebelung, (Paul-Friedrich): Der Landkreis Eichenbrück (Wongrowitz) im Reichsgau Wartheland. in: Heimatbuch für den Kreis Eichenbrück-Wongrowitz. [Bd. 1]. Lüneburg [1967], S. 87-89.

Nechamkis, Wlodzimierz: Die Grenze. In: Wir waren damals 19. 50 Jahre 8. Mai in und um Frankfurt. Berichte, Dokumente, Recherchen, Tagebücher, Erinnerungen, Gespräche. Ein Lesebuch. Hrsg.: Jürgen Maerz. Frankfurt (Oder) 1995, S. 395-399.

Necker, Ernst: Friedensfeld, Bessarabien. Familien- und Sippenregister. Von der Gründung der Gemeinde im Jahre 1879 bis zur Seßhaftmachung nach der Flucht im Jahr 1945. Hrsg.: Christian Fiess, Vorsitzender des Heimatmuseums der Deutschen aus Bessarabien e. V. Stuttgart/Mühlacker 1984.

Neis, Kurt: Fürstenberg/Havel. Eine Perle ohne Glanz? Erinnerungen und Betrachtungen aus der Zeit von 1946 bis zur Gegenwart 2011. Text- u-. Bildbd. Privatdruck. 9., erg. Aufl. Fürstenberg/Havrel 2011. [Verf. geb. 1936 Aussig/Elbe, 1946 von dort vertrieben, lebt seitdem in Fürstenberg/Havel]. 
Neitmann, Klaus / Schröder, Kathrin / Weirauch, Kärstin: „Ist eine Zierde des Landes gewest“. Lübben (Spreewald) im Spiegel archivalischer Quellen. Berlin 2006 (Einzelveröffentlichung des Brandenburgischen Landeshauptarchivs, Bd. 2).

Nerlich, Bruno P.: Die Hilfe der sowjetischen Kommandantur beim wirtschaftlichen Wiederaufbau der Stadt Eberswalde (1945-1949). In: Befreiung und Neubeginn. Zur Stellung des 8. Mai 1945 in der deutschen Geschichte. Wiss. Red.: Bernhard Weißel (Deutsche Akademie der Wissenschaften zu Berlin. Schriften der Deutschen Sektion der Kommission der Historiker der DDR und der UdSSR, Bd. 5). Berlin 1968, S. 210-220.

Neumann, Monika / Ziegler, Martin: Flucht, Vertreibung und Neuanfang in der neuen Heimat nach 1945 am Beispiel Pießigs. In: Sonnewalder Heimatblätter 19 (2019), S. 93-110.

Neuzelle einst und jetzt. Frank Mangelsdorf (Hg.). Texte Janet Neiser. Berlin 2018.

Niederlage - Sieg - Neubeginn. Kriegsende 1945. Werner Künzel, Richard Lakowski (Hg). Eine gemeinsame Konferenz des Landkreises Märkisch-Oderland und der Brandenburgischen Landeszentrale für politische Bildung, Seelow, 31.1.2005. Hrsg.: Brandenburgische Landeszentrale für politische Bildung und der Landkreis Märkisch-Oderland. Potsdam 2005 (Protokolle).

Niedzballa, Gustav: Ein Stein des Gedenkens und der Versöhnung und nicht ein Stein des Anstoßes. In: 10 Jahre Bund der Vertriebenen in Rüdersdorf und Umgebung. Rüdersdorf 2002, S. 23-26.

Nieschalk, Margarete: Lazarettstadt Guben. In: Gubener Heimatbrief (1994)2, S. 58.

Nitschke, Johannes: 150 Jahre Pfarrkirche „Heilige Dreifaltigkeit“ Brandenburg an der Havel. Hrsg. von der Katholischen Kirchengemeinde „Heilige Dreifaltigkeit“, Brandenburg an der Havel. Brandenburg an der Havel [2001].

Nitschke, Klaus: Das Leben ging auch in Mecklenburg weiter. In: Jahrbuch der Deutschen aus Bessarabien 47 (1996), S. 75-78.

Noetzel, Andreas: Bemerkungen zur demokratischen Bodenreform am Beispiel der Region Kyritz. In: Jahrbuch Ostprignitz-Ruppin 25 (2016), S. 217-237.

Oberling, Ines: Falkenseer Wirtschaftsgeschichte (3): Von der Zigarettenfabrik Leon Mardirossian zum VEB Gablona Falkensee. In: Heimatjahrbuch für Falkensee und Umgebung 2009, S. 42-48.

Oehlsen, Sven: Flucht aus Schlesien. Auf eigene Faust zurück. In: Spiegel online, 10.11.2007 [16.6.2017]. [Schicksal einer niederschlesischen Vertriebenenfamilie aus Schmottseiffen (Kr. Löwenberg), 1947 Vertreibung, Treck nach Görlitz, Grenzübertritt 10.6.1947, Transport nach Brandenburg/Havel, Quenz-Lager (Quarantäneaufenthalt), dann per Güterzug nach Nauen, über Flatow (Kr. Osthavelland) Weitertransport nach Karwesee (Kr. Osthavelland), hier Unterkunft bei Bauern, 1948/49 eigene Wohnung].

-, -: Vertriebenenlager in Brandenburg 1945-1953. Potsdam 2006 (Brandenburgische Historische Hefte, 18).

-, -: Deutsche Vertriebene in Brandenburg und Sachsen nach 1945. In: Preußen, Sachsen, Brandenburg. Nachbarschaften im Wandel. Hrsg. Brandenburgische Gesellschaft für Kultur und Geschichte gGmbH, Kulturland Brandenburg, Potsdam. Leipzig 2014, S. 38-45.

Oette, Heinz: Fremdarbeiterlager Wiesenhain. In: Der Speicher 12 (2009), S. 94-98. [Finsterwalde; S. 96-97: „persönliche Erinnerungen“ des Verf. „an das Wiesenlager während und nach dem Krieg"].

Olschowsky, Heinrich: Als Deutscher in Polen - als „Spätaussiedler“ in der DDR. In: „Wach auf, mein Herz, und denke“. Zur Geschichte der Beziehungen zwischen Schlesien und Berlin-Brandenburg von 1740 bis heute. Hrsg.: Gesellschaft für interregionalen Kulturaustausch e. V., Berlin, u. Verein Schlesisches Institut, Oppeln. Berlin/Opole 1995, S. 524-531.

Onnen, Hans-Joachim: Profile aus Potsdam und dem Landkreis Potsdam-Mittelmark. Bürger unserer Zeit. Bd. 1-3. Potsdam 1998, 1999, 2000. 
Opitz, Erich: Anfang und Ende einer Schiffergaststätte an der Oberschleuse. In: Heimatkalender Eisenhüttenstadt und Umgebung 15 (1997), S. 35-40.

-, -: Ereignisse der Nachkriegszeit in Fürstenberg (Oder) und Umgebung. In: Fürstenberger Blätter 1 (2011), S. 71-84. [Minen- und Munitionstote, Wohnungsnot (dabei auch starker Zuzug von Flüchtlingen u. Vertriebenen), Nachkriegsverbrechen; S. 74-76: Liste der vom 15. Mai 1945 bis Februar 1957 durch Minen- oder Munitionsexplosionen zu Tode Gekommenen].

-, -: Tragische Folgen eines Weltkrieges. In: Jahrbuch für Gubener Geschichte 2012/13 (2013), S. 133-171. [Minen- u. Sprengstofftote im Raum Guben 1945-1950; Verbrechen gegen Kriegsende u. in der Nachkriegszeit 1945-1949, mit detaillierter Opferliste].

Der Ort des Terrors. Geschichte der nationalsozialistischen Konzentrationslager. Hrsg. von Wolfgang Benz u. Barbara Distel. Bd. 4: Flossenbürg, Mauthausen, Ravensbrück. München 2006.

Orte des Erinnerns. Gedenkzeichen, Gedenkstätten und Museen zur Diktatur in SBZ und DDR. Hrsg. von Anna Kaminsky. Erarb. von Ruth Gleinig im Auftr. der Bundesstiftung zur Aufarbeitung der SED-Diktatur. 3., überarb. u. erw. Aufl. Berlin 2016.

Ost- und Westpreußen. Hrsg. von Erich Weise. Stuttgart 1966 (Handbuch der Historischen Stätten).

Die Ostpreußenhilfe im Ersten Weltkrieg. Hrsg. vom Ostpreußischen Landesmuseum Lüneburg zur Ausstellung „Zum Besten der Ostpreußenhilfe“ (23.9.2006-28.1.2007). Husum 2006.

Otto, Kathy: Zur Entnazifizierung des Lehrpersonals und zur Ausbildung von Neulehrern in den Jahren 1945/1946 in Potsdam. In: Beiträge zur Geschichte des Potsdamer Schulwesens. Vorbem.: (Wolfgang) Rocksch (Potsdamer Forschungen der Pädagogischen Hochschule „Karl Liebknecht“ Potsdam, Erziehungswiss. Reihe, H. 86). Potsdam 1990, S. 112-135, bes. S. 119-135.

Pape, Kurt / Schultze, Alfred: Werder (Havel) 1945. Zwischen fünf vor zwölf und fünf nach zwölf. Unter Mitarb. von Klaus Froh. Hrsg. vom Heimatverein Werder (H.) e. V. Potsdam 2015.

Pape, Petra: Flüchtlinge und Vertriebene in der Provinz Brandenburg. In: Sie hatten alles verloren. Flüchtlinge und Vertriebene in der sowjetischen Besatzungszone Deutschlands. Hrsg. von Manfred Wille, Johannes Hoffmann u. Wolfgang Meinicke (Studien der Forschungsstelle Ostmitteleuropa an der Universität Dortmund, Bd. 13). Wiesbaden 1993, S. 110-132.

Parisius, Bernhard: Neubürger. In: Online-Lexikon zur Kultur und Geschichte der Deutschen im östlichen Europa, 2012. URL: ome-lexikon.uni-oldenburg.de/55207.html (Stand: 22.5.2015).

Partnerschaften. Die Stadt Potsdam und ihre Partnerstädte. In: Potsdam heute [1] (1991), H. 1, S. 52-53.

Pauksch, Wolfgang: Tag des Gedenkens und der Versöhnung am 30. Januar 2015. In: Heimatblatt der ehemaligen Kirchengemeinden Landsberg/Warthe Stadt und Land 50 (2015), S. 25-26.

Pech, Gisela: Entstehung und Entwicklung der Volkssolidarität in Fürstenberg und Eisenhüttenstadt. In: Heimatkalender Eisenhüttenstadt 18 (2000), S. 104-110.

Pelzer, Rotraut / Pelzer, Susanne: Das Gehörlosenschulwesen der Provinz Brandenburg. Pritzwalk als Zufluchtsort taubstummer Kinder. In: Pritzwalker Heimatblätter 2 (1989), S. 12-14.

Pergande, Frank: Leben in Deutschland lernen. Aussiedler in fremder Umgebung. In: Frankfurter Allgemeine Zeitung, 29.4.2006.

Peschke, Reinhard und Cornelia: „Ein Haus voll Glorie ...“ 75 Jahre katholische Kirche Erkner. Erkner 2007 (Erkneraner Hefte, 10).

Peter, Andreas: Der Juni-Aufstand im Bezirk Cottbus. In: Deutschland Archiv 27 (1994), S. 585-594.

-, -: Schmerzhafte Wunden europäischer Geschichte. „Geteilte Städte an Oder und Neiße“ - eine Rezension. In: Gubener Heimatbrief (2000)2, S. 97-98.

-, -: 50 Jahre Gubener Heimatbund. In: Gubener Heimatkalender 46 (2002), S. 31.

Peters, Jan: 600 Jahre Blankenfelde Kr. Zossen. Blankenfelde, Kr. Zossen 1975. 
Petzold, Heinz: Cottbus zwischen Januar und Mai 1945. In: Brandenburg im Jahr 1945. Studien. Hrsg. von Werner Stang unter Mitarb. von Kurt Arlt. Potsdam 1995, S. 106-135.

-, -: Als für Cottbus der 2. Weltkrieg endete. Zum Geschehen vor 60 Jahren. Cottbus 2005.

Petzoldt, Maria: Die Bibliothek im Haus Brandenburg - Was bietet sie, was leistet sie ... In: Königsberger Kreiskalender 2003, S. 94-96.

Pfarrer Günther Brandt. Eine Dokumentation zum 100. Geburtstag. Hrsg.: Evang. St. Nikolai-Kirchengemeinde Potsdam. Texte u. Ausw. der Dokumente: Marina Lewkowicz. 2. Aufl. Potsdam 2012.

Pfeiler, Jürgen: „Der Krieg war plötzlich da.“ Alltag westlich Oder, Spree und Dahme zwischen Neujahr und Himmelfahrt. Eine Chronik. In: Brandenburg im Jahr 1945. Studien. Hrsg. von Werner Stang unter Mitarb. von Kurt Arlt. Potsdam 1995, S. 84-105. [Mit zahlreichen kurzen Auszügen aus zeitgenössischen Berichten und Tagebüchern].

Pietsch, Herbert: Tote Soldaten auf dem Zentral-Waldfriedhof in Halbe. In: Der 8. Mai 1945 als historische Zäsur. Hrsg. von Arnd Bauerkämper, Christoph Kleßmann, Hans Misselwitz. Potsdam 1995, S. $185-200$.

Pilvousek, Josef / Preuß, Elisabeth: Katholische Flüchtlinge und Vertriebene in der SBZ/DDR. Eine Bestandsaufnahme. In: Vertriebene finden Heimat in der Kirche. Integrationsprozesse im geteilten Deutschland nach 1945. Hrsg. von Rainer Bendel (Forschungen und Quellen zur Kirchen- und Kulturgeschichte Ostdeutschlands, Bd. 38). Köln u. a. 2008, S. 15-27.

Pischel, Barbara: Gestaltung und Wandlung von Bräuchen am Beispiel Heimatvertriebener in Berlin. in: Jahrbuch für Volkskunde der Heimatvertriebenen 3 (1958), S. 123-150.

Plato, Alexander von / Meinicke, Wolfgang: Alte Heimat - neue Zeit. Flüchtlinge, Umgesiedelte, Vertriebene in der Sowjetischen Besatzungszone und in der DDR. Berlin 1991.

Platzke, Max: Geschichte einer ostdeutschen Kleinstadt kommunalpolitisch betrachtet. Berlin-Charlottenburg 1956. [Sommerfeld/NL].

Polley, Detlef: Schrecken, Not und Tod. Dabendorf am Ende des Zweiten Weltkriegs. In: Heimatjahrbuch für den Landkreis Teltow-Fläming 23 (2016), S. 113-119.

Die pommerschen Heimatkreise 1945-1995. 50 Jahre Arbeit für Pommern. Hrsg. vom Pommerschen Kreis- und Städtetag. Zsgest. von Hans-Günter Cnotka. Lübeck 1998.

Poppe, Gertrud: [Der Neuanfang 1945/46. T. 1]. Die Biesenthaler Kriegstoten. In: Biesenthaler Anzeiger 5 (1995)6, S. 20.

-, -: Der Neuanfang 1945/46. T. 2: Arbeit war für alle mehr als genug. In: Biesenthaler Anzeiger 5 (1995)8, S. 15-16.

-, -: Der Neuanfang 1945/46. T. 3: Die Schule beginnt wieder. In Biesenthaler Anzeiger 5 (1995)8, S. 17-20.

-, -: Der Neuanfang 1945/46. T. 4: Die Kindertagesstätten entstehen neu. In: Biesenthaler Anzeiger 5 (1995)9, S. 14-16.

-, -: Der Neuanfang 1945/46. T. 5: Die Land- und Forstwirtschaft nach dem Kriege. Bodenreform und Umsiedlerfürsorge. In: Biesenthaler Anzeiger 5 (1995)9, S. 16-17.

Potsdam. Ausgewählte Ergebnisse der Entwicklung der Stadt seit der Befreiung vom Hitlerfaschismus durch die ruhmreiche Sowjetarmee. Hrsg.: Rat der Stadt Potsdam. Potsdam 1975.

Potsdam und das Jahr 1945. Begleitheft zur Ausstellung. Konzeption: Hartmut Knitter u. Thomas Wernicke. Autoren: Peter Herrmann u. a. Hrsg.: Potsdam-Museum. Potsdam 1995.

Pragal, Peter: Von Gablonz nach Neuheim. Wie Sudetendeutsche ,Antifa-Umsiedler' in Brandenburg ihre industrielle Tradition fortsetzten. http://www.kulturforum.info/de/startseite-de/1019554themen/6992-von-gablonz-nach-neuheim (aufgerufen 27.5.2016). 
Prenzlau. Hauptstadt der Uckermark 1234-1984. Ein bürgerliches deutsches Lesebuch. Hrsg.: Heimatkreis Prenzlau. Barendorf 1984.

Preußen, Sachsen, Brandenburg. Nachbarschaften im Wandel. Hrsg. Brandenburgische Gesellschaft für Kultur und Geschichte gGmbH, Kulturland Brandenburg, Konzeption u. Red.: Jeanette Toussaint. Fotos: Jürgen Homuth. Potsdam. Leipzig 2014, S. 46-55.

Priesterseminar Bernardinum Neuzelle 1948-1988. Neuzelle 1988.

Puhlmann, Bernd: Die Kirche zu Werben. In: Siegfried Ramoth: Das Gemüsedorf Werben im Wandel eines Jahrhunderts. Ein Lausitzer Heimatbuch. Bearb. u. hrsg. von Jürgen Heinrich. Cottbus 2001 (Cottbuser Bücher, Bd. 9). Cottbus 2001, S. 90-96.

Putz, Jakob: Wie aus Fremden Nachbarn wurden. Nachbarschaften zwischen Vertriebenen und Uckermärkern nach dem zweiten Weltkrieg. Wettbewerbsbeitrag (am Christa-und-Peter-Scherpf-Gymnasium Prenzlau) zum Thema: Vertraute Fremde - Nachbarn in der Geschichte. Prenzlau 2013, www. uckermaerkischer-geschichtsverein.de/online-lesesaal. [Zeitzeugenbefragung].

Radochla, Rolf: Vor 70 Jahren - Zonenreisebestimmungen im Kreisblatt. In: Kippensand. Heimatkalender für das Senftenberger Gebiet 5 (2017), S. 6.

Radoy, Renate: Umzug zum Jubiläum von Rüdersdorf. Volkssolidarität und BdV gestalteten zwei eindrucksvolle Bilder. In: Volkssolidarität im Barnim aktuell 2 (2010)4, S. 48-49.

Ragösen. Beiträge zur Geschichte. T. 2: 1945 bis 1991. Autorenkollektiv: Helmut Bessel u. a. Hrsg.: Gemeinde Ragösen. Red.: Helga Kästner. Ragösen 2002.

Ramoth, Siegfried: Das Gemüsedorf Werben im Wandel eines Jahrhunderts. Ein Lausitzer Heimatbuch. Bearb. u. hrsg. von Jürgen Heinrich. Cottbus 2001 (Cottbuser Bücher, Bd. 9).

Rathenow. Chronik 1216-2007. Hrsg. in Zsarb. mit der Stadtverwaltung Rathenow. Text: Stadtverwaltung Rathenow. Nordhorn 2007.

Rathenow in Flammen. Kriegskinder auf den Spuren ihrer Geschichte. Klaus Weidt (Hg.). Böttingen 2015.

Rau, Lucie / Wegener, Frieda: 20 Jahre DFD in Zehdenick. In: Festschrift zur 750-Jahr-Feier der Havelstadt Zehdenick. Hrsg. vom Rat der Stadt Zehdenick. Zehdenick 1967, S. 109-112.

Rehberg, Rolf / Simon, Wolfgang: Illustrierte Geschichte Pritzwalks. Pritzwalk 2006.

Reinert, Fritz: Methodische Hinwesie zur Quellenauswertung von Archivalien über die Geschichte der demokratischen Bodenreform. In: Beiträge zur Geschichte der demokratischen Bodenreform im Land Brandenburg. Hrsg. vom Staatsarchiv Potsdam u. der SED-Bezirksleitung Potsdam, Kommission zur Erforschung der Geschichte der örtlichen Arbeiterbewegung. Potsdam 1966, S. 23-44.

Reiser, Alexander: Russlanddeutsche. Angekommen zu Hause in der Fremde. In: Besiedlung, Bevölkerung, Migration. Hrsg.: Heimatverein Marzahn-Hellersdorf e. V. Red.: Christa Hübner u. a. (Beiträge zur Regionalgeschichte, 13). Berlin 2016, S. 142-166.

Reiß, Eckard: Das Ende der Frankfurter Dammvorstadt und das Entstehen von Slubice. Eine Chronologie. In: Historischer Verein zu Frankfurt (Oder) e. V. Mitteilungen 2003, H. 2, S. $26-40$.

-, -: Die Oderübergänge der Roten Armee als Ersatz für die im April 1945 gesprengte Oderbrücke. in: ebd. 2014, H. 2, S. 19-23.

Remus, Barbara: Gewachsenes Miteinander zwischen Guben und Gubin. In: Gubener Heimatbrief (2001)1, S. 62-64.

Ribbe, Wolfgang: Das Land Brandenburg in der SBZ/DDR (1945 bis 1952). In: Brandenburgische Geschichte. Hrsg. von Ingo Materna u. Wolfgang Ribbe. Berlin 1995, S. 677-726.

-, -: Berlin 1945-2000. Grundzüge der Stadtgeschichte. Berlin 2002 (Kleine Schriftenreihe der Historischen Kommission zu Berlin, H. 6).

-, -: Der Juni-Aufstand 1953 in den Regionen der DDR. Ein Forschungs- und Literaturbericht. In: Jahrbuch für die Geschichte Mittel- und Ostdeutschlands 51 (2005[2006]), S. 147-226. 
-, -: Flüchtlinge - Vertriebene - Displaced Persons. Ihre Aufnahme, Weiterleitung bzw. Eingliederung in Berlin und Brandenburg bei Kriegsende 1945. In: Schaufenster der Systemkonkurrenz. Die Region Berlin-Brandenburg im Kalten Krieg. Michael Lemke (Hg.) (Zeithistorische Studien, Bd. 37). Köln u. a. 2006, S. 145-162.

Richter, Hans: Franz Fühmann. Ein (un)verlorener Sohn Böhmens. In: Böhmen. Vielfalt und Einheit einer literarischen Provinz. Hrsg. von Frank-Lothar Kroll (Literarische Landschaften, Bd. 2). Berlin 2000, S. $127-150$

Richter, Ute: 70 Jahre Volkssolidarität. In: Gubener Heimatkalender 59 (2015), S. 36-38.

Riedel, Christhart: Kirchliches Leben in Strasburg. In: Festschrift 750 Jahr Stadt Strasburg (Um.). Hrsg von Anette Görl. Milow 2000, S. S. 42-51.

Ritter, Christian: Hans-Gottfried Bluhm (1924-2010). In: Landesgeschichtliche Vereinigung für die Mark Brandenburg. Mitteilungsblatt 114 (2013), S. 55-56.

Rodegast, Günter: „Umsiedler“ in Wittenberge. Eine Dokumentation. In: Prignitzer Heimat 29 (2001), S. 14-17.

-, -: 6000 Flüchtlinge in der Stadt. Die Gesundheitslage in Wittenberge 1945. In: Prignitzer Heimat 58 (2015), S. 54-55.

Röder, Hans-Jürgen: Im Angesicht der Mauer. Diakonisches Leben im DDR-Sozialismus. Hrsg. vom Evang. Diakonissenhaus Berlin Teltow Lehnin. Berlin 2016.

Roeder, Hermann / Roeder, Hedwig: Unser Heimatdorf Zatten. Göttingen 1974.

Röhr, Rita: Polen in Frankfurt (Oder) zur Zeit der DDR. In: Frankfurt an der Oder 1253-2003. Hrsg. von Ulrich Knefelkamp u. Siegfried Griesa. Berlin 2003, S. 249-262.

Rössler, Katrin: Kriegsende und Zerstörung. Schwedt von 1933 bis 1945: Leben im Dritten Reich. Zwischen Einschulung und Einberufung. Hrsg.: Stadt Schwedt/Oder, Der Bürgermeister. Städtische Museen Schwedt/Oder, Stadtmuseum. Red.: Anke Grodon u. a. Schwedt/Oder [2013?]. S. 129-133.

Rogall, Joachim: Krieg, Vertreibung und Neuanfang. Die Entwicklung Schlesiens und das Schicksal seiner Bewohner von 1939-1995. In: Joachim Bahlcke [Hrsg.]: Schlesien und die Schlesier (Vertreibungsgebiete und vertriebene Deutsche. Studienbuchreihe der Stiftung Ostdeutscher Kulturrat, Bd. 7). München 1996, S. 156-223.

Rose, Lars: Ein Golßener Haus mit viel Geschichte(n). In: Luckauer Heimatkalender 49 (2017), S. 62-66 [Gasthof "Goldener Adler"].

-, - / Bock, Michael: Golßen in historischen Ansichten. Horb am Neckar 2001.

Rose, Wolfgang: Anstaltspsychiatrie in der DDR. Die brandenburgischen Kliniken zwischen 1945 und 1990. Mit einem Beitr. von Annette Weinke. Berlin 2005 (Schriftenreihe zur Medizingeschichte des Landes Brandenburg, Bd. 9).

-, -: Teupitz am See 1905-1945. In: Teupitz. Eine märkische Stadt im Wandel der Zeiten. Heinrich Krause / Karsten Kuhl (Hrsg.) (Einzelveröffentlichungen der Brandenburgischen Historischen Kommission). Berlin 2007, S. 193-246.

-, -: Teupitz von 1945 bis in die jüngste Vergangenheit. In: Teupitz. Eine märkische Stadt im Wandel der Zeiten. Heinrich Krause / Karsten Kuhl (Hrsg.) (Einzelveröffentlichungen der Brandenburgischen Historischen Kommission). Berlin 2007, S. 247-291.

-, -: Die SBZ-Zeit und die DDR-Zeit 1945 bis 1990. In: St. Josefs-Krankenhaus Potsdam-Sanssouci 1862-2012. „Die Liebe Christi drängt uns“. Eckart Frantz (Hrsg.). Berlin 2012, S. 135-174.

-, -: Die Samariteranstalten in der SBZ und DDR (1945-1990). In: Die Samariteranstalten Fürstenwalde. Eine diakonische Stiftung zwischen Kaiserreich und Bundesrepublik. Jens C. Franze / Paul-Gerhardt Voget (Hrsg.) (Einzelveröffentlichungen zur Medizingeschichte bei der Brandenburgischen Historischen Kommission, Bd. 7). Berlin 2013, S. 105-140. 
-, - / Dill, Hans-Dieter: Das Naemi-Wilke-Stift in der SBZ/DDR. In: Das Naemi-Wilke-Stift in Guben. Eine Stiftung zwischen Tradition und Moderne. Stefan Süß / Gottfried Hain (Hrsg.). Berlin 2005, S. 109-132.

Roske, Peter: Die Katholische Kirchengemeinde Heilig Kreuz in Frankfurt (Oder) 1945. In: WichmannJahrbuch des Diözesangeschichtsvereins Berlin, N. F. 14 (2016/17 [2017]), S. 162-168. [Teilweise autobiographisch, Verf. war 19459 Jahre alt].

Ruch, Christamaria: Gerhard Pöhlchen ist fest verwurzelt. In: Märkische Allgemeine, OstprignitzRuppin, 6.11.2017.

Ruchniewicz, Krzysztof: Wilde Vertreibung aus Polen. In: Lexikon der Vertreibungen. Deportation, Zwangsaussiedlung und ethnische Säuberung im Europa des 20. Jahrhunderts. Detlef Brandes / Holm Sundhausen / Stefan Troebst (Hg.). Wien/Köln/Weimar 2010, S. 725-729.

Ruchniewicz, Małgorzata: Deutsche und Polen aus den ehemaligen deutschen Ostgebieten: Deportation in die Sowjetunion. In: Lexikon der Vertreibungen. Detlef Brandes / Holm Sundhausen / Stefan Troebst (Hg.). Wien/Köln/Weimar 2010, S. 163-165.

Rückling, Stefan: Familienbuch Wartenberg und Hohenwartenberg, Kreis Königsberg in der Neumark. Berlin 2018.

Rüdiger, Jens / Gudden-Lüddeke, Ilse: Die Pommern in der Bundesrepublik Deutschland. In: Eberhard Völker [Hrsg.: Pommern und Ostbrandenburrg (Vertreibungsgebiete und vertriebene Deutsche. Studienbuchreihe der Stiftung Ostdeutscher Kulturrat, Bd. 9). München 2000, S. 126-132.

Runde, Dorothea: Straßennamen Pritzwalks im Wandel der Zeit. In: Pritzwalker Heimatblätter 7 (1996), S. 12-21.

Ruhl, Johannes: St. Marien Biesenthal 1909-1999. Festvortrag anlässlich des 90-jährigen Kirchweihjubiläums von St. Marien, Biesnthal, am Sonntag, dem 10. Oktober 1999. [Biesenthal] 1999.

-, -: Katholisches Leben in der Stadt Altlandsberg seit 1230. (Altlandsberg) 2008.

Rusche, Michael: Die Eingliederung der Vertriebenen in Mecklenburg-Vorpommern, dargestellt unter besonderer Berücksichtigung der Wohnraumproblematik. In: Sie hatten alles verloren. Flüchtlinge und Vertriebene in der sowjetischen Besatzungszone Deutschlands. Hrsg. von Manfred Wille, Johannes Hoffmann u. Wolfgang Meinicke (Studien der Forschungsstelle Ostmitteleuropa an der Universität Dortmund, Bd. 13). Wiesbaden 1993, S. 133-147.

Rymar, Edward: Tankow / Danków im Wandel der Geschichte. Einstiges neumärkisches Städtchen und heutiges Dorf. Strzelce Krajeńskie 2009.

Sachse, Christian: Spezialheime der DDR-Jugendhilfe im Land Brandenburg (Elektronische Ressource: http://www.aufarbeitung.brandenburg.de/ (27.4.2016).

Die Samariteranstalten Fürstenwalde. Eine diakonische Stiftung zwischen Kaiserreich und Bundesrepublik. Jens C. Franze / Paul-Gerhardt Voget (Hrsg.). Berlin 2013 (Einzelveröffentlichungen zur Medizingeschichte bei der Brandenburgischen Historischen Kommission, Bd. 7).

Schade, Rolf: Die Geschichte an der Oder befragt. Gedanken zu einem zwei Jahre alten Projekt. In: Heimatkalender Eisenhüttenstadt und Umgebung 11 (1993), S. 55-58.

Schädler, Verena: Katholischer Sakralbau in der SBZ und in der DDR. Regensburg 2013 (Bild - Raum Feier, Bd. 11).

Schäffer, Harry: Bestensee im Winter und Frühjahr 1945 und das Ende der nationalsozialistischen Herrschaft. In: Heimatkalender Königs Wusterhausen und Dahmeland 2014, S. 122-125.

Scharf, Hans-Wolfgang: Eisenbahnen in Westpreußen. Rückzug, Räumung und Auflösung der Reichsbahndirektion Danzig. In: Westpreußen-Jahrbuch 37 (1987 [1986]), S. 83-95.

Schatte, Hartmut: Groß Drewitz. Geschichte und Geschichten eines Dorfes in der Niederlausitz. Cottbus/Guben 1999. 
-, -: Krayne. Teichperle der Niederlausitz. [Cottbus] 2005.

-, -: Kowalski trifft Schmidt ... In: Gubener Heimatkalender 50 (2006), S. 90-93.

-, -: Der Schmerz ist gewichen, die Erinnerung bleibt. In: Gubener Heimatkalender 59 (2015), S. 82-87

[Besuch des Gubeners Heinz Meschke in seinem Heimatort Wallwitz, Kr. Guben, nach 1990].

Scheer, Regina: Der Umgang mit den Denkmälern. Eine Recherche in Brandenburg. [Potsdam] 2003

[S. 145-148 Kapitel: Gedenkzeichen für "Heimatvertriebene" und "Heimkehrer"].

Schelenz, Curt: Die Steinbartsche Stiftung in Züllichau. Pädagogium und Alumnat. In: Kreis ZüllichauSchwiebus. Hrsg. im Auftr. der Heimatkreisvereinigung von Curt Schelenz. Frankfurt am Main 1970, 2. Aufl. 1975, S. 59-62.

-, -: Heimatkreis Züllichau-Schwiebus. 25 Jahre Heimatkreisbetreuung. In: Kreis Züllichau-Schwiebus. Hrsg. im Auftr. der Heimatkreisvereinigung von Curt Schelenz. Frankfurt am Main 1970, 2. Aufl. 1975, S. 196-201.

Schellhaas, Ingrid: Kultur- und Begegnungsstätte - Haus Brandenburg - Fürstenwalde. In: Kreiskalender Oder-Spree 2002, S. 44-45.

Schellhorn, Karin: Chronik eines Umbruchs - Paretz 1945. In: Paretz. Ein Streifzug durch zwei Jahrhunderte eines berühmten Dorfes. Eine Anthologie. Hrsg. von Matthias Marr (Führungen durch die Mark Brandenburg, Bd. 1). Magdeburg 1991, S. 71-76 [nach Augenzeugenberichten].

Schenzel, Leopold: Königsbach. Das Schicksal einer ostdeutschen Schwabensiedlung. In: Otto Heike: 150 Jahre Schwabensiedlungen in Polen 1795-1945. Leverkusen 1979, S. 217-293.

Schicksal in Zahlen. Informationen über die Arbeit des Volksbundes Deutsche Kriegsgräberfürsorge. Hrsg. vom Volksbund Deutsche Kriegsgräberfürsorge. Verantw. für den Inh.: Gerhard Holz. 5. Aufl. Kassel 1997/98.

Schicksale deutscher Baudenkmale im Zweiten Weltkrieg. 2. Aufl. Bd. 1. Berlin [1980].

Schieb, Roswitha: Jeder zweite Berliner. Schlesische Spuren an der Spree. Potsdam 2012 (Potsdamer Bibliothek östliches Europa).

Schieche, Manfred: Typhusepidemie im Jahre 1945 in Fürstenberg/Oder und Umgebung. In: Heimatkalender Eisenhüttenstadt und Umgebung 15 (1997), S. 43-46.

-, -: Die Krankenanstalten der Stadt Fürstenberg (Oder). In: Heimatkalender Eisenhüttenstadt und Umgebung 16 (1998), S. 66-72.

-, - / Jaeschke, Gerhard: Ziebingen. Ein Marktflecken im Sternberger Land. Eisenhüttenstadt u. a. 2001.

Schiefelbein, Siegfried: Niederfinow - Ein Ort mit schwebenden Schiffen. 1258 - 1267 - 2008. Niederfinow 2008.

Schilde, Kurt: Flucht über die Balkonmauer. Politische Biographie des Kommunisten Josef Schlaffer. In: Jahrbuch für historische Kommunismusforschung 2008, S. 310-318.

Schiller: Das Entstehen und die Entwicklung der LPG „Friedensgrenze“ Groß-Gastrose. In: Gubener Heimatkalender für das Jahr 1959, S. 54-55.

Schiller, Gertraud: Im havelländischen Tal der Wublitz. Bd. 1: Königliches Falkenrehde. Potsdam 2013.

Schiller, Hartmut / Rüdiger, Jens: Flucht und Vertreibung der deutschen Bevölkerung aus Hinter- und Mittelpommern. In: Eberhard Völker [Hrsg.]: Pommern und Ostbrandenburger. (Vertreibungsgebiete und vertriebene Deutsche. Studienbuchreihe der Stiftung Ostdeutscher Kulturrat, Bd. 9). München 2000, S. 122-126.

Schiller, Werner: Kriegsende und Neuanfang. Aus Dokumenten von Zeitzeugen. In: Wildauer Heimatbuch. T. 2. Horb am Neckar 2001, S. 9-17.

Schindler, Christine: Eine neue Heimat im Dorf. In: Dorf und Familie. Bauernzeitung 2017, 13. Woche, S. 52-53. 
Schlasse, Heike Eva: Die Oderdrücke bei Neurüdnitz. Ein Denkmal der Verkehrsgeschichte und des Kalten Krieges. Petersberg 2019 (Arbeitshefte des Brandenburgischen Landesamtes für Denkmalpflege und Archäologischen Landesmuseums, Nr. 53).

Schloß Cecilienhof und die Potsdamer Konferenz 1945. Von der Hohenzollernwohnung zur Gedenkstätte. Hrsg. von Chronos-Film u. Stiftung Preußische Schlösser Berlin-Brandenburg. Berlin u. a. 1995.

Schmeissner, Dorte: Kyritz, die Stadt der Bodenreform. T. I. In: Jahrbuch Ostprignitz-Ruppin 15 (2006), S. 77-87.

-, -: Kyritz, die Stadt der Bodenreform. T. II. In: Jahrbuch Ostprignitz-Ruppin 17 (2008), S. 77-92.

Schmichen, Günter: Wilhelm Pieck bleibt unvergessen. In: Gubener Heimatkalender 6 (1961), S. 28-32.

Schmidt, Karl-Heinz: Der Antennenmessplatz Brück. Drei Türme und ein Hubschrauberplatz. In: Das Archiv. Magazin für Kommunikationsgeschichte (2016) 4, S. 68-71.

Schmidt, Ute: „Drei- oder viermal im Leben neu anfangen zu müssen ...“- Beobachtungen zur ländlichen Vertriebenenintegration in mecklenburgischen „Bessarabier-Dörfern“. In: Geglückte Integration? Spezifika und Vergleichbarkeiten der Vertriebenen-Eingliederung in der SBZ/DDR. Hrsg. von Dierk Hoffmann u. Michael Schwartz (Schriftenreihe der Vierteljahrshefte für Zeitgeschichte, Sondernr.). München 1999, S. 291-320.

-, -: Die Deutschen aus Bessarabien. Eine Minderheit aus Südosteuropa (1814 bis heute). 3., unveränd. Aufl. Köln/Weimar/Wien 2006.

-, -: Flucht - Vertreibung - Deportation - Internierung. Erfahrungsberichte von Frauen in der Bundesrepublik und in der früheren DDR. Berlin 2007 (Arbeitspapiere des Forschungsverbundes SEDStaat, 37).

Schmiechen, Ernst: Fünfzig Jahre Diakonissenmutterhaus Luise-Henriette-Stift in Lehnin (Mark) 1911-1961. In kurzer Fassung berichtet. [Lehnin (Mark) 1961].

Schmook, Reinhard: Erfahrungen beim Wiederaufbau der Marienkiche in Chojna - Königsberg/ Neumark - ein deutsch-polnisches Stiftungsprojekt. In: Schwierige Nachbarn? 300 Jahre deutschpolnische Nachbarschaft. Hrsg. im Auftr. des Landfrauenvereins „Mittleres Oderbruch“ e. V. Groß Neuendorf von Wolfgang Michalka u. Reinhard Schmook. Berlin 2007, S. 135-141.

-, -: 150 Jahre Waldhaus in Bad Freienwalde. In: Bad Freienwalder Heimatkalender 51 (2007), S. 93-98.

-, -: Eine neue Grenze im Osten. In: Grenzgänge. Brandenburgs Grenzen und Nachbarn in Geschichte und Gegenwart. Begleitschrift zur Ausstellung im Schloss Freienwalde 16. Mai bis 31. Oktober 2014 und im Dominikanerkloster Prenzlau 23. Mai bis 26. Oktober 2014. Bad Freienwalde (Oder)/Prenzlau 2014, S. 92-94.

-, -: Schwierige Nachbarn im Osten. In: Grenzgänge. Brandenburgs Grenzen und Nachbarn in Geschichte und Gegenwart (wie vor), S. 96-97.

-, -: Wo liegt „Ostbrandenburg“? Zur Geographie und Geschichte der historischen Region. In: Königsberger Kreiskalender 71 (2016), S. 32-39.

-, -: 700 Jahre Bad Freienwalde (Oder). Geschichte der ältesten Kur- und Badesatdt in Brandenburg. Horb 2016 (Heimatkundliche und regionalgeschichtliche Schriften der Albert Heyde Stiftung in Bad Freienwalde, Bd. 5).

-, -: Neue Heimat links der Oder - Vom Flüchtlingsalltag in den ersten Nachkriegsjahren. in: Museumsblätter. Mitteilungen des Museumsverbandes Brandenburg 30 (2017), S. 26-33.

Schneider, Claudia: Als Deutsche unter Deutschen? „Übersiedler aus der VR Polen“ in der DDR ab 1964. In: Transit - Transfer. Politik und Praxis der Einwanderung in die DDR 1945-1990. Kim 
Christian Priemel (Hrsg.) (Almanach des Instituts für Angewandte Geschichte). Berlin 2011, S. 51-74.

Schneider, Friedrich: Reppenstedt. In: Heimatbuch für den Kreis Eichenbrück-Wongrowitz. [Bd. 1]. Lüneburg [1967], S. 76-78.

Schneider, Gerold: Seelsorge für Heimatvertriebene in der ehemaligen DDR. In: Kirche und Heimat. Die katholische Vertriebenen- und Aussiedlerseelsorge in Deutschland (Arbeitshilfen, 146). Bonn 1999, S. 26-33. [Teilweise autobiographisch; der Verf. (geb. 1927 Freystadt/Schlesien, gest. 2011) war 1969-1987 kath. Pfarrer in Cottbus; 1953 Priesterweihe in Neuzelle, dann 1943-1969 im Bistum Dresden/Meißen tätig, 1988-1998 Kuratialpfarrer in Altdöbern u. Dekan des Dekanats Senftenberg, ab 1998 i. R. in Jena].

Schneider, Hans-Georg: Zur Rolle und Bedeutung des Frankfurter Heimkehrerlagers Gronenfelde. In: Frankfurter Beiträge zur Geschichte 16 (1987), S. 5-9.

Schneider, Inge: Reichenwalde in den letzten Kriegswochen des Jahres 1945. In: Gerd Tschechne: Das Kriegsende in und um Storkow (Mark). Dokumentation und Zeitzeugenberichte (Beiträge zur Geschichte der Stadt Storkow (Mark) und Umgebung, H. 4). Storkow (Mark) 2005, S. 81-84.

Schneider, Joachim: Rückkehr nach Deutschland und doch nicht daheim. In: Historischer Verein zu Frankfurt (Oder) e. V. Mitteilungen 1993, H. 2, S. 2-3.

-, -: Die Oder während der Kriegshandlungen im Frühjahr 1945. In: Historischer Verein zu Frankfurt (Oder) e. V. Mitteilungen 2001, H. 2, S. 7-21.

-. -: Die Frankfurter Oderbrücken im Wandel der Zeit. In: Historischer Verein zu Frankfurt (Oder) e.V. Mitteilungen 2002, H. 1, S. 7-21.

-, -: Der Aufmarsch der Roten Armee vor der Frankfurter Dammvorstadt im Februar 1945. In: Historischer Verein zu Frankfurt (Oder) e. V. Mitteilungen 2002, H. 2, S. 2-20.

Schöler, Heinrich Artur: Neu-Sulzfeld/Nowosolna. 23. Mai 1801 - 17. Januar 1945. Ein Gedenkbuch. Erlangen 2009.

Schöning, Wilfried: Die Brücke über die Oder bei Hohenwutzen. In: Königsberger Kreiskalender 1996 (1995), S. 148-153.

Scholl-Schneider, Sarah: „Besucht die alte Heimat, ein schönes Land und liebe Menschen erwarten Euch!“ Zum Potenzial von Heimatperiodika als Quelle zur Erforschung von Heimatreisen. In: Heimatzeitschriften. Funktionen, Netzwerke, Quellenwert. Tilman Kasten u. Elisabeth Fendl (Hg.) (Schriftenreihe des Instituts für Volkskunde der Deutschen des östlichen Europa, Bd. 18). Münster/ New York 2017, S. 237-255.

Scholz, Michael: Personenstandsunterlagen - eine neue Quellengruppe in den Archiven des Landes Brandenburg. In: Berichte und Forschungen aus dem Domstift Brandenburg 4 (2011), S. 171-181.

Scholze-Irrlitz, Leonore: Die Bürde der Frauen. Erinnerungen an Vertreibung und Neuanfang im Landkreis Beeskow/Storkow 1945-50. In: Kreiskalender Oder-Spree 2002, S. 16-19.

Schonert, Udo: Gedenken an 70 Jahre Kriegsende im nördlichen Oderbruch. In: Bad Freienwalder Heimatkalender 59 (2015 [2014]), S. 69-75.

Schott, Christian-Erdmann: Die Rolle der Kirchen bei der Integration von Flüchtlingen und Vertriebenen nach dem II. Weltkrieg. In: Jahrbuch der Schlesischen Friedrichs-Wilhelms-Universität zu Breslau 47/48 (2006/07 [2008]), S. 291-308.

-, - : Wandlungen in der Wahrnehmung. Die evangelische Kirche und ihre Vertriebenen. In: Vertriebene finden Heimat in der Kirche. Hrsg. von Rainer Bendel. Köln u. a. 2008, S. 147-162.

Schreckenbach, Hans-Joachim: Archivalische Quellen zur Geschichte der demokratischen Bodenreform im Staatsarchiv Potsdam. In: Beiträge zur Geschichte der demokratischen Bodenreform im Land Brandenburg. Hrsg. vom Staatsarchiv Potsdam u. der SED-Bezirksleitung Potsdam, Kommission zur Erforschung der Geschichte der örtlichen Arbeiterbewegung. Potsdam 1966, S. 45-61. 
-, -: Der Aufbau einer neuen Verwaltung in Brandenburg im Jahr 1945. In: Brandenburg im Jahr 1945. Studien. Hrsg. von Werner Stang unter Mitarb. von Kurt Arlt. Potsdam 1995, S. 223-264.

Schreiber, Hugo: Umbrüche im Leben der Bessarabiendeutschen. In: Jahrbuch der Deutschen aus Bessarabien 56 (2005), S. 25-29.

Schreiter, Jürgen: 100 Jahre Samariteranstalten Fürstenwalde. In: Heimatkalender Landkreis Fürstenwalde 1992, S. 41-44.

Schreiter, Jürgen: Einer Kultur der Barmherzigkeit Raum schaffen. In: Kreiskalender Oder-Spree 2002, S. 31-35. [Samariteranstalten Fürstenwalde].

Schroubek, Georg R.: Wallfahrt und Heimatverlust. Ein Beitrag zur religiösen Volkskunde der Gegenwart. Marburg 1968 (Schriftenreihe der Kommission für ostdeutsche Volkskunde in der Deutschen Gesellschaft für Volkskunde e. V., Bd. 5).

Schubert, Dagmar: Schlange stehen in Havelland und der Lüneburger Heide. In: Mitteilungsblatt des Bessarabiendeutschen Vereins 70 (2015), H. 1, S. 20.

Schultz, Rudolf: Vor 45 Jahren befreiten sowjetische Truppen unsere Stadt. In: Heimatkalender Kreis Fürstenwalde 1990, S. 2-3.

Schulz, Arno: Bahnüberquerungen in Guben in vergangenen Zeiten und heute. In: Gubener Heimatkalender 61 (2017), S. 107-114.

Schulz, Erwin: Chronik der Stadt Strasburg (Uckermark). Hrsg. von Norbert Raulin. Milow 2000.

Schulz, Gisela: Aus dem Leben der Ortsgruppe 18 der Volkssolidarität in Guben. In: Gubener Heimatkalender 55 (2009), S. 77-80.

Schulz, Günter: Ein Werk des Friedens an der Friedensgrenze. In: Gubener Heimatkalender 29 (1985), S. 378-43 [VEB Chemiefaserwerk].

Schulz, Kristin: Heiner Müller: Die Umsiedlerin oder Das Leben auf dem Lande (1961). In: Handbuch Nachkriegsliteratur. Literatur, Sachbuch und Film in Deutschland (1945-1962). Hrsg. von Elena Agazzi u. Erhard Schütz. Berlin/Boston 2013, S. 270-275.

Schulze, Dietmar: Die Landesanstalt Neuruppin in der NS-Zeit. Berlin 2004 (Schriftenreihe zur Medizin-Geschichte des Landes Brandenburg, Bd. 8).

Schulze, Henrik: Jammerbock I: von den Anfängen bis 1918. Hoppegarten 2014 (Militärgeschichte Jüterbog, 1792-2014, [Bd. 2].

-, -: Jammerbock III: 1935-1945. Hoppegarten bei Berlin 2016 (Militärgeschichte Jüterbog, 1792 2014, [Bd. 3]).

-, -: Jammerbock IV: Sowjetarmee, deutsche Streitkräfte und Konversion (1945-2014). Jüterbog 2018 (Militärgeschichte Jüterbog, 1792-2014, [Bd. 4]).

-, H(enrik): Kriegsgräberstätte in Dahme/M. In: Barbara-Meldung 37 (2018), S. 26-27.

Schulze, Sieglinde: Als Baruth wieder mal in Schutt und Asche lag. Erinnerumgen an die ersten Nachkriegsjahre 1945-1947. In: Heimatjahrbuch für den Landkreis Teltow-Fläming 9 (2002), S. 60-64.

Schwabe, Karl-Heinz: Chronik des Krankenhauses Perleberg - Reetzer Straße -. [Perleberg 2000]. [Masch.].

Schwartz, Michael: Zwischen Zusammenbruch und Stalinisierung. Zur Ortsbestimmung der Zentralverwaltung für deutsche Umsiedler (ZVU) im politisch-administrativen System der SBZ. In: Von der SBZ zur DDR. Studien zum Herrschaftssystem in der Sowjetischen Besatzungszone Deutschlands und in der Deutschen Demokratischen Republik. Hartmut Mehringer (Hg.) (Schriftenreihe der Vierteljahrshefte für Zeitgeschichte, Sondernr.). München 1995, S. 43-96.

-, -: Kontrollierte Partizipation. Die „Umsiedler-Ausschüsse“ der Sowjetischen Besatzungszone

Deutschlands im Spannungsfeld von Sonderverwaltung, Parteipolitik und sozialen Interessen 
1945-1949. In: Die Flüchtlingsfrage in der deutschen Nachkriegsgesellschaft. Sylvia Schraut / Thomas Grosser (Hg.) (Mannheimer historische Forschungen 11). Mannheim 1996, S. 161-191.

-, -: Apparate und Kurswechsel. Zur institutionellen und personellen Dynamik von „Umsiedler“Politik in der SBZ/DDR 1945-1953. In: Geglückte Integration? Spezifika und Vergleichbarkeiten der Vertriebenen-Eingliederung in der SBZ/DDR. Hrsg. von Dierk Hoffmann u. Michael Schwartz (Schriftenreihe der Vierteljahrshefte für Zeitgeschichte, Sondernr.). München 1999, S. 105-135.

-, -: Vertrieben in die Arbeiterschaft: „Umsiedler“ als „Arbeiter“ in der SBZ/DDR 1945-1952. In: Arbeiter in der SBZ/DDR. Peter Hübner / Klaus Tenfelde (Hg.). Essen 1999, S. 81-128.

-, -: „Vom Umsiedler zum Staatsbürger“. Totalitäres und Subversives in der Sprachpolitik der SBZ/ DDR. In: Vertriebene in Deutschland. Interdisziplinäre Ergebnisse und Forschungsperspektiven. Dierk Hoffmann u. a. (Hg.) (Schriftenreihe der Vierteljahrshefte für Zeitgeschichte, Sondernr.). München 2000, S. 135-165.

-, -: Brandenburg als Schmelztiegel? Vertriebenenproblem, „Umsiedlerpolitik“ und regionale Gesellschaftsentwicklung 1945-1953. In: Vertreibung, Neuanfang, Integration. Erfahrungen in Brandenburg. Christoph Kleßmann / Burghard Ciesla / Hans-Hermann Hertle (Hrsg.) (Protokolle). Potsdam 2001, S. 59-73.

-, -: Tabu und Erinnerung. Zur Vertriebenen-Problematik in Politik und literarischer Öffentlichkeit der DDR. In: Zeitschrift für Geschichtswissenschaft 51 (2003), S. 85-101.

-, -: Verteilungskonflikte unter Werktätigen müssen unter allen Umständen vermieden werden.“ Lastenausgleichs-Diskussionen und Soforthilfe-Politik in der SBZ/DDR. In: Rechnung für Hitlers Krieg. Aspekte und Probleme des Lastenausgleichs. Paul Erker (Hg.) (Pforzheimer Gespräche 3). Heidelberg u. a. 2004, S. 217-233.

-, -: Vertriebene und „Umsiedlerpolitik“. Integrationskonflikte in den deutschen Nachkriegs-Gesellschaften und die Assimilationsstrategien in der SBZ/DDR 1945-1961. München 2004 (Quellen und Darstellungen zur Zeitgeschichte, Bd. 61). [Habil.-Schr. Münster 2001].

-, -: Vertriebene als Fremde. Integrationsprozesse deutscher Zwangsmigranten in der SBZ/DDR. In: Ankunft - Alltag - Ausreise. Migration und interkulturelle Begegnung in der DDR-Gesellschaft. Christian Th. Müller / Patrice G. Poutrus (Hg.). Köln/Weimar/Wien 2005, 135-173.

-, -: Vertriebene im doppelten Deutschland. Integrations- und Erinnerungspolitik in der DDR und in der Bundesrepublik. In: Vierteljahrshefte für Zeitgeschichte 56 (2008), S. 101-151.

Schwarz, Erika: (Außenlager) Dahmshöhe. In: Der Ort des Terrors. Geschichte der nationalsozialistischen Konzentrationslager. Hrsg. von Wolfgang Benz u. Barbara Distel. Bd. 4: Flossenbürg, Mauthausen, Ravensbrück. München 2006, S. 538-539.

Schwarz, Kathrin: Die Eingliederung der Flüchtlinge und Vertriebenen in die Sowjetische Besatzungszone und die DDR. Lebensberichte - Am Beispiel der Stadt Eberswalde (Land Brandenburg). Schriftliche Hausarbeit TU Dresden. Dresden 1993 (unveröff. Typoskript, vorhanden im Kreisarchiv Barnim, Eberswalde).

Schwarzlose, Gerd / Senninger, Maik: Friedhöfe im Land Brandenburg. Die Prignitz. In: Brandenburgische Genealogische Nachrichten 12 (2017), S. 85-88.

... schwere Kämpfe in und um Treuenbrietzen (OKW-Bericht). 1945. Das Jahr zwischen Krieg und Frieden. Treuenbrietzen und Umgebung. Hrsg.: Heimatverein Treuenbrietzen e. V. Red.: Wolfgang Ucksche u. a. Treuenbrietzen 1995.

Schwillus, Harald / Brühe, Matthias: Erzbistum Berlin. Eine junge Diözese in langer Tradition. Kehl am Rhein 2009.

Sebastian, Günter: Zeittafel zur Geschichte Gubens nach 1945 (I): Guben im Jahre 1945. In: Gubener Heimatkalender 17 (1972), S. 35-48. 
-, -: Zeittafel zur Geschichte Gubens nach 1945 (II): Guben im Jahre 1946. In: Gubener Heimatkalender 18 (1973), S. 29-39.

-, -: Zeittafel: Zur Geschichte Gubens nach 1945 (III): Guben im Jahre 1947. In: Gubener Heimatkalender 19 (1974), S. 22-27.

600 Jahre Rangsdorf. Hrsg.: Rat der Gemeinde Rangsdorf. Redaktionskollektiv: Siegfried Wietstruk (Leitung) u. a. Rangsdorf [1975].

600 Jahre Wiesenau 1368-2018. Hrsg.: Gemeinde Wiesenau. Red.: Hans-Dieter Walz u. a. Wiesenau 2018.

650 Jahre Schützengilde zu Spandau (Korp. 1334). Ausstellung 7. Sept. 1984 - 15. Jan. 1985 Kunstamt Spandau. Katalogred.: Rudolf Pfefferkorn. Berlin 1985 (Aus der Geschichte der Stadt und Festung Spandau.

Seele, Johannes: Über 100 Jahre Kreissparkasse Flatow. In: Heimatbuch für den Kreis Flatow, Grenzmark Posen-Westpreußen, Provinz Pommern. Hrsg. vom Heimatkreisausschuß für den Kreis Flatow. (Gifhorn) 1971, S. 129-131.

Seidel: Der volkseigene Betrieb Wasserwirtschaft Oder-Neiße. In: Heimatkalender für den Kreis Bad Freienwalde 1 (1957), 79-82.

Seidel, Hellmut / Loch, Ekkehard: Obernigk bei Breslau. Ein schlesisches Heimatbuch. Hrsg. von Wolfgang Sanft. Weiden 1996.

Seidel, Hellmut: Die Obernigker Gemeindebriefe. In: Ders. / Ekkehard Loch: Obernigk bei Breslau. Weiden 1996, S. 263-267.

-, -: Die Obernigker Heimatkartei (Stand 7/1995). In: Ders. / Ekkehard Loch: Obernigk bei Breslau. Weiden 1996, S. 268-269.

Seils, Mirjam: Die fremde Hälfte. Aufnahme und Integration der Flüchtlinge und Vertriebenen in Mecklenburg nach 1945. Schwerin 2012.

Sembritzki, Mario: Flucht per Bahn aus Ostpreußen. Wie die Belegschaft des Reichsbahn-Ausbesserungswerkes Osterode mit vier Zügen nach Wittenberge kam. (Erstdruck in: Schweriner Volkszeitung, 10.2.2015). In: Brandenburger Rundschau 14 (2016) 8, S. 8-9.

-, -: 125 Jahre Eisenbahnwerkstätten in Wittenberge - Tradition, die verpflichtet. In: Jahrbuch des Prignitzer Heimatvereins Wittenberge 1 (2001), S. 105-114.

Semmelmann, Dagmar: November 1989: Krisenverarbeitung „an der Basis“ an einem biographischen Beispiel. In: Der lange Schatten. Widerspruchsvolle Erinnerungen an den Zweiten Weltkrieg und die Nachkriegszeit aus der Mitte Europas 1939-1989. Hrsg. von Karin Hartewig (Bios, 6, 1993, Sonderh.). Leverkusen 1993, 65-72.

-, -: Zur Integration aus lebensgeschichtlicher Sicht. Eingliederungsverläufe von Flüchtlingen und Vertriebenen in der SBZ/DDR dargestellt am Sonderfall Eisenhüttenstadt. In: Geglückte Integration? Spezifika und Vergleichbarkeiten der Vertriebenen-Eingliederung in der SBZ/DDR. Hrsg. von Dierk Hoffmann u. Michael Schwartz (Schriftenreihe der Vierteljahrshefte für Zeitgeschichte, Sondernr.). München 1999, S. 320-333.

-, -: „Man war total entwurzelt und mußte erst wieder Wurzeln schlagen“. Zur Integration von Flüchtlingen und Vertriebenen in der SBZ/DDR aus lebensgeschichtlicher Sicht - dargestellt am Sonderfall Eisenhüttenstadt. Berlin 2005 (CD).

-, -: Der 17. Juni 1953 in Stalinstadt, Fürstenberg in der Erinnerung von Bauarbeitern aus Eisenhüttenstadt : zur Wahrnehmungs- und Verarbeitungsweise der Junierhebung durch Beschäftigte der Region. Berlin 2008 (CD).

-, -: Der 17. Juni 1953 in Stalinstadt/Fürstenberg in der Erinnerung von Bauarbeitern aus Eisenhüttenstadt. Zur Wahrnehmungs- und Verarbeitungsweise der Junierhebung durch Beschäftigte der Region. Eine DDR-Studie. München 2015. 
Senftleben, Peter: „Steige hoch, du roter Adler .... Ein Versuch der Annäherung an die Landsmannschaft Berlin-Mark Brandenburg. In: Der Speicher 17 (2015), S. 141-145.

Senst, Gerhard: Aus den Dörfern Jeserig und Niederwerbig. In: ... schwere Kämpfe in und um Treuenbrietzen (OKW-Bericht). 1945. Das Jahr zwischen Krieg und Frieden. Treuenbrietzen und Umgebung. Hrsg.: Heimatverein Treuenbrietzen e. V. Red.: Wolfgang Ucksche u. a. Treuenbrietzen 1995, S. 79-83.

Seraphim, Peter-Heinz: Die Heimatvertriebenen in der Sowjetzone. Berlin 1954 (Untersuchungen zum deutschen Vertriebenen- und Flüchtlingsproblem, Abt. 2; Schriften des Vereins für Socialpolitik, N.F., Bd. 7,1).

-, P [eter] H[einz]: Die Heimatvertriebenen in der Sowjetischen Besatzungszone. Bonn 1955 (Bonner Berichte aus Mittel- und Ostdeutschland).

Seybold, Wolff-Hasso: Die „Engelsburg“ und ihre Entwicklung. In: Templiner Heimatkalender 1999 (1998), S. 50-52.

Sie gehören zu uns. Von Glatzer Heimatpriestern. Hrsg. von Großdechant Leo Christoph. Reinbek b. Hamburg 1969.

Siebel-Achenbach, Sebastian: Niederschlesien 1942 bis 1949. Alliierte Diplomatie und Nachkriegswirklichkeit. Würzburg 2006.

Sieberhagen, Maik: Etwas zum Lager Wiesenhagen. In: Finsterwalder Heimatkalender 52 (2013 [2012]), S. 69-71.

700 Jahre Arnswalde Neumark 1269-1969. Hrsg. von der Heimatkreiskommission Arnswalde in Wunstorf. Bearb.: Fritz Mörke. Wunstorf 1969.

700 Jahre Golzow 1308-2008. Golzow 2008. [Golzow/Oderbruch].

70 Jahre Kriegsende in Fürstenwalde. [Ausstellungstexte]. [Hrsg.:] Museum Fürstenwalde. Fürstenwalde [2015].

Siefert, Peter: Transportlisten von Vertriebenen 1947. In: www.stolp.de/akff (31.3.2017).

Siek, Erich: Kindergartentradition in Neuenhagen. In: Jahrbuch Märkisch-Oderland 27 (2020 [2019]), S. 88-89.

Simon, Wolfgang: Folgen des Kriegsendes - dargestellt anhand ausgewählter Beispiele. In: Pritzwalker Heimatblätter 16 (2015), S. 17-23.

Skotnicki, Jutta: Die höchste Jesus-Statue der Welt blickt auf Neuenhagens Partnerstadt. In: Lebenszeit XIV. Neuenhagener Geschichten. Neuenhagen o.J. [ca. 2012], S. 85-90.

Skrabania, David: Die Zentrale Aufnahmestelle für Aussiedler in Berlin-Marienfelde. 14. April 1953 bis 31. Juli 2010. Berlin 2011 (Blaue Reihe, Bd. 4).

Słubice. Historia, topografia, rozwój/Geschichte, Topografie, Entwicklung. Autorzy i wspólpracownicy/ Autoren u. Mitarb.: Sebastian Preiss u. a. Opracowane w Collegium Polonicum w katedrze „European Cultural Heritage“/Bearb. am Collegium Polonicum, Studiengang „European Cultural Heritage“. Słubice 2003.

Sobottka-Heese, K(athrin): Die Gründung der LPG „Friedensgrenze“ und der Aufbau der Rinderzucht in Hohenwutzen. In: Hohenwutzener Heimatzeitung 18/19 (2016/17), S. 1-4.

Sommermeyer, Ruth: Die Diakonissengemeinschaft des Luise-Henrietten-Stifts. Ein Rückblick zur 100-Jahrfeier im Jahr 2011. In: 100 Jahre Diakonissenmutterhaus Luise-Henriette in Lehnin.

Festschrift. Hrsg.: Evangelisches Diakonissenhaus Teltow Lehnin. Red.: Stefan Beier. Unna [2011], S. 13-24.

Spatz, Christopher: Ostpreußische Wolfskinder. Erfahrungsräume und Identitäten in der deutschen Nachkriegsgesellschaft. Osnabrück 2016 (Einzelveröffentlichungen des Deutschen Historischen Instituts Warschau, Bd. 35). 
-, -: Nur der Himmel blieb derselbe. Ostpreußens Hungerkinder erzählen vom Überleben. Hamburg 2016. 3. Aufl. 2018.

Sperling, Margret: Zeitzeugenarbeit im Stadtarchiv Angermünde. In: Angermünder Heimatkalender 2001, S. 168-170.

Spieker, Ira: Neubauern. In: Online-Lexikon zur Kultur und Geschichte der Deutschen im östlichen Europa, 2012. URL: ome-lexikon.uni-oldenburg.de/55207.html (Stand: 3.6.2015).

Spix, Boris: Die Bodenreform in Brandenburg 1945-47. Konstruktion einer Gesellschaft am Beispiel der Kreise Ost- und Westprignitz. Münster 1997 (Zeitgeschichte - Zeitverständnis, Bd. 2). [Mag.Arb. Univ. Münster 1996/97].

Springer, Philipp: Da konnt' ich mich dann so'n bißchen entfalten - Die Volkssolidarität in der SBZ/ DDR 1945-1969. Frankfurt am Main u. a. 1999 (Europäische Hochschulschriften, Reihe 3: Geschichte und ihre Hilfswissenschaften, Bd. 836).

-, -: Verbaute Träume. Herrschaft, Stadtentwicklung und Alltag in der sozialistischen Industriestadt Schwedt. Berlin 2006.

Spuren suchen 17 (2003).

Spurný, Matěj: Flucht und Vertreibung. Das Ende des Zweiten Weltkrieges in Niederschlesien, Sachsen und Nordböhmen. Hrsg. von der Sächsischen Landeeszentrale für politische Bildung und der Brücke/Most-Stiftung zur Förderung der deutsch-tschechischen Verständigung und Zusammenarbeit Dresden. Dresden 2008.

St. Josefs-Krankenhaus Potsdam-Sanssouci 1862-2012. „Die Liebe Christi drängt uns“. Eckart Frantz (Hrsg.). Berlin 2012.

Stadt Müncheberg von 1991 bis 2014. Erarb. von einer Arbeitsgruppe (Frank Geißler u. a.). Hrsg.: Verein für Heimatgeschichte der Stadt Müncheberg e. V. Müncheberg 2015.

Stadt und Kreis Meseritz. Ein Heimatbuch. [Bd. 1]. Hrsg. vom Heimatkreis Meseritz. O. O. [1972].

Stahl, Hans-Joachim: Schloss Boitzenburg in den Jahren 1944/45 bis 1956. In: Beatrix Bluhm / Detlev von Heydebrand / Hans-Joachim Stahl: Schloss Boitzenburg in der Uckermark. Angermünde 2011, S. 86-138.

Stechow, Bernhard: Der Angermünder Seniorenbeirat. In: Angermünder Heimatkalender 2001, S. 191-193.

Stegemann, Wolfgang: Fürstenberg / Havel, Ravensbrück. Beiträge zur Kulturgeschichte einer Region zwischen Brandenburg und Mecklenburg. Bd. 1: Von den Anfängen bis zum Beginn des 20. Jahrhunderts. Bd. 1. Teetz (1999). [Kapitel „Die kirchliche Entwicklung in Fürstenberg“ (S. 58-77) behandelt auch die kath. Kirchengemeinde und reicht hier bis 1971].

-, -: Die Nachkriegszeit 1945 bis 1948 in Zeitdokumenten. In: Ders. / Wolfgang Jacobeit: Fürstenberg / Havel, Ravensbrück. Beiträge zur Alltags- und Sozialgeschichte einer Region zwischen Brandenburg und Mecklenburg. Bd. 2: Im Wechsel der Machtsysteme des 20. Jahrhunderts. Teetz 2004, S. 223-257.

Stein, Jürgen: Die Entwicklung des Spremberger Krankenhauses - ein Beispiel für den Fortschritt der medizinischen Betreuung in unserer Region. In: Festschrift 700 Jahre Stadt Spremberg. Aus der Geschichte der Stadt Spremberg. Hrsg.: Stadt Spremberg. Spremberg 2000, S. 127-151.

Steiner, Edgar: Flüchtlinge und Vertriebene im Elb-Havel-Winkel. In: Kriegsende und Nachkriegszeit in Havelberg [II]. Hrsg.: Heimatverein Havelberg e. V. (Havelberger Regionalgeschichtliche Beiträge, Bd. 2). Havelberg 1994, S. 77-79.

Steinhauf, Andy: Die wirschaftliche Entwicklung in Küstrin-Kietz von 1945 bis 1995. Ein Report. Frankfurt (Oder) 2018.

-, -: Das Auffanglager Küstrin / Alt-Drewitz 1945. In: www.cuestrin.de [online seit 5.9.2019]. 
-, -: Die Geschichte der Stadt Küstrin auf www.cuestrin.de: Ein Arbeitsbericht. In: Arbeitsbericht der Arbeitsgemeinschaft ostdeutscher Familienforscher (2019), H. 4, S. 30-31.

Steinhoff, Karl: Das Land Brandenburg in den ersten Nachkriegsjahren. In: Märkische Heimat 3 (1959), S. $138-145$.

Steinkraus, Doris: Von Polen ins Oderbruch. Weltpolitik führte Familie aus Neuenkirchen ins neue gelobte Land und zwang sie später auch wieder zum Verlassen. In: Märkische Oderzeitung, 20.2.2004.

Stephan, Alexander: Christa Wolf. München 1976 (Autorenbücher, 4).

Stephan, Herbert: Die demokratische Bodenreform - erster Schritt auf dem Wege zur endgültigen Befreiung der Bauern (dargestellt am Beispiel des Landkreises Ostprignitz im ehemaligen Land Brandenburg). Kyritz 1965.

Stephan, Ulrich: Guben und die Oder-Neiße-Grenze. In: Gubener Heimatkalender 39 (1995), S. 40-47.

Stichling, Hans-Werner: Die „Schubert-Gruppe“ oder: Späte Opfer stalinistischen Terrors in Guben. In: Gubener Heimatbrief (1998)1, S. 28-33.

Stickler, Matthias: „Ostdeutsch heißt Gesamtdeutsch“. Organisation, Selbstverständnis und heimatpolitische Zielsetzungen der deutschen Vertriebenenverbände 1949-1972. Düsseldorf 2004 (Forschungen und Quellen zur Zeitgeschichte, Bd. 46).

-, -: Charta der deutschen Heimatvertriebenen. In: Online-Lexikon zur Kultur und Geschichte der Deutschen im östlichen Europa, 2012. URL: ome-lexikon.uni-oldenburg.de/54028.html.

Stier, Frank / Zabel, Marco: Königs Wusterhausen von 1945 bis zur Gegenwart. In: Königs Wusterhausen. Eine illustrierte Orts- und Stadtgeschichte. Hrsg. von Kurt Adamy, Kristina Hübener, Marko Leps. Berlin 1998, S. 175-226. [Ohne Behandlung des Flüchtlingszuzugs].

Stier, Frank: Kriegsauftrag 160. Behelfsheimbau im Ghetto Litzmannstadt (Łódź) und im KZ-Außenlager Königs Wusterhausen durch das Deutsche Wohnungshilfswerk. Berlin 1999 (Einzelveröffentlichung der Brandenburgischen Historischen Kommission, Bd. 1).

Stift Heiligengrabe. Ein Erinnerungsbuch. Hrsg. von alten Stiftskindern i. A. Nora Neese. T. I. Salzgitter 1992. T. VI. Salzgitter 2005.

Stiftung Flucht, Vertreibung, Versöhnung. Konzept für die Dauerausstellung. Berlin 2017, www.sfvv.de [23.6.2017].

Stokłossa, Katarzyna: Integration durch Zwang 1948-1953. Die Oder-Neiße-Grenze und die mühsame Integration. In: Vertreibung, Neuanfang, Integration. Erfahrungen in Brandenburg. Christoph Kleßmann / Burghard Ciesla / Hans-Hermann Hertle (Hrsg.) (Protokolle). Potsdam 2001, S. 74-88.

-, -: Die Oder-Neiße-Grenze im Bewußtsein der Bewohner von Guben und Gubin (1945-1972). In: Grenzen im Ostblock und ihre Überwindung. Helga Schultz (Hg.) (Frankfurter Studien zur Grenzregion, 6). Berlin 2001, S. 113-134.

Stolpe, Manfred: Der 8. Mai als Symbol deutscher Geschichte. In: Der 8. Mai 1945 als historische Zäsur. Hrsg. von Arnd Bauerkämper, Christoph Kleßmann, Hans Misselwitz (Protokolle). Potsdam 1995, S. 25-34.

Strenge, Sigrid / Tankeren, Marga van: Letschiner Chronik. Von der ersten Besiedlung bis ins zweite Jahrtausend. Hrsg.: Heimatverein Letschin e.V. Bd. 5. Letschin 2011.

Stribrny, Wolfgang / Zäpke, Fritz: Frankfurt/Oder. Porträt einer Brückenstadt. Berlin/Bonn 1990.

Strich, Hans-Joachim: Kleine Michendorfer Chronik. In: Zwischen Havelland und Flänming 2000, S. 27-33.

Die Sudetendeutschen in der Sowjetischen Besatzungszone Deutschlands. Ankunft, Aufnahme und erste Integrationsversuche. Manfred Wille (Hrsg.). Magdeburg 1993 (Magdeburger Forschungen, 10: Geschichte). 
Sychold, Erich: Chronik Waltersdorf. 12000 v.u. Z. - 2000. Waltersdorf (2001). [Verf. 1928 geb. in Ostpreußen (Masuren), 1942-1945 Lehrerbildungsanstalt in Schlesien, 1945 Lehrerstudium in Rostock begonnen, 1946 als Lehramtsbewerber eingesetzt, nach mehreren Lehrerprüfungen, Fernstudium u. Tätigkeiten in versch. Orten in Mecklenburg u. Brandenburg ab 1955 Schulleiter in Waltersdorf bei Berlin].

Taubenthal, Walter: Die Räumung des Kreises Treuburg. In: Der Kreis Treuburg. Ein ostpreußisches Heimatbuch. Zsgest. im Auftr. der Kreisgemeinschaft Treuburg von Rudolf Grenz. Lübeck 1971, S. 422-423.

Tausend Jahre Kirche in Berlin-Brandenburg. Hrsg. von Gerd Heinrich. Berlin 1999.

Teupitz. Eine märkische Stadt im Wandel der Zeiten. Heinrich Krause / Karsten Kuhl (Hrsg.). Berlin 2007 (Einzelveröffentlichungen der Brandenburgischen Historischen Kommission).

Theil, Jürgen: Prenzlauer Stadtlexikon und Geschichte in Daten. Prenzlau 2005.

-, -: Die Stettiner Straße im Wandel der Zeit. In: Mitteilungen des Uckermärkischen Geschichtsvereins zu Prenzlau 26 (2019), S. 149-158.

Ther, Philipp: Die Vertriebenenpolitik in der SBZ/DDR 1945-1953 am Beispiel des Kreises CalauSenftenberg. In: Jahrbuch für brandenburgische Landesgeschichte 46 (1995), S. 159-168.

-, -: Von Schlesien in die Lausitz. Ein Beispiel der Integration von Vertriebenen in der DDR. In: „Wach auf, mein Herz, und denke“. Zur Geschichte der Beziehungen zwischen Schlesien und Berlin-Brandenburg von 1740 bis heute. Hrsg.: Gesellschaft für interregionalen Kulturaustausch e. V., Berlin, u. Verein Schlesisches Institut, Oppeln. Berlin/Opole 1995, S. 488-494 [Am Beispiel des Kreises Calau-Senftenberg].

-, -: Die Vertriebenenproblematik in Brandenburg und im Oppelner Schlesien 1945-1952. Ausgewählte Aspekte einer vergleichenden Landesgeschichte. In: Zeitschrift für Ostmitteleuropa-Forschung 46 (1997), S. 513-534.

-,-: Deutsche und polnische Vertriebene. Gesellschaft und Vertriebenenpolitik in der SBZ/DDR und in Polen 1945-1956. Göttingen 1998 (Kritische Studien zur Geschichtswissenschaft, Bd. 127).

-, -: Vertriebenenpolitik in der SBZ/DDR und in Polen 1945 bis 1950. In: Geglückte Integration? Spezifika und Vergleichbarkeiten der Vertriebenen-Eingliederung in der SBZ/DDR. Hrsg. von Dierk Hoffmann u. Michael Schwartz (Schriftenreihe der Vierteljahrshefte für Zeitgeschichte, Sondernr.). München 1999, S. 137-159.

-, -: Vertriebenenpolitik in der Sowjetischen Besatzungszone und der DDR 1945 bis 1953. In: Vertreibung, Neuanfang, Integration. Erfahrungen in Brandenburg. Christoph Kleßmann / Burghard Ciesla / Hans-Hermann Hertle (Hrsg.) (Protokolle). Potsdam 2001, S. 89-111.

Theune, Claudia: Zeitgeschichtliche Archäologie in ehemaligen Konzentrationslagern - Erinnerungsort, Denkmalpflege, Forschung. In: Archäologie und Gedächtnis. NS-Lagerstandorte. Erforschen - Bewahren - Vermitteln. Interdisziplinäre Konferenz im Archäologischen Landesmuseum Brandenburg an der Havel 17. bis 19. September 2015. Hrsg.: Thomas Kersting u. a. (Denkmalpflege in Berlin und Brandenburg, Arbeitsheft 4/2016). Petersberg 2016, S. 7-16.

Thiel, Hans-Jürgen: Die Bedeutung der Stadt Frankfurt (Oder) als „Tor der Freundschaft“ und als Verkehrsknotenpunkt zur Sowjetunion. In: Frankfurter Beiträge zur Geschichte 16 (1987), S. 16-19.

Thiel, Heinz Dietrich: Johannes Zinke (1903-1968). In: 75 Jahre Bistum Berlin. 20 Persönlichkeiten. Hrsg. von Michael Höhle (Wichmann-Jahrbuch des Diözesangeschichtsvereins Berlin, N. F. 8, 2004/05). Heiligenstadt 2005, S. 177-185.

Tiefe Spuren. Kriegsflüchtlinge 1945-2005. Begleitband zur Ausstellung. Udo Gößwald (Hg.). Im Auftr. des Bezirksamts Neukölln von Berlin, Abt. Bildung, Schule u. Kultur, Kulturamt/Museum Neukölln. Berlin 2005.

Thum, Gregor: Die fremde Stadt - Breslau nach 1945. München 2006. 
Tiews, Alina Laura: ,Umsiedlerpolitik' in der SBZ/DDR 1948-1952: Maßnahmen und Reaktionen. Magisterarbeit. o. O. 2009.

Timm, Marion u. Reinhard: (Außenlager) Prenzlau. In: Der Ort des Terrors. Geschichte der nationalsozialistischen Konzentrationslager. Hrsg. von Wolfgang Benz u. Barbara Distel. Bd. 4: Flossenbürg, Mauthausen, Ravensbrück. Mümchen 2006, S. 585-587.

Tischner, Wolfgang: Katholische Kirche in der SBZ/DDR 1945-1951. Die Formierung einer Subgesellschaft im entstehenden sozialistischen Staat. Paderborn u. a. 2001 (Veröffentlichungen der Kommission für Zeitgeschichte, Reihe B: Forschungen, Bd. 90).

Toom, Friedhild den / Klein, Sven Michael: Hermine - die zweite Gemahlin von Wilhelm II. Greiz 2007.

Totenbuch Sowjetisches Speziallager Nr. 6, Frankfurt/Oder 1945, Jamlitz 1945-1947. Im Auftr. der Evang. Kirchengemeinde Lieberose und Land hrsg. u. bearb. von Andreas Weigelt. 2. Aufl. Lieberose 2009.

Totenbuch sowjetisches Speziallager Nr. 7/Nr. 1 in Weesow und Sachsenhausen 1945-1950. Hrsg. von der Gedenkstätte und Museum Sachsenhausen/Stiftung Brandenburgische Gedenkstätten. Bearb. von Ines Reich. Berlin 2010.

Transit - Transfer. Politik und Praxis der Einwanderung in die DDR 1945-1990. Kim Christian Priemel (Hrsg.). Berlin 2011 (Almanach des Institutts für Angewandte Geschichte).

Transitzone Dorf. Ein Ort zwischen Bodenreform und Kollektivierung. Hrsg. von: Projektgruppe Umsiedlerin: Maria Hetzer [u. a.]. [Leipzig] 2015.

Treder-Schmidt, Lothar: Ein Neusiedlerhaus als Baudenkmal? T. 1: Vom Planen und Bauen. In: Luckauer Heimatkalender 50 (2018), S. 48-54.

-, -: Ein Neusiedlerhaus als Baudenkmal? T. 2: Vom Leben und Arbeiten. In: Luckauer Heimatkalender 51 (2019), S. 25-29.

Treziak, Ulrike: Die vertriebenen Schlesier in West-Berlin. In: „Wach auf, mein Herz, und denke“. Zur Geschichte der Beziehungen zwischen Schlesien und Berlin-Brandenburg von 1740 bis heute. Hrsg.: Gesellschaft für interregionalen Kulturaustausch e. V., Berlin, u. Verein Schlesisches Institut, Oppeln. Berlin/Opole 1995, S. 495-502.

Trzcielińska-Polus, Aleksandra: Beziehungen zwischen dem Oppelner Schlesien und dem Bezirk Potsdam bis 1989. In: „Wach auf, mein Herz, und denke“. Zur Geschichte der Beziehungen zwischen Schleien und Berlin-Brandenburg von 1740 bis heute. Hrsg.: Gesellschaft für interregionalen Kulturaustausch e. V., Berlin, u. Verein Schlesisches Institut, Oppeln. Gesamtred.: Klaus Bździach. Berlin/ Opole 1995, S. 532-542.

Tschäpe, Karl-Konrad. Chronologie zu Deportation, Zwangsarbeit und Heimkehr in Frankfurt (Oder) 1938-1956 sowie zu deren Rezeprion bis 2018. In: Frankfurter Jahrbuch 2018, S. 86-179.

Tschechne, Gerd: Das Kriegsende in und um Storkow (Mark). Dokumentation und Zeitzeugenberichte. Storkow (Mark) 2005 (Beiträge zur Geschichte der Stadt Storkow (Mark) und Umgebung, H. 4).

Tscheschner, Dorothea: Die Brieger in SBZ und DDR und die Goslarer Patenschaft. Rückblick 20 Jahre nach der friedlichen Revolution. In: Briegische Briefe 31 (2009)6, S. 35-38; 32 (2010)1, S. 19-22, 32 (2010)2, 25-28.

Tuchscherer, Steffen: Vom Hitlerjungen zum FDJ-Funktionär. Geschichte der Nachkriegsjugend in Angermünde. In: Angermünder Heimatkalender 2016 (2015), S. 203-111.

Die Uckermark 1945. T. 1. Hrsg.: Gesamtschule mit gymnasialer Oberstufe „Carl Friedrich Grabow“ Prenzlau und Uckermärkischer Geschichtsverein zu Prenzlau e. V. Prenzlau 1995.

Udolph, Jürgen: Schall und Rauch. Orts- und Familiennamen. In: Das Brandenbuch. Ein Land in Stichworten. Hrsg. von der Brandenburgischen Landeszentrale für politische Bildung. Potsdam 2015, S. 189-192. 
Uhlemann, Manfred: Neubeginn in Potsdam. Politische und soziale Verhältnisse. In: Brandenburg im Jahr 1945. Studien. Hrsg. von Werner Stang unter Mitarb. von Kurt Arlt. Potsdam 1995, S. 297-332.

Unverricht, Wilfried: Schenkenberg. 70 Jahre selbständige Landgemeinde. Schenkenberg 1998.

Verdenhalven, Fritz: Namensänderungen ehemals preußischer Gemeinden von 1850 bis 1942 (mit Nachträgen bis 1950). Nachdr. Neustadt an der Aisch 1999.

Vertreibung, Neuanfang, Integration. Erfahrungen in Brandenburg. Christoph Kleßmann / Burghard Ciesla / Hans-Hermann Hertle (Hrsg.). Potsdam 2001 (Protokolle).

Die Vertreibung der Deutschen aus dem Osten. Ursachen, Ereignisse, Folgen. Hrsg. von Wolfgang Benz. Frankfurt am Main 1985.

Vertriebene finden Heimat in der Kirche. Integrationsprozesse im geteilten Deutschland nach 1945. Hrsg. von Rainer Bendel. Köln u. a. 2008 (Forschungen und Quellen zur Kirchen- und Kulturgeschichte Ostdeutschlands, Bd. 38).

Vier Jahrzehnte Gablona Schmuckwaren Neuheim. Ein Entwicklungsweg von der Glas- und Bijouteriegenossenschaft zum Leitbetrieb der Erzeugnisgruppe „Modeschmuck“ in der Deutschen Demokratischen Republik. In: Heimatkalender des Kreises Jüterbog 1986, S. 21-25.

Völker, Eberhard [Hrsg.]: Pommern und Ostbrandenburger. Mit Beitr. von Manfred Pawlitta u. a. München 2000 (Vertreibungsgebiete und vertriebene Deutsche. Studienbuchreihe der Stiftung Ostdeutscher Kulturrat, Bd. 9).

Vogel, Georg: Die Volkssolidarität in Neuenhagen. In: Lebenszeit. T. III. Zeitzeugen berichten. Hrsg. vom Landesseniorenbeirat Brandenburg u. dem Seniorenbeirat Neuenhagen. [Red.:] Günter Voigt. Neuenhagen [1998], S. 117-120.

Vogel, Werner: Das Haus Brandenburg. Geschichte und Wirksamkeit. In: Landesherr, Adel und Städte in der mittelalterlichen und frühneuzeitlichen Neumark. Klaus Neitmann (Hrsg.) (Bibliothek der Brandenburgischen und Preußischen Geschichte, Bd. 14). Berlin 2015, S. 407-411.

-, -: Die Stiftung Brandenburg. Geschichte, Aufgaben, Wirksamkeit. In: Historiker und Archivar im Dienste Preußens. Festschrift für Jürgen Kloosterhuis. Hrsg. von Hans-Christof Kraus u. FrankLothar Kroll. Berlin 2015, S. 245-262.

Voigt, Horst: Die Ostmarkbauten in Frankfurt (Oder). In: Historischer Verein zu Frankfurt (Oder) e.V. Mitteilungen 2003, H. 2, S. 2-25.

Volkmann, Rolf / Volkmann, Helga: Das Flüchtlingslager Mariental (1945-1947) und die Vertriebenentransporte aus Schlesien (1946-1947). Ein Beitrag zur Nachkriegsgeschichte der Gemeinde Mariental und des Landkreises Helmstedt. Grasleben 1997.

Vom Sterben schlesischer Priester 1945/56. Ein Ausschnitt aus der schlesischen Passion. München 1950.

Vorländer, Herwart: Die NSV. Darstellung und Dokumentation einer nationalsozialistischen Organisation. Boppard am Rhein 1988 (Schriften des Bundesarchivs 35).

Vsevolodov, Vladimir: Über die Repatriierung der deutschen Kriegsgefangenen und das Lager 69 in Frankfurt (Oder) - Ein Blick aus Moskau. In: Historischer Verein zu Frankfurt (Oder) e. V. Mitteilungen 2010, H. 2, S. 2-22.

-, -: „Russische Tage“ in Frankfurt an der Oder (1945-1949): Alltag im Spiegel von Dokumenten aus russischen Archiven. In: ebd. 2018, H. 2, S. 2-22.

Waack, Christoph: Stadträume und Staatsgrenzen. Geteilte Grenzstädte des mittleren und östlichen Europa im Kontext lokaler Alltagswelten, nationaler Politik und supranationaler Anforderungen. Leipzig 2000 (Beiträge zur Regionalen Geographie, 51).

„Wach auf, mein Herz, und denke“. Zur Geschichte der Beziehungen zwischen Schlesien und BerlinBrandenburg von 1740 bis heute. Hrsg.: Gesellschaft für interregionalen Kulturaustausch e. V., Berlin, u. Verein Schlesisches Institut, Oppeln. Gesamtred.: Klaus Bździach. Berlin/Opole 1995, S. 532-542. 
Wachs, Reiner: Das letzte Jahrhundert der Entwicklung Teltows. In: Potsdamer Land 1 (1990), S. 21-29.

Wachtmann, Marianne: In eigener Sache - die Geschichte der Broschüre „Lebenszeit“ mit Geschichten aus Neuenhagen. In: Lebenszeit XVI. Neuenhagener Geschichten. Hrsg. von: Seniorenbeirat u. Gemeinde Neuenhagen bei Berlin. Red.: Marianne Wachtmann u. a. Neuenhagen bei Berlin [2018], S. 100-104.

Wacker, Günther: Paulinenaue. Eine Ortschronik aus dem Havelland. Digitalisierte Version der ersten Ausgabe von 1984 (http://archiv.paulinenaue.info/allgemeines/chroniken/wacker.pdf [7.1.2017]).

Wagner, Hans: 100 Jahre Krankenhaus Luckau (1903-2003). In: Luckauer Heimatkalender 36 (2004), S. 24-36.

Wagner, Jens-Christian: Mut zum Verlust - ein Plädoyer gegen den Fetisch der Relikte. In: Archäologie und Gedächtnis. NS-Lagerstandorte. Erforschen - Bewahren - Vermitteln. Interdisziplinäre Konferenz im Archäologischen Landesmuseum Brandenburg an der Havel 17. bis 19. September 2015. Hrsg.: Thomas Kersting u. a. (Denkmalpflege in Berlin und Brandenburg, Arbeitsheft 4/2016). Petersberg 2016, S. 169-171.

Wagner, Richard: Illustrierte Geschichte von Falkensee. Falkensee 2003.

Walther, Karl Klaus: Die Bergung von Kulturgut in Cottbus im Jahre 1945. In: Mitteldeutsches Jahrbuch für Kultur und Geschichte 16 (2009), S. 165-171.

Wandke, Horst: Aufbruch ins Ungewisse. Wie die Kuscherner das Kriegsende erlebten. In: Heimatkalender Eisenhüttenstadt und Umgebung 23 (2005), S. 259-260. [Verf. geb. im unmittelbar östlich der Neiße gelegenen Dorf Kuschern (Kr. Guben)].

Wargenau, Katalin: Feste feiern - Traditionen bei den Aussiedlerfamilien in Wiesenau, Ortsteil KunitzLoose. In: Heimatkalender Eisenhüttenstadt und Umgebung 12 (1994), S. 91-92. [Festtagsbräuche nach 1991 aus Kasachstan, Frunse u. Kirgisien nach Brandenburg gekommener Russlanddeutscher].

Weber, Babette / Rasemann, Christian: Spuren sichern - Geschichte erfahren. Massener Oberschüler befragen Zeitzeugen zum Weltkriegsende und zeigen die Ergebnise in einer Facebook-Chronik. In: Der Speicher 17 (1995), S. 138-140.

Wedel-Schunk, Theda von: Eva Gonda - engagiert für „Alte Kirchen“. In: Offene Kirchen 2016, S. 92-93.

Wegemund, Andreas: Eisenbahnknoten Eberswalde. Berlin 2012.

Weger, Tobias: Straßennamen. In: Die Erinnerung an Flucht und Vertreibung. Ein Handbuch der Medien und Praktiken. Stephan Scholz / Maren Röger / Bill Niven (Hg.). Paderborn 2015, S. 409-419.

Weigelt, Andreas: Jamlitz - Speziallager Nr. 6 (September 1945 - April 1947). In: Jörg Morré: Speziallager des NKWD. Sowjetische Internierungslager in Brandenburg 1945-1952. Potsdam 1997, S. 33-42.

-, -: Totenbuch Sowjetisches Speziallager Nr. 5 Ketschendorf 1945-1947. Hrsg. von der Initiativgruppe Internierungslager Ketschendorf/Speziallager Nr. 5 e. V. Berlin 2014.

-, -: „Umschulungslager existieren nicht“. Zur Geschichte des sowjetischen Speziallagers Nr. 6 in Jamlitz 1945-1947. Potsdam 2001 (Brandenburgische Historische Hefte, 16).

-, -: Flucht, Vertreibung, Neubeginn 1945. Schicksale und Berichte aus dem Raum Lieberose. In: Flucht, Vertreibung, Neubeginn 1945. Schicksale und Berichte aus dem Raum Lieberose. Hrsg. von der Evang. Kirchengemeinde Lieberose und Land. Red.: Andreas Weigelt. Lieberose 2006, S. 2-23.

Weiß, W[alter]: Prof. Dr. Paul Müller. Ein Leben für die Heimat. In: Heimatkalender für den Kreis Angermünde 1960, S. 114-117.

Wekel, Friederike: Die Evangelisch-Lutherische Landeskirche Mecklenburgs und die ostdeutschen „Flüchtlingspastoren“ nach dem Zweiten Weltkrieg. In: Mecklenburgia Sacra. Jahrbuch für Meck- 
lenburgische Kirchengeschchte 17 (2015), S. 171-215. [Dipl.-Arb. Theol. Fak. der Humboldt-Univ. Berlin 2013].

Wellnitz, Britta: Deutsche evangelische Gemeinden im Ausland. Ihre Entstehungsgeschichte und die Entwicklung ihrer Rechtsbeziehungen zur Evangelischen Kirche in Deutschland. Tübingen 2003 (Jus ecclesiasticum, Bd, 71).

Wendler, Simone: Abschied vom Haus der Eltern in gerade mal zehn Minuten. Gubener erinnern sich an die Verrtreibung aus dem Ostteil der Stadt. In: Gubener Heimatbrief (2005)1, S. 100-102.

Wenzel, Mario: Die Aufnahme und Versorgung von Flüchtlingen und Vertriebenen in Eberswalde 1945-1948. In: Eberswalder Jahrbuch 2015, S. 136-145; auch online (ohne Abb., aber textgleich) unter dem Titel „Zur Aufnahme und Integration der Vertriebenen in Eberswalde 1945-1948“ im Internetportal: „Transodra online“ <http://www.transodra-online.net/de/node/1414>.

Wenzel, Renate: Kladow und seine Flüchtlinge. In: 750 Jahre Kladow 1267-2017. Hrsg.: Kladower Forum e. V. Red.: Rainer Nitsch u. a. Berlin 2017, S. 107-123.

Wernicke, Thomas / Bork, Julia: Beiderseits der Oder. Geschichtsraum/Grenzraum/Begegnungsraum. Haus der Brandenburgisch-Preußischen Geschichte 7. September 2018 bis 20. Januar 2019. In: MuseumsJournal Berlin \& Potsdam (2018) 3, S. 78-79.

Wieke, Thomas: Alles kann anders kommen jederzeit. 175 Jahre Evangelisches Diakonissenhaus Berlin Teltow Lehnin. Hrsg. vom Evang. Diakonissenhaus Berlin Teltow Lehnin. Berlin 2016.

Wiesner, H.: Die Entwicklung des Spremberger Krankenhauses seit 1945. In: Heimatkalender für den Kreis Spremberg 1959, S. 55-61.

Wietstruk, Siegfried: 750 Jahre Ahrensdorf (Kreis Zossen). Ahrensdorf 1992.

Wilde, Eberhard: Leo Wistuba. In: Lebensbilder aus Hennigsdorf. Hrsg.: Hennigsdorfer Geschichtsverein. Hennigsdorf 2000, S. 173-188.

W[ilke], J[ana]: Heimatbund tagte in Guben. In: Gubener Heimatkalender 40 (1996), S. 36-37. [Gubener Heimatbund e. V.]

Wilke, Jana: Kleine Insel in der Lausitzer Neiße. In: Jahrbuch für Gubener Geschichte 1 (2011/12), S. 27-48.

Wille, Manfred: Die Entnazifizierung in Sachsen-Anhalt. in: Magdeburger Blätter 1982, S. 15-27.

-, -: Heimatvertriebene in den ersten Nachkriegsjahren in der sowjetischen Besatzungszone Deutschlands - Anmerkungen zur Statistik. In: Manfred Wille / Karlheinz Lau / Jörg Bernhard Bilke: Die Vertriebenen in Mitteldeutschland. Hrsg.: Bund der Vertriebenen (Deutschlandpolitische Schriftenreihe, 10). Bonn 1991, S. 1-8.

-, -: Not und Elend der Ostflüchtlinge und der Vertriebenen im ersten Nachkriegsjahr in der Provinz Sachsen. In: Magdeburger Blätter 1991, S. 59-62.

-, -: Entnazifizierung in der Sowjetischen Besatzungszone Deutschlands 1945-48. Magdeburg 1993.

-, -: Die „freiwillige Ausreise“ sudetendeutscher Antifaschisten in die Sowjetische Besatzungszone Deutschlands - erfüllte und enttäuschte Hoffnungen und Erwartungen. In: Die Sudetendeutschen in der Sowjetischen Besatzungszone Deutschlands. Ankunft, Aufnahme und erste Integrationsversuche. Manfred Wille (Hrsg.) (Magdeburger Forschungen, 10: Geschichte). Magdeburg 1993, S. 28-61.

-, -: Die Zentralverwaltung für deutsche Umsiedler - Möglichkeiten und Grenzen ihres Wirkens (1945-1948). In: Sie hatten alles verloren. Flüchtlinge und Vertriebene in der sowjetischen Besatzungszone Deutschlands. Hrsg. von Manfred Wille, Johannes Hoffmann u. Wolfgang Meinicke (Studien der Forschungsstelle Ostmitteleuropa an der Universität Dortmund, Bd. 13). Wiesbaden 1993, S. 27-54.

-, -: SED und „Umsiedler“ - Vertriebenenpolitik der Einheitspartei im ersten Nachkriegsjahrzehnt. In: Geglückte Integration? Spezifika und Vergleichbarkeiten der Vertriebenen-Eingliederung in der 
SBZ/DDR. Hrsg. von Dierk Hoffmann u. Michael Schwartz (Schriftenreihe der Vierteljahrshefte für Zeitgeschichte, Sondernr.). München 1999, S. 91-104.

Winkler, Joachim: Aus der Geschichte der Achenbachbrücke. In: Gubener Heimatbrief (2010)2, S. 33-36.

Winkler, Gunnar: Zur Geschichte der Volkssolidarität 1945 bis 2010. Hrsg.: Volkssolidarität Bundesverband e. V. Berlin 2010.

Winterberg, Sonya: Wir sind die Wolfskinder. Verlassen in Ostpreußen. Mit einem Vorw. von Rita Süßmuth u. Fotografien von Claudia Heinermann. München/Zürich 2012.

Winterstein, Ulrike: Der vertriebene Klerus in der SBZ/DDR. Zur Integration vertriebener Eliten im Bistum Meißen und im Diözesangebiet Görlitz-Cottbus. In: Vertriebene finden Heimat in der Kirche. Integrationsprozesse im geteilten Deutschland nach 1945. Hrsg. von Rainer Bendel (Forschungen und Quellen zur Kirchen- und Kulturgeschichte Ostdeutschlands, Bd. 38). Köln u. a. 2008, S. 131-143.

Wir wollten eigentlich nicht fliehen ... Schwedt im Frühjahr 1945. Das Militär und die Zivilisten. Lagebetrachtungen und Erinnerungen. Hrsg.: Stadtmuseum Schwedt/Oder. Red.: André Vogel u. a. Schwedt/Oder 2007.

Wirth, Gisela: Zum 30. Jahrestag der Durchführung der demokratischen Bodenreform in Letschin. In: Heimatkalender für die Gemeine Letschin 1 (1975/76), S. 21-27.

Wirth, Günter: Das geistig-literarische Klima in Potsdam 1945 bis 1950. In: „Hoffnung und Erinnerung". Potsdamer Literatur 1945 bis 1950. Texte und Betrachtungen. Zsgest. u. hrsg. im Auftr. des Urania-Vereins „Wilhelm Foerster“ Potsdam e. V. von Mathias Iven. Milow/Berlin 1998, S. 16-39.

-, -: Potsdamer Kulturkalender 1945 bis 1950. In: „Hoffnung und Erinnerung“ [wie vor], S. 473-492.

-, -: Der andere Geist von Potsdam. Zur Kulturgeschichte einer Stadt 1918-1989. Frankfurt am Main 2000.

-, -: Heimat in dreifach gebrochener Perspektive: Böhmen - DDR - Deutschland. Zur Rolle der Vertriebenen in der DDR-Literatur am Beispiel von Hanns Cibulka. In: Böhmen. Vielfalt und Einheit einer literarischen Provinz. Hrsg. von Frank-Lothar Kroll (Literarische Landschaften, Bd. 2). Berlin 2000, S. 151-165.

Wittenberg, Hannes. Russen in Potsdam zwischen 1945 und heute. In: Ankommen in Potsdam. Integration als Teil der Stadtgeschichte. Hrsg.: ArchitraV e. V. c/o Thomas Sander. Potsdam 2018, S. $72-81$.

Wölfle-Fischer, Susanne: 725 Jahre Mahlow (1287-2012). Von der urkundlichen Ersterwähnung bis zur Gegenwart. [Mahlow] 2011.

Woinar, Klaus: (Außenlager) Falkensee. In: Der Ort des Terrors. Geschichte der nationalsozialistischen Konzentrationslager. Hrsg. von Wolfgang Benz u. Barbara Distel. Bd. 3: Sachsenhausen, Buchenwald. München 2006, S. 585-587.

Woitzik, Manfred: Was geschah vor 70 Jahren in Finsterwalde? In: Der Speicher 17 (2015), S. 104-122.

-, -: Die Dolmetscherin Elisabeth Makschakowa - das Schicksal einer Rußlanddeutschen. In: Der Speicher 17 (2015), S. 133-137. [Geb. 1900 Selz bei Odessa als Tochter eines russlanddeutschen Weingutbesitzers, verheiratet mit dem ukrainischen Brückenbauingenieur Makschalow, der 1941 Offizier der Roten Armee wird u. sich von seiner Familie trennt; sie 1944 in „Warthegau“ umgesiedelt, Jan. 1945 Evakuierung nach Finsterwalde (Lager Wiesenhain), April 1945 bis Jan. 1946 ebd. Dolmetscherin für die sowjet. Kommandantur, dann als Russlanddeutsche nach Kasachstan deportiert, dort 1984 verstorben].

Wojahn, Eberhard: Über Entwicklung und Aufgaben des Institutes für Futterproduktion Paulinenaue der Akademie der Landwirtschaftswissenschaften der DDR. In: Wanderungen durch den Kreis Nauen. Natur- und heimatgeschichtliche Betrachtungen. [H.] 3. Nauen (1984), S. 16-27.

Wolff, Gerhard: Vom Hospital zum modernen Krankenhaus. In: Bad Freienwalder Heimatkalender 40 (1996), S. 109-112. 
Worbs, Susanne, u. a.: (Spät-)Aussiedler in Deutschland. Eine Analyse aktueller Daten und Forschungsergebnisse. Forschungsbericht 20. Hrsg.: Bundesamt für Migration und Flüchtlinge. Nürnberg 2013.

Wühle, Eberhard: Die Grauen Schwestern in Eberswalde - eine Chronik. In: Eberswalder Jahrbuch 2012, S. 158-163.

Wunnicke, Christoph: Schlaglichter der CDU-Geschichte in der Uckermark von 1945 bis Anfang der 1950er Jahre. In: Mitteilungen des Uckermärkischen Geschichtsvereins zu Prenzlau 22 (2015), S. 200-214.

Z., W.: Flüchtlinge fanden im Ländchen Friesack eine neue Heimat. In: Friesacker Quitzow-Kurier, Nr. 34, 2010 (Online-Ausg., o. S.).

Zeitreise durch die Geschichte des Klinikums Frankfurt (Oder). Die Entwicklung von 1945 bis 2002. Hrsg. von Ulrich Knefelkamp in Verb. mit Andreas Grahlemann. Berlin 2003.

Zeuthen. Geschichte und Geschichten. Zsgest. von Hans-Georg Schuster. Bd. [1]-2. Horb am Neckar 1998-2001.

Zimmermann, Wilhelm: Zehn Tage im April 1945. Die Zerstörung der Stadt Prenzlau im Zweiten Weltkrieg. Buchholz i.d. Nordheide 1992.

Żurek, Robert: Kurt Reuter. Ein vergessener Vorreiter der deutsch-polnischen Versöhnung. In: Wichmann-Jahrbuch, N. F. 11 (2010/11 [2011]), S. 132-143.

Die Zusammenarbeit deutscher und polnischer Arbeiter im CFG. Forschungsauftrag der Klasse 11 I der EOS „Erich Weinert“. In: Gubener Heimatkalender 22 (1978), S. 25-27 [Chemiefaserwerk Guben].

Zwangsumsiedlung, Flucht und Vertreibung 1939-1959. Atlas zur Geschichte Ostmitteleuropas. Red.: Witold Sienkiewicz, Grzegorz Hryciuk. Warsazwa 2010. Lizenzausg. Bonn 2010.

Der Zweite Weltkrieg in Luckenwalde!? Eine Ausstellung der Stadt Luckenwalde. 02.09-29.11.2015 HeimatMuseum. Ausstellungskatalog. Text u. Bildausw.: Roman Schmidt. (Luckenwalde 2015).

Zysnarski, Jerzy: Duchowni landsberskich kościołów przed 1945 r. [Die Geistlichen der Landsberger Kirchen bis 1945]. In: Nadwarciański Rocznik Historyczno-Archiwalny 9 (2002), S. 49-77. 


\section{Danksagung}

Für Hinweise, Auskünfte und hilfreiche Gespräche danke ich folgenden Damen und Herren:

Dr. Reinhard Anders, Meinsdorf

Prof. Dr. Eckart Henning M. A., Berlin

Dr. Klaus Arlt, Potsdam

Dieter Hering $(\dagger)$, Langenhagen

Elsbeth B., Berlin

Doris Horlitz, Potsdam

Prof. Dr. Ernst Badstübner, Berlin

Dr. Silke Kamp, Berlin

Prof. Dr. Bernhard v. Barsewisch,

Elfriede Kapahnke, Rathenow-Semlin

Groß Pankow

Dr. Rolf Barthel, Strausberg

Dieter Bartusch, Kiekebusch

Prof. Christoph Bernard, Müncheberg

Christian Blasshofer, Essen

Dr. Frank Böttcher, Berlin

Dr. Harald Bresch, Berlin

Albert Burkhardt $(\dagger)$, Berlin

Eberhard Clemens, Berlin

Dr. Lars-Arne Dannenberg, Königsbrück

Michael Demko, Brück

Ingrid Fischer, Berlin

Dr. Reinhard E. Fischer, Berlin

Tilman Asmus Fischer, Berlin

Willi Gerlach, Wermelskirchen

Dorothee Geßner geb. Hanke, Potsdam

Dr. Bettina Giersberg, Näfels

Prof. Dr. Frank Göse, Potsdam

Dr. Bettina Götze, Knoblauch/Rathenow

Dietrich Goldbeck, Bielefeld

Stefan Guzy, Berlin

Lisa Haberkern M. A., Katowice

Harald Heerwagen, Potsdam

Dr. Matthias Helle, Fredersdorf

Klaus-Peter Kendzia, Berlin

Hartmut Knitter, Potsdam

Frau Köhler, Bredereiche

Gerhard König, Eisenach

Horst König, Storkow (Mark)

Lieselotte Koppe $(+)$, Potsdam

Prof. Dr. Heinz-Dieter Krausch $(+)$, Potsdam

Arne Liedtke, Sellin

Ekkehard Lindner, Moringen

Andrea Lindow-Bahl, Berlin

Jörg Lüderitz, Frankfurt (Oder)/Łagów

Johannes Mertens, Blankenfelde

Hermann Mertke, Groß Leuthen

Gregor Curt Meyer, Neufahrn

Jürgen Meyer, Rathenow

Klaus-Peter Möller, Potsdam

Siegfried Müller, Berlin

Dr. Sylvia Müller-Pfeifruck, Berlin

Kurt Neis, Fürstenberg/Havel

Siegfried Neubauer, Frankfurt (Oder)

Frank Nürnberger, Eisenhüttenstadt

Dr. Ines Oberling, Falkensee

Sven Olaf Oehlsen, Potsdam

Erich Opitz, Fürstenberg (Oder) 
Frank Owczarek, Forst (Lausitz)

Angelika und Olaf Pasenau, Gransee

Andreas Peter, Guben

Anja Peter-Palaske, Strausberg

Robert Piotrowski, Gorzów Wlkp.

Ilse Frfr. von Puttkamer, Mönchengladbach

Dr. Martin Richau, Berlin

Christian Ritter, Berlin

Andreas Rösler, Berlin

Dr. Peter P. Rohrlach, Berlin

Augustin Rotzer, Teltow

Stefan Rückling, Berlin

Irmgard Schädlich geb. Stein, Berlin

Peter Schaefer, Potsdam

Prof. Dr. Winfried Schich, Berlin

Dr. Kurt Schilde, Berlin

Michael Schimmel, Berlin

Dr. Reinhard Schmook, Bad Freienwalde

Simone Schober-Wischkony, Braunschweig

Jochen Schröder, Stuttgart

Melitta Schubert, Buckow
Dr. Ilona Schulz, Spremberg

Karl Wilhelm Schulz, Berlin

Gerd Schwarzlose, Stahnsdorf

Frank-J. Seider, Teltow

Oliver Sonntag, Potsdam

Dr. Martin Sprungala, Dortmund

Detlev Stark, Hoya/Weser

Andy Steinhauf, Frankfurt (Oder)

Karin Többe-Wehberg, Liepe

Dr. Winfried Töpler, Görlitz

Eckhard Tolzmann, Lübben

Gregor Tumpach, Jena

Judith Uhlig, Berlin

Prof. Dr. Werner Vogel $(\dagger)$, Berlin

Manfred Walther, Berlin

Gerhard Weiduschat, Berlin

Florian Wilke, Fürstenwalde/Spree

Ingrid Zache, Hohen Neuendorf

Prof. Dr. Joachim Zdrenka, Bergholz-Rehbrücke

Dr. Gerd-H. Zuchold ( + ), Berlin

Für Auskünfte und logistische Unterstützung danke ich folgenden Institutionen:

Amt Joachimsthal (Schorfheide) (Frau Schwarz)

Arbeitsgemeinschaft ostdeutscher Familienforscher e. V., Herne (Jürgen Frantz, Mario Seifert; Forschungsgruppe Brieg: Andreas Rösler; Forschungsstelle Neumark/Ostbrandenburg)

Brandenburger Seniorenverband, Ortsverband Storkow (Horst König)

Brandenburgisches Landeshauptarchiv, Potsdam (Prof. Dr. Klaus Neitmann, Kerstin Bühring, Torsten Hartisch, Florian Seher)

Brandenburg-Preußen-Museum, Wustrau (Dr. Stephan Theilig)

Bürgervereinigung „Fürstenberg (Oder)“e.V. (Erich Opitz) 
Bund der Vertriebenen, Landesverband Brandenburg, Geschäftsstelle, Potsdam (Eberhard Clemens)

Bundesarchiv, Berlin-Lichterfelde (Tobias Westhoff)

Bundesarchiv-Lastenausgleichsarchiv, Bayreuth

Caritasverband der Diözese Görlitz e. V., Regionalstelle Cottbus (Jutta Lehmann)

Diözesanarchiv Berlin (Dr. Gotthard Klein)

Evangelisches Diakonissenhaus Berlin Teltow Lehnin, Teltow, Sekretariat (Stephan Gellbach); Museum im Zisterzienserkloster Lehnin (Stefan Beier)

Evangelisches Landeskirchliches Archiv in Berlin (Bert Buchholz, Dr. Wolfgang Krogel, Jürgen Stenzel)

Förderverein Haus der Senioren e. V., Neuenhagen (Marianne Wachtmann)

Friedrich-Meinecke-Institut der Freien Universität Berlin, Bibliothek

Geheimes Staatsarchiv Preußischer Kulturbesitz, Berlin (Prof. Dr. Jürgen Kloosterhuis)

Gemeinde Letschin, Archiv (Edgar Petrick)

Heimatkreis Königsberg/Nm. (Christian Ritter)

Heimatkreis Meseritz e. V. (Albrecht Fischer von Mollard)

Herold. Verein für Heraldik, Genealogie und verwandte Wissenschaften e. V. Berlin, Bibliothek

Humboldt-Universität zu Berlin, Institut für Geschichtswissenschaften (Prof. Dr. Michael Wildt, Annelies Scheel)

Institut für Volkskunde der Deutschen des östlichen Europa, Freiburg i. Br.

Kreisarchiv Dahme-Spreewald, Luckau

Kreisarchiv - Landkreis Barnim, Eberswalde (Brigitta Heine)

Landesgeschichtliche Vereinigung für die Mark Brandenburg e. V., Berlin, Bibliothek (Bernd Kleist, Christian Ritter, Fabian Rohde, Hilmar Schermall, Ingrid Zache)

Landeshauptstadt Potsdam, Seniorenbeirat (Katrin David)

Landsmannschaft Ostpreußen, Bundesgeschäftsstelle, Archiv, Hamburg (Dr. Sebastian Husen)

Landsmannschaft Ostpreußen, Landesgruppe Brandenburg e.V. (Hans-Jörg Froese, Werder/ Havel)

Letschiner Heimatstuben, Letschin (Edgar Petrick)

Museum Fürstenwalde (Guido Strohfeldt)

Namslauer Heimatfreunde e. V. (Hannelore Suntheim, Marburg/L.; Edeltraud Hoppe, Kyritz)

Seniorenbeirat der Stadt Cottbus, AG Zeitzeugen (Irina Lehmann) 
Stadt Buckow (Märkische Schweiz), Partnerschaftsbeauftragte (Melitta Schubert, Maxi PincusPamperin)

Stadt Luckau, Hauptamt (Birgit Lehmann)

Stadt Teltow, Sachgebiet Öffentlichkeitsarbeit, Stadtmarketing, Tourismus (Jürgen Stich)

Stadtarchiv Angermünde (Steve Schmidt)

Stadtarchiv Bernau b. Berlin (Bernd Eccarius)

Stadtarchiv Eisenhüttenstadt (Gabriele Urban)

Stadtarchiv Frankfurt (Oder) (Ralf-Rüdiger Targiel)

Stadtarchiv Prenzlau (Steffi Huth)

Stadt- und Landesbibliothek Potsdam (Marlies Sell, Hannelore Rüger)

Stadtverwaltung Finsterwalde (Frau Freund)

Stadtverwaltung Welzow (Kerstin Hellwig, Carmen Lehnigk)

Stiftung Brandenburg, Fürstenwalde (Maria Petzoldt)

Stiftung Martin-Opitz-Bibliothek, Herne (Dr. Hans-Jakob Tebarth, Bernhard Kwoka, Dorothea Marschollek)

Verein für Heimatgeschichte der Stadt Müncheberg e.V. (Prof. Christoph Bernard, Dr. Ralf Dannowski, Frank Geißler)

Vereinigte Kurländische Stiftungen (Andreas Baron von Mirbach)

Zentrale Ausländerbehörde, Eisenhüttenstadt (Frank Nürnberger)

Zentral- und Landesbibliothek Berlin (hier auch: Digitale Landesbibliothek Berlin) 


\section{Register}

Mehrfachnennung auf derselben Seite ist nicht gekennzeichnet.

$\ddot{a}=a e, \ddot{o}=$ oe, $\ddot{\mathrm{u}}=$ ue.

\section{Geographisches Register A-Z (mit Ortsnamenkonkordanz)}

Bei Verweisen auf Kreis- und Ortsartikel im Teil 2 (Ortsdokumentation) sind die Seitenzahlen kursiv gesetzt. Orte in Brandenburg sowie in den ehemaligen deutschen Ostgebieten werden i.d.R. nach der Kreiszugehörigkeit von vor 1933/39 lokalisiert. Orte, für die deutsche Namen existieren, stehen unter ihrem deutschen Namen, vom litauischen, polnischen, russischen, tschechischen oder ukrainischen (der in Klammern mit angegeben ist), wird verwiesen, so dass das Register zugleich als Ortsnamen-Konkordanz dient. (Würden beide Namen im Alphabet unmittelbar aufeinander folgen, wird auf die Verweisung aus Platzgründen verzichtet.) Germanisierende Umbenennungen aus der NS-Zeit sind lediglich zur Orientierung hinzugesetzt, da sie vielfach in Quellen begegnen können.

Aachen 71,392

Abbendorf (Kr. Westprignitz) 57, 314, 889

Abschwangen (Kr. Preußisch Eylau) (russ. Tischino) 1439

Abtsdorf bei Zwittau (Sudetenland) (tschech. Opatov v Čechach) 811

Adlershof $($ Berlin $) \rightarrow$ Berlin-Adlershof

Adlig Baubeln (Kr. Tilsit) (lit. Būbliškè) 1466

Adolin (Kr. Nowograd-Wolynsk), Wolhynien

(Westukraine) 1463

Afghanistan 512

Agneshof (Lager) $\rightarrow$ Falkensee

Ahrensdorf (Kr. Beeskow-Storkow) 1028

Ahrensdorf (Kr. Teltow) 164, 544, 551, 1101, $1126 \mathrm{f}$.

Ahrensfelde (Kr. Niederbarnim) 1033

Ahrenshoop (Vorpommern) 327

Albrechtsdorf (Kr. Sorau) (poln. Olbrachtów) 582

Albrechtshof (Berlin) $\rightarrow$ Falkensee, Lager Agneshof

Alexanderdorf (Kr. Teltow) 551f., 1199

Alexanderhof (Kr. Teltow) 544

Alexandersdorf (Kr. Landsberg/W.) (poln. Gościnowo) 440

Alexandrow bei Lodz (poln. Aleksandrów

Łódzki) 489, 1453, 1472

Alexandrowka (Russland) 863

Alexandrowka, Kolonie $\rightarrow$ Potsdam
Allenstein (Ostpreußen) (poln. Olsztyn) 224, 597, 704, 1138, 1208, 1457, 1475

Allenstein (Woiwodschaft) $\rightarrow$ Olsztyn

Alsace $\rightarrow$ Elsaß

Alt Blessin (Kr. Königsberg/Nm.) (poln. Stary Błeszyn) 968

Altbleyen (Kr. Königsberg/Nm.) 1434

Alt Buchhorst (Kr. Niederbarnim) 536, 552

Altburgund (Kreis) $\rightarrow$ Schubin

Altcüstrinchen (Kr. Königsberg/Nm.) (poln. Stary Kostrzynek) 412, 555, 815, 817

Altdamm (Kr. Randow) $\rightarrow$ Stettin-Altdamm

Altdöbern (Kr. Calau) 232, 447, 484, 526, 552f., 1527

Altdrewitz (Kr. Königsberg/Nm.) $\rightarrow$ KüstrinAltdrewitz

Altenhof am Werbellinsee (Kr. Angermünde) 112, 164, 524, 554f., 1063, 1315, 1481;

Kinderheim 225, 554, 571, 1436; St. Maria-

Elisabeth-Heim 210, 450, 554, 954

Altensorge (Kr. Landsberg/W.) (poln. Glinik) 440

Altentreptow (Vorpommern) 192, 447

Altes Lager (Kr. Jüterbog-Luckenwalde) 745, 746, 1246 f., 1374

Altfriedland (Kr. Oberbarnim) 93

Alt Garz (Kr. Ruppin) 1209

Altglietzen (Kr. Königsberg/Nm.) 412, 483, 531, $537,555,815$ 
Alt Golm (Kr. Beeskow-Storkow) 1028

Alt Habendorf bei Reichenberg (tschech. Starý

Habendorf) 294, 820

Althüttendorf (Kr. Angermünde) 1314, 1319

Alt Jablonke (Kr. Meseritz) (Grüntal) (poln.

Jabłonka Stara) 1201

Alt Jauer (Kr. Jauer) (poln. Stary Jawor) 503

Altkarbe (Kr. Friedeberg/Nm.) (poln. Stare

Kurowo) 206, 255, 1457

Alt Küstrinchen $\rightarrow$ Altcüstrinchen

Altlandsberg (Kr. Niederbarnim) 130, 187, 288, 455, 495, 536, 556f., 1032, 1453, 1479

Alt Lietzegöricke (Kr. Königsberg/Nm.) (poln.

Stare Łysogórki) 816

Alt Madlitz (Kr. Lebus) 843

Alt Mahlisch (Kr. Lebus) 758

Altmark 1467

Alt Obra (Kr. Koschmin) (poln. Obra Stara) 582

Altranft (Kr. Oberbarnim) 1478

Alt Rehse bei Penzlin (Mecklenburg) 225

Alt Ruda bei Hohensalza (Kr. Hermannsbad/

Ciechoncinek) 1453

Alt Rüdnitz (Kr. Königsberg/Nm.) (poln. Stara

Rudnica) 818

Alt Ruppin (Kr. Ruppin) 820 f.; Gildenhall 362, 463, 465, 482, 820

Alt Schadow (Kr. Beeskow-Storkow) 1028, 1070, 1131

Alt Schlawe (Kr. Schlawe) (poln. Sławsko) 1436

Alt Schwerin (Mecklenburg) 29

Alt Stahnsdorf (Kr. Beeskow-Storkow) 1028, 1074

Altthymen-Dahmshöhe (Kr. Templin) 281, 546, $557 f ., 680,682$

Alttucheband (Kr. Lebus) 533, 558f., 891(?)

Altwasser (Kr. Sorau) (poln. Stara Woda) 504

Alt Zeschdorf (Kr. Lebus) 310, 533, 559

Amalienfelde $\rightarrow$ Kremmen-Amalienfelde

Amerika $\rightarrow$ Vereinigte Staaten von Amerika

Amerikanische (Besatzungs-)Zone Deutschlands 236, 1035-1037, 1072, 1390

Amsterdam (Niederlande) 1338

Amtitz (Kr. Guben) (poln. Gębice) 619, 739, 1440

Amtshagen (Kr. Gumbinnen) $\rightarrow$ Schirgupönen

Angerburg (Ostpreußen) (Węgorzewo) 398, 1341,1345

Angerburg (Kreis) 371 f., 394, 397 f., 404, 863, 1340 f., 1344
Angermünde 63, 65, 105 f., 115, 119 f., 138, 180, 213 f., 221 f., $280,394,416,428,455$, 494, 524, 559-564, 827, 829, 840, 903, 977 f., 996, 1012 f., 1017 f., 1090, 1117, 1152, 1230, 1313f., 1316, 1325, 1329, 1343, 1397, 1434, 1458, 1465, 1544; Bahnhof 276, 560 f., 1454; Kreiskrankenhaus 186f., 554, 560 f., 829, 840, 904; Landratsamt, Rat des Kreises 1313, 1323, 1329; Standesamt 44, 55, 69, 120, 221, 554, 559-561-564, 829, 840, 904, 1420; Umsiedlerlager (Hotel Kaisergarten) 164, 176, 280, 523 f., 561, 563 f., 904, 1016-1018, 1022, 1063, 1197, 1440

Angermünde (Kreis) 83, 91, 106, 110, 115, 164, $166,199,202,214,217,232,313,350$ f., 455 , 522-524, 531, 564, 827 f., 865, 975, 989 f., 996, 1017 f., 1034, 1063, 1103, 1151, 1204, 1206, 1230, 1253, 1313-1325, 1329-1331, 1401

Anhalt (Land) 189

Anhalt-Zerbst (Fürstentum) 1265

Anklam (Pommern) 208, 220, 857, 1377

Anseith (Sudetenland) 1453

Antonufka (Wolhynien/Ukraine) (ukrain. Antoniwka) 505

Apolda (Thüringen) 405

Arensdorf (Kr. Lebus) 375

Arenshausen (Eichsfeld) 179

Arneburg/Elbe 584

Arnsdorf (Kr. Schweidnitz) (poln. Milikowice) 606

Arnsdorf (Kr. Teltow) $\rightarrow$ Ahrensdorf

Arnstadt (Thüringen) 386

Arnswalde (poln. Choszczno) 25, 494, 504, 690, $856,919,971,1453,1456,1458,1474$

Arnswalde (Kirchenkreis) 435, 441

Arnswalde (Kreis) 213, 404, 1458

Arzis (Bessarabien) (ukrain. Arzys) 876

Arzys $\rightarrow$ Arzis

Asch (Sudetenland) (tschech. Aš) 157 f., 284, 915

Aschersleben 1231, 1250

Atterwasch (Kr. Guben) 720, 1297-1299

Augustfelde (Kr. Prenzlau) 884

Aurith (Kr. Weststernberg) (poln. Urad) 86, 212, $314,355,420,425,492,529,564 f ., 953,970$, 1459

Aue (Erzgebirge) 294, 1092

Auschwitz (poln. Oświęcim), KZ 1248, 1451

Aussig/Elbe (Ústí nad Labem) 281, 284, 395 
Babelsberg $\rightarrow$ Potsdam-Babelsberg

Babieniec $\rightarrow$ Babziens (Kr. Rastenburg)

Babimost $\rightarrow$ Bomst

Babitz (Kr. Ostprignitz) 106

Baborów $\rightarrow$ Bauerwitz (Kr. Leobschütz)

Babziens (Kr. Rastenburg) (poln. Babieniec) 1450

Bad ... $\rightarrow$ Ortsname ohne „Bad“

Baden-Württemberg 31, 204, 208, 236, 339, 474-476, 505, 691, 1468

Badingen (Kr. Templin) 821

„Bäderstraße“ 192

Bärdorf (Kr. Frankenstein) (poln. Niedźwiedź) 625

Bärenklau (Kr. Guben) 529, 572, 706

Bärenklau (Kr. Osthavelland) 1111

Bärensprung (Kr. Ostprignitz) 227, 1458

Bärfelde (Kr. Königsberg/Nm.) (poln. Smolnica) 505

Bärhorst bei Paulinenaue (Kr. Westhavelland) 316

Bärwalde (Kr. Jüterbog-Luckenwalde) 1246

Bärwalde/Nm. (Kr. Königsberg/Nm.) (poln. Mieszkowice) 207 f., 375 f., 380, 384, 394, 396, 398-401, 494, 962, $1338 \mathrm{f}$.

Bagrationowsk $\rightarrow$ Preußisch Eylau

Bahnitz (Kr. Jerichow II) 1458

Bahnsdorf (Kr. Calau) 1100

Bahrensdorf (Kr. Beeskow-Storkow) 1013

Bahro (Kr. Guben) 134, 1444

Baitz (Kr. Zauch-Belzig) 367

Bajohrgallen $\rightarrow$ Trakehnen-Bajohrgallen

Balkan 138, 893, 1004, 1007, 1282, 1399

Balkow (Kr. Weststernberg) (poln. Bałków) 409

Balm (Usedom, Vorpommern) 1101

Baltikum, Baltische Staaten (siehe auch $\rightarrow$ Estland, $\rightarrow$ Kurland, $\rightarrow$ Lettland, $\rightarrow$ Litauen) 71 , 75, 99, 185, 193, 199, 203, 218, 232 f., 433, 441, 523, 525-527, 529f., 532, 534-541, 543 f., 546-548, 550, 590 f., 599, 619, 637, $659,667,715,732,764,885,935,957-959$, 1392,1399

Banat 828, 1478

Bantikow (Kr. Ostprignitz) 227 f., 776

Banzendorf bei Lindow (Kr. Ruppin) 495, 787

Barciany $\rightarrow$ Barten (Ostpreußen)

Barcikowice $\rightarrow$ Hänchen (Kr. Freystadt)

Barlinek $\rightarrow$ Berlinchen/Nm.
Barnim (Land) 208, 221

Barnim (Landkreis) 268, 637, 1543

Barop $\rightarrow$ Dortmund-Barop

Barschdorf (Kr. Liegnitz) (poln. Bartoszów) 1477

Barsdorf bei Fürstenberg/Havel 680

Barsdorf-Qualzow 680

Barten (Ostpreußen) (Kr. Mohrungen [poln. Barty] oder Kr. Rastenburg [poln. Barciany]) 821

Bartenstein (Ostpreußen) (poln. Bartoszyce) 1457

Barth (Vorpommern) 1438, 1449

Bartoszów $\rightarrow$ Barschdorf (Kr. Liegnitz)

Bartoszyce $\rightarrow$ Bartenstein (Ostpreußen)

Barty $\rightarrow$ Barten (Ostpreußen)

Baruth/Mark (Kr. Jüterbog-Luckenwalde) 27, $164,193,217,456,530,573,586,699,729$, 1063

Basdorf (Kr. Niederbarnim) 536, 573, 1034

Baubeln (Kr. Tilsit) $\rightarrow$ Adlig Baubeln

Bauerwitz (Kr. Leobschütz) (poln. Baborów) 428 f., 968

Baumgarten (Kr. Frankenstein) (poln. Braszowice) 826

Bautzen (Sachsen) 32, 409

Bayern 97, 204, 229, 236, 240, 371, 379, 397, 411 f., 414 f., 535, 915, 1341, 1431, 1444, 1455, 1467,1479

Bayreuth 230, 414 f.; Lastenausgleichsarchiv 54, $402,1419,1543$

Bayreuth-Wendelhöfen 94

Bayreuth (Gau) 94

Beberen (Kr. Leipe) $\rightarrow$ Bobrowniki

Bechlin (Kr. Ruppin) 277f., 541, 1468

Będów $\rightarrow$ Bindow (Kr. Crossen)

Beelitz (Kr. Zauch-Belzig) 44, 117, 128, 221, 260, 549f., 574-576, 932, 1205, 1476-1478, 1482

Beelitz-Heilstätten (Kr. Zauch-Belzig) 131, 574, 576, 580, 1441, 1478

Beenz (Kr. Templin) 546, 576, 603, 931

Beesdau (Kr. Luckau) 1102

Beesgen-Plesse (Kr. Guben) (poln. Pleśno-Bezki) 707

Beeskow (Kr. Beeskow-Storkow) 27, 31, 151, 196, 275, 291, 409, 455, 495, 525, 576f., 735, 739f., 794, 806, 977-980, 982, 984 f., 996 , 999 f., 1002, 1007, 1013f., 1028, 1071, 1073 f., 1085 f., 1090, 1093, 1390 f., 1435, 1437, 1471

Beeskow-Storkow (Kreis) 31, 131, 150-152, 164, 166, 172, 196, 199, 204, 214, 242, 244, 246, 
255, 257, 275 f., 278, 285, 300 f., 314, 324, 442, 455, 524f., 739, 766 f., 975, 977-980, 984 f., 996, 998-1002, 1004-1008, 1011-1015, 1027-1031, 1034, 1047-1049, 1058, 1061, 1064, 1070-1075, 1084-1086, 1089, 1091, 1093-1096, 1098, 1103 f., 1124, 1130 f., 1142, 1147, 1151, 1178-1182, 1185, 1204, 1213-1215, 1217 f., 1230, 1232-1235, 1398, 1407, 1419, 1441

Beetzendorf (Kr. Salzwedel) 648

Behrensdorf (Kr. Beeskow-Storkow) 136, 177, 287, 1028, $1461 \mathrm{f}$.

Beijewonnen (Litauen) 861

Belarus $\rightarrow$ Weißrussland

Belgien 1034f., 1037, 1466

Bellin (Kr. Königsberg/Nm.) (poln. Bielin) 384

Bellinchen (Kr. Königsberg/Nm.) (poln. Bielinek) 1329

Belzig, Bad (Kr. Zauch-Belzig) 26, 37, 64, 88, $114,119,121,164,217,234,237,416,428 \mathrm{f}$., 439, 456, 549f., 577-583, 605 f., 614, 806, $827,882,938,954,1010,1151,1191,1205$, 1257 f., 1461, 1468, 1475, 1478, 1481; Lager 164, 550, 579-582, 1062, 1230; Lager Roederhof (KZ-Außenlager) 174, 580, 582, 1466

Belzig (Kirchenkreis) 1257

Benau (Kr. Sorau) (poln. Bieniów) 915

Bensdorf bei Wusterwitz 470

Bentschen (Kr. Meseritz) (Posen/Polen) (poln. Zbąszyń) 192, 368, 597, 648, 689, 741, 890

Beresinchen $\rightarrow$ Frankfurt-Beresinchen

Berg-Dievenow (Kr. Cammin) (poln. Dziwnów) 495, 952

Berg Vorwerk bei Königswalde (Kr. Oststernberg) (poln. Osia Góra) 1441

Bergau (Kr. Königsberg i. Pr.) (russ. Zwetkowo) 487

Berge (Prignitz) (Kr. Westprignitz) 1146

Bergen (Kr. Celle) 1436, 1455

Bergen (Kr. Schweidnitz) (poln. Borzygniew) 726

Bergen (Kr. Wanzleben) 1438

Bergen-Belsen, KZ 102

Bergenau (Kr. Treuburg) $\rightarrow$ Krzywen

Bergerdamm (Kr. Westhavelland) 547, 583

Bergfelde (Kr. Niederbarnim) 1032, 1231

Bergholz-Rehbrücke $\rightarrow$ Potsdam-Rehbrücke

Bergkirchen (bei Minden/W.) 384

Bergsdorf (Berndorf, Kr. Liegnitz?) 332
Bergstadt Platten (Westböhmen/Sudetenland) (tschech. Horní Blatná) 1469

Berka, Bad (Thüringen) 399, 1438

Berkenbrück (Kr. Jüterbog-Luckenwalde) 1042, 1246

Berlin 5f., 9-11, 15-18, 21, 23-26, 28, 31-38, 51, $56,59,63,74,76,80,82-85,88,90$ f., 93,95 f., $98,100,103,107,112,114,120,127,129-132$, $137,147,149,151,158-162,166,168,176$, 179, 181 f., 186, 189, 194, 203-208, 211-213, $218,220-222,233,235,240-243,249,254$, 261, 265, 273, 277, 285, 291, 297 f., 303, 313, $323,328,336,338-340,347-349,360,368$, $370,380,385$ f., 388, 405, 411, 415, 418, 421, 430-436, 438 f., 441 f., $445-448$, 451 f., 458 , 462, 469, 472, 474, 477, 485-487, 498, 500, $504,507,512,532$ f., $554,574-577,586,588$ f., 595 f., 601, 606, 609, 612, 626 f., 639 f., 645 , 647, 649, 656, 664-666, 668f., 677, 683, 685, 689, 691 f., 695, 698, 705, 727, 731, 749, 767, 771, 787, 792, 798 f., 804, 816, 819, 828 f., 831, $833,835,843,845-847,851-853$ f., 857,860 f., 873, 879 f., 893, 895, 907 f., 928-932, 935, 942, 950, 956, 963-965, 967, 971, 997, 1013, 1016, 1023, 1031, 1035-1037, 1041, 1049, 1069, 1090, 1093, 1097, 1099, 1103, 1105, 1107, $1124,1132,1138,1146,1162,1205,1217 \mathrm{f}$., 1240, 1249 f., 1252, 1254, 1256-1264, 1269, 1272 f., 1280, 1293, 1295, 1341, 1354, 1368, 1372 f., 1376, 1399, 1415f., 1418-1420, 1431, 1434-1438, 1440-1442, 1446, 1448-1450, 1454-1456, 1458-1460, 1463-1465-1468, 1470-1473, 1476, 1478 f., 1480, 1482 f., 1541-1544; Flüchtlingslager, „Umsiedlerlager“ 6, 159-162, 227, 232, 895, 1061, 1069, 1456; Magistrat und dessen Ämter 6, 25, 159-162, 240, 265, 1016, 1184, 1240, 1407

Berlin (Ost) („Ostberlin“, „Ostsektor“, sowjet. Sektor) 14, 83, 106, 142, 182, 204-207, 234, 254, 257, 306, 341 f., 367, 371 f., 374-376, $378,380,386,388,391,394-403,405,408 \mathrm{f}$., 411, 417 f., 421 f., 424, 426, 430, 439, 441, 505, 552, 653 f., $671,675,734,755$ f., 760,785 , 801, 834, 896, 909, 963, 967, 1044f., 1081 f., 1106, 1109, 1116, 1146, 1154, 1183, 1202, 1228 f., 1252, 1254, 1258, 1339-1342, $1348 \mathrm{f}$., 1354-1357, 1396 f., 1407, 1415-1417, 1439 f., 1444, 1458 f., 1462, 1468, 1470 f., 1474 f., 1478, 1482; Lager 6; Straßennamen $342 \mathrm{f}$. 
Berlin (West) (West-Berlin, „Westberlin“, Westsektoren, „Westsektor“) $13,38,83,143,172$, $176,182,198,204-207,234,255,299,342$, 349, 352, 356, 364f., 367-381, 384, 386, 388, 394-396, 401, 403-406, 408, 411, 427, 430, 435, 438-441, 448f., 452, 464, 472, 486, 533, $552,603,735,822,846,905,919,1113,1174$, 1240, 1258-1260, 1338-1342, 1347, 1349 f., 1353 f., 1412, 1416, 1440, 1442-1444, 1449, 1454, 1459 f., 1462, 1465, 1470, 1472 f., 1480, 1482; Amerikanischer Sektor 375, 395, 1350

Berlin-Adlershof 397, 892, 1340

Berlin-Albrechtshof $\rightarrow$ Falkensee, Lager Agneshof Berlin-Biesdorf, Anstalt Wuhlgarten 186

Berlin-Britz, Siedlung am Quarzweg $356 \mathrm{f}$.

Berlin-Buch 343, 471

Berlin-Buckow, Lager 1184

Berlin-Charlottenburg 6, 77, 263, 289, 370, 411, 435, 440, 448, 451 f., 571, 649, 669, 831, 1257, 1262 f., 1339; Bahnhof Zoologischer Garten 82, 371; Notaufnahmestelle (Kuno-FischerStr. 8) 1109; Studentenhaus Hardenbergstraße 1339; Waldbühne 374

Berlin-Dahlem 433; Kirchendienst Ost (Reichensteiner Weg 24) 431, 1264

Berlin-Falkenberg, kath. Pfarrei 816

Berlin-Friedenau 342, 451

Berlin-Friedrichsfelde 206, 246; Zentralverwaltung für deutsche Umsiedler (Alt-Friedrichsfelde 1-2) 239, 1009, 1012 f., 1016 f., 1048

Berlin-Friedrichshagen, St. Antonius-Krankenhaus 450, 896 f.; Westend-Siedlung 343

Berlin-Friedrichshain 1412; Salvator-Kolleg (Warschauer Str. 57) 446; Schlesischer Bahnhof (Ost-, Hauptbahnhof) 82, 119, 150 f., 343, 678, 1064, 1069, 1413, 1436, 1448, $1467 \mathrm{f}$;

Straßennamen 342, 1416f.; Weberwiese 130

Berlin-Frohnau 114, 182; Marienschwestern 450 Berlin-Gesundbrunnen $\rightarrow$ Berlin-Wedding

Berlin-Grunewald 436, 1269, 1354, 1463

Berlin-Heiligensee 1453

Berlin-Hellersdorf 6, 501

Berlin-Hohenschönhausen 395

Berlin-Johannisthal 1341, 1346

Berlin-Karlshorst, Hochschule für Ökonomie 909, 1416; SMA 1022f., 1039, 1041, 1054, 1082

Berlin-Kladow 273

Berlin-Köpenick 99, 896
Berlin-Kreuzberg 249

- Anhalter Bahnhof 88, 293, 1434, 1459, 1479

- Deutschlandhaus 375, 393 f., 851, 1360

- Diakonissen-Mutterhaus Bethanien 1258

- Haus Vaterland 1459

- Kliems Festsäle, Hasenheide 376, 1344, 1349

- Luisenstadt-Kirchgemeinde 586

Berlin-Lankwitz 251, 375 f.; Hospital Maria Trost 450; Marienschwestern (Gallwitzallee; Kaulbachstr.) 450; Pichler's Viktoriagarten (Leomorenstr.) 375

Berlin-Lichtenberg 1002, 1055, 1434, 1455; Lazarett Herzberge 1480; Ministerium für Staatssicherheit 1348; Umsiedlerlager $159 \mathrm{f}$.

Berlin-Lichterfelde 342, 376, 420, 1341, 1419, 1472, 1543; Superintendentur Kölln-Land I: 1261 f.; „Volkdeutsches“ (Umsiedler-)Lager Lichterfelde-Süd 99

Berlin-Mahlsdorf 114

Berlin-Mariendorf 1339

Berlin-Marienfelde 13, 232, 1463

Berlin-Marzahn 6, 88, 160, 273, 471, 501, 1455

Berlin-Mitte 253, 1409

- Admiralspalast 1296, 1410

- Bahnhof Alexanderplatz 809

- Bahnhof Friedrichstraße 1090

- Bischöfliches Ordinariat 1269, 1419

- Charité 669

- DDR-Außenministerium (Luisenstr. 56) 1356

- DDR-Innenministerium (Luisenstr. 46:) 1355; (Mauerstr. 25, 29/32:) 1106, 1109, $1356 \mathrm{f}$.

- Friedrichstadtpalast 372

- Haus der Verwaltungen/Ministerien (Leipziger Str. 5-7) 240, 249, 300

- Marienkirche 431

- Provinzhaus der Marienschwestern (Michaelkirchplatz) 450

- Reichskanzlei-Lazarett 1479

- St. Hedwigskathedrale 442

- St. Hedwigskrankenhaus 447

- Sophienkirchhof (Bergstr.) $327 \mathrm{f}$.

- Staatsoper 300

- Stettiner Bahnhof (Nordbahnhof) 343, 1413, 1434

- Suchdienst (Kanonier-/Glinkastr. 35) 1408

- Volksbühne 1416

- VP-Hauptverwaltung (Glinkastr. 35) $1353 \mathrm{f}$.

- VP-Präsidium (Neue Königstr. 27-37) 1340, 1344-1346 
Berlin-Moabit $\rightarrow$ Berlin-Tiergarten

Berlin-Neukölln 512, 1344, 1349, 1459; Bahnhof 132, 1454; Lokal „Pfannenberg“ 206; Museum Neukölln 512

Berlin-Niederschöneweide 461

Berlin-Niederschönhausen, Ev. Wohnstätten Siloah 929; VP-Hauptverwaltung (Seckendorfstr. 31) 394-397, 406, 408, 1340, 1344-1346, $1348 \mathrm{f}$.

Berlin-Nikolassee 438, 1341 f.; Ev. Krankenhaus Hubertus (Schlachtensee) 782, 1258; Hedwigschwestern 570 f.; Hilfswerk der Ev. Kirchen (Teutonenstr. 9) 432, 1256 (Hauptbüro Brandenburg, Waltharistr. 2-4) 1257; Kirche, ev. 440, 1342; Restaurant „Schloß Wannsee“ 206

Berlin-Oberschöneweide 132, 375, 461, 1345 f., 1454; Christuskirche $1345 \mathrm{f}$.

Berlin-Pankow 30, 343, 929

Berlin-Prenzlauer Berg 667; Gethsemanekirche $409 \mathrm{f}$; Niederlassung der Marienschwestern (Bötzowstr.) 450; Straßennamen 342

Berlin-Reinickendorf 411, 783, 1347; Flüchtlingslager 162, 261

Berlin-Rudow 1434; Lager 1184

Berlin-Schöneberg 246; Hedwigschwestern 588, 632; Patenschaft für Schlesien 74, 342, 368, 427; St. Annaheim 447

Berlin-Spandau 35, 289, 370 f., 440, 648, 835, 1443, 1461; Bahnhof Spandau-West (jetzt Hauptbahnhof) 132, 1454; Ev. Johannesstift 369-371, 410 f., 439, 923, 1130; Schützenhof 372

Berlin-Steglitz 394 f.; Patenschaft für Ostpreußen 342, 368, 427; Restaurant „Elefant“ (Steglitzer Damm) 375

Berlin-Südende 1479

Berlin-Tegel 388; „Kirche am See“ 411

Berlin-Tempelhof 1338; Provinzhaus der Grauen Schwestern 581, 592, 612, 668, 1271; St. Joseph-Krankenhaus 1271

Berlin-Tiergarten, Lager Kruppstraße 979; Japanische Botschaft 91; Lehrter Bahnhof 1454; Lehrter Güterbahnhof 132; Moabit 1483; Patenschaft für Oberschlesien 427

Berlin-Treptow, „Eierhäuschen“ 369

Berlin-Wartenberg, Ingenieurschule für Landmaschinentechnik 1468

Berlin-Wedding 254; Gesundbrunnen 132, 1454

Berlin-Weißensee 242, 386, 628, 816, 1346, 1457
Berlin-Wilmersdorf 451; Caritasverband (Düsseldorfer Str. 15) 451, 896f., 1275, 1277-1279; Diözesan-Beauftragter für Flüchtlingsseelsorge (Düsseldorfer Str. 13); Kath. Flüchtlingsdienst (Pfalzburger Str. 18) 446, 451

Berlin-Zehlendorf 93, 375, 1349f.; DRK (Berliner Str. 11) 452

Berlin (Bistum, Erzbistum) 37f., 56, 209, 263, 442-462, 552, 559, 575 f., 704, 826, 896, 906, 1267, 1275-1281, 1417, 1419, 1543

Berlinchen/Nm. (Kr. Soldin) (poln. Barlinek) 75, 95, 205, 291, 369, 495, 865, 1456, 1465

Berlinchen (Kr. Ostprignitz) 539, 1270

Berlitt (Kr. Ostprignitz) 539

Bernau bei Berlin (Kr. Niederbarnim) 96, 428, 447, 455, 471, 494, 501, 536, 583-585, 587, $609,735,942,978,983,1031,1048,1078$, 1081 f., 1167, 1457, 1460, 1464, 1544; Lager 164, 166, 536, 584 f., 1062; Landrat, Landratsamt, Rat des Kreises 1076f., 1082, 1167, 1356 f.; Oberlandrat 750, 769, 890, 1011, 1027, 1031, 1048, 1076-1079, 1081, 1109 f., $1155,1176,1178,1217-1219,1393,1419$

Bernau-Friedenstal 585

Bernau (Kreis) 568, 585, 641, 1356f., 1364 f., 1372 f., 1447

Bernburg/Saale (Anhalt) 127, 412, 414, 823, 1438,1482

Berndorf (Kr. Liegnitz) (poln. Biernatki) 332

Bernöwe (Kr. Niederbarnim) 1033

Bernstein (Kr. Soldin) (poln. Pełczyce) 369

Bersenbrück bei Osnabrück 1373

Bersenbrück (Landkreis) 1373

Berzdorf (Kr. Strehlen) (poln. Bożnowice) 873

Bessarabien (siehe auch $\rightarrow$ Schwarzes Meer) $39,71,88,91,99,118,193,201,203,213$, 218, 234-236, 285, 312, 314f., 337, 560, 582, 591f., 612, 629f., 652, 696, 784f., 806, 824, 838f., 861, 863, 876, 898, 911, 920, 1177, $1354,1439,1442,1448,1452,1457,1467-$ $1469,1481 \mathrm{f}$.

Bestensee (Kr. Teltow) 99, 209, 221, 469, 496, 544, 585-587, 1102

Betsche (Kr. Meseritz) (poln. Pszczew) 452

Betten (Kr. Luckau) 80, 509

Betzin (Kr. Osthavelland) 395

Beuthen (O.S.) (poln. Bytom) 144f., 328, 479, $745,792,802,888,1438$

Beutnitz (Kr. Crossen) (poln. Bytnica) 735 
Bezki-Pleśno $\rightarrow$ Pleśno-Bezki

Białobrzezie $\rightarrow$ Rotschloß (Kr. Strehlen)

Białowice $\rightarrow$ Billendorf (Kr. Sorau)

Białystok (Polen) 122

Biegen bei Briesen/Mark (Kr. Lebus) 690

Bielawa $\rightarrow$ Langenbielau (Kr. Reichenbach)

Bielawa Dolna $\rightarrow$ Nieder Bielau (Kr. Görlitz)

Bielefeld (Westfalen) 4, 381, 415, 1467, 1541

Bielin $\rightarrow$ Bellin (Kr. Königsberg/Nm.)

Bielinek $\rightarrow$ Bellinchen (Kr. Königsberg/Nm.)

Bienenwerder bei Müncheberg (Kr. Lebus) 1456

Bieniów $\rightarrow$ Benau (Kr. Sorau)

Biernatki $\rightarrow$ Berndorf (Kr. Liegnitz)

Biesdorf (Berlin) $\rightarrow$ Berlin-Biesdorf

Biesenbrow (Kr. Angermünde) 562

Biesenthal (Kr. Oberbarnim) 450, 537, 587-589, $637,975,977,993-995$

Biesenthal-Barnim (Amt) 496, 589

Biesenthal-Danewitz 506

Bilchengrund (Kr. Rybnik) $\rightarrow$ Pilchowitz

Billendorf (Kr. Sorau) (poln. Białowice) 653

Bindow (Kr. Beeskow-Storkow) 1028

Bindow (Kr. Crossen) (poln. Będów) 634

Birkenhain $\rightarrow$ Prenzlau-Birkenhain

Birkenwerder (Kr. Niederbarnim) 536, 590f., 796, 925, 1032

Birkholz bei Beeskow (Kr. Beeskow-Storkow) 1028

Birkholz bei Märkisch Buchholz (Kr. Beeskow-

Storkow) 1028

Birkholz (Kr. Niederbarnim) 1031

Birkholz (Kr. Züllichau-Schwiebus) (poln.

Borów) 664

Birnbaum (Posen) (poln. Międzychód) 794, 907

Birnbaum (Kreis) 110, 124, 217, 496, 548 f., 566, 799, 838, 869, 996

Bischofstal (Kr. Groß Strehlitz) $\rightarrow$ Ujest

Bischofstein (Kr. Rößel) (poln. Bisztynek) 251

Bischofswerda (Sachsen), Lager 172, 225, 688, 785, 1107-1109, 1472

Bisztynek $\rightarrow$ Bischofstein

Bitterfeld 366; Lager 225, 411

Blandikow (Kr. Ostprignitz) 1270

Blankenburg (Kr. Angermünde) 1317

Blankenburg/Harz 290

Blankenfelde (Kr. Teltow) 221, 342, 544, $591 \mathrm{f}$., 630, 1101, 1251, 1391, 1420, 1541; Haus St. Marien der Grauen Schwestern 450, $591 \mathrm{f}$.

Blankensee (Kr. Jüterbog-Luckenwalde) 1222, 1451
Blasdorf (Kr. Lübben) 416

Bleckede (Niedersachsen) 1452

Bleyen (Kr. Königsberg/Nm.) 345, 532, 700

Blorsdorf (Kr. Lübben) $\rightarrow$ Blasdorf

Blossin (Kr. Beeskow-Storkow) 1028

Błotnica $\rightarrow$ Brenkenhofswalde

Blüthen (Kr. Westprignitz) 395

Blumberg bei Berlin (Kr. Niederbarnim) 207, 498, 836, 1034

Blumberg (Kr. Randow) 91

Blumenhagen (Kr. Springe) 1476

Blumenow bei Fürstenberg/Havel 680

Blumenthal (Kr. Ostprignitz) 234, 359, 539, $592 f$.

Bober (Fluss) (poln. Bóbr) 1437, 1443, 1445

Boberhöh (Kr. Crossen) $\rightarrow$ Deutsch Sagar

Boberow (Kr. Westprignitz) 90, 549

Bobolice $\rightarrow$ Bublitz (Pommern)

Bóbr $\rightarrow$ Bober (Fluss)

Bobrek (Oberschlesien) 144f., 1456

Bobrowniki (Kr. Lipno) (1939-1945 Beberen,

Kr. Leipe) 1458

Bochow (Kr. Jüterbog-Luckenwalde) 1042

Bochum 1479

Bockwitz bei Ruhland 620

Bodzanów $\rightarrow$ Langendorf (Kr. Neisse)

Böblingen 378

Böhlen (Sachsen oder Thüringen) 1101

Böhmen (siehe auch $\rightarrow$ Sudetenland, $\rightarrow$ Tschechoslowakei) 78, 228f., 296, 303, 326, 338, 363, 417 f., 505, 801 f., 811, 970, 1441, 1447

Böhmisch Leipa (Sudetenland) (tschech. Česká Lípa) 157, 858, 878, 915

Böhne (Kr. Jerichow II) 45, 1466, 1470

Bölzke (Kr. Ostprignitz) 289

Börnichen (Kr. Lübben) 535, 593; „Waldlager“ 593, 794, 894, 1063

Börnicke (Kr. Niederbarnim) 1032

Bösdorf (Kr. Neisse) (poln. Pakosławice) 825

Bötzow (Kr. Osthavelland) 538, 593f., 1100

Bogdaniec $\rightarrow$ Dühringshof (Kr. Landsberg/W.)

Boitzenburg (Kr. Templin) 91 f., 106, 112, 539 f., 545 f., 594f., 933, 1476

Boizenburg/Elbe (Mecklenburg) 389

Bojadła $\rightarrow$ Boyadel (Kr. Grünberg)

Bolesławiec $\rightarrow$ Bunzlau

Boleszkowice $\rightarrow$ Fürstenfelde

Bomst (poln. Babimost) 97, 100, 320 f., 331 f., 486, 491 f., 495, 540 f., 545, 819 f., 822, 1435 , 1460 
Bomst (Restkreis) 996

Bonn 464, 469, 875, 891, 1364, 1370, 1431

Borek (Kr. Kreuzburg/OS.?) 704

Borgsdorf (Kr. Niederbarnim) 1032, 1099

Borkheide (Kr. Zauch-Belzig) 550, $595 f$.

Bornim (Kr. Osthavelland) $\rightarrow$ Potsdam-Bornim

Bornow (Kr. Beeskow-Storkow) 1028

Bornsdorf (Kr. Luckau) 185

Bornstedt (Kr. Osthavelland) $\rightarrow$ PotsdamBornstedt

Borów $\rightarrow$ Birkholz (Kr. Züllichau-Schwiebus)

Borowo $\rightarrow$ Waldhof bei Schwartow (Kr. Lauenburg)

Borsiglager $\rightarrow$ Guben

Bergen (Kr. Schweidnitz) $\rightarrow$ Borzygniew

Boryszyn $\rightarrow$ Burschen (Kr. Oststernberg)

Boyadel (Kr. Grünberg) (poln. Bojadła) 440

Bożnowice $\rightarrow$ Berzdorf (Kr. Strehlen)

Brädikow (Kr. Westhavelland) 547, 596

Brätz (Kr. Meseritz) (poln. Brójce) 323, 628, 1435

Bralitz (Kr. Königsberg/Nm.) 105, 164, 531, 537, 597

Bramsche 499

Bramstedt, Bad 472

Brandenburg (Provinz, Land) passim

Brandenburg an der Havel 27 f., 55 f., 96, 98, 175, 199, 201, 210 f., 218, 221, 223 f., 395, 428 f., 456 f., 465, 469 f., 482, 509, 549, 597-603, 613f., 649, 754, 782, 843, 849, 874, 954, 987, 996, 1024, 1035, 1103, 1118, 1151, 1154, 1156-1158, 1183, 1185, 1191 f., 1236, 1251, 1275-1277, 1343, 1362, 1367, 1371 f., 1397, 1440, 1456, 1458, 1462; Bahnhöfe 221, 597, 601, 1277; Gedenkstein (Marienberg) 356, 480, 599, 602; Oberlandrat 1188 f., 1192, 1195,1230

- Quenz-Lager 164-166, 172, 182, 185 f., 221, 223, 598-602, 865, 987, 1022-1024, 1062, 1083, 1230, 1251, 1277, 1519

Brandenburg-Görden 73, 597-600

Brandenburg-Hohenstücken, Opel-Siedlung 598; VP-Dienststelle $293 \mathrm{f}$.

Brandenburg-Kirchmöser $\rightarrow$ Kirchmöser

Brandenburg-Plaue $\rightarrow$ Plaue/Havel

Brandenburg (Kreis) 140, 396, 601, 1370 f.f.

Brandenburg (Oberlandratsbezirk) 1189

Brandmühle bei Vetschau (Kr. Calau) 99, 940

Branice $\rightarrow$ Branitz (Kr. Leobschütz)

Braniewo $\rightarrow$ Braunsberg
Branitz (Kr. Cottbus) 527, 619

Branitz (Kr. Leobschütz) (poln. Branice) 632

Braschen (Kr. Crossen) (poln. Brozózka) 740, 925

Brasilien 445, 731

Braszowice $\rightarrow$ Baumgarten

Brauchitschdorf (Kr. Lüben) (poln. Chróstnik) 505

Braunsberg (Kreis) (poln. Braniewo) 222

Braunschweig 14, 204, 207, 211, 379, 412, 555, 569,1542

Braunsdorf (Kr. Beeskow-Storkow) 1028, 1070

Bredenborn (Kr. Höxter) 1458

Bredenfelde (Mecklenburg) 90

Bredereiche (Kr. Templin) 42, 198, 200, 546, 576, 603f., 931, 1480, 1541

Breese (Prignitz) (Kr. Westprignitz) 1140

Breitenau (Kr. Luckau) 656

Breitenstein (Kr. Deutsch Krone) (poln. Dobino) 451

Brekendorf bei Eckernförde 504, 1436

Bremen 205, 208, 725

Brenkenhofswalde (Kr. Friedeberg/Nm.) (poln. Błotnica) 1457

Bresinchen (Kr. Guben) 721

Breslack (Kr. Guben) 83, 196

Breslau (Schlesien) (poln. Wrocław) 67, 94, 104, $128,149,156,173,240,248,321,327-329$, $345,450,503-505,570,577,584,590,595$, $613,623,649,666,734,750,752$ f., 756, 796, $825,837,846,852$ f., $856,870,890,909$, $916,928,939-941,955,1207-1209,1211 \mathrm{f}$., $1258,1268,1403,1413,1436,1444,1458$, 1464, 1473; Bistumsverwaltung 444, 825; Caritas-Geschäftsstelle 451, 620 f., 1250; DDR-Konsulat 143; Deutscher Freundeskreis 870; Domkapitel 826; Festung 321; Graue Schwestern 451, 612; Hedwigschwestern (Mutterhaus) 450 f., 632, 903; Marienschwestern 450, 958; St. Matthias-Gymnasium 427; im Straßennamen 340, 342, 591, 721, 1414, 1416; Theologenkonvikt 825

Breslau-Carlowitz 825

Breslau-Hundsfeld (poln. Psie Pole), Lager 137, 1442

Breslau-Tschansch (1939-1945 Breslau-Ohlewiesen; poln. Wrocław-Księże) 447

Breslau (Erzbistum) 37, 209, 442-445, 451, 559, $573,577,584,590,600,606,613,619$ f., 625 , 
630, 632f., 654, 659, 678, 684, 699, 701 f., 716, 726, 752, 756, 772, 785 f., 789, 796, 800 f., 808, 816, 824f., 842, 873, 881, 900, 906, 909, 912 f., 915, 919, 921, 934, 939, 941, 946 f., 950 f., 1250, 1268, 1417

Bresnitz (Südböhmen) (tschech. Břesnice) 787 Brest (Weißrussland) 907

Brieg (Schlesien) (poln. Brzeg) 84, 153, $210 \mathrm{f}$., 279, 402-404, 413-416, 429, 790, 792

Brieg (Kreis) 210, 389, 402-404, 413-416, 429, 790, 1542

Briescht (Kr. Beeskow-Storkow) 1028

Brieselang (Kr. Osthavelland) 538, 604, 832, $1338 \mathrm{f}$.

Briesen (Kr. Luckau) 935

Briesen (Kr. Westhavelland) 283

Brieskow(-Finkenheerd) (Kr. Lebus) (siehe auch $\rightarrow$ Finkenheerd) 533, 604, 666, 807, 953

Briesnitz (Kr. Frankenstein) (poln. Brzeźnica) $570 \mathrm{f}$.

Brietzig (Kr. Pyritz) (poln. Brzesko) 1454

Britische (Besatzungs-)Zone Deutschlands (auch: „Englische Zone“) 150, 162, 169, 178, 214, 416, 768, 1021, 1035-1037, 1458, 1464

Britz (Kr. Angermünde) 164, 350, 524, 537, 605, 1063, 1313-1315, 1443

Britz (Berlin) $\rightarrow$ Berlin-Britz

Brno $\rightarrow$ Brünn

Brody $\rightarrow$ Pförten (Kr. Sorau)

Brójce $\rightarrow$ Brätz (Kr. Meseritz)

Bromberg (poln. Bydgoszcz) 89, 330, 336, 341, $368,505,927,1438$ f., 1465; im Straßennamen: 339-341, 567 f., 672, 689, 802, 958

Bromberg (Kreis) 215, 341, 863

Broniszów $\rightarrow$ Brunzelwaldau (Kr. Freystadt)

Brotterode bei Schmalkalden (Thüringen) 869

Brozózka $\rightarrow$ Braschen (Kr. Crossen)

Bruchmühle (Kr. Niederbarnim) 1033

Bruchmühle bei Groß Kölzig (Kr. Sorau), Lager 164, 709

Brück/Mark (Kr. Zauch-Belzig) 203, 211, $237 \mathrm{f}$., 279, 456, 481, 493, 496, 549f., 579, 595, 605-607, 937, 1541

Brünn (tschech. Brno) 1444

Brüssow (Kr. Prenzlau) 481, 495, 540, 568, 608, 1443

Brüx (tschech. Most) 189

Brunzelwaldau (Kr. Freystadt) (poln. Broniszów) $620,654,913$
Brusendorf (Kr. Teltow) 1102

Brzeg $\rightarrow$ Brieg (Schlesien)

Brzesko $\rightarrow$ Brietzig (Kr. Pyritz)

Brzeżnica $\rightarrow$ Briesnitz (Kr. Crossen)

Būbliškè (Litauen) $\rightarrow$ Adlig Baubeln

Bublitz (Pommern) (poln. Bobolice) 402

Buch (Berlin) $\rightarrow$ Berlin-Buch

Buchenwald bei Weimar, KZ 242, 249

Buchhain (Kr. Luckau) 1102

Buchholz (Kr. Oberbarnim) 333

Buchholz (Kr. Ostprignitz) 539, 609, 871, 1480

Buchholz (Kr. Zauch-Belzig) 1448

Buckow (Kr. Beeskow-Storkow) 275, 1028, 1086

Buckow (Berlin) $\rightarrow$ Berlin-Buckow

Buckow (Märkische Schweiz) (Kr. Lebus) 96, $386,455,494,533,609 f$., 810, 942, 1542, 1544

Buckow (Kr. Westhavelland) 164, 547, 610

Buczek Wielki $\rightarrow$ Groß Butzig (Kr. Flatow)

Buderose (Kr. Guben) (poln. Budoradz) 84, 196, 615

Bückeburg (Niedersachsen) 224

Bückwitz (Kr. Ruppin) 1454

Bülstringen bei Haldensleben 758

Bündigershof $\rightarrow$ Prenzlau-Bündigershof

Bürgerwiesen (Kr. Landsberg/W.) (poln. Osiedle

Poznańskie) 440

Büschdorf bei Halle/S. 371

Bützer (Kr. Jerichow II) 1439

Bugk (Kr. Beeskow-Storkow) 1028, 1436, 1440

Bukarest (Rumänien) 955

Bukowiec $\rightarrow$ Gramsdorf (Kr. Obornik)

Bukowiec $\rightarrow$ Königsbach bei Lodz

Bukowina 193, 201, 203, 218, 452, 652, 839, 852, 924, 1270, 1399, 1467

Bulgarien (vgl. $\rightarrow$ Balkan) 1008 f., 1438

Bundesrepublik Deutschland

- (bis 1990) $\rightarrow$ Westdeutschland

- (nach 1990) $\rightarrow$ Deutschland

Bunzlau (Schlesien) (poln. Bolesławiec) 803, 1210

Burg (Spreewald) (Kr. Cottbus) 220, 285 f., 472, 948 f., 1446, 1460, 1474

Burg-Dorf (Kr. Cottbus) 1212

Burgstadt bei Lask $\rightarrow$ Pabianitz

Burow (Kr. Westprignitz) 1199

Burschen (Kr. Oststernberg) (poln. Boryszyn) 130, $1345 \mathrm{f}$.

Burxdorf bei Mühlberg/Elbe 1465 
Butterfelde (Kr. Königsberg/Nm.) (poln. Przyjezierze) 1475

Buxtehude (Niedersachsen) 1467

Bydgoszcz $\rightarrow$ Bromberg

Byhleguhre (Kr. Lübben) 1474

Bystrzyca $\rightarrow$ Peisterwitz (Kr. Ohlau)

Bystrzyca Kłodzka $\rightarrow$ Habelschwerdt

Bytnica $\rightarrow$ Beutnitz (Kr. Crossen)

Bytom $\rightarrow$ Beuthen (O.S.)

Bytom-Miechowice $\rightarrow$ Miechowitz

Bzie $\rightarrow$ Goldmannsdorf (Kr. Pleß)

Cadinen (Kr. Elbing) (poln. Kadyny) 1438

Cahnsdorf (Kr. Luckau) 480, 534, $611 f$., 789

- Lager 164, 335, 451, 533 f., 611f., 656, 789

Calau (Kr. Calau) 81, 110, 457, 526, 612f., 620, $711,723,753,941,1199,1230,1253,1460$

Calau (Kreis) 11, 17, 164, 194, 199, 210, 230, 525f., 613, 996, 1035, 1063, 1086, 1100

Calberwisch (Kr. Osterburg, Altmark) 1101

Caminchen (Kr. Lübben) 1467

Cammer (Kr. Zauch-Belzig) 550, 613f.

Cammin (Pommern) (poln. Kamień Pomorski) 704

Cammin (Kreis) 864

Cantdorf $\rightarrow$ Spremberg-Cantdorf

Caputh (Kr. Zauch-Belzig) 164, 221, 550, 614f., 1422,1473

Carlowitz $\rightarrow$ Breslau-Carlowitz

Casel (Kr. Calau) $633 \mathrm{f}$.

Caule (Kr. Luckau) 29, 534

Cedynia $\rightarrow$ Zehden/Oder

Cegielnia $\rightarrow$ Ziegelnia (Kr. Konin)

Celle (Niedersachsen) 107, 472, 823, 1464

Cersk $\rightarrow$ Tschernitz (Kr. Sorau)

Česká Lípa $\rightarrow$ Böhmisch Leipa

Charlottenbrunn, Bad (Kr. Waldenburg) (poln. Jedlina Zdrój) 580

Charlottenburg (Berlin) $\rightarrow$ Berlin-Charlottenburg

Charlottenhof (Kr. Landsberg/W.) (poln. Sosny) 92, 1449

Cheb $\rightarrow$ Eger

Chęciny $\rightarrow$ Sachsdorf (Kr. Guben)

Chełm bei Lublin (Polen) 1446

Chełm Dolny $\rightarrow$ Wartenberg (Kr. Königsberg/ Nm.)

Chełm Górny $\rightarrow$ Hohenwartenberg

Chełmno $\rightarrow$ Kulm (Westpreußen)
Chemnitz (Sachsen) 1100, 1441; Lager 1446

Chile 512

Chlebowo $\rightarrow$ Niemaschkleba (Kr. Guben)

Chlewice $\rightarrow$ Klewitz (Kr. Königsberg/Nm.)

Chocianów $\rightarrow$ Kotzenau (Kr. Lüben)

Chocicz $\rightarrow$ Hermswalde (Kr. Crossen)

Chociule $\rightarrow$ Kutschlau (Kr. Züllichau-Schwiebus)

Chociwel $\rightarrow$ Freienwalde (Pommern)

Chodzież (Kreis) $\rightarrow$ Kolmar (Kreis)

Chojnice $\rightarrow$ Konitz (Westpreußen)

Chojnowo $\rightarrow$ Konradswalde (Kr. Elbing)

Chomiąża $\rightarrow$ Kamöse (Kr. Neumarkt)

Chorin (Kr. Angermünde) 472, 1323

Choszczno $\rightarrow$ Arnswalde

Chotyně $\rightarrow$ Ketten bei Reichenberg

Christburg (Kr. Stuhm) (poln. Dzierzgoń) 560, 656, 1397

Christdorf (Kr. Ostprignitz) 1270

Christianstadt (Bober) (Kr. Sorau) (poln. Krzystkowice) 86, 102, 133, 274, 657, 661, 789, 1461,1463

Chropaczow bei Schwientochlowitz (1909-1922 u. 1939-1945 Schlesiergrube) (Kr. Beuthen/ OS.) (poln. Chropaczów) $328 \mathrm{f}$.

Chróstnik $\rightarrow$ Brauchitschdorf (Kr. Lüben)

Chursdorf (Kr. Soldin) (poln. Mostkowo) 1456

Cibórz $\rightarrow$ Tiborlager

Ciechocinek (Kreis) $\rightarrow$ Hermannsbad (Kreis)

Ciemino (Główczyce) $\rightarrow$ Zemmin (Kr. Stolp)

Ciepielów $\rightarrow$ Tschöplau (Kr. Freystadt)

Cisowo $\rightarrow$ Zizow (Kr. Rügenwalde)

Čistá $\rightarrow$ Lauterbach

Citice $\rightarrow$ Zieditz bei Falkenau/Eger

Clessin (Kr. Lebus) $\rightarrow$ Klessin

Cloppenburg 386

Coburg 211

Collin $\rightarrow$ Kollin

Conradswalde (Kr. Elbing) $\rightarrow$ Konradswalde

Coschen (Kr. Guben) 84, 196, 529, 615

Cosel (Oberschesien) (poln. Kożle) (siehe auch Kandrzin-Cosel) 84

Cottbus 30, 39, 44, 55, 61, 76 f., 101, 104, 130, 181, 199, 208 f., 211, 260, 295, 359, 389, 405 f., 421, 428, 442, 457, 480, 482-484, 496, 503, $507,509,526 \mathrm{f} ., 609,615-624,628,654,657 \mathrm{f}$., 670, 727, 729, 735, 739 f., 751, 753 f., 761, 789, 795, 806, 824, 835 f., 851, 909, 921, 937, 942, 946, 948, 977, 987, 990 f., 996-998, 1000, 1002, 1009, 1010, 1035, 1153 f., 1158 f., 1187, 
$1198,1207,1210-1212,1230,1265-1267$, 1269,1325 f., 1331, 1351-1353, 1403, 1405, $1437,1445,1457-1460,1463,1466,1469 \mathrm{f}$, $1473-1477,1479,1483,1543$

- Altersheime 621-623, 948, 1154

- Altmarkt 1326

- Bahnhof 148, 615-619, 621, 750, $997 \mathrm{f}$., 1352 f., 1405, 1459, 1464, 1474

- Bezirksheim 622, $1357 \mathrm{f}$.

- Bezirkskommandantur 194

- Caritas-Geschäftsstelle (Lausitzer Str./Wilhelm-Külz-Str.) 451, 620 f., 753, 909, 1250, 1269,1543

- Firmen, Betriebe 621, 1326

- Katechetinnenseminar 620,624

- Kath. Pfarrei (Lausitzer Str./Wilhelm-KülzStr. 59) 619, 1264-1267, 1464, 1527

- Krankenhaus 184, 624, 761 f., 948, $761 \mathrm{f}$., 1479

- Lager 76, 99, 416, 527, 618, 621f., 623, 1470

- Landesamt für Soziales und Versorgung bzw. Verwaltung 497, 499f., 623, $835 \mathrm{f}$.

- Lutherkirche 619, 1352, 1414

- Marienkirche 618

- Messehalle 619

- Neues Rathaus (Neumarkt) 616

- Oberlandrat 527, 530, 572, 611, 619, 706, $1011,1230,1251$

- OT-Baracken 617,621

- Rat des Kreises, Amt für Information (Dresdner Str. 84a, Bahnhofstr. 24) 1331, 1333, 1336

- Rat des Bezirks (Neumarkt 5) 143, 1356 f.

- Sozialamt (Thiemstr.) 616

- Südfriedhof 616,620f., 623

- VP-Kreisamt 1351-1353

- Wichernhaus 1352

- Zuchthaus 845

Cottbus-Branitz $\rightarrow$ Branitz (Kr. Cottbus)

Cottbus-Brunschwig 616

Cottbus-Sandow 947; Lokal „Lindengarten“ $1351 \mathrm{f}$.

Cottbus-Schmellwitz $\rightarrow$ Schmellwitz

Cottbus (Bezirk) 143, 252, 295, 352 f., 428, 522, 1356-1358, 1399

Cottbus (Kreis, Landkreis) 11, 199, 208, $210 \mathrm{f}$., 468, 507, 526f., 542, 618 f., 622 f., 739, 796, $835,975,996,1001$ f., 1035, 1086, 1103, 1151, 1153, 1158, 1204, 1210-1213, 1230, 1254, 1265, 1326, 1331, 1333, 1348, 1351 f., 1407
Cottbus (Oberlandratsbezirk) 1158 und öfter

Cottbus (Verwaltungsbezirk) 572, 593, 632, 659, $706,709,744,753,765,783,797,894,910$, 912, 917 f., 946

Criewen (Kr. Angermünde) 522, 524, 624f., 928

Crinitz (Kr. Luckau) 224, 404, 534, 625f., 655, 1102

Crivitz (Mecklenburg) 114, 821

Crossen/Oder (poln. Krosno Odrzańskie) 86, $88,101,103,106,193,275,297,437,488$, $617,647,712,714,750,788,810,1211,1463$, 1471,1479

Crossen (Kreis) 100, 208, 211, 272, 284, 376, 392 f., 411-413, 537 f., 544, 712, 722 f., 739, 799, 947 f., 996, 1000 f., 1344, 1467

Crostau bei Bautzen 32

Crussow (Kr. Angermünde) 1443

ČSR $\rightarrow$ Tschechoslowakei

Cüstrin $\rightarrow$ Küstrin

Culm $\rightarrow$ Kulm (Westpreußen)

Culm (Bistum) 445

Cybinka $\rightarrow$ Ziebingen

Cychry $\rightarrow$ Zicher (Kr. Königsberg/Nm.)

Czarne $\rightarrow$ Hammerstein (Westpreußen)

Czarnikau (1940-1945 Scharnikau) (Kreis) (poln. Czarnków) 120, 216, 368, 837

Czarnowice $\rightarrow$ Tzschernowitz (Kr. Guben)

Czechoslovakei $\rightarrow$ Tschechoslowakei

Czelin $\rightarrow$ Zellin (Kr. Königsberg/Nm.)

Czernowitz (Bukowina) (ukrain. Tscherniwzi) 452,1443

Czerwieńsk $\rightarrow$ Rothenburg/Oder

Czólnów $\rightarrow$ Zollen (Kr. Soldin)

Dabendorf (Kr. Teltow) 44, 89, 164, 171, 544, $626,827 \mathrm{f}$.

Dabergotz (Kr. Ruppin) 137, 541

Dąbie $\rightarrow$ Gersdorf (Kr. Crossen)

Dąbie $\rightarrow$ Stettin-Altdamm

Dąbroszyn $\rightarrow$ Tamsel (Kr. Landsberg/W.)

Dabrowice (Dombrowice, 1943-1945 Dommstätt) bei Kutno (Polen) (poln. Dąbrowice) 965, 1443

Dąbrówka $\rightarrow$ Deppen (Kr. Heilsberg)

Dąbrówno $\rightarrow$ Gilgenburg (Kr. Osterode)

Dachau, KZ 307, 921

Dänemark 68, 81, 151, 878, 1034 f., 1037 f., 1482

- Lager 207, 222

Dahlem (Berlin) $\rightarrow$ Berlin-Dahlem 
Dahlenburg (Kr. Bleckede) 108, 221

Dahlhausen (Kr. Ostprignitz) 593

Dahlwitz-Hoppegarten (Kr. Niederbarnim) 1033

Dahme/Mark (Kr. Jüterbog-Luckenwalde) 27, 44, 217, 232, 447, 456, 530, 627-629, 1198 f., $1222,1247,1306,1459$

Dahme-Spreewald (Landkreis) 18, 111, 140, 544, 798 f., 1543

Dahmsdorf (Kr. Beeskow-Storkow) 1028, 1205

Dahmsdorf (Kr. Lebus) $\rightarrow$ Müncheberg-Dahmsdorf

Dahmshöhe (Kr. Templin) $\rightarrow$ Altthymen-Dahmshöhe

Dallgow (Kr. Osthavelland) 221, 332, 538, 629f., 1100

Dallgow-Döberitz $\rightarrow$ Döberitz (Kr. Osthavelland)

Dallmin (Kr. Westprignitz) 297, 1437, 1471, 1480

Dalneje $\rightarrow$ Schirgupönen (Kr. Gumbinnen)

Damasławek $\rightarrow$ Elsenau (Kr. Wongrowitz)

Damelack bei Breddin (Kr. Ostprignitz) 1476

Damerow [Welches?] 218

Damsdorf (Kr. Zauch-Belzig) 601, 1370

Dammvorstadt $\rightarrow$ Frankfurt (Oder)

Danewitz (Kr. Oberbarnim) $\rightarrow$ BiesenthalDanewitz

Danków $\rightarrow$ Tankow (Kr. Friedeberg/Nm.)

Dannenberg/Elbe 85, 92, 106

Dannenreich (Kr. Beeskow-Storkow) 1028, $1147 \mathrm{f}$.

Dannenwalde bei Fürstenberg/Havel 226, 680, 704

Dannhof (Kr. Westprignitz) 1140

Danzig (poln. Gdańsk) 102, 143, 150, 199, 203, $219,327,345,368,402,438,449,523,525-$ 527, 529 f., 532, 534-541, 543 f., 546-548, 550, 560-562, 587, 595, 599, 601, 619, 637, $659,667,673,715,752,754,823,847,876$, $878,921,929,958,1064,1066,1231,1261$, 1342-1344, 1356, 1372, 1453, 1468, 1483; im Straßennamen: 340-342, 671, 721, 792, 871, 927, 958, 1414

Danzig-Langfuhr (poln. Gdańsk-Wrzeszcz) 628

Danzig (Bistum) 445, 628, 826, 1343

Danzig-Westpreußen (Reichsgau) 203, 215, 232, 234

Dargomyśl $\rightarrow$ Darrmietzel (Kr. Königsberg/Nm.)

Darmstadt 233

Darnawa $\rightarrow$ Dornau (Kr. Züllichau-Schwiebus)

Darritz (Kr. Ruppin) 821
Darrmietzel (Kr. Königsberg/Nm.) (poln. Dargomyśl) 696, $1440 \mathrm{f}$.

DDR (Deutsche Demokratische Republik) („SBZ“ nach $1949 \rightarrow$ Sowjetische Besatzungszone) passim; „Mitteldeutschland“ 232, 329, 339, 378f., 380, 385, 390, 398, 853, 1228 und öfter; „Mittelzone“ 373, 394f.; „Ostzone“ 179, 230 f., 248, 270, 367, 386, 390-392, 442, 1095, $1137,1169,1217,1243,1289,1299,1335$, 1343, 1354 und öfter; „Sowjetzone“ 390-392; „Zone“ 394

Dębno $\rightarrow$ Schöneiche (Kr. Wohlau)

Dębowiec $\rightarrow$ Dembowitz (Kr. Neidenburg)

Dechsel (Kr. Landsberg/W.) (poln. Deszczno) 440

Dechtow (Kr. Osthavelland) 821

Děčín $\rightarrow$ Tetschen(-Bodenbach)

Deetz (Kr. Soldin) (poln. Dziedzice) 71, 1454

Deggendorf (Niederbayern) 1444

Deibow (Kr. Westprignitz) 270, 783, 1139

Deisenhofen (Bayern) 1399

Delitzsch 1455

Dembowitz (Kr. Neidenburg) (1938-1945 Eichenau) (poln. Dębowiec) 1456

Demerthin (Kr. Ostprignitz) 777

Demker (Kr. Stendal) 1451

Demmin (Kreis) 192

Dennewitz (Kr. Jüterbog-Luckenwalde) 1042

Deppen (Kr. Heilsberg) (poln. Dąbrówka) 1274

Derenburg (Harz) 31, 299

Dergenthin (Kr. Westprignitz) 107, 217, 548

Deszczno $\rightarrow$ Dechsel (Kr. Landsberg/W.)

Dessau (Anhalt) 209, 1342

Dessau-Köthen (Kreis) 1002

Dessow (Kr. Ruppin) 155

Detmold (Lippe) 26, 415, 435, 1461, 1465

Detmold-Hiddessen 435

Deulowitz (Kr. Guben) 1297

Deutsche Demokratische Republik $\rightarrow$ DDR

Deutschendorf (Zips) (slowak. Poprad), Lager 236, 937

Deutschhof (Kr. Osthavelland) 1111

Deutsch Karstnitz (Kr. Stolp) $\rightarrow$ Karstnitz

Deutsch Krone (Westpreußen, 1938-1945 Pommern) (poln. Wałcz) 192, 342, 378, 495, 777, 924, 1438

Deutsch Krone (Kreis) 94, 192, 378, 863

Deutschland (siehe auch $\rightarrow$ Amerikanische (Besatzungs-)Zone, $\rightarrow$ Britische (Besat- 
zungs-)Zone, $\rightarrow$ DDR, $\rightarrow$ Französische (Besatzungs-)Zone, $\rightarrow$ Mittel-, $\rightarrow$ Nordwest-, $\rightarrow$ Sowjetische Besatzungszone, $\rightarrow$ Süd-, $\rightarrow$ Westdeutschland, $\rightarrow$ Westzonen) 1010, 1023, 1040, 1042f., 1095, 1114, 1116, 1145, 1152, 1159, 1168, 1174f., 1193, 1215-1217, $1228,1235,1241,1245,1249,1273,1284 \mathrm{f}$., 1288-1290, 1292-1296, 1300, 1303, 1305 f., 1307, 1310-1312, 1322, 1327, 1336, 1355, 1358,1360 , 1365 f., 1375, 1391, 1394, $1397-$ $1400,1402,1406,1415-1417$ und öfter

- Deutsches Reich 24, 72, 75, 78, 86 f., 93, 100, $123,155,169,229,235,569,596,727,738$, 998, 1118, 1396-1399

- Ostgebiete, historische $\rightarrow$ Polen, Westgebiete

- Ostgrenze $\rightarrow$ Polen, Westgrenze

Deutsch-Litta (Kr. Kremnitz), Slowakei (slowak. Kopernica) $1350 \mathrm{f}$.

Deutsch Nettkow (Kr. Crossen) (1937-1945 Straßburg/Oder; poln. Nietkowice) 634,786

Deutsch Sagar (Kr. Crossen) (1937-1945 Boberhöh) (poln. Nowy Zagór) 103, 624, 629, 723, 740, 812, 1459

Deutsch Wartenberg (Kr. Grünberg) (poln. Otyń) 211, 527, 919

Diedersdorf (Kr. Lebus) 908, 1478

Diedersdorf (Kr. Teltow) 544, 630, 1471

Diensdorf (Kr. Beeskow-Storkow) 1028

Dierberg (Kr. Ruppin) 821

Dietfurt (Kreis) $\rightarrow$ Znin

Dievenow (Kr. Cammin) $\rightarrow$ Berg-Dievenow

Dirschau (Westpreußen) (poln. Tczew) $340 \mathrm{f}$., 671f., 689, 927, 1471

Dissen (Kr. Cottbus) 1213

Dissenchen (Kr. Cottbus) 1213

Dittersbach (Kr. Sagan/Sprottau) (poln.

Dzietrzychowice) 447

Dittersdorf (Sachsen oder Thüringen) 366

Dnjepr (Fluss) 875

Dobberzin (Kr. Angermünde) 1455

Doberan, Bad (Mecklenburg) 562, 1434, 1450

Doberlug(-Kirchhain) (Kr. Luckau) (siehe auch

$\rightarrow$ Kirchhain) 443, 457, 534, 630, 1463, 1466

Dobersaul (Kr. Crossen) (1937-1945 Schönrode/Mark) (poln. Dobrosułów) 1456

Dobiegniew $\rightarrow$ Woldenberg/Nm.

Dobino $\rightarrow$ Breitenstein (Kr. Deutsch Krone)

Dobre Miasto $\rightarrow$ Guttstadt

Dobrojewo $\rightarrow$ Johanneswunsch
Dobrosułów $\rightarrow$ Dobersaul (Kr. Crossen)

Dobrudscha 99, 219, 235 f., 337, 602, 951, 1265, 1354f., 1482

Dobrzyń $\rightarrow$ Döbern (Kr. Guben)

Döbeln (Sachsen) 396

Döberitz (Kr. Osthavelland) 538, 631, 964, $1279 \mathrm{f} .(?)$

Döberitz (Kr. Westhavelland) 164, 547, 631, 877, 1063

Döbern (Kr. Guben) (poln. Dobrzyń) 195, 763

Döbern (Niederlausitz) (Kr. Sorau) 164, 404, 457, 542 f., 631-633, 659, 944; Caritasheim $447,450,632$

Dölitz (Pommern) (Kr. Pyritz) (poln. Dolice) 1453

Dömitz (Mecklenburg) 106 f., 1455

Dörna (Kr. Mühlhausen) 1469

Dörstewitz bei Halle (Saale) 1444

Doksy am Mácha-See $\rightarrow$ Hirschberg am See

Dolgelin (Kr. Lebus) 375, 891, 1350

Dolgen (Kr. Prenzlau) 113, 541

Dolgenbrodt (Kr. Beeskow-Storkow) 1028

Dolice $\rightarrow$ Dölitz (Pommern)

Dolní Poustevna $\rightarrow$ Nieder Einsiedel

Dołuje $\rightarrow$ Neuenkirchen bei Stettin

Domaszków $\rightarrow$ Ebersdorf

Dombrowice (Polen) $\rightarrow$ Dabrowice

Dommstätt bei Kutno $\rightarrow$ Dabrowice

Domnau (Kr. Bartenstein) (russ. Domnowo) 74

Domnowo $\rightarrow$ Domnau (Kr. Bartenstein)

Donbass (Donezbecken), Ukraine 1463

Dorf Zinna $\rightarrow$ Neuheim

Dornau (Kr. Züllichau-Schwiebus) (poln. Darnawa) 1468

Dortmund 242, 660, 1542; -Barop 1327; -Hörde 1277

Drachhausen (Kr. Cottbus) 527, 633

Drągowina $\rightarrow$ Neuwaldau (Kr. Freystadt)

Drahendorf (Kr. Beeskow-Storkow) 1028

Dramburg (Pommern) (poln. Drawsko Pomorskie) 495, 503, 924, 1456

Dramburg (Kreis) 864

Dranse (Kr. Ostprignitz) 1270

Drawsko Pomorskie $\rightarrow$ Dramburg

Drebkau (Kr. Calau) 496, 526, 633f., 1459, 1483

Dreetz (Kr. Ruppin) 361 f., 1209

Drehna (Kr. Luckau) $\rightarrow$ Walddrehna

Drehnow (Kr. Cottbus) 492, 496, 527, $634 f$. 
Drehnow (Kr. Crossen) (poln. Drzeniów) 422, 970

Drenzig (Kr. Weststernberg) (poln. Drzeńsko) 195, 763

Dresden $11,48,61,88,103,251,266,307,386$, 402 f., 577, 647, 656, 1343, 1405, 1440, 1446, 1458, 1470; Lager 1468; SED 252

Dresden (Bezirk) 252, 353

Dresden (Kreis) 252, 407

Dresden-Meißen (Bistum) 460, 484, 620, 826, 1527

Drewitz $\rightarrow$ Potsdam-Drewitz

Driesen (Kr. Friedeberg/Nm.) (poln. Drezdenko) 206, 368, 1457, 1459

Drögen $\rightarrow$ Fürstenberg-Drögen

Drößig bei Finsterwalde (Kr. Luckau) 416

Drołtowice $\rightarrow$ Rudelsdorf (Kr. Groß Wartenberg)

Drossen (Kr. Weststernberg) (poln, Ośno Lubuskie) 367 f., 379, 384 f., 491, 493 f., 644, 664, $672,1420,1445,1452$

Drzeniów $\rightarrow$ Drehnow (Kr. Crossen)

Drzeńsk Mały $\rightarrow$ Klein Drenzig (Kr. Guben)

Drzeńsk Wielki $\rightarrow$ Groß Drenzig (Kr. Guben)

Drzeńsko $\rightarrow$ Drenzig (Kr. Weststernberg)

Drzonowo $\rightarrow$ Schönau (Kr. Schlochau)

Dubeningken (Kr. Goldap) (1938-1945 Dubeningen) (poln. Dubeninki) 74, 844

Duderstadt 1451

Dühringshof (Kr. Landsberg/W.) (poln. Bogdaniec) 1443

Dürrkunzendorf (Kr. Glatz) (poln. Suszyna) 54

Dürrlettel (Kr. Meseritz) (poln. Lutol Suchy) 820

Dürwangen (Kr. Rößel) (Łężany) 934

Düsseldorf 20, 72

Dux (Sudetenland) (tschech. Duchcov) 416

Dyszno $\rightarrow$ Ringenwalde (Kr. Soldin)

Działdowo $\rightarrow$ Soldau

Dzialyn (Kr. Gnesen) (1939-1945 Sprengersfelde) (poln. Dzialyń) 890

Dziedzice $\rightarrow$ Deetz (Kr. Soldin)

Dzierzgoń $\rightarrow$ Christburg

Dzierżoniów $\rightarrow$ Reichenbach (Schlesien)

Dzietrzychowice $\rightarrow$ Dittersbach

Dziwnów $\rightarrow$ Berg-Dievenow (Kr. Cammin)

Ebersdorf (Kr. Habelschwerdt) (poln. Domaszków) 596

Eberswalde 11, 18, 45, 68, 94, 96, 105, 127, 164, 166, 184 f., 199, 221, 448 f., 455, 459 f., 469,
$482,495,501,512$ f., 537, 566, 585, 635-643, 646, 803, 870, 1035, 1103, 1151, 1188, $1196 \mathrm{f}$., 1204, 1206, 1230, 1250, 1364, 1372 f., 1434, 1440, 1457, 1463 f., 1474, 1482, 1543; Krankenhäuser 96, 116, 185, 636, 640; Lager 164, $166,537,635$ f., 638 f., 889, 1062, 1188, 1230; Migrationsberatungsstelle des BdV 471, $641 \mathrm{f}$.; Oberlandrat 263, 639, 1250

Eberswalde (Kreis) 488, 568, 585, 641 f., 1364 f., $1372 \mathrm{f}$.

Eger (Sudetenland) (tschech. Cheb) 94

Eggersdorf (Kr. Niederbarnim) 1033

Eichberge bei Paulinenaue (Kr. Westhavelland) 316

Eiche (Kr. Niederbarnim) 1033

Eiche (Kr. Osthavelland) $\rightarrow$ Potsdam-Eiche

Eichenau (Kr. Neidenburg) $\rightarrow$ Dembowitz

Eichenbrück $\rightarrow$ Wongrowitz

Eichhorst (Kr. Niederbarnim) 1034, 1099

Eichow (Kr. Cottbus) 1213

Eichsfeld 442

Eichstädt (Kr. Osthavelland) 940

Eichwalde (Kr. Teltow) 45, 83, 178, 194, 323, 386, 491, 493 f., 544, 643f., 814, 943, 1102 , 1199,1446

Eidlitz bei Komotau (Sudetenland) (tschech. Údlice) 1448

Eifel 1466

Einbeck (Niedersachsen) 919

Eisenach 103, 411 f., 1270, 1340, 1437 f., 1454, 1541

Eisenhüttenstadt (1953-1961 Stalinstadt) (siehe auch $\rightarrow$ Fürstenberg (Oder)) 19, 23, 27, 29, 49, 144, 196, 237, 267, 280, 295, 335, 352, $354,428,457,496,498,682-686,1415,1541$, 1544; Eisenhüttenkombinat Ost, EKO-Stahlwerk 18, 29, 144, 280, 295, 352, 683, 685

Eisenhüttenstadt (Kreis) 355, 514, $684 \mathrm{f}$.

Eisleben (Sachsen-Anhalt) 1188

Eitelsdorf (Kr. Znin) $\rightarrow$ Nowawies

Elbe (Fluss) 92, 107-109, 265, 290, 340, 399, 683, 731, 871, 956 f., 1405f., 1446, 1454, 1459

Elbe-Elster (Landkreis) 656, 948

Elbing (Westpreußen) (poln. Elbląg) 27, 342, 370

Elbing (Kreis) 861

Elbląg $\rightarrow$ Elbing (Westpreußen)

Elde (Fluss) 290

Ełk $\rightarrow$ Lyck 
Ellguth Turawa (Kr. Oppeln) (poln. Ligota Turawska) 186

Elsaß (französ. Alsace) 1265

Elsenau (Kr. Wongrowitz) (poln. Damasławek) $106,549,839,1446$

Elsholz (Kr. Zauch-Belzig) 1199

Elsterhorst bei Hoyerswerda, Lager 168, 172

Elsterwerda 656

Emden (Niedersachsen) 1466

Engelsburg bei Milmersdorf (Kr. Templin) 164, $166,172,546,645,931,933,1063,1230$

Engelskirchen (Bergisches Land) 900

England $\rightarrow$ Großbritannien

Englische Zone $\rightarrow$ Britische Zone

Erfurt 127, 229, 385, 404, 654, 657, 826, 1439

Ergoldsbach (Niederbayern) 414

Eritrea 667

Erkner (Kr. Niederbarnim) 164, 450, 455, 460 f., 482, 536, 645f., 704, 826, 967, 1032, 1354, 1472

Erlbach (Vogtland), Kinderheim 225

Ermland (poln. Warmia) 143, 442, 458 f., 671, 1208,1391

Ermland (Bistum) 442, 445, 459, 752 f., 896, 954

Ernst-Thälmann-Siedlung $\rightarrow$ Ziltendorf

Erpfingen (Kr. Reutlingen) 1148

Ervěnice $\rightarrow$ Seestadtl (bei Komotau)

Erzgebirge 42, 198, 294, 298, 487, 1137, 1440, 1451

Essen (Ruhr) 396, 731, 796, 1541

Essen, Bad (Niedersachsen) 378

Estland 78, 199, 233, 569, 759, 860, 863, 935, 957, 959, 1452

Etashof bei Hammelspring (Kr. Templin) 1472

Etzin (Kr. Osthavelland) 1449

Europa 331, 472, 511-513, 662, 673, 684, 811, $854,907,960,1327,1360-1362,1365-1368$, 1378, 1406; Europäische Union 21, 235, 512, 565,684

Euskirchen 465

Fahlenwerder (Kr. Soldin) (poln. Ściechów) 441

Fahrland (Kr. Osthavelland) 857

Falkenberg (Berlin) $\rightarrow$ Berlin-Falkenberg

Falkenberg (Kr. Beeskow-Storkow) 1028

Falkenberg/Mark (Kr. Oberbarnim) 207 f., 537, 567, $646 f$.

Falkenberg bei Liebenwerda 1445

Falkenhöh, Lager $\rightarrow$ Falkensee, Lager Agneshof
Falkenrehde (Kr. Osthavelland) 470, 833, 852, 1464

Falkensee (Kr. Osthavelland) 30, 53, 175, 273, 289, 299, 310, 325 f., 365 f., 399, 456, 538, 647-650, 920, 1100, 1199, 1446, 1455, 1471, 1480, 1541; Lager Agneshof (Falkenhöh, Berlin-Albrechtshof) 26, 34, $166 \mathrm{f}$., 170, 172-175, 225, 538, 648-650, 852, 980, 1062, 1079-1082, 1230, $1253 \mathrm{f}$.

Falkensee-Finkenkrug 225, 273, 649, 1461

Falkensee (Kirchenkreis) 436

Falkenthal (Kr. Templin) 1280

Fangschleuse (Kr. Niederbarnim) 1460

Fehrbellin (Kr. Osthavelland) 27, 395, 456 f., $538,651,811,1100,1111 \mathrm{f}$.

Felchow (Kr. Angermünde) 164, 524, 651

Feldberg (Mecklenburg) 862

Feldheim (Kr. Wittenberg) 329

Felgentreu (Kr. Jüterbog-Luckenwalde) 221, 530, $651 f ., 1246$

Ferch (Kr. Zauch-Belzig) 550, 652

Ferchesar (Kr. Westhavelland) 416, 920

Fichtelgebirge 327

Fichtenau $\rightarrow$ Schöneiche-Fichtenau

Fiddichow (Kr. Greifenhagen) (poln. Widuchowa) 1454

Filehne (Posen) (poln. Wieleń) 96, 368, 548, $869,872,892,919,931$

Finkenheerd (Kr. Lebus) (siehe auch $\rightarrow$ BrieskowFinkenheerd) 341, 399f., 672; Grube 1187

Finkenhübel bei Dürrkunzendorf (Kr. Glatz) (poln. Mrówieniec) 54

Finkenkrug $\rightarrow$ Falkensee-Finkenkrug

Finow bei Eberswalde (Kr. Oberbarnim) 68, 112, 537, 638, 652f., 809, 841, 1481 f.; „Waldlager“ 653

Finowfurt (Kr. Oberbarnim) 127, 641, 1464

Finsterwalde (Kr. Luckau) 41, 55, 80, 99, 104, 222, 405, 457, 498 f., 509, 534, 612, 625 f., 653-657, 699, 753, 913, 971, 977, 983, 997 f., 1154 f., 1230, 1368 f., 1444, 1452, 1544; Lager Wiesenhain $166,172,534,658-660,1062,1230,1539$

Finsterwalde (Kreis) 656, $1368 \mathrm{f}$.

Fitzerie (Kr. Czarnikau) (poln. Marunowo) 106

Fläming 237, 606

Flatow (Kr. Osthavelland) 1519

Flatow (Westpreußen bzw. Grenzmark PosenWestpreußen, 1938-1945 Pommern) (poln. Złotów) 104, 495, 878 f., 868 
Flatow (Kreis) 104

Flemsdorf (Kr. Angermünde) 523

Flensburg 340, 792

Flessenow (Mecklenburg), Lager 169

Flieth (Kr. Templin) 112, 1476

Flinsberg, Bad (Kr. Löwenberg) (poln. Świeradów-Zdrój) 683

Förderstedt (Kr. Calbe) 1100

Försterei Tschinka (Kr. Beeskow-Storkow) 1070

Fohrde (Kr. Westhavelland) 598

Fontanka $\rightarrow$ Petricken (Kr. Labiau)

Forst (Lausitz) 26, 99, 102, 148 f., 151, 156, 164, $177,199,208,212,268,274,277,292,295$, $348,371,389,391,405$ f., 420, 457, 467, 483, 495, 530, 550, 616, 632, 657-661, 706, 745, 761, 836, 852, 912, 977, 1003, 1008-1011, $1020,1035,1039,1154,1210,1212,1239$, $1250,1304,1325,1412,1435,1438,1445$, 1450, 1460 f., 1464, 1470, 1474f., 1542; Lager 579, 1003, 1008 f., 1022, 1152, 1230, 1239; Lager Hotel Kaiserhof 164, 173, 659, 661, 1009, 1062; Lager Jahnschule 164, 167 f., 172 f., 659-661; Neißebrücke 137, 658

Forst-Noßdorf 542, 661

Forst (Kreis) 199, 202, 210, 260, 542 f., 619, 660, 1151, 1204, 1230

Forst Zinna (Kr. Jüterbog-Luckenwalde) 304; Lager 979, 1058

Franken 102, 327

Frankenberg (Sachsen) 27

Frankenfelde (Kr. Jüterbog-Luckenwalde) 530, 662,852

Frankenhausen, Bad 1471

Frankenstein in Schlesien (poln. Ząbkowice Śląskie) 1446

Frankfurt am Main 211, 379, 452

Frankfurt (Oder) 15, 27, 32 f., 39-41, 55, 61, 81, 84 f., 87, 98, 101, 114f., 120, 124, 127, 137, 149, 188, 190 f., 196, 199, 273, 275, 288-290 f., 293, 298, 333 f., 340 f., 343 f., 347, 351-353, 355,357 f., 372 f., 409 f., 412 , 418, 420 f., 424, 428, 440 f., 447, 455, 471, 474, 477, 480, 494 f., 507, 532, 582, 609f., 662-675, 692, 701, 721, $727,758,771,773,794,806-808,843,852$, $875,906,908,912,929,942,945,950,952 \mathrm{f}$., 1020, 1022-1024, 1035, 1039 f., 1083, 1103 , 1108, 1151 f., 1158, 1204, 1230, 1249, 1271, $1273,1275,1304,1341$ f., 1354, 1403-1407, $1412,1415,1420,1436,1438,1445-1447$,
1450, 1453-1456, 1458-1461, 1464 f., 1467 f., 1471-1474, 1476f., 1479-1481, 1541 f., 1544

- Brücken 662-664, 666, 670, 674f., 14031405, 1416f., 1453, 1457, 1459, 1463, 1466

- Dammvorstadt (poln. Słubice) 32f., 39, 86, 418, 420, 428, 471, 494, 663 f., 667, 670f., 672-675, 772, 1404-1406, 1452, 1474; Sowjet. Speziallager Nr. 6: 183, 670, 673, 739, 1406, 1480

- Elektrizitätswerke (Kameradschaftsheim Fischerstraße) 124

- Firma Schütz \& Bethke 288f., 343 f., 1206, 1444

- Friedensglocke 355, 671, 1415

- Friedhöfe 675, 1407

- Grenzbahnhof 1463

- Gubener Vorstadt 663, 1405

- Güterbahnhof 291

- Hansaviertel 341

- Hauptbahnhof $663 \mathrm{f}$.

- Haus der DSF 1414

- Haus der Künste 666

- Heimkehrer-Krankenhaus Horn-Kaserne (Nuhnenstr.) 669f., 674, 676, 1041

- Heimkehrer-Lazarett 669 f., 1450

- Heimkehrer-Mahnmal 669f., 674, 676

- Heimkehrerlager Kleist-Kaserne 673, 1480

- Kasernen 291,298,669f.

- Krankenhäuser 184,188,358f.,669f.,674, 1342

- Lebuser Vorstadt 663,1405

- Lippehner Straße 344, 671f., 1206

- Lutherstift 433,669,929

- Marienkirchengemeinde 440 f., 1342

- Marienstift 446f., 668, 674

- Musikerviertel 341

- Notkrankenhaus (Halbe Stadt) 188, 1449

- NS-Frauenschaftsküche (Junkerstr.) $124 \mathrm{f}$.

- NSV-Gauamt, Zentralstelle für vermisste Flüchtlinge (Halbe Stadt 7) 662, $1403 \mathrm{f}$.

- Oderbrücken, -übergang 193, 275, 410, 418, 420, 662-664, 666, 670, 674f., 806, 1342

- „Ostmarksiedlung“ (Paulinenhof) 73, 341, 662, $671 \mathrm{f}$.

- RAD-Küchenanlagen (Gubener Str. 9) 124

- Rat des Bezirkes (Wilhelm-Pieck-Str. 3/4) 249, 897, 1356

- Realgymnasium 1461

- Regierung 93, 101, 616, 663, 844f., 1405

- Schulen 119, 124, 188, 298 f., 333 f., 663, 1404 
- Seuchenkrankenhaus (Junkerstr.) 188

- Straßennamen 340 f., 343 f., 671 f., 1416

- VP-Bezirksbehörde (Wilhelm-Pieck-Str. 53) $1353 \mathrm{f}$.

- Wehrbezirkskommandantur81,663,1405,1482

Frankfurt-Beresinchen 663, 1404

Frankfurt-Dammvorstadt $\rightarrow$ Frankfurt (Oder)

Frankfurt-Gronenfelde 675-677; Heimkehrerlager 27, 40 f., 46, 53, 165, 167 f., 172, 251, 667, 670, 675-677, 689, 843, 978, 1039-1041, 1043-1045, 1087, 1108, 1230, 1239, 1249, $1391,1436,1458,1473,1481$

Frankfurt-Güldendorf $\rightarrow$ Güldendorf (Kr. Lebus) Frankfurt-Kliestow $\rightarrow$ Kliestow (Kr. Lebus)

Frankfurt-Neuberesinchen 671

Frankfurt-Rosengarten $\rightarrow$ Rosengarten (Kr. Lebus)

Frankfurt (Oder) (Bezirk) 295, 353; 428, 496 f., $504,522,672,903,1353,1439$

Frankfurt (Oder) (Landkreis) 75, 529, 667, 672, 796, 1103, 1151, 1348, 1352, 1419, 1477

Frankfurt (Oder) (Regierungsbezirk) 443

Frankreich 72, 133, 331, 511, 569, 654, 656, 716, $728,774,811,938,943,1291,1310,1335$, $1439,1456,1462$

Französische (Besatzungs-)Zone Deutschlands 162, 1035-1037

Frauenburg (Ostpreußen) (poln. Frombork) 489,1465

Frauendorf (Kr. Cottbus) 527

Frauendorf (Kr. Randow) (poln. Szczecin Golęcino), Krankenhaus 864

Frauendorf (Kr. Weststernberg) (poln. Pamięcin) 1454

Fraustadt (Provinz Posen/Grenzmark, 19381945 Schlesien) (poln. Wschowa) 789, 905

Fraustadt (Kreis) 100, 542, 623, 702 f., 996, 1476

Fredersdorf (Kr. Niederbarnim) 61, 221, 323, 1033, 1099, 1466

Fredersdorf (Kr. Zauch-Belzig) 1541

Frehne (Kr. Ostprignitz) 803

Freiburg im Breisgau 30, 56, 1543

Freienhagen (Kr. Niederbarnim) 536, 677, 1033

Freienthal (Kr. Zauch-Belzig) 605

Freienwalde/Oder, Bad (Kr. Oberbarnim) 28, 33, 93, 100 f., 105, 112, 196, 207 f., 216, 221 f., 248, 339 f., 395, 455, 466, 472, 487, 495, 507, $531,537,548,566-569,641,646,829,853$, 906, 962, 996, 1188, 1206, 1243 f., 1273, 1440,
1443, 1449, 1457, 1481, 1542; Lager 164, 537, 566f., 569, 961, 1063, 1188

Freienwalde/Oder, Bad (Kreis) 568, 585, 641, 1364f., $1372 \mathrm{f}$.

Freienwalde (Pommern) (Kr. Saatzig) (poln. Chociwel) 1449

Freileben bei Herzberg/Elster 30, 312, 1472

Freital (Sachsen) 233

Freiwaldau (Sudetenland) (tschech. Jeseník) 909

Fretzdorf (Kr. Ostprignitz) 460, 1270

Freudenberg (Kr. Rößel) (poln. Radostowo) 896

Freyenstein (Kr. Ostprignitz) 454, 460, 539, 677f., 960, 1270, 1448

Freystadt in Schlesien (poln. Kożuchów) 104, $210,483,620,789,1464,1527$

Freystadt in Schlesien (Kreis) 100, 104, 135, 210 f., 284, 526 f., 549, 597, 760 f., 996

Friedeberg/Nm. (poln. Strzelce Krajeńske) 206, $214,255,368,428,435,494,564,888,1205$, 1457

Friedeberg/Nm. (Kreis) 94, 206f., 213, 435

Friedeberg-Woldenberg Nm. (Kirchenkreis) 435

Friedenau $\rightarrow$ Berlin-Friedenau

Friedensfeld (Bessarabien) (ukrain. Myrnopillya) 218

Friedenstal $\rightarrow$ Bernau-Friedenstal

Friedersdorf (Kr. Beeskow-Storkow) 1028, 1069, 1074, $1234 \mathrm{f}$.

Friedersdorf (Kr. Grünberg) (poln. Ługi) 527

Friedland [Welches?] 556

Friedland (Böhmen) $\rightarrow$ Friedland im Isergebirge

Friedland (Niederlausitz) (Kr. Lübben) 495, 535, 678

Friedland (Niedersachsen), Lager 499f., 836, 1442

Friedland im Isergebirge (Sudetenland) (tschech. Frýdlant v Čechách) 157, 231, 395, 574, 579

Friedrichsaue (Kr. Lebus) 96, 99, 112, 121, 132, 1479

Friedrichsfelde (Berlin) $\rightarrow$ Berlin-Friedrichsfelde

Friedrichshafen (Bodensee) 599

Friedrichshagen (Berlin) $\rightarrow$ Berlin-Friedrichshagen

Friedrichshain (Berlin) $\rightarrow$ Berlin-Friedrichhain

Friedrichshain (Niederlausitz) (Kr. Spremberg) 416

Friedrichshof (Kr. Beeskow-Storkow) 1028

Friedrichshof bei Walkendorf (Mecklenburg) 1438

Friedrichsthal (Kr. Niederbarnim) 1033 
Friesack (Kr. Westhavelland) 164, 283, 456 f., 496, 547, 679, 1062, 1199

Frische Nehrung (West-/Ostpreußen) 1453

Frisches Haff (West-/Ostpreußen) 87, $823 \mathrm{f}$., 1440,1453

Frohnau (Berlin) $\rightarrow$ Berlin-Frohnau

Frombork $\rightarrow$ Frauenburg (Ostpreußen)

Fronau (Kr. Briesen) (poln. Wronie) 1482

Frunse (Sowjetunion) [Welches?] 1537

Frýdlant v Čechách $\rightarrow$ Friedland im Isergebirge

„Fuchsbau“ (SS-Lager) $\rightarrow$ Fürstenwalde-Ketschendorf

Fürstenberg/Havel 35, 45, 68, 106, 112, 198, $226,261,272,278,280-284,517,546,557$ f., 679-682, 704, 1482 f., 1541; Bornmühlensiedlung 281

Fürstenberg-Drögen 112

Fürstenberg/Oder (Kr. Guben) (siehe auch $\rightarrow$ Eisenhüttenstadt) 27, 45, 49, 84, $116 \mathrm{f}$., 134, 187, 196, 253, 257, 267 f., 273, 279 f., 335, $340,348,352$, 354 f., $442,454,457,507,528$ f., $682-686,806,1027,1282,1297,1304,1404$, $1415,1444,1459,1467,1481,1541 \mathrm{f}$.

Fürstenberg/Oder (Kommandanturbezirk) 187

Fürsteneich $\rightarrow$ Saabor (Kr. Grünberg)

Fürstenfelde (Kr. Königsberg/Nm.) (poln. Boleszkowice) 696, 1474

Fürstenwalde/Spree (Kr. Lebus) 85, 93, 178, 207, $340,343,375$, 392, 455, 457, 481 f., 493-495, 513, 533, 663, 686-692, 888, 923, 928, 1004, $1007,1349,1366,1401,1405,1452,1459$, 1542 f.; Aufnahmeheim 143, 167, 688; Gedenkkreuz für die Russlanddeutschen (Neuer Friedhof) 356, 480, 687, 691; Haus Brandenburg 22 f., 59, 364, 384f., 470-472, 474-477, 494, 691f., 775, 1418, 1420, 1544; Umsiedler-, Heimkehrerlager 17, 26, 147, 167 f., 172, 221, $225,252,416,533,687-689,768,978$, 980 f., 1041, 1045 f., 1106-1108, 1126, 1230, 1240; „Waldlager Pintsch“ 688

Fürstenwalde-Ketschendorf (Kr. Lebus) 441, 533, 689, 692-694, 1006, 1029, 1048, 1069, 1074, 1235; Samariteranstalten 432 f., 687, 693f., 923; Sowjet. Speziallager Nr. 5: 37, 692, 694, 728, $1048 \mathrm{f}$.

Fürstenwalde (Kreis) 687, 690, 888, 1107, 1353

Fürstenwerder/Uckermark (Kr. Prenzlau) 90, $112,116,181,221$ f., 263, 275, 277, 335, 431, 694f., 1449, 1470
Fuhlen/Weser 415

Fulda 379; Bonitatiushaus 385

Fulda (Bistum) 445

Funkenhagen (Kr. Templin) 106

Gablonz an der Neiße (tschech. Jablonec nad Nisou) 157, 230 f., 299, 301-303, 306, 745, 778, 813-815, 1200 f., 1228, 1441, 1447

Gądków Mały $\rightarrow$ Klein Gandern

Gądków Wielki $\rightarrow$ Groß Gandern

Gadow (Kr. Ostprignitz) 1270

Gadsdorf (Kr. Teltow) 889

Gaiki $\rightarrow$ Hainbach (Kr. Goldberg)

Galizien 71, 99, 193, 203, 218, 441, 452, 585, $587,615,653,657,697,711,752,755,794$, 914, 917 f., $931,940,1261,1392,1460$

Gallun (Kr. Teltow) 1102

Gantikow (Kr. Ostprignitz) 539

Ganz (Kr. Ostprignitz) 539, 1270, 1344

Garlitz (Kr. Westhavelland) 285, 547, 695f., 1453,1473

Gartz/Oder 818, 1278

Gaschwitz bei Leipzig (Sachsen) 117, 1101, 1481

Gassen (Kr. Sorau) (poln. Jasień) 392, 658, 661, 714,912

Gasten (Kreis) $\rightarrow$ Waldrode (Kreis)

Gdańsk $\rightarrow$ Danzig

Gdańsk-Wrzeszcz $\rightarrow$ Danzig-Langfuhr

Gdingen bei Danzig (1939-1945 Gotenhafen) (poln. Gdynia) 87, 1404, 1453, 1455

Gebersdorf (Kr. Jüterbog-Luckenwalde) 1222

Gębice $\rightarrow$ Amtitz (Kr. Guben)

Gehren (Kr. Luckau) 185, 331, 921, 1449 f., 1511

Gehrenberge (Kr. Niederbarnim) $\rightarrow$ Schwanebeck-Gehrenberge

Geiseltal (bei Merseburg) 1469

Gellmersdorf (Kr. Angermünde) 1331

Gelsenkirchen 380, 384, 401, 472

Geltow (Kr. Osthavelland) 845

Gemeinschaft Unabhängiger Staaten $\rightarrow$ GUS

Generalgouvernement 215, 615, 1443

Genschmar (Kr. Lebus) 532f., 696, 700, 1473

Genshagen (Kr. Teltow) 164, 544, 696, 793, 1063

Genthin 96, 359, 595, 1184, 1461, 1469

Georgenburg (Kr. Insterburg) (russ. Majowka) 823

Gera (Thüringen) 23, 209, 1016-1018, 1102

Gerdauen (Ostpreußen) (russ. Schelesnodoroschny) 74 
Gerdauen (Kreis) 75, 544

Gerdshagen-Giesenshagen $\rightarrow$ Giesenshagen

Gerlachshain (Kr. Brieg) $\rightarrow$ Tschöplowitz

Germendorf (Kr. Niederbarnim) 1033

Gersdorf (Böhmen) [Welches?] 954

Gersdorf (Kr. Crossen) (poln. Dąbie) 1443

Gerswalde (Uckermark) (Kr. Templin) 545, 933, 1443

Geseß (Kr. Neisse) (poln. Ujeździec) 294

Gesundbrunnen $\rightarrow$ Berlin-Wedding

Giesensdorf (Kr. Beeskow-Storkow) 1028

Giesenshagen (Kr. Ostprignitz) 871

Giesmannsdorf (Kr. Jauer) (poln. Gostków) 590

Gießen (Hessen) 1465

Gildenhall $\rightarrow$ Alt Ruppin, Gildenhall

Gilgenburg (Kr. Osterode) (poln. Dąbrówno) 343

Glashütte bei Baruth (Kr. Jüterbog-Luckenwalde) $285,1374,1481$

Glatz (Schlesien) 152, 596

Glatz (Grafschaft) 75, 368, 609, 942, 1265, 1405

Glatz (Kreis) 54, 284

Glau (Kr. Jüterbog-Luckenwalde) 99, 697, 1199, 1451

Glauchow, Kr. Züllichau-Schwiebus) (poln. Głuchów) 623

Glębice $\rightarrow$ Glumpenau (Kr. Neisse)

Gleißen (Kr. Oststernberg) (poln. Glisno) 441

Gleiwitz/OS. (poln. Gliwice) 613, 846, 854

Glienecke bei Ziesar (Kr. Jerichow I) 218

Glienicke (Kr. Beeskow-Storkow) 1028

Glienicke/Nordbahn (Kr. Niederbarnim) 182, 402, 1032, 1090

Glinik $\rightarrow$ Altensorge (Kr. Landsberg/W.)

Glisno $\rightarrow$ Gleißen (Kr. Oststernberg)

Gliwice $\rightarrow$ Gleiwitz

Glövzin (Kr. Westprignitz) 89f., 395, 549

Glöwen (Kr. Westprignitz) 416, 549, 697f.; Lager 26, 164, 166 f., 172, 416, 549, 697f., 979, 1062, 1066 f., 1230

Glogau (Schlesien) (poln. Głogów) 211, 276, $428,496,527,617,620,659,684,750,1208$, 1212, 1438; Hedwigschwestern 450, 570, 632, 944; St. Klemens-Hofbauer-Stift 944

Głogów $\rightarrow$ Glogau

Głogówek $\rightarrow$ Oberglogau

Głubczyce $\rightarrow$ Leobschütz

Głuchów $\rightarrow$ Glauchow, Kr. Züllichau-Schwiebus)

Głuchowo $\rightarrow$ Woxfelde (Kr. Oststernberg)
Glumpenau (Kr. Neisse) (poln. Głębice) 600

Gnadau bei Barby 234, 784, 838

Gnadenthal bei Arzis (Bessarabien) 1467

Gnesen (Posen) (poln. Gniezno) 340, 689, 927, 1465

Gnesen (Kreis) 216, 751, 996

Gnewikow (Kr. Ruppin) 821

Gniezno $\rightarrow$ Gnesen

Göhren (Kr. Crossen) (poln. Górzyn) 947-949

Göppingen (Württemberg) 31

Göritz (Oder) (Kr. Weststernberg) (poln. Górzy-

ca) $347,400,532,672,881,891,907$

Görkau bei Komotau (tschech. Jirkov) 471

Görlitz (Schlesien) 33, 39, 56, 209, 342 f., 346, $349,351,353,415,601,620$ f., 666, 750, 756, $791,824,825,854,1413,1415,1435,1444$, $1473,1519,1542$

Görlitz(-Ost) (poln. Zgorzelec) 39, 620 f., 1464

Görlitz (Bistum, Erzbischöfliches Amt, Kath. Administratur) $37 \mathrm{f} ., 56,442-445,458,484$, $559,573,577,613,619,625,628,630,632 \mathrm{f}$., 654, 659, 678, 684, 699, 701 f., 716, 726, 752 f., 756, 772, 785 f., 789, 796, 800 f., 816, 824 f., $836,881,900,906,909,913,915,921,934$, 939, 941, 946 f., 951, 1269, 1417, 1543

Görlitz (ev. Kirchengebiet) 36f.

Görne (Kr. Westhavelland) 207, 283, 476, 547, $698,1376,1443$

Görsdorf bei Beeskow (Kr. Beeskow-Storkow) 1028

Görsdorf bei Storkow (Kr. Beeskow-Storkow) $702,1028,1463$

Görsdorf (Kr. Jüterbog-Luckenwalde) 1287

Görzig (Kr. Beeskow-Storkow) 702, 1028, 1343

Götschendorf (Kr. Templin) 106

Göttin bei Brandenburg/H. (Kr. Zauch-Belzig) 1276,1451

Göttingen (Niedersachsen) 211, 232, 427, 627

Gołańcz $\rightarrow$ Gollantsch (Kr. Wongrowitz)

Golczewo $\rightarrow$ Gülzow (Kr. Cammin)

Goldap (Kreis) (poln. Gołdap) 844

Goldbeck (Kr. Osterburg), Lager 957, 1435

Goldberg in Schlesien (poln. Złotoryja) 1274

Goldmannsdorf (Kr. Pleß) (poln. Bzie) 1450

Gołębiewo Wielkie $\rightarrow$ Groß Golmkau

Goleniów $\rightarrow$ Gollnow (Kr. Naugard)

Gollantsch (Kr. Wongrowitz) (1942-1945

Schwertburg, Kr. Eichenbrück) (poln.

Gołańcz) 106 
Gollmitz (Kr. Luckau) 1199

Gollmitz (Kr. Prenzlau) 112, 1483

Gollnow (Kr. Naugard) (poln. Goleniów) 791, 903

Golm (Kr. Angermünde) 1316

Golm (Kr. Osthavelland) $\rightarrow$ Potsdam-Golm

Golm (Usedom) 1456

Golßen (Kr. Luckau) 102, 457, 534, 573, $698 f$., 1441, 1459

Golzow (Kr. Angermünde) 96

Golzow (Oderbruch) (Kr. Lebus) 98, 187, 216, 443 f., 533, 700f., 891, 906, 1434, 1439, 1443

Golzow (Kr. Zauch-Belzig) 42, 601, 613, 1449

Gommern bei Magdeburg 387

Góra $\rightarrow$ Guhrau (Kreis)

Góra $\rightarrow$ Gurten (Kr. Posen-West)

Gorgast (Kr. Lebus) 83, 95, 533, 701 f., $1438-$ 1440, 1442, 1460, 1482

Gorki (Russland), Kriegsgefangenenlager 251

Górny Śląsk $\rightarrow$ Oberschlesien

Gorzów Wlkp. $\rightarrow$ Landsberg/Warthe

Gorzów Wlkp.-Małyszyn $\rightarrow$ Merzdorf (Kr. Landsberg/W.)

Gorzów Wlkp.-Karnin $\rightarrow$ Kernein

Gorzów Wlkp.-Siedlice $\rightarrow$ Seidlitz

Gorzów Wlkp. (Woiwodschaft) 771

Górzyca $\rightarrow$ Göritz (Oder)

Górzyn $\rightarrow$ Göhren (Kr. Crossen)

Gościkowo $\rightarrow$ Paradies (Kr. Meseritz)

Gościm $\rightarrow$ Gottschimm

Gościmiec $\rightarrow$ Gottschimmerbruch

Gościnowo $\rightarrow$ Alexandersdorf (Kr. Landsberg/W.)

Gosen (Kr. Beeskow-Storkow) 525, 702, 1028

Goslar 402-404, 415

Gossow (Kr. Königsberg/Nm.) (poln. Goszków) 384

Gostingen (Wartheland) (Kreis) (Gostin, poln. Gostyń) 533, 996

Gostków $\rightarrow$ Giesmannsdorf (Kr. Jauer)

Gostyń $\rightarrow$ Gostingen (Kreis)

Gostynin (Kreis) $\rightarrow$ Waldrode (Kreis)

Goszków $\rightarrow$ Gossow (Kr. Königsberg/Nm.)

Gotenhafen $\rightarrow$ Gdingen

Gotha (Thüringen) 408

Gottschimm (Kr. Friedeberg/Nm.) (poln. Gościm) 1461

Gottschimmerbruch (Kr. Friedeberg/Nm.) (poln Gościmiec) 530, 1461

Gozdowice $\rightarrow$ Güstebiese (Kr. Königsberg/Nm.)
Grabice $\rightarrow$ Reichersdorf (Kr. Guben)

Grabow bei Blumenthal (Kr. Ostprignitz) 460, 956, 1270

Gräbendorf (Kr. Teltow) 1102, $1126 f$.

Gräfendorf (Kr. Jüterbog-Luckenwalde) 1222

Gräfenhain (Kr. Sagan bzw. Rothenburg) (poln. Grotów) 1207

Grätz (Posen) (Kreis) (poln. Grodzisk) 549, 996, 1452

Grätzwalde (Kr. Niederbarnim) 895

Grafschaft Glatz $\rightarrow$ Glatz (Grafschaft)

Gralow (Kr. Landsberg/W.) (poln. Gralewo) 370, 440

Gramsdorf (Kr. Obornik) (poln. Bukowiec) 1457

Gramzow (Kr. Angermünde) 164, 350, 524, 702f., 1063, 1315, 1321

Gramzow bei Fürstenberg/Havel 680

Grano (Kr. Guben) 1299

Granow (Neumark) (Kr. Arnswalde) (poln. Granowo) 1456

Gransee (Kr. Ruppin) 27, 226, 390, 454, 508, 542, 644, 703-705, 830, 967, 1208 f., 1542

Grassel (Kr. Gifhorn) 417

Graudenz (Westpreußen) (poln. Grudziądz) 340 f., 672, 689, 792, 802, 927, 1206, 1448, 1481

Graudenz (Kreis) 861

Greifenberg in Pommern (poln. Gryfice) 389, 847,1210

Greifendorf bei Döbeln (Sachsen) 1465

Greifenhagen (Pommern) (poln. Gryfino) 214, $495,540,904,1458$

Greifenhagen (Kreis) 185, 214, 368, 860, 863

Greifenhain (Kr. Calau) 634

Greiffenberg/Uckermark (Kr. Angermünde) 106, 113, 239, 455, 524, 705, 1434

Greifswald (Vorpommern) 11, 104, 152, 1117, 1434, 1439, 1456, 1458, 1466

Greifswald (Kreis) 83

Grenzmark Posen-Westpreußen (Provinz) 213, $215,248,361$

Grenztal $\rightarrow$ Kamitz (Kr. Neisse)

Griebnitzsee (Bahnhof) $\rightarrow$ Potsdam-Babelsberg

Griechenland 1034f., 1037, 1135

Grießen (Kr. Guben) 529, 706

Grimma (Kreis) 1435

Grimnitz (Kr. Weststernberg) (poln. Grzmiąca) 409

Grodków $\rightarrow$ Grottkau (Schlesien) 
Grodzisk (Kreis) $\rightarrow$ Grätz

Gronenfelde $\rightarrow$ Frankfurt-Gronenfelde

Groschowitz (Kr. Oppeln) (poln. Groszowice) 825

Großbeeren (Kr. Teltow) 114, 1101

Groß Behnitz (Kr. Westhavelland) 49, 547, $706 f$.

Groß-Berlin $\rightarrow$ Berlin

Groß Breese (Kr. Westprignitz) 549, 707

Groß Breesen (Kr. Guben) 314, 529, $707 f$., 1282

Großbritannien („England“; siehe auch $\rightarrow$ Britische (Besatzungs-)Zone) 109, 150, 938, 998, 1084, 1281 f., 1290, 1328, 1408, 1458, 1466, 1472,1482

Groß Butzig (Kr. Flatow) (poln. Buczek Wielki) 874

Groß Cammin (Kr. Landsberg/W.) (poln. Kamień Wielki) 74

Groß Drenzig (Kr. Guben) (poln. Drzeńsk Wielki) 763

Groß Drewitz (Kr. Guben) 338, 529, 708, 1283

Groß Eichholz (Kr. Beeskow-Storkow) 702, 1028

Großendorf (Kr. Stolp) (poln. Wielka Wieś) 823

Großenstein bei Gera 398

Groß Gandern (Kr. Weststernberg) (poln. Gądków Wielki) 84, 149, 275, 291, 336, 1437, 1449, 1456

Groß Gastrose (Kr. Guben) 355, 529, 706, 708, $712,739,1296$

Groß Glienicke (Kr. Osthavelland) 42, 1100

Groß Golmkau (Kr. Dirschau) (poln. Gołębiewo Wielkie) 777

Großgörschen bei Leipzig 408 f., 779

Groß Gottschow (Kr. Westprignitz) 549

Groß Hubnicken (Kr. Samland) 404

Groß Jenznick (Kr. Schlochau) (poln. Jęczniki Wielkie) 628

Großkayna bei Weißenfels 1469

Groß Kienitz (Kr. Teltow) 1127

Groß Klessow (Kr. Calau) 169

Groß Kniegnitz (Kr. Reichenbach) (poln.

Księginice Wielkie) 1449

Groß Kölzig (Kr. Sorau) 164, 542 f., 709

Groß Köris (Kr. Teltow) 935

Groß Koschen (Kr. Calau) 1100

Groß Krausnik (Kr. Luckau) 1102

Groß Kreutz (Kr. Zauch-Belzig) 601, 893, $1371 \mathrm{f}$.

Groß Langerwisch (Kr. Ostprignitz) 823

Groß Lenkeningken (Kr. Tilsit-Ragnit) (19381946 Groß Lenkenau) (russ. Lesnoje) 838
Groß Lessen (Kr. Grünberg) (poln. Leśniów Wielki) 634

Groß Leuthen (Kr. Lübben) 785, 925, 1541

Groß Linde (Kr. Westprignitz) 395

Groß Lunow (Mecklenburg) 24

Groß Machnow (Kr. Teltow) 1460

Groß Muckrow (Kr. Lübben) 279

Groß Mutz (Kr. Ruppin) 1209

Groß Neuenedorf (Oderbruch) (Kr. Lebus) 33, 207, 532, 1404

Groß Pankow (Kr. Ostprignitz) 227, 394, 774, $871,1345,1458,1476,1541$

Großpillingsdorf (Kr. Gera) 1101

Groß Plowenz (Kr. Strasburg, Westpreußen) (poln. Płowęż) 1327

Großräschen (Kr. Calau) 526, 709, 1253

Groß Rietz (Kr. Beeskow-Storkow) 278, 702, 1028

Groß Rominten (Kr. Goldap) (1938-1946 Hardteck) (russ. Krasnolessje) 74, 844

Groß Rosen (Kr. Schweidnitz), KZ 101

Groß Särchen (Kr. Sorau) (poln. Żarki Wielkie) 356,741

Groß Salzdorf (Kr. Schubin) (Salzdorf, poln. Slonawy) 107, 1436, 1455

Groß Schacksdorf (Kr. Sorau) (bis 1937 Groß Tzschacksdorf) 744

Groß Schauen (Kr. Beeskow-Storkow) 131, 1028,1441

Groß Schönebeck (Kr. Niederbarnim) 164, 536, 709f., 1033, 1063

Groß Strehlitz (Kreis) (Oberschlesien) (poln. Strzelce Opolskie) 623

Groß Tzschacksdorf (Kr. Sorau) $\rightarrow$ Groß Schacksdorf

Groß Wasserburg (Kr. Beeskow-Storkow) 1028

Großwusterwitz (Kr. Jerichow II) 218, 470

Groß Ziethen (Kr. Teltow) 1101

Groszowice $\rightarrow$ Groschowitz (Kr. Oppeln)

Grotów $\rightarrow$ Gräfenhain

Grottkau (Schlesien) (poln. Grodków) 413

Grube (Kr. Osthavelland) $\rightarrow$ Potsdam-Grube

Grube Finkenheerd $\rightarrow$ Finkenheerd

Grube Gülitz $\rightarrow$ Gülitz

Grudziądz $\rightarrow$ Graudenz

Grün (Vogtland) 1472

Grüna bei Jüterbog (Kr. Jüterbog-Luckenwalde) 1058,1247

Grünberg in Schlesien (poln. Zielona Góra) 65, 86, 133, 171, 181, 210 f., 272, 362, 392, 405, 
413, 422, 428, 432, 488, 496, 591, 622, 634, $658,695,699,712,715,732,789,793,796$, 799, 816, 903, 926, 1213, 1257, 1278, 1348 f., 1463, 1470, 1502; Altersheime 211, 428, 621, 624; KZ-Außenlager 101

Grünberg in Schlesien (Kreis) 100, 135, $210 \mathrm{f}$., 421 f., 428, 536 f., 712, 816, 844, 948, 996, $1348 \mathrm{f}$.

Grünberg (Woiwodschaft) $\rightarrow$ Zielona Góra

Grüneberg (Kr. Ruppin) 542, 710, 1063

Grünheide (Mark) (Kr. Niederbarnim) 301, 536, 710, 1032, 1198, 1456

Grüntal (Kr. Meseritz) $\rightarrow$ Alt Jablonke

Grüntal bei Biesenthal (Kr. Oberbarnim) 588

Gruhno (Kr. Luckau) 656, 1102

Grunau (Kr. Hirschberg/Schlesien) (poln. Jeżów Sudecki) 1446

Grunewald (Berlin) $\rightarrow$ Berlin-Grunewald

Grunewald (Kr. Guben) 711

Gryfice $\rightarrow$ Greifenberg in Pommern

Gryfino $\rightarrow$ Greifenhagen (Pommern)

Grzebienisko $\rightarrow$ Kammthal (Kr. Samter)

Grzmiąca $\rightarrow$ Grimnitz (Kr. Weststernberg)

Grzymalin $\rightarrow$ Langenwaldau (Kr. Liegnitz)

Guben (Stadtkreis, Gesamtstadt bis 1945) $27 \mathrm{f}$., $37,39,45,49,57,81,83,99,110,129,195$, 353, 401 f., 420 f., 466 f., 507, 572, 616, 706, 711-713, 715, 722-725, 740 f., 1291, 1447, 1463, 1470, 1473; KZ-Außenlager 101

Guben (Stadt, Ostteil ab 1945) (poln. Gubin) $27,33,37,39,45,49,57,58,129,133,195$, 280, 284, 295, 349, 353, 355, 401, 419-421, 426, 472, 481, 487, 492, 494, 507, 528 f., 534, 711-715, 719, 721-723, 947, 1207, 1212, 1281 f., 1291, 1332, 1406, 1437, 1441, 1447, 1470, 1478, 1511; Klärwerk 713, 714 f.; Krankenhaus, städt. 711 f.; Ostfriedhof 421, 478, 723 f., 1445; Schützenhausinsel (Neiße-Insel) $487,711,715$

Guben (Stadt, Westteil ab 1945; 1961-1990 Wilhelm-Pieck-Stadt Guben) 19, 27 f., 33, $37-39,45,49,57,81,84,129,134,144,164$, 166, 195 f., 199, 232, 267, 284, 295, 340, 348 f., 353 f., 401 f., 419-422, 442, 457, 467, 472, 481, 485, 487, 492, 494, 507, 528f., 612, 621, 706, 711-725, 739, 853, 987-990, 1035, 1118, 1151, 1153 f., 1204, 1207, 1230, 1282, 1284, 1290-1292, 1296-1298, 1300, 1303 f., 1325, 1331-1333-1337, 1413-1415, 1437, 1444,
1447, 1456, 1459, 1470, 1473, 1478, 1481, 1511,1542

- Bahnhof 716f., 1331

- Behelfskrankenhäuser $711 \mathrm{f}$.

- Borsiglager 164, 166, 280, 712, 716, 717-719, 1062

- Brücken, Notsteg 355, 711 f., 714 f., 724 f., 1325, 1332, 1441, 1459

- Chemiefaserwerk 295, 714, 716, 719, 724, 1473

- Crossener Heimatstube $722 \mathrm{f}$.

- „Feldschlößchen“ (Flüchtlingslager) 712, 716, 719

- Filmtheater „Friedensgrenze“ 354 f., 714

- Firmen, Betriebe 346, 348, 350, 714, 720, 723, 1284, 1292-1294, 1299f., 1333-1336, 1473

- Heimatstube des Gubener Heimatbundes $467,481,722$

- Herberge zur Heimat (Altersheim) 720, 724

- Hotel Berliner Hof (Flüchtlingslager) 716

- Hotel zum Kronprinzen (Flüchtlingslager) $485,713,716 f$.

- Kindergärten (Flüchtlingslager) 712, 716, 720

- Krankenhäuser 133f., 711f., 717, 719, 720, 724

- Lager 1022, 1282

- Landrat, Landratsamt 81,346, 683, 12811283, 1285, 1290-1298, 1300, 1393, 1419

- Liehr's Hotel (Flüchtlingslager) 164, 166, 712, 716, 717, 718

- Magistrat, Rat der Stadt, Oberbürgermeister 1282, 1292, 1304, 1333, 1502

- Naemi-Wilke-Stift (Flüchtlingslager) 712, 716, 719, 720, 724

- Pestalozzischule 712, 716, 719,724

- Reipoplatz (Reichsbahn- u. Post-Sportplatz) 349, 713, 1331, f.

- Straßennamen 340, 721, 1414

- Volkshaus 485, 713, 716f., 722

- Waldfriedhof 481

- Waldsiedlung 280, 717, 719, 1296, 1478

Guben (Kreis, Landkreis) 81, 100, 195 f., 216, 401 f., 524, 528, 721 f., 996, 1440

- Ostteil 211, 272, 274, 528, 534, 707 f., 712, $763,1281,1470,1514$

- Westteil 199, 202, 208, 210, 231 f., 268, 274, 282, 284, 295, 317, 353, 426, 528-530, $572,574,619,683,706,712,722,739,975$, 987-989, 1012, 1035, 1204, 1207, 1230, 1281-1283, 1291-1300, 1419, 1470 
Gubinchen (Kr. Guben) (poln. Gubinek) 81, 134

Gudzisz $\rightarrow$ Kutzdorf (Kr. Königsberg/Nm.)

Güldendorf bei Frankfurt (Oder) (Kr. Lebus), Lager 101, 672

Gülitz (Kr. Westprignitz), Grube 1206

Gülzow (Kr. Cammin) (poln. Golczewo) 495, 743

Güntershagen (Kr. Dramburg) (poln. Lubieszewo) 1468

Günthersdorf (Kr. Grünberg) (poln. Zatonie) 133

Güstebiese (Kr. Königsberg/Nm.) (poln. Gozdowice) $725 \mathrm{f}$.

Güstebieser Loose (Kr. Königsberg/Nm.) 481, $531,537,725 f$.

Güterfelde (Kr. Teltow) 1102

Guhlsdorf (Kr. Westprignitz) 210, 549, 726, 839

Guhrau (Kreis) (poln. Góra) 409, 1466

Gumbinnen (Ostpreußen) (russ. Gusev/Gussew) 74, 220, 398, 597, 1131, 1341

Gumbinnen (Kreis) 381, 705

Gumieńce $\rightarrow$ Stettin-Scheune

Gummersbach 780

Gurten (Kr. Posen-West) (poln. Góra) 784

GUS (Gemeinschaft Unabhängiger Staaten) 498

Guschau (Kr. Sorau) (poln. Guzów) 389

Gusev $\rightarrow$ Gumbinnen

Gusow (Kr. Lebus) 441, 533, $726 f$.

Gussew $\rightarrow$ Gumbinnen

Gutengermendorf (Kr. Ruppin) $1226 \mathrm{f}$.

Guttstadt (Kr. Heilsberg) (poln. Dobre Miasto) 1274

Guzów $\rightarrow$ Guschau (Kr. Sorau)

Haage (Kr. Westhavelland) 547, 727, 911

Haaso (Kr. Guben) (poln. Jazów) 418, 1443

Habelschwerdt (poln. Bystrzyca Kłodzka) 781

Hackenow (Kr. Lebus) 559

Hänchen (Kr. Cottbus) 156

Hänchen (Kr. Freystadt) (poln. Barcikowice) 133,1470

Häsen (Kr. Ruppin) 1226

Haff $\rightarrow$ Frisches Haff

Hagenow (Mecklenburg) 1474

Hainbach (Kr. Goldberg in Schlesien) (poln. Gaiki) 1465

Hainrode bei Nordhausen, Kinderheim Wöbelsburg 225

Hainspach bei Schluckenau (tschech. Lipová, früher Hanšpach) 553
Hakenberg (Kr. Osthavelland) 1100

Halbe (Kr. Teltow) 83, 86, 544, 586, 727-729, $801,766,935,1453,1470,1473$ f., 1482

Halberstadt 1456

Halle (Saale) 12, 103 f., 209, 363, 371, 408, 414 f., $823,1184,1257,1417,1439,1444,1463$, 1471; Zoologischer Garten 374, $407 \mathrm{f}$.

Halle-Kreuz, Gestüt 824

Halle/S. (Bezirk) 54

Halle/S. (Kreis) 407

Halle-Merseburg (Gau) 24

Hamburg 24, 72, 204, 208, 224, 372, 384, 411, $415,628,722,843,868,871,894,956,1065$, 1444, 1451, 1543; „Glockenfriedhof“ 653, 970

Hamburg (Erzbistum) 680

Hamm (Westfalen) 352, 390 f., 440, 660

Hammelspring (Kr. Templin) 314, 546

Hammer (Kr. Niederbarnim) 1032

Hammer (Kr. Züllichau-Schwiebus) (poln. Przetocznica) 929

Hammerstein (Westpreußen) (Kr. Schlochau) (poln. Czarne) 826, 860, 1209

Hann. Münden 385

Hannover 138, 211, 384, 386, 411, 415 f., 466, $472,510,555,721,784,1259,1449$

Hannover (Provinz/Land) (siehe auch $\rightarrow$ Niedersachsen) 111, 384, 386, 414, 774

Hanšpach $\rightarrow$ Hainspach

Hardteck (Kr. Goldap) $\rightarrow$ Groß Rominten

Hartau bei Zittau 1438

Hartmannsdorf (Kr. Beeskow-Storkow) 729, 1028

Harz 31

Haselberg (Kr. Oberbarnim) 93, 1449

Hasenpoth (Kr. Eichenbrück) $\rightarrow$ Mokronos (Kr. Wongrowitz)

Hasseloe (Dänemark) 151

Hassleben (Kr. Templin) 106, 934

Hathenow (Kr. Lebus) 533, 729, 881

Hattingen (Ruhr) 384

Hauerland (Slowakei) 1350

Haus Hellesen bei Lüdenscheid (Westfalen) 693

Havel (Fluss) 868

Havelberg (Kr. Westprignitz) 27, 39, 45, 58, 187, 257, 264, 337, 398, 411, 454, 549, 730-732, 958, 982, 991, 1143, 1346-1348, 1459

Havelberg-Müggenbusch 731, 1347

Havelland 28, 203, 221 f., 234 f., 282-284, 440, 461 f., $469,546,695,920,1438$ 
Havelland (Landkreis) 878, 1376

Heerwegen (Kr. Glogau) $\rightarrow$ Polkwitz

Heidelberg (am Neckar) 386, 1447

Heidelberg, Kolonie (Kr. Ostprignitz) 733

Heidewilxen (Kr. Trebnitz) (poln. Wilczyn) 294

Heilbronn 1445

Heiligengrabe (Kr. Ostprignitz) 539, 592, $732 f$;

Diakonissenhaus „Friedenshort“" 210, $732 \mathrm{f}$.

Heiligensee (Berlin) $\rightarrow$ Berlin-Heiligensee

Heiligenstadt (Thüringen), Lager 179, 1442

Heilsberg (Ostpreußen) (poln. Lidzbark

Warmiński) 1457

Heinrichsfelde bei Kyritz $\rightarrow$ Kyritz-Heinrichsfelde

Heinsdorf (Kr. Jüterbog-Luckenwalde) $1119 \mathrm{f}$., 1222, 1287

Hellburg (Kr. Westprignitz) 1140

Hellersdorf $($ Berlin) $\rightarrow$ Berlin-Hellersdorf

Hellesen $\rightarrow$ Haus Hellesen

Helmstedt (Kreis) 169

Henkenhagen (Kr. Kolberg) (poln. Ustronie Morskie) 495, 952

Hennersdorf (Kr. Luckau) 1102

Hennersdorf (Kr. Ohlau) (poln. Osiek) 535, 1437

Hennickendorf (Kr. Niederbarnim) 69, 114f., 1032, 1477

Hennigsdorf (Kr. Osthavelland) 49, 164, 428, $456,496,538,583,733-735,899,1026,1063$, $1152,1230,1455$

Henzendorf (Kr. Guben) 279

Herford (Westfalen) $400 \mathrm{f}$., $691 \mathrm{f}$.

Hermania (Kr. Weststernberg) (poln. Jerzmanice Lubuskie) $84 \mathrm{f}$.

Heřmanice u Frýdlantu $\rightarrow$ Hermsdorf bei Friedland

Hermannsbad (Wartheland) (Kreis) (poln. Ciechocinek) 216, 996

Hermersdorf (Kr. Lebus) 784, 1437

Hermsdorf (Kr. Beeskow-Storkow) 324, 1029, 1464

Hermsdorf (Kr. Sorau) (poln. Łukawy) 796

Hermsdorf bei Friedland (Nordböhmen) (tschech. Heřmanice u Frýdlantu) 1446

Hermswalde bei Sommerfeld (Kr. Crossen) (poln. Chocicz) 619

Herne 327, 623, 853, 1542; Martin-Opitz-Bibliothek $60,364,1420,1544$

Herrnskretschen bei Tetschen (tschech. Hřensko) 229
Hersbruck (Mittelfranken) 591

Herzberg (Kr. Beeskow-Storkow) 525, 735, 1029

Herzberg/Elster 404, 656, 722, 1407

Herzfelde (Kr. Niederbarnim) 145 f., 1032

Herzogswalde (Kr. Oststernberg) (poln. Żubrów) 491

Herzsprung (Kr. Angermünde) 1434

Herzsprung (Kr. Ostprignitz) 1270

Hessen 204, 233, 505, 1465

Heydebreck/OS. $\rightarrow$ Kandrzin(-Cosel)

Hildesheim 379

Himmelpfort (Kr. Templin) 164, 546, 736, 801

Hindenberg (Kr. Ruppin) 1436, 1455

Hirschberg am See (tschech. Doksy) 1452

Hindenburg/OS. (poln. Zabrze) 600, 1210

Hindenburg (Kr. Templin) 1473

Hinterpommern $\rightarrow$ Pommern

Hirschberg im Riesengebirge (Schlesien) (poln. Jelenia Góra) 151, 177, 548, 644, 769, 1211, 1446, 1448

Hirschberg/Schlesien (Kreis) 151

Hirschfeldau (Kr. Sagan) (poln. Jelenin) 753

Hirschfelde (Mark) (Kr. Oberbarnim) $423 \mathrm{f}$.

Hirschluch (Kr. Beeskow-Storkow) $\rightarrow$ StorkowHirschluch

Hitzacker (Niedersachsen) 106

Hochzeit (Kr. Arnswalde) (poln. Stare Osieczno) 1456

Höfgen (Kr. Jüterbog-Luckenwalde) 1222

Hönow (Kr. Niederbarnim) 312, 536, 1033

Hörde $\rightarrow$ Dortmund-Hörde

Hörlitz (Kr. Calau) 1100

Hoffmannstal (Kr. Meseritz) $\rightarrow$ Rybojadel

Hoffnungstaler Anstalten $\rightarrow$ Lobetal

Hohe Tatra 238, 607

Hohen Ahlsdorf (Kr. Jüterbog-Luckenwalde) 1222

Hohenbrück (Kr. Beeskow-Storkow) 1029

Hohengüstow (Kr. Angermünde) 1206

Hohennauen (Kr. Westhavelland) 312, 898

Hohen Neuendorf (Kr. Niederbarnim) 482, 536, 736f., 1032, 1457, 1542

Hohenofen (Kr. Ruppin) 149, 1209, 1456

Hohenprießnitz (Kr. Delitzsch) 171

Hohensaaten (Kr. Angermünde) 725

Hohensalza (Posen) (bis 1904 Inowrazlaw) (poln. Inowrocław) 88, 217 f., 522, 578, 690, $829,996,1447$

Hohensalza (Landkreis) (bis 1904 Inowrazlaw) 74, 217 f., 540, 863, 996 
Hohensalza (Regierungsbezirk) 215

Hohensaaten (Kr. Angermünde) 196

Hohenschönhausen (Berlin) $\rightarrow$ Berlin-Hohenschönhausen

Hohenseefeld (Kr. Jüterbog-Luckenwalde) 1150

Hohenstein (Kr. Osterode) (poln. Jagiełek) 554

Hohenstücken $\rightarrow$ Brandenburg-Hohenstücken

Hohenvier (Kr. Westprignitz) $1144 \mathrm{f}$.

Hohenwalde (Kr. Lebus) 218

Hohenwalde (Kr. Templin) 218

Hohenwartenberg (Kr. Königsberg/Nm.) (poln. Chełm Górny) 208

Hohenwutzen (Kr. Königsberg/Nm.) 196-198, 531, 537; Gedenkstein 356, 481, 567; Saldernbücke 105, $487 \mathrm{f}$.

Holbeck (Kr. Jüterbog-Luckenwalde) 1224

Holland $\rightarrow$ Niederlande

Hoppegarten (Kr. Lebus) 1440

Hoppegarten (Kr. Niederbarnim) 113, 1032

Hora Svatého Šebestiána-Nová Ves $\rightarrow$ Neudorf bei Sebastiansberg

Horní Blatná $\rightarrow$ Bergstadt Platten

Horní Maxov $\rightarrow$ Ober Maxdorf

Horní Podluží $\rightarrow$ Obergrund bei Warnsdorf

Horno (Kr. Guben) 76, 529

Horst, Seebad (Kr. Greifenberg) (poln. Niechor-

ze) 1474

Horst (Kr. Westprignitz) 1140

Horstdorf bei Oranienbaum (Anhalt) 1439

Hostenitz bei Aussig/Elbe (tschech. Hostěnice) 1450

Hoya/Weser 401, 423, 1542

Hoyerswerda 36 f., 168, 915, 1101, 1464, 1469

Hradec Králové $\rightarrow$ Königgrätz

Hřensko $\rightarrow$ Herrnskretschen

Hubertushöhe (Krankenhaus) $\rightarrow$ Storkow

Hürth bei Köln 472

Hundsfeld $\rightarrow$ Breslau-Hundsfeld

Husum (Nordfriesland) 396

Iaşi (Diözese) (dt. Jassy) 1265

Illmersdorf (Kr. Jüterbog-Luckenwalde) 1158

Ilmenau (Thüringen) 302, 1439

Ingolstadt 82, 1434

Inowrazlaw, Inowrocław $\rightarrow$ Hohensalza

Ińsko $\rightarrow$ Nörenberg (Kr. Saatzig)

Insterburg (Ostpreußen) (russ. Tschernjachowsk)

$152,221,225$

Irrel bei Bitburg 404
Isergebirge 230, 302, 336

Italien 331 , 445, 573, 916, 926, 1034 f., 1037,

1268,1399

Itzehoe (Holstein) 392

Iwano-Frankiwsk $\rightarrow$ Stanislau

Jablonec nad Nisou $\rightarrow$ Gablonz

Jabłonka Stara $\rightarrow$ Alt Jablonke

Jabłonoów $\rightarrow$ Schönbrunn (Kr. Sagan)

Jáchymov $\rightarrow$ Sankt Joachimsthal

Jähnsdorf (Kr. Crossen) (poln. Janiszowice) 925

Jänickendorf (Kr. Jüterbog-Luckenwalde) 1158,

1246

Jänschwalde (Kr. Cottbus) 836

Jagiełek $\rightarrow$ Hohenstein

Jagow (Kr. Prenzlau) 113, 541, 1465

Jahnberge (Kr. Westhavelland) 221, 547, 738

Jahnsfelde (Kr. Landsberg/W.) (poln. Jańczewo)

$370,440,1458$

Jalta, Konferenz (1945) 135, 302, 1335, 1404

Jamlitz bei Lieberose (Kr. Lübben) 37, 529, 535,

738-741, 1441; Lager 22, 37, 183, 529, 535,

670, 739-741, 787, 794, 1459; „Waldlager“

740

Jańczewo $\rightarrow$ Jahnsfelde (Kr. Landsberg/W.)

Janiszowice $\rightarrow$ Jähnsdorf (Kr. Crossen)

Jannowitz (Riesengebirge) (Kr. Hirschberg)

(poln. Janowice Wielkie) 288

Jarandowo $\rightarrow$ Süßenberg (Kr. Heilsberg)

Jarmen (Kr. Demmin) 447

Jarotschin (Posen) (Kreis) (poln. Jarocin) 542, 996

Jasień $\rightarrow$ Gassen (Kr. Sorau)

Jasnaja Poljana $\rightarrow$ Trakehnen

Jassy $\rightarrow$ Iaşi

Jastrow (Kr. Deutsch Krone) (poln. Jastrowie) 343, 1439

Jastrzemb, Bad (Kr. Rybnik) (poln. JastrzębieZdrój) 1451

Jauer (Schlesien) (poln. Jawor) 324, 402, 924, $1399,1435,1466 \mathrm{f}$.

Jauer (Kreis) 402, 1399

Jawor $\rightarrow$ Jauer

Jaworówka $\rightarrow$ Liebenau (Kr. Wongrowitz)

Jaworzno bei Kattowitz, Lager 1268

Jazów $\rightarrow$ Haaso (Kr. Guben)

Jęczniki Wielkie $\rightarrow$ Groß Jenznick (Kr. Schlochau)

Jedlina Zdrój $\rightarrow$ Charlottenbrunn, Bad 
Jedlová $\rightarrow$ Schönbrunn bei Zwittau

Jehser (Kr. Züllichau-Schwiebus) (poln. Jeziory) 361

Jehserig (Kr. Spremberg) 634

Jelenia Góra $\rightarrow$ Hirschberg im Riesengebirge

Jelenin $\rightarrow$ Hirschfeldau (Kr. Sagan)

Jemiołów $\rightarrow$ Petersdorf (Kr. Oststernberg)

Jena (Thüringen) 11, 414, 852, 1466, 1471, 1527, 1542

Jerichow II (Kreis) 877

Jerischke-Pusack (Kr. Sorau) 356, 481, 542 f., 741

Jerzmanice Lubuskie $\rightarrow$ Hermania

Jeseník $\rightarrow$ Freiwaldau

Jeserig (bei Brandenburg/H.) (Kr. Zauch-Belzig) 550, 741f., 1457(?)

Jeserig/Fläming (bei Brück) (Kr. Zauch-Belzig) 43, 309, 550, 742f., 954, 1457(?)

Jeserigerhütten (Kr. Zauch-Belzig) 550, 743, 1205

Jesionowo $\rightarrow$ Schönow (Kr. Pyritz)

Jeßnigk (Kr. Schweinitz) [„Jessenigk“] 1101 (?)

Jeßnitz (Anhalt) 413

Jeziory $\rightarrow$ Jehser

Jeżów Sudecki $\rightarrow$ Grunau (Kr. Hirschberg)

Jirkov $\rightarrow$ Görkau

Joachimsthal (Kr. Angermünde) 164, 455, 495, 524, 743, 1063, 1542; Oberförsterei-, Forstamtsbezirk 351, 1323-1325

Jocksdorf (Kr. Sorau) 527, 542 f., $743 f$.

Johanneswunsch (Kr. Landsberg/W.) (poln.

Dobrojewo) 440

Johanngeorgenstadt (Erzgebirge) 293

Johannisthal (Berlin) $\rightarrow$ Berlin-Johannisthal

Jordan (Kr. Züllichau-Schwiebus) (poln. Jordanowo) $446,667,1273$

Jordanów Śląski $\rightarrow$ Jordansmühl

Jordanowo $\rightarrow$ Jordan

Jordansmühl (Kr. Reichenbach) (poln. Jordanów Śląski) 568

Jüterbog (Kr. Jüterbog-Luckenwalde) 102 , 154,212 , 270, 300 f., 304-306, 329, 365 f., 428 f., 456, 530, 744-746, 813 f., 912, 937, 982, 984, 1041-1043, 1138, 1156f., 1198, 1205, 1215-1217, 1247, 1251, 1373 f., 1441, 1446, 1461; Lager (Fuchsberg-)Kaserne 164, 166, 231, 531, 744, 745f., 1062, 1152, 1441; Schießplatz 813, 1247

Jüterbog (Kreis) 306, 746, 792, 847, 849, 971, 1373
Jüterbog-Luckenwalde (Kreis) (siehe auch $\rightarrow$ Luckenwalde [Kreis]) 102, 111, 164, 166, 193, 210, 217, 222, 248, 301, 442, 456, 530f., 537, $573,975,985,996,1002,1245-1248$

Jugoslawien (vgl. $\rightarrow$ Balkan) 530, 579, 657, 695, $847,1008,1010,1034$ f., 1037, 1135, 1407, 1448

Kaaden a. d. Eger (tschech. Kadaň) 151, 1181

Kaaso (Kr. Guben) (poln. Kozów) 916

Kablow (Kr. Beeskow-Storkow) 1029

Kablow-Ziegelei (Kr. Beeskow-Storkow) 1029

Kadaň $\rightarrow$ Kaaden a. d. Eger

Kadyny $\rightarrow$ Cadinen (Kr. Elbing)

Kagel (Kr. Niederbarnim) 1032

Kahnsdorf (Kr. Luckau) $\rightarrow$ Cahnsdorf

Kaja bei Leipzig 409

Kalau (Kr. Meseritz) (poln. Kaława) 1465

Kalaushöfen (Kr. Fischhausen) 831

Kaława $\rightarrow$ Kalau (Kr. Meseritz)

Kalenovke (Mittelukraine) 1463

Kaleńsko $\rightarrow$ Kalenzig (Kr. Königsberg/Nm.)

Kalenzig (Kr. Königsberg/Nm.) (poln. Kaleńsko) 696

Kalin bei Kutno (Polen) 1445

Kaliningrad $\rightarrow$ Königsberg i. Pr.

Kaliningrader Gebiet (Oblast Kaliningrad; nördliches Ostpreußen) (russ. Kaliningradskaja Oblast) 220, 223, 514, 601 f., 649, 688, 768, 785, 887, 932, 937 f., 1311, 1355, 1357, 1397, $1400,1414,1418$

Kalisch (Polen/Wartheland) (poln. Kalisz) 215, 218, 418, 855, 924, 1467, 1506

Kalisch (Kreis) 542, 996

Kalkberge (Kr. Niederbarnim) $\rightarrow$ Rüdersdorf

Kaltenborn (Kr. Guben) 134, 1282, 1286, 1303

Kamehlen (Kr. Karthaus) (poln. Kamela) 878

Kamień Mały $\rightarrow$ Stolberg (Nm.)

Kamień Pomorski $\rightarrow$ Cammin (Pommern)

Kamień Wielki $\rightarrow$ Groß Cammin (Kr. Landsberg/W.)

Kamitz (Kr. Neisse) (1936-1945 Grenztal) (poln. Kamienica) 625

Kammermark bei Pritzwalk (Kr. Ostprignitz) 823

Kammin (Pommern) $\rightarrow$ Cammin

Kammthal (Kr. Samter) (1940-1945 Kammtal) (poln. Grzebienisko) 192

Kamöse (Kr. Neumarkt) (poln. Chomiąża) 210, 726 
Kandrzin-Cosel (Oberschlesien; Kandrzin: 1934-1945 Heydebreck O.S.) (poln.

Kędzierzyn-Koźle) 428 f., 601

Kantdorf $\rightarrow$ Spremberg-Cantdorf

Kanth (Kr. Neumarkt bzw. Breslau) (poln. Kąty Wrocławskie) 1269

Kantow (Kr. Ruppin) 1460

Karasu (Kasachstan) 641

Kargowa $\rightarrow$ Unruhstadt (Kr. Bomst)

Karlsbad (Sudetenland) (tschech. Karlovy Vary) 1469

Karlshorst (Berlin) $\rightarrow$ Berlin-Karlshorst

Karlstein (Kr. Prenzlau) 113, 541

Karnin $\rightarrow$ Kernein (Kr. Landsberg/W.)

Karpaten („Karpatenland“) 203, 236-238, 492 f., 605-608, 652, 937, 1350 f., 1413

Karpatenukraine 99

Karsko $\rightarrow$ Karzig (Kr. Soldin)

Karstädt (Kr. Westprignitz) 395, 1453

Karstnitz (Kr. Stolp) (poln. Karzniczka) 1453

Kartzow (Kr. Osthavelland) 538, 747

Karwesee (Kr. Osthavelland) 17, 1519

Karzig (Kr. Soldin) (poln. Karsko) 75, 386

Karzniczka $\rightarrow$ Karstnitz (Kr. Stolp)

Kasachstan 220, 498-500, 641, 1435, 1452, 1539

Kaschubei 671

Kasel (Kr. Calau) $\rightarrow$ Casel

Kassel (Hessen) 1472

Katerbow (Kr. Ruppin) 108, 263, 542, $747 f$., $1251,1254,1475$

Kathrinowka, Lager 1450

Katlebug (Bessarabien) 898

Katowice $\rightarrow$ Kattowitz/OS.

Katowice (Woiwodschaft) 141

Katscher (Kr. Leobschütz) (poln. Kietrz) 428f., 870

Kattowitz (poln. Katowice) 33, 103, 689, 854, 1211,1541

Kattowitz (Woiwodschaft) $\rightarrow$ Katowice

Kąty Wrocławskie $\rightarrow$ Kanth

Kaulwitz (Kr. Namslau) (poln. Kowalowice) 912

Kausche (Kr. Calau) 634

Kay (Kr. Züllichau-Schwiebus) (poln. Kije) 1447

Kędzierzyn-Koźle $\rightarrow$ Kandrzin-Cosel

Kehrigk (Kr. Beeskow-Storkow) 285, 1029, 1435

Kemnath (Kr. Oststernberg) (poln. Kownaty) 365 f., 417, 1461

Kempen (Posen) (Kreis) (poln Kępno) 543, 996

Kempten (Bayern) 1467
Kępno (Kreis) $\rightarrow$ Kempen (Kreis)

Kerkwitz (Kr. Guben) 529, 748, 761, 824, 1290

Kernein (Kr. Landsberg/W.) (poln. Karnin bzw. Gorzów Wlkp.-Karnin) 370, 440

Kętrzyn $\rightarrow$ Rastenburg (Ostpreußen)

Ketschendorf $\rightarrow$ Fürstenwalde-Ketschendorf

Ketten bei Reichenberg (tschech. Chotyně) 294

Ketzelsdorf (Sudetenland) [Welches? K. bei Königinhof, Riesengebirge (tschech. Kocléřov) oder K. bei Zwittau, Schönhengstgau (tschech. Koclírov)] 789

Ketzin/Havel (Kr. Osthavelland) 93, 456, 490, 538, 747-751, 1111, 1156 f., 1450, 1459

Kiekebusch (Kr. Cottbus) 527, 750f., 1541

Kiekebusch (Kr. Teltow) 42, 178, 644, 1446

Kiel 60

Kiełcz $\rightarrow$ Költsch/Oder (Kr. Freystadt)

Kienbaum (Kr. Niederbarnim) 1032

Kienitz (Kr. Lebus) 98, 121, 312, 532 f., 751 f., 891, 1404

Kieselwitz (Kr. Guben) 279, 1300

Kietrz $\rightarrow$ Katscher (Kr. Leobschütz)

Kietz (b. Küstrin) $\rightarrow$ Küstrin-Kietz

Kije $\rightarrow$ Kay (Kr. Züllichau-Schwiebus)

Kirchberg (Kr. Falkenberg/OS.) (poln. Tłustoręby) 700

Kirchhain (Niederlausitz) (Kr. Luckau) (siehe auch $\rightarrow$ Doberlug-Kirchhain) 99, 231, 416, 443, 459, 534, 752f., 800, 941, 1102, 1199

Kirchhofen (Kr. Beeskow-Storkow) 1029

Kirchmöser (Kr. Jerichow II) 102, 517, 754, 685, 1448; Lager 170-172, 174-176, 547, 754, 982, 1132-1134, 1397, 1470

Kirchwerder bei Bergedorf (Hamburg) 843

Kirgisien 1537

Kladen (Mittelböhmen) (tschech. Kladno) 667

Kladow (Berlin) $\rightarrow$ Berlin-Kladow

Klaipeda $\rightarrow$ Memel

Klandorf (Kr. Niederbarnim) 1033, 1099

Klášterec nad Ohří $\rightarrow$ Klösterle an der Eger

Klausdorf (Kr. Soldin) (poln. Płonno) 1322

Klein Bahren (Kr. Luckau) 1102

Klein Behnitz (Kr. Westhavelland) 49, $706 \mathrm{f}$.

Klein Breese (Kr. Westprignitz) 1140

Klein Drenzig (Kr. Guben) (poln. Drzeńsk Mały) 81

Kleine Heide bei Prenzlau 113

Klein Gandern (Kr. Weststernberg) (poln.

Gądków Mały) 85, 291, 1437 
Klein Gastrose (Kr. Guben) 1296

Kleingörschen bei Leipzig 409

Klein Kölzig (Kr. Sorau) 164, 542 f., $754 f$., 1063

Klein Köris (Kr. Teltow) 99, 544, 755

Klein Krausnik (Kr. Luckau) 1102

Klein Leppin (Kr. Westprignitz) 1206

Kleinmachnow (Kr. Teltow) 85, 243, 349, 418, 504, 544, 755f., 919, 928, 1459, 1471-1473

Kleinow (Kr. Westprignitz) 1132

Klein Podel (Kr. Stolp) (poln. Podole Mały) 852

Kleinpolen 1261

Klein Rade (Kr. Weststernberg) (poln. Radówek) 1436

Klein Rietz (Kr. Beeskow-Storkow) 1029

Klein Särchen (Kr. Sorau) (poln. Żarki Małe) 741

Klein Schauen (Kr. Beeskow-Storkow) 1029

Klein Dchönebeck (Kr. Niederbarnim) 895

Klein Wanzleben bei Magdeburg 96, 1463

Klein Warnow (Kr. Westprignitz) 549, $756 f$., 839

Klein Zerlang (Kr. Ostprignitz) 821

Kleistdorf (Kr. Bomst) $\rightarrow$ Neukramzig

Klepzig (Kr. Zauch-Belzig) 578

Klessin bei Podelzig (Kr. Lebus) 533, $757 f$., 1472

Klettwitz (Kr. Calau) 416, 915

Kletzke (Kr. Westprignitz) 1144

Klewitz (Kr. Königsberg/Nm.) (poln. Chlewice) 913

Kliestow (Kr. Lebus) 124, 298 f., 355, 533, 758

Klietz (Kr. Jerichow II) 1470

Klinkengrund $\rightarrow$ Belzig

Klösterle an der Eger (Sudetenland) (tschech. Klášterec nad Ohří) 1446

Klossow (Kr. Königsberg/Nm.) (poln. Kłosów)

Klosterfelde (Kr. Niederbarnim) 1034

Kloster Lehnin $\rightarrow$ Lehnin

Kloster Zinna (Kr. Jüterbog-Luckenwalde) 1247, 1300-1302, 1305

Klosterwalde (Kr. Templin) 934

Kłosów $\rightarrow$ Klossow (Kr. Königsberg/Nm.)

Kluczbork $\rightarrow$ Kreuzburg (Schlesien)

Klütz (Mecklenburg) 112, 1481

Knoblauch (Kr. Osthavelland) 449, 1541

Kobbeln (Kr. Guben) 1302

Koblenz 1357, 1449

Kocléřov $\rightarrow$ Ketzelsdorf (Sudetenland)

Koclírov $\rightarrow$ Ketzelsdorf (Sudetenland)

Köhra bei Grimma 1435

Kölln-Land I (Kirchenkreis) 434f.

Köln (am Rhein) 38, 99, 336
Költsch/Oder (Kr. Freystadt) (poln. Kiełcz) 619

Königgrätz (tschech. Hradec Králové) (Bistum) 811

Königsbach bei Lodz (poln. Bukowiec) $408 \mathrm{f}$., 779

Königsberg/Nm. (poln. Chojna) 71, 105, 130, 204, 208, 472, 494, 518, 560, 566 f., 598, 646, $744,795,828,862,875,879,901-904,952$, $1404,1458,1475$

Königsberg/Nm. (Kreis) 43, 100, 105 f., 111, 195, 216, 274, 384, 394, 443, 466, 481, 531, $545,560,567,569,725,737,902,931,996$, 1456,1543

Königsberg/Nm. (Restkreis) 443, 466, 531, 770

Königsberg i. Pr. (Ostpreußen) (russ. Kaliningrad) $81,104,141,147,152-154,172,175 \mathrm{f}$., $183,220-225,249,286,327,338,420,554$, $560,596,668,688,704,799,834,854,874$, $929,1038,1045,1058,1094,1107,1109$, $1135,1254,1304,1309,1311,1397,1435$, $1439,1448,1454,1457,1467,1469$; im Straßennamen: 340, 342, 672, 1416

Königsberg-Rothenstein, Lager 1469

Königsberg i. Pr. (Gebiet) $\rightarrow$ Kaliningrader Gebiet

Königsberg (Kr. Ostprignitz) 1270

Königsbrück bei Dresden 1541

Königsfelde (Kr. Stettin) (poln. Niekłończyca) 918

Königstein/Taunus 403, 444, 448

Königswalde (Kr. Oststernberg) (poln. Lubniewice) 130,441

Königs Wusterhausen (Kr. Teltow) 164, 166, 456, 544, 609, 759f., 806, 935, 942 f., 1062 f., 1102, 1176, 1471, 1482; KZ-Außenlager 281

Königs Wusterhausen-Zernsdorf $\rightarrow$ Zernsdorf

Königs Wusterhausen (Kreis) 760

Könnern/Saale 939

Köpenick $\rightarrow$ Berlin-Köpenick

Körbelitz (Kr. Jerichow I) 1438

Körbiskrug (Kr. Teltow) 164, 544, 760

Köritz (Kr. Ruppin) 1210

Kösen, Bad, Kinderheim 225

Köslin (Pommern) (poln. Koszalin) 61, 87, 191, $287,495,904,1208,1436,1465$

Köthen (Kr. Beeskow-Storkow) 728, 801, 1029

Kohlfurt (Kr. Görlitz) (poln. Węgliniec), Bahnhof $148,150,153,1464$

Kohlsdorf (Kr. Beeskow-Storkow) 275, 1029 
Kolberg (Pommern) (poln. Kołobrzeg) 1451

Kolberg (Kr. Beeskow-Storkow) 241, 1029, 1214

Kolding (Dänemark) 151

Kolin (bei Pyritz) $\rightarrow$ Kollin

Kolkwitz (Kr. Cottbus) 44, 156, 210, 385, 480, 527, 623, 658 f., 748, 760-762, 824, 1470

Kollin (Kr. Pyritz) (Collin, poln. Kolin) 705, 996

Kolmar (Posen/Wartheland) (poln. Chodzież) 106

Kolmar (Wartheland) (Kreis) 106, 120, 548, 837, 996

Koło (Kreis) $\rightarrow$ Warthbrücken (Kreis)

Kołobrzeg $\rightarrow$ Kolberg (Pommern)

Kolonie Heidelberg $\rightarrow$ Heidelberg, Kolonie

Kolpin (Kr. Beeskow-Storkow) 1029

Konin (Polen/Wartheland) (Kreis) 546, 996

Konitz (Westpreußen) (poln. Chojnice) 74, 689

Konradswalde (Conradswalde) (Kr. Elbing) (poln. Chojnowo) 1453

Konstantinow (bei Lodz) (poln. Konstantynów) 186

Konstantynów $\rightarrow$ Konstantinow

Kopernica $\rightarrow$ Deutsch-Litta

Korea 1328

Korytowo $\rightarrow$ Kürtow (Kr. Arnswalde)

Korzybie $\rightarrow$ Zollbrück (Kr. Rummelsburg)

Kosarzyn $\rightarrow$ Kuschern (Kr. Guben)

Kościan (Kreis) $\rightarrow$ Kosten (Kreis)

Kosieczyn $\rightarrow$ Kuschten (Kr. Meseritz)

Kosobudki $\rightarrow$ Neu Kunersdorf (Kr. Crossen)

Kosovo 500

Kossenblatt (Kr. Beeskow-Storkow) 1029, 1071

Kosten (Posen) (Kreis) (poln. Kościan) 530, 544, 996

Kostrzyn $\rightarrow$ Kostschin (Kr. Schroda)

Kostrzyn $\rightarrow$ Küstrin

Kostschin (Kr. Schroda) (poln. Kostrzyn) 1446

Koszalin $\rightarrow$ Köslin

Kottbus $\rightarrow$ Cottbus

Kotzenau (Kr. Lüben) (poln. Chocianów) 591

Kowalowice $\rightarrow$ Kaulwitz (Kr. Namslau)

Kownaty $\rightarrow$ Kemnath (Kr. Oststernberg)

Koziczyn $\rightarrow$ Steinbockwerk

Kożle $\rightarrow$ Cosel (Oberschesien)

Kozów $\rightarrow$ Kaaso (Kr. Guben)

Kożuchów $\rightarrow$ Freystadt in Schlesien

Kraatz (Kr. Prenzlau) 90

Kränzlin (Kr. Ruppin) 821

Krajenka $\rightarrow$ Krojanke (Kr. Flatow)
Krajnik Dolny $\rightarrow$ Niederkränig

Kralup an der Moldau (tschech. Kralupy nad Vltavou) 428,735

Krampe (Kr. Grünberg) (poln. Krępa) 1465

Krampnitz (Kr. Osthavelland) $\rightarrow$ Potsdam-

Krampnitz

Krappitz (Kr. Oppeln) (poln. Krapkowice) 428 f., 959

Krasnolessje $\rightarrow$ Groß Rominten (Kr. Goldap)

Krausnick (Kr. Beeskow-Storkow) 1029, 1074, 1142

Krayne (Kr. Guben) 187, 195, 529, 763

Krebsjauche $\rightarrow$ Wiesenau

Krefeld 722, 1480

Krehlau (Kr. Wohlau) (poln. Krzelów) 620

Kremmen (Kr. Osthavelland) 114, 218, 233, 456, 538, 763-765, 831, 1100

Kremmen-Amalienfelde, Lager 164, 764

Krępa $\rightarrow$ Krampe (Kr. Grünberg)

Kreutz (Kr. Grünberg) (poln. Krzyż) 212, 565, 970

Kreuz/Ostbahn (Netzekr.) (poln. Krzyż) 754

Kreutzberg/Ahr 900

Kreuz (Gestüt) $\rightarrow$ Halle-Kreuz

Kreuzberg (Berlin) $\rightarrow$ Berlin-Kreuzberg

Kreuzbruch (Kr. Niederbarnim) 1032

Kreuzburg (Schlesien) (poln. Kluczbork) 428f., $877,929 \mathrm{f}$.

Krickau (Kr. Namslau) (poln. Krzyków) 1435

Kriebau (Kr. Sorau) (poln. Krzywa) 1460

Kriescht (Kr. Oststernberg) (poln. Krzeszyce) 495, 557

Krim 1265

Krinitz (Kr. Westprignitz) 1199

Kroatien 1469

Krockow (Kr. Putzig/Neustadt in Westpreußen) (poln. Krokowa) 470

Kröchlendorf (Kr. Templin) 113, 1472

Kröslin (Kr. Wolgast) 1450

Krojanke (Kr. Flatow) (poln. Krajenka) 554, 954

Krokowa $\rightarrow$ Krockow

Kromlau (Kr. Sorau) 542 f., 765

Kronach (Oberfranken) 1463

Krosno Odrzańskie $\rightarrow$ Crossen/Oder

Krotoschin (Posen) (Kreis) (poln. Krotoszyn) 216, 612, 996

Krügersdorf (Kr. Beeskow-Storkow) 1029

Krugau (Kr. Lübben) 535, 765f., 794, 1063

Krugberg bei Seelow $\rightarrow$ Seelow 
Krummensee (Kr. Niederbarnim) 1032

Krylowo $\rightarrow$ Nordenburg

Krzczonów $\rightarrow$ Weißkirschdorf

Krzelów $\rightarrow$ Krehlau (Kr. Wohlau)

Krześnica $\rightarrow$ Wilkersdorf bei Küstrin

Krzeszyce $\rightarrow$ Kriescht (Kr. Oststernberg)

Krzyków $\rightarrow$ Krickau (Kr. Namslau)

Krzystkowice $\rightarrow$ Christianstadt (Bober)

Krzywa $\rightarrow$ Kriebau (Kr. Sorau)

Krzywen (1934-1945 Bergenau) (Kr. Treuburg) (poln. Krzywe) 487, 1462

Krzyż $\rightarrow$ Kreutz (Kreis Grünberg)

Krzyż $\rightarrow$ Kreuz/Ostbahn (Netzekr.)

Księginice Wielkie $\rightarrow$ Groß Kniegnitz

Küchensee (Kr. Beeskow-Storkow) 525, 766-769, 1436; Lager 22, 53, 147, 149-152, 164, 166-168, 172, 174, 176-180, 214, 216, $221,285,294,297,323,356,525,643$ f., 676, 766-769, 826, 858, 921 f., 978-980, 1046-1048, 1061 f., 1064-1075, 1084-1086, 1088-1106, 1182, 1184, 1230, 1233 f., 1240, 1253, 1390-1392, 1419, 1435 f., 1446, 1453, $1462,1465,1482$

Kürtow (Kr. Arnswalde) (poln. Korytowo) 503, 651,811

Küstrin (Kr. Königsberg/Nm.) (poln. Kostrzyn) 33, 61, 82, 96, 120, 122, 130 f., 138, 171, 290, $343,345,347,376,420$, 494f., 503, 518, 524, $532,546,560,566,569,582,590,645$ f., 672 , 689, 700-702, 754, 757, 769-773, 785, 796, $810,835,837$ f., 848,860 f., 863 , 905-907, $925,956,978,1019,1403-1405,1417,1431$, 1434, 1438-1443, 1450, 1455, 1457 f., 1460, 1463 f., 1472 f.; Neustadt, Lager 517, 769, 773, 978, 1019f., 1049-1059, 1061, 1391; Oderbrücken 95, 130, 424; Oderinsel 770; Stülpnagelkaserne 129

Küstrin-Altdrewitz 1440; Lager 517, 769 f., 771, 978, 1046, 1391

Küstrin-Kietz 95, 126, 207, 345 f., 420, 444, 531, 533, 770-772, 908, 1438, 1440, 1443, 1478

Küstrin/Seelow (Pfarrei) 444

Küstriner Vorland 772

Kuhbier (Kr. Ostprignitz) 539, 774, 1455

Kuhblank (Kr. Westprignitz) 1199

Kuhfort $\rightarrow$ Potsdam-Golm

Kuhsdorf (Kr. Ostprignitz) 110f., 217, 538 f., 774

Kulm (Kr. Akkermann, Bessarabien) (ukrain. Pidgirne) 630
Kulm (Culm) (Westpreußen) (poln. Chełmno) $341,672,689$

Kulsen (Kr. Angerburg) (poln. Kulsze) 294

Kummerow (Kr. Beeskow-Storkow) 1029

Kummersdorf (Kr. Beeskow-Storkow) 1029

Kunersdorf (Kr. Beeskow-Storkow) 1029

Kunersdorf (Kr. Cottbus) 1213

Kunersdorf (Kr. Weststernberg) (poln. Kunowice) 84 f., $663,773,1404,1464$

Kunitz (Kr. Weststernberg) (poln. Kunice) 604, $666,953,1459$

Kunitz-Loose bei Wiesenau 497, 953

Kunowice $\rightarrow$ Kunersdorf (Kr. Weststernberg)

Kupferhammer (Kr. Meseritz) (Posen/Polen) (poln. Miedzichowo) 648

Kurland (Baltikum) 590, 1544

Kurmark 94

Kuschern (Kr. Guben) (poln. Kosarzyn) 81, 83 f., 196

Kuschkow (Kr. Lübben) 534f., 774f., 1447

Kuschten (Kr. Meseritz) (poln. Kosieczyn) 1349

Kutschlau (Kr. Züllichau-Schiwebus) (poln. Chociule) 137, 834

Kutzdorf (Kr. Königsberg/Nm.) (poln. Gudzisz) 1456

Kutzerow (Kr. Prenzlau) 113, 541

Kutno (Polen/Wartheland) 149

Kutno (Kreis) 216, 996

Kwidzyn $\rightarrow$ Marienwerder (Westpreußen)

Kwielice $\rightarrow$ Quilitz (Kr. Glogau)

Kyritz (Kr. Ostprignitz) 94, 114, 192, 211, 308$310,314,429,454,465,495,504,508,538 \mathrm{f}$., 548, 775-777, 820, 830, 837, 963, 1063, 1151, 1190, 1195, 1407, 1418, 1448, 1453, 1458, 1543; Kinderheim, -dorf 179, 221, 225-228, 785, 840, 1436, 1458, 1467

Kyritz-Heinrichsfelde 1199

Kyritz (Kreis) 468, 472 f., 777, 963, 1460

Księże (Wrocław-Księże) $\rightarrow$ Breslau-Tschansch

Laage (Mecklenburg), Lager 1440

Laaso (Kr. Guben) (poln. Łazy) 633

Laasow (Kr. Lübben) 1466

Laatzen (Niedersachsen) 721

Labiau (Kreis) (russ. Polessk) 861

Labolz (?), Forsthaus bei Königs Wusterhausen (wohl Lubolz, Kr. Lübben) 416

Läsgen (Kr. Grünberg) (poln. Laski) 634

Läsikow (Kr. Ruppin) 504 
Lagow (Kr. Oststernberg) (poln. Łagów) 420, 494, 610, 788, 1541

Lagowo (Kr. Kosten) (1939-1945 Ludwigsberg) (poln. Łagowo) 1448

Łąkie $\rightarrow$ Lanken (Kr. Züllichau-Schiwebus)

Lamsdorf (Kr. Falkenberg/OS.) (poln. Łambinowice) 753

Landeshut in Schlesien (Kreis) 151

Landsberg/Warthe (poln. Gorzów Wlkp.) 82, 86, 93-95, 119, 137 f., 189, 327, 342, 369-371, 374, 398 f., 401, 411 f., 418 f., 423 f., 427 f., 439 f., 452, 461, 472, 487, 494 f., 503, 642, 672, $692,755,771,808,821,838,854,875,905$, 921 f., $965,1091,1208$ f., 1305, 1347, 1353 f., 1375, 1406, 1417, 1434, 1438, 1442 f., 1447, $1450,1457,1460,1463,1468,1471,1473$, 1542; Brückenvorstadt 440, 1443; Sowjet. Speziallager Nr. 4: 183

Landsberg/Warthe (Archipresbyterat) $443 \mathrm{f}$.

Landsberg/Warthe (Kirchenkreis) 435

Landsberg/Warthe (Landkreis) 93 f., 100, 216, 369-371, 374, 388, 401, 411, 439f., 461, 692, $965,996,1130,1270,1346-1348,1353 \mathrm{f}$., $1409 \mathrm{f}$.

Landsberg/Warthe (Woiwodschaft) $\rightarrow$ Gorzów Wlkp.

Landshut (Bayern) 94

Landskron (tschech. Lanškroun) 328

Langenbielau (Kr. Reichenbach, Schleisen) (poln. Bielawa) 937, 1473

Langendorf (Kr. Neisse) (poln. Bodzanów) 1458

Langendorf (Kr. Wehlau) (russ. Sokolniki) 249

Langengrassau bei Luckau 389

Langenhagen bei Hannover 82, 1482, 1541

Langenlipsdorf (Kr. Jüterbog-Luckenwalde) 1289

Langenpfuhl (Kr. Oststernberg) (poln.

Wielowieś) 130, 1452

Langenstein bei Halberstadt 1456

Langenwaldau (Kr. Liegnitz) (poln. Grzymalin) 949

Langewahl (Kr. Beeskow-Storkow) 1029

Langfuhr $\rightarrow$ Danzig-Langfuhr

Lanke (Kr. Niederbarnim) 1034, 1099

Lanken (Kr. Züllichau-Schiwebus) (poln. Łąkie) 137, 1456

Lankwitz (Berlin) $\rightarrow$ Berlin-Lankwitz

Lanškroun $\rightarrow$ Landskron

Lanz (Kr. Westprignitz) 106f., 217, 434, 548
Lask (Polen/Wartheland) (poln. Łask) (Kreis) 526, 996

Laski $\rightarrow$ Läsgen (Kr. Grünberg)

Lauban (Schlesien) (poln. Lubań) 359, 1469

Laubnitz (Kr. Sorau) (poln. Lubanice) 796

Lauchhammer 910

Lauchhammer-Mückenberg $\rightarrow$ Mückenberg

Lauenburg/Elbe 109

Lauenhof (Kr. Prenzlau) 113, 541

Lauscha/Unstrut 1464

Lausick (Bad) (Sachsen) 171, 1100

Lausitz (Nieder- und Oberlausitz) 32, 209, 358, $407,428,1464$

Lausitzer Neiße (Fluss) $\rightarrow$ Neiße

Lauta (Kr. Calau) 526, 778, 1253

Lautawerk bei Hoyerswerda 82, 778, 1465, 1468

Lauterbach (Schönhengstgau/Böhmen) (tschech. Město Litrbachy, nach 1945 Čistá) 579

Lawitz (Kr. Guben) 1302

Ławszowa $\rightarrow$ Lorenzdorf (Kr. Bunzlau)

Łazy $\rightarrow$ Laaso (Kr. Guben)

Lebbin (Kr. Beeskow-Storkow) 1029

Lebus (Kr. Lebus) 216, 399, 408, 455, 532 f., 582, $778 f$., 874 f., 892

Lebus (Kreis) 92, 100 f., 112, 117, 164, 193, 199, 202, 204, 208 f., 216, 222, 375, 455, 494, 531, 658, 757, 769 f., 773, 1001 f., 1007 f., 1035, $1103,1151,1204,1230,1409,1479$

Lebusa bei Herzberg/Elster 389, 1472

Lebuser Land (Ziemia Lubuska) 135, 210, 673

Łęczno $\rightarrow$ Lentschen (Kr. Meseritz)

Łęczyca (Kreis) $\rightarrow$ Lentschütz (Kreis)

Leegebruch (Kr. Osthavelland) 157 f., 229, 299, 301 f., 307 f., 356, 386, 469, 538, 779-780, $831,1100,1198$

Leeskow (Kr. Lübben) 1459

Legde (Kr. Westprignitz) 56, 1437, 1443

Legnica $\rightarrow$ Liegnitz

Lehnin (Kr. Zauch-Belzig) 399, 550, 597, 601, 606, 741 f., 781f., 1449, 1543; Diakonissenmutterhaus Luise-Henriette 221, 433, 782, 1259

Lehnitz/Nordbahn (Kr. Niederbarnim) 222, 1033

Leibchel (Kr. Lübben) 535, 783

Leibsch (Kr. Beeskow-Storkow) 728, 801, 1029, $1142 \mathrm{f}$.

Leimnitz (Kr. Züllichau-Schwiebus) (poln. Glińsk) 684, 1450 
Leipa $\rightarrow$ Böhmisch Leipa

Leipe (Kreis) (poln. Lipno) $863 \mathrm{f}$.

Leipzig 54, 116, 137, 240, 243, 263, 363, 397, 666, 806, 1229, 1257, 1417, 1434-1436;

Deutsche Bücherei 383, 394, 402; Georgi-Dimitroff-Museum 243; Lager 588, 1447; Messe 1200, 1228, 1479; Universität 10, 21, 36, 1439, 1471; Zoologischer Garten 407 f.

Leipzig (Kreis) 54, 407

Leitersdorf (Kr. Crossen) (poln. Sycowice) 852

Leitmeritz (tschech. Litoměřice) 1443

Leitmeritz (Bistum) 445, $882 \mathrm{f}$., $954 \mathrm{f}$.

Lemberg (poln. Lwów, ukrain. Lwiw) 653

Lemmersdorf (Kr. Prenzlau) 924

Lentschen (1939-1945 Weidenfeld) (Kr. Meseritz) (poln. Łęczno) 582

Lentschütz (Polen/Wartheland) (Kreis) (poln. Łęczyca) 546, 582, 996

Lentzke (Kr. Osthavelland) 1100, $1111 \mathrm{f}$.

Lenzen (Elbe) (Kr. Westprignitz) 106, 222, 454, 462, 549, 783f., 958, 1199, 1455

Leobschütz/OS. (poln. Głubczyce) 428f., 746

Leonow [Leonowo?] 185

Leslau (Wartheland) (poln. Włocławek) 863

Leslau (Kreis) 111, 216, 218, 774, 996

Leśniów Wielki $\rightarrow$ Groß Lessen (Kr. Grünberg)

Lesnoje $\rightarrow$ Groß Lenkeningken (Kr. TilsitRagnit)

Lesten (Kr. Guhrau) $\rightarrow$ Tschirnau

Leszno $\rightarrow$ Lissa (Posen)

Letschin (Kr. Lebus) 39f., 46, 74, 234, 314, 469, 501, 533, 784f., 1443, 1467, 1474, 1543

Letschow (Mecklenburg), Lager 1440

Lettland 78, 199, 233, 654, 759, 860, 935, 957, 959, 1034f., 1037, 1414

Leuthen (Kr. Cottbus) 225, 527, 634, 785f.

Łężany $\rightarrow$ Dürwangen (Kr. Rößel)

Libbenichen (Kr. Lebus) 770, 971

Liberec $\rightarrow$ Reichenberg (Sudetenland)

Lichtenberg (Berlin) $\rightarrow$ Berlin-Lichtenberg

Lichtenberg (Mecklenburg) 90

Lichtenfels (Oberfranken) 1463

Lichtenow (Kr. Niederbarnim) 1032

Lichterfelde (Berlin) $\rightarrow$ Berlin-Lichterfelde

Lichterfelde (Kr. Jüterbog-Luckenwalde) 1306

Lidzbark Warmiński $\rightarrow$ Heilsberg (Ostpreußen)

Liebenau (Kr. Wongrowitz) (poln. Jaworówka) 109, 1456

Liebenberg (Kr. Templin) 118 f., 1474
Liebenow (Kr. Greifenhagen) (poln. Lubanowo) 1438

Liebenthal (Kr. Niederbarnim) 1033

Liebenwalde (Kr. Niederbarnim) 221, 455, 536, $786,1032,1280$

Liebenwerda, Bad 498, 656, 1407

Liebenzig (Kr. Freystadt) (poln. Lubięncin) 620

Lieberose (Kr. Lübben) 22, 37, 45, 133, 191, 535, 739 f., 786 f., 794

Liebstadt (Ostpreußen) (poln. Miłakowo) 343

Liège $\rightarrow$ Lüttich

Liegnitz (Schlesien) (poln. Legnica) 421, 504, $562,576,875,1274$

Liepe (Kr. Angermünde) 208, 1542

Lieskau (Kr. Luckau) 1102

Lietzen (Kr. Lebus) 1438

Ligota Turawska $\rightarrow$ Ellguth Turawa

Liliendorf (Kr. Strelno) (poln. Sławsko Górny) 330

Limsdorf (Kr. Beeskow-Storkow) 1029

Lindau (Anhalt) 399

Lindena (Kr. Luckau) 134, 1444

Lindenberg (Kr. Beeskow-Storkow) 1029, 1074, 1454

Lindenberg (Kr. Niederbarnim) 1031, 1099

Lindenberg (Kr. Ostprignitz) 539, 787

Lindenhain (Kr. Guben) $\rightarrow$ Niemaschkleba

Lindewiese (Kr. Neisse) 328

Lindow (Kr. Ruppin) 214, 452, 542, $787 f$., 820 f., 882, 1209

Lindow-Banzendorf $\rightarrow$ Banzendorf

Lindthal (Kr. Luckau) 416

Linthe (Kr. Zauch-Belzig) 237, 605

Lipiany $\rightarrow$ Lippehne (Kr. Soldin)

Lipno (Kreis) $\rightarrow$ Leipe (Kreis)

Lipová $\rightarrow$ Hainspach

Lippehne (Kr. Soldin) (poln. Lipiany) 205, $288 \mathrm{f}$., 343 f., 386, 671 f., 1444, 1454

Lissa (Posen) (poln. Leszno) 340, 368, 689, 874, 927

Lissa (Kreis) 284, 533, 544, 996

Litauen 141, 199, 220, 225, 233, 688, 703 f., 706, 730, 760, 830, 846, 957, 1094, 1414, 1421, 1436,1448

Litoměřice $\rightarrow$ Leitmeritz

Litrbachy (Město Litrbachy) $\rightarrow$ Lauterbach

Litzmannstadt (Stadt) $\rightarrow$ Lodz

Litzmannstadt (Landkreis) (Lodz) 526, 534, 996

Litzmannstadt (Regierungsbezirk) 215 
Lobetal (Kr. Oberbarnim) 44, 222, 537, 788, 1031; Hoffnungstaler Anstalten 588, $880 \mathrm{f}$.

Lodenau (Rothenburg/Oberlausitz) 36

Lodz (Lodsch, poln. Łódź, dt. 1940-1945 Litzmannstadt) (Polen/Wartheland) 65, 124f., 149, 152, 185 f., 215 f., 232, 273, 330 f., 408, $417,433,552,582,597,616,653,662,733$, $838,862,869,883,915,960,996,1068,1096$, 1098, 1207, 1392, 1449; Ghetto 281, 1446; Sportlager 1446; Verkehrsbusse 662

Löbau (Westpreußen) (poln. Lubawa) 343

Löcknitz (Kreis), Rat des Kreises 817

Lögow (Kr. Ruppin) 155

Löhme (Kr. Niederbarnim) 1032

Löwenberg (Mark) (Kr. Ruppin) 1209, 1441

Löwenberg (Kreis) 151, 422

London, Außenministerkonferenz (1947) 348, 1292-1296, 1298, 1407, 1410

Lorenzdorf (Kr. Bunzlau?) (poln. Ławszowa) 954

Louisa (Warthebruch) (Kr. Oststernberg) (poln. Przemysław) 1440

Lubań $\rightarrow$ Lauban (Schlesien)

Lubanice $\rightarrow$ Laubnitz (Kr. Sorau)

Lubanowo $\rightarrow$ Liebenow (Kr. Greifenhagen)

Lubast (Kr. Wittenberg) 293

Lubawa $\rightarrow$ Löbau (Westpreußen)

Lubięncin $\rightarrow$ Liebenzig (Kr. Freystadt)

Lubieszewo $\rightarrow$ Güntershagen (Kr. Dramburg)

Lubin $\rightarrow$ Lüben (Schlesien)

Lublin (Polen) 1443

Lubniewice $\rightarrow$ Königswalde (Kr. Oststernberg)

Lubolz, Forsthaus (Kr. Luckau) 416

Lubsko $\rightarrow$ Sommerfeld (Niederlausitz)

Luckau 18, 101 f., 211, 274, 276, 292 f., 416, 457, 496, 534, 573, 611 f., 617, 619, 651, 699, 788-790, 945, 1153, 1351, 1450, 1461, 1502, $1543 \mathrm{f}$.

Luckau (Kreis) 139, 164, 166, 199, 210, 217, 228, 231, 335, 379, 533f., 611, 790, 798 f., 996, $1035,1063,1102,1117,1151,1158,1230$, $1236,1352,1363,1407$

Luckenwalde (Kr. Jüterbog-Luckenwalde) 211, $218,245,270,306,338,340,356,362,414$, 416, 428 f., 456, 482, 530, 745 f., 790-793, 813, $852,971,982,1010,1042$ f., 1135-1137, 1149 , 1152, 1156-1158, 1204f., 1238, 1244, $1246 \mathrm{f}$., $1265,1286,1289,1305-1307,1372,1451 \mathrm{f}$.; Lager 164, 531, 1063, 1230; Landrat, Landrat- samt, Rat des Kreises 248, 744, 1041-1043, 1058, 1119 f., 1135 f., 1138, 1149 f., 1200, $1215,1221,1227$ f., $1238,1285,1289,1300$, 1304 f., 1307 f., 1419; Waldfriedhof, Ehrenfeld Mohrungen 222, 356, 480, $791 f$.

Luckenwalde(-Jüterbog) (Kreis) (siehe auch $\rightarrow$ Jüterbog-Luckenwalde) 199, 210, 245, 248, 304, 530f., 657, 746, 792, 813 f., 971, 978, 983-985, 988 f., 1035, 1041-1043, 1058, 1063, 1101, 1103, 1117, 1119 f., 1135-1138, 1149-1151, 1158 f., 1182, 1221-1224, 1228, 1230, 1235, 1238 f., 1247, 1250, 1285-1290, 1300, 1304-1306, 1373, 1419, 1451

Ludwigsberg $\rightarrow$ Lagowo (Kr. Kosten)

Ludwigsburg bei Stuttgart 703

Ludwigslust (Mecklenburg) 168, 1340, 1441

Ludwigsfelde (Kr. Teltow) 544, 793f., 1063, 1101, 1457, 1468

Lübben/Spreewald 18, 32, 44 f., 83, 99, 101, 140, 191, 279, 322, 396 f., 399, 412f., 457, 496 f., 535, 590, 634, 729, 739, 765, 790, 794-799, 852, 925 f., 934, 991, 1348 f., 1363, 1412, 1459, 1461, 1542; Bahnhof 795, 998; Gedenkstein (Friedhof) 480, 798; Jägerkaserne 535, $796 \mathrm{f}$;; Lager 164, 534f., 794f., $796 f ., 1063$

Lübben-Steinkirchen 798, 1349

Lübben-Treppendorf $\rightarrow$ Treppendorf (Kr. Lübben)

Lübben (Kreis) 11, 18, 52, 102, 140, 164, 199, 202, 211, 397, 534-536, 739 f., 765 f., 783, 790, 794, 796, 798 f., 996, 1001 f., 1007 f., $1035,1063,1086,1151,1230,1348,1352$, 1363,1407

Lübbenau (Spreewald) (Kr. Calau) 102, 164, 457, 496, 526, 616, 753, 799f., 1063, 1198

Lübbinchen (Kr. Guben) 282, 317

Lübeck 112, 427, 467, 1440, 1451, 1474, 1481

Lüben (Schlesien) (poln. Lubin) 1466

Lüderitz (Kr. Stendal) 1451

Lüdersdorf (Kr. Angermünde) 524, 1315, 1317, 1322, 1329

Lüdersdorf (Kr. Teltow) 1468

Lüdersen bei Hannover 413, 415

Lüllemin (Kr. Stolp) (poln. Lulemino) 1436

Lüneburg 74, 107 f., 207, 362, 394, 669, 704

Lüneburg (Kreis) 107-109, 1446

Lüneburger Heide 234

Lütkendorf (Kr. Westprignitz) $1146 \mathrm{f}$.

Lüttich (Belgien) (wallonisch Liège) 511 
Lützlow (Kr. Angermünde) 1317, 1322

Lugau (Erzgebirge) 413

Ługi $\rightarrow$ Friedersdorf (Kr. Grünberg)

Łukawy $\rightarrow$ Hermsdorf (Kr. Sorau)

Lulemino $\rightarrow$ Lüllemin (Kr. Stolp)

Lunow (Kr. Angermünde) $1329 \mathrm{f}$.

Lutol Suchy $\rightarrow$ Dürrlettel (Kr. Meseritz)

Lwiw, Lwów $\rightarrow$ Lemberg

Lychen (Kr. Templin) 106, 164, 191, 279, 455, 540, 545 f., 705, 736, 800 f., 932 f., 1063, 1343, 1480

Lyck (Kreis) (poln. Ełk) 1455

Madlow (Kr. Cottbus) 324, 1483

Mähren 655

Mährisch-Ostrau (Ostrau; tschech. Ostrava) 667, 912, 997

Mährisch-Ostrau-Witkowitz (tschech. OstravaVítkowice) 667

Märkisch Buchholz (Kr. Beeskow-Storkow) (bis 1937 Wendisch Buchholz) 417, 525, 586, 727, $801 f$., 1028, 1069, 1235, 1483

Märkische Schweiz 96

Märkisch-Oderland (Landkreis) 501, 507, $510 \mathrm{f}$., $907 \mathrm{f}$.

Märkisch Rietz $\rightarrow$ Wendisch Rietz

Magazininsel $\rightarrow$ Rathenow, Lager

Magdeburg 9-13, 209, 218, 233, 290, 411 f., 426, $1440,1447,1456,1463,1468$

Magdeburg-Neustadt, Bahnhof 96

Magdeburg (Bezirk) 54

Mahlow (Kr. Teltow) 544, 802, 1101 f., 1127, 1176-1178, 1219

Mahlsdorf (Berlin) $\rightarrow$ Berlin-Mahlsdorf

Mainz 336

Majowka $\rightarrow$ Georgenburg (Kr. Insterburg)

Mąkoszyce $\rightarrow$ Mangschütz (Kr. Brieg)

Małbork $\rightarrow$ Marienburg (Westpreußen)

Malchow (Mecklenburg) 404

Malenuppen (Kr. Darkehmen/Angerapp) (russ. Sadoroschje) 504

Mallnow (Kr. Lebus) 758

Małyszyn $\rightarrow$ Merzdorf (Kr. Landsberg/W.)

Malz (Kr. Niederbarnim) 1033

Mangschütz (Kr. Brieg) (poln. Mąkoszyce) 413

Manschnow (Kr. Lebus) 95, 772, 1437, 1443, 1455

Mansfeld (Sachsen-Anhalt) 1188

Marburg/Lahn 296, 1543
Margonin (Posen) 106

Marggrabowa $\rightarrow$ Treuburg

Marienburg (Westpreußen) (poln. Małbork) 441, 1209, 1471

Mariendorf $($ Berlin $) \rightarrow$ Berlin-Mariendorf

Marienfeld bei Müncheberg $\rightarrow$ MünchebergMarienfeld

Marienfelde (Berlin) $\rightarrow$ Berlin-Marienfelde

Mariengrund $\rightarrow$ Poremba

Marienquell (Kr. Glogau) $\rightarrow$ Quilitz

Mariental bei Helmstedt, Lager 169

Marienwerder (Kr. Niederbarnim) 1034

Marienwerder (Westpreußen) (poln. Kwidzyn) 152 f., $181,343,823$

Markau (Kr. Osthavelland) 1111

Markee (Kr. Osthavelland) 1111

Markendorf (Kr. Jüterbog-Luckenwalde) 1222

Markersdorf (Kr. Guben) (poln. Markosice) 708, 916, 1444

Markgrafpieske (Kr. Beeskow-Storkow) 1029, 1069, 1074

Markosice $\rightarrow$ Markersdorf (Kr. Guben)

Markranstädt (Sachsen) 387

Marl (Westfalen) 585

Marnitz (Kr. Parchim) 1450

Marquardt (Kr. Osthavelland) 538, 641, 802f., 870

Marunowo $\rightarrow$ Fitzerie (Kr. Czarnikau)

Marwalde (Kr. Osterode) (poln. Marwałd) 838

Marwitz (Kr. Osthavelland) 1100, 1111, 1343

Marzahn (Berlin) $\rightarrow$ Berlin-Marzahn

Massen (Kr. Luckau) 509

Massow (Kr. Naugard) (poln. Maszewo) 495, 946

Masuren (poln. Mazury) 141, 143, 340, 504, 671, 792, 1279, 1372, 1391, 1467, 1534

Maszewo $\rightarrow$ Massow (Kr. Naugard)

Matzdorf (Kr. Löwenberg) (poln. Maciejowiec) 329

Mazury $\rightarrow$ Masuren

Mechow (Kr. Ostprignitz) 539

Mecklenburg (Land) 36, 47, 51, 68, 83, 91, 95, 106f., 112, 115-118, 120, 126, 139, 160, 168, $189,192,207,213,219,222,225,234,236$, 258, 294 f., 327, 364, 375, 388 f., 395, 399, 404f., 415, 425, 503, 533, 535, 557, 559, 611, 634, 827, 847, 849, 927, 971, 1001, $1012 \mathrm{f}$., 1035-1038, 1066, 1103, 1108, 1117, $1126 \mathrm{f}$., 1153 f., 1249 f., 1304, 1342, 1350, 1394, 1407, 
$1416,1437,1439$ f., 1442 f., $1457,1460,1468$, 1470 f., 1477,1534

Mecklenburg-Vorpommern 10 f., 31, 47, 51, 168 f., 189, 192, 204 f., 207 f., 218, 271, 416, 475,485

Meglitz (Fluss) 902

Mehlsdorf (Kr. Jüterbog-Luckenwalde) 651

Mehrow (Kr. Niederbarnim) 1033

Meinsdorf (Kr. Jüterbog-Luckenwalde) 852, 1541

Meißen (Bistum) 37, 443, 445, 460, 484

Melchow (Kr. Oberbarnim) 587

Mellen (Kr. Westprignitz) 548, 783, 1448

Mellenau (Kr. Templin) 106

Mellensee (Kr. Teltow) 222, 1374, 1468

Melnik (Tschechien) (tschech. Mělník) 428, 830, 1441,1470

Memel (Ostpreußen) (lit. Klaipeda) 340, 342, 704, 792, 853, 962

Memelland 73, 199, 368, 592, 597, 730, 853, 964

Menden (Westfalen) 1343

Merseburg 1444

Merz (Kr. Beeskow-Storkow) 1029, 1074

Merzdorf (Kr. Cottbus) 1358

Merzdorf (Kr. Landsberg/W.) (poln. Małyszyn bzw. Gorzów Wlkp.-Małyszyn) 94, 1358, 1463

Merzwiese (Kr. Crossen) (poln. Wężyska) 418

Meschede (Sauerland) 912

Mescherin (Kr. Randow) 302

Mesendorf (Kr. Ostprignitz) 774

Meseritz (poln. Międzyrzecz) 88, 120, 289, 396, 495, 539, 548 f., 568, 653, 667, 775, 837, 869, 971, 1464

Meseritz-Obrawalde $\rightarrow$ Obrawalde

Meseritz (Kreis) 94, 110, 127, 347, 359, 383, 396, 484 f., 489, 539, 548 f., 648, 775, 837 f., 841, 868 f., 881,1000 f., 1270,1339 f., 1459 f., 1543

Město Litrbachy $\rightarrow$ Lauterbach

Meyenburg (Kr. Angermünde) 522

Meyenburg (Kr. Ostprignitz) 101, 454, 539, 638, 803f., $870 \mathrm{f}$.

Miastko $\rightarrow$ Rummelsburg (Pommern)

Michelsdorf (Kr. Zauch-Belzig) 1370

Michelsfeld (Kr. Briesen) $\rightarrow$ Myśliwiec

Michendorf (Kr. Zauch-Belzig) 230, 550, 575, 804

Miechowitz (Kr. Beuthen/OS.) (1936-1945 Mechtal) (poln. [Bytom-] Miechowice) 210, 732
Miedzichowo $\rightarrow$ Kupferhammer (Kr. Meseritz)

Międzychód (Kreis) $\rightarrow$ Birnbaum (Kreis)

Miedzygórze $\rightarrow$ Wölfelsgrund

Międzylesie $\rightarrow$ Mittwalde

Międzylesie $\rightarrow$ Schönwiese bei Guttstadt

Międzyrzecz $\rightarrow$ Meseritz

Miersdorf (Kr. Teltow) 1102, 1199

Mieszkowice $\rightarrow$ Bärwalde/Nm.

Mietzelfelde (Kr. Soldin) (poln. Myśliborzyce) 685

Mikulášovice $\rightarrow$ Nixdorf

Miłakowo $\rightarrow$ Liebstadt (Ostpreußen)

Mildenberg (Kr. Templin) 459, 546, 804f.

Milikowice $\rightarrow$ Arnsdorf (Kr. Schweidnitz)

Milmersdorf (Kr. Templin) 106

Milow/Havel (Kr. Jerichow II) 1439

Milsko $\rightarrow$ Milzig (Kr. Grünberg)

Miltern (Kr. Stendal) 1452

Milzig (Kr. Grünberg) (poln. Milsko) 211, 481, 607

Mirow (Mecklenburg) 1481

Mischlewitz (Kr. Briesen) (1942-1945 Michelsfeld) (poln. Myśliwiec) 1448

Mittelberg (Walsertal, Österreich) 9

Mitteldeutschland (geographisch) 121, 127,363, 1306

„Mitteldeutschland“ (politisch) (siehe $\rightarrow$ DDR (1949-1990), $\rightarrow$ Neue Bundesländer (ab 1990) $\rightarrow$ SBZ (1945-1949)

Mitteleuropa (siehe auch $\rightarrow$ Ostmitteleuropa) 64, 853; „Mittelosteuropa“ $\rightarrow$ Ostmitteleuropa

Mittelpolen $\rightarrow$ Polen

Mittelsteine (Kr. Neurode/Glatz) (poln. Ścinawka Średnia) 899

„Mittelzone“ $\rightarrow$ DDR

Mittenwalde (Kr. Teltow) 196, 456, 544, 805, 1102

Mittwalde (Kr. Züllichau-Schwiebus) (poln. Międzylesie) 1444

Moabit (Berlin) $\rightarrow$ Berlin-Moabit

Moderschan $\rightarrow$ Prag-Modřany

Mödlich (Kr. Westprignitz) 106 f., 1446

Möllen (Kr. Lübben) 1466

Möllenbeck bei Neustrelitz 137

Möllendorf (Kr. Beeskow-Storkow) 1029

Mölln (Schleswig-Holstein) 860, 1436

Mönchengladbach 25, 82, 1542

Mönchwinkel (Kr. Niederbarnim) 536, 805, 1032

Mörz (Kr. Zauch-Belzig) 234, 314, 550, 806, 1468 
Möthlow (Kr. Westhavelland) 283

Möthlowshof bei Böhne (Kr. Jerichow II) 1471

Mogilno (Posen) 869

Mogilno (Kreis) 217, 484, 538, 905, 996

Mohrin (Kr. Königsberg/Nm.) (poln. Moryń) 103-106, 495, 743, 874, 1435

Mohrungen (Kreis) (poln. Morąg) 222, 356, 480, 791-793

Mokronosy (Kr. Wongrowitz) (1939 Mokronos, 1940?-1945 Hasenpoth, Kr. Eichenbrück) (poln. Mokronosy) 106

Molchow (Kr. Ruppin) 821

Moldavien 235

Molkenberg (Kr. Lebus) 687

Montabaur (Westerwald) 1466

Morąg $\rightarrow$ Mohrungen

Moringen (Niedersachsen) 1541

Morrn (Kr. Landsberg/W.) (poln. Murzynowo) 440

Moryń $\rightarrow$ Mohrin (Kr. Königsberg/Nm.)

Moschen (Kr. Neumark) $\rightarrow$ Mroczno

Moskau 149, 242, 251 f., 331; Außenministerkonferenzen (1945:) 1407; (1947:) 1286, $1290 \mathrm{f}$., 1409; DDR-Botschaft 158

Most $\rightarrow$ Brüx

Mostkowo $\rightarrow$ Chursdorf (Kr. Soldin)

Mrągowo $\rightarrow$ Sensburg

Mroczno (Kr. Löbau, Westpreußen) (1939-1945 Moschen, Kr. Neumark) (poln. Mroczno) 1467

Mrówieniec $\rightarrow$ Finkenhübel bei Dürrkunzendorf

Mückenberg (Lauchhammer) 1459

Mückendorf (Kr. Jüterbog-Luckenwalde) 1287

Müggenbusch bei Havelberg $\rightarrow$ Havelberg-Müggenbusch

Mühlberg/Elbe 517, 656; Sowjet. Speziallager Nr. 1: 291, 1465

Mühlbock (Kr. Züllichau-Schwiebus) (poln. Obłobok) 136, 1468

Mühlenbeck (Kr. Niederbarnim) 1032, 1099

Mühlhausen (Thüringen) 405

Müllrose (Kr. Lebus) 22, 101, 251, 275, 410-412, $455,533,664,666,806-808,945,1467$

Müncheberg (Kr. Lebus) 61, 96, 113, 190, 193, 221, 282, 455, 480, 494, 503, 532 f., 609 f., 623 , 808-810, 1436, 1438-1442, 1447, 1449 f., 1453 f., 1456 f., 1463, 1468, 1474f., 1482, 1541,1544

Müncheberg-Dahmsdorf 101, 1439

Müncheberg-Marienfeld 1441, 1463
Münchehofe (Kr. Beeskow-Storkow) 83, 1029

Münchehofe (Kr. Niederbarnim) 1033

München 53, 75, 147 f., 211, 336, 397, 444, 510, 590, 1444

Münnichwies (Münichwiesen) bei DeutschProben (slowak. Vrícko) 236

Münster/Westf. 9, 414f., 427, 879

Münster (Bistum) 445, 592

Münster (Regierungsbezirk) 403

Müschen (Kr. Cottbus) 1460

Muggerkuhl (Kr. Westprignitz) 1206

Muralto bei Locarno (Schweiz) 1049

Murowana Goslin (Kr. Obornik) (poln. Murowana Goślina) 126

Murowana Goślina $\rightarrow$ Murowana Goslin

Murzynowo $\rightarrow$ Morrn (Kr. Landsberg/W.)

Muschten (Kr. Züllichau-Schwiebus) (poln. Myszęcin) 1453

Muskau, Bad (Kr. Rothenburg, Oberlausitz) 632, 657,915

Myrnopillya (Ukraine) $\rightarrow$ Friedensfeld

Myślibórz $\rightarrow$ Soldin/Nm.

Myśliborzyce $\rightarrow$ Mietzelfelde (Kr. Soldin)

Myśliwiec $\rightarrow$ Mischlewitz (Kr. Briesen)

Myszęcin $\rightarrow$ Muschten (Kr. Züllichau-Schwiebus)

Nachterstedt bei Aschersleben 391

Nadrauen 343

Näfels (Schweiz) 504, 1541

Nahausen (Kr. Königsberg/Nm.) (poln. Nawodna) $42,198,200,576,603,901,931$

Nahrten (Kr. Guhrau) (poln. Naratów) 1467

Nakel (Kr. Oppeln) (poln. Nakło) 1458

Namslau (Schlesien) (poln. Namysłów) 151, 428 f., 465, 756, 795, 820, 822 f., 877, 1181, 1435,1443

Namslau (Kreis) 211, 823 f., 883, 911 f., 948, 1075,1543

Namyślin $\rightarrow$ Neumühl (Kr. Königsberg/Nm.)

Namysłów $\rightarrow$ Namslau

Naratów $\rightarrow$ Nahrten (Kr. Guhrau)

Narew (Fluss) 1403

Narva (Estland) 863

Nassenheide (Kr. Niederbarnim) 1033

Nattwerder (Kr. Osthavelland) $\rightarrow$ Potsdam-Grube

Nauen (Kr. Osthavelland) 103, 114, 121, 386, 447, 537 f., 597, 651, 810-812, 964, 971, 984, $996,1100,1201,1338,1340,1343,1519$

Nauen-Bergerdamm $\rightarrow$ Bergeredamm 
Nauen (Kreis) 193, 456, $811 \mathrm{f}$.

Naugard (Pommern) (Kreis) (poln. Nowogard) $861,863,1465$

Naumburg am Bober (Kr. Freystadt) (poln. Nowogród Bobrzański) 102, 428, 496, 800, 1463

Naumburg (Saale) 399

Nausdorf (Kr. Westprignitz) 1455

Nawodna $\rightarrow$ Nahausen (Kr. Königsberg/Nm.)

Nebelin (Kr. Westprignitz) 106, 1446

Neberg (Kr. Sensburg) (poln. Nibork) 1450

Neckarhausen (Kr. Nürtingen) 1249

Nedlitz (Kr. Osthavelland) $\rightarrow$ Potsdam-Nedlitz

Nehesdorf (Kr. Luckau) 1064

Neinstedt/Harz, Neinstedter Anstalten 1456

Neisse (Schlesien) (poln. Nysa) 379, 428, 590, $600,648,789,796,925,971$

Neisse (Kreis) 379

Neiße (Fluss) (poln. Nysa) (siehe auch $\rightarrow$ Polen/ Westgrenze) 83 f., 129, 133 f., 137, 195 f., 198, 284, 322, 347-349, 356, 422, 442, 467, 487, $507,526,528,542,585,615,657$ f., 706-708, 711-715, 741, 947, 997, 1003, 1009, 1153, $1284,1296,1300,1303,1325,1332,1404$, $1406,1441,1444,1459,1465,1470$

Nennhausen (Kr. Westhavelland) 547, 812, 878

Nettkow (Kr. Grünberg) $\rightarrow$ Polnisch Nettkow

Netzebruch 531, 837, 1461

Netzedistrikt 841

Netzekreis 217, 863, 1456

Netzschkau (Vogtland) 1444

Neubarnim (Oderbruch) (Kr. Oberbarnim) 1443

Neu Behrensdorf (Kr. Beeskow-Storkow) 1028

Neu Bentschen (Kr. Meseritz) (poln. Zbąszynek) $193,495,835,1349,1445,1464$

Neuberesinchen $\rightarrow$ Frankfurt-Neuberesinchen

Neu Boston (Kr. Beeskow-Storkow) 1029

Neubrandenburg (Mecklenburg) 192, 1439

Neubrandenburg (Bezirk) 381, 405, 407, 903

Neubrück/Spree (Kr. Beeskow-Storkow) 1029

Neubrück bei Hennigsdorf/Oranienburg (Kr. Niederbarnim) 734

Neudamm (Kr. Königsberg/Nm.) (poln. Dębno) $129,146,420,428,490,494,700,784,927$, $1206,1441,1450$

Neu Döberitz (Kr. Osthavelland) 631

Neudorf (Schlesien) [Welches?] 690

Neudorf bei Sebastiansberg (Sudetenland) (tschech. Hora Svatého Šebestiána-Nová Ves) 1470
Neue Bundesländer 4, 10, 12 f., 31, 58, 61, 209, 220, 228, 233, 324, 326f., 362, 385, 403, 463-464, 478, 483-485, 491 f., 497, 501, 1378

Neuendorf bei Beeskow (Kr. Beeskow-Storkow) 999, 1007, 1029

Neuendorf bei Brück (Kr. Zauch-Belzig) 42, 605

Neuendorf (am See) bei Märkisch Buchholz (Kr. Beeskow-Storkow) 728, 801, 1029

Neuendorf (im Sande) bei Fürstenwalde/Spree (Kr. Lebus) 693

Neuenhagen (Kr. Niederbarnim) 61, 63-65, 74, 113 f., 149 f., 157, 171, 265 f., 288, 333, 417, 495, 503, 536, 812f., 1033, 1099, 1445, 1448, $1453,1467,1475,1483,1543$

Neuenkirchen bei Osnabrück 74

Neuenkirchen bei Stettin (Kr. Randow) (poln. Dołuje) 562

Neue Schleuse (Kr. Jerichow II) 876 f., 879

Neu Fahrland $\rightarrow$ Potsdam-Neu Fahrland

Neufahrn bei München 1541

Neuglietzen (Kr. Königsberg/Nm.) $196 \mathrm{f}$.

Neu Golm (Kr. Beeskow-Storkow) 1029

Neuhardenberg (Kr. Lebus) 92f., 164, 533, 784, $813,1437,1449$

Neuheim (Dorf Zinna) (Kr. Jüterbog-Luckenwalde) 158, 164, 229 f., 299, 301-306, 315, 335 f., 530 f., 651, 745, 813-815, 984 f., 1138, 1198,1200 f., 1205, 1220 f., 1224, 1227-1229, 1246-1248, 1412, 1414f., 1441

Neuholland (Kr. Niederbarnim) 218, 1032

Neuhorno (Forst/Lausitz) 1401

Neu Kietz bei Bad Freienwalde 567

Neukölln (Berlin) $\rightarrow$ Berlin-Neukölln

Neukramzig (Kr. Bomst) (1937-1945 Kleistdorf) (poln. Nowe Kramsko) 572

Neu Krüssow (Kr. Ostprignitz) 289f., 869, 1464

Neu Künkendorf (Kr. Angermünde) 164, 524, 815,1063

Neuküstrinchen (Kr. Königsberg/Nm.) 531, 537, 815,817

Neu Kunersdorf (Kr. Crossen) (poln. Kosobudki) 1467

Neuli?schaften bei Frankfurt (Oder) [?] 647

Neulietzegöricke (Kr. Königsberg/Nm.) 531, $537,815 f$.

Neu Lindenberg (Kr. Niederbarnim) 536, 816

Neulübbenau (Kr. Beeskow-Storkow) 1030, 1086, 1142 
Neumark (Landschaft) (siehe auch $\rightarrow$ Ostbrandenburg) 22, 29, 43, 74, 79, 82, 86, 92, $99 \mathrm{f}$., $103,107,109,117,120,128-130,132,134$, 146, 171, 183, 187 f., 195 f., 203-208, 210, 212, 216f., 273-275, 284f., 290, 294, 298, 309, $323,329,336,345,355,361,367-369,379$, 394f., 399, 405, 418f., 427-430, 435-437, 443, 452, 471 f., 474 f., 477 f., 482 f., 488, 492 , $503,532,540,545,555,560,562$ f., 566, 591, $644,662,673,687,691,696,700,775,802$, $854,901-903,928,977,1210,1347,1352$, 1417,1435 f., 1443, 1450, 1454-1456, 1460, $1463,1471,1542$

Neumark in Westpreußen (Kreis) (poln. Nowe Miasto Lubawskie) 864

Neumühl (Kr. Königsberg/Nm.) (poln. Namyślin) 696, 929

Neumünster (Schleswig-Holstein) 1453

Neupetershain (Kr. Calau) 312, 416, 428, 526, $816 f$.

Neuranft (Kr. Königsberg/Nm.) 531, 537, 815, 817

Neu Reichenwalde (Kr. Beeskow-Storkow) 1030

Neurochlitz bei Gartz/Oder 302, $817 f$.

Neurüdnitz (Kr. Königsberg/Nm.) 531, 537, $818 f$.

Neuruppin (Kr. Ruppin) 16, 66, 81, 96 f., 100 f., 110 f., 114, 116, 131, 137, 189, 193, 207, 211, $218,222,277$ f., 286 f., 320 f., $330-332,372$, $397,428,454,463,465,480,483,486,491 \mathrm{f}$., 495, 541 f., 612, 711, 723, 819-822, 831, $852,959,986,991,1063,1101,1151,1189$, 1192-1195, 1205, 1208, 1254f., 1344, 1349, 1374f., 1418, 1435, 1440 f., 1456, 1460, 1468, 1473; Landesanstalt 116, 189

Neuruppin-Gildenhall $\rightarrow$ Alt-Ruppin

Neuruppin-Treskow $\rightarrow$ Treskow

Neuruppin (Kreis) 820 f., 1374-1376, 1460

Neusalz/Oder (Kr. Freystadt) (poln. Nowa Sól) 193, 334, 380, 496, 505, 619, 852, 910, 1213

Neu Schadow (Kr. Beeskow-Storkow) 1030

Neuseddin (Kr. Zauch-Belzig) 237, 550, 605, 822

Neustadt (Dosse) (Kr. Ruppin) 211, 221, 399, $429,454,473,480,482,542,597,601,777$, $822-824,883,1205,1475$

Neustadt/OS. (poln. Prudnik) 428f., 830, 1212

Neustadt/Orla 1444

Neu Stahnsdorf (Kr. Beeskow-Storkow) 1030

Neustettin (Pommern) (poln. Szczecinek) 368, 1438
Neustrelitz (Mecklenburg) 281, 558, 681, 1439, 1462

Neusulzfeld bei Lodz (poln. Nowosolna) 915

Neutomischel (Posen) (poln. Nowy Tomyśl) $192,496,589,648$

Neutrebbin (Oderbruch) (Kr. Oberbarnim) 323, 399,1435

Neutucheband (Kr. Lebus) 891(?)

Neuwaldau (Kr. Freystadt) (poln. Drągowina) 939

Neuwerder (Kr. Westhavelland) 898

Neuwied am Rhein 1478

Neuwiese (Kr. Hoyerswerda) 1464

Neuzauche (Spreewald) (Kr. Lübben) 582

Neuzelle (Kr. Guben) 49, 84, 196, 209, 442, 447, $484,529,748,761,824-826,1282,1480$, 1527

Neu Zittau (Kr. Beeskow-Storkow) 83, 229, 300 f., 447, 525, 826f., 984, 1030, 1069, 1074, 1214 f., 1235

Nibork $\rightarrow$ Neberg (Kr. Sensburg)

Niebendorf (Kr. Jüterbog-Luckenwalde) 1290, 1459

Niechorze $\rightarrow$ Horst, Seebad (Kr. Greifenberg)

Niederbarnim (Kreis) 94, 164, 166, 199, 210 f., 213, 222 f., 301, 307, 455, 536, 556, 583 f., 844, 978, 983, 996, 1031-1035, 1063, 1076f., 1082, 1086, 1090, 1099, 1103, 1167, 1230, 1419

Niederbayern 414, 1431, 1479

Nieder Bielau (Kr. Görlitz) (poln. Bielawa Dolna) 623

Nieder Einsiedel bei Schluckenau (tschech. Dolní Poustevna) 1216

Niederfinow (Kr. Angermünde) 115 f., 524, 537, $827,1440,1475,1480$

Niedergörsdorf (Kr. Jüterbog-Luckenwalde) (siehe auch $\rightarrow$ Altes Lager) 1374

Niederhermsdorf (Kr. Waldenburg) (poln. Sobięcin) 753, 909

Niederkränig (Kr. Königsberg/Nm.) (poln. Krajnik Dolny) 564, 780, 902 f., 1443, 1458

Niederlande (auch „Holland“) 445, 462, 511, 1034f., 1037, 1466

Niederlausitz (siehe auch $\rightarrow$ Lausitz) 32, $37 \mathrm{f}$., 48, 58, 101 f., 104, 106, 190 f., 195 f., 202, 209-211, 222, 284, 301, 331, 413, 416, 421 f., 428, 442-445, 451, 454, 457 f., 472, 475, 494, 504, 527 f., 543, 659, 670, 739, 796, 909, 957, 998, 1352, 1417, 1459 und öfter; Ostteil (heu- 
te poln.) (siehe auch $\rightarrow$ Ostbrandenburg) 22, $82,99,134,195$ f., 202 f., 208, 210, 272, 274, 428, 435, 472, 474, 478, 691, 947, 957

Niederlehme (Kr. Beeskow-Storkow) 114, 131, 1030, 1069, 1441, 1443

Niederoderbruch 345

Niedersaathen (Kr. Königsberg/Nm.) (poln. Zatoń Dolna) 972

Niedersachsen 54, 91, 99, 106, 110 f., 138, 204 f., 207 f., 222, 365, 378 f., 384, 386, 411, 414f., $809,1438,1448,1454,1468$

Niederschlesien (poln. Dolny Śląsk) (siehe auch $\rightarrow$ Schlesien) 100, 120, 128, 134, 150, 156, 171, 208-211, 213, 216, 272, 312, 336, 338, $428,430,436,458,483,503,619,644,799$, 831,909 f., $947,977,996,1265,1404,1408$, $1449,1466,1519$

Niederschöneweide (Berlin) $\rightarrow$ Berlin-Niederschöneweide

Niederschönhausen (Berlin) $\rightarrow$ Berlin-Niederschönhausen

Nieder Seefeld (Kr. Jüterbog-Luckenwalde) 1150

Niedersteine (Kr. Neurode) (poln. Ścinawka Dolna), Hedwigschwestern 450, $588 \mathrm{f}$.

Niederwutzen (Kr. Königsberg/Nm.) (poln. Osinów Dolny) 196-198, 555, 737, 1437

Niedźwiedź $\rightarrow$ Bärdorf (Kr. Frankenstein)

Niegosławice $\rightarrow$ Waltersdorf (Kr. Sprottau)

Niehof $($ Kr. Eichenbrück $) \rightarrow$ Niemtschin

Niekłończyca $\rightarrow$ Königsfelde (Kr. Stettin)

Niemaschkleba (Kr. Guben) (1939-1945 Lindenhain) (poln. 1945-1994 Niemaszchleba, seit 1994 Chlebowo) 504

Niemcza $\rightarrow$ Nimptsch (Schlesien)

Niemczyn $\rightarrow$ Niemtschin (Kr. Wongrowitz)

Niemegk (Kr. Zauch-Belzig) 215, 456, 550, 626, 827f., 938, 1460, 1478

Niemtsch (Kr. Hoyerswerda) 910

Niemtschin (Kr. Wongrowitz) (1939-1945 Niehof, Kr. Eichenbrück) (poln. Niemczyn) 108

Niesky (Oberlausitz) 1101

Niesky (Kreis) 504

Nietków $\rightarrow$ Polnisch Nettkow

Nietkowice $\rightarrow$ Deutsch Nettkow

Nietoperek $\rightarrow$ Nipter (Kr. Meseritz)

Nietwerder (Kr. Ruppin) 821

Nikolassee (Berlin) $\rightarrow$ Berlin-Nikolassee

Nimburg (Mittelböhmen) (tschech. Nymburk) 820
Nimptsch (Kr. Reichenbach) (poln. Niemcza) 504, 934

Nipperwiese (Kr. Greifenhagen) (poln. Ognica) 901

Nipter (Kr. Meseritz) (poln. Nietoperek) 402, 1201

Nixdorf bei Tetschen (Sudetenland) (tschech. Mikulášovice) 157, 301, 307 f., $779 \mathrm{f}$.

Nörenberg (Kr. Saatzig) (poln. Ińsko) 503

Nörten-Hardenberg bei Göttingen 291

Norden (Ostfriesland) 327

Nordenburg (Kr. Gerdauen) (russ. Krylowo) 1345

Nord-Korea 1328, 1338

Nordrhein-Westfalen 204f., 403, 467, 667

Nordwestdeutschland 336

Normandie 331

Norwegen 331, 1034 f., 1037

Noßdorf (Kr. Sorau) $\rightarrow$ Forst-Noßdorf

Nová Ves (Hora Svatého Šebestiána) $\rightarrow$ Neudorf bei Sebastiansberg

Nováky $\rightarrow$ Oberstuben

Nowawes $\rightarrow$ Potsdam-Babelsberg

Nowawies (Kr. Znin) (1939-1945 Eitelsdorf)

(poln. Nowa Wieś Pałucka) 960

Nowa Wieś Pałucka $\rightarrow$ Nowawies (Kr. Znin)

Nowe Kramsko $\rightarrow$ Neukramzig

Nowe Miasto Lubawskie $\rightarrow$ Neumark (WestpreuBen)

Nowogard $\rightarrow$ Naugard (Pommern)

Nowogród Bobrzański $\rightarrow$ Naumburg am Bober

Nowosolna $\rightarrow$ Neusulzfeld bei Lodz

Nowy Tomyśl $\rightarrow$ Neutomischel

Nowy Zagór $\rightarrow$ Deutsch Sagar (Kr. Crossen)

Nürnberg 230, 497, 1282

Nuthe-Urstromtal (Ldkr. Teltow-Fläming) 792

Nymburk $\rightarrow$ Nimburg (Mittelböhmen)

$\mathrm{Nysa} \rightarrow$ Neisse (Stadt/Kreis); $\rightarrow$ Neiße (Fluss)

Oberbarnim (Kreis) 92, 94, 100 f., 116, 164, 166, 199, 204, 208 f., 222, 248, 257, 346, 455, 494, $531,537,805,844,952,985,1035,1063$, $1103,1172,1204,1206,1230,1243$

Oberbösa (Thüringen) 1436

Oberglogau (Kr. Neustadt/OS.) (poln. Głogówek) 428f., 582, 756

Obergrund bei Warnsdorf (Sudetenland) (tschech. Horní Podluží) 826

Oberhavel (Landkreis) 830; BdV-Kreisverband $468,473,705,830-832$ 
Oberhof (Thüringen) 487

Ober Langenau (Kr. Habelschwerdt) (poln. Długopole Górne) 614

Oberlausitz (siehe auch $\rightarrow$ Lausitz) 32, 35 f., 209, 336

Ober Maxdorf bei Gablonz (Sudetenland) (tschech. Horní Maxov) 157

Ober Mois (Kr. Neumarkt) (poln. Ujazd Górny) 909

Ober Mützkow (Kr. Franzburg) 1438

Obernigk (Kr. Trebnitz) (poln. Oborniki Śląskie) 94, 209, 396, 622, 1399

Oberpöllnitz (Kr. Gera) 1101

Oberschlesien (poln. Górny Śląsk) 17, 30, 33, 103, 120, 141, 143-146, 156, 209-210, $212 \mathrm{f}$., 215 f., $274,307,315,322,368,406,426$ f., 442 , $458,461,503,560,658,700,761,831,837$, $854,886,890,909,951,1212,1265,1268$, 1305,1312 , 1391, 1432, 1456; Ost-Oberschlesien $1450-1452$

Oberschöneweide (Berlin) $\rightarrow$ Berlin-Oberschöneweide

Oberschreiberhau (Kr. Hirschberg/Schlesien) (poln. Szlarska Poręba Górna) 753, 800, 1471

Obersdorf (Kr. Lebus) 1441, 1475

Oberspreewald-Lausitz (Landkreis) 473, 910

Oberstuben (Hauerland, Slowakei) (slowak. Nováky), Lager 236

Oberurff (Hessen), Jugenddorfwerk 427

Oberzips (Slowakei) 236-238, 493, 605-607, 937

Oblast Kaliningrad $\rightarrow$ Kaliningrader Gebiet

Obłobok $\rightarrow$ Mühlbock

Obórki $\rightarrow$ Schönfeld (Kr. Brieg)

Obornik (Kreis) (auch Obornick (Warthe), poln. Oborniki) 125, 217, 538, 905, 996

Oborniki Śląskie $\rightarrow$ Obernigk (Kr. Trebnitz)

Obra (Fluss) 290, 1464

Obra Stara $\rightarrow$ Alt Obra (Kr. Koschmin)

Obrawalde (Kr. Meseritz) (poln. Obrzyce) 775

Ochelhermsdorf (Kr. Grünberg) (poln. Ochla) 422, 492, 496, $634 \mathrm{f}$.

Oder (Fluss) (poln. Odra) (siehe auch $\rightarrow$ Polen/Westgrenze) 33, 83-86, 95, $130 \mathrm{f} ., 151$, 195-198, 208, 214, 216, 275, 284, 345, 347, 353, 400, 409, 418, 424 f., 443, 507 f., 523, $531,555,565$ f., $585,616,619,625,662-666$, 671, 683, 725, 729, 737, 739, 751 f., 757 f., 770 f., $773,778,815-818,843,854,885,891$, 902-904, 913, 921, 928, 953, 957, 965, 968,
970, 972, 1019, 1246, 1275, 1296 f., 1303, 1329f., 1403-1406, 1437, 1441, 1458, 1467, 1472, 1474; Brücken 85, 95, 103, 275, 409, 424, 487 f., 662-664, 666, 670, 673-675, $682,737,751,770$ f., 773, 779, 806, 818 f., 901-903, 1020, 1342, 1403-1405, 1416f., $1438,1441,1445,1452$ f., 1455 f., 1463, 1466, 1471, 1478; Brückenköpfe 773, 902, 1404f.; Hochwasser (1947) 3, 151, 567, 634, 701, 881, 960, 970; Regulierung, Deiche 960, 1161, 1192, 1194; Übergänge 86, 109, 121, 131, 193, $273,347,418,424,532,537,663,665,751$, $757,773,778,819,881,890$ f., 903, 997, 1441, 1443, 1445, 1454, 1456-1459, 1463, 1467; Vereisung 86, 891

Oderberg/Mark (Kr. Angermünde) 164, 455, 524, 537, 828f., 1063

Oderbruch $33,113,208,236,323,339,345,443$, 532 f., 537, 555, 567, 576, 655, 701, 752, 881, 906, 951, 1409, 1457, 1461, 1478

Oderin (Kr. Luckau) 935

Oderkanal Güstebiese-Hohensaaten 725

Oderland, -raum, -region 202, 673, 757, 902 und öfter

Odermünde bei Pölitz (Kr. Randow) (bis 1929 Scholwin) (poln. Szczecin-Skolwin) 882

Oder-Neiße-Grenze $\rightarrow$ Polen, Westgrenze

Oder-Spree (Landkreis) 31, 667, 690 f., 888, $1366 \mathrm{f}$.

Oder-Spree-Kanal, Brückensprengung 806

Odessa 824

Odra $\rightarrow$ Oder

Oegeln (Kr. Beeskow-Storkow) 1030

Oels (Schlesien) (poln. Oleśnica) 104, 579

Oelsnitz (Vogtland) 137, 854, 1442, 1475

Österreich 146f., 151, 157, 162, 511, 811, 847, 1022, 1034f., 1037, 1260, 1268, 1355

Österreich-Ungarn 301, 307, 326, 780

Östliches Europa $\rightarrow$ Osteuropa

Östliches Mitteleuropa $\rightarrow$ Ostmitteleuropa

Ötscher (Kr. Weststernberg) (poln. Owczary) 729,1445

Offenbach (Main) 380

Ognica $\rightarrow$ Nipperwiese (Kr. Greifenhagen)

Ohlewiesen (Breslau) $\rightarrow$ Breslau-Tschansch

Ohnewitz (Kr. Westhavelland) 284

Olbrachtów $\rightarrow$ Albrechtsdorf (Kr. Sorau)

Oldenburg 414

Olecko $\rightarrow$ Treuburg 
Oleśnica $\rightarrow$ Oels (Schlesien)

Oletzko (Kreis) (1933-1945 Treuburg) $86 f$.

Olsztyn $\rightarrow$ Allenstein

Olsztyn (Woiwodschaft) 141

Opalenitza (Kr. Grätz) (poln. Opalenica) 496, 922

Opatov v Čechach $\rightarrow$ Abtsdorf bei Zwittau

Opava $\rightarrow$ Troppau

Opole (Woiwodschaft) 141, $428 \mathrm{f}$.

Oppeln (Oberschlesien) (poln. Opole) 144, 345, $428 \mathrm{f} ., 496,802,846,851,856,1458$

Oppersdorf (Kr. Neisse) (poln. Wierzbięcice) 873

Oranienbaum (Anhalt) 1439

Oranienburg (Kr. Niederbarnim) 223f., 226, 307, 412, 428 f., 455, 469, 473, 480, 482, 508, 536, $704,775,779,830-832,894,967,1033,1418$, 1468; Lager 164, 536, 1063

Oranienburg (Kreis) 223, 831

Ortelsburg (Ostpreußen (Szczytno) 74

Oschatz (Sachsen) 526

Oschersleben 218, 1447

Osia Góra $\rightarrow$ Berg Vorwerk bei Königswalde

Osiedle Poznańskie $\rightarrow$ Bürgerwiesen

Osiek $\rightarrow$ Hennersdorf (Kr. Ohlau)

Osiek $\rightarrow$ Ossig (Kr. Guben)

Osinów Dolny $\rightarrow$ Niederwutzen

Osłowice $\rightarrow$ Osselwitz (Kr. Guhrau)

Osnabrück 499, 1435

Osnabrück (Bistum) 680

Osnabrück (Landkreis) 1373

Ośno Lubuskie $\rightarrow$ Drossen

Ossack (Kr. Luckau) 1199

Osselwitz (Kr. Guhrau) (poln. Osłowice) 909, 1466

Ossig (Kr. Guben) (poln. Osiek) 1447

Ostbrandenburg (aktuell) 475

Ostbrandenburg (historisch) (siehe auch $\rightarrow$ Neumark) 22, 79, 128, 201-210, 213-215, 219,222 , 369, 379, 395, 427, 435, 470-472, 474-478, 493-495, 503, 523, 525-527, 529 f., 532, 534-541, 543-545, 547 f., 550, 599, 619, 637, 659, 662, 667, 691, 715, 761, 831, 841, $847,876,878,958,964,1284,1347,1542$

Ostdeutschland (historisch) $\rightarrow$ Polen, Westgebiete

Osterburg/Altmark (Kreis) 1435

Osterne (Kr. Templin) 821

Osterode (Ostpreußen) (poln. Ostróda) 102, 956, $958 \mathrm{f}$.
Osterode (Kreis) 223

Osteuropa, östliches Europa 16, 30, 64, 500, 513, $853 \mathrm{f} ., 1362,1391 \mathrm{f}$.

Ostgalizien 1460

Osthavelland (Kreis) 94, 164, 166, 193, 199, 204, $211,217,223,283,301,307,441,456,537 f$., 544, 734, 802, 981, 996, 1035, 1100, 1103, 1109-1113, 1158, 1181, 1230

„Ostmark“ (Ostbrandenburg/Posen/WestpreuBen) $341,361,368,525,662,671$

Ostmitteleuropa, östliches Mitteleuropa 16, $46 \mathrm{f}$., 64, 72, 1362, 1391

Ost-Oberschlesien $\rightarrow$ Oberschlesien

Ostpolen $\rightarrow$ Polen/Ostgebiete

Ostpreußen (sowjetischer/russischer Teil siehe auch $\rightarrow$ Kaliningrader Gebiet) 16, 45, 66, 71 f., 74 f., 81 f., 87, 90 f., 102, 123, 128, 136, 168, 171 f., 174, 176f., 199-203, 210, 212 f., 215 f., 219-228, 249, 265, 269, 273 f., 285-287, 294, 307, 315, 327, 336, 342 f., 350, $368,390,397,404-406,417,427,436,449$, 451, 465, 471, 473, 475, 487, 489f., 503-505, $512,523,525-527,529$ f., 532, 534-541, 543-545, 547 f., 550, 554, 559-562, 566, 569, 574, 578, 586, 591, 597, 599, 601 f., 613 f., 619, 626, 628 f., 635, 637, 639, 642, 644, 644, 649, 652, 659, 662, 666 f., 686-689, 695 f., 700, 703-705, 715, 738, 747, 757, 768, 776, $779,782,785$ f., $791,802,808$ f., 821,823 f., 830 f., 838,840 f., $844-847,853,855,860$ f., $863,871,874,876,878,887,894,902,906$, 914, 931 f., 937 f., 958, 960, 964, 967, 993, 1058, 1089, 1135, 1209, 1273, 1277, 1284, 1305, 1312, 1321, 1340 f., 1344, 1367, 1374f., 1377 f., 1402 f., 1431, 1439, 1441, 1446, 1450, 1454-1457, 1461-1463, 1467, 1472, 1475, 414, 1431, 1479 f., 1482 f., 1534, 1543; polnischer Teil $1356 \mathrm{f}$.

Ostprignitz (Kreis) 94, 100 f., 106, 126, 199, 202, 204, 208, 211, 217, 219, 223, 233, 308-310, 314, 359, 441, 454, 489, 538f., 775, 905, 984, 990, 996, 1035, 1103, 1156f., 1190, 1195, 1230, 1407, 1453

Ostprignitz-Ruppin (Landkreis) 56, 66, 211, 820, 1374

Ostrau $\rightarrow$ Mährisch-Ostrau

Ostrava-Vítkowice $\rightarrow$ Mährisch-Ostrau-Witkowitz

Ostróda $\rightarrow$ Osterode (Ostpreußen) 
Ostrowiec $\rightarrow$ Wusterwitz (Kr. Soldin)

Ostsee 1404, 1449, 1474

Ostrau $\rightarrow$ Mährisch Ostrau

Ostrowo (Posen) (poln. Ostrów Wielkopolski) 368,418

Ostrowo (Kreis) 216, 543, 996

Oststernberg (Kreis) 205, 372, 441, 463, 472, $669,770,1000 \mathrm{f} ., 1345 \mathrm{f}$.

Ostwall 757

„Ostzone“ $\rightarrow$ DDR

Oświęcim $\rightarrow$ Auschwitz

Otanów $\rightarrow$ Wuthenow (Kr. Soldin)

Otyń $\rightarrow$ Deutsch Wartenberg (Kr. Grünberg)

Owczary $\rightarrow$ Oetscher (Kr. Weststernberg)

Paaren im Glien (Kr. Osthavelland) 482 f., 538, 832, 852(?), 1110 f.

Pabianitz bei Lask (Polen/Wartheland) (19391940 Burgstadt) (poln. Pabianice) 601

Paderborn 166, 381 f., 485, 838, 869, 1271

Pärnu $\rightarrow$ Pernau (Estland)

Pätze (Kr. Teltow) 83

Päwesin (Kr. Westhavelland) 164, 547, 833, 1188

Pahlsdorf (Kr. Luckau) 499

Pakosławice $\rightarrow$ Bösdorf (Kr. Neisse)

Palästina 512

Palmnicken (Kr. Lebus) 1459

Pamięcin $\rightarrow$ Frauendorf (Kr. Weststernberg)

Panama (Mittelamerika) 1064

Pankow (Berlin) $\rightarrow$ Berlin-Pankow

Papenbruch (Kr. Ostprignitz) 218, 1270

Paradies (Kr. Meseritz) (poln. Gościkowo) 88, 1479

Parchau (Kr. Karthaus) (poln. Parchowo) 496, 679

Parchim (Mecklenburg) 112, 114, 220, 798, 852, 865, 1474, 1483

Parchowo $\rightarrow$ Parchau (Kr. Karthaus)

Paretz (Kr. Osthavelland) 538, 749, $833 f$.

Paretzhof (Kr. Osthavelland) 833

Paris 1332

Parmalager $\rightarrow$ Spremberg-Cantdorf

Parmen (Kr. Templin) 112, 1477

Parstein (Kr. Angermünde) 737

Pasewalk (Vorpommern) 104, 220, 867, 1089, 1094, 1434, 1460

Pasewalk (Kreis) $1459 \mathrm{f}$.

Pasłęk $\rightarrow$ Preußisch Holland

Passau (Niederbayern) 415
Passow (Kr. Angermünde) 278f., 524, 564, 1454

Paulinenaue (Kr. Westhavelland) 316, 547, 596, 834

Paulsdorf, Kr. Rosenberg/OS.) (poln. Pawłowice Gorzowskie) 809

Peetzig (Oder) (Kr. Königsberg/Nm.) (poln. Piasek) 196, 423, 545 f., 625, 928, 1443

Peiskersdorf (Kr. Reichenbach) (poln. Piskorzów) 82

Peisterwitz (Kr. Ohlau) (poln. Bystrzyca) 1441

Peitz (Kr. Cottbus) 27, 211, 295, 457, 494, 498-500, 527, 622 f., 635, 835-837, 1213, 1358,1452

Peitz (Amt) 495, 634

Pełczyce $\rightarrow$ Bernstein (Kr. Soldin)

Peloponnes (Griechenland) 1135

Pelplin (Westpreußen) (poln. Pelplin) 1212

Penkun (Vorpommern) 121, 703, 1459

Penzlin (Kr. Ostprignitz) 803

Perach (Oberbayern) 1350

Perleberg (Kr. Westprignitz) 106f., 110, 120, 395, 454, 484f., 539, 548 f., 756, 775, 837-839, $869,901,904,1145,1235,1343,1412,1446$, 1454 f., 1474, 1476; Landrat, Landratsamt 94, 1132, 1134, 1139, 1144, 1146, 1148 f., 1189

Perleberg (Kreis) 484, 838 f., 841

Pernau (Estland) (estn. Pärnu) 582

Pernitz (Kr. Zauch-Belzig) 1449

Perwenitz (Kr. Osthavelland) 832, $1111 \mathrm{f}$.

Petersdorf bei Briesen/Mark (Kr. Lebus) 690

Petersdorf bei Saarow-Pieskow (Kr. BeeskowStorkow) 1030

Petersdorf (Kr. Goldberg) (poln. Piotrowice) 852

Petersdorf (Kr. Oststernberg) (poln. Jemiołów) 495, 787

Petershagen (Kr. Niederbarnim) 987, 1033, 1099, 1272-1275

Peterswaldau (Kr. Reichenbach/Schlesien) (poln. Pieszyce) 450, 571, 573, $588 \mathrm{f}$.

Petkus (Kr. Jüterbog-Luckenwalde) $1307 \mathrm{f}$.

Petricken (Kr. Labiau) (russ. Fontanka) 1345

Petzow (Kr. Osthavelland) 388, 483, 949

Pfaffendorf (Kr. Beeskow-Storkow) 278, 1030

Pfalz 74

Pförten (Kr. Sorau) (poln. Brody) 495, 654, 657, 659 f., 761

Pforzheim 1443

Philadelphia (Kr. Beeskow-Storkow) 176, 190, 1030, 1074, 1214, 1477 
Philippinenhof bei Müncheberg (Kr. Lebus) 809, 1436,1482

Piasek $\rightarrow$ Peetzig (Oder)

Pidgirne $\rightarrow$ Kulm (Kr. Akkermann)

Pielgrzymowice $\rightarrow$ Pilgramsdorf (Kr. Pleß)

Pieskow bei Bad Saarow (Kr. Beeskow-Storkow) (siehe auch $\rightarrow$ Saarow) 570, 1015, 1030, 1059, 1448

Pießig (Kr. Luckau) 328, 534

Pieszyce $\rightarrow$ Peterswaldau (Kr. Reichenbach)

Piła $\rightarrow$ Schneidemühl

Pilchowitz (Kr. Rybnik) (1936 Bilchengrund) (poln. Pilchowice) 912

Pilgramsdorf (Kr. Pleß) (poln. Pielgrzymowice) 1450

Pillau (Ostpreußen) (russ. Baltijsk) 87, 273, 1455,1467

Pillgram (Mark) (Kr. Lebus) 664

Piotrowice $\rightarrow$ Petersdorf (Kr. Goldberg)

Pinne (Kr. Samter) (poln. Pniewe) 496, 800

Pinnow (Kr. Angermünde) 208, 524, $840 f$., 1330; Kinderdorf, -heim 225, 776, 840, 1102, 1436; Lager 150, 164, 166, 174, 176, 180, 276, $523 \mathrm{f}$., 563, 653, 840f., 1062, 1064 f., 1230, 1462, 1465

Pinnow (am See) (Kr. Lübben) 133

Pinnow (Kr. Weststernberg) (poln. Pniów) 324, 1464

Pirna (Sachsen) 151, 159, 277, 1101, 1446, 1450, 1458

Pirow (Kr. Westprignitz) 395

Piskorzów $\rightarrow$ Peiskersdorf (Kr. Reichenbach)

Platkow (Kr. Lebus) $726 \mathrm{f}$.

Platten $\rightarrow$ Bergstadt Platten

Plattenburg (Kr. Westprignitz) 485, 549, 841; Gedenkstein 110, 356, 480, 484f., 839, 841

Plaue/Havel (Kr. Westhavelland) 164, 210, 416, 456, 547, 598, 841-843, 1063, 1199

Plauen (Vogtland) 137

Pławna $\rightarrow$ Schmottseiffen (Kr. Löwenberg)

Pleschen (Posen) (poln. Pleszew) 433, 669

Pleśno-Bezki $\rightarrow$ Beesgen-Plesse

Plesse (Kr. Guben) $\rightarrow$ Beesgen-Plesse

Pleszew $\rightarrow$ Pleschen

Plettenberg (Westfalen), Flüchtlingslager 392

Plichta $\rightarrow$ Plichten

Plichten (Kr. Osterode) (poln. Plichta) 853

Plötzenhof (Kr. Lebus) 757

Plötzin (Kr. Zauch-Belzig) 601
Płonno $\rightarrow$ Klausdorf (Kr. Soldin)

Plothow (Kr. Grünberg) (poln. Płoty) 634

Płowęż $\rightarrow$ Groß Plowenz

Pniewe $\rightarrow$ Pinne (Kr. Samter)

Pniów $\rightarrow$ Pinnow (Kr. Weststernberg)

Podelzig (Kr. Lebus) 533, 757 f., $843 f$., 881

Podelzig-Klessin (Kr. Lebus) $\rightarrow$ Klessin

Podlachien (poln. Podlasie) (Woiwodschaft) 705

Podletitz (Böhmen) (tschech. Podlesice) 1469

Podole Mały $\rightarrow$ Klein Podel (Kr. Stolp)

Pohlo (Kr. Guben) (poln. Pole) 763

Pohsen (Kr. Guben) (poln. Późna) 706, 708

Połczyn-Zdrój $\rightarrow$ Polzin, Bad (Pommern)

Połecko $\rightarrow$ Pollenzig (Kr. Crossen)

Pole $\rightarrow$ Pohlo (Kr. Guben)

Polen 11 f., 16, 30, 33, 41, 47, 50, 72, 78, 103, 135, 138-150, 162, 171, 178, 185 f., 193, 199, 202 f., 215, 218 f., 243 f., 296, 339, 342, 346, 349, 351 f., 354-356, 359 f., 363, 401, 406, 419 f., 426, 447, 468, 472, 477, 483, 487-489, 493-496, 500, 511 f., 518, 523, 525, 565, 575, 577 f., 599, 615, 617, 622, 634, 638, 644, $652,654,657,666,673,676,683$ f., 688, 690 f., 703, 713-715, 718, 725, 730, 737, 769, 771, 774, 787 f., 846, 851, 854, 879, 885 f., 906f., 909, 923, 931, 952, 1004, 1019, 1021, 1034f., 1039-1041, 1043-1045, 1107, 1153, $1157,1175,1203,1239,1244,1281$ f., 1312, 1324-1333, 1336f., 1339, 1355-1358 f., 1373, 1377, 1396f., 1407-1410, 1412-1418, 1438, $1442,1445,1450$ f., $1454,1458,1460,1463$, $1469,1478,1511$

- Armee/Truppen 426, 537, 593, 764

- deutsche Minderheit 12, 33, 75 f., 140-144, 149, 203, 215 f., 218 f., 222, 233, 441, 459, 479, 500, 523, 525-527, 529f., 532, 534-541, 543 f., 546-548, 550, 591, 596, 599, 619, 622 f., 637, 659, 667, 687, 715, 831, 847, 870 f., $876,892,957$ f., 1044, 1399, 1415, 1452, 1456, 1458

- Flagge 90

- Miliz 129, 154, 712

- Mittelpolen 441, 591, 853

- Ostgebiete, Ostpolen (historisch) 65, 508, $787,865,885,1285,1396,1460$

- Westgebiete („polnisch besetzte Gebiete“; [deutsche] Ostgebiete, -provinzen) 32, 35, 65, 79f., 84, 128-130, 133, 136, 140-146, 153, $156,159,198,266,291,295,321,344,346 \mathrm{f}$., 
351 f., 355 f., 359, 401, 417-427, 448, 452, 468, 472 f., 477, 483, 486-490, 492-496, 507f., 514, 518, 561, 565, 621, 634, 657 f., 670 f., 673, $683 \mathrm{f} ., 690,713,740,759,770,772,796,854$, $865,870,885,887,906$ f., 931, 938-940, 952, 957, 1009, 1011 f., 1034f., 1039 f., 1063, 1195, 1203, 1233, 1244, 1283, 1285 f., 1288-1296, 1299 f., 1302 f., 1305 f., 1309-1312, 1321, $1327,1330,1333$, 1337 f., 1342, 1350, 13591365, 1367-1369, 1377, 1391, 1396-1999, 1402, 1406-1410, 1435 f., 1443, 1450 f., 1463, $1466,1482,1511$ und öfter

- Westgrenze (Oder-Neiße-Grenze) 26, 48, 156, 177, 197, 202, 209, 247, 295 f., 299, 326, 340, 342, 344f., 345-355, 394, 405, 407, 418-426, 443, 483, 488, 492, 507, 524, $528 \mathrm{f}$., $531,542,565,604,618,625,657$ f., 665 f., 670 f., 683, 696, 703,706, 708, 712-715, 718 f., 724 f., $729,737,758,770$ f., $815-817$ f., 828 , 881, 885 f., 903,905 f., 913, 919, 928, 953 , 965 f., 968, 970, 972, 997, 1009, 1044, 1153, 1168, 1171, 1240-1242, 1284, 1290, 1296, 1309-1312, 1333, 1343, 1348, 1353, 1391, 1398, 1400, 1406, 1409 f., 1413-1417, 1461, 1466, 1274f., 1277, 1281, 1284-1286, 1290, 1292-1296, 1298-1300, 1302, 1305, 1307, 1309-1312, 1322, 1328, 1330, 1333, $1335 \mathrm{f}$., 1343, 1348, 1353, 1359, 1391 f., 1396, 1406 f., 1409f., 1413-1418, 1437 f., 1461, 1465, 1476, 1519 und öfter

- Woiwoden 483,771

- Zentralpolen 202f., 219, 274, 508

Polenz (Sachsen) 1439

Polessk $\rightarrow$ Labiau

Politzig (Kr. Meseritz) (poln. Policko) 289, 869

Polkwitz (Kr. Glogau) (1937-1945 Heerwegen) (poln. Polkowice) 65, 648

Pollenzig (Kr. Crossen) (poln. Połecko) 84, 279, 1457

Pollychen (Kr. Landsberg/W.) (poln. Stare Polichno) 440

Polnisch Nettkow (Kr. Grünberg) (poln. Nietków) 634, 1466

Polzin, Bad (Pommern) (poln. Połczyn-Zdrój) 327, 428, 495, 933

Pomellen (Kr. Randow) 418

Pommern (Hinterpommern, poln. Pomorze Zachodnie [Westpommern]) (vgl. $\rightarrow$ Vorpommern) 29f., 71, 91, 98, 135 f., 149-153,
174, 180, 184f., 192, 199, 201-203, 206, 210, 213 f., 219 f., 222 f., 268, 285, 298, 302 , $360,368,392,406,427,430,445,447$ f., 475 , 492, 495, 503, 505, 523, 525-527, 529 f., 532, 534-541, 543-545, 547 f., 550, 560-563, 566, 586 f., 591, 599, 602, 619, 637, 639, 644, 659, 667, 686 f., 695, 715, 747, 802, 821, 831, 840 f., $847,852,860$ f., $863-865,870$ f., 876,878 , 885 f., 892, 921, 957 f., 964, 969 f., 1174, 1209, 1272, 1323, 1373-1375, 1377 f., 1404, 1449, 1452, 1457-1459, 1461 f., 1467

Pommersche Schweiz 1372

Ponitz (Kr. Westprignitz) 1206

Poprad $\rightarrow$ Deutschendorf (Zips)

Poremba (Kr. Groß Strehlitz) (1936-1945 Mariengrund; poln. Poręba) 817

Posedin (Kr. Lebus) 546

Posen (Stadtkreis) (1939-1945 Wartheland) (poln. Poznań) 32, 90, 98, 104, 108, 124, 136f., 215, 273, 341, 431-433, 438, 441, 568, 576, 582, 658, 669 f., 741, 757, 874f., 890, 929, 952, 996, 1261, 1403, 1438, 1445 f., 1449 f., 1456, 1468, 1473, 1482; Diakonissenanstalt 432 f., 687, 693 f., 782, 929; Gehörlosenschule 641, 802, 870; Posen in Straßennamen: 339-341, 568, 672, 689, 792, 958

Posen (Landkreis) 549, 670, 996, 1445

Posen (Provinz; „Posener Land“) 50, 71, 73 f., 120, 128, 185, 203, 213, 215-219, 284, 298, $339,368,392,418,430,433,438,441,496$, $560,567,574,662$ f., 669 f., 687, 700, 730, 784, 861, 863 f., 890, 923, 951, 1284, 1445, 1459, 1472,1479

Posen (Regierungsbezirk) 215

Posen-Westpreußen (Provinz Grenzmark)

$\rightarrow$ Grenzmark

Postheim $\rightarrow$ Templin, Postheim

Postlin (Kr. Westprignitz) 1141

Potsdam 13-15, 17, 19, 23, 25, 28, 51, 55 f., 61, 70, 74, 82 f., 88, 94, 96, 101-104, 114, 130 f., $135,146,164,178$ f., 183, 199, 201, 206 f., 210 f., 213, 215, 218, 221 f., 224, 229, 236 f., 239-243, 245-254, 260, 267, 270, 279, 293, 297, 305, 321 f., 325, 330, 336, 341, 345, 351, 356, 360, 368 f., 371, 416, 421, 428 f., 456, 469-471, 480, 482, 486f., 496, 501, 503-505, 507, 511 f., 514, 532, 535, 548, 575, 593, 605, $614,640,648,705,731,734,746,753,778$, $782,793,798,800,844-856,892,896,924$, 
932, 975, 977-991, 996, 1035, 1039, 1043, 1055, 1086, 1113 f., 1120-1124, 1135, 1156 f., 1160, 1168, 1171, 1173 f., 1196, 1204, 1220 f., 1224-1227, 1230 f., 1235 f., 1242, 1248 f., $1251,1253,1255,1283,1309-1313,1333$, 1344, 1350, 1358 f., 1361, 1364, 1372, 1390, 1396 f., 1409 f., 1412, 1418 f., 1432, 1436 f., 1441, 1444, 1449, 1451 f., 1457 f., 1465-1467, 1472 f., $1475-1479,1541-1543 \mathrm{f}$.

- Abkommen („Potsdamer Abkommen“ „Beschlüsse“, Konferenz 1945) 25, 70, 135, 146, $211,325,535,763,845,850,856,1244,1290$, 1306, 1311, 1335, 1391, 1402, 1406, 1469

- Alter Markt (siehe auch $\rightarrow$ Gedenkstein) 845, 855

- Amtsgericht 224, 746, 852 f., 1360

- Astrophysikalisches Observatorium 505

- Auffanglager am Obelisk (Winzerberg-Bunker) 848

- BdV-Landesgeschäftsstelle 56, 224, 250, 468, 472, 473, 478, $851 f$.

- Bezirkspolizeibehörde 390

- Club- u. Konferenzhaus der SED 1168

- Erlöserkirchengemeinde 430 f., 850, 855

- Frauenausschuss (Brandenburger Str.) 1248

- Gedenkstein des BdV (Am Alten Markt) 356, 479 f., 762, 846, 850f., 852, 1418

- Glienicker Brücke 845

- Handwerkskammer 260

- Hochschule für Recht u. Verwaltung 505

- Humboldt-Schule 1326

- Industrie- u. Handelskammer 260, 1186 1188,1204

- Informationsamt der Landesregierung (Seestr. 43) $260,1119,1248,1294,1298,1300,1304$

- Informationsamt, -kontrolle der Landesregierung (Hebbelstr. 39) 1324, 1326, 1329, 1333, 1336

- Karl-Marx-Werk 1310 f.

- Kath. Kirche 1473

- Kinder- u. Jugendsportschule (KJS) $1451 \mathrm{f}$.

- Kolonie Alexandrowka 511 f., 846

- Kommandantur, sowjet. 131, 1121, 1309

- Krankenhäuser 850, 1249

- Kreisgericht 1358, 1418

- Landesanstalt 250

- Landesarbeitsamt 1176, 1178, 1184, 1188

- Landespolizeibehörde (Bauhofstr. 11/13) 394, 396f., 1342, 1344-1346, 1348-1350
- Landesregierung $\rightarrow$ Provinzialverwaltung

- Landessender (Kapellenbergstr. 4) 1249, 1252

- Landestheater 1123

- Lange Brücke 101, 845

- Landtagsgebäude (Heinrich-Mann-Allee) 250,260

- Luftschiffhafen (Aufbaulager, Zeppelinstr.) $164,598,848-850,854$ f., 981, 1062, 1120 f., 1248

- Magistrat, Rat der Stadt und Oberbürgermeister $480,505,511,1120-1124,1135,1224$, 1226, 1308-1313, 1326, 1333, 1337 f., 1472, 1543

- Nikolaikirche 480, 762, 851

- Obdachlosenunterkunft Pappelallee 279

- Pädagogische Hochschule 293, 297, 326, 334, 504f., 1446, $1451 \mathrm{f}$.

- Potsdam-Museum 505, 509f., 512

- Provinzialverwaltung und Landesregierung 240-252, 254f., 262, 563, 598, 668, 782, $847 f$., 998-1000, 1002-1005, 1007 f., 1017-1019, 1027, 1034, 1036, 1046, 1048f., 1054-1057, 1061 f., 1065 f., 1076 f., 1081, 1084, 1086 f., 1096, 1099, 1106, 1109, 1113, 1115, 1119, 1126f., 1130, 1135, 1144, 1147, 1151, 1155, 1157, 1160-1167, 1178, 1180-1188, 1192, $1195,1213,1215,1217,1224,1231$ f., 1235 f., 1239, 1241, 1245, 1248, 1255 f., 1290, 1293 f., 1308f., 1310-1312, 1326, 1329, 1333, 1336, 1344, 1355, 1449

- Regierungsgebäude (heute Stadthaus) Friedrich-Ebert-Str.: 250, 267, 845, 848, 1165, 1464

- Regierungsgelände Alte Zauche 67: 848, 1027, 1056 f., 1096, 1106, 1109, 1113, 1115, $1176,1188,1192,1215,1217,1248$ f., 1255 f.

- Regierungsgelände Saarmunder Str. 23, Heinrich-Mann-Allee 107: 250, 260, 848, 1106, 1204, 1224, 1308, $1311 \mathrm{f}$.

- Reichsbahnausbesserungswerk (RAW) 259, 1231

- Schloss Cecilienhof (Gedenkstätte) 325, 845, 850,856

- SMA Brandenburg 1003, 1008, 1155-1157

- Stadtverordnetenversammlung 480, $1121 \mathrm{f}$., 1326-1328

- St. Josefs-Krankenhaus 847, 850, 856

- Suchdienst (Hebbelstr. 6) 848 
- Suchdienst-Annahmestellen 1248

- Teltower Vorstadt 845, 1225

- Übergangswohnheim 1370

- VP-Bezirksbehörde 1354

- VP-Kreisamt 235, 1354

- Waldstadt 1444

- Wasserwirtschaftsdirektion (WWD) 290

Potsdam-Babelsberg (Nowawes) 164, 229, 329, $368,399,505,767,845,850,853,856,1249$, 1259, 1337, 1447, 1473; Bahnhof Griebnitzsee 367; Beethovenschule 1122 f., 1473

Potsdam-Bornim 845, 1224

Potsdam-Bornstedt 345, 436 f., 505, 845, 851, 856f., 1063, 1224, 1226

Potsdam-Drewitz 196, 251, 329

Potsdam-Eiche 845, 855

Potsdam-Fahrland $1225 \mathrm{f}$.

Potsdam-Golm 1224, 1226 f., 1465; Kuhfort 1224

Potsdam-Grube 1225 f.; Nattwerder 1225; Schlänitzsee 1225

Potsdam-Hermannswerder, Krankenhaus 850; Kirchliches Oberseminar 1456

Potsdam-Klein-Glienicke, Schule 844

Potsdam-Krampnitz 845

Potsdam-Mittelmark (Landkreis) 140, 191, 201, $328,473,488,497,545,550,601,1367 \mathrm{f}$.

Potsdam-Nattwerder $\rightarrow$ Potsdam-Grube

Potsdam-Nedlitz 845

Potsdam-Neu Fahrland 532, 857, 1063, 1337

Potsdam-Rehbrücke 368,1542

Potsdam-Sanssouci 504, 845, 1452; Antikentempel 665; Friedenskirche 1465

Potsdam-Wildpark, Bahnhof 88

Potsdam (Bezirk) 143, 309, 325, 428 f., 522

Potsdam (Kreis) 202, 235, 1354; BdV-Kreisverband 201, 505; Rat des Kreises 140; SED-

Kreisleitung 344

Potsdam (Regierungsbezirk) 75, 168

Potulice bei Lodz (Polen) (dt. Potulitz), Lager 152, 172, 888, 1096, 1438, 1447

Późna $\rightarrow$ Pohsen (Kr. Guben)

Poznań $\rightarrow$ Posen

Prag (tschech. Praha) 147, 334, 426, 1209, 1413, 1444,1451

Prag-Modřany (dt. Prag-Moderschan) 937

Prag (Erzbistum) 445, 573, 595, 613, 667, 912

Praga $\rightarrow$ Warschau-Praga

Praha $\rightarrow$ Prag
Prakwice $\rightarrow$ Prökelwitz (Kr. Mohrungen)

Prażuchy bei Kalisch 1205

Preichow (Kr. Crossen) (poln. Przychów) 329, 925

Premnitz (Kr. Westhavelland) 28, 169, 173, 232, $345,404,421,456,547,853,857-860,920$, 938, 984, 1183-1186, 1190 f., 1376-1378, $1436,1439,1458$

Premslin (Kr. Westprignitz) 89

Prenden (Kr. Niederbarnim) 504, 1034, 1447

Prensdorf (Kr. Jüterbog-Luckenwalde) 1120, 1287

Prenzlau (Kr. Prenzlau) 15f., 28, 45, 56, 108, 112 f., 121, 184, 192, 213, 221, 275, 313, 455, $480,495,509,539-541,545,703,860-866$, $867,905,931,934,1009,1101,1323,1434$, $1458,1468,1470,1474,1479,1481,1483$, 1544; Bahnhof 860-862, 1465; Kreiskrankenhaus 184-186, 540, 860 f., 863, 864f., 867; Lager 174, 181, 860, 862-864, 866, 1470; Pflegeanstalt, -heim 860, 864; Städt. Krankenhaus 185, 864; Standesamt 44, 55, 68, 120, $185,192,218,233,540,860-868,1420$

Prenzlau-Birkenhain, Lager 46, 164, 166, $540 \mathrm{f}$., 865, 866f., 1062

Prenzlau-Bündigershof 540 f., 868

Prenzlau (Kreis) 56, 110, 164, 166, 199, 212, 214, 217, 221, 231 f., 313, 381, 407, 455, 522, 539-541, 545, 847, 849, 862, 865, 905, 934, 996, 1035, 1103, 1230, 1250, 1420

Prenzlauer Berg $\rightarrow$ Berlin-Prenzlauer Berg

Prerow (Ostsee) 387

Preußen (Königreich, Freistaat/Land) 5, 25, 311, 1260, 1409

Preußisch Eylau (Ostpreußen) (russ. Bagrationowsk) 174, 1440, 1457

Preußisch Eylau (Kreis) 861

Preußisch Holland (Ostpreußen) (poln. Pasłęk) 754

Preußisch Holland (Kreis) 863

Preußnitz (Kr. Zauch-Belzig) 1460

Pribram (Mittelböhmen) (tschech. Přibram) 760

Prieros (Kr. Beeskow-Storkow) 1030

Prignitz (Landkreis) 290, 328

Prignitz (Landschaft) 79, 100 f., 106 f., 110, 190, 213, 217, 222, 289, 297, 328, 382, 420, $484 \mathrm{f}$., $505,548,775,803,837,1436,1460$

Priment (Kr. Bomst) (poln. Przemęt) 496, 587

Primkenau (Kr. Sprottau) (poln. Przemków) 329 
Prittisch (Kr. Schwerin/W.) (poln. Przytoczna) 495, 963

Pritzerbe (Kr. Westhavelland) 164, 456, 547, 868, 1063

Pritzwalk (Kr. Ostprignitz) 106, 110, 112, 114, $218,223,272,290,428$ f., 447 f., 454, 457, 484f., 539, 593, 641, 802 f., 838, 868-871, $957,1345,1435,1450,1455,1462-1464$, 1468, 1474; Bahnhof 869, 871, 1474; Lager $484,539,870,1391,1474$

Pritzwalk (Kreis) 870

Prökelwitz (Kr. Mohrungen) (poln. Prakwice) 91

Prötzel (Kr. Oberbarnim) 188

Prossen bei Bad Schandau (Sachsen), Bahnhof 151

Prudnik $\rightarrow$ Neustadt/OS.

Przemęt $\rightarrow$ Priment (Kr. Bomst)

Przemków $\rightarrow$ Primkenau (Kr. Sprottau)

Przemysław $\rightarrow$ Louisa (Warthebruch)

Przetocznica $\rightarrow$ Hammer (Kr. Züllichau-Schwiebus)

Przychów $\rightarrow$ Preichow (Kr. Crossen)

Przyjezierze $\rightarrow$ Butterfelde (Kr. Königsberg/ Nm.)

Przytoczna $\rightarrow$ Prittisch (Kr. Schwerin/W.)

Psie Pole $\rightarrow$ Breslau-Hundsfeld

Pszczew $\rightarrow$ Betsche (Kr. Meseritz)

Puck $\rightarrow$ Putzig bei Danzig

Pulsnitz (Sachsen) 1261

Pulverkrug (Kr. Weststernberg) (poln. Rosiejewo) 471,1464

Putlitz (Kr. Westprignitz) 454, 549, 871f., 1146

Putzig bei Danzig (poln. Puck) 1467

Pyritz (Pommern) (poln. Pyrzice) 787

Pyritz (Kreis) 214, 216, 860, 863, 1454

Pyrmont, Bad 414 f., 622

Pyrzice $\rightarrow$ Pyritz

Qualzow bei Fürstenberg/H. $\rightarrow$ Barsdorf-Qualzow

Quedlinburg (Kreis) 1447

Quenz-Lager $\rightarrow$ Brandenburg an der Havel

Quermathen (Kr. Westhavelland) 49, 706

Quilitz (Kr. Glogau) (1937-1945 Marienquell)

(poln. Kwielice) 632

Quitzow (Kr. Westprignitz) 838, 1453

Rabensteinfeld bei Schwerin 1450

Raddusch (Kr. Calau) 169 f., 173
Radebeul (Sachsen) 1102

Radęcin $\rightarrow$ Regenthin (Kr. Arnswalde)

Radensdorf (Lausitz) (Kr. Lübben) 535, 872

Radensleben (Kr. Ruppin) 96, 542, 821, 872

Radinkendorf (Kr. Beeskow-Storkow) 1030

Radlow (Kr. Beeskow-Storkow) 1030

Radostowo $\rightarrow$ Freudenberg (Kr. Rößel)

Radówek $\rightarrow$ Klein Rade (Kr. Weststernberg)

Raduhn (Kr. Königsberg/Nm.) (poln. Raduń) 625

Radewitz bei Penkun 91

Räbel (Elbe) (Kr. Osterburg) 1459

Ragösen (Kr. Zauch-Belzig) 46, 126, 264f., 269, 276, 314, 367, 437 f., 550, 873

Ragow (Kr. Beeskow-Storkow) 196, 275, 1030

Rahmel (Kr. Neustadt in Westpreußen) (poln.

Rumia) 468

Rahna bei Leipzig 409

Randen (Livland) (estn. Rannu) 1465

Randow (Fluss) 540

Randow (Kreis) 864

Rangsdorf (Kr. Teltow) 544, 873f., 971, 1101

Ranis (Thüringen), Kinderheim 225

Rannu $\rightarrow$ Randen (Livland)

Ranzig (Kr. Beeskow-Storkow) 1030

Rapshagen (Kr. Ostprignitz) 733

Raßmannsdorf (Kr. Beeskow-Storkow) 981, 983, 1030, 1124, 1147

Rastenburg (Ostpreußen) (poln. Kętrzyn) 823

Rathenow 28, 44 f., 96, 103-106, 166, 169, 199, $211,218,223$ f., 233, 237, 268, 330, 370, 406, 428 f., 440, 456, 465, 469, 480-482, 495, 547, 598, 874-879, 898, 911, 920, 981, 984, 996, 1035, 1101, 1124-1126, 1151, 1183 f., 1188, 1190 f., 1230, 1376, 1435, 1451, 1458, 1466, 1471, 1476, 1481, 1490, 1541; Lager Magazininsel 22, 164, 166, 182, 517, 547, 876 f., 879, 883, 911 f., 980, 1062, 1075, 1230, 1443

Rathenow-Semlin $\rightarrow$ Semlin

Rathenow (Kreis) 878, 1376

Rathstock (Kr. Lebus) 881

Ratzdorf (Kr. Guben) 84, 196

Raudin [?] (Kr. Calau) [Reuden?] 1100

Raudten (Kr. Lüben) (poln. Rudna) 941

Rauen (Kr. Beeskow-Storkow) 1030

Rauscha (Kr. Görlitz) (poln. Ruszów) 1454

Ravensbrück (Kr. Templin) 261, 546, 880; KZ 20, 281, 557, 631, 710, 880

Rawitsch (Posen) (poln. Rawicz) 690 
Rawitsch (Kreis) 216, 612, 996

Recklinghausen 9

Reesdorf (Kr. Zauch-Belzig) 1476

Refrath bei Köln 900

Regensburg 1434

Regensburg (Bistum) 445

Regenthin (Kr. Arnswalde) (poln. Radęcin) 1456

Rehberg bei Strasburg (Mecklenburg) 386

Rehbrücke $\rightarrow$ Potsdam-Rehbrücke

Rehdorf (Kr. Königsberg/Nm.) (poln. Stoki) 294

Rehfelde (Kr. Niederbarnim) 1032, 1440

Reichenau (Kr. Frankenstein) (poln. Topola) 753

Reichenauer Gebiet („Zipfel“) (bei Zittau) 134, 475

Reichenbach (Kr. Guben) 1459

Reichenbach (Schlesien) (poln. Dzierżoniów) (Kreis) 1470

Reichenbach (Vogtland) 1446

Reichenberg (Sudetenland) (tschech. Liberec) 327, 734, 799, 813, 820, 1209

Reichenberg (Landkreis) (Sudetenland) 937

Reichenwalde (Kr. Beeskow-Storkow) 275, 437, 525, 880f., 1030

Reichenwalde (Kr. Lyck) $\rightarrow$ Saborowen

Reichersdorf (Kr. Guben) (poln. Grabice) $1460 \mathrm{f}$.

Reichthal (Kr. Namslau; 1939-1945 Reichtal) (poln. Rychtal) 433, 669

Reinickendorf (Berlin) $\rightarrow$ Berlin-Reinickendorf

Reinowitz bei Gablonz/Neiße (tschech. Rynovice) 504, 1447

Reipzig (Kr. Weststernberg) (poln. Rybocice) 1459

Reitwein (Kr. Lebus) 113, 347, 481, 532 f., $881 f$., 891, 960, 1435, 1477

Remscheid, Tannenhof 693

Rendsburg (Schleswig-Holstein) 504, 1436

Repente (Kr. Ostprignitz) 821

Reppen (Kr. Weststernberg) (poln. Rzepin) 84f., 127, 273, 290 f., 399, 672, $1460 \mathrm{f}$.

Reppenstedt bei Lüneburg 100, 109

Reppinchen (Kr. Zauch-Belzig) 550, 882, 954

Retzin (Kr. Westprignitz) 106

Retzow bei Lübz (Mecklenburg) 803

Rezsel $\rightarrow$ Rößel (Ostpreußen)

Reuden (Kr. Calau) 1100

Rewahl (Kr. Greifenberg) (poln. Rewal) 495, 608, 955

Rheinland 72, 99, 388, 858, 892, 1466
Rheinland-Pfalz 204f.

Rheinsberg (Kr. Ruppin) 106, 447, 454, 504, 542, 820 f., $882 f$., 1063, 1375

Rhinow (Kr. Westhavelland) 283, 301, $330 \mathrm{f}$., 456f., 547, 877, 878, 883f., 898, 1190 f., 1198, 1443

Ribbeckshorst (Kr. Osthavelland) 821

Rieben (Kr. Zauch-Belzig) 549

Riedebeck (Kr. Luckau) 185

Rieplos (Kr. Beeskow-Storkow) 1030

Riesengebirge 327, 368, 417, 419, 426, 1260

Rießen (Kr. Guben) 683

Rietschütz (Kr. Züllichau-Schwiebus) (poln. Rzeczyca) $361 \mathrm{f}$.

Rietz (Kr. Zauch-Belzig) 605, 1205

Rietz-Neuendorf (Kr. Beeskow-Storkow) 1030

Riga (Lettland) 122, 232 f., 505, 552 f., 875

Ringenwalde (Kr. Soldin) (poln. Dyszno) $1440 \mathrm{f}$.

Rinnersdorf (Kr. Züllichau-Schwiebus) (poln. Rusinów) 684

Rippin (Danzig-Westpreußen) $\rightarrow$ Rypin (Polen)

Ritschenwalde (Kr. Obornik) (poln. Ryczywół) 1457

Rittgarten (Kr. Prenzlau) 540, 884

Rochau (Kr. Stendal) 1461

Rocher (Kr. Beeskow-Storkow) $\rightarrow$ TrebatschRocher

Rochlitz (Sachsen) 302, 817

Rochlitz (Kreis) $817 \mathrm{f}$.

Rochlitz an der Iser (Sudetenland) (tschech. Rokytnice nad Jizerou) 418

Roddahn (Kr. Westprignitz) 549, 884

Röddelin (Kr. Templin) 545

Roederhof (Lager) $\rightarrow$ Belzig

Röbel (Mecklenburg) 385, 1441

Rößel (Ostpreußen) (poln. Rezsel) 86

Rogasen (Kr. Obornik) (poln. Rogożno) 1457

Rogoziniec $\rightarrow$ Rogsen (Kr. Meseritz)

Rogożno $\rightarrow$ Rogasen (Kr. Obornik)

Rogsen (Kr. Meseritz) (poln. Rogoziniec) 808

Rohrbeck (Kr. Jüterbog-Luckenwalde) $1042 \mathrm{f}$.

Rokytnice nad Jizerou $\rightarrow$ Rochlitz an der Iser

Rom 76, 575

Rościn $\rightarrow$ Rostin (Kr. Soldin)

Rościszów $\rightarrow$ Steinseifersdorf (Kr. Reichenbach)

Rosenau bei Wusterwitz 470

Rosenberg (Westpreußen) (poln. Susz) 863

Rosengarten (Kr. Lebus) 298f., 474

Rosenthal (Kr. Jüterbog-Luckenwalde) 1459 
Rosiejewo $\rightarrow$ Pulverkrug

Roskow (Kr. Westhavelland) 224, 601

Rosochata $\rightarrow$ Seifersdorf (Kr. Liegnitz)

Rosow (Kr. Randow) 481, 524, 818, $885 f$.

Roßla (Südharz) 665

Rostin (Kr. Soldin) (poln. Rościn) 98, 100, 1454

Rostock 11, 553, 672, 1432, 1434, 1439, 1458, 1465, 1482, 1534

Rostock-Warnemünde 68, 1482

Rostock (Bezirk) 381

Rotenburg/Wümme 693

Rothenburg/Oberlausitz 37

Rothenburg/Oder (Kr. Grünberg) (poln. Czerwieńsk) 496, 633

Rothenburg ob der Tauber 1341

Rothenfelde, Bad (Niedersachsen) 378

Rothenkirchen (Kr. Auerbach/Vogtland) 1465

Rothenstein, Lager $\rightarrow$ Königsberg-Rothenstein

Rotschloß (Kr. Strehlen) (poln. Białobrzezie) 1449

Rottstock (Kr. Zauch-Belzig) 605

Rudelsdorf (Kr. Groß Wartenberg) (poln. Drołtowice) 584

Rudna $\rightarrow$ Raudten (Kr. Lüben)

Rudolstadt (Thüringen) 1101

Rudow (Berlin) $\rightarrow$ Berlin-Rudow

Rückersdorf (Kr. Luckau) 1102

Rüdersdorf (Kr. Niederbarnim) 61, 144-146, 210, 266, 268 f., 323, 463-465, 479 f., 489, 536, 690 f., 886-889, 1033, 1187, 1365, 1435, 1438, 1454, 1464f., 1475; Lager 22, 164, 166, 172-174, 181 f., 187, 221, 536, 887f., 895, 980, 1062, 1076-1079, 1230

Rüdersdorf (Amt) 888, 1365 f., 1438

Rügen (Insel) 11, 71, 78, 294, 327, 1467

Rühstädt (Kr. Westprignitz) 56f., 121, 314, 549, 889

Rüschendorf (Kr. Vechta) 940

Rüthnick (Kr. Ruppin) 399

Ruhland 910

Ruhlsdorf (Kr. Jüterbog-Luckenwalde) 1246

Ruhlsdorf (Kr. Niederbarnim) 1034, 1099

Ruhrgebiet 24, 892, 1305 f., 1312

Rumänien 199, 203, 219, 235, 500, 523, 525527, 529f., 532, 534-541, 543 f., 546-548, $550,599,612,619,637,652,659,667,715$, $727,847,876,898,935,937,951,955,958$, 1034f., 1037, 1265, 1354

Rumia $\rightarrow$ Rahmel
Rummelsburg (Pommern) (poln. Miastko) 934, 1477

Ruppin (Kreis) 79, 81, 107 f., 110, 114, 199, 204, 208, 213, 222 f., 286 f., 372, 394, 429, 454, 484, 522, 541f., 963, 984, 996, 1035, 1063, 1103, 1151, 1189, 1192-1195, 1204f., 1208, 1227, $1230,1254 \mathrm{f}$.

Rusinów $\rightarrow$ Rinnersdorf

Russisch-Polen $\rightarrow$ Polen

Russland (siehe auch $\rightarrow$ Sowjetunion; Russlanddeutsche siehe Sachregister) 49, 74, 149, 155, 232, 251, 470, 486, 498, 511f., 530, 567, 585, $612,627,645,666,681,706,811,821,875$, $907,957,1083,1098,1104,1177,1265,1273$, 1374, 1421, 1454, 1456, 1459, 1467; Archive 146 f., 183, 675

Ruszów $\rightarrow$ Rauscha (Kr. Görlitz)

Rybnik (Oberschlesien), Handelsschule 1450-1452

Rybocice $\rightarrow$ Reipzig (Kr. Weststernberg)

Rybojadel (Hoffmannstal) (Kr. Meseritz)

(poln. Rybojady) 1349

Rychtal $\rightarrow$ Reichthal

Ryczywół $\rightarrow$ Ritschenwalde (Kr. Obornik)

Rydultau (Kr. Rybnik) (poln. Rydultowy) 887

Rynovice $\rightarrow$ Reinowitz bei Gablonz

Rypin (Polen) (dt. 1939-1945 Rippin, Gau

Danzig-Westpreußen) 730

Rzeczyca $\rightarrow$ Rietschütz

Rzepin $\rightarrow$ Reppen

Saabor (Kr. Grünberg) (1937-1945 Fürsteneich) (poln. Zabór) 665

Saalfeld (Thüringen) 1463

Saalow (Kr. Teltow) 544, 889f., 1102; Lager 164, $166,172,544,640,928,1230$

Saarland 205

Saarow(-Pieskow), Bad (Kr. Beeskow-Storkow) (siehe auch $\rightarrow$ Pieskow) 210, 525, 569-571, 944, 1014 f., 1028, 1059, 1070, 1441; CaritasKinderheim St. Antonius 225, 450 f., 554, 570 f., 632,1436

Saarow-Silberberg 569

Saargebiet 1284, 1310

Saatzig (Kreis) (poln. Szadzko) $860 \mathrm{f}$.

Saborowen (Kr. Lyck) (1938-1945 Reichenwalde) (poln. Zaborowo) 1455

Sabrodt (Kr. Beeskow-Storkow) 1030

Sachsdorf (Kr. Guben) (poln. Chęciny) 633 
Sachsen (Land) 10f., 17, 36, 47, 51, 54, 78, 86 f., 99, 160, 168, 172, 189, 195, 198 f., 205, 207, $209,214,218,225,228,231,233,257$ f., 294 f., 307, 330, 375, 395, 397, 399, $406 \mathrm{f} ., 413$, $415 \mathrm{f}$., 425, 436f., 475, 489, 511, 513, 517, 526, 632, $817,823,1017,1019,1035-1037,1069,1103$, $1108,1132,1137,1152,1181,1188,1249 \mathrm{f}$., 1274, 1306, 1342 f., 1392, 1400, 1437, 1470

Sachsen (Provinz) 189, 258, 517, 927, 1000 f., 1184, 1188, 1407

Sachsen-Anhalt („Provinz“/Land) 10, 47, 51, 54, $171,205,207,218,225,228,230$ f., 233, 312, $335,395,404,407,411,413-416,474,517$, $606,654,877,929,1035-1037,1103,1250$, $1257,1342,1344,1447,1453$

Sachsendorf (Kr. Lebus) 532 f., 890-892, 951, 1409,1480

Sachsendorf-Werder $\rightarrow$ Werder (Oderbruch)

Sachsenhausen (Kr. Niederbarnim) 1033; Gedenkstätte 21; KZ 20, 631, 648, 697, 739, 821,1135

Sadenbeck (Kr. Ostprignitz) 1450, 1462

Sadoroschje $\rightarrow$ Malenuppen

Säpzig (Kr. Weststernberg) (poln. Żabice) $1475(?)$

Sagan (Schlesien) (poln. Żagań) 104, 156, 447, 496, 623, 840, 930, 940, 1442, 1475 f.; Lager 130,1154

Sagan (Kreis) 284

Sagast (Kr. Westprignitz) 549, 892

Salderrnbücke $\rightarrow$ Hohenwutzen

Sallgast (Kr. Luckau) 1199

Salzdorf (Kr. Schubin) $\rightarrow$ Groß Salzdorf

Salzgitter $\rightarrow$ Watenstedt-Salzgitter

Salzwedel, Kreiskrankenhaus 693

Samland (Kreis) 864

Samter (Posen) (poln. Szamotuly) 192

Samter (Kreis) 120 f., 192 f., 217, 284, 548, 566, $837,996,1452$

Sandow bei Cottbus $\rightarrow$ Cottbus-Sandow

Sandow (Kr. Weststernberg) (poln. Sąndów) 410

Sandow, Papierfabrik (Kr. Weststernberg) $\rightarrow$ Steinbockwerk

Sankt Augustin (bei Bonn) 722

Sankt Joachimsthal (Böhmen) (tschech. Jáchymov) 937

Santok $\rightarrow$ Zantoch (Kr. Landsberg/W.)

Sarbinowo $\rightarrow$ Zorndorf (Kr. Königsberg/Nm.)

Sarnowo $\rightarrow$ Scharnau (Kr. Neidenburg)
Sassen (Kr. Grimmen, Vorpommern) 1101

Saude (Kr. Guben) (poln. Zawada) 425

Sauen (Kr. Beeskow-Storkow) 1030, 1131

Sawall (Kr. Beeskow-Storkow) 1031

$\mathrm{SBZ} \rightarrow$ Sowjetische Besatzungszone

Schäferberg (Kr. Grünberg) $\rightarrow$ Woitscheke

Schalauen 343

Schandau, Bad (Sachsen) 307

Scharnau (Kr. Neidenburg) (poln. Sarnowo) 221

Scharnikau $\rightarrow$ Czarnikau

Schatzlar (Sudetenland) (tschech. Žacléř) 811

Schaumburg (Kr. Königsberg/Nm.) (poln. Szumiłowo) 696

Schelesnodoroschny $\rightarrow$ Gerdauen

Schenkenberg (Kr. Prenzlau) 865

Schenkenberg (Kr. Zauch-Belzig) 550, 742, $892 f ., 1480$

Schenkendöbern (Kr. Guben) 401, 925

Schenkendorf (Kr. Guben) (poln. Sekowice) 715

Schernewitz (Kr. Guben) $\rightarrow$ Tzschernowitz

Schernsdorf (Kr. Guben) 1294, 1443

Scheune (Kr. Randow) $\rightarrow$ Stettin-Scheune

Schiedlo (Kr. Guben) (poln. Szydłów) 1404

Schieratz (Kreis) (poln. Sieradz) 874, 996

Schierzig (Kr. Meseritz) (poln. Siercz) 549, $592 \mathrm{f}$.

Schilda bei Kirchhain (Kr. Luckau) 534

Schildow (Kr. Niederbarnim) 83, 1032, 1099

Schipkau (Kr. Calau) 416

Schirgupönen (1938-1945 Amtshagen) (Kr. Gumbinnen) (russ. Dalneje) 82

Schivelbein (Pommern) (poln. Świdwin) 176, 503,1462

Schlabendorf (Kr. Luckau) 1481

Schlänitzsee $\rightarrow$ Potsdam-Grube

Schlagsdorf (Kr. Guben) 1296

Schlalach (Kr. Zauch-Belzig) 605

Schlaubetal (Amt) 807

Schlawa (Kr. Glogau) (1937-1945 Schlesiersee) (poln. Sława) 496, 790; KZ-Außenlager Schlesiersee I: 101

Schlawe (Pommern) (poln. Sławno) 151, 214, 1234

Schleiz (Thüringen) 208

Schleps (Kr. Kolberg-Körlin) (poln. Stare Ślepce) 1461

Schlepzig (Kr. Lübben) 221 f., 535, 582, 593, 894

Schlesien (poln. Śląsk) (siehe auch $\rightarrow$ Niederschlesien, $\rightarrow$ Oberschlesien) 17, 30, 35 f., 46, 57, 76, 78 f., 82, 99, 101-104, 120, 128, 135, 
$137,148,153,156,169-171,174,177,185$, 189 f., 195, 199-202, 208-214, 216, 222 f., 240 f., 265, 275, 277, 284f., 287, 292-294, 296-298, 302, 314f., 319, 322-324, 329, 332-334, 338-340, 342 f., 347, 350, 354f., 358 f., 363 f., 366, 368, 377-379, 389, 394, 396f., 405 f., 413, 419, 421, 427-429, 436, 439, 442-444, 447, 449-452, 458 f., 475, $483,496,503,505,517,523,525-527,529 \mathrm{f}$., 532-541, 543-545, 547 f., 550, 553 f., 558 f., 562,565 f., 568, 571, 575, 578, 581, 586, 591, $593,595,597-599,602$ f., 611, 616, $618 \mathrm{f}$., 624f., 635, 637, 639, 643, 651, 657-659, 667, 673, 677, 683, 687, 696, 715, 721, 731 f., 740 f., 744,747 f., 752 f., $761,779,784,802,808,811$, $817,821,824$ f., 831 f., 839,841 f., 844,846 f., 853,855 f., $858,861,871,876,878,892,906$, 916, 928, 932, 939 f., 955,957 f., 964,969 f., 986, 994, 1000-1002, 1004, 1007, 1125, 1173, $1186,1211,1213,1251,1256-1260,1265$, 1268-1270, 1275, 1279, 1284, 1288, 1290, 1305, 1321, 1323, 1375, 1377 f., 1414, 1417, $1442,1444,1446,1448-1450,1454,1461$, 1464, 1469 f., 1475, 1479, 1483, 1534

Schlesiergrube (Kr. Beuthen/OS.) $\rightarrow$ Chropaczow Schlesiersee (Kr. Glogau) $\rightarrow$ Schlawa

Schleswig-Holstein 85, 191 f., 204 f., 207 f., 222, 411, 485, 503 f., 878, 1436, 1453, 1456, 1471

Schlieben (bei Schweinitz) 517

Schlobitten (Kr. Preußisch Holland) (poln. Słobity) 91

Schluckenau (Sudetenland) (tschech. Śluknov) 157,307

Schluft (Kr. Niederbarnim) 1034

Schmachtenhagen (Kr. Niederbarnim) 224, 395, 536, 831, 894f., 1034

Schmagorei (Kr. Weststernberg) (poln. Smogóry) 339

Schmarl bei Rostock 1449

Schmellwitz (Kr. Cottbus) 76f., 416, 459, 527, $895,1213,1251$

Schmergow (Kr. Zauch-Belzig) 235, $1354 \mathrm{f}$.

Schmerzke (Kr. Zauch-Belzig) 597, 1275

Schmerwitz (Kr. Zauch-Belzig) 1460

Schmiedeberg, Bad, bei Wittenberg 1447

Schmiegel (Kr. Kosten) (poln. Śmigiel) 368

Schmölln (Kr. Prenzlau) 861

Schmograu (Kr. Namslau) (poln. Smogrzów) 699,823
Schmolde (Kr. Ostprignitz) 206

Schmottseiffen (Kr. Löwenberg) (poln. Pławna) $17,843,1519$

Schneeberg (Kr. Beeskow-Storkow) 1030, 1086

Schnega (Kr. Lüchow-Dannenberg) 224

Schneidemühl (poln. Piła) 102, 489, 563, 497,

751, 754, 863, 890, 900, 1094, 1133, 1511

Schneidemühl (Prälatur) 445, 571, 584, 628, 752, 874,963

Schneverdingen bei Soltau 386, 388

Schöbendorf (Kr. Jüterbog-Luckenwalde) 1306

Schönau/Katzbach (Kr. Goldberg) (poln.

Świerzawa) 871

Schönau (Kr. Schlochau) (poln. Drzonowo) 504

Schönblick (Kr. Niederbarnim) $\rightarrow$ Woltersdorf-

Schönblick

Schönbrunn (Kr. Sagan) (poln. Jabłonoów) 835

Schönbrunn bei Mährisch Ostrau (tschech.

Svinov) 997

Schönbrunn bei Zwittau, Schönhengstgau

(tschech. Jedlová) 328

Schöndorf $\rightarrow$ Weimar-Schöndorf

Schönebeck/Elbe 302

Schöneberg (Berlin) $\rightarrow$ Berlin-Schöneberg

Schönefeld (Kr. Teltow) 42, 643, 1102

Schöneiche b. Berlin (Kr. Niederbarnim) 297, 449f., 536, 628, 895-897, 1033, 1435, 1436, 1463,1471

Schöneiche (Kr. Wohlau) (poln. Dębno) 153, 1445

Schöneiche-Fichtenau (Kr. Niederbarnim) 895

Schönerlinde (Kr. Niederbarnim) 1033, $1356 \mathrm{f}$.

Schönermark (Kr. Ostprignitz) 777, 1453

Schöneweide (Kr. Teltow) (?) 461

Schönfeld (Kr. Brieg) (poln. Obórki) 414

Schönfließ, Bad (Kr. Königsberg/Nm.) (poln.

Trzcińsko-Zdrój) 375, 394f.

Schönfließ (Kr. Lebus) 532

Schönfließ (Kr. Niederbarnim) 1032

Schönhagen (Kr. Jüterbog-Luckenwalde) 793, 1451

Schönhausen/Elbe (Kr. Jerichow II) 1454

Schönhengstgau 328, 579

Schönholz (Kr. Westhavelland) 234, 312, 547, 898

Schönlage bei Wismar (Mecklenburg) 118

Schönow (Kr. Niederbarnim) 1031

Schönow (Kr. Pyritz) (poln. Jesionowo) 71

Schönrade (Kr. Friedeberg/Nm.) (poln. Tuczno) 1449 
Schönrode (Mark) (Kr. Crossen) $\rightarrow$ Dobersaul Schönwald (Oberfranken) 239

Schönwalde (Kr. Luckau) 534f., 899

Schönwalde (Kr. Niederbarnim) 207, 1033

Schönwalde (Kr. Osthavelland) 538, 899f., 1100, 1198

Schönwiese bei Guttstadt (Kr. Heilsberg) (Międzylesie) 1463

Schollendorf (Kr. Groß Wartenberg) (poln. Szczodrów) 699

Scholwin $(\mathrm{Kr}$. Randow) $\rightarrow$ Odermünde

Schorbus (Kr. Cottbus) 634

Schrimm (Kreis) (poln. Śrem) 530, 996

Schroda (Posen) (poln. Środa Wlkp.) 232, 496, $627,735,1459$

Schroda (Kreis) 111, 217, 530, 627, 996

Schubin (Kreis) (1942-1945 Altburgund; poln. Szubin) 541, 863, 996

Schüttenitz bei Leitmeritz (Sudetenland) (tschech. Žitenice) 831

Schulzendorf bei Wriezen (Kr. Oberbarnim) 207, 218

Schulzendorf (Kr. Teltow) 194, 1102

Schwaan (Mecklenburg), Lager 1440

Schwabach (Bayern) 379

Schwaben 1265

Schwäbisch Gmünd, Kanzlei der EKD 433

Schwanebeck (Kr. Niederbarnim) 584, 1031, 1457

Schwanebeck (Kr. Zauch-Belzig) 1205

Schwanebeck-Gehrenberge (Kr. Niederbarnim) $536,584,900$

Schwante (Kr. Osthavelland) 940, 1100

Schwarme bei Verden/Aller 54

Schwartow (Kr. Lauenburg) (poln. Zwartowo) 1436

Schwarze Pumpe (Kr. Spremberg) 916, 1358

Schwarzes Meer (siehe auch $\rightarrow$ Bessarabien) 283, 322, 337, 574, 578, 612, 652, 698, 801, 880, 893, 943, 951, 1264-1267, 1480, 1482

Schwarzhauland [Welches?] (Provinz Posen) 201

Schwarzheide (Kr. Calau) 526, $900 f ., 1458,1473$

Schwarzmeerraum $\rightarrow$ Schwarzes Meer

Schweden 1228

Schwedt/Oder (Kr. Angermünde) 29, 33, 104-106, 144, 196, 198, 214, 218, 221 f., 295, 298, 455, 467, 492, 494f., 518, 524, 561, 571, 901-904, 1278 f., 1329f., 1404, 1443, 1446, 1454; Lager 524, 563, 904, 1063; Oderbrücke, -übergang 95, 109, 901 f., 1455 f., 1458; Uckermärkische Tabakverwertungs-Genossenschaft (UTVG) 350, 1313 f., 1319

Schwedt (Kreis) 564

Schweidnitz (Schlesien) (poln. Świdnica) 496, $685,800,1435,1476$

Schweinitz 1407

Schweinrich (Kr. Ostprignitz) 106, 1455

Schweiz 511, 693, 727, 811, 1071

Schwenow (Kr. Beeskow-Storkow) 1030

Schwente (Kr. Flatow) (poln. Święta) 821

Schwerin (Kr. Beeskow-Storkow) 1030

Schwerin (Kr. Teltow) 935

Schwerin (Mecklenburg) 102, 112-115, 561 f., $826,1350,1407,1439,1443,1450,1472$, 1477

Schwerin (Bezirk) 353, 389, 405

Schwerin (Bischöfliches Amt) 680

Schwerin/Warthe (poln. Skwierzyna) 327, 368, $428,494,585$

Schwerin/Warthe (Kreis) 94, 371, 381-384, 538, 963, 1000 f., 1130, 1270

Schwertburg (Kr. Eichenbrück) $\rightarrow$ Gollantsch

Schwetig (Kr. Weststernberg) (poln. Świecko) 666,1459

Schwetz/Weichsel (Kreis (poln. Świecie) 861

Schwiebus (Kr. Züllichau-Schwiebus) (poln. Świebodzin) 65, 103, 127, 135, 137, 277, 416, $487,495,583,626,693,812,827,874,1375$, 1450, 1456, 1459, 1468, 1474, 1479; Sowjet. Speziallager 149, 291, 1437, 1465

Schwientochlowitz (Oberschlesien) (poln. Świętochłowice) 329

Schwirz (Kr. Namslau) (poln. Świerczów) 1443

Ściechów $\rightarrow$ Fahlenwerder (Kr. Soldin)

Ścinawa $\rightarrow$ Steinau/Oder

Ścinawka Dolna $\rightarrow$ Niedersteine

Ścinawka Średnia $\rightarrow$ Mittelsteine

Seddin (Kr. Zauch-Belzig) 575, 1445

Sedlitz (Kr. Calau) 1100

Seebad Horst (Kr. Greifenberg) $\rightarrow$ Horst, Seebad

Seeberg (Kr. Niederbarnim) 1032

Seefeld (Kr. Niederbarnim) 1032

Seehausen (Kr. Angermünde) 524, 905, 1434

Seehausen/Altmark (Kreis) 1435

Seehof bei Wuthenow (Kr. Ruppin) 1460

Seelow (Kr. Lebus) 100, 127, 208, 221, 375, 444, 455, 480, 495 f., 511, 518, 533, 538, 701, 739, 769, 784, 905-908, 996, 1056, 1090, 1349, 
1478; Landrat, Rat des Kreises 769, 773, 1054, 1056, 1441; VP-Kreisamt 1349f., 1438

Seelow (Kreis) 208, 514, 784, 907, 1090, 1349, 1353, 1407, 1441

Seelower Höhen 112; Gedenkstätte $906 f$.

Seelübbe (Kr. Prenzlau) 416

Seeren (Kr. Oststernberg) (poln. Żarzyn) $1345 \mathrm{f}$.

Seestadtl (bei Komotau) (tschech. Ervěnice) 1469

Segeletz (kr. Ruppin) 1210

Sehlen (Kr. Tuchel) (poln. Żalno) 1481

Seidelsdorf (Kr. Sorau?) 744

Seidlitz (Kr. Landsberg/W.) (poln. Siedlice bzw. Gorzów Wlkp.-Siedlice) 440, 601

Seifersdorf (Kr. Liegnitz) (poln. Rosochata) 852

Seifersdorf bei Radeberg (Sachsen) 1460

Seiffersdorf (Kr. Ohlau) (poln. Zabardowice) 1449

Seitwann (Kr. Guben) (poln. Żytowań) $83 \mathrm{f}$.

Sekowice $\rightarrow$ Schenkendorf (Kr. Guben)

Selbelang (Kr. Westhavelland) 1457

Selchow (Kr. Beeskow-Storkow) 131, 1030, 1471

Selchow (Kr. Teltow) 544, 908, 1101

Selletau bei Brünn (schech. Želeteva) 1444

Sellin (Kr. Königsberg/Nm.) (poln. Zielin) 384, 399, 1339

Sellin (Rügen) 327, 1541

Selterhof $\rightarrow$ Treuenbrietzen, Lager Selterhof

Selz bei Odessa (jetzt Teil von Lymanske, Ukraine) 1539

Selzig $(\rightarrow$ Säpzig?) 1475

Sembten (Kr. Guben) 1292

Semlin bei Rathenow (Kr. Westhavelland) 224, 878 f., 1541

Senftenberg in Böhmen (tschech. Žamberk) 910

Senftenberg (Kr. Calau) 29, 82, 164, 457, 496, 498, 525 f., 620, 753, 909f., 915, 939, 1063, $1187,1416,1435,1459,1463,1527$

Senftenberg (Kreis) 796, 909 f., 1348, 1352

Sensburg (Ostpreußen) (poln. Mrągowo) 870

Sensburg (Kreis) 87, 136

Senzig (Kr. Teltow) 1102

Senzke (Kr. Westhavelland) 547, 911

Sępólno Krajeńskie $\rightarrow$ Zempelburg

Serbien (vgl. $\rightarrow$ Balkan) $1008 \mathrm{f}$.

Sernow (Kr. Jüterbog-Luckenwalde) 1306

Serwest (Kr. Angermünde) 1434, 1443

Setzsteig (Kr. Zauch-Belzig) 309

Sibirien $174,1460,1463,1468$
Siebenborn bei Eisenach, Lager 656

Siebenbürgen 828, 1478

Siedlice $\rightarrow$ Seidlitz (Kr. Landsberg/W.)

Siegburg (Rheinland) 390

Siekierki $\rightarrow$ Zäckerick (Kr. Königsberg/Nm.)

Siemiatyce (Podlachien) 705, 967

Sieradz (Kreis) $\rightarrow$ Schieratz (Kreis)

Sieraków $\rightarrow$ Zirke (Kr. Birnbaum)

Siercz $\rightarrow$ Schierzig (Kr. Meseritz)

Sieversdorf (Kr. Ruppin) 339, 542, 823, $911 f$., 1210

Siewisch (Kr. Calau) 634

Silberberg (Kr. Beeskow-Storkow) $\rightarrow$ SaarowSilberberg

Simmersdorf (Kr. Sorau) 542 f., 658, 661, $912 f$.

Skorschenno (Kr. Preuß. Stargard) (1942-1945

Wurzelacker) (poln. Skrzynka) 753

Śląsk $\rightarrow$ Schlesien, $\rightarrow$ Oberschlesien

Slawa $\rightarrow$ Schlawa (Kr. Glogau)

Sławno $\rightarrow$ Schlawe (Pommern)

Sławsko $\rightarrow$ Alt Schlawe (Kr. Schlawe)

Sławsko Górny $\rightarrow$ Liliendorf (Kr. Strelno)

Słobity $\rightarrow$ Schlobitten (Kr. Preußisch Holland)

Słonawy $\rightarrow$ Groß Salzdorf

Slowakei 146f., 236f., 492-494, 496, 605, 607, 937, 1350

Slowenien 932

Słubice (Stadt) $\rightarrow$ Frankfurt (Oder), Dammvorstadt

Słubice (Kreis) 495

Śluknov $\rightarrow$ Schluckenau (Sudetenland)

Słupsk $\rightarrow$ Stolp (Pommern)

Śmigiel $\rightarrow$ Schmiegel

Smogóry $\rightarrow$ Schmagorei (Kr. Weststernberg)

Smogrzów $\rightarrow$ Schmograu (Kr. Namslau)

Smolnica $\rightarrow$ Bärfelde (Kr. Königsberg/Nm.)

Snamensk $\rightarrow$ Wehlau

Sobięcin $\rightarrow$ Niederhermsdorf (Kr. Waldenburg)

Sobicisko $\rightarrow$ Zottwitz (Kr. Ohlau)

Sobutnow (Polen, heute Weißrußland) $1445 \mathrm{f}$.

Sömmerda (Thüringen) 385

Sokolniki $\rightarrow$ Langendorf (Kr. Wehlau)

Soldau (poln. Działdowo) 74, 689

Soldin/Nm. (poln. Myślibórz) 75, 95, 100, 205, 368 f., 408, 505, 560, 1438

Soldin (Kirchenkreis) 369

Soldin (Kreis) 75, 100, 205, 369, 384, 386-388, $408,839,1420$

Soltau (Niedersachsen) 384, 386, 388 
Soltau (Landkreis) 384, 388, 1420

Sommerau bei Deutsch Eylau (Kr. Rosenberg, Westpreußen) (poln. Ząbrowo) 1471

Sommerfeld (Niederlausitz) (Kr. Crossen) (poln. Lubsko) 133, 272, 289, 412f., 495, 617, 647, $657,660,712,714,718,795,799,851,925$, 947,1211

Sommerfeld (Kr. Oberbarnim) 639

Sommerschenburg bei Marienborn (Kr. Oschersleben) 1456

Sommersdorf bei Marienborn (Kr. Oschersleben) 1456

Somse (Kr. Berent) (poln. Zomrze) 1448

Sonnenburg/Nm. (Kr. Oststernberg) (poln. Słońsk) 399, 472

Sonnewalde (Kr. Luckau) 457, 534, 654, 913

Sontra-Wichmannshausen 472

Sophienstädt (Kr. Niederbarnim) 1034

Sophienthal (Kr. Lebus) 533, 913

Sorau (Niederlausitz) (poln. Żary) 25, 130, 148, 208, 272, 352, 359, 392, 403, 467, 617, 619, 658-661, 672, 789, 853, 869, 1207, 1268, 1476,1483

Sorau (Kreis) 100, 216, 272, 274, 352, 372, 389-392, 403, 443, 542, 658-661, 761, 799, 947, 996

Sorau(-Forst) (Restkreis) 164, 199, 202, 210, $274,443,542 f$.

Sorkwity $\rightarrow$ Sorquitten (Kr. Sensburg)

Sorno (Kr. Calau) 440, 526, 914

Sorquitten (Kr. Sensburg) (poln. Sorkwity) 1450

Sosny $\rightarrow$ Charlottenhof (Kr. Landsberg/W.)

Sovetsk $\rightarrow$ Tilsit

Sowjetische Besatzungszone Deutschlands (SBZ) 3 f., 7, 9, 12 f., 18, 37, 47 f., 50 f., 54, 64, 82 f., 97, 103 f., 106, 133, 136, 138, 144, 147, 149 f., 156, 162 f., 174 f., 187, 189 f., 196, 198-201, 203-205, 207, 212, 214, 219f., 228-231, 234, 236, 239 f., 244 f., 248, 252-254, 257 f., 262 f., 266, 270, 315 f., 319, 333, 336, 339, 356, 364 f., 369-373, 377 f., 406, 436, 442, 620, 658, 712, $809,847,885,1154$ f., 1168 f., 1240 f., 1243 , $1257,1289,1300,1306,1390,1394$ f., 1406 , 1408 f., 1412,1446 und passim

Sowjetsk $\rightarrow$ Tilsit

Sowjetunion (SU, UdSSR, „Sowjet-Russland“) (siehe auch $\rightarrow$ Russland) 50, 72, 97, 133, 140, $142,146,153,155,199,203,207,220,251$, $253,291-294,355,406,418,448,496-500$,
$505,523,525-527,529$ f., 532, 534-541, 543 f., 546-548, 550, 599 f., 619, 627, 637, $647,659,665,667,676,688,691,714$ f., 728, 769, 846f., 860, 876, 880, 885, 893, 958, 1034 f., 1037 f., 1041, 1138, 1169, 1234, 1239, 1244, 1265, 1281 f., 1284f., 1296, 1300, 1303, 1307, 1309, 1311, 1319, 1328, 1332 f., 1335 , 1348, 1370, 1396-1399, 1407-1409, 1413, $1415,1437,1450,1462$

Spaatz (Kr. Westhavelland) 330

Spandau (Berlin) $\rightarrow$ Berlin-Spandau

Spanien 331

Sperenberg (Kr. Teltow) 221, 544, 914, 971

Spišská Bela $\rightarrow$ Zipser Bela

Spree (Fluss) 915

Spreeau (Kr. Niederbarnim) 1032

Spreenhagen (Kr. Beeskow-Storkow) 1030, 1465

Spreetal 321

Spreewald 102, 211, 321 f., 535, 553, 836, 1437, $1460,1466,1470$

Spremberg 115, 158, 166, 186, 416, 440, 457, 480, 496, 498f., 543, 616, 750, 836, 914-917, 987, 1020, 1100, 1102, 1154, 1198f., 1267, 1444, 1456, 1542; Lager 26, 99, 164, 166, 231, 543, 915f., 1022, 1027, 1152, 1230, 1268 f., 1444

Spremberg-Cantdorf (Kr. Spremberg) 99, 543, 917f.; Parmalager 164, 917, 1062; Wilhelmstal (Lager) 918

Spremberg-Schwarze Pumpe $\rightarrow$ Schwarze Pumpe Spremberg-Trattendorf 543, 918

Spremberg (Kreis) 115, 164, 166, 199, 476, 542, 543, 796, 915 f., 946, 996, 1035, 1158, 1182, 1230, 1235 f., 1348,1352

Sprengersfeld (Kr. Gnesen) $\rightarrow$ Dzialyn

Springe/Deister 414

Sprottau (Schlesien) (poln. Szprotawa) 496, 916

Śrem (Kreis) $\rightarrow$ Schrimm (Kreis)

Środa Wlkp. $\rightarrow$ Schroda

St. ... $\rightarrow$ Sankt ...

Stade (Niedersachsen) 1261

Staffelde (Kr. Osthavelland) 387, 1111

Stahnsdorf (Kr. Teltow) 231, 328, 544, 756, 918f., 1101, 1468, 1542

Stalingrad (Wolgograd) 251, 1307

Stalinhorst bei Moskau, Lager $1274 \mathrm{f}$.

Stalinstadt $\rightarrow$ Eisenhüttenstadt

Stallberg (Vorpommern) 1468

Stangenhagen (Kr. Jüterbog-Luckenwalde) 1246, 1451 
Stanislau (Galizien) (ukrain. Stanyslawiw bzw.

Iwano-Frankiwsk, poln. Stanisławów) 1261

Stanowice $\rightarrow$ Stennewitz

Stańsk $\rightarrow$ Stenzig

Stanyslawiw $\rightarrow$ Stanislau

Stara Rudnica $\rightarrow$ Alt Rüdnitz

Stara Woda $\rightarrow$ Altwasser

Stare Kurowo $\rightarrow$ Altkarbe

Stare Osieczno $\rightarrow$ Hochzeit

Stare Polichno $\rightarrow$ Pollychen

Stare Ślepce $\rightarrow$ Schleps

Stargard (Mecklenburg) (Kreis) 557

Stargard in Pommern (poln. Stargard) 560, 658, 1205

Stargard Gubiński $\rightarrow$ Stargardt (Kr. Guben)

Stargardt (Kr. Guben) (poln. Stargard Gubiński) 707

Staropole $\rightarrow$ Starpel

Starosiedle $\rightarrow$ Starzeddel

Starpel (Kr. Züllichau-Schwiebus) (poln. Staropole) $1345 \mathrm{f}$.

Stary Bleszyn $\rightarrow$ Alt Blessin

Starý Habendorf $\rightarrow$ Alt Habendorf

Stary Jawor $\rightarrow$ Alt Jauer

Stary Kostrzynek $\rightarrow$ Altcüstrinchen

Stare Łysogórki $\rightarrow$ Alt Lietzegöricke

Starzeddel (Kr. Guben) (poln. Starosiedle) 748, 761 f., 824

Stavenhagen (Mecklenburg) 116

Stavenow (Kr. Westprignitz) 549, 919

Stębark $\rightarrow$ Tannenberg (Kr. Osterode)

Stechow (Kr. Westhavelland) 235, 547, 920, 1481

Steglitz (Berlin) $\rightarrow$ Berlin-Steglitz

Steinau/Oder (Kreis) (poln. Ścinawa) 396, 796

Steinbockwerk (Sandow, Papierfabrik) (Kr. Weststernberg) (poln. Koziczyn) 1453

Steinförde bei Fürstenberg/Havel 680

Steinkirchen bei Lübben $\rightarrow$ Lübben-Steinkirchen

Steinseifersdorf (Kr. Reichenbach) (poln.

Rościszów) 919

Stendal (Altmark) 960

Stendell (Kr. Angermünde) 115

Stennewitz (Kr. Landsberg/W.) (poln. Stanowice) $388 \mathrm{f}$.

Stenzig (Kr. Weststernberg) (poln. Stańsk) 1445

Sternberg/Nm. (Kr. Oststernberg) (poln. Torzym) $127,373,1463$

Sternberg (Land) („Sternberger Land“) $372 \mathrm{f}$., 379, 399 f., 410, 669
Stettin (Pommern) (poln. Szczecin) 33, $87 \mathrm{f}$., $147 \mathrm{f} ., 150,152,172,253,273,275,327,337$, $345,392,402,503$ f., 540, 641, 653, 658, 672, $703,853,861,865,883,885,918$ f., 1084 f., 1137, 1206, 1208, 1372, 1406 f., 1436, 1438, 1442, 1449, 1453, 1455, 1458f., 1466 f., 1471

Stettin-Altdamm (poln. Dąbie) 861, 1466

Stettin-Scheune (poln. Gumieńce), Bahnhof 150, $561 \mathrm{f} ., 1012$

Stettin-Züllchow (poln. Żelechowa) 1462

Stettin (Woiwodschaft) $\rightarrow$ Szczecin

Stiebsdorf (Kr. Luckau) 626

Stilow (Kr. Greifswald) 623

Stoberau (Kr. Brieg) (poln. Stobrawa) 1458

Stockholm (Schweden) 854

Stöffin (Kr. Ruppin) 821

Stölln (Kr. Westhavelland) 878

Stoki $\rightarrow$ Rehdorf

Stolberg (Nm.) (Kr. Landsberg/W.) (poln.

Kamień Mały) 1437

Stolp (Pommern) (poln. Słupsk) 87, 1455

Stolp (Kreis) 148, 150,153

Stolpe (Kr. Niederbarnim) 734, 1032, 1099

Stolpmünde (Kr. Stolp) (poln. Ustka) 1404

Stolzenfelde (Kr. Arnswalde) (poln. Stradzewo) 1458

Stolzenhagen (Kr. Angermünde) $1329 \mathrm{f}$.

Stolzenhagen (Kr. Niederbarnim) 504, 1034, 1099, 1437

Storkow (Kr. Beeskow-Storkow) 61, 64f., 86, 89, 131, 133, 136, 153, 176-178, 180, 187, 196, 225, 265, 273, 276, 287, 291, 293, 297, 455, 461, 487, 489 f., 496, 525, 766-769, 920-922, 1028, 1067f., 1073, 1084-1086, 1091-1093, $1098,1104,1435,1441$ f., 1450, 1452 f., 1454f., 1461-1463, 1465, 1470-1472, 1479, 1541 f.; Bahnhof 150-152, 178 f., 766, 1091, 1098; Krankenhaus Hubertushöhe 699, 768, 921, 1064

Storkow-Hirschluch 525, $922 f$., 1092

Storkow-Küchensee $\rightarrow$ Küchensee

Stradzewo $\rightarrow$ Stolzenfelde (Kr. Arnswalde)

Stralsund (Vorpommern) 530, 1010, 1100, 1434, 1449

Strasburg (Uckermark) (Kr. Prenzlau) 192, 218, 495, 540 f., 843, 923f., 1250, 1467

Straßburg (Oder) $\rightarrow$ Deutsch Nettkow

Straubing (Niederbayern) 415

Straupitz (Kr. Lübben) 329, 535, 794, 796, 925 
Strausberg (Kr. Oberbarnim) 61, 113, 116, 246, 288, 332, 340, 413, 428, 455, 482, 494, 537, 754, 796, 926f., 1137, 1348, 1413, 1440, 1447, 1460, 1467, 1472, 1479, 1541 f.; Lager 164, 537, $926 f ., 1063$

Strausberg (Kreis) 907

Streganz (Kr. Beeskow-Storkow) 1030

Stremmen (Kr. Beeskow-Storkow) 275, 410, 1030

Strese (Kr. Meseritz) (Posen/Polen) (poln. Strzyżewo) 323, 648, 1435

Stretzin (Kr. Schlochau) 1441

Strickscheid/Eifel 1436

Ströbitz (Kr. Cottbus) 616, 618 f., 1213

Strzelce Krajeńske $\rightarrow$ Friedeberg/Nm.

Strzelce Opolskie $\rightarrow$ Groß Strehlitz

Strzyżewo $\rightarrow$ Strese (Kr. Meseritz)

Stubbendorf (Kr. Grimmen) 1350

Stücken (Kr. Zauch-Belzig) 1445

Stülpe (Kr. Jüterbog-Luckenwalde) 1452

Stuer bei Waren (Mecklenburg) $1440 \mathrm{f}$.

Stützkow (Kr. Angermünde) 524, 625, 928, 1443

Stuhm (Kreis) (poln. Sztum) 152 f., 402

Stuttgart 103, 211, 234, 329, 339, 415, 474, 691, 745, 1327, 1443, 1477, 1542

Stuttgart (Kreis), BdV-Kreisverband 339

Sudauen 343

Sude (Fluss) 290

Sudetenland („Sudetengau“, Sudetengebiete; siehe auch $\rightarrow$ Böhmen, $\rightarrow$ Tschechoslowakei) 75, 78, 99, 129, 147 f., 150, 157-159, 171, 189, 200-202, 212 f., 228-232, 281, 284, 293 f., 300-303, 307 f., 315 f., 325-327, 333 f., 368, 405, 407f., 418, 421, 425-427, 430, 432, 442, 458 f., 462, 465, 471, 503, 509 f., 513 f., 526, $547,557,578,583,586,591,602,605,610$, $614,617,625,627,648,680$ f., 710, 734, $743 \mathrm{f}$., 752-754, 765, 778, 802, 808, 814, 819, 826, 831 f., 847, 853, 857-859, 873, 875, 877, 883, $889,899,910,915,917$ f., 930 f., $937,950,963$, $1210,1212,1220,1248,1265,1268,1270$, 1279, 1290, 1350 f., 1377 f., 1390, 1402, 1413, 1434f., 1437, 1441, 1446-1448, 1453, 1469

Süddeutschland 336, 409, 809

Südende (Berlin) $\rightarrow$ Berlin-Südende

Südosteuropa 16, 234, 513, 1362, 1392

Sükow (Kr. Westprignitz) 1455

Süsel (Kr. Eutin) 224

Süßenberg (Kr. Heilsberg) (poln. Jarandowo) 1457
Suhl (Thüringen) 414

Suhlendorf bei Uelzen 193

Sukow bei Schwerin (Meckl.) 1448

Sulechów $\rightarrow$ Züllichau

Susz $\rightarrow$ Rosenberg (Westpreußen)

Suszyna $\rightarrow$ Dürrkunzendorf

Svinow $\rightarrow$ Schönbrunn bei Mährisch Ostrau

Svitavy $\rightarrow$ Zwittau

Świdnica $\rightarrow$ Schweidnitz (Schlesien)

Świdwin $\rightarrow$ Schivelbein

Świebodzin $\rightarrow$ Schwiebus

Świecie $\rightarrow$ Schwetz/Weichsel

Świecko $\rightarrow$ Schwetig

Świętochłowice $\rightarrow$ Schwientochlowitz

Świeradów-Zdrój $\rightarrow$ Flinsberg, Bad

Świerzawa $\rightarrow$ Schönau/Katzbach

Święta $\rightarrow$ Schwente

Swinemünde (poln. Świnoujście) 447, 638, 688, $803,870,1456$

Sycowice $\rightarrow$ Leitersdorf

Syrien 775

Szadzko $\rightarrow$ Saatzig

Szamotuły $\rightarrow$ Samter

Szczawno $\rightarrow$ Tschausdorf

Szczecin $\rightarrow$ Stettin

Szczecin Golęcino $\rightarrow$ Frauendorf (Kr. Randow)

Szczecin-Skolwin $\rightarrow$ Odermünde

Szczecin (Woiwodschaft) 147

Szczecinek $\rightarrow$ Neustettin

Szczodrów $\rightarrow$ Schollendorf

Szczytno $\rightarrow$ Ortelsburg

Szlarska Poręba Górna $\rightarrow$ Oberschreiberhau

Szprotawa $\rightarrow$ Sprottau

Sztum $\rightarrow$ Stuhm

Szubin (Schubin) (Kreis) $\rightarrow$ Altburgund (Kreis)

Szumiłowo $\rightarrow$ Schaumburg (Kr. Königsberg/ $\mathrm{Nm}$.)

Szydłów $\rightarrow$ Schiedlo

Tabarz (Thüringer Wald) 503

Tamsel (Kr. Landsberg/W.) (poln. Dąbroszyn) 95, 1406

Tangermünde 133, 265, 399, 1065, 1454

Tankow (Kr. Friedeberg/Nm.) (poln. Danków) 402

Tannenberg (Kr. Osterode) (poln. Stębark) 340, 671

Tannenhof $\rightarrow$ Remscheid

Tarnowitz/OS. (poln. Tarnowskie Góry) 689 
Tarnowke (Kr. Flatow) (poln. Tarnówka) 1468

Tarnowskie Góry $\rightarrow$ Tarnowitz

Taschenberg (Kr. Prenzlau) 113, 541

Taubendorf (Kr. Guben) 1299, 1444

Tauche (Kr. Beeskow-Storkow) 275, 291, 1030, 1086

Tczew $\rightarrow$ Dirschau

Techow (Kr. Ostprignitz) 416

Tegel (Berlin) $\rightarrow$ Berlin-Tegel

Tegernsee 1465

Teheran, Konferenz (1944) 135

Teltow (Kr. Teltow) 218, 456, 496, 544, 756, 928-930, 981, 1483, 1542, $1543 \mathrm{f}$.

Teltow (Kreis/Land) 74, 94, 164, 166, 194, 199, 210, 222 f., 442, 456, 538, 544f., 643, 658, 889, 975, 984, 996, 1035, 1063, 1085 f., 1101, 1103, 1126f., 1176-1178, 1219f., 1230, 1235, 1254, 1398

Teltow-Fläming (Landkreis) 55, 328, 746, 792 f., 971, 1373

Teltowkanal 511

Telz (Kr. Teltow) 544, 930

Tempelberg (Kr. Lebus) 503

Tempelhof (Berlin) $\rightarrow$ Berlin-Tempelhof

Templin (Kr. Templin) 99, 107 f., 191, 213, 273, $428,455,495,545$ f., $576,603,705,860$, 931-934, 1187, 1446, 1450, 1473, 1481

- Postheim (Lager) 166, 546, 645, 931, 932f., 1062, 1230

Templin (Kreis) 43, 91, 106, 110, 140, 164, 166, 191, 199, 221, 231 f., 297, 455, 522, 545f., 576, 603, 865, 932-934, 996, 1035, 1063, 1103, $1230,1254,1420$

Terezín $\rightarrow$ Theresienstadt

Tetschen(-Bodenbach) (Sudetenland) (tschech. Děčín) 505, 937, 1443, $1446 \mathrm{f}$.

Teupitz (Kr. Teltow) 456, 544, 934f., 1065, 1235

Teuplitz (Kr. Sorau) (poln. Tuplice) 148, 389, 658

Thälmannsiedlung $\rightarrow$ Ziltendorf

Thale/Harz $1456 \mathrm{f}$.

Thalwinkel bei Naumburg/Saale 1480

Theresienstadt (Nordböhmen) (tschech. Terezín) 927

Thorn (Westpreußen) (poln. Toruń) 433, 441, 694; im Straßennamen: 340 f., 672, 289, 871, 927, 958

Thorn (Kreis) 861

Thränsdorf (Pommern) [?] 641
Thüringen (Land) $10 \mathrm{f} ., 47,51,54,86,99,104$, $149,179,189,205,207$ f., $218,225,228-230$, 258, 299, 388, 395, 398 f., 404f., 407, 413-416, $436,442,474,478,505,512,553,587,847$, 849, 856, 1016-1019, 1035-1037, 1039, 1069, 1101, 1103, 1108, 1201, 1250, 1342, 1437, $1450,1452,1467-1469$

Thüringer Wald 230

Tiborlager bei Skampe (Kr. Züllichau-Schwiebus) (poln. Cibórz) 1444

Tiergarten (Berlin) $\rightarrow$ Berlin-Tiergarten

Tietzow (Kr. Osthavelland) 74

Tilsit (Ostpreußen) (russ. Sovetsk/Sowjetsk) 221, 340, 343, 927, 1145, 1209

Tilsit-Ragnit (Kreis) 861

Tirschtiegel (Kr. Meseritz) (poln. Trzciel) 417, 485, 900, 1464

Tischino $\rightarrow$ Abschwangen

Tłustoręby $\rightarrow$ Kirchberg (Kr. Falkenberg/OS.)

Tölz, Bad (Bayern) 412

Tomaszów Maz. (Polen) (dt. Tomaschow) 869

Topola $\rightarrow$ Reichenau (Kr. Frankenstein)

Toppel (Kr. Westprignitz) 1145

Torgau 1407

Tornow bei Fürstenberg/Havel 680

Tornow (Kr. Oberbarnim) $1481 \mathrm{f}$.

Torun $\rightarrow$ Thorn

Torzym $\rightarrow$ Sternberg/Nm.

Trachenberg (Schlesien) (poln. Żmigród) 1210

Trakehnen (Kr. Stallupönen/Ebenrode) (russ. Jasnaja Poljana) 221, 823

Trakehnen-Bajohrgallen 823

Trattendorf $\rightarrow$ Spremberg-Trattendorf

Trautenau (Sudetenland) (tschech. Trutnov) 157, 1207

Trebatsch (Kr. Beeskow-Storkow) 370, 440, 1030, 1074

Trebatsch-Rocher (Kr. Beeskow-Storkow) 1030

Trebenow (Kr. Prenzlau) 540

Trebbin (Kr. Deutsch Krone) (poln. Trzebin) 192

Trebbin (Kr. Teltow) 456, 544, 593, 935f., 1101

Trebbin-Schönhagen $\rightarrow$ Schönhagen

Třebenice $\rightarrow$ Trebnitz bei Lobositz

Trebnitz (Mark) (Kr. Lebus) 282, 507 f., 1457

Trebnitz (Schlesien) (poln. Trzebnica) 579

Trebnitz bei Lobositz (Sudetenland) (tschech. Třebenice) 579

Trebschen (Kr. Züllichau-Schwiebus) (poln. Trzebiechów) 416, 440 f., $1341 \mathrm{f}$. 
Trebus (Kr. Lebus) 1468

Tremmen (Kr. Westhavelland) 218

Treppeln (Kr. Guben) 1466

Treppendorf (Kr. Lübben) 796, 798

Treptow (Berlin) $\rightarrow$ Berlin-Treptow

Treskow bei Neuruppin (Kr. Ruppin) 277, 541

Treuburg (Stadt) (bis 1928 Marggrabowa) (poln. Olecko) 87

Treuburg (Kreis) $\rightarrow$ Oletzko (Kreis) 87

Treuenbrietzen (Kr. Zauch-Belzig) 14, 127, 154, 447, 456, 550, 579, 605, 936-939, 1118, 1352, 1460; Lager 164, 166, 550, 936-938, 1438, 1478; Lager Landesanstalt 222, 251, 550, 938, 1062, 1230; Lager Selterhof 167 f., 172, 221, 550, 605, 936-938, 1062, 1230, 1444

Triebel (Kr. Sorau) (poln. Trzebiel) 268, 391, 619, 658, 789, 1212, 1351-1353, 1414, 1476

Tröbitz (Kr. Luckau) 404, 534, 753, 909, 939

Troppau (Österreichisch Schlesien/Sudetenland) (tschech. Opava) 512

Trutnov $\rightarrow$ Trautenau

Trzciel $\rightarrow$ Tirschtiegel

Trzcińsko-Zdrój $\rightarrow$ Schönfließ, Bad (Kr. Königsberg/Nm.)

Trzebiechów $\rightarrow$ Trebschen

Trzebiel $\rightarrow$ Triebel (Kr. Sorau)

Trzebin $\rightarrow$ Trebbin (Kr. Deutsch Krone)

Trzebnica $\rightarrow$ Trebnitz (Schlesien)

Tschansch (Breslau) $\rightarrow$ Breslau-Tschansch

Tschausdorf (Kr. Crossen) (poln. Szczawno) 925

Tschechische Republik (Tschechien) 147

Tschechisches Erzgebirge 1451

Tschechoslowakei (ČSR, ČSSR; „Tschechei“) (siehe auch $\rightarrow$ Böhmen, $\rightarrow$ Slowakei, $\rightarrow$ Sudetenland) $32,75,135$ f., $138,140 \mathrm{f}$., $146 \mathrm{f}$., 150 f., 157 f., 162, 189, 194, 199 f., 228, 231, 242, 294, 296, 301 f., 306, 315, 334, 363, 407 f., 417, 419, 426, 514, 519, 523, 525-527, 529f., 532, 534-541, 543 f., 546-548, 550, 575, 583 f., 599, 617, 619, 637, 648, 655, 659, 667, $699,715,735,745,813,826,842,847,875 \mathrm{f}$., $893,899,939,958,997,1022,1027,1034 \mathrm{f}$., 1037, 1069, 1072, 1152, 1157, 1177, 1180 f., $1188,1191,1198,1203,1213,1216,1228$, $1250,1278,1351,1355,1390,1396,1400$, 1402, 1406 f., 1413, 1443 f., 1447, 1469 f.

Tschernitz (Kr. Sorau) (poln. Cersk) 195, 763

Tscherniwzi $\rightarrow$ Czernowitz

Tschernjachowsk $\rightarrow$ Insterburg
Tschinka $\rightarrow$ Försterei Tschinka

Tschirnau (Kr. Guhrau) (1937-1945 Lesten) (poln. Czernina) 825

Tschöplau (Kr. Freystadt) (1937-1945 Waldruh) (polbn. Ciepielów) 821

Tschöplowitz (Kr. Brieg) (1937-1945 Gerlachshain) (poln. Czepielowice) 1438

Tucheband (Kr. Lebus) 891

Tuczno $\rightarrow$ Schönrade (Kr. Friedeberg/Nm.)

Tuczno $\rightarrow$ Tütz (Kr. Deutsch Krone)

Tübingen 33

Tütz (Kr. Deutsch Krone) (poln. Tuczno) 789

Tugam (Kr. Luckau) 626

Tunskirch/OS. (Kr. Ratibor) $\rightarrow$ Tworkau

Tuplice $\rightarrow$ Teuplitz (Kr. Sorau)

Turek (Polen/Wartheland) 597

Turek (Kreis) 546, 996

Tworkau (Kr. Ratibor) (1936-1945 Tunskirch/ OS.) (poln. Tworków) 1210

Tzschernowitz (Kr. Guben) (1939-1945 Schernewitz) (poln. Czarnowice) 134, 707, 748, 1444

Ucker (Fluss) 540

Uckermark (KZ) 631

Uckermark (Landkreis) 523, 540, 545, 564, 865

Uckermark (Landschaft) 56, 79, 91, 98, 106-108, 110, 112 f., 115, 119, 132, 192, 202, 208, 213 f., 217 f., 221 f., 232, 265, 275, 277, 423, 455, 492, 494, 509, 539-541, 827, 860, 1394, 1436, $1439,1453,1460,1465,1475$

Uckro (Kr. Luckau) 1459

Údlice $\rightarrow$ Eidlitz

UdSSR $\rightarrow$ Sowjetunion

Übersee 280, 445, 491, 634

Uebigau bei Liebenwerda 1445

Ueckermünde (Vorpommern) 104, 562, 1440

Uelzen (Niedersachsen) 193, 920, 1476

Uelzen (Kreis) 193, 537

Uenze (Kr. Westprignitz) 1132, $1148 \mathrm{f}$.

Ützdorf bei Wandlitz (Kr. Niederbarnim), Haus Afra 554

Uhlendorf (Kr. Prenzlau) 113, 541

Ujest (Kr. Groß Strehlitz) (1936-1945 Bischofstal) (poln. Ujazd) 817

Ujazd $\rightarrow$ Ujest (Kr. Groß Strehlitz)

Ujazd Górny $\rightarrow$ Ober Mois (Kr. Neumarkt)

Ujeździec $\rightarrow$ Geseß (Kr. Neisse)

Ukraine 133, 500, 508, 574, 728, 892, 1414, 1463, 1539 
Ungarn 138, 140, 146 f., 162, 500, 1004, $1034 \mathrm{f}$, $1037,1270,1406,1474$

Unruhstadt (Kr. Bomst) (poln. Kargowa) 847

Unterlindow (Kr. Lebus) 410

Urad $\rightarrow$ Aurith

$\mathrm{USA} \rightarrow$ Vereinigte Staaten von Amerika

Usedom (Vorpommern) 389

Ústí nad Labem $\rightarrow$ Aussig/Elbe

Ústí nad Orlicí $\rightarrow$ Wildenschwert a.d. Adler

Ustka $\rightarrow$ Stolpmünde

Ustronie Morskie $\rightarrow$ Henkenhagen

Vahldorf bei Magdeburg 408, 779

Varnsdorf $\rightarrow$ Warnsdorf bei Tetschen

Vatikan 452, 1417

Vehlefanz (Kr. Osthavelland) 940, 1100, 1109-1111

Velten (Kr. Osthavelland) 114, 456, 538, $939 f$.

Vereinigte Staaten von Amerika (USA; „Amerika“; siehe auch $\rightarrow$ Amerikanische (Besatzungs-) Zone) 55, 90, 181, 218, 380, 751, 998, 1217, $1284,1290,1303,1312,1328,1332,1335$ f., $1435,1444,1456,1465,1467,1470,1474$

Vetschau (Spreewald) (Kr. Calau) 101, 104, 370, 457, 526, 613, 753, 940f., 1358, 1459

Vettersfelde (Kr. Guben) (poln. Witaszkowo) 195,763

Vierraden (Kr. Angermünde) 455, 524, 941

Viersen 948

Vietmannsdorf (Kr. Templin) 1472

Vietnam 512, 867

Vietz/Ostbahn (Kr. Landsberg/W.) (poln. Witnica) $95,370,494,810,1457$

Vildštein $\rightarrow$ Wildstein (Egerland)

Vítkowice $\rightarrow$ Mährisch-Ostrau-Witkowitz

Vöcklabruck (Österreich) 842

Völpke/Saale 150

Vogelsdorf (Kr. Niederbarnim) 61, 1033

Vogtland 307, 326, 333, 583, 1465

Vorketzin (Kr. Osthavelland) 1113

Vorpommern (siehe auch $\rightarrow$ Pommern) 38, 71, $83,192,207,213,219,327,443,445,447$

Võru $\rightarrow$ Werro (Estland)

„Vorweis“[?] bei Angermünde (vmtl. Serwest) 1443

Vrícko $\rightarrow$ Münnichwies

Wabnitz (Kr. Oels) (poln. Wabienice) 678, 1448 Wachow (Kr. Westhavelland) 164, 547, 941
Wągrowiec $\rightarrow$ Wongrowitz

Wahlsdorf (Kr. Jüterbog-Luckenwalde) 1302

Wałbrzych $\rightarrow$ Waldenburg in Schlesien

Wałcz $\rightarrow$ Deutsch Krone

Walddrehna (Kr. Luckau) 164, 297, 534, 942, 1063, 1391

Waldenburg in Schlesien (poln. Wałbrzych) 141, 790, 1096, 1210

Waldenburg (Kreis) 141, 151, 735, 790

Waldheim (Sachsen), Zuchthaus 628, 1459

Waldhof bei Schwartow (Kr. Lauenburg) (poln.

Borowo) 1436

„Waldlager" $\rightarrow$ Börnichen, $\rightarrow$ Finow, $\rightarrow$ Jamlitz

„Waldlager Pintsch“ $\rightarrow$ Fürstenwalde/Spree

Waldrode (Wartheland) (Kreis) (1941-1942

Gasten) (poln. Gostynin) 216, 996

Waldruh (Kr. Freystadt) $\rightarrow$ Tschöplau

Waldsieversdorf (Kr. Lebus) 533 f., 609, 692, 942

Walkendorf (Mecklenburg) 1438

Wall (Kr. Ruppin) 218

Wallwitz (Kr. Guben) (poln. Wałowice) 84, 725, 1466,1525

Waltersdorf (Kr. Jüterbog-Luckenwalde) 1158, 1307

Waltersdorf (Kr. Luckau) 789, 1449

Waltersdorf (Kr. Sprottau) (poln. Niegosławice) 789

Waltersdorf (Kr. Teltow) 310 f., 544, 759, $942 f$., 1534

Wandern (Kr. Oststernberg) (poln. Wędrzyn) 1436

Wandlitz (Kr. Niederbarnim) 487, 504, 536, 944, 1034, 1099, 1462

Wandlitzsee (Kr. Niederbarnim) 210, 243, 536, 571, 632 f., 944

Wanninchen (Kr. Luckau) 626

Wansdorf (Kr. Osthavelland) 1100

Waren/Müritz 404, 1471

Warendorf (Westfalen) 592

Warmia $\rightarrow$ Ermland

Warnemünde $\rightarrow$ Rostock-Warnemünde

Warnick (Kr. Landsberg/W.) (poln. Warniki) 1437

Warnow (Pommern) (Kr. Usedom-Wollin) (poln. Warnowo) 18

Warnsdorf bei Tetschen (Sudetenland) (tschech. Varnsdorf) 151, 826

Warschau (Polen) (poln. Warszawa) 158, 342, $421,483,565,802,1211,1328,1332,1413$, 1416 
Warschau-Praga 754

Warsow (Kr. Westhavelland) 738

Warszawa $\rightarrow$ Warschau

Warta $\rightarrow$ Warthe

Wartenberg (Berlin) $\rightarrow$ Berlin-Wartenberg

Wartenberg (Kr. Königsberg/Nm.) (poln. Chełm Dolny) 208

Wartenburg (Kr. Allenstein), Zuchthaus 249, 1135

Warthbrücken (Wartheland) (Kreis) (poln. Koło) $110,216,996$

Warthe (Fluss) (poln. Warta) 424, 739, 771, 1000-1002, 1004, 1008, 1407, 1443

Wartheland (NSDAP-Gau) 215

Wartheland (Reichsgau) („Warthegau“) 71,76, 99-102, 108, 120, 124, 192, 201-203, 208, 215-219, 232-235, 285, 302, 309, 315, 322, $337,433,441,496,504,549,577,582,587$, 591, 606, 612, 644, 662 f., 686, 712, 748, 774, 784, 831, 841, 845, 847, 860 f., 863 f., 871, 876, 906, 951, 977, 993, 996, 1001, 1261, 1265, $1279,1399,1403,1457,1472,1475,1482$, 1539

Watenstedt-Salzgitter 1317, $1322 \mathrm{f}$.

Wedding (Berlin) $\rightarrow$ Berlin-Wedding

Wędrzyn $\rightarrow$ Wandern (Kr. Oststernberg)

Weesow (Kr. Oberbarnim), Sowjet. Speziallager

Nr. 7: 952

Węgliniec $\rightarrow$ Kohlfurt

Węgorzewo $\rightarrow$ Angerburg

Wehlau (Ostpreußen) (russ. Snamensk) 223, 505, 1436

Wehlau (Kreis) 223, 484f., 863, 869 f.

Weichau (Kr. Freystadt) (poln. Wichów) 1453

Weichsel (Fluss) (poln. Wisła) 228, 337, 508, $585,616,754,1403,1442$

Weidenfeld (Kr. Meseritz) $\rightarrow$ Lentschen

Weidhausen bei Coburg 211

Weimar (Thüringen) 144, 847, 1016, 1417, 1458

Weimar-Schöndorf 1438

Weißack (Kr. Luckau) 164, 211, 534, 944f., 1063, 1461

Weissagk (Kr. Sorau) 527, 542 f., 945

Weißenfels/Saale 82, 404, 1455, 1468

Weißensee (Berlin) $\rightarrow$ Berlin-Weißensee

Weißenspring (Kr. Lebus) 533, 666, 807, 945

Weißkirschdorf (Kr. Schweidnitz) (poln. Krzczonów) 1435

Weißrussland (Belarus) 322, 1414
Weißwasser (Oberlausitz) 415, 796

Wellmitz (Kr. Guben) 824, 1480

Welsickendorf (Kr. Jüterbog-Luckenwalde) 530, 1461

Welun (gen) (Polen/Wartheland) $\rightarrow$ Wieluń

Welzow (Niederlausitz) (Kr. Spremberg) 88, $164,166,187,265,441,457,495,543,655$, 761, $945 f ., 1062,1478 \mathrm{f}$.

Wendefeld bei Gransee (Kr. Ruppin) 1468

Wendelhöfen $\rightarrow$ Bayreuth-Wendelhöfen

Wendisch Buchholz $\rightarrow$ Märkisch Buchholz

Wendisch Rietz (Kr. Beeskow-Storkow) (1937-1947 Märkisch Rietz) 177, 266, 437, $525,1029,1471$

Wensickendorf (Kr. Niederbarnim) 1034

Wepritz (Neumark) (Kr. Landsberg/W.) (poln. Wieprzyce) 86, 95, 424

Werbellinsee $\rightarrow$ Altenhof am Werbellinsee

Werben (Spreewald) (Kr. Cottbus) 116, 272, $322,480,527,762,946-949,1390,1475$

Werbig (Kr. Lebus) 906, 1434

Werblitz (Kr. Soldin) (poln. Wierzbnica) 560, 960

Werdau (Sachsen) 583

Werder (Kr. Beeskow-Storkow) 1030

Werder (Kr. Jüterbog-Luckenwalde) 365 f., 1307

Werder (Havel) (Kr. Zauch-Belzig) 223 f., 436, 456, 550, 575, 598, 853, 855, 949-951, 1370, 1444,1543

Werder (Oderbruch) (Kr. Lebus) 219, $235 \mathrm{f}$, $337,533,951$

Werder/Ostbahn bei Strausberg (Kr. Niederbarnim) 257, 371, 1032, 1127-1130

Werftpfuhl (Kr. Oberbarnim) 424

Werl bei Soest 166, 900

Wermelskirchen 1541

Werneuchen (Kr. Oberbarnim) 455, 462, 495, 537,952

Werneuchen-Weesow $\rightarrow$ Weesow

Wernigerode 221, 513, 1340; Lager 150, 171, 1445

Wernsdorf (Kr. Beeskow-Storkow) 1030

Werro (Estland) (estn. Võru) 232, 627, 1459

Wesenberg (Mecklenburg) 112, 1483

Weskow (Kr. Spremberg) 543, 953

Wesprim, Ungarn (ungar. Veszprém) 910

West-Berlin $\rightarrow$ Berlin (West)

Westdeutschland, alte Bundesländer („Westen“; siehe auch $\rightarrow$ Westzonen) 58, 60, 64, 66, 80, 
83 f., 101, 104, 106, 137 f., 140-145, 193 f., 200, 207 f., 218, 232 f., 235 f., 244, 279, 292, $299,306,316,319,327,331,334,336,338 \mathrm{f}$., $353,364-366,368,373,377-396,400-403$, 405, 408f., 413, 417, 419, 425, 432, 435, 441, 445, 463-467, 474, 478, 482, 486, 488, 491, $493,503-506,556,620,628,634,660,713$, 735, 738, 753, 779, 807, 809, 843, $846 \mathrm{f}$., $885,905,946$ f.. 950, 956, 1037, 1045, 1083, $1108,1152,1240,1259,1289,1303,1319$, 1321, 1323, 1327, 1334, 1336-1338, 1351, 1354, 1358, 1360, 1369, 1377, 1391, 1393 f., 1398-1400, 1402, 1414, 1416f., 1435 f., 1438, $1444,1448,1452,1454,1459,1464,1466 f$.

Westerland (Sylt) 853

Westfalen 54, 109, 679, 892, 1457, 1483

Westhavelland (Kreis) 160, 164, 199, 209, 217, $219,228,231-235,237,283,301,375,456$, 482, 546f., 859, 876 f., 883, 996, 1035, 1063, 1103, 1124, 1188, 1190 f., 1230, 1276, 1345 f.

Westpommern (poln. Pomorze Zachodnie)

$\rightarrow$ Pommern

Westpreußen 50, 73 f., 102, 118, 172, 201-203, 210, 212 f., 219 f., 223 f., 227, 339, 343, 368, 427, 433, 441, 473, 475, 496, 503, 505, 539, $559,561,567,597,601,629,662,687,694$, $700,730,784,809,831,841,847,853,860 \mathrm{f}$., $863,871,875,878$ f., $892,932,964,1284$, 1342-1344, 1367, 1403, 1442, 1481

Westprignitz (Kreis) 94, 96, 100 f., 106, 110, 164, 166, 192 f., 199, 202, 217, 219, 223, 257, 270, 356, 398, 454, 548f., 566, 697 f., 730 f., 838, $841,845,891,982$ f., 996, 1035, 1103, 1132, 1139-1141, 1143-1146, 1148 f., 1151, 1189 f., 1204, 1206, 1230, 1236, 1347, 1409, 1419, 1457

Weststernberg (Kreis) 212, 284, 336, 339, 367, 372, 400, 410, 471, 585, 950, 1000 f., 1464

Westwall 1441

Westzonen (westliche Besatzungszonen; auch „Westzone“; siehe auch $\rightarrow$ Westdeutschland und einzelne Zonen) 53f., 141, 172, 204, 207, 214, 236, 255, 270 f., 339, 364 f., 369-379, $383,394,403,408$, 413 f., 416, 442, 452, 462 , $825,950,1066,1083,1095,1137,1168$ f., 1171 f., 1187, 1299, 1355, 1395 f.

Wewelsburg bei Paderborn 383

Wężyska $\rightarrow$ Merzwiese

Wichów $\rightarrow$ Weichau
Wicina $\rightarrow$ Witzen

Widuchowa $\rightarrow$ Fiddichow

Wieleń $\rightarrow$ Filehne

Wielka Wieś $\rightarrow$ Großendorf (Kr. Stolp)

Wielowieś $\rightarrow$ Langenpfuhl (Kr. Oststernberg)

Wieluń (Kreis) (dt. Welun, Welungen) 524, 528, 784, 996

Wien 1452

Wiepersdorf (Kr. Jüterbog-Luckenwalde) 118, 328,1472

Wieprzyce $\rightarrow$ Wepritz (Neumark)

Wierzbięcice $\rightarrow$ Oppersdorf (Kr. Neisse)

Wierzbnica $\rightarrow$ Werblitz

Wiesbaden 469, 1449

Wiesenau (Kr. Guben) (bis 1919 Krebsjauche) 497, 529, 666, 684, 738, 953f.

Wiesenburg/Mark (Kr. Zauch-Belzig) 43, 447, $550,554,742,773,882,954,1205,1370$

Wiesengrund bei Pilsen (tschech. Plzeň), Heil- u. Pflegeanstalt 189

Wiesenhain, Lager $\rightarrow$ Finsterwalde

Wildau (Kr. Jüterbog-Luckenwalde) 1224

Wildau (Kr. Teltow) 495, 544, 643, 954f., 1441

Wildberg (Kr. Ruppin) 821

Wildenschwert a.d. Adler (Ostböhmen) (tschech. Ústí nad Orlicí) 151

Wildstein (Egerland) (Vildštein) 1399

Wilhelminenhof bei Böhne (Kr. Jerichow II) 1471

Wilhelm-Pieck-Stadt Guben $\rightarrow$ Guben

Wilhelmsdorf (Kr. Zauch-Belzig) 598

Wilhelmshayn (Kr. Prenzlau) $313 \mathrm{f}$.

Wilhelmshorst (Kr. Zauch-Belzig) 46, 72, 81 f., 104, 152, 171, 210, 276, 286, 293, 324, 550, $852,955,1435,1450,1476$

Wilhelmstal (Lager) $\rightarrow$ Spremberg-Cantdorf

Wilkersdorf bei Küstrin (Kr. Königsberg/Nm.) (poln. Krześnica) 1460

Wilmersdorf (Kr. Angermünde) 91

Wilmersdorf (Kr. Beeskow-Storkow) 1030

Wilmersdorf (Berlin) $\rightarrow$ Berlin-Wilmersdorf

Wilmersdorf (Kr. Lebus) 908

Wilsnack, Bad (Kr. Westprignitz) 447, 505, 548 f., 571f., 783, 958, 963, 1199, 1443; Lager 164, 549,1062

Wirchensee bei Fürstenberg/Oder, RAD-Lager 279

Wirsitz (Kreis) (poln. Wyrzysk) 215, 863

Wisła $\rightarrow$ Weichsel (Fluss) 
Wismar (Mecklenburg) 340, 415, 672

Witkowitz (Mähren) $\rightarrow$ Mährisch-Ostrau-Witkowitz

Witnica $\rightarrow$ Vietz/Ostbahn

Witaszkowo $\rightarrow$ Vettersfelde (Kr. Guben)

Witków $\rightarrow$ Wittgendorf (Kr. Landeshut)

Wittenberg/Elbe 154, 293, 1257

Wittenberge/Elbe 45, 102, 107, 184, 199, 223, 297, 395, 454, 549, 756 f., 774, 783 f., 821, 955-959, 1035, 1063, 1151, 1154, $1156 \mathrm{f}$., 1191, 1204, 1206, 1230, 1250, 1343, 1435, $1450,1475,1480$

Wittgendorf (Kr. Landeshut) (poln. Witków) 940

Wittichenau (Kr. Hoyerswerda) 753, 796

Wittstock (Kr. Ostprignitz) 106, 160, 428 f., 435, 454, 460, 539, 959 f., 987, 1154, 1269-1271, 1370, 1440, 1455, 1462

Wittstock (Kreis) $959 \mathrm{f}$.

Wittstock (Kr. Prenzlau) 540

Witzen (Kr. Sorau) (poln. Wicina) 1065

Włocławek (Kreis) $\rightarrow$ Leslau (Kreis)

Wochowsee (Kr. Beeskow-Storkow) 1030

Wöbbelin bei Ludwigslust, Lager 168

Wöbelsburg bei Hainrode $\rightarrow$ Hainrode

Wölfelsgrund (Kr. Habelschwerdt) (poln. Miedzygórze) 579, 582, $899 \mathrm{f}$.

Wohlau (Schlesien) (poln. Wołów) 152, 617

Wohlau (Kreis) 152, 1440

Woitscheke (Kr. Grünberg) (1936-1945 Schäferberg) (poln. Wysokie) 634

Woldegk (Mecklenburg) 192

Woldenberg/Nm. (Kr. Friedeberg/Nm.) (poln. Dobiegniew) 169, 206, 345, 421, 560, 636, $638,702,837,857,859,902,1376-1378$, $1436,1456,1460$

Wolfen (Kr. Bitterfeld), Lager 172, 225, 688, 1044, 1107 f., 1438

Wolfsburg (Niedersachsen) 394

Wolfshagen (Kr. Westprignitz) 270, $1139 \mathrm{f}$.

Wolga (Fluss) 1265

Wolgagebiet, -republik 498 f., 656, 860, 1265, 1435,1452

Wolgograd $\rightarrow$ Stalingrad

Wolhynien 99, 203, 441, 585, 587, 609, 615, 652 f., $657,697,705,711,718,727,738,752$, 755, 794, 853, 869, 889, 911, 914, 917 f., 931 , 940 f., 1399, 1463, 1480

Wollin (Kr. Prenzlau) 861
Wollstein (Posen) (poln. Wolsztyn) 193, 368, 496, 798, 1208

Wollstein (Kreis) 193, 217, 530, 537, 573, 808, 996

Wołów $\rightarrow$ Wohlau (Schlesien)

Wolsztyn $\rightarrow$ Wollstein

Woltersdorf (Kr. Jüterbog-Luckenwalde) 1246

Woltersdorf (Kr. Niederbarnim) 89, 100, 114, 395, 1033, 1099

Woltersdorf-Schönblick (Kr. Niederbarnim) 89, 1474

Wolzig (Kr. Beeskow-Storkow) 1031

Wongrowitz (Kreis) (1942-1945 Eichenbrück) (poln. Wągrowiec) 99f., 106-110, 541, 545, $860,931,996$

Wonno (Kr. Löbau, Westpreußen) (1942-1945 Wonne) (poln. Wonna) 936

Woopen (Kr. Bartenstein) (wüst) 224

Worbis (Eichsfeld, Thüringen) 614

Worin (Kr. Lebus) 314, 533, 726

Woxfelde (Kr. Oststernberg) (poln. Głuchowo) 1443

Wrechen (Mecklenburg) bei Fürstenwerder 90

Wreschen (Kreis) (poln. Września) 525, 757, 996

Wriezen/Oder (Kr. Oberbarnim) 339, 455, 494, 537, 546, 960-962, 1060 f., 1090, 1443, 1457; Lager 164, 166, 517, 537, 773, 961, 979, 1050, 1059-1062

Wrocław $\rightarrow$ Breslau

Wrocław-Księże $\rightarrow$ Breslau-Tschansch

Wronie $\rightarrow$ Fronau (Kr. Briesen)

Września (Kreis) $\rightarrow$ Wreschen (Kreis)

Wrzeszcz (Gdańsk-Wrzeszcz) $\rightarrow$ Danzig-Langfuhr

Wschowa $\rightarrow$ Fraustadt

Wünsdorf (Kr. Teltow) 544, 962

Württemberg $\rightarrow$ Baden-Württemberg

Würzburg 853

Wuhlgarten $\rightarrow$ Berlin-Biesdorf

Wulfersdorf (Kr. Beeskow-Storkow) 1030

Wulfersdorf (Kr. Ostprignitz) 668, 1271

Wulkow (Kr. Lebus) 1478

Wulkow (Kr. Ruppin) 287, 388

Wurzelacker (Kr. Preuß. Stargard) $\rightarrow$ Skorschenno

Wußwerk (Kr. Lübben) 535, 962

Wusterhausen/Dosse (Kr. Ruppin) 356, 454, 495, 542, 775, 777, 823, 963f., 967, 1209, 1412

Wusterhausen (Kreis) 963 
Wusterhusen bei Wolgast (Kr. Greifswald) 1450 Wustermark (Kr. Osthavelland) 538, 964, 1100 Wusterwitz (Kr. Jerichow II) $\rightarrow$ Großwusterwitz Wusterwitz (Amt) 470

Wusterwitz (Kr. Soldin) (poln. Ostrowiec) 1441 Wustrau (Kr. Ruppin) 218, 481, 542, 964, 1209, 1542

Wuthenow (Kr. Soldin) (poln. Otanów) 71

Wutike (Kr. Ostprignitz) 190, 539, 965, 1443

Wutzetz (Kr. Ruppin) 83

Wyrzysk $\rightarrow$ Wirsitz

Wyschni Wolotoschok bei Twer (Russland) 1473

Wysokie $\rightarrow$ Woitscheke (Kr. Grünberg)

Zaatzke (Kr. Ostprignitz) 412, 539, 965

Zabardowice $\rightarrow$ Seiffersdorf (Kr. Ohlau)

Żabice $\rightarrow$ Säpzig (Kr. Weststernberg)

Ząbkowice Śląskie $\rightarrow$ Frankenstein in Schlesien

Zabór $\rightarrow$ Saabor (Kr. Grünberg)

Zaborowo $\rightarrow$ Saborowen (Kr. Lyck)

Zabridnow [?] bei Lublin (Polen) 1445

Ząbrowo $\rightarrow$ Sommerau

Zabrze $\rightarrow$ Hindenburg/OS.

Žacléř $\rightarrow$ Schatzlar (Sudetenland)

Zäckerick (Kr. Königsberg/Nm.) (poln. Siekierki) $818,965 \mathrm{f}$.

Zäckericker Loose (Kr. Königsberg/Nm.) 531, 537, $965 f$.

Zägensdorf (Kr. Arnswalde) (poln. Żeliszewo) 370

Żagań $\rightarrow$ Sagan

Zagelsdorf (Kr. Jüterbog-Luckenwalde) 1120

Żalno $\rightarrow$ Sehlen (Kr. Tuchel)

Žamberk $\rightarrow$ Senftenberg in Böhmen

Zantoch (Kr. Landsberg/W.) (poln. Santok) 83, 370, 440, 495, 690

Żarki Małe $\rightarrow$ Klein Särchen (Kr. Sorau)

Żarki Wielkie $\rightarrow$ Groß Särchen (Kr. Sorau)

Żary $\rightarrow$ Sorau (Niederlausitz)

Żarzyn $\rightarrow$ Seeren (Kr. Oststernberg)

Zatom $\rightarrow$ Zatten (Kr. Arnswalde)

Zatoń Dolna $\rightarrow$ Niedersaathen

Zatonie $\rightarrow$ Günthersdorf (Kr. Grünberg)

Zatten (Kr. Arnswalde) (poln. Zatom) 83

Zauch-Belzig (Kreis) 26, 44, 164, 166, 199, 209-211, 217, 221 f., 228, 231, 234, 441, 456, 549f., 577, 579 f., 597, 657, 742, 791, 806, 847, $849,938,996,1002,1035,1062,1101,1151$, 1158, 1191, 1204f., 1230, 1276, 1468
Zawada $\rightarrow$ Saude (Kr. Guben)

Zbąszyń $\rightarrow$ Bentschen (Kr. Meseritz)

Zbąszynek $\rightarrow$ Neu Bentschen

Zduńska Wola (Polen) 284

Zechin (Oderbruch) (Kr. Lebus) 99, 112, 121, 1482

Zechlin (Kr. Ostprignitz) 106

Zeesen-Körbiskrig $\rightarrow$ Körbiskrig

Zehden/Oder (Kr. Königsberg/Nm.) (poln. Cedynia) 555

Zehdenick (Kr. Templin) 191, 356, 386, 455, 459, 546, 646, 704f., 830, 931, 963, 966f., 987, 1251, 1280 f., 1396, 1412

Zehlendorf $($ Berlin $) \rightarrow$ Berlin-Zehlendorf

Zeitz (Sachsen-Anhalt) 450

Zeitz (Kreis) 54

Żelechowa $\rightarrow$ Stettin-Züllchow

Želeteva $\rightarrow$ Selletau

Żeliszewo $\rightarrow$ Zägensdorf

Zellin (Kr. Königsberg/Nm.) (poln. Czelin) 968

Zelliner Loose (Kr. Königsberg/Nm.) 531, 537, 968

Zemmin (Kr. Stolp) (poln. Ciemino/Główczyce) 1449

Zempelburg (Kreis) (poln. Sępólno Krajeńskie) 861

Zentralpolen $\rightarrow$ Polen

Zepernick (Kr. Niederbarnim) 394, 416, 584, 1031

Zerbst (Kreis) 54

Zerkwitz (Kr. Calau) 1100

Zernikow (Kr. Prenzlau) 218

Zernitz (Kr. Ostprignitz) 428f., 539, 968, 1453

Zernsdorf (Kr. Teltow) 164, 544, 968, 1063, 1127

Zerpenschleuse (Kr. Niederbarnim) 1034

Zesch (Kr. Jüterbog-Luckenwalde) 1287

Zeuthen (Kr. Teltow) 44, 434, 544, 969, 1102

Zgorzelec $\rightarrow$ Görlitz(-Ost)

Zicher (Kr. Königsberg/Nm.) (poln. Cychry) 696, 1440

Ziebingen (Kr. Weststernberg) (poln. Cybinka) 190, 196, 329, 409-412, 525, 577, 666, 672, $678,805,807$ f., 945,1453

Zieditz bei Falkenau/Eger (tschech. Citice) 1437

Ziegelnia (Kr. Konin) (Ziegelgrube) (poln. Cegielnia) 1468

Ziegelscheune (Kr. Meseritz) (poln. Prądówka) 629,648 
Zielen (Kr. Briesen, Westpreußen) (poln. Zieleń) 1442

Zielenzig (Kr. Oststernberg) (poln. Sulęcin) 98, 205, 495, 663, 837, 1346, 1460

Zielin $\rightarrow$ Sellin (Kr. Königsberg/Nm.)

Zielona Góra (Stadt) $\rightarrow$ Grünberg in Schlesien

Zielona Góra (Woiwodschaft) 428, 496, 672

Ziemia Lubuska $\rightarrow$ Lebuser Land

Ziesar (Kr. Jerichow I) 224, 456f., 470, 517, 601, 970

Ziltendorf (Kr. Guben) 212, 529, 565, 970, 1291; Ernst-Thälmann-Siedlung 314, 953

Zingst (Darß) 327

Zinna, Dorf $\rightarrow$ Neuheim

Zinna, Forst $\rightarrow$ Forst Zinna

Zinna, Kloster $\rightarrow$ Kloster Zinna

Zinndorf (Kr. Niederbarnim) 1032

Zinnitz (Kr. Calau) 416, 1100, 1459

Zips $\rightarrow$ Oberzips

Zipser Bela (slowak. Spišská Bela) 493, 496, 607

Zirke (Kr. Birnbaum) (poln. Sieraków) 823, 839

Žitenice $\rightarrow$ Schüttenitz bei Leitmeritz

Zittau 307

Zittauer Zipfel 195, 198

Zizow (Kr. Rügenwalde) (poln. Cisowo) 1436

Złotoryja $\rightarrow$ Goldberg in Schlesien

Złotów $\rightarrow$ Flatow (Westpreußen)

Żmigród $\rightarrow$ Trachenberg (Schlesien)

Znin (Kreis) (1941-1945 Dietfurt; poln. Żnin) 545, 996

Zollbrück (Kr. Rummelsburg) (poln. Korzybie) 504, 1436

Zollen (Kr. Soldin) (poln. Czółnów) 71

Zomrze $\rightarrow$ Somse (Kr. Berent)
Zootzen (Kr. Ostprignitz) 222

Zorndorf (Kr. Königsberg/Nm.) (poln. Sarbinowo) 696

Zossen (Kr. Teltow) 428, 447, 452, 456, 544, $653,874,889,971,1101,1127,1467$

Zossen (Kirchenkeis) 971

Zossen (Kreis) 746

Zottwitz (Kr. Ohlau) (poln. Sobicisko) 1449

Zschopau, Motorradwerk 227 f., 1458

Zschortau bei Delitzsch 171

Żubrów $\rightarrow$ Herzogswalde (Kr. Oststernberg)

Zühlen (Kr. Ruppin) 852

Zühlsdorf (Kr. Niederbarnim) 1034

Züllichau (poln. Sulechów) 81, 88, 101, 110, 320, $341,427,435$, 487, 494f., 578, 612, 620, 672, 690, 711, 723, 804, 819f., 822, 846, 929, 1416, 1457, 1474; (Sammel-)Lager 577, 1468

Züllichau (Kirchenkreis) 436

Züllichau-Schwiebus (Kreis) 81, 100 f., 110, 136, 208, 211, 216, 362, 416, 436, 463, 465, $482 \mathrm{f}$., 491 f., 522, 540-542, 545, 560, 612, 626, 711, 723, 819-822, 828, 996, 1000 f., 1375, 1419, $1445,1449,1452,1460$

Züllchow (Kr. Randow) $\rightarrow$ Stettin-Züllchow

Zürich (Schweiz) 1049

Züsedom (Kr. Prenzlau) 1472

Zützen (Kr. Angermünde) 522, 524, 972

Zug bei Freiberg/Sachsen 823

Zwartowo $\rightarrow$ Schwartow (Kr. Lauenburg)

Zwetkowo $\rightarrow$ Bergau (Kr. Königsberg i. Pr.)

Zwittau (tschech. Svitavy) 811

Zwönitz (Sachsen) 1101

Żytowań $\rightarrow$ Seitwann (Kr. Guben) 


\section{Personenregister}

Abel (Gastwirt) 416

Abendroth, Herbert 447, 882

Abraham-Diefenbach, Magdalena 128

Ackermann, Anton 254

-, Felix 420

Adalbert (Heiliger) 826

Adam, Erika $\rightarrow$ Solbrig

Adamski, Roman 915, 1268

Adamy, Kurt 504

Adelheim, Georg 232, 1425

Adler (Firma) 780

- (Frau) 269

Adolph (Informationsabt.)

1252

Agapitow (sowj. Offizier) 1059

Ahrens, Helmuth 649

Albedyll, Otto von 757 f., 1472

Albert, Josef 1343

Albinus, M. 1290

-, Robert 104

Albrecht, Dorothea 82, 189, 1434

Alpermann, Willi 678

Altmann (Cottbus) 616

Altweck, Helmut 260

Alvensleben, von (Frl., Heiligengrabe) 732

-, Armgard (Aja) von $732 \mathrm{f}$.

Ambrosch, Rudolf (Rudi) 153, 293, 1434

Ammon, Ewald 1434

-, Margarete, geb. Gutsche 121, $642,861,866,1434$

Amos, Heike 9, 53, 68, 140 143, 200, 364, 380 f., 405

Amtsberg, Wolfgang 396

Anders, Gustav 1211

-, Johanna 851

-, Reinhard 851 f., 1541

Andreae, Almut 283

Andreas, Horst 835

Andres (Stadtrat, Luckenwalde) 1137

Anweiler, Brunhilde $\rightarrow$ Hanke

Apelt (Cottbus) 1230

-, Hans 690
Arburg, Adrian von 157

Ardelt (Firma) $640 \mathrm{f}$.

Arlt (Potsdam) 1121

-, Gernod 28

-, Hubert 656

-, Klaus 1541

-, Klaus-Dieter 503

-, Kurt 41

Arndt (Neuruppin) 277

Arnim, Clara von, geb. von Hagens $98,118,126,1472$

- (-Kröchlendorff), Bertha von, geb. von Arnim 113, 1472

- (-Kröchlendorff), Detlev von 1472

-, Hans Ludwig von 1262, 1472

- (-Boitzenburg), Joachim Graf von $91,540,545$

-, Peter-Anton von 98

Arnold, Johannes 446, 667

Assenbaum, Christian 474, 1425

Assing, Helmut 27

Aßmann, Johannes 919

Assmann, Waldemar 618

Ast, Jürgen 14

Augsten, Gisbert 308

Aulich, (Kurt?) 1248

Aulig (Informant) 260

Autze, Rajan 13

Axen, Hermann 1310

Ayrer, Franz 719

Baar, Arno 853

Baas, Friedrich-Karl 1435

Baaske, Günter 64

Babbe, Dieter 626

Bachmann, Ursel 746

Bade, Klaus J. 140

Bader, Werner 427, 475 f., 478, 691, 1376

Badstübner, Ernst 1541

Badstübner-Gröger, Sybille 282

Bähr, Siegfried 401

Baehr, Ulrich 876
Bär (Krayne) 763

Baganz, Willi 749

Bahl, Peter 4, 23, 59, 327, 381, 436, 477, 846

Bahlcke, Joachim 209

Bahr (Familie) 411

- (Lagerarzt) 563

Bahro, Bernd 49

- Rudolf 683

Baier (ZVU-Mitarb.) $1008 \mathrm{f}$.

Baillie, Ilhug 1284

Balau, Horst 104

Baller, Kurt 480

Ballschuh (Sachbearb.) 1202

Balschinat, Grete 72, 81, 171, 286, 1435

Balz, Hans-Jürgen 485

Balzarek, Bernd 721

Balzer, Bernhard 1206

-, Stefan 869

-, W. 1206

Balzke (Gastwirt) 354

Bandemer, Elli 74

Bandt, Marianne 347, 1472

Baradoy, Claudia 818

Barkau, Margarete 822, 1435

Barnert, Felix 620, 654, 913

Barsewisch, Bernhard von 1345, 1541

Bart (Berkenbrück) 1042

Bartel, Karl-Heinz 1213

-, Kathrin 704

Bartelt, Albert 904

Barthel, Rolf 27, 116, 926 f., 1541

Bartke (Krayne) 763

Bartky, Herbert 401

-, Lotti 401

Bartning, Otto 36

Bartol (Fürstenwalde) 1107, 1109

Bartsch, Erich 1211

-, Paul 704

Bartusch, Dieter 750 f., 761 f., 948, 1541

-, Hertha 948

-, Renate 750 
Baudis, Anna 236, 337, 951

Baudisch, Rosemarie 25

Bauer (Dahme) 627

-, Else 258, 1113, 1121, 1231

-, Friederike 264

Bauerkämper, Arnd 11 f., 14, 19, 26, 308

Baues, Ludwig 845

Baumann, Arnulf 234

-, Friedrich 101

-, Reinhardt 498, 1435

Baumgart, Hildegard 366, 1429

Bautz, Michael 620

Bazer, Ernst $1148 \mathrm{f}$.

Becher, Alois $882 \mathrm{f}$.

-, Gunther 14

Bechler, Bernhard 248, 316, 348, 1008, 1412, 1427, 1472

Beck (Sparkassendir.) 104, 1425

-, Friedrich 18, 52

Becken, Jörg 45, 766, 799

Becker (Frau) 1243

-, Franz 921 f., 1093, 1099, 1104

-, Lieselotte 323, 881, $957 \mathrm{f}$., 1435

-, Margarete 110

Bednorz, Emil 1210

Beer, Hubert 744, 1198

-, Mathias 47, 57, 497

Beerfelde, Karl 22, 1430

Beethoven, Ludwig van 300

Behrend, Georg 331

Behrns (Fürstenberg/H.) 680

Beier (Potsdam) 1245

- (VP-Kommissar) 1351

-, Peter 703

-, Stefan 1543

Bein, Otto 103, 105 f., 879, 1435,1490

Beinlich (Potsdam) 1326, 1328

Beißert, Elly 1435

Below, Ruth 177, 285, 769, $1435 \mathrm{f}$.

Bels, Sandra 777

Bendel, Rainer 36

Bender, Friedrich $918 \mathrm{f}$.

Benekendorf (Ziegelei) 567
Beneš, Edvard 157

Bengsch, Alfred 808, 858

Benn, Ingrid 871

Benz, Wolfgang 17, 19

Berendt, Thomas 511

Berg-André, Martha 1135

Bergemann (Lebus) 1230

- (Mörz) 806

-, Carl 1208

-, Helmut 93

-, Paul 1208

Berger, (Edeltraut-)Marianne, $\rightarrow$ Kühn-Berger

- , Elsa $\rightarrow$ Eberlein

-, Josef 618, 1198

Berger \& Stumpe (Firma) 1207

Bergner, Christoph 140

Béringuier, Claus 340, 927

Berkenkamp (Verf.) 302, 818

Berlin, Hermann 314, 1472

Bernard, Christoph 810, 1541, 1544

Bernatzky, Rochus $899 \mathrm{f}$.

Berndt (Vertriebenenfamilie) 363

-, Friedel, $\rightarrow$ Reemenyi

Bernert, Agnes 625

-, Franz 625

Bernhardt 1188

- (Kyritz) 1195

-, Rudolf 620

-, Wilna 1212

Bernweisler, Ernst 899, 1198

Besendahl, Maria 1214

Beske, Hans 94, 427, 439

Besler, Dietrich 1228

Besrutschenko (sowjet. Oberstleutnant) 1246

Bessel, Helmut 46

Bestehorn, Friedrich 847, 855, 1472

Bestmann, Christa 934, 1473

Bethke $\rightarrow$ Schütz \& Bethke

-, Susann 228

Beuster (FDGB-Funktionär) 1160, 1163, $1165 \mathrm{f}$.

- (Pastor) 732

Beyer, Elsa $\rightarrow$ Eberlein

-, Josef 941
-, Peter 957

Biela, Paul 208

Bielak, Stefan 607

Bienek, Horst 846, 856

Biens, Paul 1454

Bier, August 1131

Bierfreund, Otto $684 \mathrm{f}$.

Biernoth, Immaculata 570

Bierut, Bolesław $1332 \mathrm{f}$.

Bierwald (Suchdienstmitarb.) 1085, 1092, 1098, 1104

Bietsch, Ella 1292

Bigalke, Anton 192, 924

Bilke, Jörg Bernhard 139, 363

Birkner, Gustav 925

Birnbach, Joseph 684

Bischof, N. N., geb. Oberhauser 807

Biskupek, Matthias 338

Bisky, Lothar 229, 503 f., 1436

Bitter, geb. Kopp, Margot 107, 1455

Bittner (SED-Mitglied) 1174

Bjelfvenstamm, Dorothea 854

Blaschke, Fritz 331

-, Wolfgang 27

Blasshofer, Christian 730 f., 1541

-, Erna $730 f$.

-, Paul $730 \mathrm{f}$.

Bleich, Ute 263, 1436

Bleschke, Otto 1436

Blieske, Gottfried 568

Bloch, Peter 310, 349, 1473

Blochwitz, Gottfried $928 \mathrm{f}$.

Block, Ilse, geb. Eknigk 653

Blöß, Wolfgang 26, 312, 341, 346, 443

Blümel (Ketzin) 1113

Blüml, Heinz 684

Blümner (Fürsorgerin) 1261

Blüthner, Gustav 1113

Bluhm, Beatrix 92

-, Hans-Gottfried 466, 737

Blume (Raßmannsdorf) 1124, 1147

Blumeier (Havelberg) 730

Blunck, Christina, geb. Bokelmann 289 
Bober (Frau, Schenkenberg) 893

Boberach, Heinz 435

Boche, Mirko 792

Bochmann, Gertrud 1343

Bock, Michael 102

Bode, Sabine 63

Bodelschwingh, Friedrich von 881

Böddecker, Ehrhardt 481, 964

Boede, Lutz 480

Bög (Krayne) 763

Bögner, Josef 826

Böhm, Friedrich 413, 796, 926, 1257, $1348 \mathrm{f}$.

-, Jürgen 919

Böhnke (MVS-Vors.) 267

Bömelburg, Hans-Jürgen 196, 1433

Bönigk, Hubert 447, 667, 936

Börnert, Gottfried 48

Boese, Hans 669

Bösenberg, Jost-Arend 503, 1466

Böthig, Peter 59, 1432

Böttcher (Firma) $\rightarrow$ Rohde \& Böttcher

-, Frank 1541

Böttge (Frau) 1113

Böttger, Marieta 501, 512

Bogatzki (Wriezen) 961

Bohley, Heidi 1432

Bohr, Robert 1206

Bokelmann, Christa $\rightarrow$ Blunck

-, Peter 289

Boldorf, Marcel 70

Boldt (Brandenburg/H.) 1230

Bolduan, Erwin 1436

-, Waltraud 777, 1436

Bolle, Konrad 789

Bolwin, Jacob 784, 956, 958

Bonin, Michael 511

Borbély, Karin von 232, 1426

Borbs, Friedrich 948 f.

- , Inge $\rightarrow$ Sonntag

Borchert (Flüchtlingsfrau) 274

Borgmann (Brück) 607

Borgmeyer, O. 1211

Bork, Julia 508, 854
Borkmann, Hartmut 224, 601

Bormann, Hedwig 947

-, Martin 122

Borngräber (Prof.) 875

Bornmann, Elfi $\rightarrow$ Kardach

-, Käte 384, 1425

Bornstädt, Helga 1434, 1473

-, Wolfgang 169, 173, 421, 858f., 1376-1378, 1436

Borodziej, Włodzimierz 47

Borrmann, Walter 558

Borsig (Firma) 164, 714, $717 \mathrm{f}$.

Borstorff, Ursula 844

Borsutki, Wranja 267

Bothe, Hannelore 1433

Boulanger (Sozialdir.) $1310 \mathrm{f}$.

Bradler (SED-Funktionärin) 1126

Bräsike, Erhard 197, 1437

Bräunig (Belzig) 938

Bräuning, Uwe 772

Bräutigam, Helmut 168

Brahms, Johannes 1138

Brammer, Günter 585

Brand, Hans 932

Brandes, Detlef 20, 129, 157, 235

Brandt (Angestellte) 1241

- (Engelsburg) 645

- (Templin) 931

- (Werder) 1130

-, Günther (Pfarrer, Potsdam) 844

-, Hans Jürgen 452

Brauer, Erwin 852

-, Max 1326

Braun (Flüchtling) 90

-, Michael 312, 314

-, Rainer 14

Braune, Paul Gerhard 881

Braunschweig, Frieda 279

Brebeck, Wulff-Eberhard 383

Brechlin, Reinhold 1130

Brecht, Bertolt 628

Bregulla, Richard 735

Brehmer (Referatsleiter) 259, 1114-1118, 1160, 11621164 f., 1174, 1232, 1241, 1393
Brekow, Frank 659

Bremer, Hans 839

Bresch, Adolf 1205

-, Harald 1205, 1541

Breske, Erika, geb. Roy 290-292, 1437

Bretschneider, Dietlinde 1437

-, Uta 11.417

Breuel, Johanna $\rightarrow$ Schladitz

Breuer, Paul 940

Breyer, Richard 128

Briesemeister, Otto 1447

Brilke, Rudolf (Rudi) 1297

Brisch, Brigitte 41

Britzen, Edith, geb. Spitz 404

Brockmann (Flüchtling) 95

Brodöhl, Kurt 601

Brönstrup, Rolf 721

Brösemann, Herbert 729, 1473

Brommauer, Albrecht 224, 878

-, Ursula 482, 878

Broniewski, Władysław 1327

Brose (Lütkendorf) 1146

- , Charlotte $\rightarrow$ Lettenbauer

Brosien (Beeskow) 1131

Brosius, Ida 929

Broß, Bruno 617f., 620-622, 632, 1266

Brucks, Alfred 573, 699

Brüggemann, Elly $\rightarrow$ Prietz

-, Sophie 621

Brühe, H. J. 385

-, Mathias 38

Brüllke, Wolfgang 723, 1437

Bruhn, Fritz 1209

Brummack, Carl 438

Brunzel, Peter 851

Bruyn, Günter de 285, 337, 461 f., 695 f., 1473

Brzoska, Alfred 1437

Brzycki, Josef 588

Buch, von (Gutsbesitzer) 91

Buchheim, Christoph 299

Buchholtz, Elisabeth 819, 822, 1473

-, Karl 933

Buchholz, Bert 434, 1543

-, Elvira $\rightarrow$ Noack

-, Karl 1437 
-, Meta, geb. Struwe 1437

Budach, Edeltraud $\rightarrow$ Gosdschick

Budek, Franz 613, 617, 620

Budting, Ernst 185

Büring, Kerstin 1542

Bürkner, Eckhart 153, $1437 \mathrm{f}$.

-, Herbert 1437

-, Margarete 1437

Büttner (Waldarbeiter) 1283

-, Kurt 142, 225, 1045, 1107

Bujok, Reinhold 144-146, 463 f., 479, 690, 888, 1365, 1426,1438

Bundschuh, Eveline 371

Burauskaite, Birute Terese 846

Burchart, Krystian 509

Burda, August 855, 1473

Burggraf, Fred 768

Burghardt, Alfred 655

Burghause, Horst 290, 1438

Burkhardt, Albert 1541

Burmeister, Hildegard 808, 810, $879,905,908,1438$

Busch, Franz 940

Buschmann, Gerhard 295

Busse (Vertriebene) 366

-, Theodor 727

Butschke, Heinz 810

Buwert, Wolfgang $40 \mathrm{f}$.

Buzek, Jerzy 666

Cajar, Wolfgang $896 \mathrm{f}$.

Carstens (Firma) 661

Caspar, R. 1289

Cebulla, Hans-Werner 621

Chlupke (Zehdenick) 966

Chmielewski, Horst von 58

Christe (Kreisarzt) 1082

Christopei, Herbert 577

Christopeit, Gerald 13, 31, 47, 203, 229

Cibis (Gewerbelehrer) 957, 1250

Cibulka, Hanns 363

Ciesla, Burghard $14 \mathrm{f}$.

Cimbal, Hanswerner 822

Ciocci, Aurelio 235

Clauss, Ernst 211
Clemens, Eberhard 201, 468, 471, 473, 479f., 482, 691, $851,1541,1543$

Cnotka, Hans-Günter 427

Coburg, Hartwig Frhr. von 385

Cochlovius (Kreisverwaltung Teltow) 1126

Collin, Otto 679

Condereit, Gustav 823

Conrad, Gisela 299

Cuno Ludwig 825

Czech, Karin 42

Dähne (Frau) 556

Dalbert (SPD Luckenwalde) 1223

Dalichow, Bärbel, geb. Hanke 229

Dallorso, Inge, geb. Stuttrich 614f., 1473

Damaschke, Alfred 93

Damerow, Ulrich 440

Daniels (Templin) 933, 1477

Dannehl, Herbert 872, 1477

Dannenberg[?] (Potsdam) 1249

-, Lars-Arne 11, 195, 198, 1541

Dannowski, Ralf 1544

Darge, Hans-Jürgen $1438 \mathrm{f}$.

Dartsch, Winfried 314, 340, 723, 1427

Dau, Else 260, 1086

Daubitz, Fritz 373

David, Alfred 173, 649

-, Katrin 1543

Dawidowski, Rudolf 702, 771 f., 1439

Deckart, Emil 1212

Deeg, Arthur 239

Degen, Ilmar 222, 793

Deimling, August 1121

Dejardin, Eduard 314, 1210

Delbrück, Walter 721

Dellmin[?] (Potsdam) 1121

Demko, Michael 237, 493, 605-608, 1541

Demmer, Carl 214, 787

Demps, Laurenz 24
Dibelius, Otto 431, 438, 669, $1257,1263 \mathrm{f}$.

Dichte (Luckenwalde) 1058

Dictus, Frieda 260

Diebe, Johannes 1473

Diefenbach, Matthias 22, 101

Diehr, Hans-Joachim 65

Dierke (Wittenberge) 1230

Diestelkamp, Adolf 46

Dieterich (Stenotypistin) 1252

Dietrich (Müllrose) 807

- (Schenkenberg) 893

-, Edith, geb. Raasch 807, 945

-, Marianne 807

Dietz (Schirmfabrikant) 286

Dietze, Peter 476

Dischereit (Referent) 1183

Dittberner, Jörg 866

Dobler, Gustav 698

Döbber, Elli 1467

-, Willi 1467

Döpfner, Julius 448

Dörr, Margarete 97

Dohna-Schlobitten, Alexander

Fürst zu 90-92, 121, 1439

Doil, Herta 44

Dolata (Brandenburg/H.) 598

Dolke, Gerda 643

Dombrowski, Dieter 846

Domke (Pfarrer) 56

-, Alfons $792 \mathrm{f}$.

-, Frieda 366

-, Helmut 504

Domscheit, Margarete, geb.

Kehrer 1439

-, Wolfgang 1439

Domcheit-Berg, Anke 1439

Donat, Bruno 392

-, Liesel, geb. Hientzsch 392

Donath $\rightarrow$ Rennert \& Donath

- (Frau) 1119

Donau (Berlin) 1202

Donderer, Josef 934

Donth, Stefan 10

Dorbritz, Gerhard 43, 309, 582, 742

Dorn, Christian 700

-, Fritz 368

Dosdall, Manfred $1439 \mathrm{f}$. 
Drabach, Pauline $\rightarrow$ Lohan

Draeger, Ernst-W. 777

-, Roland 839

Dräger, Sigrid 42

Dreikandt, C. 1209

-, Günter 1209

Drescher (Ketzin) 1113

-, Anne 168

-, Judith 46

-, Konrad 595

-, Lina 410

Drewes, Wilhelm 1474

Drews, Bernhard 756, 862, 865

Dreyer (Bad Saarow) 1059

Drichel, Renate 916

Drieschner, Axel 34

Drose, Paul 711

Dubbick, Wilhelm 1094

Dubianski, Paul 461, 766, 769, 921, 1091 f., 1098, 1104

Duda, Andreas (Andree) 735

Dudlitz (Kreispolizeichef) 1104

Düllick, Franz 447, 584, 900

Düring (Heimleiterin) 1440

Düspohl, Martin 213

Dulitz (Firma) 717

Duncklau, Heinz 1440

Dutkowski, Ilse, geb. Schönemann 871, 1474

Dutzschke, Martin 921

Dworschak, Emma 1112

Dziadek, Anna 472

Dziumbla, Erika 661

Eberlein, Elsa, geb. Beyer 241

-, Gotthard 241 f., 244, 740, $905,1017,1027,1186$

-, Hellmut 36

Ebert, Erich 1113

-, Friedrich $1120 \mathrm{f}$.

-, Rolf 45, 799

Eccarius, Bernd 585, 1544

Eckart (FDGB-Mitglied) 259, 1231

Eckert (Havelberg) 1143

Eckhart, Dieter 1440

Eckstein (Potsdam) 1186

Effenberger (Lagerltr.) 557
-, Käte 1212

-, Wilfried 916

Ehlers, Heinrich 636

Ehlert, Siegfried 1440

-, Vera 1440

Ehrecke (Frl., Heiligengrabe) 732

Ehrhardt, Dietrich 662

Ehrich, Brigitte, geb. Lehmann $623,665,673,1474$

Ehrlich, Josef 909

-, Rosa 307

Eichberg (Beeskow) 1013

- (Himmelpfort) 736

Eichel, Hans Joachim 959

Eichenberger (Putlitz) 872

Eichendorff, Joseph Frhr. von 347

Eichholtz, Dietrich 24

Eichler, Klaus 40, 878

Eichner, Gerhard 718

Eickhoff (Dipl.-Ing.) 1186

Einhorn (Referent) 1160

Eisfeld, Alfred 140

Eisler, Cornelia 60

Eismann, Joseph 459, 967, 1280

Eknigk, Ilse $\rightarrow$ Block

Elske, Gerhard 785, 1474

Elstermann, Michael 907

Elwert, Hertha 969

Emmrich, Eva 673, 1430, 1474

Enders, Lieselott 15, 27

Engel, Evamaria 19, 27

-, Hans-Georg 934

-, Rudolf 240, 300, 1017, 1081

Engelbrecht (SED-Mitglied) 1174

Engels, Otto 764

Engl, Josef 1350

Engler, Alfons 606, 741 f., $781 \mathrm{f}$.

-, Franz 583

-, Harald V, 13, 22, 27, 104, 113

Epphard, Paul 1144

Erbs, Karl 259, 312

Erker, Paul 271

Ernst, Hans-Eberhard 113

Erzepky, Anton 612

Escher, Felix 458
Eschholz, Willi 606

Eschler, Ernst 564

Esselbach, Leopold $513 \mathrm{f}$.

Esslinger, Elmira 185

Euent, Sandra 268

Eulenburg-Hertefeld, Marie Fürstin zu, geb. Freiin von Mayr-Melnhof 118 f., 1474

-, Wend Graf zu 119, 1474

Faber-Schmidt, Brigitte 512

Fabian, Franz 965, 1433

Fabig, Heidelinde, geb. Weber 722

Faehndrich, Jutta 57

Fandung[?] (Wolfshagen) 1139

Faour, Adnan 775

Faßke, Joachim 619, 740, 761, 1440

Fechtner (Krayne) 763

-, Herbert 232, 853

Fedler, Franz 1113, 1115

Fedotow (Fedotoff), Alexandr Alexandrowitsch $252 \mathrm{f}$.

-, Pjotr Wassiljewitsch 253

Feiber, Albert A. 58

Feige, Emil 1207

Felis, Josef 835

Felix, Fritz 1211

Fellert (Betriebsratsvorsitzender) $1292 \mathrm{f}$.

Felsch, Erich 741

Fendl, Elisabeth 58

Fengler (Betriebsleiter) $1292 \mathrm{f}$.

Fiddecke, Marlies 962

Fidus (Hugo Höppener) 89, 1474

Fiedler (Arzt) 1107

Fiege, Otto 823

Fietze, Emma $\rightarrow$ Kergel

Fink (Fleischer) 627

Firlej, Rudolf 613

Fisch, Bernhard 147

Fischbach (Flüchtlingsfrau) 137

Fischer (Frau, Potsdam) 1121, 1242

-, Inge $1440 \mathrm{f}$.

-, Ingrid 45, 512, 1541 
-, Lothar 306, 746, 814, 1441

-, Max 259, 1115 f., 1160 f., 1163, 1165, 1186, 1232

-, Oskar 158, 915

-, Reinhard E. 504, 1541

-, Tilman Asmus 879, 1541

Fischer von Mollard, Albrecht 1543

Fitzner, Rudolf 821

Flamm, Kurt 1284

Flämming, Max 1349

Flatau, Johannes 653

Fleischer (Frau) 1160, $1162 \mathrm{f}$, 1165

-, Herbert 862

Fleischmann, Ruth 330 f., 883

Fliege, Otto 823

Flock, Hans 251

Flöher (Sparkassenleiter) 104

Flöter, Kurt 901, 1404

Fluch, Detlef 14

Fölber (Referent) 1165

Förstemann (Hotel) 632

Förster (Frau, Beeskow) 1131

- (Landrat) 1095

- (Perleberg) 837

-, Hubert 722

Försterling (Falkensee) 649

- (Saalow) 889

Foitzik, Jan 157, 253

Fontane, Theodor 476

Forch, Georg Walter 89

Forst[?] (Beeskow) 1218

Franck, Joachim 503

Frank (Luckenwalde) 792

Franke (Lagerltr.) 887

-, Ellen VI

-, Johanna, geb. Roß 821, 1374-1376

-, Reinhard 934

Frankes Verlag 1211

Frantz, Jürgen 1542

Franz, Ernst 1113f.

-, Rosemarie, geb. Rachner 777

Franzke, Willy 1208

Frede, Ulrike 57

Freund (Finsterwalde) 656, 1544
-, Franz 287 f., 1479

Freytag von Loringhoven, Hanns Baron 532

Frick, Gustav 369

Friedberg, Eva-Maria 1441

Friedensburg, Ferdinand 1293

Friedrich II., der Große, König von Preußen 1260

Friedrich, Cornelia 469

-, Franz 449, 896

-, Gertrud 131, 1441

-, Karl 1210

Friedrichs, Erich 243, 245-249, 251, 254f., 258, 1018, 1027, 1076, 1081, 1084, 1093, 1096, 1099, 1104, $1117 \mathrm{f}$., 1136, 1155, 1173, 1185, 1217, 1231 f., 1235 f., 1241 f., 1249

-, Gertrud, geb. Timm 254f., 1242,1251

-, Walter 250, 1242

Friemel, Franz Georg 443

Friesen, Astrid von 61

Frigge, Heinrich 838

Frind, Wenzel 553

Friske, Matthias 187

Fritsch, Gunter 503, 820

Fritsche, Renate 112, 1474

Fritz, Alfred 930

Fritz-Krockow, Libussa 98, 1452

Fröhlich, Heinz 338, 362, 793

Froese, Hans-Jörg 223f., 853, 855,1543

Froh, Klaus 294

Fromm, Günter 314, 970

Frost, Richard 900

Fuchs, Konrad 213

Fudel, Thorsten 908

Fühmann, Franz 417 f., 801 f.

Führling, Günter G. 729, 1474

Fürste, Lonni 748, 761, 824

Fuhrmann, Elfriede, geb. Ludewig 723,1441

-, Rudolf 789

Funk, Jürgen 831

Funke, Alfred jun. 307

-, Alfred sen. 307
Furian, Hans-Georg 651, 811

-, Hans-Otto 437, 503 f., 971

Gabloffsky, Werner 86, 137, 1442

Gabriel, Siegfried 564

Gadow, Karl 1327

Gäbler, Werner 613, 798

Gaedtke, Carl 1245

Gärtner, Paul 909

Gahr, Adolf 891

Gahrau (Lagerltr.) 660

Gaida, Edith 1429-1431, 1433

Gaidar, Arkadi 175

Gailus, Manfred 77

Galke (Flüchtlingsfrau) 137

Ganke (Informationsamtsleiterin Rathenow) 1126

Gansleweit, Klaus-Dieter 27, 355

Gappa (Kaufstätte) 1210

Garleff, Michael 232

Gasiecki, Joachim 95, 1442

Gassan, Kurt 1291

Gattig, Wolfgang 655, 768, 921, 1064, 1075

Gatzke, Margitta 967

Gaul, Anna Maria 184

Gauland, Alexander 59, 667, 1432

Gaulle, Charles de 1291

Gawel, Heinrich 396, 796

-, Martha 396f., 796

Gebauer (Briefträger) 277

- (Flüchtlingsfrau) 277

Gebert (poln. Oberstleutnant) 1039

Gebhart (Stadtrat, Jüterbog) $1041 \mathrm{f}$.

Gedack, Otto 117, 313, 1442

Gehring (Arzt) 676

Gehrke, Andreas 282, 1432

Gehrmann (Referent) 1160, 1164-1166

-, Alfred 805

-, Otto 1208

Geier (Frau) 416

Geike, Margit 722

Geilich, Bernhard 620 
Geiseler, Udo 283

Geisler, Herbert 1420

Geißler, Frank 282, 810, 1432, 1544

Gelfort, Erich 1442

-, Hubertus 1442

Gellbach, Stephan 930, 1543

Genske, Ferdinand 259, 1113, 1231

Genz (FDGB-Funktionär) 351, 1324

-, Ewald 608

-, Wilhelm 565

Genzius, Wilhelm 185

Georg II., Herzog von Brieg 414

Gerbig (Flüchtling) 874

Gericke (Verwaltungsangest.) 259

-, Anna 607

Gerigk, Hermann 224, 856, 1326, $1337 \mathrm{f}$.

Gerlach, Dieter 416

-, Hans 84

-, Helene 416

-, Otto 772, $1442 \mathrm{f}$.

-, Willi 1541

Gerter, Irina $\rightarrow$ Holzmann

Gerth, Ewald 431

Geschke, Ottomar $161 \mathrm{f}$.

Gesell, Paula, geb. Sauter 330

Geske, Bernd 859

Geßler, Wolfgang 1472

Geßner, Dorothee, geb. Hanke 505, 1541

Giebel, Wieland 1479

Giebler, Ingrid 722

Giering, Gregor 967

Giersberg, Bettina 504, 1541

-, Hans Herbert 504

-, Hans-Joachim 504

Gildemeister (Saarow-Pieskow) 1015

Glanz, J. 758

Glaser, Markus 1266

Glasmacher, André $740 \mathrm{f}$.

Glass, Anna 965, 1443

Gleß, Karlheinz 196, 423, 1443

Glimm, Peter 108, 747 f., 1475
Globig (SED-Funktionär) 1124

Glombeck (Frankfurt/O.) 1341

Glomptner, Bruno 873

Glück, Annemarie 96

Gnida, Manfred 917

Gock (Fürsorgerin) 1261

Goebbels, Joseph 1175

Göbel, Anneliese 944

Göhler, Horst 418, 490, 1443

Göhre, Kurt 641

Gö(h)ring (Beeskow) 999, 1001, $1004 \mathrm{f}$.

Goerke, Heinz 183, 845, 855, 1475

Görlach, Rudolf 773, 1049, 1055

Görlich, Christopher 426

-, Julius 620

Görner, Max 80

Goerz, Hildegard 659

Göse, Frank 504, 1541

Gößwald, Udo 512

Goethe, Johann Wolfgang von 414

Götze (Beeskow) 1091, 1185, 1230, 1233

-, Bettina, 1541

-, Johannes $394 \mathrm{f}$.

Goffiné, Leonhard 1277

Goldbeck, Dietrich 1541

Golisch, Leo 753

Gollasch, Erwin 116, 946, 1475

Goller, Alexander 33, 295

Gomulka, Władysław 346

Gonda, Eva 896, 1443

Goralczyk, Peter 282

Gorholt, Martin 268, 599

Gorny, Fritz 628

Gosdschick, Edeltraud, geb. Budach 1443

Gospodarek, Gerhard 879, 884, 1443

Gossert, Friedhelm 610

Gottberg, Elard von 224, 831

-, Wilhelm von 224

Gotthardt, Werner 821

Gottke (Familie) 1113

Gottschalk, Fritz 369

-, Rudolf 368
-, Wolff [?] 369

Grabisch, Franz 816

Grabner, Sigrid, geb. Hauf 320, $363 \mathrm{f} ., 505,1443 \mathrm{f}$.

Grabowski (Referent) 1165

Gräber (Treuenbrietzen) 937

-, Jürgen 722

Gräfe, Karl-Heinz 346

Grätsch, Elsa 1444

Graff, Karl-Heinz 137, 1456

Grajewski, Hubert 421, 1511

Gralow, Erna $\rightarrow$ Kreutz-Gralow

Gramlich, Horst 505

-, Sybille 30,73

Grandke, Sarah 45, 313

Granzow (Gärtner) 1127

Graske, Paul 275

Grasnick, Magdalena 511

Grasshoff, Eberhard 907

Grassow (Luckenwalde) 1238

Graudenz (Arzt) 735

Gregor, Walli 938 f., 1444

Greischel (Spremberg) 1230

Greiser, Arthur 662, 1403

Grenz, Rudolf 86

Greschan, Walter $1368 \mathrm{f}$.

Gretzinger, Michael 721

Griebenow, Ferdinand 940

Grieger, Else 1475

-, Ulf 508, 701, 771 f., 906

Griesa, Siegfried 420

Grimm, Arthur 855

-, Karl 741

-, Thomas 507

-, Ulrich 207

Grittner, Wolfgang 804

Grodon, Anke 34

Gröschke (CDU-Funktionär) 1086

Gronefeld, Gerhard $701 \mathrm{f}$.

Gronke (Krayne) 763

Grosch (Guben) 1334-1336

Groß (Kantor) 414

-, Charlotte 328, 1426

-, Reinhard 831

-, Sebastian 777, 963

Große (Werder/H.) 949

-, Lieselotte $\rightarrow$ Koppe

-, Werner 950 
Grosser, Thomas 255

Grotewohl, Otto 1242, 1307

Grothe (Frau) 1165

Grüber, Heinrich 438

Grün (Kreisrat) 1223

Grünbaum, Kurt 825

Grünberg, Hans 739

Grünberger, Hildegard 1112

Gründel (Rüdersdorf) 887, 1076

-, Olaf 15

Grünert, Bernhard 314, 726

Grünwald, Max 690

Grützmacher (Flüchtlingsfamilie) 837

Gruhl, Otto 77

Gruhn, Florentine 205, 389

Grunau, Leo 370

Grunenberg, Reinhard 853

Gruner, Petra 296

Grunert, Luise 389

Gudat, Anna Kathrin 509

Gudden-Lüddeke, Ilse 214

Güldas, Ömür 832

Güldenhaupt, Günther 1475

Günther (Arzt) 259

-, Anton 1137

-, Johann Christian 413

-, Lieselotte 1444

Guhl, Renate 65

Gunia, Gerhard 420

Guski, Roman 509

Gutsche (Barackenverantwortliche) 173

-, Ilse $\rightarrow$ Hendzlik

-, Margarete $\rightarrow$ Ammon

-, Paul 749

-, Peter 1432, 1475

Guzy, Stefan 1541

Haack (Sachbearb.) $1243 \mathrm{f}$.

Haacken, Johann 957

Haak (SED-Funktionär) 248, 1172

Haalck (Frau) 1113

Haarstrich, Fritz 834

Haase, Felix 613, 752 f., 941

Haase-Dresing, Ursula 1430

Habel, Fritz Peter 129, 228
-, Walter 1428

Haberkern, Lisa 33, 338, 357, 362,1541

Habermann (SED-Funktionär) 1043

Hacker, Anne 46, 867

Hähnel (SED-Funktionär) 1125

Händel (Krayne) 763

Häusler, Adelheid 621

Hagelweide, Gert 58

Hagemann, Wolfgang 114, 1475

Hagen, von der (Gutsbesitzerin) 283

Hagens, Clara von $\rightarrow$ Arnim

Hahn, Eva 78

-, Gottfried 1502

-, Hans Henning 78

-, Peter-Michael 25

-, Wilhelmine 329, 925

Hahne, Kurt 548

Hain, Gottfried 721

Hainke, Eva $\rightarrow$ Haut

Hakus, Paul 288, 1444

Halbach 768

Halbrock, Christian 36

Halicka, Beata 22, $32 \mathrm{f}$.

Halm (Bischofswerda) 1109

Halter, Hans 652

Hamann, G. 1207

-, Karl Heinrich 1444

-, Wilhelm 102, 1475

Hamdali, Mohamed 501, 512

Hammer (Arzt) 130, 623, 1475

Hamsch, Siegfried 134f., 422, 1444

Handke, Ernst 94, 427

Handreck, Elli, geb. Kitsching 1444

Handrow, Fritz 762

Handt, Dietrich 474, 691, 1425

Hanke, Bärbel $\rightarrow$ Dalichow

-, Brunhilde, geb. Anweiler 229

-, Dorothee $\rightarrow$ Geßner

-, Helmut 229

-, Karl 67

-, Willi 436f., 505, $856 \mathrm{f}$.
Hannemann, Mathilde 128

Hapke, Willi 1207

Harbich, Milo 532, 548, 845, 891, 1409

Harder, Friedrich 104

Hardt, Franz 1212

Harmuth, Karl 940

Hartelt, Konrad 37

Harterl, Anna $\rightarrow$ Schiemenz

Hartert, Georg 1213

Hartisch, Torsten 50, 675, 1542

Hartmann (Beeskow) 1093

-, Josef 915, 1198

-, Michael 14

Hartung (Frau, Bernau) 1031

-, Hugo 153, 321 f., 846, 1444

Hartwich, Mateusz J. 426

Hartwig, Christa, verehel. $\rightarrow$ Stark

-, Hans 423

-, Helmut $423 \mathrm{f}$.

-, Ida 424

Haslinger (Mitarb. der Provinzialverwaltung?) 1081

Hasse (Kreisarzt) 1282

-, Felix 673, 1476

Haucke, Albert 874

Hauf, Sigrid $\rightarrow$ Grabner

Hauk, Anton 1445

Hauke (Familie) 291

-, Hilde 291

Hauptmann, Gerhart 1260

Hausdorf (Verwaltungsangest.) 259

Hauske, Marianne, geb. Mühle 723,1445

Hausmann, Adolf 1121

Haustein, Petra 21

Haut, Eva, geb. Hainke 224, 831

-, Horst 223 f., 831, 894

Hawellek, Josef 935, 1119

Hawlitzky, Karl 447, 571 f., 783, $963 \mathrm{f}$.

Hecklau, Svenja 445

Heckrodt (VP-Oberrat) 1346, $1348 \mathrm{f}$.

Hedwig (Heilige), Herzogin von Schlesien 209, 442, 586, $810,824,903$ 
Heermann, Johannes 413

Heerwagen, Harald 21, 852, 1373, 1541

Hegel, Georg Wilhelm Friedrich 341

Hehn, Jürgen von 232

Heide, Richardis 656

Heidenreich, Willy 1354

Heidlas (Küchensee) 768

Heike, Otto 408

Heiland (Biesenthal) 995

Heilmann, Paul 415

Heimann, Anton 955

-, Marga 864

Heimerdinger, Georg 44, 874-876, 879, 1476

Hein (Drogist) 966

-, Helmut 777

-, Siegfried 1445

Heine, Brigitta 1543

Heinisch, Käthe 806

Heinke, Artur 595

Heinkel (Firma) 307, 310, 779 f., 943

Heinrich, Gerd 19, 26-29, 36, 283

-, Jürgen 116

-, Meta 274

-, Paul 274

Heintz, Adolf 74

Heinz, Daniel 335

Heinze (Verf.) 942

- (MdI-Mitarb., Berlin) 1044

Heise, Rosemarie 325

Helene (Schwester) 1013

Heling, Martin 823

Helle, Matthias 23, 26, 28, 1541

Heller(-Schoelzgen), Gisela, geb. Hielscher 504, 756, 928

Hellmer, Karl 1412

Hellwig (Storkow) 922

-, Kerstin 1544

Helm, Joachim 296

Helmann (Vertriebener) 1445

Helms, Friedrich 104, 855, 955, 1476

Helwig, Gisela 69

Hemmerling, Dietrich 433, 669

Hempel, Herbert 1428
-, Karl-Heinz 168

-, Lucie 187, 1476

Hendzlik, Ilse, geb. Gutsche 923

Henk [?] (Gemeindevorst. Bad

Saarow-Pieskow) 1015

Henkel, H. S. G. 1211

Henlein, Konrad 583

Henniger, Gerhard 233

Henning, Eckart 1541

Hennings Hof (Perleberg) 838

Henningsen, Hermann 735

Henschel (Ministerialdir.) 1241

-, Adam 185

Henschke (Potsdam) 1121

-, Georg 735

Hensel, Christel 831

-, Josef 307

Hensen, Jürgen 140

Hensky, Herbert 859

Hentschel (Ministerialdir.) 259

-, Julius 1210

Henzel, Paulus 874

Heppener, Sieglinde 64, 1434

Heppner (Pfarrer) 1339

Herden, Max 600

Hering, Bernhard 1272

-, Dieter 82, 1541

-, Max 307

Herkner, Käthe 661

-, Walter 294

Hermann, Hans 618

Hermine, Prinzessin Reuß ä. L. 665

Herms, Toni 153, 1445

Herre (Uenze) 1132

Herrmann, Peter 1432

Herrmann \& Schilde (Firma) 1213

Herrn, Mia 598

Hertle, Hans-Hermann $14 \mathrm{f}$.

Hertzsch, Hellmuth 620

Herzig, Arno 67

Herzog, N. N., geb. Witt 699

-, Bernhard 112, 1476

Herzog-von der Heide, Elisabeth 792

Hess, Harro 98, 1481

Hesse, Hans 478

Heßke, Ortrun 1429f., 1432 f.
Hetzer, Maria 56, 889

Hetzke, Eberhard 30

Heuss, Tabitha 964

Heydebrand, Detlev von 92

Heye, Uwe-Karsten 229

Heymann, Hans-Christoph $313 \mathrm{f}$.

-, Paul 1284

Hielscher, Gisela $\rightarrow$ Heller

-, Karl Alexander (Alexander

Karl) 110, 538 f., 653, 658, 971

Hiemke, Alfred 1337

-, Otto

Hientzsch, Liesel $\rightarrow$ Donat

Hildebrandt, Emma 1467

Hilgenfeldt, Erich 123

Hill, Grete 626

Hille, August 783

Hilling, Nikolaus 445

Himmler, Heinrich 663, $866 \mathrm{f}$.

Hinderlich, Hans 793

Hinrichsen (Cottbus) 1212

-, Kerstin 419

Hinz, Alfred 482, 879

Hirsch, Helga 63

Hirschmann, Heinz 1445

Hirschnitz, Kathleen 443, 459

Hirt, Alfred 150, 171, 1445

Hirte, Siegfried 314

Hirthe, Helmut 40 f., 46

Hitler, Adolf 75, 232, 503, 615, $811,1010,1023,1042 \mathrm{f}$., $1150,1156,1175,1227$, $1322,1332,1335$

Hix (Potsdam) 1173

Hochschultz (Postlin) 1141

Hockwin, Otto 467, $721 \mathrm{f}$.

Höger (Deibow) 1139

Höhle, Michael 451

-, Theobald 1277

Höhne, E. 706

-, Emil 369

-, Ilse 1476

-, Josef 307

-, Maria $1445 \mathrm{f}$.

Höntsch(-Harendt), Ursula 69 f., 363 f., 577, 666, 846, 1417,1446 
Höper, Eva-Maria 73

Höpfner, Rudi 220, 285, 1446

Höpner (Gronenfelde) 676

Höppener, Hans-Peter 1430

- , Hugo $\rightarrow$ Fidus

Höricke, Horst 611

Hoff, Rulemann von 768

Hoffmann (Krayne) 763

- (Lagerltr.) 563

- (SED-Funktionär) $270 \mathrm{f}$., 1172, 1174

-, Artur 1109

-, Dierk 68, 295

-, Ernst 360

-, Heike 339

-, Josef 925

-, Karl Friedrich 693

-, Lisa 339

-, Maria 339

-, Otto 804

-, Roland 237f., 605-607

Hofmann, Andreas R. 128

-, Horst 626

-, Jürgen 5

-, Robert 626

-, Wolfgang 70

Hoheisel, Wilhelm 106, 839, 1446

Hohenschild, Irmgard 128, 1476

Hohenstein, Aileen 223

Hohenzollern (Haus) 341

Holland (Landrat Luckau) 611

Hollert, Waldemar $288 \mathrm{f}$.

Hollmann, Henriette 1476

Holz (Fürstenwalde) 687

-, Martin 11,78

Holzmann, Irina, geb. Gerter 541

Homagk, Mathias 443, 459

Honecker, Erich 571

Hoorn, Heike van 157 f., 302 f., 814

Hoppe (Regierungsangest.) 1109

-, Albert 120,837-839, 1476

-, Edeltraud 824, 912, 1543

-, Heinz 823

-, Jutta 1464
-, Paul 1208

-, Richard 152 f., 1440

Hora, Friedrich 325 f., 333 f., 418, 421, 1446

Horlbeck, Else 1006, 1014, 1075

Horlitz, Doris 505, 1541

-, Harry 852

-, Manfred 505

Horn, Anton 452

-, Ruthardt 504

-, Theodor Paul 1207

Hornstein, Erika von 1446

Horzin, Bruno 620

Hryciuk, Grzegorz 72

Huber, Edi 218, 855

Hubrich (Stremmen) 410

Hudak, Adalbert 236

Hübel, Anton 169

Hübener, Erhard 877

-, Kristina 70, 499

Hüber, Otto 749

Hübner, Christa 6

-, Hans 178, 643 f., 769, 1446

-, Otto 749

-, Peter 14, 101

-, Werner $1446 \mathrm{f}$.

Hühne (Potsdam) 1157

Hüning, Ilse 272, 871, 1476

Hüttemann, Hannes 415

Hugler, Klaus 1430

Huhnt (Krayne) 763

Hullin, Karl 460, 1269

Hultsch, Gerhard 1425

Husen, Sebastian 1543

Huth, Steffi 1544

Hysek, Josef 814

Igel(-Allzeit), Annett 762

Ihlenfeld, Christa $\rightarrow$ Wolf

-, Kurt 1260

Ihlenfeldt, Karl 275

Illing, A. H. 1327

Illmann, Norbert 460

Imme, Fritz 746

Inatowitz (Arzt) 889

Isakow (sowjet. Major/Oberst) 1023

Iven, Mathias 321
Iwanow, Wassili Wladimirowitsch 253

Iwanzow (sowjet. Major) 253, 740, 1003, $1008 \mathrm{f}$.

Jachnick, Erwin 1447

Jachomowski, Dirk 234

Jacob, Günter 1352

Jacobeit, Wolfgang 31, 45

Jacobs (Ministerial-Abteilungsleiterin)

-, Joachim 792

Jaeckel, Gerhard 121, 192 f.

Jänisch (Krayne) 763

Jaensch (Umsiedlerbetreuer,

Beeskow) 1013

Jänsch (Guben) 712

Jäschke (CDU-Mitglied) $1243 \mathrm{f}$.

Jäzoch, Jutta, geb. Thiele 1447

Jaeschke, Gerhard 190, 329, 410

Jagode, Emil 418

Jagodzinski, Karl $1116 f$.

Jagott, Willi 708

Jahl, Martha 1112

Jahn (Luckau) 274

- (Potsdam) $1165 \mathrm{f}$.

-, Manfred 10, 47

Jahnke, Willy 89

Jahr, Werner 903, $1278 \mathrm{f}$.

Jajeśniak-Quast, Dagmara 33

Jakob, Dagmar 831

Jakobs, Jann 480

Jammer, Alois 651

Jančik, Christa 512

Janek (Pole) 197

Janis, Frieda 1149, 1238 f.

Janissek, Franz 795-797, 934

Janke, Dieter 888

Jannaschke, Theo 790

Janowski, Bernd $885 \mathrm{f}$.

Jantes, Franz 610

Jarczyk, Franz-Christian 379

Jebram, Julius 221

Jendreiek, Helmut 722 f., 1447

Jendritzko, Anton 912

Jentsch (Kreisrat) $1238 \mathrm{f}$, $1304 \mathrm{f}$.

-, Richard 1205

-, Willy $1476 f$. 
Jeremicz, Jacek 94

Jesse, Johann 315

Jetzki (Zehdenick) 966

Jeute, Gerson H. 34

Joachim, Joseph 1138

Jochmann, Albrecht 599

Johm[?] (Mahlow) 1219

John, Manfred 691

Johne, Fritz 294

Jonas, Bertold $725 \mathrm{f}$.

Jonca, Karol 68

Jugert (Arzt) 736

Juhnke (VdgB-Funktionär) 1085

Jun, Wilhelm $146 \mathrm{f}$.

Jung (Beeskow) 1004, 1178

-, (Dezernent) 1073

-, Franz 609, 942

Junge (Ketzin) 1113

Junker (FDGB-Funktionär)

1085

Jurat, Dagmar 775

Jurk (Krayne) 763

-, Hermann 1207

Just, Emmy 1210

-, Gustav 503 f., 1447

-, Hans Joachim 721

-, Helga 268, 887

Kaatz (Lütkendorf) 1146

-, Gebhard 1447

-, Siegfried 601, $1370 \mathrm{f}$.

-, Walter 1447

Kabisch, Winfried 723, 1447

Kaczmarek, Günther 115, 918

Käding, Otto 216, 418

Kähler, Horst 960

Kämpf, Emil 172, 754, 1448

Kärger, Bruno 809

Kästner, Erich 602

-, Helga 43, 46, 882, 1429

Kahle (Zehdenick) 966

Kahlert (Verwaltungsangest.) 259

-, Josef 1212

Kaiser (Cottbus) $1356 \mathrm{f}$.

-, Hermann 881

Kalcher, Jutta 115, 1477

Kaleck, Martin 1448
Kaller, Maximilian 452

Kalliske, Adelheit $\rightarrow$ Wöhlke

-, Bernhard 362

Kalteis, Otto 773, 1049, 1057

Kaltenborn, Steffi 11, 47, 299

Kaminski (Arzt) 773, 1049, 1055

-, Gerhard 908

Kaminsky, Anna (Annette) 21, 23, 97, 165

Kamm, Otto 1205

Kammel, Richard 431, 438, 1257,1264

Kamp, Silke 789, 1541

Kanisch, N.N. $\rightarrow$ Sack

- (Schneider) 410

Kante (Lagerltr.) 557

Kantor, Ernst 917

Kanzler, Magda, geb. Kirsch 678,1448

Kapahnke, Elfriede 879, 1541

-, Herbert 224, 481, $878 \mathrm{f}$., 1376, 1378

Kapinski (Arbeiter) 733

Kaplan (sowjet. Offizier) 253, 1039 f., 1082, 1116, 1118

Kaplick, Otto 427

Kappel (Ketzin) 1113

Kaps, Agnes 625

-, Hedwig 625

-, Johannes 443 f., 1427

Kardach, Elfi, geb. Bornmann 385

-, Walter 385

Karg, Otto 112, 1477

Karge (Ketzin) 1113

- , Johanna $\rightarrow$ Keller

-, Karl 372

-, Karl-Heinz 1430

-, Willi 1334f.

Karnal, Anneliese 750

Karnauke (Werben) 946

Karner, Stefan 97

Karsch, Theodor 1448

Karstädt (Prenzlau) 1230

Kasack, Hermann 322, 1477

-, Wolfgang 322, 1477

Kasakewitsch, Emmanuil G. 1246
Kaschuba, Wolfgang 31

Kasprzik, Horst 1448, 1477

Kaß, Hans 1205

Kaßner, Bernhard 796, 909, 939

Kasten, Tilman 58

Kastner, R. 1211

Katerbitz, Horst 823

Katharina II., Zarin von Rußland 1265

Kaule, Martin 26

Kaulich, Canisia 554

Kauschke, Maximilian (Max) 210,726

Kautz, Ernst 1448

-, Helmut 237 f., 605

-, Hugo 1448

Kayser, Heinz 775

Kegler, Hartmut 1448

Kehrer, Margarete $\rightarrow$ Domscheit

Keil (Lagerltr.) 698

-, Hannelore 1468

Keiler, Otfried 505

Keiner, Juliane 605

Keller, Elfriede 691

-, Erika 273, $1448 \mathrm{f}$.

-, Ines 32, 60, 335, 357, 422

-, Johanna, geb. Karge 669

Kellert, Herbert 234

Kellner, Henning 469

Kempowski, Walter 322, 862, 959, 1431, 1477

Kendzia, Klaus-Peter 1541

Kenzler, Heinrich 776, 831

Keppler, Günter 855, 1449

Kergel, Emma, geb. Fietze 1046

Kermer (Guben) 721

Kernchen, Herbert 275, 335, 695, 1449

Kersten, Oliver 125

Kersting, Thomas 34

Kessler (Kapelle) 1092

-, Robert 1212

Keßler, Rudolf 625

Kessler, Wolfgang 58, 60, 403

Ketelhohn (Beeskow) 1014

Ketsch (sowjet. Major) 1246

Kewitz, Adolf 827

Kibelka, Ruth $\rightarrow$ Leiserowitz 
Kieckbusch, Werner 297, 1477

Kiedrowski, Johannes von 461

Kiekebusch, Albert 380

-, Heinz $379 \mathrm{f}$.

Kieling (SED-Landesvorstandsmitarb.) 1044

Kienast (SED) 1025 f., 1154

-, G. 579

Kiene, Ingeborg 412, 555, 815

Kiesewetter, Reinhard 190, 1477

Kießhauer, Inge 343

-, Rolf 343

Kießling, Martin 73, 341

-, Waltraud 746, 1373

Kikels, Christa 61, $1430 \mathrm{f}$.

Kinder, Sebastian 28

Kindermann, Carl 778

Kionka, Alfred 887

Kirchner, Gabriele 568

Kirsch, Fritz 678, 1448

-, Hanna 678

-, Magda $\rightarrow$ Kanzler

-, Rita 295, 419

Kirschner, Erich 1432

-, Ludwig 954

Kirstein, Hans 1042, 1150, 1224, 1305, 1307

Kirsten, Holm 183

Kissner, Franz 789

Kitsching, Elli $\rightarrow$ Handreck

Kittan, Horst 312, 428

Kittel, Josef jun. 307

-, Josef sen. 307, $779 \mathrm{f}$.

-, Viktor 853

Klaar, Conrad 447

Kläske (Strasburg) 924, 1250

Klahre, Hans 619, 789, 1351-1353

Klank (SED-Funktionär) 1174

Klausch, Rosemarie 626

Klecker, Alexander 1213

Kleemann (Krayne) 763

- (Saalow) 889

Klehr (Arzt) 938

- (VdgB-Funktionär) 1085

Klein (Fotograf) 652

- (Krayne) 763

-, Georg 447, 628
-, Gotthard 1543

-, Hemjö 771

-, Joachim 584

Kleindienst, Jürgen 175

Kleist, Bernd 1543

Klemeševa, Marina 147

Klemp, Eva-Maria 575

Klemt, Erich 382, 384, 1425

Klepper, Jochen 1260

Klessen, Ursula 188, 1449

Kleßmann, Christoph 14f., 19

Klewitz, Fritz 822, 1433

Kliche, Manfred $169 \mathrm{f}$.

Klicks (DFD Rathenow) 1126

Kliemann, Joachim 469

Kliems Festsäle 1344, 1349

Klier, Freya 97, 226

Klimpel, Erich 806

-, Gustav 161

Klinger (Buckow) 610

Klinke (SED-Funktionär) 1293

-, Helmut 329, 925

Klitzing, Anne von, geb. von Wedemeyer 92, 1449

-, Hans von 1449

-, Karl-Ludwig von 357-359, 1477

Kloosterhuis, Jürgen 474, 1543

Klose, Andreas 75, 853

-, Dirk 119

Kluchert, Ursula 332

Knaack, Rudolf $430 \mathrm{f}$.

Knaak, Jens-Michael $792 \mathrm{f}$.

Knackmuß, Heinz-Walter 876

Knak, Joachim 715

-, Johannes 721

Knapp (Arzt) 773, 1049

Knauerhase, Gustav 396

Knauft, Wolfgang 442

Knefelkamp, Ulrich 184, 420

Kneler (SED-Funktionär) 1220

Knigge, Volkhard 21

Knitter, Eitel 273, 933 f., 1477

-, Hartmut 279, 505, 1541

Knoblich, Herbert 503, 948

Knobloch, Reinhold 1208

Knode (Schmergow) 1355

Knodel, Ludwig 1209

Knöschke, Fritz 1206
Knorre, Dietrich von 553

-, Georg Heinrich von 553

-, Heinrich von 232, $552 \mathrm{f}$.

Knospe, Erich 1449

-, Marianne, geb. Redlich 1449

Knüppel, Fritz 98, 1432, 1477

Knuth, Reinhard 331, 945, $1449 \mathrm{f}$.

Kober, Hans 504

-, Steffen 910

Kobert (Reichsbahnamtmann?) 997

Koblischke, Erich 328

Koch (Frankfurt/O.) 1230

- (Hausvater) 880

-, Eva 370, 440

Kochner, Otto 618

Kockjoy (VP-Oberrat) 1352

Kockott, Karl 76 f., 459

Köhler (Bernau/Rüdersdorf) 1230

- (Frau, Bredereiche) 1541

-, Christel 872, 1477

-, Erich 42 f., 198, 200, 604

-, Erwin 845, 1224, 1311

-, Günter 13

-, Jürgen 224

König, von (Familie) 1132

- (Krayne) 763

- (SED-Funktionär) 1172

-, Gerhard 1541

-, Gisela 971

-, Hans-Joachim 482, 878

-, Horst 62, 64, 131, 177, 1429-1431, 1433, $1541 \mathrm{f}$.

-, Ilse von 1132

-, Winfried 443

Koerber, Ingo von 1327

Körner, Emil 331

Körper, Anna $267 \mathrm{f}$.

Köstering, Susanne 29

Kösters, Christoph 458

Kohl, Helmut 666

-, Paul 408

Kohlase, Fritz 1432

Kohlmay, Erwin 294

Kohlstock, Ullrich 658, 745

Kohs, Marcel 1450

Kokott, Raimund 294 
Kolbe, A. 413

Kolberg (Eberswalde) 1372

Kollmeier, Kathrin 15

Kolodziej, Josef 846

Konhäusner, Renate 74

Konieczny, Alfred 68

Konopińska, Jana 577, 666, 846

Koop, Herbert 678

Kopka, Anton 699

Kopp, Margot $\rightarrow$ Bitter

Kopp \& Co. (Firma) 164, 936 f.

Kopp-Colomb, Agnes von 110

-, Henning von 110

Koppe, Lieselotte, geb. Große 83, 1541

Korallus, Eduard 222

Korfes, Otto 1307

Kornrumpf (Wehrmachtspfarrer) 77

Korsan, Katarzyna 421

Kort, Eberhard 967

Koruhn, Klaus 723

Korzs, Erwin 225, 1450

Koschack (Stadtrat Guben) 1290

-, Bärbel 717

Kositz, Martha 1112

Koskull, Walter Baron 590

Koslowski, Günter 168

Kosmehl, Kurt 909

Kossert, Andreas 319, 327, 363 f., 510, 513

Kotsch, Detlef V, 15 f., 22, 25 f., 352

Kotulan (VP-Inspekteur) 1349

Kotzian, Ortrud 99, 441

Kowalewski (Frl., Falkensee) 647

Kracht, Walter $387 \mathrm{f}$.

Krätzner, Claus 71, 195, 204

Krakau, Kai-Uwe 506

-, Winfried 276, 293, 1450

Kramer (Krayne) 763

Kranert, Gudrun 225, 879

Krantz, Lily 1113

Kratschke (Fürstenwalde) 688, 1109

Kratzert, Hans 648

Kraus (SED-Mitglied) 1247
-, Hans-Christof 474

-, Walter 672

Krausch, Heinz-Dieter 421, 723, 1477, 1541

Krause (Luckenwalde) 1136, 1230

-, Albrecht 447, 971

-, Georg 205, 379

-, Günther 658, $660 \mathrm{f}$.

-, Kurt 129, 490, 1450

-, Marta 734

Kraut, Rudolf 1112

Krautz (Kripo Potsdam) 1226

-, Friedrich 1212

Krebs, Gerhard 1450

-, Peter 641

Krecklow, Wilhelm 1208

Kretschmann, Ralf 21

Kretschmer (Cottbus) 617, 624,1477

-, Frieda 332 f., 1479

Kretzschmar, Ida 498, 500

Kreutz, Karl 61

Kreutz-Gralow, Erna 14291431 f., 1450-1452

Kreutzmüller, Christoph 24

Krey, Otto 809, 1482

-, Ursula, geb. Seidel $\rightarrow$ Weinkauf

Kriegel (Lagerltr.) $687 \mathrm{f}$.

Krieglstein, Hannelore, geb. Siewert 960

Krockow, Christian Graf von 98, 152, 1452

Kröhl, Erna 286

Krönert, Hans 1209

Krogel, Wolfgang 1543

Kroll (sowjet. Oberst) 160

-, Frank-Lothar 363, 418, 474

-, Rosemarie $721 \mathrm{f}$.

Krolopp (Vertriebener) 558

Krost (Beeskow) 1013

Krowarz, Johannes 882, 954

Krüger (Fürstenberg/Oder) 683

- (Krayne) 763

- (Leibsch) 1142

- (Neuheim) 814

- (RAW Potsdam) 259, 1231
-, Arnold 438

-, Bert 34, 170

-, Erwin 1147

-, Helmut 399

-, Horst 494

-, Karl 863

Krüger-Dümchen, Werner 371

Krugmann, Reinhold 774

Krumm, Gerhard 467, 660

Krummschmidt, Bernhard 632

Kruppa, Ruth 1146

Krusche, Fritz 803

Kruska, Harald 438, 441, 1261

Krzywinsky, Ursula 934, 1477

Kschammer, Fritz 634

Kubatzki, Rainer 168

Kuberski, Jan 722

Kubi, Erich 582

Kubiak, Georg 791

-, Gerda 690

Kucharczyk, Heinrich 356, 478

Kuchel, Paul 825

Kuckelmann, Bernhard 592

Kübelstein, Hedwig $\rightarrow$ Schob

Kühl, Vilma 498, 837, 1452

Kühn, Detlef 624

-, E. 40

Kühn-Berger, Edeltraut-Marianne, geb. Berger $851 \mathrm{f}$., $1368 \mathrm{f}$.

Kühne, Horst 921 f., 1452

-, Lutz 314

Kühnel, Elisabeth 644

Künkel, Horst 71

-, Ulrich 340

Künzel, Werner 100, 511

Küpper, Elfriede 763

Küster, Elise 806

Kugel (Litauendeutsche) 760

Kuhbein (Krayne) 763

Kuhlmey (Frau) 417

Kuhlo, Johannes 1208

Kuhn, Erich 247, 249, 848, 1044, 1092, 1106 f., 1109, $1135,1173,1239,1244 \mathrm{f}$., 1355

-, Günter 513f., 923

-, Herta geb. Manneck 249

Kuhse, Horst 812

Kukla, Dietrich 115 
Kulke, Erich 1303

Kulla, Barbara 130, 1452 f.

Kummer, Werner 1120, 1136, 1200

Kumpf, Marta 307

Kunde, Joachim 251

Kundoch, Dietrich 42, 178

-, Ingelore 42, 178

Kunert, Edith 417, 489, 1453

Kunisch, Gerd 744

Kunstmann, Johanna 122

Kunz, Leo 179, 768, 1098, 1104

Kunze, Martin 273, 934

Kupferschmidt, Frank 851

Kupke (Potsdam) 1121, 1173

-, Wolfgang 1432

Kuppe (Guben) 1335

Kupsch, Rudolf 1210

Kurts, Alfred 847

Kurzweg, Christian 10

Kusch, Bernard 1511

-, Melanie 413

Kuschbert, Alfons 590, 796, 925

Kusche, Else 1144

Kuschinske, Dieter 672

$\mathrm{Ku}(\mathrm{t})$ zenko (sowjet. Offizier) 530, 1061

Kwaschik, Martin 431

Kwaschny, Reinharda 656

Kwoka, Bernhard 1544

Kyburg (Firma) 791

Lade, Otto 567

Ladwig, Anastasius 1209

Lakowski, Richard 24, 100, 510

Lambrecht, Rainer 855, 951

Lammert, Markus 39

Lampe (Neuruppin) 1254

Lande, Karl 392

Lang, Karolina 442

-, Rolf F. 89

Langas, J. 1147

Langbein (Premnitz) 1184f.

Lange (Gutsbesitzer) 898

-, Erich 1208

-, Günter 86, 297, 769, 1453

-, Klaus 30

Langemark, Helene 1453
Langer, Irmgard 871

-, Johannes 753, 800

-, Karl (Carl) 1269

-, Ursula 511

-, Wilhelm 1258

Langfeldt, W. 1146

Langhammer, Christian 479

Langhans, Hilda 642

Laser, Werner 493

Laskus (Revierförster) 1294

Lass, Edgar Günter 87

Lau, Karl 885

-, Karlheinz 139, 203, 325, 692

Laube (Bad Freienwalde) 1230

Laubsch (Brieselang) 1339

-, Richard 1209

Lauenstein, Johann Dietrich 93

Laurisch (Calau) 1230

Lauterbach, Jürgen 601

-, Werner 735

Lebek (Volkspolizist) 1344f.

Lede, Elsbeth 1453

Leder, Helmut 1453

Lehmann (Guben) 572

- (Templin) 1230

-, Birgit 1544

-, Brigitte $\rightarrow$ Lehmann

-, Irina 1543

-, Johannes 1453

-, Jutta 836, 1543

-, Käte 912

-, Matthias 82

-, Otto 686

-, Paul 375, 1426

-, Ralf 569

-, Richard 763

-, Rudolf 191

-, Werner 1477

Lehmann's Wwe. \& Sohn, C. (Firma) 1284, 1294

Lehmberg, Otto 42

Lehnigk, Carmen 1544

Leibner, Max 130

Leichnitz, W. 754, 1132-1134

Leiserowitz, Ruth, geb. Kibelka $16,220,226$

Leitzmann (Potsdam) 1360

Lemberg, Hans 47

Lemmen, Daniel J. 215
Lenin, Wladmir I. 560

Lentzsch, Bruno 248

Lenz, Siegfried 1469

-, Willy 1209

Leo, Annette 20, 880

Leopold, Prinz von Braunschweig 664

Leppin, Günther 416f., 427, $435 \mathrm{f}$.

Lesch, Kurt 554

Leske, Arthur 777, 1453

Lettenbauer, Charlotte, geb. Brose 1346

-, G. 1345

Lewicki, Wolfram 552

Lichteblau, Johanna $870 \mathrm{f}$.

Lichtenberg, Emma 433, 693

Lidl \& Schwarz (Firma) 781

Liebelt (Küchensee) 768

Liebert, Bodo 766, 799

Liebig (Luckau) 1230

Liebsch (VP-Wachtmstr.) 1347

Lieckefett, Herbert 1113

Liedke, Arne 327, 1541

Liehr (Guben) 712, 716-718

-, Bärbel 42

Lienhard (Kapelle) 1094

Liesert, Karl 558

Lieske (Familie) 128

Lind (Arzt) 1082

Lindemann, Stefan 49, 56, 706 f., 889

Lindner, Clemens $1453 \mathrm{f}$.

-, Ekkehard 298f., 333 f., 352, 1454, 1541

-, Fritz 306

-, Heinrich 314

-, Karin 1453

Lindow-Bahl, Andrea 1541

Lingk, Eduarda 592

Linke (Krayne) 763

-, F. 899

-, Gottlieb 1201

-, Walter 1207, 1212

Linkesch, Franz 1350

Lipske, Helmut 473, 910

Lisch, Heinz 251, 1185

Liß, Gerda 119, 1477

Lißke, Birgit 21 
Lißner, Anton 307

Lissner, Wilhelm 772, 1478

List, Jenny 1046

Loch, Ekkehard 94

Lochowitz, Alfons 809

Löchelt, Wolfgang 690

Loeck, Gottfried 427

Löffler, Fritz 98, 132, 265, 1454

Lösche, Ernst 524

Löschmann (Frau) 401

Loeser, N. N., geb. Ostrowski 839

Löwenstein, F. 1173

Logau, Friedrich von 413

Lohan, Erich 289, 648

-, Gertrud, geb. Pfütze 289

-, Julius 289, $647 \mathrm{f}$.

-, Pauline, geb. Drabach 289

Lohkamp, Giesela, geb. Schönemann 971

Lohmann, Peter 721

Lokai $\rightarrow$ Schneider \& Lokai

Lompa, Georg 447

Loose, Ingo 103

Lootz (Potsdam) 1151

Loppuch (Mahlow) 1176

Lorenz, Willy 664, 673, 1454

Lotz, Christian 342

Loziol, Jan 385

Lucher (VVD-Mitglied) 260

Lucht, Paul 64, 1434

Lucke (Cottbus) 1230

Ludewig, Elfriede $\rightarrow$ Fuhrmann

Ludwig, Fritz 975, 1136, 1221, 1224, 1245, 1288 f., 1419

Lücht, Annett 722

Lück (Eberswalde) 1230

-, Siegfried 480

-, Wanda $\rightarrow$ Melcher

Lüdemann, Kai 853

Lüderitz, Jörg 98, 100, 187, 323, $420,610,1454,1541$

Lüdtke, Dieter 851

Lunkeit, Heinz 1454f.

Lust, Erich 1342, 1345

Luther (Zehdenick) 966

-, Martin 432, 461

Lutter, Ernst 679

Lyhs, Dieter 87, 220, 273, 1455
Maaß, Ernst 839

Machnik, Bernhard 896

Machrowiak, Chrysanta 581, 656

Macknow, Hildegard 863

-, Martin 863

Maćkowiak, Michał 101

Maddey, Ernst 581

Maerz, Jürgen 41, 1431, 1433

Maether, Bernd 282

Maetz, Dietrich 340

Magnuszewski, Peter 1212

Mahowski (Mahovsky), Josef 735

Mai, Jürgen 860

Maier, Johannes 447, 826

Maillard, H. 1039

Makarenko, Anton S. 226

Makosch, Hugo 951

Makowitz, Bärbel 273

Makschakow (Ing.) 1539

Makschakowa, Barbara 1539

Malachow, (Nikolai I.?) 253

Malk, Kurt 635

Malskeit (Beeskow) 1131

Malten, Gerhard 376

Mampe, J. 1205

Mandelkow, Hedwig 1208

-, Martin 1208

Manegold, Bodo $356 \mathrm{f}$.

Mangelsdorf, Frank 826

Maniera, Edgar $842 \mathrm{f}$.

Manneck, Herta $\rightarrow$ Kuhn

Manteuffel, Ada Baronin von 590

Manthey, Gerda 1478

Maron, Karl 160

Maronde, Manfred 1475

Marquardt (Flüchtling) 96

Marsch, Erich 576

Marschall (Lagerangestellte) 645

Marschner, Heinrich 883

-, Hermann 274

-, Rudolf 274

Marschner-Katzur, Lieselotte 42

Marschollek, Dorothea 1544
Marshall, George C. 1293

Martin, Lotte 107, 1455

Marx, Karl 781

-, Wolf-Rainer 951

Maschek, Johann 1112

Mascher, August 787

Maschke, Franz 814

Materna, Ingo $24 \mathrm{f}$.

Materne (Henzendorf) 279

-, Heinz 84

-, Lutz 467, 478, 722

- , Renate $\rightarrow$ Müllers

Mathes (Familie) 941

Mattern (Lehrer) $1338 \mathrm{f}$.

Matthus, Siegfried 504

Mattigk (Kaltenborn) 1296

Mattigka, geb. Pahl (Rumäniendeutsche) 935

Mattke, Heinz 723

Matz, Elisabeth $\rightarrow$ Schläwe

Mau, Rudolf 36

Mauersberger, Kerstin 14

May (Arzt) 887, 1077

Mayer, August 253

Mayr-Melnhof, Marie Freiin zu

$\rightarrow$ Eulenburg-Hertefeld

Maziul, Eckart 799

Meckel, Markus 480, 851

Mehlhase, Thorsten 10

Mehnert, Elke 363

Meier, Brigitte 67

-, Christa $\rightarrow$ Stiemke

-, Günter 342

-, Karl 408, 779

-, Uwe 26

Meincke, Irmgard 114

Meinecke[?] (Topper) 1145

Meineke, Hermann 833

Meinert, Anna 132

Meinicke, Wolfgang 9, 11 f., 308

Meißner, Georg 451, $821 \mathrm{f}$.

-, Lothar 136f., 463, 483, 1433

Meister, Hans-Peter 910

Mekas, Gerhard 1337

Melcher, Fritz 328, 745

-, Wanda, geb. Lück 328

Melchert, Monika 321

Melis, Damian von 11

Mende, Hans-Jürgen 342 
-, Paul 429, 790

Mendel-Oberüber, Else 1138

Mengel, Thomas 148, 450

Mentzel, Klaus-Peter 30, 310

Menz (Verwaltungsangest.) 259, 1231

Menzel, Stefan 102

-, Walter (Autor) 102

-, Walter (Händler) 1210

Merkel, Hans-Gotthard 81

Merker, Paul 1204

-, Wolfgang 48, 1204

Mertel (Hauptsachbearb.) 1058, 1090, $1030 \mathrm{f}$.

Mertens, Johannes 38, 450, 1541

-, Sonja, geb. Prestel 1455

Merting, August 441

Mertke, Hermann 925, 1541

Meschar, Albin 607

Meschke, Heinz 1525

Messmer, Horst 296

Methke, Richard 1207

Metscher, Gustav 800

Metschulat, Edmund 861

Metting (Golm) 1226

Metzen, Karl Rudolph 600

Metzger, Konrad 447

Metzner, Thorsten 504

Meusinger, Paul 70

Meuß, Joachim 370

Mewes, Fritz 879

Meyer, Curt Gregor 1541

-, Emanuel (Firma) $1292 \mathrm{f}$.

-, Erna 929

-, Jürgen 1541

-, Sibylle 120, 1432

Meyer-Ranke, Peter 862

Michaelis, Charlotte 416

Michalka, Wolfgang 33

Michaltsek, Bernhard 570

Michel, (Karl oder Richard) (Arzt) 765

Mickin (SED-Funktionär) 1168,1170

Mielack (Nauen) 1230

Mierzwa, Rudolf 144f., 1456

Mieth, Else 1204

Mietk, Thomas 18, 45, 52, 790, 799,872
Mietz, Alfred 1456

Mikisch, Werner 267

Milark (Bernau) 1082

Mildner, Erika 1456

Minia, Günther 612

Mirbach, Andreas Baron von 590 f., 1544

Misselwitz, Hans 19

Mitscherlich, Eilhard Alfred 596, 834, 1468

Mitschke, Erich 961

Mitschulat (Berlin) 1339

Mittelstädt, Gerhard 501

Mitzner, Rolf 505

Modrau, Marianne 137, 822, 1456

Möbius, Dagmar 227

-, Nele 49, 706

Moeck, Helga 339

Möhring, Werner 716, 1478

Möller, Klaus-Peter 1541

Mog (Potsdam) 241

Mohaupt, Heinz 818

Molotow, Wjatscheslaw M. 665, 1283, 1296

Mommert, Robert 621

Mones, Bernd 501

Monse, Franz Xaver 1425

Morche (Informant) $1339 \mathrm{f}$.

Moretti, (Giuliano?) 773, 1049, $1055 \mathrm{f}$.

Morré, Jörg 183, 952

Morzynski, Albert 447

Mothes, E. 758

Motzkus, Erwin 224, 505

Muchin, Theodor 218, 876

Muchow, Heinz 297, 959

Mudra, Hannelore 623, 835

Mühle, Marianne $\rightarrow$ Hauske

Müller (Dr., Frau) 1160, 1163

- (Forst/L.) 1230

- (Ketzin) 1113

- (Krayne) 763

- (Premnitz) 1376

- (Ministerialdir.) 259

-, Anne-Kathrin 34f.

-, Armin 363

-, Carl 573

-, Dieter 713
-, Franz (Chronist) 801

-, Franz (Pfarrer) 781

-, Günter 879, 1478

-, Heiner $909 \mathrm{f} ., 1416$

-, Helga 1456

-, Herbert 960

-, Helga, geb. Paschke 149

-, Hubert 1456

-, Johannes 74

-, Karl 392

- , Magdalene $\rightarrow$ Sendhoff(Trinkaus), Magda

-, Manfred 90

-, Paul 564

-, Siegfried 100, 1541

-, Wolfgang (Eichwalde) 45, 50

-, Wolfgang (Neuzelle) 443

Müller-Pfeifruck, Sylvia 1541

Müllers, Renate, geb. Materne 85,1456

Münchenhagen, Margarete, geb. Raatz 251

-, Walter 251 f., 1086, $1092 \mathrm{f}$., 1098, 1126 f., 1160, 1163

Münzberg, Josef 307

Müske, Adoline $\rightarrow$ Rosenke

Mummert, Kurt 1205

Munkow, Helmut 386, 491, 644

Mysona, Władysław 771

Nädtke, Hasso 871, $1462 \mathrm{f}$.

Napieralla, Adalbert 741

-, Albert 741

Napparell (Prediger) 211

Natho, Herbert 1205

Natusch, Willi 1213

Nau (Dr., Schönerlinde) 1356

Naujoks (Perleberg) 1230

-, Helga 174

Nayhauß, Anette von 221

Nebel, Erich 1211

Nebelung, Paul-Friedrich 99, 107-109

Necker, Ernst 218

Neddermeyer (Landesbauernsekretär) 1306

Neidnicht, Bernhard 509

Neigmann (Potsdam) 1341 
Neis, Kurt 34, 45, 280 f., 1518, 1541

Neitmann, Klaus Vf., 15, 1542

Nenast, Gertrud, geb. Will 100, $1456 \mathrm{f}$.

Nennhaus (Sparkassendir.) 105

Netzker (Golßen) 699

Neubacher, Kurt 768, 1065, $1067 \mathrm{f}$.

Neubauer, Siegfried 61, $121 \mathrm{f}$., 290, 343, 376, 770, 773, 1431,1541

Neuendorf, Ernst 43

-, Lieselotte 1436

-, Peter 728

Neumann, Christel, geb. Ziegler 1457

-, Ernst 805

-, Franz 1457

-, Gustav 763

-, Josef 1147

-, Monika 328

Neumann (Eberswalde) 635

Neupauer, Hans 607

Neuwald (Lütkendorf) 1146

Nickel (Flüchtlinge) 647

- (Landarbeiter) 647

-, Irmgard 1478

-, Ottargo 485

-, Ulrich 1478

Niebsch, Kerstin 906

Niedenzu, Heinrich 654

Niedrich, Hartmut 187

Niedzballa, Gustav 479

Niepelt. Joachim 828, 938, 1478

Nikolai (Teltow) 1230

Nikolaisen, Carsten 435

Nikoley, Horst 1457

Nissel, Reinhard 505

Nitsch, Kurt 408

Nitschke, Klaus 234

-, Max 1457

-, Werner 1283, 1291, $1293 \mathrm{f}$., 1298, 1300, 1302, 1304

Nitz (VdgB Golm) 1224

Niven, Bill 339

Noa, Wolfgang 1432

Noack (Frau, Storkow) 922, 1085
-, Elvira, geb. Buchholz 1457

-, Jürgen 84, 279 f., 1457

-, Wolfgang 723, 1478

Noel, Anna von 928

Noel (Vorname) (Flüchtlingsmädchen) $728 \mathrm{f}$.

Noetzel, Andreas 309, 314

Noll-Haiduga, Jutta, geb. Tschirpig 361

Nolte, Eva 260, 1478

Nora, Pierre V

Norbert (Zehdenick) 967

Normann, Käthe von 152 f., 1457

Nossack, Hans-Jürgen 42, 178

Nowak, Elisabeth 296

-, Reiner 471

Nürnberger, Frank 498, 1541, 1544

Nutsch, Eva-Maria 88, 184, $187,1478 \mathrm{f}$.

Oberhauser, N.N. $\rightarrow$ Bischof

Oberling, Ines 53, 299, 1541

Oehlsen, Sven Olaf 10, 16 f., 286, 513, 1541

Oelschläger, Volker 852

Oesterreich, Hans-Heinrich 335

Oestreich, Hermann 206

Oette, Heinz 655 f., 1519

Ohm, Arthur 379

Ohmenzetter, Arno 1205

Ohnesorge, Hans 1479, 1481

-, Ina Maria $\rightarrow$ Sielmann

-, Lena, geb. Voss 184, 860, $863,866,1479,1481$

Okun, Heidi 1479

Oleniczak (Familie) 1113

Olschowsky, Burkhard 346

-, Heinrich 144, 325, 1458

Olterburg[?] (Rathenow) 1188

Onassis, Aristoteles 1065

Onnen, Hans-Joachim 504

Oole, Sven 963

Opitz, Erich 45, 49, 117, 279, 284, 354 f., 685, 1480, $1541 \mathrm{f}$.

Orlowski, (Auguste?) $253 \mathrm{f}$., $1255 \mathrm{f}$.
Oschlies, Renate 846

Ost, Anna 329

Osten, von der (Gutsbesitzer) 91

Ostrowski, N. N. $\rightarrow$ Loeser

Oswald, Kurt 1213

Otto, Gerhard 1458

-, Kathy 297

Owczarek, Hildegard 173, 659

-, Frank 1542

Paatz, Max 1167

Pabel, Hilmar 855

Pabst, Ruth 435

Pachl, Wenzel 1112

Paech, Wolfgang 1458

Paetau, Rainer 46, 955

Pätschke (Ketzin) 1113

Paffrath, Constanze 791

Page, Regina 589

Pahl $\rightarrow$ Mattigka

Pahm, Albert 221

Pallesche, Christa 618

Palleschke, Gertrud 619

Palm, Emil 399

-, Fritz 610

-, Wolfgang 1458

Pape, Kurt 951

-, Petra 13

Papke (Landrat) 1056

Papst, Erwin 597

Parak, Michael 209

Parchert, Heinz 265, 1458

Paschke, Hildegard $\rightarrow$ Müller

Pasenau, Angelika 646, 703-705, 967, 1542

-, Olaf 226, 646, 703-705, 967,1542

Passlack (VP-Oberkommissar) 1353

Patzelt, Martin $666 \mathrm{f}$.

Paul (VP-Kommandeur) 1344, 1346

-, Rudolf 1016, 1326

Pauli (SED-Funktionär) 1173

Pavlik, Peter $\rightarrow$ Schmidt, Peter

Pawlitzki (Arzt) 938

Pech (MfS-Inspektor) 1348

-, Alois 701, 773, 906, 954 
-, Gisela 267

Peibi[ck?] (Beeskow) 1047

Peikert, Paul 67, 1458

Peisel[?] (VP-Kommandeur) 1340

Pekrul, Paul 228

-, Richard 227 f., 1458

Pelinka, Josef 307

-, Wenzel 307

Penner, Berta 172

Pereliwtschenko (sowjet. Offizier) 239

Pergande, Frank 497, $836 f$.

Perkuhn, Emma 126

Peschke, Cornelia 461

-, Reinhard 461

Pestka (Frau) 1243

Peter (Krayne) 763

-, Andreas 45, 353, 401 f., 717, 720-724, 1542

Peter-Palaske, Anja 1542

Peters, Curt 132, 1479

-, Dietlinde 213

Petersilie (Guben) $1334 \mathrm{f}$.

Petrick, Edgar 785, 1543

Petzoldt, Hans-Christian 477, $691 \mathrm{f}$.

-, Maria 384, 691 f., 1544

Pfandke (Guben) 1282

Pfeiffer (Joachimsthal) $1324 \mathrm{f}$.

-, Günter Wilhelm 676f., 1458

-, Gustav (Firma) 1295

-, Werner 217, 232, 627, 629, 1459

-, Willi 1425

Pfeiler, Jürgen 921, 1479

Pfitzner (Suchdienst) 591, 1251

Pflaum, Herbert 103, 629, 723, $740,810,812,1459$

Pfütze, Gertrud $\rightarrow$ Lohan

Philipp, Alois 1112

-, Fritz 852

-, Josef 1199

Pickert, Artur 1144

Pieck, Wilhelm 308, 348 f., 354, 618, 713f., 723-725, 775, 911, 1171, 1307, 1332f., 1336f., 1407, 1413, 1427

Pienski, Johannes 447
-, Paulinus 554, 954

Piepenburg, Fritz 688, 768, 1064, 1067, 1069, 1072, 1089, 1091, 1094, 1096, 1104, 1109

Pietsch (Kreisrat) 1285-1288

-, Helmut 1254

-, Luise 1295

Pillkahn, Hans-Dieter 1254

Pilvousek, Josef 37, 443

Pincus-Pamperin, Maxi 610, 1544

Pintsch (Firma) 687, 840

Pinzer, Hans 601

Piontek (Familie) 557

-, Ferdinand 37, 444, 756, 906

Piotrowski, Robert 1542

Piperek (Bergbaureferent) 1186

Pischel, Barbara 338

Piter, Martha 598

Pitschel (Buchhalterin) $105 \mathrm{f}$.

Pitschmann, Daniel 405

Pius XII., Papst 452

Plagemann, Karl-Ernst 511

Plath (Informant) 1300, 1304

-, Lothar 264, 337, 731, 1459

Plato, Alexander von 12

Platzeck, Matthias 480

Platzke, Max 289

Plinz. Emmi 259, 1231

Plontke, Paul 575

Pöhl, Gustav 1459

Pöhlchen, Brigitte 593

-, Gerhard 359, 489, $592 \mathrm{f}$.

Pötsch (Potsdam) 1241

Pohl (SED-Mitglied) 1243

-, Arthur 963, 967

-, Winfried 454

Pohland, Gertrud 1459

Pokriefke (Informant) 1083

Poldrack, Nele 781

Pollanetz, Maria 967, 1251

Polley, Detlef 89, 171

Polomka (Ketzin) 1113

Polzin, Ludwig 449, 451

Poppe, Gertrud 587-589, 637

Porada, Haik Thomas 28

Porras, Nery Arias 471

Porsack, Hugo 647
Porzig (Förster) 306

Posseldt, Gabriele 1459

-, Klaus 1459

Post, Georg 665, 673

Postkeller, Inge 728

Potratz (Frau) 269

-, Rainer 1482

Powal(l)ka (Frau) 1073

Praatz (Waltersdorf) 943

Pracht (Firma) 1244

Praetsch, Dora $\rightarrow$ Quast

Pragal, Peter 303, 814

Prange, Maximilian 166, 447, 453

Pratsch (Amtsleiter) 1243

Prause, Albrecht 874

-, Leonhard 900

Prawitz (Flüchtlingsfamilie) 197

Prenzel, Heinrich 367, 379

Prerauer (Zehdenick) 967

Prestel, Sonja $\rightarrow$ Mertens

Prestin (Dolmetscher) 1157

Preuß, Elisabeth 37, 443

-, Karl-Heinz 294, 418, 1459 f.

-, Ruth 97, 132, 287, 320 f., 331 f., 463, 486 f., 492, 819, 822,1460

Preysing, Konrad von 453, 1267, 1275, 1277-1280

Priemel, Kim Christian 12, 33

Prietz, Elly. geb. Brüggemann 622

-, Horst 505

Prihoda, Karl 831

Prillwitz (Altenhof) 1315

Probst, Richard 614

Prochnow, Ernst 560, 564, 637 f., 642, 702 f., 837, 839, 902, 904, 1460

Prutean, Steffi 818

Przemski (Frau, FDGB-Funktionärin) 260

Przyjemski, Frieda 1160, 1162

Przylucki (Lagerltr.) 563

Puchowski, Georg 586

Pündik (Major, Arzt) 673, 1422

Püschel, Almuth 24

Puhlmann, Bernd 322 
-, Karl 714

Pusowski, Boleslaus 1213

Puttkamer, Ilse Frhr. von, geb.

Schwabe 82, 1542

Putz, Jakob 509, 866

Puzik, Erich 825

Pusz, Zbigniew 771

Qualzek (SED-Funktionär) 1170

Quast, Dora, geb. Praetsch 1460

Quiel, Günter 472

Raabe, Moritz 752

Raasch (Schuhmacher) 410

-, Edith $\rightarrow$ Dietrich

Raatz, Margarete $\rightarrow$ Münchenhagen

Rabaschus, Gerhard 89, 1479

Rachner, Rosemarie $\rightarrow$ Franz

Radach, Hans 1211

Rademacher, Willi 763

Radochla, Rolf 194

Radoy, Renate 266, 268, 888

Rätzel, Hermann 1212

Rajche, Zbygniew 65

Ramatschi, Paul 825

Ramm (Ministerialdir.) 259

Ramoth, Siegfried 947-949

Randacek, Hans-Martin 511

Range (Firma) 1074

Raschke, Alfons 590

-, Karl 1296

Rasemann, Christian 509

Rasztuttis, Jürgen 601

-, Marianne 602

Rau (Zehdenick) 967

-, Heinrich 1225

-, Lucie 967

Rauer, Max 856

Rauh, Klaus 1016

Rauscher, Norbert 29

Rausendorff, Kurt 441

Rautenberg (Guben) 719

Reckling, Karl 749

Redlich, Marianne $\rightarrow$ Knospe

-, Wilfried 629, 648

Reemer (sowjet. Offizier) 1126

Reetz (VdgB-Mitglied) 1243
-, Joachim 479

Regieli, Marta 490, 1460

Reglin, Fritz 90, 112, 116, 695, 1479

Reibe (Frau) 289

Reich, Albert 339

-, Ines 952

-, Julius 606

Reiche, Steffen 19

Reichert, Werner 1460

Reiffler, Kathrin 705

Reile, Gebr. (Firma) 230, 778

Reim, Martin 416

Reimann (ZVU-Mitarb.) 1016

-, Bruno 54

-, Ceslawa 581, 656

-, Siegfried 416, 465

Reimnitz, Gisela 320, $1460 \mathrm{f}$.

Reinert, Fritz 48, 309

Reinitz (Familie) 74

Reiser, Alexander 501

Reising (Potsdam) 1230

Reißdorf (Schuhmacher) 678

Reitemeier, Ulrich 140

Reiter, Josef 749

Reitmeier-Zwick, Brunhilde 237, 606

Rekus, Helmut 895, 1251

Rellech[?], Kurt 1140

Remenyi, Friedel, geb. Berndt 365 f., 1461

Renke, Herbert 412, 799

Rennert \& Donath (Firma) 1299

Renziehausen (Rathenow) 1183

Resag, Petra 925

Rettig, Hanna 410

-, Herbert $409 \mathrm{f}$.

Reuscher, Joachim 105

Reuß ä. L., Hermine Prinzessin $\rightarrow$ Hermine

Reuter, Kurt 447-449, 638, 803, 870

Rex, Franz 197

Rhein (Familie) 1271

Rhinow, Hans-Ulrich 273, 1461

Ribbe, Klaus 963

-, Wolfgang 5, 15, 24f., 352
Richau, Martin 1542

Richter (Krayne) 763

- (VP-Oberkommissar) 1351

-, Hans (Germnaist) 418

-, Hans (Pfarrer) 440 f., 1341 f.

-, L. 740, 949

-, Lieselotte 75

-, Margarete 265, 946, 1461

-, Paul 649, 1079

-, Ute 267

Richtsteig, Eberhard 413

Riech, Benno 375, 1426

Riechert (Sembten) 1292

Riedel, Christhart 924

-, Heinz 700

-, Willi 763

Riedler, Willi $1243 \mathrm{f}$.

Rieger (Offizier) 532

-, Christian 790, 945, 1461

-, Helmut 274, 789 f., 1461

Riemann, Hartmut (Vaiciulis, Kazys) $220 \mathrm{f}$.

Rietdorf (Dallgow) 629

Rietschel, Wilhelm 1207

Ring, Walter 104

Rinsche, Cordula 19

Risch, Theodor 530, 1461

Risse, Kerstin 51

Rissmann (Lagerltr.) 937

Ritsche, Georg 1128

Rittau (Vertriebener) 558

Ritter (Falkenberg) 645

- (Pfarrer) 562

-, Christian 466, 569, $1542 \mathrm{f}$.

Rittwagen (Gutsbesitzerfamilie) 365, 417

Roch (Kaltenborn) 1286

Rocholl, Horst 288, 332 f., 1479

Rocksch, Wolfgang 297

Rodegast, Günter 45, 959

Roderburg, Hans 649

Rodewald, Karl 838

Rodominsky (Gastwirt) 586

Röder, Hans-Jürgen 930

Roeder, Hedwig 83

-, Hermann 83

Röger, Maren 339

Roehl, Christian 670 
Rölke, Hildegard 136, 149, 177, 220, 265, 287, 487, 490, 769, $1461 \mathrm{f}$.

Rösch (Lagerltr.) 676, 1422

Rösler, Andreas 60, 403, 1542

Rötche, Armin 865

Rogall, Joachim 99, 209

Rogge, Martin $771 \mathrm{f}$.

Rohde (Hauptgeschäftsf.) 438

-, Fabian 1543

-, Martina 691

Rohde \& Böttcher (Firma) 1206

Rohrlach, Peter P. 396, 421, 1479,1542

Roisch (Lagerltr.) 173

Rokohl, Rudolf 1092, 1104

Roland (Schöneiche) 896

Rommel, Barbara, geb. Scholtyssek $623 \mathrm{f}$.

Rooft (Frau) 1243

Rosal, Heribert 458, 783

Rosalski, Johannes 632

Rosenbaum, Katja 871, 1462

Rosenborn, Alida 1149

Rosenfeld, Max 394, $1344 \mathrm{f}$.

Rosenke, Adoline, geb. Müske 1463

Rosenow (LDP-Mitglied) 260

Roske, Peter 667, 1524

Roß, Signe 31

-, Werner 634

Rother (Referent) 1165

Rothgänger, Gertrud 865

Rothkegel, Gerhard 370

Rotzer, Augustin 890, 928, 930, 1542

Roy (Flüchtling) 85

-, Erika $\rightarrow$ Breske

Ruch, Christamaria 359, 489

Ruchniewicz, Krzysztof 129, 135,150

-, Małgorzata 97

Rudat, Joachim 485

Rübe (Lagerltr.) 1051

Rübensam, Erich 809

Rücker, Fritz 241 f., 245, 1232

-, Heinrich 811

Rückling, Stefan 147, 208, 1542
Rückwald (Lagerltr.) 877, 1075

Rüdiger, Adolf 1207

-, Jens $213 \mathrm{f}$.

Rüger, Hannelore 1544

Rühe (Lagerltr.) 773

Ruf, Johanna 673, 1479

Ruge, Ernst 668

Runge, Reinhard 44

-, Stefan 1210

Ruppert, Andreas 383

Rupprecht, Hans Joachim 606

Ruprecht, Karl 378

Rusche, Michael Richard 11, 271

Ruß (Neuruppin) 1192

Russe, Josephine 595

Russow (Stadtpolizeichef Rathenow) 1126

Rustin (Firma) 956

Rutschke, Auguste 750

Ruttig (Arzt) 789

Rymar, Edward 402

Saarfels (Grabow) 956

Sachse, Christian 841

Sack, N. N., geb. Kanisch 807

Saenger, Hedwig von 732

Salefsky, Herbert 110, 217, 538, 774

Sallanz, Josef 235

Samson-Himmelstjerna, Jesko von 853

Samulski, Robert 414

Sander, Thomas 512

Sanne, Annelise $\rightarrow$ Zippan

Saretz, Ernst 76

Sattler (Potsdam) 1185

-, Paul 767

Sauer, Kurt 606

Sauerwein, Katrin 27

Sauter, Paula $\rightarrow$ Gesell

Schaar, Max 1463

Schackwitz (Verwaltungsangest.) 259

Schade, Rolf 196

Schädler, Verena 209

Schädlich, Irmgard, geb. Stein 1542

Schäfer (Angermünde) 1012
-, Jeanette 821, 1375

Schaefer, Peter 505, 1542

Schäffer, Harry 1480

Schäpe, Günther 610

Schahn, Margarete 260

Schaper, Carl 893, 1480

-, Uwe 52

Schardt, Michael Matthias 1460

Scharf (Flüchtling) 875

-, Hans Wolfgang 102

-, Martha 259, 1231

Scharlowski, Hildegard 433, 694

S(c)harow (Sharov), Wassili M. 540, 1003, 1008, 1159

Schatta, Monika 1463

Schatte, Hartmut 187, 338, 355, 708,763

Schaudt (Storkow) 922

Schauer, Hans 368, 435

Schauka, Adolf 251

Scheel, Annelies 1543

Scheffler, Johann 307

Schefter, Liselotte 660

Schelenz, Curt 416, 427

Schellhaas, Ingrid 473, 692

Schellhorn, Karin 834

Schendel, Erhard 368, 435 f., 1354,1480

Schenzel, Leopold 408

Scherer (Geschäftsstellenmitarb.) 1261

-, Johannes 847

Scherhag (Steinmetz) 964

Schermall, Hilmar 1543

Schettler, H. 1211

-, Otto 416

Schian, Walter 438 f., 1256 f., 1263

Schich, Winfried 27, 457, 1542

Schicht (Frankfurt/O.) 672

Schieb, Roswitha 213, 339

Schieche, Manfred 187, 190, 329, 410

Schieck, Martin 41

Schieder, Theodor 46

Schiefelbein, Siegfried 115 f., 1480

Schieferdecker, Hans 368 
Schiemenz, Anna, geb. Harterl 391

Schietke, L. 86, 102, 1463

Schiff, Helmut 628

Schilde $\rightarrow$ Hermann \& Schilde

-, Kurt 240, 1542

Schildt, Paul 390

Schiller (Verf.) 355, 708

-, Fritz 259, 1231

-, Hartmut 213

-, Kurt 485

-, Werner 955

Schilling (Premnitz) 1376

-, Dieter 735

Schimmel, Michael 907 f., 1542

Schindler, Christine 701

Schippke, Günther 416

Schlabe, Heinz 912

Schladitz, Johanna, geb. Breuel 609,1480

Schläwe, Edeltraud 1440

-, Elisabeth, geb. Matz 1440

-, Otto 1440

Schlaffer, Josef 240, $1048 \mathrm{f}$.

Schlasse, Heike Eva 103

Schlaier, Claudia 509

Schleizer, Max 1212

Schlensog, Herbert 379

Schleusener, Erwin 300, 1215

-, Frank (Franz) 1186

-, Harald 1186

-, Werner 94, 1463

Schlösser, Udo 86, $1463 \mathrm{f}$.

Schlüter (Kremmen) 764

Schmaeling, Else 369, $411 \mathrm{f}$., 439, 1347, 1354

-, Paul 439, 1347, 1354

Schmahel, Ernst 698

Schmeissner, Dorte 309 f., 314

Schmelz, Ulrich 511

Schmelzer, Hans-Adolf 890-892, 1480

-, Hans-Jürgen 892, 1480

Schmetsdorf (Postlin) 1141

Schmidt (Abteilungsleiter) 242, 1356

- (Biesenthal) 995

- (Fürstenwerder) 90

- (Küchensee) 1061
- (Neuruppin) 1230

- (Premnitz) 859

- (Zehdenick) 967

- (Prof., Musiker) 1097, 1099, 1104

- (Referent der Textilindustrie) 1186

- (SED-Funktionär) 1160, 1164

- (Standortpfarrer) 77

-, Addi 1138

-, Christin 331, 884

-, E. (Elli?) 1248

-, Eberhard 1327

-, Elli 254

-, Gernot 907

-, H. (Pfarrer) 409

-, Herta 1295

-, Karl-Heinz 279

-, Laura Kerstin 509

-, Lucia 1464

-, Natalie (Natalya) 777

-, Paul 767

-, Peter (Paul Pavlik) 655

-, Roman 793

-, Steve 65, 1544

-, Ute 97, 234, 876, 898

Schmiedel, Wieland 821

Schmoger, Petra 499

Schmook, Reinhard 33, 339, $345,419,472,475,568 \mathrm{f}$., 907, 951, 961 f., 1542

Schmorell, Hans 962

Schmück, Hermann 690 f., 888, 1366

Schmückert (Potsdam) 1309f., 1333

Schmutzer, Hans $157 \mathrm{f}$., 301-306, 315 f., 335 f., 815 , 1428

Schnabel (Spremberg) 915

Schneemann, Elfriede 1113

Schneider, Aurelia 592

-, Claudia 12, 141, 143

-, Frank 504

-, Friedrich 100, $108 \mathrm{f}$.

-, Gerold 445, 483f., 618, 620, 1464, 1527

-, Hans-Georg 46
-, Hildegard 826, 1480

-, Inge 881

-, Joachim 46, 103, 966, 970

-, Karl-Heinz 471, 585, 1464

-, Rolf 193

Schneider \& Lokai (Firma) 1207

Schnell, Gabriele 352

Schnick, Horst 227, 472 f., 777

Schnirpel (Wollstein) 193

Schob, Hedwig, geb. Kübelstein 647,1480

Schober, Albert 750

Schober-Wischkony, Simone 1542

Schöbitz, Ernst 351, 1324

Schöller, Margarete 1121

Schön, Albert 343

Schönberger (Konditor) 422

Schönbohm, Jörg 470

Schoenborn, Heinrich 414

Schönebeck (Stadtrat) 1326

Schönemann, Giesela $\rightarrow$ Lohkamp

-, Ilse $\rightarrow$ Dutkowski

Schönfeld (Jüterbog) $1041 \mathrm{f}$.

-, Wilhelm 384

Schönfeldt, von (Gutsbesitzer) 272, 947

Schönherr, Hans 948

Schönig, Gertrud 297, 1480

Schöning, Erich 251, 1081

-, Wilfried 488

Schönke, Günther 673, 1480

Schönleber, Albert 512

Schöps (Gramzow) 350, 1321

-, Manuela 82

Schötschel, Friedrich 788

Schöttler, Hermann 595

Scholl-Schneider, Sarah 417

Scholtyssek, Barbara $\rightarrow$ Rommel

Scholz (Kyritz) 1230

- (Ministerialdir.) 259

- (ZVU-Mitarb.) 1081

-, Anton 600

-, E.J. 1208

-, Franz (Görlitz/Cottbus)

620 f., 1464 
-, Franz (Leegebruch) 307

-, G. 1208

-, Gesine 509

-, H. 1211

-, Joachim 433, 669

-, Michael 55

- , Selma $\rightarrow$ Wehner

-, Stephan 339, 478

Scholz-Padiéra, Friedrich 932

Scholze, Thomas 31

Scholze-Irrlitz, Leonore 31, 60, 335

Schopper, Franz 34

Schott, Christian-Erdmann 36

Schrader, Hans-Georg 969

Schramm, Theodor 573

Schrammek, Notker 10, 47

Schraut, Sylvia 255

Schreckenbach, Hans-Joachim 48, 309

Schreiber (Flüchtlingsfamilie) 452

-, Hugo 234

Schreiner, Klaus 29

Schröder (Firma) 1074

-, Jochen 329, 745, 1542

-, Kathrin 799

-, Kurt 618

Schroubek, Georg R. 705

Schubert (Wittenberge) 957

-, Blandina 612, 656

-, Dagmar 234, 920

-, Ernst 76

-, Franz 609, 942, 1137

-, Gertrud 385

-, Melitta 610, 1542, 1544

Schüler, Paul 1352

Schülke, Gustav 433, 782

Schünemann (Flüchtlingsfrau) 89

Schüttke, Helmut 658

Schütz, Erich 700

-, Frank 700

Schütz \& Bethke (Firma) 288 f., 343 f., 1206

Schütze (Krayne) 763

Schukow (Shukov), Georgi K. $157,160,647,739$

Schuler, Peter-Johannes 17
Schultz, Helga 348

Schultze, Alfred 949, 951

-, Jeannette 1412

Schulz (Frau) 1243

- (Gutsbesitzer) 474

- (Ketzin) 1113

- (Krayne) 763

- (Kreisrat) 1244

- (Wollstein) 193

-, Alfred 362

-, Alwin 653, 1154

-, Barbara 34, 170

-, Emma 1213

-, Friedrich 289 f., 869

-, Fritz (Bürgermstr. Fürstenberg/O.) 685

-, Fritz (Flüchtling) 127, 1464

-, Georg 289f., 869

-, Gerd 1464

-, Gisela 267, 763

-, Gustav 949

-, Heinrich 272, 623, 947

-, Herybert 110, 289 f., 548, $841,871,1464$

-, Ilona 498 f., 623, 836, 1542

-, Karl Wilhelm 695, 1542

-, Martha-Maria 488, 541, 1364

-, Otto 382

-, P. (ZVU-Mitarb.) 1012

-, Paul 289

-, Ruth 416

-, Trautchen 362

-, Walter 415

Schulz \& Schöler (Firma) 289

Schulz-Rosengarten (Familie) 474

Schulze (Arzt) 698

- (Kreisinspektor) 1296

- (Luckenwalde) $1238 \mathrm{f}$.

- (Vertriebene) 365

-, Dietmar 116, 189

-, Erika 1460

-, Eva 120, 1432

-, Heinz 84

-, Henryk 745

-, Honorata 581

-, Irene 488

-, Jörg 102
-, Martha 117, $1480 \mathrm{f}$.

-, Otto (Guben) 716

-, Otto (Kriebau) 1460

-, Renate 469, 1370

-, Siegfried 324, 1464

-, Sieglinde 285, 1481

-, Werner 851

Schumacher, Kurt 271, 1299

-, Siegfried (Firma) 780

Schuppan, Erich 635-637, 639, 641

Schurig, Leander 490

Schuster, Hans-Georg 969

-, Manfred 1481

Schwab, Irina 10

Schwabe, Ilse $\rightarrow$ Puttkamer

-, Karl-Heinz 839

Schwachenwalde, Karl 155

Schwadtke (Stadtrat Guben) 1295

Schwark, Erich 1208

Schwartz, Michael 9, 1-15, 53, $68,239,243,245-249,255$, 270, 363 f., 380, 405, 407, 507,846

Schwarz $\rightarrow$ Lidl \& Schwarz

- (Amt Joachimsthal) 1542

- (Oberbürgermstr. Guben) 1292

- (Potsdam) 249

-, Elimar $792 \mathrm{f}$.

-, Erna 948

-, Friedrich 249

-, Kathrin 11, 45

Schwarzlose, Gerd 328f., 1542

Schweitzer, Albert 356, 851

-, Willy 653

Schwerin (Flüchtlingsfrau) 274

-, Detlef Graf von 314

Schwillus, Harald 38, 442, 449

Schwob, Fritz 248, 1116, 1130, $1166,1235,1412$

Schymiezek, Josef 1210

Sebastian, Aloysiana 581

Seeberg, Heinrich 869

Seefeld, Erich 718, 723, 1481

Seeger, Dieter 1481

-, Kurt 112, 1481

-, Ronald 481, 878 
Seehawer (Neubauer) 316

Seele, Johannes 104

-, (Rudolf?) (Gesundheitsdezernent Eberswalde) $635 \mathrm{f}$., 638

Seering, Kurt 104

Seghers, Anna 69 f., 1415

Seher, Florian 1542

Seibt, Kurt 1026, 1235

Seidel, Bruno 600

-, Hellmut 94, 209, 396

-, Ursula $\rightarrow$ Weinkauf

Seider, Frank-J. 1542

Seidler (Arzt) 698

Seifer (Kerkwitz) 748

Seifert (Neukietz) 367

- (VP-Rat) 1354

-, J. 1212

-, Mario 853, 1542

Seils, Mirjam 11, 53, 78, 364, 405, 407

Sell, Marlies 1544

Sellschopp, Ursula 669

Semaška, Darius 846

Sembritzki, Mario 102, 956, $958 \mathrm{f}$.

Semmelmann, Dagmar 18, 60, 290, 357, 1429

Sendhoff, Heinrich 242

Sendhoff(-Trinkaus), Magda (Magdalene), geb. Müller 163, 240-245, 260 f., 999, 1004, 1009, 1019, $1025 \mathrm{f}$., 1151, 1419

Senftleben, Peter 376

Sengbusch (Gastwirt) 484, 870

Senninger, Maik 328

Senst (Neuheim) 814

-, Gerhard 743

Sepanski, Arnold 705

Seraphim, Peter Heinz 196, 406

Settegast, Thomas 776

Sewerin, Gertraud 88, 121, 218, $582,827 \mathrm{f} ., 1481$

Sharov (Sharow) $\rightarrow$ Scharow

Shukov, Georgi K. $\rightarrow$ Schukow

Sicker, Karl 1281, 1283 f., 1290 f., 1293-1295, 1298, 1300, 1302-1304, 1334
Siebel-Achenbach, Sebastian 128

Sieberhagen, Maik 656

Siebert (Storkow) 1098

Siedler, Alois 489, 1465

-, Helga 489, $1464 \mathrm{f}$.

Siefert, Peter 148

Siegener, Heinz 1209

Siegert (Pieskow) 1059

Siek, Erich 812

Sielmann, Ina Maria, geb. Ohnesorge 112,1481

-, Michael 112, 1481

Siemens (Firma) 647

Sienkiewicz, Witold 72

Siewert, Hannelore $\rightarrow$ Krieglstein

Silz (Ofensetzer) 274

Simke (Herzberg) 735

Simmack, Irene 1334

Simon, H. (Werder/H.) 951

-, Werner Oskar 400

-, Wolfgang 871

Sindakowski, Willi 1209

Singelnstein, Christoph 503, 1466

Singer (Grünheide) 710, 1198

Sivers, Siegfried von 291, 1465

Sjöberg, Hanna 854

Skerl (Flüchtlingsfrau) 130

Skerra, Horst 294

Skomski (Firma) 1191

Skotnicki, Jutta 812, 1432

Skrabania, David 13

Smelz, Gregor 742

Smolka (Frau, Finsterwalde) 656

Snoppek, Georg 1212

Sobol (Frau, Großenstein) 398

Sobottka-Heese, Kathrin 737

Sokolowski, Wassili D. 1232

Solbrig, Erika, geb. Adam 855, 1465

Sömisch (Lübben) 1230

Sommer (Kreisbaudir.) 93

-, Fritz 1331, 1336

-, Rosemarie 576

Sommerfeld, Willy 1206

Somow (sowjet. Major) 1039, 1082
Sonnenberg (Frau, Kremmen) 764

Sonnemann, Lothar 61, 149, $180,191,214,276,287,841$, $921 \mathrm{f} ., 1465$

Sonntag, Inge, geb. Borbs 948

-, Oliver 1542

Spangenberg (Angermünde)

1313, 1323, 1329

Spatz, Christopher 16, 224

Speckmann, Hans-Joachim $830 \mathrm{f}$.

Speich, Olga 869

Spenn, Wilhelm 98, 1481

Sperfeld (Jeserig) 742

Sperling, Margret 63

Spiegel, Georg $1327 \mathrm{f}$.

Spiegelberg, Annemarie 250, 1419

Spiegel-Schmidt, Friedrich 510

Spieler, Silke 1433

Spiesecke (Kaufmann) 873

Spiller (Referent) 1165, 1167

Spillner (Ausschussleiter) $1160 \mathrm{f}$.

Spittmann, Ilse 69

Spitz, Edith $\rightarrow$ Britzen

-, Karl 404

Spitzer, Hartwig 330, 336, 505, 1465

Spix, Boris 313

Spree, Richard 653

Springer (Beeskow) 1085

-, Philipp 266

Sproßmann, Heinz 1465

Sprungala, Martin 1542

Spurný, Matěj 78, 128 f., 157

Sschistow $\rightarrow$ Tschistow

Staaden, Elisabeth 930

Stabingis (Lagerltr.) 645

Stach, Rudolf 1211

Stachat, Elfriede 1439

-, Friedrich Kurt 1439

Stachowiak, Alfons $1465 \mathrm{f}$.

Stade, Martin 907

Stage, Hannelore 673, 1481

Stahl, Hans-Joachim 92

Stahlberg (Frau) 411

Stalin, Josef W. 232, 296, 560, 691, 914, 1284f., $1332 \mathrm{f}$. 
Stang, Werner 41

Stange, Max 1334

Starig, Walter 655

Stark, Detlev 401, 423 f., 1542

-, Inge, geb. Hartwig $423 \mathrm{f}$., 821

-, Meinhard 1482

Starkbauer, Karl 565

Starke, Karin $\rightarrow$ Uhlemann

Staske, Konrad 1466

Ste(e)ger (Referentin) $1184 \mathrm{f}$., 1187

Stechbart, Monika 938

Stechow, Bernhard 63

Steffani, Johannes 433, 669

Steffen, Willi 908

Steffens-Pritzkuleit, Annett 1474

Stege (Kletzke) 1144

Stegemann, Wolfgang 45, 112, 682,880

Steimer (Ministerialdir.) 259

Stein (Beeskow) 1093

- (Storkow) 1085

-, Fritz 1211

-, Irmgard $\rightarrow$ Schädlich

-, Norbert 235

Steinbach, Erika 468, 832

Steiner (Kapelle) $1085 \mathrm{f}$.

-, Edgar 39, 45

Steingräber, Joh. 368

Steinhauf, Andy 346, 770-772, 1542

Steinhaus, Heinz 1210

Steinhoff, Karl 297, 839, 1000, $1017 \mathrm{f} ., 1156 \mathrm{f}$.

Steinmetzger, Waltraud 853, 859

Steinwachs, Friedrich 930

Stellmacher, Gerda 112, $1481 \mathrm{f}$.

Stelter, [Gerhard?] sen. (Pritzwalk) 870

-, Siegfried 871

Stelzer, Fritz 1211

Stempel, M. 1261

Stengler, G. 707

Stenzel (Strasburg) 924

-, Jürgen 36, 1543

Stephan, Klara 587, 589, 975, 993-995
-, Ulrich 348

Stern, Carola 1429

Stertz, Herbert 1459

Steudtner (Potsdam) 1226

Steyer, Claus-Dieter 500

Stich, Jürgen 930, 1544

-, Karl

Stickler, Matthias 381, 473

Stiemke, Christa, geb. Meier $152,174,319,324,332$, 1466

Stier, Frank 281

Stiller, Charlotte 412

Stober, Reinhard 852, 1359

Stock (Lagerarzt) 877

Stockmann, Heinrich 1213

Stöcker, Joachim 831, 1466

Stößinger, Renate 196, 1433

Stojanowski, Michał 1460

Stokłossa, Katarzyna 14, 33, 348

Stolpe, Manfred 19f., 463, 470, 474, 482 f., 503, 691, 771, 820, 832, 1418, 1466

Stolpmann, Bruno 628

Stolz (Flüchtlingsfamilie) 837

Storch (Dr.) 330

Stosiek, Robert 756

Straaten, Werenfried van 462

Streckenbach, Elke $\rightarrow$ Wöstenbach

Streese (Flüchtlinge) 838

Streit (Ministerialdir.) 259

Strenge, Sigrid 39

Streuber (Rathenow) 1230

Strich, Hans-Joachim 804

Strohfeldt, Guido 689, 1543

Stroilow (sowjet. Major) 1309

Strom (Premnitz) 1376

Struck (Potsdam) 1121

-, Wilhelm 870

Strunk (Wollstein) 193

Struwe, Kurt 908

-, Meta $\rightarrow$ Buchholz

Struzina, Rudolf 701

Stümke (Arzt) 865

Stünzner-Karbe, Karl-Christoph von 692

Stürmer, Wilhelm 960
Stumpe $\rightarrow$ Berger \& Stumpe

Sturm, Christa 707

Stuttland (sowjet. Major) 1082

Stuttrich, Inge $\rightarrow$ Dallorso

Sucker, Gerda 258f., 267 f., 1196 (Su.), 1200, 1231

Suckut, Siegfried 1473

Sudaref(f) (sowjet. Offizier) 1067, 1073

Sühring, Johanna 966

Süßenbach (Luckenwalde) 1119

-, E. 1289

-, W. 1135, 1138

Suhr (Brandenburg/H.) 1185

Sundhausen, Holm 20

Suntheim, Hannelore 1543

Svenson (Beeskow) 1178

Swobodzinski, (Franz?) 789

Sychold, Erich 310, 942 f., 1534

Sydow, Georg 927

-, Richard 742, 938

Syma, Josef $733 \mathrm{f}$.

Szalai, Wendelin 61

Szillat, Paul 1124

Taag, Werner 851

Tamaschke, Grete 323, 1466

Tankeren, Marga van 39

Targiel, Ralf-Rüdiger 81, $671 \mathrm{f}$., 1482,1544

Taube, Silke 831

-, Walter 438, 1261

Taubenthal, Walter 86

Tebarth, Hans-Jakob 1544

Teichmann, Ernst 728 f., 1482

Teubner, Anika 920

Thal, von (Arzt) 768

Thälmann, Ernst 776, 1446

Theel, Otto 852

Theil, Jürgen 15, 509

Theilig, Stephan 964, 1542

Theissing, Heinrich 450, 620

Themel, Karl 76 f.

Ther, Philipp 9, 11, 17

Theune, Claudia $34 \mathrm{f}$.

Thiede, Hans-Joachim 58, 504, 1466

Thiel, Anneliese 220, 1467 
-, Heinz 688

-, Heinz Dietrich 451

Thiele (Belzig) 578

-, Herbert 259, 1160, 1164, 1231

-, Jutta $\rightarrow$ Jäzoch

Thielow (Firma) 655

Thieme, Bernhard 208, 567, 646

-, Hans 99, 1482

-, Lotte 99, 112, 121, 1482

Thom, Fritz 1482

Thomas, A. 413

Thüsing, Andreas 47

Thüte (Lanz) 548

Thum, Gregor 128

Thurian, Heinz 355, 425

Tiemann (Wollstein) 193

Tietz, Alfred 1285

Tiews, Alina Laura 334

Tilgner (Krayne) 763

Timm (Referent) 251

-, Gertrud $\rightarrow$ Friedrichs

-, Marion 867

-, Reinhard 867

Tippmann, Manfred 1434

Tischner, Wolfgang 47, 126, 451

Titze, Heribert 621, 753, 909

Többe-Wehberg, Karin 208, 1542

Töpler, Winfried $37 \mathrm{f}$., $48 \mathrm{f}$., $56 \mathrm{f} ., 443,1542$

Töppel, Erich 1368

Tolzmann, Eckhard 799, 1542

Tonn, Hans, 1186

Topp (SED-Funktionär) 371, 1128-1130

Traba, Robert 196, 1433

Träger (Kriminalpolizeileiter Rathenow) 1127

Tragelehn, Bernhard Klaus 909, 1416

Treder-Schmidt, Lothar 29, 1461

Treichel, Ursel 794

Treziak, Ulrike 213

Trimkowski, Horst 831

Trinkaus, Hermann 242 f., 1419
Trispel, Fritz 263, 748, 1251, 1254

Troebst, Stefan 20

Trüschel (Lübben) 797

Trzcielińska-Polus, Alexandra $428 \mathrm{f}$.

Tschaikowsky, Peter 300

Tschäpe, Karl-Konrad 46

Tschampel (VP-Kommandeur) 1350

Tschebattero (sowjet. Offizier) 1061

Tschechne, Gerd 921-923

Tscheschner, Dorothea $402 \mathrm{f}$.

Tschesno(-Hell), Michael 240, 300, 1081

Tschetschog, Erich 578 f., 581, 606

Tschirpig, Gerhard $361 \mathrm{f}$.

- , Jutta $\rightarrow$ Noll-Haiduga

Tschistow (Sschistow), Wladimir Afanasjewitsch 253, 1157

Tschöcke, Werner 623

Tumpach, Gregor 1542

Turek, Gertrud 607

Tyrolt, Margarete 1482

Udolph, Jürgen 30

Ueberholz, Kurt 932

Uhle, Reinhard 1132

Uhlemann, Karin, geb. Starke 777,1467

Uhlig, Judith 1542

Ulbricht, Walter 346, 348, $1171,1242,1413$

Ullmann, Alois 157

Ulm (Bernau) 1082

Ulrich, Karl 307

Ungar, Erwin 447, 667, 912

Unger, Hans-Dieter 68, 1482

-, Johannes 14

-, Ulrike 781

Urban, Gabriele 1544

-, Martin 592

Urbansky, Josef 315

Vaiciulis, Kazys $\rightarrow$ Riemann, Hartmut
Varchmin, Bertha 782

Vastag, Hans 339

Vattenfall (Firma) 655, 762

Veihelmann, Tina 212

Versen, Ernst 208, 619

Verwiebe, Franz 1205

Vier (Familie) 694

Viergott (Familie) 388

Völck (Firma) 956

Völker (Lehnin) 781

-, Eberhard 203, $213 \mathrm{f}$.

-, Elisabeth 702, 1482

Völz, Otto 1137, 1186, 1204

Vogel (Lagerltr.) 676

-, Georg 266, 813

-, M. 1213

-, Martin 480

-, Werner 22, 474, $476 \mathrm{f}$., 691 f., 1542

Vogenbeck, Bernd 128, 419

Vogt, Art(h)ur 2401168 1171, 1175, $1243 \mathrm{f}$.

Voigt, Detlef 945

-, Günter 65, 1431 f., 1467

-, Horst 73, 1209

-, Irina 64

-, Karl 524

-, Waltraut 1467

Volkmann, Helga 169

-, Rolf 169

Volkner, Joseph 939

Vollmer, Katharina 130, 1452

Vollrath (Arzt) 1016

Vorländer, Herwart 122, 125

Vorwerg (Eberswalde) 636

Voss (Frau, SED-Mitglied) 1174

-, Heli 66, 1431, 1460

- , Lena $\rightarrow$ Ohnesorge

Wachs, Reiner 930

-, Thomas 607

Wachtmann, Marianne 64, 1432, 1448, 1543

Wacker, Günther 316, 834

Wackernagel, Hans 779

Wagenknecht, Günter 111, 217

Wagner (Flüchtling) 95

-, Frieda 966 
-, H. (Arzt) 769, 773, 1046, 1049, 1056

-, Hans 790

-, Jens-Christian 35

-, Stephan 459, 753

Walde, Charlotte 1113, 1204

Walde-Verlag 1211

Waldoch (Fürstenwalde) 688

Wallenta, Roy 859, 1376, 1378

Wallis, Max 369

Walpuski (Mitarb. des Landesarbeitsamtes) 259, 1187

Walter (Arzt) 611

- (Krayne) 763

Walther, Gerhard 838

-, Manfred 471,798f., 852, 1542

-, Otto 838

-, Peter 59, 1432

Walz, Hans-Dieter 954

-, Tilo 964

Wancerz-Gluza, Alicja 421

Wandam, Johannes 370, 440

Wandke, Horst 83, 196

Wargenau, Katalin 497, 954

Wargin, Ben 906

Warmbold, Alfred 685, $1467 \mathrm{f}$.

Warnecke (Arzt) 1055

Warnke, Johannes 1348

Wartenberg,, Emil 412

Weber (Konrektor) 993

-, Babette 509

-, Emil 1468

-, Ernst-Günter 82, 119, 1468

- , Heidelinde $\rightarrow$ Fabig

-, Matthias 140

-, Marianne 97

-, Max 97

-, Otto 104

-, Paul 1269

-, Simone 859

Wedemeyer, Anne von, $\rightarrow$ Klitzing

Wegener (Ministerialdir.) 1160

-, Anne 1480

-, Frieda 967

Weger, Kurt 1212

-, Tobias 339, 342

Wegert (Fürstenberg/H.) 272, 680
Wegner (Ministerialdir.) 259

-, Georg 411, 439 f., 1347

Wehner, Selma, geb. Scholz 329

Weidland (Rathenow) 1126

Weidner, Dagmar 178, 768 f., 1482

Weiduschat, Gerhard 692, 1542

Weigelt, Andreas 22, 37, 183, 740 f., 1430

-, Reinhard 31

Weimann, Horst 136, 1468

Wein, Karl 392

Weinkauf, Harold 1468

-, Ursula, geb. Seidel 1468, 1482

Weise, Gerhard 1468

-, Kurt 1468

-, Sigrid 908

Weiß, Arthur 88, 234f., 315, $806,1468 \mathrm{f}$.

-, Josef 369

Weiss, Karl 1210

Weiß, Konrad 359, 1469

-, Paul 750

-, Waltraud 692, 1482

Wekel, Friedrich 36

Welk, Ehm 562

Wellnitz, Britta 76

Wendel (SED-Mitglied) 1174

Wendisch, Otto $843 \mathrm{f}$.

Wendler, Simone 468

Wendt (Forst/L.) 660

-, Kurt 222, 902

Wenzel, Alfred 801

-, Berta 365

-, Mario 11, 17 f., 45

-, Reinhard 690

-, Renate 273

-, Theodor 432

Wenzke, Rüdiger 294

Wenzl, Thomas 1350

Werdeck, Luise von $929 \mathrm{f}$.

Werin (sowjet. Oberst) 1121

Werner, Heinrich 825

Wernicke, Hilda 1469

-, Thomas 508, 854

Wernitz, Wolfgang 1482

Wernsdorf (SED-Funktionär) 260, 1126, 1196, 1235
Westhoff, Tobias 1543

Westphal (Frl., Flüchtling) 647

- (Kabarett-Truppe) 1092

- Mitarb. d. Landesarbeitsamts) 1185

-, Hans 447, 811

Wetschorek (Bernau) 1081

Wetzel (Freyenstein) 678

Weyer, Annemarie 112, 1483

-, Helmut 126

Wichmann, Henryk 705

Wicke, Fritz 260

Wiebach, Albert 930, 1483

Wieck, Michael 153f., 170, 172, $175 \mathrm{f} ., 1469 \mathrm{f}$.

Wiede, Walter 181, 277, 695, 866,1470

Wieke, Thomas 930

Wiesenthal, Simon 473

Wiesner, H. 186

Wietzke (Suchdienst) 598, 1251

Wilbers, Peter 788

Wildt, Michael Vf., 24, 1543

Wilhelm I., Deutscher Kaiser, König von Preußen 341

Wilhelm II., Deutscher Kaiser, König von Preußen 665

Wilhelm, Ulrich 472

Wilk, Werner 321

Wilke, C. G. (Firma) 716, 1295, 1473

-, Dorothea 729, 1483

-, Florian 343, 689, 1542

-, Jana 487, 725

Wilkens, Henrich 447

Will (Flüchtlingsfamilie) 109

-, Gertrud $\rightarrow$ Will

Wille, H. (Kremmen) 764

-, Manfred 9, 11-13, 47 f., 51, $78,139,157,240,308,335$

Wimbauer, Tobias 104,855 , 955

Winkler (Guben) 1230

-, Gunnar 266

-, Hans-Dieter 472

Winogradsky (sowjet. Hauptmann) 253

Winter (Ministerialdir.) 259 
-, Gertrud 574

-, Heinz 133, 1470

-, Wal(d)traut 156, 1470

Winterberg, Sonya 221, 226

Winterstein, Ulrike 10, 37

Wintsche, O. 1207

Wintzingerode, von (Frl., Heiligengrabe) 732

Winz, Ulrich 324, 359, 1483

Wirth, Alma 1470

-, Gisela 314, 785

-, Günter 321 f., 363

Wistuba, Leo 734

Witt $\rightarrow$ Herzog

-, Hans 699

-, Hermann 1209

Wittchen, Luzie 129, 723, 1470

-, Mathy 806

Wittenberg, Hannes 512

Wittig, Ricardo 818

Witthuhn, Werner 1059

Wittmeyer, (Heinrich?) 1014

Witzke, Franz 373

Wlassow, Andrej 171

Wodarz, Leo 1211

Wodtke, Hans-Jürgen 45, 1432, $1470 \mathrm{f}$.

Wöhler (Fahrland) 1226

Wöhling (Sachbearb.) 1165

Wöhlke, Adelheit, geb. Kalliske 362

Woelk, Franz 1208

Wöstenberg, Elke, geb. Streckenbach 418

Woike (Bauer) 131

Woitzik, Manfred 41, 55

Wojahn, Eberhard 834

Wolf (Kreisbaumstr.) 1296

- (Potsdam) 855

- (Tuchfabrik, Guben) 1470
-, Christa, geb. Ihlenfeld 417-419, 755, 1417, 1471

-, Hans-Jürgen 1463, 1474

-, Tilo 628

Wolff (Berlin) [?] 369

- (Lagerltr.) 961

- (Vehlefanz) 1111

-, Paul 114, 1483

Wollbrügge (Ketzin) 1113

Wolter (Angermünde) 1230

- (ZVU-Mitarb.) 1009, $1081 \mathrm{f}$.

-, Michael 903

Worbs, Susanne 497

Worgull (VdgB Bornstedt) 1226

Woth, F. 1208

Wrzesiński, Wojciech 213

Wulff (Lagerltr.) 557

Wuntke, Hildegard 62, 297, 437, 1471

Wustmann, Markus 10, 36

Wuttke, Alois 450

Wylezalek, Horst 847

Wypyrczyk, Hildegard 957

Zache, Ingrid $1542 \mathrm{f}$.

Zachow (Glöwen) 698

Zahn (Lagerltr.) 649

Zalewski, Paul 103

Zann[?] (Potsdam) 1213, 1215

Zappe, Günther 910

Zarbock, Paul 1205

Zastrow, Fritz 567

Zawacki, Josef Maria 734, 899

Zdrenka, Joachim 960, 1542

Zeh, Alfons 775

-, Manfred 294

Zehbe, Lucie 1471

Zeidler, Hans 297, 897, 1471

Zeihn, K. 758

Zeise[?] (Neuruppin) 1192
Zemmin, Harry 806

Zeptner, Katrin 722

Zerssen, Hanns Wulfert von 1144

Zeschke (Groß Breesen) 1282

Ziebarth (Kreisrat) 1289

Ziegenhagen (Belzig) 1230

Ziegler, Christel $\rightarrow$ Neumann

-, Martin 328

Ziel, Alwin 62, 64, 503

Zielke, Reinhold 62, 1429

Zietmann, Uwe 704

Zietz (Sparkassenangestellte) $105 \mathrm{f}$.

Zimmer (Frau) 412

-, Gerhard 412

-, Siegfried 584

-, Volker 157

Zimmermann (Ärztin) 1011

- (Handwerkskammer-Mitarb.) 260

- (Potsdam) $1165 \mathrm{f}$.

- (Rathenow) 1230

-, Birgit 511

-, Irma 1472

-, Volker 228

Zindler (Potsdam) 270f., 1171-1173

Zinke, Johannes 451, 621, 1369

Zinnau, Rudolf 1058

Zippan, Annelise, geb. Sanne 376, 1472

Zirkel (Küchensee) 768

Zöbisch (Zoebisch?), (Karl?) (Arzt) 1055

Zoeckler, Theodor 1261

Zölker, Christian 290

Zuch, Käte 385

Zuchold, Gerd-H. 1542

Żurek, Robert 447

Zwiers, Rainer 500, 623, 835 


\section{Sachregister}

Bei Verweisen auf dem Sachbegriff in Gänze gewidmete Abschnitte sind die Seitenzahlen kursiv gesetzt.

Abendmahlsfeier 76, 439, 693, 1092

Abendstudium 1440

$\mathrm{ABF} \rightarrow$ Arbeiter-und-Bauern-Fakultät

Abgabesoll $\rightarrow$ Ablieferungssoll

"Abgebrannte“ 695

Abkündigung 431, 875

Ablieferungs-, Abgabe-, Getreidesoll, Getreide-, Sollabgabe, Kontingent-, Pflicht-, Sollablieferung $304,695,1119,1221$ f., 1224, 1227 $1229,1291,1413$

ABM (Arbeitsbeschaffungsmaßnahme) 37, 472, 799,878

Abort, -anlage $\rightarrow$ Bedürfnisanstalt

„Abreisebescheinigung “ 122

Abrüstung 1303, 1306

Abschleusung 1046

Abstammung (ethnischer Bezug), deutsche, „deutschstämmig“ (vgl. $\rightarrow$ „Volksdeutsche“) 145, 496, 671, 859, 893, 1394; polnische 671

Abtreibung $\rightarrow$ Frauen

Abzeichen $\rightarrow$ Friedensabzeichen

Ackergerät (vgl. $\rightarrow$ Wirtschaftsgeräte) 1138, $1147,1218-1220,1225$

Ackerkutscher 1315, 1322

Ackerwagen 108, 1138

Ada-von-Manteuffel-Stift 590

Adelsfamilien, ,Junker“ 90-93, 113, 118 f., 283, 298, 311, 590, 732, 883, 1132, 1449, 1472

AdM $\rightarrow$ Arbeitsgemeinschaft der Memellandkreise ADN (Allgemeiner Deutscher Nachrichtendienst) 652, 1251, 1381

Adressenlisten $\rightarrow$ Anschriftenlisten

Adventgemeinde 335

Adventsfeiern $439 \mathrm{f}$.

Ängste $\rightarrow$ Angst

Ärzte, ärztliche Betreuung, Hilfe, Untersuchung (siehe auch $\rightarrow$ Amts-, $\rightarrow$ Kreis-, $\rightarrow$ Tier-, $\rightarrow$ Treck-, $\rightarrow$ „Umsiedlerlager"/Lagerarzt, $\rightarrow$ Zahnarzt) 30, 52, 56, 61, 98, 101, 124, 130, 132, 153, 179, 181, 183, 187 f., 191, 232, 251, 284, 287 f., 332, 357 f., 433, 499, 504, 552 f., $561,568,576,593,611,618,625,636$ f., 664 f., $679,688,700,720,736,739,768$ f., 773, 782, $789,795,806,828,921,938,959,1004,1010$
1013, 1016f., 1019, 1040, 1045, 1049-1051, 1054f., 1064-1066, 1075 f., 1131, 1159, 1165, 1177, 1192, 1194, 1275, 1339, 1344 f., 1439, $1465,1475-1481$

- Dienstverpflichtung im Lager 789, 1055

- Gynäkologe 232, 504, 552 f., 669, 962, 865, 1055,1478

- Lungenfacharzt 655

- sonstige Fachärzte 251, 553, 962, 1049, 1065 , 1439,1478

Ärztin 177, 184, 289, 500, 595, 669, 848, 1006, $1011,1014,1075,1479,1481$

AfD (Alternative für Deutschland) 469

Afghanen 512

AGoFF $\rightarrow$ Arbeitsgemeinschaft ostdeutscher Familienforscher

Agrarhistorisches Museum Schwerin $\rightarrow$ Museen

Akademie der Bundeswehr (Strausberg) 926

Akademie der Landwirtschaftswissenschaften 834

Akademie der Wissenschaften der DDR 1458

Akademie für Gesellschaftswissenschaften beim ZK der SED 229

Akademie für Staats- u. Rechtswissenschaften (Potsdam-Babelsberg) 505

Akten, Verwaltungsschriftgut (Evakuierung, Verlagerung; siehe auch $\rightarrow$ Dokumente) 108 , $647,675,814,819,836,931$

Aktentasche 784

Aktion „600.000“ 228

Aktion „Aus Alt mach Neu“ 966

Aktion „Kaliningrad“ 225, 1045

Aktion „Rettet das Kind!“ 267, 587, 624

Aktion „Rote Faust“ 652

Aktion "Shukow" $\rightarrow$ Shukow-Aktion

Aktion „Swallow“ (Schwalbe) (1946) 150

Aktion „Ullmann“ 157

Aktion „Wir bauen auf“ 1411

Aktionsausschuss Bodenreform 957

Aktivist 1315

Albert-Heyde-Stiftung 569

Albertinum $\rightarrow$ Pastoralseminar Albertinum

Albertus-Magnus-Kolleg (Königstein im Ts.) 444

Alkohol (siehe auch $\rightarrow$ Bier, $\rightarrow$ Branntwein) 128, $197,354,626,1069,1242$ 
Alleinerziehende $\rightarrow$ Väter

Alleinstehende $\rightarrow$ Frauen/Mütter, $\rightarrow$ Männer

Allgemeine Schwäche $\rightarrow$ Krankheiten, $\rightarrow$ Todesursachen

Allgemeiner Deutscher Nachrichtendienst

$$
\rightarrow \mathrm{ADN}
$$

Alliierte, Groß-, Siegermächte 80, 114, 129, 155, $342,348,508,535,712,1284,1299,1303$, $1323,1360,1410,1415,1417$

Alliierte Kommandantur 162

Alliierter Kontrollrat 162, 389, 1290, 1339, 1407, 1409

- Direktive Nr. 38: 389

- Gesetz Nr. 18 (Wohnungsgesetz) 1114-1118, 1187,1238

- Gesetz Nr. 24: 649

Alltagsgeschichte, -sorgen 22, 30-33, 60, 264 266, 269, 290, 305, 332, 811, 907 und öfter

Altar 459, 552, 575, 753, 791, 847

Altbauern 317, 843, 1128, 1144, 1166, 1222f., 1246, 1286 f., 1298 f., 1303, 1316

„Altbürger" 818, 1148, 1301

Alte (alte Menschen; siehe auch $\rightarrow$ Sieche) 172 und öfter

Alteingesessene $\rightarrow$ Einheimische

Altenbetreuung, -pflege 570, 584, 668 und öfter

Altenfeierabendheim des Landes Brandenburg (Engelsburg) 645

Alternative für Deutschland $\rightarrow$ AfD

Altersarmut 183

Alters-, Altenheim 151, 161 f., 206, 211, 262, 280, $315,428,472$, 553 f., 560, 567, 581, 586, 595, 621 f., 632, 645, 668, 694, 719 f., 759, 810, 842 f., 860, 864, 923, 931, 933, 935, 948 f., 955 , 959, 969, 999, 1007, 1012, 1074, 1095, 1154, 1159, 1256, 1259, 1278 f., 1296, 1455, 1478

- Evakuierung, Vertreibung 101, 211, 639, 718, 863, 948 f., 1074, 1268

Alters-Invalidenrente 1112

Altersrente $\rightarrow$ Rente

Altersschwachsinn $\rightarrow$ Krankheiten

Altersschwäche $\rightarrow$ Krankheiten, $\rightarrow$ Todesursachen

Alterssterblichkeit 620

Altersstruktur des BdV Pritzwalk 871

Altpreußische Union $\rightarrow$ Evangelische Kirche der Altpreußischen Union

„Altsiedler" 1302

Altsitzerwohnung 1139

Ambulatorium 712, 915, 1054, 1439, 1453
Amnestie 1438

Amputation 1273, 1276

Amt für deutsche Umsiedler (Potsdam) $\rightarrow$ Amt für Umsiedler (Provinzialebene)

Amt für Information (Brandenburg) $\rightarrow$ Informationsamt

Amt für Information der DDR 243

Amt für Umsiedler (Kreisebene) $\rightarrow$ Kreisumsiedleramt

Amt für Umsiedler (Provinzialebene), Amt für deutsche Umsiedler, Umsiedlerabt., -amt der Provinzial-/Landesregierung 48, 53, 163, 165, 169, 240-252, 260, 262, 300, 644, 687, 847f., 937, 1018 f., 1040, 1066, 1069, 1076 f., 1084, 1086, 1092 f., 1096, 1098f., 1104, 1106, 1117 , $1119,1123,1126$ f., 1135 f., 1151, 1155, 1160, $1163,1165,1173,1180$ f., 1197, 1213, 1215, $1217,1231,1233,1235-1245,1248,1251 \mathrm{f}$., 1355, 1392, 1400 f., 1408

Amt für Volkswohlfahrt $\rightarrow$ NSDAP

Amt für Zoll und Kontrolle des Warenverkehrs (AZKW) 374

Amtsanwaltschaft Zossen 1127

Amtsarzt 24, 179, 1016, 1066, 1192, 1194

Amtsbezirke 252, 278, 525, 694, 705, $826 \mathrm{f}$., 1069, 1074 und öfter

Amtsgerichte 276, 852, 1326, 1461; Genossenschaftsregister 301, 814; Handelsregister 229, 1360; Vereinsregister 224, 601, 672, 690, 746, 777,792 f., 798, 811, 831, 839, 852 f., 865, 870 , 888, 908, 910, 933 f., 959, 1363 f., 1367

Amtsvormundschaft 783

Amtsvorsteher 1134

Amtswalter $\rightarrow$ NSDAP, $\rightarrow$ NSV

"Ännchen von Tharau“ $\rightarrow$ Lieder

Analphabet 337

„ancestry.de“ 55, 1420

Andenkenpflege $\rightarrow$ Erinnerungskultur

Angehörige $\rightarrow$ Familie

Angestellte 167, 173, 247, 249, 489, 552, 562, $675,822,841,866,937,1055,1059,1077$, 1079, 1094, 1114, 1116 f., 1123, 1128 f., 1137, 1194, 1225 f., 1241 f., 1252, 1313 f., 1319, 1320, 1330 und öfter

- als Empfänger von Bodenreformland 552

Angorazucht 541

Angst, Ängste, Furcht, Schrecken 84f., 102, 154, 156, 278, 291, 320, 402, 419, 633, 774, 901 und öfter 
Anhänger 1467

Anhanglose 849, 1122 und öfter

Anschriftenlisten, -verzeichnisse 58, 206, 222, 230, 384, 394f., 403f., 413, 444, 465, 542, 1425 f.

Ansichtskarten 396

Ansiedlungskommission 74

Ansiedlungssoll 1186

Antifa-Aktionsausschuss 927

Antifa-Ausschuss 126, 264, 269, 276, 873, 927, 1083

Antifa-Block $\rightarrow$ Antifaschistisch-demokratischer Einheitsblock

Antifa-Familien $\rightarrow$ Antifa-Transporte

Antifa-Genossenschaft 899, 1198

„Antifa-Gruppe“ Potsdam 470, 480, 851

„Antifaschisten“" 810, 1285

Antifaschistisch-demokratischer Einheitsblock, Antifaschistischer Block („Antifa-Block“) 69, 598, 734, 1085, $1121 \mathrm{f}$.

Antifaschistische Parteien („Antifa-Parteien“) $\rightarrow$ Parteien

Antifaschistischer Frauenausschuss $\rightarrow$ Frauenausschuss

Antifaschistisches Komitee 893

Antifaschule 251

Antifa-Transporte, ,-Umsiedler", -Familien $150 \mathrm{f}$, 157-159, 200, 228-230, 257, 301 f., 305-308, $315,335,536,547,559,583$ f., 735, 746, 779, $813,826,1180,1191,1197,1220$ f., 1247, $1390,1441,1470$

Antiquitätenhändler 932

„Antisowjetische Haltung “ $\rightarrow$ Propaganda

Antrag auf Einreise in die DDR 1357

Apathie (vgl. $\rightarrow$ Lethargie) 188, 615, 617, 627

Apostolischer Administrator 826, 906, 1417

Apotheker, Apotheke 187, 208, 298, 328 f., 371, $567,619,649,700,730$ f., $745,838,846,1211$, 1268

Arbeit, Arbeitsbeschaffung, -kräfte, -platz, -prozess, -suche, -verhältnis 244, 259, 261, 264, 284 $290,296,364,528,551,584,608,646,767$, 772, 833, 1021, 1023 f., 1047 f., 1092 f., 1127 , 1151 f., 1156-1159, 1170 f., 1173 f., 1176-1217, 1232-1234-1236, 1240, 1247, 1272, 1283, 1356-1358, 1466, 1469 f. und öfter

- (Verwaltungsressort in Kommunen) 1070, 1073, 1084, 1238, 1243, 1355 und öfter

Arbeiter (siehe auch $\rightarrow$ Bau-, $\rightarrow$ Ernte-, $\rightarrow$ Fach, $\rightarrow$ Forst-, $\rightarrow$ Gast-, $\rightarrow$ Guts-, $\rightarrow$ Heim-, $\rightarrow$ Industrie-, $\rightarrow$ Land-, $\rightarrow$ Vertrags-, $\rightarrow$ Waldarbeiter) $18,131,143,173,290,302,305$, 307, 314f., 354, 618, 627, 649, 710, 720, 733, 749, 774, 778-780, 799, 801, 836, 858, 883, $892,914,1023,1047,1055,1074,1116,1125$, $1138,1159,1166,1171,1192,1194,1197-$ $1201,1228,1247,1283,1291,1293,1296$, 1305, 1309, 1311, 1313-1315, 1320, 1322, 1324, 1330, 1415, 1435, 1440, 1442, 1447, 1458 f., 1470 und öfter

- ungelernte 1195

Arbeiterbewegung 343, 689, 1331

Arbeitererholungsheim 572

Arbeiterhaus 1172

Arbeiterin 290, 301, 714, 858, 1077, 1216, 1275, $1313,1324,1469,1473$

Arbeiterkolonie 880

Arbeiter-Samariterbund 945

Arbeiterschaft 352, 458, 1305 und öfter

Arbeiter-Turnverein Nixdorf 780

Arbeiter-und-Bauern-Fakultät (ABF) 1439

Arbeiterwohnungsbaugenossenschaften (AWG) 280, 355, 671

Arbeitsamt (siehe auch $\rightarrow$ Landesarbeitsamt) 51, 137, 239, 284, 294, 499, 749, 799, $1023 \mathrm{f}$., 1071, 1081, 1183-1185, 1189-1197, 1221, 1324f., 1371, 1463, 1482; Kreisarbeitsamt 547, 584, 1176-1182, 1189-1195

Arbeitsbekleidung 1167

Arbeitsbeschaffung $\rightarrow$ Arbeit

Arbeitsbeschaffungsmaßnahme $\rightarrow$ ABM

Arbeitsbuch 243, 280

Arbeitsdienst $\rightarrow$ Reichsarbeitsdienst

Arbeitseingewiesene 850

Arbeitseinsatz 719, 1009, 1012, 1071, $1176 \mathrm{f}$., 1187-1189, 1192-1194, 1399, 1458

Arbeitseinsatzleiter 1001

Arbeitserziehungslager 34

Arbeitsgemeinschaft der Karpatendeutschen aus der Slowakei

Arbeitsgemeinschaft der Memellandkreise (AdM) 853

Arbeitsgemeinschaft deutscher Flüchtlinge $653 \mathrm{f}$., $1154 \mathrm{f}$.

Arbeitsgemeinschaft ostdeutscher Familienforscher (AGoFF) 853, 1542

- Archiv (Herne) 60, 1420

- Forschungsgruppe Brieg 403, 1542

- Forschungsgruppe Groß-Strehlitz 623 
- Forschungsstelle Mittelpolen-Wolhynien 853

- Forschungsstelle Neumark (Ostbrandenburg) 1542

Arbeitskleidung 1142, 1186, 1197

Arbeitskräfte $\rightarrow$ Arbeit

Arbeitskreis Bärwalde Nm. 207, 375, 384, 392, 401

Arbeitskreis Crossen 392

Arbeitskreis der Historiker Frankfurts 40

Arbeitskreis Heimat- und Familienforschung im Stolper Heimatkreis 148

Arbeitskreis Sorau 741

Arbeitslager, poln. (vgl. $\rightarrow$ Sammellager) 172, 468, 1096, 1269, 1447

-, sowjet. 97, 291, 484, 628, 1274, 1437, 1456

Arbeitslenkung 1177, 1183, 1190, 1202

Arbeitslose, -losigkeit, Nichtbeschäftigte 294, 551, $1021,1058,1110,1130,1144,1169,1189 \mathrm{f}$., 1193 f., 1276, 1278, 1315, 1322 und öfter

Arbeitsmaid $\rightarrow$ Reichsarbeitsdienst

Arbeitsmarkt 162, 307, 1176-1217 und öfter

Arbeitsmigranten 30, 213

Arbeitsmoral 143, 1161

Arbeitsplanung 1177, 1193, 1200

Arbeitsplatz, -prozess $\rightarrow$ Arbeit

Arbeitsschuhe 1142

Arbeitsschutz, -amt 1151, 1165

Arbeitsstelle $\rightarrow$ Arbeit

Arbeitsunfähigkeit 527, 554, 706, 778, 1040, 1076, 1133, 1177, 1179f., 1192, 1233, 1275

Arbeitsvermittlung 252, 734, 1085, 1184, 1190

Arbeitsverpflichtung 650, 849

Arbeitsverweigerung 650

Archäologie 33-35, 170, 281, 661

Archäologisches Landesmuseum $\rightarrow$ Museen

Archipresbyterat Landsberg an der Warthe 443

Architekten 1221

Architektur 73

„ArchitraV e.V““ 512

Archivalien 661, 675, 707, 1419f. und öfter

Archivare 15-18, 513, 1262, 1478

Archive (siehe auch $\rightarrow$ Arbeitsgemeinschaft ostdeutscher Familienforscher, $\rightarrow$ Bistums-,

$\rightarrow$ Brandenburgisches Landeshaupt-, $\rightarrow$ Bundes- $\rightarrow$ Deutsches Zentral-, $\rightarrow$ Diözesan-, $\rightarrow$ Domstifts-, $\rightarrow$ Evangelisches Landeskirchliches, $\rightarrow$ Gemeinde-, $\rightarrow$ „Heimat-“, $\rightarrow$ Kirchen-, $\rightarrow$ Kreis-, $\rightarrow$ Pfarr-, $\rightarrow$ Staats-, $\rightarrow$ Stadt-, $\rightarrow$ Zentrales Staatsarchiv) 21, 29, 47 f., 50-57,
60, 146-148, 253, 381, 421, 497, 509, 519,

$569,675,1419 \mathrm{f}$.

Archivum Państwowe $\rightarrow$ Staatsarchiv

Arme Dienstmägde Jesu Christi 620, 657, 1267

Arme Schulschwestern vom 3. Orden des hl.

Franziskus 553, 842

Armenunterstützung 1475

Armut 183, 779, 1276 und öfter

Arzneimittel $\rightarrow$ Medikamente

Arzt $\rightarrow$ Ärzte

„Asoziale“ 688

Assimilation, Assimilierung 32, 141 f., 200, 212, 246, 257 f., 294 f., 330, 335 f., 338, 432, 510

Asthma $\rightarrow$ Krankheiten

Asylbewerber 143, 497

Asylbewerberleistungsgesetz 499

ATG (Autotransportgemeinschaft) 1094, 1099, 1381,1440

Atheist (vgl. $\rightarrow$ Konfessionslose) 249

Atombomben, -waffen 1106 f., 1304

Aufbaulager (Potsdam) 848-850, 854, 1120 f., 1248

Aufbau-Verlag $\rightarrow$ Verlage

Aufenthaltsdauerbeschränkung 795

"Auffangbahnhof" 1434

"Auffangbecken“ 1010

Auffanglager, -stelle, -station (vgl. $\rightarrow$ Aufnahmelager) (1945-1947) 10, 26, 43, 138, 159 f., 163, $170,172,225,231,411,451,523,527,533$, $567,570,572,579,584$ f., 611 f., $621,638,649$, 655 f., $659,684,716,718,736,739,745,759$, 770 f., 776, 840, 844, 848, 877, 914-916, 947 f., 961, 1007, 1009 f., 1011, 1019 f., 1022, 1027, 1059, 1152, 1237, 1390, 1421, 1440, 1464; für bessarabien-, galizien- und wolhyniendeutsche Umsiedler (1940) 99, 585, 615, 653, 657, 697, $711,752,755,794,917,931,1468$

Aufklärungsarbeit $\rightarrow$ Propaganda

Aufklärungseinheit $\rightarrow$ Rote Armee

Aufklärungslokal 1337

Aufnahmebüro für Flüchtlinge 1459

Aufnahmegau 121, 123-125

Aufnahmegesellschaft $\rightarrow$ Einheimische

Aufnahmeheim Fürstenwalde 143, 688

Aufnahme-, Bestimmungskreis 87, $93 \mathrm{f}$., $99 \mathrm{f}$., 107 f., 110 f., 124 f., 139, 192 f., 201, 211, 216 f., 218 f., 441, 484, 522, 524-526, 528, 530, 533 f., 536-538, 540-546, 548 f., 597, 844, $869,905,996,1453$ 
Aufnahmelager (Erstaufnahme, vgl. $\rightarrow$ Auffanglager) $165,182,655,681,1390$ f., 1450, 1468

„Aufnahmesoll“ 124, 522, 849, 1007, 1123, 1152, 1195

Aufnahmestopp, Sperrgebiet (vgl. $\rightarrow$ Zuzugssperre) $242,261,614,618,657,744,838,960$, 999, 1002, 1153

Aufräumarbeiten 284, 358, 584, 778, 849, 1194, 1449

Aufregungen $\rightarrow$ Todesursachen

Aufrüstung 1303

„Der Augenzeuge“ $\rightarrow$ Film

„Aus unserer Heimat“ $\rightarrow$ Heimatzeitschriften

Ausbauten 312

Ausgebombte, Bomben(kriegs-), Fliegergeschädigte (siehe auch $\rightarrow$ Bombenkrieg) 99, 131, 281, 298, 302, 432, 574, 626-628, 647, 749, 797, 804, 847 f., 868, 871, 873, 889, 892, 895, $903,919,949,956,1134,1136,1138,1280$, 1390, 1400, 1461, 1469, 1474, 1476

Ausgehverbot 1434

"Ausgewiesene“ $1390 \mathrm{f}$.

Auskunftei 1251

Auskunftsstelle für Umsiedler 598

„Ausländer“ 145 f., 497, 512, 507, 626, 957 f., 1003, 1156

Ausländeraufnahmeheim Blumberg 498, 836

Ausländerbeauftragte 637

Ausländerbehörde, -dezernent 835, 1370

„Ausländerlager“ $\rightarrow$ „Fremdarbeiter“

„Ausländerviertel“ 1003

„Ausländische Arbeiter“ 511, 720, 749, 774

„Auslandsdeutsche“, „Deutsche im Ausland“ 336, $1265,1360 \mathrm{f}$.

Ausnahmezustand (1953) 876

Ausplünderung (von Vertriebenen kurz vor der Grenze) 129, 133, 561, 997, 1012, 1020, 1045, 1050 f., 1053, 1056 f., 1269, 1274 f., 1277 , 1435,1441

Ausreiseanträge (Polen) 143, 145, 427

Außengottesdienst (kath.) 620

Außenlager $\rightarrow$ Konzentrationslager

Außenminister $\rightarrow$ Minister

Außenministerkonferenzen 348, 352, 12901296, 1298, 1303, 1407, 1409 f., 1415

Außenpolitik 1164, 1281 f., 1284, 1291

Aussiedler, Spätaussiedler, Übersiedler 11 f.. 31, $70,136,140-146,212,325,469,496-501$, 540, 545, 607, 622 f., 641 f., 654, 673, 685,
688, 777, 793, 799, 811, 835 f., 846, 886, 888, 1355-1358, 1361, 1370-1372, 1374, 1391, 1398-1400, 1412-1415, 1435, 1438, 1452, $1456,1458,1463$

Aussiedlerbetreuung, -betreuer, -beratung, -hilfe, -integration (siehe auch $\rightarrow$ Migrationsberatung) 469, 601, 642, 777, 799, 835, 851, 878, $1365,1370 \mathrm{f}$.

Aussiedlerchöre 654, 1374

Aussiedlerheim 497 f., 799

Aussiedlerin, Spätaussiedlerin 500, 641, 1452

Aussiedlerrecht $1366 \mathrm{f}$.

„Aussiger Bote“ $\rightarrow$ Heimatzeitschriften

Ausstellungen (siehe auch $\rightarrow$ Heimatstuben, $\rightarrow$ Museen) 9f., 23, 45, 223, 300, 383, 477, 503, 508 f., 512 f., 587, 589, 599, 602, 637, 642, 646, 650, 660 f., 669, 691, 703-705, $775 \mathrm{f}$., 781, 788 f., 807, 811, 820, 830, 846 f., 851 f., $854,876,967,1138,1418$

Auswanderung, Auswanderer 731, 1265, 1396

Ausweichkrankenhaus 782

Ausweichlager 611

Ausweichpflegeheim 949

Ausweis, Pass, Personalausweis, -papiere (siehe auch $\rightarrow$ Dokumente, $\rightarrow$ Reisepass) 141, 171, $335,374,378,419,500,576,591,623,731$, 771, 844, 862-864, 1297

- „Ausweis der deutschen Volksliste“ (Jan./ Febr. 1945) 862-864

- DPA (Deutsche-Polizei-Ausweis) 1340

- Flüchtlingsausweis (West bzw. nach 1990) 623, 1448

- Flüchtlingspass (SBZ, Sept. 1945) 177, 241, 1001, 1005, 1007 f., 1470

- Kennkarte (Febr. 1945) 863

- polnische Begleitpapiere 1040

- Reisepass, -dokumente 194, 421

- Umsiedler-Kennkarte (1941) 1399

- Umsiedlerpass (Nov. 1945) 171, 335, 1048

- Vertriebenenausweis 500,623

Ausweiskontrolle 374, 1297

Ausweisung 54, 79, 137

Ausweisungsbefehl, -verfügung 129 f., 134, 632, 740, 1400, 1435, 1457

Auto $\rightarrow$ Kraftfahrzeuge

Autobahn, Reichsautobahn 115, 192, 750, 861, 886, 1434, 1465, 1471

Autobiographien 69, 577, 755, 846, 1400 und öfter Autobus $\rightarrow$ Omnibus 
"Autochthone“ 141, 670

Autotransportfirma 1208, 1210

Autotransportgemeinschaft $\rightarrow$ ATG

Autowrack als Nachtquartier 1125

AWG $\rightarrow$ Arbeiterwohnungsbaugenossenschaften

AZKW $\rightarrow$ Amt für Zoll und Kontrolle des Warenverkehrs

Babys $\rightarrow$ Kinder

Babysachen 1142

Bäcker, Bäckerei 124, 556, 614, 647, 664, 867, 877, 948 f., 1052 f., 1440, 1444 f., 1449

„Bäderstraße“ 192

Bäuerin 172, 867, 1126, 1225 f., 1478 und öfter

Bäuerliche Handelsgenossenschaft $\rightarrow$ BHG

Bahnfahrt $\rightarrow$ Eisenbahn

Bahnhof, -station 43, 82, 84f., 87-89, 119, 123, $125,132,137,139,147-156,159,178,182$, 191 f., 221, 284, 291, 293, 337, 367, 371, 560 f., 584, 587, 597, 611, 615, 617 f., 621, 634, 636f., 664, 669, 672, 675, 677 f., 700 f., 703, 711, 716 f., 736, 745, 750, 764, 770 f., 795, 809, 860-862, 869, 871, 873, 877, 922, 949, 956, 997 f., 1008, 1010, 1012, 1016, 1041 f., 1050 f., 1060 f., 1064, 1069, 1074, 1090 f., 1261, 1277, 1305, 1331, 1352 f., 1376, 1403, 1405, 1413, 1434-1436, 1438, 1440, 1445, 1448, 1450, 1454, 1459, 1462-1465, 1467 f., 1474, 1479

- Güterbahnhof, -abfertigung 132, 153, 291, $618,643,745,1201$

- Rangierbahnhof 822

Bahnhofsdienst 125, 616, 663, 1404

Bahnhofsgaststätte 619

Bahnhofskommandant 794

Bahnhofsmission 126f., 435, 451, 618, 637, 1275

Bahnhofsnamen (Umbenennung) 343, 1413

Bahnhofswache 615

Bahnkommission, poln. 1050

Bahnstation $\rightarrow$ Bahnhof

Bahntransport $\rightarrow$ Eisenbahn

Ball, Bühnenball 1286

Baltdendeutsche $\rightarrow$ Deutschbalten

Baltische Ritterschaften 590

$\mathrm{BAMF} \rightarrow$ Bundesamt für Migration und Flüchtlinge

Banden 1246; polnische 130, 1049, $1052 \mathrm{f}$.

Banken, Bankkonten, Geldinstitute (siehe auch $\rightarrow$ Sparkassen, $\rightarrow$ Sparkonten) 101, 103f., 106, 286, 377, 394f., 500, 1148, 1336, 1476
Bankrott 1287

„Banner der Arbeit“ $\rightarrow$ Orden

Baptisten 685

Baracken, -lager, -teile 25, 35, 46, 168-170, 171, 173 f., 176-181, 187, 206, 268, 272 f., 279-282, 302, 310 f., 389, 462, 534, 557 f., 567 f., 570 , $573,575,579-581,586,593,597,600,606$, 609, 617 f., 621, 631, 639 f., 643, 647, 649, 655, $669,675,680-682,687,701,703,717-720$, 729, 734, 736, 738f., 746, 749, 765-767, 769, $775,782,788,791,794-796,802,811,813$, $818,832,840,849,858-860,866$ f., 877, 880, 887, 893 f., 899 , 905 f., $914,923,932$, 936 f., 941, 943, 956f., 961, 967, 1013-1015, 1019, 1046, 1048, 1059f., 1064, 1068, 1070, 10731075, 1078, 1088, 1091, 1098 f., 1108, 1112 f., $1120,1133,1158$ f., 1163 f., 1186-1188, 1196, $1232,1234,1246,1268,1278,1377,1435 \mathrm{f}$., $1459,1463,1470,1474$

- Holzbaracken 169, 177 f., 279, 580, 606, 766, $818,840,858$ f., $887,889,916,919,1268$, 1377,1463

- Steinbaracken 648f., 858, 877, 1080, 1377

Barackenbau 1074

„Barmherziger Brotkorb“ 431, 850

„Barmherziger Kleiderschrank“ 432

Bastfaserfabrik 883, $1190 \mathrm{f}$.

Bauamt 101, 788, 795, 1121, 1194, 1227, 1296

Bauarbeiter 314, 609, 1195, 1222

Bauarchäologie 281

Bauchtyphus, -epidemie $\rightarrow$ Krankheiten, $\rightarrow$ Todesursachen

Bauern (siehe auch $\rightarrow$ Altbauern $\rightarrow$ Neubauern) $43,89,107,113,116,118,120,129$, 131, 133 f., 171 f., 181, 191, 195 f., 206, 227, 235, 256, 265 f., 285 f., 299, 304 f., 309, 313, $315-317,321-323,337,376,425,509,577$, 615, 619, 629f., 643, 664, 678, 698, 701, 727, $764,779,806,843,858,891,897,905,911$, 943, 965, 1015, 1119, 1126-1128-1132, 1139, 1144, 1147, 1150, 1156, 1161, 1166, 1198, 1219, 1222 f., 1227-1229, 1246 f., 1250, 1275, 1278, 1280, 1286f., 1291, 1296-1299, 1303, 1306, 1308, 1316, 1321, 1344, 1409, 1416, 1436f., 1442-1444, 1446, 1448-1450, 14551457, 1459-1461, 1463-1466, 1468, 1470 f., $1474,1477-1479,1482,1519$ und öfter

Bauernhaus 1015, 1436

Bauernhochschule „Edwin Hoernle“ 833 
Bauernpolitik 1166

Bauernstube 951, 1139

Bauerntag (Leipzig 1951) 1229

Bauernverband der Vertriebenen 691

Bauernversammlung $1225 \mathrm{f}$.

Baugeschichte 29, 73, 281

Baugewerbe, -industrie, -unternehmer 1189, 1356, 1447

Bauhandwerker 162, 1047, 1124

Baumaterial, -stoffe (siehe auch $\rightarrow$ Holz) 1110-1112, 1118, 1120-1124, 1139, 1167, $1188,1190,1200,1222,1247$

Baumeister 1221

Bauprogramm (siehe auch $\rightarrow$ Neubauernprogramm) 1128, 1163

Bau-Union 850, 1438

Bauverwaltung, -wesen (Ressort) (siehe auch $\rightarrow$ Baumat) 259, 312, 1014, 1223

BDM (Bund Deutscher Mädel) 119, 121, 184, 615 f., 635, 663, 1083, 1404, 1474, 1479

BDO $\rightarrow$ Bund Deutscher Offiziere, $\rightarrow$ Bund deutscher Osten

$\mathrm{BdV} \rightarrow$ Bund der Vertriebenen

„BdV Notizen“ 471

Beamte 81, 93, 175 f., 192, 246-248, 421, 423, $616,647,663,822,902,1066,1115,1201$, $1245,1320,1405$

Beamtenpension 1274

Beamtensohn/-tochter 1439, 1455, 1464, $1468 \mathrm{f}$.

Beauftragte der Bundesregierung für Kultur und Medien (BKM) Vf., 853

Beauftragter der Kirchenleitung für die ehem. OstBrandenburgischen Kirchengemeinden 436

Beauftragter für deutsche katholische Flüchtlinge 452

Bedrohung $\rightarrow$ Kriminalität

Bedürfnisanstalt, Abort, -anlage, Klosett, Latrine, Notdurft, Sanitäre Anlagen, Toiletten (siehe auch $\rightarrow$ Hygiene) 88, 154, 170 f., 176, 636, $638,682,867,719,896,961,1005$ f., 1052 , 1060, 1067, 1078, 1116

Befehl $\rightarrow$ Ausweisungs-, $\rightarrow$ Führer-, $\rightarrow$ Räumungs-, $\rightarrow$ Treckbefehl, $\rightarrow$ SMA/Befehle

Begegnungsstätten 223, 473, 508, 554, $601 \mathrm{f}$., 672, 690 f., 722, $885 \mathrm{f}$.

Begleitpapiere $\rightarrow$ Transport

Begräbnis, -erdigung, -stattung (siehe auch $\rightarrow$ Friedhof, $\rightarrow$ Grab, Grabstein, $\rightarrow$ Massengräber) $49,92,132,305,424,431,461,582$,
$595,613,634,654,660,665,694,707,740$,

750, 756, 759, 761, 782, 791 f., 796 f., 838, 850,

875 f., 881, 919, 925, 956, 994, 1053, 1269

- ohne Sarg 92, 566, 728, 770, 872, 948, 969, 997, 1274

Behelfsheim (siehe auch $\rightarrow$ Notunterkünfte) 281 f., 647, 827, 931, 1113, 1125

Behelfskrankenhaus $\rightarrow$ Krankenhaus

Behelfswohnung $\rightarrow$ Notunterkunft

Behinderte 568, 819, 929

Behinderteneinrichtung 101, 625, 694, 798, 933

Behörden-Evakuierung, -Auslagerung 81, 91, 93, 100-102, 108, 110, 612 f., 616f., 647, 663, 669, 711, 723, 788, 819, 822, 844f., 860, 931, 1405

Beichte, Beichtstuhl 461, 484, 613, $1072 \mathrm{f}$, $1265 \mathrm{f} ., 1269,1278 \mathrm{f}$.

Beihilfe (siehe auch $\rightarrow$ „Umsiedlerbeihilfe“) 1302

Beisetzung $\rightarrow$ Begräbnis

Bekleidung $\rightarrow$ Kleidung

Belagerung 663, 1405

Beleidigung $\rightarrow$ Kriminalität

Benediktinerorden 791

Beneš-Dekrete 157

Benzin, -mangel, Brennstoff 96, 245, 1126, 1169, 1236

Benzol 640

Beobachtungslager der Reichsbahn 918

„Bereicherung“" (negativ, kriminell) 173, 966

„Bereicherung“" (positiv) 6, 292, 299, 330-333, 430, 458, 1247

Bereichsverband $\rightarrow$ Bund der Vertriebenen

Bergbau, -leute, Gruben (siehe auch $\rightarrow$ Uranerzabbau) 141, 210, 909, 1186-1188, 1206, 1312, 1356, 1401

Berliner Initiative europareportage 854

Berliner Konvent der Hilfskomitees der zerstreuten evangelischen Ostkirchen 438

Berliner Landesverband der Vertriebenen 6, $368 \mathrm{f}$.

Berliner Stadtmission 586, 930

„Berliner Zeitung“ $\rightarrow$ Zeitungen

Berlin-Gubener Hutfabrik 348

Bernhardinum $\rightarrow$ Pastoralseminar Bernhardinum

Beruf, Berufsgliederung, -gruppe (vgl. $\rightarrow$ Mangelberufe) 1097, 1110, 1180, 1189-1191, 1194, $1196,1233,1240,1313$ und öfter

Berufsausbildung 280, 717, 1171 und öfter

Berufsberatung 1045, 1180, 1463

Berufsfremde Beschäftigung $1313 \mathrm{f} ., 1320$ und öfter 
Berufskleidung 1144, $1189 \mathrm{f}$.

Berufspendler 295

Berufsschule 561, 1311, 1441

Besatzungsmacht, sowjet. $\rightarrow$ SMA

Beschäftigunglosigkeit $\rightarrow$ Arbeitslosigkeit

Bessarabiendeutsche 71, 91, 99, 118, 193, 203, 213, 218, 234f., 236, 285, 312, 314, 337, 560, 591 f., 629 f., 652, 696, 784, 806, 824, 838, 861, $863,876,898,911,920,1177,1354$ f., 1425 , $1439,1442,1448,1452,1457,1467-1469$, $1481 \mathrm{f}$.

Bessarabiendeutscher Verein, Regionalverband Havelland 920

Bestattung $\rightarrow$ Begräbnis

Bestimmungskreis $\rightarrow$ Aufnahmekreis

„Besuchsdienst im Evangelisch Kirchlichen Gnadauer Gemeinschaftswerk in der DDR" 234, 784,838

Betonwerk 1207

Betreuungsstelle Brieg (Goslar) 403

Betreuungsstelle für Rückwanderer 855

Betreuungsstelle für Umsiedler 850

Betriebe (siehe auch $\rightarrow$ Firmen, $\rightarrow$ „Umsiedlerbetriebe“, $\rightarrow$,-genossenschaften“, $\rightarrow$ VEB) 52, 734, 1108, 1183-1185, 1189 f., 1245, 1293 f., 1299, 1313 f., 1319, 1332, 1358, 1458, 1469, 1473 und öfter

Betriebsberufsschule 1311

Betriebsgewerkschaftsleitung (BGL) 685, 1242, 1335, 1447

Betriebsgruppen $\rightarrow$ Kreisforstamt, $\rightarrow$ SED

Betriebsrat 259, 887, 1185, 1231, $1292 \mathrm{f}$.

Betriebsschulung 1158

Betriebsverlagerte 1400

Betriebsversammlung 347, 351, 1299 f., 1302, 1310 f., 1324f., 1333-1336

Betrug $\rightarrow$ Kriminalität

Betsaal 694, 742

Betteln 131, 171 f., 617, 754, 1019, 1281

Betten, Bettstellen, Bettgestelle, Bettenmangel (siehe auch $\rightarrow$ Pritschen, $\rightarrow$ Strohschütten) $118 \mathrm{f} ., 133,153,156,174,178 \mathrm{f} ., 181,274,574$, $580,588,616,638$ f., $647,718,720,837,858$, 865,896 f., 1005 f., 1014f., 1040, 1056, 1059, $1080,1086,1088,1118,1140,1149,1268$, 1274, 1278f., 1292, 1317, 1376; Eisenbetten 1095, 1125; Etagenbetten 1281; Feldbetten 837; Schlafcouch 1135

Bettlägerigkeit $\rightarrow$ Krankheiten
Bettsäcke (vgl. $\rightarrow$ Strohballen) 182

Bettzeug, -bezüge, -laken, -wäsche, Federbett (siehe auch $\rightarrow$ Decken) 98, 120,172, 177, 184, 197, 268, 568, 588, 664, 754, 897, 944, 948, 961, 1141-1143, 1153, 1268, 1278, 1281, 1291

Bevölkerungsgeschichte 30, 512

Bevölkerungspolitik 1122, 1170

- (Referat) 141, 225, 247, 249, 848, $1044 \mathrm{f}$., 1106f., 1109, 1170, 1237, 1355, 1397

Bevölkerungsstatistik, -zählung (siehe auch $\rightarrow$ Einwohnerzahl) 50, 139, 189 f., 202-204, 315, 457, $518,522-527$, 529-532, 534-551, 1157

Bewährungsbataillon $\rightarrow$ Wehrmacht

Bezirke (Bezirksgliederung der DDR) 1415

Bezirksämter, -bürgermeister (Berlin) 159, 242, 1002

Bezirksgericht Schwerin 389

Bezirksheim 622, $1357 \mathrm{f}$.

Bezirkskommandant(ur), sowjet. 194, 527, 575, 659

Bezirksparteischule 1447

Bezirkspartnerschaft 672

Bezirksumsiedlerausschuss 1408

Bezirksverwaltung $\rightarrow$ Oberlandratsbezirk, $\rightarrow$ Rat des Bezirks

Bezirksverwaltungsbehörde Cottbus 835

Bezirksverwaltungsbehörde Frankfurt 497

Bezugsschein, -waren (siehe auch $\rightarrow$ Kleidung,

$\rightarrow$ Lebensmittelkarten) 995, 1144, 1158, 1197, 1301

BGL $\rightarrow$ Betriebsgewerkschaftsleitungen

BHE $\rightarrow$ Block der Heimatvertriebenen und

Entrechteten

BHG (Bäuerliche Handelsgenossenschaft) 917, 1382

Bibel 446, 489, 575, $1276 \mathrm{f}$.

Bibelforscher $\rightarrow$ Ernste Bibelforscher

Bibliothekar/in 414, 421, 474, 505

Bibliotheken (siehe auch $\rightarrow$ Kulturförderverein, $\rightarrow$ „Umsiedlerlager") 63, 158, 303, 364, $402 \mathrm{f}$., 429, 476, 1162, 1276

- Deutsche Bücherei (Leipzig) 383, 394, 402

- Landesgeschichtliche Vereinigung für die Mark Brandenburg (Berlin) 303, 1543

- Martin-Opitz-Bibliothek (Herne) 60, 364, 1420, 1544

- Stadt- und Landesbibliothek Potsdam 1544

- Stiftung Brandenburg (Stuttgart/Fürstenwalde) $364,476,691 \mathrm{f}$. 
- Wanderbibliothek 1162

- Zentral- und Landesbibliothek Berlin 1544

Bier 367, 487, 1069, $1072 \mathrm{f}$.

Biersoße 338

Bijouterieherstellung, -industrie 299, 301, 303, $814,1138,1198,1200$ f., 1205, 1215, 1247 f.

Bildende Kunst $\rightarrow$ Kunst

Bildhauer 1190

Bildreklame 1252

Binnenschiffer $\rightarrow$ Schiff

Biographie, Lebenslauf 18, 34, 61, 64, 79, 117, 290, 358, 506, 700, 854 und öfter

Birkenruten 1215

Bischöfe, evang. 431 f., 438, 669, 998, 1257, $1263 \mathrm{f}$.

-, kath. (siehe auch $\rightarrow$ Bistümer) 444f., 998, 1266

Bischöfliches Amt Schwerin 680

Bischöfliches Ordinariat Berlin 56, 186, 446-449, 451, 453, 460, 1269, 1419

Bischöfliches Vorseminar 897

Bistümer, Diözesen 166, 442, 444f., 448

Bistum Berlin (Erzbistum) 38, 209, 263, 442445, 448-450-453, 458, 559, 575, 826, 896, 906, 1417; Bischof 808, 858, 1267 f., 1275, 1277-1280; Bischöfliches Jugendamt 552; Bistumsjugendtag 552; Domkapitular 586; Generalvikar 447 f., 453, 1269; Jugendhaus 552; Weihbischof 450

Bistum Breslau $\rightarrow$ Erzbistum Breslau

Bistum Danzig 628, 826, $1342 \mathrm{f}$.

Bistum Dresden/Meißen 37, 460, 484, 826, 1527

Bistum Ermland 954

Bistum Görlitz (siehe auch $\rightarrow$ Erzbischöfliches Amt Görlitz) 37 f., 190, 442-445, 458, 484, 628; Bischof 906

Bistum Hamburg $\rightarrow$ Erzbistum Hamburg

Bistum Königgrätz 811

Bistum Leitmeritz 882 f., 954 f.

Bistum Münster 592

Bistum Osnabrück 680

Bistum Prag $\rightarrow$ Erzbistum Prag

Bistum Schneidemühl $\rightarrow$ Freie Prälatur Schneidemühl

Bistumsarchiv Görlitz 56

BKGE $\rightarrow$ Bundesinstitut ...

$\mathrm{BKM} \rightarrow$ Beauftragte der Bundesregierung ...

Blässe $\rightarrow$ Krankheiten

Block der Heimatvertriebenen und Entrechteten (BHE) 138, 1394

Blockfrau $\rightarrow$ NSDAP
Blockhaus, -bau 1163

Blockleiter $\rightarrow$ „Umsiedlerlager“

Blockwart $\rightarrow$ NSDAP

Blutunterdruck $\rightarrow$ Krankheiten

Bodendenkmalpflege 34

Bodenkammer, -raum $\rightarrow$ Dachkammer

Bodenkommission $\rightarrow$ Bodenreformkommission

Bodenreform 11, 18, 29, 42 f., 48 f., 234, 298 f., $304,308-317,423,523,528,538,556,559$, 562, 566, 569, 573, 576, 583, 586f., 591, 593, 595 f., 603 f., 614, 629, 631, 651, 662, 680, $683,695,707,727,733,735,738,742,747$, 756, 758, 763 f., 775, 779, 781, 784, 791, 801, 804,812 f., 816 , 832-834, 841, 843, 868 f., $880,882,884,886,889,894$ f., 898-900, 902, 908, 911 f., 920, 924, 926, 928, 932, 935, 939, 942-944, 951, 957, 968, 1021, 1128 f., 1132, 1134, 1159, 1162, 1176f., 1191, 1217-1221, 1225-1227, 1241, 1246, 1282, 1284, 1313, 1395, 1401, 1407 f., 1412, 1442, 1455, 1457, $1459,1463,1467,1472,1478,1482$

- Aktionsausschuß 957

- Denkmal 775

Boden(reform)kommission, Gemeinde- 309, $315 \mathrm{f} ., 552,742,763,1225 \mathrm{f}$.

Bodenreformsiedlung 29, 314

Bombenkrieg, -angriff, Bombardierung, Luftangriff, -krieg 24, 82 f., 85, 88, 113, 123, 127, 132, 176, 181, 322, 574, 614, 617 f., 645, 647, $657,759,847$ f., 861, 903, 921, 929, 956, 1274, 1336, 1390, 1405, 1456, 1463-1465, 1474

- Evakuierung, Flucht 3, 71 f., 80, 82 f., 90 f., 112, $122,139,193$ f., 272 f., 281, 524-527, 529 f., 532, 534-540, 542-544, 546 f., 549 f., 586, 627 f., 639, 833, 923, 931, 942, 955, 965, 967, 1262 f., 1274, 1449, 1463, 1476, 1482 und öfter

- Geschädigte $\rightarrow$ Ausgebombte

- Opfer (siehe auch $\rightarrow$ Ausgebombte, $\rightarrow$ Todesursachen/Luftangriff) 20, 125, 586, 617, 821, 837, 1336, 1405

- deutscher Luftangriff 635, 751

Bonifatiusverein für das kath. Deutschland 447, 1271

Bonifatiuswerk 858

Borromäerinnen 210, $842 \mathrm{f}$.

„Borsiglager" (Guben) 716, 717-719

Boten 1189, 1314, 1474, 1477

Botschaften, Botschafter $\rightarrow$ Diplomatie „Boykotthetze“ 389 
Brachflächen, -land 827, 1001, 1224, 1228, 1330, 1412

Bräuche $\rightarrow$ Brauchtum

Branchenstatistik 1356

„Brandenburger Anzeiger" $\rightarrow$ Zeitungen

„Brandenburger Rundschau“ 468, 470 f.

Brandenburger Seniorenverband 1542

„Brandenburger Vertriebenenseminare“ 470

Brandenburgische Genealogische Gesellschaft „Roter Adler“ 328

Brandenburgische Gesellschaft für Kultur und Geschichte 17, 512

Brandenburgische Idiotenanstalt 798

Brandenburgische Landesanstalten $\rightarrow$ Landesanstalten

Brandenburgische Landeshochschule (Potsdam) 293, 505

„Brandenburgische Landesversammlung“ 474, 1359, 1361

Brandenburgische Landeszentrale für politische Bildung (Potsdam) 13, 16, 19 f., 40 f., 64, 225, $511,577,666,830,846$

Brandenburgische Schiffahrts- u. UmschlagsGesellschaft 340, 683

Brandenburgische Städtebahn $597 \mathrm{f}$.

Brandenburgischer Archivpreis 692

Brandenburgischer Sparkassen- und Giroverband 103-105

Brandenburgisches Landeshauptarchiv (BLHA), Potsdam Vf., 14-16, 22, 26, 47 f., 50, 52, 55, $110,140,309,519,675,846,854,1419,1542$

Brandenburgisches Landesjugendheim $926 \mathrm{f}$.

Brandenburgisches Literaturbüro (Potsdam) 59, 1444

Brandenburgisches Textilmuseum $\rightarrow$ Museen

„Brandenburg Nachrichten“ 471

Brandenburg-Preußen-Museum $\rightarrow$ Museen

Brandstiftung 931, 1377

Branntwein 1072

Brauchtum 234, 335, 338, 497, 625, 898, 1265, 1364

Brauerei 1205

Braunkohlentagebau 909, 1356, 1401

Brechdurchfall $\rightarrow$ Todesursachen

Brenn(stoff)-, Heizmaterial, Holz, Kohle, Briketts 95, 154, 156, 664, 828, 897, 1014, 1048, 1061, $1067,1070,1073,1082,1088,1112,1120$,

1145 f., 1158, 1201, 1272, 1291

Brennstoff für Fahrzeuge $\rightarrow$ Benzin

„Breslauer Novelle“ $\rightarrow$ Novellen
Bretter $\rightarrow \mathrm{Holz}$

Briefe, Briefwechsel, Korrespondenz (siehe auch $\rightarrow$ Kommunikation, $\rightarrow$ Leserbriefe, $\rightarrow$ Post) 59, 137, 182, 197, 364-366, 373, 376, 390 f., 396f., 404, 411, 417, 436, 439, 633, 807, 1091, $1146,1339,1461,1476$

Briefkasten 306

Briefmarken 1254

Brieftauben 584, 1439

„Brieger Anschriften-Verzeichnis“ $\rightarrow$ Heimatzeitschriften

„Briegische Briefe“ $\rightarrow$ Heimatzeitschriften

Briketts $\rightarrow$ Brennmaterial

Britische Armee/Besatzungsmacht 178

Bromberger Heimatbund 368

Bronchialasthma $\rightarrow$ Todesursachen

Broschüre $\rightarrow$ Flugschrift

Brot $\rightarrow$ Lebensmittel

Brotgetreide 1299

„Die Brücke“ $\rightarrow$ Film

Brücken, -übergang 84f., 95, 103, 105, 107-109, 130, 275, 284, 347, 355 f., 410, 424, 487 f., 598, 657 f., 663 f., 666, 673 f., 712, 714 f., 737, 741, 750 f., $771,773,806,818,829,861,901$ f., 966 , $1009,1020,1332,1342,1438,1453,1455$, 1471,1478

- Behelfs-, Holz-, Not-, Pontonbrücken 664, 670, 711 f., 715, 771, 806, 828 f., 1405, 1441, 1443, 1445, 1454, 1457, 1459, 1463, 1466

- Sprengung, Zerstörung 84f., 95, 176, 488, 598, 635, 662 f., 682, 711 f., 737, 779, 806, 818, $828,845,902,1403-1405,1438$

Brückenkopf 105, 663 f., 751, 773, 891, 902, $1404 f$. Brüdergemeine 512

Brustkrebs $\rightarrow$ Krankheiten

BStU (Bundesbeauftragte für die Unterlagen des Staatssicherheitsdienstes der ehem. DDR) 373, 380, 405, 407, 426, 905, 1382

Buch, Bücher (siehe auch $\rightarrow$ Bibel, $\rightarrow$ Bibliotheken, $\rightarrow$ Gesangbuch) 446, 509, 1162, $1228 \mathrm{f}$., 1261

Buchbindermeister 1481

Bucheckern 855

Buchhandel, -händler 403, 932, 1208, 1434, 1454

Bündnis 90/Die Grünen 1439

Bürger der Vereinten Nationen 1391

Bürgermeister (siehe auch $\rightarrow$ Gemeindeverwaltung) $98,101,132,138,160,192,194$, $197,217,222,224,229,241,251,253,256$, 
258, 260, 274f., 278, 313, 321, 348, 405, 424, 437, 466, 470, 474, 479-482, 486, 505, 511, $524,528,548,554,556,560-562,569,573 \mathrm{f}$., $577,584,587,592,594,607,615,622,626$, 633, 635, 637, 641, 646-648, 656f., 666, $668,683,700,710,721,726,736,739,749$, $762,771,775,788,792,802,810,820,828$, 832 f., $835,842,845,847,849,855$ f., 859 , $869,877,885,888,895,902$ f., $907,918,920$, 924, 931 f., 935, 943, 950, 956 f., 1000-1003, 1005, 1007, 1013 f., 1038, 1041-1043, 1069, 1093, 1099, 1104, 1110 f., 1114, 1116-1118f., 1123 f., 1126, 1128, 1132, 1136f., 1139-1141, 1146f., 1155, 1162 f., 1166, 1169, 1185-1187, 1221-1224, 1229 f., 1250 f., 1253, 1286, 1292f., 1301, 1308, 1311 f., 1326-1328, 1333, $1337 \mathrm{f} ., 1345,1350,1376,1378,1382,1422$, 1437, 1440 f., 1443, 1446, 1450, 1454 f., 1457, $1467 \mathrm{f} ., 1472,1477,1483,1502$

Bürgermeister-Konferenz 1253

Bürgerrechtler (DDR) 359, 480, 1469

Bürgervereinigung „Fürstenberg (Oder)“ 683-685, 1542

Büro für Chancengleichheit (Potsdam) 511

„Büro Grüber“ 438

„Büro Kruska“ 438

Büromaschinen, -reparatur 1447

Büromaterialhandel 1208

Bürstenherstellung 1199

Bukowinadeutsche 193, 203, 218, 452, 852, 924, 935, 1270, 1399, 1443, 1467

Bund der Vertriebenen (BdV) 200, 212, 362, 364, 381, 463-466, 468, 473, 478, 481, 487, $599,775,799,852,887,1364,1367,1369$, $1378,1402,1453$

- Arbeitsgemeinschaft „Grenzüberschreitende Arbeit" der Region Oder-Spree 690

- Bereichsverband Wittstock/Dosse 959

- Bundesverband, -vorstand 852

- Gebietsverband Rathenow 268, 469, 481, 878 f., 1376, 1378

- Gebietsverband Spremberg 916

- Heimatgruppen Neuruppin Rheinsberg 821

- Kreisgruppen 1367

- Kreisverbände (KV) 224, 464 f., 468-471, 478 f., 481, 507, $1359 \mathrm{f}$.

- KV Altkreis Kyritz 777

- KV Amt Rüdersdorf und Umgebung 690, 887 f., 1365 f., 1438
- KV Angermünde/Schwedt 564

- KV Brandenburg/Havel 223 f., 465, 599, 601 f., 1362 f., $1370-1372$

- KV Calau 613

- KV Cottbus Stadt und Land 272, 468, 622 f., $835,947 \mathrm{f}$.

- KV Eberswalde, Freienwalde, Bernau 568, 585, 637, 641 f., 1364 f., 1372 f.

- KV Eisenhüttenstadt 684

- KV Elbe-Elster 656

- KV Finsterwalde 656, $1369 \mathrm{f}$.

- KV Forst/Nl. 660

- KV Frankfurt (Oder) 672

- KV Fürstenwalde 687,690

- KV Guben 722

- KV Jüterbog 746

KV Kyritz 468, 472, 777, 1460

- KV Luckenwalde, Jüterbog, Teltow-Fläming, Zossen 362, 746, 792, 971, 1373

- KV Lübben/Luckau 790, 798, 1363

- KV Lübben, Luckau, Dahme/Spreewald 798

- KV Märkisch-Oderland 907

- KVMärkisch-Oderland,Seelow-Strausberg907f.

- KV Nauen $811 \mathrm{f}$.

- KV Neuruppin 820,1374-1376, 1460

- KV Oberhavel 468, 473, 775, 830-832

- KV Oberspreewald-Lausitz 473,910

- KV Oder-Spree 690f., $1366 \mathrm{f}$.

- KV Oranienburg 831

- KV Perleberg 110, 484, 839, 841

- KV Potsdam 201, 505, $852 \mathrm{f}$.

- KV Potsdam-Mittelmark 201, 601, 1367 f.

- KV Prenzlau 56, 865

- KV Prenzlau/Templin 934

- KV Pritzwalk 870

- KV Rathenow 465, 878

- KV Seelow 907

- KV Senftenberg $909 \mathrm{f}$.

- KV Spremberg 916

- KV Teltow-Fläming 746, 792, 971

- KV Uckermark 564, 865 f.

- KVWittstock 959

- KVWusterhausen 963

- Landesverband Berlin 464, 851, 1368

- Landesverband Brandenburg 21, 56, 201, 250, 356, 464f., 468-471, 478, 482, 519, 599, 601, $619,637,646,687,690,731,736,761,790$, 792 f., 822, 830, 846, 851f., 871, 876, 879, 926, 960, 1358-1362, 1364f., 1366, 1368-1370, 
1373, 1375, 1418f., 1543; Aussiedlerbeauftragte 469, 1370; Landesschiedsgericht 672

- Landesverband Thüringen 11

- Ortsverbände (OV) 1363

- OV Eisenhüttenstadt 684f.

- OV Luckenwalde und Nuthe-Urstromtal 792

- Präsidentin 468, 832

- Regionalverbände (RV) 468

- RV Alte Heimat, Jüterbog 746, $1373 \mathrm{f}$.

- RV Fürstenwalde/Rüdersdorf und Umgebung 144, 210, 464 f., 478, 888

- RV Luckenwalde und Umgebung 793

- RV Mark Brandenburg 793

- RV Templin 933

- RVZossen 971

- Stadtverband Spremberg 916

Bund der heimatvertriebenen Ostpreußen 1341

Bund Deutscher Mädel $\rightarrow$ BDM

Bund Deutscher Offiziere (BDO) 1307

Bund deutscher Osten (BDO) 368

Bund heimattreuer Ost- und Westpreußen 368

Bund heimattreuer Posener 368

Bund heimattreuer Schlesier 368

Bundesamt für Migration und Flüchtlinge (BAMF) 471, 497, 500

Bundesarchiv (BArch) 16, 50 f., 53, 140, 142, 303, 402, 519, 1419 f., 1543; Lastenausgleichsarchiv (LAA) 54, 402, 1419, 1543

Bundesgruppe „Heimattreue Westpreußen Potsdam" 368

Bundesinstitut für Kultur und Geschichte der Deutschen im östlichen Europa (BKGE) V, 60,140

Bundesminister, -ministerien: Inneres 497, 836; Verteidigung 715; Vertriebene 46

Bundespräsident $\rightarrow$ Geschichtswettbewerb

Bundesregierung (bis 1990) 54, 1400; (nach 1990) Vf., 20, 469, 475, 477, 497, 1360, 1369

Bundesstiftung zur Aufarbeitung der SED-Diktatur 23

Bundestag $\rightarrow$ Deutscher Bundestag

Bundesverdienstkreuz $\rightarrow$ Orden

Bundesvereinigung der Brieger 402-404

Bundesvertriebenengesetz (BVFG) 463, 475, 477, 496 f., 499 f., 684, 1359, 1363, 13651367, 1393 f., 1402

Bundesverwaltungsamt 468, 499

Bundeswehr 715, 765, 926, 948

Bunker 85, 606, 843, 848, 858f., 938, 943, 1436
Bunkerhaft 1275

„Bunter Abend“ 1136f.; im Lager: 172, 719, 1081, 1085 f., 1088 f., 1093, 1097-1099, 1104

Buntmetall 1201

„Buschfunk" $\rightarrow$ Kommunikation

$\mathrm{BvD} \rightarrow$ Bund der Vertriebenen

Caritas (siehe auch $\rightarrow$ Deutscher Caritasverband) 451-453, 489, 499, 588, 620 f., 734, 791, 795, 896f., 998, 1250, 1254, 1266, 1276

Caritasdirektor (Breslau/Cottbus) 620 f., 909, 1269

Caritasheim 447, 450 f., 553 f., 570 f., 621, 632

Caritas-Kreisstelle Cottbus 835

Caritasreferent für das Gebiet der russischen Zone 620

Caritasverband der Diözese Görlitz 451, 484, $553,620,836,1269,1543$

Caritasverband für das Erzbistum Berlin 442, 446, 449, 554, 570 f., 832, 896, 1275, 1277-1280

Caritasverband für das Erzbistum Breslau 620, 1250

Carolusheim Neuzelle 447

CDU (bis 1990:) 126, 239, 248, 259f., 310, 324, 349 f., 371, 592, 671, 734f., 792, 845, 852, 856, $918,924,1086,1094,1104,1113,1121,1128$, 1130, 1160, 1164, 1172f., 1186, 1197, 1220, $1231,1245,1251$ f., $1318,1329,1412,1446$, 1454,1473

- (nach 1990:) 40, 366, 468, 470, 479, 505, 658, 666, 705, 761 f., 846, 852 f., 963, 967, 1440

„Charta der deutschen Heimatvertriebenen“ 473, 1358-1362, 1364, 1366f., 1375

Chausseen 545, 616, 862

Chemiefaserwerk Guben 27, 295, 714, 719, 1473

Chemische Industrie 1356, 1435

Chilenen (im Exil) 512

"Chirurgische Fälle“ $\rightarrow$ Krankheiten

Chlorkalk 1051

Chöre $\rightarrow$ Musik

Cholera $\rightarrow$ Krankheiten

„Christ Unterwegs“ (Verlag) 444

Christenlehre 770

Christian-Schreiber-Haus (Alt Buchhorst) 552

Christlich-Demokratische Union $\rightarrow$ CDU

"Christliche Bewegung“ 1172

„Christliche Weltanschauung", Prägung 1338, 1456

Christlicher Verein Junger Menschen $\rightarrow$ CVJM

Chronische Krankheiten $\rightarrow$ Krankheiten 
Chronistenvereinigung Potsdam-Mittelmark 42

Codex Juris Canonici 445

Collegium Polonicum (Słubice) 32, 471

"Crossener Heimatgrüße" $\rightarrow$ Heimatzeitschriften

Crossener Sparkasse 810

CVJM (Christlicher Verein Junger Menschen) 609, 942

Dachdeckermeister 1470

Dachkammer, -boden, -wohnung, Bodenkammer, -raum, Mansardenzimmer 276f., 279, 287, 808, 928, 1118, 1140, 1158, 1279, 1441, 1458, 1470

Dachsteinfabrikation 1205

Dachziegel 1222

Dänentransporte, Dänemark-Rückkehrer 1038

$\mathrm{DAF} \rightarrow$ Deutsche Arbeitsfront

Danziger Bundesgruppe Berlin 368

Darmkatarrh, -krankheiten $\rightarrow$ Krankheiten

„Das Ostpreußenblatt“ $\rightarrow$ Heimatzeitschriften

Datenschutz 42, 56, 147

Dauerlager 1152

DBP (Demokratische Bauernpartei) 350, 1318, 1329(?)

DDT-Bepuderung 175

Decken, Schlaf-, Wolldecken (siehe auch $\rightarrow$ Bettzeug) 598, 620, 811, 872, 897, 922, 944, 961, 1007, 1080, 1088, 1142f., 1148, 1192, 1194, $1268,1274,1278$

DEFA (siehe auch $\rightarrow$ Film) 302, 356, 359, 532, $548,648,700,767,780,845,963,967,1093$, $1409,1412,1469$

Deichbruch $\rightarrow$ Hochwasser

Deichverband Oderbruch 567

Dekanat Berlin-Weißensee 816

Dekanatswochen, -wochenenden 552

Deklassierung $\rightarrow$ Sozialer Abstieg

Demokratische Bauernpartei $\rightarrow$ DBP

Demokratischer Frauenbund Deutschlands (DFB, DFD) 243, 254, 260, 333, 862, 1094, 1104, 1126, 1149, 1238, 1251, 1302, 1323, $1446,1471,1479$

„Demokratisierung“ 1159, 1169, 1241, 1245, 1323

Demonstration (vgl. $\rightarrow$ Kundgebung) 352, 683, 1305

Demontage $\rightarrow$ Rote Armee/Beschlagnahmung

- (Watenstedt-Salzgitter) 1317, $1322 \mathrm{f}$.

Demontagearbeiten 643, 1176

Denkmal $\rightarrow$ Gedenkort

Denkmalpflege 29f., 34, 341, 932
Denkmalschutz 29, 279, 281, 312, 818, 867

Deportation, Verschleppung 46, 72, 321, 356, $602,751,875,1049,1084,1280,1435,1440$, $1457,1463,1468$

- in die Sowjetunion, nach Sibirien (Zwangsarbeit) $54,97,133,149,155,174,232,291 \mathrm{f}$., 600, 627f., 666, 1024, 1243, 1273-1275, 1304, 1436f., 1454, 1456, 1459 f., 1463, 1468

- nach Ostpreußen (Zwangsarbeit) 931

Deputat $\rightarrow$ Naturalien (Lohn)

„Der Augenzeuge“ $\rightarrow$ Film

„Der Märker" $\rightarrow$ Zeitungen

„Der Morgen“ $\rightarrow$ Zeitungen

„Der Vertriebene“ $\rightarrow$ Heimatzeitschriften

Deserteure 88, 627, 1463

Desinfizierung, Desinfektionsmittel, -anstalt $175,177,523,649,675$ f., 1048, 1050-1053, 1064 f., 1209

Deutsch $\rightarrow$ Sprache

Deutschbalten (Baltendeutsche) 75, 99, 193, 203, 218, 232-233, 234, 441, 732, 764, 860, $863,875,959,1399,1452,1465$

Deutsch-Baltische Genealogische Gesellschaft $232 \mathrm{f}$.

Deutsch-Baltische Gesellschaft 233

Deutsch-Baltische Landsmannschaft, Berliner Landesgruppe $\rightarrow$ Landsmannschaften

Deutsche Arbeitsfront (DAF) 75, 246, 1201

Deutsche Bücherei (Leipzig) $\rightarrow$ Bibliotheken

Deutsche Bundesbahn (DB) 771

Deutsche Evangelische Kirche, Kirchenkanzlei (Berlin) 77

Deutsche Forschungsgemeinschaft (DFG) 12

Deutsche Freundeskreise (in Polen) 870

Deutsche Gesellschaft für Volkskunde 57

Deutsche Grenzpolizei 374, 1474

Deutsche Kultur- und Siedlungs-Gesellschaft 893

Deutsche Minderheit 140, 690, 870, 1365, 1372 f., 1452

Deutsche Reichsbahn (DR) $\rightarrow$ Reichsbahn

Deutsche Reichspost 645

Deutsche Verwaltungen (SBZ) $\rightarrow$ Zentralverwaltungen

Deutsche Volksliste 193, 862-864

Deutsche Volkspolizei $\rightarrow$ Volkspolizei

Deutsche Wirtschaftskommission (DWK) 1128, 1174, 1242 f., 1253, 1355

Deutsche Zentralverwaltungen $(\mathrm{SBZ}) \rightarrow$ Zentralverwaltungen 
Deutscher Bundestag 463, 666, 851, 853, 963

Deutscher Caritasverband 56, 263, 451 f., 571, 621, 998

Deutscher Gemeindetag 246

Deutscher Gemeindeverlag $\rightarrow$ Verlage

Deutscher Ostbund $\rightarrow$ Ostbund

„Deutscher Umsiedler“ 1399

„Deutscher Volkskongreß für Einheit und gerechten Frieden“ 1296, 1410

Deutscher Zentralverlag $\rightarrow$ Verlage

Deutsches Frauenwerk 124

Deutsches Historisches Institut Warschau 16

Deutsches Historisches Museum (DHM) (Berlin) 1419

Deutsches Kulturforum östliches Europa (Potsdam) $15,212,846,853 f$.

Deutsches Polen-Institut 666

Deutsches Rotes Kreuz (DRK) 87, 121, 125, 127, 187, 452, 499, 615, 806, 838, 993 f.; Baracke 775; Helferin 217, 578, 640, 665; Notküche 997; Schwestern 88, 119, 121, 178, 187, 576, 637, 806, 927, 1471, 1481; Suchdienst 57, 147

Deutsches Wohnungs-Hilfswerk (DWH) 281

Deutsches Zentralarchiv 253

Deutsch Kroner Heimathaus 378

Deutschlandhaus (Berlin) 375, 851

Deutschlandlied $\rightarrow$ Lieder

Deutschlandtreffen (Berlin) 1474

Deutschnationaler Handlungsgehilfenverband 251

Deutsch-Polnische Gesellschaft Brandenburg $577,666,846$

Deutsch-Polnische Gesellschaft für Frieden und gute Nachbarschaft 714, 879

Deutsch-Polnisches Literaturbüro Oderregion 666

Deutsch-Sowjetische Aktiengesellschaft $\rightarrow$ Sowjetisch-Deutsche Aktiengesellschaft

„Deutschstämmig“ $\rightarrow$ Abstammung

Devisen 1216

DFB, DFD $\rightarrow$ Demokratischer Frauenbund Deutschlands

DFG $\rightarrow$ Deutsche Forschungsgemeinschaft

Diakonie, Diakonisches Werk 499, 654, 1259, 1456

Diakonissen, Schwestern 210, 222, 432 f., 595, $718,782,928$ f., 1345

Diakonissenanstalt, -haus, -mutterhaus (siehe auch $\rightarrow$ Samariteranstalten) 210, 693, 732,
1259; Berlin (Bethanien) 1258; Danzig 595, 929; Frankfurt (Oder) 433, 669; Grünberg in Schlesien 210 f., 732; Heiligengrabe 210, 732 f.; Königsberg 929; Kreuzburg 929 f.; Lehnin 782, 1259, 1543; Miechowitz 210, 732; Posen 432f., 687, 693f., 782; PotsdamBabelsberg 1259; Teltow 928-930, 1543

Dialekt $\rightarrow$ Mundart

Diapositive 1252

Diaspora 37, 308, 371, 430, 442, 446, 454, 458, $460,462,510,596,613,654,704,808,1261$, 1265

Diaspora-Kommissariat der deutschen Bischöfe (Paderborn) 166

„Die Andere“ (Potsdam) 480

„Die Brücke“ $\rightarrow$ Film

„Die Kinder von Golzow“ $\rightarrow$ Film

„Die Kirche“ (Zeitschrift) 1261

Die Linke 852

„Die letzte Etappe“ $\rightarrow$ Film

„Die Neue Heimat“ (Zeitschrift) 1146

„Die Neue Zeitung" $\rightarrow$ Zeitungen

„Die Stimme der Vertriebenen“ 1344

„Die Tagespost“ $\rightarrow$ Zeitungen

„Die Umsiedlerin“ $\rightarrow$ Novellen

Diebstahl $\rightarrow$ Kriminalität

Dienstmädchen 132, 213

Dienstverpflichtete (im Krieg) 81 f., 880, 1467, 1474

- (für sowjet. Besatzungsmacht; siehe auch $\rightarrow$ Aufräumarbeiten) 849f., 1121-1123

Diözese, Diözesanverband $\rightarrow$ Bistum ...

Diözesanarchiv Berlin (DAB) 56, 1419, 1543

Diözesan-Beauftragter für Flüchtlingsseelsorge und -fürsorge (Berlin) 451

Diözesankonservator (Glatz) 596

Diphterie $\rightarrow$ Krankheiten

Diplomatie, Diplomaten 142, 159, 665

- DDR-Botschaft in Prag 426

- DDR-Botschaft in Warschau 1328

- DDR-Konsulate in Polen 143, 1357

- Japanische Botschaft in Berlin 91

- Litauische/r Botschaft/er in Berlin 846; Kulturattaché 704

- Moldavischer Botschafter in Berlin 235

- Polnische Botschaft in Berlin (Ost) 426, 1328

Direktorium für Deutsche Umsiedler (Potsdam) 242

DM-Mark $\rightarrow$ Geld 
„Dobrucza-Deutsche“ (Verein) 235

Dobrudschadeutsche 219, 235f., 337, 951, 1354

„Dokumentation der Vertreibung der Deutschen aus Ostmitteleuropa“" 46f., 54, 1419

Dokumentationszentrum Alltagskultur der DDR (Eisenhüttenstadt) 23, 684

Dokumente, „Papiere“, Urkunden (Mitnahme, Verlust; siehe auch $\rightarrow$ Akten, $\rightarrow$ Ausweis) 84, $105,129,137,168,241,287,358,434,584$, $661,693,1023-1025,1040,1067,1262,1369$, $1371,1454,1470$

Dolmetscher/in 233, 582, 752, 838, 1079, 1157, $1329,1463,1481,1539$

Domänenpächter 132

Domstiftsarchiv Brandenburg 56

Donauschwaben 602, 1482

„Dorf des Friedens“ (Titel) 813

Dorfchronik 361 f., 387, 1457 und öfter

Dorffest 412, 555, 815

Dorfgemeinschaften 148, 212, 234, 408, 514

Dorfkirchen $\rightarrow$ Kirchenbau

Dorfklub 1437, 1451

Dorfschule (vgl. $\rightarrow$ Schule) 113, 278, 330, 1437, 1479,1483

Dorfwaschhaus 1229

Dorfwirtschaftsplan 1228

DPA (Deutsche-Polizei-Ausweis) $\rightarrow$ Ausweise

Dreck $\rightarrow$ Schmutz

Dresdner Bank $\rightarrow$ Banken

„Driesener Flüchtlingsausschuß“ 206

DRK $\rightarrow$ Deutsches Rotes Kreuz

Drogerie 1209, 1211 f., 1443

Druckerei 767, 826, 1211, 1253, 1390, 1438

Druckschrift $\rightarrow$ Flugschrift

DSF $\rightarrow$ Gesellschaft für deutsch-sowjetische Freundschaft

Duolit $1050 \mathrm{f}$.

Durchfall $\rightarrow$ Krankheiten

Durchgangslager 159f., 167, 183, 199, 232, $499,517,557,567,579,585,588,591,655$, 658-660, 667, 675 f., 717 f., 769, 773, 791, $796,840,866,904,915,927,942,961,993$, 1008f., 1027, 1046-1109, 1268, 1276, 1391, 1401 und öfter

- sowjet. $\rightarrow$ Speziallager

Durchgangslazarett, sowjet. 1480

Durchschleusung, Durchschleusungspunkt, Weiterleitung 276, 523f., 530, 538, 548, 550, 556, $566,578,594,611,621$ f., 657,688 f., 744 f.,
$768,774,791,796,800,806,837,847,849$, 901, 904 f., 926, 931, 937, 997, 1000 f., 1003 f., 1009f., 1019, 1022, 1026f., 1066, 1151-1154, 1235 f., 1239, 1357 f., 1396, 1404, 1458, 1467, 1483 und öfter

Durst 424

DWH $\rightarrow$ Deutsches Wohnungs-Hilfswerk

DWK $\rightarrow$ Deutsche Wirtschaftskommission

Dysenterie $\rightarrow$ Todesursachen/Ruhr

Dystrophie $\rightarrow$ Todesursachen

EALG $\rightarrow$ Entschädigungs- und Ausgleichsleistungsgesetz

„Echo des Ostens" $\rightarrow$ Zeitung

„Edelweiß“ (Chor) $\rightarrow$ Aussiedlerchor

„Edelweiß“ (litauischer Wolfskinder-Verein) $703 \mathrm{f}$.

Ehe, -schließung, Heirat, Hochzeit (siehe auch

$\rightarrow$ Trauungen) 49, 371, 389 f., 399, 461, 873, 1094, 1280, 1435 f., 1438 f., 1445, 1447, 1449 f., $1453-1459,1463$ f., 1473 f.

- unter Vertriebenen 280, 288, 593, 1442, 1459, 1462, 1465

- zwischen Einheimischen und Vertriebenen 32, 200, 338, 507, 1119, 1439-1441, 1451, $1458,1474 \mathrm{f}$.

- zwischen Deutschen und Polen 671

- Goldene Hochzeit 389, 410, 767

- Hochzeitstag 1066

- konfessionverschieden 459,461

- Scheidung 1439, 1468

Ehemaligen-Treffen $\rightarrow$ Schule, Klassentreffen

Ehemaligen-Vereinigungen $\rightarrow$ Schule

„Ehetragödie“ 1280

Ehrenbürger, -recht 330, 349, 429, 467, 472, 504, $562,579,660,713,719,721,790,883,1460$

Ehrenpreis 1136

Ehrenzeichen $\rightarrow$ Orden und Ehrenzeichen

Eichenbrücker Vereinigung 108

Eier 1288

Eigentum, Eigentumsrecht, Privatvermögen 311, 363, 1134, 1148 f., 1167, 1359-1365, 1369, 1469 und öfter

Eilhard-Alfred-Mitscherlich-Preis 1468

Einbruchsdiebstahl $\rightarrow$ Kriminalität

Einbürgerung 501, 644

Einheimische, -geborene, Altbürger, Alteingesessene, Ortsansässige, Stammeinwohner, -bevölkerung, Aufnahmegesellschaft, Hilfsbereitschaft, „Kalte Heimat“, Mitmenschlichkeit 
(siehe auch $\rightarrow$ Wohnungseinweisung) 57, 59, 79 f., 89 f., 97, 102, 112-119, 162, 191, 203, $238,255,258,260,262,264,269$ f., 272,274 , 276, 283, 285 f., 288, 294, 296f., 300, 302, 311-313, 317, 321-324, 332-337, 344, 358, $360,467,504,506$ f., 510, 525, 528, 530 f., 535, $578,584-586,605,608,617,620,626,629$, $633,639,643,646-648,665,678,691,694$, $700-702,727,742,755,764,774,783,788 \mathrm{f}$., $791,800,805$ f., 809 f., $818,827,833,864,872$, 874f., 877, 893, 911, 914, 919, 921, 925, 931, 963, 966 f., 969, 1009, 1016, 1020, 1027-1031, 1038, 1042f., 1110, 1118-1121, 1124, 11261134, 1137, 1139 f., 1143-1150, 1154-1158, 1161 f., 1166, 1173, 1196f., 1215, 1222, 1227, $1234,1236,1239,1246,1250,1263,1269$, 1273 f., 1276, 1280, 1286, 1291 f., 1294, 1297, 1306, 1313, 1316 f., 1319 f., 1323, 1352, 1376, 1390, 1392 f., 1395, 1398, 1400-1402, 1409, 1429 f., 1432, 1436, 1448, 1461, 1465, 1467, $1472-1483$ und öfter

„Einheit Deutschlands“, Wiedervereinigung 385, 388, 463, 471, 478, 484, 1042 f., 1095, 1168 , $1174,1217,1235,1241,1245,1284 \mathrm{f} ., 1288 \mathrm{f}$., 1292 f., 1295 f., 1298, 1300, 1306, 1322, 1328, 1352, 1358, 1360, 1365 f., 1411, 1415, 1417

Einheitsschule 1142

Einheitsliste 1334

Einkaufs- und Liefergenossenschaft des Handwerks $\rightarrow$ ELG

Einkellerung 1301

Einquartierung $\rightarrow$ Wohnungsweinweisung

Einreiseerlaubnis, -genehmigung 372, 1069

Einschleuspunkt 1019 f., 1022

Einsegnung $\rightarrow$ Konfirmation

Eintopf $\rightarrow$ Lebensmittel

„Einwanderer“ 1398

Einweisung $\rightarrow$ Wohnungsweinweisung

Einwohner, zugezogene 1392

Einwohnerlisten $\rightarrow$ Seelenlisten

Einwohnermeldeamt, -bücher, -kartei, -register, polizeiliche Meldung 49, 56, 93, 291, 535, $687,706,765,842,935,1038,1263,1392$, 1412

Einwohnerzahl (in Teil 2 bei jedem Ort angegeben; siehe auch $\rightarrow$ Bevölkerungsstatistik, $\rightarrow$ Statistik) 71, 190 f., 218, 528, 547, 551, 586, 596, 734, 871, 882, 920, 943, 1138, $1177 \mathrm{f}$., $1194,1247,1313$ und öfter
„Einzelgänger", -reisende (siehe auch $\rightarrow$ „Wandern“) 1038, 1069, 1078, 1096 f., 1103, 1236, 1392, 1468, 1471

„Einzelrückführung“ 1355

Eis (vereiste Flüsse u. Straßen) $\rightarrow$ Wetter

Eisenbahn, Bahn-, Zugtransport, Flüchtlingszug (siehe auch $\rightarrow$ Reichsbahn, $\rightarrow$ Transporte) 68, $82,84-88,96,98,102$ f., 105, 108, 110, 116 f., $119,124,127,132$ f., $135-137,146,148-153$, 158, 175, 177-179, 191-193, 201, 212, 218, 220 f., 223 f., 243, 281, 295, 298, 351, 367, 374 f., 408, 411, 480, 487, 514, 530, 532, 560, $562,565,577$ f., 585, 587, 597 f., 602, 616, 621, 636f., 641, 662-664, 669, 672, 678, 706, 715, $735,750,754,770-772,802,806,809,829$, $837,843,857,861$ f., 868 f., $886,890,902$ f., 916, 920, 932, 936, 957 f., 960, 993, 997 f., 1011, 1017, 1020, 1040-1042, 1050 f., 1057, 1082, 1090, 1094, 1125, 1133, 1146 f., 1154, 1236, 1274f., 1277, 1330, 1349, 1376 f., 1397, $1403,1412,1434-1436,1438,1440,1442$, 1444-1446, 1448, 1450, 1455 f., 1459, 1461, 1463-1465, 1467 f., 1470-1472, 1479, 1483 und öfter

- Güterwagen, -waggons, -zug 84, 88, 102, 137, 148 f., 154f., 159, 176f., 180, 218, 277, 287, $291,615,637,890,924,956,1010,1194$, 1435, 1437, 1462, 1467 f., 1471, 1519

- _ offene 84, 88, 98, 152, 578, 616, 890, 993, $1434,1450,1454$

- _ als Notwohnung, -quartier 1125, 1434

- Isolierwagen 1053

- Kohlenwagen, -züge 156, 664, 997

- Krankenwagen, -waggon 179, 1040

- Küchenwagen 179

- Lazarettzug 179, 560, 862, 1444

- „letzter Zug“ 84, 598, 686, 711, 891, 902

- Lokführer 85, 156, 1437

- Lokomotive, Lok 85, 87, 148, 153, 156, 179, 664, 734, 771, 862, 997 f., 1050, 1434, 1434

- Personenwagen, -zug 85 f., 88, 148 f., 159, 408, 638 f., 862, 1011, 1376, 1434, 1451, 1468

- Sanitätswagen 153, 1045, 1051

- Schlafwagen 137

- Sonderzug 408, 901, 1090, 1095, 1097, 1099

- Viehwagen, -waggons 85, 152 f., 154, 291, 862, $1275,1440,1443,1446,1463,1469$

- Zugunglück 587, 637

Eisenbahnbrücken $\rightarrow$ Brücken 
Eisenbahndirektionen, -verwaltungen $\rightarrow$ Reichsbahndirektionen

Eisenwarenhandel 1208, $1212 \mathrm{f}$.

Eisenwerk 350, 714, 1313-1315, 1319

EJB Werbellinsee $\mathrm{GmbH} 554$

EKD $\rightarrow$ Evangelische Kirche in Deutschland

Elektrische Heizkörper 1199

Elektrisches Licht 843, 896, 1013, 1019, 1054, 1059,1277

Elektrohandel 1208, 1211

Elektromeister 1438

ELG (Einkaufs- und Liefergenossenschaft des Handwerks) 1475

Eltern passim

Energiewirtschaft 1356

Entbehrungen $\rightarrow$ Todesursachen

Entbindung $\rightarrow$ Frauen

Entbindungsheim 1453

Enteignung 1360 f., 1396, 1435 und öfter

Enten 1134

Enteritis $\rightarrow$ Todesursachen

Entkräftung $\rightarrow$ Todesursachen

Entlassungslager (für Heimkehrer) 667, 675

Entlassungsschein (für Heimkehrer) 654

Entlausung, Entlausungsstation, -anlage, -anstalt (siehe auch $\rightarrow$ Läuse) $137,165,175,188$, $561,566,611,640,654,676,684,717,719$, 749, 848-850, 866, 895, 916, 1001, 1005 f., 1014, 1017-1019, 1022, 1024f., 1027, 1048, 1050-1052, 1067, 1072-1075, 1078, 1080, $1152,1268,1282,1451,1464$

Entnazifizierung 246, 297, 335, 649, 1027, 1201, 1245,1298 f., 1419, 1472

Entschädigungsforderungen (vgl. $\rightarrow$ Lastenausgleich)

- (Jan./Febr. 1945) 616

- (1948-1950) 1299, 1311

- (1992-1994) 463, 1360, 1368, 1375

- (nach 1994) 468, 1365

Entschädigungs- und Ausgleichsleistungsgesetz (EALG) 464, 468, 498

Enttrümmerung 97

Entwesung 640

Epidemien $\rightarrow$ Krankheiten

Epilepsie, Epileptiker $\rightarrow$ Krankheiten

Erbauungsbuch 1277

Erblindung $\rightarrow$ Krankheiten

Erbschaft 1046

Erdhütte 565
Erfrieren, Erfrierungen $\rightarrow$ Krankheiten, $\rightarrow$ Todesursachen

Erhängen $\rightarrow$ Todesursachen

Erholungsheim $\rightarrow$ Arbeiter, $\rightarrow$ Heimkehrer-, $\rightarrow$ Kindererholungs-, $\rightarrow$ NS-Mütter-Erholungsheim

Erinnerungsberichte $\rightarrow$ Zeitzeugenberichte

Erinnerungskultur, -arbeit, Andenkenpflege, Geschichtskultur (siehe auch $\rightarrow$ Gedenkorte) V, 5, 8, 9, 19-21, 36f., 43, 57, 183, 210, 363, 403, $425,431,460,468,470,473,475,477,482$, $510,513,602,628,691,776,885$ f., 1361 f., $1365,1367,1378$

Erinnerungsstücke 602

Erkältung $\rightarrow$ Krankheiten

Erlebnisgeneration, „Generation der Betroffenen“ $330,359,362,366,605,910,1376$ und öfter

Ermländische Feuersozietät 1208

Ernährung $\rightarrow$ Lebensmittel

Ernährungsamt 1154

Ernährungsstörungen $\rightarrow$ Hunger, $\rightarrow$ Krankheiten

Ernste Bibelforscher 733

Ernte, -einbringung, -einsatz, -arbeiter $160 \mathrm{f} ., 275$, $528,652,678,733,999,1133$ f., 1193, 1229, $1246,1277,1441,1448$

Erntedankfest, -treffen 384, 485, 1372

Erntekindergarten 286, 951, 1460

Erntewettbewerb 1167

Erpressung $\rightarrow$ Kriminalität

Erschießung $\rightarrow$ Todesursachen

Erschlagen $\rightarrow$ Todesursachen

Erschöpfung $\rightarrow$ Krankheiten, $\rightarrow$ Todesursachen

Erstkommunion 940, $1266 \mathrm{f}$.

Erweckungsbewegung 924

Erwerbsbeschränkte 1189-1193 und öfter

„Erzähl-Café“ $1373 \mathrm{f}$.

Erzbergbau 293f., 1092, 1188

Erzbischöflicher Kommissar/Commissarius in Finsterwalde 699, 752 f., 939

Erzbischöfliches Amt Görlitz 443, 559, 577, 613, 619 f., 625, 630, 632 f., 654, 659, 678, 696, 699, 701 f., 709, 716, 726, 753, 772, 785, 787, 789, 796,800 f., 816,824 f., $881,900,906,909$ f., 915, 921, 934, 939, 941, $946 \mathrm{f}$., 951, 1417

Erzbischöfliches Pastoralseminar $\rightarrow$ Pastoralseminar Bernhardinum

Erzbistum Berlin $\rightarrow$ Bistum Berlin

Erzbistum Breslau (siehe auch Geographisches Register s.v. Breslau) 37, 190, 209, 442-445, 
559, 577, 584, 590, 613, 619f., 625, 630, 632 f., 654, 659, 678, 696, 699, 701 f., 709, 716, 726, 756, 772, 785, 787, 789, 796, 800 f., 816, 824 f., $842,873,881,900,906,909,912$ f., 915,919 , 921, 934, 939, 941, 946 f., 950 f., 1268, 1417; Domkapitel 756, 825; Generalvikariat 825

Erzbistum Hamburg 680

Erzbistum Prag 573, 595, 613, 667

Erzieher/in 179, 226-228, 767, 776, 1451 f., 1469

Erziehungsbeihilfe 760, 1320

Erziehungshelferin 1462

Essenmarken $\rightarrow$ Lebensmittelkarten

Essgeschirr $\rightarrow$ Geschirr

Esskultur 235

Esten 569

„Ethnische Säuberungen“ 15, 360

Ethnologie, -graphie $\rightarrow$ Volkskunde

$\mathrm{EU} \rightarrow$ Europäische Union

Europäische Jugenderholungs- und -begegnungsstätte Werbelinsee 554

Europäische Union (EU) 235, 684, 885

Europaparlament 1368

„europareportage“ 854

„Europatag" 715

Europa-Universität Viadrina $\rightarrow$ Universitäten, Frankfurt (Oder)

„Euthanasie“ 608

Evakuierte (Begriff) 69

Evakuierung, Evakuierte, Flucht, (Zwangs-)Räumung, auch Rückkehr (siehe auch $\rightarrow$ Ausgebombte, $\rightarrow$ Bombenkriegsevakuierung) 597, $751,891,893,1038$ und öfter

- vor der Front 27, 100, 112, 484, 523, 566, $569,574,595,609,614,616,627,632,634$, 657, 663f., 667, 670, 686, 700f., 705, 711, 730, $752,757,763,784,800,827,829,843,857$, $860,862,869,874$ f., 880, 891, 901 f., 906 , $923,926,931,944,953,955,993,996,1201$, 1265, 1273f., 1279, 1377, 1390, 1392 f., 1396 f., 1399f., 1403-1405, 1431, 1434-1475 und öfter

Evakuierungsbefehle $\rightarrow$ Räumungsbefehle

Evakuierungsplan 100, 996

Evangelisation 924

Evangelische Flüchtlingshilfe 499

Evangelische Kirche $\rightarrow$ Kirche, evang.

Evangelische Kirche Berlin-Brandenburg-schlesische Oberlausitz (EKBO) 35-37

Evangelische Kirche der Altpreußischen Union 430, 437, 1257, 1264
Evangelische Kirche in Berlin-Brandenburg (EKiBB) 35 f., 430, 432, 449, 504, 513, 770, 923, 1256, 1263

Evangelische Kirche in Deutschland (EKD) 36, 433 f., 1261

Evangelische Verlagsanstalt 513

Evangelischer Bischof von Berlin $\rightarrow$ Bischöfe

Evangelischer Flüchtlingsseelsorger in West-Berlin

Evangelischer Oberkirchenrat 76, 669, 1420, 1481

EvangelischesDiakonissenhaus $\rightarrow$ Diakonissenhaus

Evangelisches Frauenwerk des Kreises Prenzlau $212,540,862$

Evangelisches Johannesstift Berlin(-Spandau) 369 f., 410 f., 439, 923, 1130

Evangelisches Jugend- und Fürsorgewerk 568

Evangelisches Konsistorium der Mark Brandenburg 56, 69, 76-78, 433, 435, 779f., 960, 1256 f., $1262 \mathrm{f}$., 1420

Evangelisches Landeskirchliches Archiv in Berlin (ELAB) 56, 1420, 1543

Evangelisches Vereinshaus 791

Evangelisches Zentralarchiv in Berlin (EZA) 732, 1420

Evangelisch-Freikirchliche Gemeinde Eisenhüttenstadt (Baptisten) 685

Evangelisch Kirchliches Gnadauer Gemeinschaftswerk in der DDR 234, 784, 838

Exhumierung 750, 875

Explosion 869

Export 1200, 1216, 1228, 1247

„Facebook“ 509

Facharbeiter, -mangel 229, 713, 826f., 875, 1047, 1073, 1075, 1097, 1117, 1123, 1171, 1180, 1190, 1192 f., 1196, 1200, 1222, 1240, 1283, $1321,1450,1457$

Facharbeiter(wohn)heim 850

Facharbeiterumschulung $1196 \mathrm{f}$.

Facharzt $\rightarrow$ Ärzte

Fachhochschule Lausitz (Cottbus) 503

Fachhochschule Potsdam 17, 575

Fachschulen, -schüler 236, 823, 1350, 1438, 1446 f., 1450 f., 1454

Fähren, Fährleute, -verkehr 197, 532, 565, 778, 868

Fahne $\rightarrow$ Flagge

„Fahnenflucht" (vgl. $\rightarrow$ Deserteure) 88

Fahrkarten, -ausgabe 1025, 1438

Fahrrad 85, 94, 114, 169, 266, 280, 295, 614, 818, $901,932,940,1175,1271,1276,1280,1353$ 
Fahrschule, -lehrer, -prüfung 1451, 1468, 1474

Fahrverbindungen $\rightarrow$ Verkehrsverbindungen

„Die Falken“ 1454

Fallschirmjäger $\rightarrow$ Wehrmacht

Familie, Verwandtschaft, Angehörige (vgl. $\rightarrow$ Ehe) $81,85,100,134,137$ f., 141, 156, 172, 175, 178, 184, 193, 197 f., 226, 229, 235, 237, 242, 262, $265,268,271-275,277,280,286,289,291$ f., $298,313,320-322,336,338,347,358,365$, 404, 421, 423-425, 490 f., 499, 508-510, 616, 620, 646f., 664, 678, 683, 730, 747, 754, 799, $863,869,872,876,887,891,924,928,930$, 948, 951, 958, 1024, 1047, 1066, 1096, 1110, 1120, 1152 f., 1185, 1187 f., 1191, 1201, 1225, $1227,1234,1242,1259,1261,1266,1273 \mathrm{f}$., 1277, 1280, 1313, 1315, 1357f., 1377, 1394, 1399, 1435-1438-1483 und öfter

- Großeltern 324, 359, 421, 425, 506, 574, 775, $1377,1443,1452,1458,1474,1483$ und öfter

- Großmütter 84, 86, 112, 197, 323, 1120, 1280, $1435,1445,1461,1463,1474,1477$ und öfter

- Großväter 46, 64, 74, 82, 90, 97, 99, 227, 272, 287, 320, 338, 404, 1274, 1448, 1471 und öfter

- Kinder $\rightarrow$ Kinder

- Mütter $\rightarrow$ Frauen

- Trennung durch Flucht und Krieg 81, 136, 140 f., 193, 197, 269, 293, 901, 1127, 1394, $1448,1452,1456,1459,1468 \mathrm{f}$. und öfter

Familienanzeigen, -nachrichten 230 f., 389 f., 393, 399 f., 404, 416, 685, 879

Familienfest 654

„Familiengedächtnis“, -überlieferung 8, 33, 45 f., $74 f ., 183,360-363,424,509,854$

Familiengeschichte $60,229,237,289,811,854,1460$

Familiengeschichtsforschung (Genealogie) 60, 77, 145, 148, 218, 233, 328 f., 403

Familiennachrichten $\rightarrow$ Familienanzeigen

Familiennamen 30, 326, $1094 \mathrm{f}$.

Familienpflegestelle 588

Familientradition 338

Familienverband, Großfamilie 198, 292, 298

Familienwallfahrt 552

Familienzusammenführung 137, 140-142, 145, $225,409,594,730,747,849,1012,1024$, $1044,1083,1117,1122,1125,1127,1186$, 1249, 1322, 1355 f., 1371, 1412, 1414 f., 1447

Fanfarenzug 227, 1331

„Faschist", „faschistische Tendenzen“ $\rightarrow$ Nationalsozialisten
FDGB (Freier Deutscher Gewerkschaftsbund; vgl. $\rightarrow$ Gewerkschaft) 51, 68 f., 190, 243, 259f., 351, 563, 699, 735, 933, 1085, 1093, 1104, 1113, 1121, 1144, 1161, 1163, 1165, $1167,1231,1241,1243$ f., 1302, 1323, 1335, 1420, 1440, 1447

- Kreissekretär 1324

FDJ (Freie Deutsche Jugend) 158, 175, 256, 259f., 334, 451, 563, 570, 713, 847, 915, 945, 1086, 1089-1091, 1093, 1098, 1104, 1109, $1138,1198,1222,1231,1235,1244,1306$, $1323,1326,1329,1416,1440,1442,1455$, 1457, 1461, 1474, 1478; Mitgliedsbücher 1109

Fédération Internationale des Anciens Prisonniers Politiques $\rightarrow$ FIAPP

Federbett $\rightarrow$ Bettzeug

„Feelinchen“ $\rightarrow$ Heimatzeitschriften

Feier, -stunde, Fest (siehe auch $\rightarrow$ Weihnachtsfeier) $69,75-77,237,268,280,300,372,380$, 386,412 f., 427,439 f., 459, 473, 478 f., 481 , 487, 556, 592, 605 f., 609, 653, 666, 671, 691, $693,715,722,762,767,792,795,813,821$, 830-832, 850 f., 878, 887, 898, 900, 914, 916, 1042, 1098, 1104, 1109, 1216, 1227 f., 1253, 1267, 1297, 1325, 1329-1331, 1373 f., 1415, 1456 und öfter

Feierabendheim, -haus 57, 621, 645, 889, 915, 933

Feiertag 435, 558, 588, 914, 1290, 1327

Feinkostgeschäft 1209

Feldbetten $\rightarrow$ Betten

Feldgendarmerie 627

Feldjäger, Militärstreife 114

Feldküchen 92, 833

Feldlazarette $\rightarrow$ Lazarette

Fensterglas, -scheiben $\rightarrow$ Glas

Fensterrahmen 1014f.

Ferienlager 227

Fernschreiben (vgl. $\rightarrow$ Telegramm) 123, 378, 1349,1353

Fernsehen, -seher 14, 226, 305 f., 334, 463

Fernsprecher $\rightarrow$ Telefon

Fest $\rightarrow$ Feier

Festtagsbräuche $\rightarrow$ Brauchtum

Festumzug 830, 887

Festung, Festungsstatus 566, 635, 663, 667, $711,771,773,786,801,835,890,915,921$, 1403-1405, 1458

Festungskommandant Frankfurt/O. 101

Fett, -mangel $\rightarrow$ Lebensmittel 
Feuersozietät 1208

Feuerversicherung 1305

Feuerwehr 114, 488, 639, 643, 738, 744, 1013, $1440,1457,1474$

Feuerwehrfahrzeuge 626, $827 \mathrm{f}$.

$\mathrm{FH} \rightarrow$ Fachhochschule

FIAPP (Fédération Internationale des Anciens Prisonniers Politiques) 1332

Fieber $\rightarrow$ Krankheiten

Filehner Landsmannschaft $\rightarrow$ Landsmannschaften Film, Filmvorführung (siehe auch $\rightarrow$ DEFA) 14, $334,347,356,507,519,558,648,714,818$, $876,906,921,1085$ f., 1092 f., 1104, 1329, $1411,1469,1475$

- „Der Augenzeuge 1947/38“ 302, 767, 780, 1085

- „Die Brücke“ (1949) 963, 967, 1412

- „Die Kinder von Golzow“ 700

- „Die letzte Etappe“ (1948) 1329

_ „Freies Land“ (1946) 532, 548, 845, 891 f., 1409

- Wochenschauen (1947) 356

Filmmuseum Potsdam $\rightarrow$ Museen

Filmtheater $\rightarrow$ Kino

Filzschuhmacher 583

FIMAG 654f.

Finanzamt, -verwaltung 464, 794f., 867, 1197, $1237,1244,1263,1373$

- Friedeberg/Nm. 206

Findelkinder $\rightarrow$ Kinder

Firmen (siehe auch $\rightarrow$ Betriebe, $\rightarrow$ „Umsiedlerbetriebe“, $\rightarrow$,-genossenschaften“, $\rightarrow$ VEB) 164, 288-290 , 307, 343 f., 350, 537, 647 f., 650, 654f., 681, 730, 734, 777, 780, 791, 814, $869,883,936,1074,1080,1149,1183-1186$, 1190 f., 1194, 1217, 1284, 1292-1295, 1312, 1326, 1438, 1444, 1464 und öfter

- Evakuierung 86f., 91, 101 f., 1400

Firmung 906, 1280

Fisch $\rightarrow$ Lebensmittel

„Flämmchen“ (Verein) 777

Flagge, Fahne, Landesfarben, Beflaggung 602, 780, 1329, 1331 f., 1418; Brandenburg 771, 1418; DDR 1329; Polen 90, 771, 1329; Rote $182,305,1329$

Flakhelfer/in 181, 416, 844, 1438, 1470

Flakstellung 115

Fleckfieber, -typhus $\rightarrow$ Krankheiten

Fleisch, -mangel $\rightarrow$ Lebensmittel

Fleischer, Fleischerei 323, 627, 678, 963, 1323, 1448, 1450, 1472, 1477
Flickstube 1023

Fliegeralarm 136, 574, 647, 861, 1474

„Fliegerbeschuss“ $\rightarrow$ Tiefflieger, $\rightarrow$ Todesursachen/Luftangriff

„Fliegergeschädigte“ $\rightarrow$ Ausgebombte

Fliegerhorst 663, 901, 1404

„Fliegerschaden“ 122

Flohbefall 859

Flucht (aus SBZ/DDR in den Westen $\rightarrow$ „Republikflucht"; vor der Front $\rightarrow$ Evakuierung) 1393

Fluchttunnel 34

Flüchtling passim

- (Begriff) 68-70, 1225, 1393

- Geflüchtete nach 1990 (siehe auch $\rightarrow$ Migration) 481, 508, 510 f., 570, 607, 655, 667, 700, 775

Flüchtlingsausschuss (SBZ) (vgl. ( $\rightarrow$ Umsiedlerausschuss) 255, 957, 1001, 1005

- (Westzonen) 255

„Flüchtlingsausschuß Friedeberg/Nm., Altkarbe und Umgegend“ 206, 255

Flüchtlingsausweis $\rightarrow$ Ausweis

Flüchtlingsbaracken (siehe auch $\rightarrow$ Baracken) 646,680

Flüchtlingsbeauftragter (ev. Kirche) 435 f.

Flüchtlingsbetreuung, „Umsiedlerbetreuung“ (siehe auch $\rightarrow$ Lehrer, $\rightarrow$ Schule/Schüler) 89, $97,109,117,199-128,174,260-262,369$, 430 f., 439, 451-453, 468, 523, 576, 582, 612, $663,712,718,736,786,800,827,837,880$, 927, 993-995, 998f., 1004-1009, 1011-1015, 1027, 1047 f., 1070, 1132, 1147, 1244, 1259, $1403,1459,1463,1472,1479-1481$ und öfter

Flüchtlingsbuch (ev. Kirche) 434, 969, 1262 f.

Flüchtlingsdienst, kath. $\rightarrow$ Katholischer Flüchtlingsdienst

Flüchtlingsdurchgangslager $\rightarrow$ Durchgangslager

Flüchtlingseinquartierung $\rightarrow$ Wohnungseinweisung

„Flüchtlingsfamilie“ 111, 128, 285, 322, 332, 574, 666, 774, 893, 932 f., 1119

Flüchtlingsfragen (Ressort) 896

„Flüchtlingsfrau“ 98, 173, 660, 955, 1119, 1278, 1479

Flüchtlingsfürsorge (vgl. $\rightarrow$ Umsiedlerfürsorge) 587, 646, 679, 733, 749, 786, 896, 902

- (evang.) 435, 1261 und öfter

- (kath.) 451, 916 und öfter 
Flüchtlingsfürsorgepfarrer 411, 440

Flüchtlingsfürsorgerin 411 f., 679

Flüchtlingsgeistliche (kath.) 444f., 447, 449, 462, $572,584,628,667,811,826,882,936,954,971$

Flüchtlingsgottesdienst 797

Flüchtlingsheim 68, 561, 590, 812, 848, 864, 1046

Flüchtlingskartei (ev. Kirche) 434, 1262

Flüchtlingskinder $\rightarrow$ Kinder

Flüchtlingskinderheim $\rightarrow$ Kinderheim

Flüchtlingsklasse $\rightarrow$ Schule

Flüchtlingskomitee 969

Flüchtlingskrankenhaus 68,864

Flüchtlingslager (siehe auch $\rightarrow$ Auffanglager, $\rightarrow$ „Umsiedlerlager“) $16,34,68,75,81$, 161 f., 168 f., 176 f., 181 f., $185,232,261,322$, 392, 484f., 561, 566f., 581-584, 611, 618, 621-623, 627, 641, 645, 649f., 680, 682, 716, 719 f., 734, 744, 766, 769, 775 f., 788, 797, 829, 862-864, 866-868, 870, 880, 899, 904, 924, 926f., 931, 957, 962, 964, 971, 979, 1057 f., $1282,1393,1435,1440,1446,1456,1462 \mathrm{f}$., 1467 f., 1470, 1474, 1539 und öfter

-, dänische 207, 222

- , in der SBZ $\rightarrow$ „Umsiedlerlager“

Flüchtlingslehrerin 449

Flüchtlingsleitstelle (siehe auch $\rightarrow$ Meldestelle) $124,556,775,838,1002,1004,1453$

Flüchtlingslisten 1002

„Flüchtlingsmädchen“ 509, 1119, 1442

Flüchtlingspass $\rightarrow$ Ausweis

Flüchtlingspfarrer, -pastor 36, 91, 432 f., 447, 449, $458,461,558,753,779,870$

Flüchtlingspriester 445 f., 571, 734, 1267, 1269

Flüchtlingsregistrierung 844

Flüchtlingssammelstelle (siehe auch $\rightarrow$ Sammellager) 950, 1399

Flüchtlingsschiffe, -transporter $\rightarrow$ Schiff

Flüchtlingsseelsorge (siehe auch $\rightarrow$ Seelsorge)

- (ev.) 435, 438, 446, 499, 584, 612, 835 und öfter

- (kath.) 166, 446, 451, 460, 600 f., 620, 621, $803,1264-1281,1419$ und öfter

Flüchtlingsstelle 548, 571, 1007

Flüchtlingsstudenten 448

Flüchtlingstransporter 68

Flüchtlingstreck $\rightarrow$ Treck

Flüchtlingsunterkunft (siehe auch $\rightarrow$ Notunterkunft) 587, 933

Flüchtlingsvieh 736
Flüchtlingswesen (Ressort) 712, $1000 \mathrm{f}$. und öfter

Flüchtlingszentrale 837

Flüchtlingszug 560, 598 und öfter

„Flüsterpropaganda“ 1321

Flugblatt (siehe auch $\rightarrow$ Handzettel) 618, 628, 1140,1399

Flugplatz 71, 689, 837, 946, 1466

Flugschrift, Druckschrift, Broschüre 236f., 1105, 1261, 1350 f., 1354

Flugzeuge 84, 89

Flussnamen 518, 585

Förderkreis Alte Kirchen Berlin-Brandenburg 885 f., 896

Förderverein Haus der Senioren Neuenhagen 1543

Förster 156, 306, 1294, 1321, 1324, 1450

Försterei 166, 285, 351, 1058, 1070, 1324, 1450

Forschungsstelle Ostmitteleuropa an der Universität Dortmund 47

Forschungsverbund SED-Staat 97

Forstamt 1145

Forstarbeiter 285, 351, 1163, 1165-1167, 1450

Forsthaus 686, 764

Forstwesen, -wirtschaft 351, 681, 1160, 1163, 1221

Fotoalben 362

Fotografien (siehe auch $\rightarrow$ Film) 18, 20, 39, 41, $143,172,183,226,249,251,281,312,328 \mathrm{f}$., $349,362,373,384,399,402,405,408,410$, 421, 477, 519, 558, 569, 579f., 602, 607, 652, 661, 682, 691, 701 f., 713, 719, 767, 788, 792, $845,851,854-856,858-860,898,907,934$, 949, 1124 f., 1252, 1255, 1373, 1437, 1440

Fragebogen 54, 194, 294, 460, 499, 551, 1155 , 1201, 1215, 1298

„Frankfurt (Oder)-Sternberger Kurier“ $\rightarrow$ Zeitschriften/Heimatblatt

Franziskaner 896

Franziskanerinnen 842, 896

Franzosen 133, 569, 716, 728, 774, 880

Frau (Referat) 1238

Frauen, -anteil 31, 44, 81, 86, 92, 96, 97-99, 100, 102,120 f., 125, 129, 132, 134, 148, 152-156, 159,172 f., $180,189,243$ f., 254 f., 269,285 f., 295, 301, 315, 320 f., 358f., 365-367, 377 , 450 f., 522, 540, 546, 560, 566, 574, 586, 590, 598 f., 617, 619, 621, 627, 629, 631, 637, 643f., 649, 660, 666, 696, 714, 720, 728, 730, 734, $749,757,761,767,774,778,795,805,819$, $847,849,860-862,869,902,908,919,923$, $933,943,953,995,1021,1060,1076$ f., 1083 , 
1085, 1094, 1096, 1115, 1121, 1130, 1133 , 1142, 1149, 1151, 1177-1185, 1191 f., 1194 f., $1199,1202-1204,1216,1225,1229,1233$, 1235, 1238 f., 1242, 1247, 1250, 1268 f., 1274f., $1277,1280,1288,1295,1298$ f., 1301-1303, 1310, 1315, 1329, 1331, 1336, 1344, 1347, $1356,1373,1435,1439,1452$ und öfter

- Abtreibung 358

- alte 546

- Ehefrauen 1107 und öfter

- Entbindung 98, 121, 1054, 1056f., 1357, 1458

- Großmütter $\rightarrow$ Familie

- Menstruation 320

- Mütter, alleinstehende Frauen mit Kindern 63, 81, 84, 98 f., 101, 109, 114, 121, 124 f., 127 f., 131, 181 f., 189, 225, 228, 265, 269, 272, 286, 358 f., 361, 398, 423, 553, 574, 578, 608, $680,821,863,924,955,960,994,1021,1044$, 1056, 1072, 1090, 1095f., 1140, 1151, 1160, 1196 f., 1201, 1250, 1273-1276, 1279-1281, 1310, 1347, 1376, 1435-1438, 1440-1454, 1456-1459, 1461, 1463-1471, 1473-1478, 1481 und öfter

- Schwangerschaft, Schwangere, „Wöchnerin“ 358, 795, 1056 f., 1072, 1090, 1095 f., 1152

- Totgeburt 861

- Untreue 1280

- Witwen passim

„Frau und Kind“ (Referat) 1160

Frauenanstalt 1152

Frauenausschuss 243 f., 256, 259, 556, 641, 842, 966, 1020, 1023, 1073, 1081, 1085, 1111, $1113,1149,1152$ f., 1160-1162, 1165, 1231, $1248,1282,1285-1287$

Frauenchor Raduga 1374

Frauenfachschule 1446

Frauengruppen 1374

Frauenhilfe $946 \mathrm{f}$.

Frauenklink $\rightarrow$ Krankenhaus

„Frauenleiden“ $\rightarrow$ Krankheiten

Frauenreferat 1142, 1149

Frauentag 1374

Frauentagungen 556

Frauenversammlung (im Lager) 1085

Frauenzeitschrift „Für Dich“ $\rightarrow$ Zeitschriften

Freie Deutsche Jugend $\rightarrow$ FDJ

Freie Prälatur Schneidemühl 571, 628, 752, 936, 963

„Freie Spitzen“ 1322
Freie Universität Berlin $\rightarrow$ Universitäten, Berlin (FU)

Freier Deutscher Gewerkschaftsbund $\rightarrow$ FDGB

„Freies Land“ $\rightarrow$ Film

Freikirchen 335, 685, 1264

Freitisch (Mittagstisch im Pfarrhaus) 269

Freitod $\rightarrow$ Selbstmord

„Fremdarbeiter“, -lager, „Ausländerlager“ (vgl. $\rightarrow$ „Ostarbeiter", $\rightarrow$ Zwangsarbeit, $\rightarrow$ Zwangsarbeiterlager) 310, 598, 626, 654, 687, 738, $749,936,943,1187$

Fremdenfeindlichkeit (siehe auch $\rightarrow$ Einheimische) $637,1156,1158$

„Fremdvölkische“ 569

Freude 321 f., 324

Freundschaftsabkommen 690

Freundschaftstreffen, -kundgebung (mit Polen) $355,468,487,489$, 491, 622, 635, 684, $713 \mathrm{f}$., 1478

„Frieden“ 41, 306, 325, 350, 487, 669-671, $713 \mathrm{f}$., 813 f., 879, 907, 1168, 1175, 1227-1229, 1296, 1300, 1302, 1311, 1321-1323, 1326-1333, 1337 f., 1352, 1410, 1415

„Friedensabzeichen“, blaues 1108, 1332

„Friedensfeuer“ 355

„Friedensglocke“ (Frankfurt/O.) 355, 671, 1415

„Friedensgrenze“ 295, 346, 349f., 352-355, 405, $529,671,683,708,713 \mathrm{f} ., 737,758,1242$, $1307,1310,1312,1319,1321$ f., 1328, 1332, $1333,1348,1409,1413,1415$

„Friedenshort“ (Heiligengrabe) $732 \mathrm{f}$.

Friedenskonferenz $\rightarrow$ Friedensvertrag

„Friedenskundgebung“ 1331-1333

„Friedensresolution“ 1306

„Friedensstörer" 1302

„Friedenstaube“ 1331

„Friedenstreffen“ $714 \mathrm{f}$.

Friedensvertrag, -bedingungen, -konferenz, -verhandlungen $348-350,448,618,713,1286$, 1290, 1292, 1294 f., 1306, 1311 f., 1321, 1330

Friedenswald 907

Friedhof (siehe auch $\rightarrow$ Begräbnis, $\rightarrow$ Grab, $\rightarrow$ Grabstein, $\rightarrow$ Massengrab) 44, 90, 177, $222,322,326-330,356,421,478$, 480 f., 484, $486,490,559,566,578$ f., 582, 587, 590, 595 f., $601,611,616,620$ f., $623,625,628,634,660$, 675, 687, 691, 720 f., 728 f., 740, 742, 750 f., 761-762, 767, 770, 788, 791 f., 797 f., 800, $817,821,824,838,850,860,872,881,898$, 
901, 907, 916, 919, 924f., 936, 947-949, 961, 1053, 1407, 1475

- Toten-, Bestattungsbuch, -register 595, 798

Friedrich-Ebert-Stiftung 666

Friedrich-Meinecke-Institut (FU Berlin) 26, 1543

Friseur/in 293, 1349, 1449, 1475

Frisur 337

„Fröhliche Sänger“ (Chor) 690

Frömmigkeit, Glaube, Kirchlichkeit, Religiosität $359,436,442,459$ f., 509, 598, 613, 638, 774, $1259,1264-1266,1278$

Fronleichnamsfest, -prozession 459, 557, 575, $625,753,847$

Frost $\rightarrow$ Wetter

Frühstücksbrötchen 1148

$\mathrm{FU} \rightarrow$ Universitäten, Berlin (FU)

„Für Dich“" (Zeitschrift) 1105

Führerbefehl, -erlass" 78, 727, 1398

Fürsorge, Sozialfürsorge 56, 126f., 262, 266-269, $276,568,614,810,1026,1053,1196,1231 \mathrm{f}$, 1243

Fürsorgearzt 1055

Fürsorgeheim 668

Fürsorgerin 1165 f., 1261

Fürsprache 1190

Fuhrgeschäft, -unternehmer, -leute 655 , 1208-1210, 1225

Fuhrwerk $\rightarrow$ Pferde

Fundacja Kościół Mariacki w Chojnie-Königsberg/Neumark (Stiftung Marienkirche in Königsberg/NM-Chojna) 472

Furcht $\rightarrow$ Angst

Furunkulose $\rightarrow$ Krankheiten

Fußboden (als Nachtlager; vgl. $\rightarrow$ Strohschütten) 114, 131, 170, 176, 178, 277, 664, 1140 und öfter

Fußleiden $\rightarrow$ Krankheiten

Fußmarsch 105, 129, 135, 146, 264, 275, 877, 1057, 1274, 1279, 1377, 1404, 1434f., 1441, 1449 f., 1453 f., $1457-1459,1463$, 1465, 1467, 1471 und öfter

Futtergetreide 1299

Futterküche 1119

Futtermittelhandel 1209, 1212

„Gablonzer Heimat-Bote“ $\rightarrow$ Heimatzeitschriften

Gänse 1134

Gärtnerei 646

Gästebücher 384-386
Galiziendeutsche 71, 99, 193, 203, 218, 441, 452, $585,615,653,657,697,711,752,755,794$, 914, 917 f., 931, 940, 1261, 1392

Garnisonverwaltung 844

Gartenbau 1451

Gartenland, -grundstücke (siehe auch $\rightarrow$ Kleingärten) $570,733,749,897,1128,1133,1186$, $1219,1226,1278,1374,1411,1452,1463$ und öfter

Gartenlaube 586, 1450

Gastarbeiter, polnische 27

Gasthof, -stätte, -wirtschaft, -haus, Lokal, Restaurant (siehe auch $\rightarrow$ Hotel) 43, 95, 119, 160, $166,169,184,206,267,332,343,354$ f., 369 , $372,375,386,395,405,407,410-414,460$, $465,483-486,506,555,561-563,577,579$, 585 f., 607, 619, 629, 635 f., 638 f., 656, 658 f., 683, 689 f., 699, 707, 716, 721 f., 735, 748, 761, $775,784,786,795$ f., $803,806,807,824,833$, 848 f., $870,896,902,906,912,917,920,925$, 933, 945, 950, 1012, 1091, 1142, 1216, 1238, 1337, 1342, 1344, 1347, 1349, 1351-1353, $1368,1376,1436,1459,1461,1464,1466$, 1523

Gastwirt 315, 1323, 1349, 1437 und öfter

Gasvergiftung 231

Gasversorgung 896

Gau, -leiter, -propagandaleitung $\rightarrow$ NSDAP

Gauschule Grießen 572, 706

Gebetbuch, -büchlein 446, 453

Gebietsverband $\rightarrow$ Bund der Vertriebenen

Gebrauchsgegenstände, -güter 1272, 1303, 1309, 1411

Gebrechliche (siehe auch $\rightarrow$ Sieche) 665, 901 und öfter

Geburten (auf der Flucht $\rightarrow$ Kinder) 305, 616, 782,1458

Geburtenzahl 1010, 1039, 1152

Geburtshelfer 1152

Geburtsurkunde 1454, 1470

Gedächtniskirche Rosow 481, $885 f$.

Gedenkbuch 232

Gedenkfeier 878 und öfter

Gedenkgottesdienst 707, 748, 856 und öfter

Gedenkkultur $\rightarrow$ Erinnerungskultur

Gedenkkundgebung 878 und öfter

Gedenkort, -stein, -tafel, Denkmal, Mahnmal 41, $44,110,222,227,356,466,478-482,484$, 486, 567, 590 f., 602, 607 f., 611 f., 623, 628, 
633 f., 642, 654f., 666, 669 f., 674, 676, 681, 687, 691 f., 693, 714, 721, 725, 728, 737, $740 \mathrm{f}$., 750 f., 761 f., 775 f., 780 f., 788,791 f., 798,821 , $824,830-832,838,841,846,850$ f., 856, 859, $865,876,878$ f., 881 , 885 f., $888,901,906$ f., 916, 948 f., 964, 1373, 1378, 1418, 1456, 1525

Gedenkstätte (in KZ) 21, 34, 36, 325

Gedenktag für die Opfer von Flucht und Bertreibung 1418

Gedichte 347, 373, 417, 1142, 1469

Gefängnis 1113

Gefängnisseelsorger 1342

Gefallene 54, 285, 383, 578, 608, 695, 727 f., 747, 750 f., $808,821,881,901,1225,1346$ und öfter

Gefangenenlazarett 1453

Gefangenschaft $\rightarrow$ Kriegsgefangenschaft

"Geflüchtete" (siehe auch $\rightarrow$ Flüchtlinge) 511

Geflügel $\rightarrow$ Vieh

Gegenreformation 1260

Gehalt $\rightarrow$ Lohn

Geheime Mitarbeiter (des MfS) (GM) 374, 905

Geheime Staatspolizei (Gestapo) 76

Geheimes Staatsarchiv PK 1543

Geheimpolizei (nach 1945) 294, 406

Gehörlosenschule Posen 641, 802, 870

Gehörschaden $\rightarrow$ Krankheiten

Geisteswissenschaftliches Zentrum für Geschichte und Kultur Ostmitteleuropas (GWZO) (Leipzig) 666

Geistige Behinderung $\rightarrow$ Krankheiten

Geiz 1161

Geld (siehe auch $\rightarrow$ Lohn, $\rightarrow$ Preise) 103-105, 267, 276, 286, 291, 293, 391, 406, 416, 699, 733, 749, 796, 1089-1091, 1098, 1134, 1139, 1142, 1145, 1166, 1171-1174, 1244, 1269, 1273-1275, 1278, 1280, 1306, 1323, 1343

- DM-Mark Ost, Ostgeld, Ostmark 372, 387, 392, 1224, 1226, 1228 f., 1311, 1314f., 1317, 1323, 1354

- DM-Mark West, Westgeld 367, 372, 377, 387, 392, 401, 1341, 1354

- Reichsmark, „altes Geld“ 1089, 1138 f., 1147 f., 1164, 1171, 1173, 1183, 1198, 1200, $1216,1234,1250,1254,1286$

- Rubel 1094

- Zloty 1283

Gelenkrheumatismus $\rightarrow$ Krankheiten

Gemeindeamt $\rightarrow$ Gemeindeverwaltung
Gemeindearchive (nichtkirchl.) 56, 1420

Gemeindebodenkommissionen $\rightarrow$ Bodenreformkommission

Gemeindebrief 395f., 409, 441

Gemeindediakonie 929

Gemeindehaus, -zentrum, kirchl. 272, 635 f., 638 f., 720, 789, 878, 898, 906, 947, 1346

Gemeindekartei (evang.) 1262

Gemeindekasse 604

Gemeindekirchenrat 57, 434, 1257, 1259, 1463, 1465

Gemeindepartnerschaft (vgl. $\rightarrow$ Städtepartnerschaft) $422,491,518$ f., 587, 608, 610, $633 \mathrm{f}$., $644,672,679,705,772,786,946,952,955$, 968

Gemeinderat $\rightarrow$ Gemeindeverwaltung

Gemeindeschwester 98, 955, 1258 und öfter

Gemeindesekretär 43, 190, 1146, 1477

Gemeindeversammlung 1139f., 1150, 1298 f., 1302,1306

Gemeindevertreter/in 1238, 1318

Gemeindevertreter-Tagung 1253

Gemeindevertretung 700, 877, 1139, 1147, 1298, 1318

Gemeindeverwaltung, -vorstand, -vorsteher/in, -rat, -amt (siehe auch $\rightarrow$ Bürgermeister, $\rightarrow$ Rat der Gemeinde) 192, 310 f., 323, 332, 423, 586, 604, 629, 643, 645 f., 650, 695, 707, 734, 737, $780,804,888,914,919,943,962,1005,1007$, $1009,1015,1059,1124,1128,1147,1155$, 1172,1225 f., 1292, 1301, 1357, 1398, 1412, $1451,1472,1474$ und öfter

Gemeindeverwaltungsschule 246

Gemeinnützige Siedlungsgesellschaft Deutscher Ostbund $\rightarrow$ Ostbund

Gemeinschaft der ehemaligen Aufbau-/Heimschüler von Drossen 1420

Gemeinschaft evangelischer Schlesier 1256, 1259

Gemeinschaftskeller 1301

Gemeinschaftsküche 749, 869, 1007

Gemeinschaftsverpflegung 829, 869, 1133

Gemeinschaftswaschküche 1080, 1243

Gemischtwarenhandel 1209, $1212 \mathrm{f}$.

Gemüse $\rightarrow$ Lebensmittel

Gemüseverwertung 1206

Gendarmerie 101, 844

Genealogie $\rightarrow$ Familiengeschichtsforschung

„Generals-Sammellager“ 926

Generalvikar $\rightarrow$ Bistum Berlin 
Generalvikariat $\rightarrow$ Erzbistum Breslau

Generationen 8, 29, 32, 59f., 62-65, 73-75, 97, 300

Genesungsheim 572, 747

Genossenschaften (siehe auch $\rightarrow$ BHG, $\rightarrow$ ELG, $\rightarrow$ Handels-, $\rightarrow$ Handwerks-, $\rightarrow$ Konsum-, $\rightarrow$ Landwirtschaftliche Produktions-, $\rightarrow$ Produktions-, $\rightarrow$ Produktiv-, $\rightarrow$ Umsiedlergenossenschaften) 350, $1173 \mathrm{f} ., 1197,1214,1216$, $1313 \mathrm{f} ., 1319$

Genossenschaftsregister $\rightarrow$ Amtsgerichte

Genussmittelhandel 1209

Georgi-Dimitroff-Museum $\rightarrow$ Museen

Gepäck, Wertgegenstände, -sachen, „Habseligkeiten“, „Hab und Gut“, „Habe“, Handgepäck, „Bündel“, Traglasten (siehe auch $\rightarrow$ Ausplünderung, $\rightarrow$ Hausrat) 83 f., 114, 116, 130-132, 134, 142, 154, 182, 266, 269, 278, 307, 530, 559, 561, 574, 637, 639, 664f., 750, 758, 763, $784,786,800,819,829,842,875,887,891$, $896,921,966,993,997,1010,1012,1040 \mathrm{f}$., 1044, 1057, 1074f., 1080, 1089, 1094, 1145, 1273-1275, 1277, 1289, 1299, 1437 f., 1441, 1453, 1464, 1469

Gereiztheit 183

Germanisierung 215, 218, 329, 1168

Gerüchte 149, 154, 182, 322, 348, 554, 591, 658, 700, 713, 757, 891, 940, 1023 f., 1084, 1092, $1164,1168,1175,1281$ f., 1286, 1290, 1292, 1304

Gesamtverband der Berliner Inneren Missionen 432

Gesang $\rightarrow$ Lieder, $\rightarrow$ Musik

Gesangbuch 1260, 1276

Geschenkartikelherstellung 563

Geschenke 175, 385, 693, 742, 755, 1142 f., 1277, 1286

Geschichtsbücher 63, 622

Geschichtskultur $\rightarrow$ Erinnerungskultur

„Geschichtspark“ 650

Geschichtsunterricht $\rightarrow$ Schule

Geschichtsverein Leegebruch 781

Geschichtswerkstätten 45

Geschichtswettbewerb des Bundespräsidenten 45, 509

Geschirr, Ess-, Kochgeschirr 754, 811, 896, 1142, 1145, 1148, 1376

Geschlechtskrankheiten $\rightarrow$ Krankheiten

Geschwüre $\rightarrow$ Krankheiten
Geselligkeit 459, 629

Gesellschaft für deutsch-sowjetische Freundschaft (DSF) 243, 350, 714, 1319, 1323, 1446

Gesellschaft für interregionalen Kulturaustausch (Berlin) 9, 577, 666, 846

Gesellschaft für Sport und Technik (GST) 681, 1440, 1451, 1457

Gesetz $\rightarrow$ (Einzelgesetze); siehe auch Alliierter Kontrollrat, $\rightarrow$ SMA/Befehle

Gesetz über die Angelegenheiten der Vertriebenen und Flüchtlinge $\rightarrow$ Bundesvertriebenengesetz

Gesetz über die Aufnahme eines Kredites von 45.000.000 RM für Auszahlung einmaliger Unterstützung an Umsiedler 1410

Gesetz über die weitere Verbesserung der Lage der ehemaligen Umsiedler in der DDR (1950) $1413 \mathrm{f}$

Gesetz über Sachleistungen für Reichsaufgaben $\rightarrow$ Reichsleistungsgesetz

Gesetz zur Förderung der Jugend 1318

Gestapo $\rightarrow$ Geheime Staatspolizei

Gestüte 823

Gesundheit, Gesundheitszustand (siehe auch $\rightarrow$ Krankheiten) 183-189, 241, 291 f., 412, 522, 608, 622, 736, 794 f., 828 f., 1016 f., 1053, 1056, 1069, 1078, 1089, 1094, 1096, 1115 , $1126,1163,1189,1192,1194,1247,1282$, $1475 \mathrm{f}$. und öfter

Gesundheitsamt (siehe auch $\rightarrow$ Kreis-, $\rightarrow$ Provinzialverwaltung, Abt. Provinzial-Gesundheitsamt) 161, 789, 1004-1007, 1014f., 1024, 1055, 1065

Gesundheitsdezernent, -dezernat u.ä. 52, 552, 635 f., 640, 875, 1054

Gesundheitswesen (Ressort; siehe auch $\rightarrow$ Zentralverwaltungen) $24,251,259,523,602$, 1160, 1237, 1473, 1476

Getränke $\rightarrow$ Lebensmittel

Getreide $\rightarrow$ Lebensmittel/Mehl

Getreideabgabe, -soll $\rightarrow$ Ablieferungssoll

Getreideernte $\rightarrow$ Ernte

Getreidemühle 1206

Gewalt, -erfahrung (siehe auch $\rightarrow$ Ausplünderung, $\rightarrow$ Vergewaltigung) 3, 73, 97, 115, 129 f., 176, 183, 272, 278, 320, 346 f., 354, $359,459,566,666,686,888,916,1012,1130$, $1269,1277,1441,1477$ und öfter

Gewaltbereitschaft 350 f., 354, 1299, 1303, 1324 
Gewerbe 1189 und öfter

Gewerbegenossenschaft 899, 1159

Gewerbekonzession, -genehmigung 1143, 1320

Gewerbetreibende 1110, 1159, 1227, 1248, 1320 und öfter

Gewerke 584

Gewerkschaft (siehe auch $\rightarrow$ Betriebsgewerkschaftsleitung, $\rightarrow$ FDGB) 256, 685, 969, $1020,1160,1165,1214,1332,1447$

Gewerkschaftshaus 699

GEWOBA 689

Ghetto Litzmannstadt (Lodz) 281, 1446

Gießerei 754

Gift 1013

Glas, -mangel, Fensterglas, -scheiben, -verglasung 1008, 1014f., 1060, 1080, 1088, 1112, 1140, 1268

Glaswarenherstellung, -industrie, -veredelung, -facharbeiter, -bläser 31, 230, 301-303, 315, $702,778,814,842,1138,1186,1188-1190$, 1198-1201, 1205, 1215, 1228

Glatteis $\rightarrow$ Wetter

Glaube $\rightarrow$ Frömmigkeit

Glaubenstage für bessarabiendeutsche Flüchtinge $234,592,838$

Gleichbehandlung (Vertriebene Ost/West) 1368

Gleichberechtigung (Vertriebene/Einheimische) $333,437,1043,1154,1174,1263,1337$ und öfter

Gleichstellung (Vertriebene/Einheimische) $1133,1137,1145,1151,1155,1157,1166$, $1197,1234,1258,1316,1366$ f., 1409 und öfter

Gleichstellungsbeauftragte 1439

Glocken $\rightarrow$ Friedensglocke, $\rightarrow$ Kirchenglocken

Glogauer Heimatbund 659

$\mathrm{GM} \rightarrow$ Geheime Mitarbeiter (des MfS)

Gnadauer Gemeinschaftswerk in der DDR

$\rightarrow$ Evangelisch Kirchliches Gnadauer Gemeinschaftswerk in der DDR

Görlitzer Abkommen/Vertrag 342 f., 346, 349, 351, 354f., 666, 1328, 1413

Goldene Hochzeit $\rightarrow$ Ehe

Gold-und-Silberwarenhandel 1210

Gonorrhoe $\rightarrow$ Krankheiten

Goßner-Mission 770

Gottesdienst, evang.; Andacht 77, 91, 237, 369 f., 408-413, 431, 436, 439-441, 606, 619, 625, $641,693,707,733,774,776,795$ f., 856, 1086,
1092 f., 1098 f., 1104, 1269 f., 1276, 1339,

1341, 1346, 1348 f., 1352

-, kath. (hl. Messe; siehe auch $\rightarrow$ Kirchenbau, evang./Nutzung für kath. Gemeinden) 308, 385 , 453, 459-462, 553, 556, 558, 571, 573, $575,588,594,599$ f., 606, 609 f., 613, 620, 625, 644, 699, 703 f., 734, 753, 769, 783 f., 797, $808,832,842,847,858,881,900,906,932$, 935, 940, 942, 950, 964, $1072 \mathrm{f} ., 1085,1091 \mathrm{f}$. , 1098 f., 1104, 1265, 1269-1271, 1275 f., $1278-1280$

- ökumenisch 480, 691, 851

Grab, -stätte (siehe auch $\rightarrow$ Friedhof, $\rightarrow$ Massengrab) $417,612,620,665,727-729,750,770$, $817,821,852,875,919,948$ f., 997,1377 und öfter

Grabpflege, -besuch 417, 420, 750, 925, 948

Grabstein, -inschrift 326-330, 424, 578, 635, 740 f., $798,817,860,925,948$ f.

Grafik 704

Graue Schwestern von der heiligen Elisabeth 38, 148, 210, 450 f., 554, 581, 591, 612, 621, 638, $654,656,668,789,1271$

„Greifenberger Heimatbrief“ $\rightarrow$ Heimatzeitschriften

Greise 627, 696 und öfter

Grenzabkommen, Schweriner 1407

Grenzanlagen 34

Grenzbahnhof 148, 151, 770-772, 1463 und öfter

Grenzbereinigung 557

Grenzblockade $714 \mathrm{f}$.

Grenzdurchgangslager Friedland 499, 1442, 1457

Grenze (siehe auch $\rightarrow$ Oder-Neiße-Grenze) passim

„Grenzfrage“, -ziehung $\rightarrow$ Oder-Neiße-Grenze

„grenzgänger | forschung \& training “ 811

Grenzkontrolle 374, 387, 418, 488, 1025, 1434

Grenzkreise 214, 216f., 275, 352, 483, 1153 und öfter

„Grenzlandtreffen“ 713, 1331-1333

Grenzpolizei, deutsche $\rightarrow$ Deutsche Grenzpolizei

- sowjet. 1296

Grenzschutz, poln. 1330

Grenzstädte 28, 49, 340, 354, 357, 419, 426, 664f., 683, 712, 716, 718, 902, 1068, 1154, 1281 f., 1291, 1300, 1304

Grenzstein 821

Grenztruppen 488 
Grenzübergang, -übertritt 424, 488, 632, $657 \mathrm{f}$., 714f., 722, 737, 770-772, 818, 903, 1274, 1406, 1444, 1451, 1457, 1469, 1476, 1519 und öfter

Grenzübungslager 1444

Grenzverkehr 666, 771

Grippe $\rightarrow$ Krankheiten

Grobkeramikindustrie, -herstellung 1186, 1188

Großbauern 285, 314, 1128-1130, 1171, 1459

Großküchen 838, 1053

Großeltern $\rightarrow$ Familie

Großgrundbesitz, -besitzer 1168, 1247

Großmütter, -väter $\rightarrow$ Familie

Großwäscherei, sowjet. 923

Gruben $\rightarrow$ Bergbau

Grütze $\rightarrow$ Lebensmittel

Grundbesitz, „Haus und Hof “ (vgl. $\rightarrow$ Hausbesitz) 54, 135, 191, 313, 359, 362, 423, 1308

Grundbuch, -auszüge 311, 814

Grundgesetz 1360-1362, 1364, 1417

„Gruppe Ackermann“ 254

GST $\rightarrow$ Gesellschaft für Sport und Technik

Gubener Heimatbund 401 f., 466f., 720-722, 1440

- Regionalgruppe Guben 721

„Gubener Heimatkalender" $\rightarrow$ Heimatzeitschriften

Gürtlerei 1199

Güterbahnhof $\rightarrow$ Bahnhof

Güterwagen, -waggons $\rightarrow$ Eisenbahn

„Gumbinner Heimatbrief“ $\rightarrow$ Heimatzeitschriften

Gurtweberei 1199

Gustav-Adolf-Werk 439, 1261

"Gustloff" $\rightarrow$ Schiff

Gut 1224, 1480 und passim

Gutsangestellter 1436, 1449, 1466

Gutsarbeiter 314, 1221, 1450

Gutsbesitzer, ,Junker" 81, 90-93, 96, 117-119, 298, 311, 314, 320, 365, 417, 707, 757, 791, $883,890,898,947,1131$ f., 1449, 1461, 1472, 1480

Gutsbesitzerin, „-frau“, „-herrin“ 1460, 1472

Gutsdorf 117, 283, 298, 314, 409

Gutshaus, -hof, Herrenhaus, Schloss (vgl. $\rightarrow$ Gut) 91 f., 95, 100, 164, 171, 182, 191, 272, 279, 282284, 299, 311 f., 474, 527, 535, 545, 547, 553, 557, 572, 594f., 616, 631, 679f., 687, 698, 707, $727,747,755,783,785,789,802,812,815$, $817,824,832-834,881,884,889$ f., 895,898 , $911,920,934,943,947,954,999,1015,1119$, 1131 f., 1145, 1167, 1225, 1227, 1247, 1345, 1436f., 1440, 1457 f., 1463; Inventar 1132, 1144
Gutshof 91, 96, 114, 116, 311, 816, 1441 und öfter

Gutsland (siehe auch $\rightarrow$ Bodenreform) 29, $816 \mathrm{f}$., 1001 und öfter

Gutstreck 118, 1458

Gutsverwalter 1167, 1466

Gutsvorsteher, -verwaltung 192

Gutswirtschaftsgebäude 763, 898, 911 und öfter

GWZO $\rightarrow$ Geisteswissenschaftliches Zentrum für Geschichte und Kultur Ostmitteleuropas

Gymnasium $\rightarrow$ Schule

Haager Landkriegsordnung 1360

„Habseligkeiten“, „Hab und Gut", „Habe“ $\rightarrow$ Gepäck

Hafer 96

Haferflockensuppe $\rightarrow$ Lebensmittel

Hakenkreuz 145

Hamstern, Hamsterer, Hamsterfahrt 810, 1291, $1461 \mathrm{f}$

Handel (siehe auch $\rightarrow$ Buch-, $\rightarrow$ Schwarz-, $\rightarrow$ Tauschhandel) 259, 297, 1003, 1021, 1189, 1296, 1312, 1314, 1338 und öfter

Handelsabkommen (Polen/DDR) 1328

Handelsbetriebe 1204, 1208-1213

Handelsgenossenschaften 300, 744, 814, 1138, 1198, 1205, 1216

Handelsorganisation $\rightarrow \mathrm{HO}$

Handelsregister $\rightarrow$ Amtsgerichte

Handelsschule Rybnik 1450-1452

Handelsvertreter 1208 f., 1212

Handgepäck $\rightarrow$ Gepäck

Handschlitten 95

Handschuhe 1106

Handschuhmacher 1199

Handtücher 897

Handwagen, Karren 82, 84, 90, 95, 114, 130 f., 134, 146, 180, 188, 269, 276, 424, 614, 637, 657, 664f., 750, 763, 786, 801, 830, 875, 887, 893, 896, 901 f., 969, 997, 1051, 1058, 1149 f., $1274,1302,1304,1439,1441,1443,1459$, 1464,1472

Handweberei 1026

Handwerk, -werker, -werksbetriebe 226, 229, 315, 588 f., 646, 826, 965, 1014 f., 1021 f., 1026, 1052, 1080, 1110, 1121, 1124, 1152, 1177 , 1190 f., 1194 f., 1200, 1225, 1240, 1278, 1281, $1309,1314,1320,1458,1473,1475$ und öfter Handwerkerversammlung 1305

Handwerksamt 1214f. 
Handwerksgenossenschaften 1174

Handwerkskammer Potsdam 260, 1090, 1173 f.

Handwerkszeug 1191

Handzettel 862, 1253

„Hass gegen Polen“ 1045

Hauptabteilung für Deutsche Umsiedler im Sowjet. Okkupationsgebiet 1146

Hauptabteilung Paß- und Meldewesen $\rightarrow$ Minister (DDR), Inneres

Hauptabteilung Umsiedler und Heimkehrer $(\mathrm{SBZ}) \rightarrow$ Zentralverwaltungen, Inneres

Hauptamt für Sozialfürsorge $\rightarrow$ Magistrat von Groß-Berlin

Hauptamt für Volkswohlfahrt $\rightarrow$ NSDAP

Haupt-Einschleuspunkt 1019

Hauptkampflinie (HKL) 902

Hauptkommandantur 1309

Hauptverwaltung Ausbildung (HVA) $\rightarrow$ Minister, DDR, Inneres

Hauptverwaltung Deutsche Volkspolizei $\rightarrow \mathrm{Mi}$ nister, DDR, Inneres

Haus $\rightarrow$ Neubauernhaus, $\rightarrow$ Wohnungsbau

Haus Brandenburg (Fürstenwalde) 22 f., 386, 470-472, 474-477, 494, 691f., 1418

Haus der Begegnung 601, 672

Haus der Brandenburgisch-Preußischen Geschichte (HBPG) (Potsdam) 23, 507 f., 811, 854,1361

Haus der Jugend 563

Haus der Kultur $\rightarrow$ Kulturhaus

Hausangestellte 1129, 1194

Hausarbeitsgemeinschaft 1199

Hausbesitz, -bau, „Eigenheim“ (vgl. $\rightarrow$ Grundbesitz) $54,275,313,324,362,565,616,1435$, 1443,1457 f., 1466 f., 1481

Hausfrau 91, 315, 392, 869, 1310, 1312, 1451

Hausgeistlicher 446f., 699, 753, 825, 847, 896

Hausgerät, Haus- und Küchengerät, Haushaltsartikel, -gegenstände, -waren (vgl. $\rightarrow$ Hausrat) 598, 895 f., 1140 f., 1148, 1158, 1208-1213, 1401, 1408 und öfter

Haushaltspass 1145

Haushaltsschule 1441

„Haushaltsverlust“ 616

Hauskrankenpflege 592

Hausmutter 222

Hausobleute 1236

Hausrat (siehe auch $\rightarrow$ Gepäck, $\rightarrow$ Hausgerät) $118,131,172,195,258,265$ f., 270, 282, 362,
661, 700, 734, 926, 931, 969, 1040, 1089,

$1111,1118,1125,1132,1134,1148,1156$,

1196f., 1221, 1235, 1402, 1408

Hausschlüssel 1150

Hausschuhe $\rightarrow$ Schuhe

Hausstand 1172

Hausvater 880

Hauswerbung 1331

Hauswirtschaftslehrling 1435, 1460

Hautkrankheiten $\rightarrow$ Krankheiten

Havelberger Heimatverein 58

Hebamme 329, 925

Hedwigschwestern (Kongregation) 38, 210, 450 f., 570 f., 588 f., 632,903 f., 944

Hedwigswallfahrt 824

Heeresmunitionsdepot 765

Heerespfarrer 77

Heil- u. Pflegeanstalten 189, 959

Heilige Hedwig 209, 442, 586, 610, 810, 824

Heiligenbilder 1278

Heimarbeit, -industrie 301, 618, 627, 710, 842, 1110, $1198 \mathrm{f}$., $1220 \mathrm{f}$.

Heimarbeiter/in 301, 1198, 1200, 1216

„Heimat", -dorf, -gebiet, -gedanke, -kreis, land, -losigkeit, -ort, -verlust; „Alte“, „Kalte“, „Neue“ "Zweite" Heimat (siehe auch $\rightarrow$ „Heimatlose“, $\rightarrow$ „Tag der Heimat") 14,32 f., 35, 43, 60, 62, 64f., 67-69, 74f., 78-84, 89, 98 f., 110, 112, $116-118,129$ f., 133 f., 136 f., 145 f., 152 f., 177 , 188,190 f., 196, 205 f., 208 f., 212-214, 219 , 228,230 f., 235,237 f., 244 f., 260 f., 268,270 , 280, 285, 287 f., 292-294-299, 302, 306 f., $313,316,319-364,366-426,430,434-437$, 439, 442, 448 f., 453, 459, 465-468, 471, 473, 475, 482-493, 498, 500, 504f., 508, 512, 1008, 1019-1021, 1024, 1038, 1041, 1043 f., 1047, $1083,1117,1124,1137,1146,1152,1164$, 1166-1171, 1173-1175, 1186, 1200, 1213, 1216, 1228, 1234-1236, 1240 f., 1246 f., 1249, $1258,1260,1265,1277,1279,1286,1288$, 1291-1296, 1298-1300, 1302 f., 1306 f., 1309, $1317,1319,1321-1322,1330-1333,1335$, 1337, 1340-1344, 1347, 1350-1352, 1354, 1358-1368, 1371-1378, 1400, 1411, 1434f., 1437-1439, 1441 f., 1444f., 1449, 1452-1454, 1456-1458, 1460, 1464-1466, 1469-1472, $1474,1477,1482$ und öfter

Heimatabend 1374

„Heimatadresse“, -anschrift 206, 1249 
„Heimatarchive“ (Heimatkreisarchive, -sammlungen; siehe auch $\rightarrow$ Heimatstuben 59f., 401, 466 f., 531, 569, 658, 660 f., 691 f., 721

Heimatauskunftsstellen 54

Heimatbewusstsein 1260

Heimatblatt, -brief $\rightarrow$ Heimatzeitschriften

Heimatbuch 57, 64, 79, 211, 369, $402 \mathrm{f}$.

Heimatbund Kreis Soldin/Neumark im Patenkreis Soltau 1420

Heimatchronik 361 f., 387, 409 und öfter

Heimatfest 635, 1373

Heimatforschung, -forscher, Ortschronisten (vgl. $\rightarrow$ Ortgeschichtsforschung) 16, 39-46, 309, 883,1454

Heimatgedicht 373

Heimatgottesdienst 436, 439-441, 461, 486, 1258, 1341, 1346, 1348 f., 1352

Heimatgruppen $\rightarrow$ Bund der Vertriebenen

„Heimatgruß-Rundbrief Arnswalde“ $\rightarrow$ Heimatzeitschriften

Heimatkalender 28, 43, 58, 106, 306, 314, 355, 467, 507

„Heimatkalender für Schlesier“ $\rightarrow$ Heimatzeitschriften

Heimatkarteien 71, 204f., 209, 452, 560, 566, 598, $637,646,744,795,827,862,875,931,952$

Heimatkreis $\rightarrow$ Heimatkreisgemeinschaft

Heimatkreisarchive $\rightarrow$ Heimatarchive

Heimatkreisgemeinschaften, -vereinigungen, -betreuer, -freunde, Heimatkreise, Kreisgemeinschaften 79, 204f., 364, 369, 379, $389 \mathrm{f}$., 392, 402 f., 406, 464-467, 471 f., 478 f., 481, 488, 493 f., 691 und öfter

- Angerburg 371 f., 397 f., 404, 1340 f., 1344

- Bärwalde/Nm. 400

- Bad Schönfließ/Nm. 375

- Birnbaum 110,838

- Crossen/Oder $722 \mathrm{f}$.

- Eichenbrück (Wongrowitz) 108

- Forst 660

- Gablonz 230

- Gumbinnen 381

- Königsberg/Neumark 204, 466, 567, 725, 737, 1543

- Meseritz 110, 485, 838, 841, 869, 1339, 1543

- Mogilno 484

- Namslau $\rightarrow$ Namslauer Heimatfreunde

- Oststernberg 379, 472

- Schwerin/Warthe 382,384
- Soldin 369, 387, 1420

- Sorau 390,658f.

- Stolp 148

- Wehlau 223, 484f., 869

- Weststernberg 400, 585, 950

- Züllichau-Schwiebus 110, 465, 491, 820

Heimatkreiskarteien $\rightarrow$ Heimatkarteien

Heimatkreisvereinigung $\rightarrow$ Heimatkreisgemeinschaften

Heimatliebe 369

Heimatlieder $\rightarrow$ Lieder

„Heimatlose“, „Heimatlose Menschen“ 779, 840, 1047, 1111, 1124, 1234 und öfter

„Heimatlose Binnenschiffer“ 683

„Heimatlose Flüchtlinge“ 117

„Heimatlose Heimkehrer“ 435, 768, 840, 850, $1111,1167,1234$

„Heimatlose Kinder“ 776

„Heimatlose Männer“ 850, 1122

„Heimatlose Umsiedler“ $1120 \mathrm{f}$.

Heimatmuseen $\rightarrow$ Museen

Heimatortskarteien 53

„Heimatpfarrer“ 370

Heimatpflege 1367

Heimatreisen, -fahrten („Heimwehtourismus“) $331,355,363,402,417-427,472,486$, 488-491, 518 f., 548, 673, 684, 690, 796, 870, 878,1371 f., $1438,1441-1443,1445,1448$, 1450, 1453-1455, 1458-1460, 1462, 1465 f., 1469,1471 f., 1474,1525

Heimatsammlungen $\rightarrow$ „Heimatarchive“

Heimatstuben (siehe auch $\rightarrow$ „Heimatarchive“) 39, 59 f., 169, 381, 384, 386, 402, 467, 473, 476, 481, 599, 602, 660, 722 f., 888, 1543

Heimattreffen (siehe auch $\rightarrow$ Heimatgottesdienste, $\rightarrow$ „Umsiedlerversammlung") $6,53,220$, 234, 335f., 385, 387 f., 467, 482, 1169, 1372 f.

- in Brandenburg und SBZ/DDR (vor 1990) 268, 397, 405-417, 429, 461, 577, 619, 623, 661, 666, 789 f., 795 f., 799, 807 f., 815, 926, 945, 991, 1346-1349, 1351-1353, 1412, 1414

- in Brandenburg (nach 1990) $110 \mathrm{f} ., 200 \mathrm{f}$., $223,235,237,268,362,388,398,429,463$, 465-467, 470, 474, 482-488, 491 f., 517, 555, $567,579,598,605,607,609$ f., $619,629,633$ f., 648, 658f., 661, 666, 707, 720-723, 735, 737, $740,748,760-762,796,820,822-824,838$, 869 f., 878 f., $887,903,909,912,920,925,942$, 945, 950, 963, 1169(?), 1258, 1371-1375, 1462 
- in Ost-Berlin 371 f., 375 f., 401, 439, 1345 f.

- in West-Berlin 58, 206, 364f., 367-377, 381, 388, 401, 415, 439-441, 533, 822, 990 f., 1130, 1174, 1258 f., 1338 f., 1341f, 1344, 1349 f., 1353 f., 1412, 1440, 1472

- in Westdeutschland (vor 1990) 58, 364f., 368, 377-388, 390 f., 400 f., 404, 416, 452, 660, 900, 905

- Teilnehmerlisten 385, 519, 619, 748, 761, 823, 1340

Heimattreue Westpreußen Potsdam 368

Heimatverein 39, $368 \mathrm{f}$.

Heimatverein Biesenthal 587, 589, 993

Heimatverein Drossen (Berlin, vor 1945) 368

Heimatverein Havelberg 39, 45

Heimatverein Kyritz 776

„Heimatvertriebene“ 26, 28, 30, 32, 155, 190, 272, 1394 und öfter

„Heimatvertriebene in der Uckermark“ (HVU) 56,865

Heimatwerk der Katholiken Danzigs und Westpreußens $1342 \mathrm{f}$.

Heimatzeitschriften, -zeitungen (Vertriebenenpresse; siehe auch $\rightarrow$ Rundbriefe) $57 \mathrm{f} ., 64,79$, 104, 230 f., 364 f., 372, 377 f., 381 f., 388-405, 407, 413-417, 461, 463, 466, 471 f., 481, 485, $585,601,658,731,796,1258,1340$ f., $1343 \mathrm{f}$., 1347 f., 1424 f., 1464 und öfter

- Aus unserer Heimat 401

- Aussiger Bote 395

- BdV Notizen 471

- Brieger Anschriften-Verzeichnis 403, 413

- Briegische Briefe 389, 403f., 413-416

- Brandenburg Nachrichten 471

- Crossener Heimatgrüße 392, 413

- Das Heimatblatt für Sorau N./L.-Stadt und Land 372, 390-392

- Das Ostpreußenblatt 390, 404

- Der Schlesier 396

- Der Vertriebene 878

- Die Stimme der Vertriebenen 1344

- Feelinchen (Informationsblatt) 690 f., 888

- Gablonzer Heimat-Bote $230 \mathrm{f}$.

- Greifenberger Heimatbrief 389

- Gubener Heimatkalender 28, 467, 507, 722

- Gumbinner Heimatbrief 381

- Heimatblatt für deutsche Volksgemeinschaft. Frankfurt (Oder)-Sternberger Kurier" 399 f.

- Heimatgruß-Rundbrief Arnswalde 404
- Heimatkalender für Schlesier 397

- Isergebirgs-Rundschau 230

- Karpatenpost 492

- Königsberger Kreiskalender 43

- Königsteiner Rufe 403

- Königsteiner Schematismus 444

- Mohrunger Heimatkreis-Nachrichten 222, $792 \mathrm{f}$.

- Oststernberger Heimatbrief 472, 669

- Preußische Allgemeine Zeitung 830

- Schönfließer Heimatbrief 394

- Sorauer Heimatblatt 352

- Steinauer Rundbrief 396, 796

- Trebschener Gemeindebrief 441

- Trebschener Heimatbrief 1341

- Unsere Märkische Heimat 395

Heimerzieher 1350

„Heimgekehrte“ 1394

Heimindustrie $\rightarrow$ Heimarbeit

Heimkehrer $\rightarrow$ Kriegsgefangene (siehe auch $\rightarrow$ „Heimatlose Heimkehrer")

- (Begriff) 1394

Heimkehrerausschuss 255, 259 f., 268, 849 f., 855, 1166,1235

Heimkehrer-Erholungsheim 172, 768, 1088

Heimkehrerkonferenz, -tagung 838 f., 1167, 1221,1412

Heimkehrerkrankenhaus 669, 676

Heimkehrerlager (Gebäude und Personal siehe $\rightarrow$ Umsiedlerlager) 26, 165, 167, 251, 294, $577,579,582,603,640,645,648-650$, 653-655, 767-769, 687-689, 840 f., 849, 855, 931, 936-938, 1041, 1104, 1127, 1177, 1237, $1240,1253,1391,1396,1480$

- Glöwen 167, 549, 697f.

- Gronenfelde 27, 40 f., 46, 53, 165, 167, 251, $667,670,675-677,843,1023,1040,1041$, 1043-1045, 1239, 1436, 1481

- Quenzlager 598, 600f., 865, 1022, $1023 \mathrm{f}$., $1083,1251,1277$

- Selterhof 167, 936, 938

Heimkehrerlazarett 669, 1450

Heimkehrerliste 1249

Heimkehrersiedlung 935

Heimkehrertagung $\rightarrow$ Heimkehrerkonferenz

Heimkehrertransporte $1239 \mathrm{f}$. und öfter

Heimkehrertreffen 713, 723

Heimkehrerverband $\rightarrow$ Verband der Heimkehrer

Heimkinder $\rightarrow$ Kinderheim 
Heimweh, Sehnsucht, Trennungs-, Verlustschmerz 319, 327, 347, 359, 363 f., 376, 389, 424 und öfter

„Heimwehtourismus" $\rightarrow$ Heimatreisen

Heinkel-Werke (Leegebruch) 307, 310, 779 f., 943

Heirat $\rightarrow$ Ehe

Heizkörper 1199

Heizmaterial $\rightarrow$ Brennmaterial

Heizprobleme 85, 183, 802, 897, 1014f., 1050, $1054,1082,1279$ und öfter

Heizung 119, 171, 279, 281 f., 639, 786, 1024, 1059 f., $1067,1080,1269,1458$

Herberge zur Heimat 561, 562f., 720

Herd, Kochherd (vgl. $\rightarrow$ Ofen) 1118 f., 1139, $1143,1301 \mathrm{f}$.

Herold (Verein) 1543

Herrenhaus $\rightarrow$ Gutshaus

Herrenkleiderfabrik 1206

Herz-Jesu-Anstalt 638

Herzschwäche, -schlag, -muskelschwäche $\rightarrow$ Krankheiten, $\rightarrow$ Todesursachen

Hetze $\rightarrow$ „Boykotthetze“, $\rightarrow$ „Kriegshetze“, $\rightarrow$ Propaganda

Heulieferung nach Sachsen 1306

High Church 998

Hilfsbereitschaft $\rightarrow$ Einheimische

Hilfserzieherin 1451

Hilfsförster 1321

Hilfsgeistliche (kath.) 446, $1270 \mathrm{f}$.

Hilfskomitee der ehem. ost-brandenburgischen Kirchengemeinden östlich der Oder $435 \mathrm{f}$.

Hilfskomitee der Galiziendeutschen A. u. H. B. 1261

Hilfskomitee der Glieder der Posener Evang. Kirche 669

Hilfskomitees der zerstreuten evang. Ostkirchen 438, 1256, 1263

Hilfskrankenhaus $\rightarrow$ Krankenhaus

Hilfspolizisten 764

Hilfsschule 870

Hilfsschullehrer 863

Hilfswerk der evangelischen Kirche 263, $431 \mathrm{f}$., 435, 438 f., 452, 639, 1095, 1250, 1257 und öfter

Hilfswerk für Berlin-Brandenburg („Büro Grüber") 438

Hilfszüge 415

„Himmlerbaracke“ 867
Hinrichtung 901, 1404, 1443

Hirnhautentzündung $\rightarrow$ Todesursachen

Hirnschlag $\rightarrow$ Todesursachen

Hirtenbrief 453

Historische Demographie 30

Historische Kommission zu Berlin VI, 15

Historische Landeskunde 29

Historischer Verein zu Frankfurt (Oder) 40 f., 46

Historisches Ortslexikon für Brandenburg (HOL) 191, 309

Hitlerjugend $\rightarrow \mathrm{HJ}$

Hitler-Stalin-Pakt 232

Hitze $\rightarrow$ Wetter

HJ (Hitlerjugend) 119, 124, 627, 663, 728, 864, $1404,1449,1468,1474$

HO (Handelsorganisation) 354, 422, 1315, 1322 f., 1326,1440

Hobbock 154

Hobby 35, 1439

Hochschule für Bildende Künste (Berlin) 575

Hochschule für Film und Fernsehen (PotsdamBabelsberg) 229, 1436, 1469

Hochschule für Ökonomie (Berlin-Karlshorst) 909, 1416

Hochschule für Recht und Verwaltung (PotsdamBabelsberg) 505

Hochverrat (1935) 1135

Hochwasser (Oder 1945) 970

- (Oder, 1947), Deichbruch 151, 565, 567, 701, $881,960,1409$

- (Oder 1997) 634

Hochzeit, Hochzeitstag $\rightarrow$ Ehe

Hofdienst 1161

Hoffnungstaler Anstalten Lobetal 222, 588, 880, 1031

HO-Gaststättenverband Stalinstadt-Fürstenberg 354

HO-Konditorei 422

Holocaust $\rightarrow$ Judenverfolgung

Holz (siehe auch $\rightarrow$ Brennmaterial, $\rightarrow$ Wald), Bauholz, Bretter 1014f., 1060, 1110, 1134, 1136, 1145 f., 1190, 1222, 1225, 1273, 1299, 1301, 1303

Holzbaracken $\rightarrow$ Baracken

Holzbearbeitung 1198

Holzbrücke $\rightarrow$ Brücken

Holzhandel $1207 \mathrm{f}$.

Holznägel 1143

Holzpantinen, -pantoffel, -schuhe $\rightarrow$ Schuhe 
Holzpritschen 574

Holzverarbeitung, -warenerzeugung 578, 743, 799,1205

Hospitäler 52, 450, 581, 664, 790

Hotel (siehe auch $\rightarrow$ Gasthof) 87, 156, 164, 169, $177,242,266,272,355,415,483,485,487$, $563,567,619,632,659,680,683,712$ f., 716 f., 776, 820, 822 f., 838, 848, 869 f., 1009, 1473

Hotelier, Hotelbesitzer 699, 1460

Hufnägel 1143

Hugenotten 511, 599, 811

Humboldt-Universität zu Berlin $\rightarrow$ Universitäten, Berlin (HUB)

Humor, Lachen, Spaß, Spott, Übermut, Witz 320, $326,358,361,461 \mathrm{f}$.

Hunger, Ernährungsstörungen, Unterernährung (siehe auch $\rightarrow$ Krankheiten, $\rightarrow$ Lebensmittel, $\rightarrow$ Todesursachen) 3, 16, 119, 131 f., 149, 153 f., 171 f., 174, 176, 181, 183-186, 188, 220, 260, 265 f., 272, 274, 277, 285-287, 292, 304, 321, 323 f., 459, 509, 561 f., 608, 617, 620, 626, 687, 726, 759, 875 f., 881, 906, 932, 947, 997, 1012, 1016, 1020, 1053, 1075, 1245, 1273, 1284, 1288, 1312, 1377, 1437, 1442, 1449

Hungerödeme $\rightarrow$ Krankheiten

Hungersnot 906, 1273

Hungertyphus $\rightarrow$ Krankheiten

Hussitenfestspiele (Bernau) 583

HVA (Hauptverwaltung Ausbildung) $\rightarrow$ Minister, DDR

HVU $\rightarrow$ „Heimatvertriebene in der Uckermark“ Hygiene, Körperpflege, „Reinlichkeit“, Sauberkeit, Unsauberkeit (siehe auch $\rightarrow$ Bedürfnisanstalt, $\rightarrow$ Desinfizierung, $\rightarrow$ Entlausung, $\rightarrow$ Entwesung, $\rightarrow$ Kläranlage, $\rightarrow$ Quarantäne, $\rightarrow$ Schmutz, $\rightarrow$ Seife, $\rightarrow$ Ungeziefer) 132 , 137, 153 f., 170 f., 175-180, 183 f., 188, 227, $259,285,304,321,424$ f., 523, 556, 561, 565, 567 f., 598, 612, 617, 627, 635 f., 638, 640 f., 668, 680, 694, 719, 755, 767, 795, 811, $819,844,848-850,858-860,867,897,927$, 961, 1003-1006, 1010 f., 1014, 1022, 1024, 1050-1052, 1060, 1066 f., 1073-1075, 1081, $1083,1090,1106,1123,1275,1278,1475$ und öfter

Identität (Gruppe, Nation usw.) 200, 212, 220, $335,344,373,402,442,459,498,673,721$, $846,885,1370$
Igelit 1088

IG-Farben (Premnitz) 858

$\mathrm{IM} \rightarrow$ Inoffizielle Mitarbeiter (des MfS)

Immigranten 511

"Imperialismus“ 1328, 1332

Impfstoff, Serum 736, 739, 1053-1055

Impfung, Immunisierung, Schutzimpfung 580, $593,736,749,765,829,957,1011,1014$, 1053, 1055, 1072 f., 1075, 1273, 1478

Industrialisierung 599

Industrie, -betriebe, -standorte, -gemeinden (siehe auch $\rightarrow$ Textilindustrie) 29, 191, 229, 259, 280, 288, 292, 293, 295f., 300f., 307, 313, 344, 518, $683,714,734,772,858,999,1002,1021,1107$, $1170,1176,1186,1189,1196-1198,1201$, 1204-1207, 1216, 1286, 1313-1315, 1320

Industriearbeiter (siehe auch $\rightarrow$ Arbeiter) $143 \mathrm{f}$, 1130, 1134, 1170, 1190, 1197, 1227-1229, $1303,1415,1435$

Industrieartikel 1215

Industrieausstellung 1138

Industrie-Gewerkschaft 1165

Industrie- u. Handelskammer Mark Brandenburg (Potsdam) 260, 344, 1137, 1186-1188, 1204

Industriewaren 1158

Infektion $\rightarrow$ Krankheiten

Infektionskrankenhaus $\rightarrow$ Krankenhaus

Informační kancelár ANTIFA (Jablonec n. N.)

[Informationskanzlei] 306

Informanten, Informationsdienst 259 f., 350 , 373 f., 394, 398, 440, 914, 1084f., 1119 f., 1124, 1126, 1135-1138, 1150, 1200, 1221, 1223 f., 1251, 1281-1338

Informantenberichte, Informations- und Stimmungsberichte $51 \mathrm{f}$., $260,313,348,350-352$, 441, 522, 1041-1043, 1083, 1281-1338

Informationsamt, Amt für Information $51 \mathrm{f}$., $350,441,520,1119,1135$ f., 1138, 1200, 1224, 1248, 1251 f., 1293 f., 1298, 1302, 1304, 1309 f., 1312, 1313, 1326, 1341, 1401, 1419

Informationskontrolle (Abt.) 1324, 1329, 1333, $1336 \mathrm{f}$.

Informationsweitergabe (private) $\rightarrow$ Kommunikation

Ingenieur 243, $288 \mathrm{f} ., 324,392,505,593,821$, $908,1208,1445,1450,1464,1473,1477$,

1539 und öfter

Ingenieurbüro 1208

Ingenieurschulen 1440, 1468 
Initiative „Kriegskinder“ 705

Innenpolitik 1164

Innere Mission 432, 439, 720, 731, 998, 1263, 1347

Inoffizielle Mitarbeiter (des MfS) (IM) 374, 381, 407, 905

Inschriften $\rightarrow$ Grabstein

Installationsgeschäft 1214

Institut für angewandte Geschichte (Frankfurt/O.) 33, 672f.

Institut für europäische Ethnologie der Humboldt-Universität zu Berlin 31

Institut für Futterproduktion 834

Institut für Grünland- und Moorforschung 834

Institut für Lehrerbildung Potsdam $1451 \mathrm{f}$.

Institut für ostdeutsche Volkskunde (Freiburg/ Br.) 30

Institut für Pflanzenbau an der Universität Königsberg 834

Institut für sorbische Volksforschung (Bautzen) 32

Institut für Volkskunde der deutschen des östlichen Europa (Freiburg/Br.) 30, 58, 1543

Institut für Vorurteils- und Konfliktforschung (Berlin) $17 \mathrm{f}$.

Institut für Zeitgeschichte (München/Berlin) 15, 18

Institut zur Steigerung der Pflanzenerträge 834

Integration (siehe auch $\rightarrow$ Assimilation) passim

Integrationspreis des Landes Brandenburg 641

Interessengemeinschaft ausgesiedelter Schlesier in der russisch besetzten Zone Deutschlands $212,406,658$

Interessengemeinschaft für Umsiedler 405

Interessengemeinschaft Märkische Schweiz 1440

Internat, Internatsschule 922, 1159, 1446, $1451 \mathrm{f}$.

Internationale Arbeiterhilfe 242

Internationales Rotes Kreuz $\rightarrow$ Rotes Kreuz

Internet 57, 147 f., 468, 477, 499, 509, 519, 771, 887

Internierung, Internierte, Zivilinternierte 54, $133,642,665,670,689,938,952,1041,1083$, $1436,1438,1440$

Internierungslager, slowak. 236

-, poln. 670,1438

- , sowjet. $\rightarrow$ Speziallager, sowjet.

Interview, Gesprächsprotokoll 11, 18, 32, 34, $42,60,66,97,290,296,335,338,357-359$, $362,486,509,512,577,609,760,1374-1376$, $1429,1438,1440,1450,1455,1462,1466$, $1480,1490,1511$
Interzonenhandel 1296

Interzonenpass 141,378

Interzonen-, Transitverkehr 377, 411, 896, 1239, 1249

Invaliden 1158 f., 1456

Invalidenleitstelle 1002

Invalidenrente 1112

„Isergebirgs-Rundschau“ $\rightarrow$ Heimatzeitschriften

Isolierstation $\rightarrow$ Krankenhaus

Italiener 573, 923, 926

„Jahrbuch Märkisch Oderland“ 507

Johannes-Hoever-Haus 896

Johannesstift Berlin(-Spandau) $\rightarrow$ Evangelisches Johannesstift

Journalist/in, Redakteure/-in 63, 475, 627, 756, $896,907,1373,1447,1464$

Juden 21 , 482, 498-500, 511-513, 844

Judenverfolgung, Holocaust 18, 21, 72, $102 \mathrm{f}$., $154,438,599,844,1168,1446,1451$

Jüdische Gemeinde Fürstenwalde 513

Jugend, -liche 32, 59, 62-65, 179, 198, 294, 323, $332,334,359,383,501,511,552,606,622$, 628 f., 644, 690, 733, 738, 804, 885, 1027, 1045, 1072, 1105 f., 1109, 1139, 1158, 1198, 1240, 1266 f., 1282, 1298 f., 1302 f., 1317, 1329, 1344, 1376, 1438, 1464, 1469, 1478, 1481 und öfter

Jugendamt 511, 1240

Jugendaustausch, -begegnung, -camps 518, 684

Jugendbewegung, kath. 1270

Jugenderholungsstätte 554

Jugendfürsorge 568,1198

Jugendheim 249, 305, 552, 791, 923, 1013, 1244

Jugendherberge 164, 554, 1349

Jugendklubhaus 639

Jugendorganisationen 1045

Jugendrüstzeitheim 923

Jugendtreffen, ev. Kirche 439

Jugendwallfahrt 552, $824 \mathrm{f}$.

Jugendveranstaltungen 552

Jugendweihe 227

Jungbäuerin 1225

Junge Pioniere 1323, 1442

Junge Union, Kreisverband Teltow-Fläming 792

Junglehrer 1297

Jungmädel (bis 1945) 119, 616

- (nach 1945) 1142 
Kälte $\rightarrow$ Todesursachen, $\rightarrow$ Wetter

Kaffee $\rightarrow$ Lebensmittel

Kaiserschnitt 1057

Kaiserswerther Verband deutscher DiakonissenMutterhäuser 694, 733

Kaiserwitwe 665

„Kalte Heimat" $\rightarrow$ Einheimische

Kameradschaftshaus 859

Kampagne gegen Wehrpflicht, Zwangsdienste und Militär (Potsdam) 470, 480, 851

Kampfgruppen der Arbeiterklasse 326, 334

Kanonenofen 273

Kapelle (kath.) 462, 552, 556, 558, 570, 572, 575, 586, 600, 606, 609 f., 625, 628, 680, 703 f., 734, $742,782,803$ f., 808, 816, 832, 858, 874, 897, $899,906,914,919,932,935,942,954-956$

Kapellenraum in Druckerei 826

Kapellenwagen 462

Kapitulation 79, 242, $1405 \mathrm{f}$.

Karl-Marx-Orden $\rightarrow$ Orden

Karpatendeutsche (siehe auch $\rightarrow$ Landsmannschaften) 236-237, 493, 605-608, 936, 1350, 1413

„Karpatenpost“ $\rightarrow$ Heimatzeitschriften

„Karpfen in Biersoße $\rightarrow$ Speisen

Karren $\rightarrow$ Handwagen

Kartei $\rightarrow$ Heimatkartei, $\rightarrow$ Heimatortskartei, $\rightarrow$ Suchkartei, $\rightarrow$ Wohnungskartei

Kartoffelbrennerei 1206

Kartoffelkäfer, -plage 43, 1307 f., 1436

Kartoffeln $\rightarrow$ Lebensmittel

Kartoffelschälerin 1077

Kartoffelschalen 131

Kartoffelsperre 1145

Kartoffelverband im Bezirk Frankfurt 1439

Kaschuben 148

Kaschubisches Zentrum für Europa (Krockow/ Krokowa) 470

Kasernen 268, 291, 298, 303 f., 535, 584, 669 f., 744-746, 765, 794-797, 819, 860, 904, 914, 938, 1017, 1041, 1435, 1441, 1463 und öfter

Kasernierte Volkspolizei (KVP) 293, 840, 850, $852,926,938,1440,1468$

Katechet(inn)enseminar 620

Katechismus 76, 446, 1270

Katarrh $\rightarrow$ Krankheiten

Katharinenschwestern 1457

Katholiken (siehe auch $\rightarrow$ Kirche, kath.) 27, 48 f., 144, 146, 190, 209, 216, 305, 307, 359,
430, 440, 444, 446, 450, 452, 454-458, 461,

$509,511,527,552-554,556,558$ f., 562,

$567,570-573,575,577,579,581,584,586$,

$588-592,594$ f., 599 f., 606, 610, 612 f., 619 f.,

$625,628,632$ f., 638, 644, 646, 648, 651, 653 f.,

656, 659, 667f., 678-680, 684, 687, 696,

699, 701 f., 704 f., 709 f., 716, 726, 731, 734,

741-743, 745, 748, 750, 752 f., 756, 759, 764,

$769,772,776,779,781-783,785-787,789$,

$791,793,796,800$ f., 803-805, 808-811, 816,

$820,823-826,828-830,832,835,839,842$ f.,

$847,850,856,858,862,868,870,872-874$,

876, 881-883, 887, 896 f., 899 f., 903 f., 906 ,

909, 912-915, 919, 921, 924-926, 928932,

934-936, 939-941, 946f., 950-952, 954f.,

958 f., 961, 963 f., 967, 970 f., 1072, 1265 f.,

1269 f., 1278-1280, 1447, 1468 f. und öfter

Katholische Administratur Görlitz 443

Katholische Aussiedlerhilfe 835

Katholische Kirche $\rightarrow$ Kirche, kath.

Katholischer Flüchtlingsdienst (Berlin-Wilmersdorf) 448, 451

Kaufmännische Berufe 1189, 1194, 1330, 1434, 1442, 1445, 1457, 1463, 1466, 1469, 1475

KDLM $\rightarrow$ Landsmannschaften/Karpatendeutsche

Kegelbahn 783, 936

Keller, -wohnung (siehe auch $\rightarrow$ Luftschutz) 86, $90,113,115,354,422,425,590,602,609$, $647,662,728,757,759,911,935,953,1044$, $1080,1118,1140,1158,1266,1288,1301$, 1463,1471

Kennkarte $\rightarrow$ Ausweis

Keramikindustrie, -herstellung 1186, 1188

Kessel(schlacht) von Halbe 727 f., 766, 1453, $1470,1473,1482$

Kinder, Kindheit, Kinderanteil (siehe auch $\rightarrow$ Jugend, $\rightarrow$ Schule, $\rightarrow$ Waisenhaus, $\rightarrow$ Wolfskinder) $32,42,44,59,61,63,86,95,97-99$, 101 f., 112, 118, 120 f., 125, 127, 130, 132, 144-146, 148, 152, 155, 159, 172, 174-182, $184,189,197,225-228,244,267,269,280$, 284-287, 305, 320, 323 f., 336, 359, 361, 480, $484,506,522,527,546,560,566,568,570 \mathrm{f}$., 574, 577, 587-589, 591, 594, 598, 616 f., 619, 624, 626 f., 630, 641, 644, 668, 676, 683, 687, $690,696,700$ f., 728 f., $732,757,760$ f., 764 , $767,774,778,783,786,791,796,802-804$, $819,825,845,847,854,858,860-863,869 \mathrm{f}$., $873,875,895,902,904,916,928,944,949$, 
953, 955, 960, 997, 999, 1013, 1021, 1044f., 1050, 1057, 1072f., 1076, 1083, 1090-1092, 1094-1097, 1105f., 1108, 1110, 1120, 1125, 1133, 1142f., 1147, 1150, 1153, 1177-1182, 1201 f., 1227, 1233, 1240, 1250, 1252, 1254f., 1261, 1266-1268, 1270, 1273-1277, 1280f., 1286, 1288, 1308, 1320, 1322 f., 1334, 1336, 1356, 1376, 1394, 1435, 1437, 1443-1445f., $1453,1463,1466,1469,1475$ f., 1481 und öfter

- Findelkinder 287, 568, 629, 728

- Geburt auf der Flucht 98, 1275 f.

- Halbwaisen 1013

- „Kriegskinder“ 63, 320, 691, 705, 830

- „Kriegswaisen“ 785

- Säuglinge, Babys, Klein-, Kleinstkinder 92, 98, 101, 118, 120 f., 125, 154, 172, 178 f., 192, $267,269,287,320,560,568,574,582,608$, 615, 653, 665, 667, 669, 861, 863 f., 875, 891, 929, 950, 956, 993 f., 1053, 1056f., 1091, 1105, $1108,1153,1376,1453$

- uneheliche 1119

- Waisen, -kinder, „anhanglose“, elternlose Kinder (siehe auch $\rightarrow$ Waisenhaus, $\rightarrow$ „Wolfskinder") 89, 141, 174f., 178, 225-227, 244, 267, 435, 451, 535, 554, 556, 562, 568, 570 f., 595, 616, 646, 664, 668 f., 680, 728, 733, 782 f., 785, $795,801,810,817,896,904,922,927,929$, 944, 999, 1013, 1021, 1045, 1054, 1091, 1095, $1108,1233,1235,1253,1277$

„Kinder des Krieges“ (poln. Verein) 691

„Die Kinder von Golzow“ $\rightarrow$ Film

Kinderarbeit 286

Kinderaustauschtransporte (Zonen) 1240

Kinderbetreuung 97, 174f., 178f., 226, 267, 287, $499,574,577,693,810,1048,1165$ und öfter

Kinderbuch 175

„Kinderdorf“ 179, 226f., 776, 840, 1045, 1458

Kindererholungsheim (siehe auch $\rightarrow$ Kinderheim) 896

Kinderferienheim 867

Kinderfest 1085

Kinderfriedhof $797 \mathrm{f}$.

Kindergärtnerin 178, 286f., 777, 1080, 1091, $1437,1451,1453,1460,1462,1482$

Kindergarten 244, 268, 280, 291, 570, 632, 669, $679,682,712,716,719$ f., 756, 769, 810, 864, $957,969,1021,1080,1085,1090,1094 \mathrm{f}$., 1097, 1105, 1110, 1149, 1285, 1311, 1451, $1453,1465,1478$
Kindergeld 500

Kindergenesungsheim 747, 867

Kindergräber 750, 821 und öfter

Kinderheim (siehe auch $\rightarrow$ Kinderdorf, $\rightarrow$ Waisenhaus) 177 f., 224-228, 262, 267, 269, 287, 299, 450 f., 527,553 f., 568,570 f., 588 f., 595, 608, 625, 645 f., 649, 668 f., 680, 706, 747, 753, 760, 776f., 782f., 785, 788, 810, 840, 867, 896f., 902-904, 922, 929 f., 944 f., 1013, 1095, 1250, $1261,1271,1274,1436,1458,1462,1467$

- Evakuierung 101,668

- Flüchtlingskinderheim 810,922

- Kriegskinderheim 121

- Säuglingsheim 553, 568, 669

- Spezialkinderheim 568,776,785

Kinderhort 859

Kinderkartei 1252

Kinderkleidung 1142, 1150

Kinderklinik $\rightarrow$ Krankenhaus

Kinderkrippe 1474

Kinderkurheim, -haus (siehe auch $\rightarrow$ Kinderheim) 897, 1345

Kinderlähmung $\rightarrow$ Krankheiten

Kinderlager 656

Kinderlandverschickung (KLV) 121, 606, 1455, 1474

Kinderlose 251, 331, 1447 f., $1460 \mathrm{f}$.

Kinderpflegerin 1474

Kinderreiche Familien 1227, 1280 f., 1445, 1453, $1456,1463,1468,1473 \mathrm{f}$.

Kinderskelette 594

Kinderspiel, -zeug 563, 791, 1091, 1142, 1277, 1443

Kinder- u. Jugendsportschule Potsdam (KJS) $1451 \mathrm{f}$

Kindersterblichkeit 92, 98, 187, 546, 620, 653, $774,796,821,860$ f., 863, 875, 891, 956, 994, 1010, 1153, 1453

Kindersuchformular 1253

Kindertransporte 142, 168, 201, 220, 225, 649, 688,768 f., $776,785,840,1239$ f. und öfter

Kindervermisstenkarte 1253

Kinderverschickung (nach 1945) 267, 584

Kinderwagen 80, 85, 154, 614, 1205, 1434

„Kindheitsmuster" $\rightarrow$ Romane

Kino, Filmtheater (siehe auch $\rightarrow$ Film) 172, 264, $354,558,563,577,711,714,775,780,837$, $845,931,1236,1252,1409,1411,1468$, 1475 
Kirche $161,255,262,270,294,305,319,406$, $415,416,430-462,924,1136,1169,1229$, $1240,1256-1281,1460$

- evang. 10, 35-38, 76-78, 237, 305, 369 f., 412, 430, 431-441, 449 f., 499, 668 f., 693, 733, 774, 1256-1264, 1338f., 1348, 1412, 1414

- kath. (siehe auch $\rightarrow$ Bistum, $\rightarrow$ Erzbistum, $\rightarrow$ Katholiken) 35-38, 48 f., 146, 216, 263, $305,430,440,442-462,575,591,808,905$, 1264-1281, 1417, 1473

„Kirche“ (Zeitschrift) $\rightarrow$ „Die Kirche“ „Kirche in Not“ (Hilfswerk) 462

Kirchenarchive $56 f$.

Kirchenbau, -gebäude (auch -neubau) 209, 296, $439,600,632,703,794,817,858,862,885$, $899,906,919,932,940,954,970,1260,1342$, 1345 f., 1352

- als Notunterkunft 586, 612, 774, 776

- evang., Nutzung für kath. Gemeinden 35-37, $460,571-573,594,606,699,783,803,873$, 882,935 f., $940,964,1276,1280$

- kath., Nutzung für evang. Gemeinden $37 f$., $460 \mathrm{f}$.

Kirchenbuch 49, 57, 434, 582, 694, 706f., 762, $796,949,969,1262$ f., 1341

Kirchendienst Ost 431, 433, 438, 1257, 1264

Kirchengemeinde 430, 440 f., 457, 499, 651, 726, $756,780,789,835,839,850,869,896,898 \mathrm{f}$., $960,1259,1263,1272,1351,1437$ und öfter

Kirchengeschichtsforschung, -schreibung 35-38, $430,459 \mathrm{f}$.

Kirchenglocke 85, 412f., 438, 479, 653, 780, 795, 960, 970

Kirchenkanzlei $\rightarrow$ Deutsche Evangelische Kirche

Kirchenkreise 369, 434-436, 439-441, 1420

Kirchenlieder $\rightarrow$ Lieder

Kirchenrecht (kath.) 445

Kirchentag 369-371, 410-412, 439, 965, 1257

Kirchhof $\rightarrow$ Friedhof

Kirchliche Hilfsstelle (München) 397

Kirchlicher Betreuungsdienst 369, 435

Kirchlicher Erziehungsverband der Mark Brandenburg 608

Kirchlicher Suchdienst $\rightarrow$ Suchdienste

Kirchliches Amtsblatt (evang.) 1262

Kirchliches Hilfswerk (evang.) $\rightarrow$ Hilfswerk der evang. Kirche

Kirchlichkeit $\rightarrow$ Frömmigkeit

Kirchsaal 559, 770

Kissen, -bezug 897
$\mathrm{KL} \rightarrow$ Konzentrationslager

Kläranlage, -werk 713-715

„Klassenbewusstsein“ 247, 1242

Klassentreffen $\rightarrow$ Schule

Kleiderfabrik 1206

Kleiderkammer 799

Kleiderkarte 1322

Kleiderläuse $\rightarrow$ Läuse

Kleiderrationierung 1475

Kleiderschränke $\rightarrow$ Mobiliar

Kleidung, Be-, Einkleidung (siehe auch $\rightarrow$ Kopftuch, $\rightarrow$ Schuhe, $\rightarrow$ Strümpfe, $\rightarrow$ Textilien,

$\rightarrow$ Wäsche) $81,86,126,172,175,177$, 179-181, 184, 197, 255, 262, 264-270, 283, $287,322,337,364,439,556,574,577,586$, 598 f., 615, 668, 679, 693, 719, 730, 734, 749, 754f., 764, 791, 829, 887, 895, 922, 926, 966, 969, 997 f., 1014, 1017, 1023, 1040, 1044, 1046, 1053, 1055 f., 1068, 1076, 1083, 1096f., 1106, 1108, 1111, 1133-1135, 1139, 1142, 1144 f., 1154, 1156, 1162, 1183, 1186, 1189, 1191-1194, 1197, 1221, 1247, 1261, 1267-1270, 1272, 1275 f., 1278-1281, 1285 f., 1303, 1315, 1332, 1371, 1376, 1401 f., 1469

- Bezugsscheine 833, 1133, 1135, 1144, 1283, 1322

- Herrenanzug 1167

- Kopftuch 269, 337, 730,887

- Pfarrer, evang. (Talar u.a.) 432

- Uniform 126f., 175, 293, 1058, 1275

Kleinbahn Fürstenwalde-Seelow 375, 1349

Kleinbauern, -landwirte 235, 309, 313 f., 425, $552,678,1273,1320,1354,1445,1448$, 1450

Kleingärten 655,827

Kleingärtner 957, 1466

Kleinkinder $\rightarrow$ Kinder

Kleinkindernahrung $\rightarrow$ Lebensmittel

Kleinkindersammelstelle 950

Kleinkinderstation 863

Kleinkunst-Gürtlerei 1199

Kleinpächter 309, 314

Kleinsiedler, -stelle 303, 315, 1128, 1219

Kleinstwohnungen 1161

Kleinvieh 763

Klima $\rightarrow$ Wetter

Klinik $\rightarrow$ Krankenhaus

Klobbenholz 1145

Klöster, Evakuierung 101 
Klosett $\rightarrow$ Bedürfnisanstalt

Klub der Friedeberger (Berlin) 368

Klubhaus 306

Klubhaus der Jugend 639

Knechte 1144

Knochen-Tbc $\rightarrow$ Krankheiten

Knöpfe, Knopfherstellung 1200, 1220

Kochgelegenheit, -einrichtung $\rightarrow$ Küche

Kochherd $\rightarrow$ Herd

„Kochklopse“ $\rightarrow$ Speisen

Kochrezepte $\rightarrow$ Speisen

Kochtopf, -mangel 1143

Köchin 1440, 1449

Königin-Luise-Bund 1231

„Königsberger Klopse“ $\rightarrow$ Speisen

„Königsberger Kreiskalender“ $\rightarrow$ Heimatzeitschriften

„Königsteiner Rufe“ $\rightarrow$ Heimatzeitschriften

„Königsteiner Schematismus" $\rightarrow$ Heimatzeitschriften

Körperschwäche $\rightarrow$ Todesursachen

Koffer 116, 134, 637, 891, 940, 1068, 1275, 1304, 1441

Kohle $\rightarrow$ Brennmaterial

Kohleautos 525

Kohlenzüge $\rightarrow$ Eisenbahn

Kohleofen 285

Kohlsuppe $\rightarrow$ Lebensmittel

Kollekten 435, 453

Kolonialwarenhandel 1209, 1212

Kolonien, deutsche 592

Komendant wagonu $\rightarrow$ Waggonältester

Kommandant, Kommandantur, poln. 1050, 1052

- sowjet. ([Orts-]Kommandant; siehe auch $\rightarrow$ Bezirks-, $\rightarrow$ Haupt-, $\rightarrow$ Kreis-, $\rightarrow$ Militär-, $\rightarrow$ Stadtkommandant) 239, 242, 262, 274, 284, 297, 437, 528, 556f., 561, 663, 670, 707, 712, 747, 749, 769, 773, 778, 783, 794f., 838, 848, 902-904, 911, 943, 969, 1008, 1013, 1015, 1073, 1153, 1246, 1309, 1405 f., 1460 f.

Kommandeur der Gendarmerie bei der Regierung Frankfurt (Oder) 844 f.

Kommission für deutsche und osteuropäische Volkskunde 57

Kommission für Umsiedler und Heimkehrer 240

Kommunale Wohnungsverwaltung (KWV) 933

Kommunales Wirtschaftsunternehmen (KWU) 350

Kommunikantenanstalt 897
Kommunikation, Informationsweitergabe, Kontakte, „Netzwerke“, „Buschfunk“, Zusammenhalt (siehe auch $\rightarrow$ Briefe, $\rightarrow$ Familiengedächtnis, $\rightarrow$ Fernschreiben, $\rightarrow$ Heimattreffen, $\rightarrow$ Post, $\rightarrow$ Telefon, $\rightarrow$ Telegramm) 198, 332, 360-362, 365 f., 369-371, 373, 375, 381-383, 387-389, 396, 401, 406, 410-414, 424 f., 439, $486,556,629,633,661,678,730,779,807$, $815,899,950,1439,1442,1453,1455,1457$, 1460 f., 1466, 1481, 1483 und öfter

Kommunion, hl. 613, 797, 940, 956, 1265 f., $1278-1280$

Kommunistische Partei $\rightarrow$ KP. .

Kommunistischer Jugendverband 251

Komödie 909

Konfektionsschneiderei 915, 1199

Konferenz (vgl. $\rightarrow$ Außenministerkonferenzen)

- von Jalta (1945) 302, 1404

- von London (1947) 348, 1292, 1296, 1298, 1410

- von Potsdam (1945) $\rightarrow$ „Potsdamer Abkommen"

- von Teheran (1944) 135

Konfession, Bekenntnis 56, 76, 126, 189, 195, $241,431,436,450,453,459-461,506,575$, 1257, 1260 f., 1269, 1358-1363, $1366 \mathrm{f}$.

Konfessionslose (vgl. $\rightarrow$ Atheisten) 305, 458, 648

Konfessionsstruktur 35, 190, 195, 292, 305, 430, $442,454,458,1280$

Konfirmation, Einsegnung, Konfirmanden, -unterricht 49, 77, 410, 437, 707, 774, 1263, 1449, 1456, 1460, 1468

Kongregation der Hedwigschwestern $\rightarrow$ Hedwigschwestern

Konkurrenz (zwischen gewerbetreibenden Einheimischen $u$. Vertriebenen) 1143

Konrad-Adenauer-Stiftung 21, 666, 846

Konservenfabrik 1205

Konsistorium, Evangelisches $\rightarrow$ Evangelisches Konsistorium der Mark Brandenburg

Konsistorium der Evangelischen Kirche in BerlinBrandenburg 56, 1420

Konsistorium der Posener Evangelischen Kirche 669

Konsulate $\rightarrow$ Diplomatie

Konsum 1466

Konsumgaststätte 735

Konsumgenossenschaft 682, 1242, 1313 f., 1319, 1473 
Konsumladen 738

„Kontakt“ $\rightarrow$ Selbsthilfegruppe „Kontakt“

Kontakte $\rightarrow$ Kommunikation

„konterrevolutionär“ (Begriff) 1416

Kontingent-Ablieferung $\rightarrow$ Ablieferungssoll

Konto $\rightarrow$ Sparkonto

Kontrollkarte für Reihenuntersuchungen 580

Kontrollratsdirektive, -gesetz $\rightarrow$ Alliierter Kontrollrat

Konversion 505, 584, 746

Konzentrationslager (KL, KZ), -häftlinge, -opfer 3, 20 f., 33-35, 101, 155, 169 f., 194, 728, 901 , 1168, 1451, 1475; Auschwitz 1248, 1329, 1451; Bergen-Belsen 102; Buchenwald 242, 1477; Dachau 307, 921; Groß Rosen 101; Ravensbrück 20, 281, 284, 557, 631, 681, 710, 880; Sachsenhausen 20, 249, 631, 648, 697, 739, 821, 1135; Sonnenburg 472; Uckermark 631

- KZ-Außenlager 34, 163; Falkensee-Agneshof (Falkenhöh, Berlin-Albrechtshof) 170, 648650; Dahmshöhe 557; Döberitz 631; Glöwen 697; Grüneberg 710; Königs Wusterhausen 281; Roederhof 174, 580

- KZ-Nebenlager 20; Lieberose (Jamlitz) 37, 739 f., 787,1459

Kopfläuse $\rightarrow$ Läuse

Kopftausch, -austausch 1096, 1100-1102

Kopftuch $\rightarrow$ Kleidung

Korbflechterei 1199

„Korkeln“ 265

Korrespondenz $\rightarrow$ Briefe

Korruption 1114, 1117, 1242

Kosaken 890

Kot 927

KPČ (Kommunistische Partei der Tschechoslowakei) 150, 157-159, 230, 294, 1390, 1447

KPD (Kommunistische Partei Deutschlands)

126, 159, 239-243, 246-249, 251, 253 f., 260, 271, 282, 298, 305 f., 308 f., 314, 348, 626, 664, 726, 775, 869, 893, 1019f., 1023 f., 1108, $1135,1231,1248,1299,1390,1400,1407$, 1441, 1477; Kreisleitung Zauch-Belzig 742; Ortsgruppe Nauen 811; Zentralkomitee 242

Krätze $\rightarrow$ Krankheiten

Kraftfahrer 233, 250, 1440, 1454 f., 1468

Kraftfahrzeuge, -wagen (Kfz, Auto, bes. Pkw; siehe auch $\rightarrow$ Lastkraftwagen, $\rightarrow$ Omnibus, $\rightarrow$ Traktor, $\rightarrow$ Transportmittel) 114, 305, 375, 398, 418, 420 f., 424, 489, 662, 664, 801, 861,
$890,940,1049,1057,1061,1074,1082,1094$, 1099, 1125 f., 1169, 1370, 1403 f., 1434, 1441, $1445,1451,1468,1483$ und öfter

- Reparaturwerkstatt 558

- „Trabant“" (Pkw) 421, 1445, 1451

- „Wartburg“ (Pkw) 418

Kranke $\rightarrow$ Krankheiten

Krankenbaracke 675

Krankenbericht 1046

Krankenhaus, Klinik (siehe auch $\rightarrow$ Lazarett) 30, $52,68,96,101,133$ f., 145, 180, 184-189, 206, 222, 261 f., 267, 291, 358 f., 377, 391, 504, 540, $552-554$, , 556, 560 f., 566 f., 574, 576-578, $590,600,611,632,636,640,643,669,676$, 693, 711 f., 720, 731, 733, 761 f., 768, 782, 797, $819,829,840,843,847,850,860$ f., 863-868, 871,896 f., 904, 915, 921, 931, 959 f., 999, 1005 f., 1011, 1013 f., 1017, 1064, 1066, 1126, 1234, 1249, 1258 f., 1271, 1274, 1342, 1347, $1439,1453,1475,1479$

- Außenstelle 867

- Behelfs-, Hilfs-, Not-, Ersatz-, provisorisches Krankenhaus (siehe auch $\rightarrow$ Lazarett) 52, 176, 186-189, 553, 560, 593, 595, 598, 608, 632, 664, 686 f., 694, 711f., 719, 733, 764, 767, 782, $786,789,819,868,873,902,915,941,957$, 959,1449

- Frauenklink 553,865

- Infektionskrankenhaus, -abteilung 566, 598, 669

- Isolierstation 712, 717, 782, 895, 933, 959, 961

- Kinderklinik 1344

- Seuchenkrankenhaus, -station, -lazarett $187 \mathrm{f}$., 552 f., 561, 764, 789f., 865, 895, 924, 948, 957, 961

- Typhusklinik, -station 556, 566, 931

Krankenhausschule 804

Krankenhausseelsorger 440, 811, 1342

Krankenkasse 1306, 1371

Krankenpflege, -betreuung 184, 188, 554, 570, 581 f., 589, 591 f., 929 und öfter

- ambulant 632, 638, 897, 904, 958 und öfter

Krankenpfleger/in 648,731

Krankensammelstelle 950

Krankenschwestern, Schwestern 75, 121, 184, $187,359,554,570,576,578,581,636,638$, $649,693,782,795,850,1017,1045,1055$, $1067,1078,1345,1347,1460,1478-1481$ und öfter 
Krankenstation 44, 767, 1017, 1050, 1054

Krankenstube 98, 124

Krankentrage 1051

Krankentransport 1051, 1126, 1468 und öfter

Krankenwagen $\rightarrow$ Eisenbahn

Krankheiten, Kranke, Gebrechen, Verletzungen, Wunden (vgl. $\rightarrow$ Todesursachen) 90, 96, $118,127,132,148,160,171,178,183-188$, 264, 267, 269, 276, 284, 290-292, 366, 391, $522,561,574,577$ f., 583, 594, 608, 611, 618, 622, 636, 638, 641, 643, 645, 664f., 694, 700, $728,759,795-798,858,901$ f., $940,950,956$, 993, 997, 999, 1003, 1011-1013, 1016f., 1021, 1026, 1040, 1045 f., 1050-1054, 1057 f., 1064, 1066, 1076, 1078, 1094f., 1115, 1126, $1154,1159,1183,1192,1233$ f., 1249, 1268 f., 1273-1275, 1358, 1377, 1438 f., 1482

- Allgemeine Schwäche 1076 und öfter

- Altersschwachsinn 1075

- Altersschwäche, -gebrechlichkeit 1053, 1075 und öfter

- Asthma 1075

- Augenkrankheiten 1374

- Bauchtyphus (Typhus abdominalis) 185, 1046, 1066

- Bauchtyphusepidemie 683

- Bettlägerigkeit 1040, 1094

- Blässe 1076

- Blutunterdruck 1076

- Bronchialasthma 863, 1075

- Brustkrebs (Mamma-Carcinom) 1076

- chirurgische Fälle 1046

- Cholera 948, 1055

- chronische 1095

- Darmkatarrh 562, 861, 1057

- Darmkrankheiten 186,636,875

- Diphterie 120, 523, 557, 561, 750, 794, 798, 819, 999 f., 1007, 1046, 1066, 1096

- Durchfall, schwerer Durchfall 863, 956, 1016, 1057

- Enteritis (Darmentzündung) 186

- Epidemien (vgl. $\rightarrow$ Seuchen; siehe auch $\rightarrow$ Typhusepidemie) $3,187,188,523,561,583,593$, 617 f., $680,687,860,875$, $999 f$. und öfter

- Epilepsie, Epileptiker 1045

- Erblindung 244

- Erfrierungen 98, 184, 559, 578, 582, 616, 627, $861,891,901,960,1275$

- Erkältung 179, 1057
- Ernährungsstörungen 184f., 562, 591, 819, 876, 1057, 1075, 1194

- Erschöpfung 109, 186, 560 f., 597, 619, 881, 1004, 1016, 1022, 1057, 1075, 1269, 1274

- Fieber 188

- Fleckfieber 598, 745, 865, 1017, 1027, 1066

- Flecktyphus 867, 938, 1024 f.

- „Frauenleiden“ 1076

- Furunkulose 1076

- Fußleiden 184

- Gasvergiftung 231

- Geistige Behinderung 568, 819, 929, 1065

- Gehörschaden 1451

- Gelenkrheumatismus 1438

- Geschlechtskrankheiten (siehe auch $\rightarrow$ Gonorrhoe, $\rightarrow$ Lues, $\rightarrow$ Syphilis) 635, 1017, 1086, 1095, 1108, 1282, 1478

- Geschwüre 700, 1076

- Gonorrhoe („Tripper“) 1057, 1066, 1233

- Grippe 183, 1005 f., 1017, 1275

- Hautkrankheiten, -ausschlag, -infektion, impetigenöse Erkrankungen 1075 f., 1273

- Herzinfarkt 1473

- Herzkrankheit 1076

- Herzmuskelschädigung 291

- Herzmuskelschwäche 133, 591, 1057

- Herzschwäche 185 f., 561 f., 591, 630, 750

- Hirnhautentzündung 554

- Hungerödeme 186, 1016, 1273

- Hungertyphus 590, 598, 700, 906, 1436

- Infektion, Infektionskranke 636, 1040, 1054, 1057, 1064, 1095, 1108

- innere Fälle 1046

- jauchende Unterschenkel-Geschwüre 1076

- Katarrh 1057

- Kinderlähmung 593

- Knochen-Tbc 1233

- Körperschwäche 186

- Krätze, Verkrätzung (Scabies) 668, 745, 1016f., 1066, 1075

- Krebs 819, 1076

- Kreislaufschwäche 560, 591, 829, 861, 863, 868

- Kreislaufstörungen 591

- Kriegsverletzung 1478

- „Krüppelkranke“ 1076

- Leichtkranke 645, 687, 1017, 1050

- Leistenbruch 1076

- Lues 1233 
- Lungenembolie 750

- Lungenentzündung (Pneumonie) 133, 591, $819,861,1017,1275$

- Lungenkrankheit, -leiden 155, 1183, 1269, 1280

- Lungentuberkulose (Tbc) 101, 582, 635, 655, $680,695,761,798,819,829,865,867,875$, $895,897,933,1017,1066,1233,1280$

- Magenbeschwerden, -leiden 1076, 1183

- Magengeschwür 358

- Magenkrebs, -Carcinom 1076

- Mangelerkrankungen, -krankheiten 1076, 1273

- Mangelernährung 269, 590, 798, 1076

- Marasmus 185

- Masern 179, 860, 1074, 1233

- Masern-Epidemie 860

- Meningitis tuberculosa 863

- Menstruationsstörungen 320

- Nervenfieber 1275

- Nervenkrankheiten 568

- Oedeme 1076

- Paratyphus 1066, 1474

- Paratyphusepidemie 618

- Pilzvergiftung 171

- Pyodermie 1076

- psychische, siehe $\rightarrow$ Psychische Aspekte

- Rachendiphtherie 750

- Rheuma 1273, 1275, 1438

- Rose 590

- Ruhr (Dysenterie) 183f., 187 f., 552, 590, $612,635,712,750,764,895,956,1046,1055$, $1057,1066,1233,1269,1274$

- Ruhrepidemie 583, 782, 784, 923

- Ruhrtyphus 187

- Scharlach 120, 179, 1066, 1095, 1438

- Schilddrüsenunterfunktion (Thyerotexikose) 1076

- Schilddrüsenvergrößerung 1076

- Schlagaderverhärtung 861

- Schlaganfall 582, 1468

- Schussverletzung 1057

- Schwäche 1076, 1464

- Seuchen, -gefahr, -bekämpfung, -inspektion, -kranke, -verdacht (vgl. $\rightarrow$ Epidemien) 3, 24, $30,160,184,241,459,552,561,567,608$, 611, 617f., 636, 640, 664f., 712, 726, 764, 788-790, 794, 808, 819, 829, 875, 895, 943, 956, 961, 1001 f., 1007, 1012 f., 1017 f., 1020,
1022, 1024f., 1047, 1051 f., 1064, 1066 f., 1115,1233

- Skorbut 1273

- Syphilis 184, 865, 1066

- Tuberkulose $\rightarrow$ Lungentuberkulose

- Typhus 44, 132, 134, 184-188, 272, 291, 523, $552,557,561,566,587,590,595,598,608$, 611 f., 635 f., 665, 712, 726, 736, 749 f., 764, 784, 796, 798, 808f., 819, 829, 865, 867, 875 f., 895, 924, 931, 938, 947, 956 f., 960 f., 967, 1004 1007, 1011, 1013f., 1017, 1024f., 1046, 1057, 1066, 1072, 1075, 1269, 1274f., 1345, 1437, 1440, 1449f., 1453, 1467, 1476, 1478, 1481

- Typhusepidemie 44, 113, 186-188, 523, 561, $593,618,665,682$ f., 687, 784, 789, 794, 809, $862,875,886,902,923$ f., $947,953,956$ f., 960 , 999, 1002, 1004, 1006 f., 1014, 1273, 1481

- Übermüdung 1016

- Unterernährung (Dystrophie) 171, $187 \mathrm{f}$., $269,680,726,762,873,875$ f., 896, 1005 f., $1016,1053,1076,1273,1280$ und öfter

- Unterleibserkrankungen 284,750

- Verdauungsstörungen 653

- Verlausung, Verlauste $\rightarrow$ Läuse

- Wassersucht 133, 590

Krebs $\rightarrow$ Krankheiten

Kredit (vgl. $\rightarrow$ Schulden) 1174, 1214, 1248, 1316f., 1322

Kreidezeichen 576

Kreisärztin 1075

Kreisaltersheim 567, 931

Kreisapotheker 208, 619, 838

Kreisarbeitsamt $\rightarrow$ Arbeitsamt

Kreisarchive 18, 52, 55 f., 519, 1543

Kreisarzt (siehe auch $\rightarrow$ Kreisärztin) 288, 332, 1001, 1046, 1078, 1082, 1233, 1479

Kreisausschuss Soldin 75

Kreisbahn 1465

Kreisbauamt, -baumeister 1296

Kreisbauernkonferenz Ostprignitz (1945) (Kyritz) $308,775,1407$

Kreisbeauftragte für Umsiedler $1229 \mathrm{f}$.

Kreisbeauftragter für Männerarbeit 1342

Kreise (vgl. $\rightarrow$ Landkreise) 522-550, $1213 \mathrm{f}$., $1217,1229,1237,1240,1256,1355$ und öfter

Kreiseinwohnermeldeamt $\rightarrow$ Einwohnermeldeamt Kreisforstamt 351; Betriebsgruppe 1324

Kreisfrauenausschuss 1073

Kreisfrauenreferentin 1238 
Kreisgemeinschaft $\rightarrow$ Heimatkreisgemeinschaften Kreisgericht, Vereinsregister $601,865,870,878$, $1358,1362,1418$

Kreisgesundheitsamt 522, 528, 650, $1074 \mathrm{f}$.

Kreisgruppen der Ost- u. Westpreußen im BdV 223, 601, 628

Kreiskalender (vgl. $\rightarrow$ Heimatkalender) 58

Kreiskasse 1244

Kreiskinderheim 944

Kreiskommandant(ur), sowjet. 194, 242, 244, 304, 406, 530, 739, 746, 769, 773, 795, 918, $1049,1067,1073,1098,1126,1223,1246$, 1296,1398

Kreiskommunalkasse Züllichau 81

Kreiskonsumgenossenschaft 1313 f., 1319

Kreiskontor 1229

Kreiskrankenhaus, -poliklinik 693, 719, 797, 829, 838, 840, 860 f., 863-865, 867, 904, 921, 1064, 1345; Evakuierung 864; Wirtschaftsleiterin 871

Kreiskriminalpolizei 1058

Kreiskulturhaus 563f., 639, 775

Kreislager $\rightarrow$ Kreisumsiedlerlager

Kreislandwirtschaftsrat 1460

Kreislaufschwäche, -störungen $\rightarrow$ Todesursachen

Kreisleiter $\rightarrow$ NSDAP

Kreismeldestelle 93

Kreismuseum Wewelsburg $\rightarrow$ Museen

Kreisplanungsamt, -ausschuss $1214 \mathrm{f}$.

Kreispolizei 584, 1098, 1104, 1144

Kreispolizeiamt $\rightarrow$ Volkspolizei

Kreisquarantänelager 961

Kreisrat 948, 1084, 1218, 1223, 1238 f., 1244, 1251, 1285-1289, $1304 \mathrm{f}$.

Kreissozialamt $\rightarrow$ Sozialamt

Kreissparkasse $\rightarrow$ Sparkasse

Kreissynode 1259

Kreistag 556, 813, 1222

Kreistreffen $\rightarrow$ Heimattreffen

Kreisumsiedleramt, -stelle, -betreuungsstelle, Amt für Umsiedler bzw. Umsiedlerabt./-stelle des Landratsamtes 165, 172 f., 245, 248 f., 562 f., 643, 744, 827, 1015, 1084f., 1124, 1134, 1136, 1140, 1143, 1145, 1172 f., 1179, 1182, 1184, $1188,1213-1215,1230,1232-1236,1240$, 1243 f., 1252-1255, 1300, 1398 f., 1412 und öfter

Kreisumsiedlerausschuss 248, 255-257, 524, 533, 731, 1048, 1070, 1136, 1243 f., 1156, 1191, 1196, 1233 f., 1243f., 1401, 1408
Kreisumsiedlerlager, Kreislager 165, 173, 525, 531, 533, 536-538, 541, 543 f., 546 f., 549 f., 584, 639 f., 648, 654, 687, 697 f., $710,888,895$, 710, 745, 759, 766 f., 866 f., 877, 887 f., 895, 932f., 946, 961, 1019 f., 1022, 1048, 1066, 1076-1078, 1152, 1237, 1401 und öfter

Kreisumsiedlerstelle $\rightarrow$ Kreisumsiedleramt

Kreisumsiedlertagung 1144, 1146 f., 1163

Kreisverband $\rightarrow$ Bund der Vertriebenen

Kreisvereinigung der gegenseitigen Bauernhilfe, Kreisausschuss, -sekretariat der VdgB 1150, 1226, 1243, 1287, 1306

Kreisverwaltung $\rightarrow$ Landrat

Kreiswohnungsamt $\rightarrow$ Wohnungsamt

Kreiswohnungsausschuss 1146

Kresolseifenlösung 1051

Kreuz (Symbol) 305, 578, 751, 792, 821, 824, $832,858,874,949,1278$

Kreuzweg 625, 816, 832

Kriegerdenkmal, -gedächtnismal 594, 608

Kriegerheimstättensiedlung 700

Kriegsbeschädigte 563, 1025, 1059, 1153, 1273

Kriegsdienstverpflichtung $\rightarrow$ Dienstverpflichtete

Kriegs-Entbindungsheim 121

Kriegsfolgenbereinigungsgesetz (KfbG) 497, 1398

Kriegsgefangenenlager 34, 168, 199, 251, 412, $580,583,675,696,730,772,794,797,943$, $961,964,1394,1478$

Kriegsgefangenenlazarett 766, 769, 1453

Kriegsgefangenschaft, -gefangene und (Kriegs-) "Heimkehrer" (deutsche), allgemein und insbes. in sowjet. Gefangenschaft (siehe auch $\rightarrow$ „Heimatlose Heimkehrer", $\rightarrow$ Heimkehrer..., $\rightarrow$ „Ostheimkehrer") $3,22,25,40$ f., 46, 54, 69 f., 72, 80, 82, 109, 114, 128, 133, 142 f., $149,153,155$ f., 158,160 f., $165,172,178$, $190,194,225,240,246,249,251,256,262$, 265-267, 269, 283, 285, 290 f., 293 f., 297 f., 357,412 , 431 f., 435, 438, 522, 524-527, 529, 531, 533-539, 541-547, 549-551, 555 f., $561,578,584,586,598-600,618,638,642$, 645, 648 f., 654 f., 656, 664f., 667, 669 f., 673, 675 f., 679,687 f., 697 f., $723,730,740,747$, $751,765,768,771,786,796,806,809,821$, 838,849 f., 855,875 f., $880,883,887,924,931$, 936-938, 957, 1000, 1012 f., 1019, 1022-1024, 1026f., 1041, 1071, 1083, 1086, 1088, 1105 , 1119-1122, 1124f., 1152-1154, 1159, 1167, 1175-1177, 1183, 1185, 1189-1191, 1193, 
1198, 1231-1241, 1249, 1253, 1280, 1283, 1285-1287, 1307, 1312, 1330, 1391 f., 1394, 1398, 1407, 1411, 1434, 1436-1439, 1441, $1443,1447,1450,1454,1456-1458,1465$, $1471,1473,1476,1478,1525$

- ausländische (französ., ital. u. sowjet.) Soldaten in deutscher Gefangenschaft 95, 101, 155, 310, $626,680,682,718,728,880,916,943,1268$

- Deutsche in brit. Gefangenschaft 1458, 1466, 1482

- Deutsche in französ. Gefangenschaft 1462

- Deutsche in US-amerikan. Gefangenschaft 181, 751, 1456, 1467, 1470, 1474

- Entlassungspapiere 1023

Kriegsgericht 901, 1404

Kriegsgräberstätten, Kriegstote 44, 222, 480, 565 , 728 f., 750 f., 762, 770, 821, 1475

Kriegsheimkehrer $\rightarrow$ Kriegsgefangene

„Kriegshetze“ 347, 389, 1332, 1335 f., 1343

Kriegshilfsdienst 1465

Kriegshilfsverein 74, 544, 844

Kriegskinder $\rightarrow$ Kinder

Kriegskommandant 838

Kriegs-Kinderheim $\rightarrow$ Kinderheim

Kriegs-Mutter-und Kind-Heime 121

Kriegsopfer, zivile (siehe auch $\rightarrow$ Vermisste) 575, $577,587,595,705,750$ f., 762, 767, 792, 881 und öfter

Kriegsopferversorgung 292

Kriegsschadensamt 616

Kriegsschäden, -zerstörungen (siehe auch $\rightarrow$ Ausgebombte, $\rightarrow$ Ruinen) 64, 84, 131, 134, 170, $183,186,190,231,238,262,271,273,278$, $283,291,298,337,372,535,573,590,613$, 617 f., 632, 646, 643, 650, 657, 663 f., 668, 678, 682, 700, 711 f., 719 f., $741,750,761,770$ f., $778,784,794,808,828$ f., 843 f., 847, 862 f., $875,877,881,902$ f., $905,915,923,929,931$, 933, 950 f., 954, 960, 970, 997-999, 1002 f., 1005, 1028-1034, 1043, 1052, 1054, 1067, 1116f., 1159, 1190, 1245, 1278, 1337, 1434, 1442, 1464, 1474 und öfter

- in Polen 1175

Kriegsschuld 1134, 1244, 1264, $1302 \mathrm{f}$.

Kriegstagebuch (OKW) 598, 613, 657, 917

- (privat), Belzig 580, 582; Biesenthal 589, 993-995

Kriegsverbrecher, -prozesse 311, 1282

Kriegsverletzung $\rightarrow$ Krankheiten
Kriegswaisen $\rightarrow$ Kinder

Kriminalisierung 325, 394-398, 406, 731, 1248, 1335

Kriminalität (siehe auch $\rightarrow$ Banden, $\rightarrow$ Gewalt, $\rightarrow$ Korruption, $\rightarrow$ Misshandlung, $\rightarrow$ Plünderung, $\rightarrow$ Schmuggel, $\rightarrow$ Schwarzhandel, $\rightarrow$ Vergewaltigung, $\rightarrow$ Wirtschaftsvergehen, $\rightarrow$ Wucher) $140,636,686,1088,1520$

- Bedrohung 636

- Beleidigung 1226

- Betrug 1273

- Diebstahl 131, 133, 282, 315, 636, 698, 774, 1011, 1016, 1046, 1052, 1065 f., 1068, 1080, 1095, 1133, 1144, 1273, 1281, 1301, 1396

- Einbruchsdiebstahl 840

- Erpressung 1095

- Mord 224, 1058, 1277

- Raub 636, 1273

- Unterschlagung 698, 1273

- Verschiebung $\rightarrow$ Schwarzhandel

Kriminalpolizei 406, 852, 966, 1058, 1126, 1226, 1438

„Krüppelkranke“ $\rightarrow$ Krankheiten

Kuchen 1291

Küche, Kochgelegenheit, -einrichtung (siehe auch $\rightarrow$ Feld-, $\rightarrow$ Gemeinschafts-, $\rightarrow$ Groß-, $\rightarrow$ Suppenküche, $\rightarrow$ Lebensmittel, $\rightarrow$ Speisen, $\rightarrow$ Umsiedlerlager, $\rightarrow$ „Volksküche“) 95, 640, 943, 949, 966, 997 f., 1112, 1119, 1133, 1139, $1150,1342,1376$

Küchenbaracke $\rightarrow$ Umsiedlerlager

Küchengerät $\rightarrow$ Hausgerät

Küchenhilfe 1440

Küchenwagen $\rightarrow$ Eisenbahn

Kühe $\rightarrow$ Vieh

Kümmel 180

Künstler/in (siehe auch $\rightarrow$ Kunst) 89, 575, 592, $852,907,1073,1469,1474$

Küster, -dienste 638, 855, 1473

Kuhgespann 83, 133

Kulturbund zur demokratischen Erneuerung Deutschlands, Kulturbund der DDR 325, 422, 846, 856, 1138, 1334, 1444

„Kulturelle Betreuung der Werktätigen“ (Referat) $1160 \mathrm{f}$.

„Kulturelles Erbe“, Kulturpflege 1361 f., 13641368

Kulturförderverein Mark Brandenburg 476, 1376

Kulturfunktionäre 1441 
Kulturgeschichte 30-33

Kulturgut 1359, 1361, $1363 \mathrm{f}$.

Kulturhaus, -raum 29, 43, 305, 555, 563, 578, 639, 775 f., 812, 815, 818, 859, 878, 1246

Kulturheim 1042

„Kulturland Brandenburg“ 17, 45, 512, 599, 807, 811

Kulturprogramm 172

„Kulturtag“( des BdV) $\rightarrow$ „Ostdeutsche Kulturtage“

Kulturwissenschaft 31-33

Kundgebung 172, 348 f., 376, 618, 670, 675, $713 \mathrm{f} ., 719,780,878,1085,1104,1109,1290$, 1305, 1325 f., 1329-1331, 1336, 1413, 1478

Kunst, bildende (siehe auch $\rightarrow$ Künstler) 222, $368,507,565,575,816,854,907,1364$

Kunstblumen- und -früchtefertigung 744, 1198, 1205, 1215-1217, 1247

Kunstgewerbliche Werkstatt 805

Kunstgeschichte, -historiker 29, 504, 1439

Kunstglasindustriearbeiter 1190

Kunstseidenfabrik 1183-1186, $1190 \mathrm{f}$.

Kurden 512

Kurländische Ritterschaft 590

Kurländischer Landtag 590

Kurzwarenhandel 1209

Kutscher (siehe auch $\rightarrow$ Treckkutscher) 1119, $1315,1322,1349,1443,1476$

Kutscherstube 131, 1468

$\mathrm{KVP} \rightarrow$ Kasernierte Volkspolizei

KWU Hochbau Guben 350

$\mathrm{KZ} \rightarrow$ Konzentrationslager

Läuse, -plage, Verlausung (siehe auch $\rightarrow$ Entlausung) $175,177,180$ f., 574, 641, 668, 895, 924, 1012-1014, 1016f., 1053, 1064, 1066, $1075,1094,1274 \mathrm{f}$.

- Kleiderläuse 668,1013f., 1066

- Kopfläuse 1013 f., 1075

Läusepulver 1065

Lager $\rightarrow$ Arbeits-, $\rightarrow$ Auffang-, $\rightarrow$ Aufnahme-, $\rightarrow$ Durchgangs-, $\rightarrow$ Heimkehrer-,

$\rightarrow$ Konzentrations-, $\rightarrow$ Kreisumsiedler-, $\rightarrow$ Quarantänelager, $\rightarrow$ Reichsarbeitsdienst/ Lager, $\rightarrow$ Sammel-, $\rightarrow$ Spezial-, $\rightarrow$ Umsiedler-, $\rightarrow$ Zwangsarbeitslager

Lagerärzte $\rightarrow$ Umsiedlerlager

„Lagerarchäologie“ 33

Lagerbibliothek $\rightarrow$ „Umsiedlerlager“

Lagerleiter $\rightarrow$ Umsiedlerlager
Laiengottesdienst (kath.) 1270

Laienhelfer 1270

Landarbeit, -arbeiter, landwirtschaftliche Arbeiter 134, 285 f., 297, 309, 313, 315, 523, 533, 552, 643, 647, 677, 905, 926, 1047, 1112, 1126, 1160-1166, 1177, 1190, 1193, 1196 f., 1274, $1313,1318,1322,1436,1441,1460,1468$, 1446, 1460, 1468, 1475

Landarbeiterin, landwirtschaftliche Arbeiterin 1313,1441

Landarbeiter-Schutzgesetz 1318

Landarme Bauern 707, 764, 812, 1219, 1247

Landarzt 1478

Landbau GmbH (Potsdam) 247, 1221

Landesamt für Arbeit $\rightarrow$ Landesarbeitsamt

Landesamt für Soziales und Versorgung 497, $499 \mathrm{f} ., 623,835-837$

Landesamt für Soziales und Verwaltung 499

Landesanstalten 189, 759, 798, 860, 934 f., $938 \mathrm{f}$.

Landesarbeitsamt 259, 1073, 1176, 1178, 1182, 1184, 1187 f., 1192, 1196, 1325

Landesarbeitsgemeinschaft evangelischer Schlesier (Berlin) 1259

Landesaufnahmegesetz (LAufnG) 499, 623

Landesausstellung 513

Landesbauernsekretär 1306

Landesbehörden der Volkspolizei $\rightarrow$ Volkspolizei

Landesblockausschuss der antifaschistisch-demokratischen Parteien Brandenburgs 48, 69, 1164, 1396

Landesforstamt 259

Landesgartenschau 642, 1451

Landesgehörlosenschule der Provinz Brandenburg 597, 641, 803

Landesgeschichtliche Vereinigung für die Mark Brandenburg (LGV) VI, 5, 59, 303, 1420, 1543

Landesgeschichtsforschung, Landeshistoriker 4 f., 15 f., 23-29, 32, 147, 518

Landesgesundheitsamt 1237

Landesheilanstalt $934 \mathrm{f}$.

Landesjugendamt Brandenburg 178f., 501, 1251, 1253

Landesjugendfürsorge 1240

Landesjugendheim $\rightarrow$ Brandenburgisches Landesjugendheim

Landesjugendring Brandenburg 501

Landeskinderheim 785

Landeskirchliche Gemeinschaft Schönholz/Rathenow 898 
Landeskontrollkommission 1130, 1224, $1226 \mathrm{f}$.

Landeskrankenhaus 797

Landesmedizinalrat 101

Landespolizeibehörden $\rightarrow$ Volkspolizei

Landespreisamt 1226, 1244

Landesrechnungshof Brandenburg 497

Landesregierung Brandenburg (1947-1952)

(siehe auch $\rightarrow$ Minister, $\rightarrow$ Ministerpräsident, $\rightarrow$ Provinzialverwaltung) 48, 51 f., 138, 140, $163,165,167,173$ f., 240, 246, 251, 254, 301, $517,522,554,619,648,655,668,850,895$, 924, 957, 967, 1090, 1108, 1122f., 1141, 1150, 1165 f., 1172 f., 1200, 1229, 1236, 1244, 1288, 1312, 1395; Regierungsprogramm 1309, 1312

- (ab 1990) (siehe auch $\rightarrow$ Minister, $\rightarrow$ Ministerpräsident) V, 5, 8, 19-23, 37, 44, 463, 470, 474-477, 767, 836, 854, 948, 1360, 1394

Landesregierung Sachsen 1108, 1132

Landesschule für Aussiedler 825

Landessender Potsdam 1249, $1252 \mathrm{f}$.

Landessender Sachsen 1137

Landesseniorenbeirat Brandenburg 61

Landesstelle für Aussiedler des Landes Brandenburg (Peitz) 498-500, 623, 835-837

Landesstelle für Berlin-Brandenburgische Volkskunde 31

Landestheater 1123

Landesumsiedler- und Heimkehrerausschuss 255, 259f., 268, 1235

Landesvertriebenenamt Nordrhein-Westfalen 403

Landesvertriebenen- und Aussiedleramt (Brandenburg) 499f., 623, 836

Landesverwaltung $\rightarrow$ Landesregierung

Landeswirtschaftsamt 432

Landeswohnungsamt $\rightarrow$ Wohnungsamt

Landeszentrale für politische Bildung (Potsdam)

$\rightarrow$ Brandenburgische Landeszentrale für politische Bildung

Landflucht 306, 506, 738, 889

Landfrauenverein „Mittleres Oderbruch“ 33

Landgericht Potsdam 852

Landgestüte 823

Landheim der Berliner Stadtmission 930

Landhelfer 1196, 1198

Landjugend GmbH Charlottenburg 649

Landjugendheim Finkenkrug 649

Landkarten 602, 661

Landkreise (vgl. $\rightarrow$ Kreise) 522-550, 1320, 1407 und öfter
Landlose 309, 523, 707, 779, 812, 1128-1130, 1247

Landmaschinen, -fabrik, -handel, -reparatur 288, $343,1206,1208,1468$

Landmaschinenschlosser 1455

Landrat, Landratsamt, Kreisverwaltung, Rat des Kreises (siehe auch $\rightarrow$ Kreisumsiedleramt) 50, 52, 54, 81, 93, 111, 138, 140, 158, 165, 172 f., 241, 245, 255 f., 258, 260, 272, 274, 278, $348,470,1001,1054,1118,1151,1155,1162$, 1166 f., 1169, 1230, 1236, 1256, 1314, 1319, 1401, 1407

- Angermünde 562-564, 840, 1313-1325, 1329-1331

- Beeskow-Storkow 172, 255, 275, 300, $524 \mathrm{f}$., 826, 922, 998-1002, 1004-1008, 1011-1015, 1027, 1047 f., 1058 f., 1069 f., 1072, 1084 f., 1089-1091, 1095 f., 1124, 1130 f., 1142 f., $1147 \mathrm{f} ., 1178,1213,1215,1218,1232,1234 \mathrm{f}$., 1398,1419

- Bernau $1356 \mathrm{f}$.

- Brandenburg 140

- Calau/Senftenberg 526, 800,910, 941

- Cottbus 526f., 618, 947, 1326, 1331-1333, $1336 \mathrm{f}$.

- Dessau-Köthen 1002

- Eichenbrück/Wongrowitz 99f., 107-109, 860,931

- Forst 260

- Guben/Frankfurt (Oder) 81, 317, $528 \mathrm{f}$., 574, 683, 1281-1285, 1290-1300, 1302f., 1333-1336, 1393, 1419

- Havelland 469

- Jerichow II: 877

- Jüterbog 306

- Jüterbog-Luckenwalde $\rightarrow$ Luckenwalde

- Königsberg/Nm. 105

- Kyritz 94

- Landsberg/Warthe 93

- Lebus/Seelow 406, 533, 658, 757, 769, 773, $1054,1056,1441$

- Luckau 139, 534,611

- Luckenwalde, Jüterbog-Luckenwalde 531, 746, 814, 1041-1043, 1058, 1119 f., 11351138, 1148-1150, 1200, 1221, 1223 f., 1228, $1238,1245-1248,1285-1290,1300-1302$, 1304-1308, 1419

- Lübben 140, 535, 765 f., 783, 797 f., 894, 925

- Märkisch-Oderland 479,510f.

- Meseritz 94 
- Niederbarnim (Bernau) 536, 584, 710, 888, 1076f., 1082, 1167, 1419

- Oberbarnim 537, 805, 1243

- Oberhavel 830

- Osthavelland 538, 735, 802, 1110

- Ostprignitz 539, 869

- Perleberg 94

- Prenzlau 108, 541, 545, 860, 867, 931

- Prignitz 841

- Ruppin 542, 703, $1254 \mathrm{f}$.

- Samter 192

- Schwerin/W. 94

- Soldin 100

- Spree-Neiße 948

- Spremberg 543,917

- Stargard (Mecklenburg) 557

- Teltow 544, 643, 1126f., 1176, 1219

- Templin 108, 140, 191, 545 f., 860, 880, $931 \mathrm{f}$.

- Uckermark 865

- Westhavelland 547, 879, 1124, 1186, 1188

- Westprignitz 548f., 1132, 1139-1141, 1143-1147, 1149, 1419

- Wollstein 573

- Zauch-Belzig 550, 742, 938

- Züllichau-Schwiebus 81, 100, 110, 612f., 711, $723,819,822,1419,1445$

Landsberger Kirchentag 411, 965

Landschaftsnamen 343,518

„Landser“ 181

Landsmannschaften $6,364,368,374,376$, 379-381, 401, 403, 408, 427, 464-466, 479, $482,487,839,1240,1259,1339,1359 \mathrm{f} .$, 1363 f., 1375, 1378

- Bentschen 368

- Berlin-Mark Brandenburg 379f., 401, 463, 471, 474-476, 660, 691, 731, 831, 1376

- -, Kreisgruppe Forst/Nl. 660

- -, Landesverband Brandenburg 658, 685, 745

- -, Ortsverband Eisenhüttenstadt 685

- Czarnikau 368

- Deutsch-Baltische, Berliner Landesgruppe 233

- Filehne 368

- Karpatendeutsche (KDLM), Landesverband Brandenburg 237, 605-608

- Kreisgruppen 223, 831, 878

- Lissa 368

- Oberschlesier 427

- Ostbrandenburg/Neumark 367, 369, 379, $395,427,474,493,831,878$
- Ostmark 368

- Ostpreußen (LMO) 224, 427, 504, 628, 831, 853,1543

- -, Kreisgruppen 831, 878

- -, Landesgruppe Brandenburg 223 f., 226, $465,470,853,894,1543$

- Ostprignitz-Ruppin 820

- Ostrowo 368

- Pommern 427, 831

- -, Kreisgruppen 831, 878

- Schlesien 212, 378, 427, 831, 878

- -, Kreisgruppen 831

- Sudetendeutsche 326, 427, 831

- -, Kreisgruppen 831

- -, Landesgruppe Brandenburg 232, 465, 853, 859

- Weichsel-Warthe 441,831,878

- Westpreußen 427, 831, $878 \mathrm{f}$.

- -, Kreisverband Oberhavel 831

- -, Landesgruppe Brandenburg, Landesobmann $224,878 \mathrm{f}$.

- Wollstein 368

Landtag Brandenburg (1945-1952) 51, 158, $239,250,252,260,314,854,1113,1120$, 1122, 1124, 1137, 1171, 1231, 1236, 1327, 1419, 1473; Landtagspräsident 1120 f., 1123; Landtagswahl 1220

- (ab 1990) 12, 21, 503, 705, 820, 836, 846, 852, 1447; Landtagspräsident ; 948,1436 ; Landtagswahl 846

Landwehrlager 797

Landwirtschaft, -wirte (siehe auch $\rightarrow$ Bauern) 226, 259, 289, 313, 315f., 523, 526, 595, $608,611,652,695,705,834,897,911,951$, 1021, 1044f., 1047, 1138, 1160 f., 1165, 1170, 1177, 1187, 1189-1191, 1193, 1195, 1197, $1221,1226,1228,1272,1306,1356,1436$, 1438-1443, 1445 f., 1449-1451, 1453 f., 1456 f., 1460 f., 1463, 1466, 1472, 1476, 1482 und öfter

Landwirtschaftliche Geräte $\rightarrow$ Ackergerät, $\rightarrow$ Maschinen, $\rightarrow$ Wirtschaftsartikel

Landwirtschaftliche Produktionsgenossenschaften (LPG) 299, 314, 317, 353, 355, 424, 681, $708,727,737,758,809,905,1436,1442$, 1450, 1453, 1456f., 1463, 1467, 1482

- LPG Typ III ,Professor Mitscherlich` 596

- LPG „Vereinte Kraft“ (Schönerlinde) 1356 f.

Landwirtschaftlicher Arbeiter $\rightarrow$ Landarbeiter 
Landwirtschaftsschule 567, 1320, 1436, 1438, 1460

Lastenausgleich (Ost) 270, 1026, 1134, 1244, 1368 f., 1394

- (West) 54, 463, 1330

Lastenausgleichsarchiv (Bayreuth) $\rightarrow$ Bundesarchiv

Lastkraftwagen (Lkw) 120, 150, 171, 178 f., 274, $525,643,662,678,714,801,827$ f., 1068, 1070, 1074, 1082, 1094, 1201, 1222, 1236, 1440, 1444, 1451, 1455, 1459, 1461, 1463, 1465,1474 und öfter

Latrinenanlage 682, 1052

Lauben 586, 874, 1272, 1450

Laus $\rightarrow$ Läuse

Lautsprecherdurchsagen 862

Lazarett, Feldlazarett (siehe auch $\rightarrow$ Krankenhaus) $177,180,187 \mathrm{f} ., 291,297,415,552,570$, 578, 586 f., 597, 659, 686, 762, 766, 782, 790, $794,796,802,819,833,862,889,895,923$, $933,956,1276,1447,1453,1464,1466,1475$, 1478-1480; Notlazarett 22, 719; ReserveLazarett 653, 659, 719, 971

Lazarettzug $\rightarrow$ Eisenbahn

LDP(D) 126, 259 f., 298 f., 918, 1084, 1104, $1113,1121,1128,1160,1164,1197,1220$, 1231, 1251, 1282, 1318 f., 1327, 1329, 1334

Lebensmittel, -versorgung, -zuteilung, -knappheit, Ernährung, Nahrung, Naturalien, Verpflegung, Versorgungslage, Essen, Essensausgabe (siehe auch $\rightarrow$ Alkohol, $\rightarrow$ Hunger, $\rightarrow$ Küche, $\rightarrow$ Marschverpflegung, $\rightarrow$ Wasserversorgung, $\rightarrow$ Selbstversorger, $\rightarrow$ Speisen, $\rightarrow$ Tee, $\rightarrow$ Zigaretten) 81, 85-89, 92, 95 f., 98, 116, 118-121, 124-126, 131-133, 152-154, 160-162, 171, 174, 177-182, 185, 188, 191, 194, 197 f., 227, 244, 255, 261, 264, 266, 268 f., 277 f., 283, 285, 304, 311, 313, 322 f., 367, $390,431,523,528,545,560-562,570,578$, 588, 590 f., 593, 597, 608, 611, 614, 617 f., 620, 626 f., 630, 636-639, 645, 647, 656 f., 664f., 677, 679, 683, 686, 694-696, 700, 718 f., 739, $745,749,755,759,764,778$ f., $786,806,809$ f., 819,827 f., $833,837,849$ f., $861,869,875,877$, $880,886,891,896,902,905$ f., 915,922 f., 927, 929, 946, 949-951, 956, 961, 966f., 994, 998 f., 1002 f., 1005, 1008 f., 1011-1013, 1016, 1020, 1022, 1039, 1042, 1047, 1050 f., 1053, 1057, 1062, 1065, 1068 f., 1075, 1083, 1088-1090, 1094, 1096, 1134, 1141, 1147, 1153 f., 1164, 1183, 1187, 1194, 1233, 1236,
$1239,1246,1269,1271-1273,1275$ f., 1278 , 1280, 1286-1288, 1291, 1298, 1303, 1305, 1309 f., 1312, 1315, 1351, 1403, 1437, 1442, 1446, 1461, 1469 und öfter

- Brause 1075

- Brötchen 182, 861, 1148

- Brot, -schnitten, „Stullen“ 87, 118, 131 f., 154, 160, 171 f., 179-182, 227, 266, 274, 277, 289, 431, 556, 598, 614, 664, 700, 718, 754, 778, $786,861,893,895,943,966,993,997,1010$, 1042, 1082, 1094, 1107, 1130, 1153, $1272 \mathrm{f}$., 1278,1283 f., $1288,1304,1461$

- Bucheckern 855

- Eier 1288

- Eintopf, Suppe 98, 119f., 126, 133, 153, 160, $177,180,182,266$ f., 338, 615 f., 678, 861, 873, 877, 993 f., 997, 1141, 1153, 1278

- Fett, -mangel 876, 1141, 1153, 1280, 1303, 1461

- Fisch 1134, 1282

- Fleisch, -mangel 116, 268, 736, 767, 876, 1042, 1134, 1297, 1303, 1437

- Gemüse (siehe auch Kartoffeln) 274, 570, 614, 617, 652, 802, 943, 951, 957, 1042, 1073, 1079, 1081-1083, 1090, 1133 f., 1145, 1206, $1224,1282,1287$ f., 1411

- Getränke 950, 1091

- Grütze 829

- Haferflockensuppe 176

- Kaffee 95, 118 f., 181, 274, 322, 367, 369, 375, $387,401,414,424,486,490,556,598,610$, 614, 638, 718, 837, 993 f., 1042, 1153

- Kartoffeln 43, 86, 116, 119, 129, 155, 171, $180,227,266,278,388,556,617,767,802$, $875,943,1016,1042,1079,1081,1083,1134$, $1145,1153,1246,1272,1282,1287$ f., 1291 , 1301, 1439

- Kartoffelschalen 131

- Kleinkindernahrung 993

- Kohlsuppe 1278

- Kuchen 1291

- Kümmel 180

- Magermilch 1147

- Malzkaffee 614

- Mehl, Getreide 86, 116, 269, 280, 556, 614, $626,664,700,877,1073$

- Milch, -versorgung, -mangel 96, 118, 124f., $131,322,626,664,736,755,758,993,1057$, $1147,1153,1227,1280$

- Mittagessen 1090, 1096, 1183, 1239 
- Obst, Beeren 614, 665, 767, 957, $1072 \mathrm{f}$., 1133 f., 1206,1226

- Pferdefleisch 323

- Pilze 171, 1042, 1250

- Pilzsuppe 1042

- Quark 1042

- Salz 1272

- Schmalz 274

- Schokolade 1091

- Süßigkeiten 1286

- Suppe $\rightarrow$ Eintopf

- Tee 119,614,616

- Torte 280

- „Warme Mahlzeit“" „warmes Essen“ 181, 266, $665,678,873,929,950,1024,1039,1050$, $1061,1083,1149,1154,1459$

- Warme Getränke 860

- Wasser 1016, 1051

- Wassersuppe 877

- Wurst 861

- Zucker 844, 1153

- Zusatzkost, -verpflegung für werdende u. stillende Mütter 1090, 1096

Lebensmittelkarten, -marken, „Essenmarken“ 81, $88,161,261,345$ f., 358, 614, 654f., 765, 833, $896,1025,1112,1133,1162-1164,1226,1253$, $1278,1287,1298,1310,1312,1457,1461$

Lebensmittellager, -magazin 1053, 1061, 1073, 1080

Lebensmittelpakete 280, 365 f., 388, 390 f., 399 f.

Lebensmittelrationierung 1475

„Lebensraum“ 1290

Lebensstandard 280, 1292 f., 1338 und öfter

"Lebenszeichen“ 1394

„Lebenszeit“ (Neuenhagen) 812

Lebertran 181

Ledige Männer $\rightarrow$ Männer

Ledigenheim $1122 \mathrm{f}$.

Lehrer (siehe auch $\rightarrow$ Lehrerin, $\rightarrow$ Neulehrer, $\rightarrow$ Schule) $65 \mathrm{f}$., $113 \mathrm{f}$., 130, 218, $227 \mathrm{f}$., 297-299, 326, 328, 333, 368, 385, 408, 413, $415,508,564,601,613,627,714,779,792 \mathrm{f}$., $824,827,830,838,852,876,1250,1276$, 1284, 1297, 1306, 1334, 1350, 1437, $1446 \mathrm{f}$., 1454, 1457 f., 1476, 1480, 1483, 1534

- als Flüchtlingsbetreuer (-dienst) 120, 663, $837,863,921,1403,1476$

Lehrerbildungsanstalt, -seminar 127, $1451 \mathrm{f}$., $1457,1464,1468,1534$
Lehrerin $330,449,659,750,775,824,883$, 993-995, 1143, 1146, 1270, 1334, 1437, 1441, $1446,1450,1452,1457,1471,1480$

- als Flüchtlingsbetreuer (-dienst) 993-995

Lehrlinge 290, 1136, 1198, 1240, 1321, 1435, $1449,1454,1477$

Lehrlingsausbilder 1474

Lehrlingswerkstatt 1171

Lehrlings(wohn)heim 288, 593, 867, 1171, 1240

Lehrstellen 1130

„leibniz“" (Zeitschrift) 15

Leibniz-Gemeinschaft 15

Leibniz-Institut für Länderkunde (Leipzig) 28

Leichen, Skelette, Totgeborgene, Leichenbergung (siehe auch $\rightarrow$ Exhumierung, $\rightarrow$ Massengräber, $\rightarrow$ Umbettung) 131 f., 148, 184, 480, 546, $565,578,587,594,617,653,677,750,762$, $778,927,960,1053,1055,1058,1068$

Leichenhalle, -aufbewahrung 720, 956

Leichtkranke $\rightarrow$ Krankheiten

Leihgetreide 1287

Leipziger Messe $\rightarrow$ Messe

Leistenbruch $\rightarrow$ Krankheiten

Leistungsabteilung 1371

Leistungslohn 1323

Leistungsprämie für Bauern $1166 \mathrm{f}$., $1228 \mathrm{f}$.

Leiterwagen 84, 92, 893, 1435

Leserbriefe 243, 363, 381, 390, 439, 1132-1134, 1283

Lesungen $226,507,577,666,704,846,854,856$, 885

Lethargie (vgl. $\rightarrow$ Apathie) 308, 1241, 1245

„Die letzte Etappe“ $\rightarrow$ Film

Leutelt-Gesellschaft 230

Liberaldemokratische Partei $\rightarrow$ LDP(D)

Licht $\rightarrow$ Elektrisches Licht

Lichtbildervortrag 693, 1373

Lichtspieltheater $\rightarrow$ Kino

Lieder, Gesang (siehe auch $\rightarrow$ Nationalhymne) 75, 178 f., 237, 268, 347, 354, 606, 898, 1088, 1137 f., 1326 f., 1335

_ „Ännchen von Tharau“ 268

- Deutschlandlied 75

- „Heimat, deine Sterne“ 373

- Heimatlieder 369, 406, 824, 1137

- „In einem kühlen Grunde“ 347, 1335

- „Kampflieder der Arbeiterbewegung“ 1331

- Kirchenlieder 1339, 1345

- „Pommernlied“ 268 
- schlesische 598

- Volkslieder 377, 1072f., 1265, 1327

- Weihnachtslieder 440, 755, 1143, 1278

Linke $\rightarrow$ Die Linke

Linksextremismus 470, 480, 851

Litauendeutsche 760

Litauisch $\rightarrow$ Sprache

Literarische Verarbeitung $363 \mathrm{f}$.

Literatur, Belletristik (siehe auch $\rightarrow$ Novellen, $\rightarrow$ Romane, $\rightarrow$ Schriftsteller) 1364, 1400

Liturgie 437

Lkw $\rightarrow$ Lastkraftwagen

LMO $\rightarrow$ Landsmannschaften/Ostpreußen

Lohn und Gehalt 259, 287, 293, 1111 f., 1138, $1148,1151,1155,1161,1214,1216,1226$, $1250,1271,1283,1314$ f., 1320-1324, 1452 und öfter

Lokal $\rightarrow$ Gasthof

Lokalgeschichtsforschung $\rightarrow$ Heimatforschung, $\rightarrow$ Ortsgeschichtsforschung

Londoner Konferenz (1947) $\rightarrow$ Konferenz von London

LPG $\rightarrow$ Landwirtschaftliche Produktionsgenossenschaft

Lues $\rightarrow$ Krankheiten

Luftangriff, -krieg $\rightarrow$ Bombenkrieg, $\rightarrow$ Tiefflieger, $\rightarrow$ Todesursachen

Luftschutz, -keller, -bunker 89, 98, 322, 640, 647, $759,847,858 \mathrm{f}$.

Luftschutzbetten 896

Luftwaffe $\rightarrow$ Wehrmacht

Luftwaffenhelfer (siehe auch $\rightarrow$ Flakhelfer) 1438

Luise-Henriette-Stift Lehnin 221, 433, 782, 1259

Lumpen, Fetzen 1017, 1125, 1134, 1268, 1273, 1308

Lungenembolie $\rightarrow$ Todesursachen

Lungenentzündung $\rightarrow$ Krankheiten

Lungenfacharzt $\rightarrow$ Ärzte

Lungenheilstätte, -heilanstalt 655, $761 \mathrm{f}$.

Lungenkrankheit, -leiden $\rightarrow$ Krankheiten

Lungentuberkulose $\rightarrow$ Krankheiten

Lutherstift (Frankfurt/O.) 669

Maden 132

Mädchenheim 858, 1377

Mägde 314, 875, 1144

Mägde Christi $\rightarrow$ Arme Dienstmägde Jesu Christi

Mägde Mariens von der unbefleckten Empfängnis $210,817,955$
Männer, -anteil 57, 75, 87, 95, 97, 100, 129, 141, 148 f., 152, 154, 156, 189, 197, 244, 274, 284 f., $354,358,362,370,438,522,579,588,609$, 629, 631, 637 f., 641, 665, 695, 730 f., 761, 767, 806, 809, 827, 849f., 896, 903, 908, 931, 1021, 1044 f., 1060, 1076, 1083, 1094, 1096, 1099-1103, 1107, 1121 f., 1133, 1177-1186, 1193, 1195 f., 1202-1204, 1216, 1233, 1269, 1277, 1279 f., 1298 f., 1301-1303, 1310, 1315, 1329, 1356, 1371, 1434 und öfter

- alleinstehende, ledige 849, 1122 f., 1187

Männerarbeit 1342

Männerchor 845

„Der Märker" $\rightarrow$ Zeitungen

Märkische Akademie ländlicher Raum 29

„Märkische Allgemeine Zeitung “ $\rightarrow$ Zeitungen

Märkische Gehörlosenschule 641, 802, 870

„Märkische Heimat“ (Zeitschrift) 325

„Märkische Union“ $\rightarrow$ Zeitungen

Märkische Volkssolidarität (MVS) $\rightarrow$ Volkssolidarität

"Märkische Volksstimme“ $\rightarrow$ Zeitungen

„Märkischer Informationsdienst“ 463, 467, 483

„Märkisches Gesprächsforum“ 692

Mäuse 1013

Magenbeschwerden, -geschwür, -krebs $\rightarrow$ Krankheiten

Magermilch 1147

Magistrat von Groß-Berlin 6, 159-162, 240, 1016, 1407; Hauptamt für Sozialfürsorge/wesen 1183,1407

Mahnmal $\rightarrow$ Gedenkort

Maiandacht 625

Mai-Kundgebung (1. Mai) 1290

Malerbedarfsartikel 1198

Malzkaffee 614

Mamma-Carcinom $\rightarrow$ Krankheiten/Brustkrebs

Mangelberufe 1045, 1081, 1190, 1240

Mangelernährung, -erkrankungen $\rightarrow$ Krankheiten

Mansardenzimmer 1441

Manufakturwarenhandel 1209, 1212

Marasmus $\rightarrow$ Todesursachen

Marienschwestern von der Unbefleckten Empfängnis $38,450,896 \mathrm{f}$., 958

Marienstift Frankfurt (Oder) 446, 668

Marienverehrung 784, 803, 825, 858

Marschbefehl 1446

Marschmusik 1334 
Marschverpflegung 178, 323, 895, 1039 f., 1061 f., 1153

Marshall-Plan 1293

Martin-Opitz-Bibliothek $\rightarrow$ Bibliotheken

Maschinen, -mangel 102, 282, 307, 310, 317, 565, 754, 765, 780, 814, 899, 915, 936, 1147, 1187, 1198, 1201, 1208, 1218, 1220, 1311

Maschinenausleihstation (MAS) 324, 1228, $1315,1449,1457$

Maschinenbau, -fabrik 224, 1206, 1208, 1313

Maschinengewehr 90

Maschinenmeister 132, 369

Maschinenpistole (MP) 133, 1306

Maschinen-Traktoren-Station (MTS) 1457, 1459,1474

Masern, -epidemie $\rightarrow$ Krankheiten

Massenerschießung 936

Massenflucht (siehe auch $\rightarrow$ Evakuierung, $\rightarrow \mathrm{Pa}$ nik) $113,827,862$

Massengrab, -sterben, -beerdigung (siehe auch $\rightarrow$ Friedhof) 44, 138, 171, 186, 561, 574, 621, 623, 628 f., 665, 761 f., 770, 782, 788, 792, 797 f., 860, 875, 901, 923 f., 969, 971, 997, 1013,1282

Masseninfektion 1077

Massenorganisationen (DDR), „Organisationen“ 1098, 1109, 1139, 1163, 1166f., 1171, 1197, $1221,1223,1239,1241,1318,1326$

Massenquartier, -unterkunft (siehe auch $\rightarrow$ Notunterkunft) $764,795,806,1122$ f., 1133 und öfter

Masuren (als Personenbezeichnung) 141

Matsch $\rightarrow$ Wetter

Matthesianer-Verband 427

Mauerbau 58, 191, 202, 204, 207, 299, 306, 365 f., 373-377, 379 f., 387, 400, 403-405, 441, 444, 450, 656, 1259 f., 1416

Maurer 185, 314, 560, 1337, 1445, 1468

Medikamente, Arzneimittel, Verbandszeug, „Medizin“, -mangel 132, 184, 188, 262, 321, 377, 560, 640, 664f., 719, 739, 767, 819, 865, 889, 1005 f., 1010 f., 1054, 1056, 1058, 1067, 1069, 1078,1268 f., 1275

Medizingeschichte 29

Medizinische Akademie Danzig 921, 1064

Medizinische Instrumente (Fabrikation) 627

Mehl $\rightarrow$ Lebensmittel

Meldebücher, -kartei $\rightarrow$ Einwohnermeldeamt

Meldekarten $\rightarrow$ Suchdienst für vermißte Deutsche in der SBZ
Meldestelle, -kopf für Flüchtlinge/Zwangsevakuierte $124,193,217,530,548,573$

Memellandbund 368

Memelland-Gruppe Potsdam 853

Memorandum, polnisches 665

Meningitis tuberculosa $\rightarrow$ Todesursachen

Mennonitenprediger 155

Menschenrechte 470, 1361, 1365 f.

Menschenwürde, -rechte 170, 563, 580, 877, 1003, 1015f., 1021, 1123-1126, 1131, 1151, $1153,1156,1323$

Menstruation $\rightarrow$ Frauen

Messe, hl. $\rightarrow$ Gottesdienst, kath.

Messe, Leipziger 1200, 1228, 1479

Messerschmiede, -fabrikation 229, 301, 307, 779-781, 1198, 1247

Messkoffer 940

Metallgießerei 1198, 1207

MfS $\rightarrow$ Ministerium für Staatssicherheit der DDR

MGB $\rightarrow$ Minister (UdSSR), Staatssicherheit

Miete $\rightarrow$ Wohnungsmiete

Migration, Zuwanderung 29f., 32, 36, 213, 506, $508,510-512,599,637,748,811,858$

Migrationsberatung, -beratungsstellen (siehe auch $\rightarrow$ Aussiedlerbetreuung) 469, 471, 641, $793,851,1362$

Migrationsforschung 32

Milch, -versorgung, -mangel $\rightarrow$ Lebensmittel

Milchhändler 1227

Milchkühe 1147, 1218

Militär (siehe auch $\rightarrow$ NVA, $\rightarrow$ Rote Armee, $\rightarrow$ Wehrmacht) 770

Militärkommandant, sowjet. 159, 575, 673, 1121

Militärkommandantur, deutsche (in Polen) 615

Militärmission $\rightarrow$ Polnische Militärmission

Militärstreife $\rightarrow$ Feldjäger

Militärtribunal, sowjet. 628

Miliz, poln. 129, 154, 1052 f., 1329

Minderheiten, deutsche $\rightarrow$ Deutsche Minderheit

Minen, -räumung, -tote 113, 284, 686, 1520

Minensuch- und -räumboote 87

Minister, Ministerien (Baden-Württemberg), Inneres 476

Minister, Ministerien (Brandenburg bis 1952, anfangs Haupt-/Abteilungen der Provinzialverwaltung) 50-53, 240

- Arbeit und Soziales/Sozialwesen 51, 53, 240, 243, 245-247 f., 250, 847, 1116 f., 1123, 1130, 1144, 1147, 1161, 1165 f., 1178, 1186, 1188 f., 
1192, 1195, 1231 f., 1235-1237, 1251, 1408, $1411 \mathrm{f}$.

- Finanzen 51, 1327

- Gesundheit 51, 769, 773, 1327, 1419, 1476

- Inneres 51, 53, 166 f., 230, 246-250, 258, 341, $348,371,1119,1224,1245,1251,1285,1290$, 1308, 1311 f., 1333, 1409, 1411 f., 1419, 1472; Abt. Bevölkerungspolitik 247, 249, 848, 1107, 1109, 1170, 1237, 1397, 1107, 1109, 1397

- Landwirtschaft 1228

- Volksbildung 527

- Wirtschaft (und Arbeit) 859, 1160, 1165, 1183-1188, 1192, 1197, 1202, 1393, 1419

- Wirtschaftsplanung 259, 1174, 1225, 1409-1411

Minister, Ministerien (Brandenburg ab 1990)

- Arbeit, Soziales, Gesundheit und Frauen 64, 497, 499, 836

- Bildung, Jugend und Sport 296

- Inneres 470, 476, 498, 569, 836

- Landwirtschaft, Umweltschutz und Raumordnung 29, 852

- Wissenschaft, Forschung und Kultur 5, 19-21, 476; Kulturstaatssekretär 268, 599

Minister, Ministerien (Bundesrepublik Deutschland) $\rightarrow$ Bundesminister

Minister, Ministerien (DDR) 50

- Auswärtige Angelegenheiten 158, 915, 1356, 1414

- Inneres 51, 140, $142 \mathrm{f}$., 212, $341 \mathrm{f}$., 374, $394 \mathrm{f}$., $533,540,623,673,688,799,822,850,862$, 1106, 1340, 1342, 1344-1357, 1391, 1396, 1402, 1413, 1419

- -, Hauptabt. Paß- und Meldewesen (PM) 378,1354

- -, Hauptabt. Staatl. Verwaltung, Abt. Bevölkerungspolitik 141, 225, $1044 \mathrm{f}$., $1106 \mathrm{f}$., 1109, 1355, 1109, 1355, 1397

- -, Hauptabt. Verwaltungspolizei 394-397, 403

- -, Hauptverwaltung Ausbildung (HVA) 293, 398

- -, Hauptverwaltung Deutsche Volkspolizei $378,393,398,403,406,408,1340,1342$, $1344,1346,1348-1350,1352-1354$

- Justiz 852

- Staatssicherheit (MfS, Stasi) 53, 141, 147, $159,295,326,349,353$ f., 373 f., 380 f., 383 , 389, 393 f., 396-398, 405-407, 426, 484, 655,
905, 914, 1045 f., 1107 f., 1345, 1348-1350, 1354,1400

- Volksbildung 225, 785

Minister, Ministerien (Deutsches Reich)

$\rightarrow$ Reichsminister

Minister, Ministerien (Niedersachsen), Flüchtlinge und Vertriebene 138

Minister, Ministerien (Polen); Außenminister 666, 1414; Verteidigung 715; „Wiedergewonnene Gebiete" 346

Minister, Ministerien (Sachsen), Gesundheit 1132; Inneres 1108; Justiz 1132

Minister, Ministerien (UdSSR), Außenminister 665, 1283, 1296; Inneres (MWD) 1127;

Staatssicherheit (MGB), stellv. 253

Ministerpräsidenten

- Brandenburg (bis 1952) 839, 1156 f., 1251, 1408,1410

- Brandenburg (ab 1990) 19, 463, 470, 474, 480, 482f., 503, 505, 691, 771, 820, 832, 1418, 1466

- Polen 666, 1326

- Sachsen-Anhalt 877

- Thüringen 1016

Ministerrat der DDR 380, 1416

Ministranten 940

„Mischehe" $\rightarrow$ Ehe

Misshandlung (siehe auch $\rightarrow$ Gewalt) 566, 1010, 1095

Missionare der hl. Familie (MSF) 741 f., 782

Missionsinspektor 592

Missmut 183

Misstrauen 118

Mitmenschlichkeit $\rightarrow$ Einheimische

Mitropa 1438

Mittagessen $\rightarrow$ Lebensmittel

Mitteldeutscher Verlag $\rightarrow$ Verlage

Mobiliar, Möbel (siehe auch $\rightarrow$ Betten, $\rightarrow$ Hausrat) $87,91,257,267,277,279,282$ f., 285 , $311,575,585,588,647,699$ f., $718,734,747$, 764, 802, 842, 896, 926, 931, 944 f., 964, 1059, $1113,1118,1125,1132,1135,1137,1139-$ $1141,1144,1148$ f., 1156, 1158, 1172, 1175 , 1221, 1247, 1271, 1278 f., 1291 f., 1315, 1338, $1342,1401,1408,1459$

- Kleiderschränke 897, 1139

- Schränke 85, 575, 1078, 1113, 1141, 1243 f., 1278, 1291

- Stühle als Nachtlager 1434

Modehaus 1213 
Möbel $\rightarrow$ Mobiliar

Möbelherstellung, -fabrikanten 710, 1139, 1198 f., 1244

Möbelmiete, -nutzung $1148 \mathrm{f}$.

Mohnkuchen, schlesischer $\rightarrow$ Speisen

„Mohrunger Heimatkreis-Nachrichten“ $\rightarrow$ Heimatzeitschriften

Mord $\rightarrow$ Kriminalität, $\rightarrow$ Todesursachen

„Der Morgen“ $\rightarrow$ Zeitungen

Motorrad 940

Motorsportschule 961

MSF $\rightarrow$ Missionare von der hl. Familie

MTS $\rightarrow$ Maschinen-Traktoren-Station

Mühlen, Müller 664, 1206, 1448, 1470

Müllabfuhr 1188

Müllplätze 171

„Münchener Abkommen“ 75

Mütterheim 553, 586

Mütterschule 124

MUNA $\rightarrow$ Munitionsanstalt, -depot

Mundart, Akzent, Aussprache, Dialekt (siehe auch $\rightarrow$ Sprache) 195, 326, 333, 335-337, $409,461,509,578,609,942,994,1305$

Munition 604, 901, 1404

Munitionsanstalt, -depot, -lager (MUNA) 287, 765 f., 794, 840

Munitionsbergung, -explosionen, -tote 684, 1520

Munitionsfabrik 936, 938

Munitionskisten 180

Museen (siehe auch $\rightarrow$ Ausstellungen, $\rightarrow$ Heimatstuben) 5, 7, 21, 29, 33, 60, 475, 599, 601, 886, $906 \mathrm{f}$.

- Agrarhistorisches Museum Schwerin 29

- Archäologisches Landesmuseum (Brandenburg/H.) 34

- Brandenburgisches Textilmuseum (Forst/L.) 660

- Brandenburg-Preußen-Museum (Wustrau) 481, 964, 1542

- Deutsches Historisches Museum (Berlin) 469

- Filmmuseum Potsdam 229

- Gedenkstätte und Museum Sachsenhausen 21

- Georgi-Dimitroff-Museum Leipzig 243

- Heimatmuseum Angermünde 564

- Heimatmuseum Gransee 704

- Heimatmuseum Guben 1444

- Kreismuseum Wewelsburg 383

- Museum für Natur- und Heimatgeschichte des Landkreises Beeskow 31
- Museum Bernau 585

- Museum Fürstenwalde 343, 1543

- Museum im Zisterzienserkloster Lehnin 1543

- Museum in der Adler-Apotheke (Eberswalde) $512,637,642$

- Museum Neukölln (Berlin) 512

- Museum Templin 932

- Museum Viadrina Frankfurt (Oder) 40, 669 f.

- Muzeum Śląskie w Katowicach (Schlesisches Museum Kattowitz) 854

- Muzeum Twierdzy Kostrzyn (Museum Festung Küstrin) 907

- Muzeum w Gliwicach (Museum in Gleiwitz) 854

- Niederlausitz-Museum Luckau 789

- Oderlandmuseum 33, 569, 906, 962

- Ostpreußisches Landesmuseum Lüneburg 74, 704

- Potsdam-Museum 279, 505, 509 f., 512

- Regionalmuseum „Burg Beeskow“ 31, 577

- Sänger- und Kaufmannsmuseum Finsterwalde 509

- Schlesisches Museum zu Görlitz 209, 854

- Stadtmuseum Schwedt 33

- Stadt- und Regionalmuseum Lübben 45

- Telefon- und Raketenmuseum Pinnow 840

Museumsdorf Glashütte 1374

Museumsverband Brandenburg 29, 33, $509 \mathrm{f}$., $906 \mathrm{f}$.

Museumsverein Forst 658

Musik, Musiker (Chor, Kapelle u. a.; siehe auch $\rightarrow$ Lieder) 227, 276, 300, 319, 341, 373, 376, $387,461,479,481,504,606,629,654,684$, $690,719,734,742,767,779,824,845,878$, 885, 942, 1072 f., 1086, 1091 f., 1094, 1097 , 1099, 1104, 1137 f., 1141, 1241, 1265, 1267, 1326-1329, 1331, 1334, 1373, 1439, 1463, 1469 f., 1511

Muslime 512

„Musterdorf“, „Mustersiedlung“ 312, 315

Musterheim für elternlose Kinder 595

Mutter-und Kind-Heime 121, 228

Muzeum ... $\rightarrow$ Museen

MVS $\rightarrow$ Volkssolidarität, Märkische

MWD $\rightarrow$ Minister (UdSSR), Inneres

Nachlass 1053, 1055, 1419

Nachrichtenagenturen $\rightarrow$ ADN $\rightarrow$ United Press

Nachrichtenwesen 998 
Nachtmarsch 95

„Nachumsiedler" 78

Nägel 1139, 1143

Näherinnen 752, 1199

Nähmaschinen 752, 966, 1199, 1447, 1469, 1447,1469

Nähstube 97, 268, 586, 598 f., 734, 838, 966, $1023,1285,1287$

Nahrungsmittelhandel 1209

Nahverkehr $\rightarrow$ Omnibus, $\rightarrow$ Straßenbahn

Namen $\rightarrow$ Familien-, $\rightarrow$ Fluss-, $\rightarrow$ Orts-, $\rightarrow$ StraBennamen

Namenforschung 30

Namengebung $\rightarrow$ "Sozialistische Namengebung“"

„Namslauer Heimatfreunde“ 211, 465, 822, 824, 912,1543

Nationaldemokratische Partei Deutschlands $\rightarrow$ NDPD, $\rightarrow$ NPD

„Nationale Front“ 350, 592, 1043, 1245, 13211323, 1326, 1334, 1345, 1446; Ortsausschüsse 1319

Nationale Identität $\rightarrow$ Identität

Nationale Volksarmee $\rightarrow$ NVA

"Nationalhass“ 1330

Nationalhymne (DDR) 1328

Nationalität, deutsche 1400

Nationalkomitee „Freies Deutschland“ (NKFD) 251, 1307

Nationalsozialismus VI, 3, 16, 18-21, 34f., 73, 77, 96, 126f., 229, 406, 508, 510, 692, 1201

- Widerstand, Gegnerschaft 241, 408, 1248, 1272, 1328, 1332

Nationalsozialisten, (aktive) „Nazis“, „Faschisten“, „faschistische Elemente“ (siehe auch $\rightarrow$ Entnazifizierung, $\rightarrow$ NSDAP/Parteimitglied) $126,161,335,591,1026,1126,1128,1173$, 1282, 1350; „faschistische Tendenzen“ (im Lager) 1077; „Nazi-Frauen“ 943; „politische Erfassung" 611

Nationalsozialistische $\ldots \rightarrow$ NS-...

„Nationalzeitung" $\rightarrow$ Zeitungen

Naturalien 265, 1141

Naturallohn, Deputat 285, 1130, 1161, 1250, 1321

„Nazis" $\rightarrow$ Nationalsozialisten

NDPD 235, 350, 426, 1305-1307, 1318 f., 1324

Nebengelass 1305

Nebenlager $\rightarrow$ Konzentrationslager

Neinstedter Anstalten 1456
Neisser Kultur- und Heimatbund 379

Nervenfieber, -krankheiten $\rightarrow$ Krankheiten

Nervosität, nervliche Anspannung 86, 94, 123, $156,349,358$

„Netzwerke“ $\rightarrow$ Kommunikation

Neuarbeiter 1192

Neubäuerin 867

Neubauern (siehe auch $\rightarrow$ Bodenreform, $\rightarrow$ Neusiedler) 17, 292, 299, 303 f., 309 f., 312, 314-317, 371, 504, 533, 595, 631, 695, 707, $726,801,809,818,867,911,943,1128,1130$, 1176, 1196, 1217-1229, 1241, 1246, $1298 \mathrm{f}$., $1316,1322,1395,1436,1442,1457,1475$

- nichtsiedelnd 1120

Neubauerndorf 312, 1224

Neubauernhaus, -gehöft, -hof, -stelle, -wirtschaft (siehe auch $\rightarrow$ Neusiedlerhaus) 17, 29, 57, $234,283,304,310-312,316,565,587,652$, $695,706,727,738,763,814,816,818,898$, $911,926,943,951,1123,1128$ f., 1167, 1172, $1197,1221,1223,1225,1247,1299,1317$, $1395,1410,1454,1456,1463,1467$

Neubauernprogramm, „Neusiedlerprogramm“, „Siedlerprogramm“ 11, 169, 311, 565, 1128, $1167,1217,1221-1223,1240,1299,1317$

Neubauernsiedlung 30

Neubauernumsiedler 1395

Neubauernwald 312

Neubauwohnung 143, $1357 \mathrm{f}$.

Neubürger (Begriff) 70, 230, 1137, 1221, 1301, 1395,1400

Neubürgerverein Apolda 405

Neue Norddeutsche und Vereinigte Elbeschiffahrt AG (Berlin) 340, 683

„Neue Heimat“ (Begriff) $\rightarrow$ Heimat

„Die Neue Heimat“ (Zeitschrift) 1146

„Neue Zeit" $\rightarrow$ Zeitungen

„Die Neue Zeitung“ $\rightarrow$ Zeitungen

„Neuer Tag" $\rightarrow$ Zeitungen

„Neues Deutschland“ $\rightarrow$ Zeitungen

Neues Forum 1439, 1447

„Neuheiten-Großhandel“ 1212

Neulehrer 285, 296-299, 333, 337, 461, 695, $876,1437,1447,1454,1471,1473,1477 \mathrm{f}$.

Neulehrerin 824, 884, 1437, 1479

Neulehrerkursus, -lehrgang 957, 1454, 1471, 1480

Neusiedler (in SBZ, siehe auch $\rightarrow$ Neubauern) 42, 302, 311, 371, 577, 588, 698, 706, 727, $884,898,943,951,1118,1128-1130,1144$, 
1222 f., 1281,1286 f., $1302,1306,1316,1320$, 1322,1395

- (in poln. Westgebieten) 907 und öfter

Neusiedlerhaus, -stelle (siehe auch $\rightarrow$ Neubauernhaus) $74,310,643,1128,1409$

Neusiedlerin 706, 1287

Niederlausitzer Bank AG (Cottbus) 106

Niederlausitzer Gesellschaft für Geschichte und Landeskunde 58

„Niederlausitzer Studien“ (Zeitschrift) 58

Niederlausitz-Museum Luckau $\rightarrow$ Museen

NKFD $\rightarrow$ Nationalkomitee „Freies Deutschland“

NKWD (Nadrodnyi Kommissariat Wnutrennich Del/Volkskommissariat für innere Angelegenheiten) 670,739 f., 952, 1459, 1465

„Nomaden“ 77

Norm, -erfüllung 1336

Notaltersheim $621 \mathrm{f}$.

Notar 1435

Notaufnahmestelle für Flüchtlinge aus der DDR (Berlin-Charlottenburg) 1109

Notbeleuchtung 1054, 1056

Notbrücke $\rightarrow$ Brücken/Behelfsbrücken

Notdurft $\rightarrow$ Bedürfnisanstalt

Notkirche, -kapelle 36, 575, 600, 956

Notkrankenhaus $\rightarrow$ Krankenhaus

Notlazarett $\rightarrow$ Lazarett

Notstandsgebiet 828, 892, 1002, 1166, 1282, 1409

Notunterkunft, -quartier, -lager, -wohnung, Behelfswohnung (siehe auch $\rightarrow$ Baracken, $\rightarrow$ Behelfsheim, $\rightarrow$ Gasthof, $\rightarrow$ Gutshaus, $\rightarrow$ Hotel, $\rightarrow$ Keller, $\rightarrow$ Kirchenbau, $\rightarrow$ Pfarrhaus, $\rightarrow$ Sammellager, $\rightarrow$ Schule) 125,163 , 236, 279, 310 f., 511, 561 f., 567, 574, 586 f., 612, 634, 636, 638f., 643, 657, 680, 695, 699, 701-703, 712, 716-720, 732, 739, 745, $759,764,774,784,791,794,800,808,849$, 859, 868, 877, 922-924, 929, 933, 941, 947, 949-951, 956f., 961, 966 f., 1005, 1009, 1012 f., 1124 f., 1163, 1234, 1237, 1434, 1449, 1470 und öfter

Notverordnung 1188

Novellen (vgl. $\rightarrow$ Romane) 69f., 846, 1415 f.

- „Breslauer Novelle“ 846

- „Die Umsiedlerin“ 69f., 1415 f.

NPD (nach 1990) 473, 831

NSDAP („Nazipartei“) 99, 108 f., 125, 173, 246, 437, 570, 891, 895, 949, 1128

- Amt für Volkswohlfahrt 94
- Amtswalter 89

- Blockfrau, -wart 117, 949, 1480

- Gaue 24, 94, 121, 123-125

- Gauleiter, -leitung 67, 94, 662, 1403

- Gaupropagandaleitung 75

- Hauptamt für Volkswohlfahrt 122

- Kreisleiter, -leitung 81, 93, 99, 116 f., 192, $538,663,757,827,862,1399,1405,1445$

- Ortsgruppenleiter 83, 85, 91 f., 99, 891

- Parteikanzlei 122

- Parteimitglied (Pg.) (siehe auch $\rightarrow$ Entnazifizierung, $\rightarrow$ Nationalsozialisten) 246, 335, $683,739,874,895,943,993,1027,1083$, 1097, 1119, 1128, 1201, 1241 f., 1298, 1449

NS-Frauenschaft (NSF) 98, 121, 124, 578, 615, 993-995, 1083

NSKK 961, 1060

NS-Lehrerbund 296

NS-Müttererholungsheim am Seechen (Bestensee) 586

NS-Notopfer (N.S.N.) 89

NS-Volkswohlfahrt (NSV) 93, 95, 119-128, 184, 246, 617, 635, 863 f., 950, 960, 994, 1459, 1463

- Amtswalter 617

- Büro 574

- Gauamt 123f., 662, 1403

- Gauamtsleitung 93

- Hauptamtsleiter 1399

- Kreisamtsleiter 93, 124, 662, 1403

- Oberbefehlsleiter $122 \mathrm{f}$.

- Ortsamtsleiter 993

- Schwestern 75, 119, 121, 123, $125 \mathrm{f}$.

NVA (Nationale Volksarmee) 134, 159, $294 \mathrm{f}$., $488,714,765,840,1439$ f., 1468

Obdachlosenheim, -unterkunft 279, 937

Obdachlosigkeit $664,688,847 \mathrm{f}$. und öfter

Oberbürgermeister $\rightarrow$ Bürgermeister

Oberförsterei Joachimsthal 351, $1323 \mathrm{f}$.

Oberkommando der Wehrmacht (OKW) (siehe auch $\rightarrow$ Kriegstagebuch des OKW)

- Außenstelle 579

Oberkommando des Heeres (OKH), Entwicklungsbüro 169

Oberlandesgericht Königsberg 249

Oberlandrat, -landratsamt 52

- Bernau 769, 888, 890, 1011, 1027, 1048, 1076-1079, 1081, 1109f., 1155, 1176, 1178, $1188,1217-1219,1393,1419$ 
- Brandenburg/H. 1189, 1192, 1195

- Cottbus 527, 530, 572, 611, 619, 706, 1011, 1251

- Eberswalde 263,639,1250

Oberlandratsbezirk 527, 530, 659

Oberlinhaus (Potsdam-Babelsberg) 1259

„Obernigker Gemeindebrief“ 396

"Oberoffizier für Umsiedlung" 253

Oberpostdirektion (OPD) Berlin 1254

Oberschlesier (siehe auch Geographisches Register s.v. Oberschlesien) 141, 143

Oberschlesisch 145

Oberstaatsanwaltschaft Potsdam 855

Oberste Bauleitung 247

Oblaten der Unbefleckten Jungfrau Maria (OMI) (Orden) 883

Obst $\rightarrow$ Lebensmittel

Obstplantagen 557

Obstverwertung 1206

Ochelhermsdorfer Gruppe $633 \mathrm{f}$.

Ochsen als Zugtiere 843

Odereinsatz 1192

Oderevakuierte 151

Oderhochwasser $\rightarrow$ Hochwasser

Oderlandmuseum $\rightarrow$ Museen

Oder-Neiße-Grenze (siehe auch $\rightarrow$ Friedensgrenze“; $\rightarrow$ Geographisches Register) 345-355, 1281 f., 1284 f., 1288, 1290-1296, 1299 f., 1302, 1304-1307, 1309-1312, 1319, 13211333, 1335 f., 1413-1418 und öfter

Oderregulierung 1161, 1194

OdF $\rightarrow$ „Opfer des Faschismus“

Oedeme $\rightarrow$ Krankheiten

„Öffentliche Meinung“ 1254

Öffentlicher Nahverkehr 1405

Ökumene 460 f., 480

Ofen $114,154,159,175-178,180,273,281 \mathrm{f}$., $285,575,640,643,648,680,951,1014$ f., 1059 f., 1080, 1112, 1118, 1145 und öfter

Ofenheizung 279, 1276

Ofenrohr, -mangel 1145

Offener Befehl $\rightarrow$ SMA/Befehle

$\mathrm{OKH} \rightarrow$ Oberkommando des Heeres

Oktoberrevolution, Russische 1098, 1104

OKW $\rightarrow$ Oberkommando der Wehrmacht

$\mathrm{OMI} \rightarrow$ Oblaten der Unbefleckten Jungfrau Maria

Omnibus, -verkehr, Autobus 96, 662 f., 993, $1247,1353,1405,1455,1468$
„Opfer des Faschismus“ (OdF) 249, 265, 810,

1135, 1311, 1331

Optantensiedlung 892

Optik 1210

„Option“" (für Polen) 1045

„Oral History“ 18, 33, 357

ORB $\rightarrow$ Ostdeutscher Rundfunk Brandenburg

Orden und Ehrenzeichen 872

- Banner der Arbeit 760

- Bundesverdienstkreuz 885

- Ehrenmedaille der Stadt Neuruppin 492

- Karl-Marx-Orden 780

- Vaterländischer Verdienstorden in Bronze 1468

- Verdienstorden der Republik Polen 360

Orden der Steyler Missionare 447

Ordenspriester 462, 741 f., 896

Organisation Todt (OT), OT-Lager 617, 621, 961

Ornithologe 553

Ortsälteste 528

Ortsansässige $\rightarrow$ Einheimische

Ortsbauernführer 994, 1442

Ortsbetreuer (für Heimatvertriebene) 367, 373, 379, 395, 406

Ortschroniken 661

Ortsgeschichtsforschung, -literatur (siehe auch $\rightarrow$ Heimatforschung) 4, 7, 28-30, 35, 39-46, 48, 59, 147, 168 f., 217, 233, 272, 282, 314, 367,413 f., 501, 507, 518 f., 661

Ortskommandant, sowjet. $\rightarrow$ Kommandant

Ortsnamen, -änderung 215f., 327-330, 339-345, $356,505,518,770,813,817,1247,1412,1415$

Ortssatzung 1118

Ortsumsiedlerausschuss (siehe auch $\rightarrow$ Umsiedlerausschuss) 255-258, 270, 282, 406, 578, $624,640,658,935,1110,1117,1139-1148$, 1155 f., 1196, 1233, 1401, 1408, 1410

Ortsvorsteher 192, $1225 \mathrm{f}$.

„Ostarbeiter“ 41, 72, 101, 156, 916, 1268, 1396

Ostbahn 771

„Ostbund“ (Gemeinnützige Siedlungsgesellschaft Deutscher Ostbund, Berlin) 339

"Ostdeutsche Kulturtage" (des BdV) 482, 599, $619,637,646,687,704,736,790,822,830$, $832,846,876,926,1372 \mathrm{f}$.

Ost- und Mitteldeutsche Vereinigung der CDU Brandenburg 853

Ostdeutscher Rundfunk Brandenburg (ORB) 14

Ostdeutscher Rosengarten (Forst/L.) 658, 836 
„Ost-Dokumentation“ $\rightarrow$ „Dokumentation der Vertreibung der Deutschen aus Ostmitteleuropa“"

Osteuropahistoriker 16

„Ostflüchtlinge“ $73,89,166,189,257,431$, 434, 662, 847, 901, 967, 999 f., 1201, 1395, 1404, 1479 f., 1538

„Ostgeld“ $\rightarrow$ Geld

„Ostheimkehrer“ $640,645,649,687,840,867$, 933, 938

„Ostlandbauern“ 615

„Ostlegionen“ (Tataren) 964

„Ostmark“ (Gebiet) 104

„Ostmark“ (Währung) $\rightarrow$ Geld

„Ostpfarrer" 36

„Das Ostpreußenblatt“ $\rightarrow$ Heimatzeitschriften

Ostpreußengruppe Oranienburg/Oberhavel 831

"Ostpreußenhilfe“ $74 \mathrm{f}$.

Ostpreußisches Landesmuseum $\rightarrow$ Museen

Ostpriesterverzeichnis 444

„Ost-Rückwanderer" 78

„Oststernberger Heimatbrief“ $\rightarrow$ Heimatzeitschriften

„Ostumsiedler“ 405, 618, 622, 624, 1195, 1202, 1395-1397

„Ostvertriebene“ 1171, 1396

Ostwall 757

OT $\rightarrow$ Organisation Todt

Pachtland 1224

Packpapier 197

Pächter 309, 314

Päckchenversand $\rightarrow$ Post

Pädagogik 226

Pädagogische Hochschule Magdeburg 9, 12 f.

Pädagogische Hochschule Potsdam 293, 297, 325 f., 334, 504 f., 1446, 1451

Pädagogium Züllichau 427

Paketversand $\rightarrow$ Post

Palästinenser 512

Palmsonntagsprozession 625

Panik, Kopflosigkeit 83 f., 86, 94, 128, 757, 862

Państwowy Urząd Repatriacyjny $\rightarrow$ PUR

Pantoffelmacher 583

Panzer 85, 95, 105, 112, 616, 700, 728, 757, 765, $890,961,1187$

Panzerfaust 960

Panzergraben 861

Panzersperre 115
Panzerzug 597

Papier, -beschaffung, -knappheit, -mangel 132, 197, 413, 1051, 1117, 1215f., 1253, 1262

„Papiere“ $\rightarrow$ Dokumente

Papierfabrik 1453

Papiergeld 1275

Papiersäcke 897

Papierstrohsäcke 1268

Papierwarenhandel 1208, 1212 f., 1434

Papst 452, 1417

Papstspende 1280

Paratyphus, -epidemie $\rightarrow$ Krankheiten

„Parmalager" 917

Parteien, Blockparteien (siehe auch: $\rightarrow$ AfD,

$\rightarrow$ Block der Heimatvertriebenen und

Entrechteten (BHE), $\rightarrow$ Bündnis 90/Die

Grünen, $\rightarrow$ CDU, $\rightarrow$ Die Linke, $\rightarrow$ KPD,

$\rightarrow$ LDP(D), $\rightarrow$ Nationale Front, $\rightarrow$ Neues Forum, $\rightarrow \mathrm{NDPD}, \rightarrow \mathrm{NPD}, \rightarrow \mathrm{NSDAP}, \rightarrow \mathrm{PDS}$, $\rightarrow$ SED, $\rightarrow$ SPD, $\rightarrow$ UWVB, $\rightarrow$ Zentrum) 48 , 52, 255f., 259, 262, 298, 309, 346, 349 f., 470, 734, 888, 1001, 1020, 1023, 1081, 1098, 1109, 1114, 1123, 1136 f., 1139, 1161-1163, 1196, $1221,1223,1235,1238$ f., 1241,1318 f., 1326 , 1331, 1360, 1362 f., 1366 f., 1378, 1408

Parteilose (ptl.) 222, 246, 309, 333, 552, 735, $809,859,902,1128,1283,1291,1315,1318$, 1321-1323, 1329f., 1386, 1447, 1460, 1457

Partisanenaufstand 607

Partnerbezirk $\rightarrow$ Bezirkspartnerschaft

Partnergemeinde $\rightarrow$ Gemeindepartnerschaft

Partnerschule $\rightarrow$ Schulpartnerschaft

Partnerstadt $\rightarrow$ Städtepartnerschaft

Pass $\rightarrow$ Ausweis

Passierschein 957, 1266

Pastor $\rightarrow$ Pfarrer, evang.

Pastoralseminar 825

Paten 919

Patenschaften (nach 1914) 74

Patenschaften (nach 1945), Patenstädte 109, 211, $342,345,364,368,378-380,387,396,403 \mathrm{f}$., 427, 474f., 491-493, 569, 659, 693, 841, 1373, 1420

- von Berliner Bezirken 368, 427

Patenschaftsbetrieb 1228

Patenstellen für elternlose, junge Heimkehrer 1233

Patenwirtschaft (Alt-/Neubauer) 1286

Patrozinium $\rightarrow$ Heilige Hedwig, $\rightarrow$ Marienverehrung 
Pazifismus 241

PDS 479, 1436

Personalakten 449, 647, 649, 1006, 1241, 1245, 1386, 1419

Personalausweis, -papiere $\rightarrow$ Ausweis

Personenkraftwagen $\rightarrow$ Kraftfahrzeuge

Petitionsausschuss $\rightarrow$ Deutscher Bundestag

„Petrusblatt" $\rightarrow$ Zeitungen

Pfarramt 263, 1264-1269

Pfarrarchiv 56f.

Pfarrei (kath.) 38, 57, 186, 223, 458, 612 f., $625,644,701,756,883,897,928,958,971$, 1264-1268, 1276, 1417, 1419 und öfter

Pfarrer 262, 305, 357, 1196, 1250

-, evang., Pastor 36, 44, 56, 76 f., 91 f., 96, 110 f., 125 f., 155, 211, 216, 222 f., 237 f., 241, 322, 369 f., 372, 396, 409, 411, 413, 416 f., 424, 431-441, 460, 479 f., 503-505, 512 f., 530, $558,560,605$ f., 612, 619, 635-637, 639, 641, $651,653,669,718,721,728,770,787,789$, 796, 811, 838, 844, 850, 856f., 869, 873 f., $880,888,926,928-930,933,971,1092,1104$, 1256-1264, 1338 f., 1341 f., 1346-1349, 1351-1353, 1453, 1456, 1461, 1473, 1476, 1480, 1482

-, kath., Priester, Kaplan 37 f., 56, 214, 359, 379, 430, 444-450, 453, 458-461, 479, $483 \mathrm{f}$., 553 f., 562, 570-573, 578 f., 581, 584, 588, $590,592,595$ f., 599 f., 606, 610, 612-614, 617 f., 620-622, 624f., 628, 632, 638, 651, 653 f., 667, 680, 684, 699, 701, 703 f., 726, 734, 740, 752 f., 756, 766, 769, 773, 781, 783, 787, 789, 791, 795-797, 800, 803 f., 808 f., 811 , 816 f., 825 f., $832,835,839,842$ f., 847,862 , 870,873 f., 882 f., 887 f., 896,899 f., 903,906 , 909, 912-914, 919, 921, 925, 932, 934-936, 939, 941 f., 950 f., 954 f., 963 f., 967,971 , 1091 f., 1098, 1104, 1264-1281, 1343, 1437, $1458,1464,1476,1527$

Pfarrfamilie 453

Pfarrhaus, -büro 238, 269, 560, 562, 575, 610, 619-621, 629, 667 f., 694, 701, 703 f., 752, $759,782,787,811,817,847,873,887,906$, 921,1271

Pfarrhelferin 921, 964

Pfarrhof 943

Pfarrscheune 774

Pfarrsekretärin 921

Pferde $\rightarrow$ Vieh
Pferdefleisch 323

Pferdefuhrwerk, -gespann, -wagen, Acker-, Plan-, Treckwagen, Wagen 83-86, 90, 94-96, 108 f., 111, 114-116, 118-120, 127, 130, 133, 146, $177,184,291,315,437,525,546,549,559$, $574,578,597,614,616,627,638,647,652$, 662-664, 711, 728, 757 f., 763, 774, 786, 794, $801,819,823,837,845,861,863$ f., 890 f., 901 , 921, 931, 946, 949, 969, 994, 997, 1004, 1145, 1225 f., 1377, 1404, 1435, 1441, 1453, 1457, 1465,1472

Pferdefutter 747 und öfter

Pferdestall 556, 782

Pflanzenbauforschung 834

Pflanzenproduktion 596

Pflegeanstalt 101, 189, 860

Pflegebedürftigkeit 1047 und öfter

Pflegeeltern 178, 227, 358, 1095, $1467 \mathrm{f}$.

Pflegeheim 116, 625f., 632, 645, 668, 720, 864, 949

Pflegekinder 783 und öfter

Pflegepersonal 415, 664 und öfter

Pflegestelle 588

Pflichtablieferung $\rightarrow$ Ablieferungssoll

„Pflichtjahr“ 136, 1453, 1474

Pflug 1138

Pg. $\rightarrow$ NSDAP/Parteimitglied

PGH Holz 581

Pilze, Pilzsuppe $\rightarrow$ Lebensmittel

Pilzsammeln 1250

Pilzvergiftung 171

Pioniere $\rightarrow$ Wehrmacht

Pionierrepublik Wilhelm Pieck 554

$\mathrm{Pkw} \rightarrow$ Kraftfahrzeuge

Plakate 353, 922, 1139, 1252, 1286, 1330

Planwagen $\rightarrow$ Pferde

Plünderung (siehe auch $\rightarrow$ Ausplünderung) 132, $279,283,322,655,763,896,911,915,926$, 932, 943, 1052 f., 1273 f., 1276

„Polacke $\rightarrow$ „Pollacke“

Polen, „Zivilpolen“ 133, 136 f., 1127 und öfter; Restauratoren $511 \mathrm{f}$.

„Polen-Heimkehrer“ 1041

„Politische Erfassung“ 611

Politische Gefangene/Häftlinge 1048 f., 1447

Politische Parteien $\rightarrow$ Parteien

Politische Prüfstelle (im Lager) 611

Politische Stimmungs-, Monatsberichte 1281$1325,1333-1338$ 
„Politische Verhältnisse“ 1083

„Politischer Flüchtling“ (aus DDR) 1109

Politisierung, Ideologisierung, „Politische Bedeutung", „politische Gründe“, „politische Schulung“" „Politische Wichtigkeit" (siehe auch $\rightarrow$ Propaganda) 172, 480, 482, 886, 919, 1023, 1038, 1081, 1083, 1098, 1104, 1109, 1120, 1122 f., 1130, 1168, 1170, 1174, $1220 \mathrm{f}$., 1236, 1240-1242, 1244f., 1334 und öfter

Polit-Schule der KVP 938

Polizei, Polizisten (siehe auch $\rightarrow$ Geheim-, $\rightarrow$ Kreis-, $\rightarrow$ Kriminal-, $\rightarrow$ Volkspolizei, $\rightarrow$ Umsiedlerlager/Lagerpolizei) 77, 172, 179, 184, 236, 259, 294, 374, 563, 584, 735, 745, 749, $764,768,773,776,837,840,852,875,957$, 993 f., 1005, 1009, 1024f., 1039, 1061, 1068, 1081, 1104, 1134, 1152, 1400, 1449, 1457

- Evakuierung 617

- internationale 1306

- Schutzpolizei 773, 852, 961, 1059-1061

Polizeiberichte 237, 411, 731, 796, 990 f., 1340-1355

Polizeichef 749, 1126, 1248, 1337

Polizeischutz 1464

„Pol(1)acke/n“" (als Schimpfwort) 144, 1312, 1456

Polnisch $\rightarrow$ Sprache

Polnische Militärmission 1039

Polnische Miliz $\rightarrow$ Miliz, poln.

Polnische Truppen (vgl. $\rightarrow$ Miliz) 537, 587, 593, $712,763,1328,1332,1406$

Polnische Vereinigte Arbeiterpartei (PVAP) 346, 529, 713

Polnisches Nationales Befreiungskomitee 1328

Polonistik 144, 1458

Pommernbund zur Förderung heimatlicher Kunst und Art (gegr. 1914) 368

Pommernlied $\rightarrow$ Lieder

Pommerntreffen 1174

Pontonbrücke 664, 715

Porzellan 661

Post, Briefverkehr, Päckchen, Pakete (siehe auch $\rightarrow$ Lebensmittelpakete) 58, 105, 128, 142, 265, 280, 365 f., 389 f., 396 f., 401, 403, 504, $581,767,794,1055,1090,1254,1258,1269$, 1343,1394

Postamt 389, 1254

Posterholungs-, -genesungsheim 932-934, 1015 Postkarten 373, 391, 396, 439, 658, 1394
Postüberwachung, -kontrolle 1108 und öfter

„Potsdamer Abkommen“, Konferenz 25, 70, 135, $146,211,325,535,763,845,850,856,1244$, 1306, 1311, 1391, 1402, 1406, 1469

„Potsdamer Bibliothek östliches Europa“ 854

„Potsdamer Neueste Nachrichten“ $\rightarrow$ Zeitungen

„Potsdamer Tageszeitung “ $\rightarrow$ Zeitungen

Prälatur Schneidemühl $\rightarrow$ Freie Prälatur Schneidemühl

Prämie $\rightarrow$ Leistungsprämie

Präsidium der Volkspolizei (VP) Berlin $\rightarrow$ Volkspolizei

„Prager Abkommen“ 1413

Predigerseminar 1456

Predigten 410, 431, 480, 699, 1352

Preise (Ehrungen), Eilhard-Alfred-MitscherlichPreis 1468

Preise (Warenpreise) 304, 367, 585, 1145, 1173, 1183, 1244, 1273, 1283, 1291, 1302, 1315, 1323

Presse $\rightarrow$ Zeitungen

Pressekonferenz 676

Pressereferent 712

Pressetext 1150, 1224, $1307 \mathrm{f}$.

„Preußische Allgemeine Zeitung “ $\rightarrow$ Heimatzeitschriften

„Preußische Treuhand“ 468, 690

Preußischer Staatsrat 248

Priester $\rightarrow$ Ordenspriester, $\rightarrow$ Pfarrer, kath.

Priesterkonvent 740

Priesterreferat (Königstein im Ts.) 444

Priesterseminar $825 \mathrm{f}$.

Pritschen (siehe auch $\rightarrow$ Betten, $\rightarrow$ Strohschütten) $153,174,181,574,638,867,1022,1080$

Privatleben, -leute, private Kontakte $8,59 \mathrm{f}$., $69,198,200,265,293,319,324,326,338$, 356-364, 366, 388 f., 396-398, 405 f., 411, 415 f., 421 f., 426, 489, 509

Privatquartier, -unterkunft, -wohnung 82, 111, 127, 171, 182, 195, 273, 323, 358, 616f., 667, 695, 754, 774, 811, 849, 872, 947, 962, 1005 f., $1121,1133,1183,1274,1434,1440$ f., 1454 , $1461 \mathrm{f.}, 1468$ und öfter

Privatsphäre, Intimität $182,594,1113$

Privatvermögen $\rightarrow$ Eigentum

Produktionsgenossenschaften (siehe auch $\rightarrow$ PGH) 299, 578, 627, 681, 710, 744, 1174, $1228,1473,1475$

Produktivgenossenschaften 300, 744, 814, 1138, 1198-1200, 1205, 1216 
„Projektgruppe Umsiedlerin“ 56

Propaganda, politische „Arbeit“, „Aufklärungsarbeit", „Betreuung“, Ideologie (siehe auch $\rightarrow$ Broschüren, $\rightarrow$ Flugblatt, $\rightarrow$ Flugschrift, $\rightarrow$ Hauswerbung, $\rightarrow$ Kundgebung, $\rightarrow$ Politisierung, $\rightarrow$ Transparente) $172,175,182$, $229,270,300$ f., 306, 308, 310, 316, 324 f., $334,353,359,366,403,480,560,618,775$, 922, 1022-1024, 1045 f., 1073, 1083, 1085, 1089, 1096, 1104, 1106f., 1122, 1130, 1137 f., 1140 f., 1164, 1169 f., 1172, 1240 f., 1255, $1326,1328,1332,1446$

- „Westpropaganda“, „Hetze“, „antisowjetische Haltung“ 353, 627, 919, 1130, 1168 f., 1175, 1240 f., 1288, 1304, 1321-1323, 1330, 1335 f., 1402

Prostitution 1273

Protest, -aktionen 172, 1415

Provinzialaltersheim 581

Provinzialarbeitsamt Sachsen 1184

Provinzialausschuss für Heimkehrer und Umsiedler $1231 \mathrm{f} ., 1408$

Provinzial-Frauenausschuss 1160, 1162, 1165

Provinzialgesundheitsamt $\rightarrow$ Provinzialverwaltung

Provinzialgut 1111, 1219

Provinziallandtag $\rightarrow$ Landtag Brandenburg

Provinzialstraßenbauamt Crossen 101, 788

Provinzialsynode 1259

Provinzialumsiedlerausschuss 255, 258-260, 267 f., 1231 f., 1401, 1408

Provinzialverband 545

Provinzialversicherungsanstalt Brandenburg 1208,1210

Provinzialverwaltung Mark Brandenburg (siehe auch $\rightarrow$ Landesregierung) 48, 51 f., 138, 158, 173, 191, 240, 243, 246, 253, 255 f., 260 f., 278, $311,517,523$ f., 526-528, 530-533, 535-545, $547-549,578,583,618,641,739,745$ f., 782 , $802,825,845,870,1001-1004,1007$ f., 1010 , 1047 f., 1054, 1061, 1065-1067, 1069 f., 1072, 1075, 1081, 1156f., 1185, 1188, 1219, 1229, 1236, 1406 f., 1449

- Abt. Polizei 138f.

- Abt. Arbeit und Sozialwesen, -fürsorge 170, 242, 246, 258 f., 1004, 1027, 1114, $1120 \mathrm{f}$. $($ Amt für Umsiedler und Heimkehrer $\rightarrow$ Amt für Umsiedler)

- Abt. Provinzial-Gesundheitsamt 961, 1046, 1049, 1054, 1057
- Abt. Landwirtschaft 259

- KPD-/SED-Betriebsgruppe 243

- Präsident, Präsidium 770, 927, 998-1000, 1003, 1008, 1016-1018, 1232

- Runderlasse 311, 1233, 1408, $1410 \mathrm{f}$.

- Vizepräsident 241, 245, 1232

- Wohnungsausschuss 1113

Provokation 172

Prußen-Stiftung Tolkemita (Potsdam) 853

Prussia. Gesellschaft für Heimatkunde Ost- und Westpreußens 853

Psychische und psychologische Aspekte, Probleme und Erkrankungen, seelische Belastung/Haltung/Verfassung, Angst, Gefühle, Hoffnungen, Lebensmut, „moralischer Zustand“, Vereinsamung, Verzweiflung (siehe auch $\rightarrow$ Apathie, $\rightarrow$ Gerüchte, $\rightarrow$ Heimweh, $\rightarrow$ Lethargie, $\rightarrow$ Menschenwürde, $\rightarrow$ Tabu, $\rightarrow$ Traumata) 63, 80, 179, 183 f., 290-292, 302, 319-322, 332, 345, 357-360, 362-364, $439,489,503,523,568,626,719,755,930$, 994, 1003, 1016, 1022, 1042, 1084, 1114, $1124,1133,1137,1139,1152,1158,1241$, $1260,1263,1269,1273,1276,1278-1280$, 1291, 1304, 1334, 1434 und öfter

Psychologie 358

Puppenherstellung 563

Puppenwagen 1443

PUR (Państwowy Urząd Repatriacyjny = Staatliches Repatriierungsamt) 1396

Pyodermie $\rightarrow$ Krankheiten

Quäkerverbände 998

Quarantäne, -frist, -zeit, -aufenthalt 17, 101, 139, $142,150,170,221,244,277,281,285,536$, $601,605,611,759,765-768,789,883,911$, $937,943,1019,1022-1025,1027,1039,1041$, 1052, 1061, 1064 f., 1069-1074, 1077, 1082 f., 1085 f., 1092, 1094 f., 1097, 1158, 1179 f., 1236, 1240, 1391 f., 1435, 1441, 1443, 1446, 1519

Quarantänebaracken 712

Quarantänelager 10, 17, 139, 147, 149 f., 165, 167, 169-172, 175 f., 221, 225, 265, 276 f., $281,285,570,579$ f., 583 f., 602, 611, 625, 640, 644, 648 f., 654 f., 659, 687 f., 697, 718, 734, 739, 746, 759, 765-768, 789, 840, 849, 866 f., $877,887,889,895,933,937$ f., 946 , 961, 1038-1040, 1044f., 1078f., 1106-1109, 
$1237,1253,1275,1396,1401,1410$ f., 1438 ,

$1441,1447,1450,1462,1464,1470,1478$

und öfter

Quarantäneschein, -nachweis 698, 765

Quarantänestation 557, 580, 767, 895, 957, 1001, 1007

Quark 1042

Quartieramt 949

Quartierschein 573, 580

Rachendiphtherie $\rightarrow$ Todesursachen

$\mathrm{RAD} \rightarrow$ Reichsarbeitsdienst

Radfahrer $\rightarrow$ Fahrrad

Radio $\rightarrow$ Rundfunk

„Radio Vatikan“ 452

Raduga-Chor 1374

Räumungs-, Evakuierungsbefehl, Zwangsräumung $67,81,83,86,94,99,112-115,124$, 192, 657, 663, 705, 711, 757 f., 891, 902, 1396, 1404f., 1434f., 1434; Aushang (Foto) 566

„Räumungsfamilienunterhalt“ 1398

„Räumungsgebiete“ 1002

„Räumungszug“ 102, 754

Rat der Gemeinde 1148f., 1301

Rat der Stadt: Angermünde 563; Brandenburg/H. 602; Frankfurt/O. 1304; Cottbus 621; Potsdam 849, 1120-1123, 1226, 1326

Rat des Bezirkes 142; Cottbus 140, 143, 1356 f., 1399; Dresden 252; Frankfurt (Oder) 249, 897,1356

Rat des Kreises $\rightarrow$ Landrat

Rathenower Heimatbund 45

Ratten, -plage 1013

Raub $\rightarrow$ Kriminalität

RAW $\rightarrow$ Reichsbahnausbesserungswerke

Razzia 584

Recht, Rechtswesen (Ressort) 1132, $1148 \mathrm{f}$.

„Recht auf Heimat“" 1359f., 1362, 1364-1366

Rechtsansprüche 1365

Rechtsanwalt 792, 798, 852, 893, 1480

Rechtsextremismus 1359

Rechtswesen (Ressort) $\rightarrow$ Recht

Reformierte 811

Regen $\rightarrow$ Wetter

Regierung, Regierungspräsident: Frankfurt (Oder) 93, 101, 616, 663, 844f., 1405; Lüneburg 108; Potsdam 845, 848, 932

Regierungsangestellter 1225
Regionalgeschichtsforschung, -literatur 4, 23-29, $32,59,144,518$

Regionalmuseum „Burg Beeskow“ $\rightarrow$ Museen

Regionalverband $\rightarrow$ Bund der Vertriebenen

Registrierung, Erfassung, polizeiliche Meldung 837, 844, 847, 903, 932, 956 f., 1009, 1013, 1019, 1023, 1042, 1047, 1051, 1053, 1055, 1074 f., 1077, 1081, 1091, 1094f., 1098, 1253

- kirchliche (evang.) 1262

Reichsarbeitsdienst (RAD) 88, 124, 169, 293, 416, 570, 577, 1058, 1453, 1456, 1460, 1473

- Arbeitsmaiden 861, 946, $1478 \mathrm{f}$.

- Baracken, -lager 88, 124, 163, 169 f., 272, 304, 534, 696, 738, 765, 774, 794-797, 813, 894, $899,931,946-949,962,964,967,1479$

Reichsautobahn $\rightarrow$ Autobahn

Reichsbahn, -bahner (siehe auch $\rightarrow$ Eisenbahn) 102 f., 341, 408, 597, 636, 717, 771, 918, 997 f., $1009,1041,1125,1201,1353,1459,1480$

Reichsbahnausbesserungswerke (RAW) 102, 259, 754, 956, 958, 1231, 1440, 1473

Reichsbahn-, Eisenbahndirektionen: Berlin 997, 1201; Cottbus 1010, 1326; Danzig 102; Halle; 997, 1002; Osten 341

Reichsbund der deutschen Beamten 246, 1201

„Reichsdeutsche“ 569, 596, 727

Reichsfeuerwehrschule (Eberswalde) $639 \mathrm{f}$.

Reichsführer SS 78, 866

Reichskanzlei 1479

Reichskommissar für die Festigung des deutschen Volkstums 78

Reichskommissar für Optantenvermittlung, stellv. 248

Reichsleistungsgesetz 1118, 1396

Reichsmark $\rightarrow$ Geld

Reichsminister, -ministerien: Inneres 24, 738; Luftfahrt, Entwicklungsbüro 169

Reichsluftschutzbund (RLB) 246

Reichsmark $\rightarrow$ Geld

Reichsstatthalter (Posen) 99, 108, 662, 1403

Reichsstelle für Landbeschaffung 93

Reichsstraßen 275

Reichsumsiedlungsgesellschaft 93

Reichsverteidigungskommissar 87

Reifenpanne 95

Reihenuntersuchung 580

„Reinemachefrau“ 1314, 1440

Reisegenehmigung 194

Reisekader 334 
Reisen (siehe auch $\rightarrow$ Heimatreisen, $\rightarrow$ Westreisen) $331,334,401,896,1416 \mathrm{f} ., 1450,1452$, 1462

Reisepass, -dokumente $\rightarrow$ Ausweise

Reisevarieté 1212

Reitsport 681

Reitschule der Waffen-SS 557

Relegation 293

Religionsunterricht (kath.) 446, 581, 599, 753, $862,940,1276,1345$ und öfter

Religiosität $\rightarrow$ Frömmigkeit

Remise 804

Rente, Rentenantrag, -stelle 500, 1099, 1112, 1323, 1369, 1371

Rentner/in (vgl. $\rightarrow$ Senioren) 267, 375 f., 380-382, 384, 389, 398, 563, 690, 792 f., 852, $864,1025,1125,1312,1347,1416,1458$ und öfter

Rentnerheim 843

Reparationen 1299, 1303, 1317

Reparationsaufträge 1222

„Repatrianten“, „Repatriierte“",Repatriierung“ (siehe auch $\rightarrow$ „Westrepatrianten“) 146, 148, 225, 654, 688, 1012, 1045, 1107-1109, $1396 \mathrm{f}$.

Repatriierungslager 584, 670

„Republikflucht“, „illegaler Grenzübertritt“, Abwanderung in den Westen 29, 64, 141, 201, 204, 235, 292, 299, 306, 319, 353, 374, 377, $435,458,518,556,628,727,731,738,843$, 903, 919, 951, 1109, 1248, 1319 f., 1354f., $1377,1393,1435,1438,1440,1443,1454$, $1459,1461,1465,1467,1470,1473$ und öfter

Reservelager 527

Reserve-Lazarette $\rightarrow$ Lazarette

Restaurant $\rightarrow$ Gasthof

Restkreise 203, 210, 443, 466, 531, 542, 555, 564, $597,631,709,725,737,741,743,754,765$, 770, 815, 817 f., 912, 945, 965, 968

„Rettet das Kind!“ $\rightarrow$ Aktion ...

Rettungshaus Coethenerheim 568

„Revanchist“, „Revanchismus“, Revanche-Gedanke (vgl. $\rightarrow$ Revision) 685, 701, 869, 1312

Revierförster 1294, 1450

Revierkriminalstelle Stalinstadt 354

„Revision“ der Ostgrenze, „Revisionismusverdacht" (vgl. $\rightarrow$ Revanche) 325, 344, 348, 350, 352 f., 618, 658, 713, 1240 f., 1281 f., 1286, $1288,1299,1307,1319,1415$ und öfter Revolte 1008, 1313; im Lager: 579
Rheinmetall-Borsig (Firma) 714, 717-719

Rheuma $\rightarrow$ Krankheiten

RIAS Berlin 1313, 1321-1323, 1330, 1335

Riesengebirgsverein 368

Rinder $\rightarrow$ Vieh

Roma 21

Romane (vgl. $\rightarrow$ Novellen) 69, 363, 577, 846, 1246,1260

- „Kindheitsmuster“ 417, 419, 755, 1417, 1471

- „Wir Flüchtlingskinder“ 70, 363 f., 1417, 1446

Rose $\rightarrow$ Krankheiten

Rosenkranzandacht, -gebet 625, 1265, 1278

Rote Armbinde 893

Rote Armee (ab 1946 Sowjetarmee), „Rotarmisten“, „Russen“, sowjet. Soldaten (siehe auch

$\rightarrow$ Kommandanturen) 95, 99, 198, 617, 648,

711, 1002, 1024, 1266, 1304, 1475, 1478, 1481

- Abt. MWD 1127

- Abzug (Gerücht, Forderung) 1282, 1306, 1311

- als Arbeitgeber 1441, 1470, 923, 1441 f., 1470

- Arbeitseinsatz/-anforderung von deutschen Zivilisten, Dienstverpflichtung 286f., 638, 665, 681, 923, 1011, 1176 f., 1185, 1190, 1194, 1441, 1453, 1458, 1465

- Aufklärungseinheit $858 \mathrm{f}$.

- Ausschreitungen einzelner Soldaten 128, 1058

- Beschlagnahmung von Gebäuden und Wohnungen, Demontage, Einquartierung, Entnahme, Garnisonen, Sperrgebiete 34, 186 f., 261, 271 f., 278, 303-305, 505, 512, 535, 557, 560, $567,570,590,608,614,648,659,665,681$, 732, 736, 746f., 783, 797, 800 f., 804, 819, 833, $842,845,856,858$ f., 864 f., 874 f., 904,915 , 938, 943, 950, 962, 1003, 1014 f., 1048 f., 1111, $1116,1127,1132,1144,1176,1187,1192$, 1224, 1271, 1289 f., 1303 f., 1311, 1441

- Beschlagnahmung von Lebensmitteln und Pferden 823, 1153, 1282

- Betriebe, (Versorgungs-)Güter 834, 1176, 1224, 1441

- Einheiten, einzelne 1015

- Einmarsch 55, 71, 86-88, 90, 106, 109, 112$116,118,123,130,134,193,241,320,358$, $552,556,560,566,574,578,583,585-587$, 590 f., 593 f., 598, 604, 609, 613 f., 617, 627, 629-632, 635, 643, 646f., 651-653, 663, 670, $677,679,683,686,697,700,711,730,732$, 742-744, 751 f., 758 f., 763 f., 770-773, 778, $782,788,790,794,808,810,819,823,827 \mathrm{f}$., 
$833,837,845,857,862,865,868$ f., 872-875, $881,886,889,895,902,908,915,917$ f., 921 , 923, 926, 928, 931, 934, 936, 939, 942, $945 \mathrm{f}$., 950, 953 f., 956, 960, 966, 969, 1274, 1377, 1393, 1403-1406, 1437, 1441-1445, 1448 f., 1452-1454, 1456f., 1460, 1463-1465, 1471 f., $1477,1480-1482$

- Flucht vor (vgl. $\rightarrow$ Evakuierung vor der Front) 24, 67 f., 82-84, 88, 103, 107-109, 112 f., 115 f., 120, 127, 130, 156, 190, 503, 532, 616, $639,653,663,751,929,947,953,1265,1273$, 1279, 1377, 1393, 1405, 1457, 1463 f., 1475

- Gewalt gegen Zivilisten, Übergriffe, Wegnahme von Eigentum (siehe auch $\rightarrow$ Deportation, $\rightarrow$ Vergewaltigung) $71,85,98,130$ f., 133 , $278,290,320,358,587,636,872,875,891$, 922 f., 933, 953, 1049, 1056-1058, 1175, 1274, 1276, 1290, 1296, 1377, 1440, 1443, 1445, $1448,1453,1457,1459$ f., 1465, 1478, 1520

- Hilfe für Zivilbevölkerung 133, 197, 241, 274, $608,664,739,749,786,794$ f., 865, 966, 997 , 1011, 1024, 1050, 1223, 1441

- Kampfhandlungen, Vormarsch, Sieg (siehe auch $\rightarrow$ Brückenkopf) $82-86,117,358,532$, $597,609,616,657,663,700,711,727,773$, 778, 880, 890 f., 902, 918, 929, 936, 1274, $1328,1332,1377,1403-1406,1522,1527$

- Offiziere (einzelne) 160, 239, 252 f., 530, 540, 740, 794, 865, 962, 1003, 1008 f., 1015, 1023, 1039 f., 1049, 1059, 1061, 1073, 1081 f., 1121, $1126,1157,1159,1167,1175,1246,1539$

- Reparationsaufträge 1222

- Wirtschaftsoffiziere 834,794f.

Rote Fahne $\rightarrow$ Flagge

Rote Hilfe 242

Rotes Kreuz (siehe auch $\rightarrow$ Deutsches Rotes Kreuz) 137, 153, 998, 1078, 1082, 1435

Rubel $\rightarrow$ Geld

Rucksack, Bündel auf Rücken 182, 266, 891, 901 „Rucksackpriester“ 445, 803

Rübezahl (siehe auch $\rightarrow$ Schlesier-RiesengebirgsZweigverein Rübezahl Berlin) 1260

„Rückführung“ 78, 122, 1241, 1355

„Rückführungsantrag“ 1356

„Rückführungsfahrt“ 560, 1397

„Rückführungslager“ 1397

„Rückführungspropaganda von Ostumsiedlern“ 1397

„Rückgeführte“ 597, 844, 1275, $1397 \mathrm{f}$.
„Rückkehrer“ 78, 555 f., 1177 f., 1398

„Rückkehrrecht" $1366 \mathrm{f}$.

„Rückwanderer“ 76, 77f., 194, 453, 459, 654, $786,855,874,1010,1398$

„Rückwandern“ 80

Rüsttage 1261

Rüstung $\rightarrow$ Abrüstung, $\rightarrow$ Aufrüstung

Rüstungsindustrie 1322

Rüstungskontrolle 1306

Ruhestandspriester 882

Ruhr, -epidemie $\rightarrow$ Krankheiten, $\rightarrow$ Todesursachen

Ruhrtyphus $\rightarrow$ Krankheiten

Ruhr-Umsiedler 892

Ruinen $\rightarrow$ Trümmer

Rumäniendeutsche 727, 898, 935, 937

Rundbriefe (vgl. $\rightarrow$ Heimatzeitschriften [Einzeltitel siehe dort]) 377, 379, 382, 394, 396f., 408 f., 411, 431, 436, 438, 441, 733, 796, 869, $986,1258,1263,1424 \mathrm{f}$. und öfter

Rundfunk, Radio (siehe auch $\rightarrow$ Landessender Potsdam, $\rightarrow$ RIAS Berlin) 14, 75, 280, 319, $321,347,377,452,712,890,1039,1084$, 1118, 1136-1138, 1140, 1147, 1161, 1164, 1208, 1211, 1221, 1249, 1251 f., 1283, 1309, 1313, 1317 f., 1321-1323, 1330, $1334 \mathrm{f}$.

„Russen“ $\rightarrow$ Rote Armee

Russisch $\rightarrow$ Sprache

Russlanddeutsche (siehe auch $\rightarrow$ Bessarabien-, $\rightarrow$ Schwarzmeer-, $\rightarrow$ Wolgadeutsche) 72, 140, 155, 469, 479f., 497, 498-501, 567, 599, 641, 654, 687, 691, 799, 811, 836, 846, 863, 875, 892, 1265, 1370, 1374, 1435, 1452, 1539

Saatgut 1221, 1305

"Sächsische Volkszeitung" $\rightarrow$ Zeitungen

Sägewerk 1189, 1207, 1222, 1436, 1440

Säuglinge $\rightarrow$ Kinder

Säuglingsheim $\rightarrow$ Kinderheim

Säuglingspflegeschule 669

Säuglingsschwester 1460

Säuglingsstation 863

Sagen 1260

Sakristei 783

Salvator-Kolleg (Berlin) 446

Salz 1272

Samariteranstalten 687, 693 f., 923

Sammellager, -punkt, -quartier, -stelle, -unterkunft in Deutschland 119f., 123, 155, 163, 
$179,220,271,501,527,534,578,627,640$,

$796,841,927,950,956,1007,1064,1436$

und öfter

-, poln. (vgl. $\rightarrow$ Arbeitslager) 133, 137, 149, $153,172,181,291,577,658,888,1096,1154$, 1437 f., 1442, 1456, 1464

-, slowak. 236

- sowjet. $\rightarrow$ Speziallager

- tschech. 1441

Sammeltransport $\rightarrow$ Transporte

Sammlung Sorau $660 \mathrm{f}$.

Sammlungen $\rightarrow$ Spenden

Sanitäre Anlagen $\rightarrow$ Bedürfnisanstalt

Sanitäter, Sanitätspersonal 617, 640, 675, 1010, $1039,1055,1067,1078$ und öfter

Sanitätsgeschäft 1210

Sanitätspass 1040, 1096

Sanitätsstation, -baracke (siehe auch $\rightarrow$ Umsiedlerlager) 1007

Sanitätswagen $\rightarrow$ Eisenbahn

Sarg, -fabrikation (siehe auch $\rightarrow$ Begräbnis ohne Sarg) 92, 132, 838, 1207

S-Bahn (Berlin) 88, 96, 182, 343, 1090

Scabies $\rightarrow$ Krankheiten/Krätze

Schädlingsbekämpfung 917, 1209

Schafe, Schafzucht 1138, $1217 \mathrm{f}$.

Schalmeienkapelle 1331

Schanzarbeiten, -einsatz 902, 1457

Scharlach $\rightarrow$ Krankheiten

Scheck, -zahlung 1244

Scheidung $\rightarrow$ Ehe

Scheune 774, 875, 890, 943, 1274

„Schieber“ $\rightarrow$ Schwarzhandel

Schießstände 827, 837

Schiff, Schiffer, Boot, Kahn 81, 84, 87, 280, 340, $354,565,619,683,731,1372,1443,1446$, 1449, 1457, 1459; „Theresa Rus“ 68, 1482;

„Wilhelm Gustloff“" 1404, 1453

Schiffs-, Seetransport 150

Schikane 1131, 1150, 1454

Schilddrüsenunterfunktion, -vergrößerung

$\rightarrow$ Krankheiten

Schlafdecken $\rightarrow$ Decken

Schlaflosigkeit, -störung 152

Schlagaderverhärtung $\rightarrow$ Todesursachen

Schlaganfall $\rightarrow$ Krankheiten

Schleichhandel $\rightarrow$ Schwarzhandel

„Der Schlesier" $\rightarrow$ Heimatzeitschriften

Schlesier-Gruppen (Berlin) 368
Schlesier-Riesengebirgs-Zweigverein Rübezahl Berlin 368

„Schlesiersuchdienst“ 212, 744, 1251

Schlesische Dampfer Compagnie-Berliner Lloyd AG Fürstenberg/Oder und Berlin 340, 683

Schlesische Dampferkompanie (Havelberg) 731

„Schlesische Geschichtsblätter" 853

Schlesische Universität Kattowitz $\rightarrow$ Universitäten, Kattowitz

Schlesischer Pfarrerverein 1257

Schlesisches Institut (Oppeln) 9

Schlesisches Museum Kattowitz $\rightarrow$ Museen, Muzeum Śląskie w Katowicach

Schlesisches Museum zu Görlitz $\rightarrow$ Museen

Schleusung (siehe auch $\rightarrow$ Durchschleusung) 1046

Schlitten 85, 89, 95, 197

Schloss $\rightarrow$ Gutshaus

Schlosser, -lehre, -meister 1440, 1449, 1452, 1455,1475

Schlosserin 1436

Schlüssel $\rightarrow$ Hausschlüssel

Schmalz 274

Schmerz $\rightarrow$ Traurigkeit

Schmied, Hufschmied 546, 616, 1435, 1466

Schmuck, -diebstahl 266

Schmuckwarenherstellung, -industrie 229 f., 299, 301 f., $814,1200,1215,1228$

Schmuggel $197 \mathrm{f}$.

Schmutz, Dreck, Unrat (siehe auch $\rightarrow$ Hygiene) 91, 184, 188, 561, 636, 641, 668, 719, 901, 927, 930, 1012, 1016f., 1020, 1053, 1075 f., 1094

Schnee $\rightarrow$ Wetter

Schneider, Schneiderei 81, 158, 286 f., 410, 915, 1127, 1199, 1321, 1435, 1462 f., 1465, 1467

Schneiderin 286, 1463

Schneidwarengenossenschaft 627, 1198

Schnitter 1452

Schnitterkaserne 1466

"Schönfließer Heimatbrief" $\rightarrow$ Heimatzeitschriften

Schönstätter Marienschwestern 940

Schokolade 1091

Schokoladenfabrik $647 \mathrm{f}$.

Schornstein 34

Schornsteinfeger 233, 1474

Schotterwerk Althüttendorf 1314, 1319

Schränke $\rightarrow$ Mobiliar 
Schrecken $\rightarrow$ Angst

Schreibbüro 1251

Schreibmaschine 361, 1134, 1441

Schreibwarenhandel 1208, $1212 \mathrm{f}$.

Schreibwettbewerbe 61

Schriftsteller/in 417 f., 504, 562, 577, 695, 755 f., $801,846,907,928,1246,1260,1327,1444$, $1447,1465,1471,1477$

Schrottlagerplatz 1125

Schubkarren 657

Schüler $\rightarrow$ Schule

Schülerheim 552

Schülerwettbewerb $1307 \mathrm{f}$.

Schützengraben 115

Schützenhaus 164, 372, 462, 485, 561, 563, 581, $607,627,711,715,752,783,837,906,917,966$

Schützenverein 479

Schuhe, Schuhmangel 113, 131, 179, 262, $264 \mathrm{f}$, 321 f., 611, 678, 997, 1023, 1073, 1090, 1110, 1142, 1145, 1186, 1189, 1192-1194, 1270, 1275 f., 1278, 1280 f., 1301, 1303

- Hausschuhe 1142

- Holzpantinen, -pantoffel, -schuhe 102, 107, $265,764,1026,1147$

- Lederschuhe 1140

- Pantoffeln 322, 583

- Stoffschuhe 1110

Schuhfabrik 1073, 1205

Schuhmacher, -werkstatt, Schuhreparatur 583, $719,966,1023,1026,1090,1143,1340,1466$

Schulbildung, -abschluss $1044 \mathrm{f}$.

Schuld 64, 261, 359, 420, 1264, 1442

Schulden (vgl. $\rightarrow$ Kredit) 1303, 1322, 1338

Schule, Schüler, Klassenzimmer 22, 43, 45 f., 49, $66,83,85,89$ f., 98, 111 f., 118-120, 127, 162, 184, 188, 227, 264, 272, 278f., 296-299, 324, 331, 333 f., 337, 385, 427, 449, 470, 472, 484, 504 f., 509 f., 524, 553, 560 f., 566 f., 572, 574, 586 f., 599, 604, 609, 616, 624, 627 f., 632, 636-638, 640 f., 643 f., 659-661, 673, 680 f., 683, 686f., 703-705, 711 f., 719 f., 730,747 f., 750, 755, 764, 769, 774 f., 778 f., 786, 790, 794, 799 f., 802 f., 808, 812, 829 f., 836-838, 844 f., $867,870,876,884,892$ f., 895, 901, 904, 911 , 921 f., 924, 931, 933, 956 f., 965, 969, $993-$ 995, 1012, 1042, 1044f., 1085, 1122f., 1133, $1142,1146,1148,1225,1227,1237,1270$, 1276, 1281, 1308, 1320, 1326, 1334f., 1372, 1376, 1404, 1436-1441, 1443 f., 1446-1456,
1458-1461, 1465, 1468, 1470-1475, 1477, 1479f., 1481-1483

- Chroniken 449

- Ehemaligen-Vereinigungen 427, 1420

- Flüchtlingsklasse 845

- Geschichtsunterricht 5, 7, 15, 144 f., 325, 508

- Klassenfahrt 1452

- Klassentreffen 376, 384f., 410, 412, 487, 761, 807

- Schüler als Flüchtlingsbetreuer 616, 663, 863, 921, 1376, 1404

- Schwänzen 1281

- Staatsbürgerkunde 145

- Turnhallen, -säle 89, 127, 162, 171, 180, 187, $272,511,616,636,711,947,961,1013,1060$, 1122, 1478 f.; als Leichenaufbewahrungsstätte 956

- Unterricht, Projekte 145, 227, 264, 499, 508-510, 637, 684, 764, 769, 775, 790, 800, $811,837,921,956$ f., 965,1090 f., 1094 f., $1097,1105,1108,1473$

Schulentlassungsfeier 1331

Schulferien 187, 227, 358, 802, 867, 945, 1461

Schulgeld, -befreiung 1320

Schulpartnerschaft 334

Schulpatenschaft 368, 427

Schulreform 1105

Schulspeisung 267, 269, 556, 1148, 1287

Schulungsschriften 270

Schulweg 1142

Schuppen 703

Schussverletzung $\rightarrow$ Krankheiten

Schutzimpfung $\rightarrow$ Impfung

Schutzmantelmadonna 825

Schutzpolizei $\rightarrow$ Polizei

Schwäche $\rightarrow$ Krankheiten, $\rightarrow$ Todesursachen

„Schwalbe“ $\rightarrow$ Aktion „Swallow"

Schwangerschaft $\rightarrow$ Frauen

Schwarzblech 1145

Schwarzes Brett (Gemeinde) 1301

Schwarzhandel, -markt, „Schieber“, Schleichhandel (siehe auch $\rightarrow$ Schmuggel, $\rightarrow$ Tauschhandel) $171,304,966,1093,1118,1148,1273$

Schwarzmeerdeutsche $75,283,322,367,574$, $578,612,698,801,875,880,893,943$, $1264-1267,1480,1482$

Schweine $\rightarrow$ Vieh

Schwerbeschädigte 1191

Schwererziehbare 785 
Schweriner Grenzabkommen 1407

Schwerkriegsbeschädigte 563

Schwesternhaus 621, 632

Schwesternkongregationen, -konvente 38, $450 \mathrm{f}$.

Schwesternstation 1271 und öfter

Schwesternwallfahrt 552

Schwesternwohnheim 590

SDAG $\rightarrow$ Sowjetisch-Deutsche Aktiengesellschaft SED 10, 21, 23, 51, 68, 70, 126, 134, 142, 158, 163, 172 f., 182, 200, 229 f., 237, 239 f., 243, 246-248, 251, 253-260, 262, 270 f., 282, 288, 292-295, 298, 300 f., 304-308, 314 f., 325 f., 333 f., 341, 344-346, 348-350, 352-354, 356, $359,371,373$ f., 405 f., 418, 420, 451-453, $518,586,618,713,649,683,713$ f., 726, 735, 780, 918, 922, 969, 1089, 1094-1099, 1104, $1108,1113,1121,1126,1128,1130,1137$, 1163, 1165, 1168-1175, 1196, 1220 f., 1231, 1234, 1241-1243, 1245, 1247 f., 1252, 1284, 1286, 1290, 1297, 1299, 1305, 1307 f., 1310, 1315, 1318 f., 1321, 1323 f., 1327, 1329, 1334, 1347, 1390 f., 1396, 1400, 1410, 1438, 1441, 1446, 1450, 1454 f., 1468 f., 1471, 1477

- Betriebsgruppe 1292 f., 1324, 1331; der Landesregierung 1150, 1242; der ZVU 243, 760

- Bezirksleitung Cottbus 252

- Bezirksleitung Frankfurt (Oder) 353

- Kandidat 1324

- Kinderheim 649

- Kreisdelegiertenkonferenz Guben 529, 713

- Kreisleitung, -verband, -vorstand, -sekretär 256, 1196 f., 1477; Beeskow-Storkow 1084, 1107; Dresden-Land 252; Kreisleitung Guben 713; Jüterbog 1446; Luckenwalde 1221, 1305, 1451; Nauen 1338; Potsdam 344, 1204, 1327; Oberbarnim 346, 952; Teltow 1127

- Landesleitung (-vorstand) Brandenburg, -sekretariat, -verband 51, 163, 252, 256, $270,300,689,710,800,855,899,938,1039$, 1043 f., 1075, 1084, 1107, 1113, 1124-1127, 1160, 1168, 1172, 1174, 1196f., 1200, 1204, $1220,1231,1235,1239,1243,1251,1283$, 1338, 1396, 1401, 1419

- Ortsgruppen, -leiter, Ortsverband 952, 972, 1130, 1136, 1139 f., 1220, 1297, 1338f., 1347, 1396

- Parteikonferenz 1171

- Provinzialvorstand Brandenburg 246, 258, 1231, 1327
- Stadtleitung Dresden 252

- Zentralkomitee 1447

- Zentralsekretariat 240, 246, 1168, 1171, 1173, 1196, 1310, 1196, 1310, $1396 \mathrm{f}$.

- Zentralvorstand 1124

Seelenkartei (evang.) 1262

Seelenlisten 54, 83

Seelische Verfassung $\rightarrow$ psychische Aspekte

Seelsorge (siehe auch $\rightarrow$ Flüchtlingsseelsorge) $35,56,77,155,186,436,446,449,552,571$, $589,600,612,620,638,897,904,1261-1265$

Seelsorgeschwester 795 und öfter

Seelsorgestelle (kath.) 595, 606, 1419

Seelsorgshelferin 446, 1271

Seetransport $\rightarrow$ Schiffstransport

Seidenbau, -raupenzucht 524, 541, 959

Seidenstrümpfe 1142

Seife 961, 1056, 1091, 1275

Seifenpulver 844

Selbstbestimmungsrecht 1358, 1360-1362, 1364

Selbsthilfegruppe (SHG) „Kontakt“ 637, 642, 1372

„Selbstkritik“ (SED) 271, 1172

Selbstmord $\rightarrow$ Todesursachen

Selbstmordversuch 347, 1274, 1478

Selbstverpflichtung 1227-1229

Selbstversorger, -verpflegung 1162f., 1183, 1287

Selbstverwaltung 1367

Selbstzeugnisse (Ego-Dokumente) $\rightarrow$ Zeitzeugenberichte

Sender Freies Berlin (SFB) 377

Seniorenarbeit 622

Seniorenbeirat 61-65, 812, 1543

Seniorenberatung 602

Senioren-Union der CDU 658, 761

Seniorengruppen, -vereine 8, 61-66, 419, 488, $518,812,922,1450 \mathrm{f}$.

Seniorenrat des Landes Brandenburg 61, 64

Seniorenwallfahrt 552

Seniorenzentrum, -residenz 720, 776

Serum $\rightarrow$ Impfstoff

Seuchen $\rightarrow$ Krankheiten

Seuchenbaracke 859

Seuchenstation, -krankenhaus $\rightarrow$ Krankenhaus

SFB $\rightarrow$ Sender Freies Berlin 377

„Shukow-Aktion“ 157

Siebenten-Tages-Adventisten 335

Sieche (siehe auch $\rightarrow$ Gebrechliche) 622, 719, 999, 1021, 1026, 1045, 1269 
Siechenhaus, -heim 720, 1200, 1235

Siedler (vgl. $\rightarrow$ Neusiedler) 1128, 1132 f., 1144, 1315, 1320, 1409, 1438 und öfter

Siedlerstelle 1459

Siedlungsausschuss 1221

Siedlungsentzug 577

Siedlungsforschung 29

Siedlungsgesellschaft Arbeiterheimstätten (Berlin-Adlershof) 892

Siedlungsgesellschaft Deutsch-Land (Berlin) 892

Siedlungsgesellschaft Ostmark (Frankfurt/O.) 341

Siedlungshaus $82,1200,1441,1481$

Siedlungsland 1111

Siegel 105

Sinti und Roma 21

Sitten 335,1364

Skelette $\rightarrow$ Leichen

Skorbut $\rightarrow$ Krankheiten

Slawen 30

Slawistik 32

SMA(D) (Sowjetische Militäradministration), Sowjetische Besatzungsmacht 10, 52, 68, 104, $115,130,138,150,157,159,161$ f., 239, 248, $252,300,350,356,643,699,732,739,746$, 789, 833, 845, 849 f., 1002, 1018, 1022 f., 1039, 1041, 1047, 1049 f., 1054, 1059, 1082, 1109, $1116,1118,1152,1164,1167,1187,1213 \mathrm{f}$., $1258,1305,1319,1341,1391$

- Befehle 138, 160, 166, 239, 282, 523f., 526-528, 530, 532 f., 535-541, 543-545, 547 f., 575, 601, 645, 654, 740, 745, 765, 813, $840,887,890,894,1011,1024,1027,1038$, $1047,1148,1155-1159,1187,1233,1390$, 1393, 1400, 1406f., 1408, 1411

- Befehl Nr. 14: 1407

- Befehl Nr. 15: 159

- Befehl Nr. 31: 1214

- Befehl Nr. 46: 1412

- Befehl Nr. 54: 1408

- Befehl Nr. 71: 655, 1411

- Befehl Nr. 92: 1090

- Befehl Nr. 105: 395

- Befehl Nr. 124: 647, 1167

- Befehl Nr. 163: 1410

- Befehl Nr. 189: 1411

- Befehl Nr. 201: 1291

- Befehl Nr. 202: 1410

- Befehl Nr. 204: 253, 1408
- Befehl Nr. 209: 17, 252, 1123, 1128, 1174f., 1241, 1411

- Befehl Nr. 255: 1410

- Befehl Nr. 304: 17, 522, 1197, 1408-1410

- Befehl Nr. 314: 1233

- Befehl Nr. 1467: 1118

- Befehl Nr. 75 38: 1409

- Berlin 159, $161 \mathrm{f}$.

- Brandenburg (SMAB) 52, 162, 165, 239, 252 f., 261 f., 264, 271 f., 278, 554, 645, 813, $834,848,894,1003,1008,1117,1122$, 1155-1160, 1162, 1232, 1245, $1410 \mathrm{f}$.

- -, Umsiedlerabteilung 252 f., 1041

Societas Verbi Divini (Gesellschaft des Göttlichen Worts) 447

Soforthilfe 1308

Sokolowski-Plan 1232

Soldaten (siehe auch $\rightarrow$ Rote Armee, $\rightarrow$ Wehrmacht) 514

- polnische (siehe auch $\rightarrow$ Polnische Truppen) 133, 197 f., $488,537,715$

Soldatenbetreuung 121

Soldatenfriedhof, -gräber 821

Soldiner Heimatabend Stadt und Land Hannover 384, 386

Solidarność 420

Sollablieferung, -abgabe $\rightarrow$ Ablieferungssoll

Sonderbeauftragter des Heiligen Vaters für die heimatvertriebenen Deutschen 452

Sonderrechte 1238

Sonderzüge $\rightarrow$ Eisenbahn

„Sonnewalder Heimatblätter“ 913

Sonntagsarbeit 1077

„Sorauer Heimatarchiv“ 660

„Sorauer Heimatblatt“ $\rightarrow$ Heimatzeitschriften

Sorauer Heimatfreunde zu Berlin 372

Sorauer Hilfswerk $390 \mathrm{f}$.

Sorben, Sorabistik 32, 633

Sorbisch $\rightarrow$ Sprache

Sorbisches Institut (Bautzen) 32

Souveränität, staatliche (DDR) 1415

Sowjetarmee $\rightarrow$ Rote Armee

Sowjetisch-Deutsche Aktiengesellschaft (SDAG)

Wismut 294, 1092, 1457

Sowjetische Armee $\rightarrow$ Rote Armee

Sowjetische Besatzungsmacht $\rightarrow$ SMA

Sowjetische Kontrollkommission 1224

Sowjetische Militäradministration $\rightarrow$ SMA

Sowjetische Speziallager $\rightarrow$ Speziallager 
Sozialamt, -abteilung (SBZ) (vgl. $\rightarrow$ Sozialwesen) 406, 499, 528, 554, 616, 621, 842, 855, 739, 848-850, 855, 1047, 1090, 1121, 1153, 1173, 1197 f., 1229, 1242, 1342, 1371

- (Westzonen) 377

- Kreissozialamt 256, 260, 528, 534, 539, 739, 938, 1058 f., 1127, 1143, 1151, 1190, 1229, 1240

Sozialausschuss 746,1174

Sozialdemokratische Partei Deutschlands, Sozialdemokraten $\rightarrow$ SPD

Sozialdirektor $1310 \mathrm{f}$.

Soziale Betreuung 1214

„Soziale Betreuung der Landarbeiter" (Ausschuss) 1160-1162, 1165-1167

Soziale Stellung, Ansehen 286-288 und öfter

Sozialer Abstieg, Deklassierung 285-287, 290, $314,323,331$, 333, 678, 1323 und öfter; „Karriereknick“ 293

Sozialer Aufstieg 290, 324, 1469 und öfter

Sozialfürsorge $\rightarrow$ Fürsorge

„Sozialgefährdete“ 688

Sozialhilfe 487

Sozialismus 296, 334, 366, 423, 484, 1138, 1175, 1311

Sozialist (Selbstbezeichnung) 271, 1171

Sozialistische Einheitspartei Deutschlands $\rightarrow$ SED

"Sozialistische Namengebung“ 305

"Sozialistische Spielgemeinschaft“ 1136

"Sozialistisches Dorf" 312

Sozialkommission 248, 1243

Sozialunterstützung $\rightarrow$ Unterstützungszahlung

Sozialversicherung, - versicherungskasse (SVK) 595, 1025 f., 1085, 1092 f., 1098, 1104, 1112, 1151, 1154, 1198

Sozialwesen (Dezernat, Ressort) (vgl. $\rightarrow$ Sozialamt) 602, 849 f., 927, 1007, 1067, 1073, $1076 \mathrm{f}$., 1084, 1238, 1355 und öfter

Spätaussiedler $\rightarrow$ Aussiedler

Spätausiedlerbescheinigung 500

Spätaussiedlerin $\rightarrow$ Aussiedlerin

Sparbuch 104, 1289

Sparkasse 103-106, 462, 783 f., 794, 810, 874, 1435,1440

Sparkassenverband $\rightarrow$ Brandenburgischer Sparkassen- und Giroverband

Sparkonto, -guthaben 1134, 1148, 1289, 1344

Sparteriegenossenschaft 1199
SPD 126, 241, 243, 246f., 271, 298, 309, 480, $649,776,969,1019,1020,1023$ f., 1113, 1137, $1223,1231,1299,1447,1454,1477$

- Tschechoslowakei 150, 157, 1390

Speisen, Kochrezepte (vgl. $\rightarrow$ Lebensmittel) 337-339, 811, 1437

- „Karpfen in Biersoße“ 338

- „Kochklopse“ 338

- „Königsberger Klopse“ 338

- Mohnkuchen, schlesischer 338

Speisewirtschaften 683

Spenden, -aufrufe, -sammlungen (siehe auch $\rightarrow$ „Umsiedlerwoche“) 184 264, 258, 265, 267, 269 f., 378, 390-394, 396, 403 f., 431 f., 435, 441, 446, 453, 472, 583, 587, 598, 691, 693, 700, 734, 791, 796, 811, 842, 896, 926, 957, 964, 966, 969, 994f., 1090, 1105, 1137, 1145, 1149 f., 1162, 1190 f., 1197, 1235 f., 1260 f., 1269, 1280, 1343, 1369, 1371, $1401 \mathrm{f}$. Sperrgebiet $\rightarrow$ Aufnahmestopp, $\rightarrow$ Rote Armee, Beschlagnahmung von Gebäuden

Sperrzeit 1281

Speziallager, sowjet. 21, 34, 183, 335, 1459

- Nr. 1 Mühlberg 291, 1465

- Nr. 4 Landsberg/Warthe 183

- Nr. 5 Ketschendorf (Fürstenwalde-) 37, 692, $694,728,1048 \mathrm{f}$.

- Nr. 6 Frankfurt/O.-Dammvorstadt 183, 670, $673,739,1406,1480$

- Nr. 6 Jamlitz 37, 670, 739-741

- Nr. 7 Weesow 952

- Rothenstein 1469

- Schwiebus 149, 291, 1437, 1465

Spielgemeinschaft 1136

Spielmannszug 1331

Spielwarenhandel, -herstellung 563, 1208

Spielzeug $\rightarrow$ Kinderspielzeug

Spinnerin 1470

Spinnstoff 749, 1149, 1190, 1235, 1301

Spirituosenfabrik 1205

Spitzel $\rightarrow$ Geheime Mitarbeiter, $\rightarrow$ Informanten, $\rightarrow$ Inoffizielle Mitarbeiter

Spitzenklöppeln 710, 1198

Sport 119, 227, 331, 355, 681, 780, 1107, 1446, $1450 \mathrm{f}$.

Sprache, Sprachkenntnisse (siehe auch $\rightarrow$ Dolmetscher, $\rightarrow$ Mundart, $\rightarrow$ Terminologie) 32, $68-70,78,90,234,326,336,652,811,897$, 1364 
- Deutsch 52, 76 f., 145 f., 148, 178, 194, 215, $220,336,345,423,425,461,489,499$ f., 576, $622,627,633,824,1265,1371$

- Englisch 851

- Litauisch 220, 225, 846

- Oberschlesisch 145

- Polnisch 76f., 90, 137, 144-146, 148, 153, 178,422 f., 425, 461, 622, 670, 838, 854, 1463

- Russisch 148, 194, 233, 576, 609, 752, 767, $769,773,779,838,876,1046$

- Sorbisch/Wendisch 32, 633

- Tschechisch 148, 158

- Zeichensprache 422

Sprachlehrer 1443

Sprachlosigkeit 320

Sprachpflege 1364

„Sprecher der Umsiedler“ 536, 584

Spreewaldbahn 102

Sprengstofftote 284, 724, 1520

Sprengung (siehe auch $\rightarrow$ Brücken) 1278, 1404

Spritzen 1067

SS (Schutzstaffel der NSDAP) (siehe auch $\rightarrow$ Waffen-SS) 78, 584, 597, 766, 828, 866, 1049, 1126, 1468

SS-Lehr- und Versorgungsabteilung für Brieftauben (Bernau) 584

St. Annaheim Berlin-Schöneberg 447

St. Elisabeth-Stiftung (Berlin) 645

St. Florian-Stiftung (Neuzelle) 825

St. Klemens-Hofbauer-Stift (Glogau) 632, 944

St. Maria-Elisabeth-Heim (Altenhof) 554, 954

Staatenlosigkeit 1450

Staatliche Archivverwaltung der DDR 48

Staatliche Archivverwaltung Warschau 421

Staatliches Repatriierungsamt, poln. $\rightarrow$ PUR

Staatsangehörigkeit 1355 f., 1390 f., 1399, 1402, $1412,1414,1445,1450$

Staatsanwaltschaft 855, 1018, 1226

Staatsarchiv Potsdam 48, 309

Staatsarchiv Landsberg/W. (Archiwum Państwowe Gorzów Wikp.) 854

Staatsarchiv Stettin (Archiwum Państwowe w Szczecinie) $147 \mathrm{f}$.

Staatsbürgerkunde $\rightarrow$ Schule

Staatsbürgerschaft $\rightarrow$ Staatsangehörigkeit

Staatsorgane, -apparat $293 \mathrm{f}$., 407 und öfter

Stabshelferinnenheim 794,797

Stacheldraht 178
Stadtarchive 30, 55 f., 63, 65, 364, 391, 519, 623, 660 f., $675,1420,1544$

Stadtbauamt 1121, 1194

Stadtkolonne 298

Stadtkommandant, sowjet. 253, 664, 759, 829, $845,902,1010,1121,1454$

Stadtmission (siehe auch $\rightarrow$ Berliner Stadtmission) 1258

Stadtmuseum Schwedt $\rightarrow$ Museen

Stadtsparkasse $\rightarrow$ Sparkasse

Stadtverordnete, Stadtverordnetenversammlung $340,345,480,505,607,672,721,776,845$, 859,1121 f., 1318, 1326-1328, 1378, 1414, 1439 f., 1447

Stadtverwaltung passim

Stadtwachtdienst 1476

Stadtwappen $\rightarrow$ Wappen

Städtebahn $\rightarrow$ Brandenburgische Städtebahn

Städtepatenschaften $\rightarrow$ Patenschaften

Städtepartnerschaft (vgl. $\rightarrow$ Gemeindepartnerschaft) $65,192,211,214,427-430,491-496$, 518 f., 557, 564, 568, 577, 582, 585, 589, 601, $607,622,633$ f., 642, 644, 656, 660, 672, 678, $684,690,705,721,735,743,746,760,777$, $787,790,792,798,800,810,812,820,830$, $835,846,851,865,870,877$ f., 904, 907, 910 , 916, 922, 924, 927, 930, 933, 959, 962 f., 967 , 971,1544

Städtebau 73, 811

Städtewappen $\rightarrow$ Wappen

Ständige Einreise (in die DDR) 140

Stärkefabrik 1190

Stahlhelm (als Kochtopf) 1143

Stahlwarenfabrikation 307, 627

Stalag III A 652

Stalag III B $279 \mathrm{f}$.

Stalinismus 21

Stall, -boden, Stallung 556, 609, 662, 700 f., 727, $890,893,911,914,943,951,1279$

Stammeinwohner, -bevölkerung $\rightarrow$ Einheimische

Stammlager $\rightarrow$ Stalag

Standesamt I in Berlin 861

Standesamtsregister 44, 55, 57, 68 f., 120, 185, $192,218,221,233,540,554,559,561-564$, $591 \mathrm{f} ., 630,726,829,840,860-864,866-868$, $904,1397,1420$

Standgericht 901, 1404

Standortpfarrer 77

Stasi $\rightarrow$ Minister (DDR), Staatssicherheit 
Statistik (siehe auch $\rightarrow$ Bevölkerungsstatistik) 49 f., 139, 147, 165, 167, 189 f., 202-204, 213, $219,231,233,242,261,277-279,308$ f., 315, $360,404,454-457,522,524-551,642,673$, 688, 707, 723, 855, 1000, 1027-1039, 1078, 1089, 1096, 1104, 1195, 1202-1213, 1226, $1232,1237,1252,1356$

Statistisches Landesamt (Brandenburg) 522, $551,1251,1253,1395$

Statistisches Bundesamt 204

"Steinauer Rundbrief“ $\rightarrow$ Heimatzeitschriften Steinbaracken $\rightarrow$ Baracken

Steinbartsche Stiftung (Züllichau) 427

Steinkohle 1201

Stellmacher 361, 404, 1147, 1227, 1323, 1439

Stempel 105

Stenographie-Kursus 1441

Stenotypistin 122, 1252, 1440

Stephanus-Stiftung 568, 645, 933

Sterberegister $\rightarrow$ Kirchenbuch, $\rightarrow$ Standesamtsregister, $\rightarrow$ Totenbuch

Sterbeurkunden (siehe auch $\rightarrow$ Standesamtsregiser) 656

Sterblichkeit, erhöhte, Sterbeziffern, -rate, -fälle 186f., 189, 523, 561, 583, 595, 598, 611, 617, 620-622, 635, 665, 683, 686, 700, 712, 838, 860 f., $863,875,906,921,948,953,956,999$, 1003, 1010, 1017, 1046, 1053 f., 1064, 1153, $1274 \mathrm{f}$.

„Sternberger Kurier“ $\rightarrow$ Heimatzeitschreiften/ Heimatblatt für deutsche Volksgemeinschaft

Steuern 1212, 1306, 1366-1368

Steyler Missionare 447

Stiefelsohlen 1276

Stiftung Brandenburg 23, 59, 364, 474, $476 \mathrm{f}$., 691 f., 1420, 1544

Stiftung Deutsches Historisches Museum 469

Stiftung Flucht, Vertreibung, Versöhnung 9 f., 60, 462,469

Stiftung Gedenkstätten Buchenwald und Mittelbau-Dora 183

Stiftung Heimatkreisarchiv Königsberg/Neumark $466,531,569$

Stiftung Landsberg/Warthe 692

Stiftung Marienkirche in Königsberg/NM-Chojna $\rightarrow$ Fundacja Kościół Mariacki w Chojnie-

Königsberg/Neumark

Stiftung Martin-Opitz-Bibliothek $\rightarrow$ Bibliotheken Stiftung Ostdeutscher Kulturrat (OKR) 58, 60, 209
Stiftung Preußische Schlösser und Gärten berlinBrandenburg 17, 504

Stiftung West-Östliche Begegnungen 505

Stiftung „Zentrum gegen Vertreibungen“ $\rightarrow$ Zentrum gegen Vertreibungen

„Die Stimme der Vertriebenen“ $\rightarrow$ Heimatzeitschriften

Stimmungsberichte $\rightarrow$ Informantenberichte

Stolper Heimatkreis $\rightarrow$ Heimatkreisgemeinschaften, Stolp

Strafen, Strafandrohung, Bestrafung 1018, 1045, $1052,1134,1162,1226,1275,1346$

Strafvollzugseinrichtungen 87

Strapazen $\rightarrow$ Todesursachen

Straßen, verstopfte 90, 95, 931, 1377, 1483

Straßenbahn, -verkehr 370, 663, 849, 895

Straßenbau 1206, 1447

Straßennamen, -umbenennung 237, 339-345, 493, 518, 568, 585, 592, 605, 607, 641, 670-672, 689f., 707, 714, 721, 785, 792, 802, $810,851,857,859,865,871,907,910,927$, 930, 958, 1376-1379, 1406, $1413 \mathrm{f} ., 1416 \mathrm{f}$.

Straßenrand 95, 115, 594, 627, 727

Straßenumzug 1139

Strickwaren, -fabrik 1198, 1207

Strickwolle 1142

Stroh 1017, 1052, 1153, 1215, 1306

Strohballen, -säcke 174, 182, 280, 588, 616, 664, $858,865,897,944,1059,1080,1088,1095$, $1143,1268,1281$

Strohflechterei 1199, 1214

Strohschütten, -lager 87, 91, 98, 112, 120, 127, 153 f., 176, 180 f., 184, 274, 285, 323, 568, 578, $609,638,774,837,870,890,921,943,961$, 993, 1022, 1056, 1088, 1125, 1268, $1277 \mathrm{f}$., 1481

Stromsperre 1277

Stromversorgung 113, 843, 890, 896

Strümpfe 665, 1058, 1106, 1142; Großhandel 1212

Strumpfwarenfabrik 1207, 1473

Stubben 1014

Studenten 673, 1439, 1442, 1474

Studienfahrt, -reise 1368,1414

Suchaktion 1002, 1005, 1008

Suchanzeigen, -anträge $263 \mathrm{f} ., 416,452,1234$, $1248,1250,1255,1409$

Suchdienste 212, 245, 254, 262, 263f., 379, 416, 431, 436, 591, 598, 600, 619, 744f., 748, 895, 924, 957, 967, 1250 f., 1254 
- Kirchlicher Suchdienst 431, 436, 451 f., 620, 639

- Suchdienst des DRK 53, 147

Suchdienst für vermißte Deutsche in der SBZ (staatl. Suchdienst) 147, 168, 253 f., 263f., $598,619,639,675,745,768,1090,1092$, $1098,1104,1232,1234,1250,1255,1235$, $1237,1242,1248-1256,1250,1255$ f., 1399, $1408 \mathrm{f}$.

- Annahmestellen 848, 1234f., 1248, 1252, 1255,1399

- Meldekarten 1145, 1252-1254, 1256, 1412

- Provinzial-/Landesbeauftragte 848, 1237, 1242, 1249-1256

- Werbefilm 1411

Suchkartei, -karten 53, 120, 168, 263, 768, 837, 1008, 1092; nach Herkunftsorten 1008; Kinderkartei 1252

Suchmeldungen 132, 230, 264, 369, 441, 1249

Suchpostkarten 263, $1253 \mathrm{f}$.

Suchstellen 120, 397, 837, 1404

Suchzeitung 1254f., 1409

Sudetendeutsche (siehe auch $\rightarrow$ „Antifa-Transporte", $\rightarrow$ Landsmannschaften) 75, 157-159, 189, 200, 202, 212 f., 228-232, 281, 293 f., 301-308, 315, 325, 327, 334f., 405, 462, 509, $514,550,557,574,578$ f., 583 f., 591, 602, $610,614,617,625,648,680$ f., $710,734,743$ f., $752-754,765,778,783,789,799,802,808$, 814,819 f., $826,832,842,847,850,857$ f., $873,875,877,883,889$ f., $893,899,915,917$ f., 923, 928, 930 f., 936, 939, 963, 1200, 1220, 1228,1247 f., $1265,1268,1270,1278$ f., 1290 , 1350 f., 1377, 1390, 1413, 1434, 1437, 1441, 1443, 1446-1448, 1453, 1469f. und öfter

Sudetendeutscher Heimatbund $368 \mathrm{f}$.

Sudetendeutsches Institut (SDI) (München) $147 \mathrm{f}$.

Sühnekreuzwege 816

Sühnemaßnahmen, -arbeiten (Wiedergutmachung) 133

Süßigkeiten 1286

Sütterlinschrift 145

Suizid $\rightarrow$ Selbstmord

Superintendent $\rightarrow$ Pfarrer, evang.

Superintendentur 76, 435, 874, 1258, $1261 \mathrm{f}$.

Suppe $\rightarrow$ Lebensmittel

Suppenküche 873

SVK $\rightarrow$ Sozialversicherung
„Swallow" (Schwalbe) $\rightarrow$ Aktion "Swallow“

Synode, Synodale 35, 852, 1259

Syphilis $\rightarrow$ Krankheiten

Syrer 775

Tabernakel 638

Tabu, Tabuisierung, „Totschweigen“ $8,10,12,14$, $25,28,39$ f., 42-44, 53, 73, 144, 146, 258, 292, 319-363, 383, 387, 403 f., 420, 422, 430, 491, 493, 508 f., 513, 885, $1455 \mathrm{f}$.

„Tägliche Rundschau“ $\rightarrow$ Zeitungen

„Tag der Arbeit“ 914

„Tag der Befreiung“ 326

„Tag der Heimat“ (1947-1989) 374, 381, 407, 578,1412

- (ab 1990:) 599, 831, 865, 870, 878, 957, $1372 \mathrm{f}$

Tagebuch 7, 37, 44, 59, 67, 80 f., 89, 98, 110-113, 117, 120 f., 216, 218, 272, 322, 409, 538, $562,564,576,589,617,705,757$ f., 775, 861, 890, 924, 993-995, 1398, 1431-1435, 1438, 1444 f., 1447-1449, 1453 f., 1456 f., 1460 , 1464 f., 1467 f., $1472-1474,1476$ f., 1479 1483 und öfter

Tagelöhner 1449

Tageskindergarten 810

„Tagespost“ $\rightarrow$ Zeitungen, Die Tagespost

Tagungen, behördliche 421, 527, 572, 662, 706, $1005,1007,1115-1118,1235,1238$ f., 1253 , $1403,1407,1410,1412$ und öfter

- wissenschaftliche 13-15, 33 f., 57 f., 421, 601, 666, $906 \mathrm{f}$.

Talbothaus Aachen 392

Tankholzzubereitung 1205

Tanklager 1061

Tanz 227, 332, 372 f., 629, 684, 716 f., 719, 837, 1069,1072 f. , 1075, 1085 f., 1088 f., 1092 1094, 1098 f., 1104, 1141, 1325, 1354, 1371

Tanzsaal 562, 586, 936, 966

Tariflohn $\rightarrow$ Lohn

Tataren 964

Taubenstation (Bernau) $\rightarrow$ SS-Lehr- und Versorgungsabteilung für Brieftauben

Taufe 49, 305, 613, 873, 919, $1262 \mathrm{f}$.

Taufschein 434

Tauschhandel (siehe auch $\rightarrow$ Schwarzhandel) 265 f., 594, 1134

Tauschzentrale 274

Tauwetter $\rightarrow$ Wetter 
Tbc (Lungentuberkulose) $\rightarrow$ Krankheiten,

$\rightarrow$ Todesursachen

Tbc-Baracke 867

Tbc-Heilstätte $\rightarrow$ Lungenheilstätte

Tbc-Station 655

Technische Nothilfe 579

Technische Universität Berlin $\rightarrow$ Universitäten, Berlin (TU)

Tee $\rightarrow$ Lebensmittel

Teilnehmerlisten $\rightarrow$ Anwesenheitslisten

Telefon, Fernsprecher 93, 99, 108, 123, 141, 561, $767,861,901,994,1008,1012,1014,1045$, $1049,1061,1065,1142,1214,1253,1336$

Telefon- und Raketenmuseum $\rightarrow$ Museen

Telefonsperre 901

Telegramm (vgl. $\rightarrow$ Fernschreiben) 239, 372, 378, 439, 529, 713, 767, 1016, 1091, 1326

Temperatur $\rightarrow$ Wetter

Terminologie 27, 33, 42, 67-71, 77 f., 140, 300, $437,696,747,885,1137,1174,1215,1320$, 1390-1402, 1439

Terrorismus 482

Testament 1046

Textilfacharbeiter, -kräfte 229, 826 f., 1075, 1097, $1180,1185,1187$

Textilgenossenschaften $648,826,915,899,915$, 1198 f., 1214

Textilien, -mangel, -sammlung, -versorgung, -verteilung, -zuteilung (siehe auch $\rightarrow$ Kleidung) $661,966,1095,1107,1110,1136,1137,1142$, 1147 f., 1150, 1160 f., 1163, 1166 f., 1248, 1411

- Anzugsstoff 1283

Textilindustrie 26, 307, 583, 648, 1180, 1186, $1188 \mathrm{f}$.

Textilwarenhandel 1208, 1210, 1213

Theater 718, 790, 909, 1123, 1286, 1416, 1437, 1440; Aufführung im Lager 172, 558, 1104

Theologenkonvikt Breslau 825

Theodor-Fontane-Archiv (Potsdam) 505

„Theresa Rus" $\rightarrow$ Schiff

Theresienheim (Schöneiche) 896

Thermometer 1014

Tiefbau 1206

Tief-, Schlachtflieger (Luftangriffe) $89 \mathrm{f}$., $113 \mathrm{f}$., $321,578,587,700,728,763,818,827$

Tierarzt $187,700,852,934,1451$

Tiere (siehe auch $\rightarrow$ Hunde, $\rightarrow$ Kartoffelkäfer,

$\rightarrow$ Mäuse, $\rightarrow$ Ratten, $\rightarrow$ Ungeziefer, $\rightarrow$ Vieh) 92, 131, 574, 1401
Tischler, Tischlerei 169, 249, 288, 331, 798, 1080, 1199, 1443, 1456, 1463, 1466

Tod, Todesfälle, Sterben, Sterbefälle, Sterbende (siehe auch $\rightarrow$ Kindersterblichkeit, $\rightarrow$ Leichen, $\rightarrow$ Sterblichkeit) 44, 54 f., 98, 131, 171, 183 f., 204, 233, 276, 321, 389, 560-562, 566f., 577-579, 583, 590, 594, 611, 617, 620 f., 636 f., 668, 700, 708, 718 f., 728, 740, $759,795,838,860-862$ f., $910,927,948$, 952, 956, 960, 994, 997, 1017, 1246, 1277, 1377, 1439,1441 und öfter

Todesanzeigen $\rightarrow$ Familienanzeigen

Todesmärsche $101 \mathrm{f}$., 821

Todesstrafe $\rightarrow$ Hinrichtung

Todesursachen (vgl. $\rightarrow$ Krankheiten) 55, 183, 185f., 566, 583, 590, 608, 668, 686, 728, 798, $819,861,875,947$

- Allgemeine Schwäche 186, 947

- Altersschwäche 183, 185, 582, 668, $860 \mathrm{f}$., 864, 1021, 1046, 1074, 1269 und öfter

- Aufregungen 621

- Bauchtyphus 185,683

- Brechdurchfall 861

- Bronchialasthma 863

- Cholera 948

- Darmerkrankung 875

- Darmkatarrh 562,861

- Diphterie 561, 750,798,819

- Durchfall 863

- Dysenterie $\rightarrow$ Ruhr

- Entbehrungen 133, 183, 272, 947

- Enteritis (Darmentzündung) 186

- Entkräftung 185, 269, 562, 566, 591, 616, 621, $628,665,881$

- Erfrieren 98, 582, 616, 627, 891, 901, 1126

- Erfrierung der Füße 861

- Erhängen 901, 1404, 1443

- Ernährungsstörung(en) 185, 562, 591, 819

- Erschießen, Erschießung 44, 98, 101 f., 751, 788, 872, 936, 1377, 1451, 1453, 1460

- Erschlagen 1377

- Erschöpfung 109, 186, 560 f., 881, 1279

- „Euthanasie“ 608

- Explosion 869

- Fleckfieber 598

- Flecktyphus 867,938

- Folgen und Leiden der Flucht 566, 601, 774

- Gasvergiftung 231

- Geburt 1458 
- Gewalt 1477

- Gonorrhoe 1057

- Herzmuskelschwäche 133, 591

- Herzschlag 392

- Herzschwäche 185f., 561 f., 591, 630, 750, 1269

- Hirnhautentzündung 554

- Hirnschlag 750

- Hunger 98, 131, 220, 608, 617, 621, 665, 808, 875 f., 906, 947, 997, 1273, 1284

- Hungerödeme 186

- Hungertyphus 590, 598, 906, 1436

- Kälteeinwirkung 560

- Körperschwäche 186

- Krebs 819

- Kreislaufschwäche 560, 591, 829, 861, 863, 868

- Kreislaufstörungen 591

- Kreislaufversagen 863

- Luft-, Bomben-, Fliegerangriff 125, 614, 617, $821,837,861$

- Lungenembolie 750

- Lungenentzündung 133, 591, 819, 861

- Lungenleiden 1269

- Lungentuberkulose, Tbc 582, 695, 798, 819, 829,875

- Marasmus 185

- Meningitis tuberculosa 863

- Minenexplosion 284, 686, 1520

- Misshandlungen 566

- Mord 101, 242, 608, 1058, 1277, $1279 f$.

- Munitionsexplosion 686, 1520

- Pilzvergiftung 171

- Rachendiphtherie 750

- Ruhr (Dysenterie) 183, 187, 590, 712, 750, 784, 956, 1269

- Schlagaderverhärtung 861

- Schlaganfall 582

- Schwäche 969

- Selbstmord/Suizid 44, 171, 320, 560, 563, $591,628,639,664,653,788,928,1153,1274$, $1491,1304,1478$

- Seuchen 665, 788, 808, 829, 956

- Strapazen 621, 761, 791, 875, 881, 1274

- Tbc, Tuberkulose $\rightarrow$ Lungentuberkulose

- Totgeburt 861, 1056

- Typhus 44, 132, 134, 187 f., 272, 561, 587, $590,595,598,665,712,726,750,784,798$, 808 f., 819, 829, 867, 876, 924, 938, 947, 956 f., $960,967,999,1269,1450,1467$
- Überanstrengung 875

- Unfall, Unglück 284, 637, 686, 819, 869, 923, 1280, 1451

- Unterernährung (Dystrophie), Verhungern 171, 183, 185 f., 522, 591, 712, 750, 762, 788, 798,875

- Unterleibsentzündung 750

- Verdauungsstörungen 653

- Wassersucht 133, 590

Todesurteil $\rightarrow$ Hinrichtung

Toiletten, Notdurft $\rightarrow$ Bedürfnisanstalt (siehe auch $\rightarrow$ Hygiene)

Toleranz 637, 673, 684

Tolkemita $\rightarrow$ Prußen-Stiftung Tolkemita

Tomback 1201

Tonbandaufzeichnung, Tondokumente 361 f., 519

Torte $\rightarrow$ Lebensmittel

Tote $\rightarrow$ Leichen

„Tote Berufe“ 1194

Totenbuch (siehe auch $\rightarrow$ Friedhof, $\rightarrow$ Kirchenbuch, $\rightarrow$ Standesamtsregister) 950

Totenehrung, -gedenken 482, 490

- (ev. Kirche) 370, 439, 856

Totenmeldeformular 1253

Totenregistrierung (im Lager) 1053

Totenzettel 900

Totgeburt 861, 1056

Tourismus (siehe auch $\rightarrow$ Heimatreisen, $\rightarrow$ Reisen) 836

„Trabant" (Pkw) $\rightarrow$ Kraftfahrzeuge

Trachtengruppen 376

Tradition 497, 885, 1364

Trakehner 823

Traktor 1217,1467

Transitverkehr $\rightarrow$ Interzonenverkehr

Transparente 480, 830, 1325, 1329, 1331

Transporte, Flüchtlings-, Sammel-, Heimkehrer-, Umsiedlertransporte (siehe auch $\rightarrow$ AntifaTransporte, $\rightarrow$ Eisenbahn, $\rightarrow$ Kindertransporte ) $50 \mathrm{f}$., $54,70 \mathrm{f}$., $75,79,81 \mathrm{f}$., $87,98,111$, 121, 123-125, 132, 136-139, 141 f., 146-159, 161-163, 165, 167-169, 172, 176-183, 191, 193, 195, 201, 209, 211, 214, 216, $220 \mathrm{f}$., 223-225, 230, 236, 243-245, 252, 260, 269, 276f., 281, 287, 291, 302, 307, 428, 480, 522, $530,541,561-563,574,577,579,585,587$, 601 f., 618, 620 f., 626, 641, 647, 657 f., 666, 675-677, 688f., 698, 712, 717, 734f., 755, 768 f., 791 f., $795,802,820,827,840,867$, 
$877,883,887,889,902,915-917,937,952$, 956, 961, 963, 993, 998, 1010, 1016-1019, 1021-1023, 1038-1046, 1050 f., 1053, 1057, 1061, 1064-1069, 1072, 1075 f., 1081, 1083-1085, 1089-1091, 1093 f., 1096-1104, 1107 f., 1152-1154, 1177, 1179-1182, 1185, 1187 f., 1196, 1232-1236, 1239 f., 1247, 1250, 1253, 1268 f., 1277, 1289, 1305, 1376f., 1390, $1405,1408,1413$ f., 1432, 1444-1448, 1451, $1453,1457,1460,1465,1469$ und öfter

- Begleitpapiere 1040, 1067

- Begleitpersonal 1051, 1053

- Waggonmusterung 1051, 1053

Transportarzt 1051, 1053

Transportfähigkeit 616, 902, 1053, 1377

Transportfirma 1208

Transportführer, -begleiter, -leiter 159, 306, 1040, 1045, 1090, 1094, 1106, 1153

Transportkapazitäten, -mittel 245, 262, 664, 1051

Transportkommando 1051

Transportlisten 51, 146-148, 688 f., 1040

Transportmittel 1052 und öfter

Transportpolizei (Trapo) 374, $1352 \mathrm{f}$.

Transportschein 1040, 1391

Transportunfähigkeit 611, 795, 1047, 1053, 1074 und öfter

Transportversorgung 1051

Transportwesen (Referat) 1237, 1242

Trapo $\rightarrow$ Transportpolizei

Traum 365

Traumata 63, 320, 358 f., 1477

Traurigkeit, Schmerz 15, 195, 319, 268, 325, 331 f., 359, 376, 420, 488, 622

Trauung (siehe auch $\rightarrow$ Ehe) 49, 410, 461 f., 873, $1262 \mathrm{f}$.

„Trebnitzer Schlossgespräche“ 507

„Trebschener Gemeinde-“, „Heimatbrief“ $\rightarrow$ Heimatzeitschriften

Treck (Flüchtlingstreck) 24, 51, 64, 72, 81-83, 87-96, 98 f., 106-112, 113-120, 130 f., 133 f., 136, 146, 184, 187, 192 f., 198, 201, 211, 273 f., $323,337,437,514,522,525$ f., 538-541, 544-546, 548f., 566, 574, 576, 578, 594, 597, $603,612,614,616-618,621,623$ f., 627, 629, 633, 636, 638, 657, 663 f., 673, 694, 701 f., 726, 729, 739, 744, 747, 749, 757 f., 771, 773 f., 786, 789 f., $801,808,819,830,833,837,843-845$, 852,855 f., 860 f., 863 f., $869,871-875,881$, 890-892, 901 f., 905, 915, 919, 921, 931, 934,
946, 949, 955, 975, 993 f., 1273, 1399, 1403 f., 1435-1439, 1441-1444, 1446, 1448-1450, 1452, 1454 f., 1457-1461, 1463, 1465, 1468, 1470-1480, $1482 \mathrm{f}$.

- (Begriff) 68, 1477

Treckarzt 20, 130, $1475 \mathrm{f}$.

Treckbefehl 915

Treckdienst (Flüchtlingsbetreuung) 119, 1477

Treckführer 90 f., $94,96,106,192,436$ f., 560 , $960,1439,1446,1460,1463,1476$

Treckführerin 121, 127, 1482

Treckkutscher 95, 100, 112, 774

Trecklaufzettel 863

Treckleitstelle 92

Treckplatz 113

„Treckmarsch“ (vgl. $\rightarrow$ Fußmarsch) 1435, 1465

Treckstelle 94

Treckstraße, -strecke, -weg 108, $545 \mathrm{f}$.

Trecktagebuch 624

Treckverbot 85, 117, 757

Treckwagen $\rightarrow$ Ochsen, $\rightarrow$ Pferde

Treckziel 1471

Treffen $\rightarrow$ Heimattreffen, $\rightarrow$ Umsiedlertreffen

„Treffen der Generationen“ $830 \mathrm{f}$.

Treibriemenfabrikation, -weberei 1199, 1247

Treuhandanstalt 780, 1439

„Tribüne“ $\rightarrow$ Zeitungen

Trümmer, -schutt, Ruinen (siehe auch $\rightarrow$ Kriegsschäden) 132, 181, 280, 358, 638, 650, 664, $669,829,917,997,1009,1054,1125,1167$, $1227,1377,1454,1472$

Trümmerfrauen, -arbeiten 269, 358, 887, 1474

Truppentransportschiff 1404

Truppenübungsplatz 631, $738 \mathrm{f}$.

Tschechisch $\rightarrow$ Sprache

$\mathrm{TU} \rightarrow$ Universität

Tuberkulose (Lungen-) $\rightarrow$ Krankheiten, $\rightarrow$ Todesursachen

Turnhallen $\rightarrow$ Schulen

Thyerotexikose $\rightarrow$ Krankheiten/Schilddrüsenunterfunktion

Typ 53/4 Neuheim $\rightarrow$ Wohnungsbau

Typenhaus 898

Typhus $\rightarrow$ Krankheiten, $\rightarrow$ Todesursachen

Typhusbaracken 712

Typhusepidemie $\rightarrow$ Krankheiten

Typhusimpfung 187, 736, 749, 957, 1011, 1014, $1075,1273,1478$

Typhusstation $895,961,1345$ 
Uckermärkische Tabakverwertungs-Genossenschaft (UTVG) 350, 1313 f., 1319

Uckermärkischer Geschichtsverein zu Prenzlau $15,28,45$ f., 867

Überanstrengung $\rightarrow$ Todesursachen

Überbrückungslager 849

Überführung $\rightarrow$ Umbettung

Übergangswohnheim (Ü-Wohnheim) 497, 1370 f.

Überleitungsstation 1009

Übermüdung 1016

Übernachtungsstelle 638 und öfter

Übernahmelager 1017

„Übersiedler“ $\rightarrow$ Aussiedler

Übersiedlung aus DDR in Bundesrepublik (vgl. $\rightarrow$ „Republikflucht“) 1327, 1399, 1436, 1438, 1453

- in die DDR 1436

Ü-Wohnheim $\rightarrow$ Übergangswohnheim

Uhren, -diebstahl 1175, 1437

Uhrenhandel 1210

Ukrainer 133, 819

Umbettung, Überführung 750, 762, 875, 923

„Umgesiedelte“ 1399

„Umherwandern“ $\rightarrow$ Wandern

„Umquartierte“ 608, 958, 1399

„Umquartierung“ 121 f., 124, 1127, 1130, 1140, $1170,1173,1225,1227$

„Umquartierung Ost“ 24

„Umroller" 114

Umschulung 267, 1026, 1093, 1151, 1194, 1196f., 1314, 1320

„Umsiedler“ passim

- (Begriff) 68-70, 78, 300, 309, 347, 360, 407, $517,747,1137,1174,1215,1306,1320,1391$, 1393, 1395-1401, 1439

Umsiedleramt, -abteilung, -stelle 1122, $1173 \mathrm{f}$., $1240,1243,1411 \mathrm{f}$. und öfter

- Kreise $\rightarrow$ Kreisumsiedleramt

- Provinzialebene $\rightarrow$ Amt für Umsiedler

Umsiedlerausschuss (siehe auch $\rightarrow$ Flüchtlings-, $\rightarrow$ Kreis-, $\rightarrow$ Landes-, $\rightarrow$ Orts-, $\rightarrow$ Provinzialumsiedlerausschuss) 248, 255-260, 282, 541, $546,603,658,683,734,746,842,849$ f., 855 , 1020, 1026, 1062, 1073, 1085f., 1091-1093, 1095, 1099, 1112, $1121 \mathrm{f} ., 1124,1128$, 1138f., 1141-1148, 1153, 1156, 1166, 1170, 1172-1174, 1196 f., 1235 f., 1240, 1243, 1401, $1407,1408,1412,1473$

- (Begriff) 1137, 1401
Umsiedlerausweis 591

Umsiedlerball 661

Umsiedlerbeihilfe“ 694, 842, 1408 f.

„Umsiedlerbesuche“ 1305

Umsiedlerbetreuung $\rightarrow$ Flüchtlingsbetreuung

Umsiedlerbetriebe (siehe auch $\rightarrow$ Firmen) $344,522,525,563,583,588,646,730,778$, $801,805,869,949,965,1143,1159,1199$, 1204-1213, 1247 und öfter

Umsiedlerfürsorge“ (vgl. $\rightarrow$ „Umsiedlerfürsorge) $587 \mathrm{f} ., 1012,1155$

„Umsiedlergelände“ 1001

Umsiedlergenossenschaften 26f., 31, 158 f., 229, 299-308, 551, 578, 618, 627, 648, 702, 710, 743 f., $752,766,778-781,799,814,826,842$, $883,899,915,917,925,1138,1159,1173 \mathrm{f}$., 1198-1201, 1213-1217, 1235, 1248

Umsiedlergesetz 1413

Umsiedlerheim 766, 810, 848, 909

„Umsiedlerin“ 69f., 254, 644, 805, 909, 1129 , $1255,1322,1415 \mathrm{f}$.

Umsiedler-Kennkarte $\rightarrow$ Ausweis

„Umsiedlerkinder“ 624

Umsiedlerlager, Flüchtlings-, Vertriebenenlager (einzelne siehe Geographisches Register) 16f., $22,26,46,53,76,81,111,137-139,147,149$ $152,162-183,199,206,214,216,221,223$, $225,245,248,256,261,266,271,276$ f., $279 f$ f., $287,335,411,416,451,484$ f., 517, 523-527, 529, 531, 533-539, 541-544, 546f., 549-551, 554 f., 557, 561, 563 f., 566-570, 572 f., 579584, 593, 597f., 600-603, 605, 610-612, 615, 618, 621 f., 626f., 631 f., 639-641, 642-646, 649-651, 654-656, 659-661, 679-682, 684, 687-689, 695-698, 703, 706, 709f., 716-720, 723, 734-736, 739 f., $743-746,753$ f., 759 f., 765-769, 773, 776 f., 783, 787 f., 791, 793, 796 f., 800 f., $813-815,820,829$ f., 833,840 , 848-850, 852, 854-859, 862-868, 870, $876 \mathrm{f}$., $883,887-890,894,899,904,910,912$ f., $915-$ 918, 921 f., 924, 926-928, 932-934, 936-938, 941 f., 945-948, 953, 958, 961 f., 964, 967 f., 971, 1009, 1016-1024, 1026, 1046-1109, 1120 f., 1123, 1126f., 1132-1134, 1153, 1158, $1176,1179-1186,1193,1197,1230,1232$ f., 1236 f., 1246,1250 f., $1253,1266,1268$ f., 1277-1279, 1282, 1390-1392, 1396f., 1410 f., $1419,1435,1438-1446,1453,1456,1462$, 1465 f., 1468, 1470, 1472, 1482 und öfter 
- Alltag, Lagerleben 168-183, 276, 1444

- Ambulatorium 1052, 1054

- Barackenälteste 173, 1095, 1099, 1107

- Bestattungsdienst, -kommando 1053

- Betriebsrat 1076

- Bibliothek 675, 769, 1105

- Blockleiter 563, 1052, 1061

- Dolmetscher 1079

- Einbruchsdiebstahl 840

- Einsatzstelle des Arbeitsamtes 1185

- Friedhof 1053

- Gebäude, Baracken, Ausrüstung, Einrichtung, Aufbau (siehe auch $\rightarrow$ Baracken) 168-171, 176, 178-181, 581, 640, 655, 675, $717 \mathrm{f}$., 766 f., $769,840,858$ f., $867,887,961,1022$, 1024, 1026, 1050-1052, 1054, 1059-1061, 1066, 1078, 1080, 1088, 1246, 1268 f., 1436

- Geburtshilfliche Station $1056 \mathrm{f}$.

- Haus- und Lagerordnung 6, 173, 698

- Kinderbetreuung 1482

- Krankenbetten 840

- Krankenstation, -baracke, -revier, Revierbaracke, Lazarett 767, 1050, 1054, 1066 f., 1075, $1268,1435,1453$

- Küche, Küchenbaracke, -personal, Koch $169,182,581,640,675,719,746,767,769$, $927,1020,1048,1052$ f., 1060, 1066, 1073 f., 1079-1081, 1088, 1091, 1246

- Lagerarzt 52f., 174, 563, 640, 649f., 660, $676,688,698,735,767$ f., $773,849,877,887$, $889,938,1046,1049-1058,1066$ f., 1075, 1077-1079, 1095, 1107 f., 1233, 1268

- Lagerausschuss 1020

- Lagerbetreuer 754, 863, 1132-1134

- Lagerleiter, -leitung, -verwaltung 41, 172-174, 178 f., 557 f., 562 f., 597, 640, 648, 600, 661, 675f., 687-689, 698, 710, 734f., 766-768, $773,859,864,877,887,889,895,927,937$, 961, 1020, 1024, 1040, 1046-1049, 1059f., 1064, 1067-1069, 1072 f., 1079, 1084, 1086, 1089, 1091, 1094-1098, 1104, 1106-1108, 1268 f., 1392

- Lagerordnung 1048, 1081, 1085, 1091, 1098

- Lagerplan, Grundriss 558, 689, 773, 859, 1436

- Lagerpolizei, Schutzpolizeikommando 563, 735, 745, 961, 1049, 1059-1061, 1065, 1068, 1070, 1077, 1079, 1081

- Lagerseelsorge 612
- Melde, -Suchkartei 53, $168 \mathrm{f}$.

- Personal, Stammpersonal, Stellenbesetzung $167,173,181,251$ f., 564, 648-650, 656, 660, 675f., 687-689, 698, 735, 768 f., 773, 840 f., $887,937,961,1020,1022,1045-1048,1053$, 1056, 1060, 1067, 1070 f., 1076-1079, 1087, $1107,1237,1268$

- Pfarrei-Außenstation, kath. 766, 769

- Quarantäne-, Infektionsstation, Seuchenbaracke 767, 859, 1051, 1056 f., 1064

- Registrier(ungs)stelle 1077, 1089

- Sanitätspersonal, Pflegepersonal 1077-1079, 1268

- Sanitätsstation, -baracke, bereitschaft, sanitäre Einrichtung 611, 717, 769, 773, 1007, 1077-1080, 1087, 1234, 1246

- Stubenälteste 173, 1107

- Veranstaltungen, „kulturelle Betreuung“ 172, 174f., 179, 294, 698, 719, 767, 1023, 1069, 1072f., 1075, 1081, 1083-1086, 1088-1095, 1097-1099, 1104, 1108, $1235 \mathrm{f}$.

- Verwaltung 53, 168, 1053, 1077, 1081, 1087, $1107,1134,1186,1233$

- Wirtschaftsleiter/in 563, 649, 660, 676, $687 \mathrm{f}$., $698,735,768,937,1046,1079$

- Zaun 640

„Umsiedler-Neubauer“ 310, 1130, 1241, 1316 f., 1401

„Umsiedlerorganisation“ 618,731

Umsiedlerpass $\rightarrow$ Ausweis

Umsiedler-Sprecher $\rightarrow$ "Sprecher der Umsiedler“

Umsiedlerstelle (siehe auch $\rightarrow$ Kreisumsiedleramt) 744, 1015, 1134, $1172 \mathrm{f} ., 1184,1243 \mathrm{f}$.

- der KPD Pirna 159

Umsiedlertagung 1144, 1146, 1244, 1339, 1412

Umsiedler-Transporte $\rightarrow$ Transporte

„Umsiedlertreffen“ 905, siehe sonst $\rightarrow$ Heimattreffen

„Umsiedlertum“ 1141

Umsiedlerunterstützung (siehe auch $\rightarrow$ Unterstützungszahlung) 522, 1092, 1244, 1411

„Umsiedlerversammlung“ (SBZ) (vgl. $\rightarrow$ Heimattreffen) 349, 406, 408, 856, 1300, 1305, $1337 \mathrm{f}$.

Umsiedlerverwaltung Brandenburg $\rightarrow$ Amt für deutsche Umsiedler

Umsiedlerwesen (Ressort) 842

„Umsiedlerwoche“ 258, 270f., 525, 578, 931, 1135-1141, 1171, 1174, 1236, 1401, $1410 \mathrm{f}$. 
„Umsiedlerzentrale Berlin“ 239

Umzug $\rightarrow$ Straßenumzug

Umzugsgut 1358

Unabhängige Wählergemeinschaft der Vertriebenen und anderer Benachteiligter (UWVB) 846

Unbegleitete Flüchtlinge 511

Uneheliche $\rightarrow$ Kinder

Unfall, Unglück (siehe auch $\rightarrow$ Eisenbahn/Zugunglücke, $\rightarrow$ Todesursachen) 284, 1467, 1474

Unfallstation 1478

Unfallschutz 1151, 1165

Ungeziefer (siehe auch $\rightarrow$ Flohbefall, $\rightarrow$ Läuse, $\rightarrow$ Wanzen) 641, 1050, 1078

Unierte Kirche $\rightarrow$ Evangelische Kirche der Altpreußischen Union

Uniform $\rightarrow$ Kleidung

United Press 1284

Universitäten 7, 11 f., 17, 23

- Berlin (FU) 9, 11 f., 15, 21, 26, 125, 299

- Berlin (FWU) 1131

- Berlin (HUB) (nach 1990) VI, 8, 16, 31, 144, 1458,1543

- Berlin (HUB) (vor 1990) 12, 144, 683, 1436, 1442, 1444, 1458-1459, 1436, 1442, 1444, $1458 \mathrm{f}$

- $\operatorname{Berlin}(\mathrm{TU}) 17,854$

- Breslau 450, 613, 753, 941

- Dortmund 9,47

- Dresden (TU) 11

- Frankfurt (Oder) 32 f., 103, 477, 507, 666, 673

- Gießen 1465

- Greifswald 11, 1439, 1456, 1458

- Halle-Wittenberg 12

- Jena 11, 1466, 1471

- Kattowitz 33

- Kiel 60

- Königsberg 834

- Leipzig 10, 21, 36, 1439, 1471

- Magdeburg $10 \mathrm{f}$.

- Marburg 296

- Münster 9

- Posen 32

- Potsdam 23, 25, $504 \mathrm{f}$.

- Prag 334

- Rostock 11,553

- Stettin 33

„Universität des dritten Lebensalters“ 622

$\mathrm{UNO} \rightarrow$ Vereinte Nationen
Unrat $\rightarrow$ Schmutz

„Unsere Märkische Heimat" $\rightarrow$ Heimatzeitschriften

Unterernährung $\rightarrow$ Krankheiten, $\rightarrow$ Todesursachen

Unterleibsentzündung $\rightarrow$ Todesursachen

Unterleibserkrankungen $\rightarrow$ Krankheiten

Untermiete, -mieter, (Hinter-)Zimmer (siehe auch $\rightarrow$ Wohnungsweinweisung) 222, 260, 273, 279, 285 f., 308, 323, 876, 1196, 1288, $1316,1435,1450$ und öfter

Unternehmer 262, 288-290, 306, 896, 940, 1110, 1248,1312 und öfter

Unterricht $\rightarrow$ Schulen

Unterschlagung $\rightarrow$ Kriminalität

Unterschriftensammlung $1106 \mathrm{f}$.

Unterstützungszahlung 17, 377 f., 401, 476, 522, 593, 644, 733, 897, 1025, 1090, 1092, 1130, 1137, 1145, 1147 f., 1233, 1244, 1273, 1316, $1342,1410 \mathrm{f}$.

Untersuchungshaft 1095, 1248

Untreue, eheliche 1280

Uraltguthaben 104, 1344

Uranerzabbau, -bergbau 172, 175, 294, 1092

Urlaub, Sommerferien 105f., 419, 426, 676

Urlaubsbescheinigung 584

US-Armee 1405, 1444, 1465

Utraquist 448

UTVG $\rightarrow$ Uckermärkische TabakverwertungsGenossenschaft

UWVB $\rightarrow$ Unabhängige Wählergemeinschaft der Vertriebenen und anderer Benachteiligter

Väter 764, 1280 und öfter

- alleinerziehend 1446 und öfter

Vandalismus 480

Varieté 1069, 1104, 1212

„Vater Unser“ 691

Vaterländischer Verdienstorden in Bronze $\rightarrow$ Orden

Vattenfall (Firma) 655, 762

VDA $\rightarrow$ Volksbund für das Deutschtum im Ausland

$V d g B \rightarrow$ Vereinigung der gegenseitigen Bauernhilfe

$\mathrm{VdH} \rightarrow$ Verband der Heimkehrer ...

VdN (Verfolgter des Naziregimes) 249

VEB (Volkseigene Betriebe) (vgl. $\rightarrow$ „Volkseigentum") 288, 567, 654f., 840, 1228, 1313, 1323, 1335, 1440, 1444, 1460 
VEB Gablona(-Schmuckwaren) 299, 301, 303, 305 f., $814,1228,1247,1414$

VEB Gubener Eisenwerke 714

VEB Gubener Schuhfabrik 347, 1333-1336

VEB (K) ([kreisgeleitete]) Volkseigene Betriebe) 290, 650, 869, 1229, 1464

VEB (K) Messerschmiede Leegebruch 780

VEB (Z) Wasserwirtschaft Oder-Neiße 567

VEG (Volkseigenes Gut) 823, 1438, 1440, 1454, $1457,1460,1475$

Verband der Heimkehrer, Kriegsgefangenen und Vermisstenangehörigen Deutschlands (VdH) $41,669 \mathrm{f}$.

Verband der Ostflüchtlinge und Evakuierten 257

Verband der Ostumsiedler 405, 618 f., 622, 624

Verband deutscher Archivarinnen und Archivare, Landesverband Brandenburg 692

Verbandskrankenhaus 819

Verbandszeug $\rightarrow$ Medikamente

Verdauungsstörungen 653

„Verdienter Lehrer des Volkes“ 297, 1471

Verdienstorden der Republik Polen $\rightarrow$ Orden

Verdunklung 90

Verein der Berliner Künstlerinnen 575

Verein der Driesener zu Berlin 368

Verein der Heimatfreunde Krs. Greifenhagen i. Pom. 368

Verein der Landsleute der Grafschaft Glatz zu Berlin 369

Verein der Neustettiner 369

Verein der Schweriner a.W. 369

Verein Deutsch Kroner Heimathaus 378

Verein für Computergenealogie 328, 949

Verein für die Geschichte Küstrins 771

Verein für Geschichte der Neumark 427

Verein für Geschichte Schlesiens 853

Verein für Heimatgeschichte der Stadt Müncheberg $61,810,1544$

Verein für internationale Beziehungen der Stadt Lindow 788

Verein für religiöse Kunst (Königsberg/Pr.) 222

Verein heimattreuer Schmiegler 368

Verein heimattreuer Soldiner in Berlin 369

Verein Lebenshilfe Finsterwalde 626

Verein zur Errichtung Evangelischer Krankenhäuser 1258

Vereine 294 und öfter

Vereinigte Kurländische Stiftungen (VKS) 590, 1544
Vereinigte Oberschlesier und Schlesier 368

Vereinigung der Ehemaligen des Pädagogiums und Waisenhauses bei Züllichau 427

Vereinigung der gegenseitigen Bauernhilfe ( $V d g B)$ $260,309,315,733,833,1085,1128,1150$, 1160 f., $1165,1167,1221,1224-1227,1243$, 1297 f., 1302, 1306, 1449, 1477

Vereinigung der Verfolgten des Naziregimes (VVN) 243, 1229, 1332-1334

Vereinigung ehem. Marienstifter 427

Vereinigung Sudetendeutscher Familienforscher (VSFF) 148

Vereinigung Volkseigener Betriebe $\rightarrow$ VVB

Vereinsregister $\rightarrow$ Amts-, $\rightarrow$ Kreisgerichte

Vereinte Nationen (UNO) 1368, 1391

Verfassung der DDR 389

Verfolgter des Naziregimes $\rightarrow$ VdN

Vergewaltigung 97, 132, 175, 320, 358, 875, 923, 928, 953, 1273 f., 1279, 1377

Verhaftung 1454 und öfter

Verhungern $\rightarrow$ Todesursachen

Verkehr (Ressort) 259

Verkehrsbusse $\rightarrow$ Omnibus

Verkehrsgendarm 96

Verkehrsverbindungen, -mittel, -not, -verhältnisse, Fahrverbindungen (siehe auch $\rightarrow$ Autobahn, $\rightarrow$ Chausseen, $\rightarrow$ Eisenbahn, $\rightarrow$ Straßen) 595, 806, 829, 901-903, 932, 998, 1005 f., 1130, 1146f., 1154, 1180, 1189, 1217, 1258, 1270, 1289, 1291, 1296 f., 1353, 1416 f. und öfter

Verkrätzung $\rightarrow$ Krankheiten/Krätze

Verlage $402 \mathrm{f}$., 1211

- Aufbau-Verlag (Berlin/Weimar) 1417

- Christ Unterwegs 444

- Deutscher Gemeindeverlag 1117

- Deutscher Zentralverlag 1146, 1409

- Evang. Verlagsanstalt 513

- Mitteldeutscher Verlag (Halle/Leipzig) 363, 1417

- Verlag der Nation (Berlin) 505

- Volk und Wissen Verlag (Berlin/Leipzig) 397

- Walde-Verlag (Cottbus) 1211

Verlausung $\rightarrow$ Läuse

Verletzte $86,89,587,643,728$ und öfter

Verlobung 371

Verlosung 1141

Vermisste 53 f., 369, 397, 438, 663, 747, 1404, 1436, 1440, $1457 \mathrm{f}$., $1465 \mathrm{f}$.

Verpflegung $\rightarrow$ Lebensmittel 
Verpflegungsreservelager 1011

Verschiebung $\rightarrow$ Schwarzhandel

Verschleppung $\rightarrow$ Deportation

„Verschmelzungsprozess“, „Verschmelzung mit den Alteingesessenen" "246, 258, 300, 1137, 1215,1302

Verschollene 205

Versicherungsvertreter 1208-1210

Versorgung, Versorgungsbetriebe 251, 259, 260$262,269,566,1237,1356,1358$ und öfter

Versorgungslage $\rightarrow$ Lebensmittel

Versprengte 837

Vertragsarbeiter (siehe auch $\rightarrow$ Vietnamesen) 836

Vertriebene passim

- (Begriff) 67-71, 1393, 1402

„Der Vertriebene“ $\rightarrow$ Heimatzeitschriften

Vertriebenenausweis $\rightarrow$ Ausweis

Vertriebenenfunktionäre $210,467,482,487$ und öfter

„Vertriebenen-Heimatgruppen Neuruppin“ 821

Vertriebenenlager $\rightarrow$ Umsiedlerlager

Vertriebenenpresse $\rightarrow$ Heimatzeitschriften

„Vertriebenenseminare" $\rightarrow$ Brandenburger Vertriebenenseminare

Vertriebenensiedlungen 339

Vertriebenentreffen $\rightarrow$ Heimattreffen

Vertriebenenverbände (siehe auch $\rightarrow$ Bund der $\rightarrow$ Vertriebenen, $\rightarrow$ Heimatkreisgemeinschaften, $\rightarrow$ Landsmannschaften) $56,58,183,200$, 204, 235, 364, 367, 380-383, 388, 464-473, $487,507,519,731,841,865,905,1340-1355$, 1358-1376 und öfter

- in der SBZ 212, 257, 405-407, 618 f., 622, 624, $653 \mathrm{f} ., 658,1154 \mathrm{f}$.

Vertriebenenzeitschriften, -zeitungen $\rightarrow$ Heimatzeitschriften

Vertriebenenzuwendungsgesetz (VertrZuwG) $464,466,1418$

Verwaltung passim

Verwandtenbesuch 377,380

Verwandtschaft $\rightarrow$ Familie

„Verweltlichung“ 459

Verwesung 927

Verwundete 598, 766, 850, 923, 941, 1335, 1453, 1478 und öfter

Verwundetenbetreuung 582, 1479, 1481

Verwundetentransport 125, 578, 1404, 1453, 1455
Viadrina $\rightarrow$ Universitäten, Frankfurt (Oder)

„Viadrus“ (Jahrbuch) 507

Vieh, -bestand, -herden, -haltung (vgl. $\rightarrow$ Tiere) 115,310 f., 317, 322, 736, 763, 843, 884, $890,901,917,969,1047,1217-1219,1221$, 1225-1227, 1297, 1317, 1436; Enten 1134; Gänse 1134; Geflügel 1218, 1227; Kühe 14, 133, 969, 1138, 1147, 1217 f., 1227; Ochsen (als Zugtiere) 843; Pferde 1138, 1217-1220, 1225; Rinder 1297 f.; Schafe 1138, 1217 f.; Schweine 81, 1119, 1130, 1217 f., 1227, 1297; Ziegen 969, 1218; Zuchtbullen 1218

Viehstall 700, 1150

Viehwagen, -waggons $\rightarrow$ Eisenbahn

Viermächtestatus (Berlin) 342

Vietnamesen (vgl. $\rightarrow$ Vertragsarbeiter) 512, 867

Visafreiheit 666, 714, $1416 \mathrm{f}$.

VKS $\rightarrow$ Vereinigte Kurländische Stiftungen

Vöcklabrucker Franziskanerinnen 842

„Völkerfreundschaft“ $1327 \mathrm{f}$.

Völkermord 21, 1361

Völkerrecht 1361, 1377

„Völkisch-nationale“ Gesinnung 76

Volksaufstand (1953) 299, 306, 352-354, 1415

Volksbegehren für die Einheit Deutschlands $1288,1298,1300$

Volksbildung (Referat) 1238

Volksbund Deutsche Kriegsgräberfürsorge 751, 761 f., 948

Volksbund für das Deutschtum im Ausland (VDA) 932

„Volksdeutsche“ (siehe auch $\rightarrow$ Abstammung) $75,99,155,530,569,596,752,880,895$, $1008,1044,1450$

Volksdeutsche Mittelstelle (VoMi) 932

„Volksdeutschen-Lager“ 858

„Volkseigentum“ (siehe auch $\rightarrow$ VEB, $\rightarrow$ VEG) $554,1228,1312$

„Volksfeinde“ 1269

„Volksgenossen“ 78, 311, 943, 1134

„Volksgesundheit“ 1194

„Volksgruppentreffen“ 406

„Volkshaus“ 639, 713, 716 f., 722, 873

Volkskammer der DDR 852, 1413

Volkskongress 1296, 1410

"Volkskorrespondent" $302 \mathrm{f}$.

„Volksküche“ 124, 267, 809, 926, 949, 966

Volkskunde (Ethnologie, -graphie) 18, 29, 30-32, $60,290,335,497,886$ 
Volksliste $\rightarrow$ Deutsche Volksliste

„Volksopfer“ $994 \mathrm{f}$.

Volkspolizei (VP) (siehe auch $\rightarrow$ Kasernierte Volkspolizei, $\rightarrow$ Polizei) 158, 172, $236 \mathrm{f}$., 293-296, 353 f., 367, 374f., 392-398, 403, 405, 426, 488, 948, 1098, 1104, 1175, 1326, 1329, 1340-1342-1355, 1436, 1438, 1455, 1459

- Abt. K 1350, 1352, 1355

- Bezirksbehörde Frankfurt 1353

- Bezirksbehörde Potsdam 390, 1354

- Bezirksbehörden, -verwaltungen 378, 408

- Informanten $373 \mathrm{f} ., 376,397 \mathrm{f}$.

- Landesbehörde Potsdam (LBdVP), Landespolizeibehörde Brandenburg 371, 394-397, 403, $1251,1342,1345$ f., $1348-1350$

- Landesbehörde Mecklenburg 395, 1342

- Landesbehörde Sachsen 397, 406, 1342 f.

- Landesbehörde Sachsen-Anhalt 1342

- Landesbehörde Thüringen 398, 1342

- Präsidium der VP Berlin 378, 394 f., 398, 408, 1340, 1344-1346

Volkspolizei-Kreisamt (VPKA) 371, 420, 1353; Bernau 371; Brandenburg/H. 396; Cottbus 351-1353; Fürstenberg/Oder 354; Gransee 390; Lübben 397; Mühlhausen/Th. 405; Potsdam 1354; Ruppin 372, 394, 1344; Seelow 1349 f., 1438; Senftenberg 1348; Westhavelland 375, 1345 f.; Westprignitz 398, 1347

Volksratswahlen 1316

Volksschule $\rightarrow$ Schule

Volkssolidarität 179, 226, 243, 258, 266-269, $283,584,658,679,722,776,862,878,887$, $1148,1155,1197,1452$

- Bundesverband 887

- Märkische Volkssolidarität (MVS) 258, $266 f$., 268, 926, 1089-1091, 1095, 1097 f., 1104, $1160,1170,1231,1251,1253,1394$

- Ortsausschuss, -gruppe 267-269,926

- Volkssolidarität Brandenburg (VSB) 1172

- Zentralausschuss 243

Volkssturm 92, 100, 105, 114, 128 f., 532, 663, $757,902,960,993,1405,1436,1456,1457$, 1474-1476, 1481

Volkstanz 227, $1088 \mathrm{f}$.

Volkstrauertag 110, 481, 484, 761, 841, 878f., 881,948

„Volkstum“ 1264, $1360 \mathrm{f}$.

„Volkswille“ $\rightarrow$ Zeitungen

Volkswirtschaftsplan 1951: 1229
Volkszählung (1946) 139, 190, 199, 202 f., 214, 219 f., 228, 231-233, 518, 522, 619, 659, 707, 847,876

Volkszugehörigkeit, deutsche 497, 1399, 1402

Volk-und-Wissen-Verlag $\rightarrow$ Verlage

$\mathrm{VoMi} \rightarrow$ Volksdeutsche Mittelstelle

Vormund, -schaft 783, 1453

Vorurteile 359 und öfter

VSB $\rightarrow$ Volkssolidarität Brandenburg

VVB (Vereinigung Volkseigener Betriebe) 814

VVB Braunkohle 1357

VVB Glas-Keramik 814

VVD 260

$\mathrm{VVN} \rightarrow$ Vereinigung der Verfolgten des Naziregimes

Wachmänner 1189

Währungsreform, „Abwertung“ 1171, 1173, 1289,1411

Wärmestuben, -hallen 267, 598

Wäsche (siehe auch $\rightarrow$ Bettzeug, $\rightarrow$ Kleidung) $599,719,754,791,829,865,895,1040,1056$, $1068,1142,1145,1154,1276,1278$

Wäscherei, sowjet. 923

Waffen 901, 943, 960, 1095, 1404

Waffen-SS 557, 597, 728, 738 f., 1447

Wagen-, Waggonältester (poln. komendant wagonu) 149,1040

Wagenbau 1199

Wahlen, Wahlergebnisse, -vorbereitungen 42, $304,347,434,707,922,1072,1108,1114$, $1128,1220,1247,1316,1319,1333$ f., 1345

Wahlkampf, -kundgebung 618, 1336 f., 1413

Wahlrecht 434, 583, 1072, 1319

Waisenhaus, -heim (siehe auch $\rightarrow$ Kinderheim) $224,269,561,640,825,862,897,922,924$, 930, 1013, 1021, 1159

Waisenkinder $\rightarrow$ Kinder

Waisenrente 1099

Wald 554, 727 f., 1131, 1142, 1246 und öfter

- (Bodenreformland), Waldzulage 312, 314, $523,738,784,843,1226,1246$

- (Erholungsort) 1092

- (Fluchtaufenthalt) 86, 90, 96, 114, 117, 322, $744,800,837,862,874 \mathrm{f}$.

- (Heimat-Bestandteil) 410

- (Holzquelle) 180, 285, 304, 312, 897, 1058, 1146 f., 1303

- (Nahrungsquelle) 855, 1250

- (Massengrab) 971 
- (sowjet. Übungsgebiet) 304

Waldarbeiter 134, 285, 351, 1047, 1283, 1321, 1324,1450

Waldarbeiterin 351, 1324

„Waldbühne“ (Berlin) 369, 374

Walde-Verlag $\rightarrow$ Verlage

„Waldhaus“ (Birkenwerder) 590

Waldlager (Heimkehrer-/Umsiedlerlager) 178, 593, 653, 688, 740, 794f., 840, 894, 971

Waldpilze 171,1250

„Waldsiedlung“ (Guben) 717, 719

Wallfahrt 452, 552, 598, 704f., 824, 900

Wandbilder 356

Wanderarbeiterheim, Wanderheim 776

Wanderbibliothek $\rightarrow$ Bibliotheken

Wanderheim $\rightarrow$ Wanderarbeiterheim

„Wandern“, „Umher-“, „Weiterwandern“ (unerlaubte, „schwarze“ individuelle Weiterreise; siehe auch $\rightarrow$ Einzelgänger) 150, 241, 271, 1012 f., 1019, 1023, 1152

„Wanderpriester" 803

Wandzeitung 565

Wanzen, -plage 859, 1275

Wappen 343, 356, 405, 479, 602, 689, 888, 1224 , 1260, 1311, 1323, 1329, 1363; Provinz/Land Brandenburg 1106, 1213, 1215, 1249, 1359

Warengutschein 644

Warme Mahlzeit $\rightarrow$ Lebensmittel

„Warschauer Deklaration“ (1950) 1413

Warschauer Vertrag (1970) 1416

„Wartburg“ (Pkw) $\rightarrow$ Kraftfahrzeuge

„Wartelager“ 1265, 1267

Waschgelegenheit, -küche, -schüssel (siehe auch $\rightarrow$ Hygiene) 95, 120, 616, 640, 693, 897, 961, 1080 und öfter

Waschmaschine 1229

Wasser $\rightarrow$ Lebensmittel

Wasser-, ver-/entsorgung, -leitung, -mangel, -bau (siehe auch $\rightarrow$ Kläranlage) $113,132,170 \mathrm{f}$., 179 f., 188,279 f., $285,425,580,618,635,770$, $819,829,893,896$ f., 901, 1014, 1019, 1052, 1056, 1060, 1150, 1464

Wasserstraßendirektion Kurmark (Potsdam) 253

Wassersucht $\rightarrow$ Todesursachen

Wassersuppe $\rightarrow$ Lebensmittel

Wasserwirtschaft 290, 567

Weberei, -genossenschaft 551, 883, 1026, $1198 \mathrm{f}$., 1228

Webstühle 1199
Wehrbezirkskommandantur Frankfurt/O. 81, $663,1405,1482$

Wehrmacht, (Wehrmachts-)Soldaten (siehe auch $\rightarrow$ Gefallene, $\rightarrow$ Kriegsgefangenschaft, $\rightarrow$ Kriegstagebuch des OKW, $\rightarrow$ Oberkommando des Heeres, $\rightarrow$ Vermisste, $\rightarrow$ Verwundete, $\rightarrow$ Volkssturm) 83, 86, 89-91-96, 108, 113-115, 124, 127, 131, 133 f. , 149, 155 f., 163, 169, 177, 181, 193 f., 246, 251, 298, 525, 532, 552, 559, 565 f., 570, 574, 577 f., 581, 586 f., 597 f., 608, 616, 645, 651, 654, 663, 962, $670,698,711,727$ f., 750, 757, 759, 763, 771, 786, 801, 840, 845, 866, 868 f., 876, 880, 891, $918,923,962,1058$ f., $1237,1241,1265,1307$, $1332,1335,1377,1399,1403-1406,1436$, 1444, 1446 f., 1451, 1454, 1456, 1459, 1463, $1466,1471,1473,1478,1481-1483$ und öfter

- 9. Armee 727

- Bewährungsbataillon Nr. 999: 249, 1135

- Fahrzeuge, Lkw 88, 890, 931

- Feldwebel 1335, 1438

- Fallschirmjägerdivision 1466

- Generale (Sammellager) 926

- Luftwaffe 736, 1434, 1466

- Pioniere 597, 682, 757, 902, 1404

- Schießplatz 813, 1247

Wehrmachtsbericht 118

Wehrmachtspfarrer 77

Weidenruten 1215

Weihbischof $\rightarrow$ Bistum Berlin

Weihnachten, Weihnachtsfeier 174, 260, 338, 372,412 , 435, 440, 485, 506, 626, 742, 755, $798,947,1142$ f., $1278,1286,1354,1372$ f., 1446

Weihnachtsrundbrief 439

Weihwasser 1265, 1278

„Weiße Binde“ 1435

Weißrussen 322

Weiterleitung $\rightarrow$ Durchschleusung

„Weiterwandern“ $\rightarrow$ Wandern

Weltfestspiele der Jugend, dritte (Berlin 1951) 1228 f., 1462

Weltflüchtlingstag 481, 1418

Weltfrauentag 1374

Weltfriedenstag 355, 671

„Wende“ (1989) 1473

Wendisch $\rightarrow$ Sprache, Sorbisch

Werkstätten 640, 1197

Werkwohnung 1187 
Werkzeug, -fabrik 102, 288, 307, 754, 780, 1023, 1052, 1208 f., 1247

Wertgegenstände, -sachen $\rightarrow$ Gepäck

Westevakuierte 1152

„Westgeld“ $\rightarrow$ Geld

„West-Kontakte“ 53, 364-430, 1454, 1479

„Westpropaganda“ $\rightarrow$ Propaganda

Westreisen 377, 1416, 1452

„Westrepatrianten“ $141 \mathrm{f}$., 1045, 1402

Westverwandtschaft 1459

Westwall 1441

Wetter, Witterung, Klima, Temperatur 93, 95 f., 195, 197, 1005 f., 1057

- Eis, Glatteis (vereiste Flüsse u. Straßen) 84, $86,118,120,179,197,532,559,574,629$, $757,778,891,953,1142$

- Frost 197

- Hitze 98

- Kälte, Winterkälte 85,87 f., 90, 92, 98 f., 119 , 148 f., 179 f., 183, 193, 197, 218, 331, 546, 559 f., 562, 565, 577, 588, 598, 608, 616, 627, $701,703,774,786,795,802,833,875,881$, 890 f., 901, 993, 1000, 1050, 1052, 1076, 1088, 1119 f., 1126, 1140, 1159, 1190, 1223, 1272, 1274-1276, 1279, 1376f., 1457

- Matsch 901

- Regen 93, 114, 131, 581, 774, 881, 897, 1332

- Schnee 87f., 90, 93-95, 99, 118, 179, 197, 574, 629, 774, 786, 890, 901, 1058, $1376 \mathrm{f}$.

- Schneesturm, -treiben, -wehen 193, 994, 1058

- Tauwetter 91, 93, 95 f., 757, 901

Widerstand $\rightarrow$ Nationalsozialismus

Wiederaufbau 259, 312, 349, 483, 565, 604, 650, $811,818,849$ f., 862, 932, 999, 1020, 1023, 1043, 1093, 1121 f., 1124, 1152, 1192, 1194, 1240 f., 1294, 1332, 1438, 1473

„Wiedergewonnene Gebiete“ 346

Wiedergutmachung $\rightarrow$ Sühnemaßnahmen

Wiedervereinigung $\rightarrow$ „Einheit Deutschlands“

Wiesenland 1001, 1224, 1226

„Wilde Vertreibungen“ 28, 51, 70, 79, 109, 128-135, 146, 186, 188, 195, 274f., 292, 359,

$763,1402,1406,1454,1460,1469$ und öfter

„Wilhelm Gustloff“ $\rightarrow$ Schiff

Windeln 120, 1056

Winter, -kälte $\rightarrow$ Wetter/Kälte

Winterhilfswerk (WHV) 119

„Wir Flüchtlingskinder" $\rightarrow$ Romane

Wirkerei, Wirkwaren $1198 \mathrm{f}$.
Wirtschaft (siehe auch $\rightarrow$ Arbeit, $\rightarrow$ Firmen, $\rightarrow$ Industrie) 522, 829, 836, 1003, 1043, 1093, 1097, 1171, 1174, 1187, 1189, 1193, 1200, 1240 f., 1244, 1260, 1284, 1292 f., 1305, 1311, $1315,1322 \mathrm{f}$. und öfter

- (Ressort) 251, 1237

Wirtschaftsamt 578, 604, 837, 995, 1118, 1135

Wirtschaftsartikel, -geräte (vgl. $\rightarrow$ Ackergerät) $1139,1159,1209,1215,1217-1221$

Wirtschaftskommandant, sowjet. 794

Wirtschaftsoffizier, sowjet. $\rightarrow$ Rote Armee

Wirtschaftsplanung (Ressort) $\rightarrow$ Minister (Brandenburg bis 1952)

Wirtschaftspolitik 288, 299, 1122

Wirtschafts-, Gewerberaum 1118 und öfter

Wirtschaftsvergehen 1248

Wismut AG $\rightarrow$ Sowjetisch-Deutsche Aktiengesellschaft Wismut

Wissenschaft 1367 und öfter

Witterung $\rightarrow$ Wetter

Witwe/r passim

Witwenrente 1099, 1112

Witwenstift 590

Wlassow-Armee 171

„Woche des Kindes“ 1252

Wochenendhaus 1127, 1227, 1476

„Wochenpost“ (Zeitung) 243

Wochenschau (siehe auch $\rightarrow$ Film) 158, 172, $356,767,780$

„Wöchnerin" $\rightarrow$ Frauen/Schwangerschaft

Wohlfahrtsamt, -pflege 122, 126

Wohlfahrtspflege (Ressort) 896

Wohltätigkeitsveranstaltungen 267

Wohngeld 1371

Wohnhaus $\rightarrow$ Neubauernhaus, $\rightarrow$ Wohnungsbau

Wohnheim 586, 631, 836, 867

Wohnküche 1120

Wohnlager 718

Wohnlauben $\rightarrow$ Lauben

Wohnort, -sitz 50, 139 f., 177, 190, 195, 199, 204-238, 273, 353, 366, 384, 388, 395, 404, 411, 416, 441, 465, 483 f., 486, 522, 525, 528, $535,542,555,577,603,634,644,690,740$, $807,823,940,950,963,1132,1158,1164$, 1170, 1179, 1234f., 1343, 1392, 1394, 1400, $1402,1412,1437,1460 \mathrm{f}$.

Wohnortzuweisungsgesetz 497

Wohnraumbewirtschaftung $1115 \mathrm{f}$. 
Wohnung, Wohnraum, -beschaffung, -knappheit, -mangel, Wohnsituation, -verhältnisse, Wohnungsfrage, -not, -suche, -wesen, Unterkunft (siehe auch $\rightarrow$ Baracken, $\rightarrow$ Gutshaus, $\rightarrow$ Keller, $\rightarrow$ Notunterkunft, $\rightarrow$ Privatquartier, $\rightarrow$ Untermiete) 49, 122, 134, 143, 168, 171, 176, 183, 190 f., 194, 206, 236, 252, 255, 257, 261, 264, 271-284, 296, 304, 306, 310-312, $324,347,364,424,497,499,522,528,545$, 547, 551, 565, 578, 580 f., 594, 601, 604, 609, 626, 630, 640, 643-647, 655 f., 667, 670 f., 678,680 f., 683, 686, 694, 699, 727, 747-749, 764, 772, 779, 786 f., 795, 803, 809, 829, 842, 844, 849, 854 f., 875-877, 895, 926, 931-933, $943,949,951,1003,1005,1010,1013,1022$, 1086, 1092, 1094-1096, 1110-1135, 1137, 1139 f., 1143, 1145 f., 1152, 1155 f., 1158, 1161-1164, 1170, 1172-1175, 1180, $1186 \mathrm{f}$., 1189-1193, 1196, 1200, 1214, 1224-1227, 1231 f., 1234 f., 1239 f., 1242, 1270-1273, 1287, 1291 f., 1301, 1306, 1311, 1315-1317, 1320-1322, 1338, 1342, 1357 f., 1401, 1408, $1411,1441,1445$ f., 1450, 1456, 1461, 1474, 1520 und öfter

Wohnungsamt, -behörde 239, 712, 749, 764, 842, 848, 950, 1041-1043, 1113-1119, $1123-$ $1127,1162,1225,1227,1229,1232,1238$ f., 1271,1316

- Kreiswohnungsamt 1041, 1043, 1120, 1131, 1229, 1240, 1316

- Landeswohnungsamt 1241

Wohnungsausschuss 248, 868, 1042 f., 1113 , $1116,1128,1166,1174,1234,1243,1393$

Wohnungsbau, -ausbau, -wiederaufbau, Erweiterungsbau 130, 724, 859, 882, 892, 898, 951, 1120-1124, 1161, 1163, 1172, 1174, 1200 und öfter

- Typ 53/4 Neuheim 814

Wohnungsbaugenossenschaft 671, 689

Wohnungsbrand 1446

Wohnungseinrichtung $\rightarrow$ Mobiliar

Wohnungseinweisung, -beschlagnahmung, -zuweisung, (Zwangs-)Einquartierung, „Eingemeindung", Verteilung (vgl. $\rightarrow$ Einheimische) 89 f., 122, 131, 165, 170 f., 177, 180, 182, 193, 260 f., 266, 272-274, 276f., 283-285, 303, 321-323, 522, 524-530, 532, 534-544, 546$551,573,577$ f., 580, 584, 586, 594, 603 f., 609, $611,625,627,629,643,645-647,665,727$,
$730,745,747,764,766,786,789$ f., 794 f., 800 , $803,806,811,833,837,842,844,857,859$, 873 f., 876 f., 880,882 f., $889,893,902,910$, 914, 921, 928, 931 f., 937, 940, 943, 947, 950, 965 f., 969, 1010, 1012 f., 1019, 1041-1043, 1070, 1073 f., 1085 f., 1092-1094f., $1097-$ $1102,1117,1119,1121,1125$ f., 1156, 1158 f., 1162, 1196, 1225, 1227, 1232f., 1236, 1240, $1247,1253,1305,1308,1316,1376,1391 \mathrm{f}$., 1396, 1401, 1435, 1441, 1443, 1446, 1457, 1459-1462, 1464-1466, 1468, 1470, 1475 f., 1478 und öfter

Wohnungsfürsorge 1114, 1118, 1160, 1165 f., 1174,1393

Wohnungsgesetz 1114-1118, 1238

Wohnungshygiene (siehe auch $\rightarrow$ Hygiene) 259, 304

Wohnungskartei 1117, 1163

Wohnungskommission 1126, 1129, 1316, 1322

Wohnungsmiete 283, 873, 883, 1125, 1159, 1224

- Mietfreiheit 1013

Wohnungsnot 273, 311 und öfter

Wohnungspolitik 1114

Wohnungsprüfer/in $1114 \mathrm{f}$.

Wohnungstausch 311, 943

Woiwoden, Woiwodschaften 483, 672, 705, 771

„Woldenberger Flüchtlingsausschuß“ 205

„Wolfskinder“" 16, 220 f., 224-227, 269, 554, 570, $703-705,776,830,840,846,1436,1448,1450$

Wolfskinder-Geschichtsverein 220, 226

Wolgadeutsche 860, 1265

Wolhyniendeutsche 99, 203, 441, 585, 609, 615, $653,657,697,705,711,718,727,738,752$, $755,794,853,889,911,914,917$ f., 931,935 , 940 f., $1399,1463,1480$

Wolldecken $\rightarrow$ Decken

Wolle 1142

Workshops 684

Wucher 1273

Wurst 861

\section{Zahnarzt 653,1480}

Zeitgeschichtliche Archäologie 33-35, 281

Zeitgeschichtsforschung, Zeithistoriker $4 \mathrm{f}$., 9-19, 20, 31-34, 40, 50, 58, 510

Zeitschriften (siehe auch $\rightarrow$ Heimatzeitschriften, $\rightarrow$ Rundbriefe) 767, 1089, 1105

- Die Kirche 1261

- Die Neue Heimat 1146 
- Für Dich 1105

- Gustav-Adolf-Bote 1261

- Märkische Heimat 325

Zeitungen, Presse, -berichte (siehe auch $\rightarrow$ Heimatzeitschriften/-zeitungen, $\rightarrow$ Suchzeitung) 70, 235 f., 249, 264, 268, 303 f., 352, 465, 470, 481, 492, 507, 519, 611, 723, 767, 951, 1044, 1081, 1089, 1095, 1105, 1118, 1136, 1140, 1147, 1161, 1164, 1173, 1175, 1254, 1282, 1295, 1309, 1318, 1369, 1374

- Berliner Zeitung 836, 1105

- Brandenburger Anzeiger 1397

- Der Märker 69,266

- Der Morgen 1132-1134

- Die Neue Zeitung 602

- Die Tagespost 846, 1136, 1138, 1150, 1224, 1251 f., 1308

- Echo des Ostens 249

- Lausitzer Rundschau passim

- Märkische Allgemeine Zeitung (MAZ) 1374f., 1378

- Märkische Union 896, $1251 \mathrm{f}$.

- Märkische Volksstimme 288, 344, 346, 540, 556, 584, 638, 708, 1135f., 1138, 1150, 1200, $1221,1224,1251$ f., 1283, 1308, 1414

- Nationalzeitung 1105

- Neue Zeit 896

- Neuer Tag 672

- Neues Deutschland 243, 348, 713, 836, 1105, 1135 f., 1138, 1200, 1221, 1224, 1242

- Petrusblatt 446, 452f.

- Potsdamer Neueste Nachrichten 851

- Potsdamer Tageszeitung 844, 1397

- Sächsische Volkszeitung 1343

- Tägliche Rundschau 1105, 1221, 1224

- Tribüne 1105

- Volkswille 69

- Wochenpost 243

Zeitzeugen, -berichte, Erinnerungen 3, 6f., 18, $30,34,41-43,46-48,52,57,58-66,72$ f., 79 f., 88 f., $97,102,112$ f., 117, 121, 123, 134-136, 140, 144, 153, 173 f., 182 f., 192, 195, 198, 210, $215,219,226,233,267,269,271$ f., 277, 292, 306, 319-324, 332, 345, 357, 359-364, 377, 402, 418, 420, 423, 486, 489, 507, 509, 519, $541,545,576,582,622,628,723,776,787 \mathrm{f}$., $812,830,837,847,855,861,906,908,922$, $926,969,1393,1400,1429-1483,1543$ und öfter
Zelio-Paste 1013

Zensur 39

Zentralbüro Ost (evang.) 435

Zentrale Aufnahmestelle für Asylbewerber (Eisenhüttenstadt) 498

Zentrale Aufnahmestelle für Aussiedler (BerlinMarienfelde) 13

Zentrale Ausländerbehörde (Eisenhüttenstadt) 498, 1544

„Zentrale der Danziger Geistlichkeit“ (Rundschreiben) 1343

Zentrale Suchkartei (Leipzig) 263

Zentrale Vereinigung der gegenseitigen Bauernhilfe $(\mathrm{ZVdgB}) 833$

Zentraler Frauen-Ausschuss 243

Zentrales Jugendamt 1240

Zentrales Staatsarchiv der DDR, Deutsches Zentralarchiv (SBZ) 253, 1307

Zentralstelle für vermisste Flüchtlinge 663, 1404

Zentralverwaltungen (SBZ), Deutsche Verwaltungen 51, 1054, 1115, 1117

- Arbeit und Soziales/Sozialfürsorge 243, 1183, 1202, 1407

- Finanzen 1411

- Flüchtlinge und Heimkehrer 239 f., 1152

- Gesundheit 523, 561, 567, 640, 961, 1010

- Inneres 240, 248, 1168, 1355, $1411 \mathrm{f}$.

- -, Hauptabteilung Umsiedler und Heimkehrer (SBZ) 240, 1168

- Land- und Forstwirtschaft 311, 1165

- Umsiedler (ZVU) 6, 51, 53, 69, 147, $173 \mathrm{f}$., 228, 239 f., 245, 248 f., 251, 257, 300 f., 563, 649, 653f., 657, 659, 661, 689, 746, 760, 790, 829, 840, 904, 1003, 1008-1013, 1016-1018, 1022, 1026, 1048 f., 1059, 1081 f., 1086, 1116, 1154 , 1229, 1236, 1339, 1396, 1407, 1411, 1419

- Verkehr 1010

- Volksbildung 243

Zentralwaggonstelle 1010

Zentrum (Zentrumspartei) 248

Zentrum für Zeithistorische Forschung (ZZF), Potsdam $14 \mathrm{f}$.

Zentrum gegen Vertreibungen (Stiftung) 469, $586,637,730,785,830$

Zentrum zur Erforschung des Genozids und Widerstandes in Litauen 846

Zeppelin 872

Ziegelei 703, 1189, 1205 f., 1281, 1442

Ziegelstein-Putzaktion 1222 
Ziegen $\rightarrow$ Vieh

Zigaretten 1091

Zimmerkontrollen 844

Zimmermann, -meister 1342, 1440 f., 1447

Zirkus 1099, 1104

„Zivilausländer“ 1003

Zivilinternierte $\rightarrow$ Internierung

„Zivilrussen“ 1058

Zloty $\rightarrow$ Geld

Zoll 403

Zonengrenzen, innerdeutsche Grenze 348, 896, 950, 1292, 1296, 1298

Zoologe 553

Zuchtbullen 1218

Zuchthaus 1248; Cottbus 845; Luckau 651; Waldheim 628, 1459; Wartenburg 1135

Zucker 844, 1153

Zugkontrollen 374

Zugkraft 1159

Zugtransport, -unglück $\rightarrow$ Eisenbahn

Zukunftsangst (siehe auch $\rightarrow$ Angst) 633, 1483

Zusammenhalt $\rightarrow$ Kommunikation

Zusatzkost $\rightarrow$ Lebensmittel

Zuwanderung $\rightarrow$ Migration

Zuzugsgenehmigung 137, 225, 277, 588, 932, 1027, 1038, 1044, 1083, 1091 f., 1096-1098, $1103,1126,1192,1271,1355$ f., 1440 f., 1450 , 1470 und öfter

Zuzugs-, Zuwanderungssperre (vgl. $\rightarrow$ Aufnahmestopp) $25,161,665,845,902,956$ f., 1441
Zwangsarbeit, -arbeiter/-innen (NS) (siehe auch $\rightarrow$,Ausländische Arbeiter“, $\rightarrow$ „Fremdarbeiter", $\rightarrow$ „Ostarbeiter") 34f., 46, 65, 80, 97, 100 f., 133, 155, 194, 508, 511, 598 f., 626, 628, 654f., 718, 728, 738, 821, 916, 932, 1010, 1168, 1396 f., 1463

- Deutsche in Polen 468, 1438, 1447, 1470

- Deutsche in der Sowjetunion $\rightarrow$ Deportation

Zwangsarbeiterlager (siehe auch $\rightarrow$ „Fremdarbeiterlager") 21, 25, 33-35, 163, 168-170, 173, $183,310,580,600,631$, 647 f., 654-656, 681, 687, 717 f., 734, 738, 858, 886 f., 936, 1237, 1268

„Zwangsarbeitseinweisung für Aufräumarbeiten“ (1946) 1194

Zwangsevakuierung (vor der Front) $\rightarrow$ Evakuierung

Zwangskollektivierung 191, 236, 292, 299, 314, $317,409,424,727,951,1436,1467$

Zwangsräumung (Ostgebiete) $\rightarrow$ Evakuierung

- eines Dorfes bei Luckau 789

Zwangsumquartierung (siehe auch $\rightarrow$ Umquartierung) 1173

Zwangsverheiratung 1463

Zwangsvereinigung (KPD/SPD) 1299, 1408

Zwangsvermietung 1227

Zweijahresplan 1170, 1336

Zwei-Plus-Vier-Vertrag 1417

„Zweite Heimat“ (Begriff) $\rightarrow$ Heimat

Zweiter Weltkrieg passim 


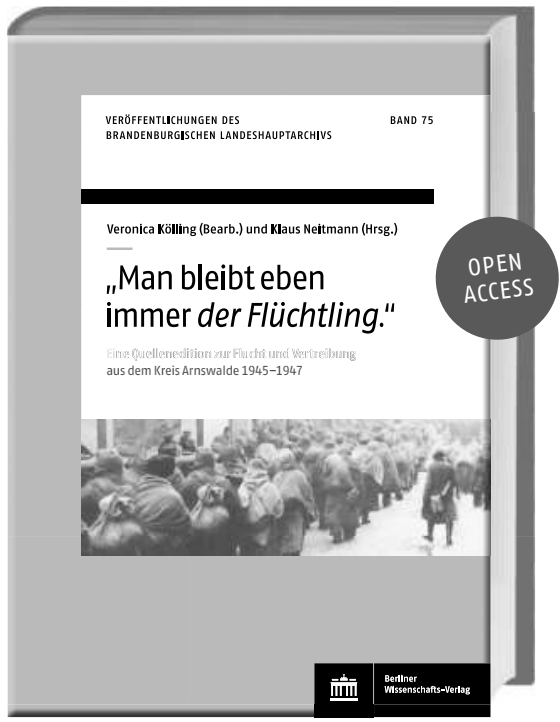

\section{DIE BEARBEITERIN}

Veronica Kölling, geb. 1984, Master of Arts Studium „Schutz europäischer Kulturgüter“ an der Europa-Universität Viadrina in Frankfurt Oder, Bachelor of Arts Studium „Modern Languages and Intercultural Communication " an der University of Southern Denmark, 2014-2019 wissenschaftliche Mitarbeiterin im Archiv der Stiftung Brandenburg, derzeit freie Historikerin und Projektmanagerin.

\section{AUS DEM INHALT}

Die Kämpfe um den Kreis und die Stadt Arnswalde | Evakuierung nach Anklam und Flucht über die Ostsee | Arnswalder in dänischen Flüchtlingslagern | Flucht, Rückkehr und Vertreibung aus Arnswalde | Flucht und Verschleppung aus Zühlsdorf | Evakuierung aus Reetz und Besatzungszeit | Krankenpflege unter sowjetischer und polnischer Verwaltung in Marienwalde | Die sowjetische Besatzungszeit im Kreis Arnswalde | Leben unter polnischer Verwaltung | Die Vertreibung der deutschen Bevölkerung | Neuanfang in Westdeutschland.
Veronica Kölling (Bearb.), Klaus Neitmann (Hrsg.)

\section{„Man bleibt eben immer der Flüchtling. “}

Eine Quellenedition zur Flucht und Vertreibung aus dem Kreis Arnswalde 1945-1947

Lange Zeit blieb Arnswalde im Zweiten Weltkrieg von militärischen Auseinandersetzungen verschont. Erst Anfang Februar 1945 belagerten sowjetische Truppen die Stadt. Tausende Bewohner konnten nicht mehr rechtzeitig fliehen und wurden in Arnswalde eingeschlossen. Zwei Wochen lang bangten sie um ihr Leben, bis die deutsche Wehrmacht sie schließlich vom Feind unbemerkt aus der Stadt schleusen konnte.

In dieser Quellenedition kommen neben Autoritätspersonen vor allem einfache Bürger zu Wort, die eindrucksvoll von ihrer Flucht aus der eingeschlossenen Stadt berichten, von ihrer Rückkehr in die Heimat, ihrer späteren Vertreibung und von den Schwierigkeiten beim Neuanfang westlich der Oder in einer Gesellschaft, die sie nicht wollte.

„Man bleibt eben immer ,der Flüchtling;, etwas bemitleidet, geduldet, manchem allein schon durch seinen Anblick lästig, da er nur zu sehr an die Vergänglichkeit irdischen Besitzes erinnert", schrieb der Arnswalder Lehrer Werner Riepe 1946 an seine Lebensgefährtin. Seine Einschätzung scheint angesichts heutiger politischer und gesellschaftlicher Entwicklungen immer noch erschreckend aktuell zu sein.

2020, 342 S., 51 s/w Fotos, 2 s/w Tab., geb., $60,-€, 978-3-8305-5009-9$

eBook PDF 978-3-8305-4182-0

(Veröffentlichungen des Brandenburgischen Landeshauptarchivs, Bd. 75)

Berliner Wissenschafts-Verlag | Behaimstr. 25 | 10585 Berlin Tel. 0308417 70-0 | Fax 0308417 70-21

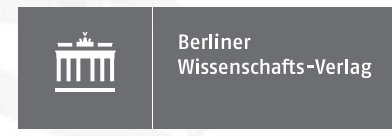




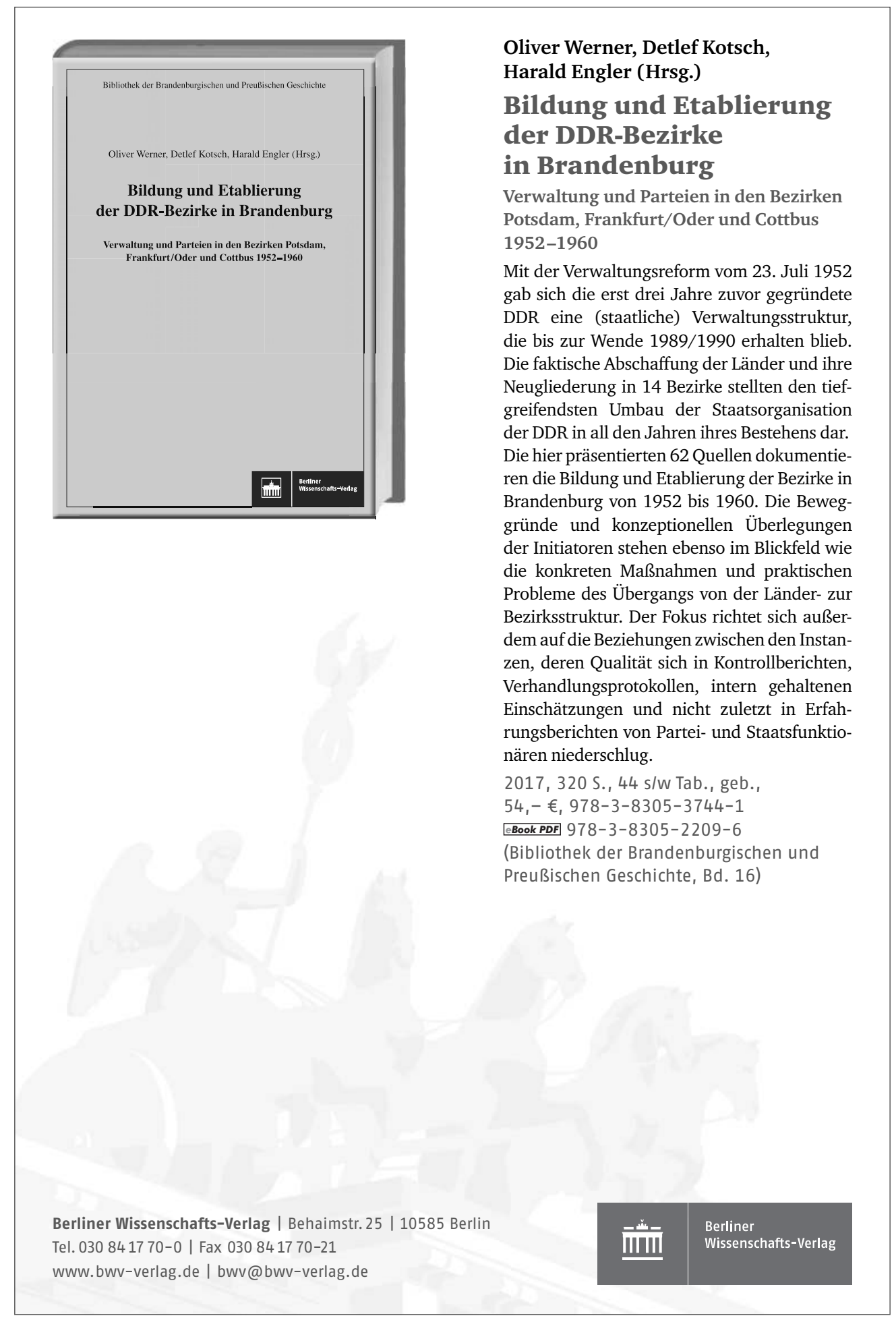



Flüchtlinge und Vertriebene aus den ehemaligen deutschen 0stgebieten und anderen Siedlungsräumen in 0stmittel- und 0steuropa kamen ab 1945 in sehr großer Zahl auch nach Brandenburg. Bis Ende 1946 nahm das Land mehr als 616.000 Menschen auf, was die Bevölkerung nicht nur erheblich vergrößerte, sondern auch in ihrer Zusammensetzung stark veränderte.

Das weitere Schicksal der Betroffenen in der DDR ist jedoch kaum bekannt. Peter Bahl zeichnet erstmals auf breiter Quellenbasis ihre Ankunft und Integration sowie die Erinnerungskultur bis zur Gegenwart nach. Neben Akten lässt er dabei vielfach Zeitzeugen sowohl aus dem Kreis der Vertriebenen als auch dem der Einheimischen zu Wort kommen.

An die Darstellung der Ereignisgeschichte schließt er eine Dokumentation für alle Städte und ausgewählte Landgemeinden mit handbuchartigen Informationen zur konkreten lokalen Entwicklung in 340 Orten an. In einem Editionsteil sind ferner 261 Quellentexte aus den Jahren 1945-2018 abgedruckt, die sich für eine vertiefende Beschäftigung mit dem Thema in Bildungsarbeit und Wissenschaft eignen. 